- Digitalisierte Fassung im Format PDF -

\title{
The Herball or Generall Historie of Plantes
}

\author{
John Gerarde
}

Die Digitalisierung dieses Werkes erfolgte im Rahmen des Projektes BioLib (www.BioLib.de).

Die Bilddateien wurden im Rahmen des Projektes Virtuelle Fachbibliothek Biologie (ViFaBio) durch die Universitätsbibliothek Johann Christian Senckenberg (Frankfurt am Main) in das Format PDF überführt, archiviert und zugänglich gemacht. 


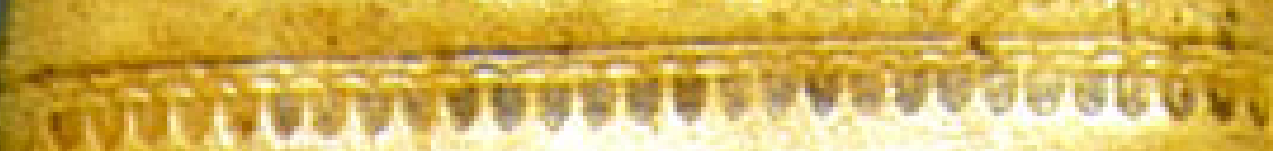

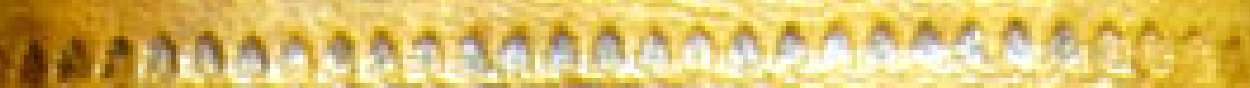

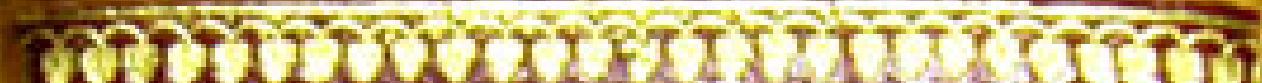

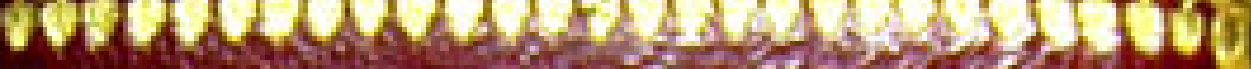

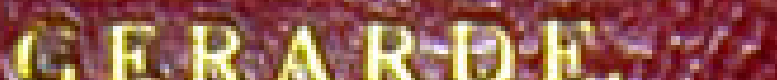

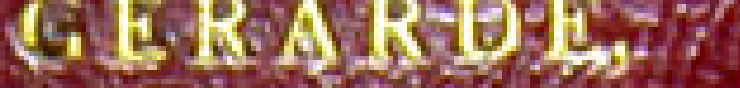 ME

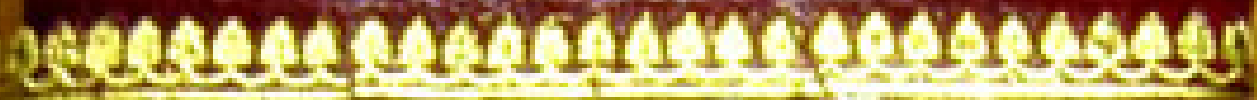




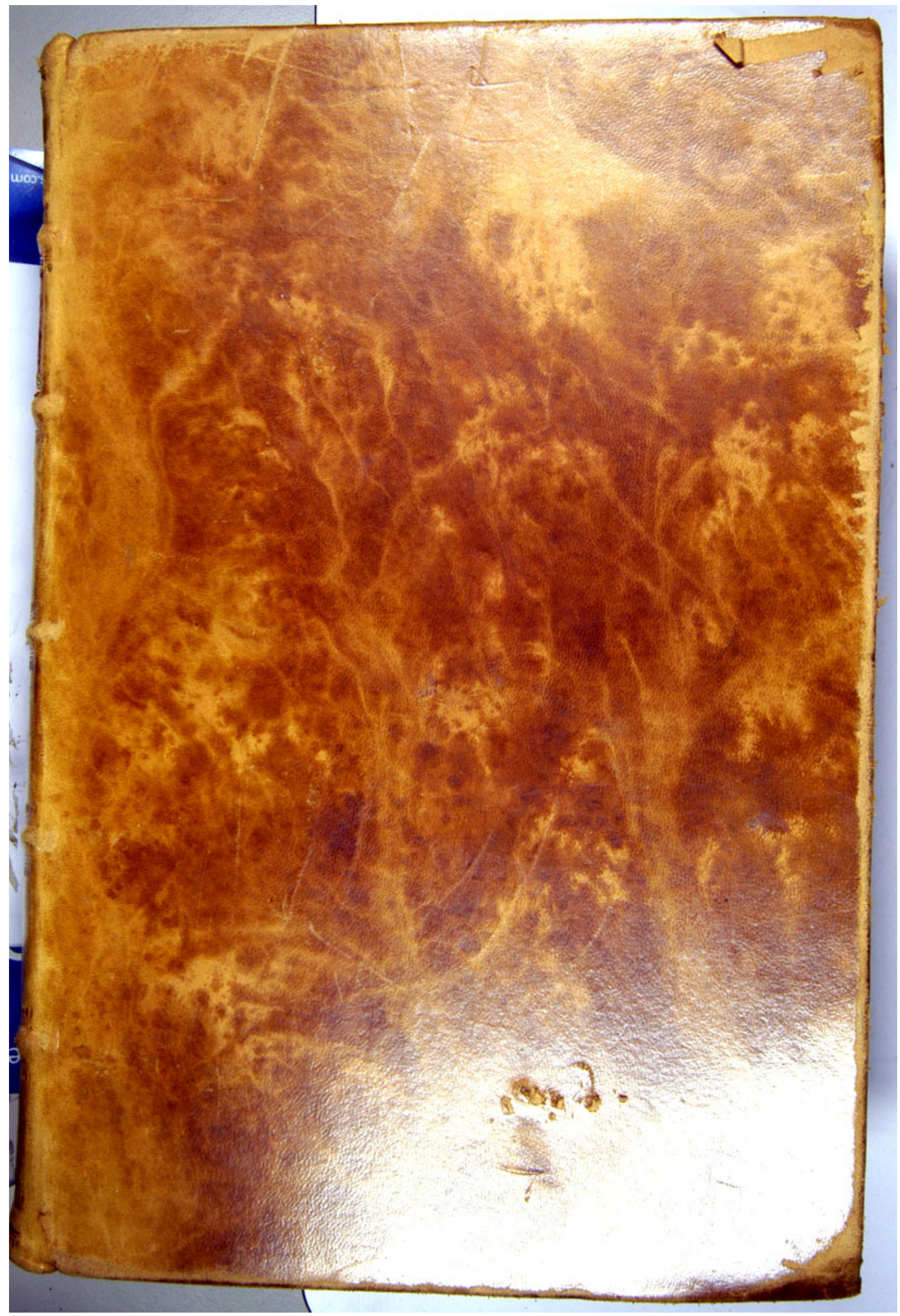




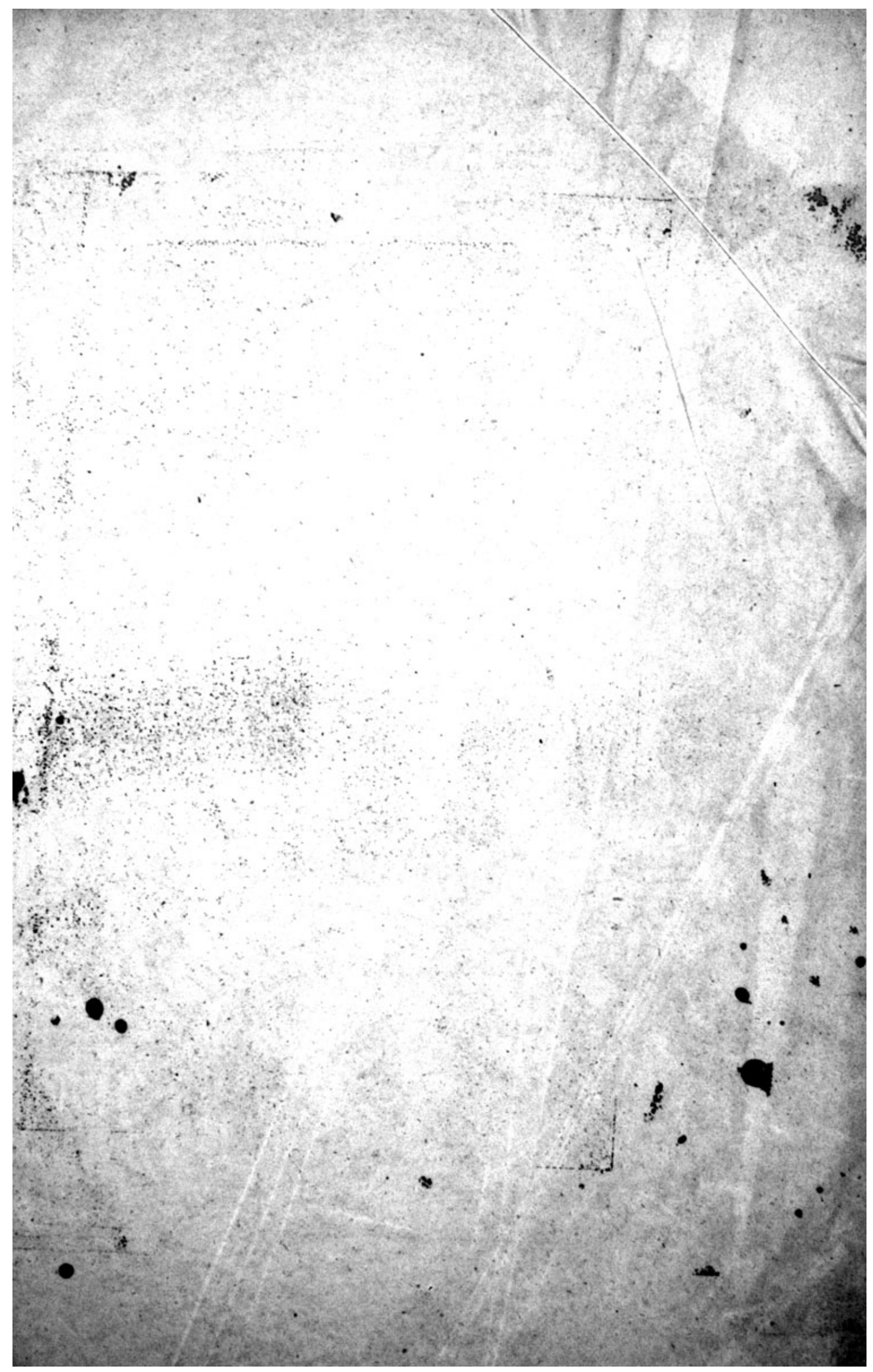




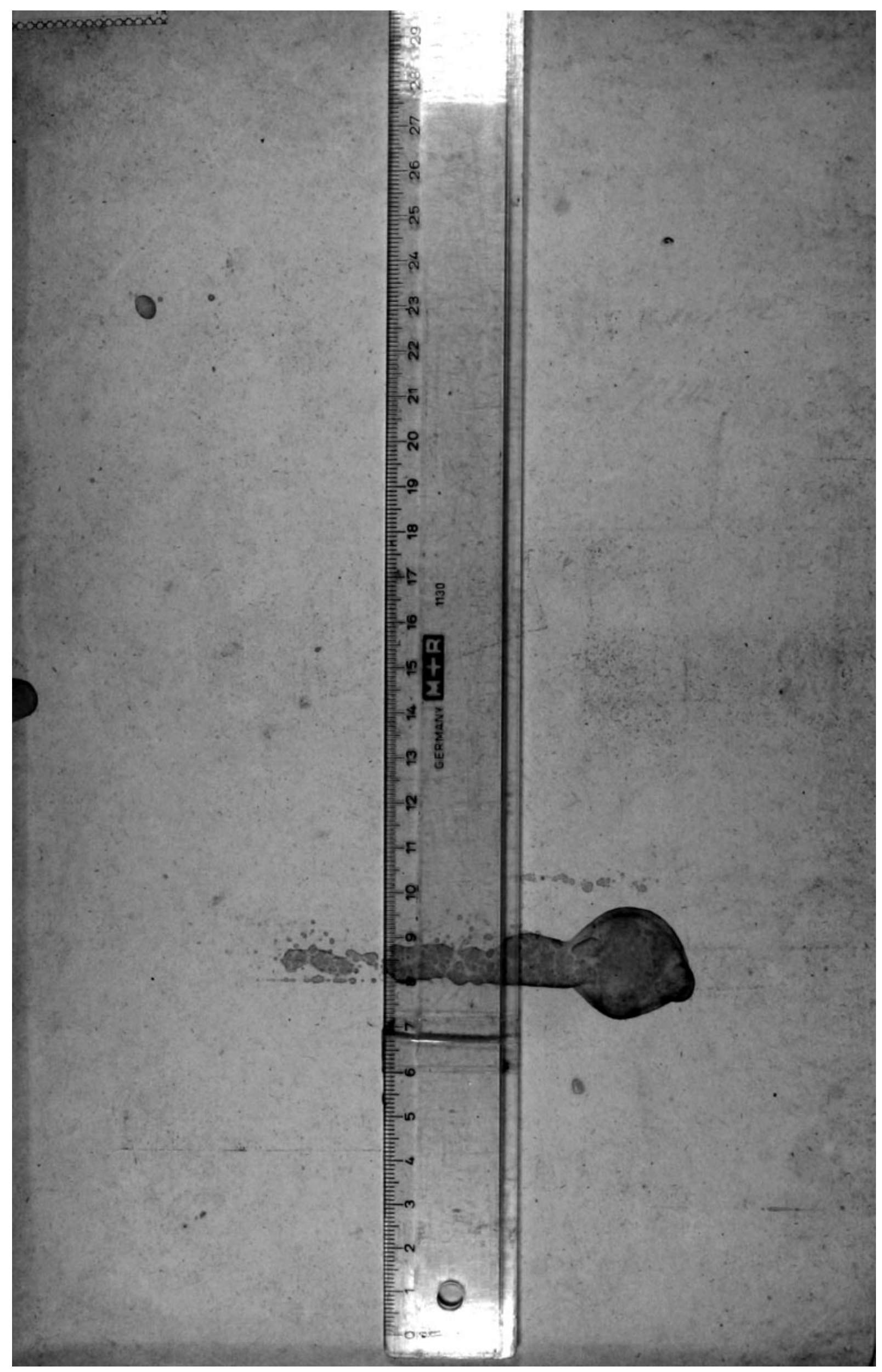




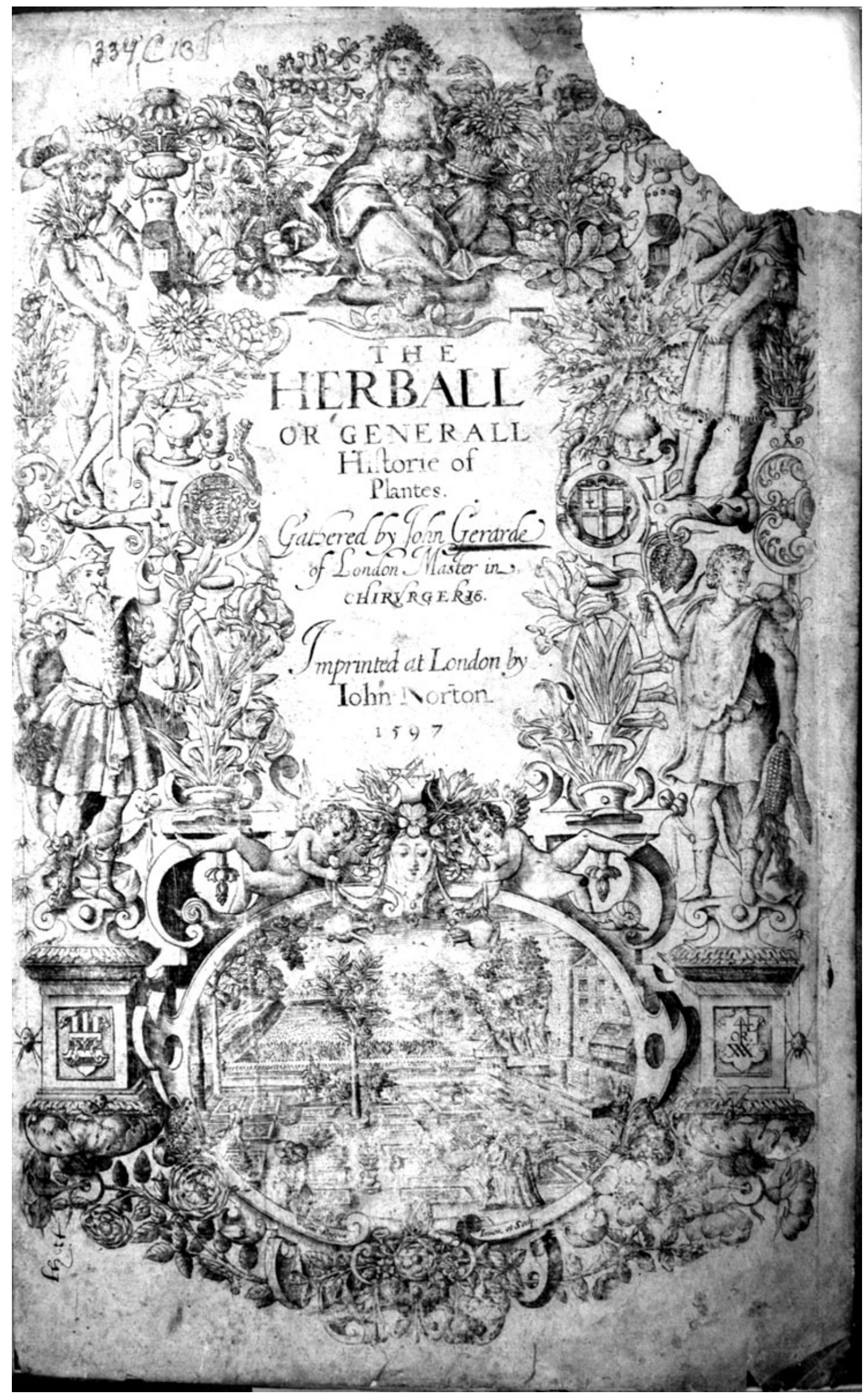




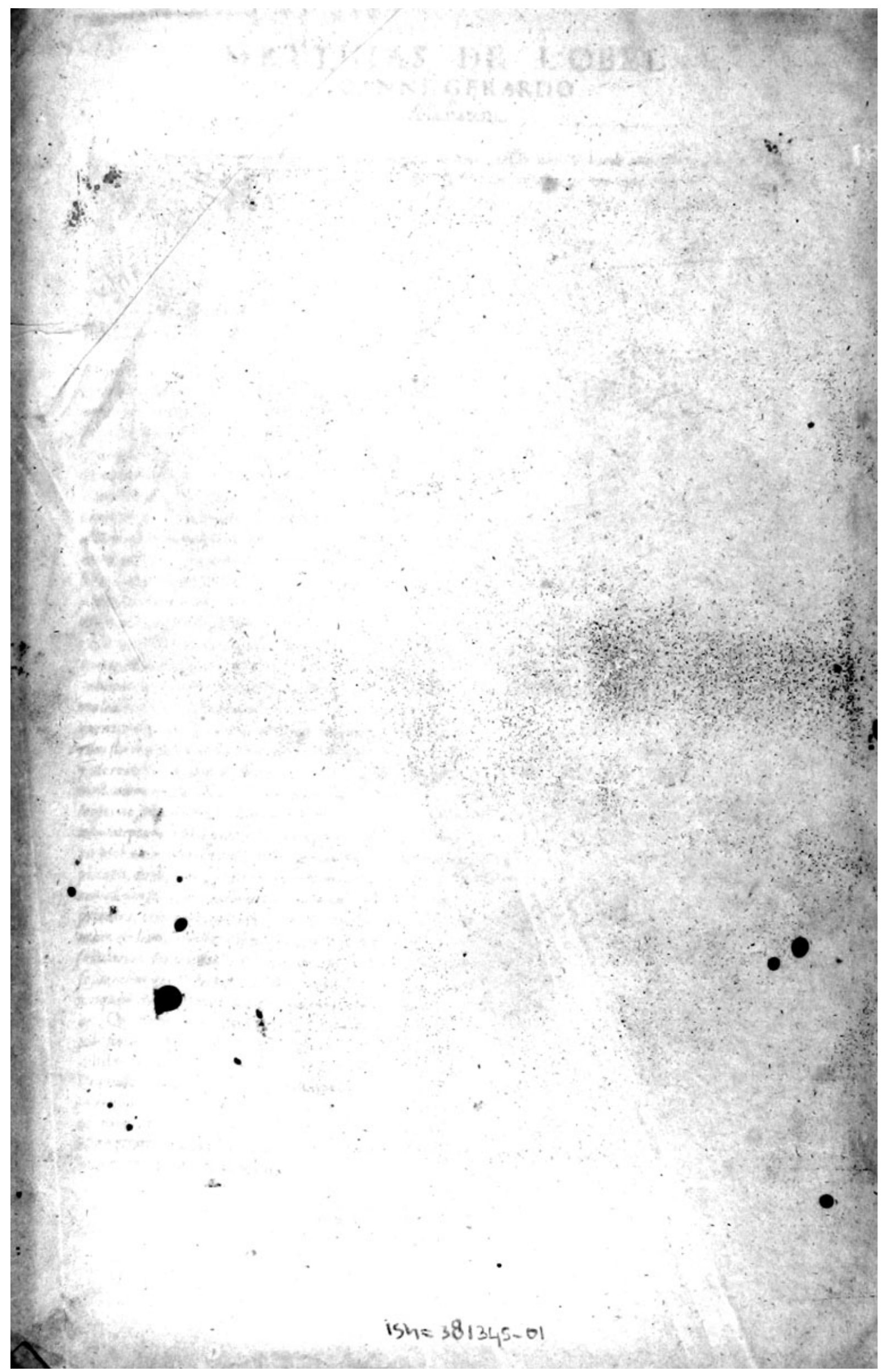




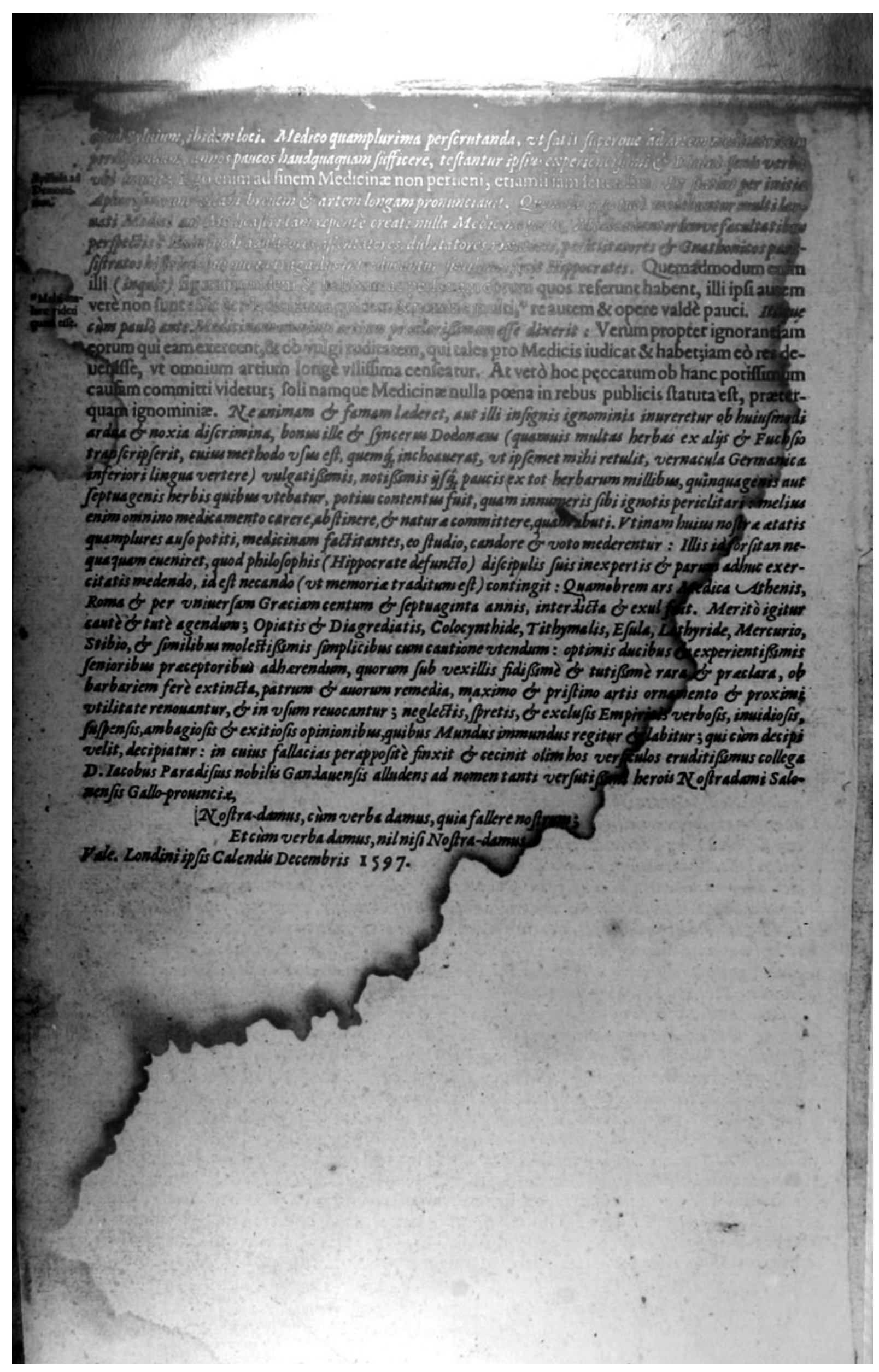




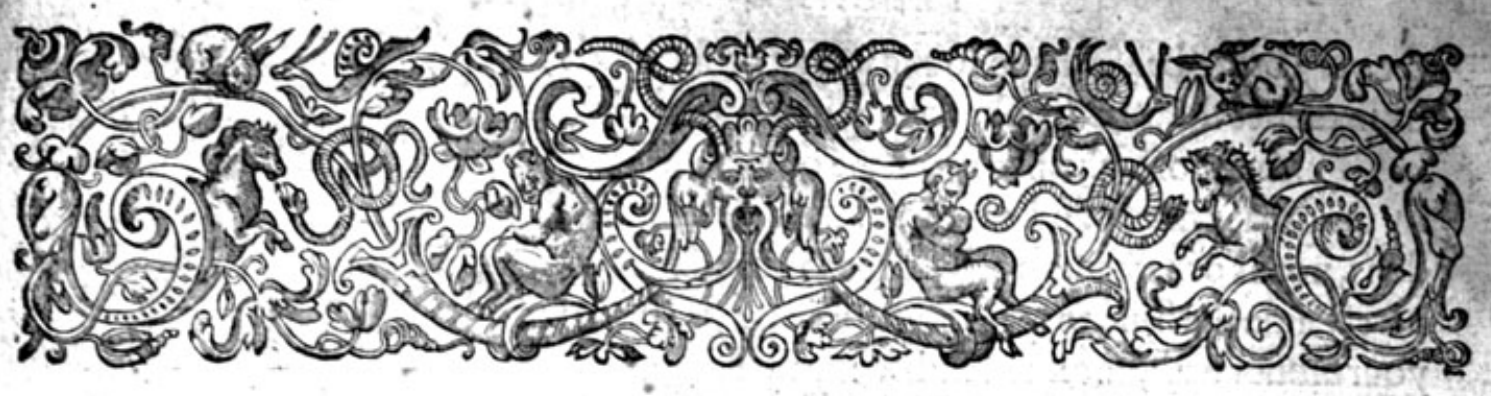

\section{TO THE RIGHT HONORABLE, HIS SINGVLAR GOOD LORD AND} MASTER, SIR WILLIAM CECILL KNIGHT, BARON of Burghley, Mafter of the Court of wardes and Liueries, Chancellor of the Vniuerfitie of Cambridge, Knight of the most ioble order of the Garter, one of the Lords of bir CT Taiesties: most bonorable priuie Counfell, and Lord

$$
\begin{gathered}
\text { High Treafurer of } \\
\text { England. }
\end{gathered}
$$

and Mong the manifold creaures of God (right Honorable and

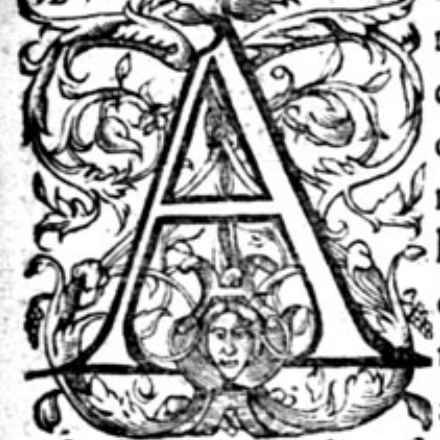
my fingular good Lord) that haue all in all ages diuerfly entertained many cxcellent wits, and drawen them to the contemplation of the diuine wifedome, none haue prouoked mens ftudies more, or fatisficd their defires fo much,as plants haue done, and that vpon iuft and woorthic caufes : For if delight may prouoke mens labour, what greater delight is there than to behold the earth apparelled with plants, as with a robe of imbroidered worke, fet with orient pearles, and garinth great diuerfitic of rare and coltly iewels? If this varietie and perfection of colours may affect the eie, it is fuch in herbes and flowers, that no Apelles, no Zeuxis cuer could by any art expreffe the like : if odours, or if tafte may worke fatisfaction, they are both fo foueraigne in plants, and fo comfortable, that no confection of the Apothecaries can equall their excellent vertuc. But thefe delights are in the outward fenfes : the principall delight is in the minde, fingularly enriched with the knowledge of thefe vifible things, fetting foorth to vs the inuifible wifedome and admirable workmanfhip of almightie God. The delight is great, but the vfe greater,andioyned often withneceffitic. In the firft ages of the world they were the ordinaric meate of men, and haue continued euer fince of neceffarie vfe both for meates to maintaine life, and for medicine to recouer bealth. The hidden vertue of them is fuch, that (as Plinienoreth) 


\section{The Epistle Dedicatorie.}

planss. the very brute beafts haue found it out: and (which is another vfe that he obferueth) sadian from thence the Diars tooke the beginning of their art.

Furthermore, the neceffaric vfe of thefe fruits of the earth doth plainly appeere by the great charge and carc of almoft all men in planting and maintaining of gardens, not as ornaments onely, but as a neceffarie prouifion alfo to their houfes. And here befide the fruit, to fpeake againe in a word of delight; gardens, efpecially fuch as your Honor hath, furnilhed with many rare fimples, do fingularly delight, when in them a man doth behold a flourilhing thew of fommer beauties in the middeft of winters force, and a goodly fpring of flowers, when abroad a leafe is not to be feenc. Befide thefe and other caufes, there are many examples of thofe that haue honored this fcience : for to paffe by a multitude of the Philofophers, it may pleafe your Honor to call to remembrance that which you knowe of fome noble Princes that hauc ioyned this ftudie with their moft important matters of ftate : Mithridates the great was famous for his knowledge herein, as Plutarch noteth: Euan alfo king of Arabia, the happie garden of the world for principall fimples, wrote of this argument, as Plinie fheweth : Diocletian might he haue his praife, had he not drowned all his honor in the blood of his perfecution. To conclude this point, the example of Salomon is before the reft and greater, whofe wifedome and knowledge was fuch, that he was able to fet out the nature of all plantes, from the highelt Cedar to the loweft Moffe. But my very good Lord, that which fometime was the fudie of great Philofophers and mightie Princes, is now neglected,except it be of fome few, whofe firit and wifedome hath carried them among other partes of wifedome and counfell, to a care and ftudic of fpeciall herbes, both for the furnilhing of their gardens, and the furtherance of their knowledge : among whome I may iuftly affirme and publith your Honor to be one, being my felfe one of your feruants,and a long time witneffe thcreof: for vnder your Lordhhip I haue ferued, and that way imployed my principall ftudie, and almoft all my time now by the fpace of twenty yecres. To the large and fingular furniture of this noble Iland, I haue added from forren places all the varietic of herbes and flowers that I might any way obtaine, I hauc laboured with the foile to make it fit for the plants, and with the plants to make them to delight in the foile, that fo they might liue and profper vnder our climate, as in their natiue and proper countrie : what my fucceffe hath beenc, and what my furniture is, Ileauc to the report of them that haue feene your Lordlhips gardens, and the little plot of my fpeciall care and husbandrie. But bicaufe gardens are priuate, and many times finding an ignorant or a negligent fucceffor, comc foone to ruine, there be that haue follicited me firft by my pen, and after by the Preffe, to make my labours common, and to free them from the danger whereunto a garden is fubiect: wherein when I was ouercome, and had brought this hiftorie, or report of the nature of plants to a iuft volume, and had made it, as the Reader may by comparifon fec, richer than former Herbals, I found it no queftion to whome I might dedicate my labours: for confidering of your good Lordhip, I found none of whofe fauour and goodneffe I might fooner prefume, feeing I found you euer my very good Lord and Mafter. Againe, confidering my dutie and your Honors merits, to whom may I better recommend my labours than tohim, to whome Iowe my felfe, and all that I am able in any feruice 


\section{The Epistle Dedicatorie.}

feruice or deuotion to performe? Therefore vider hope of your Honorable and accuftomed fauour, I prefent this Herball to your Lordhips protection; not as an exquifite worke(for I know my meanneffe) but as the greateft gift and chiefeft argument of dutie that my labour and feruice can affoord: whereof if there be no further fruit, yet this is of fome vfe, that I haue miniftred matter for riper wits, and men of deeper iudgement to polifh; and to adde to my large additions where any thing is defectiue, that in time the worke may be perfect. Thus I humbly take my leaue, befeeching God to grant you yet many daies to liue to his glorie, to the fupport of this ftate vnder hir Maieftie our dread Soueraigne, and that with

greatincreafe of honor in this world, and all fulneffe of glorie in the world to come.

Your Lord/hips most bumble and obedient feruant, 


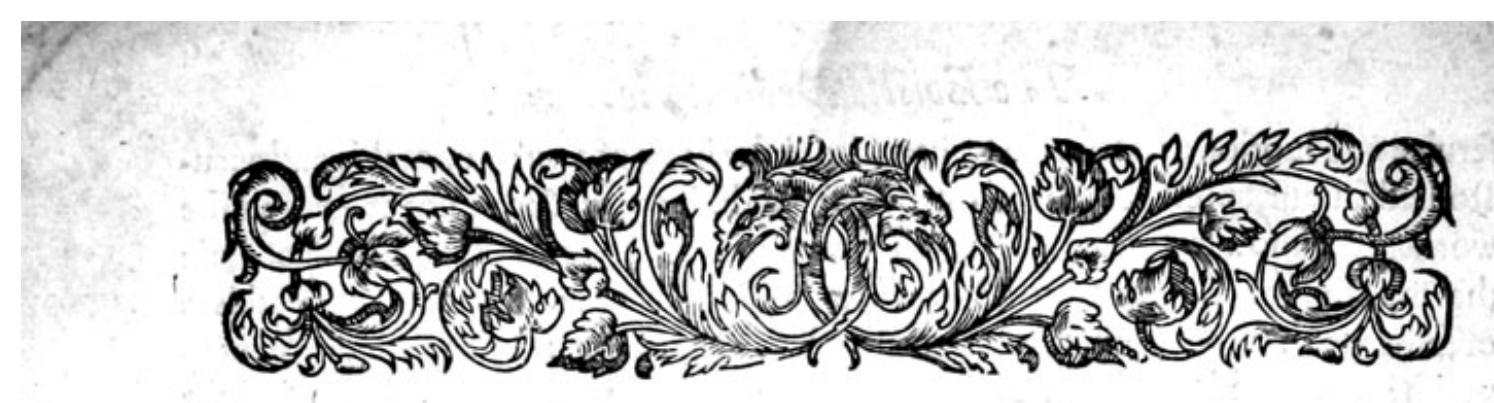

\author{
LANCELOTVS BRVNIVS MEDICVS REGINEVS \\ IOANNI GERARDO CHIRVRGO \\ peritifsimo, \& rei herbariæ \\ callentiflimo S.D.P.
}

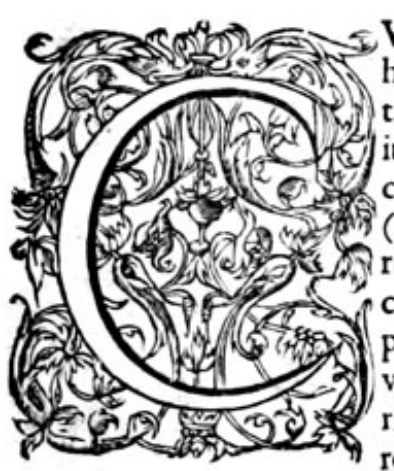

Vm fingularum medicinx partium cognițio atque intelligentia libero homine digna cenfenda eft; tum earum nulla vel antiquitate, vel dignitate, vel vtilitate, vel denique iucunditate, cum ftirpium cognitione iure comparari debet. Antiquiffimam eam effe ex eo liquet, quod quum cxteræ medicin $x$ partes (ficut reliquæ ctiam artes) ab ipfis hominibus (prout cos dura preffit neceffitas) primum excogitat $x \&$ inuent $x$ fuerunt : fola herbarum arborumque cognitio ante bominem formatum condita, eidemque mòx creato ab ipfo mundi architecto donata videri poteft. Cuiustanta apud antiqua fecula cxiftimatio ac dignitas erat, vt \& ipfius inuentionem fapientiffimo Deorum Apollini veteres tribuerint, \& reges celeberrimi in ftirpium viribus indagandis ftudium laboremque fuum confumere, fumma fibi apud pofteros laudi honorique futurum cenfuerint. Iam verò plantarum vtilitas, atque etiam neceffitas, adeò latè patet, vt eius im. menfitatem nullius vel acutifsimi hominis animus capere, nedum meus calamus exprimere queat. Stirpium enim complurimæ nobis in cibos, alimentumque cedunt : innumeræ aduerfus morbos remedia fuppeditant: ex alijs domos, naues, inftumenta tam bellica quam ruftica fabricamus : aliquot etiam earum veftes noftris corporibus fubminiftrant. In quibus fingulis recenfendis diutiùs perfiftere, hominis effet intemperantèr abutentis \& otio \& literis. Quantas autem, \& quam varias voluptates exftirpium fiue amœnitate oculiscapiamus, fiue fragrantia naribus hauriamus, fine fumma in earum conditorem impietate inficiari non poffumus. Adeò vt abfque ftirpium ope $\&$ fubfidio vita nobis ne vitalis quidem haberi debeat.

Quum igitur res plantaria rcliquis omnibus medicinæ partibus antiquitate antecedat, dignitate nulli cedat, vtilitate infuper oblectationeq; cæteras longè fuperet, quis futurus eft, adeo, aut infen. fatus vt non exploratum habeat, aut ingratus vt non ingenuè agnofcat, quanta vniuerfis Anglis commoda, quantafque voluptates tuus mi Gerarde in ftirpium inueftigatione \& cultu labor indefeffus, ftudium inexhauftum, immenfique fumptus hoc de ftirpibus edito libro allaturi funt. Macte itaque ifta tua virtute, iftoque de republica benè merendi ftudio, \& quod infigni tua cum laude ingrefflus es virtutis gloriæque curriculum, eidem infifte animosè \& gnauitèr, neque à re plantaria promouenda priùs defifte, quam eam à te ad vmbilicum iam fermè productam ipfe plenè abfoluas atque perficias. Sic enim \& tibi adhùc fuperftiti gloriam paries immortalem, \& poft obitum tantam tuinominis celebritatem relinques, vt tuarum laudum pofteros noftros nulla vnquam captura fit obliuio. Bene vale. Ex'AulaReginea Weftmonafterij,ipfis Calendis Decemb. I 597 : $^{\circ}$ 


\section{IN GERARDI Botanologian \\ espáruper.}

Ltimusecce Gerardus : at edit an optimus herbas?

Quid ni? non notas feddedit ille nowas.

Ergo ne inuideas, videas cion nomen or omen

crovígs, miruon est ardus quanta gerit.

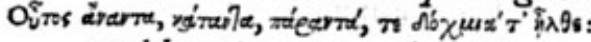

Sic liber est promsus, condus vt hortses erat.

Et pailu àpour celiomíg folvomó fubegit :

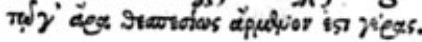

\section{ANTONIVS HVNTONVS}

Medicinæ candidatus.

\section{Adfobannem Gerardum Chirurgum Herbariomǵs peritis.smum.}

Vlla oculos hominum fpeciesmagis allicit illa,

1 Quam præftante manu duxit generofus Apelles;

Nulla aures animofq; magis facundia, quam qux

Se fufam loquitur Ciceronis ab ore diferti :

Hæc eadem hunc librum commendat caufa Gerarde,

Cuipro laude fatis tali natum effe parente,

Artifices cui inter dextras pro numine, nomen

Nobilius reliquis herbæ, plantæq; magiftris.

Illi etenim Europ $x$ fuccos, Afiæq; liquores

Quæque arente folo fitiens parit $A$ frica, tractant:

Tu veterum inuentis noua confuis omnia, fi qua

Indus vterque dedit noftram fotura falutem,

Siue aliunde vehit noftras mercator ad oras,

Hoc ipfo vtilius. Quia qux funt credita fcriptis,

Illa manu expertus medico, \& bene diues ab horto

Explorata diu multumq; emittis in auras

Quæ curent hominumlanguentia corpora, multi

Prxeftantesq; viri docuere fideliter artem.

Sed fi fuftuleris plantas, quem verba iuuabunt

Sic animo fic fronte minax. In prælia miles

Profilit, at ftrieto cedit victoria ferro.

Quæ tibi pro tanto cedit victoria ferro

Præmia perfoluet, Myrtilauriq; coronas ?

Iftam nouit edax mercedem abolere vetuftas,

At tibipro ftudio impenfifq; laboribusiftis,

Queis hominum curas fartam tectamq; falutem,

Ille opifex rerum, cuftosq; authorq; falutis

Eterna ftatuit frontem redimire corona.

\section{G. Launanus CMedicus.}

B I 


\section{In hiftoriam plantarum Io.Gerardi ciuis \& Chirurgi Londinen/is, M. M. Iacobi Iohnftonij Scoti Ballincrifx Regijpagi portionarij Epigramma.}

Efine qux vaftis pomaria montibus Atlas Clauferat (Hefperij munera rara foli)

Auratis folijs auratos define ramos Mirari, \& ramis pendula poma fuis.

Singula cum Domino periere, \& Gorgone vifo In montis riguit vifcera verfus Atlas.

Alcinoi perijt qui, cedat penfilis hortus, Quem celebrat prifcitemporis aura fugax :

Vna Gerardinifpecies durabilis horti Acterno fanæ marmore fculpta manet.

Hic quicquid Zephyrus produxit, quicquid \& Eurus, Antiquus quicquid \& nouus orbis habet,

Intulit in patriam naturamq; exprimit arte : Sic nullo cedit terra Britanna folo.

Quod magis eft Graium \& Latium concludit in vno Margine,\& Anglorumiam facit ore loqui :

Sic erit æternum hinc ve viuas horte Gerardi, Cultoris ftudio nobilitate tui.

\section{Fn Plantarum biftoriam, d folertißimo viro, Reiq; Herbarie peritiffimo, D.Ioanne Gerardo,Anglicè editam Epigramma.}

F Gregiam certì laudem, decus immort ale refert is

Tu, focijg, tui, magnum ơ mernorabile nomen

(Illustr is $D E V O R A X$ ) raptoribus orbis $I B E R I S$

Deutet is claffe $\triangle \mathcal{N} G L O R V M$; Tuǵs (Dicafta

Maxime EG ERTON E) veterem fuperins Rhadimant ham,

$H E R O V M$ merit ò inustễy cen fendius in albo.

Nec laus veftra minor ( facr a pietatis alumni)

Quimentes hominum diuina pafcitisefca.

Ornat is Patriam cuncti, nomen $g_{3}$ Britannum

Augetis, vobisǵ viam munitis ad aftra.

Quin agite, $\sigma$ in partem faltem permittite homoris

Phabe ve niant Vates, quipellere gnari

Agimina morborum, humane infidsunt ia vita.

Hutrus of ingentes, ferena fronte labores

ANGLO-DIOSCORID IS, Patrie, veftreás faluti

Excipitc exhaustos : pauliom hic dinort ite in $H O R T$ OS

Qwos C HOR TEIA colit, quos Flora exornat, \& omnes

Naiades, \& Dryades, Charites, Nymphég, Britanna.

Corporibses hic grata falus, animisó, volupt.us.

Hic laxate animos: $H A B I T A V I T$ NVMEN IN HORTIS.

Fran. Hering Med. D. 


\section{Thomas Nesotonis, Ceftrefhyrius, D.fo.Gerardo, amico non vulgari. $\mathrm{S}$.}

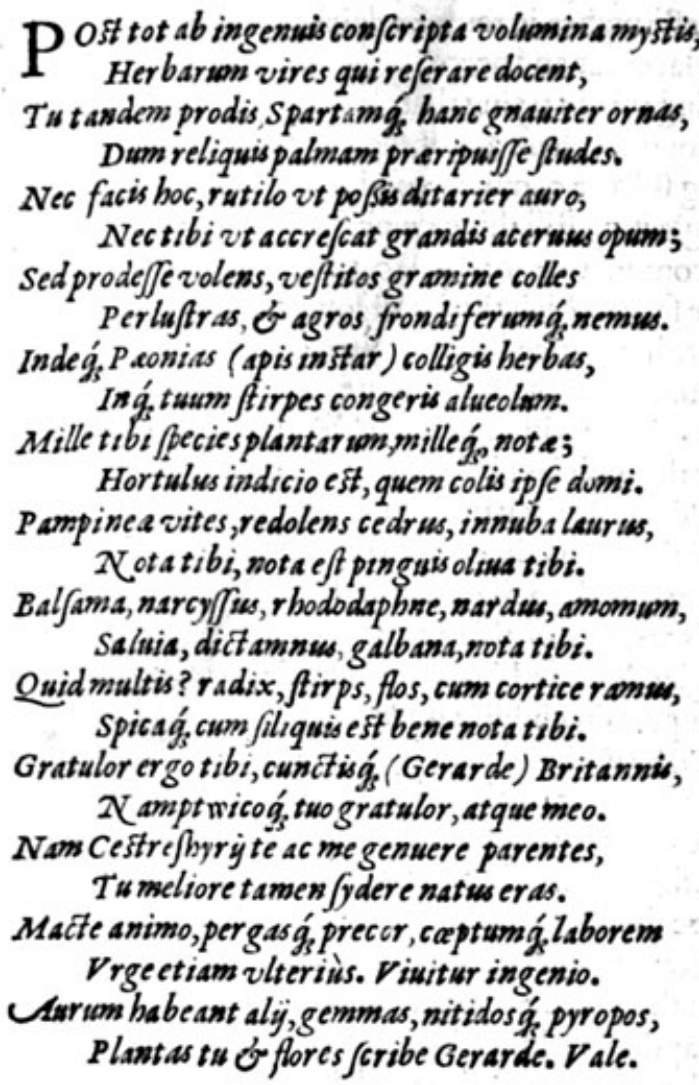

Verè \& ex animo tuus, Thomas Newton, Ilfordenfis isegains.

\section{Thomas Thorney Mafter in Chirurgerie, to his learned friend and louing brother in Art, M.Fobn Gerard.}

Fthaue I heard, and of haue read In bookes of learned lore, That Man, the name of Litsle vvorld, Or Microcofmos bore.

And rightly fure; whofe minde doth range The circled world about, Whofe head (a little Globe) conceiues Each worldly thing throughout. As this in all, fo now in thee, This thing appeereth trew By fpeciall note (fweete Gerard) heere In this thine Herball new. 
Wherein (as in aglaffe) we fee How thou thy minde haft bent,

Thy bodie toyld, thy time beftowde, And many a pound haft fpent,

In fleepeleffe nights, in reftleffe daies, In places far and neere,

In fearching this, in trying that, In countries here and there,

Preferring ftill the common good, Neglecting ftill thine owne,

And art content that we fhall reape The feede which thou haft fowne.

No priuate hindrance, loffe nor paine Could daunt thy harts defire

To profit others: which thou tak'ft For thy fufficient hire.

Difcharg'd heerin thou truly haft A right good Chriftian part,

In bringing foorth to publike good This treafure of thine art :

Not bungled, botched, hackt and hewde, Nor pend in childirh guife,

But fquar'd by skill,and tride by proofe, In iudgement of the wife.

Of fimples here we do behold Within our Englifh foyle,

More ftore than ere afore we did, Through this thy learned toyle :

And each thing fo methodicall, So aptly coucht in place,

As Imuch mufe, how fuch 2 worke Could fram'de be in fuch fpace.

For in well viewing of the fame Weneede not far to rome,

But may behold dame Natures ftore By fitting ftill at home.

We fee here a perpetuall fpring, A gallant flowring May,

Which month is painter of the world, As fome great Clerks do fay.

Reioice in God (good Gerard) ftill, Who thus hath lent thee ftrength,

And eke infpirde thee with fuch grace, Toend this worke at length:

And doubt not but herein thou haft Both pleafed God and man :

Happie art thou in doing this, Happie when thou began. 


\section{Fn commendation of M.Iohn Gerard for bis diligence in fimpling, by W.Westerman.}

Aze they that lift vpon the loftie skies, As rapt with Iunoes painted peacocks traine

When in the aire fhe vaunts hir Argus eies,

And dips hir bowe in partic-colourde raine,

How firft the fpredes, then wraps it vp againe:

Heauens azure curtaine let whofe will behold, Bedafht with aglets and with fpangs of gold.

My friend likes not to mount aboue his reach, Or meddle there where diftance maketh dout: High things arehard to learne and bad to teach, And no leffe dangerous to go about :

The funne we fee puts of the eiefight out;

And vpright gazers minding not their feete,

Stumbling dolay their length vpon the ftreete.

A lowly courfe more fitter for his looke

Doth pleafe him better, than thefe loftie fhowes:

The fruitfull earth he makes his daily booke,

And turnes fuch leaues as all his fenfes knowes:

He marks the fertill ground whereon he goes,

And viewes the plentic of our mother Earth,

Which yeelds fupplie againft difeafe and dearth.

Our mother Earth poffeft with womans pride,

Perceiuing Gerard to be beauties iudge,

And that hir treafurc is not vnefpide,

Of hir faire flowring brats the is no fnudge:

But here and there where Ger ard loues to trudge,

Hir verdant mantle fpreading round about,

She boafts the pleafance of hir goodly rout.

They all take Gerard for chiefe friend of theirs,

To whom they frame a garland for a figne

Of that pure loue, which each to other beares;

Olet the red Rofe and the Eglantine

Vouchfafe their prefence in his garland twine:

Let thofe faire flowers of our Englin field,

Vnwitherde long their fragrant odours yeeld. 


\section{To the well affected Reader and perufer of this booke, St.Bredwell Pbifition, \\ greeting.}

Pintan.
inpan.

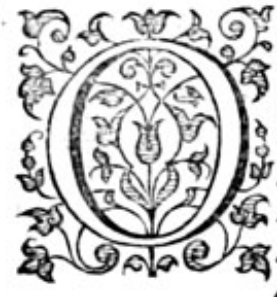
titles, are feene therein, and have the garland of praife and preferment waiting to crowne theirmerits; but euen the common foldier likewife: fo as be, whofe name and note was er st all objcure, may by egregious actes of valour, obtaine a place among the noble. The fchoole of fcience keepeth femblable proportion: whofe amplitude, as not alwaies, nur only, men of great titles and degrees, la bour to illustrate; $\int 0$ wbofocuer doth, may confidently account of, at the least, his name to be immortall. What is he then that will denie bis voice of gracious commendation, to the asthors of this booke: to cue rie one (no doubt) Tumenus. there is due a condigne meafure. The first gatherers out of the Ancients, and augmenturs by their ourne
Dodouras paines, have alreadie fread the odour of their good names, through all the lands of learned habitations. Pena
1 Obelius. D. Prieft, for his tranflation of fo much as Dodonxus, hat h hereby left a tombe for his honorable jepulmonemas, ture. Master Gerard comming last, but not the least, hath many waies accommodated the whole v vorke vnto our Englifh nation: for this historie of plants, as it is richly replenifhed by thofe fuue mens labours laid togither, $\rho$ yet could it full ill baue wanted that new acce ßson he hath made vnto ut. Many things hath he nourifhed in bis garden, and obferued in our Englifh fieldes, that nener came into their pens to write of. Againe, the greatest number of thefe plants, hawing never beene written of in the Englifh toong, would haue wanted names for the vulgar fort to call them by: in which defect, he hath beene curi. oufly care fail, toucheng both old and new names to make fupplie. And least the Reader flould too ofien languifh with frust ate defire, to finde fome plant he readeth, of rare vertue, he paret h not to tell (if himfelfe have feene it in England) in v what vvood,pafture or ditcb the fame may be feene and gat hered.IWhich vohen I thinke of, and ther withall remember, vvith vo hat cheer efull alacritie, and refolute attendance be hath many yeeres tilde this ground, and nov v brought foort h the fruit of it, vwhether I fhould more commend his great diligence to att aine tbis skill, or his large benewolence in bestovving it on his countrie, Icannot eafly determine. This bookebirt h thus brought foort h by Gerard, as it is in forme and difpofition faire and comly, enery f pecies being referred to his likeliest genus, of v vhofeflocke it came: fo is it accomplifhed voith furpa Sing varietie, to fuch Jpreading growtho ftrength of euerie lim as that it may feeme fome heroicallimpe of illuftrious race, able to draw the eies and exfectation of eueryman wnto it. Somwhat a rare it vill be heere for a man to mooue a queftion of th is nature, and depart againe vithout fome good Jatisfaction. Manifold vvill be the vfe both tothe Phifition and others : for euerie man delighteth in caen.1.5. knovvledge naturally, vvhich(as Ariftotle faid) is in pro(peritic an ornament, in aduer fiti a refugc. But this booke a boue many ot hers vvill fute vvith the most, bicanfe it both plentionfly miniftrethknovvledge, vwhich is the foode of the minde; and doth it alfo vvith a familiar and pleafing tafte to euerie capacitie. Novv, as this commoditic is communicated to all and many fhall receiue much fruit there of; $\int 1$ I $v v i f h$ fome

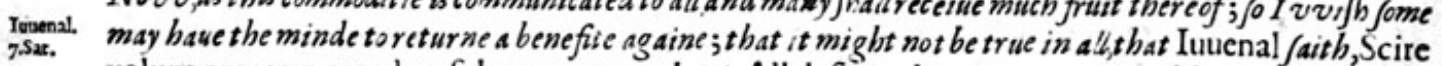
volunt omncs, mercedem foluere nemo: that is, All defire to knowe, none to yeeld reward. Let men thinke, that the perfection of this knovvledge is the high aduancement of the bealt hof man: that pe' fection is not to be attained, but by frong endewour: neither can frong endewour be accomplifhed, vvithout free maintenance. 7 his $i$ at h not be, vobo is forced to labour for his daily bread: but if he vilso from the jhort hovvers of his daily and neciffarie tranell, ftealing (as it vevere) forme, for the publike behoofe, and fetting at length tho/e pecces togither, can bring fourt h fo comely a garment as this, meete to coucr or put avvay the ignorance of many: vwhat may be thought be vvould do, if publike maintenance did free him from that prituate care and vnite his thoughts to be wholy intent to the gener all good.O Reader, if fuch men as this ftick not to rob them felues of fuch vvealth as thou baft to inrich thes, vvith that fubftance thow vvanteft, detract not to fhare out of thine abundance to merit and encour a ge thcirpaines: that $f o$, fuxible

Cic ofic.. riches, and permanent jciences, may the one become a prop vnto the other. Althought raife and revivarde ioined as companions to fruitfull endeuours,are (in part) defired of all men, that vndertake loffes, labours,

compon. in or dangers for the publike bohoofe; bicaufe they adde finev ves (as at vvere) vrito reafon, and able bir more and more to refine hir felfe: yet do they not imbrace that honer in refpect of it felfe, nor in refpect of thofe. 
that conferre it upen them, bat as hawing thereby an argument in them felues, that there is fome thing in them vvoorthie efimation among men: vvbich then dowbleth their diligence to deferue it more abun. dantly. Lamirable and for the imitation of Princes, vvas that ait of Alexander, vvbo fetting Ariftotle capas. the \& to compile commentaries of the brute creatures, allowved him for the better performance thereof, certaine thoufands of men, mall Afia and Greece, moft skilfull obferuers of fucht hings, to giue bim information tonching all beasts, fifhes, foules ferpents and flies. What came of it? Abooke voritten, voherein allearned men in all ages fince do excrcife themfelues principally, for the knovvledge of the creatures. Great us the number of thofe that of their ovvne private, haue laboured in the fame matter, from his age dovowe to our prefent time, vohich all do not in comparifon fatisfie vs. Where.ts if in thofe enfuing ages there had rifen Aillnevv Alexanders, there (certainly) vvould not have vvanted Ariftodes to haue made the esidence of thofe things a bandred fold more cleered vnto vs, than novv they be. Whereby you may perceine the vnequall effects that follow thofe vnjut able cauf es of publike and priwate maintenances vnto labours and findses. Novv that I might not de/paire in this my exhortation, I fee fome examples of this munificence in our age, to giue me comfort: Ferdinand the Emperor and Cofmus Medices Prince of $T u$ fcane are herem Grlus in

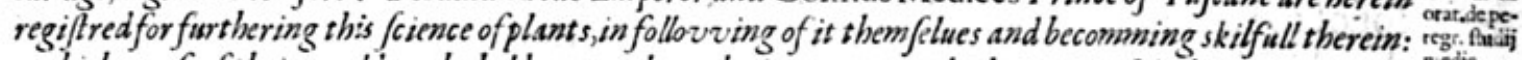
vibich courfe of theirs could not be holden, vvithout the fupsorting and aduancing of fwch as vvere ftudious to excell in thiskinde. Bẹllonius likevvife (vvhom for honors c.alle I name) a man of high attempts Bellon, de

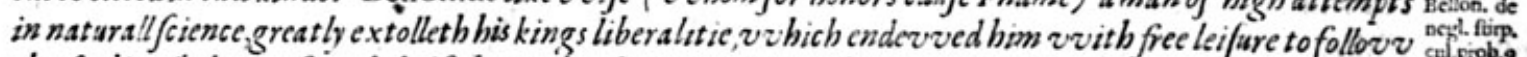
the fiudie of plants, feconded alfo herein by Montmorencie the Confable, the Cardinals Caftilon and Lorraine, vvith Oluerius the chancellor; by vvhofe meanes he vvats enabled to performe thcf: bus notable peregrimations in Italie, Africa and 1 fia : the fvveete fruit vo hereof, as vve baue receiucd fome teste by his obferuations, fo vve hould plention/ly hauc beene filled vvith, if violent death by moft accurfed rob. bers, had not cut hem off. Ind as I finde thefe examples of comfort in forren nations. fo vve are (I confegfe) much to be thankfull to God, for the expertence vve hasue of the like things at home. If (neuertheleffe) vnto that Phificke lecture lately fo vvell erected,men vi.ho ha we this viorldes goodes pall hasue harts alfo of that pirit, to adde fome ingeniosu labourer in the skill of fimples, they fkall mightily augment and adorne the vobole fcience of $P$ hificke. But if to that likevvife they iogne a third, namely the art of chimicalloreparation; that out of thofe good creatures, vvhich God hath given man for bis health, pure fubstances may be procured for thofe that be ficke: (I feare not to fay it though I fee hov Momus feorneth) this prefent generation voould purchafe more to the perfection of Phificke, than all the generations paft fince $\mathrm{G}$ alens time hase done : that I fay, nothing of this one frust that voould grovve thereof, to v vit, the difcouering and abolifhing of the e pernicious impostures and fophistications, which monnt promijing Paraceifians ewery vibere obtrude, through vvant of a true and conftant light amongst vs to difcerne them by. In vvbich behalfe, remembring that moturnfull /peech of graue Hippocrates; The art of Phificke truly excelleth Hippde all arts, howbeit, through the ignorance partly of thofe that exercife it, and partly of thofe that iudge rafhly of Phifitions, it is accounted of all arts the moft inferiour: Ifay m like manner, the art of Chimifree is in it felfe the moft noble inf trument of naturall knovvledges; but throagh the rgnorance and

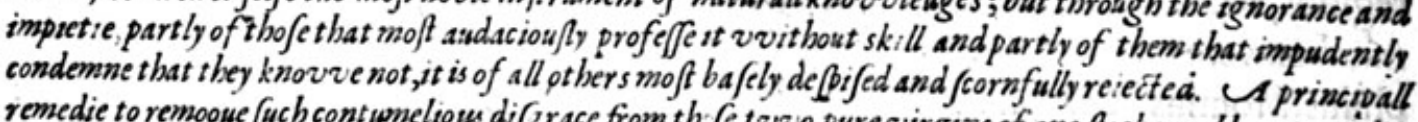
remedie to remooue fuch contwolions dif 3 race from th: fe twio pure virgins of one flocke and linage, is this that I haue novv infinuated, euen by ere 7 ing the laboratorie of an mduftriom Chimift, by the fvoete

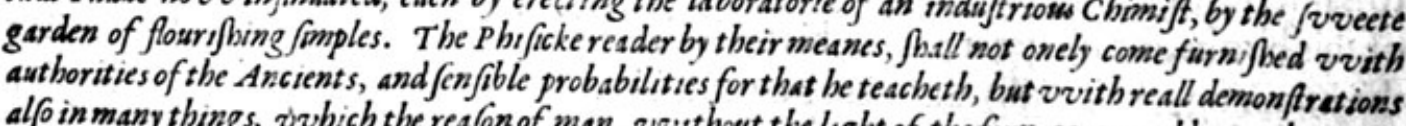
alfo in many things, wibich the reafon of man, vvithout the light of the formace, vvould newer base resched vnto. I haue vitered my barts defire, for promoting firft the perfection of my profe $c$ sion, and next by neceffarie confequence, tbe bealthie limes of men. If Gud open mens harts to prowide for the former, it cannot be, but that the happie fruites fball be feene in the latier. Let the ingenious learned indge vvbet her I haue reafon on $m y$

fide: the partiall addicted feet I Shun, as men that newer meane good to pofteritie. 


\section{George Baker, one of hir Maiefties chiefe Chirurgions in ordinarie, and M.of the Chirurgions of the citie of London, to the Reader.}

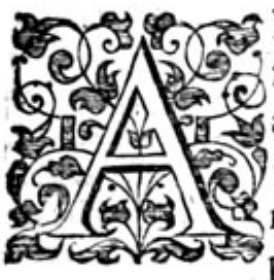

Riftotle a Prince amongft the Philofophers, writing in his Metaphyficks of the nature of mankinde, faith, that man is naturally inclined and defirous of fcience. The which fentence doth teach vs, that all creatures (being vertuoufly giuen)do ftriue to perfection, and drawe neere in what he can to the Creator, and this knowledge is one of the principal parts which doth concerne the perfection of vnderftanding: for of the fame doth follow, that all fuch are generally inclined to knowe the meanes by the which he may conferue his life, health, and reputation. And although it be neceffarie for man to learne and knowe all fciences, yet neucrtheleffe the knowledge of naturall philofophic ought to be preferred, as being the moft neceffarie; and moreouer, it doth bring with it a fingular pleafure and contentment. The firft inuentors of this knowledge was Chiron Centaure of great renowme, fonne to Saturne and Phillyre : and others fay that it was inuented of Apollo, and others of Efculape his fonne; efteeming that fo excellent a fcience could neuer proceede but from the gods immortall, and that it was impoffible for man to finde out the nature of plants, if the great worker which is God, had not firft inftructed and taught them. For, as Plinie faith, if any thinke that thefe things haue beene inuented by man, he is vngratcfull for the works of God. The firft that we can learne of amongft the Greekes that haue diligently written of herbes, haue beene Orpheus, Mufee and Hefiode, hauing beene taught by the Egyptians; then Pythagoras of great renowme for his wifedome, which did write bookes of the nature of plants, and did acknowledge to learne the fame from Apollo and Efculape. Democrite alfo did compofe bookes of plants, hauing firft trauelled ouer all Perfia, Arabia, Ethiopia and Egypt. Many other excellent firits haue taken great pleafure in this feience, which to accomplifh haue hazarded their liues in pafling many vnknowen regions, to learne the true knowledge of Ellcborus, and other medicaments; of which number were Hippocrates, Crateua, Ariftotle, Theophraft, Diocles, Carifticr, Pamphilus, Montius, Hierophile, Diofcorides, Galen, Plinie, and many others, which Ileaue to name, fearing to be too long. And if I may fpeake without partialitie of the author of this booke, for his great paines, his no leffe expences in trauelling far and neere (for the attaining of his skill) was neuer contented with the knowledge of thofe fimples which grow in thefe parts, but vpon his proper colt and charges hath had out of al parts of the world all the rare fimples which by any meanes he could attaine vnto, not onely to haue them brought, but hath procured by his excellent knowledge to haue them growing in his garden, which as the time of the yeere doth ferue may be feen : for there thall you fee all manner of ftrange trees, herbes, rootes, plants, flowers, and other fuch rarcthings, that it would make a man woonder, how one of his degree, not hauing the purf 2 of a number,could cuer accomplifh the fame. I proteft vpon my confcience, I do not thinke for the knowledge of plants, that he is inferior to any : for I did once fee him tried with one of the beft ftrangers that euer camc into England, and was accounted in 
Parife the onely man, being recommended to me by that famous man M.Amb.Pareus, and he being here was defirous to go abroad with fome of our herbarifts, for the which I was the meane to bring them togither; and one whole day we fpent therein, fearching the moft rareft fimples: but when it came to the triall, my French man did not know one to his fower. What doth this man deferue that hath taken fo much paines for his countrie, in fetting out a booke that to this day neuer any in what language foeuer did the like? Firtf for correcting their faults in fo many hundred places being fally named, miftaken the one for the other; and then the pictures of a great number of plants now newly cut. If this man had taken this paines in Italie and Germanie where Mathiolus did write, he fhould haue fped as well as he did : For(faith he) I had fo great a defire euer to finifh my booke, that I neuer regarded any thing in refpect of the publike good, not fo much as to thinke how I hould finilh fo great a charge, which I had neuer caried out, but that by Gods ftirring vp the Emperor Ferdinando of famous memoric, and the excellent Princes had not holpen me with great fummes of money, fo that the Common wealth may fay, that this bleffing doth rather proceede of thein than from me. There haue beene alfo other Princes of Almaine, which hauc beene liberall in the preferring of this booke; and the moft excellent Elector of the Empire the Duke of Saxonie, which fent me his pofte with much money toward my charges. The liberalitie of the which, and the magnificence towards me, I cannot commend fufficiently. They which followed in their liberalitie were the excellent Fredericke Count Palatine of the Rhine, and the excellent Ioachim Marques of Brandeberg, which much fupplied my wants; and the like did the reuerend Cardinall and Prince of Trent, and the cxcellent Archbilhop of Saltzperg, the excellent Duke of Bauare, and the Duke of Cleues, the Duke Megapolencis Prince of Vandalis, the ftate Republike of Noremberg; the liberalitic of whom ought to be celebrated for euer: and it doth much reioice me that $I$ had the helpe and reward of Emperors, Kings; Electors of the Romane Empire,Archdukes, Cardinals, Bilhops, Dukes and Princes; for it giueth more credite to our labours than any thing that can be faid. Thus far Mathiolus his owne writing of the liberalitie of Princes towards him. What age do we liue in here, that will fuffer all vertue to go vnrewarded? Mafter Gerard hath taken more paines than euer Mathiolus did in his Commentaries,and hath corrected a number of faults that he paffed ouer, and I dare affirme in reuerence be it fpoken of that excellent man, that Mafter Gerard doth knowe a great number of fimples that were not knowen in his time : and yetI doubt whether he fhall tafte of the liberalitie of either Prince, Duke, Earle,Bifhop, or publike eftate. Let a man excell neuer fo much in any excellent kno:viedge, and he is not fo much regarded as a iefter, a boafter, a quackfaluer or mountchanke : for fuch kinde of men can flatter, diffemble, make of trifles great matters, in praifing of this rare fecret, or that excellent firit, or this Elixer or quinteffence; which when it thall come to the triall, nothing fhall be found but boalting wordes.

Vale. 


\section{To the courteous and well-willing Readers.}

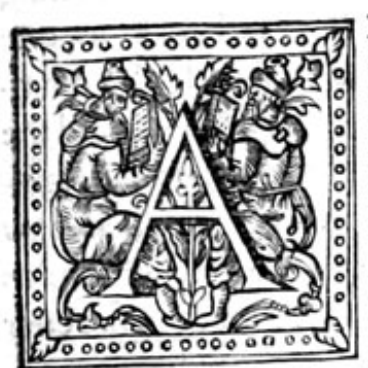

Lthough my paines haue not been fpent (courteous Reader) in the gracious difcouerie of golden mynes, nor in the tracing after filuer vaines, whereby my natiue countrie might be inriched, with fuch marchandize as it hath moft in requeft and admiration : yet hath my labour(I truft) beene otherwife profitably imployed, in defcrying of fuch harmleffe treafure of herbes, trees and plants, as the earth frankly without violence offereth vnto our mof neceffarie vfes. Harmeleffe I call them, bicaufe they were fuch delights, as man in the perfecteft eftate of his innocencie did earft enioy : and treafure I may well termethem, feeing both Kings and Princes haue efteemed them as Iewels; fith wife men haue made their whole life as a pilgrimage, to attaine to the knowledge of them. By the which they haue gained the harts of all, and opened the mouthes of many, in commendation of thofe rare vertues, which are contained of all, andre Pbabus, and yet this duftie mettall, or excrement of the earth (which was firft deeply buried, leaft it fhould bean efore to greeue the corrupt hart of man) by forcible entrie made into the bowels of the earth, is rather fnatched at of man to his owne deftruction, than directly fent of God, to the comfort of this life. And yer bebold in the compaffing of this worldlie droffe, what care, what coft, what aduentures, what myfticall proofes, and chymicall trials are fet abroach; when as notwithltanding the chiefeft end is but vncertaine wealth. Contrarywife, in the expert knowledge of Herbes, what pleafures fill renewed with varietie ? what fmall expenfe? what fecuritie ? and yet what an apt and ordinarie meanes to conduct man to that moft defired benefit of health ? Which as I deuoutly wifh vnto my natiue Countric, and to the carefull nourfing Mother of the fame; fo hauing bent my labours to the benefiting of fuch as are fudioufly pratifed in the conferuation thereof, I thought it a chiefe point of nuy dutie, thus out of my poore ftore, to offer vp thefe my far fetched experiments, togither with mine owne countries vnknowen treafure, combined in this compendious Herball (not vnprofitable, though vn polifhed) vnto your wife conftructions and courteous confiderations. The drift whereof is a readie introduction to that excellent Art of Simpling, which is neither fo bafe nor contemptible, as (perhaps)the Englifh name may feeme to intimate; but fuch is it, as altogither hath been a ftudie for the wifeft, an exercife for the nobleft, a paftime for the beft. From whence there fpring flowers, not onely to adorne the garlands of the Mufes, to decke the bofoms of the beautifull, to paint the gardens of the curious, to garnih the glorious crownes of Kings; but alfo fuch fruit as learned Diofcorides long trauelled for; and princely CMitbridutes referued as precious in his owne priuate clofet : Muthridates I meane, better knowen by his foueraigne Mithridate, than by his fometime fpeaking two and twentie languages. But what this famous Prince did by tradition, Emax King of the Arabians did deliter in a difcourfe written of the vertues of Herbes, and dedicated Vnto the Emperour Nero. Eueric greene Herbarift can make mention of the herbe Lyfimachia, whofe vertues were found out by King Ly fimachus, and his vertues no lefie eternized in the felfefame plant than the name of Phydias, queintly beaten into the fhield of Pallas, or the firft letters of Aiax or Hyacinthus (whether you pleafe)regiftred in that beloued flower of Apollo. As for Artemifia, firft called rú, fifnis, whether the title thereof fprang fromèpress, Diana hirfelfe, or from the renowmed Queene of Caria, which difclofed the vfe therof vnto pofteritie, it furuiueth as a monument to reuiue the memories of them both for euer. What fhould we fpeake of Gentiana, bearing ftill the cognifance of Gentins ? or of diuers other Herbes, taking their denomination of their Princely inuentors? What fhould I fay of thofe royall perfonages, Iuba, Attalus,Climenus, Achylles, Cyrus, Mafynifa, Semyramis, Dioclefian? but onely thus, to befpeake their princely loues to Herbarifme, \& their euerlafting honors (which neither old Plmius dead, nor yong Lipfius liuing, will permit to die? ) Crefcent berbe, crefcetis amores : crefcent berbe, crefcetis bowores. But had this woonted facultie wanted the authorifement of fuch a royall companie : one King Salomon, excelling all the reft for wifedome, of greater royaltie than they all (though the Lillies of the field outbraued him) he onely (I fay)might yeeld hereunto fufficient countenance and commendation, in that his lofty wirdome thought no fcorne to ftoupe vnto the lowly plants. I lift not feeke the common colours of antiquitie; when notwithftanding the world can b:ag of no more ancient monument than Paradife, and the garden of Eden : and the fruits of the earth may contend for feignioritic, feeing their mother was the fir $\mathrm{f}$ creature that conceiued, and they themfelues, the firft fruit the brought foorth. Talke of perfect happineffe or pleafure, and what place was fo fit for that, as the garden place where Adam was fet, to be the Herbarift ? Whither did the Poets hunt for their fyncere delights, but into the gardens of Alcinosu, of Adonis, and the orchards of Heperides? Where did they dreame that heauen thould be, but in the pleafant garden of Elyfum ? Whither do all men walke for their honeft recreation but thither, where the earth hath moft beneficially painted hir face with flourifhing colours? And what feafon of the yeere more longed for, than the Spring? whofe gentle breth inticeth foorth the kindly fweetes, and makes them yeeld their fragrant fmels ? Who would therefore looke dangeroufly vp at Planets, that might fafely loke downe at Plants? And if true be 


\section{Totbe Reader.}

the olde prouerbe, Qme fupramos, nibilad nos; I fuppole this new faying cannot be falfe, Que inframos, ea waxime admos. Eafie therefore is this treafure to be gained, and yet pretious. The fcience is nobly fupported by wife and kingly fauorites : the fubie $A$ thereof fo neceffarie and delectable, that nothing can be confected, either delicate for the tafte, daintie for fmell, pleafant for fight, wholefome for bodie, conferuatiue or reftoratiue for health, but it borroweth the relifh of an herbe, the fauour of a flower, the colour of a leafe, the iuice of a plant, or the decoction of a roote : and fuch is the treafure that this my treatife is furnithed withal, wherin though mine art be not able to counteruaile nature in hir liuely portraitures; yet haue I counterfeited likeneffe for life, thapes and fhadowes for fubftance, being rcadie with the bad painter, to explane the imperfeCtions of my penfill with ny pen, choofing rather to fcore vpon my piaures fuch rude marks, as may defcribe my meaning, than to let the beholder to geffe at randon and miffe. I haue heere thercfore fet downe not onely the names of fundrie plants, but alfo their natures, their proportions and properties, their affects and eftects, their increafe and decreafe, their flourifhing and fading, their diftine varieties and feuerall qualities, as well of thofe which our owne countrie yeeldeth, as of others which I haue fetched further, or drawen out by perufing diuers Herbals, fet foorth in other languages, wherein none of our countrie men hath to my knowledge taken any paines, fince that excellent worke of Mafter Doctor Turner: after which time Mafter Lyte a worfhipfuli Gentleman, tranflated Dodonem out of French into Englifh; and fince that Doctor Pries7, one of our London Colledge, hath (as I heard) tran (lated the laft edition of Dodonew, which meant to publifh the fame; but being preuented by death, his tranflation likewifeperifhed: laftly, my felfe one of the leaft among many, haue prefumed to fet foorth vnto the view of the world, the firft fruits of thefe mine owne labours, which if they be fuch . as may content the Reader, I fhall thinke my felfe well rewarded, otherwife there is no man to be blamed but my felfe, being $\mathbf{a}$ worke, I confeffe, for greater clerks to vndertake, yet may my biant attempt ferue as a whetfone to fet'an edge vpon fome harper wits, by whome I with this my courfe difcourfe migbt be both fined and refined. Faules I confeffe haue efcaped, fome by the Printers ouerfight, fome through defects in my felfe to performe fo great a worke, and fome by meanes of the greatneffe of the labour, and that I was conftrained to feeke after ny liuing, being voide of friends to beare fome part of the burthen. The rather therefore accept this at my hands (louing countriemen) as a token of my good will, trufting that the beft and well minded will not rafhly condemne me, although fome thing haue pafied woorthie reprehenfion. But as for the flanderer or enduious, l paffe not for them, but returne vpon themfelues, any thing they fhall without caufe either murmure in corners, or iangle in fecret. Farew ell. From my houfe in Holburne within the fuburbs of London, this firft of December

1597 .

Thy fincere and vinfained friend, fobn Gerard. 


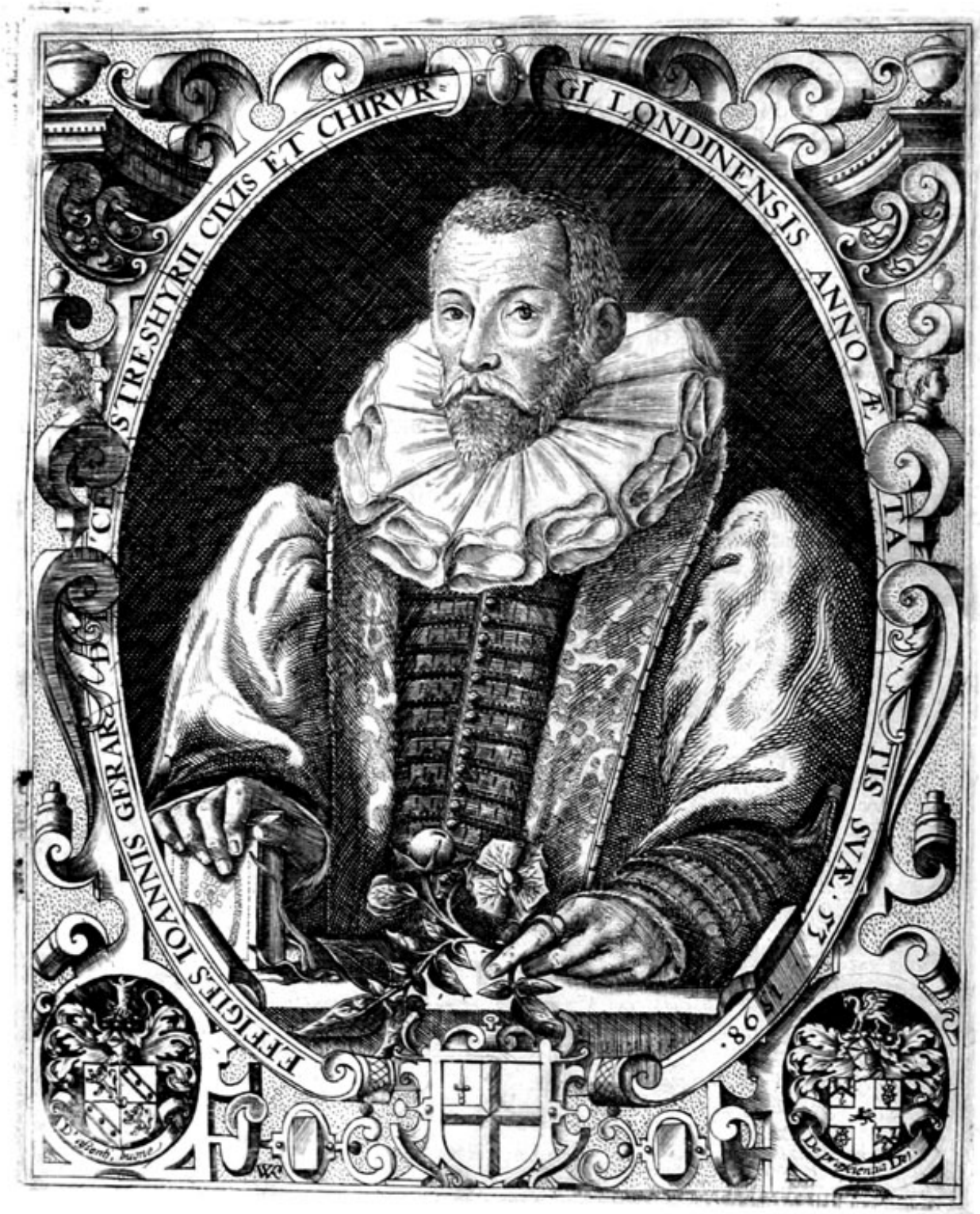




\section{THE FIRST BOOKE OF. THE HISTORIE OF \\ $P$ L A N T S,}

Containing Graffes, Ru/hes, Corne, Flags, Bulbofe, or Onion-rooted Plants.

* The Proeme.

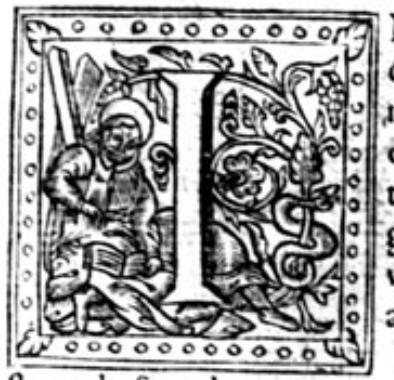

$\mathrm{N}$ this hiftorie of plants it would be tedious to vee by way of introduction, any curious difcourfe vpon the generall ditifion of plants, contained in Latine vader Arbor, Frutex, Suffrutex, Her ba: or to fpeake of the differing names of their feuerall parts, more in Latine thanour vulgar toong can well expreffe. Or to go about to teach thee, or rather to beguile thee by the fmell or tafte, to geffeat the temperature of plants: when as all and euery of thefe in their place thall have their true face and note, whereby thou maif both know and vfe them.

In three bookes therefore, as in three gardens, all our plants are beftowed: forted as neere as might be, in kindred and neighborhood.

The firft booke hath Graffes, Rufhes, Corne,Flags,Bulbofe,or Onion-rooted plants.

The fecond, all forts of herbes for meate, medicine, or fweete fimelling vfe.

The third hath trees, thrubs, bufhes, fruit-bearing plants, Rofins, Gums, Rofes, Heath, Moffes, Mufhroms, Corallgand their feuerall kindes.

Each booke liath chapters, as for each herbe a bed : and euery plant prefents thee with the Latine and Englifh name in the title. Then followes the kindes, defcription, place, time,names, nature, and vertues, agreeing with
the beft receiued opinions. Laft of all thou haft a generall Index as well in Latine as Englifh, with a carefull fupply likewife
of an Indicis bilinguis of barbarous names.

And thus hauing giuen thee a generall view of this garden, now with our friendly labors we will accompanie thee, and lead thee through a graffe plot, little or nothing of many Herbarifts heertofore touched: and begin with the moft common, or beft knowen Grafle, which is called in Latine, Gramen pratenfe. Then by little and little conduct thee through moft pleafant gardens, and other delighttull places, where any herbe or plant may be found, fit for meate or medicine.

$$
\text { Of Medow graffe. Chap... }
$$

* The kindes.

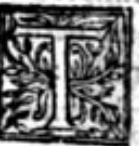

Here be fundry and infinite kinds of graffes not mentioned by the ancients, eitheras vnneceffarie to be fet downe, or vnknowen to them: oncly they make mention of fomefew, whofe wants we meane to fupplie, in fuch as haue come to our knowledge, referring the
reft to the curious fearcher of fimples. * The defcription.

1 . Ommon Medow graffc hath very finall tufts of rootes, 'with thicke hairic threds depending vpon the higheft turfe, matting and creeping on the ground with a moft thicke and apparent fhew of wheaten leaues, lifting vp long, thin, iointed with an eare which is or a cubite high, growing finall and fharpe at the top, common Reedecalled $V$ allatoris. 2 Small Medow graffe differet

groweth in medowes, fo doth this from the former in varietic of the foile : foras the firft kinde is. 


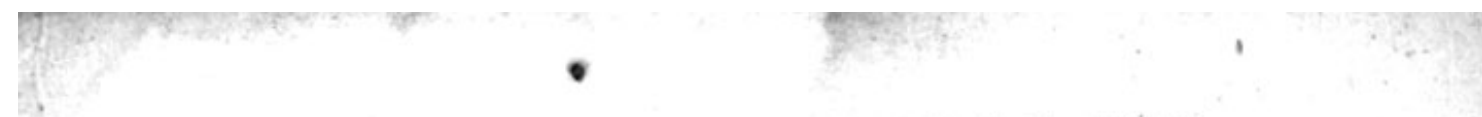

barren by nature : a graffe more fit for heepe, than for greater cattell. And bicaufe the kindes of graffe do differ apparantly in roote, tuft, ftaffe, leafe, theath, eare or creft, we may affure our felues of their feuerall vertues, formed by the Creator for the vfe of man, although that they haue been by a common negligence hidden and vnknowen. And therefore in this our labor, we haue placed each of them in their feuerall bed, where the diligent fearcher of nature may, if fo he pleafe, place his learned obferuations.

I Gramen pratenfe. Medow grafie.

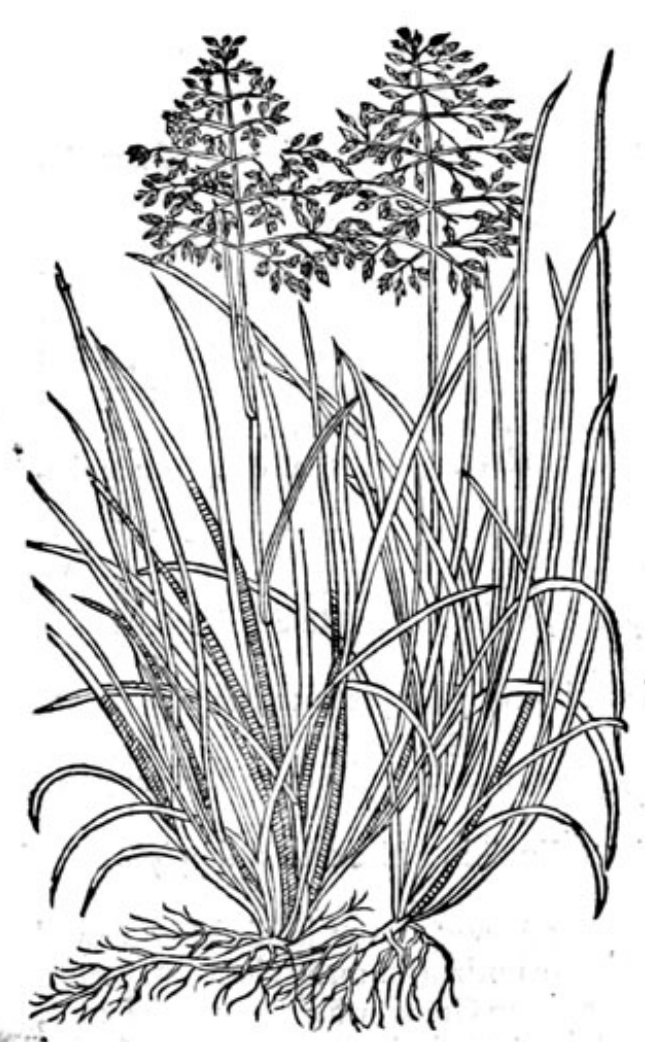

2 Gramen praten/eminus. Small medow graffe.

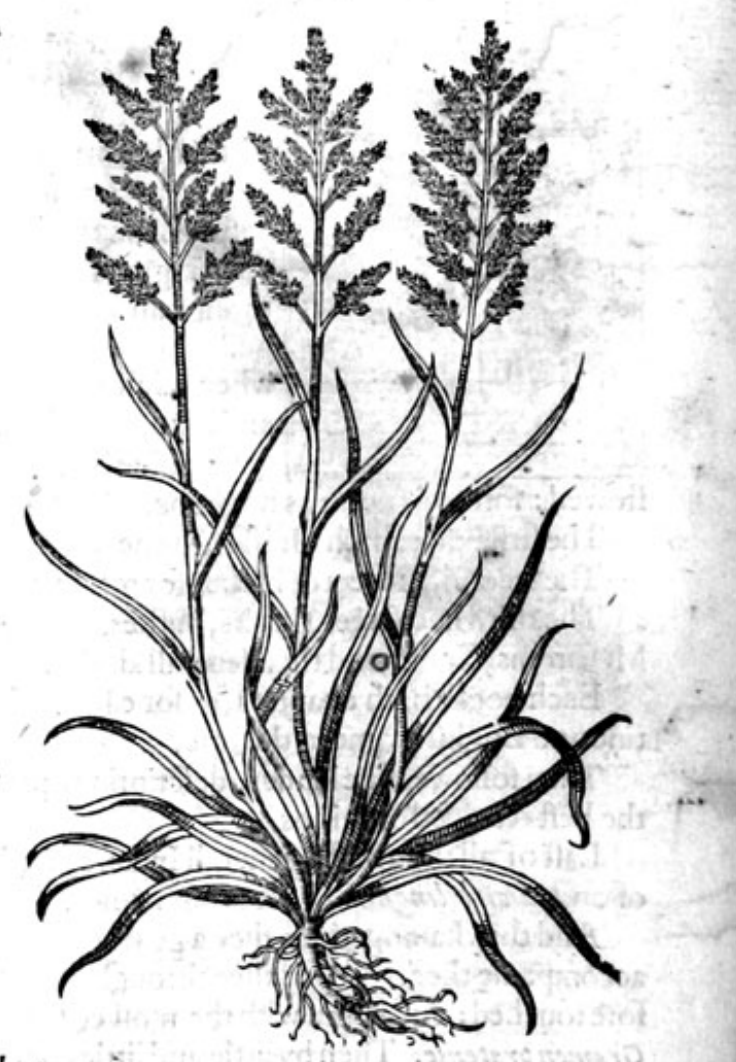

* The place.

Common Medow graffe groweth of it felfe, vnfet or vnfowen, euery where:but the Small Medow graffe for the moft part groweth vpon dric and barren grounds, as partly we haue touched in the defcription.

Concerning the time, when graffe fpringeth and feedeth, I fuppofe there is none fo fimple but knoweth it, and that it continueth all the whole yeere, feeding in Iune and Iuly. Neither needeth it any propagation or replanting by feede or otherwife, no not fo much as the waterie graffes: but that they recouer themfelues againe, although they hate been drowned in water all the winter long, as may appeere in the wilde fennes in Lincoln?hire, and fuch like places.

$$
\text { * Therames. }
$$

Graffe is called in Greeke ärpess, of the Latines Gramen, as it is thought a gradiendo, quod geniculatis internodys ferpat crebrog, nouas pargat radices : for it groweth, goeth and fpreadech itielfe vnfet or vnfowen naturally ouer all fields or grounds, clothing them with a perfeet greene. It is yeerely mowed, in fome places twife, and in fome rare places thrife: then is it dried and withered by the heate of thè funne, with often turning it. And now it is called Fanume, nefcro an à fanore aut fatu. In Englifh Hay : in French Le herbe du praiz.

* The nature.

The rootes and feedes of graffe are of more vfe in phificke than the herbe, and are accounted of 
all writers, moderately to open and prouoke vrine.

\author{
* The vertues.
}

- The decoetion of graffe with the rootes of parley drunke, helpeth the diffurie and prouoketh $\mathbf{A}$ vrine.

The rootes of grafle, according to Galen, doe glew and confolidate togither new and bleeding $\mathbf{B}$ wounds.

The inice of graffe mixed with honic and the powder of Sothernwood taken in drinke, killeth C wormes in children, but if the childe be yoong, or tender of nature, it thall fuffice to mixe the iuice of graffe and the gall of an oxe orbull togither, and therewith annoint the childes bellie, and lay a clout wet therein vpon the nauell.

Fernelisws laith, that graffe doth helpct the obftructions of the liuer, raines and kidneies, and all D euillaffections of the raines called Nephritis,

Hay foddentin ivater till it be tender, andapplied hot to the chaps of beafts that be chap-fallen $\mathrm{E}$ through long ftanding in pound, or ftable wishout meate, is a prefent remedie.
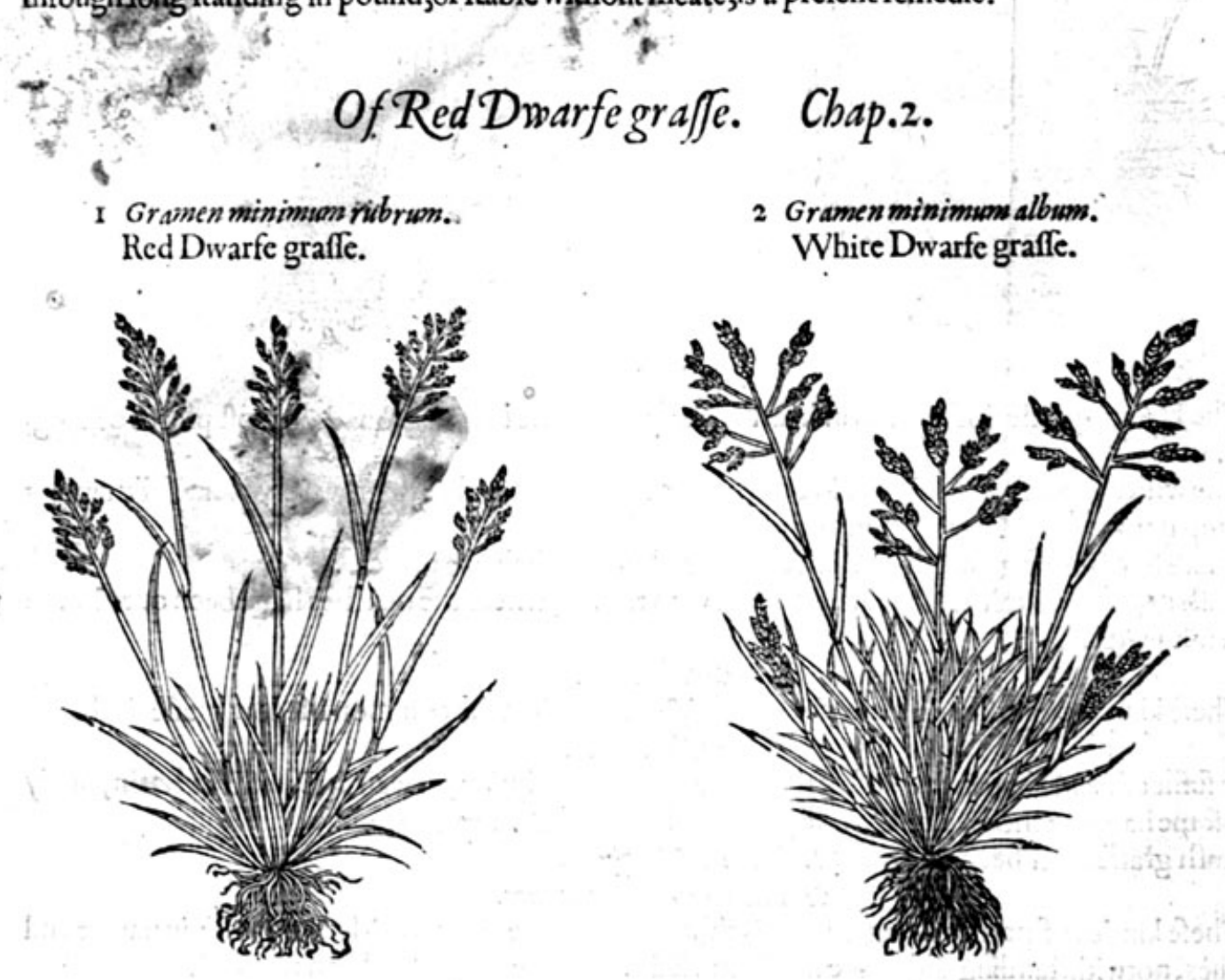

* The defaription.

I Warfe graffe is the leaft of all graffes. The roote is very fmall,hairie,and white, with many hollow ftrings: the tuft or eare is of a reddifh colour, and not much differing from the graffe called Ifchemon, though the eare be fofter, broader, and more beautifull.

2 The fecond kinde of Dwarfe graffe differeth not from the former, but that both rootes and flowers of thisare white, and the leaues fomewhat hairie aboue, and reddifh next the ground. 3 Small hard graffe hath fmall rootes compact of little ftrings or threds, from the which come foorthmany fower, rufhieleaues of the length of an inch and a halfe: the tuft or eare is compact of fcales, being as it were nothing elfe than chaffe. This graffe is vnpleafant, and no wholefome fpode for cattell.

4 Ruftigraffe hathmany fyall rufhie leaues, tough and pliant, as are the common Rufshes : whervohidogrow fmall cealie or chaffic husks, in fteed of tlowers, like thofe of Rufhes, bur fmaller. The rootc is hireddie like the former. 
3. Gramen minus duriufculum. Small hard graffe.

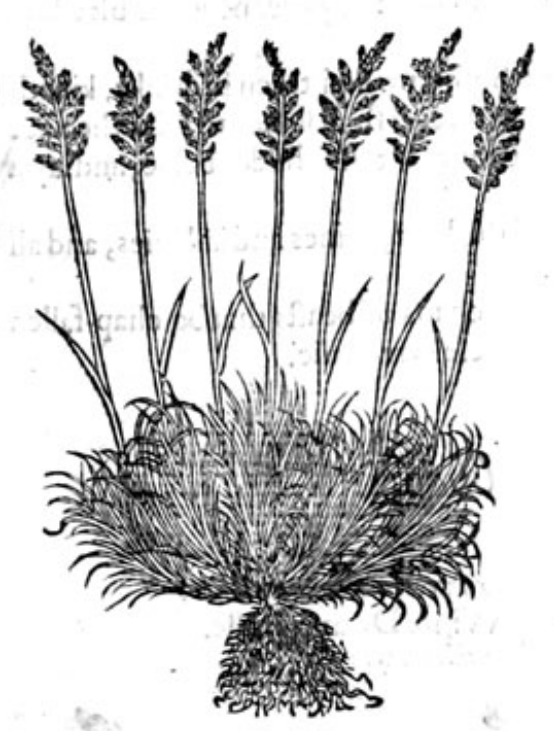

4 Gramen Iunceum.

Rufh graffe.

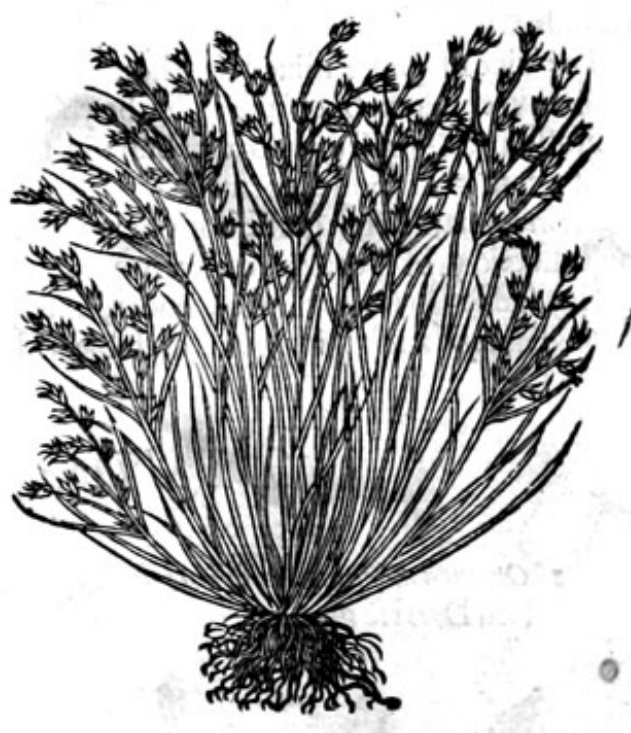

* The place. land.

The Dwarfe graffe doth grow on heathie, rough and drie barren grounds in moft places of Eng-

The white Dwarfe graffe is not fo common as the former,and doth grow very plentifully among the hop gardens in Effex and many other places.

Small hard grafle groweth in moift frefh marhes and fuch like places.

Rufh graffe groweth in falt marfhes neere vnto the fea, where the marf hes haue been ouerflowen with falt water.

Thefe kindes of graffes do grow, flower, and flourifh, when the common Medow graffe doth. * The names.

It fufficeth whathath been faid of the names in the defcription, as well in Englifh as Latin, onely that fome haue deemed white Dwarfe graffe, to be called Xer ampelinum.

Rufh graffe hath been taken for Holosteum Matthioli.

$\approx$ The nature and vertues.

Thefe kindes of graffes do agree as it is thought, with the common Medow graffe, in nature and vertues, notwithftanding they haue not been vfed in phificke as yet that I can reade of.

\section{OfCorne graffe. Chap.3.}

* The defcription.

I Orne graffe hath many graffie leaues, refembling thofe of Rie, or rather Otes, among the which commeth vp flender bentie ftalks, kneed or iointed like thofe of corne, whereupon doth grow a faire tuft or pannicle, not much vnlike to the feather-like tuft of common Reede,but rotnder compact togither like vnto Millet. The roote is threddie like thofe of Otes. 2 Reede graffe hath many thin graffie leaties, like vinto the former. The burhie top, with his long feather-like pannicles do refemble the common Reede, which is lightly fhaken with the winde: branched vpon a long flender reeden ftalke, kneed or iointed like corne. The roote is fmall and fibrous,

a Gramen 


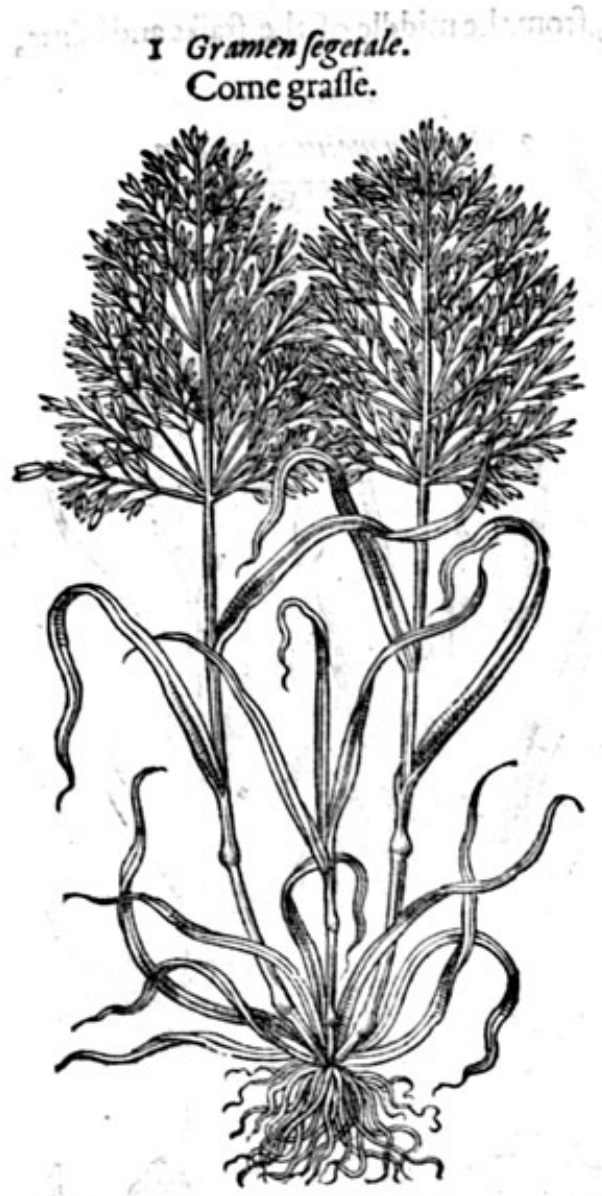

2 Gramen barundinaceum. Reede graffe.

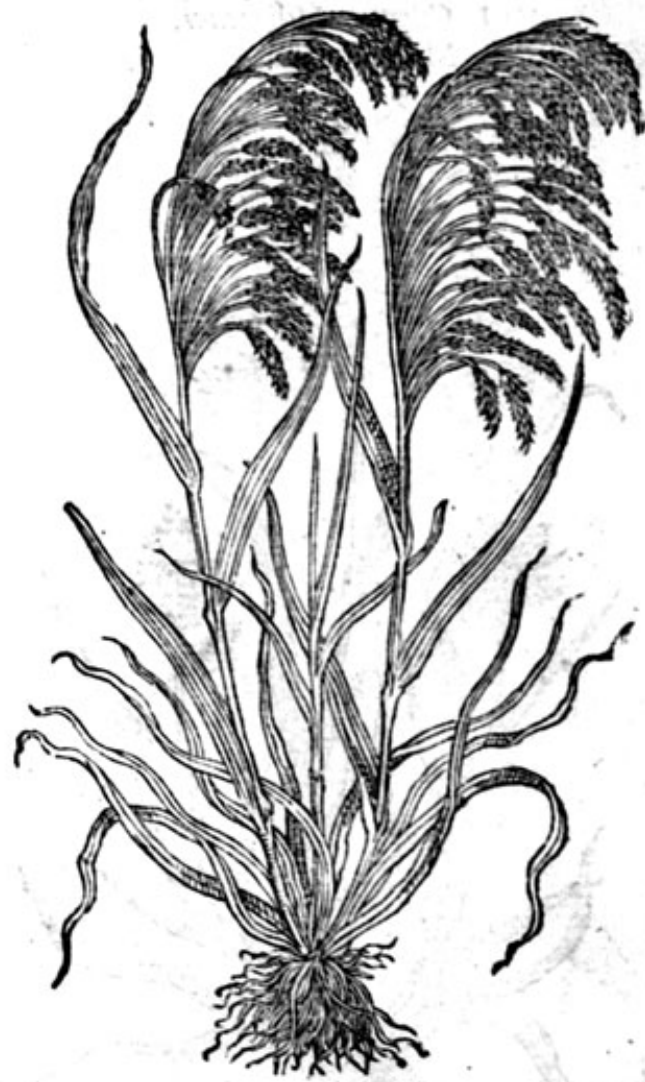

* The place.

Thefe kindes of graffes do growe for the moft part neere vnto hedges, and in fallow fields in moft places.

$*$ The time.

Their time offpringing,flowring and fading, may be referred to the common Medow graffe. * The numes.

The firft is called in Englifh Corne grafie. Of Lobelius in his learned obferuations Agrorion venti_pica, and Gramen agrorum: of others Gramen fegetale, either of the likenes it hath with corne, or that it groweth among corne, the which I haue not as yet feene.

The fecond is called in Englifh Reede graffe. Of Lobelisus in Latine Gramen harundinaceum, or Gramen agrorion, latiore arundinacea of comofa pannicula, for that his tuft or pannicles do refemble the Reedc. And Spica venti agrorum: for by reafon of his feather top, which is eafily fhaken with the winde.

* The temperature and vertucs.

Thefegraffes are thought to agree with common graffe, as well in temperature, as vertues, although not ved in phificke, as yet knowen.

\section{Of Millet grafe. Chap.4.}

I 1 Illet graffe beareth a tuft or eare like vito the common Reede, although not fo great and thicke, but rather like to crilium, Mill or Millet whereof it tooke his name. Theitalke or leaues do refemble the Bent, wherewith countrie people do trim their houfes.

2 The great Water graffe in roote, leafe, tuft and reeden ftalke, doth very wel refemble the graffe called in Latine Gromen fulcatum, or PiCfum: and by our Englifh women, Ladies Laces, bicaufe it is ftript or furrowed with white and greene itrakes, like filke laces : but yet differeth from that, that 
this Water graffe doth get vnto it felfe fome new rootes, from the middle of the ftalks and ioints; which the other doth not.

I Gramen Miliaceum. Millet grafle.

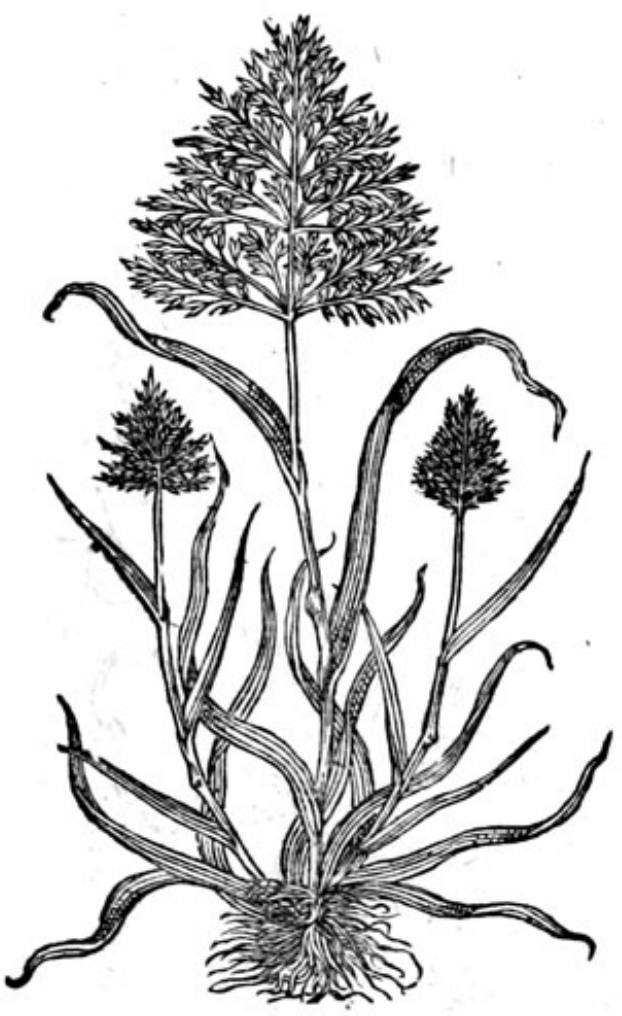

2 Gramen maius aquaticum. Great Water graffe.

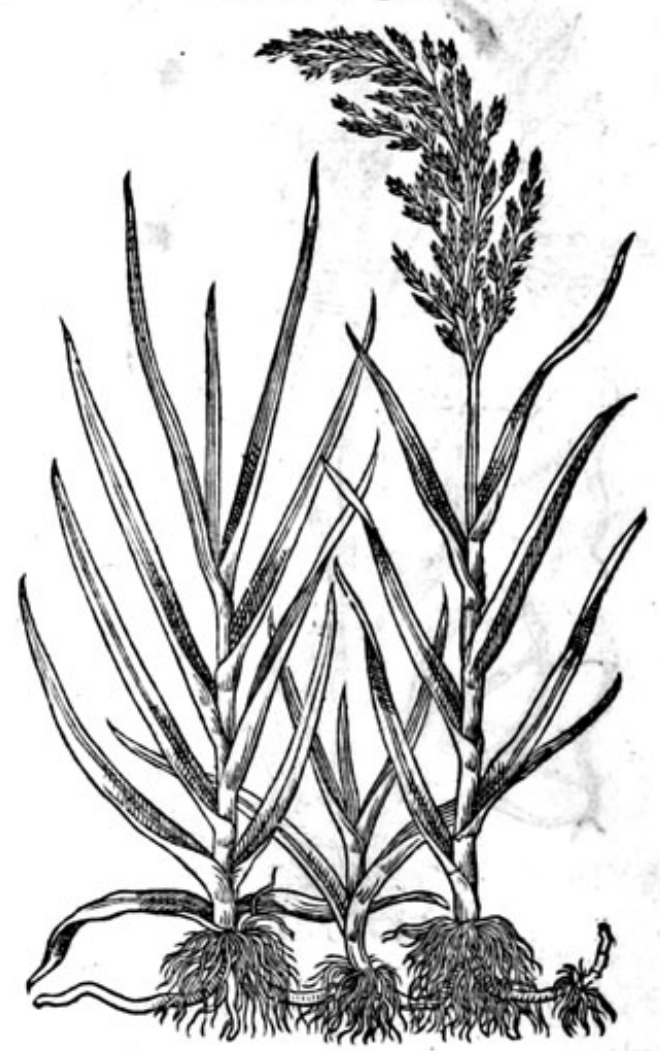

* The place, time, names, nature and vertues.

They grow in fennie and waterie places, at the fame time that other graffes do: and haue their vertues and natures common with other graffes, for any thing that we can finde in writing. The reafon of their names may be gathered out of the defcription.

$$
\text { OfDarnellgraffe. Chap.5. }
$$

* The defription.

I Arnell graffe or Sorghinum, as Lobelius hath very properly fet downe, hath a brownifh ftalke, thicke and knottic, fet with long tharpe leaucs like vnto the common Reede: at the top whereof groweth a tuft or eare, of a browne colour, fomewhat like Sorghwem, whereof it tooke his name, as alfo of the Italian corne Pannicke, it is called Panniculatum.

2 Wilde Reede or Gramen harundinaceum, or Panniculatum, called alfo Calamogrostis, is far leffer than Couch graffe, or Dogs graffe; \& yet in ftalks and leaues more rough, rugged and cutting. Bad foode for cattell, vnleffe they want, or be very hungrie : bicaufe that, as the husbandman doth fay, it is a caufe of leannes in them, thirft, and confumption, cutteth their toong, ftraiteneth the gullet or throte, and draweth downeblood into the ftomacke or mawe: whereof infueth inflammation, and death for the moft part. And not onely this Calamogrost is is hurtfull, but alfo all other kindes of fhearing leaued reedes, flags, fedge, or whinne, which haue as it were edges, and cut on both fides like kniues as well mens fingers as cattels mouthes. This herbe is in a meane betweene reedeand graffe. The roote is white, creeping downward very deepe. The fpike or eare is like vnto the reede, being foft and cottonie, fomewhat refembling Pannicke. 
1 Graven Sorghinum. Darnell grafle.

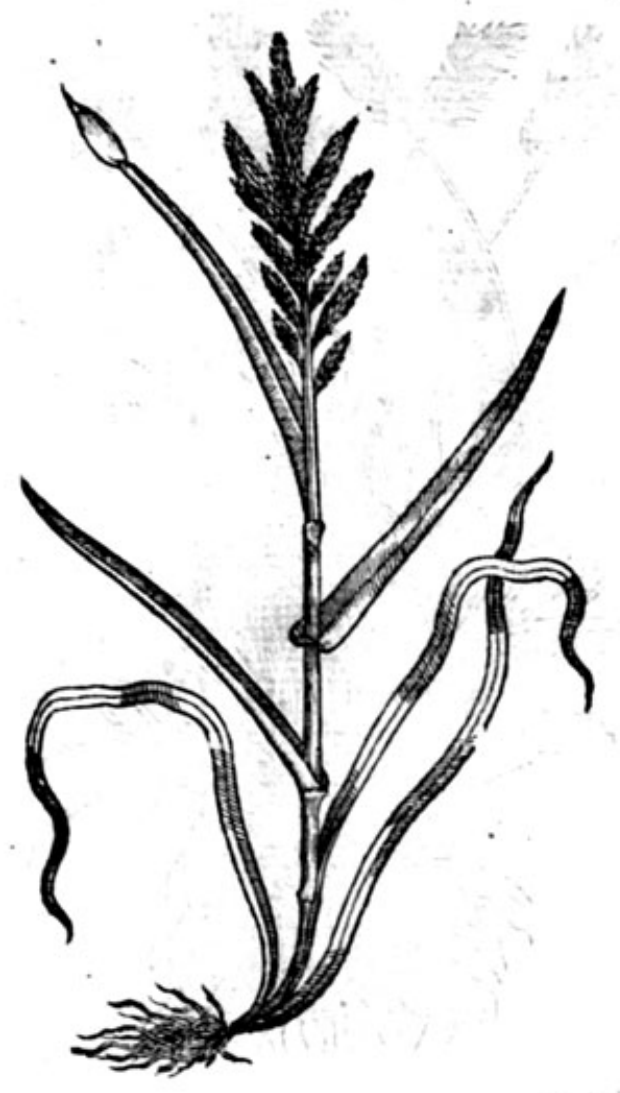

2 Gramen harundlinaceion, panniculatum. Wilde Reede.

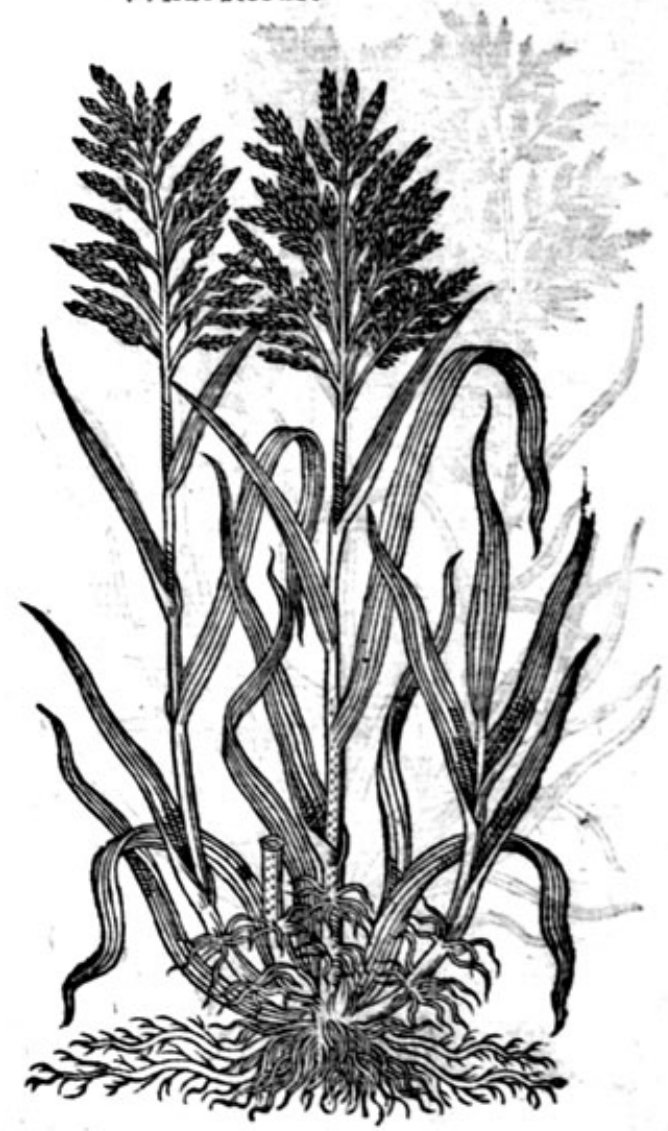

* The place.

They grow in fennie waterifh places like vnto the former.

* The time.

They flower and fade at the fame time that the others do.

* The names.

In Lincolnefhire, it is called Sheeregrafic or Henne: in other places of the land, Wilde Reede: in Latine Calamogrostis, out of the Greeke, xerapespàss. As for their natures and vertues, we do not finde any great vfe of them worth the fetting downe.

\section{OfPanickegrafje. Chap.6.}

\section{* The defcription.}

I Annicke graffe is garnifhed with chaffie and downie tufts, fet vpon a long bentie ftalke, of two cubits high or fomewhat more, naked without any blades or leaues, for the moft part.
His roote is tough and hard.

2 Wood graffe hath many thicke and threadie rootes, compact togither in maner of a tuft, from which fpring immediately out of the ground many graffie leaues, among the which are fundrie eare, much like vnto a Foxe taile, of a brownifh colour. 
I Gramen Panniculation.

Pannicke grafle.

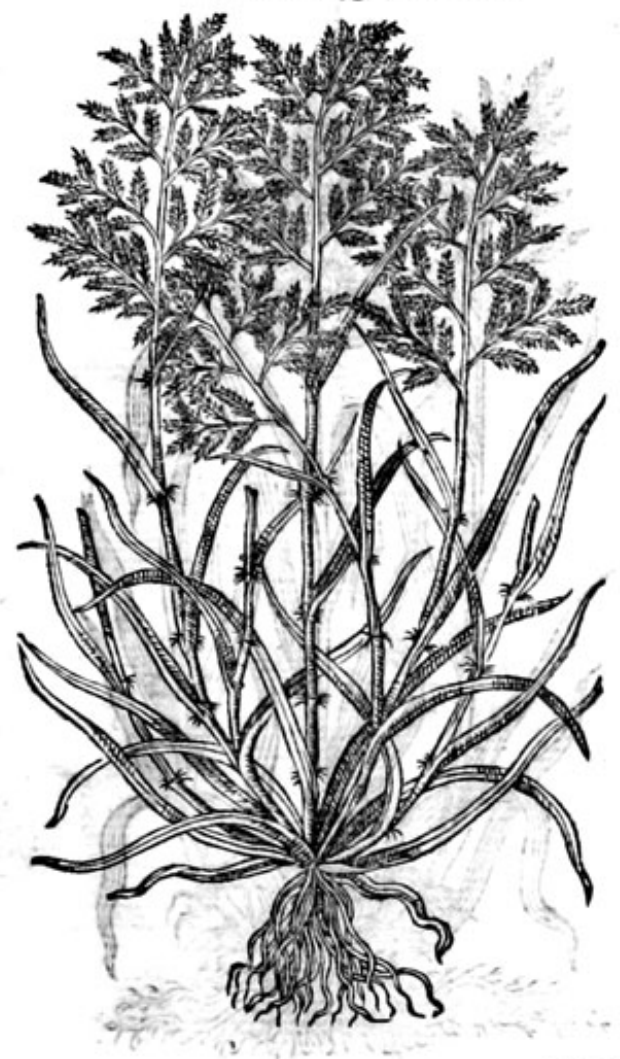

2 Gramen flluaticum.

Wood graffe.

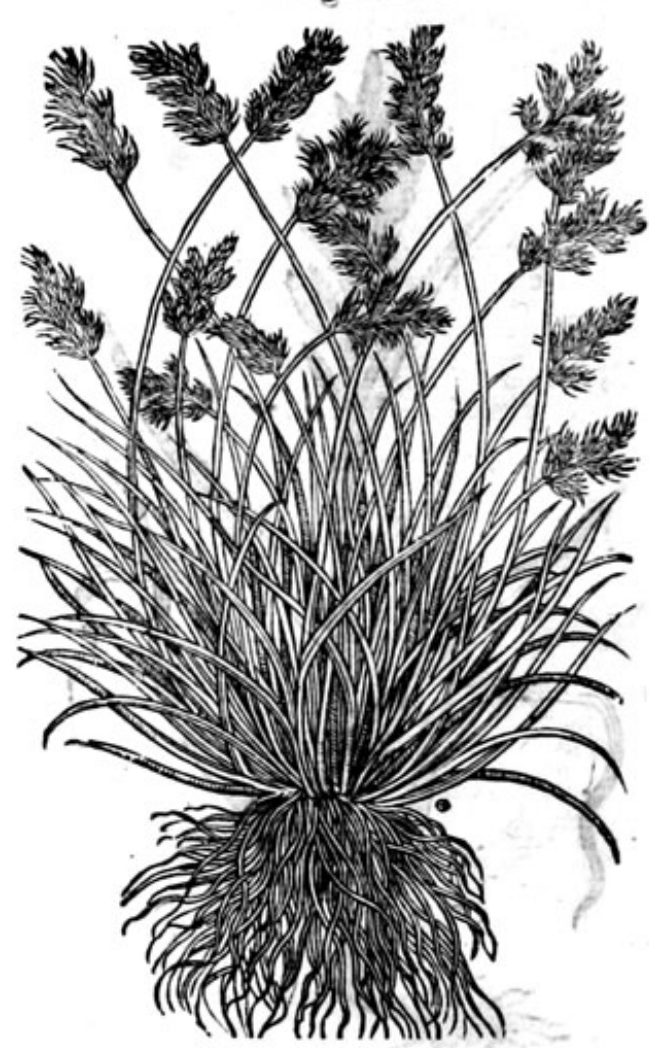

* Theplace and time.

Thefe kindes of graffes do growe in fertill fields and paftures, at the fame time that others do. * The names.

Gramen panniculatum is called Heragrost is in Greeke, and of Lobelius in Latin Gramen Tomentofum er Acerofiom. Some haue taken it for the fecond kinde of Calamogrost is : but moft commonlyit is called Gramen pltomofum: and in Englifh a Bent, or Feather-top graffe. Gramen fyluaticum, or as it pleafeth others, Gromen nemorofum, is called in our toong Wood graffe, or Shadow graffe. * The natureand vertues.

. There is no vertue afcribed vnto thefe graffes, for the vfe of phificke, but they are reckoned vnprofitable, both for man and beaft.

$$
\text { Of great Foxe-taile grafse. Chap.7. }
$$

* The defription.

I He great Foxe-taile graffe hath many threddie rootes like the common Medow graffe. And the ftalke rifeth immediately from the roote, in fafhion like vnto Barley, with two or three leaues or blades like Otes: but is nothing rough in handling like the precedent, but foft and downie, and fomewhat hoarie, bearing one eare or tuft on the top and neuer more: fafhioned like vnto a foxe taile, where of it tooke his name. At the approch of winter it dieth, and recoueteth it felfe the next yeere by falling of his feede.

The leffer Foxe-taile graffe, hath a tough and hard roote, compact of many fmall ftrings, yeelding a ftrawie ftalke like the former, though fomewhat leffer, with the like top or creft, but of a
whitifh colour. 


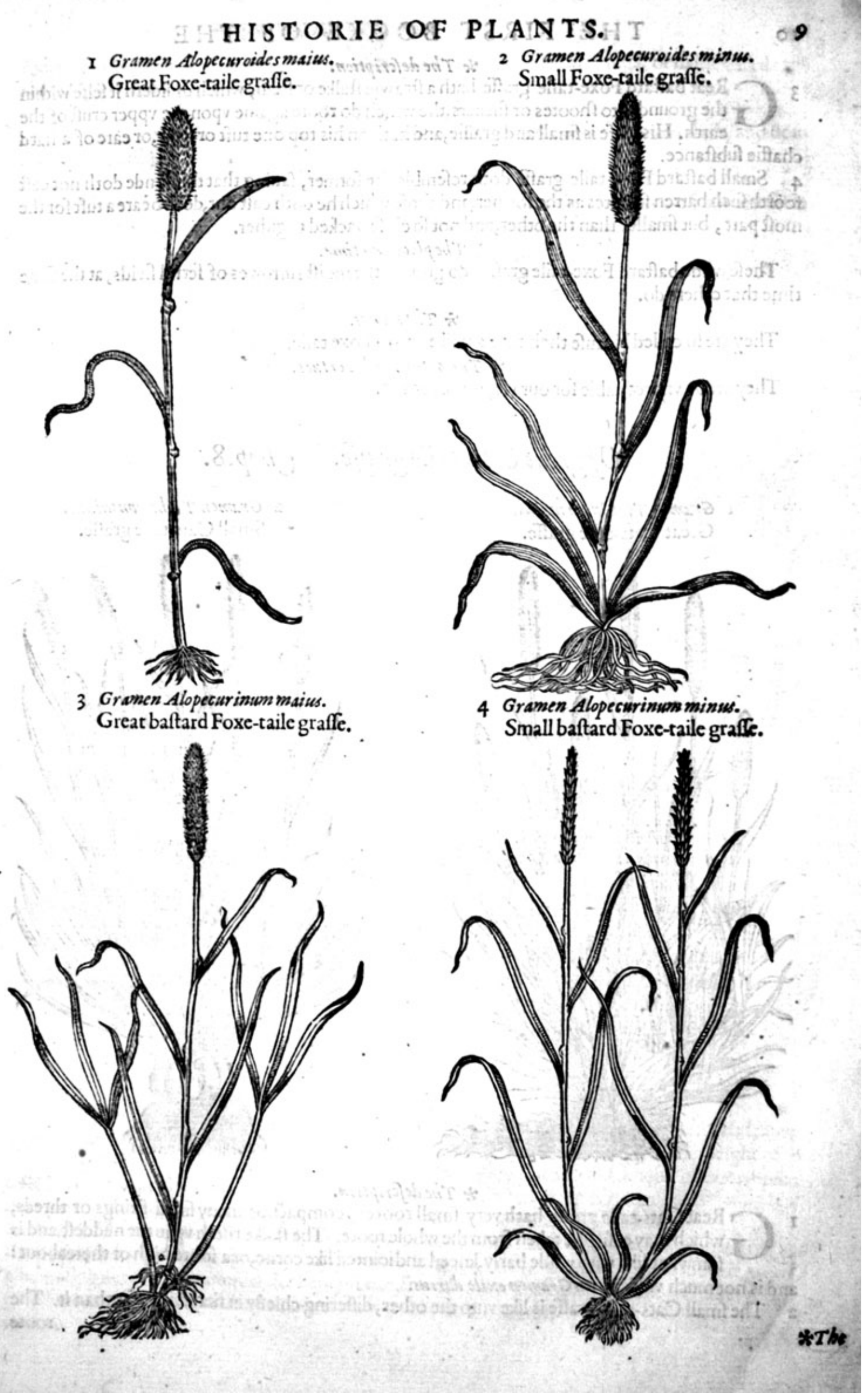


3

$*$ The defcription: Reat baftard Foxe-taile graffe hath a ftrawie ftalke orftem, which diuidech it felfe'within the ground into fhootes or fuckers, the which do roote againe vpon the vpper cruft of the carth. His leafe is fmall and graffie, and hath on his top one tuft or f pike, or eare of a hard chaffie fubftance.

4 Small baftard Foxe-taile graffe doth refemble the former, faning that this kinde doth not caft foorth fuch barren fhootes as the former, and thofe which he doth caft out,doth bearea tuft for the moft part, but fmaller than the other, and not foclofe packed togither. * The place and time.

Thefe wilde baftard Foxe-taile graffes do grow in the moift furrowes of fertill fields, at the fame time that others do.

$*$ The names.
They are fo called bicaufe their tops are like vnto a Foxe taile. * The nature and vertues.

They are as viprofitable for our vfe, as the former.

\section{Ofgreat Cats-taile grafje. Chap.8.}

I Gramen Typhinum majus. Great Cats-taile graffe.

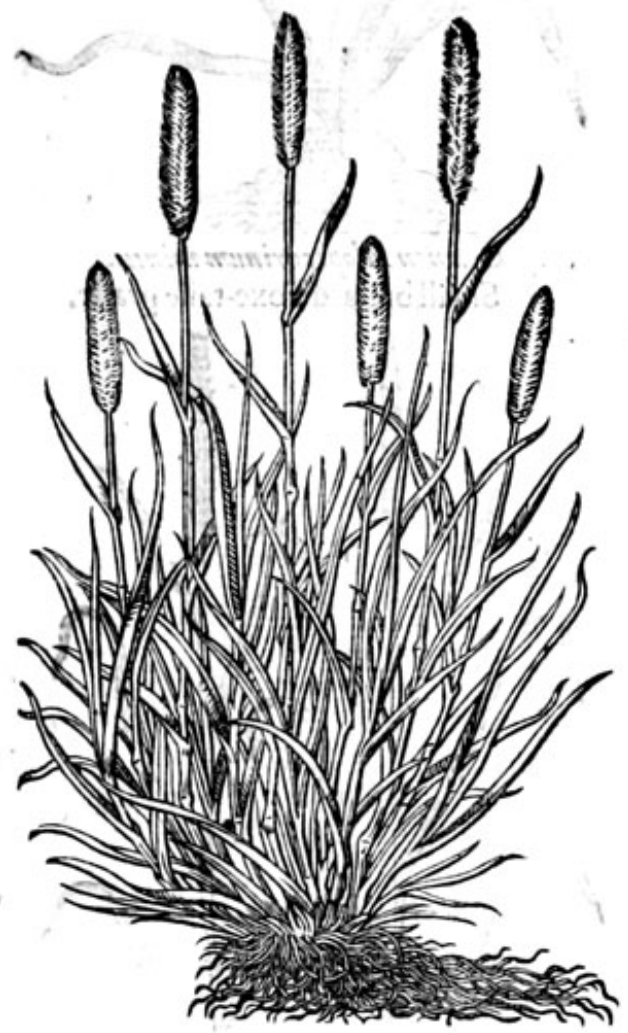

2 Gramen Typhinum minus. Small Cats-taile graffe.

\section{* The defcription.}

I Reat Cats-taile graffe hath very fmall rootes, compact of many fmall ftrings or threds,

J which may eafily be taken from the whole roote. The ftalke rifeth vp in the niddeft, and is fomwhat like vnto wilde barly, kneed and iointed like corne, of a foote high or thereabout : and is not much vnlike vnto Gramen extle durrus.

2 The fmall Cats-taile graffe is like vneo the other, differing chiefly in that it is leffer than it. The 
poote is thicke, and cloued like rufh onions or ciues, with many fmall ftrings, or hairie threds an, nexed vnto it.

$$
\text { * The place and time. }
$$

Thefe kindes of graffes do grow very well neere the fea fide, as Gramen cyperoides doth, and tou* rifh at the fame time that allothers do.

\section{* The names.}

The Latins borrow thefe names of the Greekes, and call it Gramen Typhinom, of Typha Cats taile : and it may in Englifh as well be called round Bent graffe, as Cats-taile graffe.

$$
\text { * The nature and vertues. }
$$

There is nothing written of them in phificke worth the fetting downe.

$$
\text { Of Cyperusgraffe. Chap.9. }
$$

1 Gramen Cyperoides. Cyperus Graffe.

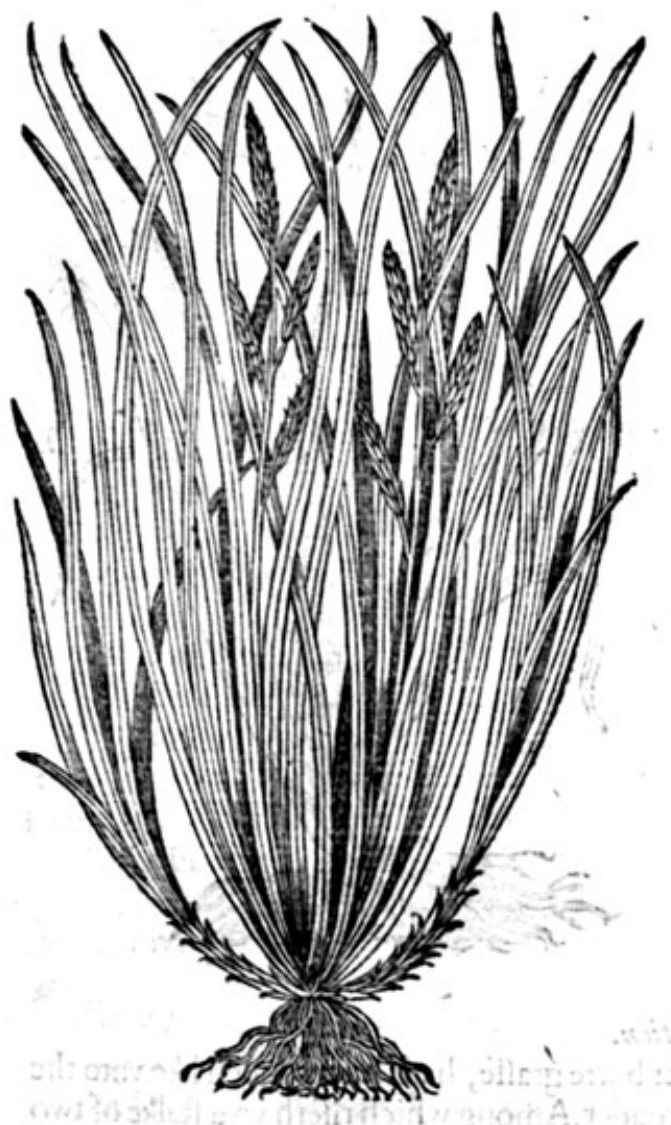

2 Granen Iuncesom aquaticiom. Rufhie Water graffe.

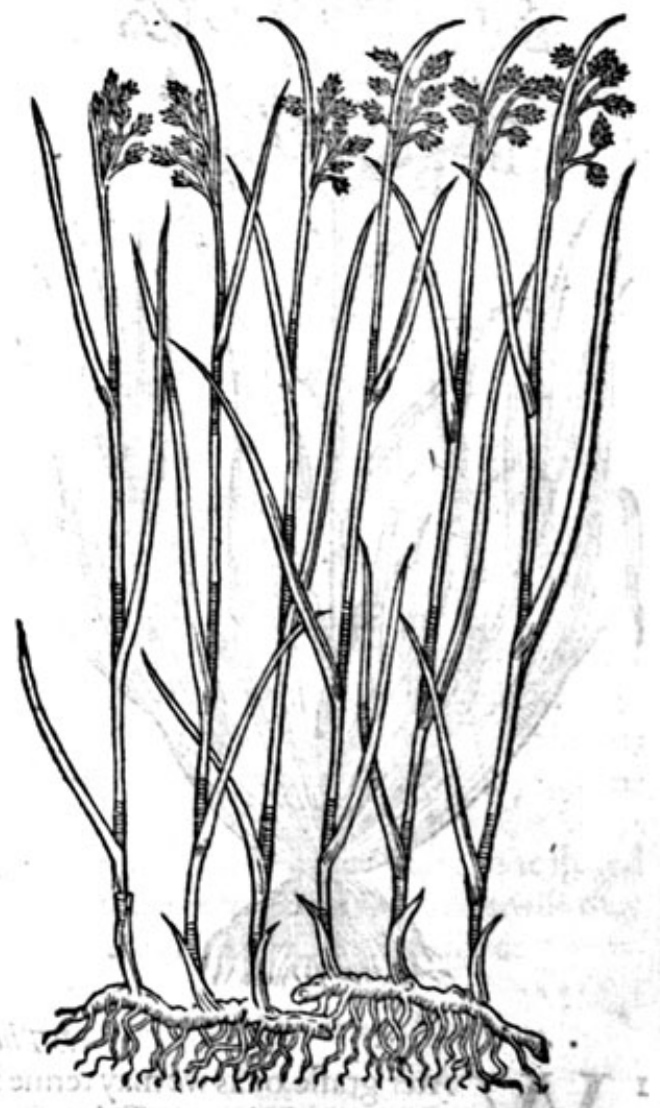

Yperus graffe hath rootes fomewhat like Cyperus whereofit tooke his name. His leaues are long andlarge like vnto the common reede. The ftalke groweth vp to the height of a cubite, or more in fome places : vpon which do growe little fcalie knobs oreares, fpike fafhion, formewhat like vnto Cats taile, or reede mace, very chaffie, rough and rugged: differing but little, fauing that it beareth but one fpike vpon one ftalke and no more, and this many.

2 Rufhic Water graffehath his rootes like the former, with many fibres or ftrings hanging at them; andereepeth along vpon the vppermoft face of the earth, or rather mud wherein it groweth, bearing at each ioint one flender benty ftalke, fet with a few fmall graffie blades or leaues : brin. ging foorth at the top in little hoods, finall feather-like tufts or eares, 


\section{THE FIRST BOOKE OF THE}

* The place and time.

They growe as I hauc infinuated, in mirie and muddie grounds, in the fame feafon that others do. * The names.

Their names I baue likewife touched, and are manifeft of themfelues.

$$
* \text { The nature and vertues. }
$$

The ancients hauc written nothing of their nature and vfe, but leaue them vnprofitable for the ve of man and bealt.

\section{OfWatergrafje. Chap.10.}

I Gramen aquaticum. Water graffe.

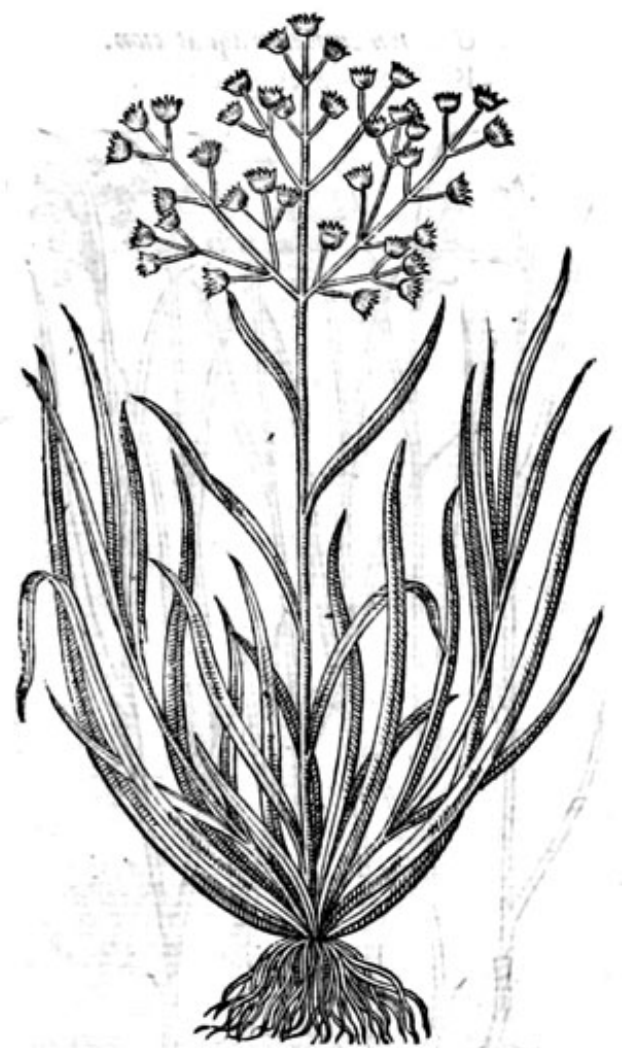

2 Gramen aquaticuon picatum. Spiked Water grafle.

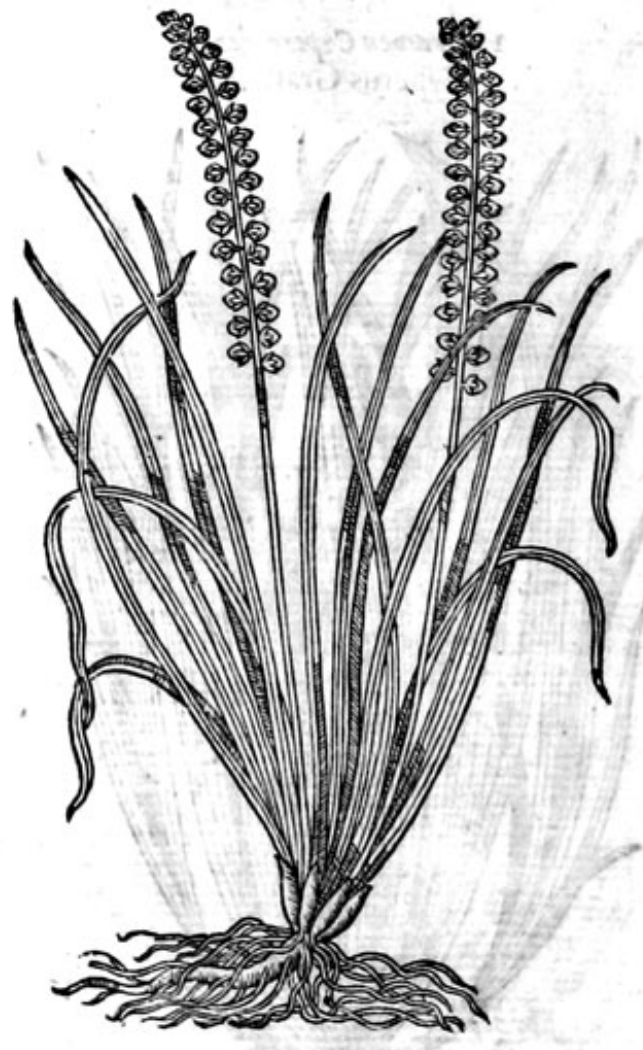

*The defription.

I 7 Ater graffe,or as we may terme it, Water burre graffe, hath leaues much like vnto the common Medow graffe, but fomwhat broader. Among which rifeth vp a ftalke of two foote high, bearing vpon his fmall and tender branches certaine little rough knobs or heads, like vnto the fmall burre, though much leffer.His roote is fmall and threddie:

2 Spiked Water graffe in his leaues refembleth the former. The ftalke is finall, fingle and naked without leaues or blades: bearing alongft the fame toward the top, fpike fafhion, an eare or fpike not vnlike vnto Darnell : and is made of certaine fmall chaffie buttons, refembling the buttonic flowers of Sea wormwood. His roote is thicke and tough, full of fibres or threds. * The place and time.

They differ not from the former kindes of graffes in place and time:and their names are manifeft.

* The natureand vertues.

Their nature and vertues are referred vnto Dogs graffe, whereof we will fpeake hecrafter. 


\section{of Flotegraffe. Chap.II.}

I Gramenflasintile. Flote grafic.

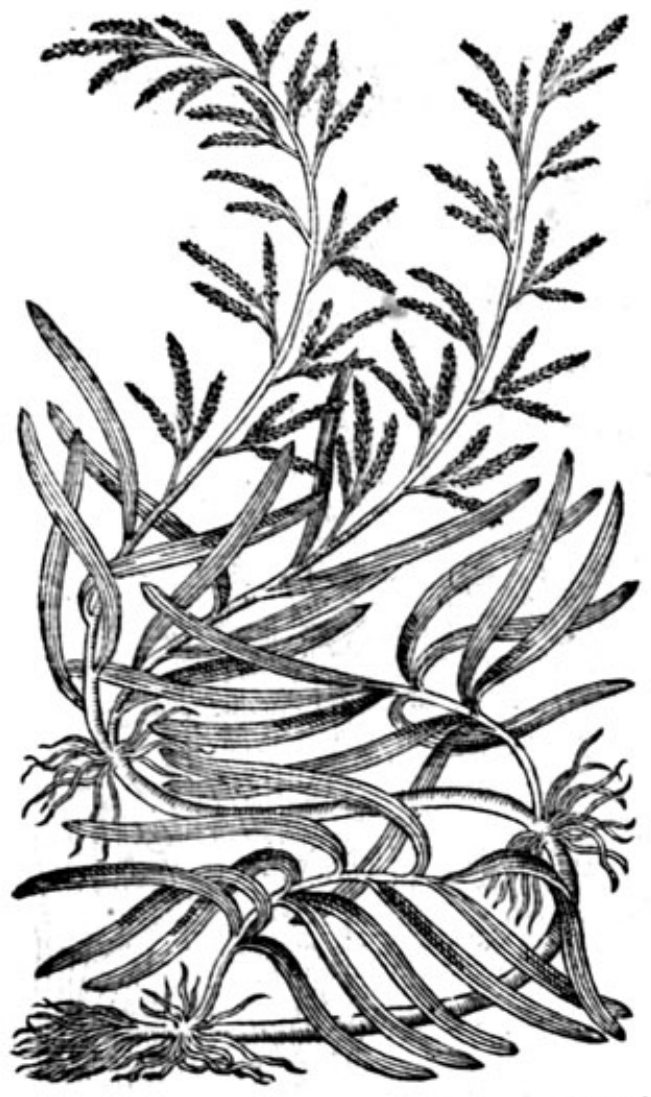

2 Gramen flusiatile Bicatum. Spiked Flote grafle.

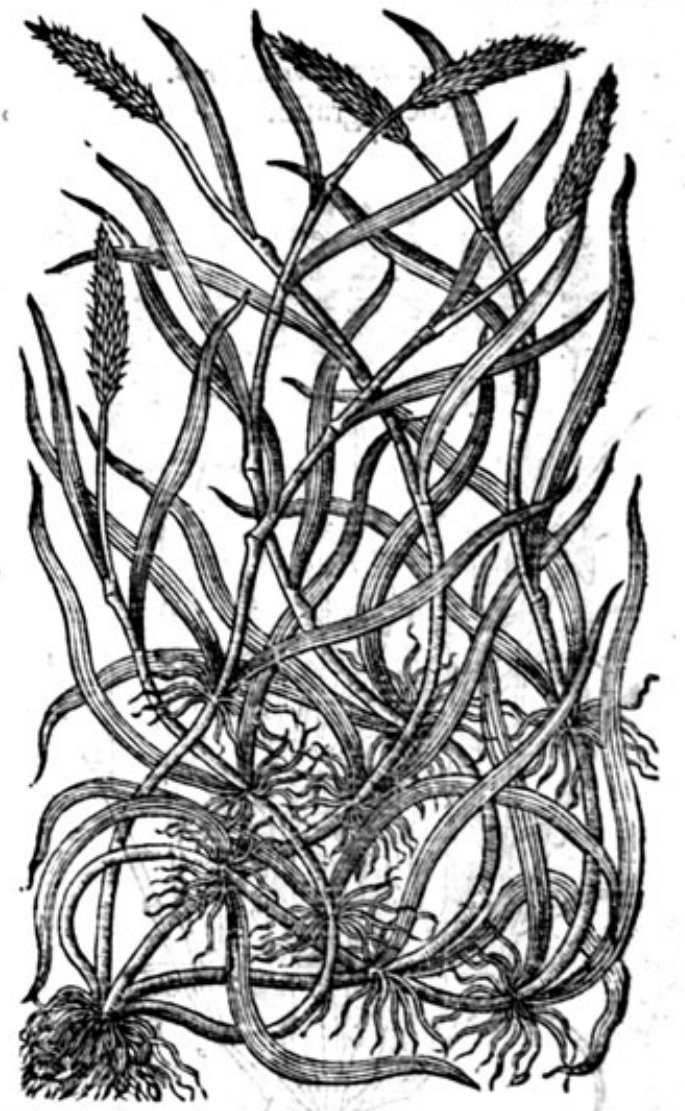

$*$ The defcription.

I Lote graffe hath a long and round roote, fomewhat thicke like vnto Dogs graffe, fet on

T euery ioint with fmall itrings or threds : from the which rifeth vp long and crooked ftalks, croffing, winding and folding one within another, with many flaggie leaues, which horfes eate greedily of. At the top of thefe italks and fomewhat lower, there do thruft foorth many tufts or taffels, of an ouerworne reddifh colour.

2 Spike Flote graffe, or fpiked Flote graffe, beareth at the top of each flender ftalke, one fpiked eare and no more, and the other many, which maketh a difference betweenecthem; otherwife they are like one the other. His roote is compact and tufted,and riade of many thrummic threds.

* Theplace and time. ind

The place and time in which they growe, differeth not from the other Water graffes.

$$
\text { * The nomes. }
$$

The firft is called Gramen flutuat $t$ le, and alfo Gramen aquis innatans : in Englifh Flote graffé.

The fecond is called Gramen fucuiatile picatum ; likewife Flote graffe and Floter graffe, bicaufe they fwim and flote in the water.

$*$ The nature and vertues,
Their natures and vertues are as vnprofitable 2 s the reft.

$$
\text { Of Kneed graffe. Chap.12. }
$$

* Thedefcription.

I Keed graffe hath ftraight and vpright ftrawie ftalks, with ioints like to the ftrawe of corne, and beareth fmall graffie leaues or blades, fpiked at the top like vato Lifimaschia, fore Ceruleo, 
or loue ftrife(as wc terme it,)of a darke browne colour. His roote is hairic or threddie. 2 Waterkneed graffe hath many long and flender ftemmes, iointed with many knobbie and gowtie knees, like vnto recde fet with brode flaggie leaues fomewhat Tharpe pointed: bearing at the top a tuft or pannicle, diuided into fundrie fmall branches of a duskifh colour. His roote is threddie like the other.

I Gramen geniculatum. Kneed graffe.

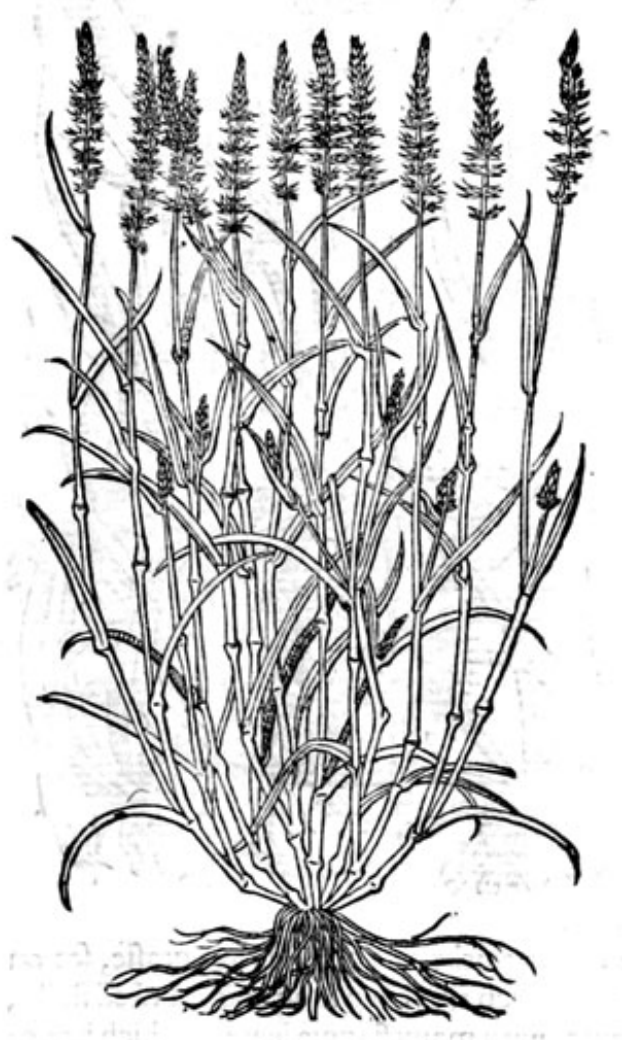

2 Gramen geniculatum aquat joup. Water Kneed graffe.

* The place and time.

Thele graffes do grow in fertill moift medowes : not differing in time from others. * The names.

It isfocalled,bicaufe it hath ioints like as it were knees, and therefore termed Geniculatum, kneed, * The nature and vertues.

We haue nothing deliuered vs by the ancients of their nature and properties.

\section{OfBearded graffe. Chap.r.}

' $\mathrm{B}$

* The defcription.

B Earded graffe hath brode and large leaues like Barly, fomewhat hoarie, or of an ouerworne ruffet color. The ftalks haue one or two ioints at the moft, and many eares on the top, without order : vpon fome ftalks more eares, on others fewer, much like vnto the eare of Holchus Plinï, or Hor dewon ßpurium ßpontaneum. In Englifh Baftard Barly graffe. 2 Sinall Pannicke, graffe as Lobelius writeth, in rootes, leaues, ioints or knots and ftalks, is like the former, falling that the eare is muchleffer, barren and chaffie. 
1 Gramen Panicesm. Bearded graffe.

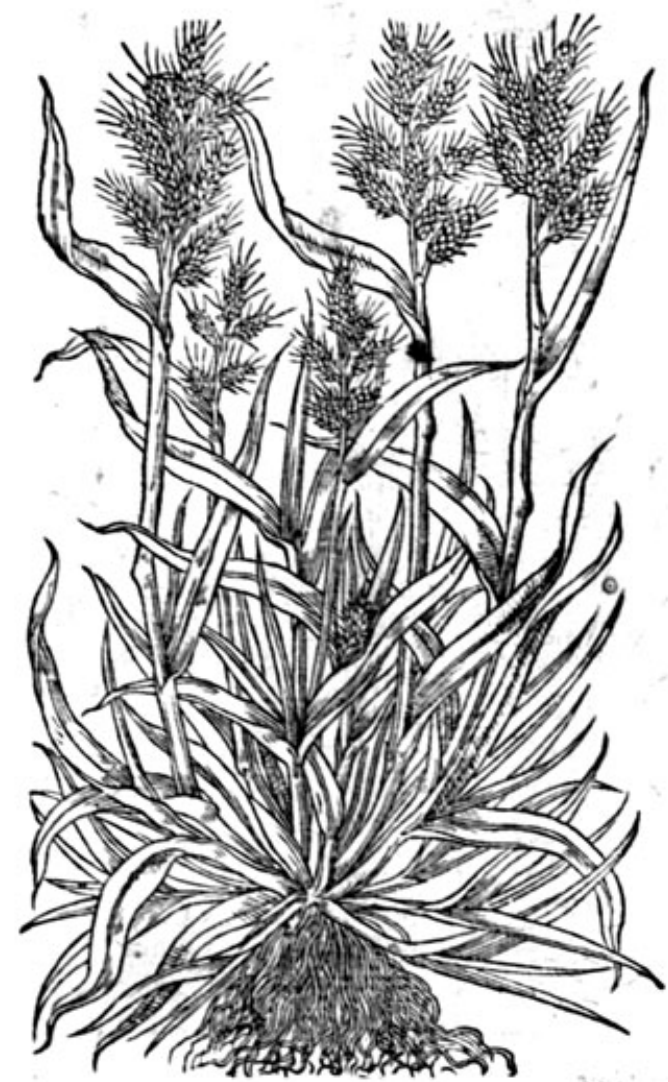

2 Grimen Panicelom paruum. Simall Pannicke graffe.

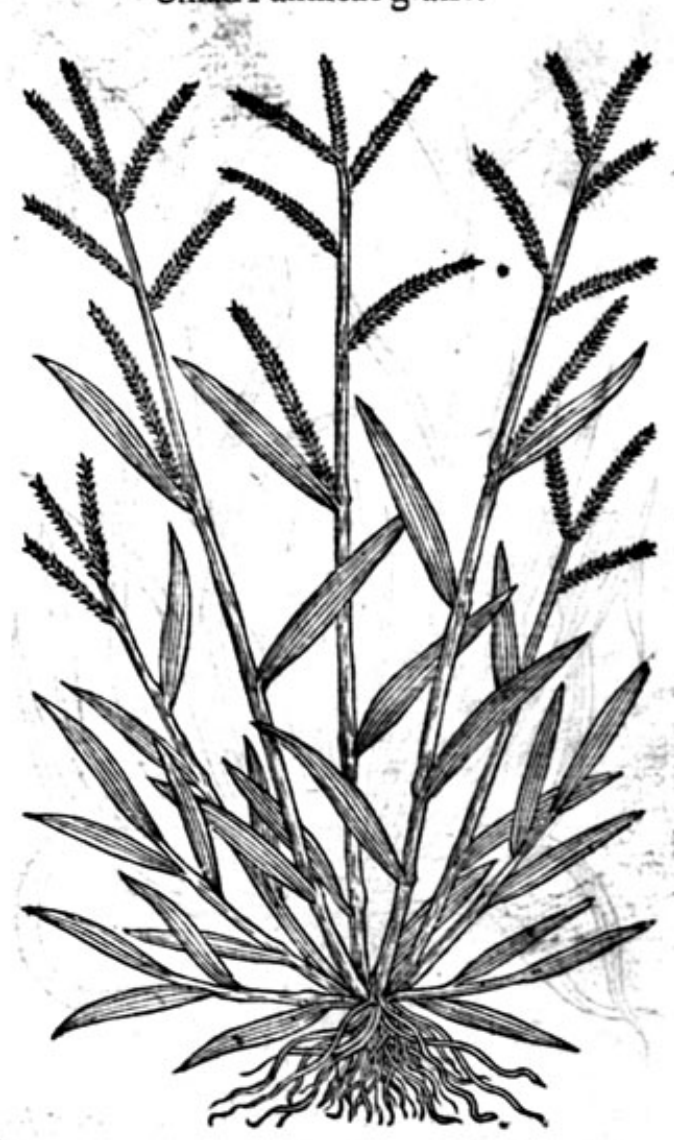

* The place and time.

The firft of thefe two doth grow neere vnto mud wals, or fuch like places not manured, yet fertill or fruitfull.

The fecond in fhallow waterie plafhes of paftures, and at the faid time with others. * The names.

It is called Pannicke,bicaufe it is like the Italian corne called Pannicke:

They are vnprofitable for phificke, and therefore there is nothing left vs of their vertucs and nature.

\section{Of Hedgehoggraffe. Chap.14.}

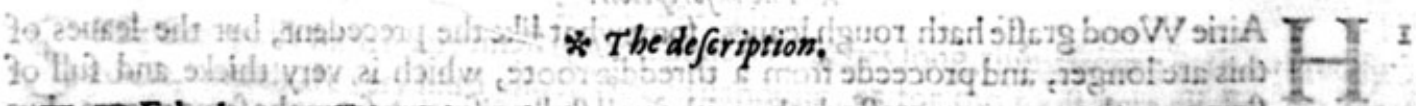
1 Tdgehog graffe hath broade, long and ftiffe daggic leaues, with divers ftalks proceeding 1 from a thicke fpreading roote. And at the top of eucric ftalke groweth certaine round and 2 The fecond, which is hairie graffe, is as rough and hairic as a goate. His rootes do fpread and creepe vnder the mud and mire as Cyperus doth; and at the top of the ftalks are certaine pricking 
I Gramen palustre Echinatum. Hedgehog graffe.

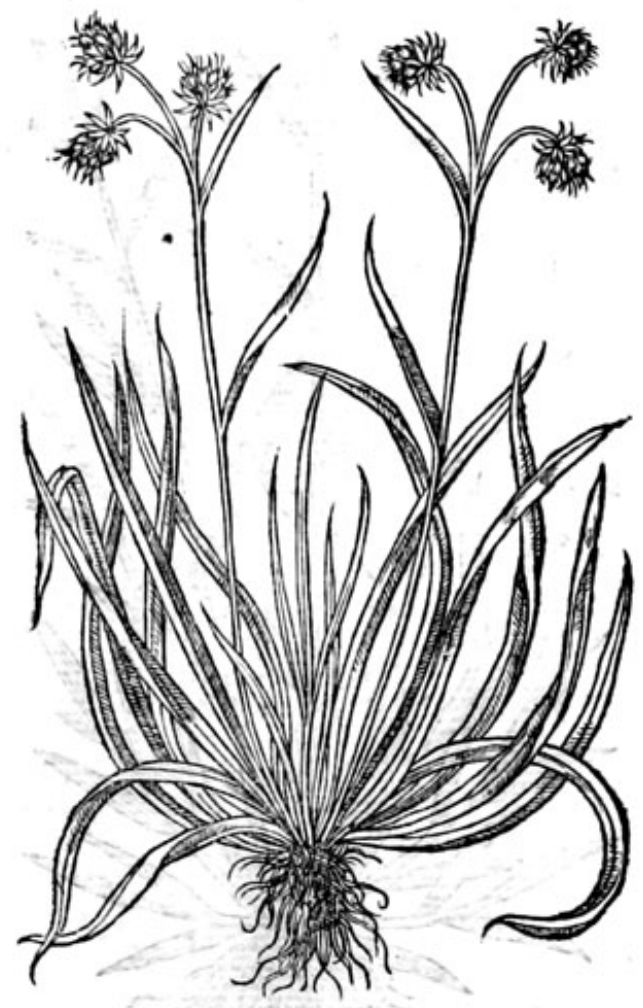

2 Gramen exile Hirfunom. Hairic graffe.

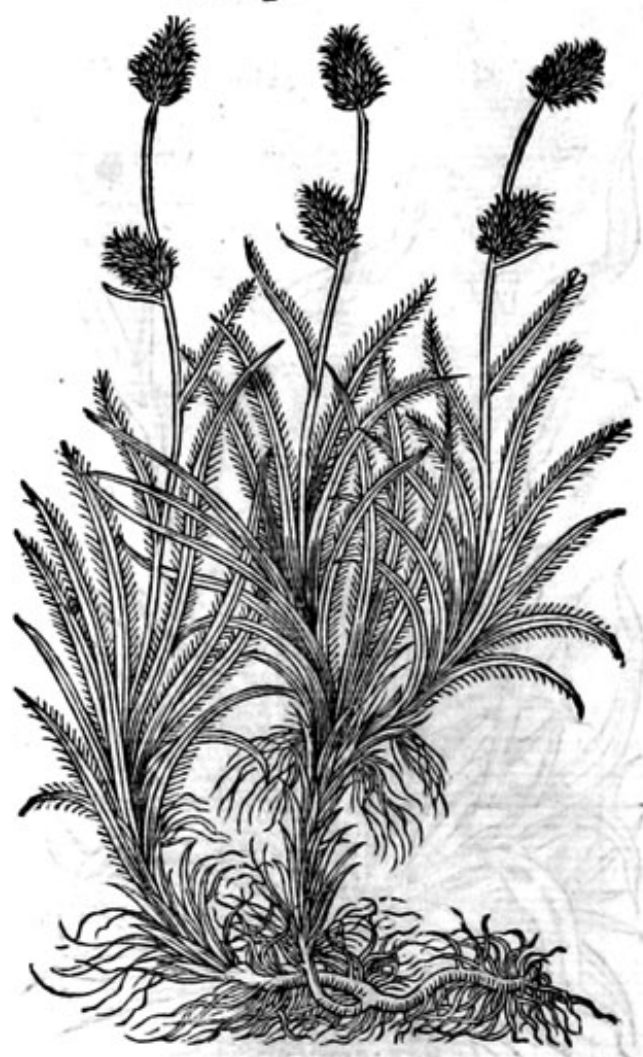

$*$ The place and time.

They grow in watery ditches, as you may fee in going from Paris garden bridge to Saint Georges fields, and fuch like places : where alfo are fome of the graffes which we haue already defcribed, tobe feene.

\section{F' The names.}

The firft is called Hedgehog graffe, and in Latine Gramen Echinatum, by reafon of thofe prickles which are like vnto a Hedgehog.

The fecond Hairie grafie, Gramen exile Hirfutum cyperoides, bicaufe it is fmall \& little, and rough or hairie like a goate : and cyperoides, bicaufe fir rootes do pread and creepe like the Cyperus.

Their natures and vertues are fruteleffe as many of the others are, and therefore nothing is delinered vs of them by our writers.

$$
\begin{gathered}
\text { Of Hairie Wood graffe: Chap.15. } \\
\text { * Thedefcription. }
\end{gathered}
$$

I $T$ Airie Wood graffe hath rough leaues, fomewhat like the precedent, but the leaues of H this are longer, and proceede from a threddie roote, which is very thicke and full of ftrings, as the common graffe doth : with fmall ftalks rifing vp from the fame rootes : bute the top of thefe ftalks are diuided into 2 number of little branches. And on the end of euerie one of them ftandeth a little flower or huske like the top of Allium $\mathrm{Kr}$ finum, or common Ramfons, wherein the feede is contained when the flower is fallen.

2 Cyperus Wood graffe hath many fheary graffic leaues, proceeding from a roote made of many hairie ftrings or threds: among which there rifeth vp fundrie ftraight and vprighr ftalks, on whofe 
tops are ceitaine fealic and chaffie hüsks, of rather fpikie eares, not much vnlike the catkins or tags which grow on nut trees and Aller trees.

I Gromen birfutum nemorofum. Hairic Wood graffe.

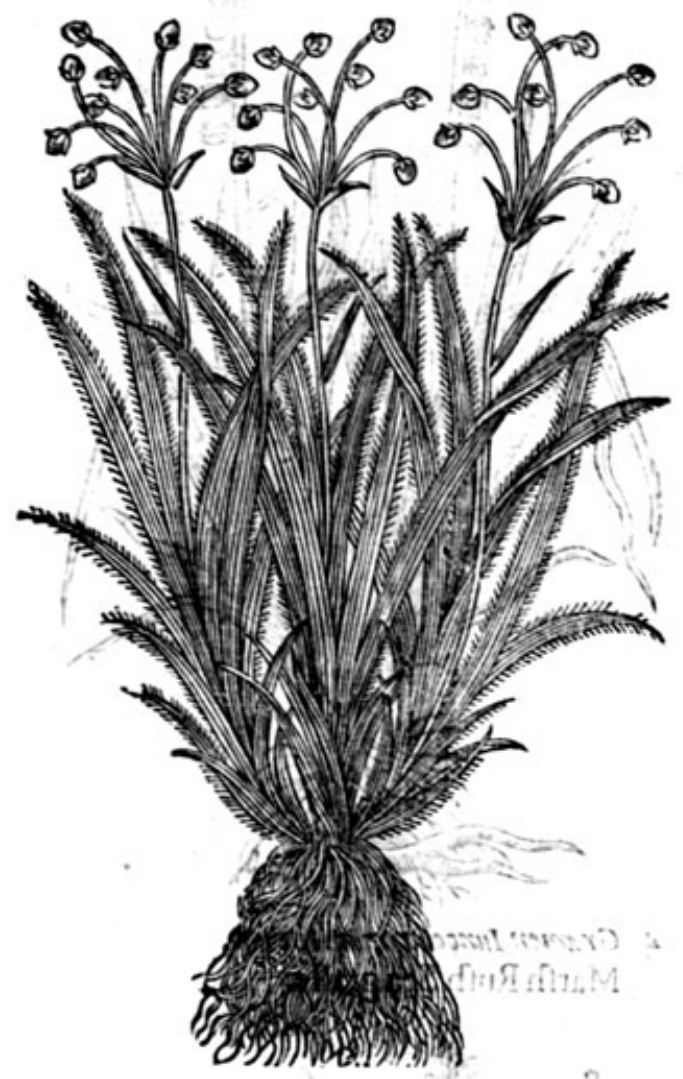

2 Gramen Cyperinum nemorofan. Cypreffe Wood graffe.

* The place and time.

Thefe two kindes do grow in woods for the moft part, or thadowie places: and may in Englifh be called the Hairic Wood graffe. The time is common with the reft, faid.

It is plaine that they are termed by that name, bicaufe they grow in woods or fhades, as we haue

There is nothing to be faid of their natures and vertues.

$$
\text { * The natures and vertwes. }
$$

\section{Of Sea Spikegraje. Chap.i6.}

* The defeription.

$\mathbf{1}$

Pike Sea graffe hath many fmall leaues about fixe inches long, rifing from a bufhie threddy roote, which are very hard and harpe in handling, as for the moft part all Sea graffes are. Among thefe leaues there do fpring vp many fmall rufhie ftalks : alongtt which are diuers fmall flowring fharpe husks, fomewhat refembling the eare of Lauander.

2 Salt Marfh Spike graffe hath a wooddie tough thicke roote, with fome fmall hairie threds faftened thereunto: out of which do arife hard and rough leaues like the former, but fomewhat broader :andamong them flender naked ruffie $t a l k s$, which haue on both fides fmall knobs or buttons
hanging on them. 


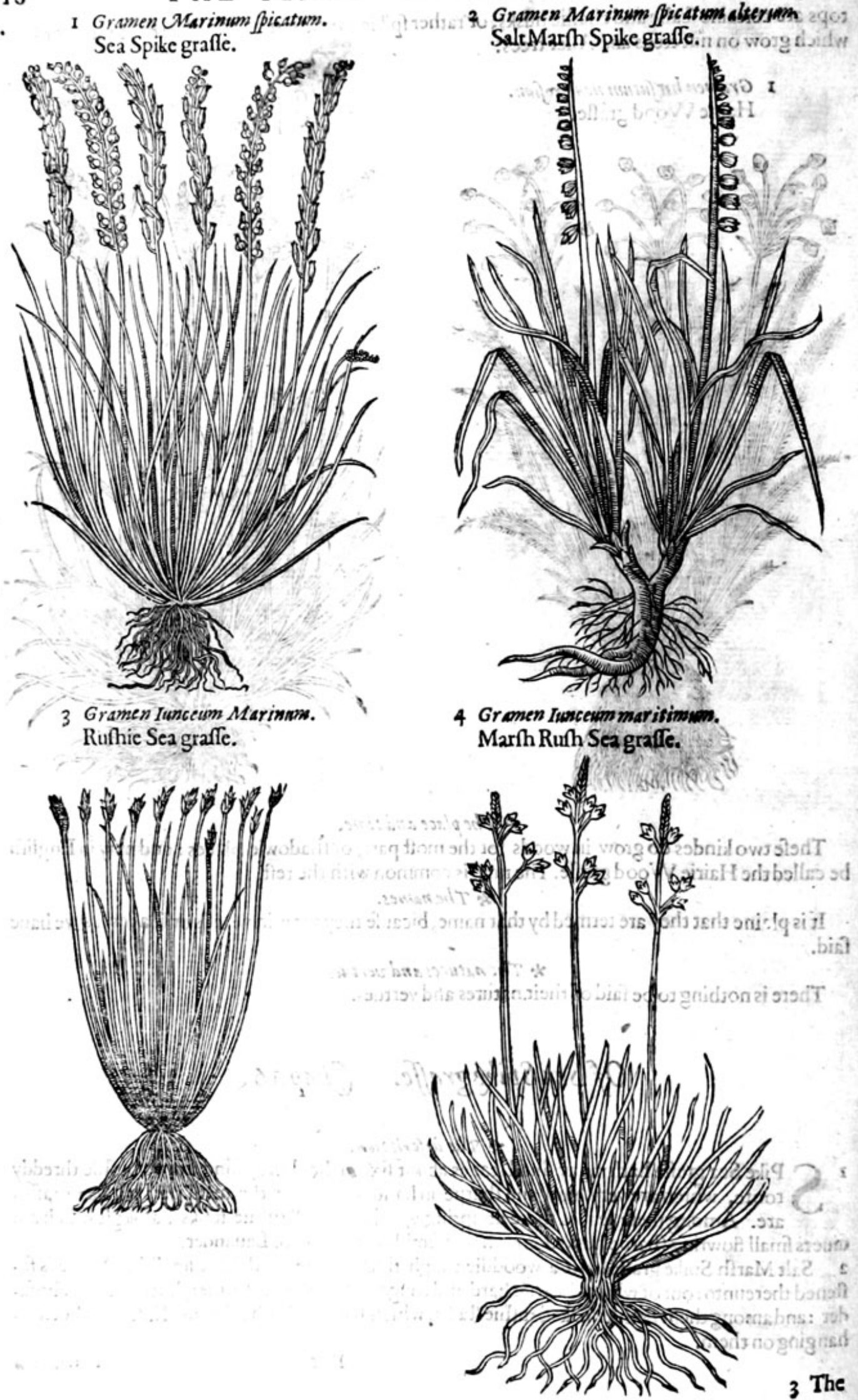


3 The third hath many rufhic leaues, tough and hard, of a browne colour, well refembling rufhes: his roote is compact of many fmall tough and long ftrings. His ftalke is bare and naked of leaues vnto the top,on which it hath many fmall, pretie and chaffie buttons.

4 Thefourth is like the third, fauing that it is fmaller:the ftalkg alfo fmall and naked, and at the top fuch huskes as are in rufhes.

5 Gromen palustre Coperoides. Great Cypreffe graffe.

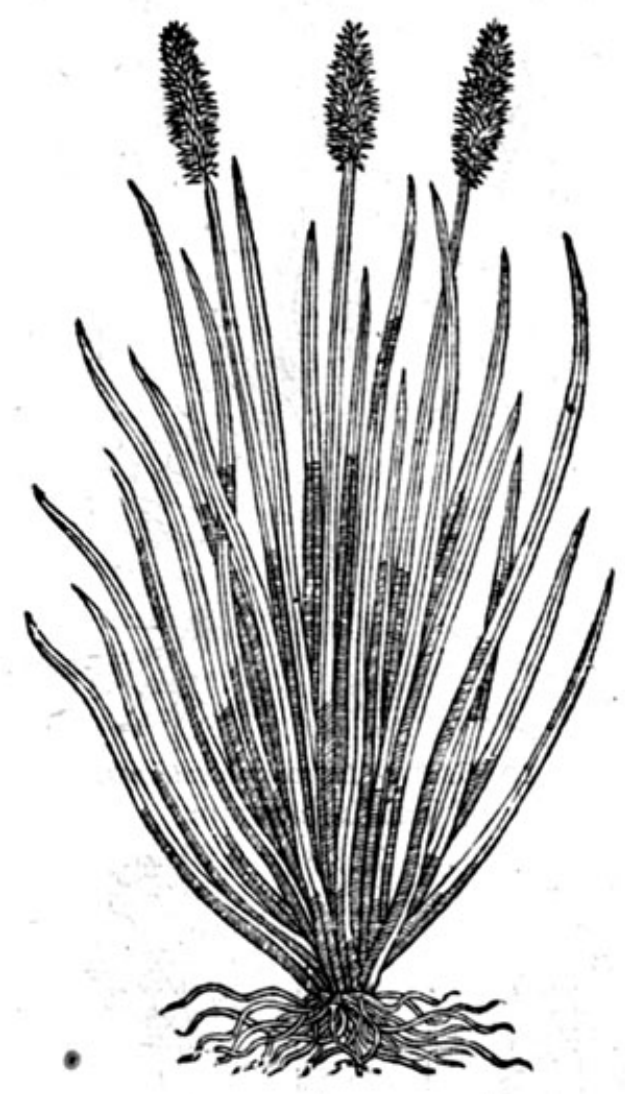

6 Gramen Cyperoides paruom. Small Cypreffe graffe.

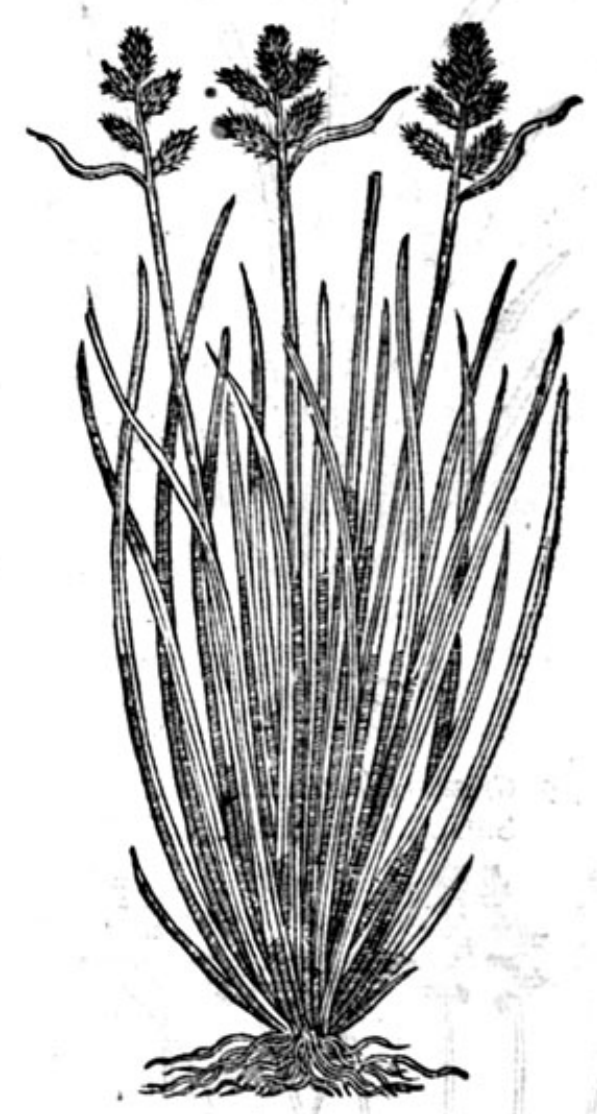

* The defcription.

5 Great Cypreffe graffe hath diuers long ftalks proceeding from a roote compact of many long and tough ftrings or threds. The leaues are long and broad, like nnto the Sedge called carex or sparganium. The fpike or carc of it is like the head of Plantaine, and very prickly.

6 Small Cypreffe graffe is like vnto the other in roote and leaues, fauing that it is fmaller. His ftalke is fmooth and plaine, bearing at the top certaine tufts or pannicles, like naked eares of wilde barly.

* The defcription.

7 The firft of thefe two kindes hath many crooked and crambling rootes, of a wooddie fub tance, very like vnto the right Cyperus, differing from it onely in fmell, bicaufe the tight Cyperus rootes haue a fragrant fimell, and thefe none at all. His leaues are long and broad,rough, tharpe or cutting at the edges like Couch graffe. His ftalke is long, big and fquare, like vnto a reede, and on his top a chaffie vmbell or tuft like vnto the true Cyperus.

8 The fecond kind hath very many broad, rough, and flaggie leaues, like vnto the former Cyperus graffe, but yet broader and Shorter, fomewhat like the grafle called Pi iftum, Painted graffe, or Ladies aces, as we terme it. His ftalke is great and large like vnto Reede, bearing at the top an eare like a Spike, of a hard and chaffie fubftance. His roote is long, and hath many threddic ftrings in it. 
7 Gramen aguaticum Cyperoides vulgatius. Water Cypreffe graffe.

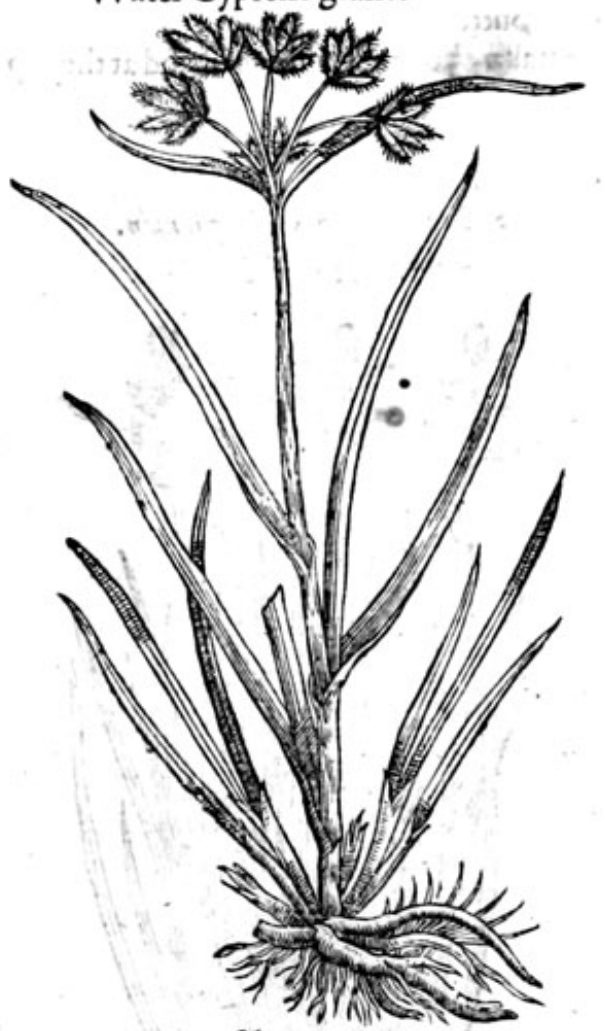

9 Gramen foluaticun minus. Small Wood graffe.

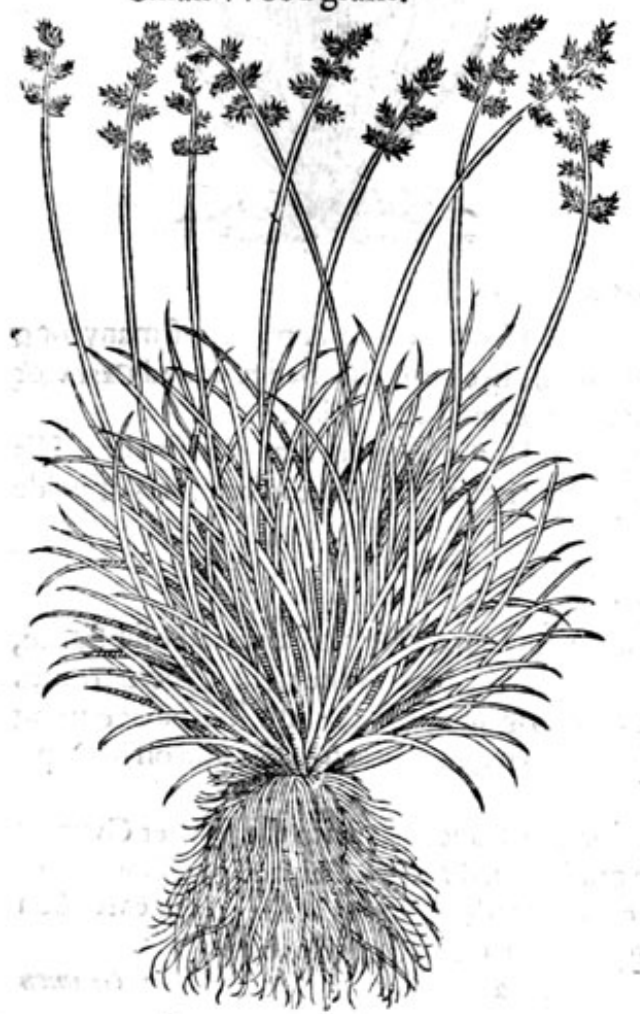

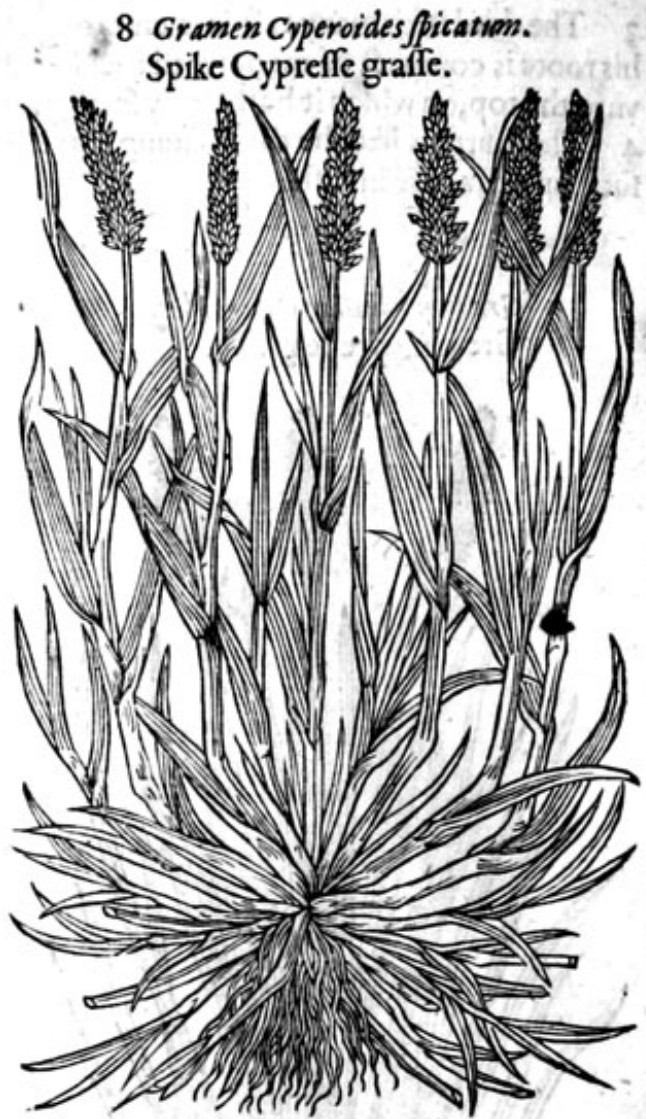

Io Gramen Iunceum fyluaticuem. WoodRufhie graffe.

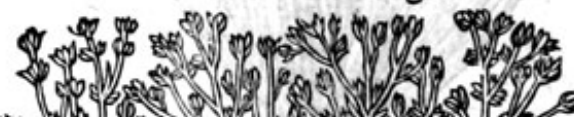

(coser.
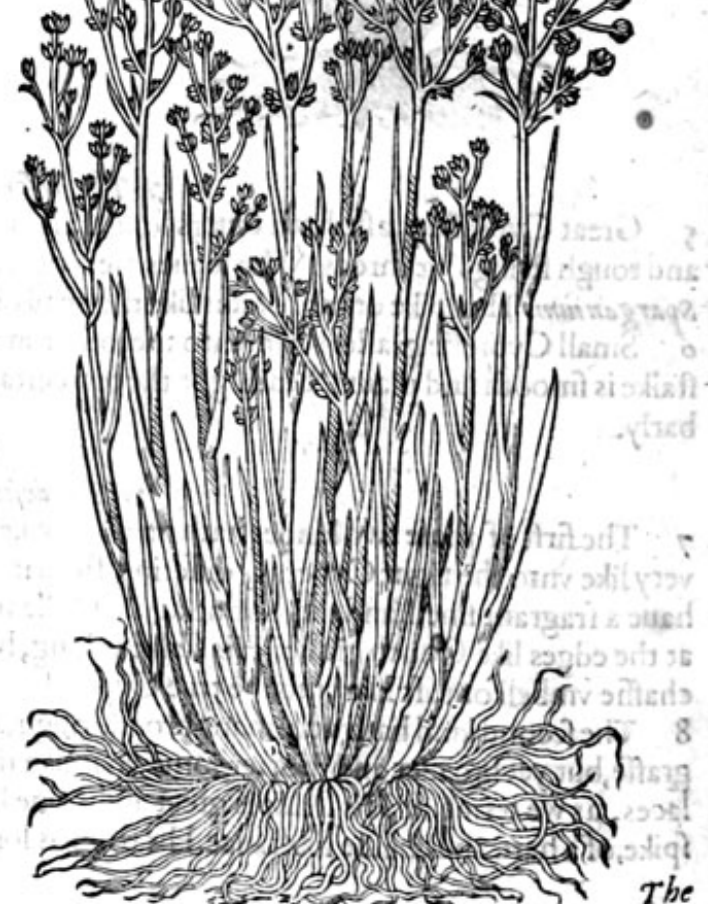
1. *. The defcriptios. 9. The firft of thefe graffes is a fmall barren graffe, and hath many narrow thin graffie leaues: out of which fpring fmall ftalks, as in Medow graffe, bearing on the top fmall feacher-like chaffie eares. His roote is long and threddie.

10 The fecond hathlong tough and tiairie ftrings, growing deepe in the earthlike a turfe, which make the roote: from which rife many crooked, tough and rufhieftalks, hauingtoward the top fcalic and chaffie knobs or buttons. 3 i F.

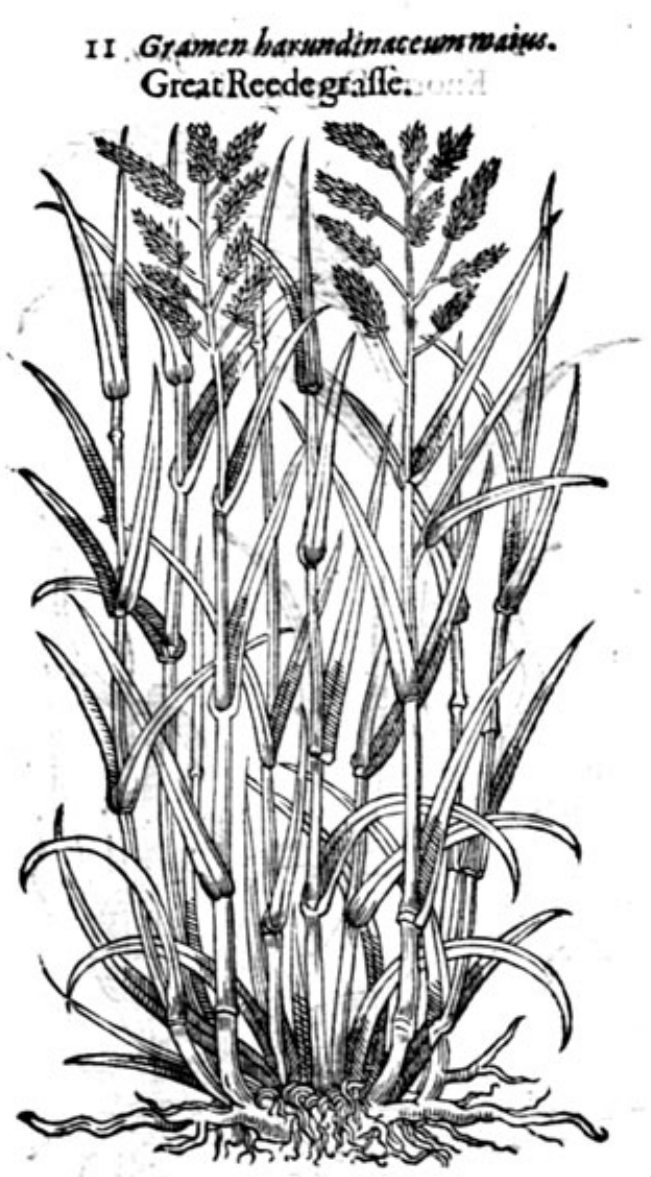

* The defcription.

12 Gramen harwadinaceven mimes. Small Reede graffe.

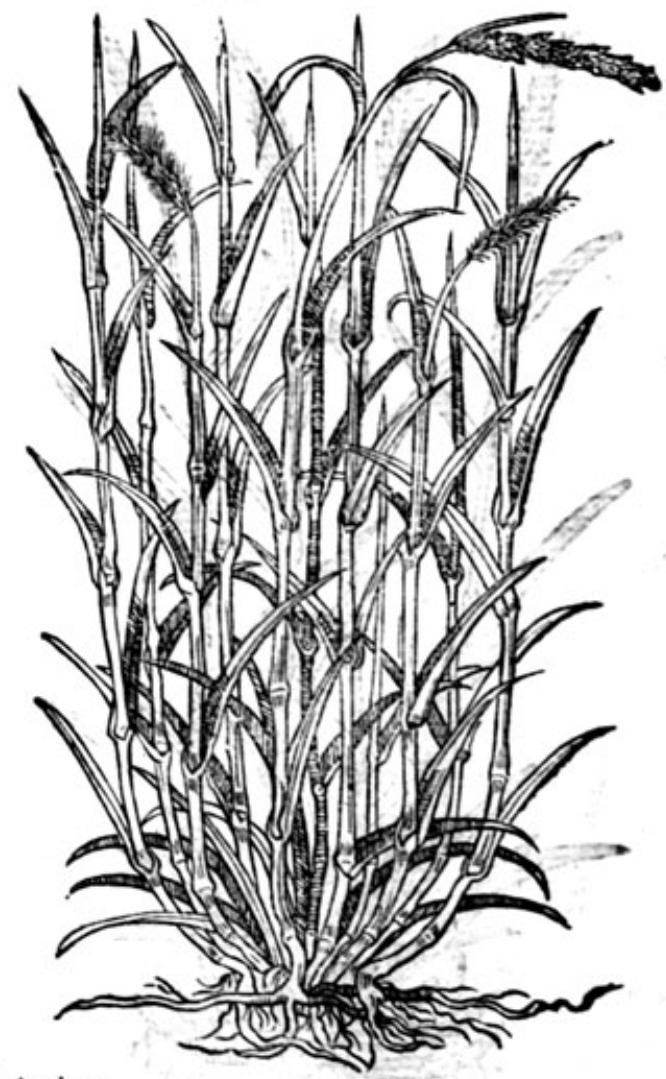

II The firft hath many faireand vpright wheaten ftalks, rifing from a thicke knobbie and tough roote, iointed and kneed like vnto Wheate. His leaues are very well like the common Reede, hauing at the top a feather-like eare, fpike or knop of a chaffie fubftance, like vnto the common Reede ivhere of it tooke his name.

12 The fecond kinde doth not differ from the precedent, fauing that this is fmaller than it. * The place, time, names, natures and vertwes.

All the graffes which we haue defcribed in this chapter, do growe in matifh and waterie places neere to the fea, or other fenny grounds, or by muddie and mirie ditches, at the fame time that the others do growe and flourifh. Their names are eafily gathered of the places they grow in,or by their defcriptions; and are of no vertue nor propertie for medicine, or neceffarie vee as yet knowen.

$$
\text { Of Couch grafe or Dogs graffe. Chap.17. }
$$

* The defcription.

I He common or beft knowen Dogs graffe or Couch graffe, hathlongleaues like vnto the fmall Reede, tharpe at the point, cutting like a knife at the edges. The ftalke is a cubit and a halfe long, with ioints or knees like wheaten ftraw : theplume or ruft is like che Reede, 
but fmaller and more chaffie : it creepeth in the ground hither and thither with long white rootes, iointed at certaine diftances, and have a pleafarit fweete tafte, platted or wrapped one within another very intricately, in fo much as where it happeneth in gardens among pot herbs, great labour nuft be taken before it can be deftroied.

2 Knottie Dogs graffe is like vnto the former inftalke and leafe. The tuft or eare is long and chaffie, of a browne colour. The roote is like vnto Saffron, knobbie or knottie, for the moft part one fet vpon another, like the rootes or bulbs of Gladiolus It alicus, or Italian corne flag.

t:Gramen Canimum.

Couch graffe or Dogs grafle.

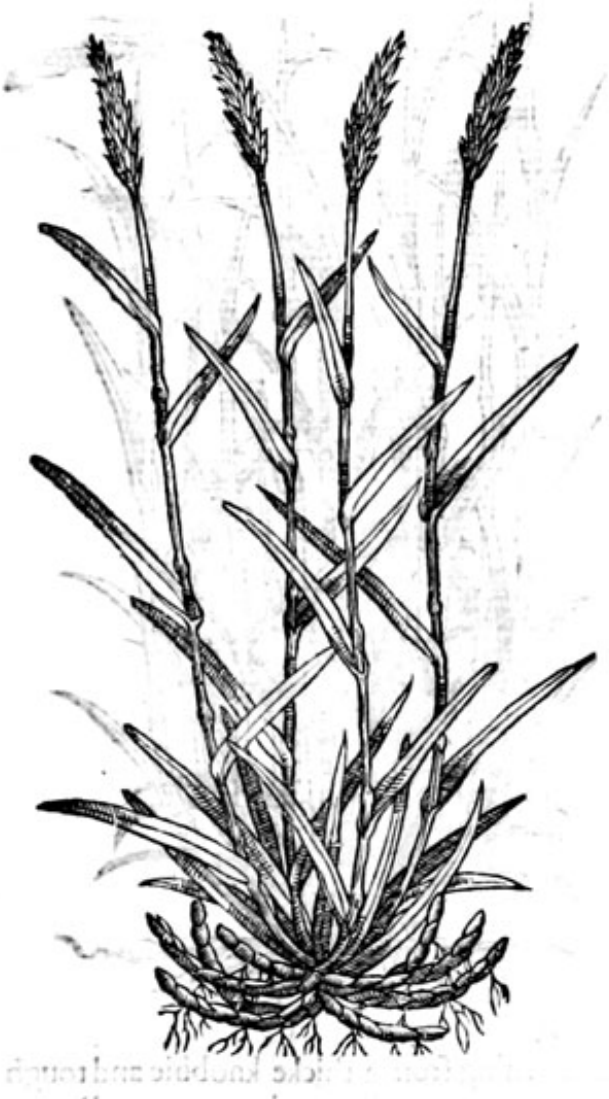

i Granen Caninumenodospon. Knotrie Dogs graffe.

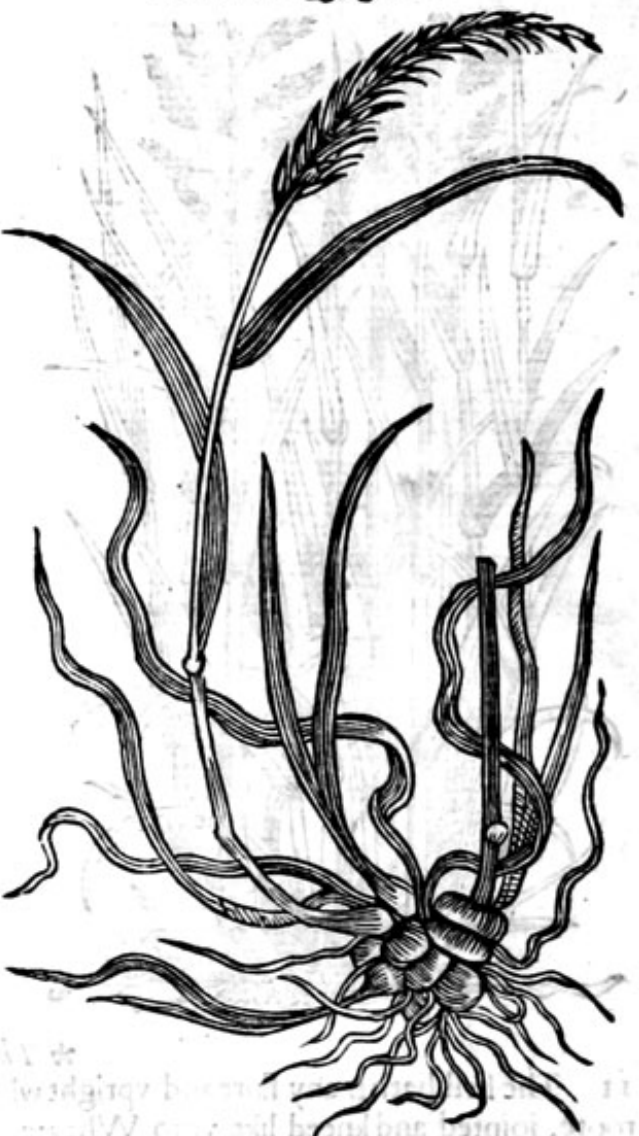

* Theplace.

1. The firf groweth in gardens and arable grounds, as an infirmitie and plague of the fields, nothing pleafing to the husbandmen; for after that the field is plowed, they are conftrained to gather the rootes togither with harrowes and rakes: and being fo gathered and laid vpon heapes, they fet thern on fire, leaft they fhould growe againe.

2 . Thefecond groweth in plowed fields and fuch like places, but not euery where as the other : I hate found of thefe in great plentie both growing, and plucked vp with harrowes, as before is reherfed, in the fields next to Saint Iames wall as ye go to Chelfey; and in the fields as ye go from the tower hill of London to Radcliffe. ,

The time anfwereth the rime of the other the

$$
\begin{aligned}
& \text { * The time. } \\
& \text { * The names. }
\end{aligned}
$$

It is called Caninum or Sanguinale, and $\nu^{\prime}$ niola. The countrie men of Brabant do name it jocen: others $\mathcal{L}$ edt grafte. Of the Grecians orpows : of the Latins by the common name Gramen. It is of fome named eixxòzr: in Englifh Couch gr affe, Quitch graffe, and Dogs graffę.

Gramen Caninum bulbofam or nodofim, is called in Englifh Knobbic or Knottic Couch graffe. 
* The nature.

The nature of Couch graffe, efpecially the rootes agreeth with the nature of common graffe:a!though that Couch graffe be an vnivelcome gueft to fields and gardens, yet his phificke vertues do recompence thofe hurts : for it openeth theftoppings of the liuer and raines, without any mani"feft heate.

The learned Phifitions of the College and focietie of London, do holde this Bulbus Couch graffe in temperature, agreeing with the common Couch graffe, but in vertues more effectuall.

\section{Couch grafe vertues.}

Couch graffe healeth greene wounds. The decoction of the roote is good for the kidneios and $\mathbf{A}$ bladder: it prouoketh vrine gently, and driueth foorth grauell. Diofcorides and Galen doagree, that the roote ftamped and laid vpon greene wounds doth heale them fpeedily.

The decoction there of ferueth againft griping paines of the bellie, and difficultic of making B water.

Marcellus an old author maketh mention in his 26.chapter, that feuen and twentyknots of this C Gramen nodofum boiled in winc till halfe be confumed, preffed foorth, ftrained and giuen to drinke to him that is troubled with the ftrangurie, hath fo great vertue, that after the patient hath once begun to make water without paine, it may not be giuen with wine any more, but with water onely. By which words it appeereth, that this knotted graffe wastaken for that which is properly called Gramen or Agrostis, and hath been alfo commended againft the ftone and difeafes of the bladder.

The later Phifitions do vec the rootes fomtimes of this, and fomtimes of the other indifferently.

\section{Of Sea Dogs graffe. Chap.18.}

I Gromen Caninum marinum. Sea Dogs graffe.

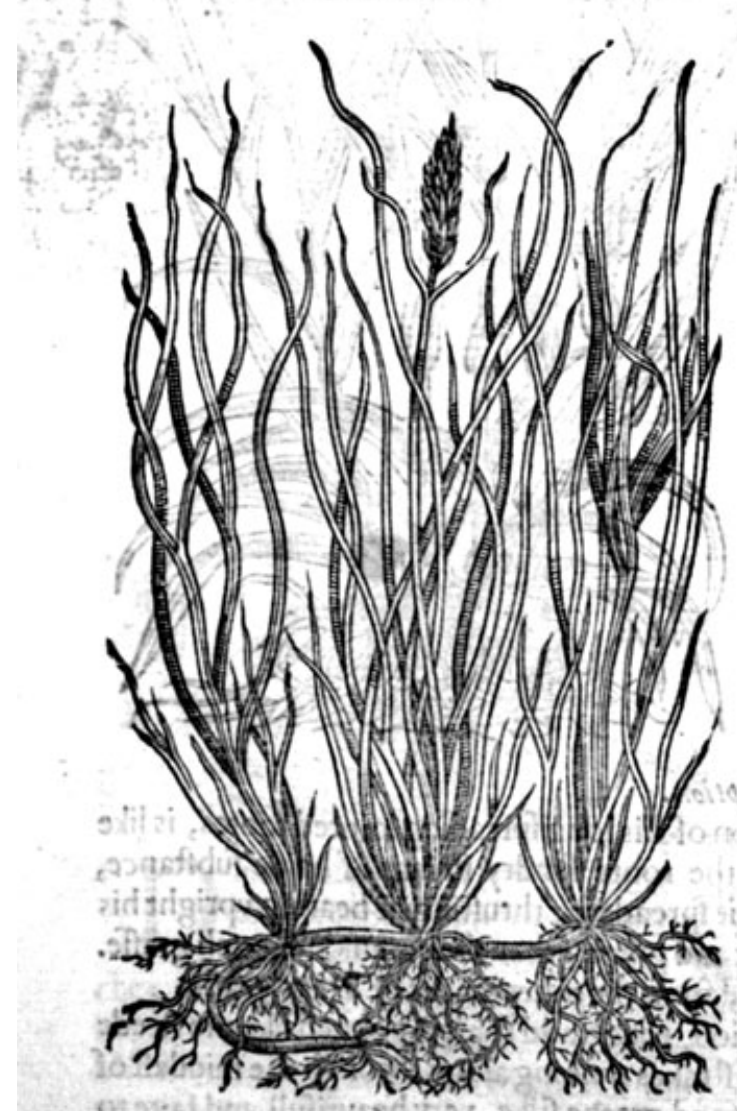

2. Gramen Canimum marinum alterion. Sea Couch grafie.

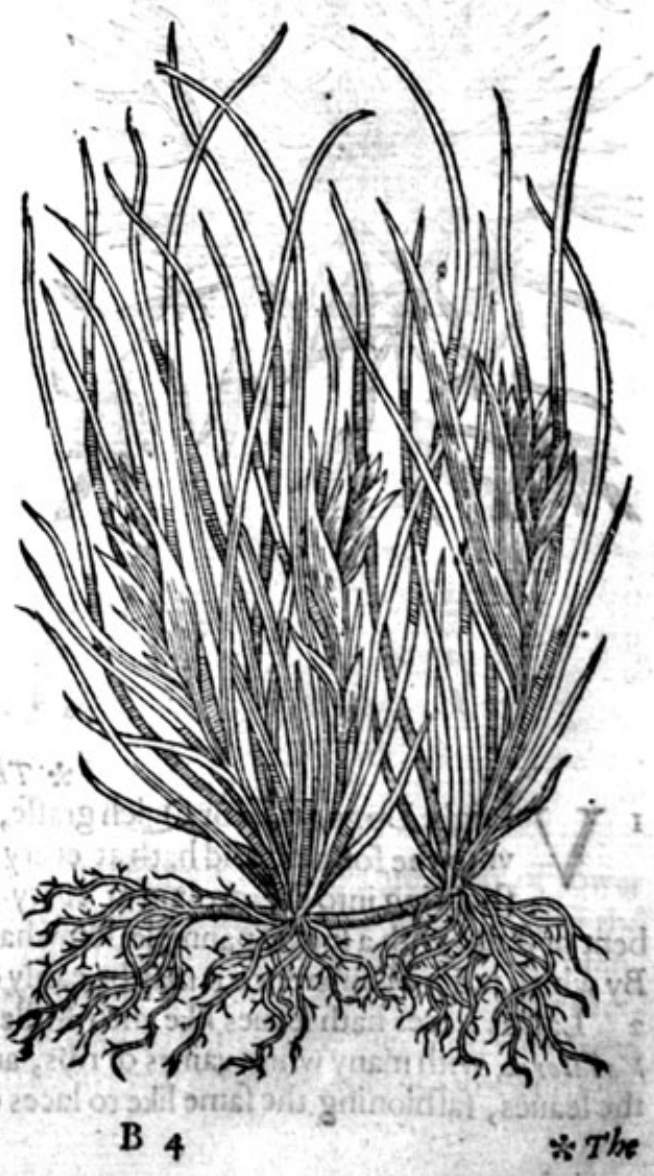


He Sea Dogs graffe is very like vnto the other before named : his leaues arelong and flender, and very thicke compaet togither, fet vpon a knottie ftalke, f piked at the top like the former: alfo the roote crambleth and creepeth hither and thither vnder the earth, occupying much ground, by reafon of his great increafe of rootes.

2 The fecond Sea Dogs graffe is according vinto $L^{\prime} O$ bell fomwhat like the former: his rootes are morefpreading and longer, difperfing themfelues vnder the ground further than any of the reft. The leaues are like the former, thicke bufhed at the top, with a clufter or bufh of fhort thicke leaues one folded within another. The ftalkc and tuft is of a middle kinde betweene If chamon and the common Couch graffe.

* The place, time, names, natureand vertues.

They grow on the fea fhore, at the fame time that others do. And are fo called bicaufe theg grow neere the fea fide. Their nature and vertues are to be referred vnto Dogs graffe.

\section{Of vpright DogsgrafJe. Chap.19.}

I Gramen Caninum fupinum. Vpright Dogs grafle.

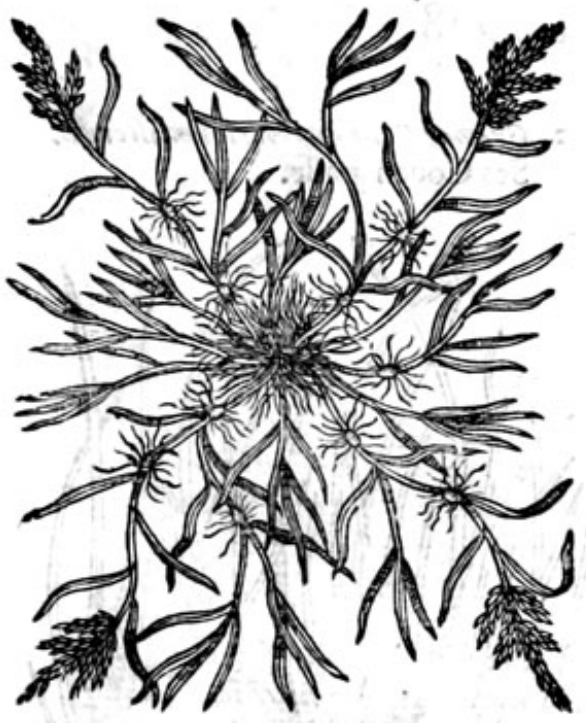

2 Gramen Striation. Ladie Lace graffe.

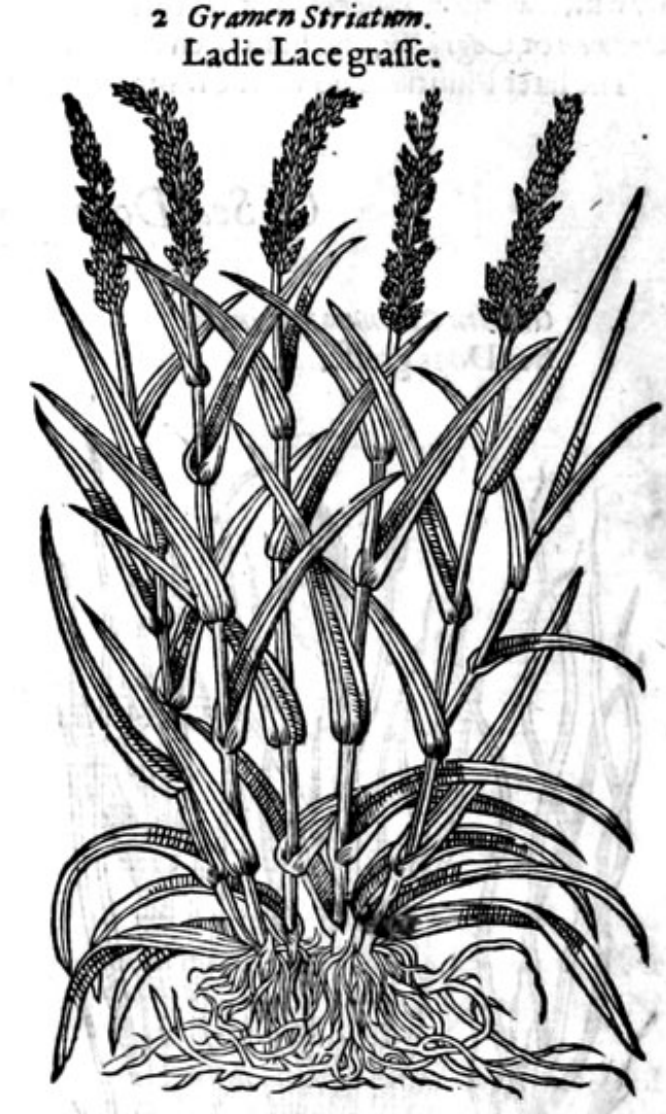

* The defcription.

1 Pright Dogs graffe or Quich graffe, by reafon of his long fpreading iointed rootes, is like vnto the former, and hath at euery knot in the toote fundry ftrings of hairie fubstance, fhooting into the ground at euery ioint as it fpreadeth, thrufting or bearing vpright his bent or ftalke, with a fpokie pannicle, fomwhat thicker and greater than the common Couch graffe. By which notes of difference, it may be eafily differned from the other kindes of Dogs graffe. 2 Ladies Laces hath leaues like vnto Millet in fafhion, rough and Tharpe pointed like the Reede Vallatoria, with many white vaines or ribs, and filuer ftrakes running along through the middeft of the leaues, fafhioning the fame like to laces of white and greene filke, very beautifull and faire to 


\section{HISTORIE OF PLANTS.}

behold; it groweth to the height of wilde Pannicke. The roote is fmall and hairie, and white of colour like the Medow graffe, hauing a faire bufh or creft at the top, like the common Reede.

$$
\text { * The place. }
$$

I Vpright Dogs graffe groweth in well dunged grounds and fertill fields.

2 Ladies Laces groweth naturally in the wooddy and hilly places of Sauoy, and anfwereth common graffe in his time of feeding.

It is kept and maintained in our Englifh gardens, rather for pleafure than for vertue as yet knowen.

$$
\text { * The names. }
$$

L'Obelius calleth it Sulcatum and Gramen friatum, or Gramen pictum : in Englifh the Furrowed graffe, the White Chameleon graffe, or ftraked graffe : and vfually of our Englifh women it is called Ladies Laces, or Painted graffe. In French Aiguillettes d'armes.

The vertues are referred to the Dogs graffes.

$$
\text { * The nature and vertues. }
$$

\section{OfDew grafe. Cbap.2o.}

1 Gramen CManne efcalentum.

Dew graffe.

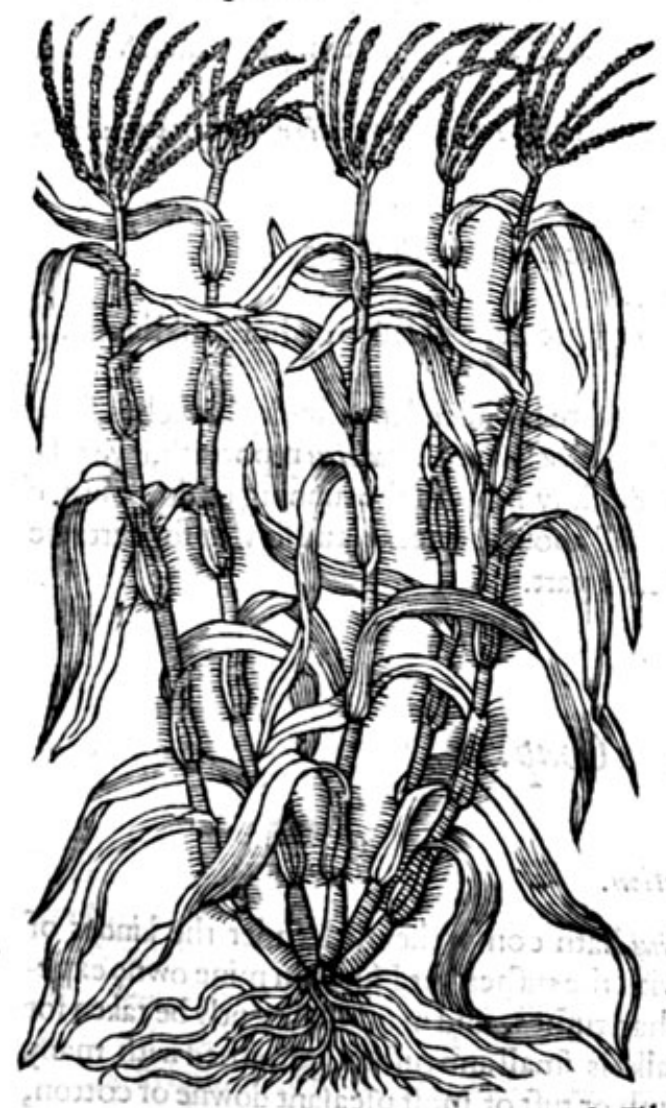

* The defcription.

'D

Ewgraffe hath very hard and tough rootes, long and fibrous, the ftalks are great, of fower

Ifchemon vulgare.
Cocks-foote graffe.

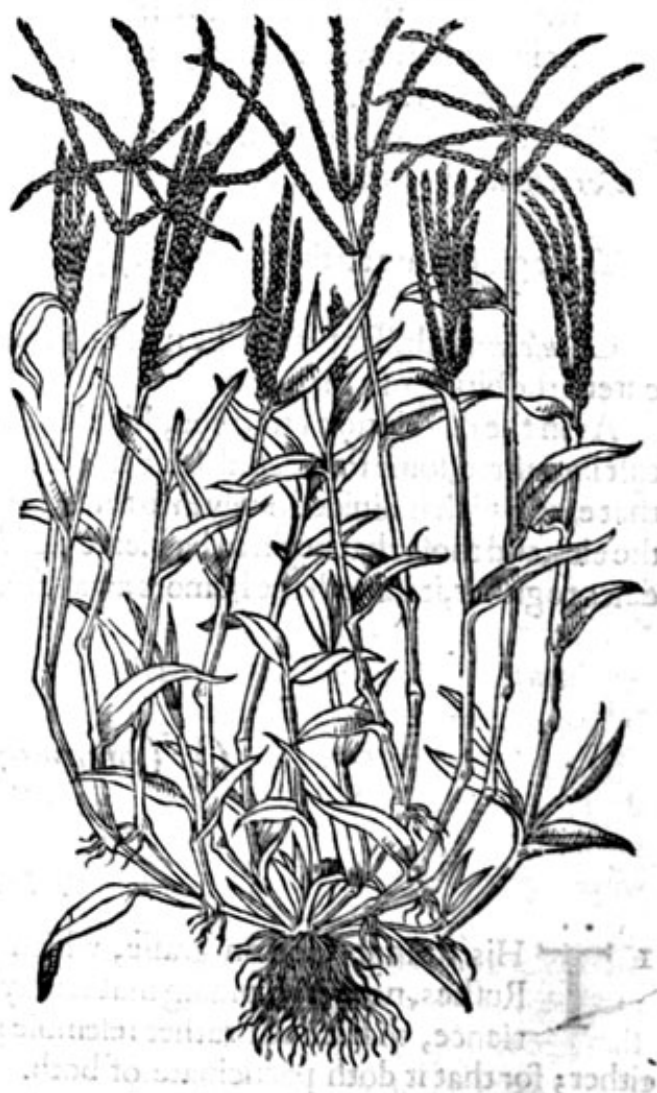

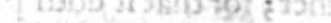
leaues are lit: high, very rough and hairie, iointed and kneed like the common Reede: the leaues are large and broad, like vnto Corne. The tuft or eare is diuided into fundiv branches, chaffic and of 2 purple colour, wherein is contained feede like $M i l i w m$, wherewith the Germans do make pottage and fuch like meate, as we in England do with Otemeale, and is fent into Middleborrough, and other townes of the Lowe countries in great quantitie, for the fame purpofe,
as L'O belims hath toldme. 
2 The fecond kinde of Dew graffe or Ifchemon, differeth little from the firft kinde of Dogs graffe, refembling one the other in pannicles, tufts and ftalks, fauing that the creft or tuft is fpred or ftretched out abroad like a Cocks foote fet downe vpon the ground, whereupon it was called Galli crus Apule $i$. The ftalke is cleere and vpright, of a gliftering purple colour, or rather violet. The tuft is diuided into fower or fiue branches like the former Dew graffe: the leaues or blades are like the common Medow graffe.

I The firft groweth naturally in Germanie,Bohemiame. Carinthia, as CMatthiolus reporteth.

2 The fecond groweth neere vnto rough banks of fields, as I my felfe have feene in the hilly banks neere Greenhithe in Kent.It differeth not in time from thofe we hauefpoken of.

* The names.

I The Germans cal it pimeldatl, that is to fay, Cali ros, whereupon it was called Gramen Manne, it feemeth to be Milium fyluestre, ac Spurium quoddam genus, a certaine wilde and baftardkinde of Millet. Leonicenus and Ruellius do name it Capriola and Janguinaria: fome would haue it to be Gramen aculeatum Plinü, but bicaufe the defcription thereof is very fhort, nothing can be certainly affirmed. But they are far deceiued, who thinke it to be Coronopus, as fome very learned haue fet downe : but euery one in thefe daies is able to controul that error. Afattus and Rondeletius haue called it Ifchemon Plinï, and Galli crus Apulei : L'Obelius calleth it Gromen Manne efculentum, for that in Germanie and other parts, as Bohemia and Italy, they vfe to eate the fame as a kinde of bread corne, as alfo to make pottage, as we do with Otemeale: for the which purpofe it is therefowen as corne, and fent into the Lowe countries, and there fold by the pound. In Englifh it may be called Manna graffe, or Dew graffe.

2 The fecond is called I/chemon, and Panicum fyluestre, and alfo Panicum palustre, Mannagraminis pecies altera : the other kinde of Dew graffe.

\section{* The nature.}

Thefe graffes are aftringent and drying, in tafte fweete like the common Dogs graffe.

$*$ The vertues.

A Apuleius faith, if a plaifter be made of this grafle, hogs greafe, andleuen of houfholdbread, it cureth the biting of a mad dog.

B As in the defcription I told you, this plant in his tuft or eare is diuided into fundry branches, fome tuft into three, fome fower, and fome fiue clouen parts like Cocks toes. Apuleins reporteth, if ye take that eare which is diuided onely into three parts, it wonderfully helpeth the running or dropping of the eies, and thofe that begin to be bleare eied, being bound about the necke, and fo vfed for certaine daies togither, it turneth the humors away from the weake part.

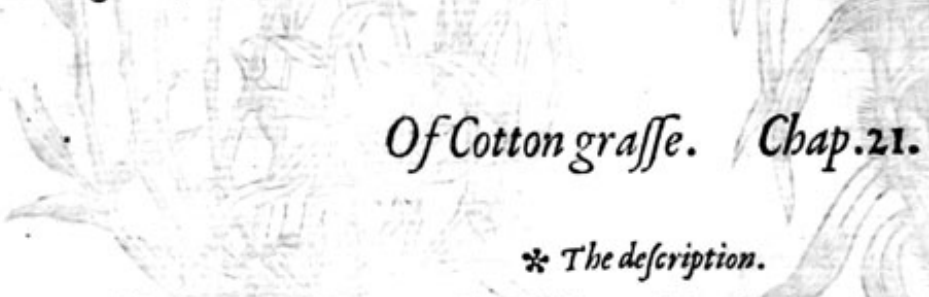

I $\Gamma^{-H i s}$ ftrange Cotton graffe, which $L^{\prime} O$ belius hath comprehended vnder the kindes of Rufhes, notwithftanding that it may paffe with the rufhes, yet I finde in mine owne experience, that it doth rather refemble graffe than rufhes, and may indifferently be taken for either; for that it doth participate of both. The ftalke is fmall and rufhie, garnifhed with many. graffie leaues along tt the fame, bearing at the top a bufh or tuft of moft pleafant downe or cotton, like vnto the moft fine and foft white filke. The roote is very tough, fmall and threddie.

2 This Water Gladiole or graffie Rufh, of all others is the faireft and moft pleafant to behold, and ferueth very well for the decking and trimming vp of houfes, bicaufe of the beautie and brauerie thereof: confifting of fundry fmall flowers, compact of fixe fmall leaues, of a white colour mixed with carnation, growing at the top of a bare and naked ftalke, fiue or fixe foote long, and fometime more. The leaues are long and fiaggic, not much vnlike the common reede. The roote is threddie, and not long. 


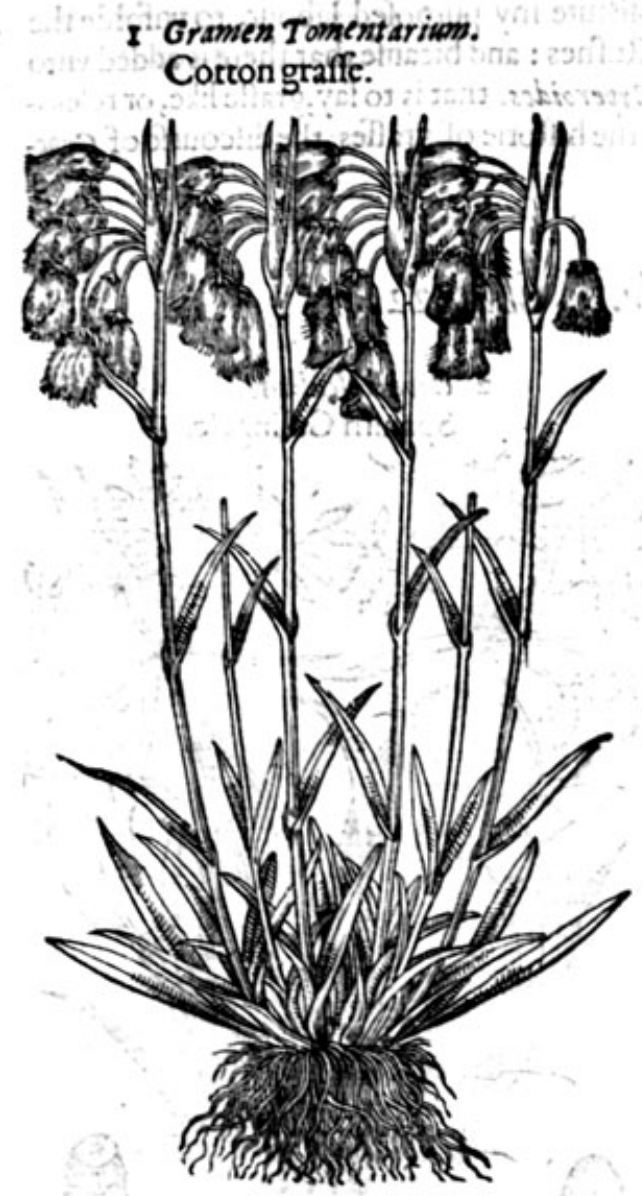

2 Gladiolus palusitris Cordi. Water Gladiole.

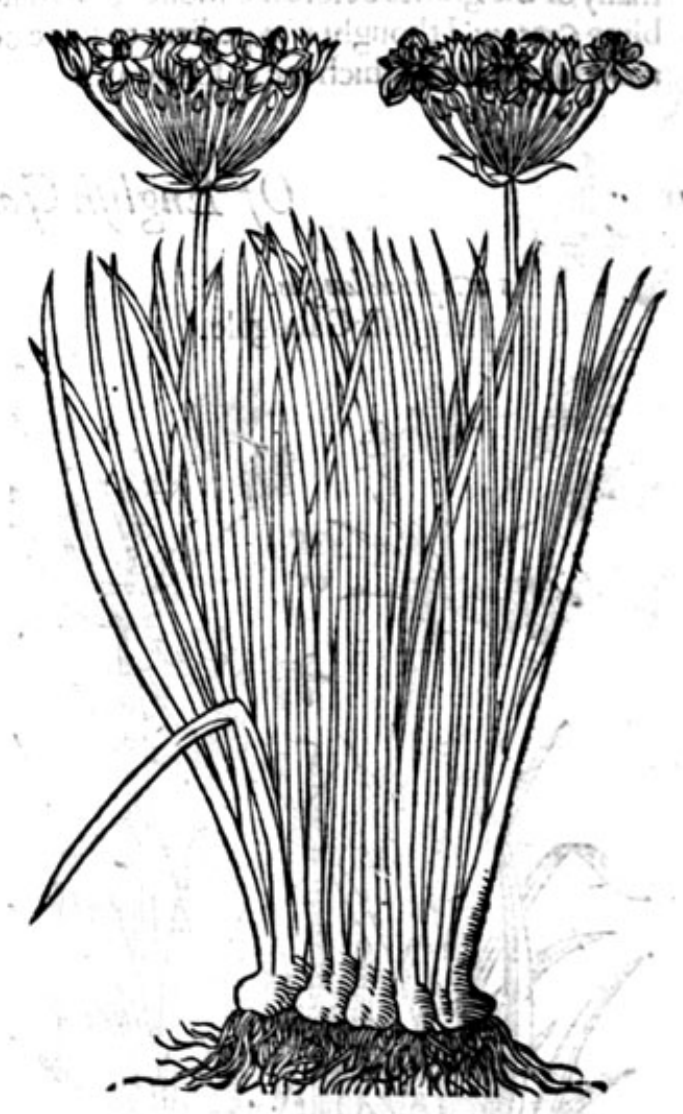

* The place and time.

I Cotton graffe groweth vpon bogs, and fuch like moorifh places, as it is to be feene vpon a bog at the further end of Hampited heath in a valley, vpon the right hand neere to a fmall cottage, as ye go from London to Henden : in which place doth growe likewife many other rare fimples, as you thall vnderftand heerafter in this treatife. It groweth likewife in Highgate parke neere London. 2 Water Gladiole groweth in ftanding pooles, motes, and water ditches. I found it in great plentie, being in companie with a worhhipfull gentleman Mafter Robert VVilbrahom, ata village fifteene miles from London called Bufhey. It groweth likewife by the famous riuer $T$ hame $/ 15$, not far from a peece of ground called the Diuels neckerchiefe neere Redriffe by London, and many other places. The feafon anfwerech all others.

\section{* The names.}

I Gramen tomentofion is called likewife Iuncus bombicinus: of Cordous, Limon pratenfe, and Gnafaliven Hieronimi Bochy. In Englifh Cotton graffe.

2 Water Gladiole is called of L'Obelius, Inncus Cyperoides floridsus paludo fus, Flowring Cypreffe rufh. Iuncus, faith he, for that his ftalke is like the Rulh: Cyperoides, bicaufe his leaues do refemble Cyperus: Elorides, bicaufe it hath on the top of euery rufhic ftalke, a fine vmble or tuft of fmall flowers, in farhion of the Lillie of Alexandria, the which it is very like, and therefore I had rather callit the Lilliegraffe.

\section{* The nature and vertues.}

Cordsus faith, that Inncus bombicinus fodden' in wine, and fo taken, helpeth the throwes and gri- A pings of the bellie, that svomen hauc in their childing.

There be alfo fundric kindes of graffes wholy vnknowen, or at the leaft not remembred of the old writers, whereof fome few are touched in name onely by the late and new writers: now for as much as they haue onely named them, I will refer the better confideration of them to the induftrie 
and diligence of painfull fearchers of nature, and profecute my purpofed labour, to vnfolde the diuers forts and manifold kindes of $c$ yperus, Flags, and Rurhes : and bicaufe that there is 3 dded vnto many of the graffes before mentioned, this difference Cyperoides, that is to fay, graffe like, or refembling Cyperus, I thought it expedient to ioine next vnto the hilftorie of graffes, the difcourfe of Cype$r s s$ and his kinds, which are as followeth.

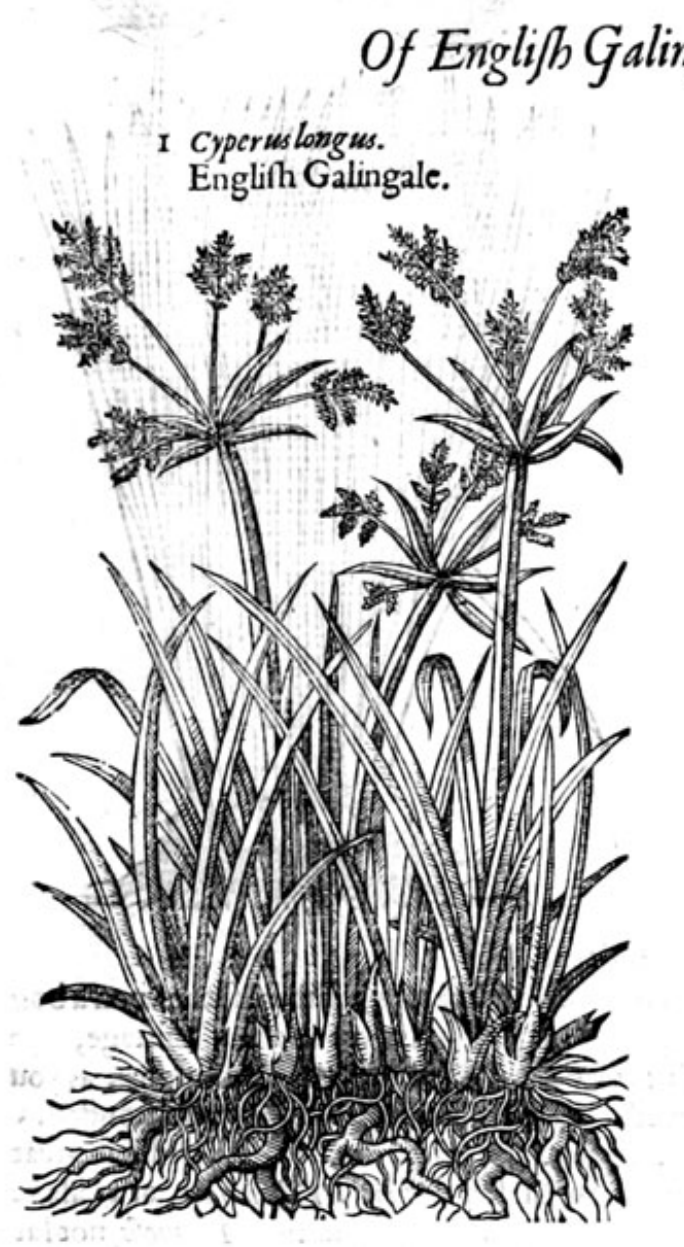

gale. Chap.22.

2 Cyperiefculenti.

Spanifh Galingale.

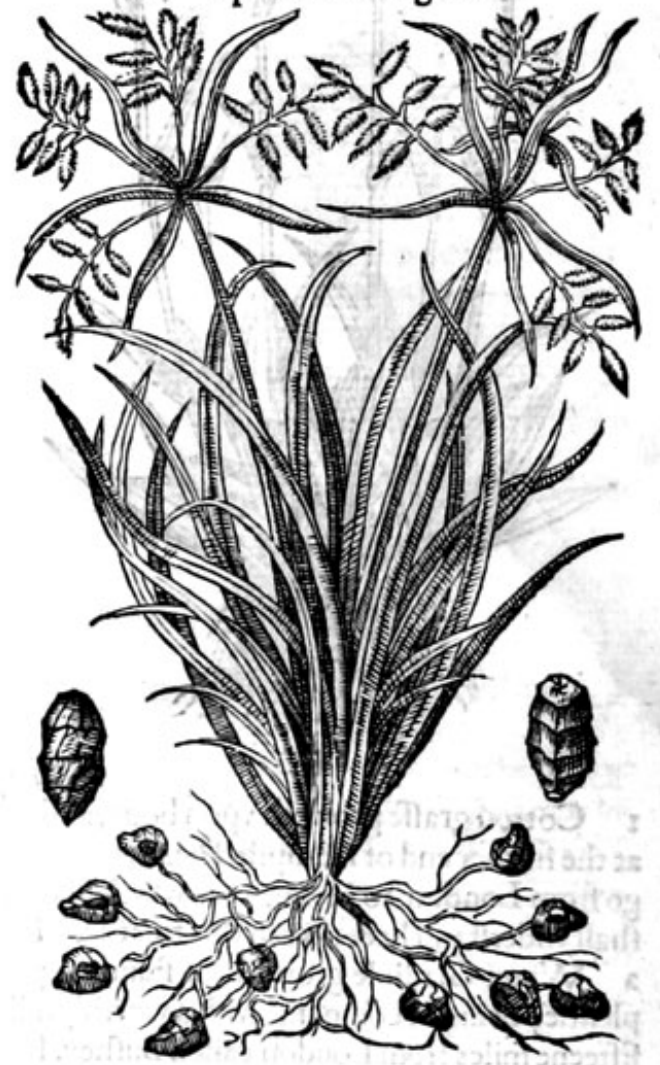

* The defcription.

I Nglih Galingale hath leaues like vnto common Reede, but leffer and Thorter. 20 His ftalke is three fquare, two cubits high: vpon whofe top ftand fundry bran1. 3 ches, euery little branch bearing many fmall chaffie fpikes. The roote is blackeand 1. 2 very long, creeping hither and thither, occupying much ground by reafon of his 2000 (preading : of a moft fweete and pleafant fmell when it is broken.

2 Spanifh Galingale or fweetc Cyperus hath his leaues rifing out of the ground like the former. The ftalks do anfwer it in fquareneffe: at the top whereof do ftand fiue leaues, amongft the tuft, ftar fafhion : among the which alfo do ftand fower chaffie leaues, fafhioned like the leaues of an Afh trec. The whole plant is moft impatient of our cold climate: for it doth perifh with the firft froft, as my felfe haue often prooued in mine owne garden in London, hauing the rootes fent me from Spaine.

3 Round Cyperus groweth almoft to the height and greatnes of Reede: the tuft or flower is very like vnto the former : the leatles are broder, and more in number. The rootes are many and knobby, ouall in forme, interlaced with many ftrings or threds, altogither without fmell.

4 Cats-taile graffe hath many long reeden leaues, comming from a fibrous or threddie roote, among 
among the which arife graffie ftalks of two cubitshigh, garnifhed at thetop with certaine chaffic aglets, refembling the reede mace, or Cats-taile, of a darke blackifh colourgs s

3 Crperus rotundius.

Round Galingale.

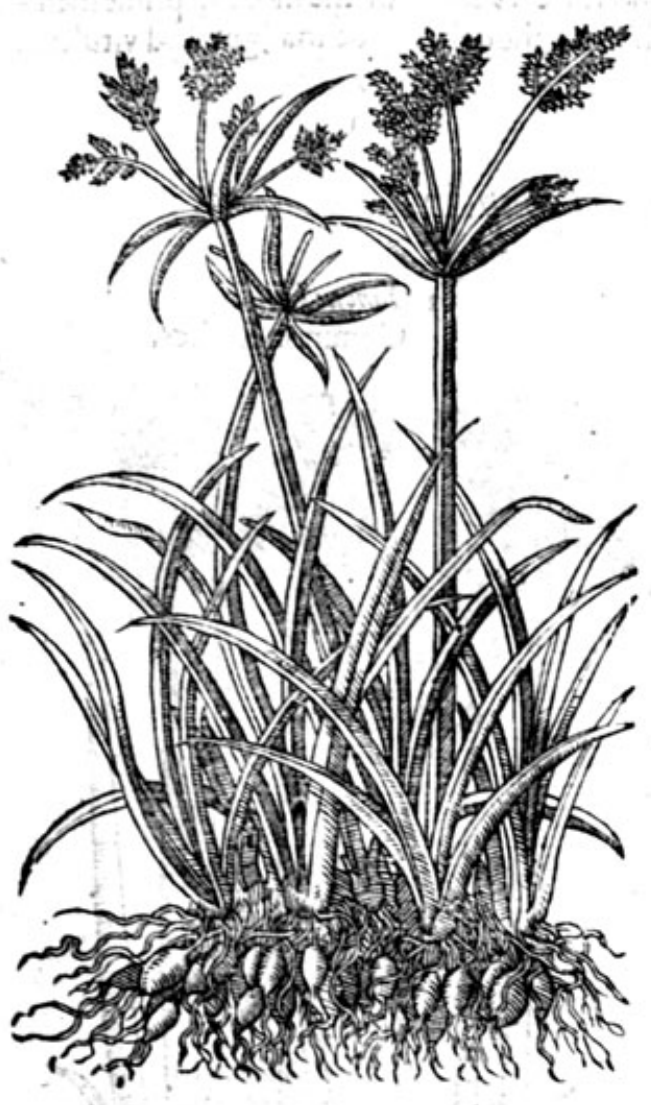

4 C.perus Typhinus. Cats-caile Galingale.

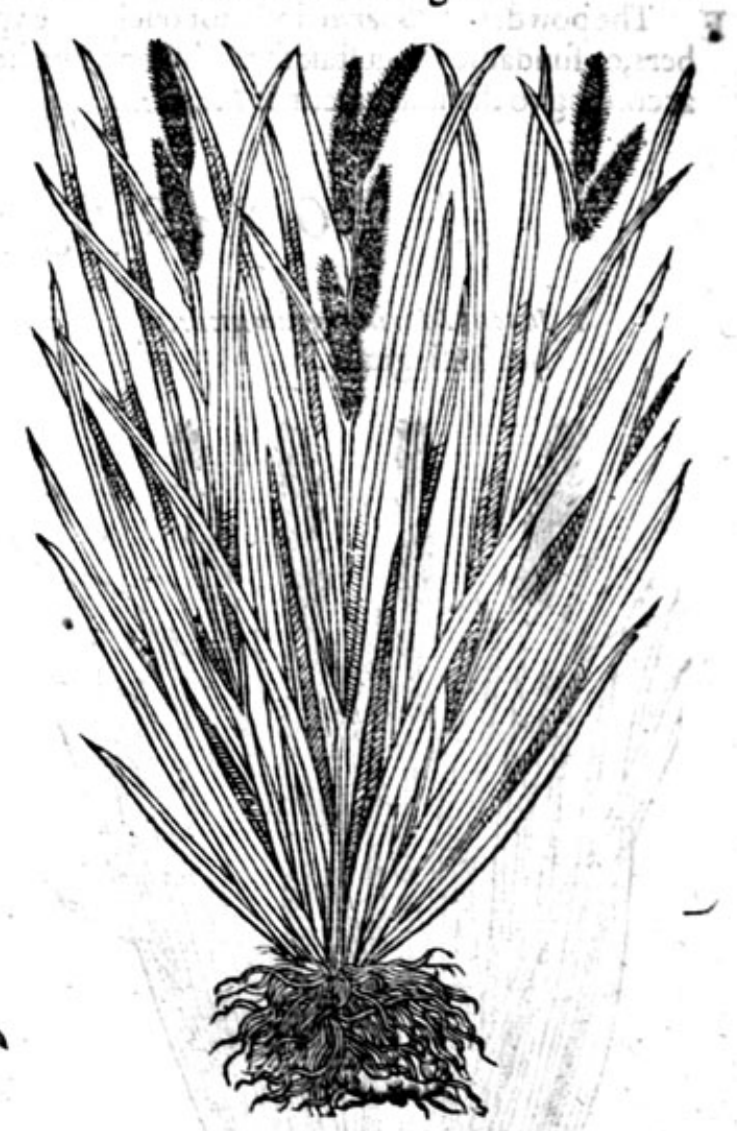

* Theplace and time.

I The firft of thefegroweth naturally in fennie grounds: yet doth it profper exceedingly in gardens, as experience hath taught vs.

2 Spanifh Galingale groweth.in Spaine,Languedoc, and fuch like hot regions.

I Cyperus longus is called $*$ The names.

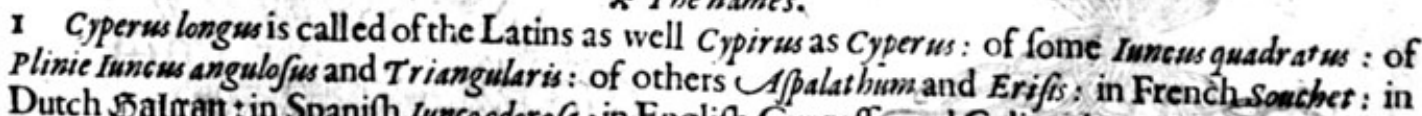
Dutch Dalgan : in Spanifh Iuncoodoro/a : in Englifh Cypreffe, and Galingale. 2 Cyperus efculentus is called of Guillandinus, Dulcichynum. Theophrastus calleth it Cypersus dulcis. The people of Verona in Italie do call it Tracidalce, and Dolzolint. It is fo named in Spaine, where the poore people crie them about the ftreetes, Trafidulce, Trafi dulce, like as our Englift wornen in London cric Orenges, Pornegranates, and fuch like, where it is eaten for fallads by rich and wealthie citizens: I thinke rather to procure luft than appetite to meate, * The nature. inmedicine, and are of an heating and drying qualitic : and fome do reckon it to be hot and drie in
the fecond degrec.

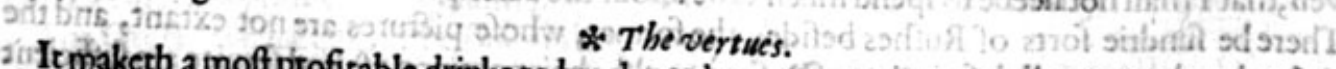

If It beth a moft profitable drinke to breake and expell grauell, and helpeth the dropfic. downe thenaturall ficknes of women 20 The fametakenas aforefaid is aren. शits 

D Fernelius faith, the roore of $C y p e r u s$ vfed in baths, helpeth the coldnes and ftopping of the ma.
trix, and protoketh the termes.

E He writeth alfo that it increafeth blood by warming the bodie, and making good digeftion; won. derfully reirefhing the fpirits, and exhilarating the minde, comforting the fenfes, andincreafing their liuelineffe, reltoring the colour decaied, and making a fiveete breath.

F The powder of cyperus doth not onely drie vp all moift vlcers either of the mouth, pritie members, or fundament, but itaieth the humor, and healeth them, though they be maligne and virulent, according to the iudgement of Fernelius.

\section{OfSea Ru/hgrafe. Chap.23.}

I Iuncus Marinus gramineus. Sea Rufh grafle.

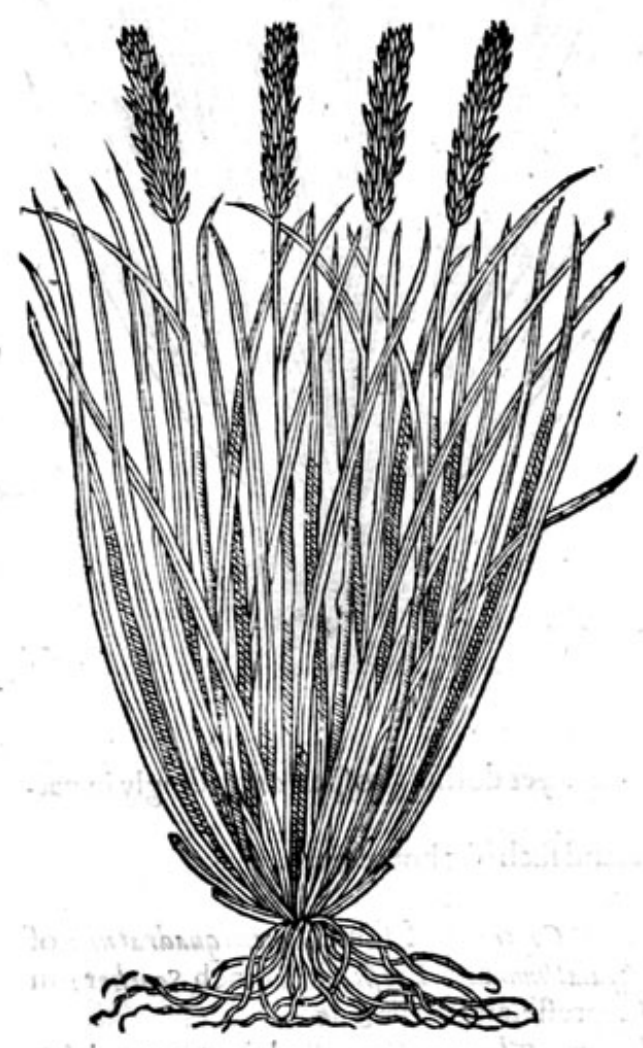

2 Iuncus lewis.

Common Rufhes.

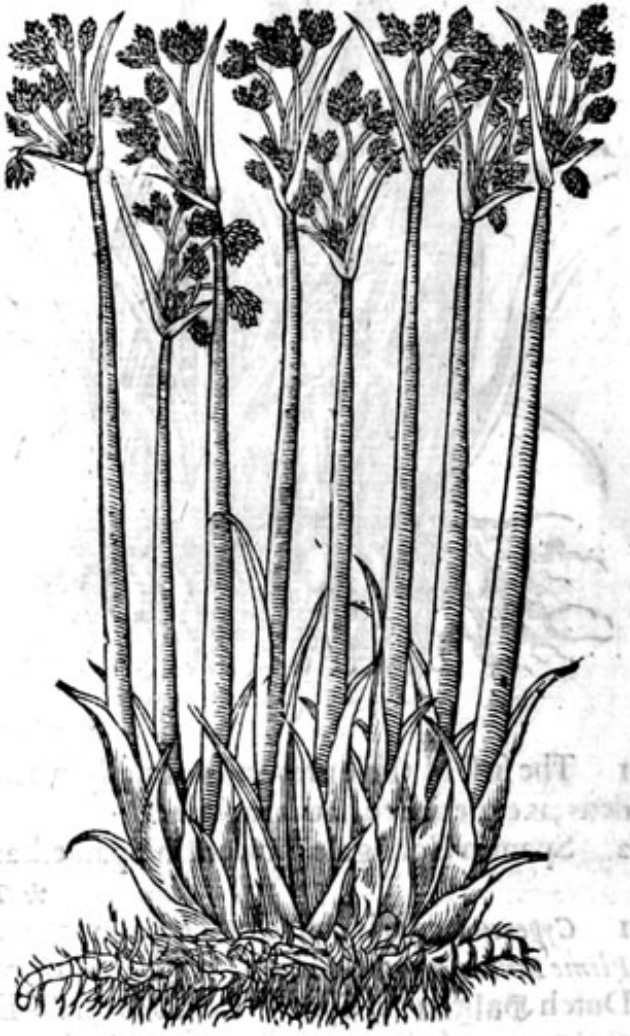

* The defcription.

I $\mathrm{He}$ flowers of this Sea Rufh grafte are faire and beautifull, very much downie, in maner like Iuncus odorat us, but thicker, growing togither like a foxe taile, fiue or fixe inches long, hauing the bright gloffe of white filke, or rather filuer, topped as aforefaid like Llupecuros, and leafed like Schanante.

2 The rootes of our Common Rufhes are long and hairie, fpreading largely in the ground, from which as from one entire tuft, proceedeth a grearcompanie of finall Rufhes : fo exceedingly well knowen, that I hall not neede to fpend much time about the defcription thereof.

3 There be fundrie forts of Ruthes befides the former, whofe pietures are not extant, and the rather for that the generall defcription of Rufhes, as alfo their common vfe and feruice are fufficient to leade vs to the knowledge of them. This great Water grafie or Bull rurh, in fteed of leaues bringeth foorth many ftraight twiggie fhootes or fprings, which be round, finooth, tharpe pointed, and without knots. Their tuft or flower breaketh foorth a little beneath the top, vpon the one fide of 
the rufh, growing vpon little fhort ftems like grapeclufters, wherein is contained the feede after the fathion of a fpeares point. The rootes be flender and full of ftrings: Plinie and Theophristus before him,affirme that the rootes of the rufh do dic eueric yeere, ard that it groweth againe of the feede. And theg alfirme likewife, that the male is bariem, and groweth againe of the yoong hootes; yet I could never obferulc anyfirch thing. 5 :

4 Inocios dentws, or the tharpe Rurh, is likewife coinmon and well knowen : not much differing from Iuncus lewis, but harder, conglter, and hasper pointed : fitter to ftraw houfes and chambers than any of thereft: for the othersare fo toft and pithie, that they turne to duft and filth with much treading; where contrariwife this ruh is fo hard, that it will laft found much longer.

3 Innews squaticses maximus.

Great Water Rufh,or BullRuih,

\section{Iunces acutis.}

Sharpe Ruh, or hard Rufh.

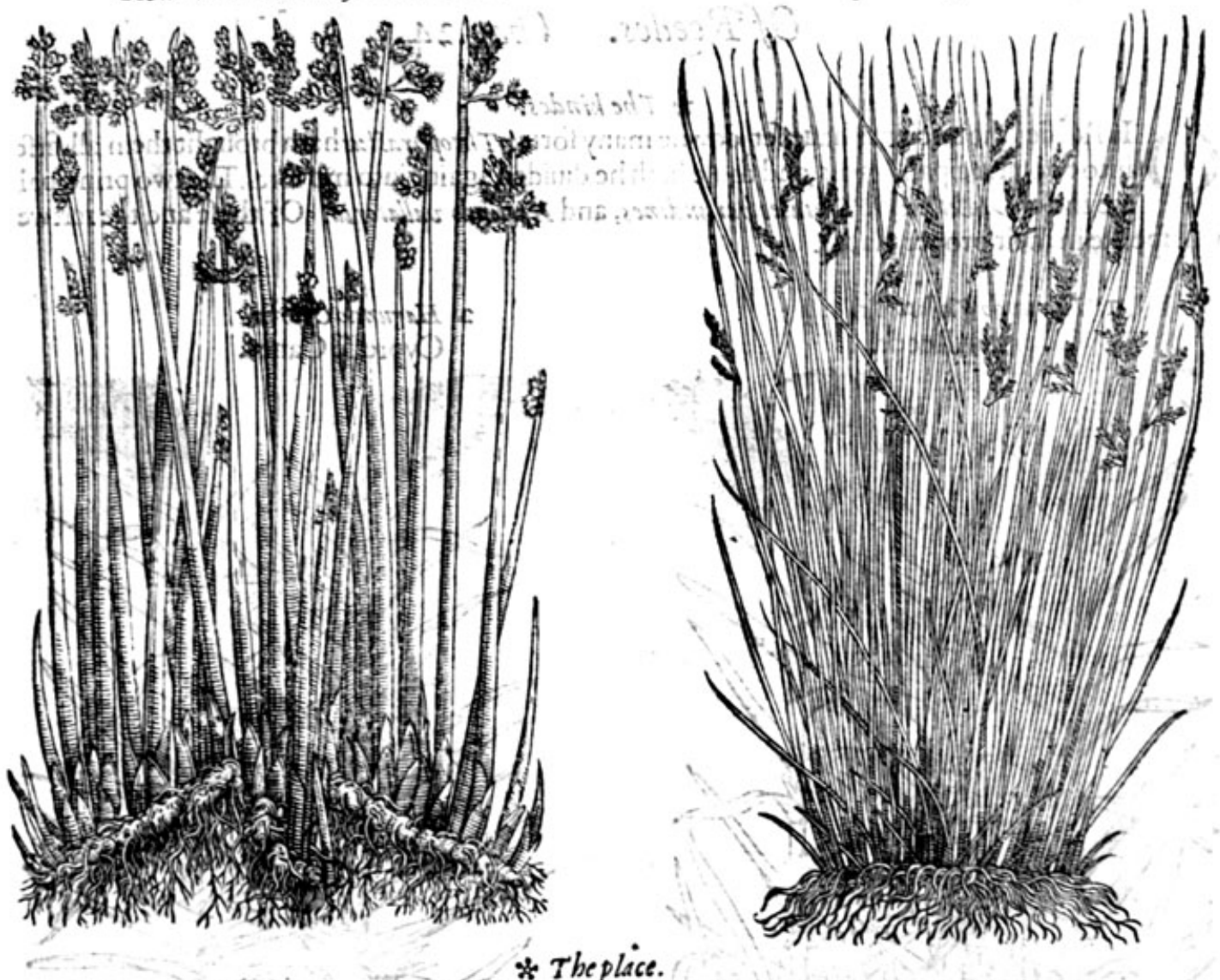

\section{* Theplace.}

I Inncius CMarinus gramineus, Francis Penny of fanous memorie, a learned phifition and expere herbarift, found this Sea rufh in the coaft of the Mediterrane fea, in the way as he trauelled to Pifcaire, and hath not as yet been found in England.

2 Inncus learis groweth in fertill fields, and medowes that are fomewhat moift.

3 Iuncus aquaticus groweth in ftanding pooles, and by riuers fides in moft places.

4 Inncus acutum groweth vpon drie and barren grounds, efpecially neere the furrowes of plowed land. I neede not fpeake of their time of growing, they being fo common as they are.

$$
\text { * The names. }
$$

The Rurh is called in Grecke giros : in Latine Iunsess: inhigh Dutch 2 sintien : in lowe Dutch 23tefen : in Italian Giunco : in Spanifh Iunco : in French Ione : in Englifh Rufhes,

The Grecians haue called the Bull rufh irooeirios.

Innews lewis is that rufh which Diogcor ides called yeiros reia

Inscus acutus is called in Greeke bsugein

Theferufhes are of a drie nature.

* The nature. 
A The feede of rufhes cried at the fire, and drunke with wihealaied with water, ftaieth the laske, and the oucrmuch flawing of womens termes.

B Galen yecldeeh this reafon therof, bicaufe that their temperature confifteth of an earthie effence, moderately cold and waterie, and meanly hot : and therefore doth the more eafily drie vpothelower, parts, and by little and little fend vp the cold humors to the head, whereby it prouoketh drowfines and defire to fleepe; but caufeth headach, whereof $G$ alen yeeldeth the reafon as before.

C The tender leaues that be next the roote, make a conuenient ointment againft the birings of the fpider called Phalangium.

D The feede of the Bull rufh is moft foporiferous; and therefore the greater care muft be had in the admiriftration thcreof, leaft in prouoking fleepe,you induce a drowfines, or deepe fleepe. II

\section{OfReedes. Chap.24.}

* The kindes.

F Reedes the ancients haue fet downe many forts. Theophrast tus hath brought them all, firft into two principall kindes, and thofe hath he diuided againe into mo forts. The two principal are thefe, Uuletica, or Tibiales harwadines, and Harundo vallatoria. Of thefe and the reft we will fpeake in their proper places.

I Harundo Vallatoria. Common Reede.

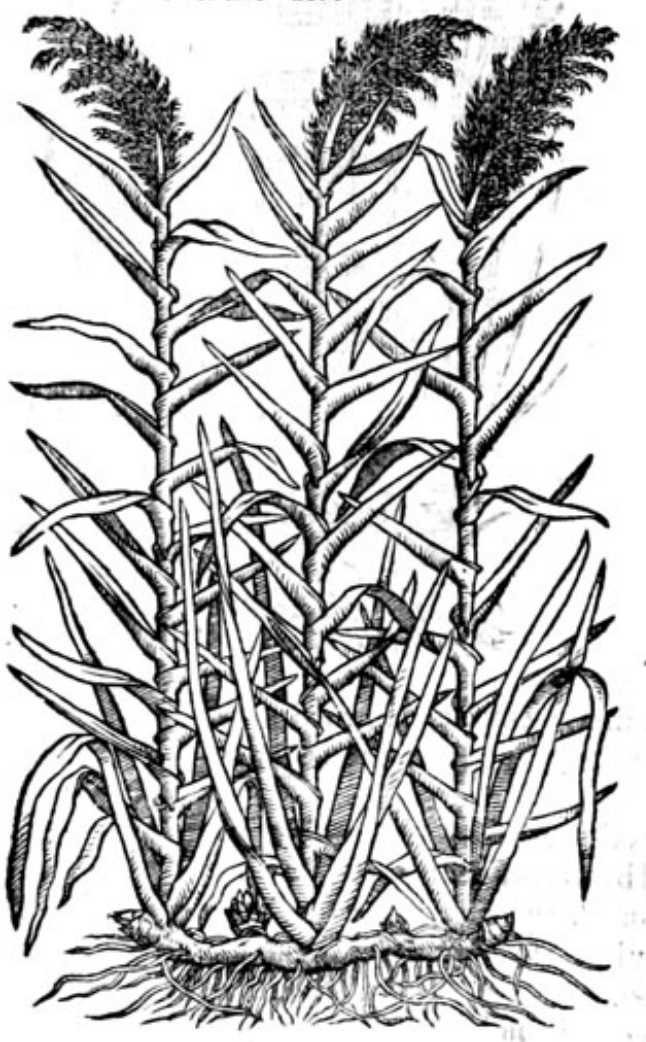

2 Harundo Cypria. Cypreffe Canes.

\section{* The defription.}

1 He Common Reede hath long ftrawie ftalks, full of knottie ioints or knees like

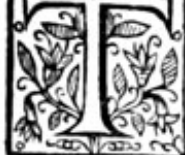
vnto corne, whereupon do grow very long rough flaggie leaues. The tuft or fpokie care doth grow at the top of the ftalks, browne of colour, barren and without feede. And doth refemble a burh of feathers, which turneth into fine downe or cotton, which is caricd away with the winde. The roote is thicke, long; and full of 
ftrings, difperfing themfelues far abrode, whereby it doth greatly increafe.

2 The Cypreffe Reede is the greateft of all reedes, hauing ftalks exceeding long, fometimes of twenty or thirty foote high, of a wooddiefubftance, fet with very great leaues, like thofe of Turkie wheate. It carieth at the top the like downie tuft that the former doth.

3 . Arundofarita.

Stuffed Canes.

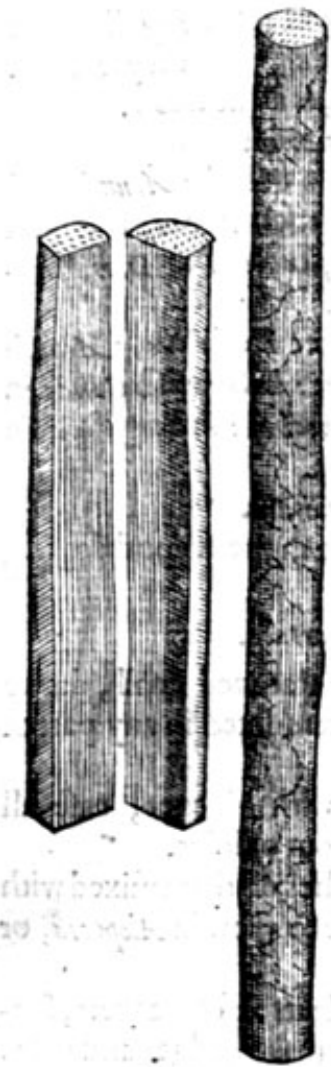

4 Calamsus fagittalis L'Obely. Small fuffed Reede.

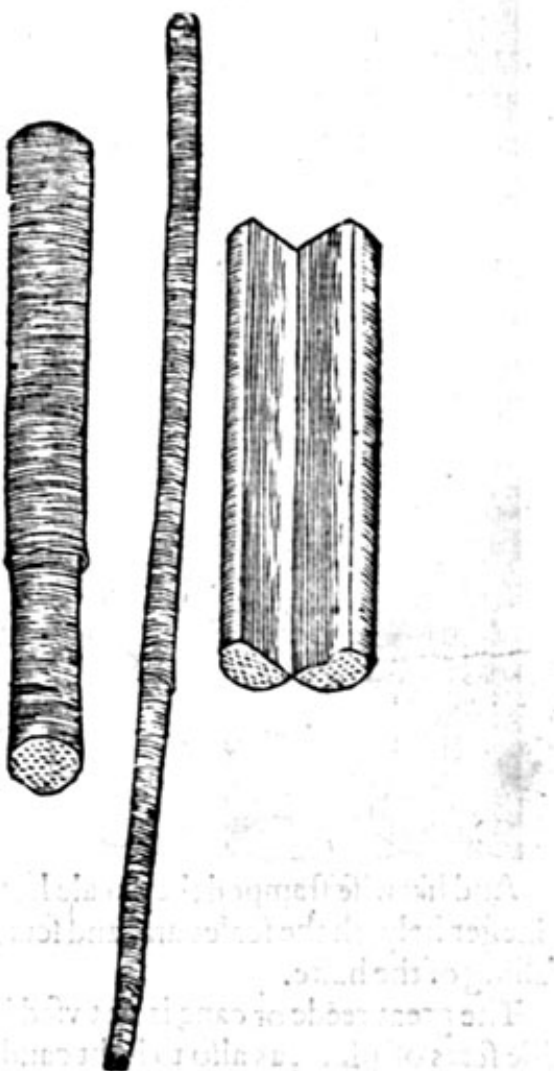

3. Thefe Reedes L'Obelisus hath feene in the Low countries brought from Conftantinople, where, as it is faid, the people of that countrie haue procured them from the parts of the Adriatike fea fide where they do grow. They are full ftuft with 2 fpongious fubftance, fo that there is no hollownes in the fame, as in Canes and other reedes, excepthere and there certaine fimall pores or paffages, of the bignes of 2 pins point; in maner fuch a pith as is to befound in the Bull rufh, butmore firme
and folide.

4 The fecond differeth in fmalnes, otherwife they are very like: which may proceede of the fertilitic of the foile where they do grow : 2 nd are vfed for darts, arrowes, and fuch like.

5This great fort of Reedes or Canes, hath no particular defcription to anfwer your expectation; for that as yet there is not any man which hath written thereof, efpecially the manner of growing of them, either of his owne knowledge or report from others: fo that it fhall fuffice that yedo know that that grear Cane is vfed efpecially in Coniftantinople and thereabout; of aged and wcalthie citizens; and alfo noble men and fuch great perfonages, to make their walking ftiues of, caruing them at the top with fundrie fcutchens, and prety toies of imagerie, for the beautifieng of them:
and fothey of the better fort do garnifh them both with filuer and golde, as the figure doth moft lively fet foorth vnto you.

6 In like maner the frnaller fort hath not as yet been feene growing of any that haue been curious in herbarifine, whereby they might fet downe any certaintie thereof: onely it hath beene vfed in Conitantinople and thereabout, euen to this day to make writing pens withall, for the which it doth very fitly ferue, as alfo to make pipes, and fuch like things of pleafure. 
5 Naftos Clusiy.

6 Arundo friptoria.

* Theplace.

Turkie walking ftaues. Turkie writing Reedes. The common reede groweth in ftanding wa-

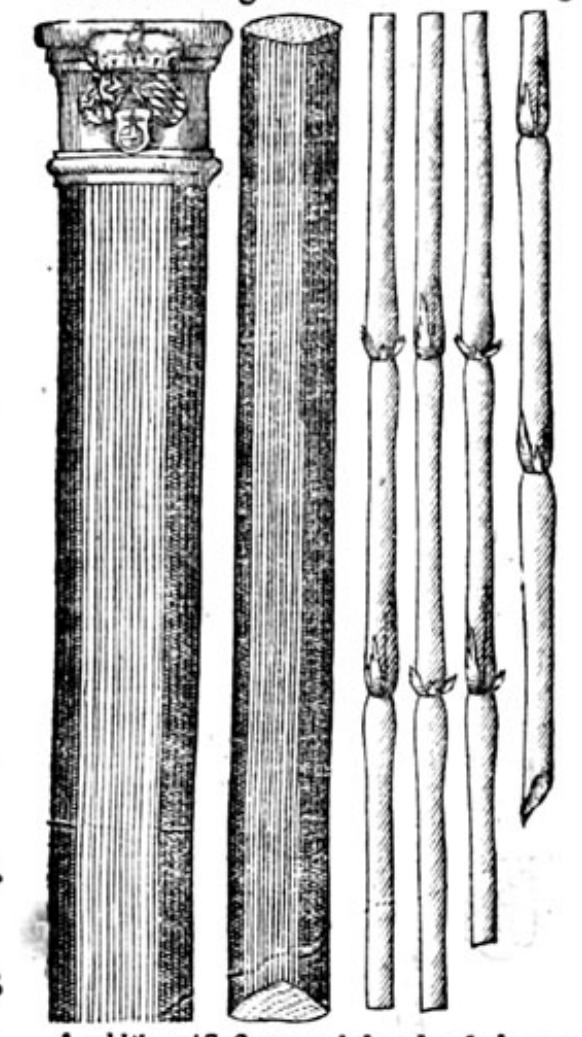
ters, and in the edges or borders of riuers almoft euery where : and the other being the angling Cane for fifhers, groweth in Spaine and thole hot regions.

\section{* The time.}

They flourifh and flower from Aprill to the end of September, at what time they are cut downe for the vfe of man, as all do know.

\section{* The nomes.}

The common Reede is called Arunds and Harundo vallatoria : in French Rofeau : in Dutch ERiet : in Italian Canne a far frepo: of Dios,P hragmistis: in Englifh Reede.

Arundo Cypria, or after L'Obelius, Arundo Donax : in French Canne: in Spanifh Cana: in Italian Calami a far Connochia : in Englifh Pole reede, and $\mathrm{C}$ ane, or Canes.

$$
\text { * The nature. }
$$

Reedes are hot and drie in the fecond degree, as Galen faith.

\section{* The vertules.}

The rootes of reede ftamped finall, drawe foorth thornes and fplinters fixed in any part of mans bodie.

The fame ftamped with vineger, eafe all luxations, and members out of ioint.

C And likewife ftamped they heale hot and harpe inflammations. The afhes of themmixed with vineger helpeth the fcales and and fcurfe of the head, and helpeth the haire to grow in Alopecia, or falling of the haire.

D The great reede or cane is not vfed in phificke, but is efteemed to make flearres for weauers, fundrie forts of pipes, as alfo to light candles that ftand before images, and to make hedges and pales as we do of laths and fuch like : and alfo to make certaine diuifions in Phips to divide the fweete orenges from the fower, the pomecitron and limons likewife in funder, and many other purpofes.

$$
\text { * The dinger. }
$$

If the downe of this common reede fall into the eares of any which vfe it, be they thatchers, or botemen, or gatherers of it, it caufeth a great deafnes in them, and hard to be cured.

\section{Of Sugar Cane. Chap.25.}

* The defcription.

$\mathbf{1}$

V Vgar Cane is a pleafant and profitable Reede, hauing long ftalkes, featien or eight foore high, iointed or kneed like vnto the great Cane: the leaues come foorth of euery ioint on euery fide of the ftalke one, like vnto wings, long,narrow and fharpe pointed. The Cane it felfe, or ftalke, is not hollow as the other Canes or Reedes are; but full, and ftuffed with a fpungious fubftance in tafte exceeding fweete: the roote is great and long, creeping along within the vpper cruft of the earth, which is likewife fweete and pleafant, but leffe hard or wooddie then other Canes or Reedes: from the which there doth fhoote foorth manie yoong fciences, which are cut away from the maine or mother plant, bicaufe they fhould not drawe away the nourifhment from the old ftocke, and fo get vnto themfelues 2 little moilture, or elfe fome fubftance not much woorth, and caufe the ftocke to be barren, and themfelues little the better, which hootes do ferue for plants to fet abroad, for encreafe. 


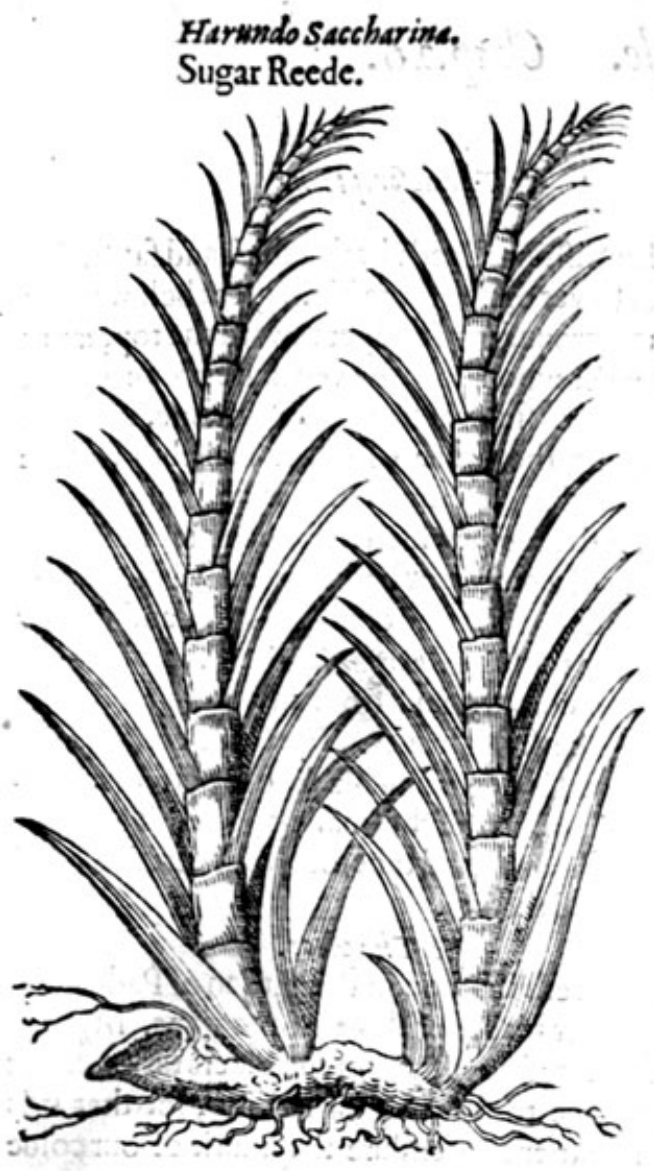

\section{*Theplace.}

The fugar Cane groweth in many parts of Eu. rope at this day, as Spaine, Portugale, Olbia and in Prouence. It groweth alfo in Barbarie, generally almoft euery where in the Canarie Ilands, and in thofe of Madera, in the eaft \&weft Indies, and manie other places. My felfe did plant fome fhootes there of in my garden, and forne in Flaunders did the like : but the coldnes of our Clymate made an end of mine, and I thinke the Flemmings will haue the like profit of their labour.

\section{$*$ The time.}

This Cane is planted at any time of the yeere in thofe hot countrics where it doth naturally growe, by reafon they feare no froftes to hurt the yoong thootes at their firft planting.

$$
* \text { The names. }
$$

The Latines haue called this plant Srundo Saccharina, with this additament Indica : bicaufe it was firft known, or brought from India. Of fome it is called Calomus Saccharatus: in Englifh Sugar Cane:in Dutch Suptcketrieot. * The nature and vertues.

The Sugar or iuice of this Reede is of a tempe- A rate qualitie: it drieth and clenfech the ftomacke, maketh fmooth the roughneffe of the breaft anid lungs, cleereth the voice, and putteth away hoarfnes, the cough, and all fowrenes and bitternes, as Ifacc faith in Dictis.

* The vese.

Of the-iuice of this Reede is made the moft pleafant and profitable fweete, called Sugar, where of is made infinite confections, confectures, firupes, and fuch like, as alfo preferuing and conferuing of fundrie fruits, herbes and towres;as Rofes, Violets, Rofemary, flowres, and fuch like, which ftill retaine with them the name of Sugar, as Sugar Rofer, Sugar Violet, \&c. The which to write of would require a peculiar volume, and not pertinent vnto this hiltorie, for that it is not my purpofe to make of my booke a confectionaic, a Sugar bakers furnace, a gentlewomans preferuing pan, nor yet an apothecaries thop or difpenfatorie, but oncly to touch the chiefeft matter that I purpofed to handle in the beginning; that is, the nature, properties, and deferiptions of plants. Notwithiftanding I thinke it not amiffe to hewe vnto you the ordering of thefe Reedes when they be new gathered, as I receiued it from the mouth of an Indian my feruant, he faith : They do cut them in finall peeces, \& put them into a trough made of one whole tree, wherein they put a great ftone in maner of a militon'e, whereunto they tie a horfe, bufle, or fome other beaft which draweth it roundc: in which trough, they put thofe peeces of $C$ anes, and fo crufh and grinde them,as we do the barkes of trees for Tanners, or apples for Cyder. But in forne places they vfe a great wheele, wherein flaues do tread and walke,as dogs do in turning the fpit :and fome othersidofeede as it were the bottome of the faid wheele, wherein are fome fharpe or hard things, which do cut and cruin the Canes into powder. And fome likewife haue found the inuention to turne the wheele with water workes, as we do our iron mils. The Canes being thus brought into duft or powder, they do put them into great caul. feede. Thendo they ftraine where they boile vntill there be no more fweetenes left in the crufhed againe vinto the confiftence of through mats and fich like things, and put the liquor to boile ing, bur fornwhat fofer : and fo a ferwertich being cold, is like vito fand both in fhewe and handhing, bur foimwat fofter : and fo afterward it is carted into all parts of Europe, where it is by the
Sugarbakers artificially purged and refined to that iphitenes, as we fee 


\section{Of the flowring Reede. Chap.26.}

Harundo florida.

Flowring Reede.

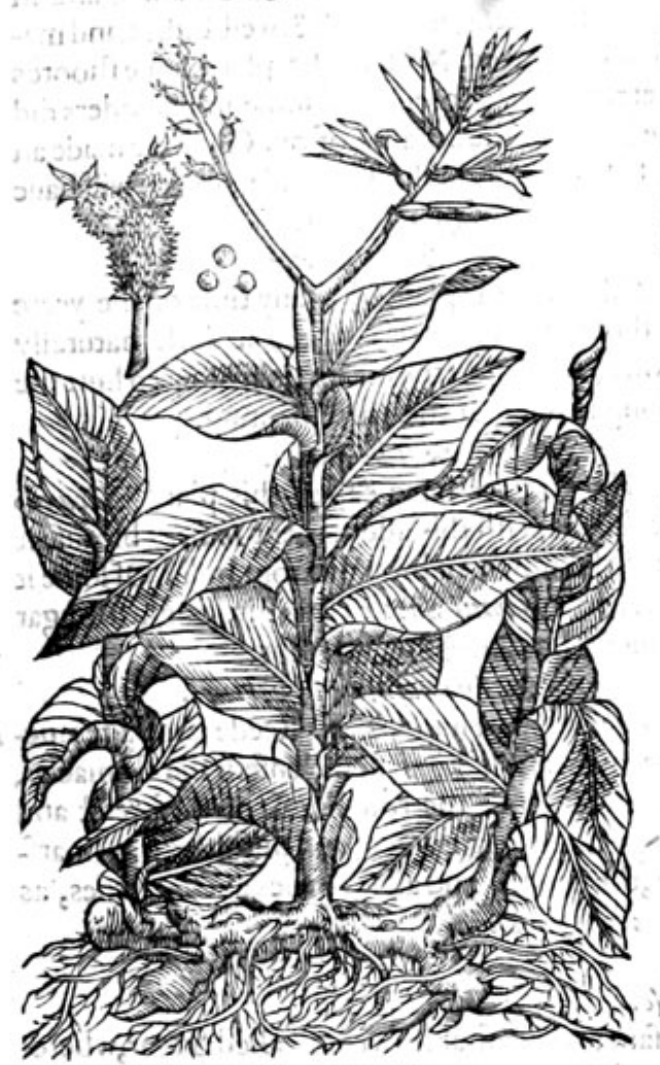

* The defcription.

Lourihing Reede hath a thick and fat ftalke, - of fower or fiuc foote high, great below neere the ground, and fmaller toward the top, taper wife: whereupon do grow very faire brode leaues, full of ribs or finewes like vnto Plantaine, in thape refembling the leaues of white Hellebor, or the great Gentian, but much broder and larger euery way. At the top of which ftalks do grow fantaftike flowers, of a greene or berbie colour; which being faded, there followe round, rough, and prickly knobs, like thofe of sparganium or Water burre, of a browne colour, and from the middle of thofe knobs three fmall leaues. The feede contained in thofe knobs is exceeding black, of a perfect roundnes, of the bignes of the finalleft peafe. The roote is thicke, knobby and tuberous, with certaine finall threds fixed thereto.

* The place.

It groweth in Italie, in the garden of Padua, and many other places of thofe hot regions. My felfe haue planted it in my garden diuers times, but it neuer came to flowring or feeding, for that it is very impatient to endure the iniuric of our colde climate.

\section{* The time.}

It muft bee fet or fowen in the beginning of Aprill, in 2 pot with fine earth, or in a bed made of horfe dung, and fome earth ftrawed thereon, in fuch manner as Cucumbers and muskeMelons are.

\section{* The names.}

- mer

The name Lrundo Indica is diuerly attributed to fundrie of the reedes, but principally vnto this: called of L'Obelius Cannacor us: of others Arundoflorids, and Harundo florida: in Englin the Flowring Reede.

\section{* T The nature and vertues.}

There is not any thing fet downe as touching the temperature and vertues of this Flourifhing reede, either of the ancients, or of the new or later writers.

\section{Of Paper Reede. Chap.27. \\ * The defcription.}

Der Reede hath many large flaggie leaues, rough in handling, and likewife tough, rifing im: mediately from a tuft of rootes compact of many ftrings, among the which hooteth vp naked ftalks, fquare and rough: at the top whereof doth ftand a tuft or bundle of chaffic threds fet in comly order, refembling a tuft of tlowers, butbarren and void of feede. 


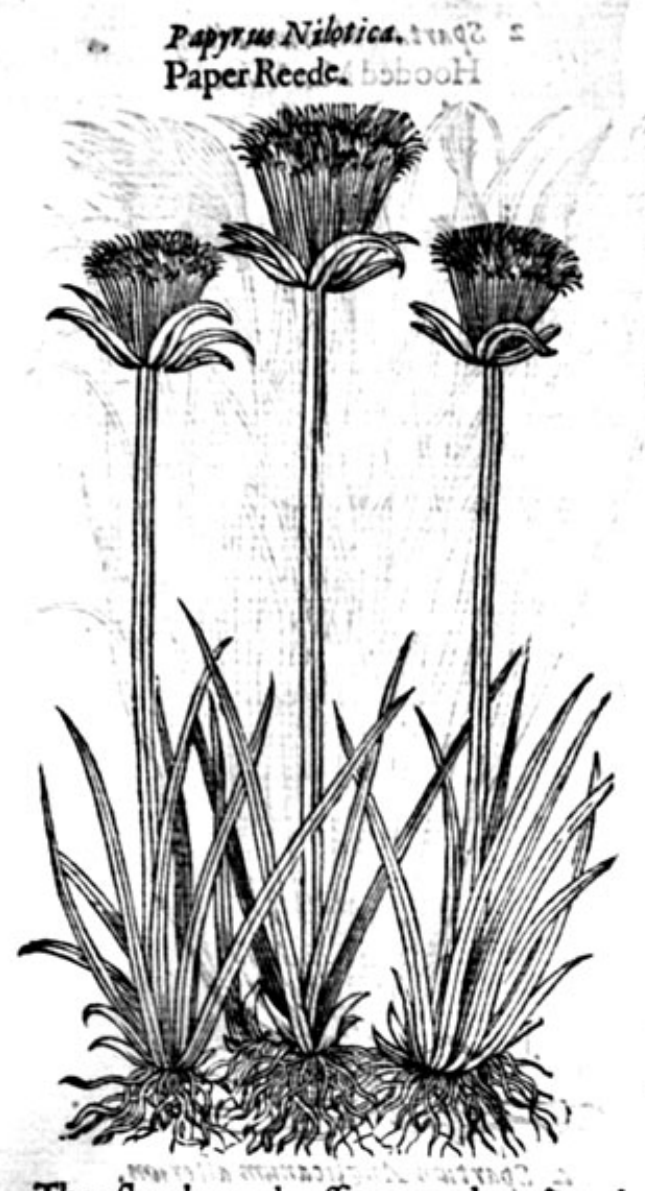

* The place avitan?

This kinde of reede doth growe in the borders of riuers about Babylon, neere the citic Alcaire, in the borders of the river Nilus, and fuch other places of thofe coun ies.

\section{* Thetime.}

The time offpringing and flourifhing, anfwereth that of the common reede.

\section{* The names.}

This kinde of reede, which I haue englifhed $\mathrm{P}_{2}$ per reede, or Paper plant, is the fame, (as I do reade), that paper was made of in Egypt, before the inuention of paper made of linnen clouts, was found out. It is thought by men of great learning and enderftanding in the Scriptures, and fet downe bytbem for truth, that this plant is the fame reedementioned in the fecond chapter of Exodus: whereofwas made that basket or cradle, which was dawbed within and without with flime of that country, called Bitumen Iudaicum, wherein cMofes was put being committed to the water, when Pharaob gaue commandement that all the male children of the Hebrues fhould be drowned.

$$
\text { * The nuture, vertuesand vfe. }
$$

The rootes of Paper reede doth nourifh :as may A appecre by the people of Egypt, which do vile to chew them in theirmouthes, and wallow down the iuice : finding therein great delight and comfort. The afhes burned, affwage and confume hard apoftumes, tumors and corrafiue vlcers in any B
part of the bodie, but chiefly in the mouth.

The burnt paper made heerof doth performe thofe effects more forcibly.

The ftalks heerof have a fingular vfe and priuilege in opening the chanell or hollow paffages of the Fiftula, being put therein: for they do fwel, as doth the pith of Elder,or a tent made of a fponge.

The people about Nilus do veftoburne the leaues and ftalks, but efpecially the rootes.

The frailes wherein they put raifons and figs, are fomrimes made heerof herbe spartwom, defcribed in the next chapter.

$$
\text { Of Mat Weede. Chap.28. }
$$

There be diuers kindes of Mat Weedes, as The kindes.

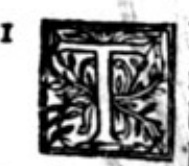

* The defcription.

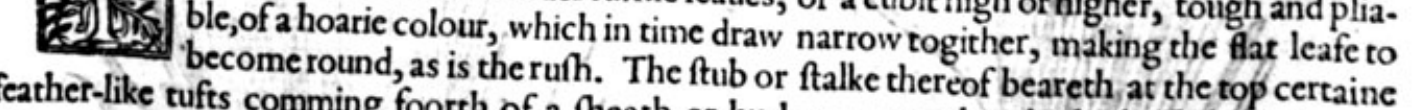
tained the feede, comming foorth of a fheath or huske, among the which chaffie hirsks is conby meanes whereof it commeth to the roote confifteth of many ftrings, folding one within another, 2 The fecond likewife Plinie do the forme of a turfe or haffocke.

upon do grow many graffie leaues, rough and 2 long ftalke, not vnlike to reede, but leffer:where. chaffie tuft groweth at the top of the ftalke pliant, hard in handling as are the rufhes. A f pokie inclofeth the flowers of Onions, leckes, Narcfflis, and foorth of a hood or finewiefheath, fuch as feede androotes like the precedent. He herbe Spartum, as Pliny faith, groweth of it felfe, and fendech foorth from the roote a multitude of flender rufhie leaues, of a cubit high orhigher, tough and plia. 
THE FIRST BOOKE OF THE

I Spartum Plini Cluffo.

2 Spartion alterium Pling. Hooded Mat Weede.

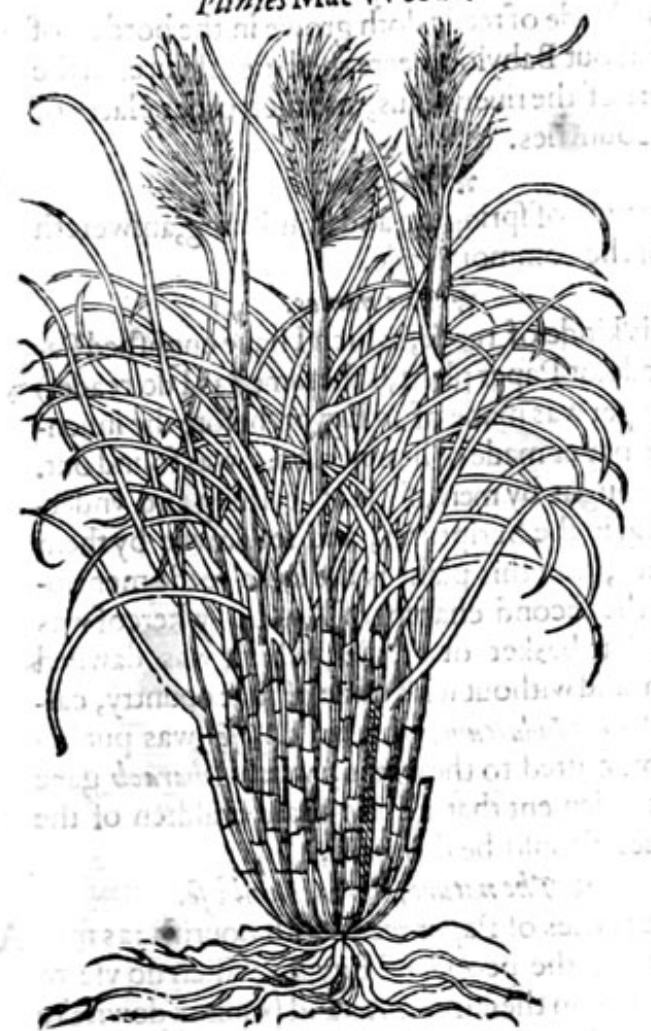

3 Spartum Unglicanum.

Englifh Mat Weede.
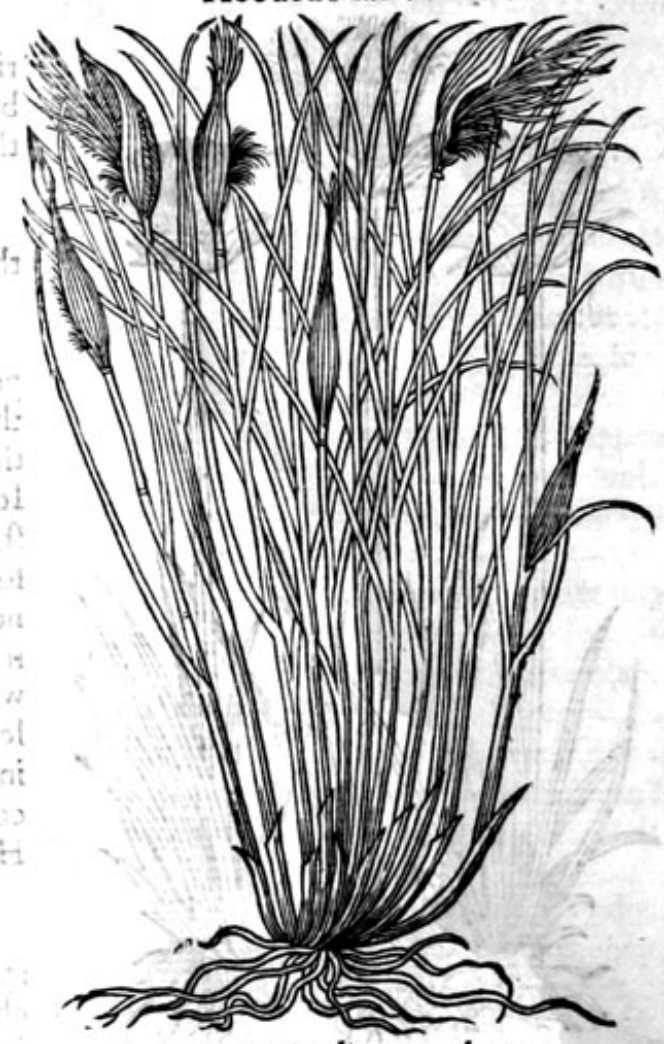

4 Spartuon Anglicanom alteriom.
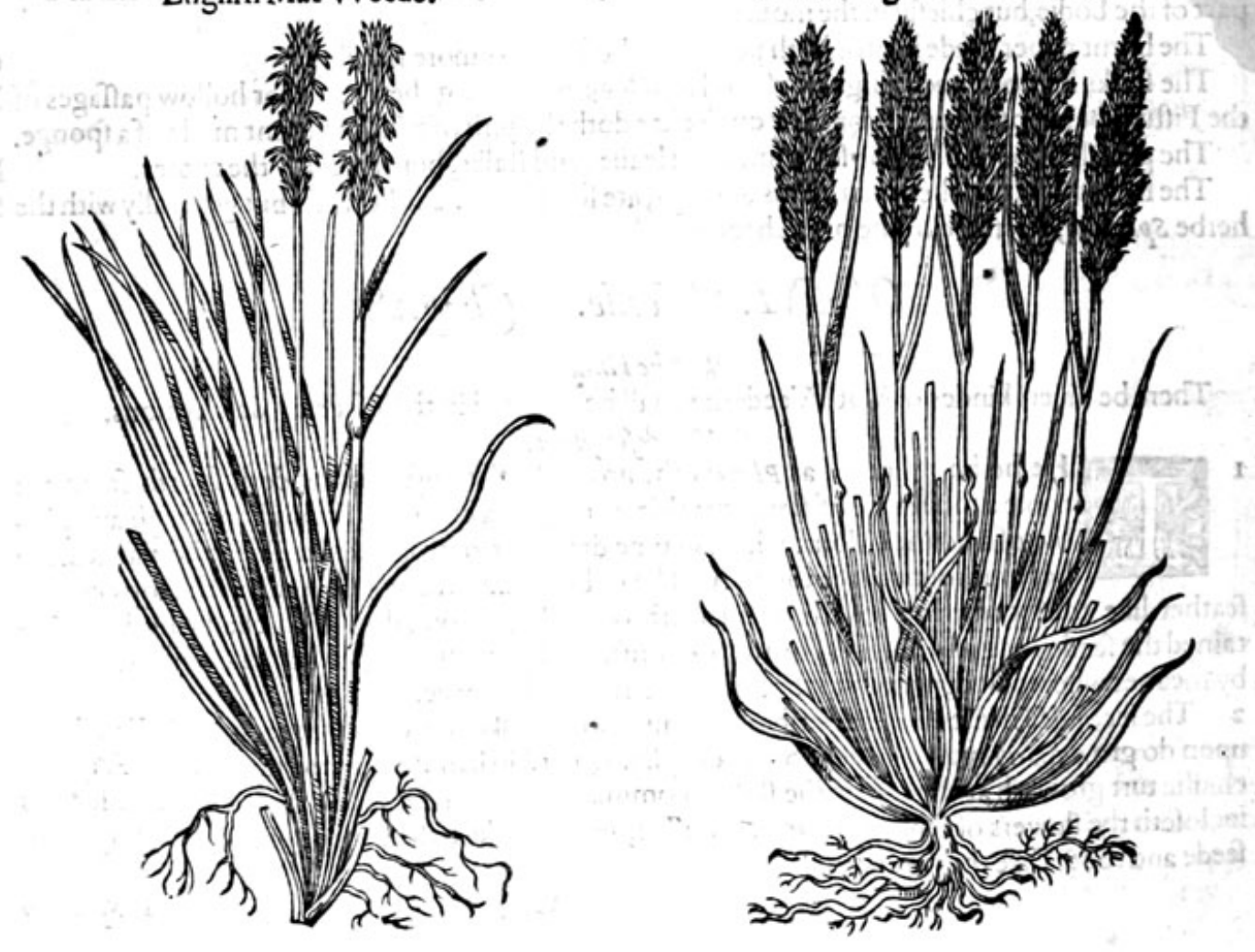
3 Englifh Mat weede hath a ruthie roote, deepely creeping and growing in heapes of fand and grauell, from the which arife ftiffe and harppepointed leatics, a foote and a halfe long. The ftalke groweth to the height of a cubite, whereupon doth grow a woollie f pike like vnto fpike graffe, wherin is contained a chaffic fecde. Of this plant ncither iheepe nor any ather cattle will taftc of eate. 4 The otherEnglith Mat weede is like vnto the former, faing that the rootes of this are long, not vnlike to dogs graffe, but do not thruft deepe into the ground as the former do, but creepc only vider the vpper crnft of the carth" the tuft or eare is greater, refembling the Foxetailegraffe.

So nistw

Thefe kinds of Mat weede do grow in Italy and Spaine, and other countries adioyning lilkewife in many places ofEnghand oecre ynto the fea fide, efpecially in the weit parts : about Norfolke alfo and Suffolke ing great plentic.

\section{The time anfivereth the other reedes.}

* The rames.

Mat weede is called in Latin Spartuon, al though there be another Spartum, which is a kind of Spanifh broome: and to make a difference of thein, this is called Spartum herba, and that other Spartwon frutex. InProuence in Fraunce they call it olpho: in Spanifh Albardin : in Engtifh Mat wecle.

$$
\text { * The natsare, vertues ard vfe. }
$$

Thefe kinds of graffie or rather rufhie reede, haue no vfe in phifick, but ferue for to make mats and $\mathbf{A}$ hangings for chambers, frailes, baskets, andfach like. The people of the countries where they grow, do make beds of them, ftrawe their houfes and chambers in fteede of rufhes, for which ve they do excell, as my felfe haue feene in the worfhipfullMafter Cooke his tioufe in Holborne, which is vfually
ftrowed therewith in winter.

They do likewife in fundry places of the Ilands of Madera,Canaria, Saint Thomas, and other of B the llands in the tract vnto the weft Indies, make of them their bootes, fhooes, herdmens cotes, fires and lights. It is very hurtfull for cattell,as is that of Sheeregrafle.

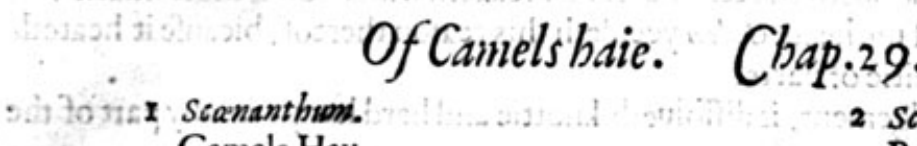

2 Scananthom adulterinum. Camels Hay. Baftard Camels Hay.

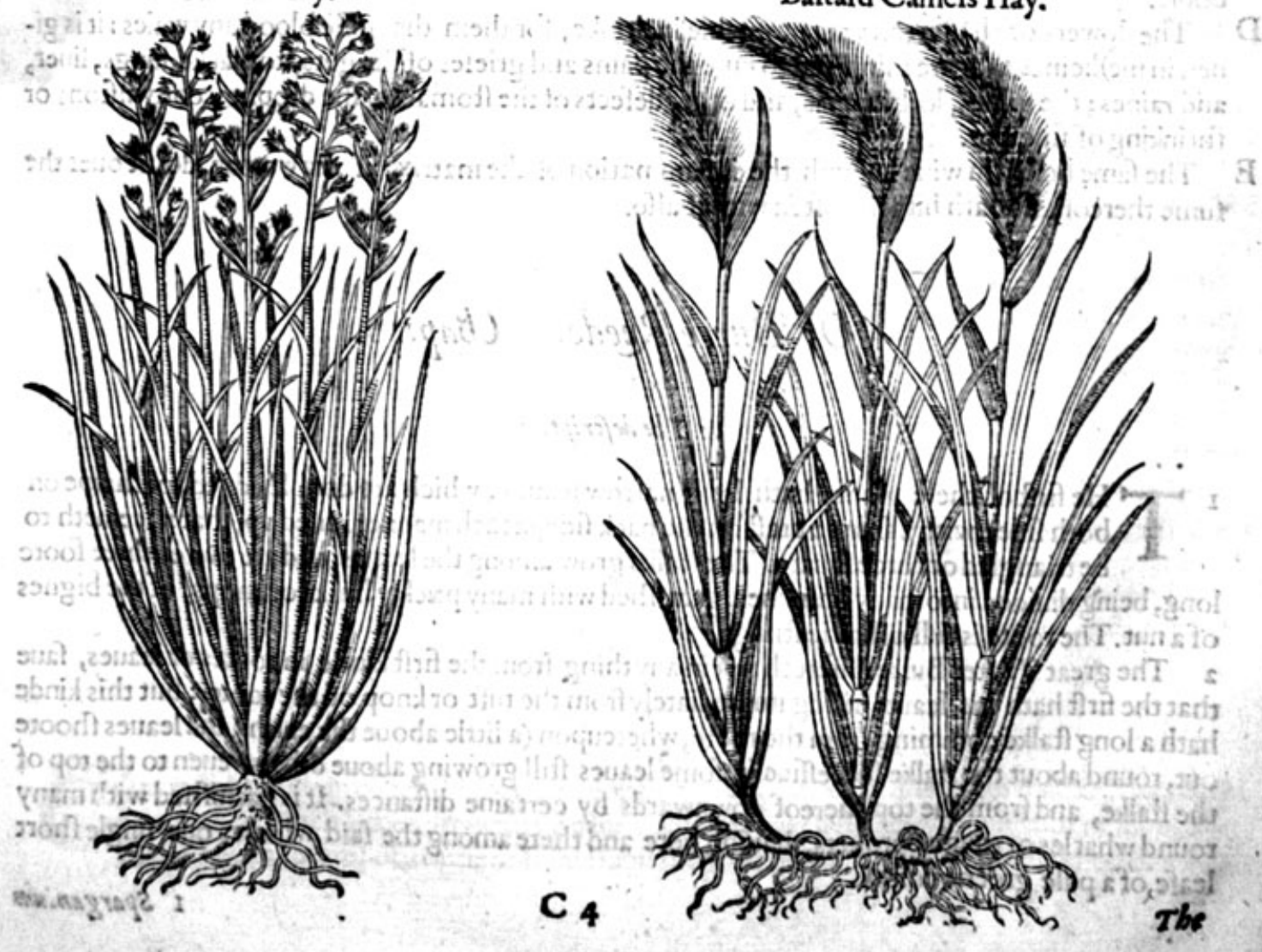


* The defaription. Amels haic hath leaucs very like vnto Cyperus, his rootes are many, in quantitie meane, full of fmall haires or threds, proceeding from the bigger roote, deepely growing in the ground, hauing diuers long ftalks like Cyperus graffe, fet with fome fmaller leaues, euen vnto the top:where do grow many fmall chaffie tufts or pannicles like vnto thofe of the wilde Otes, of a reaforable good fmell and fauour when they are broken, of the fauour of the Rofe, with a certaine biting and nipping of the toong.

2 The baftard Camels haie hath long crambling rootes, creeping vnder the vpper face of the earth in maner of the Couch graffe: the ftalkes are like to Cyperus, fet with long wheaten leaues, at eueryknot one, and toward the ground mo, by equall diftances: the fpikie eare or creft is chaffie; not vnlike to the Foxetaile graffe, but longer and bigger, fomewhat refembling barley, without finell.

$$
\text { * The place. }
$$

They grow in Africa, Nabathea, and Arabia, they areftrangers in thefe northerne regions. * The time.

Their time anfwereth the other reedes and flags. * The names.

Camels haie is called in Grecke reiro dipenudinxos: in Latin Iuncus odoratso, and Scananthum, in Thops Squinanthum, that is, Flos Iunci: in French Pafteur de Chammens: in Englifh Camels haie, and Squinant.

They do heate moderately, and are aftringent.

$$
\text { *. The nature. }
$$

* The vertues.

A Camels haie prouoketh vrine, mooueth the tearmes, and breaketh winde about the ftomacke.

B It caufeth aking and heauines of the head: Galen yceldeth this reafon thereof, bicaufe it heateth moderately and bindeth with tenuitic of parts.

C According to Diofcorides his iudgement, it diffolueth knottie and hard lumps in any part of the bodic.

D The flowers or chaffie tufts are profitable in drinke, for them that piffe blood any waies : it is giuen in medicines, that are miniftred to cure the pains and griefes of the guts, ftomacke, lungs, liuer, and raines; the fulnes, lothfomnes, and other defeets of the ftomacke, the dropfie; convulfions or thrinking of finewes.

E The fame boiled in wine helpeth the inflammation of the matrix, if the woman do fit ouer the fume thereof,and bath hir felfe often with it alfo.

\section{Of BurreReede. Chap.zo.}

$$
\text { * The defcription. }
$$

$\Upsilon T$ He firft of thefe plants hath long narrow leaues, which are double edged, or harpe on both fides, with a fharpe creft on the back fide, in fuch manner raifed vp, that it feemeth to be triangled or three fquare. The ftalks grow among the leaues, and are two or three foote long, being diuided intomany branches, garnifhed with many prickly husks or knops, of the bignes of a nut. The roote is full of hairie ftrings.

2 The great $W$ ater Burre differeth not in any thing from the firft kinde in rootes or leaues, faue that the firft hath his leaues rifing immediately from the tuft or knop of the roote : but this kinde hath a long ftalke comming from the roote, whereupon (a little aboue the earth) the leaues fhoote out, round about the ftalke fucceffiuely, fome leaues ftill growing aboue others, even to the top of the ftalke, and from the top thereof downwards by certaine diftances. It is garnifhed with many round wharles or rough coronets, hauing here and there among the faid wharles one fingle fhore leafe, of a pale greene colour. 
1 Sparganiumi. Burre Reede.

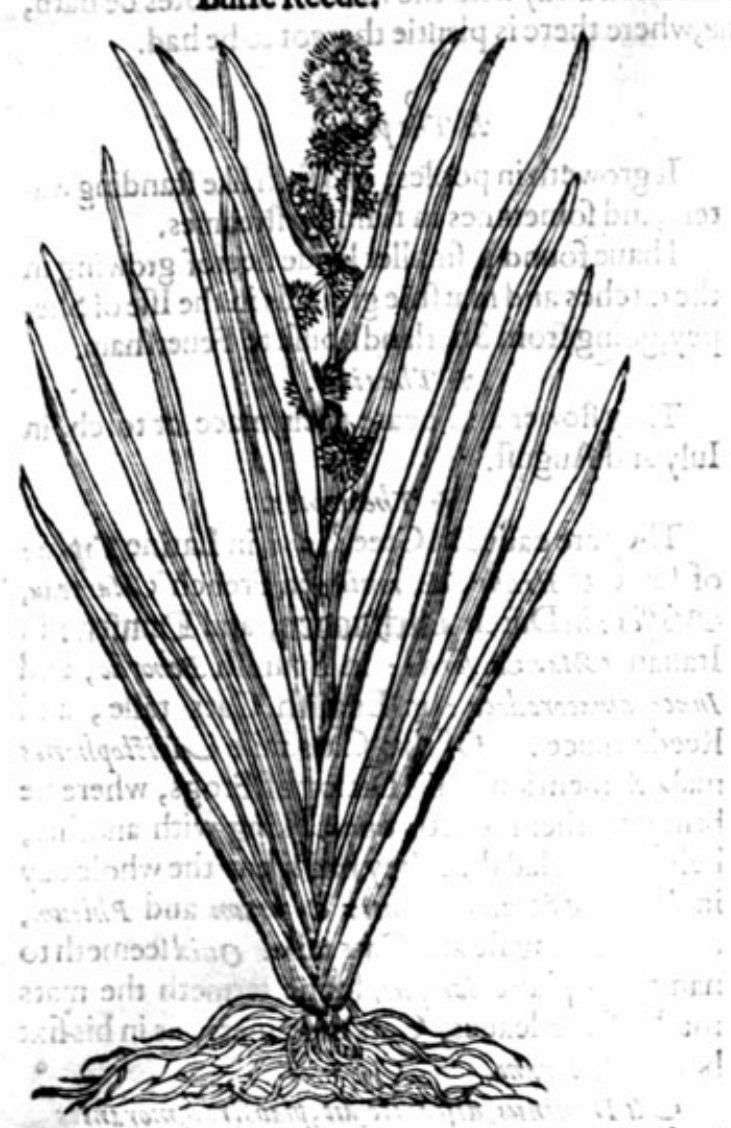

2. Spargenivas latifolivén.

- Great Water Burre.

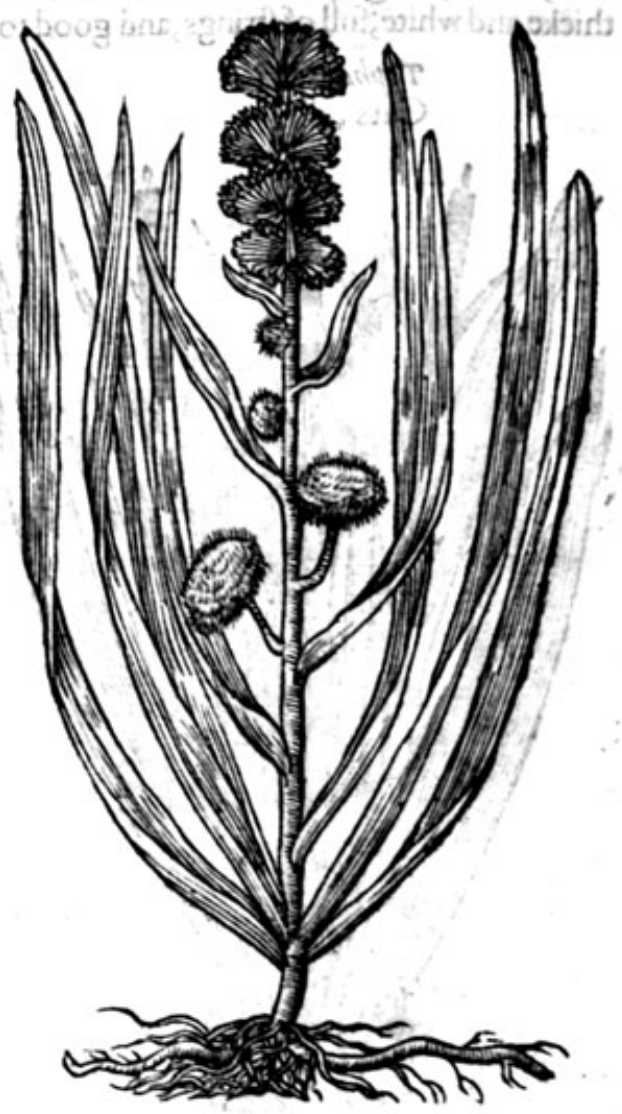

* Theplace.

Both thefe kindes are very common tluroughout England, and do growe in moift medowes, and neere vnto water coutfes. They plentifully grow in the fennie grounds of Lincolnfire, and fuch like places, in the ditches about Saint George his fields, and in the ditch right againft the place of execution; at the end of Southwarke neere London, called Saint Thumas Waterings. * The time.

They bring foorth their burrie bullets, or feedie knots in Auguft.

* The inames.

Thefe plants of fomeare called Sparganium. Theophrastus in his fourth booke and eighteenth chapter calleth them Butomus: of fome Platanaris.Maiter Lytehath called them Reede Mace, which name is not very proper in mine opinion :I rather call them Burre Reede. In the Arabian toong they: ate called Sa farhe Bamon : in Italian Sparganio : of Dodonews Carex.

They are cold and drie of complexion. * The nature.

* The vertues.

Someswrite, that the knops or rough burres of thefe plants boiled in wine, are good againft the $\mathbf{A}$ bitings of venemous beafts, if either they be drunke, or the wound wafhed therewith.

\section{Of Cats taile. Chap.3.}

* The defcription.

Ats taile hath long, rough, thicke and flaggie leaues, full of a fungious matter, ike mar. row, among which leaues, groweth vp a long fmooth naked ftalke, without knot or ioint, fa. fhioned like 2 fpeare, of a firme or folide fubitance, hauing at the top a browne knopor eare, 
foft, thicke and fmooth, feeming to be nothing elfe but a deale of flocks thicke fen and thruft togither, which being ripe turnethinto a downe, and is caried away with the winde.The rootes be hard, thicke and white, full of ftrings, and good to burne, where there is plentie thereof to be had.

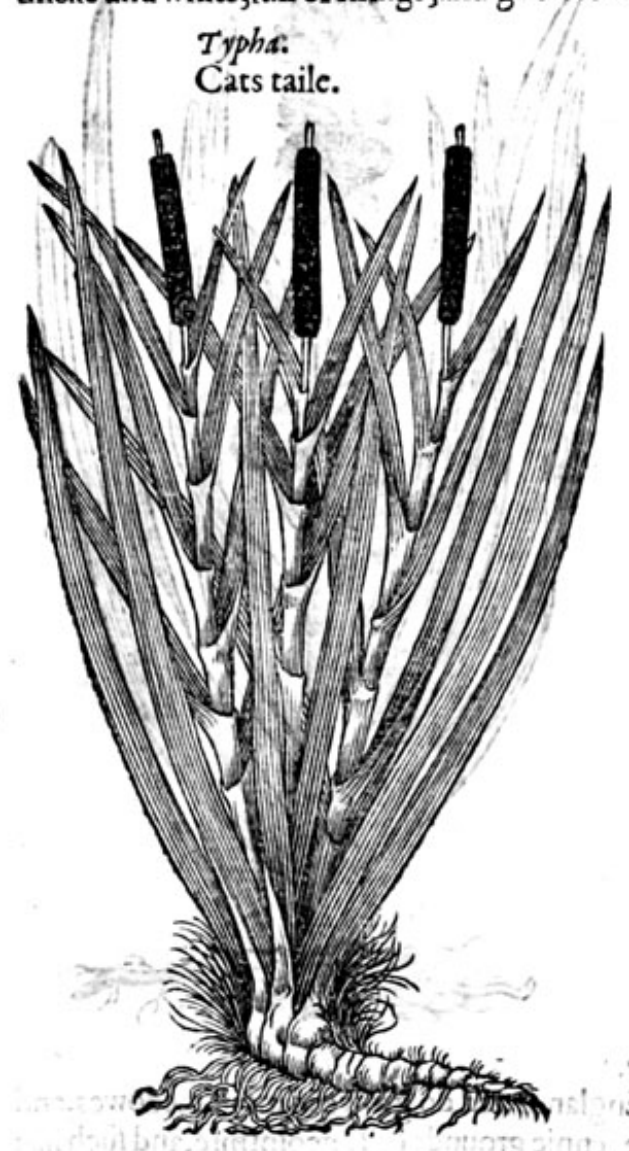

$$
\text { * The plase. }
$$

It groweth in pooles, and fuch like ftanding waters, and fometimes in running ftrearves.

Ihaue found a fmaller kinde heerof growing in the ditches and marhie grounds in the Ille of Shepey,going from Sherland houfe to Feueriham.

$$
\text { * The time. }
$$

They flower and beare their mace or torch, in Iuly and Augurt.

$$
\text { * Therrames. }
$$

They are called in Grecke rion; in Latine Typha : of forne Cestrum Morionis, in French eMarteau, Maffes : in Dutch Lifctuodien, and Donten: in Italian CMazza forda : in Spanilh Behordo, and Iunco amacorodaco : in Englifh Cats taile, and Reede mace. Of this Cats taile Uristophanes maketh mention in his Dialog of Frogt, where he bringeth them foorth one talking with another, being very glad that they had fpent the whole day in skipping \& leaping inter cyperum and Phlewm, among Galingale and Cats taile. Oui.t feemeth to name this plant Scirpus, for he termeth the mats made of the leaties, Cats taile mats, as in his fixt booke Faistorum, At Dominus, difcedite, ait, plaustróg, moranies Sastidlit, in plauftro foirped matta fuit.

\section{* The nature.}

It is cold anddric of complexion: A The foft downe ftamped with fwines greafe well wafhed, healeth burnings or fealdingswith fite
or water.

B Some practitioners by their experience haue found, that the downe of the Oats taile beaten with the leaues of Betonie, the rootes of Gladiole, and the leaties of Hippogloffon into powder, and mixed with the yelks of egshard fodden, and fo eaten, is accounted anoft perfeet medicine, againft the difeafe in children called in Greeke Brreor'sn, which is, when the gut called Inteftinum caetwo, is fallen into the cods. This medicine muft be minifted euery day fafting for the fpace of thirtiedares, the quantitie whereof to be miniftred at one time is r.5. This being vfed; as before is fpecified, doth not onely helpe children and ftriplings, but growet men alfo, if in time of their cure, they ve conuenient ligature or truffings, and fit confounding plaifters vpon the greebéd place, sccording to art appointed for that purpofe in chirurgerie.

C. This downe in fome places of the Ile of Ely, and the lowe countries adioiningthereto, is gathered and well fold, to make mattreffes of, for plowmen and poore people.

D It hath been alfo often prooued, to heale kibed or humbled heeles (as they are termed) being applied to them, either before or after the skin is broken.

$$
\text { Of Stitcbivoort. Clap.32. }
$$

1 Q Titchwoort, or (as Ruelliws termeth it) Holosteum, is of two kindes, and hath round tender ftalks, full of ioints, leaning toward the ground. At euery ioint grow two leaues one againft another. The flowers be white, compact of many finall leaues, fet in the maner of a ftar. 


\section{HHISTORIE OF PLANTS.HT}

2 The fecond is like the former in fhape of leaues and flowers, which are fet in forme of a ftar, but the leaues are orderly placed, and in good proportion by couples two togither, being of a whitifh colour, declining to crimfon: when the flowers be vaded, then followe the feedes, which are inclofed in round bullets like the feede of tlaxe.

I Granen Lewcurthemuen. Stitchwoort.

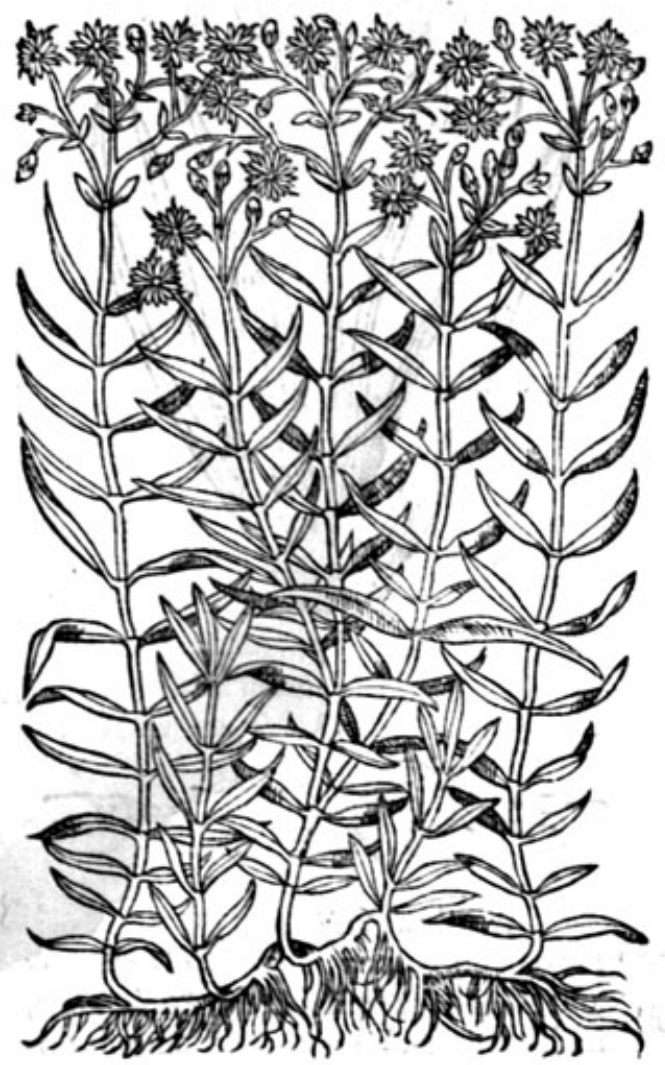

2 Gromen Lewcanthemum alserion, Sinall Stitchwoort.

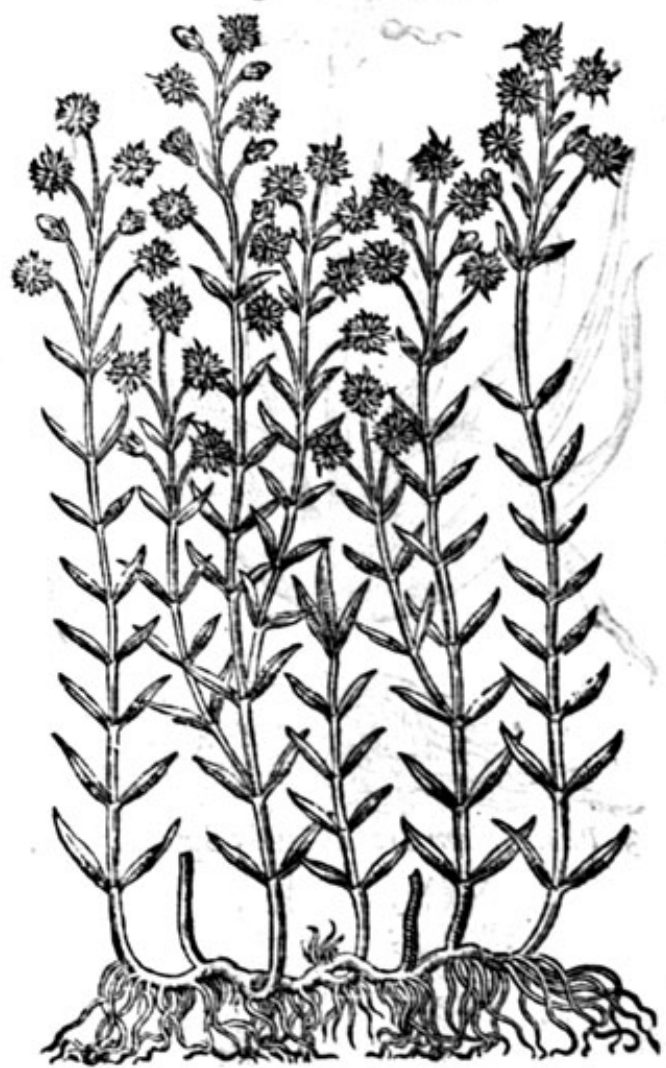

* The place.

They growe in the borders of fields vpon bank fides and hedges, almoft euery where. * The time.

They flourifh all the fommer, efpecially in May and Iune. * The names.

The Grecians call this plant órósor: in Latine Tota offes : in Englifh All-bonie: whereof Ifee no reafon, except it be by the figure Untonomia, as when we fay in Englifh, He is an honeft man, our meaning is, that he is a knauc. For vndoubtedly this is a tender herbe, lightlybraied or pound, hauing no fuch bonie or tough fubftance in him, according to the fignification of his Greeke name. Wherefore I take it to be fo called by contraries : commonly in Englifh Stitchwoort.

The feede of Stitchwoort, as Galen writeth, is fharpe or biting to him that taftech it : and to him that vfeth it, very liketo Mill.

*: The vertwes.

They are woont to drinke it in wine with the powder of Acornes, againft the paine in the fide, A Ptitches, and fuch like.

Divers report, faith Diofcorides, that the feede of Stitchwoort being dnunke, caufeth a woman B to bring foorth a man childe, if after the purgation of hir ficknes before fhe conceiue, the do drinke it fafting thrife in a day, halfe a dram at a time, in three ounces of water many daies togither. 

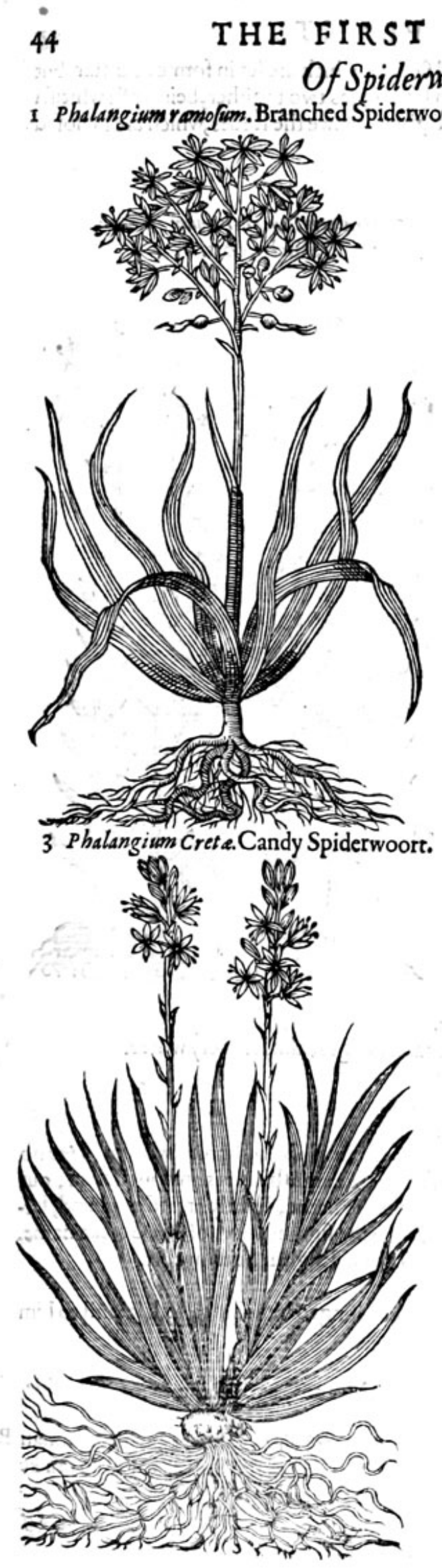

BOOKE OF THE

Chap.33.

ibnoset sily

2 Phelangiven non ranofom.

Vnbranched Spiderwoort:

○

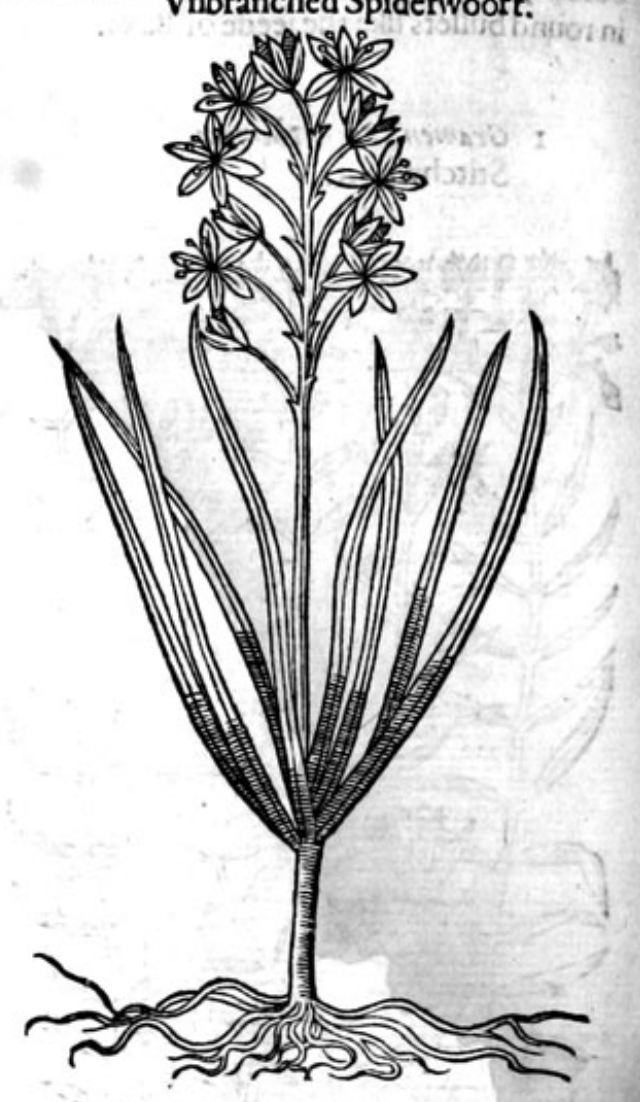

* The defcription.

$17 T^{-H e}$ obfcure defcription which Diofcorides and Pliny haue fet down for Phalangivem, hath bred much contention among writers, fome affirming that Phalangiwn is Plinies Moly, in which error Dodonews perfifteth. This plant Phalangium, hath leaues much like Couch graffe, but they are fomewhat thicker and fatter, and of a more whitith greene colour. The ftalks grow to the height of a cubit. The top of the ftalke is befet with fmall branches, garniihed with many little white flowers, compact of fixe little leaues. The threds or thrums in the middle are whitifh, mixed with a fair yellow, which being fallen, there followe blacke feedes, inclofed in fmall round knobs, which be three cornered. The rootes are many, tough, and white of colour.

2 The fecond is like the firft, but that his ftalke is not branched as the firft, and flowreth not in a monieth after.

3 The third kinde of Spiderwoore, which Carolus Clufius nameth $\cup$ /phodelusminor, hath a roote of many threddic ftrings, from the which immediately rife vp graflie leaues, narrow and tharpe pointed: 


\section{A HHI STOORE OFF TPAAN TSIIT}

pointed: among the which come foorth diuers naked ftraight ftalks, gamifhed on euery fide with

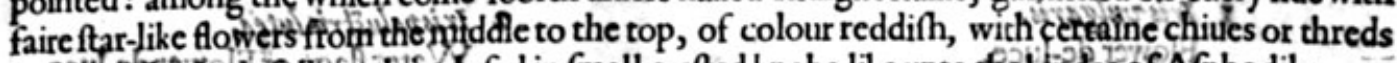

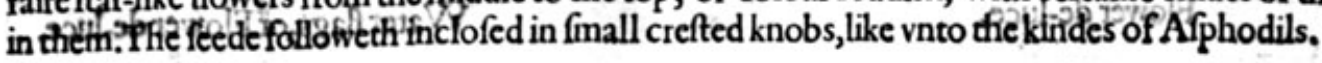

All thefe kindes growe in my garden: $*$ but not wilde in England.

I The firft floswreth in the beginning of Iune.

$$
\text { * The time. }
$$

2 The fecond flourifheth in the end of Iuly, and his feede is ripe in September.

\section{* The names.}

The firft is called of the Latines andlate herbarifts, Phalangium, bicaufe of his vertues againft the biting of the fpider Phalan : in Englifh it is called Spiderwoort:and furely it may well be fo called for this caufe likewife; The leaues being growen to their greatnes, ftand vpon the ground with long legs, and the knees bowing vp like the ipiders legs when he creepeth : and the whole tuft in the middle refembling the bodie of the fpider. Cordsu ealleth it Lilliago.

* The nature.

Galen faith,all the kindes are of a drying qualitie, by reafon of their tenuitic of parts.

$$
\text { * The vertwes. }
$$

Diofcorides faith, that the leaues, feede and flowers, or any of them drunke in wine, preuaileth $\mathbf{A}$ againft the bitings of fcorpions, and againft the ftinging and biting of the fpider called $P$ halan, and all other venemous beafts.

The rootes tunned vp in new ale, and drunke for 2 moneth togither, expelleth poifon, yea al- B though it had vniuerfally f pred it felffe through the bodie.
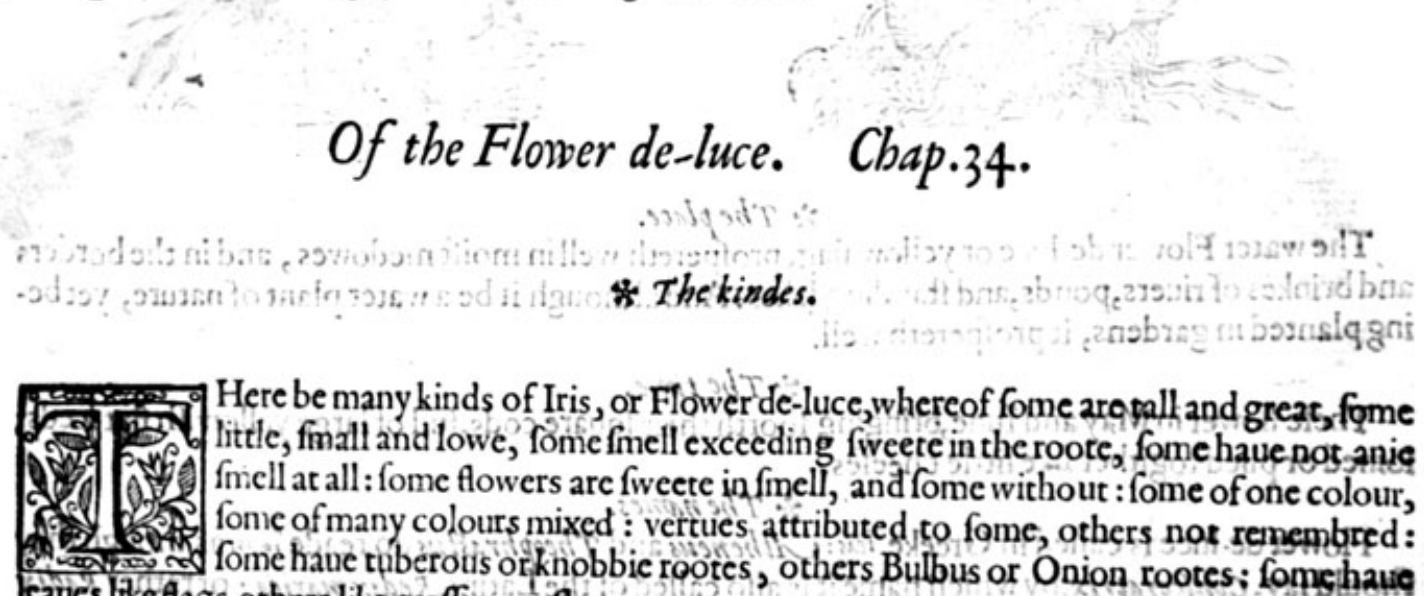

Here be many kinds of Iris, or Flower de-luce, where of fome aramell and great, forme little, fmall and lowe, fome fmell exceding fweete in the roote, fome haue pot anie friell at all: fome flowers are fweete in finell, and fome without : fome of one colour, fonc of many colours mixed : vertues attributed to fome, others not remembred: teanes like tags, others like graffe or tuinhes.

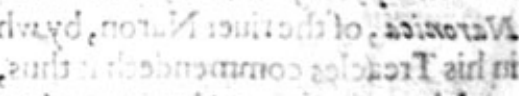

I Te common Flower de-luce hath long and large flaggie feaues, like the blade of a fworde, with two edges, amongtt which fpring ip fmooth and plaine ftalkes, two foote long, bearing flowers toward the top, compat of fixe leaues ioined togither, wherecof three thateftande vpright are sent inwardone toward another, and in thofe leaues thathang downwarde, there are certaine rough or hairie welts, growing or rifing from the neatherpartof the leafe ypitide,

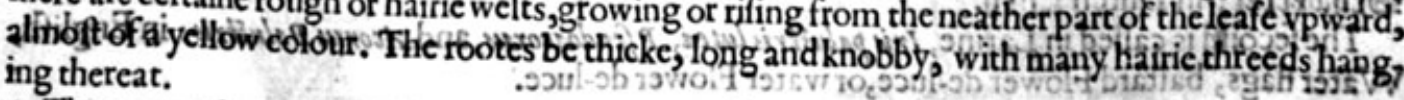
.ง

2 The water Flower de-luce or water flag, of baffard Aior rus, is like vnto the garden Flower de-luce

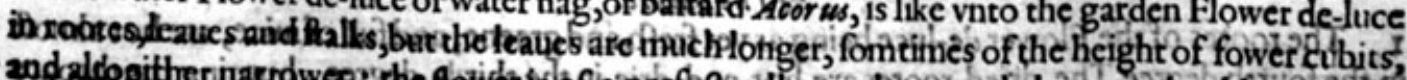

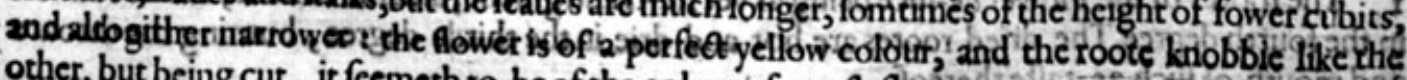

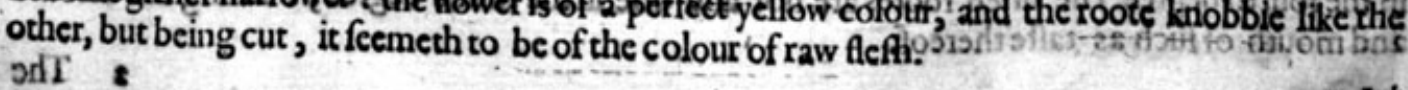


1 Irisulgaris.

Flower de-luce.

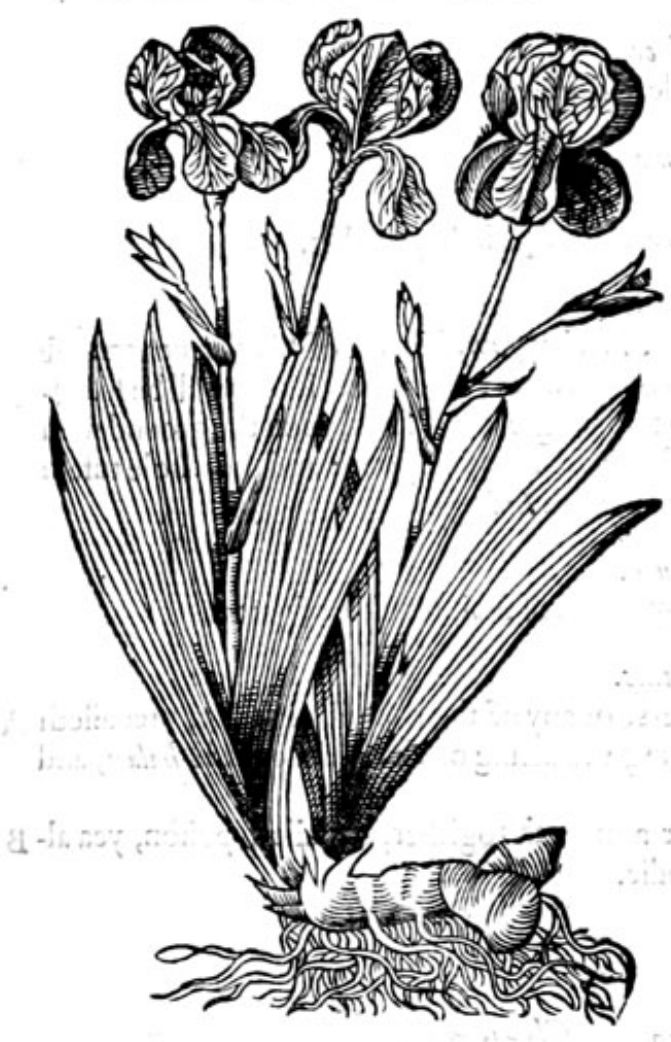

2 Irispalustrib lutea. Water flags,or Flower de-Juce.

* The place.

The water Flower de-luce or yellow flag, profpereth well in moift medowes, and in the borders and brinkes of riuers, ponds, and ftanding lakes. And although it be a water plant of nature, yetbeing planted in gardens, it profpereth well.

* The time.

Thefe flower in May and Iune, bringing foorth their fquare cods, full of large yellowilh flat feeds; ioined or piled togither like little cheefes.

* The nomes.

Flower de-luce is called in Greeke ies: Atheneus and Theophraftus do reade iress: as though they Should fay, Confecratrix, by which name it is alfo called of the Latins, Radix marics: orrather Radix Naronica, of the riuer Naron, by which the beft and greateft ftore do growe:whereupon 2 icander
in his Treacles commendeth it thus,

Which may thus be Englifhed. Iridem quam aluit Drilon o 2 aronis ripa.

Iris, which Drilon water feedes, And Narons bancke with other weedes.

The Italians Giglio azurro: in Spanin Lilio Cardeno : in French Flambe: the Germaines Stigent; Detiwertel: in Dutch Ltteb.

The feconid is called in Latine, Iris palustris lutea, Pfendoasorm, and Acorm Palustris: in Englifh, Water flags, baftard Flower de-luce, or water Flower de-luce.

Theroous $*$ The nature.

I The rootes of the Flower de-luce being as yet frefh and greene, and full of iuice, are hot almoft in the fourth degree. The dried rootes are hot and drie in the thirde degree, burning the throate
and mouth of fuch as tafte thereof. 


\section{HISTORIE OF PLANTS.}

2 The baftard Flower de-luce, his roote is colde and dric in the third degree, and of an aftringent or binding facultic.

* The vertues.

The roote of the common Flower de-luce cleane wafhed and ftamped, with a fewe drops of rofe A water, and taide plaifter wife vpon theface of man or woman, doth in two daies at the moft, take away the blacknes or blewnes of any ftroke or bruife : fo that if the skin of the fame woman, or anie other perfon, be very tender and delicate; it fhall be needfull that yee laie a peece of filke, findall, or a peece of fine laune betweene the plaifter and the skin : for otherwife in fuch tender bodies, it often caufeth heate and inflammation.

The iuice of the fame doth not onely mightily and vehemently drawe foorth choler, but moft B efpecially waterifh humours, and is a f pecial and fingular purgation for them that haue the dropfie, if it be drunke in whaie or fome other liquor, that may fomwhat temper and alaic his heate.

The dric rootes attenuate or make thin thicke and tough humors, which are hardly and with dif- C ficultie purged away.

They are good in a loche or licking medicine for fhortnes of breath, an old cough, and all infir- D mities of the cheft, which rife heereupon.

They remedie thofe that have euill fpleenes, and thofe that are troubled with convulfions or $\mathrm{E}$ cramps, biting of ferpents, and the running of the raines, being drunke with vineger, as faith Diofcorides; and drunke with wine, it bringeth downe the monthly courfe of women.

The decoction is good in womens bathes, for it mollifieth and openeth the matrix.

Being boiled very foft,and laid to plaifterwife, mollifieth or fofteneth the kings euill,and old hard G fwellings.

\section{Of Flower de-luce of Florence. Chap.35.}

\section{Iris Florentina.}

- Flower de-luce of Florence.

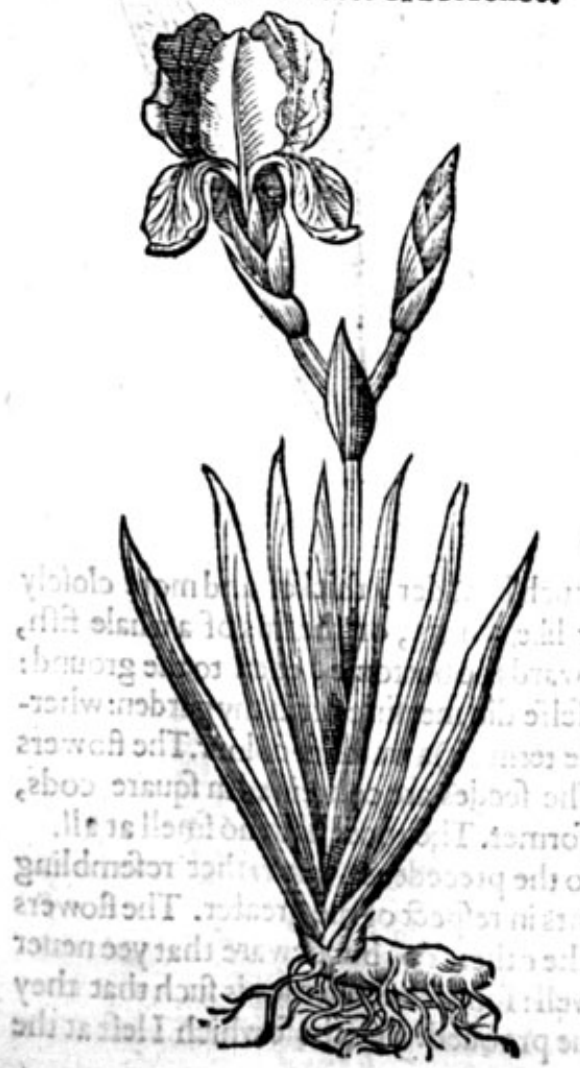

2 Iris alba. White Flower de-luce:

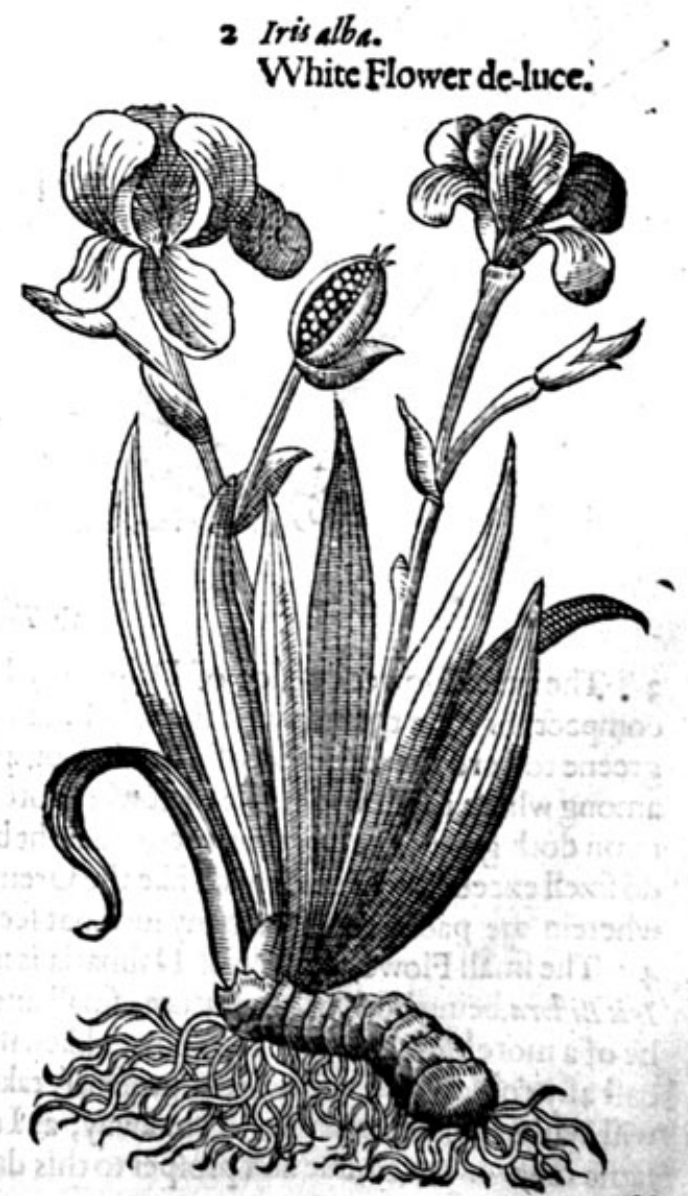


* The defription.

I He Fower de-luce of Florence, whofe rootes in fhops and generally euery where, are called Ireos, or Orice, (whereof fweete waters, fweete powders, and fuch like are made, is altogither like vnto the common Flower de-luce,fauing that the flowers of this Ireos is of a white colour, and the rootes exceeding fweete of fmell, and the other of no finell at all. 2 The white Flowerde-luce is like vnto the Florentine Flower de-luce in rootes, flaggie leaues and ftalkes, but they differ in that, that this Iris hath his flower of a bleake white colour, declining to yellownes, and the rootes haue not any fmell at all; but the other is very fweete, as we haue faid.

3 Iris Dalmatica maior.

Great Flower de-luce of Dalmatia.

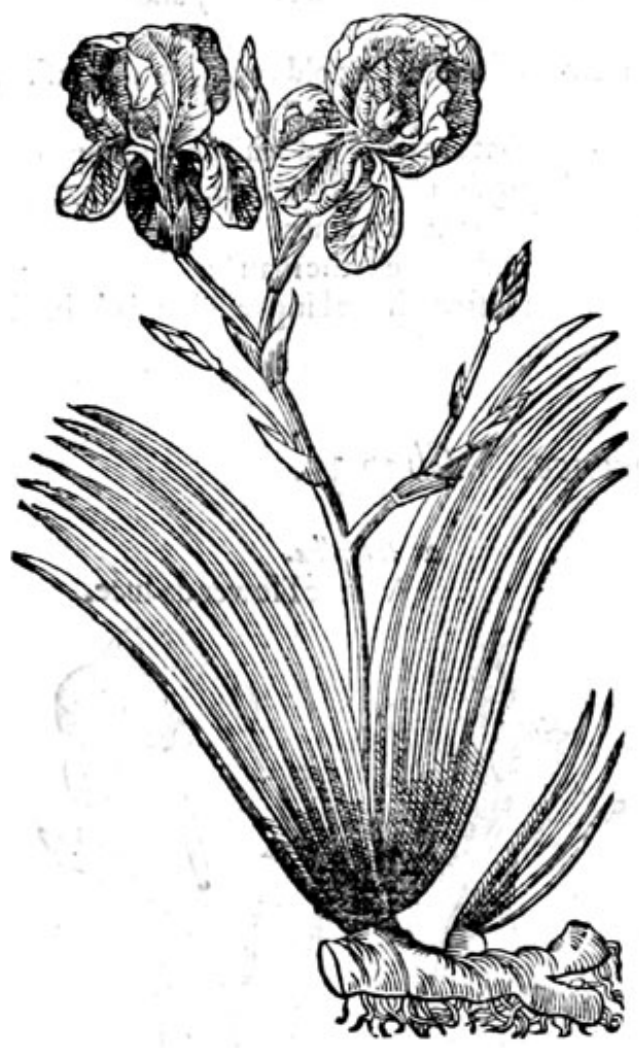

4 Iris Dalmatica minor. Small Dalmatica Iris.
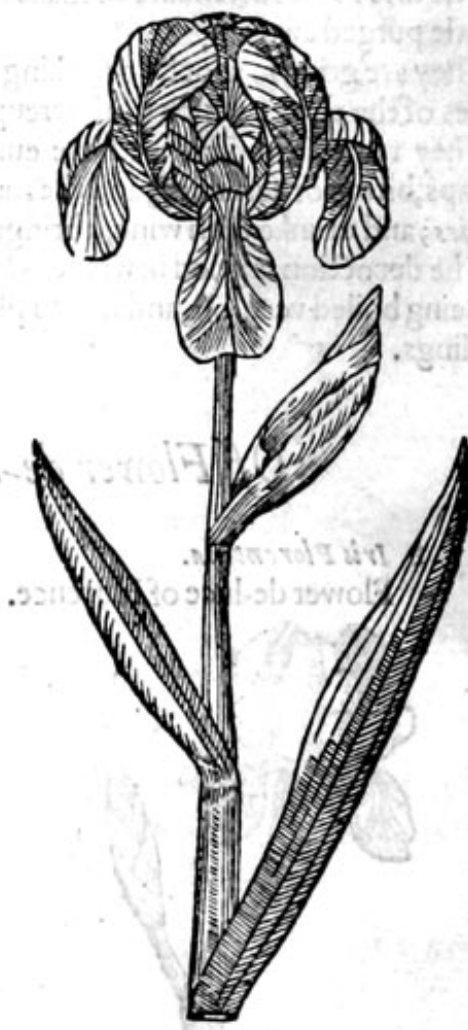

* The defcription.

3 The great Flower de-luce of Dalmatia, hath leaues much broader, thicker and more clofely compact togither then any of the other, and fet in order like wings, or the fins of awhale firh, greene toward the top, and of a fhining purple colour toward the bottome, euen to the ground: among which rifeth vp a ftalke of fower foote high, as my felfe did meafure oft in my garden: wherupon doth grow faire large flowers, of a light blew, or (as we terme it) a watchet colour.The flowers do fmell exceedingfweete, much like the Orenge flower. The feedes are conteined in fquare cods, wherein are packt togither many fuch flat feedes like the former. The roote hath no fmell at all. 4 The finall Flower de-luce of Dalmatia is in fhew like to the precedent, but rather refembling Iris Biflora,being both of one ftature, fmall and dwarfe plants in refpect of the greater. The flowers be of a more blew colour. They flower likewife in May as the others do, but beware that yee neuer caft any colde water vpon them prefently taken out of a well: for their tendernes is fuch that they will wither immediately, and rot away, as I my felfe haue prooued: but thofewhich Ileft at the fame time vnwatred, liue and profper to this day. 
HISTORIE OF PLANTS.

5 Iris Biflore.

Twife flowring Flower de-luce.

6 Iris Violacea.

Violet Flower de-luce.
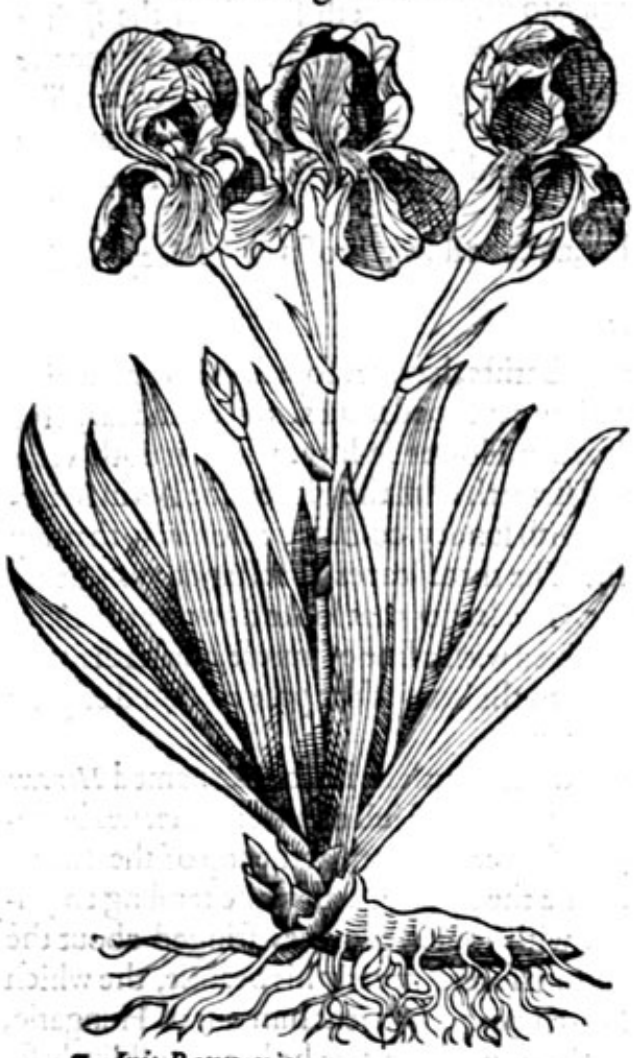

7 Iris Pannonica.

Portingale Flower de-luce.
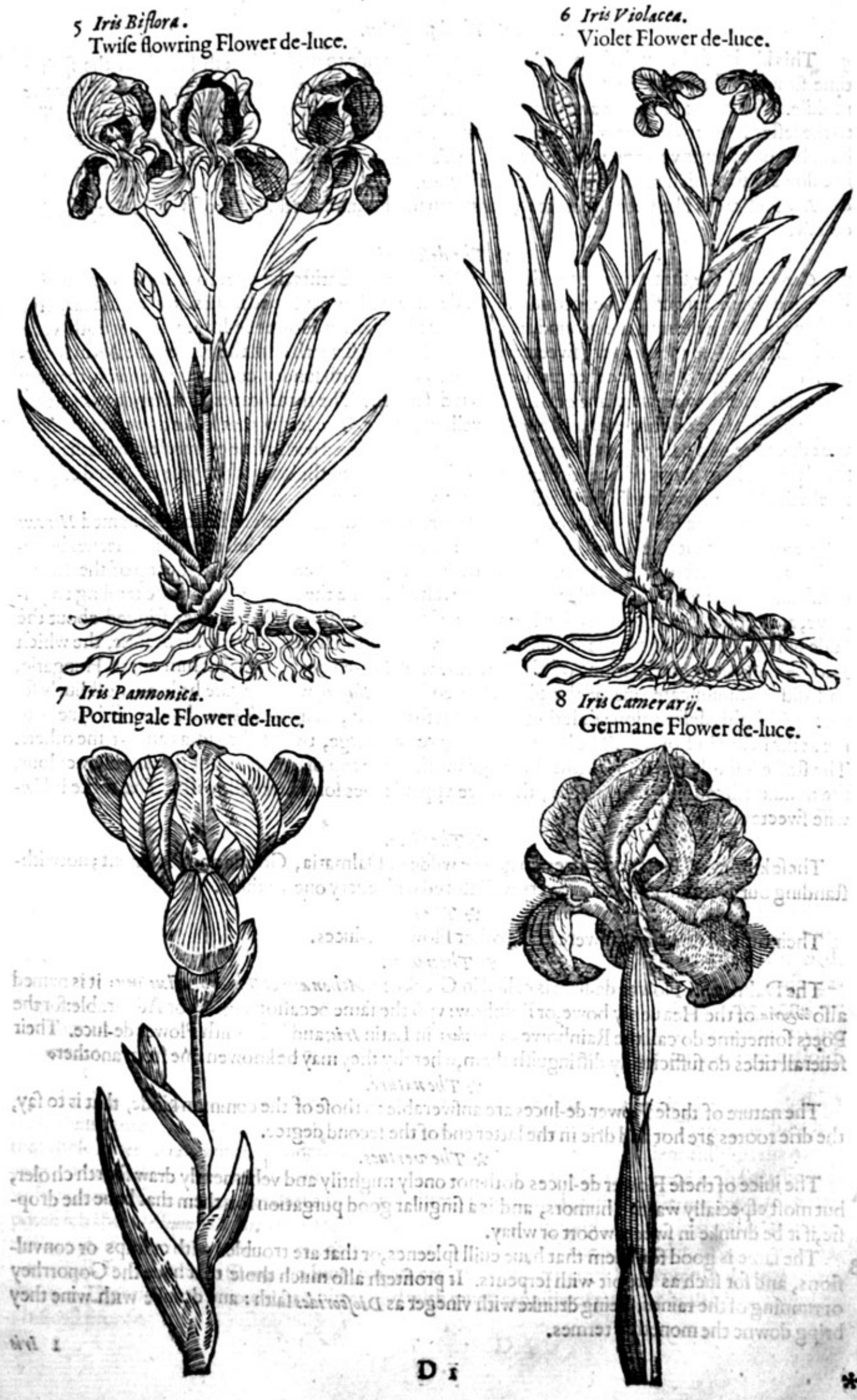


\section{* The defcription.}

5 This kinde of Flower de-luce came firft from Portingale to vs. It bringeth foorth in the fpring time flowers of a purple or violet colour, fmelling like a violet, with a white hairie welt downe the middle. The roote is thicke and fhort, ftubborne or harde to breake. In leaues and fhew it is like to the leffer Flower de-luce of Dalmatia, but the leaues be more fpred abroad, and it commonly hath but one flower vpon oneftalke, which in Autumne flowreth againe, and bringeth foorth the like flowers, for which caufe it was called Iris biflora.

6 Iris violacea is like vnto the former, but much finaller, and the flower is of a more deepe violet colour.

* The defcription.

7 Carolus Clufius, that excellent and learned father of Herbarifts, hath fet foorth in his pannonick Epitome the picture of this beautifull Flower de-luce, with great broad leaues, thicke and fat, of a purple colour neere vnto the ground, like the great Dalmatian Flower de-luce, which it doth verie well refemble. The roote is yery fweete when it is drie, and ftriueth with the Florentine Iris in fweetnes. The flower is of all the other moft confufedly mixed with fundry colours, infomuch that my pen cannot fet downe euery line or ftreake as it deferueth. The three leaues that ftande vpright do clafpe or embrace one another, and are of a yellow colour. The leaues that looke downwarde about the edges, are of a pale colour, the middle part of white, mixed with a line of purple, and hathmany fmall purple lines ftripped ouer the faid white flower, euen to the brim of the pale coloured edge.It fmelleth like the Hawthorne flowers, being lightly fmelled vnto.

8 The Germaine Flower de-luce, which Camerarius hath fet foorth in his booke named Hortus Medicus, hath great thicke and knobby rootes: the ftalke is thicke and full of iuice: the leaues be verie broad in refpect of all the reft of Flower de-luces. The flower groweth at the top of the ftalke, confifting of fixe great leaues, blew of colour, welted downe the middle, with white tending to yellowe, at the bottome next the ftalke it is white of colour, with forne yellownes fringed about the faide white, as alfo about the brims or edges, which fetteth foorth greatly his beautie, the which Ioachimus Camerarius, the fonne of old Camerar ius of Noremberg, had fent him out of Hungarie, and did communicate one of the plants thereof vnto Clufius, whofe figure he hath moft linely fet foorth with this defcription; differing fomewhat from that, that Ioashimus himfelfe did giue vnto me at his being in London. The leaues faith he, are very large, twife fo broad as any of the others. The ftalke is fingle and finooth, the flower groweth at the top of a moft bright fhining blew colour, the middle rib tending towhitenes, the three vpper leaues fomwhat yellowifh. The roote is likewife fweete as Ireos.

\section{* Theplace.}

Thefe kindes of Flower de-luces do growe wilde in Dalmatia, Gotitia ahdPiedmont; notwithftanding our London gardens are very well ftored with euery one of thern.

$$
\text { * The time. }
$$

Their time of flowring anfwereth the other Flower de-luces. * The names.

The Dalmatian Flower de-luce is called in Greek of Athen aus \& T heopbrastus isers: it is named alfo ivegria, of the Hea uenly bowe, or Rainbow: vpō the fame occafion vavpessis, or Admirable:for the Poets fometime do call the Rainbowe savusuriar: in Latin Jris, and in Englifh Flower de-luce. Their feuerall titles do fufficiently diftinguifh them, whereby they may be knowen one from'another.

$$
\text { * The nature. }
$$

The nature of thefe Flower de-luces are anfwerable to thofe of the commonkinde, that is to fay, the drie rootes are hot and drie in the latter end of the fecond degree. * The vertues.

A The iuice of thefe Flower de-luces doth not onely mightily and vehemently draw foorth choler, but moft efpecially watrifh humors, and is a fingular good purgation for them that hane the dropfie, if it be drunke in fweete woort or whay.

B The fame is good for them that haue euill fpleenes, or that are troubled with cramps or convulfions, and for fuch as are bit with ferpents. It profiteth alfo much thofe that haue the Gonorrhey or running of the raines; being drunke with vineger as Diofcorides faith: and drunke with wine they bring downe the monethly termes. 


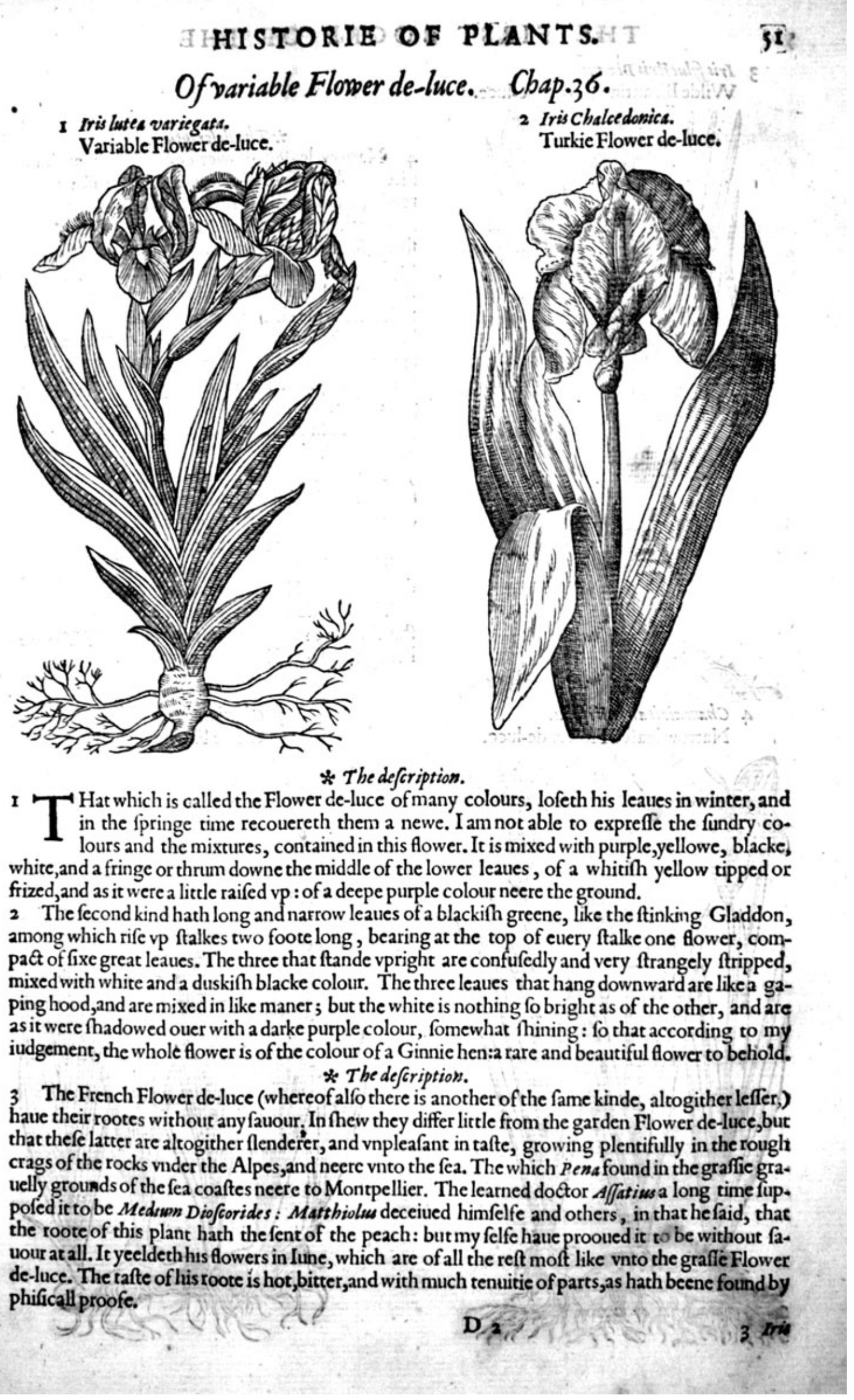


3 Iris fluestris Bizantina.

Wilde Bizantine Flower de-luce.

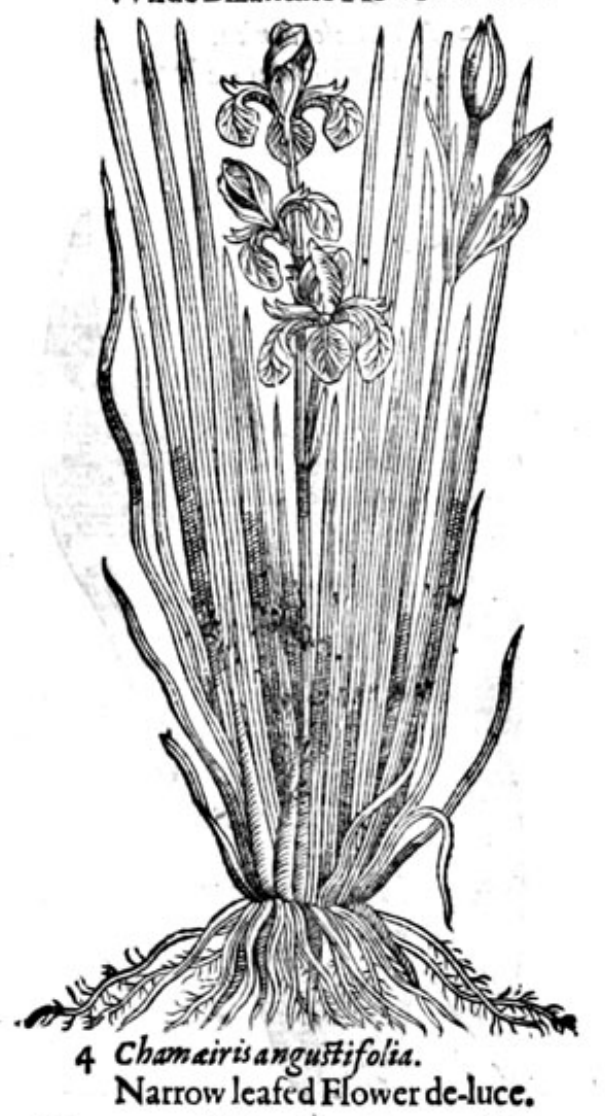

* The defcription.

4 Narrow leafed Flower de-luce hath an infinite number of graffie leaues, much like vnto reede, among which rife vp many ftalkes, much fhorter than the leaues. On the endes of the fame fpring foorth two, fometimes three, right fweete \& pleafant flowers, compact of nine leaues. Thofe three that hang downward, are greater than the reft, of a purple colour, ftripped with white and yellow: but thofe three fmall leaues that appeere next are of a purple colour without mixture: thofe three that ftand vpright are of an horfeflefh colour, tipped with purple, and vnder ech of thefeleaues appeere three fmall browne aglets, like the toong of 2 finall bird.

5 The fmall graffie Flower de-luce, differeth from the former in fmalnes and thinnes of leaues, in other refpects there is no difference.

* The place.

Thefe plants do grow in the gardens of London, amongtt Herbarifts and louers of plants.

The Turkie Flower de-luce came from Conftantinople, and doth profper well in my garden, being notplanted in ouer wet ground.

\section{Chamairistenuifolia.}

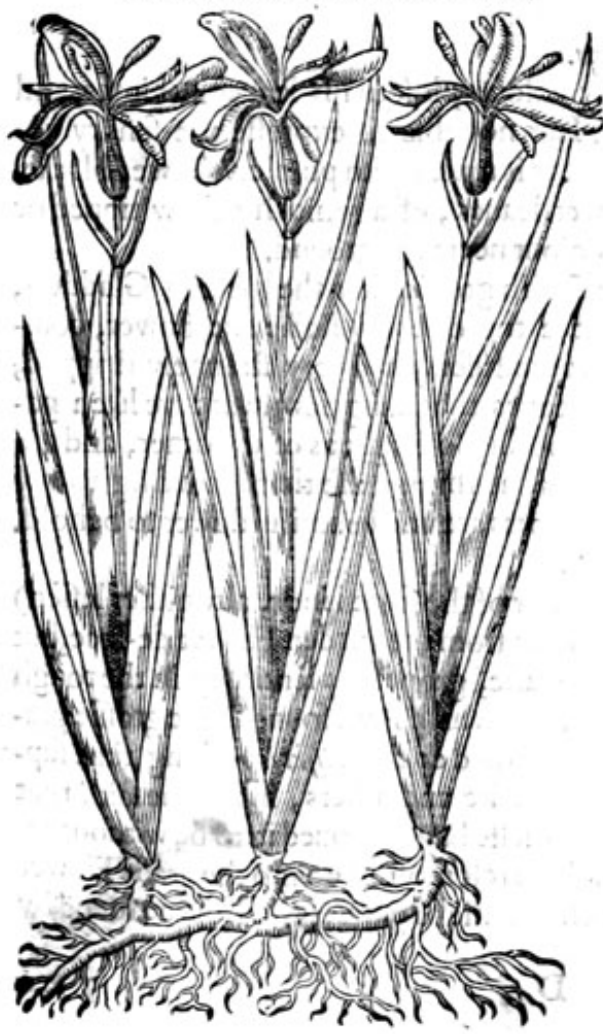
Graffe Flower de-luce.

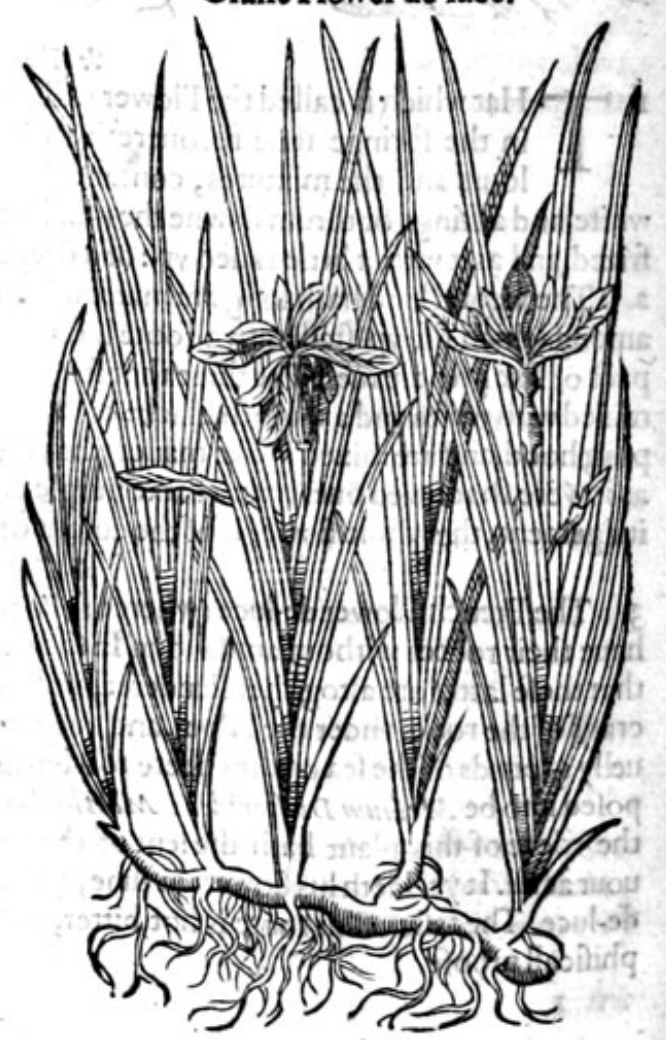


* The time.

They flower from the beginning of March to the end of May. * The names.

The Turkie Flower de-luce is called in the Turkifh toong Alsis Suffenci, with this additament from the Italians, Fiore Belle pintate, fuppofed of $L^{\prime} O$ belisus to be Medion of Diofcorides : in Englifh French Flower de-luce.

* The nature and vertues.

The faculties and temperature of thefe rare and beautifull flowers, are referred to the other $\mathbf{A}$ forts of Flower de-luces, whereunto they do very well accord. Theretsan excellent oyle made of the Flowers and rootes of Flower de-luce, of ech a like quantitie, called olewn Irinum, made after the fame maner that oyle of Rofes, Lilies, and fuch like be made: which oile profiteth much to ftrengthen the finews and ioirts, helpeth the cranpe,proceeding of repletion, and the difeafe called in Greeke Peripineumonis.

The flowers of French Flower de-luce diftilled with Diatrion fandalon, and Cinnamom, and the $B$ water drunke, preuaileth greatly againft the dropfie, as teftifieth Holleriow and Gefneras.

\section{Of finking Gladdon. Chap.37.}

1 Xyis.

Stinking Gladdon.

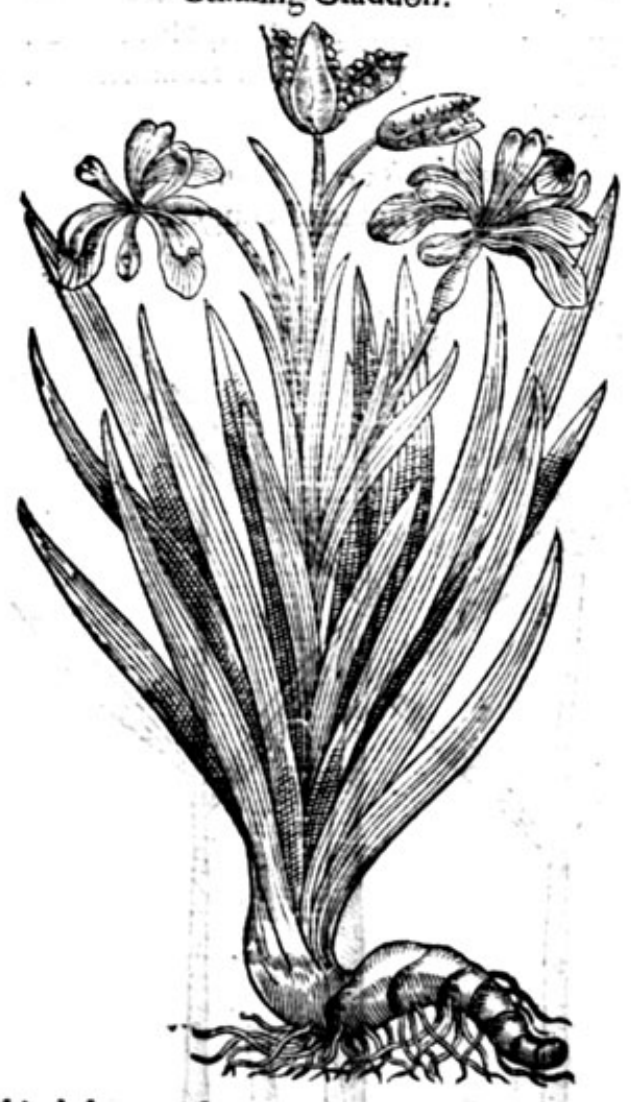

* The defcription.

Tinking Gladdon hath dong narrow leaues like Iris, but fmaller, of a darke greene coloury \& being rubbed, of a ftinking finell, verie lothforne. The ftalks are many in number, \& round toward the top,out of which dogrow flowers like the Flower de-luce, of an ouerworne blewifh colour, declining to grayifh, or an afh colouir. After the flowers be vaded, there commeth great husks or cods, wherein is contained a red berrie or feede, as big as a peafe. The roote is long and threddie.

$$
\text { * The place. }
$$

Gladdon groweth in many gardens: I haue feene it wilde in many places, as in woods and fhadowy places neere the fea.

$$
\text { * The time. }
$$

The ftinking Gladdon flowreth in Auguft: the feede whereof is ripe in September. $*$ The rames.

Stinking Gladdon is called in Latine Spatula fatida : among the apothecaries; it is called alfo $X y r i s$ : in Englifh ftinking Gladdon and Spurgewoort.

\section{* The nature.}

Gladdon is hotand dry in the third degiee. * The vertwes.

Such is the facultic of therootes of all the Irides A before named, that in pownding them they prouoke fneefing, and purge the head: generally all the

\section{kinds haue an heating, and extenuating quality.}

They are effectuall againft the cough: they eafily digeft, and confume the groffe humors, which B are hardly concotted: they purge choler and tough flegme : they procure fleepe, and helpe the gri-
pings within the bellie.

It helpeth the inuoluntaric effufion of naturall feede, as Plinie faith. If it be drunke in wine it C prouoketh the termes, andbeing put in bathes for women to fit ouer, it pronoketh the like effeet moft exquifitely. The roote pur in maner of a peffarie, haftneth the birth. They coner with flefh, 
bones that be bare, being veded in plaifters. The rootes boiled foft, and vfed plaifterwife, foften all old hard tumors, and the fwellings of the throte, called Strismuts, that is, the Kings euill; and emplaftered with honie, it draweth out broken bones.

D The meale thereof, healethall the rifts of the fundament, and the infirmities thereof, called Corm. dilomata : and openeth the Hemorrhoides. The iuice fniffed or drawne vp into the nofe, prouioketh fneefing, and draweth downe by the nofe great ftore of filthie excrements, which would fall intol other parts, by fecret and hidden waies and conueiances of the channels.

E It profiteth being vfed in 2 peffarie, to prouoke the termes, and to caufe abortion.

F It preuaileth much againft al! euill affections of the breft and lungs, being taken in a little fweete wine,with fome Spiknard, or in the whaie of milke, with a little Mafticke.

G The roote of $X y r$ is or Gladdon, is of great force againft wounds and fractures of the head, for it draweth out all thornes, ftubs, pricks and arrow heads, without greefe: which qualitie it affecteth as Galen faith, by reafon of his tenuitic of parts, and of his attracting, drying,and digefting facultie, which chiefely confifteth in the feede or fruite, which mightily pronoketh yrine.

$\mathrm{H}$ The roote giuen in wine, called in phificke Paffem, profiteth much againft convulfions, ruptures, the paine of the huckle bones, the ftrangurie, and the fluxe of the bellie. Where note, that whereas it is faid, that the potion aboue named ftaieth the fluxe of the bellie, hauing a purging qualitie:it muft be vnderftood, that it worketh in that maner as Rhabarbarum, \& $A$ farum do, in that they concoct and take away the caufe of the laske, otherwife no doubt it mooueth vnto the ftoole, as Rhewbarb, Afarum, and the other Irides do. Heereof the countrey people of Sommerfethire haue goodexperience, who vfe to drinke the decoction of this roote. Others do take the infufion thereof in ale and fuch like, wherewith they purge themfelues, and that vnto very good purpofe \& effeet.

I. The feed therof mightily purgeth by vrine as $G$ alen faith, \& the cuntry people haue found it true.

$$
\text { Of Ginger. Chap. } 38 \text {. }
$$

I Zinziberü fictum. The fained figure of Ginger,
2 Zinziberis verior Icon. The true figure of Ginger.
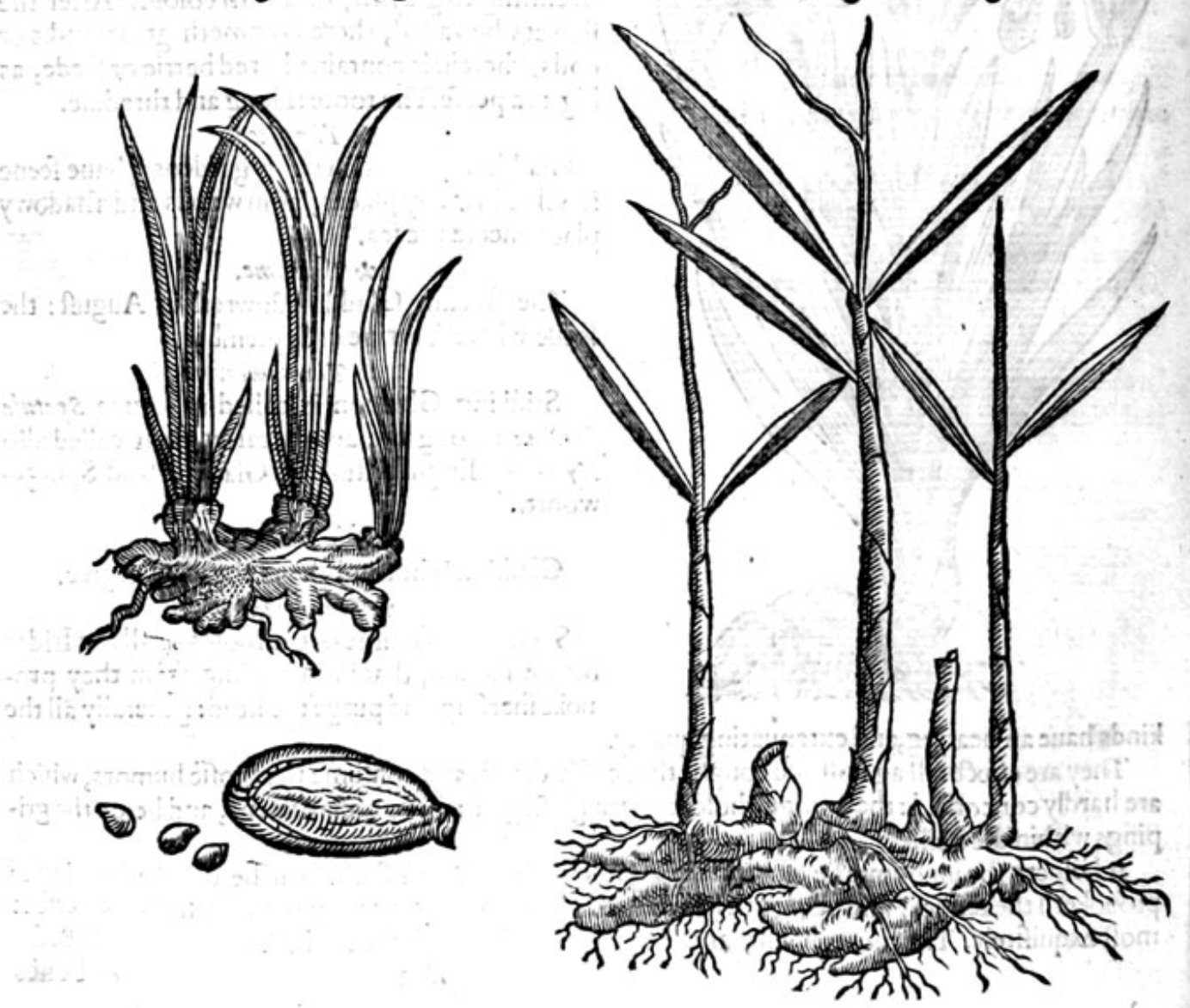


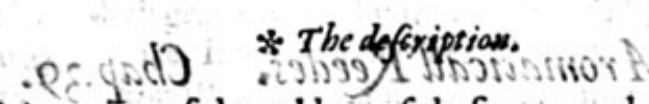

I

Inger is moft impatient of the coldnes of thefe our northerne regions, as my felfe haue found by proofe $;$ for thathere haue been brought vnto me at feuerall times fundry plants thereof, fierh, greene, anct fuff of iuice, 25 well from the Weft Indies, 25 from Barbarie and other places, which haue fprouted and budded foorth greene leaues in my garden in the heate of former; but as foone as it hath bin but touched with the firft fharp blaft of winter, it hath prefently perifhed both blade and roote. The tue forme or pieture hath not before this time been fet foorth by any that hath written, but the world hath been deceiued by a counterfet figure, which the reuerent and learned herbarilt Mat bius $L$ b bel, did fet foorth in his obferuations. The forme whereof notwithiftanding I haue heere expreffed, with the true and vndoubted pitture alfo, which I receiued from L'Obelius his owne hands at the impreffion heerof. The caufe of whofe former error, as alfo the meanes whereby he got the knowledge of the true Ginger, may appecte by his owne words fent vnto me in Latine, which I haue heere inferted. His words be thefo.

How hard and vncertainc it is, to defcribe in words the true proportion of plants, hauing no other guide than skilfull, but yet deceitfull formes of them, fent from friends or other meanes; they beft do know, who haue deeplieft waded in this fea of fimples. About thirty yeeres paft or more, an honeft and expert Apothecarie PV illian D ries, to fatisfic my defire, fent me from Antwerpe to London the pieture of Ginger, which he held to be truly and tively drawen; I my felfegate him credit eafily, bicaufel was not ignoraht, that there had been oft Ginger rootes brought greene, new, and full of iuicefrom the Indies to fhtwerpe: and further, that the fame had buddedand growen in the faid Dries garden. But not many yeeres after, I perceiued that pidure which was fent me by my friend, not to haue been truly fet foorth, but before that time to haue been drawen by the old Germane Botanicus. Therefore not fuffering this error any further to fpread abrode, (which I difcouered normany yecres palt ay Flufhing in Zealand, in the garden of $V$ Villiam of 2 afsur Prinet of Orange of famous memorie; through the meanes of a woorthie perfon, if my memorie deceiue me not, called Vander Mill, at what time he opened, and loofed his firt yoong birds and fhootes about the end of fommer, refembling in leaues, and ftalks of 2 foote high, the yoong and tender thootes of the common reede called Harendo vallaturia:) I thought it coniuenient to impart thus much vnto Mafter John Ger ard an expert herbarift, andMafter of happiefucceffe in Surgerie, to the end he might let pofteritie know thus much, in the painfull and long labored trauels whichnow he hath in hand, to the great good and bencfit of his countrie. The plane it felfe brought me to Middleborrough, and fet in my garden, perifhed through the hardnes of the winter. Thus much haue I fet downe, truly tranflated out of his owiev words in: Latine, though too fauourably by him done to the commendation of any meane skill,

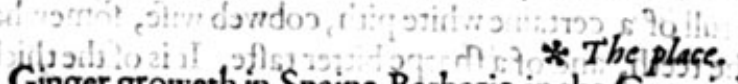

Ginger groweth in $S$ paine, Barbaric, in the Canarie Ilands, and the Acores. Our men which facked Domingo in the Indies, digged it vp there in fundry places wilde.

Ginger flouritheth in the hot time of fommer, and lofeth his leaues in winter.

Ginger is called in Latine $Z$ insaber.

Ginger heateth and drieth in the third degree

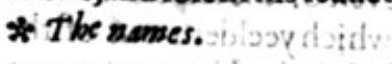

* The aertues.

Ginger, as Diofcorides reportech, is right good withes. for it is of an heating and digefting qualitie, it wentheate in fauces, or otherwife in copditures: A ftomacke, and effectually oppofeth it felfe againit all darknes the bellie, and is profitable for the and effeets of Pepper. It is to be confidered, that greene canded or font, anfwering the qualities moift in qualicie,prouoking venerie sand being dried, it heateth and driethin the third degree.

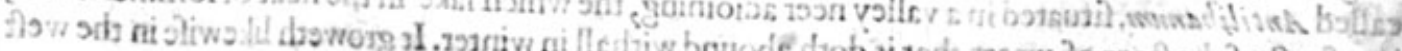




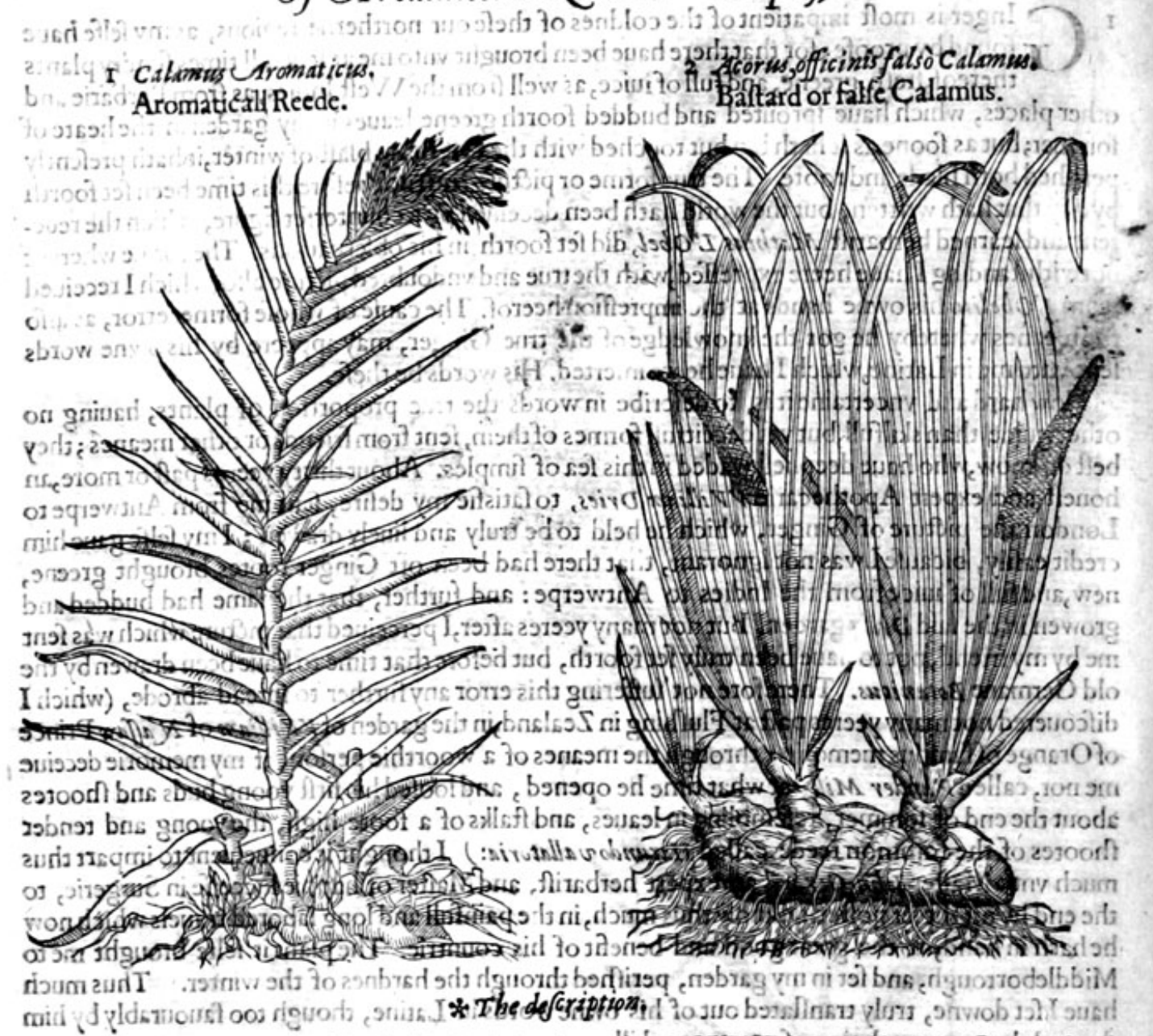

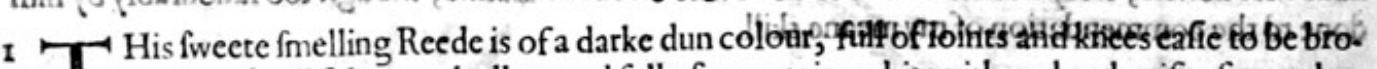

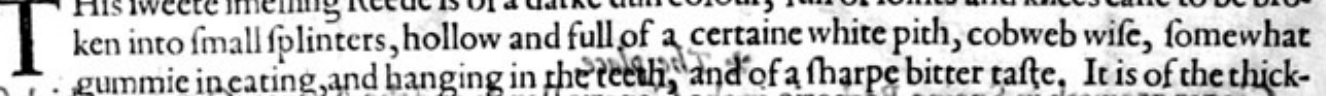

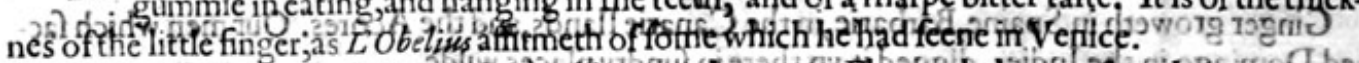

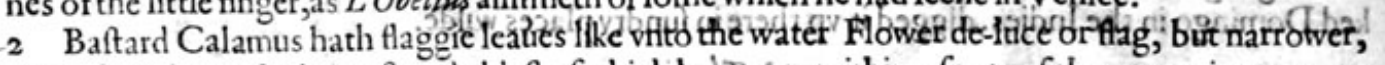
three foote long: the longeft and eldeft of whishideaties are within a foote of the top, as it were curled or pleated confufedly. The peft df the leafe is fimooth and euen, among whichieon meth ip a ftalke like the conmon reede, which yeeldetbous offtike middle a certaine long aglet or bunch, fuch as the Aller tree bringeth foorth. I haue not as yet feeneir bearehis tüftin mygavdenjiand haue read that it is barren, and by proofe have.feene it fo: yet for all that I beleeve Clufines, who faith he hath feene it beare his flower in that place where it idoth growe naurralby, alchongh in England it is altogither barren. The roote is freete in fmell, and bitter in tafte, and like vnto the

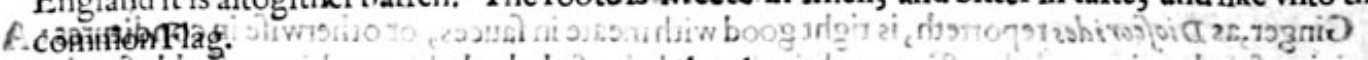

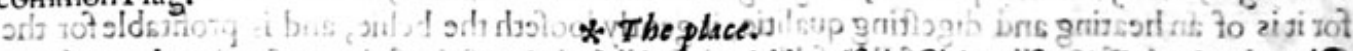

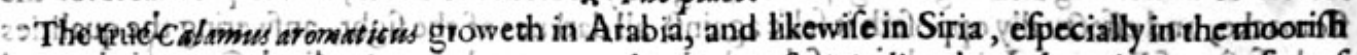

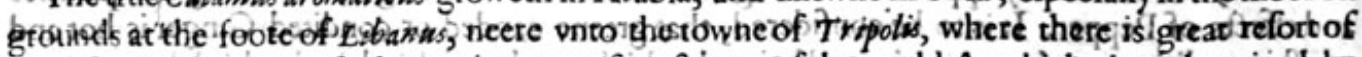
Englifinizare hants, as of other nations out of nout parts of the world. At which place there is 2lake called Antilibanum, fituated in a valley neer adioining, the which lake in the heat of fommer is drie, in refpect of the ftore of water that it doth âbound withall in winter. It groweth likewife in the weft and ealt Indies, in the like foile as aforefaid. 
Baftard or falfe Calamms doth growe naturally at the foote of a high hill neere to Pruffia, a citie of Bithynia, not far from a great lake. It profpercth exceeding well in my garden, but as yet it beareth

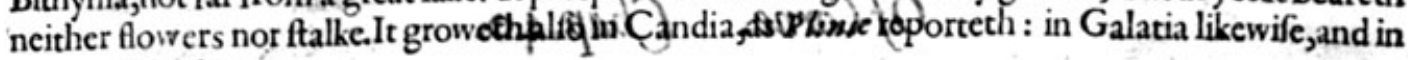
many other places.

They lafothicis leaues in the beginning of winter, and do recover them againe in the fprifgof theycete?

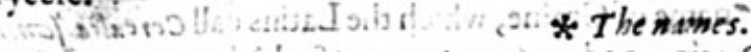

There hath betie froith time to time great controuterfic, and many difputations among writers about thefe two names, Calemessand Fitoris. The which hath been taken generally to be one, and the felfe fame plant; whech controueffe hnayeafiny be decided, if men that have trauailed in this qualitie, had but conmon fence: for that it is inoftetendeirt, that Acorms is one, and Calonus another, andBokhicedes, and yet differ as their deféripcions do ffiew. But if my cenfure might be recented, the ctrout hath growen through theignidirance of the apothecaries, who haue taken for Catamus a

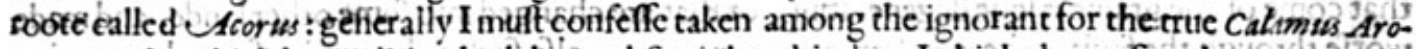

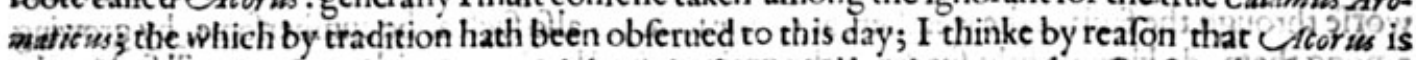

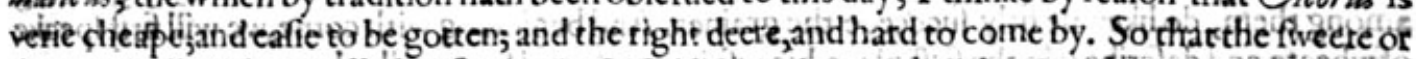
Aromaticall reede is called in Latine Calamis Aromaticus, and Galsmos Oabratus: Tiwicen and other of the ancient Arabians, haue called it $C_{3} / a b$ and Nidirira, of Serapias Hafjabel-dertre.

The falfe or baftard Calomus is called of the Latines Acorus, of fome Calames Aromaticus, but vntruly: in Italian Acoro: the Arabians Vage, or $V g i$ : in Grecke Axcess, andexoegt: ofdiuers as witnef-

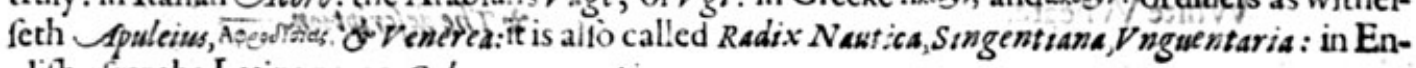
glith after the Latine name, Calamus arumaticus.

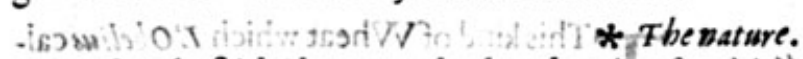

fo Digforidess faith; the rootes hath an hesting facultie Galen and $P$ linie do affirme, that they have thinand fubrillparts, both botand drie,

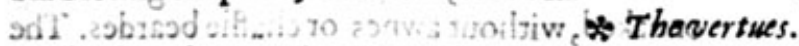

yo The decoction of the roote of Calavises drunkesprouoketh vrine, helpech the paine in the fide, li- $\mathbf{A}$ ver, fipleene, and breit? convulfions, gripings, and burftings: it cafeth and helpeth the piffing by

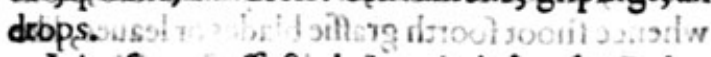

of It is of great effect, beingpit in brothof taken in furnes through a clofe ftoole, to prouoke wo- B mens naturall accidentso'd

Theinice ftrained with a little hony, tabech away the dimnes of the eies, and helpeth much againft $\mathbf{C}$ poifon, the hardnes of the fpleene, andaH infrmities of the blood.

The roote boiled in wine, enped and applied plaifterwife vnto the cods, doth woonderfullie D abate the fwelling of the fame, anit helpeth all hardnes and collections of humors.

The quansitie of two fruples anda balfe ot the roote drunke in fower ounces of Mufcadell, E helpeth them that be brufed with greeuours beating, or fals.

-fintreroore is with good fucceffe mixed with counterpoifons, In our age it is put into Eclegmas, F that is,medicines for the lungs, and efpecially when the lungs and cheft are oppreft with rawe and

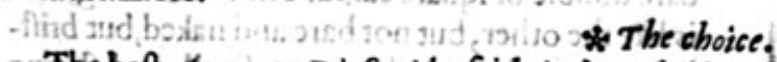

The bett Acorsus as Diof cor ides faith,ischatwhich is fib ftantiall, and well compa $\theta$, white within, not ratten, full, and well finelling. 2u Pliniewtiteth, that thofe which growin Candia are better then thofe of Pontus, and yet thofe of Candia woorfe then thofe of the eafterne countries or thofe of England, although we haue no
great quantigie thereof.

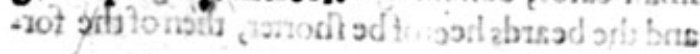

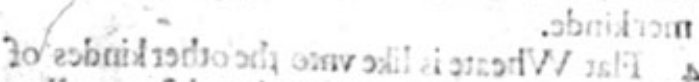

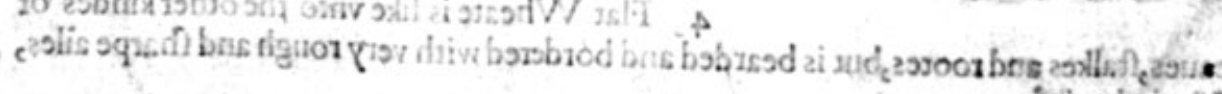

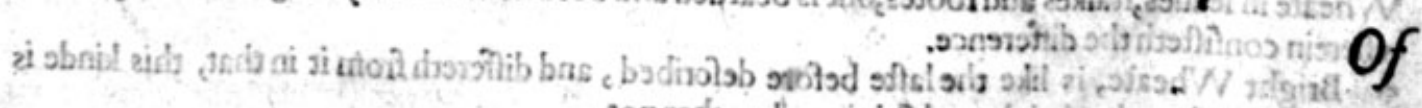
$\operatorname{sì} *$

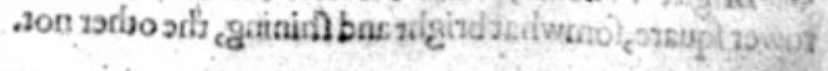




$$
\text { OfCorne. Cbap.40. }
$$

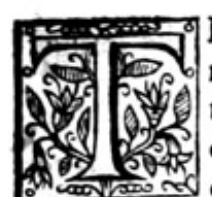

Hus far haue I difcourfed vpon Graffes, Rufhes,Spartum,Flags, and Flowver de-luces; my next labour is to fet downe for your better inftruetion, the hiftorie of Corne, and the kindes thereof, vnder the name of Graine, which the Latins call Cerealia femina,

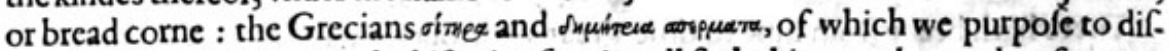
courfe. There belong to the hiftorie of graine all fuch things as be made of corne, as Far, Chondrus, Alica,Tragus, Anylum, Ptifana, Polenta, Masa;Byne or Mault, Zythwm, and whatfoeuer are of that fort. There be alfo ioined vnto them many feedes, which T beophraittus in his eight booke placeth among the graines, as Millet, Sorgum, Panicke, Indian wheate, and fuch like. Galen in his firft booke of the faculties of nourifhments, reckoneth vp the difeales of graine, as well thofe that come of the graine it felfe degenerating, or that are changed into fome other kinde, and made worfe through the fault of the weather, or of the foile; as alfo fuch as be cumberfome, by growing among them, do likewife fitly fucceede the graines. And beginning with corne, we will firft fpeake of wheate, and defcribe it in the firft place, bicaufe it is preferred before all other corne.

1 Triticion pica matica. White Wheate.

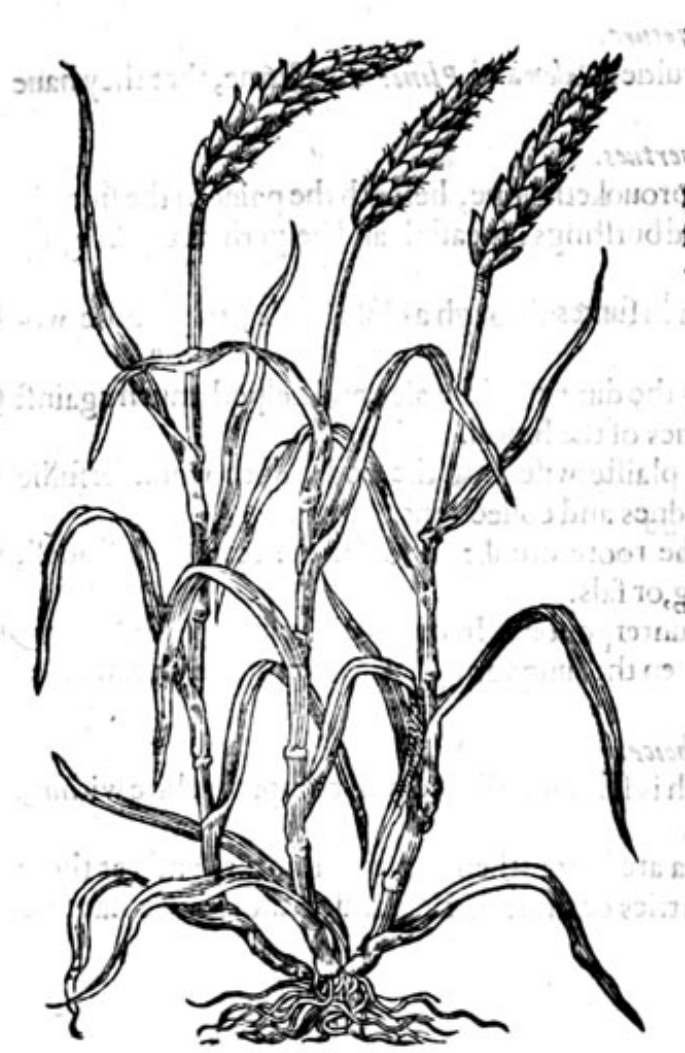

\section{* The defcription.}

This kind of Wheat which L'Obeliescalleth Spien Masica, is the moft principal of allother, whoféeares are altogitherbare ornaked, without awnes or chaffie beardes. The Atalk rifeth from 2 threddie roote, cốpact of many ftrings, iointed or kneed, at fundry diftances; from whence fhoot foorth graffie blades or leaues, like vntoRie, but broader: the plant is fo well knowne to many,and fo profitable to all, that the meaneft and moft ignorant, need no larger defcription to know the fame by. bus $*$ The defcription.

2 The fecondkinde of Wheate in roote, ftalks, ioints and blades, is like the precedent, differing onely in eare, and number of graines, whereof this kinde doth abound, hauing an eareconfifting of many ranks, which feemeth to make the eare double or fquare cared. The roote and graine is like the other, but not bare and naked, but briftled or bearded, with many finall and fharpe eiles or awnes, not vnlike to thofe of Barley.

3 The third kind is like the laft defcribed, \& thus differeth from it in that, that this kind hath many fmall eares, comming foorth of one great eare, and the beards heerof be horter, then of the formerkinde.

4 Flat Wheate is like vnto the other kindes of Wheate in leaues, ftalkes and rootes, but is bearded and bordered with very rough and fharpe ailes, wherein confifteth the difference.

5 Bright Wheate, is like the lafte before defcribed, and differeth from it in that, this kinde is fower fquare, fomwhat bright and hining, the other not. 
I HISTORIE OF PLANTS. HT

2 Triticnes aristic circumuallitwom.

3 Triticuen multiplici fics.

Bearded Wheate.

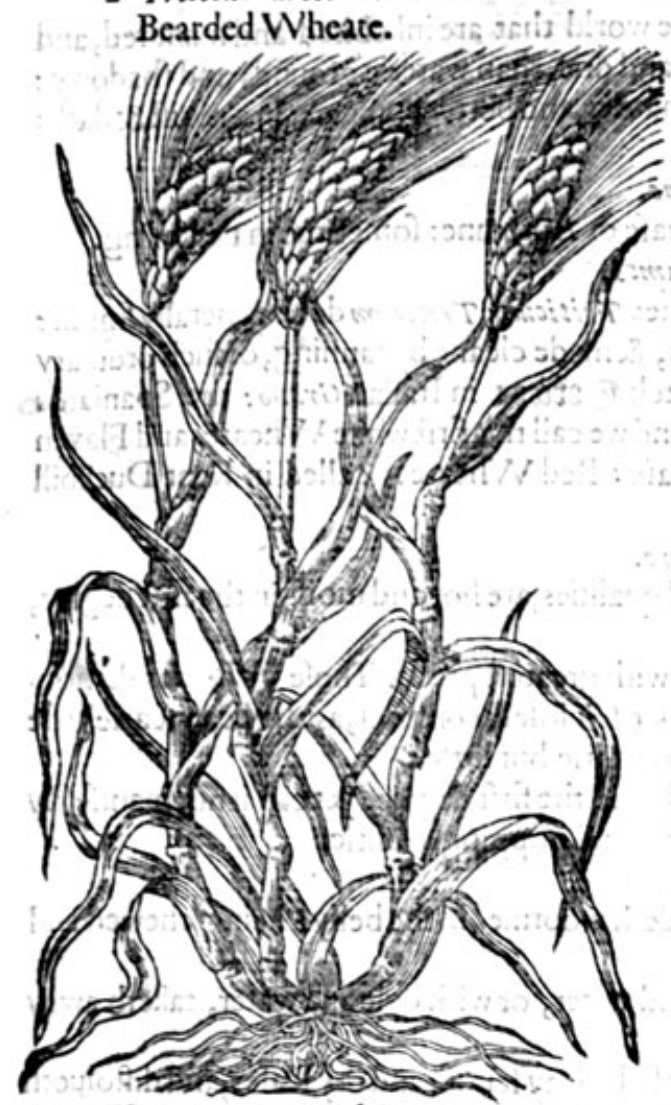

2i, 911 . Triticum Typhinum.

Flat Wheate.
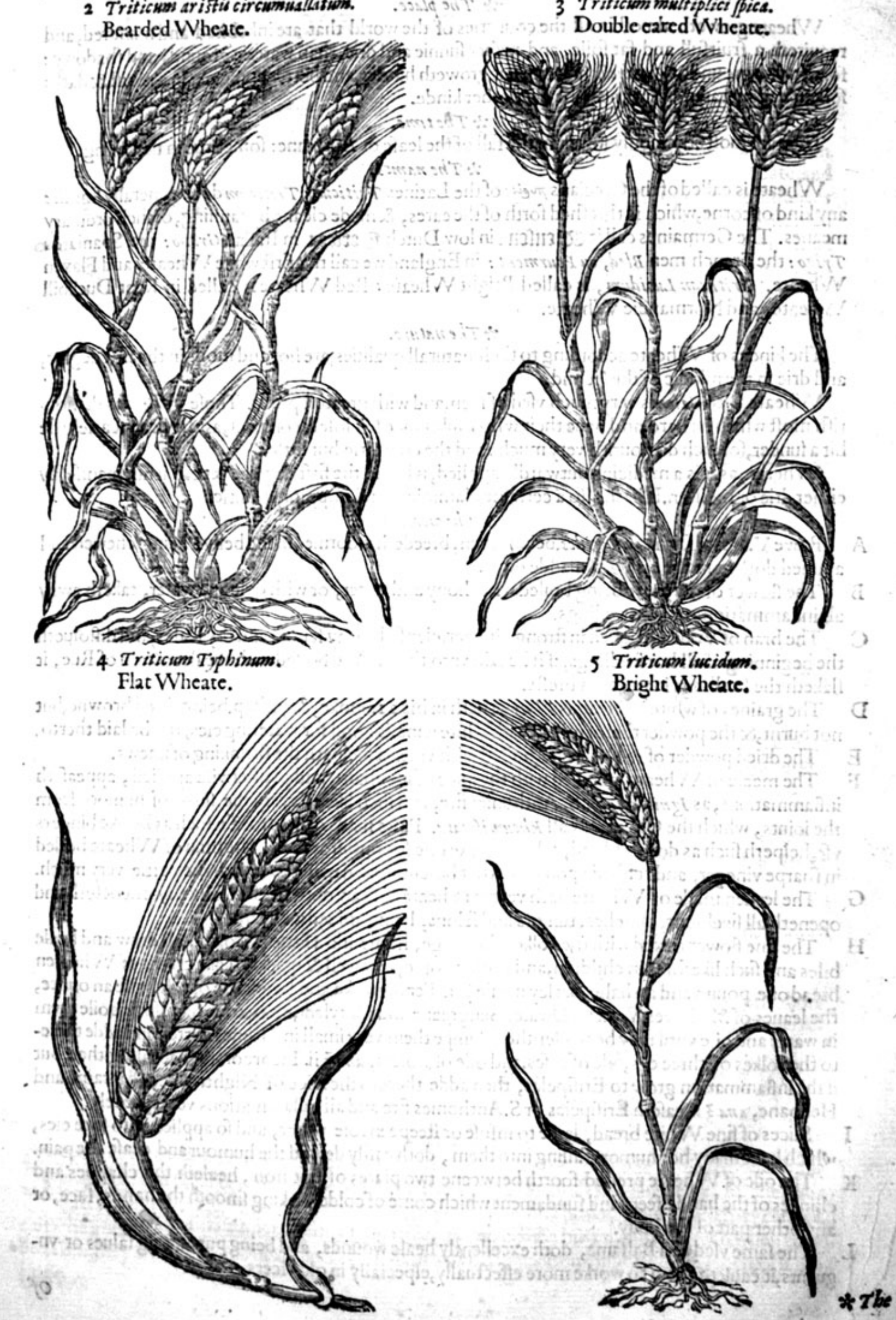
* The place.

Whearegroweth almoft in all the countries of the world that are inbabited andmanured, and requireth a fruitfull and fat foile, and rather funnie and drie, than waterie grounds and Thadowy: for in a drie ground as Colwmella reporteth, it groweth harder,and better compact: in a moift Sc darke foile, it degeneratech fomtime to be of another kinde.

* The time.

They are moft commonly fowen in the fall of the leafe or Autumne: fometime in the fpring. $*$ The names.

Wheate is called of the Grecians mues: of the Latines Triticum. Triticum doth generally fignifie any kind of corne, which is threfhed forth of the eares, \& made cleane by fanning, or fuch ordinary

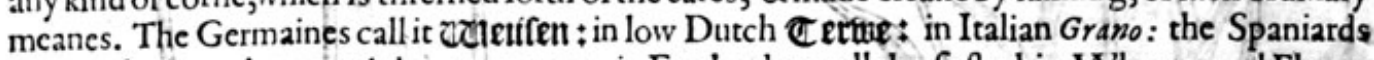
Trigo: the French men Bled, ou Fourment : in England we call the firft white Wheate, and Flaxen Wherte. Triticum Lucidum, is called Bright Wheate: Red Wheate is called in Kent Duckbill Wheate, and Normandie Wheate.

\section{* The nature.}

The kindes of Wheate according to their naturall qualities, are hot and moift in the firft degree, and drie in the middle of the fecond.

Wheate faith Galen is very much vfed of men, and with greateft profit. Thofe Wheates donourifh moft which be hard, and haue their whole fubitance fo clofely compact,as they can fcarfely be bit a funder, for fuch do nourifh very much : and the contrarie but little.

Wheate, as it is a medicine outwardly applied, is hot in the firf degree, yet can itnotmanifeftly either drie or moiften.It hath alfo a certaine clammines and ftopping qualitie.

$$
* \text { The vertues. }
$$

A Rawe Wheate faith Diofcorides, being eaten, breedeth woormes in the belly: being chewed and applied doth cure the biting of madde dogs.

B The flower of Wheate being boiled with hony and water, or with oyle and water, taketh away all inflammations or hot fwellings.

C The bran of Wheate boiled in ftrong vineger, clenfeth away fcurffe and dry fcales, and diffolueth the beginning of all hotfivellings, if it be laid vnto them. And boiled with the decoetion of Rue, it flaketh the fwetlings in womens brefts.

D The graines of white Wheat, as Pliny writeth in his 22 .booke, \& 7.chap.being dried browne, but not burnt, \& the powder therof mixed with white wine, is good for watering eies, if it be laid therto.

E The dried powder of red Wheate, boiled with vineger, helpeth the Phrinking of finews.

F The mealc of Wheate, mingled with the iuice of Henbane, and plaifterwife applied, appeafeth inflammations, as Ignis facer, or S. Anthonies fire, and fuch like: ftaying the fluxe of humors from the ioints, which the Grecians call $k$ hewnifmata. Pafte made of fine meale, fuch as Booke binders vfe, helpeth fuch as do fpit blood, taken warme one fpoonfull at once. The bran of Wheate boiled in fharpe vineger, and rubbed vpon them that be fcuruie and mangie, eafech the partie very much.

$G$ The leauen made of Wheate hath vertue to heate $\&$ draw outward, it refolueth, concoeteth and openeth all fwellings, bunches, tumors and felons, being mixed with falt.

$\mathrm{H}$ The fine flower mixed with the yolke of an egge, honie and a little faffron, doth draw and heale biles and fuch like fores in children, and in old people,very well \& quickly. Take crums of Wheaten bread one pound and an halfe, barley meale $z$ ii. Fennigreeke and Linefeede of ech halfe an ounce, the leaues of Mallowes, Violets, Dwale, Sengreene and Cotyledon, ana one handfull: boile them in water and oile vntil they be tender:then ftampe them very fmall in a ftone morter, and adde thereto the yolkes of three egs, oile of rofes, and oile of violets, ami $z$ ii. Incorporate them altogither, but if the inflammation grow to Erifipelas, then adde thereto the iuice of Night?hade, Plantaine and Henbane, ana $z$ ii.eafeth Erifipelas or $S$. Anthonies fire and all inflammations very fpeedely.

I Slices of fine White bread, laide to infufe or ftcepe in rofe water, and fo applied vnto fore eies, which have many hot humors falling into them, doth eafily defend the humour and ceafe the pain.

$\mathrm{K}$ The oilc of Wheate preffed foorth betweene two plates of hot iron, healcth the chappes and chinkes of the hands, feete and fundament which comc of colde, making fmooth the hands, face, or any other part of the body.

$L$ The fame vfed as a Balfame, doth excellently heale wounds, and being put among falues or vnguents, it caufech them to worke more effectually, efpecially in old vlcers. 


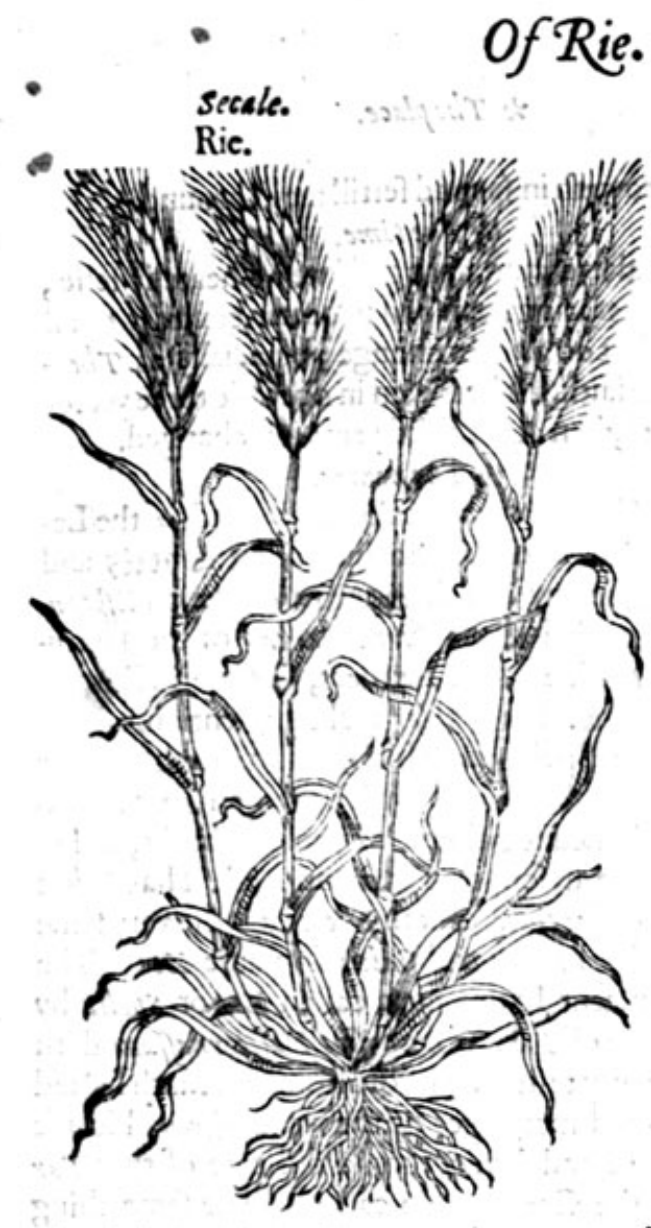

Chap.41.

* The defcription.

The leafe of Rie when it firft commeth vp; is fomewhat reddifh, afterward greene, as be the other graines. It groweth vp with many ftalks, flenderer than thofe of Wheate, and longer, with knees or ioints by certaine diftances like vnto Wheatc: the eares are orderly framed $\mathrm{vp}$ in rankes, and compaffed about with fhore beards, not iharpe but blunt, which when it flowr reth ftandech vpright, and when it is filled vp with feede it leaneth and hangeth downward. Thefeed is long,blackifh, flender and naked, which cafilie falleth out of the husks of it felfe. The rootes be many, llender and full of ftrings.

\section{* Theplace.}

Rie groweth very plentifully in the moft places of Germanie and Polonia, as appeereth by the great quantitic brought into England in times of dearch, and fearfitie of corne, as happened in the yeere 1596. and at other times, when there was a generall want of bread come, by reafon of the abundance of rain that fell the yeere before, wherby great penuric infued, as well of cattell, and all other vietuals, as of all maner of graine. It gtoweth likeswife very well in moft places of England, efpecially toward the North.

* The time.

It is for the moft part fowen in Autumne, \& fomtimes in the fpring, which proueth to be a graine more fabiect to putrifaction, than that that was fowen in the fall of the leafe, by reafon the winter doch ouertake it before it can attaine to his perfect maturitic and ripeneffe.

* The names.

Ric is called in high Dutch, Rocken, in lowe Dutch Ragre: in Spanifh centeno : in Italian segale: in Fiench Seigle, which foundeth after the old Latime name Siligu. Plinie calleth it secale and Rogge in his 18. boöke and 16 .chapter.

* The temperature.

dravis

Rie as it is a medicine, is hotter then Wheate, and more forcible in wafting and confuming away the body which is nourifhed by it.

$*$ The vertues.

Bread,or the leuen of Rie, as the Belgian Phifitions do affirme vpon their practife, doth more A forciblie digeft, drawe, ripen, and breake all apoftumes, botches, and biles, than the leuen of
wheate.

\section{Of Spelt Corne. Chap.42.}

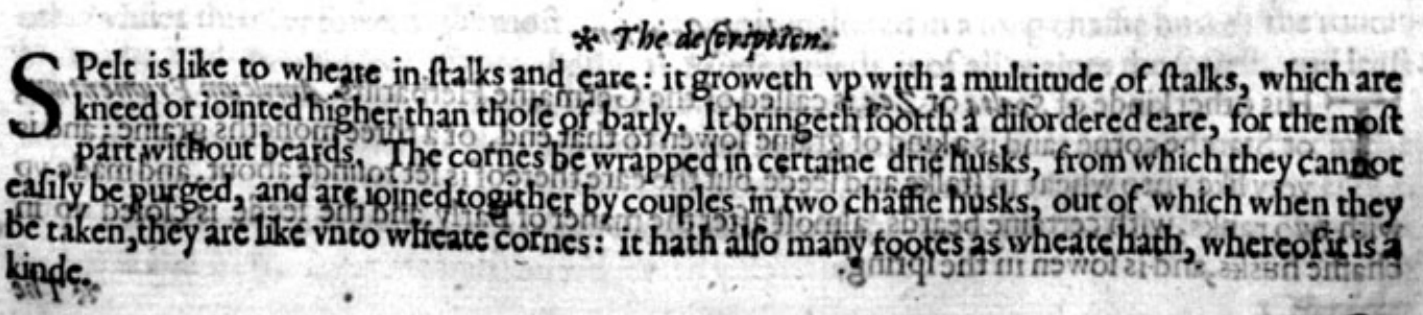




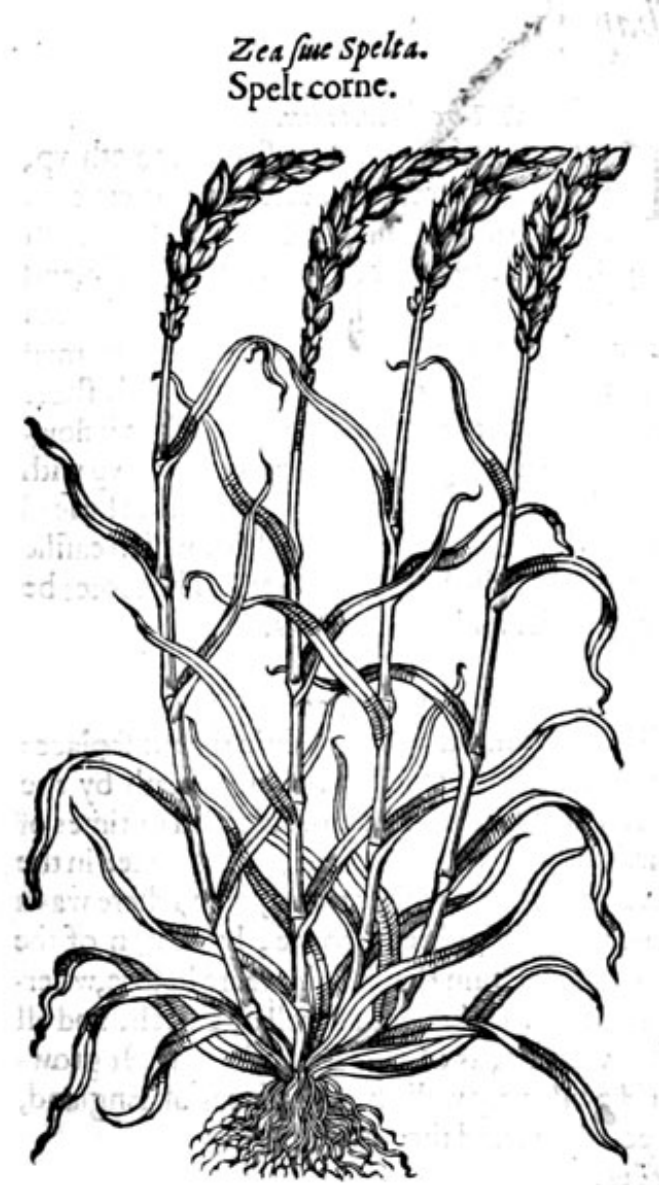

* Theplace.

It groweth in fat and fertill moift ground. * The time.

It is altered and changed into Wheate it felfe, as degenerating from bad to better, contrary to all other that do alter or change; efpecially as Theaphraftus faith, if it be fowen in one foile three yeeres togicher, then at the third yeere it is changed. * The names.

The Græcians haue called it \}ria, and ?ra: the $\mathrm{L}_{2}$ tins Spelta : in the Germaine toong peitz and inkel: in low Dutch Spelte : in French Epeaw tre : of moft Italians Pirra Farra : of the Hetrufcians Biada : of the Ilanders, Nilga : in Englifh Spelt corne. Diofcortdes maketh mention of two kindes of Spelt, one which he furnameth $\alpha^{\pi} \pi \lambda n$, or fingle : another oxboxxos, which bringeth foorth two cornes ioined togither in 2 couple of husks, as before in the defcription is mentioned. That Spelt which Diofcorides calleth Dicoccos, is the very fame that $T$ heophraftes and $G$ alen do name $Z e s$. The moft ancient Latins have called Zes or Spelta by the name of Far, as Dionyfius Halicarnaffass doth fufficiently teftifie. The oldRomanes (faith he)did call facred marriages by the word eapparua, bicaufe the bride and bridegroome did eate of that Far which the Grecians do call ria. The fame thing $\mathcal{L}$ clepiades affirmeth in Galen, in his ninth booke according to the places affeeted, writing thus, Farris quod Zea appellant, that is tofay, Far which is called $Z i a, \& c$. And this $F a r$ is allo named of the Latins Ador, cdor ewm, and Semen adorewom.

$*$ The temperature and vertues.

Speit as Diofcorides reporteth, nourifheth more than Barley. Galen writeth in bis bookes of the Faculties of fimple medicines, that Spelt is in all his temperature in a meane betweene Wheate and Barly, and may in vertue be referred to the kindes of Barly or Wheate, being indifferent to themboth.

A The ftower or meale of Spelt corne, boiled in water with the powder of red faunders, a little oile of Rofes and Lillies vnto the forme of a pultus, and appliéd hot, taketh away the fwelling of the legs gotten by cold and long ftanding.

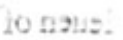

\section{Of Starch Corne. Chap.43.}

* The defcription:

$\mathrm{T}$ His other kinde of Spelta or Zes, is called of the Germaine Herbarifts Amylesen Frumention, or Starche corne : and is a kind of graine fowen to that end, or a three moneths graine; and is very like vnto wheat in ftalke and feede, but the eare thereof is fet rounde about, and made vP with two ranks, with certaine beards, almoft after the maner of $\mathrm{B}_{2}$ ly, and the feede is clofed $\mathbf{v P}_{1}$ in chaffic husks, and is fowen in the fpring.

*the 
Triticum Conylewon.

Starche corne

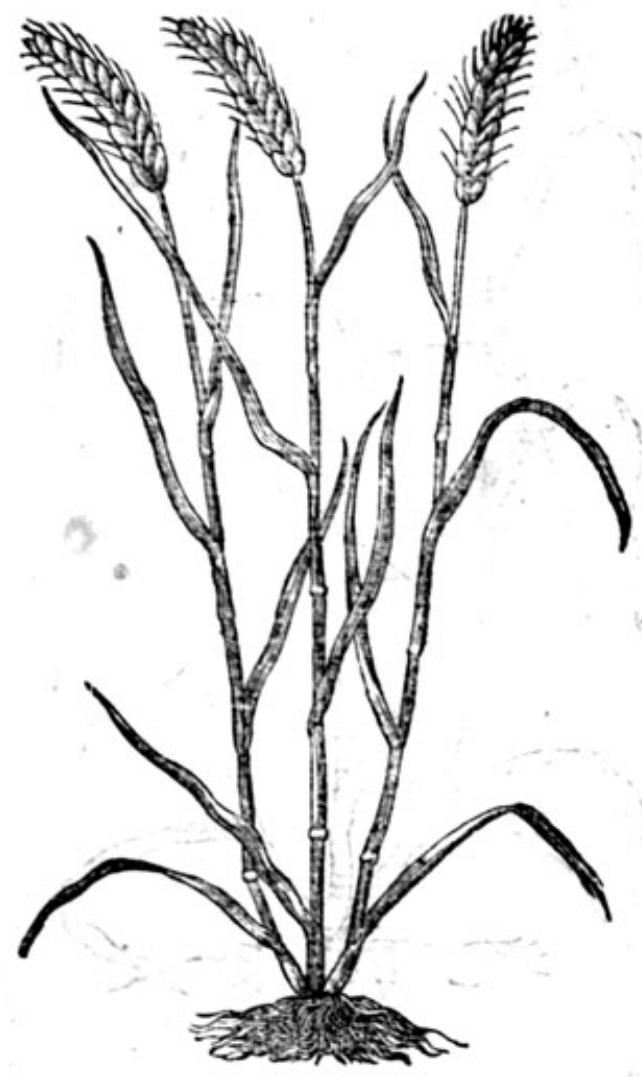

* The place.

Amilcorne or ftarche corne, is fowen in Germany,Polonia,Denmarke,\& other thofe eafterne regions, afwell to feede their cattell and pullen with, as alfo to make ftarch, for the which purpole it doth very fitly ferue.

\section{* The time.}

It is fowen in Autumne or the fall of the leafe, and oftentimes in the fpring, and for that caufe hath been called $T$ rimestre or three months graine, it bringeth hisfeede to ripenes in the beginning of Augurt, and is fowen in the low countries in the fpring of the yeere.

\section{* The names.}

Bicaufe the Germaines have great vfe of it to make ftarche with, they do call it Ameicon, we thinke good to name it in Latine Amplewon frumentum : in Englifh it may be called Amelcorne after the Germaine word, and may likewife be called Starch corne. Trages and Fuchfous tooke it to be Triticum trimestre, or three moneths Wheate. Colvomella fpeaketh of a graine called Far Halicaftrum which is fowen in the fpring: and for that caufe is furnamed Trimestre, or three moneths $F a r$, whereof is made the beft ftarche. If any be defirous to learne the making of it, let them read-Dodonema laft Edition, where they halbe fully taught, my felfe not willing to fpende time about fo vaine a thing, and not pertinent to the hiftoric.

* The nature and vertwes.

There hath not any peculiar vertues been attributed to this kinde of Amylcorne, more than hath been faid, that is to feedecattell,pullen, and to make ftarch, the nature is referred vnto the bafe kinds of Wheate or Barly.

\section{OfBarly. Chap.44.}

\section{* The defcription.}

1 Arly hath an helme or ftrawe, which is fhorter and more brittle then that of Wheate, and with moe ioints: the leaues are broder, and rougher: the eare is armed with long, rough, and pricking beards or ailes, and fet about with fundry ranckes, fometimes two, otherwhiles three, or fower at the moft. The graine is included in a long chaffie huske : the rootes beflender and grow thicke togither. Barly, as Plimie writeth, is of all graines the fofteft, and leaft fubiect to cafualtie, yeeldeth fruite very quickly and profitablie.

2 The fecond kind of Barly is like vnto the former in ftalkes, rootes, and blades : they differ in the The north parts of England hath in cornes fet very orderly, which make a fquare eare, the other not, in Aprill and May. 


\section{Hordewon. \\ Barly.}

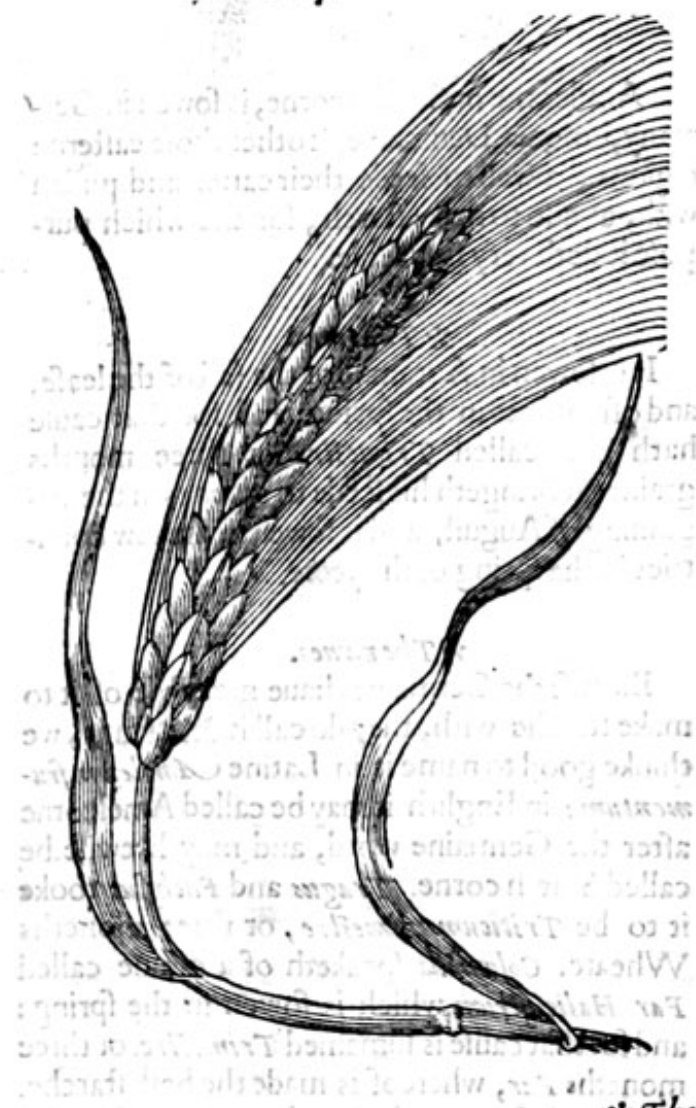

2 Hordeum Polystichum vermum. Beare Barly.

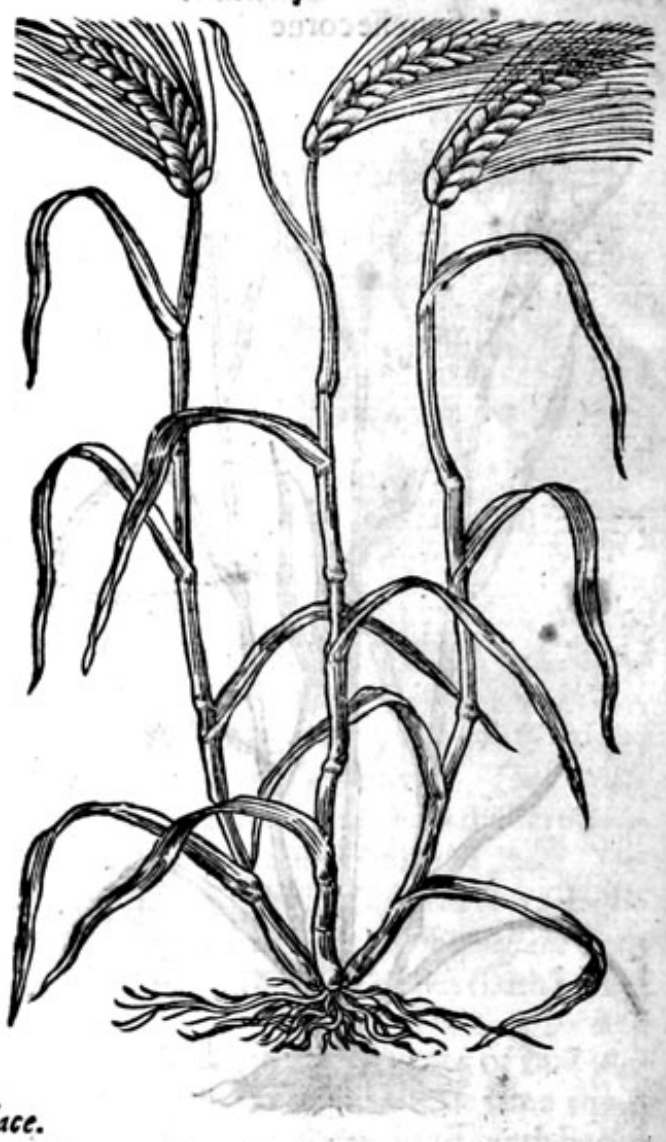

They are fowen as Colwmella teacheth, in loofe and drie ground, and are well knowenall Europe through.

$$
\text { * The names. }
$$

I The firft is called of the Grecians xel9i: in high Dutch Berten : in low Dutch Jferft: in Itali-

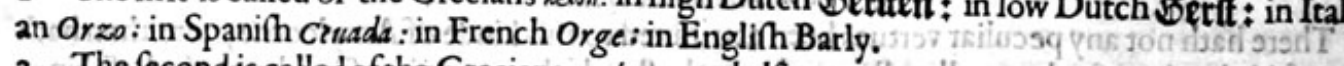

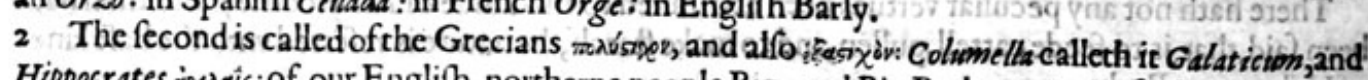
Hippocrates dexats: of our Englifh northerne people Big, and Big Barly. Crimwon faith Galen in his commentaries of the fecond book of Hippocrates his Prognoftikes, is the groffer part of Barly meal, pretation; notwithiftanding bicaufe thefe works may chance into the hands of ftrangers that neuer hard of fuch a worde, or fuch a thing, by reafon it is noteuery where made; I thought good to laie downe a word of the making thereof. Firft, it is fteeped in water vntill it dofwell, then it is dried

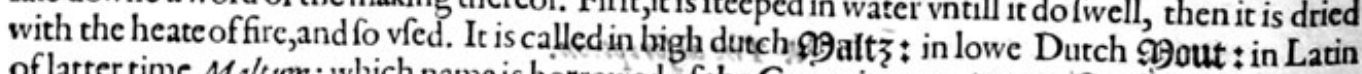
of latter time Maltom: which name is borrowed of the Germaines. Aetius a Greeke Phifition, nameth Barly thus prepared Bum, or Bine: the which author affitmet $h$ that a plaifter of the fneale of Mault is profitablic laide vpon the fwellings of the dropfie. Zwthion; as: Diodor ses Siculess affitrneth, is not onely made in Egypt, but alfo in Galatia. The aire is fo cold faith he writing of Galatias that the countrey bringeth foorth neither wine nor oile, and therefore men are compelled to make a comp pounde drinke of Barly, which they call $z$ thum; Diof for ides nameth one kinde of Barly drinke $z y$ thom, another $C u r m i$. Simeon $Z$ ethy a later Grecian, calleth this kinde of drinke by an Arabicke. name qou'res: in Englifh it is called Beere and Ale made of Barly Mault.

Barlyas $*$ The temperature.

Barly as Galen writeth in his booke of the faculties of nourihments, is not of the fame tempera ture that Wheate is : for Wheate doth manifeftly heate; but contrariwife wh.t medicine, or bread foeuer 


\section{SHISTORIEOOE RIANTSITT}

foever is made of Barly, is found to hauc a certaine force of cooling and drying in the firft degree, according to $G$ alen in his booke of the faculties of fimples. It hath alfo a little abftetfiviejor clenfing qualitie, and doth drie fomwhat more than Beane meale.

\section{* The vertues.}

Barly, faith Diofcorides, doth clenfe; prouoke vrine, breedech windines, $\$$ is an enimie to the to- A macke.

Barlymeale boiled in honied water with figs, taketh away inflammations: with pitch, rofine, and B pigeons dung, it fof tneth andripeneth bard fwellings.

With melilot and poppie feeds ic taketb away the paine in thefides : it is a remedie againft win- C dines of the guts, being applied withlinefeede, frenugreeke and rewve: with tar, waxe, oyle and the vrine of 2 yoong boy, is doth digeft, foften and ripen hard fwellings in the throte, called the Kings cuill.

Boiled with wine, mirtils, the barke of the pomegranate, wilde peares, and the leaues of brambles, D it ftoppech the laske.

Further it feruech for Ptifsest, Polents, Mazs, mault, ale, and beere. The making whereof if anie E be defirous to learne, let them reade L'Obelisus Adwerfaris, in the chapter of Barly. But I thinke our London beere brewers, would fcorne to learne to make beere of either French or Dutch, much leffe of me that can fay nothing therein of mine owne experience more than by the writings of others. But I may deliuer vnto you a confection made there of, as Culomella did concerning fweete wine, fodden to the halfe, which is this : boile ftrong ale till it come to the thicknes of honie, or the forme of an vnguent or falue, which applied to the paines of the finews and ioints, (2s hauing the propertie to abate aches and paines) may for want of better remedies be yfed for old and new fores, if it be made after thismaner.

Take ftrong ale two pound, one oxe gall, and boile them to one pound with 2 foft fire, continually $\mathrm{F}$ ftirring it, adding thereto of vineger one pound, of Olibanum one ounce, flowers of camomil and melilote of ech one ounce, rewe in fine powder halfe an ounce, 2 liette bonie, and 2 friall quantitie of the powder of comin feede, boile them altogither to the forme of an vnguens or falue, and fo applie it. The re be fundry forts of confeotions made of Barly, as Polents, Ptifana made of water and vnhusked or hulled Barly and fuch like. Polents is the meate made of parched Barly, which the Grecians do properly call áxonsov. Maza is made of parched Barly tempered with wateriafter Hippocrates and Xemophon: Cyriws hauing called his foldierstogither, exhorteth them to drinke water wherein

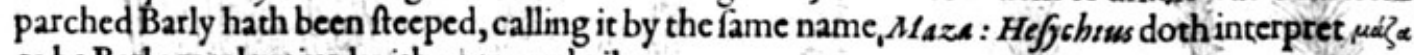
to be Barly meale mixed with water and oile.

Barly meale boiled in water with garden night hade, the leaues of garden Poppic, the powder of $G$ Fenugreke, and linefeed, and a little hogs greafe, is good againft all hot and burning fivellings, and preuaileth againft the dropfie being applied vpon.

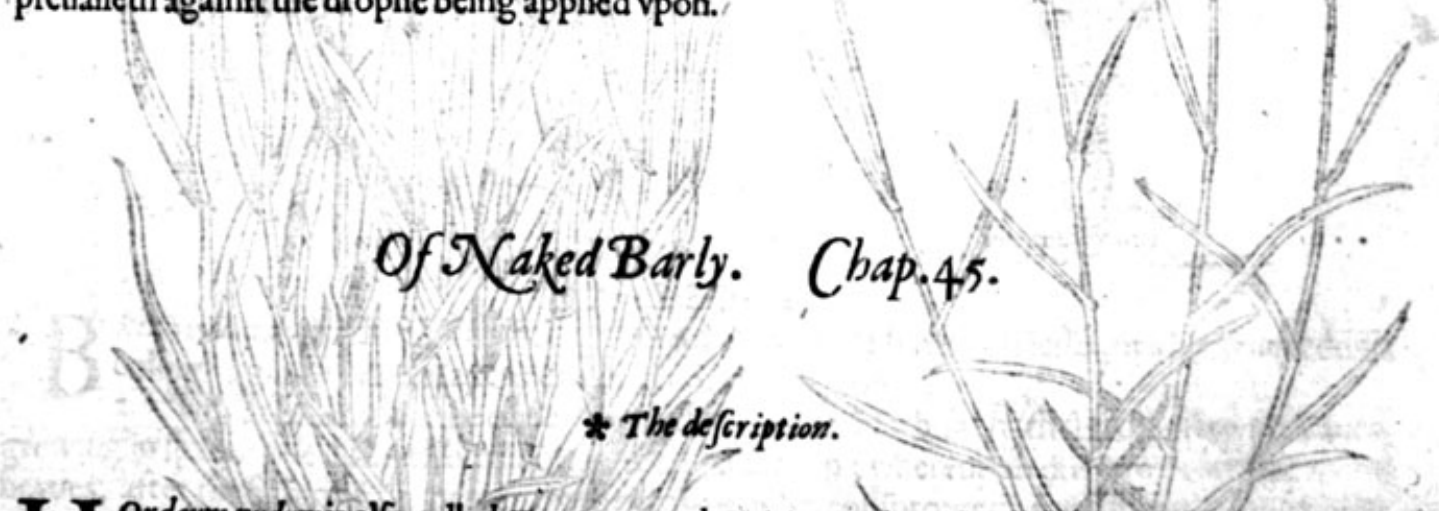

$\mathrm{H}$

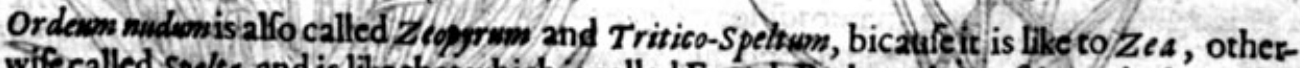
wifecalled spelss, and is likethat whichis called French Barly, whetrof is madechat noble drinkefor ficke folks called p wifass. The plant is altogither like vnto the common Barly, $f_{2}$. uing that the eares are rounder, the eiles or beards rougher and longer, and the feede or graine
naked withourhisks. 


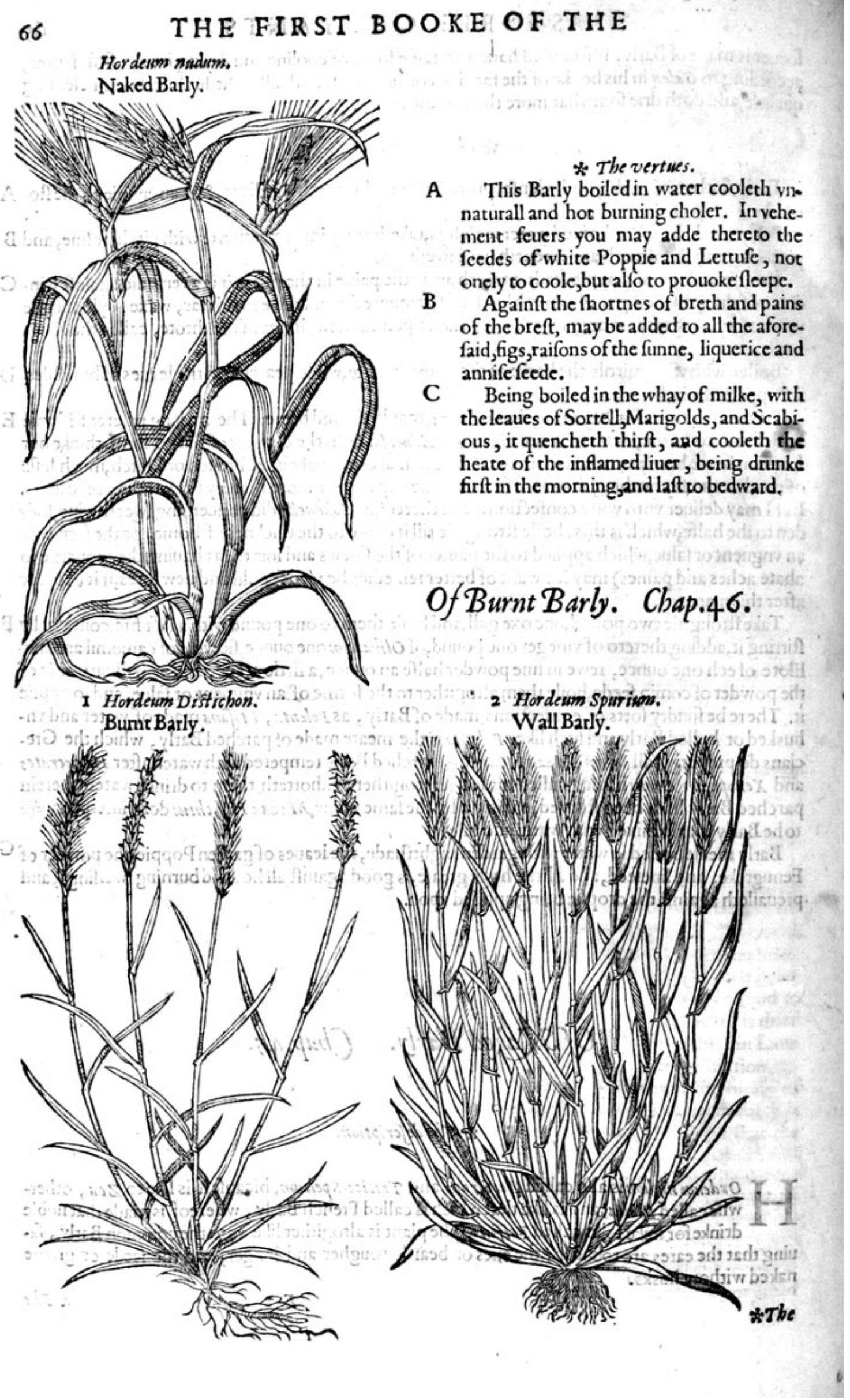




\section{IHAISPOR IE OA PLANTS.}

* The ilepirition.

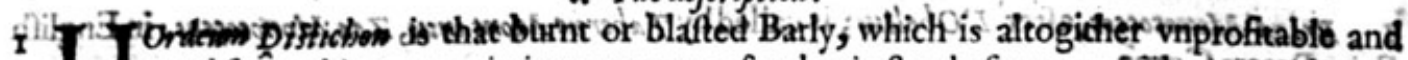

H good for nothing, an enimie vnto corne; for that in ftead of an earewith contive there is

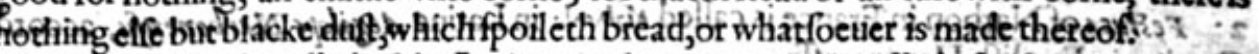

2 This kinde of wilde Barly, called of the Latins Hor deum Spurium, iscalled of Plinie Foblohos: in Englifh Wall Barly, Way Barly,or after old Enighith wiriters; Way Benner. It groweth vpon mud wals, and ftonie places by the waiesfides; very welltefembling feffe fowed Barly; yet the blades are rather like graffe than Barly.

- 10 ior

This baftard wilde Barly ftanped and applied vinto places wainting thaire, doth caufe isto growe $\mathbf{A}$ and come foorth, whereuponin old time it was called $R$ iflida.

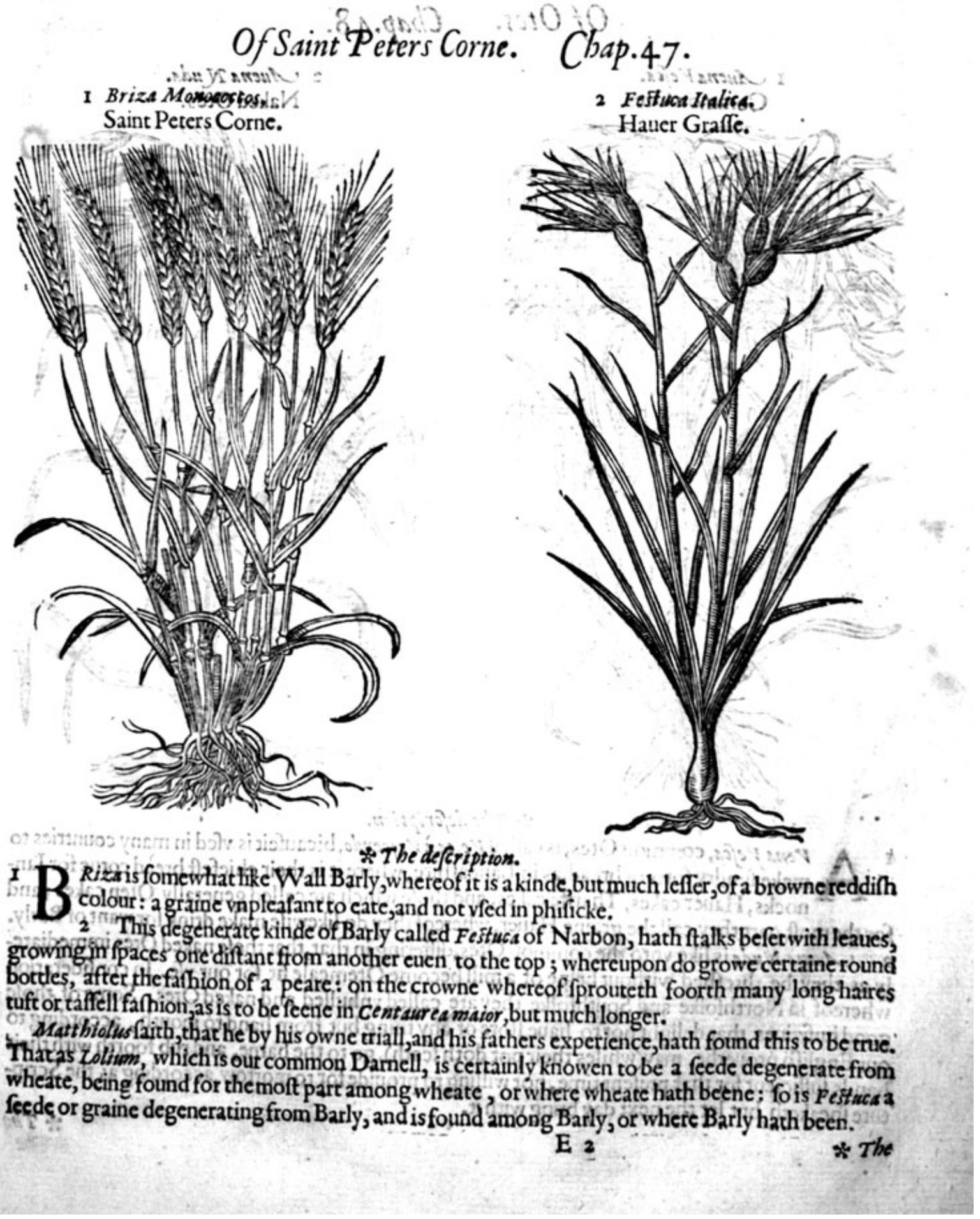




\section{* The nowes.}

I Brize Monococcos; after L'Obelisw; is called by Taberne Mont anm, Zea Momosoccos; in Englifh Saint Peters Corné.

2 Festuca of Narbon in France is called Nijinat: in Latine Aegilops Narbonenfw, according to the Greeke : in Englifh Hauergraffe.

They are of qualitie fomewhat harpe, hauing facultic to digert. * The vertues.

The iuice of Festuca mixed with barly mealedried, and at times of neede moiftned with rofe wa: ter applied plaifterwife, healeth the difeafe called Aegilops or Fiftula in the corner of the eie it mollifieth and difperfeth hard lumps, and affwageth the fwellings in the ioints.

\section{Of Otes. Chap.48.}
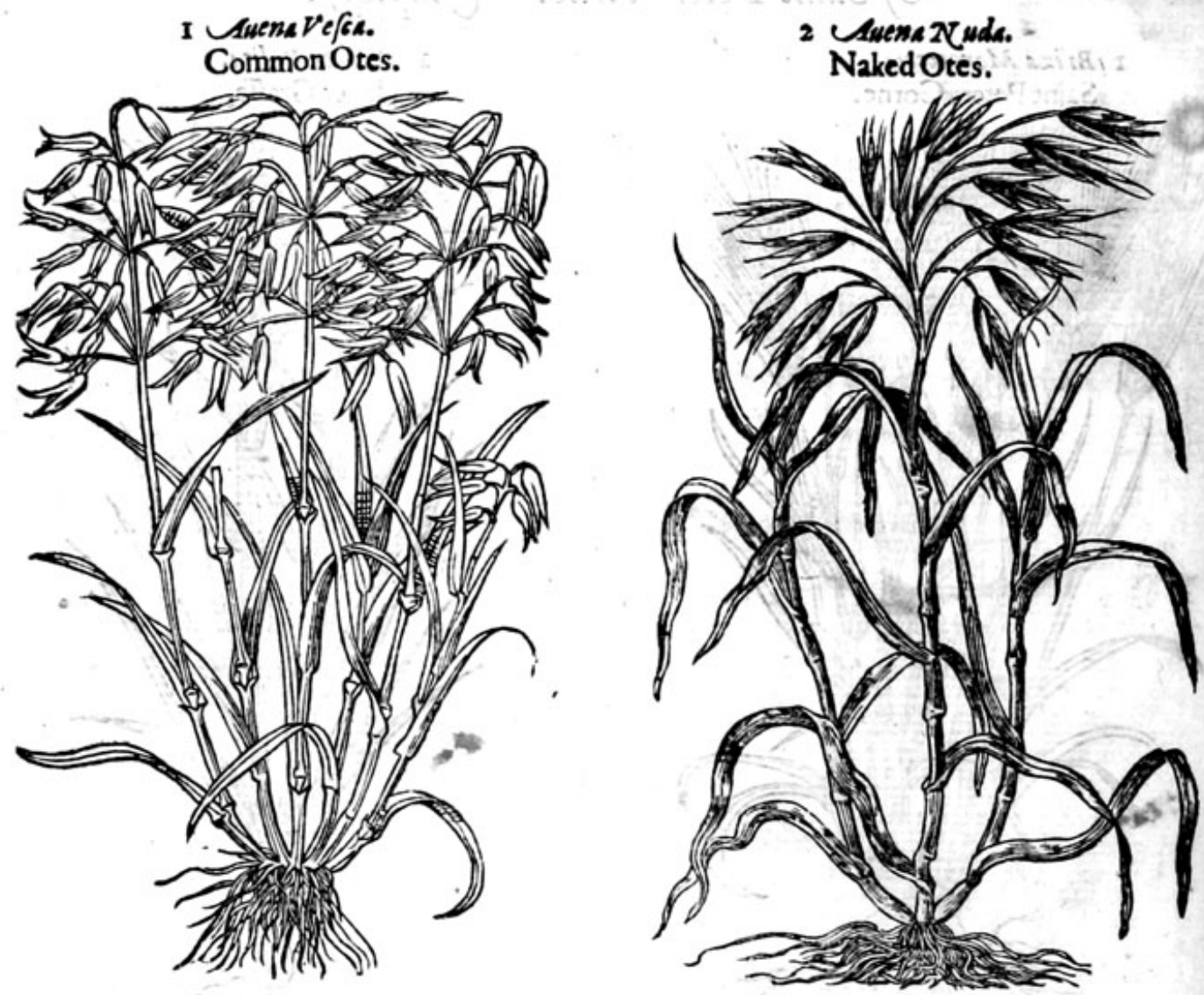

* The defaription.

I Vena $V e f c a$, common Otes, is called $V e f c a$ a $V$ efcendo, bicaufeit is vfed in many countries to make fundry forts of bread, as in Lancafhire, where it is their chiefert bread corne for Iannocks, Hauer cakes, Tharffe cakes, and thofe which are called generally Oten cakes; and for the moft part they call the graine Hauer, whereof they do likewife make drink for want of Barly. 2 Auena Nuds is like vnto the common Otes, differing in that, that thefe naked Otes immediately as they be threfhed without helpe of a mill become Otemeale fit for our vfe. In confideration whereof in Northfolke and Southfolke they are called vnhulled and naked Otes. Some of thofe good hufwiues that delight not to haue ftore of any thing but from hand to mouth, according to our Englifh prouerbe, may (whiles their pot doth feath) go to the barne, and rub foorth with their hands fufficient for that prefent time, not willing to prouidefor to morrow, according as the Scripture fpeaketh, but let the next day bring with it. 
* The nature.

Otes are dric and fomwhat cold of temperature, as Galen faith. * The vertues.

Common Otes put into a linnen bag, with a litle bay falt quilted handfomly for the fame purpofe, A and made hot in a frying pan, and applied very hot, eafeth the paine in the fide called the ftitch, or collicke in the bellie.

If Otes be boiled in water, and the hands or fecte of fuch as have Seripigo or Impetigo,that is, cer- B taine chaps, chinkes or rifts in the palmes of the hands or feete (a difeafe of great aftinitie with the pocks) be holden otier the fume or fmoke thereof, in fome bowle or other veffell wherein the Otes are put, and the patient couered with blankets to fweate, being firft annointed with that ointment or vnction vfually applied contr.t Morbom Gallicsm : it doth perfectly cure the fanie in fixe times fo annointing and fweating.

Otemeale is good for to make a faire and well coloured maide to looke likea cake of tallow, èfpe- C. cially if the take next hir ftomacke a good draught of ftrong vineger aftęr it.

\section{Of wilde Otes. Chap.49.}

I Eromos Sterilis. Wilde Otes.

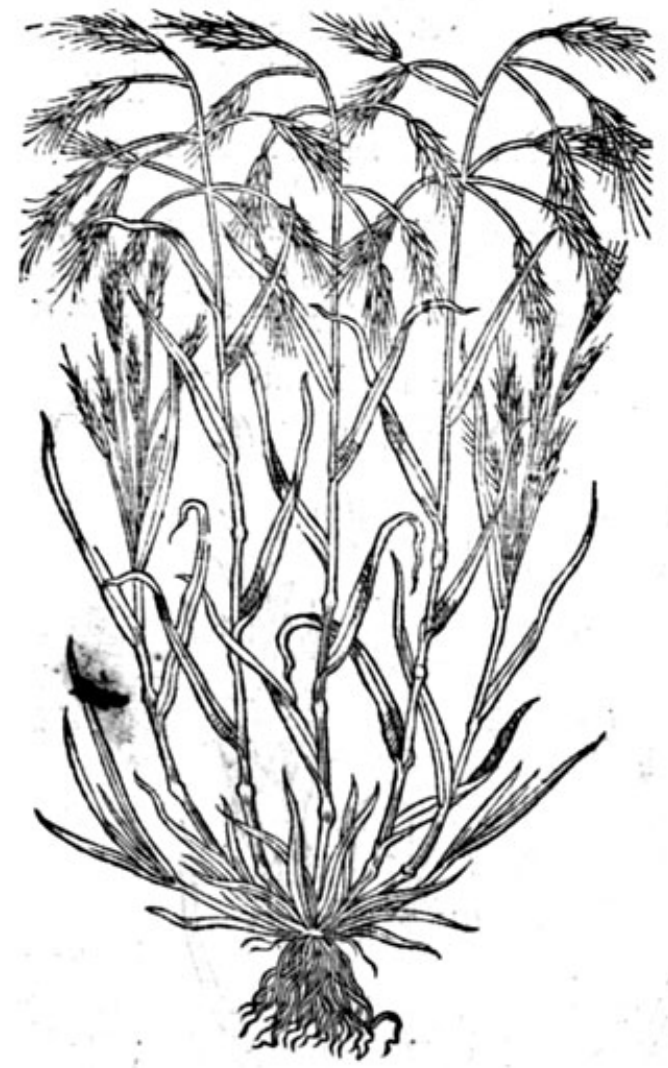

2 Eromos aitera.

Small wilde Otes.

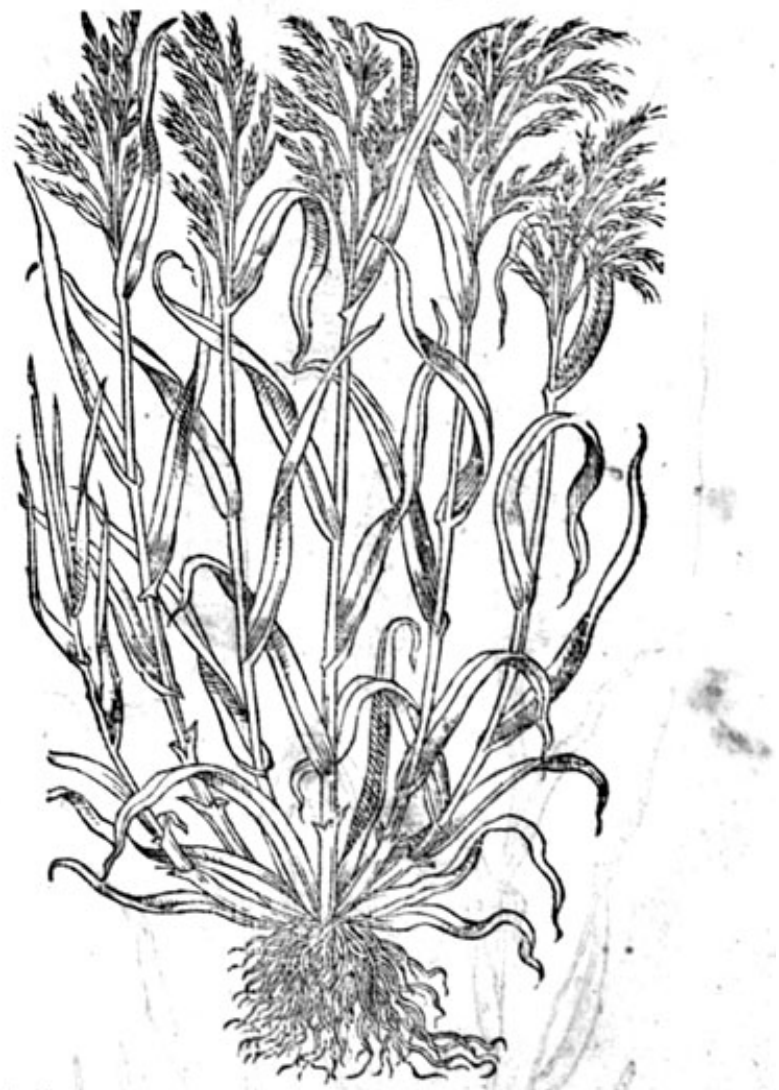

* The defcription.
Rownosfterilis, called likewife Anema fatua, which the Italians do call by a very apt name,
Vems vana, or Anena cafas; in Engliih barren Otes, or wilde Otes: hath the like qualitie that our vatna, or Anena caffa; in Engliih barren Otes, or wilde Otes: hath the like qualitie that 2 There is alfo another kinde of Bromos or wilde On that they neede no defcription. differing from the former wilde Otes, but that his Otes, which Dodonens calleth Festuces altera, not It may be called in Englifh Small wilde Otes, agreeing with Brunf elfius, that it is a kinde of Otes.
There is nothing extant woorthie the as hurtfull to corne,and vnprofitable. 
I Aegilops Bromoides.Bearded Otes.

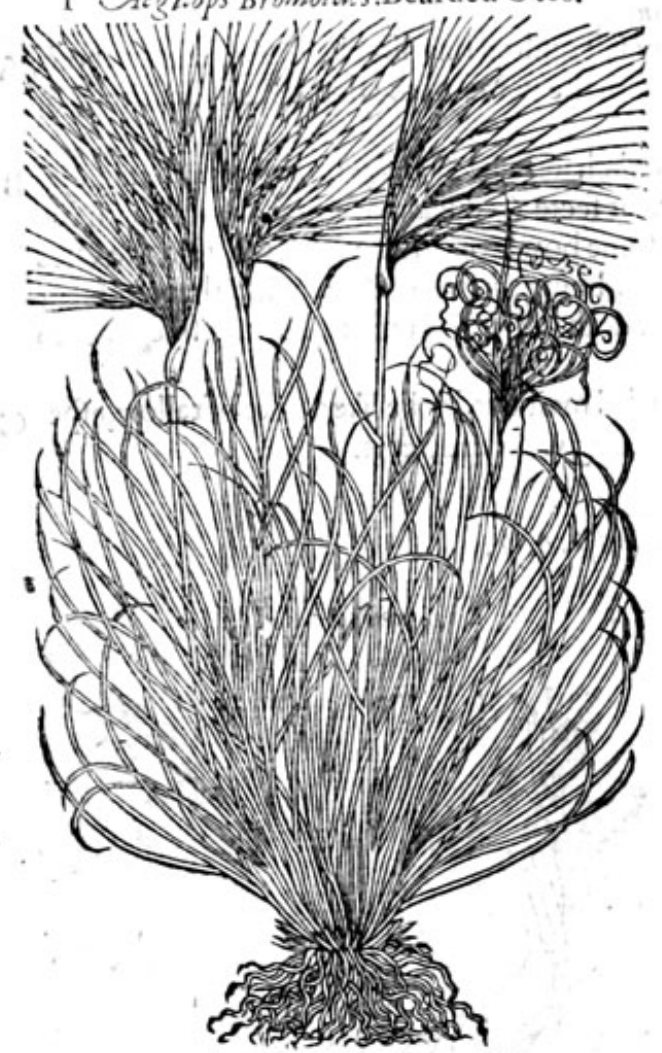

2 Vitilago fecalina. Burnt Rie.

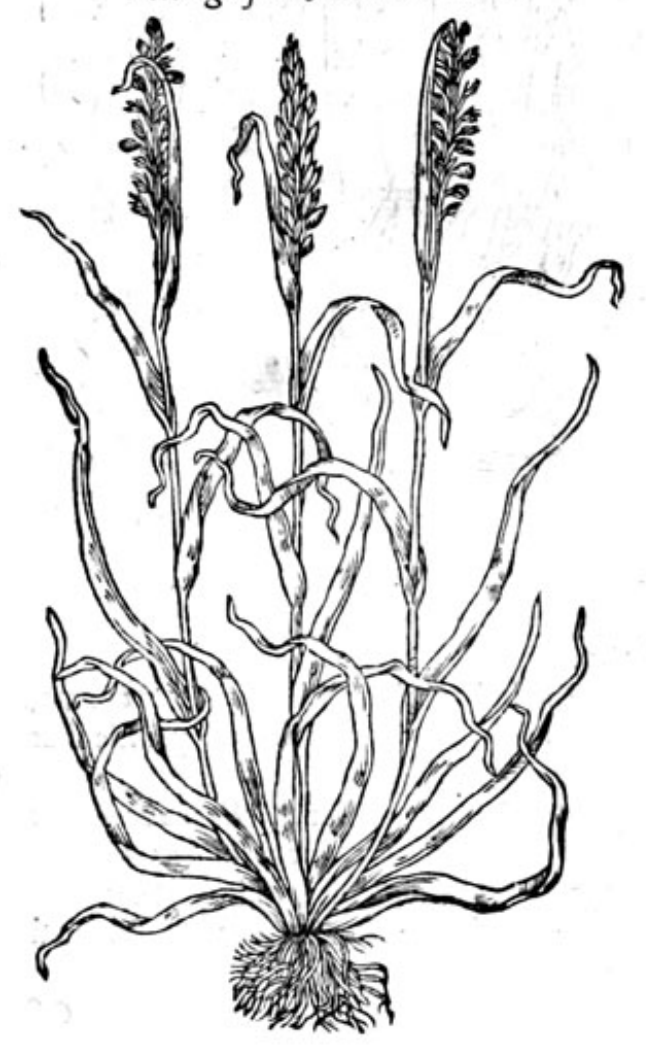

* The defcription. Egilops Lromoides Belgarum, is a plant in-
differently partaking of the nature of Aegilops and Bromus. It is in thew like to the naked Otes. The feede is tharpe, hairie, fomewhat long, and of a reddifh colour, inclofed in chaffie husks like the common Otes, and may be englined Crefted or Bearded Otes. Ihaue found it often among Barly andRie in fundrie grounds. This is likewife vnprofitable, and hurtfull to corne, whereof is no mention made by the ancients woorthie the noting.

\section{* The defcription.}

2 Burnt Ric hath no one good propertie in phificke,appropriate either to man, birds; or beafts, \&e is a hurtful maladie to all corne where it groweth, hauing an eare in fhape like to corne, but in fteed of graine it doth yecld a blacke powder or duft, which caufeth bread to looke blacke, and to haue an euill tafte. And that corne where it is, is called fmootie corne: and the thing it felfe Burnt corne, or blafted corne.

3 Burnt Otes or Vstilagoauena, or Cuenacea, is likewife an vuprofitable plant, degenerating from otes, as the other from Barly, Rie, and wheate. It

\section{Vftilago Auenacea. Burnt Otes.}

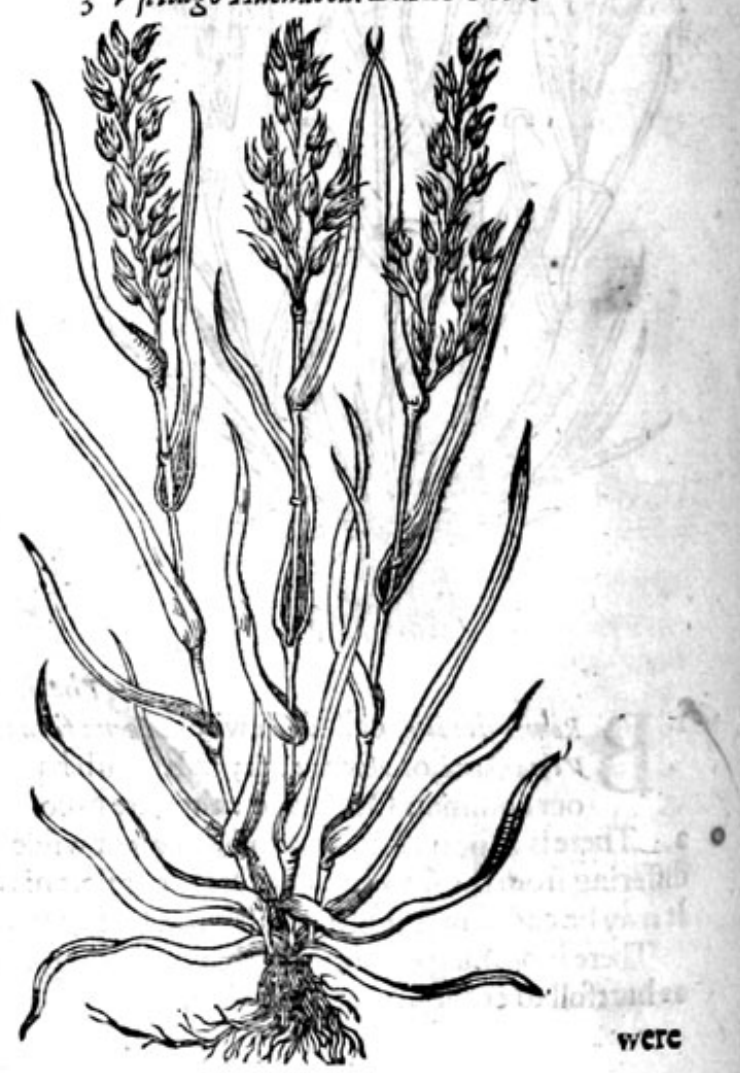


were in vaine to make a long harueft of fuch euill corne, confidering it is not poffeffed with any one good qualitic. And therefore this mich hall fuffice for the defcr $\mathrm{C}_{2}$ tion.

\section{OfDarnell. Chap.51.}

1 Lolium albon.

White Darnell.

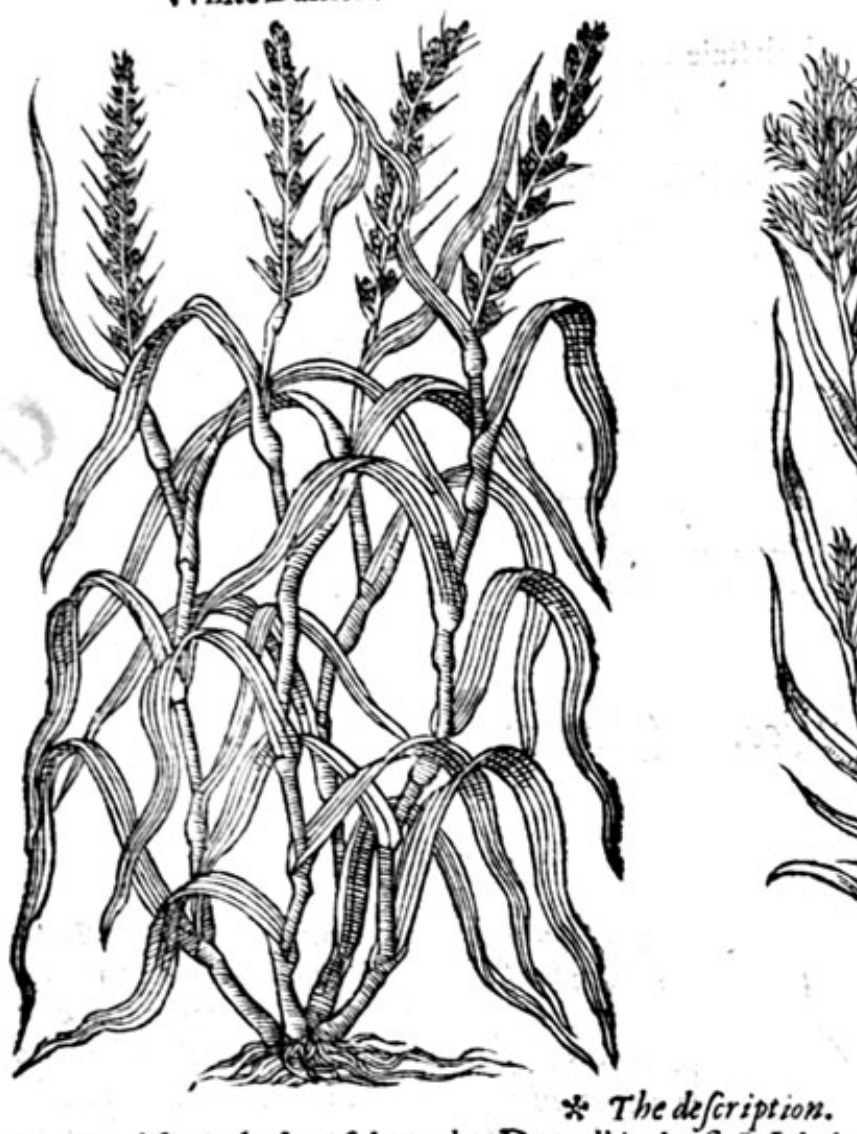

2 Lolium rubrum.

Red Darnell.

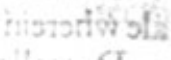

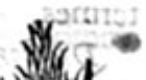

A

Mong the hurtful weedes, Darnell is the firft. It bringeth foorth leaues and ftalks like thofe of wheate or barly, yet rougher, with a long eare made vp of many little ones, euery particular one whereof containeth two or three graines, leffer than thofe of wheate, fcarfly any chaffie huske to couer them with, by reafon wherof they arc eafily fhaken cut and fcattered abrode. 2 Red Darnell is likewife an vnprofitable corne or graffe, hauing leaues like barly. The ioints of the ftraw or ftalke are of a reddifh colour,bearing at tha top a fmall and tender eare, fpike fafhion. * The place.

They grow in fields among wheate and barly, of the corrupt andbad feede as $G_{\text {alen }}$ faith,efpecially in a moift and dankifh foile.

They fpring and flourifh with the come, and in Auguft the feede is ripe.

$$
\begin{aligned}
& * \text { The time. } \\
& \text { * and in Auguft } \\
& \text { * The names. }
\end{aligned}
$$

I Damell is called in Greeke alez: in the Arabian toong Zizanis and Sceylen : in French ruray: in Italian Loglio: in low Dutch Doltek: in Englifh Darnell, of fome Iuray and Raye, and of fome of the Latines Triticion Temulentam.

2 Red Darnell is called in Greeke póm and Lolium Murimum in Englifh Wall Barly, and Waic Bennet: of fome Hordeum murimum, and Triticum murimom : in Dutch qupfe cozen.

Damellishorin the thirdistegt otis * The temperature.

Darnell is hot in the third degree, and drie in the fecond. Red Darnell driech without tharpnes, 2s Galen faith. 


\section{$7^{2}$ \\ THE FIRST BOOKE OF THE}

* Thevertues.

A The feede of Darnell,pigeo, dung, oile oline, and powder of tinefeed, boiled tathe forme of a plaifter, confumeth wens, hard lumps, and fuch like excrefcence in any part of the body.

B The new bread wherein Darnell is, eaten hot, caufech drunkennes: in like maner doth beere or ale wherein the feede is fallen, or put into the mault.

C Darnell taken with red wine ftaieth the fluxe of the belly, and the ouermuch flowing of womens termes.

D Diofcorides faith, that Darnell meale doth ftaie and keepe backe eating fores, gangrenes and putrified vicers: and being boiled with radifh rootes, falt, brimftone and vineger, it cureth fpreading fcabs and dangerous tetters, called in Greeke iexînes, and leprous or naughtie fcurffe.

E The feede of Darnell giten in white or rhenifh wine,protroketh the flowers or menfes.

F A fume made thereof with parched barly meale, myrrhe, faffron and frankenfence máde in form of a pultus, and applied vpon the belly, helpeth conception, and caufeth eafie deliuerance of childe bearing.

G Red Darnell as Diofcorides writeth, being drunke in fower or harfh red wine, ftoppeth the laske, and theouermuch flowing of the flowers or menfes, and is a remedie for thofe that piffe in bed.

$$
\text { * Thedanger. }
$$

Darnell hurteth the eies and maketh them dim, if it happen in corne either for bread or drinke, which thing Ouid in his firft booke Fastor um hath mentioned.

\section{Et carcant lolliis oculos vitiantibus agri.}

And heereupon it feemeth that the old prouerbe came, that fuch as ate dim fighted fhould be faid to eate of Darnell.
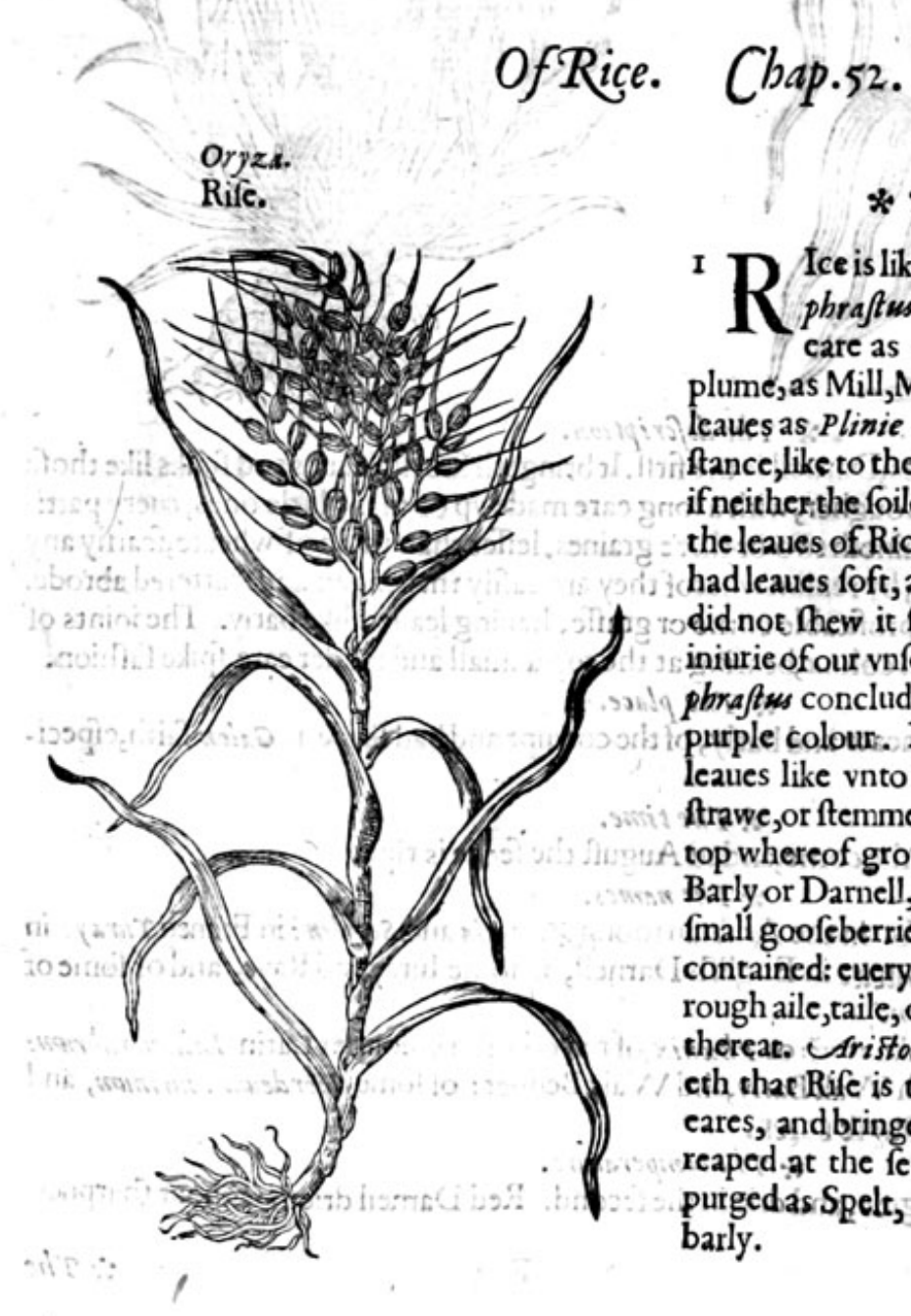

\section{* The defcription.}

I Ice is like vnto Darnell in fhew, as TheoR phraftus faith: it bringech foorth not an care as cornc, but a certaine mane or plume, as Mill,Millet, or rather like Panicke. The leaues as Plinie writeth, are fat and full of fubftance, like to the blades of leekes, but broder : but if neither the foile, nor climate did al ter the fame, the leaues of Rice that did growe in my garden, had leaues foft, and graffie like Barly. The flower did not Thew it felfe withme, by reafon of the iniurie of our vnfeafonable yeere 1596 . But $T$ hea pbraftus concludeth, that it hath a flower of 2 purple colour. But faith my Author, Rife hath leaues like vnto Dogs graffe or Barly, a fmall Atrawe, or ftemme, full of ioints like corne. At the top whereof groweth abufhor tuft, farvnlike to Barly or Darnell, garnifhed with round knobs like fmall goofeberries, wherein the feede or graine is contained: euery fuch round knob hath one fmall rough aile, taile, or beard like vnto Barly hanging theręat. CAristobulus as Strabo reportech, hew: eth thac Rife is two yardes high, and hath many eares, and bringeth foorth plentie of feede. It is reaped at the fetting of the feuen ftarres, and purged as Spelt, otemeale, or hulled; as French barly. 
It groweth in the territories of the Bactrians, in Babilon, in Sufuim; \& in the lower part of Syria. It groweth in thefe daies, not onely in thefe coumitries before named, but alfo in the fortunate Ilands, and in Spaine, from whence it is brought vnto vs, purged and prepared, as we fece afterthe maner of Frenchbarly, It profperethbelt in fenny and waterifh places.

$$
\text { * Thesime. }
$$

It is fowen in the fpring in India, as Eratost benes winefieth, when it is moiftened with fommer Phowers.

\section{* The nomes.}

The Grecians call it iputen or as Theophrastus faith opulor: the Latines keepe the Greeke wionde Oryza : in French it is called $R i z$ : in the Germaine toong Rit * The temperature and vertues.

Gilen faith, that all men vfe to ftaic the belly with this graine, being boiled after the fame mañer that Chondrus is. In England we vfe to make with milke and Rife, a certaine food, or pottagewhich doth both meanely binde the belly, and alfo nourifh. Many other good kinds of foode is made with this graine, as thoic that are skilfull in cookerie can tell.

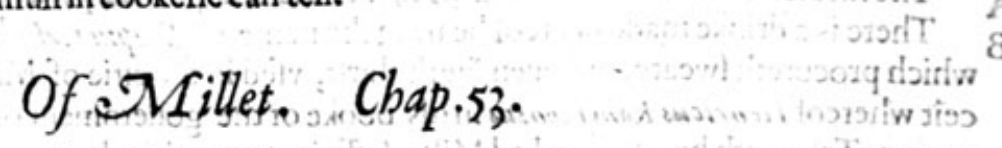

I Miliven. Mill or Millet.

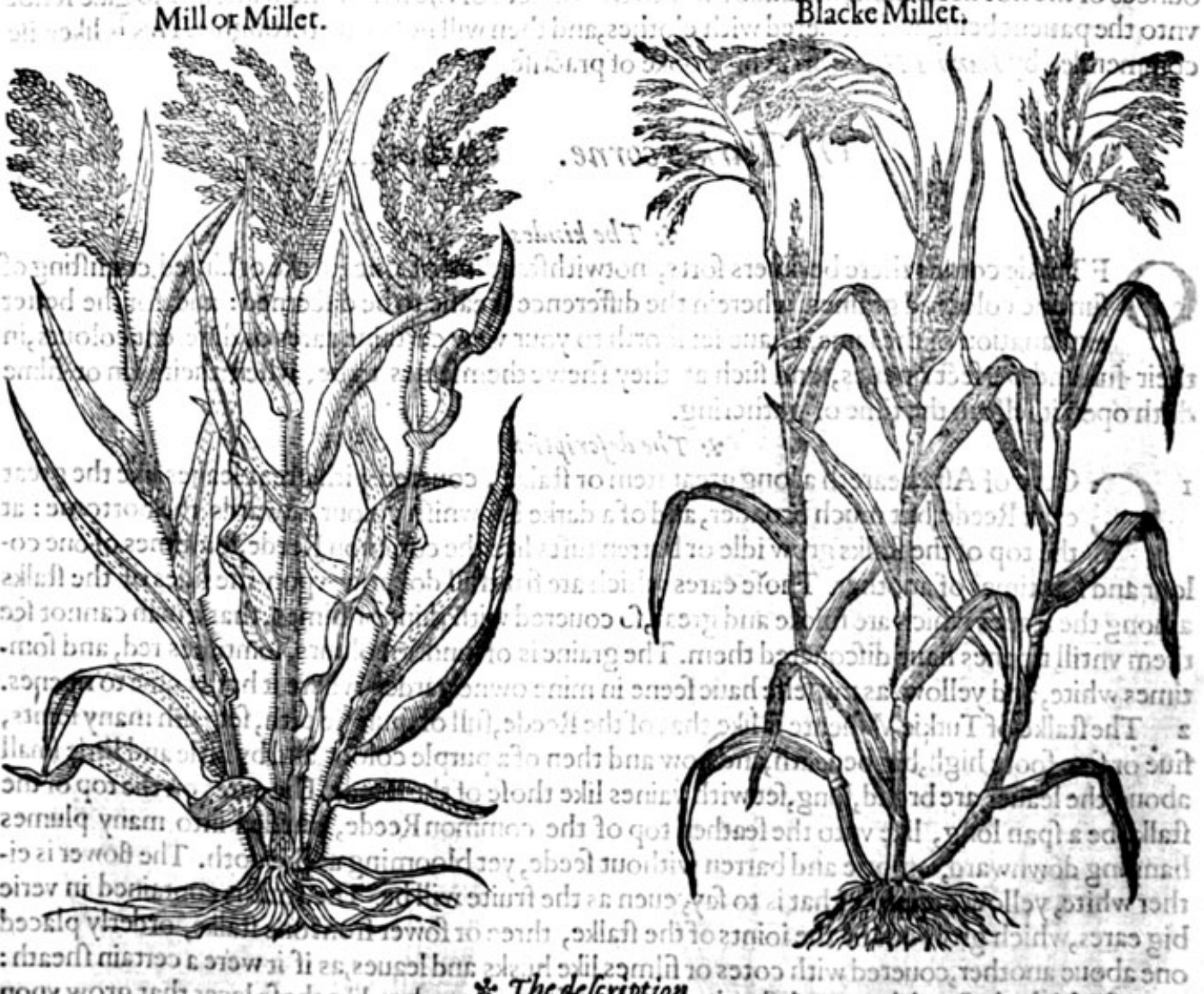

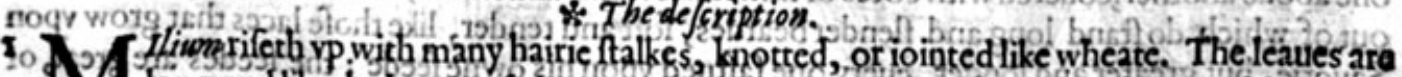

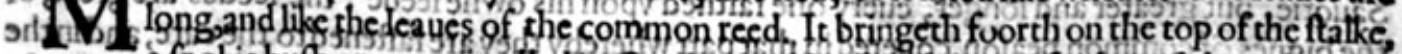

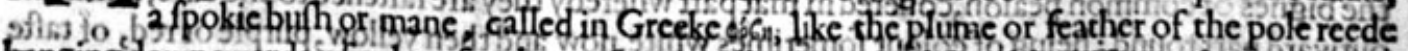

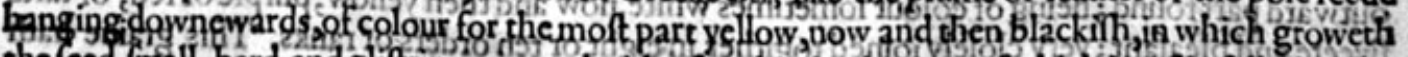

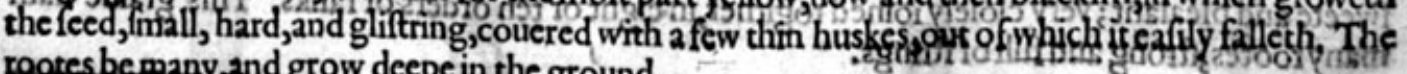
ropotes hermany, and grow deepein the ground. 
2 Milium nigrum is like vnto the former, fauing that the eare or plume of this plant is more loofe and thin, and the feed fomewhat bigger, of a hining blacke colour. * The place.

It loueth light and loofemowld, and profpereth beft in a moift and rainie time. And after columelle, it groweth in greateft abundance in Campania.I haue of it yeerely in my garden. * Thetime.

It is to be fowen in Aprill and May and not before,for it ioyech in warme weather. * The names.

It is named of the Grecians xierses: of fome ronesis:\& of Hippocrates Pa/pale, as Hermolaus faith: in Spanifhe Mijo: in Italian Miglio: in high Dutch Đitz: : in French Millet : in low Dutch Đirg : in Englirh Mill and Millet.

It is cold in the firft degree as Galen writeth, and drie in'the third, or in the later ende of the fecond, and is of a thin fubftance.

A The meale of Mill mixed with tar, is laid to the bitings of ferpents and all venemous beafts.

B There is a drinke made heereof bearing the name of fir upus Ambrofii, or Ambrofe his fyrupe, which procureth fweate, and quencheth thirft, vfed in the citie of Milan in tertian agues. The receit whereof Henricus Rant_zoniws in his booke of the gouernment of health fetteth downe in this maner: Take faith he, of vahusked Mill a fufficient quantitie, boile it till it be broken : then take fiue ounces of the hot decoction, and adde there to two ounces of the beft white wine, and fo giue it hot vnto the patient being well couered with clothes, and then will he fiveate throughly. This is likewife commended by Ioannes Heurneus in his booke of pratife.

\section{Of Turkie corne. Chap.54.}

* The kindes.

$\mathrm{O}$ F Turkie cornes there be divers forts, notwithftanding of one ftocke or kinred, confifting of fundrie coloured graines, wherein the difference is eafie to be difcerned: and for the better explanation of the fame, I haue fet foorth to your view certaine eares of different colours, in their full and perfect ripenes, and fuch as they fhewe themfelues to be, when their skin or filme doth open it felfe in the time of gathering.

$$
\text { * The defcription. }
$$

I

Ornc of Afia beareth a long great ftem or ftalke, couered with great leaues like the great cane Reede, but much broader, and of a darke brownifh colour towards the bottome: at the top of the ftalks grow idle or barren tufts like the common Reede,fomtimes of one colour and fomtimes of another. Thofe eares which are fruitfull do grow vpon the fides of the ftalks among the leaues which are thicke and great, fo couered with skins or filmes, that a man cannot fee them vntill ripenes haue difcouered them. The graine is offundrie colours, fomtimes red, and fomtimes white, and yellow, as my felfe haue feene in mine owne garden, where it hath come to ripenes. 2 The ftalke of Turkie Wheate is like that of the Reede, full of fpungie pith, fet with many ioints, fiue or fixe foote high, big beneath, and now and then of a purple colour, and by little and little fmall aboue:the leaues are broad, long, fetwith vaines like thofe of the Reede. The eares on the top of the ftalke be 2 fpan long, like vnto the feather top of the common Reede, diuided into many plumes hanging dowiward, emptic and barren without feede, yet blooming as Rie doth. The flower is either white, yellow or purple, that is to fay, euen as the fruite will be. The fruit is contained in verie big eares, which grow out of the ioints of the ftalke, three or fower from one ftalke, orderly placed one abouc another, couered with cotes or filmes like husks and leaues, as if it were a certain fheath: out of which doftand long and flender beardes, foft and tender, like thofe laces that grow vpon Sauoric, but greater and longer, euery one faftried vpon his owne feede : the feedes are great, of the bignes of common peafon, couered in that part whereby they are faftened to the eare, and inthe outward part round; being of colour fometimes white, now and then yellow, purple or red, of tafte fweete and pleafant; very clofely ioined togither, in eight or ten orders or ranks, This graine hath many rootes ftrong and full of fitngs. 
HISTORIE OF PLANTS. T

I Frwmentum Afiaticum. Corne of Afia.

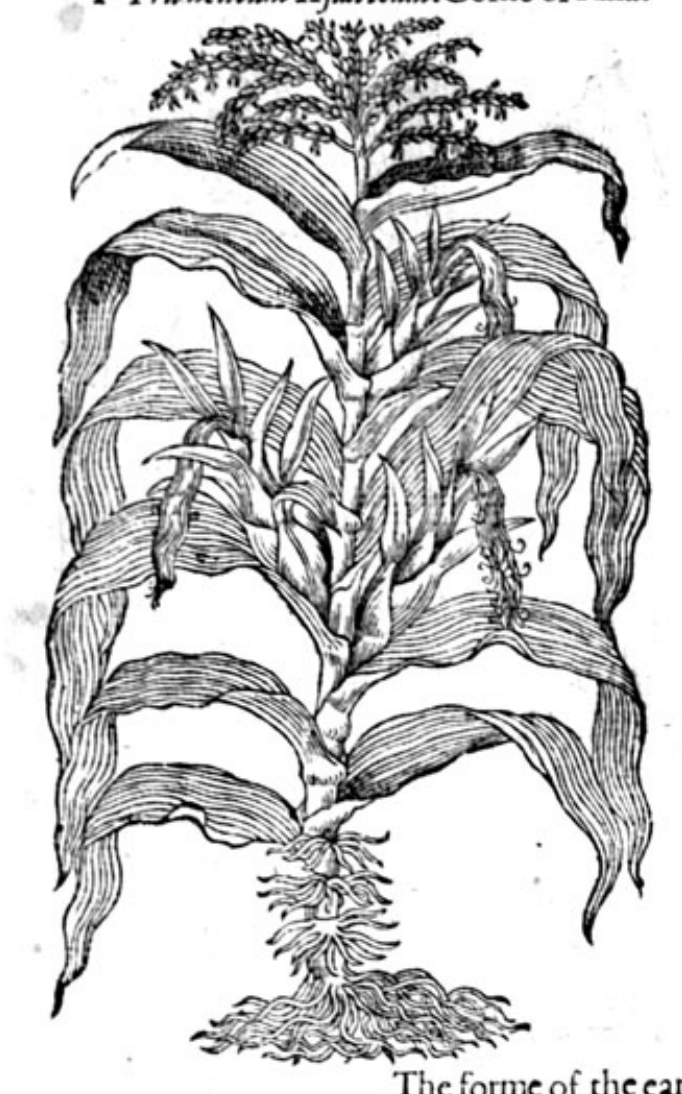

3 Frumenti Indici pica.

Turkie Wheate in the hirske, as alfo naked or bare.

2 Frumentum Turcicum.' Turkie Corne.

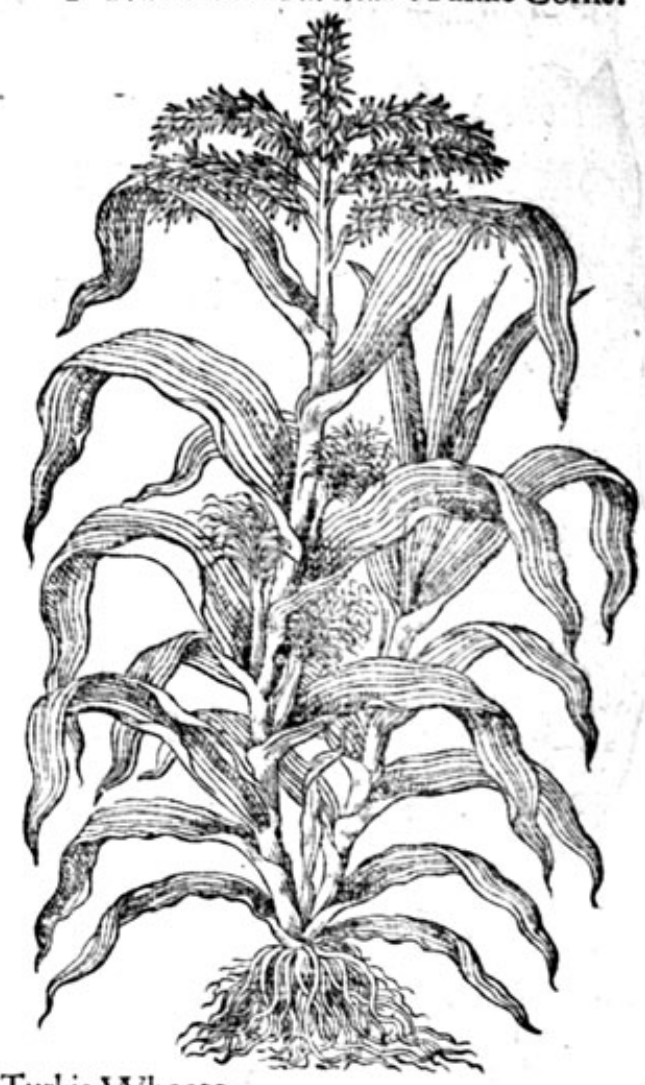

4 Frumentum Indicum album.

The eare of white Turkie Wheate.
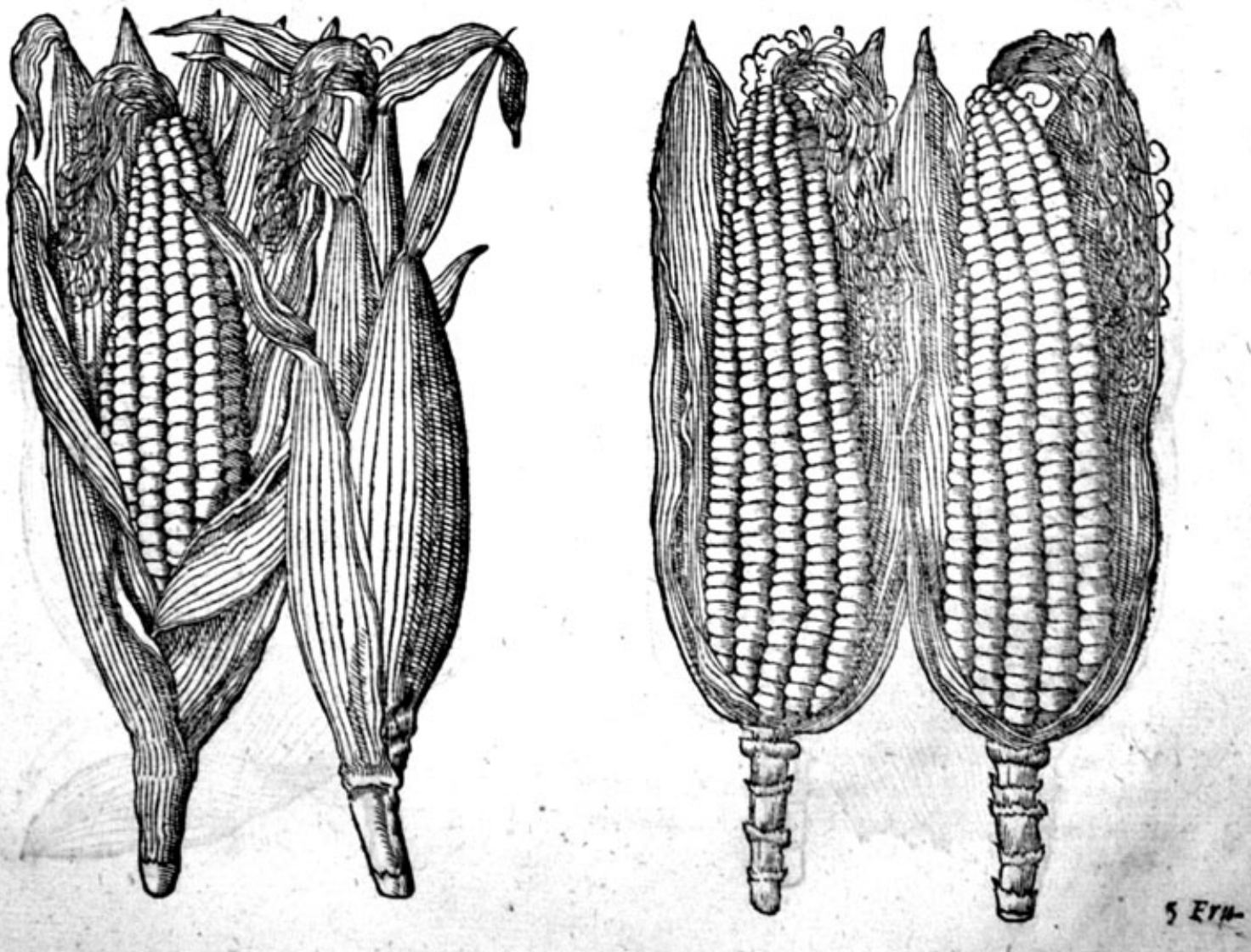
5 Frumentum Indicum luteum.

Yellow Turkie Wheate.

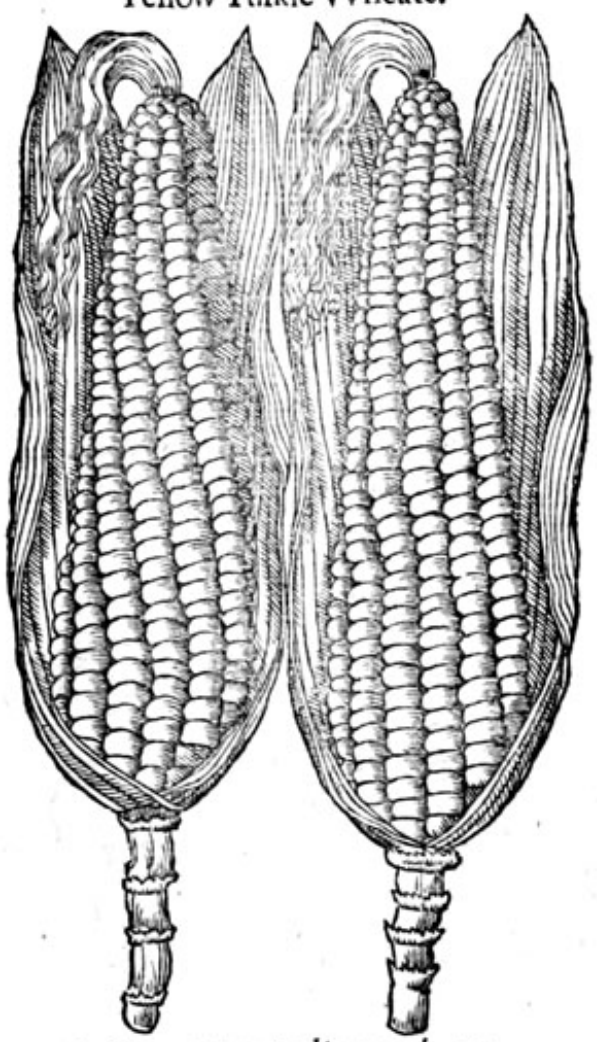

7 Frumentum Indicum rubrum.

Red Turkie Wheate.

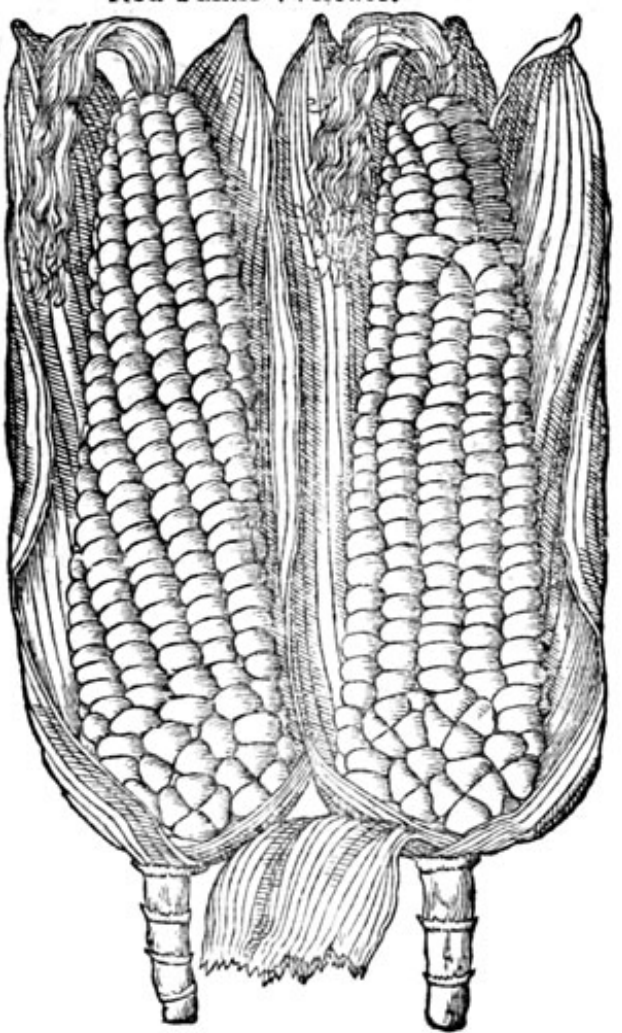

6 Frionention Indicion aureum. Gold coloured Turkie Wheate.

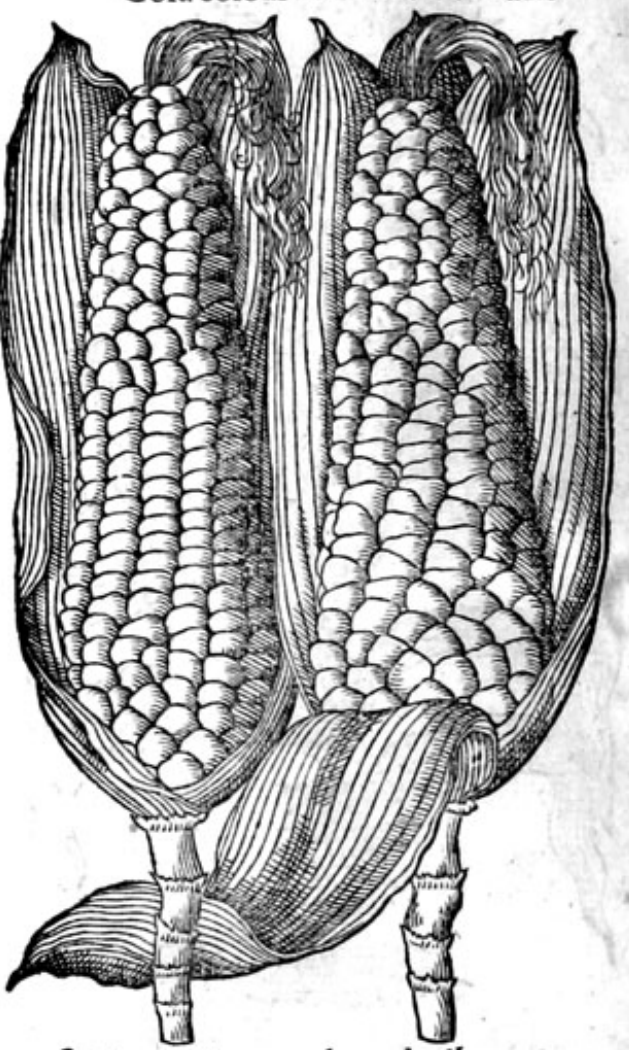

8 Frumentum caruleum or album. Blew and white Turkie Wheate mixed

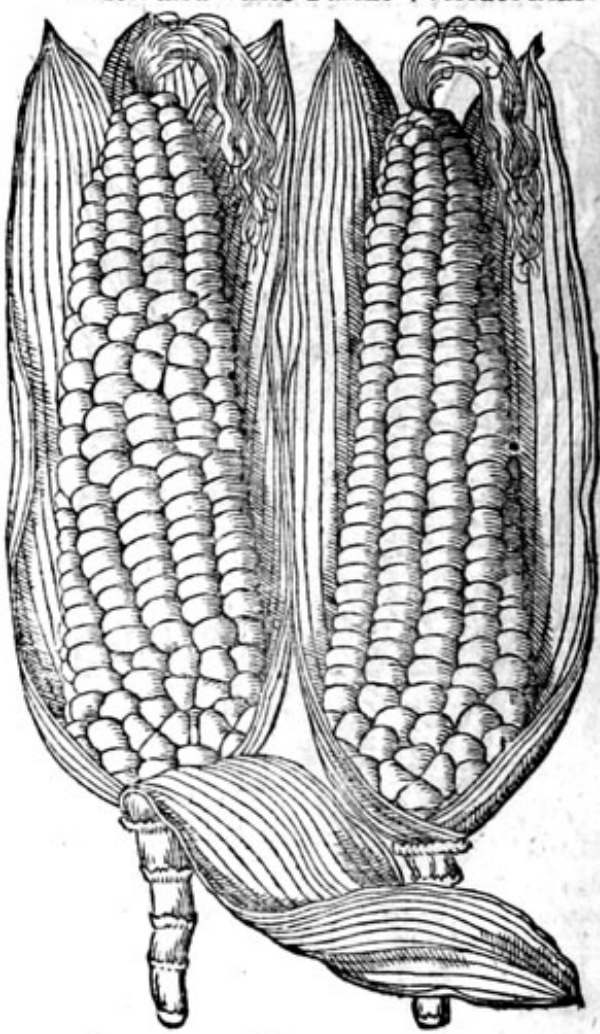


* The place.

Thefe kinds of Graine were firft brought into Spaine, and then into other prouinces of Europe, out of Afra which is in the Turkes Dominions, as alfo out of America and the Ilands adioyning from the eaft and weft Indies, and Virginia or Norembega, where they vfe to fowe or fet it, and to make bread of it, where it groweth much higher than in other countries. It is planted in the gardens of thefe northern regions, where it commeth to ripenes when the fommer falleth out to be faire and hot, as my felfe haue feene by proofe in mine owne garden.

$$
\text { * The time. }
$$

It is fowen in thefe countries in March and Aprill, and the fruite is ripe in September.

$$
\text { * The names. }
$$

Turky wheat is called of fome Fromentum Turcicuon, and Milisom Indicam. Strabo, Eratosfenes, onefarititu, Plinie and others, haue contended about the name heereof, which I minde not to re. hearfe, confidering how vaine and friuolous it is: but leauing it vntill fich time as fome one Oedippius or other fhall bewraie any other name therof that hath been deferibed, or known of the old whiters. In Englifh it is called Turky corne and Turky wheate: the inhabitants of Ameriea and the Handes adioining,as alfo the eaft and weft Indies, do call it Maizitom and Maizwon and Mais. * The temper.ture and vertwes.

Turky wheate doth nourifh far leffe than either Wheate, Rie, Barly or Otes. The bread which is made thereof is meanly white, without brantit is hard and drie as bisket is, and hath in it no clammi. nes at all: for which caufe it is of hard digeftion, and yeeldeth to the body little or no nourifhment, it flowly defcendeth and bindeth the belly, as that doth which is made of Mill or Panick. Wehaue as yet no certaine proofe or experience concerning the vertues of this kinde of Corne, although the barbarous Indians which know no better, are conftrained to make a vertue of neceffitic, and think it a good food; whereas we may eafily iudge that it nourifheth but little, and is of hard and euill digeftion, a more conuenient foode for fwine than for men.

$$
\text { Of Turkie Millet. Chap.5s. }
$$

Sorghum.

Turkie Millet.

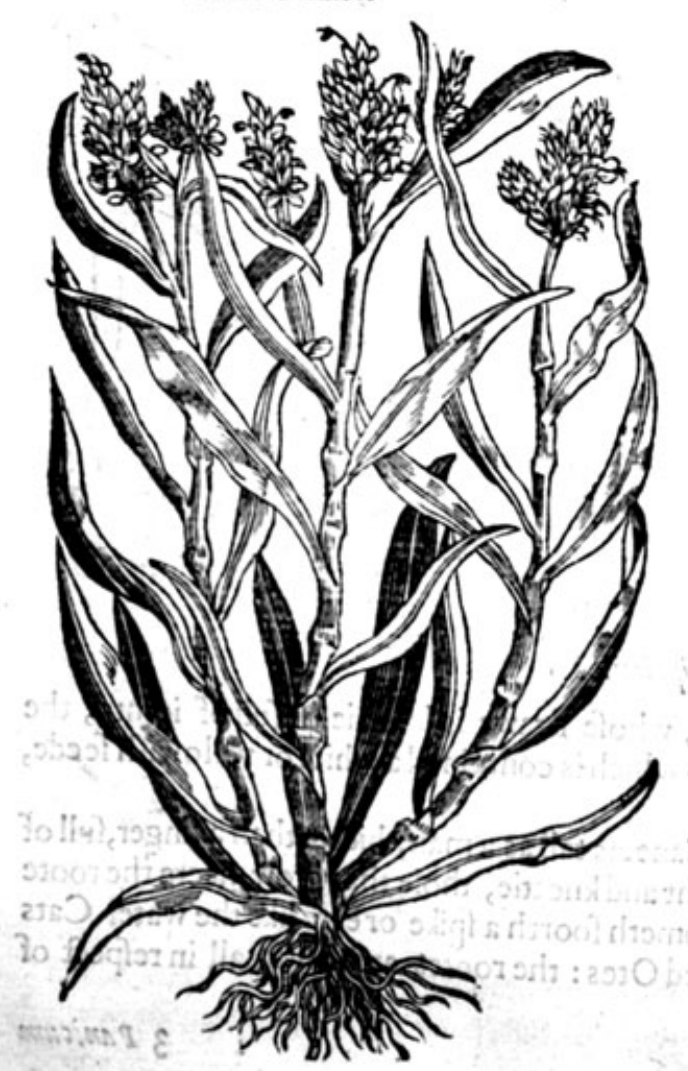

\section{* The defcription.}

Vrkie Millet is a ftranger in England. It hath many high ftalks, thicke and iointed, formewhat brownifh, befet with many long and broad leaues like Turky wheate: at the top wherof groweth a great \& large tuft or eare, like the great Reede, of a yellowih colour. The feede is rounde and fharpe pointed, of the bignes of a Lentill, fomtimes red, and now and then of a fuller blacke colour. It is faftened with a multitude of ftrong flender rootes like vnto threeds: the whole plant hath the forme of a Reede: the ftalkes and eares when the feede is ripe,are red.

\section{* The place.}

It ioieth in a fat and moift ground:it groweth in Italy, Spaine, and other hor regions.

\section{* The time.}

This is one of the fommer graines: it is ripe in Autumne.

\section{$*$ The names.}

It is called of the Infubers, Melegua, and Mele* ga : in Latine Melics: in Hetruria Saggina: in other places of Italy Sorghosin Portingale Milivem faburrum: in Englion Turkic Mill or Turkie Hirfte. 


\section{* The temperatwre and verties.}

The feed of Turkie Mill is like vnto Panicke in tafte and temperature: the countrie people fornetimes make bread heerof, but it is britcle and of little nourifhment, and for the moft part itierueth to fatten hens and pigeons with.

$$
\text { Of Tanick. Ehap. 56. }
$$

* The kindes.

THite be fundrief forts of Panick, although of the ancients, there hath beene fet downe but 1 two $x$ that is to fay, the wilde or fielde Panick, and the garden or manured Panick: the which kisis haue degenerate into other forts differing in ftature, as alfo in colourf according to the foile, climare, or countrey as fhallibe declared.

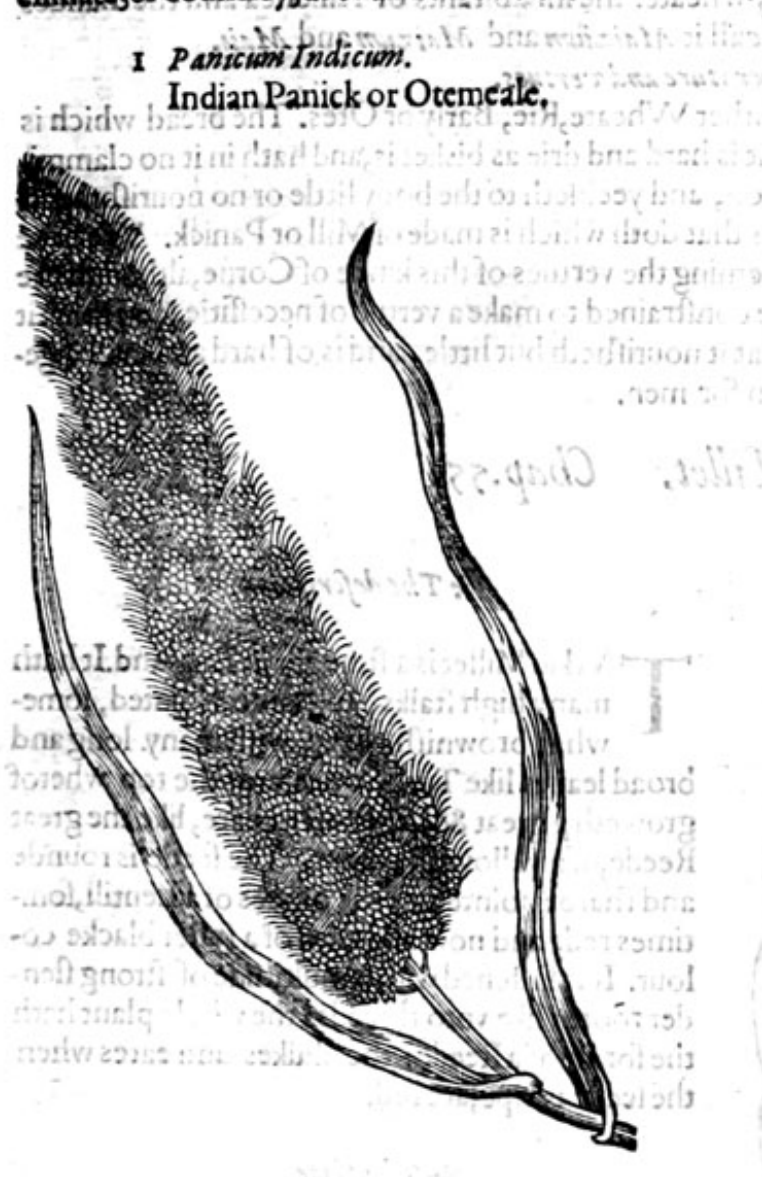

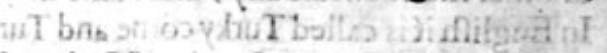

Panicion Indiciom.

2 Panioum Carilenew. Blew Panicke.

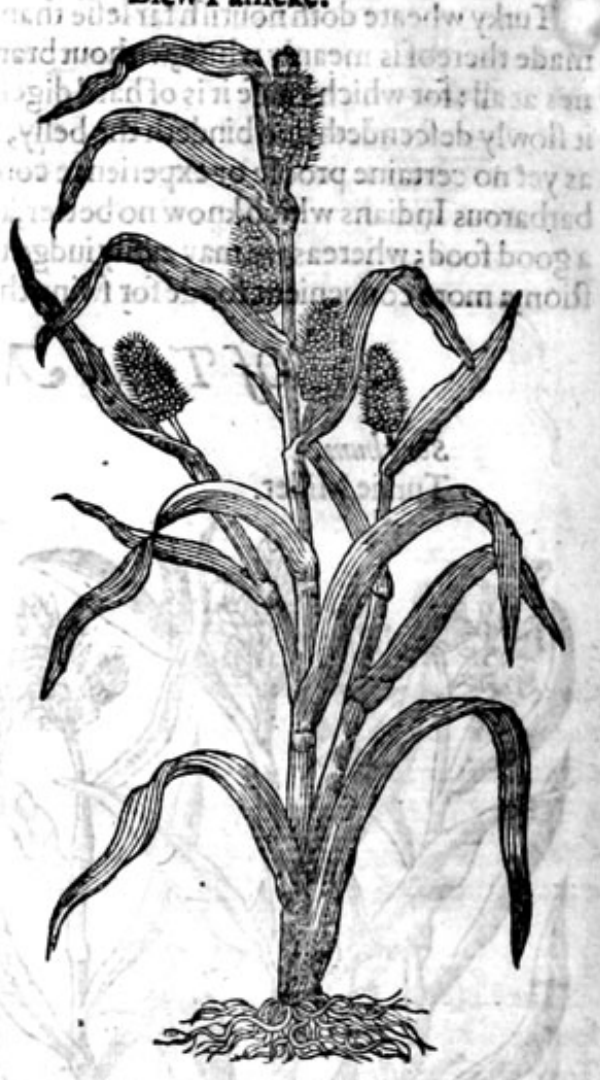

* The defcription.

17 He Panick of India groweth vplike Millet, whofe ftrawe is knottie or full of ioints; the eares be round, and hanging downward, in which is conteined a white or yellowifh feede, like Canarie feede or Alpisti.

2 Blewv Panick hath a reddirh italke like to fugar Cane, as tall as a man, thicker than a finger, full of 2 fungious pith, of a pale colour : the ftalks be vpright and knottie, thofe that grow neere the roote are of a purple colour: on the top of the ftalke commeth foorth a fpike or eare like the water Cats taile,but of a purple colour: the feede is like to naked Otes: the rootes are very fmall in refpeet of the orher parts of the plant. 
4 Panicuon Melyme. Germaine Panick.

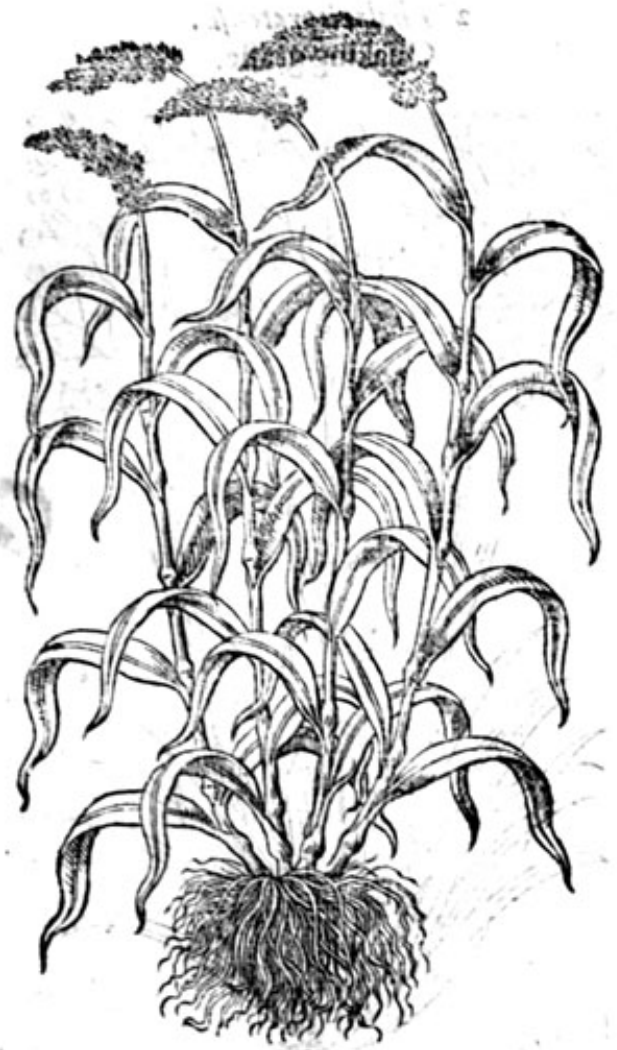

5 Panicum fluestre. Wilde Panick.

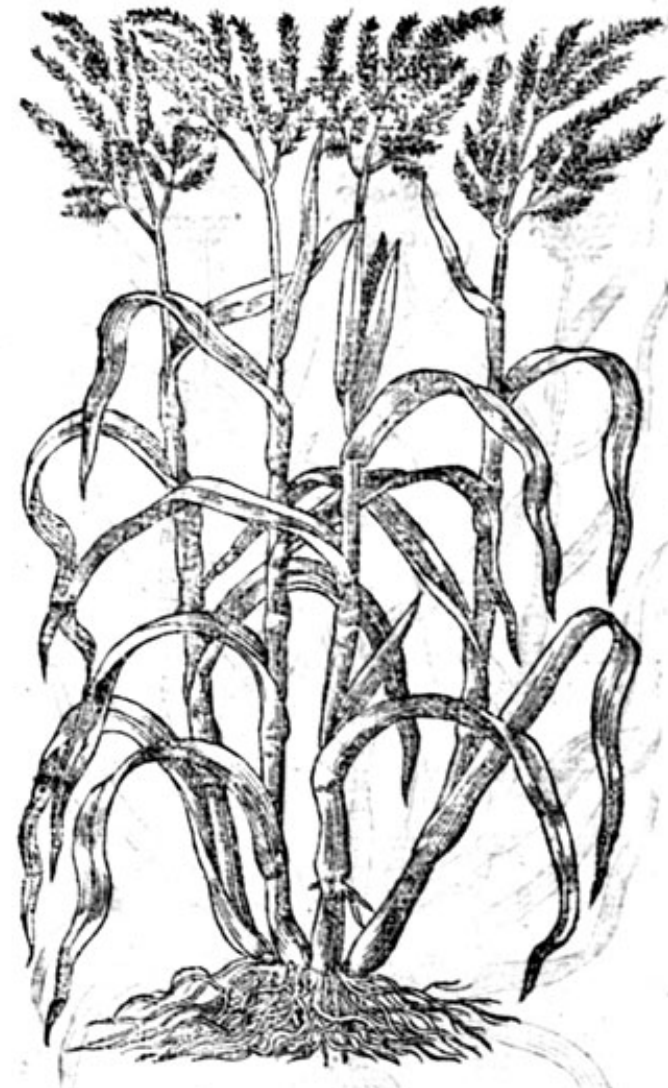

* The defcription.

3 Germanie Panick hath many hairie rootes, growing thicke togither like vnto Wheate, as is all the reft of the plant, as well leaues or blades,as ftrawe or ftalke. The eare groweth at the top fingle, not vnlike vnto Indian Panick, but much leffer. The graines are conteined in chaffie fcales, red declining to tawnie.

4 The wilde Panick groweth vp with long reedeniftalks, full of ioints, fet with bong leanes like thofe of Sor g hwm, or Indian Panick: the tuft or fearherlike top is filke vnto the common reede or the eare of the graffecalled $I$ chemion or Manna graffe; the roote is fmalland threddie. odilasusil mils.

Thekinds of Panick are fowen in the Pring, and are ripe in the beginning of Auguft : they pro fper beft in hot and drie regionis, and wither for themoft part with much watering, as doch Milland Turke Wheate : they quickly come tor ripenes, and may be kept good a long time.

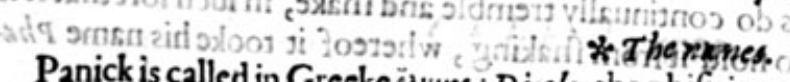

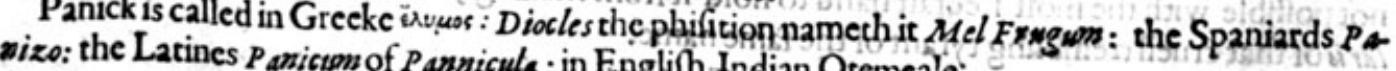

nizo: the Latines Panictom of Pannicula : in Englifh, Indian Otemeale:

Pannickes nourifh littlejand are driers as $G_{A}$ len faich

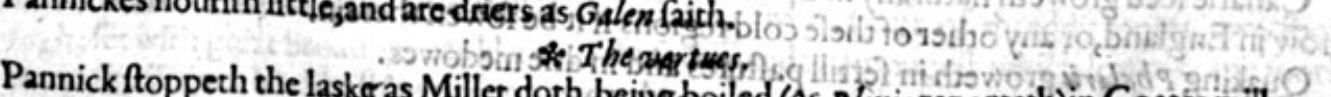
drunke twife in a day.

Bread made of Pannick nourifheth little, and iscold and dry, verie brittle, hauing in it neither B
slamminefle, nor fatneffe 2 and therefore it drieth श्tisn 


\section{Of Canariefeede, or Petie Panick. Chap.57.}
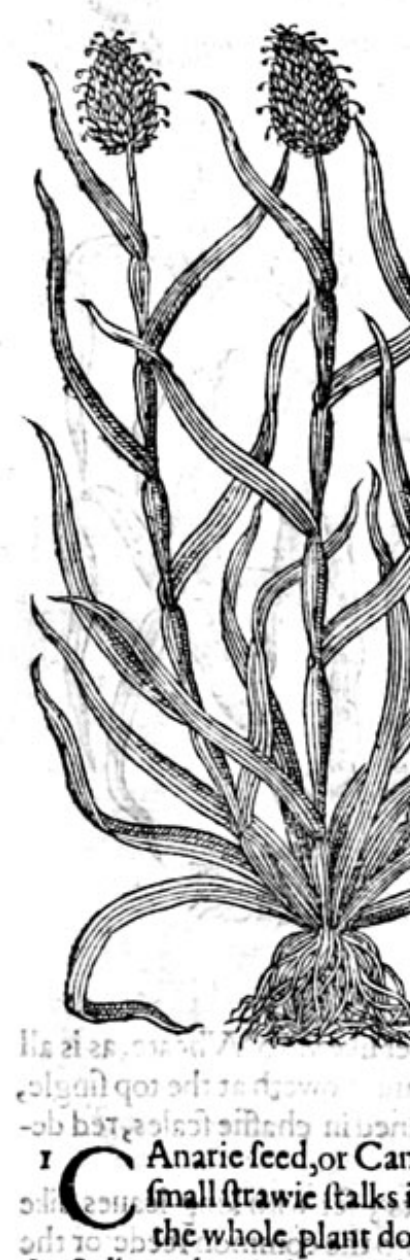

$\rightarrow$

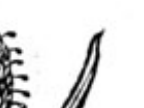

\section{Phalarispratenfis. Quaking graffe.}

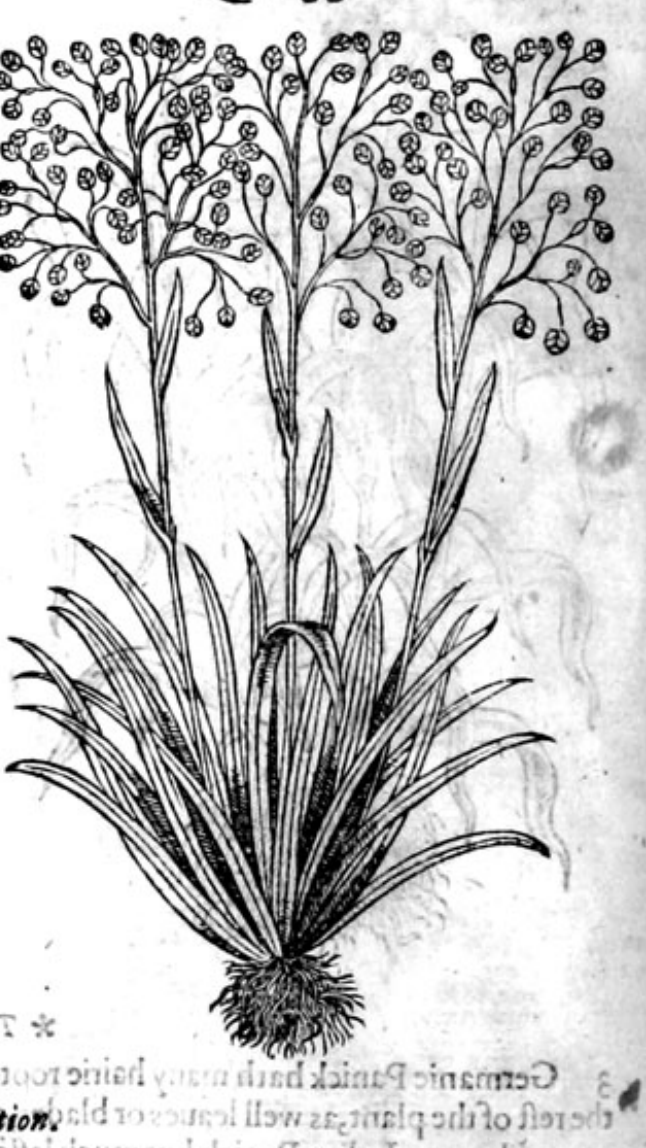

* The defription. the alkes, wherein is contained inall feeds like tbole of panike, of a yellowirh colourand hining. 2 Shakers, or quaking graffe, groweth to the heighr of halfe a foote, and fometime higher when it groweth in fertill medowes. The ftalke is very firall and bentic, fet with many graffie leaues like the coaninon medow graffe, bearing at the top a bufla of euft of flat fcalie pouches, like thofe of hepheards purfe, but thicker, ofia browne cotout fet yponthe moft finall and weakeft hairie foore italkes that may be found, whereupon thofe finall pouches dohang sy meaves of which finall hairieftrings, the knaps which are the flowers do continually tremble and hake, in fuch fort that it is not poffible with the moft ftedfaft hand to hold it frem inaking, whereof it tooke his name Phslar is of that eruell trembling tyrant of the fahte name.

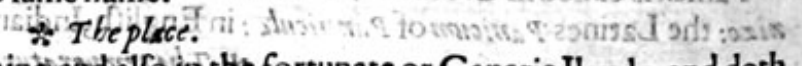

Canarie feed groweth naturally in Spaine, and alfo in the fortunate or Canarie Ilands, and doth grow in England, or any other of thefe cold regions if it be fowentherein.

Quaking Phalaris groweth in ferrill paftures and in drie medowes.

This Canariefeed is fowen in May, and is ripe in Auguft. * The names.
Canarie feede, or Canarie conne is called of the Greciaris seas the Latines retaining the fame name 


\section{HI STORIE OF PLANTS.HT}

name Phalaris : in the Ilands of Canaric Apisti : in Englifh Canariefeed, Canäriecorhe, ànd $\mathrm{Ca}_{2}$ narie graffe.

Phalaris pratenfis is called in Chefhire about Namptwich, Quakers and Shakers, takinghis name $P$ halaris of the tyrant $P$ halaris as aforefaid.

* The nature and vertues.

I finde not any thing fet downe as touching the temperature of Phalaris, notwithftanding it is thought to be of the nature of Millet.

The inice and feed as Galen faith, are thought to be profitablie drunke againft the paines of the bladder: Apothecaries for want of Millet do vfe the fame with good fucceffe in fomentations: for in drie fomentations it ferueth in fteed there of, and is his fuccedeneww, or quid pro gmo. We vfeit in England alfo to feed the Canarie birds.

\section{Of Foxetaile. Chap.58.}

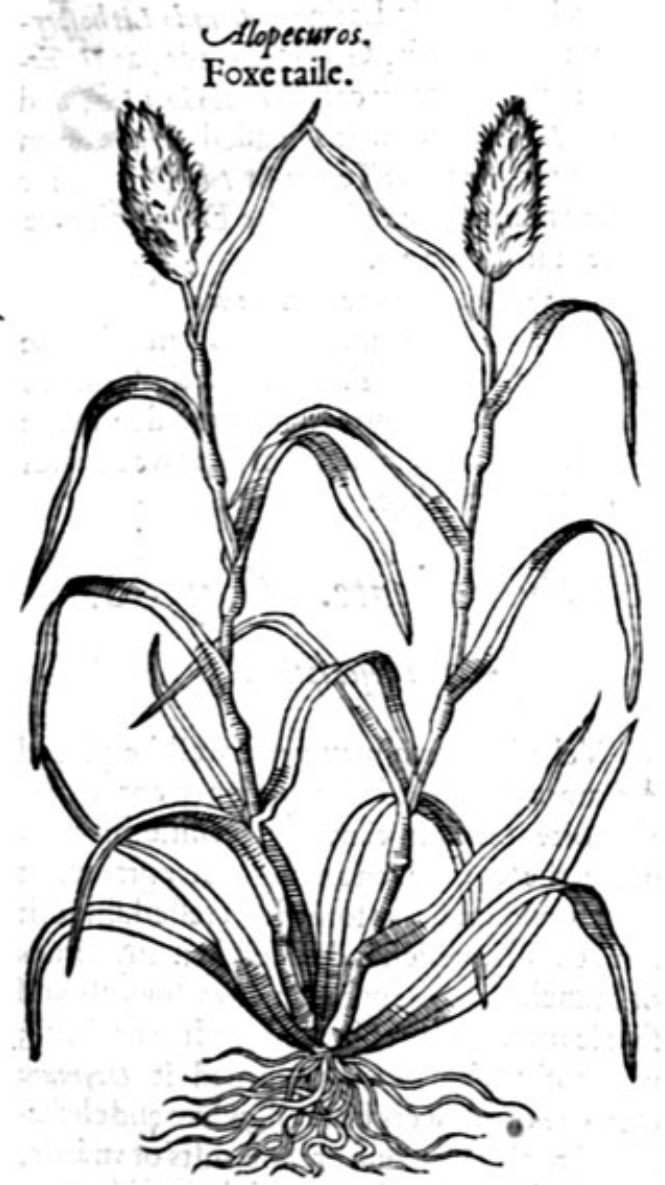

* The defcription.

D Oxetaile hath many graffie leaues or blades; 4 rough, and hairie, like vnto thofe of Barly, but leffer and horter. The ftallke is likewife foft and hairie: whereupon doth growe a fmall fpike or eare, foft, and very downie, briftled with very fmall haires in fhape like vnto a Foxetaile, whereof it tooke his name, which dieth at the approch of winter, and recouereth it felfe the next yeere by falling of his feed.

$$
\text { * The place. }
$$

This kind of Foxetaile groweth in mygarden; but not wilde in England, and is maintained in gardens, for itis a pretic toye for wantons.

$$
\text { The time. }
$$

It fpringeth vip in May of the feed that was fcattered the yeere before, and bearech his taile with his feede in Iune.

$$
\text { * The sames. }
$$

There hath not beene more faid of the ancierits or late writers, as touching the name, than is fet downe, Alopecuros : in Englifh Foxetaile.

\section{* The nature and vertives.}

I find not any thing extant woorthie the memo. rie, either of his nature or vertues.

\section{Of Iobs Teares. Chap.59.}

\section{* The defcription.}

Obes Teares hathmany knottie ftalkes proceeding from a tuft of threddy rootes, two foote high; fet with great broad leaues like vnto thofe of Reede, amongeft which leauescome foorth many fmall branches like ftrawe of corne: on the end whereof doth grow a graie fhining feede or graine hard to breake, and like in fhape to the feedes of Gromell, but greater, and of the fame colour, whereof I hold it a kinde: euery of which graines is bored through the middeft like a bead, and out of the hole commeth a fmall idle or barren chaffic eare like vnto that of Damell. 
Lachrima Iob. Iobs Teares.

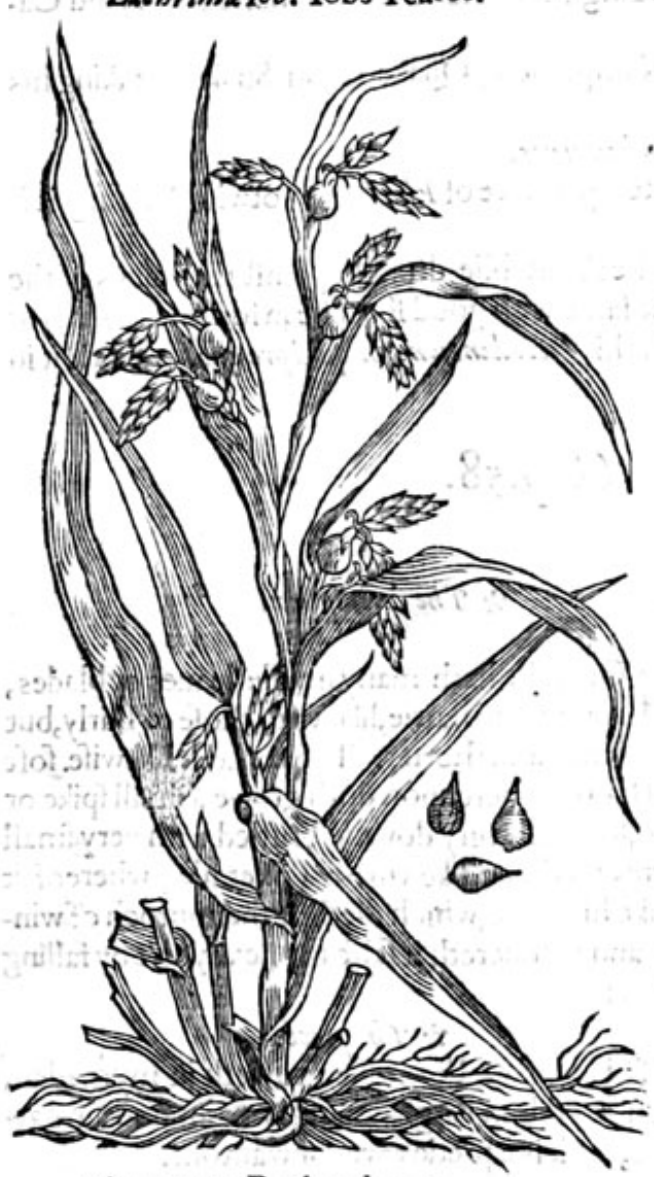

Tragopyron.Bucke wheate.

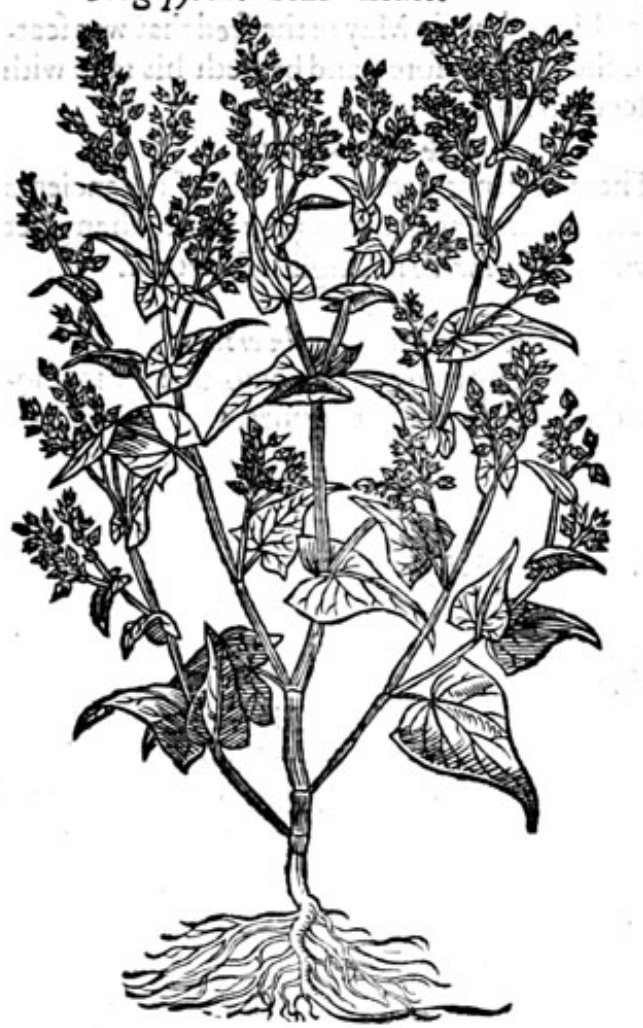

It is brought from Italie and the countries adioining, into thefe countries whereit doth grow very well, but feldome commeth to ripeneffe; yet my felfe had ripe feede thereof in my garden the fommer being very hot:

\section{* The time.}

It is fowen earely in the fpring, or elfe the winter will ouertake it before it come to ripeneffe.

$$
\text { * Thenames. }
$$

Diters haue thought it to be Lit hujpermi ßpecies, or a kind of Gromell, which the feede doth very notably refemble, and doth not much differ from Diofcorides his Gromell, and therefore it might verie aptly be called in Latine Arundo Lit ho/permos, that is in Englifh, Gromell reede, as Gefnerus faith : it is generally called Lachrima $I u b$, and Lachrima Iobi: of fome it is called Diopiros: in Englifh it is called robs Teares or Iobs Drops, for that euery graine refembleth the Drop or Teare that falleth from the eie.

$*$ The nature and vertues.

There is no mention made of this herbe for the vfe of Phificke. Onely in Fraunce and thofe places where it is plentifully growing, they doe make beades, braclets, and chaines therof, as we do with Pomander and fuch like.

\section{OfBuckwheate. Chap.6o. $*$ The defcription.}

$B$ Vcke Wheate may very well be placed among the kindes of graine or corne, for that oftentimes in time of neceffitic bread is made thereof, mixed among other graine. It hath round fat ftalks formwhat crefted, fmooth and reddifh, which is deuided in many armes or branches, whereupon do grow finooth and foft leaues, in thape like thofe of Iuie or Bafill; whereof Taber mentanus called it Ocymuon Cercale : the flowers be finall, white and clufteftered togither in one or moe tufts or vmbels, flightly dafht ouer heere and there with a florifh of light carnation colour. The feedes or graines are of a dead or darke blackifh colour, triangled or three fquare like the feede of blacke Bindeweede, called of the ancient Herbarifts Malacociffos. The roote is finall and threddic.

$$
\text { * The place. }
$$

It profpereth verie well in any ground be it neuer fo drie or barren, where it is commonly fowen to ferue as it werein fteede of a dung. ing It quickly commeth vp and is very foone 
ripe, it is very common in and aboutthe Namptwiche in Chefhire, where they fowe it afwell for foode for their cattell, pullen and fuch like, as to the vfe aforefaid. It groweth Fikewife in Eancafhire and fome parts of our fouth countrey, about London in Middlefex, as alfo in Kent and Effex.

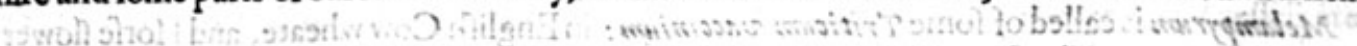

This bafe kinde of graine is fowen in Aprilland the beginning of Maie, and is ripe in the beginning of Auguft.

Buckwheat is called of the high Almaines pepdonkon: of the bafe Almaines Duckentwetat, that is tofay, Hirci Triticion, or Goates wheate. Of fome Fagi $T$ riticum, Beech wheate. In Greeke Tegremieg: in Latine Fago-Triticion : taken from the fafhion of the feede orffuit of the Beech tree. It is called alfo Fegopyrum and Tragopyros : in Englifh French wheate, Bullimong, and Bucke wheate: in French Dragee anx cheiusaux.

$$
\text { * The nature. }
$$

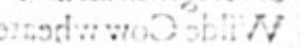

Bucke wheate nouriheth leffe than wheate, rie, barlie, or otes; yet motethan either Mill or $\mathrm{Pa}$ nicke.

* The vertues.

Breadimade of the meale of Bucke wheat is of eafie digeltion, it fpeedily paffeth through the bel- A ly, but yeeldeth littlenourifhment.

\section{OfCowwheate. Chap.6r.}

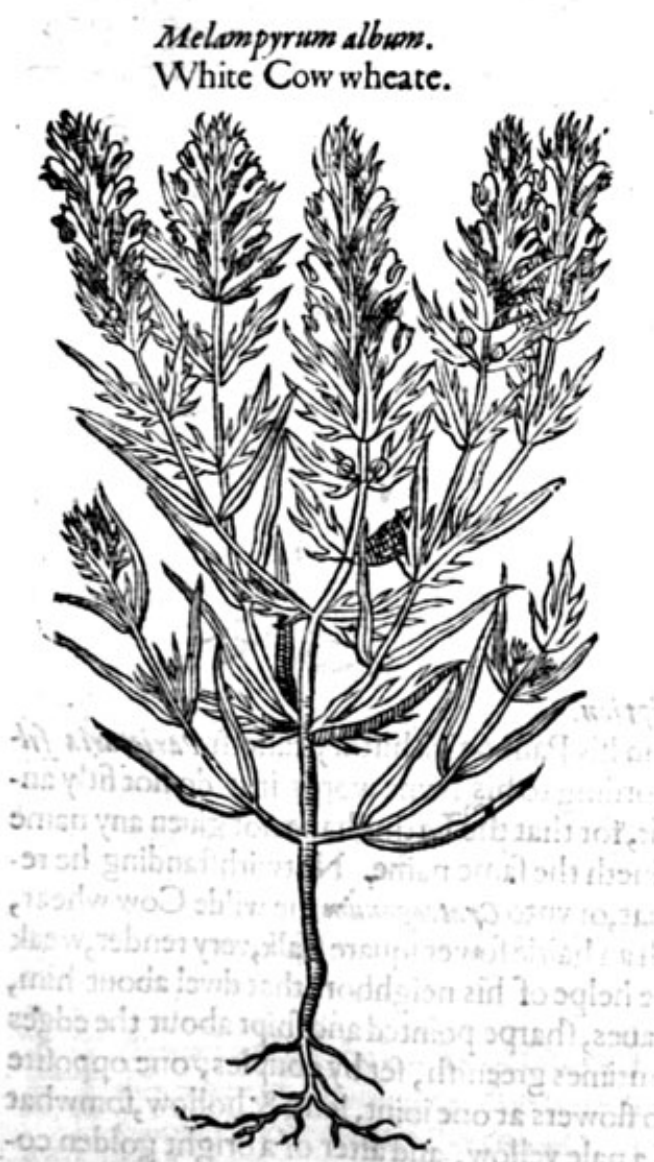

\section{* The defoription.}

Elompyrum groweth vpright, with a ftraight ftalke, having other finall ftalks comming from the fame, of a foote long. The leaues are long and narrow, and of a darke colour. On the top of the branches grow burhie or fpikie eares full of flowers, and finall leaues mixed togither, and much iagged, the whole eare refembling a Foxe taile. This care beginneth to flower below, and fo vpward by little and little vnto the top : the fmall leaues before the opening of the flowers, and likewife the buds of the flowers, are of a darke purple colour; and after their opening, of a yellow colour mixed with purple, and at the falling of the flowers thofe fmall purplith leaues become of a greene colour. Then come'vp broade husks, wherein are inclofed two feedes fomwhat like wheate, but fmaller \& browner. The roote is of a wooddy fubftance.

Of this kinde there is another called Melawpyrum lutewm, which groweth neere to the ground, withleaues not much vnlike Harts horne, among which rifech vp a fmall ftawe with an eare at the top like Alopecuros, the common Foxe taile, but of a yellow colour.

\section{* The place.}

The firft groweth among corne, and in pafture grounds that be fruiffull : it groweth plentifully in the paltures about London.

The fecond is a ftranger in England. 
They flower in Iune and Iuly.

\section{* The time.}

* The names.

Melampyrum is called of fome Triticum vacciniwn: in Englin Cow wheate, and Horfe flower: in Greeke uindunverv. The fecond is called Melampyrwm tatewm : in Englifh yellow Cow wheate.

$$
\text { * The danger. }
$$

The feede of Cow wheate raifeth vp fumes, and is hot and drie of nature, which being taken in meates or drinks in the maner of Darnell, troubleth the braine,caufeth drunkennes and headach.

\section{Of Wilde Cow wheate}

I Crateogononalbum.

Wilde Cow wheate.

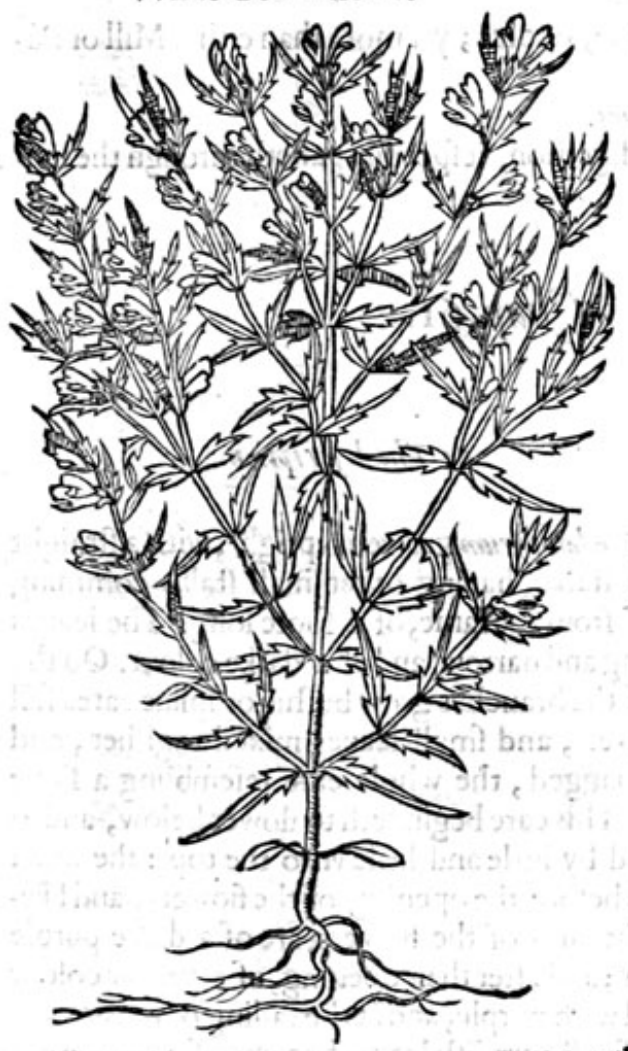

\section{Chap.62.}

2 Crateogonon rubruon. Red leafed Cow wheate.

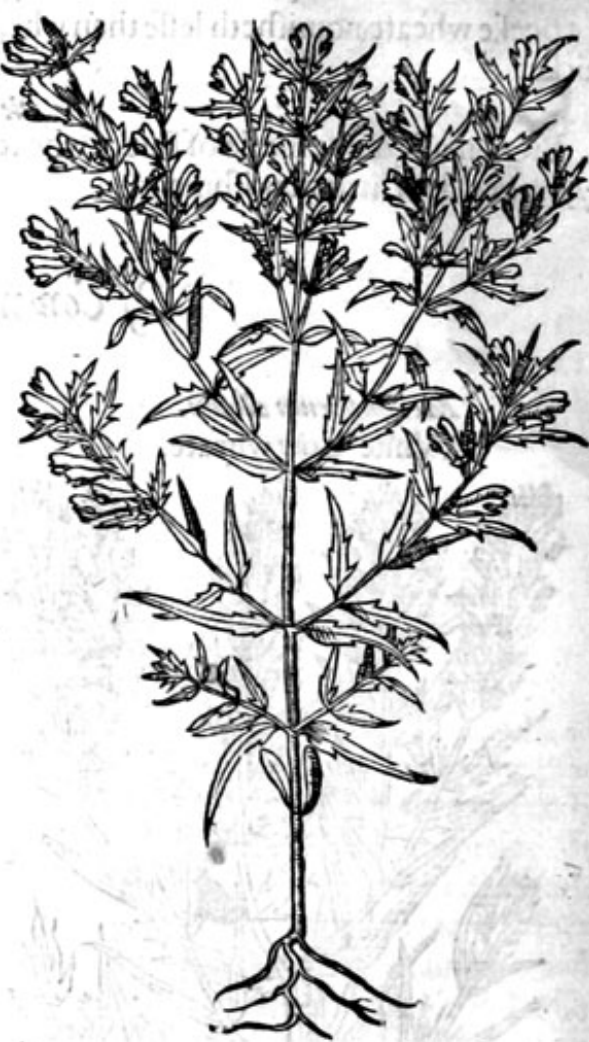

* The defcription.

1 He firft kinde of wilde Cow wheate Cliffies in his Pannonickhiftory calleth Parietaria ofme st rix, or wilde Pellitorie : which name according to his owne words if it do not fitly anfwer the plant, he knoweth not what to call it, for that the Latins haue not giuen any name thereunto; yet bicaufe fome haue fo called it, he retaineth the fame name. Notwith ftanding he referreth it vnto the kinds of Melampyrum or Cow wheat, or vnto Crateogonum the wilde Cow wheat, which iedoth very well anfwer in diuers points. It hath an hairie fower fquare ftalk, very tender, weak \&eafie to break, not able to ftand vpright without the helpe of his neighbors that dwel about him, a foote high or more, wherupon do grow long thin leaues, tharpe pointed and fnipt about the edges like the teeth of a fawe, of a darke purplifh colour, fomtimes greenifh, fet by couples, one oppofite againft the other : among the which come foorth two flowers at one ioint, long \& hollow, fomwhat gaping like the flowers of a dead netcle, at the firft of a pale yellow, and after of a bright golden colour; which do flowre by degrees, firft a few, and then more; by means wherof it is long in flowring: which being paft there fucceede fmall cups or feed veffels; wherein is conteined browne feed not vnlike to wheate. The whole plant is hairie, not differing from the plant Stichwoort. 
2 Red leafed wilde Cow wheate is very like vnto the former, fauing that the leaues be narrower, and the tuft of leaues more iagged. The ftalks and leaues are of a reddilh horfefiefh colour. The flowers in forme are like the other, but in colour differing ; for that the hollow part of the flower with the heele or fpurre is of a purple colour, the reft of the flowver yellow. The feede and veffels are like the precedent.

3 Crateogonon Eaphrofine.

Eiebright Cow wheate.

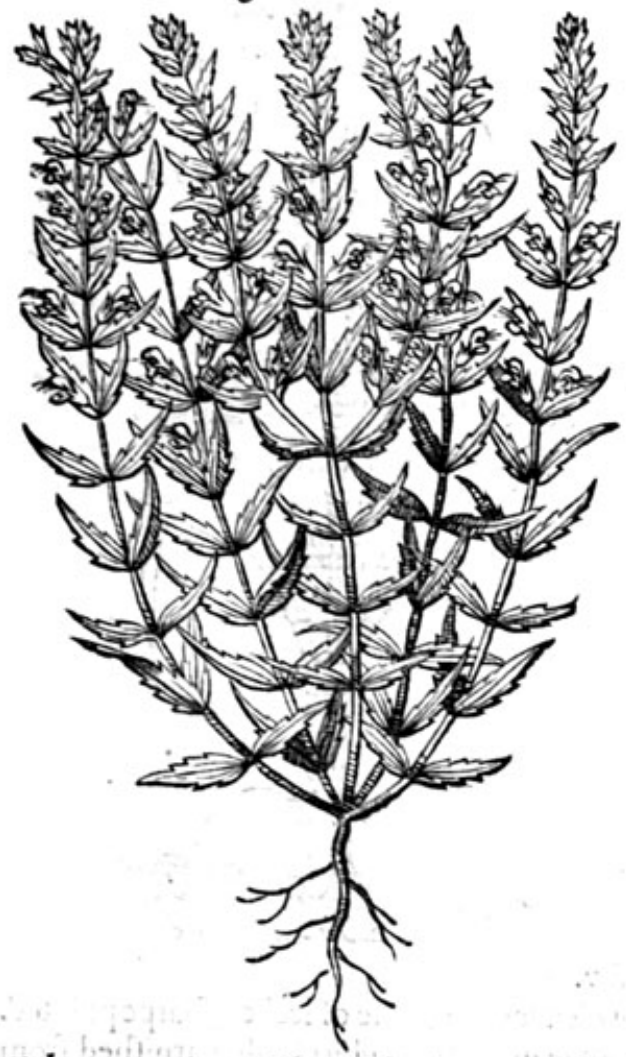

*The defcription.

3 This kinde of wilde Cow wheate Taber Montanus hath fet foorth vnder the title of Odontites: others have taken it to be a kinde of Euphrafit or Eiebright, bicaufe it doth in fome fort refemble it, efpecially in his flowers. Theftalks of this plant are fmall, tender, and weake, not able to ftand alone, rough and fquare. The leaues are indented about the edges, fharpe pointed, and in moft points refembling the former Cow wheate :fo that of neceffitic it muft be of the fame kinde, and not a kinde of Eiebright, as hath beene fet downeby fome.

$$
\text { * The place. }
$$

Thefe wilde kindes of Cow wheate do growe commonly in fertill paftures, and buthie copfes, or low woods, and among bufhes vpon barren heaths and fuch like places.

The two firft dogrowe vpon Hampfted heath neere London, among the Iuniper burhes, and Bilberrie bufhes in all the parts of the faid heath, and in enery part of Englande where I haue trauelled. * The tome.

They flower from the beginning of May to the end of Auguit.

* The names.

I. The firft is called of L'Obelitus Crateogonon: of

Taber Montanus Miliwn fluaticum, or Wood Millet, and Alfine fyluaticum, or Wood Chickweed.

2 The fecond hath the lame titles: in Englifh Wilde Cow wheate.

3 The laft is called by Taber Montanus, Odontites: of Dodonews, Euphrafs alsera and Exphrofine: whercin I thinke he miftooke it. Hippocrates called the wilde Cow wheate Polycarpoom and Poly-
critum.

* The nature and vertues.

There is not much fet downe either of the nature or vertues of thefe plants: onely it is reported that the feedes do caufe giddines and drunkennes as Darnell doth.

The feede of Crateogonum made in fine flower, and giuen in broth or otherwile, mightily prouro- $A$

Some write that it will likewife caufe women to bring foorth male children. - nov susd inol al' 10 in OfWhite A/Pbodill. Chap.63-

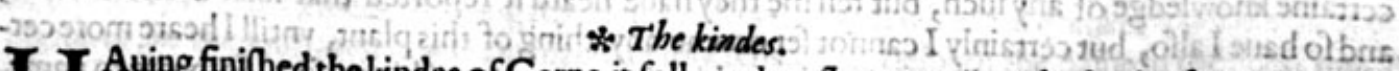
T. Auing finihed the kindes of Corne, it followeth to fhew vntoyourthe fundry forts of Afphodils, whereof fome haue bulbous rootes, other tuberousor knobbie rodes; fome of yellow Afphodill: but plinie fetrecth mixt colours, notwithftanding Dicforidesmaketh mention butoof bone and female Afphodill. The downe two, which Diony fius confirmeth faying, that there is themale Galen maketh mention, 
I Aphodelus non ramofus.

White Afphodill.

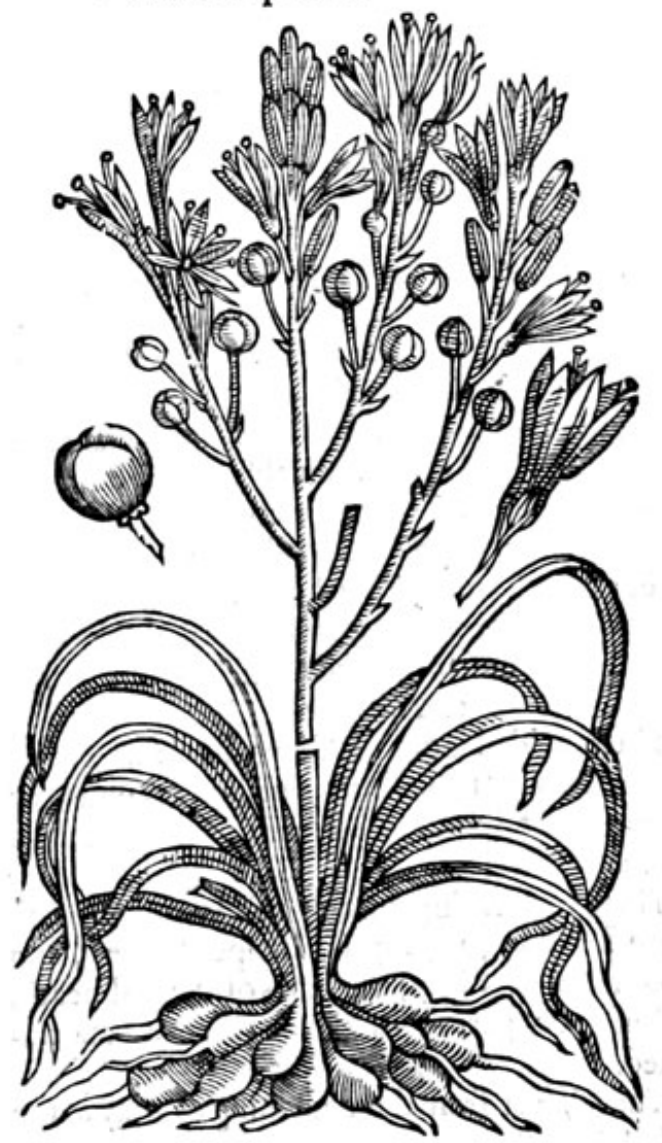

2 Aphodelus ramofres. Branched Afphodill.

* The defcription.

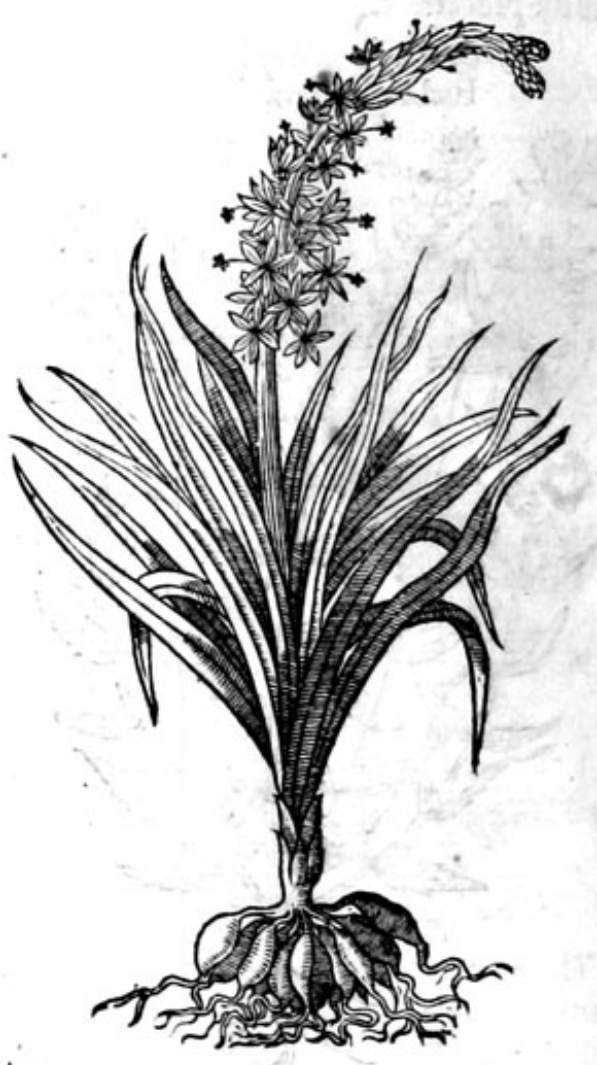

I He white Afphodil hath many long and narrow leaues, like thofe of leekes, hharpepointed. The ftalke is round, fmooth, naked, and without leaues, tivo cubits high, garnifhed from the middle vpward with a number of flowers, ftar fafhion,made of fiue leaues a peece; the colour white, with fome darke purple ftrakes drawen down the back fide. Within the flowers becertaine fmall chiues. The flower being paft, there fpring vp little round heads, wherin are contained hard, blacke, and three fquare feeds as arc thofe of Buckwheate, or Staphifacre. The roote is compact of many knobbie rootes, growing out of one head like thofe of the Peonie, full of iuice, with a fmall bitternes and binding tafte.

2 Branched Afphodill agreeth well with the former defcription, fauing that this hath many branches or armes growing out of the ftalke, whereon the flowers do grow, and the other hath notany branch at all,wherein confifteth the difference.

3 Afphodill with the reddifh flower groweth vp in rootes,ftalke,leafe, and maner of growing like the precedent, fauing that the flowers of this be of a darke red colour, and the others white, which fetteth foorth the difference, if there be any fuch difference, or any fuch plant at all; for I haue conferred with many moft excellent men in the knowledge of plants, but none of them can giue me ccrtaine knowledge of any fuch, but tell me they haue heard it reported that fuch a one there is, and fo hauc I alfo, but certainly I cannot fer downe any thing of this plant, vntill I heare morecertainty; for as yet I giue no credit to my author, which for reuerence of his perfon, I forbeare to name. 4 The yellow Afphodill hath many rootes growing out of one head, made of fundrie tough, fat, and oleous yellow fprigs, or groffe ftrings, from the which rife vp many graffie leaues, thicke and groffe,tending to fquarenes: among the which commeth vpa ftrong thicke ftalke, fet with the like leaues euen to the flowers, but leffer : vpon the which do grow ftarlike yellow fowers, otherwife like the white Afphodill. 

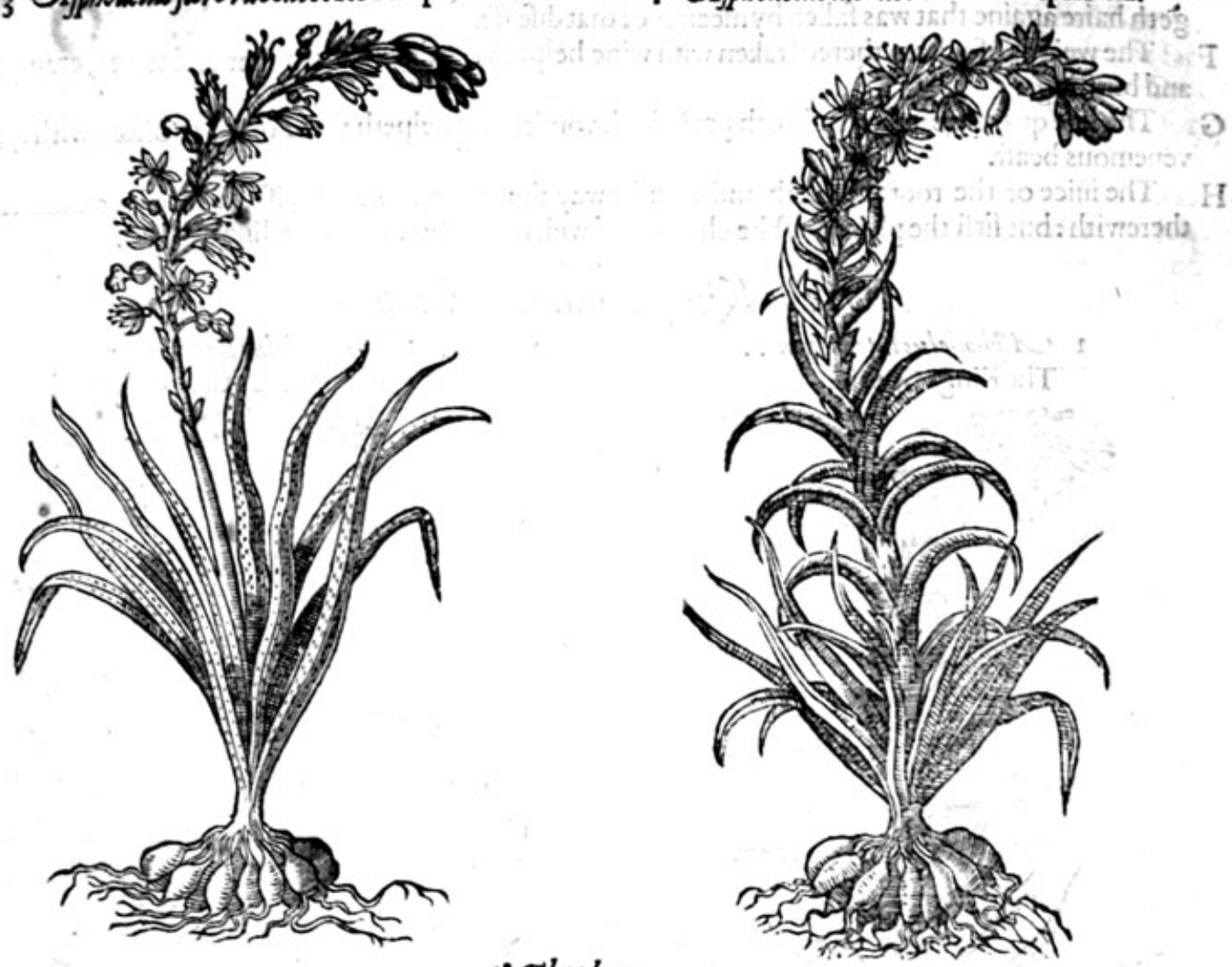

* Theplace.

Thefe kindes of Afphodils come vp of themfelues in the prouince of France, Italie, Spaine, and in other countries thereabout : we haue them in our London gardens.

* The time.

They flower in May and Iune, and that by parcels or peecemeale, beginning belowe, and fo flowring vpward.

* The names.

Afphodill is called in Latine A phodelus, Albucum, Albucus, and Hastwla Regia : in Greeke ioposuros: in Englifh Afphodill, not Daffodill; for Daffodill is 2 arciffus, another plant differing from Afphodill. Pliny writeth that the ftalke with the flowers is called Anthericos, and the roote, that is to fay, the bulbs $A$ pphodelses.

Of this Afphodill $\mathrm{Heffod}$ maketh mention in his works, where he faith, that fooles knowe not how much good there is in the Mallow and in the Afphodill, bicaufe the rootes of Afphodill are good to be eaten. Yet Galen doth not beleeue that he ment of this Afphodil,but of that bulbed one; whereof we will make mention heerafter. And he himfelfe teftifieth, that the bulbs thereof are not to be eaten without very long feething; and therefore it is not like that $\mathrm{He}$ fod hath commended any fuch: for he feemeth to vnderftand by the Mallow and the Afphodil,fuch kinde of foode as is eafily
prepared,and foone made ready. $\quad *$ The nature. * The nature.

Thefe kinds of Afphodils be hot and drie almoft in the third degree.

After the opinion of Difforides $*$ The vertues. the termes effectually, efpecially being Aetius, the rootes of Afphodill eaten, prouoke vrine and $\mathbf{A}$ One dram thereof efpecially being ftamped and ftrained with wine and drunke.

tures, conuulfions, and the in wine in maner before rehearfed, helpeth the paine in thefides, rup- B The rootes boiled in dregs cough.

ftones,and eafeth the fellons of wine cure foule eating vlcers, all inflammations of the dugs, or C

The iuice of the retlon being put thereto as a pultus. The iuice of the roote boiled in old fweete wine, togither with a little myrnhe and faffron,maketh D
an excellent Collyrie profitable for the cies. 


\section{8}

\section{THE FIRST BOOKEOOE ITHE}

E Giles faith, the rootes burnt to afhes, and mixed with the greafe of a duckey hel pech Alopecis, bringeth haire againe that was fallen by meanes of that difeafe.

F The weight of a dram there of taken with wine helpeth the drawing togicher of finewes, cramps, and burftings.

G The like quantitie taken in broth prouoketh vomit, and helpeth thofe that are bitten with any venemous beatt.

H The inice of the roote clenfeth and taketh away the white morphew, if the face be annointed therewith : but firft the place muft be chafed and well rubbed with a courfe linnen cloth.

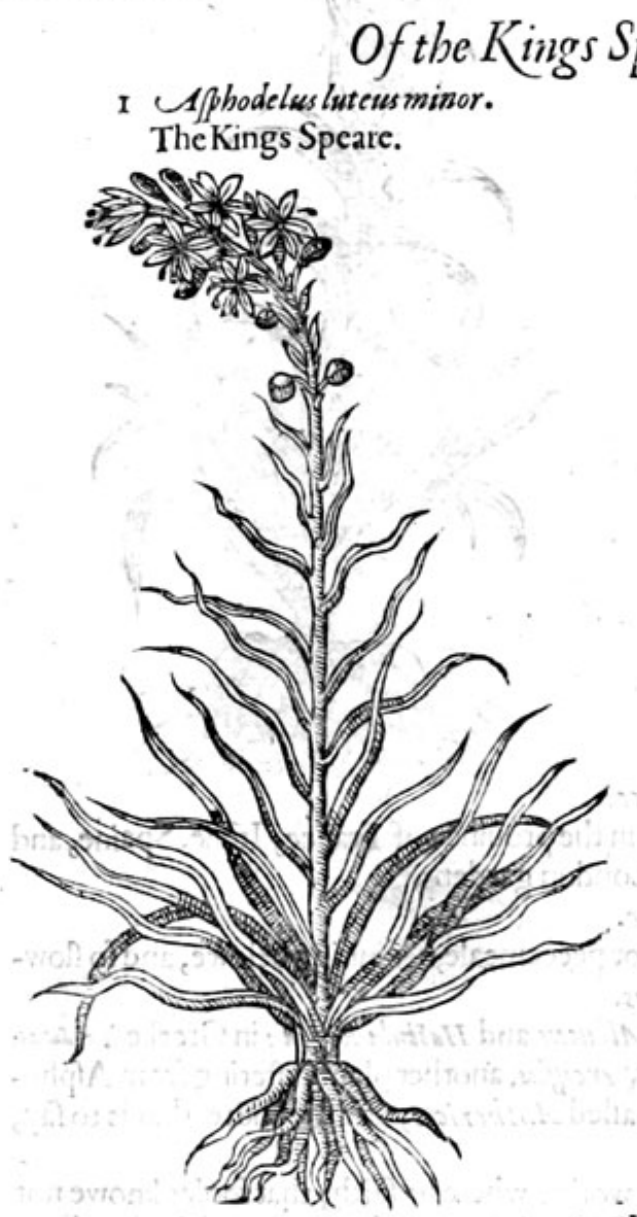

* The defcription.

Chap.64.

2 uppodelus Lancastrie.

Lancafhire Afphodill.

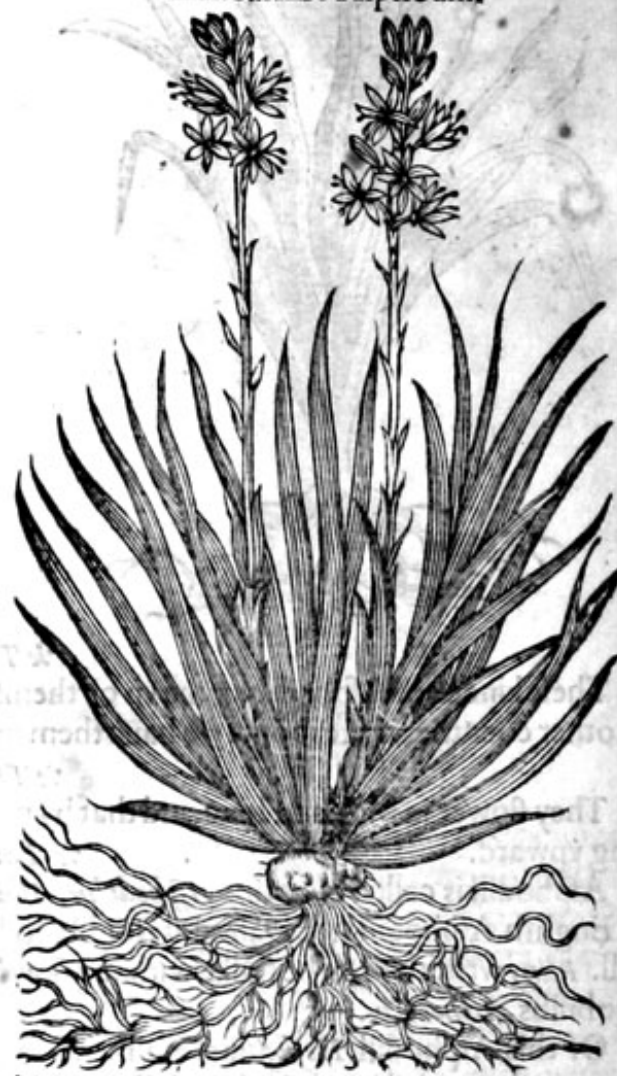

$\mathbf{I}$

Te leaues of the Kings fpeare are long,narrow, and chamfered or furrowed, of a greene blew colour. The ftalke is round, of a cubit high. The flowers which grow thereon from the middle to the top are very many, in thape like to the flowers of the other, which being paft, there come in place there of little round heads or feede veffels, wherein the feede is contained. The rootes in like maner are very many, long and flender, fmaller than thofe of the other yellow fort. Vpon the fides where of grow foorth certaine ftrings, by which the plant it felfeis eafily increafed and multiplied.

2 There is found in thefe daies a certaine wateric or marifh Afphodil like vnto this laft defcribed, in ftalke and flowers, without any difference at all. It bringeth foorth leaues of a beautifull greene fomewhat chamfered, like to thofe of the Flower de-luce or Corne flag, but narrower; not full a fpan long. The ftalke is ftraight, a foote high, whereupon growe the flowers, confifting of fixe fmall leaues: in the middle whereof come foorth fmall yellow chiues or threds. The feede is very fmall, contained in long fharpe pointed cods. The roote is long, iointed, and creepeth as graffe doth, wich many fmall ftrings.

* The place.

I The fmall yellow Afphodill groweth not of it felfe wilde in thefe parts $s_{2}$ notwithftanding we 


\section{HISTORDE DOF PEANTS}

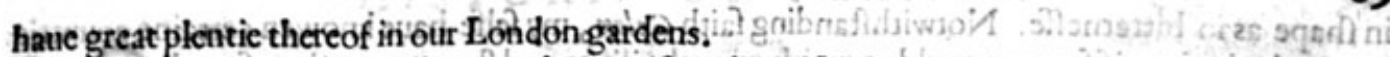

2 The Eancafhire A phodill groweth șin moift and marifh places neere vnto the towne of Lancafter in the moorifh grothds there, as alfo neere vhto Mandfley and Martom, two vilfages not far from thence; where it was found by a worfhip full and learned gentlernan, a diligent fearcher of fimples, \& ferient loverofplaits, malter T bomiss Hesket, whobrought the plants thereof vnto minc for the increafe of my garden.

I receiued fome phants thereof likewife from mafter $T$ homas Edrards Apothecarie in Excefter, kearned and skilfull inhis profeffion, as alfo in the knowledge of plants, vnto whom I reft bounden as well for this plant, as alfo other rare and ftrange plants and feedes, efpecially for the platit of Ines, which his feruant brought from the Iridies, S is the plant of whofe roots the needy naked Indian foules do make theirbread, as fhall be expreffed thore at large, where I thall haue occeffot to $\mathrm{A}$ make further mention there of. He found this Afphodill at the foote of a hill in the weft part of England, called Bagthot hill, neere vnto 2 village of the fame name,

$$
* \text { Thetime? }
$$

They flower in May and Iune : moft of the leaues thereof temaine greene in the winter, if it be not 3 extreme cold. $\therefore$ The names.

The latter herbarifts call this yellow Afphodill Xiphiwn: in Latine 1 /photelus luteus of Diongfrus: of fome it is called Hastiuly Kegia. We haue engifined it, the Speare for a King, or Imall yellowe
Afphodill.

2 The Lancafhire Afphodil is called in Latine 1 Aphodelew Lancast rie, and may likewife be called

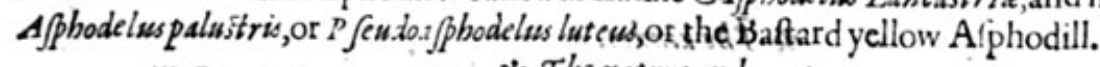

$*$ The nature and vertues.

It is not yet found out what ve there is of eithet of them in nourifhment or medicines.

$$
\text { Of Onion eAfphotill Chap. } 65
$$

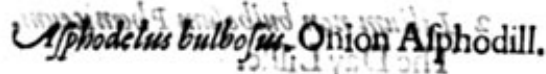

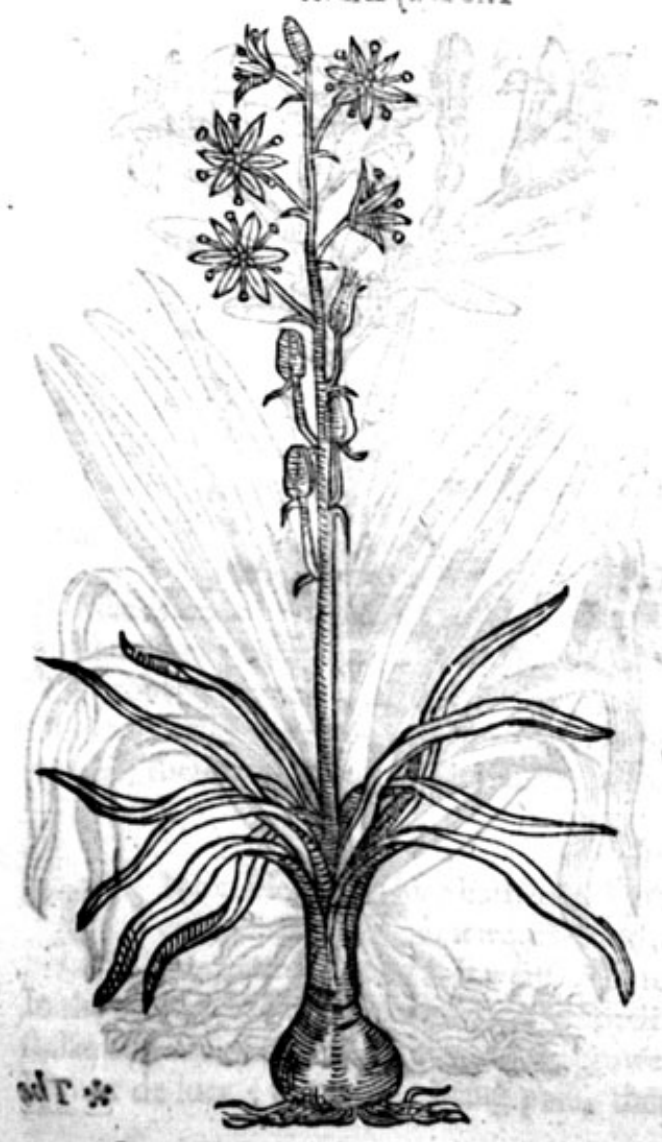

* The defiption.

7 He bulbed Afphodill hath a round bulbus or Onion roote, with fome fibres hanging thereat: from the which come vp many graffie leaues, very wel refembling the Lecke, aniongt the which leaues there rifeth vp a naked or fmooth ftem, garnifhed toward the top with many ftarlike flowers, white of colour, confifting of fixe little leaues tharpe pointed, with certaine chimes or threds in the middle. After the fower is paft, there fucceedeth finall knops or heads three fquare, wherein lieth the feede.

$$
\text { * Theplace. }
$$

It groweth in the gardens of herbatifts in London, and not elfesyhere that I know of : for it is not very common.

$$
\text { * The time. }
$$

It flowreth in Iune and Iuly, and fomwhat after. * The hames.

The ftalke and flowers being like to thofe of the Afphodill before mentioned, doe fhewe it to be Aphodeli species, or a kinde of Afphodill : for which caufe alfo it feemeth to be that Afpho. dill, of which Galen hath made mention in his feconde booke of the Faculties of nourifhments in thefe words, The roote of A f phodill is in $2 \mathrm{ma}$. ner like to the roote of Squill or feגOnion, as well 
90

\section{THE FIRST BOOKE OF THE}

in fhape as in bitterneffe. Notwithftanding faith Galen, my felfe haue knowen certaine countrie men, who in time of famine could not with many boilings and fteepings make it fit to be eaten. It is called of Dodoneus 1 sphodelus famina, and UAphodelus Bulbofus: of Galen Hyacintho-U1Phodelus, and Afphodelus Hyacinthinus, and that rightly ; for that the roote is like the Hyacinth and the flowers like Afphodelus : and therefore as it doth participate of both kindes, fo likewife doth the name : in Englifh we may call it, Bulbed Afphodill.

\section{* The nature.}

The round rooted Afphodill according to Galen, hath the fame temperature and vertue, that Aron, Arifarum, and Dracont ium haue, namely, an abfterfiue and clenfing qualitie.

$$
\text { * The vertues. }
$$

A The yoong fprouts or fprings thereof is a fingular medicine againft the yellow Iaunders, for that the roote is of power to make thin and open.

B The rootes heereof, as Galen writeth in his booke of the Faculties of fimple medicines, are like in vertues to wake Robin or Aron, and Plinies cowkowpintle, and likewife to Dragons as aforefaid,

C Galen faith that the afhes of this Bulbe mixed with oile or hens greafe, cureth the pilling or falling of the haire in fpots, as cilopecia doth.

\section{Of Yellow Lillies. Cbap.66.}

* The kindes.

D Icaufe we fhall haue occafion heereafter to fpeake of certaine Cloued or Bulbed Lillies, we wil in this chapter intreat onely of another kind not Bulbed, which likewife is of two forts, differing principally in their rootes; for in flowers they are Lillies, but in rootes Afphodils,participating $2 s$ it were of both, though neerer approching vnto $A$ pphodils than Lillies.

I Lilium non bulbofum.

The yellow Lillie.

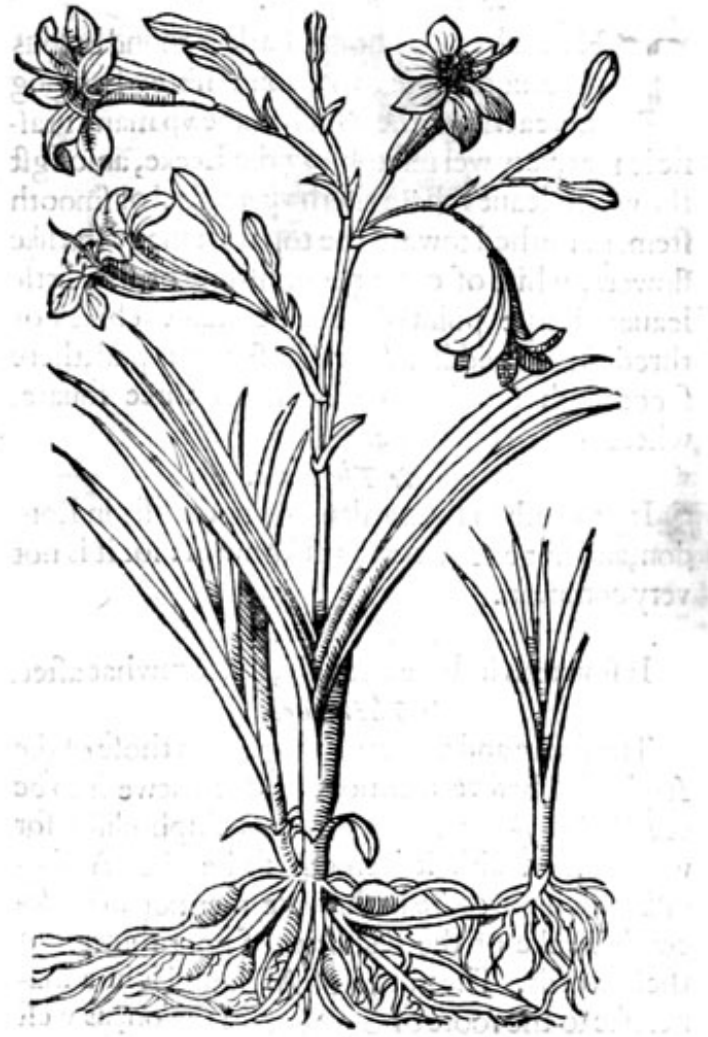

2 Liliwem non bulbofwen P beenicevion, The Day Lillie.

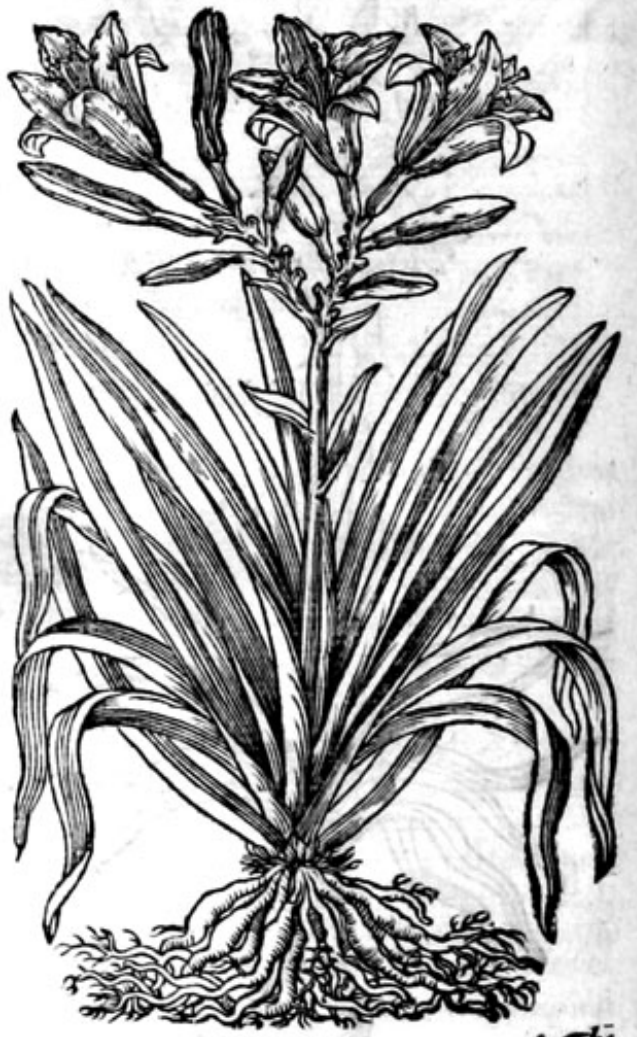



themiddeft like a gutter: among the which rifeth vp a naked or bare ftalke, two cubits high, branched toward the top, with fundrie brittle armes or branches, wheron doc grow many goodly flowers, like vnto thofe of the common white Lillie in

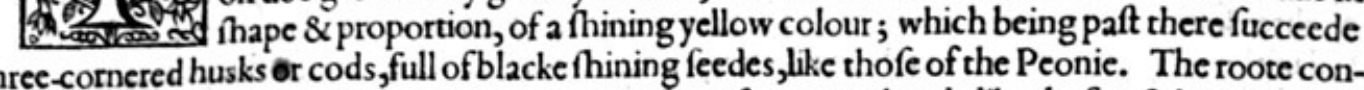
three-cornered husks or codseth of many knobs or tuberous clogs, proceeding from one head, like thofe of the white Afphodill or Pconie.

2 The Day Lilly hath ftalks and leaues like the former. The flowers be like the white Lillie in fhape, of an orenge tawnie colour : of which flowers much might befaid, which I omit. But in briefe this plant bringeth foorth in the morning his bud, which at noone is full blowen or fpred abrode, and the fame day in the euening it is as rotten and ftinking, as if it had been troden in a dunghill a moneth togither in foule and rainy weather : which is the caufe that the feede doth not follow, as in the other of his kinde, not bringing foorth any at all that I could euer obferue, according to the old prouerbe, Soone tipe, foone rotten. His rootes are like the former.

$$
\text { * Theplace. }
$$

Thefe Lillies do growe in my garden,and alfo in the gardens of herbarifts and louers of fine and rare plants; but not wilde in England,as in other countries. * The time.

Thefe Lillies do flower fomewhat before the other Lillies.

$$
\text { * The names. }
$$

Diuers do call this kinde of Lillie Lilia/Phodelw, Liliago, and alfo Liliastrum, but moft commonly Lilisom non bulbofsom : in Englifh Liricontancie, and yellow Lillie. The old herbarifts name it Hemerocallis: for they haue two kindes of Hemerocallis, the one a fhrub or wooddie plant, as witneffeth Theophrastus in his fixt booke of the hiftoric of plants. Plinie fetteth downe the fame fhrub among thofe plants, the leaues whereof onely do ferue for garlands.

The other Hemerocallis which they fet downe, is a flower which perifheth at night, and buddeth at the funne rifing,according to Athen ass, and therefore is called the Day Lillie, or Lillie for a day. $*$ The nature.

The nature is rather referred to the Afphodils than to Lillies.

* The vertues.

Diofcorides faith, that the roote ftamped with honie, and a mother peffarie made thereof with $\mathbf{A}$ wooll, and put vp, bringeth foorth water and blood.

The leaves ftamped and applied, do alay hot fwellings in the dugs after womens trauell in childe B bearing, and likewife taketh away the inflammation of the eies.

The rootes and theleaues be laid with good fucceffe vpon burnings and fcaldings.$$
\text { of Bulbed Flower deluce. Chap.67. }
$$

\section{* The kindes.}

工 Ike as we haue fet downe fundry forts of Flower de-luces, with flaggie leaues and tuberous or knobbie rootes, variyng very notablie in fundrie refpeets, which we haue diftinguifhed in their proper chaptens: it refteth that in like maner we fet foorth vnto your view, certaine Bulbofe or Onion rooted Flower de-luces, which in this place doe offer themfelues vnto our confideration, whereof there be alfo fundry forts, forted into one chapter as followeth.

I Nion Flower de-luce hath long narrow blades or leaues, crefted, chamfered, or ftraked

* The defrription.
I Dion Flower de-luce hath long narrow blades or leaues, crefted, chamfered, or ftraked on the backe fide, as itwere welred, below fomewhat round, opening it felfe toward the top,yet remaining as it were halfe round, wherby it refémbleth a hollow troughor gutter: Inthe bottome of the hollowneffe it tendeth to whiteneffe, and among thefe leaues doe rifevp a ftalke of a cubichigh, at the top wherof groweth a faire blew flower not differing from the common Flower de-luce; the which being paft, there com in place long thicke cods or feede veffels, 
whercin is contained yellowith feede of the bigneffe of a tare or fitch: the roote is rounde like the Onion, coutered ouer with certaine browne skins or filmes.

2 Changeable Flower de-luce hath leaues like the former, but thinner, narrower, and fharper pointed. The ftalke and rootes are alfo like vnto the former, but leffer. The flower groweth at the top, hauing likewife the forme of the Fower de-luce, that is to fay, confifting of fixe greater leaues, and three leffer: the greater leaues fold backward and hang downeivard, the leffer ftand vpright. And in the middle of the leaues there rifeth vp a yellow welt, white about the brims, and tha dowed all ouer with a walh of thin blew tending to a watchet colour : toward the ftalke they are ftripped ouer with a light purple colour, and likewile amongft the hollow places of thofe that ftand vpright, which cannot be expreft in the figure, there is the fame faire purple colour : the fmell and fauour very fweete and pleafant. The roote is Onion fafhion or bulbus, like the other.

3 Of which kinde or fort there is another in my garden, which I received of my brother Iames Garret Apothecarie, far more beautifull than the lait defcribed. The which is darht ouer in fteed of the blew or watchet colour, with a moft pleafant gold yellow colour, of finell exceeding fweete, with bulbed rootes like thofe of the other fort.

4 It is reported, that there is in the garden of the Prince elector the Landgraue of Heffens garden,one of this fort or kinde, with white flowers, the which as yet I haue not feene.

I Iris bulbof.

Onion Flower de-luce.

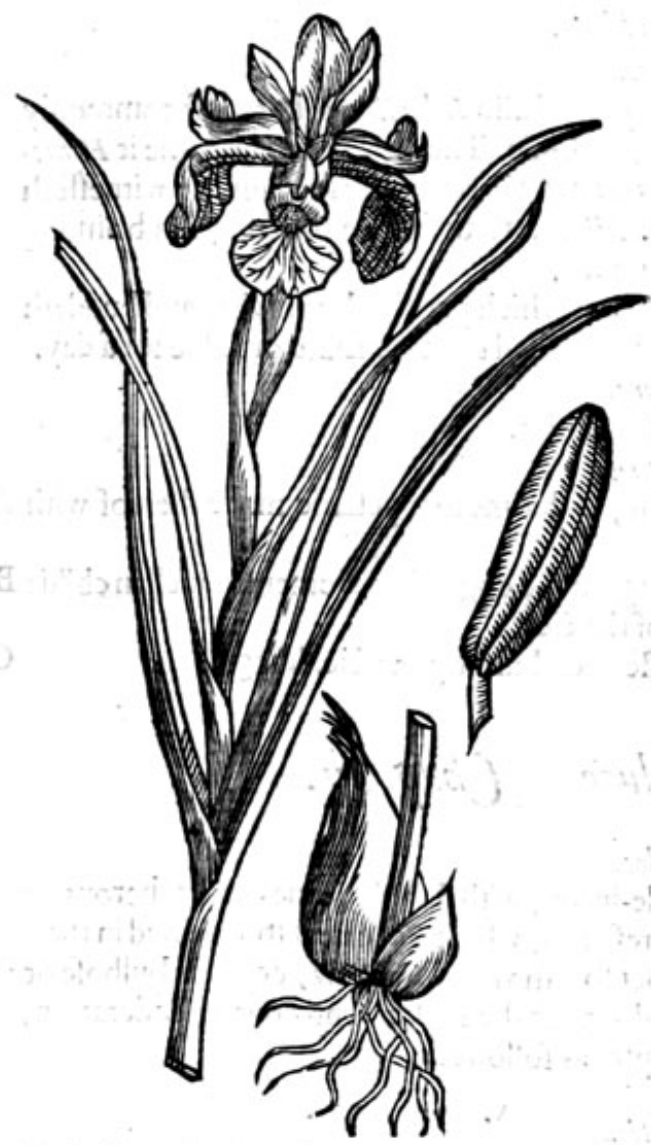

2 Iris bulbofa flore vario. Changeable Flower de-luce.

* The defcription.
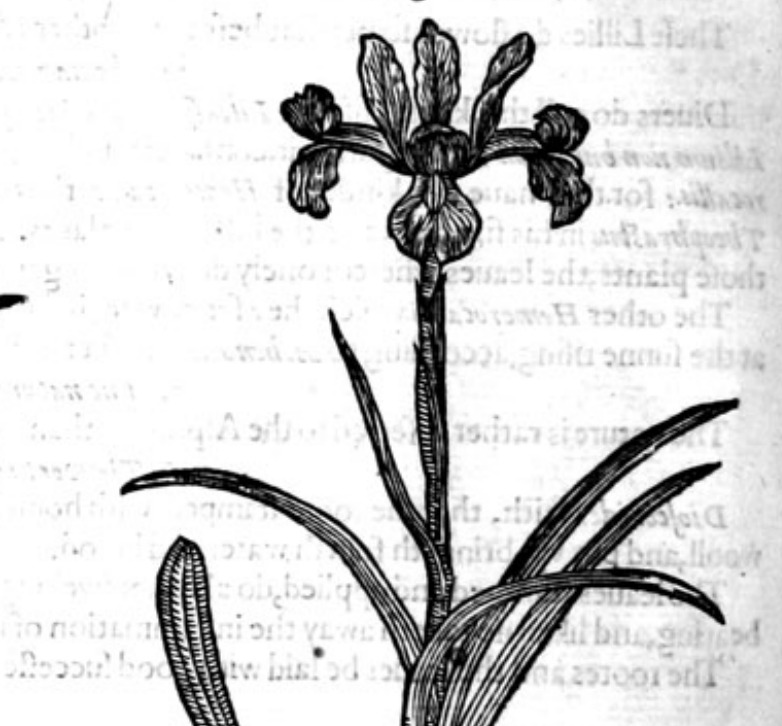

3 The yellow bulbed Flower de-luce hath leaues, rootes, ftalks and flowers like vnto the variable or changeable fort; differing notably in two points, that is to fay, the ftalks of thiskinde do appeere of a reddifh colour next vnto the ground, whereas the others are of a greenifh colour, and the flowers of thefe be of a faire gold yellow colour, and the other of variable colours. 


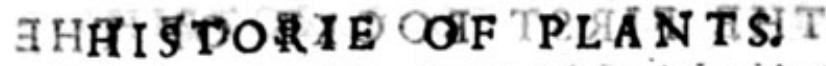

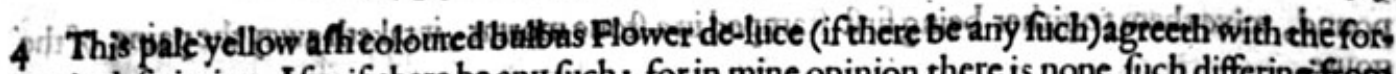
mer in delcription. Ifay if there be any fuch; for in mine opinion there is none fuch differing fitotia the other

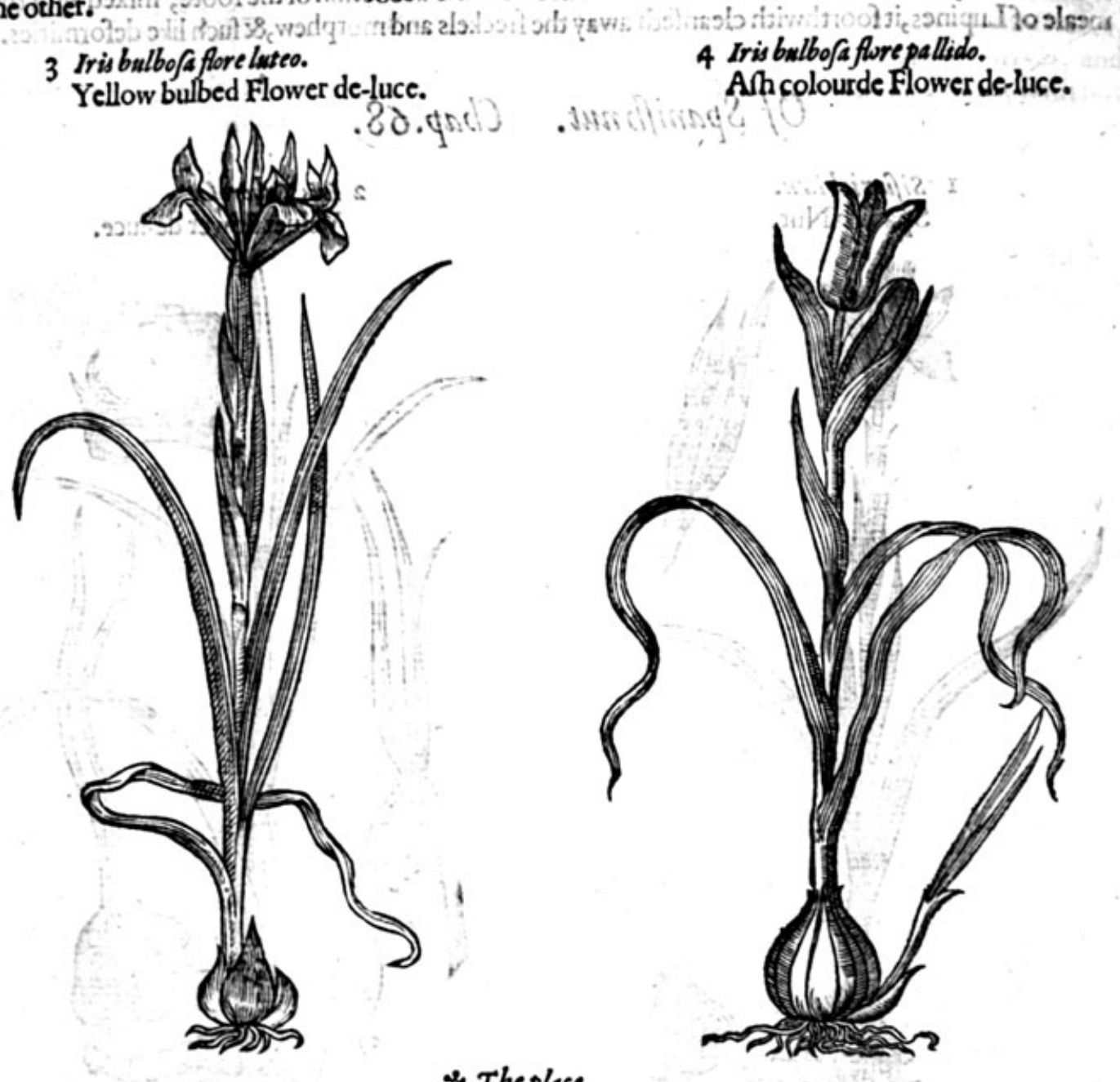

The firft of thefe bulbed Flower de-luces doth grow wilde, or of it felfe in the corne fields of the moft parts of England, as about Bathe and Wels, and thofe places adiacent,from whence they were firt brought into London, where they be naturalized and increafe in great plentic in our London gardens.

The other forts do grow naturally in Spaine \& Italie wilde, from whence we haire had plants for our London gardens, where of they do greatly abound.

They flower in Iune and Iuly, and feldome after. *. Thetime.

Thi 130 the nones.

The Bulbed Flower de-luce is called of $L^{\prime}$ Obelins Iris Bulbofa, and alfo Hyacinstbus foreiridis: of fome Hyacint bus poetarwomand peraduenture it is the fame that Apuleiws mentioneth in the twenty one chapter, faying, that Iris named among the old writers Hieris, may alfo be called and not vippros perly Hierobulbus or Hieribulbus, as though you fhould fay lrì Bulbofa, or Bulbed Ireos, vnieffe you would haueireseracos, called 2 greater or larger Bulbe: for it is certaine that great and huge things: were called of the Ancientsireg, or Sacra : in Englifh holy.

\section{* The nature.}

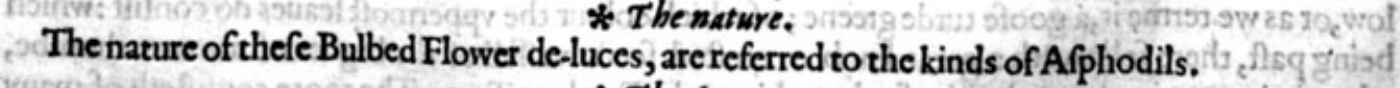
Take faith Apuleives, of the herbe Hierobulbus fixe 3 . Goates fuet as much, oile of Alcanetone'A Qlit: 2 : 


\section{4}

pound, mixe them togither being firft ftamped in a ftone mortar, it takethaway thepaine of the

B Moreouer, if a woman doe vfe to wafh her face with the decoetion of the roote, mixed with the meale of Lupines, it foorthwith cleanfech away the freckels and morphew, \& fuch like deformities.

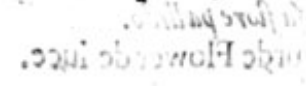

\section{Of Spanifhnut.}

1 Sifunrichisem. SpanifhNut,

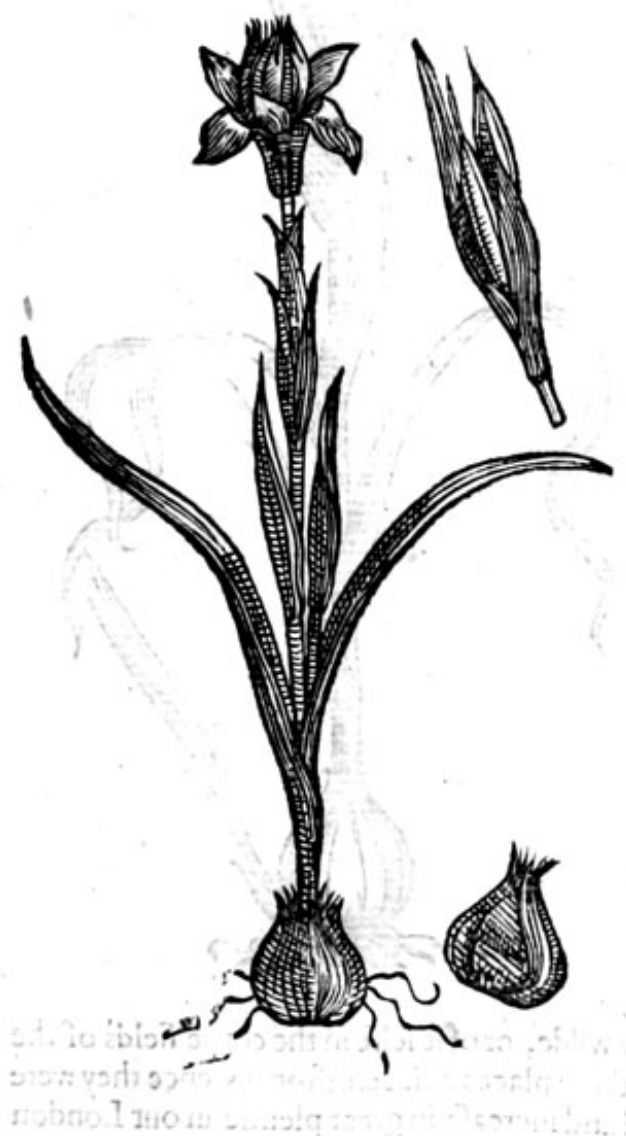

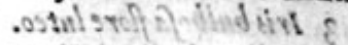

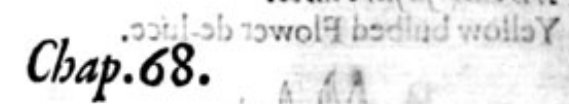

2 Iris Twberofa.

Veluet flower de-luce.

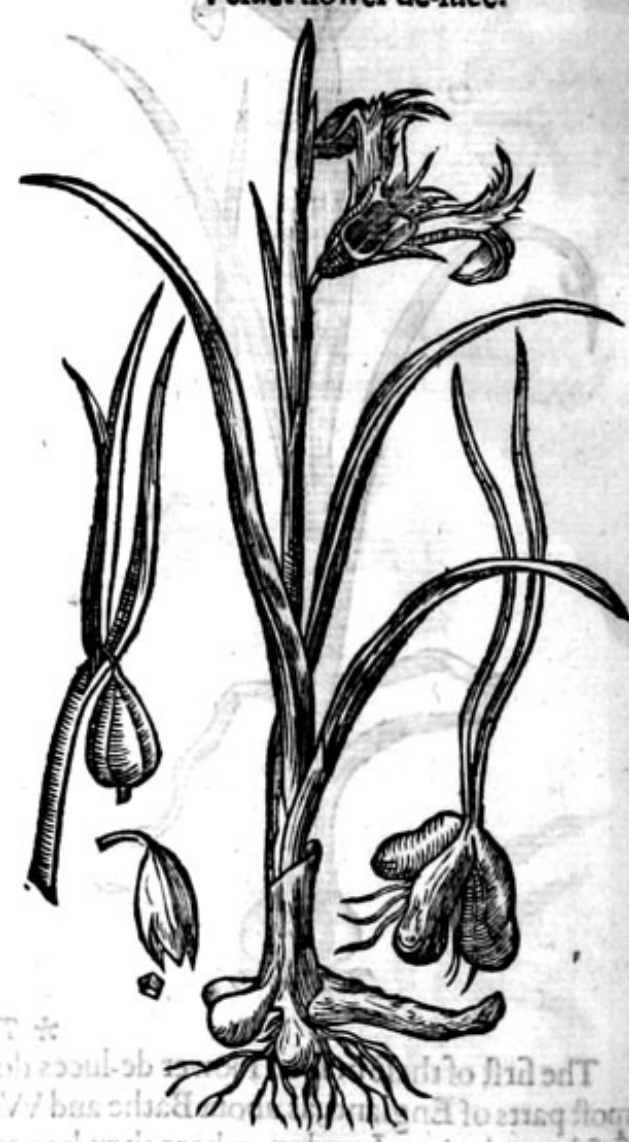

* The defoription. Panilh Nut hath fmal graffieleaues like thofe of theftars of Bethlem or Ornithog alü,among which rifeth vp a fmall italke of halfe a foote high, garninhed with the like leaues, but thorter. The flowers grow at the top, of a skic colour, in thape refembling the flowerde-luce or common Iris : which being paft, therefucceede fmall cods with feeds, like thofe of Tumeps. The roote is round, Bulbus or Onion fafhion, couered with a skin or filme, in fhape like a Net. The bulbe is fweete in tafte, and may be eaten before any other Bulbed flowers. There is fet foorth another of this kinde fomwhat leffer, which may chance by thefoile or cliniate, and yet the felfe fame plant. 2 Veluet flower de-luce hath many long fquare leaues, fpungious or full of pith, trailing vpon the ground, in fhape like to the leaues of rufhes : amoing which rifeth vp a ftalke of a foote high, bearing at the top a flower like the flower de-luce. The lower leaues that turne downward, are of a perfeat blacke colour, foft and fmooth as is blacke veluet, the blacknes is welted about with greenifh yellow, or as we terme it, a goofe turde greene; of which colour the vppermoft leaues do confift : which being paft, there followeth a great knob or crefted feede veffell of the bignes of a mans thombe, wherein is conteined round white feede, as big as the Fetch or Tare. The roote confifteth of many knobby bunches like fingers. 


\section{HIS DORIE COF PLANTS.HT \\ * Theplace.}

Thefe baftard kinds of Flower de-luces, areftrangers in England, except it be among forme fewe diligent Herbarifts in London, who haue them in their gardens where they increafe exccedingly, efpecially the laft defcribed, which is faid to grow wilde about Conftantinople, Morea and Greece, from whence it hath been tranfported into Italy, where it hath beene taken for Hermodactylis, and by fome expreft or fet foorth in writing vnder the title Hermodactylis, whereas in truth it hath not any femblance at all with Hermodactylis.

\section{* The time.}

Thefe wilde or baftard Flower de-luces, do flower from Maie to the end of Iune. * The names.

I The bulbed baftard Flower de-luce which we haue Englifhed Spanifh Nut, is called in Spaine 2 ozella : the leffer fort Parua Nozella, in their owne toong Macuca: we take it to be that kinde of noutifhing Bulbe which is named in Greeke reveryor: of Pliny Sifinrichison.

2 Pling and Theophrastus contend whether this veluet Flower de-luce bethe true Hermodactylis: The which controuerfic I intende not to meddle withall, feeing the matter fo plaine, which may be decided by the leaft and fimpleft Symplift in thefe our daies, confidering it doth not agree with the true Hermodactylis in any one point.

* The nature and vertues.

Of thefe kinds of Flower de-luce there hath been little or nothing at all left in writing concerning their natures or vertues : onely the $S$ panifh Nut is eaten at the tables of rich and delicious, paie vicious perfons in fallads,or otherwife to procure luft and lecherie.

\section{Of Corne Flag.}

1 Gladiolus 2 arbonenfis.

French corne Flag.

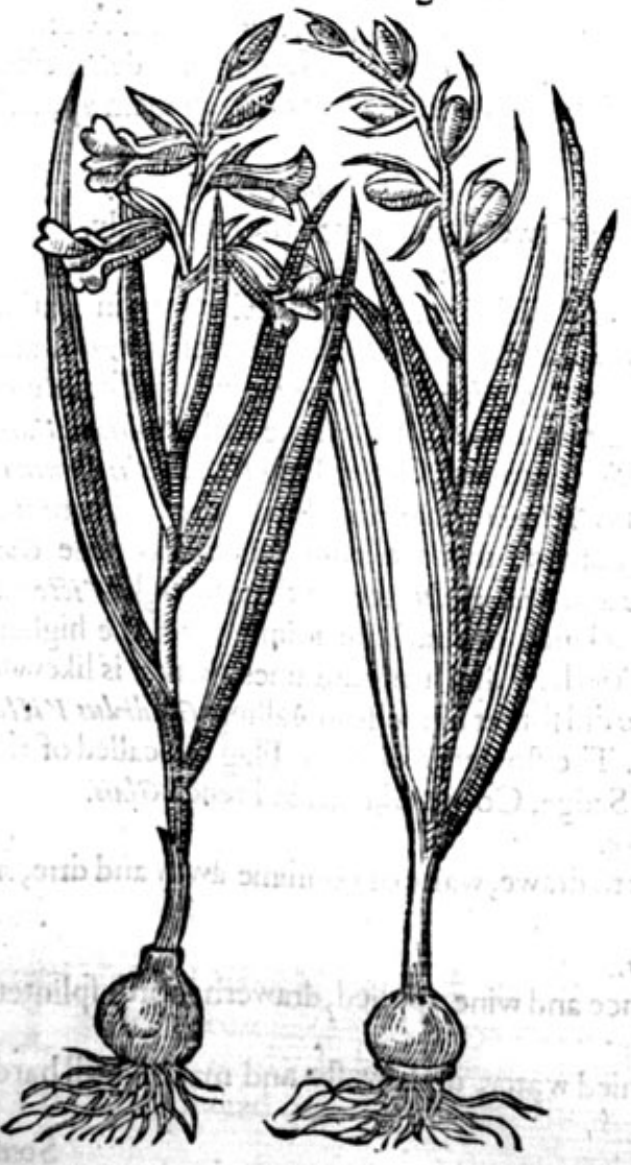

Chap.69.

2 Gladiolses Italicus. Italian corne Flag. 
* The idefoription.

I Rench Corne Flag hath fmall ftiffe leaues, ribbed or chamfered with long nenies or finewes -1 running through the fame, in thape like thofe of the fmall Flower de-luce, or the blade of 2 fivorde, tharpe pointed, of an ouerworne greene colour: among the which rifech vip. a ftiffe brittle ftalke, a cubite high, whereupon do grow in comely order many faire purple flowers, gaping as thofe of Snapdragon; or not much differing from the Foxe gloue, called in Latin Digitalis:after there come in place round knobby feede veffels, full of chaffie feede, verylight, of a browne reddifh colour. The roote confifteth of two Bulbes, one fet vpon the other, the vppermoft whereof in the beginning of the fpring is leffer and more full of iuice : the lower more greater, but more loofe and lithie, which a little while after perifheth.

2 Italian Corne Flag hath long narrow leaues, with many ribs or nerues running through the fame: the ftalke is ftiffe and brittle,whereupon do grow flowers orderly placed vpon one fide of the ftalke, whereas the precedent hath his flowers placed on both the fides of the ftalke, in fhapt and colour like the former, as are alfo the rootes, but feldome feene one aboue another, as in the'former.

Ain. 3 Gladiolus flore Pallido. Pale Corne Flag.

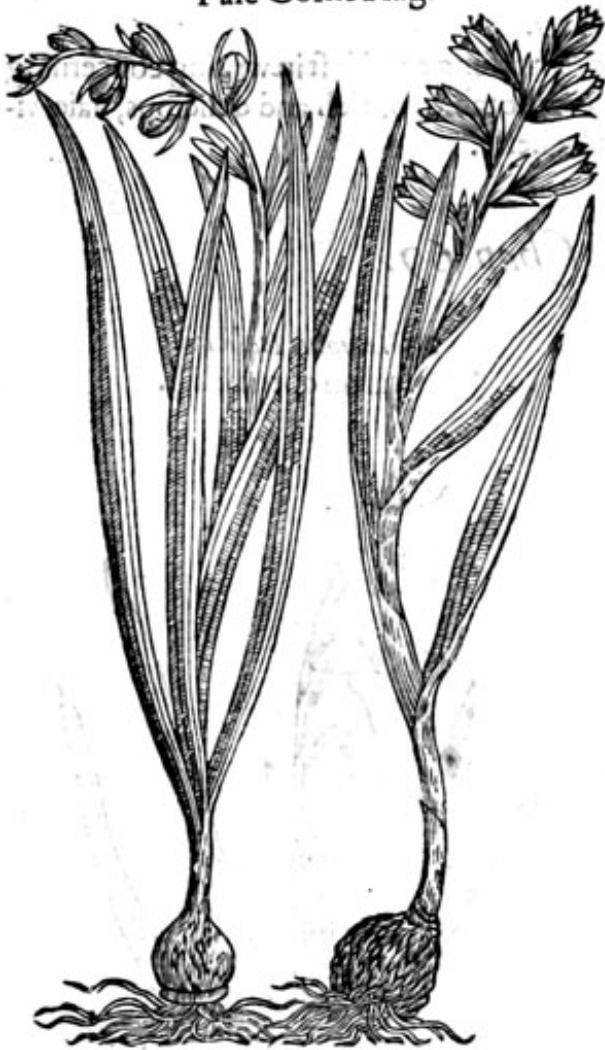

3 There is a thirde fort of Corne Flag, which agreeth with the laft defcribed in euery point, fauing that the flowers of this are of a pale colour, as it were betweene white and that which we call maidens blufh.

$$
\text { * Theplace. }
$$

Thefe kinds of Corne Flags growe in medowes, and in eareable grounds among corne in many $\mathrm{pla-}$ ces of Italy, as alfo in the parts of Fraunce bordering therunto. Neither are the fields of Auftria and Morauia without them, as Cordus writeth.We haue great plentie of them in our London gardens, efpecially for the garnifhing and decking them vp,with their feemely flowers.

$$
\text { * The time. }
$$

They flower from May to the end of Iuly.

$$
\text { * The names. }
$$

Corne Flag is called in Greeke siprov: in Latine Gladiolus, and of fome Enfws of others pdravavov, and Gladiolus fegetalis: Theophraftus in his difcourfe of $P$ hafganum, maketh it the fame with Xipbion. Valerius Cordus calleth Corne Flag Victorialis famina: others Vicforialik rotunda : In the Germaine toong Sefiminurtz: to make a difference betweene Gladiolus and Viztorialis, feeing that the right Viztoris lis is a kinde of Garlicke found vpon the higheft tops of the Alpirh mountaines, which is likeivife called of the Germains efigiwutz : fo that Cordus did forget himfelfe in calling Gladiolus Victorialis : notwithftanding the Germaines appellations. The flowers of Corne Flag are called of the Italians Monacuccio : in Englifh Corne Flag,Corne Sedge, Corne Gladin : in French Glais.

$$
\text { * The nature. }
$$

The roote of Corne Flag, as $G$ alen faith, is of force to drawe, wafte or confume away and drie, as alfo of a fubtill and digefting qualitic.

$$
* \text { The vertues. }
$$

A The roote ftamped with the powder of frankenfence and wine,applied, draweth foorth fplinters and thornes that fticke faft in the flefh.

B Being ftamped with themeale of Darnell and honied water, doth wafte and make fubtill harde lumps, nodes and fwellings being emplaiftred. 
Some affirme that the vpper roote prouoketh bodilie luft, and the lower caufeth barrenneffe. $\mathrm{C}$ The vpper roote drunke in water, is profitable againft that kinde of burfting in children called $D$ Enterocele.

1. The roote of Corne flag ftamped with hogs greafe and wheaten meale, hath been found by late $\mathrm{E}$ practitioners in Phificke and Chirurgerie to be a certaine and approoued remedie againft struma, Scrophulas, and fuch like fwellings in the throte.

The cods with the feed dried and beaten into powder, \& drunke in Goates milke, or Affes milke, F prefentlie taketh away the paine of the collicke.

\section{Of Hyacintbes and theirkinds. Chap. 70.}

* The kindes.

7 Here be likewife Bulbus or Onion rooted plants that do orderly fucceed, whereof fome are to be eaten, as Onions, Garlick, Leekes, and Ciues; notwithftanding I am firft to entreate of thofe Bulbed rootes, whofe faire and beautifull flowers haue receiued grace and ornament in gardens, and Garlands : the firft are the Hyacinths, whereof there is founde at this day diuers forts differing very nota bly in many points, as fhall be declared in their feuerall defcriptions.

I Hyacinthus fellatus Fuchsiy. Starric Iacinth.

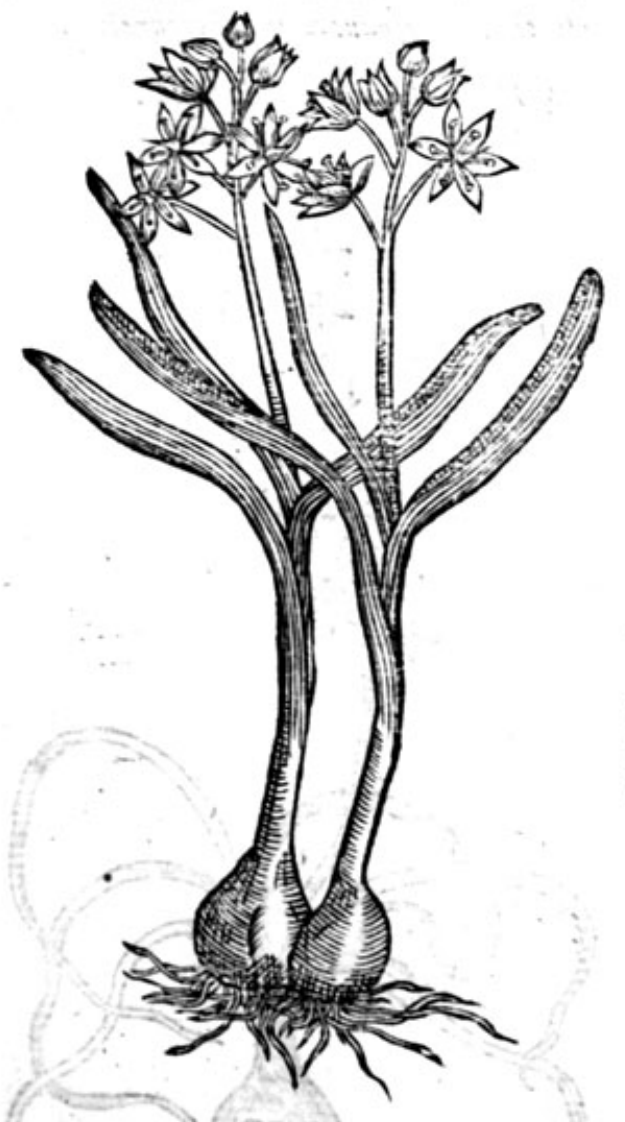

2 Hyacint hus ftellates Lilifolius. Lillie Iacinth.

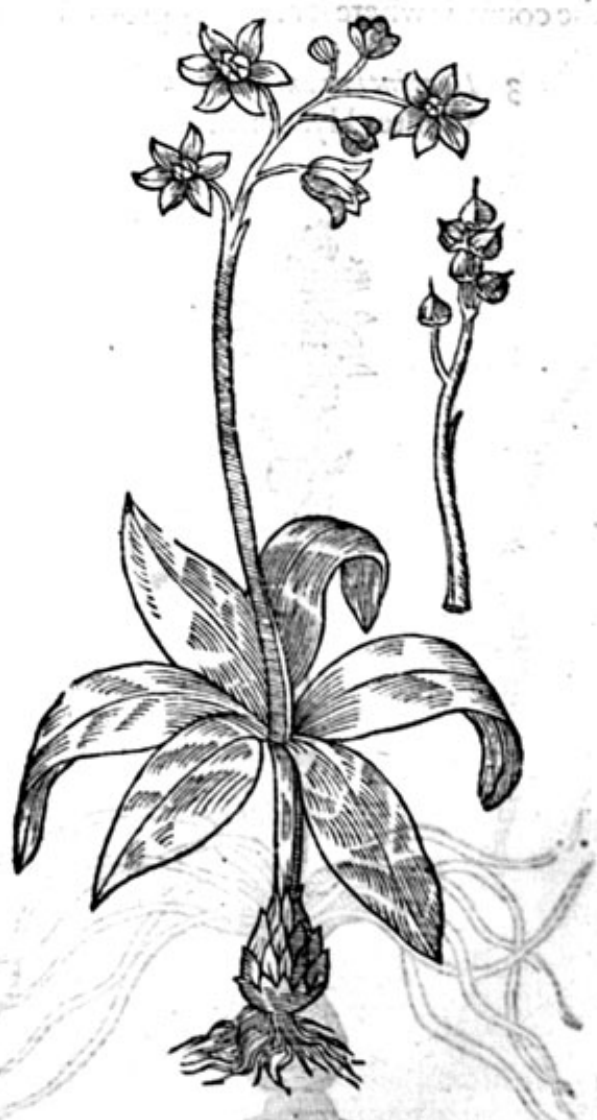

* The defription.

$x$

He firft kind of Iacinth hath very fat thicke browne leaues, hollow like alittle trough,very brittle, of the length of a finger: among which hoote vp fat thicke brownith italkes, foft axe litule leaues,fpread abrode likea ftar. The feed is contained in fmall round bullets, which are fo
f 
ponderous or heauie, that theylic trailing vpon the ground. The roote is bulbus or Onionfafhion; cotered with brownifh feales or filmes.

There is founde another of this kinde which feldome or neuer hath more than two leaues. The rootes are bulbed like the other. The flowers be whitifh ftar fafhion, tending to blewneffe, which I received from Robinus of Paris.

2 The fecond kind of Hyacinth hath many brode leaues fpread vpon the ground, like vnto thofe of garden Lillic, but fhorter.The ftalkes do rife out of the niddeft thereof bare, naked, \& verie fmooth, an handfull high; at the top whereof do grow fmall blew flowers ftar fafhion, verie like vnto the precedent. The roote is thicke and fullof iuice, compact of many fcalie cloues of a yellow colour.

Likewife we haue another fort in our London gardens of this ftarry Hyacinths, like vnto the Hyacinths of Fuch/uus defcription, hauing for the moft part three leatics. The flowers arc of a purple blew colour.

$$
\text { *. The place. }
$$

Thefe plants do grow in many places of Germanie, in woods and mountaines, as Fuchfius and $G e$ nner do teftifie. In Bohemia alfo vpon diuers banks that are full of herbs. In England we cherifh them in our gardens onely for the beautie of the flower.

* The time.

Theybegin to flower in the middeft of Ianuarie, and bring foorth their feede in May. * The names.

The firft of thefe Hyacinths is called Hyacinthus fellatus, or Stellaris Fuchsï, of the ftar-like flowers: Narciffus caruleus Bock $\dot{y}$ : of fome Flos Martius ftellatus.

The Lillie Hyacinth is called Hyacinthus Germanicus lilifor ws, or Germanie Hyacinth, taken from the countrie where it naturally groweth wilde: of others Hyacint hus bifolius, as of Theophrastus.

3 Hyacinthus autumnalis Winter Hyacinth.

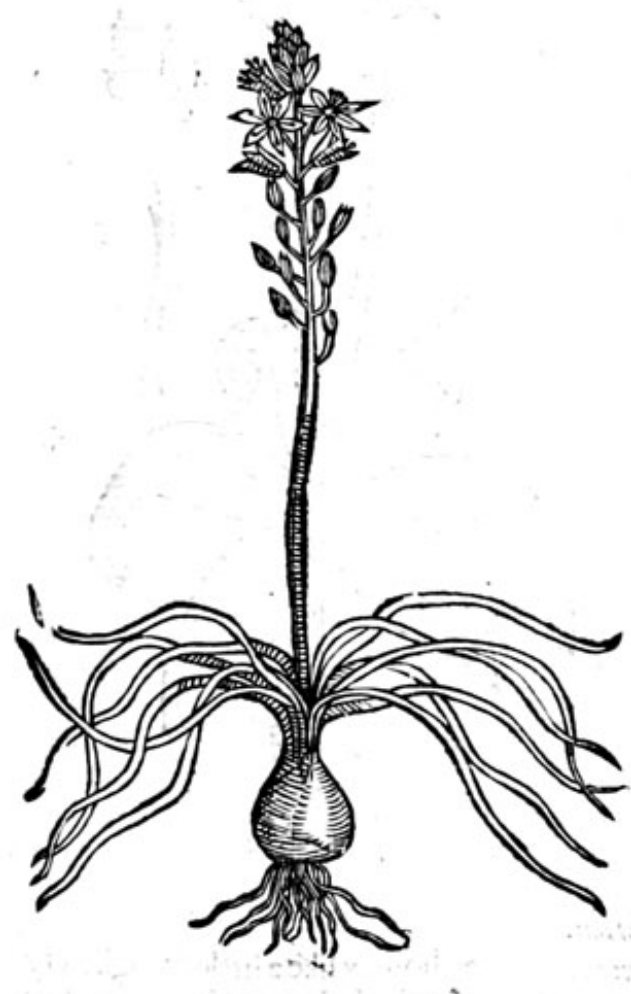

4 Hyacinthus autumnalis maior. Great Winter Hyacinth.

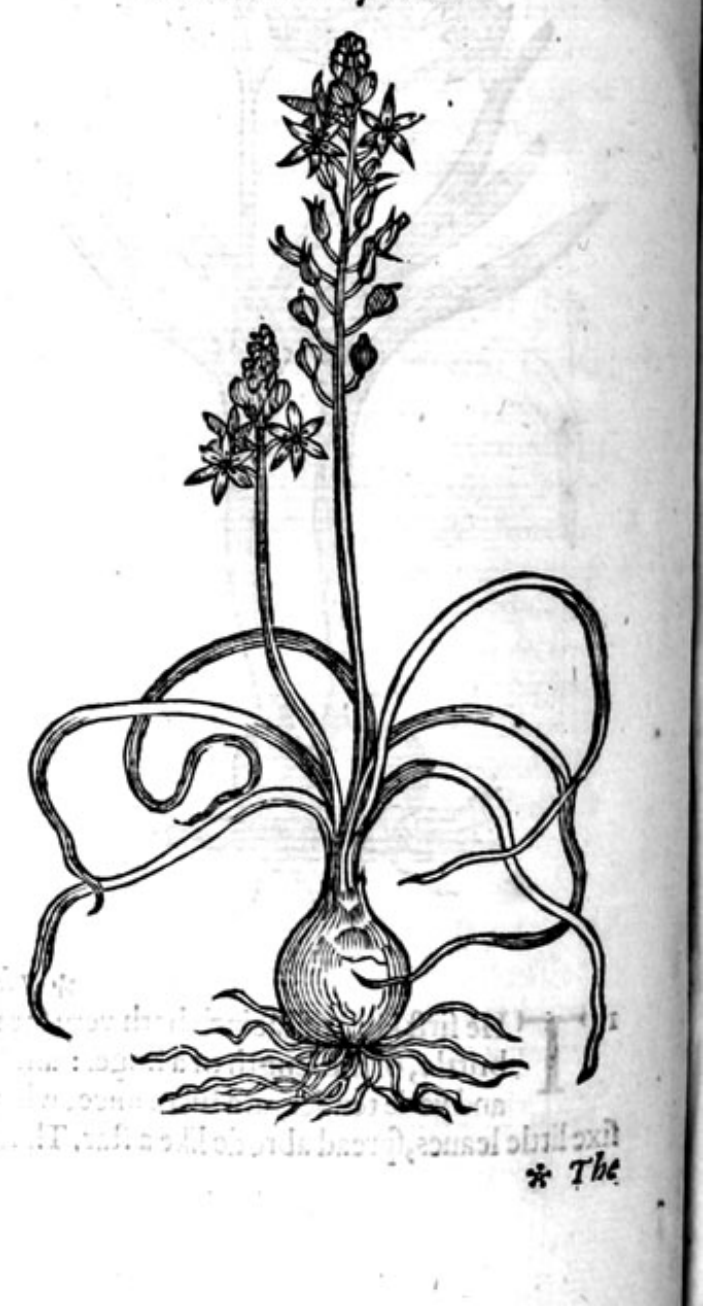




\section{HISTORIE OF PLANTS. I}

* The defoription.

3 Autumne Lacint is the leaft of all Iacints : it hath fmall narrow graffie leaues fpread abroad vpon the ground; in the middeft wherof fpringeth vp a fmall naked ftalke an handful high, fet from the middle to the top with many fmall ftarlike blew flowers, hauing certaine fimall loofechiues in the middle. The feede is blacke contained in fmall husks: the roote is Bulbus or Onion rooted.

4 The great winter Iacint is like vnto the precedent in leaues, ftalkes and flowers, not differing in any one point, but in greatneffe.

$*$ Theplace.
Thefe Autumne Iacints grow not of themfelues or wilde in England, notwithftanding I haue them in my garden, although they be very rare with vs in London.

\section{* Thetime.}

They flower in the end of September, and fometimes after.

* The names.

I The firft is called Hyacint bus Antsomnalis, or Autumne Iacint, and winter Iacint.

2 The fecond Hyacint hus Autumnalis maior, the great Autumne Iacint, or winter Iacint.

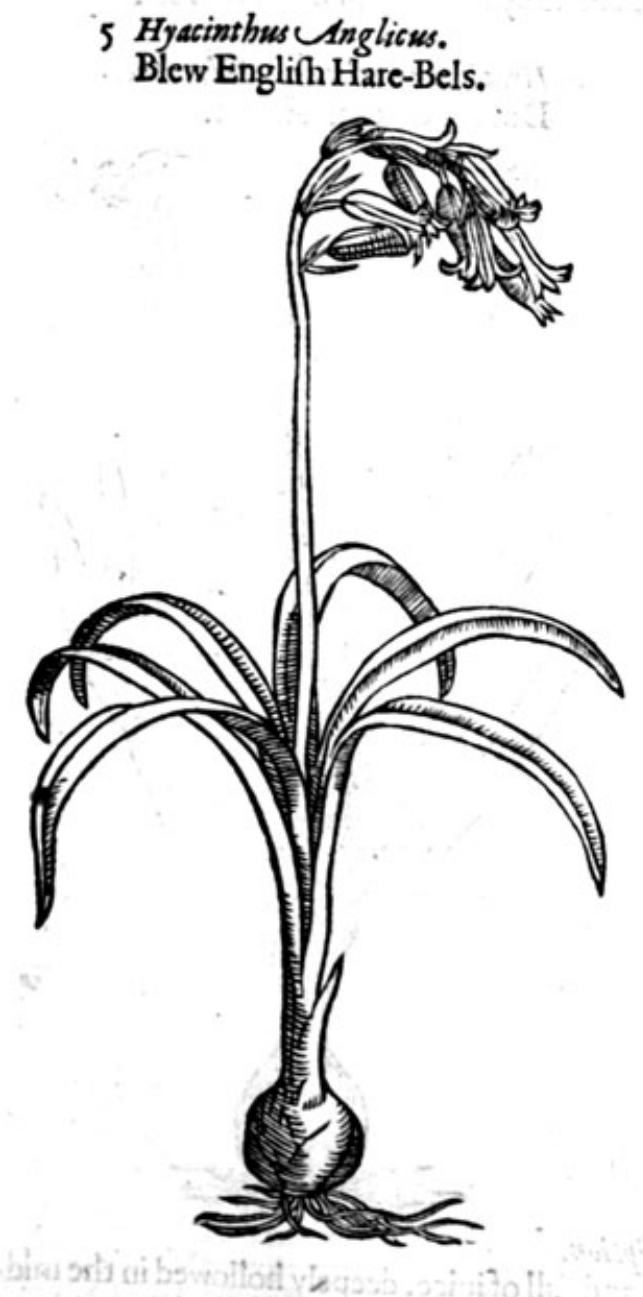

6 Hyacintbus albus Anglicus. White Englifh Hare-Bels.

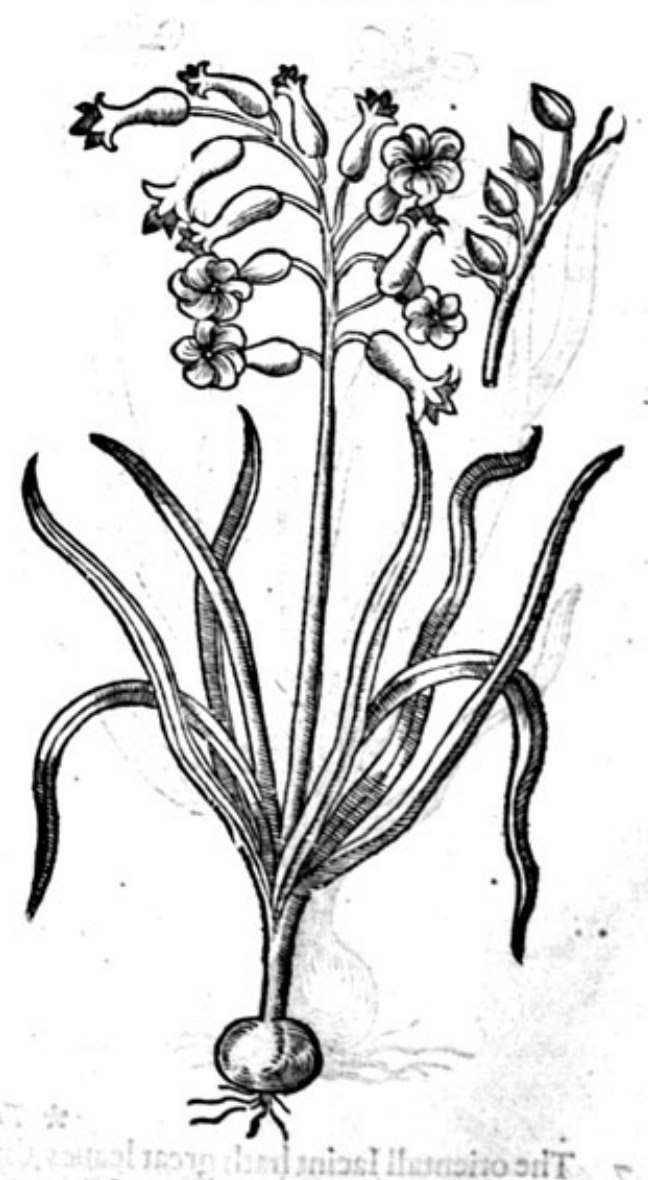

* The defcription.

5 Theblew Harebels or Englifh Iacint is very common throughout all England. It hathlong come the cods or round knobs, conteining iweete fmell, fomewhat ftuffing the head: after which is Bulbus, ful of a flimy glewifh iuice, or to pafte bookes with: whereof is made the bef ferue to fet feathers vpon arrowes in fteed of glew, 
6 The white Englifh Iacint is altogither like vnto the precedent, fauing that the leaues hereof are fomwhat broader, thic flowers more open, and very white of colour.

- There is found wilde in many places of England, another fort, which hath flowers of a faire carnation colour, which maketh a difference from the other.

$$
\text { * The place. }
$$

The blew Harebels dogrowe wilde in woods, copfes, and in the borders offields euery where through England.

The other two are not fo common,yet do they grow in the woods by Colchefter in Effex, in the ficldes and woods by Southfleete neere vnto Graues-end in Kent; as alfo in a peece of grounde by Canturburie called the Clapper, in the fields by Bathe, about the woods by Warrington in Lan. cafhire and other places. $*$ The time.

They flower from the beginning of Maie vnto the end of Iune.

$$
* \text { The names. }
$$

The firft of our Englifh Iacints is called Hiacint hus Anglicus, for that it is thought togrow more plentifully in England than elfe where : of Dodoneus Hyacint hus non f criptus, or the vnwritten Iacint. The other Hyacinthus Belgicus candidus, or the Lowe countrey Iacint with white flowers.

7 Hyacinthus orientalis caruleus.

The blew Orientall Iacint.

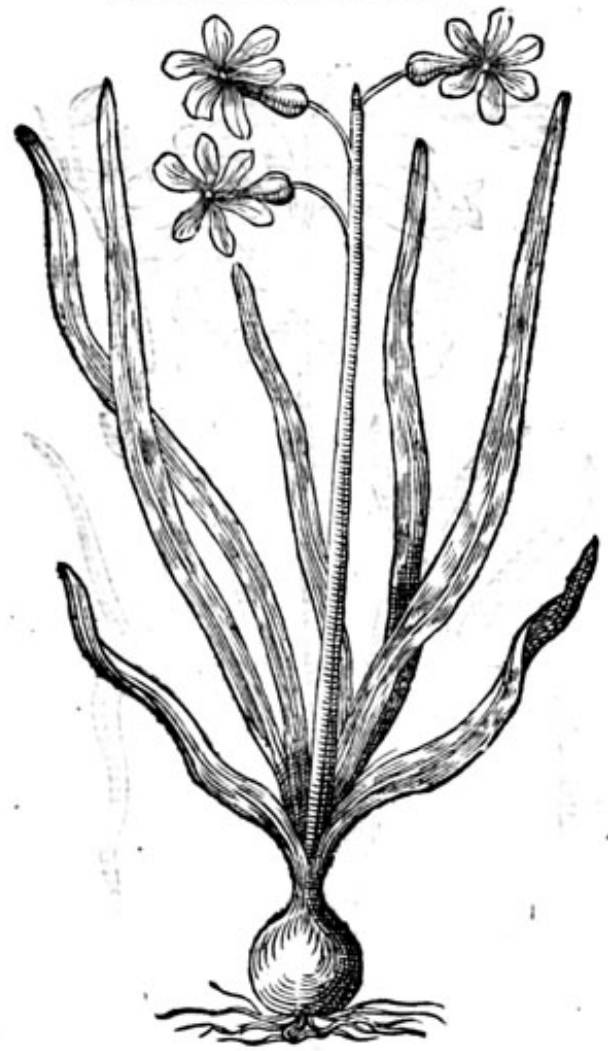

8 Hyacinthus orientalis Polyanthos. Double Orientall Iacint.

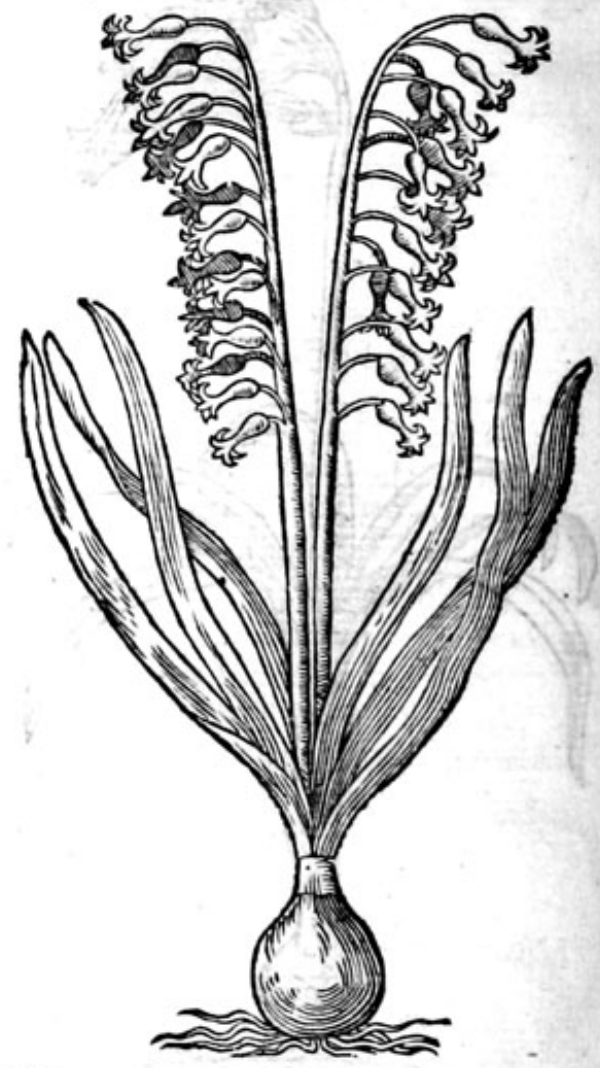

* The defcription.

7 The orientall Iacint hath great leaues, thicke, fat, and full of iuice, deepely hollowed in the middle like a trough : from the middle of thofe leaues rileth vp a ftalke two hands high, bare without leaues, very finooth, foft and full of iuice, loden toward the top with many faire blew flowers, hollow like a bell, greater than the Englifh Iacint. The roote is great, Bulbus or Onion fafhion, couered with many fcalie reddifh filmes or pillings, fuch as thofe that couer Onions.

8 The double Iacint or Iacint with many flowers ( for fo doth the word Polyanthos import) hath very many large and broad leaues, hort and very thicke, fat or full of flimie iuice : from the middle where of rife vp itrong thicke groffe ftalks, barc and naked, fet from the middle to the top with ma- 
ny blew arskic coloured flowers, grawing for themoft part vpon one fide of the ftalke. The roote is great, thicke and full of flimie iuice.

There is come vnto vs from beyond the feas diuers other forts, whofe figures are not extant with vs, of which there is one like vnto the firft of thefe orientall Lacints, Gauing that the flowers thereof are purple coloured.

Likewife there is anotier called o rient alis albus, differing alfo from the others in colour of the flowers, for that thefe are very white, and the others blew.

There is another called Hyacint bus Brwmalis, or winter Iacint, it is like the others in fhape, but differeth in the time of flowring.

$$
\text { * Theplace. }
$$

Thefe kinds of Iacints haue been brought from beyond the feas, fome outof one countrey and fome out of others, efpecially from the Ealt countries, whereof they tooke theirnames Orientalis.

$$
* \text { The time. }
$$

They flower from the end of Ianuary vnto the end of Aprill.

$$
\text { * The names. }
$$

There is a Lilly which Ouid in the tenth booke of his Metamorphofis called Hyacinthus, of the boy Hyacinth, of whofe blood he faineth that this flower fprang, when he perifhed as he was playing with Apollu, for whofe fake he faith that Apollo did prins certaine letters and notes of his mourning writting thus,

$$
\begin{aligned}
& \text { Ecce cruor, qui fufus bumo fignauer at Herbuss, } \\
& \text { Definit effe cruor, Tyriogue nitentior ostro } \\
& \text { Flos oritur, formam que capts, quam Lilia, finon } \\
& \text { Purpurens color bis, argentens effet in illis. } \\
& 2 \text { (on fatis hoc Phabo e it, (is caim fait auctor honoris). }
\end{aligned}
$$

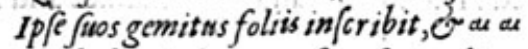

$$
\begin{aligned}
& \text { Flos habet in friptum, funeftaque liter a ducta ast. } \\
& \text { That is, } \\
& \text { Behold the blood of him }
\end{aligned}
$$

Which dide the graffe, ceaft blood to be, and vp there fprang a trim

And goodly flower, more orient then the purple cloth in graine:

In fhape a lillie, were it not that lillies do remaine

Of filuer colour,where as thofe of purple hewe are feene:

Although that $P$ baebus had the caufe of this great honor beene,

Yet thought he not that fame inough, and therefore did he wright

His fighs vpon the leaues thercof: and fo in colour bright

The flowerhath a writ thereon, which letters are of griefe.

T beocritus alfo hath made mention of this Hyacinth in Bions Epitaph in the 19.Eidyll,

Now Hyacinth, thofe letters thine tell them and do not paffe,

And take vpon thy leaues aí cü, hei(mourning notes) alaffe.

Likewife Virgillhath written heereof in the third Eclog of his Bucolicks,

Et me Phobus amat, Phebo fua femper apiud me

Munera funt, lauri of fuawe rubens Hyacint hes.

And me Phabus loues, Phabus hath his gifts alwaies with mee

Trees Laurell; flowers Hyacinth fo fweete and red to fee.

In like maner alfo Temefantus in his fecond Eclog of his Bucolicks:

Te fine me miferomibi lilia nigra vôdentur

Pallentefgue Ro Se, nec dulce rubens Hyacinthus:

- Lif fitu venits, \& candida lilia fient

Purpureaque Rofe, of dulce rubens Hyacinthus.

Me without thee, white Lillies feeme all blacke poore man to me

And Rofes pale, vnf weete the ruddieHyacinth will be:

But if fo be thou com'ft, $O$ then the Lillies fhall be white

AndRofes red, and fweete the ruddy Hyacintb in fight.

The Hyacinthes are faid to be red, which Owid calleth purple, fome would haue them celled by the name of Ruftie Iron, for that when the beft iron is made hot and wrought til it be cold, there remaineth a certaine blewnes, which they call iron colour : grounding themfelues vpon Virgils auter- 
ritic, in the fixt of his AEneidos, where he defcribeth Charons ruftie iron coloured bote, and prefently calleth the fame blew.

$$
\begin{aligned}
& \text { Ipfe ratem conto fubigit velifque miniftrat, } \\
& \text { Et ferruginea fubue ctat cor pora Cymba. }
\end{aligned}
$$

Himfelfe with piked pole his boate doth guide, and beares a charge,

Tranfporting ftill the foules in a ruftic cankered barge.

And Claudius alfo doth not a little confirme their opinıons, who writeth that the Violets are of a fwecte iron colour in his fecond booke of the carying away of Proferpina.

$$
\begin{aligned}
& \text { Sanguineo (plendore ro fas, vaccinia nigro } \\
& \text { Induit, of dulci violas ferrugine ping it. }
\end{aligned}
$$

He trims the rofe with bloudy bright

And Primetree berries black he makes,

And decks the Violet with a fweete

Darke iron colour, which it takes.

But let vs returne to the proper names from which we haue digreffed: moft of thelater Herb2. rifts do call this plant Hyacint bus Poeticus, or Poets Hyacinth. Pauf anzas in his fecond booke of his Corinthiacks, hath made mention of Hyacinthus, called of the Hermonians Comofandalos, fetting downe the ceremonies done by them on their feftiuall daies, in the honor of the goddeffe chthonia. The priefts faith he, and the magiftr.tes forthat yeere being, do leade the troupe of the pompe; the women and men follow after : the boies folemnly leade foorth the goddeffe with a ftately fhewe: They go in white veftures with garlands on their heads, made of a flower which the inhabitants call Comofindalos, which is the blew or skie coloured Hyacinth, hauing the markes and letters of mourning as aforefaid.

\section{* The nature.}

The Hyacinths mentioned in this chapter, do lightly clenfe and binde, drying in the thirdede. grec.But the rootes are dric in the firft degree, and colde in the fecond.

\section{* The vertues.}

A The root of Hyacinth boiled in wine and drunke, ftoppeth the belly, prouoketh vrine, and helpeth againft the venemous bitings of the fielde fpider.

B The feede is of the fame vertie, and is of greater force in ftopping of the laske and bloudy flixe: being drunke in wine it preuaileth againft the falling ficknes.

C The rootes after the opinion of Diofcorides, procure haire in beardleffe men, and fuch as haue been ouertaken with 1 slopesia.

\section{Of faire haired Iacint. Chap. 71 .}

\section{* The defcription.}

I ${ }^{-1}$ He faire haired Iacint bath long fat leaues, hollowed alögft the infide, trogh fafhion, as are moft of the Hyacinthes, of a darke green colour,tending to rednes. The ftalke rifeth out of the midft of the leaues, bare \& naked, foft \& ful of flimic iuice, which are befet round about with many fmall flowers of an ouerworne purple colour: the top of the fike of flowers confiftech of a number of faire fhining purple flowers, in maner of a tuft or burh of haires, whereof it tooke his name Como fus, or faire haired. The feed is conteined in fmall bullets, of a fhining blacke colour, as are moft of thofe of the Iacints. The roote is Bulbus or Onion fafhion, full of Alimic iuice with forne hairie threds, faftened vnto his bottom.

2 White haired Iacint differeth not from the precedent in rootes, ftalkes, leaues or feede. The flowers heerof are of a darke white colour,with fome blacknes in the hollow part of them, which fetteth foorth the difference.

Of this kinde I receiued another fort from Conftantinople, refembling the firft hairie lacint very notably: but differech in that, that this is altogither greater, afwell in leaties, rootes and flowers, as alfo is of greater beautie without all comparifon. 
I Hyscinthus comofus.

Faire haired Iacint.

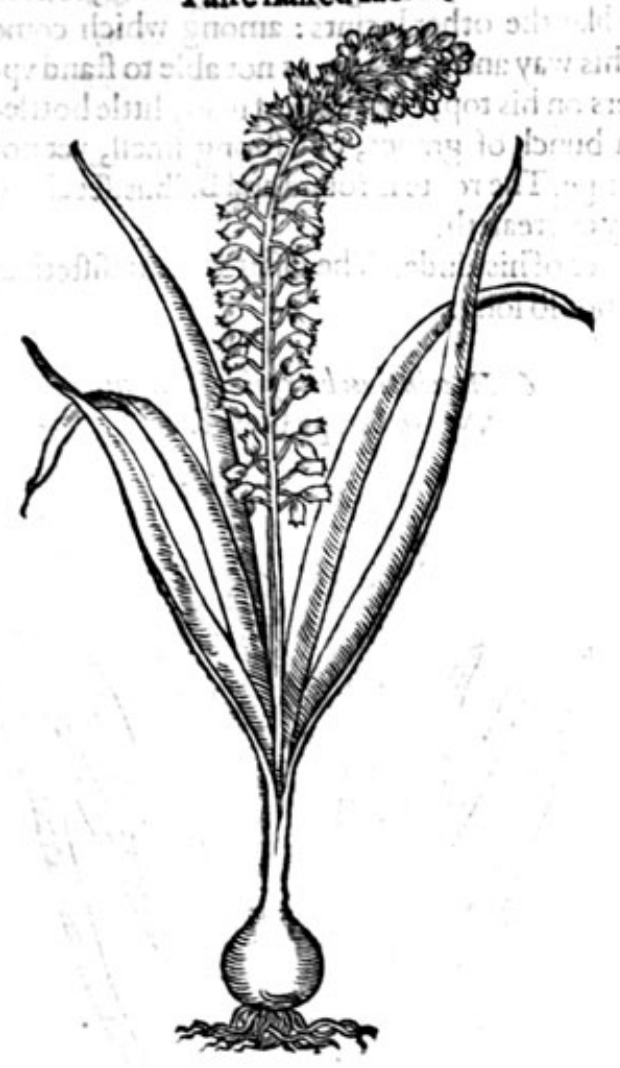

3 Hyacint hus Botryoides c.eruleus. Blew Grape flower.

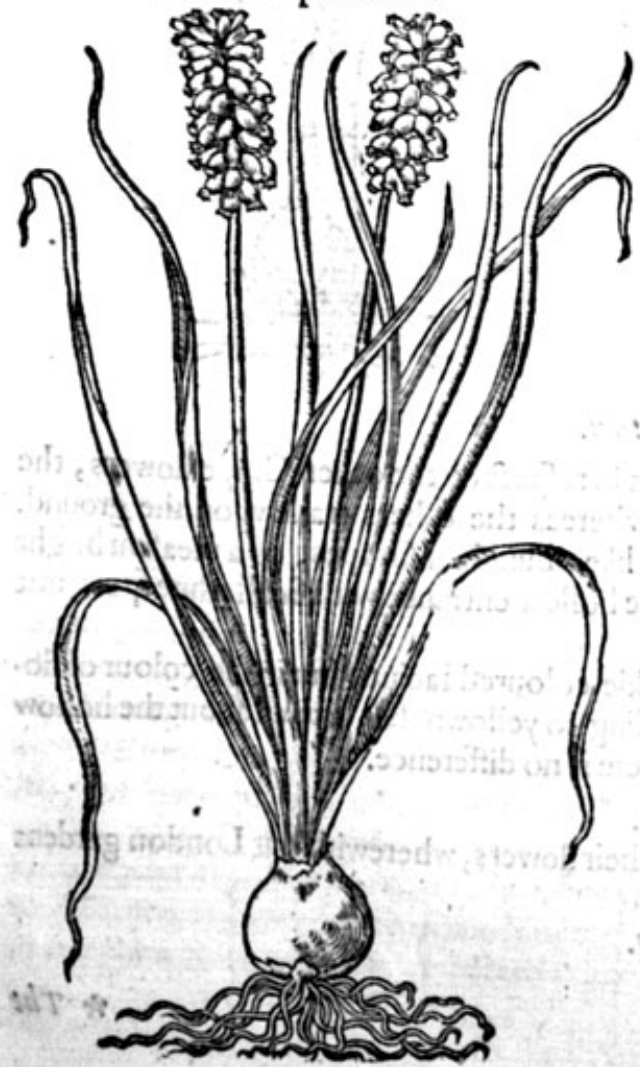

2 Hyacinthus como fus albus. Whitehaired Iacint. $^{2}$

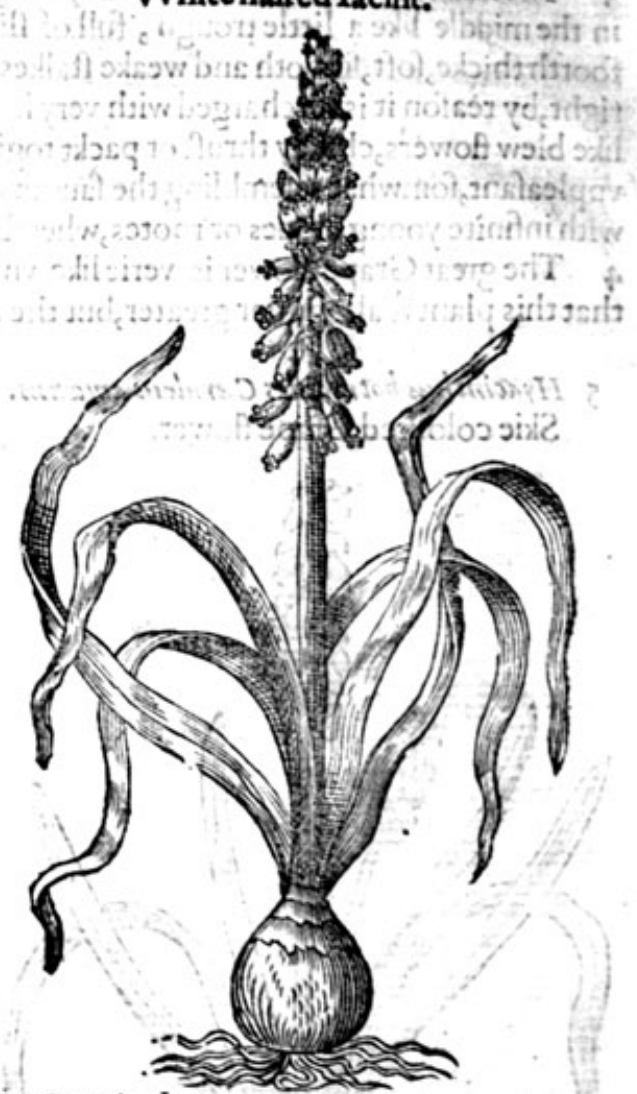

4 Hyacint hus Botryoidescerulews mator. Great Grape flower.
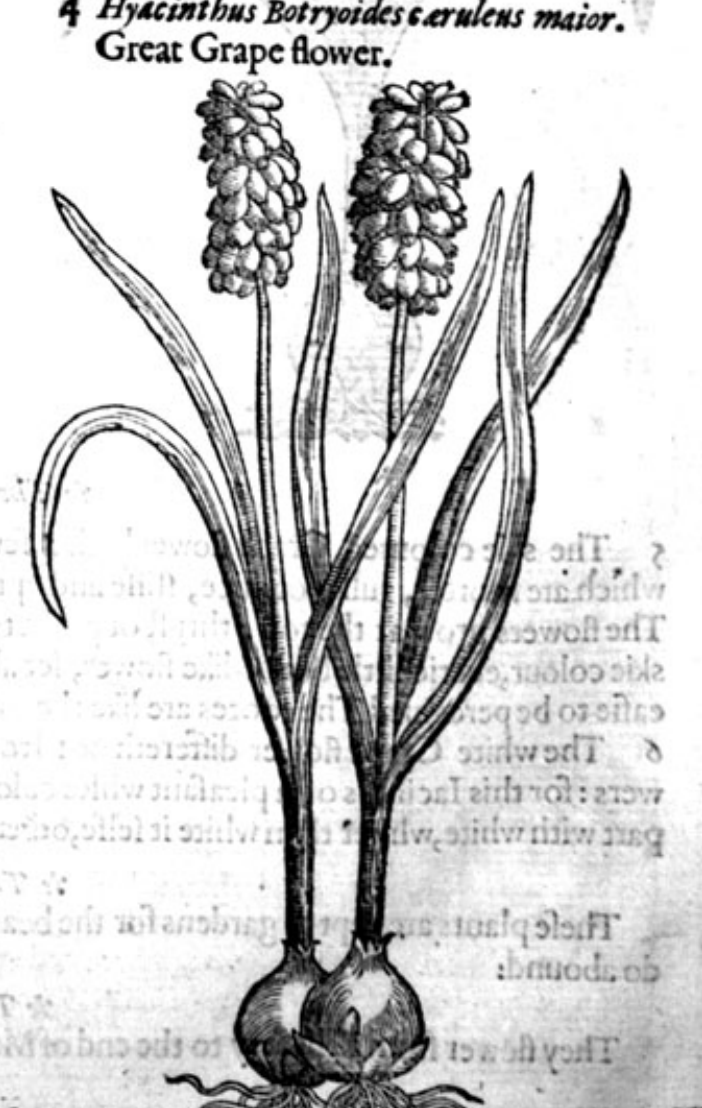

G 4 


\section{* The defcription.}

3 The fmall Grape flower hath many long fat and weake leaues, trailing vponthe ground, hollow in the middle like a little trough, full of flimie iuice like the other Iacints: among which come foorth thicke, foft, finooth and weake ftalkes, leaning this way and that way, as not able to ftand vpright, by reafon it is furcharged with very heauie flowers on his top, confifting of many little bottlelike blew flowers, clofely thruft or packt togither like a bunch of grapes, of a ftrong fmell, yet not vnpleafant, fomwhat refembling the fauour of the Orenge. The roote is round and Bulbus, fet about with infinite yoong cloues or rootes, whereby it greatly encreafeth.

4 The great Grape flower is verie like vnto the fmaller of hiskinde. The difference confifteth in that this plant is altugither greater, but the leaues are not folong.

5 Hyacinthus botryoides Caruleus amanus.

Skie coloured Grape flower.

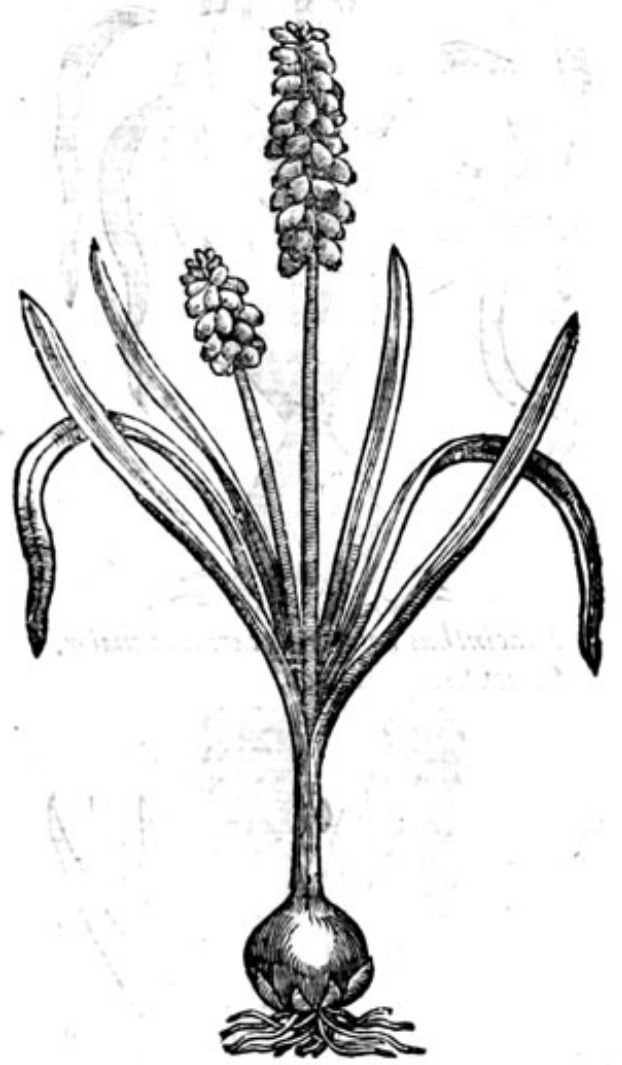

6 Hyacinthus botryoides lacteus. White Grape flower.

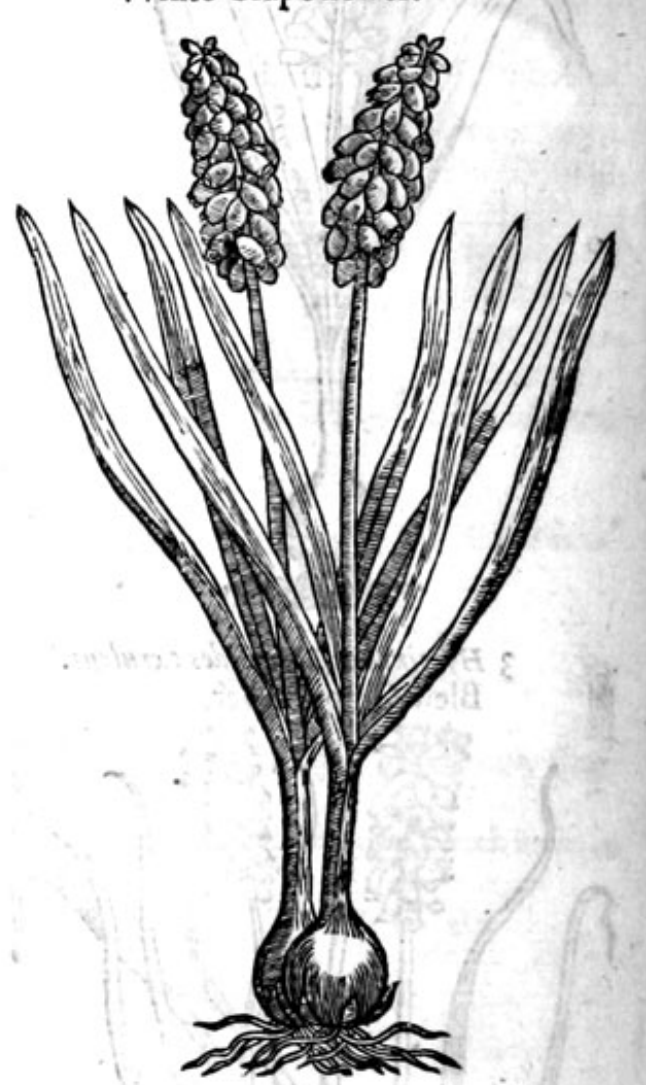

* The defcription.

5 The skie coloured Grape flower hath a few leaues in refpect of the other Grape flowers, the which are fhorter, fuller of iuice, ftiffe and vpright, whereas the others traile vpon the ground. The flowers grow at the top, thruft or packt togither like a bunch of Grapes, of a pleafantbright skie colour, euerie little bottle-like flower, fet about the hollow entrance with fmall white fpots, not eafie to be perceiued. The rootes are like the former.

6 The white Grape flower differeth not from the skie coloured Iacint, but in the colour of flowers : for this Iacint is of a pleafant white colour tending to yellowneffe, tipped about the hollow part with white, whiter than white it felfe, otherwife there is no difference.

$$
\text { * The place. }
$$

Thefe plants are kept in gardens for the beautie of their flowers, wherewith our London gardens do abound.

They flower from February to the end of May. * The time. 
The Grape flower is called Hyacintbus Botryoideg, atid Hyacinthus 2 coticorwm Dadonei: of fome

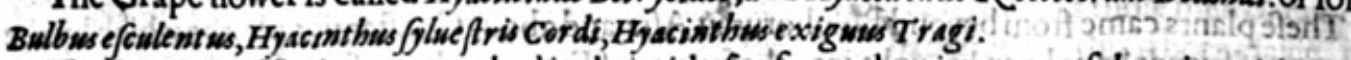

The faire haired Iacints are touched in their title, for 'fo much as isextant of them in writing. $* \quad *$ The nature and vertues.

There is not any thing fet down of the ancient or later writers, of the nature and vertues of thefe, but they are referred vnto the other Iacints.

$$
\text { Of } M \text { Mucari,or Musked grape flower. Chap.72. }
$$

Yellow musked Grape flower.

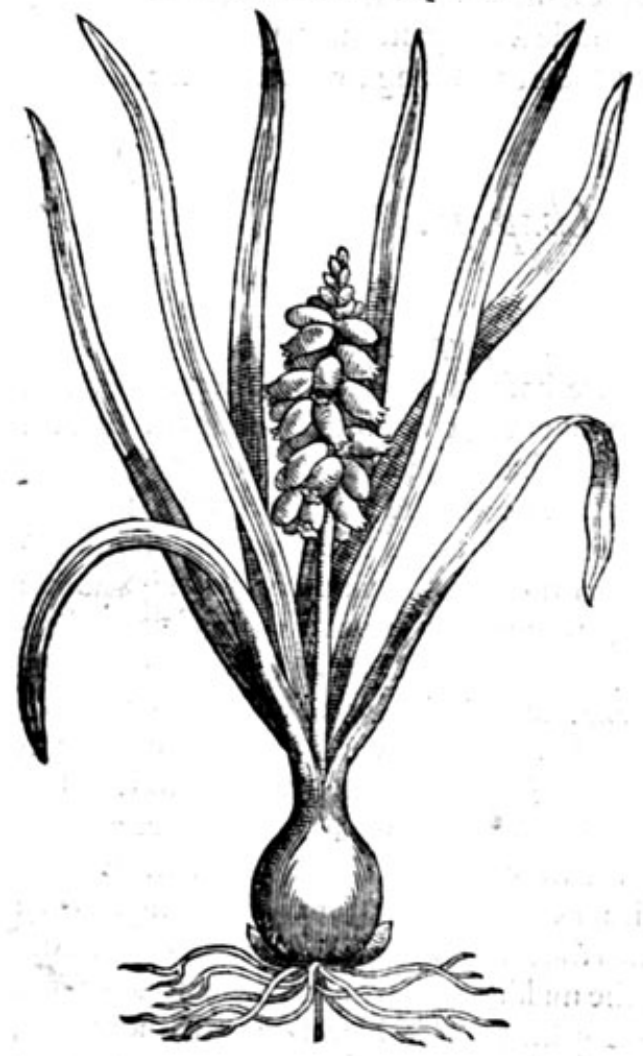

2. Mufcariclufit.
Airh coloured Grape flower.

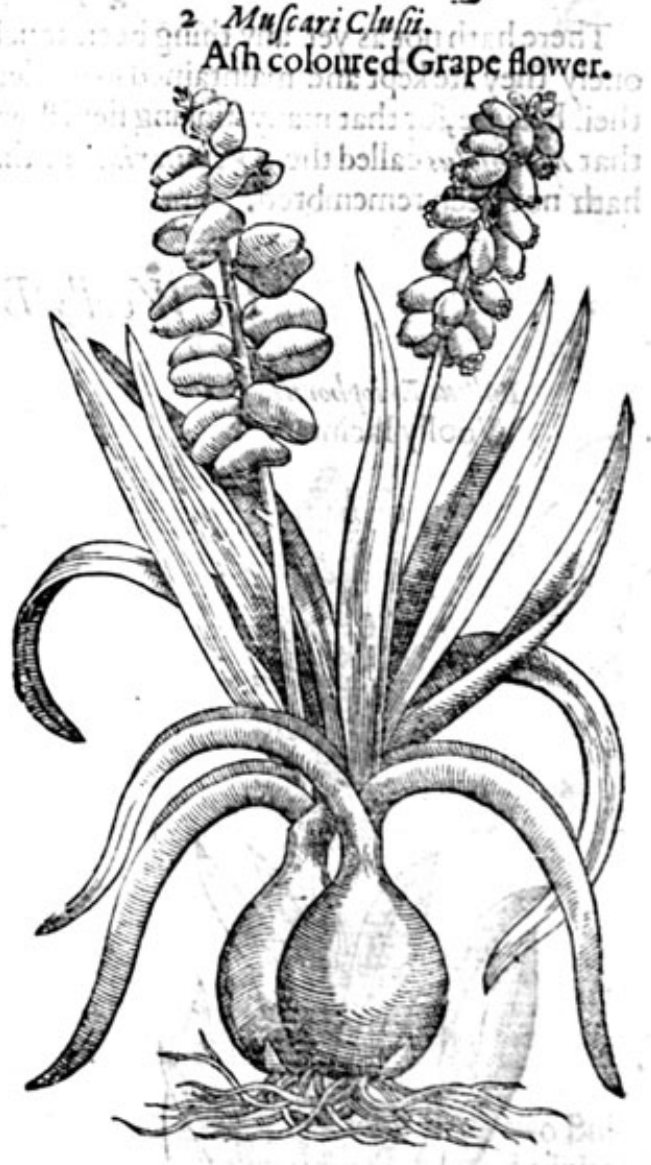

* The defcription.

1 Ellow Mufcarie hath fiue or fixe long leaues fpread vpon the ground, thicke, fat, and full of alongft the middle like winding themfelues crookedly this way and that way, hollowed ding or fpringing vp are of a purplifh colour; but be of faire harred Iacint, which at the firft budgreene colour : amonget the which leaues rife vp naked, thicke \& fat talkes, infirme and weake in retop on euery fide with many yellow flowers, eueryone as do the leaues: fet from the middle to the a nartow mouth; exceeding fwecte of fmell like the made like a fmall pitcher or little boxe, with Mufcari. The feede is inclofed in puffed or blowen vp coour of muske, whereof it tooke the name and pungious fubftance: wherein is contained round cods, confufedly made without order, of a fat fafhion, whereunto are annexed is contained round blacke feede. The roote is Bulbus or Ohion 2 Afh coloured $M u f$ cari or grape flower, hath larg and far like thofe of Dogs graffe. in any point, fauing that thefe leaues at their firft forg and fac leanes like the precedent, not differing iysp parc of a pale duftic colour like athes: 
The flowers are likewife fweete, but of a palebleake colour, wherein confifteth the difference.

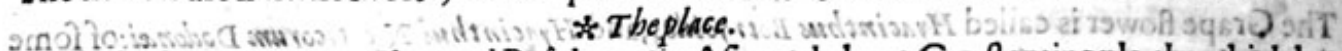

Thefe plants came from beyond Bolphorus in Afiajand about Conftantinople, the which by the meanes of friendshane been brought into thefe parts of Europe, whereofour London gardens are poffeffed.

They flower in March and Aprill,and fomtimes after.

$*$ The tome * The names.

They are called generally $M u / c a r i$, in the Thufcane or Turkie toong Mufchoromi, Mufcurimi, Tipcadi, and Dipadi, of their pleafant fweete fmell: of Mathiolus, Bulbus Vomitorius. Thele plants maybe referred vit to the Hyacinthes, whereof vindonbtedly they be kinds.

\section{$*$ The nature and vertues.}

There hath not as yet any thing been touched concerning the nature or vertues of thefeplants, onely' they arekept and maintained in gardens for the pleafant fmell of their flowers, but not for their beautic, for that many ftinking field flowers do in bealkie far furpaffe them. But it fhould feem that Mathiolus called them Vomitorius, in that they do procure vomiting, which of other auctors hath not been remembred.

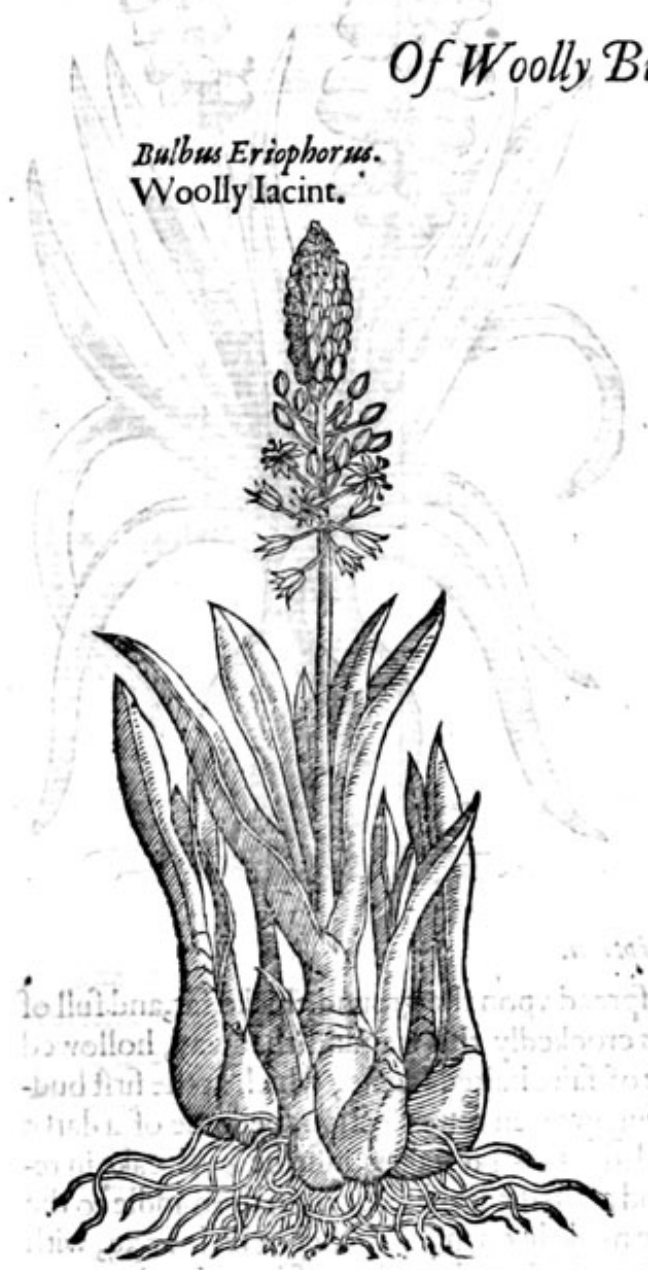

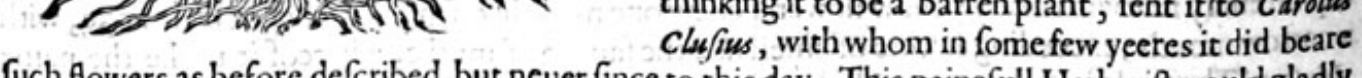
bich the this day. This painefull Herbarift would gladly hatie feene the feede that Thould fucceed thofe flowers : but they being of a nature quickly fubiect to perifh, decaie, and fade, began prefently to pine away, leauing onely a fewe chaffie andidle feede veffels without fruit.My felfe haue been poffefied with this plant at the leaft $r 2$.yeers, wherof thaue yecrely great increafe of new rootes, but I did neucr fee any token of budding or flowring to this

* The defcripsion.

7 Here hath fallen out to be heere inferted a Bulbus plant confifting of many Bulbes, which hath paffed currant amongft all our late writers. The which $\mathrm{I}$ am to fet forth to the view of our natioh, asothers haue done in fundrie languages to theirs, as a kinde of the Hyacinths: which in rootes and leaues it doth verie well refemble, called of the Grecians ieropop $\theta$ : in Latine Laniferus, bicaufe of his abundance of woolly flockes, wherewith the whole plant is in euerie part full fraughted, as wcll rootes, leaues, as ftalkes. The leaues are broade, thicke, fat, full of iuice, and of a fpiderlike webbe when they be broken. Among thefe leaue rifeth vp a ftalk two cubits high, much like vnto the ftalke of Squilla, or fea Onion. And from the middle to the top.it is befet round about with many fmal ftarlike blew flowers without fmel, verie like to the flowers of Afphodill, beginning to flower at the bottome, and fo vpward by degrees, whereby it is long before it hath done flowring: which flowers the learned Phifition of Vienna Iobannes Uicholzius defired long to fee, who brought it firft from Conftantipople, and planted it in his garden, where he nourifhed it ten yeeres with great curiofitic; which time being expired, thinking it to be a barren plant, fent itrto Caroles day: 


\section{HISTORIE OF PLANTS. T}

day: notwithitanding I thall be content to fuffer it in fome bafe place or other of my garden to ftand, as the cipher $o$ at the end of the figures to attend his time \& leafure, as thofe men of famous memorie haue done. Of whofe temperature and vertues there hathnot any thing beene faide, but kept in gardens to the end afore faid.

$$
\text { Of two fained pictures. }
$$

Chap. 74 .

1 Bulbus bombicinus commentitius. Falfe bumbafte Iacint.

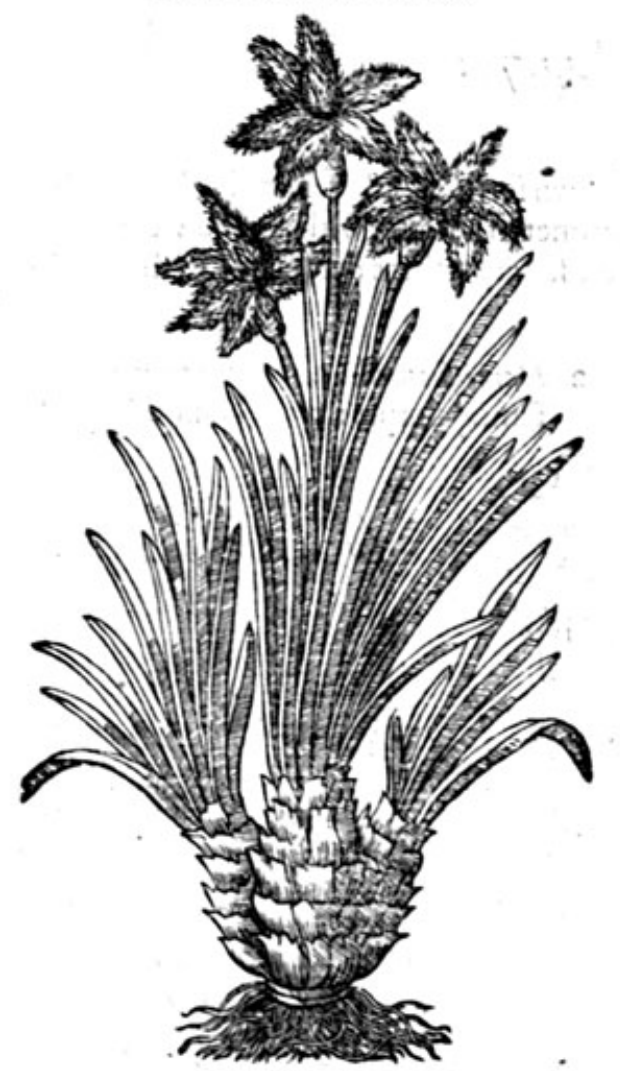

2 Tigridisflos.

The flower of Tigris.

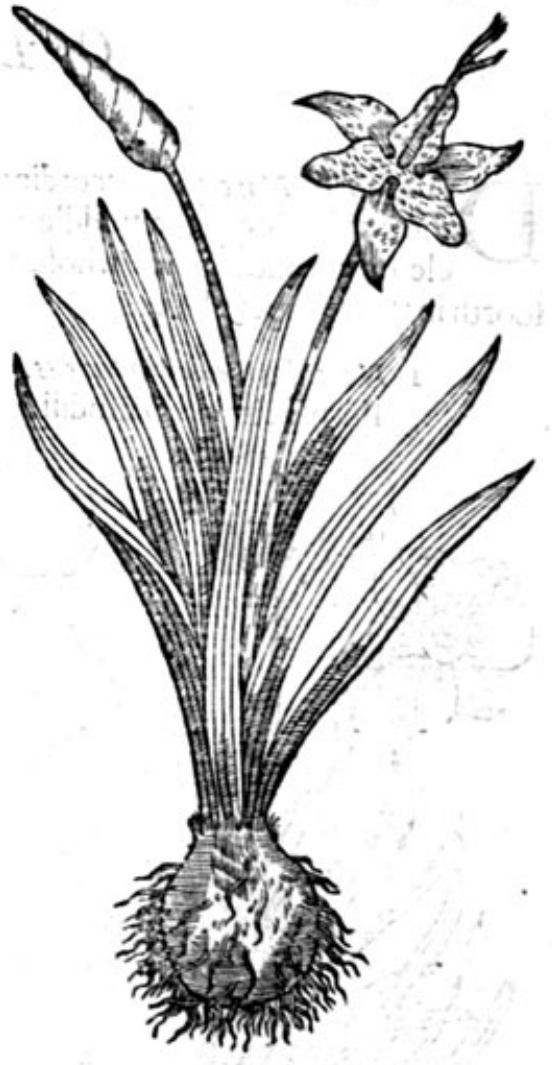

* The defcription.

$\mathbf{I}$

Haue thought it conuenient to conclude this hiftorie of the Hyacinthes with thefe two Bulbus plants, received by tradition from others, though generally holden for fained and adulterine.Their pietures I could willingly haue omitted in this hiftorie, if the curious eie could elfe where haue found them drawn \& defcribed in our Englifh toong: but bicaufe I finde them in none, I will lay them down heere to the end that it may ferue for excufe to others who hal comafter,which and called ieiogoeg, by others Bul I faid, condemned for fained and adulterine, nakedly drawen onely of thefe points, videl.The flowers (faith the author) by fon Comment it iss. The defcription confifteth \& rootes are like to thofe of Hers(laith the author) are no leffe ftrange then wonderfull. The leaues femble the Daffodils or Narcifeus. 'The whole planfed it to occupie this place. The flowers rewhich defcription with the pief Aicholzius received inftructions from the Indies Dodoneas by Iobannes Aicholzius. It may be that - in India, whereof $T$ heopbraftus and Ashen eus doe write in this in Greeke reétions, which groweth Nareiffus confifting of a flockie or woollie fubfance, in this maner, faying. The flower is like the of our bombafte Iacint. 2. The fecond fained pieture hath been taken of the difcouerer, and others of later time, to bea
kind of Dragons not feene of any that hath written thereof, which bath mooted them to thinke it a 
fained pieture likewife; notwith tanding you fiall receine the defeription'thereofas it hath come to my hands. The roote(faith my Author) is Bulbus or Onion faifhion, outwardiy blackes frotme he which fpring vplongleaues, tharpe pointed, narrow; and of a frefh gteene colour: in the middeft of which leaues rife vp naked or bare ftalkes, at the top whereof growetba pleafantyellow flower, ftait ned with many fmall red fpots, heere and there confufedly calt abroade. And in the middeft of the flower, thrufteth footth a long red toong or ftile, which in time groweth to be the cod or feed veffel, crooked or wreathed, wherein is the feed. The vertues and temperature arenot to be fpoken of, confidering that we affuredly perfwade our felues that there are no fuch plants, but meere fietions and devifes as we tearme them, to giae his freind a goudgeon, \&c. istioflichindolita

\section{Of Daffodils. Chap.75.}

\section{* The kindes.}

Affodill or Narciffus, according to Diofcorides, is of two forts. The flowers of both are white, the one hauing in the middle a purple circle or coronet: the other with a yellow cuppecircle or cotonet. Since whofe time there hath been fundry others defcribed, as fhall be fet foorth in their proper places.

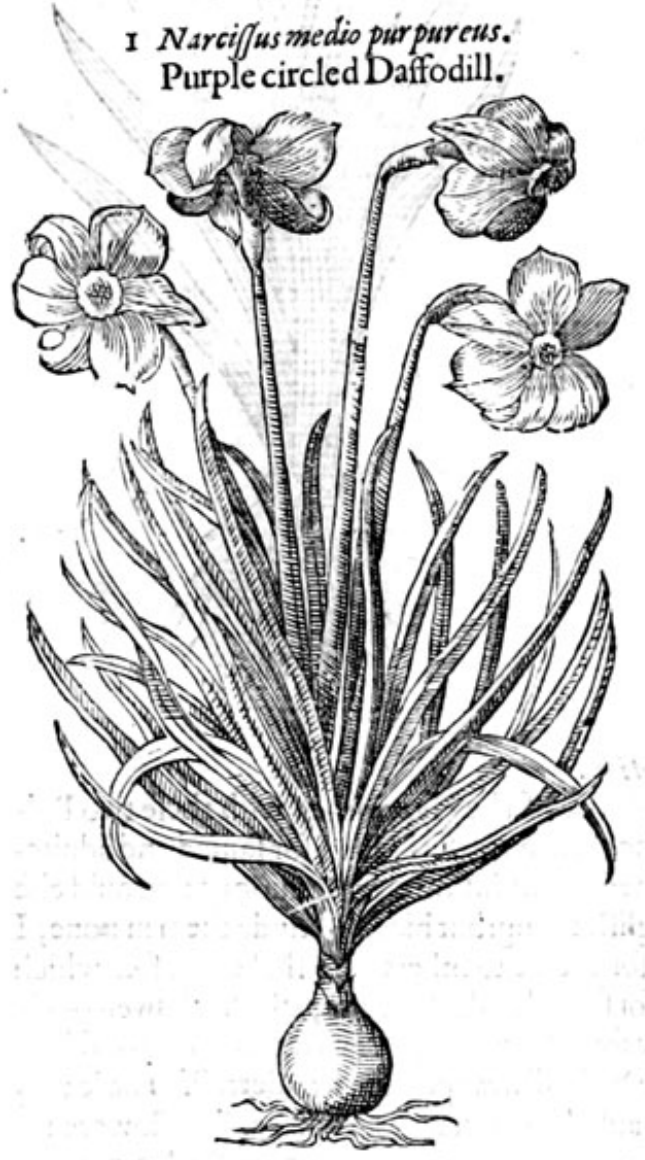

2 Narci]fus medio purpureus precox. Timely purple ringed $D$ affodill.

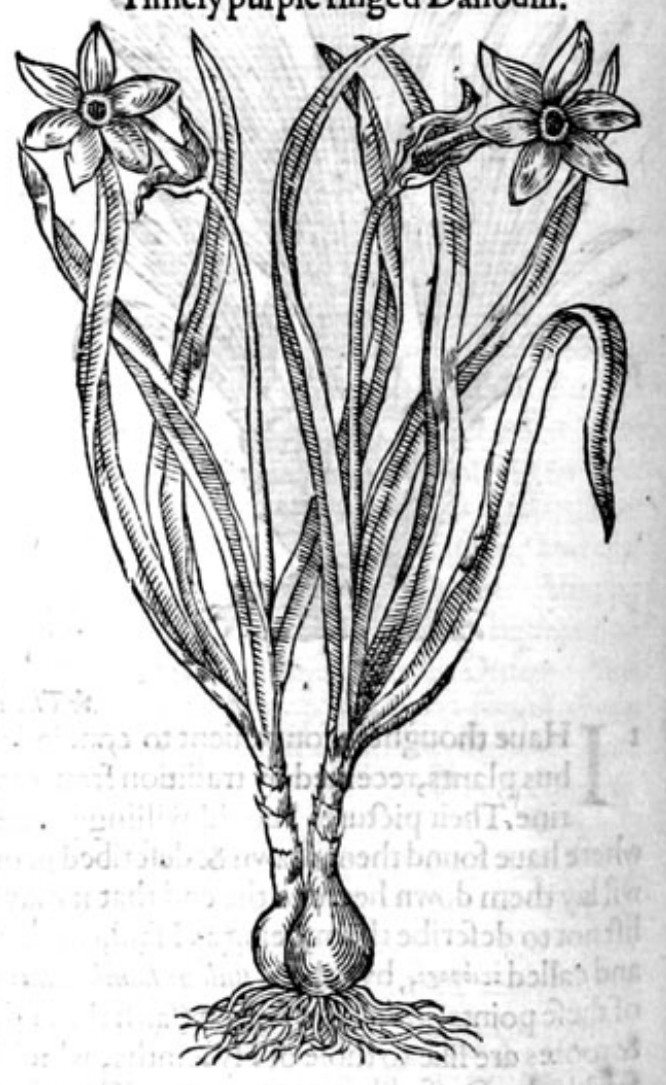

* The defcription.

I $\rightarrow$ He firft of the Daffodils is that with the purple crowne or circle, hauing finall narrowe leaues, thicke, fat, and ful of flimic iuice : among the which rifeth vp a naked ftalke, fmooth and hollow, of a foote high, bearing at the top a faire milke white flower, growing forth of a hood, or thin filme, fuch as the flowers of Onions are wrapped in : in the middeft of which flower is a round circle or finall coronet of a yellowifh colour,purfled or bordered about the edge of the faid ring or circle, with a pleafant purple colour; which being paft, there follweth a thickeknobbe or 
button, wherein is conteined blacke houndfeede, The roote is white, Bulbus or Onion'fafhion. 2 The fecohd kinde of $D$ affodill agreecth with the precedent in èurie refpect without diffésence, fauing that this Daffodill flowreth in the beginning of February, and the other not vntil Apritl, and is fomewhat leffer.

\section{* The defription.}

3 The third kinde of Daffodil with the purple ring or circle in the middle, hath many fmal narrow leaues, very flat, crookedly bending toward the top: among which rifethvp a flender bare ftalke, at whofe top doth grow a faire and pleafant filwer, like vnto thofe before delcribed, but leffer, and flowreth fooner, wherein confifteth the difference.

4 The fourth of thefe purple Daffodils is like vnto the laft before defcribed, but leffer, and doth bring foorth his pleafant flowers firlt of all the others, which maketh the difference.

\section{Narciffus medio purpurensprecocior.}

More cimely purple-ringed Daffodill.

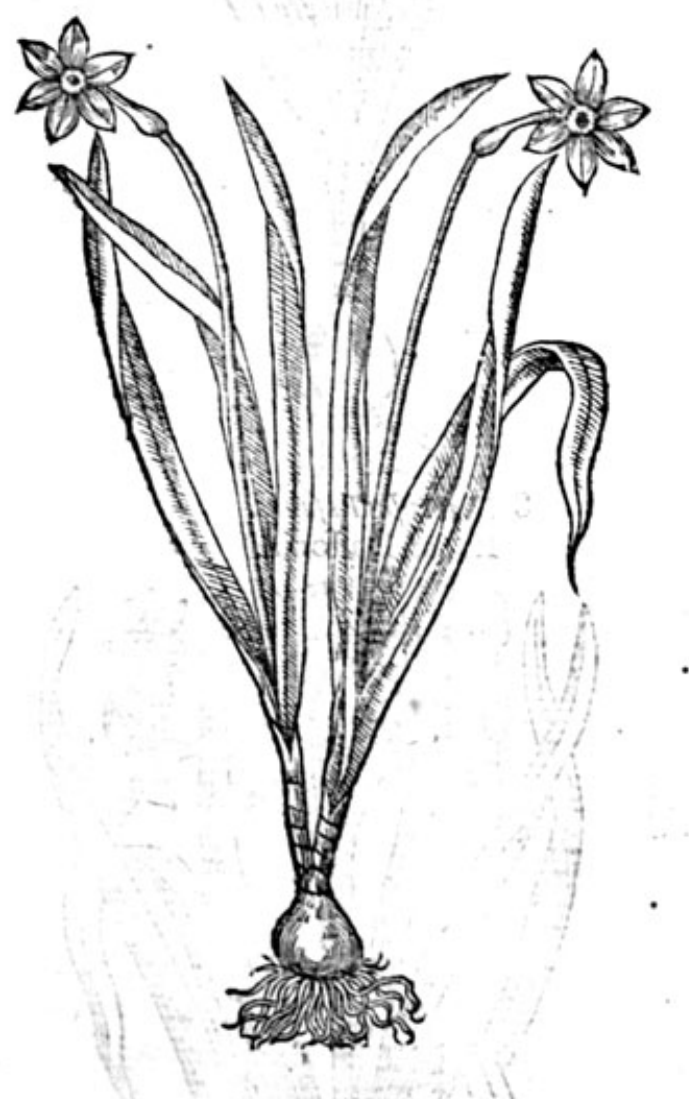

42 arciffus medio purpureus precocifsmus. The very haltie flowring $D_{\text {affodill. }}$

\section{* The defcription.}

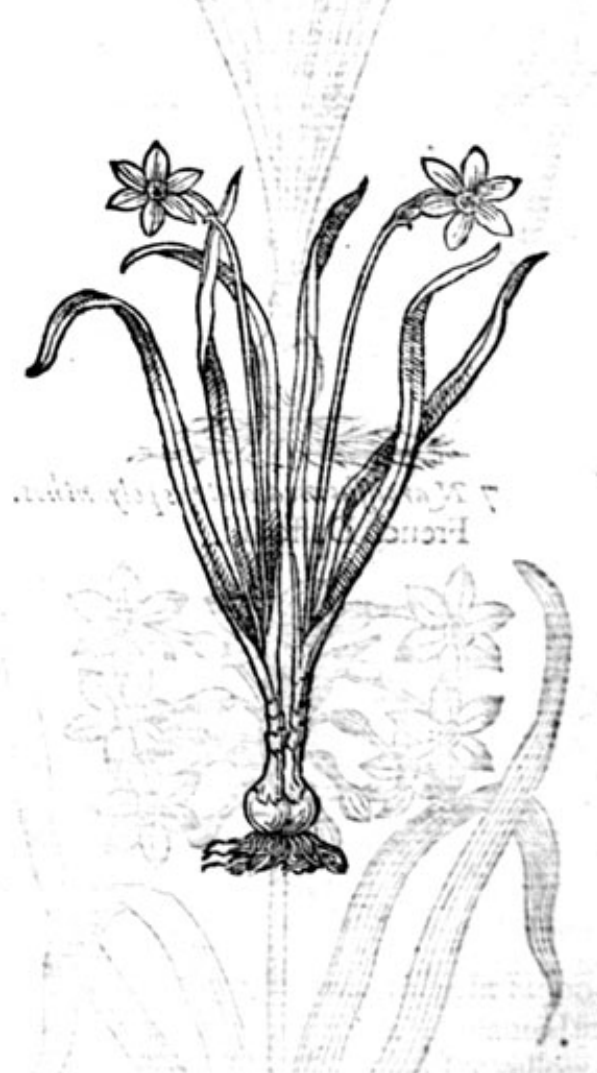

5 This late flowring Daffodill hath many flat thicke leaues, full of inice:among the which rifeth a naked ftalke, on the top where of groweth 2 faire white flower, hauing in the middle a ringe or yellow circle. The feede groweth in knobby feede veffels. The roote is Bulbus or Onion fafhion: it flowreth later than the others before defcribed, that is to fay in Aprill and May.

6 The fixt kinde of Daffodill is that fort of 2 arciffus or Primrofe peereleffe, that is moft common in our countrey gardens, generally knowne euery where. It hath long fat and thicke leaues, full of 2 flimie iuice: among which rifeth vp a bare thicke ftalke, hollow within and full of inice. The flower groweth at the top, of a yellowifh white colour, with a yellow crowne or circle in the middle : and flowreth in the month of Aprill, and fomtimes fooner. The roote is Bulbus falhion, 
HO THE FIRST BOOKE OF THE

5. Xarciffus minor ferotimus. The late flowring finall Daffodill.

6. 2)arcifus mediolutens.

No.

Primrofe peerles, or the common white $\mathrm{D}_{2}$ ffodill.

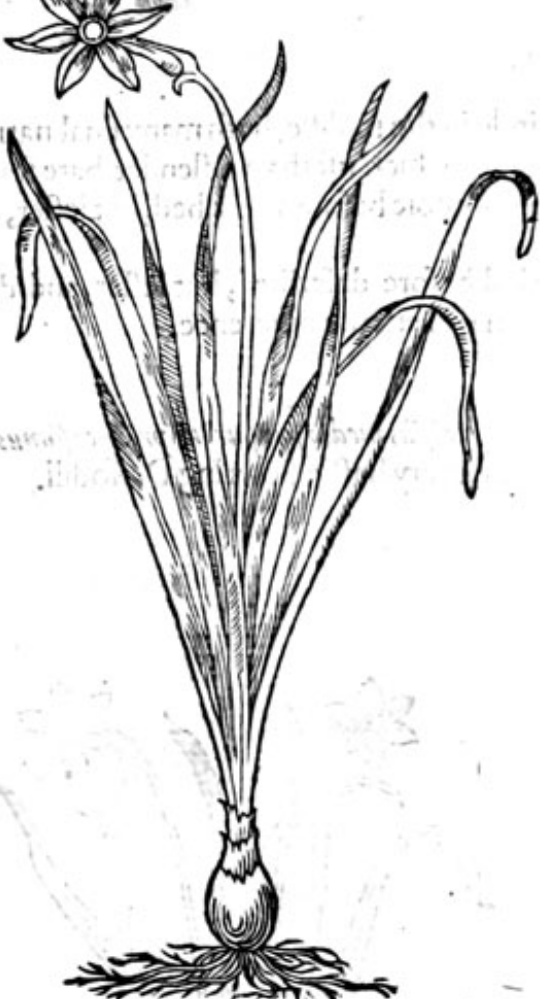

7 Carcifus medioluteus polyanthos. French Daffodill.
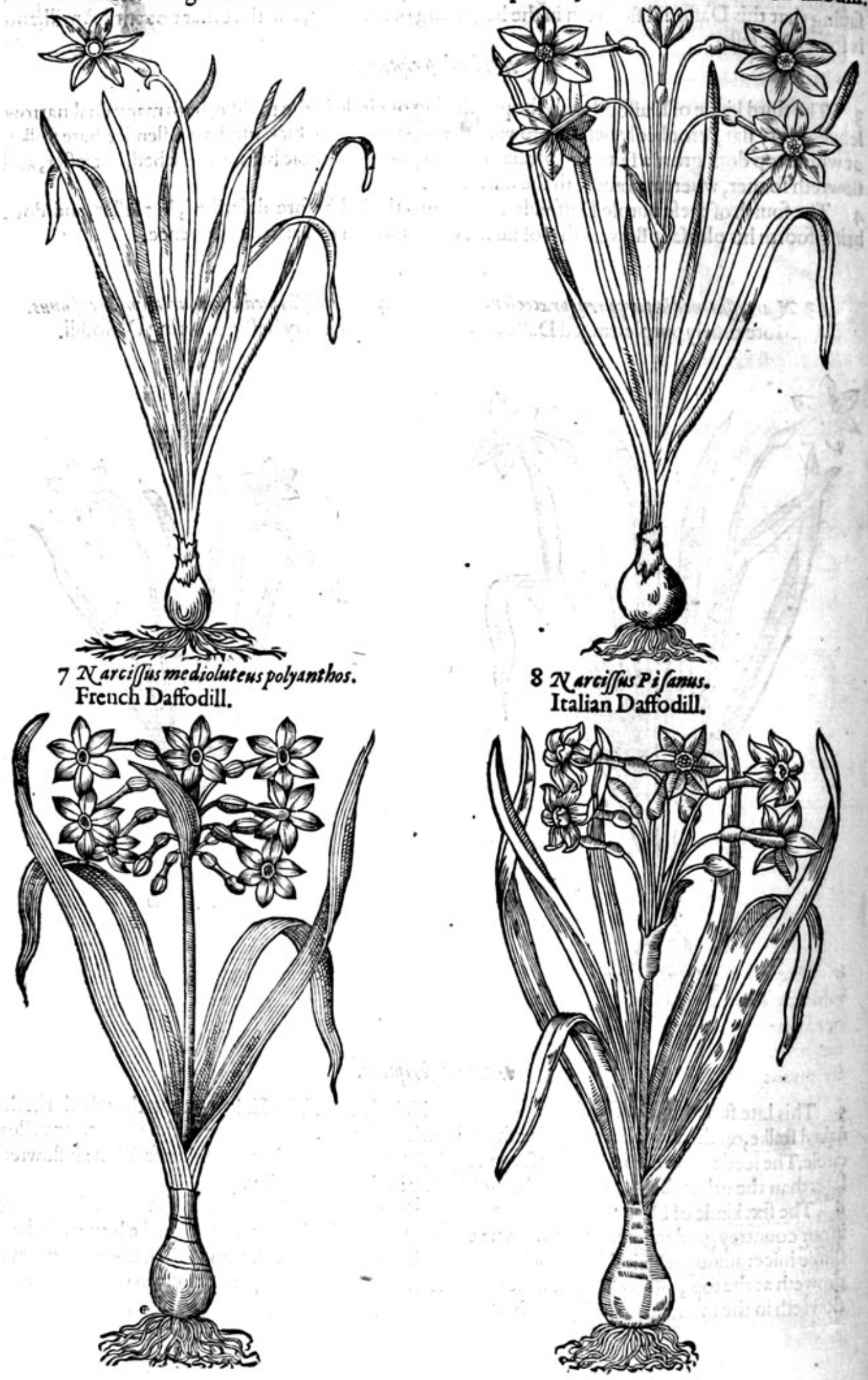


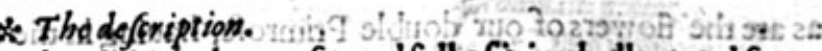
7. The feuenth Daffodill hath many broad and thicke leaues, fatand full of frice, hollow and foungious. The ftalks, flowers and rootes are like the former, and giffereth in that that this plant bring. eth foorth many fowers vpon obe ttalke, and the $g$ ther fewer s and not of fo perfect a fweerce. fmell, but more offenfruc and ftuffing the head. It hath this addition Polyanthos, that is, of many flowers, wherein efpecially confifteth the difference.

8 The Iralian Daffodill is yery like the former, the which to diftinguifh in words that they may be knowne one from another, is impoffible. Their flowers, leaues and rootes are like, fauing that the flowers of this are fiveeter and mo in number. 9 Narcifus albus polyanthos.

The double white Daffodill of Conftantinople.
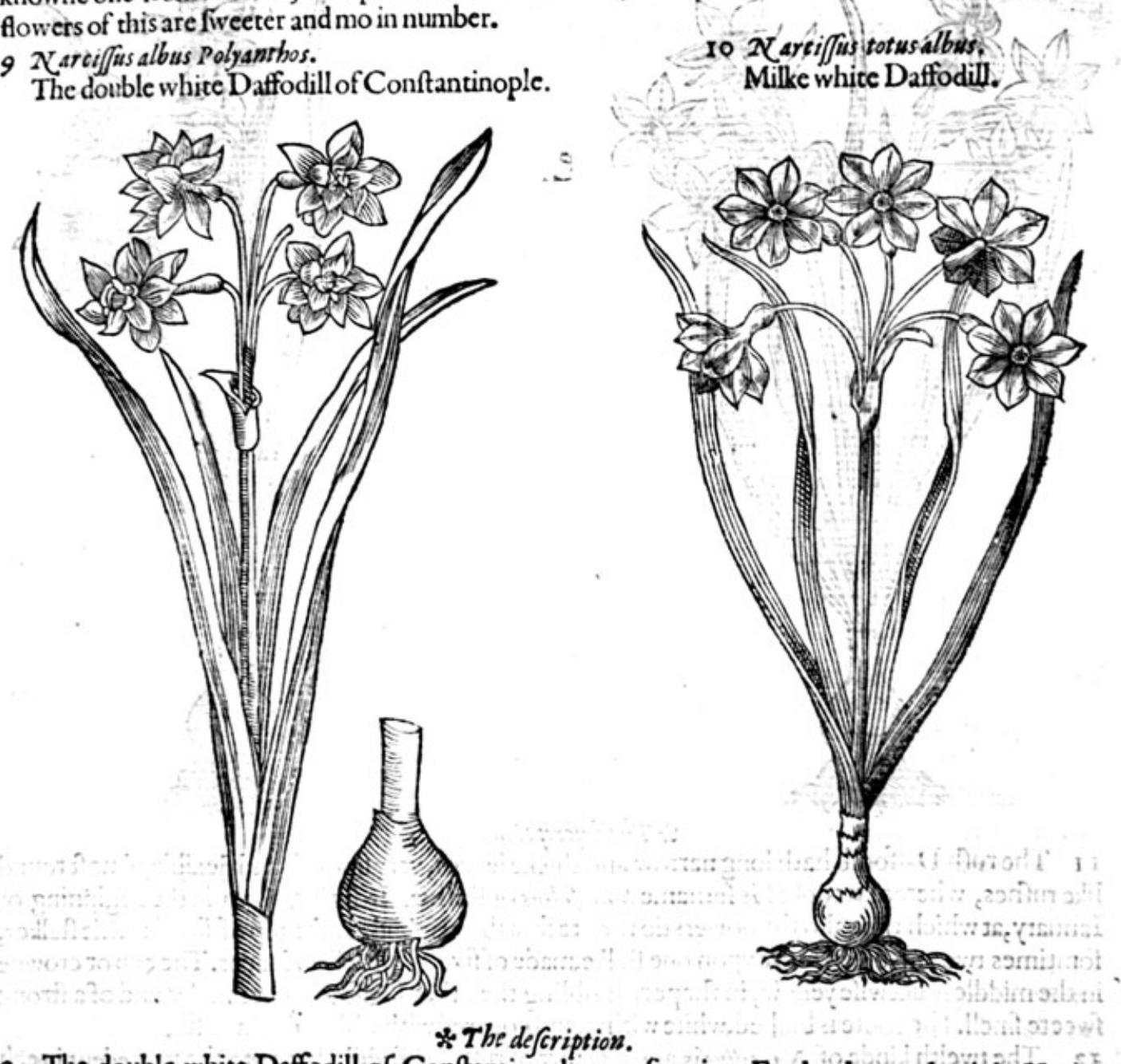

* The defcription.

9 The double white Daffodill of Conftantinople was fent into England vnto the right Honorable the Lord Treafurer, among other bulbed flowers: whofe rootes when they were planted in our London gardens, did bring foorth beautifull towers, very white and double, with fome yellownes mixed in the middle leaues, pleafant and fweete in fmell; but fince that time we neuer could by any induftrie or manuring bring them vnto flowring againe. So that it fhould appeere, when they were difcharged of that birth or burden which they had begotten in their owne countrey, and not finding that matter, foile or climate to beget more flowers, they remaine euer fince barren and fruitleffe. Befides we found by experience that thofe plants which in Autumne did hoote forth leaues, did bring foorth no flowers at all; and the others that appeered not vntill the fpring, did flourifh \& beare their flowers. The ftalks, leaues and rootes are like vnto the othenkinds of Daffodill. It is cal. led of the Turks Gial Catamer lale, that is 27arcijfus with double flowers. Notwithftanding we haue received from beyond the fe2s, as well from the lowe Countries, as alfo from Fraunce another fart of greater beautie, which from yeere to yeere doth yeeld foorth moft pleafant double flowers, and great encreafe of rootes, very like as well in ftalks as other parts of the plant, vnto the other lorts of Daffodils. It differeth onely in the flowers which are very dotble and thicke thruft togither, 
as are the flowers of our double Primrofe, haung in the middle of the flower fome fewe chines or welts, of a bright purple colour, and the other mixed with yellow as aforefaid.

10 The tnilke white Daffodill differeth not from the common white Daffodill, or Primrofe peereleffe, in leaues ftalkes, footes or flowers, fauing that the flowers of this plant hath not any other colour in the flower but white, whereas all the others are mixed with one colour or other.

II Narci]fus Iurcifoliuspracox. sivart Rưh Daffodill.

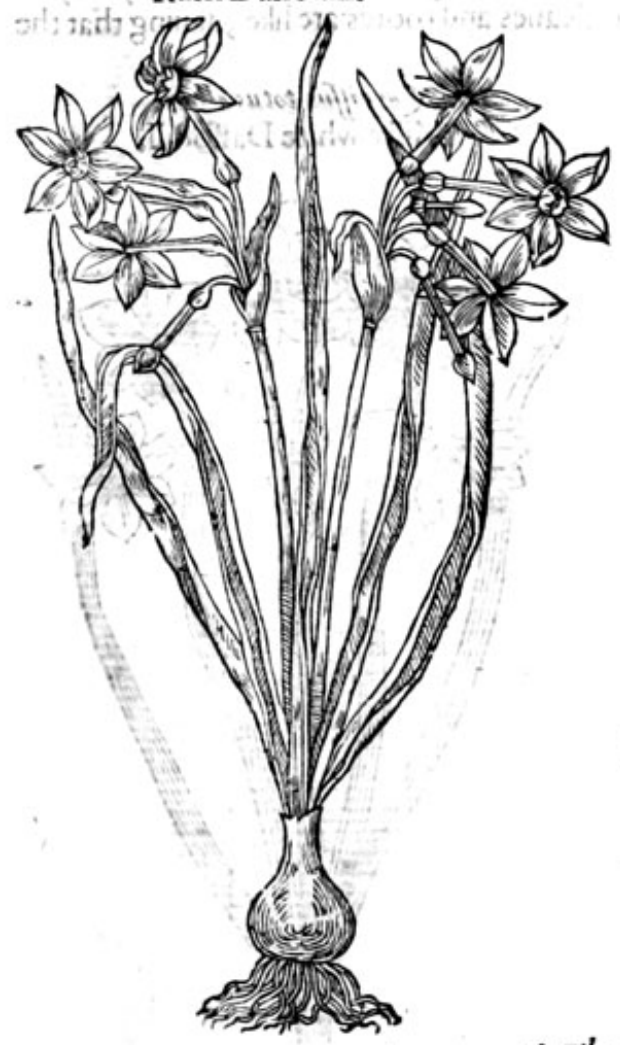

12 Tarciffus Iuncifolius ferot inus. Late flowring Rurh Daffodill.

II The rufh Daffodill hath long narrow and thicke leaues, very fmooth and flexible,atmoft round like rufhes, whereof it tooke his fnrname Inncifolius or Rufhie. It fpringeth vp in the beginning of Ianuary, at which time alfo the flowers do hoote foorth their buds at the top of fmall rufhie ftalkes, fomtimes two and often more vpon one ftalke, made of fixe fimall yellow leaues. The cup or crowne in the middle is likewife yellow, in fhaperefembling the other Daffodils, but fmaller, and of a ftrong fweete finell. The roote is bulbed, white within, and couered with a blacke skin or filme. 12 The tivelth kinde of Narcij] us is another fort of rurh Daffodill, like vnto the precedent in ech refpect, fauing that this is altogither leffer, and longer before it come to lowring.

$$
\text { * The defcription. }
$$

13. The Perfian Daffodill hath no ftalke at all, but onely a fmall and tender foote ftalke of an inch high, fuch as the Saffron flower hath: vpon which fhort and tender ftalke doth \&and a yellowilh flower, confifting of fixe fmall leaues; of which the three inner moft are narrower than thofe on the out fide. In the middle of the flower doth grow foorth a long ftile or pointell, fet a bout with many fmall chives or threds. The whole flower is of an vnpleafant fmell, much like to Poppie. The leaues rife vp a little before the flower, long, fmooth, and fhining. The roote is Bulbed, thicke and groffe, blackifh on the out fide, and pale within, with fome threds hanging at the lower part.

14. The Autumne Daffodill bringeth foorth long finooth glittering leaues, of a deepe greene colour: anong which rifeth vp a fhort ftalke, bearing at the top one flower and no more, refembling the flowers of mead Saffron, or common Saffron, confifting of fixe leaues, of a bright fhining yellow colour; in the middle whereof ftand fixe threads or chiues, and alfo a peftell or clappecyellow likewife. The roote is thicke and groffe, like vnto the precedent. 
13 2uarciffus Perficus. The Perfian Daffodill.

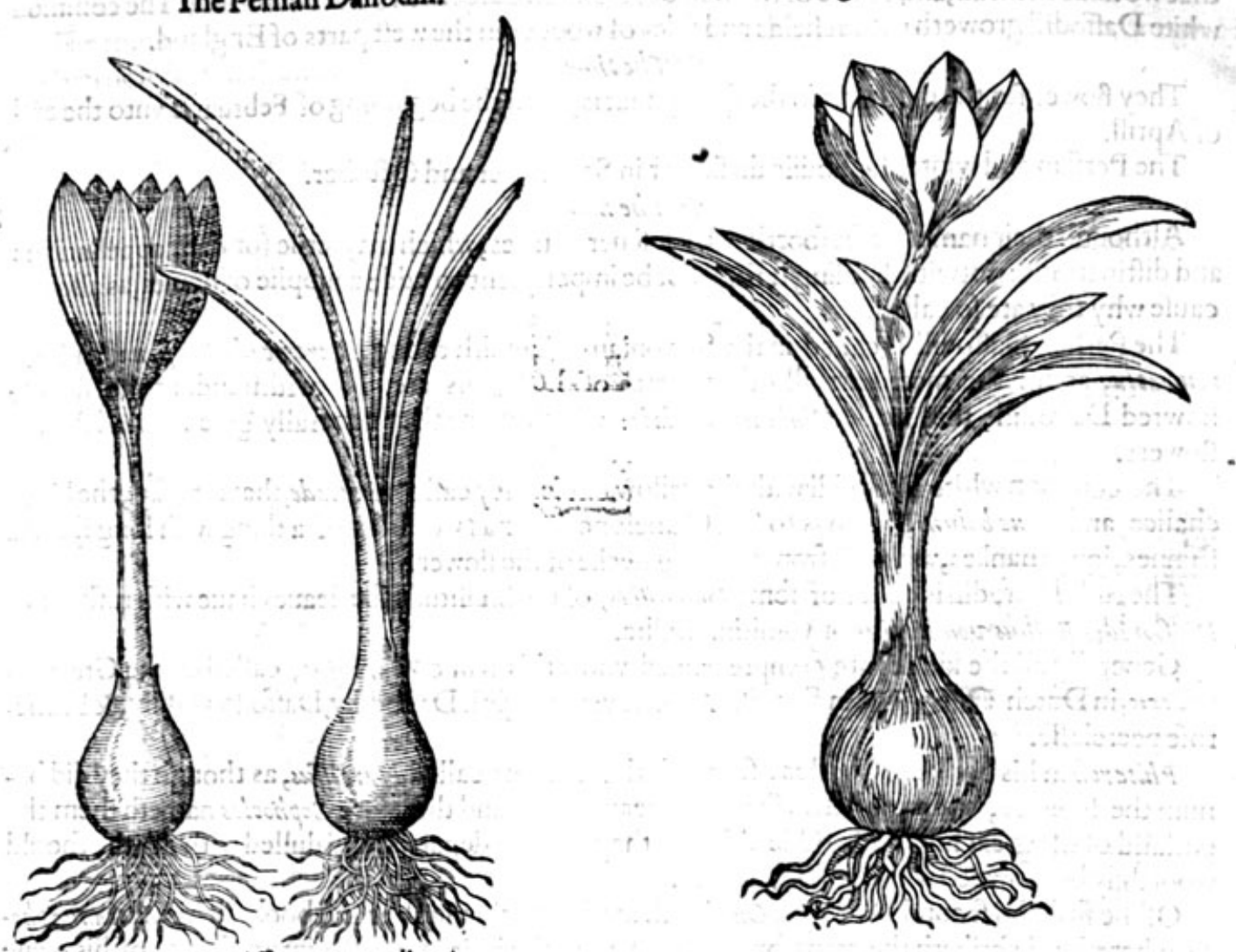

I5 2(arciffus aut umnalis minor. Small winter Daffodill.

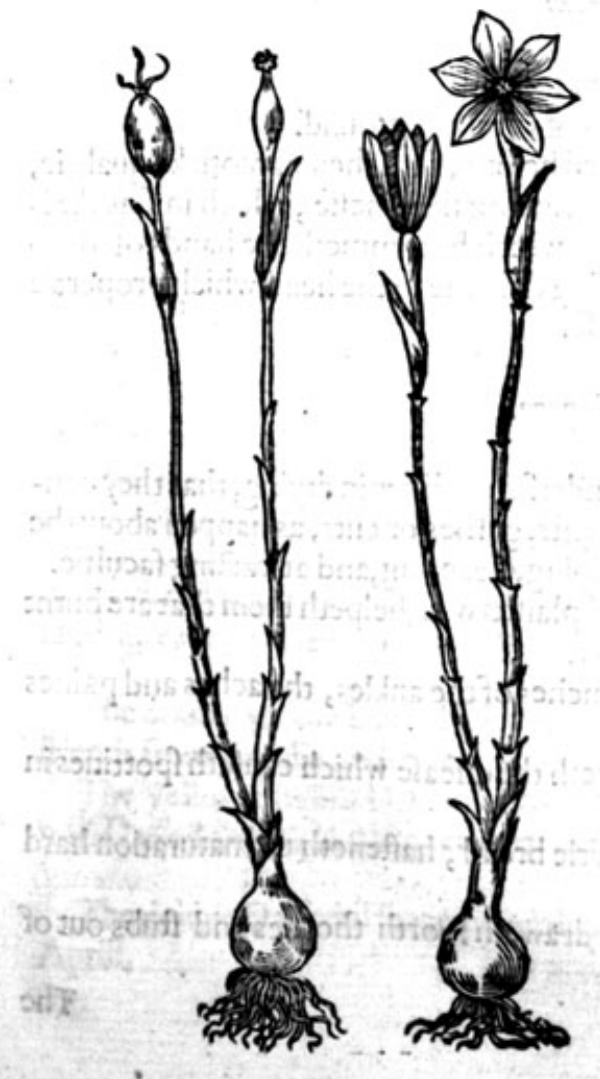

I4 Narciffus Lutionnalis maior. The great winter Daffodill. 


\section{4 THE FIRST BOOKE OF THE}

But it is not greatly to our purpofe particularly to fecke out their places of growing wild, feeing that we haue them all, and etierie of them in our London gardens in great abundance. The common white Daffodill groweth wild in fields and fides of woodes in the weft parts of England.

$$
\text { * The time. }
$$

They flower for the moft part in the fpring, that is, from the beginning of Februatie vnto the end of Aprill.

The Perfian and winter Daffodils do flower in September and October.

$$
* \text { The names. }
$$

Although their names be fet foorth in theirfeuerall titles, which may ferue for their appellations and diftinctions : notwithftanding it thall not be impertinent to adde a fupplie of names, as alfo the caufe why they are fo called.

The Perfian Daffodill is called in the Slavonian or Turkih toong, $Z_{\text {aremeada }}$ Perfiana, and $Z_{\text {a. }}$. remcatra, as for the moft part all other fortes of Daffodils are. Notwithftanding the double flowred Daffodill, they name Giul catamer lale: which name they generally giue vnto all double flowers.

The common white Daffodill with the yellow circle,they call serin Cade, that is to fay, the kings chalice, and Deue bohini, which is to fay, Camels necke, or as we do fay of a thing with long fpindle fhinnes, long fhankes, vrging it from the long necke of the flower.

The ruih Daffodill is called of fome Iongwillits, of the fimilitude the leaues haue with rurhes: of Diofour ides Bulbus vomiturius, or vomiting Bulbe.

Generally all the kindes are comprehended vnder this name A arcifues, called of the Grecians raprifos: in Dutch Jatertfert: in Spanifh Iennetten: in Englifh Daffodilly, Daffodowndilly, \& Primerofe peereleffe.

Plutarch in his booke of Feaftes, theweth that they are called Narciffus, as though they did benum the finewes, and caufe drowfineffe or heauinefie, and therefore sophocles nameth them the garland of the great infernall goddes, bicaufe they that are departed and dulled with death, fhould woorthily be crowned with a dulling Hower.

Of the firtt and fecond Daffodill, Ouid hath made mention in the third booke of his Metamorpho. fis, where he defcribeth the transformation of the faire boie Narciffus intoa flower of his owne name, faying:

\section{Nuf (quam corpus erat, croceum pro corpore florem \\ Inveniunt, foliis medium cingentibus albis.}

But as for bodic none remaind, inftead whereof they found

A yellow fower, with milke white leaues, new fprong vpon the ground.

Plimie and Plutarch affirme as partly hath beene touched before, that their narcoticke qualitie, was the verie caufe of the name Narciffus, that is a qualitic caufing fleepineffe, which in Greeke is called vapxĩas: or of the filh Torpedo called in Greeke rapkn, which benummeth the hands of them that touch him as being hurtfull to the finewes, and bringing dulneffe to the head, which propertic belongeth to the Narciffes, whofe fmell caufeth drowfineffe.

The rootes of Narciffus are hot and drie in the fecond degree. $*$ The vertues.

A . Galen faith, that the rootes of Narcifus hauc fuch woonderful qualities in drying, that they confound and glue togither verie great wounds, yea and fuch rifts, gafhes or cuts, as happen aboutche vaines, finewes, and tendons. They haue alfo a certaine wiping, cleanfing, and attracting facultie.

B The rootes of Narcif/ ws ftamped with honie and applied plaifterwife, helpeth them that are burnt with fire,and ioineth togither finewes that are cut in funder. C Being vfed in maner afor efaid, it helpeth the great wrenches of the ankles, the aches and paines
of the ioints.

D The fame taken with honie and the feed of nettles,purgeth the difeafe which caufeth fpottines in the body, called Ephelis and slphus, and funne burning.

E The fame ftamped with barrowes greafe, and lcuen of rie bread, hafteneth to maturation hard impoftumes, which are not eafily brought to ripeneffe.

F Being ftamped with the meale of cockle and honie, it draweth foorth thornes and ftubs out of any part of the bodie. 
The roote by the experiment of Apuleizs, ftamped and ftrained, and given in drinke; helpeth the $G$ cough and collicke, and thofe that be entered into a ptificke.

The rootes whether they be eaten or drunken, do moue vomit; and beingmingled with vineger $\mathrm{H}$ and nettle feed, taketh away lentiles and fpots in the face.

\section{Of the baftard Daffodils. Chap.76.}

I P feudonarciffus lutens mult iplex. Double yellow Daffodill.

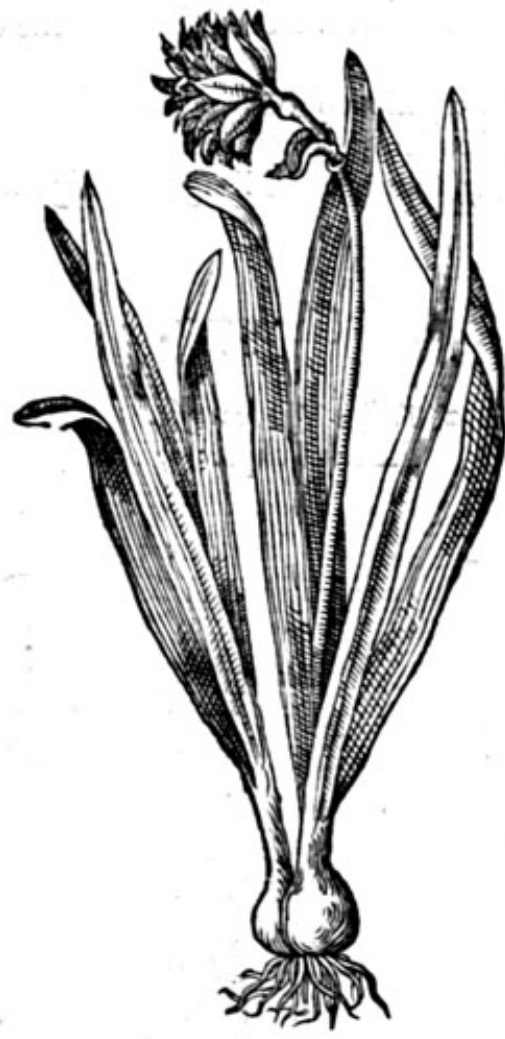

2 P feudonarciffius Anglicus or Hijpanicus. A Common yellow Daffodilly.

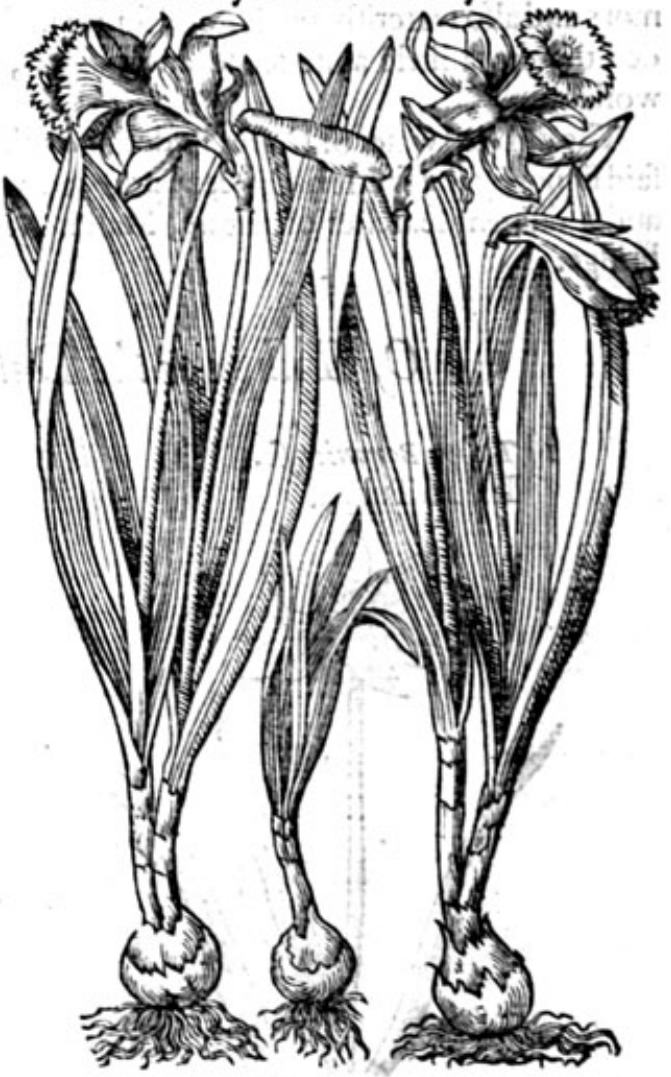

* The defcription.

1 He double yellow Daffodill hath fmall fmooth narrow leaues, of a darke greene colour : 2 mong which rifeth vp a naked hollow ftalke, of two hands high : bearing at the top a faire and beautifull double yellow flower, as is the Marigolde, of a pleafing fweete fmell.It rheadeth his flower, but there followeth no feed at all; as it hapneth in many other double flowers. The roote is fmall, bulbus or Onion fafhion like vnto the other Daffodils, but much fmaller. 2 The common yellow Daffodilly or Daffodowndilly is fo well knowne to all, that it needech no defcription. We haue in our London gardens another fort of this common kinde, which naturallie groweth in Spaine, very like vnto our beft knowne $\mathrm{D}$ affodil in fhape and proportion, but altogither fairer,greater, and lafteth longer, before the flower doth fall or fade.

* The place.

The double yellow Daffodill I receiued from Robenus of Paris, which heprocured by meanes of friends from Aurelia, and other parts of Fraunce.

The yellow Englifh Daffodill groweth almoiteuery where through England. The yellow Spa-

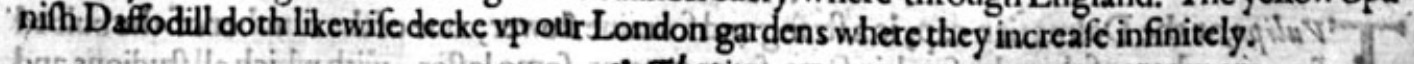

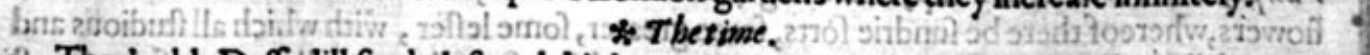
41. The doubleDaffodill fendeth foorch his leaues in the beginning of Febriarie, and his flowers in

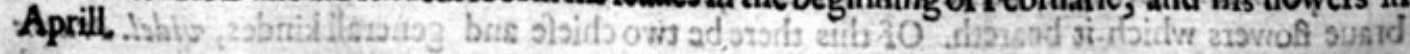


* The names.

The firft is called P feudonareifrus multiplex , and Narciffus luteus Polyant hos: in Englifh, the double ycilow Daffodill or Narcifjus.

The common fort are called in Dutch Beel spozckel bioement in Englirh yellowe Daffodill, Daffodilly, and Daffodowndilly.

The temperature is referred vnto the kind of omperature.

$$
* \text { The vertues. }
$$

A Touching the vertues heereof, it is found out by experiment of fome of the later Phifitions, that the decoction of the rootes of this yellow Daffodilly, doth purge by fiege tough and flegmatike humors and alfo waterifh, and is good for them that are full of rawe humors, efpecially if there be added thereto a little anife feede and ginger, which will correct the churlifh hardneffe of the working.

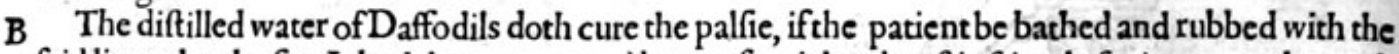
faid liquor by the fire.It hath beene prooued by an efpecial and truftie friend of mine, a man learned, and a diligent fearcher of nature, Mafter Nicholas Belfon, fomtimes of Kings colledge in Cambridge.

\section{Of Tulipa or the Dalmatian cap. Chap.77.}

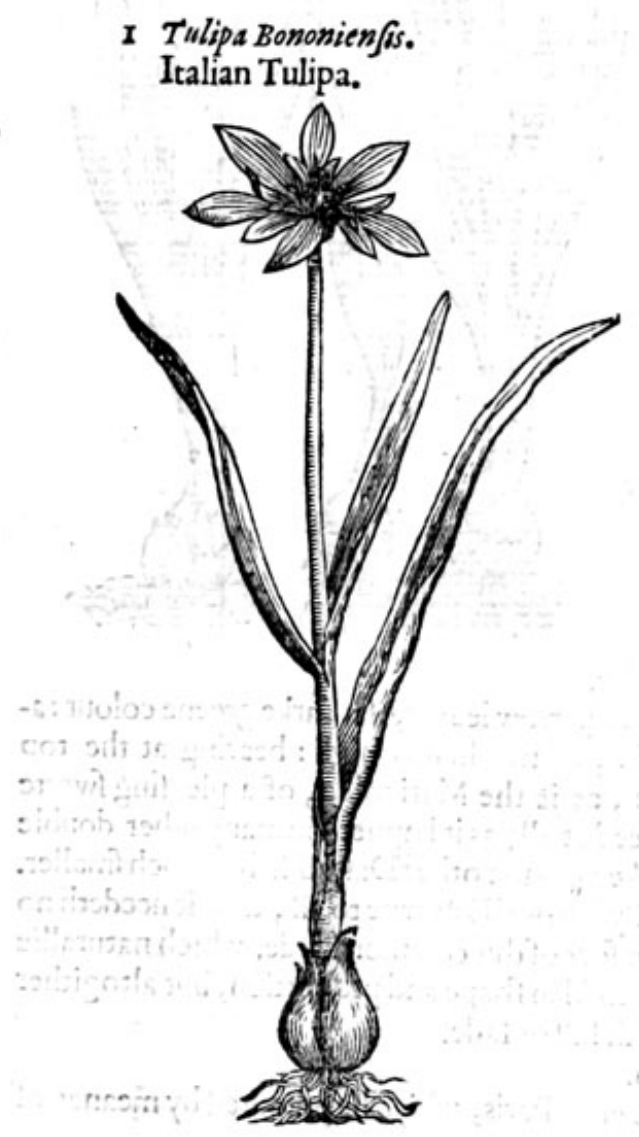

2 Tulipa 2 arbonenfis. French Tulip2.

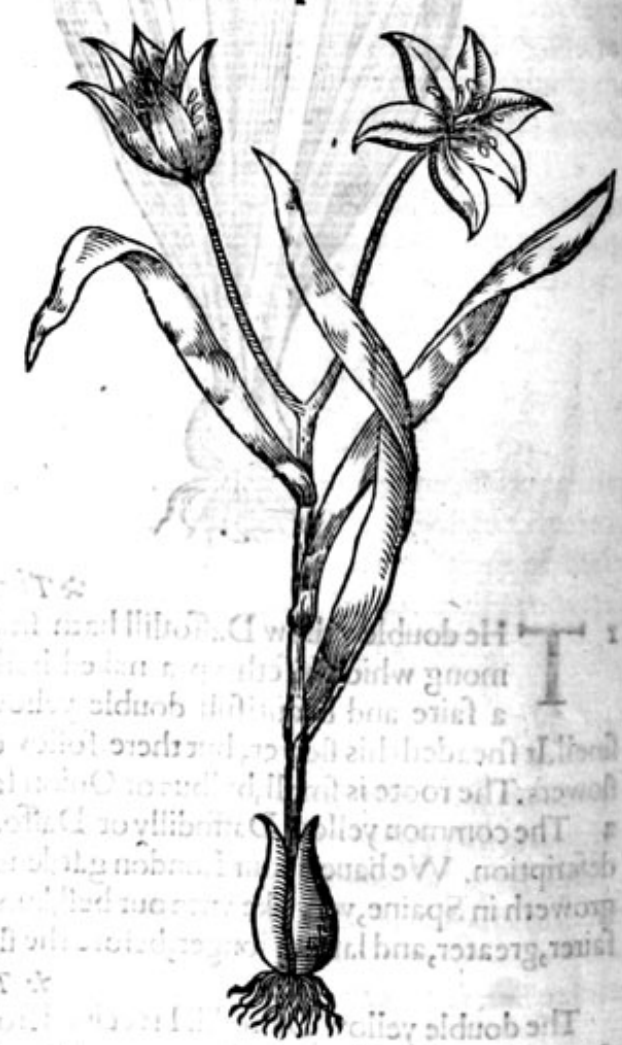

* The kindes.

$\mathrm{T}$

Vulipa, or the Dalınatian cap, is a ftrang and forraine flower, one of the number of the bulbed flowers, whereof there be fundrie forts, fome greater, fome leffer, with which all fudious and painefull Herbarifts defire to be better acquainted, bicaufe of that excellent diuerfitic of moft braue flowers which it beareth. Of this there be two chicfe and generall kindes, videl. Precox 
and Serotina, the one doth beare his flowers timely, the other later to thefe two, we will adde a third fort called Media, flowring between both the others. And from thefe three forts; as from their heads, all other kinds do proceede, which are almoft infinite in number. Notwithftanding my louing freind Mafter Iames G.arret, a curious fearcher of Simples, and learned Apothecarie in London, hath vndertaken to finde out if it were poffible, the infinite forts by diligent fowing of their feedes, and by planting thofe of his owne propagation, and by others receited from hisfriends beyond the feas, for the ipace of twentic yeeres not being yet able to attaine to the end of his traitaile, for that each new yecrebringeth foorth new plants of fundrie colours not beforc feene: all which to defcribe particularlie, were to roule Si/p hus ftone, or number the fandes: fo that it fhall fuffice to fpeak \& defcribe a few, referring the reft to fom that meane to write of $T$ ullpa a particular volume. $\therefore$ The d:fcription.

I He Tulipa of Bolonia hath fat, thicke, and groffeleates, hollow, forrowed or channeled, 1 bending a little backward, \& as it were folded to gither: which at their firft cöming vp, feem to be of a reddifh colour, and being throurghly growen, turne into a whitifh greene.In the midift of thofe leaues rife vp a naked fat ftalk a foote high, or fomthing more:on the top wher of thandeth one or two yellow flowers, fometime three, or more, confifting of fixe finall leaues, after a fort like to a deepe wide open cup, natrow abote, and wide in the bottome. After it hath beene fome fewe daies flowred, the points and brims of the flower turne backward, like a Dalmatian or Turkes cap, called Tulipan, Tolepan, Turban, and Turfan, whereof it tooke his name. The chiues or threads in the middle of the flowers, be fomtime yellow, other whiles blackifh or purplifh, but commonly of one oterworne colour or other, Nature feeming to plaie more with this flower, than any other that I do know. This flewer is of a reafonable pleafant fineil, and the other of his kinde haue little, or no fmell at all. The feed is flat, fmooth, fhining, and of a griftly fubftance. The roote is Bulbofe, and verie like to a common Onion of Saint Thom.zs.

2 The French Tulipa agreeth with the former, except in the blacke bottome which this hath in the middle of the flower, and is not fo fweete in fmell, which fetteth foorth the difference.

3 Tulipaprecox totalute.t.

Timcly flowring Tulipa.

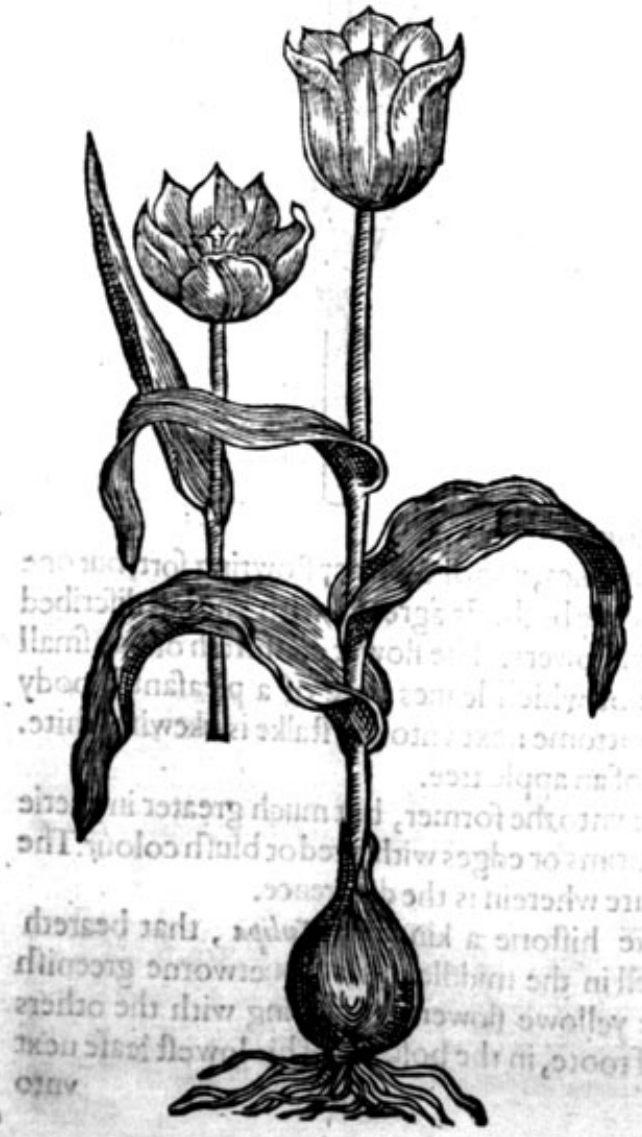

4 Tulipa Coccinea ferutina. Late flowring Tulipa.

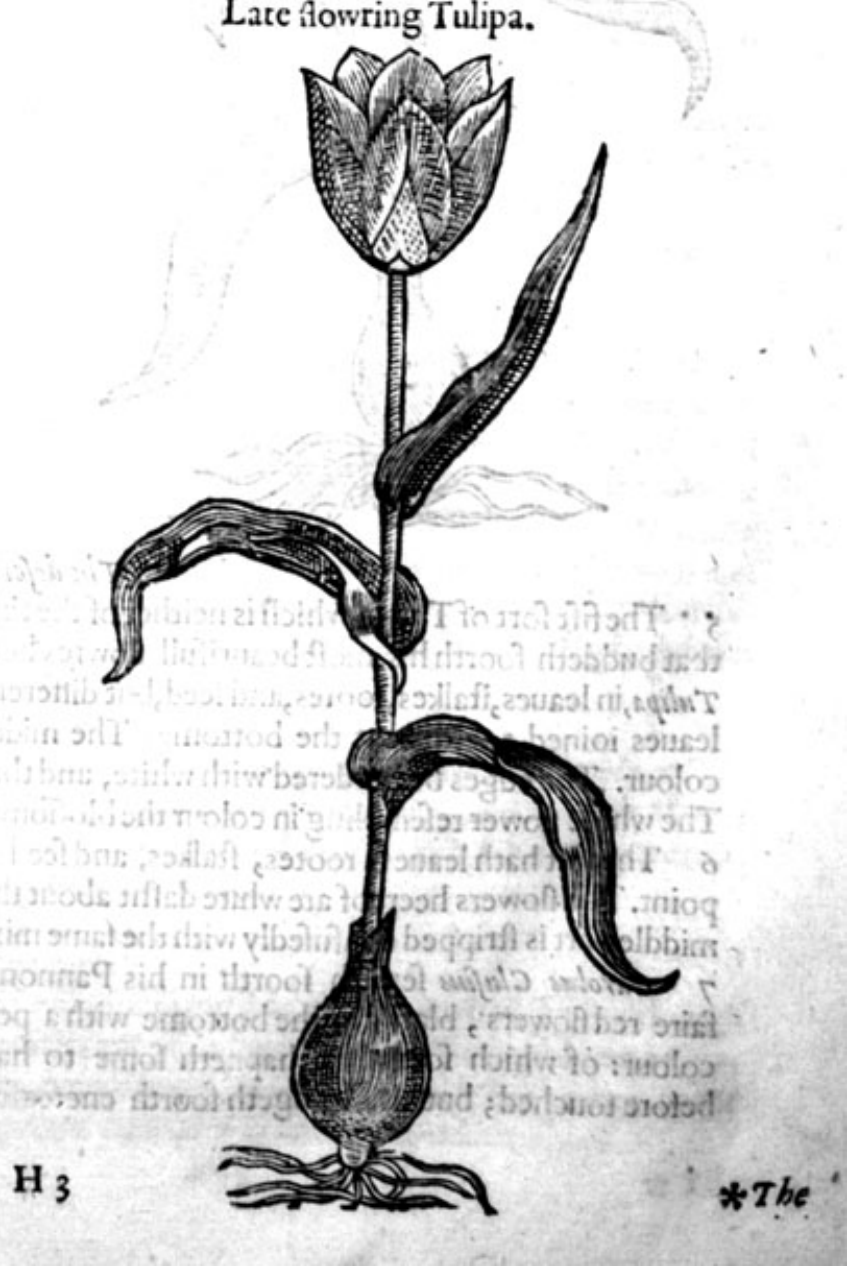


* The defcription.

3 The yellow Tulipa that flowreth timely, hath thicke and groffe leaues, ful of iuice, long, hollow or gutter fafhion, fet about a tender ftalke, at the top whereof doth grow a faire and pleafant fhining yellow flower, confifting of fixe fmall leaues without fmell. 'The roote is Bulbus or like an Onion. 4 The fourth kinde of Tulipa that flowreth later, hath leaues, ftalkes, and roote like vnto the precedent. The flowers heer of be of a skarlet colour, welted or bordered about the edges with red. The middle part is like vnto a hart tending to whiteneffe, fpotted in the fame whiteneffe with red fpeckles or fpots. The feed is conteined in fquare cods, flat, tough and finewie.

5 Tulipa media fanguinea albis oris. Apple bloome Tulipa.

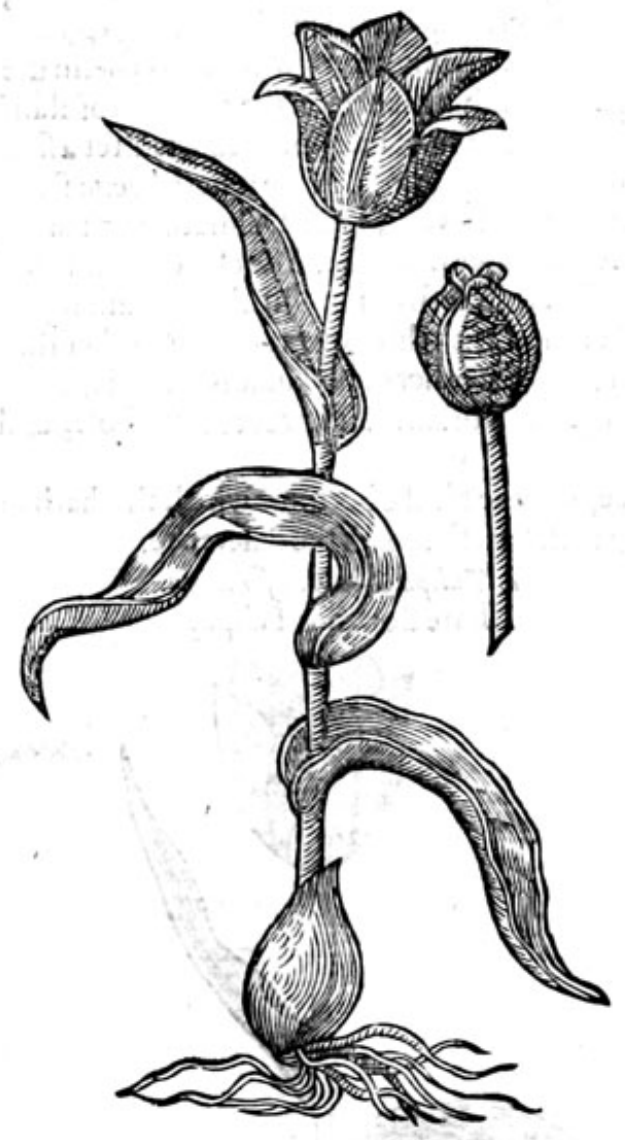

\section{Tulipa Candida fuane rubentibus oris.} Blurh coloured Tulipa.

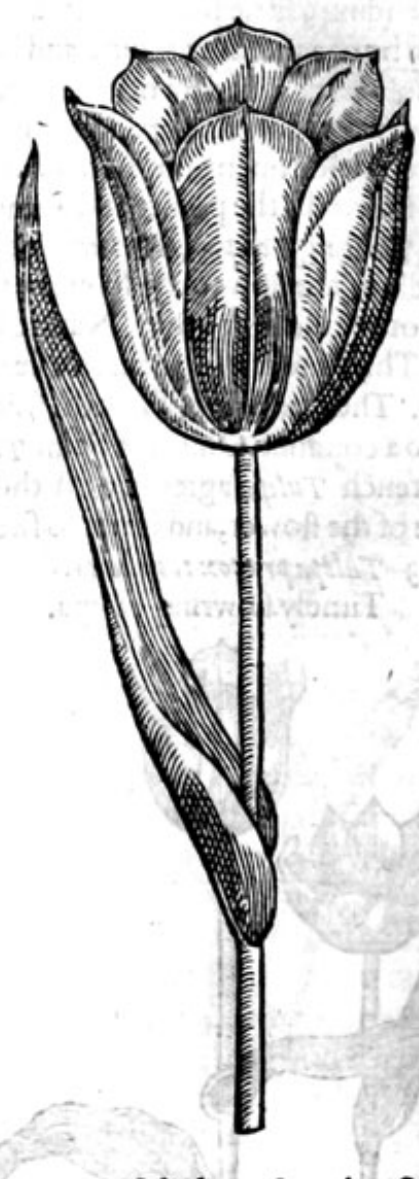

5 The fift fort of Tulipa,which is neither of the timely ones, nor of the later flowring fort, but one that buddeth foorth his moft beautifull flowres betweene both. It agreeth with the laft difcribed Tulipa, in leaues, ftalkes, rootes, and feed, but different in flowers. The flower confifteth of fixe fmall leaues ioined togither at the bottome. The middle of which leaues, are of a pleafant bloody colour. The edges be bordered with white, and the bottome next vnto the ftalke is likewife white. The whole flower refembling in colour the bloffomes of an apple tree.

6 The fixt hath leaues, rootes, ftalkes, and feed like vnto the former, but much greater in everie point. The flowers heereof are white dafht about the brims or edges with a red or blufh colour. The middle part is ftripped confufedly with the fame mixture wherein is the difference.

7. Carolus Clufium fetteth foorth in his Pannonicke hiftorie a kinde of Tulipa, that beareth faire red flowers, blacke in the bottome with a peftell in the middle, of an ouerworne greenilh colour: of which fort there hapneth fome to haue yellowe flowers, agreeing with the others before touched; but this bringeth foorth encreafe of roote, in the bofome of his loweft leafe next 
Tulipa bulbifera.

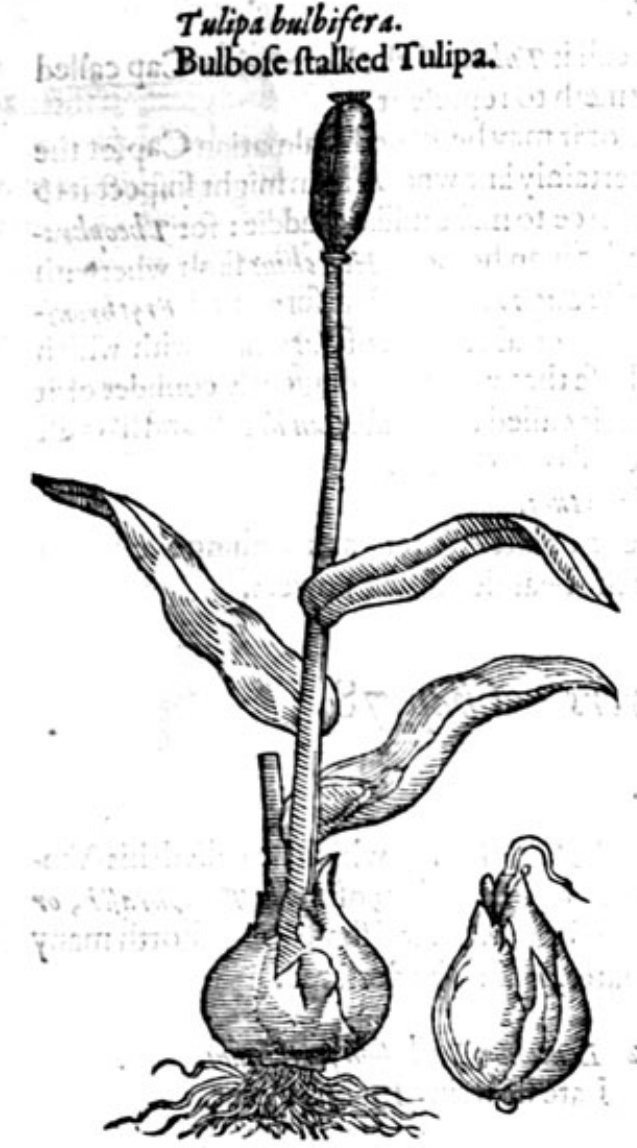

vnto the ftalke, contraric to all the other kindes of Tulipa.

8 L'Obelius in his learned obferuations hath fet foorth many other forts, one he calleth Tulipa Calcidomica, or the Turkie Tulipa, faying it is the leaft of the fmal kinds or dwarfe Tulipaes, whofe flower is of a fanguine red colour, vpon a yellow ground, agreeing with the others in roote, leafe and ftalke.

9. He hath likewife fet foorth another, his flower is like the Lillie in proportion, but in colour of a fine purplc.

10 We may alfo behold another fort altogither greater than any of the reft, whofe flower is in colour of the ftone called Amet bift, not vnlike to the flowcrs of Pxonie.

I I . We haure likewife another of great beautie, and veric much defired of all, with white flowers dafht on the backfide, with a light wafh of watchet colour.

I2 There is another alfo in our London gardens, of a fnow white colour: the edges fleightly wafht ouer with a little of that we call bluinh colour.

13 We haue another like the former, fauing that his flower is of a ftraw colour.

I4 There is another to be feene with a flower mixed with ftrakes of red and yellowe, refernbling a flambe of fire, whereupon we halle called it Flambant.

There be likewife fo many more differing fo notably in colour of their flowers, although in leaues, ftalke and rootes, for the moft part one like another, that as I laide before, to fpcake of them feue- rally, would require a peculiar volume.

There be a fort greater than the reft, which in forme are like; the leaueswherof are thicke, long broade, now and then fomwhat folded in the edges, in the middeft whereof doth rife vp a ftalke a foote high or fomthing higher, vpon which ftandeth onely one flower bolt vpright, confifting of fixe leaues, like after a fort to a deepe wide cup of this forme, vitel. the bottome turned vpwards, with threds or chiues in the middle, of the colour of faffron. The colour of the flower is fomtimes yellow, oftentimes white, now and then as it were of a light purple, and many times red: and in this there is no fmall varietic of colours: for the edges of the leaues, and oftentimes the nailes or lower part of the leaues are now and then otherwife coloured than the leaues themfelues; \& manie times there doth run all along thefe ftrakes fome other colours. They haue no fmell at all which can be perceiued. The rootes of thefe are likewife bulbed or Onion falhion. Euery of the which feuerally to fet foorth woulderouble the writer and weary the Reader, fo that it fhall fuffice what hath been faide, as touching the defcription of Tulipaes. * The place.

Tulipa groweth wilde in Thracia, Cappadocia, Italie ; in Bizantia about Conftantinople, at Tripolis, and Alepo in Syria, from whence I haue receiued plants for my garden, and likewife Mafter Garth a worfhipfull gentleman, and Mafter Iames Garret apothecarie alfo for their gardens, where they florith and increafe, as in their owne natiue countrey.

They fower from $*$ The time.

They flower from the end of February vnto the beginning of Maie and fomwhat after : although Angerius Busbequins in his iourney to Conftantinople, lawe betweene Hadrianopolis and Conftantinople, great abundance of them in flower euery where, euen in the middeft of winter in the month of Ianuarie, which that warme and temperate climate may feeme to performe. 


$$
* \text { The names. }
$$

The later Herbariftes by a Turkifh and ftrange name call it Tulipa of the Dalmatian Cap called Tulipa, the forme whereof the flower when it is open feemeth to reprefent.

It is called in Englifh after the Turkifh name Tulipa, or it may be called Dalmatian Cap,or the me the old writers gaue it, it is not certainly knowne. A man might fufpeet itto be ron'ं, if it were a Bulbe that might be eaten \& were of force to make milke cruddie: for Theophrsstus reckoneth it among the Bulbes that may beeaten: and it is an herbe as Hefychius faith wherwith milke is crudded. Conradus Gefnerus hath taken Tulipa to be Satyriuom, which is furnamed Erythroniwo that bicaufe one kinde hath a red flower, or altogither a certaine kinde of Satyrium, with which whether it doth agree or no, and how far, we leaue to thofe that will more diligently confider of it by the defcription of the Satyriens: in the Turkie toong it is called Caf'e lale, Cauale lalé, and likewife Turban and Turfan, of the Turkes Cap fo called, as aforefaid of $L^{\prime} O b e l i u s$.

$$
\text { * The temperature and vertues. }
$$

There hath not been any thing fet downe of the ancient or later writers as touching the nature or vertues of the Tulipaes, but are efteemed efpecially for the beautie of their flowers.

$$
\text { of Bulbedftocke Gilloflowers Chap. } 78 .
$$

\author{
* The kindes.
}

Teophraftus hath obferued one kinde of Bulbed itocke Gilloflower which he calleth his Violet, which retaineth the name Violet of fundrie writers to this day; of $V$ iola Theophrafti, or Theophraftus his Violet. But we haue obferued three forts, whereof fome bring foorth many leaues, others fewer, fome flower very earely, and others later, as fhall be declared.

I Leucoium Bulbofum pracox. Timely flowring Bulbus violet.

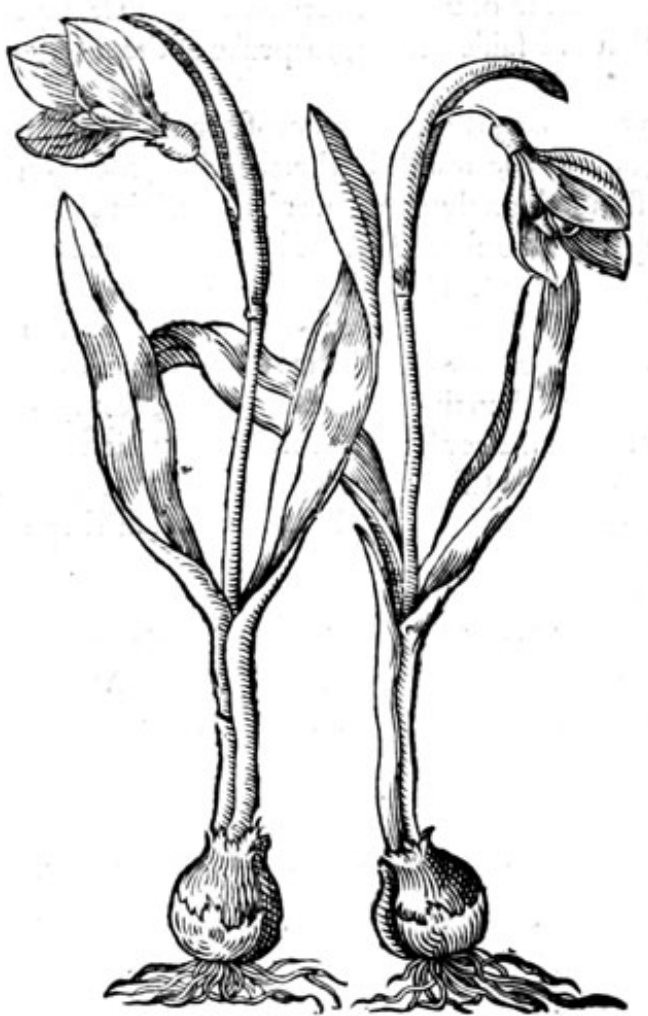

2 Leucoium Bulbofrom ferotinum. Late flowring Bulbus violet.

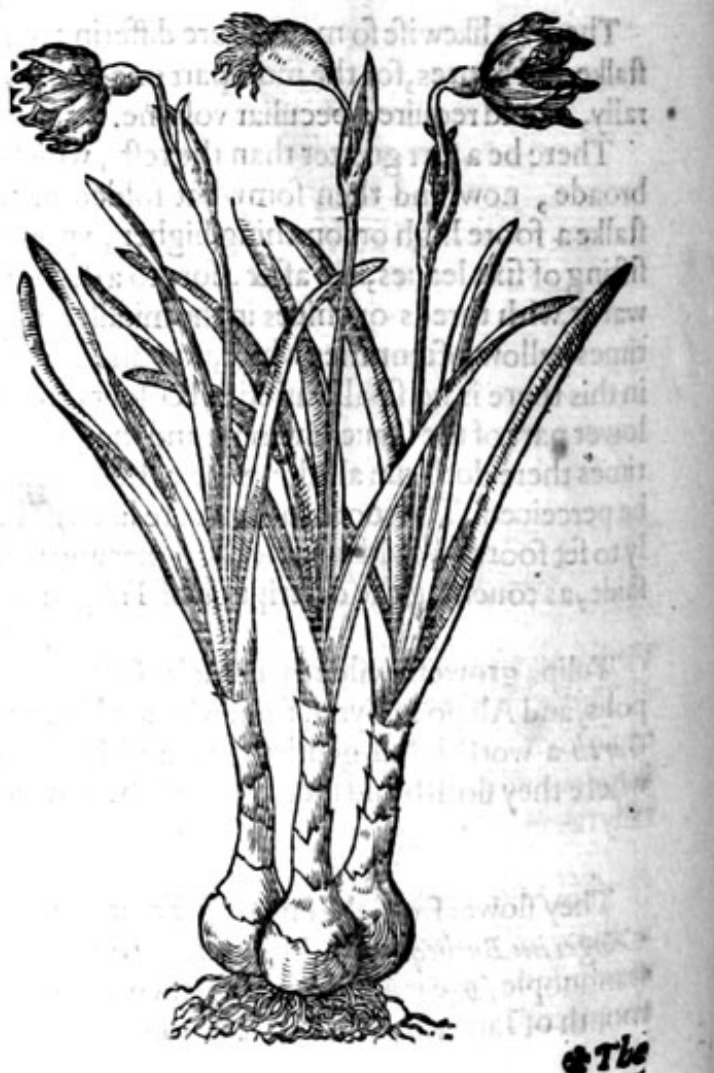




\section{* The defription.}

$\mathbf{I}$

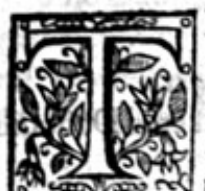

He firft of thefe Bubus violets rifech foorth of the ground with two fmall leaues, flat and crefted, of an ouerworne greene colour : among the which rifeth vp a fmal and tender ftalke, of two hands high; at the top whereof commeth foorth of a skinnie hood, a fmal white flower of the bignefie of a violet, compact of fixe leaues, three bigger and three leffer, tipped at the points with a light greene : the fmaller leaues are not fo white as the outtermoft great leaues, but tipped with greene as the others be. The whole tlower hangeth downe his head by reafon of the weake foote ftalke whereon it groweth. The roote is fmall, ivhite, and bulbofe.

2 The fecond fort of Bulbed violets hath narrow leaues like thofe of the lecke, but leffer and fmoo- ther, not vnlike to the leaues of the baftard Daffodill. The ftalkes be flender and naked, two hands high, whereupon doe grow faire white flowers, tipped with a yellowifh greene colour, with many fmall chives or threeds in the middle of the flower. The feed is contained in fmall round buttons. The roote is white and Bulbus.

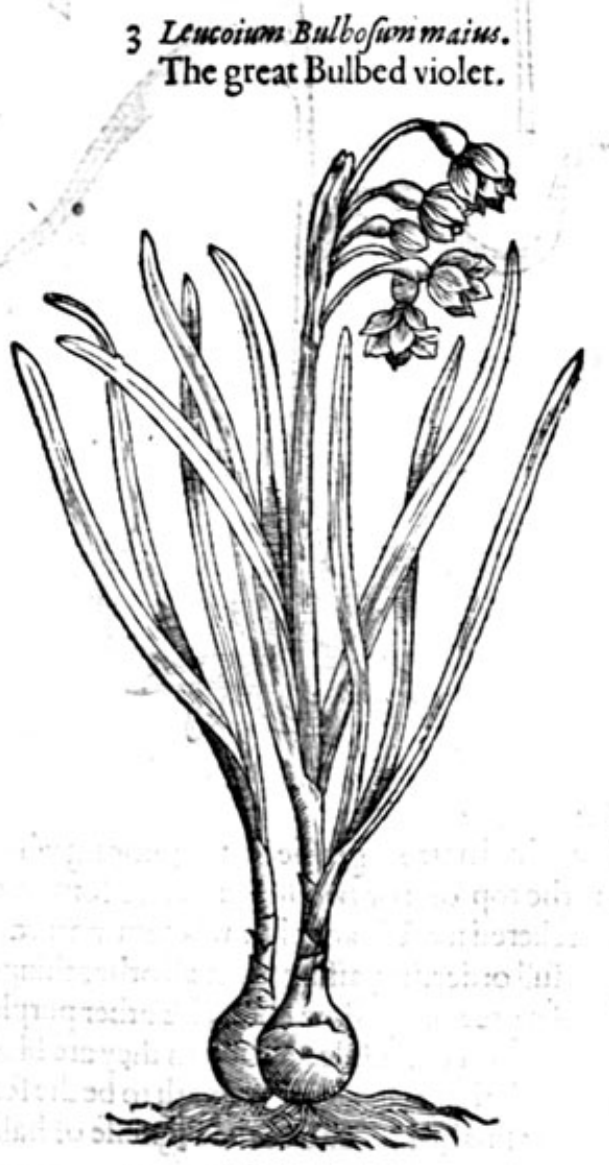

\section{* The defcription.}

3 The great Bulbed violet is like vnto the fecond in ftalke and leaues, yet greater and higher. It bringeth forth on euerie ftalke, not one flower onely, but fiue or fixe, blowing or flowring one after another, altogither like the other flowers in forme and bignes.

$$
\text { * The place. }
$$

Thefe plants do grow wilde in Italie and the places adiacent, notwithftanding our London gardens haue taken poffeffion of them all, many yeeres paft.

\section{* The time.}

The firft flowreth in the beginning of Ianu2ric: the fecond in September: and the laft in Maie.

\section{* The names.}

The firft is called of Theophrastus, Viola alba \& viola Bulbofa, or bulbed Violet: L'Obelius hath called it Lenconarciffolirion, and that very properly, confidering how it doth as it were participate of three fundry plants, that is to faic, the roote of Narciflis, the leaues of the fmall Lilly, and the white colour of the Stocke gilloflower: taking the firft part Leuco of his whitenes: Nar ciffo of the likenes that the rootes hauc vinto Narciffus, and Lirium of the leaues of Lillies, as aforefaid: in Englifh we may call it the Bulbofe

Violet, or after the Dutch name omer fottekents, that is, Sommer fooles, and Dotuptikens.

The others may more properly be called Leucoium Bulbofum, or the Bulbed ftocke Gilloflower, bicaufe that the flowers of thefe laft two defcribed, do more refemble the flowers of ftocke Gilloflowers then the firft. Whichname Leucoium although it hath another fignification, yet is it gene-
rallytaken for the ftocke Gilloflower.

* The nature and vertues.

Touching thefaculties of thefe Bulbed ftocke Gilloflowers we have nothing tofay, feeing that nothing is fet downe heerof by the old writers, nor any thing obferued by the new: onely they are maintained and cherifhed in gardens for the beautic and rareneffe of the flowers, and fiveetenes of
their fmell. 


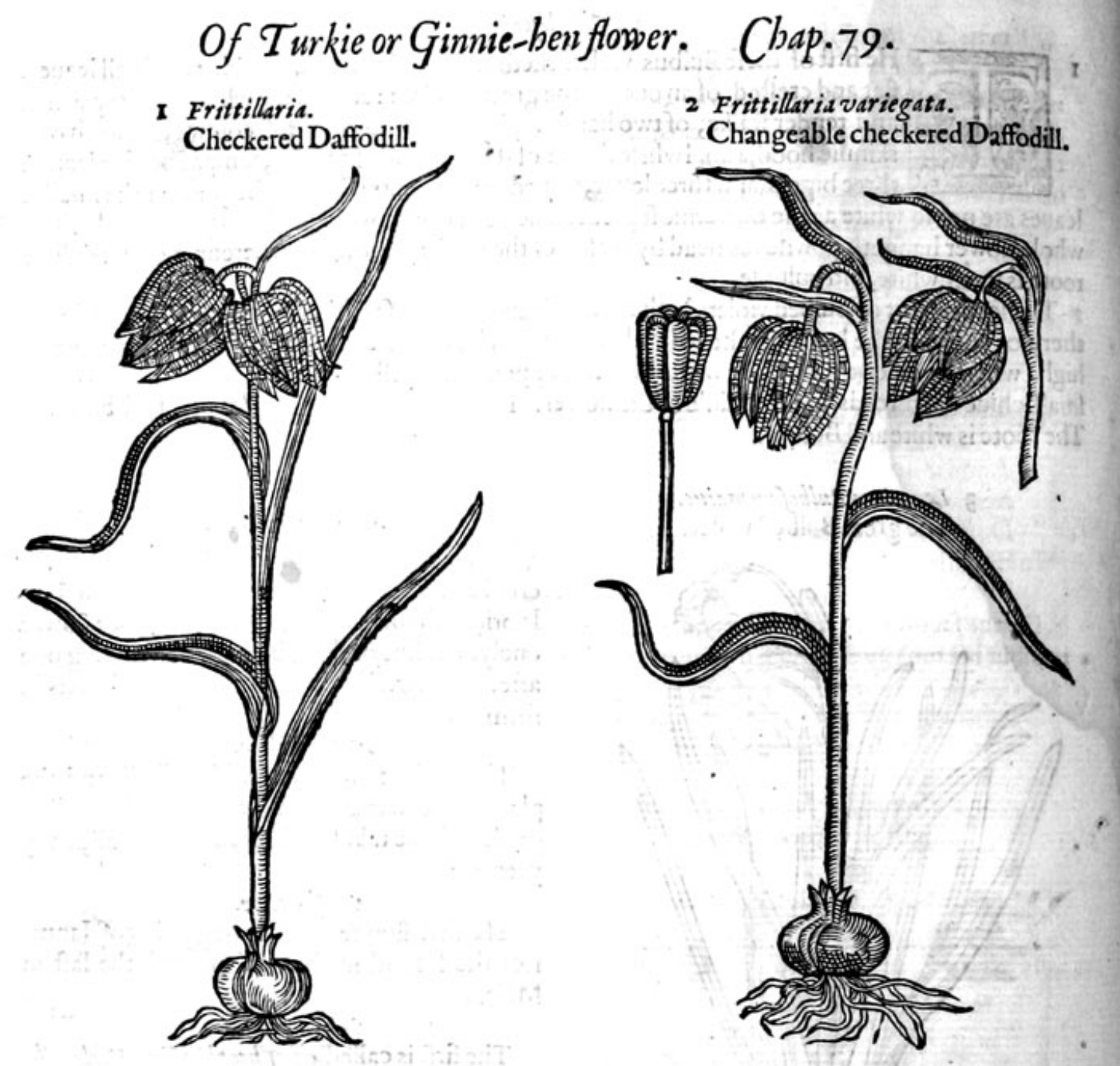

The checkered Daffodillor

* The defcription.

rifech vp a talke of rifeth vp a ftalke of three hands high, hauing at the top one or two flowers, and fomtimes
three, which confifteth of fixe fmall leaues, checkered moft ftrangely : wherein nature or rather the Creator of all things hath kept a very woonderfull order, furpaffing (as in all other things) the curieft painting that Art can fet down. One fquare is of a greenifh yellow color, the other purple, keeping the fame order as wel on the backfide of the flower as on the infide, although they are blackifh in one fquare, \& of a violet colour in another $:$ in fo much that euery leafe feemeth to be thefeather of a Ginnie hen, whereofit tooke his name.The roote is fmal, white, and of the bigneffe of halfe a garden beane.

2 The fecond kinde of checkered Daffodill is like vnto the former in ech refpeet, fauing that this hath his flower dafht ouer with a light purple, and is fomwhat greater than the other: wherein con-
fifteth the difference.

\section{$*$ Theplace.}

Thefe rare and beautifull plants grow naturally wilde in the fields about Orleance and Lions in Fraunce, from whence theyhaue been brought into the moft parts of Europe. The curious and painfull Herbarift of Paris Iobn Robin, hath fent me many plants thereof for my garden, where they
profper as in their owne natiue countrey.

They flower from the beginning of March vnto the end of Aprill. The feede is ripe in Inne. 
* The names.

The Ginny hen flower is called of Dodonets, Flos Meleagris : of L'Obelins, Lilio-narciffus varie gatus, for that it hath the flower of a Lillie and the roote of 2 (arcifjus: it hath been called Frittillaria, of the table or boord vpon which men plaie at cheffe, which fquare checkers the flower doth very much refemble, fome thinking that it was named Frittillsw, whereof there is no certaintie, for Mortialis feemeth to call Frittillses, Abatss, or the tables whereat men plaie with dice, in his firit booke of his Epigrams written to Galls.

$$
\begin{aligned}
& \text { Itm tristis, nucibsos pwer relictis, } \\
& \text { Clomofo rewocatur a magistro: } \\
& \text { Et blando male proditus Frittillo } \\
& \text { Sircana modó raptus ì popinas } \\
& \text { AEdilem rogat vdras a leator. }
\end{aligned}
$$

Now fad the boye, hauing his nuts forfaken

Of clamorous mafter called vpon a maine,

And waxt ftarke nought by flattering tables traine,

And lately from the priuic kitchen taken

Being a drunke dice-plaier,

Doth aske to be furueiour.

In Englifh we may call it Turkie hen,or Ginny hen flower, and alfo checkerdDaffodill. * The temperature and vertwes.

Of the faculties of thefe pleafant flowers there is nothing fet downe in the ancient or later writers, but are greatly efteemed for the beautifieng of our gardens, and the bofomes of the beautifull

$$
\text { Of Saffron. Chap.80. }
$$

I Crocus fine flore.

Saffron without flower.

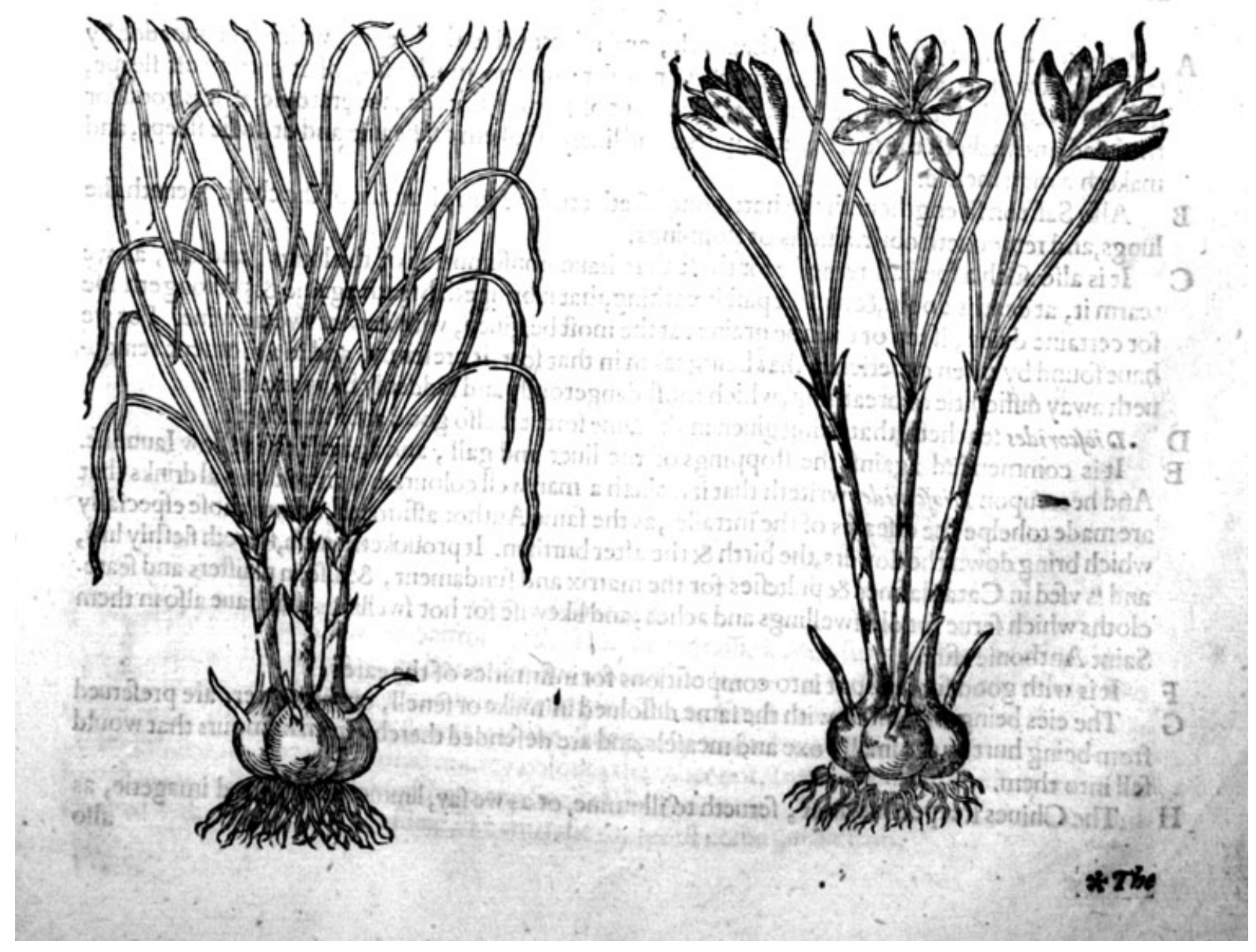

2 Crocus florens. Saffron in the flower. 


\section{* The defoription.}

A L though I haue expreffed two pictures of Saffrons as you fee,yet are you to vnderftand that thefe two do but fet foorth one kinde of plant, which could not fo eafily be conceiued by one picture as by two, bicaufe his flower doth firft rife out of the ground nakedly in September, and his long fmall graffie leaues fhortly after the flower, neuer bearing flower \&leafe at once. The which to expreffe I thought it conuenient to fet downe two pictures before you with this defcription, ridel. The roote is fmall, round and Bulbus. The flower confifteth of fixe finall blew leaues tending to purple, hauing in the middle many fmall yellow ftrings or threds, among which are two, three or more thicke fat chiues, of a fierie colour fomwhat reddifh, of a ftrong fmell when they be dried, which doth ftuffe and trouble the head. The firft picture fetteth foorth the plant when it beareth nothing but leaues, and the other expreffeth the maner of his flowring.

* The place.

Common, or the beft knowne Saffron groweth plentitully in Cambridgefhire, Saffron Walden and other places thereabout, as corne in the fieldes.

\section{* The time.}

Saffron bcginneth to flower in September, and prefently after fpring vp the leaues, and remaine greene all the winter long.

Saffron is called in Greeke vegross: in Latin Crocus : in Mauritania Zaffaran: in Spanilh Açafron: in Englifh Saffron : in the Arabicke toong Zahafaran. Some that are difpofed to diffemble and ieft with their friends and to make them merrie with pretie Poeticall figmentes, haue giuen it the name of a Damfell,whercof Ouid maketh mention, which to recite were impertinent to our hiftorie.

* The temperature.

Saffron is a little aftringent or binding, but his hot qualitie doth fo ouer rule in it, that in the whol effence it is in the number of thofe herbes which are hot in the fecond degree, and drie in the firf: therfore it alfo hath a certaine force to concoet, which is furthered by the fmal aftrietionthat is in it, as Galen faith.

\section{* The vertues.}

A Auicen affirmeth that it caufeth headach, and is hurtfull to the braine, which it cannot doe by taking it now and then, but by toomuch vfing of it: for too much ving of it cuttech off fleepe, through want whereof the head and fences are out of frame. But the moderate vfe of it is good for the head,and maketh the fences more quicke and liuely, thaketh off heauic and drowfie fleepe, and maketh a man merrie.

B Alfo Saffron ftrengtheneth the hart, concocteth crude or rawe humors of the cheit, openeth the lungs, and remooueth obftructions or ftoppings.

C It is alfo fuch a fpeciall remedie for thofe that haue confumption of the lungs, and are, as we tearm it, at deaths doore, \& almoft paft breathing, that it bringeth breath againe,\& prolongeth life for certaine daies, if ten or twentie graines at the moft be giuen, with new or fweete wine. For we haue found by often experience that being taken in that fort, it prefently, and in a moment remooueth away difficultie of breathing, which moft dangeroufly and fuddenly happeneth.

D Diofcorides teacheth, that being giten in the fame fort, it is alfo good againft a furfet.

E It is commended againft the ftoppings of the liuer and gall, and againft the yellow Iaundife. And heereupon Divfcorides writeth that it maketh a man well coloured. It is put into al drinks that are made tohelpe the difeafes of the intrailes, as the fame Author affirmeth, \& into thofe efpecially which bring down the flowers, the birth \& the after burthen. It proviokekh vrine, ftirreth flefhly luft, and is vfed in Cataplafines \& pultefies for the matrix and fundament, \&alfo in plaifters and fearecloths which ferue for old fwellings and aches, and likewife for hot fwellings that haue alfo in them Saint Anthonies fire.

F It is with good fucceffe put into compofitions for infirmities of the eares.

$G$ The eies being annointed with the fame diffolued in milke or fenell, or rofe water, are preferued from being hurt by the fmall poxe and meafels, and are defended thereby from humours that would fall into them.

$\mathrm{H}$ The Chiues fteeped in water, ferueth to illumine, or as we fay, limme pietures and imagerie, as 
alfo to colour fundry meates and confections. It is with good fucceffe giuen to procure bodilie luft. The confections called Crocomagna, Oxycrocelom, and Diacurcuma, with diuers other emplaifters and electuaries, cannot be well made without this Saffron.

The waight of ten graines of Saffron, the kernels of Walnuts ii. ounces, Figs ii. $z$.MithridateI one dram, and a fewe fage leaues, ftamped togither with a fufficient quantitic of Pimpernell water, and made into a maffe or lumpe and kept in a glaffe for your vfe, and thereof twelue graines giuen in the morning fafting, preferuech from the peftilence and expelleth it from thofe that are infected.

\section{Of wilde Saffron. Chap. 8r.}

* The kindes.

F wilde Saffrons there be fundry forts, differing as wel in colour of the flowers as alfoin the time of their flowring, of which the figures of two thall be fet foorth vnto you. The reft thall be defcribed onely, bicaufe nature hath been fo plentifull and copious in multiplying of thefe plants aboue manyothers.

1 Crocus vernus.

Early flowring wilde Saffron.
2 Crocus vernus minor. Small wilde Saffron.

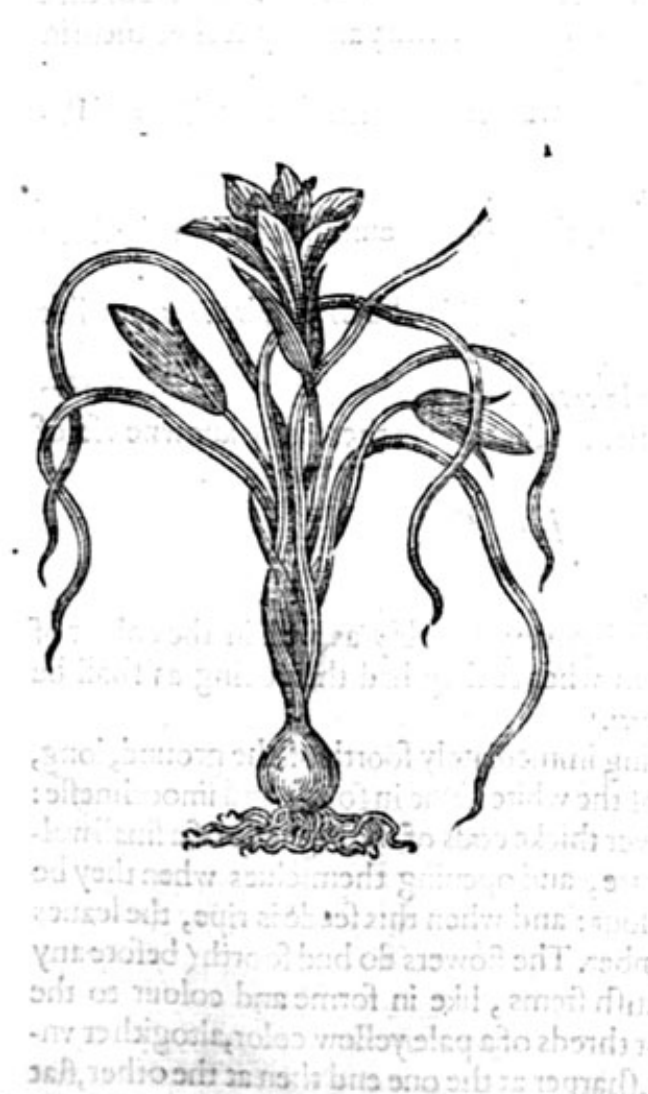

$17 \mathrm{He}$ firtkindef $*$ The defription.

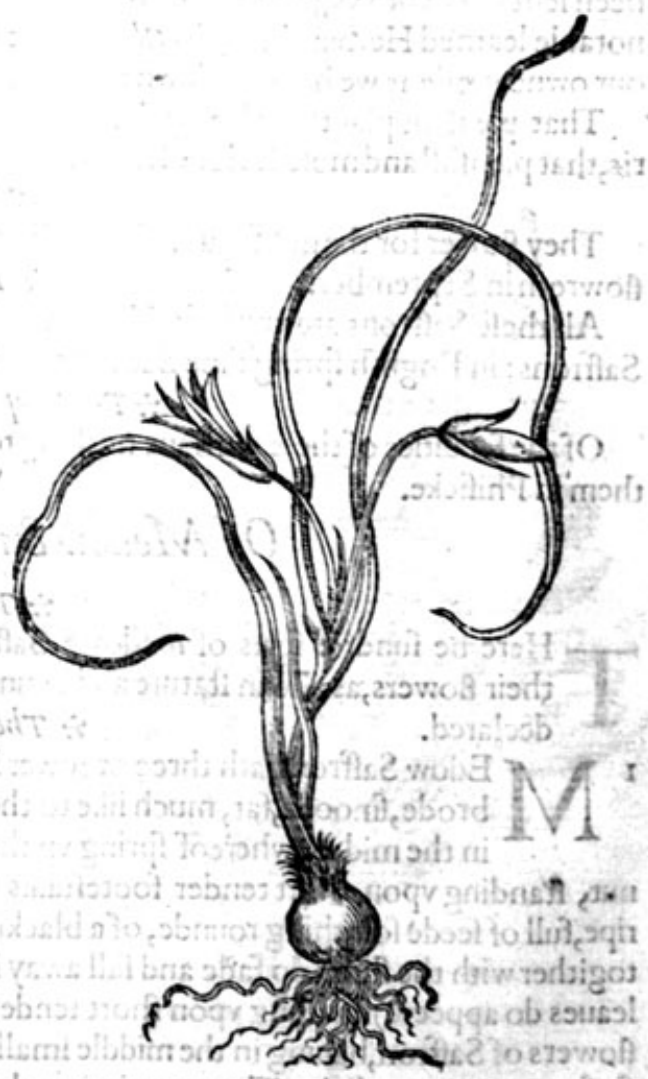

.

(1.25): 
2 The fecond wilde Saffron, in leaues, rootes, and flowers, is like vnto the precedent, but altogither leffer; and the flowers of this are of a purple or violet colour.

3 We haue likewife in our London gardens another fort, like vnto the other wilde Saffrons in -uery point, fauing that this hath flowers of a moft perfeet rhining yellow colour, feeming a far off to be a hot glowing cole of fire, which maketh the difference.

4 There is found among Herbarifts another fort, not differing from the others, fauing that this hath white flowers contraric to all the reft.

5 Louers of plants haue gotten into their gardens, one fort heere of with purple or violet colou. red flowers, in other refpects like the others.

6 Of thefe we haue another that flowreth in the fall of the leafe with flowers like vnto the common Saffron, but deftitute of thofe chiues which yeeld the colour, finell, or tafte, that the right ma. nured Saffron hath.

7. There is alfo another of Autumne wilde Saffrons with white flowers, which fetteth foorth the diftinetion.

Many forts there are in our gardens befides thofe before fpecified, which I thought needles to entreat of bicaufe their vfe is not great.

All thefe wilde Saffrons we haue growing in our London gardens. Thofe which do flower in Alltumne do grow vpon certaine craggy rocks in Portingale not far from the fea fide. The other haue been fent ouer vnto vs, fome out of ltaly, and fome out of Spaine, by the labor and diligence of that notable learned Herbarift Carolus Clufus, out of whofe obferuations, and partly by feeing themin our owne gardens we haue fet downe their defcriptions.

That pleafant plant that bringeth foorth yellow flowers, was fent vnto me from Robinus of $\mathrm{Pa}_{2}$ ris, that painfull and moft curious fearcher of Simples.

$$
\text { * The time. }
$$

They flower for the moft part in Ianuarie and Februarie, that of the mountaine excepted, which flowreth in September. * The names.

All thefe Saffrons are vnprofitablc, and therfore they be trucly faid to be Croci fluestres, or wilde Saffrons: in Engliih fpring time Saffrons, and vernall Saffrons.

\section{$*$ The temperature and vertues.}

Of the faculties of thefe we haue nothing to fet downe, for that as yet there is noknowne vfe of them in Phificke.

\section{Of Medow Saffron. Cbap. 82.}

* The kindes.

Here be fundrie forts of medowe Saffrons differing very notably as well in the colour of their flowers, as alfo in ftature and countrey, from whence they had their being as thall be declared. * The defcription.

I Edow Saffron hath three or fowcr leaues rifing immediately foorth of the ground, long, brode,fmooth,fat, much like to the leaues of the white Lillie in forme and fimoothneffe: in the middle whereof fpring vp three or fower thicke cods of the bigneffe of a fmall walnut, ftanding vpon fhort tender footeftalks three fquare, and opening themfelues when they be ripe,full of feede fomthing rounde, of a blackifh red colour : and when this feede is ripe, the leaules togither with the ftalks do fade and fall away in September. The flowers do bud foorth (before any leaues do appeere) ftanding vpon thort tender and whitifh ftems, like in forme and colour to the flowers of Saffren, hauing in the middle fmall chiues or threds of a pale yellow color, altogither vnfit for meate or medicine. The roote is tound or bulbus, tharper at the one end then at the other, that on the one fide, hauing a deepe clift or furrow in the fame flat fide when it flowreth, and not at anie time elfe : it is couered ouer with blackifh coates or filmes: it fendeth downe vnto the loweft part certaine ftrings or threds. The roote it felfe is full of white fubftance, yeelding a iuice like mille whileft it is greene and newly digged out of the earth. It is in tafte fweete, with a little bitterneffe folowing, which draweth water out of the moutb.

2 The fecond kinde of meade Saffron is like the precedent, differing onely in the colour of the Howers, for that this plant doth bring foorth white flowers, which of fome hath been taken for the true Hermodactylis, but in fo doing they haue committed the greater error. 
I Colchicam Anglicuon Parpurcum.

2 Culchium Anglicuon album.

White Engliih medow Saffron.

Purple Englith medow Saffron,

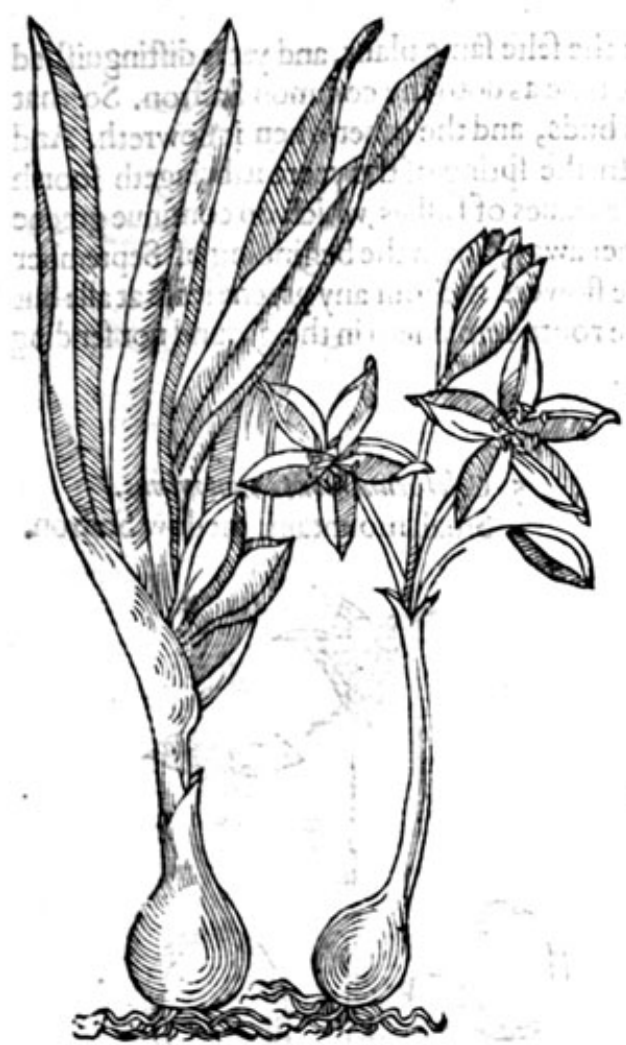

3 Colchicum Pannonicum.

Hungarie meade Saffron.

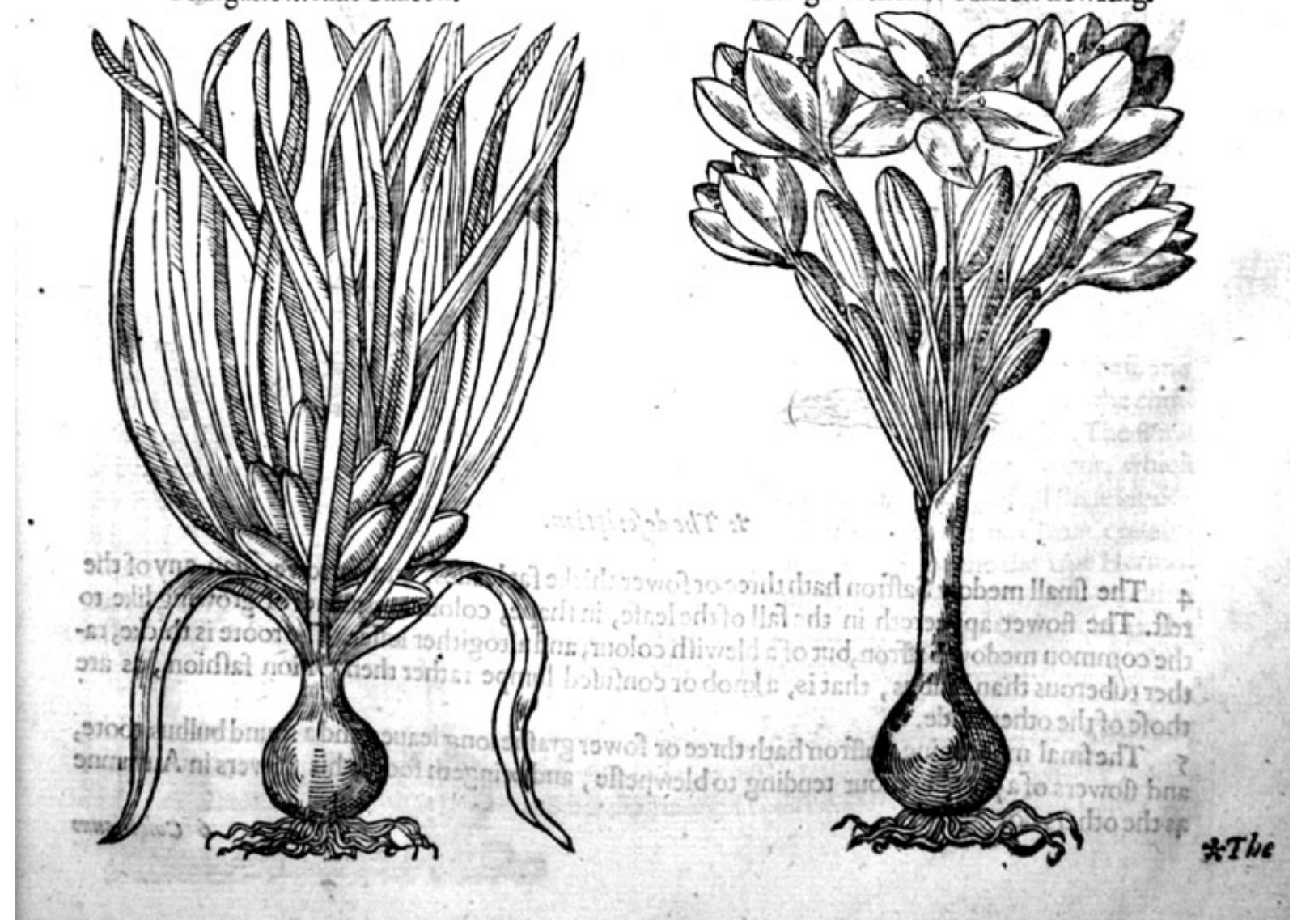

Colcbicum Pannonicum forens.
Hungaric meade Saffron flowring.

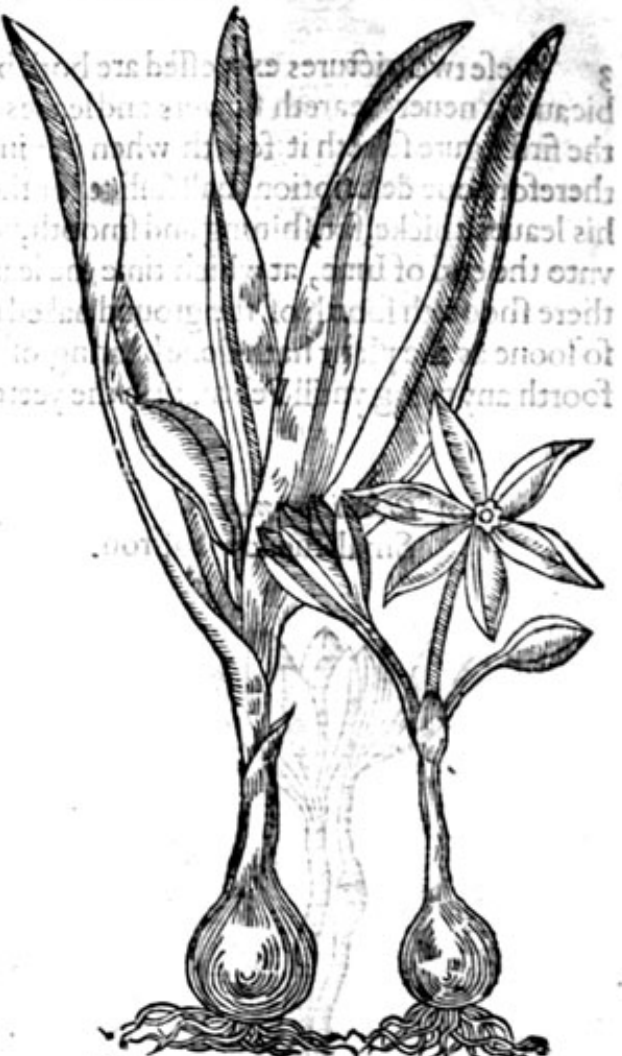




\section{* The defoription.}

3 Thefe two pietures expreffed are both but one and the felfe fame plant, and yet is diftinguithed bicaure it neuer beareth flowers and leaues both at one time as doth the common Saffron. So that the firft figure fettech it foorth when it is in leaues and buds, and the other when it flowreth. And therefore one defcription hall fuffice for themboth. In the fpring of the yeere it bringeth foorth his leaues, thicke, fat, , hining and fmooth, not vnlike the leaues of Lillies, which do continue greene vnto the end of Inne, at which time the leaues do wither away, but in the beginning of September there fhooteth foorth of the ground naked milke white flowers without anygreene leafe at all: but fo foone as the plant hath done bearing of flowers, the roote remaineth in the ground not fending foorth any thing vntill February in the yeere following.

\section{Colchicum minus.} Smallmedow Saffron.

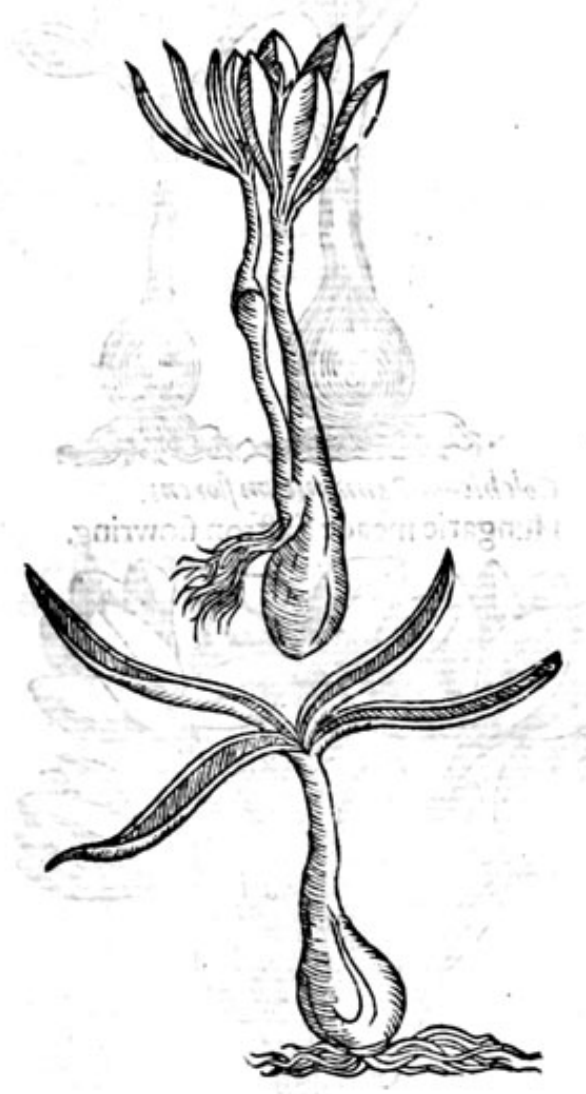

5 Colchicum montanum minus.

Small mountaine medow Saffron;

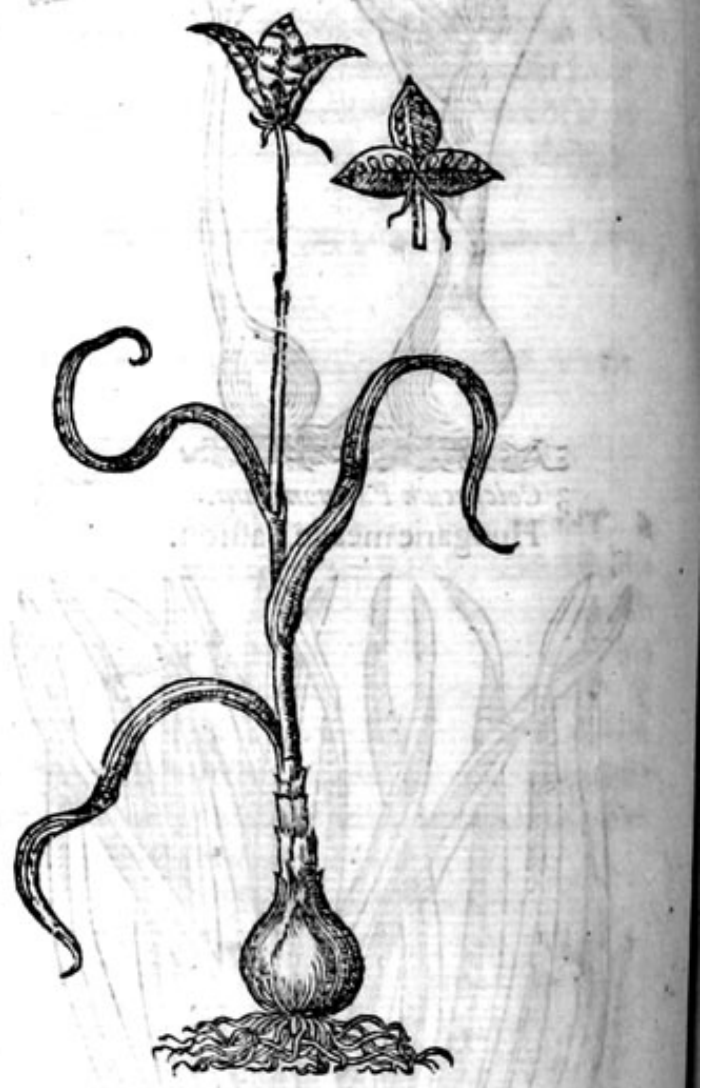

\section{$*$ The defcription.}

4 The fmall medow Saffron hath three or fower thicke fat leaues, and narrower than any of the reft. The flower appeereth in the fall of the leafe, in hape, colour andmaner of growing like to the common medow Saffron, but of a blewifh colour, and altogither leffer. The roote is thicke, $\mathrm{rt}^{-}$ ther tuberous than bulbus, that is, a knob or confufed lumpe rather then Onion fafhion, as are thofe of the other kinde.

5 The fmal mountaine Saffron hath three or fower graffie long leaues, and a round bulbus roote, and flowers of a purple colour tending to blewnefle, and bringeth foorth his flowers in Autumne as the others do. 


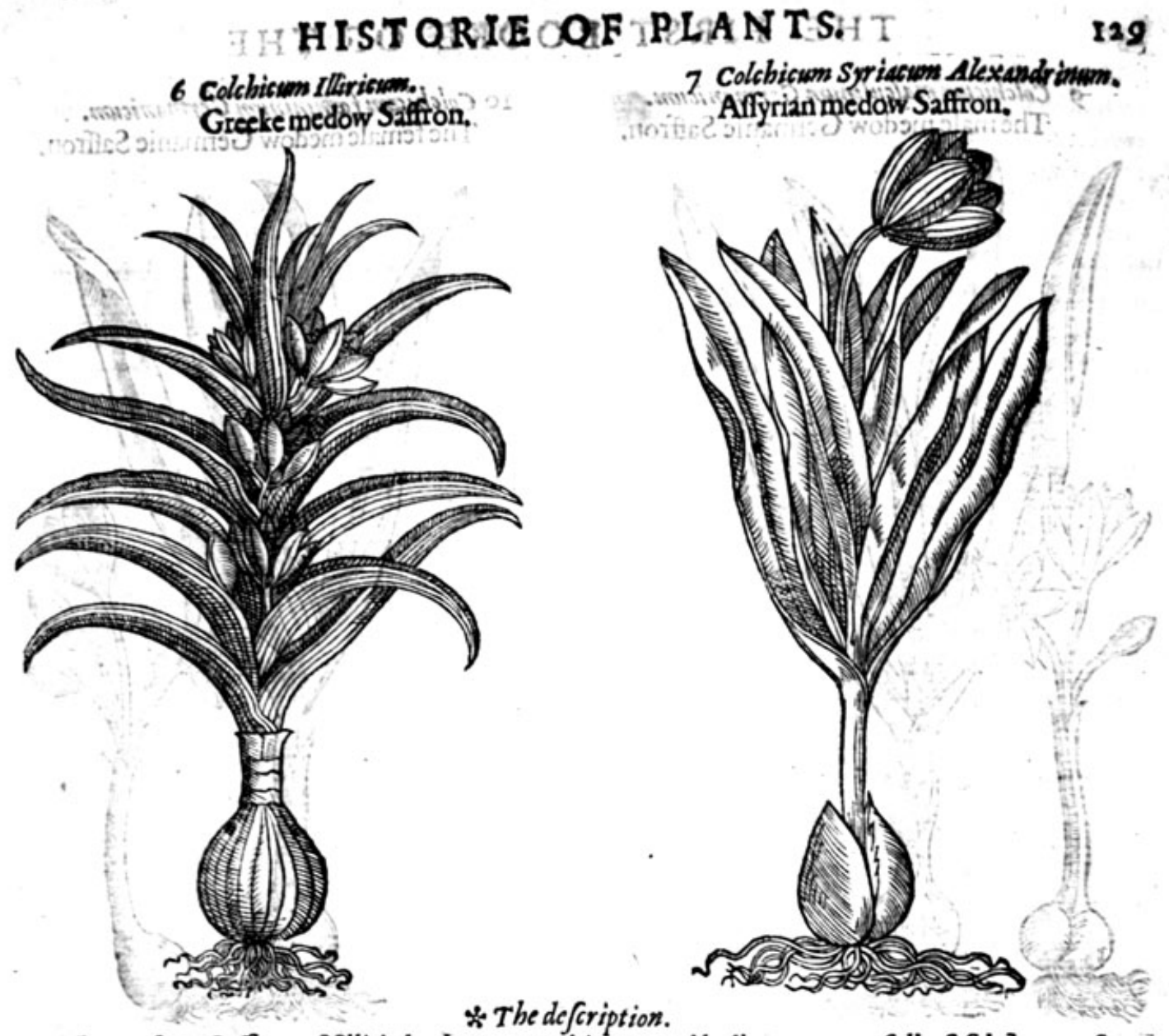

6 The medow Saffron of Illiria hath a great, thicke, and bulbus roote, full of fubitance: from which rifeth vp a fat, thicke, and groffe italker fet abotit from the lower part to the top by equall diftapces; with long, thicke, and groffe leanes; flarpe pointed, not vnlike to the leaues of Leekes: ainougivinich leaiues do grow yellowifh Howers tike vito the Englith medow Saffron, but fmaller. 7 i Ihe-Affyriandmedow Saffron hatha bulbusroote, maderas it were of two peeces; froin the middle cleft whereof rifeth vp a foft and tender ftalke, fet with faire broadeleaties from themiddle tó thotop: ainong which commeth forthone fingle t lower like vit to the common medow Saffron, or the white Anemone of Matthiolus defcription.

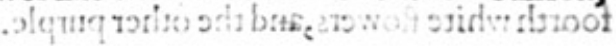

8 Colchicum parusom montanuon Lut cans. Iy sit $\therefore$

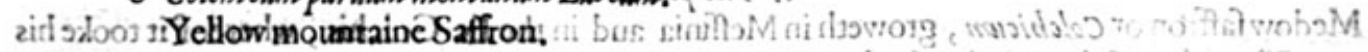

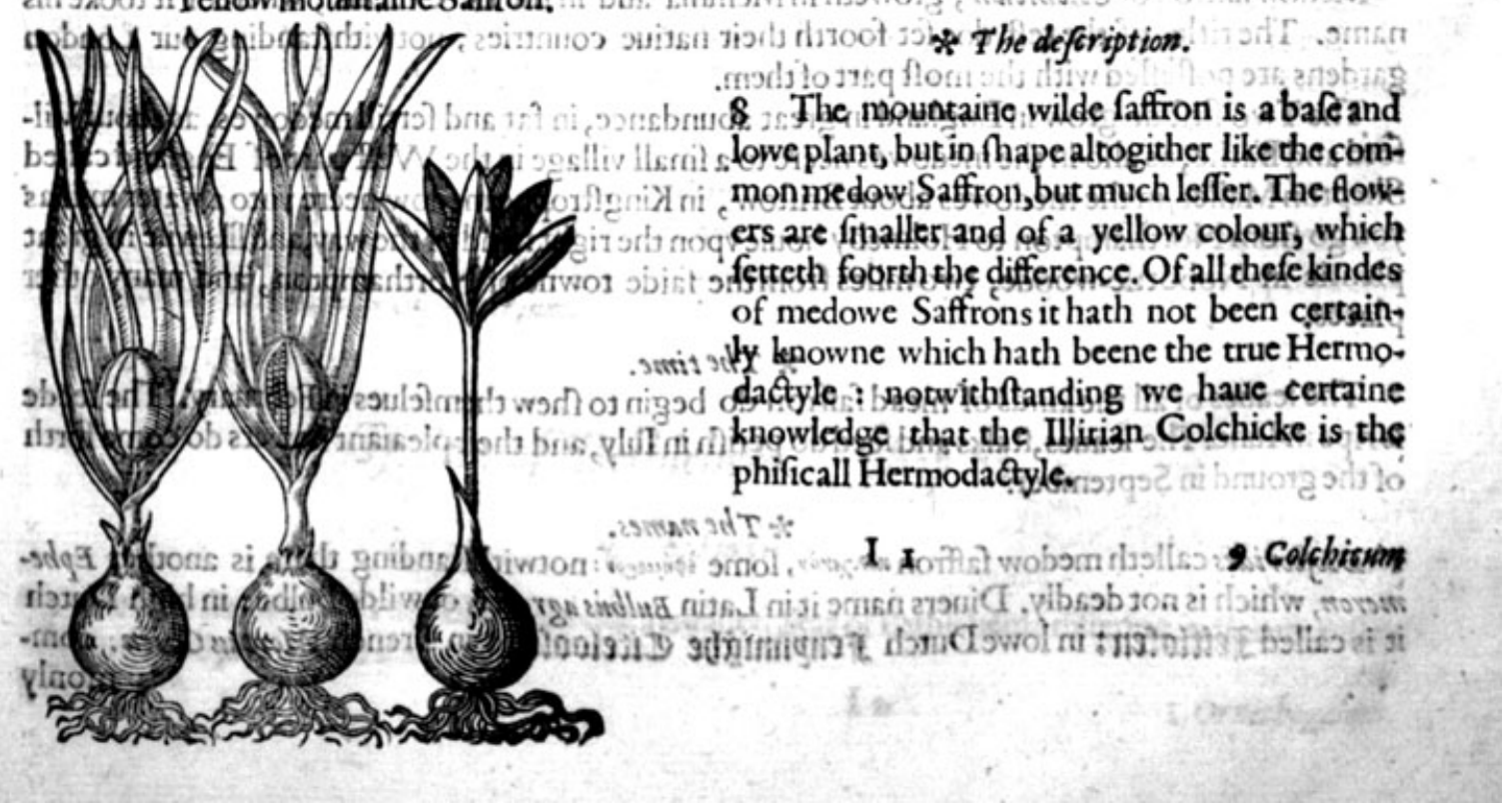


9 Colchicionmafculinuen Germanicumon The malemedow Germanie Saffron:

\author{
10 Colchic mi femininum Germanioven. \\ The female medow Germanie Saffron,
}
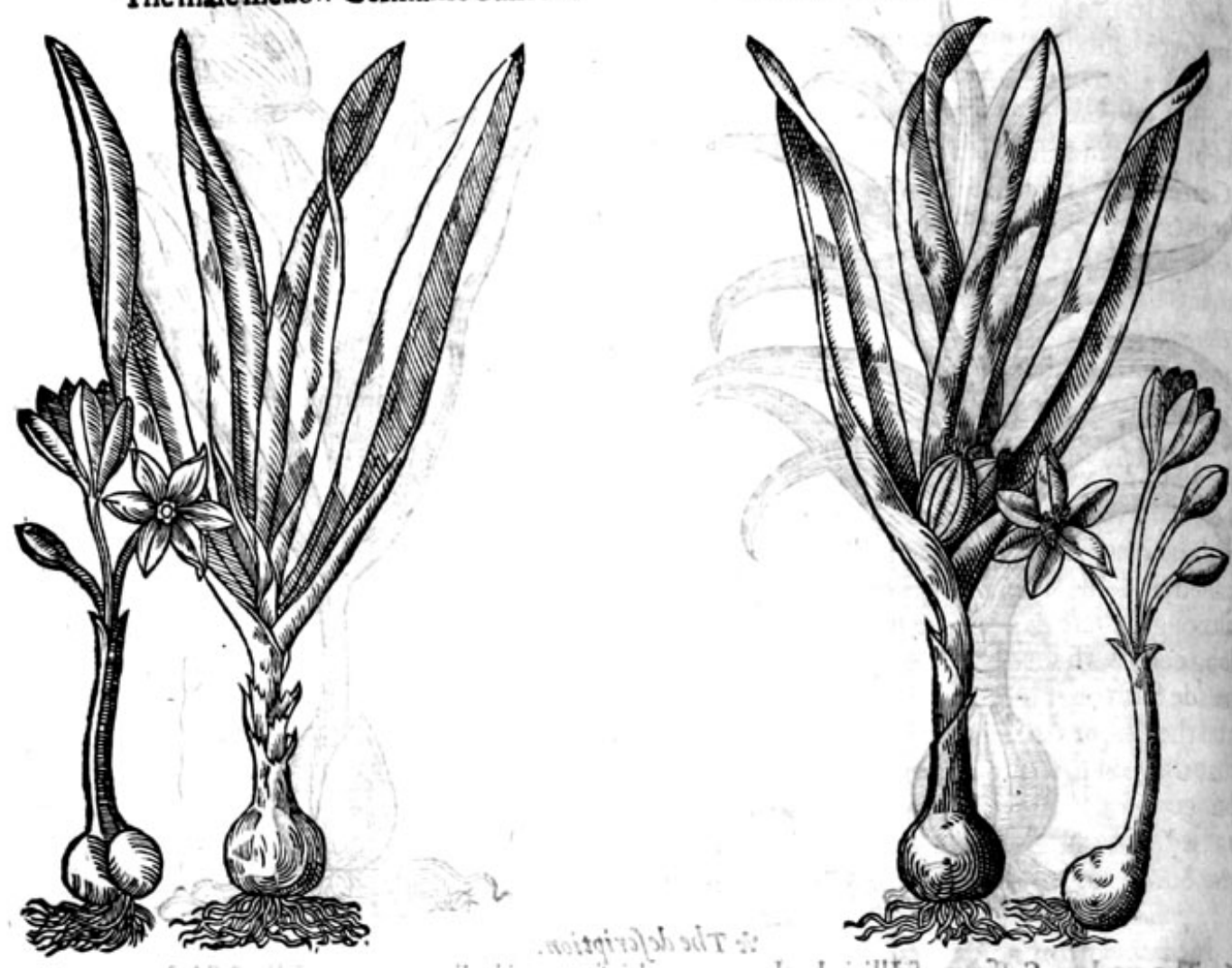
2. The male medow Saffron of Germany hathmany thicke leaues, broadey andfull of inice, and

Ifsci sizill lo tonts? viobsmsil a flowers like to thofe of the Engliifh medow Saffren, as well in colour ; as proportion'sanid differeth inthat, that this kinde is barraine, and bringeth foorth no feede at alf, contrary to all thieseft of the Colchickes, which maketh the difference.

10 The female is like vnto the male in each refpect, but differeth in that, that this plant bringeth foorth white flowers, and the other purple. * The place.

Medowfaffron or Colchicum, groweth in Meffinia and in the Ile Colchis, whereof it tooke his name. The titles of the reft doefet foorth their natiue countries, notwithftanding our London gardens are poffefled with the moft part of them.

The Two firft do grow in England ingreat abundance, in fat and fertill medowes, as abour Viford and Bathe, as alfoin the medowes neere to 2 fmall village in the Weft part of England called Shepton Mallet, in the medowes abour Briftow, in Kingftroppemedow neere vito a water mill as you go from Northarbpton to Holmeby houfe vpon the rigethand of the way, and likewife in geat plentie in Nobottle-woode, two miles from the faide towne of Northanpton, and many other places.

\title{
* The time.
}

The leaues of all the kinds of mead faffron do begin to fhew themfelues in February. The feede is ripe in Iune. The leaues, ftalks and feed do perifin in Iuly, and their pleaiant flowers do come forth of the ground in September.

* The names.

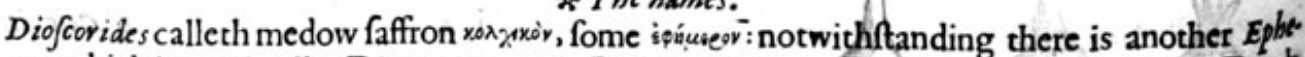
meron, which is not deadly. Diuers name it in Latin Bulbus agr stits, onwilde Bulbe: in high Durch it is called Jeitlofen: in loweDutch fenpunighe Citeloofent: in French Mortan Chien : com:

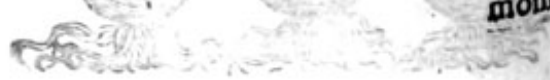




\section{HISTORIE OF PLANTS.}

monly called of the Apothecaries Hermodactylis: buegetwithftanding that Hermodactyle which we do ve in compound medicines differeth from this in many notable points, for that the true Hermodactyle hath a bulbe or rounde roote, which being dried continueth very white within and without, not wrinckled at all,but full and fmooth, of a meane hardnes. Valerisus Cordes writeth that there is found a certaine wilde Saffron like vnto the common kinde, but with white flowers, and with a bulbe, when it is dried fomwhat white on the out fide, and within very white, the powder of which being beaten is like wheate flower, with a fweete and pleafant tafte. This doth not grow faith he in Germanie, but is brought from fome other countrey : and it is very like to be the rootes of the white and ftrange wilde $S_{\text {affron }}$ which are folde in thops by the name of Hermodactyless: and Hermodactyle to be nothing elfe, but wilde Saffron with the white roote. And fo thall there be two of one kinde: that is to faie, the right Hermodactyle with a roote white both within and without: and abaftarde Hermodactyle or deadly Colchicsm, or wilde Saffron, with a roote blackifh or reddifh both without and within. And that Auicen was of this opinion thofe things declare which he hath written in his 352.chapter, for he faith that Hermodactyle is the roote of a plant bearing rofes ( that is flowers) which are white or yellow (rather purple) and that the white is the better, the red and blacke be naught, and are pernicious and deadly poifons. So to conclude, it may appeere by that that hath been faid, that the white medow faffron which we have in the weft parts of England, growing efpecially about Shepton Mallet, are the Hermodactyles vfed in thops. It was called Colchicum of an Ile called Colchis where it was firtt found, as alfo the vfe of it. It is called of fome, Filius ante Patrem, although there is a kinde of $L y$ /machia or Loue ftrife fo called, bicaufe it firft bringeth foorth his long cods with feede, and then flower after, or at the fame time at the end of the faid cod. But in this meade Saffron it is far otherwife, bicaufe it bringeth foorth his leaues in Februarie, the feed in May, and the flowers in September, which is a thing cleane contrary to all other plants whatfoeuer, for that they do firft flower and after feede: but this Saffron feedeth firft, and fower moneths after bringeth foorth flowers: and therefore the Latins thought this a fit name for it Filius ante Patrem: and we accordingly may call it, the Sonne before the Father. Of Pliny it is called Nar ciffus purpureus, \& Eülbus Agrestis, of fome $P$ feudo-Hermodactylus : in Dutch Đermodactilen afte Cbolonfen. Medow faffron is hot and drie in the fecond degree.

* The vertwes.

The rootes of meade faffron is of force to purge. It is properly giuen faith Paulus to thofe that haue the goute, euen then when the humours are in flowing.

The fame ftamped and mixed with the whites of egges, barly meale, and crums of bread, and applied plaifterwife,eafeth the paine of the goute, fwellings and aches about the ioints.

The fame ftrengtheneth, nourifheth, and maketh good iuice, increafeth fperme or naturall feede, and is alfo good to clenfe vlcers and rotten fores.

\section{* The correction.}

The powder of Ginger, long Pepper,Annife feede, or Commin feed, and a little Mafticke, correcteth the churlifh working of that Hermodactile, or meade faffron, which is vfed in fhops. But thofe which haue eaten of the common medow Saffron muft drinke the milke of a cow, or els death pre-
fently enfueth.

The rootes of $*$ The danger. and being eaten, they kill by choking as mufromes whe excepted, are very hurtfull to the ftomacke; haue called it Colchicion ftrangulatorium.

\section{Of Star of Betblebem. Chap.83.} * The kindes.

\section{Here be fundrie forts of wilde field-onions called Star of Bethlehem, differing in ftature, tafte,
and fmell, as Shall be declared.}


132

THE FIRST BOOKE OF THE

I Ornithogaliwn.
Star of Bethlehem.

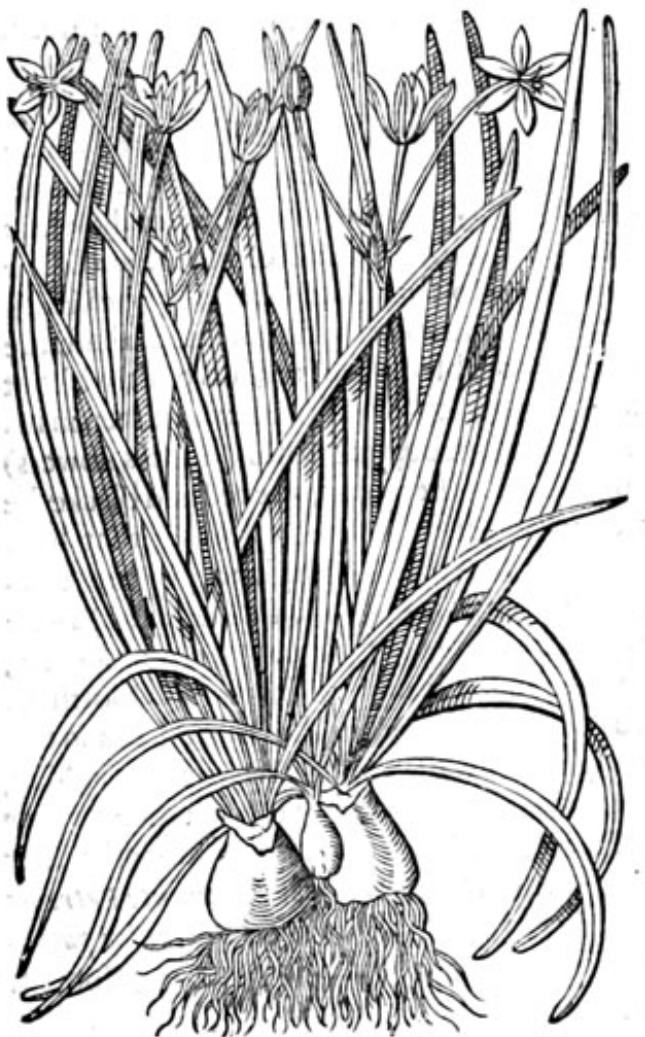

3 Ornithogalum luteum. Yellow ftar of Bethlehem.

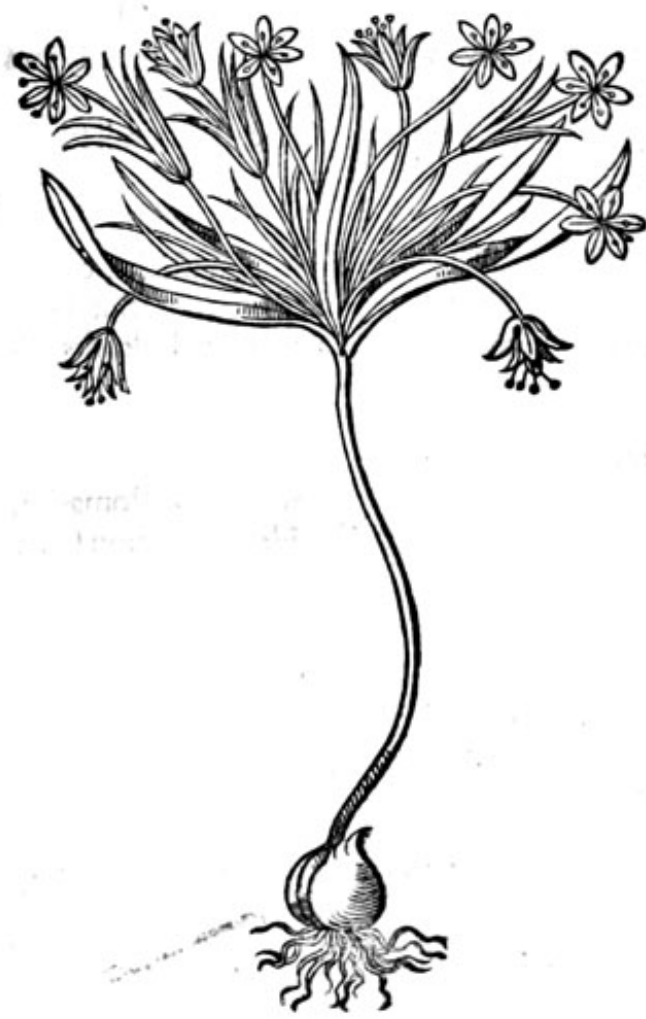

2 Cepangraria. Wilde Star of Bethlehem.
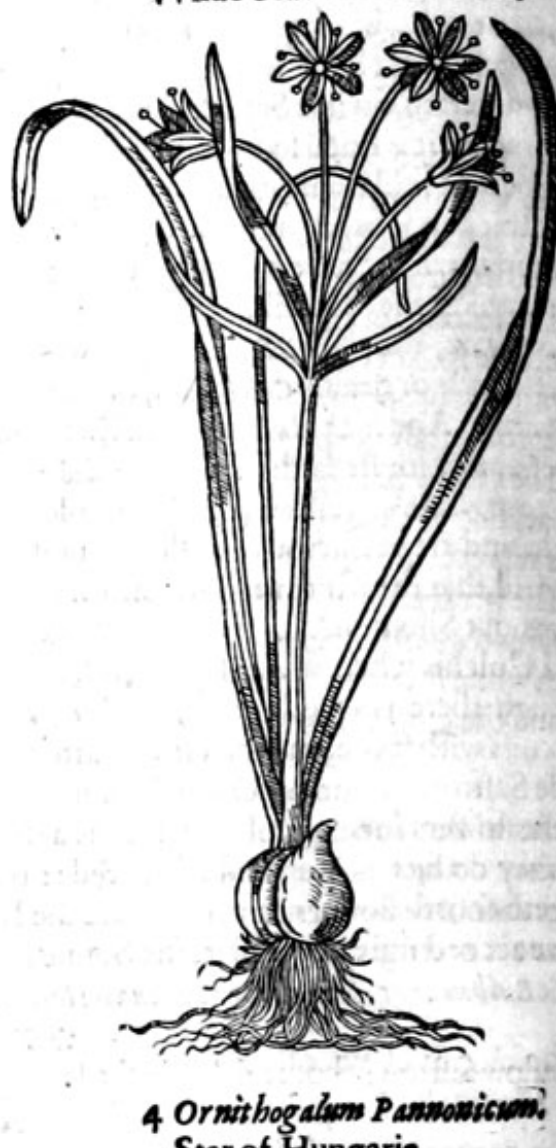
Star of Hungarie.

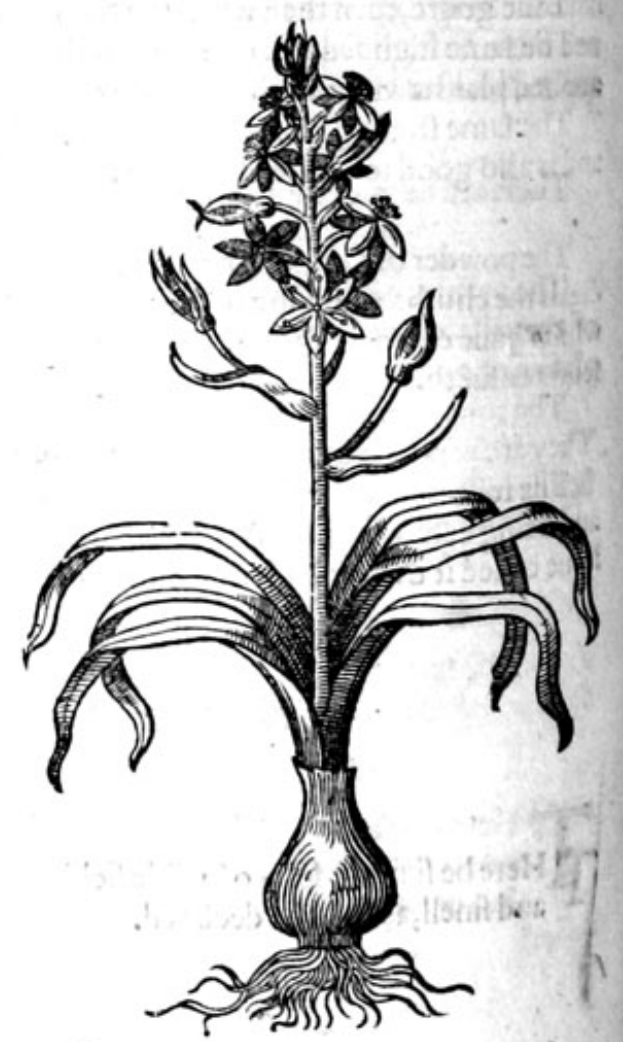




\section{HISTORIE OF PLANTS. TT * The dejcription.}

Vrcommon Star of Bethlehem hath many narrow leaues, thicke, fat, ful ofiuice, and of a very greene colour, with 2 white ftrake downe the middle of each leafe: among the which rife vp fmall naked italkes, at the top whereof do grow fmall flowers, compact of fixe fmal leaues, ftripped on the backfide with lines of a yellowifh greene. The infide is of a milke white colour, which openeth it felfe at the rifing of the funne, and fhutteth againe at the funne fetting, whereof it hath beene called of fome Bulbus Solfegrims. The flowers being paft, the feed doth follow inclofed in three cornered husks. The roote is bulbus, white both within and without.

2 The fecond fort hath two or three fmall graffie leaues, proceeding from a clouen or fcaly bulbus roote. The ftalke rifeth vp in the midft naked, but toward the top there do thruft foorth more leatues like vnto the other, but fmaller and fhorter:among which leaues do ftep foorth very fmal,weake and tender footeftalks, ech of them bearing one flower like vnto the precedent. 3 The yellow Star of Bethlehem is very like vnto the laft defcribed. The flowers of this are on the backfide, of a pale yellow ftripped with greene, on the infide of a bright $\mathrm{fhining}$ yellow colour, in other refpeets alike.

4 The great bulbed Star of Bethlehem hath many large and long leaues, thicke and crefted, refembling Galens bulbed 1 phodyll in roote, ftalke and tiowers, fauing that this plant doth bring . foorth white flowers ftripped with greene on the backfide, and altogither white on the innermoft fide, and the $\mathcal{A}$ phodyll not fo.

$$
\text { * Theplace. }
$$

Stars of Bethlehem grow in fundrie places which lie open to the aire, not onely in Germany and the Lowe countries, but alfo in England in fundry places, and in our gardens very common. The yellow kinde L'Obelius found in Somerfet?hire in the corne fields. The laft is a ftranger in England,yet we haue it and the reft in our gardens.

$$
\text { * Thetime. }
$$

Thefe kinds of bulbed plants do flower from Aprill to the end of May.

$$
\text { * The names. }
$$

Touching the names there is no certaintie, feeing that $P$ liny is fo breefe who hatbonely mentioned them.In high Dutch it is called fieldz twibel, ackerz 3 wutbel : as you fhould fay Cepa egrarias and Bulbine : in Englifh Stars of Bethlehem.

\section{Thefe are temperate in heate and drines.}

$$
\text { * The nature. }
$$

\section{* The vertues.}

The vertues of them are vnknowne, notwithitanding Hieronymus Tragus writeth that the roote $\mathbf{A}$ of the yellow Star of Bethlehem rofted in hot embers, and applied with honie in maner of a cataplafme or pultus, healeth old eating vicers.

The rootes which are to be vfed in Phificke, if any part thereof be, do not make any good inice. $B$ They are windie, faith Diofcorides, and hard to be digefted, and through their windines prouoke fiefhly luat.

\section{Of Onions. Chap.84.}

* The kindes.

$\mathrm{T}$ Here be, faith Theophr ast wos, diuers forts of Onions, which haue their furnames of the places wherethey grow. Some alfo leffer, others greater : fome be round, and diuers other long : butnone wilde as Pliny writeth. 


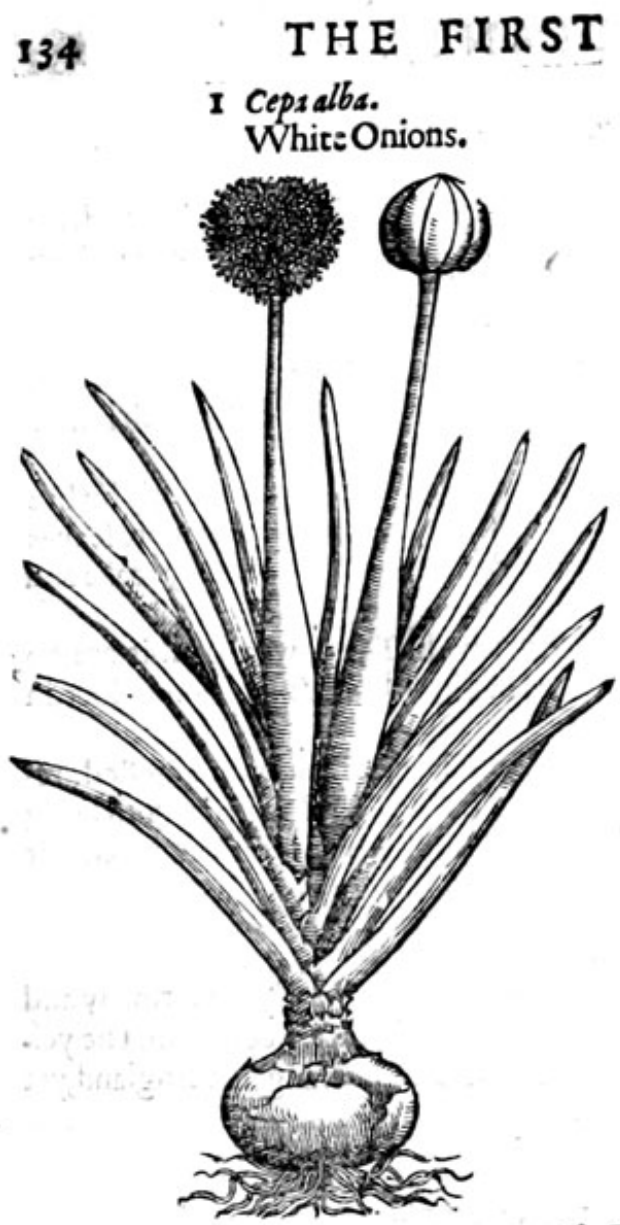

\section{* The defcription.}

\section{BOOKE OF THE}

2 Ceparubra. Red Onions:

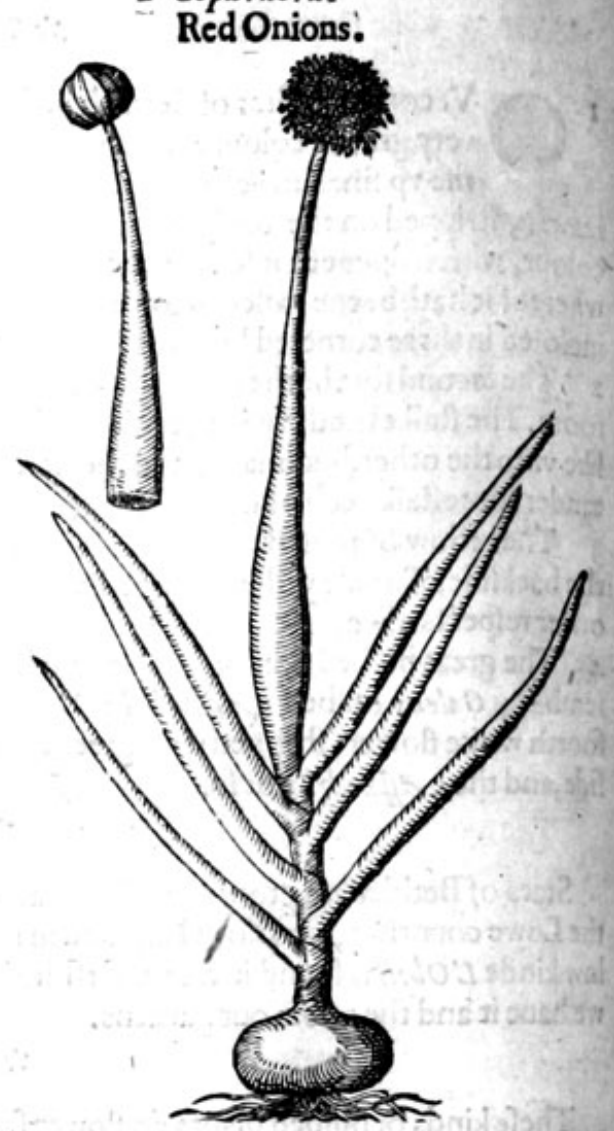

I $\mathrm{He}$ Onion hath narrow leaues and hollow within : the ftalke is fingle, round, biggeft in the middle. On the top whereof groweth a round head couered with a thin skin or filme, which being broken, there appeere little white flowers, made vp in forme of a ball,and afterward blacke feede three cornered, wrapped in thin white skins. In fteede of the roote there is a bulbe or round head compact of many coates, which oftentimes becommeth great in maner of a Turnep, many times long like an egge. To be briefe, it is couered with very fine skins, for the moft part of a whitifh colour.

2 The red Onion differeth not from the former, but in fowrenes and rednes of the roote; in other refpects there is no difference at all.

$$
\text { * The place. }
$$

The Onion requireth a fat ground well digged and durnged, as $P$ alladius faith. It is cherifhedeuerie where in kitchen gardens. It is now and then in beds fowen alone, and manie times mixed with other herbs, as with Lettuce, Parfneps, \& Carrets. Palladius liketh well that it thould be fowen with Sauorey, bicaufe faith $P$ liny, it profpereth the better and is more holfome.

$$
\text { * The time. }
$$

It is fowen in March or Aprill,and fomtimes in September.

$$
\text { * The names. }
$$

The Onion is called in Greek regumurv : in Latine Cepa, \& many times Cepe in the neuter gender:the fhops keep that name. The old writers have giuen vnto this many furnames of the places where they grow for fome are named Cyprie, Sardie, Cretica, Samotbracia, Afcalonia, of a towne in Iudea, otherwife called Pompeiann : in Englifh Onions. Moreouer, there is one named Marifca, which the country men call $V$ nio, faith Columella : and thereupon it commeth that the French men call it Oignon, as Buellius thinketh: and peraduenture the lowe Dutch men name it Giteuim of the French wordcorrupted :they be called Setania if theybe very little and fweete, and be thought to be thofe which Palladius nameth Cepulla, as though he called them parua Cepa,or little Onions. 
There is an Onion which is without an head or bulbe, and hath as it were a long neckegas hath the vnfet leeke, which is cropped or cut for the pot like a lecke : this Theophraftus nameth rifuver: of this Pliny alfo writeth in his 19. booke and 6.chapter. There be with vs two principall forts, (that is to fay of Onions)the one feruing for a fauce, or to feafon meate with, which fome call Gethyon, and another Pallacana: which in Englifh we call hollowe Leekes: the Germaines Drtan zivibel: the Italians Cipolls : the Spaniards Cebolla,Ceba, and Cebula.

$*$ The temperature.

All Onions be fharpe, andmooue teares by the finell. They be hot and drie as Galen faith, in the fourth degre, but not fo extreme hot as garlicke. The iuice is of a thin waterie and airie fubitance: the reft is of thicke parts.

* The vertues.

The Onions do fret, attenuate or make thin, and caufe drines : being boiled they dolofe their $\mathbf{A}$ Tharpnes,efpecially if the water be twife or thrife changed, and yet for all that they do not lofe their attenuating qualitie.

They alfo breake and confume winde, prouoke vrine, and be more foluble boiled than rawe, and B being rawe they nourifh not at all, and but a little though they be boiled.

They be naught for thofe that are cholericke : but good for fuch as are replete with rawe and $\mathbf{C}$ flegmatike humours : and for women that haue their termes ftaied vpon a cold caufe, by reafon they open the conduits that are ftopped.

Galen writeth that they prouoke the Hemorrhoides to bleede if they be laid unto them, either by D themfelues or ftamped with vineger. The iuice of Onions fniffed vp into the nofe,purgeth the head and draweth foorth rawe flegma- E
tike humours.

Being ftamped with falt, rewe and honic, and applied, is good againft the biting of a mad dogge. F like.

Being rofted in the embers and applied, ripeneth and breaketh colde apoftumes, biles and fuch $G$

The iuice of Onions mixed with the decoction of Penniriall and annointed vpon the goutie $\mathrm{H}$ member with a feather, or a cloth wet therein and applied,eafeth the fame very much. dily.

The iuice annointed vpon a pilde or balde head in the funne, bringeth againe the haire very fpee- I

The iuice taketh away the heate of fcalding with water or oile, as alfo burning with fire and gun- $\mathbf{K}$ powder, asis fet foorth by a very skilfull Chirurgion named matter VVilliam Clowes, one of the
Queenes Chirurgions.

Onionsfliced aud i doth take away the fit in once or twice fo taking it.

\section{* The hurts.}

The Onion being eaten, yea though it be boiled caufeth headach; hurteth the eies, and maketh 2 man dim fighted, dulleth the fences, engendreth windines, and prouoketh ouermuch fleepe, efpeci-
ally being eaten rawe.

\section{Of Sea Onion. Chap.85. * The defcription.}

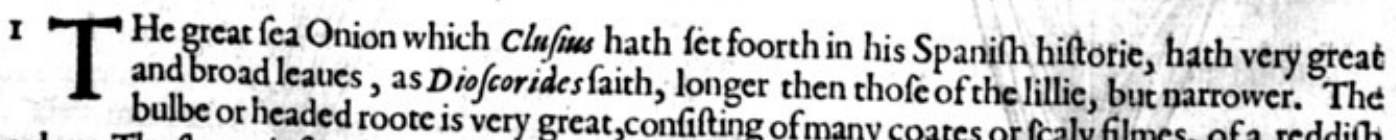
colour. The flower is fomtimes yellow, fomtimes purpling of many coates or fcaly filmes, of a reddifh 2 The fea Onion of Valentia, or rather the fea Daffodill fomtimes of a light blew. row, like thofe of Narciffus, but fmoother \& weaker, lying vpon many long andfat leaues, and nara ftalke a foote high bare \& naked, bearing at the top a tuft of white flowers, in fhape like vnto our
common yellow Daffodill. The feede is inclofed in very foft, in thape like vnto the feedes of great, white, long and bulbus. 

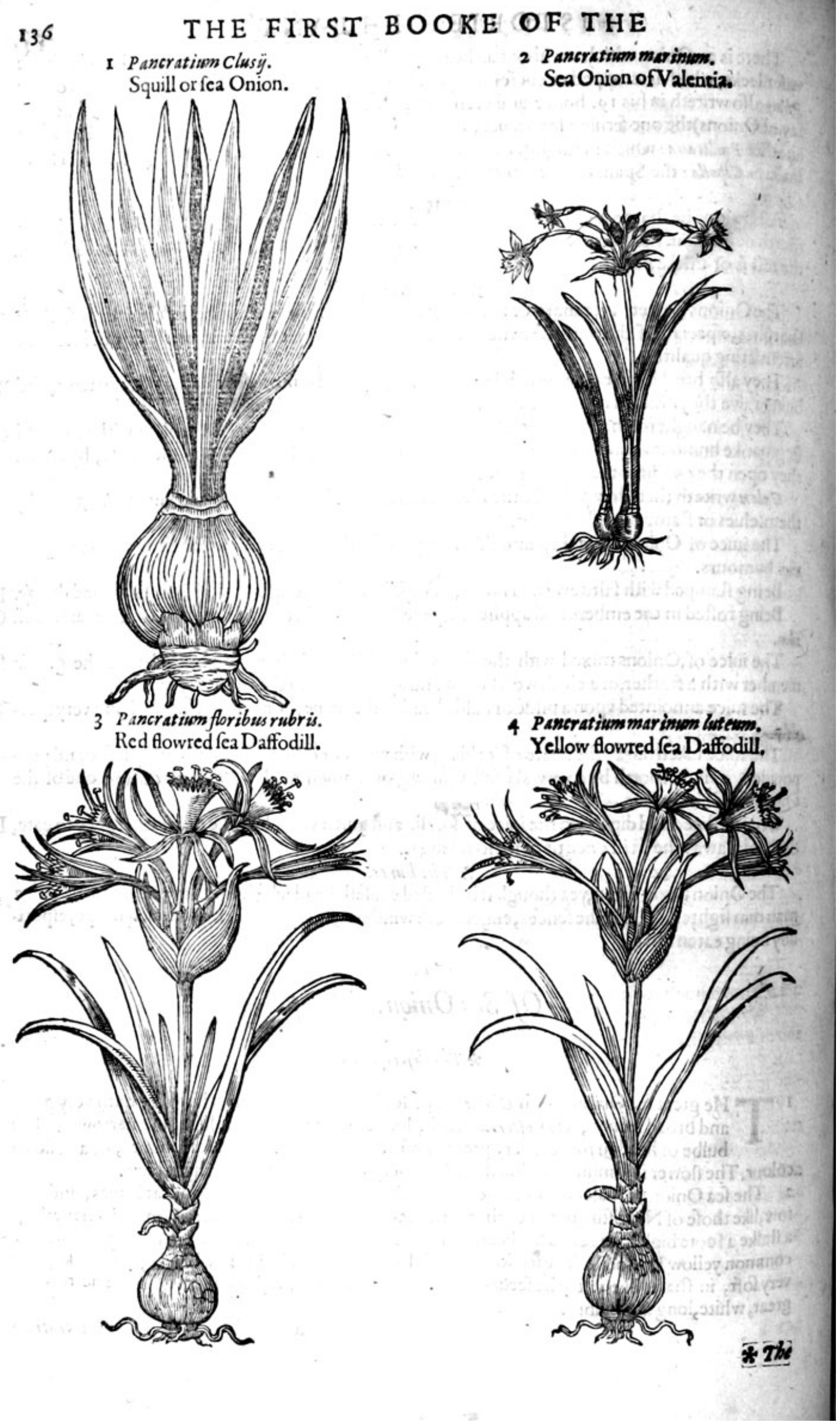


\section{HISTORIE OF PLANTS.TT}

* The defcription.

3 Red flowred fea Daffodill or fea Onion, hath a great bulbe or roote like vnto the precedent; the leaues long, fat, and fharpe pointed. The ftalke bare and naked, bearing at the top fundry faire red flowers, in hape not much vnlike to the common Daffodill.

4. The yellow flowred fea Daffodill or fea Onion, hath many thicke fat leaues like vnto the common Squill or fea Onion: among which rifeth vp a tender ftraight ftalke full of itice, bearing at the top many fowers like the common yellow Daffodill. The feede and roote is like the precedent.

\section{* The place.}

The firft is found in Spaine and Italie, not far from the fea fide.

The fecond alfo neere vnto the fea in Italy, Spaine, and Valenti.. I have had plants of them brought me from fundry parts of the Mediterrane fea fide, as alfo from Conftantinople, where it is numbred among the kinds of Narciffus.

The thirde groweth in the fandes of the fea, in moft places of the coaft of Narbone, and about Montpelier.

The fourth groweth plentifully about the coafts of Tripolie and Alopo neere vnto the fea, and alfo in the falt marfhes that are fandie and lie open to the aire.

* The time.

They flower from May to the end of Iuly, and their feede is ripe in the end of Auguft. $*$ The names.

The firft is called of the Grecians sximax : and of the Latines alfo Scilla : the Apothecariesname it

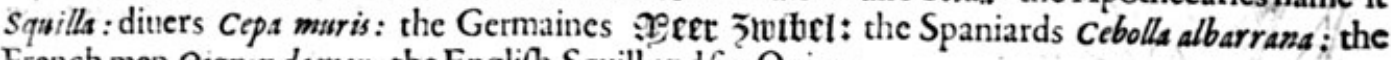
French men Otgnon demer : the Englifh Squill and fea Onion.

The feconde is called Hemerocallis Valentina : of the Turkes Confambach: in Greeke raxneginor : and likewife in Latine Pancration : in Fnglifh the white fea Daffodill or fea Onion, and of fome Nar. ctffis Codfantinupolitanus.

\section{* The temperature.}

The fea Onion is hot in the fecond degree, and cutteth very much as $G$ alen faith, if is beft when it is taken baked or rofted, for fo is the vehemencie of it taken away.

\section{* The vertues.}

The roote is to be couered with pafte or claie (as Diofcorides teacheth) and then put into an $\mathbf{A}$ ouen to be baked, or elfe buried in hot embers till fuch time as it be throughly rofted: for not being fo baked or rofted it is very hurtfull to the inner parts.

It is likewife baked in an earthen pot clofe couered, \& fet in an ouen. That is to be taken efpecially B which is in the middeft, which being cut in peeces muft be boiled, but the water ftill to be changed, till fuch time as it is neither bitter nor fharpe : then muft the peeces be hanged on a thred and dried in the fhadow, fo that no one peece touch an other.

Thefe flices of the Squil are vfed to make oile, wine, or vineger of Squill.Of this vineger of Squill C is imadean oximell or fharpe firupe. The vfe wherof is to cut thicke, tough, and clammic humours.

This rofted or baked Onion is mixed with potions and other medicines which prouoke vrine, D and open the ftoppings of the liuer \& fpleene, and is alfo put into treacles. It is giuen to thofe that haue the dropfie, the yellow Iaundife, and to fuch as are tormented with gripings of the belly, and is ved in a licking medicineagainft an old rotten cough, and for fhortneffe of breath.

One part of this Onion being mixed with eight parts of falt; and taken in the morning fafting to $\mathrm{E}$ the quantitic of a fpoonfull or two, loofech the belly.

The inner partof Squilla boiled in oile \& turpeneine, is with great profit applied to the chaps or F chilblanes of the feete or heeles. It driueth foorth long and round wormes if it be giuen with honie
and oile.

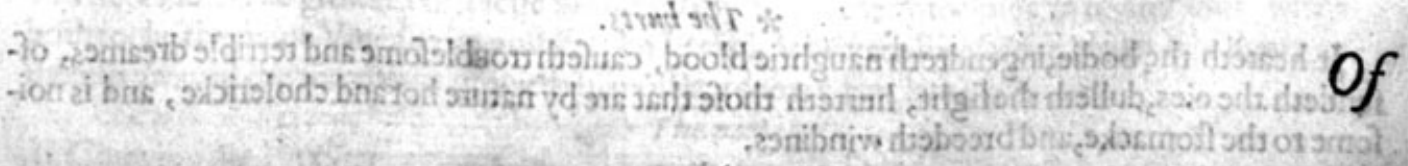




\section{Of Leekes Cbap.86.}

Porram.

Leekes.

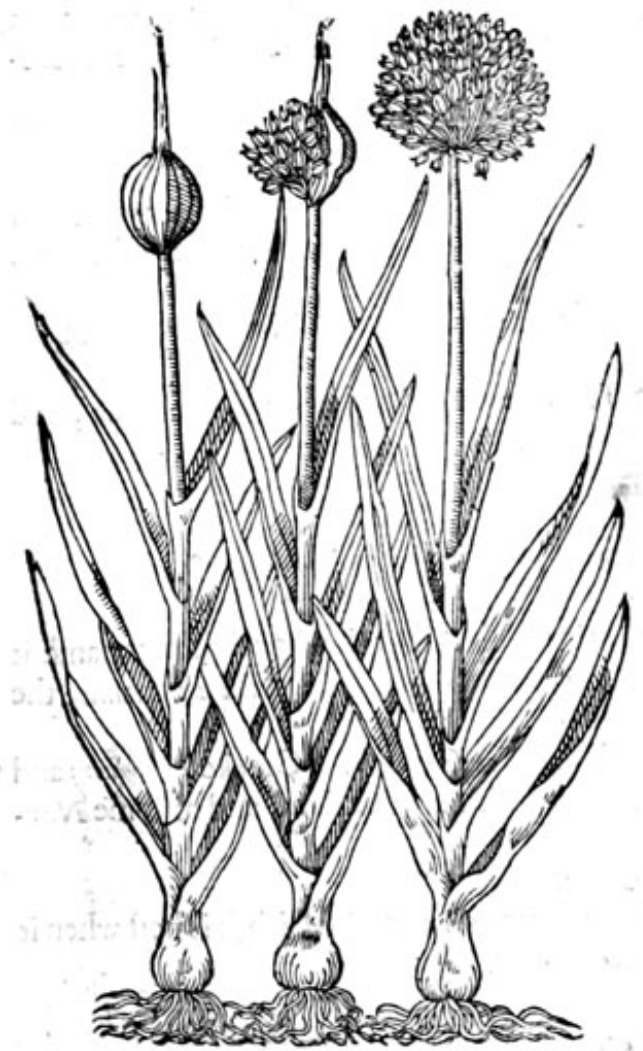

\section{* The defcription.}

7 He lealues or the blades of the Leeke be long, fomwhat broad, \& very many, hauing a keele or creft in the backfide, in finell and tafte like vnto the Onion. The ftalkes if the blades be not often cut, do in the fecond or thirde yeere grow vp round, bringing foorth on the top flowers made vp in a rounde head or ball, as doth the Onion: the feedes are like. The bulbe or roote is long and flender, efpecially of the vnfet Leeke: that of the other Leeke is thicker and greater.

$$
\text { * T'beplace. }
$$

It requireth a meane earth, fat, well dunged and digged. It is very common euery where in other countries as well as in England.

$$
\text { * The time. }
$$

It may be fowen in March or Aprill, and is to be remooued in September or Oetober.

$$
\text { * The names. }
$$

The Grecians call it redion : the Latines Porrum: The Emperour 2 (ero had great pleafure in this roote, and therefore he was called in fcorne Porro. phagus. But Palladisus in the mafculine gender calleth it Porrus: the Germaines L aucb:the Brabanders 1 Poztetie : the Spaniards Puerro : the French Porr eau : the Englifhmen Leeke or Leekes.

\section{* The temperature.}

The Lecke is hot and dry, and doth attenuate or make thin, as doth the Onion.

* The vertues.

A Being boiled it is leffe hurtfull by reafon that it lofeth a great part of his (harpenes: and yet being fo ved, it yeeldeth to the body no good iuice. But being taken with colde herbes, his qualitie is tempered.

B Being boiled and eaten with Ptifana, or barly creaine, it concocteth and bringeth vp rawe humors that lie in the cheft. Some affirme it to be good in a loch or licking medicine, and to clenie the pipes of the lunges.

C The iuice drunke with honie is profitable againft the bitings of venemous beafts, and likewife the leaues ftamped and laid thereupon.

D The fame iuice with vineger, frankenfence and milke, or oile of rofes dropped into the eares, $\mathrm{mi}$ tigateth their painc, and is good for the noife in them.

E Two drams,or a quarter of an ounce of the feede, with the like weight of Myrtill berries being drunke, ftoppeth the fpitting of bloud which hath continued a long time. The fame put into wine keepeth it from fowring, and being already fower it correcteth the fame as diuers write. It cutteth groffe and tough humours.

* The hurts.

It heateth the bodie, ingendreth naughtie blood, caufeth troublefome and terrible dreames, offenceth the cies, dulleth the fight, hurteth thofe that are by nature hot and cholericke, and is noifome to the ftomacke, and breedech windines. 


\section{Of Cines, Chines, or wilde Leekes. Chap.87.}

* The kinds. * The kinds.
Here be diuers kindes of wilde Leekes, fome wilde, and fome of the garden, as fhall be decla-
red.Thofe called Ciues, haue been taken of fome for a kinde of wilde Onion: but all the aus: thors that I haue been acquainted with, do accord that there is not any wilde Onio n.

I Schaenoprafon.

Ciucs or Chiues.

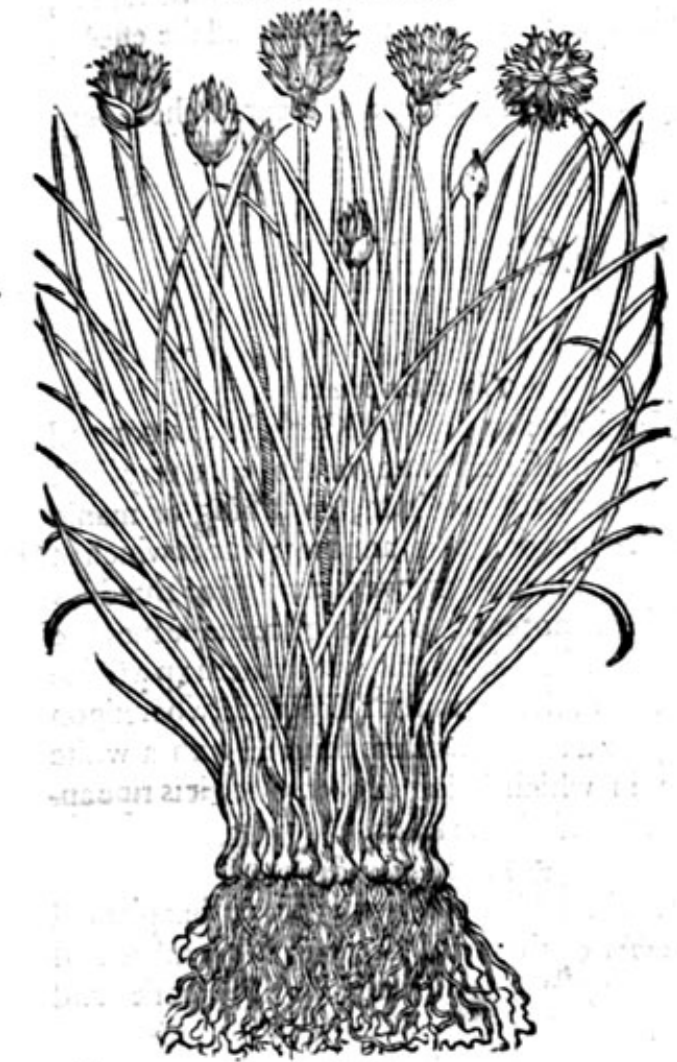

2 Porrum Tonfile.

French Leckes or Vine Leekes.

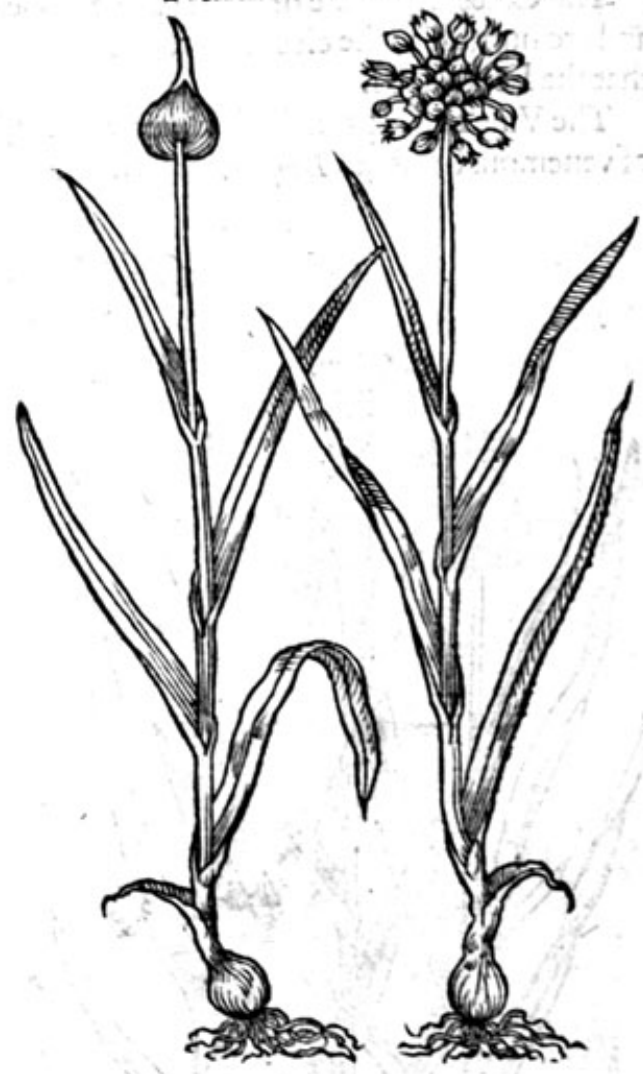

* The defcription.

I Iues bringeth foorth many leaues about a handfull high, long,flender, round, like to little rufhes: among which grow vp fmall and tender ftalks, fending foorth certaine knops with flowers like thofe of the Onion, but much leffer. It hath many little bulbes or headed rootes faftried togither, out of which grówe downe into the earth a great number of littleftringes, and hath both the fmell and tafte of the Onion and Leeke, as it were participating of both. 2. The vine Leeke or French Leeke, groweth vp with blades like thofe of Leekes. The ftalke is a cubithigh: on the top where of ftandeth a round head or button, couered at the firft with a thin skin, which being broken, the flowers \& feedes come foorth, like thofe of the Onion. The bulbe or headed roote is round, hard and found, which is quickly multiplied by fending foorth many bulbes.

* The place and time.

Ciues are fet in gardens, they florilh long, and continue many yeeres, they fuffer the colde of $A$ winter. They are cut and polled often, as is the vnfet Leeke.

- The Vine Leeke groweth of it felfe in vineyatds, and neere vnto vines in hot regions, whereof it both tooke the name Vine Leeke and French Leeke! It beareth his greene leaues in winter, and wi. thereth away in the fommer: it groweth in moft gardens in England.

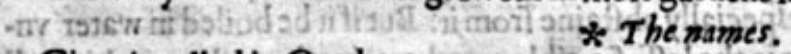

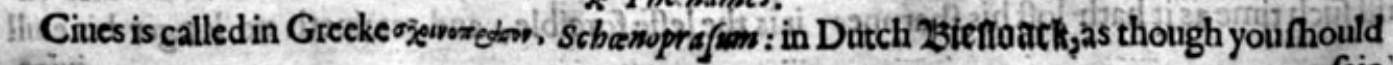
रुजing 
faie Inncewm Porrum, or Rufh Leeke: in Englifh Ciues, Chiues, Ciuet and Sweth: in French Brelles.

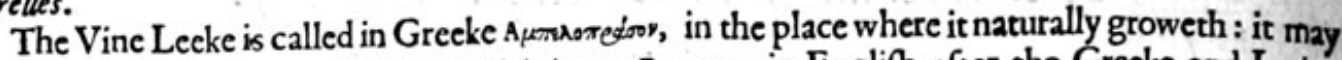
be called in Latin Porrum Vitiwn, or Vitiginewon Porrum: in Englifh after the Greeke and Latine VineLeeke, or French Leeke.

\section{* The temperature.}

Ciues are like in facultie vnto the Leeke. They are hot and drie. The Vine Leeke heatech more then doth the other Leeke.

* The vertues.

The Ciues attenuate or make thinne, open, prouoke vrine, ingender hotte and grofle vapors, and are hurtfull to the eies and braine. They caufe troublefome dreames, and worke all the effects, that the Lecke doth.

The Vine Leeke prouoketh vrine mightily, and bringeth downe the flowers. It cureth the bitings of venemous beafts, as Diofcor ides writeth.

\section{OfGarlick. Chap.88.}

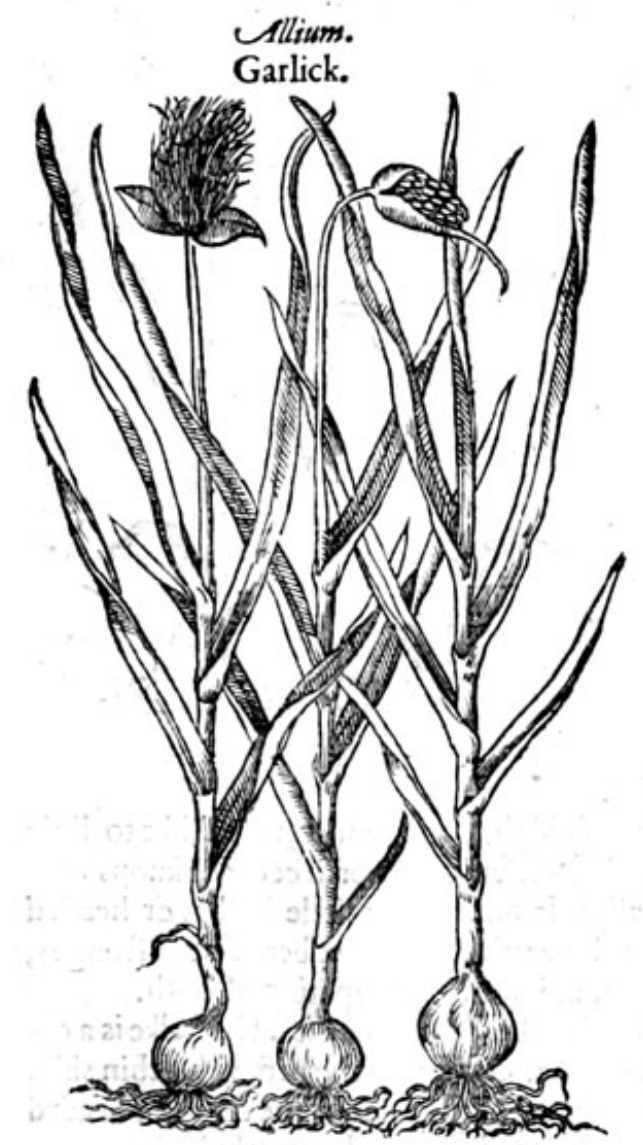

* The defcription.

He bulbe or head of Garlicke, is couered with moft thin filmes or skins, of 2 very light white purple colour, confifting of manie cloues feuered one from another; vnder which in the grounde belowe groweth a taffell of threddes in fteede of rootes: it hath long greene leaues like thofe of the Leeke, among which rifeth vp 2 ftalke at the end of the fecond or third yeere, whereupon doth grow a tuft of flowers couered with a white skinne, in which being broken when it is ripeap. peereth round blacke feeds. * The place and times.

Garlick is feldome fowen of feede, butplanted in gardens of the fmall cloues in Nouember and December, and fometimes in Februarie and March.

\section{* The names.}

It is called in Latine Lllium : in Greeke orjesson the apothecaries keepe the Latine name: the Germaines call it Hantublaucb: the low Dutch 1 ook: the Spaniards Aios, Wilho : the Italians Ualio: the French Sil or Aux : the Bohemians Czefnek: the Englifh Garlicke and poore mens Treacle. * The temperature.

Garlick is very fharpe, hot, and drie, as Galen * The vertues. faith, in the fourth degree, and exulceratech the skin by raifing of blifters.

A Being eaten it heateth the bodic extremely, attenuateth and maketh thin, thicke and groffe humors; cutteth fuch as are tough and clammie, digefteth and confumeth them, alfo openeth obftructions, is an enimie to all colde poifons, and to the bitings of venemous beafts : and therefore Gslen nameth it $T$ heriaca rusticortom, or the husbandmans Treacle.

B It yecldeth to the body no nourifhment at all,it engendreth naughtie and fharpe blood. Therefore fuch as are of a hot complexion nuft efpecially abftaine from it. But if it be boiled in water vntill fuch time as it hath loft his tharpnes, it is the leffe forcible, and retaineth no longer his eull 


\section{HISTORIE OF PLANTS.}

iuice,as Galen writeth.

It taketh away the roughnes of the throte, it helpeth an old cough, it prouoketh vrine, it breaketh C and confumeth winde, it is a remedie for the dropfie proceeding of a colde caufe.

It killeth wormes in the belly, and driueth them foorth. The m! lke alfo wherein it hath been fod-D den, is gituen to yoong children with good fucceffe againft the wormes.

It helpeth a colde itomacke, and is a preferuatiue againft the contagious and peftilent aire. E

The decoetion of Garlicke vfed for a bathe to fit ouer, bringeth downe the flowers and fecon- F dines or afterburthen, as Diofcorides faith.

It taketh away the morphew, tetters or ringwoormes, fcabbed heads in children, dandrafe and $\mathbf{G}$ fcurfe, tempered with hony and the parts annointed therewith.

With figge leaues and cummin it is laide onagainft the bitings of the moufe, called in Greeke $\mathbf{H}$ $\mu v$ pins : in Englifh a Shrew.

\section{Of wildeGarlick. Chap.89.}

\section{* The defcription.}

I He wilde Garlike or crow Garlick hath fmall tough leaues like vnto rumes, fmooth and hollow within : among which groweth vp a naked ftalke, round, flipperie, hard and found: on the top where of after the flowers be gone, growe little feedes, made vp in a rounde clufter like fmall kernels, hauing the finell and tafte of Garlick. In fteede of a roote there is $\mathbf{2}$ bulbe or rounde heade without any cloues at all.

2 Ramfons fendeth foorth two or three broade leaues fharpe pointed, fmooth and of a light greene colour. The ftalke is a fpan high, fmooth and flender, bearing at the top a clufter of white flowers. In ftced of a roote it hath a long flender bulbe, which fendeth down a multitude of ftrings, and is couered with skins or thin coates.

I Sillium fyluestre. Crowe Garlick.

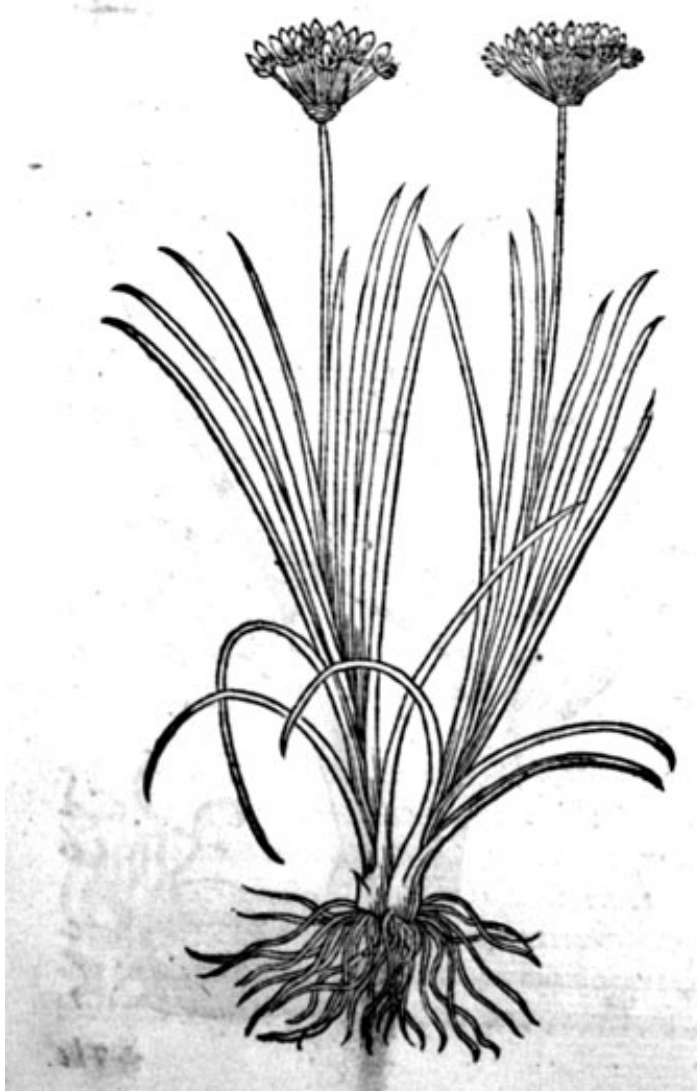

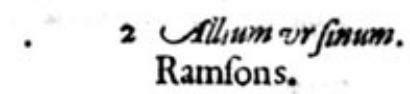
Ramfons.

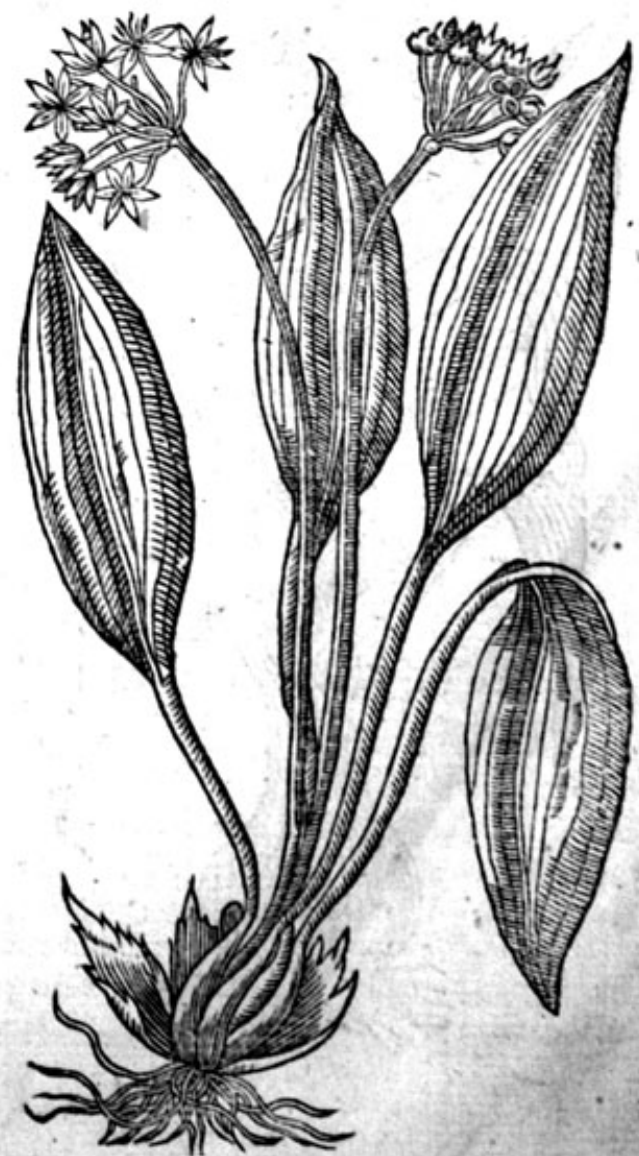


* The time.

They fpring vp n Aprill and May. Their feede is ripe in Auguft. * The place.

The Crow Garlicke groweth in fertill paftures in all parts of England. I founde it in great plentie in the field called the Mantels, on the backfide of Iflington by London.

Ramfons doe grow in the woods and borders of fields vnder hedges among the bufhes. I found it in the next field vnto Boobies barne, vnder that hedge that bordereth vpon the lane, and 21fo vpon the left hand vnder a hedge adioining to a lane that leadech to Hampiteede, both places neere London.

$*$ The names.

Both of them be wilde Garlicks, and are called in Latin cullia fyluestria: in Greeke oxieedx àzera: but the Crow Garlick is called of Diofcorides oquerroestov, that is to faie Unguinum alliwm, or Snakes Garlick,and of fome Ceruimum allium, Harts Garlick,or Stags Garlick.

Ramfons are named of the later practitioners A 1 lium V r fonum, or Beares Garlick : Cilliwm Latifoliwm, and CMoly Hippocraticum : in Englifh Ramfons, Ramfies, and Buckrams.

$$
* \text { The nature. }
$$

The temperatures of thefe wilde Garlicks are referred vnto thofe of the garden. * The vertues.

A Wilde Garlick or Crow Garlick as Galen faith, is ftronger and of more force then the garden Garlicke.

B The leaues of Ramfons be ftamped and eaten of diuers in the low countries with filh for 2 fauce, euen as we do eate greene fauce made with forrell.

C The fame leaues may very well be eaten in April and Maie with butter, of fuch as are of a ftrong conftitution, and laboring men.

D The diftilled water drunke breaketh the ftone, and driueth it foorth and prouoketh vrine.

3 Scorodoprafiam.

Great mountaine Garlick.

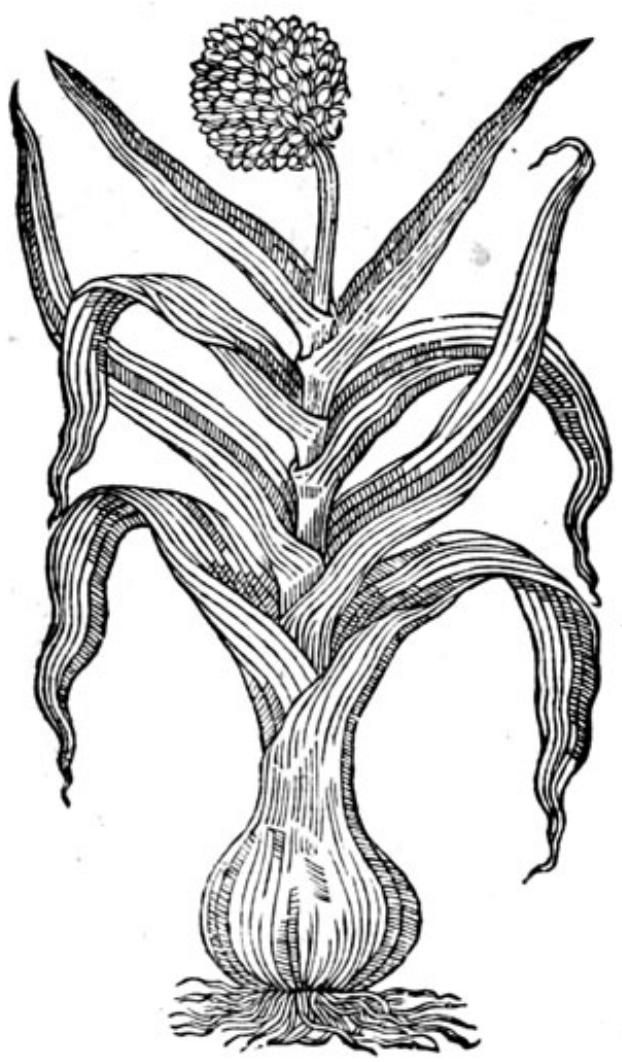

4 Allium Alpinum latifoliwm feu viltorialis. Brode leaued mountaine Garlick.

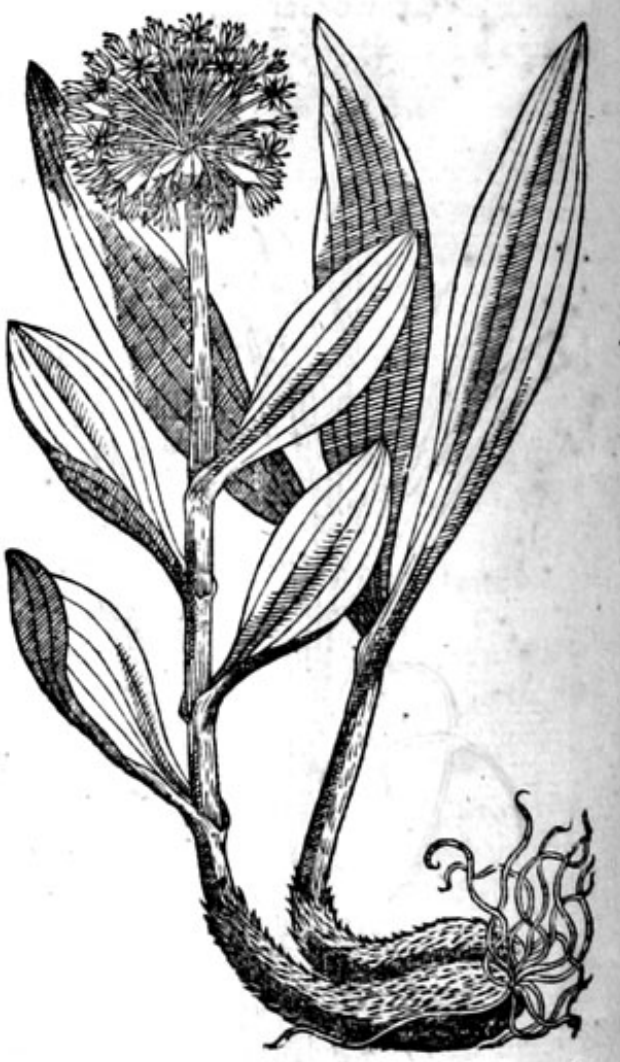




\section{HISTORIE OF PLANTS.}

* The defoription.

3 The great mountaine Garlicke hath long and brode leaues like thofe of Leekes, but much grea. ter and longer,embracing or clafping about a great thicke ftalke, foft and full of iuice, bigger thena mans finger, and bate toward the top: vpon which is fet a great head, bigger then a tennife ball, couered with a skin after the maner of an Onion. The skin when it commeth to perfection break, eth, and difclofeth a great multitude of whitifh flowers, which being paft, blacke feedes followinclofed in a three cornered huske. The roote is bulbus of the bignes of a great Onion. The whole plane fmelleth very ftrong like Garlick, and is in Shew a Leeke, whereupon it was called Scorodoprafwem, as if we fhould faic, Garlick Leeke,participating of the Leeke and Garlick, or rather 2 degenerate Garlick growen monftrous.

4 The brode leaued mountaine Garlicke, or rather the mountaine Ramfons, rifeth vp with a ftalk of a cubite high, a finger thicke, yet very weake, full of fpungious fubftance, neere to the bottom of a purplifh colour, and greene aboue, bearing at the top a multitude of fmall whitith flowers, fomwhat gaping,ftar fafhion. The leaues are three or fower, brode ribbed like the leaues of great Gentian, se. fembling thofe of Ramfons, but greater. The roote is great and long, couered with many fealey, cotes, and hairie ftrings. * Theplace.

The great mountain Garlick groweth about Conftätinople as faith $\operatorname{clu}$ frus. I received a plant of it from M.T ho Edwards apothecarie in Excefter, who found it growing in the weft parts of England.

Vifforialis groweth in the mountaines of Germanie, as faith Carolus Clufius, and is yet a ftranger in England for any thing that I dioknow.

\section{Of Moly, or the Sorcerers Garlick. Chap.90. * The kindes.}

$T$ Here be diuers forts of Moly written of by fundrie of the ancients, which thall be defcribed in this prefent chapter.

I Moly Diofcoridewen. Diofcorides his Moly.

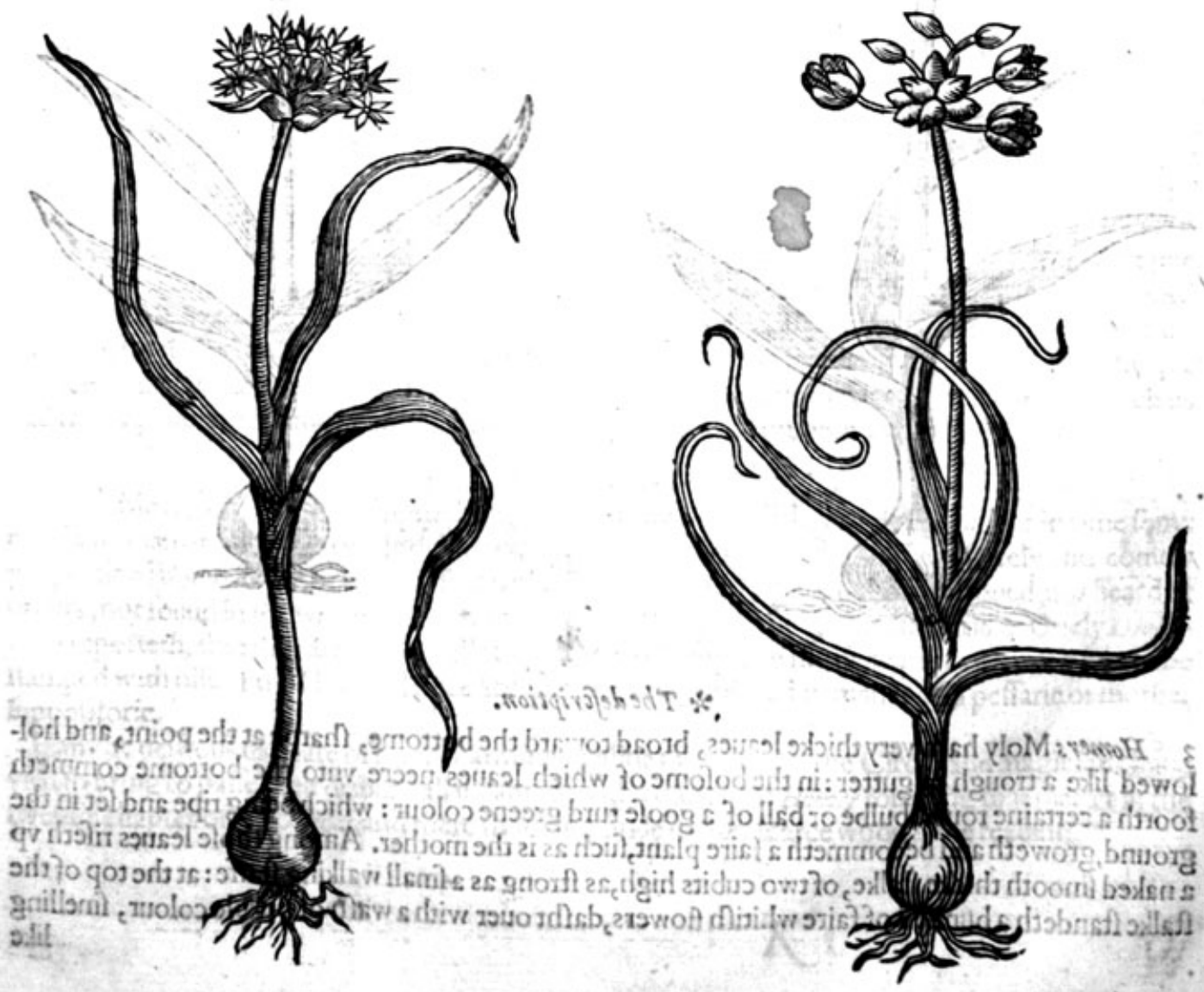

2 Moly Serpentinuem. Serpents Moly. 
I He firft kinde of Moly hath for his roote a little whitith bulbe fomewhat long, not vnlike to the roote of the vnfet Leeke, which fendeth foorth leaues like the blades of corneor graffe: among which doth rife vp a flender weake ftalke, fat, and full of iuice, at the top where of commeth foorth of a skinnie filme a bundell of milke white flowers, not vnlike to thofe of Ramfons. The whole plant hath the fmell and tafte of Garlick, whereof no doubt it is a kinde. 2 Serpents Moly hath likewife a fmall bulbus roote with forne fibres faftened to the bottome; from which rife vp weake graffie leaues, of a fhining greene colour, crookedly winding and turning themfelues toward the point like the taile of a Serpent,wherof it tooke his name. The ftalk is tough, thicke, and full of iuice: at the top whereof ftandeth a clufter of fmall red bulbes, like vnto the $\mathrm{fm}_{2}$. left cloues of Garlick, before they be pilled from their skinne. And among thofe bulbes there doe thruft foorth fmall and weake footeftalkes, euery one bearing at the end one fmall white flower tenting to a purple colour: which being paft, the bulbes do fall downe vpon the ground, wherethey without helpe do take hold and roote, and thereby greatly increafe, as alfo by the infinite bulbes thar the roote doth caft off: all the whole plant doth fmell and taft of Garlick whereof it is alfo akinde.

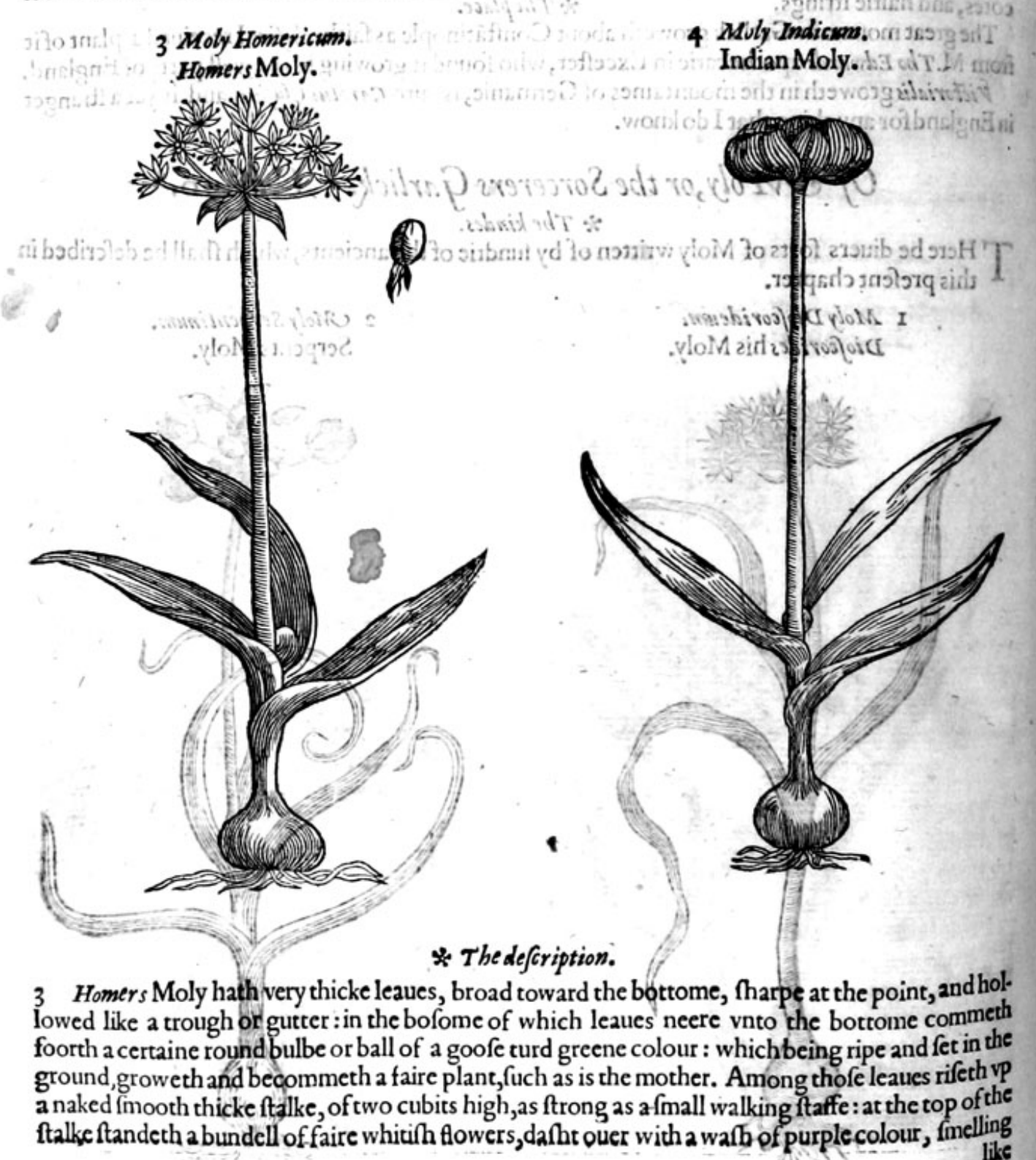


like the flowers of Onions. When they be ripe there appeereth a blacke feede wrapped in a white

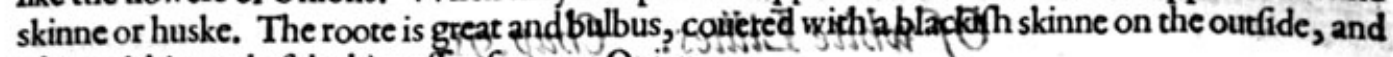
white within, and of the bignefle of a great Onion.

4 Indian Moly hath very thicke fat fhorc leaues and harpe pointed: in the bofome whereof commeth foorth a thicke knobbie bulbe like that of Homers Moly. The ftalke is alfo like the precedent, bearthy at the to $\mathrm{p}$ a clututer of fcalie bulbesincladed in arge thinne skin or fime. The rogre

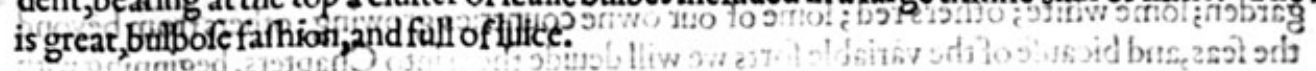

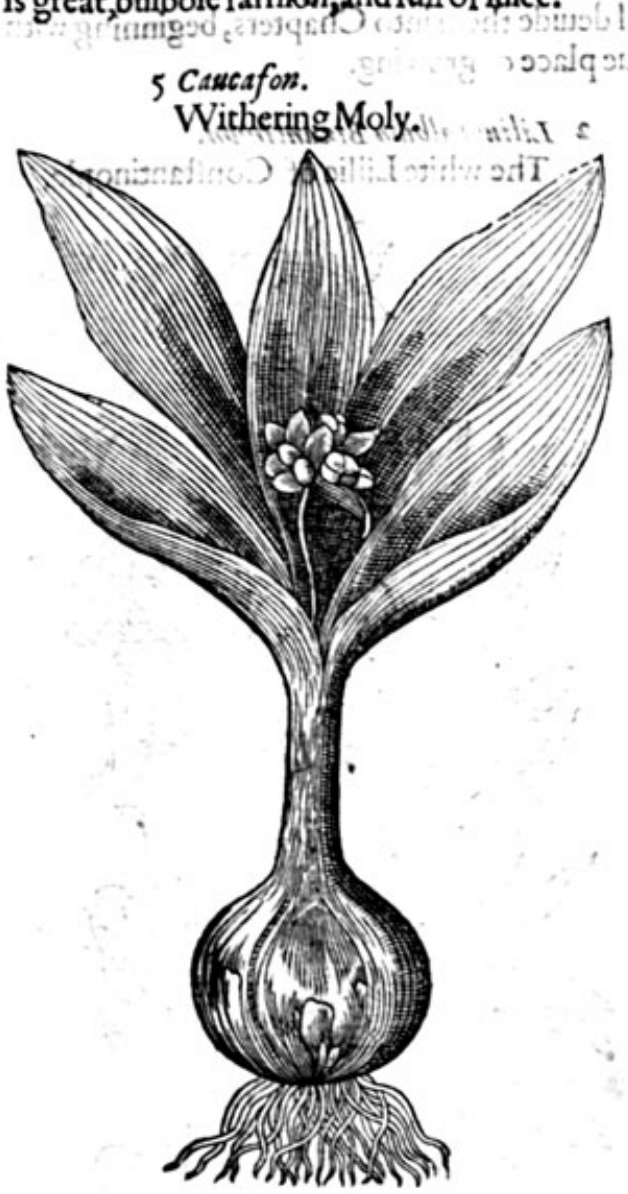

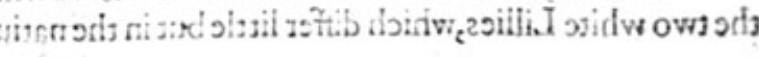

* The defariptiont. I I

5 Caucafon or withering Moly, thath a very great bulbus roote, greater than the roote of Homers Moly, and fuller, of a flimie iuice : from which doe arife three or fower great thicke and broad leaues withered alwaies at the pointe, wherein confifteth the differencebetweene thefe leates, and thofe of Homers Moly, which are not fo. In the middle of the leaues rifeth vp abunchiof fmooth grecnifh bulbes fet vpon a tender footeftalke, inf hape and bigoeffe like to a great garden worme, which being ripe and planted in the earth, doth alfogrowe vnto a faire plant like vnto the mother.

$$
* \text { The place. }
$$

Thefe plants do grow in my garden, as alfo in the gardens of Mafter lames Garret Apothecarie, and Mafter Garths,a worfhipfull gentleman and expert in the knowlege of plants.

They fpring foorth of the grounde in February, and bring foorth their flowers, fruit, and feed, in the end of Augurt.

* The names.

Some of the Greeke writers haue deriued the names of thefe plants $M$ Mly, from the Greeke word

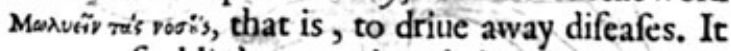
may profitablie be argued, to belong to a certaine bulbofe plant, moft like to Garlick, by thewoord Morrusa, which Hippocrates and Galen doe expound and call a Garlick head, giuing that interpretation to the Greeke word. As for repeating of foolifh and vaine figments, the conuring of witches, \& magicians inchantments, which haue beene attributed vnto thofe herbes, I leaue them to fuch as had rather plaie with thadowes, than beftow their wits about profitable and ferious matters.

Thefe $*$ The temperature and vertues.

Thefe Molyes are very hot, approching to the nature of Garlick, not doubting but in time fome excellent man or other will finde out as many good vertues of them, as their itately and comely proportion fhould feeme to be poffeffed with. But for my part, I haue neither prooued, nor heard of others, nor found in the writings of the ancients any thing touching their faculties. Onely Dio/co rides reporteth, that they are of maruellous efficacie to bring downe the tearmes, if one of thembe ftamped with oile of the Flower-deluce according to art, and vfed in maner of a peffarie or mother
fuppofitorie.

If any be defirous to heare of their charming qualities, wherewith the Circes andmagicians have vfed to bring to paffe their diabolicall incantations, let them read Homer touching that matter in the twenticchapter of his $\mathrm{Ody}$ Ses, and there fhall they finde matter fcarce woorth the reading. 


\section{Of white Lillies. Cbap.91.}

* The kindes.

$\mathrm{T}$

Here be fundry forts of Lillies whereof fome be wilde, or of the field; others tame, or of the garden; fome white; others red; fome of our owne couneries growing; others from beyond the feas, and bicaufe of the variable forts we will deuide them into Chapters, beginning with the two white Lillies, which differ little but in the natiue place of growing.

I Litioñ albrom. The white Lillie.

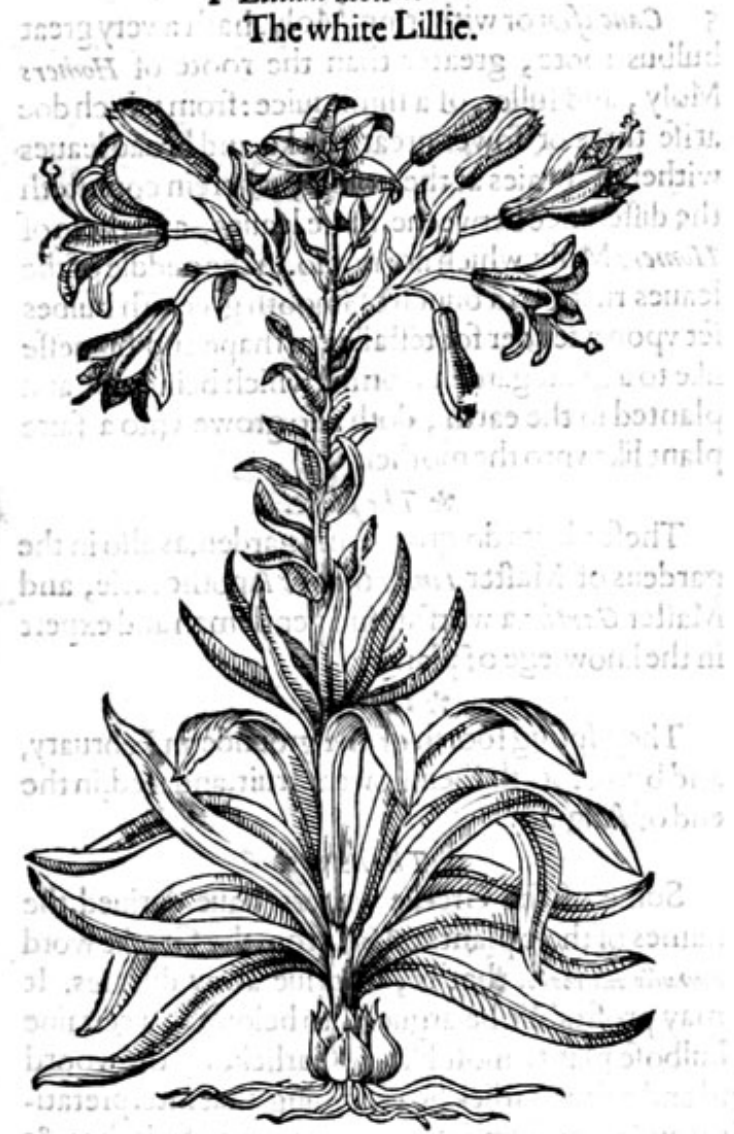

2 Lilium album Bizentinum. The white Lillie of Conftantinople.

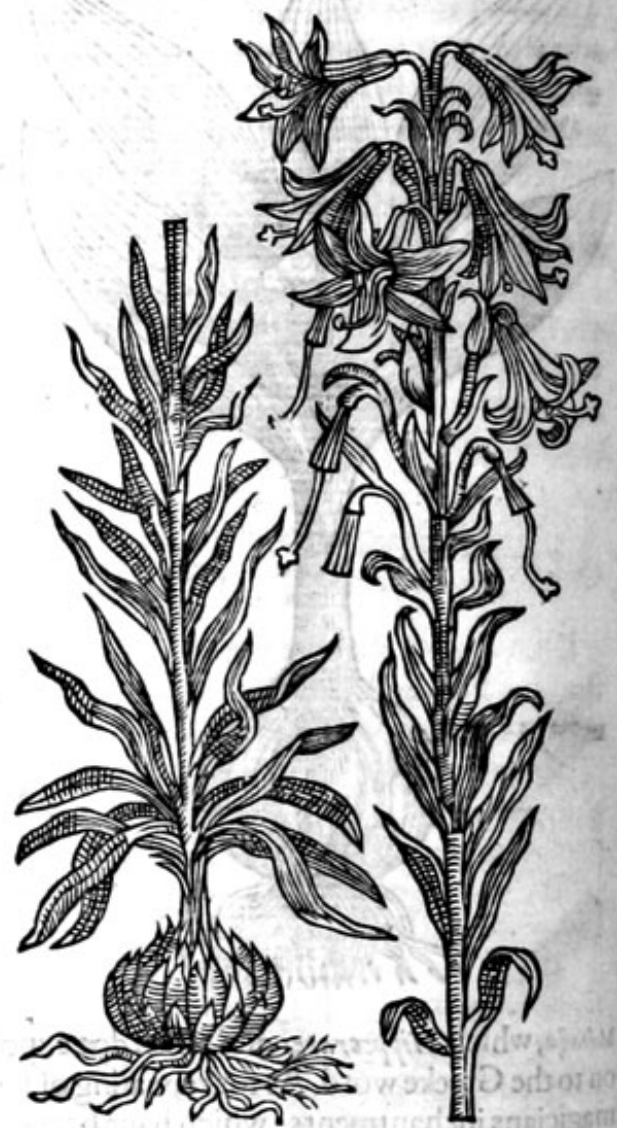

* The defcription.

$\mathbf{r}$

He white Lilly (which in beauty and brauerie excelled Salomon in his greateft roialtie)hath long, finooth, and full bodied leaues, of a graffie or light greene colour. The ftalkes betwo cubits high, and formtimes more, fet or garnifhed with the like leaues, but growing fmaller and fmaller toward the top: and vpon them do grow faire white flowers, ftrong of fimell, narrow toward the foote of the ftalke whereon they do grow, wide or open in the mouth like a bell. In the middle part of them do grow fmall tender pointels tipped with a duftie yellow colour, ribbed or chamfered on the backe fide, confifting of fixe fmall leaues thicke and fat. The roote is a bulbe made of fcaly cloues, full of tough and clammic iuice wherewith the whole plant doth greatly abound. 2 The white Lillie of Conftantinople hath verylarge and fat leaues like the former, but narrower and leffer. The ftalke rifeth vp to the height of three cubits, fet and garnifhed with leaues alfo lile the precedent, but much leffer. Which ftalke oftentimes doth alter and degenerate from his naturall roundneffe to a flat forme, as it were a lath of wood furrowed or chaneled alongtt the fame, as it were ribbes or welts. The flowers growe at the top like the former, fauing that the leaues doe turne 


\title{
I HIS TORTEOOF PISANTS. I I
}

themfelues more backward like the Turkes cap, and beareth many more flowers than our Englifh white Lillie doth.

\author{
* Theplace.
}

Our Englifh white Lillie groweth in moft gardens of England. The other groweth naturally in Conftantinople and the parts adiacent, from whence we had plants for our Englifhigatdens, where they flourilh 25 in their owne countrey.

The Lillies do flower from May to the end of Iune.

$$
\begin{aligned}
& \text { * Thetime } \\
& \text { end of Iune. }
\end{aligned}
$$

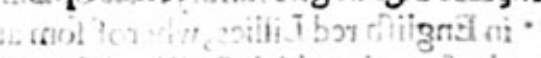

* The names.

The Lillie is called in Greeke xarraina : in Latine Lilizom, and alfo Rofa Lubronis, or Innos rofe, bicaufe $2 s$ it is reported, it came vp of hir milke that fell vpon the ground. For the Poets faine that Hercules whom Iupiter had by Alcwmena, was put to Iunos brefts whileft the was a fleepe; \& after the fucking, there fell away abundance of milke, and that one part was fpilt in the heauens, and the other on the earth, and that of this fprang the Lillie, and the circle in the beauens called Lactews Circulus, or the milkie way, or otherwife in Englifh Watling ftreete.D. Bafilius in the explication of the 44. Pfalme faith, that no hearbe doth fo liuely fet foorth the frailtie of mans life as the Lillie. It is called in high Dutch चeleffz Btlyen: in low Dutch critte Litien : in Italian Giglio : in Spanifh Lirio blanco : in French Lys blanc: in Englifh the white Lillie.

The other is called Liliven album Bizantinum, and alfo Martagon album Bizantinum : in Englifh the white Lillie of Conftantinople : of the Turkes themfelues Sultan Zambach, with this addition that it might be the better knowen which kinde of Lillie they ment, when they fent rootes of them into thefe countries Fa fiori grandi Bianchi, fo that Sultan Zambach, Fafiori grandi Dianchi, is as much to fay, Sultans great Lillie with white flowers.

\section{* The nature.}

The white Lillie is hot and partly of a fubtile fubitance. But if you regard the roote, it is drie in the firft degree, and hot in the fecond.

* The vertues.

The roote of the garden Lillie ftamped with honie, gleweth togither finewes that be cut in fun- A der. It confumeth or fcoureth away the vlcers of the head called Achores, and likewife-all fcuruineffe of the beard and face.

The roote ftamped with vineger, the leaues of Henbane, or the meale of barly, cureth the tumors B and apoftemes of the priuie members. It bringeth the haire againe vpon places which haue beene burned or fcalded, if it bemingled with oile or greafe, and the place therewith annointed.

The fame rofted in the embers and ftamped with fome leuen of rie bread and hogs greafe, brea- C keth peftilentiall botches. It ripeneth apoftemes in the flankes comming of venerie and fuch like.

The flowers fteeped in oile oliue and fhifted two or three times during fommer, and fet in the D funne in a ftrong glaffe, is good to foften the hardneffe of finewes and the hardnes of the matrix.

Florentinus friptor rei rustice faith, that if the roote be curioufly opened, and therin be put fome $\mathrm{E}$ red, blew or yellow colour that hath no caufticke or burnitig qualitie, will caufe the flowers to be of the fame colour.

Inlizs Alexandrinus faith, that the water thereof diftilled and drunke, caufeth eafie andfpedie F deliuerance, and expelleth the fecondine or after burthen in moft fpeedie maner.

Cafarim Archiater faith, the leaues boiled in fower wine, and deepe and perillous wounds fo- $G$ mented or bathed therewith, doe greatly helpe the working of the other medicines that are applied thereto, comforting the parts adioining, as Galen likewife doth report in his 7 . booke de Simplimedi:
facultati.

The roote of the white Lillie ftamped and frained with wine, and giuen to drinke for two or $\mathrm{H}$ three daies togither, expelleth poifon of the peftilence, and caufeth it to breake forth in blifters in the outward part of the skin, according to the experience of a learned gentleman mafter $V V$ illipin Godorws, Sergeant Chirurgion to the Queenes Maieftic : who alfo hath cured many of the dropfic with the iuice thereof, tempered with barly meale and baked in cakes, and fo eaten ordinatily for fome month or fixe weekes togither with nieate, but no other biead during the time. 


$$
\text { Of RedLillies. Chap. 92. }
$$

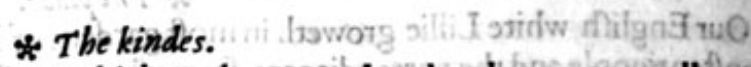

Here be likewife fundry forts of Lillies, which we do comprehend vnder one generall name:
in Englifh red Lillies, wherof fom are of our owne countries growing, and others of beyond the feas, the which fhall be diftinguifhed feuerally in this chapter that followeth.

I Lilium aur eum.

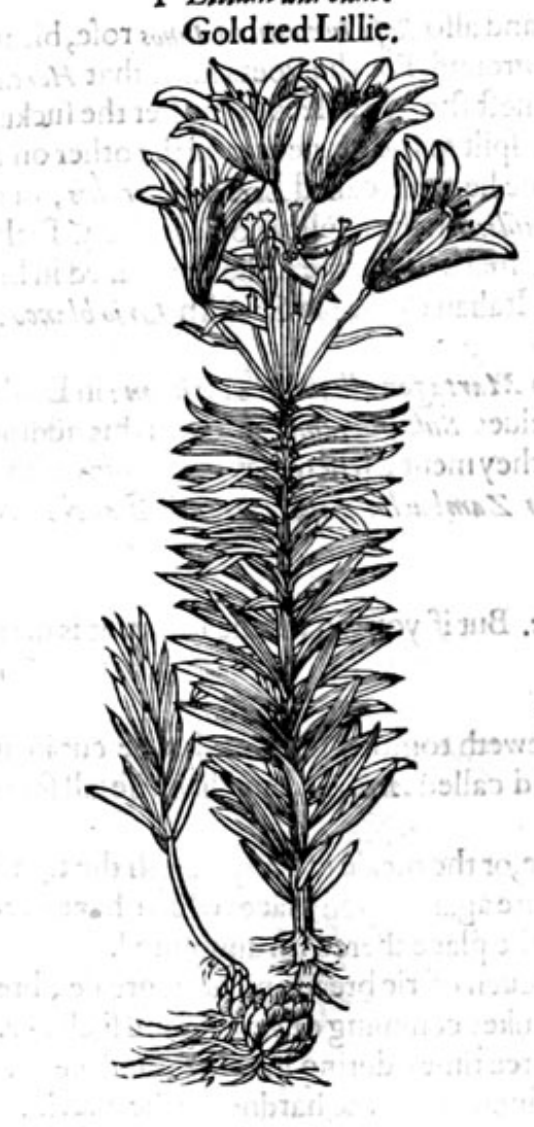

2 Lilitm rubrum. The red Lillie.

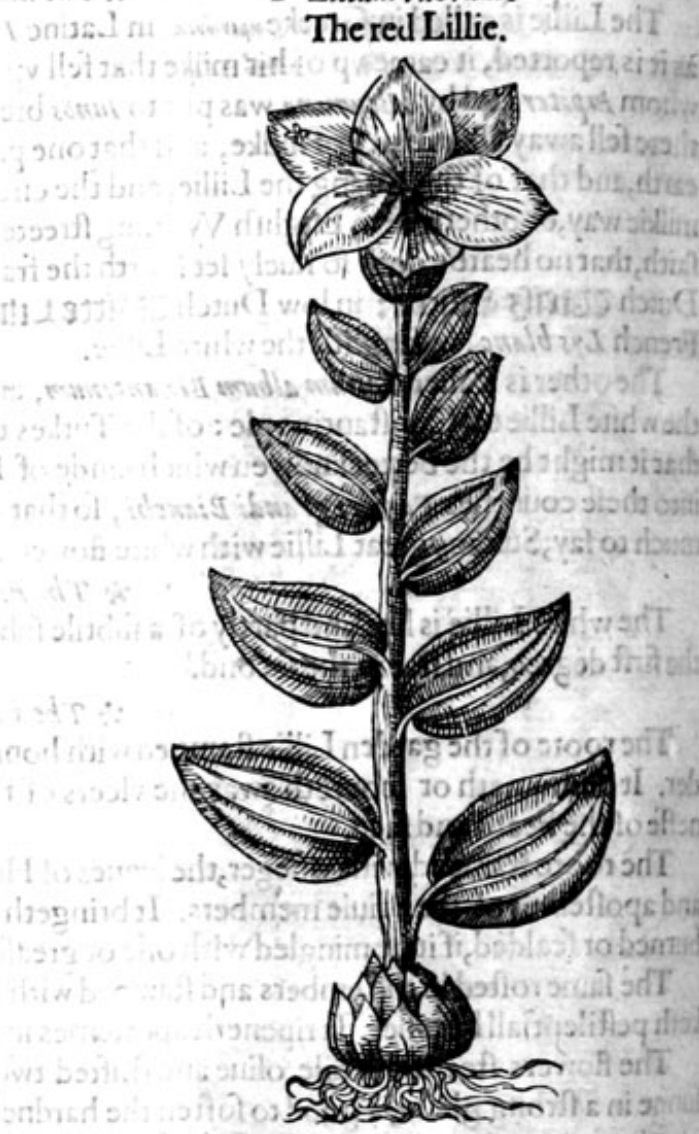

* The defcription.

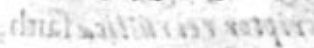

${ }^{2} \mathrm{~T}$

He gold red Lillie groweth to the height of two, and fometimes three cubits, and often higher than thofe of the common white Lillie. The leaues be blacker and narrower, fet veric thicke about the ftalke. The flowers in the top be many from ten to thirtie flowers, according to the age of the plant, and fertilitic of the foile, like in forme and greatnes to thofe of the white Lillie, but of a red colour tending to a faffron, fprinckled or poudered with many little blacke fpeckes, like to rude vnperfeet draughts of certaine letters. The rootes be great bulbes, confifting of many cloues, as thofe of the white Lillie.

2 The firie red Lillie hath rootes like the former: from the which rifeth vp a ftalke of a cubite and halfe high, fet with broad leaues like thofe of Plantaine. On the top doth grow one flower or two, feldomemany, in colour red or as the flame of fire, which quickly doth fade and perifh.

3 The great red Lillic is like vnto the former in ftature, the leaues be fewer in number, broader, \& not fo thicke fet. The flowers in thape be like the former, fauing that the colour heereofis more red, and thicke dafht with blacke f peckes. The roote is fealey like the former.

4 There is another red Lillie which hath many leaues fomwhat ribbed, broader than the laft before mentioned, but fhorter, \& not fo many in number. The ftalk groweth to the height of two cubits and 
fometimes higher, whereupon do grow flowers like the former. Among the footeftalkes of which flowers commeth foorth certaine bulbes or cloued rootes, browne of colour tending to redneflic, which do fall in the ende of Auguft vpon the ground, taking roote and growing in the fame place, whereby it greatly increafeth, for feldome or neuer it bringeth foorth feed for his propagation.

There is another fort of the red Lillies, hauing a faire fcaley or cloued roote, yellow aboue, and browne toward the bottome : from which rifeth vp a faire ftiffe fta'ke crefted or furrowed, of an ouerworne browne colour, fet from the lower part to the branches, whereon the flowers do grow with manyleaues, confufedly placed without order. Among the branches clofe by the ftemme, grow foorth certaine cloties or rootes of a reddifh colour, like vnto the clones of Garlicke before they be pilled, which being fallen vpon the grounde at their time of ripeneffe, doe fhoote foorth certaine tender ftrings or rootes that do take hold of the ground whereby it greatly increafeth. The flowers are in thape like the other red Lillies, but of a darke oreng colour, refembling a flame of fire fpotted with blacke fpots, whereof it tooke his name.

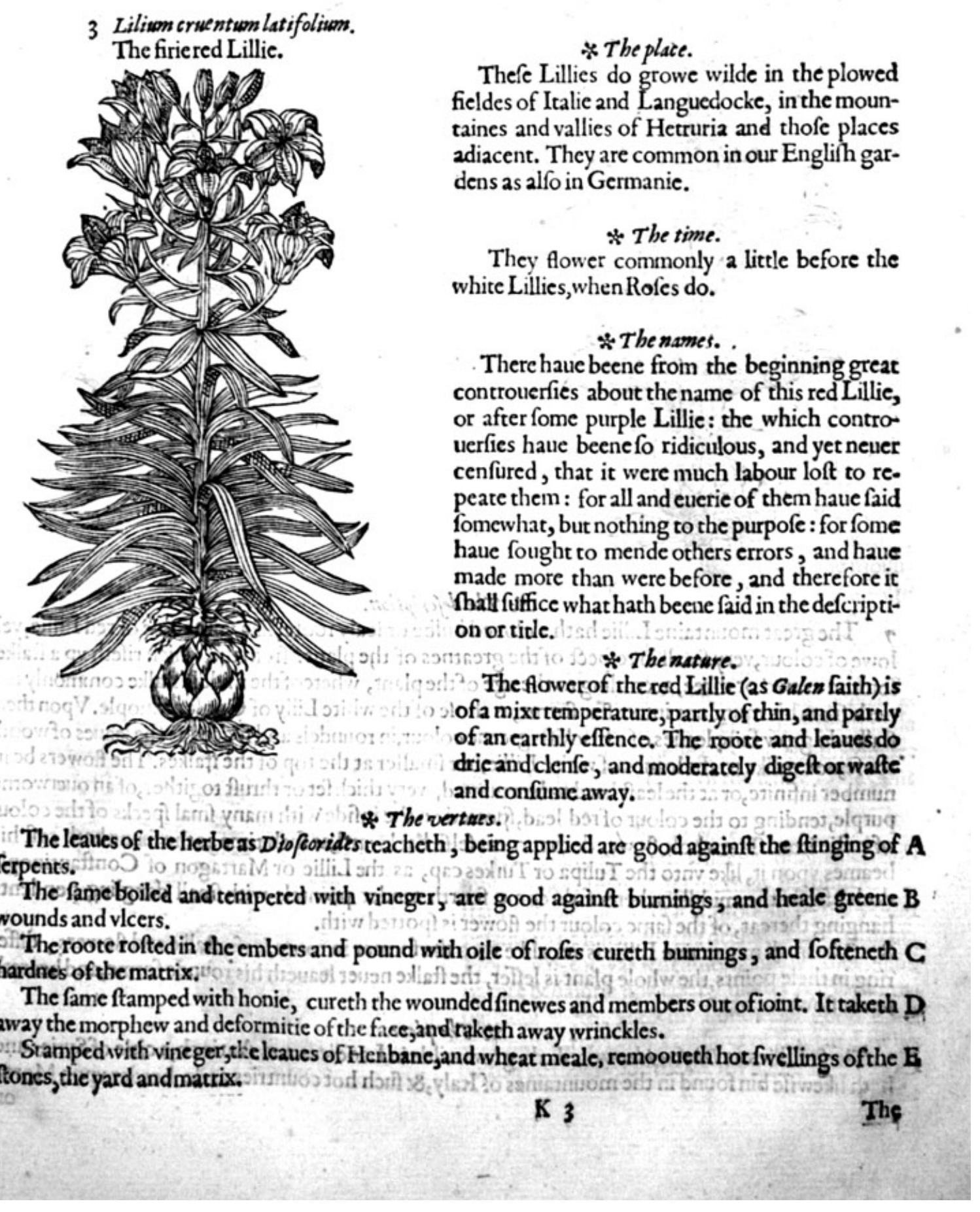


F The rootes boiled in wine, faith Pliny, caufeth the cornes of the feete to fall away within fewe daies, with remoouing the medicine vntill it haue wrought the effect.

G Being drunke in honied water, they driue out by fiege vnprofitableblood.

\section{Of mountaine Lillies. Chap.93.}

7 Lilivem montanum maius.

The great mountaine Lilly.

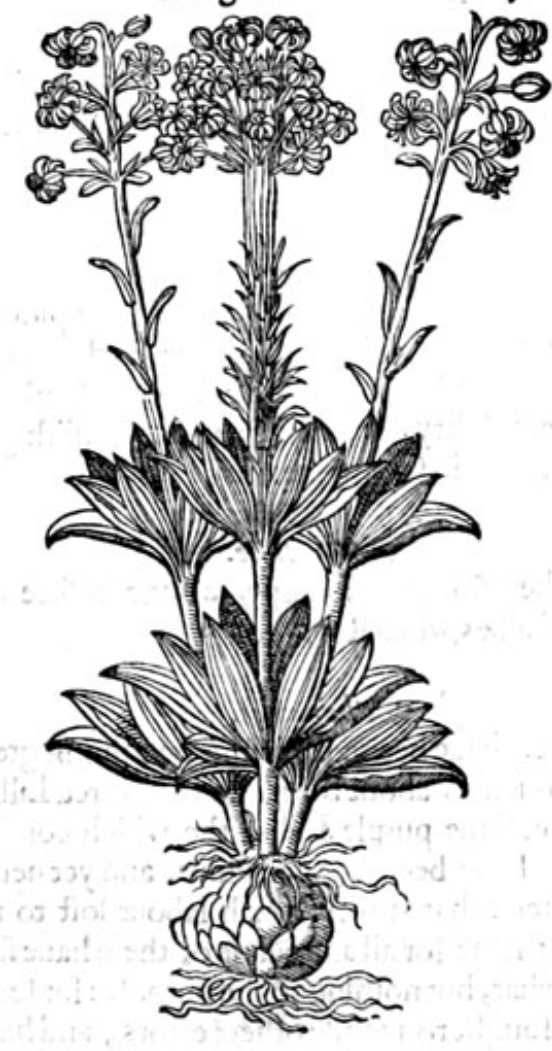

8 Liliwem montanwom minus. Small mountaine Lillie.

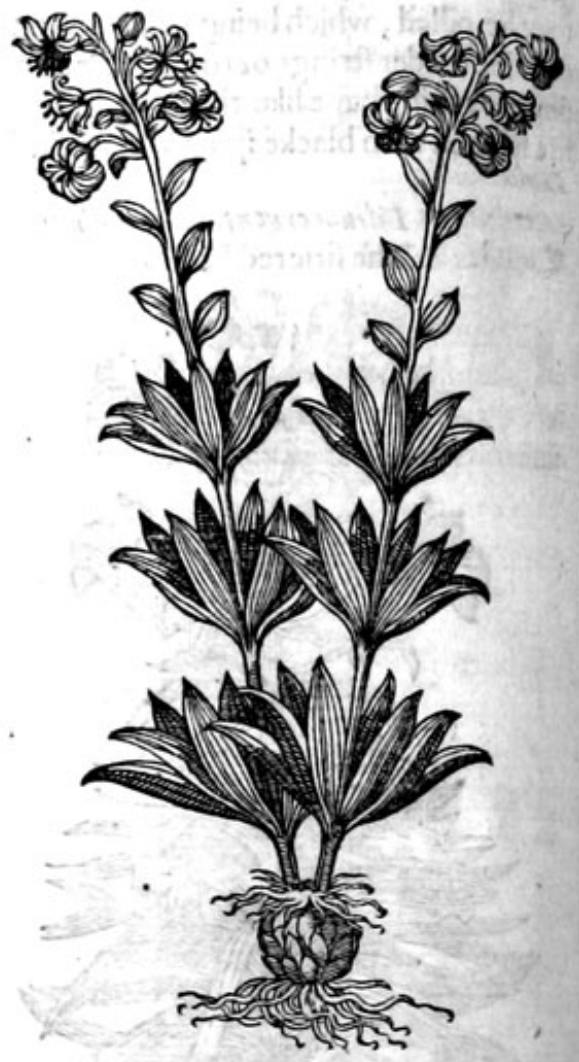

* Thedefcription.

7 The great mountaine Lillie hath a cloued bulbe or fcaly roote, like vnto thofe of red Lillie, yetlowe of colour, very fmall in refpect of the greatnes of the plant: from the which rifeth vp a ftalke, foritim es two or three, according to the age of the plant, whereof the middle ftalke commonly turneth from his roundnes into 2 flat forme, as thofe of the white Lilly of Conftantinople. Vpon thefe ftalks do grow faire leaues of a blackifh greene colour, in roundels and fpaces as the leaues of woodroofe,not vnlike to the leaues of white Lillie, but fimaller at the top of the ftalkes. The flowers be in number infinite, or at the leaft hard to be counted, very thick fet or thruft togither, of an ouerworne purple,tending to the colour of red lead, fpotted on the infide with many fmal fpecks of the colour of raftie iton. The whole flower doth turne it felfe backward,at fuch time as the funne hath cafthis beames vpon it, like vnto the Tulipa or Turkescap, as the Lillie or Martagon of Conftantinople doth; from the middle whereof do come foorth tender pointels with fmall dangling pendents hanging thereat, of the fame colour the flower is fpotted with.

8 The fmall mountaine Lillie is very like vito the former in roote, leafe, ftalke and flowers, diffe ring in thefe points, the whole plant is leffer, the ftalke neuer leaueth his rounde forme, and beareth fewer flowers.

* The place.

Thefe Lillies as Dio/corides writech,do grow wilde in Laodicea and Antioch,a citie of Syria : and hath likewife bin found in the mountaines of Italy, \& fuch hot countries as do border vpon Morea 
or Greece, many daies iourneies beyond Conftantinople, from whence they are brought among other bulbus plants for the garnifhing of the Turkes gardens, and the curious Bafhaoess;rom whence they haue beene brought to England, whore they flourifh as in their natiue countrey.

The fmall fort thaue had many yeeres growing intryy garden, but the gteater $I$ haue noe had till of late, given me by my louing friend mafter lones Grrret apothecarie in London. * Thetime.

Thefe Lillies of the mountaine flower at fuch time as the common white Lilly doth, and fomtimes fooner.

* The names.

The great mountaine Lillie is called of Taber Montanus, Liluwn Saracenicum, receiued by mafter Garret aforefaid, from Lile in Flaunders by the name M1 artagon Imperiale: of forme Liltum Saraceniciom mas.

The fmall mountaine Lillie is called in Latine Lilium montanum, and Lilium fyluestre : of fome Hemerosallis, of other Maytagom; but neither truly, for that there is of either, other plants properly calledby the fame names. In high Dutch it is called Soltinurt $z$ : in lowe Dutch Lilikens van Caluatien: in Spanifh Lirio Comarillo: in French Lys Satuage: in Englifh mountaine Lillic. * The nature and vertues.

There hath not been any thingleft in writing either of the nature or vertues of thefe plants : notwithiftanding we may deeme that God which gaue them fuch feemely and beautifull thape, hath not left them without their peculiar vertues: the finding out whereof we leaue to the learned and induftrious fearcher of nature.

\section{Thered Lilly of Conftantinople. Chap.94.}

9. Lilium Bizantinum. The red Lillie of Conftantinople.

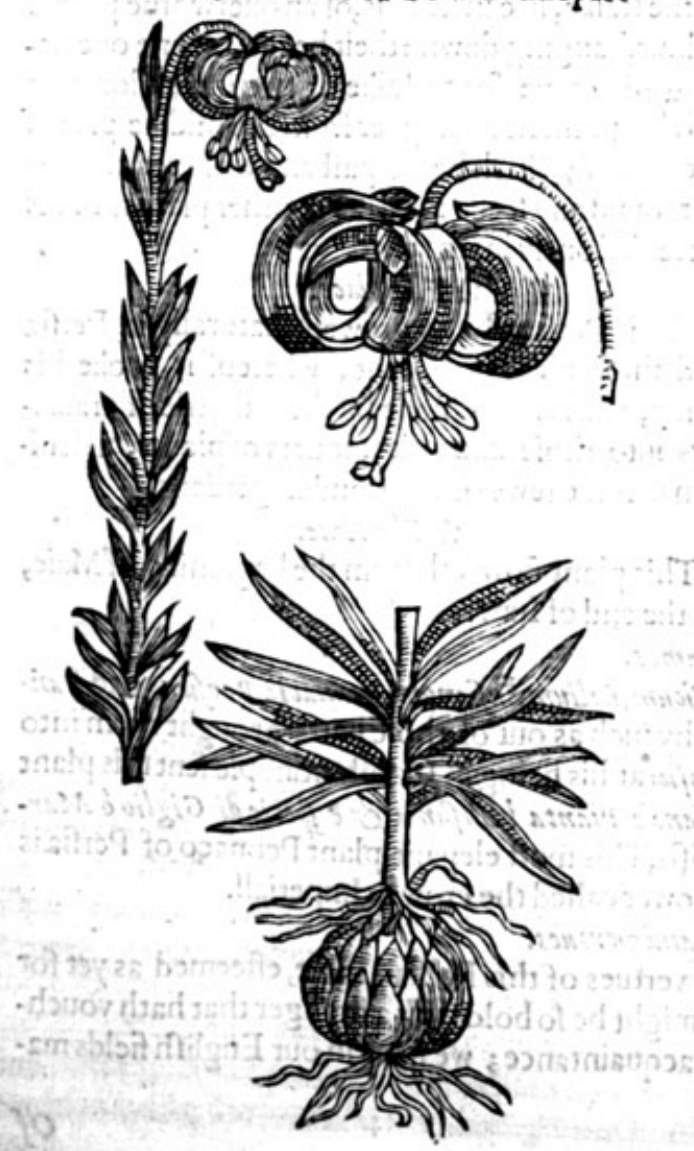

97 * The defcription. the mountain Lillie, but greater:from the which rifeth vp a faire fat ftalke 2 finger thick, of a dark purplifh colour toward the top, which fomtimes doe turne from his naturall roundnes into 2 flat forme, like as doth the great mountain Lilly: vpon which ftalke do grow fundrie faire and moft beautiful flowers, in fhape like thofe of the mountain Lilly, but of greter beauty, feeming as it were framed of red wax, tending to a red leade colour. From the middle of the flower commeth foorth a tender pointell or peftell, and likewife many fmal chiues tipped with loofe and tottering pendants hanging thereat. The flower is of a reafonable pleafant fauoure. The leaues are confufedly. fet about the ftalkelike thofe of the white Lillie, but fmaller.

$$
\text { * The place. }
$$

This plant groweth wilde in the fieldes and mountaines, many daies iourneis beyonde Conftantinopole, whither it is brought by the poore pefants to be folde, for the decking vp of gardens. From thence it was lent among many other bulbs of rare \& daintic flowers, by mafter Harbranambaffador there, vnto my honorable good Lord and maiter, the Lord Treafurer of Engtand, who beftowed them vpon me for my garden.

$$
\mathrm{K}_{4}
$$


They flower and flourifh with the other Lillies.

* The time.

* The names.

The Lillie of Conftantinople is called likewife in England Martagon of Conftantinople, of LObeliws Hemerocallis Chalcidunica, and likewife Liliwm Bizantinum: of the Turks it is called $Z_{\text {wfini- }}$ are: of the Venetians Marocali.

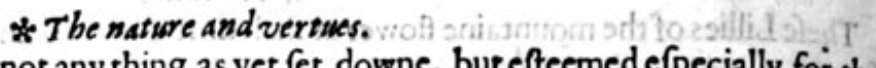

Of the nature or vertues there is not any thing as yet fet downe, but efteemed efpecially for the beautic and rarenes of the flower, referring what may be gathered hereof to a further confideration.

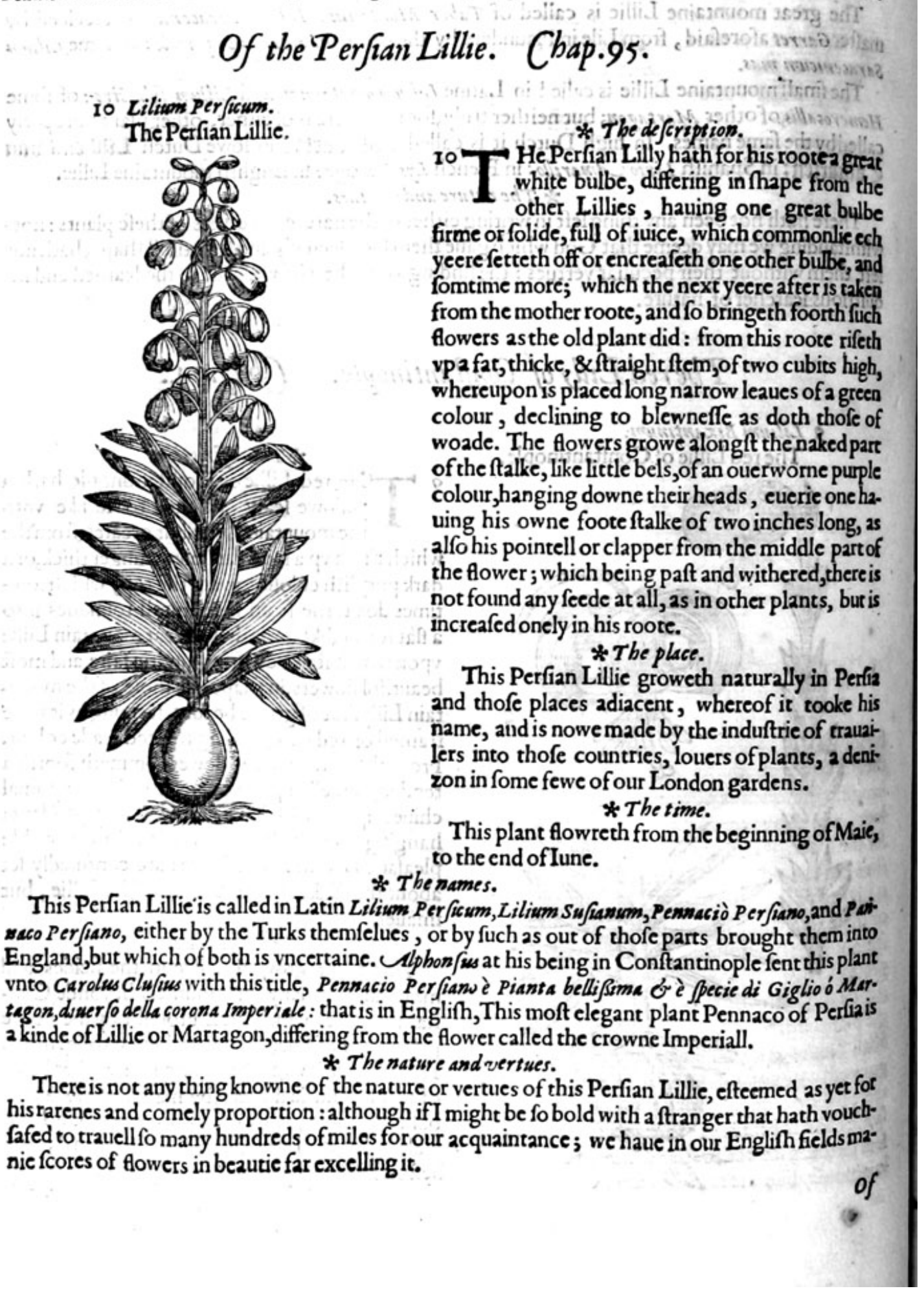




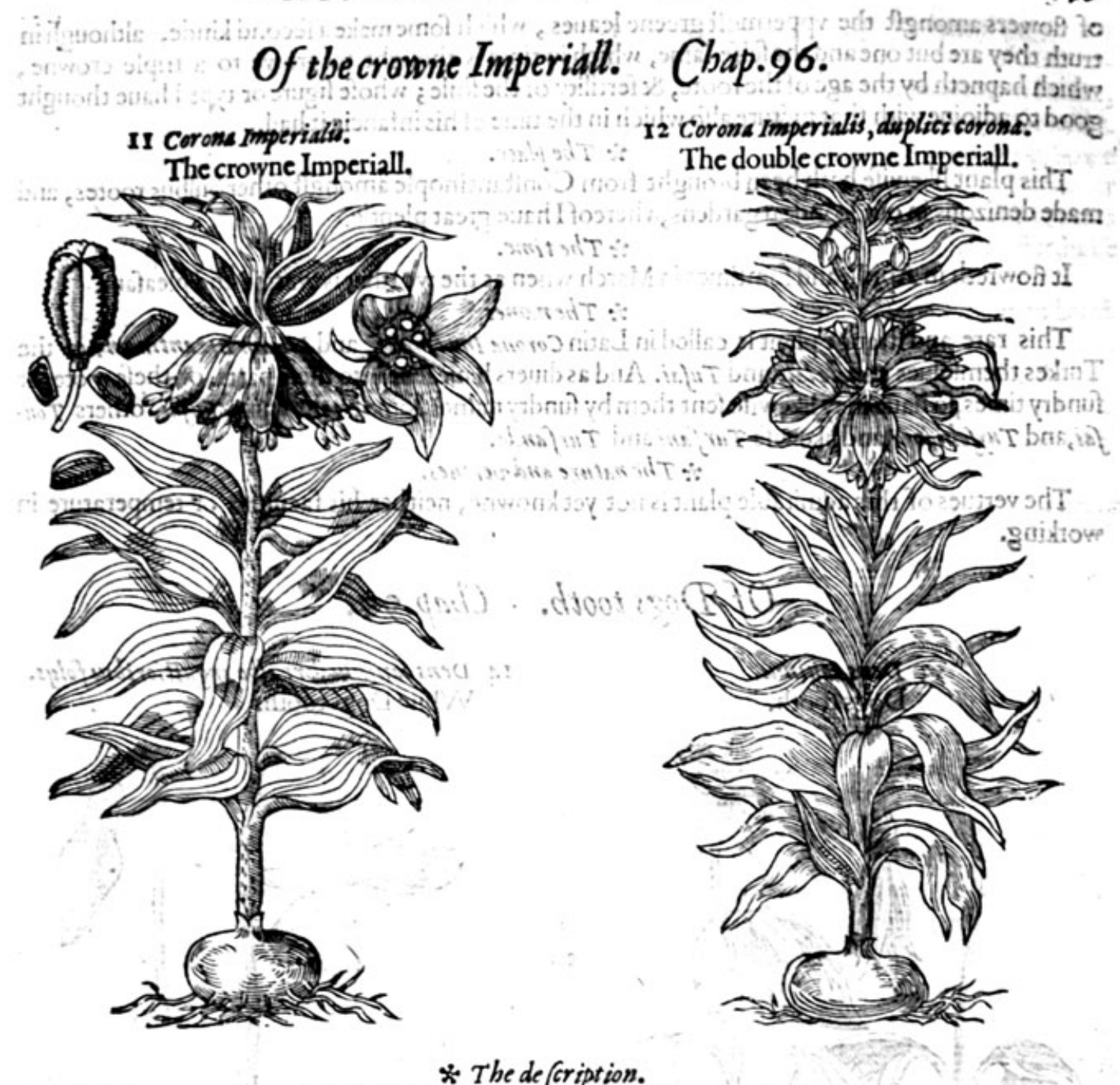

* The defcription.

II Hecrowne Imperiall hath for his roote 2 thicke, firme, and folide bulbe, couered with 2 yellowifh filme or skin : from the which rufech vp 2 great thicke fat ftalke; two cubits high, in the bare or naked part of a darke ouerworne duftie purple colour.The leaues grow confufedly about the ftalke, like thofe of the white Lillie, but narrower. The flowers grow at the top of the ftalke, compaffing it round about in forme of an Imperiall crowne, (whereof it tooke his name) hanging their heads downward as it were bels : in colour it is yellowifh, or to giue you the true colour, which by words otherwife cannot be expreffed, if you lay fap berries in fteepe in faire water for the fpace of two houres, and mixe a little Saffron with that infufion, and laie it vpon paper, it Sheweth the perfect colour to limne, or illumine the flower withall. The backfide of the faid flower is ftraked with purplifh lines, which doth greatly fet forth the beautie therof. In the bottome of ech of thefe bels there is placed fixe drops of moft cleere fhining fweete water, in tafte like fugar, refembling in thew faire orient pearles; the which drops if you take away, there doe immediately appeere the like, as well in bignes as alfo in fweetenes : notwithitanding if they may be fuffered to ftande ftill in the flower according to his owne nature, they will neuer fall away, no not if you ftrike the plant, vntill it be broken : among thefe drops there ftandet b out a certaine peftell,as alfo fundrie fmall chiues, tipped with fmall pendents, like thofe of the Lillie. Aboue the whole flowers there groweth a tuft of greene leaues like thofe vpon the ftalks, but finaller. After the flowers be faded, therefollowe cods or feede veffels fixe fquare, inithapelike the wheeles of a Iacke to turne the fpit, oblikethe nut of a crofle-bowe, wherein is conteined flat féedes, tongh and limmer, of the $\mathrm{cu}^{2}$ lour of the ficecalledmace. The whole plant as -well rootes as Howers do fatour or fmell verie loathfomly like the foxe. As the plant groweth old, fo doth it waxexich, bringing foorth a crowne 
of flowers amongit the vppermoft greene leaues, which fome make a fecond kinde, although in truth they are but one and the felfe-fame, which in time is thought to growe to a triple crowne, which hapneth by the age of the roote, \& fertility of the foile; whofe figure or type I haue thought good to adioine with that pieture alfo which in the time of his infancieit had. asto re? is

plant likewife hath been brought from Conftantinople amongt other bulbus rootes, and made denizons in our London gardens, whereof I haue great plentie.

* The time.

It flowreth in Aprill, and fomtimes in March when as the weather is warme and pleafant.

This rare and frangeplant is called in Latin Corons Imperialis, and Lisliven Bizantinuen i of the Turkes themfelues Cauale lale, and $\tau u f a i$. And as diuers haue fent into thefe parts, of thefe rootes at fundry times, fo haue they likewife fent them by fundry names, fome by the name $T w$ fai, others $T$ ow fai, and $T u y$ fchiacliz, and likewife Turfani and Turfanda.

The vertues of this admirable plant is not yet knowne, neither his faculties or temperature in working.

\section{Of Dogs tooth. Chap.97.}

13 Dens caninus.

Dogs tooth.

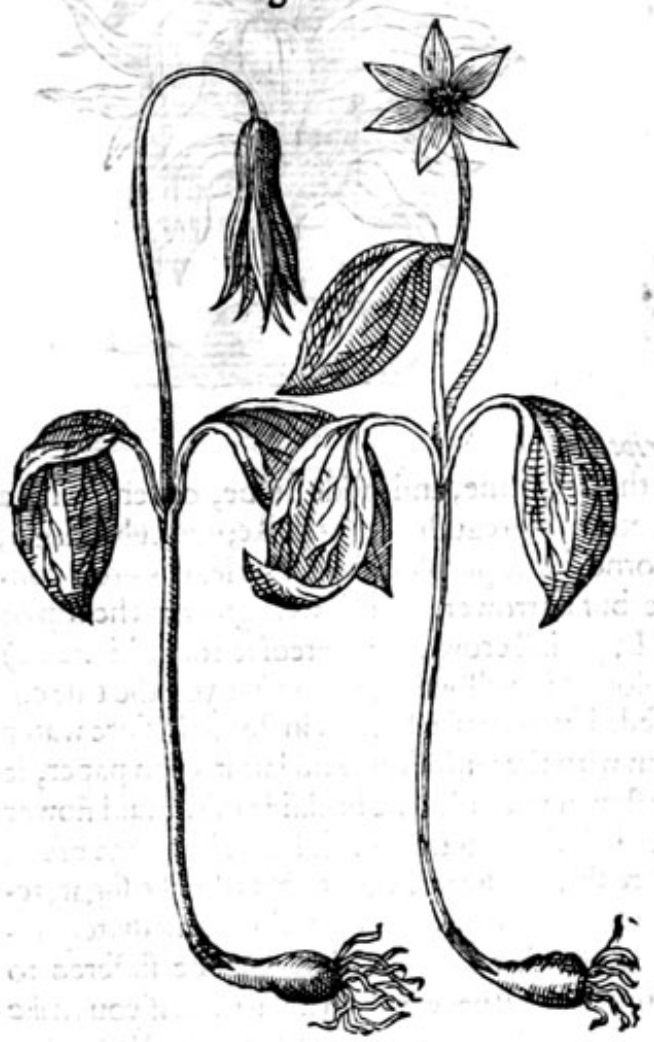

14 Dens caninum flore albo angustioribun folji. White Dogs tooth.

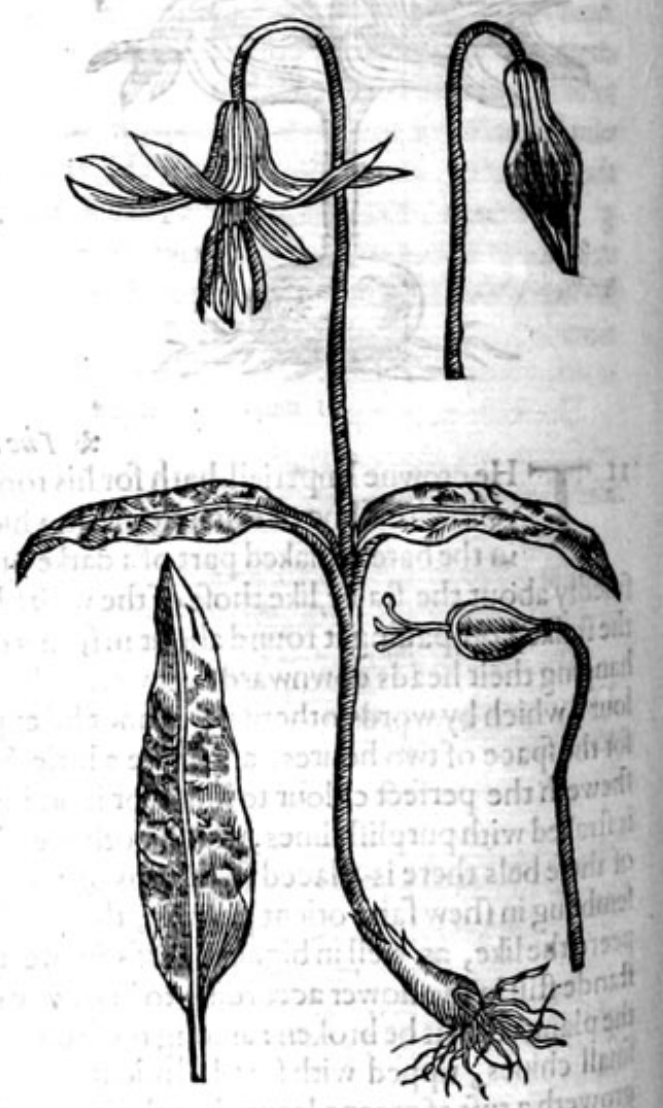

13 Here hathnot long fince been found out a goodly bulbofe rooted plant, and termed Sart; rion, which was fuppofed to be the true Satyrion of Dio/corides, after that it was cherifhed and the vertues thereof found out by the ftudious fearchers of nature. Little difference 
hathbeen found betwixt that plant of Diofcorides and this Dens canirus,except in the colour,which (as you know)doth commonly varie, according to the diuerfitic of places where they gtow, as it falleth out in Squilla, Onions, \& the other kinds of bulbofe plants. It hath moft commonly two leaues, very feldom three, which leafe in fhape is much like to Alliwon vrfinwm, or Ramfons, though far leffer. The leaues turne down to the groundivard:the ftalke is tender and flexible, like to Cyclamen or Sowe bread, about a handfull high, bare and withour leanes to the roote. The proportion of the flower is like thofe of Saffron, ot the Liliy flower, full of ftreames of a purplith white colour. The rooteis bigge and like nnto a Date, with forme fibres growing from it: vnto the faid roote is a fmall, that, halfe round butbe adioining, like vnto Gladiolus or corne flagge.

2 The fecond kinde is farre greater and larger than the firf, in bulbe, ttalke, leaues, flower and cod. It yeeldeth two leaues for the moft part, which do clofe one witnin another, and at the firft theydo hide the flower(for folong as it brings not out his flower) it feemes to haue but one leafe like the Tülipaes \& like the Lillies, though fhorter, \& for the moft part broader; wherfore I haue placed it and his kinds next vnto the Lillies, before the kinds of Orchis or ftones. Thefe leaues which he beareth, are fpotted with many great f pots of a darke purple colour, narrow below, but by little and little toward the top waxing broade, and after that growing to be fharpe pointed, in forme fomewhat neere Ramfons, but thicker \& more olcous. When the leaues be wide opened, the flower theweth it felfe vpon his long weake naked ftalke bowing to the carthward, which flower confifteth of fixe verie long leaues, of a fine delaied purple colour, which with the heate of the funne openeth it felfe, and bendeth his leaues backe againe after the maner of the Cyclamen tlower, within which there are fixe purple chiues and a white three forked ftile or peftell. This flower is of no pleafant fmell, but commendable for the beautic : when the flower is vaded, there fuccedeth a three fquare huske or head, wherein are the feedes which are very like them of Lescoitum bulbofumprecox, but longer, Aenderer, and of a yellowe colour. The roote is long, thicker below than aboue, fet with many white fibres, waxing very tender in the vpper part, hauing one or more off-fets or yoong fhootes, from which the ftalke arifeth out of the ground(as it hath been faid) bringing foorth two leaues and not three, or onely one, faue when it will not flower.

3 The third kind is in all things like the former, faue in the leaues which are narrower, and in the colour of the flower, which is altogither white, or confifting of a colour mixt of purple and white. Wherefore fith there is no other difference it fhall fuffice to haue faide this much for the defcription.

$$
\text { * The place. }
$$

Thefe three plants grow plentifully at the foote of certainc hils in the greene and moift grounds of Germanie and Italy, in Styria not farre from Gratzium, as alfo in Modena and Bononia in Italy, and likewife in my garden.

They flower in Aprill,and fomtimes fooner, as in the middle of March.

$$
* \text { The names. }
$$

The firft is called in Latine Dens caninus herbariorum, and Eritbronium, that is, the Herbarifts Dogs tooth. The men of the countrey where it groweth do call it buafturts : and the Phifitians about Styria do call it Dentali, and likewife Dens caninus flore albo, angustioribses folits, that is, Dogs tooth with the white flower and narrow leaues.

\section{* The nature.}

Thefeare of a very hot teimperament, windie and of an excrementitious nature, as may appeere by the vertues.

* The vertwes.

The women that dwell about the place where thefe grewe and do growe, haue with great pro- A fiteput the dried meale or powder of it in their childrens pottage, againft the woormes of the belly.

flo Being drunke with wine, it hath been prooved maruelloufly to affwage the collick paffion. B

Itiftrengthneth 2nd nourifheth the bodie in great meafure, and being drunke with water it cureth $\mathbf{C}$ children of the falling ficknes, 


$$
\text { OfDogsfones. Chap. } 98 \text {. }
$$

* The kindes.

Tones or Tefticles, as Diof corides faith,are of two forts, one named Cynoforcbiv or Dogs ftones, the other Orcbis Serapias, or Serapias his ftones. But bicaufe there be many and fundrie other forts differing one from another, I fee not how they may be contained vnder thefe two kinds onely: therefore I haue thought good to deuide them as followeth. The firft kinde we haue named Cynoforchis or Dogs ftones : the fecond, Testiculus Morionis, or Fooles ftones: the third, Tragorchi, or Gotes ftones: the fourth, Orchis Serapias, or Serapias ftones: the fift, TeSt icules oder atum, or fweete fmelling ftones, or after Cordiw, T esticulus Pumilio, or Dwarffe ftones.

I Cynoforchis maior.

Great Dogs ftones.

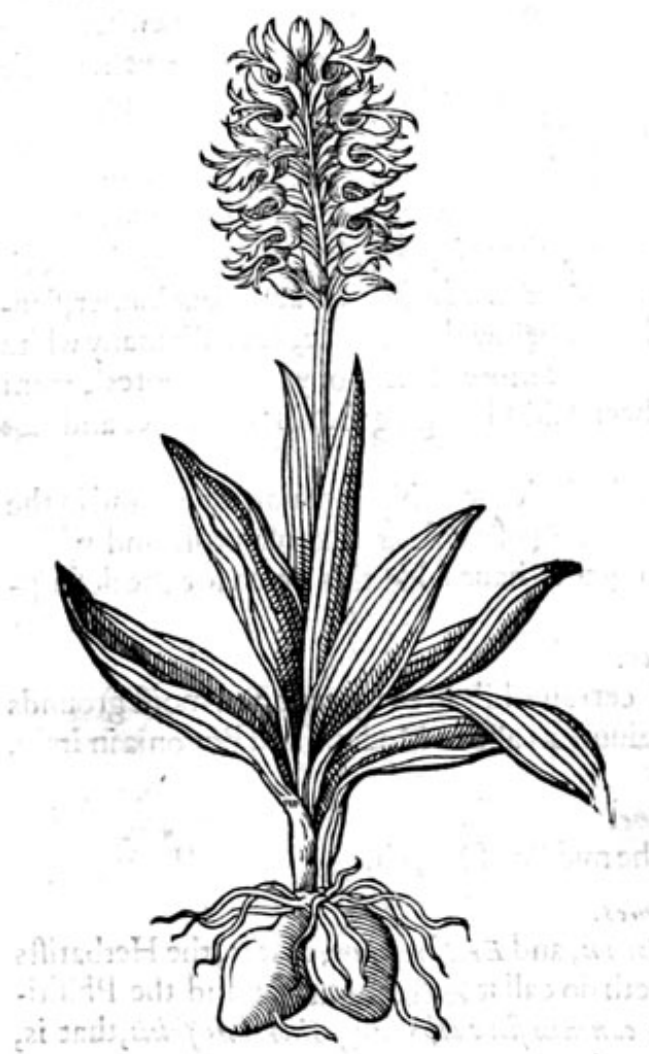

2 Cynoforchismaior altera. White Dogs ftones.

\section{* The defaription.} Reat Dogs iftones hath foure, and fometimes fiue, great broad thicke leaues, fomewhat like thofe of the garden Lillie, but finaller. The ftalke rifeth vp two hands high : at the toppe whereof doth grow a great thicke tuft of camation or horfe-flefh coloured flowers, thicke and clofe thruft togither, made of many fmall flowers fpotted with purple fpots, in fhape liketo an open hood or helmet. And from the hollow place there hangeth foorth a certaine ragged Chiue or taffell, in thape like to a foure footed beaft. The rootes be round like vnto the ftones of a dog, ot two Oliue beries, one hanging fomewhat Thorter than the other, whereof the higheft or vejermoft is the fmaller, but fuller and harder. The lowermoft is the greateft, lighteft, and moft wrinclede or Thriucled, not good for any thing.

2 White Dogs ftones hath likewife fmooth, long, and broad leaues, but leffer and natrower than thofe of the firf kind. The ftalke is a Ypan long, fet with fiue or fixe leaues clafping or embracing 


\section{HISTORIEOFTLANTS. I}

the fame round about. His fpikie flower is thicke, bufhie, compact of many fmall purple coloured flowers declining to whitenffe, fpotted on the infide with many finall purple fpots and little lines or ftrakes. The fmall flowers are like an open hood or helmet, hauing hanging out of euerie one as it were the bodie of a little man without a head, with armes ftretched out, and thighs ftradling abrod, after the fame maner almoft, that the little boies arewoont to be pictured hanging out of Saturnes mouch. The rootes be like the former.

3 Cymoforchis maculats. Spotted Dogs ftones.

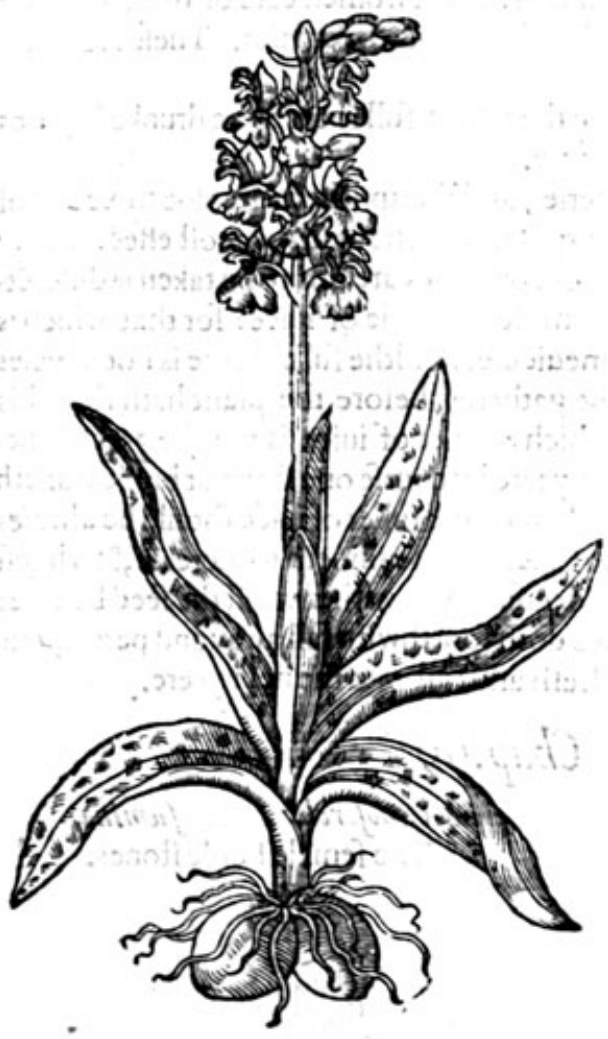

4 Cynoforchis palustris. Marifh Dogs ftones.

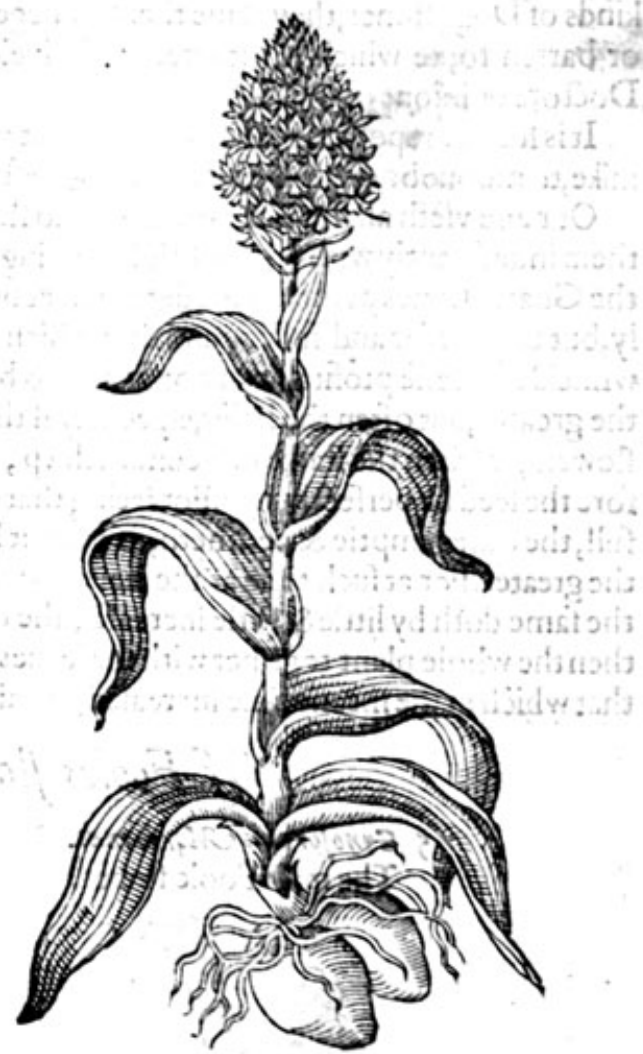

* The defeription.

3 Spotted Dogs ftones bringeth foorth narrow leaues, ribbed in fome fort like vnto the leaues of narrow Plantaine or ribwoort, dafht with many blacke ftreakes and fpots. The ftalke is halfe a foot high : at the top whereof doth grow a tuft or eare of crimfon flowers, mixed with a darke purple, but in the hollowneffe thereof whitifh, of the fame forme or fhape that the others are of, butleffer, hauing alfo hanging out of the gaping flowers a little rude and deformed hape, as it were of fome fower footed beaft. The rootes be like the fornier.

4 Marifh Dogs ftones hath many thicke blunt nerues like thofe of Plantaine. The flowe blunt leaues next the roote, thicke ftreaked with lines or the former.

Thefekinds of Dogs ftones do grow in * Theplace. weth for the moft partinmoif do grow in moilt and fertill medowes. The marifh Dogs ftones groThey flower from the begining $*$ The time.

The firft and fecond are thofe $*$ The names. Englifh Dogs ftones : after the commos Dogs ftones, which Diofcorides callech Cynoforc bis : in the leffer.

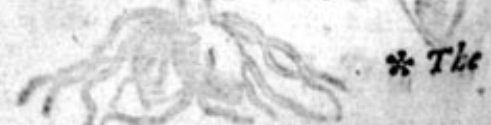


Thefe kinds of Dogs ftones be of temperature hot and moift, but the gieater feemeth to havie much fuperfluous windines, and therefore being drunke it ftirreth vp flefhly luft.

The fecond which is leffer, is quite contrarie in nature, tending to 2 hot and drie temperature: therefore his roote is fo far from moouing venerie, that contrariwife it ftaieth and keepeth it backe, as $G$ alen teacheth. He alfo affirmeth that Serapias ftones are of a more driefacultie, and do not fo much preuaile to ftir vp the luft of the flefh.

* The vertwes.

A It is reported as Diofcorides writeth, that if men do eate of the great full or fat footes of thefe kinds of Dogs ftones, they caufe them to beget male children : and if women eate of the leffer, drie or barren roote which is withered or fhriueled, they fhall bring foorth females. Thefe are fome Doctors opinions onely.

B It is further reported that in Theffalia, the women give the tender full roote to be drunke in gotes mike, to mooue bodily luft, and the drie to reftraine the fame.

C Our age vfeth all the kindes of ftones to ftirre vp venerie, and the apothecaries doe mixe any of them indifferently with compofitions feruing for that purpofe. But the beft and moft effectuall are the Goates ftones as moft haue deemed:yet both the bulbes or ftones are not to be taken indifferétly, but the harder and fuller, and that which conteineth moft quantitic of iuice: for that which is wrinckled is leffe profitable or not fit at al to be vfed in medicine. Andthe fuller roote is not alwaies the greater, but often the leffer,efpecially if the rootes be gathered before the plant hath fhed his flowers, or when the ftalke firft commeth vp, for that which is fuller of iuice is not the greateft be. fore the feed be perfeetly ripe.For fceing that euery other yeere by courfe one ftone or bulbe waxech full, the other emptic \& perilheth, it cannot be that the harder and fuller of iuice fhould be alwaies the greater. For at fuch time as the leaucs com forth, the fuller then beginneth to increafe, \& whileft the fame doth by little \& little increafe, the other doth decreafe and wither vntill the feed be ripe: then the whole plant togither with the leaues and ftalkes doth foorthwith fall away and perilh, and that which in the meane time increafed, remaineth ftill frefh and full vnto the next yeere.

\section{Of Fooles ftones. Chap.99.}

5 Cynoforchis Moriomas.

The male Foole ftones.

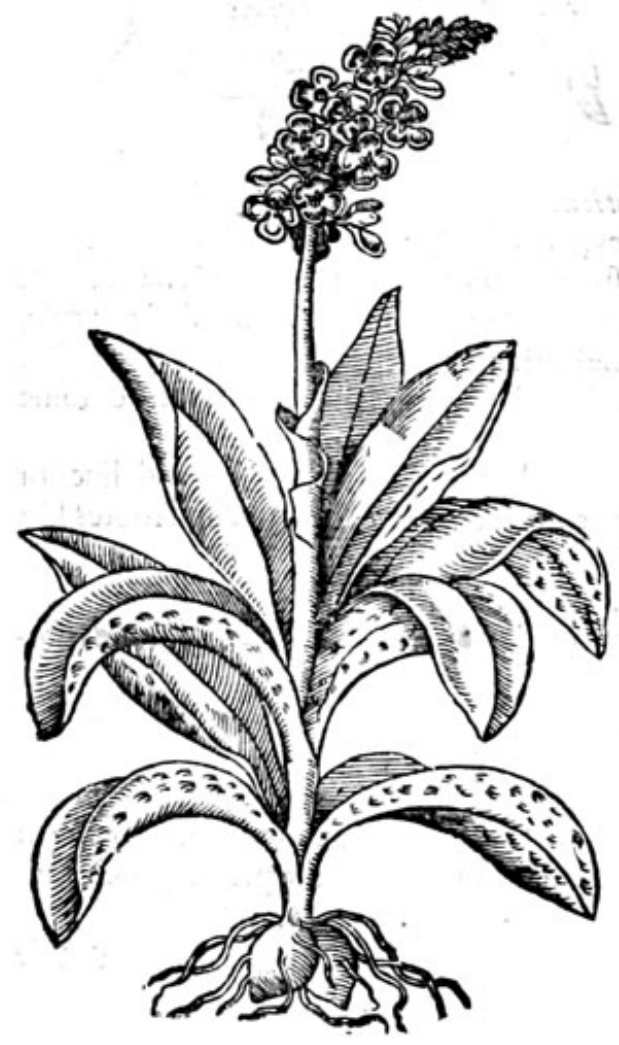

6 cyno forchio Morio famina. The female Foole ftones.

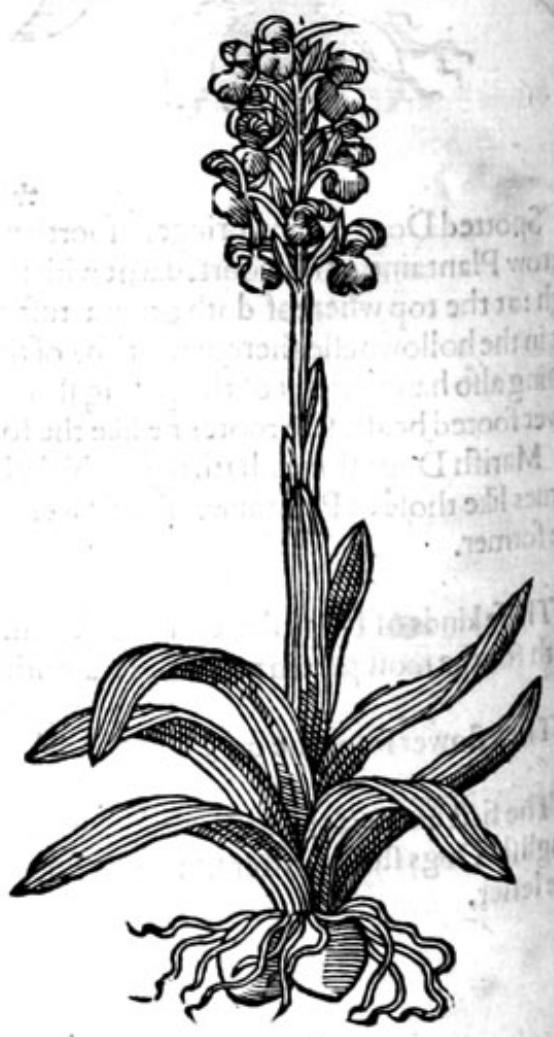




\title{
A HIISTOR HE OF PLANTSHT
}

\author{
. Mere kidstogstT s

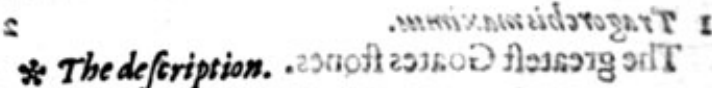

He male Fooleftones hath fiue, fometimes fixe, long broad and fmooth leaues, not vnlike
to thofe of the Lillie, fauing that they are dafht and fpotted in fundry places with blacke fpots and ftreaks. The flowers grow at the top tuft or I pike fafhion, fomewhat like the for-. mer, but thruft more thicke togither, in hhape like to a fooles hood or cocks-combe wide open, or gaping before, and as it were crefted aboue with certaine eares ftanding vp by euery fide, and a fmal taile or fpur hanging downe, the backfide declining to a violet colour, of 2 pleafant fauour or fmell.

6 The female Foolsftones hath alfo fmooth narrow leaues, ribbed with nerues like thofe of Plantaine. The flowers be likewife gaping, and like the former, as itwere open hoods, with a little horne or heele hanging behinde euery one of them, and fmall greeneleaues forted or mixed among them, refembling cocks-combes, with little eares, not ftanding ftraight vp, but lying fat vpon the hooded flower, in fuch fort, that they cannot at the fudden viewe be perceiued. The rootes are a couple of fmall ftones like the former. The flowers of this fort do varie infinitely in colour, according to the foile or conntrey where they do grow : fome bring foorth their flowers of a deepe violet colour, fome as white as fnow, fome of a flefh colour, \& fome garnifhed with fpots of diuers colours which are not poffible to be diftinguifhed.

$$
\text { * The place. }
$$

Thefe kinds of Fooles ftones do grow naturally to their beft liking in paftures and fields that feldome or neuer are dunged or manured.

\section{* The time.}

They flower in Iume, Iuly and the beginning of Auguft. Their ftones are to be gathered for medicine in September, as are thofe of the Dogs itones.

\section{* The nomes.}

The firft is called Cynoforchis morio: of Fuchfsus Orchis mas : of Apuleisus Satyrion, and alfo Orchis Delphinia : in Englifh male Foole ftones, and Cuckow Orchis.

Foole ftones both male and female are hot and moift of nature.

$$
\text { * The temperature. }
$$

* The vertues.

The vertues of thefe Foole ftones are thought to haue the vertues of Dogs ftones, whereunto they are referred.

\section{OfGoatesfones. Chap.ioo.}

* The kindes.

$\mathrm{T}$ Here be three forts or kinds of Goates ftones, which diffe from the others before mentioned, as well in hape of flowers, as alfo in the ranknes or loth fomnes of imell. The lait of the three is thought to be the true and right Tragorchis, according to the beft approoued opinions : notwithftanding among themfelues there is great contention for fenioritie, as alfo for ftature and perfonage; fome hauing leaues like vnto the Lillie; others refembling thofe of the great Plantaine; fome bringing foorth flowers of a perfect purple colour; others white, and fome of mixt colours: the which to diftinguifh particularly were too fmall purpofe, confidering the great har, ueft we haue in hand. 


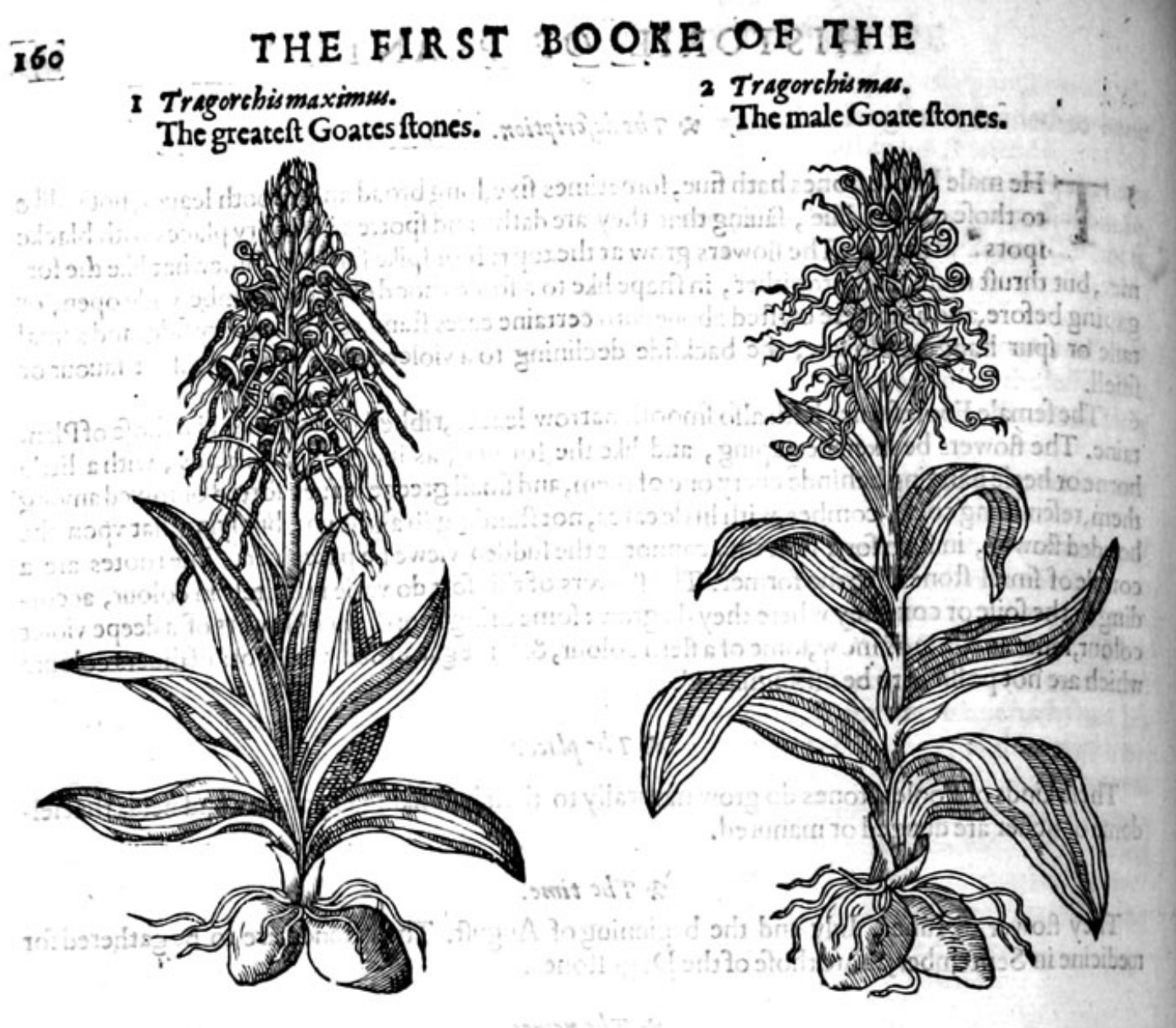

* The defcription.

$1-$ He greateft of the Goates ftones, bringeth foorth narrow leaures, ribbed in fome for like vnto the broad leafed Plantaine, but larger. The ftalke groweth to the height of halfea curbit,fet with fuch great leaues euen to the top of the ftalke by equall diftances. The tuftor burh of flowers be fmall and flat open,with many tender ftrings or laces comming from the middle part of thofe fmall flowers, crookedly tangling one with another, like the fmall tendrels of the vine, or rather the laces or ftrings that growe vpon the herbe Sauorie. The whole flower confifteth of a purple colour. The roots are like the reft of the Orchides, but greater.

2 The male Goate ftones hath leaues like to thofe of the garden Lillie, with a ftalke a footelong, wrapped about euen to the tuft of the flowers with thofe his leaues. The flowers which growe in this bufh or tuft be very fmall, in forme like vnto a lizard, bicaufe of the twifted or writhen tailes and fpotted heads : euery of thefe fmall flowers is at the firft like a round clofe huske, of the bignes of 2 peafe, which when it openeth there commeth out of it a little long and tender fpur or taile, white toward the fetting of it to the flower, the reft fpotted with red darhes, hauing vpon ech fide a fmall thing adioined vnto it, like to a little legge or foote; the reft of the faid taile is twifted crookedly about, and hangeth downwarde. The whole plant hath a rancke and ftinking fmell or fauor like the fmell of a goate, whereof it tooke his name.

3. The female Goate ftones hath leaues like the male kind, fauing that they be much finaller, ha: uingmany flowers on the tuft,refembling flies that feede vpon fiefh. The ftones or rootes are lite the former. 
OF PLANTSIT

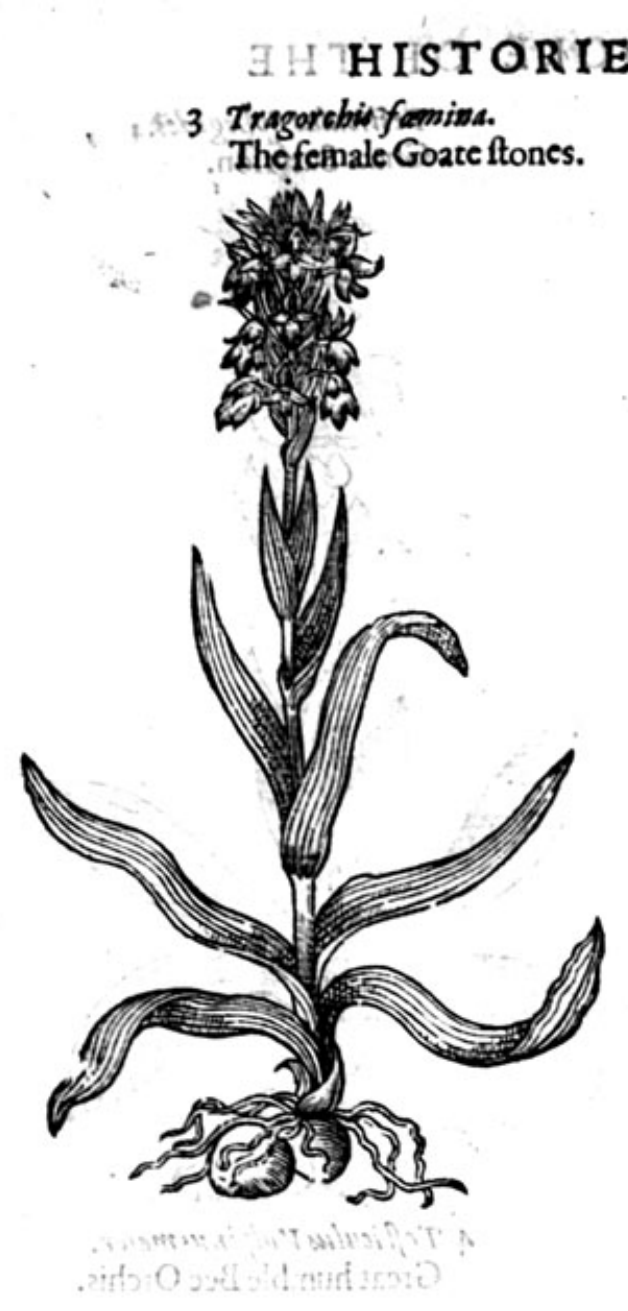

Tragorchinfamina.

The female Goate itones.

Thefe kinds of Goates itones delight to grow in fat clay grounds, and feldom in any other foile tobe found.

* The time.

They flower in Maie and Inne, with the other kinds of Orchis.

* The names:

The Grecians haue named thefe kindes of Goate ftones raxipris: in Latine Testiculus Hircinus, and alfo Orchis Saurodes, or Scincophora : in Englith great Goate ftones. ftones.

The fecond Tragorchis mas, male Goates

The third Tragorchis famina, or Coriofmikes, and of fome Coriophora: in Englirh female Gotes ftones.

$$
\text { * The nature and vertues. }
$$

The temperature and vertues of thefe are referred to the Fooleftones, notwithftanding they are feldome or neuer vfed in phifick, in regarde of the ftinking and lothfome fmell and fauour they are poffeffed with.

\section{Of Foxeftones. Chap.ioi.}

* The kindes.

$\mathrm{T}$ Here be diuers kindes of Foxeftones, differing very much in fhape of their leaues, as alfo in flowers. Somehaue flowers, wherein is to be feene the thape of fundrie forts of liuing creatures; fome the fhape and proportion of flies; in other gnats; fome humble bees; others like vnto honie bees; fome like butterflies; and others like wafpes that be dead; fome yellow of colour; others white; fome purple mixed with red; others of a browne ouerworne colour. The which feuerally to diftinguifh, as well thofe heere fet downe as alfo thofe that offer themfelues daily to our view and confideration, would require a particular volume : for there is not any plant which doth offer fuch varietie vnto vs as thefe kindes of ftones, except the Tulipaes which go beyonde all account : for that the moft fingular Simpleft that euer was in thefe latter ages, Carofus Cluf fiws (who for his fingular induftrie and knowledge heerein, is woorthie triple honor) (hath f pent at the leaft fiue and thirtie yeeres, fowing the feedes of Tulipaes from yeere to yeere, and to this day he could never yeeld is this: for if or certaintic of their feuerall kindes of colours. The greateft reafon that I can pan ortub with earth ake the feedes of a Tulipa that bare white flowers and fowe them in fome wife, fow the feedes of a plant that receiue from that feede, plants of infinite colours : contrariwill be nothing like the plant from whence the feede variable colours, and the moft of thofe plants downe what may be'comprehen whence the feede was taken, fo that it fhall be fufficient to fet comprehended in this chapter efpecially. 
I Hermaphroditica.

- Tefficuldur Sphogodes.

Bees Satyrion.

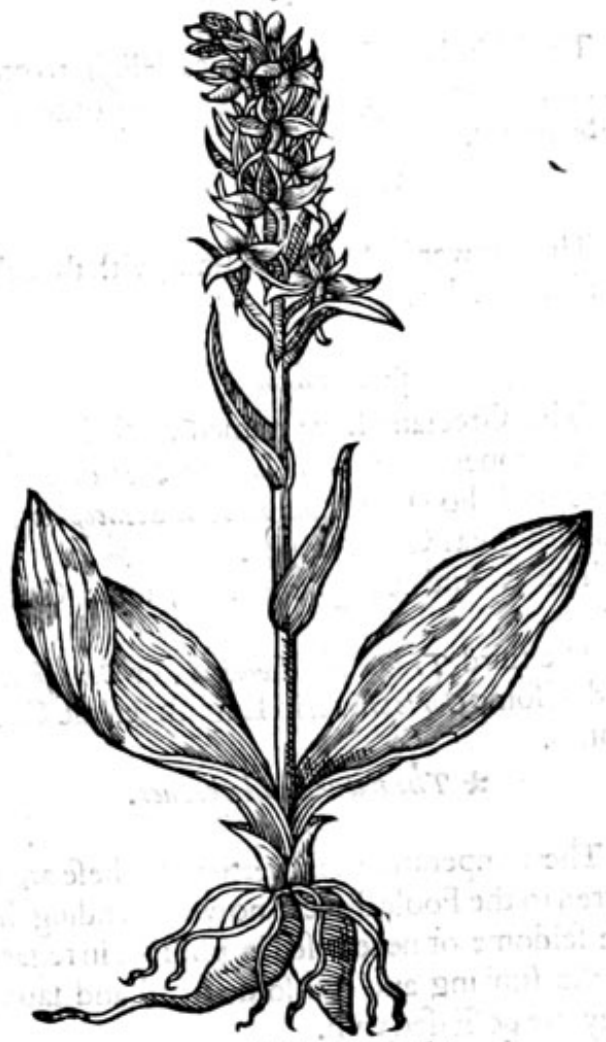

3 Tefticulus Vulpinus.

Humble Bee Orchis.

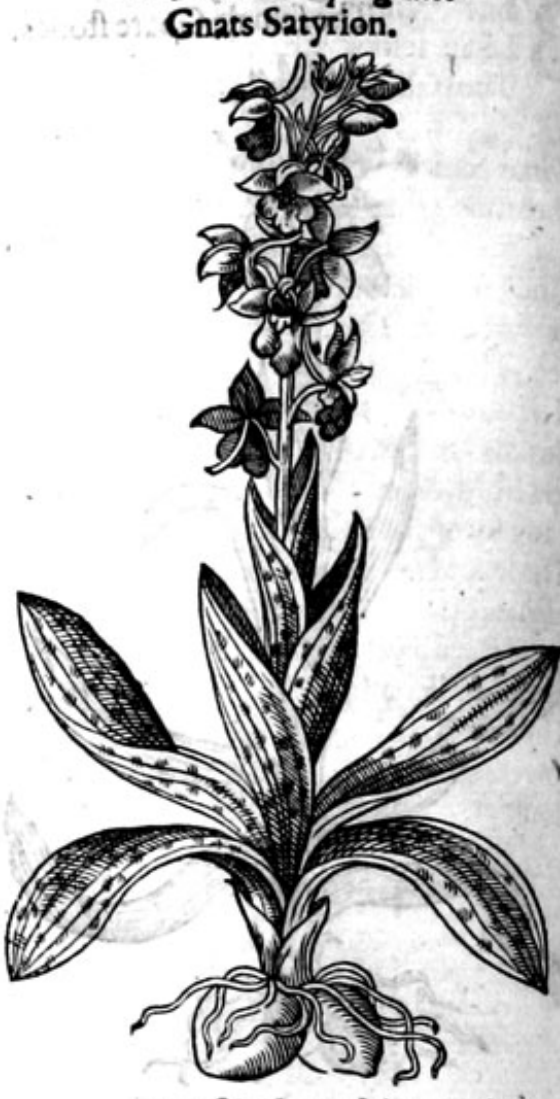

(c.) $\frac{102}{2014}$

c.iv (iv)

Ad

4.

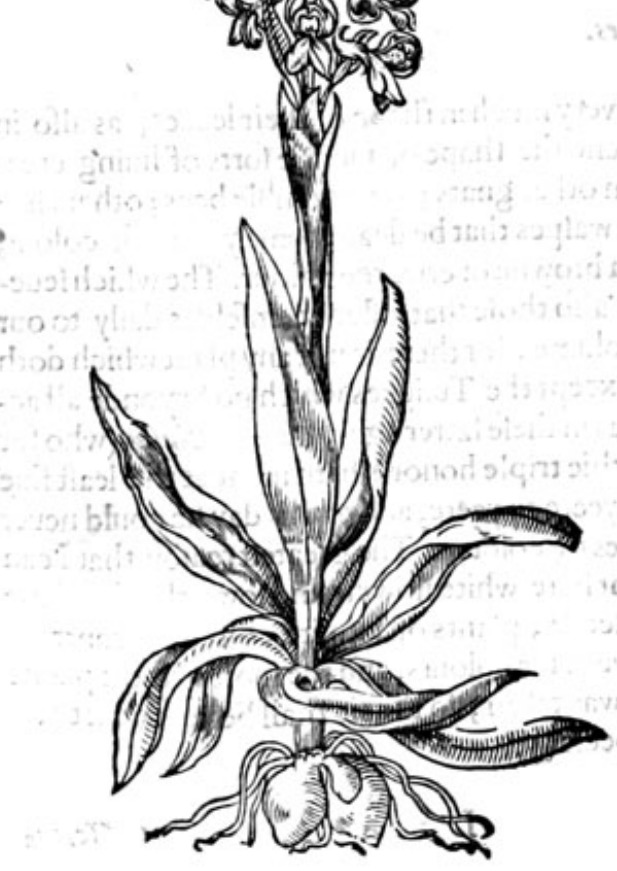

4 Tefticulus Vulpinus maior.

Great humble Bee Orchis.

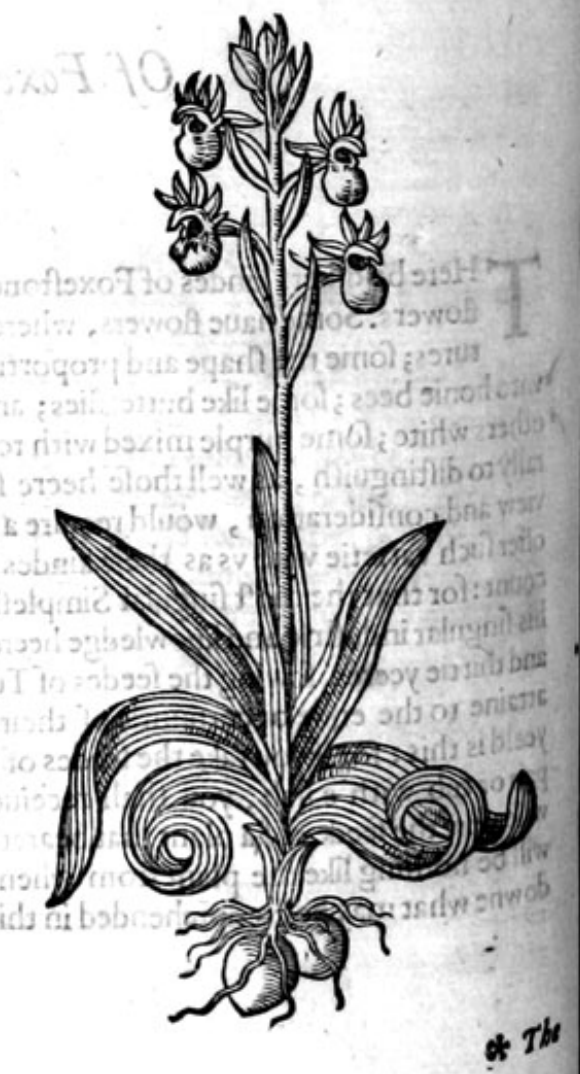




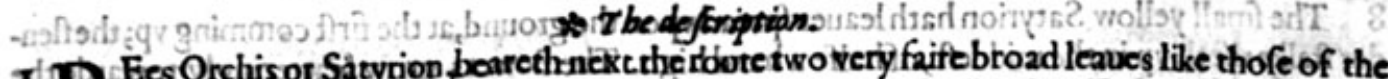
${ }_{1}^{2} \mathrm{~B}$

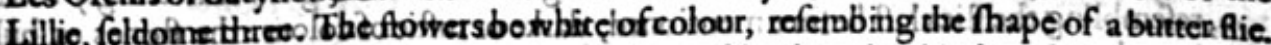
The ftalke is a foote high, the roote is two ftones like the other kindes of ftones or $\mathrm{Cul}$

- lions.

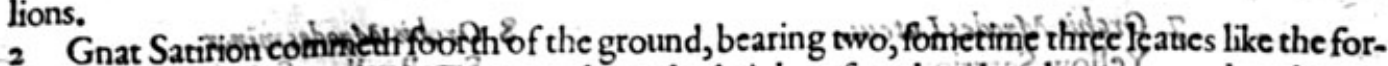
mer, but much fmaller. Thitftalfe groweth to the height of an hand, whereon are placed verie orderly finall fluwers like in fhape to Gnats and of the fame colour. The roote is like the former.

3 The Humble Bec Orchis hath 2 fewe fmall weake and fhorte leaues, which growe fcatteringly about the ftalke. The floyers grow at the top among the fmall leaues, refembling in thape the hum. ble Bee. The roote colififteth of two ftones or bulbes with fome fewe threds annexed thereto.

4 The great Humble Bee Satirion groweth out of the ground, hauing ftalkes fmall and tender. The leaues are like the former, but fomewhat greater, declining to a browne or darke colour. The flowers be fmall, of the colour of a drie oken leafe, in thape refembling the great Bee called in Englith an Hornet or drone Bee. The roote is like the other.

5 The leaues of Wafpe Satirion are longer than the laft before mentioned, narrower, turning themfelues againft the fume as it were rounde. The ftaike is ronnd, tender, and verie fragile. At the top grow the flowers, refembling the fhape of the dead carkas of a Bee. The ftones or bulbes of the rootes be fmaller and roúnder than the laft rehearfed.

6 The Flie Satirion is ih his leaues like the other, fauing the they be not of fo darke a colour: the flowers be fmaller and more plentifully growing about the falle in fhape like vnto Flies, browne of colour.

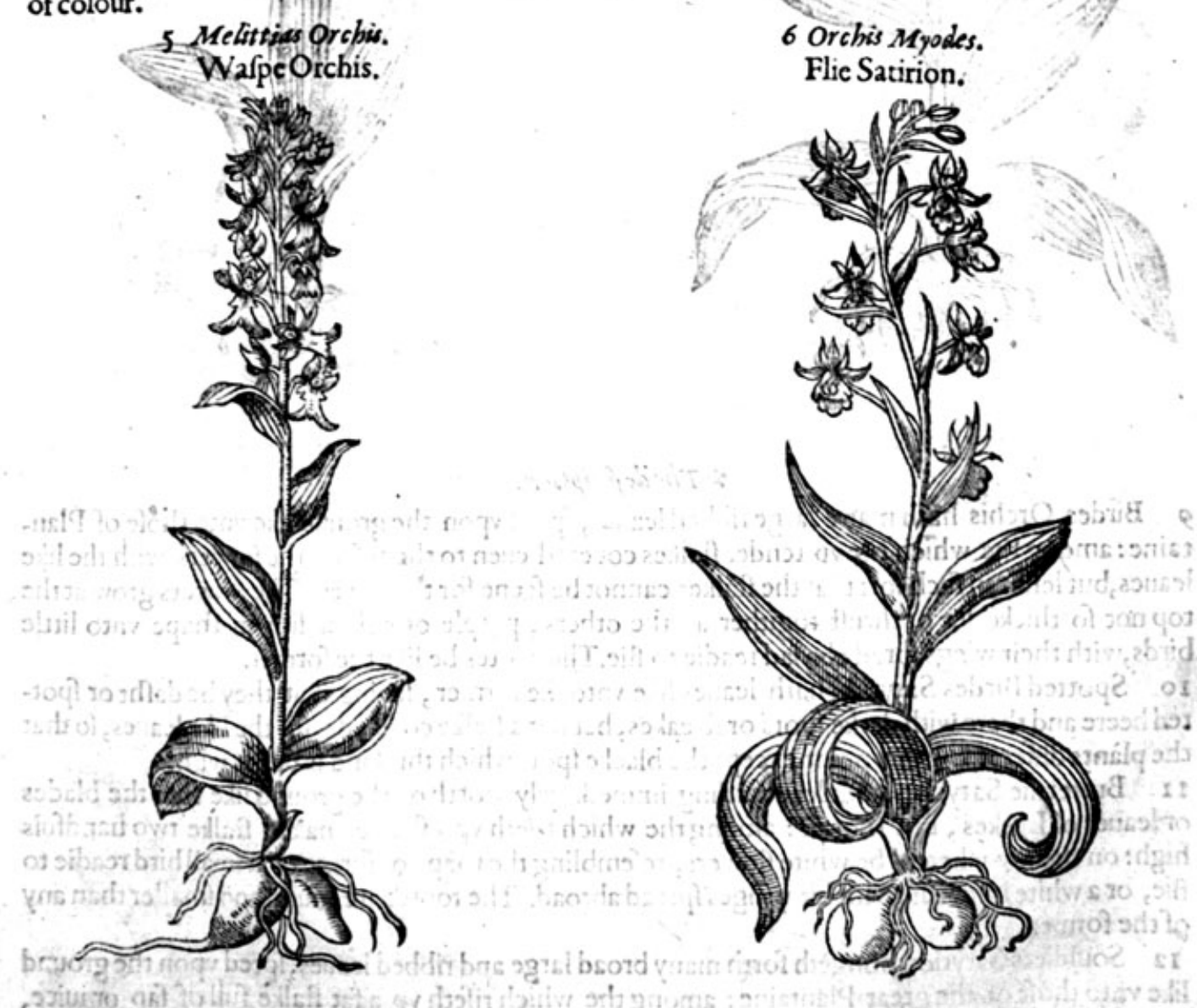

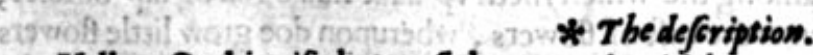

7 Yellow Orchis rifeth out of the grounde wich browne leaues, fmaller than the laft before mencioned. The ftalke is tender and crooked. The floivers grow at the top yellow of colour, in fhape refermbling the yellow Flies, bred in the dung of kine after raine. 


\section{THE FIRST BOOKE COE ITHE}

8 The fmall yellow Satyrion hath leaues fpread vpon the ground, at the firft comming vp; the flen. der ftalke rifeth yp in the middeft, of halfe a hand high. The flowers grow fectteringly towardethe top, refembling the flies laft before mentioned, darke or ruftic of colour : the ftories or bullbes are very round.

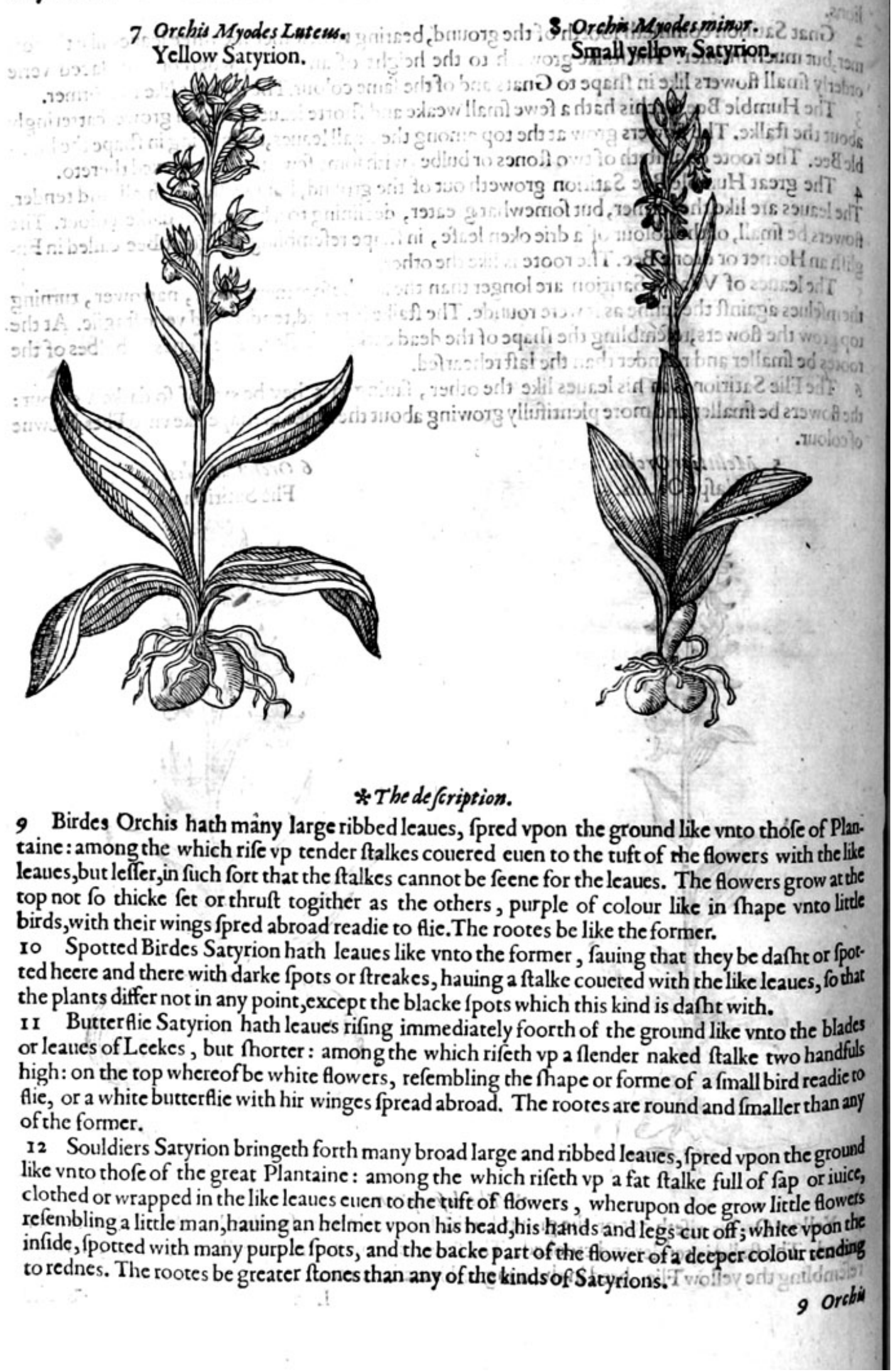




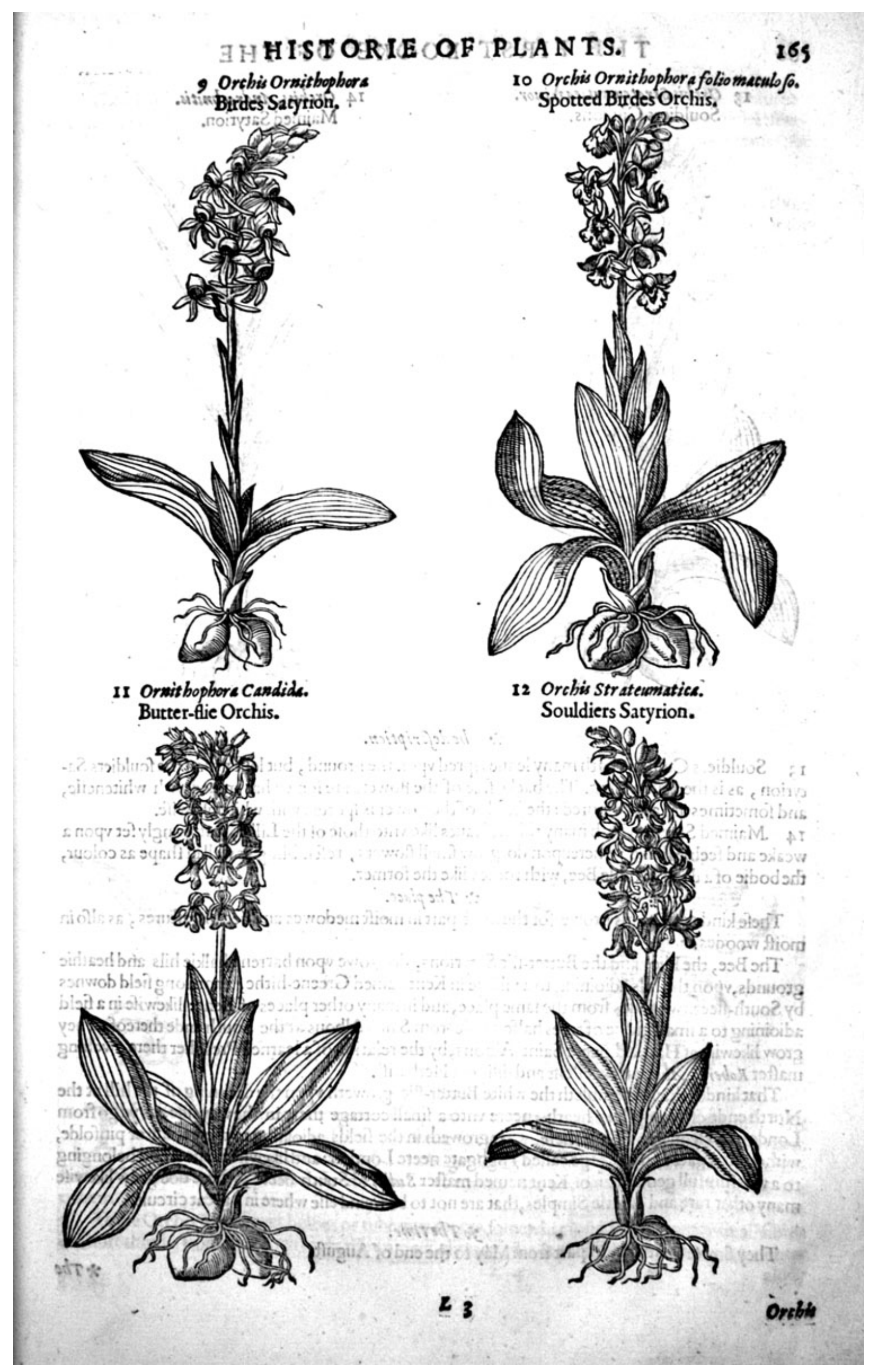


13 Orchis Stratenomaticathinor. Souldiers Cullions.

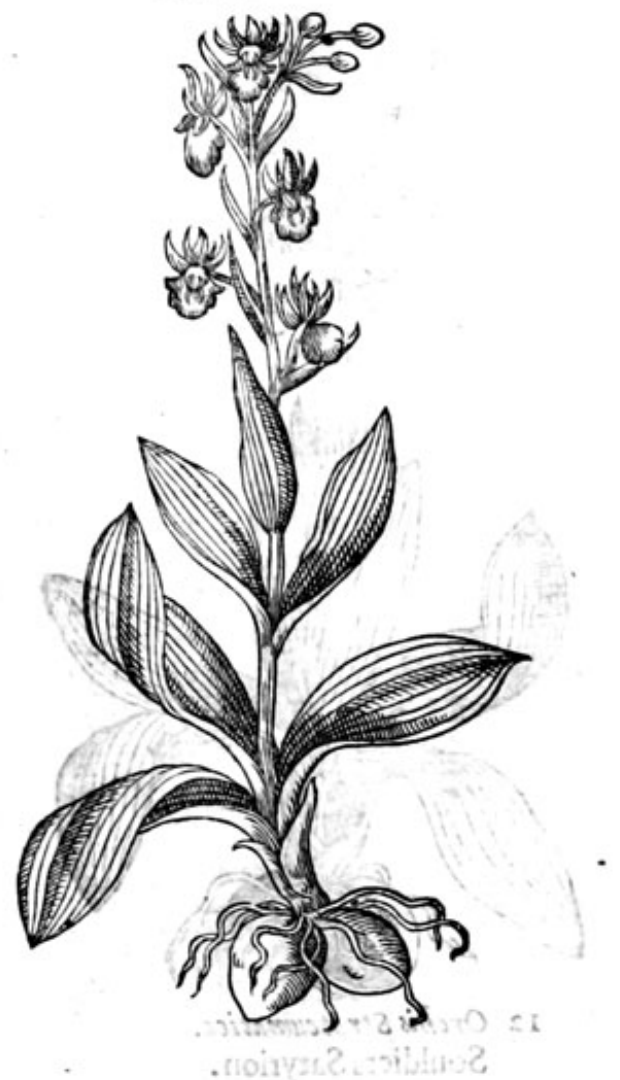

14 Orchis undrabumitio Maimed Satyrion.

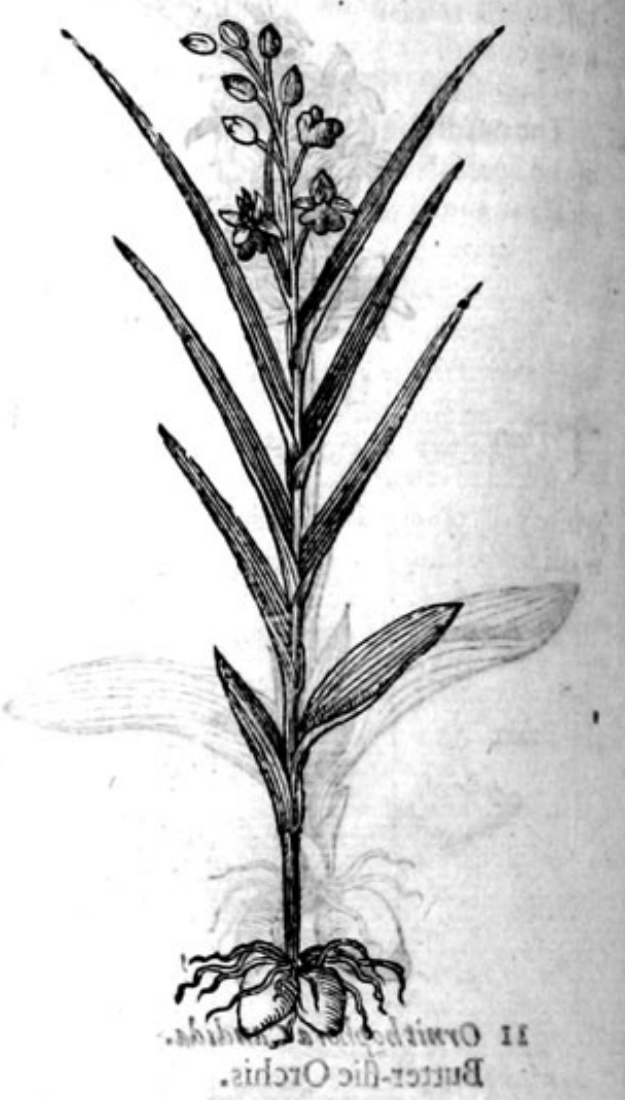

* T bedefcription.

13 Souldiers Cullions hath many leaues fpred vpon the ground, but leffer than the fouldiers $S_{2}$. tyrion, $2 s$ is the whole plant. The backe fide of the flowers are fomewhat mixed with whitenefle, and fometimes are afh coloured : the infide of the flower is fpotted with white likewife.

14 Maimed Satyrion hath many thinne leaues like vnto thofe of the Lillie, fcatteringly fet vpona weake and feeble ftalke : whereupon do grow finall flowers, refembling as well in mape as colour, the bodie of a dead humble Bee, with rootes like the former.

$$
\text { * The place. }
$$

Thefe kinds of Orchis growe for the moft part in moift medowes and fertill paftures, as alfoin moift woodes.

The Bee, the Flie, and the Butter-flie Satyrions, do growe vpon barren chalkie hils and heathic grounds, vpon the hils adioining to a village in Kent named Greene-hithe, vpon long field downes by South-feet, two miles from the fame place, and in many other places of Kent: likewife in a field adioining to a fmall groue of trees halfe a mile from Saint Albons at the South ende thereof. They grow likewife at Hatfield neere Saint Albons, by the relation of a learned Preacher there dwelling mafter Robert 1 Sbot, an excellent and diligent Herbarift.

That kinde which refembleth the white Butter-flic, groweth vpon the declining of the hill at the North ende of Hampiteed heath , neere vnto a fmall cottage there in the way fide, as ye gofrom London to Henden a village thereby. It groweth in the fields adioining to the pound or pinfolde, without the gate at the village called Highgate neere London: and likewife in the wood belonging to a worfhipfull gentleman of Kent named mafter Sidley of South-fleete, where doe grow likewile many other rare and daintie Simples, that are not to be found elfe where in a great circuit.

$$
\approx \text { The time. }
$$

They flower for the moft part from May to the end of Auguit. 


\section{IHTH IST QRIEO OFIRANTS. T}

Thefe kinds of Orchis haue not been mucb written of by the ancients, neither by thelatesuriters to any purpofe, fo that it may content you for this time to receiue the names fet downein their feue? rall titles, referuing what elfe might be faid as touching the Greeke, French, or Dutch names, or

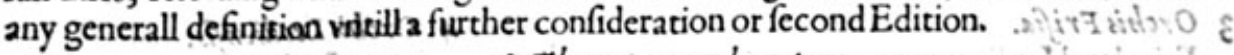

$.2925710155 .72 \ldots 1$ * The nature and vertues.

The nature and vertues of thefe kindes of Orchis are referred vnto the others, namely to thofe of the Foxe ftones : notwithitanding there is no great vfe of thefe in Phificke, but regarded for the pleafant and beaurifull flowers, wherewith nature hath feemed to plaie and difport hir felfe.

\section{Of Sweete Cullions. Chap.roz.}

* T'be kindes.

$T$ Here befundrie forts of fweete fmelling Tefticles or ftones, whereof the firft is moft fweete and pleafant in fmeli; the others of leffe fmell or fauour, differing in flowers \& rootes. Some haue white flowers; others yellow; fome flefh coloured; fome dafht vpon white with 2 little reddilh wafh, fome haue two Itones, fome three, and others fower, wherin their difference doth confift.

I Testiculus odorat m. Ladie Traces.

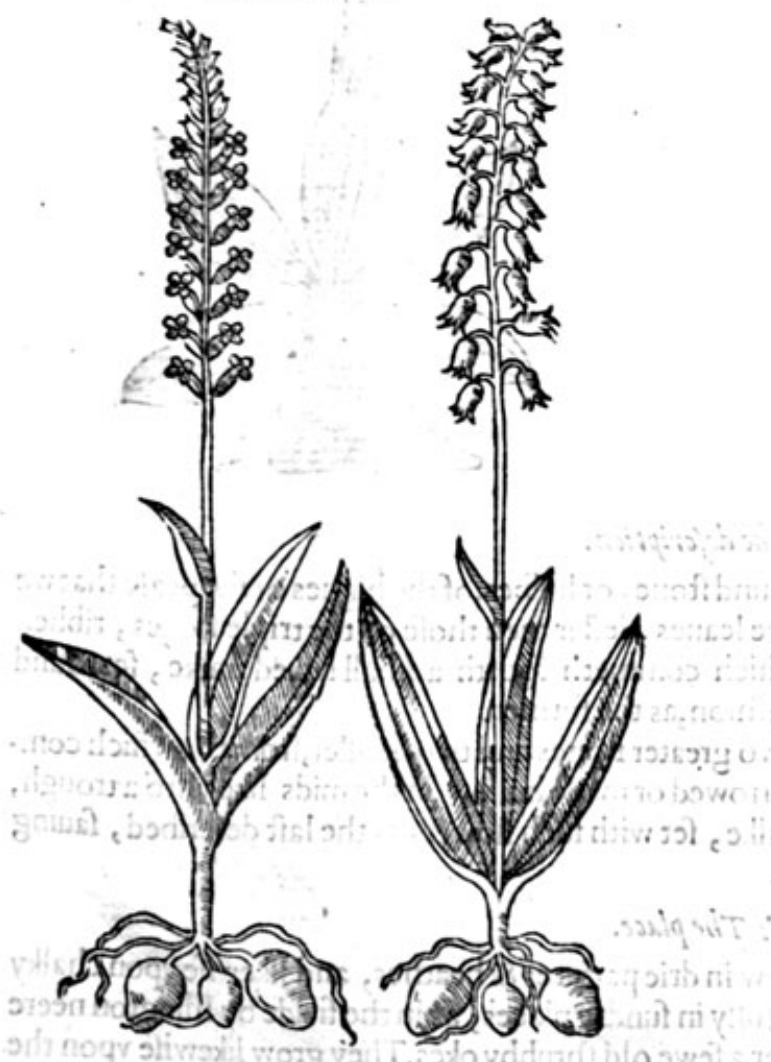

* The defoription.

2 Triorchis.

Triple Ladie Traces.

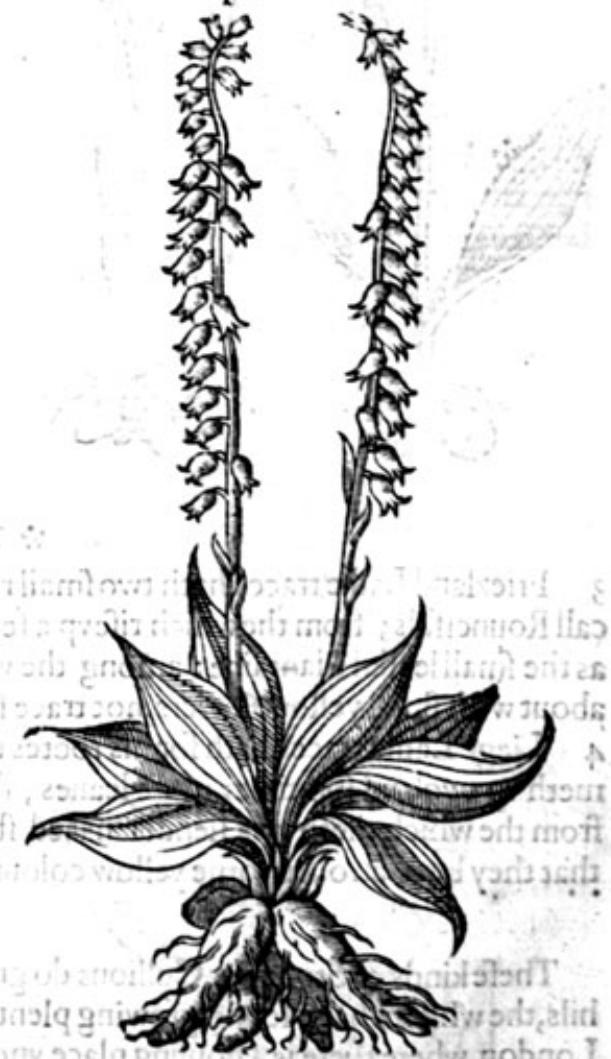
$x \supset$ le He firt kind of Sweete ftones is a fmall, bare, and lowe plant in refpect of all the reft. The leaues be fmall, narrow and, thort, growing flat vpon the ground: among the which rifeth

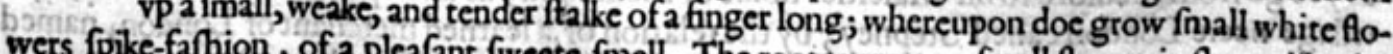
wers fpike-fafhion, of a pleafant fweete fmell. The rootes are two fmall ftones in fhape like the others.

2 Triple Orchis hath fower bulbes or tuberous rootes, fomewhat long, fet wich many fmall fibres or fhort threds, from the which roots rife immediatly many flat \& plaineleaues, ribbed with neruos 
along the leaues, like thole of Plantaine: among which come foorth naked ftalkes, fmall and tender; whereupon areplaced certaine fmall white flowers, trace farhion, not fo fweete as the former in fmell and fauour.

3 Orchis Frifin.

Friezland Ladie traces.

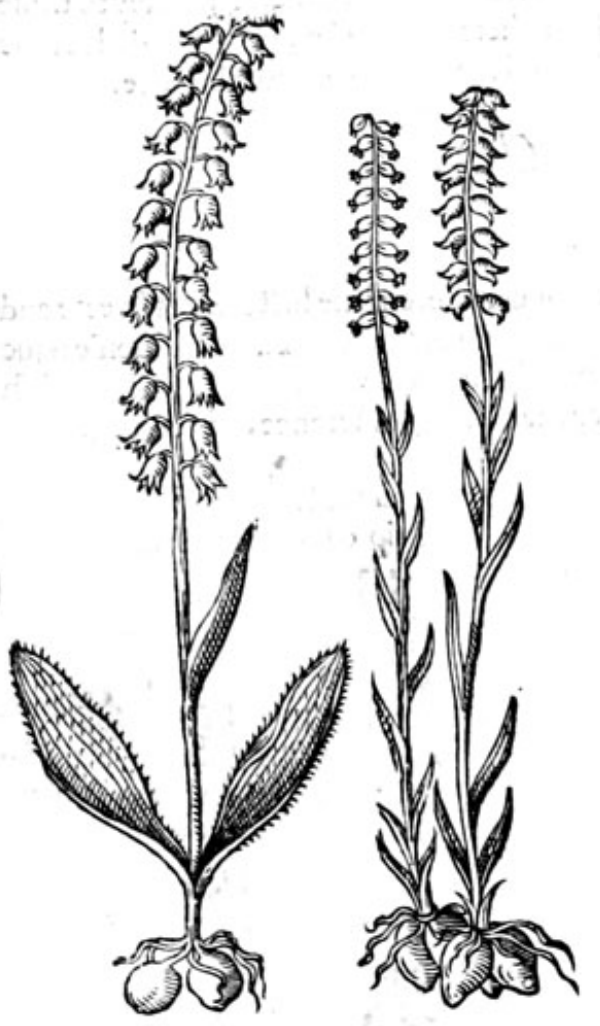

4 Orcbis Leodienfis. Liege Ladie traces.

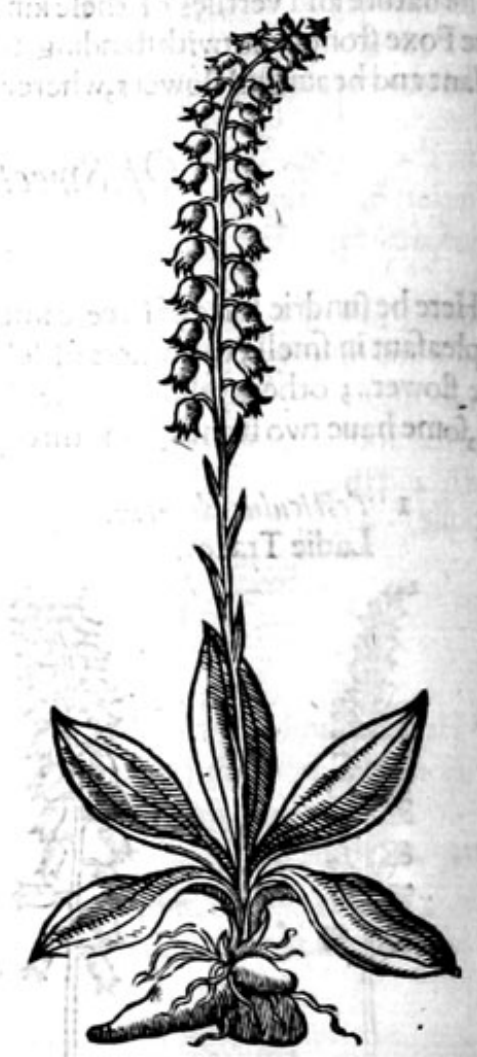

* The defcription.

3 Friezland Ladie traces hath two fmall round ftones or bulbes, of the bignes of the peafe thatwe call Rouncifals; from the which rifevp a fewe leaues, leffer then thofe of the triple ftones, ribbed as the fmall leafed Plantaine: among the which commeth foorth 2 fmall naked italke, fetround about with fmall yellow flowers, not trace fafhion, as the former.

4 Liege Ladie traces hath for his rootes two greater ftones and two fmaller; from the which commeth vp two and fomtimes more leaues, furrowed or made hollow in the mids like vnto a trough, from the which rifeth vp a flender naked ftalke, fet with fuch flowers as the laft defcribed, fauing that they be of an ouerworne yellow colour.

\section{* The place.}

Thefe kinds of Stones or Cullions do grow in drie paftures \& heathes, and likewife vpon chally hils, the which I haue found growing plentifully in fundry places, as in the fielde by Illington neere London, where there is a bouling place vnder a fewe old hrubby okes. They grow likewife vpon the heath at Barne-elmes, neere vnto the head of a conduit that fendeth water to the houfe belonging to the late fir $F$ rances $V V$ al fing ham. They grow in the field next vnto a village called Thiflewoorth, as yee go from Branford to hir Maiefties houfe of Richmond; as alfo vpon a common heath, bya village neere London called Stepney, by the relation of a learned merchant of London, named mafter lames Cole,exceedingly well experienced in the knowledge of Simples.

The yellow kinds growe in barren paftures and borders of fields about Ouenden and Clare in Effex. Likewife neere vnto Muche Dunmowe in Effex, where they were fhewed me by aleamed gentleman mafter James $T$ waights, excellently well feene in the knowledge of plants: 
Thefe kinds of Stones do flower from Auguft to the end of September. * The names.

The firft is called in Latine Testiculus Odorat us : in Englifb fweete fmelling Tefticles or Stones, not of the fwetenes of the rootes, but of the flowers. It is called alfo Orehis piralis, or cat uemnalis, for that it commeth to flowring in Autumne : of our Englifh women they becalled Ladie traces: in euery countreyby a feuerall name, as of fome fweete Ballocks, fweete Cods, fweete Cullions and Standergraffe. In Dutch finabenktaut,and stanoelctaut : in French Sat irion.

The lecond fort is called Tworchis, and alfo Tetrorchis: in Englifh triple Ladie laces, or white Orchis.

The third is called Orchis Frizia : in Englifh Friezland Orchis.

The laft of thefe kinde of Stones or Tefticles, is called of fome Orchis Leodien/is, and Orchis Lettea : in Latine likewife Bafilica minor Serapias, and Troorthis 1 Eginete : in Englifh yellowe Ladie traces. * The temperature.

Theie kinds of fweete Cullions are of nature and temperature like the Dogs ftones, although not vfed in Phificke in times paft, notwithftanding later writers haue attributed fome vertues vnto them as followeth.

$*$ The vertmes.

The full and fappy rootes of Ladie traces eaten or boiled in milke and drunke, prouoke venery, $\mathbf{A}$ nourifh and ftrengthen the bodie, and be good for fuch 25 are fallen into 2 confumption or feuer Hectique.

\section{Of Satyrion royall. Chap.103.}

\section{* The kinds.}

7 Here be fundrie forts of Stones comprehended of the auncients vnder the generall tritle Satirion roiall, notwithftanding for diftinetions fake, and for the eafier vnderftanding of the Rea. der, I haue fet downe onely two, male and female, the reft I thought good to make the kindes of Serapias Stones.

I Palma Christi mas.

The male Satyrion royall.

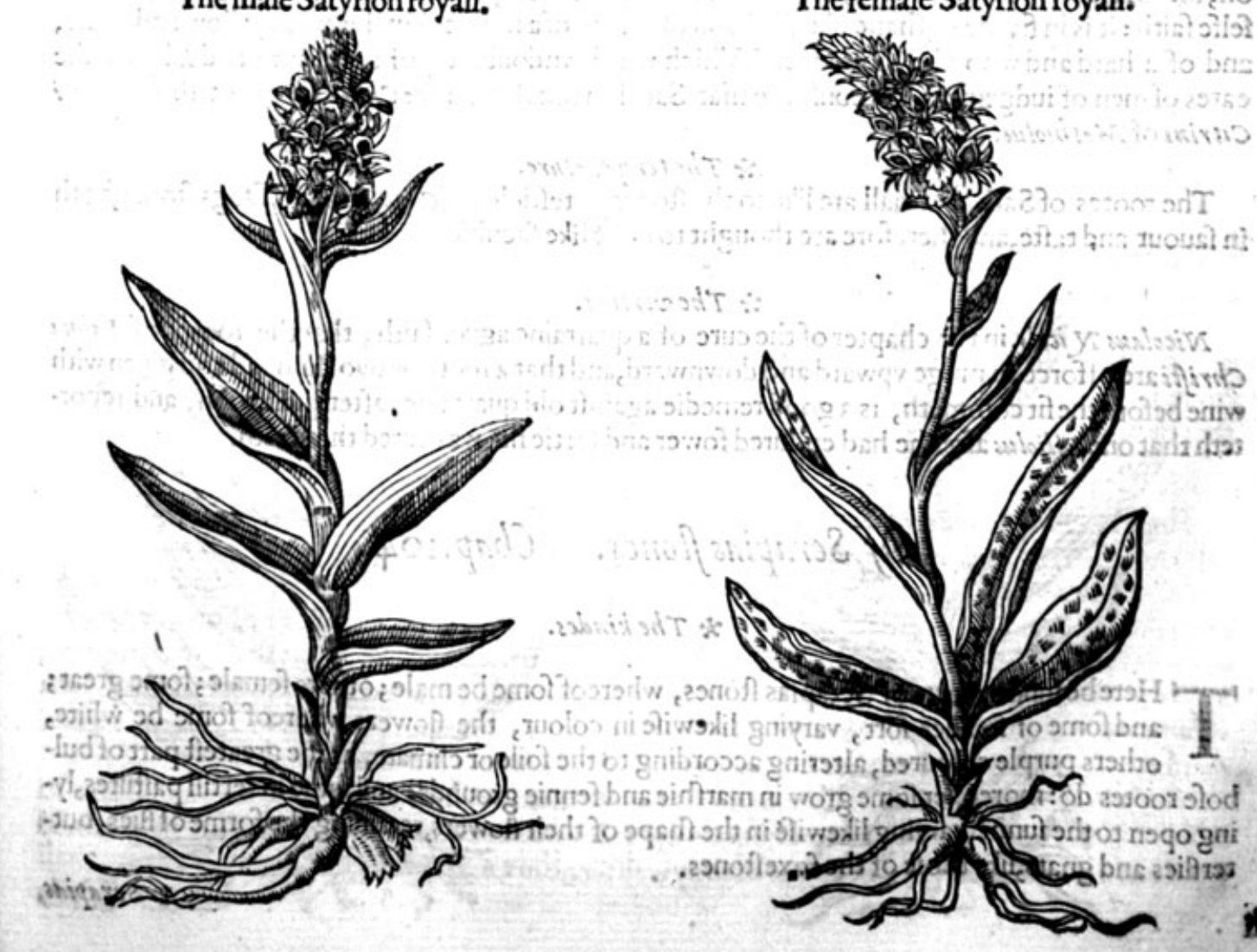

2 Palma Christi famina. The female Satyrion royall. 


\section{THE FIRST BOOKE OF THE}

\section{* The defcription.}

1 He male Satyrion roial hath large rootes, knobbed, not bulbed as the others, but branched or cut into fundrie fections like an hand, from the which come vp thicke and fatte ftalks, fet with large leaues like thofe of Plantaine: at the top whereof groweth a tuft of purple flowers, fpotted with a deeper purple colour.

2 The female Satyrion hath clouen or forked rootes, with fome fibres ioined thereto. The leaues be like the former, but finaller and narrower, and confufedly dafht or fported with black fpots: from the which fpringeth vp a tender ftalke, at the top whereof doth grow a tuft of purple flowers, in faThion like vnto a friers hood, changing or varying according to the foile and climate, fomtimes red, forntimes white, and fomtimes light carnation, or fleth colour.

\section{* The place.}

The roial Satyrions do grow for the moft part in moift and fennie grounds, medowes and woods that aie very moift and Thadowie. I haue found them in many places, efpecially in the middeft of 2 wood in Kent called Swainefcombe wood neere to Grauefend, by the village Swainefcombe, and likewife in Hampfteed wood fower miles from London.

They flower in Maie and Iune, but feldome later.

*The time.

* The names.

Roiall Satyrion or finger Orchis, is called of the Latines Palma Christi; notwithftanding there is another herbe or plant called by the fame name, which otherwife is called Ricinus. This plant is called likewife of fome Satiria Bafilica, or Satiriaregia. Some would haue it to be Buzeiden, or Buzidas LAbiom, but UAuicen faith Buzeiden bc hard white rootes, like thofe of Beben album : but contrariwife the rootes of Palma Christi are nothing leffe than wooddie, fo that it cannot bethe fime. Whatbiolus would haue Satition roiall to be Digiti Citrimi tusicenne, finding fault with themonkes which fet foorth commentarics vpon Mefues compofitions, doubting and leauing itto the cenfuring of the difcreet Reader. Yest do we better allow of the monkes doubt than of Mathiolus affertion, for Luicens words be thefe; What is LAaba/afra, or Digiti Citrini, anfwering the doubthimfelfe faith; it is in figure or thape like the hand of a man, of a mixt colour between yellow and white, and of a hard and wooddie fubstance. Which words vndoubtedly of Awicenna and $k$ hafss in the eares of men of iudgement do confirme that Satirion roiall or Palma Christi, are not thofe Digiti Citrini of Mathiolus.

* The temperature.

The rootes of Satirion roiall are like to the ftones or tefticles of cynoforcbis,or Dogs ftones, both in fauour and tafte, and therefore are thought to be of like faculties.

* The vertues.

Nicolass 2 ictals in the chapter of the cure of a quartaine ague, faith, that the rootes of $P$ dims Chrifti are of force to purge vpward and downward, and that a roote or two ftamped and given with wine before the fit commeth, is a goodremedie againft old quartaines after purgation, and reporteth that one siliolus after he had endured fower and fortie fits was cured therewith.

$$
\text { Of Serapiasftones. Chap. } 104 \text {. }
$$

* The kindes.

There befundrie forts of Serapias ftones, whereof fome be male; others female; fome great; and fone of fmaller fort, varying likewife in colour, the flowers whereof fome be white, others purple coloured, altering according to the foile or climate, as the greateft part of butbofe rootes do: moreouer fome grow in marfhic and fennie grounds, and fome in fercill paftures, $15^{\circ}$ ing open tothe funne, varying likewife in the fhape of their flowers, retaining the forme of flies, buteterties and goats like thofe of the foxeftones.

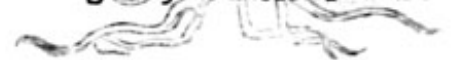


I Serapias Candido flore. White handed Orchis.

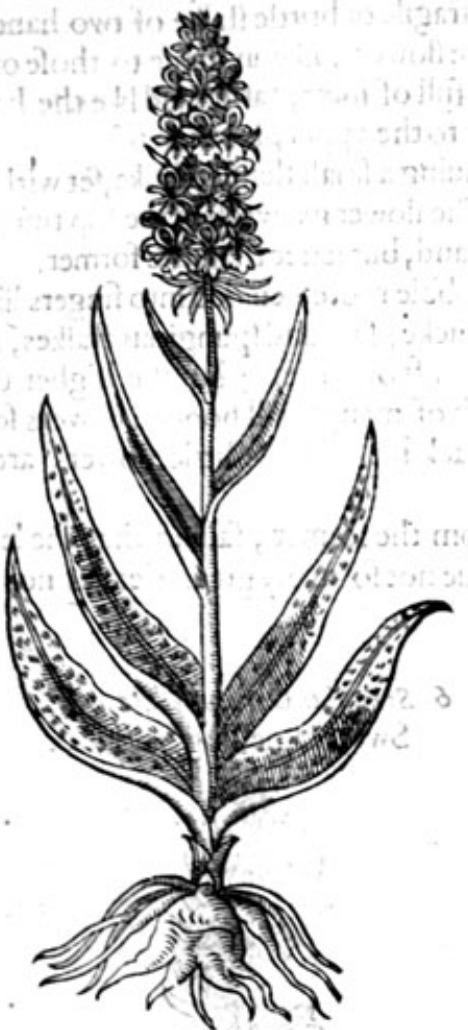

3 Serapias paluftris Latifolia. Marrifh Satyrion.

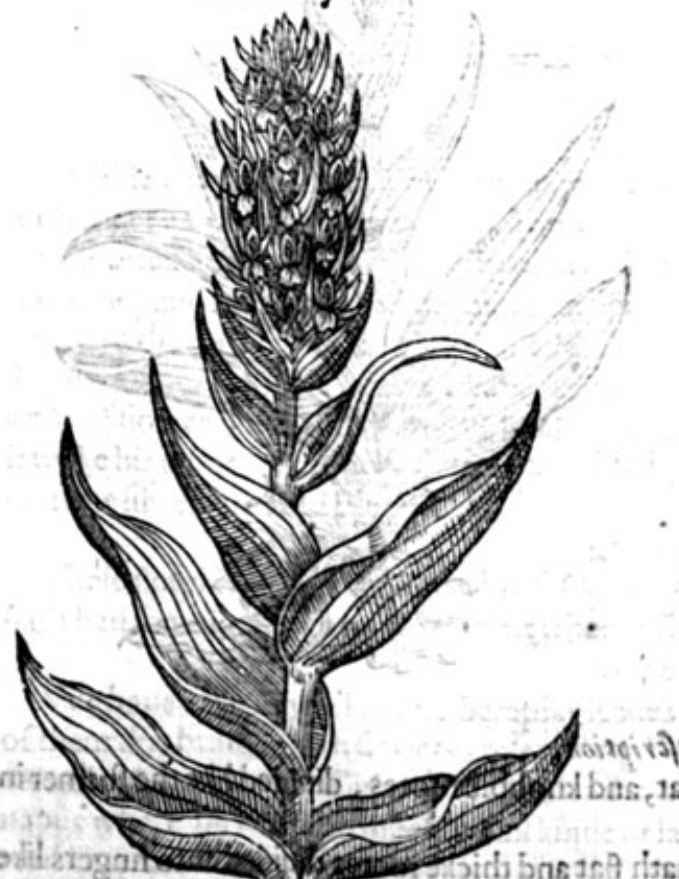

2 Ser apias minor, nitente fore.

Redhanded Orchis. (40. in
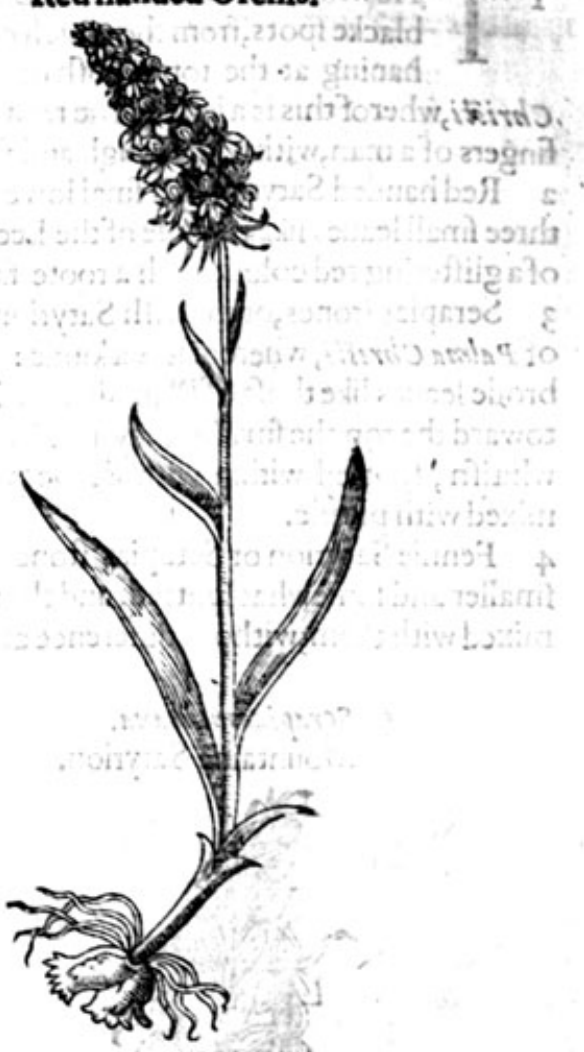

4 Serapies palistiri leptophylh. Fennic Satyrion.

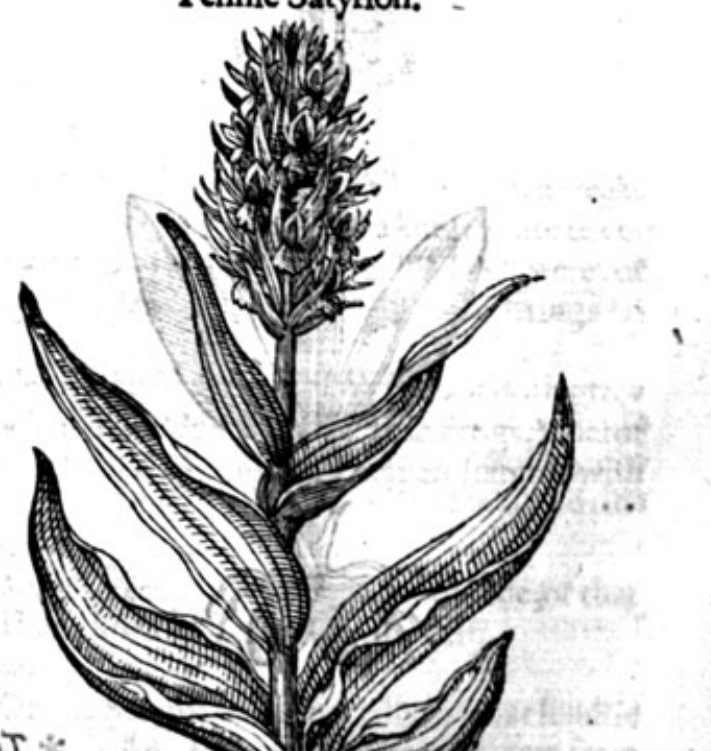

Sh xit 2

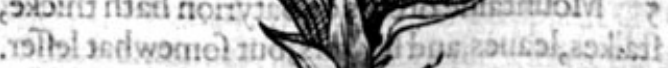

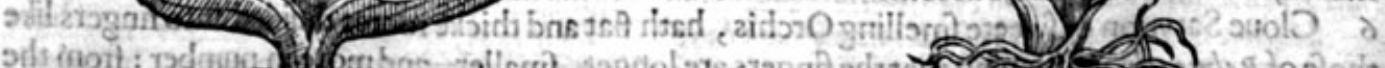

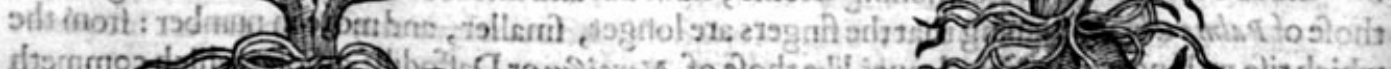

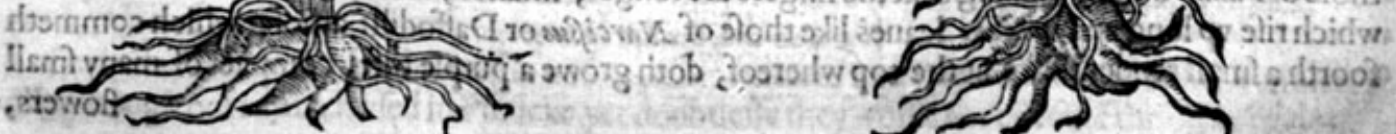



He white handed Orchis orSatyrion, hath long and largeleanes f potted and dafhe with blacke fpots, from the which doth rife vp a fmal fragile or brittle ftalke of two hands high, hauing at the top a bufh or fpokie tuft of white flowers, like in fhape to thofe of $P_{a} b_{m}$ Christi, wherof this is a kinde. The roote is thick, fat, and full of iuice, fafhioned like the hand and fingers of a man, with fome tough and fat ftrings faftened to the vpper part thereof.

2 Red handed Satyrion is a fmal lowe and bale herbe, hauing a fmall flender ftalke, fet with two or three fmall leaues like to thofe of the Leeke, but fhorter. The flower groweth at the top tuft fafhion, of a gliftering red colour, with a roote fafhioned like an hand, but leffer than the former.

3 Serapias ftones, or marrifh Satyrion, hathe thicke knobbie roote, deuided into fingers like thofe of Palma Christi, whereof it is a kinde : from which rife thicke, fat, and fpungious ftalkes, fet with brode leaues like thofe of Plantaine, euen to the top of the tuft of flowers; but the higher they rif: toward the top the fmaller they are. The flower confifteth of many fmall hooded flowers fomwhat whitifh, fpotted within with deepe purple fpots; the backfide of thefe little flowers are violet, mixed with purple.

4 Fennic Satyrion or Serapias ftones differeth little from the former, fauing that the leaues are fmaller and fomewhat fpotted, and the tuft of flowers haue not fo many greene leaues nor folong, mixed with them, without difference at all in the rootes.

5 Serapias montana.

Mountaine Satyrion.

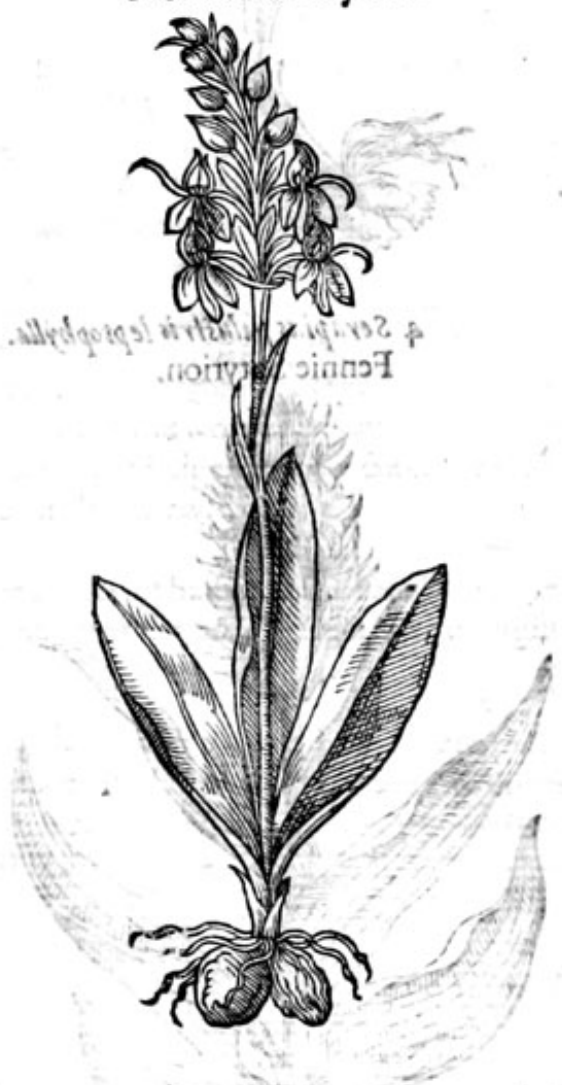

6 Serapias Gariophyllate.

Sweete finelling Satyrion.

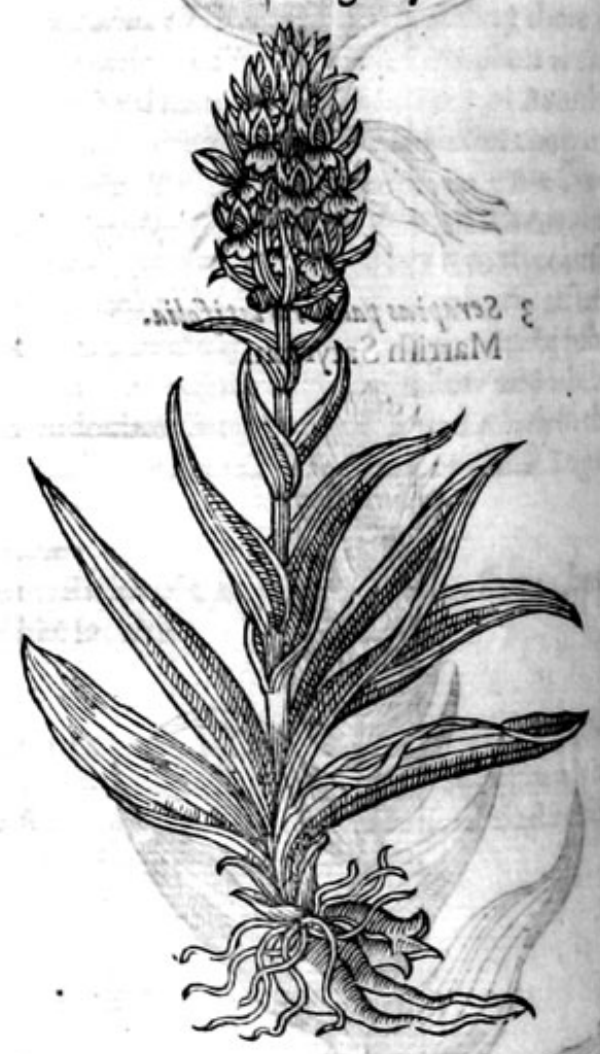

* The defcription.

5 Mountaine orchis or Satyrion hath thicke, fat, and knobbie rootes, diuided like the former in ftalkes, leaues, and flowers, but fomewhat leffer.

6 Cloue Satyrion or fweete fmelling Orchis, hath flat and thicke rootes diuided into fingers lite thofe of Palma Christi, fauing that the fingers are longen, fmaller, and more in number : from the which rife vp long and narrow leaues like thofe of Narcißsus or Daffodill: among which commeth foorth 2 fmall tender ftalke at the top whereof, doth growe a purple tuft, compact of many fmall 
flowers refembling Flies, but in fauour and fmell like the Cloue, or Cloue gillofer; but farrefweeter and pleafanter, as my felfe wich many oghers can wifnes now fining ghat haue both feene and fmele them in my garden.

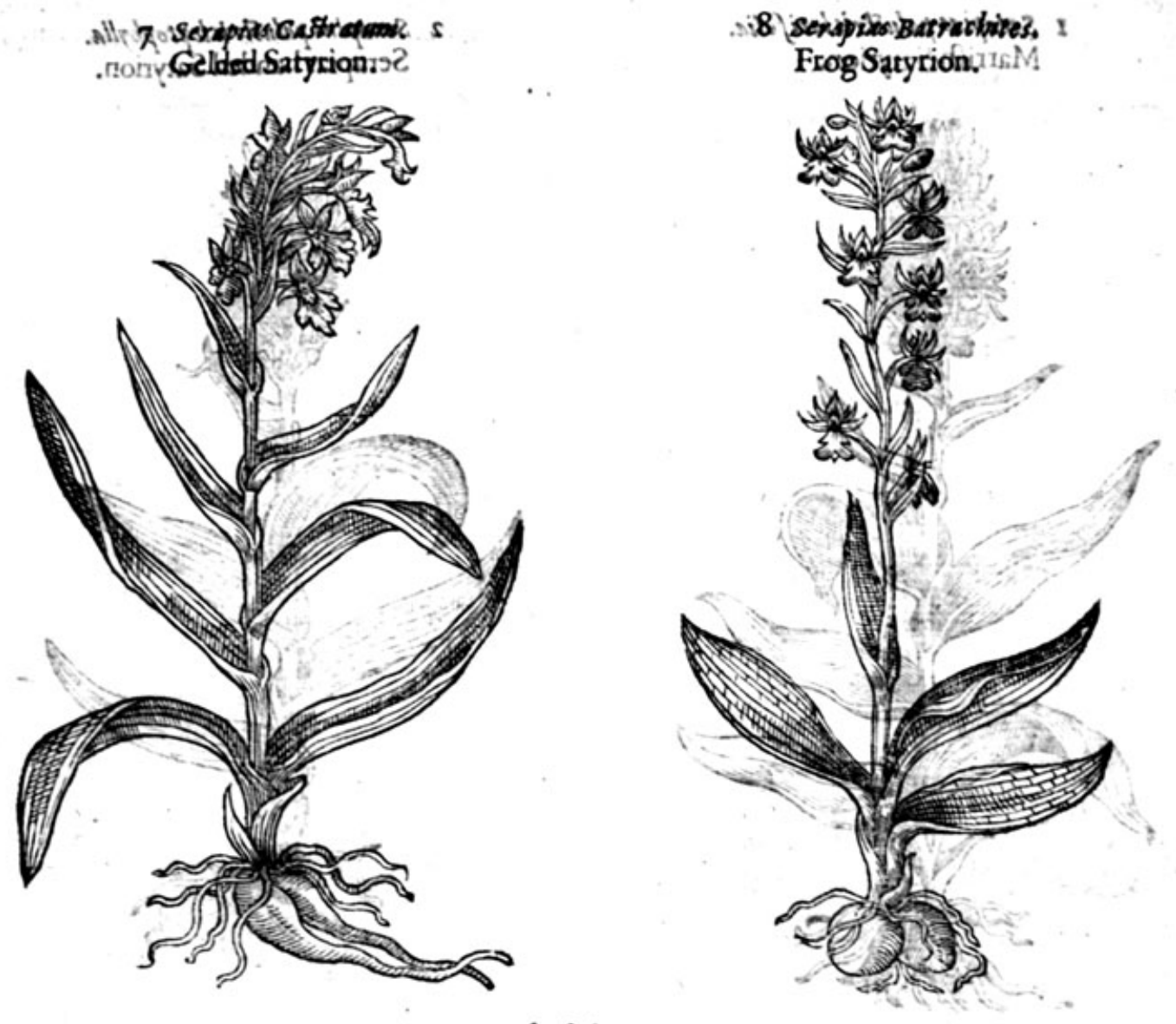

* The defription.

7 Gelded Satyrion hath leaues with nerues and finewes like to thofe of Daffodill, fet vpon a weake and tender ftalke, with flowers at the top refembling the crówne or diademe of a king, white of colour, fpotted within the flower in thape like Grats and little Flies. The ftalke is gelded as it were, or the ftones and handes cut off, leauing for the roote two longlegs or fith gers, with matry ftrings faftened to the top. 8 Frog Satyrion hath fimal fat leaues fet vpon a flender weake ftem at the top wherofdoth grow a tuft of tlowers compact of fundrie finall flowers, which in fhape doe refemble little Frogs, wherof it tooke his name. The roote is likewife gelded, onely referued two fmall milfiapen lumpes with certaine fibres annexed thereto.

Thefe flourith in May and Iune, but feldome after Auguif, except fome degenerate kinde, of that hath had fome impediment inthe time when it fhould haue lowied, as often happenethet : 270 wo

$$
\text { * The names. }
$$

We have called thefe kindes, Serapias ftones, or Orchis Serapiades, efpecially for that fundrie of them doe bring foorth flowers, re embling flies and fuch like, taking the name as it were from Serapies the god of the Citizens of Alexandria in Aegypt, whohad a moft famous Temple at Canapus where he was worfhiped by allkinde of lafcilitous wantonnes, fongs, dauncings, as wemay read in Strabo in his 17 , booke. It is allo called Entaticos, Panion, and of the Latimes Tesficulis leporimus,and Satyrium: of fome Orchis : in Englifh Satyrion, and finger Orchis, and Hares ftones.

Seclib a Serapias ftones are thought to be in nature, temperature, and vertues like vinto the Satytioh roi- all,although not fo much vied in Phificke, yet doubtlefle they worke the effectof the other it bies? 


\section{Of Fennieftones. Chap.ro5.}

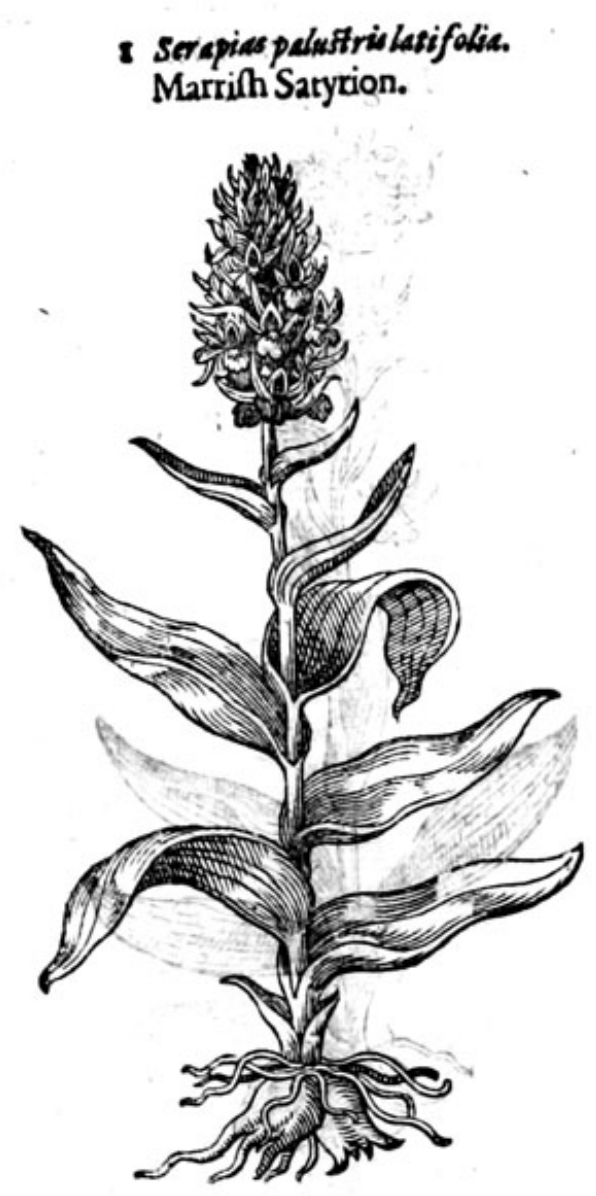

2 Serupida palafirieleptopholla.
Serapiasthanded Satyrion.

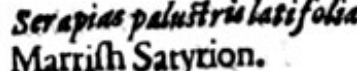
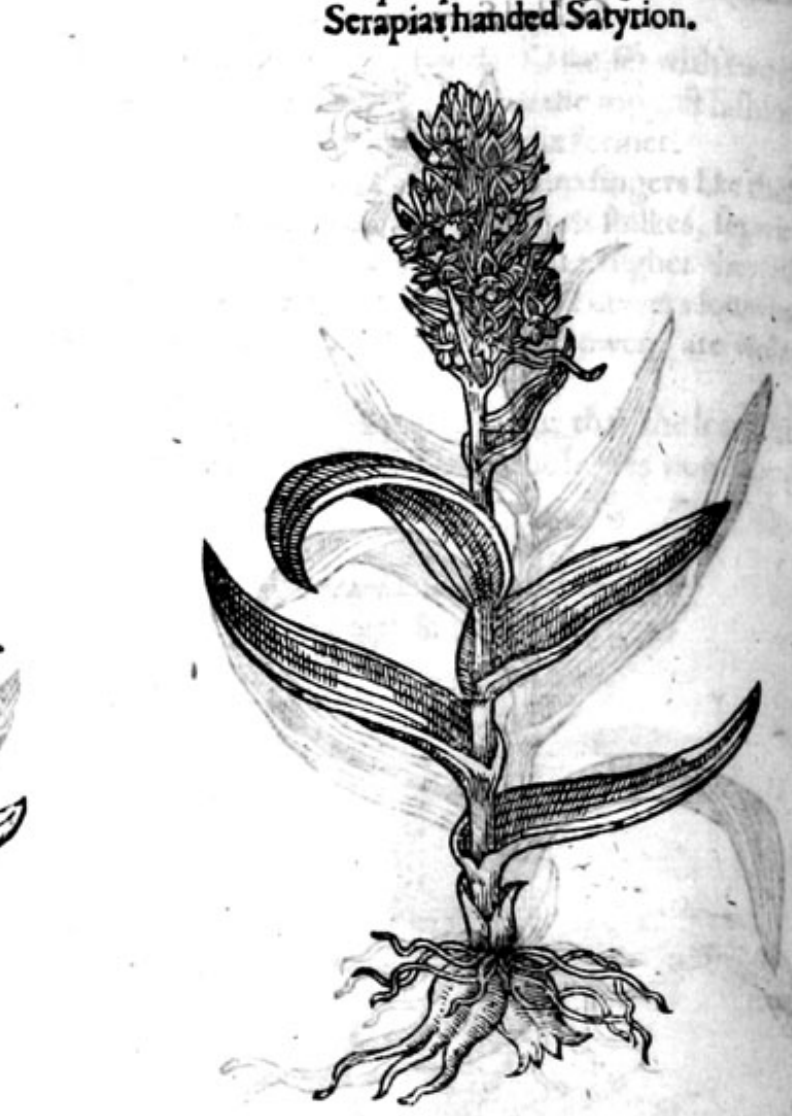

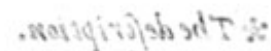

* The defoription.

I

'B Road leafed Serapias ftones hath cleft or diuided rootes like fingers, much like vnto the rootes of Palma Christi, whereof this is a kinde : from the which rifethvp a ftalke of a foore high, fet heere and there with very faire Lillie like leaues, which do clip or imbrace the ftalls almoft round about like the leaues of Thorowewax: at the top of the ftalke groweth a faire burh of white flowers, fpotted or darht ouer with purple: among the which flowers grow many finall green Tharpe pointed leaues. The feede I could neuer obferue, being a thing like duft that flieth in the winde.

2 Serapias handed Satyrion differeth little from the precedent, but in greatneffe \& colour of the flowers: for this plant bringeth foorth faire white flowers gaping wide open; in the hollownefle whereof appeere certaine things obfcurely hidden refembling litule Helmets, which fetteth foorth the difference.

3 Handed Satyrion hath very great rootes, with fome ftrings faftened to the vpper part thereof, falhioned like an hand, whereof it tooke his name; from which rifeth vp a faire ftiffe ftalke, armed with large leaues, verie notablie ftraked with blackifh fpots, clipping or embracing the ftalke round about: at the top of the ftalke ftandeth 2 faire tuft of purple flowers, with manie greene leaues mingled amongtt the fame, which inaketh the bufh or tuft much greater. The feed is nothing elfe but 25 it were duft like the other of his kinde.

4. The Eunuch Orchis or handed Satyrion with tefticles, hath manie long rootes, difperfing themfelues, or creeping farre abroad in the grounde, contrarie toall the reft of the Orchides: whic 


\section{HIS TOR IE COFI PLANTS. HT}

rootes are of the bigneffe of ftrawes in fubltance, like thole of Sopewoort; from the which immediately rife fower or fiue broade fmooth leaues like vnto the finall Plantaine, from the which Thooteth vp a fmall and tender ftalke; at the top whereof groweth a pleafant fpikie eare of a purple or incarnate colour, fpotted on the infide with little fpeckes of bloody colour. The feede is very fmall, yet better tobe obferued than any of the reft of the Orchides.

3 Palma Cloriftipalustris. Handed marilh Satyrion.

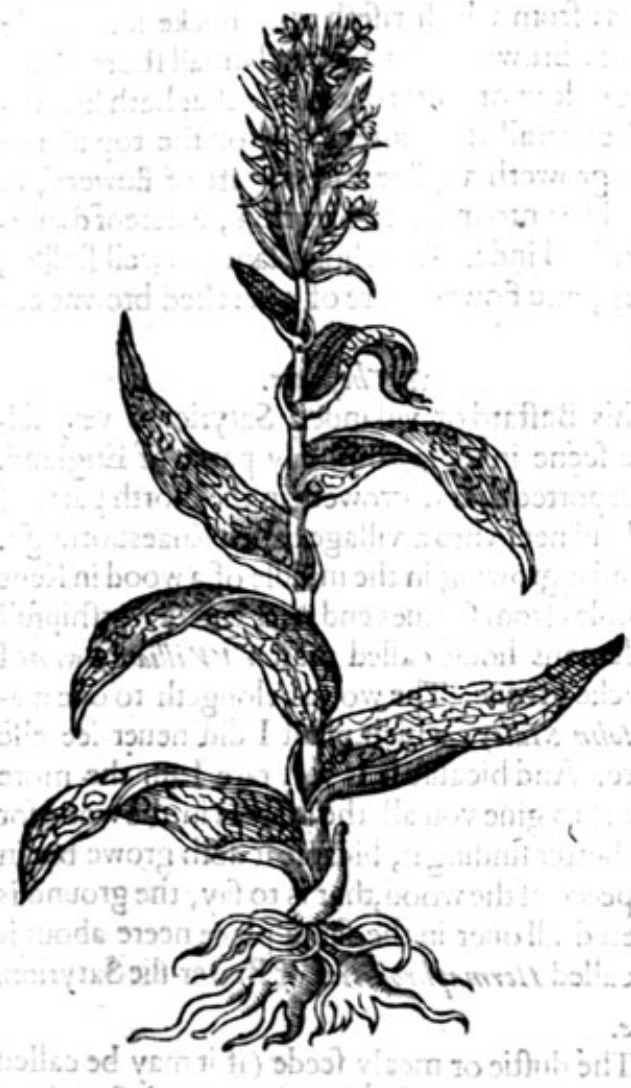

4 Palma Christi, radicérepente.

Handed Satyrion without Itones.

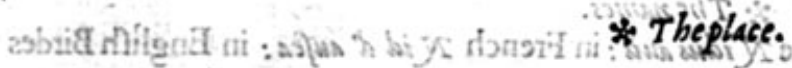

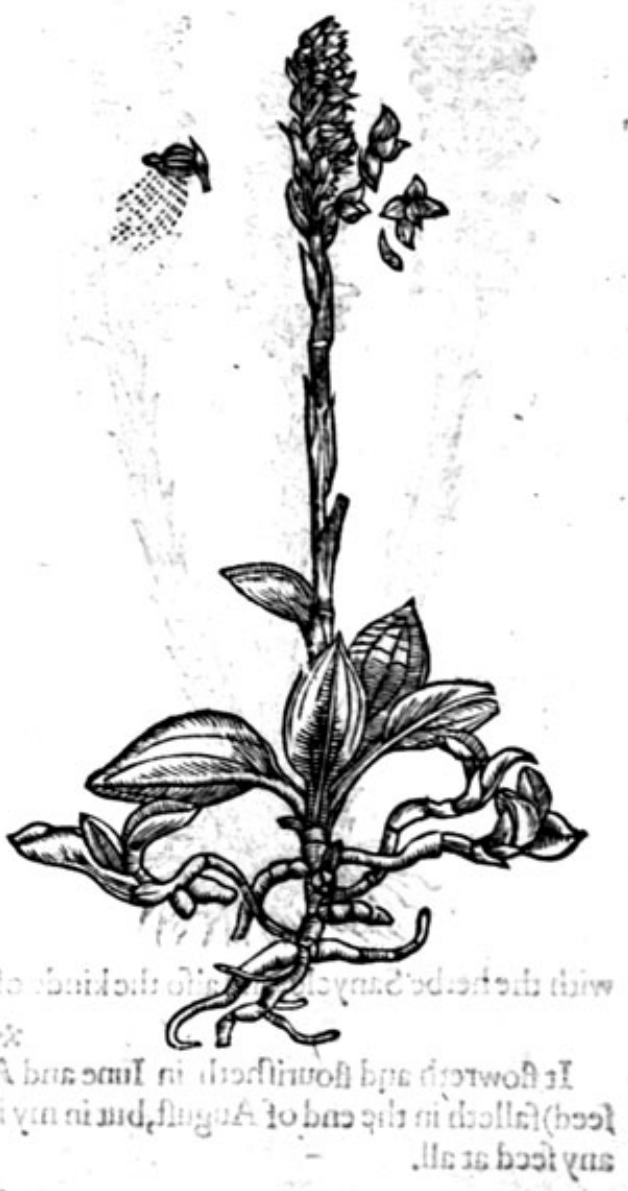

They grow in marifh and fenny groundes, and in hadowie woodes that are very moift. Bn floct The laft was found (by a learnec preacher called mafter 'sobert 1 abot of Bif hops Hatfield) in a boggie giouewhere a Conduite head doth ftand, that Pendeth water to the oreenes houfe in the fame towne.

\section{* Thesime}

They flower and flourifh about May and Iune,

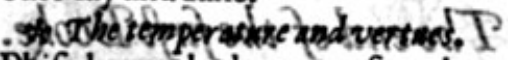

There is little vfe of thefe in Phificke, onely they arc referred vnto the handed Satyrions, wherof they are kinds: notwithftanding Dale fampins hath written in his great volume, that the marh Or. chis is of greater force than any of the Dogs ftones in procuring ofluft.

Camerarius of Noremberge, who was the firft that defcribed this kinde of creeping Orchis, hath fet it foorth with a bare defcription onely, and I am likewife conftrained to do the like, bicaufeas yet I haue had no triall thereof. 


\section{of Birdesneft. Chap.106.}

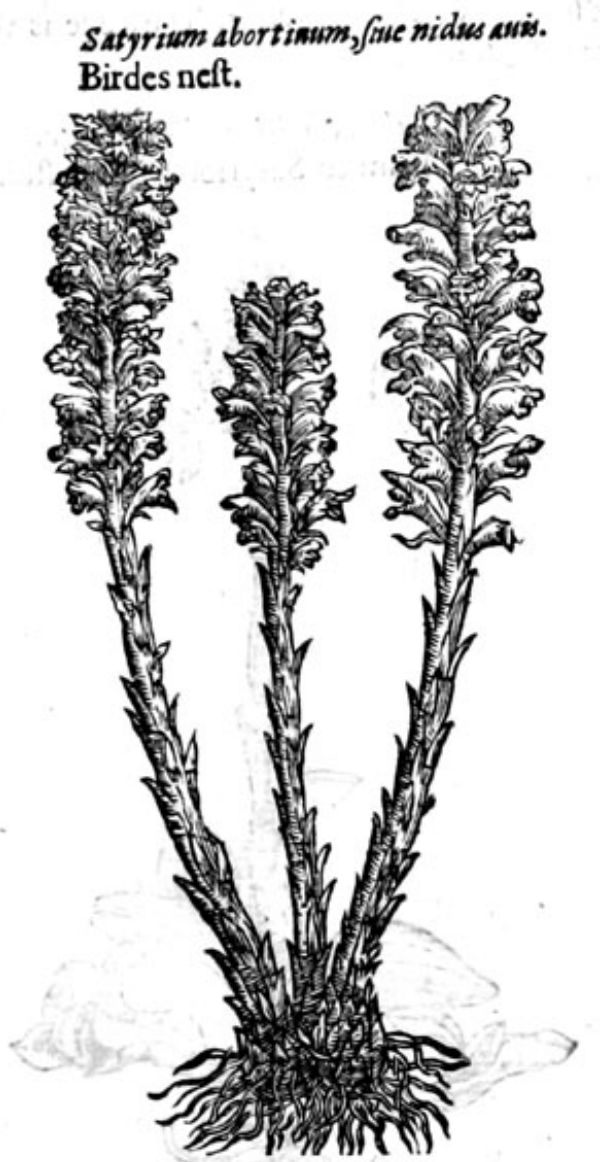

* The defoription.

$\mathrm{B}$ Irdes neft hath many tangling rootes platted or croffed one ouer another verie intricately, which refembleth a Crowes neft made of ftickes: from which rifeth vp a thicke foft groffe ftalk of a browne colour, fet with fmall hort leaues of the colour of 2 drie oken leafe that hath lien vn. der the tree all the winter long: on the top of the ftalke groweth 2 fpikie eare or tuft of flowers, in Thape like vnto maimed Satyrion, whereof doubs. leffe it is a kinde. The whole plant, as well ftalkes, leaues, and flowers, are of a parched brownecolour.

$$
\text { * Theplace. }
$$

This Baftard or vnkindely Satyrion is very fel. dome feene in thefe Southerly parts of England, It is reported that it groweth in the North parts of England neer vnto a village called Knaesborough, I found it growing in the middle of 2 wood in Kent two miles from Graues end, neer vnto a worhipfull gentlemans houfe called mafter $V V$ illiam Swan of Howcke greene. The wood belongeth to onema. fter Iubn Sidley: which plant I did neuer fee elfe where. And bicaufe it is very rare Iam the more willing to giue you all the markes in the woodfor your better finding it, bicaufe it doth growe butin one peece of the wood, that is to fay, the ground is couered all ouer in the fame place neere aboutit with the herbe Sanycle, and alfo the kinde of Orchis called Hermaphroditien, or Butter-fie Satyrion, * The time.

It flowreth and flourifheth in Iune and Auguft. The duftie or mealy feede (if it may becalled feed)falleth in the end of Auguft, but in my iudgement it is an vnprofitable or barraine duft,and not any feed at all.

* The nomes.

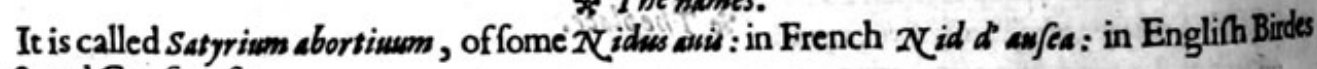
neft and Gooleneft.

* The temperature and verties.

It is not rfed in Phificke that I can finde in any autoritie, either of the auncient or later writes but is efteemed as a degenerate kinde of Orchis, and therforenot vfed.

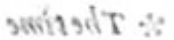

\section{The end of the firft Booke.}

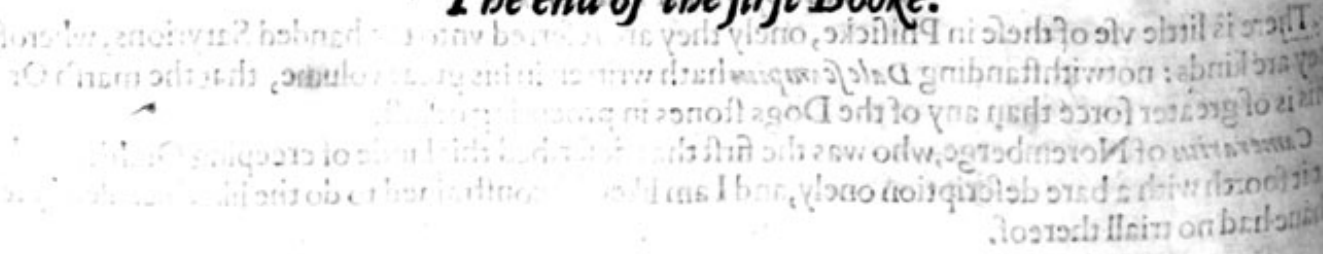




\section{THE SECOND BOOKE OF THE HISTORIE OF \\ P L A N T S: \\ Containing the defcription, place, time, names, nature, and vertues of all forts of berbs for meate; medicine, or fweete fmelling vfe, «c.}

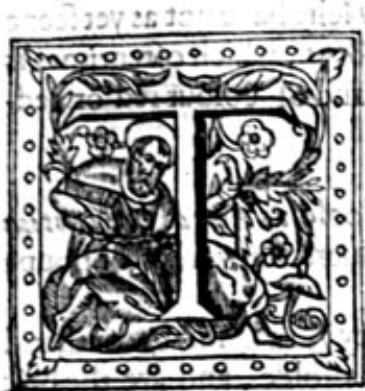

He treatic of Graffes, Ruthes, Corne and bulbus rootes, we haue in ouf fiift Booke fufficiently defcribed, \& fuch alfo as whote braue and gallant fowers do decke and beautifie Gardens, and feede rather the eies than the bellie. Befides thefe, there remaine certaine other bulbes, but yet not all feruing for foode: of which notwithftanding we will alfo difcourfe in this booke, deuiding them in fuch fort, that thofe that maybe iudged to be of one kinde, fhall be feparated one from another. It may therefore fuffice that we haue fetrered the bulbed flowers from thefe that ferue for meate and nourifhment, which otherwife might haue beene allo comprehended in one booke togither, as by fome they haue beene.

\section{Of Turneps. Thefrift Chapter. \\ * The kinds.}

T Here be fundrie forts of Turneps; fome wilde; fome of the garden; fome with round rootes globe fafhion ; other ouall or pearefalhion; fome great; and fome of a fmaller forte.

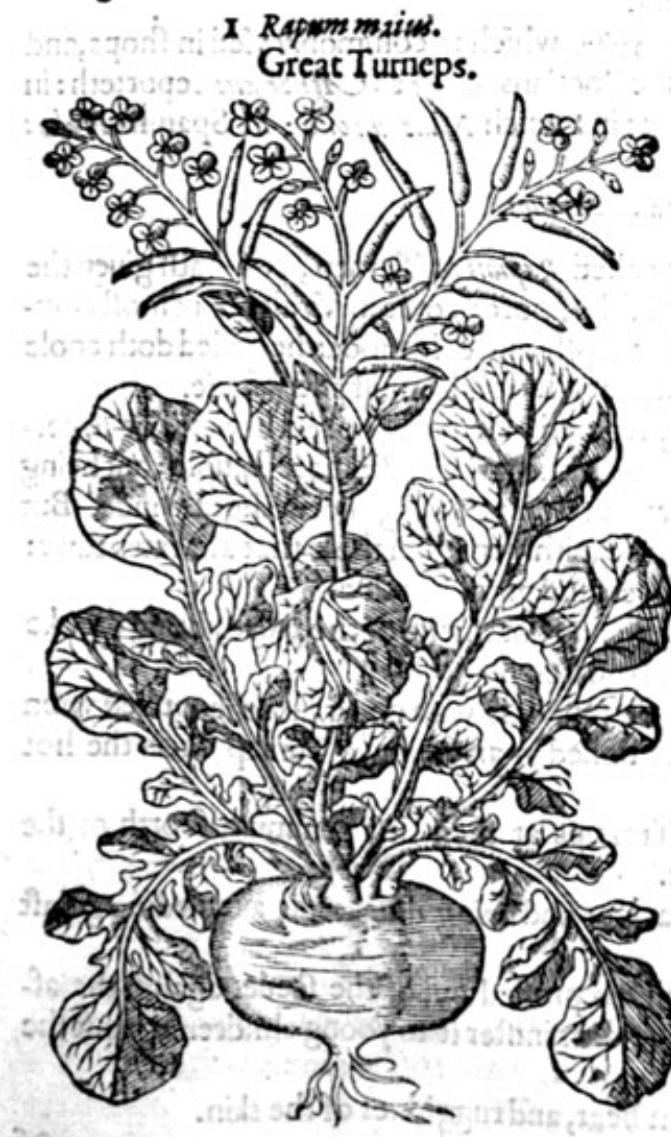

2 Rstumininus. Small Turneps.

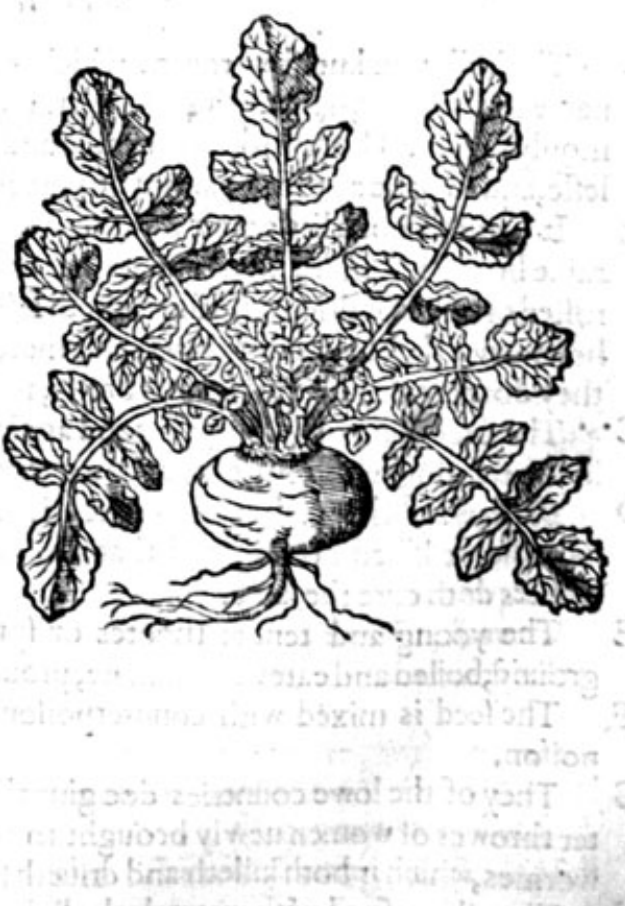




\section{$17^{8}$ \\ THE SECOND BOOKE OF THE}

\section{* The defription.}

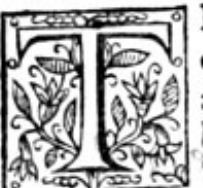

He Turnep hath long, rough \& greene leaues, cut or fnipt about the edges with deepe gafhes. The ftalke diuideth it felfe into fundrie branches or armes, bearing at the top fmall flowers of a yellow colour, and fometimes of a light purple; which being paft, there do fucceed long cods full of finall blackinh feede like rape feede. The roote is tound like a bowle; and fometimes a little ftretched out in hength, growing verie fhallow in the ground, and often fhewing ir fel fetaboue the face of the earth.

2 The fmall Turnep is like vnto the former, fauing that it is leffer. The roote is much fweeter in taft, as my felfe haue often probied.

3. There is a third fort of .mall Turnep faid to haue red rootes, but my felfe haue not as yetfeene any fuch. But I am of opinion that fome hate feene the roote of the red Beet, which ofrentimes is found in'barten grotinde to have the roote declining to roundneffe, and of eolour red or red. difh, which hath beene taken for a kinde of Turnep.

$$
\text { * The place. }
$$

The Turnep profpereth well in a light, loofe, and fat earth, and fo loofe as Petras crefcentive theweth, that it may,be turned almoft into duft. It groweth in fields and diuers vineyardes, or hoppe gardens in moft places of England.

The fmall Turnep groweth by a village neere London (called Hackeney) in a fandie ground, and brotight to the Croffe in Cheap-fide by the women of that village to be folde, and are thebet that euer I tafted.

\section{* The time.}

Turneps are fowen in the fpring, as alfo in the end of Auguif. They flower and feede thefecond yeere after they are fowen; for thofe which flower the fame yeere that they are fowen are a degene. rate kinde, called in Chefhire about the Namptwitch Mad neeps, of their euill qualitie in car. fing frenfie and giddinefle of the braine for a feafon.

\section{* The names.}

The Turnep is called in Latine Rapum : in Greeke 2020 inn, which is commohly yred in fhops,and

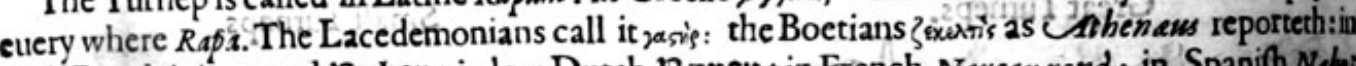
high Dutch it is namęd Ruben: in low Dutch Rapent : in French Nauesu rond : in Spanifh Nam: in Englifh Turnep and Rape.

$$
\text { * The temperature and vertues. }
$$

A The bulbus or knobbed roote, which is properly called Rapum or Turnep, and hath given the name to the plane, is many times eaten raw efpecially of the poore people in Wales, but nioftcommonly boiled. The raw roote is windie and engendreth grofle and cold blood:the boiled doth cook leffe, and fo little as that it cannot be perceiued to coole at all,yet it is moift and windie.

B It auaileth not a little after what maner it is to be prepared; for being boiled in water or in cettaine broth, it is more moift and fooner defcendeth, and maketh the bodie more foluble; but being rofted or baked it drieth and ingendreth leffe winde, and yet it is not altogither without winde. But howfocuer they be dreffed they yeclde more plentie of nourifhment than thofe that are eaten rawe: they do increafe milke in women brefts, and naturall feed, and prouoke vrine.

C The decoetion of Turneps is good againft the cough and toarfneffe of the voice, being drunke in the euening with a little fugar or a quantitie of clarified hony.

D Dicfcoridcs writeth that the Turnep it felfe being ftamped is with good fucceffeapplied vpon mouldie or kibed heeles, and that alfo oile of rofes boiled in an hollowe Turnep vnderthe hor embers doth cure the fame.

E The yoong and tender Phootes or fprings of Turneps at their firft comming foorth of the ground, boiled and eaten as a fallade, prouoke vrine.

F The feed is mixed with counterpoitons and treacles: and being drunke it is a remedie again poifon.

$G$ They of the lowe countries doe giue the oile which is preffed out of the feede, againft the 2 . ter throwes of women newly brought to bed, and alfo do minifter it to yoong children againfth wormes, which ir both killeth and driueth foorth.

H The oilc wafhed with water doth allaie the feruent heat, and ruggidnes of the skin. 
Seite

fehlt

\author{
Page \\ missing
}




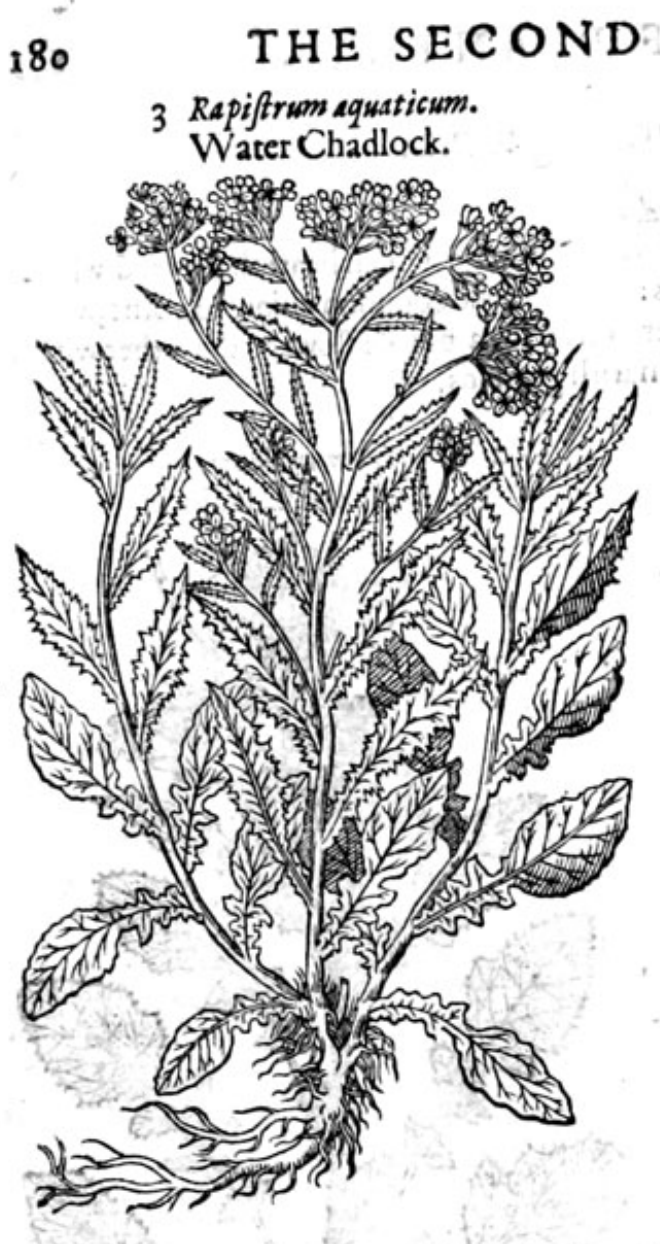

BOOKE OF THE

* The place.

Wilde Turneps or Rapes, do grow of themfelues in fallow fields, and likewife by high waies neere vnto olde walles, vpon ditche-bankes, and neere vnto townes and villages, and in other vatoiled and rough places.

The Chadlocke groweth for the moft part among corne in barraine grounds ${ }^{2}$ and often by the borders of fields and fuch like places.

Water Chàdlock groweth in moift medowes and marifh grounds, 2s alfoin water ditches, and fuch like places.

\section{* Thesime.}

Thefe do flower from March till fommer be far fpent,and in the meane feafon the feede is ripe.

\section{* The names.}

Wilde Turnep is called in Latine Repithin, Rapion flueftre, \& of fome Sinapi fyluestive, or wild muftard: in high Dutch petuerict: in low Durch Detick: in French velar: in Englifh Rape, and Rape feed. Rapistrum arworwm is called Charlock, Kedlock,and Carlock.

* The temperature.

The feede of thefe wilde kindes of Turneps as alfo the water Chadlock, are hot and drie as mu. ftard feed is. Some haue thought that Carlock hath a drying and clenfing qualititie,and fomewhat digefting.

* The vertues.

A Diuers vfe the feede of Rape in fteed of muftard feede, who either make heereof a fauce bearing the name of muftard, or elfe mixe it with muftard feede: but thiskinde of fauce is not fo pleafentio $B$ the tafte, bicaufe it is bitter.

Galen writeth that thefe being eaten engender euill blood: yet Diofcorides faith, they warme the ftomack and nourifh fomewhat.

\section{of Nanewes. Chap.3. \\ * The kindes.}

$T$ Here be fundrie kinds6f Nape or Nauewes degenerating from the kinds of Turnep; of which fome are of the garden; and other wilde, or ofthe field.

\section{* The defcription.}

I Auew gentle is like mto Turneps in leaues, ftalkes, flowers, and feede, differing in the roote: the Turnep is round like a globe, the Nauew roote is fomewhat ftretched foorthil length.

2 The fmall or wilde Nauewe is like mnto the former, fauing that it is altogither lefler. The roots is fmall, fomewhat long, with threads long and tough at the end thereof. 


\section{HISTORIE OF PLANTS. HT}

I Bunisi.

Nauew gentle.

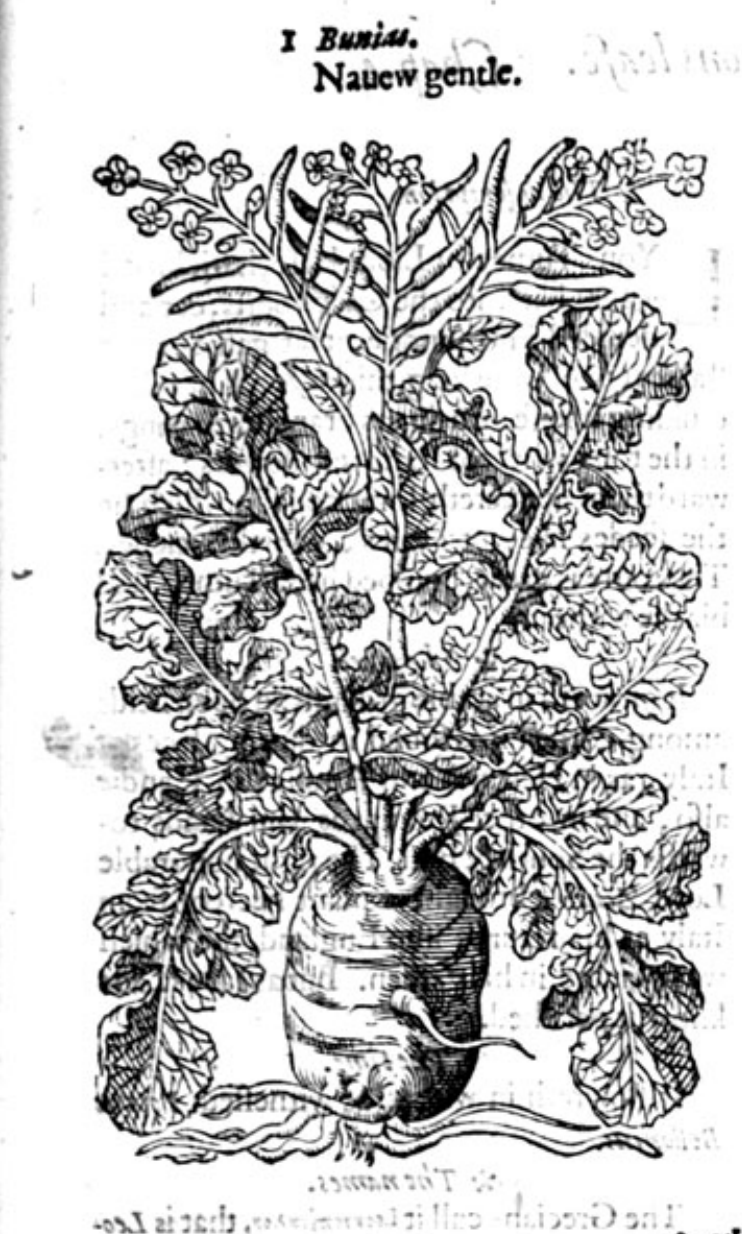

silla trob sitila : ots?
2 Bunies fluseftris L'Obeliti: Wilde Nanew:

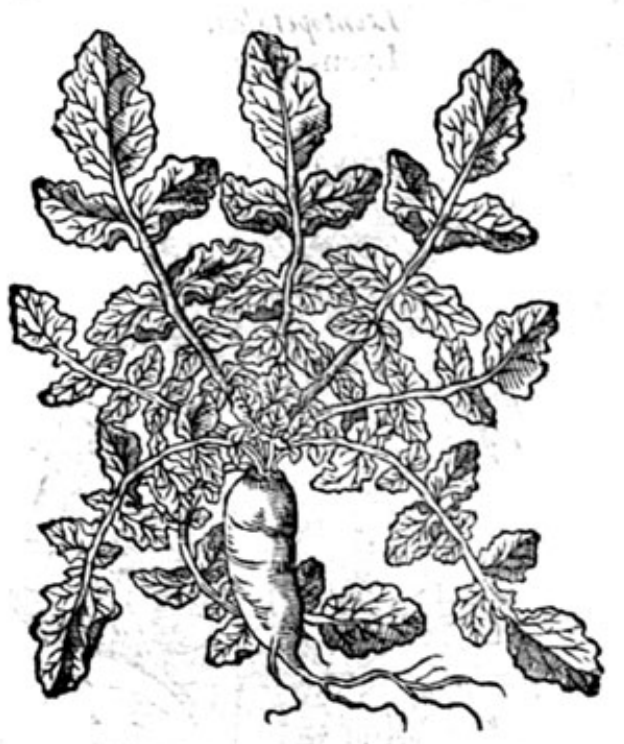

Nauev genitle tequireth a loofe \& yellow mould euen as doth the Turnep,\& profpereth in a fruitfullfoile: he is fowen in Fraunce, Bauaria, \& other places in the fields for the feed fake, 2s is likewife that wifd Colewoort called of the old writers Crembe: for the plentifyll increafe of the feeds bring. ethin ffrill gaine to the husbandmen of that countrey, bicaufe that being preffed they yeelde an oile which is vfed not onely in lampes, but alfo in the making of fope; for of this oile and a lie made of cerraine afhes, is boiled a fope.which is viled in the Loyve countries euery where to fcowre and wafh limien clothes. Thate hard it teported that it is at this day fowen in England for the fame pur-
pofe.

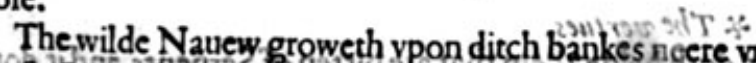

on fre

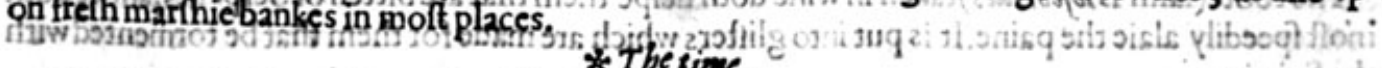

The Nauew is fowen, floureth and feedeth at the fame time that the Turnep doth.

sionsize suts

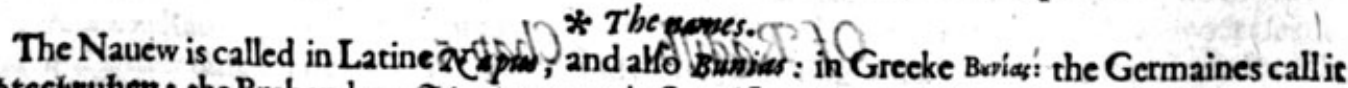
Steckruben: the Brabanders Steckrapen: in Spanifh Naps: in Italian Nawo: the Frenchmen 2 auseau : in Englith Nauew gentle, or French Naueanto:

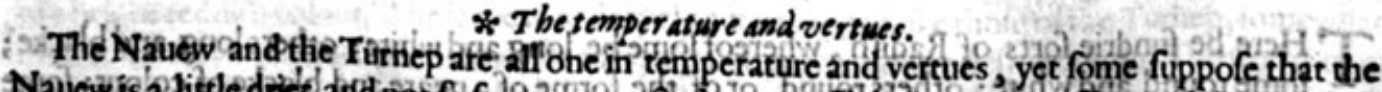

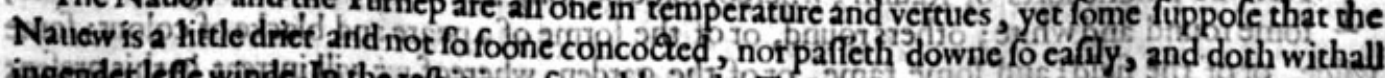
ingenderlefle windejt the relt it is anfwerable to the Tumep. 


\section{of Lyons Turnep, or Lyons leafe. Cbap.4}

Leontopetalon.

Lyons leafe.

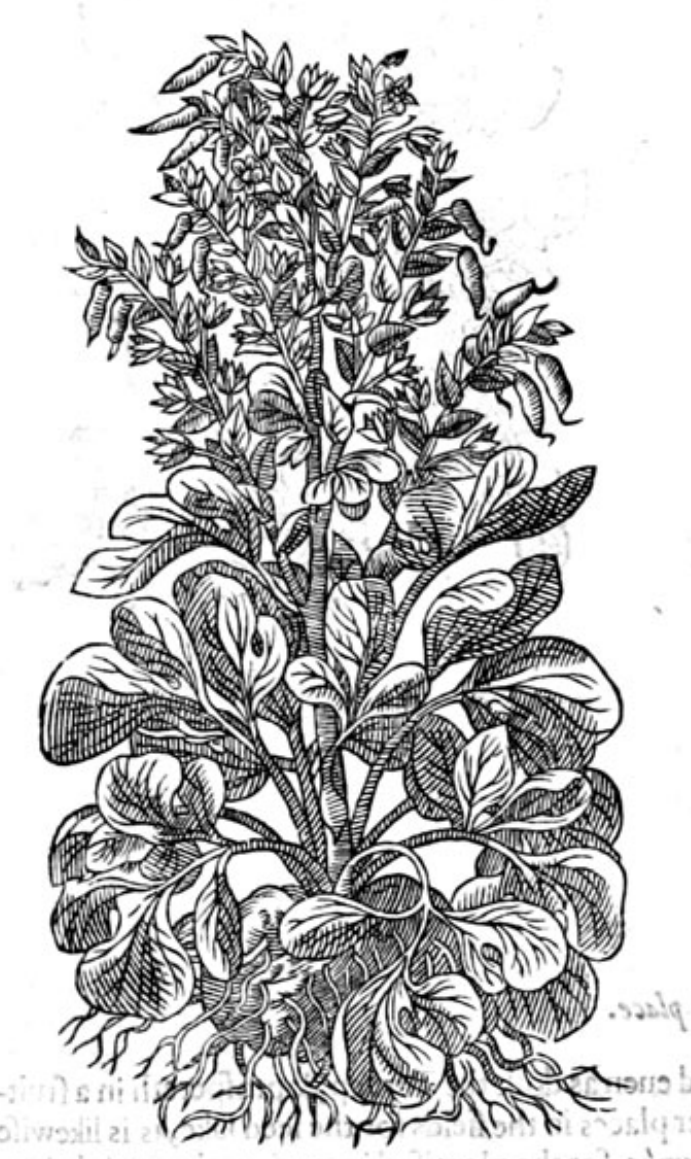

\section{* The defaripsion.}

Y Yons Turnep or Lions leafe, hath broad

leaues like vnto the Colewoorts, cut and deuided into fundrie great gafhes : the ftalke is two foote long, thicke, \& full of iuice, diuiding it felfe into diuers branches or wings; in the tops whereof ftand red flowers : afterward there appeereth long cods in which lie the feedes like vnto tares, or wilde ciches. The roote is great, bumped likea Tumep, and blacke without.

\section{* The place.}

It groweth in arable grounds, in open fields among corne : it is found in diuers places of Italy, as in Hetruria and Apulia, in Candie alfo, and in other Prouinces and Illands towards the South \&Eaft. The right honorable Lord Zouch, brought a plant heereof from Italy at his returne into England, the which was planted in his garden. Butas far as Idoe know, it perifhed.

* The time.
It flowreth in winter, as witneffech Petrw Belloniss.

$$
\text { * The names. }
$$

The Greciahs call it Leovromitrenor, that is Len mis foliwm, or Lyons leafe: Plinie doth callit alfo Leantopetalon, Lpuleims Leontopodion: yet there is another plant called by the fime name. There be many baftard Names given

vnto it, as Rapeium, Papauer culum, semen Leoninum, Pes Leoninu, and Brwmaria: in Englinh Lyons leafe and Lyons Turnep.

\section{Lyons Turnep is of force to digeft, it is bot and drie in the third degree, as $G$ alen teachech.}

\section{* The vertwes.}

The roote(faith Diofcorides)taken iri wine doth helpe them that are bitten of Sexpents, and it doth moft fpeedily alaie the paine. It is put into glitters which are made for them that be tormented with the Sciatica.

\section{OfRedif. Cbap,5. \\ * The kindes.}

$T$ Here be fundrie forts of Radifh, whereoffome be long and white; others long and blacke; fome round and white; others round, or of the forme of a peare and blacke of cqlour; fone wilde, or of the field; and fome tame, or of the garden, whereof we will intreat in this prefent chapter. 


\section{SIISTORIE OF PLANTS. AHT}

1 Raphasmafasimwions is GardenRadifh: $75 \%$ T

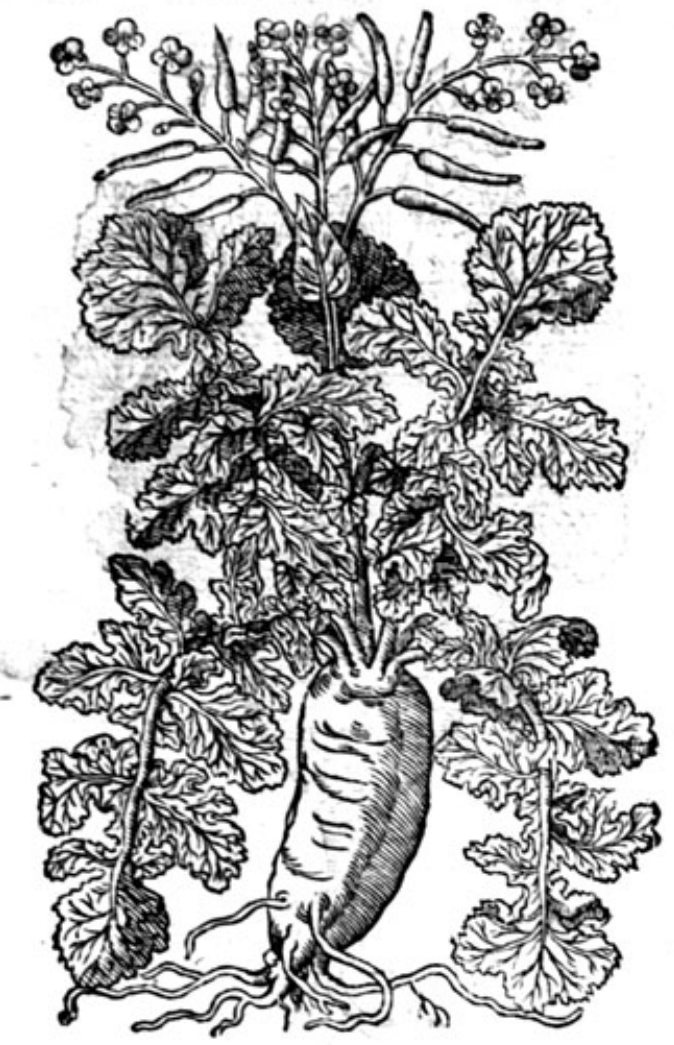

2 Radicula fat ivaminor. Small gardén Radifh.

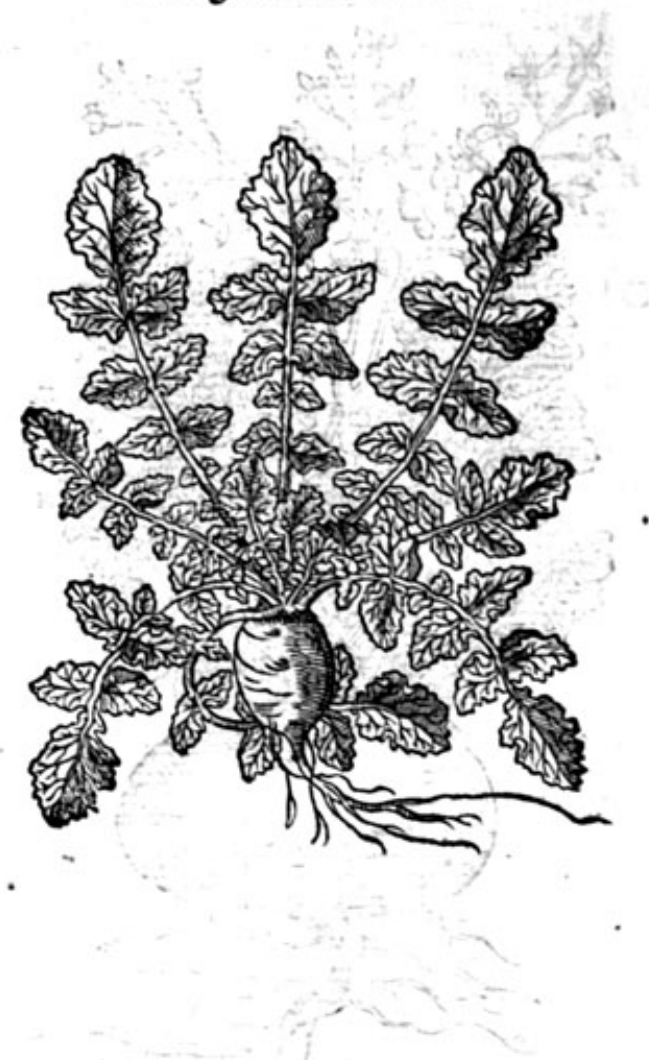

* The defcription.

I Hegarden Radifh fendeth foorth great and large leaues, greene, rough, cut on both fides with deepe gathes, nor vnlike to the garden Turnep, but greater. The it alkes be round and parted into many branches : out of which fpring fmal flowers of a light purple color, made of fower little leaues: and when they be paft, there do come in place harpe pointed cods puft or blowen vp toward the ftalke, full of a Ipungious fubftance, wherein is contained the feede of a light browne colour, fomewhat greater than the feeds of Turneps or Colewoorts. The roote is groffe, long, and white both without and within, and of a fharpe tafte.

2 The frall garden Radifh hath leaues like the former, but finaller, and more brittle in handling. The ftalke of two cubits high, wheron be the flowers like the former. The feed is fmaller and not fo fharpe in tafte. The roote is fmall, long, white both within and without, except a little that fheweth it felfe aboue the ground of a reddifh colour.

3 Radifh with a round roote hath leaues like the garden Turnep: amongft which leaues fpringeth vp a round and mooth ftalke, deuiding it felfe toward the top into two or three branches, whereondo grow fimall purplifh flowers made of fower leaues a peece: which being paft, there do come in place fmall long cods puft vp or bunched in two, and fonietimes threc places, full of pith as the common Radifh, wherein is contained the feede, fomewhat fmaller than the Colewoort feede, but of a hottertafte. The roote is rounde and firme, nothing waterifh like the common Radifh, more pleafant in tafte, holfomer, not caufing fuch ftinking belchings as the garden Radifh doth. 4 The Radifh with a roote falhioned like a peare, groweth to the height of three or fower cubits, of a brighereddifh colour. The leaues are deepely cut or iagged like thofe of the Turnep, fomewhat rough. The flowers are made of fower leanes, of a light carnation or flefhie colour. The feed is contained in fimall bunched cods like the former. The roote is fafhioned like a peare or long Turnep, blacke without and white within, of a firme and folide fubftance. The tafte is quicke and iharpe biting thetoong as the otherkindes of Radilh,butmore ftrongly. 
3 Raphanus orbiculatiw. $=$ Round Radifh.
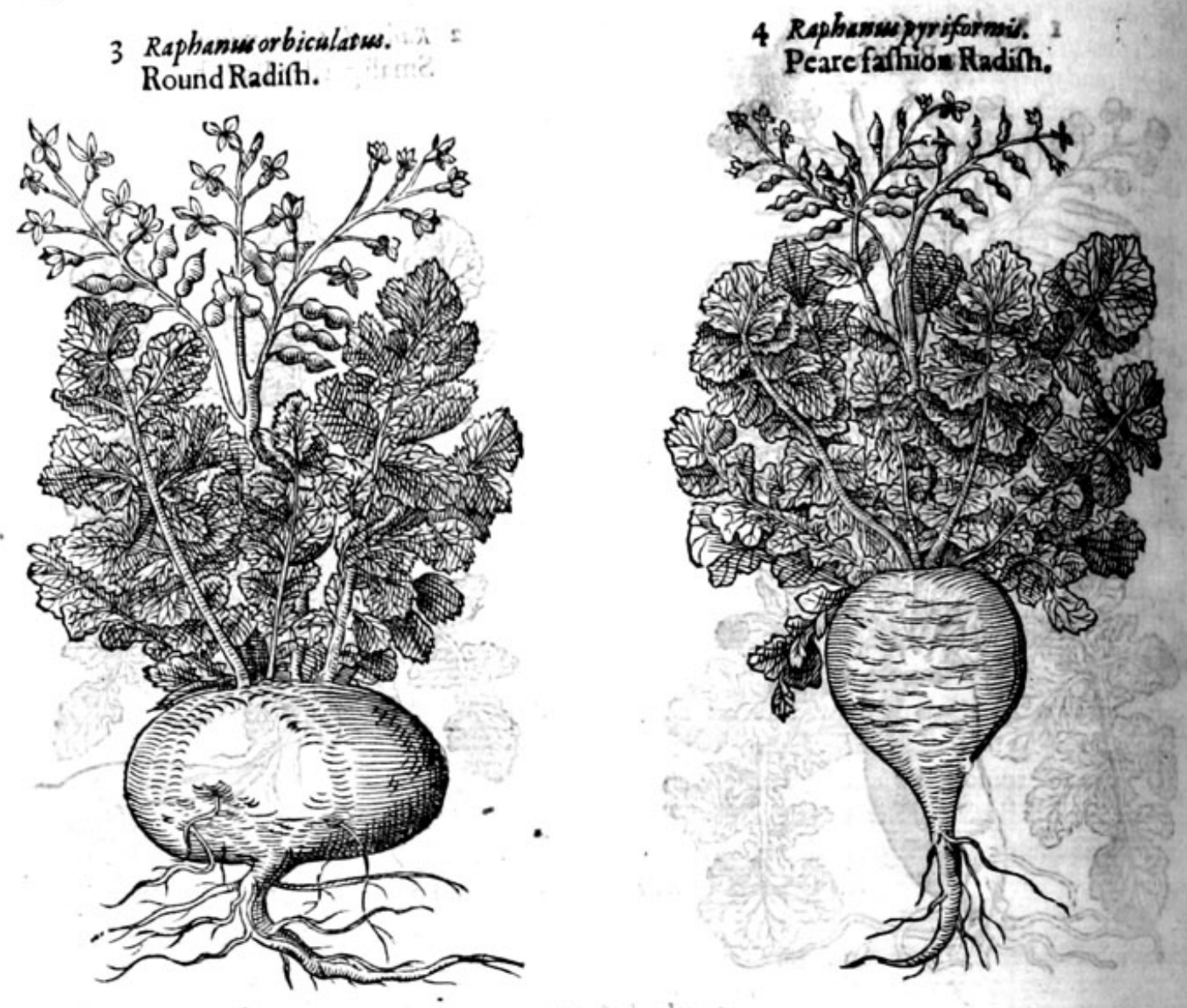

* Thepiace.

All the kindes of Radifh require a loofe grounde which hath beene long manured and is fome. what fat. They profper well in fandie ground where they are not fo fubieet to wormes, as in other grounds.

\section{* Thetime}

Thefe kindes of Radifh are molt fitly fowen after the fommer Solftice in Iune or Iulie : forbeing fowen betimes in the fpring they yeelde not their rootes fo kindely nor profitably, for then they do for the moft part quickly run vp toftalke and feede, where otherwife they do not flower and feed rill the next fpring following. They may be fowen ten moneths in the yeere, but as I faid before, the bet time is in Iune and Iulie.

\section{* The names.}

Radifh is called in Greek of $T$ heophr ast us, Diofcorides, Galen, and other old writers paseais: in fhops Raphanus, and Satiua Radicula : in high Dutch 1Retticb: in low Dutch Raditg : in French Raifort: in Italian Raphano: in Spanifh Rawano: in Englifh Radifh, and Rabone: inthe Bohemian toong Rzeofein. Celius affirmeth that the feed of Radifh is called of CMarcellews Empericm, Bacason, and fo likewife of setzes in the-fecond chapter of the fecond booke of his Tetrable : yet Cormariu doth not reed Bacanon, but Cacanon: The name of Bacenum is alfo founde in N. Mirepfere in the rss. Compofition of his firft booke.

\section{$*$ The temperature.}

Radifh doth manifeftly heat and drie, open and makethin by reafon of the biting qualicie that ruleth in it. Galen maketh them hot in the third degree, and drie in the fecond, and fheweth that it is rather a fawce than a nourifhment.

A Radifh are eaten raw with bread in ftead of other foode; but being eaten after that maner, they 
B H H IST ORIE COF PLANTS. IH T

yeeld verie little nourifhment, and that faultie and ill, But for the moft part, they are vfed as 2 fawce with meats to procure apperite, $\&$ in that fort they ingender blood leffe faultie, than eaten alone or with bread onely: but feeing they be of a harder digeftion than meates, they are alfo many times tronblefome to the ftomack; neuerthieleffe, they ferue to diftribute and difperfe the nouriffm ment, cfpecially being taken after meat; and tiken before meate, they caufe belchings, and ouerthrowe the ftomacke.

Before meate they caule yomiting, and efpecially the rinde: the which as it is more biting than $\mathrm{B}$ the inner fubftance, fo doth it with mote force caufe thateffect if it be ginen with Oximel, which is $a$ fyrupemade with vineger and hony.

Moreoiler, Radifh prouoketh vrine and diffolueth cluttered fande, and driueth it foorth, if a good C draughe of the decoction thereof be drunke in the moming. Plinie writeth and Diofecorides likewife that it is good againft an old cogh ; \& to make thin, thick \& groffe flegm which fticketh in the cheft.

Infteed heereof the Phifitions of our age do vfe water diftilled thereof : which hikewife proceureth D vrine mightily, and driueth foorth ftones in the kidneis.

The root fliced and laid ouer night in white or Rhenifh wine, and drunke in the morning, driueth $\mathrm{E}$ out vrine and grauell mightily, but in tafte and fmell it is very lothfome.

The roote ftarmped with hony and the powder of afheepes hart dried, caufeth haire to grow in F Phort fpace.

The feede caufeth romite, prouoketh vrine : and being drunke with honied vineger, it killech and $\mathrm{G}$ driveth foorth wormes.

The roote ftamped with the meale of Darnell and a little white wine vineger, taketh awary all $\mathbf{H}$ blew and blacke fpots, and brufed bleminhes of the face.

The roote boiled in broth, and the decoction drunke, is good againft an olde cough : it mooueth I womens fickenefie, and caufeth much milke.

\section{Of wilde Radifh. Chap.6.}

I Raphanus fyluestris. Wilde Radifh.

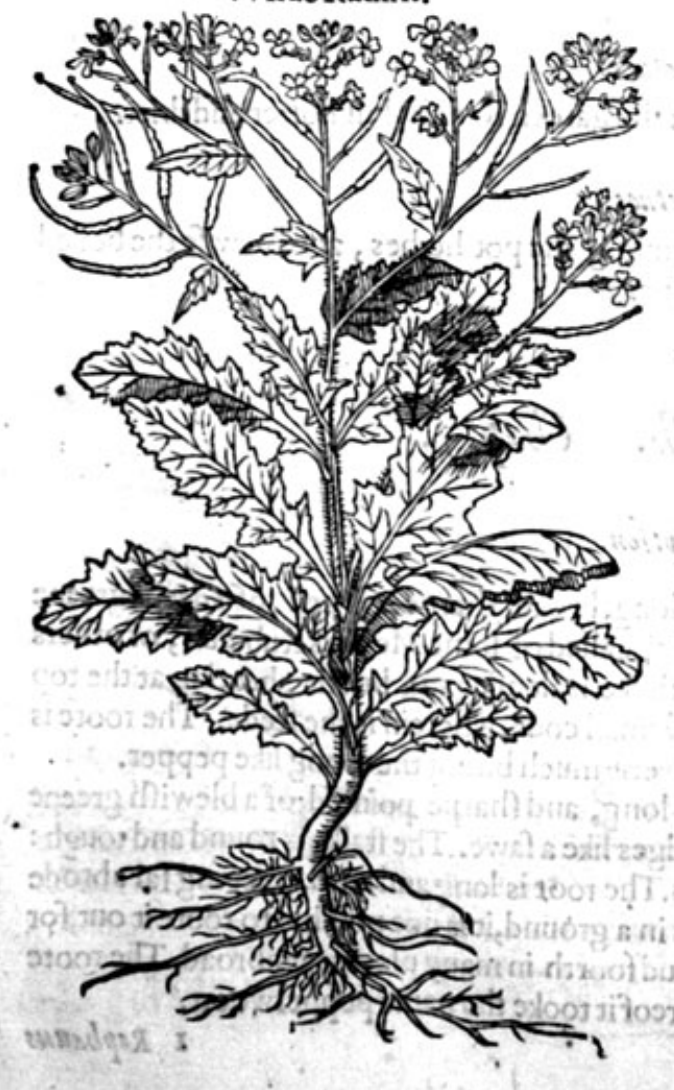

2 Raphanswaguaticu. Water Radifh.

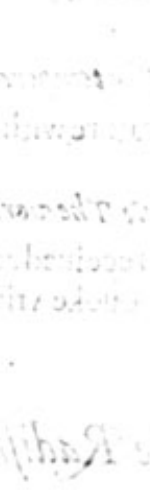




\title{
THE SECOND BOOKE OF THE
}

\author{
* The defcription.
} I $V$ Ide Radinh hath a broader $\$$ rougher leafe than the common Radin, \& not fo deeply \& rough, of two cubits high,deuided toward the top into many branches. The flowers are fmall and yellow : the cod is long and flender, wherein is the feed. The roote is of the bigneffe of a finger, white within and without, of a harpe and biting tafte.

2 The water Radifh hath long and broad teaues, deepely indented or cut euen to the middle rib, Theftalke is long, weake, and leaneth this way aud that way being not able to ftand ypright with. out a prop, in fo much that yee fhall neuer finde it, no not when it is verie yoong, but leaning down vpon themud or mire where it groweth. The flowers growe at the top made of fower fmallyellow leaues. The roote is long, fet in fundrie fpaces with fmall fibres or threds like the rowell of a f pur, hot and burning in tafte more than any of the garden Radifhes.

$$
\text { * The place. }
$$

fields.

The firf do grow vpon the borders of bankes and ditches caft vp, and in the borders of moift

Thefecond grow in ditches, ftanding waters, and rituers.

There is a kinde heereof growing in the ioints or chincks amongft the mortar of a ftone wall that bordereth vpon the riuer Thames by the Sauoy in London, the which yee cannot finde but when the tide is much fpent.

$$
\text { \& The time. }
$$

They flower in Iune, and the feede is ripe in Auguit.

\section{* The names.}

The wilde Radifh is called in Latine Radicula fyluestris, and Raphanus fyluestris, in Greeke ieari

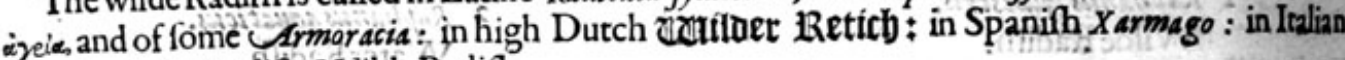
Ramolacci : in Englifh Wilde Radifh.

$$
\text { * The temperature. }
$$

Thefe wilde Radifhes are of like temperature with the garden Radifh, but hotter and drier.

* The vertues.

A Diofcorides writeth, that the leaues are receiued among the pot herbes, and likewifethe boiled roote, which as he faith, doth heate, and prouoke vrine.

\section{Of Horfe Radifh. Chap.7. \\ * The defcription.}

$\mathrm{H}$ Orle Radifh bringeth foorth great leaues, long, broad, Tharpe pointed, of a deepegreenc colour like thofe of the great garden Docke, called of fome Monkes Rubarbe, of others Patience, but greater and rougher. The ftalke is flender and brittle, bearing at the top fmall white flowers: which being paft, there follow fmall cods, wherein is the feede. The roores long and thicke, white of colour, in tafte harpe, and verie much biting the toong like pepper. 2 Dittander or pepperyoort, hath broad leaues, long, and /harpe pointed, of a blewirh greens colour like woad, fomewhat finipt or cut about the edges like a fawe. The ftalke is round and tough: vpon the branches wherof grow little white flowers. The root is long and hard, creeping far abrode in the ground, in fuch fort that when it is once taken in a ground, it is not poffible to roote it out, for it will vnder the ground creepe and fhoote vp and bud foorth in many places far abroad. The roots alfo is harpe and bitech the toong like pepper, whereof it tooke the name pepperwoort. 


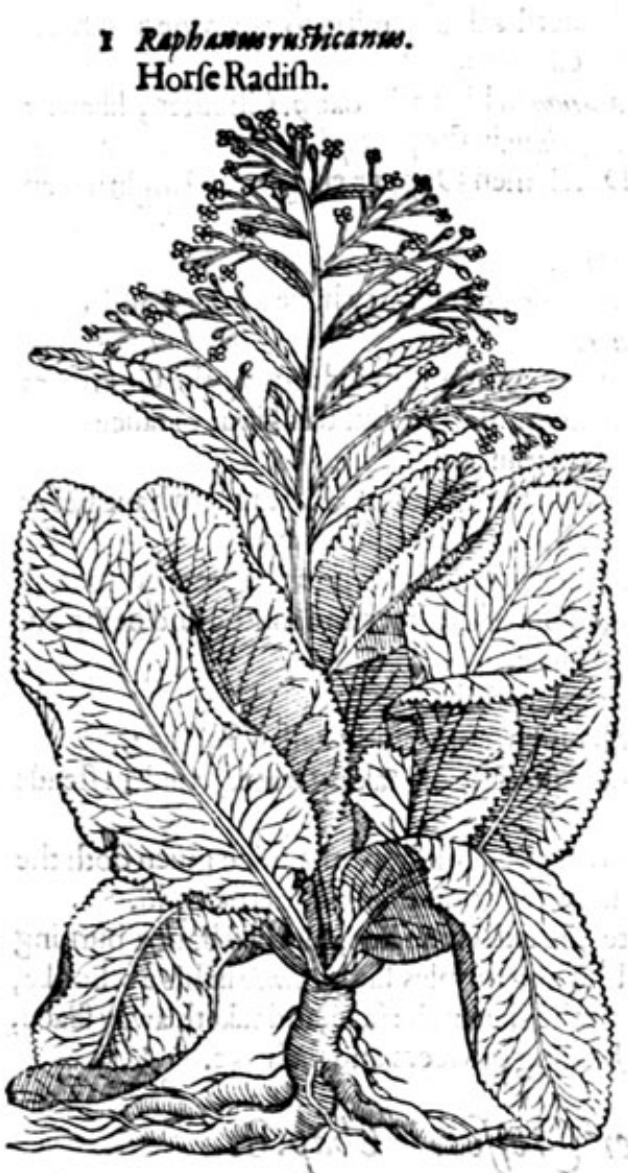

2 Raphanus fylue It r is officinarwon, lepidium Aeginete Dittander,and Pepperwoort.

(L'Obelis.

* Thepiace.

HorfeRadih for the moft pare groweth, and is planted in gardens, yet haue I found it wilde in fundrieplaces as at Namptwich in Cherhire, in a place called the Milne eye, and alfo at a fmall village neere London called Hogfdon, in the field next vnto a farme houfe leading to Kings land, where my verie goodfriend mafter Bredwellpractitioner in Phifick, a learned and diligent fearcher of Symples, and mafter $Y$ Villiam crartin one of the fellowiphip of Barbers and Chirurgians, my deereand louing friend in company with him found it, and gaue me knowledge of the place where it flouriheth to this day.

Dittander is planted in gardens, and is to be found wild alfo in England in fundrie places, as at Clare by Ouenden in Effex, at the Hall of Brinne in Lancafhire, and neere to Excefter in the. Weft parts of England. It delighteth to grow in fandie and fhadowie places fomewat moift.

* The time

Horfe Radifh for the moft part flowreth in Auguft, and the feede is ripe in September and that 10 rare or feldome feene, as that Petrm Placentisw hath written that it bringeth foorth no feede at

The leaues of Dittander come foorth in the fpring : the flowers appeere in Iune and Inly. * The names.

Horfe Radih is commonly called Raphanes rusticanus, or Magnus, and of diuers fimply Raphanws Giluestris: of the high Dutch men agettettich, Atain oz liten: in French Grend raifort: of the low Germaines 99ertabits: in Englifh mountaine Radifh, Great Raifort, and Horfe Radirh. It is called in the north part of England red-cole.

Diuersthinke that this Horfe Radifh is an enimic to Vines, and that the hatred between them is fo great, that if the rootes heereof be planted neere to the vine it bendeth backward from it as not willing to haue fellowithip with ir. 
It is alfo reported that the roote heereof ftamped, and caft into good and pleafant wine, doth foorthwith turne it into vineger. But the olde writers do afcribe this enmitie to the vineand Braffica, our cooleworts, which the moft auncients hatue named paparyos.

Dittander is defcribed of $P$ limie by the name of Lepidium in his 19. booke 9. Chapter, likewife AEgin.xt a maketh mention of this plant, by the name Lepidium, in fhops Raphanus fyluestris, and $P_{i}$. peritis: the Germanes call it fofefferktaut : the lowe Dutch men loepper ctupt : the Englifh men Dittander,Ditany, and Pepperwoort.

* The temperature.

Thefe kinds of wilde Radifhes, are hot and dric in the thirde degree:they haue a drying and clen. fing qualitic, and fomwhat digetting. $*$ The vertues. fing qualitie,and fomwer with a little vineger put thereto, is commonly vfed among the Germanes
A Horfe Radifh ftamped
for fauce to eate fifh with, and fuch like meates, as we do muftarde; but this kindeof fauce doth heate the ftomacke better, and caufeth better digeftion than muftard.

B. Oxymel or fyrupe made with vineger and honie, in which the rindes of Horfe radifh haue beene infufed three daies, caufeth vomit and is commended againft the quartaine ague.

C The leaues boiled in wine, and a little oile oliue added thereto and laid vpon the greeued parts in maner of Pultus, do mollifie and take away the hard fwellings of the liuer and milte; and being applied to the bottome of the belly is a remedie for the ftrangurie.

D It profiteth much in the expulfion of the fecondine or after-birth.

E It mittigatedh and affwageth the paine of the hip or haunch, commonly called Sciatica.

F It profiteth much againft the collicke, ftrangurie, and difficultic of making water, vfed in ftede of muftard as aforefaid.

G The roote ftamped and giten to drinke,killeth the wormes in children: the iuice given doth the fame, an ointment made thereof, doth the like: being annointed vpon the belly of the child.

H The leaues of Pepper woorte but efpecially the rootes, be extreame hot, for they hauea burning and bitter tafte. It is of the number of fcorching and bliftring fimples faith $P$ limie in his 20 . booke, 17.chapter, and therefore by his hot qualitie, it mendeth the skin in the face, and taketh away feabs, fcarres, and mangineffe, if any thing remaine after the healing of ylcers and fuch like.

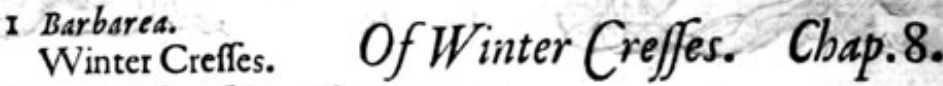

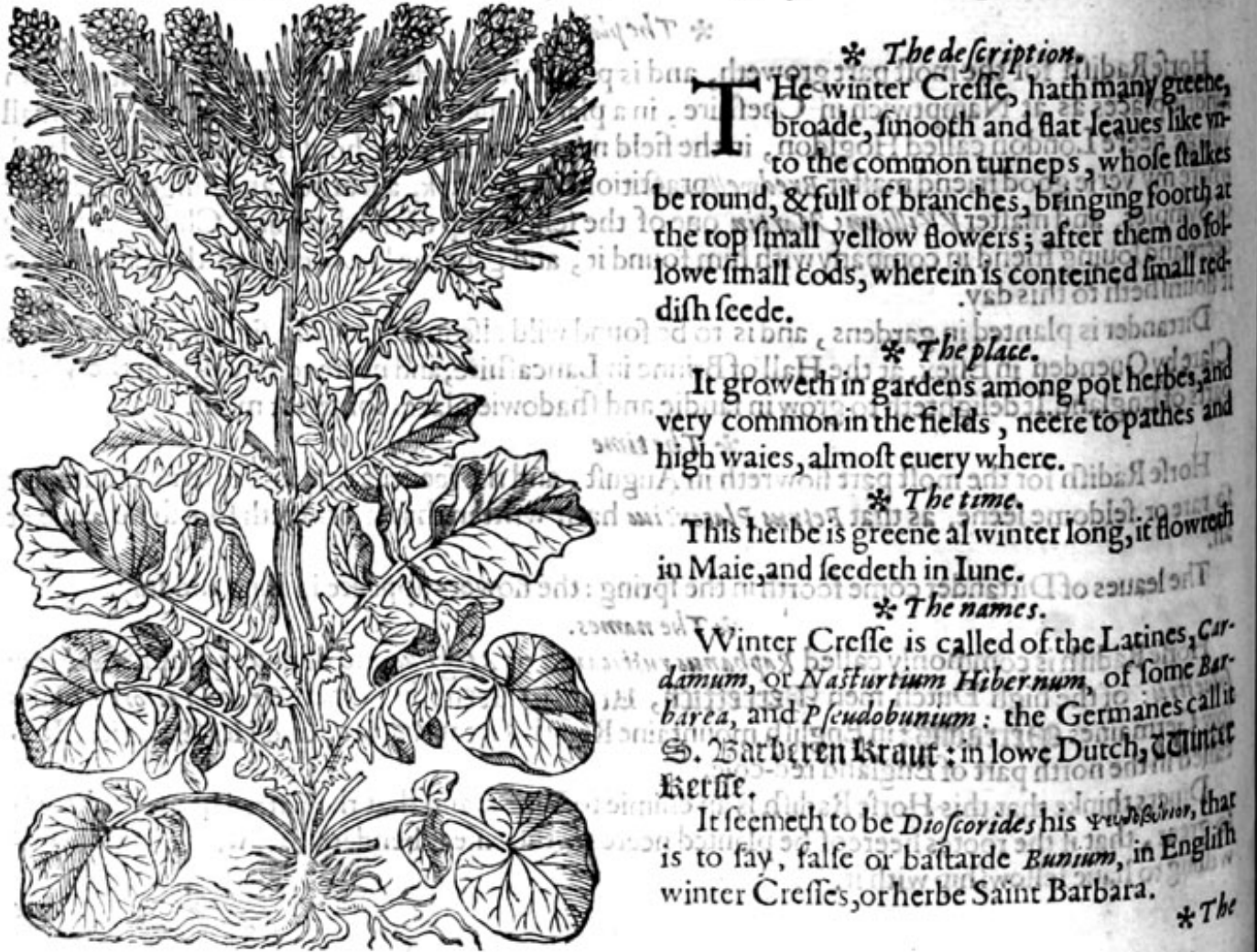


This herbe is hot and drie in the fecond degree.

\author{
* The nature.
}

The feede of winter Creffe caufect one to make water, driueth foorth gravell, and helpeth the $\mathbf{A}$

\title{
bisti nablivit
} ftrangurie.

The iuice therof mundifieth corrupt and filchie vlcers, being made in formeof an vnguent with $\mathbf{B}$ waxe, oyle, and turpentine.

In winter when fallade herbesbe fearce, this herbeis thought to beequall with Creffes of the C garden,or Rocket.

This herbe helpeth the fcuruie, being boiled among fcuruie graffe, called in Latin Cosblearia, call- D fing it to worke the more effeCtually.

\section{Of oMustard. Chap.9.}

17 erd The kindes.

There bethree kindes of Muftardo : two of the Garden, and the thirde wilde.

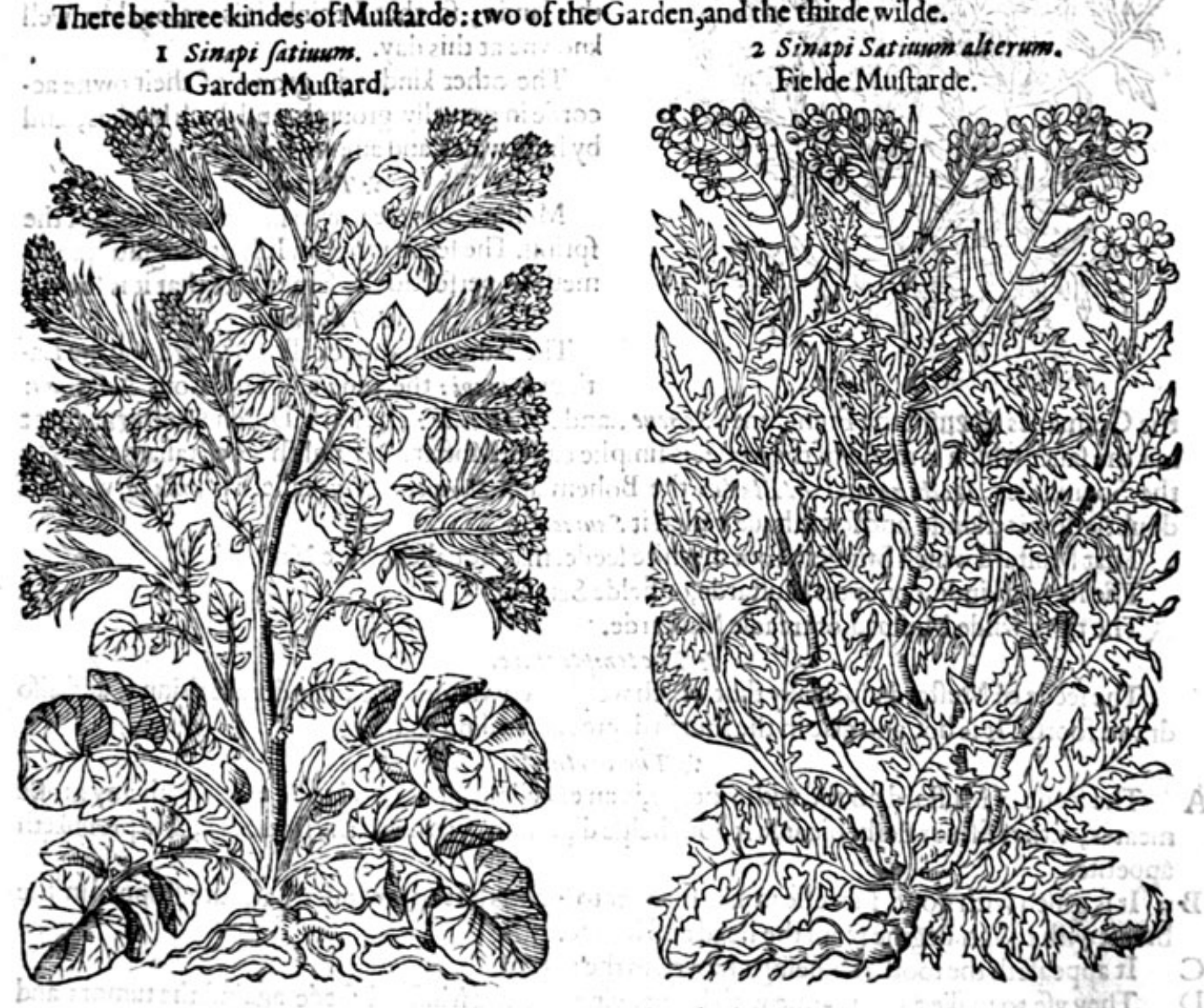

* The defeription.

I $T^{-H e}$ tame or garden Muftard, hath great rough leaues, like to thofe of the Turnep, but rougher and leffer. The ftalke is rounde, rough, and hearie, of three cubits high, ceuided into many branches; whereon do grow fmall yellowe flowers, and after them long cods, flender and rough, wherein is conteined round feede, of colour whition declining to yellowe, of tafte Tharpe and biting the toong, as doth our common fielde muftarde.

2 The other tame Muftarde is like to the former inleaues, and braunched ftalkes, butleffer, and aremore whitith and rough. The flowers are likewife yellow, and the feede browne like the Rape feede, which is alfonot a little harpe or byting. 


\section{BOOKE OF THE}

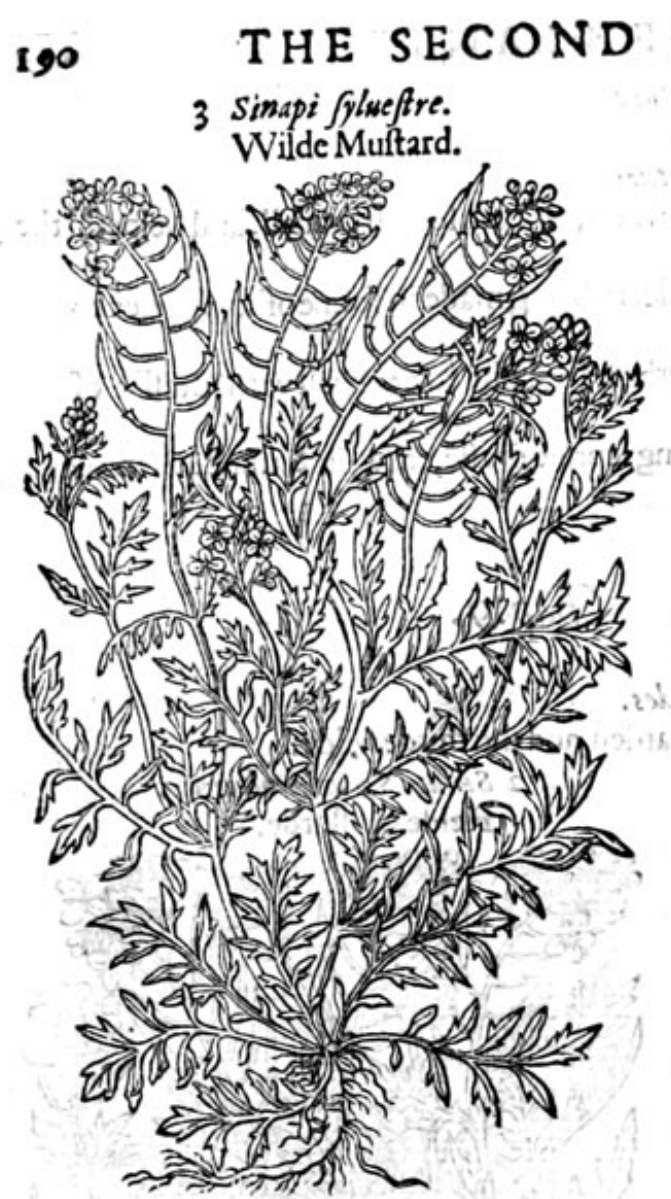

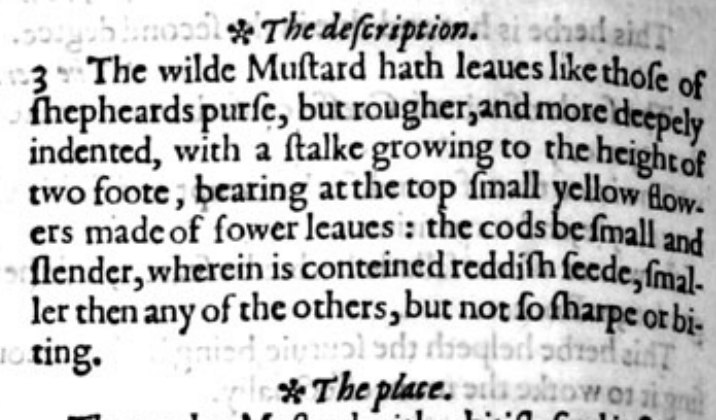

The garden Muftard, with whitifh feed is fowen in gardens : Palladius faith, it loueth to growe in - plowed gtounde, and is delighted with moifture. This kinde is not common in England, yet I have difperfed the feede thereof into fundrie parts of chis lande, fó that I thinke it is reafonablic well knowne at this day.

The other kindes do growe of their ownere. corde in grauelly grounds and ditch bankes, and by high waies, and among rubbirh.

$$
\text { * Thetime. }
$$

Muftard may be fowen in the beginning of the fpring. The feede is ripe in Iuly or Auguft itcom meth to perfectiō the fame yeere that it is fowen. * The names.

The Athenians haue called muftard virn the $L_{2}$. tines Simapi: the rude and barbarous Sinqien: the Germanes Denff : the Frenchmen Seneue, and Moustarde : the lowe Dutch Yoffant taet: but the fauce which is made of the feede, is fimplie called Muftard in Englifh : the Italians Sentep: the Spaniardes Mostaza and Mostalla : the Bohemians Horcice: Plini calleth it Thlapib, whereof doubtleffe it is akinde, and fome haue called it Saurion.

That Muftard which bringeth foorth white feede, maybe called white Muftard.

The fecond kinde, conmon Muftarde, or fielde Senuie.

The third wilde Muftard, or treacle Muftarde.

\section{* The temperature.}

The feede of Muftard, efpecially that which we chiefely vfe,doth heate and make thinne, andallo drawe foorth. It is hot and drie in the fourth degree according to Galen.

* The vertues.

A The feede of Muftard pound with vineger, is an excellent fauce good to be eaten, with any grofle meates, cither fifh or flefh, bicaufe it doth helpe digeftion, warmeth the ftomacke, and prouoketh appetite.

B It is giuen with good fucceffe in like manner to fuch as befhort winded, and are ftopped in the breaft with tough flegme from the head and braine.

C It appeafeth the toothach, being chewed in the mouth.

D They vfe to make a gargarifine with honie, vineger, and Muftard feede againft the tumors and fwelling of the Vuula, and the Almondes about the throate and roote of the toong.

E Muftard dronke with water and honie, prouoketh the tearmes and vrine.

F The feede of muftard beaten and put into the noftrils, caufeth fneezing, and raifech women iick of the mocher out of their fits.

G It is good againft the falling ficknes, and fuch as haue the Lithargie, if it be laid plaifterwife vpols the heade (after rhauing) being tempered with figs.

H It helpeth the Sciatica or ache in the hippe or huckle bone : it alfocureth all manner ofoldpins

I It is mixed with good fucceffe with drawing plaifters, and with fuch as wafte and confume nodes 
and hard fwellings.

It helpeth thofe that haue their haire pilled off; it taketh away the blew andblacke markes that $K$ come of bruifings.

\section{OfRecket. Chap.ro.}

* The kindes. Tere be fundry forres of Rocket, fome tame, or of the garden; fome wilde or of the fielde; fome
of the water, and of the fea.

\section{7) Erucs foting.} GardenRocket.

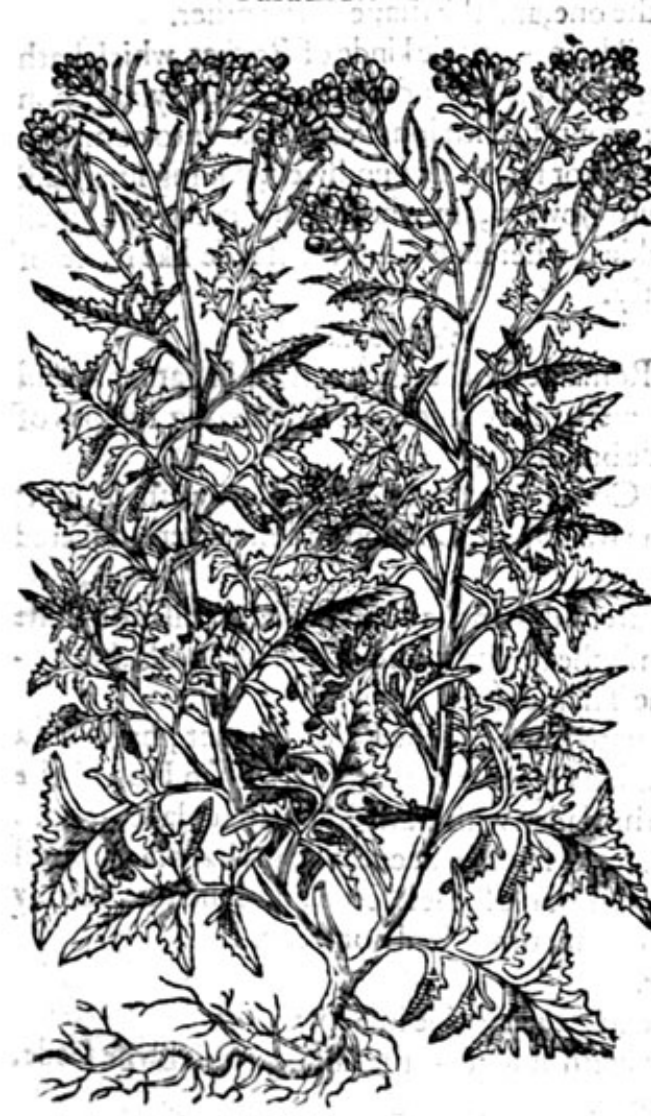

2 Erucs fluefris. Wilde Rocket.

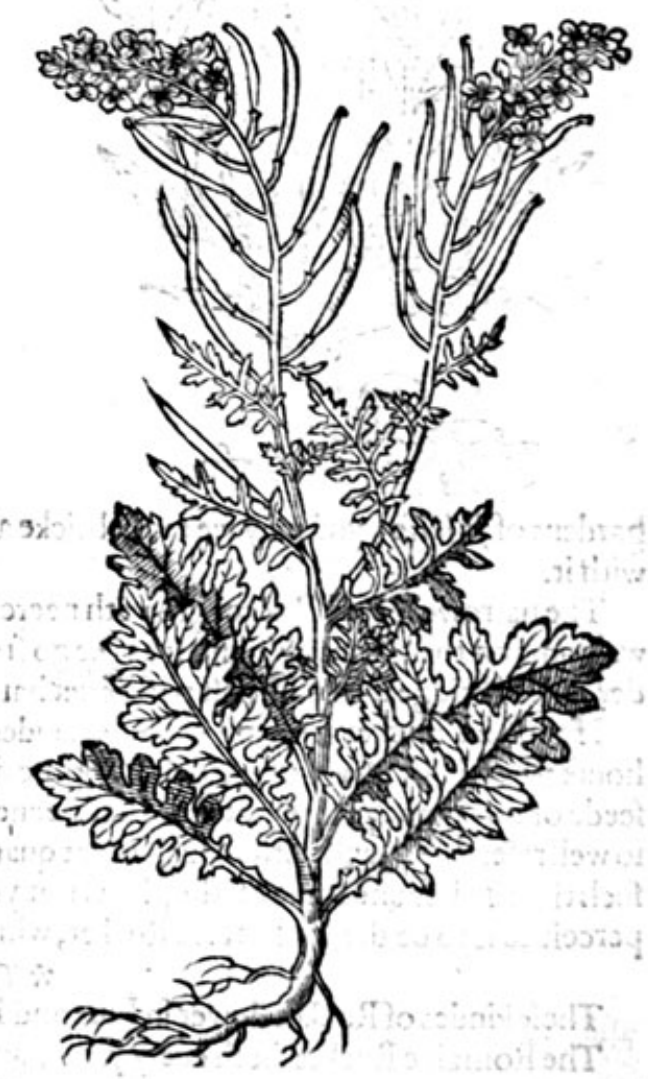

\section{* The defoription.}

1

Arden Rocket or Rocket genele, hath broade leaues like thofe of Tumeps, but not altogither fo great, nor rough. The ftalkes rife vp of a cubite, and fometimes two cubites high, weake and brittle; at the top whereofgrowe the flowers of 2 whitifh colour; and fometimes yellowifh;which being paft, there do fucceede long coddes, which conteine the feede, not vnlike to rape feede, but fmaller.

2 The common Rocket which we haue in our gardens, called the wilde Rocket, is leffer then the Romaine Rocket, or Rocket gentle, in leaues and ftalkes narower, and more iagged. The flowers be yellowe, the cods alfoflenderer, the feede is reddifh and biteth the toong. 


\section{THE SECOND BOOKE OF THE}

3 Eruca fyluestris angustifolia. Narrow leafed wilde'Rocket.

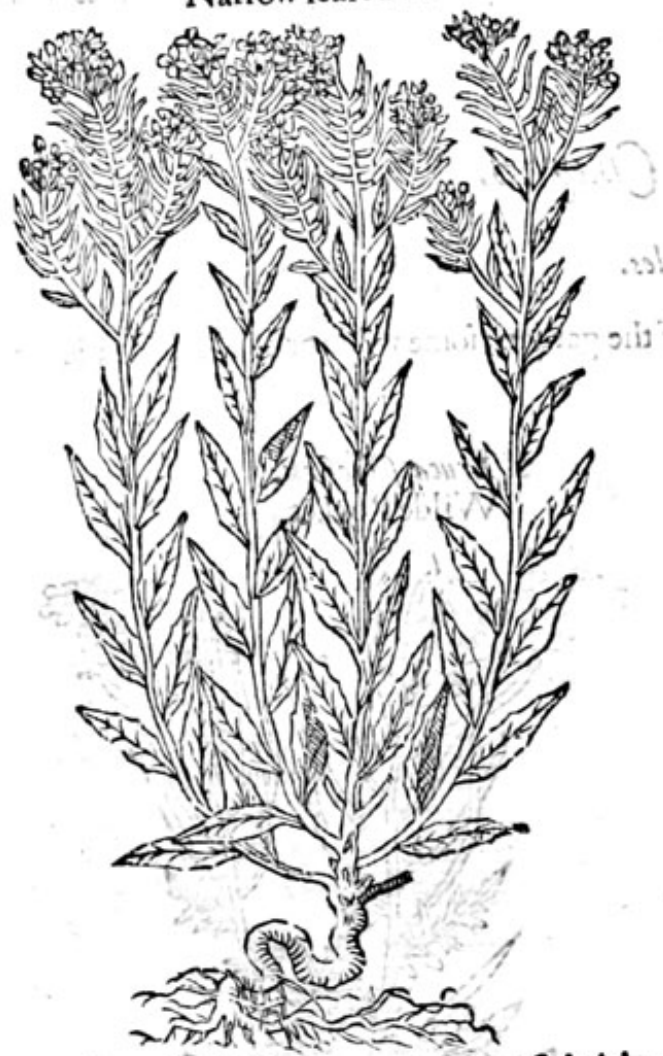

* The defaription.

3 This kinde of Rocket hath long narrowe leaues, almoft fuch as thofe of Tarragon, but thicker \& fatter, refembling rather the leaues of Myagrum, altogither vnlike any of the reft of the Rockets, fauing that the braunche, flower, and feede are like the garden Rocket.

4 There is another kinde of Rocket, thoughtby that reuerend and excellent Herbarift Carolim Clufisu, tobca kinde of Greffes, if not Crefilesit felfe, yet colin germanes at the leaft: vnto whofe cenfure L'Obelius is indifferent, whether to callit Rocket with thinne or narrowe leayes, or tocall it cofin to the kinds of Greffes, hauing the tafte of the one, and the fhape of the other.

5 There is a wilde kinde of Rocket, which hath long,weake, and tender braunches, trayling vpon the ground, with long leaues like vnto common Rocket, or rather Groundfwell, hauing fmall and white flowers, in whofe place commeth fmall coddes, wherein is conteined feede like thofe of Barly.

\section{* The place.}

Romaine Rocket is cherifhed in gardens, and groweth many times of it felfe among rubbilh of olde buildings.

Common garden Rocket groweth in mot gardens of it felfe, you may fee molt bricke and ftone wals about London and elie where, couered with it.

The narrowe leafed Rocket growech neere vnto water fides, in the chinkes and crevifes of thone wals among the morter. I found it a syee go from Lambithe bridge to the village of Lambithe, vader a fmall bridge that you mint paffe ouer hard by the Thames fide.

If found fea Rocket growing vpon the fandes neere vnto the fea in the lle of Thanet, hardebys houfe wherein fir Henry Crippe did fometime dwell, called Queakes houfe. Surely when I found the feede of this herbe, I thought there had beene fome Thip laden with Barly loft in that place, it doth fo well refemble it, and withall fuch great quantitic of it, as if it had beenefpilt in that place, vatil fucli time as I found fome of the plants not yet withered nor loft their feede, and then I euidenty perceilied it to be the feede of fea Rocker, which before that time I had not feene.

\section{* The time.}

Thefe kindes of Rocket flower in Iune and Iuly, and the feede is ripe in September.

The Romaine Rocket dieth euery yeere, and recoucreth it felfe by the falling of his owne feden $*$ The names.

Rocket is called in Greeke iv\}ouov: in Latine Eruca : in high Dutch Rauetentiraut: in French Roguette : in lowe Dutch Rakette : in Italian Ruchetta : in Spanifh Oruga : in Englifh Rocket, 200 Racket. The Poets do of tentimes name it Her ba falax : Eruca doth fignifie like wile a certaine e2tker worme, which is an enimie to pot-herbes, but efpecially to colewoorts.

Rocket of the fea is called of $L^{\prime}$ Obelizu, Kakile serapionis.

$$
\text { * Thetemperatura. }
$$

Rocket is hot and drie in the thirde degree, therefore faith Galen it is not fit nor accuftomed tob eaten alone.

$$
\text { * The vertues. }
$$

A Rocket is a good falladeherbe, if it be eaten with lettuce, purflane, and fuch colde herbes; forbe ing to eaten, it is good and wholefome for the ftomacke, and caufeth that fuch colde herbes don ouer coole the fame; otherwife to be caten alone, it caufeth headach and heateth too much. 


\section{HISTORIE OF PLANTS.}

The vfe of Rocket ftirrech vp bodelyruft, efpecially the feede.

It prouoketh vrine, and caufeth good digeftion.

Plinie reporteth, that whofoeucr taketh the feede of Rocket before he be whipt, thall be fo hard- D ned, that he fhall eafily endure the paines.

The rooteand feede ftamped, and mixed with vineger, and the gall of an oxe, taketh away frec- E kles, lentiles, blacke andblew fpots, and all fuch deformities of the face.

\section{Of Tarragon. Chap.II.}

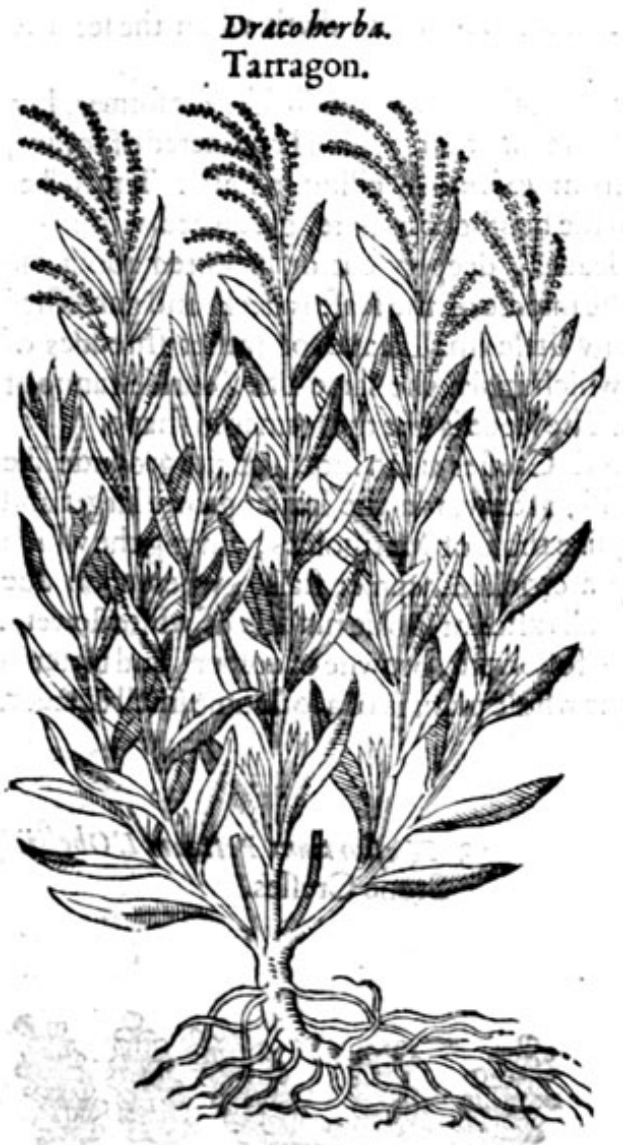

* The defoription.

Arragon the fallade herbe, hath long and
narrowe leaues, of a deepe greene colour, narrowe leaues, of a deepe greene colour,
grearer and longer than thofe of commoni Hyffope, with flender brittle rounde ftalkes, two cubites high: about the branches whereof, hang lietie rounde flowers, neuer perfectly opened, of a yellowe colour mixed with blacke, like thofe of common Wormewoode. The roote is long and fibrous, creeping farre abroad vnder the earth, 25 doe the rootes of Couch-graffe, by which fprouting foorth it increafeth, yeelding nofeede at all, but as it were a certaine chaffie or duftie matter that flieth away with the winde.

* The plase.

Tarragon is cherithed in gardens, and is encreafed by the yoong hootes: Kur lime and fuch others haue reported many ftrange tales heerof, fcarfe worth the noting, faying that the feede of flaxe put into a radifh roote or fea Onion, and fo fet doth bring foorth that herbe Tarragon.

\section{* The time.}

It is greene all fummer long, and a great part of Autumne, and flowreth in Iulie. * The names.

It is named in Latine Draco : of the Italians Dragoncelluon : in French Dragon : in Englith Tarragon.

It is thoughtrobe that Tarcon which Auicenne mentioneth in his 686. chapter, but he writeth fo little thereof, as that nothing can certainly be affirmed of it.

Moreouer it is written, that with Tarragon, which is alfo named in Greeeke moxurios, wherewith Glaucur was reftored to life.

Tarragon is hot and drie in the thirde degree.

$$
\text { * The temperature. }
$$

* The vertwes.

Tarragon is not to be eaten alone in fallades, but ioyned with other herbes, as lettuce, purflaine, $\mathbf{A}$ and fich like, that it may alfo temper the coldnes of them, like as Rocket doth, neither do we knowe what other vfe this herbe hath. 
I Naftartium Hortenfe. Garden Creffes.

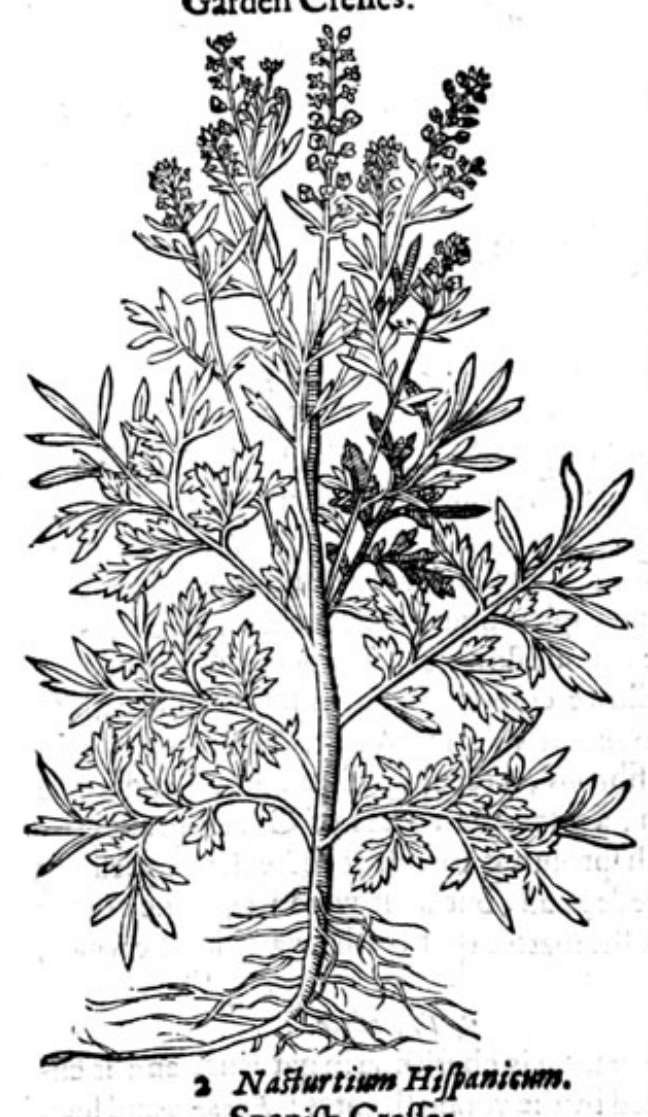

Spanilh Creffes.

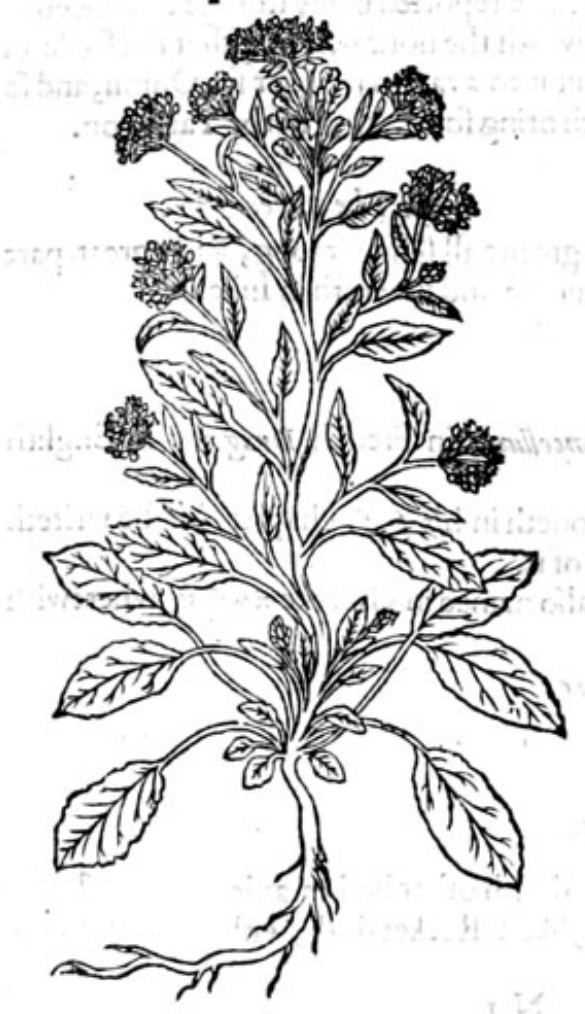

\section{$*$ The defcription.}

I Arden Creffes or Towne Creffes, hath fmall narrow iagged leaues, fharpe and burning in
tafte. The italks be round, a cubite high,which bring foorth many fmall white flowers, and after lito tie flat huskes or feede veffels, like to thofe of thep. beards purfe, wherein are conteined feeds of a brown reddifh colour. The roote dieth when the feedeis ripe.

There is another kinde in tafte like the former, bur in leaues farre different, which I recouered of feedes, fent $\mathrm{me}$ from Robinus dwelling in Paris. Theftalles rife up to the height of a foote, garnifhed with many broade leaues, deepely cut or indented about the edges : the middle of the leafe is deckt and garnifhed with many little fmall leaues or rather fhreddes of leaues, which make the fame like a curlde fanne of feathers. The feede is like the former in thape. 2 Spanifh Crefles rifeth foorth of the groundelite vnto Bafill, afterwarde the leaues growe larger and broader, 'like thofe of Marigoldes, among the which rifeth vp a crooked lymmer ftalke, whereupon doe growe imall tuftes or f pokie rundels of white flowers, The feede followeth, browne of colour, and bitterin tafte. The whole plant is of a lothfome fmell \& E fuor, 
3 Stone Creffes groweth flat vpon the grounde, with leaues iagged and cut about the edges like the oken leafe, refembling well the leaues of fhepheardes purfe. Ihaue not feene the flowers, and therefore they be not expreft in the figure; notwithftanding it is reported vnto me, that they bee fmall and white of colour, as are thofe of the garden Creffes. The feed is conteined in fmal pouches or feede veffels, like thofe of Treacle muftard or Thlafpi.

\section{*: The place.}

Creffes is fowen in gardens, it skils not what foile it be; for that it liketh any ground, efpecially if it be well watered.

$$
\text { * Thetime }
$$

It may be fowen at any time of the yeere, vnleffe it be in winter; it groweth vp quickly, \& bringeth foorth betimes both ftalke and feede : it dieth euery yeere, and recouereth it felfe of the fallen or fhakenfeede.

$$
\text { * The names. }
$$

Creffes is called in Greeke x'pdsuev : in Latine 2 asturtitum: in Englifh Creffes, being a name borrowed of the Germaines, whocall it fertfe : and in French Crefor : the Italians Yasturtio and Agretto: of fome towne Creffes and garden Karfle. It is called 2 afturtism, as Varro and Plinie thinke i naribus torquendis, that is to fay of writhing the nofethrils, which alfo by the lothfome fmell and fharpenes of the feede doth caufe Sternutamenta, or fneezings.

\section{* The temperature.}

The herbe of garden Creffes, is fharpe and biting the toong; and therefore it is very hot and drie, but lefie hot whileft it is greene and tender, by re.lfon of the watery moifture mixed therewith, by which the fharpnes is fomewhat alaied.

The feed is much more biting then the herbe, and is hot and drie almoft in the fourth degree.

* The vertues.

Galen faith that Creffes may bee eaten with bread Veluti obfonium, as the lowe Countrie men many times do, who commonly vfe to feede of Creffes with bread and butter. It is eaten with other $A$ fallade herbes, as Tarragon and Rocket : and for this cauie it is chiefely fowen.

It is good againft the difeafe which the Germaines call serazbuck and scozbuyc: in Latine Scorbutus: which we in England call the $S$ curuic, and Scurby, and vpon the feas the Skyrby: it is

Drofcorides faith, if the feede be ftamped and mixed with honie, it cureth the hardneffe of the milte: with vineger and barly meale parched, it is a remedie againft the Sciatica, and taketh awaie hard fwellings, and inflammations. It fcoureth away tetters, mixed with brine: it ripeneth felons called in Greeke dosinis: it forceablie cuttech and raifeth vp thicke and tough humours of the cheft, if it be mixed with things proper againft the ftuffing of the lunges.

Diofcorides faith it is hurtfull to the ftomacke, and troubleth the belly. It driueth foorth woormes, bringeth downe the flowers, killeth the childe in the mothers womb, E
and prouoketh bodily luft.

Being inwardly taken, it is good for fuch as haue fallen from high places: it diffolueth cluttered.F bloud, and preaenteth the fame that it donot congeale and thicken in any partof the body: it pro-
curethfweate, as the later Phyfitions haue found and tried by experience.

$$
\begin{aligned}
& \text { Of Indian Creffes. Chap.13. } \\
& \text { \% The defcription. }
\end{aligned}
$$

\section{A}


leanes are round like wall peniwoort, called Cotyledon, the footeftalke of the leafe commeth forth on the backfide almoft in the middeft of the leafe, as thofe of Frogbit, in tafte and finell like the gar. den Creffes. The flowers are difperfed throughout the whole plant, of colour yellowe, with a crof. fcd ftarre otierthwart the infide, of a perfect purple colour; vnto the backe part of the fame doth bang a taile or fpurre, fuch as hath the Larkes heele, or Monkes hoode, called in Latine Confolide negalis, but greater, and the fpurre or heele longer : which being paft there do fucceed bunched and knobbed cods or feede veffels, wherein is conteined the feede, rough, browne of colour and like vnto the feedes of the Beete, but fimaller.

I Nafturtiom Indicum. Indian Creffes.

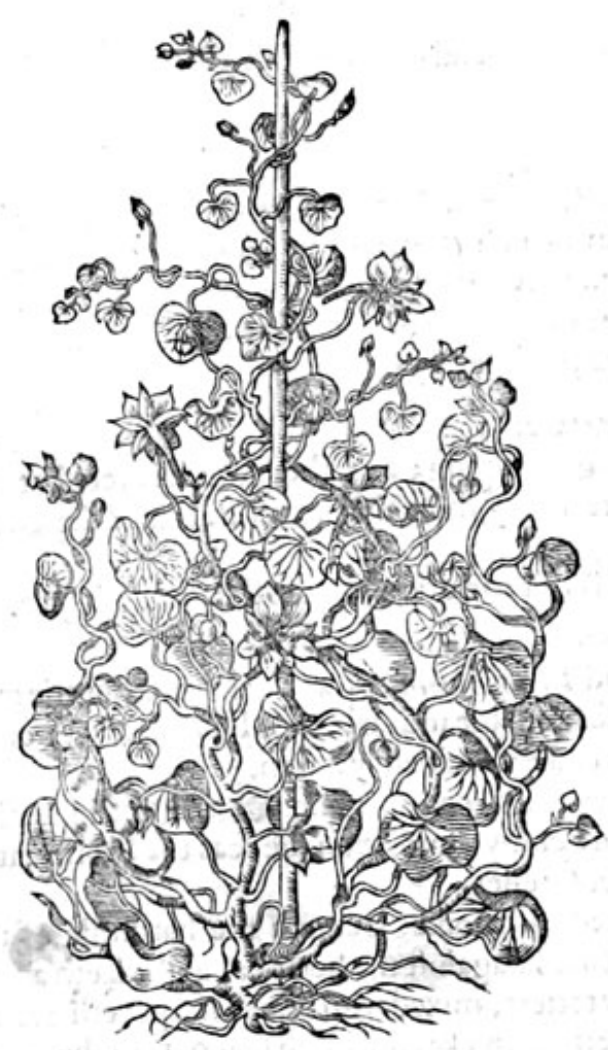

2 Flores \& femina Nasturtii Indici. The flowers and feeds of Indian Crefles,

* Thepiace.

The feedes of this rare and faire plant came firtt from the Indies into Spaine and tholehorte regions, and from thence into Fraunce and Flaunders, from whence I haue receiued feede that hath borne with me both flowers and feede, efpecially thofe I receiued from my louing friend Itoss Robin of Paris.

* The time.

The feedes muft be fowen in the beginning of Aprill, vpon a bed of hot horfe dung, \& fome fine fifted earth caft thereon, of an bandfull thicke. The bed mutt becoucredin fundrie places with hoopes and poles, to fuftaine the mat or fuch like thing that it muft be couered with in the night, and laid open to the fun in the day time; the which being fprung vp and hauing gotten threeleaves, you muft replant them abroad in the hotteft place of the garden, and moft fine and fertill moulde. Thus may you do with muske Melons, Cowcumbers, and all colde fruites that require hafte, for that otherwife the froft will ouertake them, before they come to fruite bearing. * The names.

This beautifull plant is called in Latine Nafturtium Indicum : in Englifh Indian Creffes.Atthough fome haue deemed it a kind of Conuulus or Binde-weede : yet I am well contented thas it retaine the Indian name, for that the fmell and tafte doth hewe it to be a kinde of Crefles. * The nature and vertues.

We haue no certaine knowledge of his nature or vertues, but are content to refer ic to the kinds of Creffes, or to a farther confideration. 


$$
\text { Of Sciatica CrefJes. Chap.I4. }
$$

* The defcription.

Ciatica Creffes hath many flender braunches, growing from a ftalke of a cubite high, with Imall, long, and narrowe leaues, like thofe of garden Creffes. The flowers be very finall, and vellow of colour, the feede veffels be litcle tat chaffie huskes, wherein is the feede of a reddifh golde colour, tharpe and very bitter in tafte. The roote is fmall, tough, white within and without, and of a biting tafte.

Iberis Cardamantica. Sciatica Crefles.

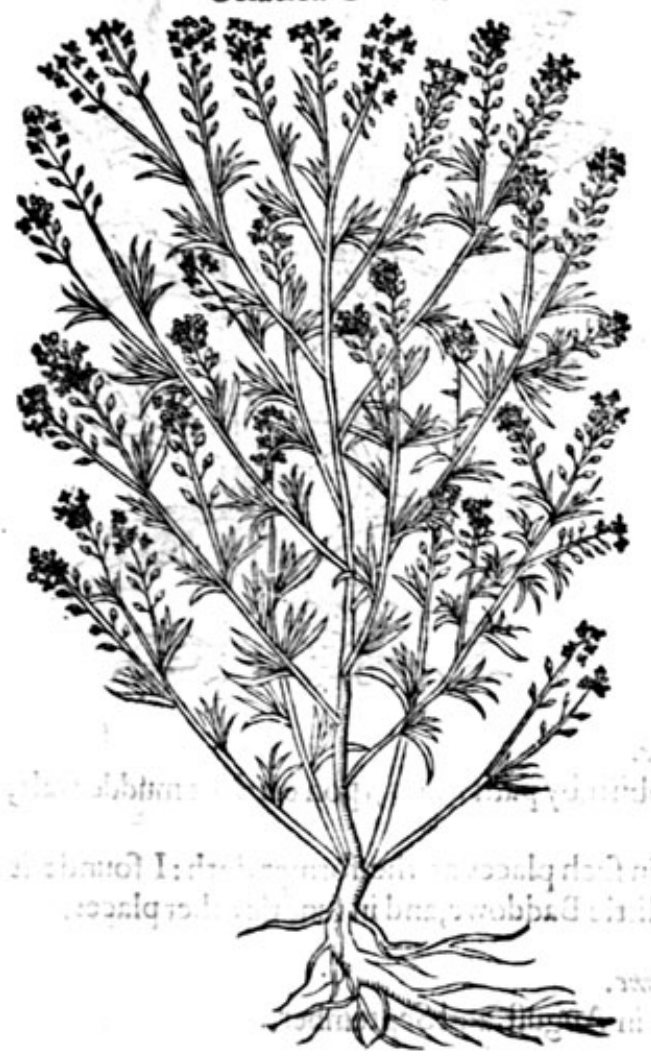

* Theplace.

It groweth vpon olde wals and rough places by high waies fides, and fuch like: I haue founde it in corne fieldes about South ticete neere to Graúefend in Kent.

* The time.

It flowreth according to the late or earely fowing of it in the fieldes, in Iune and Iuly.

\section{* The nomes.}

Sciatica Creffe is called in Greeke isiois, and

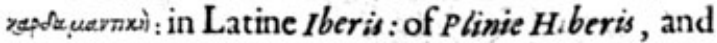
2 asturtium fyluestre, and in like maner alfo Lepidium. There is another Lepiditum of Plinie : in Englith Sciatica Creffe.

\section{$\approx$ The nature.}

Sciatica Creffe is hot in the fourth degree, and like to garden Creffes both in fmell and tafte. 15

\section{nomin azilq \&qihe verties.}

The rootes gathered in Autumne, faith Diofor A rides, do heate and burne, and ate with good fuccefle with fivines greafe madevp in manner of a plaifter, and put vpon fuch as are tormented with the Sciatica: it is to lie on the grieued place but fower howers atthe molt, and then taken away, and the patient bathed with warme water, and the place afterwards annointed with oile and woll laide on it; which things $G$ alen in his ninth booke of medicines, according to the place greeued, citeth out of Democr ates in certaine verfes tending to that effect.$$
\text { OfBankeCreffes. Chap.15. }
$$
I whinu petrbas astiv

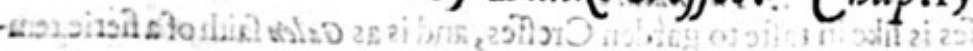

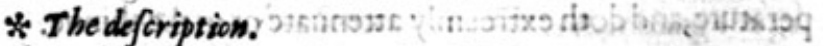

I A Ancke Creffes hath long leaues, deepely curt or aagged vpon both fides, not ynlike to thofe s:t $B$ of Rocket, or wildemuftarde. The italkes be fmall,jimber or pliant, yeovery toingh, arid will twitte and writhe as doth the Ozzer or water willowe, whereupon do growe fmall yellowe flowers, which being pafte there do fucceede little flender cods;fullof finall feedes; in tafte fharpe? and biting the toong as thofe of $\mathrm{Creffes}$.

2. The fecondekinde of bancke Creffeshath leaues tike to thofe of Dandelion, fomewhat refembling Spinach. The braunches belong, tough, and pliant like the other. The flowers be yellowe, which bring foorth fmall biting feede, like the other of his kinde. 
1 Eryfomum Diofcoridis, L'Obelii. Bancke Creffes.

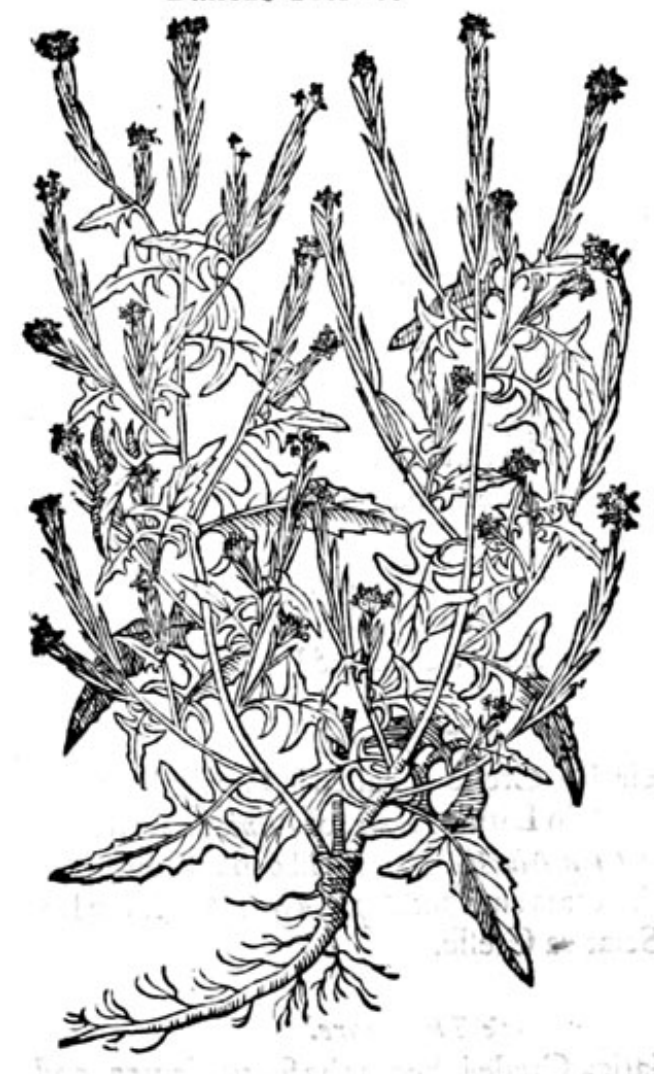

2 Eryfomum fluestre. Wilde bancke Creffes.

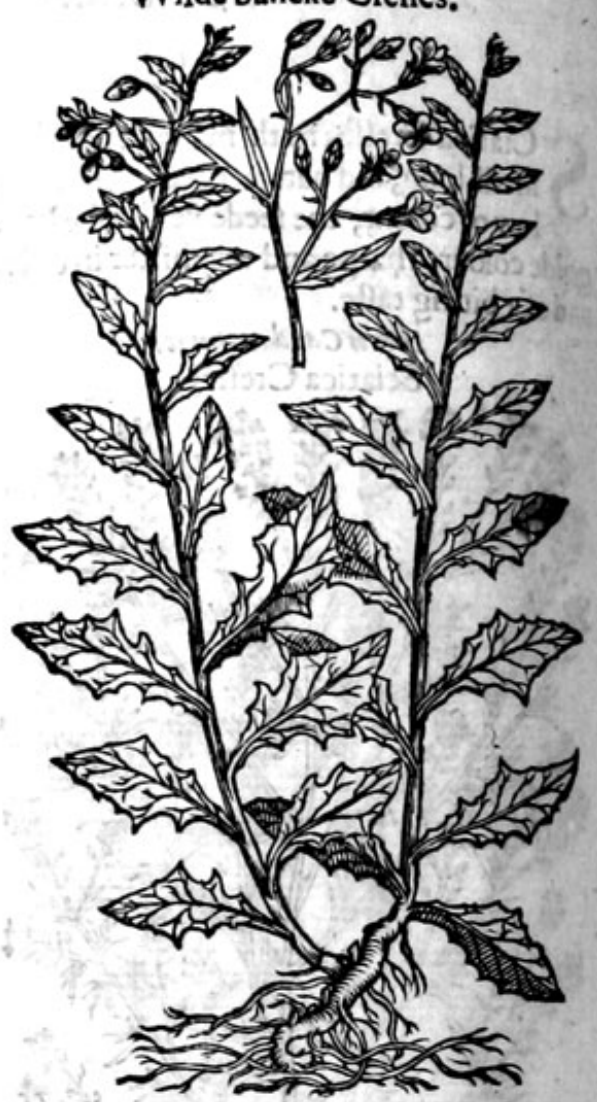

* The place.

Bancke Creffes is found in ftony places among rubbirh, by path waies, vpon earth or mudde wals, and in other vntoiled places.

The feconde kinde of bancke Creffes, groweth in fuch places as the former doth:I founde it growing at a place by Chelmesforde in Eflex called little Baddowe, and in fundric other places.

They flower in Iune and Iuly, and the feede is ripe in Auguft and September.

\section{* The names.}

Bancke Creffes is called in Greeke ípormuov, and of fome xauarasiov: Chomapliem accorditig to Diof corides: Theophraftes hath an other Eryfomum, euen that which Diofcor ides calleth $M$ y.agrum, and is the plant that Doetor William Tur ner of famous memory, called winter Creffestit is called of Diofor rides and $T$ beophrastius likewife Irio, and Irion.

\section{*. The nature.}

The feede of bancke Creffes is like in tafte to garden Creffes, and is as Galen faith of a fierie tert perature, and dcth extreamly attenuate or make thinne. * The vertues.
Aame. The feed of banc ke Creffes is good againft the rheume that falleth into the cheft, by rorting the

B It remedieth the cough, the yellow iaundife, and the Sciatica or ache of the hucklebones, ifitbe taken with honic in manner of a Lohoc and often licked.

C It is alfo drunke againft deadly poifons, as Diofcorides addeth:and being made vp in a plaitter with water and honic and applied, it is a remedie againft hidden cankrous apoftumes behinde the eares, hard fwellings, and inflammations of the pappes and ftones. 


\section{of DockeCreffes. Chap.i6.}

\section{Lomp fana.}

Docke Creffes.

$$
\text { * The defcription. }
$$

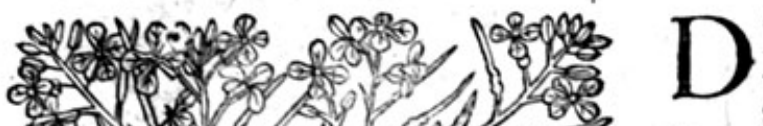

Ocke Creffes, is a wilde woort or pot herbe, hauing large leaucs of an ouerworne greene colour, deepely cut or endented, vpon both fides, like the leaues of finall Turneps, but leffer. The ftalkes growe to the height of two foote, deuiding themfelues toward the top, into fundrie fmall braunches; whereon do growe many friall yellowe flowers, like thofe of Hieracison or Haukeweede.

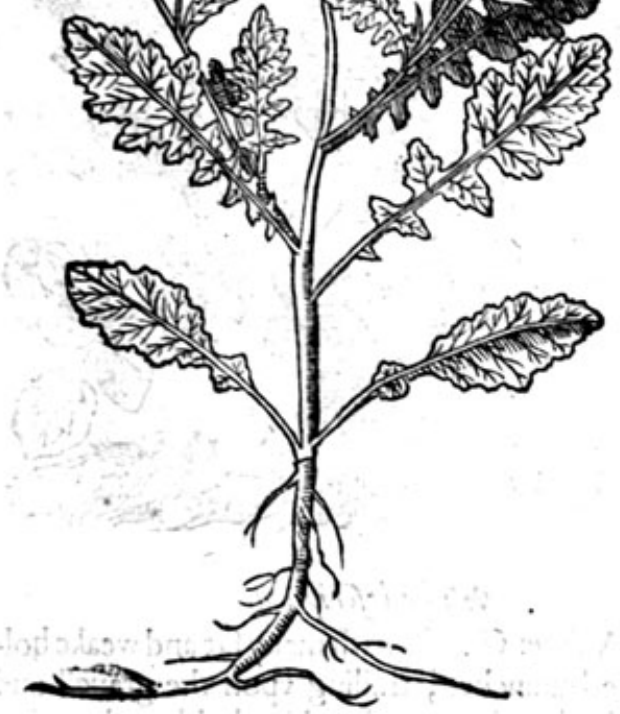

$$
\text { * The place. }
$$

Docke Creffes groweth euery where, by high waics,vpon walles made of mudde or earth, and in ftonie places.

$$
* \text { The time. }
$$

It flowreth from Maie to the ende of Auguft: the feede is ripc in September.

$$
\text { * The names. }
$$

- Docke Creffes is called in Greeke Neutim : in $\mathrm{L}_{\mathbf{a}}$ tine Lampfana and Napiom.

$$
* \text { The nature. }
$$

Lampfana is of nature hot, and fomewhat abfterfiue or fcowring.

$$
\text { *The vertwes. }
$$

Taken in meate as Galcn and Diofcorides affirme, $\mathbf{A}$ it engendreth cuill iuice, and naughtic nourifhment.

\section{Of waterCreffes. Chap.17.}

* The kindes. There be three forts of water Creffes, one of the marrifh grounde; the other of the riuer; the
laft of the clecre and filuer running fprings.<smiles>Ic1ccccc1</smiles>

\section{* The defcription.} Parfnep. The , like to Kexe or Cafshes. The roote confifteth of many fmall itringes or threddes, faftned vnto the ftalke within the water or myrie ghite flowers, in fpökierundels like Fennell, which being brufed do yeelde a ftrong fauour,fimelling like Petroleum, as doth the reft of the plant.

2. Small water Creffe hath great, thicke, and hollow ftalkes, fet with great leaues made of many finall,fet vpon a middle rib like the . of order, not much vnlike he ane, not one oppofite againft another, but confufedly and out hiskinde. 
I Sium maius.

Great water Parfnep.
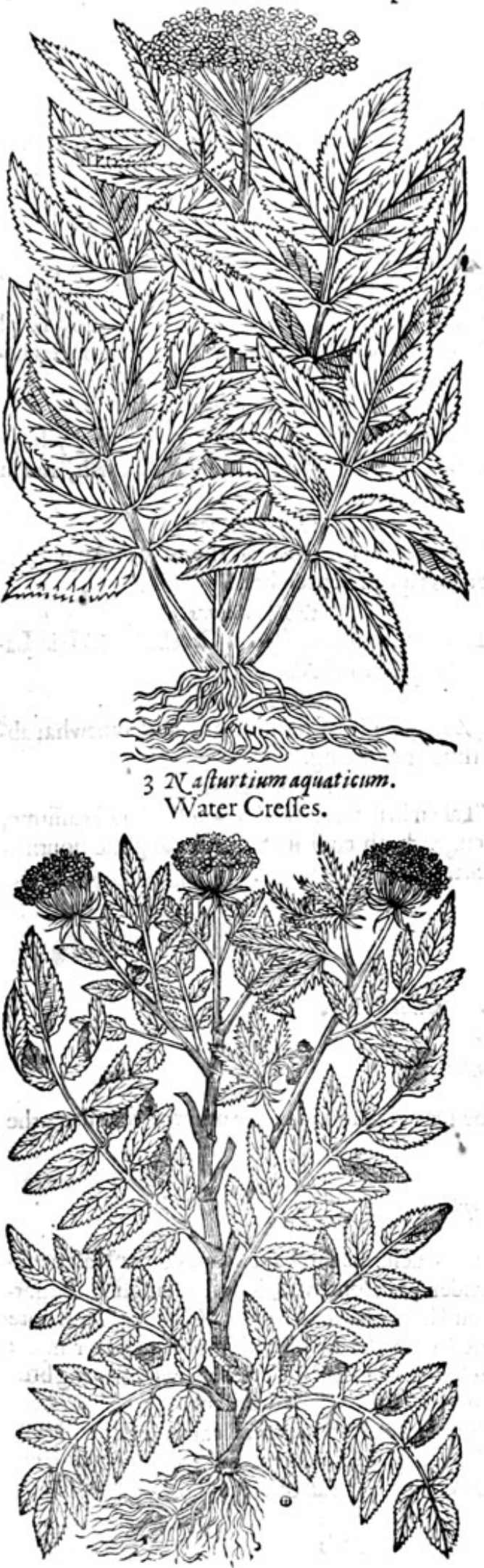

2 Sium minus.

Small water Creffe.

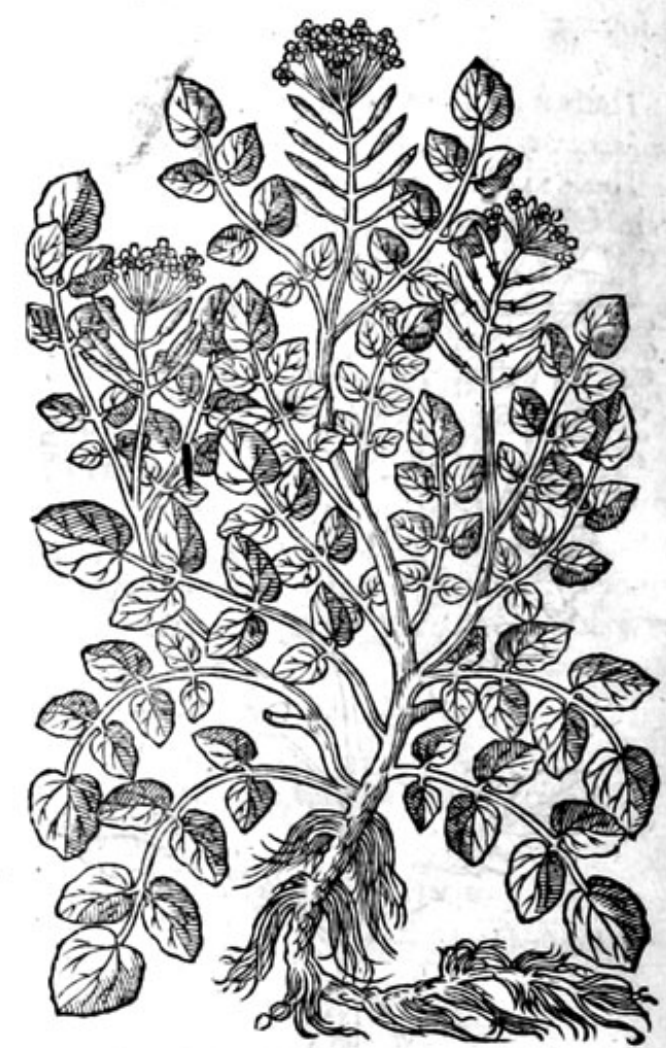

* Thedefiption.

3 Water Creffes hath many fat and weake hollowe braunches, trailing vpon the grauell and earth where it groweth, taking holde and rooting in fundrie places as it creepeth; by meanes wherof the plant fpreadeth ouer a great compaffe of grounde. The leaues are likewife compact and winged with many fmal leaues, fet vpon a middle ribbe one againft another, except the point leafe, which ftandeth by himfelfe, as doth that of the Afhe, if it growe in his naturall place, which is in a grauely fpring. The vpper face of the whole plant is of a browne colour, and greene vnder the leaues, which is a perfect marke to know the Phificall kinde from tie others. The white flowers growe in fpokic roundels. The roote is nothing elfe but as it were a thrum or bundell of threedes. $*$ The place.

The firft groweth in moorith and marfhie grounds, and in medowes and woodes that be feldome drie.

The feconde and thirde do growe in running brookes of moft cleere fountaines and grauelic fprings, where the beft for phifick do vie to grow. * The time.

They fpring and waxe greene in Aprill, and flower 
flower in Iuly.

The water Creffe to be eaten in fallades, theweth it felfe in March when it is beft, and flowreth in fommer with thereft.

$$
* \text { The names. }
$$

The firft is called in Latine Siven maisus, and Laver mains of Diofcorides : of others it is called $S$ ismodoratum Tragi, and alfo Pastinaca aquatica.

The fecond is called in Grecke riov: in Latine Situm alserum, and alfo Sifymbriven : in Englifh great water Creffe, for that it hath the tafte of garden Creffes.

Water Creffe is called of Cratewa Sium, and Sifombrium aquaticion : of the newe writers 2 affurtium aquaticum, and Laucr Cratellke: in Englifh water Creffes, or browne Crefles.

Water Creffe is euidently hot and drie.

$$
\text { * Thetemperatare. }
$$
good againft the fcuruie or fcorbute.

Being chopped and boiled in the broth of fle $\mathrm{h}$, 'andeaten for $\mathbf{x x x}$. daies togither at morning, B noone and night, prouoketh vrine, wafteth the ftone, and driueth it foorth. Taken in the fame manner, it doth cure yoong maidens of the greene fickneffe, bringeth downe their termes, and fendeth into the face their accuftomed liuely colour, loft by the ftopping of their menftrue.

\section{Of wilde water Creffes or Cuckow flowers. Chap.18. * The kindes.}

There be fixe kindes of wilde herbes numbred among the water Creffewhich followe in order.

I Cardamine.

Cockowe flowers.

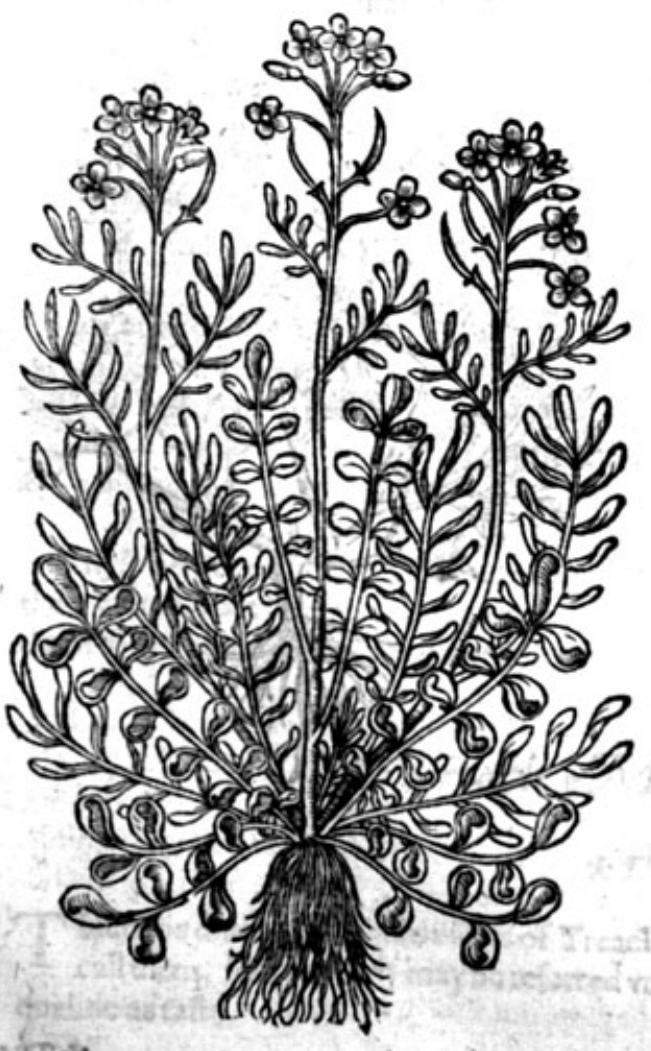

2 Cardamine alters. Ladies fmockes.

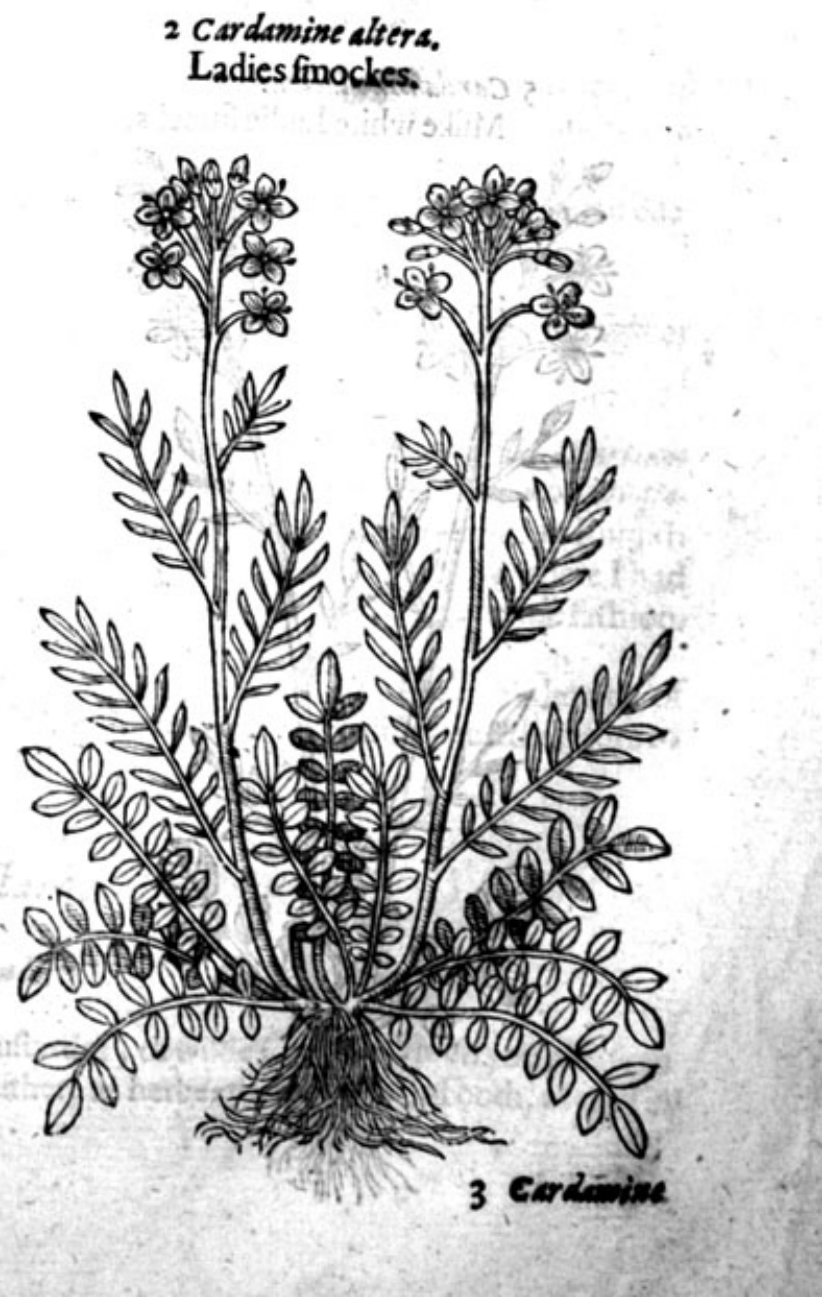


202

THE SECOND BOOKE OF THE

2 Cardamine Trifolia.

Three leafed Ladie finocks.

4 Cardamine latifolia.

Great Ladie fmocks.

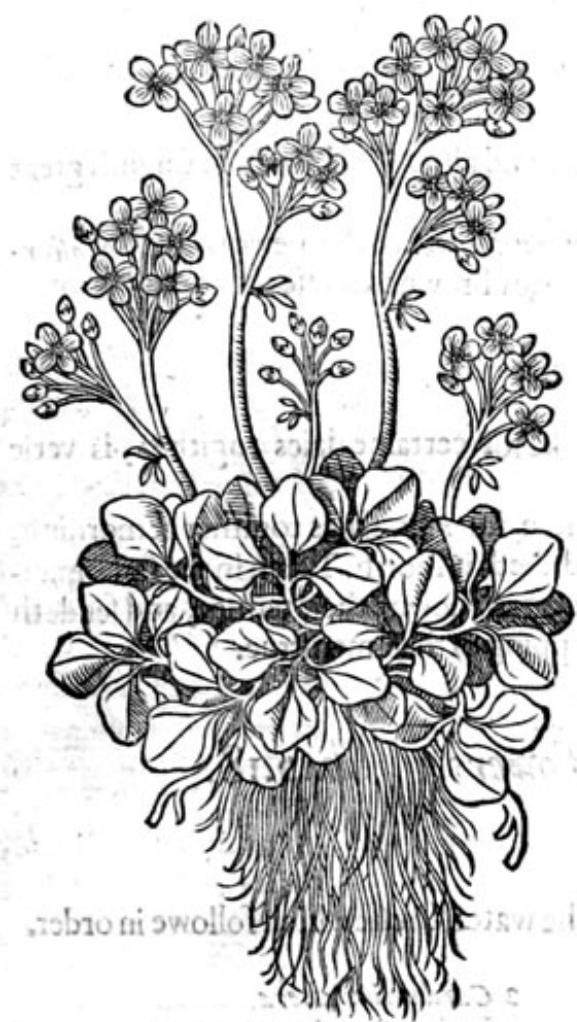

5 Cardamine lactea.

Milke white Ladie fmocks.

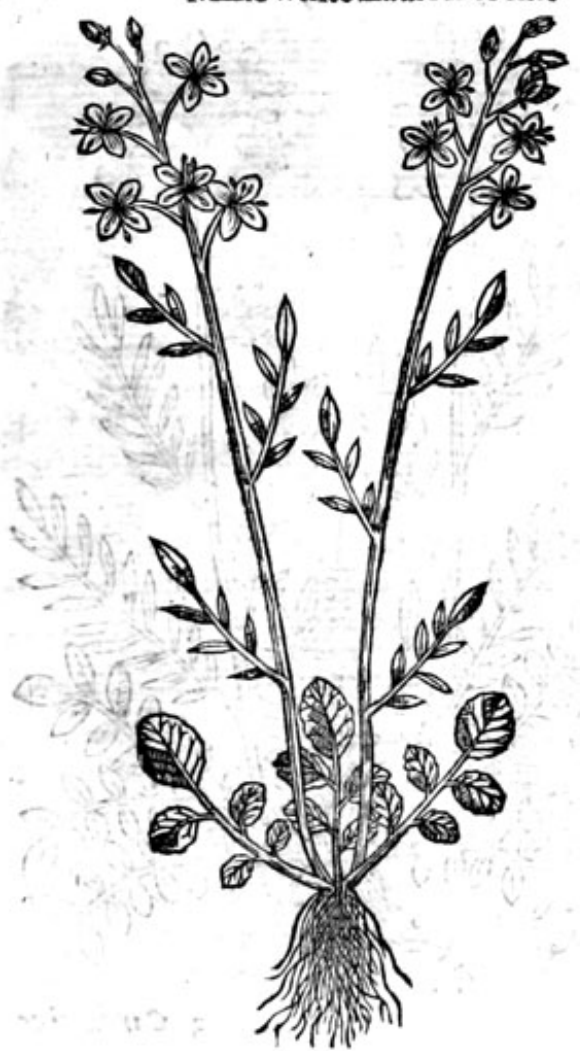

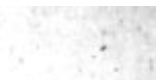
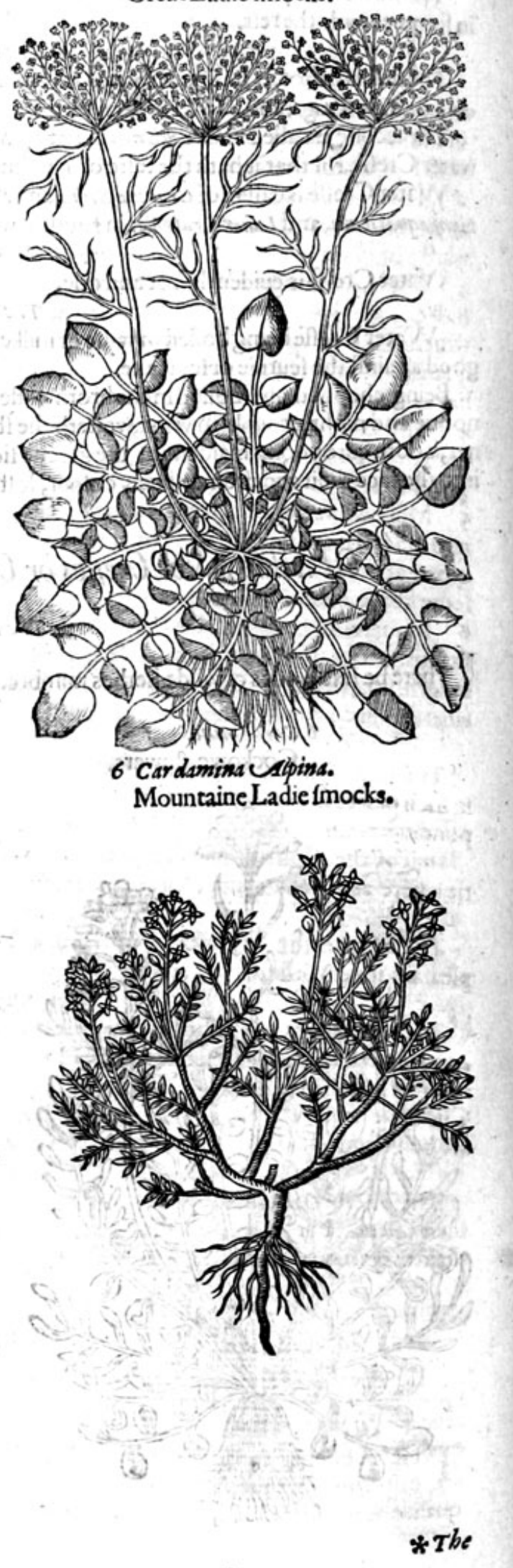


\section{* The defcription.}

1 He firf of the Cuckowe flowers, hath leaues at his fpringing vp fomewhat rounde, and thofe that fpring afterward grow iagged like the leaues of Greeke Valerian:among which rifeth vp a ftalke a foote long, fet with the like leaues, but fmalkr and more iagged, refembling the leaues of Rocket. The flowers grow at the top in finall bundels, white of colour, hollowe in the middle, refembling the white fweete Iohn: after which do comefmall chaffie huskes, or feede veffels, wherein the feede is conteined. The roote is fimall and threddie.

2 The fecond fort of Cuckowe flowers, hath fmall iagged leaues like thofe of fmall water Valerian,agreeing with the former in ftalkes and rootes. The towvers be white, ouerdafht or declining toward a light carnation.

3 The thirde fort of Cuckowe flowers groweth creeping ypon the ground, with frall threddie italkes, whereon do growe leaues like thofe of the fielde Clauer, or three leafed graffe : among which do come vp fmall and tender ftalkes two handfuls high, hauing flowers at the top in greater quantitiz than any of the reft, of a light flefhie colour $\mathrm{d} a \mathrm{fht}$ with white. The roote is nothing elfe but as it were a bundell of thrums or threds.

4 The fourth groweth likewife flat vpon the grounde: the leaues growe vpon a flender ribbe, as doth the leaues of Setwall, or rather water Trefoyle, among which do rife vp ftalkes a cubite high. The flowers growe at the top, tuft or feather fafhion, with a threddie roote like the former.

5 Milke white Ladie fmockes hath ftalkes rifing immediately from the roote, deuiding themfeltes into fundrie fmall twiggie and hard braunches, fet with leaues like thofe of Serpillun. The flowers growe at the top, made of fower leaues of a yellowifh colour. The roote is tough and wooddy, with fome fibres annexed thereto.

6 Mountaine Ladiefmockes hath many rootes, nothing elfe but as it were a bundell of threddy ftrings, from the which do come foorth three or fower finall, weake or tender leaues, made of fundrie fmall leaues, in fhewe like thofe of fmall water Valerian. Theftalkes bee fmall and brittle, whereupon do growe finall towers like the firft kinde. * The place.

Thefe kinds of Cuckowe flowers, grow not fo much in waters as they do in moift medowes, and in fuch places as be verie often ouertlowen not oncly with raine water, bux alfo with riuers and ponds.

That of the Alpirh mountaines is a ftranger in thefe colde countries, the reft are to be found eue rie where, as aforefaid,efpecially in the caftle ditch at Clare in Effex. * The time.

Thefe flower for the moft part in Aprill and Maie, when the Cuckowe doth begin to fing her pleafant notes without ftam.' cring.

*The names.

They are commonly called in Latine Flos Cuculi, for the reafon aforefaid, and alfo 2 asfurtiom aguaticum minus, or the leffer water Creffe: of fome Cardemine, and sif mbrivm alserwom of Diogoas rides: it is called in the Germaine toong Joctiloetcrefz: in French Pafferage fanurge: in Englifh Cuckowe flowers in:Northfolke, Caunterburie bels : at the Namptwich in Chefhire where Thad my beginning, Ladiefmockes, which hath giuen me caufe to chriften it after my countrie fafhion. *Thenature and vertues.

Thefe herbes be hot and drie in the fecond degree : we halle no certaine proofe or authoritic of their vertues, but furely from the kindes of water Creffe they cannot much differ, and therefore to them they may bereferred in their yertues.

\section{Of Treacle cMustarde. Chap.19.}

*The kindes.

$T$ Here be diuers and fundrieforts of Treacle Muftardes, orwilde Creffes, which you pleafe to call them, for that they may be referred vnto either, as herbes participating of both, as well in qualitic as tafte. 
THE SECOND BOOKE OF THE

I $T b l_{3}$ pi Diofcoridis.

Treacle Muftarde.
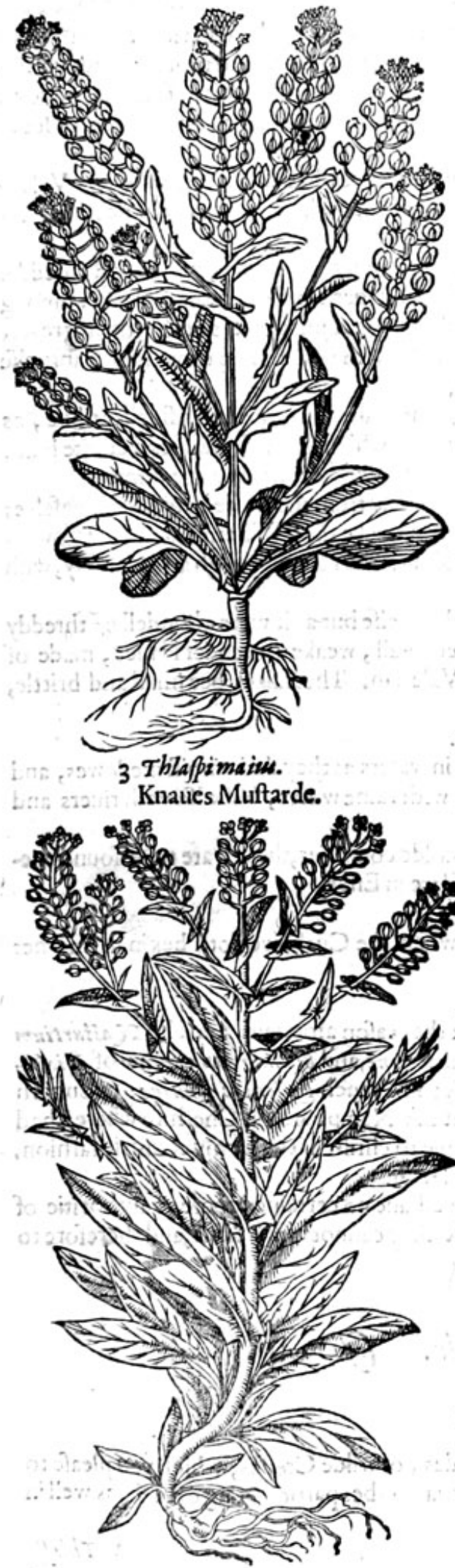

2 ThlapiVulgatifimum.

Myeridate Muftarde.
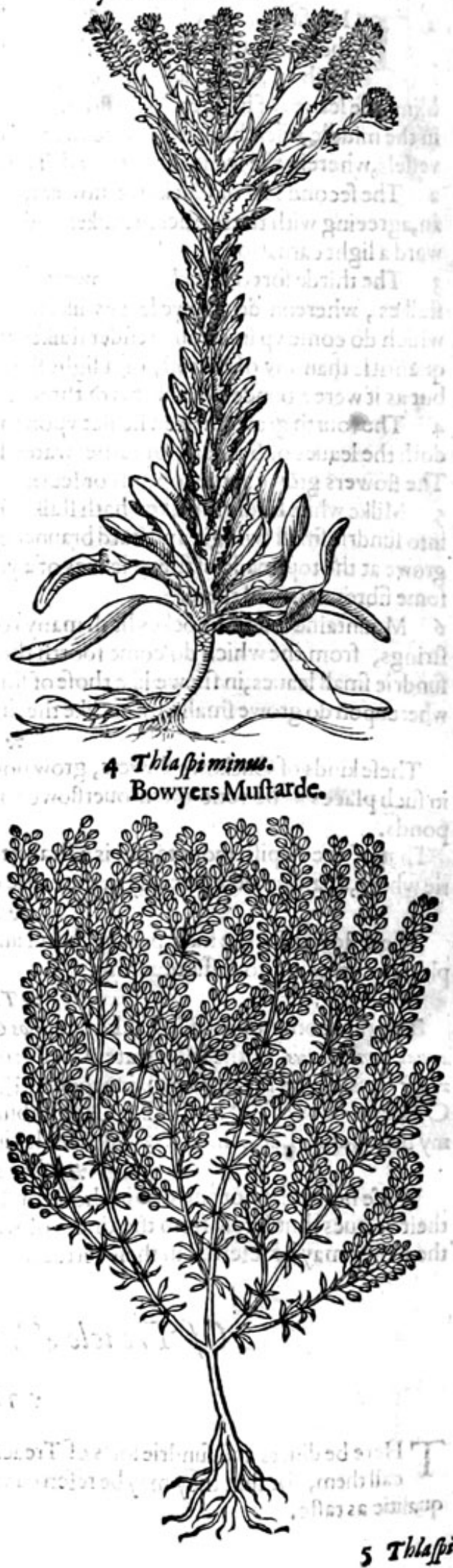

6 TblapiGrecum.

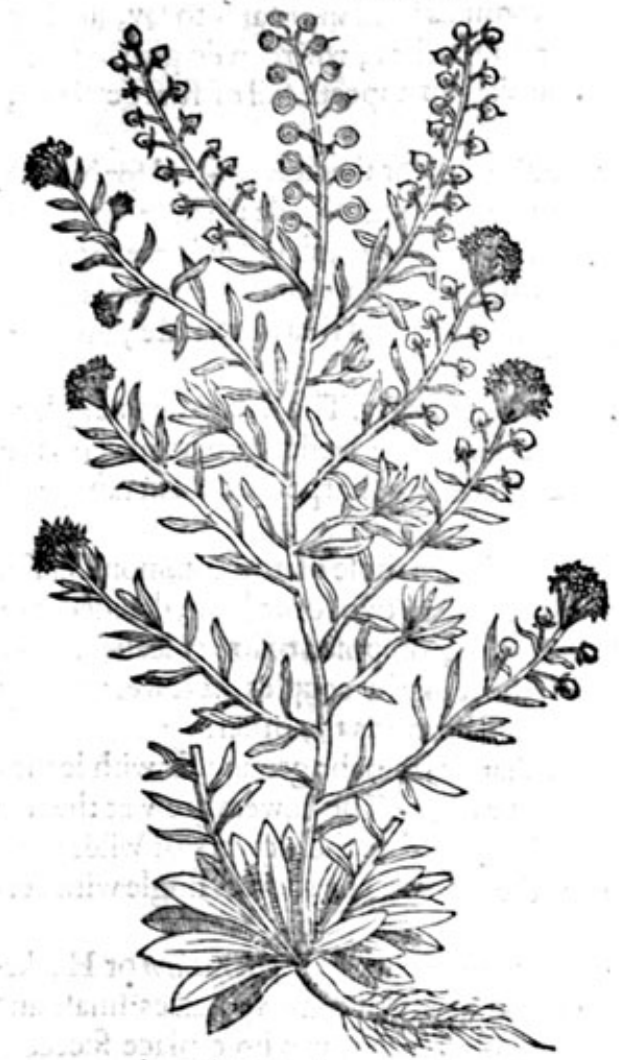

7 Thlapiclypeatum L'Obelii. Buckler Muftarde.

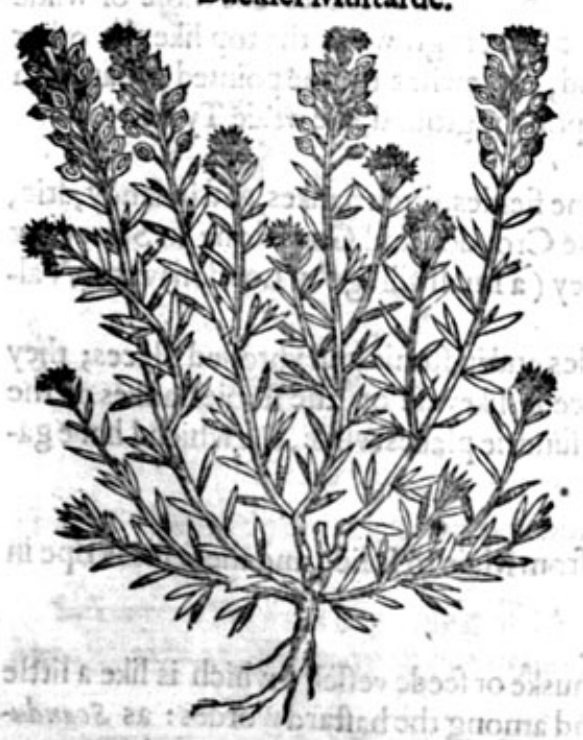

6 Thlaffiamarram. Clownes Muftard.

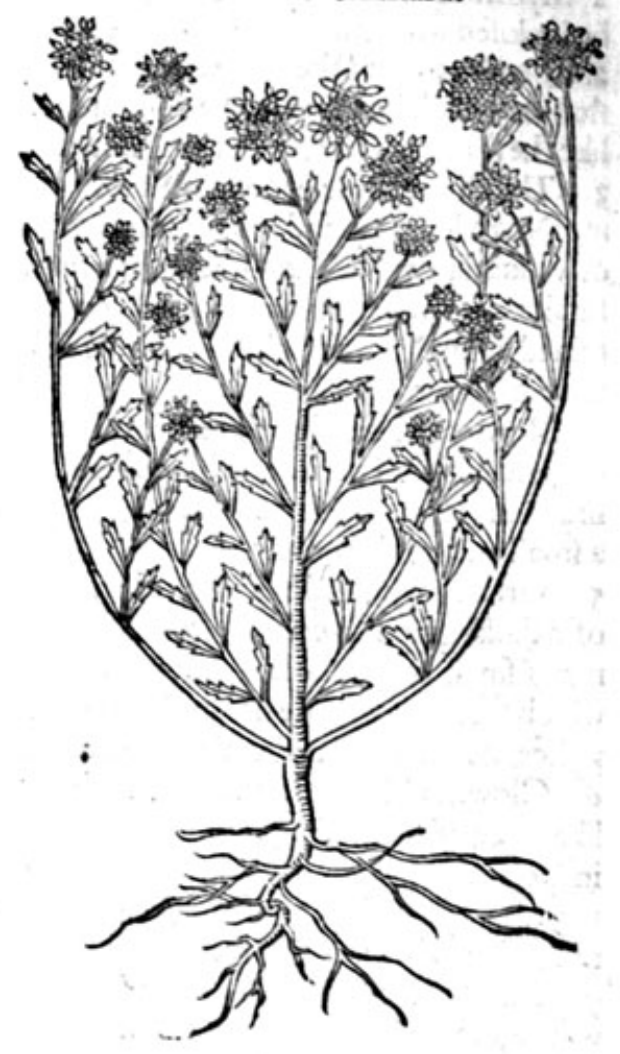

\section{Thlappiminus Clypeatuen.}

Small buckler Muiftarde.

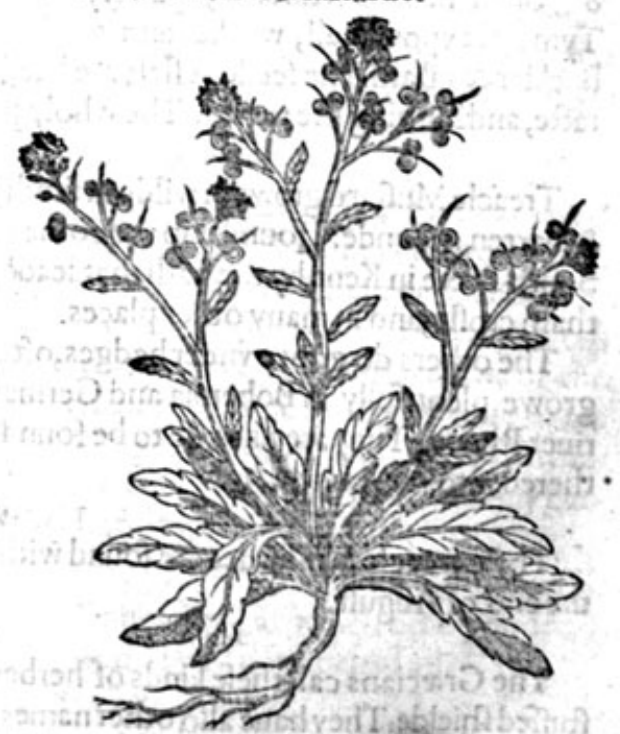

I Reacle Muftardehath * The defription.

* The defaription.

I Reacle Muftarde hath long broade leaues, ef pecially thofenext the ground, the others lefdeuided into many braunches euen from the ground to the top, where grow manye finall idle flowers tuft fafhion, after which fueceede flat, thinne, chaffie huskes or feede veffels hart fafhion, wherin are conteined browne long feedes, tharpe in tafte, burning the toong as doth Muftarde feede, 


\section{THE SECOND BOOKE OF THE}

feede, leauing a tafte or fauour of Garlicke behinde for a farewell.

2 Mythridate Muftard hath long narrow leaues like thofe of Woad,or rather cow Bafil. The ftalks be inclofed with fimall fnipt leaues euen to the braunches, Pyramidis farhion, that is to fay, fmaller and fmaller toward the top, where it is deuided into fundrie braunches, whereon do growe fmall flowers; which being paft, the cods or rather thinne chaffie huskes do appeere full of fharpe feede, like the former. The roote is long and flender.

3 The thirde kinde of treacle Muftarde, named knaues Muftard, (for that it is too bad for honeft men)hath long,fat,and broade leaues; like thofe of Dwale or deadly Nighthade : in tafte like thofe of Vuluaria or ftinking Orache, fet vpon a rounde ftalke two cubits high, deuided at the top into fmall armes or braunches, whereon do growe fmall foolifh white fpokie flowers. The feede is conteined in fmall flat pouches like thofe of Shepheardes purfe, browne and harpe in tafte, but of a rancke fauour.

4 Bowiers Muftard hath very fmall leaues like Toade flaxe, but fimaller. The ftalkes be fmall,flender, and many. The flowers be fo finall, that they feeme to be duft. The feedes be placed vpon the braunches from the loweft part of the plant euen to the top, exceeding tharpe and hot in tafte, with 2 fmall and fingle roote.

5 Grecian Muftard hath many leaues fpread vpon the ground, like thofe of the common Daifie, of a darke greenifh colour : from the midft whereof, fpring vp ftalkes two foote long, deuided into many fmall braunches: whereupon do growe fmall white flowers, compofed of fower leaues, after which fucceede rounde flat huskes or feede veffels, fer vpon the ftalke by couples, as it were fundry paires of fpectacles, wherein the feede is conteined, harpe and biting as the other.

6 Clownes Muftard hath fmall tender ftalkes rifing immediately from the ground, fet with leaues like thofe of fmall Haukes weede, fleightly ind ented about the edges. The flowers grow at the top in fpokie rundels like thofe of Sefeli Creticum, not much differing from the flowers of wilde parfneps. The feede is as fmall as fande, yet biting the toong as the former. The roote is fingle with certaine threds hanging thereat.

7 Buckler Muftard hath many large leaues, fpread vpon the grounde like Hieration or Haukeweede, fomewhat more toothed or fnipt about the edges : among which come vp ftalkes fmall and brittle, a cubite high, garnifhed with many fmall pale yellowifh flowers, in whofe place fucceede many round, flat, cods or pousches, buckler fafhion, conteining a feede like vnto the others.

8 Small buckler Muftard, is a very fmall, bafe, or lowe plant, hating leaues like thofe of wilde Tyme, fet vpon fmall, weake and tender braunches. The flowers growe at the top like the other buckler Muftard.The feede veffels are like, but not foround, fomewhat fharpe pointed, tharpe in tafte, and burning the toong. The whole plant lieth flat vpon the ground, like wilde Tyme.

$$
\text { * The place. }
$$

Treacle Muftard groweth wilde in fundry places in corne fieldes, ditch bankes, and in fandy, drie, $\&$ barren grotinde. If found it in the corne fieldes betweene Croydon and Gods ftone in Surrey, at South-fleete in Kent, by the path that leadeth from Harnfey (a fmall village by London)vnto Waltham croffe, and in many other places.

The others do growe vinder hedges, oftentimes in fieldes and in ftonie and vntoiled places; they growe plentifully in Bohemia and Germanie; they are feene likewife on the ftonie bankes of the riuer Rhene. They are likewife to be found in England in fundrie places wilde, the which I haue gathered into my garden.

\section{* The time.}

Thefe treacle Muftardes are found with their flowers from Maie to Iulie, and thefeede is ripe in the end of Auguft.

\section{* The nomes.}

The Græcians call thefe kinds of herbes $\theta \lambda \alpha^{\prime} \pi$, of the huske or feede veffell, which is like a little ftuffed hiclde. They haue alfo other names which be found among the baftard wordes: as Scanderlacewon, Capfells, Pes gallinacess. Neither be the later writers without their names, as Nasturtium

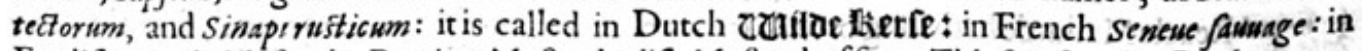
Englifh treacle Muftarde, Bowiers Muftarde, difh Muftard, of forne Thlafpiafter the Greeke name, chirles Muftarde, and wilde Creffes.

Treacle Muftarde is called of fome scorodothla/pi, that is to fay, Garlicke Thlafpi, of therancke and ftrong fimell it hath of garlicke. 
* The temperatare.

Thefeede of thefe kindes of treacle Muftards, be hot and drie in the ende of the thitrd degree.

$*$ The vertues.

The feede of Thlafpi or treacle Muftarde eaten, purgeth choler both vpward and downwarde, A prouoketh flowers, and breaketh inwarde apoftemes.

The fane vfed inclyfters, helpeth the fciatica, and is good vnto thofe purpofes for which Muitard B feedeferueth.

\section{* Thedanger.}

The feede of thefe herbes be fo extreeme hot and vehement in working, that being taken in too great a quantitie, purgeth and fcoureth euen vnto blood, and is hurtfull to women with childe, and therefore great care is to be had in giuing them inwardly.

\section{Of Candie Mustard. .Chap.zo.}

\section{Thlapicardi.e.}

Candie Muftard.

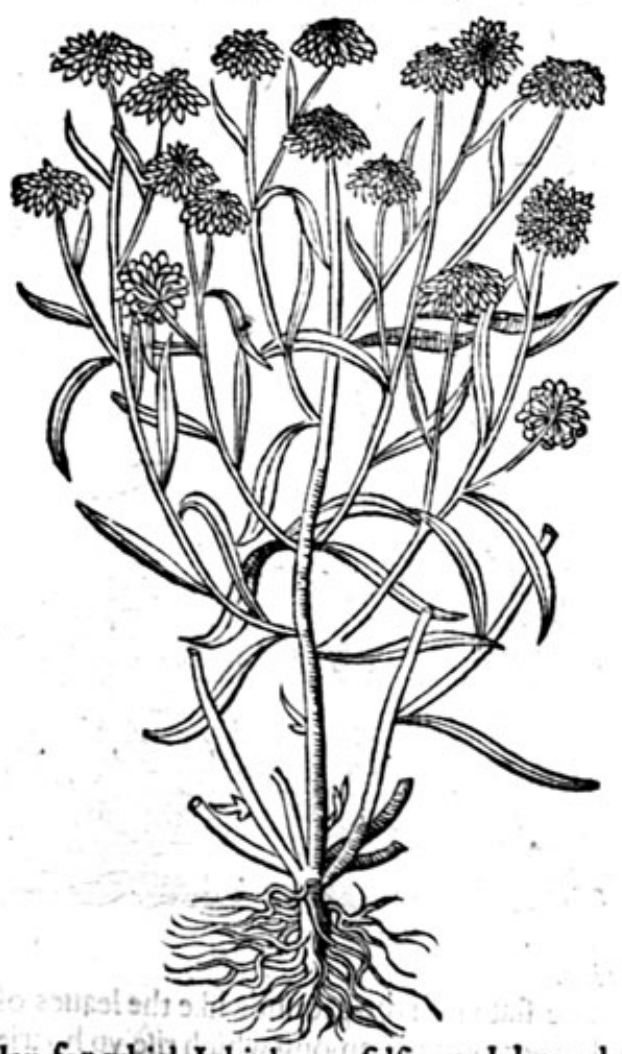

* The defcription.

Andie Muftarde excelleth all the reft, as well for the comely flowers that it bringeth foorth for the decking vp of gardens and houfes, as alfo for that it goeth beyonde the reft in his phyficall vertues. It rifeth vp with a very brittle ftalke of a cubite high, which dituideth it felfe into fundric bowes or braunches, fet with leaues like thofe of the ftocke gilloflowers, of a graie or ouerworne greene colour. The flowers growe at the top of the ftalkes rounde, thicke cluftering togither, like thofe of Scabious or Deuils bit, fomtimes blewe, often purple, fometimes carnation or horfe-flefh, and feldome white, for any thing that I haue feene, varying according to the foilc or climate. The feede is reddifh, harpe, and byting the toong, wrapped in little huskes fafhioned like a hart.

$$
\approx \text { Theplace. }
$$

This plant groweth naturally in that $\mathrm{Pannonia}$ which is nowe called Auftria, in vntoiled places, and by high waic fides: in Crète or Candia, in Spaine and Italie, and fuch like hot regions, from whence I receiued feede, by the liberalitie of the right Honorable the Lorde Edward Zouche, at his returne into England from thofe partes, with many other rare feedes, which do flourifh in my garden, for which I thinke my felfe much bounde vnto his good Lordfhip.

\section{* The time.}

It flowreth from the beginning of Maie vnto the ende of September, at which time you Mall haue flowers, and feedes vpon one braunch, fome ripe, and fome that will not ripen at all.

* The names.

This plant is called in Greeke dedBn, or Aeeris, by 2 finall errour in chaunging s into \&- in Latine Crabis and Drabs: Plinie in his 27, booke 9 . chapter, namethit Dryophonom it is vfually called Thla/pi Candie: in Englifh Candie Thlafpi, or Candie Muftarde.

The feede of andie Mufterde $*$ The temperature. Scorodotblafpior treacle Muftarde. 
* The vertwes.

A Diofcorides faith, that they vfe to eate the dried feede of this herbe with meate, as we doMuftarde, efpecially in Cappadocia.

B They vfe likewife to boile the herbe with the decoction of Barly, called Ptifana, in which being fo boiled, it concoetech and bringeth foorth of the cheft tough and rawe flegme, which fticketh therein.

C It is reckoned a chiefe among thofe Simples with which mithridate and treacle is made, and is mixed in counter poyfons and fuch like compofitions.

\section{Of Treacle Mustarde. Chap.21.}

I 7 blappi incansom. Hoarie Muftarde.

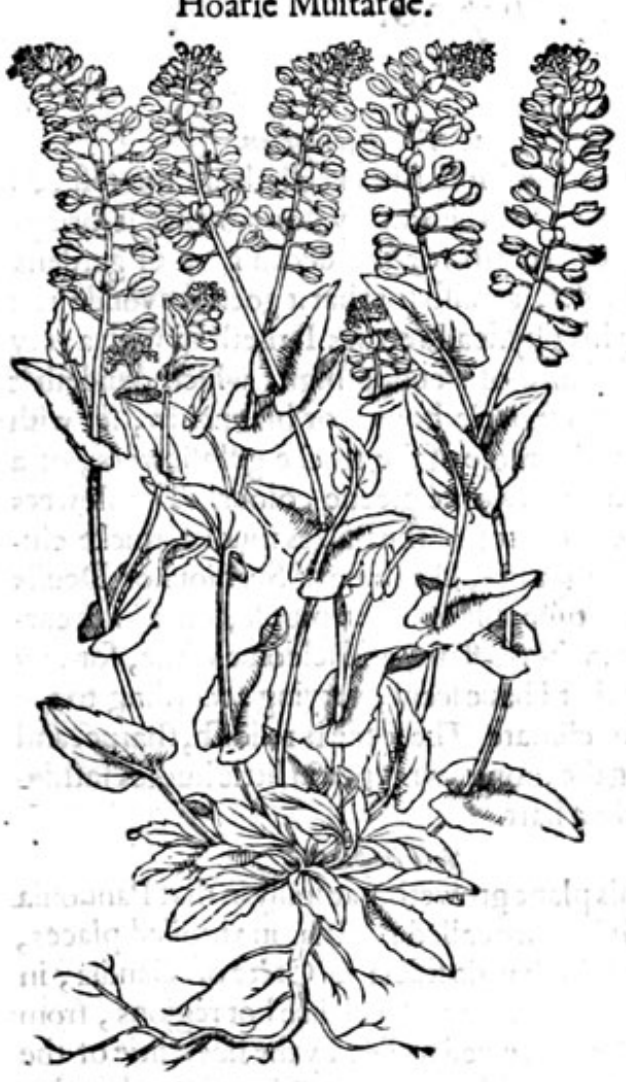

2 Thla pipi Pamonicum Cluffir. Hungarie Muftarde.

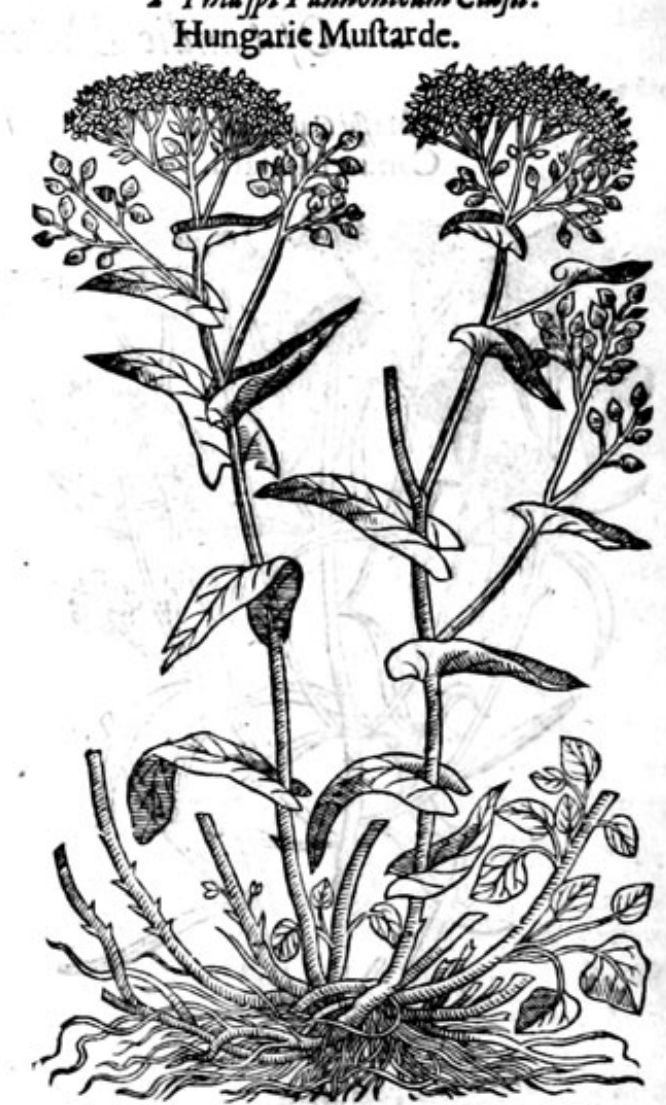

* The defcription.

I T Oarie Muftarde hath many large leaues, laide flat vpon the grounde like the leaues of<smiles>[BH3-]</smiles>
Woade, and of the fame colour, but not fo fharpe pointed: among which rife vp hoarie ftalkes declining to the colour of afhes, whereof it tooke his name,'which are fet with leaues far vnlike to thofe next the grounde, enclofing or embracing the ftalkes, as do the leaues of Perfoliatum or thorow-waxc. The flowers (being of fmall reckoning)grow ar the top of the braunches, white of colour, which being paft there do fucceede flat huskes or pouches, like thofe of Shepe heards purfe, with hot feede byting the toong.

2 Hungarie Muftard bringeth foorth flender ftalkes, two cubits high. The leaues which firft apa pecre are flat, fomwhat round like thofe of the wilde Beete; but thofe leaues which after do garnifh the ftalks are long and broade like thofe of the garden Colewoort, but leffer \& fofter,greene on the vpperfide, and vnder declining to whiteneffe, finelling like garlicke. The flowers be finall and white, confifting of fower finall leaues, which in a great tuft or vmbell do growe thicke thruft togither, which rbeing paft, there followeth in euery finall huske one duskifh leede and no more, bitter and 
tharpe in tafte. The roote is white and fmall, creeping vnider the grounde far abroadelike the roots of Couch graffe, preparing newe fhootes and braunches for the yeere following; contraric to all the reft of his kinde, which are increafed by feede, and not otherwife.

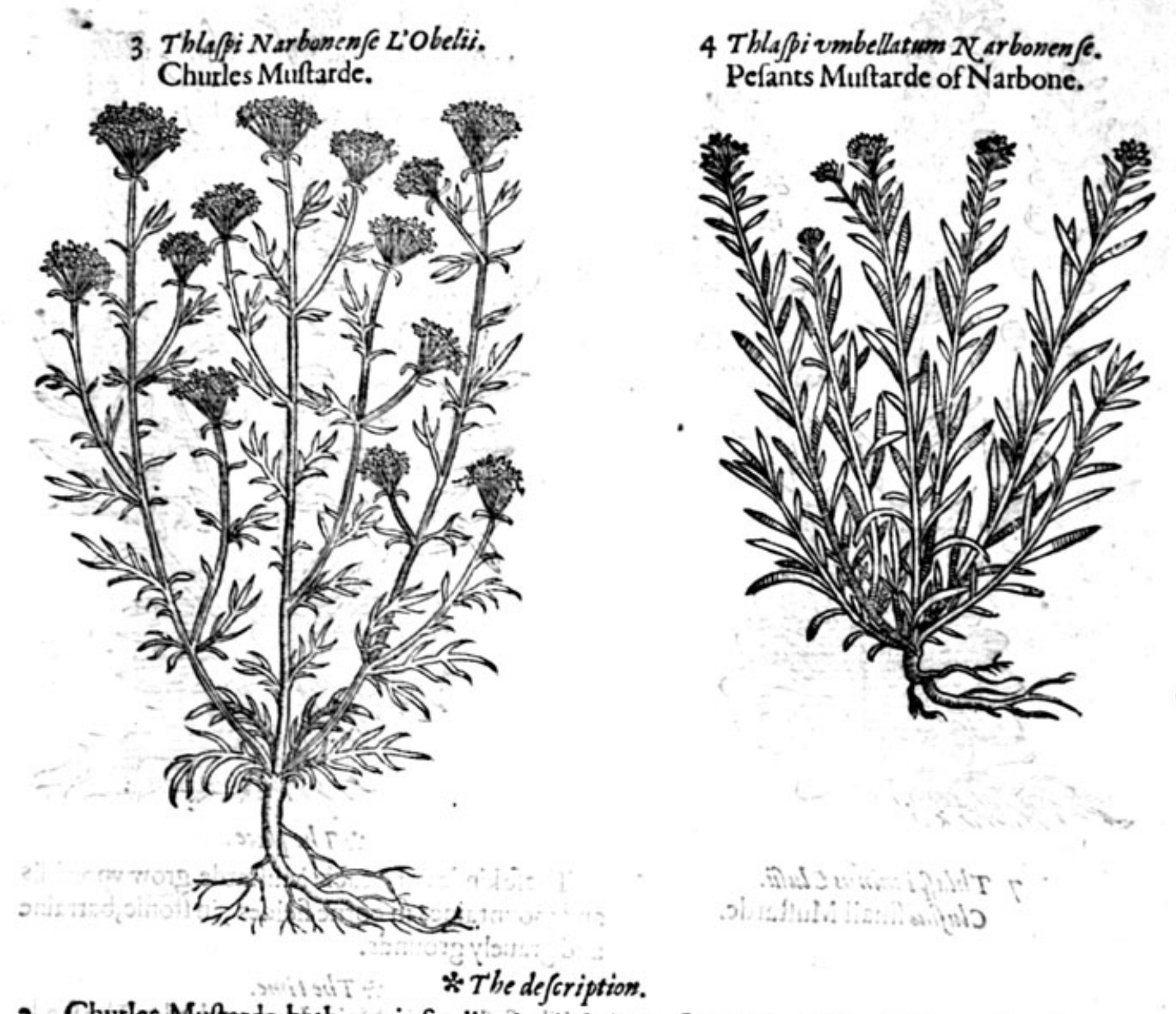

3 Churles Murfarde hithmanie fmall twiggie ftalkes, flender, tough and pliant, fet with fmall leaues like thofe of the Hyfope, with finalland idle flowers, leane husks fcarfe yeelding two feedes, and thofe fewe, tharpe, bitter and vnfauorie, not fit for meate nor medicine, and therefore we call
them as you fee, making no reckoning of then.

4. Pefants Muftarde hathmany flender, pliant braunches like the former, with thinne and iagged leaues like thofe of Harts horne but fmaller: a pleafant greene fauce lierbe, in fauour and tafte like Vuluaria: The flowers be yellowe, and grawe inz fmall fpokie tuft. The fecde in tafte and fauour is equall with the other of his kinde and countrey,

5) 3. Yellowe Miftarde hath an exceeding gumber of whitifh leaues, fpread vpon the grounde in manner of pturffe or haffocke, from the middeft wherof rifeth an vpright ftalke of three foot high, putting foorth many frnall braunches or armes; on the top whereof growe many finall yellowe pouch fafhion, wherein 6 . White Treacie Muftard hathea like Treacle Muftarde, Iharpe alfo and biting.

ftalkes rife vp from the middeft theaues Ipreade vpon the grounde like the other, but fmaller. The the grounde euen to the top, where dorh oranched, fet with leaues fmaller then thofe that lie vpon fe. The feede is like the other. 7 The frill kinde of Muftarde, hath 2 fewe fis

Moufe-eare:from which rife yP fmall tender ftalkes fet with fpred vpon the groundelike thofe of pointed leaues. The flowers grow at thescer, takes, fet with three and fomtimes fower fmal Iharpe are tlat, pouch fafhion, like thofe of She top, imall, and of no moment, but as it were duft. The cods to

O I 
5 Thlasi fupinum luteum. Yellowe Murtarde.

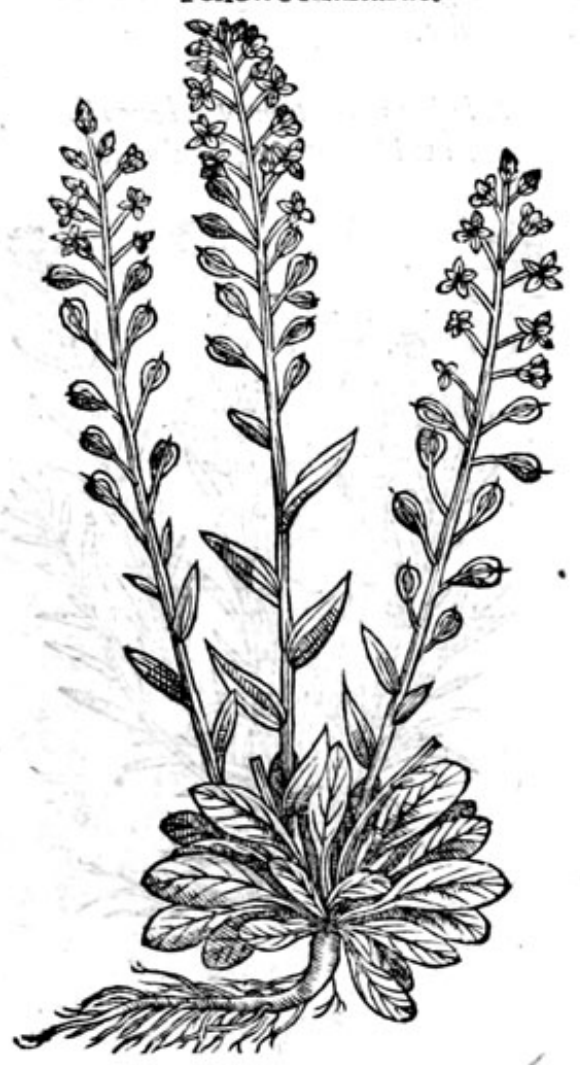

7 Thlapi minus Clufit. clufius fmall Muftarde.
6 Thlafpralbuon supinum. White treacle Muftard.

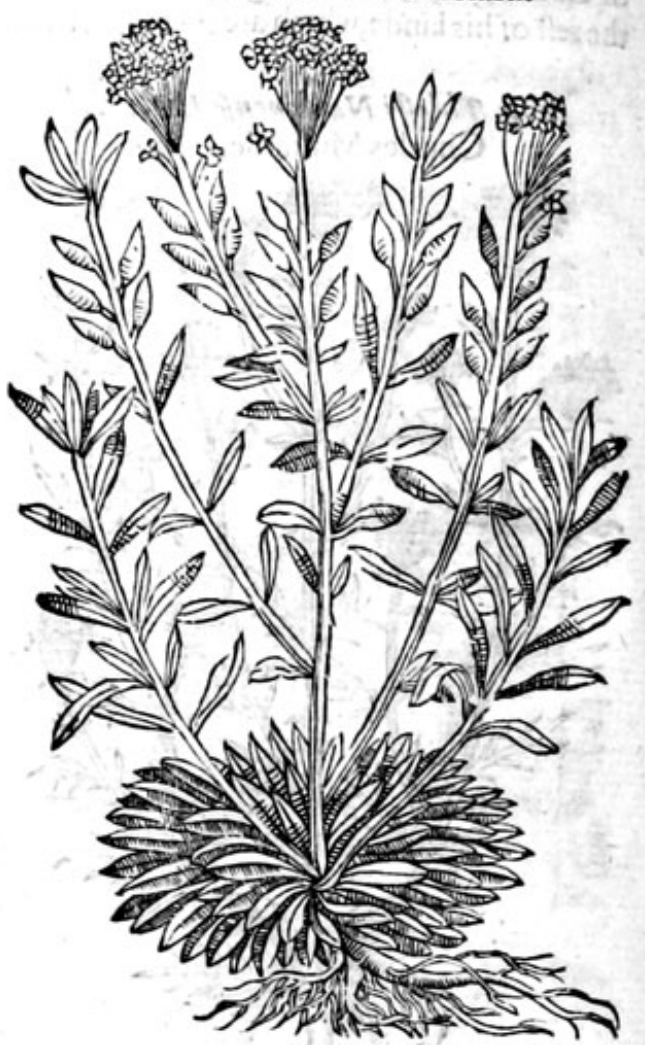

* T he place.

Thefe kindes of treacle Muftarde grow vpon hils and mountaines in corne fieldes, in ftonie, barraine and grauely grounds.

* The time.

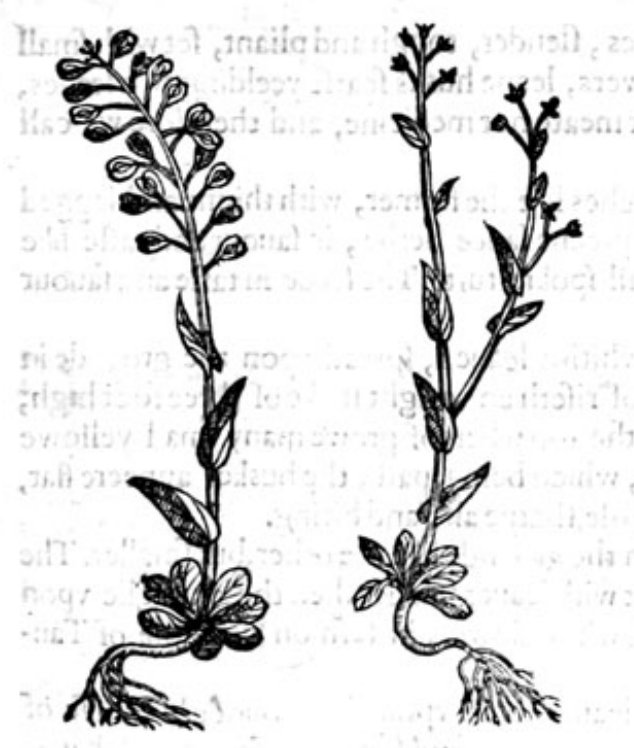

Thefe flower in Maie, Iune, and Iuly. The feede is ripe in September,

Thefe herbes are called by one generall name Thla/pi : the Germaines 23piemlraut : the Brabanders $2 B$ efemictupt: in Englifh Beeforme weede, or Broomewoorte, and treacle Muftarde. NotwithItanding, by reafon of the affinitie they have with muftarde \& Creffes, I have thought it expedient to call them al by the name of muftarde, bicaufe their nature doth not differ from it.

* The temperature and vertues.

The feeds of thefe churlifh kindes of treacle muftarde, haue a fharpe or biting qualitie: breake inwarde apoftumes, bring downe the flowers, kill the birth, and helpeth the fciatica or paine in the hip. They purge choler vpward and downewarde, if you take two ounces \& 2 halfe of them, as Diofcorides writeth. They are mixed in counterpoifons, as treacle, michridate, and fuch like compofitions. 


\section{Of woody Muftarde. Cbap.21.}

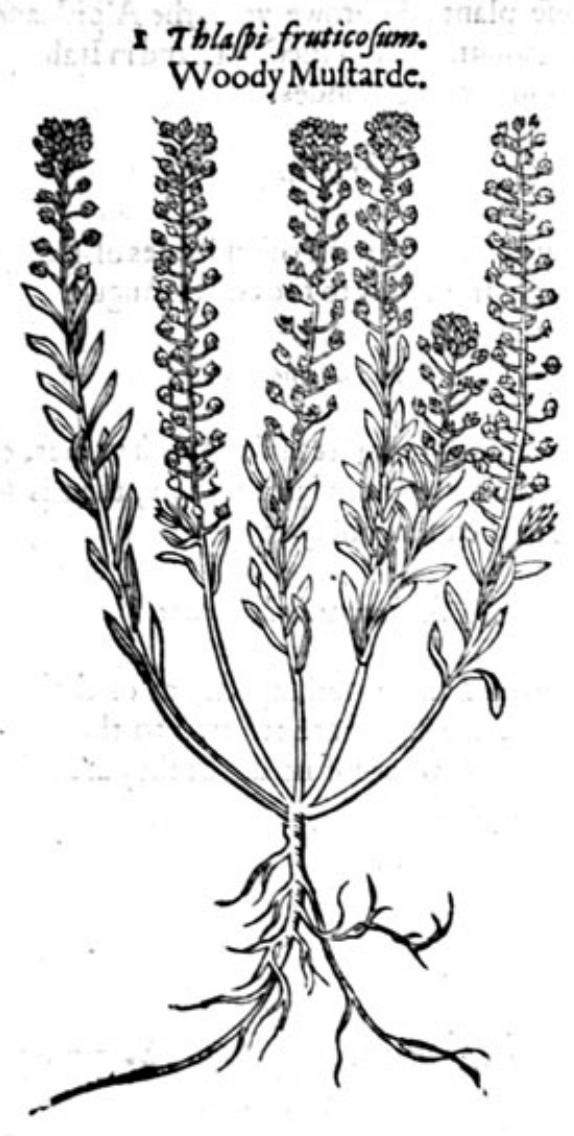

2 Tblapifrusticofum minus. Small wooddy Muftarde.

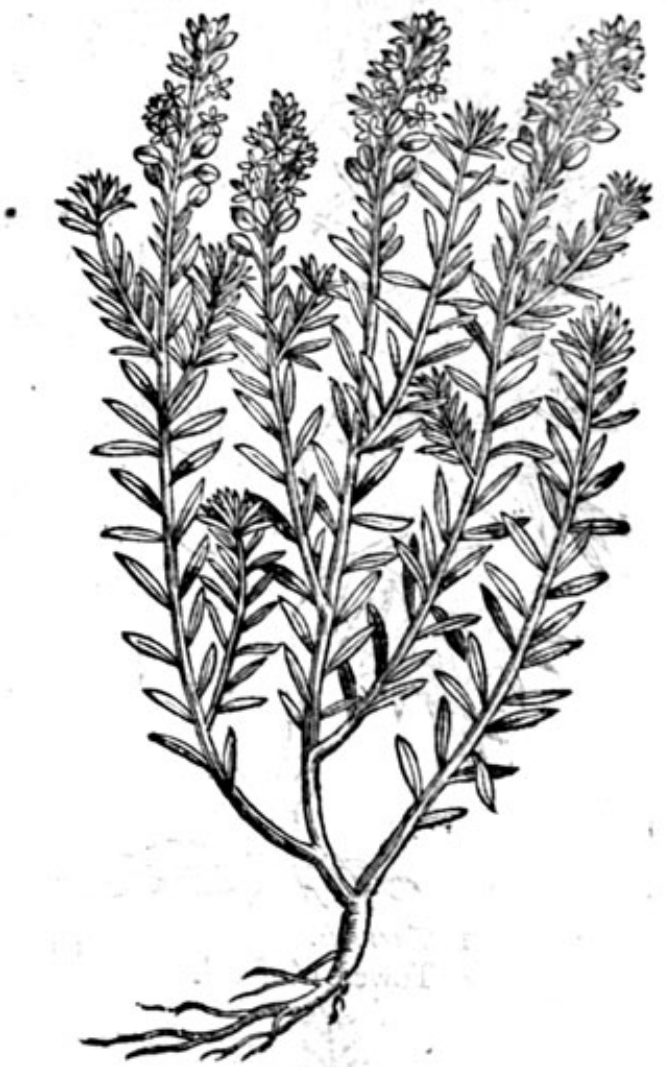

* The defcription.

1 Oodie muftarde hath long narrow greene leaues, declining to whiteneffe, like thofe of the Stock-gillofer, but fimaller, very well refembling the leaues of Rofemarie; rough ftalkes very tough and pliant, being of the fubitaunce of woode : the flowers growe at the top white of colour, in fafhion of the great Clauer or fielde Trefoile : the feedes do followe in tafte Charpe and biting: the huskes or feede veffels flat, 'pade fafhion, like the other kinds of

2 Small wooddie muftarde groweth to the height of two cubites, with many ftalkes fet with fmall narrowe leaues, like thofe of Hyffope; and at the top growe flowers like thofe of Treacle muftard,
or Thlafpi. The whole plant groweth as a fhrub or hedge bufh.

3 Thorniemuftarde groweth vp to the height of fower cubites, of a wooddy fubftaunce like vnto 2 hedge bufh or wilde fhrub, with ftalks befet with leaues, flowers, and feedes, like the laft before mentioned,agreeing in all points fauing in the cruell pricking fharpe thornes wherwith this plant is armed, the other not. The roote is tough,wooddie, and fome ftringes or fibres annexed thereto. 4 There is another fort of Thornie Muftard growing in fhadowie and obfcure mountaines, and ting taft atall,wherein confifteth the difference. 
3 Tbla/pipino/um.

Thornie Muftarde.
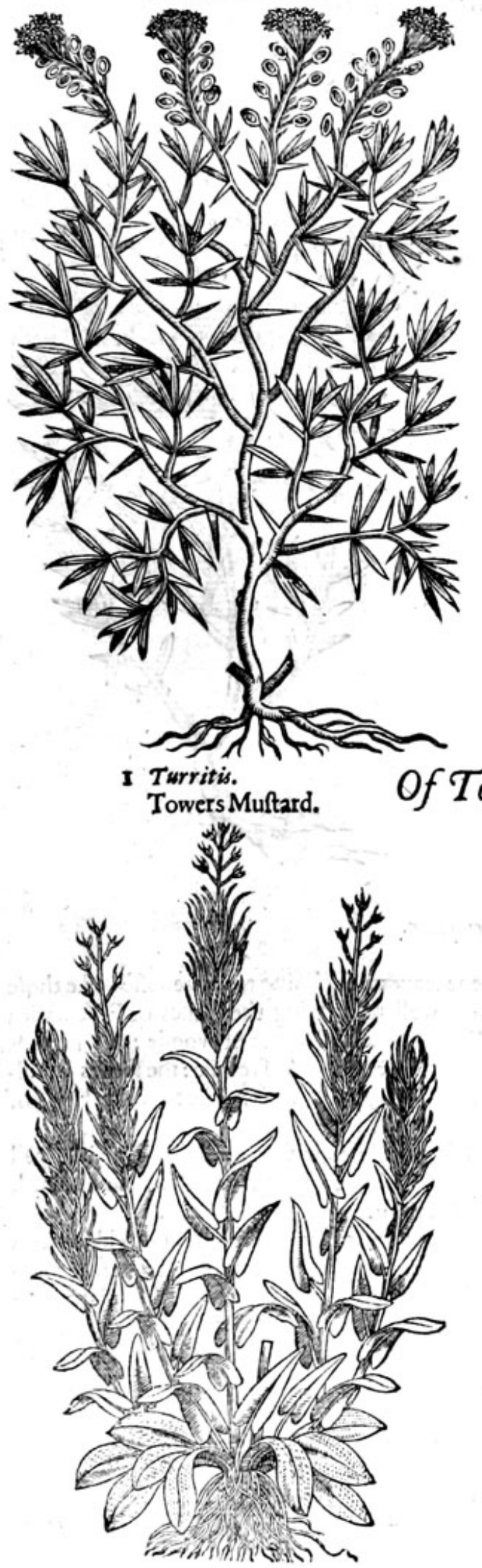

* The place.

Thefe plants do growe vpon the Alpifh and Pyrene mountaines, in Piemont, and in Italic in ftonie and rockie groundes.

\section{* The time.}

They flower when the other kindes of Thlafpi do, that is, from May to the end of Auguif.

* The names.

I finde nothing more faide of their names, either of the auncient or later writers, then is fet downe in their feuerall tytles.

\section{* The nature and vertues.}

Likewife I finde nothing extant of their natures or vertues, but are referred to the kindes of Thlafpios, whereof no doubt they are of kinred and affinitic.

\section{owers Mustarde. Chap.22. * The defcription.}

$\mathbf{x}$<smiles>[InH]</smiles>
Owers Muftarde, of fome hath beene taken for a kinde of Creffes, \& referred by them to it: of fome, for one of the Muftardes, and fo placed among the Thlafpios as a kinde thereof, and therfore my felfe muft needes beftowe it fome where with others. Therfore I haue with $\operatorname{Clu}$ fius and L'Obell, placed it among the Thlafpios as a kinde thereof; which commeth out of the grounde with many long and large rough leaues, like thofe of Houndes-toong, ef pecially thofe next the grounde: among which rifeth vp a long ftalke of a cubite or more high, fet about with harpe pointed leaues like thofe of woade. The flowers growe at the top, if I may terme them flowers, but thev are as it were a little duftie chaffe driuen vpon the leaues $\&$ branches with the winde: after which come very fmall cods, wherein is fmal reddifh feede like that of $\mathrm{Ca}$ meline, or Englifh Woormfeed,with a roote made of a tuft full of inntmer able threddes or ftrings. 2 Gulde of pleafure is an herbe with many braunches fet vpon a ftraight ftalke, rounde and deuided into fundrie wings, in height two cubites. The leaues be long, broade and fharpe pointed, fomewhat fnipt or indented about the edges like thofe 


\section{HISTORIE OF PLANTS.}

of Sowthiftles. The fowers along the ftalkes are white, the feede conteined in rounde little veffels, is fat and oilie.

3 Treacle Wormefeede rifeth vp with tough and pliant braunches, whereupon do growe manie finall yellowe flowers, after which come long flender cods like Flixe-weede, or Sophia, wherein is conteined fmall yellowifh feede, bitter as. Woormefeed or Coloquintida. The leaues are fmall and darke of colour, in fhape like thofe of the ftocke Gilloflowers, but not fo thicke, nor fat. The roote, is fmall and fingle.

There is a kinde of muftard called DrabaVulgaris, or drunkards Muftarde, it hath fmall rounde ftallkes a foote and a halfe long, fet with greene leaues like vito the Marigolde, though not fo thicke or fat: the top of the ftalke is diuid:d into many braunches of equall height, charged on the top withmany white flowers like vnto Elder, and of the fame fmell. The feede is contained in fmail flat huskes, (harpe pointed, and as it were a little raifed vp like the brefts of a woman.

There is likewife another fort of byting muftard or Treacle muftarde, which hath manie weake braunches trailing, or as it were leaning on the grounde, vpon which do grow whitifh leaues fomewhat toothed or fnipped about the edges, bearing at the top of the ftalkes fimall white flowers, after which there followe long cods like the Stocke gilloflowers, but much fmaller, wherein is the feede, of a fharpeand biting tafte.

2 Myagrom. Golde of pleafure.

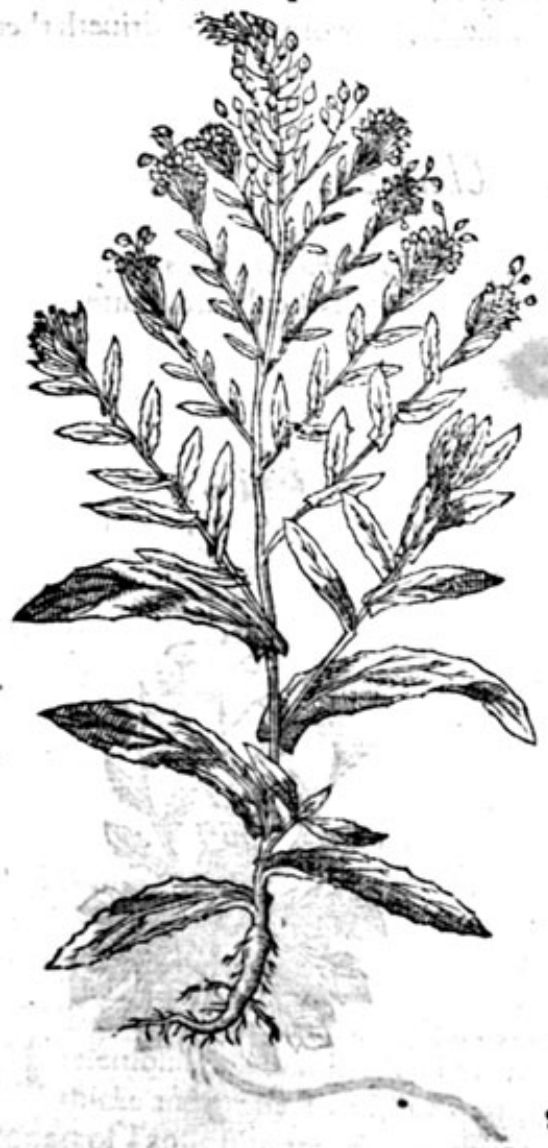

3 Comelina.

Treacle Wormefeed.

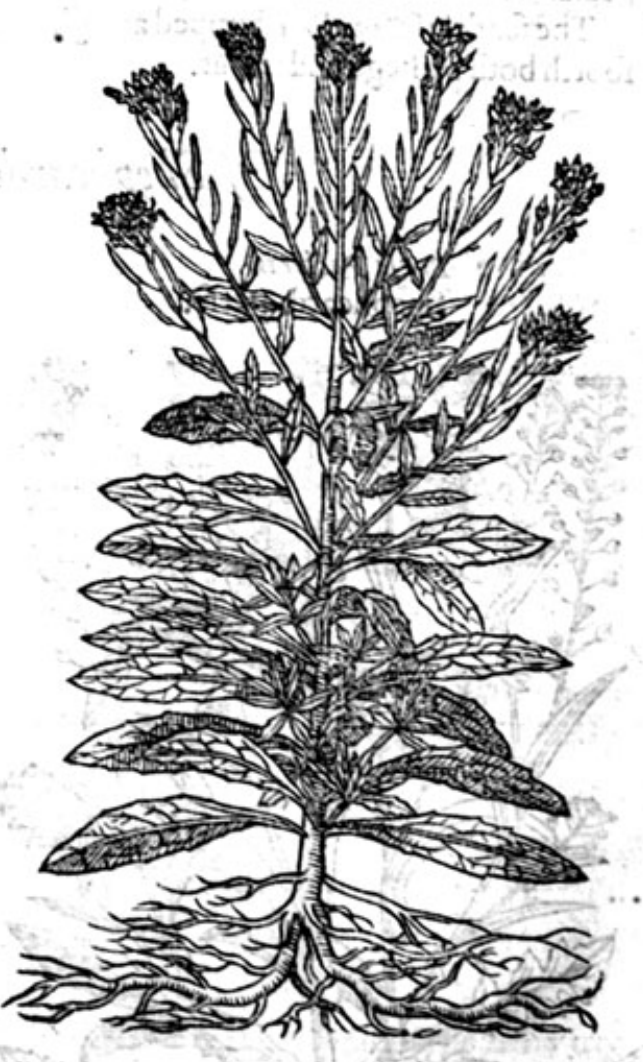

* The place.

Towers Treacle groweth in the Weft part of Englande vpon dunghils and fuch like places. I haue likewife feene it in fundrie other places, as at Pyms by a village called Edmonton neere London,by the cirie wals of Weft-chefter in the corne fieldes, and where flaxe did growerabour Cam-
bridge.

Theother growe in the territorie of Leoden in Zelande, and many places of the Lowe countries, and likewife wilde in fundry places of England. 
* The time.

Thefe herbes do flower in Maie and Iune, and their feede is ripe in September. * The numes.

Golde of pleafure, is called in the Latine toong Eryfmum;it is called properly Myagrum; for that there is another herbe called Eryfimum : in the Germain toong flacbitottern: in fhops Sefomum, where they vfe the ovle thereof in fteede of oyle of Sefarnwem, not without errour.

Treacle wormefeede is called Camelina, and is that Eryfomam or kinde of graine which Galen in his firft booke of the faculties of nourifhments, and Theophrastins likewife do call ipeompor, \& is defcribed by Divjcorides in his fecond booke:wher of Galen in his 6.booke of the faculties of fymple medicines hath made mention, much differing from this Eryfomwen of Theophraftus: for Diofcorides doth not calt this plant Ery/jmon, but Melampyrum, which fome (faith he)do call mendusver, peraduenture through the likenes of the leaues which it hath with the other Melampgrwion of Theophrafins and Galen, differing alfo from Myagrum or Camelina.

Thefe plants be hot and drie in the thirde degree.

* The temperature.

$*$ The vertwes.

A It is thought faith Diofcorides, that the roughnes of the skinne is polifhed and made fmooth with the oilie fatnefle of the feede of Myagrum.

B Ruellies teacheth', that the iuice of the herbe healeth vlcers of the mouth, and that the poore peafant doth ve the oile in banquets, and the rich in their lampes.

C The fee de of Camelina itamped and gipen children to drinke, killeth wormes, and driueth them foorth both by fiege and vomit.

\section{Of Shepbeardes purfe. Chap.22.}

1 Burfa Pastoris.

Shepheards purfe.

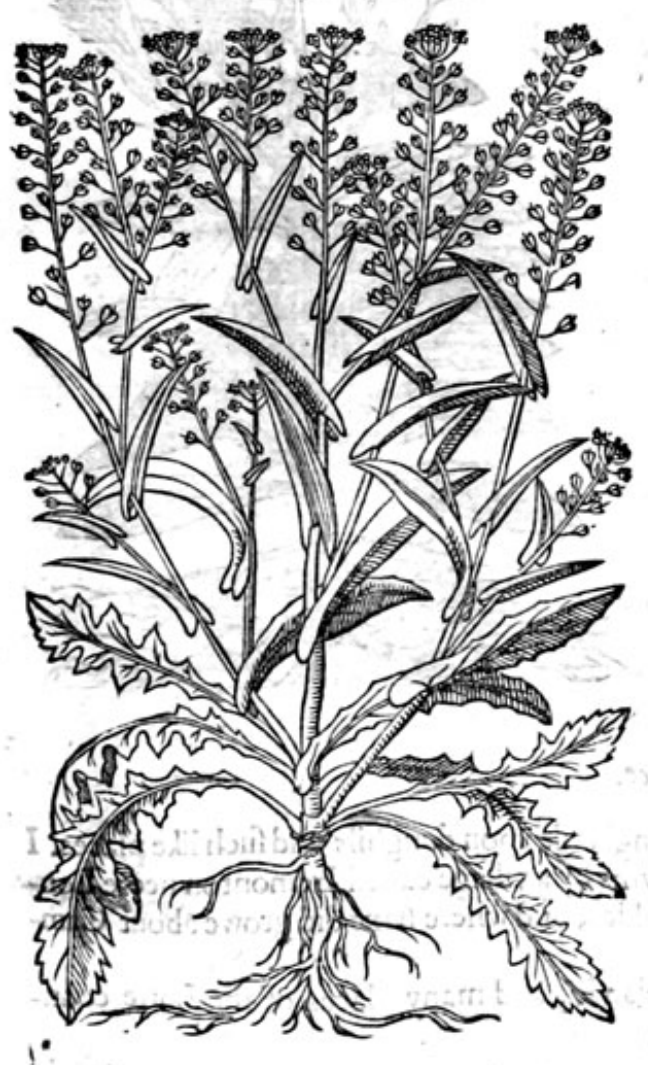

2 Burfa Paftoria minima.

Small Shepheards purfe. 


\section{ZH HIST ORIE OQ FCIPLA NNTS. I H T,

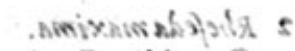 * The degcription.

$1-$ He leaues of Shepheards purfe growe vp at the firft long, gathed in the edges like thofe of Rocket, fpred vpon the ground: frō thefe fpring vp veric many little weake ftalks deuided into fundric braunches, with like leaucs growing on them, but leffer; at thetop wherof are orderly placed fmall white flowers : after thefe come vp little feede veffels, flat, and cornered, narrow at he ftemme like to a certajne little pouch or purfe, in which lieth the feed, with a whiteroote not without ftrings.

2 Thefmall Shepheardes purfe commeth foorth of the ground like the cuckowe flower, which I haue Englifhed Ladie fmockes, hauing fmall leaues deepely indented about the edges; among which rile vp finall tender ftalkes with tlowers at the top, as it were chaffe. The huskes and feede is like the other before mentioned.

* The place.

Thefe herbes do growe of themfelues for the noft pare, ueere common high waies, in defert and vncilled places,among rubbilh and olde wals.

* The time.

They tower, tourith and feede all the fommer long.

* The names.

Shepheardes purfe is called in Latine Pastoris burfa, or Pera Baftoris: in high Dutch beckel : in lowe Dutch 2 Bofielents crupt: in French Bourfe de Pafteur ou Curé : in Englifh Shepheardes purfe or Scrip : of fome Shepheards pouch, and poore mans Parmacetic, and in the North part of England Toywoort, Pickepurfe, and $\mathrm{C}_{2} f$ eweede.

\section{* The temperature.}

They are of temperaturecolde and drie, and very much binding after the opinion of Ruellizs; Mathiolus, and Dodonesw; but $L^{\prime} O b e l$ and $P$ ena hold them to be hot $\&$ dry, iudging the fame by their fharp tafte. Which hath caufed me to infert them heere among the kinds of Thlafpi, cofidering the fafhion of the leaues, cods, feede, \& tafte thereof: which do fo well agree togither, that I might very well haue placed them as kindes thereof, but rather willing to content others that haue written before, then to pleafe my felfe, I haue followed theit or der in marihalling them in this place, where they may ftande for cofin Germaines:

* The vitrimes.

Shepheardes purfe ftaieth bleeding in any part of the bodie, whether the iuice or the decoction $\mathrm{A}$ theregf be drunke, or whether it be vfed Pulcus wife, or in bath,or any other way elfe.

In a clyifter it cureth the bloudy flixe: it healeth greene and bleeding woundes: it is maruelous $B$ good for inflammations newly begun, and for all difeafes which muft be checked backe and cooled. blood.

The decoction doth ftop the laske, the fpitting and piffing of blood, and all other fluxes of C

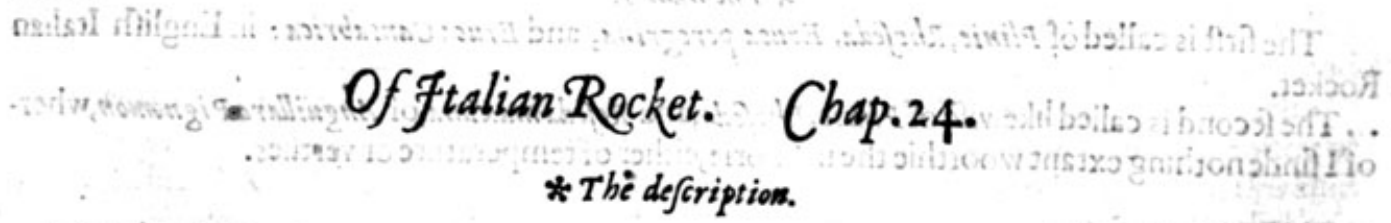

1

Talian Rocket hath long leaues cut into many parts or diuifions like thofe of the Afhe tree,

thicke and groffe, twis Buckes hotne : among which rife vp ftalkes weake and tender, bue

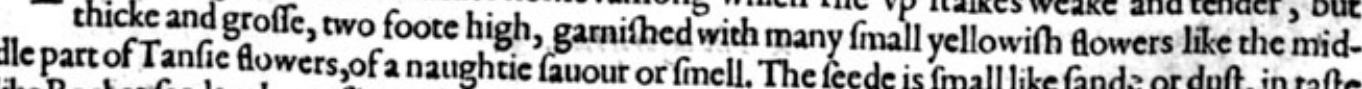
like Rocket feede, whereof in 2 Crambling Rocket hath ruth we fufpect it to be a kinde. The roote is long and wooddie. ribbe, braunched like the hornes large leaues cut into fundry feetions, deepely thruft tothe middle ftalkes two cubites high hornes of a fag or hart:among which there do rife vp long, fat \& tiefhie The flowers growe ar he top tat vpon the grojnde by reafon of his weake and feeble braunches. The feede is like the formen 
I Rhefeda Plinii. Italian Rocket:
2 Rhefeda maxima.

CramblingRocket.

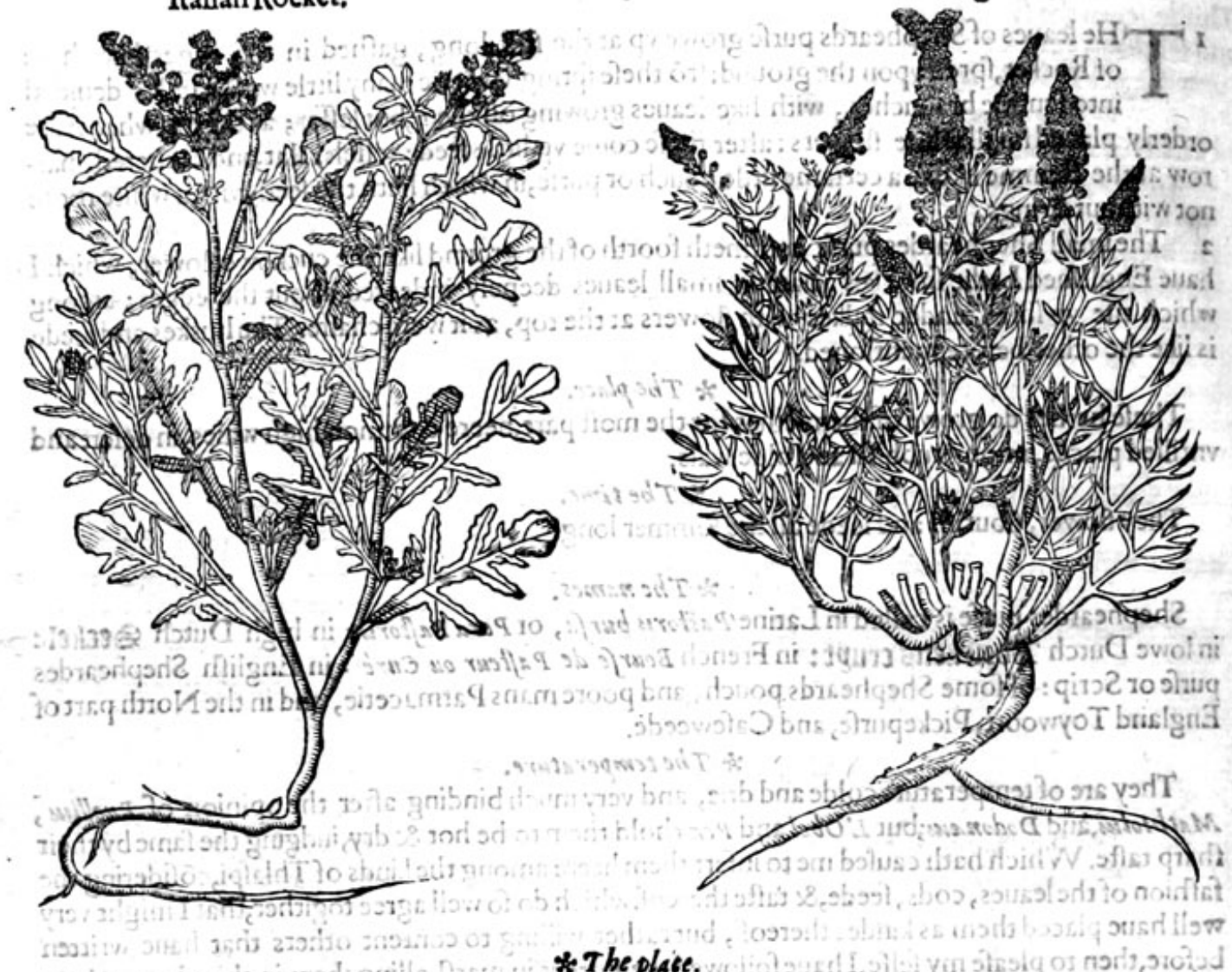

Thefe plants do growe in fandie, ftonie, grauely, and chalkie barren grounds. I haue founde them in fundrie places of Kent, as at Southfleete neere mafter $S$ wannes houfe vpon longfielde downes, which is a chalkie and hilly ground, very barren, where graffe will fcarfely growe or any thing elfe but Iuniperand thefe plants. They grow at Greene-hithe vpon the hils neere vnto the village, and in other places of Kent : but I haue not feene them elfe-where, although I doubt not but that they grow in other places of this lande.

Thefe plants do ftourịh in Iune, Iuly, and Auguft. $*$ The time.
*
* The numes. Rocket.

The firft is called of Plivie, shefeda, Eruca peregrina, and Eruca Cantabrica: in Englinh Italian

The fecond is called likewife of $P$ linie, Rhe feda, and Refeda maxima, of Angwillarap ignomon, wherof I findenothing extant woorthie the memorie, either of temperature or vertues.

\section{of Groundfell. Chap.25. * The defcription.}

I Heftalke of Groundfell is round, chamfered \& deuided into many braunches:the leaues be greene, long and cut in the edges almoft like chofe of Succorie, bur leffer, like in a manner to the leates of Rocket. The flowers be yellowe and turne into downe that is carried away with the winde. The roote is full of ftrings and threds.

2 Cotton Grotindfell hath a ftraight ftalke of a browne purple colour, couered with a fine cotton or downic haire, of the height of two cubits. The leaues are like thofe of Saint Iames woort or Ragwoort, 


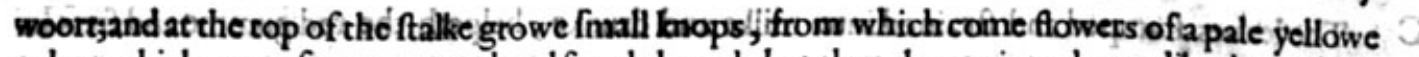
colour, which are no fooner opened and fpred abroad, but they change into downe like that of the Thifte, euen the famehewer of his flowrieg,andis caried away with thbwinded. The roote is frnall and tender.

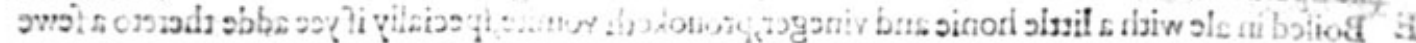

I Erigerwom. Groundfell.

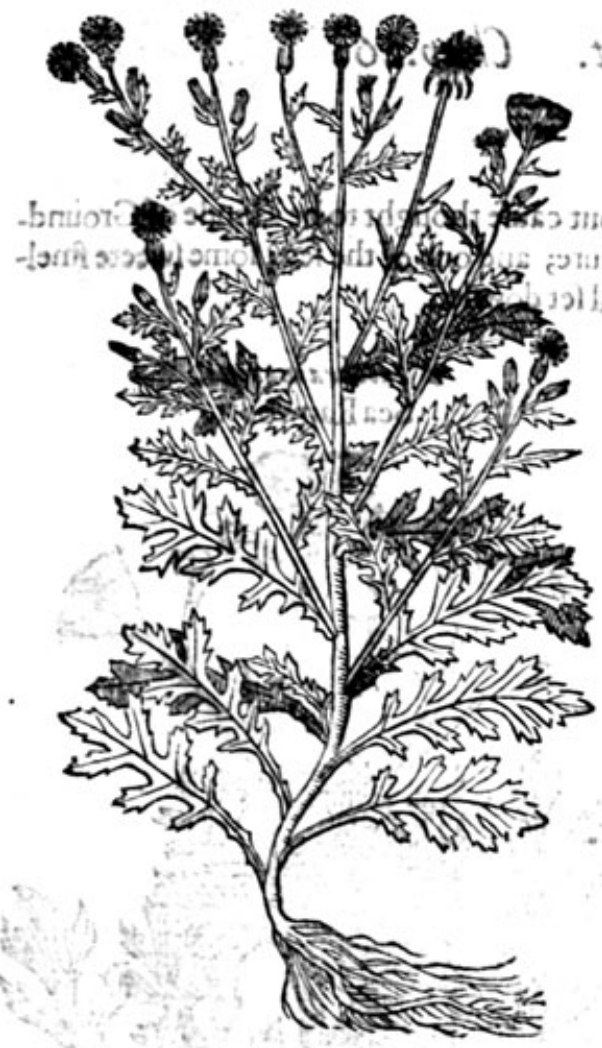

2 Erigerwom Tomentefenti to zasoor Cotton Groundfell.

* The place.
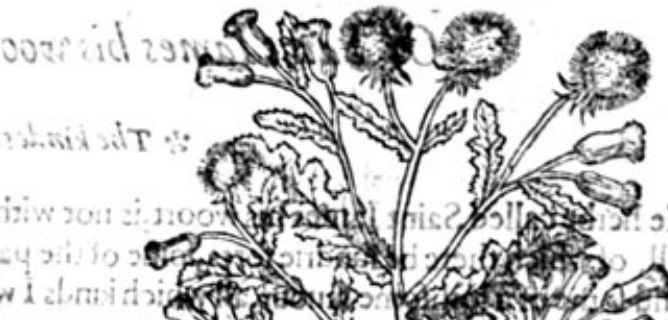

2 $37+7$
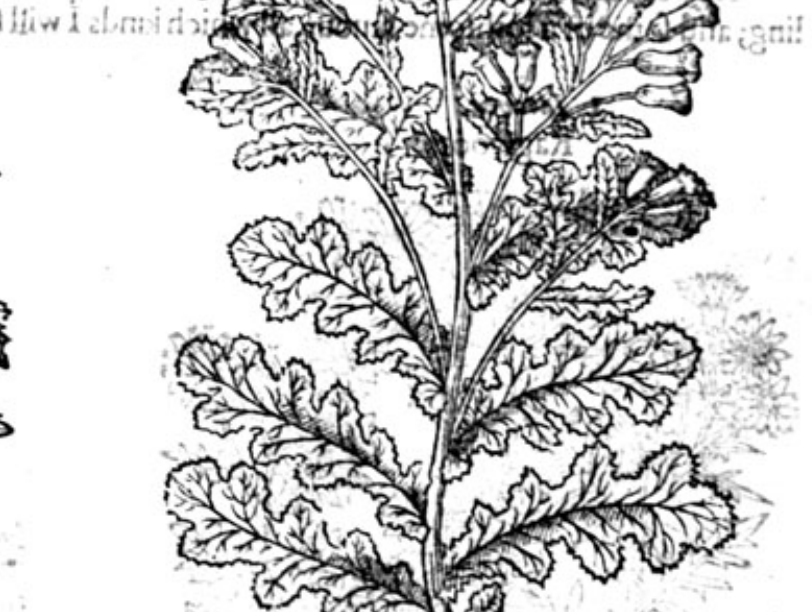

Thefe herbes are very common throughout England, and do growe almoft enery where.

They tourifh almoft euery moneth in the yeere.

$*$ The time.
The names.

- Groundfell is called in Greekeriesipar in Latine Sesecis, bicaufe it waxeth oldequickly: it is called by abaftarde name Herbutum: in Germanie Creufzwuttz: in lowe Dutch crupg crupt, and Cruptken crupt : in Spanifh rerus cans: in Italian Cardoncello _peliciofs in Englifh Groundfell.

Cotton Groundfell feemeth to be all one with Theophrast ws his L Aphace, he makethmention of Aphese in his 7 .booke, which is not onely a kinde of pulfe, but an herbe alfo, vnto which this kind of Groundfell is very like. For as Theophrastus faith, the herbe Aphace is one of the potherbes and kindes of Succorie : adding further that it flowreth in hafte, but yet foone is olde and turneth into downe, and fuch a one is this kinde of Groundfell. Bur Theophr ast w faith further, that it flowreth al the winter long,and fo long as the fpring lafteth,as my felfe haue often feene this Groundfell do.
Groundfell hath mixt facelties * The temperiature.

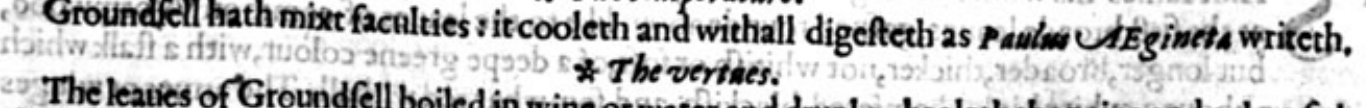

ftomackethat proceedeth of eholen wine or water and drunke, healeth the paineand ache of the $\mathbf{A}$ The leaves and flowers ftamped with a littletiogs and fundament: by adding to a little Faffon and $\mathrm{g}$ s greace, ceafeth the burning heate of the ftones $B$

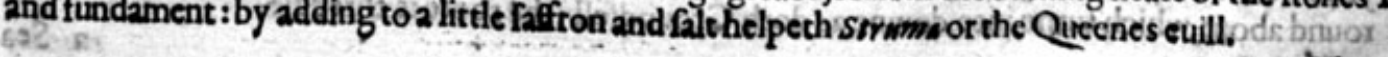


C The leaues ftamped and ftrained inta milke and Anunke, helpeth the red gummeand frets in children.

D Diofcorides faith, that with the fine powder of frankenfence it healeth wounds in the finewes The like operation hath the downe of the flowers mixed with vineger.

E Boiled in ale with a little honie and vineger,prouoketh vonite, fpecially if yee adde thereto a fewe rootes of Afforabiactis.

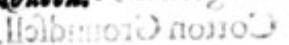

.xurisgila I

.litbanoro

\section{Of Saint Tames bis woort. Chap. 26 .}

* The kindes.

$T$ He herbecalled Saint Iames his woort, is not without caufe thought to be a kinde of Ground.

fell, of which there be fundrie forts, fome of the pafture; and one of the fea; fome fweete fmelling; and fome of a lothfome fauour, all which kinds I will fet downe.
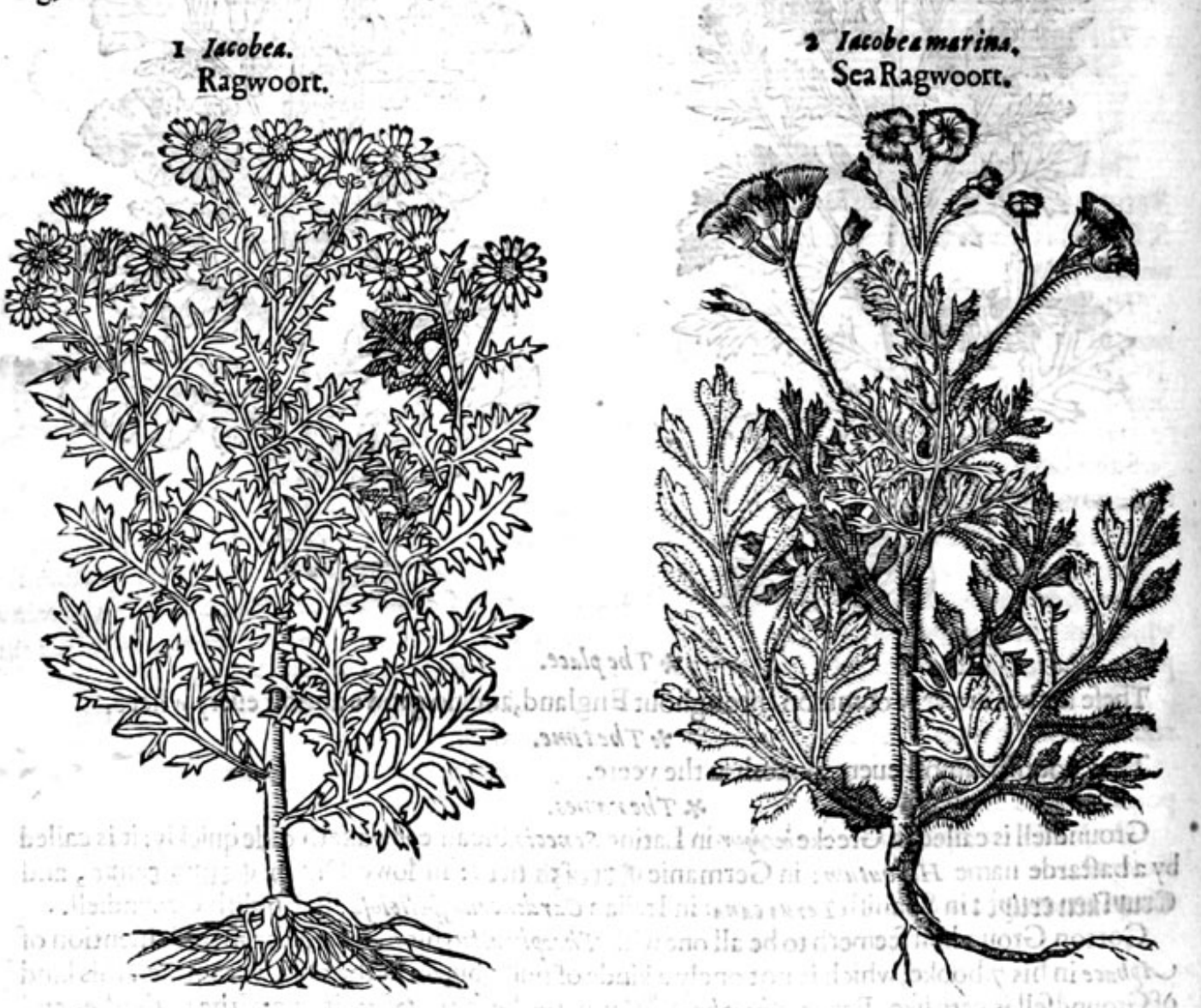

* The defoription.

$\mathbf{I}$

Aint Iames his woort or Ragwoort is very well knowne euery where, and bringeth foorth at the firft broade leaues, garhed rounde about like to the leaues of common Wormwood, but longer, broader, thicker, not whitifh or foft, of a deepe greene colour, with a ftalk which rifeth vp aboue a cubite high, chamfered, blackifh and fomwhat red withall. The armes or winges are fet with leffer leaues like thofe of Groundfell or of wilde Rocket. The flowers as the top be of 2 yellowe colour like Marigolds, afwell the middle button as the fmall flowers, which ftande in a pale round about, which turne into downe as doth Groundfell; the roote is threddie. 


\section{HISTORIE OF PEANTS. HT}

2 SeaRagwoort groweth to the height of two cubits; the ftalkes be not reddifh is the other, but contrariwite afhe coloured, graie and hoarie; the leaues be greater and broader then the other; the flowers grow at the top of a pale yellow colour, couered on the cup or huske of the flower, as alfo the leaues, with a certaine foft white downe or freeze; the flowers vanifh into downe, and flie away with the winde.

$$
\text { * Tbepalace. }
$$

Lande Ragwoort groweth euery where in vntilled paftures and fieldes which are fomwhat moift efpecially, and neere vnto the borders of fieldes.

The feconde kinde of Ragwoort groweth neere the fea fide in fundrie places : I haue feene it in the fielde by Margate by Queakes houfe, and Byrchenton in the Ile of Thanet; likewife it groweth neere the kings ferrey in the Ile of Shepey, in the way leading to Sherlande houfe where Sir Edward Hobby dwelleth; and likewife at Queeneborough caftell in the fame Ile, and in other places.

$$
\text { * Thetime. }
$$

They flower in luly and. Augurt,at which time they are carried away with the downe.

$$
\text { * The names. }
$$

The firft is called in Latine Herba S. Iacobi, or S. Iacobiflos, and Iasobes: in high Dutch Sant Iacobs blotumen: in lowe Dutch ant 3 acobs ctupt : in French Fluer de S.Jacques: in Englifh S. Larneshis woort : the countrey people do call it Stagger woort, and Stauerivoort, and alifo Rag. woorte.

The fecond is named Ciner aria, or anhe coloured Saint Iames woort: fome call it Erigeron marinum, or fea Groundfell, of fome CArtemifia marima.

$$
\text { * The temperature. }
$$

Saint Iames woort is hot and drie in the feconde degree, and alfo clenfing by reafon of the bitterneffe which it hath.

$$
\text { * The vertwes. }
$$

It is commended by the later phyfitions to bee good for greene woundes, and olde filthie vlcers $\mathbf{A}$ which are not fcoured, mundified $\&$ made cleane, and alfo healeth them with the iuice hereof tempered with honie and Maie butterhoiled togither to the formeò fan vinguent or falle:

- It ismuch commended and not without caufe to helpeolderaches and pains in the armes, hippes, B and legs, boiled with hogs greafe to the forme of an ointment?

ric Moreouer the decoction hereof gargarized is much fet byas a remedie again f fwellings and im- C poftumations of the thirote, which it wafteth away and throughly healeth.

The leaves ftamped verie fmall; and boiled with fomehogs greace vn to the confumption of the $D$ inice, adding thereto in the ende of the boiling a little Maftich and Olibanum, and then ftrained, taketh away the olde ache in the hucklebones called Sciatica.

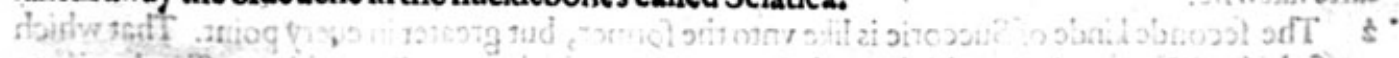

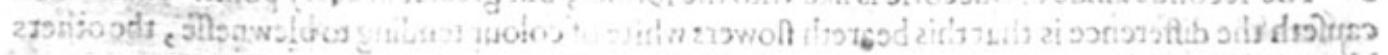

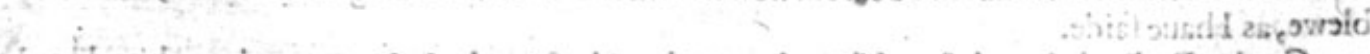
Of garden Succorie. Chap.27.

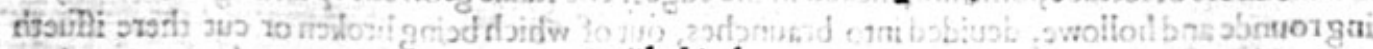

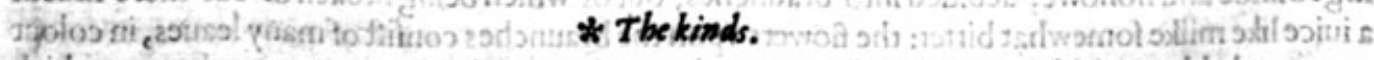
THerebe threeforts of plants comprehended vnder the title Cichorewon or Succorie, that is to 1 faic Cichorie,Endiue, \& Dandelion, differing not fo much in operation \&-working, as in fhape and forme, which hath cauled many to deeme them diuers, whohaue diftinguifhed them ypder the titles aforefaide: of euery which kinde therebe diuers forts, the which fhall be deuided in their feuerall chapters, wherein the differences thall be expreffed. 
1 Cichoriumfatioum. Garden Succorie.

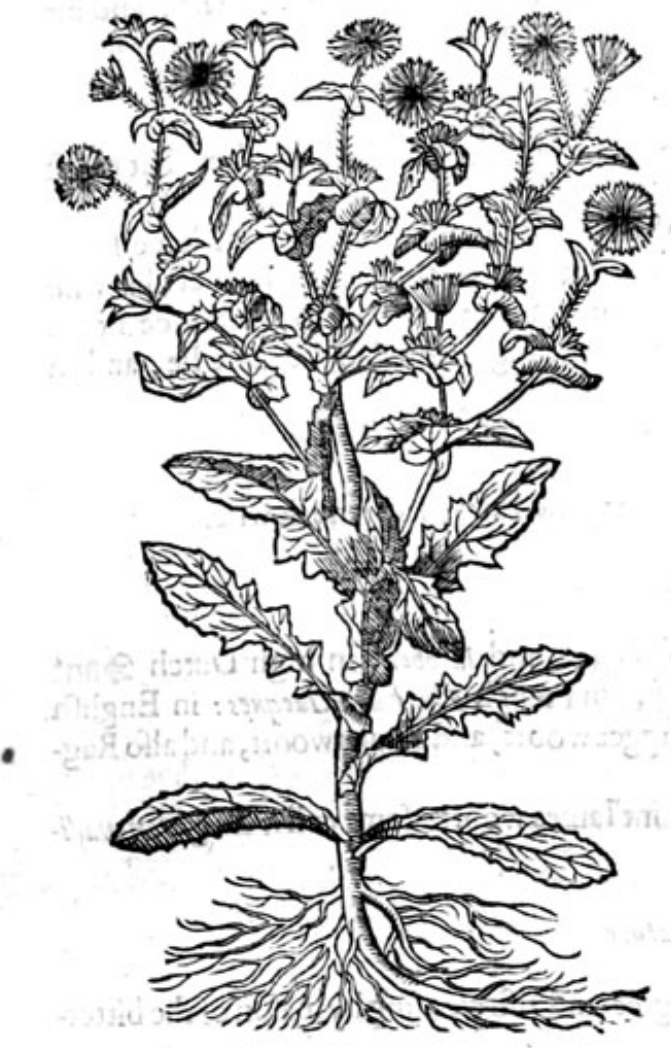

2 Cichorium fatiuum latifolium. Broade garden Succorie.

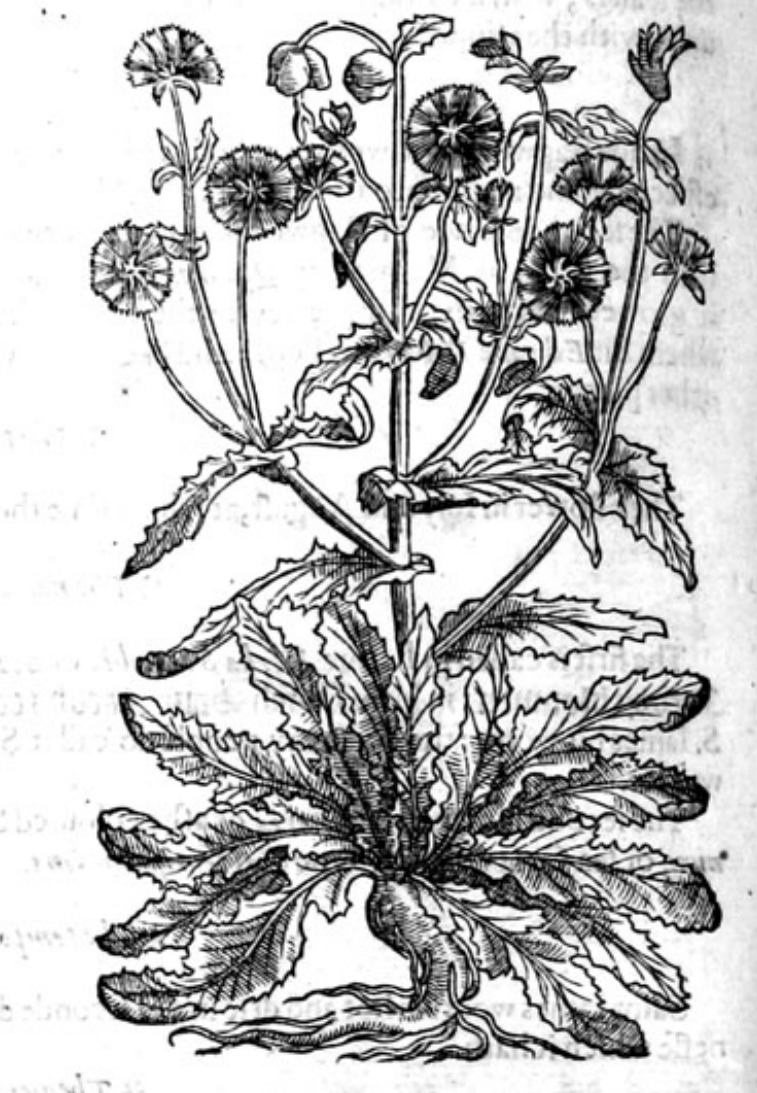

* The defoription.

x

G Arden Succorie is of two forts, one with broade leaties, and the other with narrow deepely cut and gafhed on bothfides. The firtt hath broad leaues fomwhat hairie, not much vinlike to Endiue, but narrower: amongft which do rife vp ftalkes, whereori are placed the like leaues, but fmaller. The ftalke deuideth it felfe towarde the top intomany braunches; whereon do growe little blewe flowers confifting of many fmall leaues, after which followeth white feede, The roote is tough, long, and white of colour, continuing many yeeres; from the which as from euery part of the plant doth iffue foorth white, bitter and milkie iuice. The whole plant is of a bitter tafte likewife.

2 The feconde kinde of Succorie is like vnto the former, but greater in euery point. That which caufeth the difference is that this beareth flowers white of colour tending to blewneffe, the others blewe, as I hate faide.

3 Garden Endiuc bringeth foorth long leaues, broade, fmooth, more greene then white, like almoft to thofe of lettuce, lomthing nicked in the edges. The ftalke groweth vp among the leaues, being rounde and hollowe, deuided into braunches, out of which being broken or cut there iffueth a iuice like milke fomewhat bitter: the flowers vpon the braunches confift of many leaues, in colour commonly blewe, feldome white. The roote is long, white; with ftringes growing thereat, which withereth after the feede is ripe.

4. Curled Endiuc hath leaues not vnlike to thofe of the curled or Cabbage Lettuce, But much greater, among which rife vp ftrong and thicke ftalkes, fet with the like leatues but leffer, and not fo notablie curled or crifped. The flowers growe at the top blewe of colour. The roote perifheth as doth the whole plant when it hath brought foorth his ripe feede. 

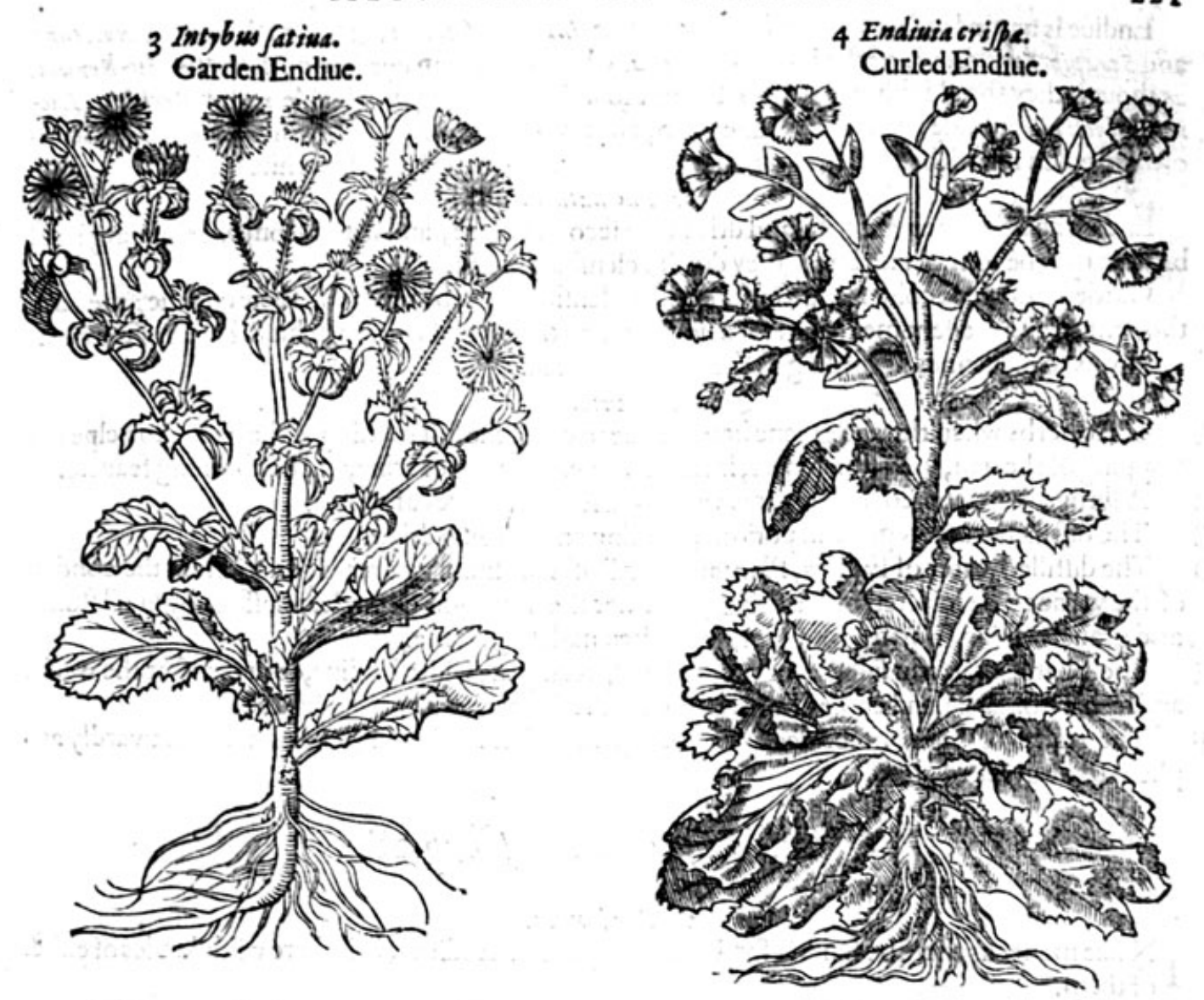

2. The place and time.

Succorie is not onely fowen in gardens, but groweth alfo by high waies fides, and in vitilled and barren grounds in moft places of Englande, and efpecially that fort which hath the deepe gaithes,
which is alfo bitterer then the reft.

Endiue being fowen in the fpring quickly commeth vp to flower, which feedect in harueit and afterwarde dieth.But being fowen in Iuly it remaineth till winter, at which time it is taken vp by the rootes and laide in the funne or aire for the fpace of two houres, then will the leanes be tough and eafily endure to be wrapped vpon an heape,\& buried in the earth with the rootes vpward, where no earth can get within it, which if it did, would caufe rottenneffe, the which fo couered may be taken vp at times conuenient,and vfed in fallades all the winter, as in London and other places is to be feene,and then is it called white Endiue, whereof Plinie feemeth not to be ignoraurt, fpeaking to
the fame purpofe in his 20 . booke 8 .chapter.

Thefe herbes becalled by one name in $\stackrel{*}{*}$ The me nimes. haue called Succoric in Greeke oies à eia: Plinie nameth the broade leafed Succorie Hedrpnois : and the bitterer Diofcorides calleth meis: in Latine Intybuon fyluestre, Intybuon agrefe, Int ybum crraticum, and cichorivom: in hops it is called Cicorea, which name is not onely alowed of the later Phifitions, but alfo of the Poet Hurace in the 31 . Ode of his firt booke,

\section{Me pafcunt oline, \\ Me Cicorea, leuefgue malue.}

With vs faith $P$ linie in his 20 .booke 8.chapter, they haue called Intybuon erraticum, or wilde Endiue, Ambugia (others read Ambubeis:) and fome there be that name it Rostrum porcimuss: and others as Guilielmus Placentinus, and Petrus Crefcentius terme it Spon $/ s$ flis : the Germaines call it niards Almeromes : the Englifhmen Cicoric and Succoric: the Bohemians Czakanka. 
Endite is named in Greekc Sizus numess : in Latine Intybum fatiunn : of fome Endiuiz: of Amicenne and Serapio Taraxacon: of the Italians Scariola, which narne remaineth in moft thops, alfo Seriola, as though they fhould fitly call it Seris, but not fo well Serriola, with a double $r$ : for Serida is Lactuca Jyluestris, or wilde lettuce : it is called in Spanifh Serraya Enuide: in Englifh Endiue and Scariole:f fod when it hath been in the earth buried as aforefaid, then is it called white Endiue. * The nature.

Endiue and Succorie are cold and dric in the fecond degree, and withall fomwhat binding :and bicaufe they be fome thing bitter, they do alfo clenfe and open.

Garden Endiue is colder and not fo drie or clenfing, and by reafon of thefe qualities they are thought to be excellent medicines for a hot liuer, as $G$ alen hath written in his 8. booke of the compofitions of medicines according to the places affeeted.

\section{* The vertues.}

A Thefe herbs when they be greene haue vertue to coole the hot burning of the liuer, to helpe the ftopping of the gall, yellow iaunders, lacke of fleepe, ftopping of vrine, and hot burning feauers.

B A fyrupe made thereof and fugar is verý good for the difeafes aforefaid.

C The diftilled water is good in potions, cooling and purging drinks.

D The diftilled water of Endiue, Plantaine and Rofes profiteth againft excoriations in the conduit of the yarde to be iniected with a firing, whether the hurt came by vncleanneffe or by finall ftones and graull iffuing foorth with the vrine as often hath been feene.

E Thefe herbes eaten in fallades or otherwife ef pecially the white Endiue, doth comfort the weake and feeble ftomacke, and coolech and refrefheth the ftomacke ouermuch heated.

F The leaues of Succorie brufed are good againft inflammation of the eies being outwardly ap. plied to the greeued place.

\section{Of wilde Succorie. Chap.28.}

* The kindes.

IN like maner as there be fundrie forts of Succories and Endiues, fo is there wilde kindes of either of them.

I Cichorium fylueftre. Wilde Succorie.
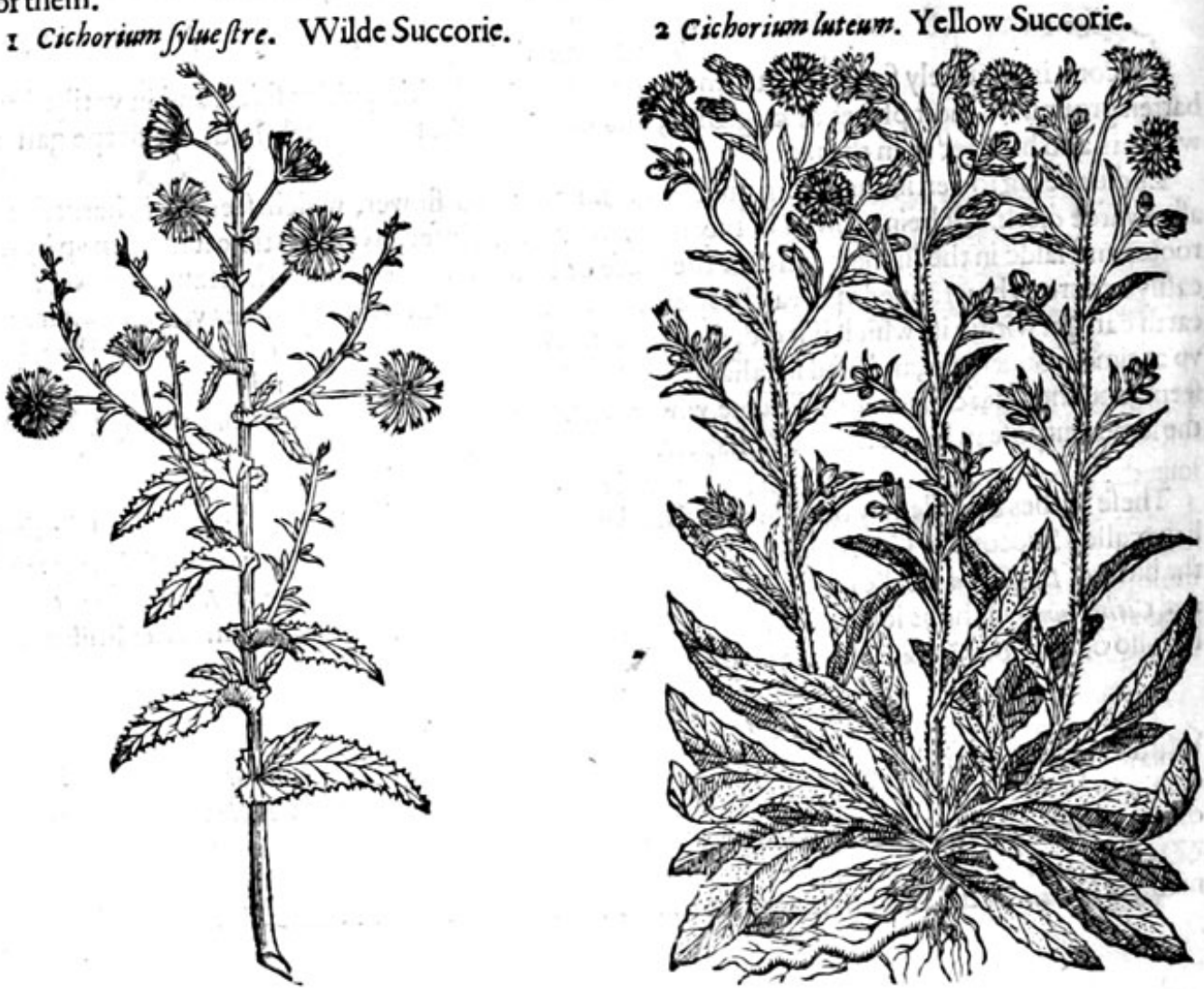


\section{HISTORIE OF PLANTS.}

* The defription.

I TT Ilde Succorie hathlong leaues, fomewhat fnipt about the edges like the leaues of Sowthiftle, with a ftalke growing to the height of two cubits, which is deuided towarde the top into many braunches. The flowers grow at the top blewe of colour: the roote is tough and woodie, with many ftrings faftned thereto.

2 Yellowe Succorie hath long and large leaues, deepely cut about the edges like thofe of the Haukeweede. The ftalke is braunched into fundrie armes, wheron do growe yellowe flowers ver; double, refembling the flowers of Dandelion or Piffe-abed, the which being withered, it tlieth away in downe with euery blafte of winde.

3 Intybuom fyluestre. Wilde Endiue.

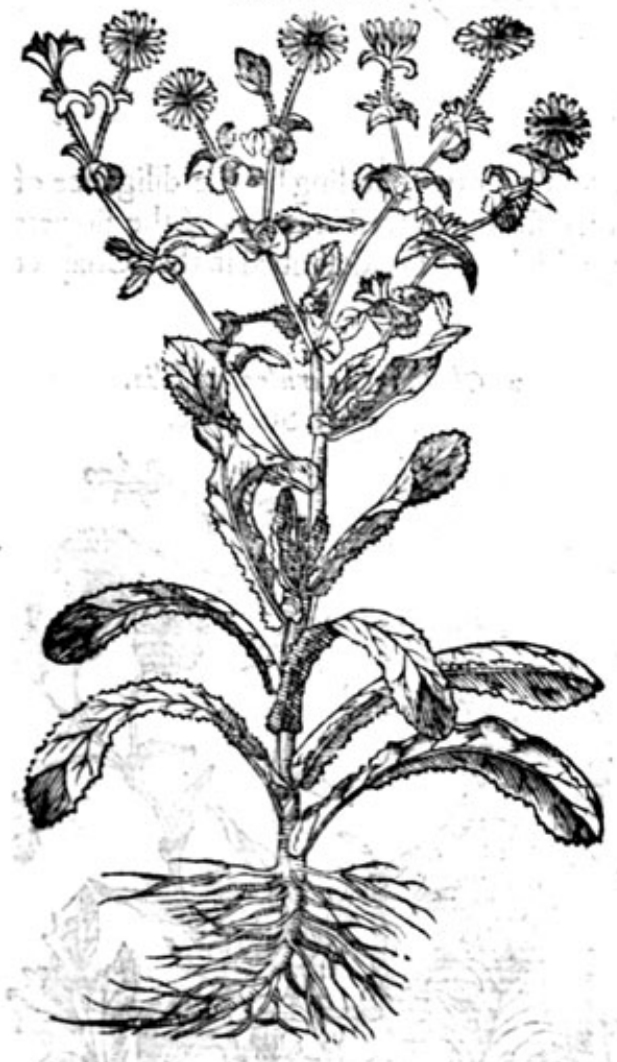

4 Intybuon flueftre latifolium. Medowe Endiue.

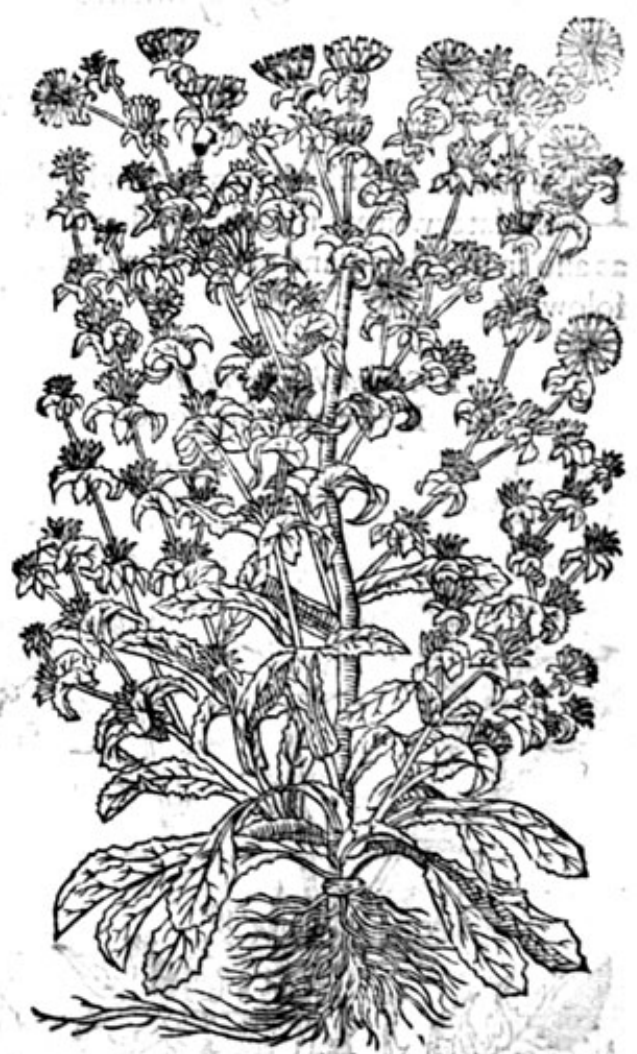

3. Wilde Endiue hath long fmooth leaues fleightly finipt about the edges. The ftalk is brittle and full of a milkie iuice, as is all the reft of the plant : the flowers grow at the top of a blewe or skie colour: the roote is tough and threddie.

4 Medorve Endiue or Endiue with broade leaues, hath a thicke, tough and woodie roote with many ftrings faftned thereto, from which rife vp many broade leaues fpread vpon the grounde like thofe of garden Endiue, but leffer and fomewhat rougher; among which rife vp many ftalkes immediately from the roote, euery of them are deuided into fundrie braunches, whereupon do growe many flowers like thofe of the former, but fmaller.

Thefe plants do growe wille * The place. grounds, efpecially incwe wilde in fundry places in Englande, vpon wilde and vneilled barren

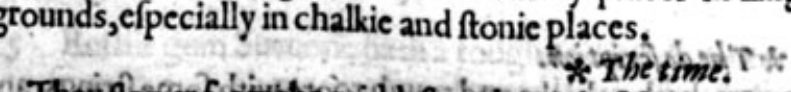

- They flower frointhemidaeft to the end of Auguft.

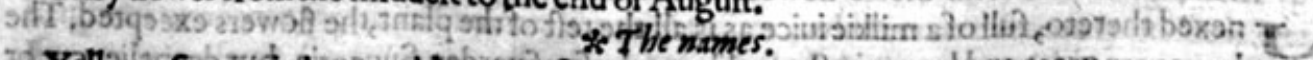

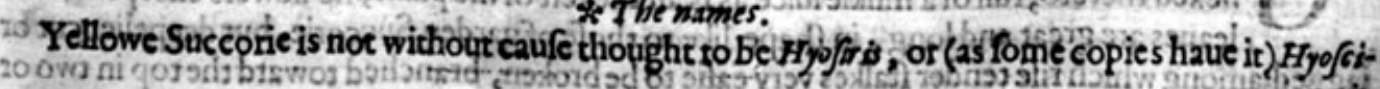
eэmisomol 


\section{4}

THE SECOND BOOKE OF THE

ris, of which Plinie in his 2o.book 8.chapter writeth; Hyofir is (faith he) is like to Endiue, but leffer and rougher, it is called of L'Obelius Hedypnois, the reft of the names fet foorth in their feuerall titles Shall be fufficient for this time.

\section{\& The temperature.}

They agree in temperature with the garden Succoric and Endiue. * The vertues.

A The leaues of thefe wilde herbes are boiled in pottage or brothes for ficke and feeble perfons that haue hot, weake and feeble ftomacks to ftrengthen the fame.

B They are iudged to haue the fame vertues with thofe of the garden, if not of more force in working.

\section{Of Gumme Succorie. Chap.29. \\ * The kindes.}

Dofcorides defcribeth two forts or kindes of gum Succorie, notwithanding by the diligence of the later writnrs there be fundrie forts founde more, differing as well in colour of the flowers as alfo in the fhape and proportion of the whole plant, whichfhall bee defcribed in this Chapter folowing.
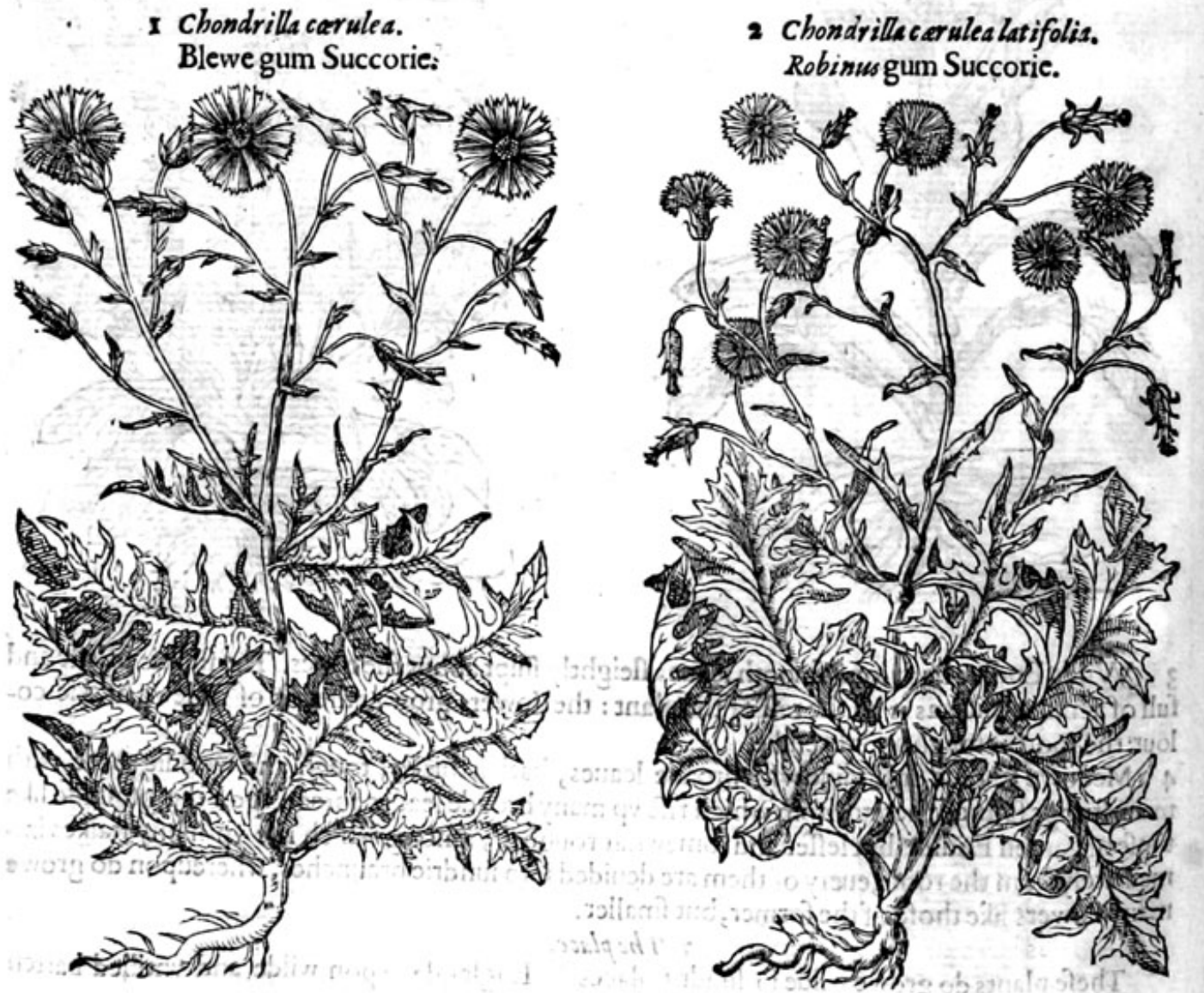

* The defcription.

$\mathbf{i}$

Vmme Succorie with blewe flowers hath a thicke,and tough roote with fome ftrings an-

nexed thereto, full of a milkie iuice as is all the reft of the plant, the flowers excepted. The leaues are great and long, in Thape like to thofe of garden Succorie, but deepeliercut or iaggedjamong which rife tender ftalkes very eafie to be broken, branched toward the top in two or fometimes 
fometime more braunches, bearing very pleafanit flowers of an azure colour or deepeblewe, which being paft the feede flicth away in downe with the winde.

2 Gum Succorie with broad leaues, which thaue named nobinwo gum Succorie (for that he was the firft that hath made any mention of a fecond kind, which he fent me as a grear dainty, as indeede Iconfeffe it)in rootes is like vnto the former; the leaues be greater not vnlike vnto thofe of Endiue, but cut more deepely euen to the middle rib;the ftalkes growe to the height of two foote: the flowers are likewife of an azure colour, but fprinckled ouer as it were with filuer fande, which addech vnto the flower great grace and beautic.

3 Yellowe gum Succorie hath long leaues like in forme and deuifion of the cut leates to thofe of wilde Succorie, but leffer, couered all ouer with a hoarie downe. The ftalke is two foote high, white and downie alfo, diuided into fundrie braunches : whereupon do growe torne flowers like thofe of Succorie, but in colour yellowe, which are turned into downe that is carried away with the winde. The roote is long and of a meane thickneffe, from the which as from all the reft of the plant doth iffuefoorth 2 milkie iuice, which being dried is of a yellowith red, tharpe or biting the toong. There is founde vpon the braunches heereof a gum as Diofcorides faith, which is vfed at this daie in Phificke in the Ile Lemnos, as Bellonius witneffeth.

4 Spanifh gum Succorie hath many leaues fpread vpon the ground, in thape like thofe of Groundfell, but not fo thicke and fat: among which rife vp braunched ftalkes fet with leaues like thofe of stoebe falemantica or filuer weede, whereof this is a kinde. The flowers growe at the top of an ouerworne purple eolour, which feldome fhewe themfelues abroade blowen.

3 Chondrilla lutea.

Yellowe gum Succorie.

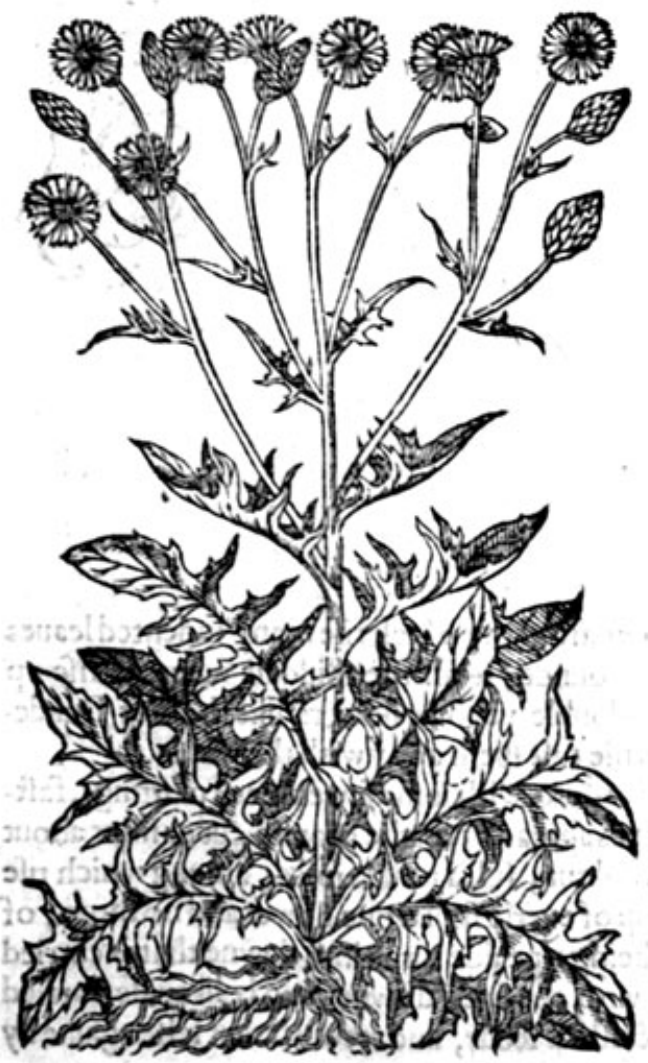

4. Chondrills Hi:panica. Spanilh gum Succorie.

5 Rufhie gum Succorie hath 2 tough and harde roote, with a fewe thort threeds faftened thereto:from the which rife vp a feweiagged leaues like thofe of fuccorie. The ftalke groweth vp to the height of two foote, tough and limmer like vnto rufhes, whereon are fet many graffie leaues. The lowers be yellowe, fingle and finall, which being faded, do flie away with the winde. The whole 
plant hauing milkie iuice like vnto the other of his kinde.

6 Sea gum Succorie hath many knobby or tuberous rootes likethofe of chamabalanus, or Pefo: earth nut, with long ftrings faftened thereto: from which inmediately rife vp a fewe fmall thinne leaues fafhioned like the point of a fpeare: among which fpring vp fmall tender ftalkes, weake and reeling this way and that way lying flat vpon the ground. The lower groweth at the top, of an'ouerworne or euill yellow colour. The whole plant is whitifh or hoarie, as are many of the fea plants.

5 Chondrilla Iuncea.
Rufhie gum Succo

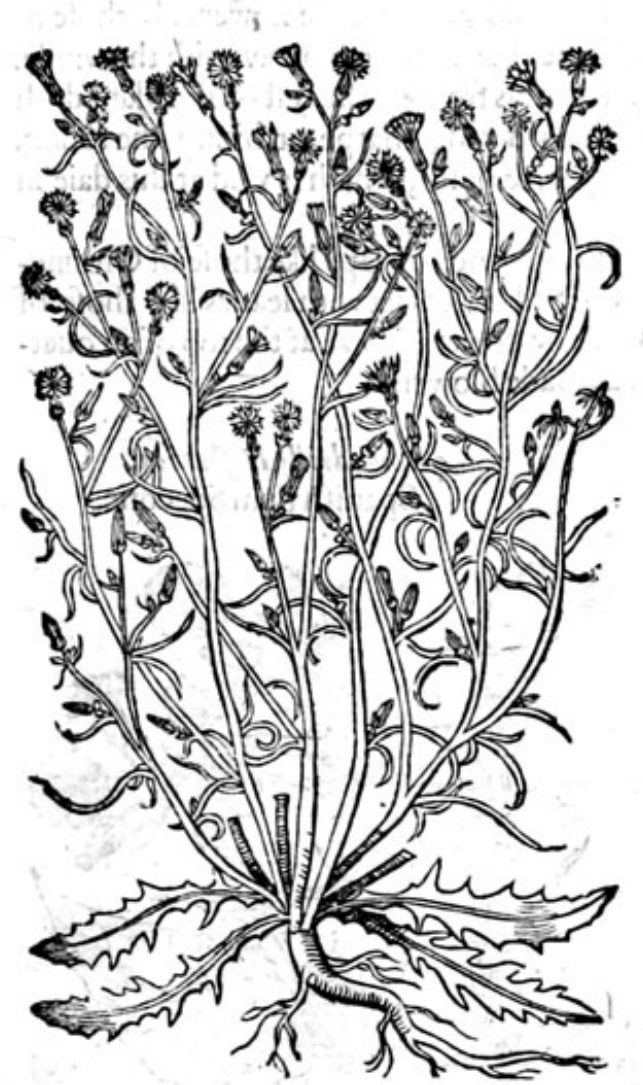

6 Chondrilla marina L'O Obelis. Seagum Succorie.

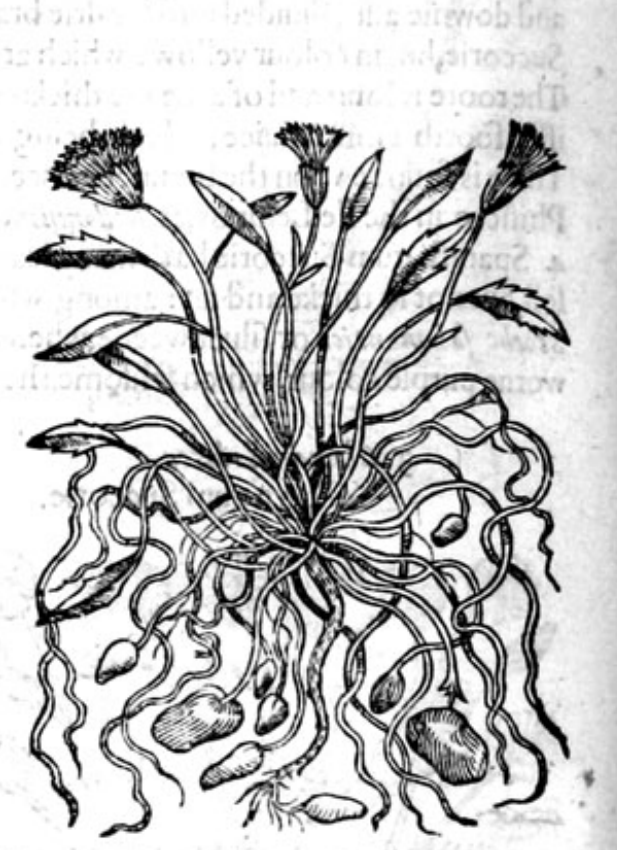

7 Swines Succorie hath long, fmall and tender rootes, from the which rife many indented leaues like thofe of Sowthiftle, fpread or laide flat vpon the grounde; from the middeft whereof rife vp fmall foft and tender ftalkes, bearing at the top fmalldouble yellowe flowers like thofe of Dandelion or pifle-abed, but fmaller.The feede with the downie tuft flieth away with the winde.

8 The male Swines Succorie hath a long and flender roote, with fome fewe threds or ftrings, faftned thereon : from which fpring vp fmall tender leaues fpread vpon the ground,cut or fnipt aboute. the edges confufedly, of an ouerworne ruftie grayilh colour, full a milkie iuice: among which rife vp diuers fmall tender naked ftalkes, bearing at the top of euerie ftalke one flower and no more, of a faint yellow colour and fomething double; which being ripe doe turne into downe that is carried away with the winde. The feede likewife cleaueth vnto the faide downe, and is likewife carried away. The whole plant perifheth when it hath perfeeted his feede, and recouereth it felfeagaine by the falling thereof. 


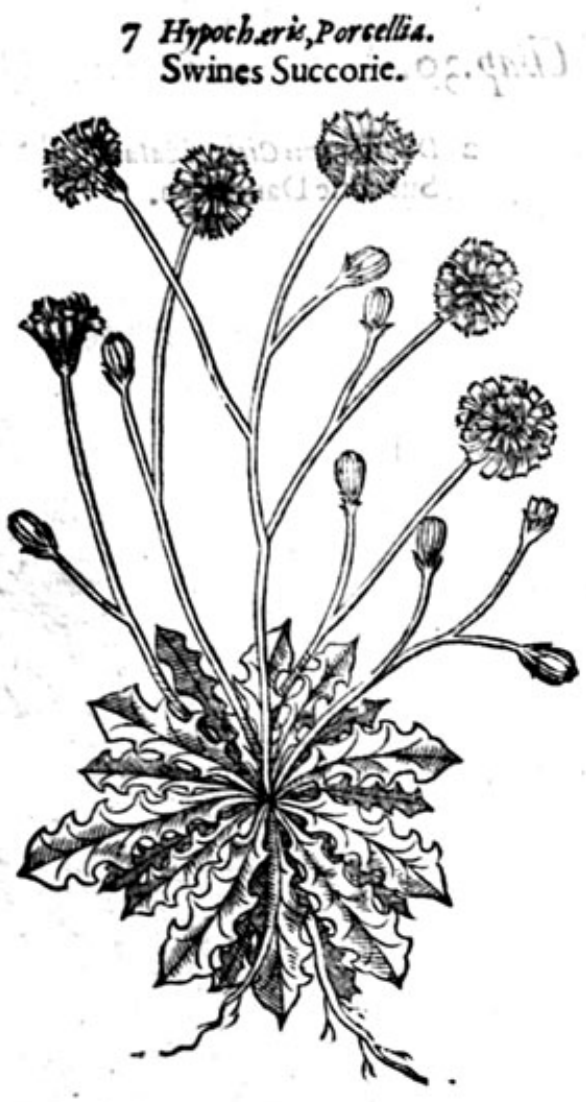

8 Hyofrismajcula.

Male Swines Succoric.

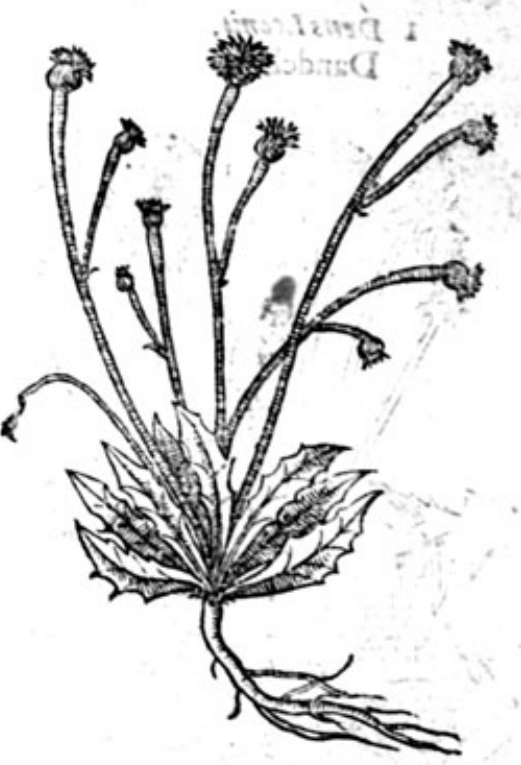

* Thepiace.

fieldes.

Thefe kinds of gum Succories dogrow in vntilled places vpon ditch bankes and the borders of

They do flower from Maie to the end of Auguft.

* The numes.

Gum fuccorie hath beene called of the Grxcians xorseiss : of the Latines Condrills and chondrilla. Diofcorides and Plinie cal it Cuchorion and Seris, by reafon of fome likeneffe they, haue with Sticcoric, efpecially the two firft which hauc blewe flowers as thofe of the Succories. LObeliss maketh Cicores verrucaria to bee Zizintha of Mathiolws. Diuers haue taken the plant with blewe fowers to be sefamoides magnow; but without any reafon,for that Sefamoides hath borrowed his name from the likeneffe it hath with Sefamwn : but this herbe is not like to Sefartom in anie one point, and therefore I thinke it better referred vnto the gurn Succories, for the flowers havie the forme and colour of gurom Succorie, and yeelde the like milkie iuice.

The kinds of gum Suiccorie are like in temperature

$$
\text { * The nature. }
$$

* The verfores.
The common Succorie, but fomwhat dries.

The inice of gum Succorie taken with red and hicke

The root and leaues tempered with \& hoic incke wine and drunke, ftaieth the laske. ${ }^{\circ}$ sgriss $\mathbf{A}$ or faltpeter added thereto, doe clenfe away the made vp into Trocis or little flat cakes with niter B

The gum which is

The gum which is gathered from the braunches whereof it tooke his name, laieth downe the C ftaring haires of the eie browes and fuch like places.

The gum powdered with nyrthe and put into a finnen cloth and a peffarie made thereoflike a D finger, and put vp, bringeth downe the rermes in yoong wenches and fuch like.

2. The feedes of Zazimiba brought to powder add given in the decreafing of the Moone to the $\mathrm{E}$ quiantitie of a poonefull, taketh away wartes and fuch fike excrefecence in what part of the bodie foever they bethe which medicine a certaine Chirurgion of Padua didmuch vfe, whereby he gained grcat fums of money, as reportechthat auncient Phyfition loachimius Canser ariwsidw liuing in No-
temiberg a famous citic in Germanic. 


\section{OfDandelion. Chap.30.}

I Dens Leomid. Dandelion.

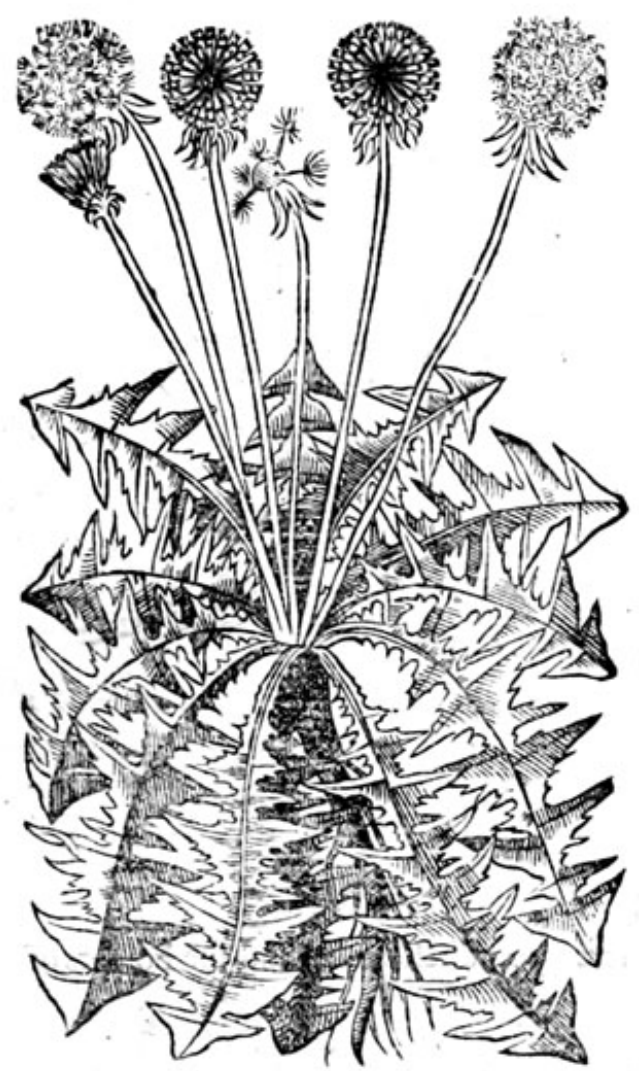

2 Dens Leomis Cichorizata. Succoric Dandelion.

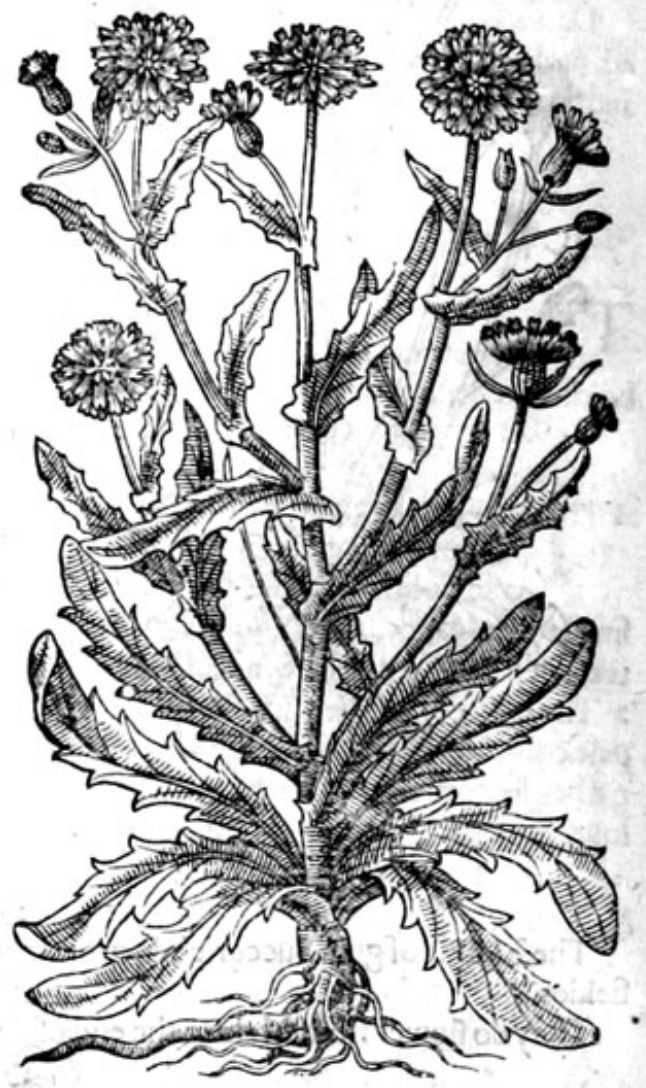

* The defcription.

I He herbe which is commonly called Dandelion; doth fende foorth from the roote long leaues deepely cut and gafhed in the edges like thofe of wilde fuccorie, but fmoother: vpon euerie ftalke ftandeth a flower greater then that of Succorie, but double and thicke fet togither, of colour yellowe and fweete in fmell, which is turned into 2 round downieblowball, that is carcied awaie with the winde. The roote is long, flender, full of milkieiuice when any part of it is broken, 25 is the Endiue or Sticcorie, but bitterer in tafte then Succorie.

2 There is alfo another kinde of Succorie which may be referred heereunto, whofeleaues are long, cut like thofe of broade leafed Succorie: the ftalkes ark not vnlike, being deuided into braunches as thofe of Dandelion, but leffer, which alfo vanifheth into downe when the feede is ripe, hauing a long and white roote.

$*$ The plase.

They are found often in medows neere vnto water ditches, as alfo in gardens and in high waies much troden.

\section{$*$ The time.}

Theyflower moft times in the yeere, efpecially if the winter be not extreame colde. * The names.

Thefe plants belong to the Succories, among which Theophraftes in his 7 . booke namech

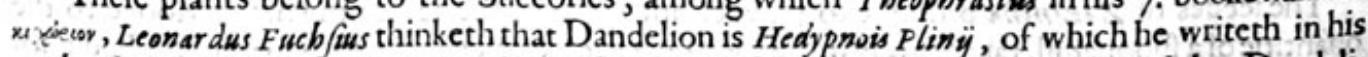
20.booke 8. chapter, affirming it to be a wilde kinde of broade leafed Succorie, and that Dandelion is Taraxacon: but Taraxacon as Uuicen teacheth in his $69_{2}^{2}$. Chapter is Garden Endiue, 2s Se- 
repio mentioneth in his 143 . chapter, who citing $P$ alulus for a witneffe concerning the faculties, fetteth downe thefe wiords which Paslus writeth of Endiue and Succorie. Diuers of the later Phifitions doalfo call it Dens seonis or Dandelionsit is called in high Dutch fralkratit: in low Dutch joa pencruit : in French Piffenlit ou cour onne deprestre, or Dent de lyon : in Englifh Dandelion, and of diuers Piffeabed.

\section{* The temperature and vertmes.}

Dandelion is like in temperature to Succoric, that is to faie to wilde Endiuc.It is colde, but it drieth more, and doth withall clenfe and open by reafon of the bitternes which it hath ioined with it: and therefore it is good for thofe things for wbich Succorie is.

\section{O, Sowtbistle. Chap.31.}

* The kinds.

$T$ Here be two kindes of Sowthiftles one tenderer and fofter: the other more pricking \& wilder, whereof there be fundrie forts more founde by the diligence of the later writers, all which fhal be comprehended in this chapter,andeuery one be diftinguifhed with a feuerall defcription.

I 1 He pricklie Sowthiftle hath long broade leaues cur very deepely euen to the middle ribbe; full of fmall prickles rounde about the edges fomething harde and fharpe, with 2 rough and hollowe ftalke. The flowers ftande on the toppes of the braunches, confifting of many fmall torne leaues, fingle and yellow of colour:and when the feede is ripe it turneth into downe, and is carried away with the winde. The whole plant is full of a white milkie iuice.

2 The ftalk of hares lettuce or fmooth Sowthiftle, is oftentimes a cubite high, edged \& hollow, of 2 pale colour and fomtimes reddifh. The leaues be greene, broad, fet round about with deepe cuts or gafhes fmooth and without prickles. The flowers ftande at the top of the braunches yellow of colour, which are caried away with the winde when the feede is ripe.

\section{Sonchus a per.}

Prickly Sowthiftle.

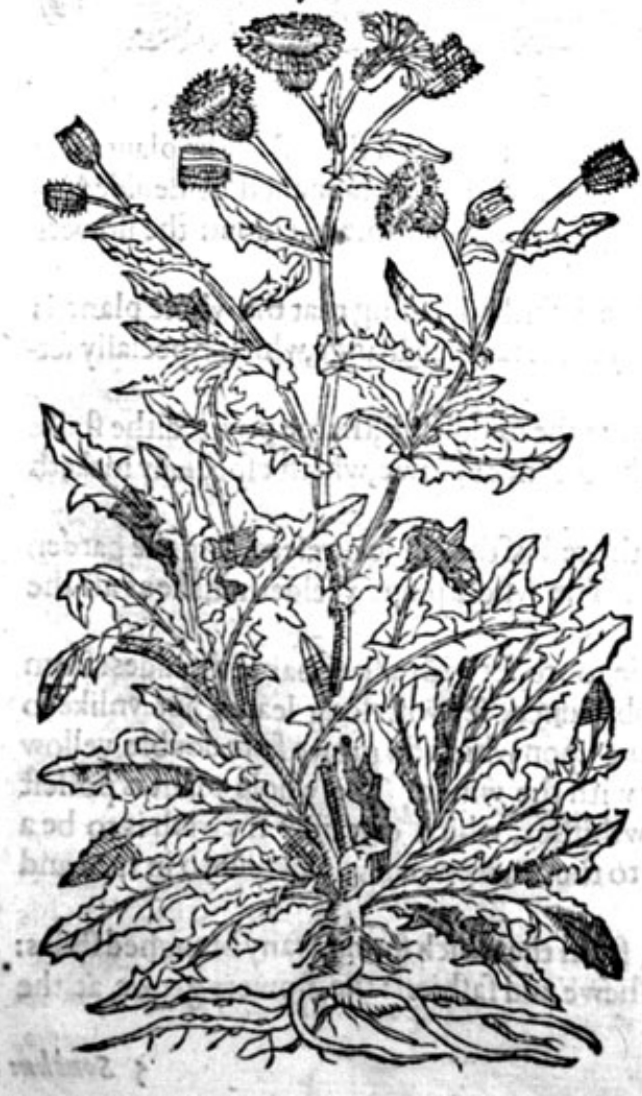

2 Sonchus Lewis. Hares Lettuce.

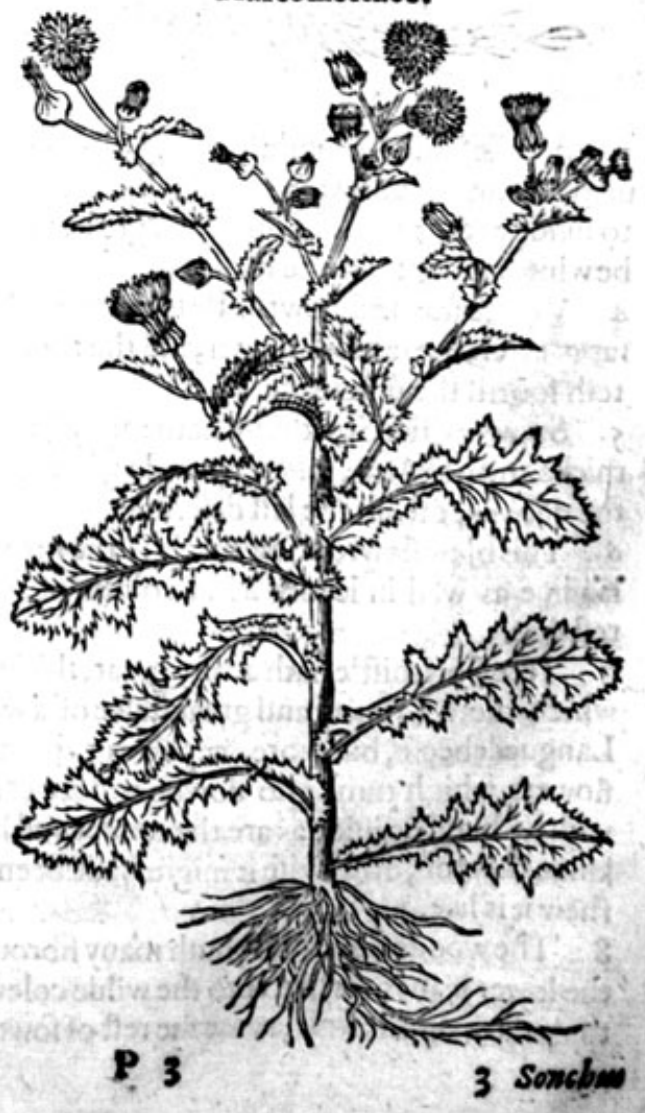


3 Sunchuisleuislatifolim:

Broad leafed Sowthiftle.

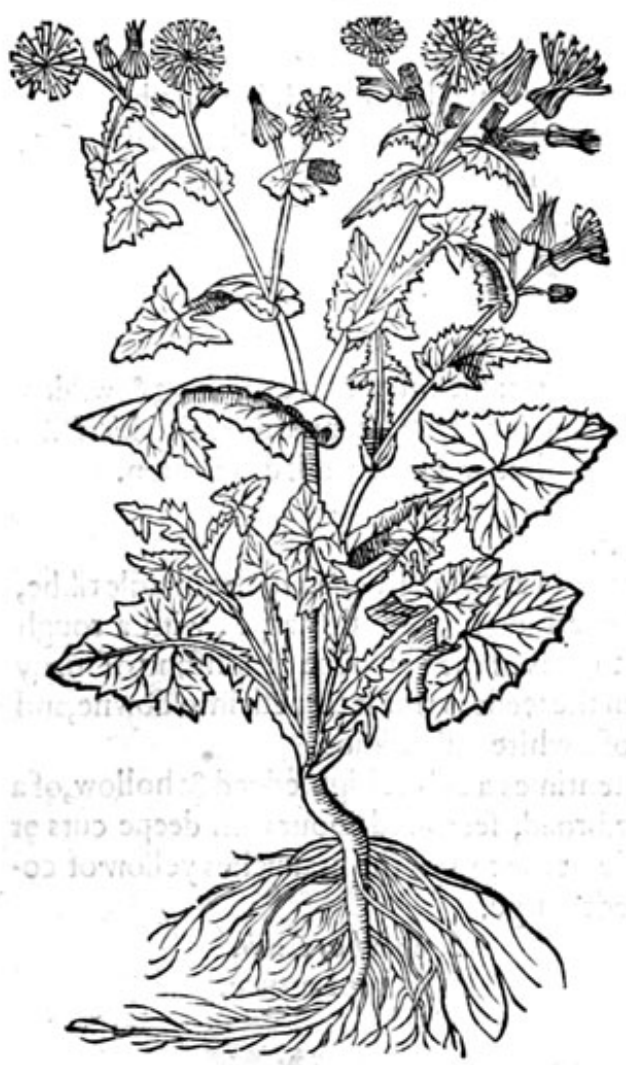

4 Sonchus lenis flore albo. White flowred Sowthifle.

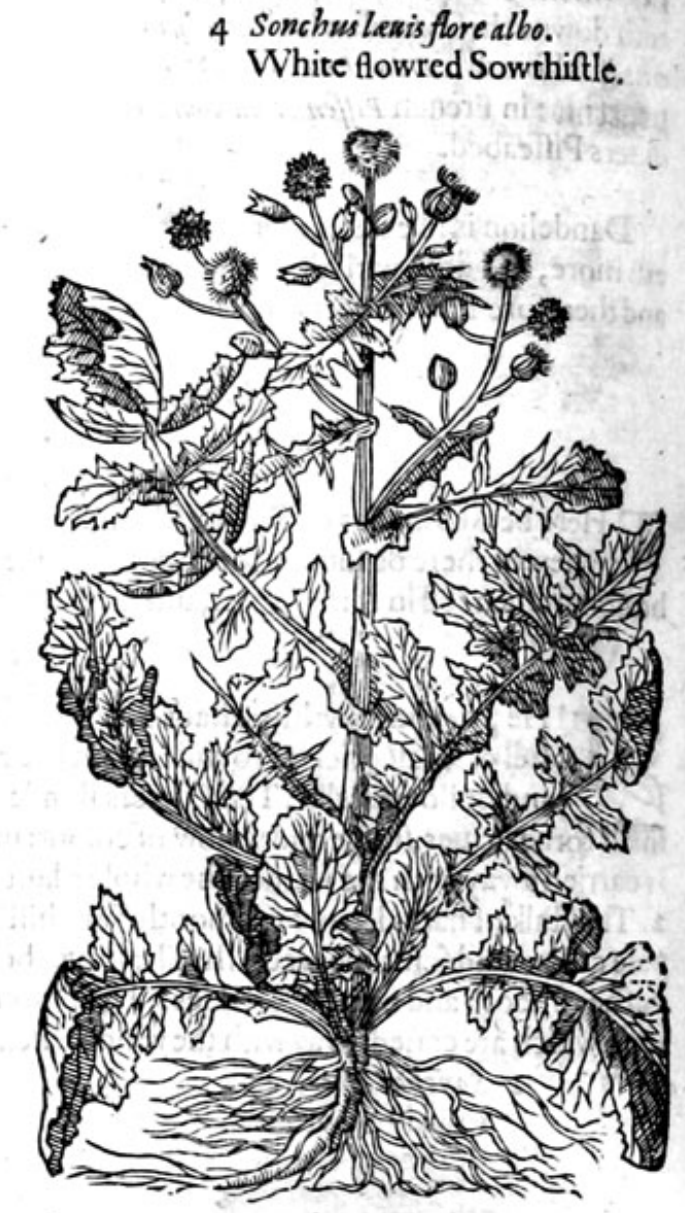

3 Broade leafed Sowthiftle hath a long, thicke and milkie roote, as is all the reft of the plant, with nuany ftrings or fibres: from the which commeth foorth a hollowe ftalke braunched or deuided into fundric fections. The leaues be great, fmooth, fharpe pointed and greene of colour: the flowers be white in hape like the former.

4 White flowred Sowthiftle is like vnto the laft before defcribed, fauing that the whole plant is far greater; the leat:es broader, and the rootes with many more tangled ftrings, which efpecially fetteth foorth the difference.

5 Snowe white Sowthiftle hath many large leaues cut to the middle rib, tharpe pointed:the ftalke thicke and hollowe, whercupon do growe flowers of the colour of fnowe, which efpecially maketh the difference from the laft defcribed.

6 This blew flowred Sowthiftle is the greateft of all the reft of the kindes, refembling the garden Endiue as well in leaues as in colour of the flowers. The whole plant yeeldeth milkeas all the
reft doc.

7 Tree Sowthiftle hath a very great, thicke and harde roote, fet with a fewe hairic threddes: from which rifeth a ftrong and great ftalke of a wooddie fubftaunce, fet with long leaues not vnlike to Languedebeefe, but more deepely cut about the cdges: vpon which do growe faire double yellow flowers which turne into downe and are caried away with the winde. The whole plant is poffeft with fuch milkic inice as are the tender and hearby fowthiftles, which certainly fheweth it to bea kinde there of, otherwife it might hatie been referred to the Haukeweedes, whereunto in face and fhew it is like.

8 The woode Sowthiftle hath many fibrous rootes, from the which fpring many branched ftalks: the lower le unes are like vnto the wilde colewoort in fhewe and fafhion: the flowers growe at the top yellow and downie, as are the relt of fowthiftes. 
5 Sonchm fore niuco.

6 sonchisuffore caru'es,

Snowb white Sowthittle. Bleiv tlowred Sowthifte. 1

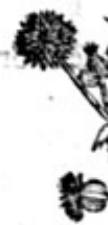

留

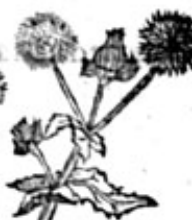

in

जo

cos y a d ans

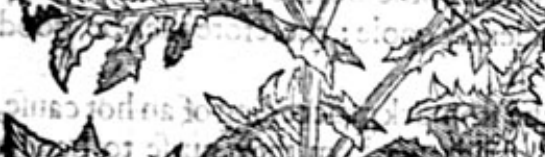

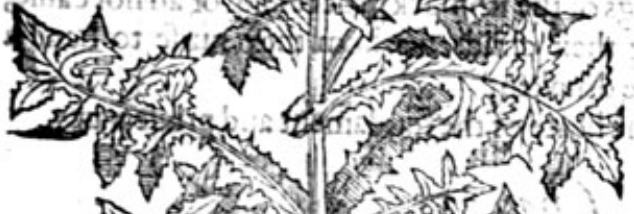

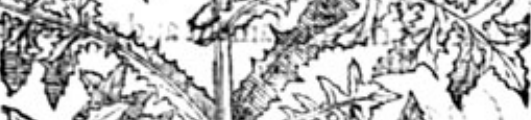
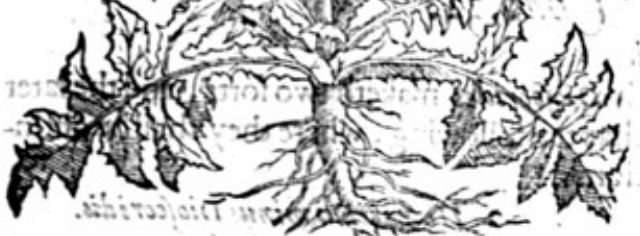

7 Soniclus arborefcens.

Tree Sowthiftle.
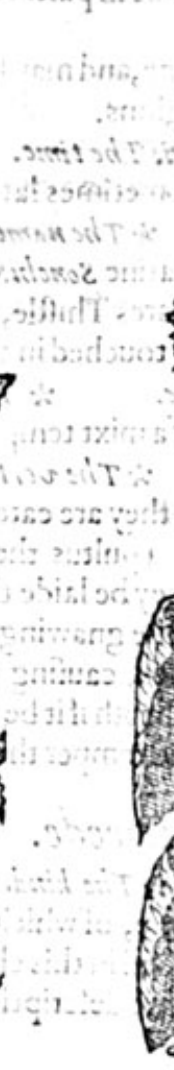

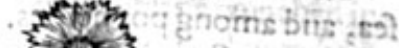

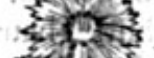

S. So $10.5 \%$

,
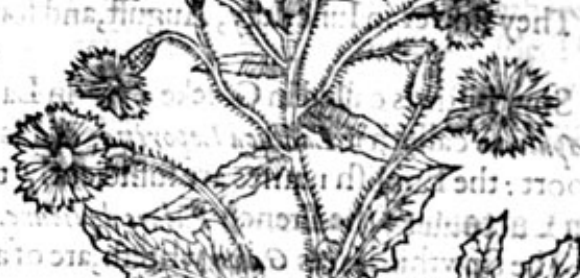

sind a

जin
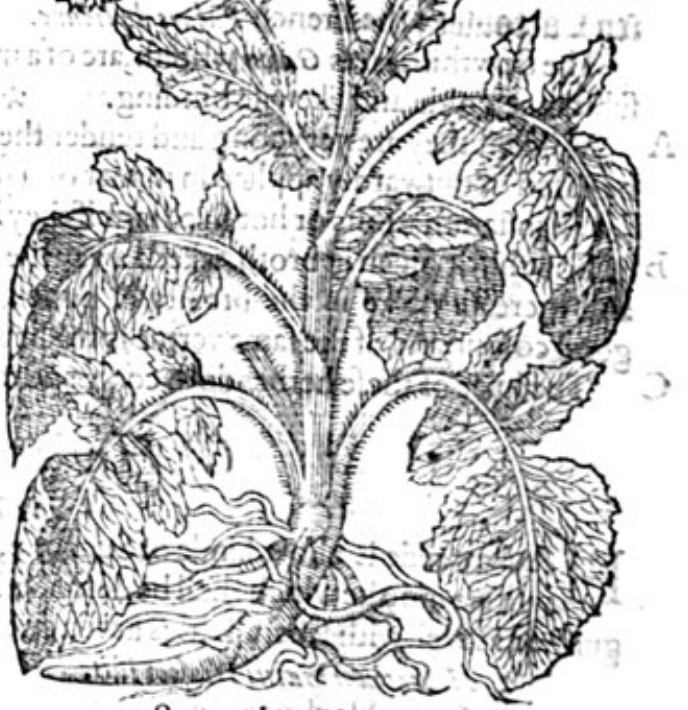

8. Sorchos fluaticus.

Wood Sorvthiltle.
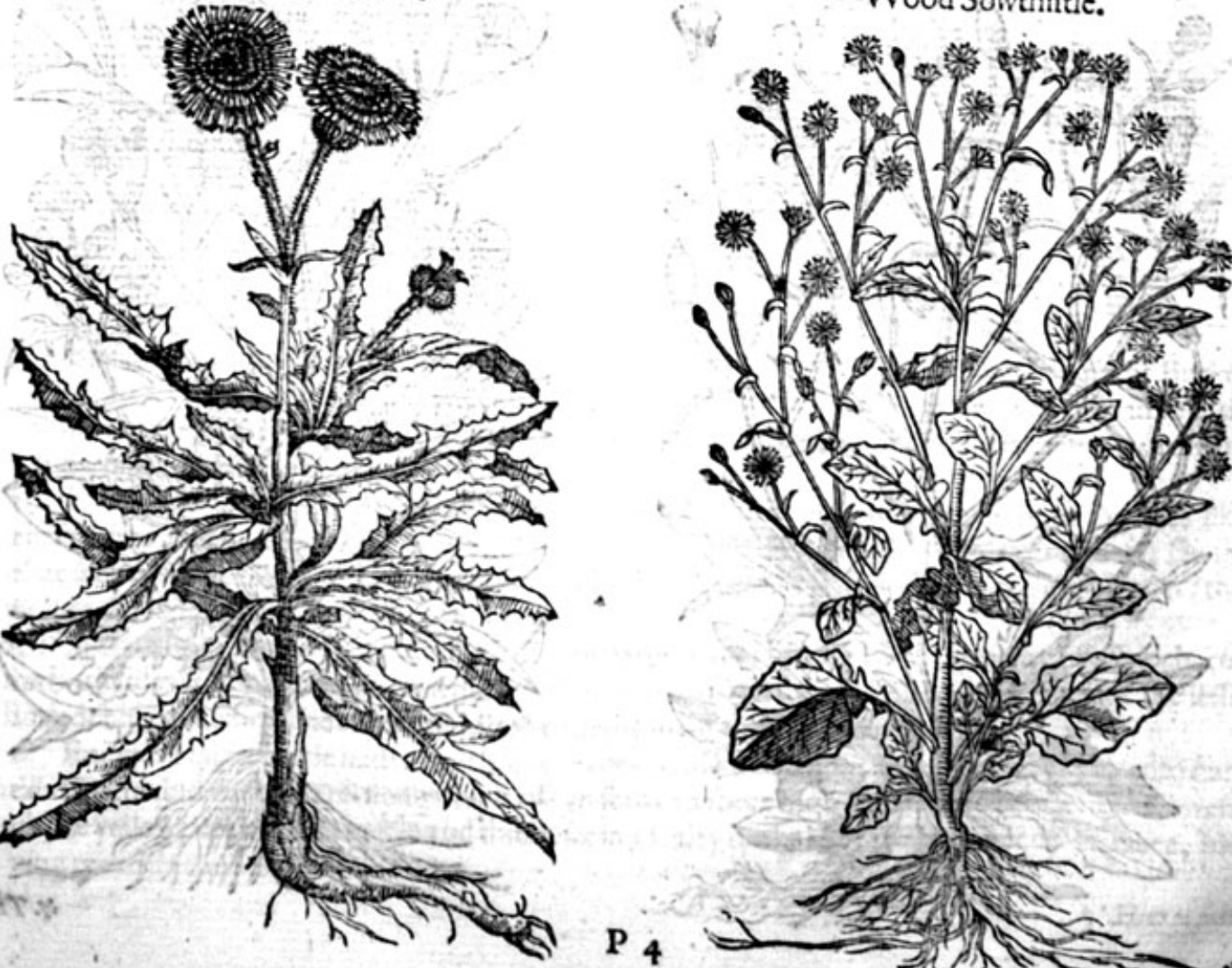

r

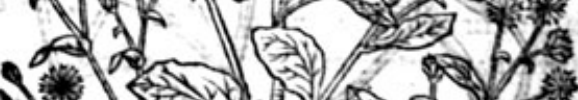

P
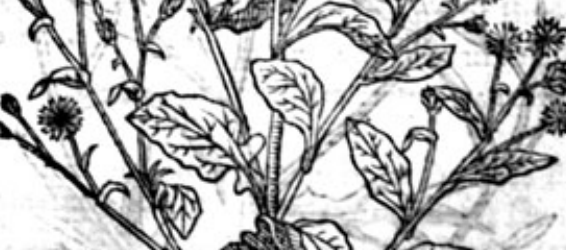

$1 \mathrm{NDC}$

测

6.

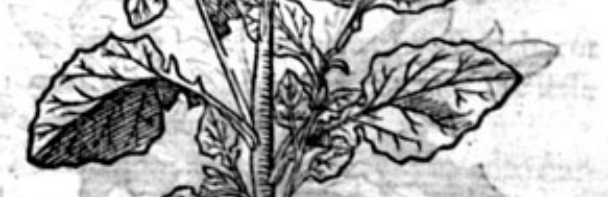

a) 1 (5)

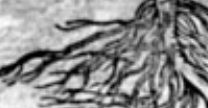


$*$ The place.

Thefe kinds of Sowthiftles do growe wilde in paftures, medowes, woods, and marfhes neere the fea, and among pot herbes.

The tree Sowthiftle I hatie not as yet feene, and may be counted a ftranger in Englifh gardens or elfewhere in thefe Northerne and colde regions.

* The time.

They flower in Iune, Iuly, Auguit, and fometimes later.

$*$ The names.

Sowthiftie is called in Greeke ornorsin Latine Sonchi:of diuers Cicerbita,lactwoella, and Lacterones: Apuleius calleth it Lactuca Leporina, or Hares Thiftle, of fome Braßica lepurina, or Hares Colewoort : the Englifh names are fufficiently touched in their feucrall titles: in Dutch it is called faa: ien 1 attotutio : the French Palays de lieure. $\quad *$ The iemperature.

The Sowthiftles, as $G$ alen writeth,are of a mixt temperature; for they cohfift of a watry \& earthie fubftance, colde and likewife binding. $\quad *$ The vertues.

A Whileft they are yet yoong and tender they are eaten as other potherbes are, but whether they be eaten or outwardly applied in maner of a pultus they euidently coole : therefore they be good for all inflammations or hot fwellings if they be laide thercon.

B Sowthiftle giuen in broth, taketh away the gnawings of the ftomack proceeding of an hot caufe, and increafe milke in the breafts of nurfes, caufing their children whom they nurfe to haue 2 good colour, and of the fame vertue is the broth if it be drunken.

C The iuice of thefe herbes doth coole and temper the heate of the fundament and priuie parts.

$$
\text { Of Haukerweede. Cbap. } 32 \text {. }
$$

H Aukeweede is alfo a kinde of Succorie, of which Diofcorides maketh two forts, and thelater writers mo, the which fhall be defcribed in this chapter following, where they fhall be diftinguifhed as well with feuerall titles as fundrie defcriptions.

I Hieracion maim Diofcoridis. Great Haukeweede.

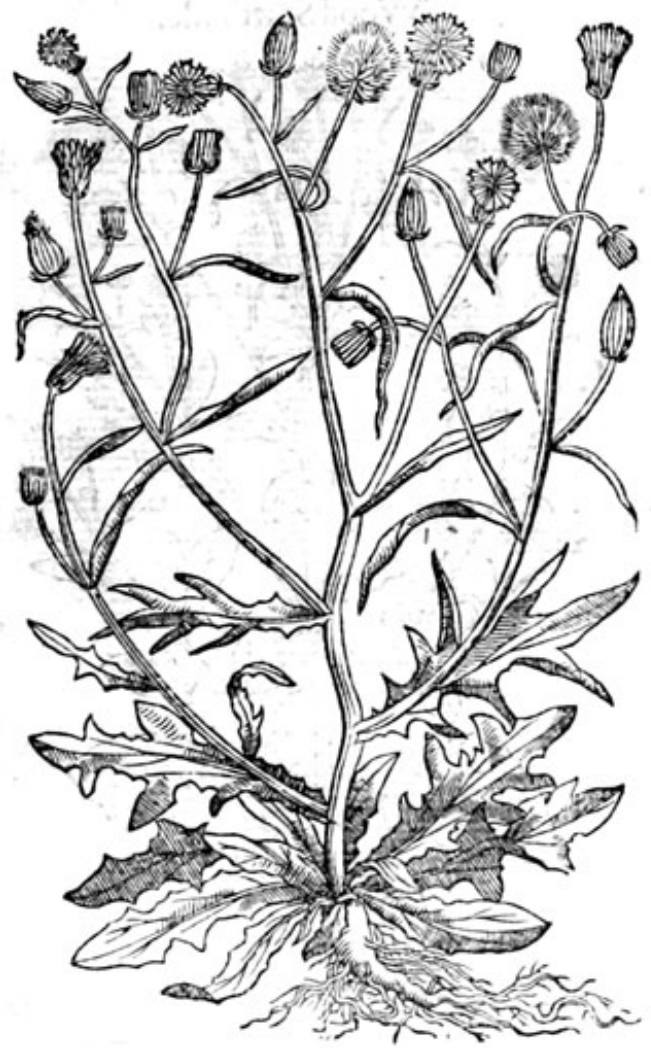

2 Hieracium minus Diofcoridis. Small Haukewaede.

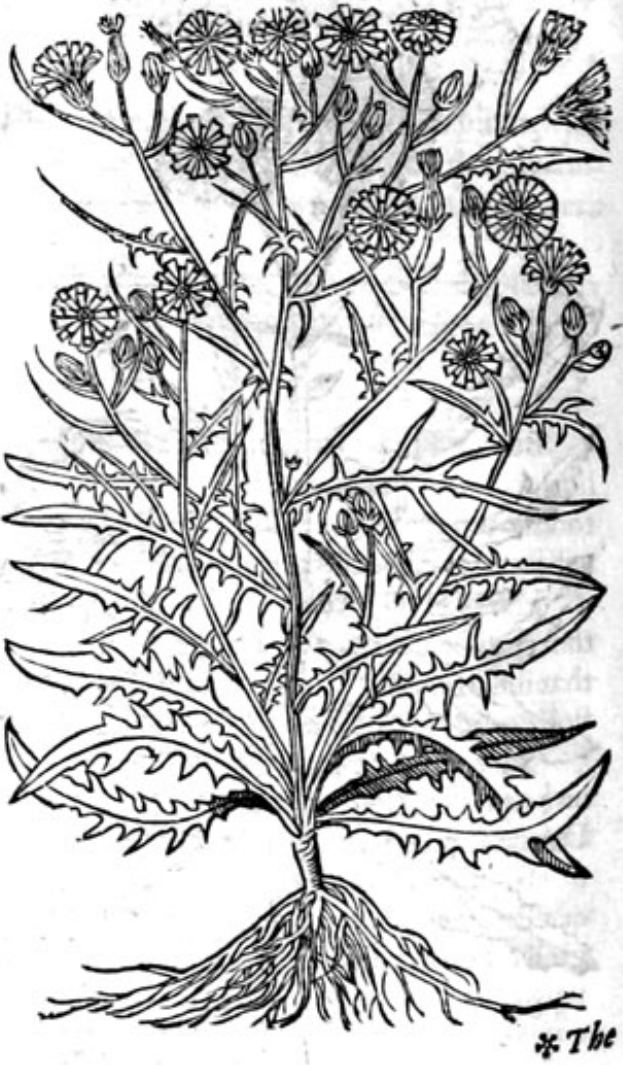


7 Hegreat Haukeweede hath large and long leaues fpread vpon the grounde, in fhape like thofe of the milke Thiftle. The ftalke groweth to the height of two cubits braunched into fundrie armes or diuifions, hollowe within as the yoong kexe, reddifh of colour:wherevpon do grow yellow flowers thicke and double, which turne into downe that flieth awaie with the winde when the feede is ripe. The roote is thicke, tough and threddie.

2 The fmal Haukeweede which of moft writers hath beene taken for yellow Diuels bit, hathlong leaues deepely cut about the edges, with fome fharpe roughneffe thereon like vnto Sowthifte. The ftalkes and flowers are like the former, the roote is compact of many final ftrings with a fmal knob, or as it were the ftumpe of an olde roote in the middle of thofe ftringes, cut or bitten off, whereupon it tooke his name Dituels bit.

3 Hicractum nigrum.

Blacke Haukeweede.

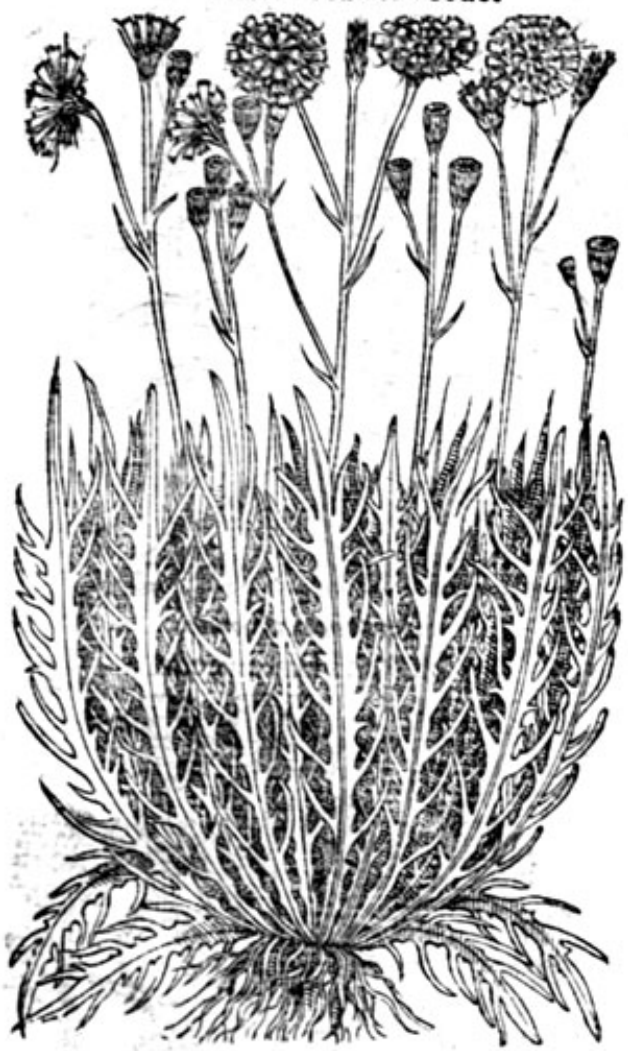

4 Hie racium Leporinum.

Hares Haukeweede.

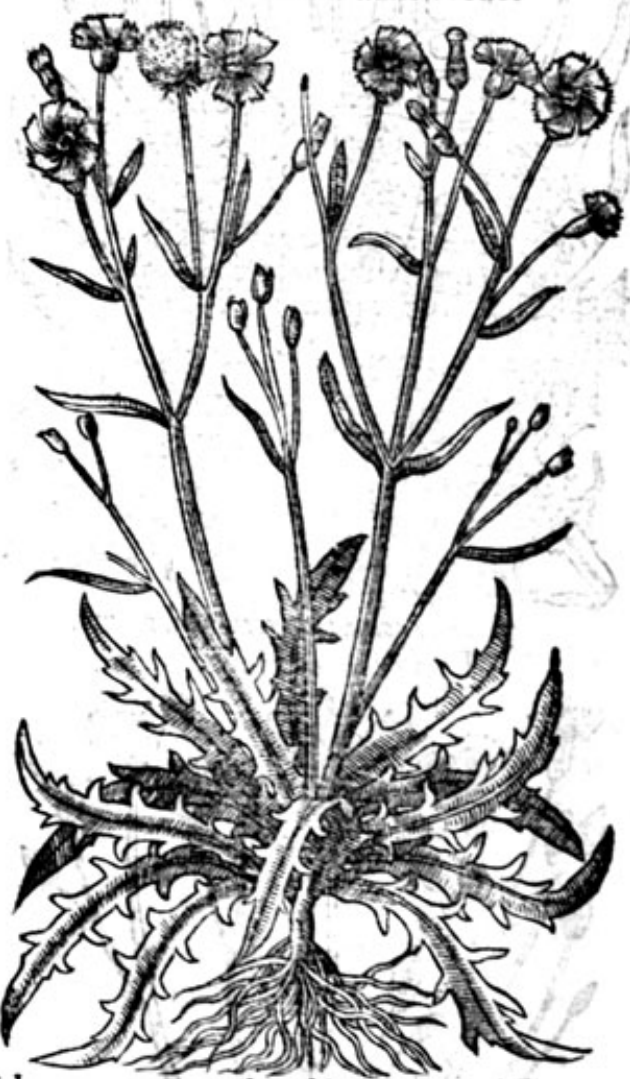

3 Blacke Haukeweede hath very manylong iagged leaues, not much vnlike to thofe of Buckes horne, fpred flat and farre abroad vpon the grounde, which the pieture cannot expreffe in follittle roome as is requifite: among which rife vp many ftalkes flender and weake, the flowers growing. yellow at the top and verie double, with a threddic roote.

4 Hares Haukeweede hath many long iagged leaues, cut about the edges on both the fides like the teeth of a fawe, refembling very well the yellowe Diuels bit as well in leaues as rootes, fauing that it hath no fuch knobbed bitten roote as it hath. The ftalke is hollowe, weake and fender : the flowers be like the former, but not fo double.

5 Succorie Haukeweede hath many long and large leaues fpread vpon the grounde, deepely cut on both fides to the middle ribbe,from which rife vp fmall ftalkes and flowers like thofe of the leffe Dandelion, but leffer. The roote confifteth of many fmall threddie ftrings.

6 Endiues Haukeweede hath many broad leaues, endented about theedges very like vnto garden Endiue, but narrower: among which rife vp ftalkes a foote high,flender and brittle. The flowers growe yellowe at the top, double and thicke fet in a fcaley huske like the Knap-weede or Iacea, ha-
uing great, 
5 Hieraciom Aphacoides.

Succoric Haukeweede.

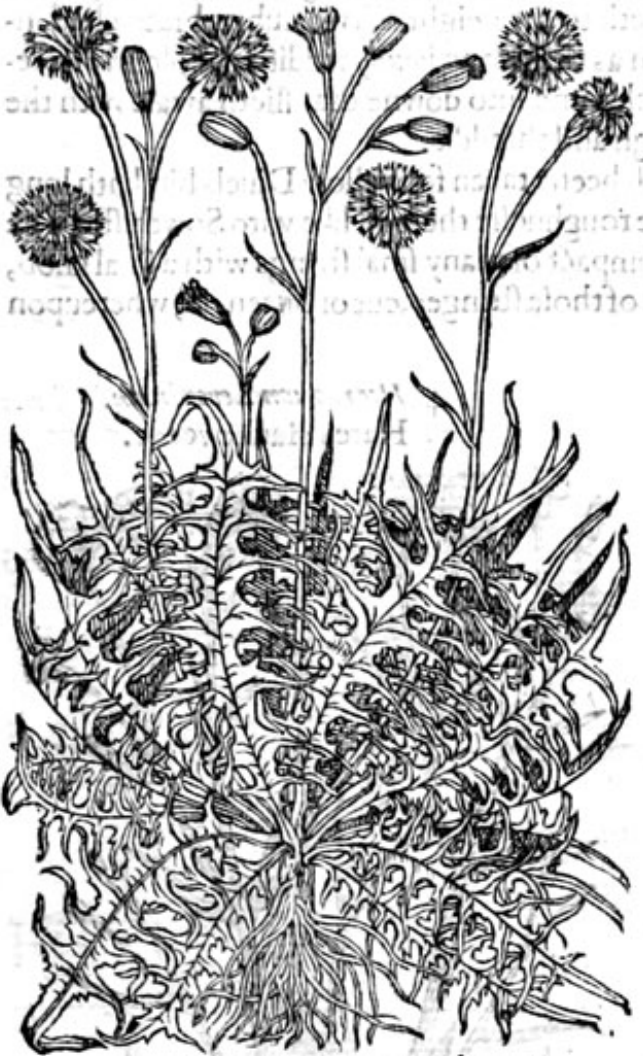

7 Hier acium longius radicatum.

Long rooted Haukeweede.

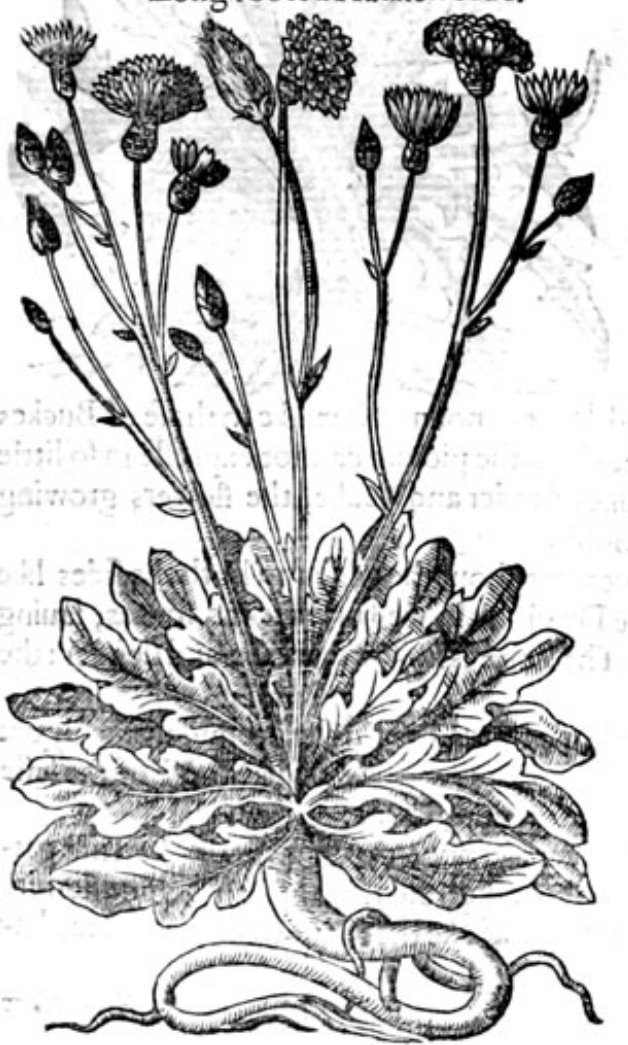

6 Hieracium intybascion.

Endiues Haukeweede,
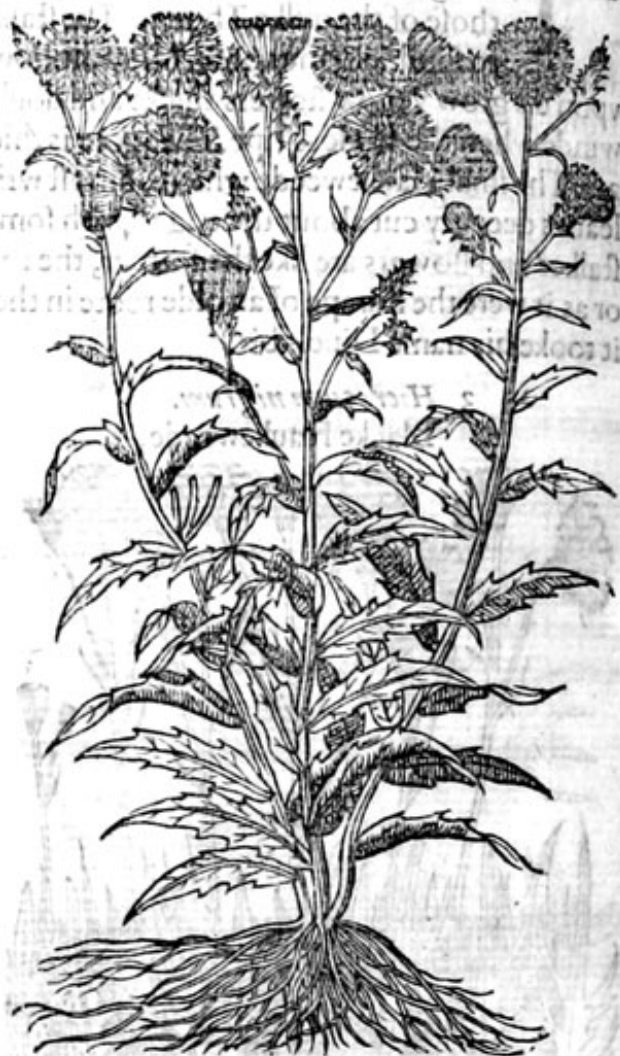

8 Hieracium afferum.

Sharpe Haukeweede.

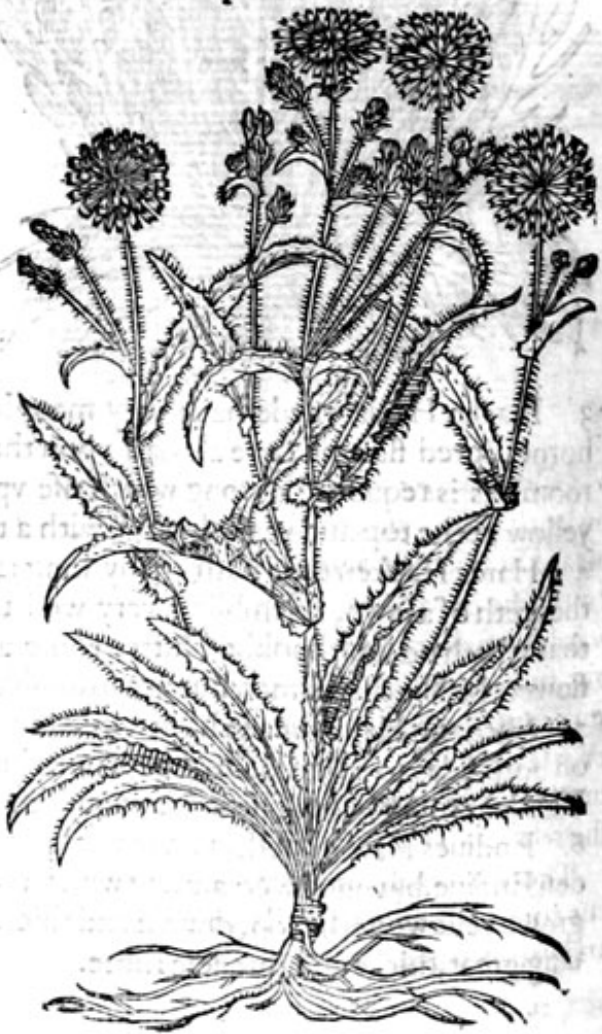




\section{HIST ORIE OFIPLANTS. HTH}

\section{codt : * The defcription.}

7. Longrooted Haukeiveede hath many broade leaues fpred vpon the ground, Alightly and conifufedly indented about the edges, not vnlike to Endiue Haukeweede:among which leaues fpring vp ftrong and tough ftalkes a foote and halfe high, fet on the top with faire double flowers, yellow and like vnto Piffeabed. The roote is very long, white and tough.

8 Sharpe Haukeweede hath leaues like to thofe of Languedebeefe or Oxetoong, fharpe about the edges and rough in the middle. The ftalkes be long and flender, fet with the like leaties, but leffer: the flowers grow at the top double, and yellowe of colour:the roote is tough and threddie.

\section{Hier atriom falcation L'Obely. Crooked Haukeweede.}

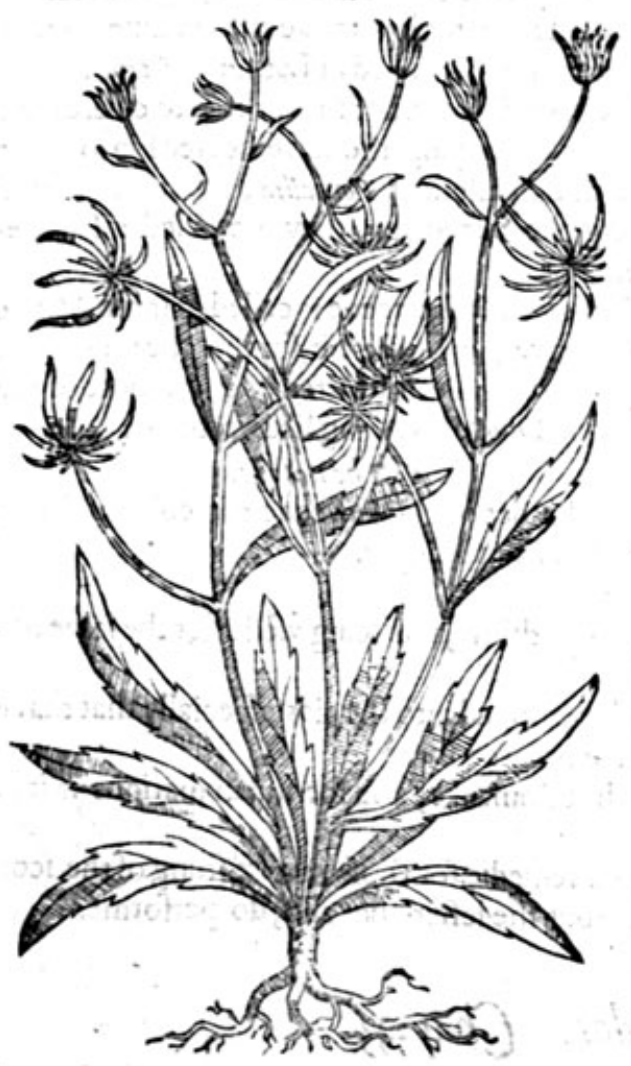

10 Hieracium latifolism.

Broade leafed Haukeweede.

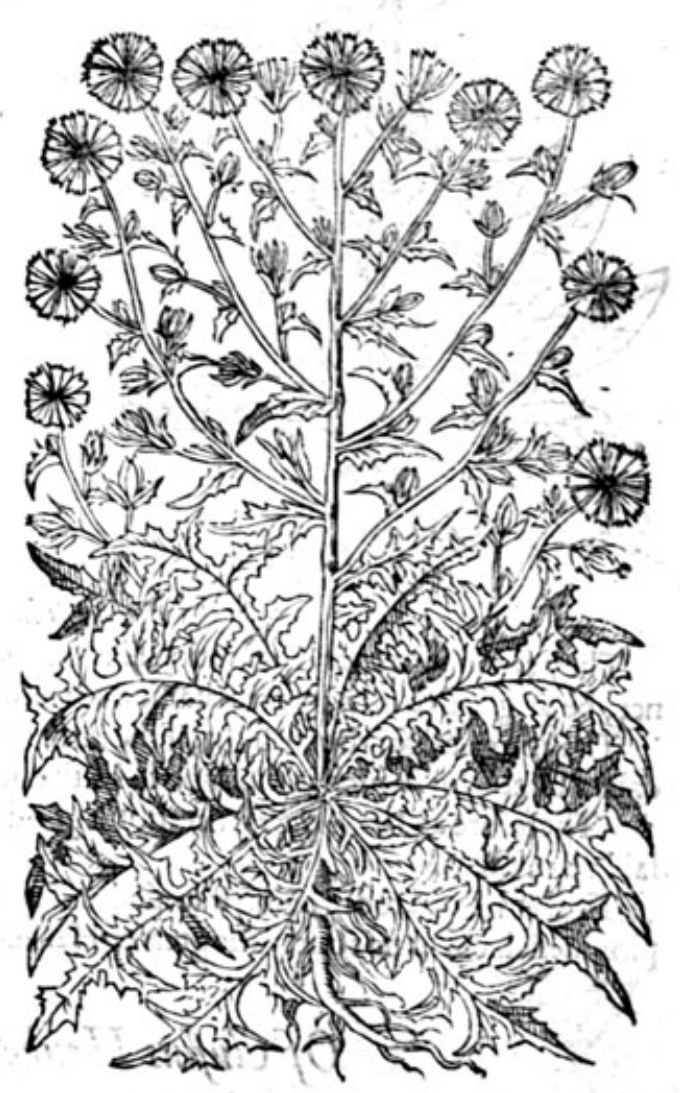

9 Crooked or falked Haukeweede hath leaues like vnto the garden Succorie, flightly endented. on both fides, with tender, weake, and crooked ftalkes; wherupon do grow foolifh idle flowers of 2 bleake or pale yellowe colour, and the roote fmall and threddy. " 10. The broadeleafed Haukeweede hath broade long leaues, rough and deepely endented toward the ftalke, refembling the leaues of the greateft Sowthiftle. The ftalke is hollowe and fpengious, full of a milkie iuice as is the reft of the plant, as alfo all the other of his kinde:the flowets grow at the top of the ftalkes double and yellowe.

II The great mountaine Haukeweede with broade leaties, growt th $\mathrm{vp}$ in forme of leaues and ftature to Golden rod or Virga awrea. The ftalks be fat, hollowe and full of inilkethe flowers growe 25 the top double and yellowe of colour.The roote is fmall and threddie.

There is a fmall mountaine. Haukeweede hauing leaues like vnto she former, but more deepely cut about the edges and harper poiriced; the ftalkes are tender and weake; the flowers be double and yellowe like thofe of Pilofella or great moufe-eare; the roore is fmall and threddie. 
II Hieracion mont anum lat ifolium.

Great leaued mountainc Haukeweede.

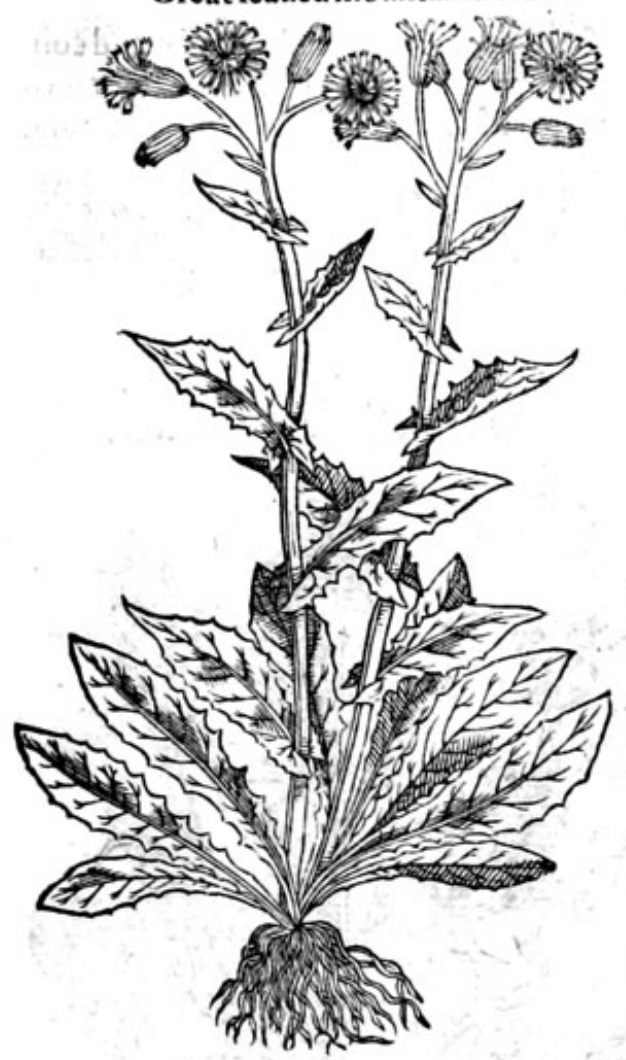

* Theplace.

Thefe kindes of herbes do growe in vntoiled places neere vinto the borders of corne fieldes, in medowes, high waies, woodes, mountaines and hillie places, and neere to the brinks of ditches, * The time.

They flower for the moit part all the fommer long, fome fooner and others later. * The names.

Thefe plants are al conteined vnder the name of Hieracium : which is called in Grecke alfo isegixur: diuers name it in Latine Accipitrina, which is termed in French Cichoree iaulne : in Englifh Haukeweede. Thefe herbes tooke their name from 2 Hauke, which is called in Latine Accipiter, and in Greek iseak, for they are reported to cleere their fight by conueying the iuice heereof into their eies. Gaza calleth it Porcellia, for it is numbred among the Succories, they arecalled alfo Lampuca.

Yellowe Haukeweede is called of fome Morfus disboli, or yellow Diuels bit, for that the roote doth very well refemble the bitten or cropt roote of the common Diuels bit, being like Scabious.

$$
\text { * The nature. }
$$

The kindes of Haukeweede are colde and drie, and fomewhat binding.

\section{* The vertues.}

They are in vertue and operation like to Sonchus or Sowthiftle, and being vfed after the fame maner, be 25 good to all purpofes that it doth ferue vnto.

They be good for the eie fight, if the iuice of them be dropped into the eies, efpecially that that is called Diuels bit, which is thought to be the beft and of greateft force.

Therefore as Diofcorides writeth, it is good for an hot ftomacke, and for inflammations if it be laid vpon them.

The herbe and roote being ftamped and applied, is a remedie for thofe that be ftung of the fcorpion, which effect not onely the greater Haukeweedes, but the leffer ones alfo, do performe.

\section{Of Clufius Haukeweedes. Chap.33.}

\section{* The kindes.}

$\mathrm{T}$ Here be likewife a greater fort or kinde of Haukeweedes, which Carolus Cluf fous hath fet foorth in his Pannonicke obferuations, refembling the kindes of Scorzonera, or vipers Graffe, whereunto they are very like; the which likewife require a particular chapter, for that they do differ in forme very notablic.

\section{* The defcription.}

I He firft of Clufins his Haukeweeds hath great broad leaues fpred vpon the ground, fomwhat hairic about the edges, oftentimes a little iagged, alfo foft as is the leafe of Mullen or $\mathrm{Hig}$ taper, and fometimes dafht heere and there with fome blacke fpots, in fhape like the garden Endiue, full of a milkie iuice : among which rifeth vp a thicke hollowe ftalke of a cubite high, deuiding it felfe at the top into two or three braunches, whereupon do grow fweet fmelling flowers nor 
vnlike to thofe of yellowe Succorie, fet or placed in a blacke hoarie and woollie cup or huske, of a pale bleak yellow colour, which turneth into 2 downie blowebal that is caried away with the ivinde: the roote entereth deepe into the ground, of the bignes of 2 finger, full of milke, and couer.d with a thicke blacke barke.

2 Thefecond fort of great Haukeweede according to my computation; and the 5.0 f $\mathrm{Cln}$ fruw, hath leaues like the former, that is to faie, foft and hoarie, and as it were couered with a kinde of woollineffe or hairineffe, bitter in tafte, of an inche broade, narrower and longer then the former. The ftalke is 2 foote high, whereupon do growe yellowe flowers like thofe of Goates-beard or Tragopogon, which are caried away with the winde when the feede is ripe. The roote is blacke and full of milkie iuice, and hath certaine white ftrings annexed thereto.

I Hierscivom primus Clufiti.

The firt Haukeweede of Clufous.

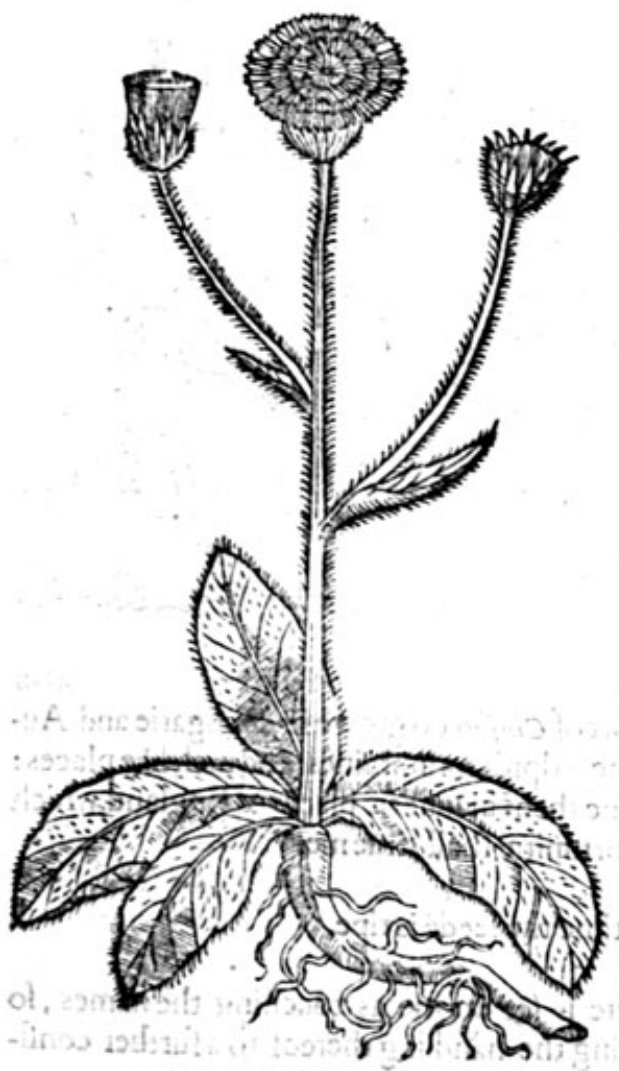

2 Hieraciom 5.Clafit.

clugurus his g.kind of Haukeweede.

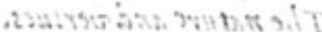

3 This kind of Haukeweede hath blacke rootes 2 finger thicke, full of milkie ivice, deepely thruft ineo the ground, with fome fmall fibres belonging thereto: from which come.vp many long leanes
halfe an inche or more broad, couered with foft downie or hairie leaues, of an ouerworne ruffet co-
lour: and amo lour: and amongft the leaues come yp naked hard ftalkes, wheripon do grow yellow flowers fer in 2 woollie cuppe or chalice, which is turned into downe and caried away with his feede by the
winde.

4. The feuenth Haukeweede hath a great thick roote not deepely thruft into the ground, but lying along vnder the vpper cruft of the carth, fomewhat bunched yp in the middeft, with many ftrings frips, not theretile; from which rifelong leaues fomewhat indented abour the edges with fleighe anps, not vnlike to the leaucs of yellowe Diuels bit, hoarie, hairie and foft as are the others prece. wain I I is hollowe, foftand f pungie:the flowers be yellowe and double as the other. 
3 Hieraciom 6. Cluffir.

1 Clufim his 6. Haukeweede.

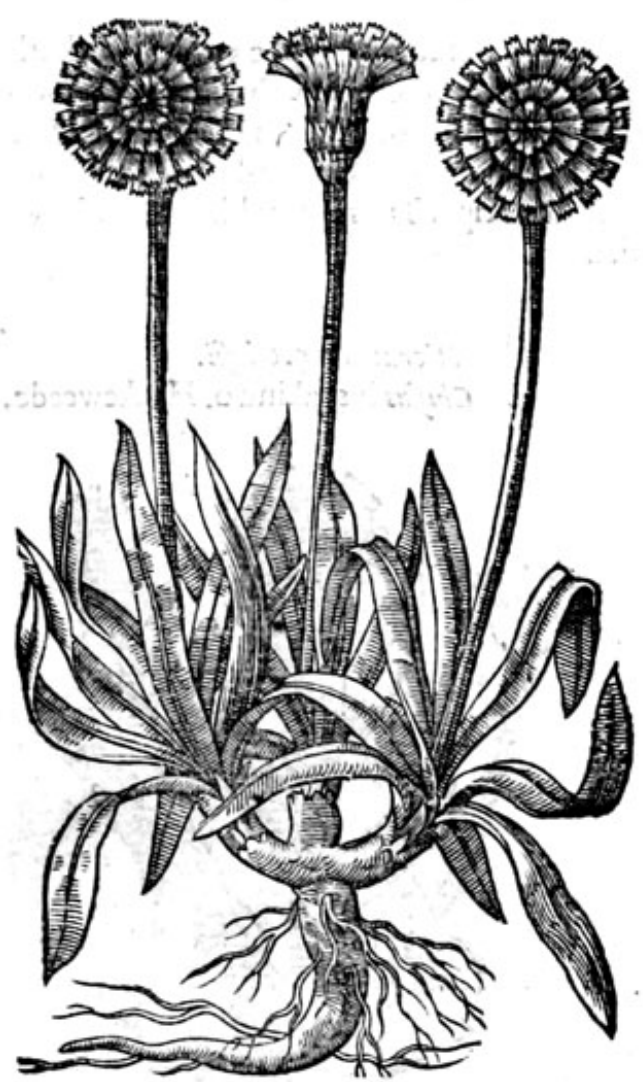

4 Hieracium 7.Clnfir. Cleyfien his 7. Haukeweede.

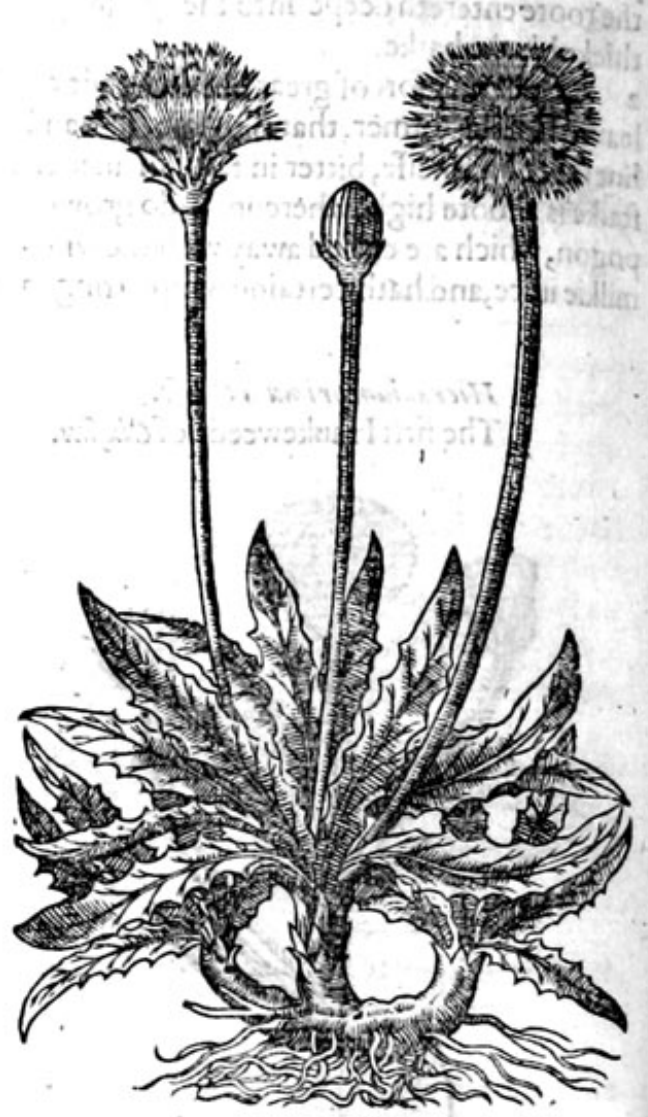

* Theplace.

There kindes of Hankeweede according to the report of clufins do growe in Hungarie and Auftrich,and in the graffie drie hils, and herbie and barraine Alpih mountaines and fuch like places: notwithftanding if my memorie faile me not I haue feene them in fundrie places of England, which I meane God willing better to obferue heerafter, as oportunitie fhall ferue me.

\section{He faith they flower from Maie to Auguft, at what time the feede is ripe.} to The names.

The authour himfelfe hath not faide more then heere is fet downe as totching the names, fo that it fhall fuffice what hath nowe beene faide, referring the handling thereof to a further confin deration.

I finde not any thing at all fer downe e eiture and vertwes.

I finde not any thing at all fet downe either of their natures or vertues, and therefore I forbeare to faie any thing elfe of them as a thing not neceffaric to write any experiment vpon my owne conceit and imagimation.

\section{Of Lettuce. Chap.34.}

$$
\text { * The kindes, }
$$

T Here are according to the opinion of the auncients, of Lettuce two forts, the one wilde or of 1 the fielde, the other tame or of the garden: but time with the induftrie of later writers have founde out others both wilde and tame, as alfo artificiall, which I purpofe to laie downe. 


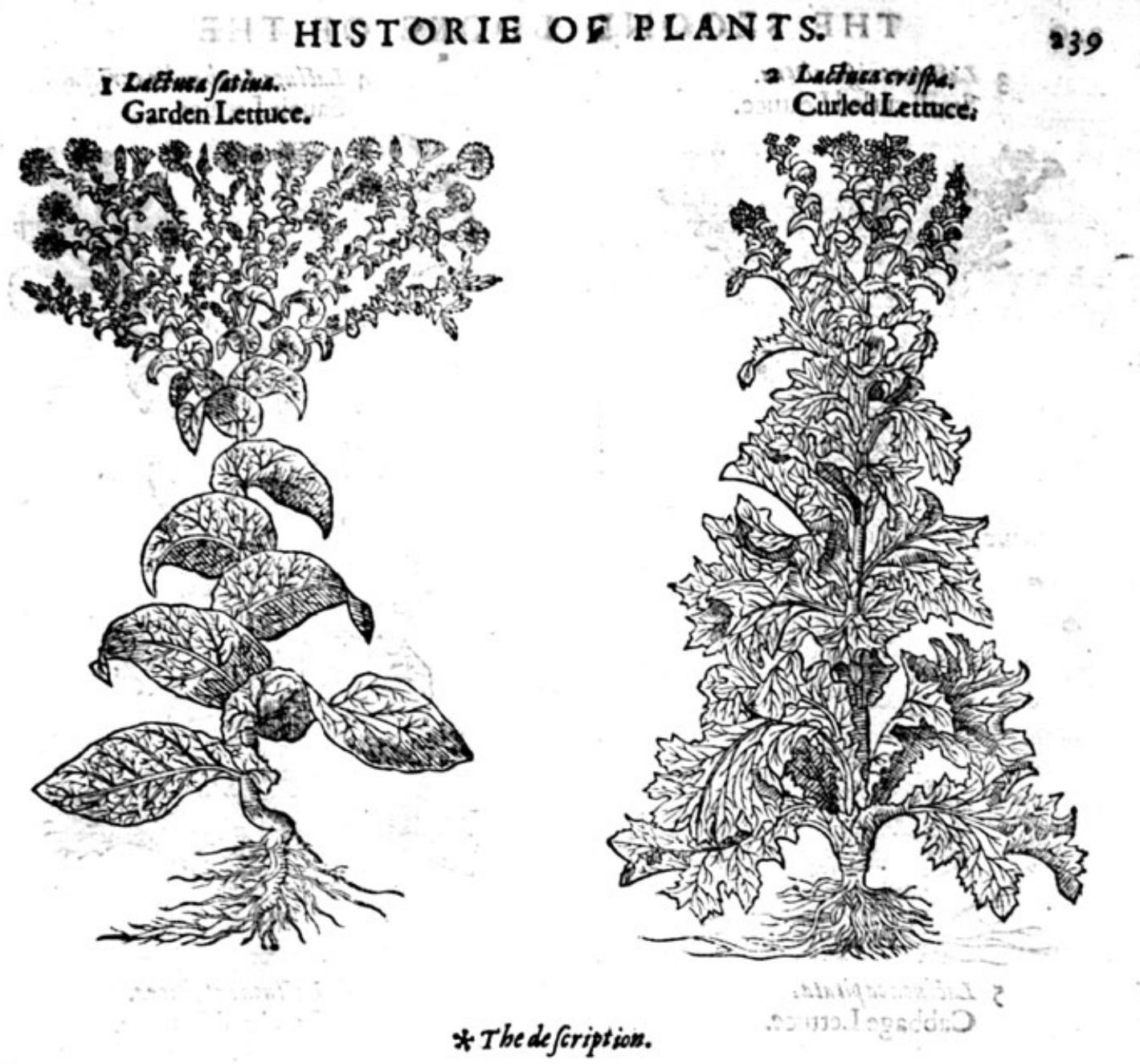

$\mathbf{1}$

G Arden Lettuce hath a long broade leafe, fmooth and of a light greene colour: the ftalke is rounde, thicke fet with leaues full of milkie iuice, bufhed or braunched at the top:wherupon do growe yellowinh flowers which turne into downe that is caried away with the winde. The feede fticketh faft vnto the cottonie downe and flieth away likewife, white of colour \& fomewhat long. The roote hath hanging on it many long tough ftrings, which being cût or broken do yeelde foorth in like maner as doth the ftalke and leaues, a iuice like to milke. And this is the true delcription of the naturall Lettuce and not of the artificiall: for by manuring, tranfplanting, and hauing regarde to the moone and other circumftances; the leatues of the artificiall Lettuce be oftentimes transformed into another hape : for either they are curled, or elfe fo drawne togither, as they feeme to be like a cabbage or headed colewoort, and the leaues which be within and in the midft, are formthing white tending to a very light yellowe.

2 The curled Lettuce hath great and large leaues, deepely cut or gafhed on both the fides, not plaine or fmooth as the former, but intricately curled and cut into many fections. The flowers are fmal, of a bleake colour, the which do turne into downe and is caried away with the winde. The feed is like the former, fauing it changeth formtime into blackneffe with a roote like the former. 3 This finall fort of curled Lettuce hath many leaues, hackt and torne in peeces very confufedly, and withall curled in fuch an admirable fort', that euery great leafe feemeth to bee made of many fmall leaues fet vpon one middle ribbe, refembling a fanne of curled feathers vfed among gentlewomen. The flowers, rootes, and feede agree with the former.

4 The Sauoie Lettuce hath very large leaues fpread vpon the grounde, at the firft comming vp broade, cut, or gafht about the edges, crifping or curling lightly this or that way, not vnlike to the leaues of garden Endiue, with ftalks, flowers and feedes like the former, $25 \mathrm{wol}$ in thape as yeelding that milkie iuice whereivith they do all abound. 
THE SECOND BOOKE OP THE

3 Laffucecripsealtera.

Small curled Lettuce.
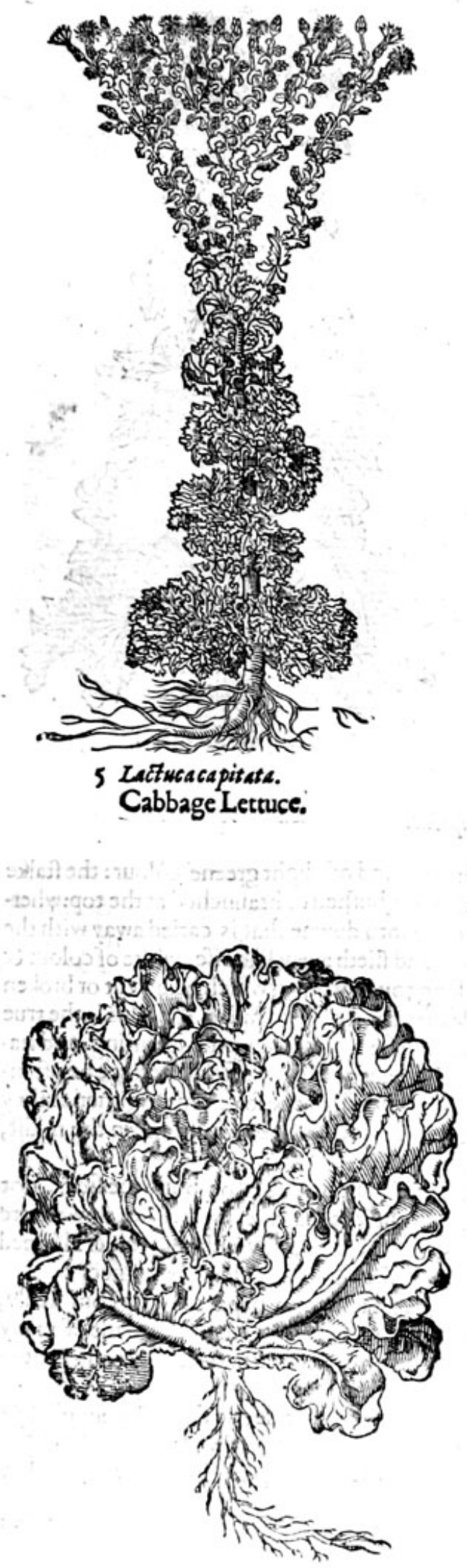

4 Lactuca Saubaudioccriffa.

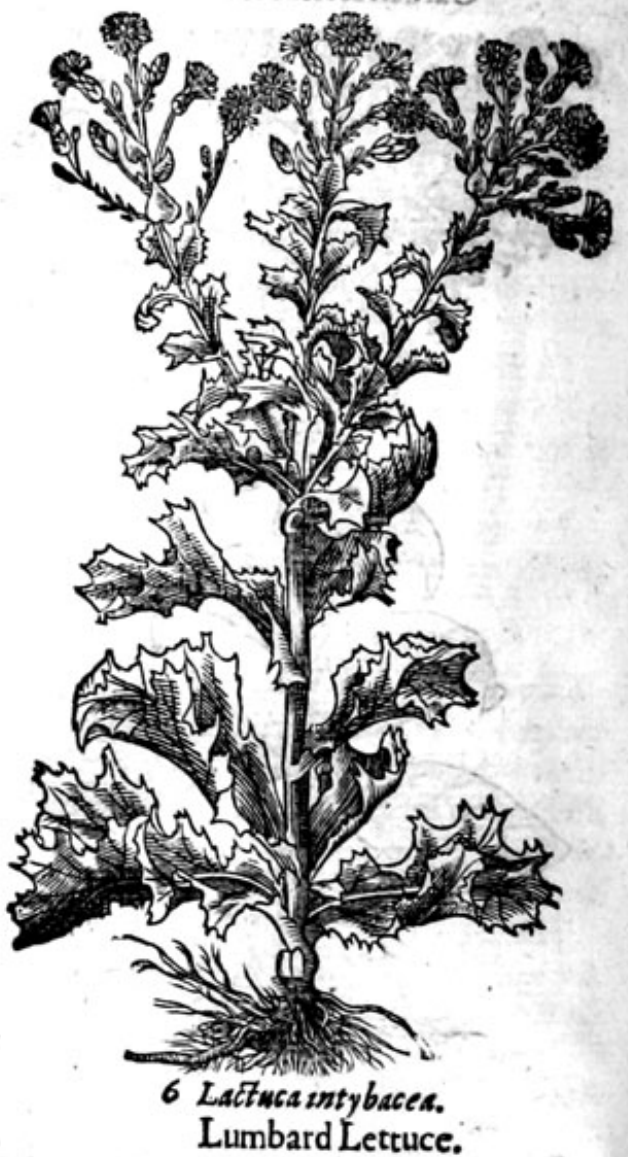

-

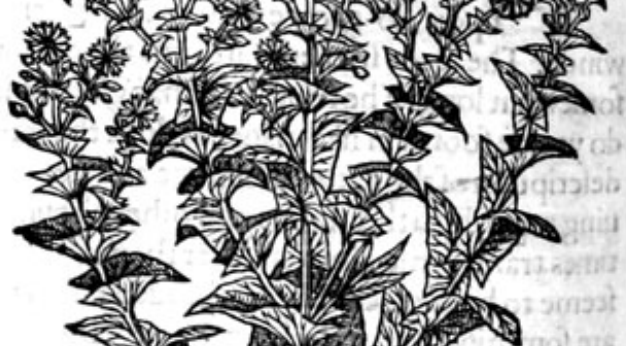

- N1

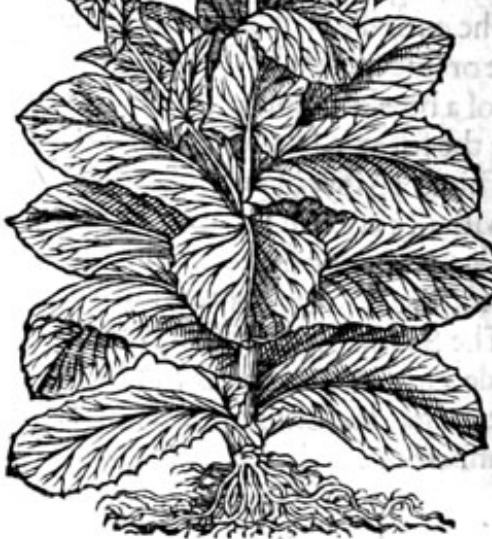




\section{AH H FOT ORIEOOF PLANTS. AHT}

5 Catbige Loctutec hath manyplaine and finiooth Jeanes-at his firft growing upp which for the moft part lie flat ftill vpon the grounde; the next that doe appeere are thofe leaties in stio aniddle; which turne themfelues togitherinbracing eelic other foclofely, that it is formed into that giobe or round head, whereof the finpleft is not ignorant. The feedeheereof is black, contrary to all the

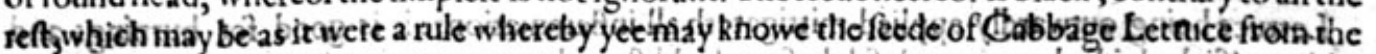

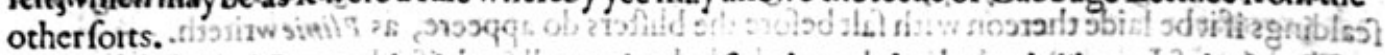

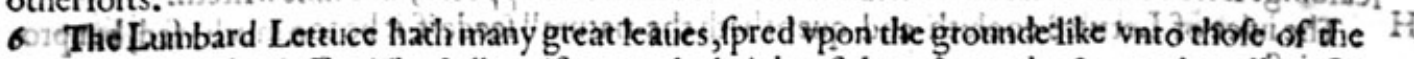
garden Endiue, but leffer. The ftalkes rife vp to the height of three foote:the flowers be yetlowithy which turne into downe and flie away with the winde: the feede is white as fnowe.

* T Te place.
Letruce delighteth to growe, as Palladius faith, in a manured, fat, moift, and dunged grounde:it muft be fowen in farte weather in places where there is plentie of water as Colomellat hittl, and profpereth beft if it be fowen very thimne.

$$
\text { * The time. }
$$

It is certaine faith Palladiws, that Lettuce may wall be fowen at any time of the yecre, butcefpeciey ally at euery firft fpring, and fo loone as winter is done, till fommer be wellfpent.

$$
\text { * The names. }
$$

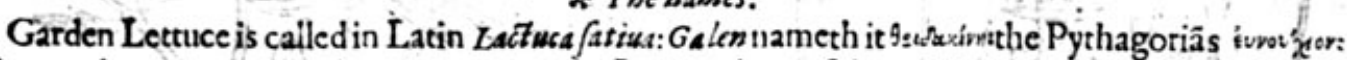
the apothecaries Lact tuca, i Lactes fucco, as the Latines doe, of the milkie iuice which iffueth foorth of thewounded ftalkes and rootes: the Germaines name it $\mathbf{l}$ atttch: the lowe Dutch Rattoune: the Spaniardes Lecbuga and Alface : the Englifh Lettuce:and the French Leictue. When the leaues of thiskinde are curled or crompled, it is named of Plinie Latfuea crifpa, and of Colvemella Lactuca Cecilisna: in Englifh curld or crompled Lettuce.

The Cabbage Lettuce is commonly called Lactuca capitata, and Lactuca fesslis, Plinie nameth it Lectuca Laconica : Columella Lactuca Bestica: Petrus Crefcentius, Lactuca Romand : in Englifh Cabbage Lettuce and Loued Lettuce. nuce.

There is another fort with reddifh leaues, called of Colamella Lactuca Cypria : in Englifh red Let-

$$
\text { thetemperature. }
$$

Lettuce is a colde and moift potherbe,yet not in the extreme degree of colde or moifture, but altogither moderately, for otherwife it were not to be eaten.

$$
\text { * The vertues. }
$$

Lettuce coolech a hot ftomacke, called the hart burning; and helpeth it when it is troubled with A choler : it quencheth thirft, caufeth fleepe, maketh plentie of milke in nurfes, who through heate \& drineffe do growe barraine and dric of milke : for itbreedeth milke by tempering the drineffe and heat. But in bodies that be naturally colde, it doth not ingender milke at all, but is rather an hinderance thereunto.

Lettuce maketh a pleafant fallade, being eaten rawe with vineger, oile, and a littlefalt : but if it be B boiled it is fooner digefted, and nourifheth more.

It is ferued in thefe daies, and in thefe countries at thie beginning of fupper, and eaten firft before $C$ any other meate, which alfo Martialis teftifieth to be done in times paft, marueiling why fomedid ve it for a feruice at the ende of fupper, in thefe veries:

$$
\begin{aligned}
& \text { Cliudere qua canas LaCtwca folebat aworum, } \\
& \text { Dic mibt, cur nostras incboat illa dapes? }
\end{aligned}
$$

Notwith tanding it may now and then be eaten at both thofe times to the health of the bodie: $D$ for being taken before meate it doth many times ftir vp appetite: and eaten after fupper it keepeth tifing vp into the head.

The iuice which is made in the veines by Lettuce is moift and colde, yet not ill nor much in quan- $\mathrm{E}$ titic: Galen affirmeth that it doth neither binde the belly nor loofe it, for it hath in it no harfhneffe
nor ftiptike qualitie by which the belly is ftaied; neither is there in it any fharpe or biting facultie,
which fcourethand prouoketh which fcoureth and prouoketh to the ftoole.

But howfoeuer Galen writeth this, and howfoener the fame wanteth thefe qualities,yet it is found $\mathbf{F}$ by experience that it makech the body foluble, elpecially if it be boiled,for by moifning of the belly 


\section{THE SECOND BOOKE OF THE}

it makethic the moreflipperie, which Martialis very well knewe writing in his $x \mathrm{r}$.booke of Epigrams in this maner,

$$
\begin{aligned}
& \text { Primasibi dabifur, ventri Lactuca mowendo- } \\
& \text { Vtilis }
\end{aligned}
$$

G Lettuce being outwardly applied mittigateth all inflammations: it is good for burnings and fcaldings if it be laide thereon with falt before the blifters do appeere, as Plinie writeth.

$\mathrm{H}$ : The iuge of Lettuce cooleth and quencheth the naturall feede if it be too much vfed, butpro. enreth flespe.

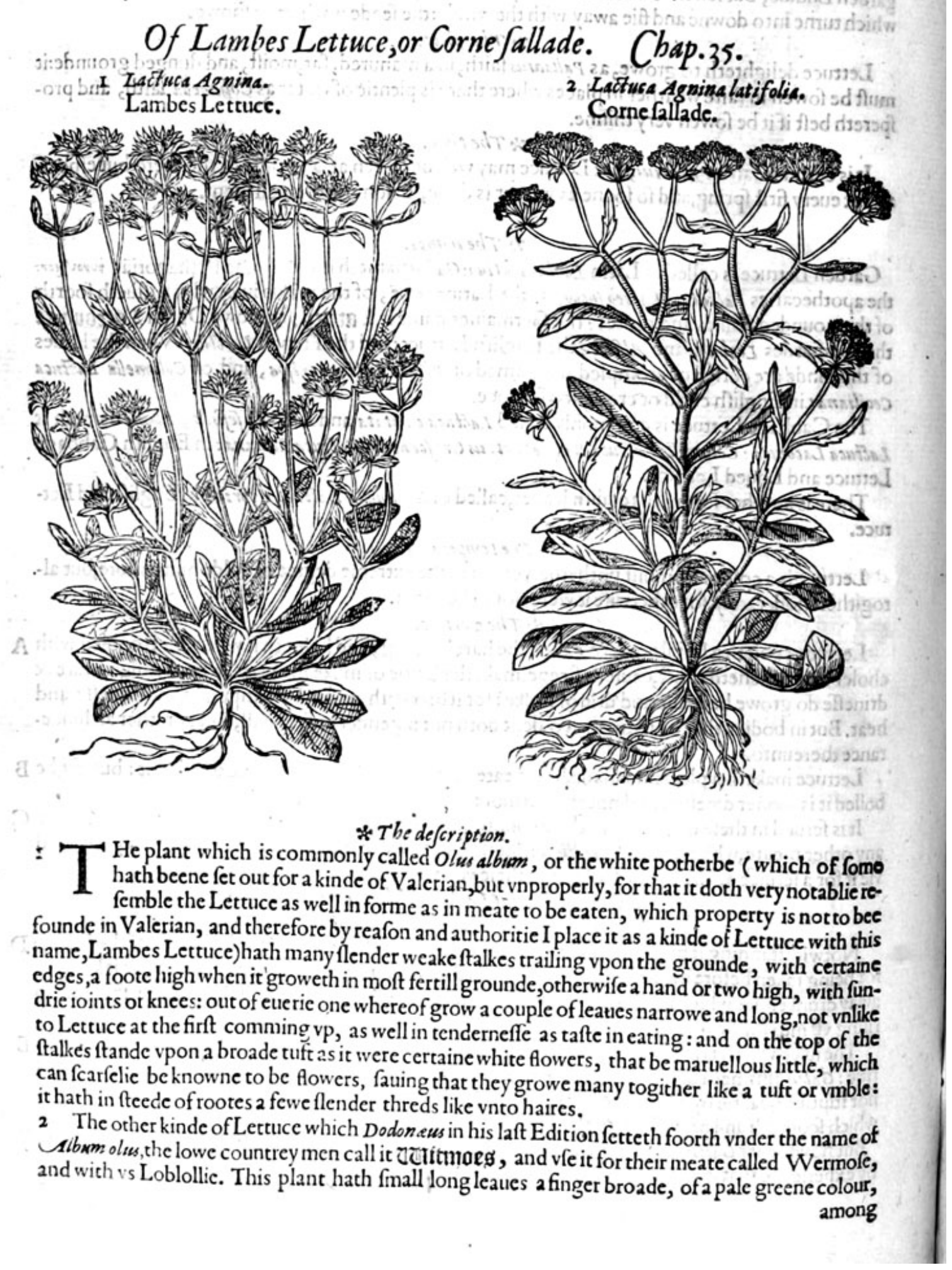


among which thooteth vp a fmal cornered and flender ftemme halfe a foote high, iointed with two or three ioints or knees;out of which proceede two leaues longer then the firft, bearing at the top of the braunches tufts of very imall white flowers clofely compact togither, with a roote like the former.

* The place.

Thefe herbes dogrowe wilde in the corne fieldes; and fince it hath growne in vfe among the French and Dutch ftrangers, in England it hath beenc forven in gardens as fallade herbes.

$$
\text { * The time. }
$$

They are found greene almoft winter and fommer.

$$
\text { * The names. }
$$

The Dutch men do call it relptmoes, that is to faie Albsm olus: of fome it is named Ceiterop: in Greeke sesxor'yaroos : in Englifh the White potherbe, fo called for that there is a blacke potherbe, which is called Alifander : the Latines Lactuca agnisa.

\section{* The temperatare and vertues.}

This herbe is colde and fomthing moift, and not vnlike in facultie and temperature to the gatden Lettuce, in fteede whereof in winter and in the firft monthes of the fpringe it ferves for a fallade herbe, and is with pleafure eaten with vineger, falt, and oile, as other fallades be, among which it is none of the woorft.

\section{Of Colewoorts. Chap.36.}

* The kinds.

DIofcor ides maketh two kinds of Colewoorts: the tame \& the wilde:but Theophr aff m maketh mo kindes heereof, the ruffed or curled Cole; the fmooth Cole; and the wilde Cole: Cato imitating Theophraftus, fetteth downe alfo three Colewoorts : the firft he defcribeth to be fmooth, great, broade leafed, with a bigge ftalke : the feconde ruffed : the thirde with littleftalkes; tenderand very much biting. The fame diftinction alfo Plinie maketh in his 20 .booke 9 chaprer wherche faith, that the moft auncient Romaines haue deuided it into threc kindes :the firft ruffed; the fecond fimooth; end the thirde which is properly called xedukn, or Colewoort: andin his 19 . booke he hath alfo added to thefc other moc kindes, that is to faic, Tritiznum, Cumanum, Pompeianum, Brutianun, Sabellicum, Sx Lacuturrison.

The Herbarifts of our time haue likewife obferued many forts, differing either in colour or elfe in forme: other headed with the leaues drawen togither; moft of them white; fome of a deepe greene; fome fmooth leafed; and others curled or ruffed, differing likewife in their ftalkes, 25 fhall bec expreffed in their feuerall deferiptions.

$$
\text { * The defoription: }
$$

$x$ He Garden Colewoort hath many great broad leaues, of a deepe blacke greene colour, mixed with ribbes and lines of reddirh and white colours. The ftalke groweth out of the middeft from among the leaues, braunched with fundrie armes, bearing at the top little yellowe flowers: and after they be paft there do fucceede long cods full of rounde feede like thofe of the Turnep, but fmaller, with a woodie roote hauing many itrings or threds faftned thereto. 2 There is another leffer fort then the former with many deepe cuts on both fides, even to the middeft of the ribbe, and very much curled and ruffed in the edges; in other things it differeth
not.

3 The red kind of Colewoort is likewife a Colewoort of the garden, and differeth from the commonin the colour of his leaves, which tende vnto redneffe, othewife very like.

4 There is alfo founde a certaine kinde heereof with the leaues wrapped togither into a rounde head or globe, whole head is white of colour efpecially toward winter when it is ripe. The roote is harde: and the ftalke of a woodic fubitaunce, 
244 THE SECOND BOOKE OF THE

I Brafsica vulgarisfatiua. Garden Colewoort.

2 Braßscafatiua cripas. Curld garden Cole.

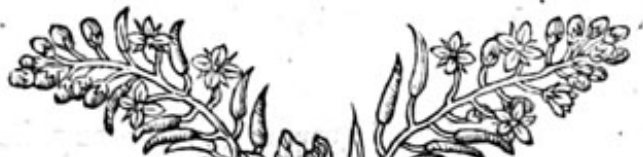

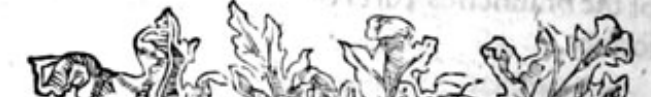
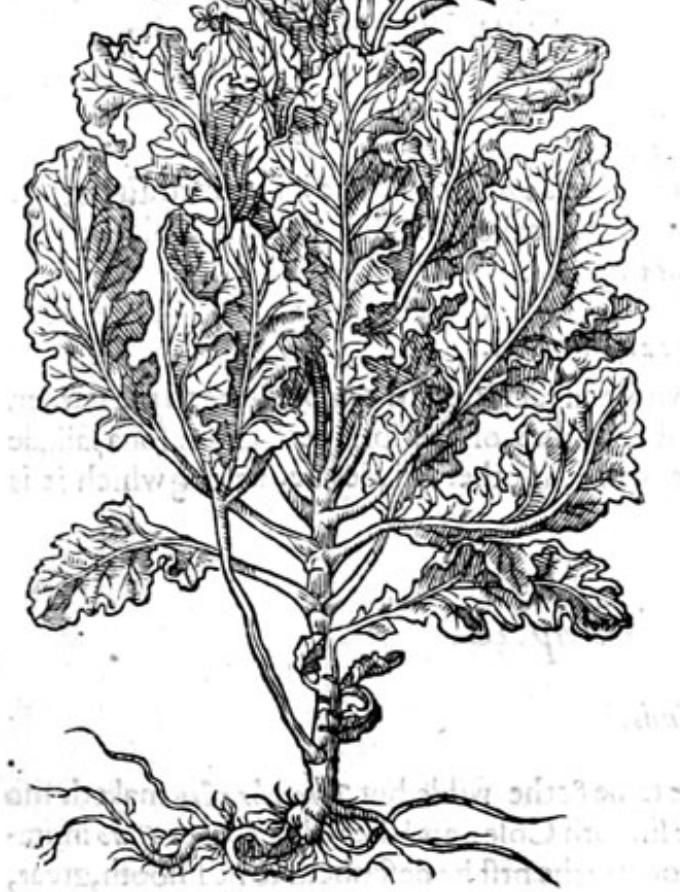

3 Brafica rubra.

Red Colewoort.
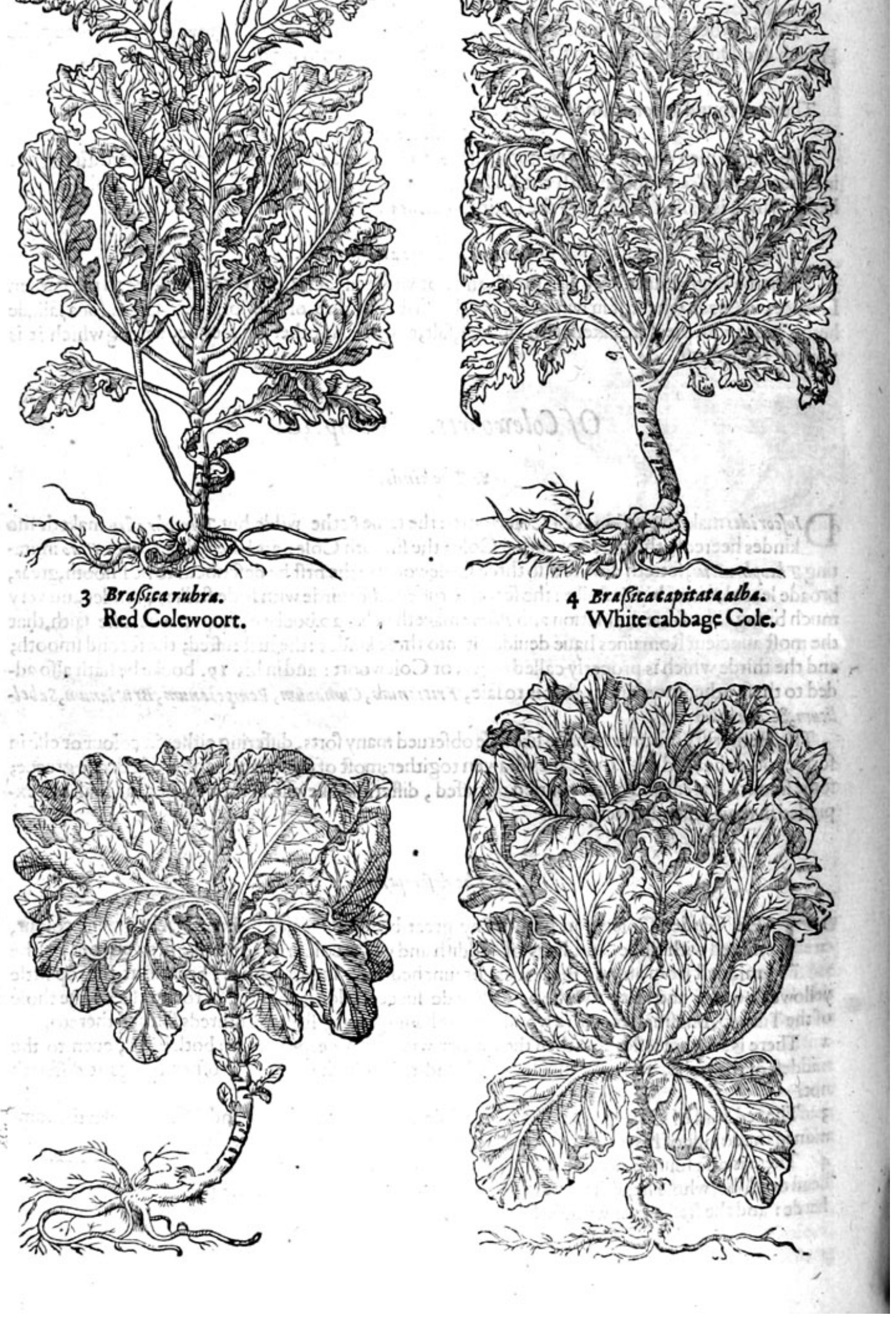


\section{HISTORIE OF PLANTS.}

5 Brafsca Capitata rubra.

Red cabbage Cole.

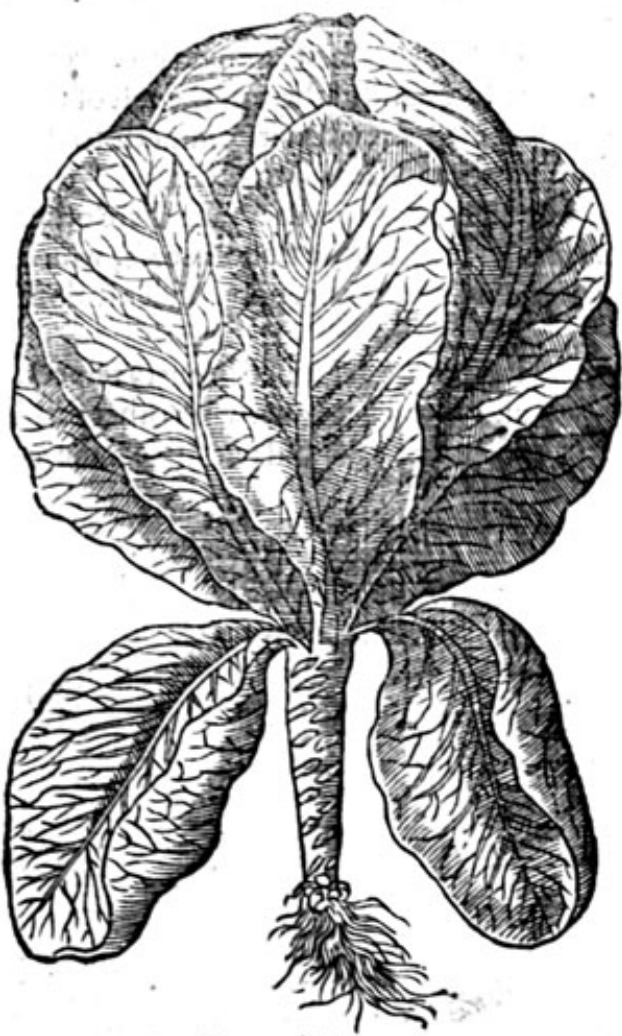

7 Brasess prolifers.

Double Colewoort.
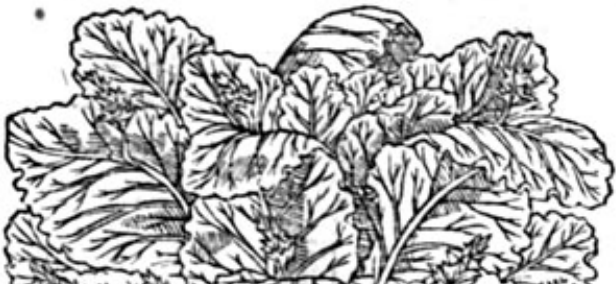

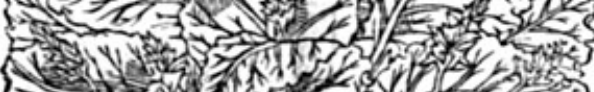

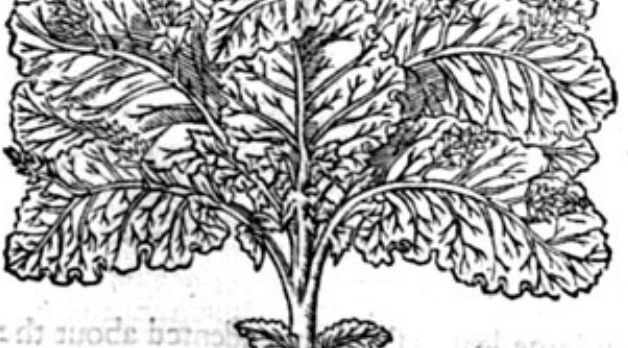

: is yode ba

thit moot.s ils efle

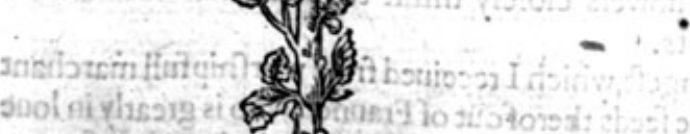

sumbis gaims iो
6 BrafNica Patule.

Open cabbage Cole.

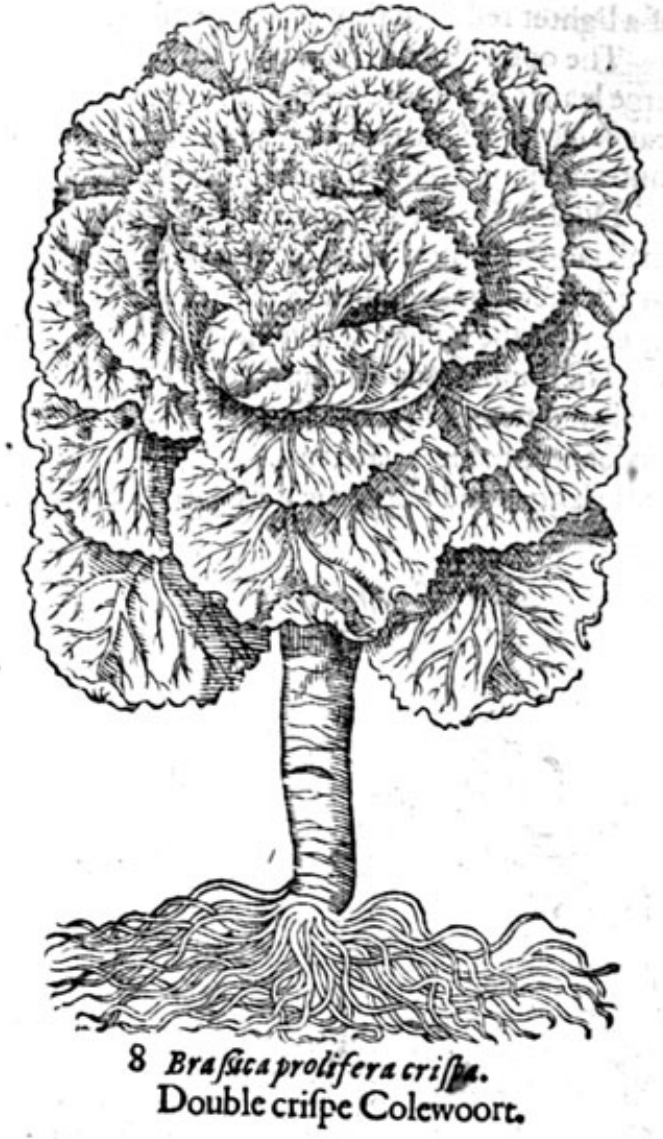

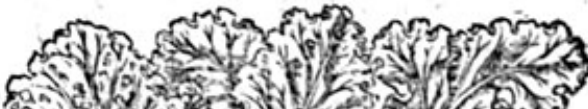

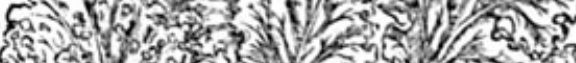
- I. 5 . I

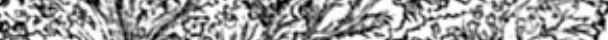

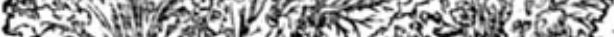

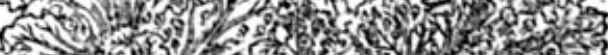
2 a 3 , Th 20 (1)

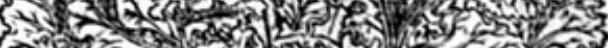

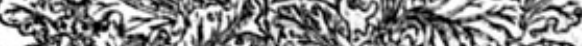

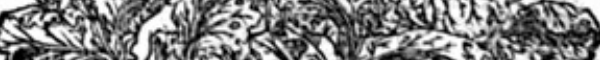

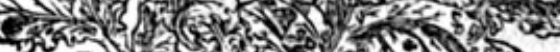

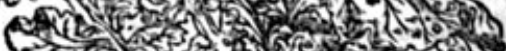
an

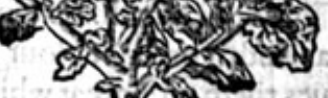

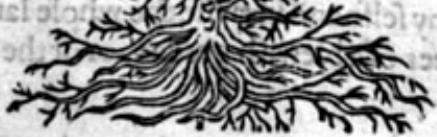


5 There is another fort of Cabbage or loued Colewoort, which hath his leaues wrapped togither into a rounde head or globe, yet leffer then that of the white Cabbage, and the colour of the leaues of a lighter red then thofe of the former.

6 The open loued Colewoort hath a very great hard or woodie ftalke, whereupon do grow verie large leaues of a white greene colour, and fet with thicke white ribbes, and gathereth the reft of the leaues clofely togither, which be leffer then thofe next the grounde; yet when it commeth to the fhutting vp or clofing togither, it rather dilateth it felfe abroade then clofeth al togither.

7 Double Colewoort hath many great \& large leaues, wherupon do grow heere and there other finall iagged leaues, as it were made of ragg ed hhreds and iagges fet vpon the fmooth leafe, which gitieth thewe of a plume or fanne of feathers. In ftalke, roote, and euery other part befides it doth agree with the garden Colewoort.

8 The double crifpe or curled Colewoort agreeth with the laft before defcribed in euery refpet, onely it differeth in the leaues, which are fo intricately curled,and fo thick fet ouer with other fmall cupleaues, that it is hard to fee any part of the leafe it felfe, except yee take and put afide fome of thofę iagges and ragged leaues with your hande.
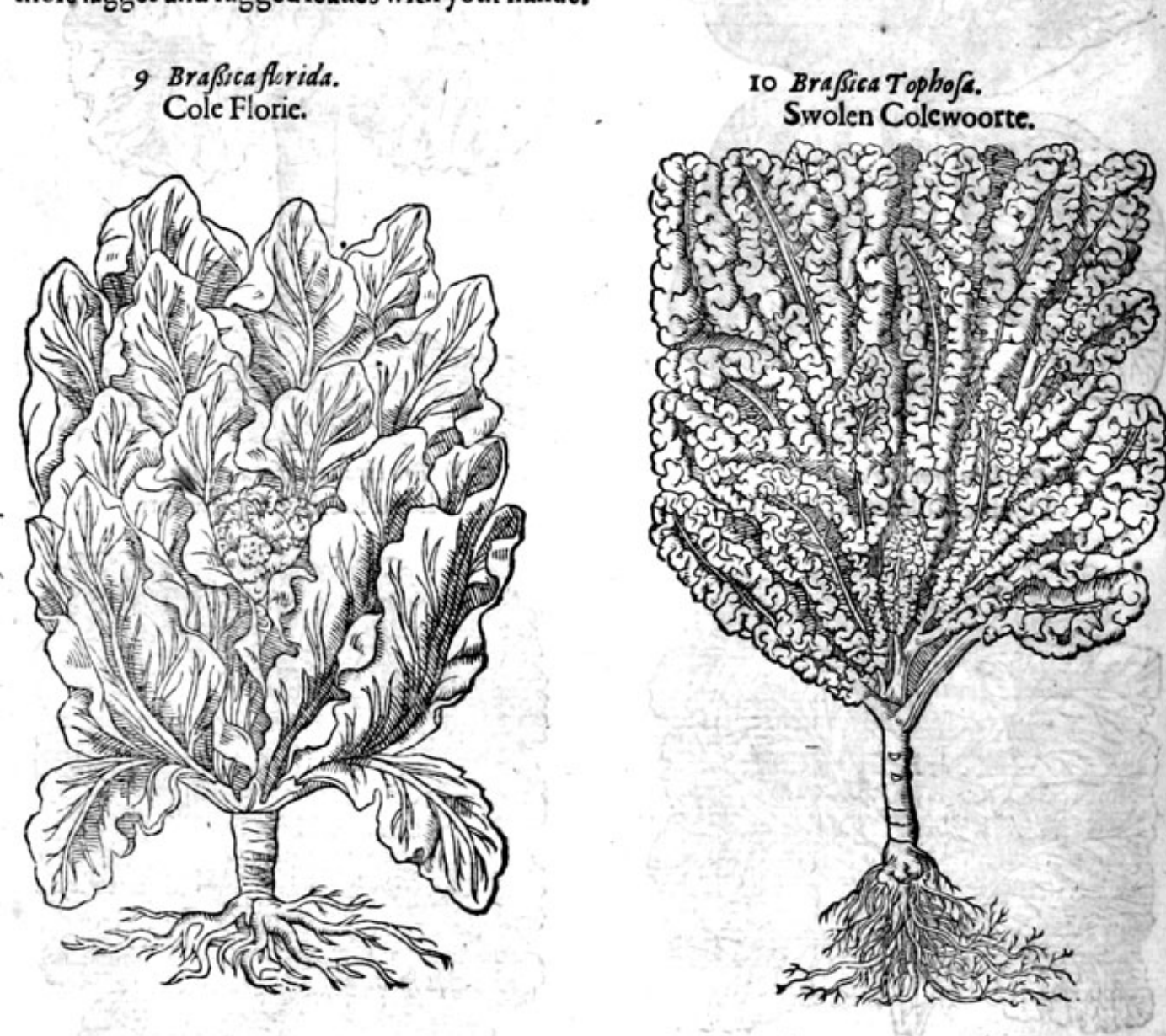

9 Cole Florie, or after fome Colieflorie, hath many large leaues fleightly endented about the edges, of a whitifh greene colour, narrower and fharper pointed then Cabbage : in the middeft of which leaues rifeth vp a great white head of hard flowers clofely thruft togither, with a roote full of ftrings; in other parts like vnto the Colewoorts.

10 The fwolen Colewoort of al other is the ftraigeft, which I reseiued frô a worhipfull marchant of Londõ mafter 2 icholas Lete, who brought the feeds therof cut of Fraunce; who is greatly in loue with rare and faire flowers and plants, for which he doth carcfully fend into Syria, hauing a feruant there at Alepo and in many other countries, for the which my felfe and likewife the whole lande are much bound vnto. This goodly Colewoort hath many leaues of a blewifh greene, or of the colour 
of Woade, bunched or fwollen vp about the edges as it were a peece of leatherwet and broiled on 2 gridiron, in fuch ftrange fort that I cannot with words defcribe it to the ful. The flowers grow at the top of the ftalkes of a bleake yellowe colour. The roote is thicke and ftrong like to the other kindec of Colewoorts.

II Brajsca Sabauda. Sauoie Cole.

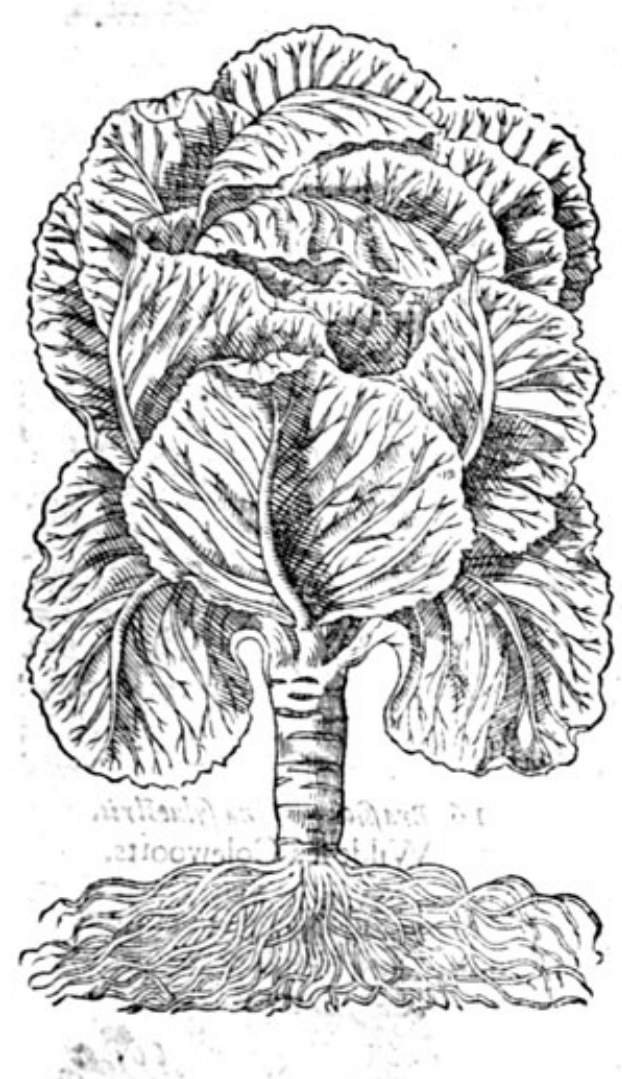

12 Braßsica Sabauda cri/pa. Curled Sauoic Cole.

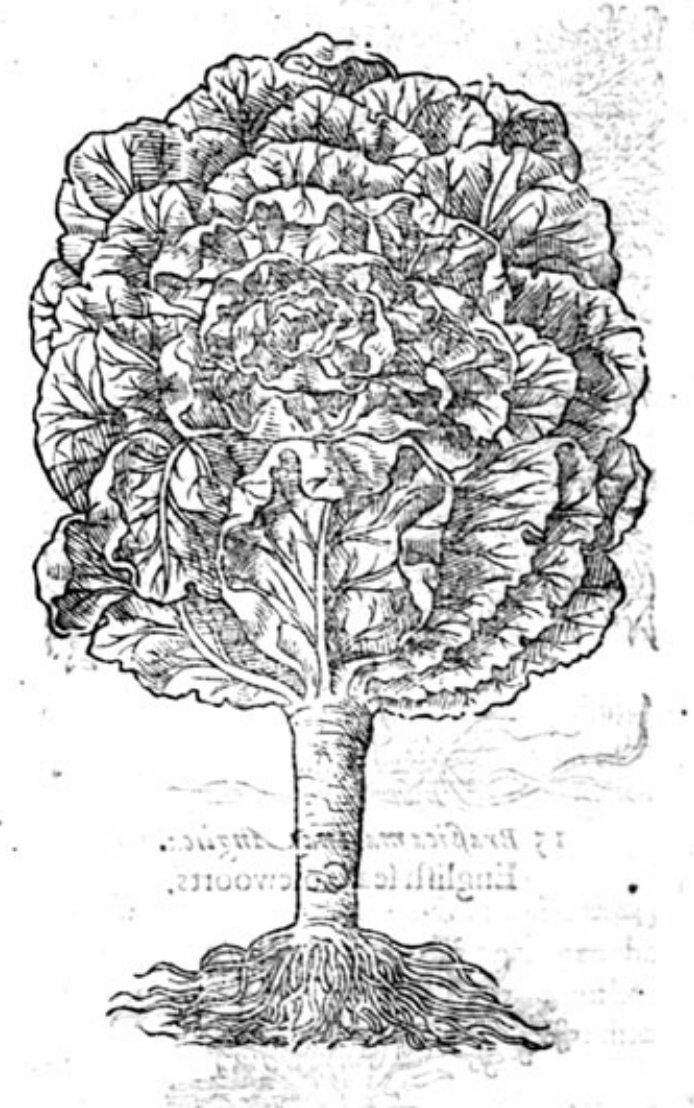

II Sauoic Cole is alfo numbred among the headed Colewoorts or Cabbages. The leaues are great and large verie like to thofe of the great Cabbage, which tume themifelues, vpwatdes as though they woulde embrace one another to make a loned Cabbage, butwhen they come to the Thutting vp they ftande at aftaie, and rather thewe themfelues wider open then fhut any neerer togither;in other refpects it is like vnto the Cabbage.

12. The curled Sauoie Colc in euery refpect is like the precedent, faving that the leaves heercof do fomwhat curle or crifpe about the middle of the plant: which plant if it beopened in the foring. time as oftentiues it is, it fendeth foorth braunched ftalkes with many fmall white flowers at the top, which being paft there followelong cods and feede like the common or firft kindedefcribed. 13. This kinde of Colewoort hath verie large leaues deepely iagged euen to the middle ribbe, in face refembling great and ranke perfley. It hath a great andthicke falke of three cubites high, whereupon do growe flowers, cods and 3 eede like the other Colewoorts. 14. The fruall cur Colewoort hath very large leaues woonderfully cut, hackt and hewen euen to not common nor hath notbeene knowen nor defcribed vntill this time) very well agreeing with thelaft beforementioned, but differeth in the curious cutcing and iagging of the leaues, in ftalke,
flowers and feede not vnlike. 


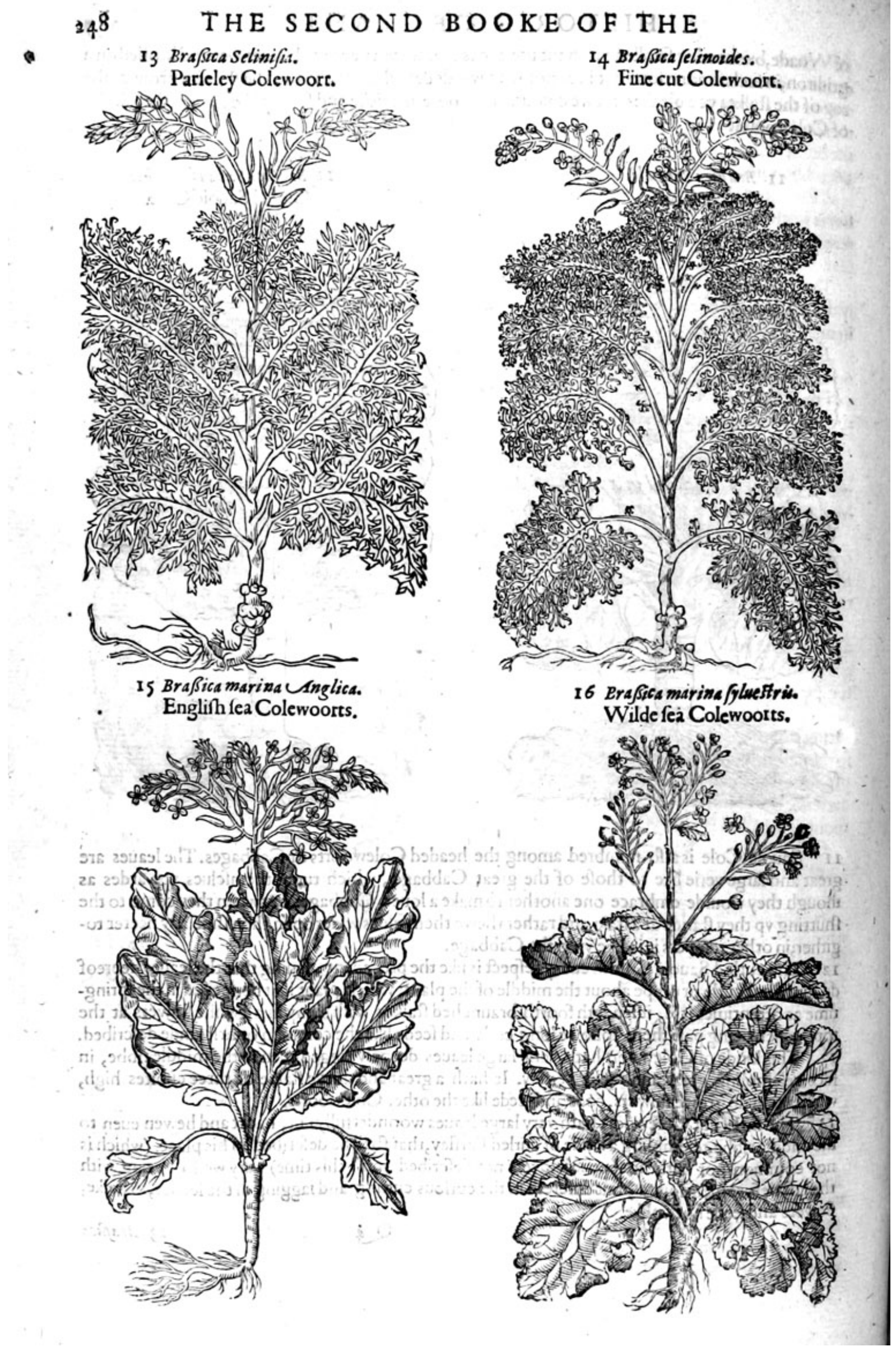


15 Sea Colewoort hath large and broade leates very thicke and curled, and fobrittle that they cannot be handled without breaking, of a deepe ouerworne greene colour tending to graineffe: among which rife vp ftalkes two cubits high, bearing fmall pale tlowers at the top, which being paft therc follow rounde knobs wherein is conteined one round feede and no more, blacke of colour, of the bigneffe of a tare or fetch.

I6 The wilde Colewoort hath long broad leaues not vnlike to the tame Colewoort, but leffer;as is all the reft of the plant, and is of his owne nature wilde, and therefore not fought after as a meate: but is fowen and husbanded vpon ditch bankes and fuch like places for the feede fake, by which oftentimes great gaine is gotten.

$$
\text { * The place. }
$$

The greateft fort of Colewoorts do grow in gardens, \& do loue a foile which is fat and throughly dunged $\&$ well manured: they dobeft profper when they be remooued, and euery of them grow in our Englifh gardens except the wilde, which groweth in ficldes and newe digged ditch banks.

The fea Colewoort groweth naturally vpon the bay he and brimmes of the fea, where there is noearth to be feene, but fande and rowling pebble ftones, which thofe that dwell neere the fea do call Bayche. I founde it growing betweene Whytitable and the lle of Thanet neere the brincke of the fea, and in many places neere to Colchefter and elfewhere by the fea fide.

\section{$*$ The time.}

Petres Crefentiws faith that the Colewoort may be fowen \& remooued at any time of the yeere; whofe opinion I altogither miflike. It is fowen in the fpring, as March, Aprill, and oftentimes in Maie, and fometimes in Auguft, but the efpeciall time is about the beginning of September,

The Colewoort, faith Coliomella, muft be remoued when it hath attained to fixe leaues after it is come vp from feede; the which muft be done in Aprill or Maie, efpecially thofe that were fowen in Autumne, which afterwarde flourifh in the winter moneths, atwhat time they are fitteft for meate.

But the Sauoie Cole, and the Cole florey muft befowen in Aprill in a bed of hot horfedung, and couered with ftrawe or fuch like, to keepe it from the cold \& froftie mornings; and when it hath gotten fixe leaues after thisfort, then fhall you remoouc him as a forefaid, otherwife if you tarrie for temperate wcather before you fowe, the yeere will be fpent before it come to ripeneffe.

$$
\text { * The nomes. }
$$

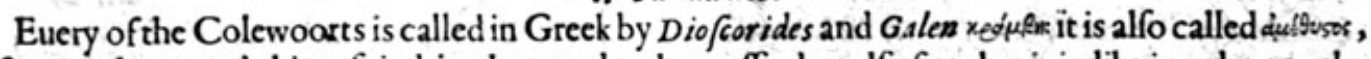
fo named, not onely bicaufe it driueth away drunkenneffe, but alfo for that it is like in colour to the pretious ftone called the Amethylt, which is ment by the firft or garden Colewoort. The Apothecaries \& the common Herbariftes do call it Caulis, of the goodneffe of the ftalke: in the Germaine toong it is called lsoole kraut : in French des Choux : in Englifh Coleworts.

Coleflorey is called in Latine Braßsca Cypria, and Caulifhra : in Italian Caulifore: it feemeth to agreewith Braßsea Pompeiams of Plinie, whereof he writeth in his 19. booke and 8. chapter.

$$
\text { * The temperature. }
$$

All the Colewoorts haue a drying and binding facultie, with a certaine nitrous or falt qualitie, whereby it mightily clenfeth, either in the iuice or in the broth therof. The whole fubitaunceor bodie of the Colewoort is of a binding and drieng facultic, bicaufe it leaucth in the decoction this falt qualitie which lieth in the iuice and waterie part thereof; the water wherein it is firt boiled - draweth to itfelfe all that qualitie; for which caufe the decoetion thereof loofeth the belly, as doth . alfo the iujce of it if it be drunke: but if the firft broth in which it was boiled be caft away, then doth the Colewoort dric and binde the belly. But it yeeldeth to the bodie fmall nourifhment, and doth not ingender good blood, bura grofle and Melancholicke. The white Cabbage is beft next into the Cole-flourey; yei Cato doth chiefly commend the ruffed Cole, buthe knewe neither the white ones, northe Colc-flourey: for if he had, his cenfure bad beene otherwife.

$$
\text { * The vertues. }
$$

Digfcorides teacheth that the Colewoort being eaten is good for them that have dimme cies, A and that are troubled with the fhaking palfie.

The fame author affirmeth, that if it be boiled and eaten with vineger it is a remedie for thofe $B$ that be troubled with the fplecte.

It is reported that the rawe Colewoort being eaten before meate, doth preferue a man from $\mathbf{C}$ drunkenneffe, the reafon is yeelded, for that there is a naturall enmitie betweene it and the vine: which 
which is fuch as if it growe neere vnto it, foorthwith the vine perifheth and withereth away: yea, if wine be poured vnto it whileft it is in boiling, it will not be any more boiled, and the colour thereof quite altered; as Cafsus and Diony/ius Vticen/is do writain their bookes of tillage: yet doth not Atheneus afcribe that vertue of driuing away drunkenneffe to the leaues, but to the fecdes of Colewoort.

D Moreouer the leaues of Colewoorts are good againft all inflamations and hot fwellings, being ftamped with barley meale and laid vpon them with falt, and alfo breake carbuncles.

E The iuice of Colewoorts, as Diof cor ides writeth, being taken with flower deluce and niter, doth make the bellie foluble: and being drunke with wine it is a remedie againft the biting of venemous beafts.

F The fame being applied with the powder of Fenugreeke, taketh away the paine of the gout :and alfo cureth olde and foule vlcers.

$G$ Being conueied into the nofthrils it purgeth the head: being put vp with barley meale it bringeth downe the Howers.

H Pliny writeth, that the iuice mixed with wine and dropped into the eares is a remedie againft deafeneffe.

I The feede as $G_{a}$ len faith, driueth foorth woormes, taketh away freckles of the face, funburning, and what things foeuer that neede to be gently fcoured or clenfed away.

$K$ They fay that the broth wherein the herbe hath beene fodden, is marueilous good for the finewes and ioints,and likewife for cankers in the eies called in Greeke Carcinomata, which cannot be healed by any other meanes, if they be wafhed therewith.

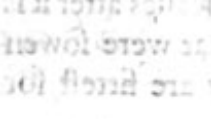

\section{Of Rape Cole. Chap.37.}

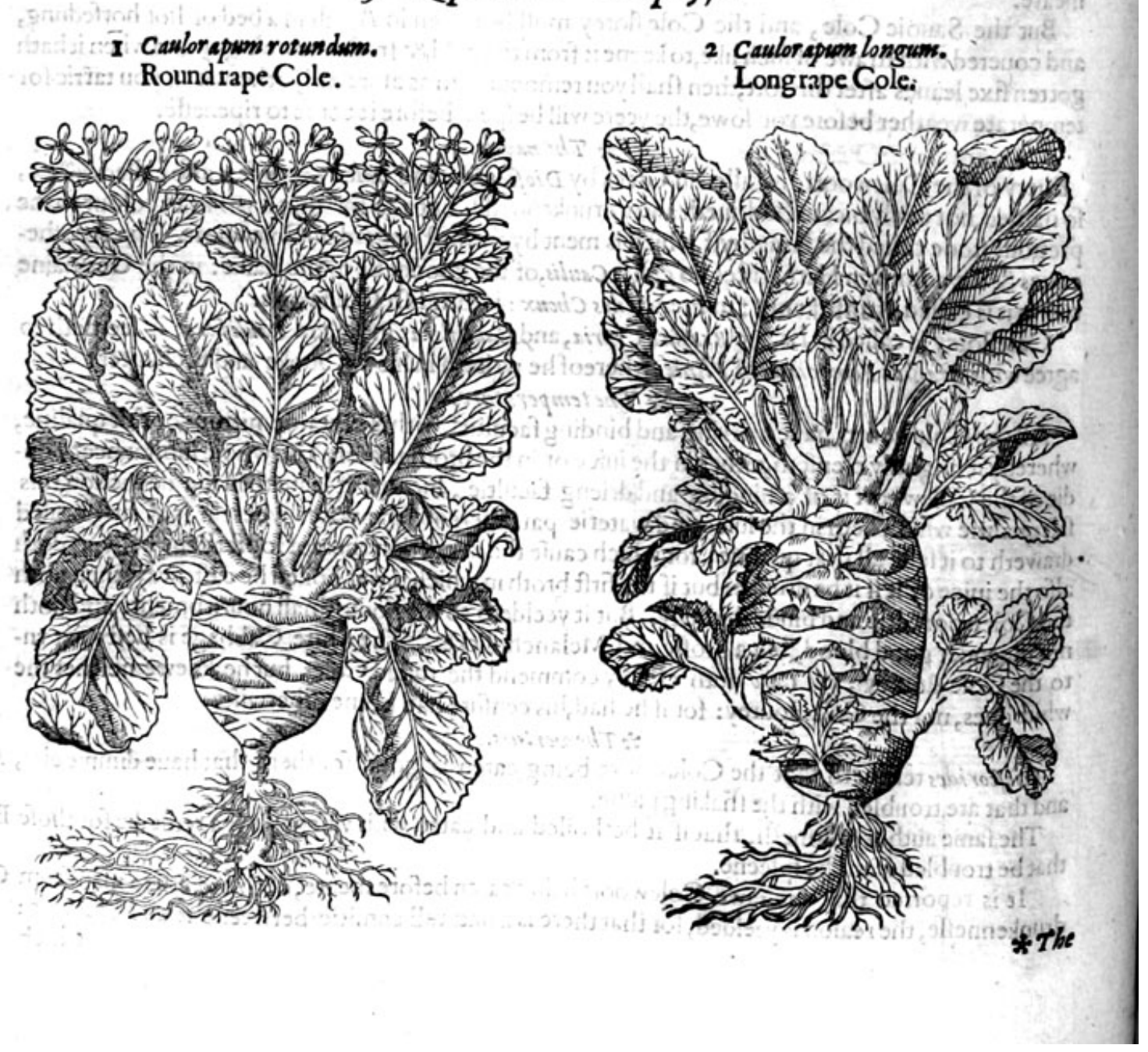


* The defeription.

frings : from which rifeth vp a great thicke ftalke bigger then a great Cucumber or great
Turnep: at the top whereof fhooteth foorth gteat broade leaues like vnto thofe of Cabbage Cole. The flowers grow at the top on flender ftalkes compact of fower fmall yellow flowers; which bcing paft the feede followeth inclofed in little long cods like the feede of Muftarde.

3 The fecond hath a long fibrous roote like vnto the precedent; the tuberous ftalke is very great and long, thrufting foorth in fome fewe places heere and there, fmall footeftalkes; whereupon doe growe fmooth leaues, flightly indented about the edges; on the top of the long Turnep ftalk growc leaneftalkes and flowers like the former.

* Thepiace.

They growe in Italy, Spaine,and fome places of Germanic, from whence I haue receiued feedes for my garden, as alfo from an honeft and curious friende of mine called mafter Goodman at the Minories neere London.

\section{* The time.}

They flower and flourifh when the other Colcwoorts do, whereof no doubt they are kinds, and muft be carefully fet and fowen as muske Melons and Cucumbers are.

* The numes.

They are called in Latine Cauloraprom, \& Rapocsulis, bearing for their ftalkes as it were Rapes or Turneps,participating of twoplants, the Colewoort and Turnep; whereof they tooke their names. * The temperature and vertues.

There is nothing fet downe of the faculties of thefe plants, but are accounted for daintie meate; contending with the $\mathrm{Cabbage}$ Cole in goodneffe and pleafant tafte.

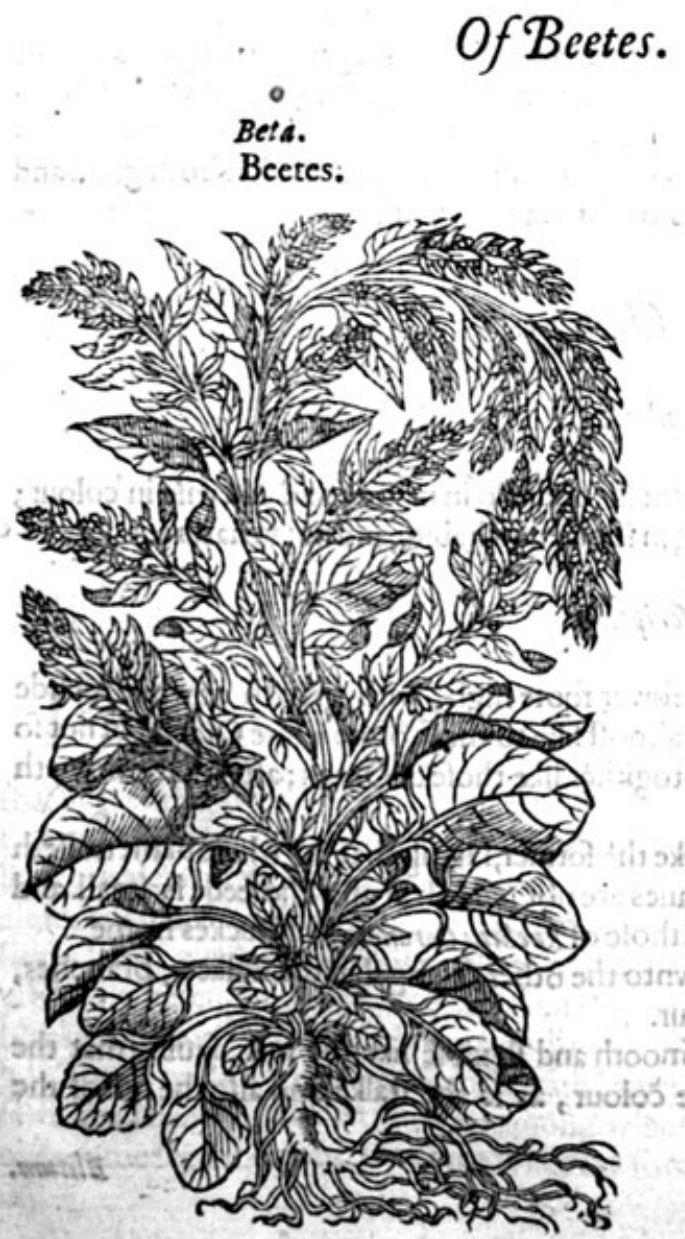

Chap.38.

* The defaription.

I. He common white Beete hath great broade leaues, fmooth and plaine : from which rife thicke crefted or chamfered ftalks. The flowers grow along the ftalkes cluftering togither, in fhape like litele ftarres, which being paft, there fuccedeth rounde and vneeuen pricklie feede. The roote is thicke,hard and great. 2 There is another fort like in thape and proportion to the former, fauing that the leaues of this be ftraked heere and there confuledly, which fetreth foorth the difference.

3 There is likewife another fort heereof that was brought vnto me from beyonde the feas by . that courteous merchant mafter Lete before remeribred, the which hath leaues very great and red of colotir, as is all the reft of the plant, as well roote as it alkes and flowers, full of a perfect purple iuice tending to redneffe: the middle ribbe of which leaues are for the moft part yeric broad and thicke, like the middle part of the Cabbage leafe, which is equall in goodneffe with theleatcs of Cabbage being boiled. If grew with me 1596 : torhe height of fiuj. cubites and did bring foorth his rough and vneeuen feede very plentifully: with which plant nature dothfeeme to plaie and 


\section{2 \\ THE SECOND BOOKE OF THE}

fport hirfelfe: for the feedes taken from that plant which was altogither of one colour and fowen, doth bring foorth plants of many and variable colours, as the worfhipfull gentleman mafter John Nor den can very well teftifie, vnto whom I gaue fome of the feedes aforefaid, which in his garden brought foorth many other of beautifull colours.

$$
\text { * Theplace. }
$$

The Beete is fowen in gardens:it loueth to growe in a moift and fertill grounde.

$$
\text { * The time. }
$$

The fitteft time to fowe it is in the fpring: it flourifheth and is greene all fommer long, and likewife in the winter, and bringeth foorth his feede the next yeere following.

$$
\text { * The names. }
$$

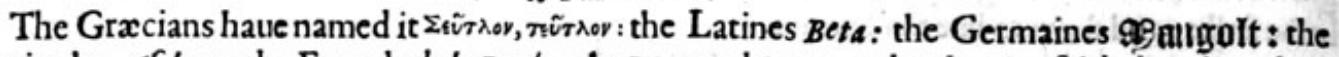
Spaniards Afelgas : the French de la Porée, des Iutes, and Betes: Theophrast ws faith that the white Beete is furnamed mxerkxi, that is to faie Sicula, or of Sicilia: heereof commeth the name Sicla, by which the Barbarians and moft of the apothecaries do call the Beete, the which worde we in Englande do vfe, taken from the fame.

\section{* The nature.}

The white Beets are in moifture and heate temperate, but the other kinds are drie, and al of them abfterfiue: fo that the white Beete is a colde \& moift pothearbe, which hath ioined with it a certain falt and nitrous qualitie, by reafon whereof it clenfeth and draweth flegme out of the nofthrils.

$$
\text { * The vertwes. }
$$

A Being eaten when it is boiled, it quickly defcendeth, loofeth the bellie,\& prouoketh to the ftoole, efpecially being taken with the broth wherein it was fodden: it nourifheth little or nothing, and is not fo holfome as Lettuce.

B The iuice conueicd vp in the nofthrils, doth gently drawe foorth flegine, and purgeth the head.

C The great and beautifull Beete laft defcribed may be vfed in winter for 2 fallade herbe with vineger, oile, and falt, and is not onely pleafant to the tafte, but alfo delightfull to the eie.

D The great red Beete or Romaine Beete boiled and eaten with oile, vineger and pepper is a moft excellent and delicate fallade : but what might be made of the red and beautifull roore (which is to be preferred before the leaues, as well in beautic as in goodneffe) I referre vnto the curious and cun ning cooke, who no doubt when he hath had the view therof, and is affured that it is both good and holfome, will make thereof many and diuers difhes both faire and good.

\section{OfBlytes. Chap.39. \\ * The kindes.}

$T$ Here be many forts of Blites differing in greatneffe and alfo in name, and likewife in colour; and yet one and of the felfe fame kinde, fauing in thewe and habite, and not in nature.

\section{* T Te defcription.}

I Te great white Blite groweth three or fower foote high, with grayilh or white rounde ftalks. The leaues are plaine and fmooth almoft like to thofe of the white Orach, but not fo foft nor mealie. The flowers grow thruft togither like thofe of Orach : after that commeth the feed inclofed in little rounde flat huskie skins.

2 There is likewife another in our gardens very like the former, fauing that the whole plant traileth vpon the ground. The ftalkes, braunches nor leaues are not reddifh at all. The feede is fmall and cluftering togither, greene of colour and like vnto thofe of Rwelliws Coronopus, or Buckes horne.

3 Therc is likewife found a thirde fort very like vnto the other, fauing that the ftalkes, branches, leaues, and the plant is altogither of a greene colour.

4. There is likewife a fourth fort of Blites very fmooth and flexible like the reft, fauing that the leaues are reddifh, mixed with a darke greene colour, as is the ftalke and alfo the reft of the
plant.

Blitum. 


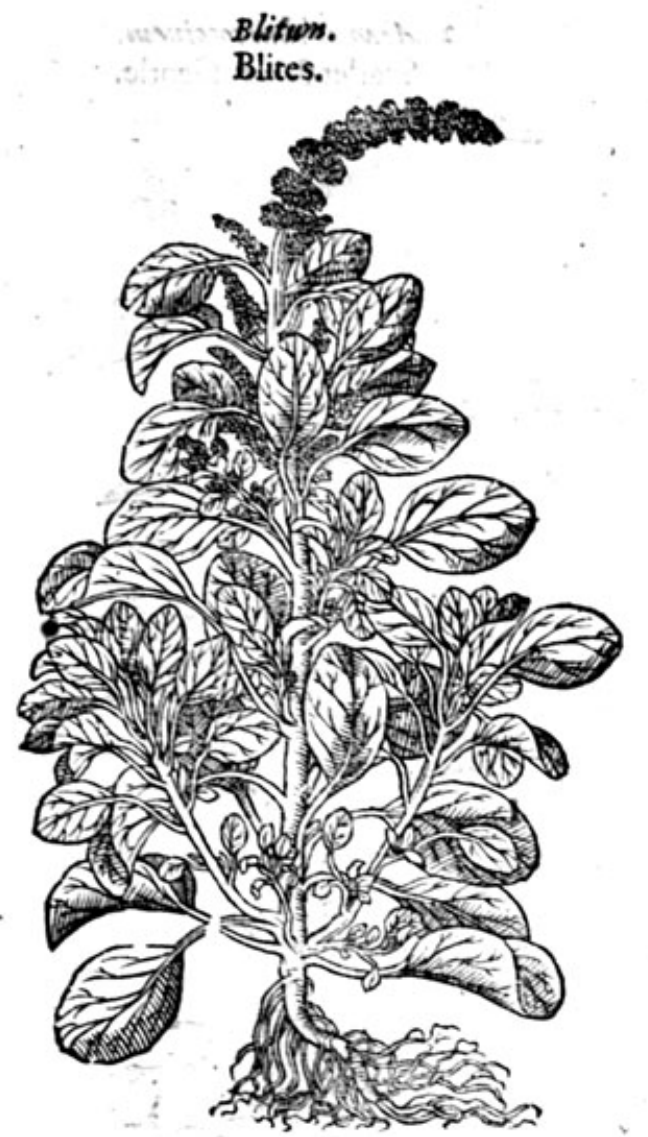

* The place.

The Blites grow in gardens for the moft part, although there be founde of them wilde manie times.

\section{* The time.}

They flourifh all the fommer long, and growe verie greene in winter likewife.

$$
\text { * T Te names. }
$$

It is called in Greeke Rnirrop: in Latine Blitum : in Englith Blite and Blites: in French Blites or Blitres: qudd fexpopuli ÿs vefcatur. * The nature.

The Blite faith Galen in his fixt booke of the faculties of fimple medicines is a potherbe, which ferueth for ineate, being of a colde \& moift temperature, and that chiefely in the feconde degrec. It yeeldeth to the body fmali nourihment, as in his fecond book of the faculties of nourithments he plainely theweth: for it is one of the potherbes that berisia, vnfauory or without tafte, whofe fubftance is waterifh. $*$ Thezertues.

The Blite doth nourifh litcle, and yet is fit to $A$ make the bellie foluble though not vehementlie, feeing it hath no nitrous or fharpe quality whereby the bellic fhoulde be prouoked. I hate heard many olde wiues faie to their feruants, gather no Blites to put into my pottage; for they are not good for the eie fight : whence they had thofe words I knowe not, it may be of fome doctor that neuer went tofchoole, for that I can finde no fuch thing vpon recorde, either ameng the olde or later writers.

\section{Offlower Gentle. Chapi4o.}

* The kindes.

Fere be diuers forts of lower Gentle, differing in many points very notablie, as in greatneffe and fmalneffe; fome purple, and others of a fcarlet colour; and one aboue the reft wherwith nature hath feemed to delight hirfelfe, ef peciallie in the leaues, which in variable colours doe ftriuc with the Parrats feathers for beaurie.

D Vipleflower Gentle rifcth $*$ The de/cription.

1 Viple flower Gentle rifcth vp with a ftalke a ctibite high, and fometime higher, ftraked or chamfred alongtt the fame, of ten reddifh towarde the roote and very fmooth: which detidech it felfe toward the top into finatl braunches, about which ftande long leaues, broade, fharpepointed, foft, flipperie, of a greene colour, and formtimes tending to a reddilh : in fteede of towers come vp eares or f pokic tufts, verie bruac to looke vpon, but without finell; of a fhining light purple with a gloffe like veluet, but farre paffing git, which when they are brufed do yeeld a iuice almolt of the like colour, \& being gathered do keepe their beautie a long time after, infomuch tirat being fet in water it will reuiuc againe/as at the time of his gathering, and remaineth fo many yeeres, whereupon likewrif it hath taken his name. The feede ftandeth in the ripocares, of colour blacke and much glittering:the roote is thort and full of ftrings.

2 The fecond fort of tower Gentle hath leaues like vnto the forner: the ftalke is vpright with a fewe fmall lender italks fet vpon it; among which do growe fmall clufters of faltey flowers, of an ouerworne fcarlet colour. The feede is like the former. 
I Aramantbus Parpuress. Purple flower Gentle.

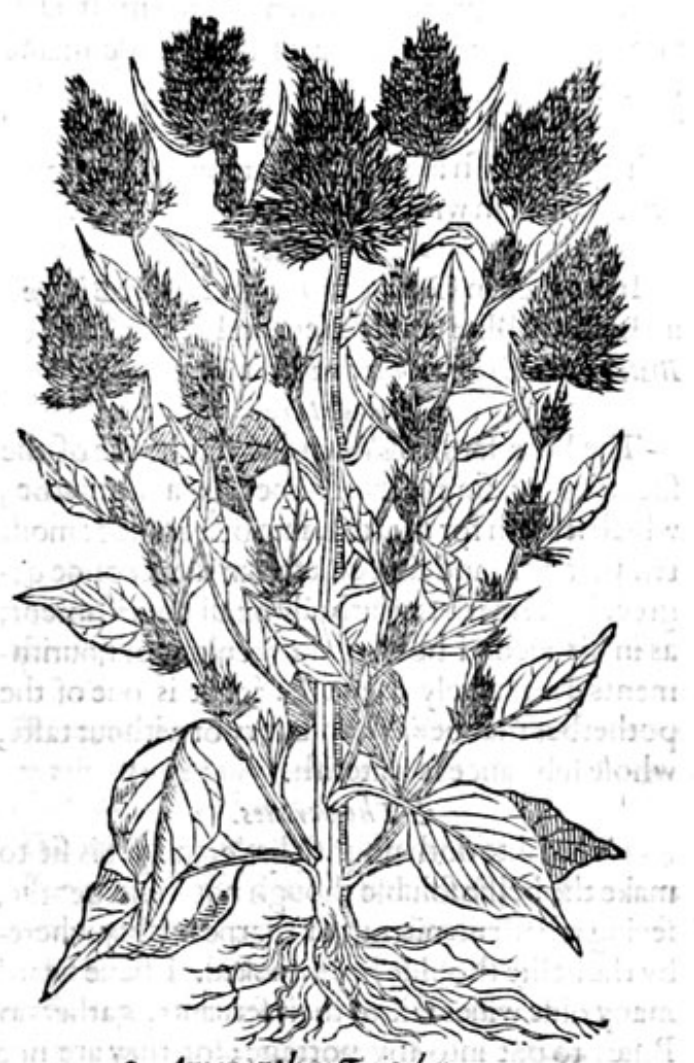

3 Amarintbus Tricolor.

Floramor and Paffeuelours.

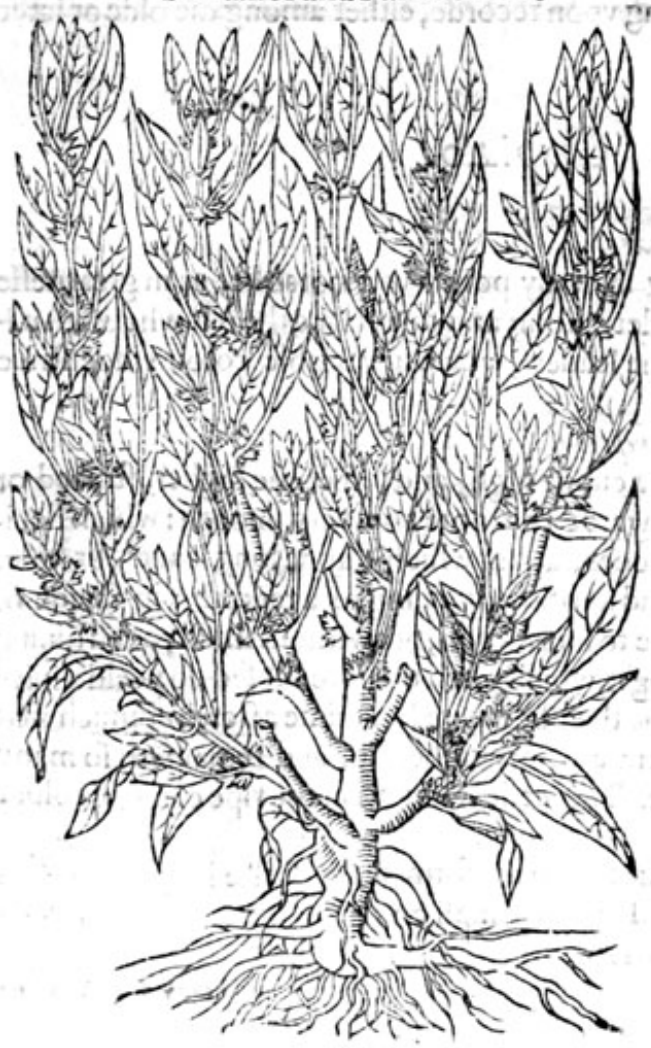

2 Aronarthwicoccinew. Scarlet flower Gentle.

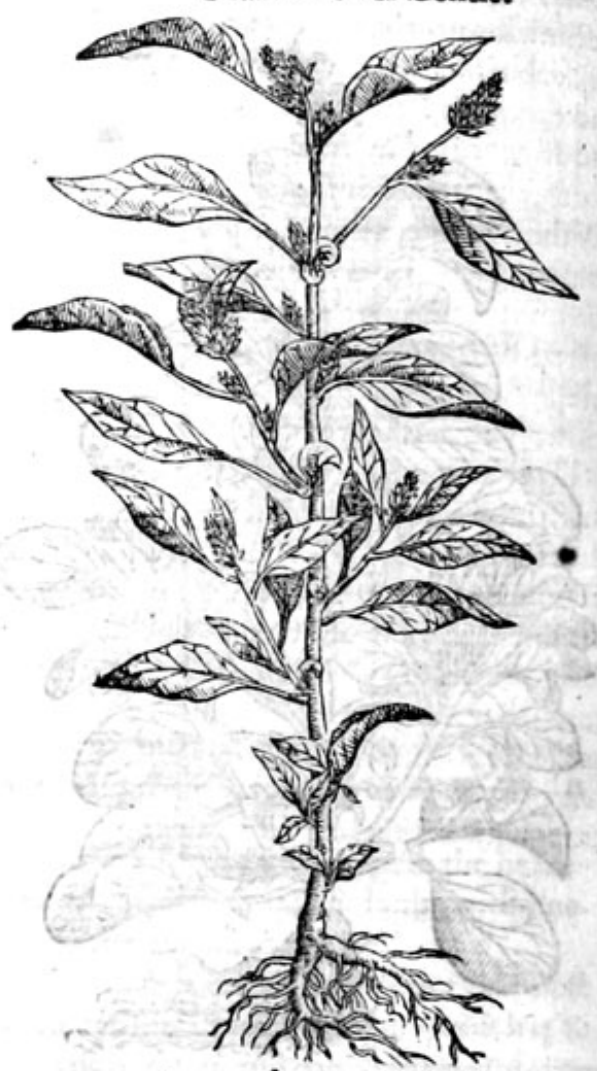

4 Aramanthus Pannicula ßparfa. Branched flower Gentle.

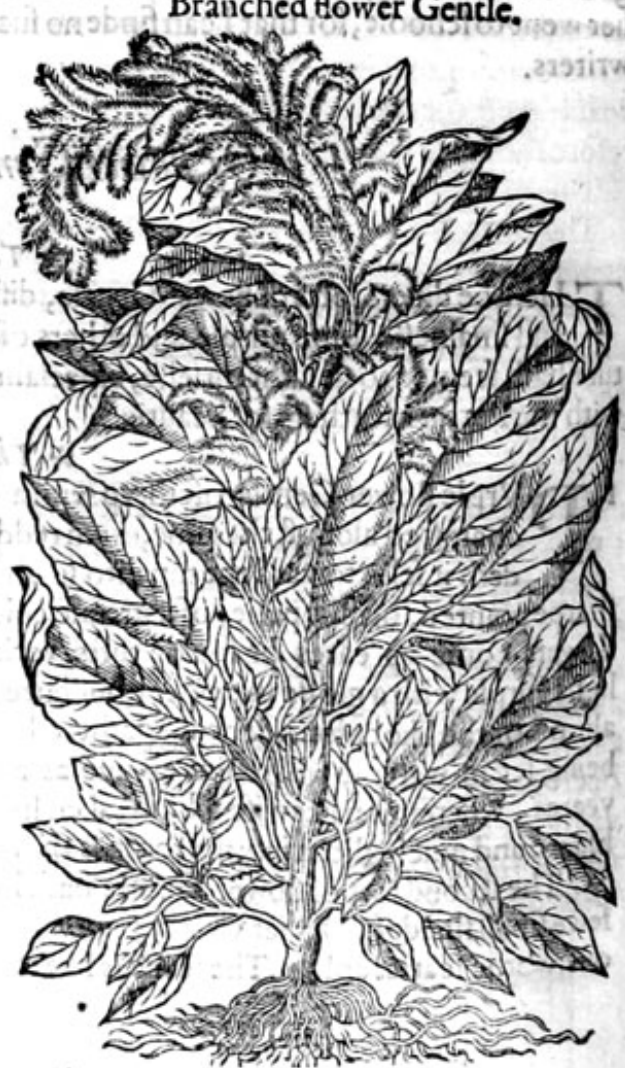


3 It farre exceedeth my skil to defcribe the beautic and excellencie of this rare plant calked Fioramore; and Ithinke the penfill of themoft cutious painter will be at a ftaie when he fhall come to fet him downe in his liuely co.'ours: but to colour it after my beft maner this I faie. Floramor hath 2 thicke knobbie roote, whereupon do growe many threddie ftrings: from which rifeth vp a thicke ftalke, but tender and foft, which beginneth to deuide himfelfe into fundry branches at the ground and fo upwarde 3 ' whereupon do growe many leaves wherein dothćonfilt his beautie : for in féwe words, every leafe doth refemble in colours the moft faire and beautifull feather of a Parrat, elpecially thofe feathers that are mixed with moft fundrie colours, as a ftripe of red, and a line of yellow; 2 dafhe of white, and a ribbe of gicene colour, which I cannot with words fet foorth, fuch is the fundrie mixtures of colours that nature hath beftowed in hir greateft iollitie vpon this flower : the flowers do growe betweene the footeftalkes of thofe leaues, and the bodie of the ftalke or trunke bafe, and ofnomoment in refpect of the leaues, being as it were little chaftie husks of an ouerworn tawnie colour : the feede is blacke, and fhining like burnifhed horne.

4 This plant hath a great many of threddes or ftrings, of which his rootes do confift, From which do rife vp very thicke, fat, and oileous ftalkes, crefted and ftraked, exceeding fmooth and of a fhining red colour, which beginne at the grounde to diuide themfeluesinto braunches: whéreupon do growe many great and lárge leaues of a darke greenecolour tending to redneffe, in hewe like thofe of the red Beete, ftraked and dafht heere and there with red, mixed with greene. The flowers growe alongt the ftalkes, from the middeft there of euen to the top, in fhape like $P_{A}$ : nicum, that is, a great number of chaffie confufed matter thruft harde togither, of a deepe purple co. lour. I can compare the thape thereof to nothing fo fitly as to the veluet head of $2 \mathrm{Stagge}$, compatt of fuch fottmatter as is the fame: wherein is the feede, in colour white, rounde, and bored through the middle.

$$
\text { * The place. }
$$

Thefe pleafant flowers are fowen in gardens, efpecially for their great beautic.

\section{* The time.}

They flower in Auguft, and continue flowring til the froft doth ouertake them, at what time they perifh \& muft be fowen the next yeere again. But the Floramor would be fowen in a bed of hor horfdung with fome carch ftrowed thereon in the end of March, and focouered with mats or fuch like in the night and laid to the fun in the day time;otherwife the winter wil approch before it commeth to perfection, for that it is verv impatient ofour colde clymate. The right honorable the Lord Edward $Z$ ous be gaue me the feedes thereof, the which brought foorthrtheir pleafant leaues, but perifhed before the feede was ripe, which chaunced for want of this inftruction.

$$
\text { * The nomes. }
$$

This plant is called in Grecke of Plinie Auderrov, bicaufe it doth not wither or waxe olde : in Latine Amar ant hus pur poresus, that it may differ from Elichryfon, which is alfo called dudgerror, whereof we will entreat heereafter in his place : in high Dutch amatbluomen, Đaufenffboon, and Floramor, taken from fome thar haue called it $F$ los amorisin Italian Fior velluto: in French Paffe velowrs: Ruellsws tranflateth it Paffene lut wm : in Englifh flower Gentle, purple Veluet flower, Floramor,and of fome flower Velure.

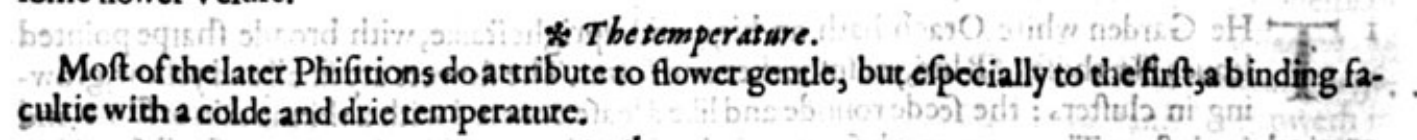

Moft of the later Phifitions do attribute to flower gentle, but efpecially to the firft,abinding fa-. cultie with a colde and drie temperature.

*The vertses.

It is reported they ftop all kindes of bleeding,which propertic is not made manifét by any-appa- $\mathbf{A}$ rant qualitie that is in thé, except peraduenture by the colour only that the red eares have: forfome are of opinion, that all red things do ftaunch bleeding inany part of the bodie: bickufe fotmethings . as Bole armoniacke, fanguis Draconos, terra Sigillata, and fuch like things of redcolont do ftop. bloud, But Galen in his fecond and fourth bookes of the faculties of fimples doth plainly fhewe, that there can be no certaintie gathered from the colours touching the vertues of fimple and compound me:dicines:wherefore in cornmon fence they are ill perfwaded that thinke the flower Gentle to ftaunch bleeding, ftop the laske and bloudie flixe bicaufe of the colour onely. 
Of Orach. Chap.4r. * The kindes.

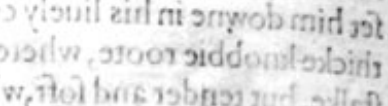

There be fundrie forts of Orach, fome white; fome of a reddifh or deepepurple colour; fome of the garden; and others wilde or of the fielde, and alfo one of thefea.

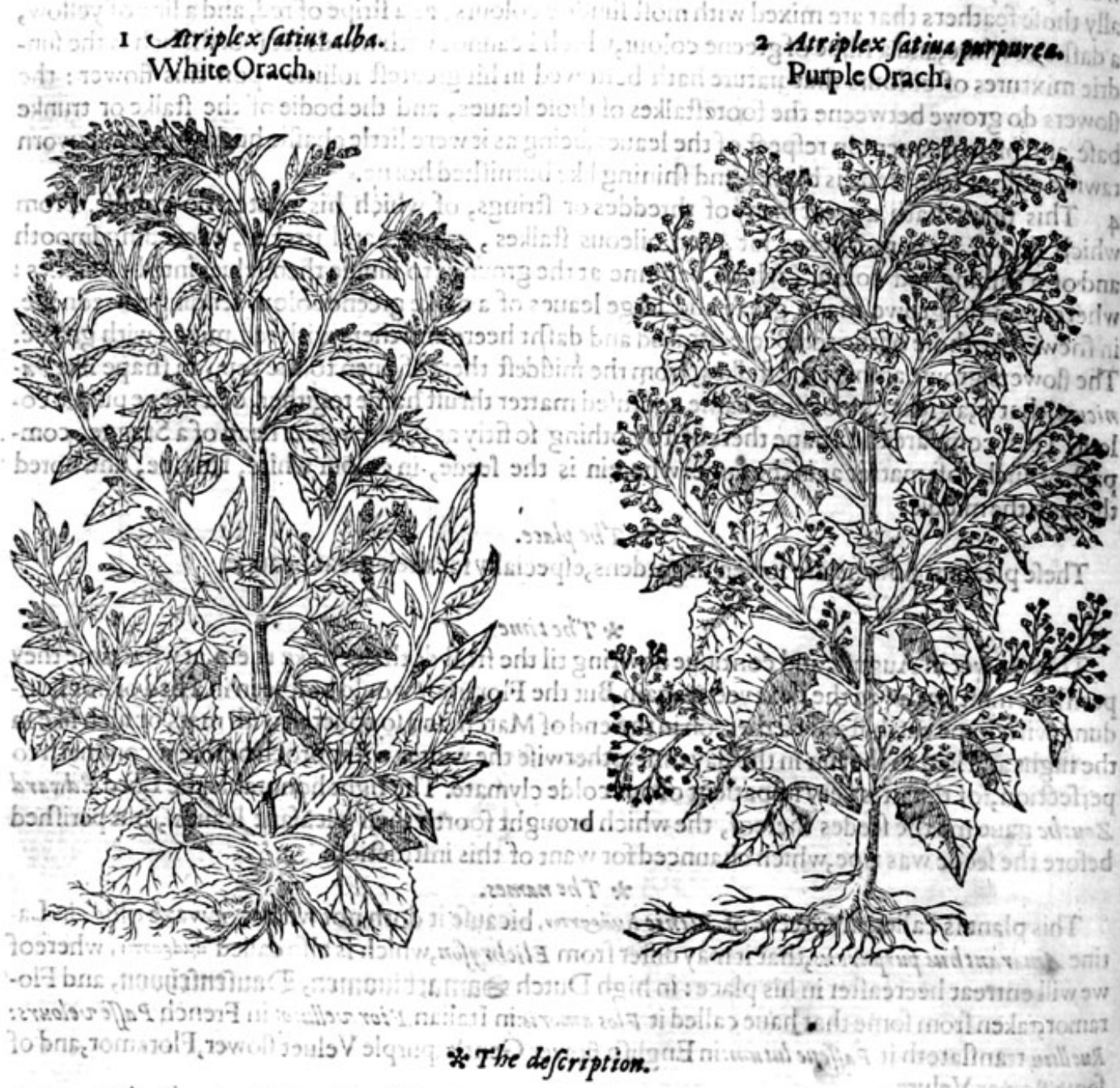

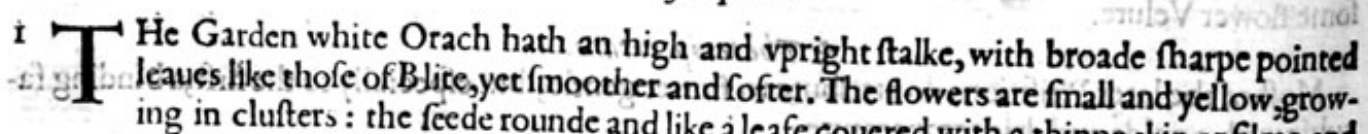
groweth in clufters. The roote goeth farre into the around couered with a thinne skin or filme, and The leaues and ftalkes at the firfte arre into the ground, vpon which hang many fmall threddes. meale or flowererises at the firft are of a glittering graie colour, and fprinckled as itwerewith 2 The fecond is like to the former, fauing that the whole plant tendeth to an ouerworne purplifh
colour, in euety other refpect alike.

3. The wilde Orach is like in fmoothneffe and fafhion of the leaues vnto the garden Orach. The

ftalkes and euery part thereof alfo are veric like, fauing it is altogither leffer.
4 There is founde a wilde kinde growing neere the fea coaft which bath long fmal narrow leaves,
flightly cut about the edges, barpe pointed, and couered ouer withe the whole plant 25 wedlles, tbarpe pointed, and couered ouer with a certaine mealineffe, fo that other fea plants.
ofell leaues as ftalkes and flowers, looke of an hoaric or graie colour, as domany 


\section{HISTORIE OF PLANTS. $I H T$}
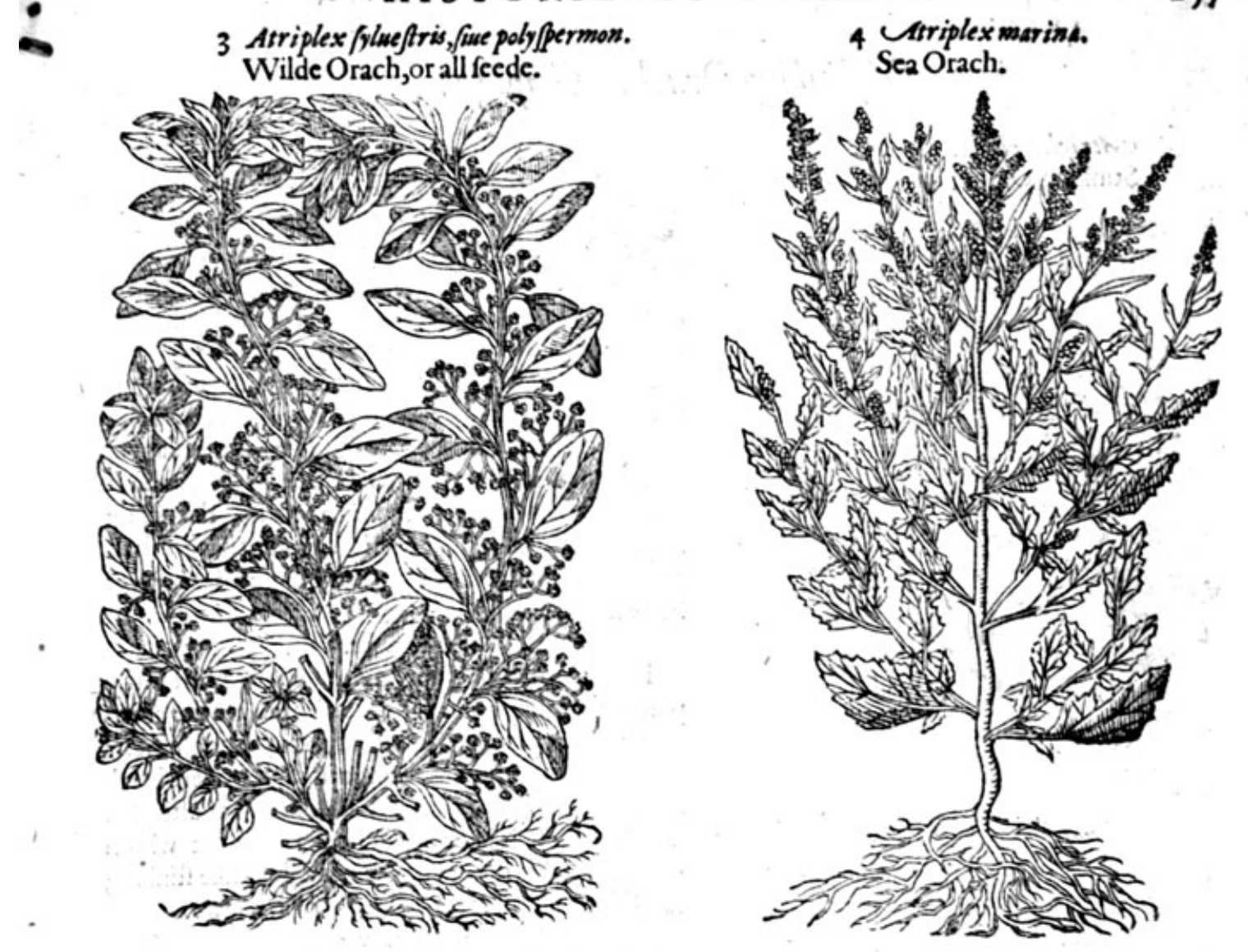

* The place.

The garden Orach doth growe in the moft fruitfull gardens.

The wilde Orach groweth neere vnto path waies by ditch fides, and in the borders of fields.

cMatt hioles reporteth that he found certaine Orach on the fea coaftes, ad Tergeffini falinas: the which I haue found in our owne countrey neere the fea fide betweene Rochefter \& Queenborough caftle, as alfo from Reculuers to Margate in the Ile of Thanet : it groweth by the blockhoufe of Tilberie, and the Fort in Kent by Grauefend right againft the fame place.

$$
\text { * The time. }
$$

They flower and feede from Iune to the end of Auguit.

* The names.

* The names. vereid: in French drrousbes on bonnes dames : in Englifh Orach and Orage: in the Bohemian toong Lebods: Plinje hath made fome difference betweene ciriplex and chryfolachamum, as though they differed one from another, for of Atriplex he writeth in his 20 booke: and of $C h r y / 6$. . lachanum in his 28,booke 8. chapter, where he writech this: Chryfolachanom Faith he groweth in Pinetum like Lettuçe : $i$ thealeth cut finewes if it be foorthwith applied.

The wilde Orach hath beene called Polyjpermon Ca/fani of L'Obelisw, or all feede. * The temperature.

Orach faith Galen is of temperature moift in the feconde degree, and colde in the firft. * The vertues.

Diofcorides writeth that the garden Orach is both moift and colde, and that it is eaten boiled as $\mathbf{A}$ other fallade herbes are, and that it foftneth and loofech the bellie.

It confumeth away the fwellings of the throate, whether it be laide on rawe or fodden.

The feede being drunke with meade or honied water, is a remedie againft the yellow iaunders. C

Galex thinketh that for that caufe it hath a clenfing qualitie, and may open the ftoppings of D the liner. 


\section{Offtinking Orach. Chap.42.}

Atriplex ollida.

Stinking Orach.

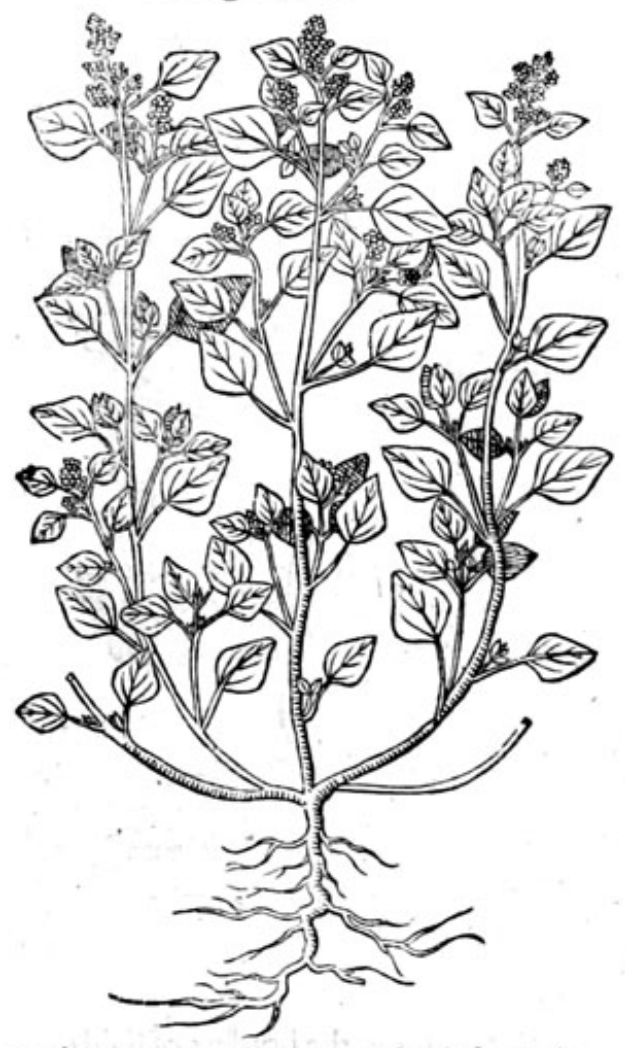

* The defription.

Tinking Orach groweth flat vpon the ground, and is a bafe and lowe plant with many weake and feeble braunches; whereupon do growe fmall leaues of a grayifh colour, fprinckled ouer with a certaine kinde of durtie mealineffe, in thape like the leaues of Bafill : among which leaues heere and there confufedly difperfed bee the feedes as it were nothing but duft or afhes. The whole plant is of a moft lothfome fauour or fmell, vpon which plant if any fhould chaunce to reft and fleepe, he might very well report to his friendes that he had repofed himfelfe amongt the chiefe of Scoggins heires.

$$
\text { * Theplace. }
$$

It groweth vpon dung hils and in the moft filthy places that may be founde, as alfo about the com. mon piffing places of great princes, \& noblemens houfes. Sometime it is founde in places neere brick kils and olde wals, which doth fomewhat alter his fmell, which is like toftedcheeffe: but that which groweth in his naturall place fmelleth like ftinking falt fifh, whereof it tooke his name Garofmus.

$$
\text { * The time }
$$

It is an herbe for 2 yeere, which fpringeth vp,and when thefeede is ripe it perifheth, and recouereth it felfe againe of his ownefeede, fo that if it be got* The names.

Stinking Orach is called of Cordus Garofmus, bicaufe it fmelleth like ftinking filh, which is called in Greeke veerv: it is likewife called Tragium Germanicum, and Atriplex faetida garum olens Pened L'Obely, for it fmelleth more ftinking then the rammilh male Goate, whereupon fome by a figure haue called it $V$ uluaris, and may be called in Englifh ftinking Motherwoort.

\section{* The nature and vertues.}

There hath beene little or nothing fet downe of the auncients either of his nature or vertues: notwithftanding it hath beene thought profitable by reafon of his ftinking finell for fuch as be troubled with the Mother: for as Hippocrates faith, when the Mother doth ftifle or ftrangle, fuch things are to be applied vnto the nofe as haue a rancke and ftinking fmell.

\section{Of Goofe-foote. Chap. 43 .}

\section{* The defcription.}

G Oofe-foote is a common herbe and thought to be a kinde of Orach: it rifeth vp with a ftalke a cubite high or higher, fomewhat chamfered and braunched: the leaues be broade, fmooth, tharpepointed, fhining, hauing certaine deepe cuts about the edges, \& refembling the foote of a Goofe. The flowers be fmall, fomething red, the feede ftandeth in clufters vponthe top of the branches, being very like to the feed of wilde Orach, $\&$ the roote is deuided into fundrie ftrings. 


\section{* Theplace.}

It groweth plentifully in obfcure places neere vnto olde walles and high waies, and in defert flaces.

* The time.

It flouritheth when the Orach doth, whereof this is a wilde kinde. $*$ The names.

The later Herbariftes haue called it Pes anferinus, of the likeneffe that the leaues haue with the foote of a Goofe:of fome Cbenopodiww: in Englinh Goofefoote and wilde Orach. * Thetemperature.

This herbe is colde and moift, and thatno leffer then Orach, but as it appeereth more colde. * The vertues.

It is reported that it killeth fwine if they do eate thereof: it is not vfed in Phyficke: and mach A Ieffe as a fallade herbe.

\section{Of Englifh Mercurie. Cbap. 44 .}

Bones Henricas.

Englifh Mercurie, or good Henrie.

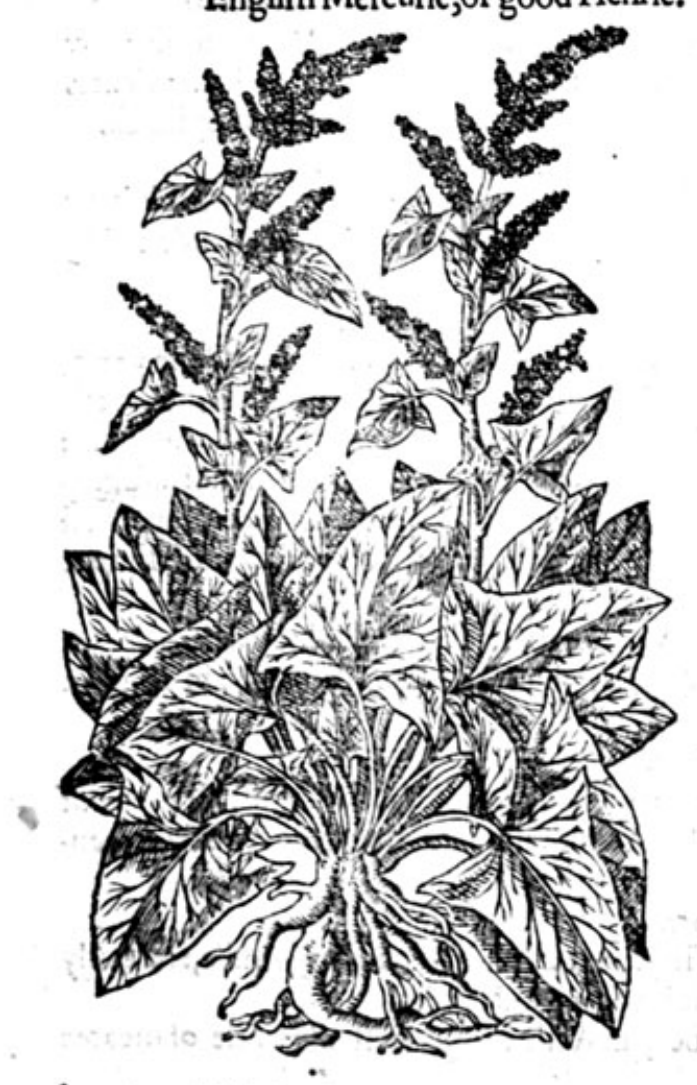

* The defcription.

Ood Henric called Tota bons, fo named of the later Herbarifts, is accounted of them to be ene of the Docks, butnotproperlic. This bringeth foorth very many thicke ftalkes, fet with leaues two foote high; on the braunches whereof towards the top ftande greene flowers in clufters, thicke thruft togither. The feede is flat like thofe of the Orach, where of this is a kinde. The leaues be faftned to long footeftalkes, broade behinde, and tharpe pointed, fafhioned like the leaues of Aron or Wake-robin, whi:e or grayifh of colour, and as it were couered ouer with a fine meale, in handling it is fat \&oleous, with a verie thicke roote, and parted into many deuifions, of 2 yellowe colour within, like the Tharpe pointed Docke.

$$
\text { * The place. }
$$

It is commonly founde in vntilled places, and among rubbith neere common waies, olde wals, and by hedges in ficldes.

$$
\text { * The time. }
$$

It flouritheth in Iune and Iuly efpecially. * The names.

It is called of fome Pes UAnferinus, and Tuta bo. $m s$ : in Englifh all Good, and Good Henire, in. Cambridge(hire it is called Good king Harry : the Germaines call it buter Deintick, of a certaine good qualitie it hath, as they alfo name a certaine pernicious herbe, Malius Henricus, or bad Henry. It is taken for a kinde of Mercuric, but vnproperly, for that it hath no participation with Mercurie, either in forme or qualitie, except yec wil call euery herbe Mercurie which hath power to loofe the bellie.

\section{* The temperature.}

Bomiu Henricws or good Henric is moderately hot and drie, clenfing and fcouring with all.

$* T$ he vertwes.
The leaues boiled with other potherbes and eaten, maketh the bodie foluble.

The fame brufed and laid vpon green wounds or foule \&cold vlcers, doth feoure, mundifie \& heale $\hat{B}$ them. 


\section{Of Spinach. Chap.45.}

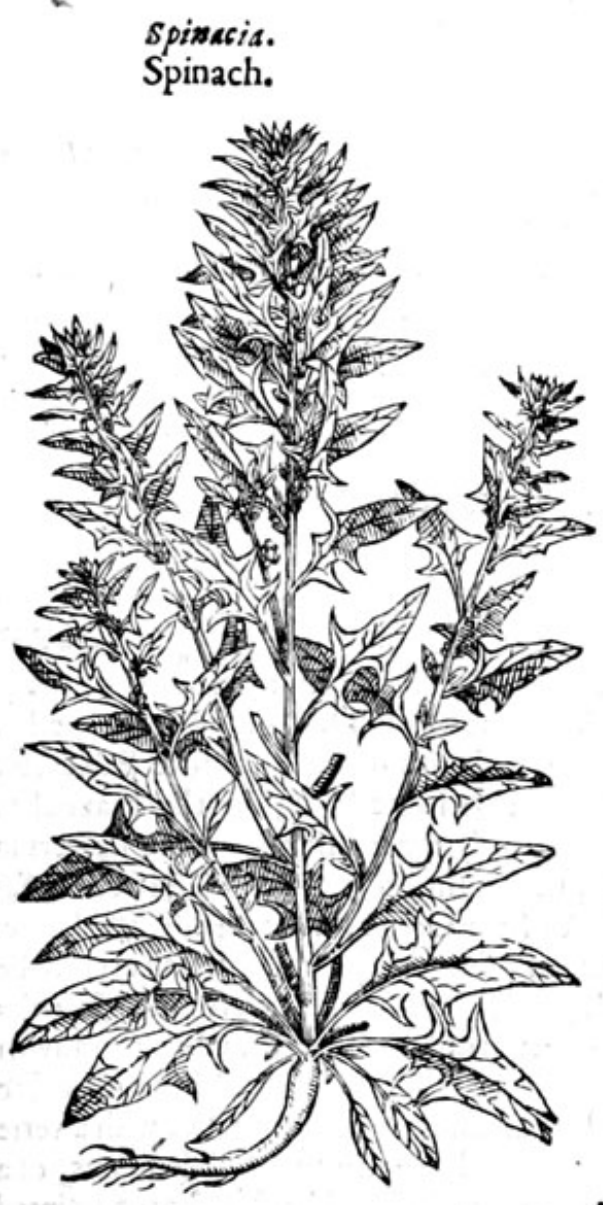

It is called in thefe daies Spinachis, of fome Spenaches. 1 Pinach is a kind of Blite after fome, notwith $\checkmark$ ftanding I rather take it for a kind of Orach. It bringeth foorth foft and tender leatues of 2 darke greene colour, full of iuice, fharpe pointed, and in the largeft part, or neather end fquare; parted oftentimes with a deepe garh on either fide; next to the ftemme or foote ftalke:the ftalke is rounde, a foote high, hollowe within : on the tops of the braunches ftande little flowers in clufters, in whofe places doth growe a prickly feede. The roote confifteth of many fimall threds.

2 There is another fort found in our gardens like vnto the former in goodneffe, as alfo in fhape, $f_{2}$. uing that the leaues are not fo great nor fo deepely gafht or indented: and the feede hath noprickels at all, for which caufe it is called round Spinach.

$$
\text { * The place. }
$$

It is fowen in gardens without any great labour or induftrie, and forfaketh not any grounde being but indifferent fertill.

$$
\text { * The time. }
$$

It may be fowen almoft at any time of the yeere; but being fowen in the fpring it quickly groweth vp;i commeth to perfection within two moneths: but that which is fowen in the fall of the leafe groweth not fo foone to perfection, yet continueth all winter and feedeth prefently vpon the firft fpring. nameth is $\Sigma$ mraj $j^{\alpha}$ : the Arabians and Serapio call it Hifpane : the Germaines @pinet: in Englifh Spinage and Spinach : in French $E$ pinas.

* The nature.

Spinach is euidently colde and moift,almoft in the feconde degree, but eather moift. It is one of the potherbes whofe fubftance is waterie, and almoft without taltc : and therefore quickly defcendeth and loofeth the belly.

* The vertwes.

A It is caten boiled, but it yeeldeth little or no nourifhment at all: it is fomething windie, and eafily caufeth a defire to vomite, it is vfed in fallades when it is yoong and tender.

B This herbe of all other pot herbes and fallade herbes, maketh the greateft diuerfitic of ineates and fallades.

\section{Of Pellitorie of the wall. Chap.46. \\ * The defcription.}

$\mathrm{P}$ Ellitoric of the wall hath rounde tender ftalkes fomewhat browne or reddifh of colour and fomewhat fhining:the leaues be rough like to the leaues of Mercurie, nothing fnipt about the cdges. The flowers be fimall, growing clofe to the ftemmes, the feede blacke and verie fmall,couered with a rough huske which hangeth faft vpon garments:the roote fomewhat reddifh. 
Parietaria.

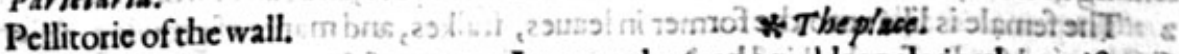

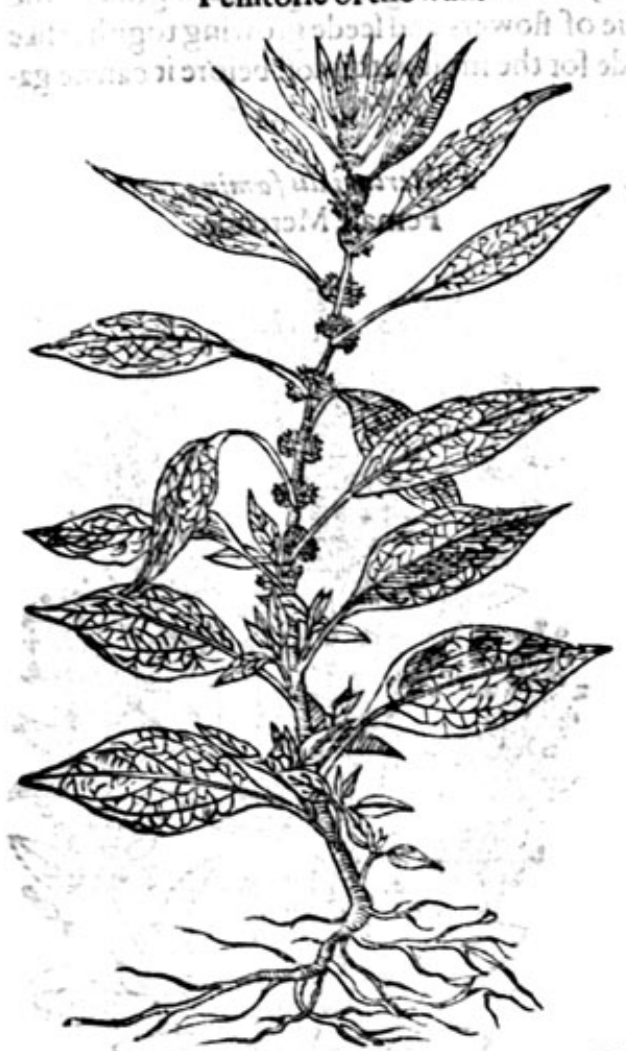

It groweth neeré to olde walts in thé moifteors hers of churches and ftone burittings, amoniftrub: bilh and fuch like places.

$$
\text { * The time. }
$$

It commeth vp in Maies it feedech in Iuly and Auguft : the roote onely continiethand is to be found in winter. $\quad *$ The nomes.

It is commonly called Parietaris, or by a corrupt worde Paritaria, bicaufe it groweth neere to wals: \& for the fame caufe it is named of diuers Muralis: alfo Muralium of Pliny and Celfus: of the Gracians ivirm. There is alfo another Helxine furnamed $\mathrm{Ci}$ f fampe'os : fornecall it Perdicium, of Partrigeswibich fomtimes feed heercof: fome Vreeolaris, and Vitraria, bicaufeit ferueth to fcoure glaffes, pipkens and fuch like: it is called in high Dutch Tarn ond nacbt : in Spanifh rerwa del muero: in Englifhpellitoric of the wall : in French Parietaire.

$$
\text { * The temperature. }
$$

Pellitorie of the wall (as Gakn faith) bath force to fcoure, and is fomthing colde and moift.

$$
\text { * The vertues. }
$$

Pellitorie of the wall boiled and the decoction of $\mathrm{A}$ it drunken, helpeth fuch as are vexed with an olde cough; the grauell and ftone; \& is good againft the difficultic of making water,\&ftopping of the fame, not onely inwerdly, but alfo outwardly applied vpon the region of the bladder; in maner of a fomentation or warme bathing, with fpunges or double clouts or fuch like.

Diofcorides faith that the iuice tempered with Cerufe or white leade, maketh 2 good ointment $B$ zgainft Saint Anthonies fire and the fhingles: \& mixed with the cerot of Alcanns or with the male Goates tallowe, it helpeth the gout of the feete; which Plimie alfo affirmeth in his 22 . booke 17 . chapter.

It is applied faith he, to the paines of the feete with goates fuet and waxe of Cyprus : where in $C$ fteede of waxe of Cyprus there muft be put the Cerote of Alcanna.

Diofcor ides addeth, that the iuice heereof is a remedie for old coughes, and taketh away hot fwel- D ling of the Almonds in the throat if it be vfed in a gargarifme or otherwife applied: it mitigateth alfothe paines in the eares being poured in with oile of rofes mixed therewith.

It is affirmed that if three ounces of the iuice be drunke, it prouoketh vrine out of hande.givo d I $\mathbf{E}$

The leaues tempered with oile of fiveete almonds in maner of a pultus and laide to the pained $\mathbf{F}$ parts, is a remedie for them that be troubled with the ftone and that can hardly make wates?

\section{Of French Mercurie. Chap.47. * The kindes.}

Therebetwokindes of Mercurie reckoned for good, and yet both fometirnes wilde ș befides other two wilde neuer founde in gardens, vnleffe they be brought thither: teib s(thisitw wst) $\odot$ Hemale garden Mercurie hath tender ftalks full of ioints and braunches, wherenpon do
riebullets rotunde and ioined togither like thofe of Goofe-grafte, or Cleuers, eche con-
teining 
teining in it felfe one fmall round feede with a tender roote, and full of white hairie ftrings.

2 The female is like vnto the former in leaues, ftalkes, and maner of growing, differingbut in the flowers and feede : for this kind bath a greater quantitic of flowers and feede growing togither like little clufters of grapes, of a yellowifh colour. The feede for the moft part is loft before it can be ga-
thered.
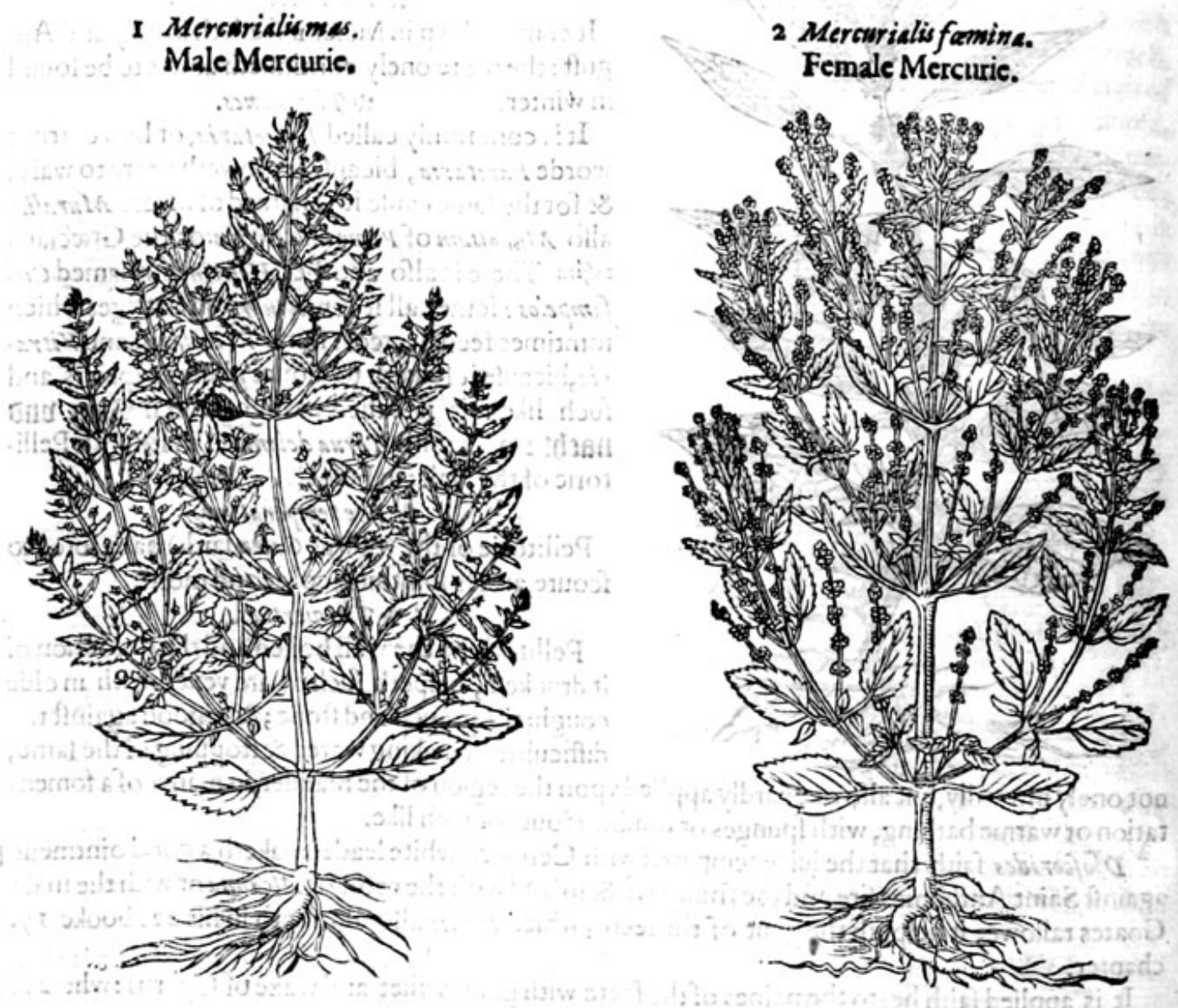

* The place.

French Mercuric is fowen in kitchen gardens among potherbes, in vineyardes, and in moift tha. dowie places, I founde it vnder the dropping of the bilhops houfe at Rochefter, from whence Ibrought a plant or two into my garden, fince which time I cannot rid my garden from it.

They flower and flourifh all the fommer long.

\section{* The time.}

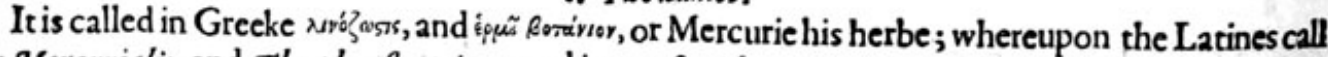

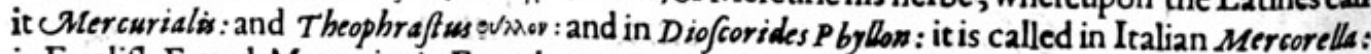
in Englifh French Mercurie : in French Mercuriale, Vignoble, and Foirelle, qwia Fluidam lexmiume, alwom reddit, Gallobelg e enim forze of forzesu, ventr is Flwor erm vocant. * The temperature.

Mercurie is hot and drie,yet not aboue the fecond degree: it hath a clenfing facultie, and (as $\sigma_{0 .}$ $k n$ writeth)a digefting qualitic alfo.

* The vertues.

A It is vfed in our age in glifters, and thought very good to clenfe and fcoure away the excrements and other filth conteined in the guts. It ferueth to purge the belly being eaten or otherwife taken, voiding out of the belly not onely the excrements, but alfo phlegme and choler. Diofsorides reporteth that the decoction heerof purgeth waterifh humours. 
The leaues ftamped with butter and applied to the fundament prouoketh to the ftoole, and the B herbe brufed and made vp in maner of a peffarie, clenfeth the mother, and helpeth conception.

Cost emu in his booke of the nature of plants faith, that the iuice of Mercurie, Hollihocks, and Pur- C flane mixed togither, and the hands bathed therein, defendeth them from burning if they be thruft into boiling leade.

\section{Of wilde Mercurie. Chap.48.}

I Cymocrembe.

Dogs Mercurie.

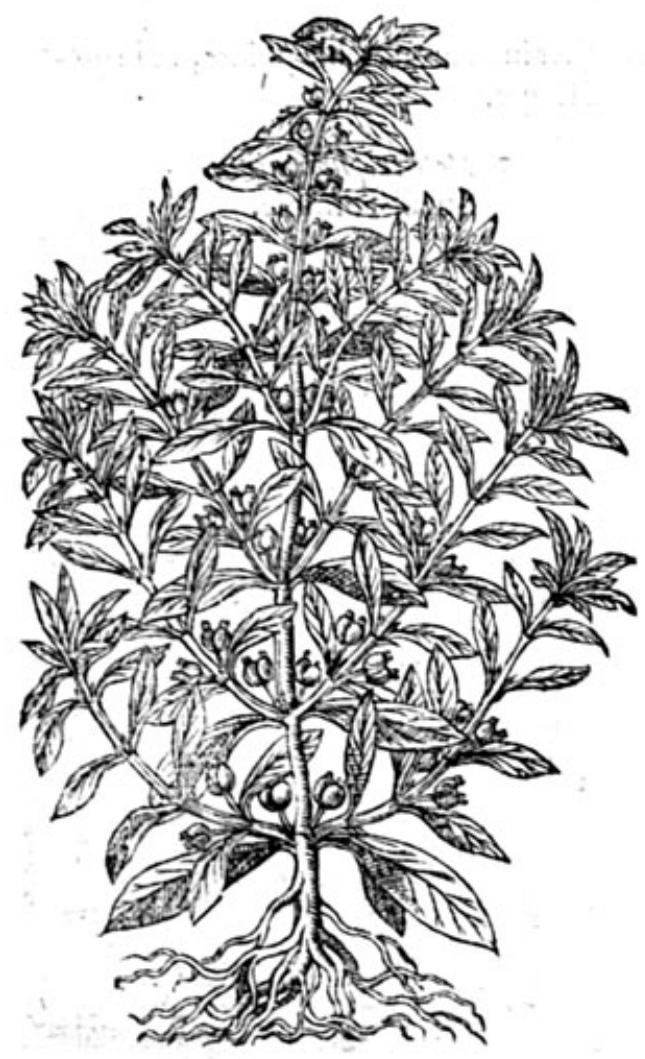

2 Phyllon Thelygonon: Childrens Mercurie.

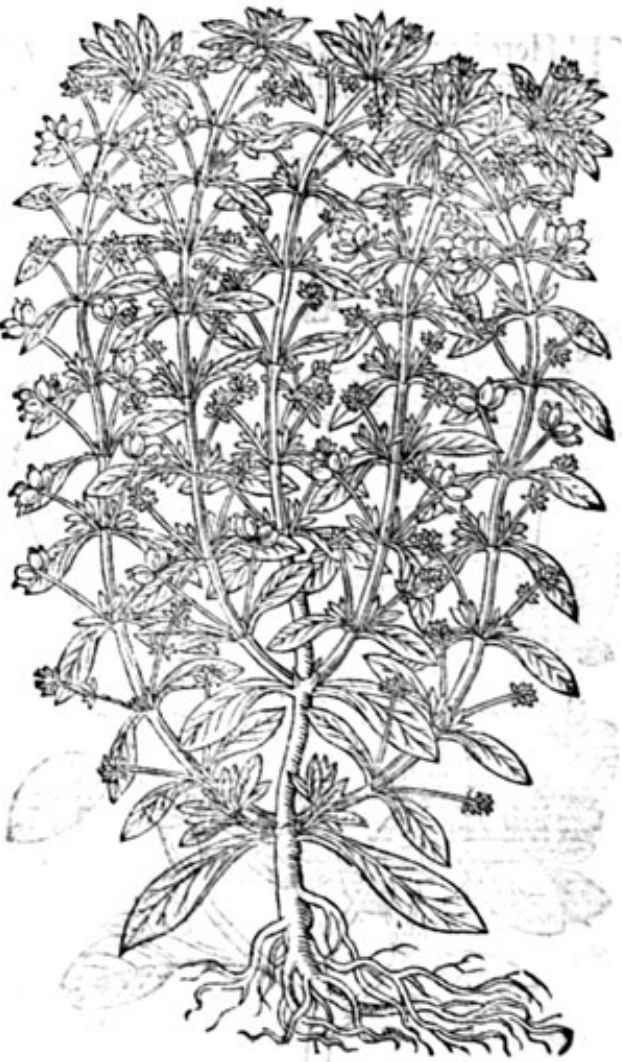

* The defcription.

I Ogs Mercurie is fomewhat like vnto the garden Mercurie, fating the leaues heereof are greater, and the ftalke not fo tender, and yet very brittle, growing to the height of $\mathbf{a}$ foote, without any braunches at all, with fmall yellowe flowers. The feede islike the fomale Mercurie.

2 Childrens Mercurie hath three or fower falkes ormo: the leaues be fomewhat long, not much vplike the leaues of the Oline tree, couered ouer with 2 foft downe or wooll, graie of colour:and the feede alfo like thofe of female Metcuric.

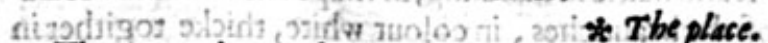

- They grosy in woods and copfes, in the bonders nneldes, and amöng bufhes and hedges.

The dogs Mercurie I haue founde in many nkces about Greene+Hith, Sivanes-combe village, Granef-ende, and South-licere in Kencs; in dampefteede woode, and all the hedges thereabout, fower miles trom London.

*Tbetimie.

orni

Thefe florvith all the formm n long vatill the extreme froft do pull them downe. 
* The names.

Dogs Mercurie is called in Greeke xuvoxpámbn :in Latine Canina, and Brafsea caminajand Mercurialis fyluestris: in Englifh Dogs Cole, and Dogs Mercurie.

Childrens Mercurie is called Phyllon theligonon, and Phyllow Arrbenogonon. $*$ The temperature and vertwes.

Thefe wilde kinds of Mercurie are not vfed in Phificke, notwithftanding it is thought they agree as well in nature as qualitie with the other kinds of Mercurie.

\section{Of Tornefole. Chap.49. \\ * Thekindes.} Here be fiue forts of Tornfole, differing one from another in many notable points, as in greate:
neffe and fmalneffe, in colour of flowcrs, in forme and hape.

I Heliotropinem maius. Great Tornfole.

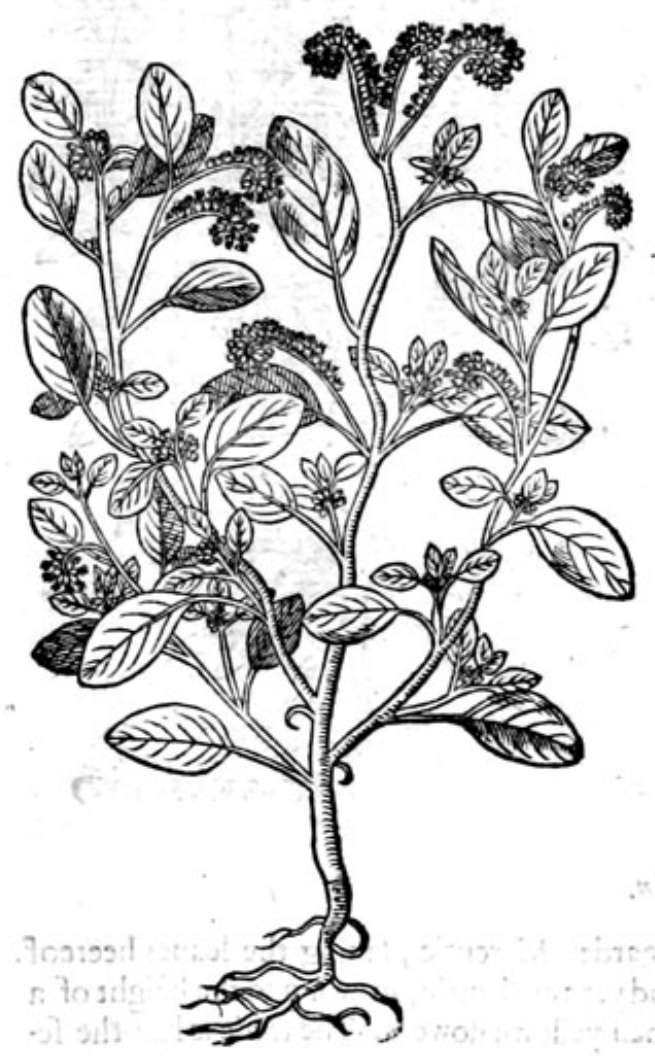

2 Heliotropium minm. Small Tornfole.

* The defcription.

I - He great Tornefole hath traight rounde ftalkes couered with 2 white hairie cotton, efpeci-

ally about the top whitifh $l_{2}, j e s$, foft and hairie in handling, in fhape like the leaues of $\mathrm{B}_{2}$ fill : the flowers growe at the to the braunches, in colour white, thicke togither in rowes vpon one fide of the ftalke, which ftalk toth bende or turne backward like the taile of 2 fcor-
pion: the roote is fmall and hard.

2 The fmall Tornefole hath many little and weake ununches trailing vpon the grounde, where: upon do growe finall leaues like thofe of the leffer Bafill. Ste howers do growe at the endes of the tender braunches, graie of colour, with a little fpot of yellow in $\mathrm{h} e$ middeit, the which turneth into crooked tailes like thofe of the precedent. 


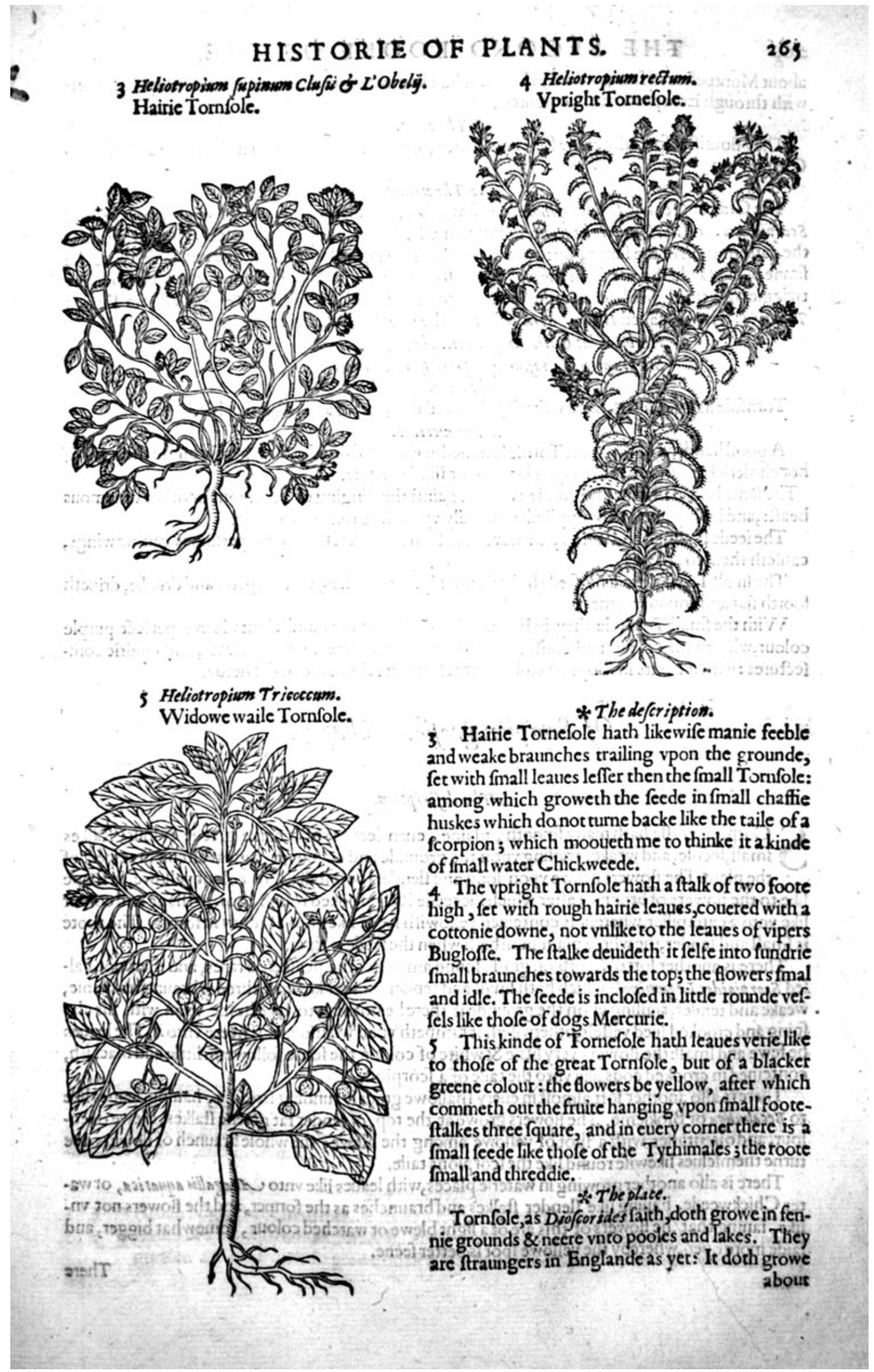


about Montpelier in Languedock, where it is had in great vie to ftaine and dic clouts withal, wwherwith through Europe meate is coloured.

* The time.

They flourifh efpecially in the fommer folltice, or about the time when the funne entreth into Cancer.

$$
\text { * The nawes. }
$$

The Grxcians call it Heliotropism: the Latines keepe thefe names Heliotropium magnum, and Scorpiurum: of Ruellius Herba Cancri : it is named Heliotropium, not bicaufe it is turned about at the daily motion of the funne, but by reafon it flowreth in the formmer folftice, at which time the funne being fartheft gone from the rquinoctiall circle, returneth to the fame; \& Scropiurum of the twiggie tops that bowe backewarde like a fcorpions taile : of the Italians Tormefol bobo: in French Tourmfol: it is alfo called Herba Clitie, whereof the poet hath thefe verfes:

$$
\begin{gathered}
\text { Herba velut Clitia femper petit obuia folem, } \\
\text { Sic pia mens Chriftum quo prece ßpectet babet. } \\
\text { * The nature. }
\end{gathered}
$$

Tornfole as Paulus AEgineta writeth, is hot and drie, and of a binding facultie. * The vertues.

A good handfull of the great Tornfole boiled in wine and drunke, doth gently purge the body of hot cholericke humours and tough clammie or flimie flegme.

The fame boiled in wine and drunke is good againft the ftinging of Scorpions or other venemous beafts,and is very good to be applied outwardly vpon the griefe or wounde.

The feede ftamped and laide vpon warts and fuch like excrefcens or fuperfluous outgrowings, caufeth them to fall away.

The fmall Tornfole and his feede boiled with Hyfope, Creffes, and faltpeter and drunke, driueth foorth flat and round wormes,

With the fmall ' Fornfole they in Fraunce doe die linnen rags and clouts into a perfect purple colour, wherewith cookes and confectionaries do colour iellies, wines, meates, and fundrie com: fectures : which clouts in fhops be called Tornefole after the name of the herbe.

\section{Of Scorpion graffe. Chap.50.}

\section{\& The defoription.}

Corpion graffe hath many finooth, plaine, euen leaues, of a darke greene colour; ftalkes fmall,feeble, and weake, trailing vpon the grounde and occupying a great circuit in refpect of the plant. The flowers growe vpon long and flender footeftalkes, of colour yellowe, in fhape like to the tlowers of broome; after which fucceede long crooked rough cods, in thape and colour likc vnto a caterpiller, wherein is conteined yellowifh feede like vnto a kidney in forme. The roote is frmall and tender, the whole plant perifheth when the feede is ripe.

There is another fort of Scorpion graffe found among corne, peafe, and tares, and therupon cals led Scorpioides Legumino fa, which hath fmall and tender rootes like fmall threds: braunches manie, weake and tender, trailing vpon the grounde if there be nothing to take holde vpon with hisclafping and crooked feed veffels, otherwifeth it rampeth ypon whatfocuer is neere vnto it. The leaues be fewe and fmall: the flowers very little \& white of colour: the feede followeth: little and blackifh, conteined in crooked cods like vnto the taile of a fcorpion.

There is alfo another fort almoft in euery fhallowe grauely running ftreame, hauing leaues like to Becabungs or Brokleme. The flowers growe at the top, of tender fat greene ftalkes, blewe of colour, and oftentimes with a fpot of yellowe among the blewe; the whole braunch of flowers doe turne themfelues likewife round like the fcorpions taile.

There is alfo another growing in wateric places, with leaues like vnto 4 inagallis a quatica, or water Chickweede, hauing like flender ftalkes and braunches as the former, and the flowers not vnlike, fauing that the flowers of this are of a light blewe or watched colour, fomewhat bigger, and laide more open, whereby the yellowe fpot is better feene.

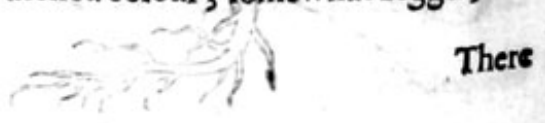



Scorpion graffe.

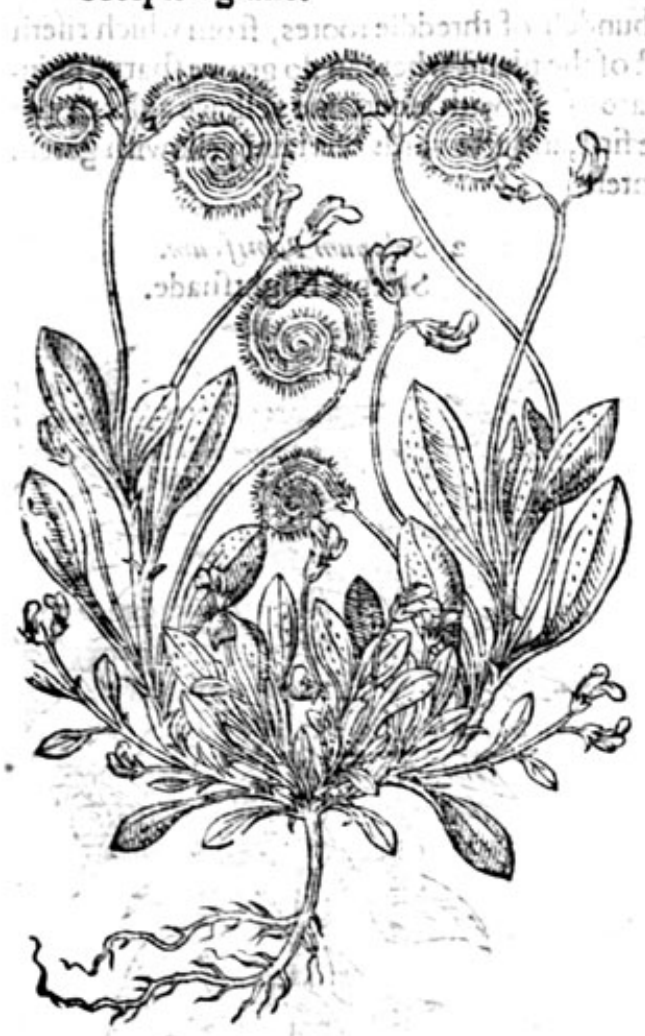

There is likewife another fort growing vpon the moft drie graticly and barren ditch bankes, with leaties like chiofe of curiciala Muris or Moufeare, called $M$ roforis for pivides, with roughand hairie leaues, of an oucrworne ruffet colour: the fluwers do grow vpon weake, fvehle, \& rough braunches, as is all the reft of the plane. They likewife growe for the moft part vpon one fide of theftalke, blewe of coloti, with a like little fpot of yellowe as the others, turning it felfe backe againe like the taile of a fcorpion.

There is another of the lande called M;ofotis Scorpioides repens, like the former : but the flowers are thicker thruft togither, and do not growe all vpon one fide as the other, and part of the flowers blewe, and part purple, confufedly mixt togithet. * Theplace.

The Scorpion graffe defcribed groweth not wilde in Englande, notwithftanding Ihaue receiued feedes therof from beyond the feas, and haue difperfed them through England, which are efteemed of gentlewomen for the beautic \& ftraungeneffe of the crooked coddes, notwithanding it is the beft feeding for cattell that may be.

The others do growe in waters and ftreames, 25 alfo in the drie and barraine bankes. $*$ The time.

The firft dowreth from Maie to the end of Auguft; the others I haute found all the fommer long. * The names.

There is not any thing remembred as touching the names more then hath beene fet downe in their defcriptions: onely our Englifh gentlewomen and others do callit Caterpillers, of the fimilitude it hath with the fhape of that canker worme called a caterpiller.

\section{* The nature and vertues.}

There is not any thing remembred of the temperature, yet Diofcorides faith that the leaves of Scorpion graffe applied to the place is a prefent remedic againft the ftinging of Scorpions: \& like wife boiled in wine and drunke preuzilech againft the faid bitings, as alfo of adders, frakes, and fuch like yenemous beafts : being made in an vnguent or falue with oile, waxe, and a little gum Elentypir, is profitable againft fuch hurts as require a healing medicine.

\section{Of Nighthade. Chap.s1.}

\section{* The kindes.}

7 Here be diuers Nightihades, whereof fome are of the garden; and fome that loue the fieldes, and yet euery of them found wilde; whereof fome caufe fleepineffe euen vnto death others caufe fleepineffe, and yet Phificall; and others very proficable vnto the kealth of man, as thall be declared in their feuerall yertues.

* The de Gription. greater: among which do growe fimall white flowers with yellowe pointels in the middle; 

which being paft, there do fuccede rounde berries, greene at the firft, and black when they be ripe;
like thofe of Iuic : the roote is whitc and full of hairie ftrings.

2 Sleeping Night thade hath for his roote a great bundell of threddie rootes, from which rileth vp a fat ftalke of a blackifh greene colour as is the reft of the plant; whereon do growe tharpe poin. ted leaues like vnto thofe of the Docke. The flowers are white with a certaine yellowe aglet in the middle, after which come forth berries, greene at the firft, and aftewards of a faint yellowilh green, The whole plant perifheth at the firft approch of winter.
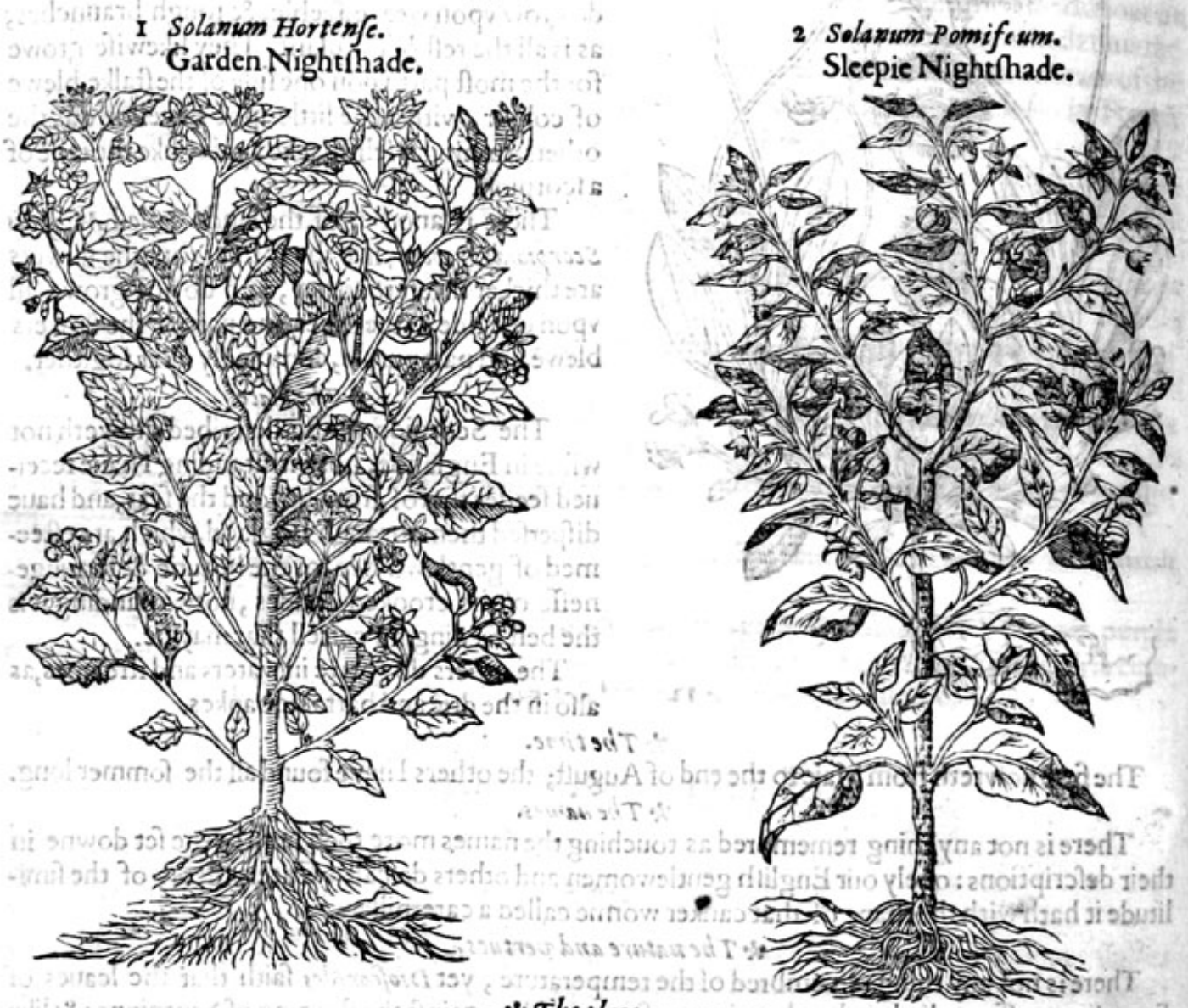

* Theplace.

Solanum Pomif cum. Sleepie Nightrhade.

This Night thade commeth vp in many places, and not onely in gardens, of whichnotwithftanding it hath taken his furname, and in which it is often founde growing with otherherbes: but alfo neere common high waies, the borders of fieldes, by olde wals and ruinous places. * The time.

It flowreth in fommer, and oftentimes till autumne be well fpent; and then the fruite commeth to ripeneffe.

* The names.

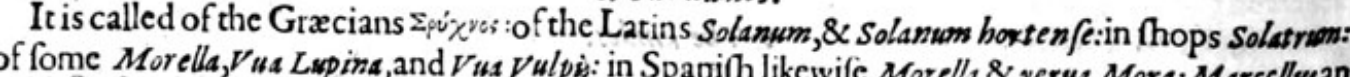
of lome Morella, ua Lapina, and Vua Vulpis: in Spanifh likewife Morells \& yerua Mora: Marcellewan olde Phificke writer, \&e diuers others of his time called it'St rumum; $P$ linie in his 27. book 8.chapter, Theweth that it is called Cucubalius: both thefe wordes are likewife extant in elpuleiw arnong the confufed names of Night fhade: who hath gathered togither in one chapter fo many, that he hath as it were confounded the name thereof: in Englifh it is called Garden Nightihade; Morell, and petie Morell: in French Morelle, Gallobelgiv: feu ardent : quia medetur igni facro.

$$
\text { *Thetemperature. }
$$

Night hade as Galen faith in his booke of the faculties of fimple medicines is vied for thofe infirmities that haue neede of cooling and binding: for thefe tivo qualities it hath in the feconde dogree: which tising alfo he affirmethin his booke of the faculties of nourifhments, where he faith 
that there is no potherbe which wee vfe to eate that hath fo great aftriction or binding as Nightthade hath, and therefore phifitions do woorthely vfe it, and that feidome as a nourifhment, but alwaies as a medicine. *The vertues.

Dio/corides writeth,that Nightrhade is good againt Saint Anthonies fire, the fhingles, paine of the head, the hart burning or heate of the ftomacke, and other like accidents proceeding of fharpe and biting humours: notwithftanding that it hath thefe vertues, yet it is not alwaies good that it fhoulde be applied vnto thofe infirmities, for that many times there hapneth more dangers by applying of thefe remedies, then of the difeafe it felfe. For as Hippocrates writech in the 6. booke of his Aphorifmes, the 25.particular, that it is not good, that Saint Anthonies fire fhould be driuen from the outward parts to the inward : and likewife in his prognoftickes he faith, that it is neceffaric that Saint Anthonies fire houlde breake foorth, and that it is death to haue it driuen in; which is to be vnderftoode not onely of Saint Anthonies fire, but alfo of other like burftings out procured by nature.For by ving of thefe kind of cooling \& repelling medicines, the bad, corrupt and harp humors are driuen back inwardly to the chiefe \& principall parts, which cannot be done without great danger and hazarde of life. And therefore we muft not vnaduifedly, lightly, or rafhly minifter fuch kinde of medicines vpon the comming out of Saint Anthonies fire, the fhingles, or fuch hot pimples and blemifhes of the skin.

The iuice of the greene leaues of garden Nighthade mixed with barley meale, is very profita- B blic applied vnto Saint Anthonies fire and to all hot inflammacions.

The iuice mixed with oile of rofes, cerufe, and littarge of golde, and applied, is more proper and C effectuall to the purpofes before fet downe.

Neither the iuice heereof nor any other part is to be giuen inwardly.

The leaues ftamped are profitablie put into the ointunent of popler buds, called $V$ mg guentwem po. pweon, good and allother ointments.

Solsmas Lesthale.

Offleeping Night/hade.

Dwale, or deadly Night?hade.

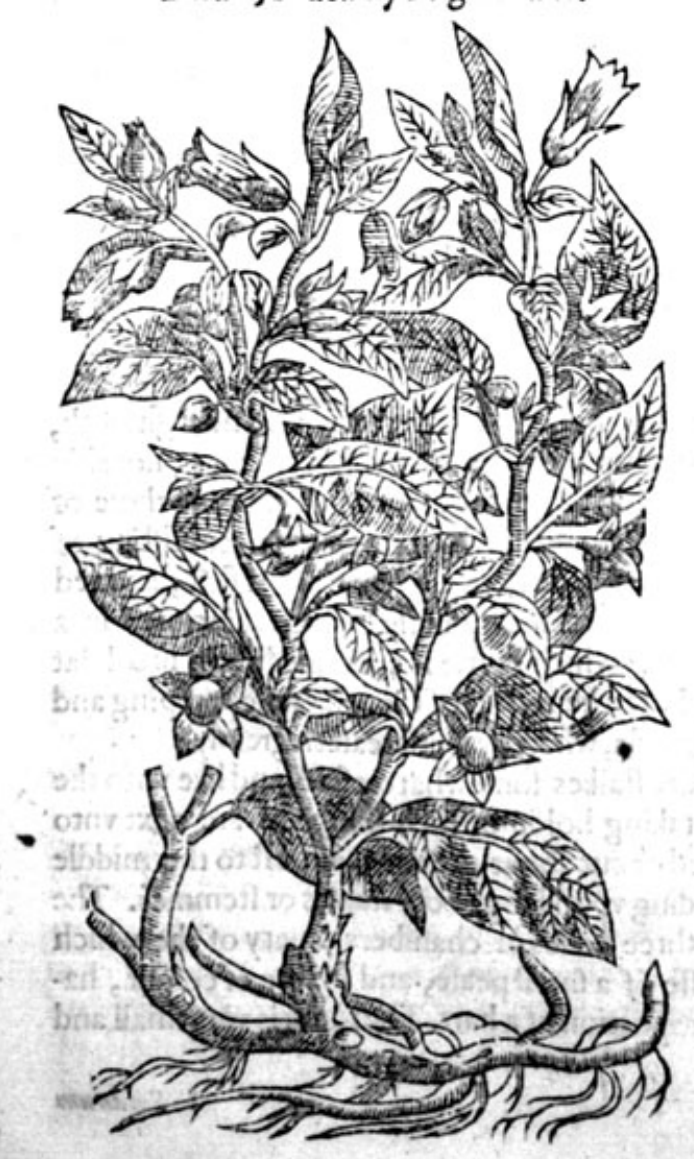

Chap.51.

\section{* Thedefcription.}

$\mathrm{D}$ Wale or fleeping Night hade hath round blackifh ftalks fixe foote high, whereupon doe growe great broade leaues of a darke greene colour; among which doe growe fmall bollowe fowers bell fafhion of an oucrworne purple colours in the place whereof come foorth great rounde berries of the bigneffe of the blacke cherrie, greene at the firft, but when they be ripe of the colour of blacke iette or burnifhed horne, foft and full of purple iuice; among which iuice lie the feeds like the berries of Iuie: theroote is very great, thicke and long lafting.

$$
\text { * The place. }
$$

It groweth in vntoiled places neere vnto high waies and the fea marfhes and fuch like pla- . ces.

It groweth very plentifully in Hollande in Lin. colnihire, and in the Ile of Elie ata place called Walfoken,neere vnto Wisbitch.

I founde it growing without the gate of High gate neere vnto a poind or pinfold on the left hăd. * The time.

This flourilheth al the fommer and fpring,bea. reth his feede and flower in Iuly and Auguft.

* T the names.

It is called of Diofsorides spix $x$ pos virvenxos : of $T$ beophraftios spixous imnobs: of the Latines Solamion founiforwo 
. fomnif erum or fleeping Nighthade; and Sulanum lethale, or deadly Nightihade; and sole nicum, raging Nighthade; of fome Apollinaris minor vlticana, \& Herba Oplago: in Eng or flecping Night thade : the Venctians and Italians call it Bclla dona : the Germaines Do the lowe Dutch Dulle befien : in French CNorelle mortelle: it commeth very neere vnto T heopbraftus his Mandragoras, (which differeth from Diofourides his Mandragor as) if there be a difference.

It is colde euen in the fourth degree.

$$
\text { * T he nature. }
$$

$$
* \text { The vertues. }
$$

A This kinde of Night hade caufeth fleepe, troubleth the minde, bringeth madnes if a fewe of the berries be inwardly taken, but if mo be giuen they alfo kill and bring prefent death. Theophraffus in his 6.booke doth likewile write of Mandrake in this maner; Mandrake caufeth fleepe, and if alfo much of it be taken it bringeth death.

B The greenc leaues of deadly Nighthade may with great aduife be vfed in fuch cafes at Pettimorrell: but if you will follow my counfell, deale not with the fame in any cafe, and banifh it from your gardens and the vfe of it alfo,being a plant fo furious and deadly : for it bringeth fuch a shaue eaten thereof into a dead fleepe wherein many haue died, as hath beene often feene and prooued by experience both in England and elfe where. But to giue you an example heereof it fhall not be amiffe: It came to paffe that three boies of Wisbich in the Ile of Ely, did eate of the pleafant and beautifull fruite hecrof, two whereof died in leffe then 8 . howers after they had eaten of them. The thirde childe had a quantitic of honie and water mixed togither giuen him to drinke, caufing him to vomite often:God bleffed this meanes and the childe recouered. Banifh therefore thefe pernicious plants out of your gardens, and all places neere to your houfes, where children or women with childe do refort, which do of tentimes long and luft after things moft vile and filthie; \& much more after a berric of a bright thining black colour, and of fuch great beautic,as it were able to allure any fuch to eate thereof.

C The leaues heerof laid vnto the temples caufe fleep, efpecially if they be imbibed or moiftened in wine vineger. It eafeth the intollerable paines of the headach proceeding of heat in furious agues, caufing reft being applied as aforcfaid.

\title{
Of winter Cherries. Chap.52.
}

\author{
* The defcription.
}

I He red winter Cherrie bringeth foorth ftalkes a cubite long, rounde, flender, fmooth; and fomewhat reddirh, reeling this way and that way by reafon of his weakenes, notable toftande vpright withoul a fupporte: whereupon do growe leaues not vnlike to thofe of common Night hade, but greater; among which leaues come foorth white fowers, confifting of fiue fmall leaues : in the middle of which leaues ftandeth out a berrie, greene at the firft, and fed whe: it is ripe, in colour of our common Cherrie and of the fame bigneffe, which is inclofed in 2 thinne htiske or little bladder of a pale reddifh colour, in which berrie is conteined many finall tat feedes of a pale colour. The rootes be long, not vilke to the rootes of Couch graffe,ramping and

2 The blacke winter Cherric hath weake and flender ftalkes fomewhat crefted, and like vneo the tendrels of the Vine, calting it felfe all about and taking holde of fuch things as are next vnt: it : wherupon are fer iagged leaues deepely indented or cut about the edgesalmoft to the ribbe. The flowers bee verie fmall and white ftanding vpon long foote ftalkes or ftem skinnie bladders fucceede the flowers, parted into three celles or chambers, cuery o conteineth one feede and nomore, of the bigneffe of a fmall peafe, and bla uing a marke of white colour vpon ech berrie, in proportion of a hart. Ther
threddic. 


\section{HISTORIE OF PLANTS.}

I Solanum Halicacabum. Red winter Cherries.

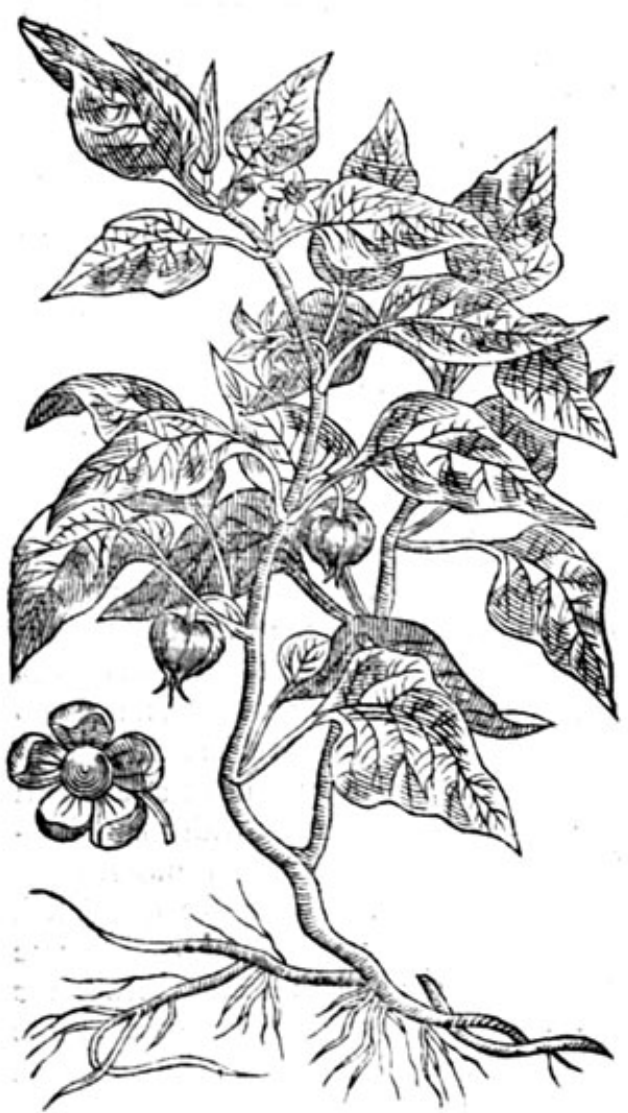

2 Halicacabum Peregrimum. Blacke winter Cherries.

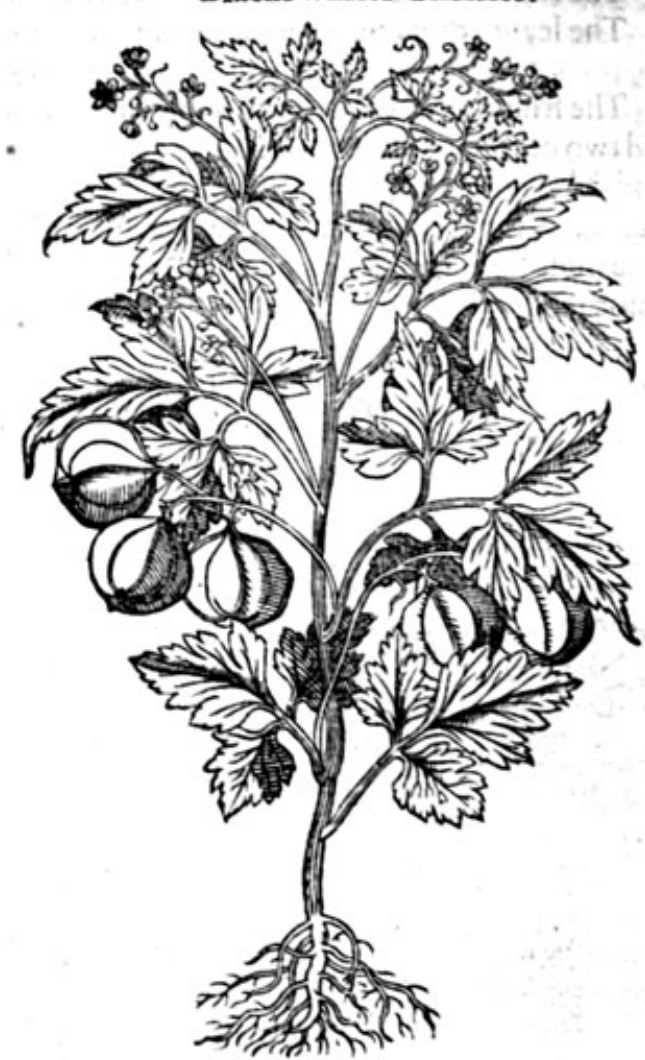

* The place.

The redde winter Cherrie groweth vpon olde broken wals about the borders of fieldes, and in moift thadowie places, and in moft gardens, where fome conferue it for the beautic of the berries, and others for the great and woorthy vertues thereof.

2 The blacke winter Cherric is brought out of Spaine \& Italy, or other hot regions, from whence I haue had of thofe blacke feedes marked with the hape of a mans hart white, as aforefaide : and haue planted them in my garden where they haue borne flowers, but haue perithed before the fruite could growe to maturitie, by reafon of thofe vnfeafonable yeeres 1594.95. and 96 .

\section{* The time.}

The red winter Cherrie beareth his flowers and fruite in Auguft:

The blacke beareth them at the fame time, where it doth naturally growe.

$$
\text { * The vames. }
$$

The red winter Cherric is called in Greeke Erso' $\chi$ ros : in Latine Veficarja, and Solanwen Veficarizem: in fhops Alkekengi: Plimie in his 21 . booke nameth it Halicacabses and Veficaria, of the little blad:ders: or as the fame author writeth bicaufe it is good for the bladder and the ftone: it is called in Spanifh Vexigadeporro: in French Alquequenges, Bagenauldes, and Cerifes dowtre mer : in Englifh red Night?hade, Winter Cherries and Alkakengie.

The blackewinter Cherric is called Halicacabus Peregrinus, Veficaria Peregrima, or ftrange winter Cherric : of Pena and $L$ Obel it is called Cor Indum, Cor Indicion : of others Pifrom Cordation: in Englifh the Indian hart, or hart Peafe: fome haue taken it to be Dorycnion, but they are greatly deceaued, being in truth not any of the Night hades; it rather feemeth to agree with the grain named of serapeo Abrong, or Ulirugi, of which he writeth in his 153 . chapter in thefe words: It is a little gtaine fpotted with blacke and whitc, rounde, and like the graine Maiz, with which notes this dothagree. 
* Thetemperature.

The red winter Cherric is thought to be colde and drie and of fubtile parts.

The leaues differ not from the temperature of the garden Nightihade as Galen faith.

\author{
$* T$ hevertu's.
}

The fruite brufed and put to infufe or ftiepe in white wine two or three howers, and after boiled two or three bublings, ftraining it and putting to the decoction a little fugar and cinamome, and drunke; preuaileth very mightily againit the ftopping of vrine, the ftone and grauell, the diff. culcie and fharpenes of making water and fuch like difeafes: if the greete be olde the greater quantitie muft be taken, if newe and not great, the leffe: it fcoureth away the yellowe iaundife alfo as fome write.

\title{
Of the maruaile of the World. Chap.53.
}

Mirabilia Peruniana.

The maruaile of Peru.

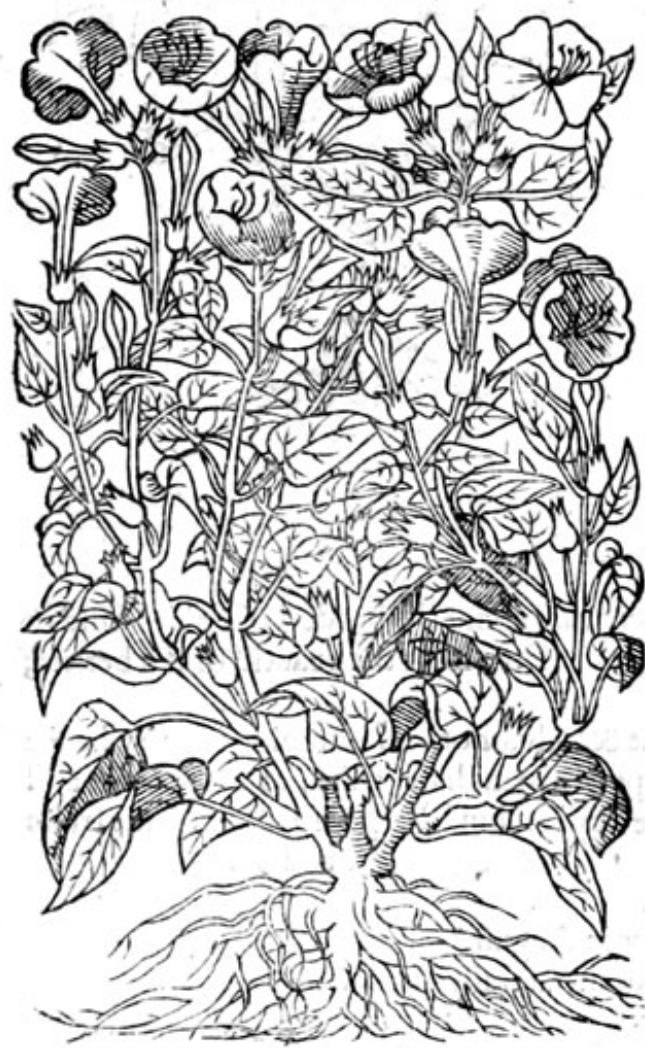

* Tle dejcription.

His admirable plant called the maruell of Peru, or the maruel of the World, fpringeth foorth of the grounde like vnto Bafill in leaues; among which it fendeth out a ftalke two cubits and a halfe high, of the thickneffe of a finger, full of iuice, very firme, and of a yellowith greene colour, knotted or kneed with ioints fomwhat bunching foorth, of purplifh colour, as in the female Balfamina : which ftalke diuideth it felfe into fundrie braunches or boughes, \& thofe alfo knottie like the ftalke: his braunches are bedecked with leaues growing by couples, at the iointes, like the leaues of wilde Peafcods, greene, flefhic,and full of iuice, which being rubbed doe yeelde the like vnpleafant finell as wilde Peafcods do, and are in tafte alfo verie vnfauorie, yet in the latter end they leaue a tafte and harpe fmacke of Tabaco. The ftalkes towards the top are garnifhed with long hollow fingle flowers, foulded as it were into five parts before they be opened, but being fully blowen do refemble the flowers of Tabaco, not ending into fharpe corners, but blunt and rounde as the flowers of Bindweede, and larger then the flowers of $\mathrm{T}_{\mathrm{ab}} \mathrm{baco}$, glittering oftentimes with a fine purple or crimfon colour; many times of an horfeflefh; fometime yellowe; fometime pale; and fometime refembling an old red or yellowe colour; fometime whitih; and moft commonly two colours occupying halfe the flower, or intercourfing the whole flower with ftreakes and orderly ftreames, nowe yellowe, nowe purple, diuided through the whole; hauing fometime great, fometime little fpots of a purple colour, fprinckled and fcattered in a moft variable order, and braue mixture. The grounde or fielde of the whole flower is either pale, red, yellowe, or white, containing in the middle of the hollowneffe a pricke or pointell fet rounde about with fixe fmall ftrings or chines. The flowers are verie fweete and pleafant, refembling tine Narciffe or white Daffodill, and are very fodainly fading; for at night they are flowred wide open, and fo continue vntill eight of the clocke the next morning: at which time they begin to clofe or fhut vp (after the maner of the Bindweede) efpecially if the weather be very hot, but if the aire be more temperate they remaine open the whole day, \& are clofed onely at night, \&\&fo perifh, one flower lafting but onely one day, like the true Ephemerum or Hemerocallis. 
8 This staucellots varictie doth not without great caufe bringineo adiniration all thofe that obferue it. Fob if the tlowers begathered and referued in feuerall papers, and compared with thofe flowvers that iviltipring and fousth the vesodaie, you fhall eafily perceite that one is wot like another in colout; shough you iboulde compare one hundrech; which flomer one day, and anothet hythered, which yolrg a dered ehe next day ; and fo from daie to day during the cime of their flowring o. The cups and huskes which containe and embrace the flowers, are ditided into fribe pointed fagtionss at which are greene, and as it were confiting of skins, wherein is conteined one feede and nomore, couered with a blackifh skin, hauing a blunt point where on the flower growech; but on the ence next the cup or huske, it is adorned with a littlc fiue cornered crowe. The feed is as biggelas a pepper corne, which of it lelfe fadeth with any light motion; within this feede is conteined a white kernell, which being brified, refolneth into a veric white pulpe like ftarch. 'The toote is thicke and like vntoagreat tad inh, ontwardly blacke, and within white, (harpe in tafte, wherewith is mingled a fuperficiall fiveetencs. It bringethnewe flowers from Inly vnto Oetober in infinite number, yea etien vntil the frotts do caufe the whole plant to perifh:notwithftanding it may be referued in pots, and fet in chambers andeellers that arc warme, and fo defended from the iniurie of our colde climate: protsided alwaies that there be not any water caft vpon the pot; or fet foorth to take any molfture in the aire vntill March following; at which time it muft be taken foorch of the pot \& replanted in the gatden. By this means haive preferuedmany (though to finall purpofe) bicauf I hane fowen feeds that haticborne flowers in as anple maner $\&$ in as good time as thofe referued plants.

- Ofthis woonderfultherbe there be other forts, but not fo amiable or fo full of varietie, and for the moff partitheir flowers are all of one colour. But I haue fince by practife founde out another way tokeepe the rootes fot the yecre following with vory little difficultie, which neuer faileth. At the firft froft I digge vp the rootes \& put vp or rather hide the rootes in a butter ferkin, or fuch lik c veffell, filled with the fande of a riu: r, the which I fuffer ftill to ftande in fome comer of a houfe where it neuer receiueth moifture vnill A prill or the middeft of March, if the weacher be warme; at which timeI take it from the fande and plant it in zhe garden, where it doth flourio exceedingyell and increafeth by rootes; which that doth not which was eitherfowen of feede the fame yeere, nor thofe plants that were prefericedafter the other maner.

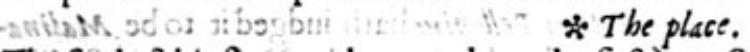

The fced of this ftringe plant was brought firttinto $S$ paine, ftom Peru, wherof it tooke his name Mirabiliz Perwane, or Perutisns: and fince difperfed into all the parts of Europe: the which my felfehaure planted many yeeres, and haue in fome temperate yeeres receiued both flowers and ripe feede. : sctumpe

\section{ic Tluetime.}

It is fowen in themiddeft of Aprill, andbringeth foorth his variable flowers in September, and perifheth with the firft froft, except it be kept as aforefaide.

$$
\text { * Tbe nomes. }
$$

It is called in Pcru of thiofe Indians there Hachal : of others after their name Hachal Indi: of the high and lowe Dutch Solanum odorifertem : of fome injiwinum mexicanum: and of Carolwo CleJassmirs bilis Perwaians : in Englifh, rather the maniell of the World, then of Peru alone.

$$
\text { \& The natimeand vertikes. }
$$

We haue not as yet any inftruetions from the people of India concerning the nature or verties of this plant: the which is efteemed as yet rather for his rareneffe, beautie, and fiveeteneffe of his flowers; then for any vertues knowne; but it is a pleafant plant to decke the gardens of the curious:? Howbit Iacobus Antonius Cortufus of Padua hath by experience found out, that two drams of the rooce there of taken inwardly doth very notably purge waterifh humours.

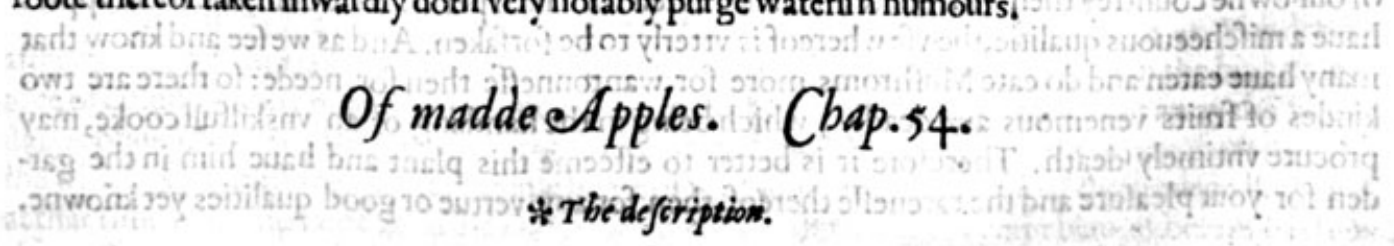
Aging Apples hath a rounde ftalke of two foote high, deuided into fundrie braunches, fet with broade leaues fomewhat indented about the edges, not vnlike the leaues of white Henbane, of a darke browne greene colour fomewhat rough: among the which come the flowers 
of a white colour, and fometimes changing into purple, made of fixe parts, wide open like a ftarre with certaine yellowe chiues or thrums in the middle; which being paft the fruite commeth in place, fet in a cornered cup or huske after the maner of the great Night hade, great and fomwhat long, of the bigneffe of a fwans egge, and fometimes much greater, of a white colour, fometimes yellowe, and often browne, wherein is conteined fmall flat feede of a yellowe colour. The root is thicke, with many threds faftned thereto.

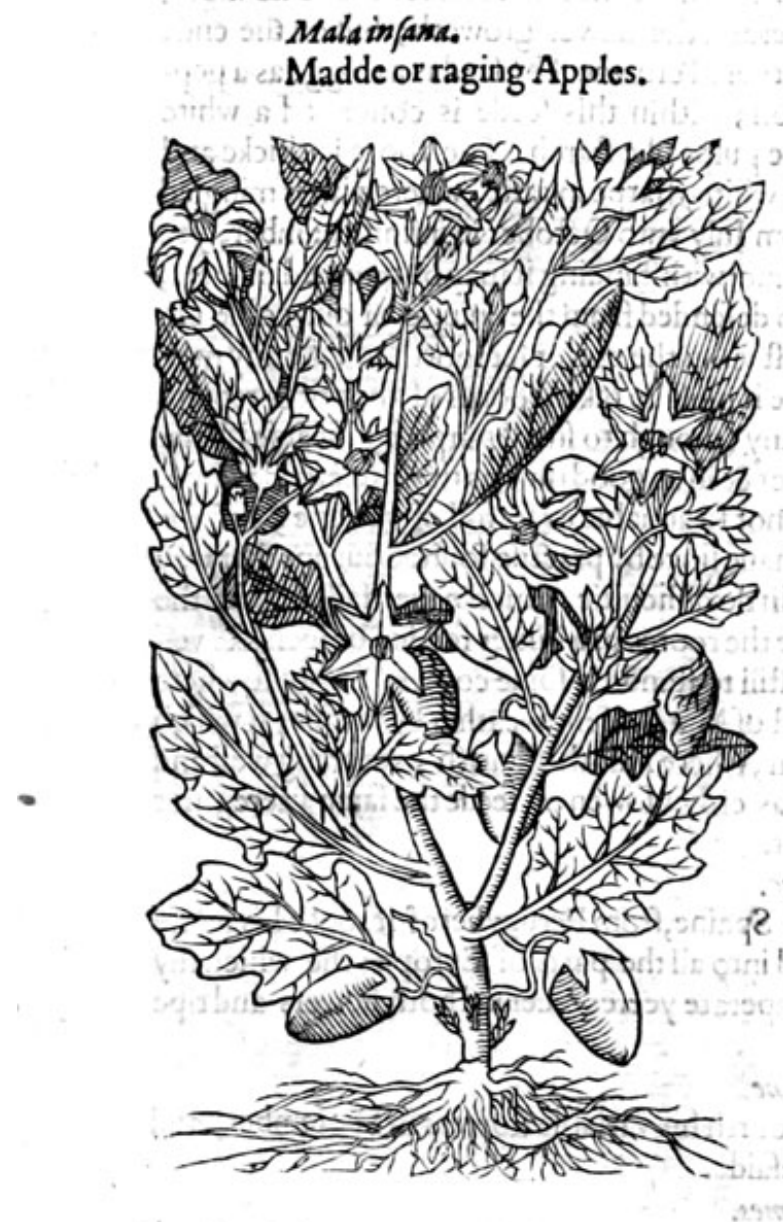

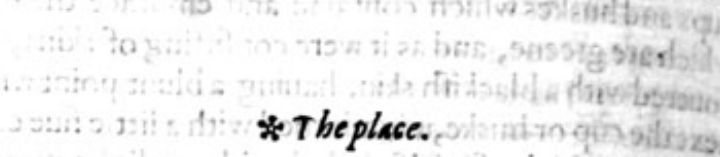

This plant groweth in Egypt almoft euery where in fandie fieldes euen of it felie, bringing foorth fruite of the bignes of a great Cucumber, as Petrus Bellonius reporteth in the fecond booke of his fingular obferuations. We haue had the fame in our London gardens, where it hath borne flowers, but the winter approching before the time of ripening, it perifhed: notwith ftanding it came to beare fruite of the bignes of a goofe egge one extraordinarie temperate yeere, as I did fee in the garden of a worfhipfull merchant, Mafter Harwie in Limieftreete, butneuer to the full ripeneffe.

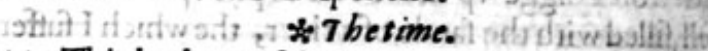

This herbe muft be fowen in Aprillina bed of hot horfe dung, as muske Melons are, and tlowreth in Auguif.

Petrus Bellonius hath iudged it to be Malinetballa Theophrafti. In the Dukedome of Milan it is called of the Infubres cMelongena : and of fome Melanzima: in Latine Mala infana: in Englifh Madde Apples: in the Germaine toong Dollopffel : in Spanifh Verangenes.

This herbe is colde almoft in the fourth degree.

* The vfe and danger.

The people of Tolledo do eate them with great deuotion being boiled with fat flefh, putting thereto fome fcraped cheefe, which they do keepein vineger, honie, or falt pickell, all winter to pro-
cure luft.

Petrus Bellonimand Hermolaus Barbarms report, that in Egypt and Barbarie, they vfe to eate the fruite of Mala in fana boiled and rofted vnder afhes with oile, vineger, and pepper, as people vfe to eate Mufhroms. But I rather wifhe Englifh men to content themfelues with the meate and fauce of our owne countrey then with fruite and fauce eaten with fuch perill: for doubtleffe thefe apples haue a mifcheeuous qualitie, the vfe whereof is vtterly to be forfaken. And as we fee and know that many haue eaten and do eate Murhroms more for wantonneffe then for neede: fo there are two kindes of fruits venemous and deadly, which being in the handling of an vnskilfull cooke, may procure vntimely ideath. Therefore it is better to efteeme this plant and baue him in the garden for your pleafure and the rareneffe thereof, then for avy vertue or good qualities yet knowne. 


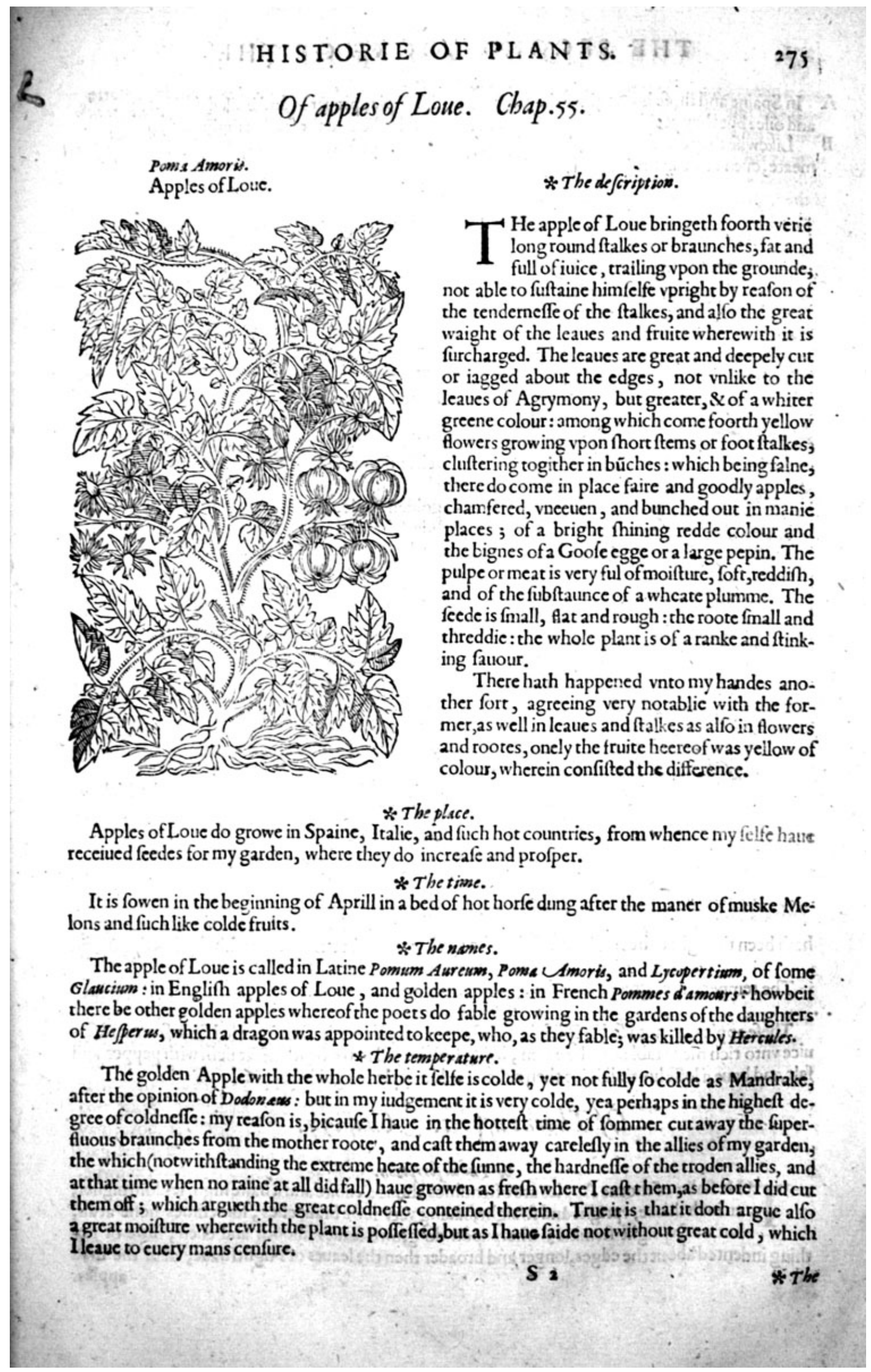




\author{
$*$ The vertues.
}

A In Spaine and thofe hot regions they vfe to eate the apples prepared and boiled with pepper, $\sqrt{2}$ lt, and oile : but they yeelde very little nourifhment to the bodie, and the fame naught and corrupt.

B Likewife they doeate the apples with oile, vineger and pepper mixed togither for fauce to their meate, euen as we in thefe cold countries do muftarde.

\title{
Of the Ethiopian apple. Chap.56.
}

\section{Mala MEthiopica.}

Apples of AEthiopia.

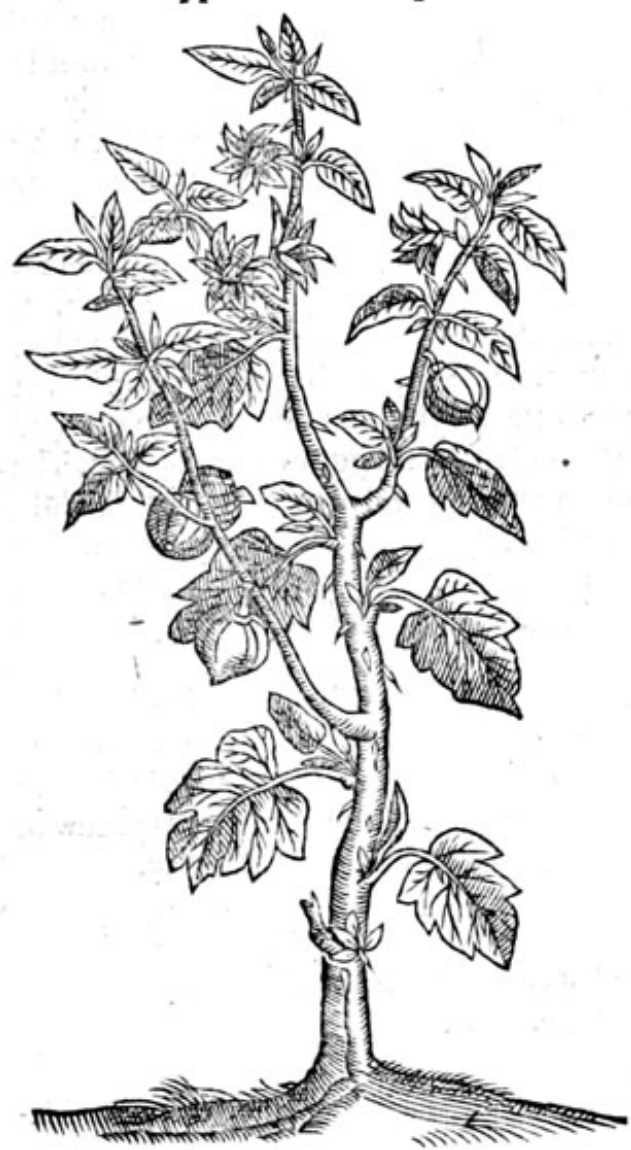

* The defcription.

He apple of AEthiopia hath largeleaues of a whitifh greene colour, deepely indented about the edges, euen to the middle ribbe; the which middle ribbe is armed with a few rharpe prickles. The flowers be white, confifting of fixe fmall leaues, with a certaine yellowe pointell in the middle. The fruite is rounde, and bunched with vneuen lobes or bankes leffer then the golden apple, of colour red, and of a firme and folide fubftaunce, wherein are conteined fmall flat feedes. The roote is fmall and threddie.

\section{* The place.}

This plant hath been brought vnto vs from out that part of Spainwhich is called Andalufia, and from other parts of the fame counntrey alfo lent into Fraunce and Flaunders : but to what perfection it hath come vnto in thofe parts I am ignoraunt. But mine perifhed at the firft approch of winter. But his firft originall was from AEchio. pia whereof it tooke his name.

$$
\text { * The time. }
$$

This plant muft be fowen as muske Melons, and at the fame time; they flower in Iuly, and the fruite is ripe in September.

In Englim wee haue thought good to call it the AEthiopian apple, for the reafon before alledged: in Latine Mala AEthiopita : of fome it hath been thought to be Malinat balla: but the apple of Loue better agreeth with the defcriptio of it, \& $T$ he nature.

The temperature agreeth with the apple of Loue. * The vertues.

Thefe apples are not vfed in Phificke that I can reade of, onely they are vfed for a fauce and feruice vnto rich mens tables to be eaten, being firft boiled in the broth of fat terh with pepper and falt,and haue a leffe hurtfull iuice then eicher madde apples or golden apples.

\section{Of Thorne apples. Chap.57.}

* The defcription.

I He ftalks of thorne Apples are oftentimes aboue a cubite and a halfe high, feldorn higher, an inch thicke, vpright and ftraight, hauing very fewe braunches, fometimes none at all, but one vpright ftemme; whereupon do growe leaues fmooth and ctien, little or nothing indented about the edges,longer and broader then the leaues of Night hade; or of the mad 


\section{HISTORIE OF PLANTS. AHT}

apples. The flowers come foorth of long toothed cups, great, white, of the forme of a bell, or like the flowers of the great Withwinde that rampeth in hedges, but altogither greater and wider at the mouth, tharpe cornered at the brims with cettaine white chiues or threds in the middeft, of a ftrong ponticke fator, offending the head when it is fmelled vnto: in the place of the fower commeth vp round fruite full of fhort andblunt prickles, of the bignes of a greene Walunt when it is at the bigget, in which are the feeds of the bignes of tares, or of mandrakes, of thefame forme. The herbe it felfe is of a ftrong fauour, and doth ftiffe the heade, and caufeth drowfineffe, The roote is fmall and threddie.

2 There is another kinde heercof altogither greater then the former, whofe feedes I receiued of the right Honorable the Lord $E d$ ward Zouch, which he brought from Conftantinople, and of his liberalitie didbeftorve them vipon me, as alfo many orther rare and ftrangefeeds, and is that Thorn apple that I haue difperfed through this lande, whereof at this prefent thauregteat vfe in Chirurgerie, as well in burnings and fcaldings, as alfo in virutent and $m$ alfigne vlcers, apoftemes, and fuch like. The which plant bath a very great ftalke in fertill ground, bigger then a mants arme, friooth \& greene of colour, which a little aboure the ground deuideth it felfe into fundric boughs or armes in maner of an hedge tree; wheretipon are placed many great leaues cut and indented déepely about the edges, with many vneuen fhatpe corners: among the feleaues come white routid flowers made of one peece in manner of a belf, fhutting it felfe vp clofe towarde night as doe the flowers of the great Bindeweede whereinto it is very like, of a f weete fmell, bue fo ftrong that it offendeth the fences. The fruite followeth rounde fometimes or of the farhion of an egge, fet about on euery part with in oft harpe prickles; wherein is conteined very much feede, of the bigneffe of tares and of thefarne falhion. The roote is thicke, made of great and fmall ftrings. The whole plant is fowen, beareth his fruite, and perifheth the fame yeere.

I Stramoniwm Peregrinum. The apple of Peru.

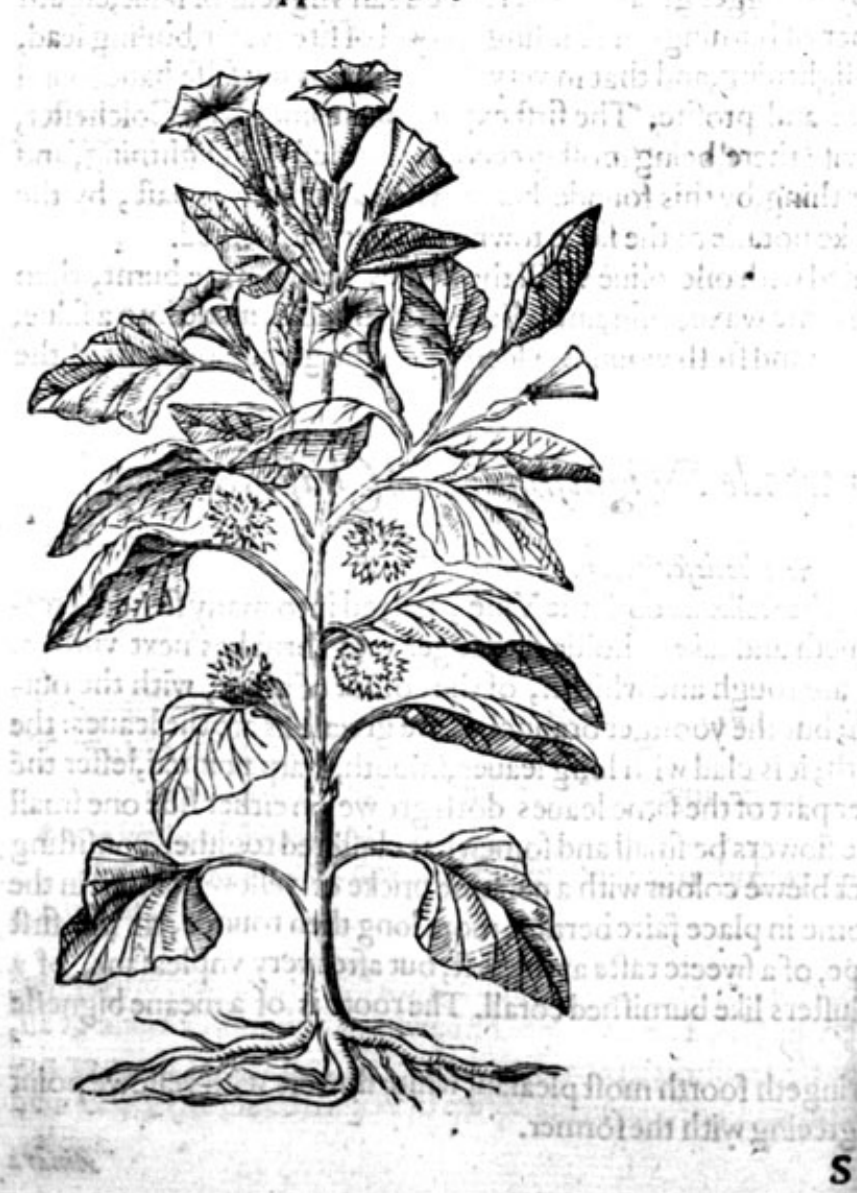

2 Stramonium pino fum. Thornie apples of Peru.
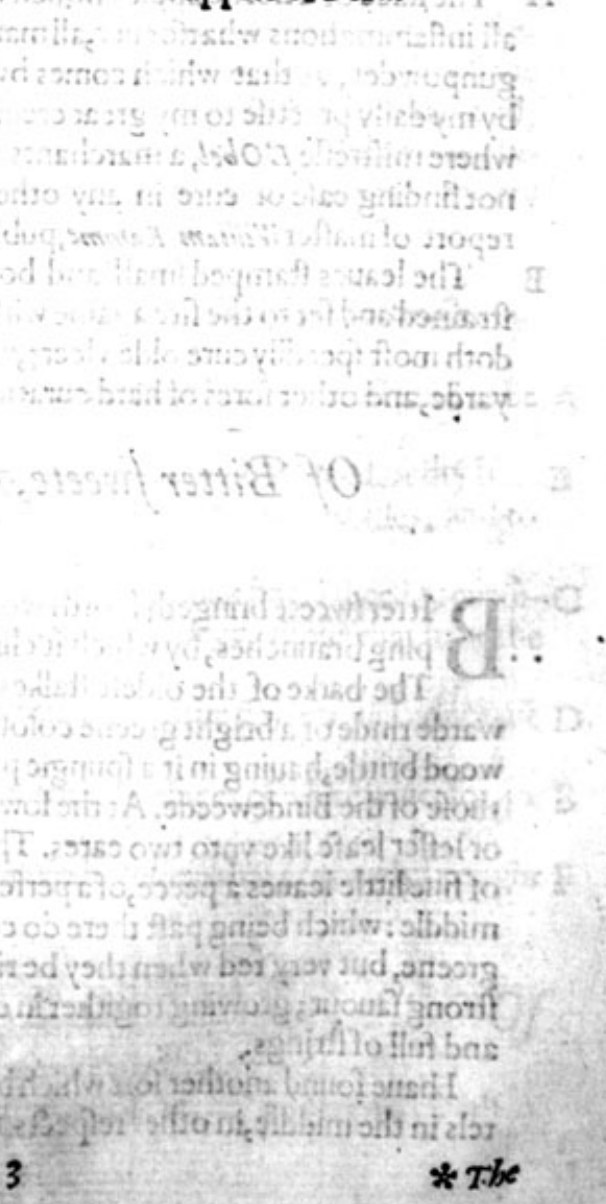
This plant is rare and ftrange as yet in Englande, I hauc receiued feedes thereof from Iohn Ro. bin of Paris, an excellent Herbarift; which did growe and beare flowers, but perifhed before the fruite came to ripeneffe.

The Thorne apple laft defcribed was brought in feede from Conftantinople, by the rightho. norable the Lorde $E$ dwarde $Z$ ouch and giuen vnto me, and beareth fruite and ripe feede,

* The time.

The firft is to be fowen in a bed of horfedung, as we do Cucumbers and Muiske Melonsei

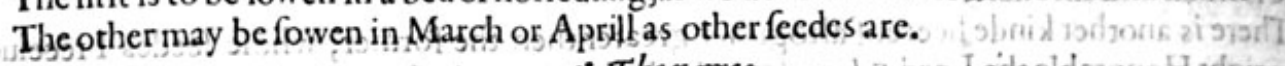

The furft of thefe Thornc apples may be called in Latine Stramonia, \& Pomyen or Malum pinofon

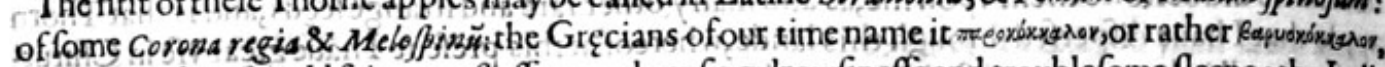
as though they fhould faic a nur ftuffing and caufing drowfineffeand troublefome fleepe : the Italians par a cocill: it feemeth to Valerius Cor dus to be Hyofoyamus Permusanim, or Henbane of Peru: Cardanus doubteth whether it fliould be infersed among the Night hades as a kind thereof : of Se-

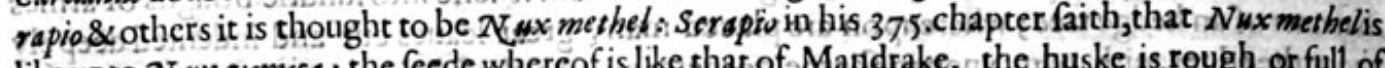
like vnto $2 u x$ vomica; the feede whercof is like that of Mandrake, the huske is, rough or full of prickles: which defcription agreeth heerewith except in the forme or Shape it houlde have with

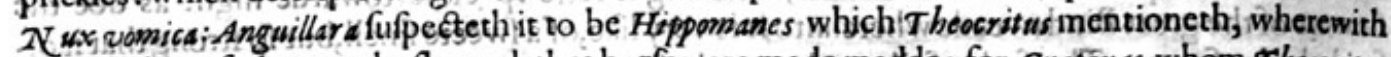
in his Eglog of charmes be hewerb that horfes are madomadde: for Crateuas whom Theocritus tranllator doth cite, writeth that the plant of Hippomanes, hath a fruite full of prickles ashath the fruite of wilde Cucumbers; in Englifh it-may be called Thorne apple or the apple of Peru: 105 iोon * The nature.

The whole plant is colde in the foorth degree, and of a drowfie and numming qualitie,not inferiour to Mandrake.

A The iuice of Thorne apples boiled with hogges greafe to the forme of an viguent or falue, cureth all inflammations whatfoeuer, allmaner of burnings or fcaldings, as wel of fire, water, boiling lead, gunpowder, as that which comes by lighening, and that in very hort time, as my felfe haue found by my daily practife to my great credite and profite. The firft experience came from Colchefter, where miftrefle $L^{\prime} O b c l$, a marchants wife there, being moft greeuoufly burned with lightning, and not finding eafe or cure in any other thing, by this founde helpe when all hopewas paft, by the report of mafter William Ramme, publike notarie of the faide towne was perfeetly cured.

B The leaues ftamped fmall and boiled with oile oliue vntill the herbes be as it were burnt, then ftrained and fet to the fire againe with fome waxe, rofin, and a little turpentine, \& made into a falue, doth inoft fpeedily cure olde vlcers, newe and frefh wounds, vlcers vpon the glandulous part of the yarde, and other fores of hard curation.

\section{Of Bitter fweete, or woode $\mathcal{N}$ ight/hade. Chap. 58.}

$*$ Thedefcription.

Itter fweete bringeth foorth wooddieftalks as doth the Vine, parted into many flender creeping braunches, by which it climeth and taketh holde of hedges and fhrubbes next vnto it. The barke of the oldeft ftalkes are rough and whitifh, of the colour of afhes, with the outwarde rinde of a bright greene colour; but the yoonger braunches are greene as are the leaues: the wood brittle, hauing in it a fpungie pith; it is clad with long leaues, fmooth, tharp pointed, leffer the thofe of the Bindeweede. At the lower part of the fame leaues doth growe on either fide one fmall or leffer leafc like vnto two eares. The flowers be fimall and fomewhat cluftered togither, confifting of fine little leaues a peece, of a perfect blewe colour with a certaine pricke or yellow pointell in the middle: which being paft there do come in place faire berries, more long then rounde, at the firt greene, but very red when they be ripe, of a fweete tafte at the firft, but after very vnpleafant, of 2 ftrong fauour; growing togither in clufters like burnifhed corall. The roote is of a meane bignefle and full of ftrings.

I haue found another fort which bringeth foorth moft pleafant white flowers with yellowe point tels in the iniddle, in other refpects agrecing with the former. 


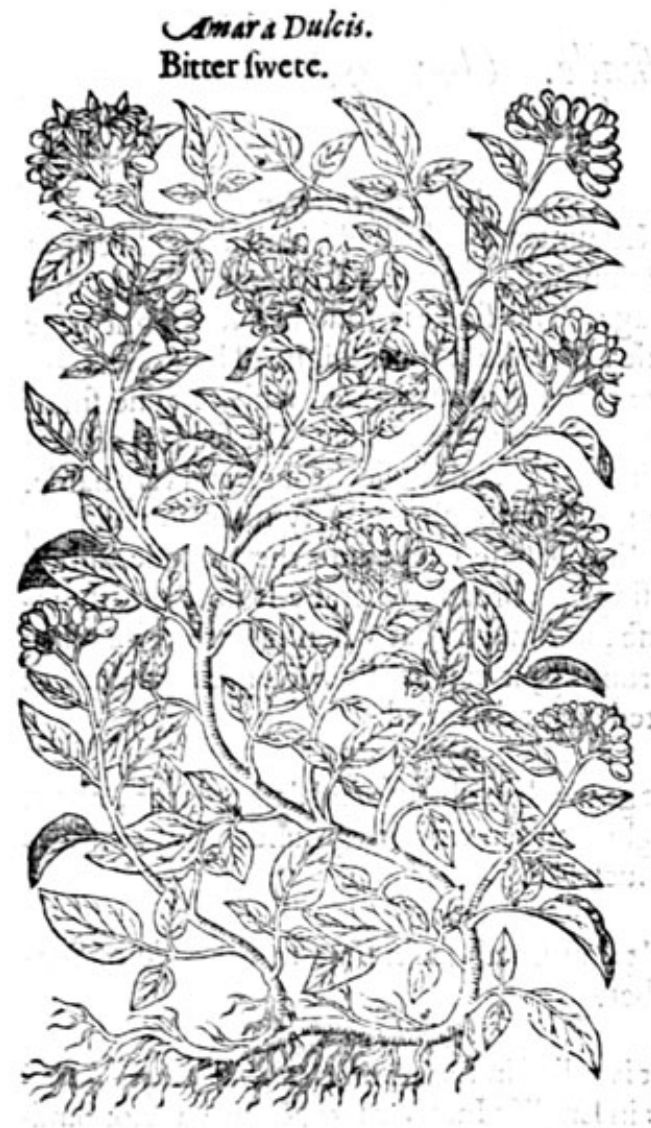

\section{* Theplate.}

Bitter fivect doth grow in moilt places about ditches, riuers, and hedges, almoft euery where.

The other fort with white flowers I found in a ditch fide againft the garden wall of the right honorable the Earle of Suffex his houfe in Bermonfey ftreetc by London, as you go from the court which is fullof trees, vinto a farme houfe neere thereunto. * The tme.

The leaues come foor h in the fpring: the flowers in Itily; the berries are ripe in Augutt.

$$
* 7 \text { be hames. }
$$

The later Herbarifts haue named this plant Dulcamara, Lmarodulcis, and Amaradalcis : the

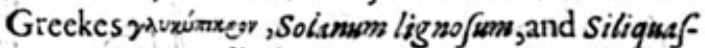
trum. Plinie calleth it Melortuon : Thesobrastives Vorsis fyluestris : in Englifh we call it Bitter fweete, and Woodnight fhade; but euery author mult for his credite faie fomthing, although to fmall purpole; for $V$ tit is fluestris is that which we call our Ladies feale, which is nokinde of Nighthade:for Tams and Vitis fylueftris are both one, as likewife Solanum lignofiom, or Fruticofun $n$ : and alfo Solaram rubrum: whereas indeede it is no fuch plant, nor any of the Night hades , although I haue followed others in placing it heere. Therefore thofe that vfe to mixe the berries thereof in compofitions of diuers cooling oinements in fteede of the

berries of Nightrhade, haue committed the greater errour: for the fruite of this is not colde at all, as is the Night hade, but hot, as foorthwith ihall be fhewed. Diofcorides faith it is Cyclaminus altera, defcribing it by the def cription of thofe with white flowers aforefaide, whercunto it doth very well agree.

$$
\begin{aligned}
& \text { * The temperatsere. } \\
& \text { The leaues and fruit of Bitterfweete are in temperature hot, and drie, clenfing and wafting away. } \\
& \\
& * T \text { the vertues. }
\end{aligned}
$$

The decoction of the leaues is reported to remooue the ftoppings of the liuer and gall:and to be A drunke with good fucceffe againft the yellow iaundife.

The iuice is good for thofe that haue fallen from high places, and thereby brufed, or dry bea- B ten: for it is thought to diffolue bloud congealed or cluttered any where in the entrailes, and to heale the hurt places.

Hyeronimisu Tragus teacheth to make a decoction of wine with the woode finely fliced \& cut in- C to fmall peeces, which he reporteth to purgegently both by vrine and fiege, thofe that have the . dropfie and iaundife.

Dioferides doch afcribe vato cyclaminus alters, or Bitter fiveete with white flowers, ás I concezue D it, the like faculties.

LThe fruite faith he, being drunke in the waight of one dram with ifj.ounces of white wine, for 40 . E

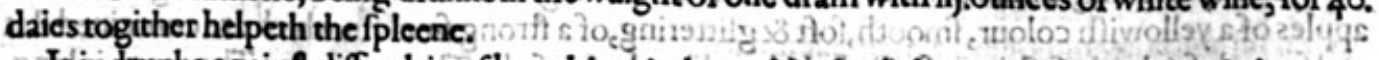

It is drunkeagainft difficultie of breathinghitchroughly clenfeti wonten that are newly brought F

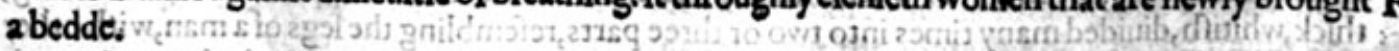

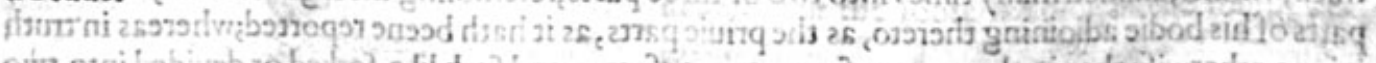

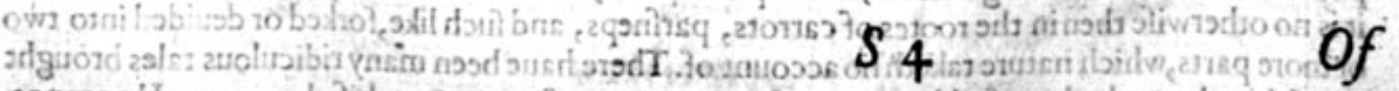

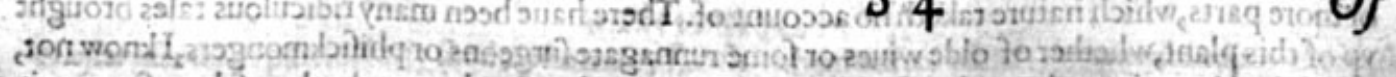

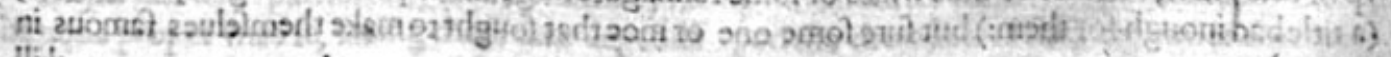
Ititis 


\section{OfBindweede Nigbt/hade. Chap.59.}

Circea Lutetiana.

Inchaunters Night?hade.

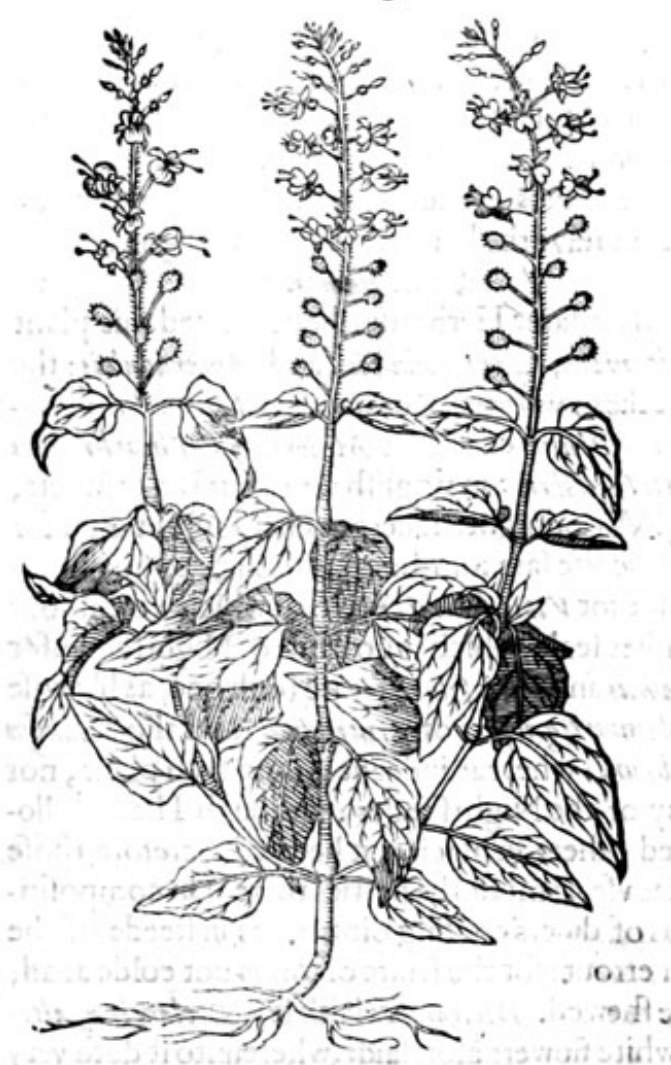

* Thedefcription.

Nchaunters Night hade hath leaues like vnto Petimorell, tharpeat the point like vnto Spi1 nage. The ftalke is ftraight and vpright verie brittle, of halfe a foote high. The flowers are white tending to carnation, with certraine fmall browne chiues in the middle. The feede is conteined in fmall rounde bullets, rough and very hairie. The roote is tough and very many in number, thrufting it felfe deepe into the grounde and difperfing far abroad, whereby it doth greatly increafe, infomuch that when it hath once taken faft rooting, it can hardly with great labour bee rooted out or deftroied.

* The place.

It groweth in obfcure and darke places, about dunghils and in vntoiled groundes, by pathwaies and fuch like.

\section{* The time}

It flourifheth from Iune to the ende of September.

It is called in Latine of $L^{\prime}$ Obelims Circea luteti. ana: in Englifh Inchaunters Night hade, or Bindweede Night hade.

* The nature and vertwes.

There is no ve of this herbeeither in Phificke or chirurgerie that I can read of, which hath hap-

ned by the corruption of time, and the errour of fome who haue taken Mandragoras for Circea, in which errour they haue ftill perfifted vnto this daie, attributing vnto Circea the vertues of Mandragoras : by which meanes there hath not any thing beene faide of the true Circea, by reafon as I haue faide, that Mandragoras hath beene called Circes : but doubtleffe it hath the vertue of garden Nighthade, and may ferue in fteede thereof without errour.

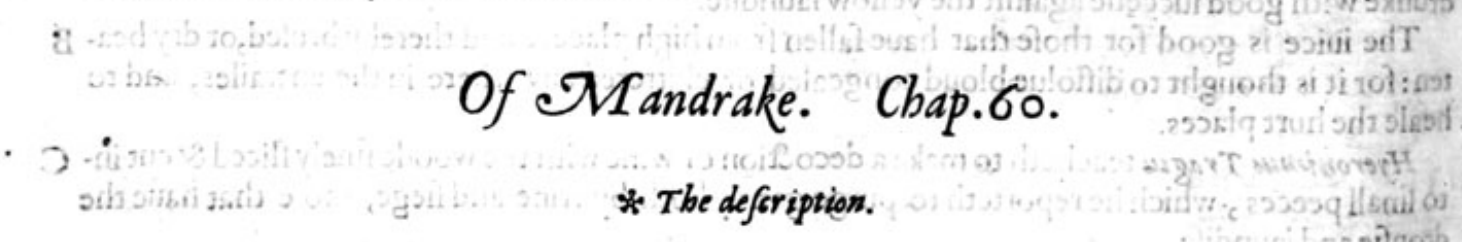

A 7 Hernale Mandrake hath great, bròad,long, fmoothleaues, of a deepe greene colour, flat fpred vpon the ground: among which come vp the flowers of a pale whitifh colour, ftanding euery one vpon a fingle fmal \& weak footftalk, of a whitifh green colour; in their places grow round apples of a yellowith colour, fmooth, foft \& glittering, of a ftrong fmel : in whicharé conteined tias and mooth feedes, infafhion of a litele kidney like thofe of the Thorne apple. The roote is long, thick, whitifh,ditided many times into two or threc parts, refembling the legs of a man, with bether parts of his bodic adioining thereto, as the priuie parts, as it hath beene reported;whereas in truth it is no otherwife then in the rootes of carrots, parfneps, and fuch like, forked or deuided into two or more parts, which nature taketh no account of. There haue been many ridiculous tales brought vp of this plant, whether of olde wiues or fome runnagate furgeons or phifickmongers, I know not, (a title bad inough for them:) but fure fome one or moe that fought to make themlelues famous in 
skillfull abouc others were the firft brochers of that errour I fpake of. They adde further, that it is neuer or verie feldome to be founde growing naturally but vnder a gallows, where the matter that hath fallen from the dead bodie, hath given it the fhape of a man : and the matter of a woman, the fubftaunce of a female plant; with many other fuch doltifh dreames. They fable further and affirm, that he who woulde take vp a plant thereof muft tie a dogge thereunto to pull it $v p$, which will giuc a great fhrike at the digging vp; otherwife if a man fhould doit, he fhould certainly die in fhort fpace after : befides many fables of louing matters, too full of fcurrilitic to fet foorth in print, which I forbeare to fpeake of : all which dreames and olde wiues tales, you fhall from hencefoorth caft out of your bookes and memorie; knowing this that they are all and euery part of them falfe and molt vntrue. For I ny felfe and my feruaunts alfo haue digged vp, planted, and replanted veric many: \&yet neuer could either perceiue fhape of man or woman, but fometimes one ftraight roote, formetimes two, and often fixe or feauen braunches comming from the maine great roote; euen as nature lift to beftowe vpon it as to other plants. But the idle drones that haue little or nothing to do but eate and drinke, haue beftowed fome of their time in caruing the rootes of Brionie, forming them to the ihape of men $\$$ women; which falfifying practife hath confirmed the errour amongit the fimple and vnlearned people, who haue taken them vpon tbeir report to bethe true Mandrakes.

The female Mandrake is like vnto the male, fauing that the leaues heereof be of a more fwarte or darke greene colour; and the fruite is long like a peare, and the other is rounde like an apple.

chandragor es mas of femina.

The male and female Mandrake.

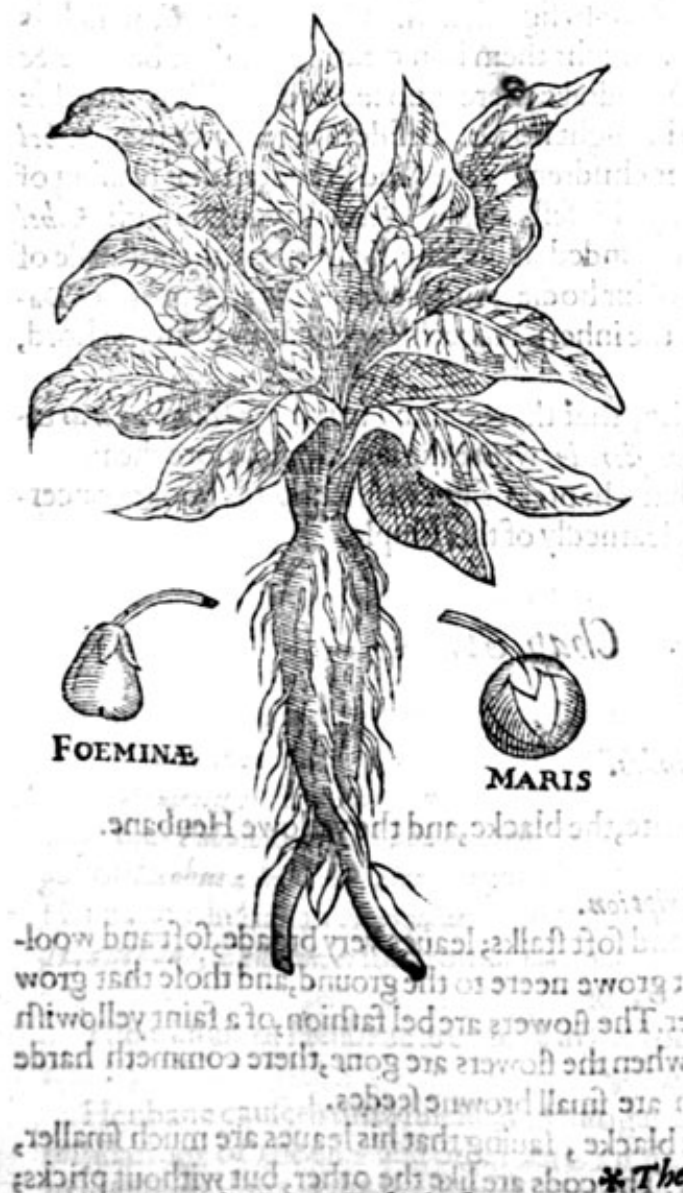

* The place.

Mandrake growethin hot regions, in woodes and mountaines, as in mount Garganus in Aptlia, and fuch like places; we haue them onelyplanted in gardens, and are not elfewhere to be found in England.

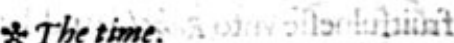

They fpring vp with their leates in March, and nower in tke ende of Aprill: the fruite is ripe in Auguit. * The names. ${ }^{2}$, th the

Mandrake is called of the Grxcians uarderheeps, of diuers ripreia: and Circes of Circe the Witch, 1 . whoby Art could procure loue : for it hath beene thought that the roote heereof ferueth to winne loue: of fome arripuner, Anthropomorphos, and Morion : fome of the Latines haue called it Terre malum, and Terrestre malum, and Canina malus : fhoppes and other nations alfo do receiue the Greeke name. Diofcorides faith that the male is called of diuersuiewriand defcribeth allo another Mandrake by the name of Morion: which is generally holden tobe Solanum Hortenfe, but of fome Circea lutetiana, but not properly: in Englifh we call it Mandrake, Mandrage, and Mandragon.

Mandrake hath a predominate colde facultie, 2s Galen faith, that is tofaie colde inthe thirde degree: but the roote is colde in the fourth idegree. bepone proper vnto it, fauing thofe that depende vpon the drowfie and fleeping power thereof, 


\section{$2 \overline{8}_{2}$ THE SECOND BOOKE OF THE}

which qualitie confifteth more in the roote then in any other part.

$B$ The apples are milder, and are reported that they may be eaten, being boiled with Pepper and other hot fpices.

C Galen faith, that the apples are fomething hot and moift, and that the barke of the roote is of greateft ftrength, and doth not oncly coole, but alfo dric.

D The iuice of the leaues is very profitablie put into the ointement called Populeon, and all cooling ointments.

E The iuice drawen foorth of the rootes, dried, and taken in fmall quantitie, purgeth the belly ex. ce edingly from flegme and melancholicke humours.

F It is good to be put into medicines and colliries, that domitigate the paine of the eies: and put vnder as a peffarie it draweth foorth the dead childe and fecondine.

G The greene leaucs ftamped with barrowes greace and barley meale, coole all hot fwellings and inflammations:and they haue vertue to confume apoftemes and hot vlcers, being brufed \&applied thereon.

H A fuppofitorie made with the fame iuice and put into the fundament caufeth fleepe.

I The wine wherein the roote hath beene boiled or infufed, prouokethfleepe, and affwageth paine.

$\mathrm{K}$ The fmell of the apples mooueth to fleepe likewife; but the iuice worketh more effectually if you take it in finall quantitie.

L Great and ftrange effects are fuppofed to be in Mandrakes, to caufe women to be fruitull and beare children if they fhall but carie the fame neer vnto their bodies. Some dofrom hence ground it, for that Raheldefired to haue hir fifters Mandrakes(as the text is tranflated) but if we looke well into the circumftaunces which there we fhall finde, we may rather deeme otherwife. Yoong zuben brought home amiable and fweete fmelling flowers ( for fo fignifieth the Hebrewe word, which is vfed Cantic. 7. 13. in the fame fence:) and the lad brought them home rather for their beautic \& finell, then for their vertue. Now in the flowers of Mandrake there is no fuch delectable or amiable finell, as was in thefe amiable flowers which Ruben brought home. Befides we read not that Rabel conceaued heereupon, for Leah Iacobs wife had fower children before God graunted that bleffing of fruitfulneffe vnto Rahel. And laft of all (which is my chiefeft reafon) Iacob was angrie with Rahel when the faid, Giue me children elfe I die : and demaunded of hir whether he were in the fteade of God or no, who had withhelde from hir the fruite of hir bodie. And we know that the prophet $D A$. wid faith, Children and thefruite of the wombe are the inheritaunce, that commeth from the Lord, Pfalm.127.

M Serapio, Auicene, and Psulus UEgineta, do write, that the feede and fruite of Mandragorastaken in drinke, do clenfe the matrix or mother, and Diofsortdes wrote the fame long before them.

He that wouldeknow more heereof may read that chapter of doctor Turner his booke concerning this matter, where he hath written largely and learnedly of this fimple.

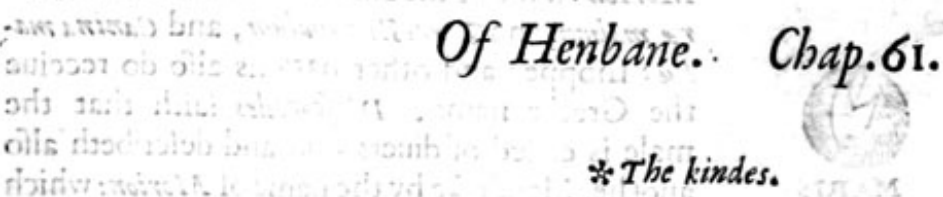

There be three forts or kinds of Henbane, the white, the blacke, and the yellowe Henbane.

* The defcription.

17 He common blacke Henbane hath great and foft ftalks; leaues very broade, foft and woollie, fomewhat iagged, ef pecially thofe that growe necre to tle ground, and thofe that grow vpö the ftalk, narrower, fmaller, \& (harper. The flowers are bel farhion, of a faint yellowilh white, and browne within towards the bottome; when the flowers are gone, there commeth harde knobbie huskes, like fmall cups or boxes wherein are fmall browne feedes.

2 The white Henbane is not much vnlike to the blacke, fauing that his leaues are much fmaller, whiter and more woollie, \& the flowers alfo whiter. The cods are like the other, but without pricks; it dieth in winter, and muft likewife be fowen againe the nextyeere. 


\section{HIHISTORIE OFIPLANTS. $\exists H I$}
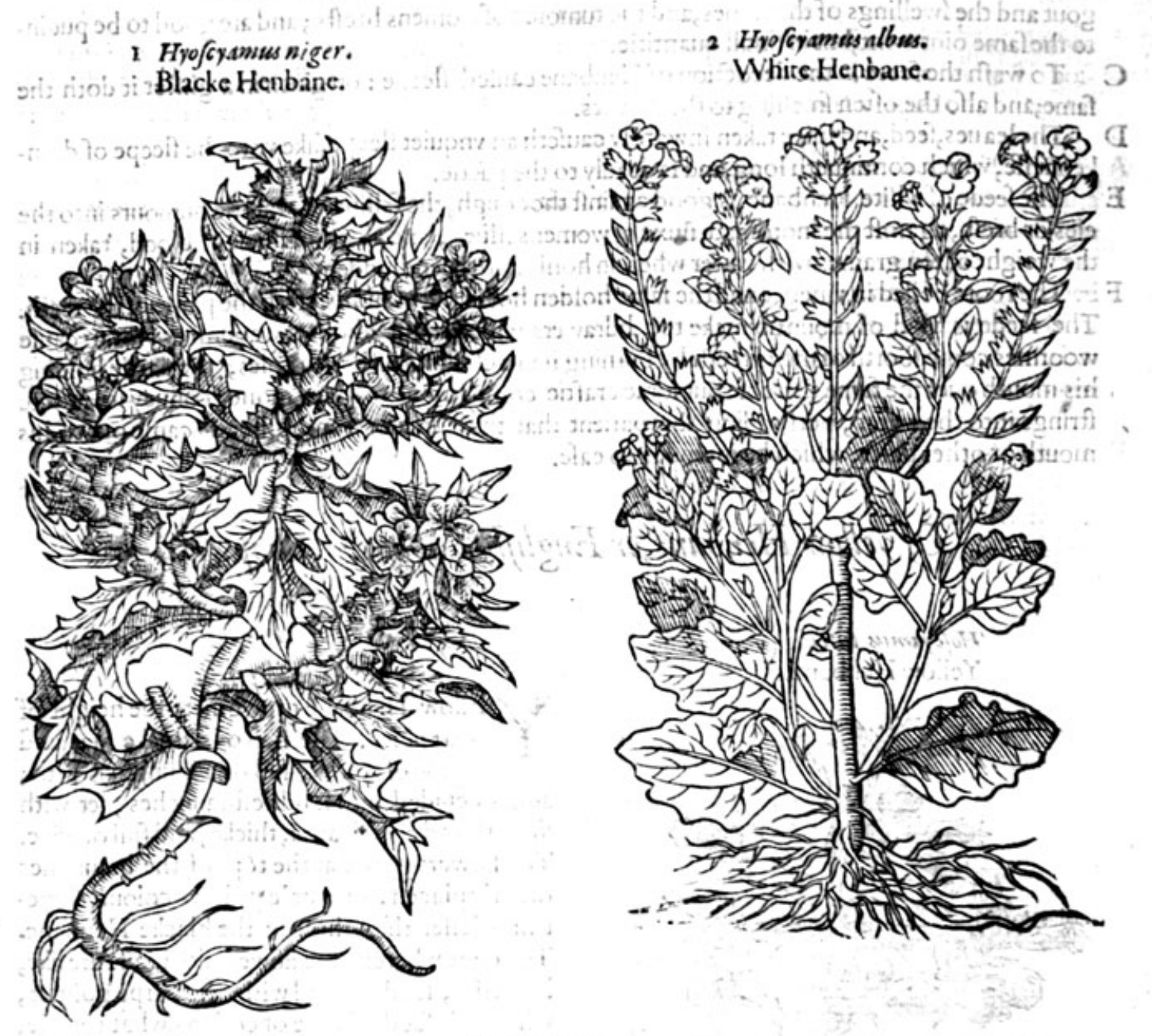

* Theplace.

The blacke Henbane groweth almoft euery where by high waies, in the borders of dunghils and vntoiled places; but the white Henbane is not found but in the gardens of thofe that loue phificall plants : the which growech in my garden and doth fowe it felfe from yeere to yeere.

\section{* The time.}

They fpring out of the grounde in Maic, bring foorth their flowers in Auguft, and the feede is ripe in October.

$$
\text { * The names. }
$$

Henbane is called of the Grxcians votristuss: of the Latines Apollinaris, and Faba fuills : of the Arabians as Pliny faith LAitercam, of fome Faba Iowis, or Iupiters beane : of Pytl agoras, Zoroaffes, and Apuleitus Infans Alterculam, yrmptroniaca, and Calicularis: of the Phrygians Remenia : of the Tufcanes Fabulonis and Faba lupima : of CHat heus Syluaticus, Dens Caballinus, Milimandrwm Caßala$g_{0}$ : of Iacobses a Mawlys Herba Pinnula : in fhops it is called In'quiamus and Hyofoyamus: in Englifh Henbane : in Italian Hyofquiamo: in Spanifh Velenno: in high Dutch 23tlfen ktaut : in French Hannebane, Endormie: Fome other Latinifts Hyofcyamus albus, or white Henbane.

$$
\text { * The temperature. }
$$

Thefe kinds of Henbane are colde in the fourth degree.

$$
\text { * The vertues. }
$$

Henbane caufech drowfineffe, and mitigateth all kinde of paine. It is good againft hot \& fharpe $\mathbf{A}$ diftillations of the eies and other parts: it ftaieth bleeding and the difeafe in women :it is applied to inflammations of the ftones and other fecret parts.

The leaues ftamped with the ointment Populeon, made of popler buds, affwageth the paine of the B 
gout and the fwellings of the ftones, and the tumours of womens brefts; and are good to be put into the fame ointmeint, but in finall quantitie.

C To wafh the feete in the decoction of Henbane caufeth fleepe : or gituen in a glifter it doth the fame; and alfo the of ten fnelling to the flowers.

D The leaucs, feed, and iuice taken inwardly caufeth an vnquiet fleepe, like vnto the fleepe of drunkenneffe, which continueth long, and is deadly to the partie.

E Thefeede of white Henbane is good againft the cough, the falling of waterie humours into the eies or breft, againft the inordinate fluxe of womens iffies, and all other iffues of blood, taken in the weight of tengraines with water wherein honie hath beene fodden.

F The roote boiled in vineger and the fame holden hot in the mouth, eafeth the paine of the teeth. The feede is ved of mountibancke toothdrawers which runne about the countrey, for to caufe woormes come foorth of niens teeth by burning it in a chafing difh with coles, thie partie bolding his nouth ouer the fume there of: bucfome craftie companions to gaine money conuey fmall lute ftrings into the water, perfwading the patient that thofe fmall creeping beafts came out of his moutbfor other parts, which he intended to cafe.

\section{Ofyellow Henbane, or Englifh Tabaco. Chap.62.}
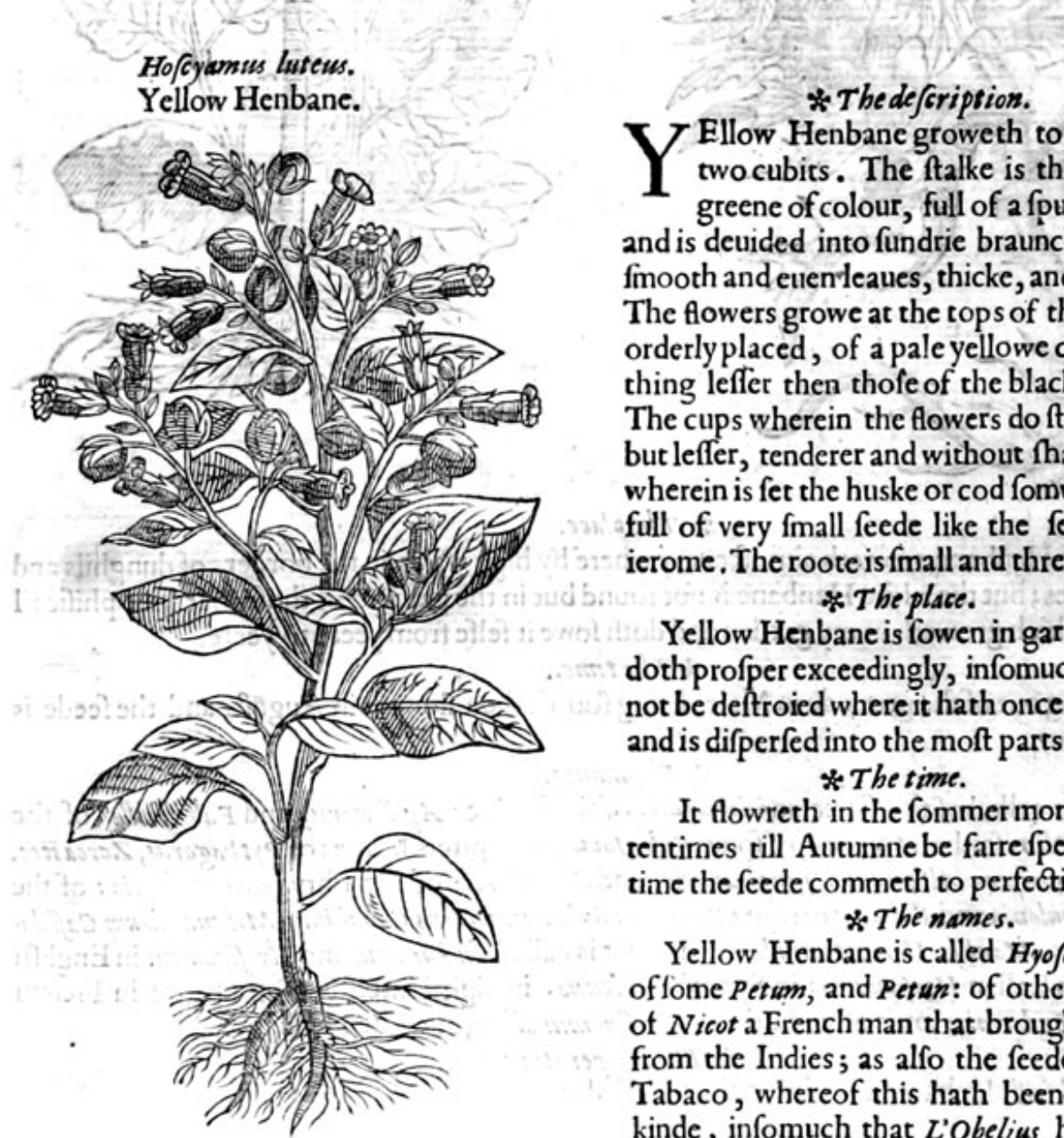

Ellow Henbane groweth to the height of two cubits. The ftalke is thicke, fat and greene of colour, full of 2 fpungious pith; and is deuided into fundrie braunches, fet with fmooth and euenteaues, thicke, and full of iuice. The flowers growe at the tops of the braunches orderly placed, of a pale yellowe colour, fomething leffer then thofe of the blacke Henbane. The cups wherein the flowers do ftande are like, but leffer, tenderer and without fharpe pointes, wherein is fet the huske or cod fomwhat rounde, full of very fmall feede like the feede of Marierome. The roote is fmall and threddic.

$$
\text { * The place. }
$$

Yellow Henbane is fowen in gardens where it doth profper exceedingly, infomuch that it cannot be deftroied where it hath once fowen it felf, and is difperfed into the moft parts of Englande. * The time.

It flowreth in the fommer moneths, and oftentimes till Autumne be farrefpent, in which time the feede commeth to perfection. *The names.

Yellow Henbane is called Hyofcyameslutem, of fome Petum, and Petun: of others : vicofians, of Nicot a French man that brought the feedes from the Indies; as alfo the feedes of the true Tabaco, whereof this hath beene taken for 2 kinde, infomuch that L'Obelius hath called it Dubius Hyofcyamus, or doubtfull Henbane, as a plant participating of Henbanc and Tabaco: and is vfed of diters in fteede of Tabaco, and called by the fame name, for that it hath beene brought from Trinidada a place fo called in the Indies; as alfo from Virginia or Norembega for Tabaco, which doubtleffe taken in fmoke worketh the fame kind of drunkennes that the right Tabaco dotb. * The 
$*$ The nature.

This kinde of Henbane is thought of fome to be colde and moift; but after $L^{\prime} O b e l i a s$ it rather heateth then cooleth at all, bicaufe of the biting tafte, as allo that rofennes or gumminefic it is poffeffed of, which is euidently perceiucd both in handling and che wing it in the mouth.

$$
\approx 7 \text { bevertu's. }
$$

This herbe preuaileth againtt all apoftemes, tumours, inueterate vlcers, botches and fuch like, $\mathbf{A}$ being made into an vnguent or falue as followeth. Take of the greene leaues threepounde and a halfe, ftampe them very finall in a ftone morter; of oile olitue one quart; fet them to boile in a braffe pan or fuch like, vpon a gentle fire, continually ftirring it vntill the herbes feeme blacke, and will not bubble nor boile any more; then fhall you haue an excellent greene oile, which being ftrained from the feces or droffe, put the cleere and ftrained oile to the fire againe, adding thereto of waxe halfe a pounde, of rofen fower ounces, and of good turpentine two ounces; melt them altogither and keepe it in pots for your vfe to cure inueterate vlcers, apoftemes, burnings, greene wounds,and all cuts and hurts in the head, wherewith I haue gotten both crownes and credit.

It is vfed of fome in fteede of Tabaco, but to fmall purpofe or profite, althotgh it doftupifie or B dull the fences, and caufe that kinde of giddineffe that Tabaco doth, and likewife fpitting, which any other herbe of hot temperature will do, as rofemarie, time, winter fatoric, fiveete marierome, and fuch like, any of the which I like better to be taken in fmoke then this kinde of doubtfull Henbane.

\section{Of Tabaco or Henbane of Peru. Chap.63.}

\section{* The kindes.}

There be two forts or kindes of Tabaco, one greater, the other leffer; the greater was brought into Europe out of the prouinces of America, which we call the weft Indics: the other from Trinidada an Ilande neere vnto the continent of the fame Indies; fome haue added a thirde fort, and others making the yellowe Henbane for a kinde thereof, although not properly.

\section{Holcyamm Perunianus.}

Tabaco or Henbane of Peru.

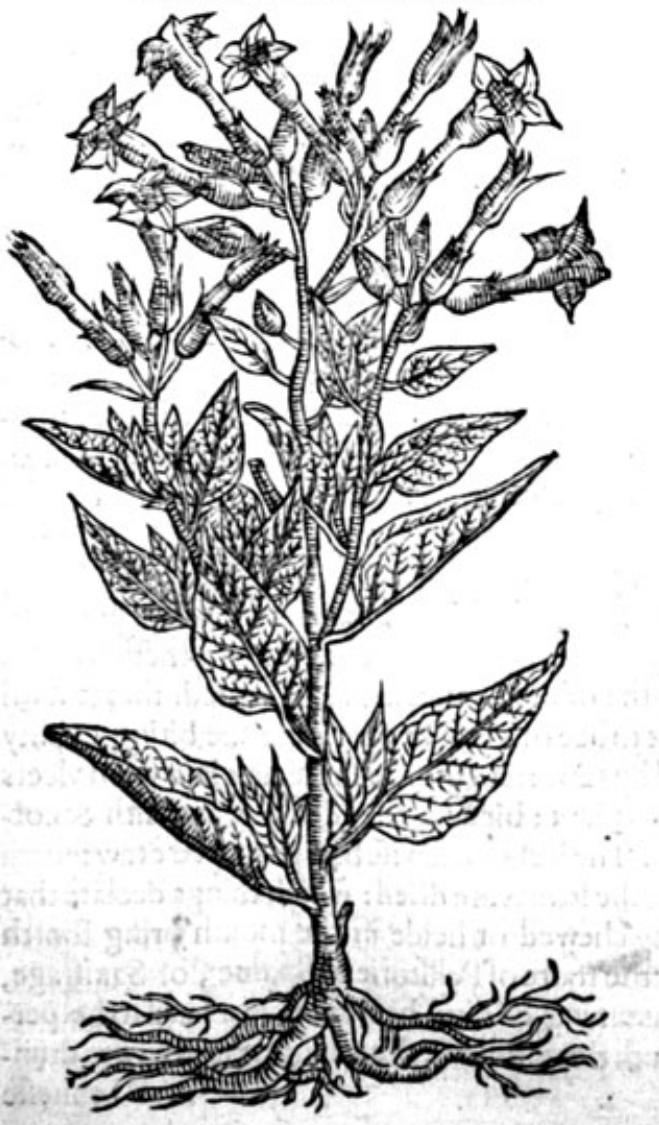

2 Sana Sancta Indoram.

Tabaco of Trinidada.

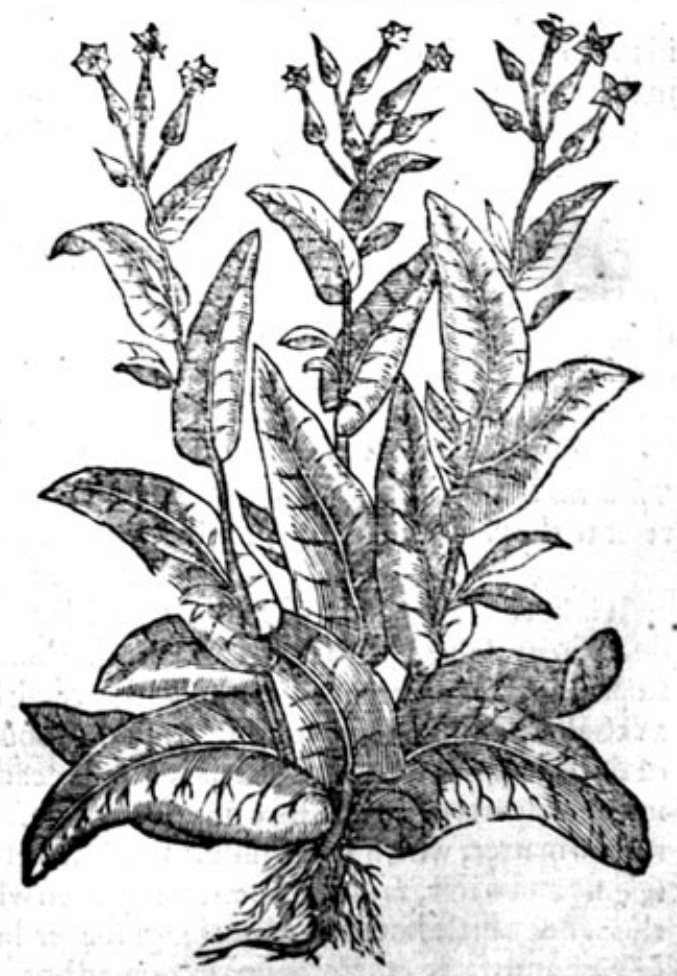


* The defoription.

I 7 Abaco or Henbane of Pcru, hath very great ftalkes of the bigneffe of a childes armes growing in fertill and well dunged ground, of feauen or cight foote high, deuiding it felfe into fundrie braunches of great length, whereon are placed in moft coinelyorder verie fairc long leates, broade, fmooth, and harpe pointed, foft, and of a light greene colour, fo faftned about the ftalks, that they feeme to embrace and compaffe it about.The flowers grow at the top of the ftalks in thape like a bel flower, fomwhat long and cornered, hollow within, of a light carnation colour, tending to whitneffe toward the brims. The feede is conteined in long fharpe pointed cods or feede veffels, like vnto the feede of yellow Henbane, but fomewhat fmaller and browner of colour. The roote is great, thicke, and of a wooddie fubftaunce, with fome threddie ftrings annexed thereto.

2. Trinidada Tabaco hath a thicke, tough and fibrous roote, from which immediately rile vp long broade le.uies, and finooth, of a greenifh colour, leffer then thofe of Peru, among which rifeth vp 2 ftalke diuiding it ?elfe at the grounde into diuers braunches, whereon are fet confufedly the like leaues, but lefier: at the top of the ftalks, ftande vp long necked hollow flowers of a pale purple,ten. ding to a bluth colour; a fter which fucceede the cods or feede veffels, including many fimall feeds like vnto the feede of Marierom. The whole plant perifheth at the firft approch of winter. * The place.

It was firft brought into Europe out of the prouinces of America, which is called the weft Indies, in which is the prouince or countrey of Peru: but being now planted in the gardens of Europe, it profpereth very well, and commeth from feede in one yeere to beare both flowers and feede. The which I take to be better for the conftitution of our bodies, then that which is brought from India; and that growing in the Indies better for the people of the fame countrey; notwithitanding it is not fo thought nor receiued of our Tabackians; for according to the Englifh prouerbe; Far fetcht and deere bought is beft for Ladies.

\section{$*$ The time.}

Tabaco muft be fowen in the moft fruitefull grounde that may be founde, carelefly caft abroade in the fowing,without raking it into the grounde or any fuch paine or induftrie taken, as is requifite in the fowing of other feedes as my felfe haue found by proofe, who haue experimented euery way to caufe it quickly togrowe: for 1 haue committed fome to the earth in the ende of March, fome in Aprill, and fome in the beginning of Maie, bicaufe I durft not hazard all my feede at one time left fome vnkindly blaft hould happen after the fowing, which might be a great enimie thereunto.

\section{* The names.}

The people of America call it Petun : others Sacra Herba, fancta Herba, and fans fancta Indodorum, L'Obcliy and Pene, and fome Hyofcyamus Pernuianus, or Henbane of Peru: 2 Ticolaws. Mo nardis nameth it Tabaco: that it is Hyofcyami pecies, or a kinde of Henbane, not onely the forme being like to yellowe Henbane, but the quialitic alfo doth declare: for it bringeth diowfineffe, troubleth the fences, and maketh a man as it were drunke by taking of the fume onely; as Uindrew
Theuetus teftificth,(and common experience fheweth:) of fome it is called Nicotiana : the whichI refer to the yellowe Henbane for diftinction fake.

\section{$\approx$ The temperature.}

It is hot and drie, and that in the fecond degree,2s Monerdisthinketh: and is withall of power to difcuffe or refolice, and to clenfe away filthic humours, hauing alfo a certaine fmall aftriotion and 2 ftupifieng or benumming qualitic, and purgeth by the ftoole: and CMonardis writeth that it hath a certaine power to refift poifon. And to prooue it tobee of a hot temperature the biting quality of the leaues doth fhewe, which is cafily perceaued by tafte: alfo the greene leaues laid vpon vicers in finewie parts may ferue for a proofe of heate in this plant; bicaufe they do draw, out filth $\&$ corrupted matter, which a cold fimple would neuer do. The leaues likewife being chewed draw foorth flegme and water, as doth alfo the fume taken when the leaues are dried: which things declare that this is not a little hot: for what things focter being chewed or helde in the mouth bring foorth flegine and water, the fame be all counted hot, as the roote of Pellitorie of Spaine, of Saxifrage, and other things of like power. Moreouer the benumming qualitie heereof is nothard to be perceited, for vpon the taking of the fume at the mouth there followeth an infirmitie like vnto drun- 
kenneffe,and many times fleepe : as after the taking of Opium, which alfo theweth inthe tafte a byting qualitie, and therefore is not without heate; which when it is chewed and inwardly taken, it doth foorthwith hewe, caufing a certainc heate in the cheft, and yet withall troubling the wits: as Petrus Belloniws in his thirde booke of fingularities doth declare; where alfohe. Theweth that the Turkes do oftentimes vfe Opium, and take one dram and a halfe thercof at one time; without anie other hurt following, fauing that they arethereupon taken with a certaine light drunkenneffe as it were. So alfo this Tabaco being in tafte biting, and in temperature hot, hath notwithftanding 2 benumming qualitie. Heereupon is feemeth to follow, that not gnely this Henbane of Peru, but alfo the iuice of poppie otherwife called Opium, confifteth of diuers parts, fome biting and hot, and others extreme colde, that is to faie, ftupifieng or benumming: if fo be that this benumming qualitic proceede of extreme colde (as Galen and all the olde phifitions holde opinion:) butif the benumming facultie doth not depende of an extreme colde qualitie, and that in the fourth degree, but proceedeth of the effence of the fubftance; then may Tabaco be both colde and alfo bennmming; of temperature hot and benumming, not by reafon of his temperature, but through the propertic of his fubftaunce; otherwife then a purging medicine, which hath his force not from the temperature, but from the effence of the whole fubitance.

\section{* The vertwes.}

Nicolass Monardis faith that the leaues hereof are a remedie for the paine in the head called the A Megram or Maigraime that hath beene of long continuance : and alfo for a colde ftomacke, efpeci-
alty in children; and that it is good againft the paines in the kidneies.

It is a prefent remedie for the fits of the mother: it mitigateth the paine of the gout if they bee B rofted in hot embers and applied to the greeued part.

It is likewife a remedie for the toothach, if the tceth and gummes bee rubbed with a linnen $C$ clorh dipped in the iuice;and afterward a rounde ball of the leaues laid vnto the place.

The iuice boiled with fugar in forme of a firupe and inwardly taken, driteth foorth woormes of $D$ the bellie; if withall a leafe be laide to the nauell. The fame doth likewife fcoure and clenfe olde and rotten vlcers, and bringethrhemto perfect $E$
digeftion as the fame author affirmeth.

Ir the low countries it is vfed againft fcabs and filthineffe of the skin,\& for the cure of wounds: $F$ but fome holde opinion that ir is to be vfedbut onely to hot and Itrong bodies: for they fay that the vef is not fafe in weake and olde folke: and for this caufe, as it feemeth, the women in America (as
Thervetus faith)abltaine from the herbe Petun or Tabaco,and do in no wife vfe it.

The weight of fower ounces of the iuice heereof drunke purgeth both vpwards and downwards, $G$ and procureth after a long \& found flecpe, as we haue learned of a friend by obferuation, affirming that a ftrong countrieman of a middle age, hauing a dropfie, tooke of it, and being wakened out of his fleepe,called for meate and drinke, and after that became perfectly whole.

Moreouer the fame man reported, that he had curedmany countriemen of agues with the deftil- $\mathbf{H}$ led water of the leaues drunke a little while before the fit.

Likewife there is an oile to be taken out of the leaues that healeth merrie galles, kibed heeles and I
arch like.

It is good againft poifon, and taketh away themalignitie there of, if the inice be giuen to drinke, $\mathrm{K}$
or the wounds of venemous beafts be wafhed therewith. or the wounds of venemous beafts be wafhed therewith.

The drie leaues are vfed to be taken in a pipe fet on fire and fuckt into the ftomacke, and thruft $L$ foorth again at the nofthirils againft the paines of the head, rheumes, aches in any part of the bodie, whereof foetuer the originall doth proceed, whether from Fraunce, Italy, Spaine, Indies, or from our familiar and beft knowne difeafes: thofe leaues do palliate or eafe for a time, but neuer performe any cure abfolutely : for although they emptie the bodie of humours, yet the caufe of the griefe cannot be fotaken away. But fome haue learned this principle, that repletion requiretheuacuation; that is, fulneffecraueth emptineffe, and by euacuation affure themfelues of health: but this doth not take. away fo much with it this day, but the next bringeth with it more; as for example, a Well doth neuer yeelde fich ftore of water as when it is moft drawne and emptied. My felfe fpeake by proofe, who haue cured of that infectious difeafe a great many;diuers of which had couered or kept viderthe ficknefle by the helpe of $T$ abaco as they thought, yet in the ende haue beene conftrained
to haue vnto fuch an hard knot, a crabbed wedge, or elfe had vtterly perifhed.

Some vfe to drinkc it (as it is tearmed) fer wantonneffe or rather cuftome, and cannot forbeare $M$ 
it,no,not in the middeft of their dinner, which kinde of taking is vnholfome and very daungerons: although to take it feldome and that Phifically is to be tolerated and may do fome good, birt Icommende the fyrupe abotie this fume or finokie medicine.

$\mathrm{N}$ Ir is taken of fome phifically in a pipe for that purpofe once in a day at the moft, and that in the morning fafting againft paines in the head, ftomacke, and griefe in the breftand lungs: againft catarrhes and rheumes, and fuch as haue gotter colde and hoarfeneffe.

O Some hane reported that it little preuaileth againft an hot difeafe, and that it profitech an hot complexion nothing at all : but experience hath not ihewed it to be iniurious to either.

P They that hate feene the proofe heereof, haue crediblie reported, that when the Moores andIn. dians hane fainted either for want of foode of reft, this hach beene a prefent remedie vnto them to fupplic the one, and to helpe them to the other.

Q The priefts and inchaunters of the hot counitries do take the fume therof vntill they bedrunken, that after they hatie lien for dead threc or fower howers, they may tell the people what droonders, vifions or illufions they hatie feene, and fo gitue them a propheticall direction or foretelling (if wee may truit the dituell)of the fuccefle of their bufineffe.

$\mathrm{R}$ The iuice or diftilled water of the firft kinde, is very good againft catarrhes, the dizzineffe of the heade and rheumes that fall downe the eies, againft the paine called the migram, if either you applie it vnto the temples or take one or two greeneleaues, or a drie leafe moiftned in wine, and dried cunningly vpon the embers and laid thereto.

$S$ It cleereth the fight, and taketh away the webs and fpots thereof, being annointed with the iuice Glood warme.

T Theoile or iuce dropped into the eares is good againft deafeneffe; a cloth dipped in the fame andlailde vpen the face, taketh away the lentils, redneffe, and fpors thereof.

$\mathrm{V}$ Many notable medicines aremade heereof againft the olde and inueterate cough, againft afthmaticall or pectorall griefes, which if I fhoulde fet downe at large, woulde require a peculiar volume.

$X$ It is giuten to fuch as are accuftomed to fwoune, and are troubled with the collicke $\&$ windineffe, agaiuft the dropfie, the woormes in children, the piles and the fciatica.

$\mathrm{Y}$ It is vfed in outtvard medicines either the herbe boiled with oile, waxe, rofin and turpentine, as before is fet downe in yellowe Henbane, or the extraction thereof with falt, oile, balfame, the diftilled water and fuch like, againft tumours, apoftemes, olde vleers, of hard curation, botches, fcabs, ftinging with nettless, carbuncles, poifoned arrowes, and woundes made with guns or any other weapon.

Z It is excellent good in burnings and fcaldings with fire, water, oile, lightning, or fuch like, boiled with hogs greace in forme of an ointment, which I haue often prooued and found moft true, adding a litcle of the iuice of thorne apple leaucs, fpreading it vpon a cloth and fo applying it.

I do make heereof an excellent balfarne to cure deepe wounds and punstures, made by fomenarrowe îharpe pointed weapon: whichbalfame doth bring vp the fle? from the bottome very fpeedily, and alfo heale fimple cuts in the fleth according to the firft intention, that is, to glewe or foder the lips of the wound togither, not proctiring matter or corruption vnto it, as is commonly feene in

A the healing of wounds. The receit is this, take oile of rofes, oile of Saint Iohns woort, of either one pint, the leaues of Tabaco ftamped fmall in a ftone morter two pound, boile them togither to the comfumption of the itice, ftraine it and put it to the firengaine, adding thereto of Venice Turpentine two ounces, of olibanum \& mafticke of either balfe an ounce, in moft fine \& fubtill powder, the which you may at all times make into an vnguent or falue by putting thereto waxe and rofin to giue vnto it a ftiffe bodie, which worketh excecding well in maligne and virulent vlcers, as in woundes and puneturcs: I fende this iewell vnto you women of all forts, efpeciaily to fuch as cure and helpe the poore and impotent of your countrie without rewarde. But vinto the beggerly rabble of witches, charmers, \& fuch like coufeners, that regarde more to get money then to helpe for charitie, I wifh thefe fewe medicines far from their vndcrftanding, and from thofe deceiuers whom I wifh to bee ignoraunte heercin. But curteous gentlewomen, I may not for the malice that I doe beare vnto fuch, hide any thing from you of fuch importaunce : and therefore take one more that followeth, wherewith I haue done very many and good cures, although of fmall colt, but regarde it

B not the leffe for that caufe. Take the leaues of Tabaco two pounde, hogges greafe one pound, ftampe the herbe fmal in a ftone morter, putting therto a final cupful of red or claret wine, ftirthem 


\section{HISTORIE OF PLANTS.}

well togither,couer the morter from filth and folet it reft vntill morning; then put it to the fire and let it boile gently, continually ftrring it vntill the confumption of the wine; ftraine it and fet it to the fire againe,putting thereto the iuice of the herbe one pounde, of Venice Turpentine fower ounces; boile them togither to the contumption of the iuice,then adde thereto of the rootes of round Arifrochis or birth woort in moft fine powder two ounces, fufficient waxe to giue it a body, the which keepe for thy wounded poore neighbour, as alfo the olde and filthie vlcers of the legges and other parts of fuch as haue neede of helpe.

\section{Of tree $\mathcal{N}$ ight/hade. Chap.64.}

Amomum Plinï.

Tree Nighth hade.

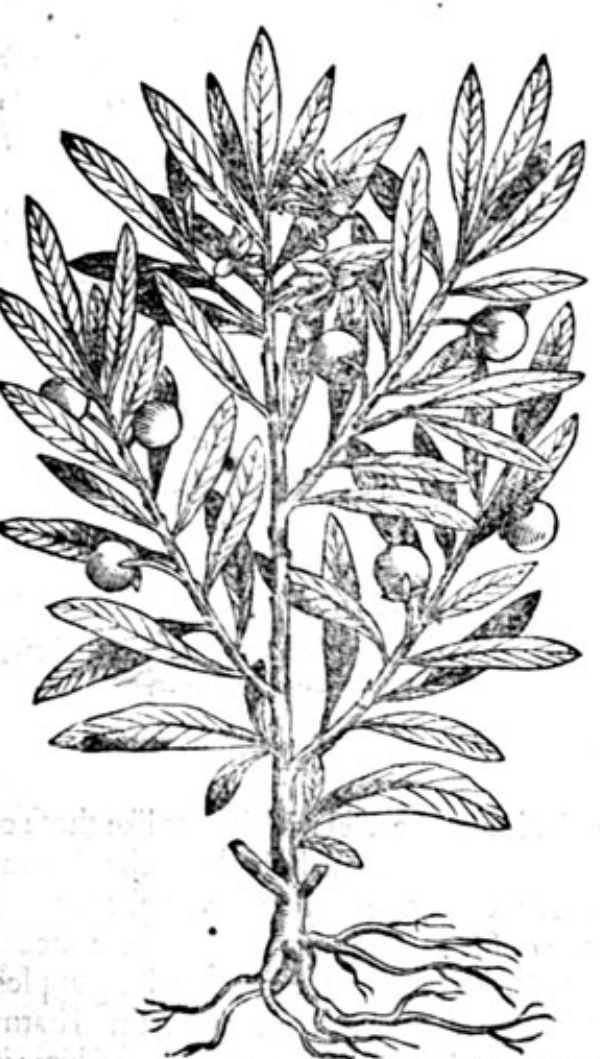

* The defcripsion.

This rare and pleafaunt plant, called tree Nighthade, is taken of fome to be akinde of Ginnie pepper, but not rightly; of others for a kinde of Night thade, whole itidgement and cenfure I gladly admit; for that it doth more fitly anfiver it both in the forme and nature. It groweth vppe like vnto a fmall fhrubbe or wooddic hedge bufh, two or three cubits high, couered with a greenifh barke fet with many fmall twiggie braunches, and garnifhed with many long leaues verie greene, like vnto thofe of the peach tree. The flowers are white, with a certaine yellowe pricke or pointell in the middle, like vnto the flowers of garden Nighthade. After which fucceede fmall rounde berries verie red of colour, and of the fame fubftance with winter cherries, wherin are conteined little flat yetlow feedes. The roore is compact of many fmall hairis yellow ftringes.

$$
* \text { The place. }
$$

It groweth not wilde in thefe colde regions, but we haue them in our gardens, rather for pleafure then profite, or any gond qualitic as yet knowne.

$$
\text { x Thetime. }
$$

It is kep in pots and tubs with earth and fuch like in houfes during the extremitic of winter, $\mathrm{bi}$ caufe it cannot endure the coldneffe of our colde clymate, and is fet abroade into the garden in March or Aprillsit flowreth in Maie, and the fruite is ripe in September.

$$
\text { * The numes. }
$$

Tree Night hade is called in Latine Solamum arborefcens, of fome Stickrodendron, and Strichnodendron: Amomum of Plinie : and Pfeadocapficum of Dodonatu.

\section{*T Te nature and vertues.}

We haue not as yet any thing fet downe as touching the temperature or vertues of this plant, but is referred of fome to the kinds of Ginnie pépper, but without any reafon at all, for Ginny pepper though it bring foorth fruite verie like in fhape vnto this plant, yet in tafte moft vnlike, for that Capficeom or Ginny pepper is more fharpe in tafte then our common pepper; and the other hath no talte of biting at all, but is like vnto the berries of garcen Nighthade in tafte, although they differ in colour : which hath mooued fome to call this plant red Nighthade, of the colour of the berries: and tree Nighthade, of the wooddy fubitance which doth continue and grow from yeere to yeere: and Ginnie pepper diethat the firt approch of winter. 
1 Baljanina mas. The male Baifam apple.

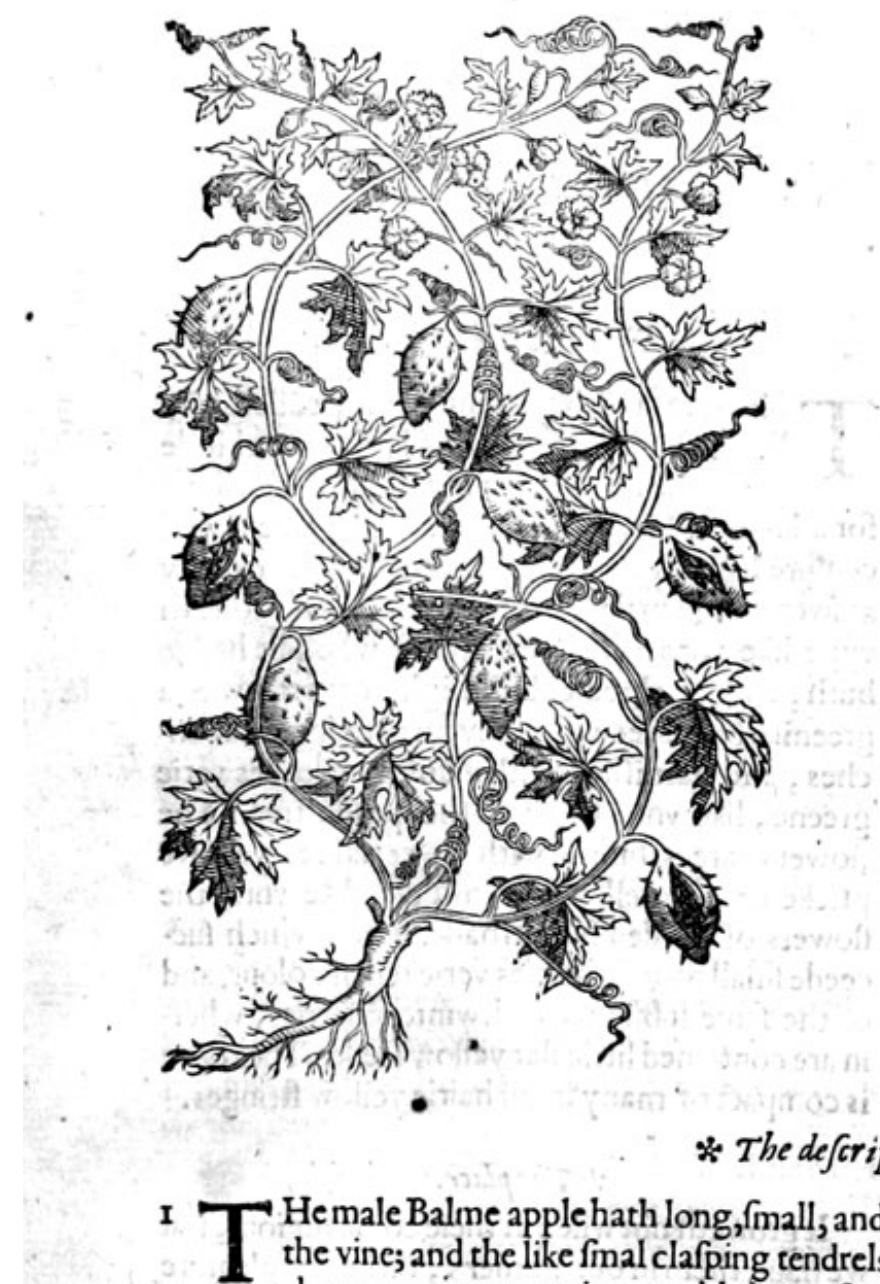

2 Baifamina farmint. The femalc Balfam apple.

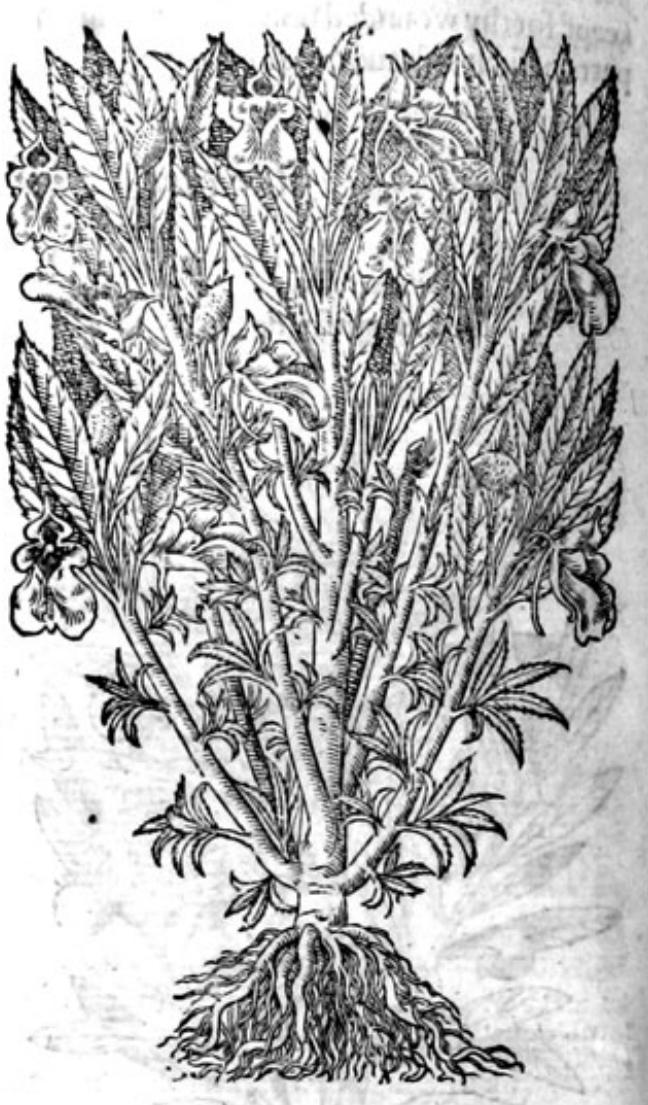

* The defcription.

do growe neere vnto it, not able by reafon of his weakeneffe to ftande vpright without in the flowers confift of fiuc fmall leaues of a meane bignes, and are of a faint yellowe colour : which being paft, there docome in place long apples, fomething tharpe toward the point alpoft like an egge, rough all ouer as it were with fmall harmleffe prickels, red both within and without when they be ripe, and cleate in funder of themfelues: in the apple lieth great broade flat feede, like thofe of Pompion or Citrull; but fomething blacke when they be withered. The roote is threddie, and difperfeth it felfe farre abroad in the ground.

2 The female Balme apple doth not a little differ from the former : it bringeth foorth ftalkes not running or clyming like the other, but a moft thicke and fat truncke or ftocke full of iuice, in fubftance like the ftalkes of Purflane, of a reddinh colour and fomwhat fhining. The leaves be long and narrowe, in thape like thofe of willowe or the peach tree, fomewhat toothed or notched about the edges: among which grow the flowers of an incarnate colour tending to blewneffe, hauing a fimall fpur or taile annexed therto as hath the Larkes heele, of a faire light crimfon colour : in their places come vp the fruite or apples rough and hairie, but leffer then thofe of the former,yellow when they be ripe, which likewife cleaue a funder of themfelues and caft abroad their feedes much like vnto Lentils fcedes faith mine author. But thofe which I hatic from ycere to yeere in my garden, bring foorth feede like the Coleflorcy or Muftarde feede; whether they bee of two kindes, or theclimate do alter the fhape, it refteth difputable. 
* The place.

Thefe plants do profper beft in hot regions: They areftraungers in England, and do with great labour and induftrie growe in the? e colde countries. * The time.

They muft be fowen in the begimning of Aprill in a bed of hor horfe dung, even as muske Melons, Cucumbers, and fuch like colde fruites are; and replanted abroad from the faide bed into the moft hot and fertill place of the garden at fuch time, as they hatic gotten three leaues a peece. * The names.

Diuerfly hath this plant beene named, fome calling it by one name, and fome by another,euerie one as it feemed good to his fancic. Baptifta Sardsus calleth it Balfamina Cucwmerina : others Viticella, and Charantia, as alfo Pomum Hierofolymitanum, or apples of Hierufalem: in Englifh Balme apple: in Italian Caranza : in the Germaine toong 23alfam opffel: in French Merweille: fome of the Latines haue called it Pomwow mirabile, or maruelous apples. It is thought to be named $B a l / a$ mina bicaufe the oile wherein the ripe apples be fteeped or infufed, is taken to be profitable for manie things, as is Carpobal Jamum, or the liquor of the plant Balfamum.

The female Balfan apple is likewife called B.ilfamini $:$ and oftentimes in the Neuter gender Balfaminum: Gefner chofech rather to name it Balfamina anygdaloides: Valeriws Cordus Balfawella:others Balfamina fermina : in Englifh the female Balme apples.

\section{* The nature.}

The fruite or apples heereof, as alfo the leaues, do notablie drie, hauing withall a certaine moderate coldneffe very neere to a meane temperature, that is, after fome hot in the firft, and drie in the fecond degree.

\section{* The vertues.}

The leaues are reported to heale greene wounds if they be brufed and laide thereon; and taken $\mathbf{A}$ with wine they are faide to be a remedie for the collicke; and an effectuall medicine for burftings and conuulfions or crampes.

Theleaues of the male Balfimina dried in the fhadowe, and beaten into powder and giuen in $\mathbf{B}$ wine vnto thofe that are mortally wounded in the bodie, doth cure them inwardly, and helpeth alfo the collicke.

Theoile which is drawen foorth of the fruite doth cure all greene and frefh woundes as the true $\mathbf{C}$ naturall Balfam : it helpeth the crampes and conuulfions and the fhrinking of finewes, being an-
nointed therewith.

It profiteth women that are in great extremitie of childbirth in taking away thie paine of the ma- D trix, caufing eafie deliuerance being applied to the place, and annointed vpon their bellies, or caft into the matrix with a fyring, and eafech the dolour of the inward parts.

It cureth the Hemorrhoices and all other paines of the fundament, being thereto applied with $\mathbf{E}$ lint of old clouts.

The leaues drunken in wine, heale ruptures.

I find little or nothing written of the propercy or verrues of the femalc kind bur that to drawe necre vnto the firft in temperament and vertuc. Oyle olive in which the fruite(the feede taken foorth)is either fet in the funve as we dowhen we $H$ make oile of roles, or boiled in 2 double glaffe fet in hot water, or elfe buried in hot horfe dung; taketh away inflammations that are in wounds. It doth alfo eafily and in fhort time confolidate or
glew them togither; anidpetfectly cure them.

It cureth the vlcers of the dugges or paps, the head of the yarde or matrix, as alfo the inflamma-I tion thercof being injected or conucied into the place with a fyringe or mother pefiarie. 5 is $T$ -

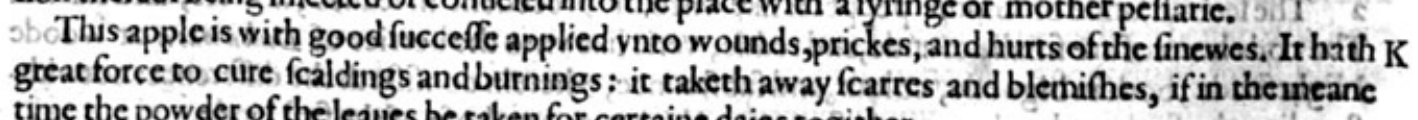
time the powder of the leaies be taken for certaine daies togither.

It is reported that fuch is be barren are made fruitfull-heercwis. afit and conuenient bath for the purt with, and the woman prefently haue the companie parts about the fhare and matrix annointed heer2i ti: vilming

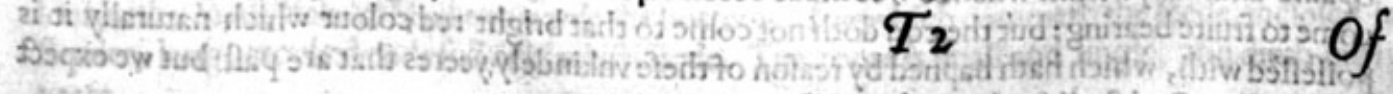
2งt? $*$.

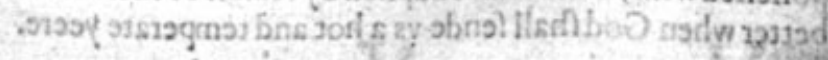




\section{of Gimie or fndian Pepper. Chap.66.}

I Capficsm longioribus filiquis. Long codded Ginnic Pepper.

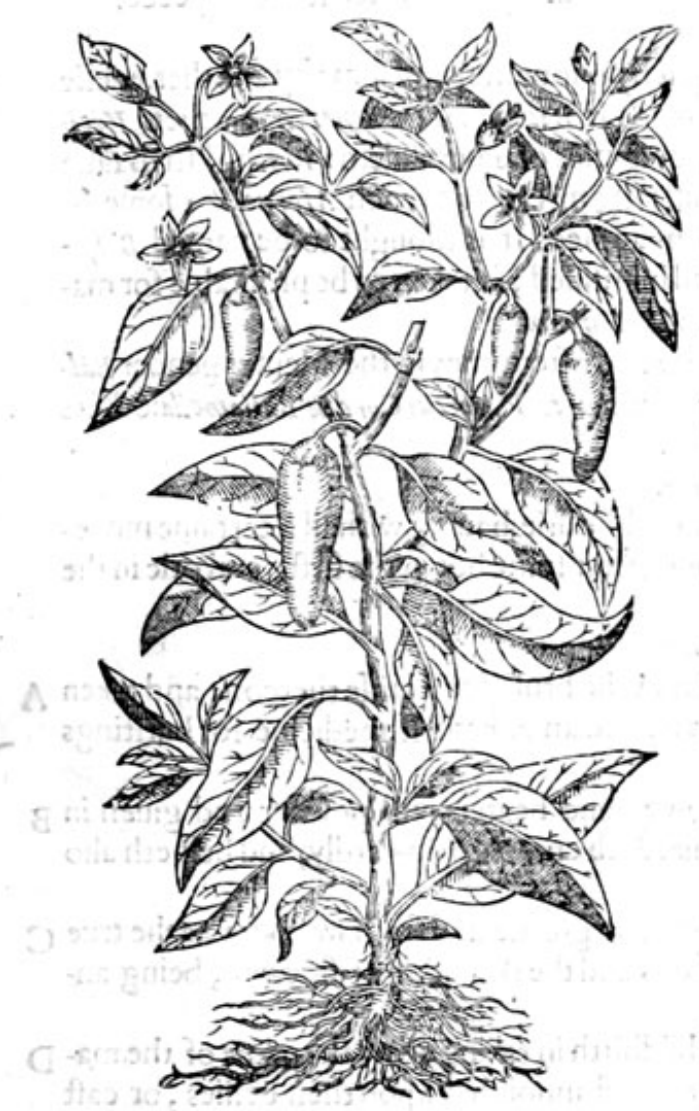

2 Capfocum minimis filiguid. Small codded Ginnie Pepper.

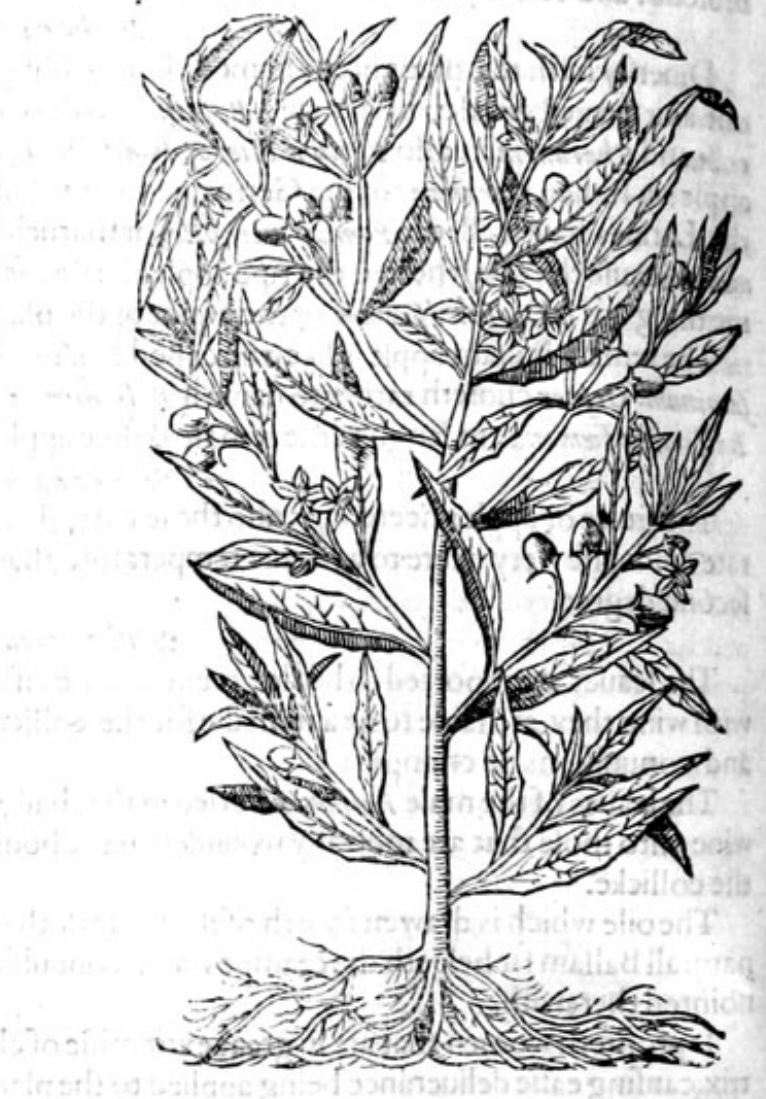

* The defcription.

I The firft of thefe plants haue fquare ftalkes a foote high or fornewhat more, fet with many thicke and fat leaues, not vnlike to thofe of garden Nighthade, but narrower \& fharper pointed, of a dark greene colour. The flowers grow alongtt the ftalks out of the wings of the leaues of a white colour, hauing for the moft part fiue finall leaues blafing out like a ftar, with 2 greene button in the middle. After them growe the cods, greene at the firf, and when they be ripe of a bratue colour glittering like red corall, in which is conteined little flat feedes of a light yellowe colour, of a hot biting tafte like common pepper, as is alfo the coditfelfe: which islong, and 2s bigge as a finger and fharpe pointed.

2 The fecond kinde of Ginnic pepper is like vnto the precedent in leaues, flowers, and ftalkes. The cods heereof are fmall, rounde, and redde, verie like vnto the berries of Dulcamara or woode Night thade, both in bigneffe, colour, and fubftaunce; whercin confifteth the difference: notwithftanding the feede and cods are verie harpe and biting, as are thofe of the firft kinde.

$$
\text { * The place. }
$$

Thefe plants are brought from forren countries, as Ginnie, India, and thofe parts, into Spaine and Italy: from whence wee hate receitued feede for our Englifh gardens, where they come to fruite bearing: but the cod doth not come to that bright red colour which naturally it is poffeffed with, which hath hapned by reafon of thefe vnkindely yeeres that are paft: but we expeet better when God hall fende vs a hot and temperate yeere. 


\title{
HISTORIE OF PLANTS.
}

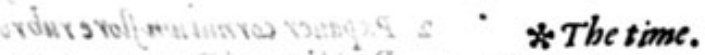

The feedes heereofmut be fowen in a bed of hot horfedung, as muske Melons are, and remooued into a pot when it hath gotten three or fower leaues, that it may the more conueniently be caried from place to place to receiue the heate of the funne : and are towarde Autumne to be caried into fome houfe, to anoide the iniurie of the colde nights of that time of the yeere when it is to beare his fruite.

$\therefore$ The names.

Acturrizus callech it in Greeke wofuòn, in Latin Cap ficum: \& it is thought to bethat which Anicenne nameth Zinziber canimum, or dogs Ginger: and Pliny Siliquaftrum, which is more like in tafte to pepper then is Panax, and it is therefore called Piperitis, as hee hath written inhis 19 :booke 12. chapter: Panax (faith he)hath the tafte of pepper and Stligua frum, for which caufe it is called Piperitis. The later Herbariftes do oftentimes call it Prper Indianom, or Indicion, fometimes Piper Calecutbium, or Piper Hifpanicum: in Englifh it is called Ginnie pepper, and Indian pepper ; in the Ger-

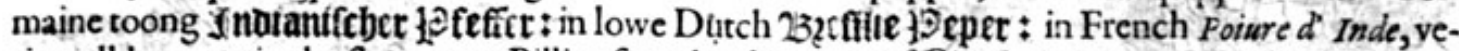
rie well knowne in the fhoppes at Billingfgate by the name of Ginnie pepper, where it is viually to be bought.

\section{* The temperature.}

Ginnie pepper is extreme hot and drie euen in the fourth degree: that is to faie, farre hotter and drier then Awicen theweth dogs ginger tobe.

$$
\text { * Thevertues. }
$$

Ginnie pepper hath the tafte of pepper, but not the power or vertue, notwithftanding in Spaine and fundrie parts of the Indies they do vfe to dreffe their meate therewith, as we do with Calecute pepper : but(faith my author)it hath in it a malitious qualitie, whereby it is an enimic to thaliuer \& other of the entrails; Auicen writeth that it killeth dogs.

It is faide to die or colour like faffron, and being receiued in fuch fort as faffron is vfually taken, $B$ it warmeth the ftomacke, and helpeth greatly the digeftion of meates.

It diffolueth the fwellings about the throte called the Kings Euill, as kernels and cold fwellings; C and taketh away fpots and lentiles from the face, being applied therto with honie.

\section{Of horned Poppie. Chap.67.}

\author{
* The kindes.
}

Here be fundrie forts of horned Poppies, differing in foile, ftature, andproportion, colour of
flowers and leaues. The figures of two of the chiefeft fhall be fet downe : the reft we intende to leaue either vnto a fecond Edition,or a further confideration.

\section{* The defcription.}

I He yellowe horned Poppie hath whitifh leaves very much cut or iagged, fomewhat like the leaues of garden Poppie, but rougher and more hairie. The ftalks be long, rounde, and brittle. The flowers be large and yellow, confifting of fower leaues; which beingpaft, there come long huskes or cods, crooked like an horne or cornet, wherein is conteined finall blacke feede. The roote is great, thicke, fcalie and rough, continuing long.

2 The fecond kinde of horned poppie is much flenderer and leffer then the precedent, and hath leaues like deepe cuts as Rocket hath, and fornething hairie. The ftalkes be verie flender, brittle, and braunched into diuers armes or wings; the flowers fmall, made of fower littleleaues, of a red colour, with a fmall ftrake of blacke towarde the bottome, after which commeth the feede, inclofed in flender, long, crooked cods full of blackilh feede. The roote is fmall and fingle, and dieth euery yeere. 
I Papaner cornutum fore lutco. Yellowe horned Poppic.

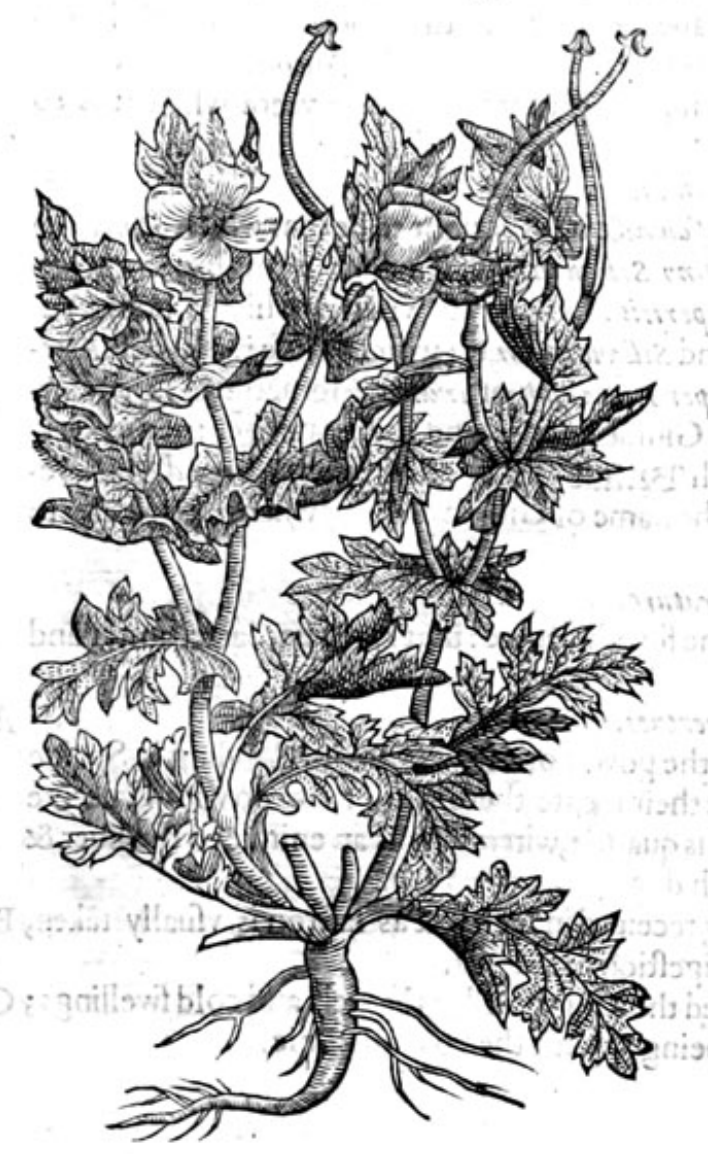

3 Papauer cornutum flore violaceo. Violet colour horned Poppey.

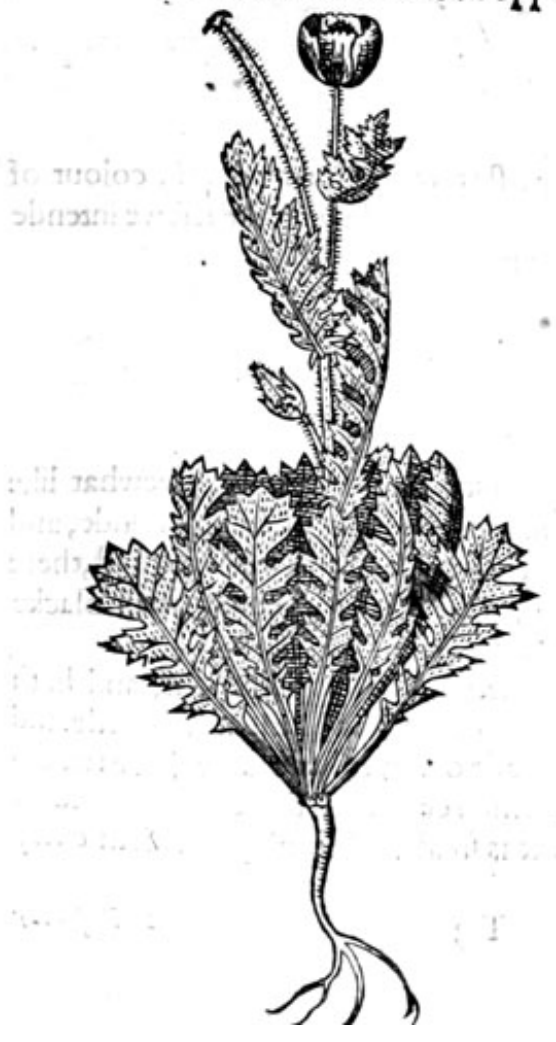

2 Papawer cornution flore rubro. Red horned Poppie.

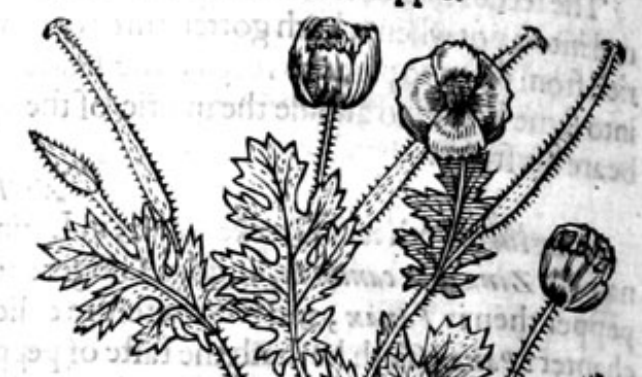

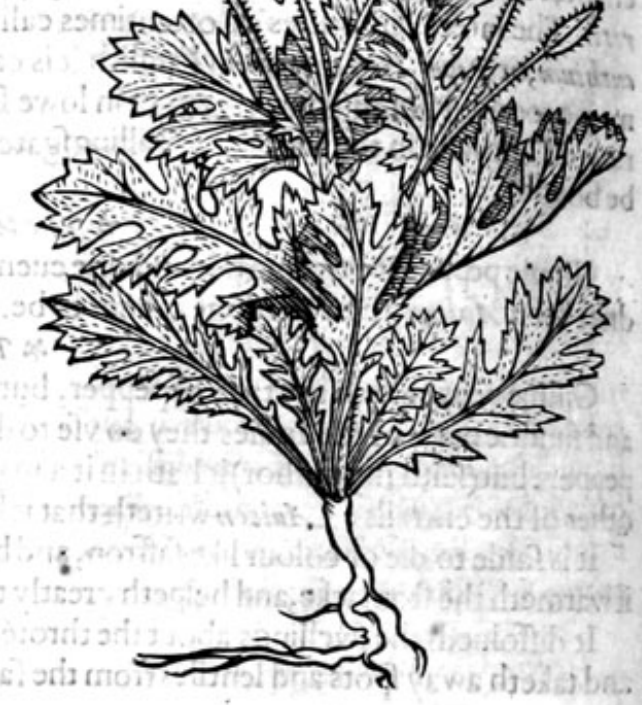

4 Papasuer cornutam lutevom minsoa. Small yellowe horned Poppie.

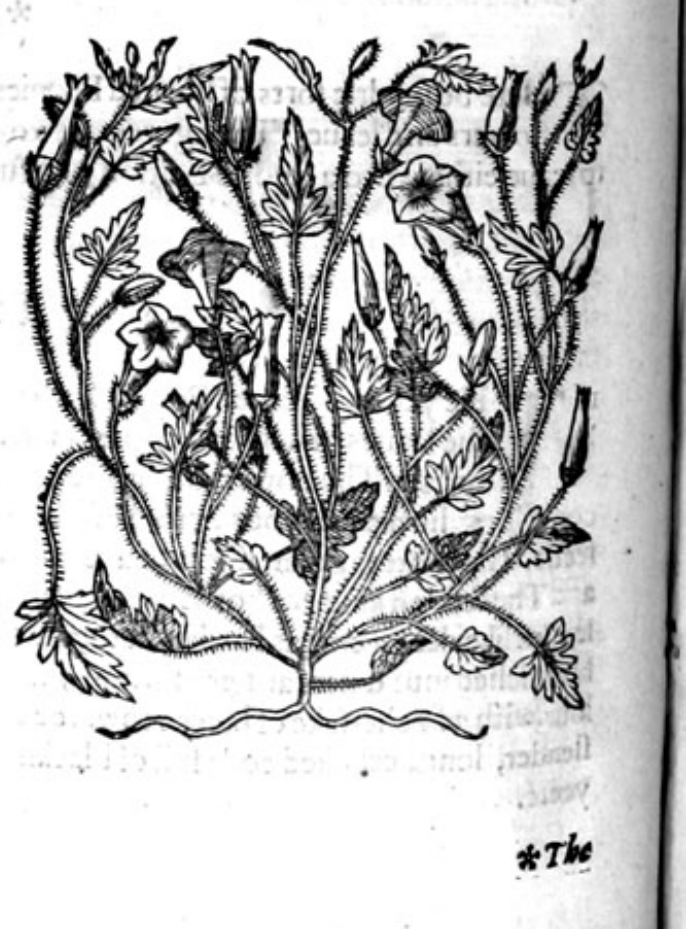


3 There is another fort of horned Poppie altogither leffer then the laft defcribed, hauing tenderer leaues, cut into fine litcle parcels: the fower is likewife leffer, of a blew purple colour like the double Violet.

4 There is founde another fort hauing leaucs like Rewe, with fmall and lowe ftalkes, and little yellowe towers compact of fixe fmall leaues, three bigger, the reft leffer.

$$
\text { * The place. }
$$

The yellowe horned Poppie groweth vpen the fandes and bankes of the fea : I found it grotving neere vnto Rie in Kent : in the Iles of Shepey and Thanet: at Lee in Effex: at Harwich, at Whiteftable, and many other places alongt the Englifh coaft.

The feconde groweth not wilde in England. Angelus Palea, and Bartholomass abVrbe-veterwen, who have commented vpon Mefue, write that they founde this red horned Poppie in the kingdomes of Arragon and Caftile in Spaine, and in fieldes neere vnto common paths. They do growe in iny garden very plentifully. $\quad *$ The time.

They flower from Maie to the ende of Augutt. * The names.

Moft writers hauc taken horned Poppie, efpecially that with red flowers to be Glawcism, neither are they in their opinion deceiued: for as Diofcor ides faith, Glascuum hath leaues like thofe of hor-

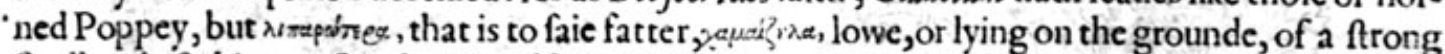
finell and of a bitter tafte: the iuice alfo is much like in colour to faffron. Morcouer L'Obelins doth witneffe that this horned Poppic hath the fame kind of iuice; as my felfe likewife can teftifie. Diofearides faith that Glaucium groweth about Hierapolis, a citic in Syria: but what hindreth that it fhould not be found alfo fome where elfe : fo that by the concordance of all authors for the mott part, it is the true and legitimate Glaucium of Dioferides: of fome it is called Mecon Ceratites: in Englith fea Poppie, and horned Poppie : in Dutch Jrelbetil and poune Leule : in the Germaine toong elelbomag : in French Paut Cornu : in Spanifh Dormidera marin a.

$* 7$ he nature.

Horned Poppies are hot and drie in the thirde degree. * T the vertues.

The roote of horned Poppie boiled in water vnto the confumption of the one halfe, and drunke, A prouoketh vrine, and openeth the ftopping of the liuer.

The ieede taken in the quantitic of 2 fpoonefull, loofeth the belliegently.

The iuice mixed with meale and honic, mundifieth olde rotten and filthie vlcers.

The leaues and flowers put into Vnguents or falues appropriate for greene woundes, digefte D them,that is, bringe them to white matter, with perfect quitture or fanies.

$$
\text { Of garden Poppie. Chap.68. }
$$

* The kinds.

Dke as there be fundry forts of horned Poppies, fo are there of tame, or of the garden. The which thall be diftinguithed isto twokinds, that is to faie, the fingle flowredPoppie of the garden, and the double flowred Poppic: and fecing the difference of thofe double ones, confifteth onely in the colour of the flowers: ir fhall fuffice to defcribe fome two of them, and giue you the figures of the reft with their feuerall colours in their titles, which fhall fufficiently fet foorth their defcription. t. The defeription.

1 He leaues of white Poppic are long, broad, fmooth, longer then the leaues of Lettuce, whihalfe high: on the top wherof grow white fowers, in which at the very beginning appecreth a fmal head, accompanied with a number of threds or chilues, which being full growen is round, and yet fornthing long withall, and hath a couer or crownet vpon the top; it is with many filmes or thinne skins diuided into coffers or feuerall partitions, in which is conteined abundaunce of fmall round and whitifh feede. The roote groweth deepe, and is of no eftimation nor continuance.

2 Like vnto this is the blacke garden Poppie, fauing that the flowers are more whitc and Ihining, fpotted or ftraked with fome lines of purple. The leaues are greater, more iagged, and fharper pointed. The feede is likewife blacker, which maketh the difference. 
I Papauer fatiuum album.

White garden Poppie.
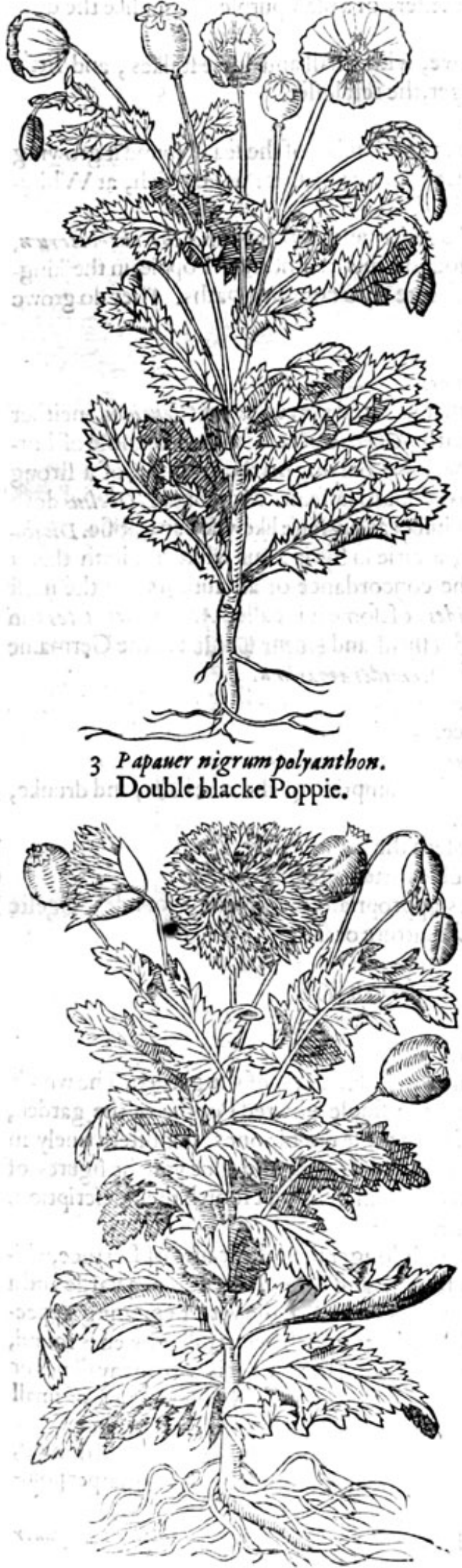

2 Papauer fatiuum nigriom. Blacke garden Poppie.

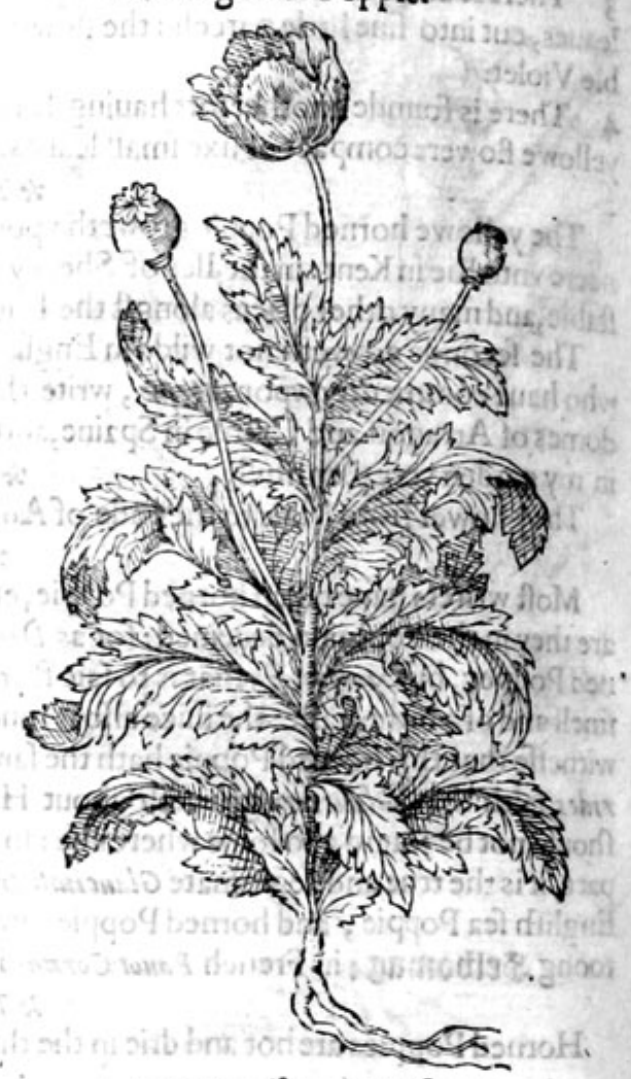

4 Papaner album multifloruom. Double white Poppie.

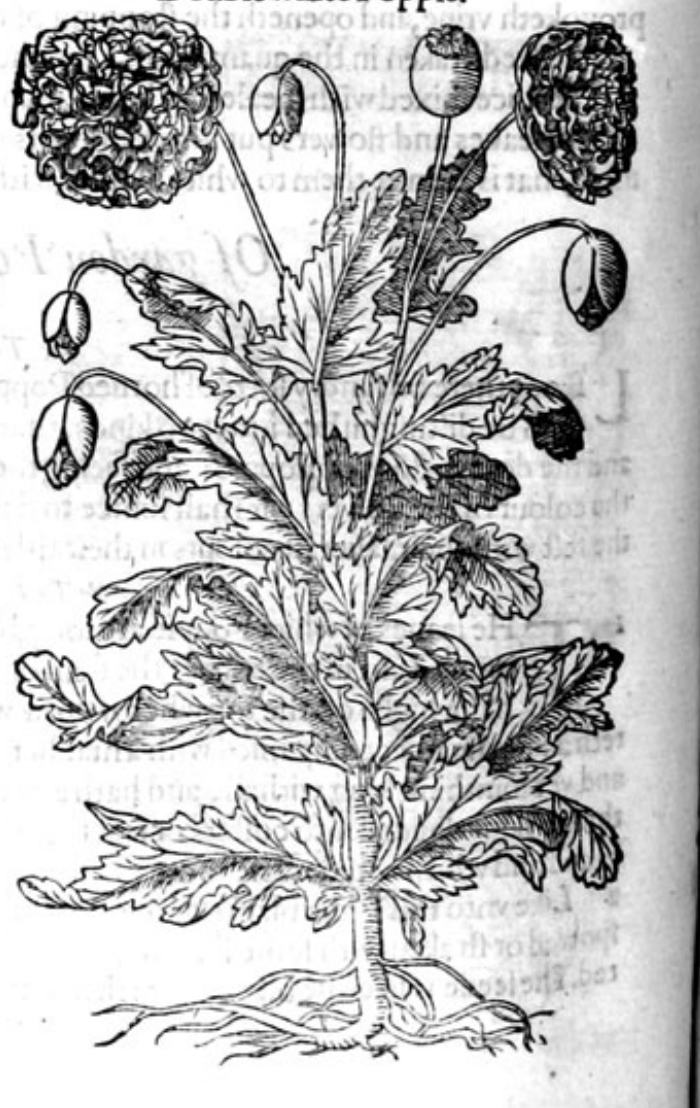


5 Papauer purpureum polyant bon.

6 Papawer maltiflorwin coccivews. Double purple Poppie.

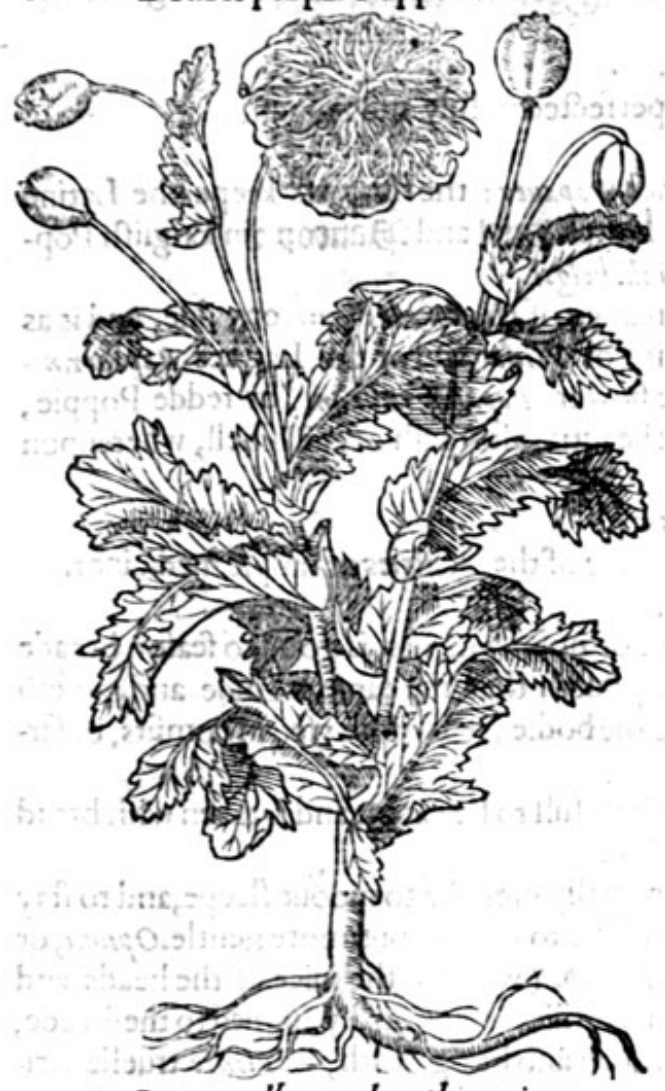

7 Papauer album polyanthon misus. Small double Poppic.
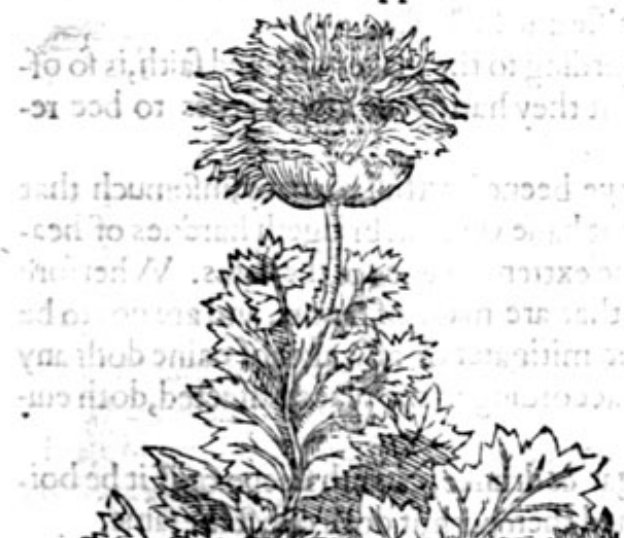

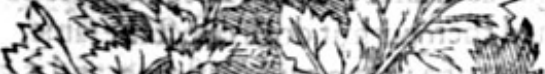
3.

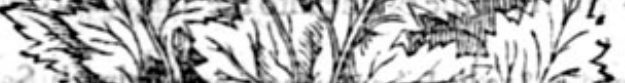

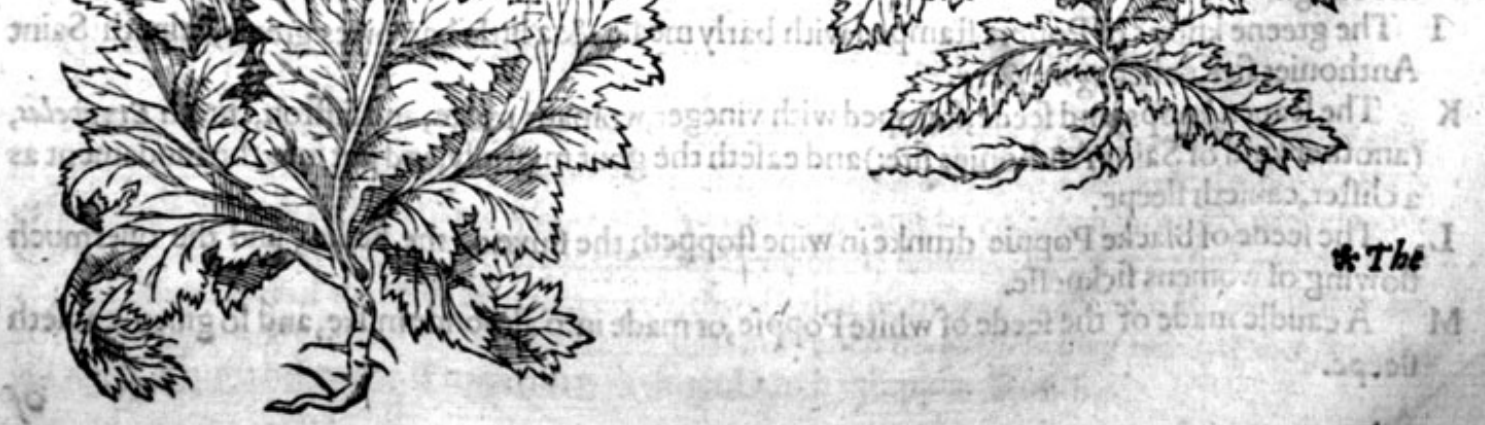



feede.

The fe kindes of Poppies are fowen in gardens, which do afterwarde come of the fallings of the
Tede.

They fower moft commonly in Iune. The feede is perfected in Iuly and Auguft. * The names.

Poppic is called of the Grxcians mirwy : of the Latines Papauer: the fhoppes keepe the Latine name: it is called in high Dutch $\mathscr{C}$ anfamen : in lowe Dutch fucl and $\mathscr{G}$ ancop : in Englifh Pop-
pie, and Cheefebowles: in French Patot, and Oliette Gallobelgis.

The garden Poppic which hath blacke feedes, is furnamed of Diofcor ides s.jpurv, or wilde, and is as he faith, called poris; bicaufe opium is gathered from it: of Plimie and of the Latines Papaner nigrum: and of moft of our age of the red colour of the flowers Papauer rubrum, or redde Poppie, whereof there bee many variable colours and of great beautie, although of euill finell, whereupon our gentlewomen do call it Ione filuer pin.

All the Poppies are Themperatire.

All the Poppies are colde, as $G_{a}$ len teftifieth in his booke of the faculties of fimple medicines. * The vertaes.

A The feede, as Galen faith in his booke of the faculties of nourifhments, is good to feafon breade with; but the white is better then the blacke. Hee alfo addeth that the fame is colde and caufeth fleepe, and yeeldeth no commendable nourifhment to the bodie; it is often vfed in comfits, or ferued at the table with other iunketting difhes.

B The oile which is preffed out of it is pleafant and delightfull to be eaten, and is taken with bread or any other waics in meate, without any fence of cooling.

C A greater force is in the knobs or heads which do fpecially preuaile to mooue fleepe,and to ftay and repreffe diftillations or rheumes, and come neere in force to $O$ piwn, but more gentle. Opiwm, or the harde iuice of Poppic heads is ftrongeft of all: Meconism (which is the iuice of the heads and leaues) is weaker. Both of them any waies taken either inwardly, or outwardly applied to the heade, prouoke fleepe. Opium fomewhat too plentifully taken doth alfo bring death, as Plinie truelie writeth.

D It mitigateth all kindes of paines: but it leaueth behinde it oftentimes a mifchiefewoorfe then the difeafe it felfe, and that hard to be cured,as a dead palfie and fuch like.

E The vfe of it,as Galen in his I 1 .booke of medicines according to the places affected faith, is fo offenfiue to the firme and folide partes of the bodie, as that they hadneede afterwardes to bee reftored.

F So alfo colliries or eie medicines made with Opium haue beene hurtfull to manyjinfomuch that they haue weakned the eies, \& dulled the fight of thofe that haue vfed it:it bringeth hardnes of hezring whatfoever is compounded of Opium to mittigate the extreme paines of the eares. Wherfore all thofe medicines and compoundes are to be fhunned that are made of $O$ pium, and are not to be vfed but in extreme neceffitic; and that is, when no other mitigater or affwager of paine doth any thing preuaile, as Galem in his thirde booke of medicines according to the places affected, doth eurdently declare.

G The leaues of Poppie boiled in water with a little fugar $\&$ drunke, caufeth fleepe:or if it be boiled without fugar, and the head, feete, and temples bathed therewith, it doth effect the fame.

$\mathrm{H}$ The heads of Poppie boiled in water with fugar in manner of a firupe caufeth fleepe, and is good againft rheumes and catarrhes that diftill and fall downe from the braine into the lungs, and eafech the cough.

I 'The greene knops of Poppie ftamped with barly meale, \& a little barrowes greafe, helpeth Saint Anthonies fier, called Ignis facer.

$\mathrm{K}$ The leaues, knops, and feede, ftamped wich vineger, womans milke, and faffron, cureth Eryfpelas, (another kind of Saint Anthonies fire:)and eafeth the gout mightily, and put into the fundament as aclifter, caufeth fleepe.

$\mathrm{L}$ The feede of blacke Poppie drunke in wine ftoppeth the fluxe of the bellie, and the ouermuch flowing of womens fickneffe. M A caudle made of the fecde of white Poppie, or made ia:o almonde milke, and fo giuen, caufech
fleepe. 


\section{Of corne Rese, or wilde Poppie. Cbap.69. \\ Wilde Poppie. \\ 2 Papaner caduco flor multiplex.. Double ivilde Poppie.}

I Papauer Rhasas.
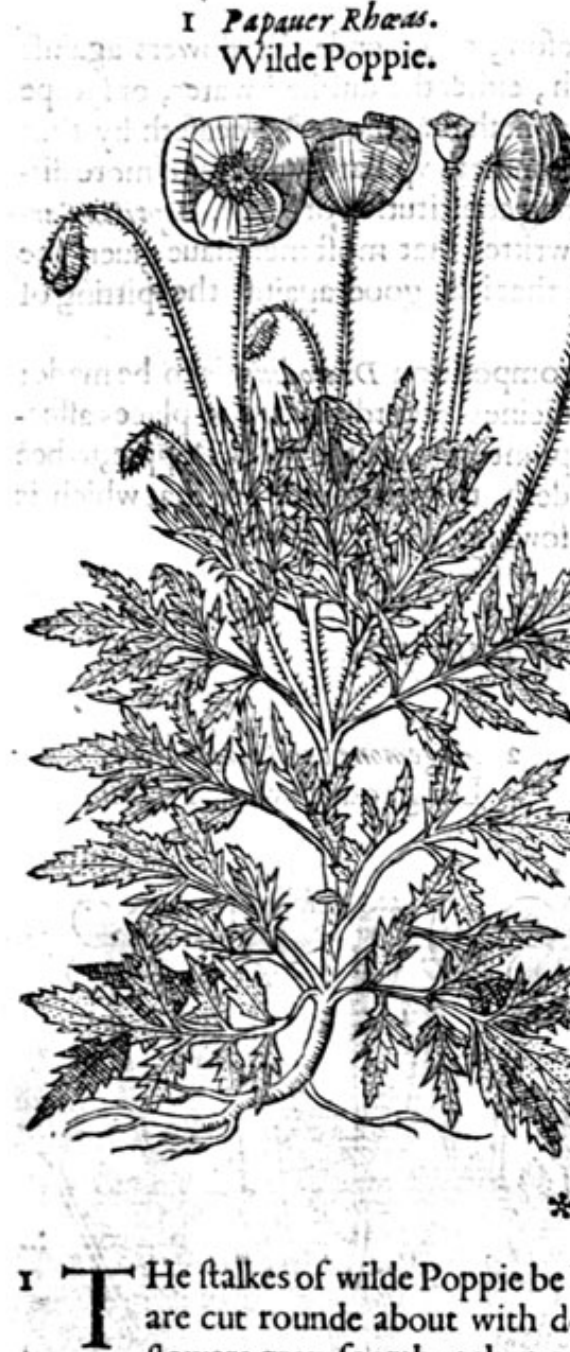

更

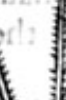

(a)
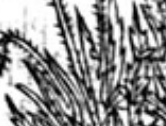

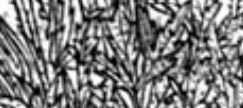

t

3 S

Ton 3 .

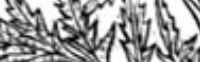

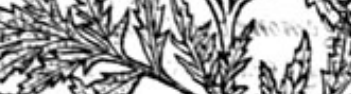

sind

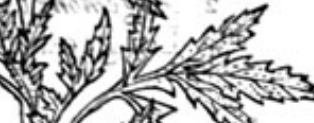

ans

sor $1 / 2$

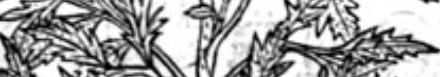

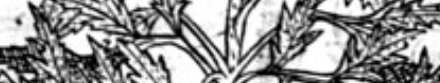

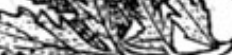

$\underbrace{2}_{2}$

3 3.

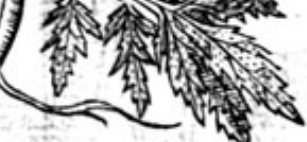

\section{* The defcription.} with blackifh threddes compaffing about the middle part of the head: which being fully growen, is leffer than that of the garden Poppic. The feede is fmall and blacke.

2 There is alfo a leffer kinde heereof, with fmaller leaues, not fo deepely fnipt about the edges, but a little nickt or toothed; in other points agreeing with the former, fauing that the flowers of this ate fomewhat doubled.

\section{* Theplace.}

They growe in earable grounds among wheat, fpelt, rie, barley, otes, and other graine, andin the borders of fieldes.

* Thetime.

The fieldes are garnifhed and ouerfpred with thefe wilde Poppies in Iune and Auguft.

\section{Withe names.}

Wilde Poppie is called in Grecke of Diofcortdes wixay potas : in Latine Papasuer erraticum: Gaza na-

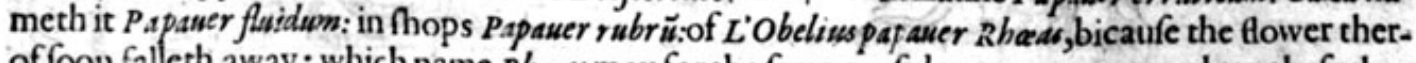
of foon falleth away; which name Rha.ts may for the fame caufe be common, not only to thefe, but alfo to the others, if it be fo called of the fpeediefalling of the flowers : but if it be furnamed $R$ hoens of the falling away of the feed (asit appeereth)tben fhall it be proper to all the reft, whofe flowers do not onely quickly fall awaic, but the feedè alfo: in Frehch cocquelitor, conf anons, Pawot fanuage,

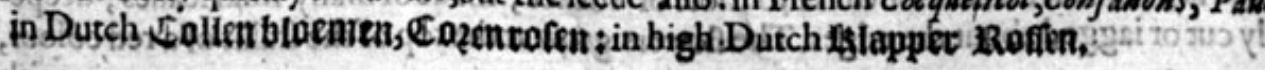


* The nature.

The facultic of the wilde Poppies is like to that of the other Poppies: that is to faie colde, and caufing fleepe.

* The vertues.

A Moft men being led rather by falfe experiments then reafon, commende the flowers againft the pleurifie, giuing to drinke affoone as the paine commeth, either the diftilled water, or fyrupe made by often infufing the leaues. And yet many times it hapneth that the paine ceafeth by that meanes, though hardly fomtimes, by reafon that the fpitcle commeth vp hardly and with more difficultie, efpecially in thofe that are weake and haue not a ftrong conftitution of bodie. Baptista Sar. des might be counted the author of this errour; who hath written that moft men haue giuen the flowers of this Poppie againft the paine of the fides : and that it is good againft the fpitting of blood.

It is manifeft that this wilde Poppie is that of which the compofition Diacodium is to be made: as $G$ alen hath at large entreated in his feuenth booke of medicines according to the places affected. Crito alfo, and after him $T$ hemifo, and Democrates do appoint $\alpha_{2 s}$ tov, or the wilde Poppic, to bee in the fame compofition; and euen that fame Democrates addeth, that it fhoulde bee that which is not fowen: and fuch an one is this, which groweth without fowing.

\section{Ofbaftarde wilde Poppie. Chap. 70.} I Lrgemone sapitulo torub.
Baftard wilde Poppie.
2 Argemone capitwlolongiore. Long codded wilde Poppie.

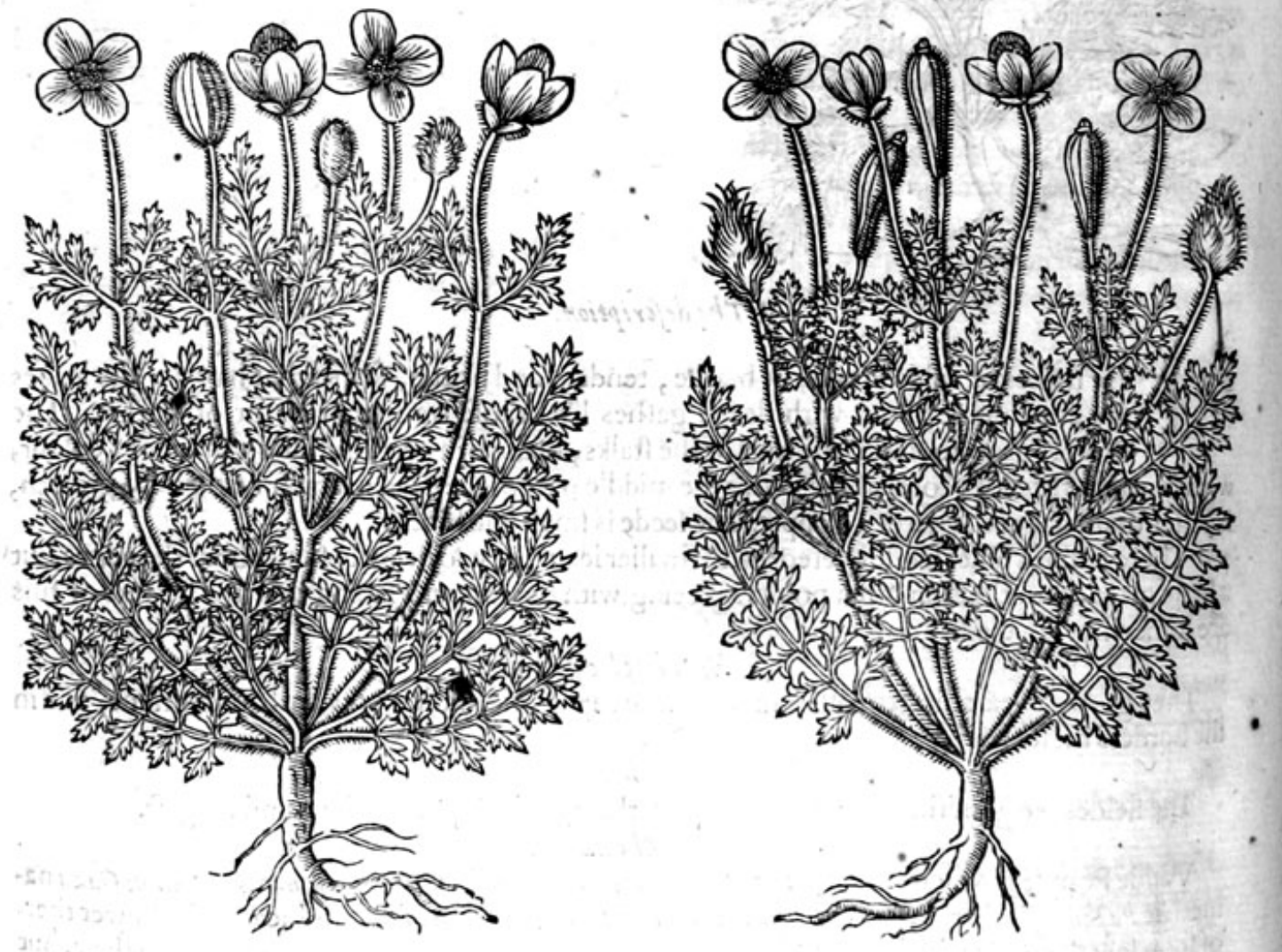

* Thedefcription.

$17 \mathrm{He}$ firft of thefe baftard wilde Poppies, hath flender weake ftems a foote high, rough and hairie, fet with leaues not vnlike to thofe of rocket, made of many fmal leaues, deepely cut or iagged about the edges. The flowers grow at the top of the ftalks of a red colour, 
with fome fmall blackneffe toward the bortome. The feede is fmall conteined int little round knobs. The roote is fmall and threddie.

2 The fecond is like the fir it,fauing that the cods beereof be long, and the other more rounde, wherein the difference doth confift.

$$
\text { *. The place. }
$$

Thefe plants do growe in the corne fieldes in Somerfethire, and by the hedges and high waies, as yee trauell from London to Bathe. L'Obelims founde it growing in the next fielde vnto a village in Kent called Southfleete, my felfe bcing in his companie, of purpofe to difcouer fome ftrange plants, not hitherto written of.

*The time.
They fower in the beginning of Auguft, and their feede is ripe at the ende thereof.

$$
\text { * The names. }
$$

The baftard wilde Poppie is called in Grecke Apreciorm : in Latine Ar gemone, Ar gemonia, Concordis, Concordalis, and Herba liburnica : of fome Pergalium, Ar/ela, and Sarcocolla Herba : in Englifh winde Rofe, and baftarde wilde Poppie.

They are hot and drie in the third degree.

$$
* \text { The temperature. }
$$

* The vertues.

The leaues ftamped, and the iuice dropped into the eies eafeth the in Alammation therof;and cu- A reth the difeafe in the cie called Argems, where of it tooke his name: which difeafe when it hapnethron the blacke of the eic it appeereth white; and contrariwife when it is in the white, then it appeereth blacke of colour.

The leaues ftamped and bound vnto the eies or face that are blacke or blewe by meanes of fome B blowe or ftripe, doth perfectly take it away. The drie herbe fteeped in warme water, worketh the like effect.

The leaues and rootes ftamped, and the iuice giuen in drinke, helpeth the wringings or gripings $\mathbf{C}$ of the belly. The drie herbe infufed in warme water doth the fame effectually.

The herbe ftamped, cureth any wounde, vlcer, canker, or filtula, being made vp into an vnguent $D$ or falue, with oile, waxe, and a little turpentine.

The iuice taken in the waight of two drammes with wine, inightely expelleth poifon or any venome.

The inice taketh awaic warts if they bee rubbed therewith; and being taken in meate it helpeth the milt or fpleene if it be wafted.

\section{$r$}

\section{Of Winde flowers. Chap. $7 \mathrm{I}$.}

* The kindes.

Tries: He ftock or kinred of the Anemones or Winde flowers, are without number, or at the leaft not known vnto any one that hath written of plants. For Dodon atw hath fet forth 5 . Forts: E'Opeliss eight: Taber Montanu, ten: my felfe haue in my garden twelue differentforts ; and yet I do heare of diuers more, differing verie notably from any of thele, which I hauc briefely fouched, though not figured; euery newe yecre bringeth with it newe and frange kindes, And euery countrey his peculiar plants of this fort, which are fent vnto vs from farre countries: in hppe to feceive from vs fuch as our countric yceldeth.

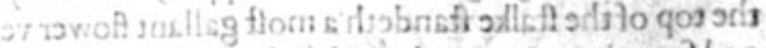

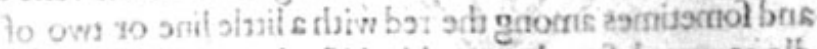

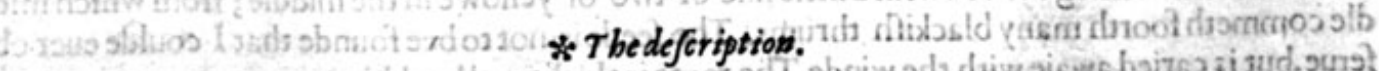

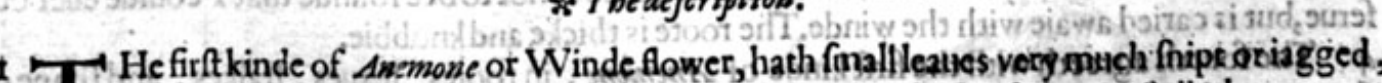
almoft like vnto Camomill, or Adonis flower; anongswhich riforhivp a stalke bare or na$\mathrm{ked}$ almoft vnto the top, at which place is fet two or three leaues like the other; andat the cop of the ftalke commeth foorth a faire and beautifull flower, compact of feauenleaues; and fometimes eight, of a violet colour tending to purple. It is impoffible to defcribe the colour in his full perfection, confidering the variable mixtures. The roote is tuberous or knobbie, and very brittle. 


\section{THE SECOND BOOKE OF THE}

2 The feconde kinde of Anemone hath leaues like vnto the precedent, infomich that it is hard to diftinguifh the one from the other but by the flowers oncly: for thofe of this plant are of a moft bright and faire fcarlet colour, and as double as the Marigolde; and the other not fo. The roote is
knobbie and verie brittle, as is the former.

Inemone tuberofa radice. Purple Winde flower.

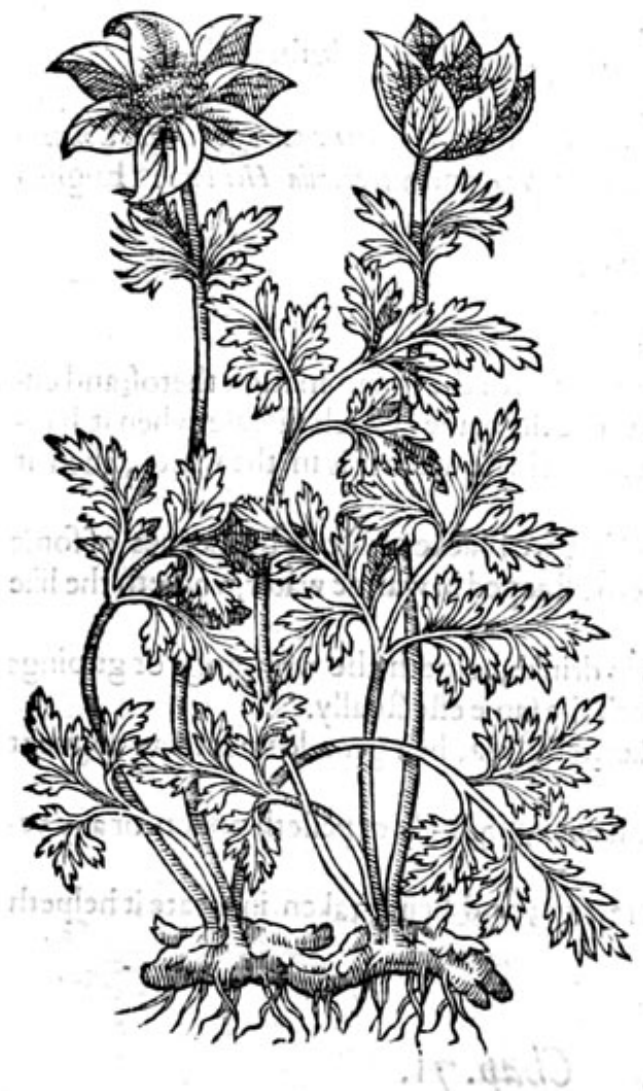

2 Anemone coccinea multiplex. Double fearlet Winde flower.

\section{* The defoription.}

3 The great Anemone with double flowers, vfually called the Anemone of Conftantinople, not farre from Bithinia; hath great broade leaues deepely cut in the edges, not vnlike to thofe of the moft vnto the top, where there ftande two or tor : among which rifeth vp a naked ftalke bare alfometimes changing into reddifh ftrippes or three leaues, in fhape like the others, but leffer; the top of the ftalke ftandech $m$ trippes, confufedly mixed hecre and there in the faid leaues. On and fometimes among the red rof gallant flower verie double, of a perfeet redde colour ftripped, dle commeth foorth many blackilh a litle line or two of yellowe in the middle; from which midferue, but is caried awaic with the thrums. The feede is not to bee founde that I coulde euer ob4 The fourth agreeth with the finde. The roote is thicke and knobbie.

tlowers,and do differ in that, that this pande of Anemone, in rootes, leaues, ftalkes, and fhape of of a violet colour as aforefaid. 


\section{HISTORIE OF PLANTS.}

303

3 Anemone maxima Chalcedonica polyant hos.

The great double Winde flower of Bithinia.

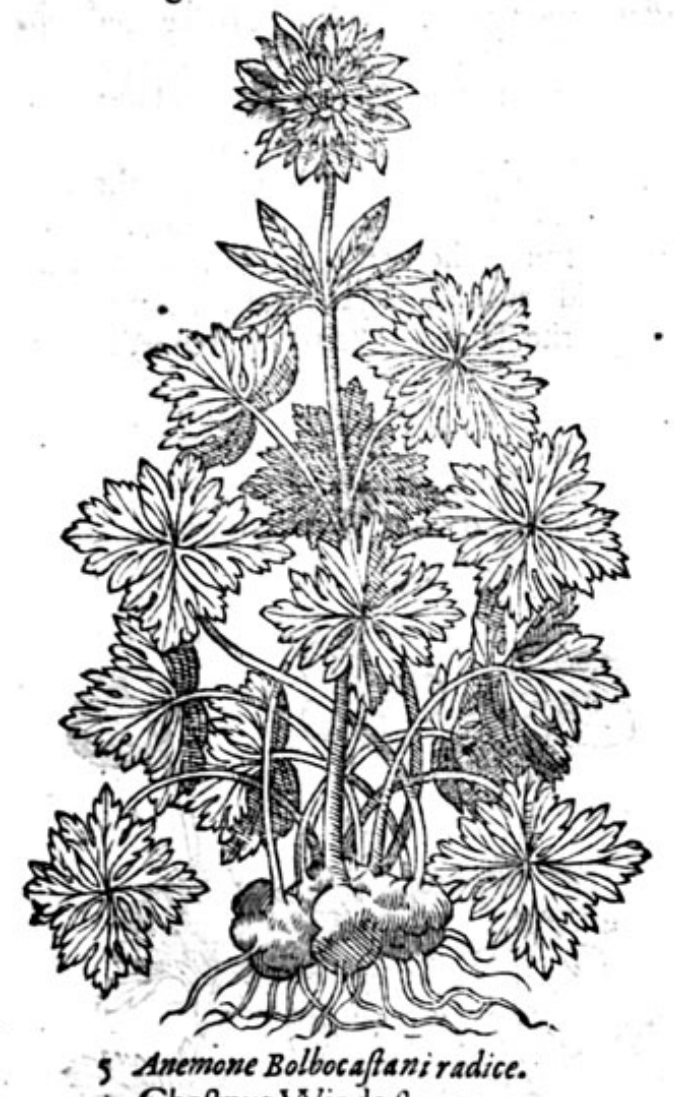

Cheftnut Winde flower.

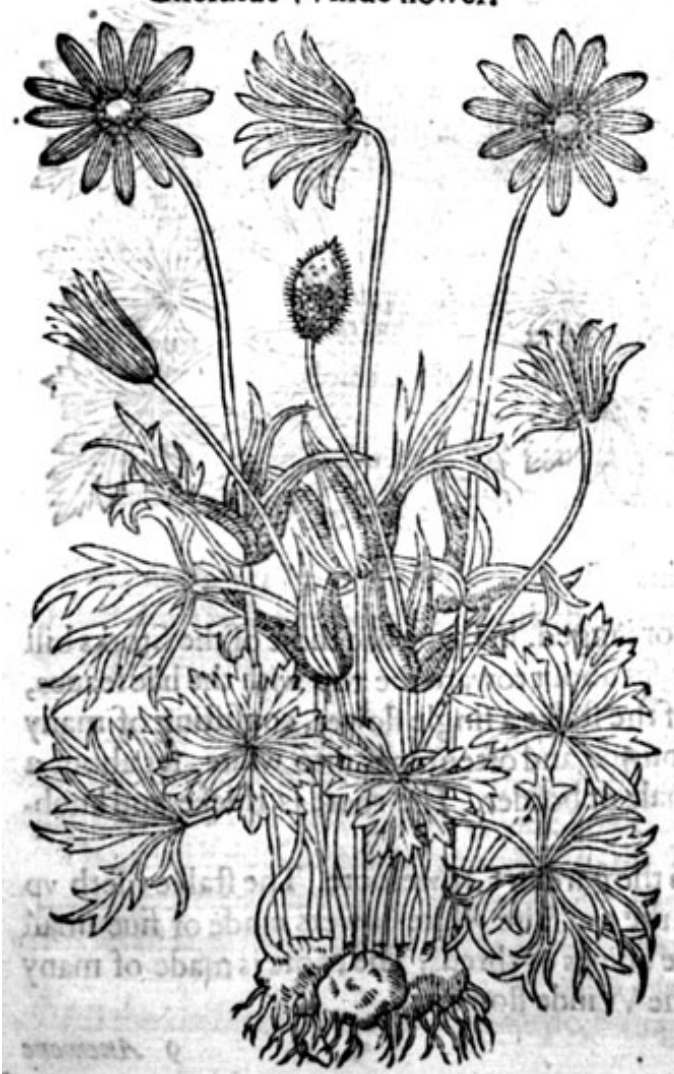

4. Anemone Chalcedonica fimplici fore.

The fingle Winde flower of Bithinia.

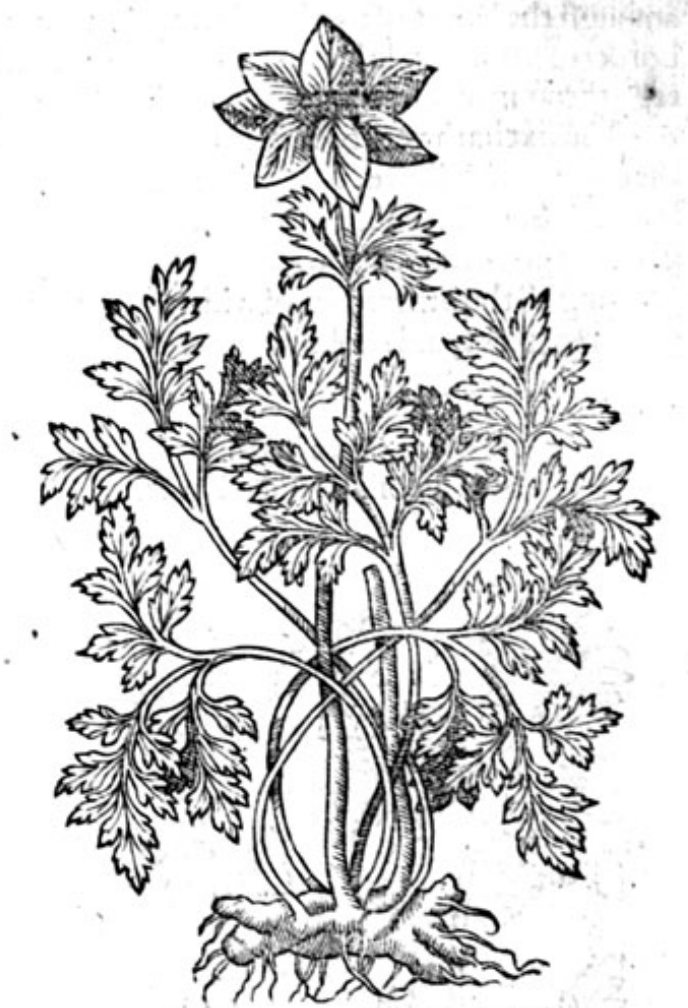

6 Unemone latifolia Clufii.

'Broade leafed Winde tower.

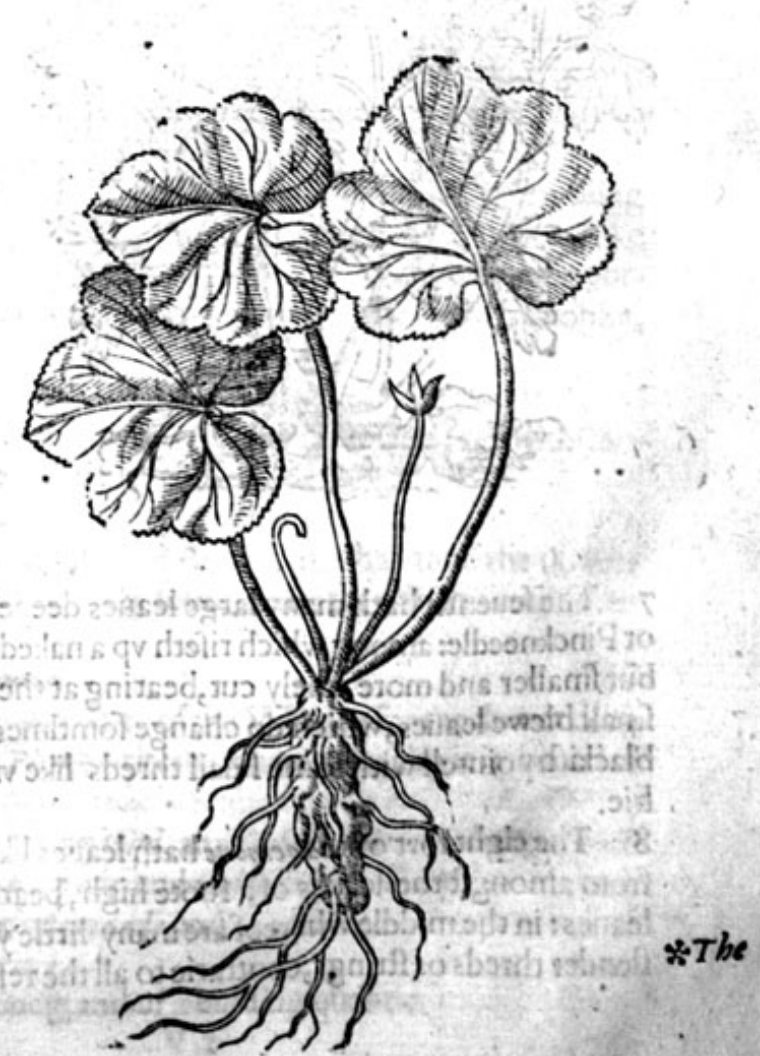




\title{
304 THE SECOND BOOKE OF THE
}

\author{
$\approx$ The defcription.
} 5 The fift fort of Anemone hath"many finall iagged leaues like thofe of Coriander, proceeding amongft the leaues of two handes higin, bearing at the top a fingle fower, confifting of a pale or border of little purple lcates, fometimes red, and often of a white colour fet about a blackilh poin-
tell, thrummed ouer with many fmall blackifh haircs. 6 The fixt hath very broade leaues in refpect of all the reft of the Anemones, not vnlike to thofe of the common Mallowe, but greene on the vpper part and tending to redneffe vnderneath, like the leanes of Sowe breade. It hath vpon very little footeftalkes fmall yellowe flowers: but my felfe can giue you no certaine knowledge of the plant; bicaufe I did neucr fee it : yet haue I in my garden growing all the other forts, of which I can more cert ainly write. The roote (faith my author) is a fin. ger long, thicke, and knobby.

7 Anemone Geranifolia. Storkes bill Winde flower.

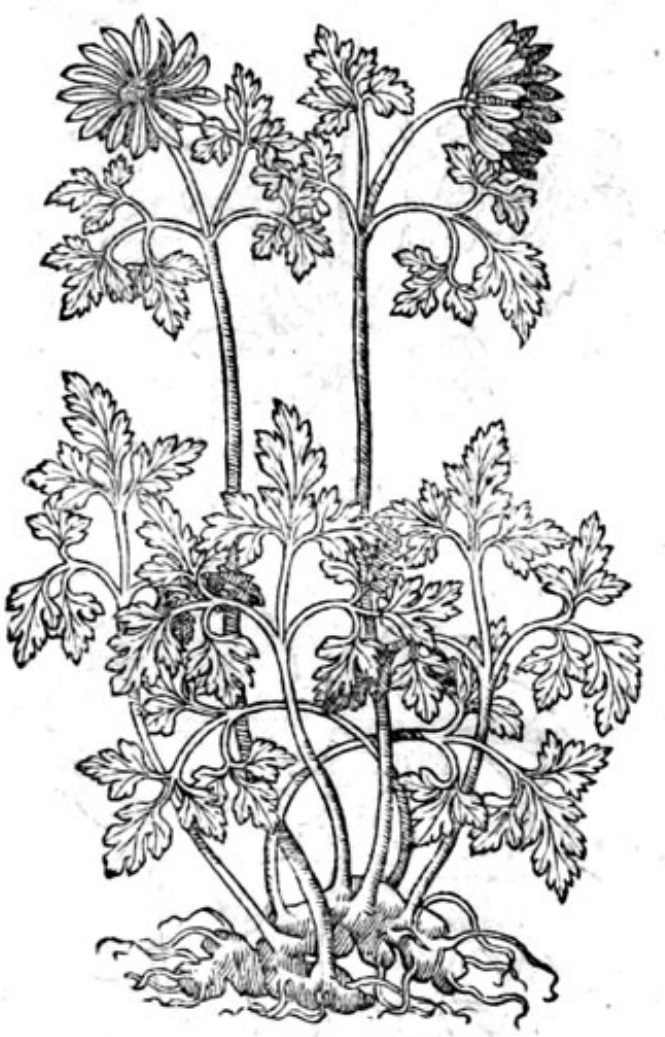

9 Anemonecrathioli. Mathiolus white Winde flower.

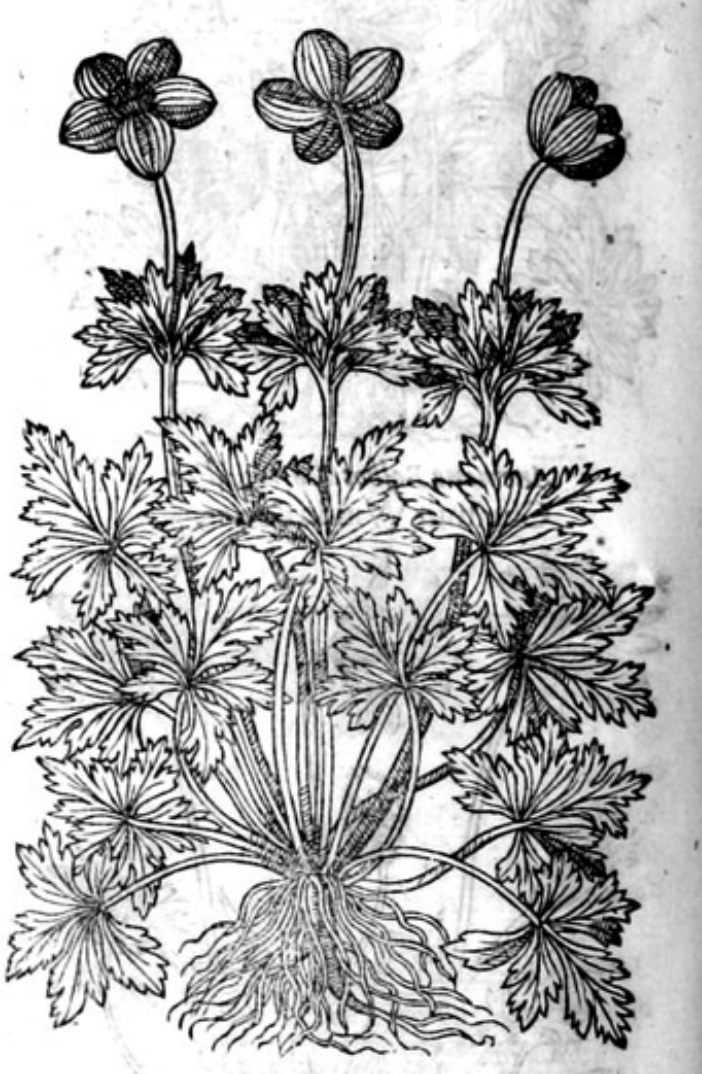

7 The feuenth hath many large leaues deepely cut or iagged, in fhape like thofe of the Storks bill or Pinckneedle: among which rifeth vp a nakcd ftalke, fet about toward the top with the like leaues, fmall blewe leaues, which cut, bearing at the top of the ftalke a fingle flower, confifting of many blackifh pointell with fomc finall threds likes into purple, and oftentimes into vhite, fet about a bic. from amongft the leaues omone hath leaues like vinto the garden Crowefoote. The ftalke rifeth vp leaues: ingt the leaues of a foote high, bearing at the top faire white flowers made of fiue fmall flender in the middle whereof are many little yellowe chines or threds. The roote is made of many 
- Anemone trifolia. Threeleafed Winde flower.

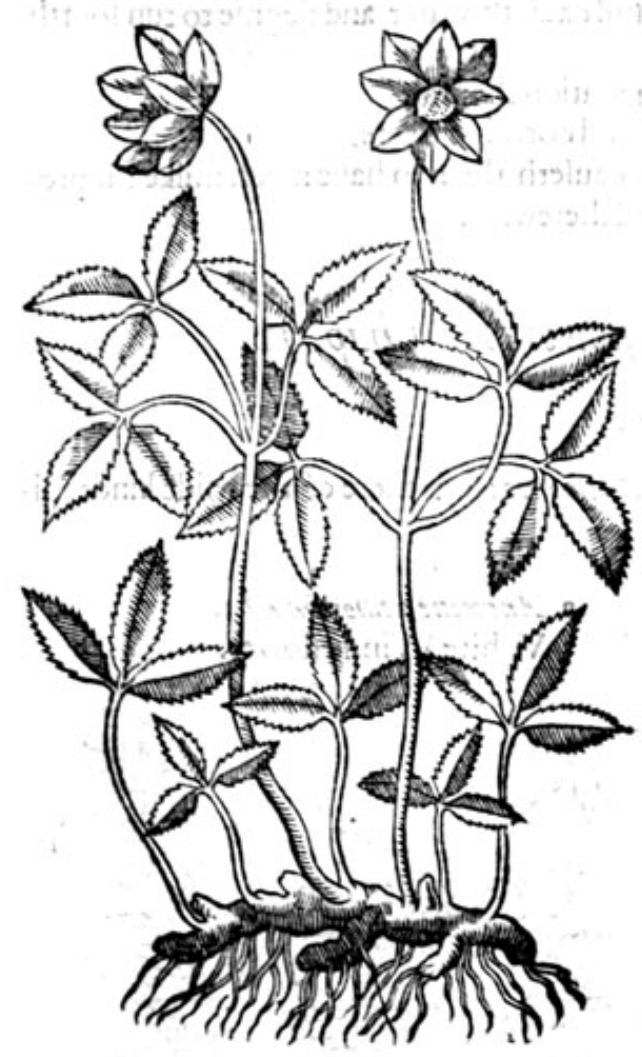

10 Anemone Papeucraces. Poppie Winde flower.

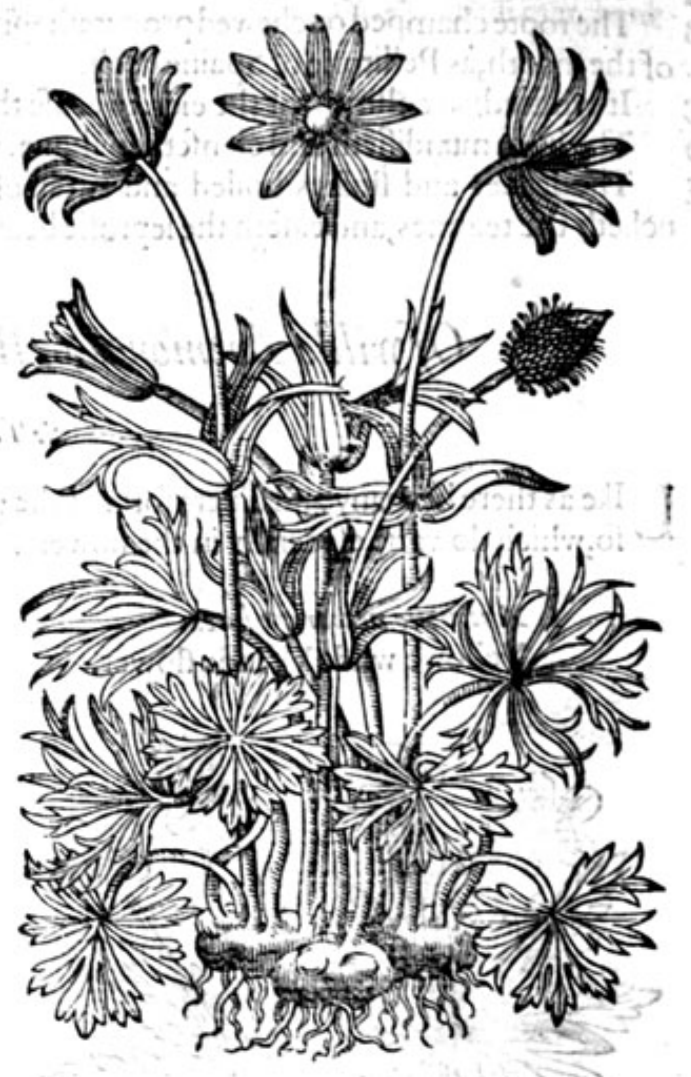

* The defcription.

9 The ninth fort of Anemone hath many leaues like vnto the common medowe Trefoile, fleightly fnipt about the edges like 2 fawe: on the top of the flender ftalkes ftandeth a fingle white flower tending to purple, confifting of eight fmal leaues, refembling in thape the flowers of common field Crowfoote. The roote is knobbie with certaine ftrings faftned thereto.

10 Thetenth kinde of Anemone hath many iagged leaues cut euen to the middle rib, refembling the leaues of Geranium columbinum, or Doues foote. The leaues that do embrace the tender weake ftalkes are flat and fleightly cut. The flowers grow at the top of the ftalkes, of a bright fhining purple colour, fet about a blackifh pointell, and fmall thrums or chiues like a pale. The roote is knobby, thicke, and verie brittle, as are molt of thofe of the Anemones.

$$
\text { * The place. }
$$

All the forts of Anemones are ftrangers, and not founde growing wilde in England; notwithftanding all and euery fort of them, do growe in my garden very plentifully.

$*$ The time.

They do flower from the beginning of Ianuarie to theende of Aprill, at what time the flowers do fade, and the feede flieth away with the winde, if there be any feede at all; the which I coulde neuer as yet obferue.

\section{* The names.}

Ameorì, or Winde flower, is fo called 'tro' $z \tilde{*}$ erive, that is to faie, of the Winde: for the flower doth neuer open it felfe but when the winde doth blowe, as Plinie writech: whereupon alfo it is named of

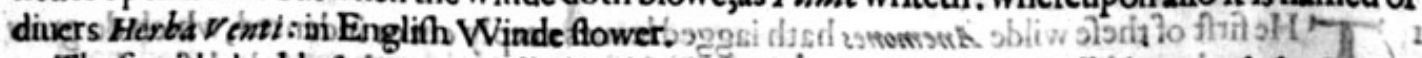

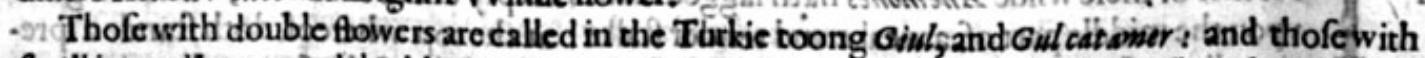

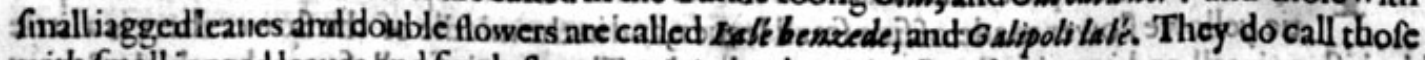

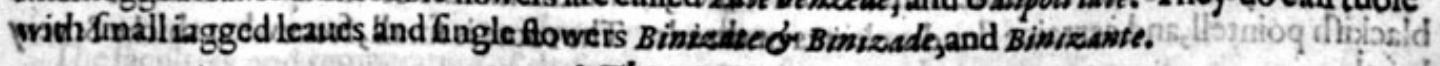
*The temperature.

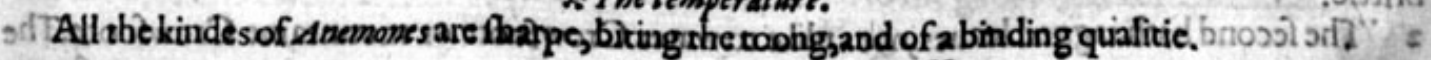
swot 
A The leaues ftamped, and the inice fniffed vp into the nofe,purgeth the headmightily.

B The roote champed or chewed procurcth fpitting, and cauleth water and flegme to run foorth of the mouth, as Pellitorie of Spaine doth.

C It profiteth in colliries for the eies, to ceafe the inflammation thereof.

D The itice mundifieth and clenfeth maligne, virulent and corofiue vlcers.

E The leaues and italkes boiled and caten of nurfes caufeth them to haue much milke: it pro uoketh the tearmes, and eafeth the leprofie being bathed therewith.

\section{Of wilde Anemones, or Winde flowers. Chap. 72. * The kindes.}

I Ike as there be many and diuers forts of the garden Amemones : fo is there of the wildekindes alfo, which do varie efpecially in the flowers.

1 Anemone nemorwe lutex.

Yellowe wilde Winde flower.

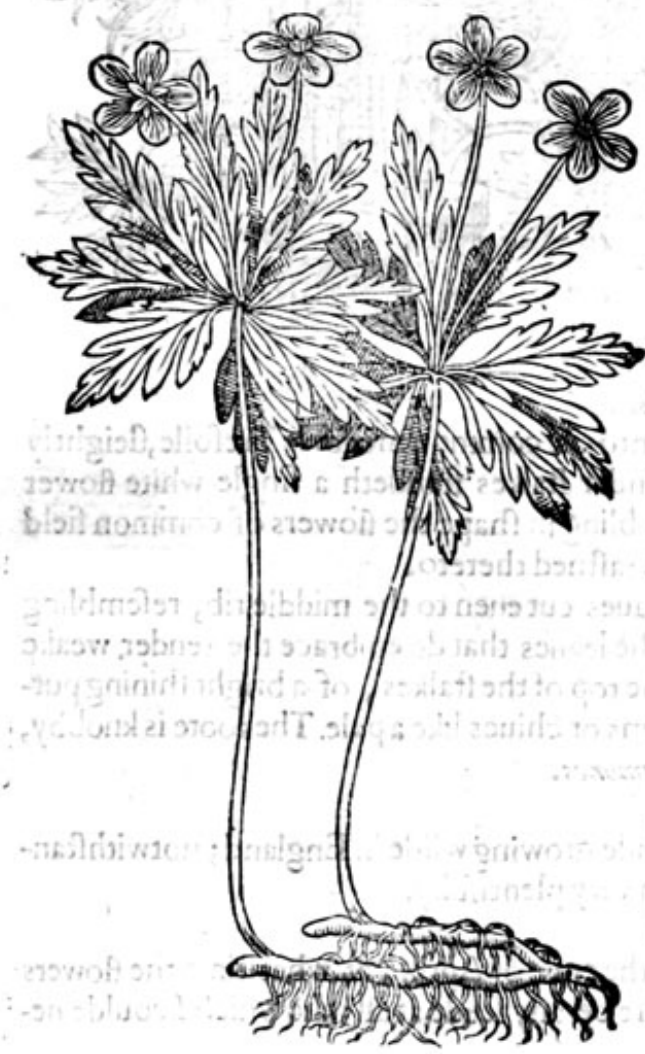

2 Anemoxe nemorion alba. White Winde flower.

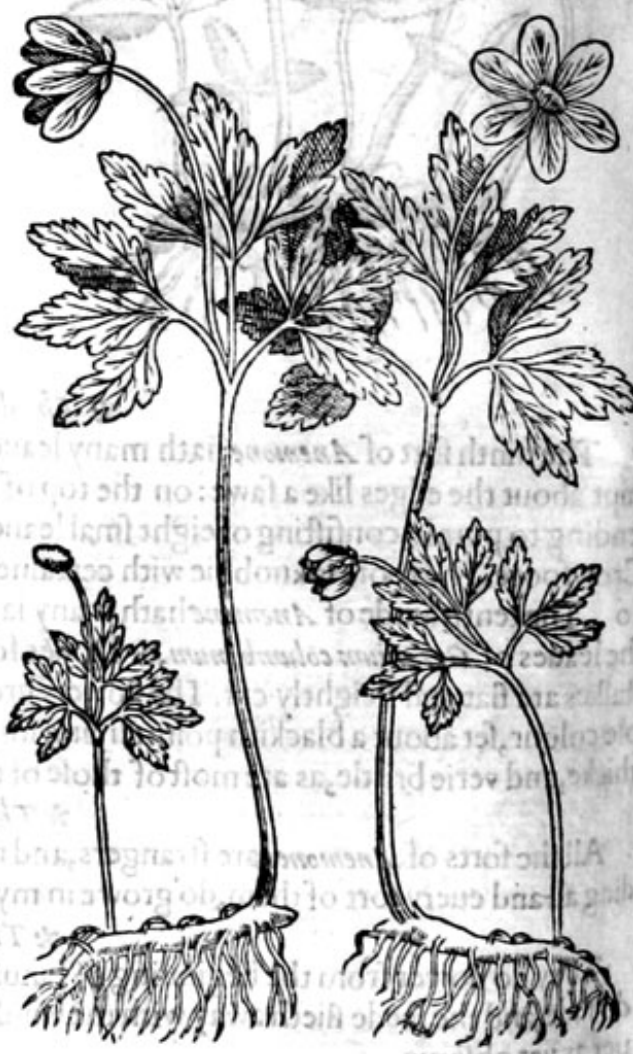

\section{* The defcription.}

I He firft of thefe wilde Anemomes hath iagged leaues deeply cur or indented, which dogrow vpon the middle part of a weake and tender ftalke : at the top whereof doth ftande 2 pretie yellowe flower made of fixe fmall leaues, and in the middle of the flower there is alitele
blackifh pointell, and certaine flender chiues or threds. The roote is fmall, fomewhat thicke \& very
bitle. brittle.

2 The fecond hath iagged leaues, not inlike to water Crowfoote or mountaine Crowfoote. The 
of the ftalke not vnliketo the precediencin fhape, fuuing that this is of a pote likethe other. I have in my gurden que of thrskinde wich white to-

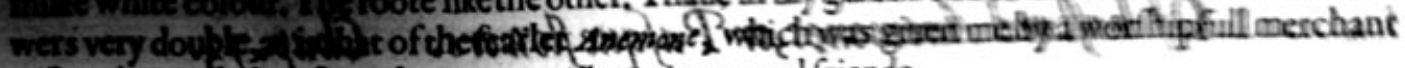
of London, calied mafter Iolm Frangwewille, mity very good friende.

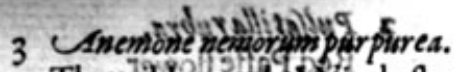
The wildepurple Winde flower.

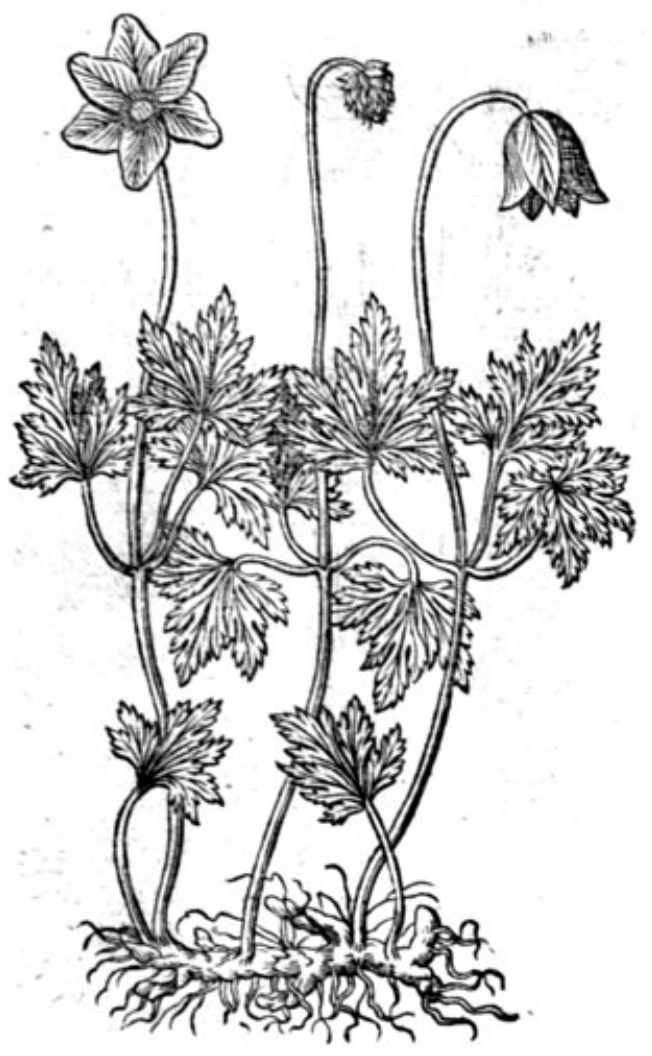

4 Anemone nich

The wilde fealtet Walde tlower.

* The defcription.

3. The thirde fort hath flowers of a purple colour, agreeing in euery other refpect with the reft of hiskinde.

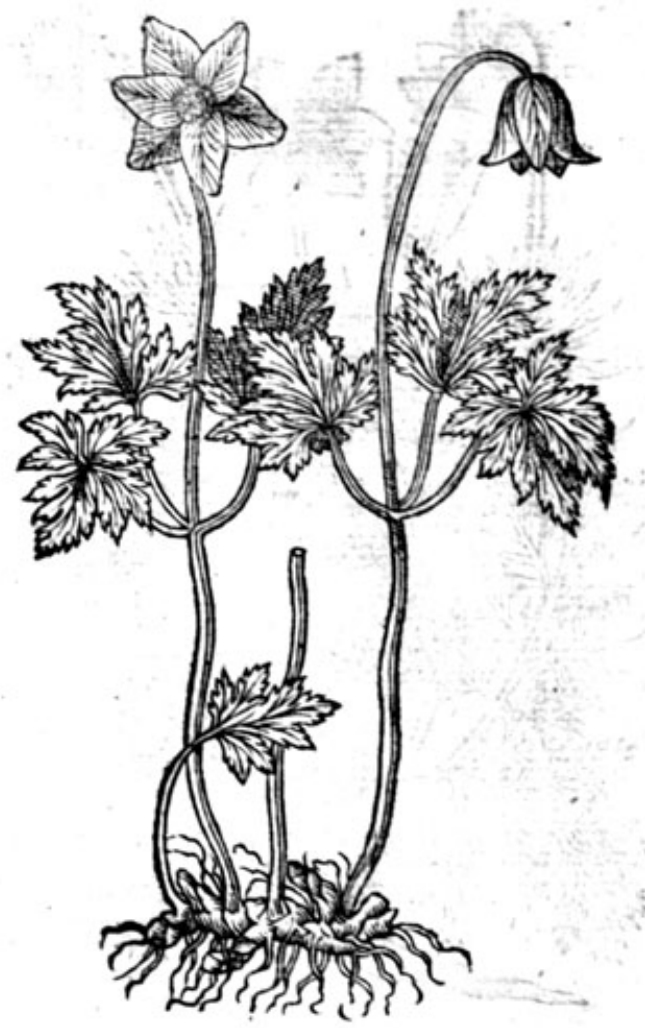

4 The fourth hath many fmall leaues deepely cut about the edges, euen to the middle ribbe like thofe of Cheruile. The flowers are of a light purplifh colour tending to fearlet, which maketh thats that we callblufh colour, and is in other refpects like the other.

$$
* \text { The place. }
$$

All thefe wilde Anemones do growe in moft woods \& copfes through England, except that with the yellowe flower, which as yet I haue not feene: notwichitanding, I haue one of the greater kinds which beareth yellowe flowers whofe figure is not expreffed nor yet defcribed, forthat it doth very notably refemble thofe with fingle flowers, but is of fmall moment, either in beautie of the flower or otherwife.

\section{*The time.}

There hath not beene any that hauefet downe other names then their feuerall titles do expreffe: we may call them in Englifh wilde Anemones, or Winde flowers.

The faculties and temperati $*$ T be temper ature and vertues. 


\section{Of baftard Anemones, or Pafqueflowers. Chap. 73 .}

\section{Pulfatills vulgaris. Purple Paffe flower.}

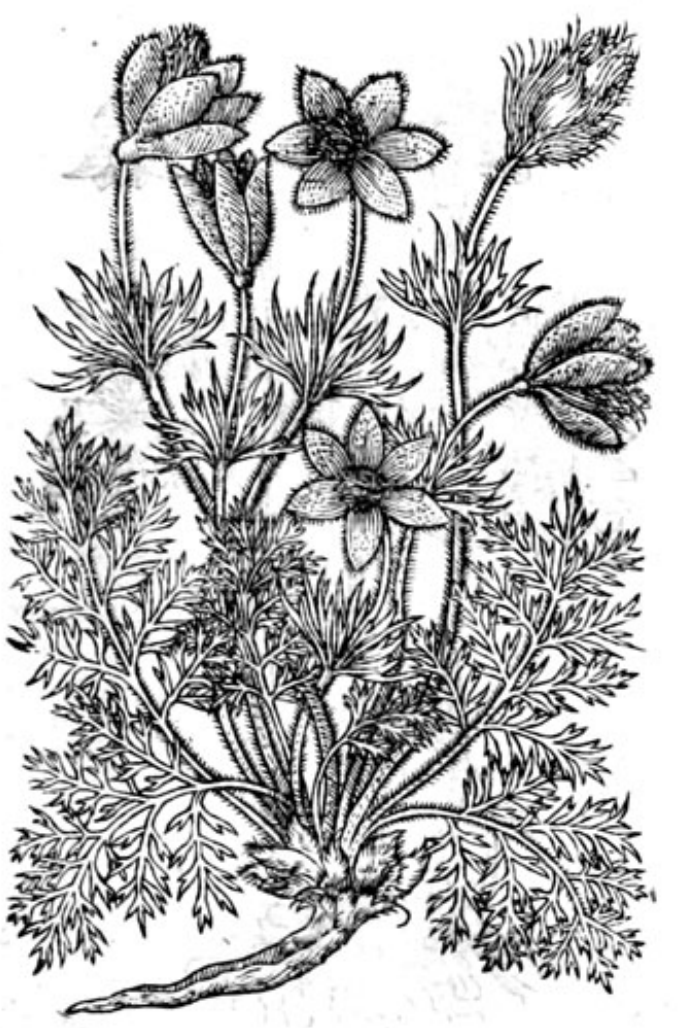

2 Pulfatillarubre. RedPaffe tlower.

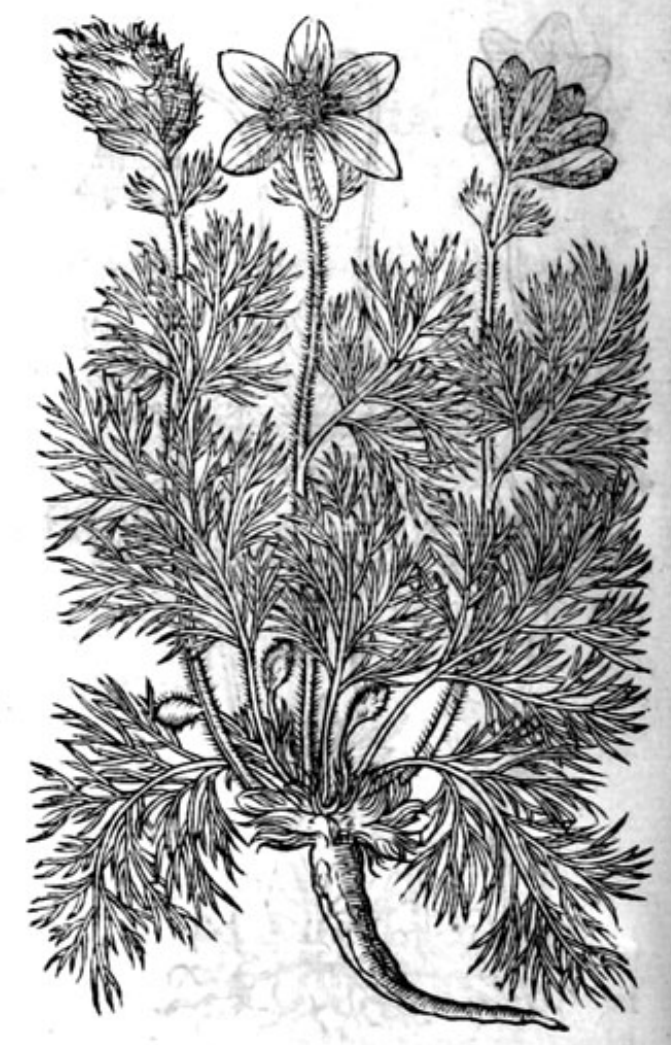

* The defcription.

I Hefirft of thefe Paffe flowers hath many fmall leaues finely cut or iagged, like thofe of car. rots : among which rife vp naked ftalkes, rough and hairie; whereupon do growe beautifull tlowers bell fafhion, of a bright delaied purple colour: in the bottome whereof groweth a tuft of yellow thrums, and in the middle of the thrums thrufteth foorth a fmall purple poin. tell: when the whole flower is paft there fucceedeth an head or knoppe, compact of many graie hairie lockes, and in the folide parts of the knops lieth the feede flat and hoaric, euery feede hauing his owa fmall haire hanging at it. The roote is thicke andknobbie of a finger long, and likevnto thofe of the Anemones, (as it doth all other parts verie notablie refemble) whereof no doubt this is a kinde.

2 There is no difference at all in leaues, rootes, or feedes, betweene this red Paffe flower and the precedent, nor in any other point, but in the colour of the flowers: for whereas the other are of a purple colour, thefe are of a bright red,which fetteth forth the difference.

3 The white Paffe flower hath many fine iagged leaues, clofely couched or thruft togither, which refemble an holi-water fprinckle, agreeing with the others in rootes, feedes and rhape of flowers, fauing that thefe are of a white colour, wherein chiefly confifteth the difference. 
3 Pulfatilla flore albo. White Paffe tower.

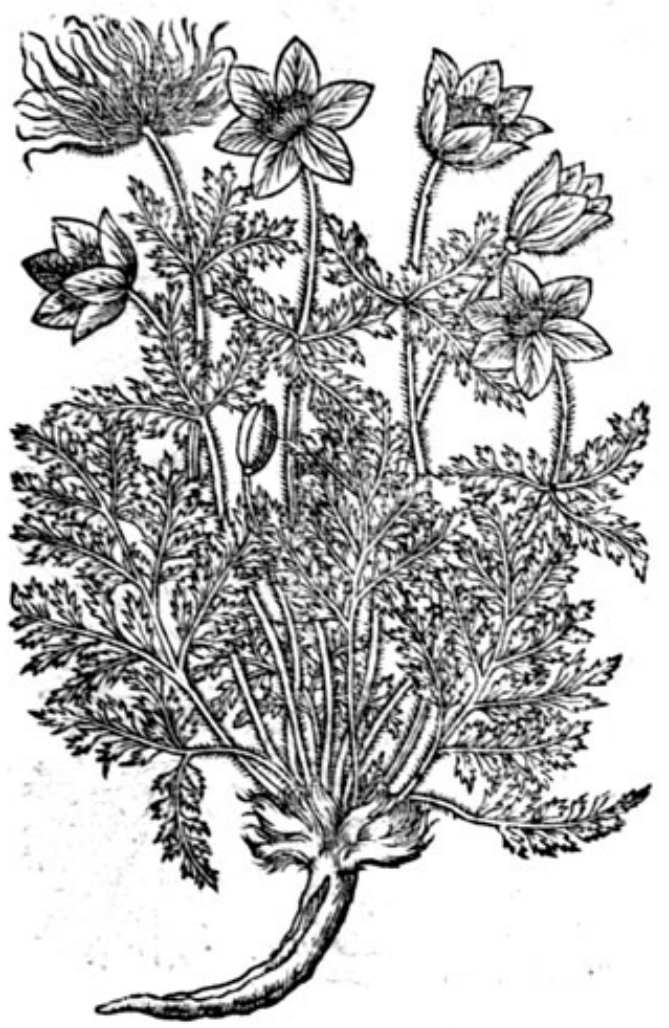

* Theplace.

Rmelliws writeth, that the Paffe flower groweth in Fraunce in vntoiledplaces : in Germanie they growe in rough and ftonie places, and of tentimes on rockes.

Thofe with purple flowers do growe very plentifully in the pafture or clofe belonging to the perfonage houfe of a fmall village fixe miles from Cambridge,called Hilderfham; the parfons name that lited at the impreffion heereof was mafter Fuller, a very kinde and louing man, and willing to fhewe vnto any man the faide clofe, who defired the fame.

\section{* The time.}

They flower for the moft part about Eafter, which hath mooued me to name it Pafque flower, or Eafter flower : and often they do flower againe in Seprember.

\section{* The names.}

Paffe flower is called commonly in Latine Pulfatrila and of fome dpum rifus: in French Coquelourdes: in Dutch Enec enichrll: in Enghirh Pafque flower,or Paffe flower: and after the Latin

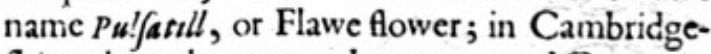
thire where they grow, they are named Couentry bels.

$$
* \text { The temperature. }
$$

Paffe flower doth extremely bite, and exulcerateth and eateth into the skin if it be ftamped and applied to any part of the bodie; whereuporr it hath beene taken of fome to be a kinde of Crowfoote, and not without reafon, for that it is not inferior to the Crowfootes: and therefore it is hot and drie.

\section{* The vertues.}

There is nothing extant in writing among authors of any peculiar vertue, but they ferue onely for the adorning of gardens and garlands, being tlowers of great beautic.

\section{Of Adonisflower. Chap. 74 .}

* The defaription.

I He firft hath verie many flender weake ftalkes, trailing or leaning to the grounde, fet on euery part with fine iagged leaues very deepely cut like thofe of $C$ amomill, or rather thofe of Maiweede: vpon which ftalkes do growe finall redde flowers, in mape like the fielde Crowfoote, with a blackifh greene pointell in the middle, which being growne to maturitie turneth into a finall greenifh bunch of feeds, in fhape like a little bunch of grapes. The roote is fmall and threddie.

2 The fecond differeth not from the precedent in any one point, but in the colour of the flowers, which are of a perfeet yellowe colour, wherein confirteth the difference. 
I Flos Adonis flore rubro. Adonis red flower.

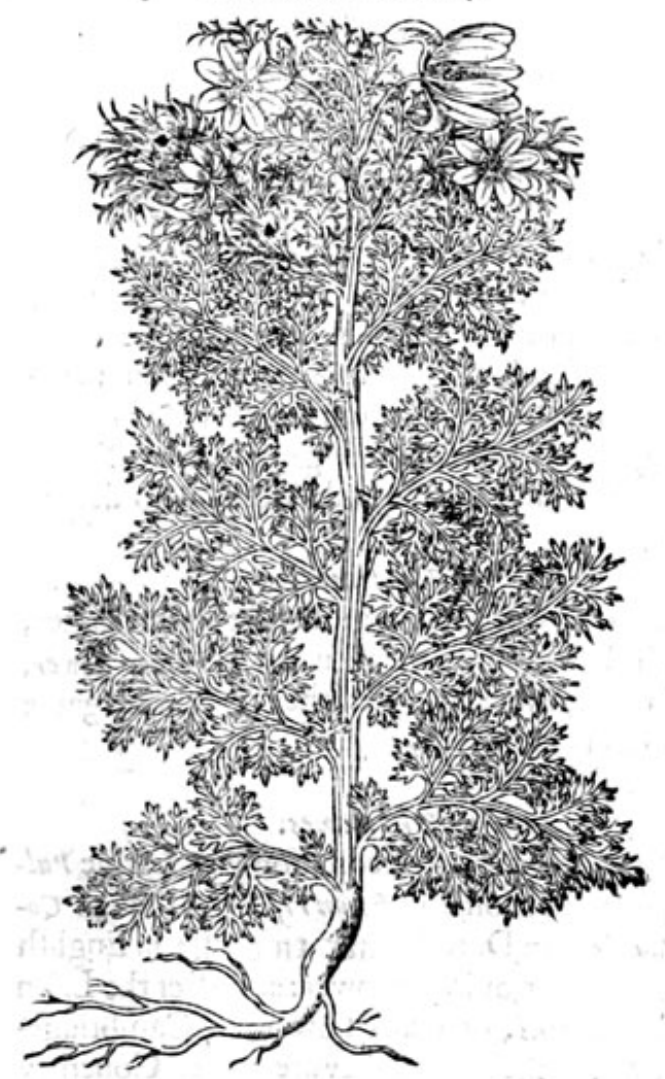

2 Flos 1 dionis flore luteo. Adonis yellow flower.

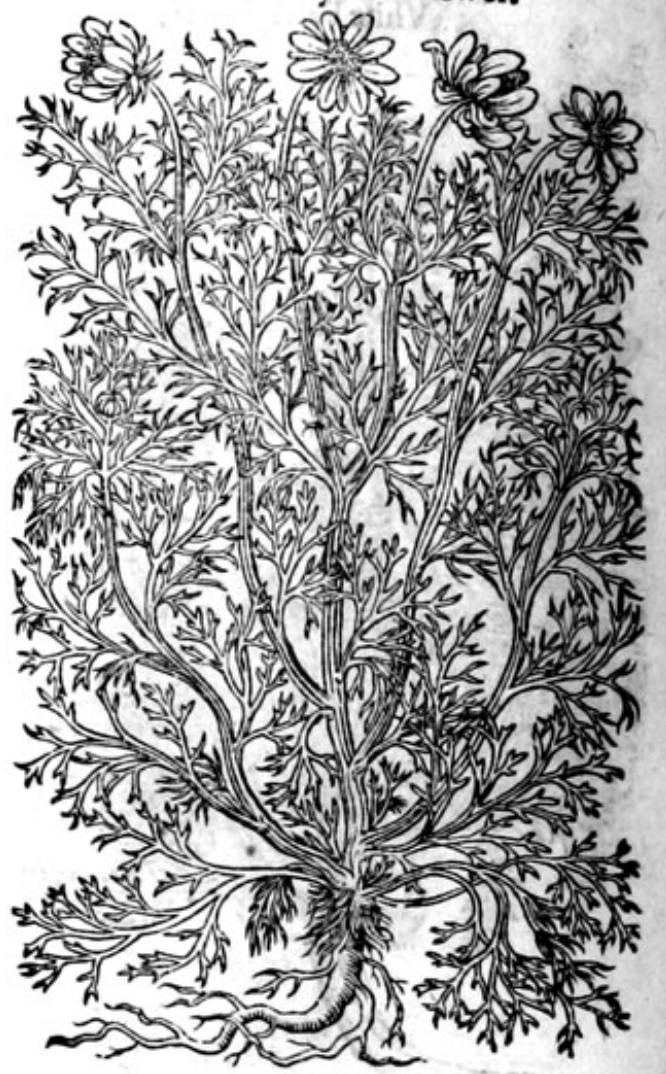

* The place.

The red flower of Adonis groweth wilde in the weft parts of Englande among their corne,euen as Maie-weede doth in other parts, and is likewile an enimie to corne as Maie-weed is, from thence I brought the feede, and haue fowen it in my garden for the beautie of the llowers fake. That with the yellowe flower is a ftranger in England.

* The time.
They flower in the fommer moneths, Maie, Iune, and Iulie, and fometimes later.

* The sames.

Adonis flower is called in Latine Flos Adonis, and Adonidis : of the Dutchmen felozinfzint in Englifh we may call it red Maythes : by which name it is called of them that dwell where it groweth naturally, and generally red Camomill : in Greekeriegryenor, and Eranthemun : our London women do call it Rolearubie. * The temperature.

There hath not beene any that hath written of the temperature heereof: notwithitanding, fo farre as the tafte thereof fheweth, it is fomething hot, but not much. $* 7$ he verturs.

The feede of Adonis flower is thought to be good againft the ftone : among the auncients it was not knowne to have anie other facultic: albeit experience hath of late taught vs, that the feede ftamped, and the powder giuen in wine, ale or beere to drinke, doth woonderfully and with great effect helpe the collicke.

$$
\begin{gathered}
\text { Of Dockes. Chap.75. } \\
\text { * The kindes. }
\end{gathered}
$$

D rofeorides fetteth foorth fower kinds of Docks, wilde or fharpe pointed Docke; garden Docke; rounde leafed Docke; and the foure Docke called Sorrell : befides thefe the later Herbariftes haue added certaine other Dockes alfo, which I purpole to make mention of. 


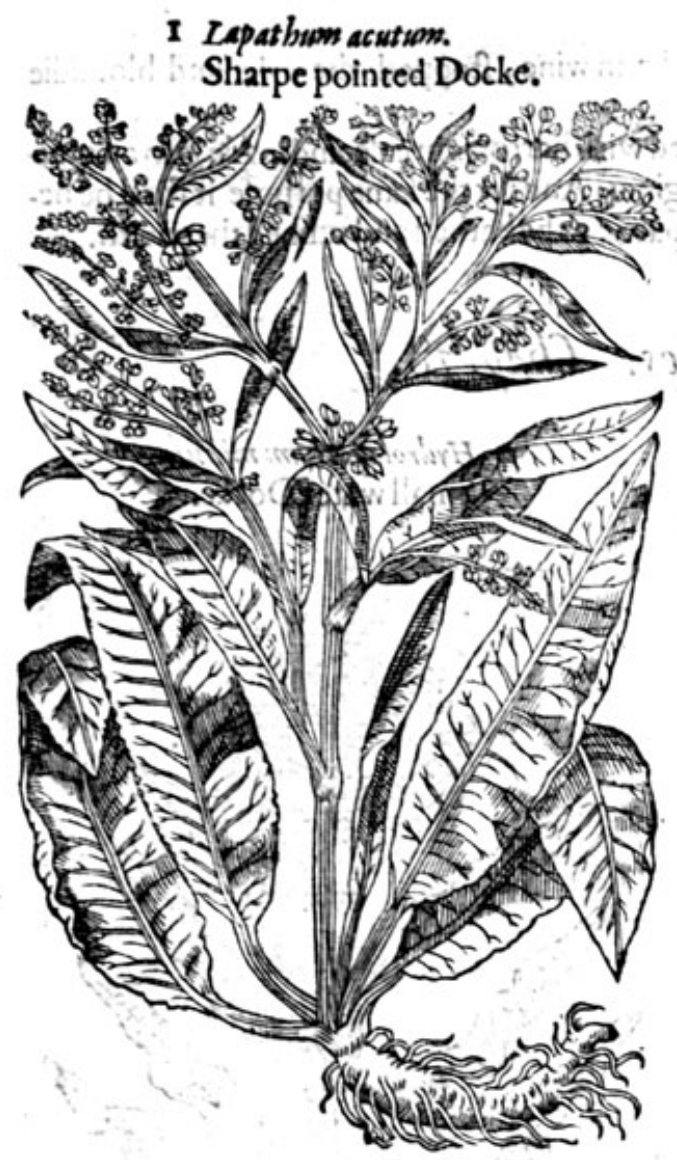

2 Lapat hion aciutuen minimuen. Small inàrpe Docke.

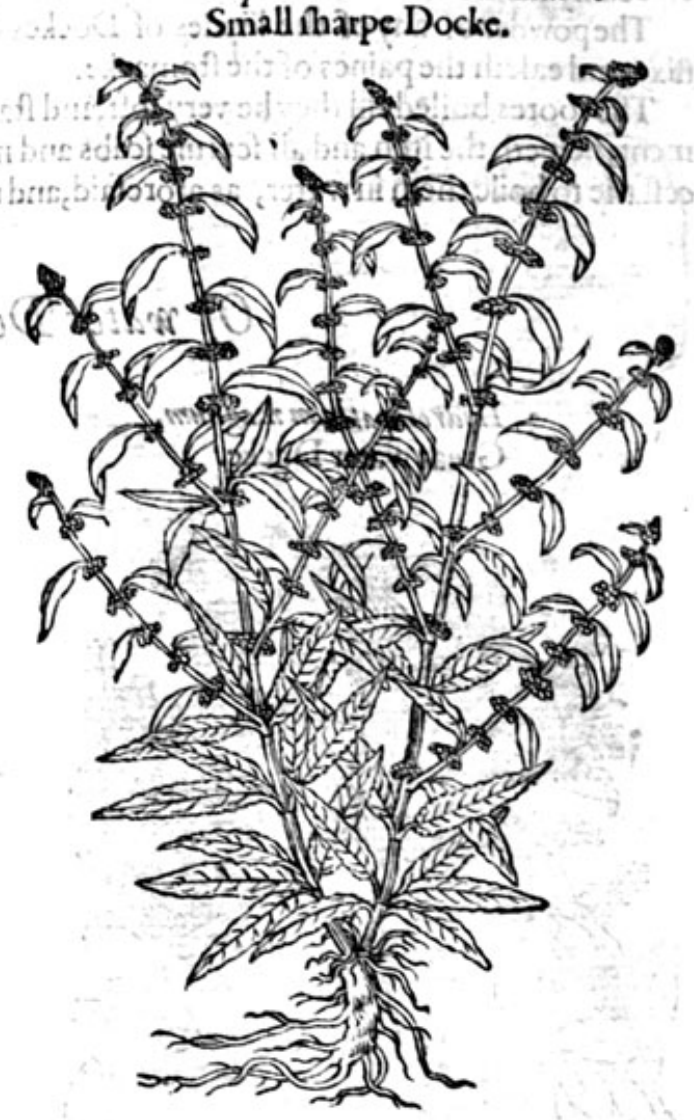

* The defription.

I Hat which among the Latines fignifieth to foften,eafe, or purge the bellie, the fame figni-

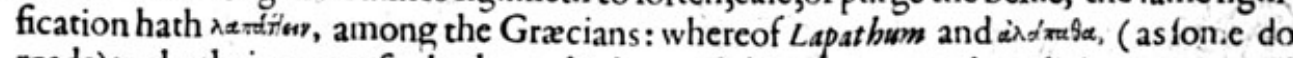
reade) tooke their names for herbes which are vfed in pottage and medicine, verie weil knowne to haue the power of clenfing : of thefe there be many kindes and differences, great ftore euery where growing, among whom is that which is now called fharpe pointed Docke, or tharpe leafed Docke. It groweth alwaies in moift medowes and by running ftreames, hauing long narrow leaues fharpe $\&$ hard pointed; among the which commeth vp round hollow ftalks of a browne colour, hauing ioints like knees, garnifhed with fuch like leaues, but fmaller : at the ende wherof grow many flowers of a pale colour, one aboue another; and after them commeth a brownifh three fquare feede, lapped in browne chaffie huskes like Patience. The roote is great, long, and yellowe
within.

2 The fecond kinde of fharpe pointed Docke is like the firt, but much fmaller, and doth beare his feede in rundles about his braunches in chaffie huskes, like Sorrell, not fo much in vfe as the former; called alfo tharpe pointed Docke.

Thele kindes of Docks do $*$ The place.

They flower in Iune and Iulie.

Theie kindes of Docks do grow, as is beforefaide, in medowes and by riuers fides.

$$
\text { * The time. }
$$

Theyare called in Latin * * The names.

Lapat hum acutum, Rumex, Lapatiü, \& Lapat hium, of fome Oxylapa: 'no: in

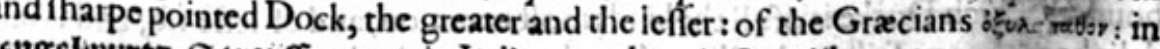

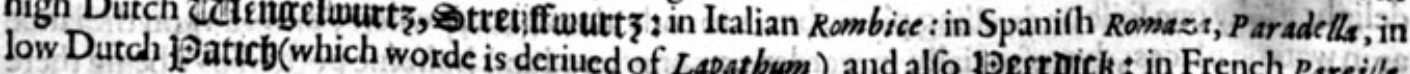

Thefe herbes are of a mixture betweene colde and heate, and almoft drie in the thirde degree, A 


\section{THE SECOND BOOKE OF THE}

efpecially the feede which is verie aftringent.

B The powder of any of the kindes of Dockes drunke in wine, ftoppeth the laske and blouddie flixe, and eafeth the paines of the ftomacke.

C The rootes boiled till they be very foft, and ftamped with barrows greafe, and made into an ointment; helpeth the itch and all fcuruie fcabs and mangines. And for the farne purpofe it fhall be necciflaric to boile them in water, as aforefaid, and the partic to bebathed and rubbed therewith.

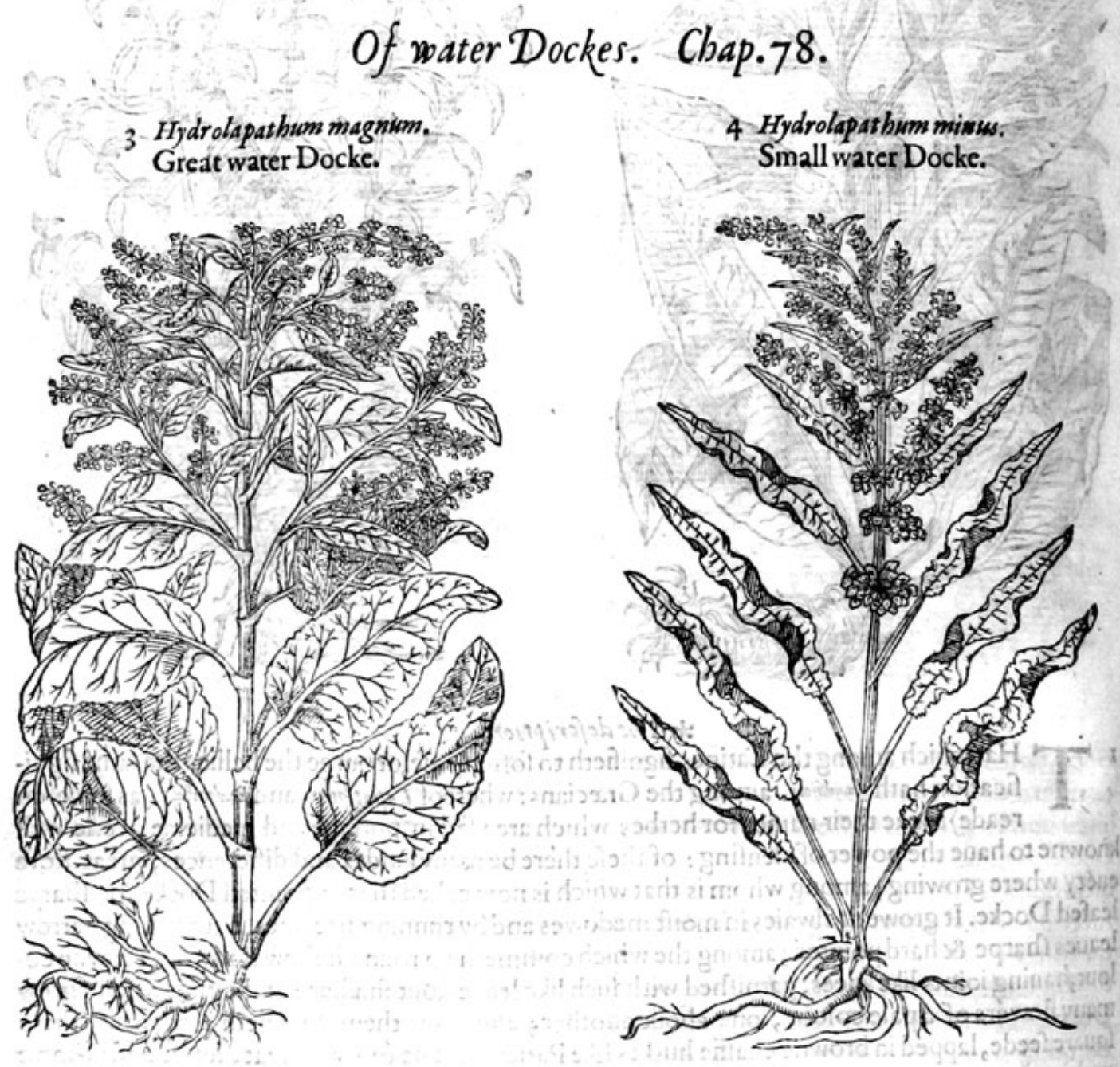

* The defcription,

$37 \mathrm{He}$ Great water Docke hath very long and great leaues, ftiffe, and harde, not vnlike to the garden Patience, but much longer and broader. The ftalke rifeth vp to a great height, of tentines to the height of fiue foote or more. The flower groweth at the top of the ftalke in fpokie tufts, browne of colour. The feede is conteined in chaffie huskes, three fquare, of a hining pale colour. The roote is verie great, thicke, browne without, and yellowifh within.

4 The Small water Docke hath long crooked and crompled leaues, plaited or folded in diuers parts, fet vpon a ftiffe ftalke. The flowers growe from the middle of the ftalke vpwarde in fpokic rundels, fet in fpaces by certaine diftances rounde about the ftalke, as are the flowers of Horehounde: which Docke is of all the kinds moft common, and of leffe vfe, and taketh no pleafure or delight in any one foile or dwelling place, but is founde almoft euery where, as well vpon the lande as in wateric places, but efpecially in gardens among good and holfome potherbes, being there better knowne then welcome or defired: wherefore I intende not to fpend further time abotit his defcription. 

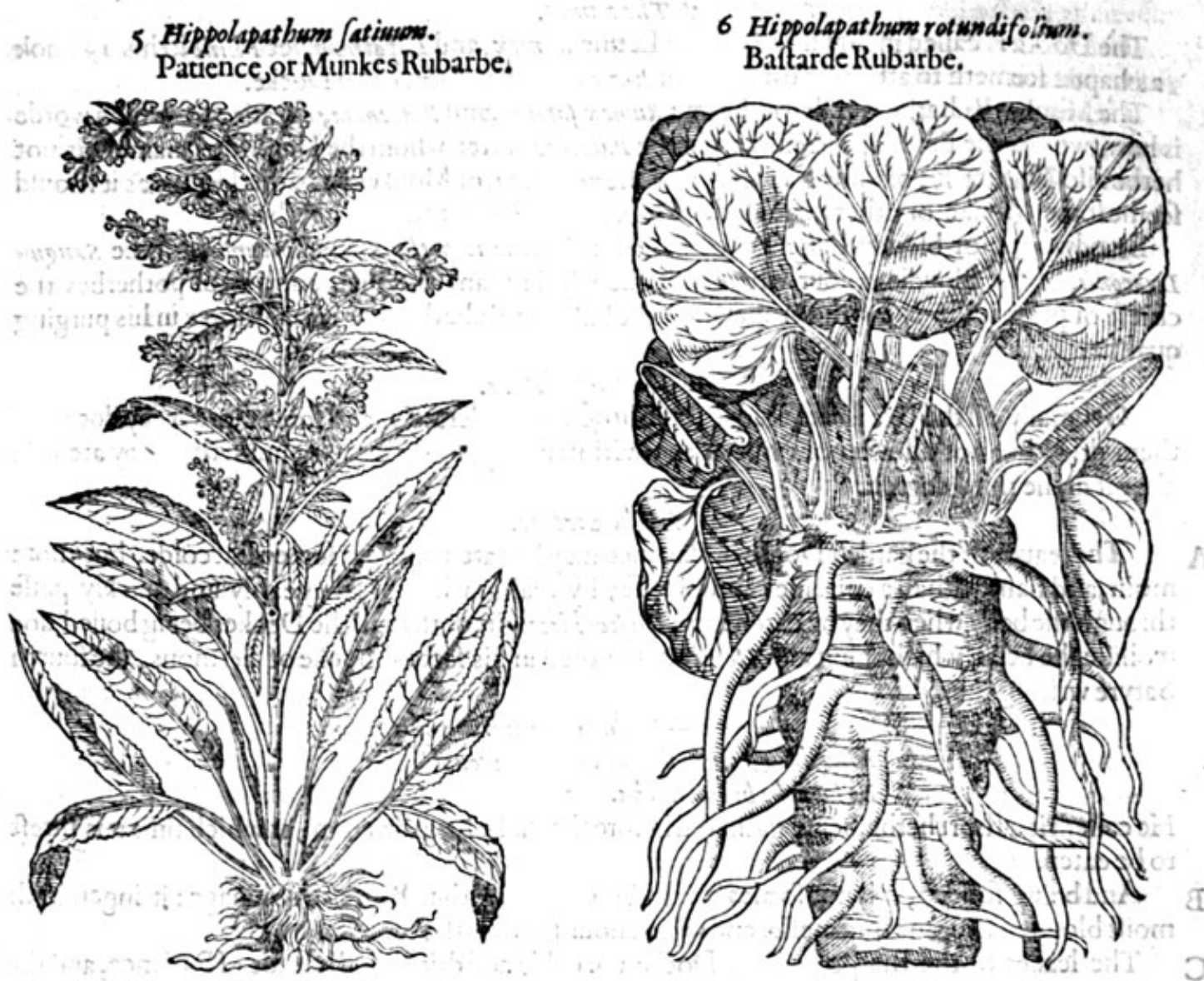

* The defcription.

5 The garden Patience hath very ftrong ftalkes, furrowed or chamfered, of ten or twelue foote high when it groweth in fertill grounde, fet about with great large leaues like to thofe of the water Docke, hauing alongtt the ftalkes towarde the toppe flowers, of a light purple colour declining to brownneffe. The feede is three fquare, conteined in thinne chaffie huskes, like thofe of the common Docke: The roote is verie great, browne without and yellowe within, in colour and tafte like the true Rubarbe.

6 Baftarde Rubarbe hath great broade rounde leaues, in thape like thofe of the great Burre Docke. The ftalke and feedes are folike vnto the precedent, that the one caunot be knowne from the other; fauing that the feeds of this are fomwhat leffer. The root is exceeding great and thicke, verie like vnto the Rha of Barbarie, as well in proportion as in colour and tafte; and purgeth after the fame maner, but muft be taken in greater quantitie, as witneffeth that famous learned phifition nowe liuing, mafter doctor Bright and others, who haue experimented the fame. 7 The feuenth kinde of Docke is beft knowne vnto all, of the ftocke or kindred of Dockes; it hathlong thinnc leates, fometimes redde in euerie part thereof, and often ftripped heere and there with lines and ftrakes, of a darke red colour: among which rife vp ftiffe brittle ftalkes of the fame colour: on the toppe whereof come foorth fuch flowers and feede as the commion wilde Docke hath. The roote is likewife red, or of a bloudie colour.

\section{* The place.}

They do growe for the moft part in ditches and water courfes, very common through Englande. The two laft do grow in gardens, my felfe and others in London and elfewhere, haue them growing for our vfe in Phificke and chirurgerie.

Moft of the Dockes dorife vp in the fpring of the yeere, and their feede is ripe in Iune and Auguift, 
* The names.

The Docke is called in Greeke rámugr: in Latine Eumex, and Lapathom,yet Plinie in his 1, book 32.chapter feemeth to attribute the name of kumex onely to the garden Docke.

The Monkes Rubarbe is called in Latine Rumex fatiuns, and Patientia, or Patience, which worde is borrowed of the French, who call this herbe Pacience : after whom the Dutch men name this por herbe alfo 1 Patientie : of fome Rhabarbarum Monachorum, or Monkes Rubarbe: bicaufe as it fhould feeme fome Monke or other haue vfed the roote heereof in fteede of Rubarbe.

Bloudwoort, or bloudy Patience, is called in Latine Lapathum fanguineum: of fome Sanguis Draconis, of the bloudic colour wherewith the whole plant is poffeft, and is of potherbes the chiefe or principall, hauing the propertie of the baftarde Rubarbe; but of leffe force in his purging qualitic.

* The temperature.

Generally all the Docks are colde, fome little and moderately, and fome more : they doe all of them drie, but not all after one maner : notwithftanding, fome are of opinion that they are drie almoft in the third degree.

* The vertues.

A The leaues of the garden Docke or Patience may be eaten, and are fomewhat colde, but more moift, and haue withall a certaine clammineffe; by reafon whereof, theyeafily and quickly paffe through the belly when they be eaten : and Diofcorides writeth that all the Dockes being boiled doe mollific the bellie, which thing alfo Horace hath noted in his fecond booke of Sermons, the fourth Satyre writing thus,

\section{Si dur a mor abitur aluses \\ Mugilus, or viles pellent obstantia concha, Et lapathe breus berba.} He callethit a fhort herbe, being gathered before the ftalke be growen vp; at which time it is fitteft
to be eaten.

B And being fodden, it is not fopleafant to be eaten as either Beetes or Spinage : it ingendreth moift bloud of a meane thickneffe, and which nourifheth little.

C The leaues of the Tharpe pointed Docke are colde and drie: but the feede of Patience, and the water Docke, do coole, with a certaine thinneffe of fibftance.

D The decoction of the rootes of Monkes Rubarbe is drunke againft the bloudie flixe, the laske, the wambling of the ftomacke which commeth of choler : and alfo againft the ftinging of ferpents as Diofcorides writeth.

E It is alfo good againft the fpitting of bloud, being taken with Acacia(or as fome would have it, the dried iuice of floes)as Plinie writeth.

F Monkes Rubarbe or Patience is an excellent holfome potherbe; for being put into the pottage infome reafonable quantitie, it doth loofen the belly; helpeth the iaunders; the tympanie and fuch like difeafes, proceeding of colde caufes.

If you take the roots of Monks Rubarbe, \& red Madder, of eche halfe a pound; Sena fower ounces; annife feede and licorice, of eche two ounces; Scabioufe and agrimonie, of eche one handfull; flice the rootes of the Rubarbe, brufe the annife feede and licorice, breake the hearbes with your hands, and put them into a ftone pot called a fteane, with fower gallons of ftrong ale to fteepeor infufe the fpace of three daies: and then drinke this liquor as your ordinarie drinke for three weeks togither at the leaft, though the longer you take it, fo much the better; prouiding in a readines an other ftean fo prepared that you may haue one vnder another, being alwais careful to keepe a good diet: it cureth the dropfie, the yellowe iaunders, all maner of itch, fcabs, breaking out, and mangineffe of the whole bodic: it purifieth the bloud from all corruption; preusileth againft the greene fickneffe very greatly, and all oppilations or ftoppings: maketh yoong wenches to looke faire and cherrie like, and bringeth downe their tearmes, the ftopping whereof hath caufed the fanie.

$G$ The feede of baftarde Rubarbe is of a manifeft aftringent nature, infomuch that it cureth the bloudie flixe, mixed with the feede of Sorrell, and giuen to drinke in red wine.

H There hatie not beene any other faculties attributed to this plant either of the auncient or later writers, but generally of all it hath beene referred to the other Docks or Monkes Rubarbe, of which number I affure my felfe this is the beft; and doth approch neereft vnto the true Rubarbe. Manie reafons induce me fo to thinke and faic: fuft this hath the fhape and proportion of Rubarbe, the 
fame colour,both within and without, without any difference. They agree as well in tafte as fmell: it coloureth the fpitrle of a yellowe colour when it is chewed, as Rubarbe doth: and laftly it purgeth the belly after the fame gentle manner that the right Rubarbe doth, onely heerein it differeth, that this muft be giuen in three times the quantitic of the other. Other diftinetions and differences with the temperature and euery other circumftance, I leaue vito the leatned phifitions of our London colledge (who are very well able to fearch into this matter) as a thing far aboue my reach, being no graduate, but a countrie fcholler, as the whole framing of this hiftorie doth well declare : but 1 hope my good meaning will be well taken, confidering I do my beft, not doubting but fome of greater learning will perfeet that which I haue begun according to my fmall skill, efpecially the ice being broken vnto him, and the woode rough hewed to his handes. Notwithftanding I thinke it good to faie thus much more in mine owne defence : that although there be manie wants and defeets in me, that were requifite to performe fuch a worke; yet may my long experience by chatunce happen vpon fome one thing or other that may do the learned good: confidering what a notable experiment I learned of one John Bennet a chirurgion of Maidftone in' Kent, a man as flenderly learned as my felfe, which he practifed vpon a butchers boie of the fame towne, as himfelfe reported vnto me; his practife was this: being defired to cure the forefaide ladde of an ague, which did greeuounly vexe him, he promifed him a medicine, \& for want of one for the prefent (for a fhift, as himfelfe confeffed vnto me)he tooke out of his garden three or fower leaues of this plant of Rubarbe, which my felfe had among other fimples giuen him, which he ftamped and ftrained with 2 draught of ale, and gaue it the ladde in the morning to drinke: it wrought extremely downwarde and vpwarde within one hower after, and neucr ecaffed vntill night. In the ende the ftrength of the boie ouercame the force of the phificke, it gaue ouer working, and the ladde lont his ague; fince which time (as hefaith) he hath cured with the fame medicine many of the like maladie, hauing euer great regarde vnto the quantitic, which was the caufe of the violent working in the firft cure. By reafon of which accident, that thing hath beene reucaled vnto pofteritie, which heeretofore was, not fo much as dreamed of. Whofe bluni attempt, may fet an edge vpon fome fharper wit, and greater indgement in the faculties of plants, to feeke fartber into their nature then any of the anncients haue done : and none fitter then the learned phifitions of the Colledge of London; where are inany fingularly well learned, and experienced in naturall things.

The rootes fliced and boiled in the water of Carduus Benedictus to the confumption of the third part, adding thereto a little honic, of the ivhich decoction eight or ten fponfuls drunke before the fit, cureth the ague in two or three times fo taking it at the moft: vnto robuftous or ftrong bo dies twelue fponfuls may be giuen. This experiment was practifed by 2 worlhipfull gentlewoman called miltrefle Unne $1 \mathrm{~V}$ lbrabam, vpon diuers of hir pcore neighbours with good fucceffe.

\title{
Of Rubarbe. Chap.79.
}

\author{
* The defoription.
}

$I T$ His kinde of Rubarbe hath very great leaues, fomewhat fnipt or indented about the edges

1 like the teeth of a fawe, not vnlike the leaues of Enula campana, called by the vulgar fort Elecampane but greater: among which rifeth vp a fraight ftalke of two cubits high, bea. ring at the top a fcalie head like thofe of Knappeweede, or lacea waior: In themiddle of which knap or head, thrafteth foorth a faire flower confifting of many purple threddes, like thofe of the Artichoke; which being paft, there followeth a great quantitie of downe, wherin is wrapped long feede like vnto the great Centorie, which the whole plant doth very well refemble. The roote is long and thicke, blackifh without, and of apale colour within : which being chewed maketh the fpittle verie yellowe,as doth the Rubarbe of Barbarie. 
I Rha Capitatum L'Obelii.

Turkie Rubarbe.

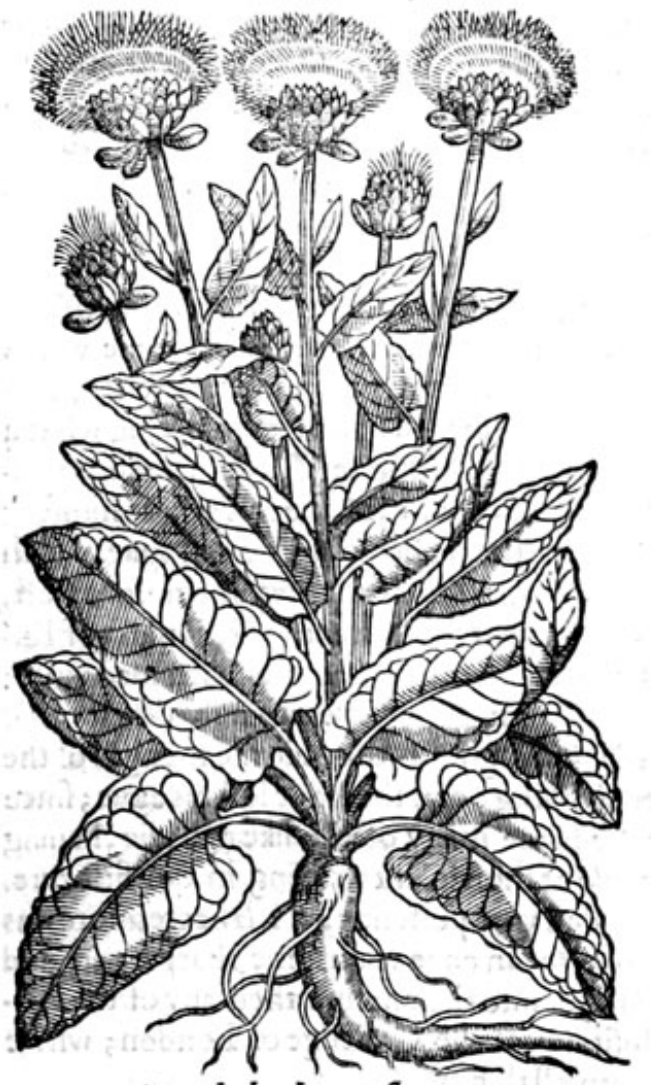

2 Rhabarbarum florens.

Flowring Rubarbe.

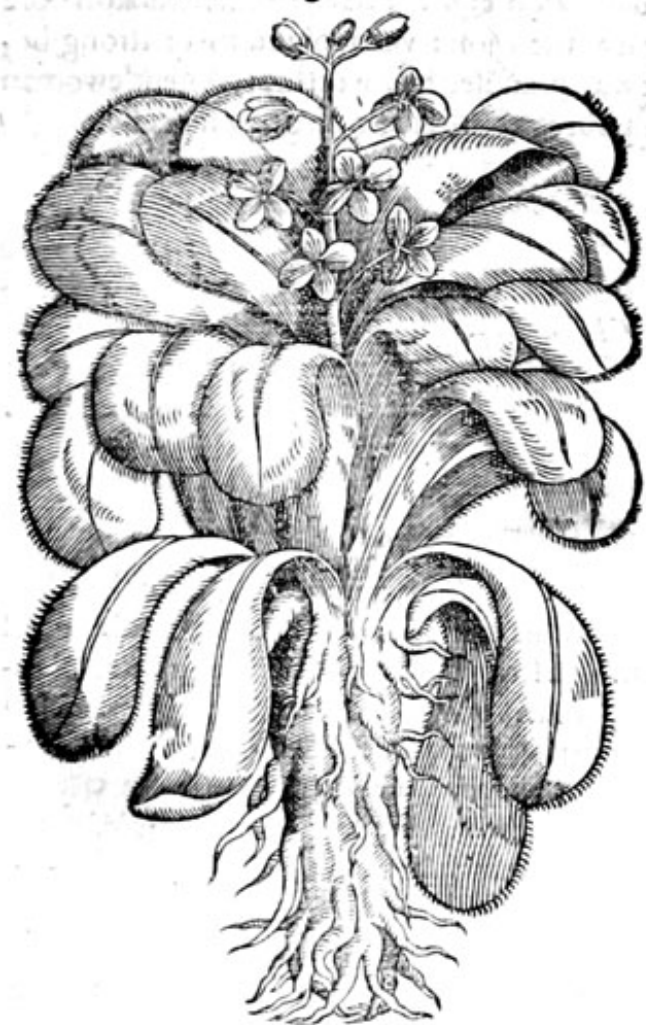

$*$ The defcription.

2 Touching the Rubarbe vfed in fhoppes of the forme or bigneffe of the plant it felfe, or of the lcaues or flowers, we finde nothing fet down in the olde writers : Diofcorides hath expreffed a certaine likeneffe, fubftance and colour of the rontes onely: and yet but of that Rubarbe which groweth in thofe places that are beyonde the ftreight of $\mathrm{Con}$ ftantinople, called the blacke fea, and Pontus Euxinus, or alfo Mrotis, called the white fea.

The greatnes of the rootes of Rubarbe (and as it is very like of the whole plant it felfe alfo)doth not a little varie according to the difference of the regions, ground and weather, which(as we muift euer nowe and then repeat) be oftentimes great caules of alteration and difference in plants.

But feeing there is extant 2 pieture of the greene Rubarbe with his flowers, ftalke, and rootes, it fhall not be amiffe to fet foorth his defcription likewife.

Rubarbe hath a greene thicke ftalke a footehigh, garnilhed with many leaues, of two fpans long, fomtimes longer or fhorter, according to their age, narrowe toward the ftemme, broad and rounde at the top like a peare, bowing backwardes towarde the ground, couered ouer with a certaine downe or woollines when they be yoong \& greene, but when they be olde of a pale yellowifh colour: out of the Rhabarbarum ficcatum.

The dry rootes of Rubarbe.

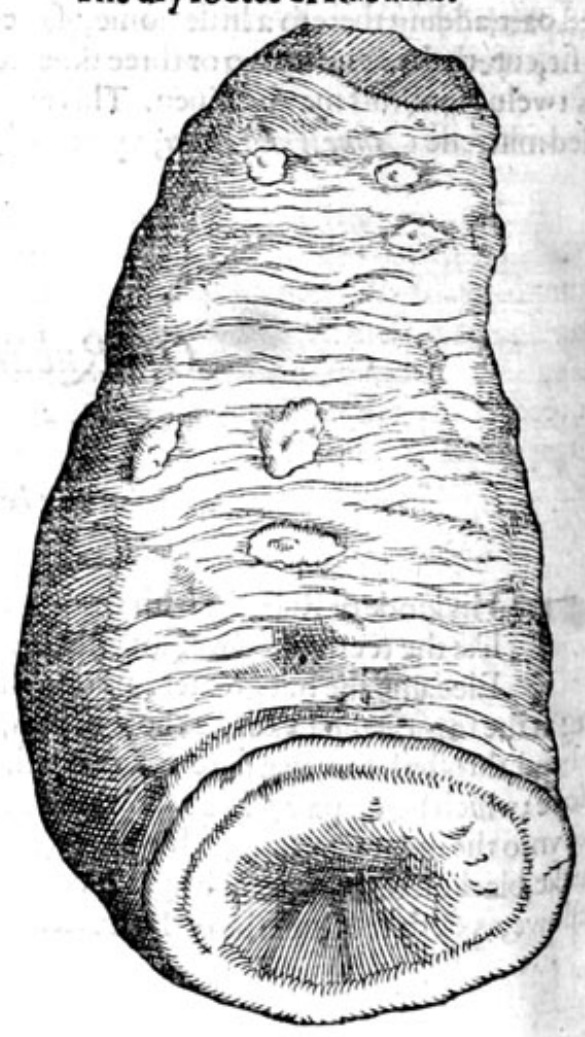


middle of the leaues there groweth vp a flender flalk bearing flowers, confifting offiue little leaues confufedly placed vpon the fmall braunches withour order, which turne from white to yellowe, in

- thape like the garden violet, but greater, \& of a ftrong vnpleafant fauour. The root groweth two or three handfuls deepe in the grounde, wrapped in a barke, of a darke browne colour 3 fometimes as bigge as the calfe of a mans legge, fometimes leffer: from the maine roote fhoote foorth manie threddes and fmall fhootes, which fpread farre abroad in the carth, whereby it increafeth.

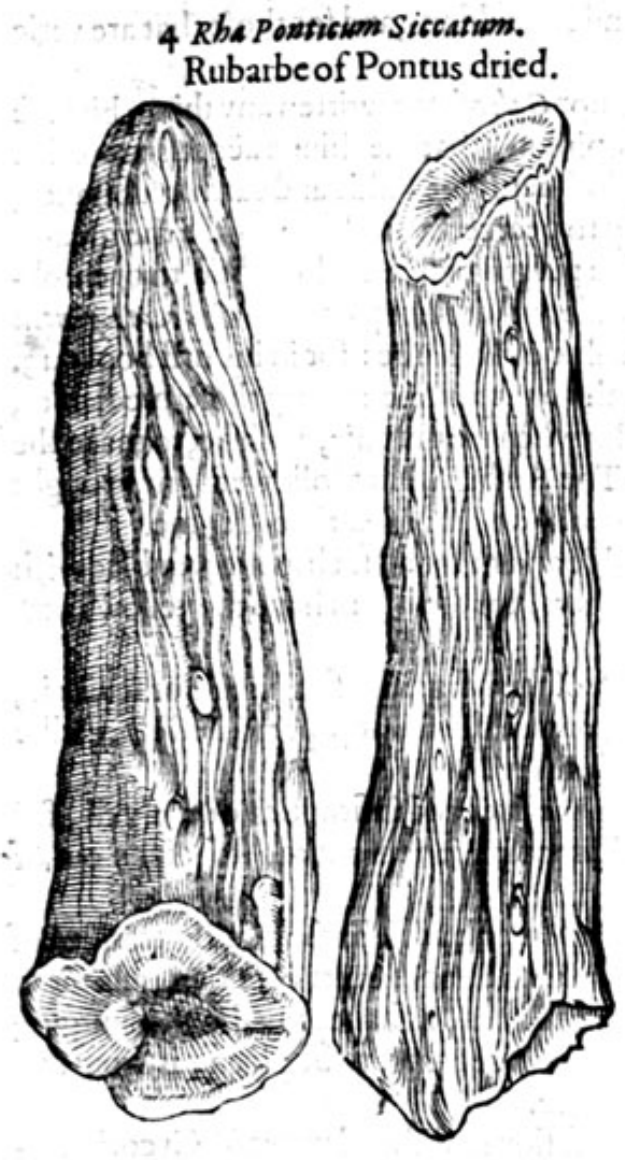

\section{* The defoription.}

4 The Ponticke Rubarbe is leffer and flenderer then that of Barbarie. Touclting Ponticke Rubarbe Diofcorides writech thus, Rha that diuers call Rheon, which groweth in thofe places that are beyond Bofphorus, from whence it is brought, hath blacke rootes like to the greatCentorie, but leffer and redder, äos $\mu$ s, thar is to fay; without fmel (as the copies haue) loofe or pungic, and fomethinglight, and of the kindes offubarbe of leatt woorth.

\section{* The place.}

It is brought out of the countrie of $\mathrm{Sina}$ (commonly called China) which is towarde the eaft in the vpper part of India, and that India which is without the riuer Ganges : and not at all Ex Scenitarum prosincis, (as many do vnaduifedly thinke) which is in Arabia the happie, \& far from China: it groweth on the fides of the river Rha as istivianus Marcellus faith, which riner fpringeth out of the Hyperborei mountaines in the high northern parts, and running through Mufcouie, it fallech into the Cafpian or Hircan fea: as alfo ypon the banckes of the riuer Rha, now calledVolga. * The choice.

The beft Rubarbe is that which is brought from China frefh and newe, of a light purplifh red, with certaine vaines and braunches, of an vncertaine varietie of colour, commonly whitirh: but when it is old the colourbecommethill fatored by turning yellowh or pale, but more, if it be worme eaten : being chewed in the mouth it is fornewhat gluie and clammie and of a faffron colour, which being rubbed vpon paper or fome white thing, (heweth the colour more plainly: the fubltance therof is neither harde or clofely compacted, nor yet heauie; but fomthing light, and as it were in a middle betweene harde and loofe and fome thing fpungie: it hath alfo a fweete and pleafant finell. The fecond in goodnes is that which commeth from Barbarie. The laft and woort from Bofphorus and Pontus.

$$
\text { * The niames. }
$$

It is commonly called in Latine Rha Barbarwm, or Rha Barbaricion, of diuers Rhew Barbarwem: the Moores and Arabians do more truely name it Raved Seni,à Sinenfiprowincia; from whence it is brought into Perfia and Arabia, and afterwards into Europe: and likewife from Tanguth, through the lande of Cataia into the lande of the Perfians, whereof the Sophie is the ruler, and from thence into Egypt,and afterwards into Europe. It is called of the Arabians and the people of China, and the parts adiacent; Rawend Cini, Rawed Seni, and Kawed Sceni, in fhops Rhabarbarwo : in Englifh Rubarbe,and Rewbarbe. * The temperature.

Rubarbe is of a mixt fubftance, temperature and facultic: fome of the parts thereof are carthic, binding and drying : others thinue, 2 ëreous hot, and purging.

$$
\text { * The vertues. }
$$

Rubarbe is commended of Diofcorides againft windineffe, weakneffe of the ftomacke and all griefes 


\section{8 \\ THE SECOND BOOKE OFFTHE}

griefes thercof, conuulfions, difeafes of the fpleene, liwer,and kidneies, gripingsand inward gnaw. ings of the guts, infirmitics of the bladder and cheft, fwelling about the hart, difeafes of the matrix, paine in the huckle bones, fpitting of bloud, hortneffe of breath, yexing or the hickets; she bloudy flixe; the laske proceeding of rawe humour s; fits in agues; andiagaint the bitings of venemous beafts.

B Moreouer he faith, that it taketh away blacke and blew fpots and tettersor ringwoormes, fitbe mixed with vineger and the place annointed therewith.

C Galen affirmeth it to be good for burftings,cramps and conuulfions;and for thafe that are verie Thort winded, and that fpit blour.

D But touching the purging facultie, neither Diofcorides nor $G$ alen hath written any thing, bicaufe it was not vfed in thofe daies to purge with. Galen helde opinion, that the thinne aërious parts doe make the binding qualitic of more force: not bicaufe it doth refilt the colde and earthie fubitance, but by reafon that it carieth the fame, \& maketh ir deeply topearce, \& therby to worke the greater effect, the drie and thinne effence conteining in it felfe a purging force and qualitie to open obftructions, but helped and made more facile by'the fubtileand aërious parts. Paslus UEgineta feemeth to be the firft that made triall of the purging facultie of Rubarbe: for in his firft booke 43 . chapter he maketh mention thereof, where hereckoneth vp turpentine among thofe medicines, which niade the bodies of fuch as are in health foluble. But when we purpofe, faith he, to make the turpentine more ftrong,we adde vnto it a little Rubarbe. The Arabians that followed him, brought it to a further vfe in phifi $\mathrm{ke}$, as chiefly purging dowiwward choler, and oftentimes flegme.

E The purgation which is made of Rubarbe is profitable and fit for all fuch as are troubled with choler, and for thofe that are ficke of fharpe and tertian feuers, for them that haue the yellow iaunders, and bad liuers.

F It is a good medicine againft the pleurifie, inflammation of the lungs, the fquinancie or fquincie, madneffe, frenfie, inflammations of the kidneies, bladder, and all the inwarde parts, and ef́peciallie againft Saint Anthonies fire, as well outwardly as inwardly taken.

Rubarbe is vndoubtedly an efpeciall good medicine for the liver and infirmities of the gall, for

befides that it purgeth foorth cholericke and natghtie humours, it remooueth ftoppings out of the conduits.

H It alfo mightily ftrengthneth the entrailes themfelues; infomuch as Rubarbe is iuftly tearmed of diuers, the life of the liuer: for Galen in his I I.booke of the methode or manner of curing, affirmeth that fuch kinde of medicines are moft fit and profitable for the liuer, as haue ioined with a purging and opening qualitie, an aftringent or binding power.The quantitie that is to be giuen, is from one dram to two : and in the infufion from one and a halfe to three.

I It is giuen or fteeped, and that in hot difeafes, with the infufion or diftilled water of Cycorie, Endiue, or fome other of the like nature; \& likewife in Whaie : andif there be no heate it may be giuen in wine.

$K$ - It is alfo oftentimes giuen being dried at the fire, but fo, that the leaft or no part thereof at all be burned; and being fo ved it is a remedie for the bloudie flixe, and for all kinds of laskes: for it both purgeth awaynaughtie and corrupt humours, and likewife withall ftoppeth the bellie.

L The fame being dried after the fame maner doth alfo ftaie the ouermuch flowing of the monthly fickneffe, and ftoppeth bloud in anie part of the bodie, efpecially that which commeth through the - bladder; but it fhoulde be giuen in a little quantie, and mixed with fome other binding thing.

Mefues faith, that Rubarbe is an harmeleffe medicine, and good at all times and for all ages, and likewife for children and women with childe.

\section{Of Sorrell. Chap.80.}

* The kindes.
$\mathrm{T}$
Here be diuers kindes of Sorrell differing in many points, fome of the garden, and others wilde, fome great and fome leffer.

$$
\text { * The }
$$



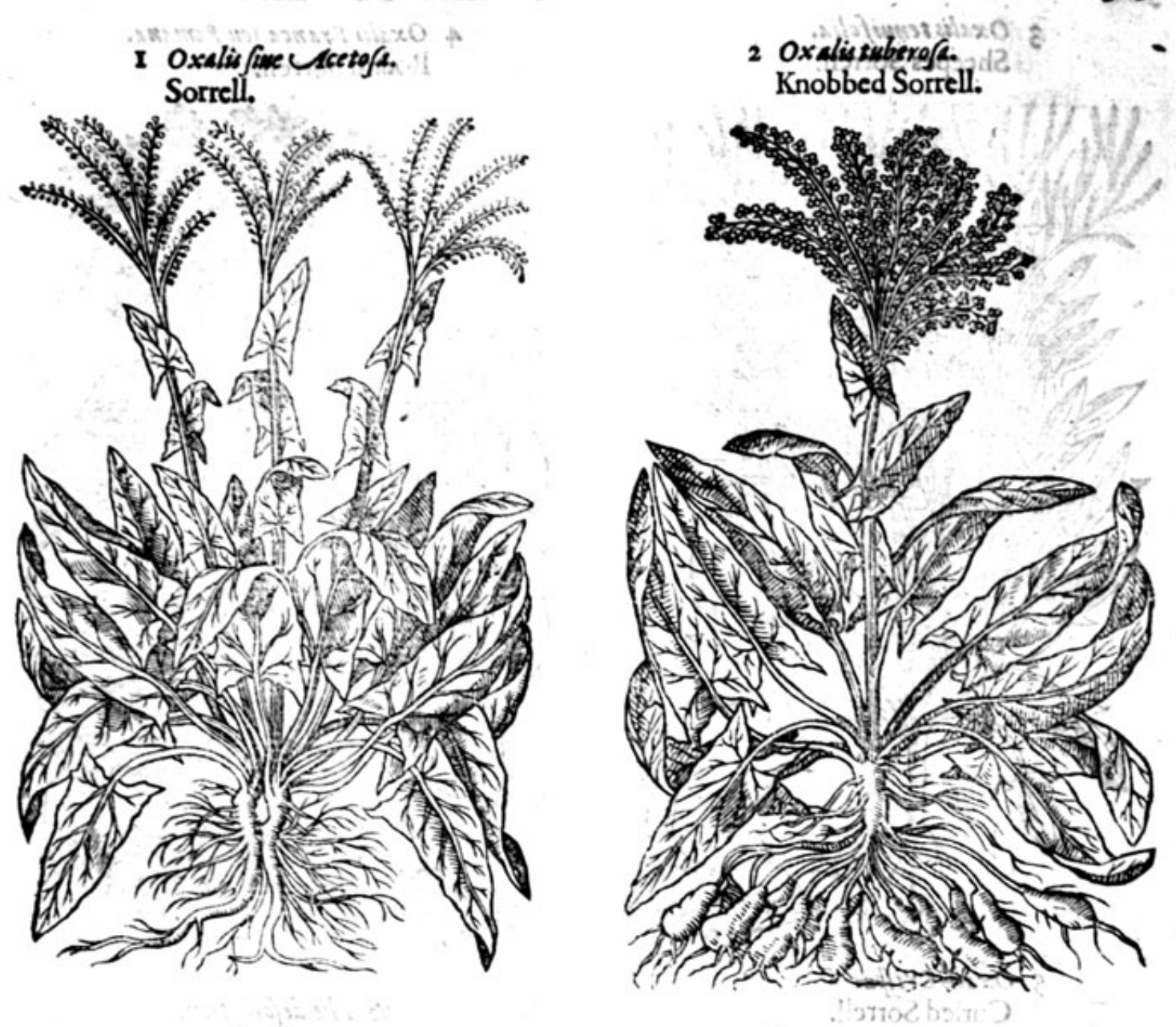

$*$ The defoription,

I Hough Diofcorides hath not in all things fufficiently expreffed the Oxalides, yet none ought to doubt but that they were taken and accounted as the fourth kinde of Lapathom. For though fome like it well that the feed inould be called $D$ rimes, yet that is to be vnderftoode according to the common phrafe, when eger things are confounded with thofe which be Tharp \& fower; elfe we might accufe him of fuch ignorance as is not amongft the fimpleft women. Moreouer the worde $O$ xius doth not onely fignific the leafe, but the fauour and tartneffe, which by a figure drawne from the Tharpnes of kniues edges, is therefore called fharpe : for 0 gis zines fignifieth a fharpeorfower inice, which pearceth the toong like a harpe knife: whereupon alfo Lapatham maybe called $O x a l i s$, as it is indeede, hauing leaues thinner, tenderer, and more oilcous then $L$ apdtiun acutum, broader next to the itemme, horned and crefted like Spinage and Atriplex. The ftalke is muchltreaked, reddin and full of iuice : the roote yellowe and fibrous: the feede fharpe corneredand fhining, growing in chaffie buskes like the other Dockes.

2 The feconde kinde of $O$ xalis or Sorrell, hath large leaues like Patience, confufedly growing togither voon a greattalfftalke, at the top ivheregf growe tufts of a chaffie fubitaunce. The roote is tuberous, much like the Peonie, or wather Philipendula, faftned to the lower part of the ftemme with fmalliongtrings andiaces.

3 The thitdkinde of Sorrell groveth very fmall, braunching hither and thither, taking holde of the groma i there it rampeth, whereby it difperleth it felfe farre abroade. The leaues are little and thinne, Mauing two mall leaues like cares faftned thereto, in theve like the herbe Sagittaria. The feede in tafte is like the other of his kinde,

4 The fourth kinde of Sorrell hath leaties fomewhat round and cornered, hating two fhort eaves annexed vinto the fame. The feede and roote in talte is like the other Sorrels. 
3 Oxalis senuifolia. Sheepes Sorrell.

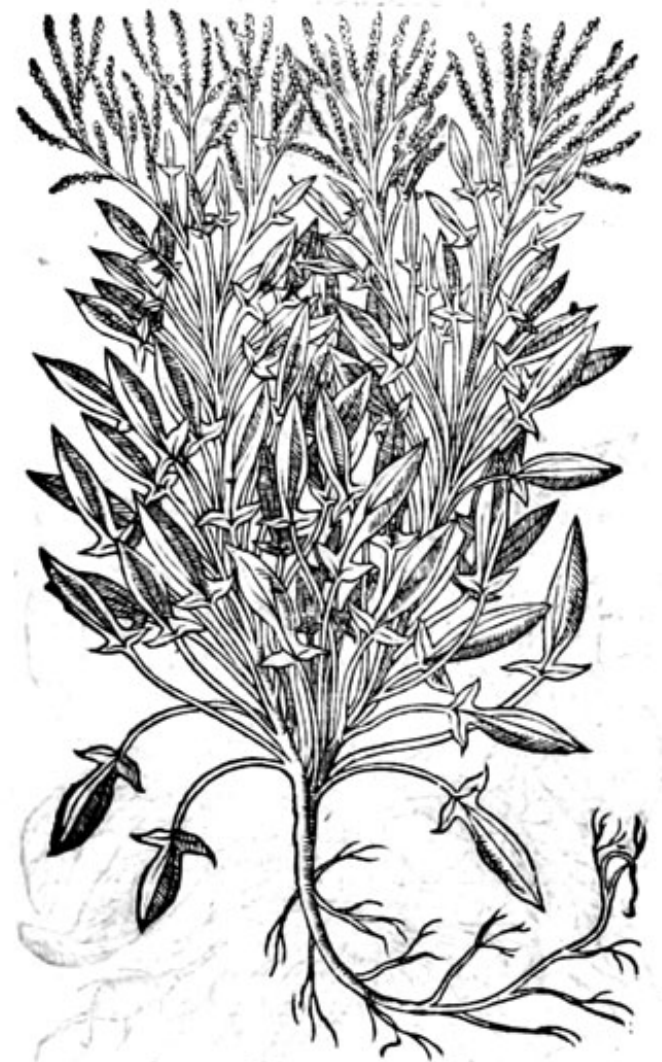

5 Oxaliscripa.

Curled Sorrell.

4.

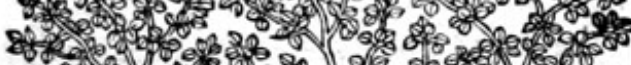

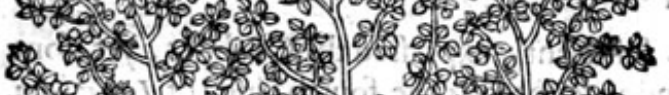
$89.25 \%$
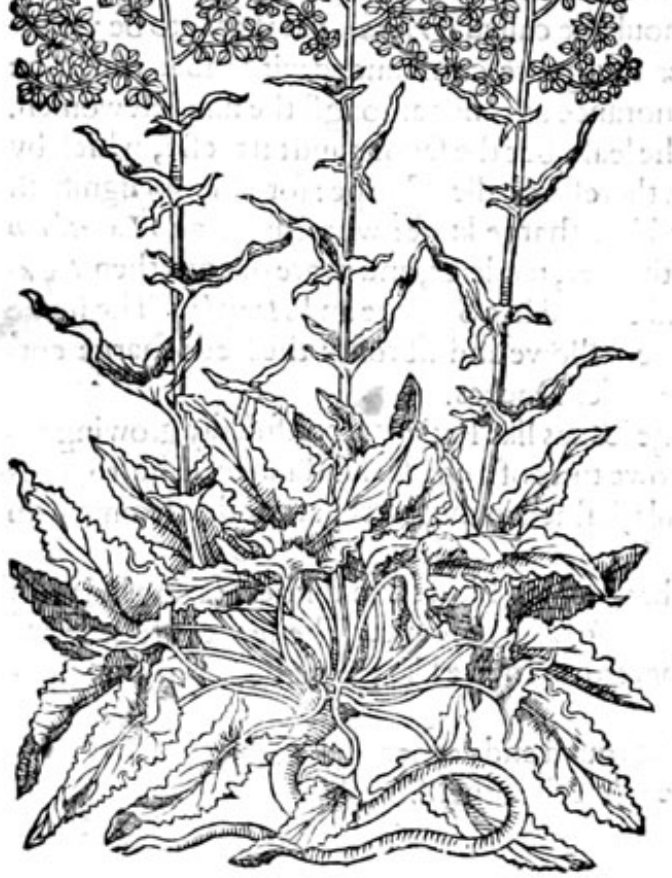

4 Oxalio Franca feu Romana. Round Sorrell.

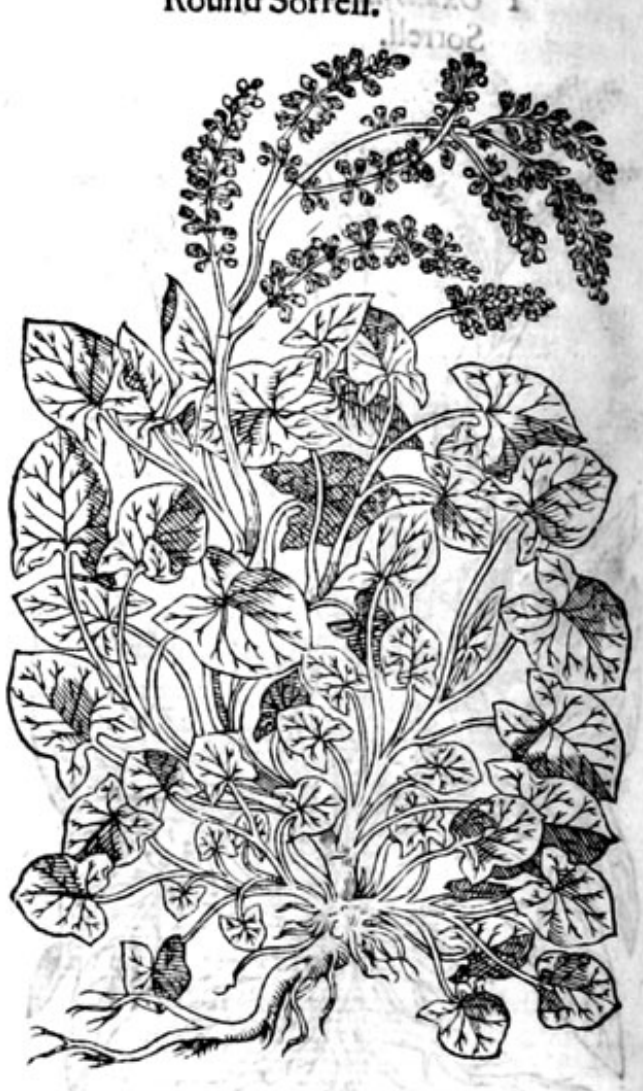

* The defcription.

5 This kinde of curled Sorrell is a ftranger in Englande, and hath verie large leaues, in thape like the garden Sorrell, b ut curled and crompled about the edges as is the curled Colewoorte. The Italk rifeth vp among the leaues, fet here \&sthere with the like leaues, but leffer: the flowers, feede, and rootes are like the common Sorrell or fower Docke.

6 The fmall Sorrell that groweth vpon dry batren fandie ditch bankes, hath fmall graffie leaues, fomewhat forked or croffed oucr like the croffe hilt of a rapier. The ftalkes rife vp among the leaues, fmall, weake,and tender, of the fame lower tafte that the leaues are of. The flower, feede, and roote, is like the other Sorrels, but altogither leffer.

7 The fmalleft fort of Sorrell is like vnto the precedent, fauing that the loweft learres that lie flat vpon the grounde be fomewhat rounde, like vnto the fimalleeft Bell flower, called companuls minor, Rotwadifolin, which fetteth foorth the difference.

$$
6 \text { oxalis }
$$




\section{HISTORIE OF PLANTS: $]$ HIT}

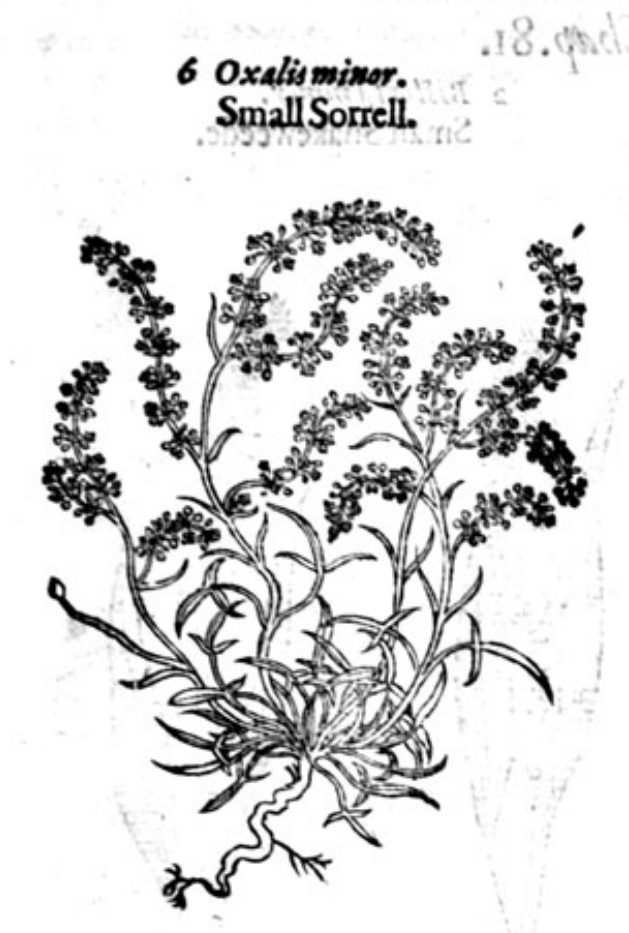

7 Oxalisminima.

The finalleft Sorrell.

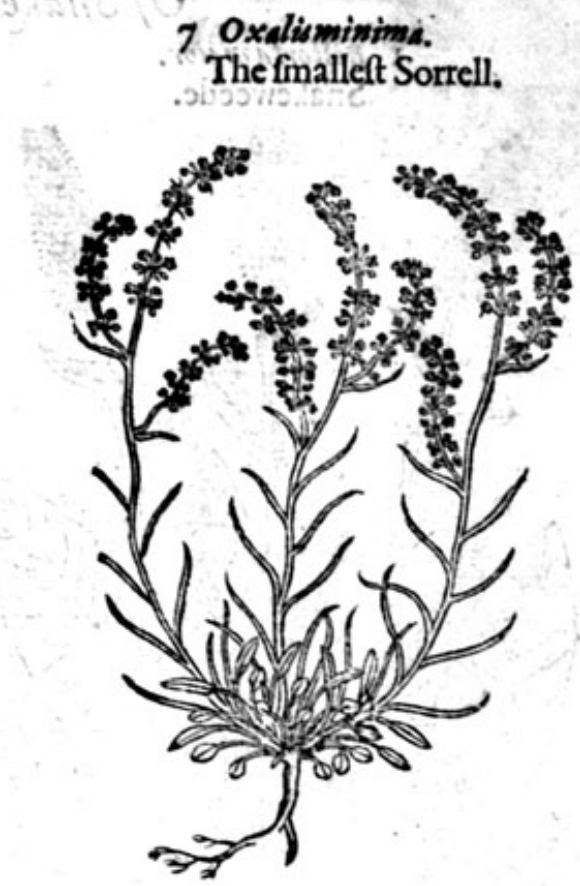

* The place.

The common Sorrell groweth for the moft part in gardens; the fecond by waters fides : the two laft vpon euerie grauelly or fandie barren ground, and ditch bankes,

* The time.

They flourith at that time, when as the other kinde of Dockes do flower.

* The names.

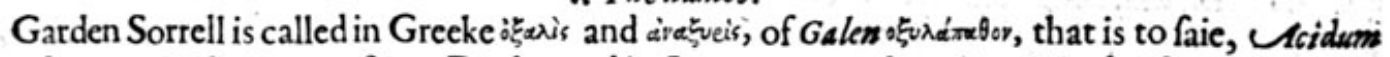
- lapathom, or Acidsu Rumex, fower Docke : and in thops commonly scetofa: in the Germain toong

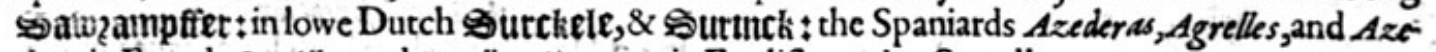
das : in French Ozeille, and Srielle, Aigrette : in Englifh garden Sorrell.

The fecond is called of the later Herbarifts Tuber ofa Accto $f_{a}$, and $T$ uberofum lapatbwom:in Englifh bunched or knobbed Sorrell.

The third is cailed in Englifh fheepes Sorrell : in Dutch oupapt.

The fourth Romaine Sorrell, or rounde Sorrell.

The fift curled Soirell. The fixt and feuenth barren Sorrell.

The Sorrels are moderately colde and drie. * The nature.

* $T$ bevertues.

Sorrell doth vndonbtedly coole, and mightily drie; but bicaufe it is fower, it likewife cutteth $\mathrm{A}$ tough humours.

The iuice heereof in fummer time is a profitable fauce in many meates, and pleafant to the tafte. B It cooleth an hot ftomacke: mooueth appetite tomeate; tempereth the heate of the liuer, and openeth the ftoppings thereof.

The leaues are with good fucceffe added to decoctions which are vfed in agues.

The leates of Sorrell taken in good quantitie, ftamped and frained into fome ale, and a poffet D made therof, cooleth the ficke bodie, quencheth the thirft, and alaieth the heate of fuch as are trosbled with a peftilent fener, hor ague, or any great inflammation within.

Theleaues fodden, and eaten in manner of a Spinnach tart, or eaten as meate, fofteneth \& loofe- E neth the bellie, and doth attemper and coole the blood exceedingly.

The feede of Sorrell drunke in groffe red wine, ftopppeth the laske and bloodie flixe. 


\section{Of Snakeweede. Chap.8I.}

\section{Biffortamajor.}

Snakeweede.

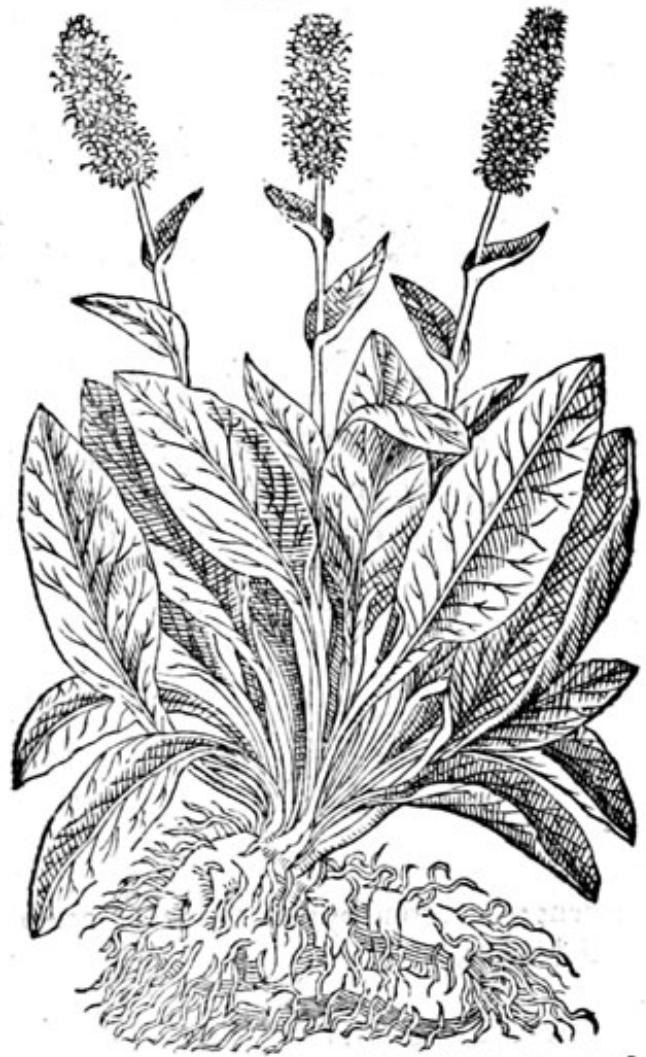

3 BiftortaLatifolia. Broad leafed Snakeweed.

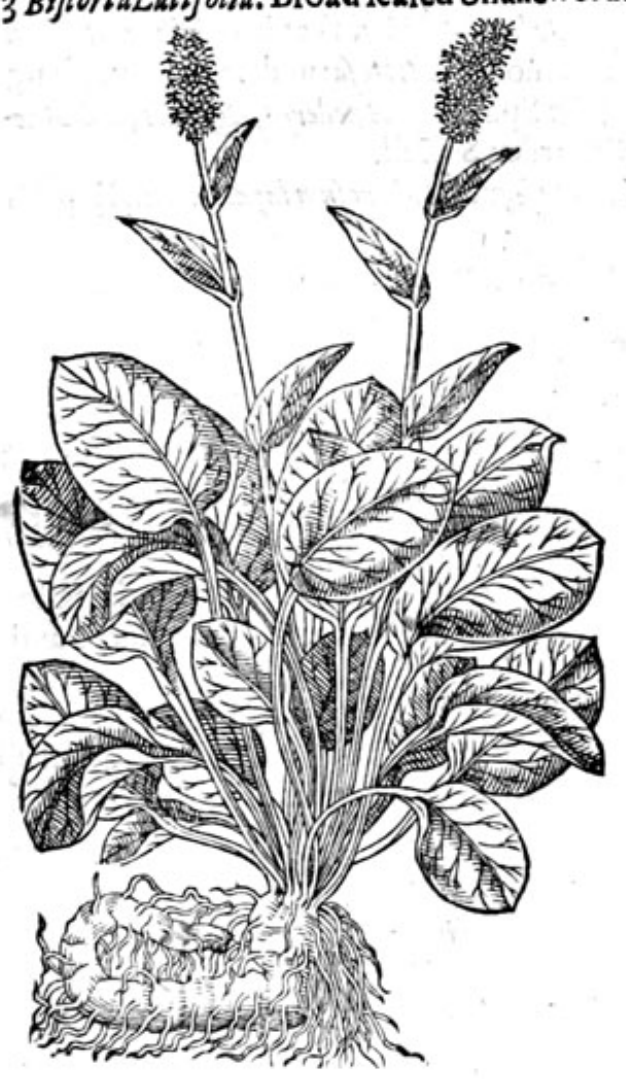

2 Bistorta minor. Small Snakeweede:

e

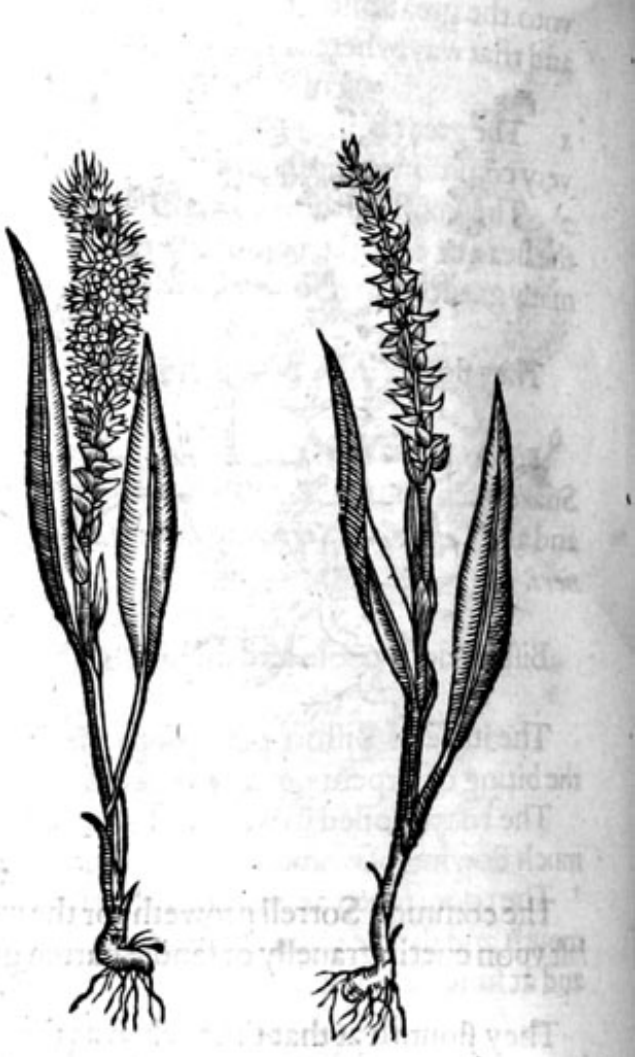

$+2$

* The defcription.

I He great Biftort hath long leaues much like Patience, but fmaller \& more wrinkled or crumpled, on the vpper fide of a darke greene, and vnderneath of a blewilh greene colour, much like Woade. The ftalke is long, fmoothe, and tender, hauing at the top a piked knap or eare, fet full of fmall whitilh flowers, de. clining to carnation. The roote is all in a lumpe, without fafhion; within of a red colour like vnto $f l e r h$, in tafte like the kernell of an acorne. 2 The fmall Biftort hath leaues about three inches long, and of the bredth of a mans naile: the vpper fide is of a greene colour, and vnderneath of an ouerworne greenifh colour: among which rifeth vp a ftalke, of the height of a fpan, ful of ioints or knees, bearing at the top fuch flowers as the great Biftort beareth; which being fallen, the feedes appeere of the bignes of a Tare, reddifh of colour ; eueric feede hauing one fmall greene leafe faftened thereunto, with many fuch leaues thruft in among the whole bunch of tow- 
ers and feed. The roote is tuberous like the other, but fmaller, and not fo much crooked os I

3 . Broade leafed Snakeweede hath many large vneuen leaues, fmooth and verry greenei: among which rife vp fmall brittle ftalks of two handes high, bearing at the top a faire fpike of flowers, like vnto the great Biftort. The roote is knobbie or bunched, crookedly turned or wrythed this way and that way, whereof it tooke his name Btstorta:

* Theplace.

I The great Biftort groweth in moift and waterie places, and in the darke fhadowie woods, and is very common in moft gardens.

2 The fmall Biftort groweth in great abundance, in Weftmerland, at Crosby, Rauenfwaith, at the head of a parke belonging to one Mafter Pickering, from whence it hath beenc difperfed into many gardens, as alfo fent vnto me from thence for my garden.

They flower in May, and the feede is ripe in Iune.

* The time.
ipe in Iune.
$*$ The numes.

Bifforta is called in Englifh Snakeweede; in other places Oifterloit : in Chesfhire Pafshions and Snakeweede, and there vfed for an excellent potherbe. It is called Bistorta, of his writhed rootes, and alfo Colmbrina, Serpentaria Britannica, Dracontion Plini, D racunculous Dodom, and Limonium Gefneri.

Biftort doth coole and drie, in the third degrce.

* 7 be nature.

* The vertues.

The iuice of Biftort put vp into the nofe, prevaileth much againft the difeafe called Polypis, and $A$ the biting of ferpents, or any venemous beaft, being drunke in wine, or the water of Argelica.

The roote boiled in wine and drunke, ftoppeth the laske, and bloodie flixe; it ftaieth alfo the ouer- $B$ much flowing of womens monethly fickneffes.

The roote taken as aforefaid, ftaieth vomiting, and healeth the inflammation, and forenes of the $\mathrm{C}$ mouth and throte: it likewife fafteneth loofe teeth, being holden in the mouth for a certaine fpace, and at fundric times.

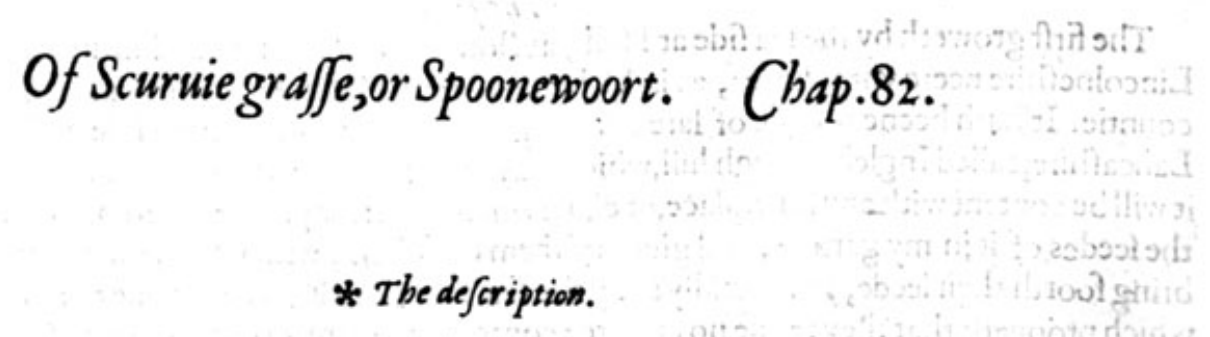

I Ound leafed Scuruie graffe is a lowe or bafe herbe: it bringeth foorth leaues vpon finall ftems or footeftalks of a meane length, comming immediately from the roote, verie manie in number, of a fhining greene colour, fomewhat broad, thicke, hollowe like a little fpoone, but of no great depth, vneeuen,or cornered about the edges: among which leaues fpring vp fimall ftalkes of a fpan high, whereon do grow many little white flowers, after which commeth the feede, fmall and reddifh, conteined in little flat pouches or feedeveffels like thofe of garden Creffes. The rootes be fmall, white, and threddie. The whole plant is of a hot and ficic tafte.

2 The common Scuruie graffe or fpoonewoort, hath leaues fomwhat like a fpoone, hollow in the middle; but altogither vnlike the former : the leaues heereof are bluntly toothed about the edges, Tharpe pointed and fomwhat long : the ftalks rife vp among the leaues, of the length of halte a foote, whereon do grow white flowers with fome yellowneffe in the middle : which being paft, there fucceede fmall feede veffels like vnto a pouch not vnlike to thofe of fheapherdspurfe, greene at the firft, next yellowifh, and laftly, when they be ripe of a browne colour or of the colour of a filberd nut. Theroote is fmall and tender, compact of a number of threddie ftrings veric thicke thruft togither in manner of a little turffe. 
1 Cochlearia rotundifolia.

Round leafed Scuruie grafte.

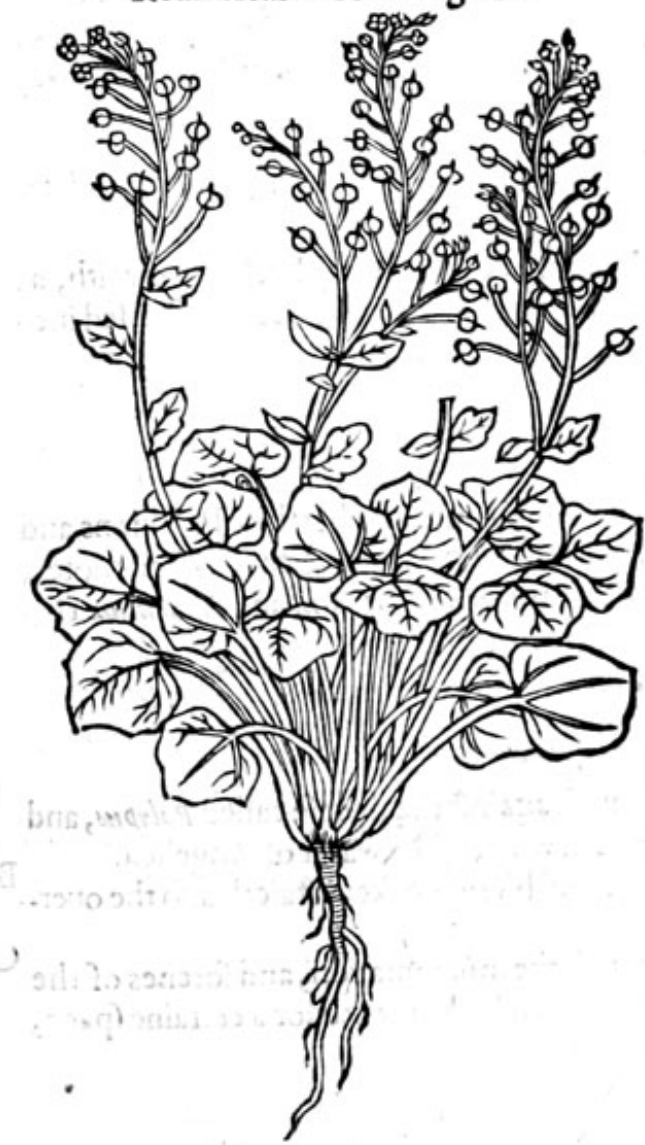

2 Coshlearias Britannica. Common Englifh Scuruie grafte.

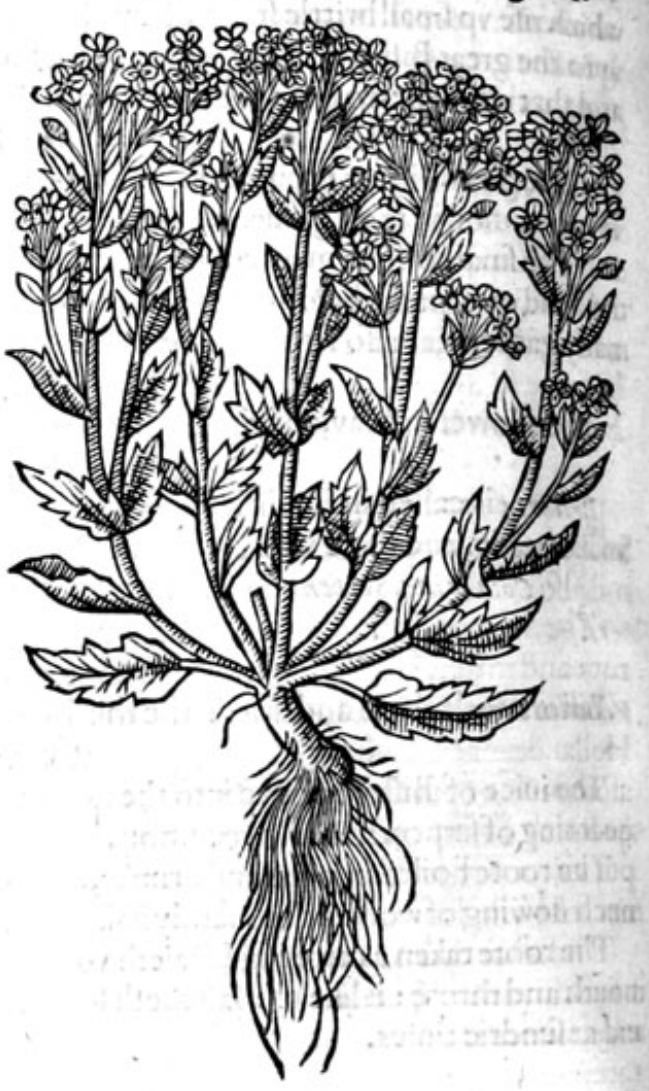

*The place.

The firft groweth by the fea fide at Hull, at Bofton, and Lynne, and in many other places of Lincolnefhire neere vnto the fea, as in Whaploade and Holbiche marrhes in Holland, in the fame countie. It hath beene founde of lare growing many miles from the fea fide vpon a great hill in Lancafhire, called Ingleborrough hill,which may feeme ftrange vnto thofe that do not knowe that it will be content with any foile, place, or clime whatfoeuer: for proofe whereof,my felfe háue fowen the feedes of it in my garden, and giuen of them to others, with whom they flower, flourifhand bring foorth theirfeede, as naturally as by the fea fide; and likewife retaine the fame fpicie tafte: which prooueth that they refufe no culture; contrarie to many other fea plants.

The fecond, which is our common Scuruie graffe, groweth in diuers places vpon the brims of the famous riuer Thames, as at Woolwich, Erith, Greenhithe, Grauefend; as well on the Effex fhore, as the Kentifh : at Porti-mouth, Briftowe, \& manyother places alongft the wefterne coaft: but toward the north I haue not hard that any of this kinde hath growen.

$$
\text { * The time. }
$$

It flowreth and flourifheth in Maie. The feede is ripe in Iune.

$$
\text { * The nomes. }
$$

We are not ignorant, that in Lowe Germanie, fome of the beft learned haue feene the true srisamnica, and namely in the Ocean next vnto Friffand and Holland, which the Germanes call Leffiel. ktaut, that is, Cocblearia or Spoonwort, by reafon of the compaffed roundnes and hollowneffe of theleaues, like a f poone; and haue thought it to be Plintes Britannica, bicaufe they finde it in the fame place growing, and endued with the fame qualities. Which excellent plant, Cafars foldiers (when they remooued their camps beyond the Rhene) found to pretraile (as the Frifians had taught it them)againft that plague and hurtfull difeafe of the teeth, gums, and finewes, called the Scuruie, being a depriuation of all good bloode and moifture, in the whole bodie, called Scorbution; in 


\section{EH THIST ORQE OFI PDANTSF T}

Englifh the Scuruie, and Skyrbie : a difeafe happening at the fea among Fifferinen, and frèn water foldiers, and fuch as delight to fieftill without labour, and exercife of their bodies ; andelpecially aboue the reft of the caufes, when they make not cleane their bisket bread from thic flower orimealyneffe that is vpon the fame, which doth fpoile many. But fith this agrees not with Plinjes defcription, and that there be many other water plants, as 2 asturtiom; Stam, Cardamime, and fuch others, like in tafte, and not vnlike in proportion \& vertues, which are remedies tgainft the difeafes aforefaid, yet can there be no certaine argument drawn therefrom, to prooue it to be Brttannica.For the leaues at their firft comming foorth, are fomewhat long like Pyrols or Adderstoong, foone after fomewhat thicker, and hollow like a nauell, after the manner of funne deaiv, but in greatneffe like Soldanella, in the compaffe formhat cornered, infafhion fomwhat like a fpoone : the flowers white, and in fhape like the Cuckorv flowers : the feede reddifh, like the feede of $T b l a / p i$, which is not to be feene in Britannica, which is rather holden to be Biftort or garden Patience, than Scuruic graffe. In Englifh it is called Spoonewort, Scrubie graffe, and Scuruie graffe.

$$
\text { * The temperature. }
$$

Scuruie graffe is euidently hot and drie, verie like in tafte and qualitie to the garden Creffes, of an aromaticke or fpicie tafte.

$$
\text { * The vertues. }
$$

The iuice of Spoonewoort giuen to drinke in ale or beere, is a fingular medicine againft the cor- $\mathbf{A}$ rupt and rotten vlcers, and ftench of the mouth: it perfectly cureth the difeafecalled of Hippocrates Voluulus Hematites : of Plinie Stomacace : of Marcellus Ofcedo: and of the Italians Scortutum : of the Hollanders and Frifians Scuerbuyck: in Engl:fh the Scuruie : either gining the iuice in drinke as aforefaide, or putting fixe great handfuls to fteepe, with long pepper, graines, annife feede, and liquorice, of eche one ounce, the fpices being braied, and the herbes brufed with your hands, and fo put into a pot, fuch as is before mentioned in the chapter of baftardekubarbe, and vfed in like maner : or boiled in milke or wine and drunke for certaine daies togither; worketh the like effect.

The iuice drunke once in a daie fafting in any liquor, ale, beere, or wine, doth caufe the forefaid $B$ medicine more fpeedilie to worke his effect in curing this filthic, lothfome, heauie, and dull difeafe, which is very troublefome and of long continuance. The gums are loofed, fwolne and exulcerate; the mouth greeuoufly ftinking; the thighes and legs are withall verie often full of blewe fpots, not much vnlike thofe that come of brufes: the face and the reft of the budic is oftentimes of a pale colour; and the feete are fwolne, as in the dropfie.

There is a difeafe, (faith Olaus magnus in his hiftory of the northern regions)haunting the campes, $\mathrm{C}$ which vexe them there that are befieged and pinned vp: and it feemeth to come by eating of falt meates, which is increafed and cherilhed with the colde vapours of the ftone wals. The Germaines call this difeafe (as we haue faid) Scorbuck, the fymptome or paffion which hapneth to the mouth,

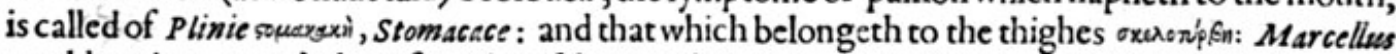
an olde writer nameth the infirmities of the mouth $O$ feedo: which difeafe commeth of a groffe, cold \&tough bloud, fuch as melancholie iuice is, not by aduftion, but of fuch a bloud as is the feculent or droffie part therof: which is gathered in the bodie by ill diet, flothfulneffe to worke, laifines(as we terme it)much fleepe and reft on (hipboorde, and not looking to make cleane the bifquet from the mealieneffe, and vncleane keeping their bodies, which are the caufes of this difeafe called the fcuruie or fcyrby. Which difeafe doth not onely touch the outwarde parts, but the inwarde alfo: for the liuer oftentimes, but moft commonly the fpleene, is filled with this kinde of thicke, cold and tough iuice, and is fwolen by reafon that the fubftance thereof is flacke, fpungic, and porrous, verie apt to receiue fuch kinde of thicke and colde humours. Which thing alfo Hippocrates hath written of in the feconde booke of his Prorrbetikes : their gums (faith he) are infected, and their mouthes ftinke that haue great fpleenes or miltes : and whofoeuer haue great miltes and vfe not to bleede, can hardly be cured of this malladie, efpeciallie of the vlcers in the legs, and blacke fpots. The fame is affirmed by $P$ aulus 1 Eg gmeta in his thirde booke 49 .chapter, where you may cafily fee the difference betweene this difeafe and the blacke iaunders; which manie times are fo confounded togither, that the diftinction or difference is harde to be knowne, but by the expert chirurgion: who oftentimes feruing in the fhips, as well hir Maiefties as merchants, is greatly peftered with the curing thereof: it fhall be requifite to carrie with them the herbe dried; the waterdiftilled, and the inice put into a bottle with a narrowe mouth, full almoft to the necke, \& the reft filled vp with oile oliue, to keepe it from putrefaction: the which preparations difcreetly vfed, will ftande them in great fteade 


\section{THE SECOND BOOKE OF THE}

for the difeafe aforefaide.

D The herbe ftamped and laide vpon fpots and blemilhes of the face, will take them awaie within fixe houres, but the place muft be walhed after with water wherein branne hath beene fodden.

\section{Of Twayblade, or berbe Bifoile. Chap.83.}

I Ophris Bifolin Twaiblade.

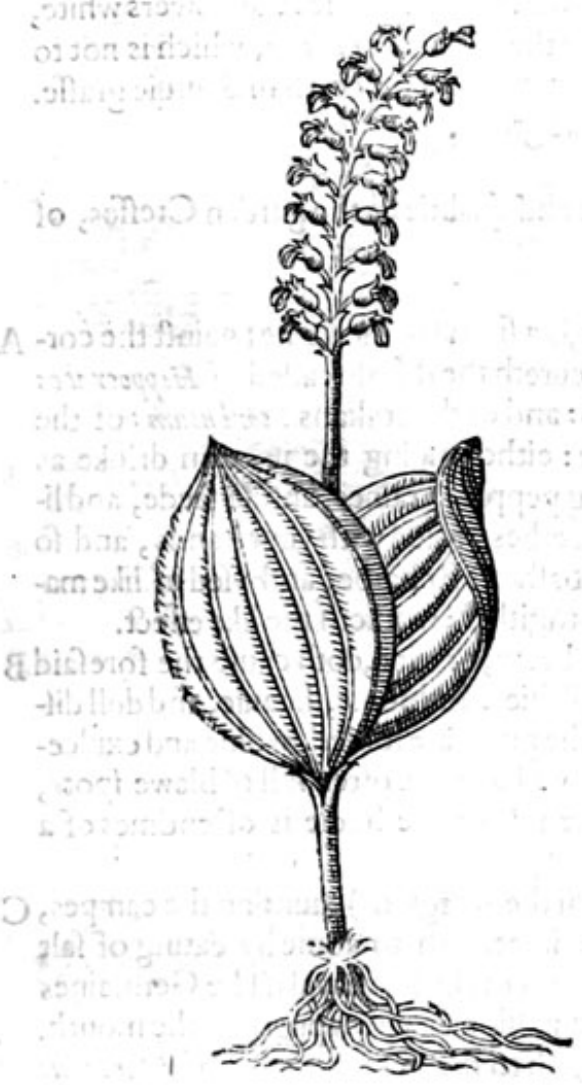

\section{Ophris trifolia.} Trefoile Twaiblade.

\section{* The defaription.}

I $T$ Erbe Byfoile hath many fmall fibres or threddie ftrings, faftened vnto 2 fmall knot or roote, from which rifeth vp a flender ftemme or ftalke, tender, fat, and full of iuice ; in the middle whereof, are placed in comely order two broade leaues, ribbed and chamfered, in Thape like the leaues of Plantaine : vpon the top of the ftalke groweth a flender greenifh bufheof flowers, made of many fmall flowers; each little flower refembling a gnat, or little gofling newly hatched, very like thofe of the third fort of Serapias ftones.

2 Ophris Trifolia or Trefoile twaiblade, hath rootes, tender ftalkes, and bufh of flowers like the precedent; but differeth in that, that this plant hath three leaues which do clippe or imbracethe it alke about; and the other hath but two, and neuer more, wherein efpecially confifteth the diffe. rence : although in truth I thinke it a degenerate kinde, and hath gotten a thirde leafe per accidens, as doth fometimes chaunce vnto the adders toong, as fhall be declared in the chapter following.

$$
\text { * Theplace. }
$$

The firft groweth in moift medowes, tennie grounds and $\mathrm{h}$ adowie places. I haue found it in many places, as at Southfleete in Kent, in a wood of Mafter Sydleys by Longfield downes, in thewood by London called Hampfteede-wood, in the fields by Highgate, in the woods by Ouenden neere to Clare in Effex, and in the woods by Dunmow in Effex. The other fort is feldome feene. 
They tofyer in May and Iune.

* T the names.

It is called of the later Herbarilts Bifolium, and Ophris.

* The nature and vertwes.

It is reported of the Herbarifts of our time, to be good for greene wounds, burftings, and ruptures; whereot Ihaue in my vnguents and Balfams for greene wounds, had great experience, and good fucceffe.

\section{Of Adders toong. Chap.84.}

ophioglogon.

Adders toonge.

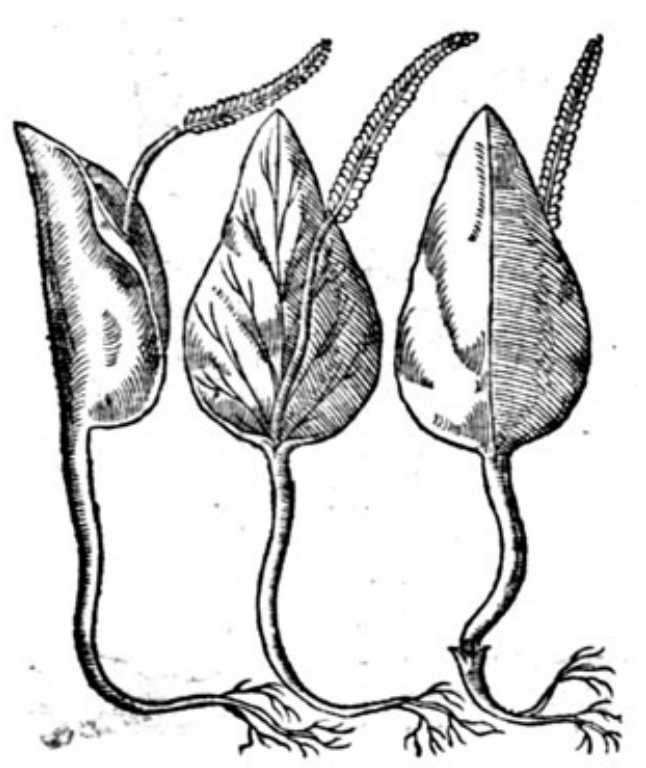

* The defcription.

Phioglofwem, or Lingua Serpentis (called in Englifh Adders toong, of fome Adders grafie, though vnproperly) rifeth foorth of the grounde, hauing one leafe and no more, fatte or oleous in fubitance, of a finger long, and very like the yoong and tender leaues of Marigoldes: from the bottome of which leafe fpringeth out a fmall and tender ftalke, one finger and an halfe long; on the ende whereof doth growe $a$ tong fmall toong, not vnlike the toong of a ferpent, whereof it tooke the name.

I hane feene an other like the former, in root, ftalke, and leafe; and differeth in that that this plant hath two and fometimes more crooked toongs, yet of the fame farhion, which if my iudgement faile not, changeth per accidens, euen as wefee children borne with two thombes vpon one hand: which mooueth me fo to thinke, for that in gathering of twentie burhels of the leaues, a man hal hardly finde one of that farhion.

* The place.

Adders toong groweth in moift medowes throughout inoft parts of Englande, as in a medowe neere the preaching fpitele adioining to London; in the Mantels by London; in the medowes by Colbrooke, in the fieldes in Waltham forreft, and many other places.

Colm ofls to 3 thetime.

They are to be found in Aprill and Maie; but in Inne they atequite vanifhed and gone. * The names.

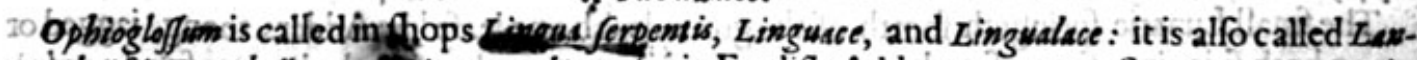
ceaChrifti, Emeaphyllom, and Lingua vulneraria : in Englifh Adders toong, or Serpents toong: in Dutch JQatertonguen: of the Germains Nater žimigelint.

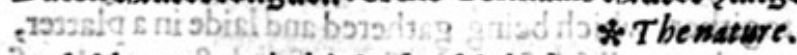

Adders toong is drie in the thirde degree.

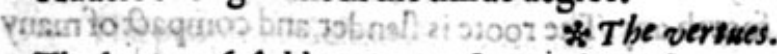

The leaues of Adders toong ftamped in a ftone morter, and boiled th oile oliue vnto the con- A fumption of the iuice, and vntill the herbes bedrieand parched, then ftrained, will yeelde a moft excellentgreene dile, or rather a Balfame for greene ivounds, comparable vnto oile of Saint Iohns woort, if it do not farre, fuirpaffe it by many degtees: whofe beautie is fuch, that very many Artifs haue thiought thefame to be mixedwith Verdigreafe:

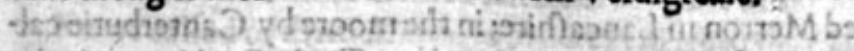

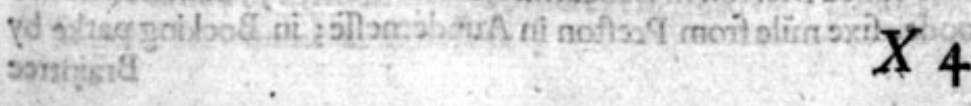


Ofone Berrie, or berbe Trueloue, and Moonewoort. Chap.85.
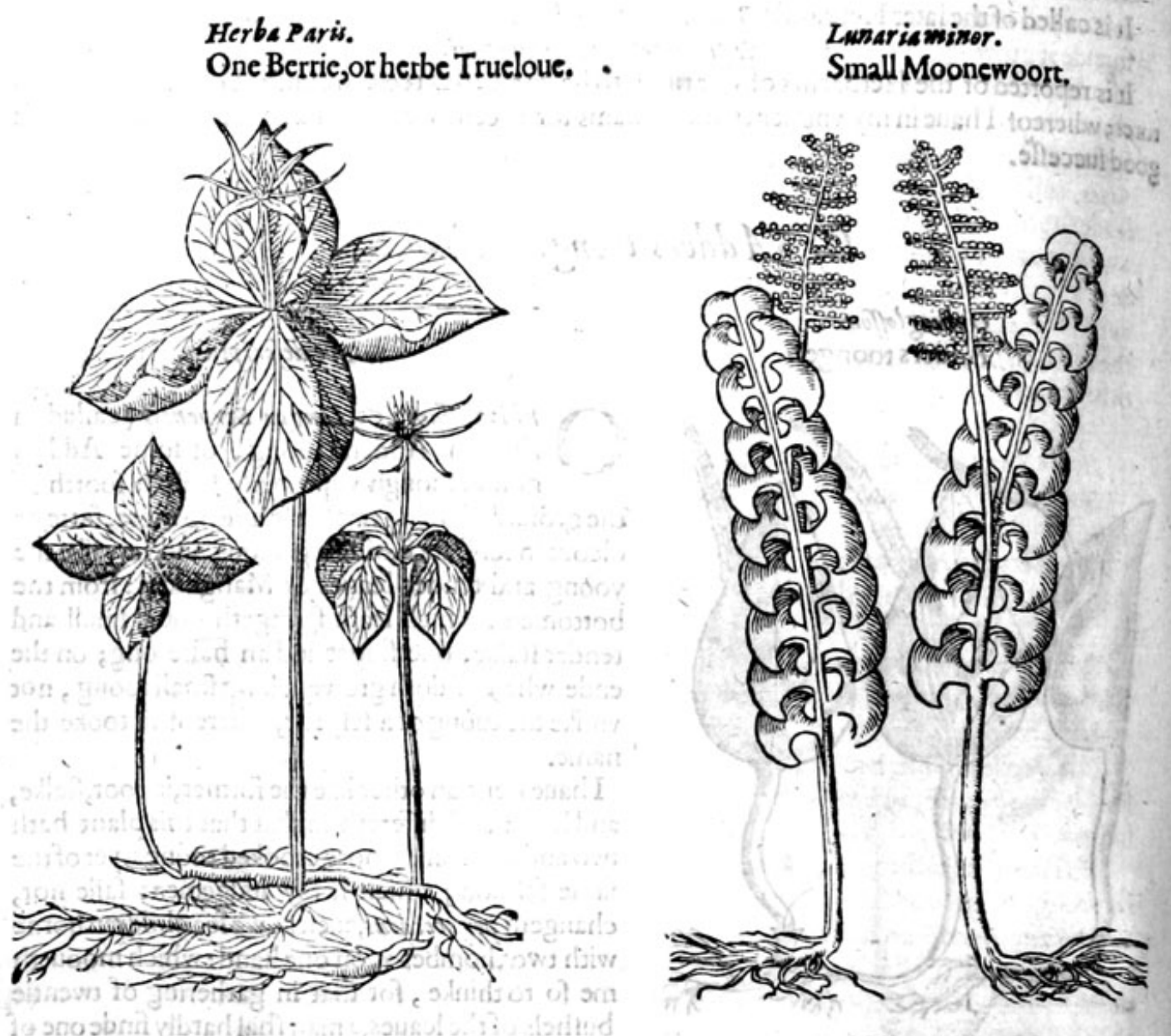

* The defiption.

Erbe Paris rifeth vp with one fmall tender ftalke two handes high, at the very top whereof come foorth fower leaues directly fet one againft another, in maner of a Burgunnion groffeor a true loue knot; for which caufe among the auncients it hath beene called herbe Truelone: in the middle of the faid leaues commeth a ftarlike flower, of an herbie or graffie colour; out of the midft whereof there arifeth vp a blackifh browne berrie: the roote is long and tender, creeping vnder the earth, and difperfing it felfe hither and thither.

The fimall Lunarie fpringeth foorth of the ground with one leafe like Adders toong, iagged os cut on both fides into fiue or fixe deepe cuts or notches, nor much vnlike the leavies of scelopendrin or Ceterach, of a greene colour; whereupon doth grow a fmall naked ftemme of a finger long, bearing at the top many little feedes cluftering togither, which being gathered and laide in a platter, or fuch like thing, for the fpace of three weckes, there will fall from the famea fine duft or meale of 2 whitith colour, which is the feed, if it bring foorth any. The roote is flender and compattof many fmall threddic ftrings.

* Theplace.

Herba Pariugroweth pentifully in all thefe places following, that is to faie, in Chalkney woode neere to wakes Coulne, feauen miles from Colchefter in Effex; and in the,wood by Robinhoods well, neere to Nottingham; in the parfonage orcharde at Radwinterin Effex, neere ro Saffron Walden ; in Blackburne at a place called Merton in Lancafhire; in the moore by Canterburie called the Clapper; in Dingley woode, fixe mile from Prefton in Aunderneffe; in Bocking parke by 
Braintree in Effex; at Heffet in Lancafhire; and in Cotting woode, in the north of Englande; as that excellent painfull and diligent. Phifition maftes dotion' wirner of late memorie doth recorde in his Herball.

Lunaria or finall Moonewoors groweth vpon drie and barren mountaines and heathes. I haue founde it growing in thele places following, that is tofaie, about Bathe in Somerferthire in manie places; efpecially at a place called Carey, two miles from Bruton, in the next clofe vnto the churchyarde; on Cockes heath betweene Lowfe and Linton, three miles from Maiditone in Kent. It groweth alfo in the ruines of an olde bricke kill by Colchefter, in the grounde of mafter George Sayer, called Miles ende: it groweth likewife vpon the fide of blacke Heath, neere vnto the ftile that leadech vntoEltham houfe, about an hundreth paces from the itile : alfo in Lancafhire neere vnto a woode called Faireft by Latham : moreouer in Nottinghamfhire, by the weft woode at Gringley, \&: at Wefton in the Ley field, by the weft fide of the towne; and in the bifhops fielde at Yorke, neerce vnto Wakefielde in the clofe where fir George Sauell his houfe itandeth, called the Heath Hall, by the relation of a learned doctor in phificke, called mafter John Merfhe of Cambridge, and many other places.

$$
\text { * The time. }
$$

Herba Paris flowreth in Aprill, and the berric is ripe in the ende of Maie.

Lunairis or fmall Moonewoort, is to be feene in the moneth of Maie.

$$
* \text { The rames. }
$$

Qne Berrie, is allocalled herbe 'Trueloue, and herbe Paris : in Latine Herbe Paris.

Lunuria minor, is called in Englifh fmall Lunaric \& Moonwoort, it is called likewife Ophiogloffon. * The nature.

Herbe Paris is exceeding colde, whereupon it is proued to reprefle the rage and force of poifon. Lunaria minor is colde and drie of temperature. $*$ The vertues.

The berries of Herbe Paris giuen by the fpace of twentie daies, are excellent good againft poi- $\AA$ fon, or the powder of the herbe drunke in like manner halfe a fpoonefull at a time in the morning fafting.

The fame is miniftred with great fuccefle, vnto fuch as are become peeuifh, or without vnder- B ftanding, being miniftred as is aforefaide, euery morning by the fpace of twenty daies, as Baptists - Sardies and Mathiolus haue recorded. Since which time, there hath beene further experience made thereof againft poifon, and put in practife in the citre of Paris, in Louaine, and at the bathes in Helnetia, by the right excellent Herbarifts Mathias de Lobel; and Petrus Pens, who hatuing of feen read, that it was one of the Aconites, called Pardalianches, and fo by confequence, of a poifoning qualitie, they gave it vnto dog's and lambes, who receiued no hurt by the fame : wherefore they further profecuted the expetience thereof, and gaue vnto two dogs faft bound or coupled together, a dram of Arfenicke, and one dram of Mercurie fublimate, mixed with flefh, which the dogs would not willingly eate, and therefore they had it cramued downe their throtes: vnto one of thefe dogs, they gave this antidore following in a little red wime, whereby he recouered his formet Realth againe, within a few howers; but the other dog, which had none of the medicine, died iff Wontinently.

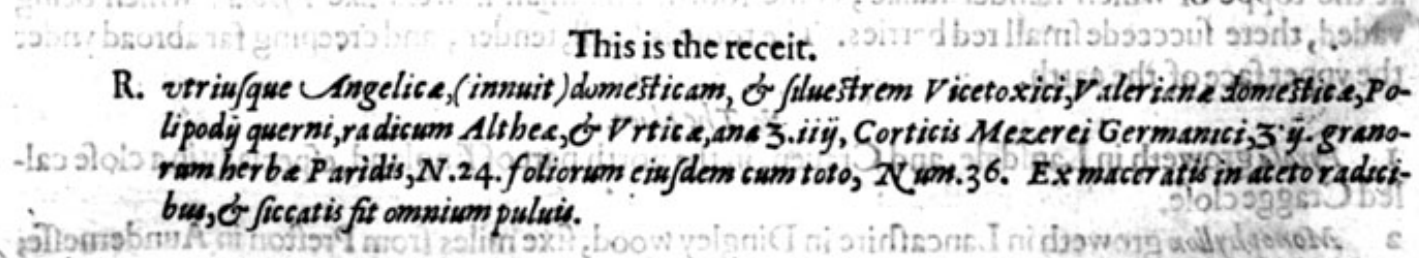

The people in Germanic do vfe the leaues of Paris herbe in greene wounds, for the which it is $\mathbf{C}$ very goød, as teporteth Ioachimus Camerarius, who likewife faith, that the powder of the rootes giuen to drinke, doth fpeedily ceafe the gripings and paine of the collicke. antI nir thotwo A a loreg

Small Mooncwort is fingularto heale greene and frefh wounds is itaieth the bloodje flixe. It D hath beene yfed among the Alchymiftes, and witehes to do wonders withall, who fay, that it will loofe tocks, and make them to fail from the feete of hiorfes that grate whete it doth growe, and hath beene called of them Martagon, whereas in truth they are all but drowfie dreames and illufions, but fingular for wounds as aforefaid. 
OfWintergreene. Chap.86.

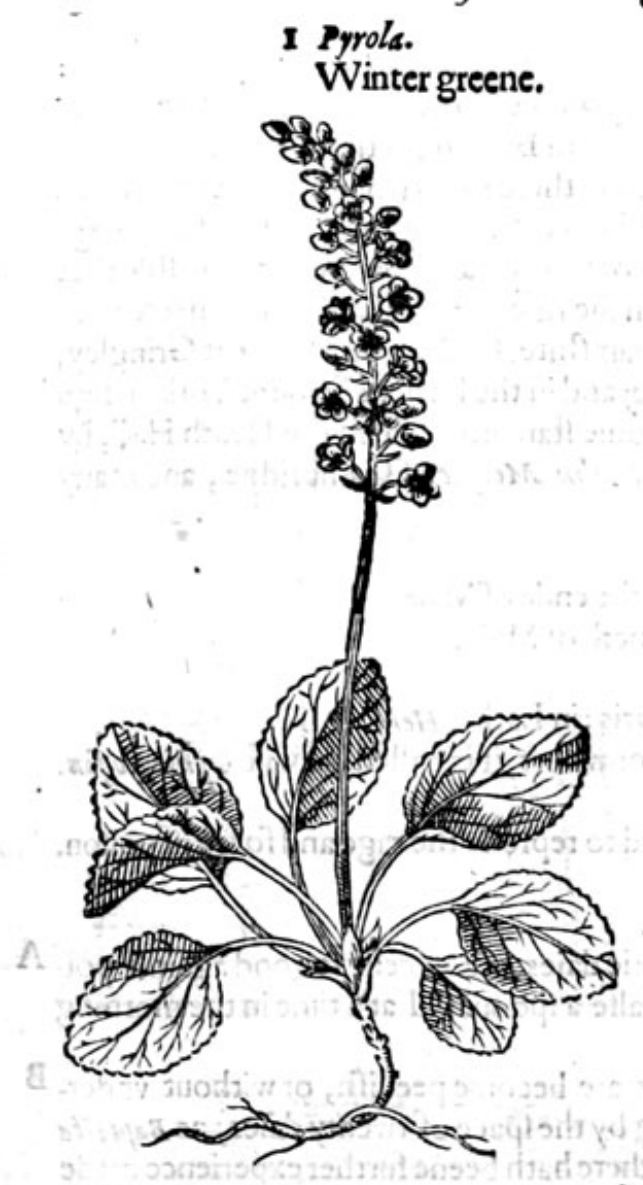

2 Cromophyllom.

Oneblade.

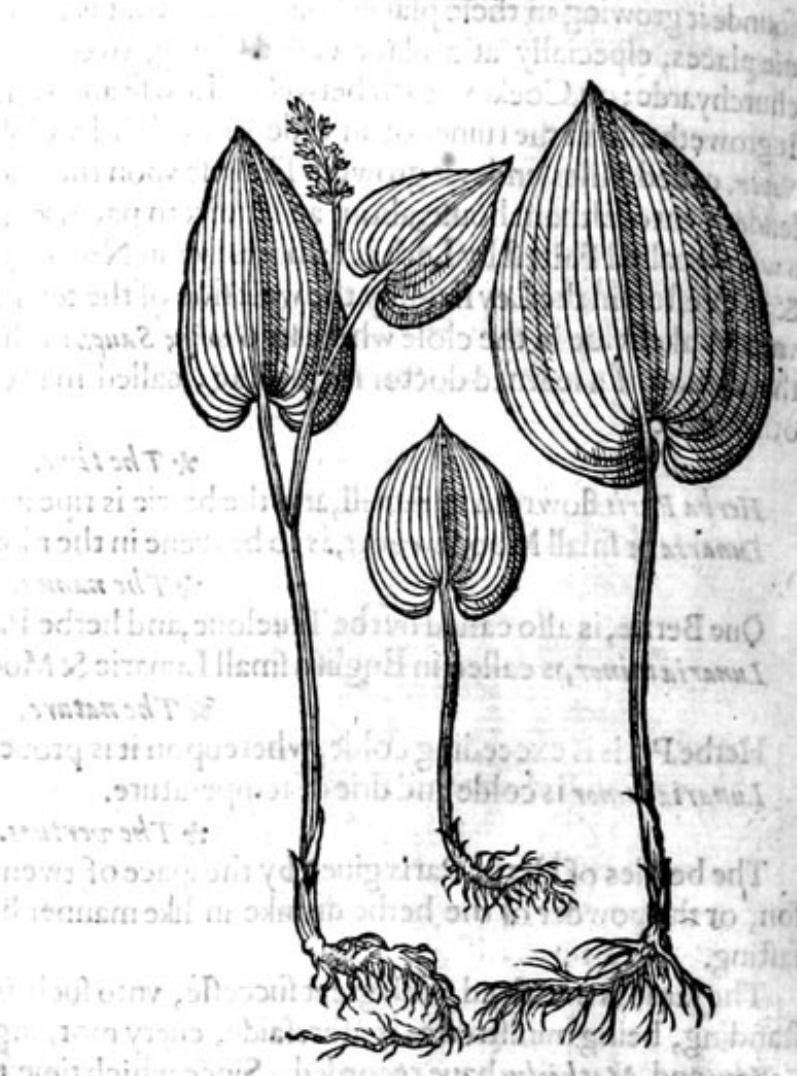

* The defoription.

1 Prola hath many tender and very greene leaues, almoft like the leaues of Beete, but rather in mine opinion like to the leaues of 2 Pearatree, whereof it tooke his name Pyrole, for that it is Pyriformis. Among thefe leaues commethyp a ftalke garnifhed with pretie white flowers, of a pleafant fweete fmell like Lillium conualliwm, or Lillie of the valley. The roote is fmall and threddie, creeping far abroad vnder the ground.

2 Monophyllon or $V$ nif olium, hath a leafe not much vnlike the greateft leafe of Iuie, with many ribs or finewes like the Plantaine leafe, which fingle leafe dothalwaies fpring foorth of the earth alone, but when the ftalke rifeth vp, it bringeth vpon his fides two leaues, in fafhion like the former; at the toppe of which flender ftalke, come foorth fine fmall flowers like Pyrola, which being vaded, there fucceede fmall red berries. The roote is fmall, tender, and creeping far abroad vnder the vpper face of the earth.

I Pyrolagroweth in Lanfdale, and Crauen, in the north part of England, efpecially in a clofecalled Craggeclofe.

2 Monophyllon groweth in Lancafhire in Dingley wood, fixe miles from Prefton in Aunderneffe; and in Harwood, neere to Blackeburne likewife.

I Pyrola $*$ Thetime.

I Pyrola flowreth in Iune and Iuly, and groweth winter and fommer.

2. Monopbyllow fowrech in May, and the fruite is ripe in September.

\section{* The names,}

I Pyrola is called in Englifh Winter greene : it hath beene called Limoniwom of diuers, but vneruly.

2 Monophyllon according to the etymologie of the word, is called in Latine Vmifoliuem : in Englith one blade, or Onc leafe. 


\section{HISTORIE OF PLANTS.}

* The nature.

I Pyrola is cold in the fecond degree, and drie in the third.

2 Monophyllon is hote and drie of complexion.

\section{* T the vertwes.}

Pyrola is a moft fingular wound herbe, either giuen inwardly, or applied outwardly, the leaues $\mathbf{A}$ whereof ftamped and itrained, and the iuice made into an vnguent, or healing falue, with waxe,oile, and turpentine, doth cure wounds, vlcers, and fiftulaes, that are mundified from the callous and tough marter, which keepeth the fame from healing.

The decoction hereof made with wine, is commended to clofe vp and heale wounds of the en- B trailes, and inward partes : it is alfogood for vlcers of the kidneies, efpecially made with water, and the rootes of Comfrey added thereto.

The leaues of Monophyllon, or Vnifolium, are of the fame force in wounds with Pyrold, efpecially C in wounds among the nerues and finewes. Moreouer, it is efteemed of fome late writers, a moft perfect medicine againft the peftilence, and all poifons, if halfe a dram of the roote be giuen in wine, and the ficke go to bed and fweate vpon it.

\section{Of Lilly in the valley, or Mady Lillie. Chap.87.}

I Lilinen conuslfium. Conuall Lillies.

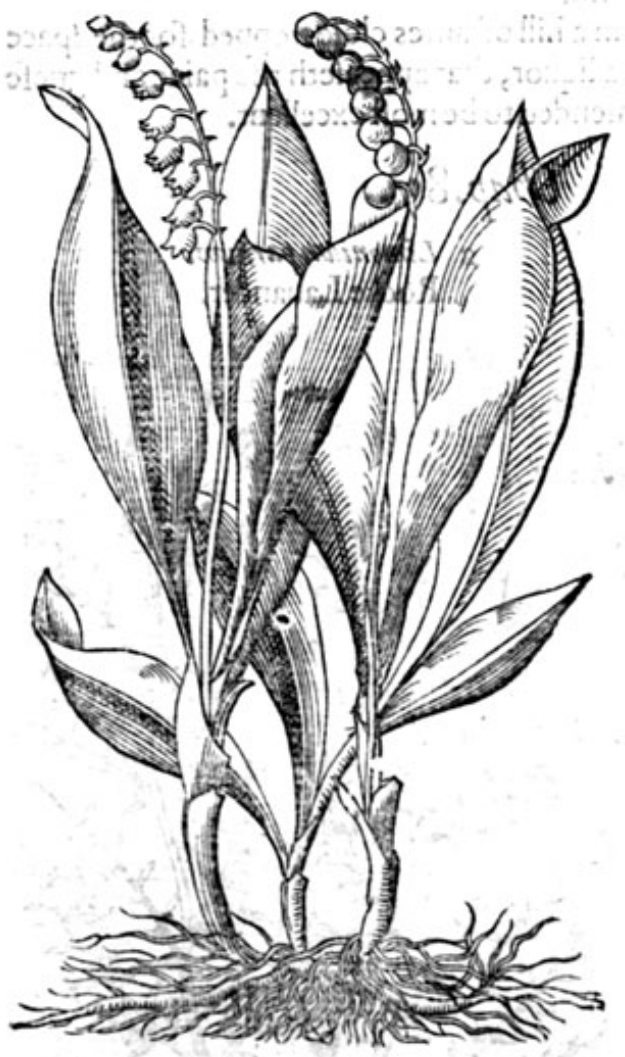

2. Lilien conualion floribus fuaste-rubentibeu. Red Conuall Lillies.

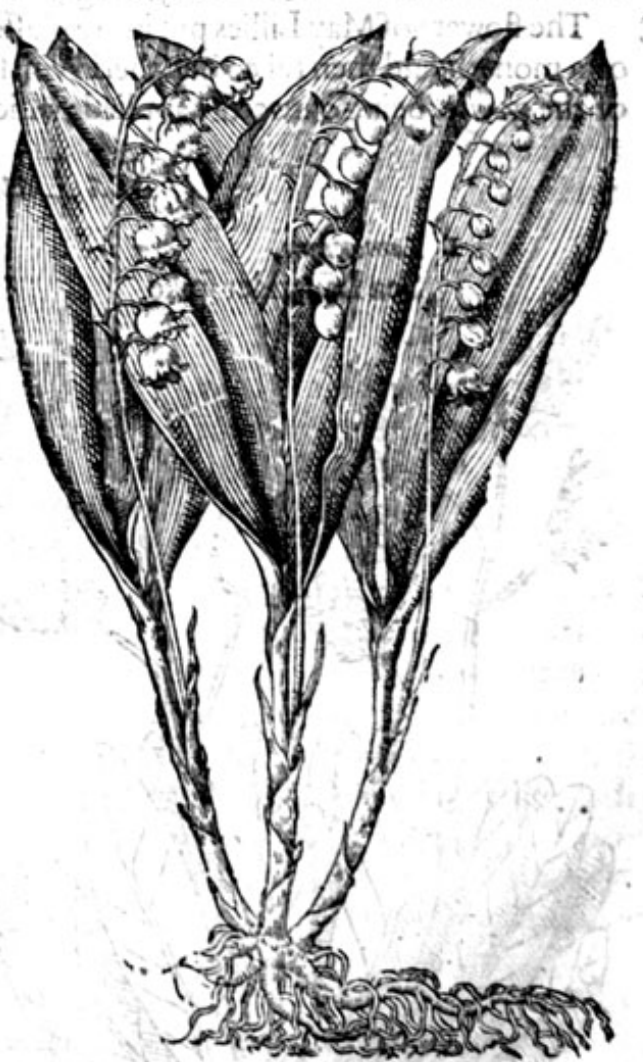

* The defcription.

I T He Conuall Lillie, or Lillie of the Vally, hath many leaues like the fmalleft leaues of Water Plantaine; among which rifeth vp a naked ftalke halfe a foote high, garnifhed with manie white flowers like little bels, with blunt and turnededges, of a frong fauour, yet pleafant ynough; which being paft, there come fmall red berries, much like the berries of A/parager wherein the feedeis contained. The roote is fmall and lender, creeping far abroad in the ground. 
2 The fecond kinde of May Lillies, is like the former in euery refpect; and herein varieth or differeth, in that this kinde hath reddifh flowers, and is thought to haue the fweeter fmell.

$$
\text { * The place. }
$$

I The firft groweth on Hampfted heath,fower miles from London, in great abundance: neere to Lee in Eflex, and vpon Bufhie heath, thirteene miles from London, and many other places.

2 That other kinde with the red flower, is a ftranger in England : howbeit I haue the fame grow. ing in my garden.

They flower in May, and their fruit is ripe in September.

\section{* The names.}

The Latins haue named it Lilium conualliwm:Gefner us doth thinke it to Callionymon ; in the Germaine toong 9even blumien : the Lowe Dutch 9even bloemkeng : in French Muguet : yet there is likewife another herbe which they call enuguet, commonly named in Englifh Woodroof. It is called in Englifh Lillie of the valley, or the Conuall Lillie, and May Lillies, and in fome places Liriconfancic. * The nature.

They are hote and drie of complexion.

* The vertues.

A The flowers of the Valley Lillie diftilled with wine, and drunke the quantitie of a fpoonefull, reftoreth fpeech vnto thofe that haue the dum palfie and that are fallen into the Apoplexie,\& is good againft the gowte, and comforteth the hart.

B The water aforefaid doth ftrengthen the memorie that is weakened and diminifhed; it helpeth alfo the inflammation of the eies, being dropped thereinto.

C The tlowers of May Lillies put into a glaffe, and fet in a hill of antes clofe ftopped for the fpace of a moneth, and then taken out, thecin you fhall finde a liquor, that appeafeth the paine and griefe of the gowte, being outwardly applied; which is commended to be moft excellent.

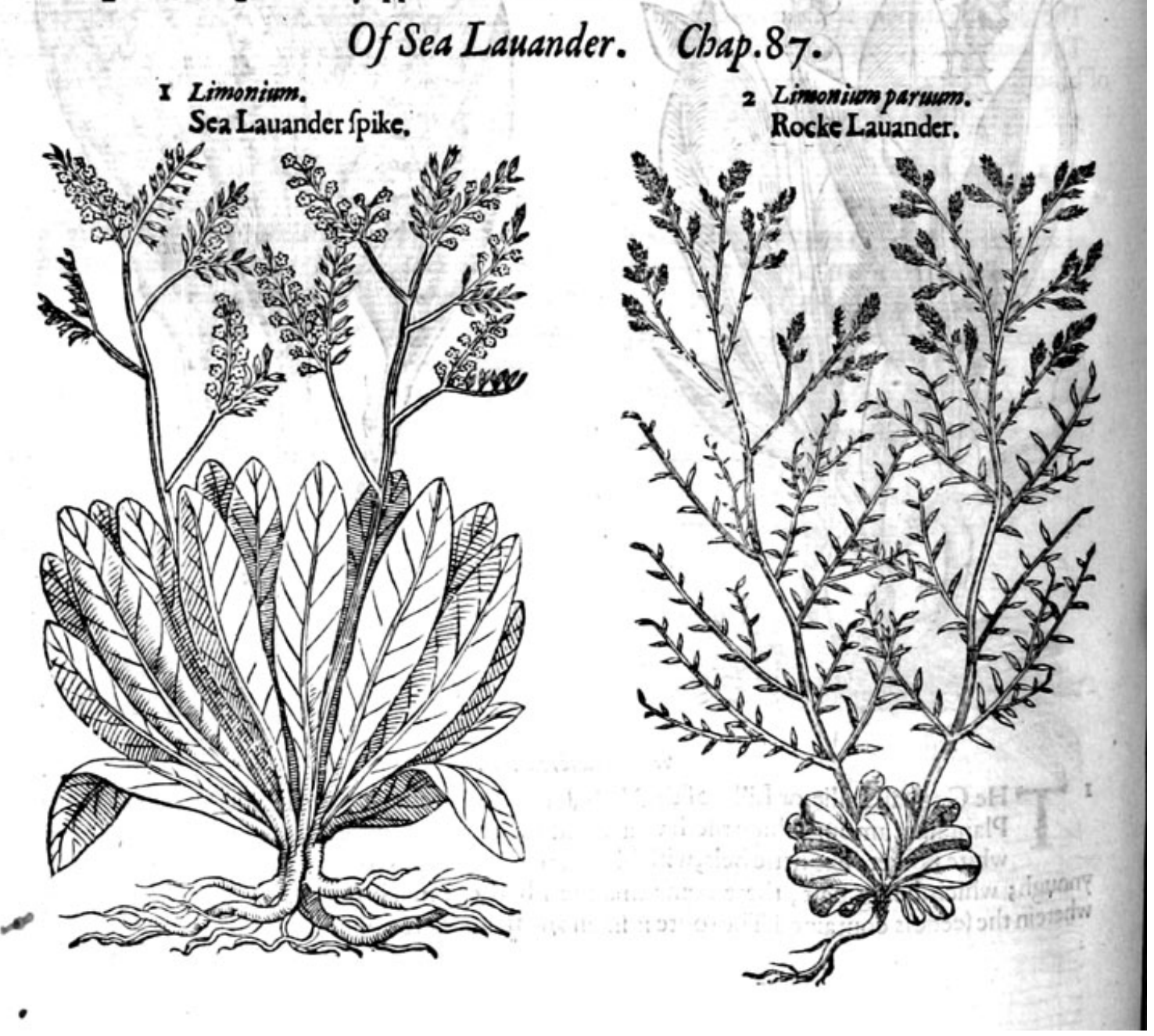




\section{The defaription.}

I Here hath beene among writers from time to time, great contention about this plantiLimonism, no one author agrecing with ainther: for fome haue called this herbe Limonivom fome another herbe by this name; and fome in remoouing the rock, haue mired thenfelues in the muid,as Mathiolus, who defcribed two kindes, bir made no diftinction of them, nonyctexpreffed which was the true Limoniampbut as a man he:ein ignorant, he fpeakes not a word of them. Now then toleaue controuerfies and cauilling, the trut $r$ jmonstom is that which hath faire leaues, like the Limon or Orenge tree, but of a dark green color, fom what fatter, Sta little crumpled:ainong which leaues rifeth vp an hard and britcle naked ftalke, of a foote tigh, diuided at the top into fundry other fmall branches, which growe for the moft part vpon the one lida, full of Jittle blewifh flow. ers, in fhew like Lauander, with long red feede, and a thicke roote like vnto the fmall Docke, nirritis 2 There is a kinde of Limoniwom like the firft in each refpect, but leffer, which groweth vpon rocks and chalkie cliffes.

$$
\text { * The place. }
$$

I The firft groweth in great plentie vpon the walles of the fort againft Graviefend:alfo faft by the Kings Ferrey going into the Ile of Shepey: in the falt marfhes by Lee in Effex: in the Marfh by Harwich, and many other places.

2 The fmal kinde I could neuer finde in any other place, but vpon the chalkiecliffe going from the towne of Margate downe to the fea fide, vpon the left hand.

$$
\text { * The time. They fower in Iune and Iuly. }
$$

* The names.

It thall be reedleffe to trouble you with any other Latine name than is expreffed in their titles: the people neere the fea fide where it groweth do call it Marnh Lauander, and Sea Lauander.

The feed of Limonium is very aftringent or binding.

$$
\text { * T'ine nature. }
$$

\section{* The vertues.}

The feede beaten into powder, and drunke in wine, helpeth the collicke, ftrangurie,\& Dyfenteria. A

The feede taken as aforefaid, ftaieth the ouermuch flowing of womens termes,and al other fluxes B of blood.

$$
\text { Of Serapias Turbith, or Sea Starwort. Chap.88. }
$$

I Tripoliwn vulgare. Sea Starwort.

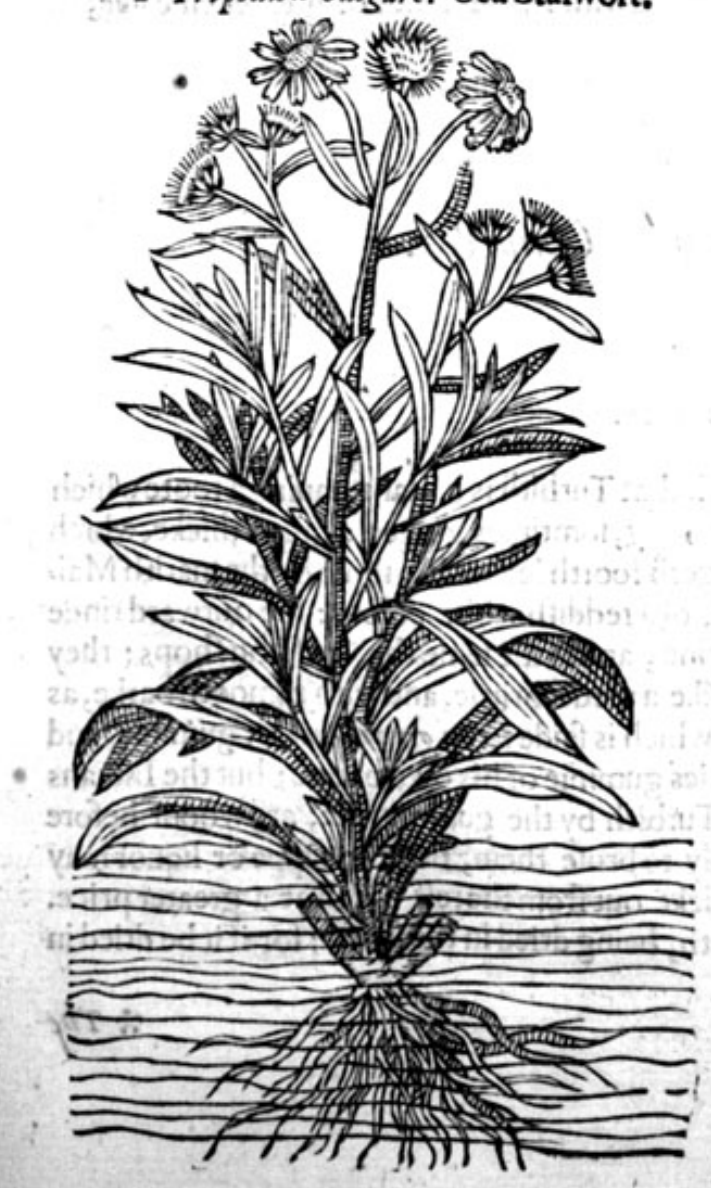

$*$ The defoription.

I $T$ He firft kinde of Tripolium hath longand

1 large leaues, fomewhat hollow or furrowed, of a fhining greene colour declining to blewneffe, like the leaues of Woade : among which rifeth vp a ftalk of two cubits high \& more; which toward the top is diuided into many fmall branches, garnifhed with many flowers like Camomill, yellow in the middle, fet about or bordered with fmall blewifh leaues, like a pale, as in the flowers of Camomill, which growe into a whitifh rough downe, that flieth away with the wịnd. The roote is long and threddie.

2 There is another kinde of Tripolivem like the firft, but much fmaller, wherein confifteth the difference. $\quad *$ The place.

Thefe herbs grow plentifully along the Englifh coaftes in many places, as by the fort againft Grauefend, in the Ile of Shepey in fundry places, in a marfh which is under the towne wals of $\mathrm{Har}$ wich, in the marfh by Lee in Effex, in a marfh which is between the Ile of Shepey \& Sandwich, efpecially where it ebbeth and floweth : being brought into gardens, it florifheth long time, but there it waxeth huge, great, \& ranke; and chan-geth the great rootes into ftrings. * 7 be time.

Thefe herbes do tlower in May and Iune. 


\author{
* Thenumes.
}

It is reported by men of great fame and learning, thuc this plant was called Tripolium, bicaufe it doth change the colour of his flowers thrice in a syy. Indeede the word Tripolium doth import fo much. This rumor we maybeleeue, and it may t true, for that we fee and perceiue things of as great and greater wonder, to proceede out of the earthin. This herbe I planted in my garden, whither(in his feafon) I did repaire to finde out the truch hereof, but I could not efpie any fuch variableneffe herein; yet thus much I may fay, that as the ineate of the funne doth change the colour of diuers flow. ers: fo it fell out with this, which in ate morning was very faire, but afterwarde of a pale or wan calour. Which prooueth that to 1 but a fable which $D$ iofcorides writeth, that in one day itchangeth the colour of his fowers thaice : that is to fay, in the morning it is white, at noonepurple, and in the euening qoivixĩy, or crimfon. But it is not vntrue, that there may be found threo colours of the flowers in one day, by reafon that the flowers are not all perfected togither (as before I partly touched,) but one after another by little and little. And there may eafily be obferued three colours in them, which is to be vnderftood of them that are beginning to flower, that are perfeetly flowred, and thofe that are falling away. For they that are blowing, and be not wide open \& perfeet, are of a purplifh calour, and thofe that are perfect and wide open, of a whitioh blew ; and fuch as are falling a way, haue 2 white downe: which changing happeneth vnto fundry other plants. This herbe is called of Serapias Turbith : women that dwell by thefea fide, call it in Englifh blew Daifies, or blew $\mathrm{C}_{2 m o \text { - }}$ mill; and about Harwich it is called Hogs beanes, for that the fwine doe greatly delight to feede thereon: as alfo for that the knobs about the rootes do fomwhat refemble the Garden Beane. It is

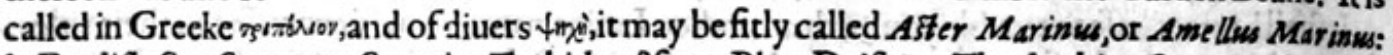
in Englifh Sea Starwort, Serapias Turbith, of fome Blew Daifies. The Arabian Serapio, doth call Sea Starwort, Turbith, and after him Auicen : yet Actuarius the Grecian doth thinke that Turbith is the roote of Alypum : Mefues iudged it to be the roote of an herbe like Fennell. The hiftorie of Turbith of the fhops fhall be difcourfed vpon in his proper place.

Tripoliven is hot in the third degree, as Galen faith.

$$
* \text { The nature. }
$$

* The vertwes.

A The roote of $\tau$ ripolium taken in wine by the quantitie of two drams, driueth forth by fiege wate. rifh and groffe humors, for which caufe it is often giuen to them that haue the dropfie.

B It is an excellent herbe againft poifon,and comparable with Pyrola, if not of greater efficacie, in healing of wounds either outward or inward.

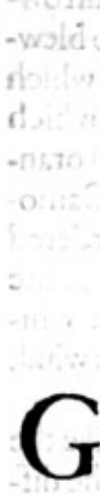

\title{
Of Turbitb of Antioch. Chap.89.
}

\section{* The defcription.}

\begin{abstract}
Arcia a Lufitanian or Portingale phifition faith that Turbith is a plant hauing a rootewhich is neither great nor long : the ftalk is of a fpan long, fomtimes longer, a finger thicke, which creepeth in the grounde like Iuic, and bringeth foorth leaues like thofe of themarifh Male lowe. The flowers be alfo like thofe of the Mallowe, of a reddifh white colour : the outward rinde of whofe rootes is that which is profitable in medicine, and is the fame that is vfed in fhops: they choofe that for the beft which is hollowe, \& round like a reede, brittle, and with a fmooth barke, as alfo that whereunto doth cleaue a congealed gum, which is faide to be grummo/um, or gummie, and fomewhat white. But, as Garcias faith, it is not alwaies gummie of his own nature; but the Indians bicaufe they fee that our marchants note the beft Turbith by the gummineffe, are woont before they gather the fame, either to writhe or elfe lightly to brufe them, that the fappe or liquor may iffue out; which roote being once hardned, they picke out from the reft to fell at a greater price. It is likewife made white, as the faide author fheweth, being dried in the funne : for if it be dried in the fhadowe, it waxeth blacke.
\end{abstract}




\section{HISTORIE OF PLANTS.}

Twrbith Alexandrinum officinarwom. Turpetsom, or Turbith of the fhops.

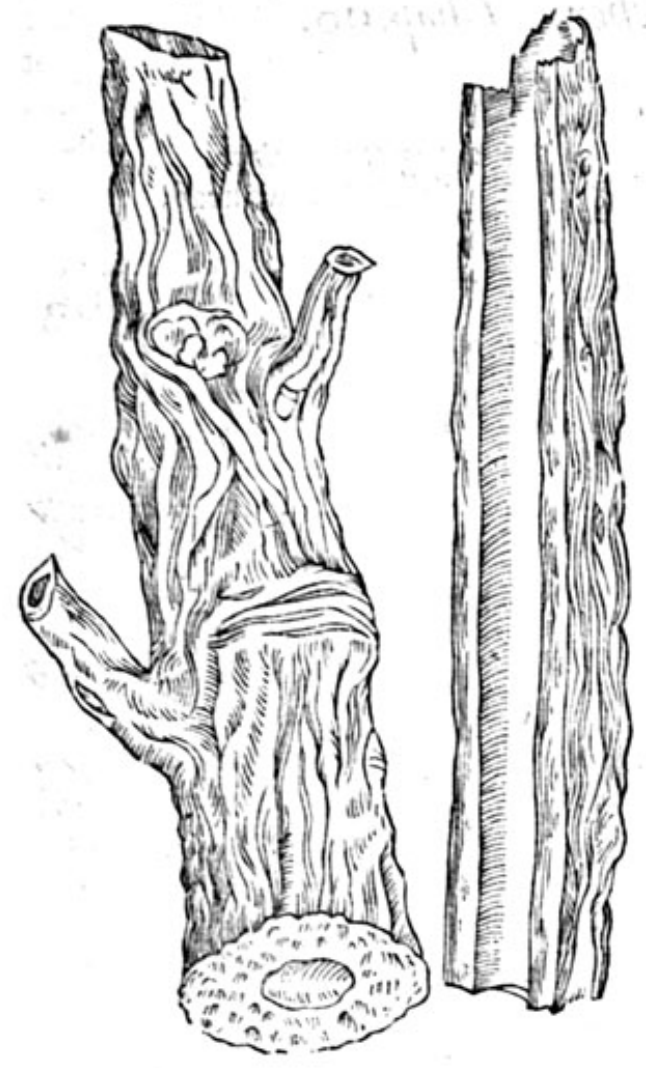

* The place.

It groweth by the fea fide, but yet not fo neere that it may receiue the vapors that rife from the fea, but two or three miles diftant, and that in vntilled grounds rather moift then drie. It is founde in Cambaya,Surrates, in the Ile Dion, Bazaim, and in places hard adioining; alfo in Guzarates, where it groweth plentifully, from whence great abundance of it is brought into Perfia, Arabia, little Afia, and fo into Europe:but that is preferred which groweth in Cambaya.

\section{* The names.}

It is called of the Arabians, Perfians; and Turks Twrbith : and in Guzarata Barcaman : in the pro. uince Canara, in which is the citic Goa, Tiguar: likewife in Europe the learned call it by fundrie names, according to their feuerall fancies, which hath bred fundrie controuerfies as it hath fallen out betweene the Hermodactyles, and Turbith; the vfe and poffeffion of which, we cannot feeme to want: but which plant is the true Turbith, we haue great caufe to doubt. Some haue thought our Tripolium marinum, defcribed in the former chap. ter to be Turbith: others haue fuppofed it to bee one of the Tythimales, but which kinde they knowe not: Guillandinus faith, that the roote of Tytbimalsw mirfinitis is the true Turbith; which caufed L'Obelisis and Pena to plucke vp by the ruotes all the kindes of $\tau$ ythimales, and drie them very curiouflie; which when they had beheld, and throughly tried, they founde it nothing fo. The Arabians and halfe Moores that dwell in the eaft parts, haue giuen diuers names vnto this plant: and as their wordes are diuers, fo haue they diuers fignifications; but this name Turbith they feeme to interpret to be any milkie root which doth ftrongly purge flegme, as this plant doth. So that as men haue thought good pleafing, themfelues, they haue made many \& diuers conftructions which haue troubled many excellent learned men, to knowe whofe roote is the true Turbith. But briefly to fet downe mine opinion, not varying from the iudgement of men which are of great experience; I thinke affuredly that the roote of Scammonie of Antioch is the true \& vndoubted Turbith: one reafon efpecially that mooueth me fo to thinke is, for that I haue taken vp the rootes of Scammonie which grewe in my garden, and compared them with the rootes of Furbith, betweene which I founde litule or no difference at all.

\section{$*$ The temperature and vertues.}

The Indian phifitions do vfe it to purge flegme, to which if there be no ague they do adde gin- $\mathbf{A}$ ger,otherwife they giue it without it in the broth of a chicken, and fometimes in faire water.

CMefwes writeth, that Turbith is hot in the thirde degree; and that it voideth thicke tough B flegme out of the ftomacke, chelt, finewes, and out of the furthermoft parts of the bodie: but (as he faith) it is flowe in working, and troubleth and ouerturneth the ftomacke : and therfore ginger, mafticke, and otherfpices are to be mixed with it; alfo oile of fweete almondes, or almondes themfelues, or fugar, leaft the bodie with the vfe heereof fhoulde pine and fall away. Others temper it with dates, fweete almonds, and certaine other things, making thereof a coinpofition (that the apothecaries call an Electuaric) which is named siapourvoury: common in fhops, and in continuall vfe among expert phifitions.

There is giuen at one time of this Turbith one dram (more or leffe)two at the moft:but in the de- $\mathbf{C}$ coction, or in the infufion three or fower. 
1 Sagittaria maior. Great Arrowe head.

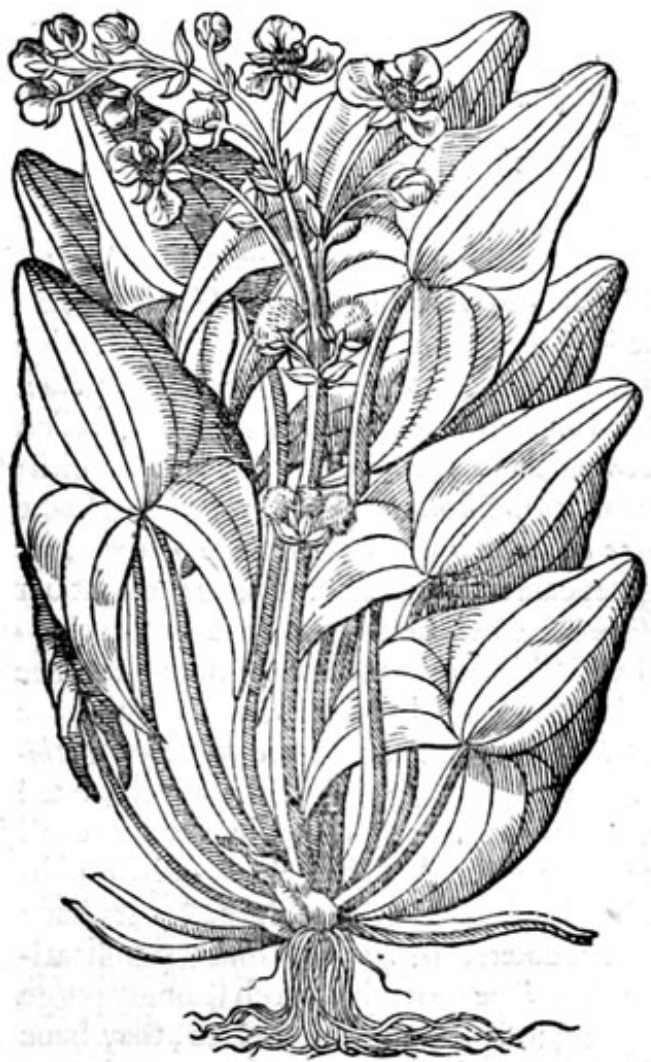

2 Sagittarisminor. Small Arrowe head.

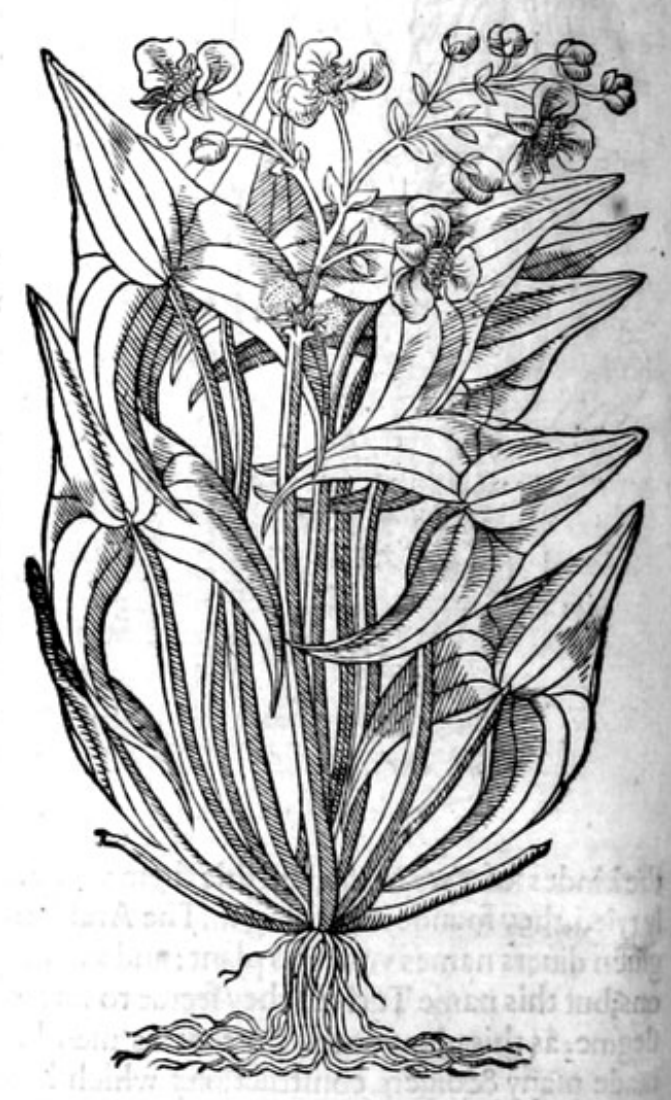

* Thedefcription.

I He firt kind of water Archer or Arrow head, hath large \& longleaues, in thape like the figne Sagittarius, or rather like a bearded broad arrowe heade: among which rifeth vp a fat and thicke ftalk, two or three foote long,hauing at the top many pretie white flowers, declining to a light carnation, compact of three fmall leaues: which being paft, there come after great rough knops or burres wherein is the feede. The roote confifteth of many ftrings.

2 The fecond is like the firft, and differeth in that this kinde hath finaller leaues and flowers, and greater burres and rootes.

3 The thirde kinde of A rrowe heade hath leaues in hape like the broade Arrowe head, ftanding vpon the endes of tender foote ftalkes a cubitelong: among which rife vp long naked fmooth ftalkes of a greenifh colour, from the middle whereof to the top do growe flowers like to the precedent. The roote is fmall and threddie. 


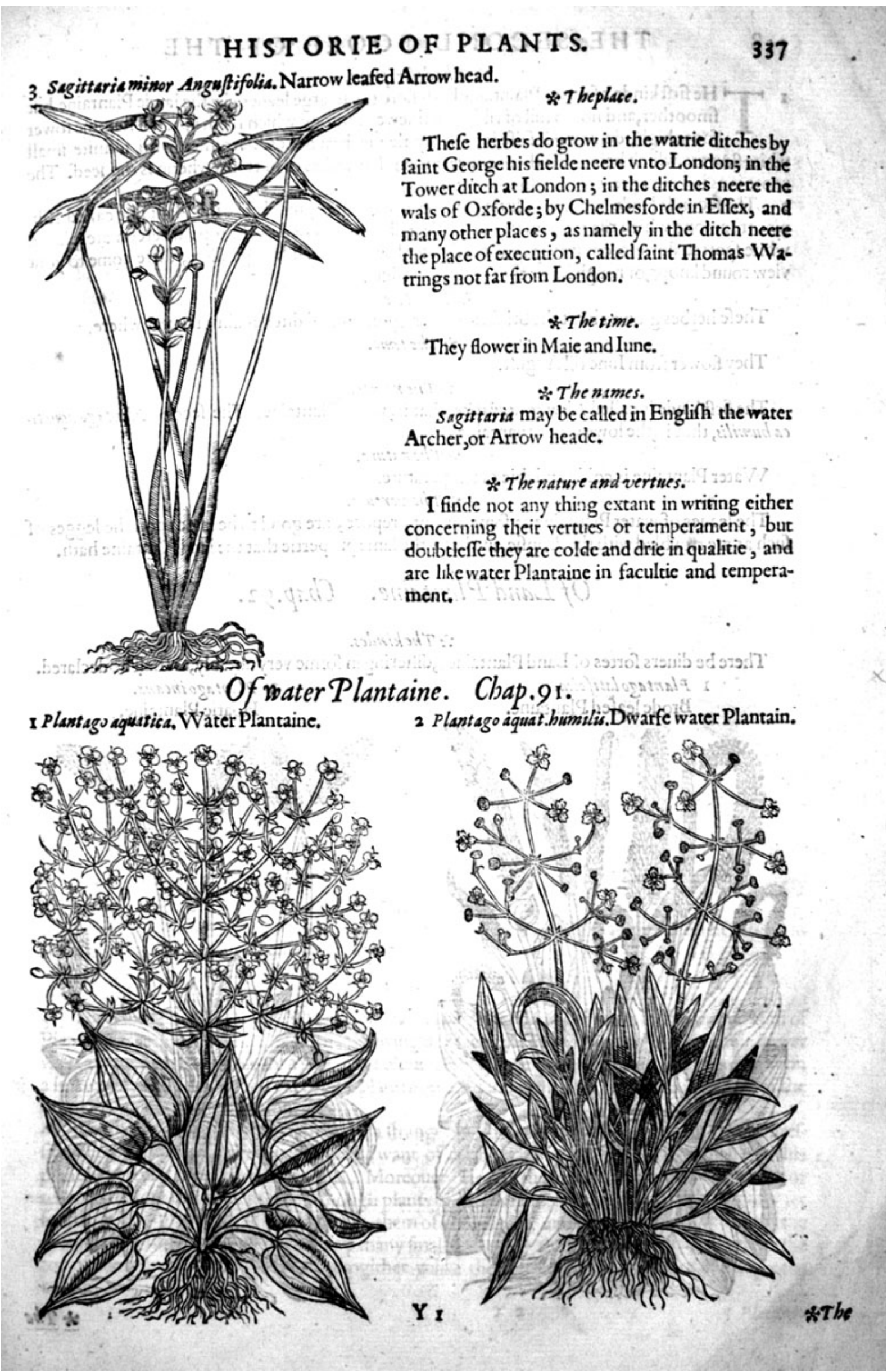


* The defoription.

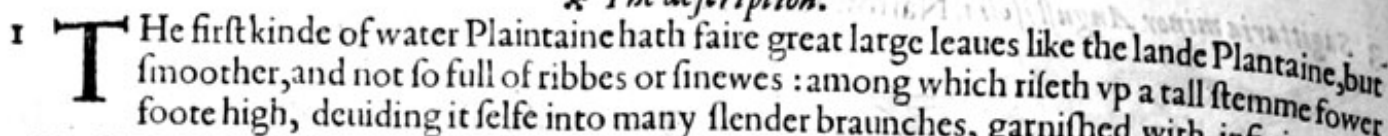
white flowers, which being paft there appeere triangled huskes or buttons, wherin is the feed fmall roote is as it were a great tuft of threds or thrums. 2 The feconde kinde hath long, little, and narrowe leaues, much like the Plantaine called Rib. white fpotted flowers, confifting of three flender leates; which being fallen, where are placed view round knops, or rough burs : the roote is threddic.

$$
\text { * Theplace. }
$$

Thefe herbes growe about the brinkes of riucrs, pondes and ditches almoifteuery where.

They flower from Iune till Auguft. * The time.

* The rames.

The firft kinde is called Plantago aquatica, that is, water Plantaine. The fecond Plantago agwati. ca humilis, that is, the lowe water Plantaine.

Water Plantaine is colde and drie of temperature.

$$
\text { * The nature. }
$$

The leaues of water Plantaine as fome authors report, are good to be laide vpon the legges of fuch as are troubled with the dropfie, and hath the fame propertie that the land Plantaine hath.

\section{Of Land Plantaine. Chap.92.}

* The kindes.

There be diuers fortes of Land Plantaines, differing in forme very notably, as fhall be declared.

I Plantagolatifolia.

Brode leafed Plantaine.

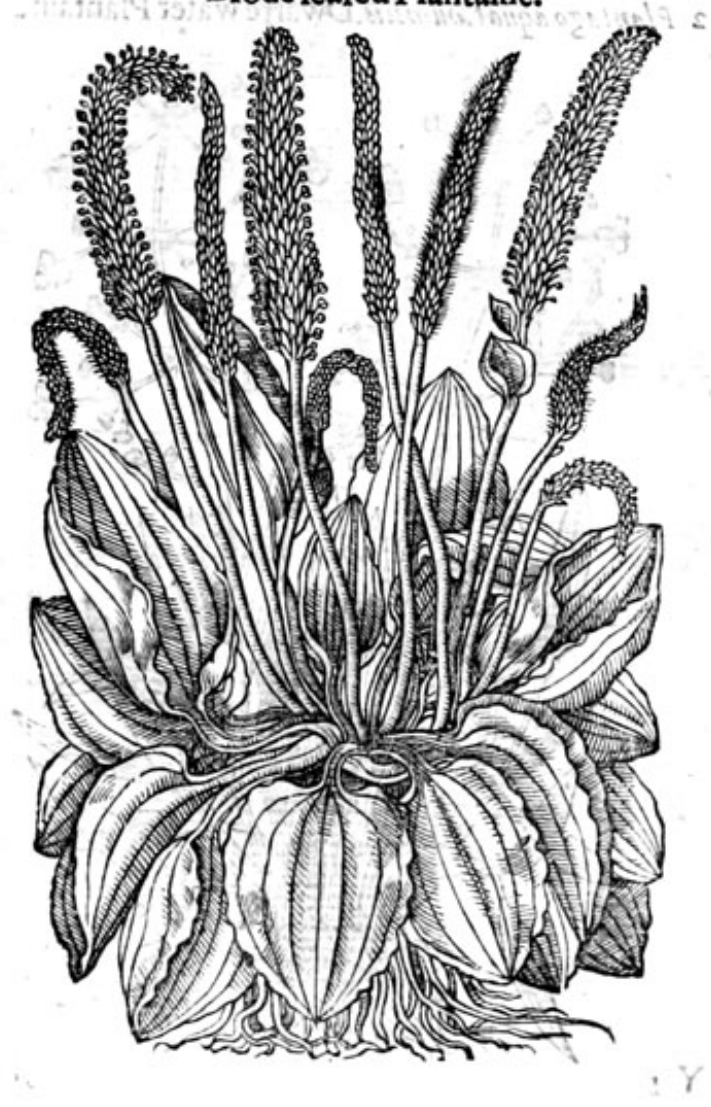

2 Plantagoincana.

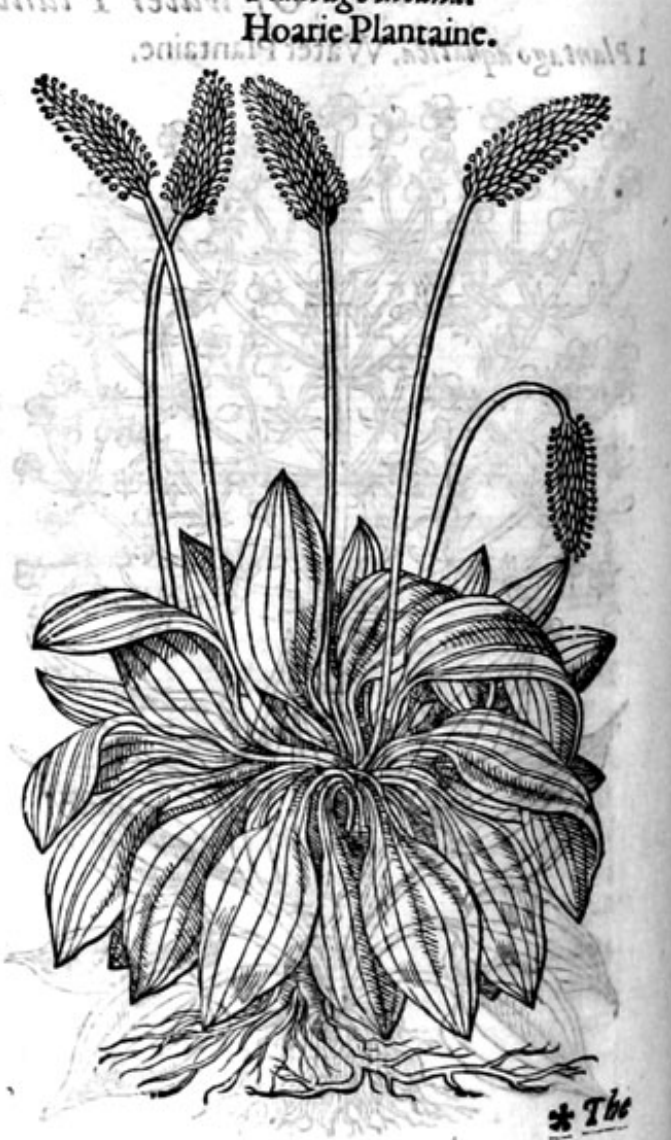




\section{HIST ORIE OF PLANTS. IHT}

* The defcription.

I S the Greekes haue called fome kinde of herbes, Serpents toong, Dogs toong, and Oxe A toong; fo haue they termed a kinde of Plantaine Arnoglo/fa, which is as if you inould fay Lambes toong, very well knowen vnto all, by reafon of the great commoditic and plentic there of growing euery where; and therefore it is needlefle to fpend time about them. The grcatnes and fafhion of the leaues hath beene the caufe of the varieties, and diuerfities of their names. 2 The fecond is like the firt kinde, and differeth in that, that this kinde of Plantaine hath greater, but fhorter fpikes or knaps:and the leaues are of an hoaric or ouerworne greene, colour : the ftalkes likewife hoarie and hairie.

3 Plantagolatifoliaminor. Small broad leafed Plantaine.

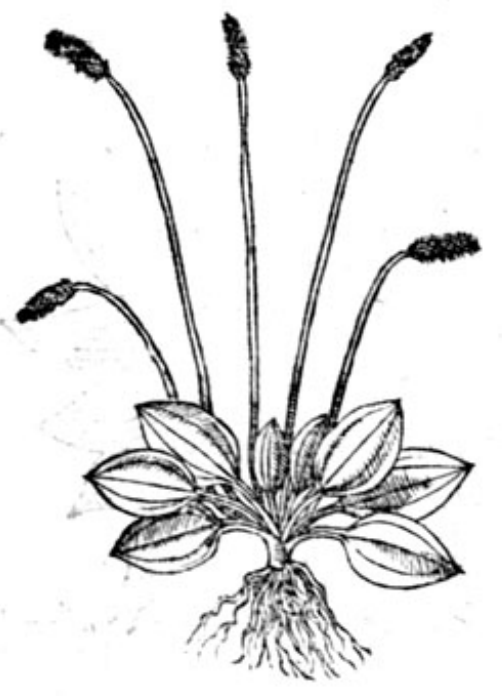

* The defcription.
4 Plantagoanguitifolis minor.

Small narrow leafed Plantaine.

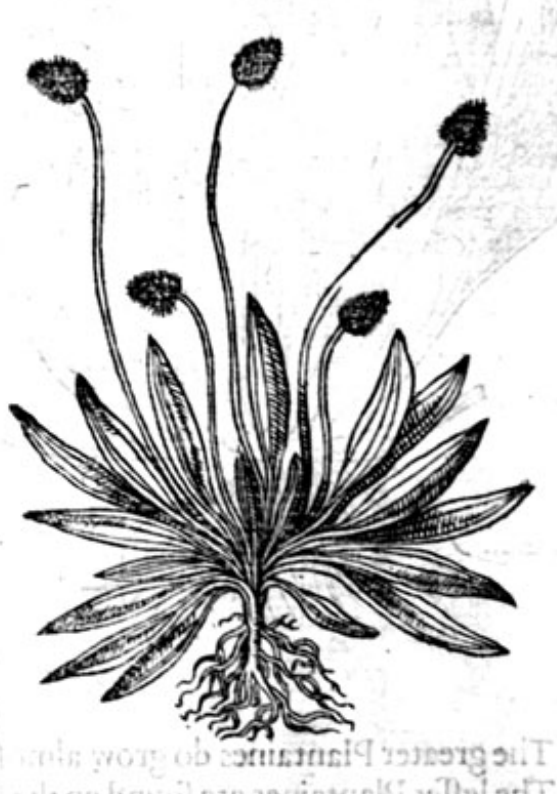

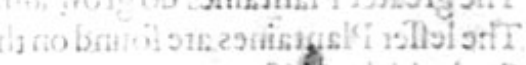

3. The fmall Plantaine hath many tender Ieaues ribbed, like ynto the greatPlantaine, andisvery like in each refpect vnto it, fauing that it is altogither lefler.

4 Thenarrowleafed Plantaine is like vnto the fmal Plantaine, fauing that the leaues of this plant are narrower, whercin confifteth the difference.

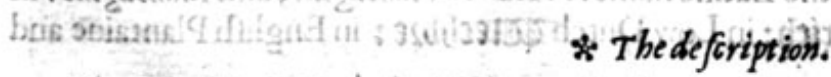

5 The fpiked Rofe Plantaine hath very few leaues, narrower than the leaues of the fecond kind of Plantaine, tharper at the ends, \& further growing one from another. It beareth 2 very double flower ypon a fhort ftem like a Rofe, of a greenifh colour tending to yellowneffe. The feede groweth vpon 2 fpikic tuft, aboue the higheft part of the plant: notwithftanding it is but yery lowe in refpeet of the other Phancaines aboue mentioned.

6 The fixt kinde of Plantaine hath beene 2ftranger in England, and elfewhere vntill the impreffion hereof. The caufe why I fay fo, is the want of confideration of that beautie, which is in this plant, wherein it excelleth all the other. Moreouer, bicaufe that it hath not beene written of, or recorded before this prefent time : though plants of leffer moment haue beene very curioufly fet foorth. This plant hath leaues like vnto them of the former, and more orderly fpred vpon the groundlikea Rofe; among which rife vp many fmall ftalkes like theother Plantaines, hauing at the top of euery one a finedouble Rofe, altogither vnlike the former; of an hoaric or ruftic greene colour. 


\section{THE SECOND BOOKE OF THE}

5 Plantago Ro/ea picata. Spiked Rofe Plantaine.

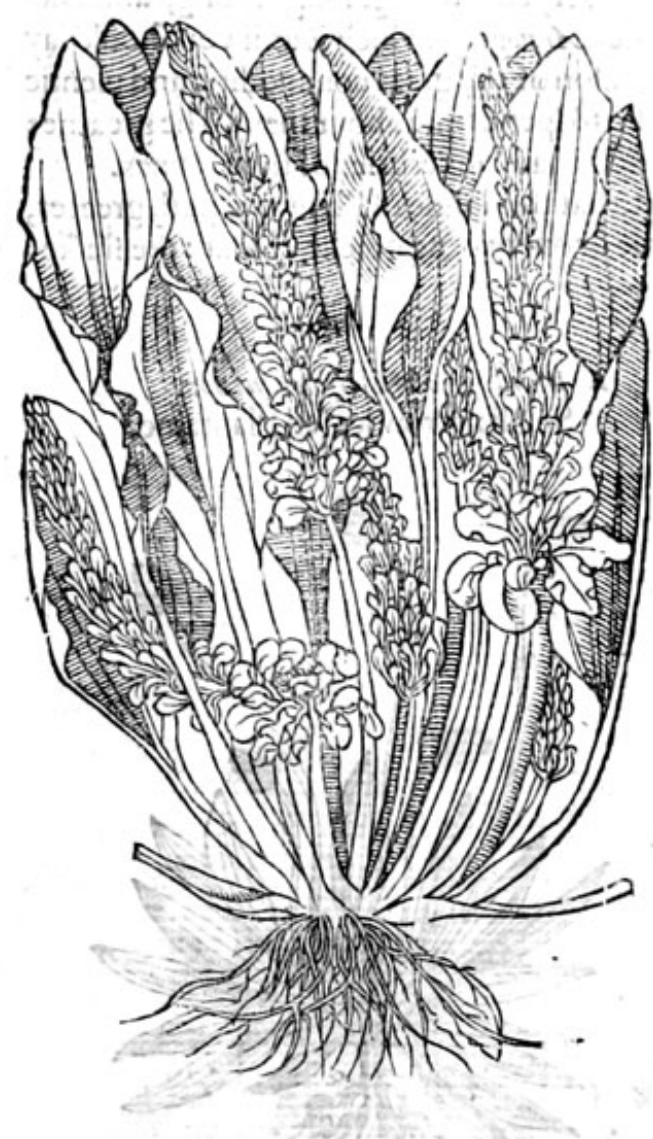

6 Plantago Rofea exotica. Strange Rooe Plantaine.

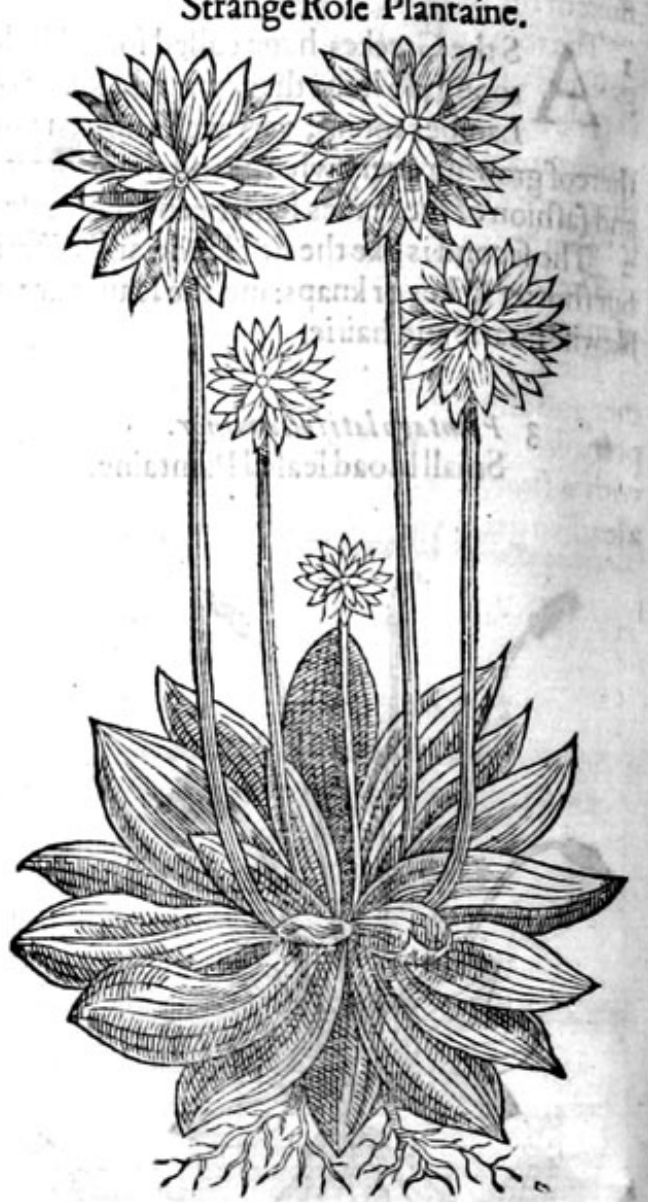

* The place.

The greater Plantaines do grow almoft euery where.

The leffer Plantaines are found on the fea coaftes, and banks of great riuers, which are fomtimes wafhed with brackifh water.

They are to be feene from Aprill vnto September.

Plantaine is called in Latine Plantago, and in Grecke aproydoars, and Urnogloffa, that is to fay, Lambes toong. The Apothecaries keepethe Latine name: in Italian Piantagine, and Planiagine: in Spanifh Lbantem : the Germaines \$Benticb: in Low Dutch שeteclybze : in Englin Plantaine and Weybred: in French Plantain.

to betho $*$ The temperature.

7antaine, as Galen faith, is of a mixt temperature: for it hath in it a certaine waterie coldneffe, with a fittle barffinneffe, earthie, drie, and cold. Therefore they are cold and दrie in the fecond degree. To bebriefe, they are drie without biting, and cold without benumming. The roote is of like temperature, but drier,and not fo cold. The feede is of fubtile partes, and of temperature leffe cold. \% The vertues.

A Plantaine is good for vlcers that are of hard curation, for fluxes, iffues, rewmes and rotemneffe, and for the bloodie flixe.It ftaieth bleeding, it fiealeth vp hollow fores, and concauate vlcers as well olde as new. Of all the Plantaines the greateft is the beft, and excelleth the reft in facultie and vertue.

B The iuice or decoction of Plantaine drunken, ftoppeth the bloodic flixe and all other fluxes of the belly, ftoppeth the piffing of blood, fpitting of blood, with all other iffues of blood in man or woman, and the defire to vomite. 
Plantaine leaues itamped and made into a Tanfie, with the yelks of egges, ftaieth the inordinate $C$ fluxe of the termes, although it have continued many yeeres.

The roote of Plantaine with the feede boiled in white wine and drunke, openeth the conduites or D paffages of the liuer and kidneies, cure the iaundies, and vicerations of the kidneies and bladder.

The iuice dropped into the eies, doth coole the heate or inflammation thercof. I tinde in ancient $\mathrm{E}$ writers many Good morrowes, which I thinke not meete to bring into your memoric againe, as that three rootes will cure one griefe, fower another difeafe, fixe hanged about the necke are good for another maladie, \$ec.all which are but ridiculous toies.

The leaues are fingular good to make a water to wafh a fore throte and mouth, or the pritie parts $F$ of man or woman.

The leaues of Plantaine ftamped, \& put into oile oliue, \& fet in the hot funne for a moneth togi- G ther, and after boiled in a kettle of feething water (which we do call Balnea Maria)\& then ftrained: preuaileth againft the paines in the cares, the yarde or matrix (being dropped into the cares, or calt with a firing into the other parts before rehear(ed) or the paines of the fundament : prooued by alearned gentleman,Mafter Willswn Godowrus Sergeant Chirurgion to the Queenes Maieftie.

\section{Of Ribwoort. Chap:93.}

I Plantagogwinquenerwia. Ribwoorte Plaintaine.

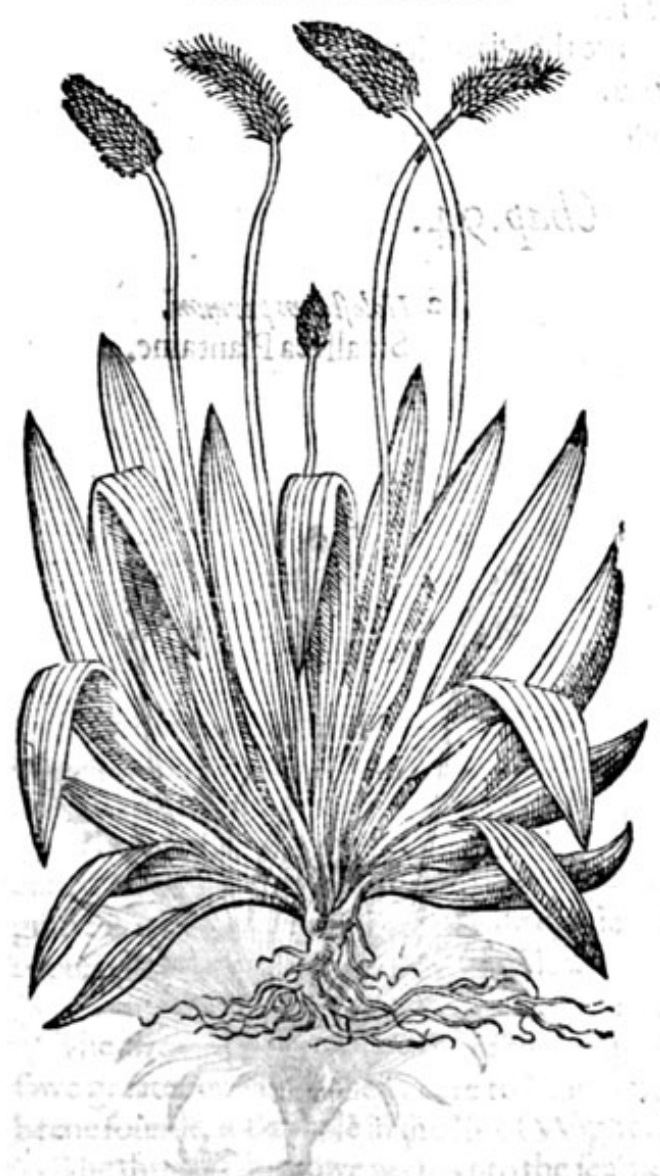

2 Plantago gainguenerwia rofea. Rofe Ribwoorte.

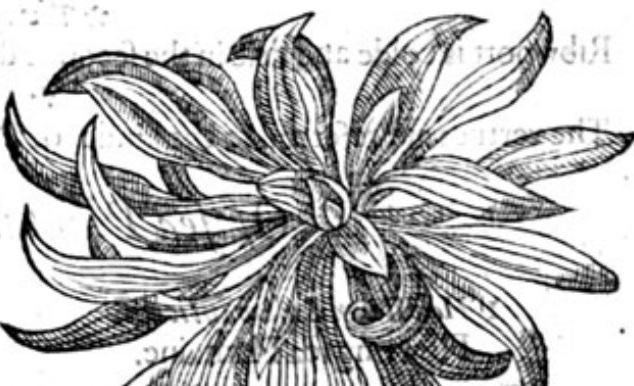

I Ibwoorte or fmall Plantaine, $\%$ The defcription.
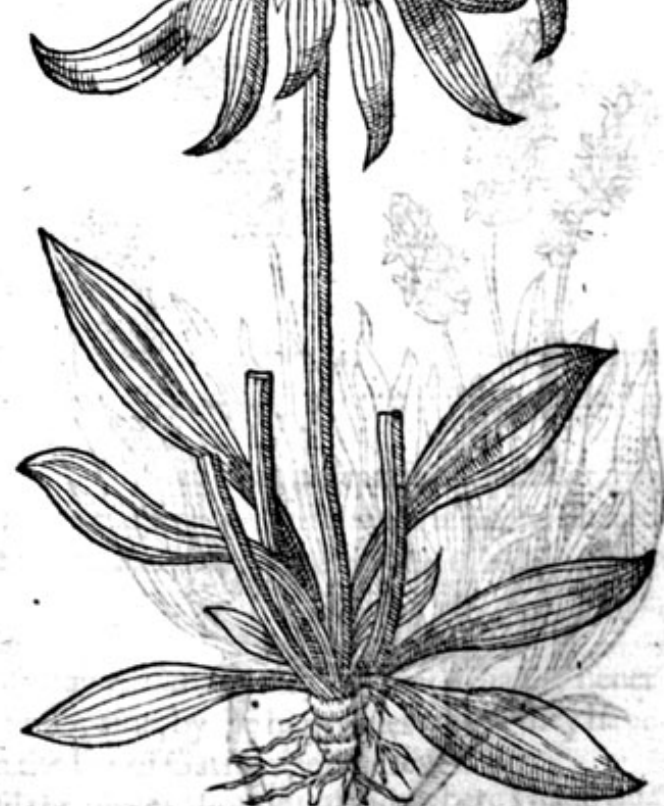

$\mathrm{R}$ pround, narrow, Tharpe pointed, and ribbed for the molt part with fiue nerues or finewes, \&ctherefore it was called Quinquenerwia: in themiddle of which leaues rifeth vp a crelted or ribbed ftalk, bearing at thetop a darke or duskieknap, fet with a fewe fuch white flowers as are the flowers of Wheate. 


\section{2}

\section{THE SECOND BOOKE OF THE}

The roote and other parts are like the other Plantaines.

2 Rofe Ribwoort hath many broade and long leaues, of a darke greene colour, tharpe pointed and ribbed with fiue nerues or finewes, like the common Ribwoort: among which rife vp naked italkes, furrowed, chamfered, or crefted with certaine fharpe cdges : at the toppe whereof groweth a great and large tuft of fuch leaties as thofe are that growe next the grounde, making one entire tuft or vmble, in thape refembling the rofe, (whereof I thought good to giue it his furname rofe) which is his flower. * T he place.

Ribwoort groweth almoft euerie where in the borders of path waies, and fertill fieldes.

Rofe Ribwoort is not very common in any place;notwithftanding it groweth in my garden, and wilde alfo in the north parts of Englande; and in a fielde neere London by a villagecalled Hoggefdon founde by a learned marchant of London mafter Iames Cole, a louer of plants, and very skilfull in the knowledge of them.

\section{* The time.}

They flower and flourifh when the other Plantaines do. * The names.

Ribwoorte is called in Greeke murárevess: in Latin Quinqueneruia, and Lanceola, or Lanseolata: in

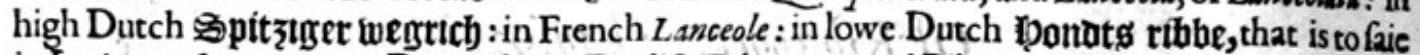
in Latine Cofta canina, or Dogs rib: in Englifh Ribwoort, and Ribwoort Plantaine. Latine.

The fecond I haue thought meete to call Rofe Ribwoort in Englifh, and Quinguenerwia Roferin

\section{R The temperature.}

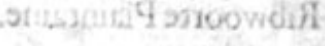

The vertues are referred to the kindes of Plantaine.

$$
\text { * The vertwes. }
$$

\section{Of Jea Plantaines. Chap.94.}

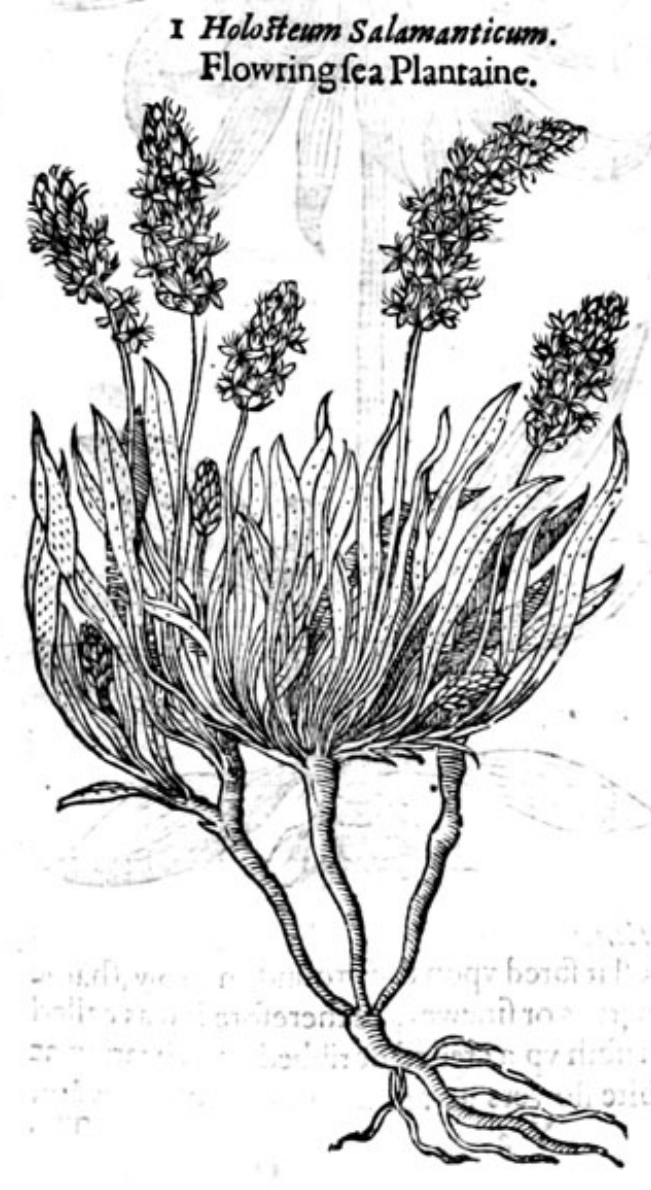

2 Holofteumparman:
Small fea Plantaine.

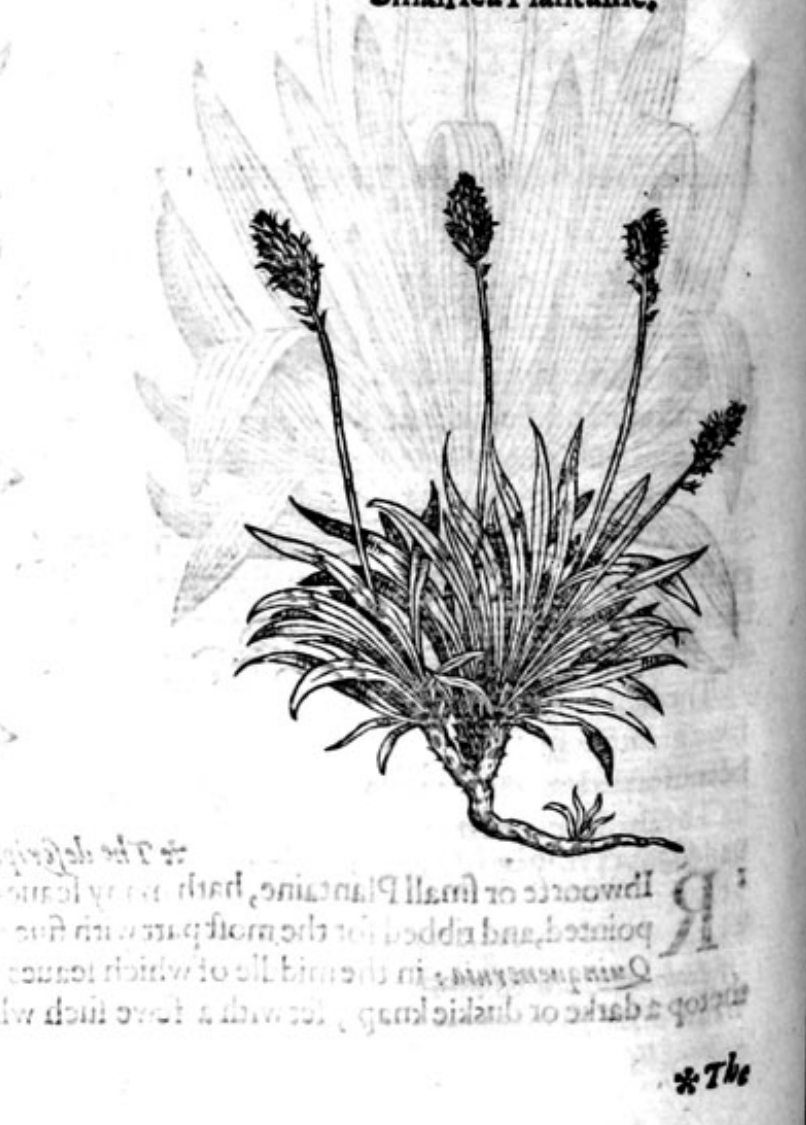




\section{THISTORIE OF PLANTS.}

$\mathbf{I}$

* Thedefoription. Arolus Clufus that excellent learned Herbarift, hath referred thefe two forts of Holoftenm vnto the kindes of fea Plantaine. The firft hath long leaues like the common Ribwoorte, but narrower, couered with an ouerworne greene colour, with fome hearineffe or woollineffe: among which there rifeth vp a ftalke, bearing at the top a f pike, like the kinds of Plantaine, befet with many fmall flowers of an herbie colour declining to whitenes. The feed is like that of the Plantaine: the roote is long and woodie.

2 The fecond is like the former, but fmaller: the flowers are like to Coronopes, or the leffer Rib, woort.

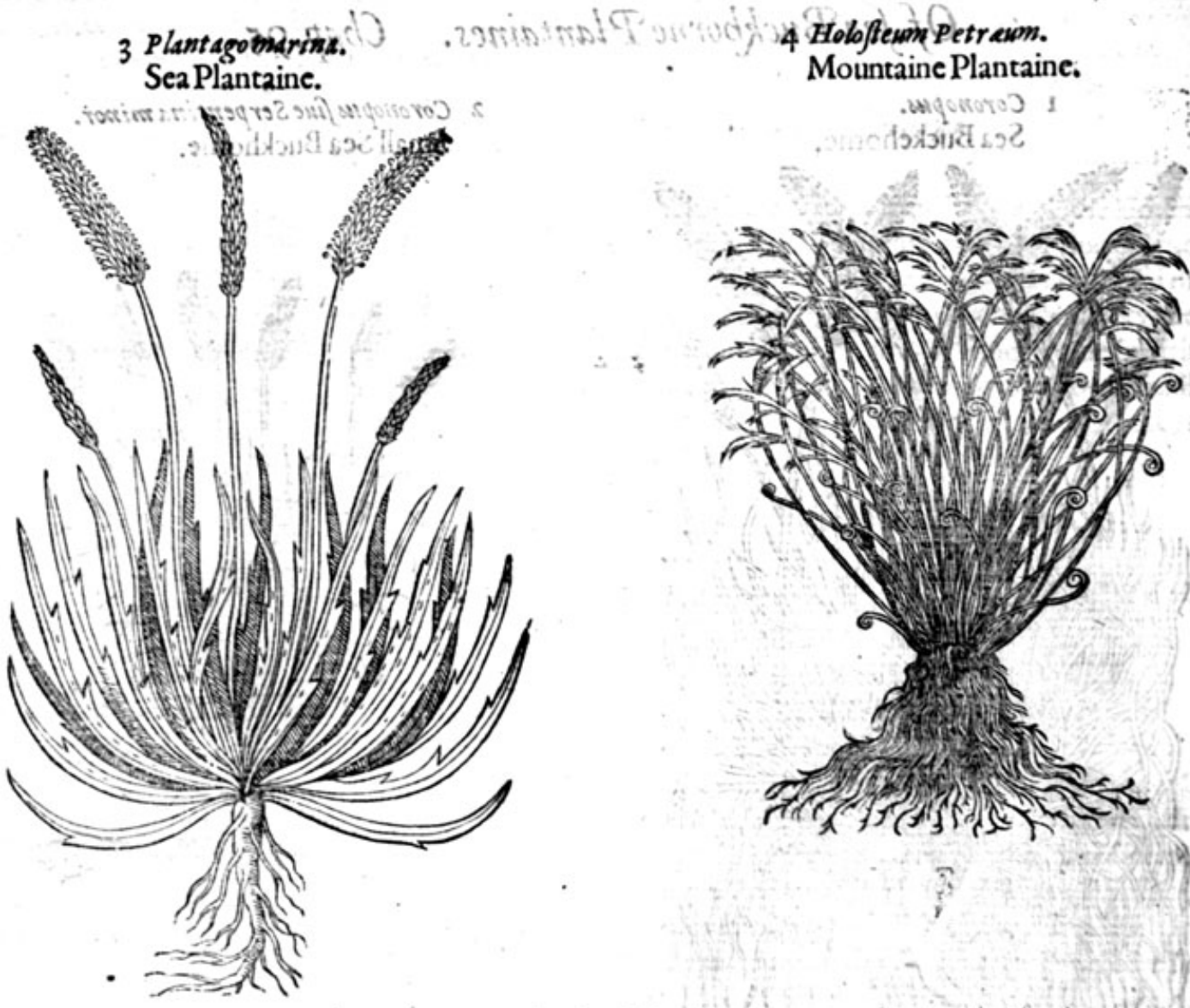

3 The thirde kinde which is the fea Plantaine, hath fmall and narrowe leaues like Buckes horne, but without any manifeft incifure, cuttings or natches vpon the one fide : among whichrifeth vp a Spikie ftalke like the common kinde, but fmaller.

4 There is a little graffie plant growing vpon ftonie mountaines and rockes couered with graffe; called Holofteum Pet reum: it hath many graffic leaues, ftiffe, bentie, rough and (hearing, as Sheere graffe is : the top of eche graffie leafe diuideth it felfe into diuers parts in maner of a fmall tuft. The roote is flender and very full of threddes.

* Theplace.

The two firft do grow in moft of the kingdomes of Spaine. Carolus cluf fues writeth that he neuer fawe greater or whiter then neere to $V_{2}$ lentia, a citie of Spaine, by the highwaies: fince they haue beene founderat Baftable in the Ile of Wight : and in the Iles of Garnfey and Iarfey.

- The thrid doth growe neere vnto the fea fide in all the places about Englande where I havie trauelled,efpecially by the fortes on both the fides of the water at Grauefend; at Erith neere London; at Lee in Eflex; at Rie in Kent; at Weftchefter, and at Briftowe.

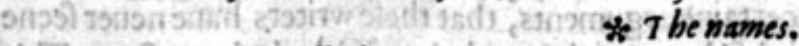

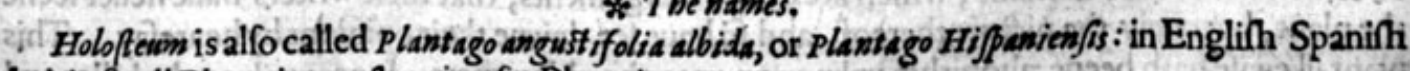
hairie finall Plantaine, or flowring fea Plantaine. 
* The temperature and vertues.

Gslen faith, that Holoftiwm is of a binding and drying facultie.

Galen,Diofcorides, and Pliny hatie prooued it to be fuch an excellent wounde herbe, that it prefently clofeth or Thutteth vp a wounde though it be very great and large: and by the farneauthority If seake it, that if it be put into a pot where many peeces of flefh are boiling, it will foderthein to. gither.

Thefe herbes haue the fame faculties and vertues that the other Plantaines haue, and are thought to be the beft of all the kindes.

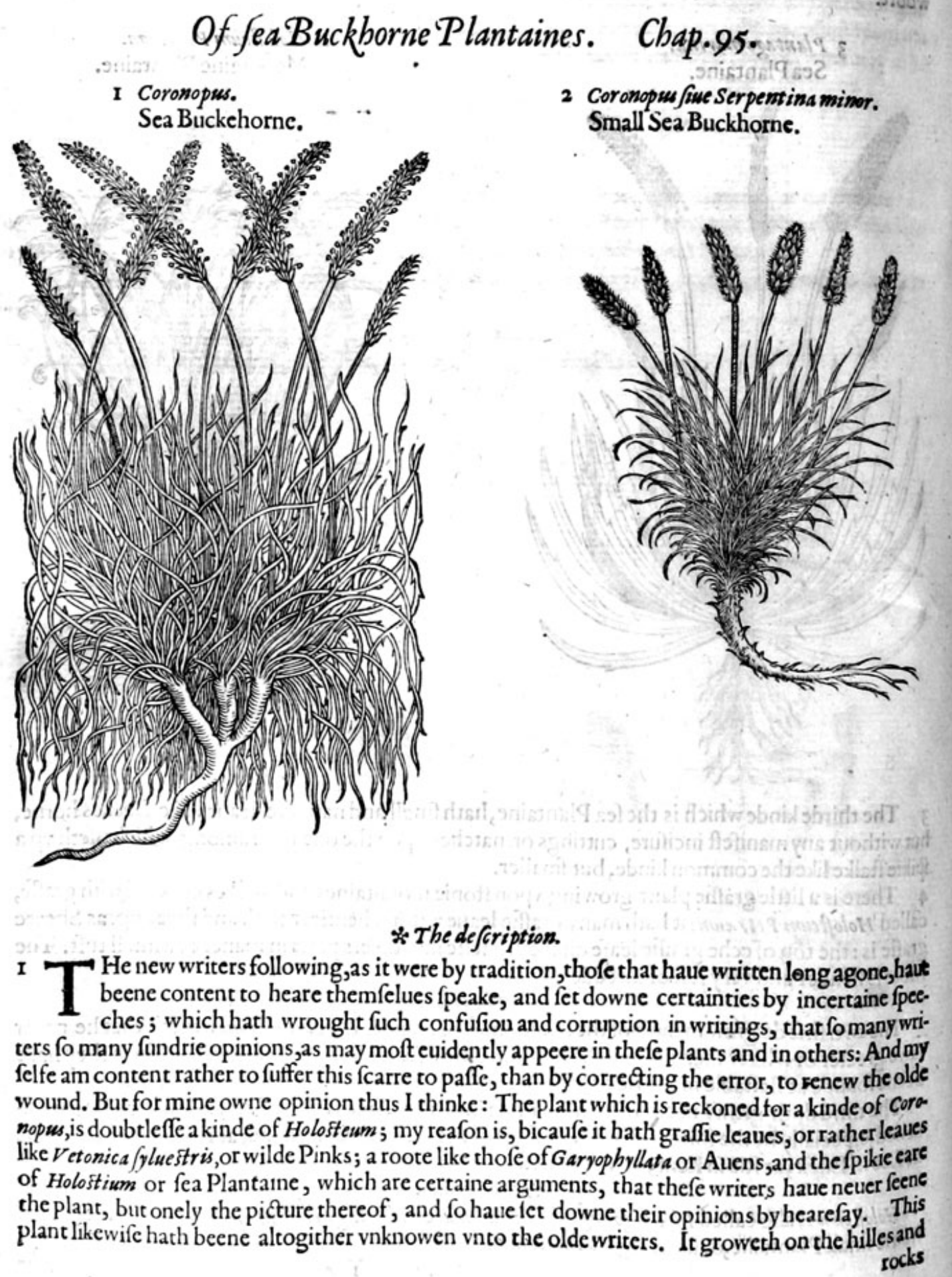




\section{HISTORIE OF PLANTS.}

rocks neere the wafhings of the fea at Maffilia in great plentie, almoft euery whereamong the Tragagant hwom, hauing a moft thicke and fpreading clufter of leaues, after the manner of seditu minimum /axerm montanum, or fmall Stonecrop, fomewhat like Pinafter, or the wilde Pine, as well in maner of growing as ftiffeneffe, and great increafe of his flendopbranches, which are nine inches long. It hath the fmall feede of Plantaine, or Serpentina vulgar is, conteined within his f pikie eares. The roote is fomewhat long,wooddie, and thicke, in tafte fomewhat hot and aromaticall.

2. The fecond fort of wilde fea Plantaine or Serpentina, differeth not from the former, but onely in quantitie and flenderneffe of his ftalks, and the fmalneffe of his leaves, which exceede not the height of two inches; growing moft plentifully vpon the cliffes and rocks, and the tops of the barren mountaines of Sauena, and Narbon in Fraunce.

3. Coronopis fare ferpentina miniona.

Small Buckhorne Plantaine.

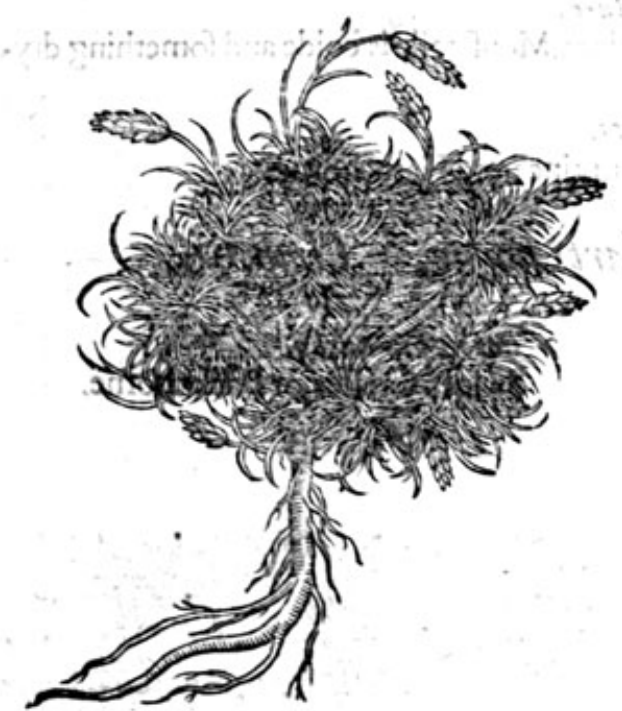

3. Thisfmall feaplant is likewife one of the kindes of fea Plantaine, participating as well of Buckhorne as of Holoftizm, being as it were a degenerate kind of fea Plantaine. It hath many graffic leaues, very like vnto the herbe Thrifte; among which come foorth little tender footeftalkes, whereon do growe fmall fpikie knops like thofe of fea Plantaine. The roote is tough and threddie.

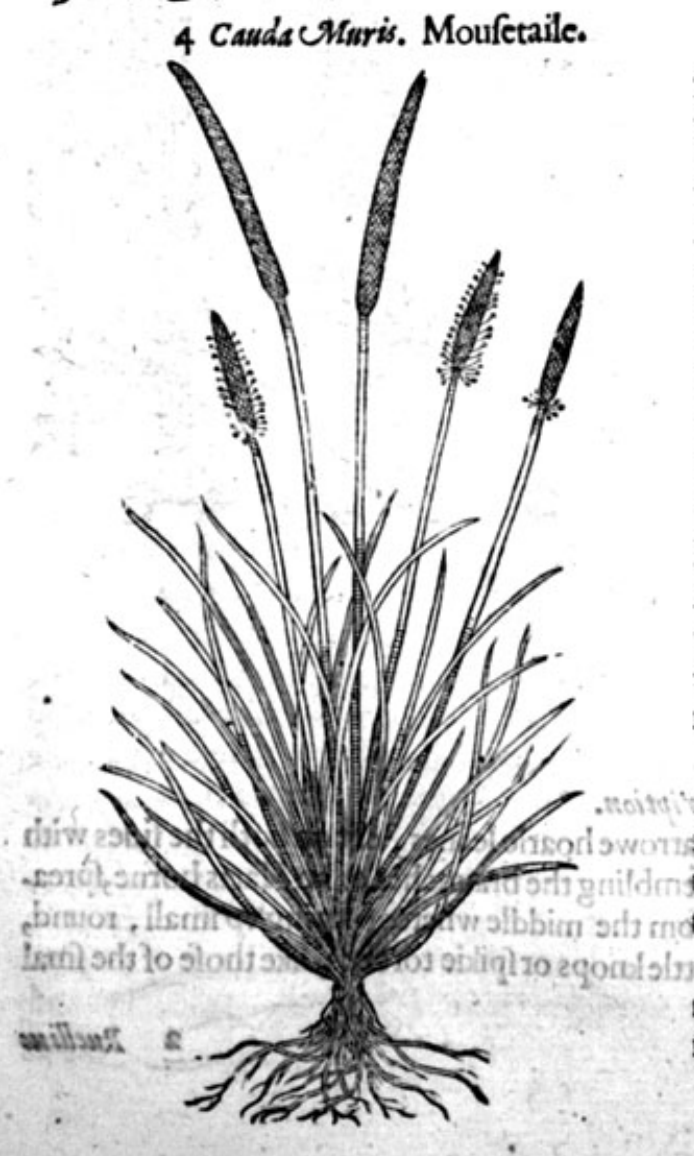

* The defription.

4 Moufetaile or Cinda muris, refembleth the laft kind of wild Coronopew or fea Plantain, in fmall fpikie knops, leaues and ftalkes, that I know no reafon to the contrarie, but that I may as well place this fmall herbe among the kinds of Coronopus or Buckhorne, as other writers haue placed kindes of Holostivem in the fame fection; \& if that be pardonable in them; I truft this may be tolerated in me,confidering that without controuerfie this little and bafe herbe is a kinde of Holost tivm, hauing many fmall hort graffie leaues fpred on the ground, an inch long or fomewhat more; among which do rife fmall tender naked ftalkes of two inches long, bearing at the top 2 little blackifh torch, or fpikie knop in fhape like that of the Plantaines, refembling very notably the taile of a moufe, whereof it tooke his name. The roote is fmall and threddie.

$$
\text { * Theplace. }
$$

Thefirft and fecond of thefe plants are ftrangers in England,notwithftanding I haué heard $\mathbf{F} y$, that they growe vpon the rockes in Scylla, Garnfey, and the Ile of Man.

Moufetaile groweth vpon 2 barren ditch banke neere vnto a gate leading into a pafture, on the right hand of the way as you go from London to a 
village called Hampteed; in a field as you go from Edmonton, a village neere London, vnto 2 houfe thereby called Pims, by the footepathes fides; in Woodford Rowe in Waltham forreft, and in the orchard belonging to Mafter Francis Whet stone in Effex,and other places.

They flower and flourifh in May and Iune. * The time.

Mathiolus writeth, that the people of Goritia do commonly call thefe two former plants Serpen. taria and Serpentina, but vnproperiy; for that there be other plants which may better becalled

- Serpentina than thefe two : we may call them in Englifh wild fea Plantaine, wherof doubeleffe they are kindes.

Moufetaile is called in Latine Cauda Muris, and Cauda murina : in Greeke puirees, or pods bued. Myofwros is called of the French men Quewe de four is : in Englifh Bloodftrange and Mouferaile.

Coronopus is cold and drie much like vnto the Plantaines.Moufetaile is colde and fomething drying, with a kinde of aftriction or binding qualitic.

* The vertues.

Their faculties in working are referred vnto the Plantaines and Harts horne.

Of Buckborne Plantaines, or Harts borne. Chap.96.

I Cornu Ceruinum.

Hartes horne.

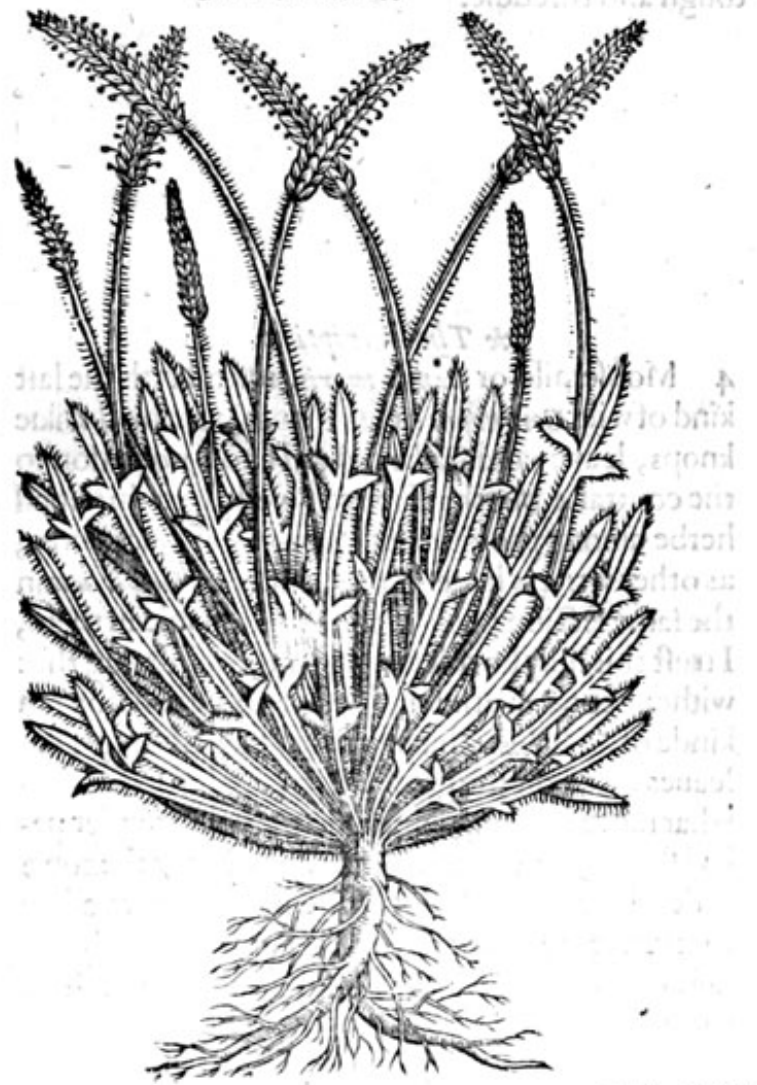

2 Coronopus Ruelly. Swines Creffes, or Bucks horne.

* The defoription. I $\mathrm{B}$ Vckes horne or Hartes horne, hath long narrowe hoarie leaues, cur on both the fides with

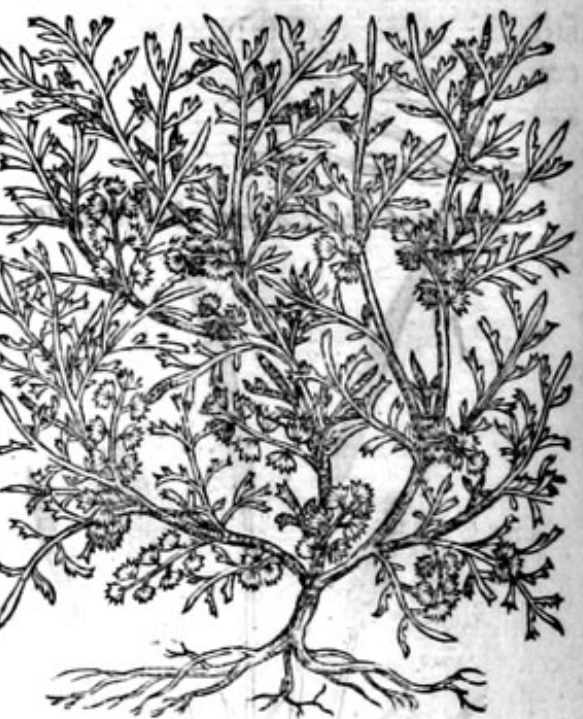
ding it felte on the ground like a ftarre: from the middle whereof fpring vp fimall, round, naked hairie ftalkes; at the top whereof do grow little knops or fpikic torches, like thofe of the final Plantainc. The roote is flender and threddie. 
2 Ruellizs Buckes horne or Swines Creffes, hath many fmall and weake ftragling braunches, trailing heere and there vpon the grounde, fet with many finall cut or iagged leates, fomewhat like the former, but fmaller and nothing at all hairie, as is the other. The flowers growe among the leaues in finall rough clufters, of an herbie greenth colour; which beingpaft, there come in place little flat pouches broad and rough, in which the feede is conteined. The roote is white, threddie, and in tafte like the garden Creffes. * Theplace.

They growe in barren plaines and vntilled places, and fandie grounds, as in Touthill fielde neere vnto Weitminfter; at Waltham twelue miles from London, and vpon blacke Heath alfo neere London. $*$ The time.

They flower and flourifh when the Plantaines do, whereof thefe haue beene taken to be kindes. * The names.

Buckes horne is called in Latine Cornu Ceruinum, or Harts home: diuers name it Herba Stella, and Stellaria, although therebe anothet herbe focalled : in lowe Dutch Đettร̧boozen : in Spaninifh Guisbells : in French Corne de Cerf.Dio/cor ides \& alfo diuers others atter him name it xoparónous, which doth fignifie Cornicis pedem, a Crowes foote : notwithftanding it is not Coronopus, which he hath expreffed vnder the fame title : it is called alfo by certaine baftarde names, as Harenarea, or Sandwoort, Sanguinaria, or Bloudwoort : and of many herbe Iuie, or herbe Euc.

$$
* \text { The temperature. }
$$

Buckes horne is like in temperature to the common Plantaine, in that it bindeth, cooleth, and drieth. $*$ The vertues.

The leaues of Bucks horne boiled in drinke, and giuen morning and euening for certaine daies $\mathbf{A}$ togither, helpeth moft woonderfully thofe that haue forc cies, waterie, or blafted, and moft of the griefes that happen vnto the eies, experimented by a learned Phifition of Colchefter calledmafter Duke, and the like by an excellent apothecarie of the fame towne called mafter Backftone.

The leaues and rootes ftamped with baic falt, and tied to the wrefts of the armes, taketh awaie B fits of the ague : and it is reported to worke the like effeet being hangedabout the necke of the patient in a certaine number, as vnto men nine plants rootes and all, and vnto women and children feauen.

\section{Of Saracenes Confound.}

Solidego Saracenica. Saracens Confound.

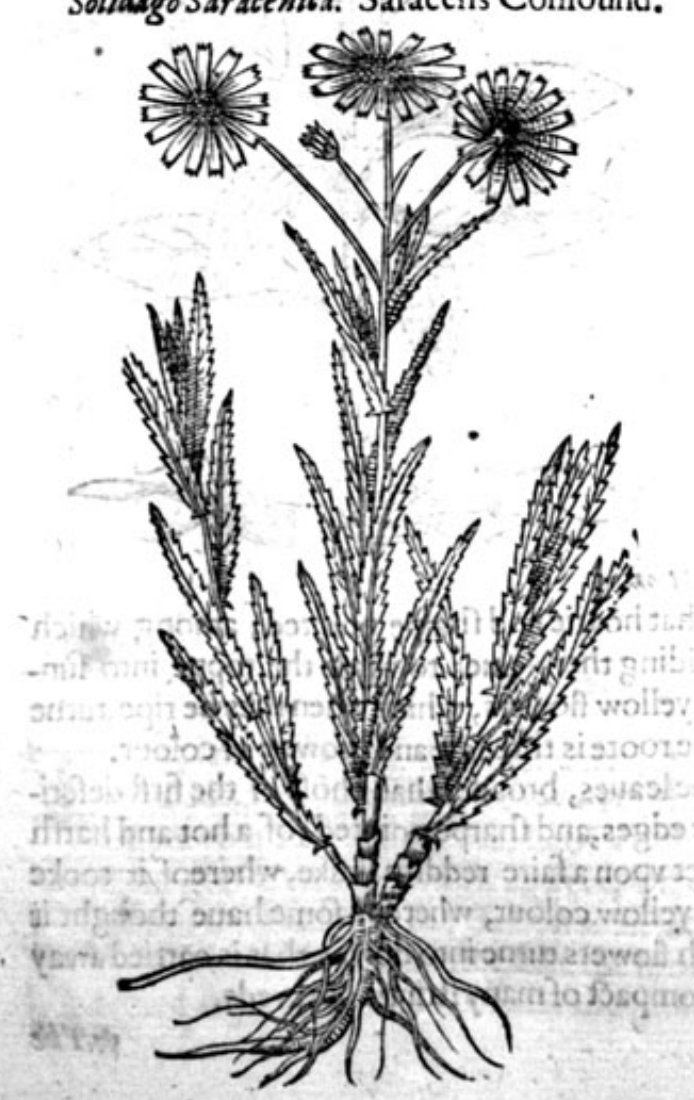

Aracens Confounde hath many long narrow $\checkmark$ leaues cut or fleightly finipt about the edges: among which rife vppe faire browne hollowe ftalkes, of the height of fower cubites; along which euen from the bottome to the top, isfetwith long, fmall, and narrowe leaues, like them of thePeach tree: at the top of the ftalkes growe little bleake yellow flowers, which turne into cowne, and are caried away with the winde. The roote is verie fibrous or threddie.

* The place.

Saracens Confounde groweth by a wood, as yee ride from great Dunmowe in Effex, vnto a place called Clare in the faide countrey; from whence I brought fome plants into nuy garden.

It flowreth in Maiesand the feede is ripe the fame moneth.

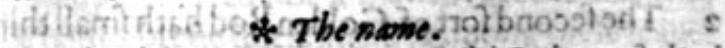

Saracenes Confounde is called his Latine solvidigo saracenica, or Saracens Comfreys and Conifolitis Saracenica : in Dutch perigunifec vediunotleratit; of fome Her ba fortis: in Englifh Saracens Contfound,and Saracenes Woundwoort. 


\subsection{THE SECOND BOOKE OF THE \\ * The nature.}

Saracens Confound is dric in the thirde degree, with fome manifert heat. $*$ The vertues.

A Saracens Confound is not inferior to any of the wounde herbes whatfoeuer, being inwardly miniftred, or outwardly applied in ointments or oiles : with it I cured mafter Cartwright a gentlemanof Grayes Inne, who was grecuoufly wounded into the lungs, and that by Gods permiffion in fhort fpace.

B The leaues boiled in water and drunken, doth reftraine and ftaie the wafting of the liter, taketh away the oppila :ion and ftopping of the fame, and profiteth againft the iaundies and feavers of long continuance.

C The decoction of the leaues made in water, is excellent againft the foreneffe of the throte, if it be therewith gargarifed 3 it increafeth alfo the vertue and force of lotion or wafhing waters, appro. priate for prituie maimes, fore mouthes, and fuch like, if it be mixed therewith.

\section{OfGolden Rod. Chap.98.}

I Virgs aurea. Golden Rod.

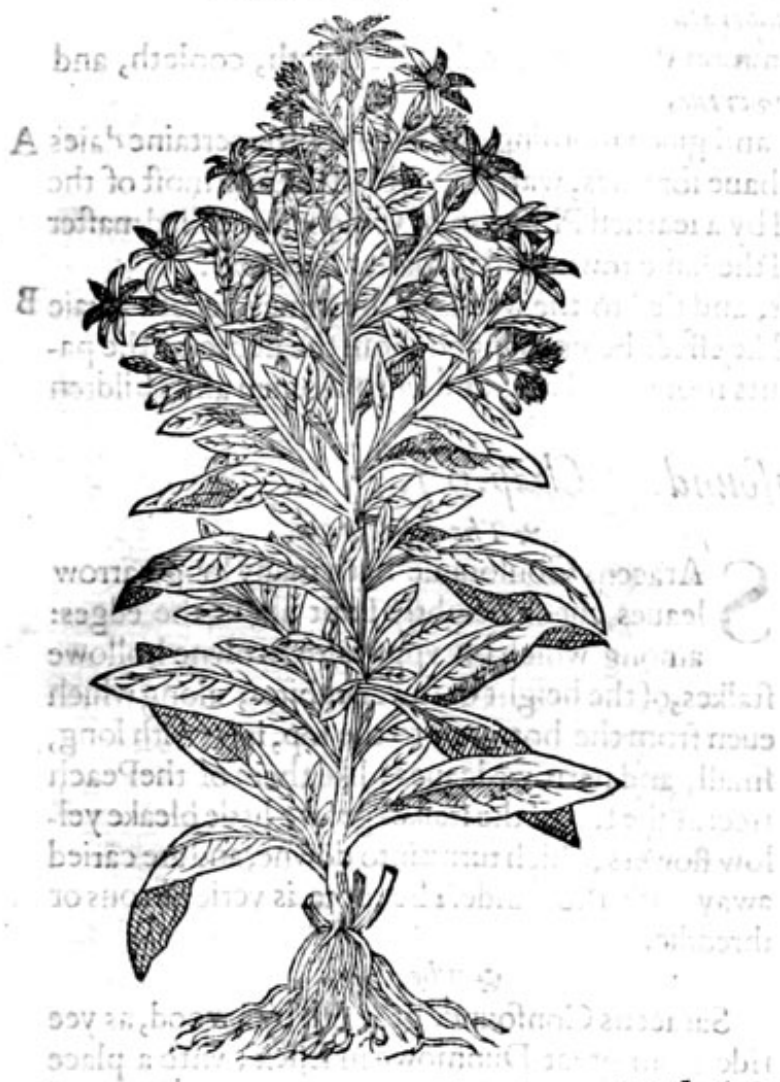

2 Virga aurea Cirnoldi Villawuani. Arnold of the new towne his Golden Rod.

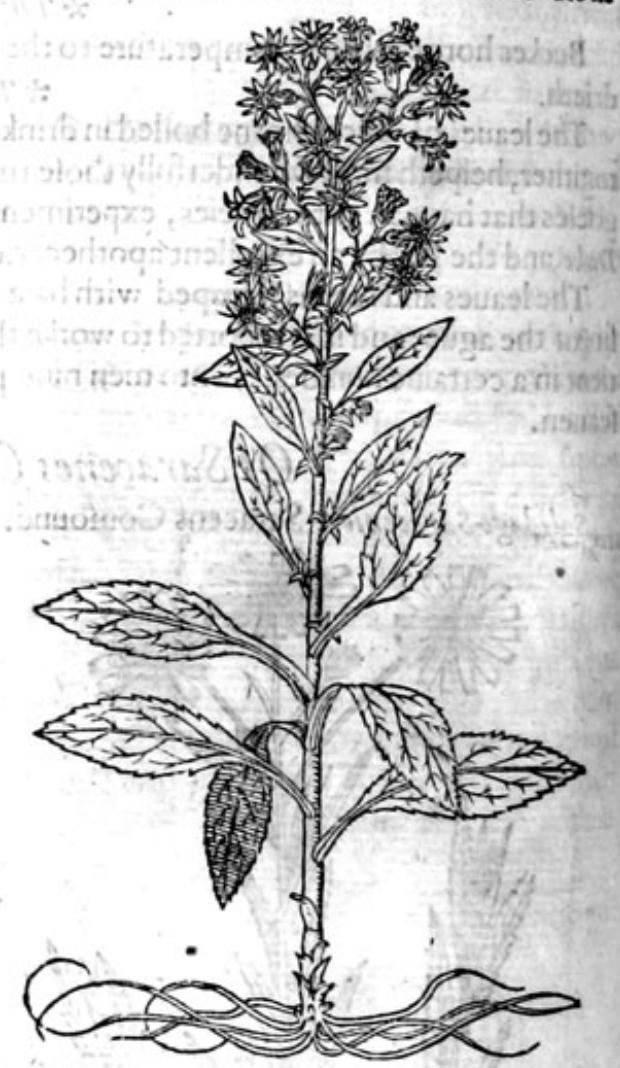

* The defcription.

I Olden Rod hath long broad leaues fomewhat hoarie and fharpe pointed; among which rife vp browne ftalkes two foote high, diuiding themfelues towarde the toppe into lundric branches, charged or loden with fnall yellow flowers, which when they be ripe, turne into downe, which is caried away with the winde. The roote is threddie and browne of colour. 2 The fecond fort of Golden kod hath fmall thinne leaues, broader than thofe of the firft deferibed, fmooth, with fome fewe cuts or nicks about the edges, and harpe pointed; of a hot and harth tafte in the throte being chewed; which leaules are fet vpon a faire reddifh ftalke, whereof it tooke his name. The flowers growe at the top of a golde yellow colour, whereof fome haue thought it tooke his name: whofe opinion I hold for beft; which flowers turne into downe that is carried away with thewinde, as is the former. The roote is fmall, compact of many ftrings or threds. 
* The place.

Theyboth growe plentifully in Hampiteed wood neere vnto the gate that leadeth out of the wood, vnto a village called Kentifh towne, not far from London; in a wood by Rayleigh in Effex, harde by a Gentlemans houfe called Mafter Leonard, dwelling vpon Dawes heath; in Southfleete, and in Swanfcombe wood alfo neere vnto Grauefend.

They flower and flourifh in the end of Augutt.

$$
\text { * } 7 \text { betime. }
$$

* Thenames.

It is called in Englifh Golden Rod: in Latine Virga aurea, bicaufe the branches are like a golden rod:in Dutch जulden roede: in French Vergedior.

* The temperature.

Golden Rod is hot and drie in the fecond degree; it clenfeth with a certaine aftriction or binding qualitie.

* The vertwes.

Golden Rod prouoketh vrine, wafteth away the ftones in the kidneies, and expelicth them; and A withall bringeth downe tough and rawe flegmatike humors fticking in the vrine veffels, which now and then do hinder the comming away of the ftones; and caufeth the grauell or fand which is brittle, to be gathered togither into one ftone. And therfore Arnoldus Villanous nuw by good reafon hath commended it againft the ftone and paine of the kidneies.

It is of the number of thofe plants that ferue for wound drinkes, and is reported that it can fully B performeall thofe things that Saracens. Confound can : and in my practife fhall be placed in the foremoft ranke.

Arnoldes writech, that the diftilled water drunke with wine for fome few daies togither, worketh $C$ the fame effeet, that is, for the ftone and grauell in the kidneies.

It is extolled aboue all other herbes for the ftopping of blood in fanguinolent vlcers and blec- D ding wounds; and hath in times paft been had in greater eftimation and regarde than in thefe daies: for within my remembrance, I haue knowne the drie herbe which came from beyond the feas, folde in Bucklers burie in London for halfe a crowne an ounce. But fince it was founde in Hampfteed wood, euen as it were at our townes end, no man will giuc halfe a crowne for an hundreci weight of it : which plainly fetteth foorth our inconftancie and fudden mutabilitie, efteeming nolonger of any thing (how pretious focuer it be) than whileft it is ftrange and rare. This verificth our Englinh prouerbe, Far fetcht and deere bought, is beft for Ladies. Yet it may be more truly faid of fantafticall Phifitions, who when they haue found an approoued medicine, \& perfect remedy neer home againft any difeafe; yet not contented with that, they will feeke for a new farther off, and by that meanes many times hurt more than they helpe. Thus muchi haue fpoken, to bring thefe new fangled fellowes backe againe to efteeme better of this admirable plant than they haue done; which no doubt hath the fame vertue row that then it had, although it do growe fo neere our own homes in neucr fogreat quantitic.

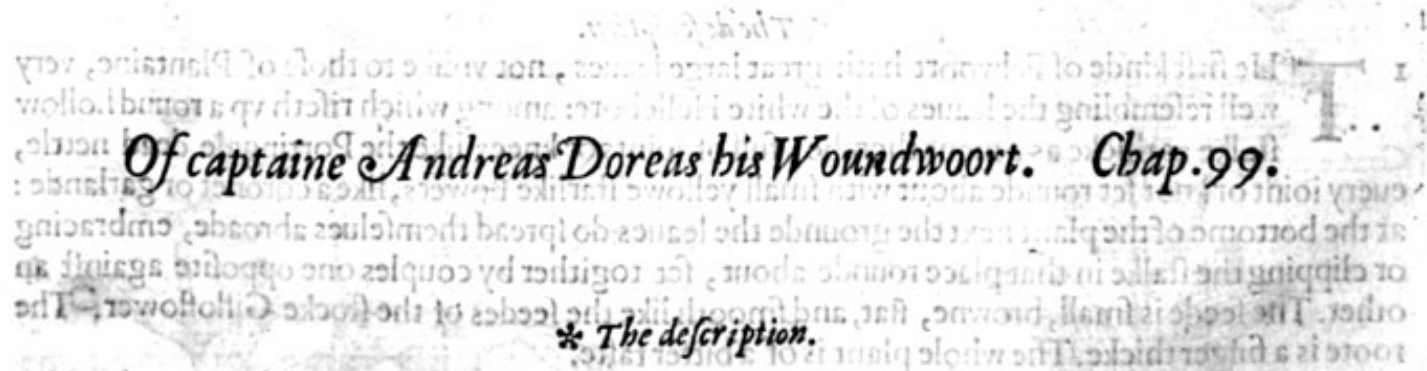

$\mathrm{T}$

His plant hath long thicke and that leaues, fharpe pointed, of a blewifh greene like vnto Woade, which being broken with the hands hath a pretie fpicie fmell. Among thefeleaues fifeth vp a ftalke of the height of a tall man, diuided at the top into many other branches, wherupon growe fmall yellowith flowers, which turne into downe that flieth away with the winde. The roote is thickealmoft like Helleboris allow.

Of which kinde there is another like the former, but that the leates are rongher, fomwhat bluntly indented at the edges, and not fo fat and grofle. 
Herba Doria L'Obeliy.

Dore.ss Woundwoort.

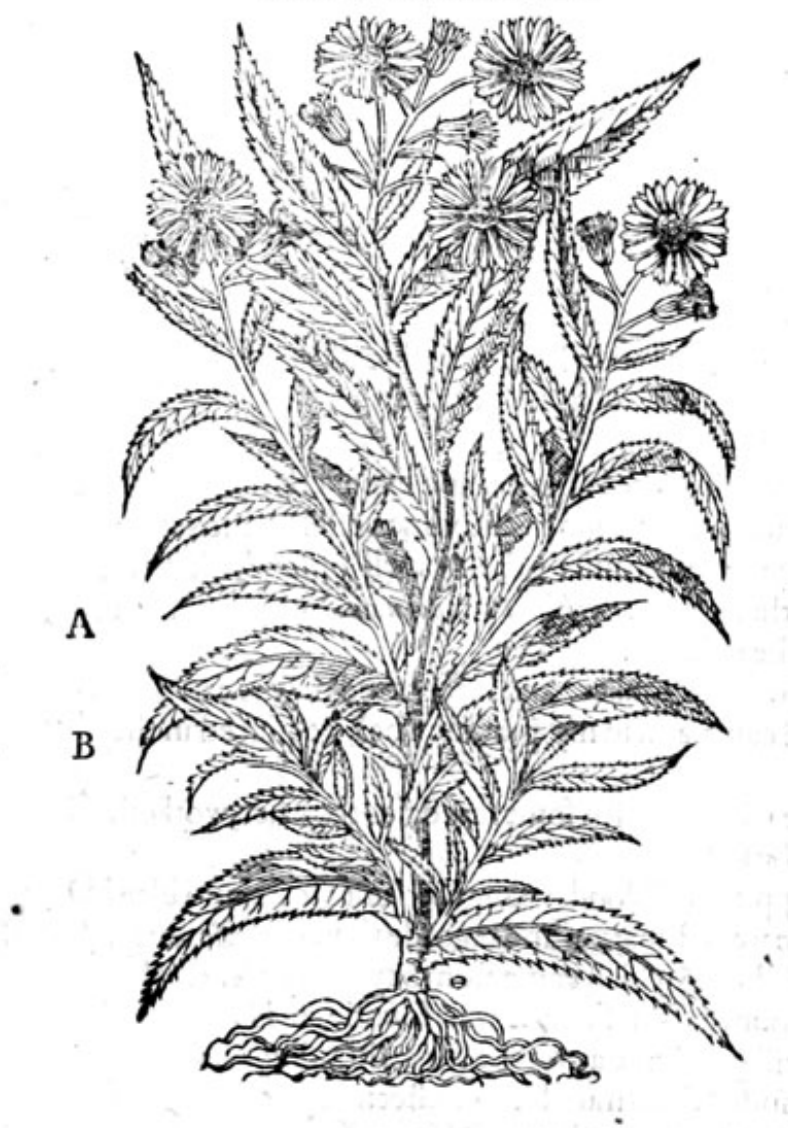

\author{
* The place.
}

Thefe plants growe naturally about the borders or brinkes of riuers neere to Narbone in Fraunce, from whence they were brought into England, and are content to be made denizons in my garden, where they flourith to the height
aforcfaide.

* The time.

They flowered in my garden about the twelfth of Iune.

\section{* The nature.}

The rootes are fweete in fmell, and hot in the third degree.

* The vertues.

Two drammes of the rootes of Her ba Doria boiled in wine and giuen to drinke, draweth down waterifh humors, and prouoketh vrine.

The fame is with good fuccefle vfed inmedicines that expell poifon.

\section{Of Felwoort, or Baldmoney. Chap.ioo.}

\section{* The kindes.}

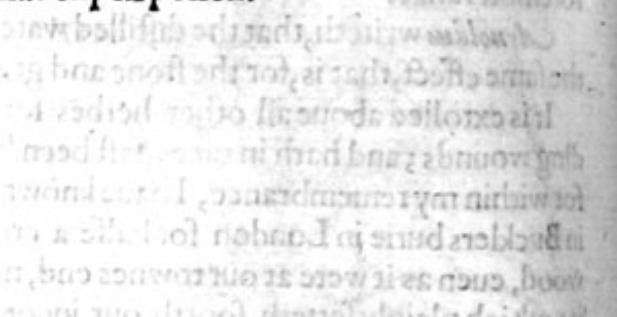

Here be diuers forts of Gentians or Felwoorts, whereof fome be of our owne countrey; others more ftrange and brought further off: and alfo fome not before this time remembred; either of the auncient or later writers, as fhall be fet foorth in this prefent chapter.

\footnotetext{
I ${ }^{-H e}$ firft kinde of Felwoort hath great large leaues, not vnlike to thofe of Plantaine, very well refembling the leaues of the white Hellebore: among which rifeth vp a round hollow ftalke asthicke as a mans thombe, full of ioints or knees like the Portingale dead nettle, every ioint or knot fet rounde about with fmall yellowe ftarlike flowers, likea coronet or garlande: at the bottome of the plant next the grounde the leaues do fpread themfelues abroade, embracing or clipping the ftalke in that place rounde about, fet togither by couples one oppofite againft an other. The feede is frnall, browne, flat, and fmooth like the feedes of the ftocke Gilloflower. The roote is a finger thicke. The whole plant is of a bitter tafte.

2 Carolus Clufus fettecth foorth an other fort of great Gentian, rifing foorth of the grounde with 2 ftiffe, firme or folide ftalke, fet with leaues like vnto $A$ /clepits, by couples one oppofite againft another euen from the bottome to the top in certaine diftances : from the bofome of the leaues there fhoote foorth fet vpon flender footeftalkes certaine long hollow flowers like bels, the mouth wherof endeth in fiue tharpe corners. The whole flower changeth many times his colour according to the foile and clymate; now and then purple or blew, fometimes whitifh, and often of the colour of afhes. The roote and feede is like the precedent. 


\section{HISTORIE OF PLANTS.}

I Gentienamaior. Great Felwoort.
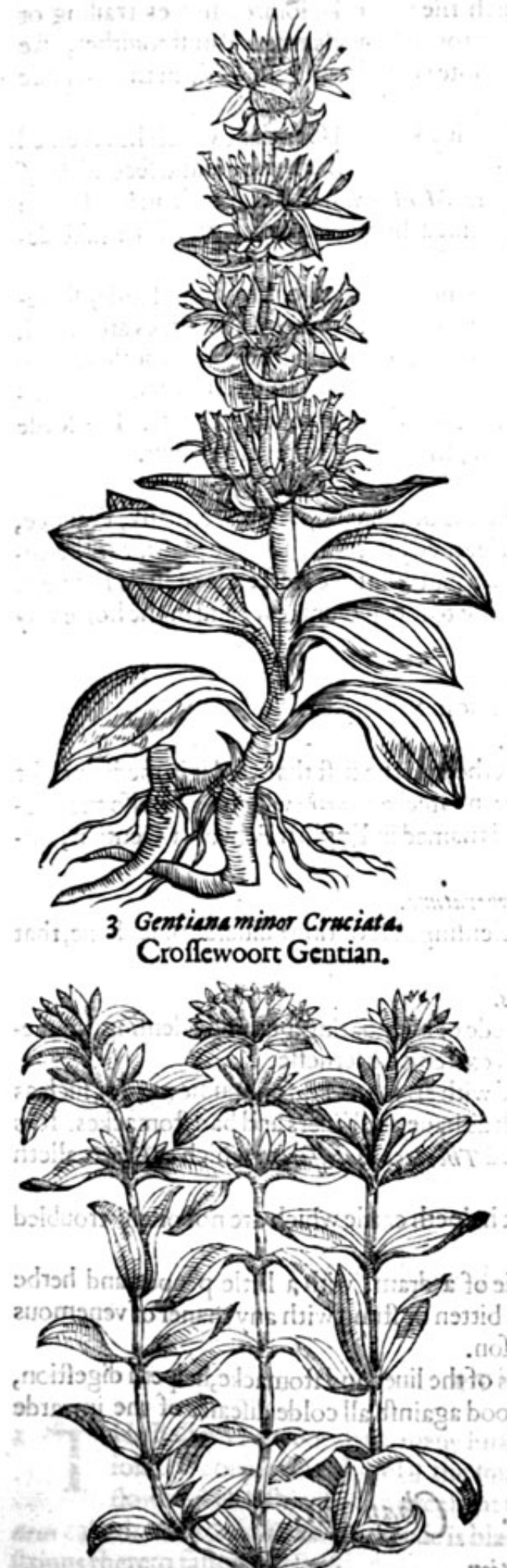

2 Gentiana maior i. Cluffiz. Purple flowred Felwoort.

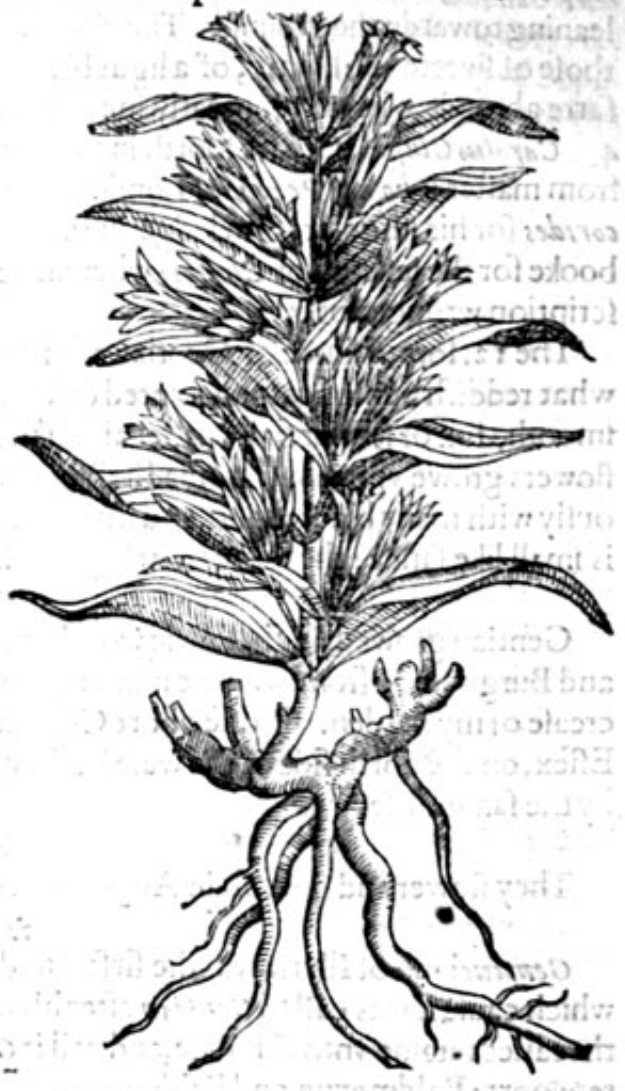

4 Gentiona Pennei minor.

Spotted Gentian of D.Pennic:

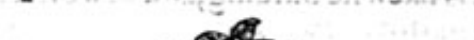

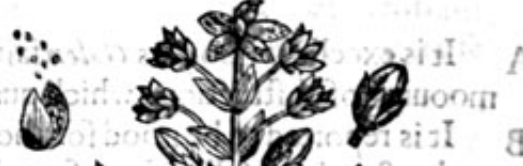

9 cov of es

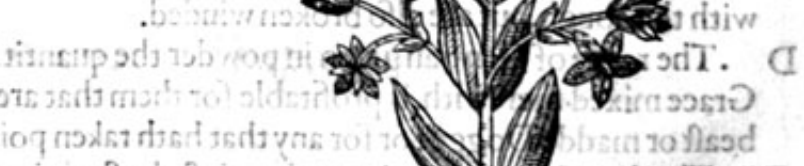


3 Croffewoort Gentian hath many ribbed leaues fpred vponthe ground, like vnto the leaules of Sopewoort, but of a blacker greene colour : among which rife vp weake iointed ftalkes trailing of leaning towarde the grounde. The flowers growe at the top in bundels thicke thruft togither, like thofe of fweete Williams, of a light blew colour. The roote is thicke, and creepeth in the grounde farre abroade, whereby it greatly increafeth.

4 Carolres Clufsus hath fet foorth in his Pannonicke hiftorie a kinde of Gentian, which he received from mafter $T$ homas P cnnic of London, doetor in Phificke of famous memorie, and a fecond Diof. corides for his fingular knowledge in Plants: which Taber Montanus hath fet foorth in his Dutch booke for the feuenth of Clufius: wherein he greatly deceiued himfelfe, and hath with a falfede. fcription wronged others.

The 1 2. fort or kinde of Gentian after Clufins, hath a rounde ftiffe ftalke, firme and folide, fomewhat reddifh at the bottom, iointed or kneed like vnto Croffewoort Gentian. The leaues are broad, fmooth, full of ribs or finewes, fet a bout the ftalkes by couples, one oppofite againft another. The flowers growe vpon fmall tender ftalkes, compact of fiue flender blewifh leaves, f potted very curioufly with many blacke fpots and little lines; hauing in the middle fiue yellowe chiues. The feede is fmall like funde: the roote is little,garnifhed with a fewe ftrings of a yellowifh colour.

$$
\text { * The place. }
$$

Gentian groweth in thadowie woods, and the mountains of Italie,Slauonia, Germany, Fraunce, and Burgundie; from whence mafter Ifaac de Laune alearned phifition, fent me plantsfor the encreafe of my garden. Croffewoort Gentian groweth in a pafture at the weft ende of little Rayne in Effex, on the north fide of the waie leading fram Braintrie to much Dunmow; and in the horfe way by the fame clofe.

\section{* The time.}

They flower and flourinh in Augult, and the feede is ripe in September. * The names.

Gentius king of Illyria was the firft founder of this herbe, and the firft that vfed it in medicine, for which caufe it was called Gentian after his owne name : in Greeke verayn : which name allo the apothecaries retaine vnto this daie, and call it Gentiana : it is named in Englifh Felwoort Gentian; Bitterwoort; Baldmoyne, and Baldmoney.

\section{* The temperature.}

The roote of Felwootc is hiot, as Dio/corides faith, clenfing or fCouring; diuers copies fiaue, that it is fikewife binding, and of a bitter tafte.

* The vertues.

A It is excellent good, as $G_{\text {alen }}$ faith, when there is neede of attenuating, purging, clenfing, and re moouing of obftruetions, which qualitie it taketh of his extreme bitternefle.

B It is reported to be good for thofe that are troubled with crampes and conuulfions; for fuch as are burft, or haue fallen from fome high place; for fuch as haue euill liuers and bad ftomackes. It is put into counterpoifons, as into the compofition named Theriaca diatefJaron: which AEtiw calleth CMysteriven, a mifterie or hid fecret.

C This is of fuch force and vertuc, faith $P$ linie, that it helpeth cattle which are not onely troubled with the cough, but are alfo broken winded.

D The roote of Gentiangiuen in powder the quantitic of a dram, with a little pepper and herbe Grace mixed therewith, is profitable for them that are bitten or ftung with any maner of venemous beaft or madde Dogge : or for any that hath taken poifon.

E The decoction drunke is good againft the ftoppings of the liuer and ftomacke, helpeth digeftion, diffolueth and fcattereth congealed bloud; and is good againft all colde difeafes of the inwarde parts.$$
\text { Of Englifh Felwoort. Chap.101. }
$$

* Thedefcription.

T Ollowe leafed Felwoort or Englifh Gentian, hath many long tough rootes, difperfed hithet and thither within the vpper cruft of the earth; from which immediately rifech a fat thicke ftalke, iointed or kneed by certaine diftances, fet at euery knot with one leafe, and fomecimes mo,kecping no certaine number: which leaues do at the firft inclofe the ftalkes round about, being 


\section{HISTORIE OF PLANTS.}

one whole and entire leafe without any incifure at all, as it were a hollowe trunke; which after it is growen to his fulnefle, breaketh in one fide or other, and becommeth a flat ribbed leafe, like vnto the great Gentian or Plantaine. The flowers come foorth of the bofome of the vpper leaues, fet vpon tender foote ftalkes, in thape like thofe of the fimall Bindweede, or rather the flowers of Sopewoort, of a whitilh colour, wafhe about the brims with a little light carnation. Then followeth the feede, which as yet I haue not obferued.

Gentiena concuas.

Hollow Felwoort.

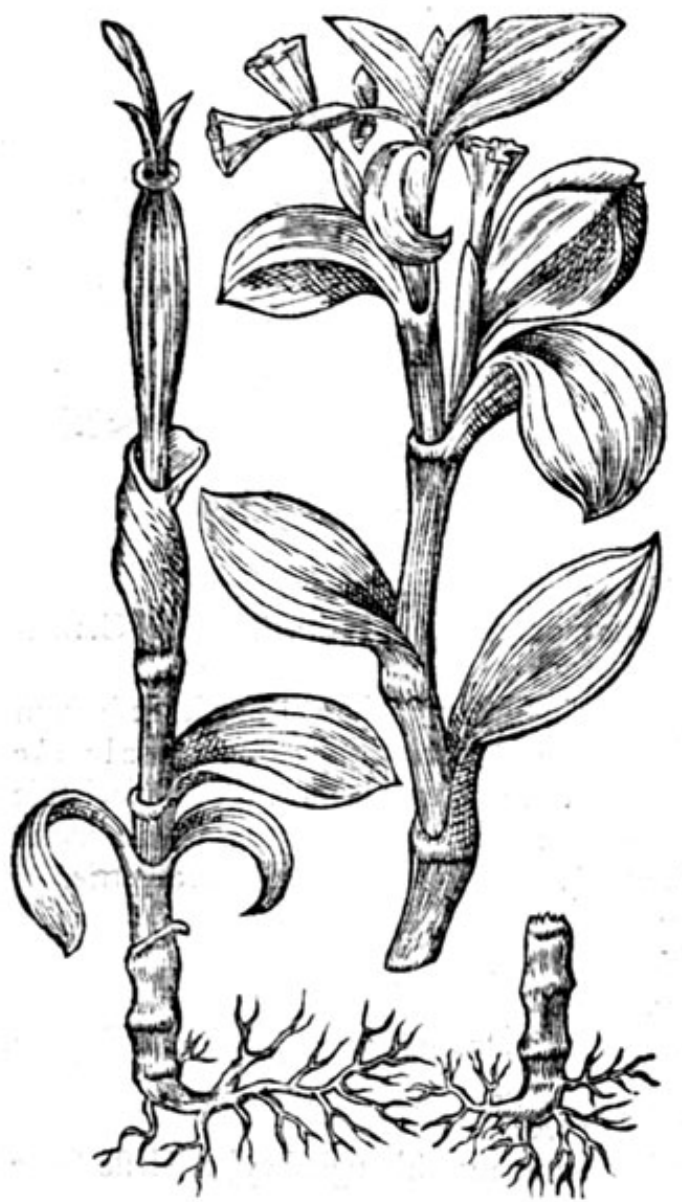

* The place.

I found this ftrange kinde of Gentian in a fmall groue of wood called the Spinnie, neere vnto a fmall village in Northampton fhire called Lichbarrow : elfewhere I haue not heard of it.

\section{* The time.}

It fpringeth foorth of the ground in Aprill, and bringeth foorth his flowers and feede in the end of Auguit.

\section{* Thenames.}

I haue thought good to giue vnto this plant; in Engliih the name Gentian,being doubtleffe 2 kinde thereof. The which hath not beene fet foorth, nor remembred by any that hath written of plants vutill this time. In Latinewe may call it Gentsana concisua, of the hollow leaues: it may be called alfo Hollow leafed Felwoort.

* The temperatwre and vertikes.

Of the faculties of this plant, as yet I can fay nothing, referring it vnto the other Gentians, vntill time fhall difclofe that, which yet is fe. crete and vnknowen.

\section{OfBaftard Felwoort. Chap.102.}

\section{* Thedefoription.}

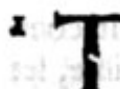
He Baftard Felwoort hath many finall tender branches, fet with many little leaves at every ioint by couples like thofe of the fmall Centorie. At the top of the italks do grow hollow flowers, bell fafhion, of an excellent faire blew colour, like vnto thofe flowers which Dodo. nens calleth Viola Calathiana. The feede is blacke, and very fmall. The roote is very little, and fome ftrings thereto faftened.

2 The fecond kind hath many little ribbed leaues, like thofe of the fmall Plantaine; among which rifeth vp a tender ftalk fet with fuch leaues by couples, as thofe were that did grow next the ground. The flowers grow at the top of the ftalkes, compa $\mathrm{Q}$ of fiue litcle leaues, of a perfect blew colour. The roote is imall and tender. 
I Gentianella Alpina xi.Clusï.

Baftard Felwoort.

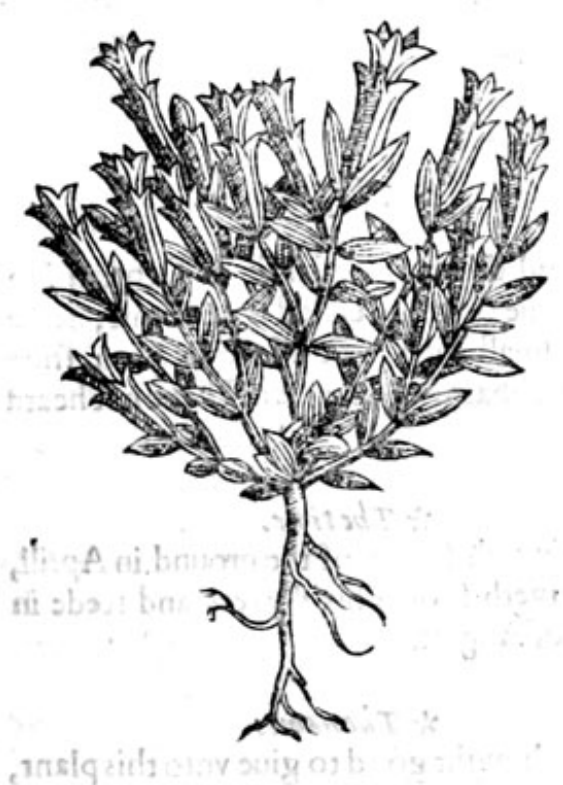

2 Gentianella Alpina verna. Alpes Felwoort of the fpring time.

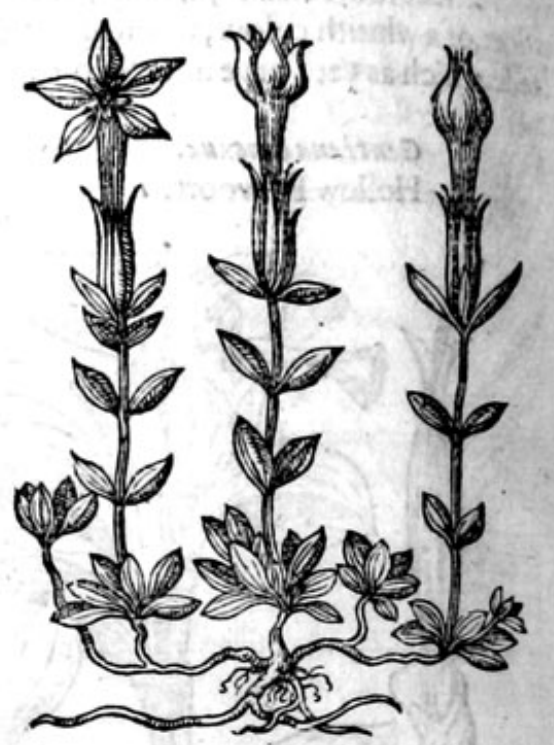

* The place.

The firft of thefe wilde Gentians doth growe vpon the mountaines of Heluetia, and of Germanie, but are ftrangers as yet in England.

The fecond groweth plentifully in Waterdowne foreft in Suffex, in the way that leadech from Charlewoodes lodge vnto a houfe of the Lord of Abergauenie, called Eridge houfe, by a brooke fide there, efpecially vpon a heath by Colbrooke neere London; on the plaine of Salisburie, harde by the turning from the faide plaine vnto the right honorable the Lorde of Pembrookes houfe at Wilton, and vpon a chalkie banke in the high waie betweene Saint Albons and Goramberrie. $*$ The time.

They flower and tourith from Auguft to the ende of Oetober.

\section{* The names.}

Their is as much faide in the title touching their names, as is extant in writing, afwell in Englith as Latinc.

* The temperature and vertues.

There faculties in working are referred vnto the other Gentians, although they be of leffe force and bitterneffe.

\section{Of Calatbian Violet, or Autumne bell flower. Chap.io3.}

$$
\text { * The defcription. }
$$
A Mong the number of the bafe Gentians there is a fmall plant, which is late before it com meth vp, hauing ftalks a fpan high, and fometimes higher, narrowe leaues like vnto Tine, fet by couples about the ftalkes by certaine diftances: long hollowe flowers growing at the top of the ftalkes, like a cup called a Beaker, wide at the top, and narrower towarde the bottome, of a deepe blewe colour tending to purple, with certaine white threds or chiues in the bottome; the flower at the mouth or brim is fiuc cornered before it be opened, but when it is opened it ap pecreth with fine cliftes or pleates. The wholc plant is of a bitter tafte, which plainly fheweth it to be akinde of wilde Gentian. The rootc is fmall, and perifheth when it hath perfected his feede, and recotereth it fele by falling of the fame 
Pnesomonanthe. Calathian Violet.

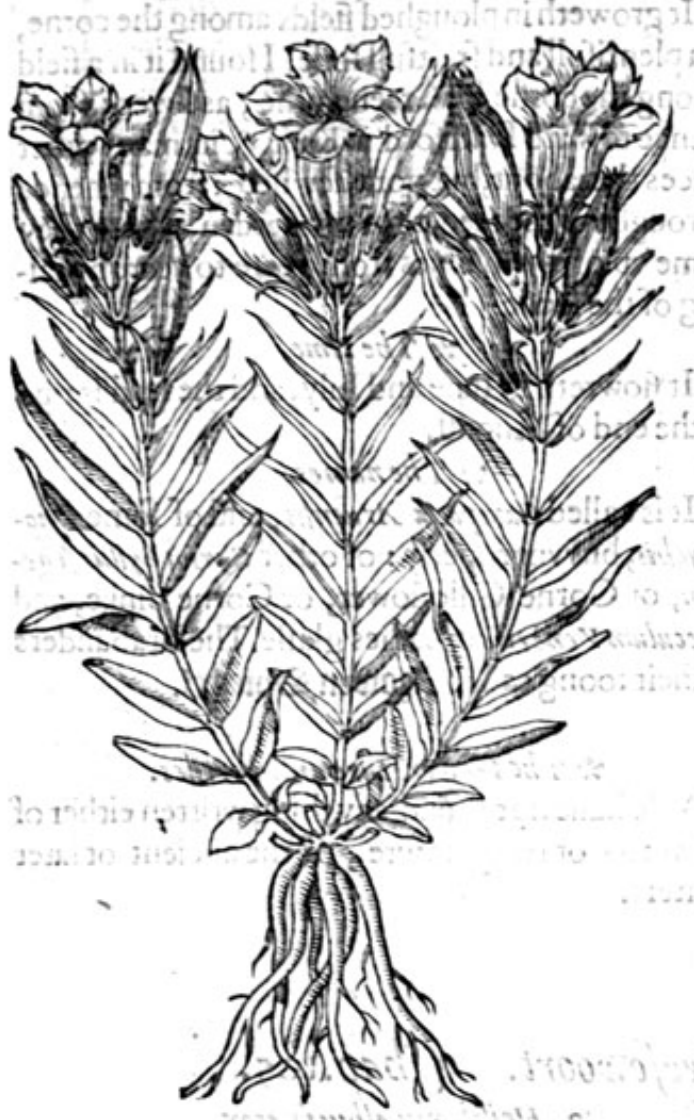

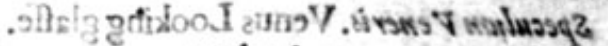
*T Theplace.

It is founde fometimes in meadowes, oftentimes in vntilled places. It groweth ypon Long. fielde downes in Kent, necrevnto a village called Longfielde by Granefende; vpon the chalkie cliffes neere Greene-Hytho \& Oobhat injent, and many other places. It Tikewi e grolveth as you ride from Stigar loafe hillvino Bande, in the weft countrey.

\section{*The time}

The gallant flowers heefeof be intheir bituerie abour the end of Augutt, andin September.

$$
* \text { The nampes. }
$$

There is great ambiguitie in the words of Plinie and Kuellius, which Ido nof intende to repeat, bicaufe they dotather confounde the memorie, then bring any profite to the Reader. They compare the yellow Marigold, wivith the blew or azured Calathian Violet, which are no more like, then things that are moft vnlike. Notwithftanding, for the better fatisfying of the curious Reader, I hall deliter vnto you the wordes of Ruelliws. Calathian Violet is the gift of Autumne: the other Violets are of the fpring, it hath, faith he, (and that truely) a little leafe, not vnlike to that of the fmall ftocke gilloflower aleg gither without finell. The flower is like a litele bell cuppe, growing onely in Autumne, of fobbetistifull a colour, that it paffeth the veryblewe it felfe. By which words we may gather, it can be nokinde of yellowe Marigolde as Plinywoulde haue it. It is called $V$ iola Autumnalis, or Auturnie Violet, and feemeth to be the fame that Valerisus Cordsus doth call P neumonant he, which he faith is named in the Germain toong $\mathcal{L}$ ungen blumen, or Lung flower : in Englifh Autumne bell flowers, Calathian violets, and of fome Harueft bels.

\section{* The temperature.}

This wilde Felwoort or Violet, is in temperature hot, fomewhac like in facultie to Gehtian, wherof it is a kinde, but farre weaker in operation.

\section{* The vertwes.}

The latter Phifitions hold it to be effectuall againft peftilent difeafes, and the bitings andfting- A ings of venemous beafts.

\section{Of Venus Looking glaffe. Chap.104. * The defcription.}

B Efides the former Bell-flowers, there is likewife a certaine other, which is low and little; the ftalks whereof are tender, two lpans long,diuided into many branches moft commonly lying vpon the ground. The leaues about the ftalkes are little, flightly nicked in theedges. The flowers are very fmall, of a bright purple colour tending blewneffe very beautifull, with wide mouthes like brode bels, hauing a white chiuc or thred in the middle. The flowers in the day time are wide open, and about the fetting of the funne are fhut $\mathrm{vp}$ and clofed faft togither, in fiue corners, as they are before their firft opening, and as the other Bell flowers are. The rootes be very flender, and perilh when they haue perfected their feed. 


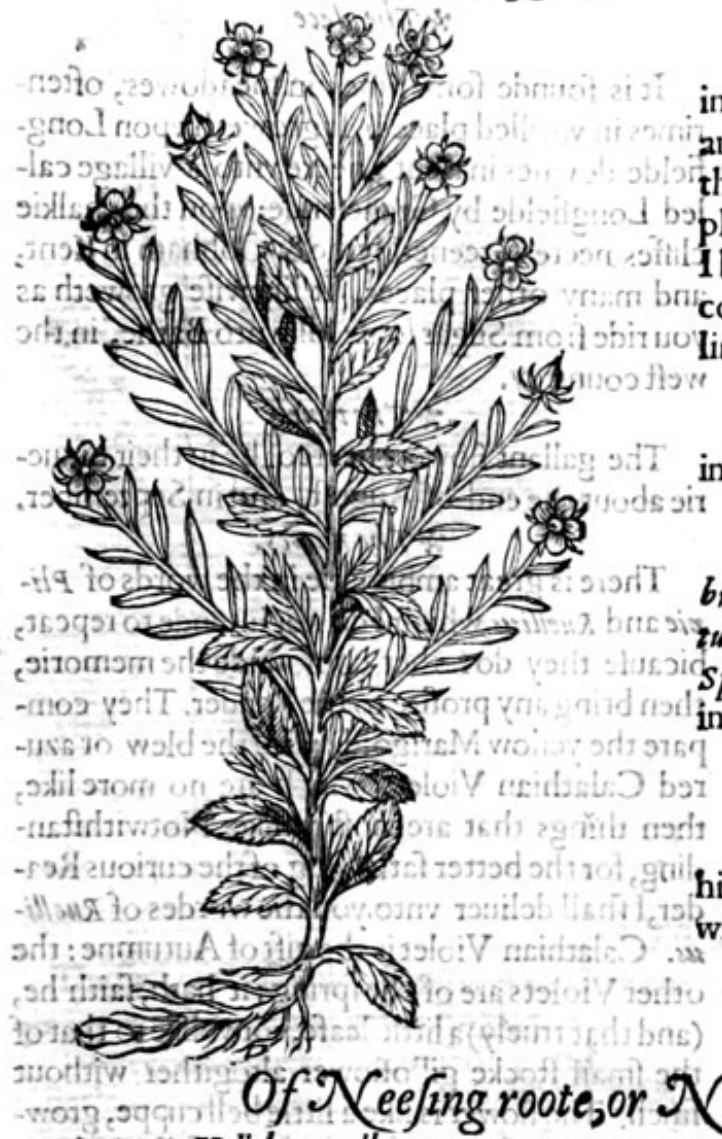

wolos a 1 Helleborms albus.

hutisy to White Hellebor.

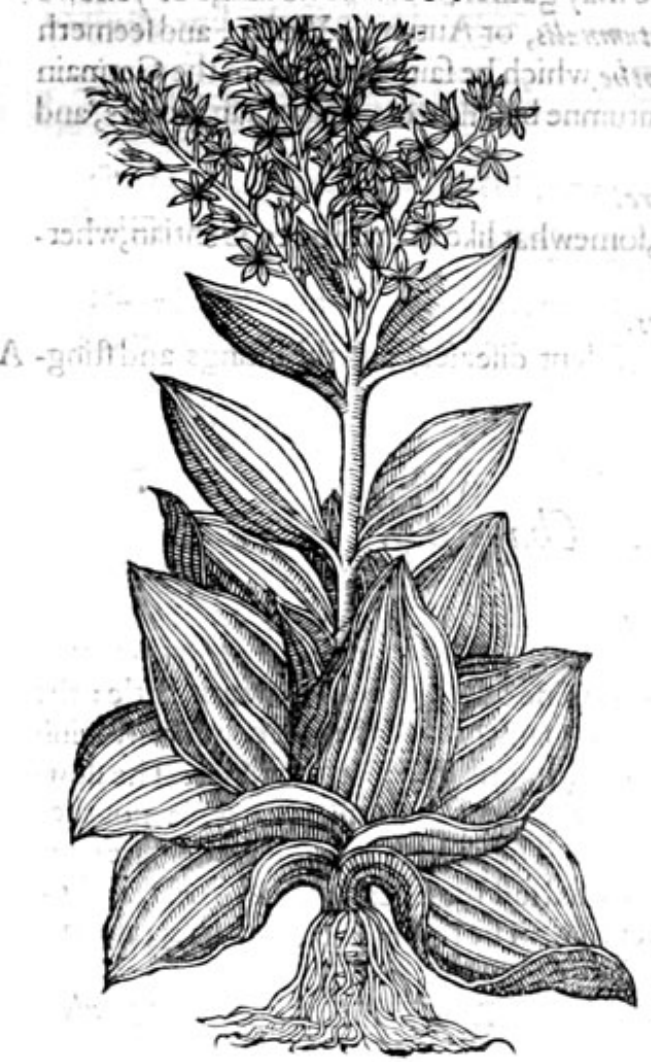

BOOKE OFITHE

sdriantukenang

* Theplace irlus (5.D

It groweth in ploughed fields among the corne, in a plentifull and fruitfull foile. I found it in a field among the corne by Greenehithe, as I went from thence toward Dartford in Kent, \& in many other places therabout, but not elfewhere : from whence 1 brought of the feedes for my garden, where they come vp of themfelues from yeere to yeere by fal. ling of the feede.

It $*$ The time.

It flowreth in Iune and Iuly, and the feed is ripe in the end of Auguit.

* Thenames.

It is called Campana Arwen fis, and of fome Ono. brychis, but vnproperly : of other Cariophylles /egezum, or Corne Gilloflower, or Corne pinke, and Speculum Veneris, or Ladies glaffe. The Brabanders in their toong call it đzabem Spiegel.

\section{7.}

* The temperatare and vertues.

We haue not found any thing written either of his vertue or temperature, of the ancient or later writers. 


\section{ZH ISTORIE OF PLANTS.}

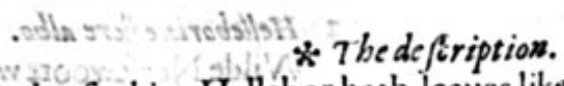

1

IIt)

to be laide vp in a cheft; among thefe leaues rifeth vp a ftalke cubite long, fet towardes the top full of little ftarlike flowers, of an herbie greene colour tending to whiteneffe; which being paft there come fimall huskes containing the feede. The roote is great and thicke, with many finall threds hanging thereat.

2 The fecond kinde is very like the firft, and differeth in that, that this hath black reddifh flowers, and commeth to flowring before the other kinde, and feldome in my garden commeth to feeding.

$$
\text { * The place. }
$$

The white Hellebor groweth on the Alpes, and fuch like mountaines where Gentian doth grow. It was reported vnto me by the Bifhop of Norwich, that white Hellebor groweth in a wood of his owne necre to his houfe at Norwich. Some fay likewife that it doth growe vpon the mountaines of Wales; I peake this vpon report, yet I thinke not, but that it may be true. Howbeit Idare affure you, that they grow in my garden at London, where the firit kinde flowreth and feedeth very well.

The firft flowreth in Iune, and the fecond in May. $* 7$ be names.

Neefewoort is called in Greeke imascoess $\lambda d x \partial_{s}:$ in Latine Veratrum album, Helleborsus albus, and

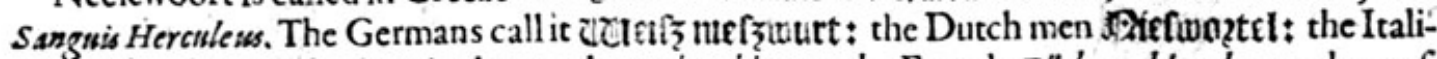
ans Elleborobianco: the Spaniardes Verd: gimbre blanco: the French Ellebore blanche: and we of England call it white Hellebor, Niefwoort, Lingwoort, and the roote Neefing powder.

$$
\text { * Thetemperature. }
$$

The roote of white Hellebor, is hot and drie in the thirde degree.

$$
* \text { The vertues. }
$$

The roote of white Hellebor procureth vomite mightely, wherein confifteth his chiefe vertue, A and by that meancs voidech all fuperfluous flime and naughtie humours. It is good againft the falling ficknes, phrenfies, fciatica, dropfies, poifon, and againft all colde difeafes that be of hard curation, and will not yceld to any gentle medicine.

This ftrong medicine made of white Hellebor, ought not to be giuen inwardly vrito delicate $\mathbf{B}$ bodics withiout great correetion, but it may mote fafely be gituen vnto countrie people which feede groffely, and haue hard, tough, and ftrong bodies.

The roote of Hellebor cut in fmall peeces, fuch as may aptly and conueniently be conueied into $\mathbf{C}$ the Fiftulaes doth mundific them, $S$ taketh away the callous matter which hindereth the curation, and afterward may be healed vp with fome incarnatiue vnguent, fit for the purpofe.

The powder drawen vp into the nofe caufeth freefing, and purgeth the braine from groffe and D flimic humours.

The roote giuen to drinke in the waight of two pence, taketh awaie the fits of agues, killeth $\mathbf{E}$ mice and rattes being made vp with honie and flower of wheate : Plenie addeth that it is a medicine againft the Lowfie euill.

\section{Of wilde white Hellebor. Chap.106.}

\section{* The defription.}

I. HElleborine is like vnto white Hellebore, and for that caufe we haue giuen it the name of Hellebcrine: it hath a ftraight ftalke of a foote high, fet from the bottome to the tuft of flowers, with faire leaues, ribbed and chamfered like thofe of white Hellebor, of a darke greene colour.The flowers be orderly placed from the middle to the toppe of the ftalke, hollowe within, and white of colour, ftraked heere and there with a dafh of purple, in fhape like the flowers of Satirion. The feede is finall like duft or motes in the funne. The roote is imall, full of iuice, and bitter in tafte.

2 The feconde is like vn'o the firft, but altogither greater, and the flowers white, without any mixture at all, wherein confifteth the difference. 
I Helleborine.

Wilde white Hellebor.

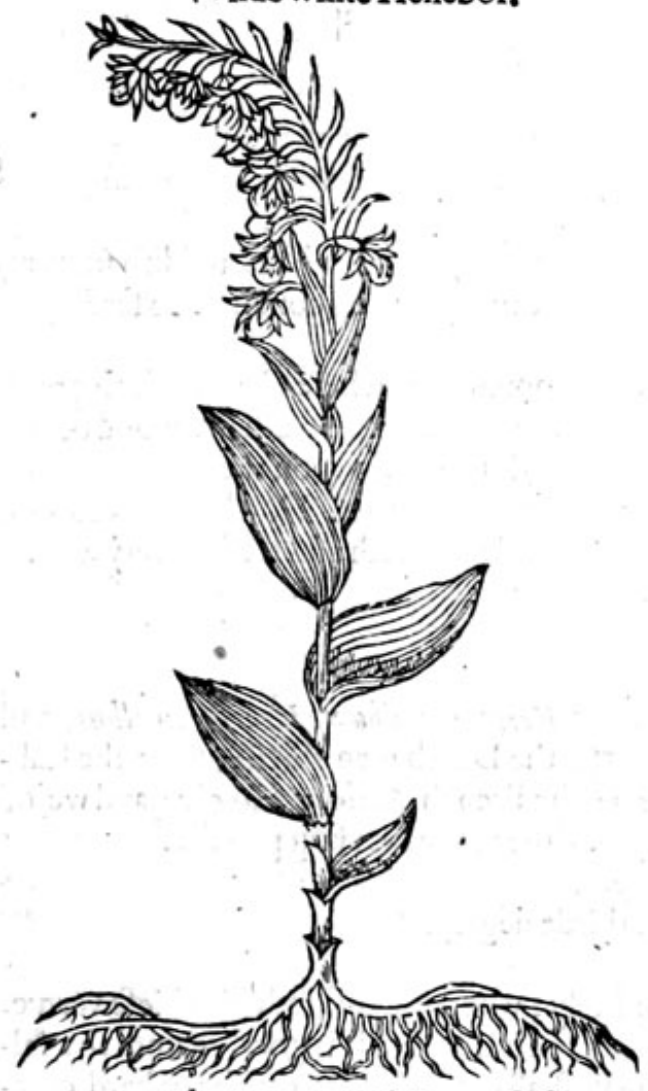

3 Helleborine anguftifolia 5. Clusfin.

Narrow leafed wilde Neefewoort.

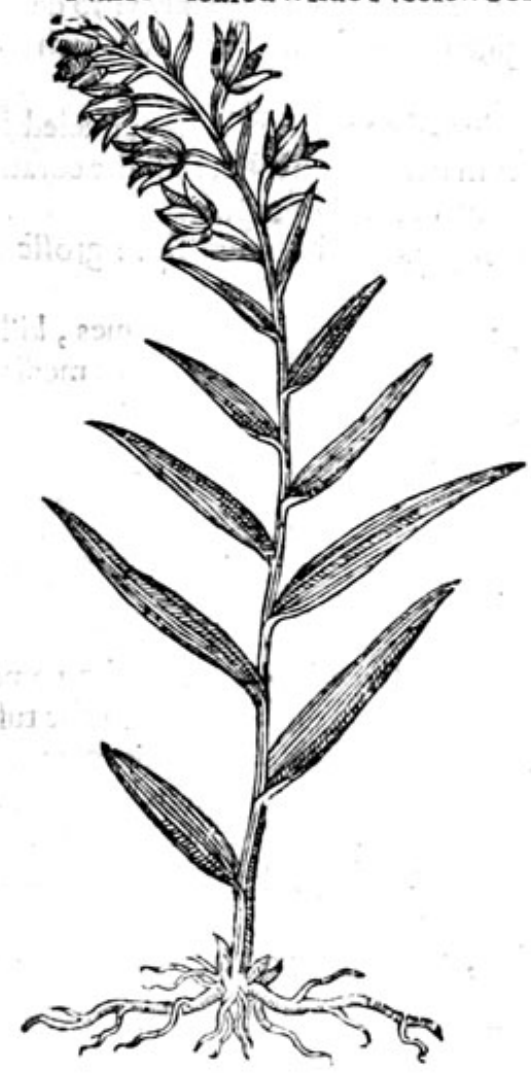

2 Helleborine fore albo. Wilde Neefewoort with white flowers.

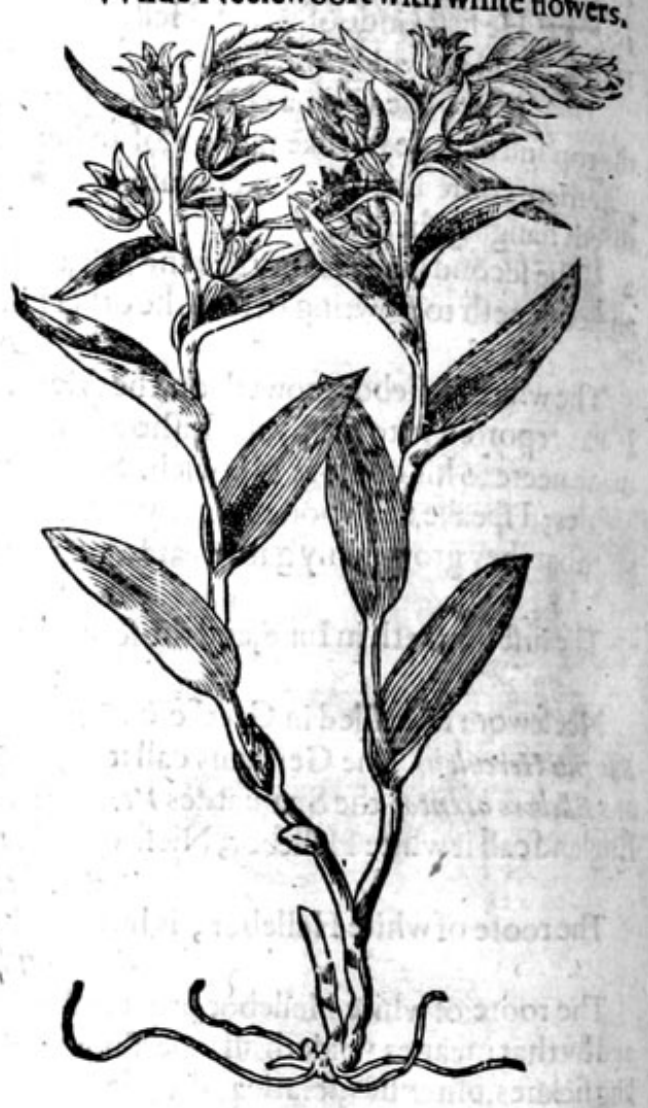

* The defcription.

3 The thirde kinde of Helleborine, being the fift after $C \ln$ frus account, hath leaues like the firft defcribed, but fmaller and narrower. The ftalke rifeth vp to the height of two fpans; at the top whereof growe faire thining purple coloured flowers, confifting of fixe little leaues, within or anong which liech hid, things like fmall helmets. The plant in proportion is like the other of his kinde. The roote is fmall and creepeth in the ground. $* 7$ be place.

They be founde in dankifh and thadowie places: the firft was found growing in the woods by Digges well paftures, halfe a mile from Welwen in Hartfordhire: it groweth in a woode fiue miles from London, neere vnto a bridge called Lockbridge: by Nottingham neerc to Robinhoode his well, where my friend mafter Stewen Bredwell a learned phiftion founde the fame: in the woods by Dunmowe in Ef fex: by Southfleete in Kent ; in a little groue of Iuniper, and in a woode by Clare in Effex.

$$
\text { to The time. }
$$

They flower in Maie and lune, and perfect their feede in Augurt.

* The names.

The likeneffe that it hath with white Hellebor, doth 
doth fhewe it may not inproperly be hamed Helleborine, or wilde white,Hellebor, which is alfocalled of Diofcorides and Plinie imraxts on Epipact is; but from whence that name came it is 'not apparent, it is alfo named disis.

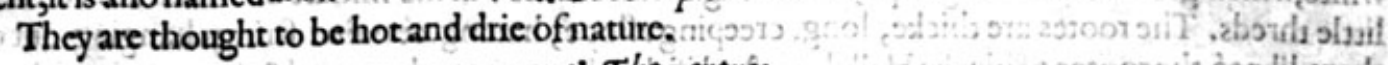

250 * The vertues.

The faculties of thefe wilde Hellebors are referred vnto the white Neefewoort, wherefofthey A are kindes.

It is reported, that the decoction of wilde Hellebor drunken, openeth the ftoppings of the liuer, B or helpeth any imperfections of the fame.

\section{Ofour Ladies Slipper. Chap.107.}

Calceolus Marie. $\div$

Our Ladies Slipper.

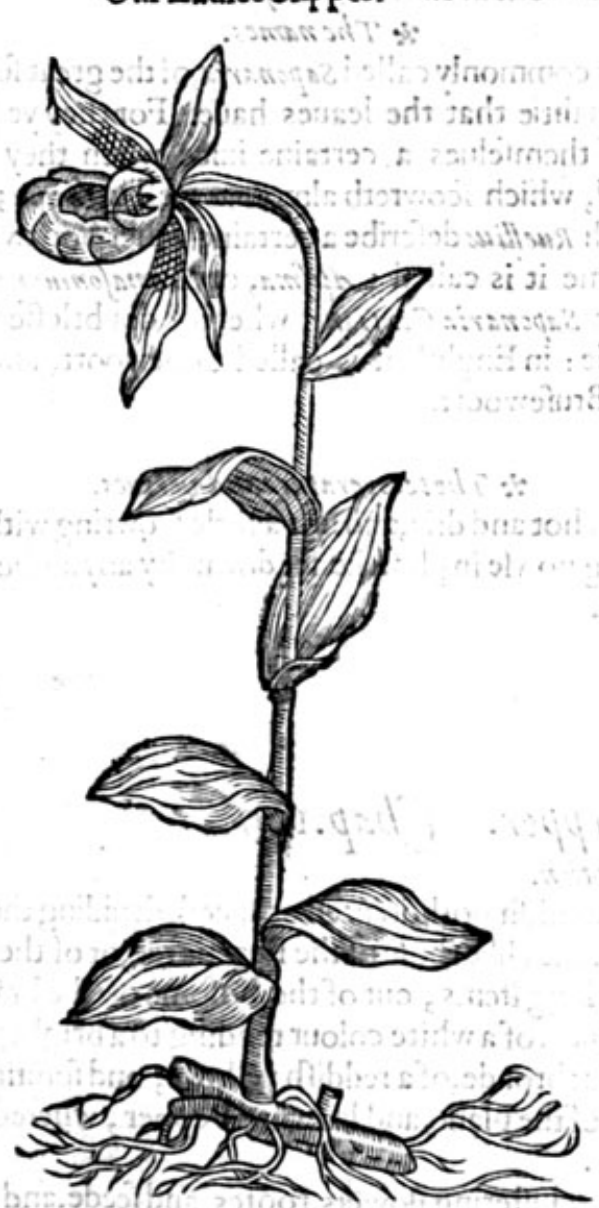

* Thedefription.

Vr Ladies Shooe or Slipper, hath 2 thicke knobbed roote, with certaine markes or notes vpon the fame, fuch as the rootes of Salamons Seale haue, but much leffer, creeping within the vpper cruft of the ground; from which rifeth vp a ftiffe and hairie italke a foote high, fet by certaine fpaces, with faire broad leates, ribbed with the like finewes or nerues, as thofe of the Plantaine. At the top of the ftalke groweth one fingle flower, feldome two, fafhioned on the one fide like an egge; on the other fice it is open,emptie, and hollow, and of the forme of a hoo or flip. per, whereofit tooke his name : of a yellow colour on the outfide, and of a fhining deepe yellow on the infide. The middle part is compaffed about with fower leaues, of a bright purple colour, often of a light red, or obfcure crimfon, and fometimes yellow as is the middle part, which in fhape is like an egge,as aforefaid.

\section{* The place.}

Ladies Slipper groweth vpon the mountaines of Germanie,Hungaric,and Poland. I haue a plant there of in my garden, which I receitued frotn $\mathrm{Ma}$. fter Garret Apothecarie my very good friend. * The time.

It flowreth about the middeft of Iune. * The names.

It is commonly called calceoles D. Marie, and Marianus: of fome Calceolus Sacerdotis : of fome Alifma but vnproperly : in Englifh our Ladies hhoo or Slipper : in the Germaine toong 1 peaffin Qcbuetb, Papen feoen: and of fome Damafonum not biom.

* The temperature and vertues.

Touching the faculties of our Ladies (hoo, wee haue nothing to write, being not fufficiently knowne to the old writers, no nor to the new.

$$
\text { Of Sopewoort Chap.108. }
$$

* The defription.

He ftalkes of Sopewoort are lipperie, flender, round, iointed, a cubite high or higher: the leaues be broad fet with vaines, very like broad leafed Plantaine, but yet leffer, ftanding out of euery ioint by couples for the moft part, and efpecially thofe that are che neereft to the 
rootes bowing backwardes. The flowers in the top of the ftalks, and about the vppermoft ioints are many, well fmelliñg, fometimes of a beautifull red colour like a Rofe, otherwhile of a light purple ot white, which growe out of long cups, confifting of fiue leaues : in the middle of which are certaine little threds. The rootes are thicke, long, creeping aflope, hauing certaine ftrings hanging out of them, like to the rootes of blacke Hellebor. And if they haue once taken good \& fure rooting in any ground, it is impoffible to deftroy them.

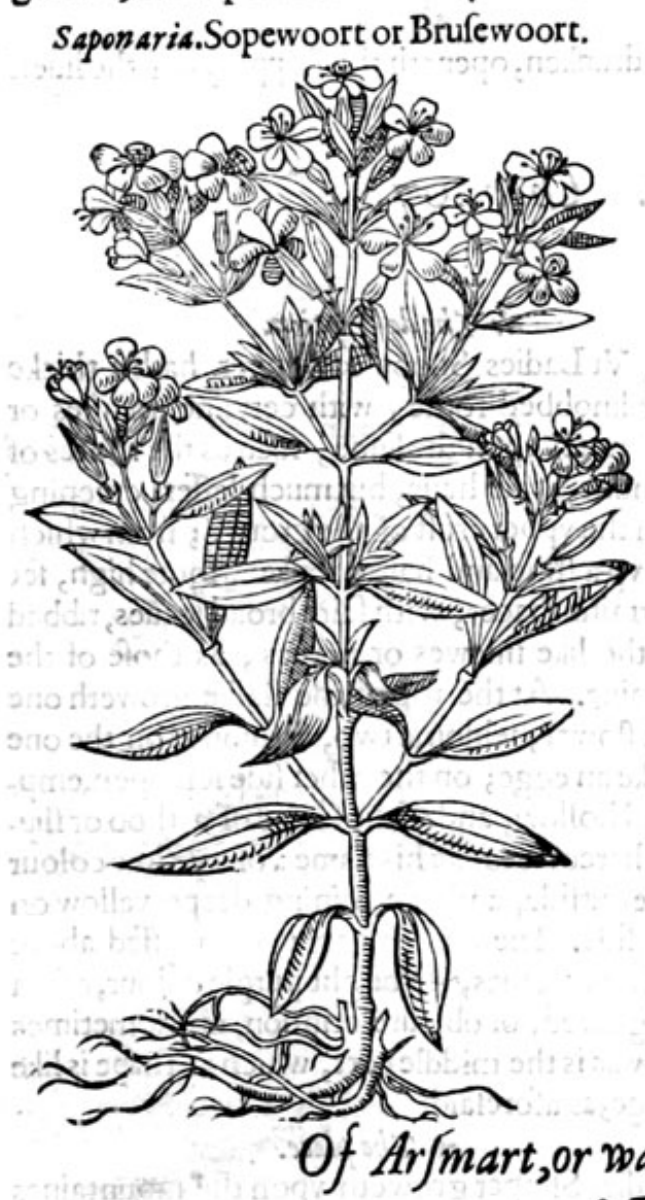

$$
\text { * Theplace. }
$$

It is planted in gardens for the flowers fake, to the decking vp of houles, for the which purpofe it chiefly ferueth. It groweth wilde of it felfe neere to rivers and running brookes in funnic places.

$$
\begin{gathered}
* \text { The time. unlossino } \\
\text { It flowreth in Iune and Iuly. } \\
* \text { The nomes. }
\end{gathered}
$$

It is commonly called saponaria, of the great fouring qualitie that the leaues haule. Forthey yeclde out of themfelues a certaine iuice when they ate brufed, which fcowreth almoft as well as Sope; 2lthough Ruellises defcribe a certaine other Sopewort. Of fome it is called Ualifma, or Damafonium : of others Saponaria Gentiana, whereof doubtleffe itis a kinde : in Englifh it is called Sopewoort, and of fome Brufewoort.

* The temperature and vertues.

It is hot and drie, and not a little fcowring withal, hauing no vfe in phificke fet downe by any author of credit.

'A * The defcription.

A Rfmart bringeth foorth ftalks a cubite high,round, fmooth,iointed or kneed, deuiding themfelues into many braunches: whereon grow leaues like thofe of the Peach tree, or of thefitlow tree. The flowers growe in clufters vpon long ftems, out of the bofome of the brannches and leaues, and likewife vpon the ftalkes themfelues, of a white colour tending to a brightpurple : after which commeth foorth little feeds fomewhat broade, of a reddifh yellowe, and fomtimes blackifh,of a fharpe and biting tafte, as is all the reft of the plant, and like vnto Pepper, whereof it tooke his name; yet hath it no fmell at all.

2 Dead Arfmart is like vnto the precedent in ftalks, cluftering flowers, rootes, and feede, and differeth in that, that this plant hath certaine fpots or markes vpon the leaues, in fafhion of a halfe moone, of the colour of lead. The roote is fmall and threddie: the whole plant hath no tharpe or biting tafte as the other hath, but as it were a little fower fmacke vpon the toong. The roote is likewife full of ftrings or threds.

3 There is (faith L'obeliss) a kindeof Perficaria growing in Germanie and Sauoy, which I have named Nolime tangere, touch me not: the reafon of the name is, faith he, bicaufe it hath the forme of Mercurie, the feede of $B$ alfamina, and the purple flowers of Larks heele; all which are moft whotfome herbes both for meate and medicine : and contrariwife this plant carying the face of wholfome herbes, is moft venemous and deadly. Therefore, faith he, take this note by theway, 2Noli mot tangere, touch me not, that is, haue fpecial regard, that in gathering of thefe wholfomeherbes, this peftilent herbe be auoided. 


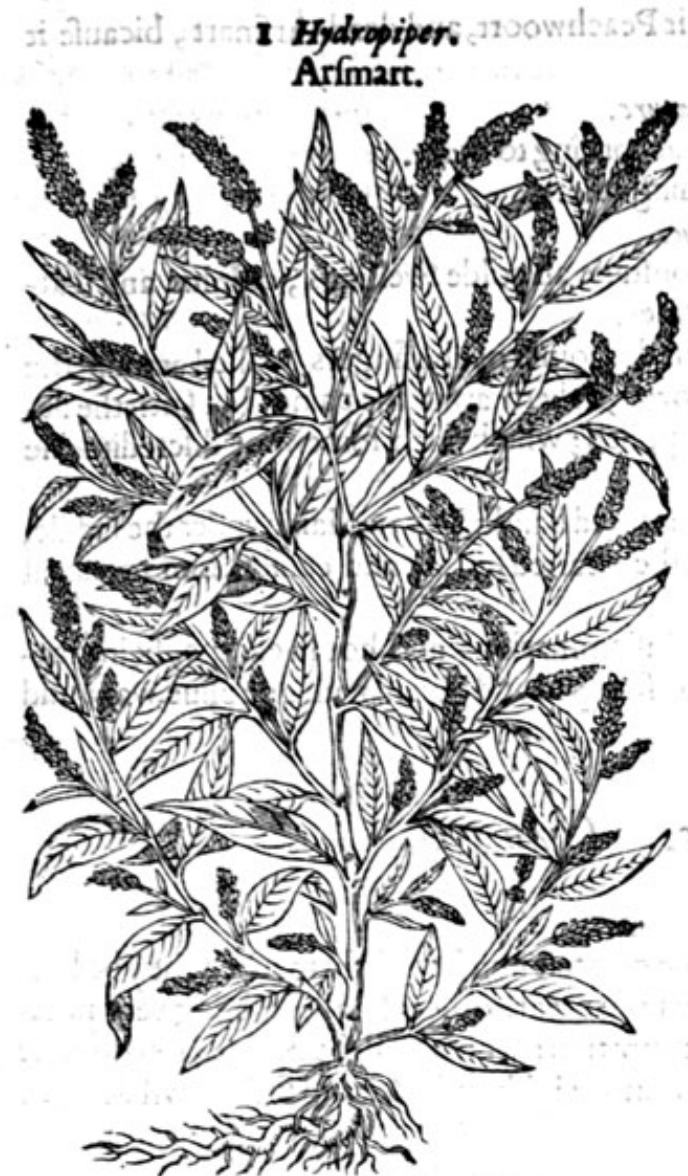

3 Perficaria fligenofa. Codded Arrmart.

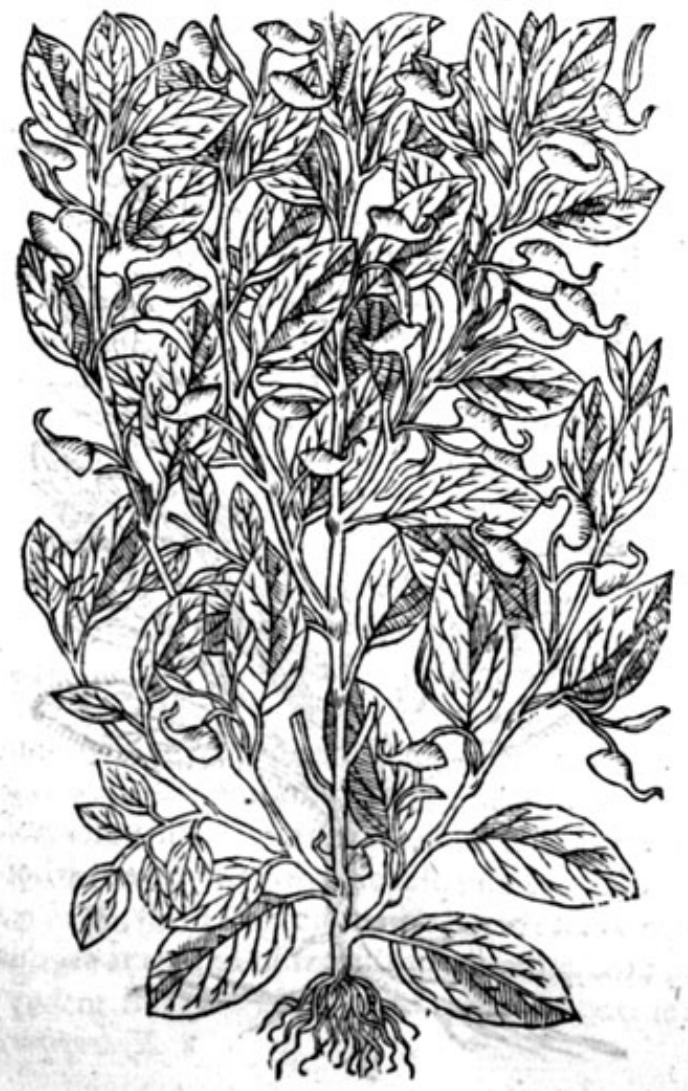

2 Perfearia waculoga. id ail bowarh? Dead Arfmart. o to sjod ton ditob

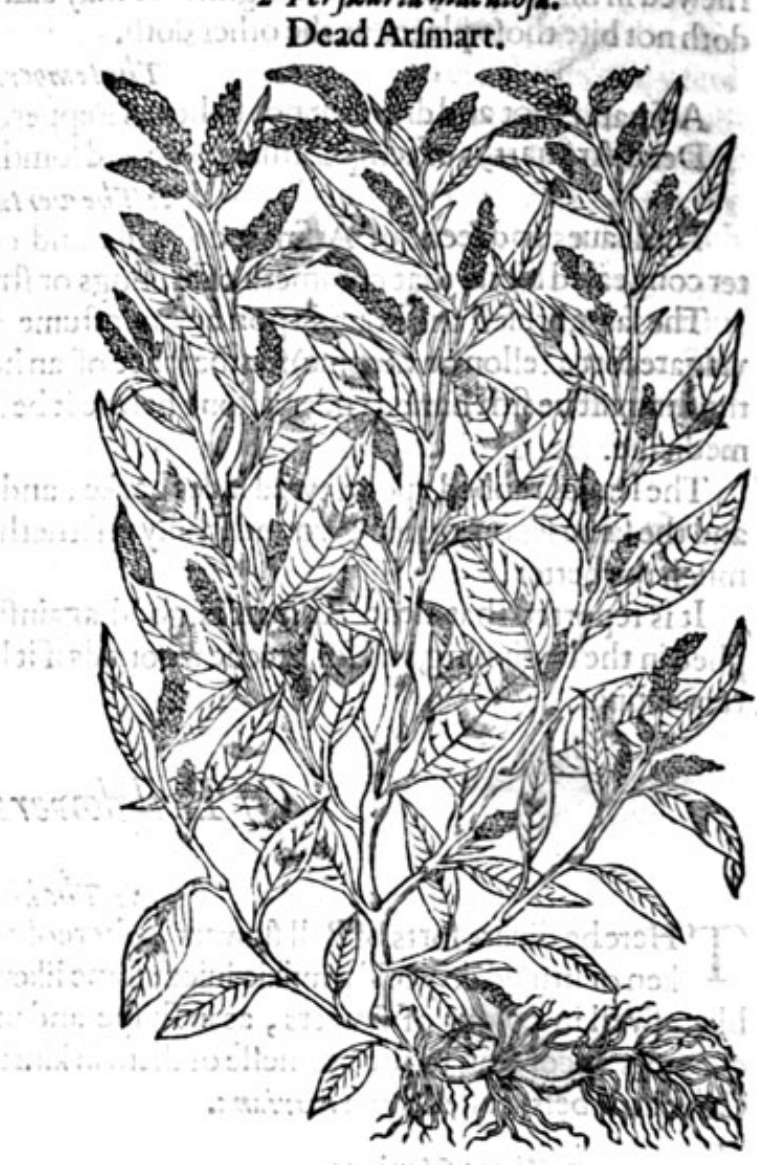

* Theplace.
They gowe very common almoft every where in moift and waterifh plafhes, and neere to the brims of riuers, ditches, and running brookes. $*$ The time.

They flower from the beginning of Iune to the ende of Auguft.

$$
\text { * The names. }
$$

Arfmart is called in Greeke v'semines: of the Latines Hydropiper, or P iper aquaticum, or Aguatile, or water Pepper : in high Dutch velaffet jofeffer : in lowe Dutch eduater Jeeper: in French Curage, or Culrage: in Spanifh Piments aquatica : in Englifh Water Pepper, Culrage, and Arfmart, according to his operation and effect, when it is vfed in thofe parts.

Dead Arfmart is called Perficaris, or Peachwoort, of the likeneffe that the leaues haue with thofe of the Peach tree. It hath beene called Plumbago of the leaden coloured markes which are feene vpon the leaues: but Plinie would haue it called Plumbago, not of the colour, but rather of the effect, by reafon that it helpeth the infirmitic of the eies called Plimbum : yet there is an other Plumbago of Plinies defcription, as f hall be 
Thewed in his proper place: in Englifh we may call it Peachwoort, zondidead Arfmart, bicaufe it doth not bite thofe places as the other doth.

Arfmart is hot and drie : yet not fo hot as Pepper, according to Galen.

Dead Arfmart, is of temperature colde and fomthing drie.

\author{
* The vertwes.
}

The leaues and feede of Arfmart do wafte and confume all colde fwellings, diffolue and fcat ter congealed bloud that commeth of brufings or ftripes.

The fame brufed and bound vpon an impottume in the ioints of the fingers (called among the vulgare fort a fellon or vncome)for the fpace of an hower, taketh away the paine: but faith the aut thor, itmuft be firft buried vnder a ftone before it be applied; which doth fomewhat diffredite the medicine.

The leaues rubbed vpon a tyred iades backe, and a good handfull or two laide vnder the faddle, and the fame fet on againe, woonderfully referheth the wearied horfe, and caufeth him torrauell much the better.

It is reported that dead Arfmart is good againft inflammations and hot fwellings, being applied in the beginning, and for greene woounds if it be ftamped and boiled with oile oliue, waxe and turpentine.

\title{
OfBellflowers. Chap.110.
}

* The kindes.

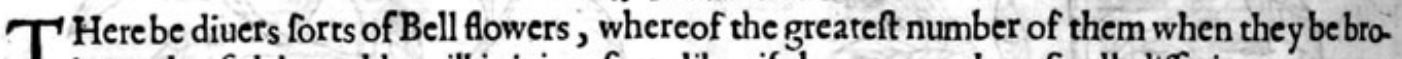
ken or brufed do yeeld a milkie iuice: fome likewife be great, others fmall; differing very notz. blie afwell in colour of flowers, as in hape and proportion: which fhall be deuided into fundrie chapters, according to the neerneffe of them in kinred and neighbourhood: and firft we wil defcribe Couentrie bels, called Viola mariana.
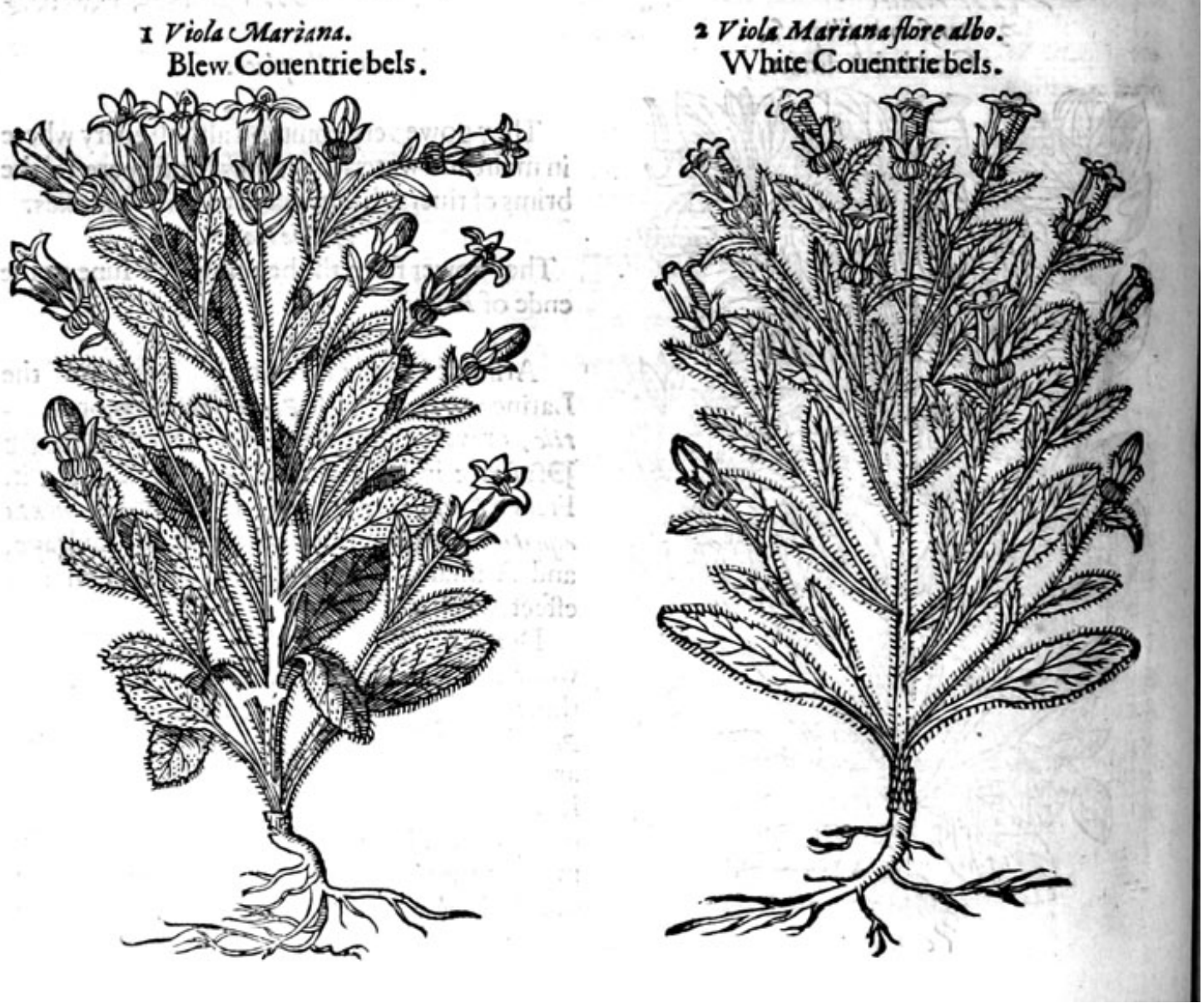
*. $T$ be defcripsion $>$

Outentrie bels hath broade leaucs, rough and hairie, not vnlike to thofe of the garden Bugloffe, of a fivart greene colour : among which do rife ftiffe hairie ftalkes, the fecond yecre after the fowing of the feede, which ftalke deuideth it felfe into fundrie braunches, whereupon doe growe many faire and pleafant Bell flowers, long, hollowe, and cut on the brim with fite fleight gafhes, ending in fiue corners toward night when the flower fhutteth it felfe vp, as do the molt of the Bell flowers : in the middle of the flowers be three or fower whitifh chiues, as alfo much downy haire,fuch as is in the eares of a dogge or fuch like beaft. The whole fower is of a blew purple colour, which being paft, there fucceede great fquare or cornered feede veffels, deuided on the infide into diuers cels, or chambers, wherein doc lie fcatteringly many fmall browne flat feeds. The roote is long and great like a parfnep, garnifhed with many threddie ftrings, which peritheth when it hath perfected his feede, which is in the feconde yeere after his fowing, and recouereth it felfe againe by the fallin of the feede.

2 The fecond agreeth with the firft in each refpect, as well in leaues, ftalks, as rootes; and differeth in that, that this plant bringeth foorth milke white flowers, and the other net fo.

\section{* Theplace.}

They growe in woods,mountaines and darke vallies, and vnder hedges among the buthes, efpecially about Couentrie, where they growe very plentifully abroad in the ficldes, and are there called Couentrie bels; and of fome about London Canterbury bels, but vnproperly; for that there is another kinde of Bell flower growing in Kent about Canterbury, which may more fitiy be called Canterburie bels, bicaufe they growe there more plentifully than in any other countrie. Thefe plea: fant Bel flowers we haue in our London gardens, efpecially for the beauty of their flowers, although they be kindes of Rampions, and the rootes caten as Rampions are.

$$
* \text { The time. }
$$

They flower in Iune, Iuly, and Auguft, thefeed waxeth ripe in the meane time; for thefe plants do not bring foorth their flowers all at once, but by parcels; for when one flowreth,another feedech, and both vpon one branch.

\section{* The numes.}

Couentrie bels are called in Latine Viols Marians, or Mercuries violets, and Couentrie Rapes; and of fome Mariettes. It hath been taken to be Medion, but vnproperly. Of fome it is called Rapum fyluestre, which the Grecians call pryinu ärece.

$$
\text { * The temperature and vertues. }
$$

The roote is colde and fomewhat binding, and not vfed in phificke, but eftcemed for one of the fallet rootes, boiled and eat en with oile, vineger and pepper.

\section{Of Throtewoort, or Canterbary Bels. Chap.iro.}

* The defription.

I 7 He firft of the Canterburic bels hath rough and hairie brittle ftalks, crefted into a certaine fquareneffe, diuiding themfelues into diuers branches, whereupon do growe very rough tharpe pointed leaues, cut about the edges like the teeth of a fawe; and folike the leaues of nettles, that it is hard to knowe the one from the other, but by touching them. The flowers are hollow, hairie within, and of a perfect blew colour, bell fafhion, not vnlike to the Couentrie beis. - The roote is white, thicke and long lafting.

2 The white Canterburie bels are fo like the precedent, that it is not poffible to diftinguifh them, but by the colour of the flowers; which of this plant is a milke white colour, \& of the other a blew; which fetteth foorth the difference.

3 The thirde fort of Canterburie Bels, called likewife Throtewoorte, of his vertue in curing the difeafes of thie throte, hathlong leates, tharpe pointed, flightly indented about the edges. The it alks are round and hairie, diuiding themfelues into fundrie braunches, euen from the bottome to the top, whereupon dogrow pleafant, flowers fafhioned like Bels, of a faint purple colour. The roote $\$$ feedes are like vnto the great Canterburie Bels.

4 The fnall Canterburie Bels, hath very rough leaues, fomwhat cut about the edges. The flowers growe at the top of the ftalke bellfafhion, of a pleafant azure blewe colour. The roote is like the precedent, but altogither fmaller, which is the true and right Calathian Violet. 
I Trachelium maius.

Blew Canterburic bels.

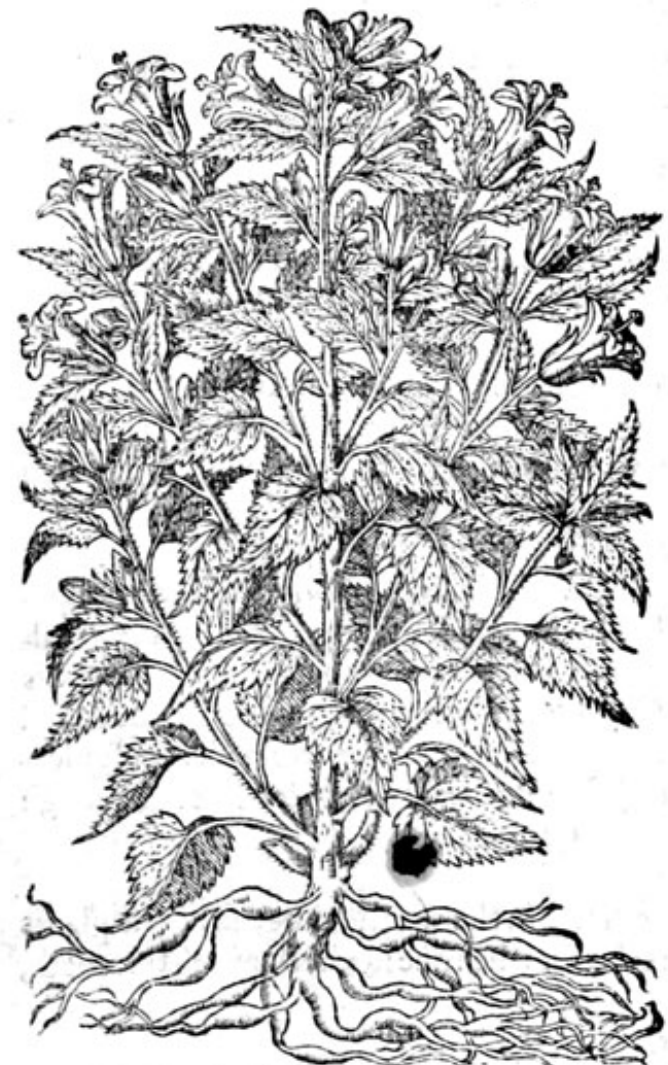

3 Tracbeliun marus Belgarwon L'obelÿ. Dutch Throtewoort.

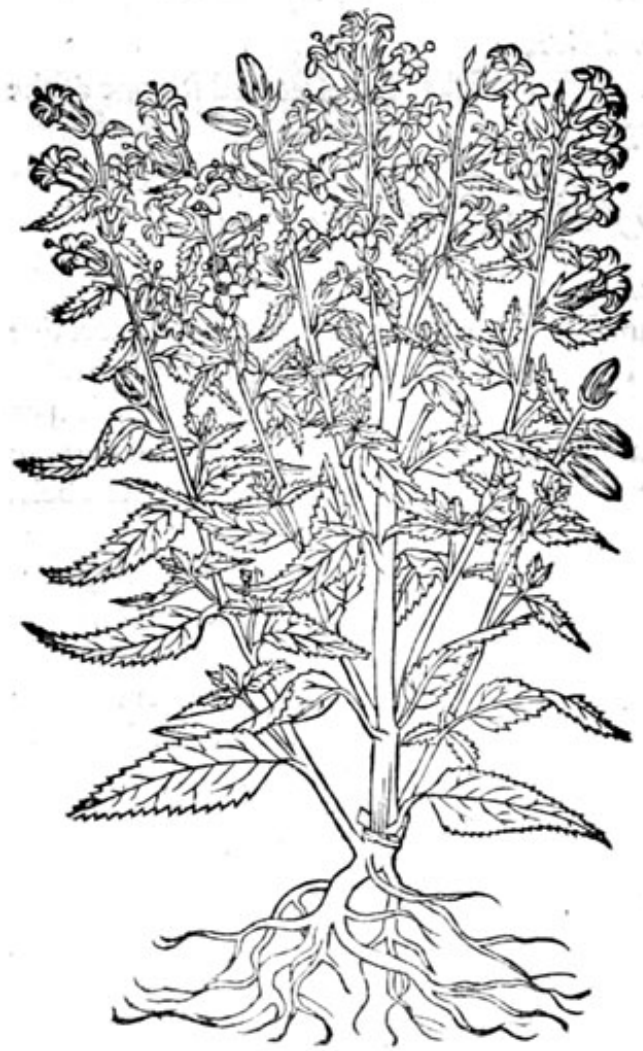

2 Trachelium maius flore albo. White Canterburie bels.

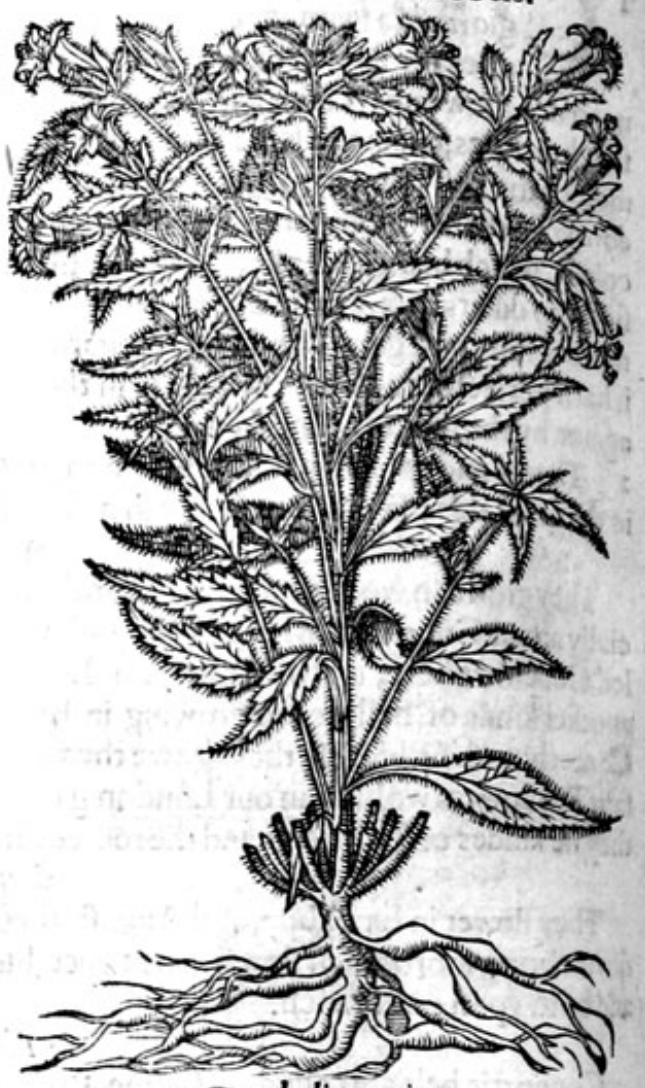

4 Tracheliuen minus.

Small Canterburie bels.
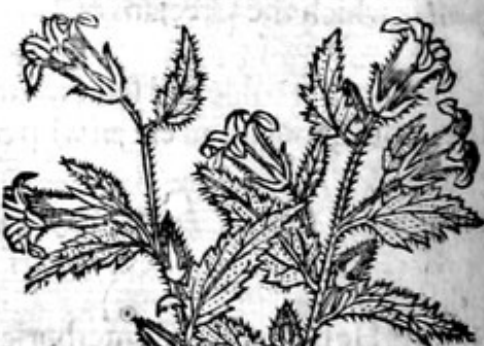

- 13 .
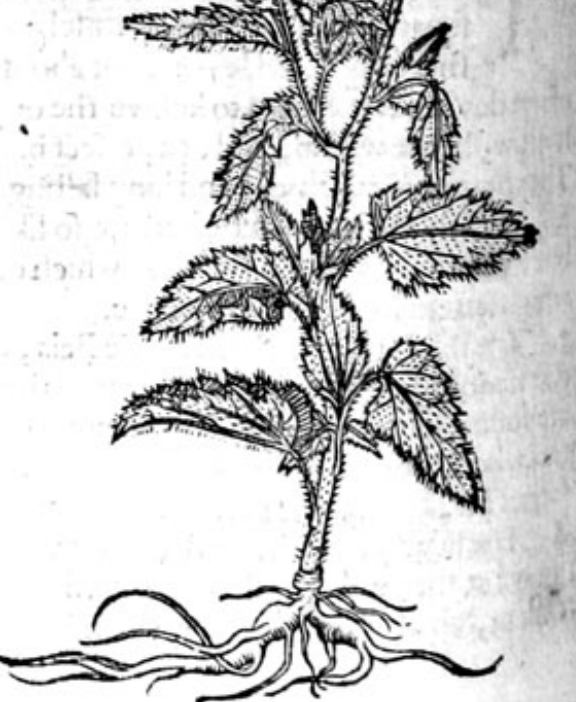


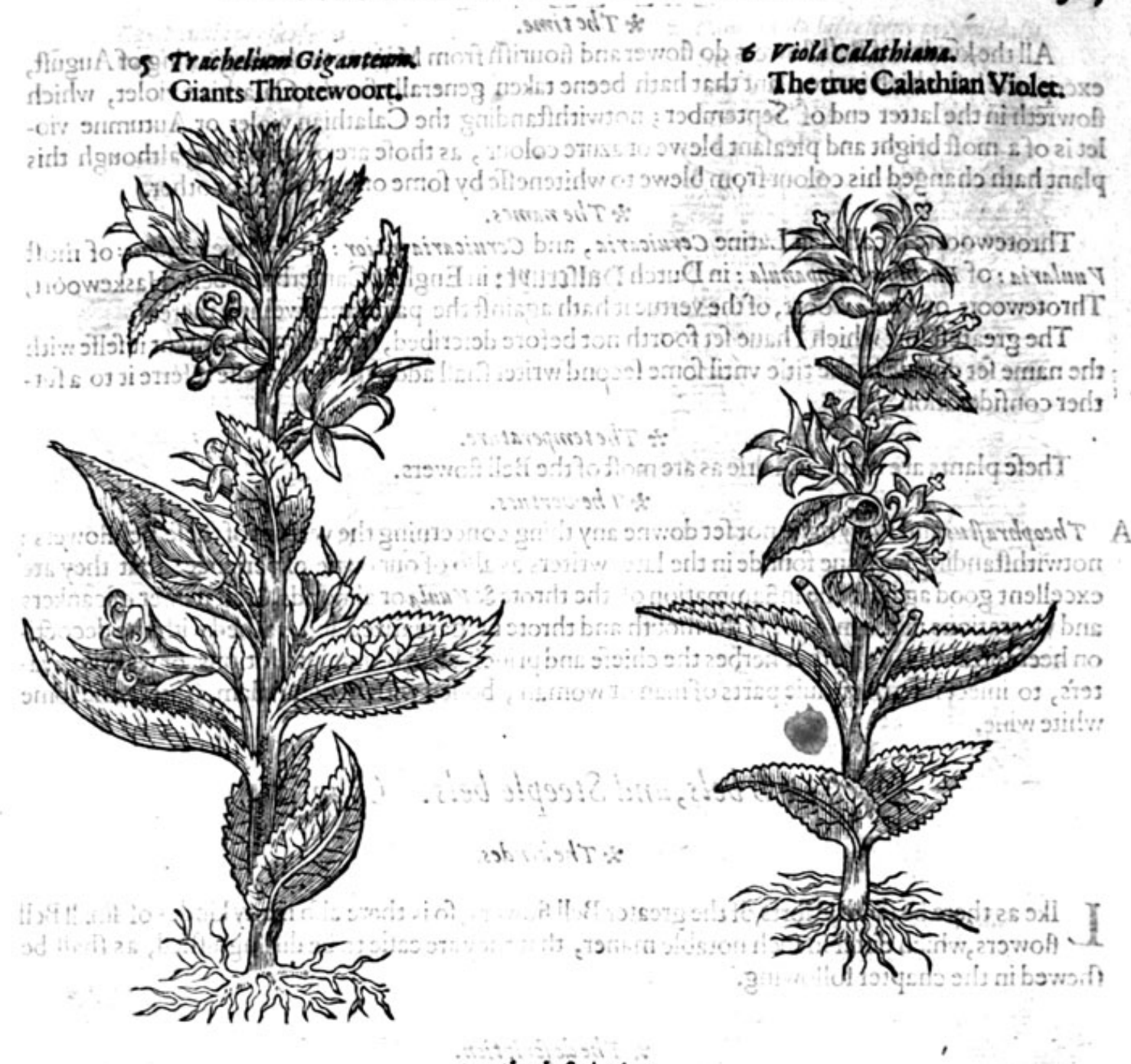

* Thedefoription.

5 Giants Throtewoort hath very large leaues of an ouerworne greene colour, hollowedin the middle like the Mofcouites fpoone, and very rough, flightly indented about the edges. The ftalke is two cubites high, whereon thofe leaues are fet from the bottome to the top; from the bofome of each leafe commeth foorth one flender footeftalke, whereon doth growe a faire flowerfáphioned like a bell, of a whitifh colour tending to purple. Thepointed corners of cach flower turnethemfelues backe like a fcroule, or the Dalmatian cap; in the middle whereof commeth foorth a fharpe ftile or clapper of a yellow, colour. The roote is thicke, with certaine ftrings annexed thereto. $I$ : 6 The finaller kinde of Throtewoort of my owne defcription hath ftalkes and leaues very likesin. to the great Throtewoort, but altogither leffer : from the bofome of whichleaues fhoote foorth very beautifull flowers bell fafhion, of a bright purple colour, with 2 fmall peftell or clapper in the middle, and in other refpects is like the precedent.

\section{*The place.}

The three firft defcribed do growe very plentifully in the lowe woods and hedgerowes of Kent, about Canterburie, Sittingborne, Grauefend, South leete, and Greenehyth, efpecially vndet Cobbam parke pale in the way leading from Southfleete to Rochefter; at El tham about the parkethere not farre from Greenwich; in moft of the paftures about Watford and Bufhey, fifteenemiles from London.

The fourth groweth in the medowe next vnto Ditton ferric as you go to Windfore, vpon the chalkie hils about Greenehyth in Kent; andin a ficlde by the high waie as you go from thence to Dartforde; in Hennyngham parke in Eflex; and in Síon medowe neere vnto Branforde, eight miles from London. 
* The time.

All the kindesiaf Bell ftowces do flower and flourifh from Marevintorhebeginningof Auguft, excepóthé laft whicB ischeplant that hath beene taken generally for the Calathian violet, which flowreth in the latter end of September; notwithftanding the Calathian violes or Autumne violet is of a moft bright and pleafant blewe or azure colour, as thofe are of this kinde, although this plant hath changed his colour from blewe to whiteneffe by fome one accident or other.

$*$ The names.

Throtewoorte is called in Latine Cervicaria, and Ceruicariamiajor: in Greeke reasidan: of moft Vuularia : of Fuchfius Campanula : in Dutch i)alfetupt: in Englifh Canterburie bels, Haskewoort, Throtewoort or Vuula svoort, of the vertue it hath againft the paine and fwelling thereof,

The greateft fort which $I$ hatue fet foorth not before defcribed, thal reftand content it felfe with the name fet downe in she title vntil fome fecond writer fhall adde thereto, or elfe referre it to a further confideration. $*$ The temperature.
Thefe plants are colde and drie as are moft of the Bell flowers.
$* T$ he vertues.

A Theophraftusand pliny haue not fet downe any thing concerning the vertues of thefe Bel flowers: notwithitanding we haue founde in the later writers as alfo of our owne experience: that they are excellent good againt the inflammation of the throte \& $V$ uula or almonds, \& all maner of cankers and vilcerations in the mouth, if the mouth and throte be gargarized and wafhed with the decoetion heereof, and is of all other herbes the chiefe and principall to be put into lotions, or wafhing waters, to iniect into the priuie parts of man or,woman, boiled with honie, Allam, water, and fome white wine.

\section{Of Peach bels, and Steeple bels. Cbap.ur. * The kindes.}

Ike as there befandrie forts of the greater Bell flowers, fo is there alfo manykindes of fmall Bell flowers, which differ in fuch notable maner, that they are eafie to be diftinguifhed, as fhall be fhewed in the chapter following.

\section{* The defcription.}

I He Peach leafe Bell flower hath a great number of fmall and long leaues, rifing in a great buth out of the ground, like the leaues of the Peach tree; among which rifeth vp a falle two cubits high : alongtt the ftalke growe many flowers like bels, fometime white, and for the moft part, of a faire blewe colour : but the bels are nothing fo deepe as they of the other kindes, and thefe alfo are more delated and fpred abroade then any of the reft. The feede is frnall like Rampions, and the roote a tuft of laces or fmall ftrings.

2 The fecond kind of Bell flower hath a great number of faire blewifh or watchet flowers, like the other laft before mentioned, growing vpon goodly tall ftems two cubits and a halfe high, which are garnifhed from the top of the plant vnto the ground, with leaues like Beetes, diforderly placed. This whole plant is exceeding full of milke, infomuch as if you do but breake one leafe of the plant, many drops of a milkie iuice will fall vpon the grounde. The roote is verie great and full of milke alfo; likewife the knops wherin the feede fhoulde be, are emptic and voide of feed, fo that the whole plant is aitogither barren, and muft be increafed with flipping of his roote.

3 The fmalleft Bell flower hath many round leaues, very like thofe of the common fieldViolet fpred vpon the ground; among which rife vp fmall flender ftems, diforderly fet withmany graffic narrow leaues like thofe of flaxe. The fmall $\mathrm{ftem}$ is diuided at the top into fundrie little branches, whereon do grow pretie blew flowers beil fafhion. The roote is fimall and threddie.

4. The yellow Bell flower is a very beautifull plant, of an handfull high, bearing at the top of his weake and tender ftalkes moft pleafant flowers bell fafhion; of a faire and bright yellow colour. The leaues and rootes are like the precedent, fauing that the leaues that grow next to the ground of this plant, are not fo round as the former. 
I Campanula perficifolia.

Peach leafed Bell flower.

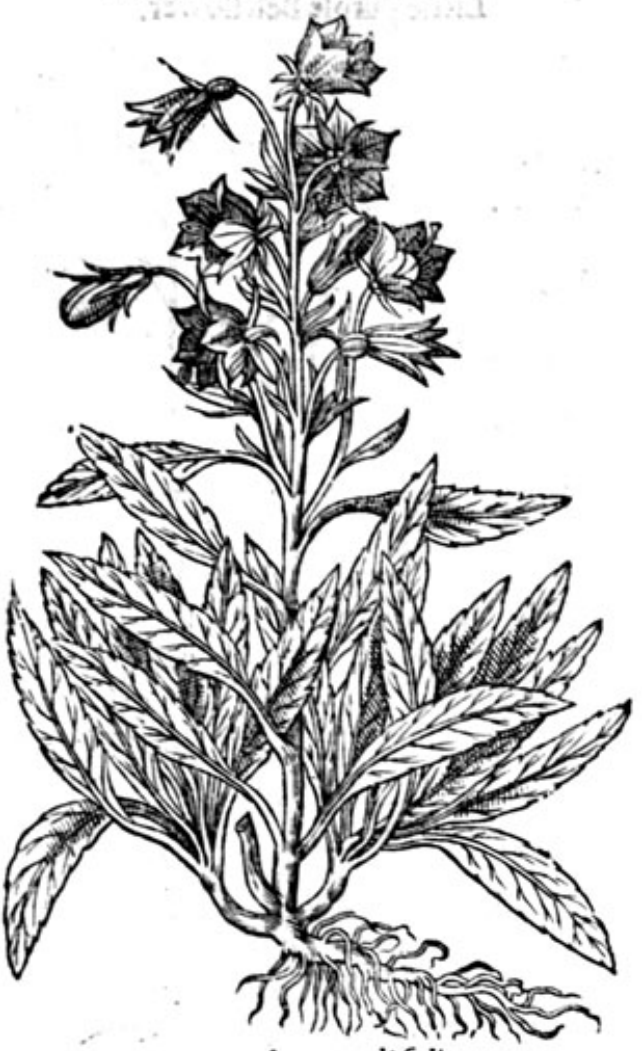

3 Companula rotundifolia.

Round leafed Bell tlowcr.

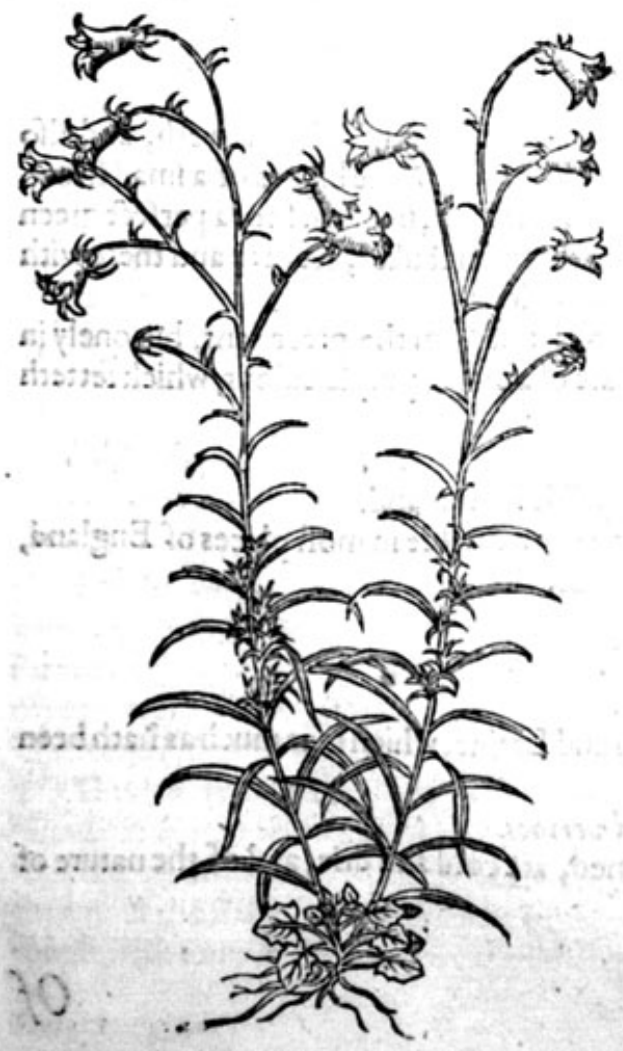

2 Campanula lactefcens pyramidalis.

Steeple milkie Bell flower?

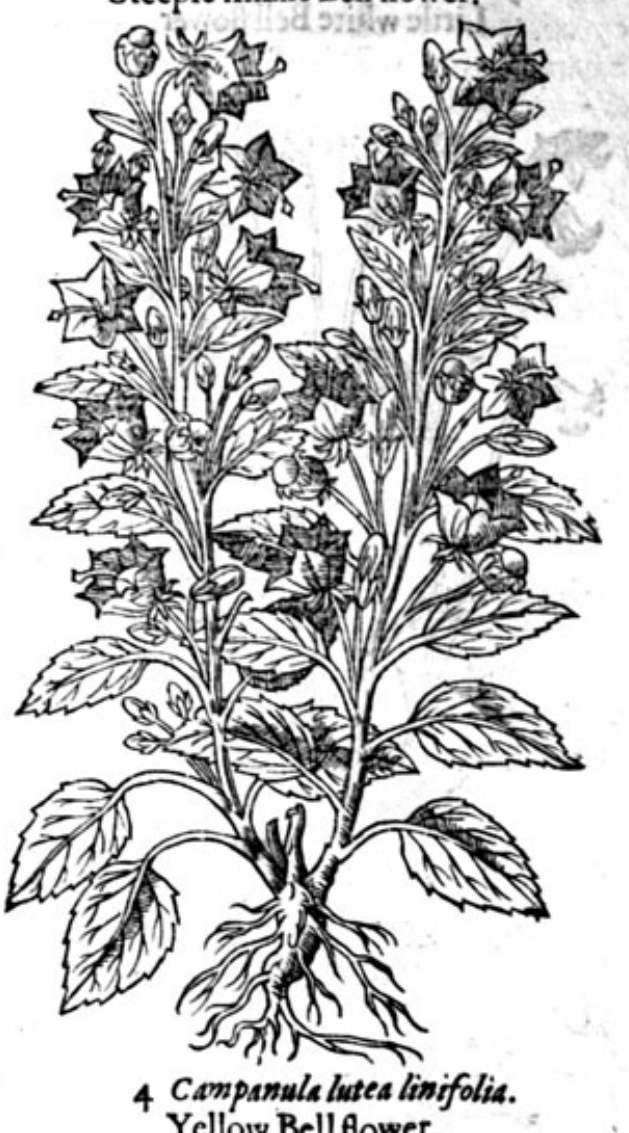

Yellory Bell Aower.

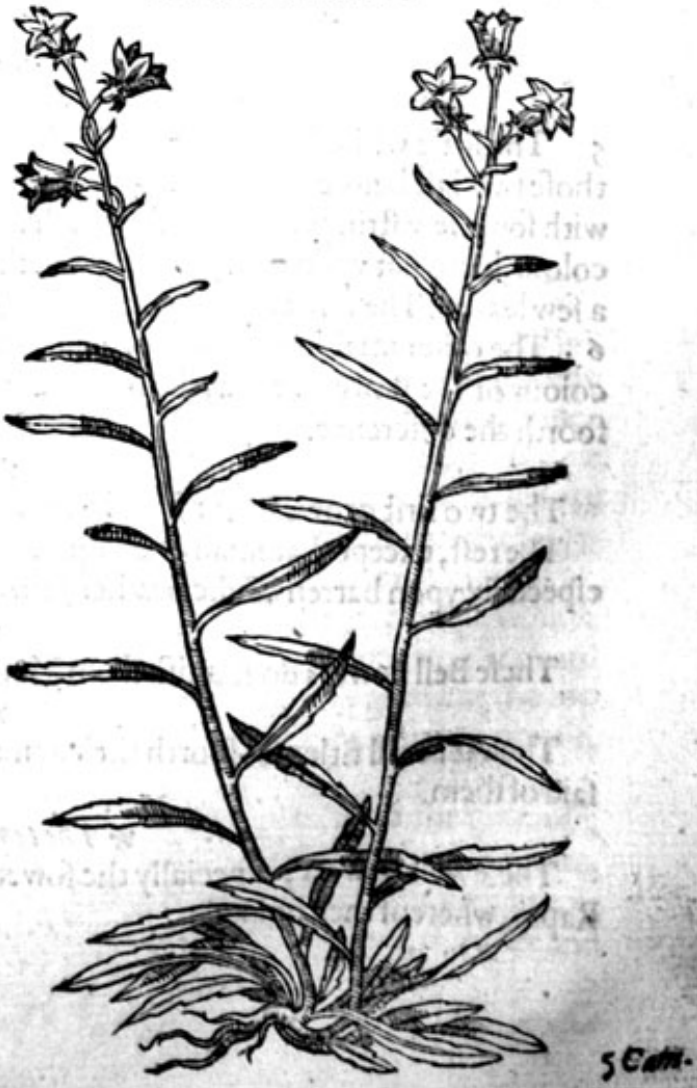


5 Campanula minor, alba.

Little white Bell Glower.

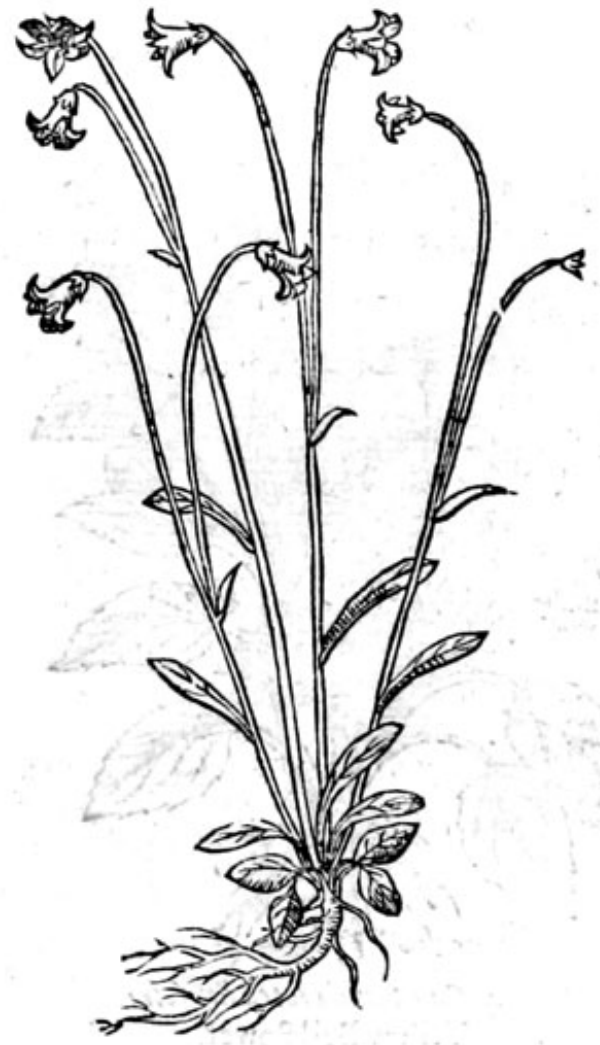

6 Companulaminor perpwrea. Little purple Bell tower.

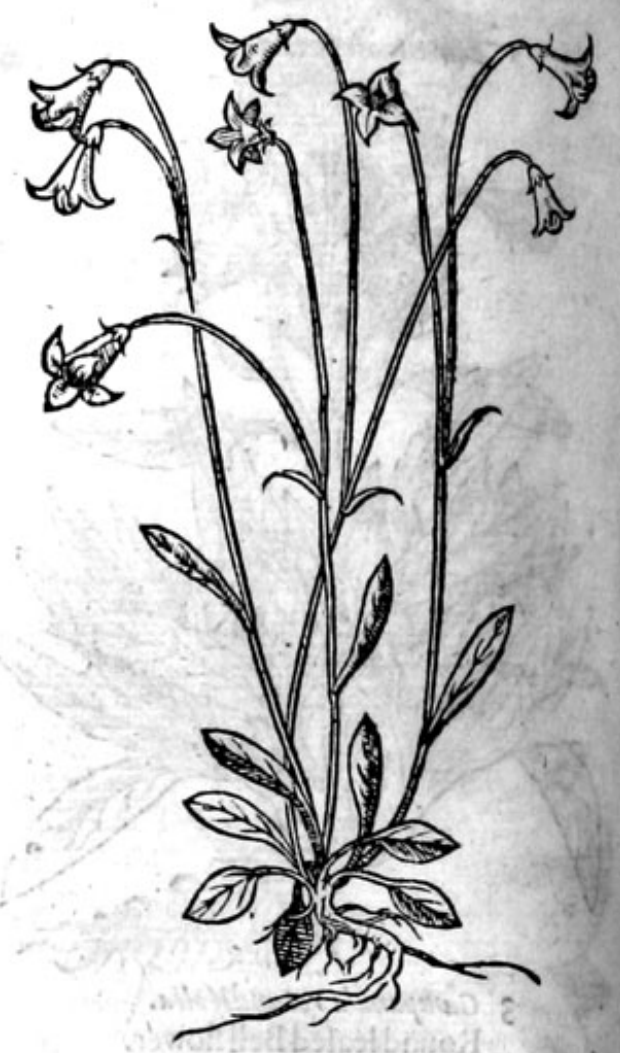

* The defcripsion.

5 The little white Bell flower is a kinde of wilde Rampions, as is that which followeth, and alfo thofe two laft before defcribed. This fmall plant hath a flender root, of the bignes of a fmall ftraw, with fome few ftrings annexed therto. The leaues are fomwhat long, fmooth, \& of a perfect green colour, lying flat vpon the ground; from thence rife vp fmall tender italkes, fethere and there with a few leaues. The flowers growe at the top, of a milke white colour.

6 The other fmall Bell tower or wilde Rampion, differeth not from the precedent, but onely in colour of the flowers: for as the others are white, thefe are of a bright purple colour, which fetreth foorth the difference.

* The place.

The two firft growe in our London gardens, and not wilde in England.

The reft, except that fmall one with yellow flowers, do growe wilde in moft places of England, efpecially vpon barren fandic heathes, and fuch like grounds.

* The time.

Thefe Bell flowers do flourifh from May vnto Auguft. * The names.

Their feuerall titles fet foorth their names in Englifh and Latine, which is as much as hath been faid of them.

* The temperature and vertues.

The?e Bell fowers, efpecially the fower laft mentioned, are cold and drie, and of the nature of Rapes, whereof they be kindes. 


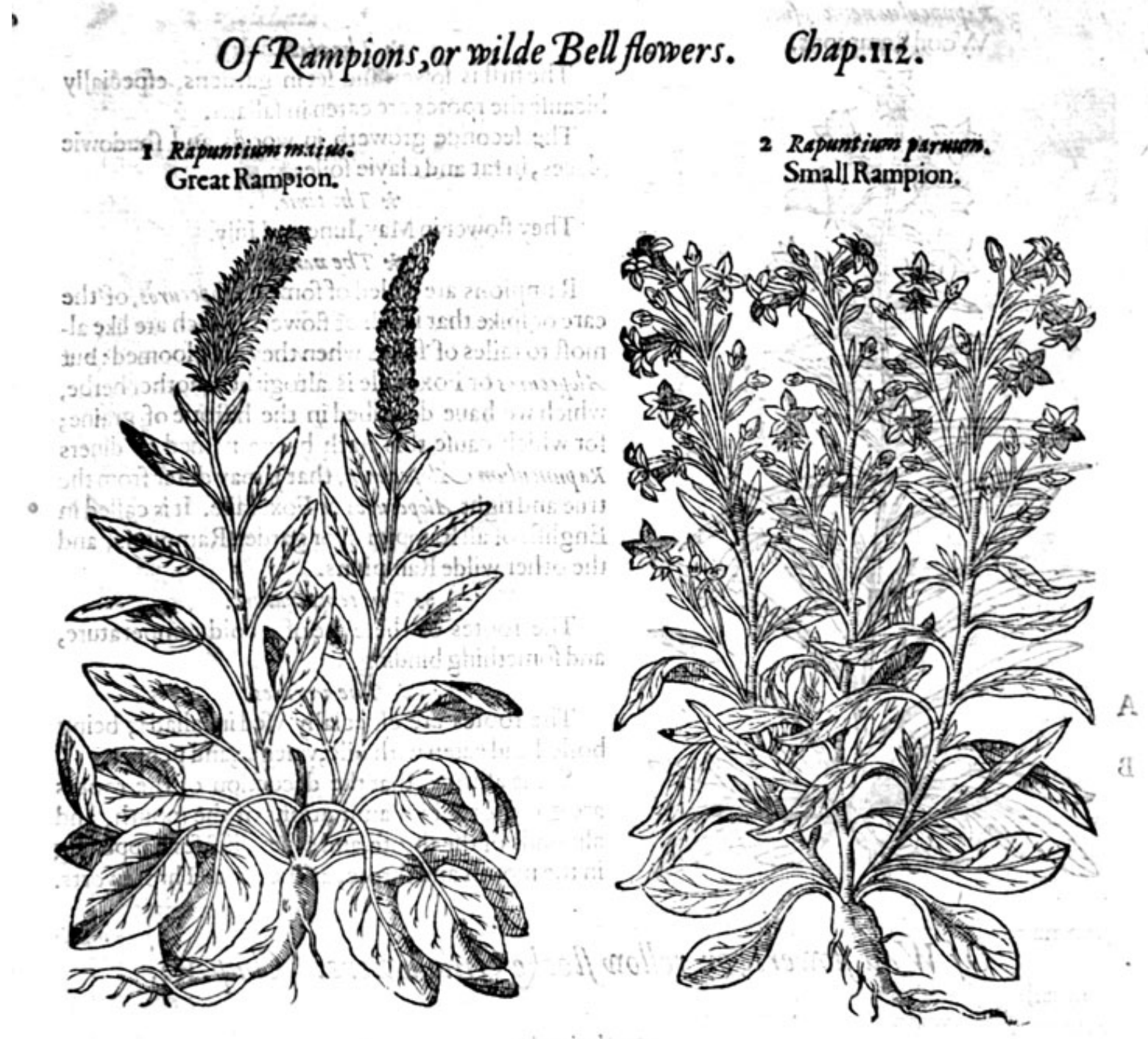

\section{llowers.} Chap.niz.

\section{Rapuntivon parmeon. SmallRampion.}

* The defaription.

$1-$ He great Rampion being one of the Bell flowers, hath leaues which appeere or come otit foorth at the beginning fomewhat large and broad, fmooth and plaine, not vnlike to the leaties of the Becte. Among which rife vp ftems two cubits high, fet with fuch like leaties as thofe are of the firft fpringing vp, but fmaller, bearing at the rop of the ftalk a great, thick, bufhie eare, full of little long flowers clofely thruft togither like a Foxe taile; which fmall flowers before their opening are like little crooked hornes; and being wide opened, they are fmall blew beis, fonietimes white, or fometimes purple. The roote is white, and as thicke as a mans thombe.

2 The fecond kinde being likewife one of the Bell towers;and yet a wilde kinde of Rampion; hath leaues at bis firft comming vplike vnto the garden Marigold. The leaues that fpring vp afterward for the decking vp of the ftalke, are fomewhat longer and narrower. The flowers growe at the top oftender and brittle ftalks, like vnto little bels, of a bright blew colour, fometimes white, or purple. The roote is fmall, long, and fomewhat thicke.

3 This is a wilde Rampion that groweth in woods ; ithath fmall leaues fpred vpon the groundè, bluntly indented abott the edges: among which rifeth vp a ftraight ftem, of the height of a cubite, fet from the bottome to the top, with longer and narrower leaues than thofe next the ground; at the top of the ftalkes growe fmall Bell flowers, of 2 watchet blewilh colour. The roote is thicke and tough, with forne few itrings annexed thereto. 
3 Rapuncalus nemorofus. Wood Rampions.

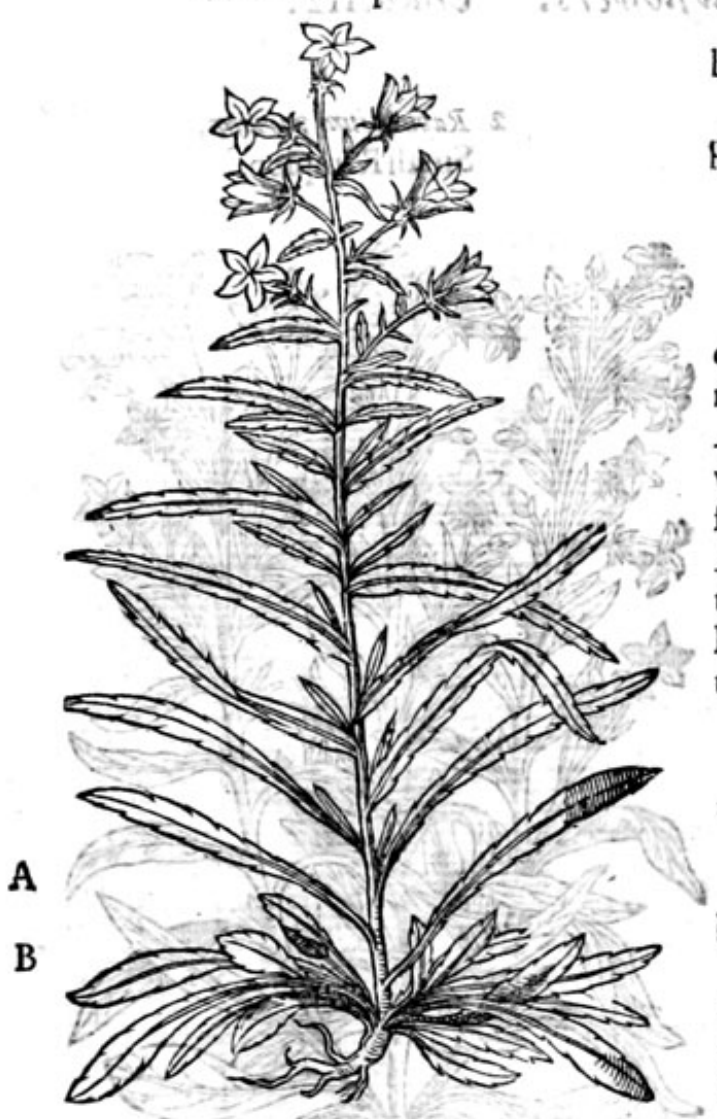

\section{* 7 be plate}

The firt is fowen and fet in gardens, efpecially
aufe the rootes are eaten in fallads.

The feconde groweth in woods. and thadowie places, in fat and clayie foileserm 8 issio

$$
\text { * T the time. }
$$

They flower in May, Iune and Iuly.

$$
\text { *. The names. }
$$

Rampions are called of fome vilopecuros, of the eare or fpike that is full of flowers, which are like al. moft to tailes of foxes when they are bloomed: bur Alopecuros or Foxetaile is altogitherangther herbe which we haue defcribed in the hiftorie of graine; for which caufe this hath beene named of diners Kapunculiem Alopecuron, that it may differ from the true and righte-Alopecuros or Foxetaile. It is called in Englifh of allRampions, or garden Rampions, and the other wilde Rampions.

$$
\text { * } 7 \text { he temperature. }
$$

The rootes of thefe are of a cold temperature, and fomething binding.

\section{* The vertues.}

The rootes are efpecially vfed in fallads, being boiled and eaten with oile, vineger, and pepper,

Some affirme, that the decoction of the rootes are good for all inflammations of the mouth, and almonds of the throte, and other difeafes happening in the mouth and throte, as the other Throteworts.

\section{Of Wall flowers, or yellow focke Gilloflowers. Chap.113.}

\section{* The kindes.}

$\mathrm{O}$ F Wall flowers there be two kindes, one with fingle flowers, the other with double, both which are comprehended vnder the title Viola, deriued of the Greeke worde isvau, Ienai, which fignifieth to go, to be foorth comming, or to come foorth firft: they are alfo called Kere, with the pleafantnefle whercof many being delighted, haue giuen it a common name Leucoium, of the whiteneffe of the flowers as forne haue deemed, but although $\lambda$ súxes, Le ucus, fignifieth white, it was not bicaufe the flowers of Violets, or ftocke Gilloflowers be white, being evident that thofe plants do differ in colour, as much as any other plants do; but as I take it of the colour of the leaues, which are for the molt part grayifh or alhe coloured.

\section{* The defcription.}

I.

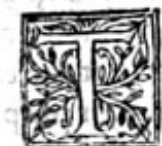

He ftalkes of the Wall flower are full of greene branches; the leaues are long, narrow, fmooth, lipperic, of a blackifh greene colour, and leffer than the leaues of tocke Gillotlowers. The flowers are finall, yellow, very fweete of fmell, and made of fower little leaties; which being paft, there fucceede long ilender cods, in which is conte2ned long reddith feede. The whole plant is fhrubbic, of a wooddie fubftance, and can eafilyendure the cold of winter.

2. The doubie Wall flower hath long leaues greene and finooth, fet vpon ftiffe branches, of a wooddie fubftance : whereupon do growe moft pleafant fweete yellow flowers very double; which plant is fo well knowen to all, that it thall be needleffe to fpend much time about the defcription. 


\section{AHHISTORIEOF PLANTS.}

I Viuls lutes.

Wall flower.
2 Viola lutea multiplex. Double Wall flower.

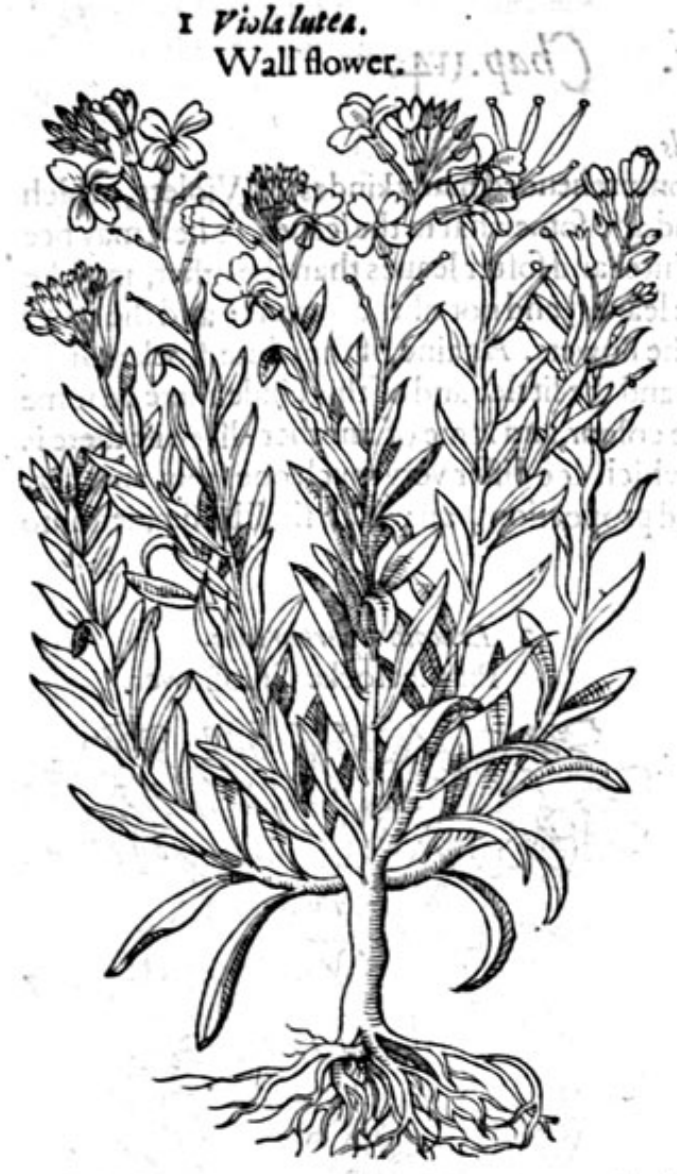

.27

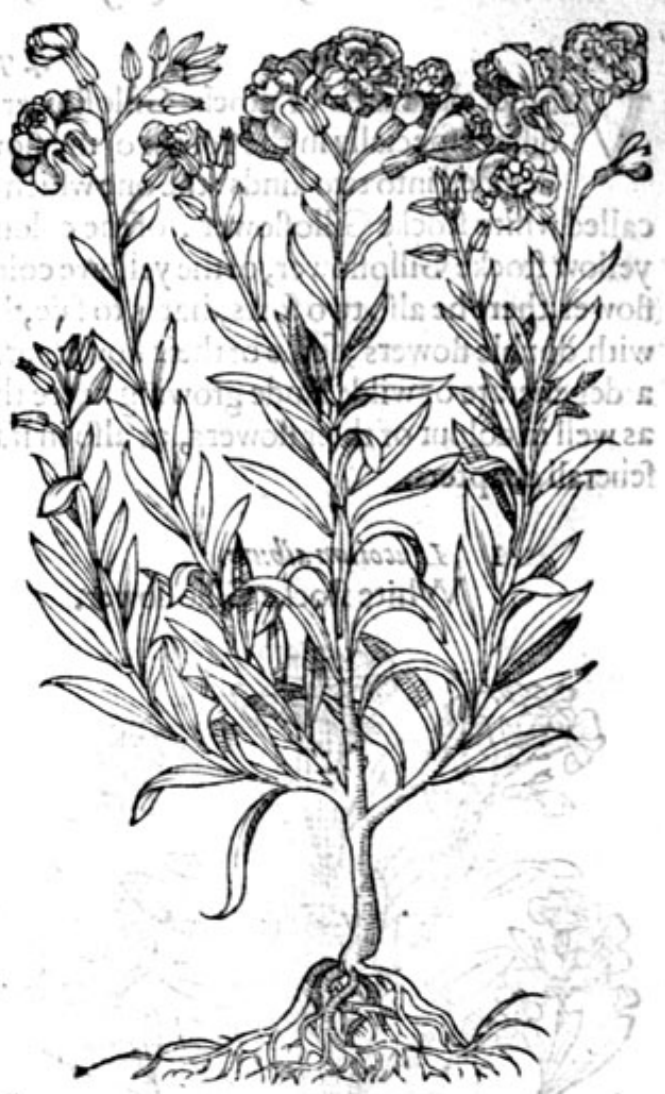

* Theplace.

The firft groweth vpon bricke and ftone wals, in the corners of churches every where among rubbilh, and other ftonie places.

The double Wall flower groweth in moft gardens of England: whereof we have another fore that bringeth his flowers open all at once, whereas the other doth fower by degrees, by meanes where of it is long in flowring.

They fowerime. They flower for the moft part all the yeere long, but efpecially in winter, whereupon the people
in Chefhire do call them Winter Gilloflowers.

* The names.

The Wall flower is called in Greeke rdxö̈or: in Latine Viola lutea, and Leucoinom luteum : in the Arabicke toong Keyri: in Spanilh Violettas Amarilhas : in Dutch Jitolieten: in French Girofflees iaulnes, Violiers des murailles: in Englifh Wall Gilloflower, Wall flower, Yellow ftocke Gilloflower,
and Winter Gilloflower.

\section{partes. \\ All the whole ${ }^{*}$ hrub of $W$ We temperature.
artes.}

\section{* The vertues.}

Diofcorides writeth that the yellowe Wall flower is moft vfed in phificke, and more then the $A$ reft of ftocke Gilloflowers, where of this is holden to be a kinde, which hath mooued me to preferre it ynto the firft place. He faith, that the inice mixed with fome vnctious or oilie thing, and boiled to the forme of a lyniment, helpeth the choppes or riftes of the fundament.

The herbe boiled with white wine, honie, and a little allom,doth cure hot vicers, and cankers of B the mouth:

The leaues ftamped with a little baie falt, and bound about the wrefts of the hands, taketh awaic $C$

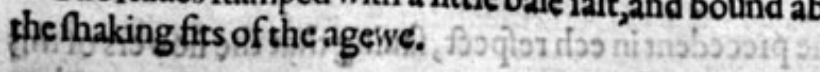




\section{Of Stocke Gilloflowers. Chap.114.}

* The kinds.

$\mathrm{V}$

Nder the name of ftocke Gilloflowers are comprehended many kindes of Violets, which differ efpecially in the colour of the flowers, and alfo fomewhat in the leaues. Thefe maybee deuided into two kinds : the one which hath whiter and fofter leaues than the other, may be called white ftocke Gilloflower, of the colour of the leaues, and not of the flowers : and the other yellow ftocke Gilloflower, of the yellowe colour of the flowers. Againe, of the white ftocke Gillo. tower, there be alfo two forts, that is to faie, the great and the little : and of this kinde there be fome with double flowers; fome of their flowers are of one colour, and fome of another : likewifethere is 2 degenerate or wilde kinde growing neere the fea, which doe differ very much one from another, as well in colour of their flowers, as alfo in ftature and proportion, all which fhall be diuided into feuerall chapters.

1 Lencoium albow.

White ftocke Gilloflower.

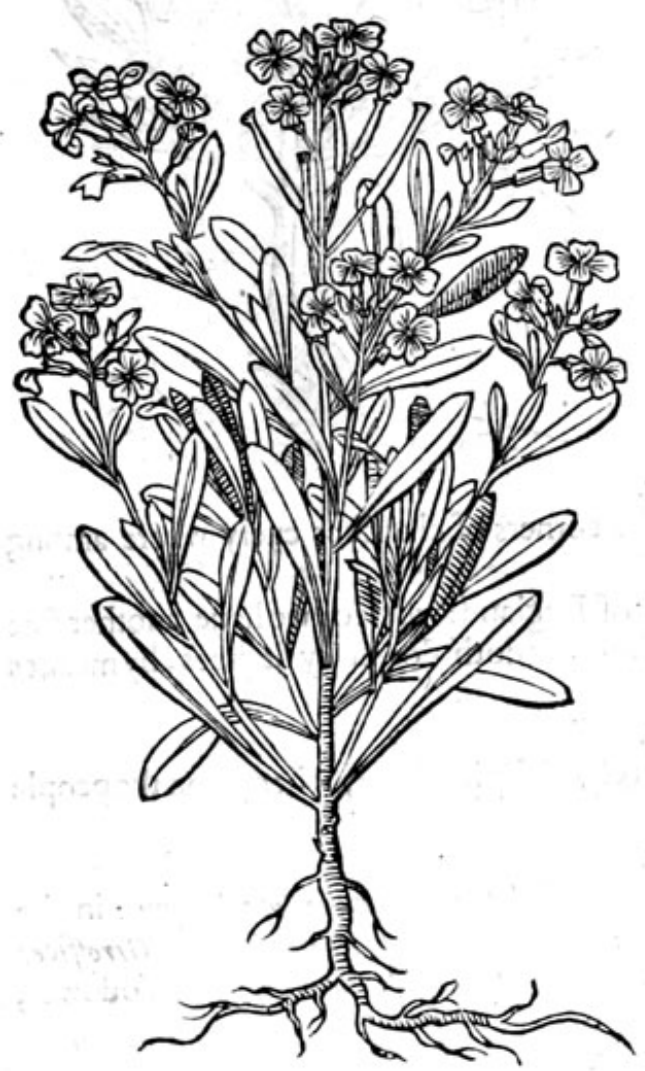

2 Leweotion purpur eum. Purpleftocke Gilloflower.

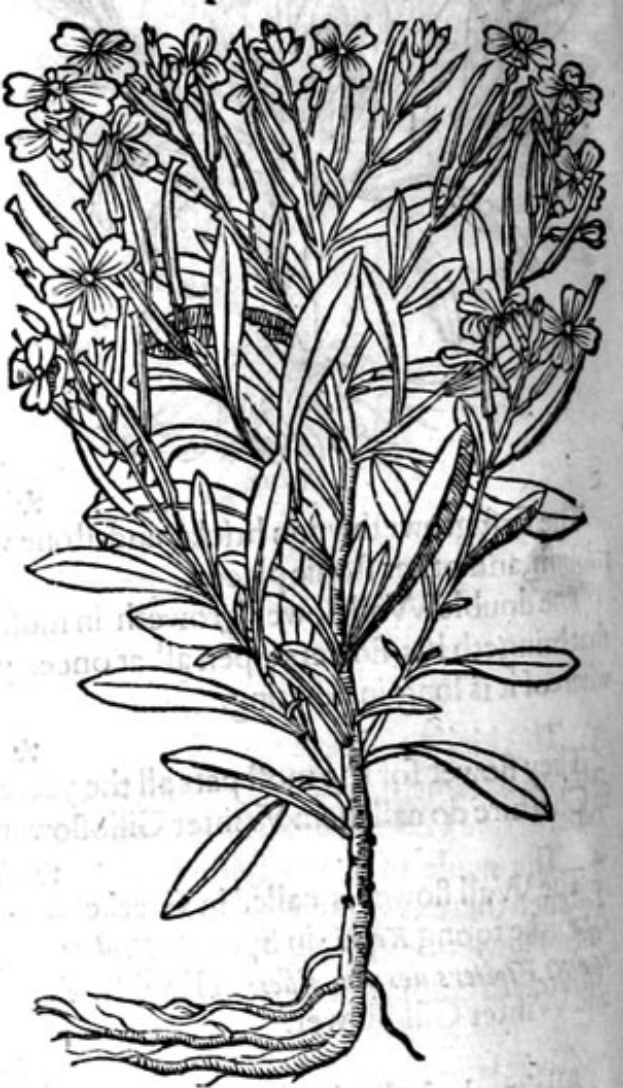

\section{* The defcription.}

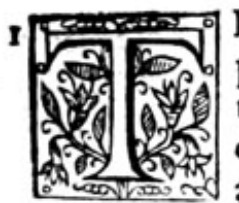

He ftalke of the great ftocke Gilliflower is two foote high or higher, rounde, and parted into diuers braunches. The leaues are long, white, foft, and hauing vpon them as it were a downe like vnto the leaues of Willowe, but fofter : the flowers confift of fower little leaues growing all along the vpper part of the branches, of a white colour, exceeding fweete of fmell: in their places come vp long and nat" rowe cods, in which is conteined broad, flat, and round feede. The roote is of a woodie fultance, ${ }^{25}$ is the ftalke alfo.

The purple ftocke Gillotlower, is like the precedent in ech refpect, fauing that the flowers of this 
plant are of a pleafant purple colour, and the others white, which fetteth foorth the difference: of which kinde we haue fome that beare double flowers, which are of diuers colours, greatly efteemed for the beautie of their flowers, and pleafant fweete fmell.

3 Lencoivon violacewm.

Violet colour ftocke Gilloflower.

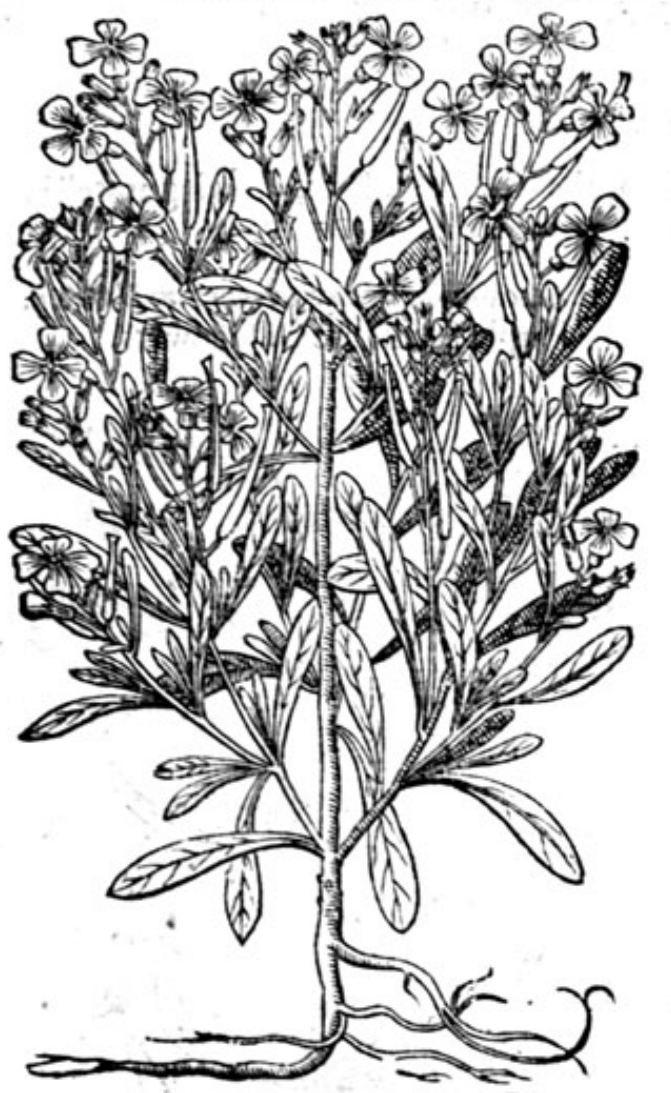

4 Lencoium fluestre.

Wilde ftocke Gilloflower.

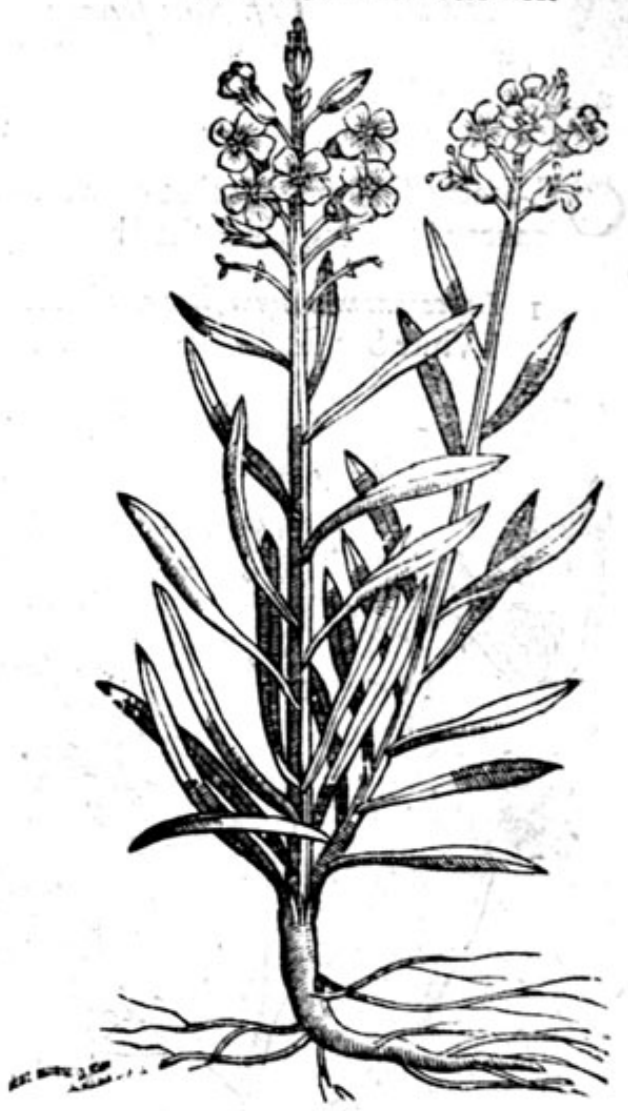

* The defcription.

3 This kinde of ftocke Gilloflower that beareth fowers of the colour of a violet, that is to faie, of a blewe tending to a purple colour, which fetteth foorth the difference betwixt this plant and the other ftocke Gilloflowers; in euerie other refpet is like the precedent.

4 The wilde ftocke Gilloflower hath a thicke and wooddie roote, with fome threddie ftrings faftened thereto: from which rifeth vp a ftiffe and brittle italke, garnifhed from the bottome to the tuft of flowers with long, fat and thicke hoarie leaues. The flowers growe at the top of the ftalkes; of a redith colour. The feede is like the garden ftocke Gilloflower, but leffer.

* The plafe.

Thefe kindes of ftocke Gilloflower's do grow in moft gardens throughour England.

The wilde ftocke Gilloflower doth growe vpon rockie and ftonie mountaines. * The time.

They flower in the beginning of the fpring, and continue flowring all the fommer long. * Thenames.

The Stocke Gilloflower is called in Greeke $\lambda Q x$ bitoy : in Latine Viola alba : in Italian Viola biancas: in Spanifh Violettas blangivas : in Englifh Stocke Gilloflower, Garnfey Violet, and Caftle Gillo:

\section{* Tbetemperature and vertues.}

They are referred vnto the Wall flower, although in vertue much inferior, yet are they not vfed $A$ inphificke, except amongft certaine Empericks and Quackfaluers, about loue and luft matters, which for modeftic I omit. 


\section{4 \\ THE SECOND BOOKE OF THE}

B Ioachimus Camerarius reporteth, that a conferue made of the flowers of Stocke Gilloflower, and given with the diftilled water thereof, helpeth the Apoplexie and the palfie: whereof $P$ lutarch pea. $_{\text {. }}$ keth in his booke De amore fraterno pulcherr. inter Echinopodas velut a ßper am, $\sigma$ inter ononin na fown. tur paßsm mollia Leacoia.

\section{Of Seaftocke Gilloflowers. Chap.irs.}

\section{* The kindes.}

F Stocke Gilloflowers that growe neere vnto the fea, there be diuers forts, differing as well in leaues as flowers, which fhall be comprehended in this chapter following.

I Lencoium marinum flore candido L'Obely. White Sea ftocke Gilloflowers.

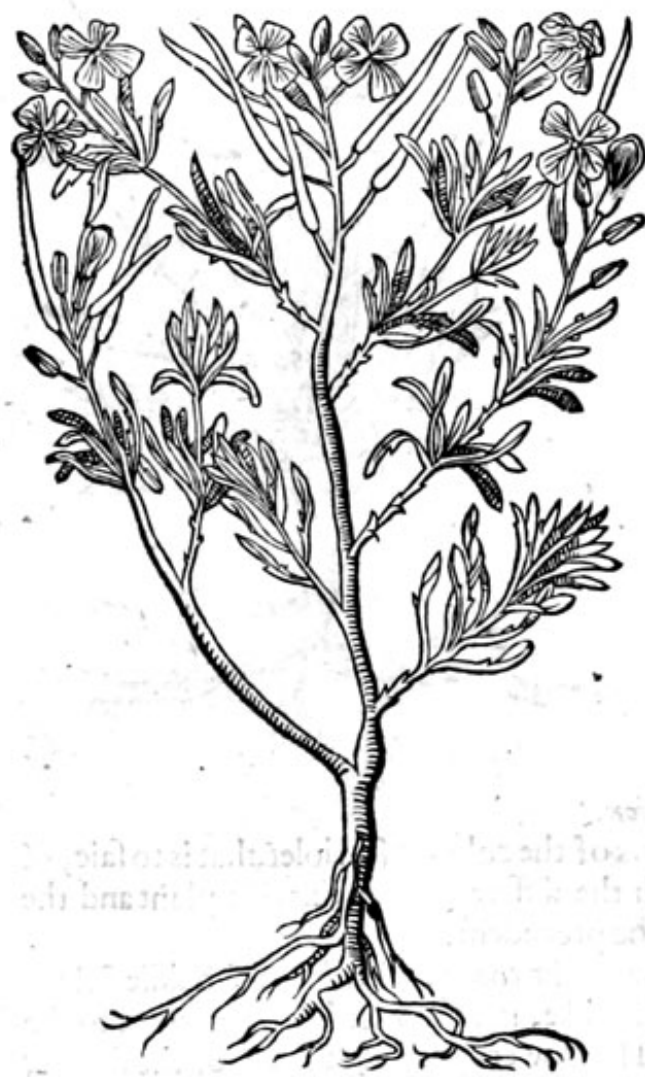

2 Leucoicom marinum purpureum L'Obely. Purple Sea ftocke Gillotlowers,
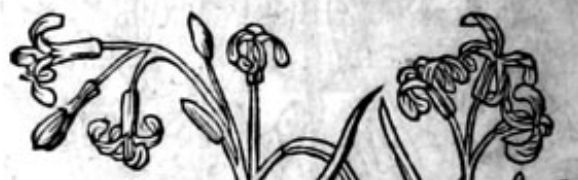
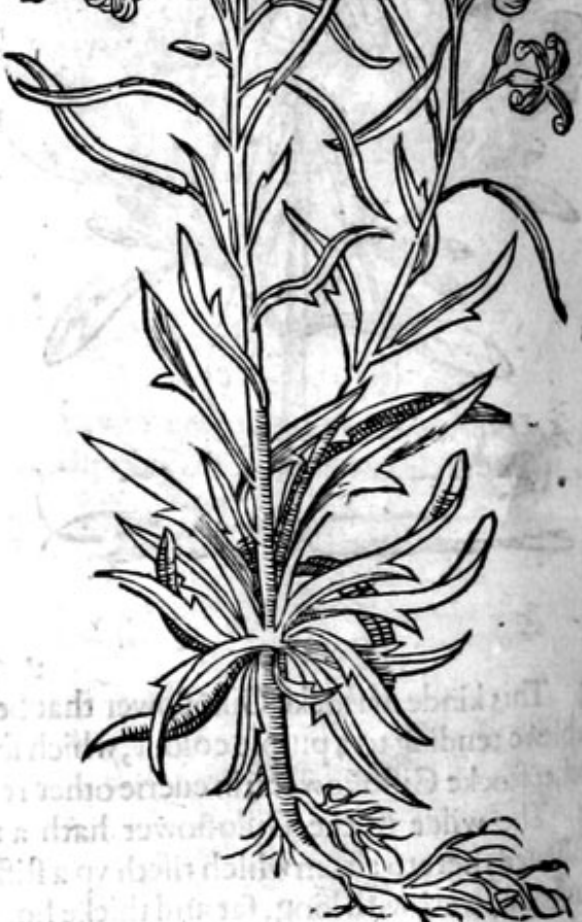

* The defcription.

I $7 \mathrm{He}$ Sea ftocke Gilloflower hath a fmall wooddie roote very threddie; from which rifech vp an hoarie white ftalke of two foote high, diuided into diuers fmall branches, whereon are placed confufedly many narrow leaues, of a foft hoarie fubftance. The flowers growe at the top of the branches, of a whitilh colour, made of fower little leaues; which being paft, there follow long cods and feede, like vnto the garden ftocke Gilloflower.

2 The purple ftocke Gilloflower hath a very long tough roote, thrufting it felfe deepe into the ground; from which rife vp thicke, fat, foft, and hoarie ftalkes. The leaues come foorth of the ftalkes next the ground long, foft, thicke, full of iuice, couered ouer with a certaine downie hoarineffe, and fnipt vpon the one fide with a fmall cut or notch, fuch as is to be feene in the leafe of Buckes horne. The ftalke is fet here and there with the like leaues, but leffer. The flowers growe at the top of the ftalks, compact of fower fmall leaues, of a darke purple colour. The feede is conteined in long crooked cods like the garden ftocke Gillolower. 


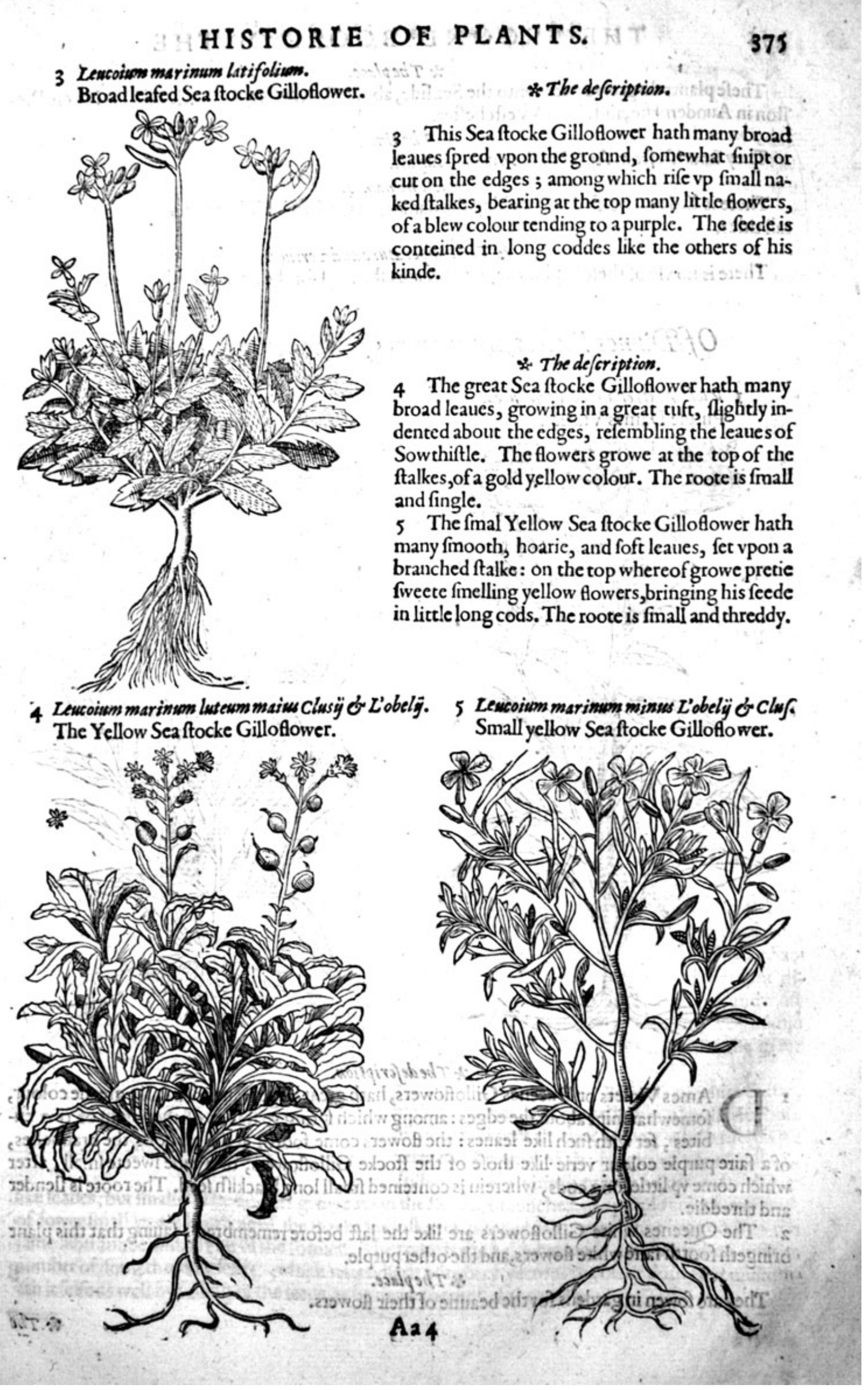


Thefe plants do growe neere vnto the Sea fide, about Colchefter, in the Ile of Man, neerePre. fton in Aundernefle, and about Weftchefter. $*$ The time.

They flourinh from Aprill to the end of Auguft.

$$
\text { * The names. }
$$

There is little to be faid as touching the names, more than hath beene touched in their feue. rall titles.

\author{
* The temperature and vertues.
}

There is no vfe of thefe in phificke, but they are efteemed for the beautie of their flowers.

\title{
OfDames Violets, or Queenes Gilloflowers. Chap.i16.
}

I Viola Matronalis fore purpureo.

Purple Dames Violets.

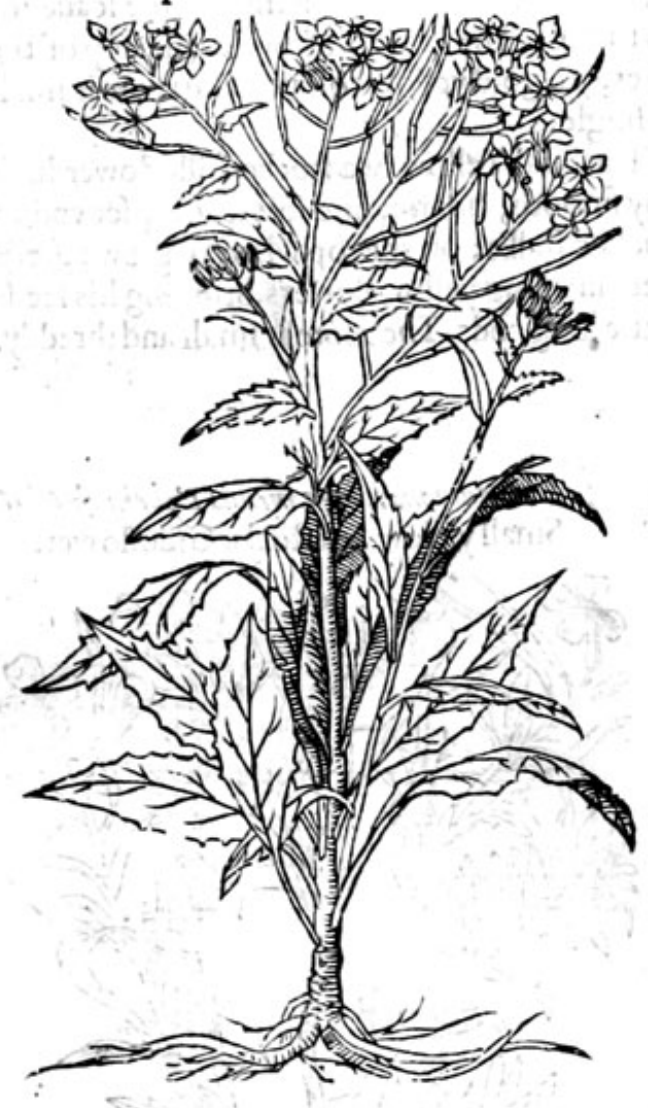

2 Viola mitronalis fure albo. White Dames Violets.

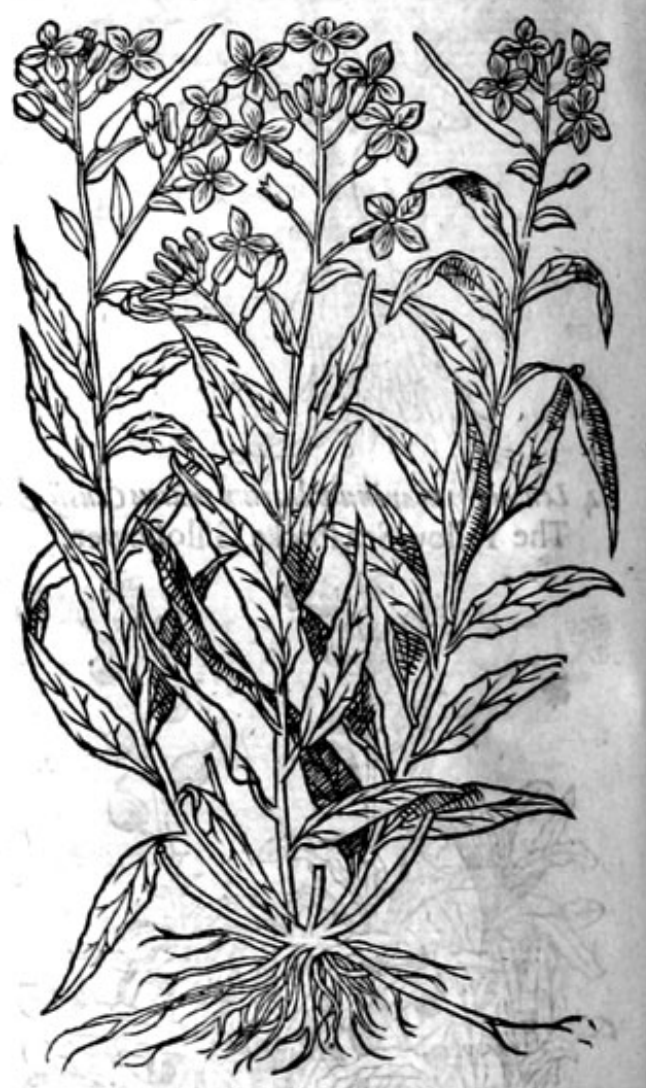

* Thedefcription.

I Ames Violets or Queenes Gilloflowers, hath great large leaues of a darke greene colout, fomewhat fnipt about the edges : among which fpring vp ftalkes of the height of two ctit bites, fet with fuch like leaues: the flowers come foorth at the toppe of the braunches, of a faire purple colour verie like thofe of the ftocke Gilloflowers, of a verie fweete fmell, after which come vp little long cods, wherein is conteined fmall long blackifh feed. The roote is lender and threddie.

2 The Queenes white Gilloflowers are like the laft before remembred, fauing that this plant bringeth foorth faire white flowers, and the other purple.

* Theplace.

They are fowen in gardens for the beautic of their flowers. 
They efpecially tower in Maie and Iune, the fecond yeere after they be fowen.

\section{* The nemes.}

Dames Violets is called in Latine $\boldsymbol{\nabla}$ iola matronalis, and Viola Hyemalis, or winter Violets, \& Viols Doma/cena: in French Violettes des Dames, $\&$ de Damas, and Girofflies des Dames, or CMatromes Violettes : in Englifh Damaske Violets, winter Gilloflowers, Rogues Gilloflowers, and clofe Sciences.

\section{* The temperature.}

The leaues of Dames Violets are in tafte fharpe and hot, very like in tafte and facultic to Erwsa or Rocket, and feemeth to be a kinde thereof.

\section{* The vertues.} fweate.

The diftilled water of the flowers heereof is counted to be amoft effectuall thing to procure

\section{Of white Sattin flower. Chap.II7.} I Viola Lennaris fuve Bolbonac.
White Sattin.

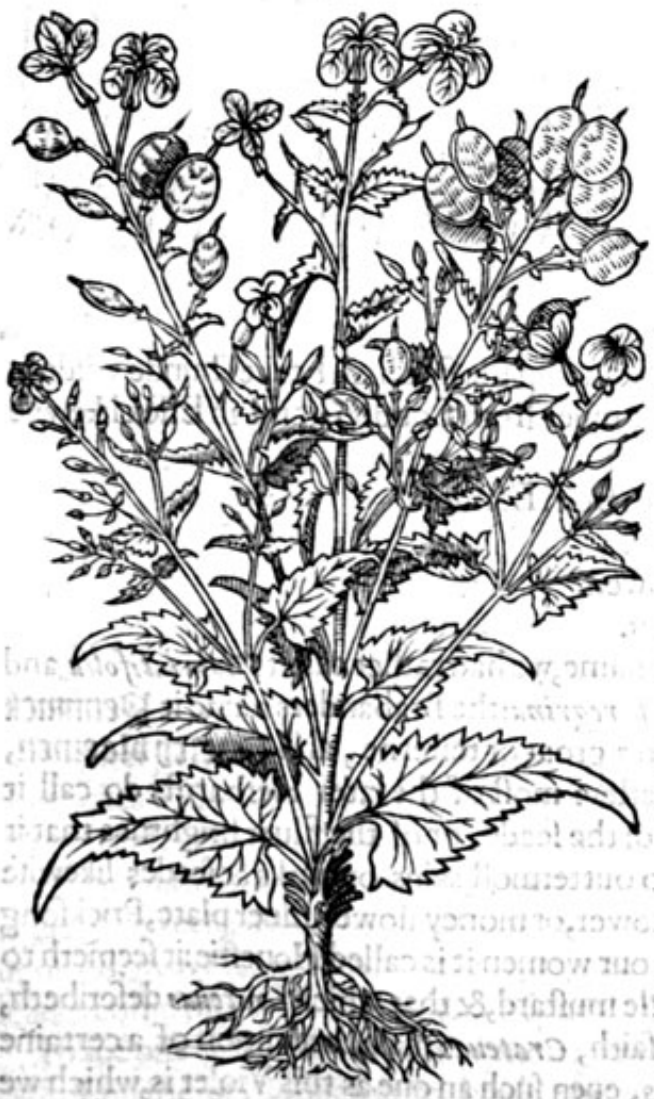

* The defcription.

I Olbonac or the Sattin flower, hath hard and round ftalkes, diuiding themfelues into manie other fmall braunches, befet with leaues like Dames Violets, or Queenes Gilloflowers, fomewhat broad and fnipt about the edges, \& in fafhion almoft like Sawce alone, or Iacke by the hedge. The ftalks are charged or loden with many flowers like the common ftocke Gilloflower, of a purple colour, which being fallen, the feede commeth foorth contcined in a flat thime cod, with a fharpe point or pricke at one ende, in farhion of the Moone, and fomewhat blackifh. This codis compofed of three filmes or skins, whereof the two outmoft are of an ouerworne afhe colour, and the innermolt or that in the middle wheron the feed doth hang or cleaue, is thinne \& cleere fhining, tike a peece of white Satten newly cut from the peece. The whole plant dieth the fame yeere that it hath borne feed, and muft be fowen yeerely. The roote is compact of manie tuberous parts like Key clogs, or like the great Afphodill.

2 The feconde kinde of Bolbonic or white Sattin, hath many great and broad leaues, almoft like thofe of the great burre Docke: among which rifeth vp a verie tall ftemme of the height of fower cubits, ftiffe, and of a whitifh greene colour, fet with the like leaues, but finaller. The flowers gtowe vpon the flender braunches, of a purple colour, compact of fower fmall leaues like thofe of the ftocke Gilloflower, after which come thinne long cods of the fame fubftaunce and colour of the former. The rodte is thicke, whereunto are faftned an infinite number of long threddie ftrings, which roote dieth not euery yeere as the other doth, but multiplieth it felfe as well by falling of the feede, as by newefhootes of the roote. 
2 Viola lunaris longioribus filiquin. Long codded white Sattin.

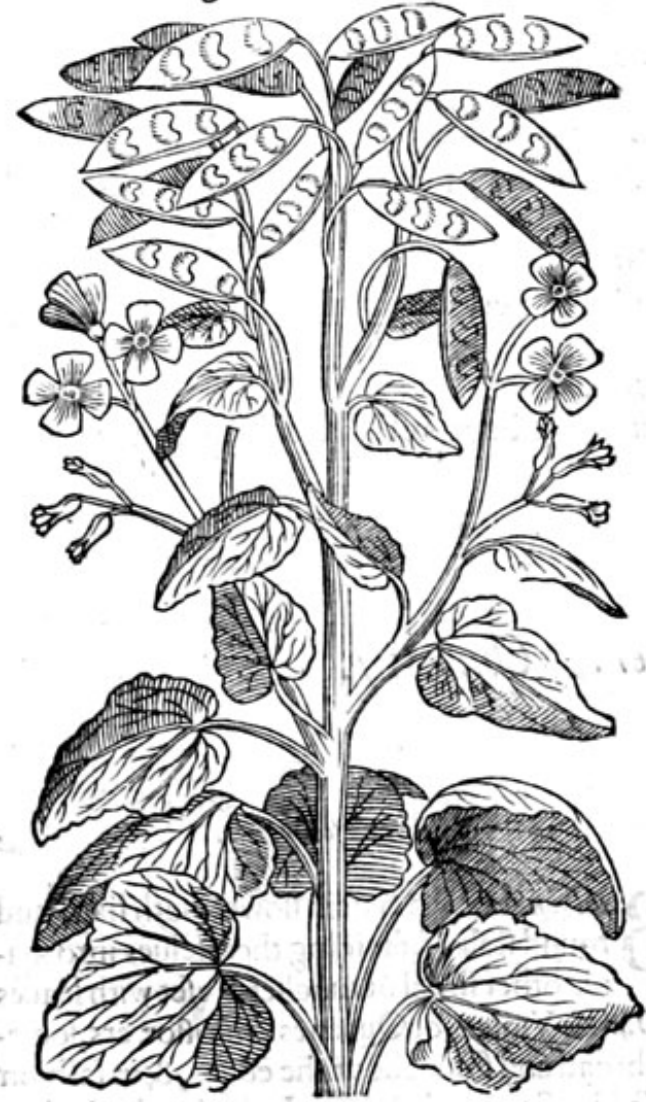

2 Viola lunaris Radix. The rootes of white Sattin.

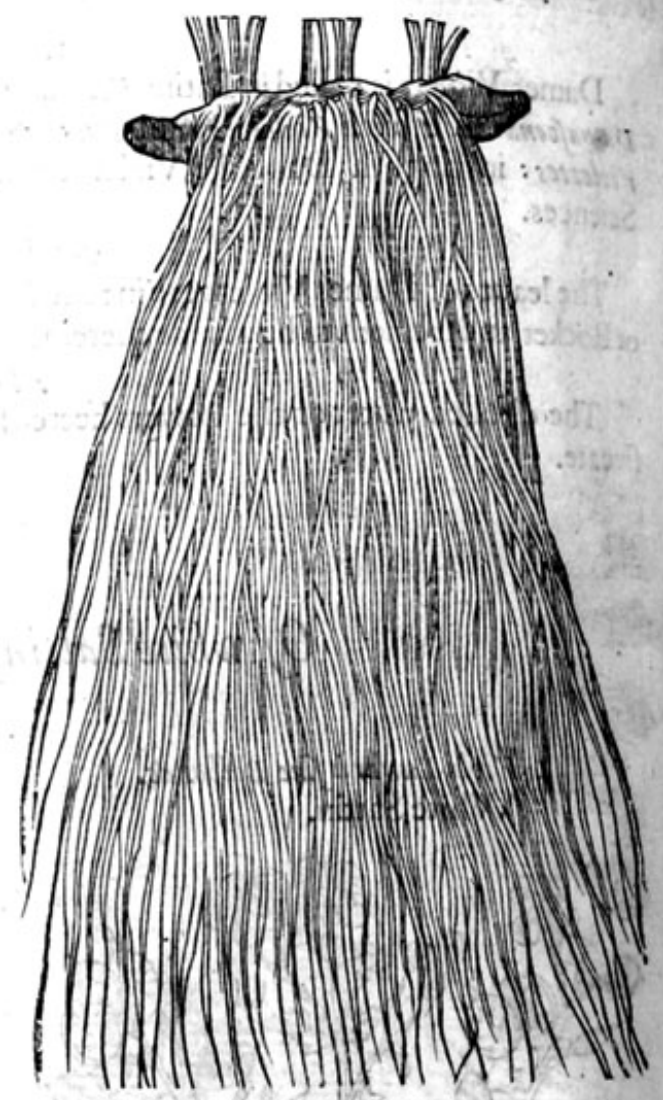

* The place.

Thefe plants are fet and fowen in gardens; notwithiftanding the firft hath beene founde wildein the woods about Pinner, and Harrow on the hill, twelue miles from London; and in Effex likewile about Hornchurch.

The fecond groweth about Watforde, fifteene miles from London.

\section{* The time.}

They flower in Aprill the next yeere after they be fowen.

* T Te names.

They are commonly called Bolbonac by a barbarous name, we had rather call it Viola lotifolit,and $V$ vola lunaris, or as it pleafeth moft Herbarifts, $V$ iola peregrina: the Brabanders name it penunch blaemen, of the farhion of the cods, like after a fort to a groat or tefterne, and JPaefchbloemen, bicaufe it alwaies flowreth neere about the feaft of Eafter: moft of the later Herbarifts do call it Lunaria ; others Lunaria Graca : either of the fafhion of the feede, or of the filuer brightnes that it hath; or of the middle skin of the cods, when the two outtermoft skins or husks \& feedes likewife are tallen away. We cal this herb in Englifh Pennie flower, or money flower, filuer plate, Prickfong woort, in Northfolk Sattin, \& white Sattin, \& among our women it is called Honeftie it feemech to be the old Herbarifts Thla pi alterum, or fecond Treacle muftard,\& that which Cratewas defcribeth, called of diuers Sinapi Perficum: for as Diofcorides faith, Crateuas maketh mention of a certaine Treacle Muftard,with broade leaues and bigge rootes, euen fuch an one as this Violet is, which we furname Latifolia or broade leafed: generally taken of all to be the great Lunaria, or great Moone woort.

\section{$*$ The temperature and vertues.}

A The feede of Bolbonac is of temperature hot and drie, and tharpe of tafte, and is like in tafte and force to the feede of Treacle muftard; the rootes likewife are fomewhat of a biting qualitie, but nos much : they are eaten with fallads as certaine other rootes are. 
A certaine Chirurgian of the Heluetians, compofed a moft fingular vnguent for wounds of the B leaues of Bolbonac and Sanicle ftamped togither, adding thereto oile and waxe. The feede is greatly commended againft the falling fickneffe.

\section{Of Galen bis Moonewoort, or Madwoort. Chap.i18.}

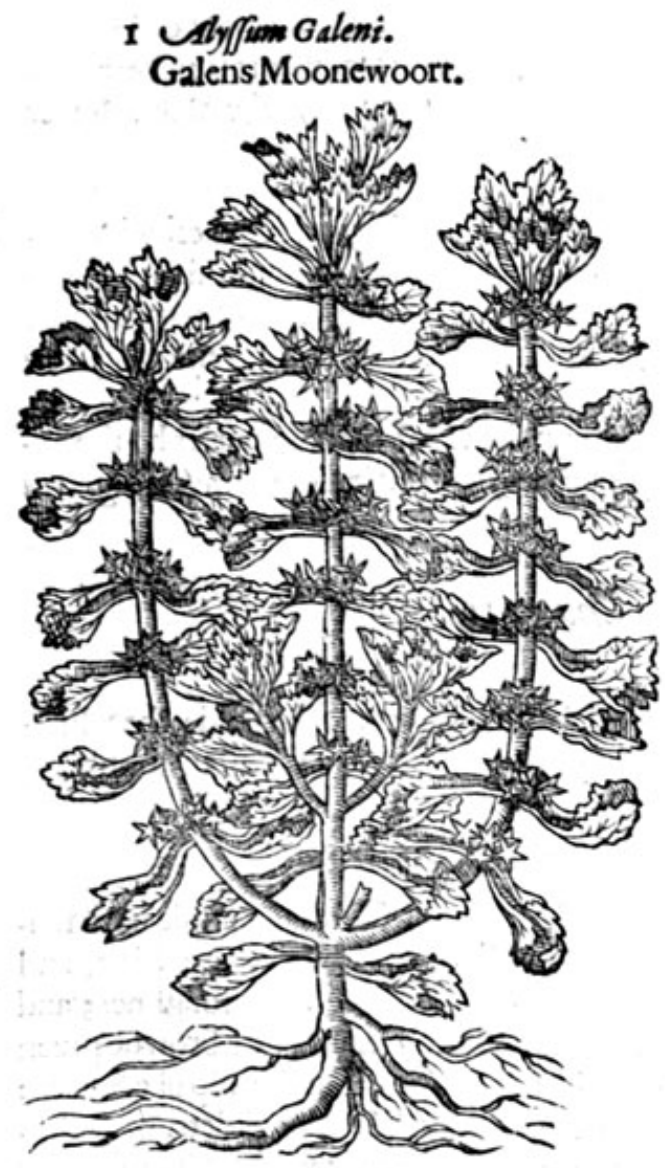

3 Niyfown Germanicum. Dutch Moonewoort.

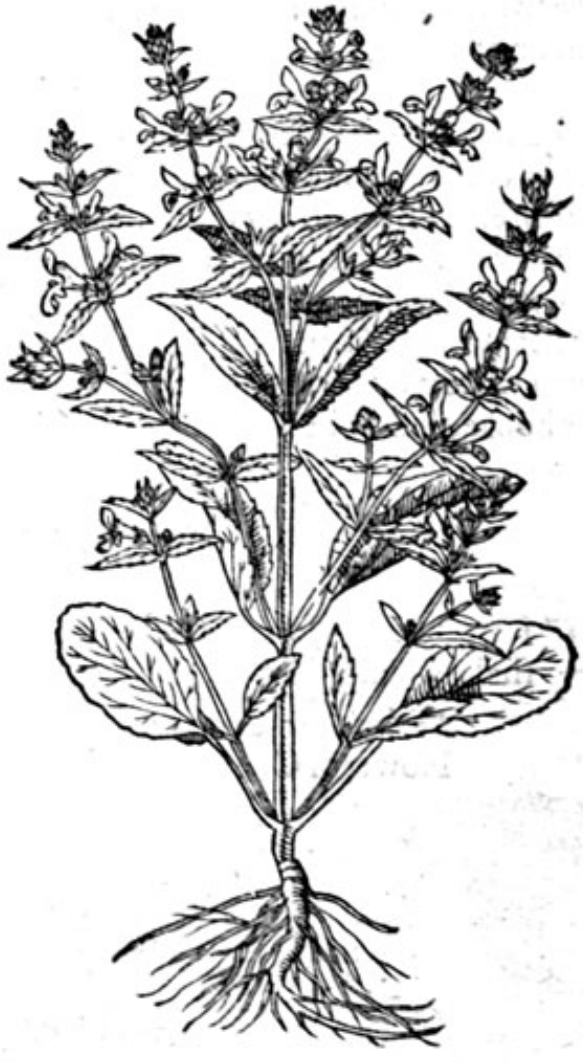

* The de/cription.

I 7 His might be one of the number of the Horehounds, but that $G_{a} l e n$ vfed it not for a kinde thereof; but for $A l_{y}$ fon, or Madwoort : it is like in forme and fhew vnto Horehound, and alfo in the number of the ftalks, but the leaues therof are leffer, more curled,more hoarie, and whiter, without any manifeft fmell at all. The little coronets or fpokie whurles that compaffe the ftalkes round about, are full of fharpe prickles : out of which growe flowers of an ouerwome grayifh colour, like to thofe of Horehound.The roote is hard, wooddie, and diuerfly parted.

2 The Germaine Madwoort bringeth foorth from a fibrous roote, two broad, rough, and hoarie leaues; betweene which rifeth vp a hoarie brittle ftalke, diuided into fundrie fmall branches, whereupon do growe long, narrow leaues, fomewhat fnipt about the edges; from the bofome of which leaues come foorth fmall roundles of purple flowers like thofe of the dead Nettle.

Ihaue one of Diofcorides defcription growing in my garden, which is thought to be the true and right Lunarie or Moonewoort, hauing his firft leaues fomewhat round, and afterward more long, whitifh, and rough, or fomewhat woolly in handeling; among which rife vp fmall, rough, brittle ftalkes, diuided into many branches, whereupon do growe many little yellow flowers; the which being paft, there folow flat and rough huskes, of a whitifh colour, in fhape like little targets or bucklers, wherein is conteined flat feede, like to the feedes of ftocke Gilloflowers. The whole huske is of the fame fubitance, fafhion and colour, that thofe are of the white Sattin. 


$$
\text { * The place: }
$$

Thefe plants are fowen now and then in gardens, efpecially for the rareneffe of them; the feede being brought out of Spaine and Italie, from whence I haue receiued fome for my garden.

$$
* \text { The time. }
$$

They llower and flourifh in May; the feede is ripe in Auguft, the fecond yeere after their fowing.
$*$ The names.

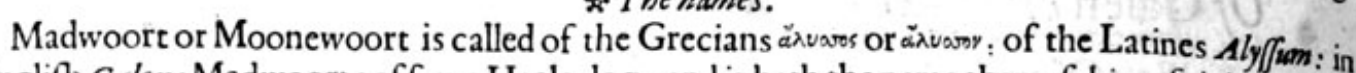
Englifh Galens Madwoort : of fome Heale dog; and it hath the name thereof, bicaufe it is a prefent remedie for them that are bitten of a mad dog,as $G$ alen writeth; who in his fecond booke of Coun. ter poifons, in Antonizes Coss his compofition defcribeth it in thefe words; Madwoort is an herb very
like to Horehound, but rougher and more full of prickles about the flowers; it beareth a flower tending to blew.

\section{* The temperature and vertues.}

A Galen faith it is giuen vnto fuch as are enraged by the biting of a mad dog, which therby areperfeetly cured, as is knowne by experience, without any artificiall application, or method at all. The which experiment if any hall prooue, he fhall finde in the working thereof. It is of temperature meanly drie, digefteth and fornething fcowreth withall; for this caufe it taketh away the morphew and funne burning, as the fame author affirmeth.

Many fabulous narrations haue been fet foorth concerning the vfe of thefe Lunaties by the ancient writers of forcerie, with which I lift not to trouble your eares, being fitter for Corneliwa Agrippas his booke, than to be inferted in our hiftorie of plants.

\section{OfRofe Campion.' Chap.i1g.}

\section{* Thekindes.}

Here be diuers forts of Rofe Campions,fome of the garden, and others of the field: the which Thall be diuided into three feuerall Chapters; and firft of the Campion of Conftantinople.

Lychnis Chalcedonica.

Flower of Conftantinople.

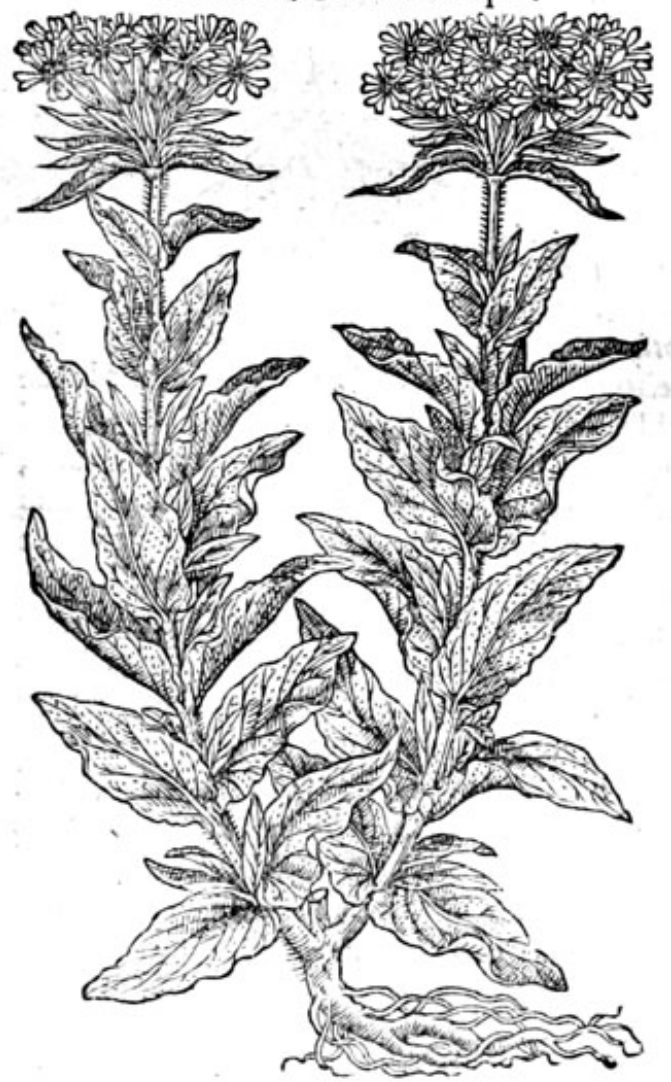

\section{The defription.}

$\boldsymbol{C}^{\mathrm{He}}$ Campion of Conftantinople hath fur. drie vpright ftalkes, two cubites high, and full of ioints, with a certaine roughnes; and at euery ioint two large leaues, of a browne green colour. The flowers growe at the top like Sweete Williains, or rather like Dames violets, of the colour of red lead, or orenge tawnie. The roote is fomewhat fharpe in tafte.

$$
\text { * Theplace. }
$$

The flower of Conftantinople is planted in gardens, and is very common almoft euery where. * The time.

It flowreth in Iune and Iuly, the fecondyeere after it is planted, and many yeeres after; foritconfifteth of a roote full of life : and endurethlong, and can away with the cold of our climate.

$$
\text { * Thenemes. }
$$

It is called Conit ast inopolitainus flos, and Lychmis Chalcedonica : of Aldroutandus Flos Creticu, or Flower of Candie: of the Germans Hierofolymo rum flos, or flower of Ierufalem : in Englifh Flower of Conftantinople: of fome Flower of Brittowe, and None fuch.

$$
\text { * The temperature and vertues. }
$$

Flower of Conitantinople, befides that grace 


\section{HISTORIE OF PLANTS.}

and beautie which it hath in gardens and garlands, is for ought we know of no vfe at all in phificke: for which caufe the vertues thereof are not yet found out.

$$
\text { OfRofe Campion. Chap.120. }
$$

\section{Lychnis Coromaris rubra.} RedRofe Campion.

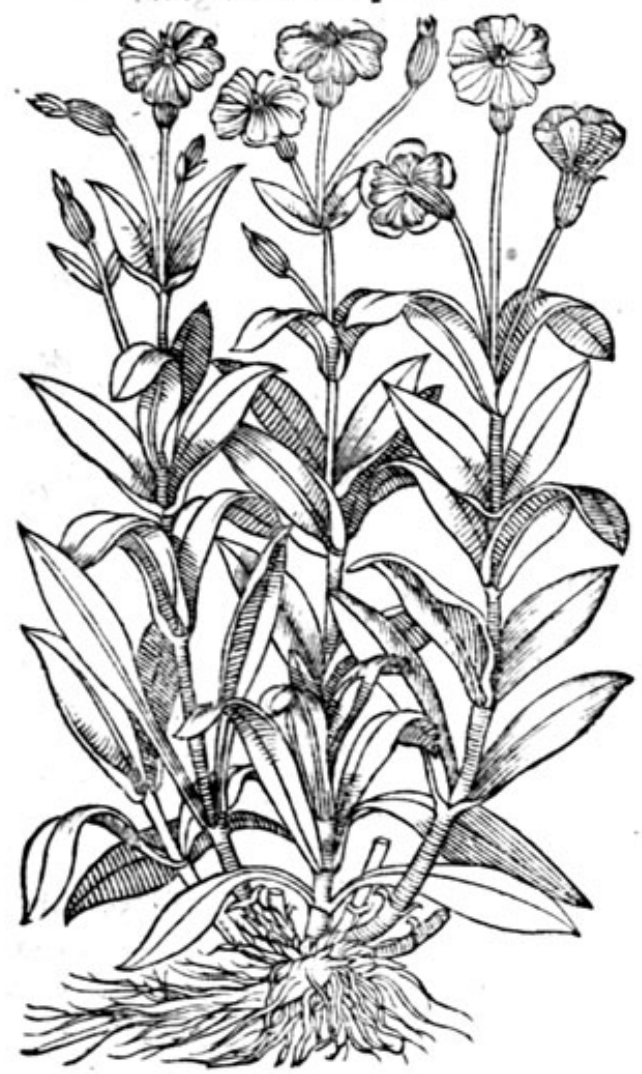

2 Lychnis Coronaria alba. White Rofe Campion.

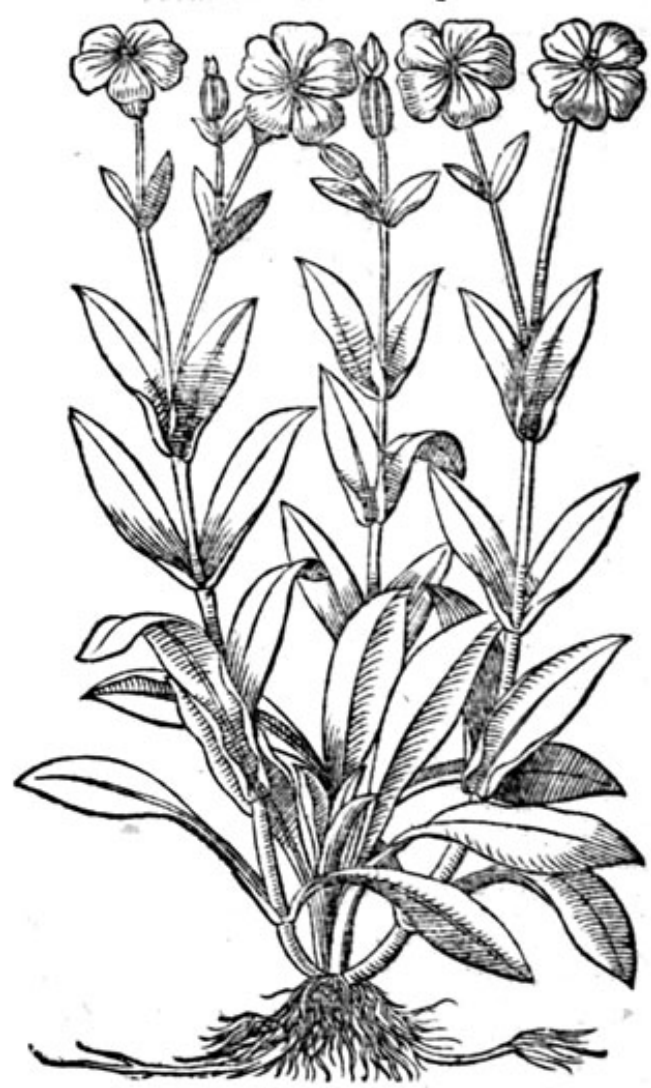

* Thedefcription.

I He firftinde of Rofe Campions hath round ftalkes, very knottie and woollie; and at euery knot or ioint there do ftand two woollie foft leaues' like Mullein, but leffer, and much narrower. The flowers growe at the top of the ftalke, of a perfeet red colour; which being paft, there follow round cods, full of blackifh feede. The roote is long and threddie.

2 The fecond Rofe campion differeth not from the precedent in ftalkes, leaues, or fafhion of the flowers : the onely difference confifteth in the colour, for the flowers of this plant are of amilke white colour, and the other red.

*Theplace.

The Rofe Campion groweth plentifully in moft gardens.

They flower from Iune to the ende of Auguft.

$$
\text { * The time. }
$$

* The names.

The Rofe Campion is called in Latin Dominarum Rofa, CMariana Rofa, Celi Rofa, Celifos : of Di-

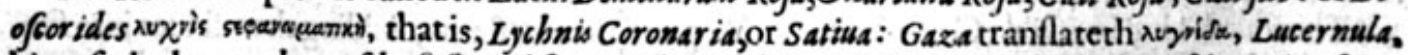
bicaufe the leaues thereof befoft, and fit to make candle weekes, according to the teftimonie of $D i$ ofcorides : it was called $L$ ychnis or $L y c h n i d e s$, that is a torch or fuch like light, according to the fignification of the worde, cleere, bright, and light giuing flowers; and therefore were called the Gardners delight, or the Gardners cie: in Dutch đbyiffeg fie : in French Oeillets, and Qcilets Diew : in high Dutch gartentofzlín, and pimmel rof̧lin. 
The Fecde of Rofe Campion, faith Galen, is hot and drie after a fort in the fecond degree. $*$ The vertues.

The feede drunken in wine is a remedie for them that are ftung with a fcorpion, as Diogcorides teftifieth.

\section{Of wilde rofe Campions. Chap.121.}

I Lychnis fluestris rubelloflore. Red wilde Campion.

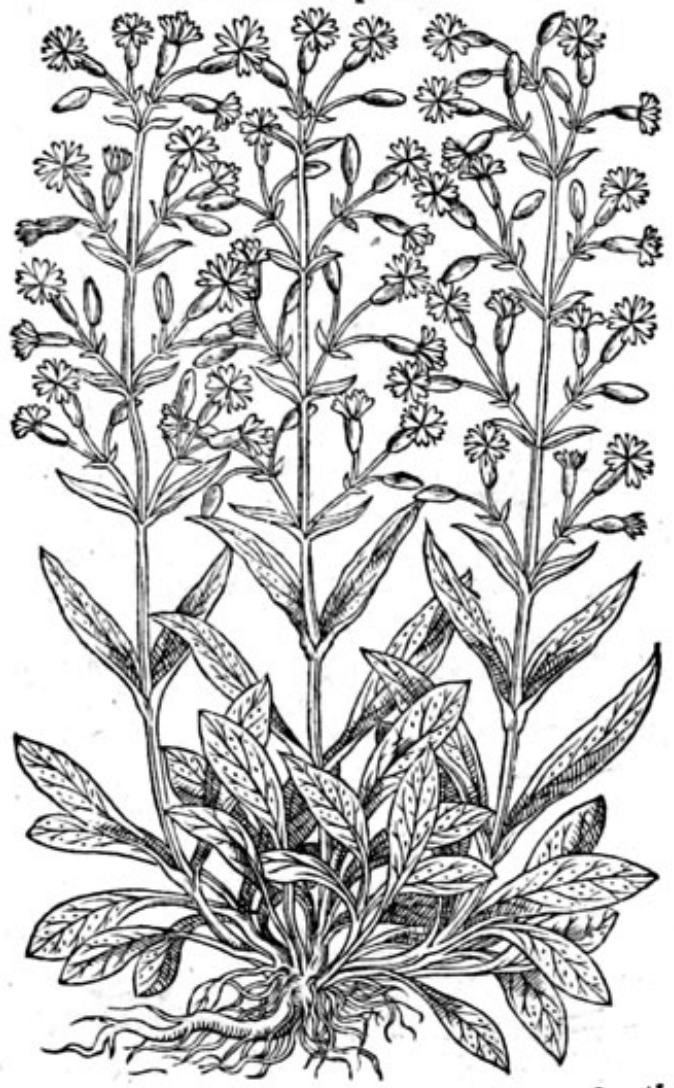

\section{* The defcription.}

I He wilde rofe Campion hath many rough broad leaues, fomewhat hoarie and woolly; among which rife vp long, foft and hairie ftalkes, branched into many armes, fet with the like leaues, but leffer. The flowers growe at the top of the ftalkes, compact of fiuefmall leaues, of a reddifh colour. The roote is thicke and woodie, with fome threds annexed thereto.

2 The fea rofe Campion is a fmall herbe, fet about with many leaues from the lower part vpward, which leaues are thicke, fomwhat leffer and narrower than the leaues of fea Purflane. It hath many crooked ftalks fpred vpon the ground, a foote long; in the vpper part whereof there is a fmall white flower, in fafhion and fhape like a little cup or boxe, after the likenes of Behen album, or Spatling Poppie, hauing within the faid flower little threds of a black colour, in tafte falt, yet not vnpleafant.

It is reported vnto me by a gentleman one Mafter Thomas Hesket, that by the fea fide inLancaShire, from whence this plant came, there is another fort hereof with red flowers.

3 The third kinde being a wilde field Campion, hath leaues like vnto the wilde red kinde, but that his ftalkes are hairie, and the flowers of a reddifh colour.

4 The fourth kinde of wilde Campions hath long and flender ftems, diuiding themfelues into fundric other branches, which are ful of ioints, hauing many fmall and narrow leaues, proceeding from the faid ioints. The flowers do grow on the top of the ftalke, of a whitith colour on the inner fide, and purplith on the outward fide, confifting of fiue fmall leaues, euery leafe hauing a cut in the end, which maketh it of the proportion and fhape of a forke: the feede is like the wilde Poppie; the roote fomewhat groffe and thicke. 
IHHISTORIE OF PLANTS.

$3^{8} 3$

3 Lychnis fluesitris birts.

4 Lychnis fylueftristrima Clasÿ.

is id z wa Wilde hairie Campion.

Hoarie wilde Campion.

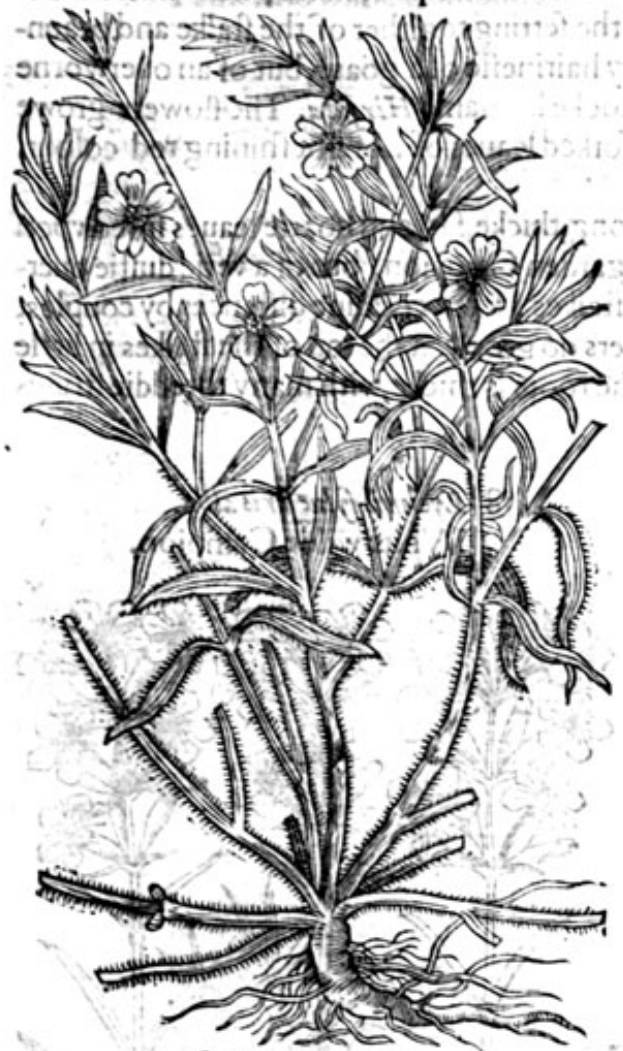

5 Lychnis Hirts minima.

Smallhairie Campion.
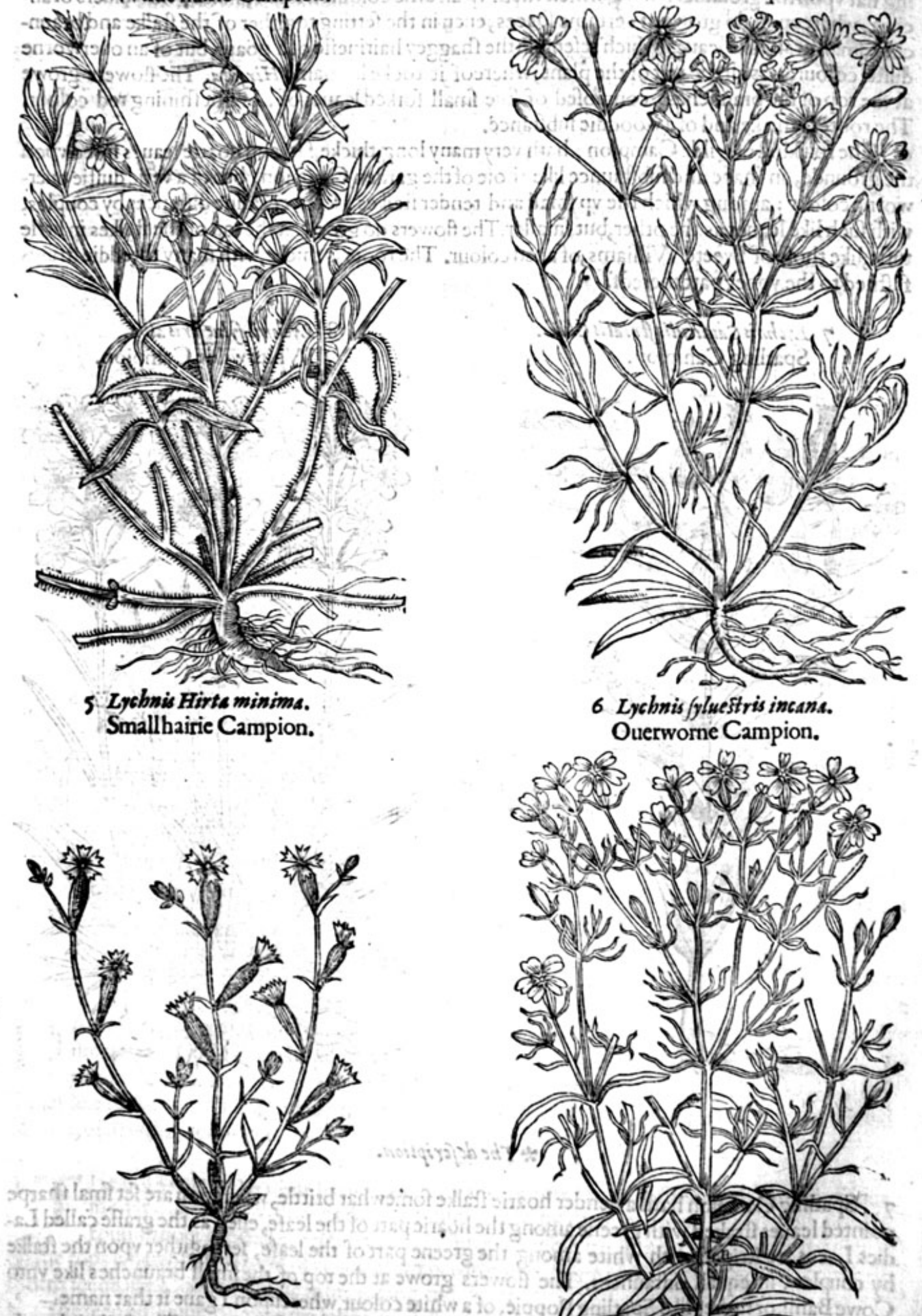

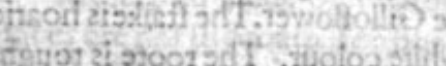

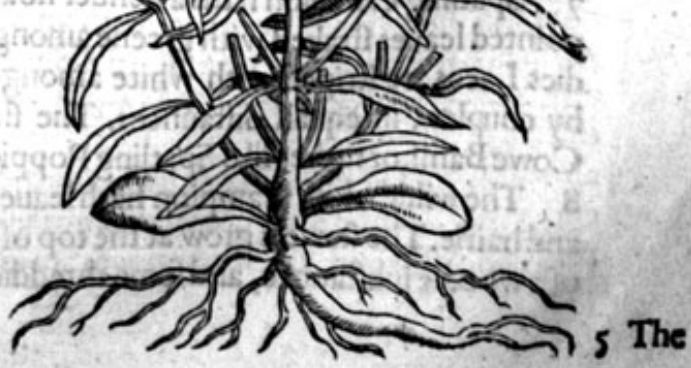




\section{$3^{84}$ THE SECOND BOORE OF THE}

5. The fift kinde of wilde Campion hath three or fower great foft leatues, fomewhat cownie, lying flat vpon the grounde: among which rifeth vp an af he coloured ftalke, diuided into diuers bran. ches : whereupon do growe at certaine fpsces, etien in the fetting togither of the ftalke and braunches, fmall graffelike leaues, which refemble the fhaggey hairineffe of a goate, but of an ouerworne duftie colour, as is all the reft of the plant, whereof it tooke his name Hirfuta. The tlowers growe at the top of the braunches, compofed of fiue fmall forked leaues of a bright ihining red colour, The roote is thicke and of a wooddie fubftance.

6 The fixt kind of wilde Campion, hath very many long, thicke, fat, and hoarie leaues fpred vpon the grounde, in thape and fubftaunce like thofe of the garden Campion, but of a verie duftie onerworne colour : among which rife vp fniall and tender italkes, fet at certaine diftances by couples, with fuch like leaues as the other, but fmaller. The flowers do growe at the top of the ftalkes in litele tufts, like thofe of fweete Williams, of a red colour. The roote is thicke, with many threddieftrings faltned to the vpper part thereof.

7, Lychnis Cauliculis friatis Clufit. Spatling Campion.

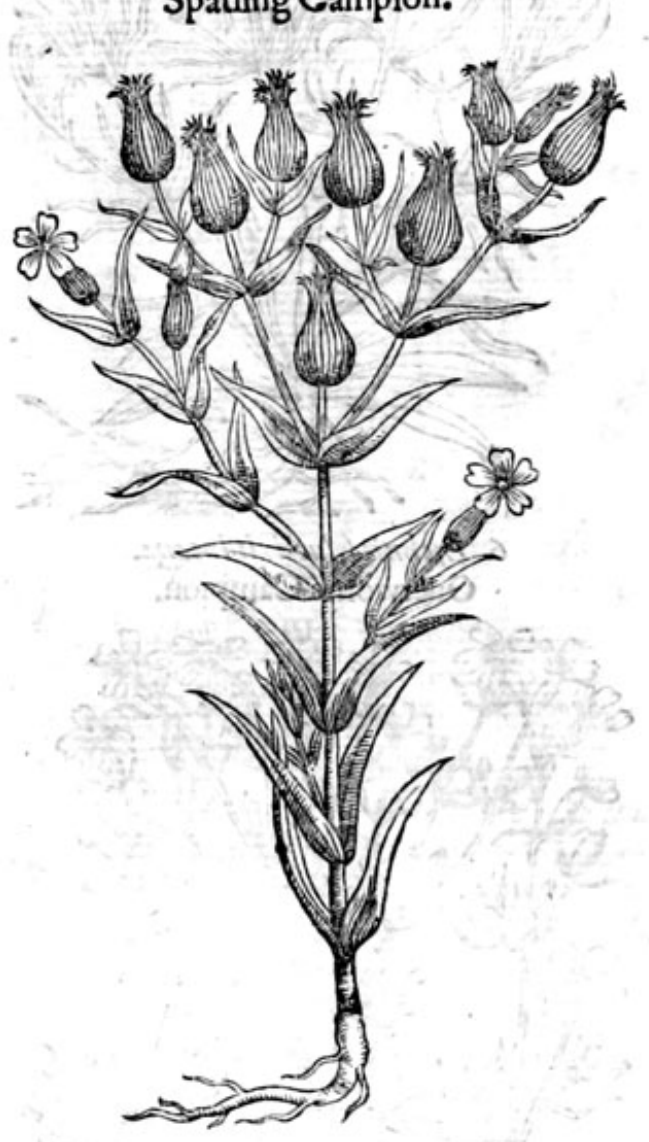

8 Lychnis glue firis alba. White wilde Campion.

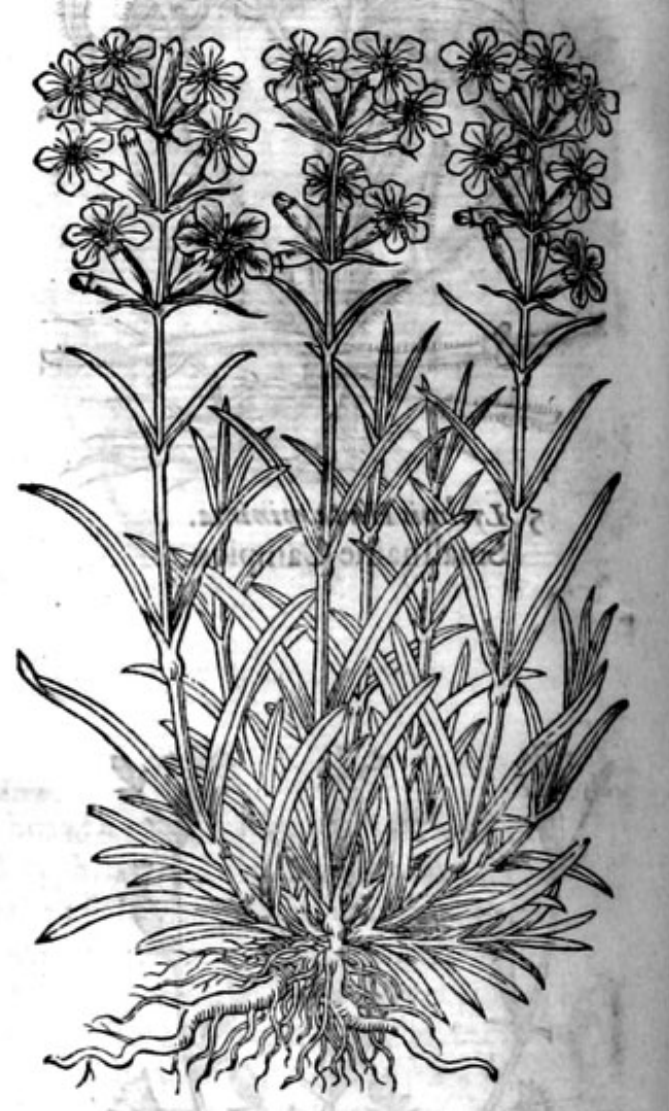

\section{* The de faription.}

7 Spatling Campion hath a flender hoarie ftalke fomewhat brittle, wherupon are fet final tharpe pointed leaues ftraked with greene among the hoarie part of the leafe, euen as the graffe called Ladies Laces are ftriped with white among the greene part of the leafe, fer togither vpon the ftalke by couples, in equall diftaunces. The flowers growe at the top of the fmall braunches like vato Cowe Bafill, or rather like Spatling Poppie, of a white colour, whereupon I gave it that name.

8 The wilde white Campion hathleaues like vnto the Sea ftocke Gilloflower. The ftalkeis hoarie and hairie. The flowers grow at the top of the ftalkes, of a milke white colour. The roote is tough, of a woodie fubitaunce, and fome threddie ftrings annexed thereto. 
9 Eychnis Plumaria.

Fethertop wilde Campion.

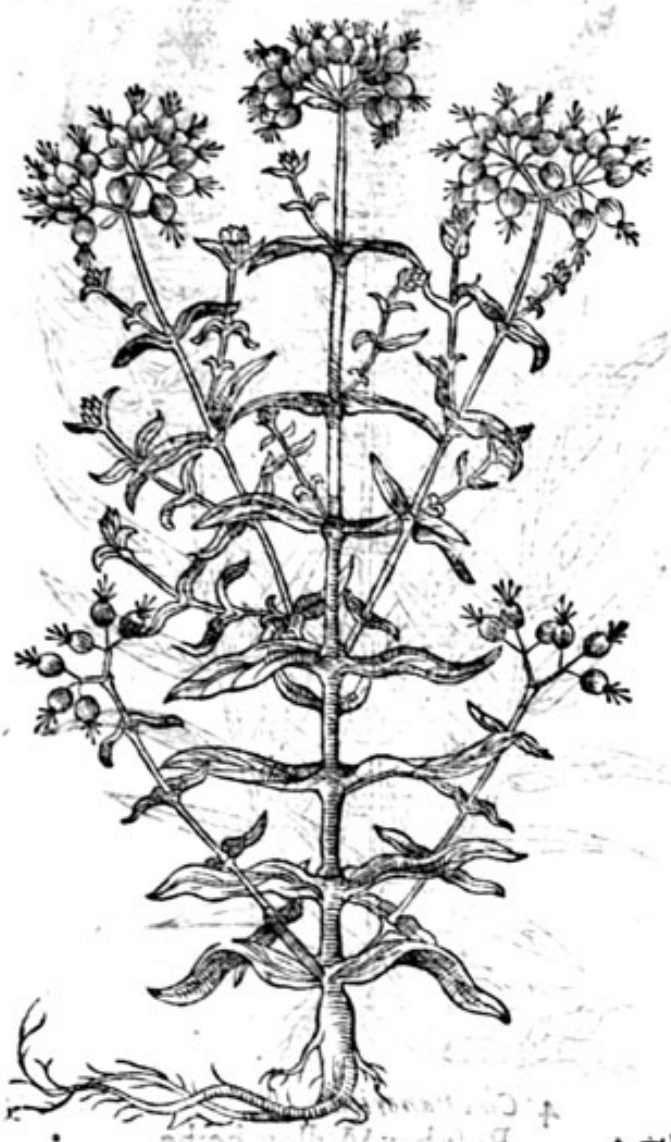

* The defoription.

9 The feathered Campion hath a thickegroffe roote, of a woodic fuftance, as moft of the Campi: ons haue:from which rifeth vp a ftiffe hoaric ftalke, fet from the bottome to the top by couples, with leaues like vnto Cowe Bafill : from the bofome of the leaues hard by the ftalke come foorth little tender fhootes, whereon do growe very fmall hoarie leaues. The flowers grow at the top of the braunches, in Thape like little goofeberries, thrufting foorth in one place of eche little flower a fmall purple taffell: the little knubbe it felfe is of a yellowifh colour.

\section{* Theplace.}

Theygrowe of themfelues neere to the borders of plowed fieldes, meddowes, and ditch bankes, common in many places.

The Sea Campion groweth by the fea fide in Lancarhire at a place called Lytham, fiuc miles from Wygan, from whence I had fome feedes brought me for my garden by a diligent fearcher of fimples, mafter Tbomas Hesketh, who hath harde it reported that in the fame place doth grow of the fame kinde forne with red flowers, which are very rare to be feene.

\section{$*$ The time.}

They flower and flourilh moft part of the fommer, euen vnto Putumne. * The names.

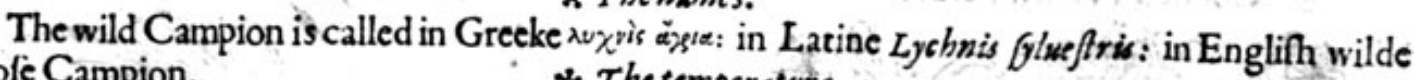
Rofe Campion.

* The temperature.

The temperature of thefe wilde Campions are referfed vnto thofe of the garden. * The vertwes.

The weight of two drams of the feede of wilde Campion, beaten to powder and drunke, doth purgecholer by the ftoole; and is good for them that are ftung or bitten of any venemous beaft.

$$
\text { OfWillow berbe, or Loofeftrife. Chap.122. }
$$

* The kindes.

$\mathrm{D}$ Iofcorides and other old writers knew but one herbe Willow, which was that with theyellow flower. The later age hath added three, which are baftarde kindes; two of a purple, and the third of a blew flower. Since wee haue difcouered diuers forts more, onc of them hauing
leaues like the water Willow, or Ofier, which fhall be fer forth; the reft we will leaue to a fecond
edition, or a further confideration edition, or a further confideration.

\section{* Thedefcription.}

17 Hefirft kinde of Willow herbe hath long and narrow leaues, of a grayifh greene colour, in fhape like the Willow or Sallow leaues, ftanding three or fower one againft another round about the ftalke, which toward the top diuideth it felfe into many otherbranches: on the tops whereof grow tuft's of yellow flowers without fmell; which being paft, thete commeth
foorth feede like Coriander. The roote is long and flender. 2 Thefecond kinde of Willow herbe in ftalkes and leaues is like the former, faning that his
leaues are not fo broad. The flowers growe along the ftalketoward the top fike fafhion, of a faire
purple colour; which being withered doegrats purple colour; which being withered, doe growe into downe that is carried away with the winde. 
1 Lyfimachia lutes.

Yellow Willow herbe.

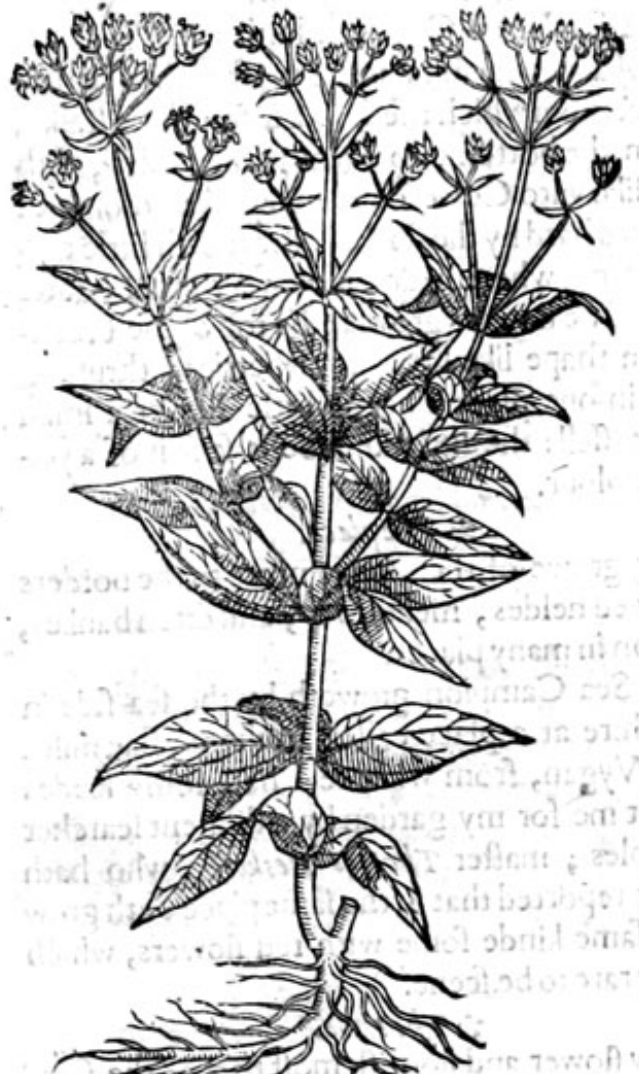

3 Lyfimachia fliquoja.

Codded Willow herbe.

gen 1V 1 .

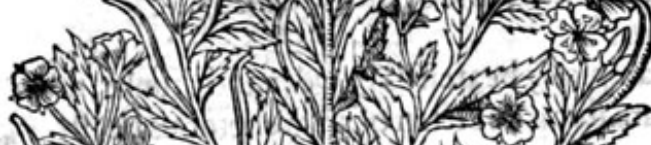

L 1 (
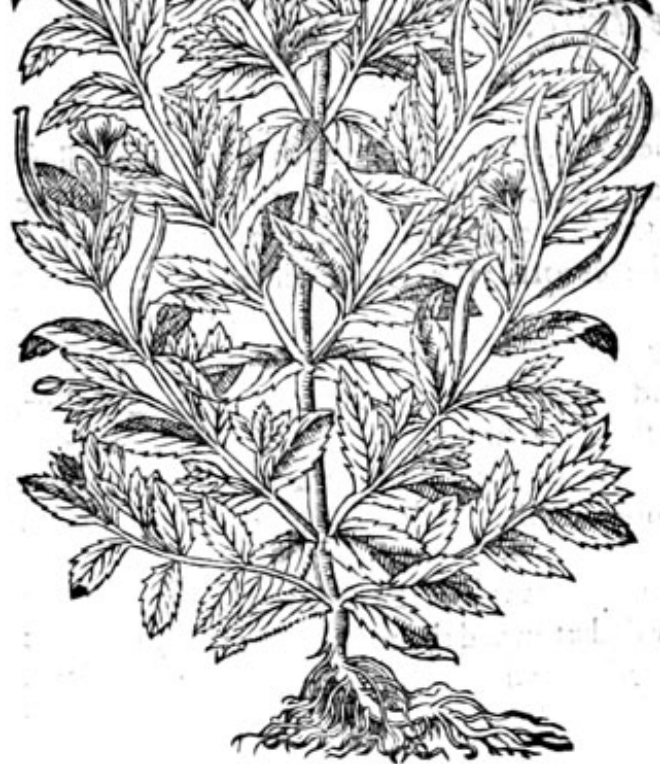

2 Lyfamachia par purea, ficata.

:10 Spiked Willow herbe,

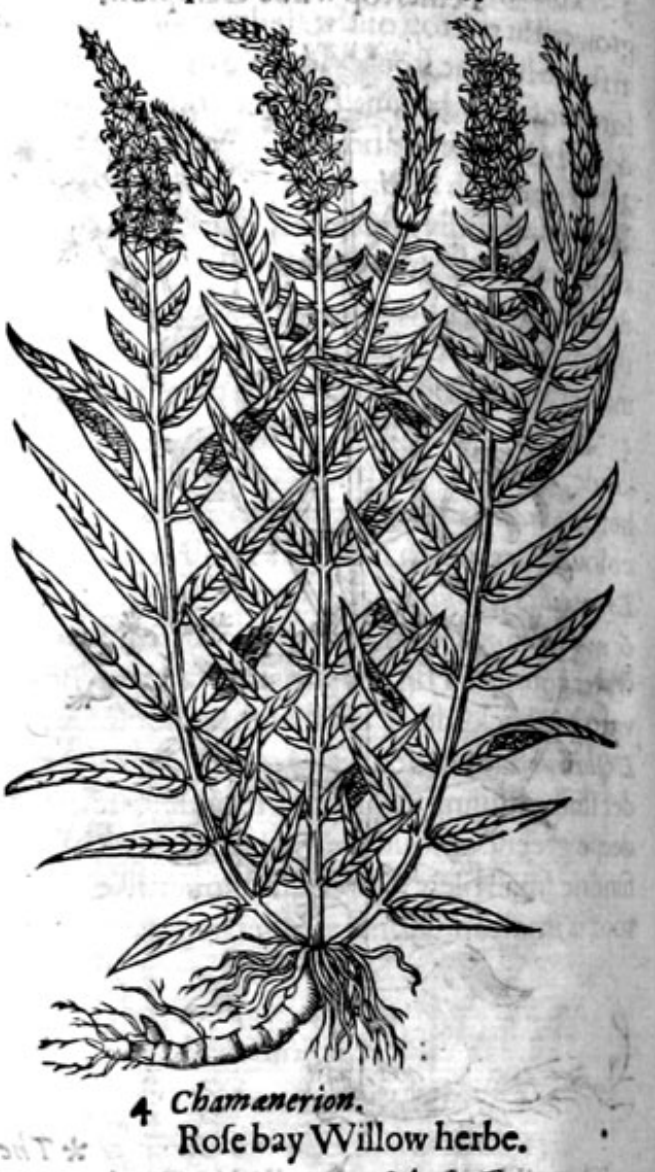

(n)

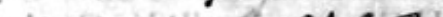




\section{HISTORLE OF PLANTS. AHT}

$\because 7$ hedefoription.

3 This Ly/ewacbis being the thirde in number, hath leaucs and ftalkes like the former. The flower groweth at the top of the italke; comming out of the ende of a fmall long codde, of a purple colour, in fhape like the ftocke Gilloflower $:$ and is called of many Ftliws ant : Patrem, that is, the fonne before the father, bicaufe that the codde commeth foorth firft hauing feedes therin, before the flower doth thewe it felfe abroade, which is of a purple colour like Geramuom called Doues foote. 4 The fourth being thought by Dodoneus to be a baftard kinde, is(as I do efteeme it) of all the reft the moft goodly and ftatcly plant, hauing leaues like the greateft $\mathrm{Willow}$ or $\mathrm{O}_{2}$ zer. The branches come out of the ground in great numbers, growing to the height of fixe foote, garnifhed with brate flowers of great beautie, confifting of fower leaues a peece, of an orient purple colour, hatung fome thrums in the middle of a yellow colour. The cod is long like the laft fpoken of; and full of downie matter,which flieth away with the winde whe: the cod is opened.

5 There is another baftarde Loofeftrife, or Willowe herbe, hauing ftalkes like the other of his kinde, whereon are placed long leaues fnipt about the edges, in fhape like the great V'erontes, or herbe Fluellen. The flowers growe along the ftalkes fipike fafhion, or like vnto Lauender, of a blewe colour; after which fucceede fmall cods or pouches. The roote is finall and fibrous. It may be called Lyfmachia Cerulea, or blewe Willowe herbe.

6 We haue likewife another Willowe herbe that groweth neere vnto the brinkes of riuers and water courfes. This I found in a waterie lane leading from the Lotd Treafurers hotefe called $T$ libals vnto the backfide of his flaughter houfe: and in other places as fhall be declated heereafter: which $L$ 'Obelises hath called Lyfamachia galericulats, or hoodded Willowe herbe. It hath many imal tender ftalks trailing vpon the grounde, befet with diuers leaues, fomewhat fnipt about the edges, of a deepe greene colour like vnto the leaues of Scordisen, or water Germander:among which are placed fundrie fmall blew flowers, fafhioned like a little hoode, in thape refemoling thofe of Alchooue. The root is fmall and fibrous, difperfing it felfe vnder the earth far abroad, wherby it greatly increafeth.

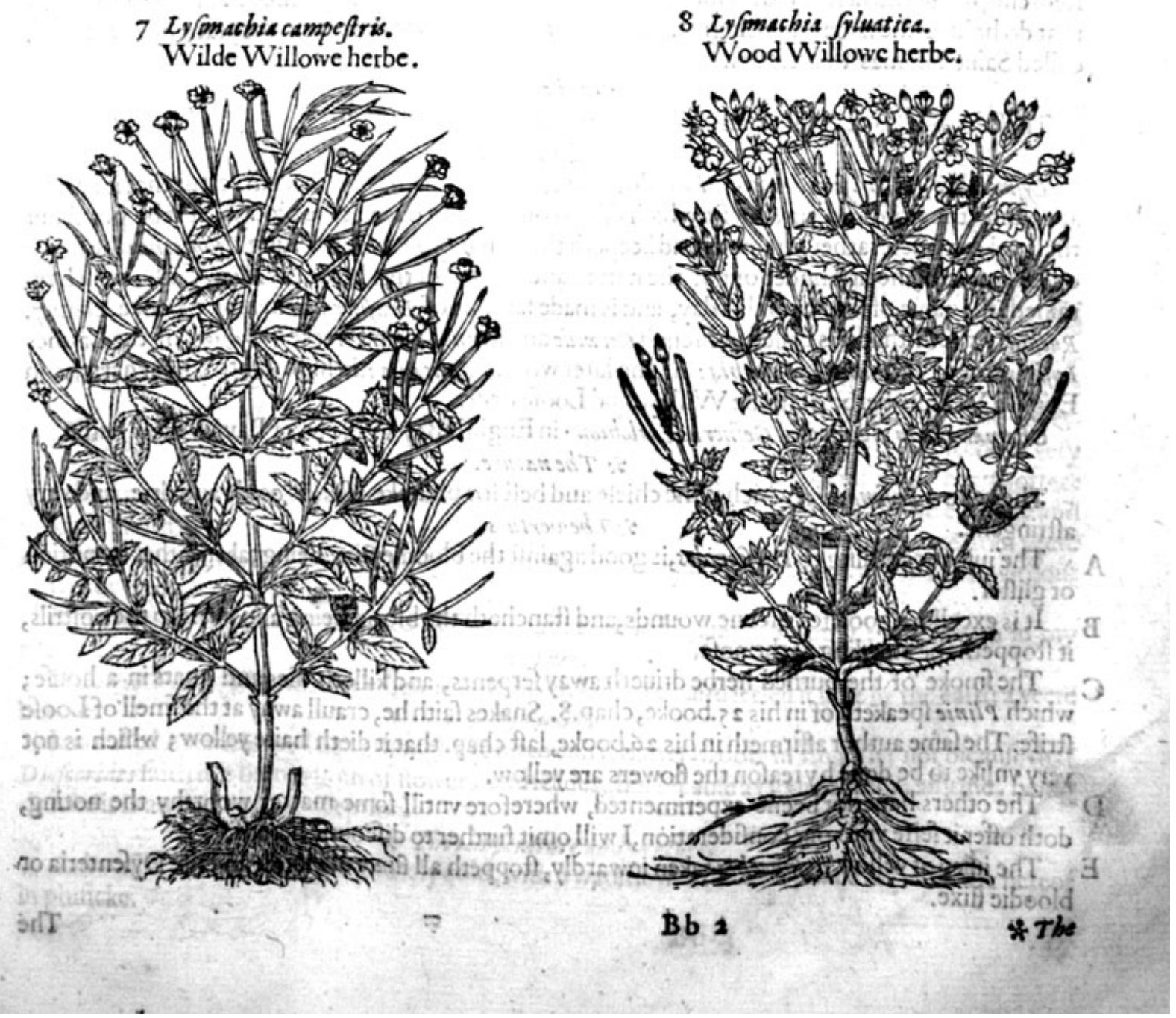


$*$ The defoription.

7. The wilde Willowe herbe hath fraile and verie brittle ftalkes, flender, and of the height of acu. bite, fometimes higher: whereupon do growe harpe pointed leaues fomewhat fnipt about the edges, fet togither by couples. There come foorth at the firft long flender coddes, wherein is conteined fmall feede, wrapped in a cottonie or downie wooll, that is caried awaie with the winde when the feede is ripe; at the ende of which commeth foorth a fmall flower of a purplifh colour whereupon it was called Filius ante Patrem, bicaufe the flower doth not appeere vntill the codbe filled with his feede: but there is another fonne before the father, as hath beene declared in the chapter of meadowe Saffron. The roote is fmall and threddie.

8 The woode Willow herbe hath a flender ftalke dituided into other fmaller braunches, wheron are fet long leaues, rough and harpe pointed, of an ouerworne greene colour. The flowers growe at the tops of the braunches, confifting of fower or fiue fmall leaues, of a pale purplifh colourten. ding to whitenes, after which come longs cods, wherin are little feeds wrapped in a certaine white
downe, that is caried away with the winde. The roote is threddie. * The place.

The yellow Ly/machia groweth plentifully in moift medowes, efpecially along the medowes as you go from Lambeth to Batterfey neer London, and in many other places throughout England.

The fecond groweth in places of greater moifture, yea almoft in the running ftreames, and $f$ tanding waters, or harde by them. It groweth inder the Bithops houfe wall at Lambeth, neerethe water of Thames, and in moift ditches in moft places of England.

The third groweth neere the waters (but not in the waters) in all places for the moft part.

The fourth groweth in Yorkfhire in a place called the Hooke, neere vnto a clofe called the $\mathrm{C}_{o}$ pafture; from whence I had thefeplants, which do grow in my garden very goodly to behold, for the decking vp of houfes and gardens.

The fift groweth hard by the Thames, as ye go from a place called the Diuels Neckerchefeto Redreffe, neere vnto a ftile that Itandeth in your way vpon the Thames banke, among the plankes that do hold vp the fame banke.It groweth alfo in a ditch fide not farre from the place of execution, called Saint Thomas Waterings.

$$
* \text { The time. }
$$

Thefe herbes flower in Iune and Iuly, and oftentimes vntill A uguit. * T The names.

Ly/imachia, as Diofcorides and Plinie doe write, tooke his name of a fpeciall vertue that it hathin appeafing the ftrife and vnrulineffe which falleth out among oxen at the plough, if it be putabout their yokes: but it rather retaineth and keepeth the name Ly/jmachia, of King Ly/imachus the fonne of Agathocles, the firft finder out of the nature and vertues of this herbe, as Plinie faith: whichre. taineth the name of him vnto this day, and is made famous of Eraf35tratus in his 25 . booke, chap.7. Ruellius writeth, that it is called in French Cornelle and Corneola; in Greeke nvorudxiop; of the Latines Lyfmachium : of Plinie Lyfomachia: of the later writers Salicaria : in high Dutch odredetick: in Englifh Willow herbe, or herbe Willow, and Loofe ftrife.

Chamenerium is called of Gefnerus Epilobion : in Englifh Bay Willow, or Bay Willow herbe * The nature.

The yellow Lyfamachia, which is the chiefe and beft for phificke vfes, is colde and drie, and very

aftringent.
A The iuice according to Diofsorides, is good againft the bloodie flixe, being taken either by potion

aftringent.
A The iuice according to Diofrorides, is good againft the bloodie flixe, being taken either by potion or glifter.

B It is excellent good for greene wounds, and ftancheth the blood:being alfo put into the notrils, it ftoppeth the bleeding at the nofe.

C The fmoke of the burned herbe driueth away ferpents, and killeth flies and gnats in a houfe; which $P$ linie fpeaketh of in his 25 . booke, chap.8. Snakes faith he, craull away at the fimell of Loofe ftrife. The fame author affirmeth in his 26 .booke, laft chap. that it dieth haire yellow; which is not very vnlike to be done by reafon the flowers are yellow.

D The others hauenot beene experimented, wherefore vntill fome matter woorthy the noting, doth offer it felfe vnto our confideration, I will omit further to difcourfe hereof.

E The inice of yellow Lyfimachia taken inwardly, ftoppeth all fluxe of blood, and the Dyfenteria of bloodie tixe. 
The iuice put into thenofe, ftoppeth the bleeding of the fame, and the bleeding of wounds, and $\mathrm{F}$ mightily clofeth and healeth them, being made into an vnguent ot falue.

The fame taken in a mother fuppofitorie of woole or cotton;bound vp with threds(as the maner $G$ thereof is very well knowne to women) ftaieth the inordinate fluxe or ouermuch flowing of women termes.

It is reported, that the fume or fmoke of the herbe burned, doth driue away flies and gnats, and $\mathrm{H}$ all maner of venemous beafts.

\section{OfBarren woort. Chap.12j.}

Epimedivem.

Barren Woort.

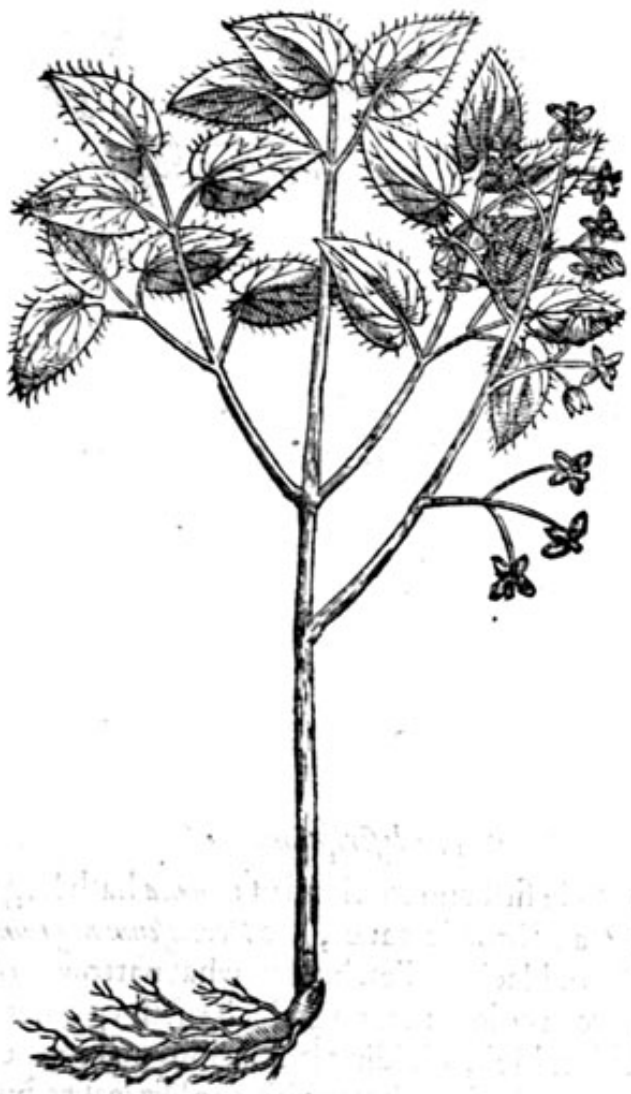

\section{* The defcription.}

$\mathrm{T}$ His rare and ftrange plant was fent to me from the French Kings Herbarift, Robinns, dwelling in Paris at the figne of the blacke head, in the ftreete called Dubout du Monde, in Englifh, The end of the world. This herbe I planted in my garden, and in the beginning of May it came foorth of the grourt, with fmall, hard and wooddie crooked ftalkes: whereupon grow rough and tharpe pointed leaues, almoft like CAlliaria, that is to fay, Sauce alone, or Iacke by the hedge. L'Obelies and Dodon.oses fay, that the leaues are fomwhat like Iuie, but in my iudgement they are rather like Alliaria, fomewhat fnipt about the edges, and turning themfelues flat vpright, as a man turneth his hande vpwardes when he receiueth money. Vpon the fame ftalks come foorth fmal flowers, confilting of fower leaues, whofe outfides are purple, the edges on the inner fide red, the bottome yellow, and the middle part of a bright red colour, and the whole flower fomewhat hollow. This have I feene, although Dodonesus faith that it neuer beareth any ubor at all. The caufe may be, for that the countrie where he fawe the fame doth not agree fo well with thenature of the plant,as our foile of England doth. The roote is fmall, and creepeth almoft vpon the vppermoft face of the earth. It beareth his feede in yety fmall cods like Saracens Confound, but fhorter: which came not to ripeneffe in my garden, by reafon that it was dried away with the extreme and vnaccuftomed heate of the funne, which happened in the yeere 1590 . fince which timefrom yeere to yeere it bringeth feede to perfection. Further Diofcorides and Plimie do report, that it is without
flower or feede.
$*$ The place.

It groweth in the moift medowes of Italie about Bononia and Vincentia : it groweth in my garden. * The time. It flowreth in Aprill and May when it hath taken faft hold, and fetled it felfe in the earth a yeere
before. * T he namss.

It is called Epimedium: I haue thoughtgood to call it Barren woort in Englifh; not bicaufechat Diofcorides faith it is barren both of flowers and feedes, but bicaufe as fome authors affirme, being drunke it is an enimic to conception.

* The temperature and vertues.

Galen affirmeth that it is moderately cold, with a waterie moifture: we haue as yet no vfe hereof in phificke. 


\section{Of Fleabane Mullet. Chap.124.}

I Conyesmaior.

Great Fleawoort.

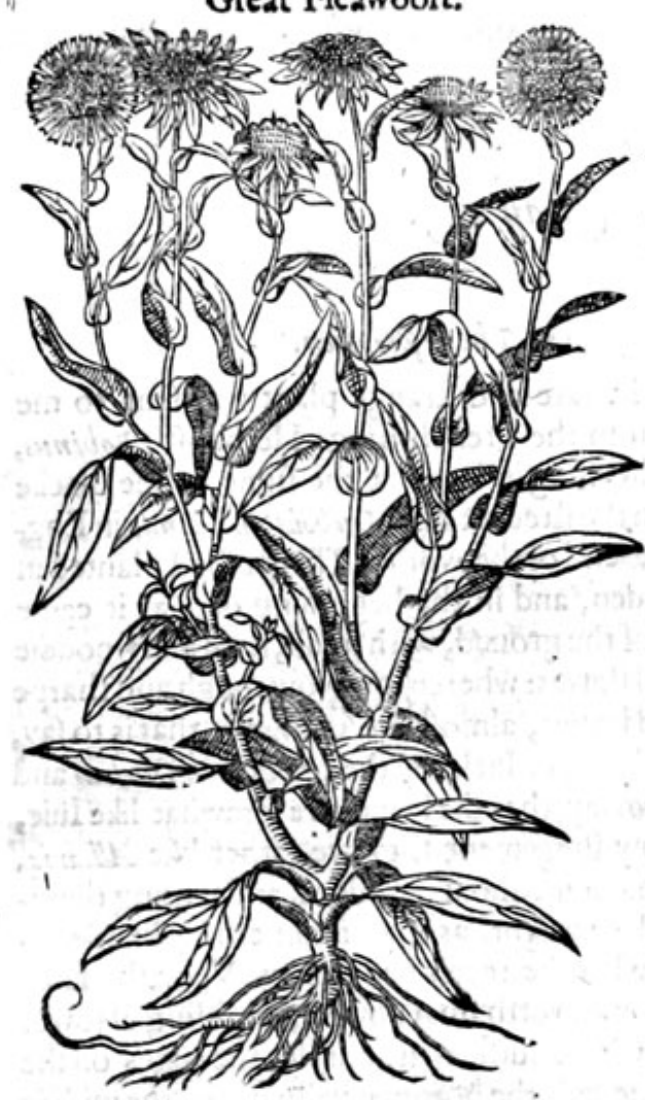

2 Conyza minor. Fleabane Mullet.

\section{Conyzs minima.}

Dwarfe Fleabane.
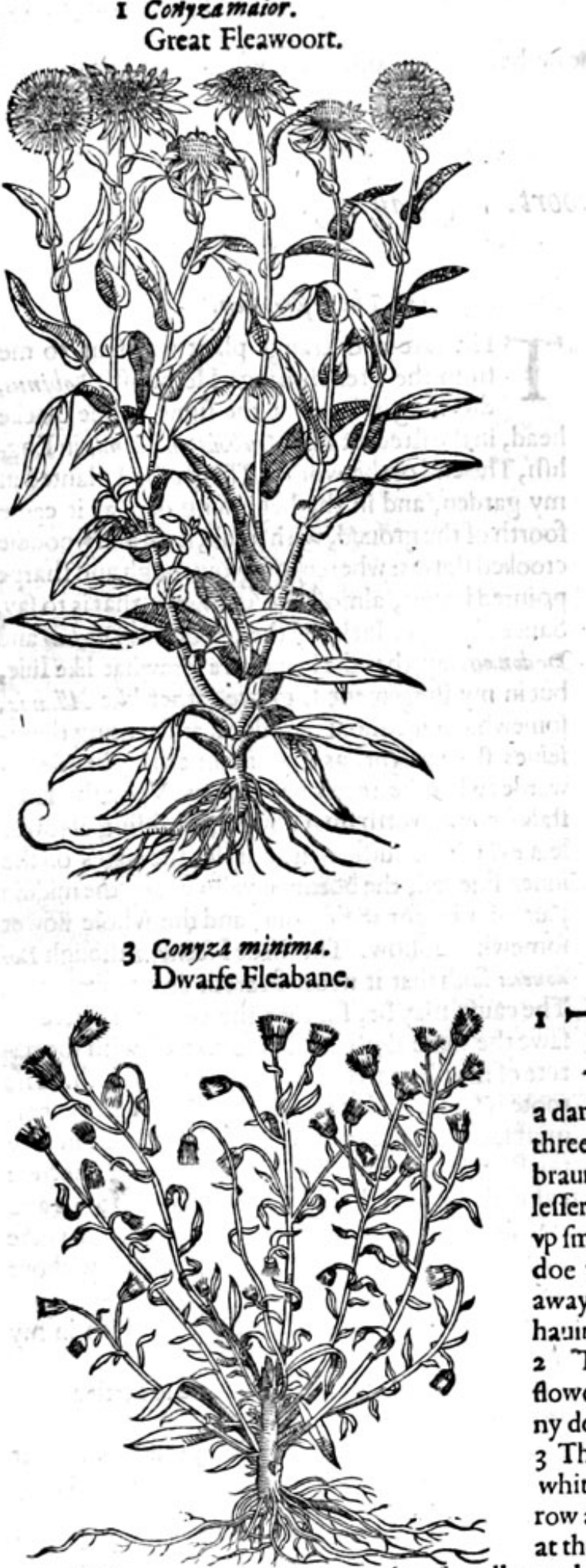
There is a fourthand fmal conyza, which differech not from the reft, fauing that iris a great deale leffe, and growerh fetdome a foote high. The tlowers be of a darke yellowe colour, almolt like Tanfie flowers, or the midft of the flowers of Cammomill: the whole plant is of a ftrong fanour.

There be threekindes more, where of I finde not any thing written: for which caule I leaue it to a further confideration: the one is called Conyza Hellenit is, Mellita Incana : another Conyzu Hellenitis folys laciniafis : and the ocher Conyza Hellemit is pilosa.

* Theplace.

The great and leffer Conyza do grow c among the chalkie ground, by Detford, three miles from London, neere vnto the place where Lime is made ; at Greenhine in Kent; at Grayes in Effex, and many other places.

The other which is the middle, groweth in euerie waterie ditch, and running ftreame.

The fmall kinde of Conyza groweth at Iflington by London, in the ftreete as ye go from the ende of the towne next London vnto the church, and in many other barren and wafte places neere London.

They flower in Iuly and Auguif.

* Thetime.

\section{* The nanes.}

Conyzs from time to time hath been called in Englifh Fleabane, but without reafon, confidering there is another herbe fo called: but if it were peffible to roote out auncient etrors, I would gladly haue Conyza to be called in Englifh Fleabane Mullet, to make a difference betweene two herbes that beare one name. In Greeke it is called xorv? $\alpha$ : in Latine Conyza : of Plinie Cunilago: of Gaza Policaria, and Palicaria; yet it differech from Pfylliwon, which is alfo called Pulicaria, Fleawoort. The great Conizs is called Diofcor ides his Baccharis, or our Ladies gloues.

Conyzs is hot and drie in the third degree.

$$
x \text { The nature. }
$$

* The vertues.

The leaues and flowers be good againft the ftrangurie, the iaundife, and the gnawing or griping $\mathbf{A}$ of the bellie,

The fame taken with vineger, helpeth the Epilepfie or falling fickneffe.

If women do fit ouer the decoction thereof, it greatly eafeth their paines of the mother.

The herbe burned, where ties, gnats, fleas, or any venemous things are, doth driue them away.

\section{Of Starre woort. Chap.125.}

* The kindes.

There be diuers forts of the Afters or Stanwoorts, as fhall be declared. * The defcription.

I Te firft kinde of 1 1ster or Ingminalis, hath large, broade leaues like $V$ erbafown, or the great

Conyza : anong which rifeth vp a ftalke fower or fiue foote long, harde, rough, and hairie, befet with leaues like rofe Campions, of a darke browne green colour. At the top of the faid ftalks come foorth flowers, of a hining \& gliftering golden colour,\& fomtimes purple : among thefe flowers growe fiuc or fixe long leaues, iharpe pointed and rough, not much vnlike the fifh called Stella maryma. The flowers turne into downe, and are caried away with the winde. The roote is fibrous, of a binding and iharpe tafte.

2 The feconde called Italian Starrewoort, hath leaues like Conyzs, among which rife vp manie fhrubbie ftalks, veric hard and blackifh, a foote high, bearing at the top yellowe flowers, mixed with fome purple, fet aboutwith chaffie fcales like Iaces or Knapweede. The roote is fibrous, of an aftringent and drying tafte.

3 The third kinde hath leaues folike Italian Starrewoort, that a man can fcarfely at the fudden diftinguifh the one from the other. The fingle ftalke is a cubite long,vpright, and tender : on the top whereof growefaire yellowe towers, like thofe of Emula Campans, in thape like a ftarre: and the

4 The fourth kinde in talneffe and flower is not much vnlike that laft before fpecified, but in ftalke and leaues more hairie, and longer, fomewhat like our fmall Hounds toong : and the roote fibrous or threddic as the former. 
I Asteratticus.

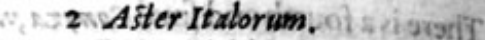
Starrewoort.

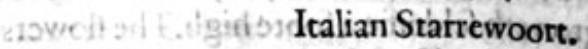

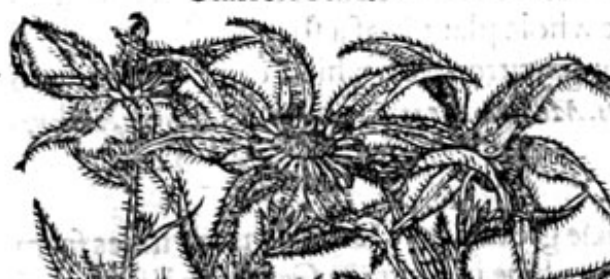

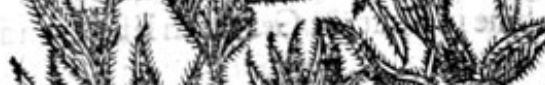

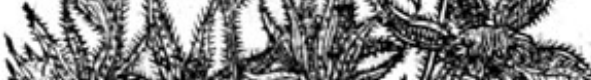

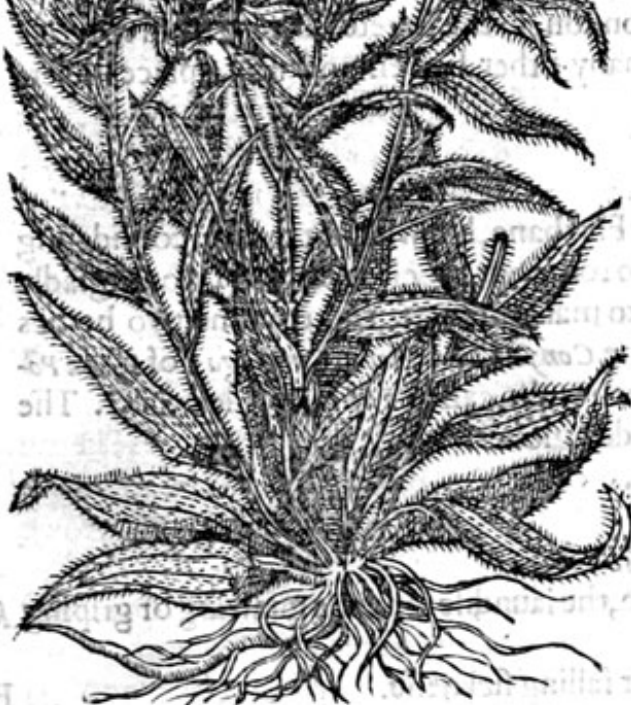

3 Uffer montanus.

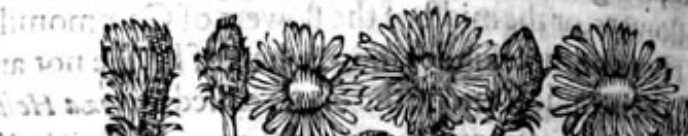
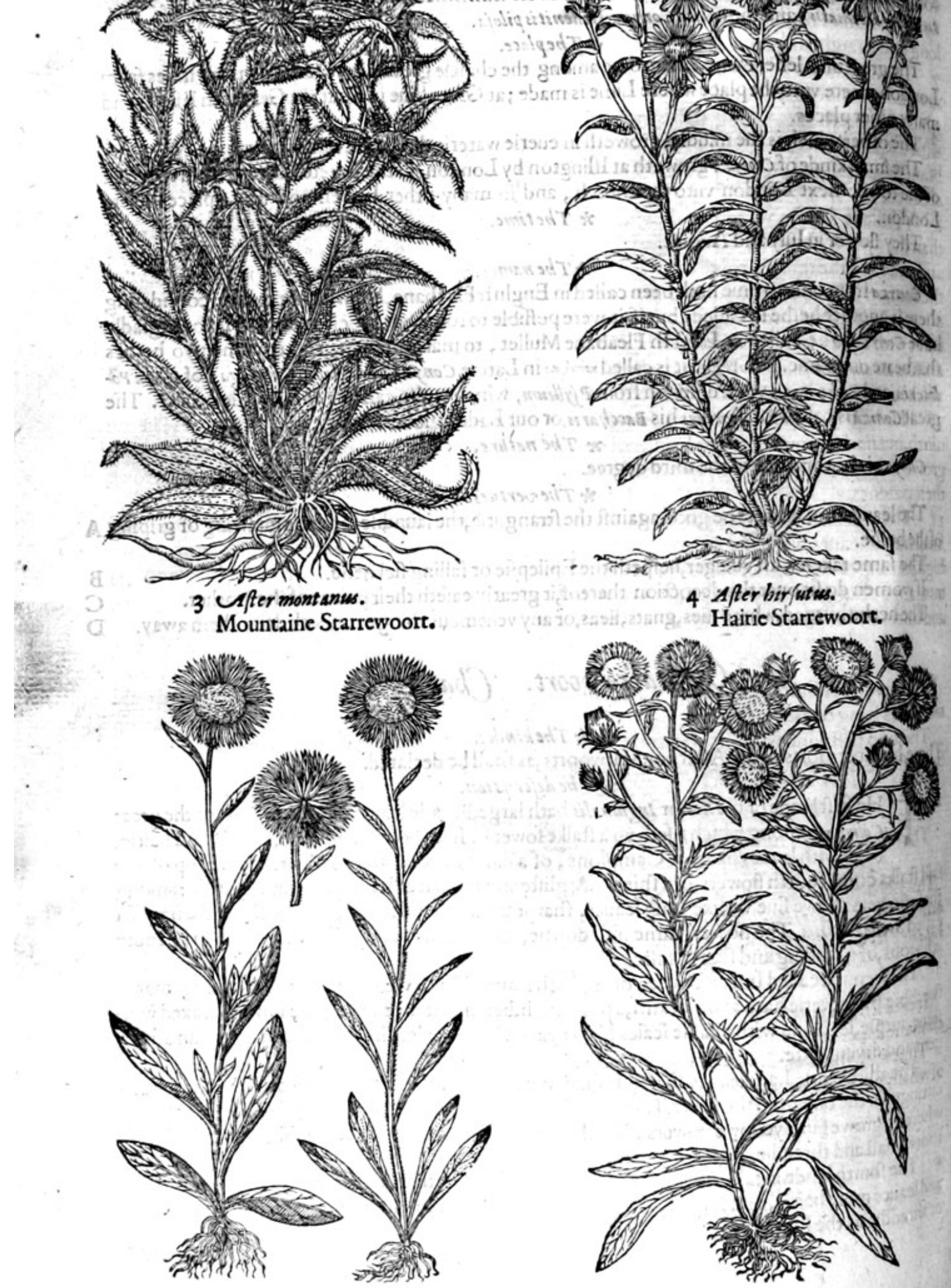
5. There is another fort that hath a browne ftalke, with leanes like the finall Comiza. The flowers are of a darke yellow, which turne into downe tbat flieth 2 way with the winde like Ganiz? The roote

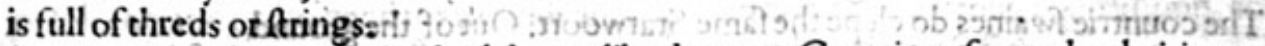

6. There is alfo another thathath leaues like the great Campiof, fomewhat hairie; among which come vp crooked crambling ftalkes, learing lamely nany waiespyhercupon degrowfaire yellow flowers, ftarre fafhion, whieh turue into downe that is caried away'switly the wigde. The roote is long and ftraight as a finger, with fome few ftrings annexed vnto the sppermoft part. $H$

7 There groweth another kinde of Starwoort, which hath many leaues like Scabious, but thinner, and of a more greene colour, couered with a wooltic hairines, tharpe and bitter in tafte; among which fpringeth vp a yoong ftalke more than a cubite high, ofreh growing to a reddifh:colbuf: fet with che likeleaves, but finatler and harper pointed, diuiding it felfectoward the top into fome few branches; whereon do grow yellow towivers like Doronicson or Soncbus. Theroote is thickeraad

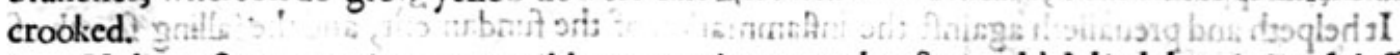
8 We haue feene growing vpon wilde mountaines, another fort, which bath feauesthuch effer than the former, fonewhat hike tơ the teaues of Willow, of a faire greene colour, which do adóne and decke vp the ftalke euen to the top; whereupon do growe yellow flowers Itarfafhion, like vnto the former. The roote is fmall and tender, creeping far abroad, whereby it mightily increafeth.

9 Clnfizes hath fet foorth a kinde that hath an vpright ftalke, fomcwhat hairic, two cubites high, befet with leaues fomewhat woollie like Willowes, hauing at the top of the ftalke faire yellow flowers like Enula Campana, which turne into downe that is caricd away with the winde. The roote is thicke, with fome haites or threds faftened thereto.

10 He hath likewife defcribed another fcrt, that hath leaues, ftalkes, flowers, and rootes like the ninth, but neuer groweth to the height of one cubite. And the mother ftalke and flower dothmeuer growe fo high as hir children, michleffe Herba impia fo called, for that the children do ouergtowe their parents.

1 I There is likewife fet foorth in his Pannonicke Obferuation, a kinde of After that hath many fmall hairie leaues like the common great Daifie; among which rifech vp an hairie ftalke of a foote high, having at the top faireblew flowers inclining to purple, which turne (in the time of feeding) into a woollie downe, that Alecth away with the winde. The whole planthath a drying, binding, and bitter tafte. The roote is threddie like the common Daifie.

$$
\text { * Theplace. }
$$

The kindes of Starwoort growe vpon mountaincs and hillie places, and fometimes in wood's and medowes lying by riuers fides.

The two firlt kindes do growe vpon Hampitecd heath fower miles from London, in Kentypon Southfleete downes, and in many other fuch downie places.

They flower from Iuly to the end of Augutt.

* The time.

* The numes.

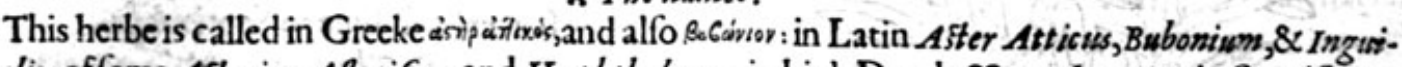
nalis : of fome Asterion, Afterifcon, and Hyopht hatmun : in high Dutch @gegerktaut : in Spanifh Bobas : in French EStrille, and A/per goutte menne : in Englifh Starwoort and Sharewoort.

\section{* 7 be nature.}

It is of a meane temperature in cooling and drying. Galen faith it doth moderately wafte and confume, efpecially while it is yet foft and new gathered.

That with the blew flower orpurple, is thought to be that, which is of Virgill called flos Amellow: of which he maketh mention in the fourth booke of his Georgickes.

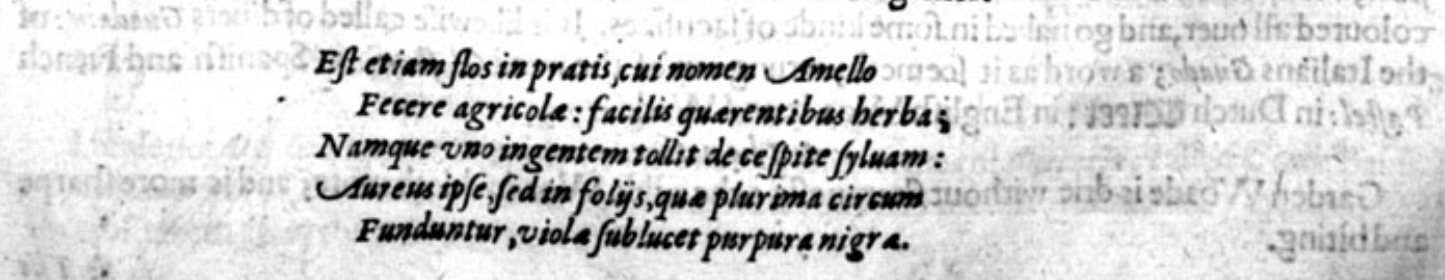


In Englifh thus.

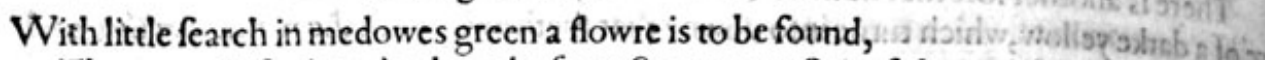
The counerie fwaines do clepe the fame Starwoort. Out of the ground

One root doth fprout, which fpredes broade with branches thicke \& wide, Of colour like the fineft golde in fire that hath beene tride.

The leaues which bud on euery fide in a round and thicke ranke Haue fuch a purple colour as darke Violets on a banke.

* The vertwes.

A The leaues of After or Inguinalis ftamped, and applied vnto botches, impoftumes, and venereoin bubones (which for the moit parthappen in Inguine, that is, the flanke or ihare) doth mightilyma. turate and fuppurate them, whereof this herbe After tooke the name Inguinalis.

B It helpeth and preuaileth againft the inflammation of the fundament, and the falling foorth of the gut called sacous ventris.

C The flowersare good to be giuen vnto children againft the Squinancie,and the falling ficknes.

Chap.126.

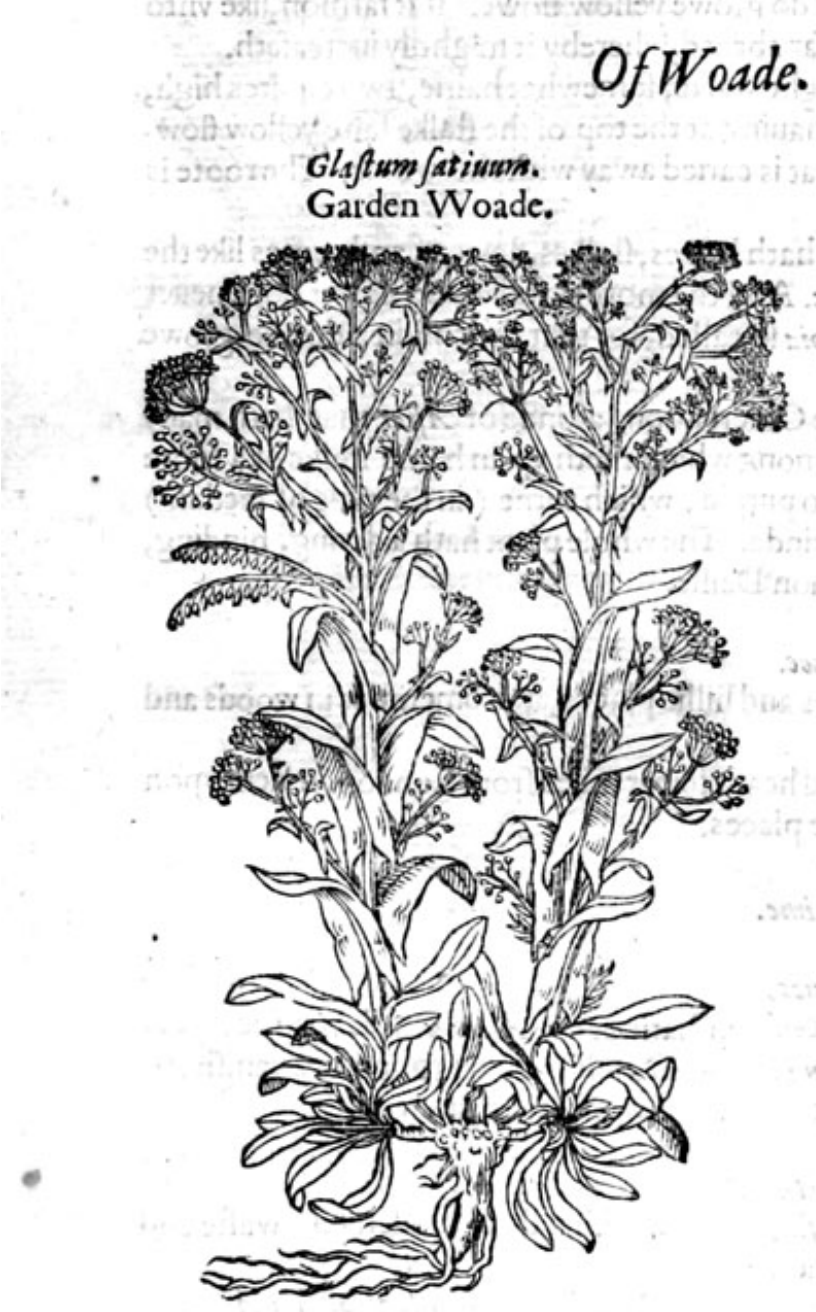

Glaftum fatiunn.

Garden Woade. $x^{2}$ The defription.

A Laftum or Garden Woade hath longleaves T of ablewirh greene colour. The ftalk groweth two cubites high, fet about with 2 great number of fich leaues as come vp firft, but fmal. ler, branching it felfe at the top into many little twigs, whereupon doe growe many fmall yellow flowers, which being paft, the feede commeth foorth like little blackifh toongs : the roote is white and fingle.

There is a wilde kinde of Woade very like vnto the former in ftalkes, leaues, and farhion, $\sqrt{2}$. uing that the ftalke is tenderer, fmaller, and browner, and the little toongs narrower; otherwife there is po difference betwixt them.

$$
\text { * The place. }
$$

The tame or garden Woade groweth in fertill fields, where it is fowen : the wilde kinde groweth where the tame kinde hath been fowen, $* 7$ be time.

They flower from Iune to September. * Tlienames.

Woade is called in Greeke iodms: in Latine Jfatis, and Glaftum. Cafar in his firft booke of the French wars, faith, that all the Britons do colour themfeltes with Woad, which giueth a blewco. lour : the which thing alfo Plinie in his 22. booke, chap.r. doth teltifie : in Fraunce they call it Glsftrom, Woad, which is like vnto Plantaine, wherewith the Britons wiues, and their fonnes wiues are coloured all ouer, and go naked in fome kinde of facrifices. It is likewife called of diuers Guadum : of the Italians Guado; a word as it fcemeth, wrung out of the word Glaftum : in Spanifh and French $P_{2}$ ftel: in Dutch wareet : in Englifh Woade and Wade.

* The nature.

Garden Woake is drie without fharpneffe : the wilde Woade drieth more, and is more harpe and biting. 


\section{HISTORIE OF PLANTS.}

* The vertues.

The decoetion of Woade drunken, is good for fuch as haue any ftopping or hardnes in the milt $\mathbf{A}$ or fpleene, and is alfo' good for wounds and vlcers in bodies of a ftrong conftitution, as of countrie people, and fuch as are accuftomed to great labour, and hard courfe fare.

It ferueth well to die and colour cloth, profitable to fome few, and hurtfull to many.

B

\section{OfCow Bafill. Chap.127.}

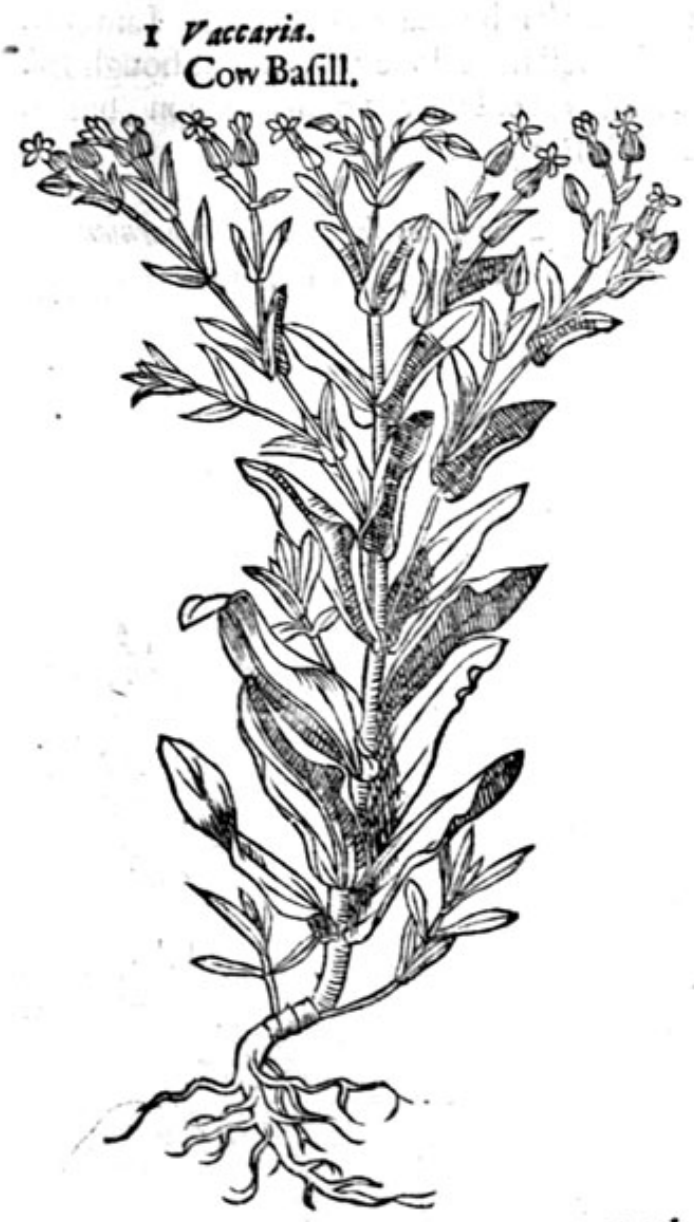

2 Ephemerum Mathioli.

* The defription.

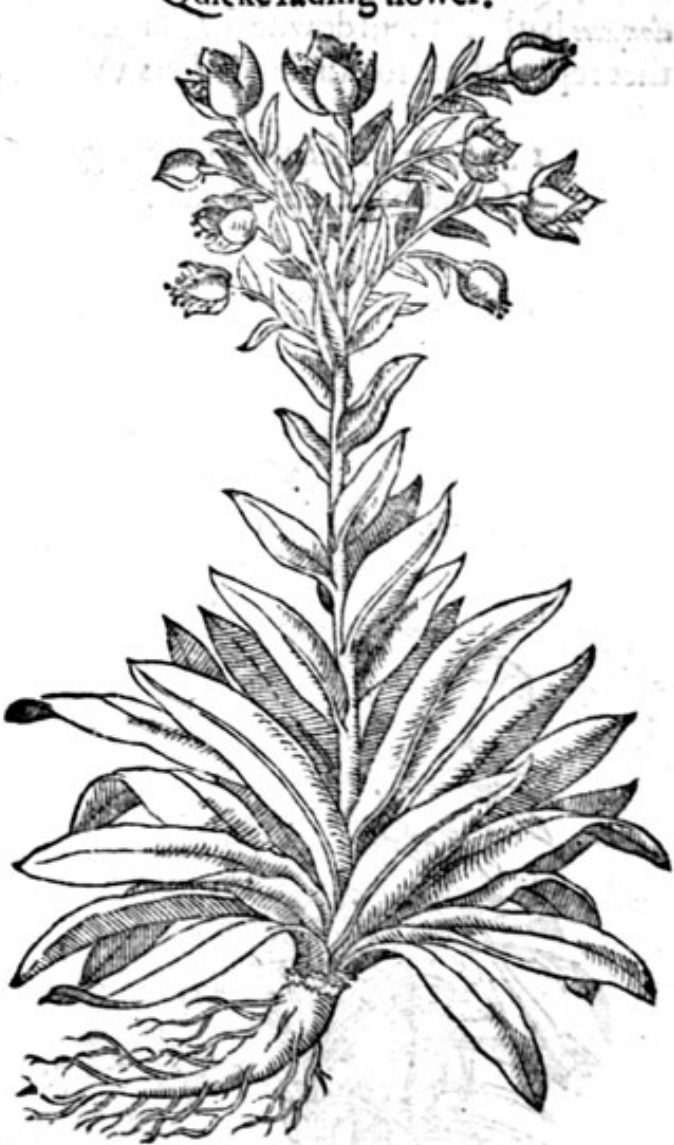

$2-$ His kinde of wilde Woade hath tat long leaues like Valerians rubra Dodonei, or Behen al. bum : the ftalke is fmall and tender, hauing thereupon little purple flowers, confifting of fower leaues; which being paft, there come fquare cornered huskes, full of round blacke feede like Colewoorts. The whole plant is couered ouer with a clamme fubftance like Birdlime, fo that in hot weather the leaues therof will take flies by the wings (as Muf cipula doth)in fuch maner, that they cannot efcape away.

2 Ephemerwm Mathiol, hath long, fat, and large leaues like vnto Woade, but much lefferamong which rifeth vp a rounde ftalke a cubite high, diuiding it felfe into many braunches at the top. The which are fet with many fmall white flowers, confifting of fiue leaues, which being paft, there followe little rounde bullets, conteining the feede. The roote is fmall and full of fibres.

Cow Bafill groweth in $*$ The place.

They flower in Maie and Iune. * The time.

I $\$$ The nature and vertwes.

I findenot any thing extant concerning the nature and vertues of $V$ aecaria, called Cowe Bafill. Ephomerum (as Diofcorides writeth) boiled in wine, and the mouth wafhed with the decoction thereof, taketh away the toothache. 


\section{Of Sefamoides, or baftardWeld or Woade, out of Diofc. Chap.128.}

\section{* The kindes.}

$T$ Here hath beene much faide of thefe plants, comprehended vnder the name sefamoides, about I which many words haue beene fpent, but to fmall purpofe; the controuerfie is as yet not decided: and bicaufe this volume groweth to be great, and much is heereafter to be faide; Iam conftrained to leaue it little better then nakedly fet downe; the beft haue done no more, although $\mathrm{Da}$ doneus hath fet them downe for purgers among the Hellebores, yet I am not of his opinion, but rather repute them for kindes of diers Woade; or of the wilde Poppies.

1 sefamoides falamanticum magnum. Great baftarde Woade.

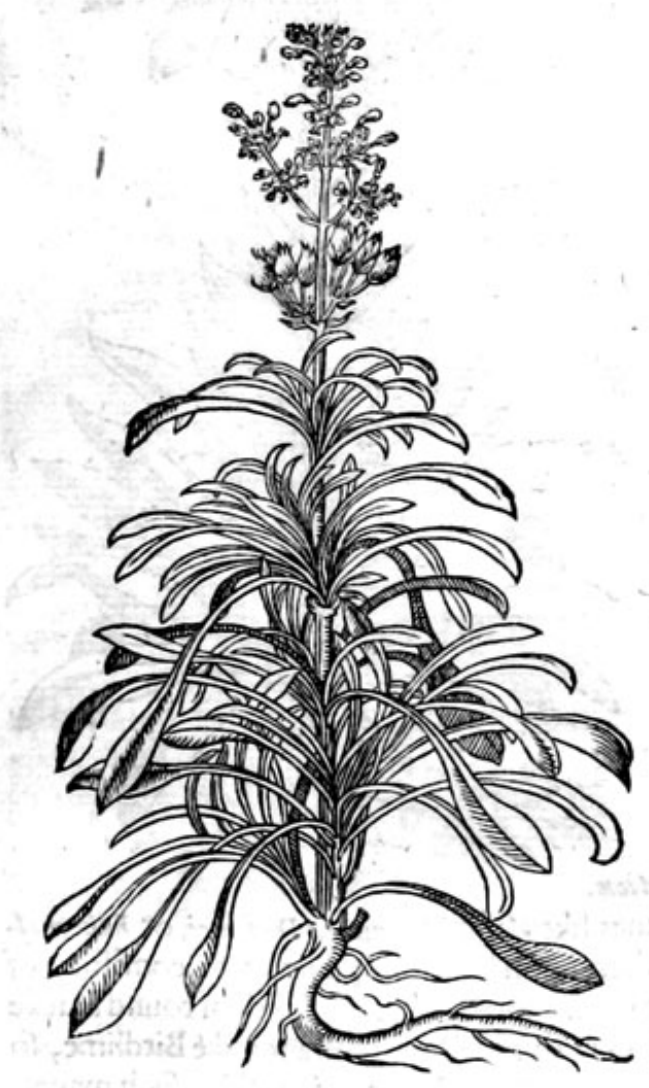

\section{Sefamoides falamanticum paruum.} Small baftarde Woade.

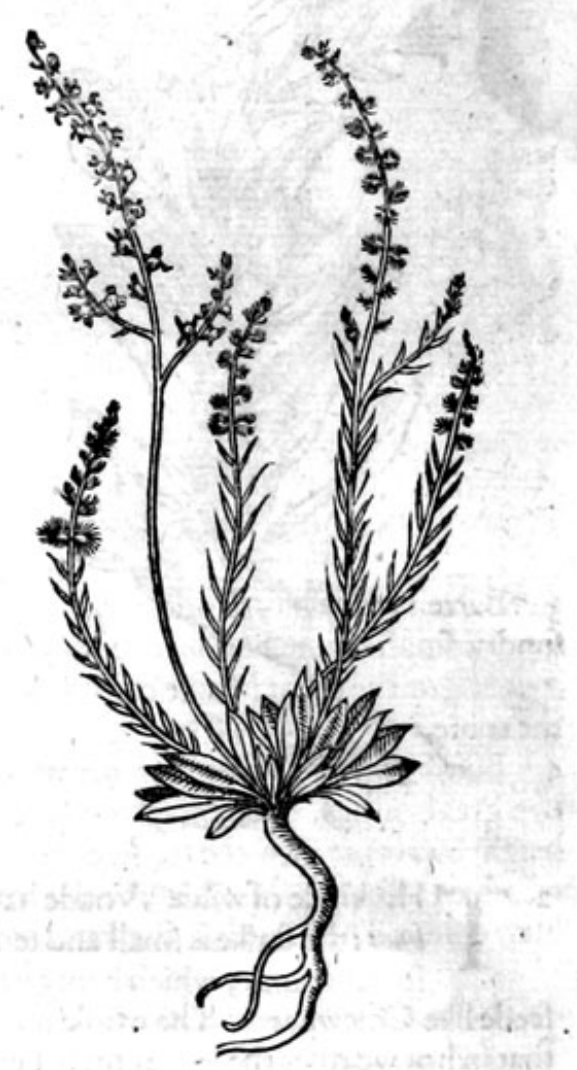

\section{* The defcription.}

I

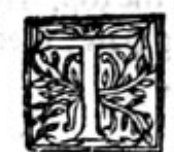

He great Sefamoides hath very long leaues \& many, flender toward the ftalke, \& broader by degrees toward the end,placed confufedly vpon a thick ftiffe ftalke: on the top wherof do growlittle, foolinh, or idle white flowers; which being paft there do follow fmall feeds like vnto the true Se/amum, whereof it tooke his name, and is not vnlike to Alpisti, or Canarie feede that birdes are fedde withall. The roote is thicke, and of a wooddie fubftance.

2 Little Sefamoides, as Diofcorides faith, hath many finall hoarie leaues fpred vpon the ground like thofe of Moufe earc; among which rifc vp fmall ftalks of a fpan high: on the top whereof are tufts of very little flowers, fomewhat of a purple colour. The middle part whereof is white, wherein lieth the feede, bitter in tafte, and of a yellowifh red colour. The roote is finall and flender. 
3 Sefamoides maim Scaligeri. Barren Welde.

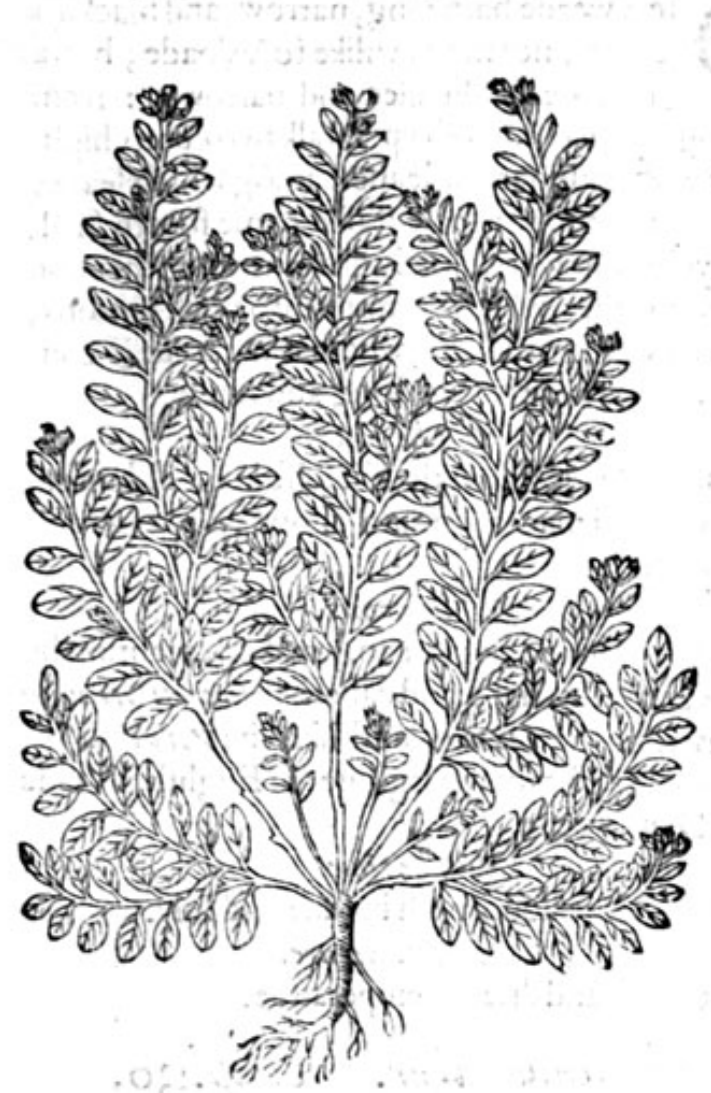

4 Sefamoides paruum Mathioli. Bucks horne Welde.

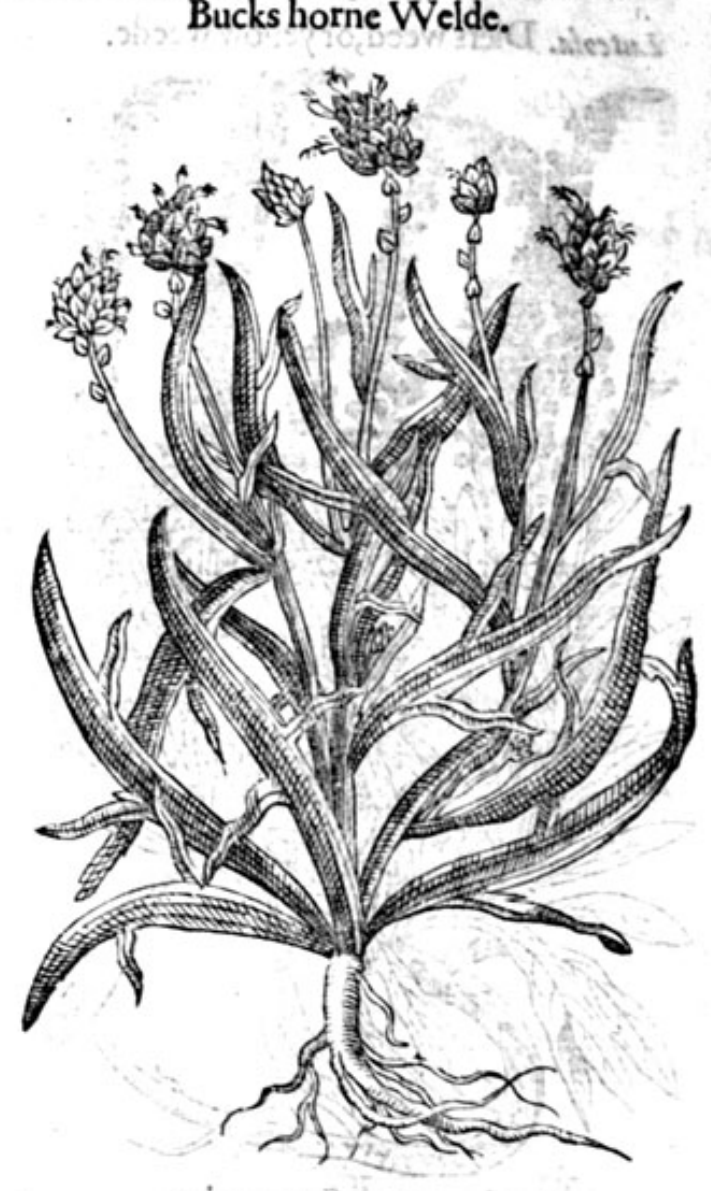

* Thedefription.

3 Barren welde hath a thicke wooddie roote, out of which rife vp immediately from the grounde fundrie fmall braunches, fet round about with many flender, rough, and hoarie leaues like thofe of Pylofella, or the great Moufe eare : it bringeth foorth neither flowers nor feede, but is increafed by the roote.

4 Buckes horne. Welde hath many fmooth and foft long leaues, cut vpon the fides with one or two great gafhes, refembling very notablie the leaues of Buckes horne. The ftalkes growe to the height ofiz foote; on the top where of do growe fcaley knops like thofe of Knapweede: from the which doe thoote foorth at the time of flowring fuch like finall flowers as Wheate hath, but of a blew colour. The roote is great, long and wooddie.

Thefe do growe in rough and ftonie places, I hauc had the feedes fentme from Padua in fralie;
. The The flowers I do expect this prefent yeere.

The time I expect to be in Iune, notwithitanding I haue no certaintic thereor bar by repore
$*$ T be names.

I doe not finde in any author that hath written heer of anyother name vied then the title doth exprefle, except fome Grecians who haue called them in Greeke avouidis the which pame Sefomoides we do retaine.

Galen affirmeth that the feede conteineth in it felfe a bitrex qualitie, and faith that it heatethibreaketh,andf coureth.

Diocorides affirmeth the the vertues.

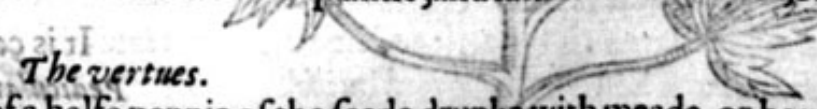

Diof corides affirmeth that the weight of a halfe pennie of the feede drunke with meade, or honied A water, purgeth flegmoand choler by the ftoole.

The fanie being applied doth watte harde knots and fwellings.

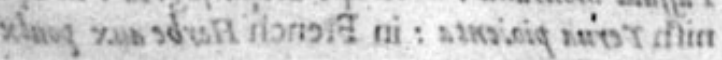

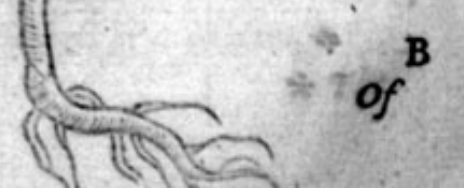


Of Diersweede. Chap.i29.

Luteola. Diers weed, or yellow weede.

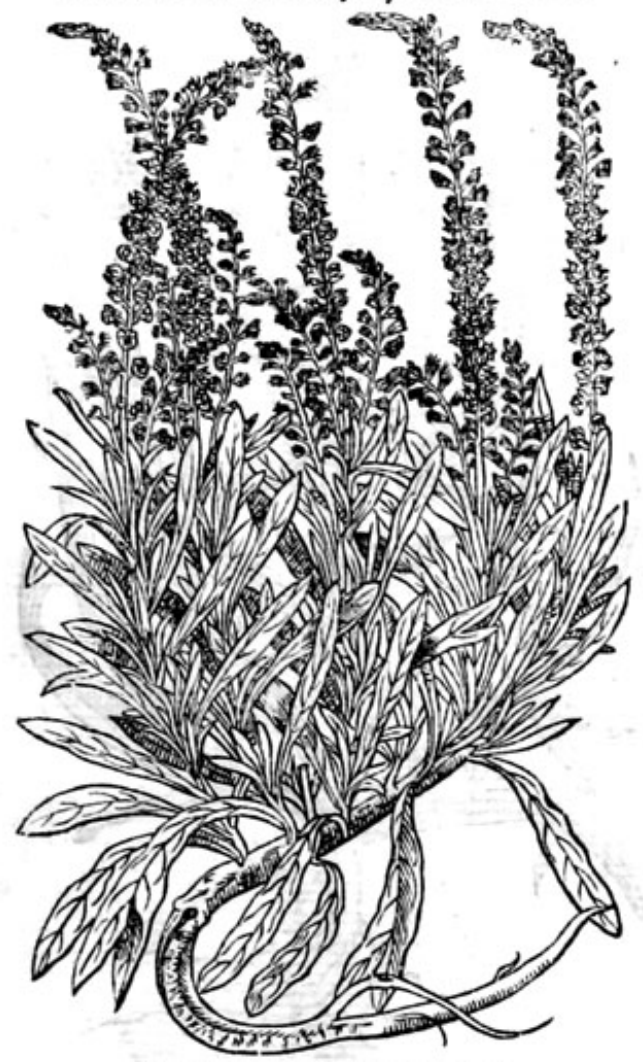

Staphis.agria Staues-akcr.

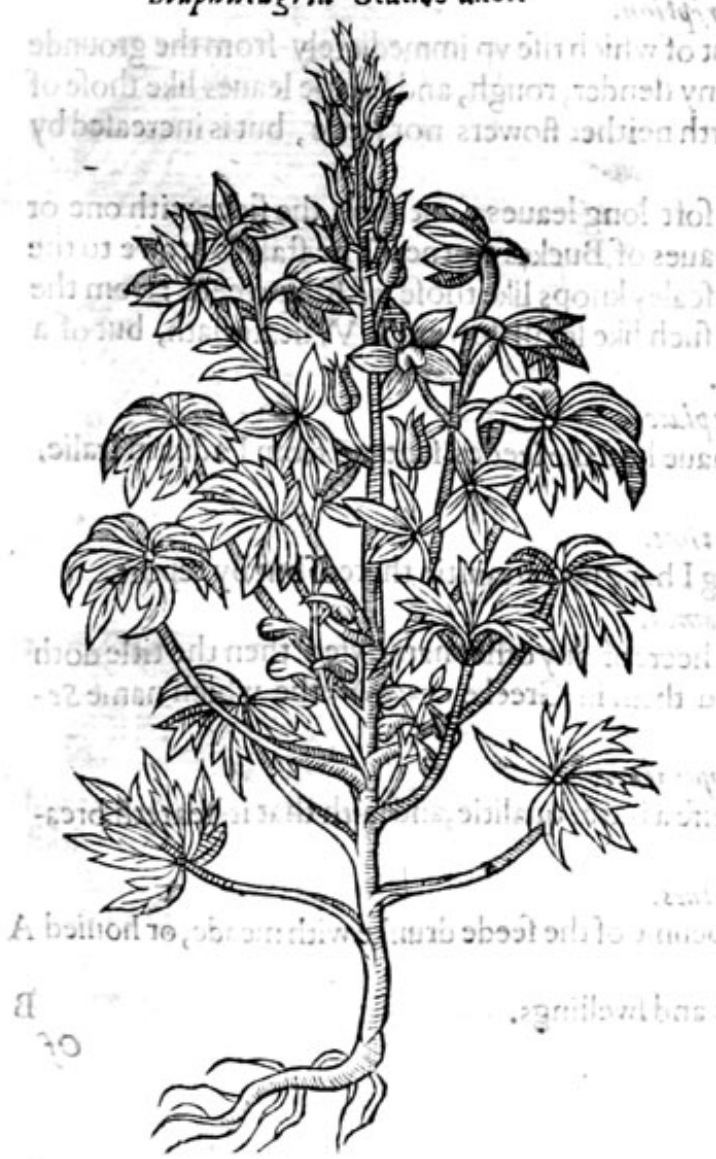

* The defcriotion.

Iers weede hath long, narrow, and blackifh leaues, not much vnlike to Woade, but a great deale fmaller and narrower: from among which commeth vp a ftalk two cubits high, befet with little narrow leaues: amóg which leaues euen to the toppe of the ftalke come foorth fmall pale ycllow flowers, clofely cluftering togither one aboue another, which do turne into fmall buttons, cut as it were croffewife, wherein the feede is conteined.The roote is very long and fingle.

$$
\text { * The place. }
$$

Diers weede groweth of it felfe in moift, barren, and vntilled places, in and about villages almoot euery where.

\section{* The names.}

Pliny in his 33 .booke cap. 5.maketh mention by the waie of this herb, and calleth it Lutea:Vitruaius in his 7. booke Lutium : and likewife Virgil in his Bucolickes, the fourth Egloge: in Englifh Welde and Diers weede.

$$
\text { * The time. }
$$

This herbe flourifheth in Iune and Iuly. * The nature.

It is hot and drie of temperature.

$$
\begin{gathered}
\text { Of Stawes aker. Chap.izo. } \\
\text { *Thedefription. }
\end{gathered}
$$

Taues aker hath ftraight ftalkes of a browpe colour, with leaues clouen or cut into fundry fections, almoft fike the leaues of the gride Vine. The flowers doe growe vpon fhore fiems, fafhioned like vnto our common Monks hoode, of a perfect blew colour; which being paft, there fucceede welted huskes like thofe of Wolfes bane, wherein is conteined triangled black feede. The root is of a wooddie fubitance, and perifheth when it hath perfected his feede.

$$
\text { * The place. }
$$

It is with great difficulty preferued in our cold countries, albeit in fome milde winters I haue kept it coucred ouer with a little ferne to defende it from the iniurie of the March winde, which doth more harme vnto plants that come foorth of hot countries, than doth the greateft froftes. * T The time.

It flowreth in Iune, and the feede is ripe the fecond yecre of his fowing.

$$
\text { * The names. }
$$

It is called in Greeke copis axiar; in Latinc Hirba Pedicularis and pedinculaxia, as Marcellus reporteth. Plinie in his 26 . booke, 13 .chap, fcemeth to name it Vua 7 aminis : of fome pitutaria, and Paffula montana: in fhops Stophifegria: in Spanifh rerut pioienta : in Feench Herbe asux poulx: 
in high Dutch Lens kraut : in Lowe Dutch lupfertuit : in Englifh Stauefaker, Lowfewoort; and Lowfe powder.

* Thetemperasare.

The feedes of Stauefaker arc exuremcly hot, almoft in the fourth degree, of a biting and burning qualitic.

\section{* The vertwes.}

Fifteene feedes of Stauefaker taken with honied water, will caufe one to vomit groffe flegme A and flimie imatter, but.with great violence;and therefore thofe that haue taken them, ought to walke without ftaying, and drinke honied water, bicaufe it bringeth daunger of choaking and burning the throte, as Diofcorides noteth. And for this caule they are reiected, and not vfed of the phifitions either in prouoking vomit, or elfe in mixing them with other inward medicines.

The feede mingled with oile or greace, driueth away lyce from the head, beard, and all othet parts B of the bodic, and cureth all fcurvie itch and mangineffe.

The fame boiled in vineger, and holden in the mouth, affwageth the tooth ache.

The fame chewed in the mouth draweth foorth much moifture from the head, and clenfeth the D braine, efpecially if a little of the roote of Pellitorie of Spaine be added thereto.

The fame tempered with vineger, is good to be rubbed vpon lowfie apparell, to deftroy and driue $\mathrm{E}$ away lice.

The feedes hereof are perilous to be taken inwardly withour good aduife, and correction of the F fame. Therefore I aduife the ignorant not to be ouer bolde to meddle with it, fith it is fo dangerous, that many times deathenfueth yponthe taking of it.

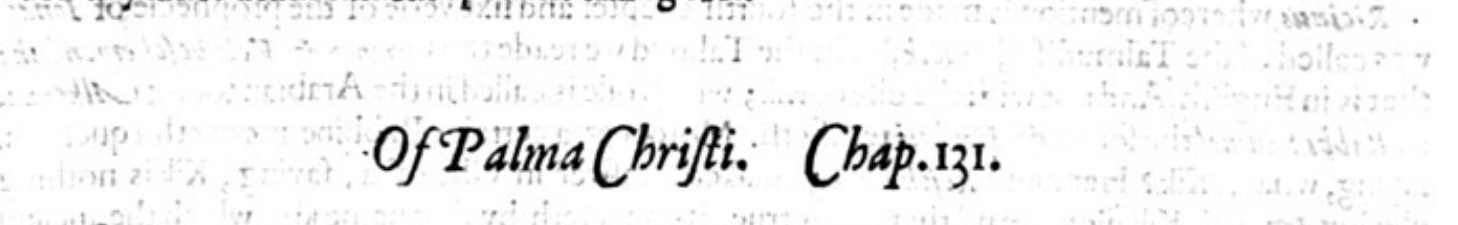

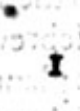

1 Ricion.

Palma Chrifti.
2 Ricinus Americas.

Palma Chrifti of America.

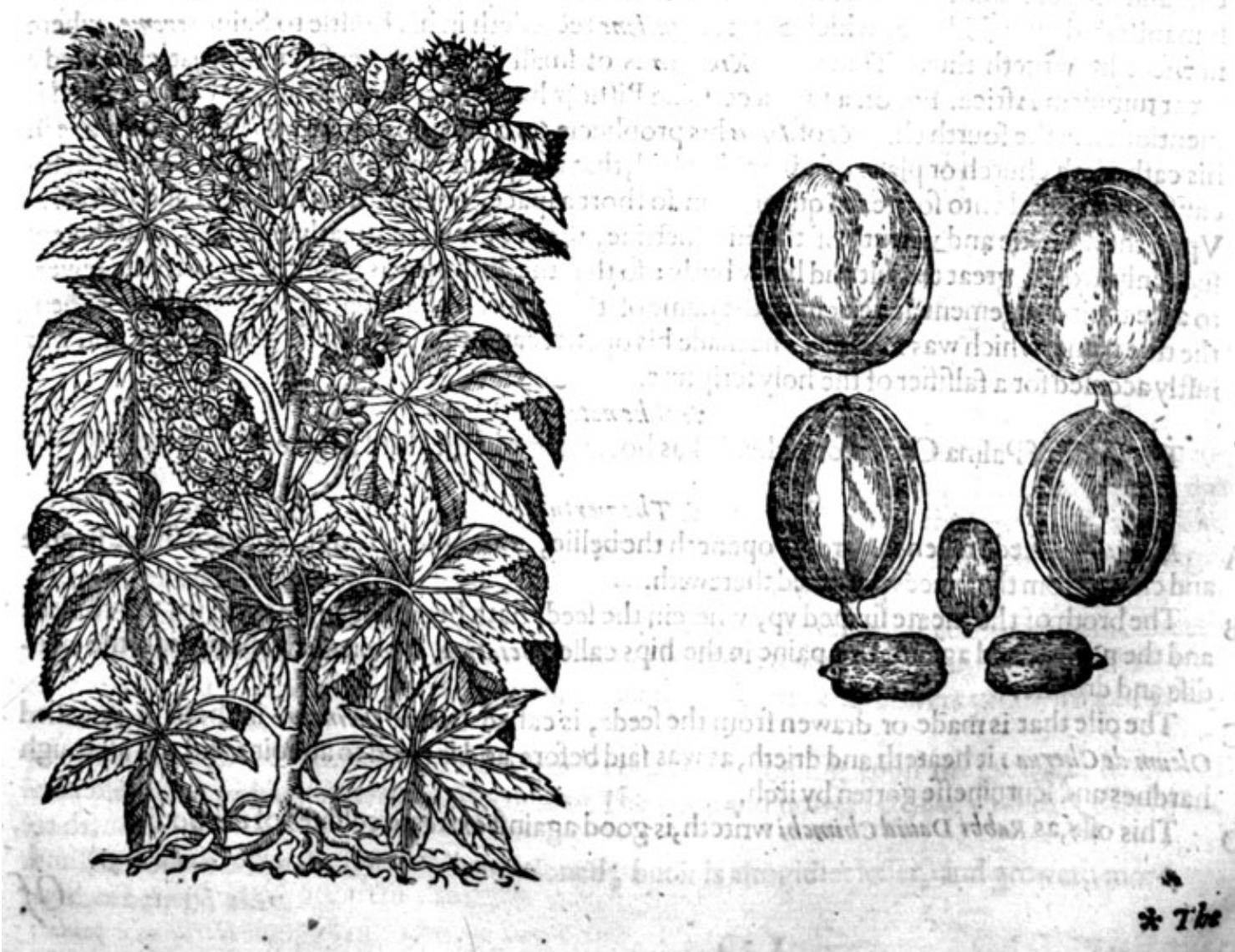




$$
\because \text { The defcription. }
$$

' $\mathrm{R}$ Icinus, Palma Chrifti, or Kik, liath a great round hollow ftalke fiue cubits high, of a browne colour, died with 2 blewirh purple vpon greene. The leaues are great and large,parted into fundrie fections or diuifions, fafhioned like the leaues of a Figge tree, but greater, fpred or wideopen like the hand of a man; and hath toward the top a bumch of flowers; cluftering togither like a bunch of grapes, whereof the loweft are of 2 pale yellow colour, \& wither away without bearing any fruit ; and the vppermoft are reddifh, bringing foorth three cornered huskes, which containe feede as big as a kidney beane, of the colour and hape of a certaine vermine which haunteth
cattell,called a Tike.

2. This Palma Chrifti of America groweth vp to the height and bignes of a fmall tree, ar hedge fhrub, of a wooddie fubftance, whofe fruit is expreffed by the figure, being of the bignes of a great beane, fomewhat long, of a blackifh colour, rough and f calic.

$$
\text { of siution * Theptace. }
$$

Ricinus or Palma Chritt, growethin my garden, and many other gardens likewife. * Thetane.

Ricinus or Kikmuft be fowen in Aprill, and the feede is ripe in the end of Auguft,

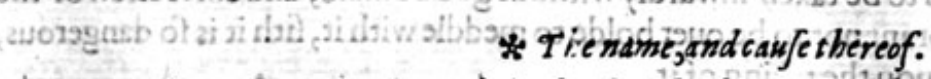

Ricinus, whereof mention is made in the fourth chapter and fixt verfe of the prophecie of lomas, was called of the Talmudifts, כיכ Kik, for in the Talmud we reade thus, כיכ, that is in Englifh, And not with the oile of Kik; which onle is called in the Arabian toong Ulkerua, as $\mathrm{K}_{a}$ bbi Samuel the fonne of Hopbnj reftificth. Moreoner a certaine Rabbine mooueth a queftion, faying, what is Kik? Hereunto Refch Lachifh maketh anfwer in Ghemara, faying, Kik is nothing elfe but Ionas his Kikaijon. And that this is true, it appecteth by that name Kiru, which the ancient Greeke phificions, and the Acgyptians vfed; which Greeke word commeth of the Hebrew word $K_{i k}$. Hereby it appeereth, that the old writers long ago, though vnwittingly,called this plant by his true and proper name. But the olde Latine writers knew it by the name Cucurbita, whicheuidently is manifefted by an hiftorie, which Saint August ine recordeth in his Epiftle to Saint Ie rome, where in effect he writeth thus; That name Kikayon is of fmall moment, yet fo fmalla matter caufed a great tumult in Africa. For on a time a ccrtaine Bilhop hauing occafion to intreat of this which is mentioned in the fourth chapter of Ionas his prophecie (iva collation or fermon, which he made in his cathedrall church or place of affemblie) faid, that this plant was called cucurbita, a Gourde, bicaufe it increafed vnto fo great a quantitie in fo mort afpace, or elfe (faith he) it is called Hedera. Vpon thenoueltie and vintruth of this his doctrine, the people were greatly offended, and thereof fuddenly arofe a great tumult and hurly burly; fo that the Bifhop was inforced to go to the Iewes, to aske their iudgement as touching the name of this plaut. And when he had receiued of them the true name, which was Kikaj̈on: he made his open recantation, and confeffed his error, and was iuftly accufed for a falfifier of the holy feripture. * 7 he nature.

The feede of Palma Chrifti,or rather Kik, is hot and drie in the third degree.

\section{* The vertues.}

A Ricinus his feede taken inwardly, openeth the bellie, and caufeth vomit, drawing flimie flegme and choler from the places poffeffed therewith.

B The broth of the meate fupped vp, wherein the feedehath been fodden, is good for the collicke and the gowte, and againft the paine in the hips called Sciatica, it preuaileth alfo againft the iaundife and dropfie.

C The oile that is made or drawen from the feede, is called oleum Cicinum: in thops it is called olewom de Cherus : it heateth and dricth, as was faid before, and is good to annoint and rub all rough hardnes and fcuruineffe gotten by itch.

D This oile, as Rabbi Dawid Chimchi writeth, is good againft extreme coldnes of the bodie. 


\section{Of Spurge. Chap.izz.}

* The kinds.

$\mathbf{T}$

Herebe diuers forts of Spurges according to Diofcor ides, Flinie, and IPmleiws, whereof fome are of the woode, fome of thefea, fome of the garden, and others of the fielde :all which thall be defcribed in this generall Chapter, efpecially bicaufe they are not all of them vfed in Phificke. Therefore to deuide them feuerally, it were but to tell one tale oftentimes ouer.

I Tithymalus paraliew.

Sez Spurge.

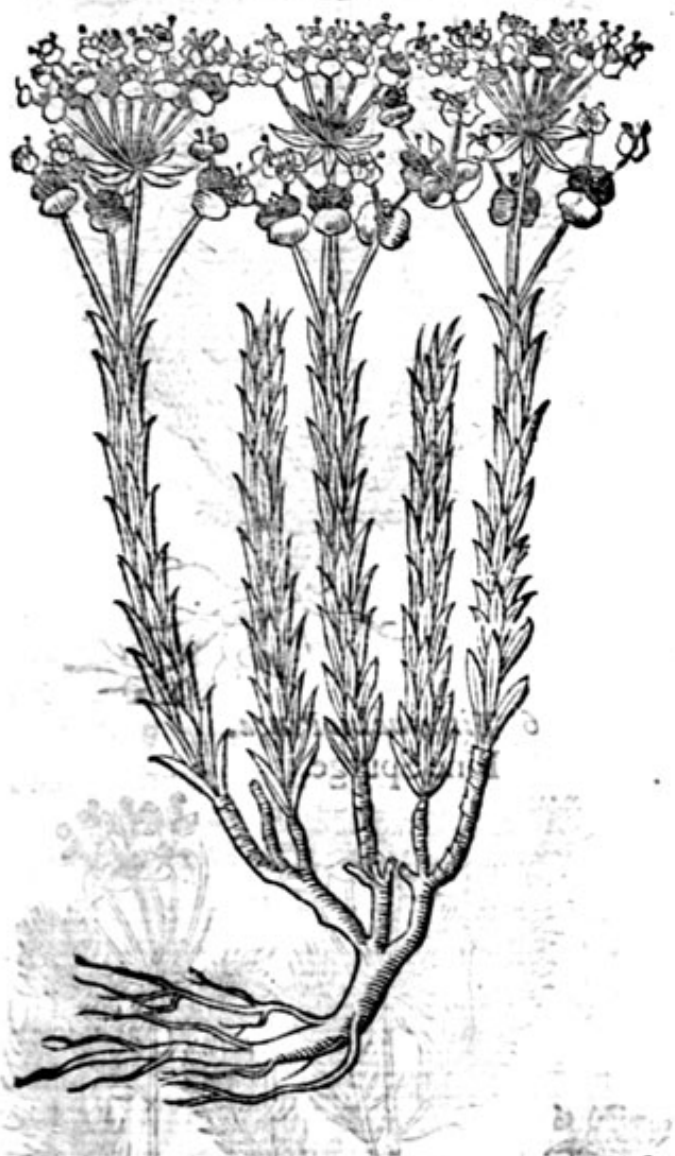

2 Tithymalus Heliogropin.

Sunne Sparge.

* The defoription.

I He firt kinde of Sea Spurge rifeth foorth of the fands, or baich of the fea, with fundry reddifh ftems or ftalkes growing vpon one fingle roote, of a wooddie fubftaunce:yand the ftalkes are befer with fmall, fat, and narrowe leaues like vnto the leaves of Flaxe. The flowets are yellowifh and growe out of little difhes or faucers like the commonkinde of Spurge. After the flowers come triangled feedes, as in the other Tithymales.

2 The fecondekinde (called Heliofcopius, or Solifequims; and in Englim, according to his Greeke name, Sume Spurge, or time Tithymale, of turning with the funine) hath fundric reddifh ftalkes of afoote high: the leauesare like vnto Purflane, but not fo great: the flowers yellowilh and growing in littie platters.

3 The thirdekinde hath thicke, fat, and flender braunches trailing vpon the grounde, befet with leaues like Kneeholme, or the great Myrele tree. The feede and flowers are like vnto the other of his kinde. 4 The fourth is like the laft beforementioned, but it is altogither leffer, and groweth more, vp.
right,otherwife alike. 
THE SECOND BOOKE OF THE

3 Tithymalus Myrtifolins. Myrtle Spurge.

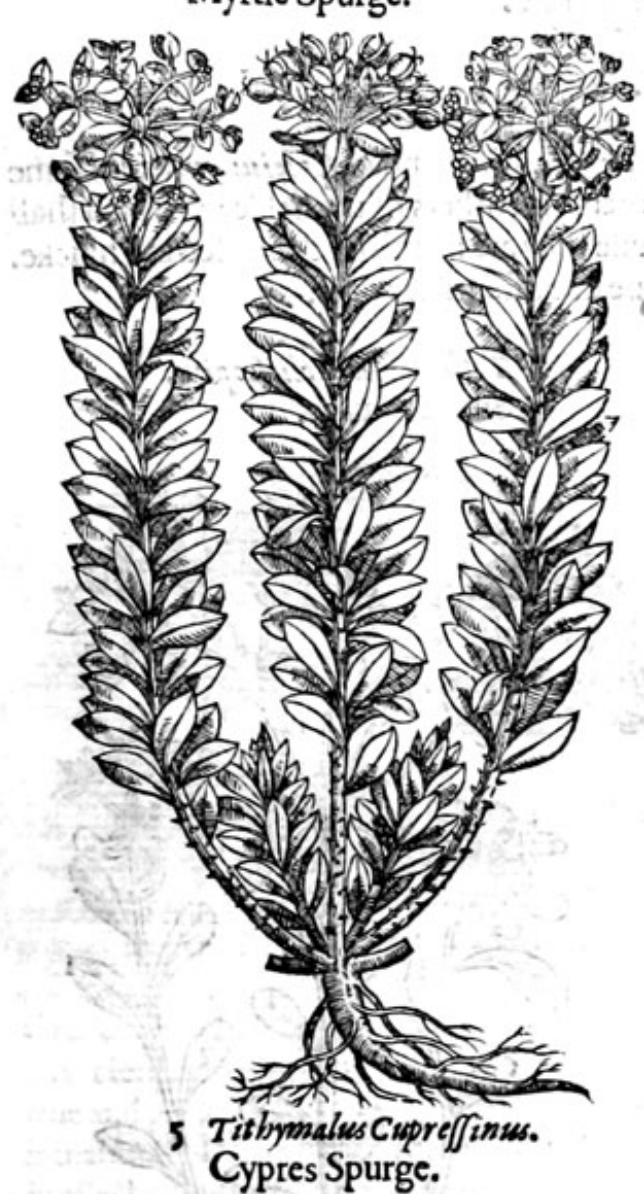

4 Tithymalses Myrfoniti.

Phificke Spurge.

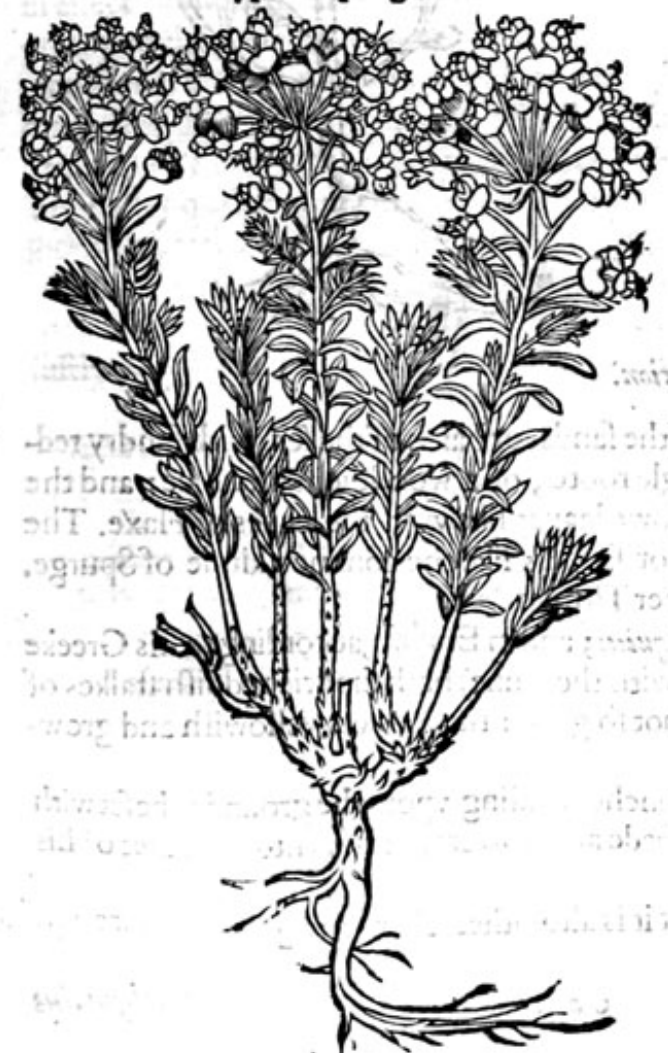

6 Tithymalus Pines.

$$
\text { Pine Spurge. }
$$

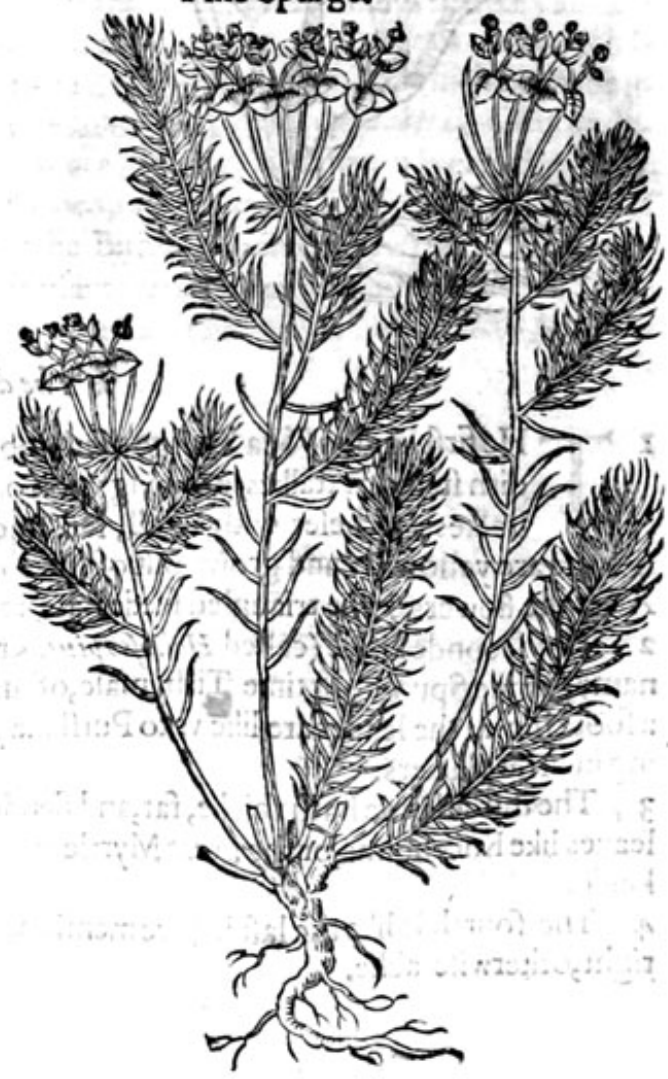


7 Tithymalus Mirfinitisaliera.

Tree Mirtle Spurge.

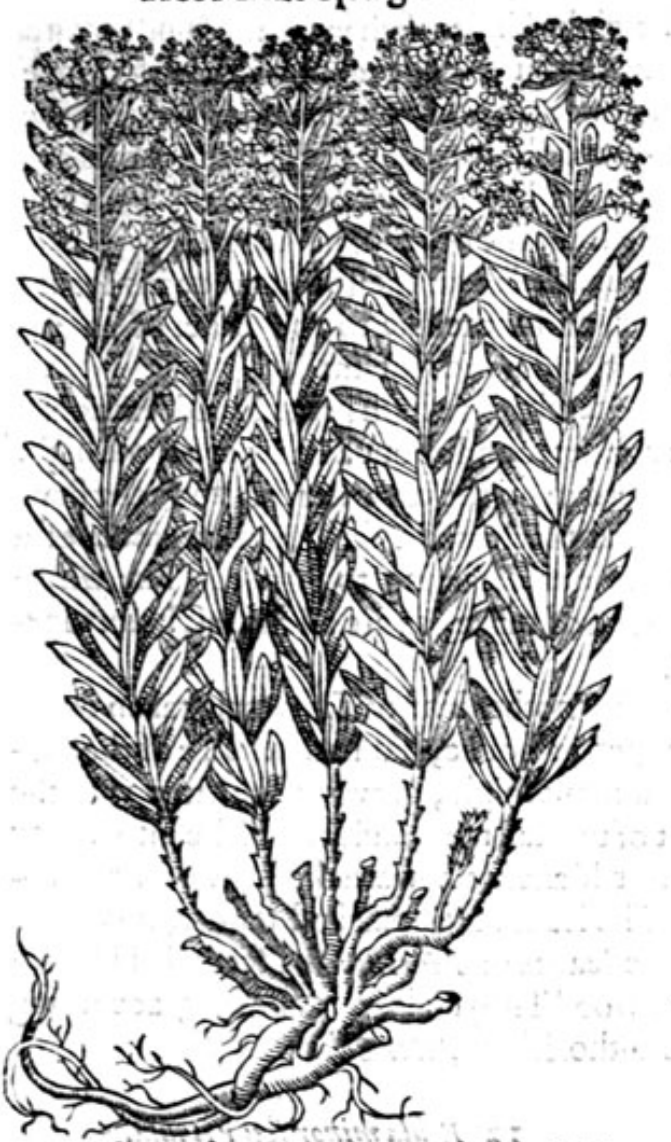

8 Tithmalus Characiats Monfpell.

Sweete wood Spurge.

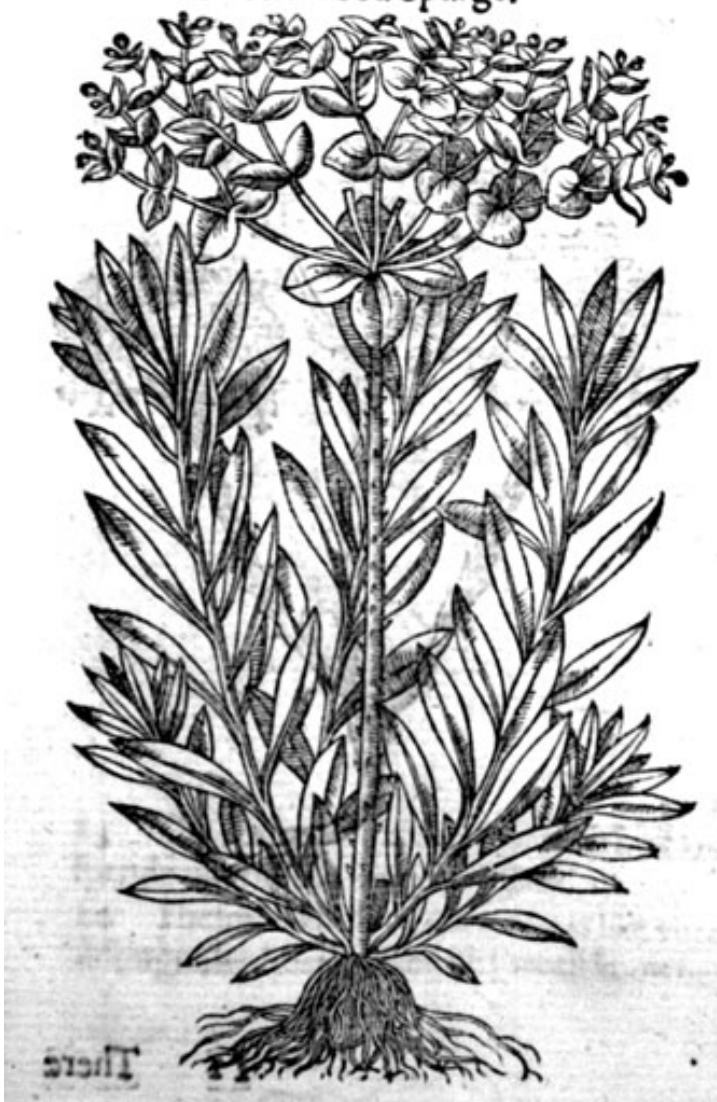

* The defcription.

5 Cypres Tithymale hath roundereddirh ftalkes a foote high, fet with leaues like to the great Cypres tree leaues. The flowers, feede and roote are like the former.

6 The fixt is like the former, in flowers, ftalkes, rootes and feedes, and differeth in that, that this kinde hath leaues like the Pine tree, otherwife it is like.

\section{* The defcription.}

7 There is fet foorth another fort likewife, that hath a round ftalke, befer with leaues like the firft kinde of Mirtle Tithymale, but fomewhat longer : in feede, flowers, and giuing milke like the others.

There is another kinde that groweth to the height of a man; theftalke is like the laft mentioned, and fomewhat hairie, not red as the others, but white; the leaues be long and narrow : in other points like to the other of his kinde.

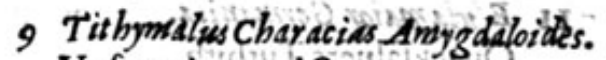
Vnfauorie wood Spurge.

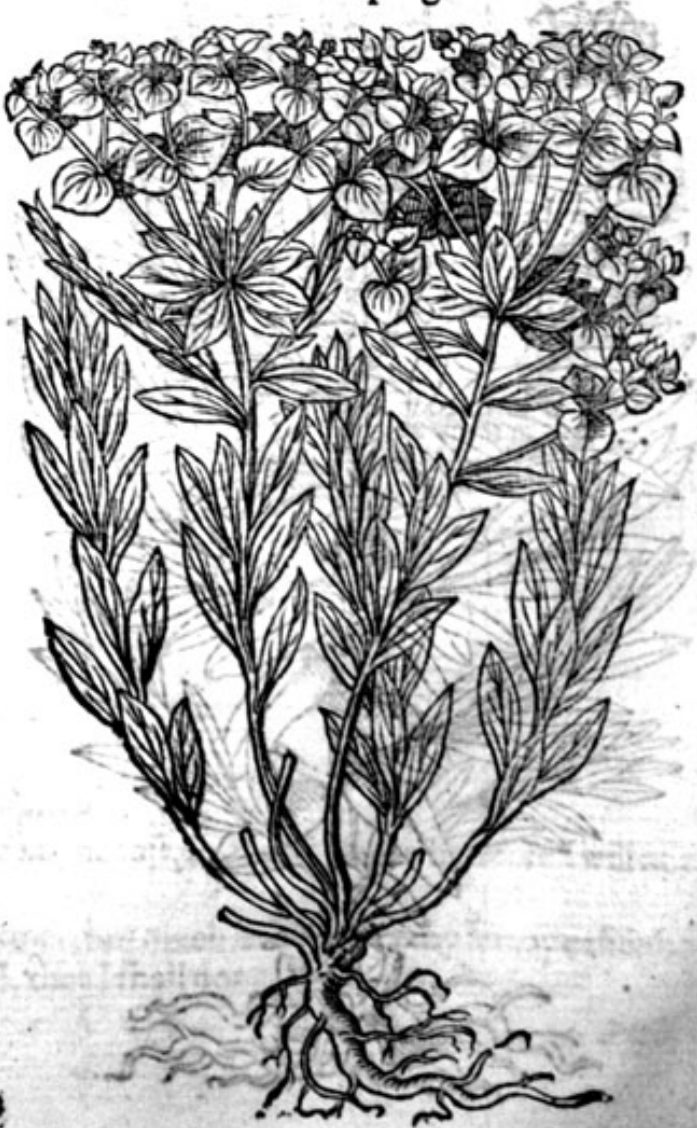


Io Tithymalus Plataphyllos. Broad leafed Spurge.

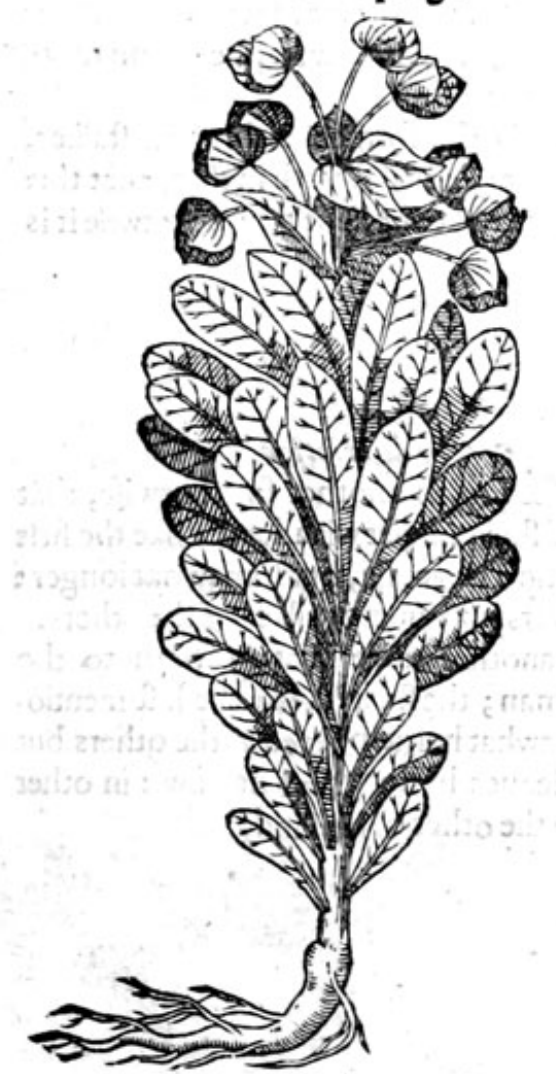

II E/mlamaior Germanica. Quackfaluers Turbith.

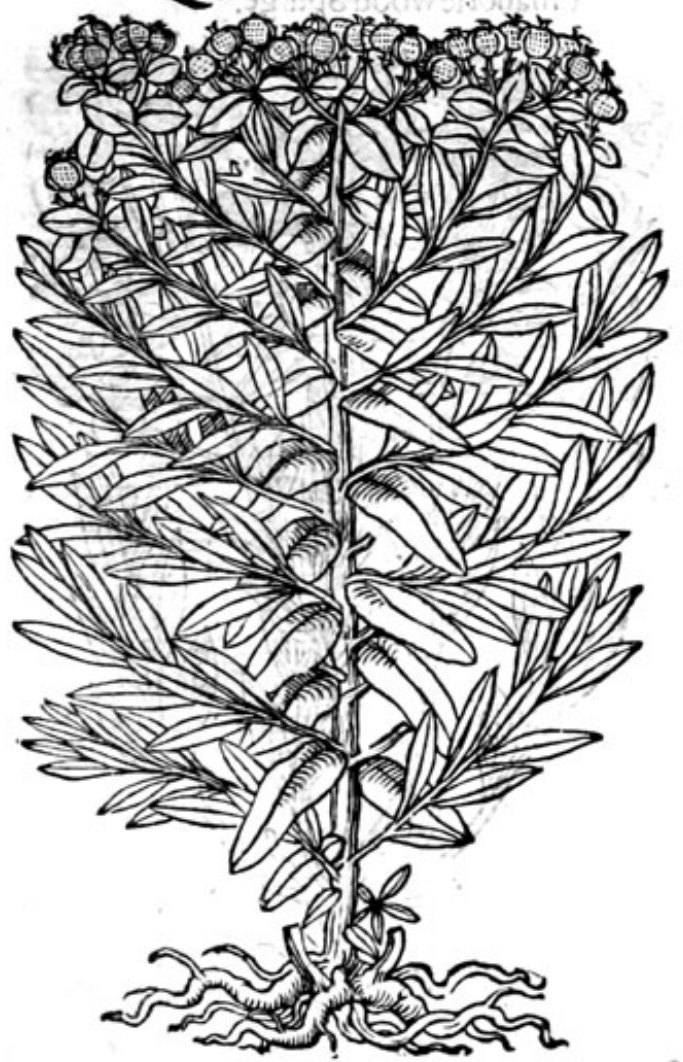

* The defcription.

8 The eight kinde rifeth vp with round reddifh ftalkes two cubits high, fet about with long, thinne and narrow leaues, like the leaues of Oliues: the flowers come foorth at the top like the others, of 2 fweete finell like Inncus odoratus : the feede and roote refemble the other of his kinde.

9 The ninth is like the former, but his leaues be longer, and more like to the leaues of an $\mathrm{Al}$ mond tree, and is without fmell.

Io The tenth kinde hath great broad leaues like $V$ erba/cum, fet round about a ftalke of a foote high, in good order; on the top whereof growe the flowers in fmall platters like the commonkinde, of a yellow colour declining to purple. The whole plant is full of milke, as are all the reft before fpecified.

There is another kind of Tithymale, taken out of the Emperors booke, that hath a ftalke of the bignes of a mansthigh, growing like a tree vnto the height of two tall men, diuiding it felfe into fundry armes or branches toward the top, of a red colour. The leaues are fmall and tender, much like vnto the leaues of Myrtus: the feede is like vnto that of wood Tithymale, or Characias, according to the authoritic of Peter Belone.

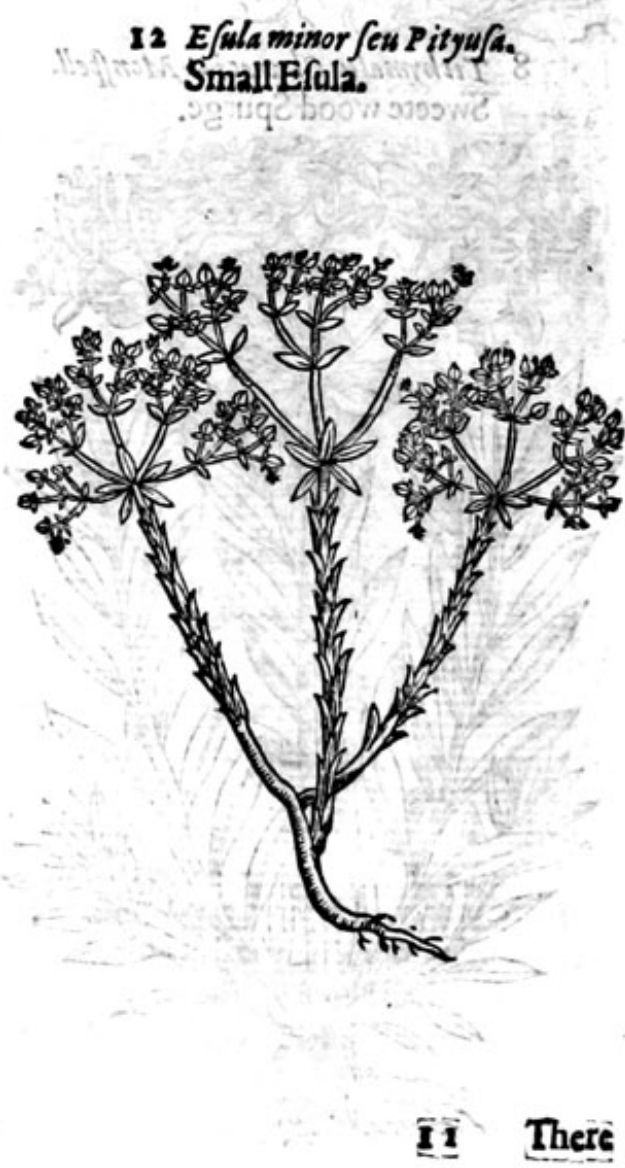




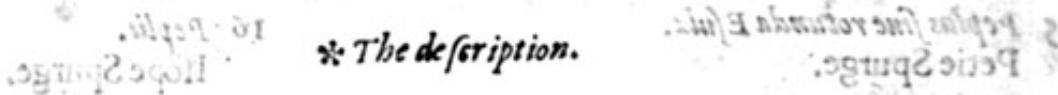

II There is a kinde of Tithymale cailed Efula maior, which Martinas nulandou had in great veneration, as his extraction he vfed for many infirmities ( may, and doth appece at large in his booke intituled Curationam empiricarum, dedicated vnto the Duke of Bauiere.) This plant of Rulandus hath verie great and many rootes, couered ouer with 2 thicke barke, phited as it werc with manyfurculous fprigs, from which rife fundrie ftrong and large ftemmes of a fingers thicknefle; in height two cubits, befet with many narrow leaues like Lashyris, that is the common garden Spurge. The feed and flower are not much vnlike the other Tithym.les.

12 The twelfth is like the eleuenth, fauc that it hath fmaller and more feeble braunches, and the whole plant is altogitherleffer.

There is another rare and itrange kinde of $E$ fuls (in alliance and tikenes neere vnto $E / w / s$ minor, that is the fmall Efwla or Pytimfa vifed among the Phyficians and Apothecaries of Venice as a kinde of $E$ wula, in the confection of their Beneducta, and Catartick pilles in ftead of the true E/wla) yeeldeth a fungous, rough, \& browne ftalke two cubits high, diuiding ir felfe into fundrie braunches, furnilhed with ftiffe and fat leaues like Licorice, growing togither by couples. The flowers are pendulous, hanging downe their heads like fmall bels, of a purple colour, and within they are of a dark colour like Ariffolochia rotunda.

\section{Lathrris feu Cataputia matior. Garden Spurge.}

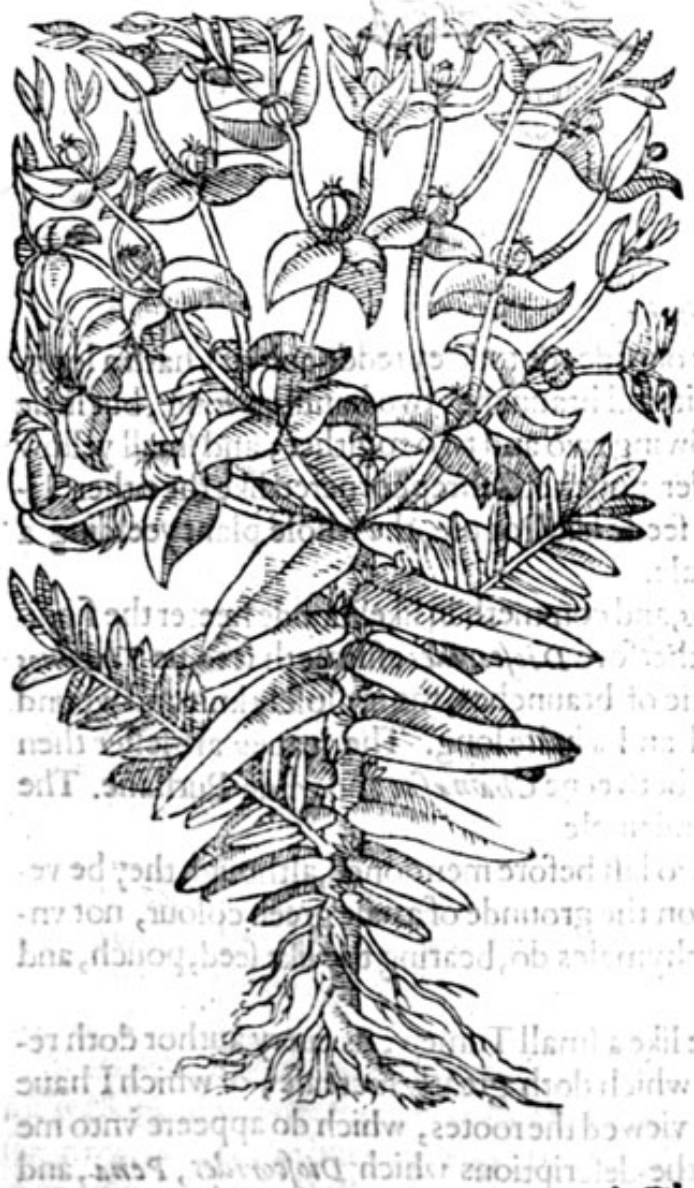

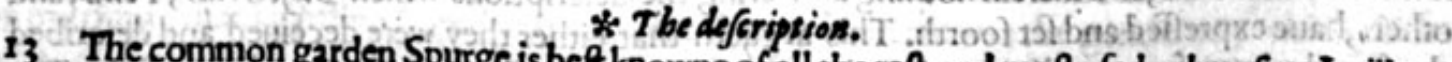

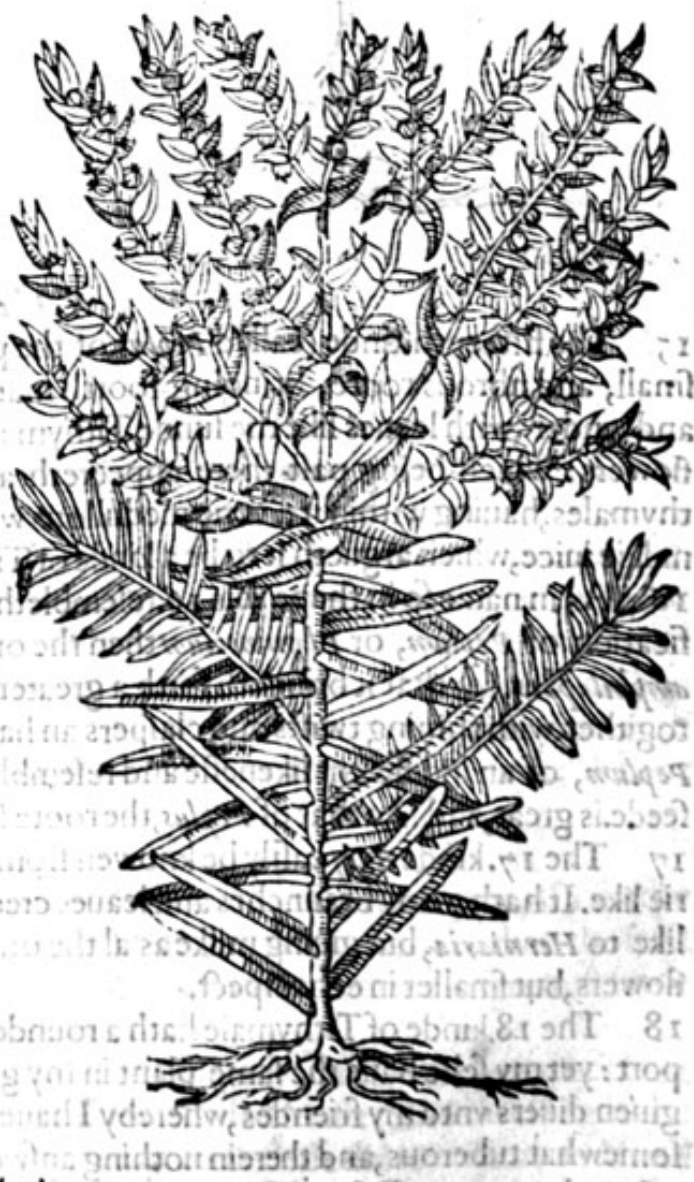
fpende time about his defcription 14 Thefmall kinde of Catspoutia is like vnto the former, but much leffer, whereby itinay eafilie be diftinguilhed, being likewife fo well knowne vnto all, that I fhall nosncedeto defcribeit. 
Is Peplus fine rotunda Efula. Petie Spurge.

Petic Spurge.

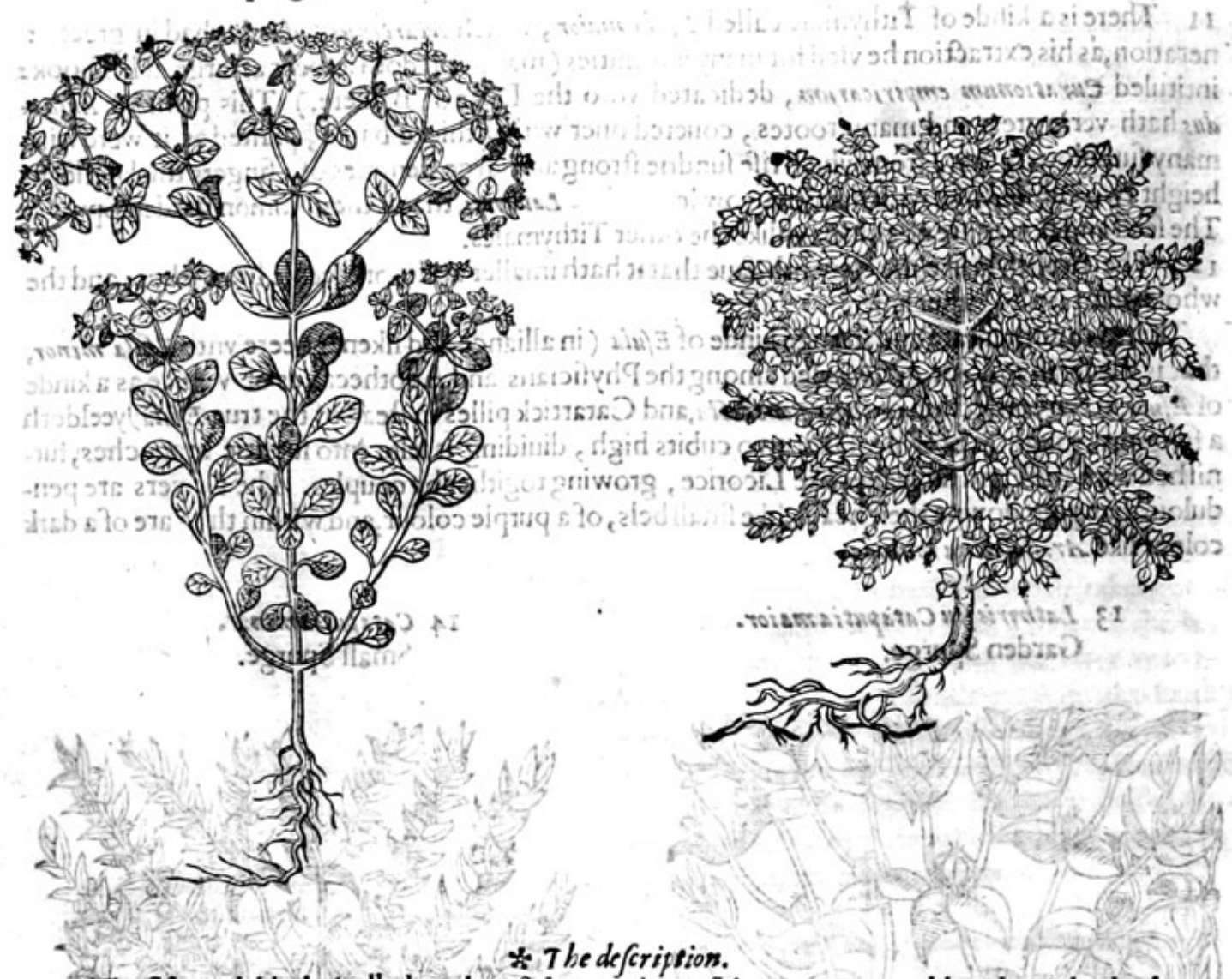

15. The fifteenth kinde (called $P$ eplus, of the purple outfide, or murrey redde colour) hath 2 long, finall, and fibrous roote, bringing foorth many fruitefull braunches two handfuls long, but little and tender, with leaues like the funne Tithymale, growing two and two togither; and fmall yellow flowers : which being paft there appeereth a flender pouchet, three cornered like the other Tithymales, hauing within it a verie medullous whitifh feede like Poppie, the whole plant yeelding a milkie iuice, which arguech it to be a kinde of Tithymale.

16 As in name fo in fhape this 16 . tefembleth $P$ eplus, and commeth in likelihoode neerer the fignification of Peplem, or Flammeolum then the other : therfore Diofcorides affirmeth it to be $T$ hamnos. amphilaphes, for that it bringeth forth a greater plentie of braunches, more clofely knit and wound togithet, with fhining twifts and clafpers an handfull and a halfe long. The leaues are leffer then Pepliwn, of an indifferent likeneffe and refemblaunce betweene Chamafice and wilde Purflane. The feede is great, and like that of peplus, the roote fmall and fingle.

I7 The i 7 . kinde may eafily be knowen from the two laft before mentioned, although they be verie like. It hath many braunches andteaues creeping on the grounde of a pale green colour, not vnlike to Hernisria, but guing milke as al the other Tithymales do, bearing the like feed, pouch, and flowers, but fmaller in echrefpect.

is The i 8.kinde of Tithymaie hath a rounde roote like a Imall Turnep, as euery author doth report: yet my felfe haue the fame plant in my garden which doth greatly increafe, of which I haue giuen diuers vnto my friendes, whereby I haue often viewed the rootes, which do appeere vnto me fomewhat tuberous, and therein nothing anfwering the defcriptions which Diofcorides, Pena, and others, hauc expreffed and fet foorth. This argueth that either they were deceiued and deferibed the fame by hearefaie ; or elfe the plant doth degenerate being brought from his natiue folle. The leaues are fet all alongt a fmall rubbe like Fraxinell.a, fomewhat rounde greene aboue, and reddith vnderneath. The fecde groweth among the leaties like the feede of Pepliss. The whole plant is full of milke like the other Tithymales.

17 Chame 


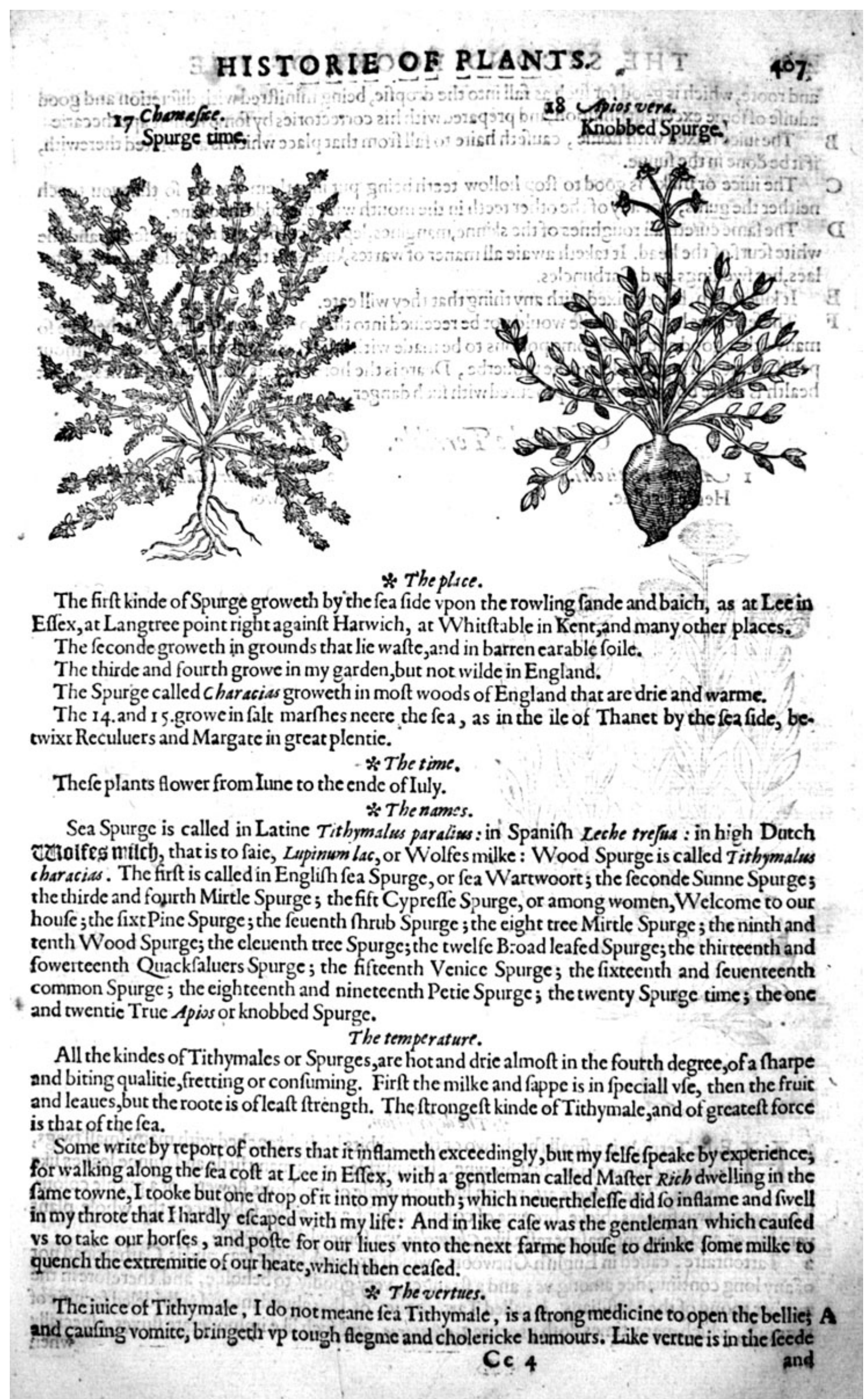




\section{THE S.ECOND BOOKE OF THE}

and roote, which is good for fuch as fall into the dropfie, being miniftred with difcretion and good aduife of fome excellentphifition, and prepared with his correctories by fome honeft aporhecarie

B The iuice tnixed with honie, caufeth haire to fall from that place whichis annointed therewith, if it be done in the funne.

C The iuice or milke is good to ftop hollow teeth being put into them warily, fo that you touch neither the gums, nor any of the other teeth in the mouth with the faide medicine.

D The fame cureth all roughnes of the skinne, mangines, lepric, fcurffe, and running fcabs, and the white fcurf of the head. It taketh awaie all maner of wartes, knobs, \& the hard calloufnes of Fiftulacs, hot fwellings, and Carbuncles.

E It killeth fifh, being inixed with any thing that they will eate.

F Thefe herbes by mine aduife would not be receiued into the bodie, confidering that there be fo many other good and wholefome potions to be made withother herbes, that may be taken without perill, remembring the old worne prouerbe, Deare is the honic that is lickt out of thornes, \& that health is deere bought which is procured with fuch danger.

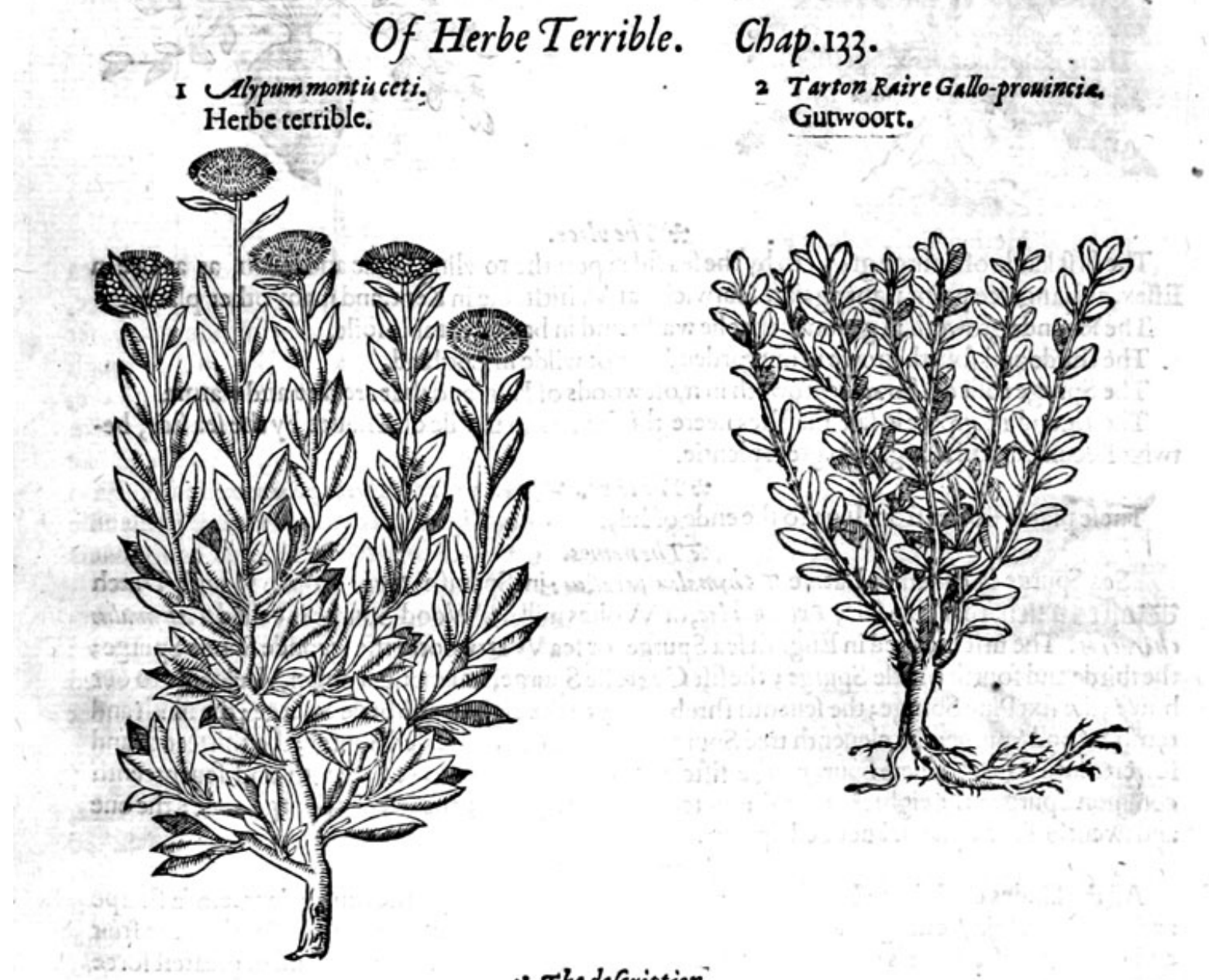

* The defcription.

I T Erbe Terrible is a fmall mrub two or three cubits high, branched with many fmall twigs,<smiles>[H]</smiles>
hauing a thinne rinde, firft browne, then purple, with many little and thinne leaues like Myrtus. The fowers are rough like the middle of Scabious flowers, of a purple colour. The roote is two fingers thicke, browne of colour, and of a wooddic fubftance : the whole plant very bitter, and of an vnpleafant tafte like Chamelea,yea fomewhat ftronger.

2 Tartonraire, called in Englifh Gutwoort, which groweth by the fea, and is Catharticall not of any long continuance among vs, and a ftranger, very goodly to beholde, and therefore in the mother toong of the Maffilians, is called Tartonraire, of that abundant and vnbrideled facultic of purging, which many times doth procure $L y$ fenterik, and fuch like immoderate tuxes, efpecially 


\section{HH H IST QR IF OF PLAN TS. HT}

when one not skilfull in the vfe thereof, Phallskinke the powder of the leaues, delaied in any liquote. This plant geoweth in manet of a fhrub, like chasieles, and boingeth foorthmany mali, tough, and pliant twigs, fet abous with a thinne and cottonic hairinelfes and hath many lesaues of 2

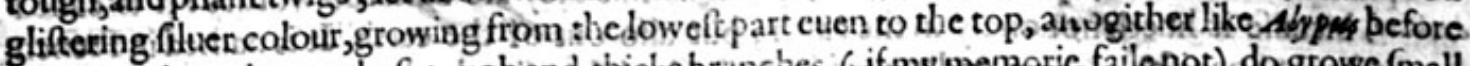
mentioned: and ypon thefe toughand thicke branches (ifmyimemaric failonot) dagrover frall flowers, firft white, afterward of a pale yeilow: the feedc is of a ruffet colour : the rogtehard and woody, not very hot in the mouthj leaung y pon the toong fome of his inbred heat \& tafte, fomwhat refembling common Turbith,and aleogither without milke.

ar o ol theplace. and are as yet ftrangers in England.

They flourilh in Auguft and September.

$$
\text { * The time. }
$$

* The rames.

There are not any other names appropriate vuto thefe plants more than is fet foorth in the titie. * Thetemperature and vertues.

There is nothing either of their nature or vertues, more then is fet forth in the defcriptions.

$$
\text { Of berbe Alö, or Sea Houfleeke. Cbap.134: }
$$

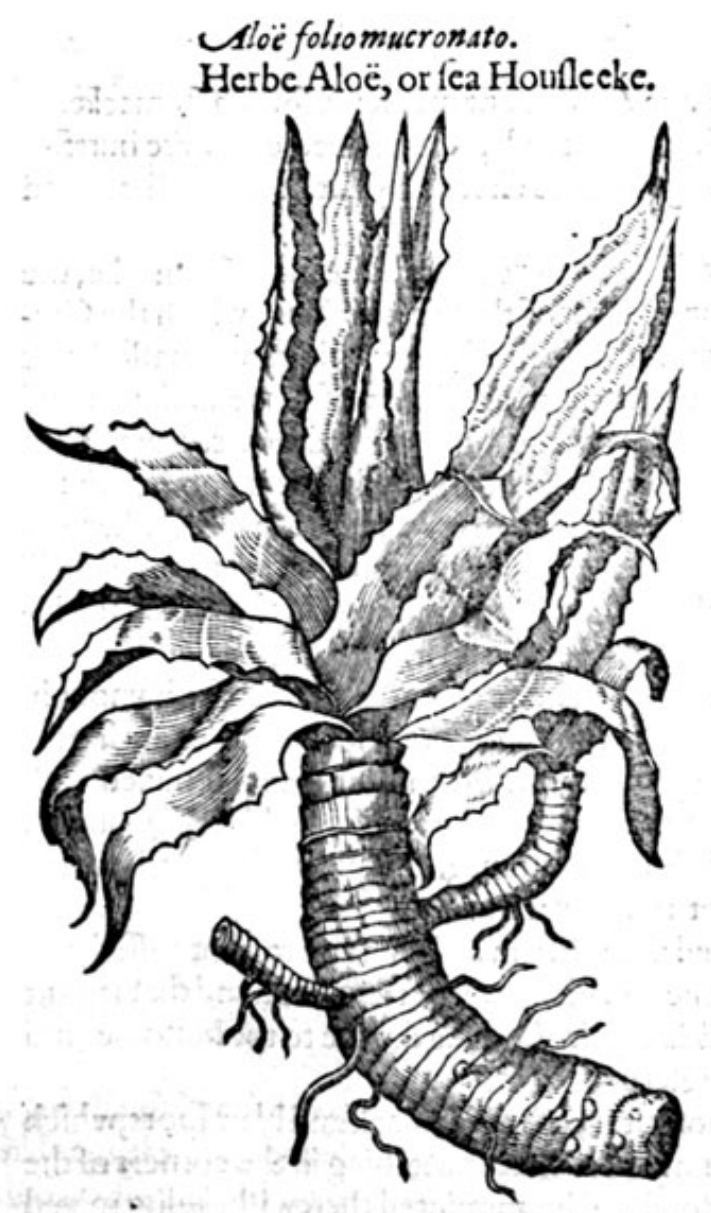

\section{* The time.}

F Earbe Aloë's hath leaues like thofe of Sea Onion, very long, broade, fmooth, thicke, bending backwardes, notched in, the edges, fet with certaine little blint prickles, full of tough and clammic iuice like the leaues of Houfleeke. The ftalke, as Diogcorid s faith, is like to the ftalke of Affodill: the flower is whitifh: the feede like that of Affodill : the roote is fingle, of the fafhion of a thicke pile thruft into the ground. The whole herbe is extreme bitter, fo is the iuice alfo that is gathered thereof.

There is another Herbe Aloe that groweth likewife in diuers prouinces of America, the leaues whereof are broader, greater, and harpe pointed like a thorne, and hath on the edges farre harder prickles.

$$
\text { * Theplace. }
$$

This plant groweth very plentifully in India, \& in Arabia,Cœlofyria, \& Egypt: from whence. the iuice put into skins is brought into Europe. It groweth alfo, as Dio/corides writeth, in Afia on the fea coafts, and in Andros, but not verie fit for iuice to be drawne out. It is likewife founde in Apulia and in diuers places of Granadoand An. dalufia, in Spaine not from the fea : the iuice of this alfo is vnprofitable.

The herbe is alwaies greene, and likewife fendeth foorthbraunches, though it remaine out of the earth, efpecially if the roote be couered with lome, \& now \& then watered: for fo being hanged on the feelings and vpper pofts of dining roomes, it doth not onely continue a long time greene, but it alfo groweth and bringeth foorth new lealles: for it muft haue a warme place in winter time, by reafonit pineth away ifit be frozen. 


\title{
THE SECOND BOOKE OF THE
}

\author{
* $T$ be names.
}

The herbe is called in Greegecixon: in Latine and in fhops alfo Nloë : and fo is likewife the iuice.

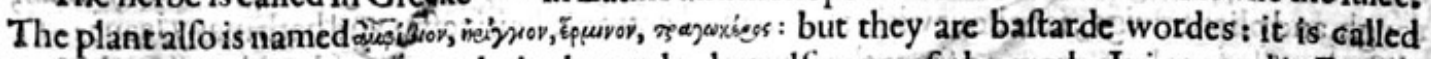
dupibirs, bicauife it livet thot onely in the earth, but alfo out of the earth. It is named in French

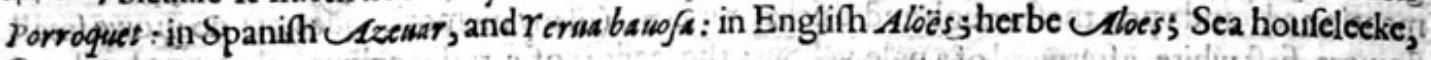
Sea Aigrene. The herbe is called of the fater Herbariftes oftentimes Semperniutum, and Semperainum martinam, bicaufe it lafteth long after the manner of Houleeke. It feemeth alfo that columella in his ro.booke nameth it Sedum, where he fetteth downe remediès againft the cankerwoormes in trees :

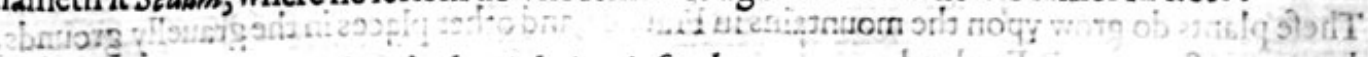

$$
\begin{aligned}
& \text { Profuit \& plant is latices infundere amaros } \\
& \text { Marruby yullogue Sedi contingere fucco. } \\
& \text { In Englifh thus, }
\end{aligned}
$$

Liquours of Horehound profit much b'ing powr'de on trees;

The fame effeet Sea Houfleeke works as wehlas thees.

For he reciteth the iuice of Seduen or Houflecke among the bitteri iuyces, and there is none of the Houfleekes bitter but this.

\section{* The temperature.}

Slö, that is to fay, the iutice which is vfed in phificke, is good for many things. It is moderately hot,and that in the firt degree, but drie in the third, extreme bitter, yet without biting: it is alfo of an emplaifticke or clammie qualitie, and fomething binding.

The vertues.

A It purgeth the belly; and is withall a wholefome and conuenient medicine for the ftomacke, if any at all be wholefome. For as $P$ aullus Aegineta writeth, when all purging medicines are hurtfull to the ftomack, Aloès onely is comfortable. And it purgeth more effectually if it be not warhed: and if it be, ir then ftrengtheneth the ftomacke the more.

B It bringeth foorth choler, but efpe ially it purgeth fuch excrements as be in the ftomacke, the firft vaines, and in the neereft paffages. For it is of the number of thofe medicines, which the Grecians callinxereorme, of the voiding away of the ordure; and of fuch whofe purging force paffeth not far beyond the ftomacke. Furthermore Aloes is an cnimie to all kindes of putrefactions; and defendeth the bodie from all manner of corruption. It alfo preferueth deade carcafes from putrifiyng; it killeth and purgeth away all maner of woormes of the belly. It is good againft a

- Ptinking breath proceeding from the imperfection of the ftomacke : it openeth the piles or hemorrhoides of the fundament: and being taken in a finall quantitie, it bringeth downe the monethly courfe: it is thought to be good and profitable for obftructions and ftoppings in the reft of the intrals. iet fome there be who thinke, that it is not conuenient for the liuer.

C One dram ther: of giuen, is fufficient to purge. Now \& then halfe a dram or little more is ynough.

D It healeth vp greene wounds and deepe fores, clenfeth vlcers, and cureth fuch fores as are hardly tobe helped, efpecially in the fundament and fecret partes. It is with good fucceffe mixed with ivaiuors, or medicines which ftanch bleeding, and with plaifters that be applied to bloodie wounds; for it helpeth them by reafon of his cmplailtike qualitie and fubftance. It is profitably put into medicines for the eies, for as much as it clenfeth and drieth without biting.

E Diofcorides faith, that it muft be torrified, or parched at the fire, in a cleane and red hot veffell, and continually ftirred with a Spatula or iron ladle, till it be torrified in all partes alike: and that itmuft alfo be wafhed; to the end, that the vnprofitable and fandy droffe finke downe to the bottome, and that which is fmooth and moft perfect, be taken and referued.

F The fame author alfo teacheth, that mixed with hony it taketh awayblack and blew fpots, which come of ftripes :that it helpeth the inward ruggidnes of the eielids, and itching in the corners of the eies : it remedieth the headache, if the temples and forehead be annointed therewith, being mixed with vineger and oile of rofes : being tempered with wine, itftaichl the falling ffr of the hairc, if the head be wahed therewith : and mixed with wine and honie, it is a remedy for the fwelling of the Vuula, and fwelling of the Almonds of the throte, tor the gums, and all vlcers of the mouth.

G Theiuice of this herbe Alö̈, (whereof is made that excellent and moft faniliar purger, called Aloës Succotrina, the beft is that which cloth necteft come vnto the colour of a liuer, clecre and thining, of a browne yellowifh colour) openeth the beliy, purging colde, fegmatike, and cholcrike humors, 


\section{HISTORIE OF PLANTS.}

humors, efpecially in thoí bodies that are furcharged with furfetting, either ofmeate or drinke, and whofe bodies are fully repleate with humors, faring daintily, and wanting exercife. This sloès If ay, takenin a fmall quartitic after fupper in a ftewed prune, or in water the quanticie of two drams in the morning, is a moft foueraigne medicine for to comfort the ftomacke, and to denfe and driue. foorthall fuperfluous humors. Some vfe to mixe the fame with Cinnamon, Ginger, and Mace, for thepurpofe aboue faid; and for the iaundies, fpiting of blood, and all extraordinarie iffuesof blood.

The fame vfed in vlcers, efpecially thofe of the fecret parts or fundament, or made into powder, $\mathbf{H}$ and ftrawed on fref $\mathrm{h}$ woundes, it $\mathrm{ftaieth}$ the blood,and healeth the fame, as thofe vlcers before fpoken of sinamis'

The fame taken inwardly caufeth the Hemorrhoides to bleede, and being laid thereon it caufeth I them roreafe bleeding.

arto sised brt?

\section{Of Houlleeke, or Sengreene. Chap.135.}

* The kindes.

Singreene, as Diof sorjdes writeth, is of three forts, the one is great, the other frmal, and the thirde is

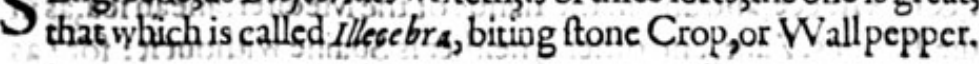

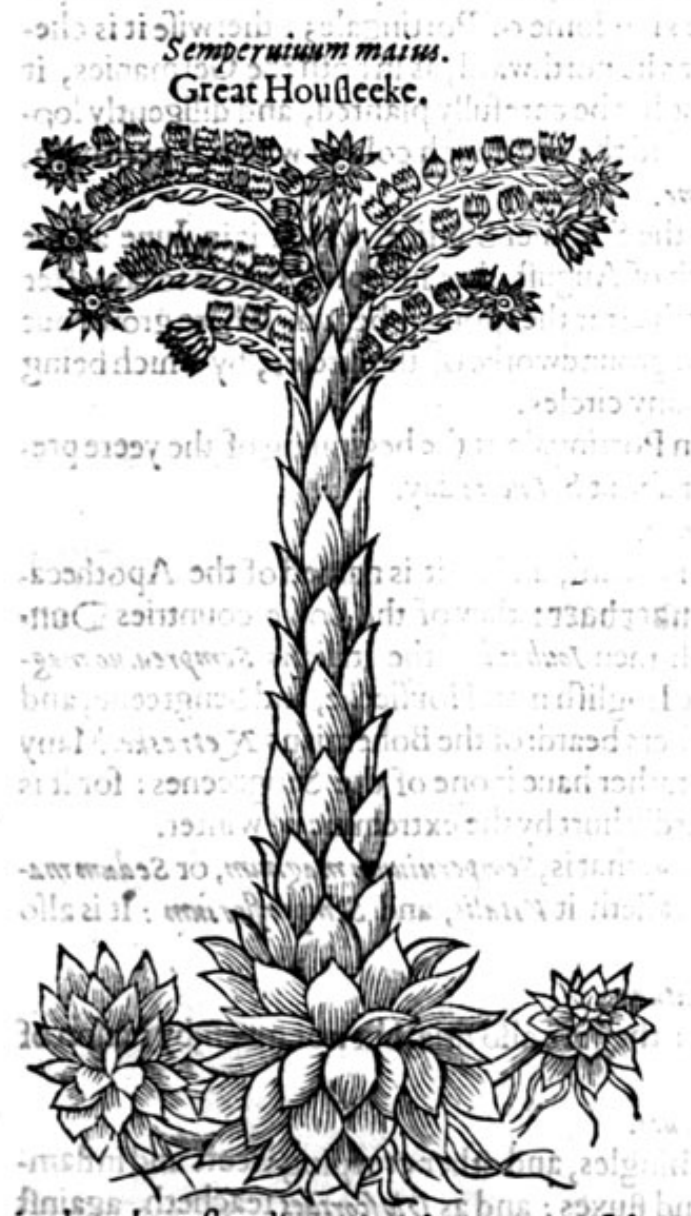

17 * The defcription.

$7 \mathrm{He}$ great Sengreene which in Latine is commonly calied Iouis barba, Iupiters bearde, bringeth foorth leaues harce adjoyning to the grounde and roote, thicke, far, full of tough iuice, tharpe pointed, groving clofe and harde togither, fet in a circle in falhion of are eie, \& bringing foorth very many fuch circles, fpreading it felfe out all abroade; it oftentimes alfo fendeth foorth fmall ftrings, by which it fprẹadeth farther, and maketh newe circles; there rifeth vppe oftentimes in the middle of thefe an vpright ftalke about a foote high, couered with leaues growing lefte and leffe towarde the points, parted at the top into certaine winges or braunches, about which are flowers orderly placed of a darke purplin colour: the roote is all of ftrings.

2 There is alfo another greats Houfleck or fengreen (furnamed trec Houflecke) that bringeth foorth a ftalk a cubite high, fomtimes higher, \& often two; which is thicke, harde, woody, tough, and that can hardly;be brokê, parted into diuers branches, \&.couered with a thick groffe barke, which in the lower part referueth certinine printsor impreffed markes of the leaues that are fallen awaic. The leaues are fat, well bodied, full of iuice, an inch long and fomwhatmore like little toongs, very curioufly minced in the edges, ftanding ypon the toppes of the braunches, hauing in them the thape of an eie. The flowers grow out of the hraunches, which are diuided into many fprigs, which flowers are flender, yelloive, Sz fpred like a ftar, in their places commeth vp very fine feede, the fprigs withering away: the roote is parted into many ofsprings. This plant is alwaies greene, neither is it hurt by the colde in winter, growing in his natiue foile; whereupon it is named dess $4^{\circ} \%$, and Semperwiuson, or Sengreene.

3 There is alfo anotber of this kinde, the circles whereof are anfwerable in bigneffe to thofe of the former, but with leffer leaues, mo in number and clofer fer, hauing ftanding on the edges yerv fine 
haires as it were like foft prickles. This is fomewhat of a decper green : the ftalke is fhorter, and the: flowers are of a pale ycliow.

There is likewife a third to be referred hereunto, the flowers whereo be of a whitin greene, and are very curioufly nicked round abour.

There is alfo a fourth, the circles wherc of are leffer, the leaucs fharpe pointed, veryclofely feet of a darke red colour on the top, and hairic in the edges : the flowers on thefprigs are of a galltwi purple colour.

$$
* \text { Theplace. }
$$

I The great Sengreene is well knowen not oncly in Italie, but alfo in Fraunce, Germanie, Bohe. $\mathrm{mia}$, and the Lowe countrics. It groweth on ftones in mountaines, vponolde wals; andancient buildings, efpecially vpon the tops of houfes. The forme hereof doth differ according tothenature of the foile: for in fome places the leaues are narrower and leffer, but mo in number; and haue one onely circle : in other foine they are fewer, thicker, and broader; they are greene and of a deeper greene in fome places; and in others of a lighter greene: for thofe, which we traue defcribed,grow
not in one place, but in diuers and fundrie.

2 Great Sengreen is found growing of it felfe on the tops of houfes, old wals, \& fuch like places in very many prouinces of the Eaft, $\&$ of Greece, and alfo in the Ilands of the Mediterrane an fea, as in Crete, which now is called Candie, Rhodes, Zant, and others; neither is Spaine without it ! for (2s C.Clufres witnefieth) it groweth in many places in the kingdome of Portingale; otherwifeit is cherifhed in earthen pots. In colde countries, and fuch as lie northward, as in both the Germanies, it neither groweth of it felfe, nor yet lafteth long, though it be carefully planted, and diligently looked vnto,but throuigh the extremitic of the weather, and the ouermuch cold of winter it perifheth. $*$ Thetime.

The ftalke of the firft doth at length flower after the Sommer Solftice, which is in Iune about Saint Barnabies day, and now and then in the moneth of Auguft; but in Aprill, that is tofay, after the equinoctiall in the fpring, which is about a moneth after the fpring is begun. Theregrowe out of this among the leaues fmallftrings, which ate the groundworke of the circles, by which being at length full growne, it fpreadeth it felfe into very many circles.

2 Houflecke that groweth like a trce, doth flower in Portingale at the beginning of the yeere prefently after the winter Solftice, which is in December about S. Lucıes day.

\section{* The names.}

The firft is commonly called louis barba, or Iupiters beard, and fo it is ramed of the Apothecaries: the Germans call it Đantzituttz, Jrofz Donzerbaer: they of the Lowe countries 1 Donperbaett : the Hollanders bup foock + the French men Ioubarbc : the Italians Semprenimo mag. giore: the Spaniards Siemprewiwa, yerua puntera : the Englifh men Houfleeke, and Sengreene, and Aygreene : of fome Iupiters eie,Bullocks eic,and Iupiters beard: of the Bohemians 2 etreske. Many take it to be Cotyledôn alter a Diofcoridis; but we had rather hauc it one of the Sengreenes: for it is
continually greene and alwaies flourifheth, and is hardly hurt by the extremitie of winter.

The other without doubt is Diofcorides his deif? wor $\mu$ ina, that is, Semperuiusem magnum, or Sedum maius,great Houfleeke, or great Sengreene: Apuleives calleth it Vitalis, and Scmperflorsum : It is alfo

\section{The temperature.}

The great Houfleckes are cold in the third degrec: they are alfo drie, but not much, by reafon of the waterie effence that is in them.

* The vertues.

A They aregood againt $S$ aint Anthonies fire, the fhingles, and other creeping vicers and inflammations, as $G$ alen faith, that proceede of rheumes and fluxes : and as Dio corides teacheth, againft the inflammations or firie heate in the eies: the leaues faith Plinie, being applied, or the iuice laide
on, are a remedie for rheumatike and watering eics. B They take away the fire in burnings and fealdings, and being applied with Barly meale dried, do
take away the paine of the gowte.

C Diofcorzdes teacheth, that they are giuen to them that are troubled with a hozlaske: that they likewife driue foorth woormes of the belly if they be drunke with wine, $\mathrm{D}$ The iuice put vp in a peffarie doftay the fluxes in women, proceeding of a hot caufe: the leaues
held in the mouth do quench thirft in hot burning feuers. 


\section{HIST ORIE OF PLANTS.}

The iuicemixed with Barly meale and vineger preuaileth againft S. Anthonies fire, all hot bur E ning and fretting vlcers, and againft fcaldings, burnings, and all inflammations, and alfothe gowte comming of an hot caufe.

The iuice of Houfleeke, Garden Nighthade, and the buds of Poplar boiled in Oxungia porci,or F hogs greafe, maketh the moft fingular Populeon that euer was vfed in Chirurgerie.

The iuice hereof taketh away cornes from the toes and feete, if they be wafhed and bathed ther- $\mathbf{G}$ with, and euery day and night as it were implaiftered with the skin of the fame Houfleeke, which certainly taketh them away without incifion, or fuch like, as hath beene experimented by my very good friend M.Nicholas Bet fon, a man painfull and curious in fearching forth the fecrets of nature.

The decoction of Houfleeke, or the iuice thereof drunke, is good againft the bloodie flixe, and $\mathbf{H}$ cooleth the inflammation of the eies being dropped thereinto, and the brufed heibelaid vpon.

\section{Of little Houfleeke or Stonecrop. Chap.136.}

* The kindes.

$T$ Here be two kindes of litcle Houllecke defcribed by the ancient; thenew writers haue found many moe.

I Sedum minus bermatoides. Stonecrop.

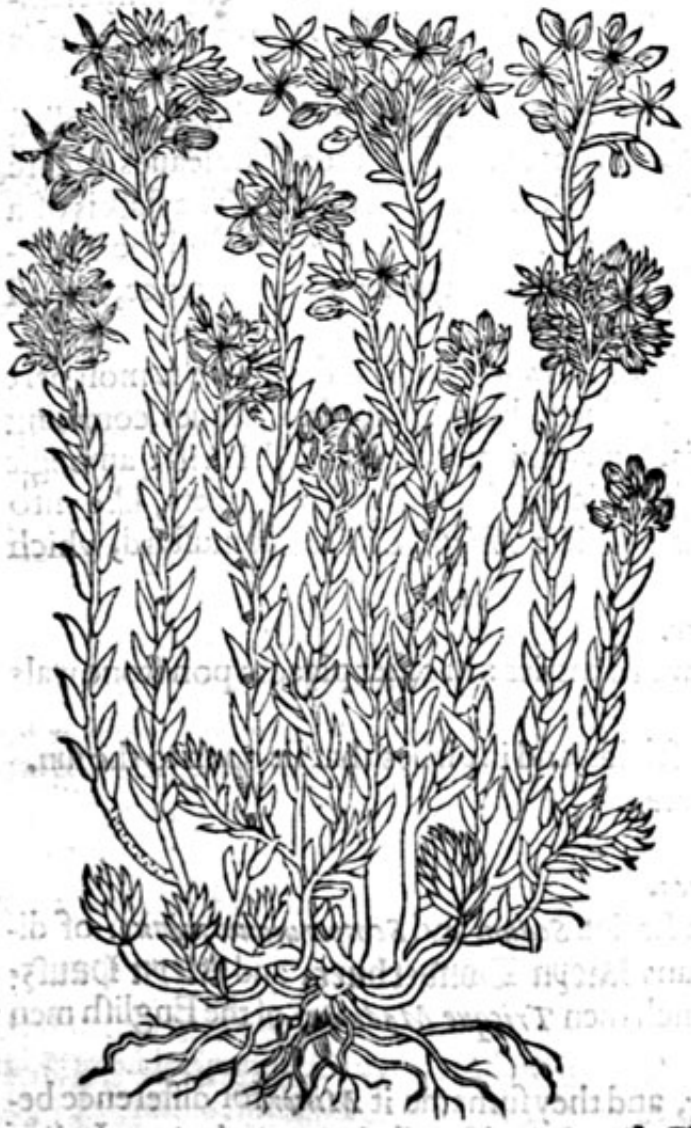

2 Sedum minus officinartum. Small Stonecrop.

\section{act last $*$ The defaription.}

I. Hefirft of thefe is a very little berbe, creeping vpon the ground with many flender ftalks; which are compaffed about with a great number of leaues, that are thicke, full of iointes, little, long, tharpe pointed, inclining toa greene blew. There rife vp among thefe, little ftalkes, a handfull high, bringing foorth at the tópjas it were a fhadowie tuft; and in the $\{$, fine yellow flowers: the roote is full of ftrings.

2 The other little Sengreene is allo a fmall herbe, bringing foorth many flender ftalkes, feldome aboue a f an high; on the tops whereof ftand litule flowers like thofe of the other, in fmall loofe 


\section{THE SECOND BOOKE OF THE}

tuftes; but they are white and fomething leffer : the leaues about the ftalkes are few and little, but long, blunt, and round, bigger than wheaten cornes, fomething leffer than the kernels of the Pine apples, otherwife not vnlike; which oftentimes are fomething red, ftalkes and all: the roote creepeth vpon the fuperficiall or vppermoft part of the earth, fending downe flender theeds.

There is a fmall kinde of Stonecrop, which hath little narrow leaues, thicke, (harpe pointed, and tender ftalkes, full of fattic juice; on the top whereof do growe fmall yellow flowers, ftar fafhion. The roote is fmall and running by the ground.

There is likewife another Stonecrop called Frog Stonecrop, which hath little tuftes of leaues rifing from fmall and threddie rootes, creeping vpon the ground like vnto Kali, 'or Frog graffe; from the which tuftes of leaues rifeth a flender ftalke, fet with a fewe fuch like leaues, hauing at the top fmall yellow flowers.

Many ignorant Apothecaries haue beene deceiued in gathering this great Stonecrop, called Vermicularis, fine Illecebra maior, for the true Prickmadam, and the rather, bicaufe it doth growe where the other doth, and fomewhat refembleth the fame, and yet of a contrarie facultie, namely, of heating \& vlcerating; neuertheleffe the difference is difcerned by the fmal round leaues, which are fmooth, long, and more oleous, and crookedly turned aboue, \& are fharpe pointed, like wormes comming foorth of the ftalkes, and hanging downe. The flowers are of a pale yellow colour: all the plant doth refemble the fmall kinde of Stonecrop.

There is another Stonecrop, or Perrillus Prickmadam called Aizoon Scorpioides, which is altogither like the great kinde of Stonecrop, and differeth in that; that this kinde of Stonecrop or Prickmadam, hath his tuft of flowers turning againe, not much vnlike the taile of a fcorpion, refembling Myofit is Scorpioides, and the leaues fomewhat thicker, and clofer thruft togither. The roote is fimall and tender.

There is a plant called Sedum Portlindicum, or Portland Stonecrop, of the Englifh Iland called Portland, lying in the fouth coaft, which hath goodly branches $\&$ a rough rinde. The leaues imitate Laureola, growing among the Tithymales, but thicker, fhorter, more fat \& tender. The ftalk is of a wooddy fubitance like Laureola, participating of the kindes of Craffula, Semperuivum, and the Tithymales, whereof we thinke it to be a kinde, yet not daring to deliuer any vncertaine fentence, it thall be leffe preiudiciall to the truth, to account it as $2 \mathrm{hrub}$, degenerating from both kindes.

There is a plant which hath receiued his name Sedum Petreum, bicaufe it doth for the moft part growe vpon the rockes, mountaines, and fuch like ftonie places, hauing very fmall leaues, comming foorth of the ground in tuftes like $P$ feudo Moly, that is, our common herbe called Thrift : amongft the leaues come foorth flender ftalks an handfull high, loden with fmall yellow flowers, like vnto the common Prickmadam; after which come little tat cods like $T h h_{a} / \beta i$, or Treacle muftard, which conteine thefecde.

The former of thefe groweth in gardens in the Lowe countries: in other places vpon ftone wals
The and tops of houfes, in England almoft euery where.

The other groweth about rubbilh, in the borders of fields, and in places that lie open to the fun.

They flower in the fommer monethes. $*$ The time.

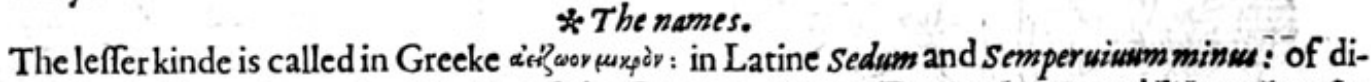

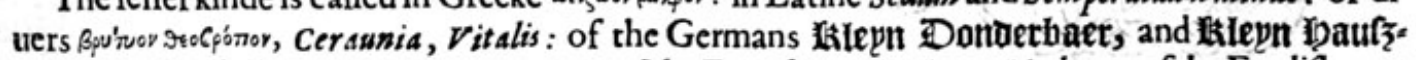
wutt 3 ; of the Italians Semperuiuo minore : of the French men Tricque Madame: of the Englin men Prickmadam.

The fecond kind is named in Thops Craffula minor, and they furname it Minor for difference betweene it and the other Crafjula, which is a kinde of Orpin. It is alfo called Vermicularis: in Italian Pignola, Granellofa, and Grafella : in Lowe Dutch 2 Blauer Loofen: in Englifh Wilde Prickmadam, great Stonecrop, or Wormegraffe.

\section{* The temperature andvertues.}

A The Orpines are of a cooling nature like vinto the great ones, and are good for thofe things that the others be. The former of thefe is vfed in many places infallads, in which it hath a fine relifh, and a pleafant tafte : it is good for the hart-burne. 


\section{HISTORIE OF PLANTSHI \\ Of the fmallest Stonecrops, called wall Pepper. Chap.137. \\ * The kindes.}

F thefe fmall Stone crops there be diuers forts, their feuerall defcriptions fhall be fet dơwine with their names for diftinctions fake.

Vermicularis fiue Itlecebra. Wall Pepper.

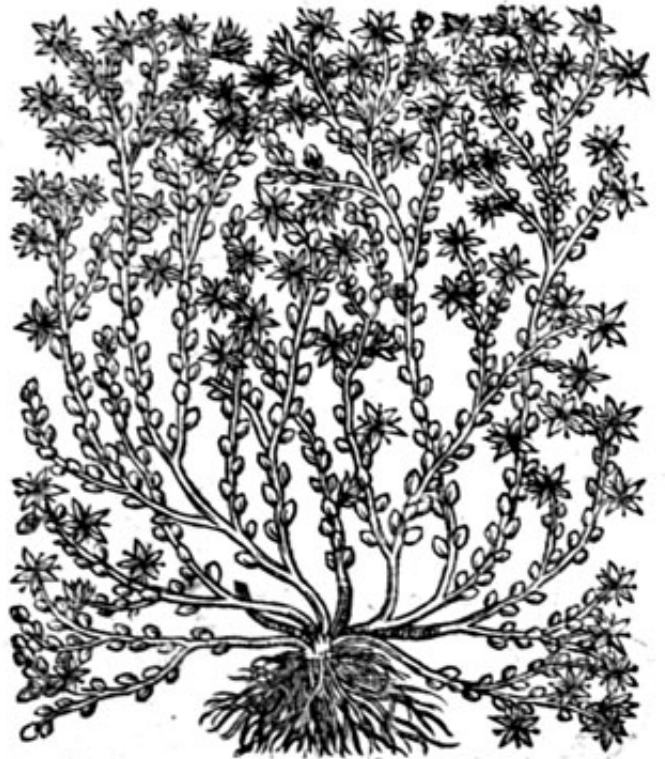

* The defription.

His is a lowe and little herbe: the ftalkes be flender and thort: the leaues about thefe ftande very thicke and fmall in growth, full bodied, tharpe pointed and full of iuice: the flowers ftand on the top, and are maruellous little, of colour yellow \& of a fharp biting tafte:the root is nothing but ftrings. * The place.

It groweth euery where in ftonie and drie places, and in chinkes or crannies of olde wals: it is alwaies greene, and therefore it is verie fitly placed among the Sengreens.

The time.

It flowreth in the fommer moneths. * T the names.

This is tertion Semperuiuem Diofcoridis, or Diofcorides his thirde Sengreene, which he faith is cal-

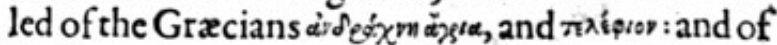
the Romaines Illecebra. Plimie alfo witneffeth that the Latines name it Illecebra. Yet there is anotherbe Paurpfeffer, and yatzent treuble: the French men Pain d' oifeau : the Low countrie men $\$$ Buer 1 Pepper : the Englifhmen Stonecrop and Stonehore, little Stonecrop, Pricket, of fome Prickmadam, Moufetaile,wall Pepper, countrey Pepper,and Iacke of the butterie.

\section{* Thetemperature.}

This little herbe is harpe and biting,and very hot. Being outwardly applied it raifeth blifters, and at length exulcerateth.

* The vertwes.

It wafteth away hard kernels, and the kings evill, if it be laide vato them, as Diogcorides writeth. A

The iuice heereof extracted or drawne forth \& taken with vineger or other liquor,procureth vo- $\mathbf{B}$ mite, and bringeth vppe groffe and flegmatike humpurs, andalfocholericke; and doth thereby oftentimes cure the quartaine ague andotber agues of Jong continuance; and giuen in this maner is is a remedie againft poifons inwardly taken.

$$
\begin{aligned}
& \text { Of Orpyne. Cbap.j8. } \\
& \text { * Thedefoription. }
\end{aligned}
$$

1 HeSpanilh Orpyne fendeth foorth round ftalkes, thicke, flipperie, hauing as it werelittle ioints, fomewhat red now and then about the roote the leaues in likemannerare thicke, fmooth, groffe, full of tough iuice, fometimes flightiynicked in the edges, broader lèned, \& greaten then thofe of Purflaine, otherwife not mueh vnlike, which by couples are fet oppofite one againft another vpon euery ioint, couering theftalke in orderby two and owoz the fiowers in the rounde tufts are of a pale yellowe : the roote groweth full of bumpes like vntolong kimels, waxing Aharpecowarde the point: thefe kernels be white and hatie ftring grotiving foorth of them. ज्ता 2 The feconde which is our common Orpyne, dothlikewifo bife vp with very many rounde ftalkes that are fmooth, butnot iointed at alf she leaues are groffe or corpulent, thicke, broade, and often. times fomewhat nicked in the edges, leffer then thole of the former, placed out of order: the flo- 
wers be either red or yellowe, or elfe whitifh: the roote is white, well bodied, \& full of kernels. This plant is very full of life; the ftalks fet onely in claie continue greene a long time,and if they be nowe and then watered they allo growe. We haue a wilde kinde of Orpyne growing in corne fieldes, and fhadowic woods in moft places of Englande, in eche refpect like that of the garden, fauing that it is altogither leffer.

I Crafulamaior Hipanica. Spanilh Orpyne.

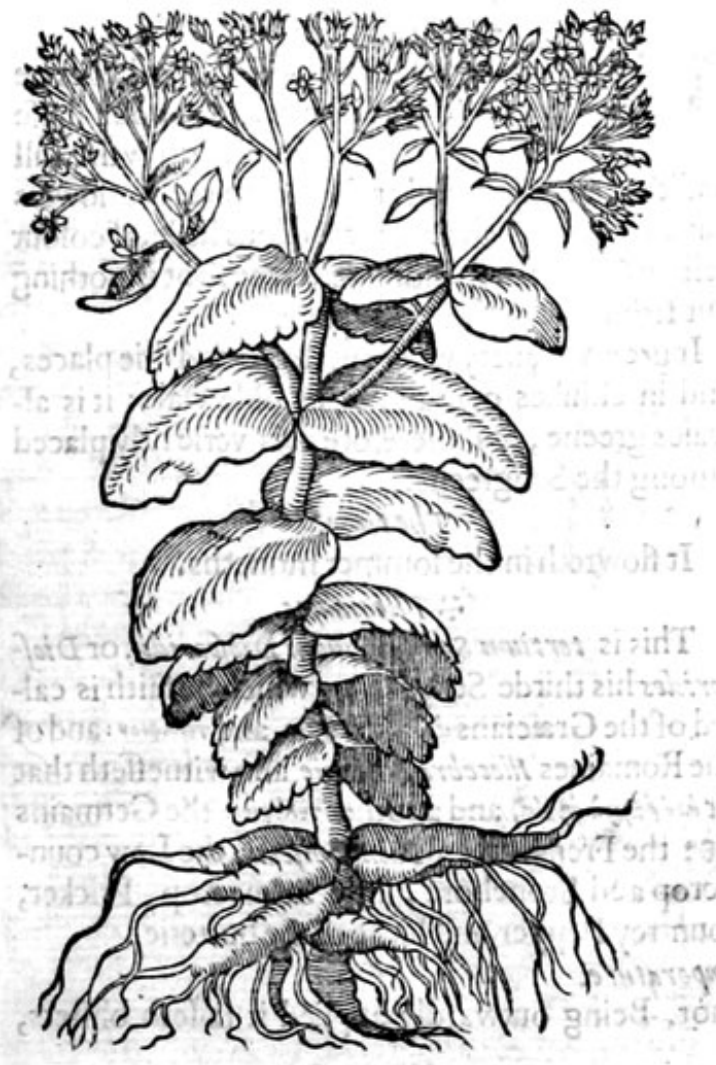

2 Craffula fine faba inverfa. Common Orpyne.

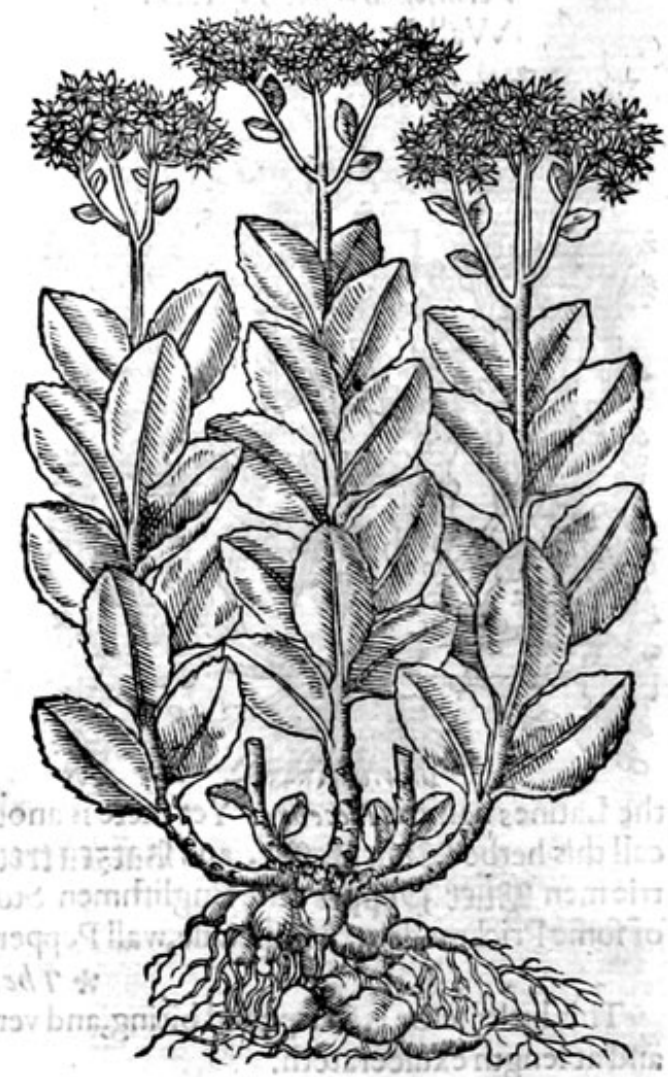

* Thephase.

They profper beft in thadowie and ftonie places, in old wals made of lome or ftone. Oribafus Gith that they grow in vineyardes and tilled places. The fiff groweth in gardens : the other euerie where: the firft is much founde in Spaine and Hungarie : neither is Germanie without it; for it groweth vpon the bankes of the river of $R$ hene neer the yineyards, in rough and ftonie places, nothing at all differing from that which is founde in Spaine,

The feconde groweth plentifully both in Germanie, Fraunce, Bohemia, Englande, and in other countries among vines, in olde lomie, daubed, and ftonic wals.

The Orpynes flower about Auguft or before. * The time.

* the names.

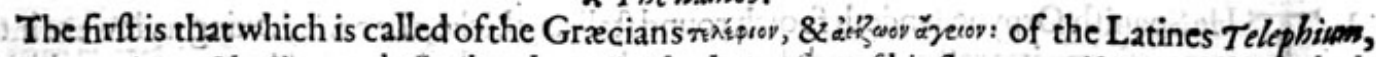
Se Seimperuinum fyluestre; and Illecebra : but Illecebra by rea! on of his fharpe and biting qualitie doth much differ from it, as we haue declared in the former chapter. Some there be that name it divd ex $x$ in, or Portulacas fyluestris: yet there is alfo another Purtulact fylwestris, or wilde Purflaine, like to that which groweth in gardens, but leffer: we may cal this in Englifh Spanifh Orpyne; Orpyne of Hungarie, or iointed Orpyne.

The feconde kinde of Orpyne is called in thops Craffula, and Crafula Fabaria, and Craffula misior, that it may differ from that which is defcribed in the chapter of little Houfleeke: it is named alfo

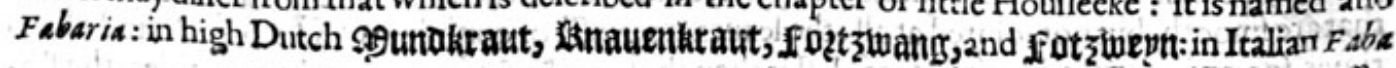




\section{HISTORIE OF PLANTS.}

grafa: in French lowbarbe des vignes, Fewe eßpeffe: in lowe Dutch omet woztele, and pemeI sioluetel : in Englinh Orpyne; alfo Liblong,or Liuelong. * The temperature.

The Orpyns be colde and drie, and of thinne or fubrile parts. The vertues.

Diofcorides faith, that being laide on with vineger it taketh away the white morphew : $\vec{G}$ alen faith $\mathbf{A}$ the blacke alfo, which thing it doth by reafon of the fcouring or clenfing qualitic that it hath : whtrerupon Galen attributeth vnto it a hot facultie, though the tafte fheweth the contrary, which forefaid fcouring qualitie declateth that the other two alfo be likewife colde. But colde things may as well clenfe, if drineffe of temperature, and thinnes of effence be ioined withall.

\section{Of the fmaller Orpins. Chap.139.}

1 Telephiven foribus por pur eis. Purple Orpin.

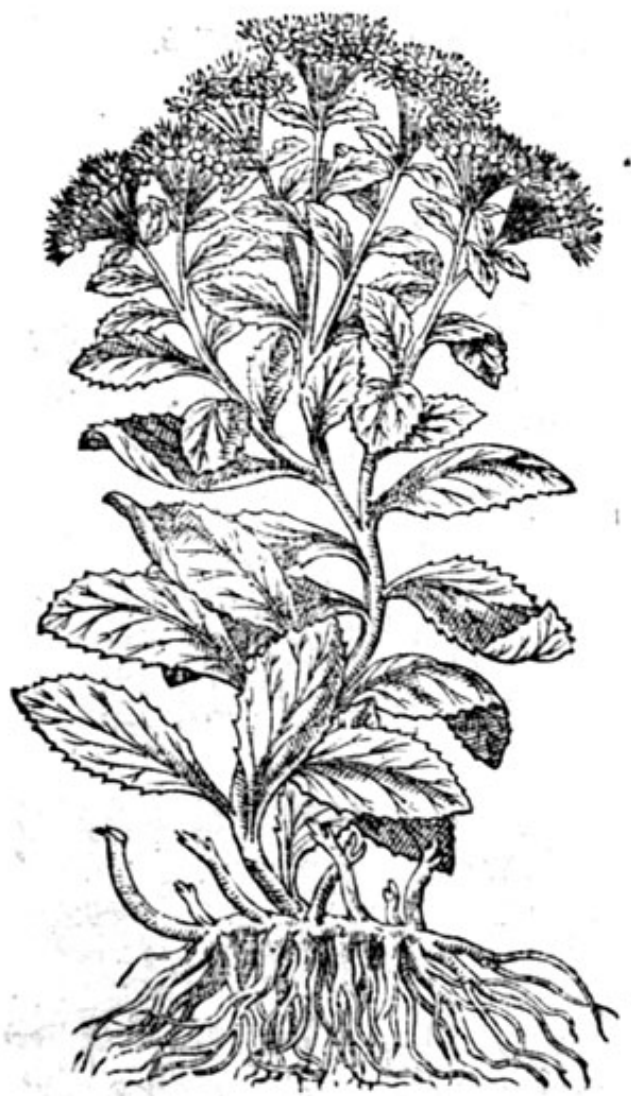

2 Telephiwon femper virens. Neuer dying Orpin.

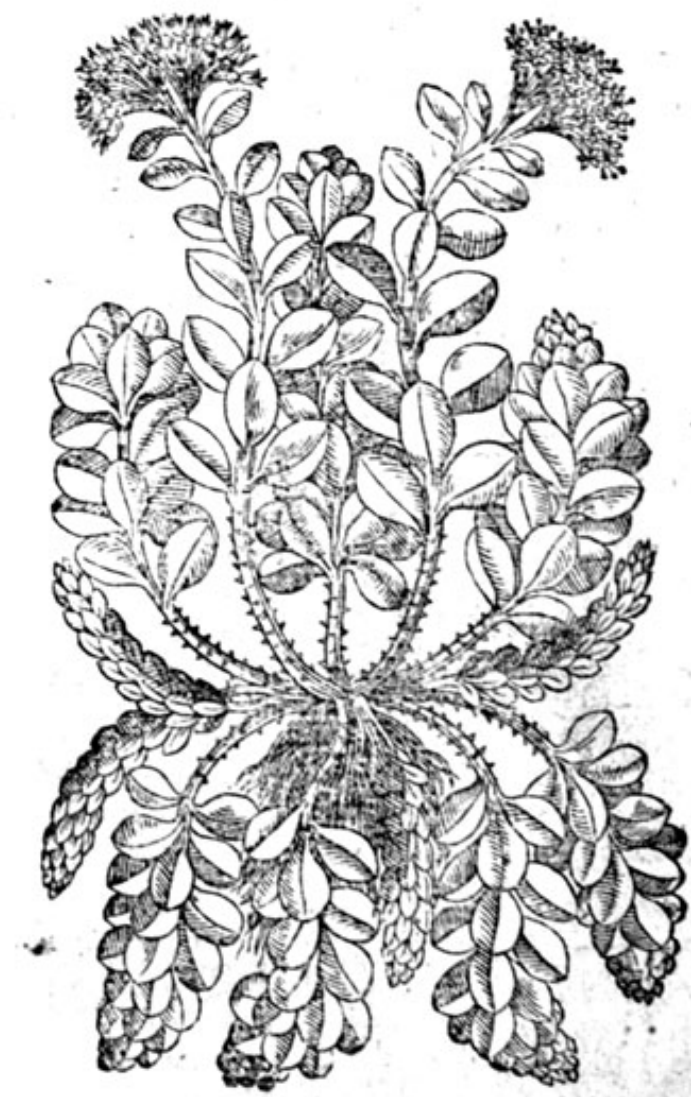

\section{*Thedefription.}

I The Orpin with purple flowers is lower and leffer than the common Örpin : the ftalkes be flenderer, and for the moft part lie along vpon the ground. The leaues are alioleffer, rounder, of a more blew greene, groffe, well bodied, ftanding thicker belowe than aboue; confufedly fet altogither without order. The flowers in the tuftes at the tops of the ftalks be of a pale blew tending to purple. The rootes be notfet with lumpes or knobbed kernels, but with 2 nultitude of bairie ftrings. 2 This fecond Orpin, as it is knowen to few, fo hath it found no name, but that fome Herbarifts do call it Telephrum femperviusm or virens; for the ftalkes of the other do wither in winter, the toote remaineth greene : but the ftalkes and leauis of this indure alfo the fharpneffe of winter, and therefore we may call it in Englifh Orpin euerlafting,or neuer dying Orpin. 
* The place.

The firft groweth not in Englande. The fecond I haue in my garden, where it flourifheth as before fpecified.

They lower when the common Orpin doth.

* The time.

* T he mames.

The names are fpecified in their feuerall defcriptions.

* The temperature and vertwes.

Their temperature and faculties in working are referred vnto the common Qrpin.

$$
\text { OfPurlane. Chap.i4o. }
$$

* The kindes.

$T$ Herebe diuers fortes or kindes of Purlane; one of the garden, and another wilde : and alfo two of the fea; one phificall, the other a baftard kinde.

I Portulaca domestica. Garden Purlane.

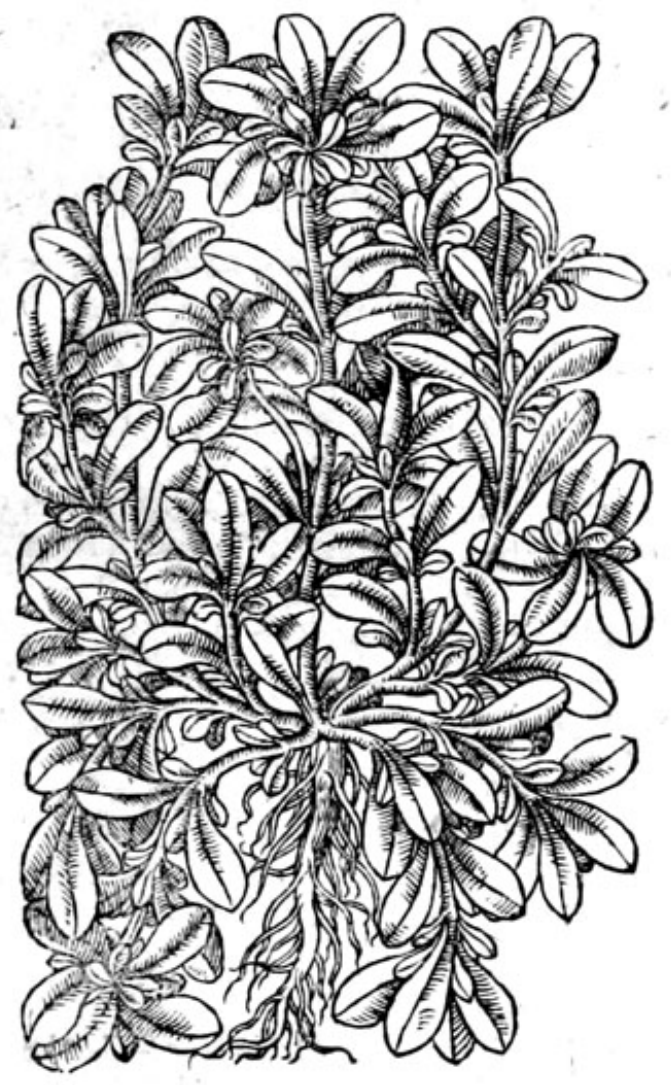

2 Portulacafglwestrio. WildePurfane.

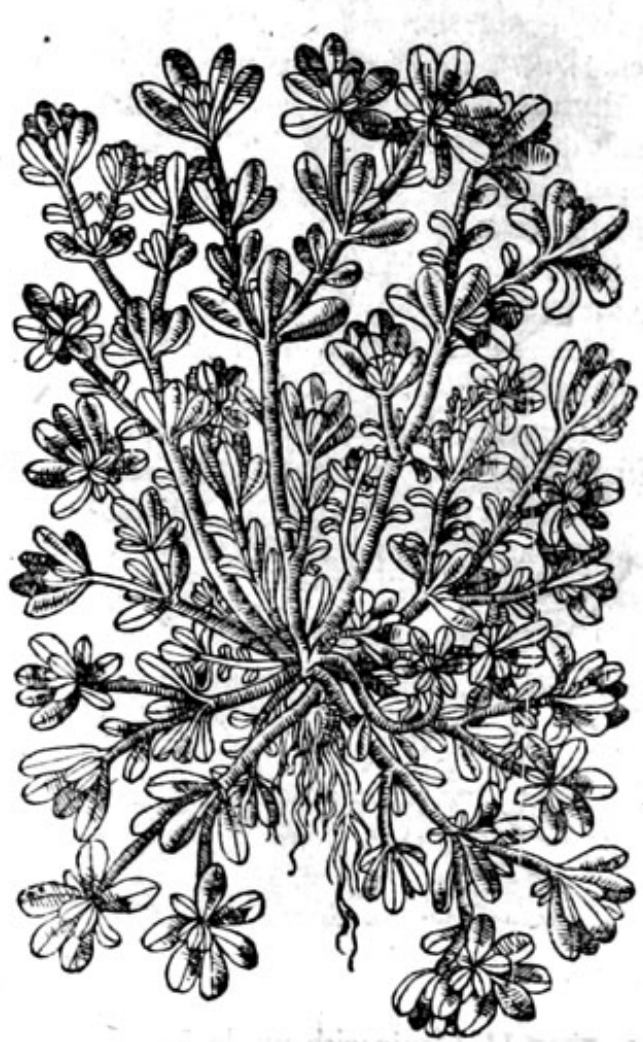

* The defription.

I He ftalkes of the great Purflane be round, thicke, fomewhat red, full of iuice, fmooth, glittering, and parted into certaine branches trailing vpon the ground: the leaues be an inch long,fomething brode, thicke, fat, glib, fomewhat greene, whiter on the neather fide: the flowers are little, of a faint yellow, and growe out at the bottome of the leaues. After them fpringeth up 2 little huske of 2 greene colour, of the bignes almoft of halfe a barly corne, in which is fmall blacke feede : the roote hath many ftrings. 


\section{HISTORIE OE PLANTS.}

2 The other is leffer, and hath like ftalkes, but fmaller, and it fpreadeth on the ground: the leaues be like the former in falhion, fmoothnes, and thicknes, but far leffer.

\section{* Theplace.}

The former is fitly fowen in gardens, and in the waies and alleis thereof being digged \& dunged; it delighteth to growe in a fruitfull and tat foile not drie.

The other commeth vp of his owne accord in aileis of gardens and vineyardes, and oftentimes vpon rocks: this alfo is delighted with waterie places being once fowen, if it be let alone till the feede be ripe it doth eafily fpring vp afreen for certaine yceres after.

* The trme.

It may be fowen in March or Aprill; it tlourithech and is greene in Iune, and afterwardes euen vntill winter.

* The names.

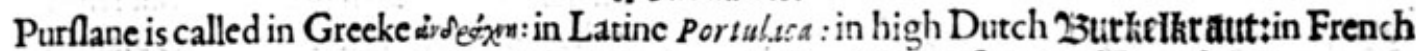
Poupier: in Italian Procacchia : in Spanifh Verdolages : in Eaglifh Purflane and Porcelaine. The temperature.

Purflane is cold, and that in the third degree, and moilt in the fecond: but wilde Purflane is not fomoint.

* The vertues.

Rawe Purflane is nuch vied in falluds wirh oile, falt, and vineger : it cololeth an hot ifomack, and $\mathbf{A}$ prouokethappetite; but the nourihment whichcommeth hereof is little, bad, colde, groffe, and moift: being chewed it is good for teeth that are fet on edge or aftonicd; the iuice doth the fame being held in the mouth, and alfo the diftilled water.

Purflane is likewife commended againft woormes in yoong children, and is fingular good efpe. B cially if an ague be ioined: for it both allaies the ouer much heate, and killeth the woormes: which thing is done through the faltnes mixed therewith, which is not onely an enimic to woormes, but alfo toputrefactions.

The leaues of Purflane either rawe or boiled, and eaten as fallads, are good for thofe that haue $\mathbf{C}$ great heate in their ftomacks and inward partes, and doth coole and temper the inflamed blood.

The fame taken in like manner is good for the bladder and kidneies, and allaieth the outragious luft of the bodic: the iuice alfo hath the fame vertue.

The iuice of Purflane ftoppeth the bloody flixe, the fluxe of the hemorrhoides, monthly termes, D fpitting of blood, and all other fluxes whatfoeuer.

The fame throwen vp with a mother firing, cureth the inflammations, frettings, and vlcerations $\mathbf{E}$ of the matrix; and put into the fundament with a clifter pipe, helpeth the vlcerations and fluxe of the guts.

The leaues eaten rawe,taketh away the paine of the teeth, and fafteneth them; and is good for $\mathbf{F}$ teeth that are fet on edge with eating of harpe things.

The feede being taken, killeth and driueth foorth woormes, and ftoppeth the laske.

\section{Of Jea $\mathcal{P}$ urflane, and of the bastarde grounde $\mathcal{P}$ ines, Antbillis, orftinking ground Pine. Chap.141.}

\section{* The defaription.}

I

EaPurfane is not a herbe as garden Purflane, but a little fhrub : the ftalkes wherof be hard and wooddie : the leaues fat, full of fubftance, like in forme to common Purflane, but whiter and harder: the flowers ftande round about the vpperparts of the ftalkes, 25 do almoft thofe of Blyte, or of Orach : neither is the feede vnlike being broad and flat : the roote is wooddy, long lafting, as is alfo the plant, which beareth out the winter with the lofle of $a$ few leaues.

There is another fea Purlaine called Halimus, or after Dodon esus Portulace marina, which hath leaues like the former, but much whiter (as though mealc had beene ftrewed ouer them) and fomewhat Jonger, not much vnlike the leaues of the Oliue tree. The branches are much greater, and the flowers of a deeper ouerworne herbie colour. 
I Portulaca marima. Sea Purflane.

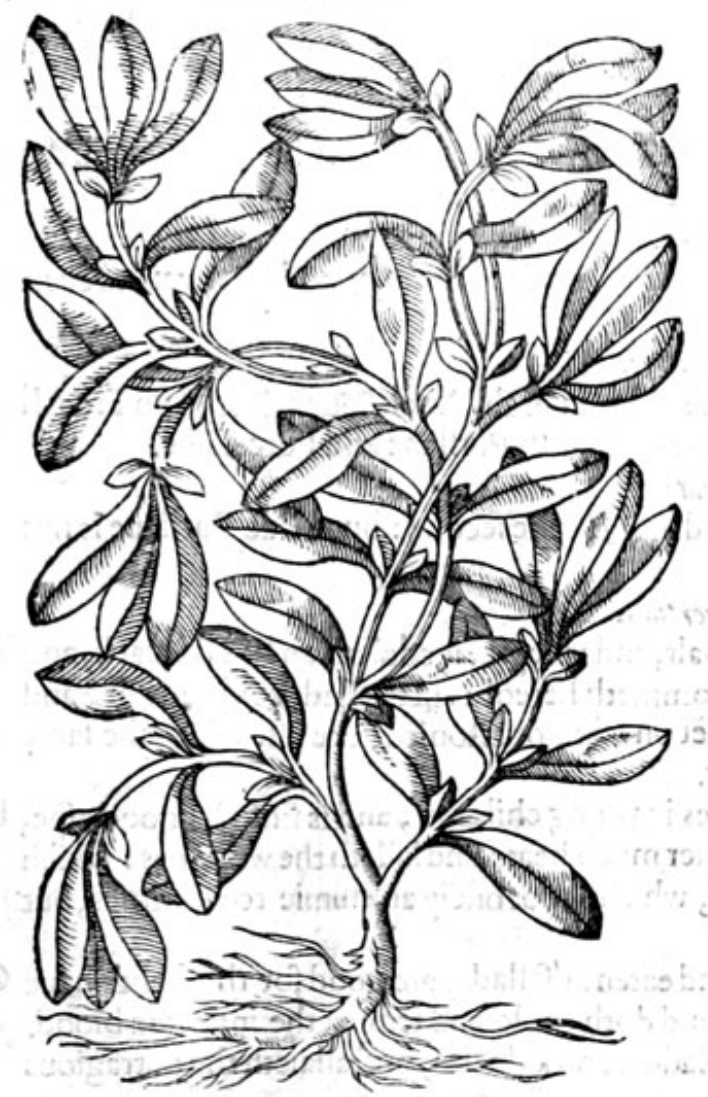

* The defcription.

There is founde another wilde fea Purlane, whereof I haue thought good to make mention; which doth refemble the kindes of Aizoes. The firft kinde groweth vpright with 2 trunke like a fmall tree or hrub, hauing many vpright woodie braunches, of an af he colour, with manie thicke, darke, greene leaues like the fmall Stone crop, called Vermicularis : the flowers are of an herbie yellowifh greene colour : the roote very harde and fibrous : the whole plant is of 2 falt tang tafte, and the iuice like that of Kaly.

There is another kinde like the former, and differeth in that, this ftrange plant is greater, the leaues more fharpe and narrower, refembling the common chamapitys, and the whole plant morewoodic, and commeth neere to the forme of a tree. The flowers are of a greenith colour. * The place.

The firft fea Purflane groweth in the falt marThes neere the fea fide, as you paffe ouer the Kings ferrey into the lle of Shepey, going to Sherlande houfe, (belonging fornetime to the Lord Cheiny, and in 1590 . vnto the right worThipfull fir Edward Hobby) faft by the ditches fides of the fame marfh; it groweth plentifully inthelle of Thanet, as yee go from Margate to Sandwich, and in many other places along the coaft. The other forts growe vpon bankes and heapes of fande on the fea coafts of Zelande, Flaunders, Hollande, and in like places in other countries, as befides the Ile of Purbeck in Englande; and on Rauen-fpurne in Holderneffe, as I my felfe haue feene.

\section{Theretime.}

Thefe flourifh and flower efpecially in Iuly. There be alfo founde other kindes heereof with whiter leaues, longer, and like almoft to Oliue leaues; and many times they be higher, and with tenderer braunches, fuch as Clufuns writeth that he himfelfe fawe and obferued in Portingale, and in the kingdome of Valentia in Spaine.

\section{* The names.}

Sea Purflane is called Portulaca marina : in Greeke कuruos: it is alfo called in Latine Halimus: in Dutch že 1 1 ozceletine: in Englifh Sea Purflane.

The baftard ground Pines are called of fome Chamepicys vermiculata, Halimws, and Antbillis: in Englifh fea ground Pine.

\section{* Thetemperature.}

Sea Purflane is (as Gales faith) of vnlike parts, but the greater part thereof is hot in a meane, with a möifture vnconcocted, and fomwhat windie.

\section{* The vertmes.}

A The leaues (Faith Diofcorides) are boiled to be eaten : a dramme waight of the roote being drunke with meade or honied water, is good againft cramps and drawings awrie of finewes, burftings, and gnawings of the belly:it alfo caufeth nurfes to haue ftore of milke. The leaues be in the Lowe countries preferued in falt or pickle as capers are, and bee ferued and eaten at mens tables in fteede of them; and that without any miflike of tafte, to which it is pleafant. $G$ alen doth alfo report that the yoong and tender buds are woont in Cilicia to be eaten, and alfo laide vp in ftore for vife. 


\section{Of berbe Iue, orground Pine. Chap.142.}

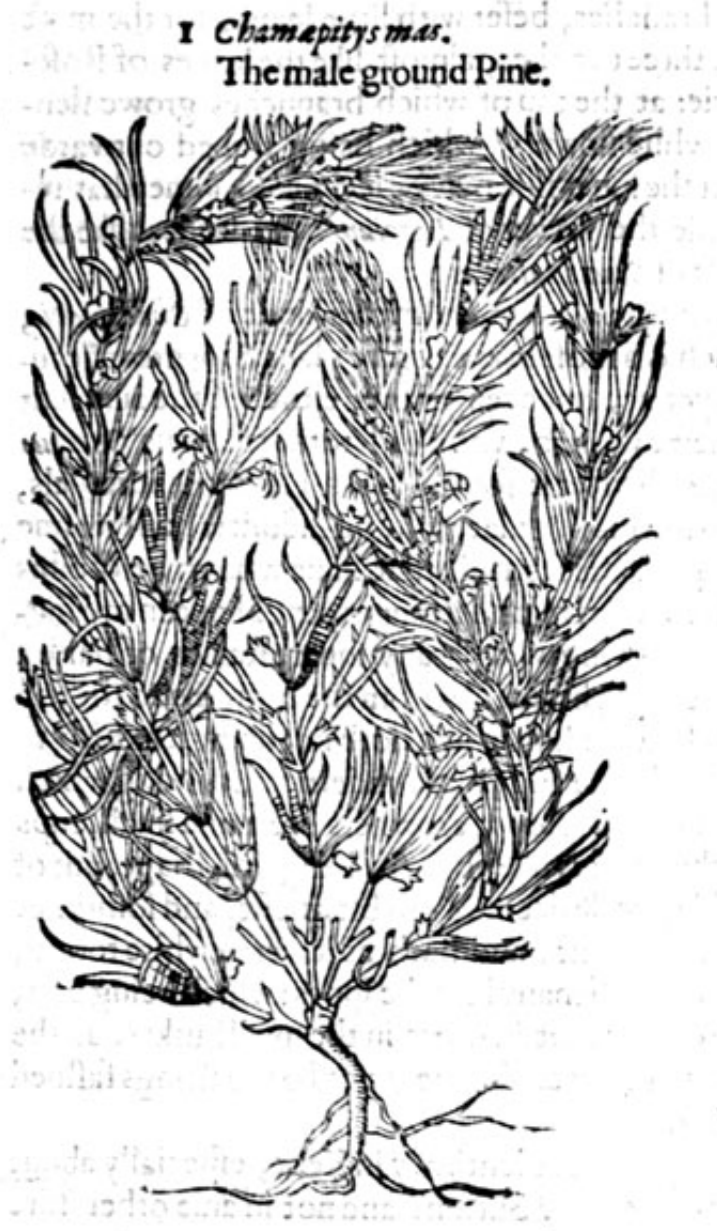

2 Chamepitys famina. The female ground Pine.

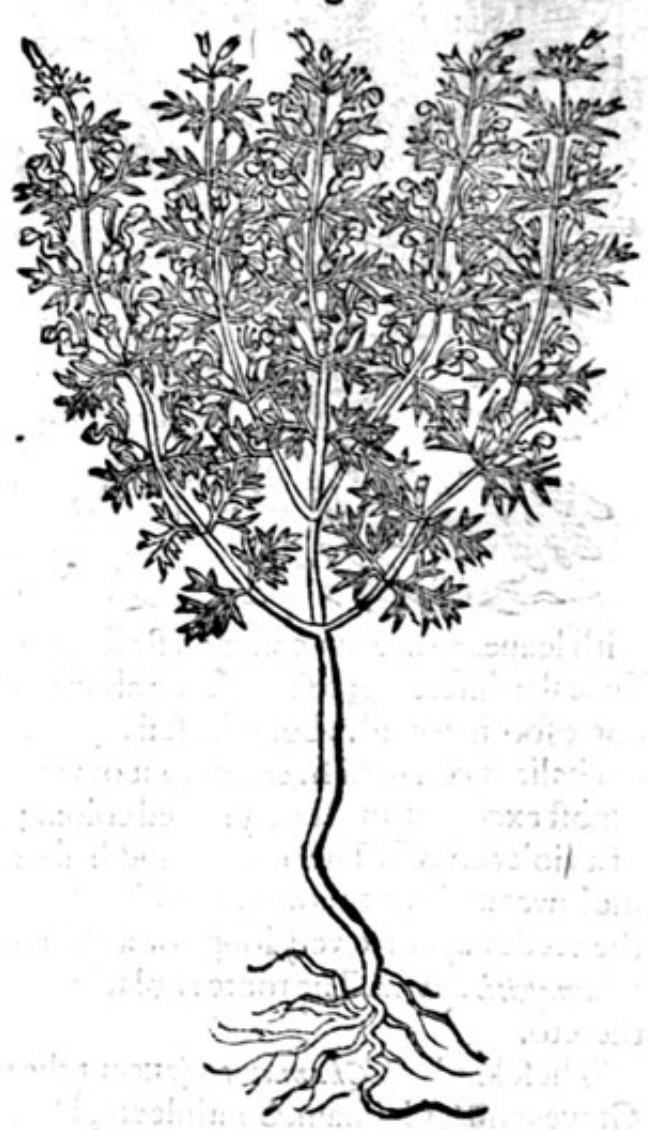

\& The defription:

I Te common kinde of chamepitys or grounde Pine, is a fmall herbe and verie tender, cree-

ping vpon the ground, hauing fmall and crooked braunches trailing about. The leaues perfea, me thinkes it is racher like vnto the finethe firre or Pine tree: but if my fence of fmelling be perfeat, me thinkes it is racher like vnto the finell of hempe. The flowers be little and of a pale yel
low colour,and fomtimes white:the roote is fmall and fingle, and of a woodie fubftance.

2 The fecond kinde hath in like mancr fmalland tender braunches, browne and hairie, verie like vnto the former: from which grow-finall hairieleaues, much clouen or cut, almoft like iagged Ger-
mander. The flowers $2 r$. of a purple colour, and growe about the ftalkes in roundles like the dead Nettell. The feede is blacke and rounde, and the whole plant fauoureth like the former.

3 Thiskinde of herbe Ine, growing tor the moft part about Montpelier in Fratince, is the leaft of all his kinde, having fmall, white, and rough leaules and yellowe flowers, in Imell and proportion
like vnto the others, but much fmaller. 2: There is a ivilde örbiat ard imaller.

vnto the fecond kinde, butnotiagged in that tyanner, or ground Pine, that hath leaues fomewhat like ftalks. The roote is fomewhat bigger, and like vnto the roote of Succoric.

about vpon the ground. The leaues apitys that hath long and fimall braunches, difperfing it felfe far finell and bittenta ground. The leaues are fomwhat broa der then the laft mentioned, being of a ftrong waile, being fower in number, and fet in virew) like vnto the feeds of clssmeles Tricoceos, of Widowe any of thereft. 


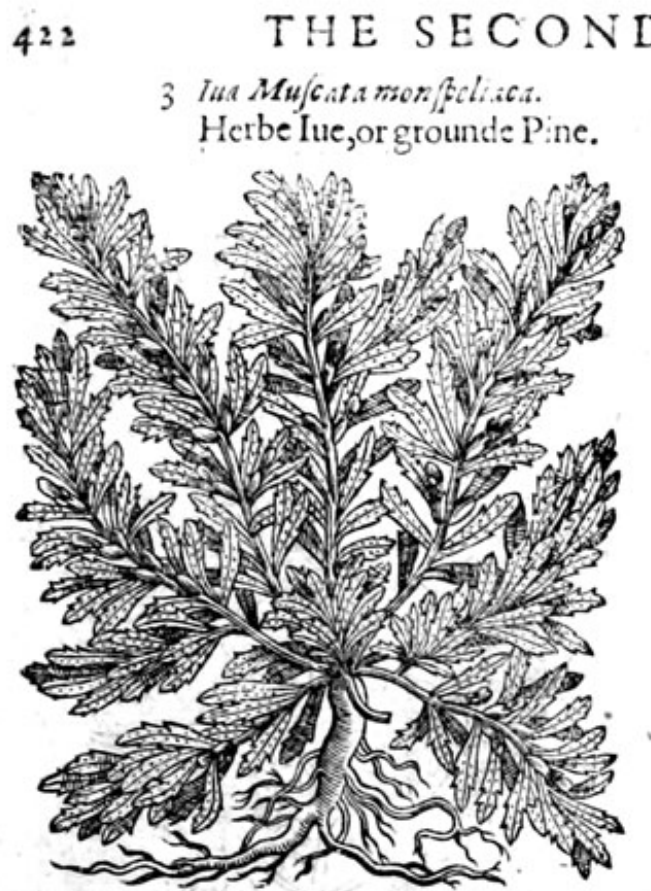

\title{
BOOKE OF THE
}

\author{
* The defoription.
}

There is another kind that hath many fmall \& $\&$ tender branches, befer with littic leaues for the moft part three togither, almoft like the leates of Rofemaric: at the top of which braunches growe flender white flowers, which being turned outwarde (that the inner fide maybe feene) do fomewhat refemble the flower of Lamiwm: the feede is like the feede of Spurinaltera.

There groweth in Auftrich a kinde of Chainapytis, which is a moft braue \& rare plant, \& of great beautie; yet not once remembred either of the auncient or newe writers, vitill of late that famous Carolise Clufins had fet it foorth in his Pannonicketrauels, who for his fingular skill and induftrie hath wonne the garlande from all that haue written before his time. This rare and ftrange plant I haue in my garden, growing with many fquareftalkes of halfe a foote high, befet euen from the bottome to the top with leaues folike our common Rofemaric, that it is hard for him which doth not know it exactly to finde the difference; being greene aboue, and fonwhat hairie and hoarie vnderneath:among which come foorth rounde about the ftalks (after the maner of roundles or crownets) certaine fmall cups or chalices, of a reddifh colour, out of which come the flowers like vnto Archangelfin fhape, but of a moft excellent and ftately mixed colour; the outfide purple declining to blewneffe, and fomtimes of a violet colour. The flower gapeth like the mouth of a beaft, and hath as it werea white toong, the lower and vpper iawes are white likewife, fpotted with many bloudie fpots: which being paft, the feedes appeere very long, of a fhining blacke colour, fet in order in the fmall huskes, as the chamapyt is spuria. The roote is blacke and harde, with many capillaments or hearie ftrings faftned thereto. *: The place.

Thefekinds of Chamapyt is (except the twolait) grow verie plentifully in Kent, efpecially about Graues ende, Cobham, Southfleete, Horton, Dartforde, and Sutton, and not in anic other hire in England that euer I could finde.

That kinde of Chamepitys which beareth the white flower, I haue not as yet feene.

$$
\text { * The time. }
$$

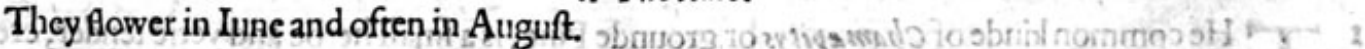

$$
\text { Ground Pine is called in Greek as }
$$

Ground Pine is called in Greek zeudarins : in Latinc Ibrga, dings \& Abiga: in fhops Iua Artherica,

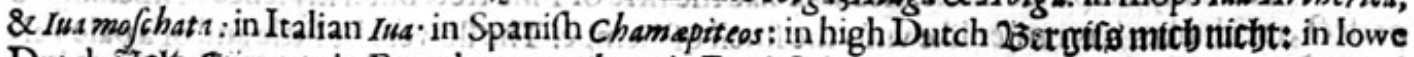
Dutch Cislt Iipes : in Fiench Jue mofi hate : in Englifh herbe Iuie, Forger menot, grounde Pine, and fielde Cypreffe. $x$ The nature.

Thefe herbes are hot in the fecond degree and drie in the third.

$$
\text { * Thevertues. }
$$

A The leaues of chamapytistunned vp in ale, or infufed in wine, or fodden with hony, and drunke by the f pace of eight or ten daies, cureth the iaundies, the Ifchiatica, the ftoppings of the liuer, the difficultic of making water, the ltoppings of the fpleenc, and caufethwomen to haue their naturall ficknes.

B Chamepyt is ftamped greene with honie cureth wounds, malignant and rebellious vlcers, and diffolueth the hardnes of womens brefts or paps, and profitably helpeth againft poifon, or biting of any venemous bealt.

C The decoetion drunke, diffolueth congealed blood, and drunke with vineger driueth foorth the dead childe.

D It clenfeth the intrals: it helpeth the infirmities of the liuer and kidneies: it cureth the yellow jaundies being drunke in wine : it bringeth downe the defired ficknes, and prouoketh vrine: being boiled in Meade or hónied water and drunke, it hel peth the Sciatica in fortie daies. The people of 
Heraclea in Pontus do vfe it againft Wolfes bane in fteed of a counterpoifon:

The powder hereof taken in pils with a fig, mollifieth the belly; itwafteth away the hardnes of $\mathrm{E}$ the paps; it healeth wounds; it cureth putrified vlcers being applied with honie : and thefe things the firftground Pine doth performe, fo doth the other two; but not fo effectually, as witneffeth Diogcorides.

Cluffus of whom mention was made, hath not faid anything of the vertues of Chamepytis Aar $\mathrm{F}$ ftriaca; but verily I thinke it better by many degrees for the purpofes aforefaid:my coniceture I take from the tafte, finell, and comely proportion of this herbe, which is more pleafing and familiar to the nature of man, than thofe which we haue plentifully in our owne countrie growing.

\section{Of Nauelwoort, or Pennimoort of the wall. Chap.143.}

I Vmbilicus Veneris. Wall Penniwoort.

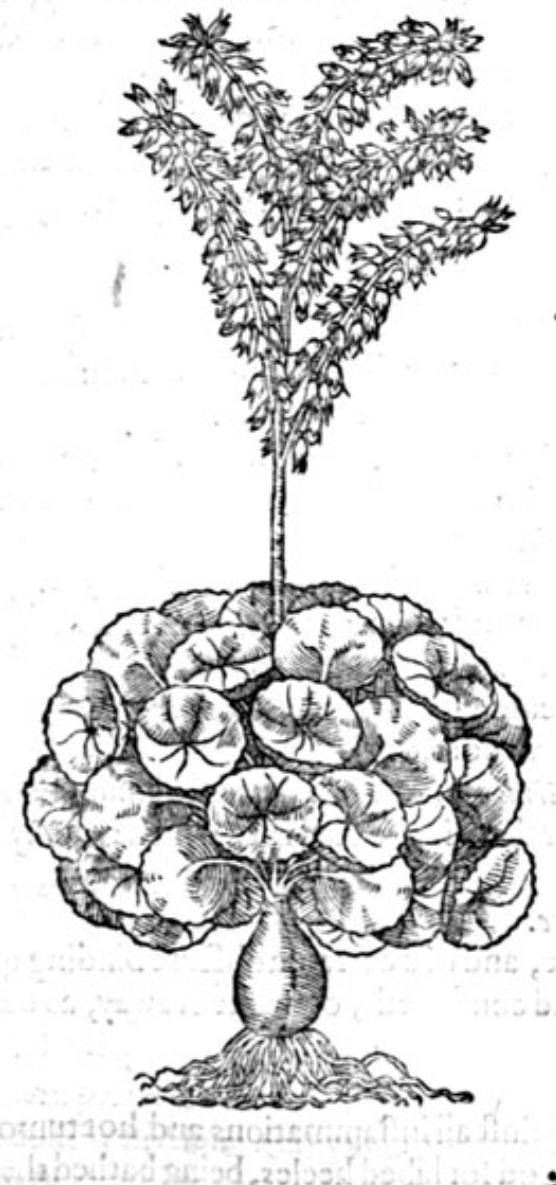

2 Vmbilicus Venerisminor. Small Nanclwoort.

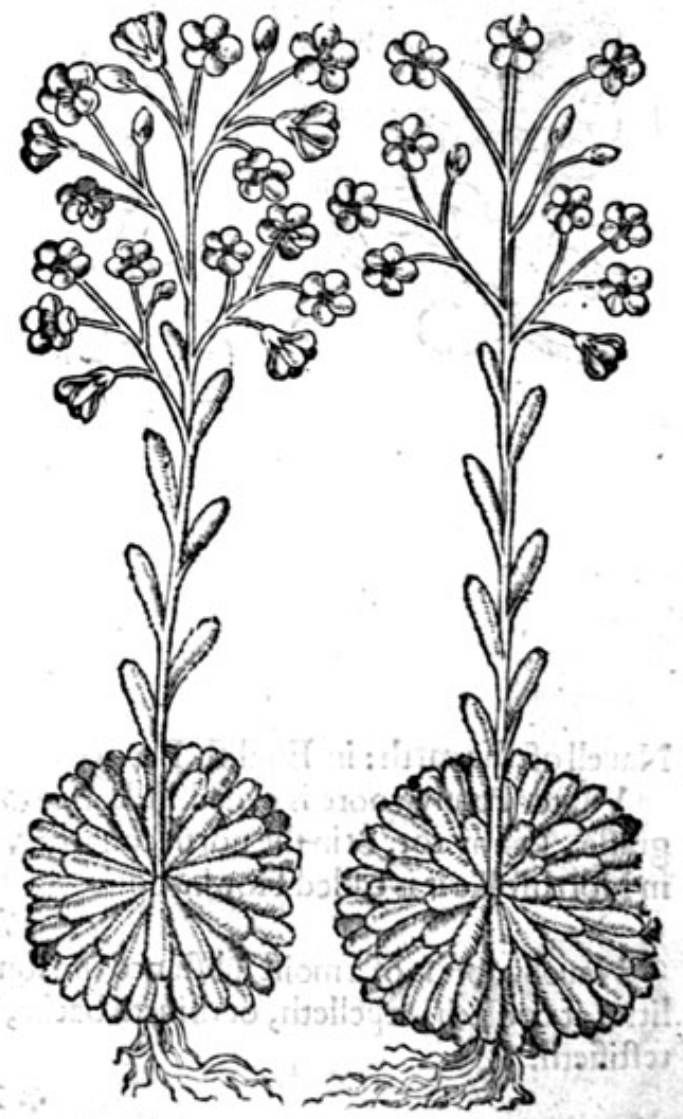

* The defcription.

I ${ }^{-H e}$ great Nauelwoort bath round and thicke leaues, fomewhat bluntly indented about the edges, and fomewhat hollow in the midft on the vpper part, hauing a fhort tender ftem faftened to the midift of the leafe, on the lower fide vnderneath the ftalke, whereon the flowers do grow, is fmall and hollow, an handfull highand more, beferwithmany fmall tlowers of an ouerworne incarnate colour. The roote is round like an oliuc of a white colour.

2 The fecond kinde of Wall Pennywoort or Nauelwoort, hath broad thicke leaues, fomewhat deeply indented about the edges, \& are not fo round as the leaues of the former, but fomwhat long like toongs, fpred vpon the ground in maner of a tuft, fet about the tender ftalke, like to Sengreene or Houfeeke; among which rifeth vp a tender ftalke whereon do grow the like leaties. The flowers ftand on the top confifting of fiue fmall leaues of a white colour. The root is fmall and threddie. 


\section{THE SECOND BOOKE OF THE}

3 Cotyledon palastris.

Water Pennywoort.

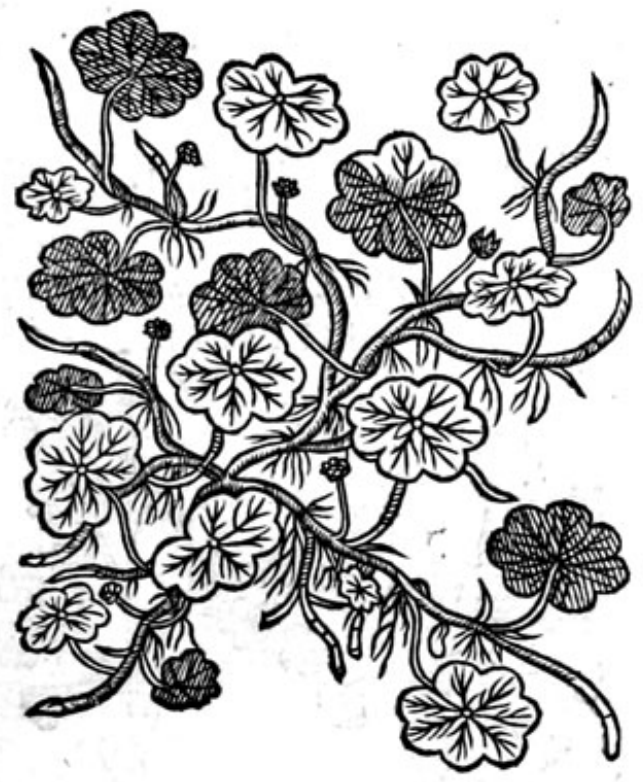

* The defcription.

3 There is a kinde of Nauelwoort, that groweth in waterie places, which is called of the hufbandman Sheepesbane, bicaufe it killeth Theepe that do eate thereof : it is not much vnlike the precedent, but the round edges of the leaues are not fo euen as the other; and this creepeth vpon the ground, and the other vpon ftone wals. * The place.

The firft kinde of Pennywoort groweth plentifully in Northampton vpon euery ftone wall about the towne, at Briftowe, Bathe, Wels; and moft places of the weft countrie vpon ftone wals. It groweth vpon Weftminfter abbay, ouer the doore that leadeth from Chaucer his tombe to the oldepalace.

The fecond groweth vpon the Alpes neere Piedmont, andBauier, and vpon the mountaines of Germany : Ifounde the fame growing vpon Biefton caftell in Chefhire. * The time.

They are greene and flourifh efpecially in winter :they flowre in the beginning of fommer. * The names.

Nauelwoort is called in Greeke xonunifury : in Latine Vmbilicus Veneris, and Ncetabulum : of diuers Herba Coxendicum: Iacobus CManlizes nameth it Scatum cali, and Scatellum : in Dutch Jaas ueictupt : in Italian Cupertoiule: in French $E$ fiuelles: in Spanifh Capadella : of fome HortusVeneris, or Venus garden, and Terre umbilicus, or the

Nauell of the earth: in Englifh Pennywoort, Wall Pennywoort, Ladies nauell,and Hipwoort.

Wațer Pennywoort is called in Latine Cotyledon palustr is : in Englifh Sheepes killing Pennygraffe, Penny rot, 8 in the north countrie White rot : for there is alfo Red rot, which is Rofa folis, in Northfolke it is called Flowkwoort.

* The temperature.

Nauelwoort is of a moift fubftance and fomewhat colde, and of a certaine obfcure binding qualitie: it cooleth, repelleth, or driueth backe, fcowreth and confumeth, or wafteth away, as Galen tc:tifieth.

\section{* The vertues.}

A The iuice of Wall Pennywoort is a fingular remedie againft all inflammations and hot tumors, as Eryfipelas, Saint Anthonies fire, and fuch like: and is good for kibed heeles, being bathed therewith, and one or more of the leaues laid vpon the heele.

B The leaues and rootes eaten do breake the ftone, prouoke vrine, and preuaile much againft the dropfie.

C The ignorant Apothecaries do vfe the Water Pennywoor in fteade of this of the wall, which they cannot do without great error, and much danger to the patient: for husbandmen know well, that it is noifome vnto heepe, and other cattell that feede thercon, and for the moft part bringeth death vnto them, much more to men, by a ftronger reafon. 


\section{Of Sea Pennywoort.}
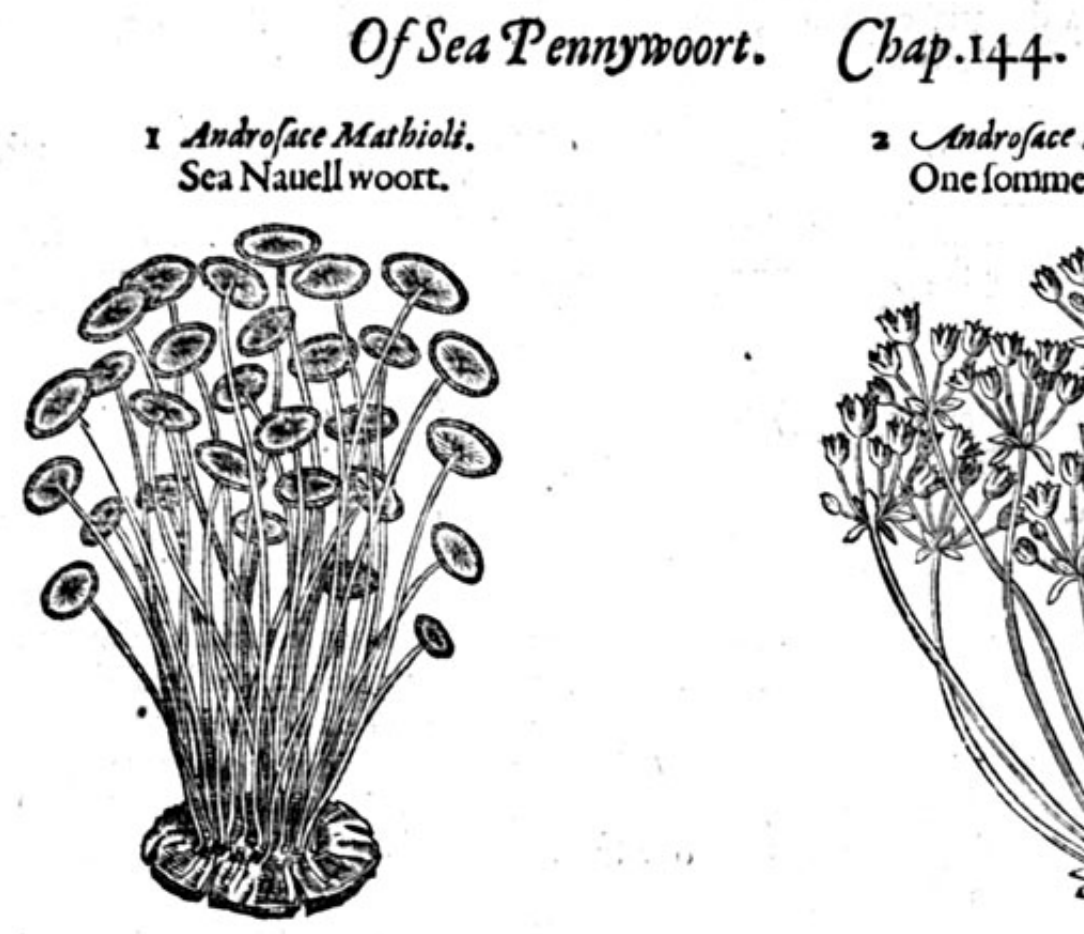

2 Androface annua purita. One fommers Nauell woort.

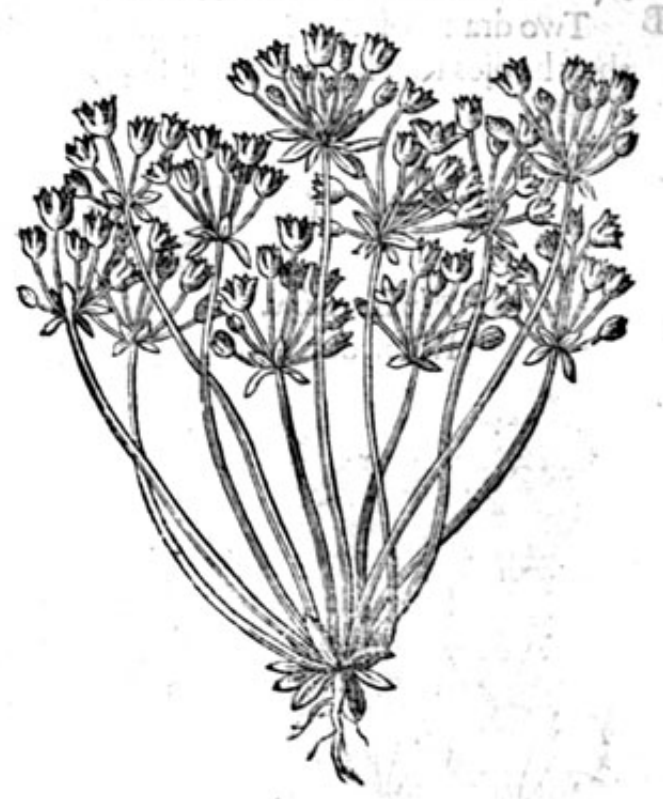

* The defoription.

I He Sea Nauelwoort hath many round thicke leaues like vnto little faucers, fet vpon finall

1 and tender ftalkes, bright, hining and mooth, of two inches long, for the moft part growing vpon the furrowed backs of the fhell filh called chamaconcha,euery fmall ftem bearing vpon the end or point, one little buckler and nomore, refembling a nauell; the ftalke and leafe fet togither in the middle of the fame. Whereupon the Herbarifts of Montpelier have called it Vmbilicus Marinus, or Sea Nauell. I he leaues and ftalkes of this plant, whileft they are yet in the water, are of a pale afhe colour, but being taken foorth, they prefently waxe white, as Sea Mofie called Corallina, or the fhell of a Cockle. It is thought to be barren of feede, and is in tafte faltifh and bitter. It were a maruell to confider (as I hulue done) how far, euen the beft writers haue beene deceiued in the defcription of this plant. But we muft remember, that no man liuing knoweth all chings, and Aliqu. indo bonus dormitat Homerus : it is a good horfe that neuer fumbleth.

2 The fecond Androface hath little fmooth leaues, ipred vpon the ground like vnto the leaues of fmall Chickweede, or Henne bit, whereof doubtlefie it is a kinde: among which rifeth vp a flender ftem, hauing at the top certaine little chaffie flowers of a purplifh colour. The feede is conteined in finall fcaley huskes, of a reddifh colour, and a bitter tafte. The whole plantperifheth when it hath perfeeted his feede, and muft be fowen againe the next yeere, which plant was gituen to $M$ itthiolus by cortufus, who (as he affirmeth) receitred it from Syria; but I thinke he faide fo to make Matbiolus more ioifull : but furely I furmife he picked it out of one olde wall or other, where it doth growe euen as the fmall Chickweede, or Nailewoort of the wall do.

Androfaces will not growe any where but in water: great ftore there is of it about Frontignah by Monpelliers in Languedoc, where euery fifher man doth knowe it.

The feconde groweth vpon olde ftore andmudde wals :notwithitanding I haue (the more to grace Mathiolus great iewell) planted it in my garden.

The The time. * The time.
y, and the feede is ripe in Auguft.

Androfaces is of fome called Vmbilicus mariniw, or fea Nauell. 
* The temperature.

The fea Nauell is of a diureticke qualitie, and more drie then Galen thought it to be, and leffe hot then others haue deemed it: there can no moifture be found in it.

A Sea Nauell woort prouoketh vrine, and digefteth the filthineffe and flimineffe gathered in the iointes.

B Two drams of it, as Dio fcorides faith, drunke in wine, bringeth downe great ftore of vrine out of their bodies that haue thedropfie, and maketh a good plaifter to ceafe the paine of the gout.

\section{Of Resewoort, or Rose roote. Chap.145.}

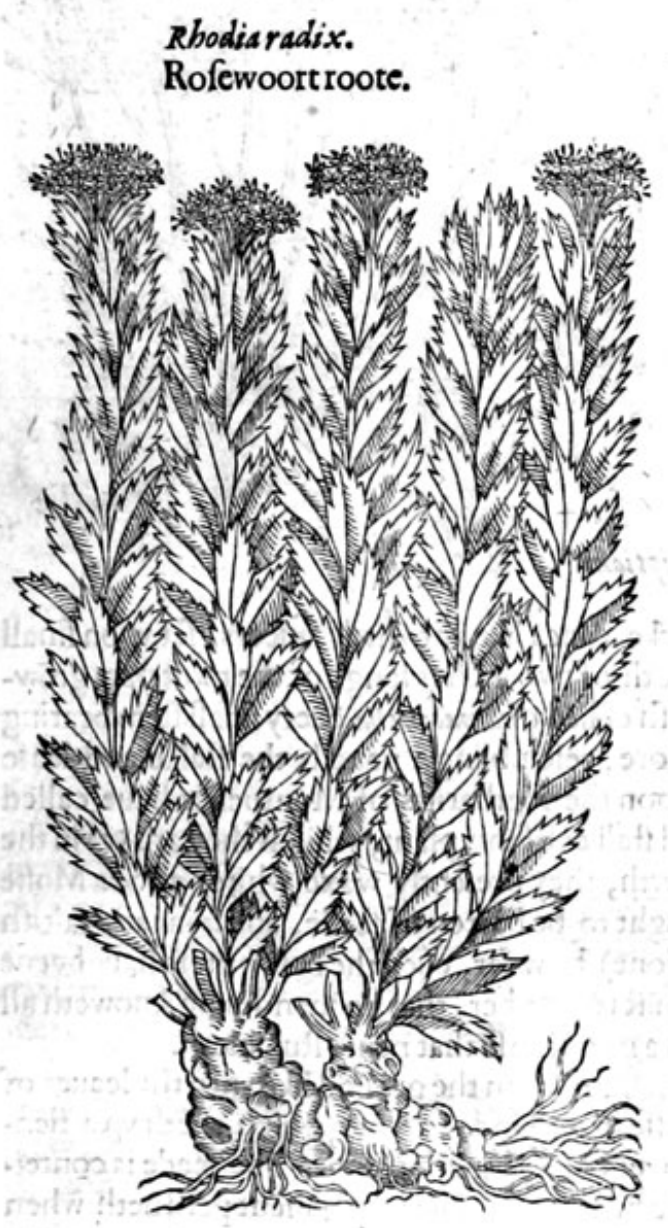

* The deforiptios.

R Ofewoort hath manie fmall, thicke, and fat Iftems, growing from a thicke and knobby roote, the vpper end of it forthe molt part ftandeth out of the ground, and is there of a purplith colour, bunched and knobbed like the roote of Orpin, with many hairie ftrings hanging thereat, of a pleafant fmell when it is broken, like the damaske Rofe, whereof it tooke his name. The leaues are fet rounde about the ftalkes, euen from the bottome to the toppe, like thofe of the fielde Orpin, but narrower and more fnipt about the edges. The flowers growe at the top of a faint yellowe colour.

$$
\text { * Theplace. }
$$

It groweth very plentifully vpon fundry mountames in the north part of England, efpecially in a place called Ingleborough Fels, neere vnto the brooke fides, and not elfe where that I can as yet finde out, from whence I haue had plants for nyy garden.

\section{* The time.}

It flowreth and flourifheth in Iuly, and the feed is ripe in Auguft. * The names.

Some haue thought it hath taken the name Rhodin of the Iland in the Mediterranean fea,called Rhodes : but doubtleffe it tooke his name Rho. dia radix, of the roote, which fmelleth like a Rofe: in Englifh Rofe roote, and Rofe woort. * The vertues.

A There is little extantin writing of the faculties of Rofewoort : but this I haue founde, that if the roote be ftamped with oile of Rofes and laide to the temples of the head, it eafeth the paine of the head.

$$
\text { Of Sampier. Chap.146. }
$$

* The kindes.

The later Herbarifts haue obferued certaine kindes of Sampier, as fhall be declared. 
1 Crithruom marinum. Rocke Sampier.

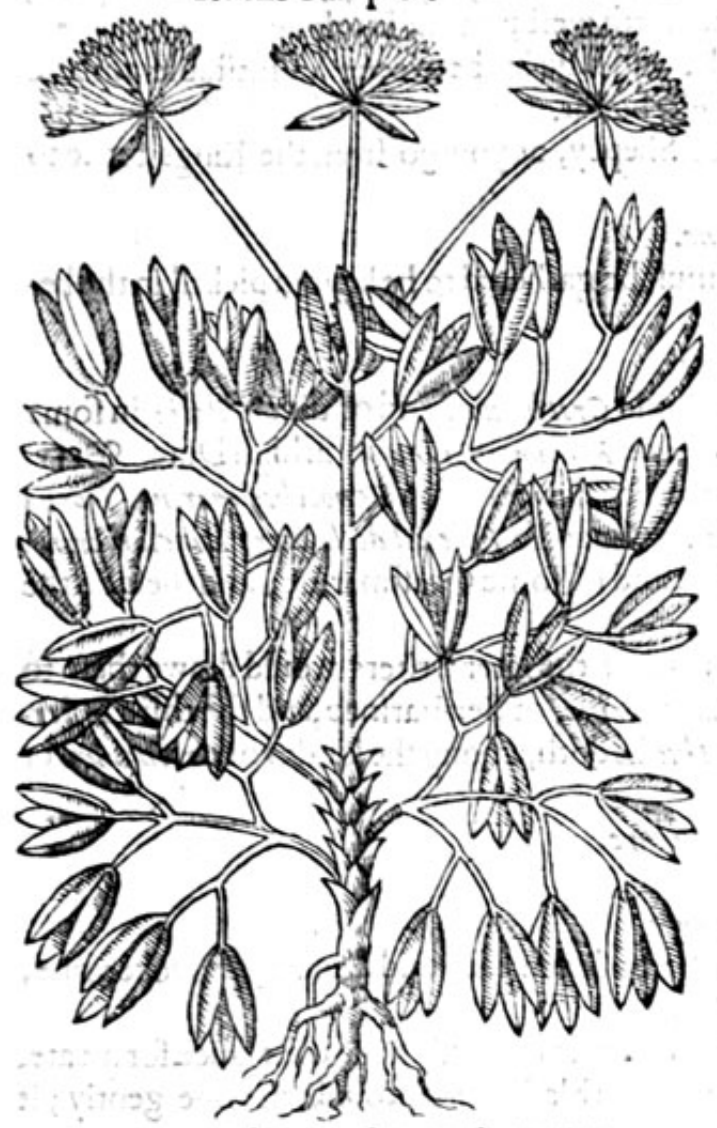

3 Crithmum Chrifasthemum. Golden Sampier.

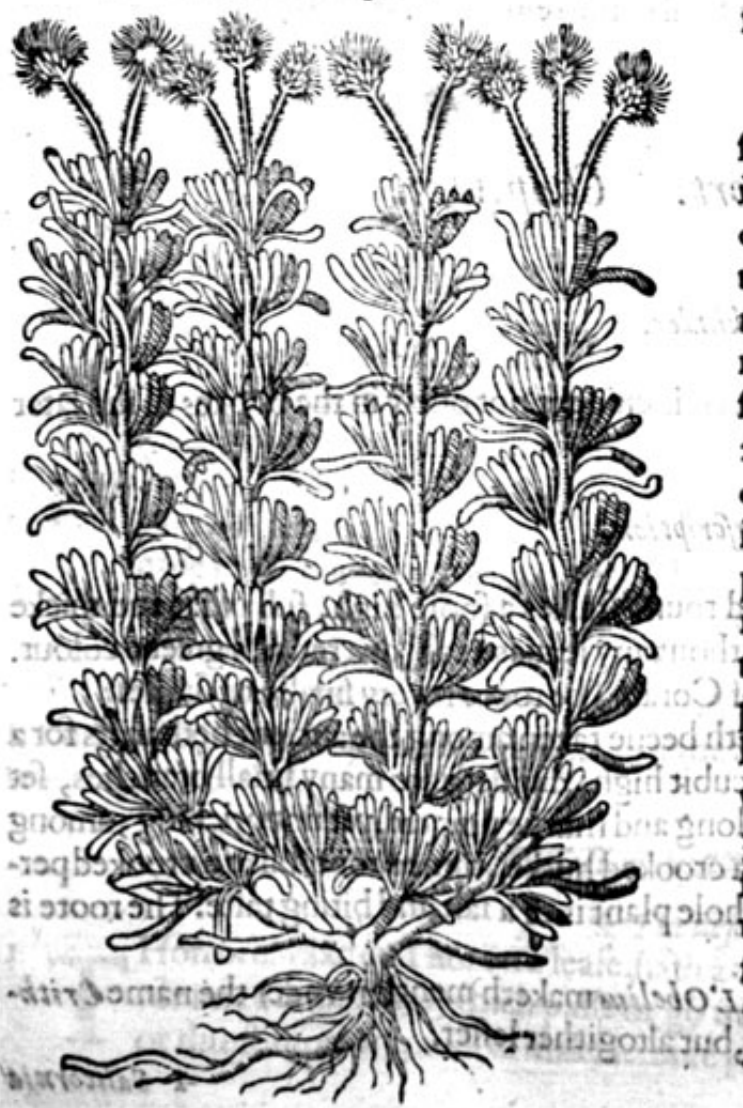

2 Crithmum foinofuen. Thorny Sampier.

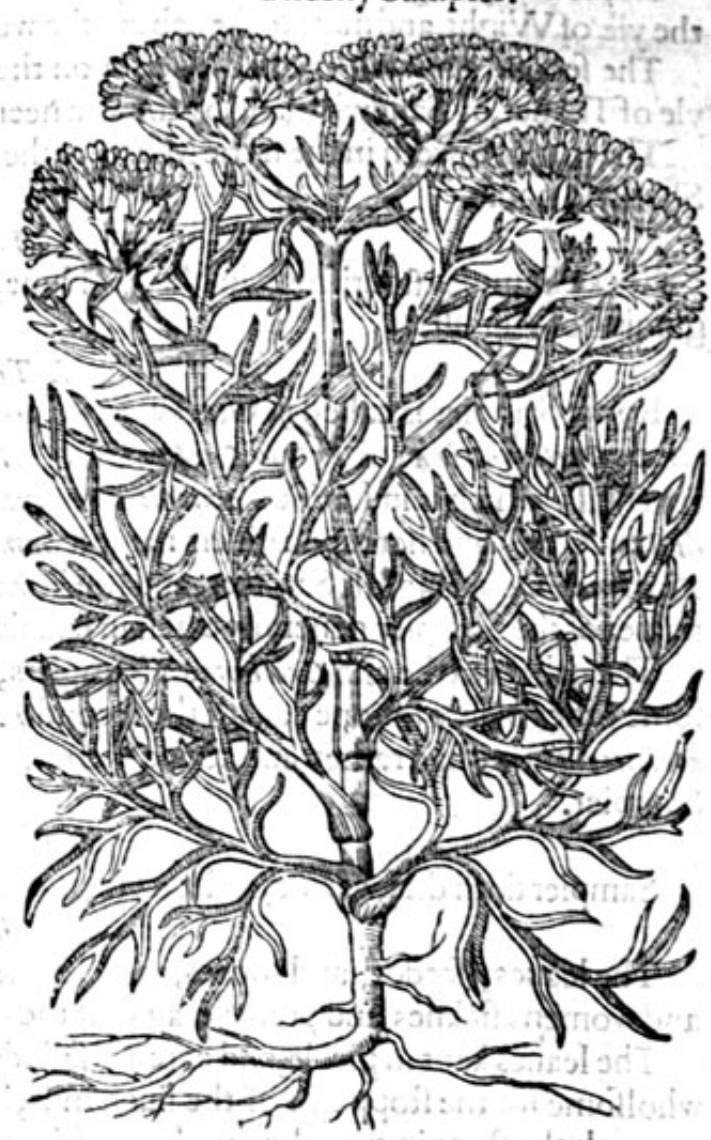

* The defoription.

I. Ocke Sampier hath many fat and thicke $R$ leaues, fomcwhat like thofe of the leffer Purflane, of a fpicic tafte with a certaine faltncffe; among which rifeth vp a ftalke, diuided into many fimallipraies or fprigs; on the top wherof do growe fpokie tuftes of white flowers, like the tuftes of Fenell or Dill; after which commeth the feede like the feede of Fenell, but greater. The roote is thick and knobbie, being of fmell delightfull and pleafant.

2 The fecond Sampier called Paftinacamerina, or Sea Parfncp, hath long fat leaues; very much iagged or cut cuen to the middle rib, fharpe or prickley pointed, which are fet vpon large fat iomred ftalkes's on the top whereof do gtowe tufres of yellowifh flowers. The feede ls wrapped in thornic huskes. The roote is thicke and lorig, not vnlike to the Parfnes, very good and wholefome to be eaten.

3 Golden Sampierbringeth footh miny ftalks from one roote companed about with 2 witltrude of long fatlezues, fet togither by equatlliftances; at the toppe whereb cone yellowe flowers. The Peede is like thole of the Rocke Sampier. 
* The piace.

Recke Sampier groweth on the rocky cliffes at Douer, Winchelfey, by Rie, about Southampton, the yle of Wight, and moft rockes about the weft and north weft parts of England.

The fecond groweth neere the fea vpon the fands, and Bayche betweene Whitftable and the yle of Thanet, by Sandwich, and by the Sea neere Weftchefter.

The third groweth in the mirie Marfh in the yle of Shepey, as you go from the Kings ferrie to Sherland houfe.

* $T$ be time.

Rocke Sampier flourifheth in May and Iune, and muft be gathered to bekept in pickell in the beginning of Augutt.

Rocke Sampier is called in Grecke apispos: in Latine alfo crithmum, and of diuers Bati: in fome thops Creta marina : of Petrus Crefcentius, Cretamum, and Rincum marinum : in high Dutch 9 Betrfencbell, which is in Latine Feniculus marinus, or Sea Fenell : in Italian Fenocchio marino, Herba di San Pietro, and hereupon diuers name it Sampetra : in Spanim Perexil de la mer, Hinoiomarino, Fenolmarin : in Englifh Sampier, and Rocke Sampier, and of fome Creftmarine; and thefe be the names of the Sampier generally eaten in fallads.

The other two be alio Crithma, or Sampiers, but moft of the later writers would drawe them to fome other plant: for one calleth the fecond Pastinaca marina, or Sea Parfnep,and thethird Afteratticus: but we had rather entertaine them, as $M$ sattholus doth, among the kindes of Crishmwom, or Sampier.

\section{Sampier doth drie, warme, and fcomre,as Galen faich.$$
\text { * The temperature. }
$$

$$
* \text { Th vertmes. }
$$

A The leaues, feedes, and rootes, as Diofcorides faith, boiled in wine and drunke, prouoke vrine, and womens ficknes, and preunile againft the iaundies.

B The leaues kept in picklc, and eaten in fallads with oileand vineger, is a pleafant face for meate, wholfome for the ftoppings of the liver, milt, kidneies, and bladder: it prouoketh vrine gently; it openeth the ftoppings of the intrals,and ftirreth vp an appetite to meate.

C It is the plealantelt fauce, moft familiar, and beft agreeing with mans bodie, both for digeftion of meates, breaking of the ftone, and voiding of grauell in the reines and bladder.

\section{Of Glafe Saltwoort. Chap.147. \\ * Thekindes.}

There be very many kindes of Glaffewoorts, as it is euident not onely in the bookes of the later

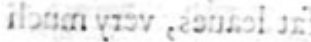

vosquen odtatibier

* The defcription.

1 Laffewoort hath many grofle, thicke and round italkes a foote high, full of fat and thicke

3 frigs, fet with many knots or ioints, without any leaues at all, of a reddifh greene colour. The wholc plant relembleth a branch of Corall. The roote is very fmall and fingle.

There is another kinde of Saltwoort, which hath beene taken among the ancient herbarifts for 2 kinde of Sampier. It hath a little tender ftalke a cubit high, diuided into many fmall branches, fet full of little thicke leaues very narrow, fomewhat long and fharpe pointed, yet not pricking; among which commeth foorth fmall feede, wrapped in a crooked huske, turned round like a crooked perwinkle. The ftalkes are of a reddifh colour. The whole plant is of a falt and biting tafte. The roote is

There is likewife another fors of Kali, whereof $L^{\circ} O$ beliss maketh mention vnder the name $C$ rithmus, which is like vnto the laft before remembred, but altogither teffer. 
Glaffewoort,or Saltwoore.

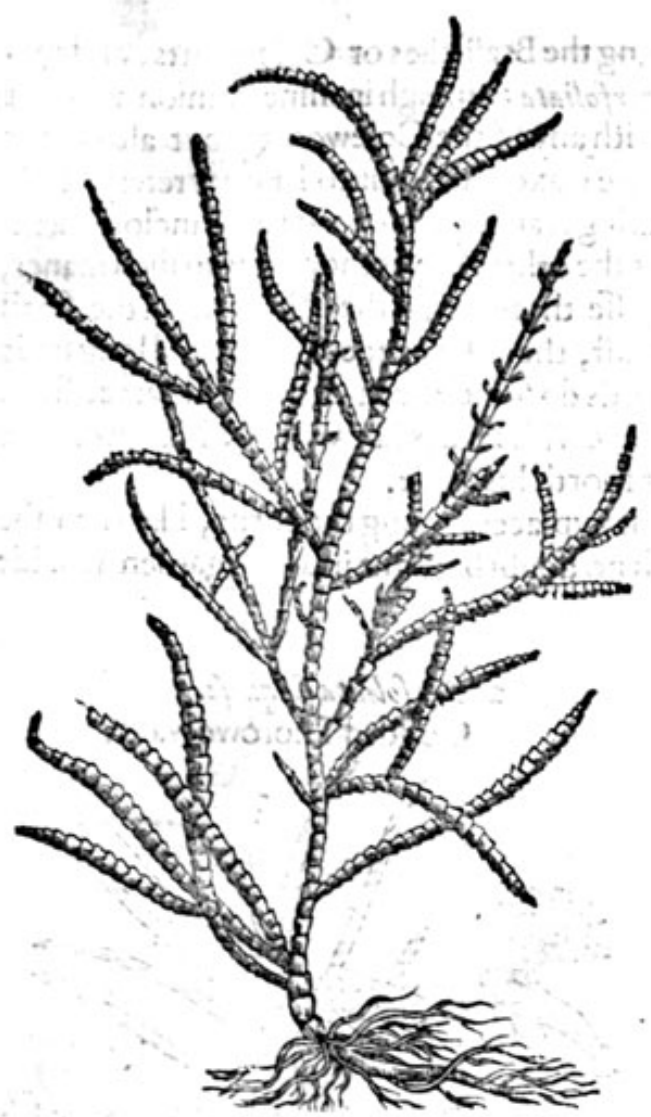

* The place.

Thefe plants are to be founde in falt marfhes 21 . moftetiery where.

$$
\text { * The time. }
$$

They flower and flourifh in the fommer mo. nethes.

$$
\text { * The names. }
$$

Saltwoort is called of the Arabians $K_{A} l i$, and Alkali. Luicen in his 724.chapter def ribeth them vider the name of $\nu / n e n$, which differeth from $\nu$ f woes for $\boldsymbol{V}$ /nee is that which the Grecians call $\beta_{p} / 0$, and the Latines Mufcus, or Moffe; of fome Empetron.

The axen or aftes hereof is named of Matthese siluaticus, soda : of moft Sal calkali : diuers call it Alumen catisum. Others make this kinde of difference betweene Sal Kali and Alumen catinum, that Alsomen catinum isithe afhes it felte. and that the falt that is made of the afhes, is Sabjilkals.

Stones are beaten to powder, and mixed with afhes, which being melted togither become the matter whercof glafles are made. Which while it is made red hot in the fornace and is melred, becomming liquide and fit to worke vpon, dothyeeld 2s it were a fat floting aloft; which, when it is cold, waxeth as hard as a ftone, yet it is brittle, and quickly broken. This is commonly called $A x$ ungia vitri : in Englifh Sandeuer : in French Suin de voirre: in Italian Fior de Christal, that is, the flower of Chriftall. The herbe is alfo called of diuers Kali articulatum, or iointed Glaffewoort : and in Englifh Crab graffe,and Frog graffe.

$$
\text { * } 7 \text { he temperature. }
$$

Glaffewoort is hot and drie: the afhes are both drier and hotter, and that euen to the fourth degree : the alhes haue a caufticke or burning qualitie.

$$
\text { A The vertues. }
$$

A little quantitie of the herbe inwardly taken, doth not onely mightily prouoke vrine, but in like $\mathbf{A}$ fort caite th foorth the dead childe. It drawcth foorth by fiege waterifh humors, and purgethaway
the dropfie.

A great quantitic taken, is mifchieuous and deadly. The fmell and moke alfo of this herbe being B burnt, doth driue away ferpents.

The alhes are likewife tempered with thofe medicines, that ferue to take away feabs and filth of $\mathbf{C}$ the skin: it eafily confumeth proud and fuperfluous flefh that groweth in poifonfome vlcers,as Awicen and Serapio do report.

We reade in the copies of Serapio, that Glaffewoort is a tree fo great, that a man may ftande vn-D det the fhadow thereof: but it is very like, that this error proceedeth rather from the interpreter, than from the author himfelfe.

The flower of Chriftall,or (as they commonly terme it, the fat of Glaffe)doth woonderfully drie. E It eafily taketh aw ay fcabs and mangineffe, if the foule partes be wafhed and bathed with the water wherein it is boiled.

$$
\text { Of Thorowe waxe. Cbap.148. }
$$

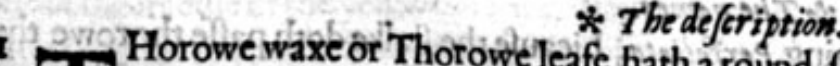

$$
* \text { The dejcription. }
$$

Horowe waxe or Thorowe leafe, hath a round, flender, and brittle ftalke, divided into m2. nie fmall braunches, which paffe or go thörow the leaues, as though they had been drawn or thruft thorowe, and(to makẹ itmore plaine) euery braunch doth grow thorowe euerie 
leafe, making them like hollowe cups or fawcers. The feede groweth in fpokie tufts or rundels like Dill, long and blackifh. The flowers are of a faint yellowe colour. The roote is fingle, white, and threddie.

2 Codded thorowe waxe reckoned by Dodoneses among the Braffickes or Colewoorts, and making it a kinde thereof, and calling it Braßsea filuestr is perfoliata : though in mine opinion without reafon, fith it hath neither rhape, affinitie, nor likeneffe with any of the Colewoorts, but altogither moft vnlike, refembling very well the common Thorowe waxe; whereunto I rather referre it. It hath fmall, tender, and brittle ftalks two foote high, bearing leaues, which wrap and inclofe themfelues round about,although they do not run thorowe as the other do, yet they grow in fuch maner, that vpon the fudden viewe thereof, they feeme to paffe thorowe as the other: vpon the fmall braunches do growe little white flowers : which being paft, there fucceede flender and long cods like thofe of Turneps or Nauewes, whofe leaues and cods do fomewhat refemble the fame, from whence it hath the name Napifolia, that is, Thorowe waxe with leaues like vnto the Nauewe. The roote is long and fingle, and dieth when it hath brought foorth his feede.

There is a wilde kinde heereof growing in Kent, in manyplaces among the corne, like vnto the former in ech refpeet, but altogither leffer: the which no doubtbrought into the garden woulde prooue the very fame.

2 Perfoliats vulgaris. Common Thorowe waxe.

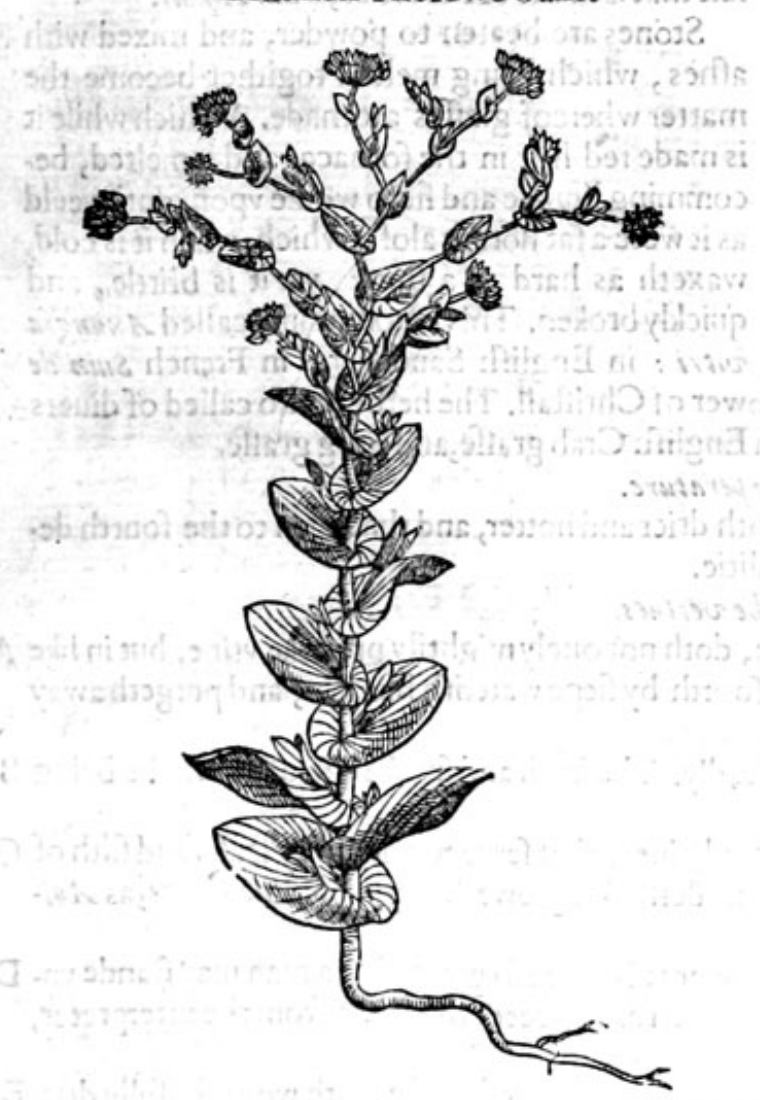

2 Perfoliata fligmofa. Codded Thorowe waxe.

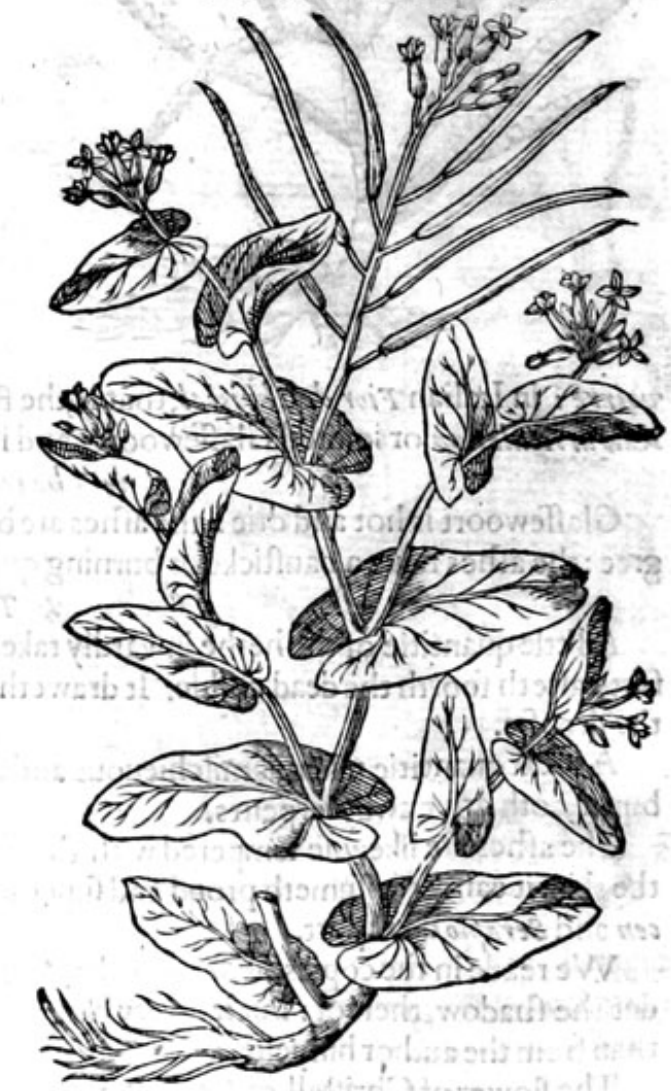

They growe in the gardens of Herbarifts, and in my garden likewife. * The time.

They flower in Maie and Iune, and their feede is ripe in Auguft. * The names.

It hath beenecalled from the beginning Perfoliate, bicaufe the ftalke doth paffe thorowe the leafe, following the fignification of the fame: we callit in Englifh Thorowe waxe, or Thorowe leafe. 
Thotowe waxe is of 2 drie complexion. * The temperasiure.

* The vertucs.

The decoction of Thorowe waxe made of water or wine, healeth wounds. The iuice is excellent $\mathbb{A}$ for wounds made either into an oile or vnguent.

The greeneleaues itamped, boiled with waxe, oile, rofin and turpentine, maketh an excellent vn- B guent orfalue to incarnate, or bring vp fleih in decpe wounds.

\section{Of Honie woort. Chap.149.}

1 Cerinthe maior.

Great Honie woort.

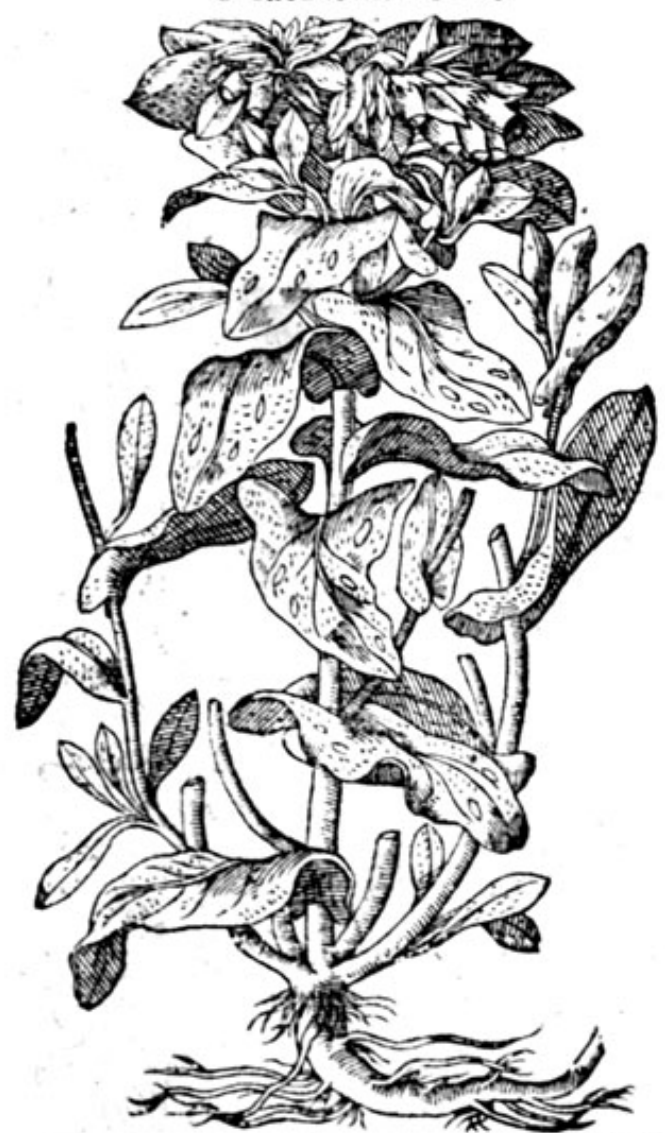

2 Cerinthe minor. Small Honie woort.

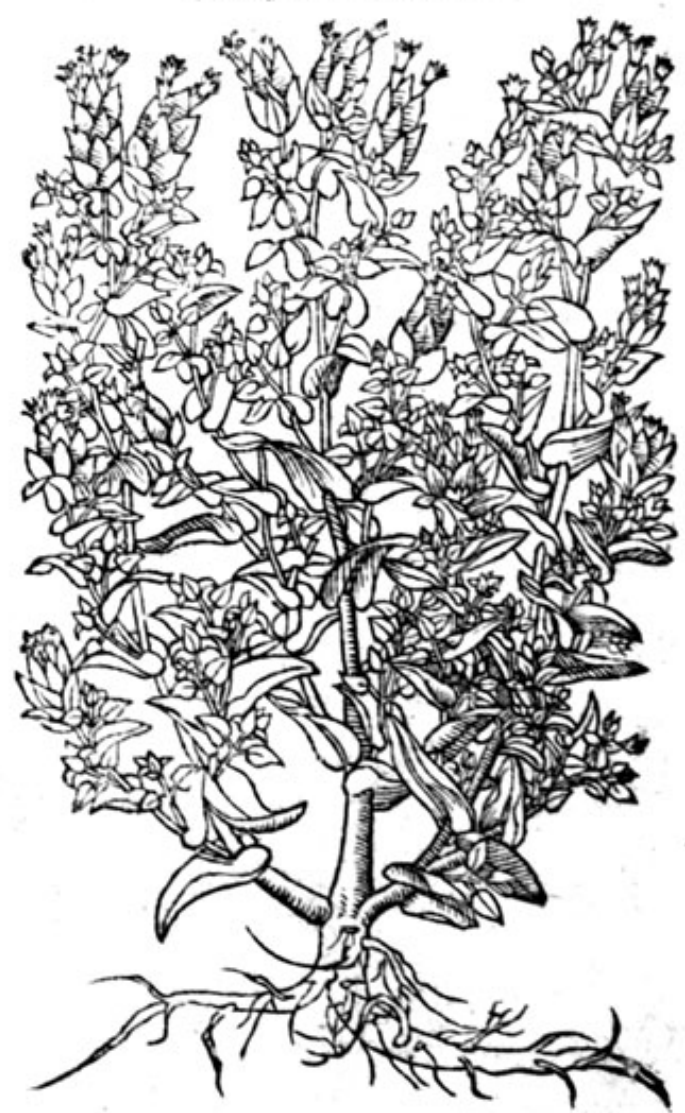

* The defcription.

I Erinsthe or Honie woort, rifeth foorth of the grounde after the fowing of his feede, with two fmall leaves like thofe of Bafill; betweene the which leaues commeth foorth a thicke, fat, fmooth, tender, and brittle ftalke full of iuice, that diuideth it felfe into many other braunches : which alfo are diuided in fundrie other armes or braunches likewife, crambling or leaning toward the grounde, being not able without props to fuftaine it felfe, by reafon of the great waight of leaues, braunches, and much iuice, the whole plant is furcharged with: vpon which braunches are placed many thicke,rough leaues, fet with very fharpe prickles like the rough skin of 2 Thornebacke, of a blewifh greene colour, fpotted very notablie with white ftrakes \& f pots, like thofe leaues of the true Pulmonaria or Cowflips of Ierufalem, and in fhape like thofe of the codded Thorowe waxe, which leaues do clippe or imbrace the ftalks round about : from the bofome wherof come foorth fmall clufters of yellowe flowers, with a hoope or bande of bright purple rounde about the middle of the yellowe flower. The flower is hollowe, fafhioned like a little boxe, of the tafte of honie when it is fucked, in the hollowneffe wherof,are many fmall chiues or threds ; which being paft, there fucceedeth round blacke feed,conteined in foft skinnic huskes. The root perifheth at the firft approch of winter, 


\section{2}

\section{THE SECOND BOOKE OF THE}

2 Pliny fetteth foorth another Cerinthe or Honie woort, which Dodoness in his laft Edition cal. leth Maru ber be : it hath fmall, long, and flender braunches, reeling this way and that way; as not able to fuftaine it felfe, verie brittle, befet with leaues not much vnlike the precedent, but leffer, iseither fo rough nor fpotted, of a blewifh greene colour. The flowers be fmall, hollow, and yellow. The feede is fniall, rounde, and as blacke as ieat: the which dieth as the former. There is no tafte, either of honie or ivaxe in the flowers or leaues, as the name doth feeme to import, neither the forner, but onely in the flowers which are exceeding fweete.

$$
\text { * The place. }
$$

Thefe plants do not growe wilde in Englande,yet I haue them in my garden: the feedes whereof Ireceaued of the right honorable the Lord $Z$ ouch, my honorable good friend.

$$
\text { * The time. }
$$

They flower from Maie to Auguft, and perifhe at the firft approch of winter, and muft bee fowen againe the next fpring.

$$
\text { * Thetemperature and vertues. }
$$

Plinie and Anices feeme to agree, that thefe herbes are of a colde complexion, notwithftanding there is not any experiment of their veitues woorth the writing.

\section{Of Saint Iobins woort. Chap.150.}

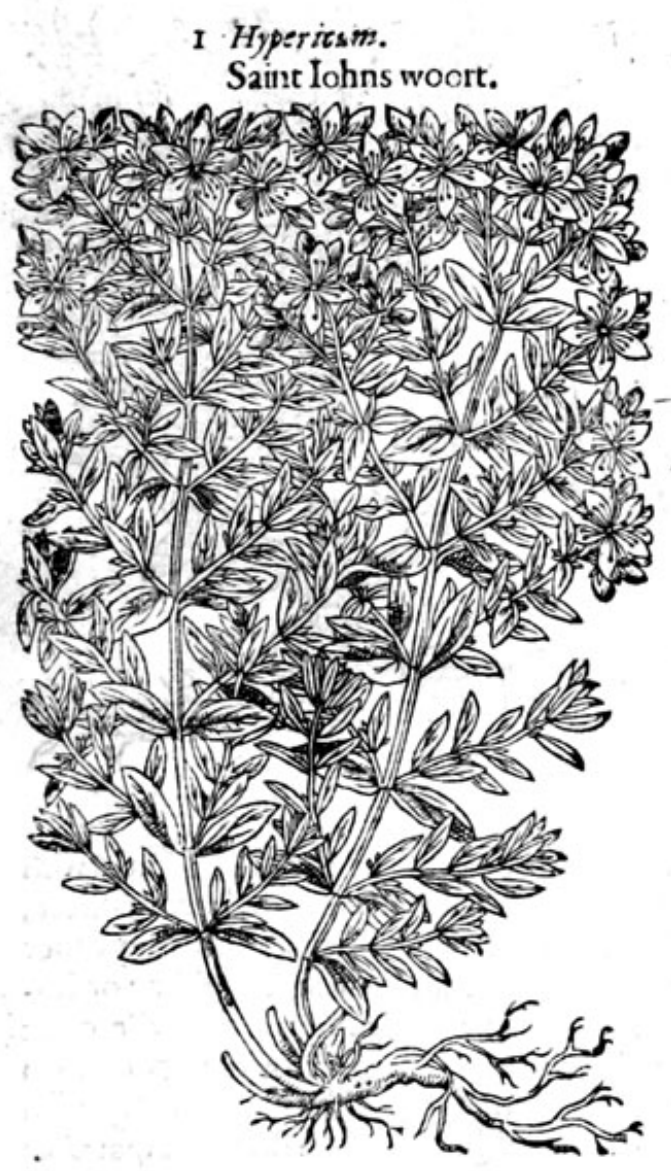

2 Hypericum Syrianums. Rewe Saint Iohns woort.

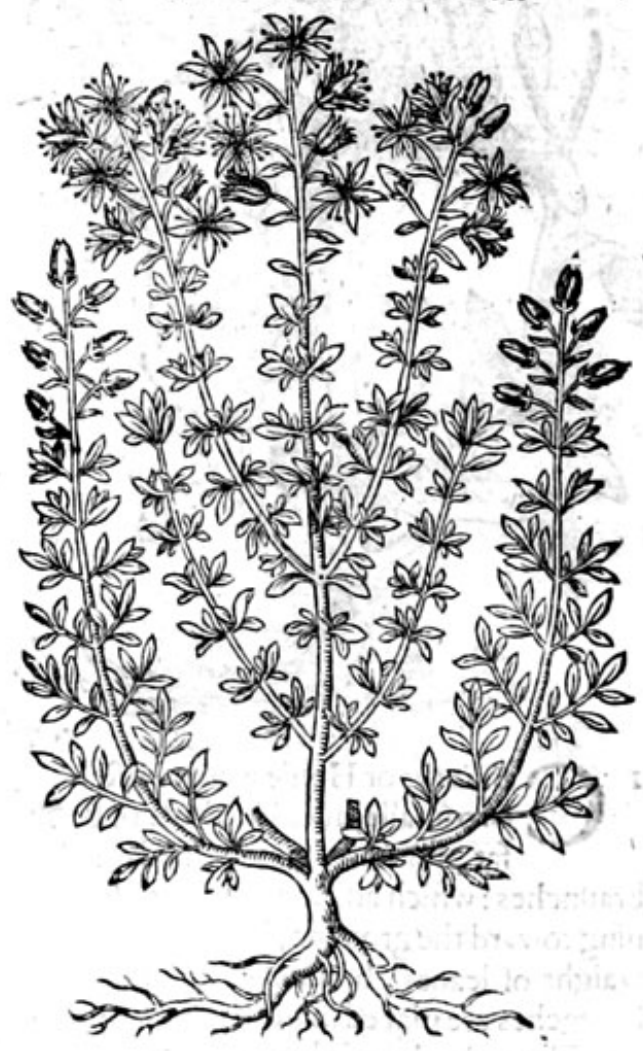

$*$ The def cription.

I Aint Iolns woort hath brownifh ftalkes, belet with many finall and narrowe leates, which if youbchold betwixt your eies and the light, doc appeere as it were bored or thrtift thorow in an infinite ntamber of places with pins points. The biaunches diuide themfelues into fundric fnall twigs; at the top whereof dogrowe many yellowe flowers, which with rhe leaues brued do yeclde a rcditin iuicect the colour of bloode. The feede is conteined in little tharpe 


\section{HISTORIE OF PLANTS.}

pointed huskes blacke of colour, and fnelling like rofin.The roote is long, yellow, and of a wooddy fubitance.

2 Thefecond kinde of S. Iohns woort named Siriacum, of thofe that haue not feene the fruitfull and plentifull fields of England, wherein it groweth abundantly, hauing fmall leauesalmoft like to Rew, or Herbe grace, wherein Dodoness hath failed, intituling the true Androfemum, with the name of Rut a fluest ris, whereas indeede it is no more like Rew, than an apple to an oifter. This plant is altogither like the precedent, but fmaller, wherein confifteth the difference.

\section{Hypericum tomentofun L'Obely.} Woolly S.Iohns woort.

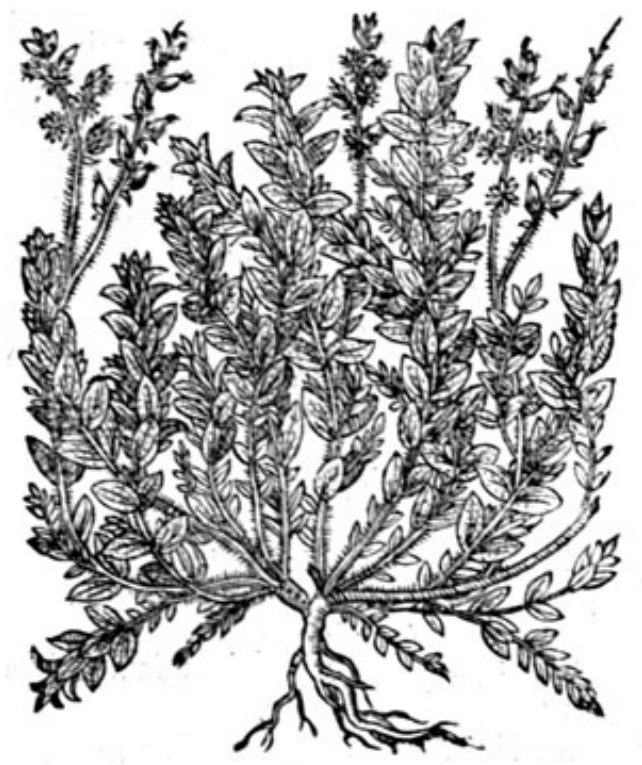

$*$ The defcription,

3 Woolly S.Iohns woort hath many finall weake branches trailing vpon the ground, befet with many little leaues, couered ouer with a certaine foft kinde of downineffe; among which commeth foorth weake and tender branches, charged with fmall pale yellow flowers. The feedes and rootes are like vnto the true S.Iohns woort.

$$
\text { * The place. }
$$

They grow very plentifully in the paftures in eue. ry countrie.

$$
\text { * Thetime. }
$$

They flower and flourifh for the moft part in Iuly and Auguft.

$$
\text { * Thenames. }
$$

S. Iohns woort is called in Greeke viriexoor: in $\mathrm{La}$ tine Hypericum : infhops Perforasa : of diuers Fuga Demonum : in Dutch an Jobants ktaut : in Italian Hyperico: in Spanifh Caraconzillo: in French crille pertays: in Englifh S.Iohns woort,or S.Iohns graffe. * Tie temperature.

S.Iohns woort, as Galen teacheth, is hot and drie, being of fubftance thinne. * The vertues.

S.Iohns woort, with his flowers and feede boiled and drunken, prouoketh vrine, and is right good A againft the ftone in the bladder, and ftoppeth the laske.

The leaues ftamped are good to be laide vpon burnings, fcaldings, and all wounds; and alfo for B rotten and filthie vicers.

The leaues, flowers, and feedes ftamped, and put into a glaffe with oile oliue, and fet in the hot $\mathbf{C}$ funne for certaine weckes togither, and then ftrained from thofe herbes, and the like quantitic of new put in,and funned in like maner, doth make an oile of the colour of blood, which is a moftpre-A tious remedy for deep wounds, \& thofe that 2 re thorow the bodie, for finewes that are prickt, or any wound made with a venomed weapon. I amaccuftomed to make a compound oile hereof, themaking of which yee fhall receiue at my hands, bicaufe that I knowe in the world there is not a better, no not naturall Balfam it felfe; for I dare vndertake to cure any fuch wound, as abfolutely in each refpect, if not fooner and better, as any man whatfoeuer fhall or may with naturall Balfam.

Take white wine two pintes, oile oliue fower pounds, oile of turpentine two pounds, the leaues, D ( flowers, and feedes of S Iohns woort, of each two great handfuls gently brufed; put themall togit ther into a great double glaffe \& fet it in the funne eightor ten daies; then boile them in the fame - glaffe per Balneum Marie, that is, in a kettle of water, with fome ftrawe in the bottome, wherein the glaffecuuft ftand to boile; which done, Ittaine the licour from the herbes, and do as you did before, purting in the like quantitie of herbes, flowers, and feedes, but not any more wine. And fo haue you

Diofcorides faith, that the feede drunke for the fpace of fortiedaies togither, cureth the Sciatica, E andall aches that happen in the hips.

The fame author fatth, that being drunke with wine, it taketh away tertian and quartan agues. F

$$
\text { Ee I }
$$




\section{OfS.Peterswoort, orfquare S. Fohns graffe. Chap.151.}

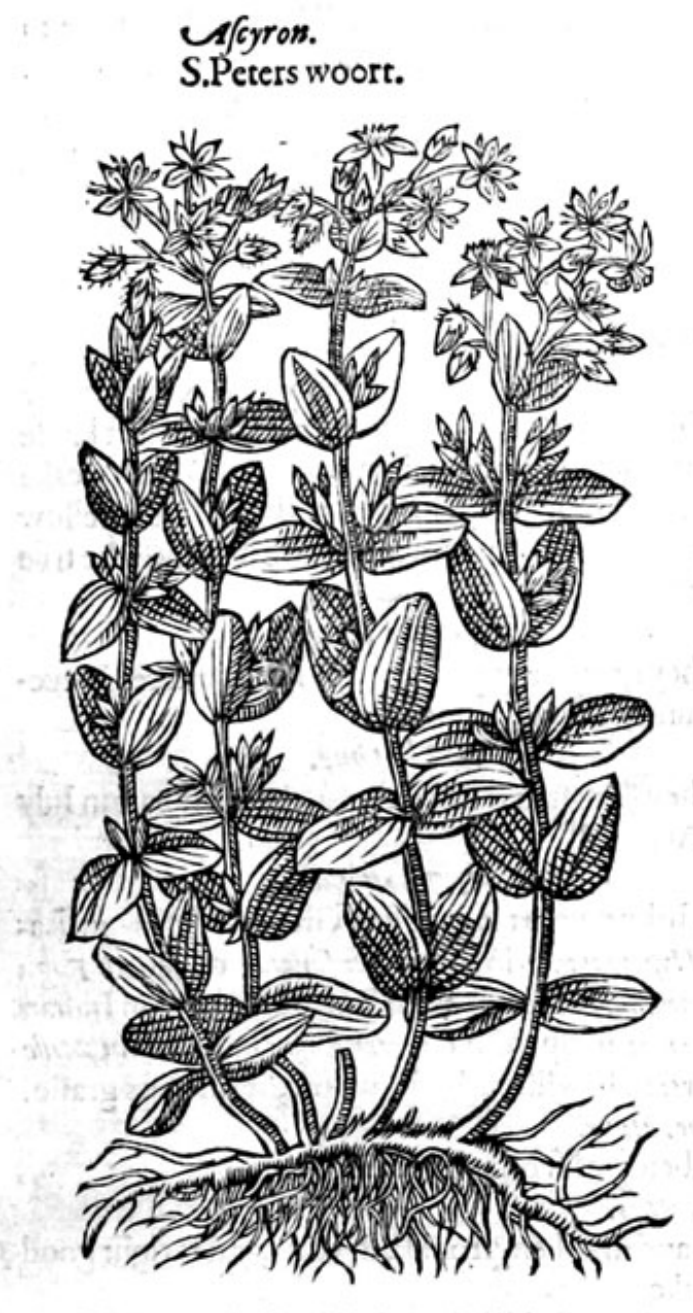

* The defcription.
Aint Peters woort groweth to the height of
2 cubit and a halfe, hauing a ftraight vp-
right fquare ftalke, fomewhat browne, fet by couples at certaine diftances with leaues much like thofe of S. Iohns woort, but greater ; from the bofome of which leaues come foorth many fmaller leaues, the which are not bored through as thofe of $S$. Iohns woort are: yet formtime there be fome few feene fo bored through. The flowers grow at the top of the branches of a yellow colour : the leaues and flowers when they are brufed, do yeeld foorth a bloodie ivice, as doth S.Iohns woort, whereof this is a kinde. The roote is tough and of a wooddie fubftance.

$$
\text { * The place. }
$$

S.Peters woort, or fquare S.Iohns graffe, groweth plentifully in the North part of England, efpecially in Landefdale and Crauen. I haue found it in many places of Kent, efpcially in a Cops by Mafter Sidleyes houfe, neere Southfleet. * Thetime.

It floureth and flourifheth when Saint Iolins woort doth. $*$ Thenames.

It is called in Greeke roxuesv : the Latines hate no other name but this Greeke name $A_{\text {jcyron. It }}$ is called of fome Androfemum : Galen maketh ic both a kinde of Tutfan, and S.Iohns woort; and faith it is named Afcyron and Afgyroides: in Englifh S. Peters woort, Square or great S. Iohns graffe : and of fome Hardhay. Few Apothecaries do knowe it from S.Iohns woort.

\section{* The temperature.}

\section{This herbe is of temperature hot and drie.
* The vertses.}

A It is endued with the fame vertues that $S$.Iohns woort is indued withall. The feede, faith Diofarides, being drunke in fower ounces and a halfe of Meade, dothplentifully purge by fiege, cholericke excrements. Galen doth likewife affirme the fame.

$$
\text { OfTutfan, or Parkeleaues. Chap.is2. }
$$

$*$ The defcription.

He ftalkes of Tutfan be ftraight, round, chamfered or crefted, hard and wooddie, being for the moft part two foote high. The leaues are three or fower times bigger than thofe of S. Iohns woort, which be at the firft greene; afterwardes, and in the end of Sommer of a darke redeo. lour. Out of which is preffed a iuice not like to blacke blood, but to Claret or Gafcoine wine: The flowers are yellow, and greater than thofc of S. Peters woort : after which rifeth vp a little round head orberrie, firft greene, afterwardes red, laft of all blacke, wherein is conteined yellowith red feede. The roote is hard, woodie, and of long continuance. 


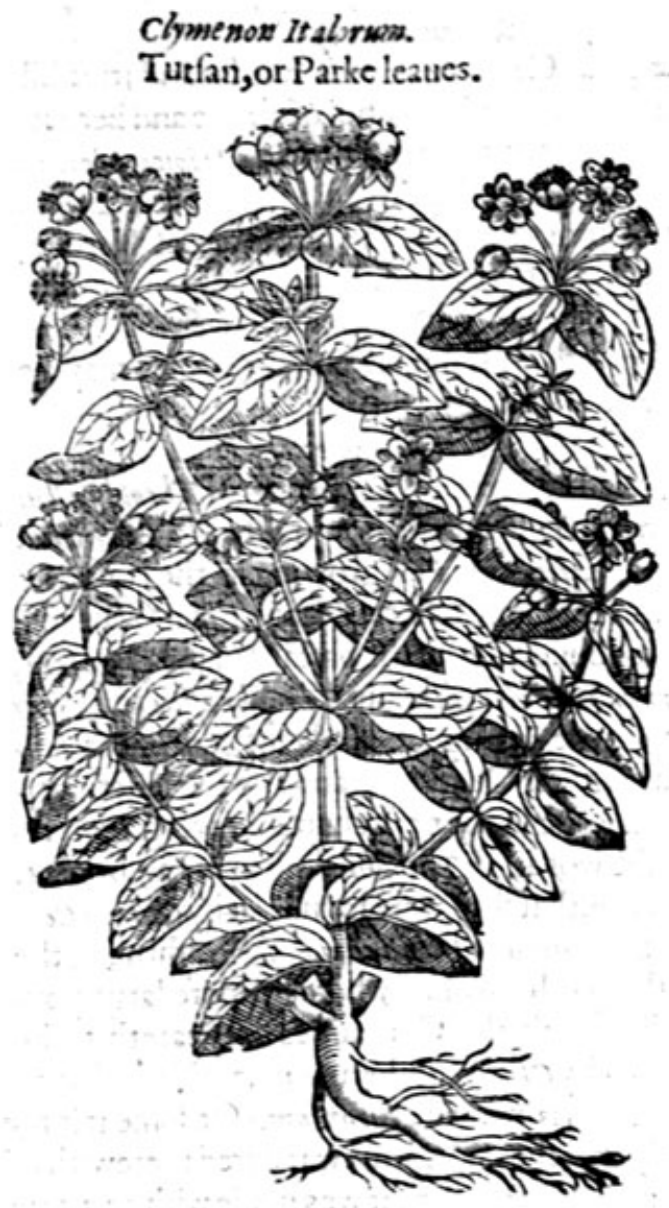

$$
\text { Theplace. }
$$

Tutfan groweth in wooddes, and by hedges, efpecially in Hampiteed wood, where the Golden rod doth growe, in a wood by Railie in Effex, and many other places.

$$
* 7 \text { be time. }
$$

It tlowreth in Iuly and Auguft. The feede in the meane time waxeth ripe. The leaues become red in Autumne; at that time is very cafily preficd foorth his winie iuice.

$$
\text { * Thenawes. }
$$

It is called in Grecke arregraucr: and the Latines alfo Androfemon; it is likewife called Dionyfaes, as $G$ alen wirnefleth. They are far from the truth, that take it to be Clymenum, and it is needleffe to finde fault with their error $:$ ir is alfo called Siciliana, and Herbs Siciliams : in Englifh Tutfan, and Parke leaues.

\section{* The temperature.}

The faculties are fuch as S. Peters woort, which doth fufficiently declare it to be hot and drie.

$$
\text { * The vertues. }
$$

The feede hereof beaten to powder, and drunke $\mathbf{A}$ to the weight of two drams, doth purge cholericke excrements, as Dio/cor ides writech, and is a fingular remedie for the Sciatica, prouided that the patient do drinke water for a day or two a fter purging.

The herbe cureth burnings, and applied vpon B new woundes, it itancheth the blood, and bealeth them.

The leaues laide vpon broken fhins and fcabbed legs, healeth them, and many other hurtes and $\mathbf{C}$ griefes, whereofit tooke his name Tout faine, or Tutfane, of healing all things.

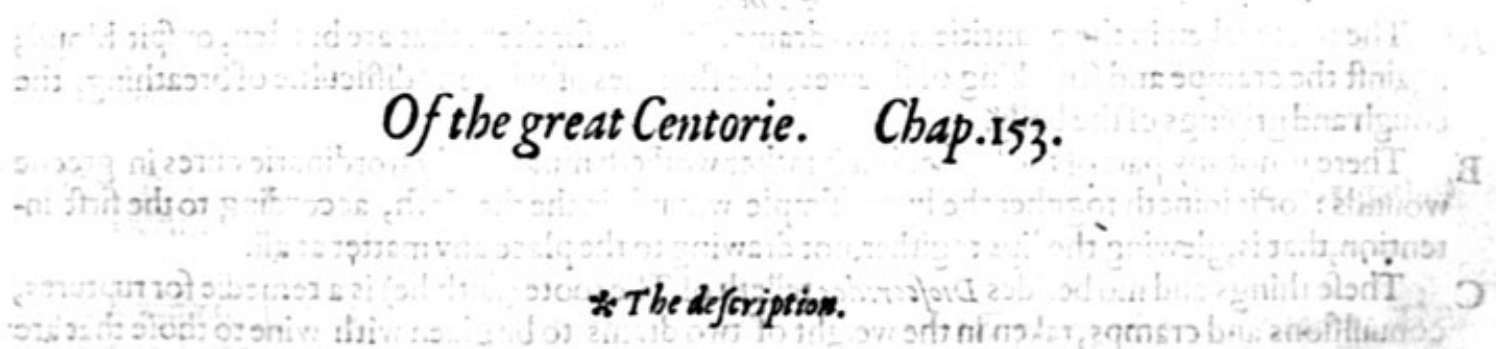

T He great Centorie bringeth foorth round fmooth ftalkes, three cubits high : the leaues are long, diuided as it were in many parcels like to thofe of the Waliue tree, fomewhar fnipt about the edges like the teethof afawe. The tlowers growe at the top of the ftalkes in fealie knaps like the great Knap weede, the middle thrums wherof are of a light blew, or skie colour; when the feede is ripe, the whole knap or head turneth to a downie fubst ance, like the head of an Artichoh; wherin is found a long fmooth feede, bearded at one end like thole of Baftard Saffion, called Carta-

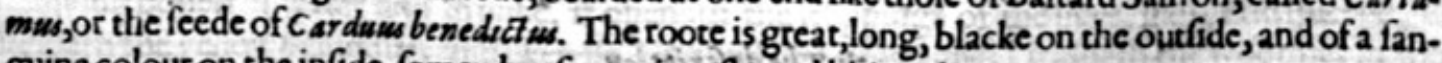
guine colour on the infide, fomewhat fivete in tafte, and biting the toong.

There is likewife another fort hereof, hauing grear and large leaves like thofe of the water Dock, fornewhat fnipt or toothed about theedges. The ftalke is Ihorter than the other, but the roote is morc oleous or fuller of iuice, otherwird like. 


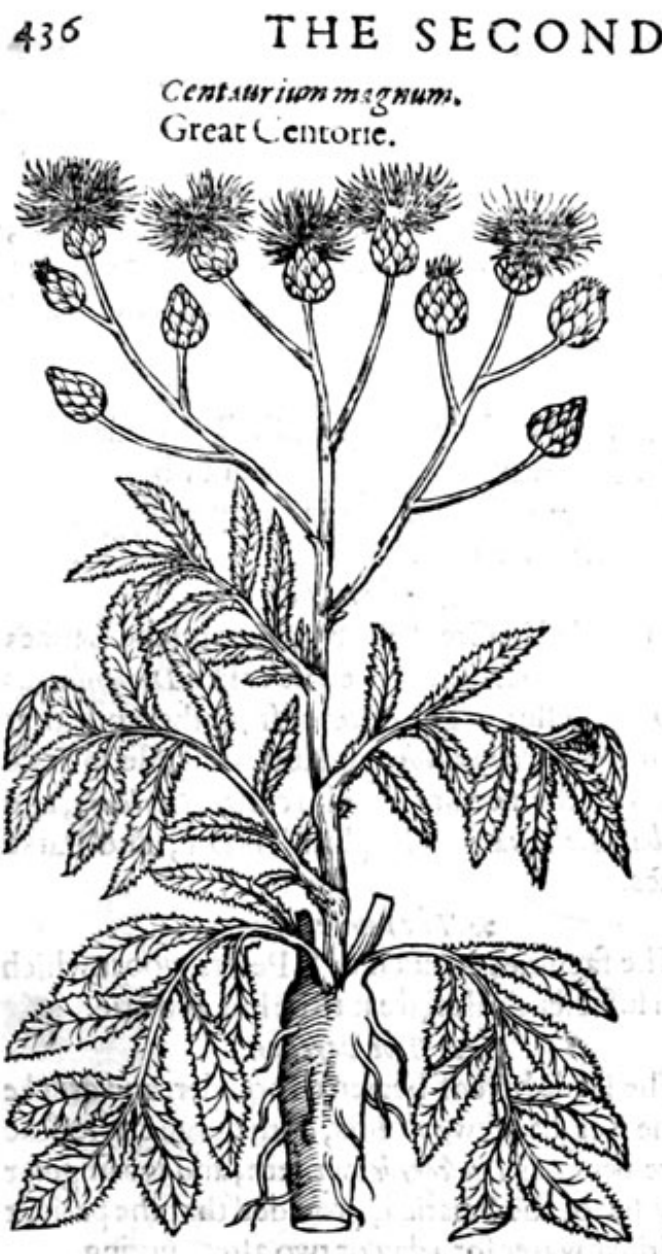

BOOKE OF THE Centaturium ms gnum. Great Centorie.

\author{
* The place.
}

The great Centorie ioyeth in a fat and fruitfull foile, and in funnie banks full of graffe and herbes. It groweth very plentifully, faith Diogcorides, in Lycia, Peloponnefus, Arcadia, in Morea, and in Baldus a mountaine in the territories of Verona, and likewife in my garden.

$$
\text { * Thetime. }
$$

It flowreth in fommer, and the rootes may be gathered in Autumne.

$$
\text { * The names. }
$$

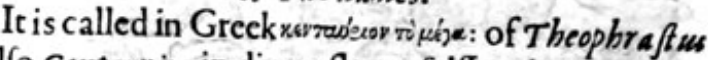
alfo Cent tur is : in diuers fhops fallly $R$ ha Ponticum: for $R$ ha Ponticuos is $R$ ha growing in the countries of Pontus : a plant differing from great Centorie. There is found among the battard names Vnefera, Fel terre, and Polyhydion:but Theophraftus and Pliny do fet downe among the kindes of Pamaces or Allheale, this great Centorie, and alfo the lefferwherof we wil write in the next chap.following.Pliny reciting the words of $T$ heophr.doth in his 25 .book 4 . chap.write, that they were found out by Chiron Centaurus and furnamed Centauria. Alfo affirming the fame thing in his 6.chap.wherc he more largely expounding both the Centauries, repeateth to be found out by Chiron: \& therupon he addeth, that either of them is named chironium. Of fome it is reported, that the faid Chiron was cured therewith of a wound in his foote, that was made with an atrow that fel vpon it, when he was entertaining of Hercwles into his houfe: wherupon it was called Chironimm : or of the curing of the woundes of his foldiers, for the which purpofe it is molt excellent.

\title{
* T be temperature.
}

It is hot and drie in the third degree. Galen faith, by the tafte of the roote it Pheweth contrarie qualities, fo in the vfe it performeth contrarie effects. * The vertues.

A The roote taken in the quantitie of two drams, is good for them that are burften, or fpit bloud; againt the crampe and fhrinking of finewes, the fhortnes of winde or difficultic of breathing, the cough and gripings of the belly.

B There is not any part of the herbe, but it rather worketh miracles then ordinarie cures in greene wounds : for it ioineth togither the lips of fimple wounds in the the flefh, according to the firft intention, that is, glewing the lips togither, not drawing to the place any matter at all.

C Thefe things and mo befides Diofcorides telleth of. The roote (faith he) is a remedie for ruptures, conuulfions and cramps, taken in the weight of two drams to be giuen with wine to thofe that are wirbout a feauer, and to thole that haue, with water.

D Galen faith, that the iuice of the leaues thereof, performeth thofe things that the roote doth,

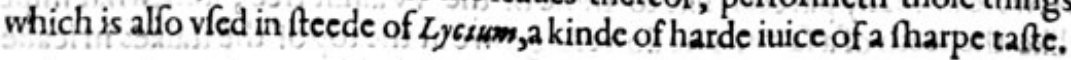

\section{Of mall Centorie. Chap.is4.}

* The defaription. I He leffer Centorie is a little herbe : it groweth vp with a comered ftalke, halfe a foot high,
with leaues in forme and bigneffe of Saint Iohns woort: the flowers growe at the top in 2 fpokie bufh or rundell, of a red colour tending to purple; which in the day time, and after 
the funne is vp doe open themfelues, and towardes euening do fhut vp againe : after them come foorth fmall feede veffels, of the fhape of wheate cornes, in which are conteined very little feedes. The roote is flender, hard, and foone fading.

2 The yellowe Centorie hath leaues, ftalkes, and feede like the other, and is in ech refpeet alike, Guing that the flowers heereof are of a perfect yellowe colour, which fettech foorth the difference.

1 Centaurium parusom.

Small Centorie.

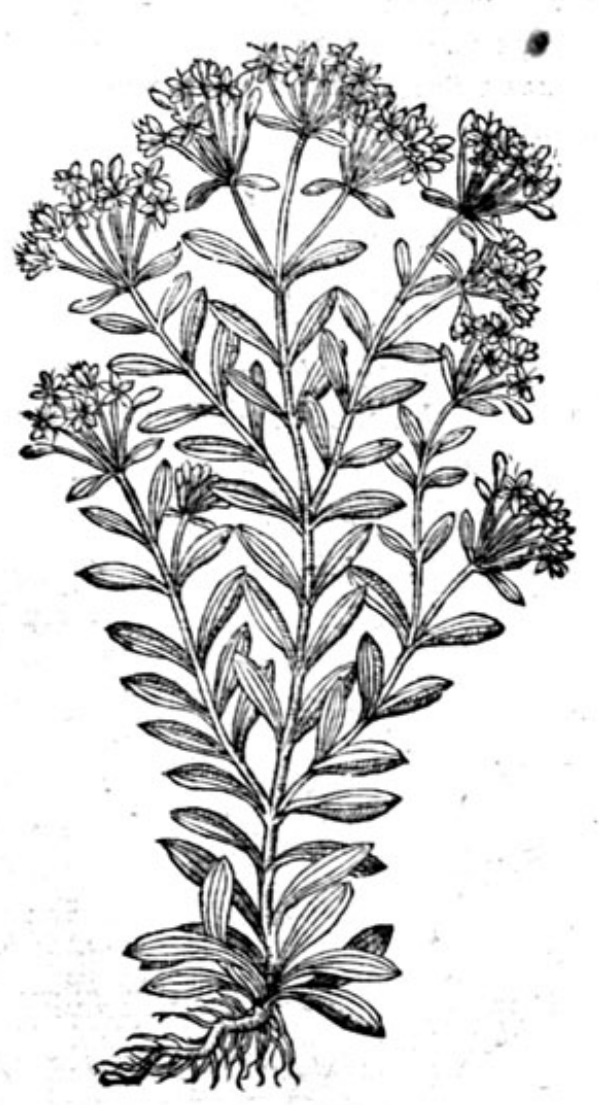

2 Centaurium parawo luteum L'Obely. Yellowe Centorie.

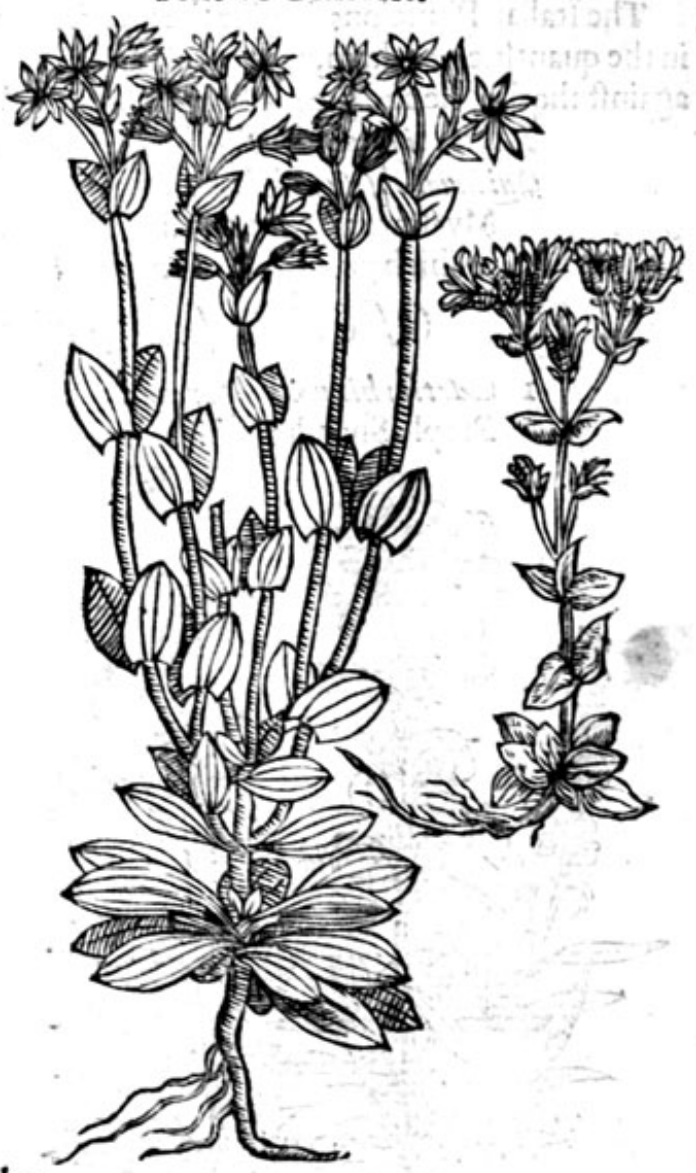

* Theplace.

The firft is growing in great plentie throughout England, in moft paftures and graffie fieldes.

The yellow doth grow vpon the chalkie cliffes of Greenehith in Kent, and fuch like places.

* The time.

They are to be gathered in their flowring time, that is, in Iuly and Auguft; of fome that gather them fuperftitiounly, they are gathered betweene the two ladie daies.

* The names.

$P$ ling nameth the fmall Centorie $L i b a d i o w$, and by reafon of his great bitterneffe Felterre. The

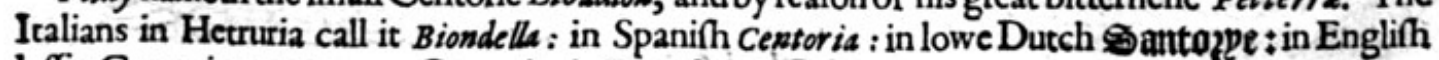
leffer Centorie, or common Centorie : in French Centoire.

\section{$*$ The temperature.}

The fmall Centorie is of a bitter qualitie, and of temperature hot and drie in the fecond degree: and the yellow Centorie is hot and drie in the third degree.

\section{* The vertives.}

Being boiled in water and drunke, it openeth the ftoppings of the liver, gall, and fpleene, it $\mathbf{A}$ helpeth the yellowe iaundife, and likewife long and lingering agues: it killeth the woormes in the bellie; to be briefe, it clenfeth, fcoureth, and maketh thinne humors that are thicke, and doth effectually performe whatfoeuer bitter things can.

Diofcorides, and Galen after him, report, that the decoction draweth downe by fiegecholer and B thicke humours, and helpeth the fciatic2: but though we haue vfed this of ten and luckely, yet could 


\section{THE SECOND BOOKE OF THE}

we not perceiue cuidently that it purgeth by the ftoole any thing at all, and yet hath performed the effects aforefaide.

C This Centorie being ftamped and laide on whileft it is fre? $\mathrm{h}$ and greene, doth heale and clofe yp greene wounds, clenfeth old vlcers, and perfeetly cureth them.

D The iuice is good in medicines for the eies, mixed with hony it clenfeth away fuch things as hinder the fight, and being drunke it hath a peculiar vertue againft the infirmities of the finewes, as Diofcorides teacheth.

E The Italian Phificions do giue the powder of the leaues of yellowe Centorie once in three daies, in the quantitic of a dram, with annife and carowaie feedes, in wine or other liquor, which preuaileth againft the dropfie and greene fickneffe, of which plant Ioannes Poftise hath thus written;

Flos mi hi fuave rubet, fed ineft quogue fuccus amarus,

Qui iuuat obfefjum bilesperitque iecur.

My flower is fwcete in fmell, bitter my iuice in tafte,

Which purge choler and helps liuer that elfe would wafte.

Of Calues jnout, or Snapdragon. Chap.155.

I Lirtirhinum pur purcum. Purple Snapdragon.

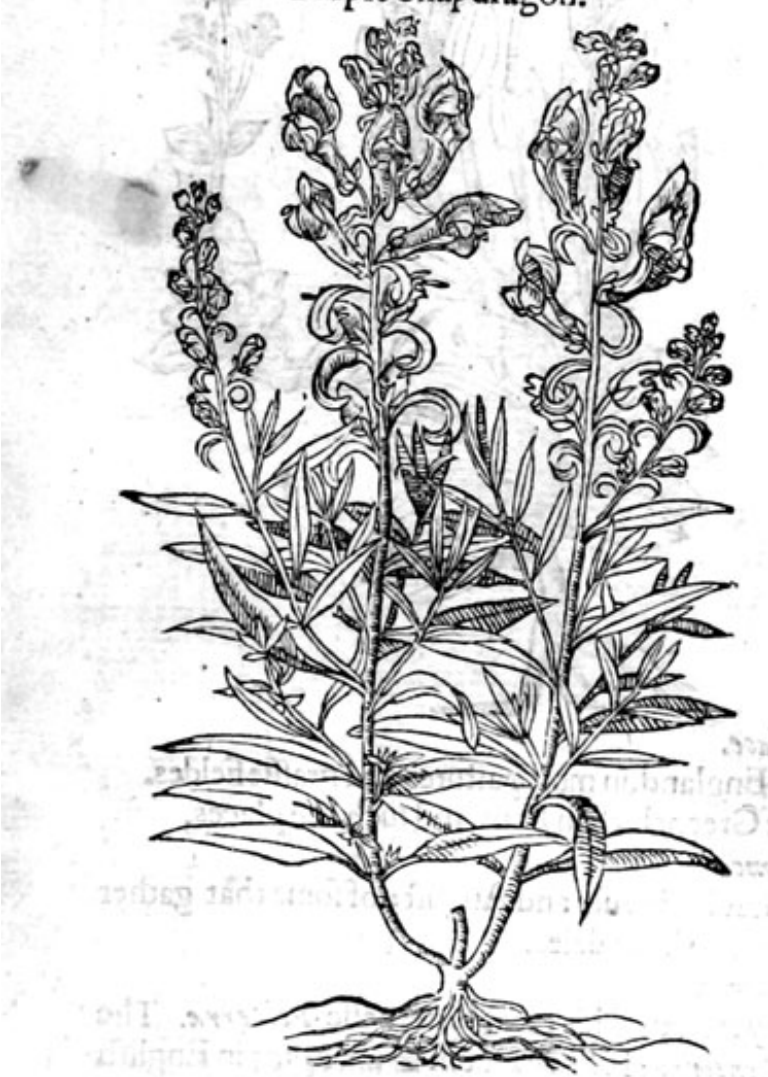

He purple Snapdragon

* The defcription.

gile braun gile braunches: whereupon do growe long leaues fharpe pointed, very greene like vnto Aowers growe at the top ofe, but much greater, fet by couples one oppofite againit another. The dragons nouth ; from whence the of a purple colour, fahioned like a frogs mouth, or rather a conteined in long husks fafhioned like 2 calues faken the riame Snapdragon. The feede is blacke, or in mine opinion it is falloned like 2 calues frout, wherupon forme haue called it Calues fnour, ter, the fefh confumed cleanc awaie.

2 The fecond agreeth with awaie.

this plant bringeth foorth white precedent in euery part, except in the colour of the flowers : for pherth white lowers, and the other purple, whercin confifteth the difference. 


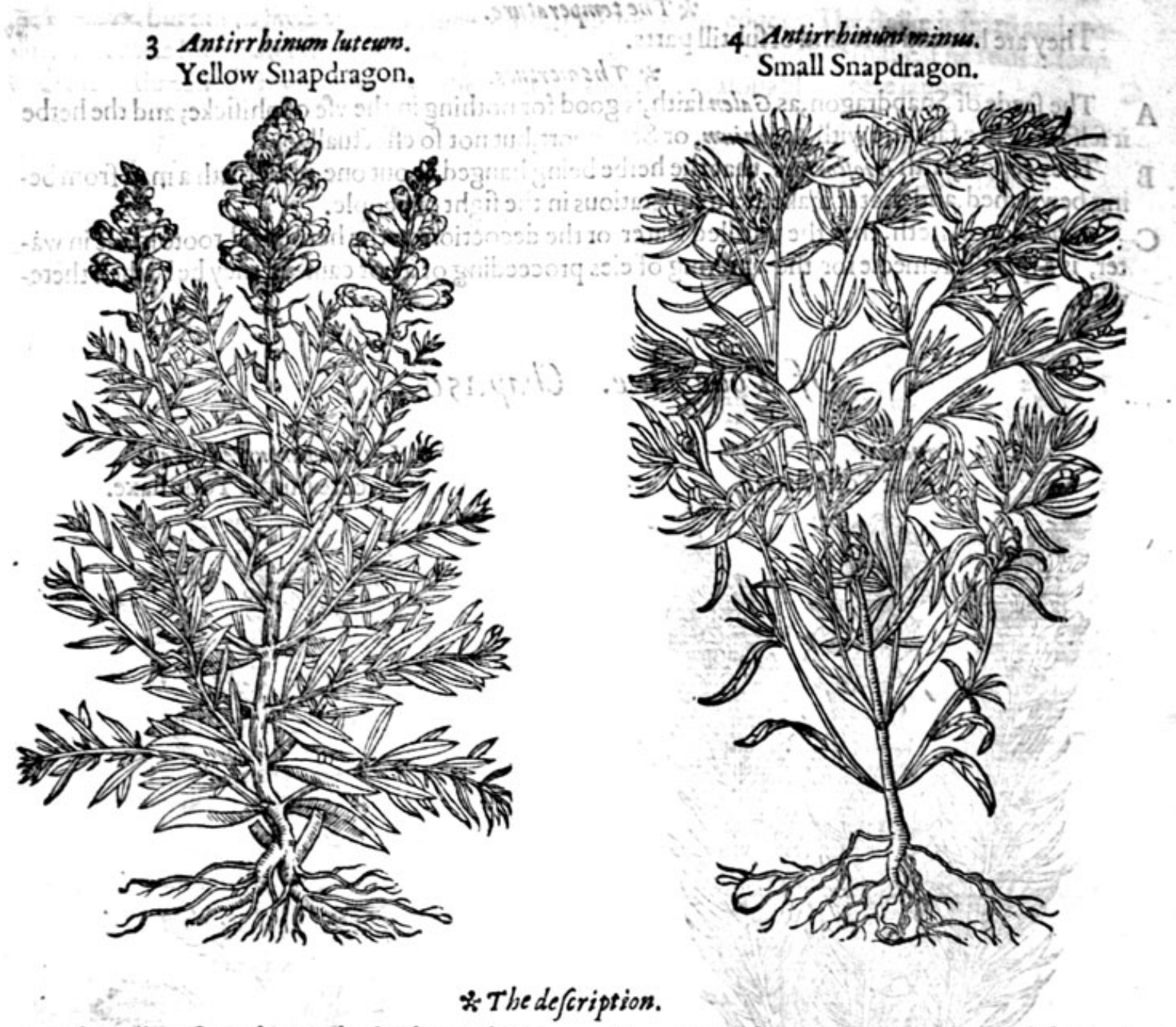

3 The yellow Snapdragon hath a long, thicke woodie roote, with certaine ftrings faftned therto: from which rifeth vp a brittle ftalke of two cubits and a halfe high, diuided from the botrone to the top into diuers braunches; wherupon do grow long green leaues like thofe of Pimpernell, but greater and longer. The flowers growe at the top of the maine braunches, of a pleafant yellowe colour, in thape like vnto the precedent.

4 The fmall or wilde Snapdragon differeth not from the others, but in ftature. The leaues are leffer and narrower. The flowers purple, but altogither fmaller.

$$
\text { * Theplace. }
$$

The three firft do growe in moft gardens; but the yellowe kinde groweth not common,except in the gardens of curious Herbarifts.

$$
\text { * The time. }
$$

That which hath continued the whole winter doth fower in Maie, and the reft of fommer afterwards : and that which is planted later and in the end of fommer, towreth in the fpring of the fame yeere: they do hardly endure the iniurie of our coldewinter.

\section{* The names.}

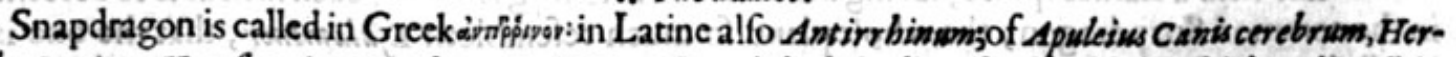
ba Smiana, Venufta minor, Opalis grata, \& Orontium : it is thought to be Leo her ba, which Colimella in his ro.booke doth reckon among the flowers: yet Gefnerus bath thought that this Leo is Columbine, which for the fame caufe hie hath called Leontoffomium : butthis name feemeth to vs in agree better with Calues fnout, then with Columbine: for the gaping flower of $\mathbf{C}_{2}$ lues fnout is more like to lyons fnap then the flotver of Columbine: it is called in Dutch Dyant: in Spanifh Cabeza deternera : in Englifh Calues fnout, Snapdragon, and Lyons fnap : in French Tefte de chien, and Tefe de Veat. 
I hey are hot and drie, and of fubtill parts.

\author{
* The temperature.
}

* The vertwes.

A The feede of Snapdragon, as G alen faith, is good for nothing in the vfe of phificke; and the herbe it felfe is of like facultie with Baboninom, or Starwoort, but not fo effectuall.

B They report, faith Diofcorides, that the herbe being hanged about one, preferueth a man from being bewitched, and that it maketh a man gratious in the fight of people.

C Usaleius writeth, that the diftilled water or the decoction of the herbe and-roote made in water, is a fpeedie remedie for the watering of eies proceeding of a hot caufe, if they be bathed therewith.
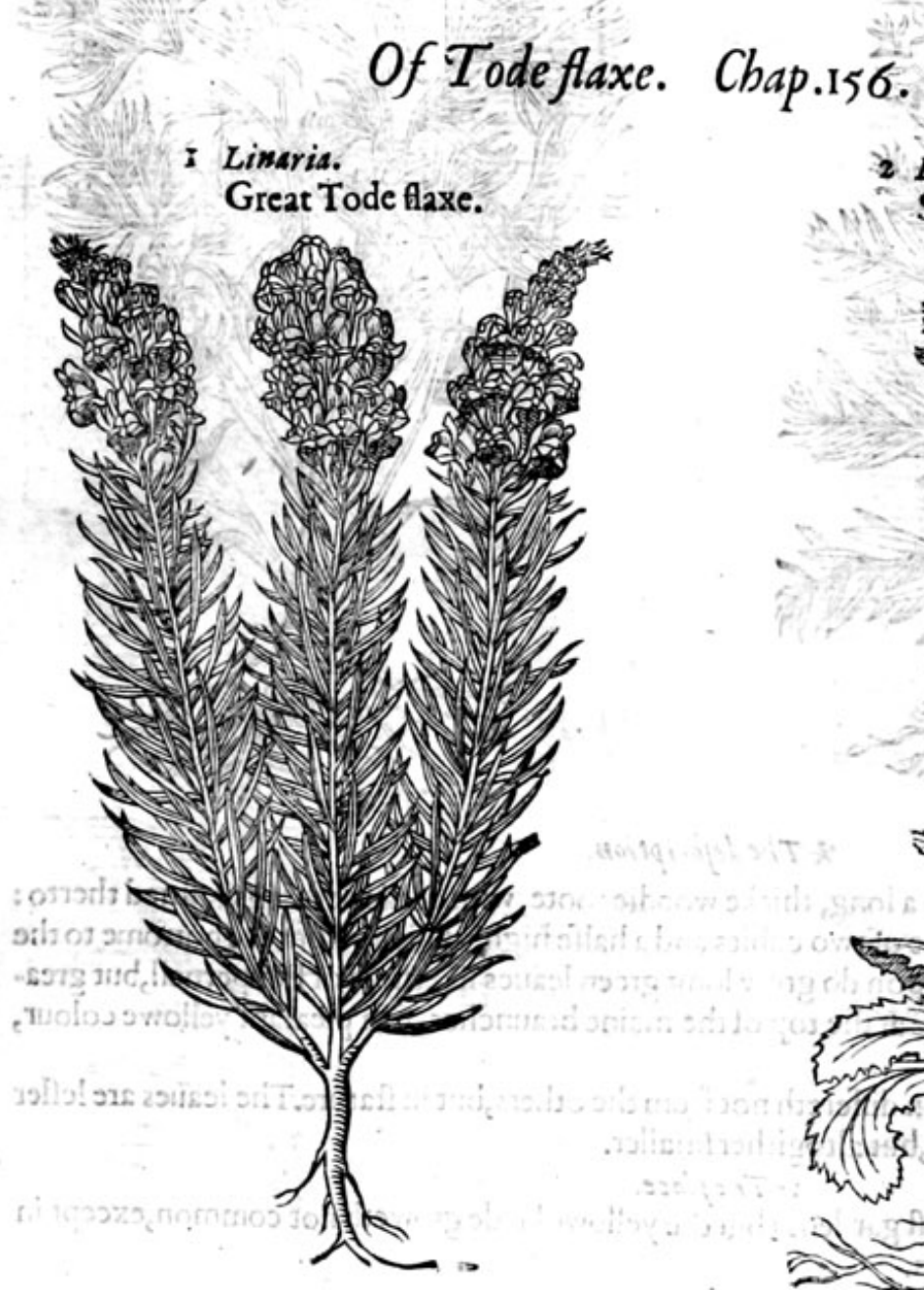

Limaria.
2 Linaria purpwres odorats. Sweete purple Tode flaxe.

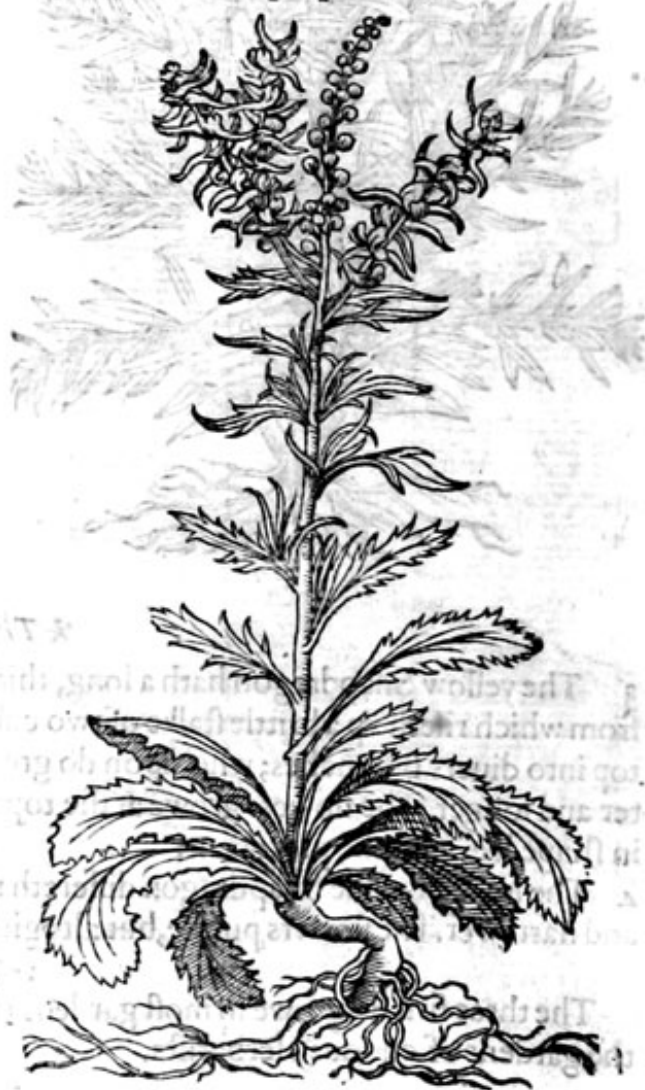

I

Inaria being a kinde of Antyrrbimam the defription.

* The defrription.
himum, hath fmall, flender, blackifh ftalkes; from which do growe many leaues like flaxe. The flowers be yellow, with a futrre hanging at the fame like vnto a Larkes fpurre, hauing a mouth like vnto frogs mouth, euen fuch as is to be feene in the common Snapdragon; the whole plant fo much refembleth Efula minor, that the one is hardly knowne from the other, but by this olde verfe: Efula lacte foit, fine lacte Linaria crefcit.

Some there be that haue confounded Scoparia, or Belueder It alorum, with this Linaria; but in that they are deceiued greatly, as in many other things; for the leaues of Belweder are longer then Limaria, and more in number, not bitter, nor of that effect.which Linaria ferueth vnito in them which be molefted with the iaundife, and brought therby very neere vnto the dropfie.

2 The feuenth kinde of Snapdragon, being the fecond kinde of Tode flaxe, hath leaues like vnto 


\section{GHTISTORIE OF PLANTS.}

Bellis maita but notfobrozde, and fomewhat iagged about the edges. The ftalke is fmall and tender, of a cubire high, befertwith many purple flowers like vnto the former in thape. The root is long, with many threddes hanging thereat : the whole plant is of a reafonable fwcetefauour.

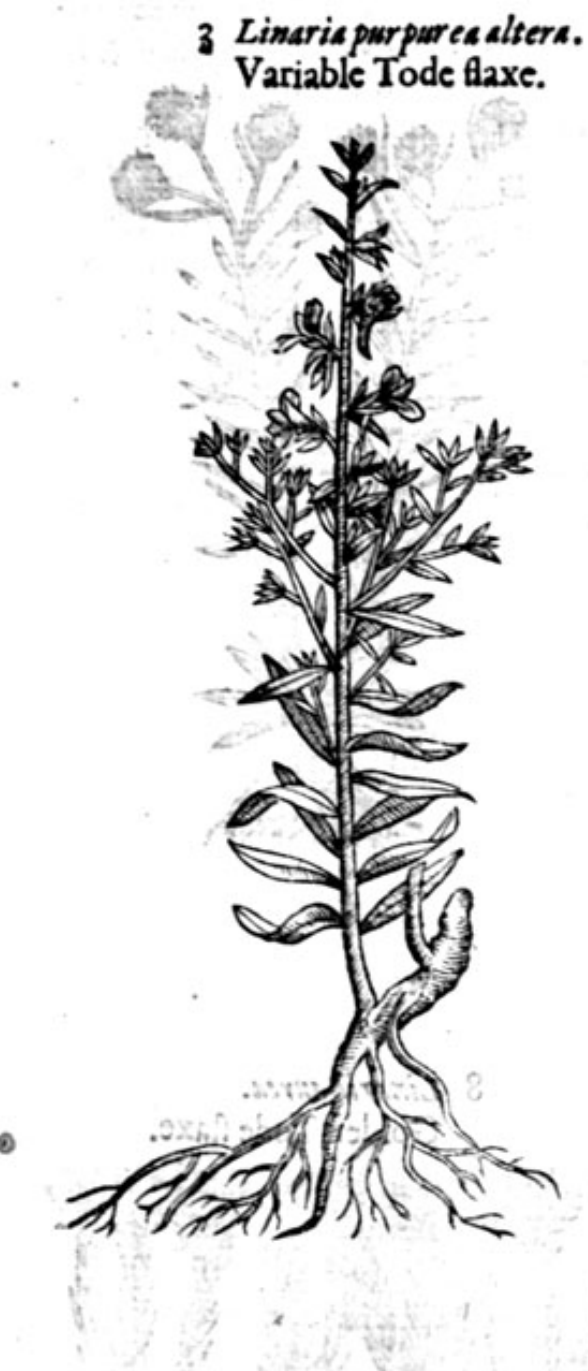

* The defoription.

4 Linaris Valemtia.

Tode tlaxe of Valentia.

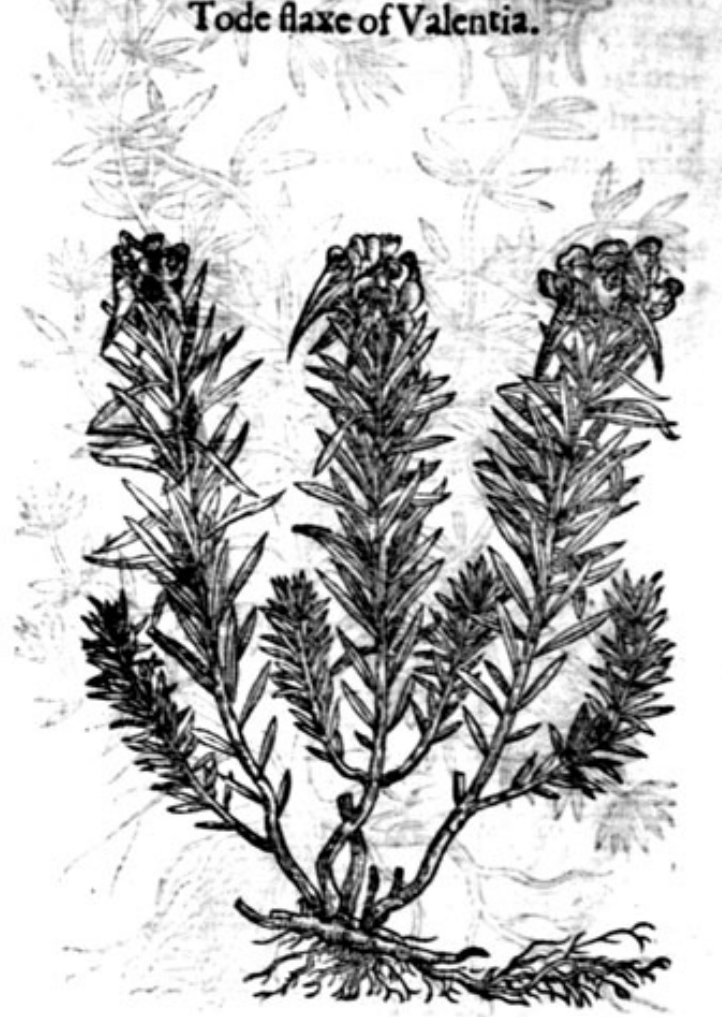

3 The eight kinde of Antyrbinum or Snapdragon, being likewife a kinde of Tode flaxe, hath fmall and narrowe leaues like vnto the firft kinde of Limaria : the ftalke is a cubite high, befet with flowers of a purplecolour, in fathion like Linaria, but that it wanteth the taile or fpurre at the ende of the flower which the other hath. The roote is fmall and threddie.

4 Linar is $V$ alentina hath leaues like Hypericon, or rąther like Cytifus, growing vpon a falke or twiggie braunch, of a foote high,and called by Cluffus V alentina, for that it was founde by himfelfe in agro Valentino, a citie in Italie; where it bearech yellowe flowers about the top of the ftalke like common Linaria, but the mouth of the flower is downie, or moffie, and the taile of a purple colour. It flowreth at Valentia in March, and groweth in the medowes there, and hath not as yet been feen
in thefenorthern parts.

5 Offrisalba hath great, thicke, and long rootes, with fome threds or ftrings hanging at the fame: from which rife vp many braunches very tough and pliant, befet towards the top with flowers, not much vnlike the fmall Snapdragon, but of a white colour, and the inner part of the mouth fomwhat more wide and open, and the leaues like the common Tode flaxe.

6 Ofris pur peroserules is a kind of Snapdragon, or Tode flaxe, that hath many fmal \& weak branches, trailing vpon the grounde, befet with many little leaues like flaxe. The flowers grow at the top of the ftalke like vnto the common kinde, but of a purple colour declining to blewneffe. The roote 
5 Ofyrisaiba.

White Tode flaxe.

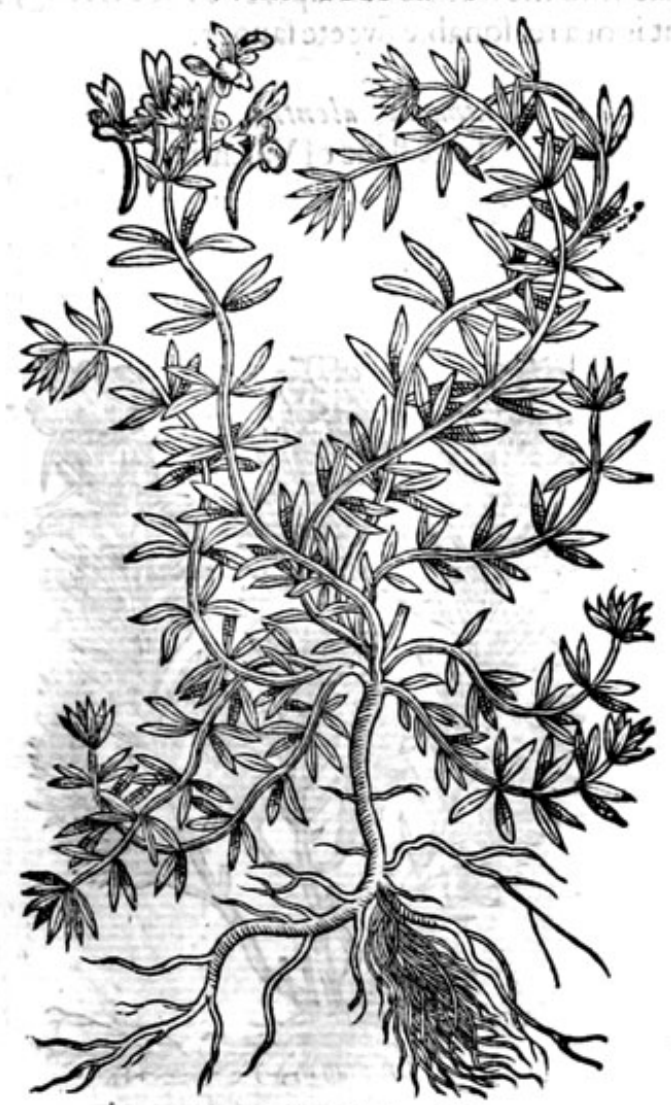

7 Linofyris 2 uperorwm.

Bufhie Tode flaxe.

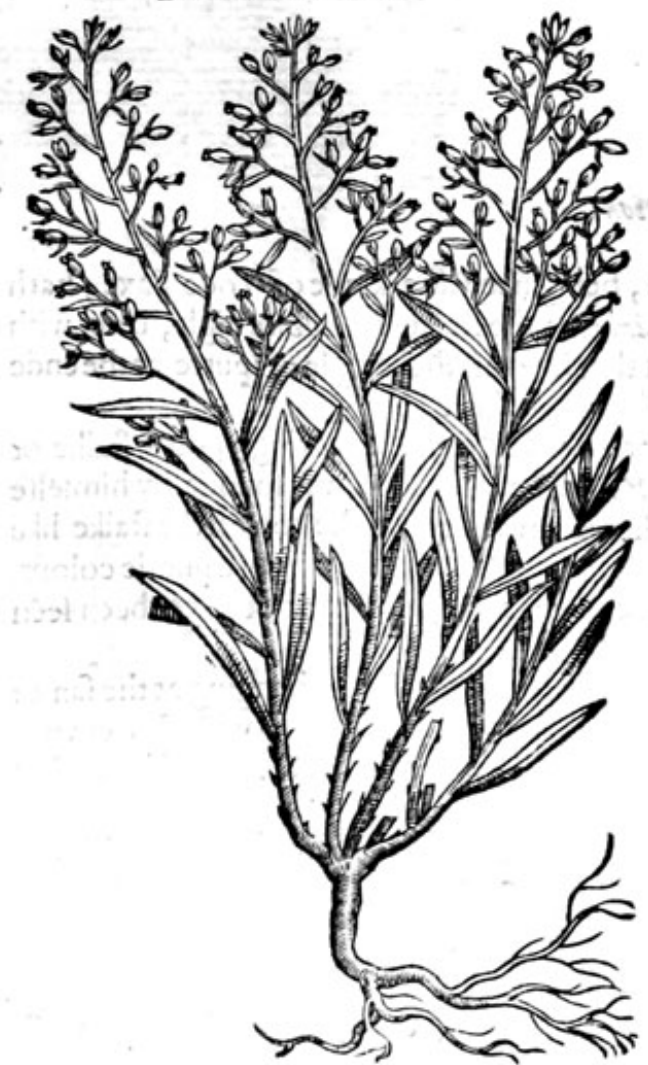

6 Ofyros purpurocaralea.

Purple Tode flaxis n to 15 b

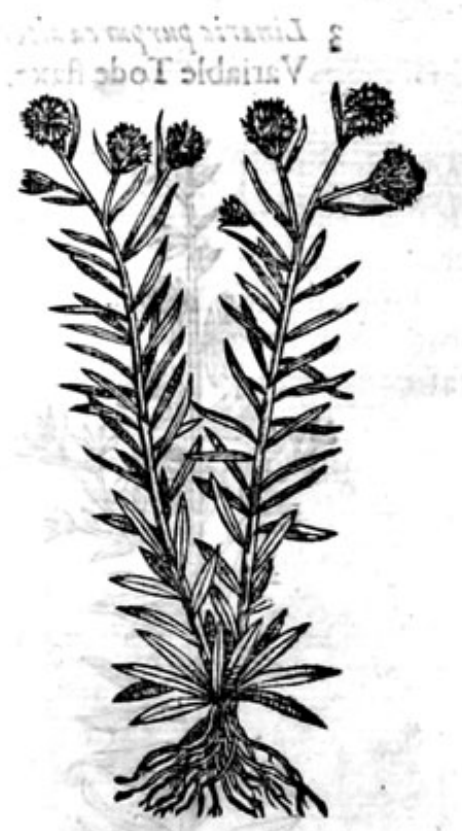

8 Linaris aurea.

Golden Tode flaxe.

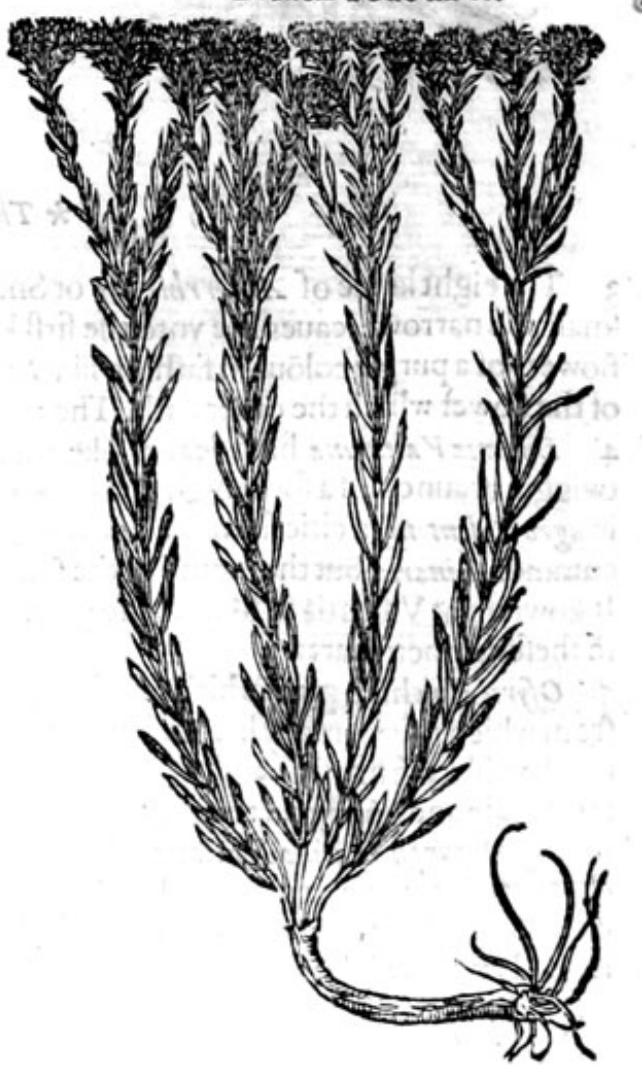




\section{HISTORIE OF PLANTS.}

7 Forafmech as this plant is ftalked and leafed like common Linaria, the new writers haue called it Linofyris: it hath ftalkes very ftiffe and wooddie, befet with leaues like the common Linaria, with flowers at the top of the ftalks of a faine fhining yellow colour, in forme or fhape fomwhat like vnto Conyza major. The whole plant groweth to the height of two cubits, \& is in tafte fharpe \& clammie, or glutinous, \& fomwhat bitter. The root is compact of many ftrings, intangled one within another. Gwillandenus calleth this plant Hy/fopes umbellifera Diofcoridis, that is, Diofcorides his Hyfope, which beareth a tuft in all points like Lino/rris, whereof it is a kinde, not differing from it in fhew and leaues. The ftalkes are a cubite high, diuided abouc into many fmall branches, the tops whereof are garnifhed with tuftes of fmall flowers, gliftering full of many golden haires or thrums, with feede as fmall as duft.

8 Golden Tode flaxe hath diuers finall vpright branches very little \& tender, garnifhed from the bottome to the top with fmall long thinne leaues like thofe of wilde flaxe: on the toppe of the ftalkes doe grow tufts of flowers of a gold yellow colour. The roote is tough and fingle.

9 Scoparia five O/yris Grasorwom. Broome Tode Glaxe.

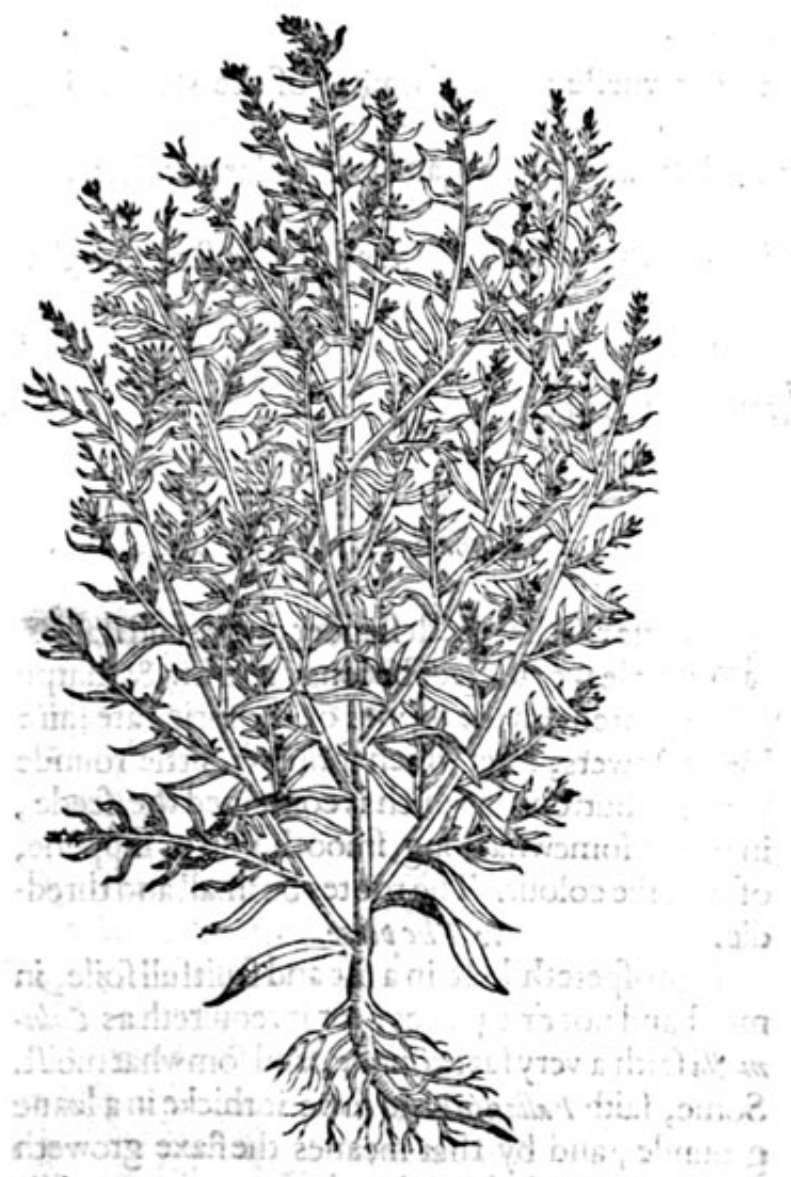

Io Pafferina linaria. Sparrowes Tode flaxe.

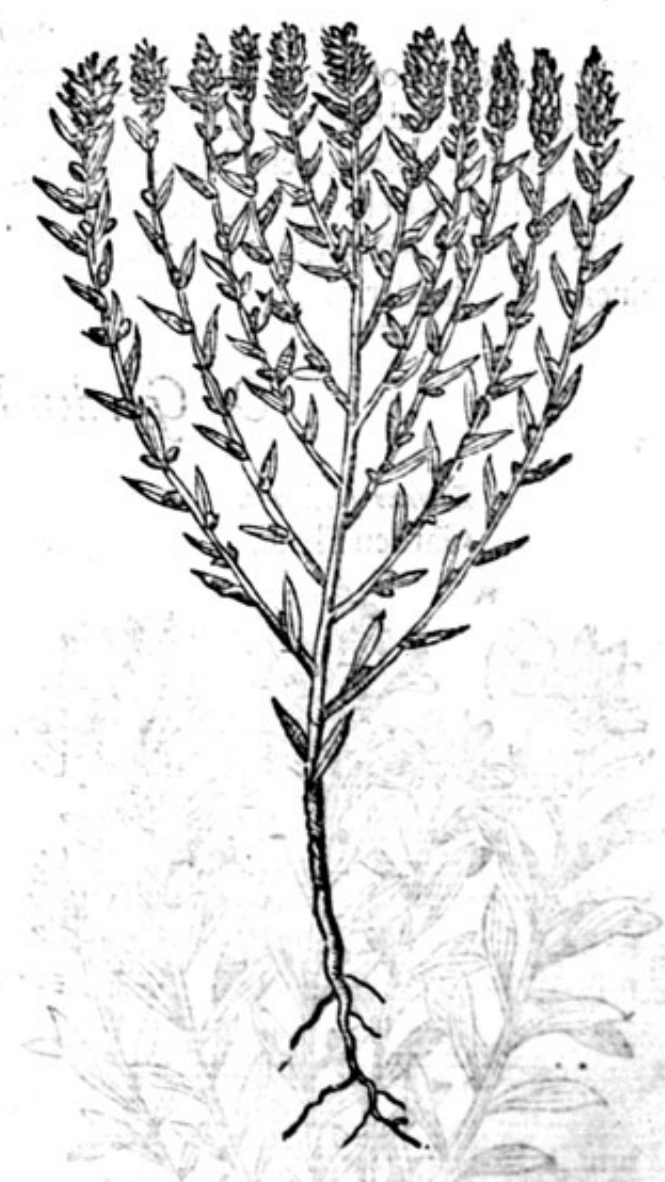

* The deforiftion.

9. Seoparia, orafter Dodoness ofrris, which the Italians call Belvidere, hath very many footes of fprigs rifing from one finall ftalke, making the whole plant to refemble a broome or beefome, wherof it tooke the name seoparia. The leaues be fmall and narrowe, almoft like to the leaues of flaxe. The flowers be as it were a bufh of herbie coloured threds, growing among the leaues, which keepe greeneallthe winter.

10 This plant alfo for refemblance fake is referred vnto the Linaries, bicaufe his leaues be like Limeric. At the top of the fmall branched ftalks, do growe little yellowifh flowers, pale of colour, fomewhat like the tops of $\mathrm{Chry}$ focome, and the ftalkes of Limonivm. Iohn Mouton of Tournay taketh it to be chryfocome altera : and bicaufe there hath beene no concordance among writers, it hail be fufficient to haue fet foorth his defcription with his name Pafferins. 
*Theplace.

The kindes of Tode flaxe growe wilde in many places, as vpon ftone wals, grauelly grounds, barren medowes, and along by hedges.

They flower from Iune to the end of Augurt. $*$ The time.

* T he names.

Tode flaxe is called of the herbariftes of our time, Linaria, or Flaxweede, and V rinalis : of fome O/gris : inhigh Dutch L pnitaut, and Dnfer ftaumen flafeb: in Lowe Dutch wailt đias: in Englith Wilde flaxe, Tode flaxe, and Flaxe weede : in Italian Bel videre, or faire in fight, which may very well agree with the firft defcribed, as being in fhew 2 moft glorious and goodly flower, but at the nofe moft lothfomly ftinking. The plant called Scoparia, is named alfo Her ba ftudioforum, bicaufe it is a fit thing to make broomes of, wherewith fchollers and ftudents may fweepe their owne ftudies and clofets. The particular names are expreffed both in Latine and Englifh in their feuerall titles, whereby they may be diftinguifhed.

* Thetemperature. kindes.

The kindes of Tode tlaxe are of the fame temperature with wilde Snapdragons, whereof they are * The vertwes.

A The decoction of Tode flaxe taketh away the yellowneffe and deformitie of the skin, being warhed and bathed therewith.

B The fame drunken openeth the ftoppings of the liuer and fpleene, and is fingular good for the iaundife which is of long continuance.

C The fame decoction doth alfo prouoke vrine, in thofe that piffe drop after drop, vnitoppecth the kidneies and bladder.

\section{Of Garden Flaxe. Chap.157.}

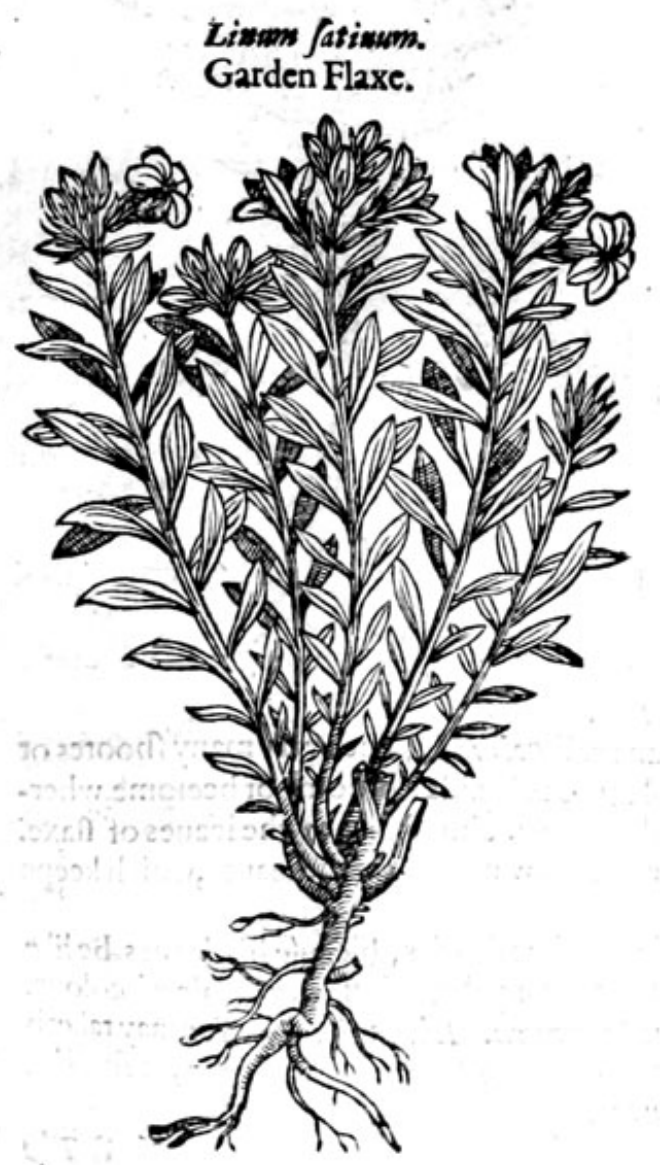

* The defaripsioi.

Laxe rifeth vp with flender and round ftalkes. The leaues thereof be long, narrow, \& tharpe pointed: on the toppes of the fprigs are faire blewe flowers, after which fpring vp little rounde knops or buttons, in which is conteined the feede, in forme fomewhat long, fmooth, glib or flipperie, of a darke colour. The rootes be fmall and threddie. * The plase.

It profpereth beft in a fat and fruitfull foile, in moift and not drie places; for it requireth as Colv$m$ llla faith a very fat grounde, and fomwhat moift. Some, faith $P$ alladises, do fowe it thicke in a leane grounde, and by that meanes the flaxe groweth fine: Pliny faith that it is tobefowen in grauellie places, efpecially in one forrowe: 2 ec magis festzmare aliud: and that it burneth the ground and maketh it woorfer, which thing alfo Virgill teftifieth in his Georgickes :

$V$ rit limi campom feges, urit Anema:

Vrwost let heo perful a pa pawera fomono.

Flaxe and Otes fowne confume the moifture of a fertile field:

The fame worketh Poppie, whofe inice a deadly Ieepe doth yeeld. 
$*$ The time.

Flaxe is fowen in the fpring, it flowreth in Iune and Inly. After it is cutte downe (as Pl tric in his 19. booke firtt chapter faith) the ftalks are put into the water fubiet to the heate of the funne,and fome waight laide on them to be fteeped therein, the loolenes of the rinde is a figne when it is well ftecped: then is it taken vp and dried in the funne, and after vfed as moft hufwiucs can tell better then my felfe.

* The names.

It is called both in Greeke and Latine niver, Limum: in high Dutch $f$ lacblz: in Iralian and Spanim Limo: in French Dulin : in lowe Dutch Clas: in Englifh Flaxe and Lyne.

$*$ Thetemperature and vertues.

Galen in his firft booke of the faculties of nourifhments faith, that diuers vfe the feede heereof $A$ parched as a fuftenance with Garum, no otherwife then made falt.

They alfo ve it mixed with honie; fome likewife put it among bread, but it is hurtfull to the fto. B macke, and is hard of digeftion, and yeeldeth to the bodic but little nourifhment: but touching the qualitiewhich maketh the belly foluble, neither wil I praife or difpraife it;yet that hath it fome force to prouoke vrine, is more apparant when it is parched : but then it alfo ftaieth the belly more.

The fame author in his bookes of the faculties of fimple medicines faith, that Linefeede being $C$ eaten is windie although it be parched, fo full is it of fuperfluous moifture: and it is alfo after a fort hot in the firft degree, and in a meane betweene moift and drie. But how windie the feede is, and how full of fupertluous moifture it is in euery part, might very wel haue been perceined a few yeeres fince at Middleborough in Zeland, where for want of graine and other corne, moft of the Citizens were faine to eate breade and cakes made heereof with honie and oile, who were in fhort time aftcr fwolne in the bellie about the fhort ribs, faces, and other parts of their bodies in fuch fort, that a great number were brought to their graues thereby: for thefe fymptomes or accidents came no otherwife then by the fuperfluous moifture of the feede, which caufeth windinefie.

Linefeed, as Diofcorides hath written, hath the fame properties that Fenugreeke hath: it wafteth D awaie and mollifieth allinflammations or hot fwellings, as well inwarde as outward, if it be boiled with honie, oile, and a little faire water, and made vp with clarifièd honie; it taketh away blemirhes of the face and the funne burning, called in Greeke Ep beleis, being rawe \& vnboiled; and alfo foule fpots, if it be mixed with falt peter\& figs : it caufeth rugged and ill fauoured nailes to fall off,mixed with honie and water Creffes.

It draweth foorth of the cheit corrupted flegme and other filthie humiours, if a compofition with $\mathrm{B}$ honie be made there of to licke on, and eafeth the cough.

Being taken largely with pepper and honie made vp into a cake, it ftirreth vp luft.

The oile which is preffed out of the feede, is profitable for many purpofes in phificke and chirur- $G$ geric; and is vfed of painters, piature makers, and other artificers.

It fofmeth all hard fwellings; it ftretcheth foorth the finewes that are fhrunke and drawne togi- $\mathrm{H}$ ther, mitigateth paine,being applied in maner of anointment.

Some alfo give it to drinke to fuch as atc troubled with paine in the fides s sollicks but it ment be I frefh and newly drawne: for if it be olde and ranke, it caufeth aptnefle ta yomite $39 d$ withall it ouermuch beateth.

Linefeed boiled in water with a little oile, $\$ 2$ quantitic of Annife feede inpoydered and implaifi $K$ ftered vpon angina, ar any fwelling in the throate, belpeth the fame.

It is with good fucceffe vfed plaifterwife, boiled in vineger, vpon the difeafes called Colizista and $\mathrm{L}$ DyJenterias shich are floxes and paines of the bellie.

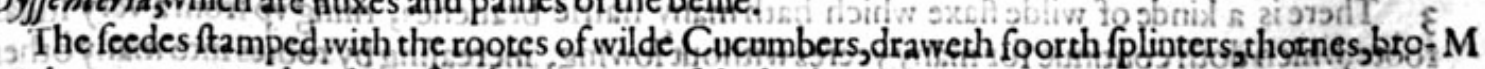
ken bones, or any other thing fixed inany part gf the bodie.

The decoction is an excellent bath for women to fit oue for the in flammation of the fecret parts, $N$

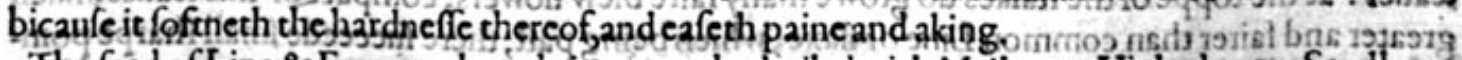

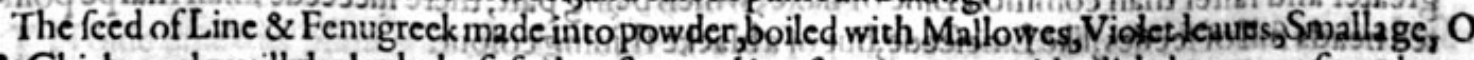
8. Chickweed, vntill the herbs befoft; then ftamped in a tone morter yith a litbe hogs greafe re the. forme of a catapla fme or pultus:appeafech all maner of paine, foftneth al colde efumors or fwellings mollifieth\&abringeth ta fuppuration all apoftemes sdefendeth wounded members from fisjllings \& rankling, and when they be alreadie rank:ed, it taketh the fame away being riglied yeris, wratse euening and morning. 


\section{OfWilde Flaxe. Chap. 158.}

I Limum flocestre floribus albis. Wilde white flaxe.

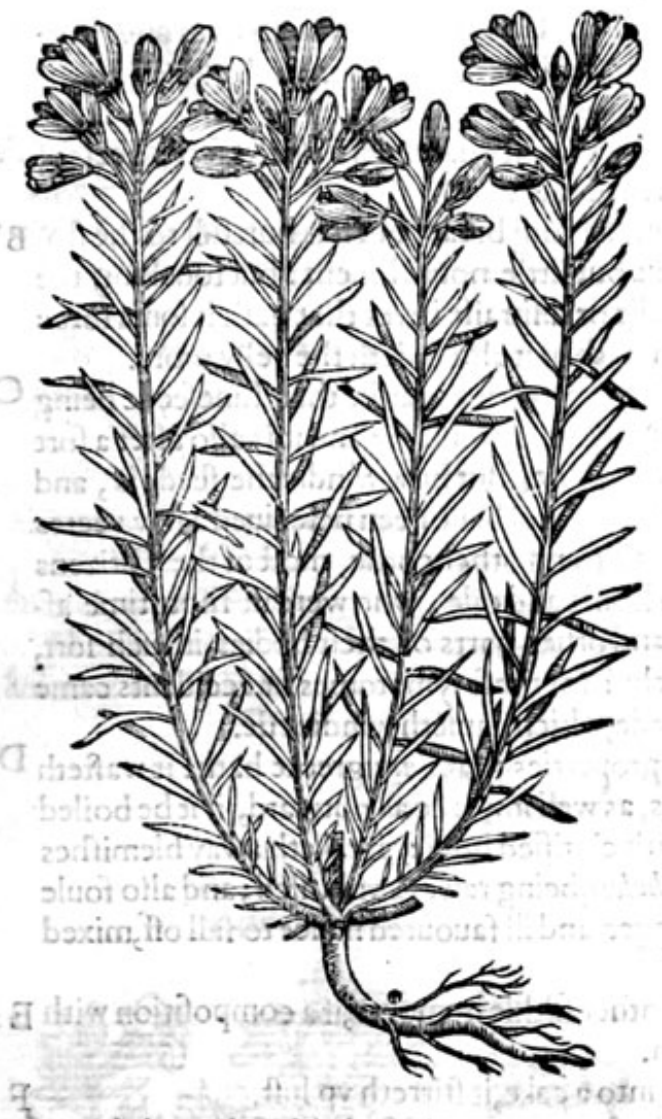

2 Linuen fluestretenuifolium. Thin leafed wilde flaxe.

\section{* The defcription.}

2 This Wilde kinde of Line or flaxe hath leaues like Apiaragus, or rather like Fennell, grow1. 1 but of a white colour. The roote is tough and fmall, with fome fibres annexed thereunto.

2 The narrow and thinne leafed kinde of Line is very like to the common flaxe, but in all pointes leffer. The flowers confift of fiue leaues, which do foone fade and fall away, hauing many ftalks proceeding from one roote, of a cubite high, belet with fmall leaues, yea lefler than thofe of Linaria purpures.

3 There is a kinde of wilde flaxe which hath many hairie branches, rifing vp from a very fulal i/ toote, which doth continue for many yeeres withodit fowing, increafing by rootes into many other plants, with ftalkes amounting to the height of one cubite, befet with many rongh and hairie broade leariés: at the toppe of the ftalkes do growe many faire blew flowers, compact of fiue leaues, much greater and fairer than common Line or flaxe; which being paft, there fucceede fmall fharpe pointed heads full of feedes, like Linefeede, but of a blacke fhining colour.

4 Cam elimum (of fome called Eintom. yluestre per puf fllsm, s may be called in Englifh very Lowe or Dwarfe wild flaxe; for this word chame ioined to any fimple doth fignifie, that it is a low or dwarfe kinde thereof) being fcarce an härdfull high, hath pale yellow flowers : but as it is in allthings like vinto $\theta$ axe ; fo the flowers, leatues; and ftalkes, and all other partes thereof, are fower times leffer than Linum. 
3 Limuon flueflire tenuifolion.

Thinne leafed Wilde flaxe.
4 Chamalinum perpufflaven.

Dwarfe wilde flaxe.
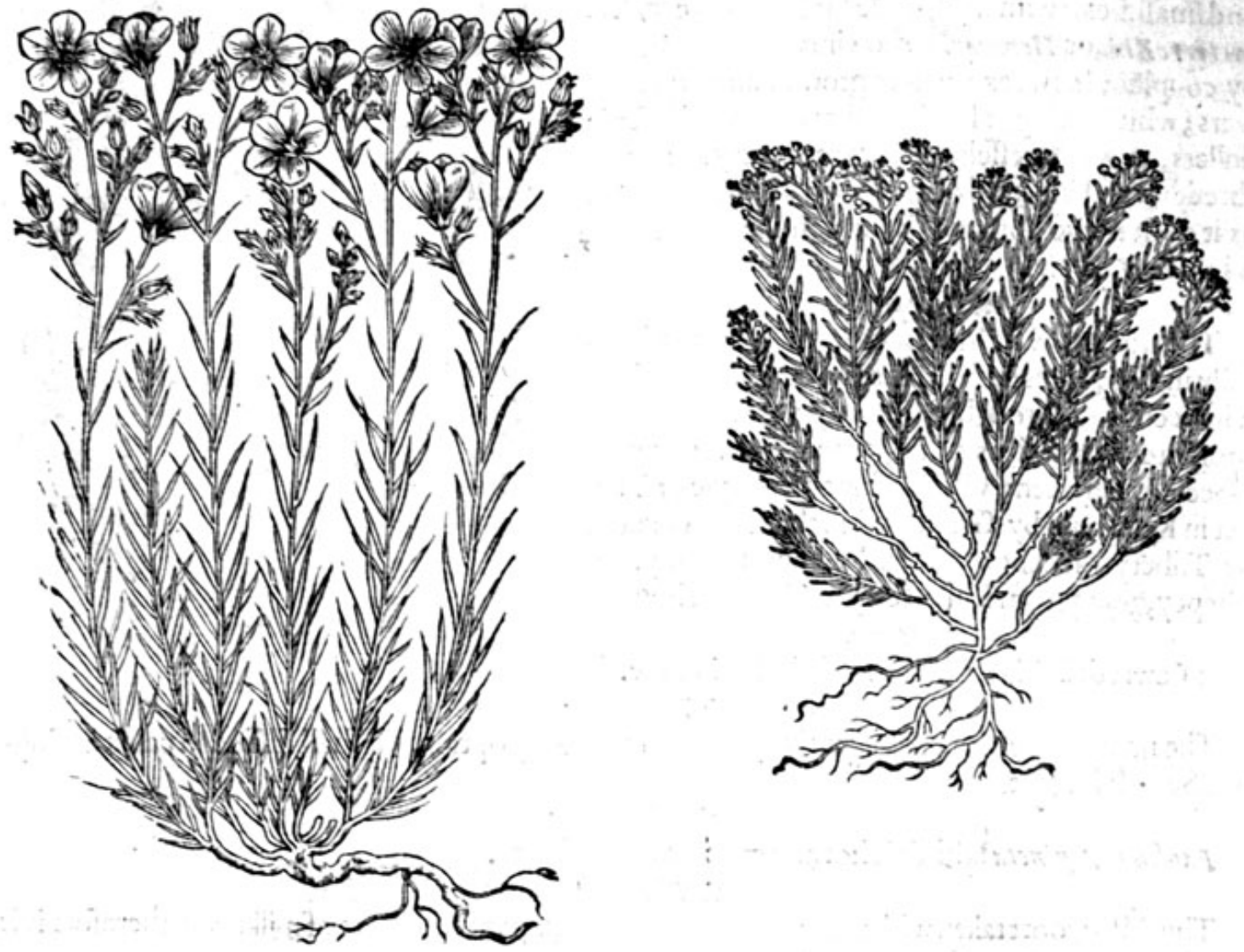

They growe generally in grauellie grounds.

* The place.

The firft groweth in well manured places, as in gardens, and fuch like foiles.

The fecond groweth by, the fea fide. The third and fourth growe vpon rocks and cliffes neere to the fea fide.

I haue feene them growe vpon the fea bankes by Lee inEffex, and in many places of the yle of Shepey. They growe alfo betweene Quinborow and Sherland houfe.

They flower from May to the middeft of Auguit. * The time.

* Thenames.

Their names are fufficiently expreffed in their feuerall titles.
it The $*$ The nature and vertwes.

feldome vied either in phificke or chinurgerie.

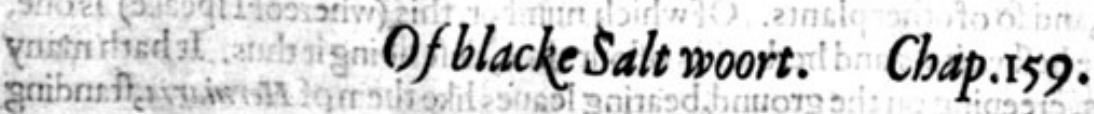

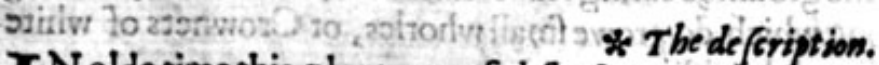

Nolde time this plant was vfed for fauce and meate, as Purflaine and other herbes are in thefe sour daies, and receiued among the Legumina. In mine opinion it was called Glawx, by reafon of Tt the colour of the leaues, which are of aligray or olde dried colour, called in Latine Glancus color, fuch as are in the Sallow leafe: of others it is called Galax or Glax : of others Engalacton, gualjolactea ot Liatifica : bicaufe it is good to increafe milke in the brefts of women, if it be much vfed. Rmelliwe and others haue fetdowne Golega, Seciridica, Polygala, and many opher plants for the true Glawx, thafto! I? 


\section{THE SECOND BOOKE OF THE}

which hath bred a confufion. The true Glaux of $D i$ ofcorides hath many fmall branches, fome creeping on the ground, and fome ftanding vpright, tender, and fmall, befet with many little fat leaues like $T$ ribulosterrestri, or Herniaria, growing along the ftalkes by couples; betweene whom grow fmall purple flowers; which being paft, there fucceed certainc little bullets, or feede veffels. The roote is very finall and threddy, \& taking hold of the vpper face of the earth, as it doth runne abroade, by which meanes it doth mightily increafe,

\section{* Theplace.}

The true Gluux or Milkwoort groweth very plentifully in falt places and marhes neere the fea, from whence I haue brought it into my garden, where it profpereth as well as in his natiue foile. I found it efpecially betwcene Whitftable and the yle of Thanet in Kent, and by Grauefend in the fame countie, by Tilbery Blockhoufe in Effex, and in the yle of Shepey,going from Kings ferry to Sherland houfe, $\rightarrow$ t The time.

It flowreth in May, and the feede is ripe in Iune. Glaux exigua maritima. Blacke Salt woort.

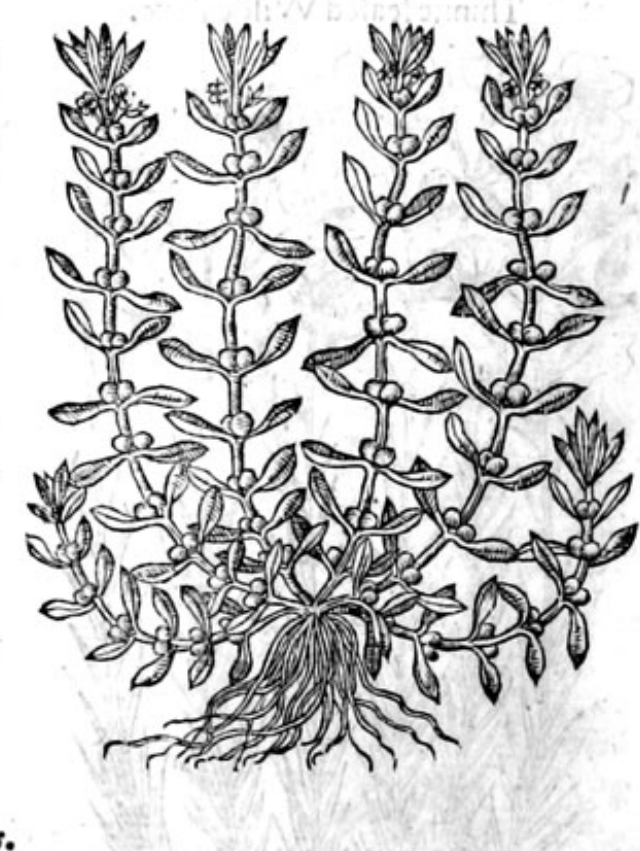

The names haue beene fufficiently fpoken of in the defcription. It fhall fuffice to call it in Englifh Sea Milkwoort.

\section{Paulus Alegineta faith, it is hot and moift of temperature. $*$ The vertues.}

A This Milkwoorttaken with milke, drinke or pottage, ingendreth ftore of millke, and therefore it is good to be vfed by nurfes that want the fame.

\section{Of Milkewoort. Chap.160.}

* The kindes.

Tere be diuers fortes of Milke woorts, varying in the colour of their flowers, wherin confifteth their difference.

* The defcription.

I Here haue beene many plants neerely relembling polygala, and yet not the fame in deede, 25. which doth verifie the Latine faying, 2N wlum fomile est idem. This neere refemblance doth rather hinder thofe that haue not fpent much time in the knowledge of fimples, than increafe their knowledge. And this alfo hath beene an occafion that many hate imagined a fundrie Polygala vnto themfelues, and fo of other plants. Of which number, this (whereoflipeake) is one, obtaining this name of the beft writers and herbarifts of our time, defcribing it thus. It hath many thicke fpreading branches, creeping on the ground, bearing leaues like them of Herniaria, ftanding in rowes like the Sea Milkwoort; among which do growefmall whorles, or Crownets of white flowers; the roote being exceeding finall and threddie.

2 The fecond kinde of Polygala is a finall herbe with flender pliant ftems, of a wooddie fub ftance, an handfull long,creeping by the ground: the leaues be fmall and nartow like vnto Lintels,orlitile Hyffope. The flowers growe at the top, of a blew colour, fafhioned like a little bird, with wings, taile, and bodie, eafie to be difcerned by them that do obferue the fame: which being paft, therefucccede fmall pouches, like thofe of Burfa pastaris, but leffer.The roote is fmall and wooddie. 
AHTHISTORIE OF PLANTS.HT

i Polygala repens.

2 Polygala flore ceruleo. vis Creeping Milke woort.

What alew Milkewoort. is aidT \&

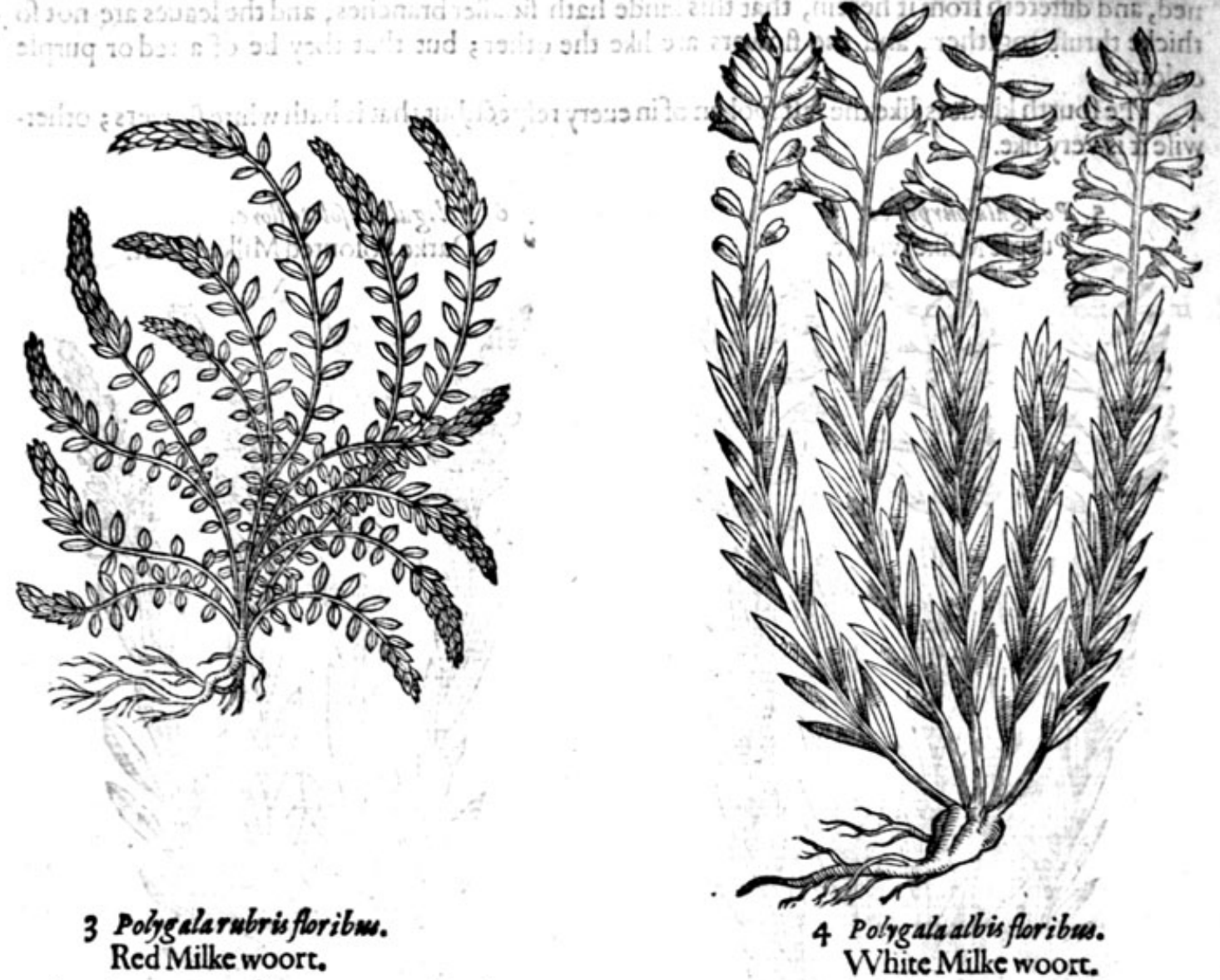

3 Polygalarubrisforibu. Red Milke woort.

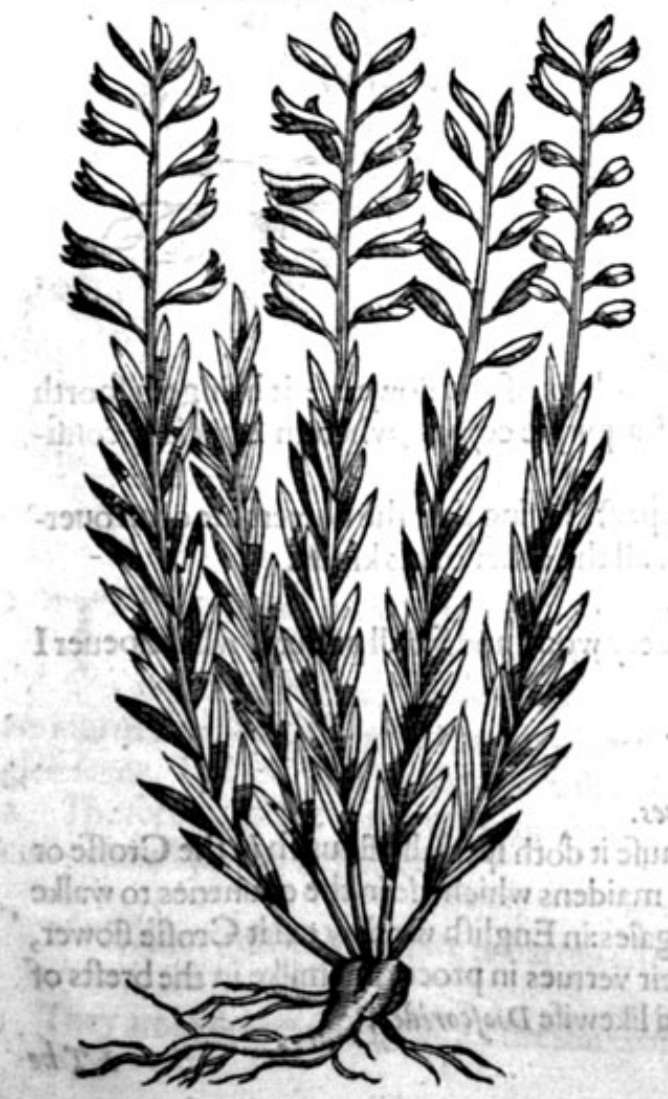

Ff :

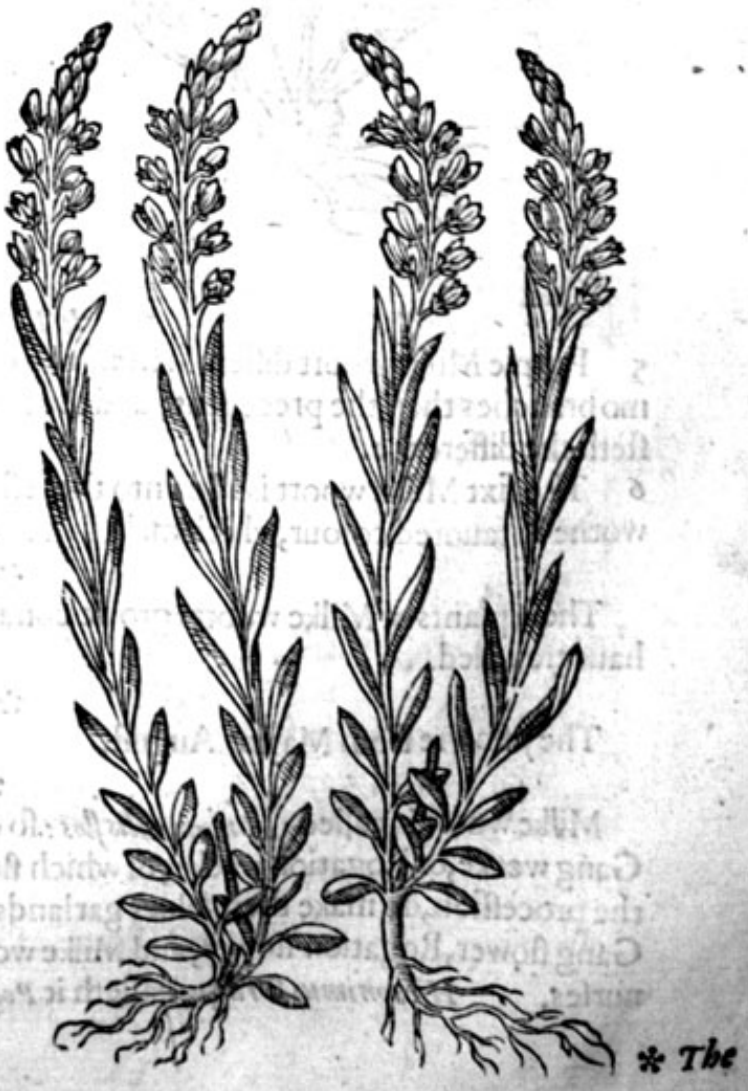


* The defcription.

3 This third kinde of Polyg gals or Milkewoort, hath leaues and ftalkes like the laft before mention ned, and differeth from it herein, that this kinde hath finaller branches, and the leaues are not fo thicke thruft togither, and the flowers are like the other; but that they be of a redor purple colour. 4. The fourth kinde is like the laft fpoken of in euery refpeet, but that it hath white flowers; otherwife it is very like.

5 Polygala purpurea. Purple Milke woort.

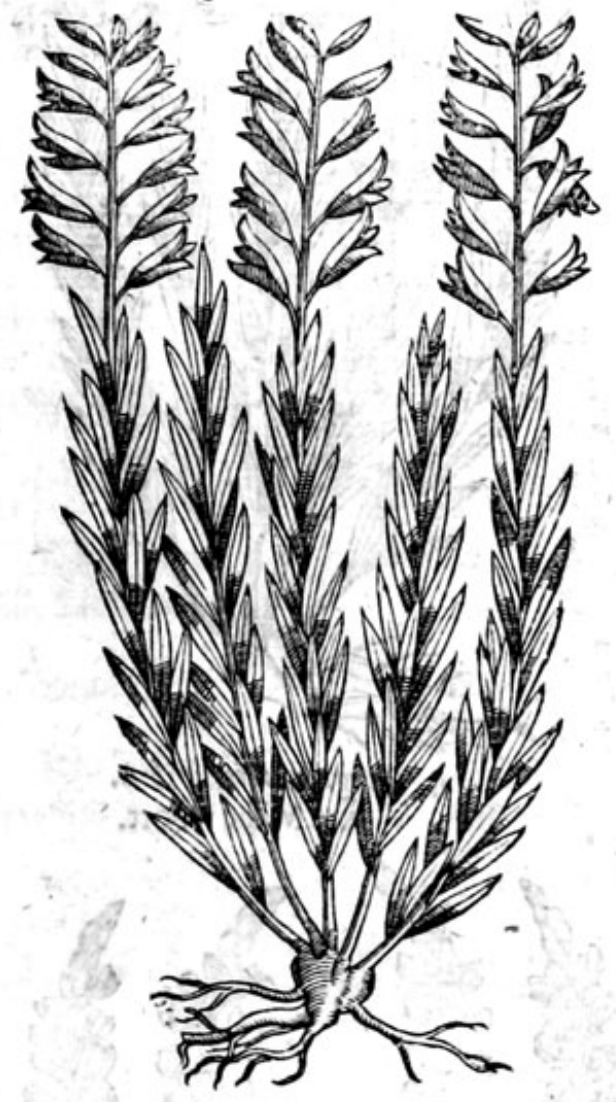

6 Polygalaobfoletoflore. Darke coloured Milke woort.

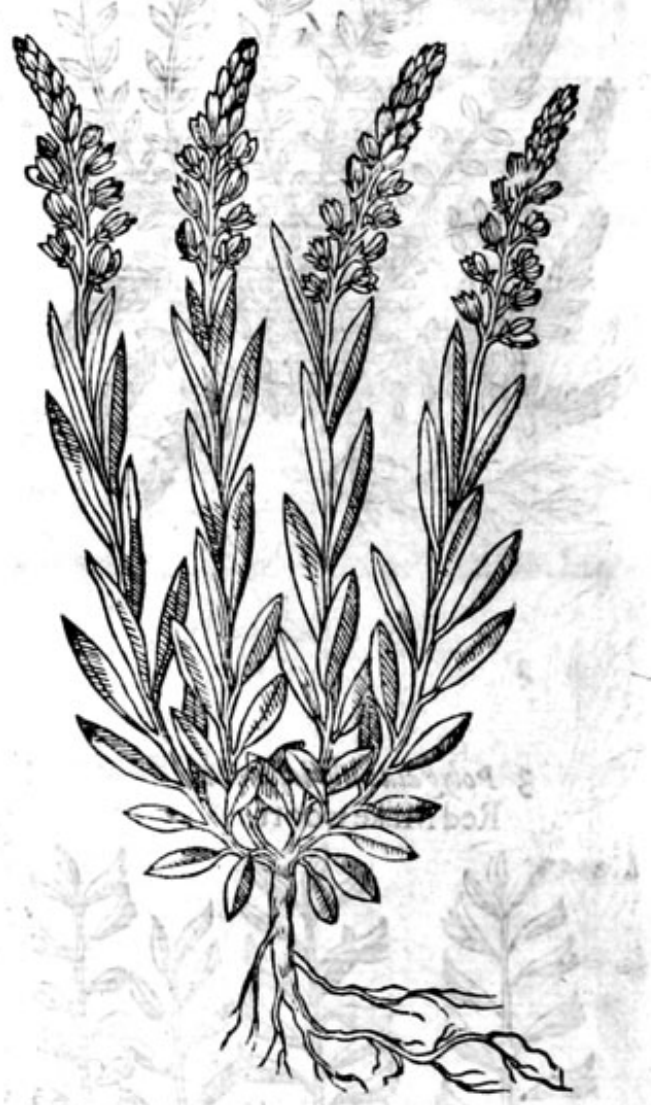

* The defcription.

5 Purple Milke woort differeth from the others in the colour of the flowers : it bringeth foorth mobranches than the precedent, and the flowers are of a purple colour; wherein efpecially confifteth the difference.

6 The fixt Milke woort is like vnto the reft in each refpect, fauing that the flowers are of an ouerworne ill fauored colour, which maketh it to differ from all the other of his kinde.

$$
\text { * Theplace. }
$$

Thefe plants or Milke woorts growe commonly in euery wood and fertill pafture, wherefoeuer I haue trauelled.

They flowre from May to Augurt.

$$
\text { * The time. }
$$

* The names.

Milke woort is called Ambarwalis fos : fo called bicaufe it doth fpecially flourifh in the Croffe or Gang weeke, or Rogation weeke; of which flowers, the maidens which vfe in the countries to walke the proceffion, do make themfelues garlands, and nofegaies:in Englin we may cal it Croffe flower, Gang flower, Rogation flower, and Milke woort, of their vertues in procuring milke in the brefts of nurfes. Hieronimu Tragw calleth it Polygalun, and likewife Diofcorides. 


\section{HISTORIE OF PLANTS, HT}

* Theodrimes.

Galen, Theoplorafisu, and Dioferides do account thefe for Milke woorts, andmay without eritor $A$ be vfed for thofe purpofes, whereunto Glesx ferueth.

$$
\begin{gathered}
\text { OfKnotgrafee Chap.16I. } \\
* \text { The kindes. }
\end{gathered}
$$

$T$ Here be diuers herbes of fundrie formes and fhapes, comprehended vnder this name Poiggo. mum, or Knot graffe. But of the cominon or beft knowen Knot graffe, we intend to intreace in this chapter : whereof there be two forts, the greater and the leffer.

I Polygonum mas vulgare.

Common Knot graffe.

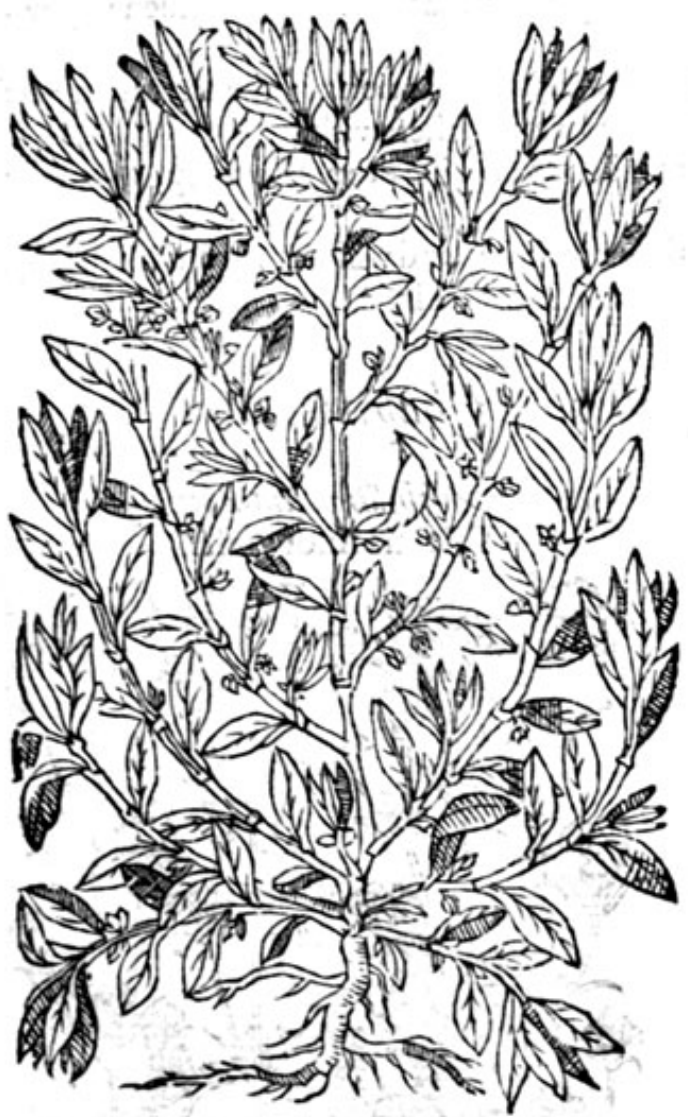

2 Polggomuon mas minus.

Small common Knotgrafle.

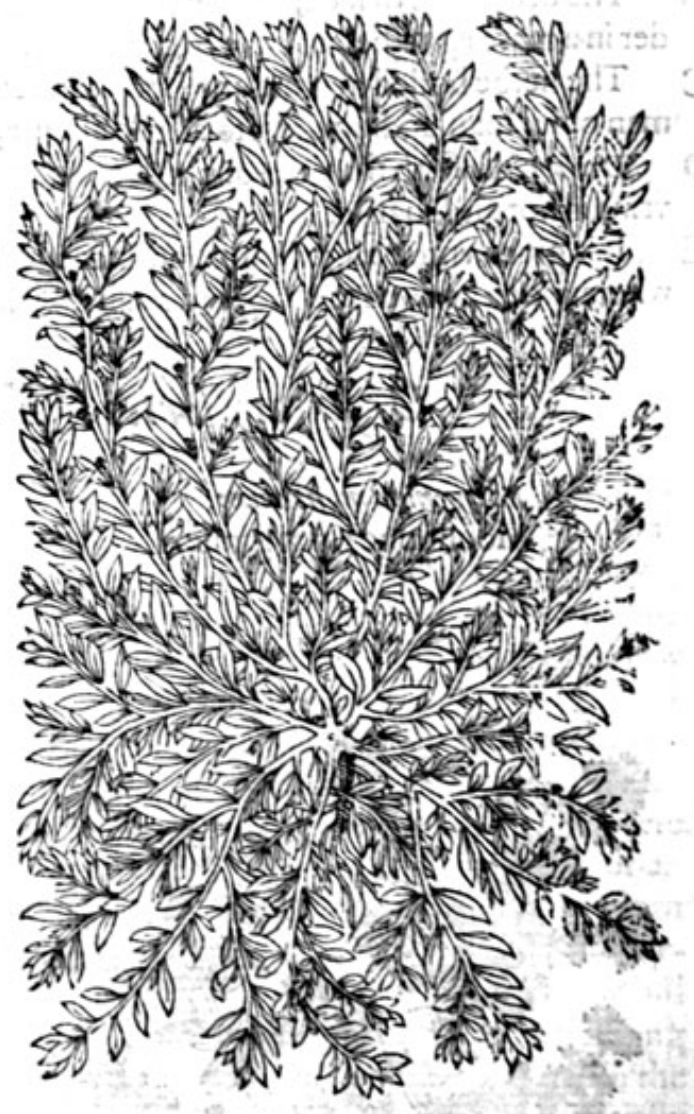

* The defoription.

17 Hecommon male Knot graffe creepeth along vpon the ground, with long flender weake branches, full of knots or ioints, whereof it tooke his name. The leaves growe vpon the weake branches like thofe offmall S. Iohns woort, but longer and narrower. The towers are maruellous little, and growe out of the knots, of an herbie colour; in their places come vp triangled feede. The roote is long, flender, and full of ftrings.

2 The fecond differeth not from the former, but onely that it is alsogither leffer, wherein efpet cially confifteth the difference.

* Theplace.

Thefe Knot grafles do growe in barren and ftonie places almofteuery whete.

They are in flower and feedeall the fommer long.

$$
\text { * The time. }
$$




\section{*uTbenases:}

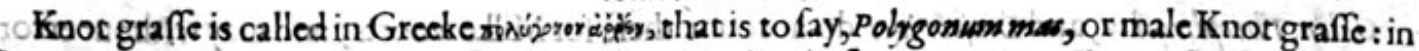
Latine Seminalis, Sanguinaria : of Columell Sangiwnalis : in thops Centiumnodia, and Corrigiola : of Apuleises Proferpinaca : in high Dutch \$goanduit : in lowe Dutch đIerkens grag, and Dutitent knop: in Italian Polygono: in Spanifh Curriola : in French Renouce : in Wallen Mariolaine de Cure: in Englifh Knot grafle, and Swines graffe: in the North;Birdes toong.

$$
* \text { The temperature. }
$$

Knot graffe,as Galen teacheth, is of a binding qualitie, yet is it colde in the fecond degree, or elfe in the beginning of the third.

A The inice of Knot graffe is good againft the fpitting of blood, the piffing of blood, and all other iffues or fluxes of blood,as Brafanolw reporteth, and Camerarims faith be hath cured many with the iuice thereof, that haue vomited blood, giuen in a little ftipticke wine. It greatly preuaileth againft the Gonorrhea, that is, the running of the reines, and the weaknes of the backe comming by mearies thereof,being fhred and made in a tanfie with egs and eaten.

B The decoetion of it cureth the difeafe aforefaid, in as ample maner as the iuice: or giuen in powder in a reare egge, helpeth the backe very much.

C The herbe boiled in wine and honie, cureth the vlcers and inflammations of the fecret partes of man or woman, adding thereto a little allume, and the parts wafhed therewith.

D Diofcorides faith thatit prouoketh vrine, and helpeth fuch as do piffe drop after drop, when the vrine is hot and harpe.

E It is giuen vnto fwine with good fucceffe, when they are ficke, and will not eate theirmeatc; whereupon the countrie people do call it Swines graffe,and Swines skir.

\section{Offundry fortes of Knot grafes. Chap.162.}

1 Polygonum montantem. Mountaine Knot graffe.

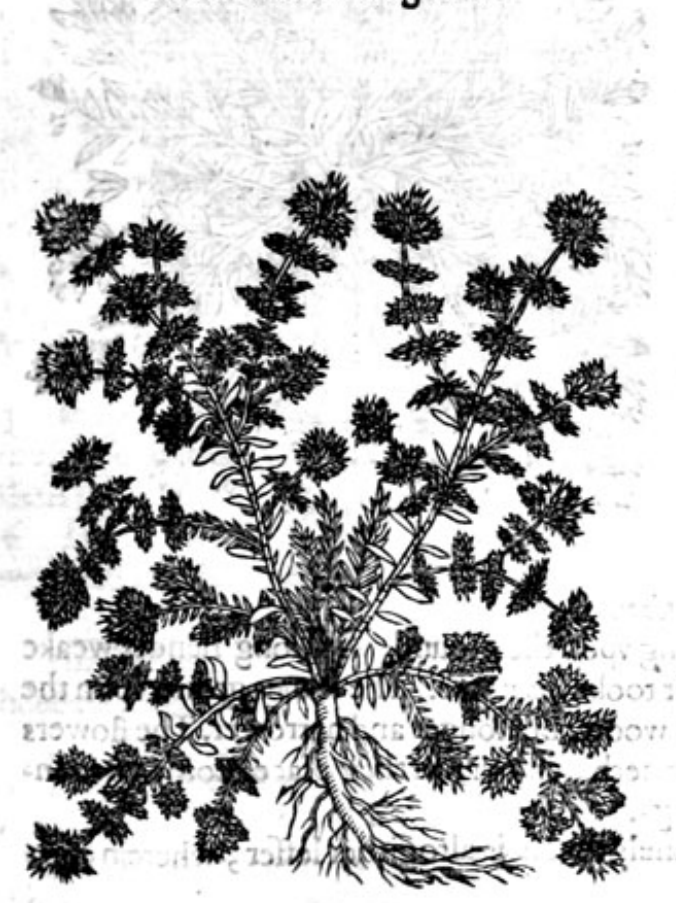

2 Untbyllis valentina Clusÿ. Valentia Knot graffe.

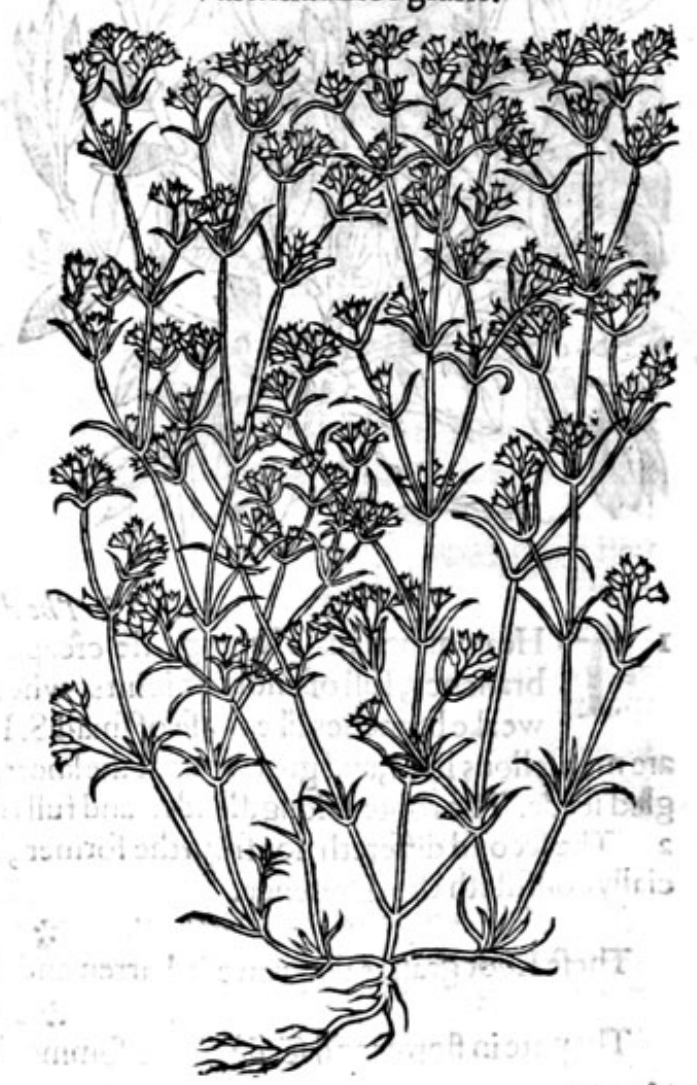

* $T$ be 
* Thedefcription.

He fnowie white and leat kinde of Polygonwom, or Knot graffe, called of Clugsurs Paromychis

1. Hiffanics, is a ftrange and woorthie plant to bchoid, handie, and confider, although it be but fmall. It is not aboue two inches long, hauing fmall branches, thicke, tough, hard, and full of ioints: out of which the leaves come foorth hike fmall teeth leffer than the leaues of Herniarza, or $T$ bymun tenuifolison. At the top of the ftalkes itand moft delicate flowers framed by nature, 25 it were, with fime parchment leaues, ftanding like fmall buttons, in their fingular whitenes and fnowie colour refembling the perfect white filke, fo many in number at the top, and fo thicke, that they ouer/ hadow the reft of the plant beneath. The roote is flender, and of a wooddie fubltance, longer than the branches, or the whole plant. The feede is couered as it were with chaffe, and is as fmall as duft, or the motes in the funne.

2 Antbytis of Valentia, being likewife a kinde of Knot graffe, hath fmall leaues like Glawx exigus, fet orderly by couples at the ioints : among which come flowers, and other fmal leaues like the hirt, but alrogither leffer. The roote is finall and long, and of a wooddie fubftance.

3 Polngonan Selinoikes, faue Knsurel. Parliey Piert.

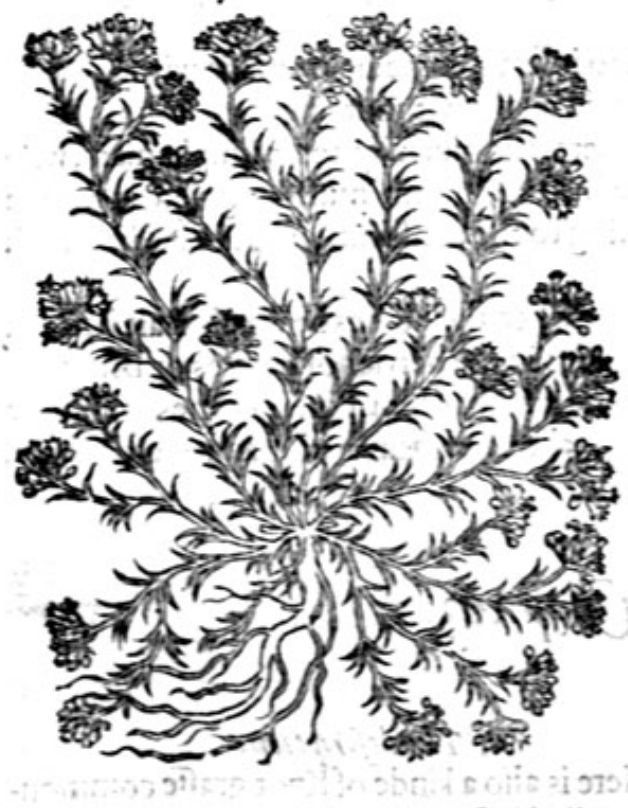

* The defcription.

3 There is a kinde of Knot graffe, which hath ma. nylong and flender branches, or rather frnall twigs, fpred and ftretched veon the ground like Serpillum: from among which leaues, do clufter in rundels like tuftes, hauing fpaces betweene each tuft; out of which proceedeth a fimall duftic flower. The whole plant is full of iuice like Aizoon, or fmall Sengreene. The roote is fomewhat long and wooddie, bitter in tafte, and hot, and fomev h.at aftringent.

Among the Knot grafles may well be futed this fmall plant but lately written of, and not fo commonly knowne as growing in Englande, being about an handf:ll high, and putteth out from a fibrous roote fundrie flender ftalkes full of little braunches and ioints : about which growe confufedly many nartow leaues, for the mo!t part of an vnequall quantitic; yet heere and there two longer then the reft, and nuich a like in greatnes: at the outmoft parts of the braunches and italkes (where it hath thickeft tufts) appeere out of the middeft of the leaues little flowers of an beiby colour. The whole plant is all ouer whitifh or hoarie. If my memorie faile menot, Pens doth meane thisherbewhere he fpeaketh of Sexifrega anglicans, in his Aducr faria pag.103. and alforeporteth that he founde this plant by the way fice as he rode from London to Briftow, on a little hill notfar from Chipnam; his picture doth very well refemble the kinde of Knot graffe, called among the Gernaines fintar efl, and calling it Saxifrags anglic ans, caufeth me to thinke that forne in the weit parts where he firit founde it do call it Saxiłtage, as we do call fundrie other herbes, efpecially if they feruefor the ftone: My friende mafter Steuen Brednell, praGtitioner in Phyfick in thofe parts, heard of a fimple man; who didmuch good with a medicine (that he made with Paifley Piert) againft the ftone, which heminiftred vnto all forts of people. This my friend requefted the foore manto thew him the hetbe called Parfley Piert, who frankly promifed it hirn, and the next moming brought him an handfull of the herbe, and tolde him the compofition of hismedicine withal, which you fhall finde fet downe in the vertues, and prooued by fundrie of good account, to be a fingular remedie for the farie.

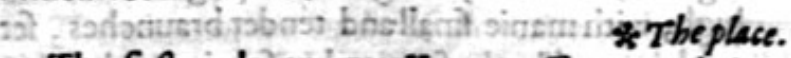

The firft and common Knot graffe groweth in euery grauely or banen grounde: the feconde groweth neere thefea banks: the thirde and fourth are ftrangers in Englande: the fift doth growe in my girden: the fixt groweth in basten fandie fieldes where Barley hath been fowen : the feuenth groweth by the fea fide vpon rockes and cliffes: and the laft doth growe in the places where corne 


\section{THE SECOND BOOKE OF THE}

hath beene fowen, as by Banc clmes, where my friende aforefaid founde the fame: it doth growe in Kent in fundrie places, from whence I bronght fome for my garden, where it profpereth weil; and by Chipnam aforefaidc, as $F$ crina reporteth.

* The time.

Thefe flower for the molt part from Maie to September.

$\varkappa$ The names.

That which hath beenc faide of their feuerall names in their defcriptions fhall fuffice. $\approx$ The nature.

They are colde in the feconde degrec, and drie in the thirde, aftringent and making thicke. $*$ The vertues.

A The iuice of Knotgraffe is good againft the fpitting of bloude, the piffing of bloud and all other iffues and fluxe of bloud: it preuaileth againft the Gonorrhxa, and the weaknefie of the backe, being made in a tanfie with egges.

B The decocticin of Knotgraffe cureth the difeafe aforefaide, in as ample mamer as the iuice, and being boiled in honie and wine, it cureth the vlcers \& inflammations of the primie or fecret parts of man or woman.

C Diofcorides faith that Knot graffe prouoketh vrinc, and helpeth fuch as piffe drop by drop, when the vrine is hot and harpe.

D Heere according to my promife I haue thought good to infert this medicine made with Knawcl, which herbe is called (as I faide before)Pariley Piert; but ifI might without offence, it thoulde be called Pesra Pungens; for that barbarous ivorde Parfley Piert, was giuen by fome fimple man, wlio bad not well learned the true terme. The compofition which followeth muift be giuen in warme white wine halfe 2 dram, yea two fcruples or more, according to the conftitution of the bodie which is to receiue it.

E The leaues of Parfley Piert, Moufeare, of eche onc ounce when the herbes be dried, Baie berries, Turmericke, Cloues, the feedes of the great Burre, the feedes in the berries of heppes or Briertree, Fenugreeke, of eche one ounce, the ftone in the oxe gall, the waight of 24 . Barley cornes, or halfe 2 dram, made togither into a moft finc and fubtill powder, taken and drunke in manner aforefaide, hath beene prooucd moft fingular for the difeafe aforefaide.

\section{Of Rupture woort.}

\section{Cbap.163.}

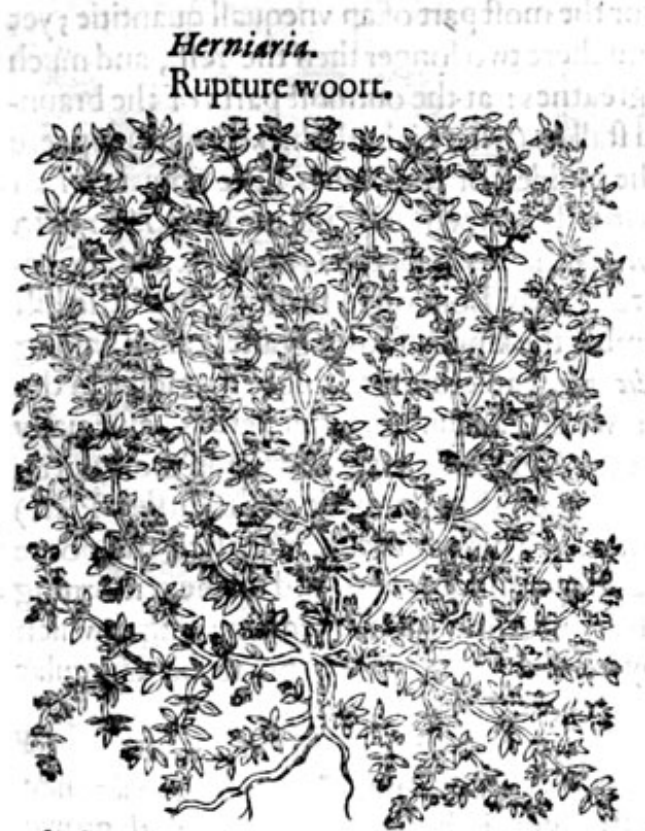

* T Thedefriptiots.

7 Here is alfo a kinde of Knot graffe commonly called in Latin Herniaria : in Engliih Ruptüre woort, or Rupture graffe. Is is a bafe and lowe creeping herbe, hauing many finall flender braunches trailing vpon the grounde, yet very tough and full of little knots fomewhat reddifh; whereupon do growe very fimall leaues like thofe of Time; among which come foorth litcle yellowifh flowers which turne into very fmall feede, $\&$ great quantitie thercof, confidering the fmaluefle of the plant, growing thicke cluftering togitber by certaine fpaces. The whole plant is of ayellowifh greene colour. The roote is very flender and fingle. There is another kinde of Herniania,called Mille grans,or all feed, that groweth vprighta handfull high, with manie fmall and tender braunches, fet with leaues like the fotmer, but feiv in number, hauing as it were two fmall leaties and no more. The whole plant fecmeth as it were couered ouer with feedesor graines, like the feedes of Panicke, but
much leffer.

$$
\therefore \text { The }
$$


* The place.

It ioyeth in barren and fandie grounds, and is likewife founde in dankilh places that lie wide open to the funne, it doth growe and profper in my garden exceedingly.

It flowreth and flourifheth in Maic, Iune, Iulie, and Auguf.

* T be names.

It is called of the latter Herbariftes Hermiaria, and Herniola : taken from the effeet in curing the difeafe Hernia : of diuers Herba Turca, and Empetron: in French Boutonet: in Englifh Rupture .woort, and Burftwoort.

Rupture woort doth notably dric,and throughly clofeth vp togither and faftneth.

* The vertues.

It is reported, that being drunke it is fingular good for ruptures, and that very many that haue $\mathbf{A}$ beene burften, were reftored to health by the vfe of this herbe : alfo the powder heereof taken with wine, doth make a man to piffe that hath his water ftopt, and that it waftech awale theftones in the kidneies, and expelleth them.

\section{Of wilde Time. Chap.I64.}

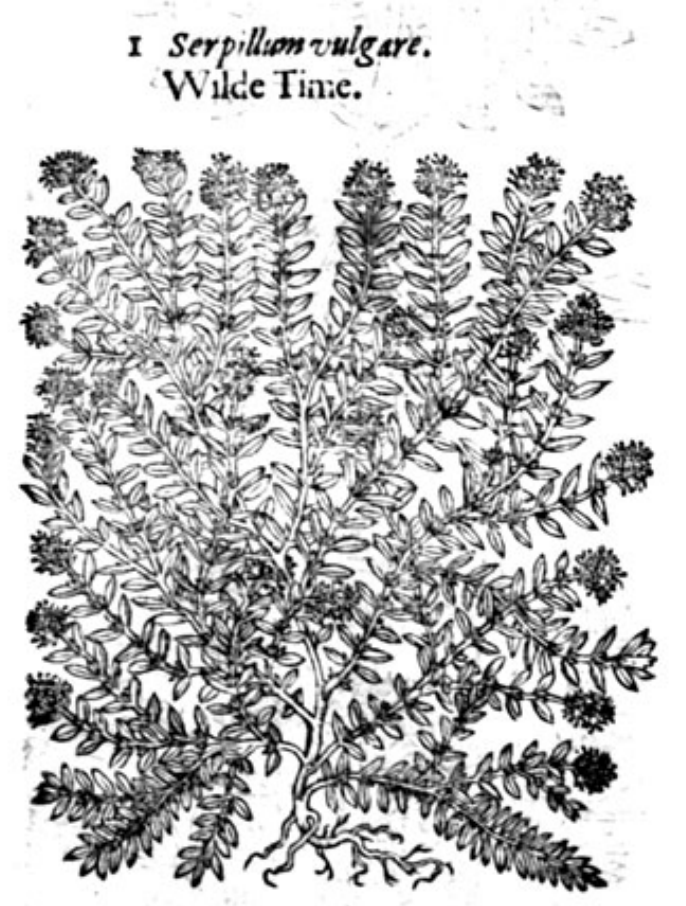

2 Serpittson vulgare flore albo, White wilde rime.

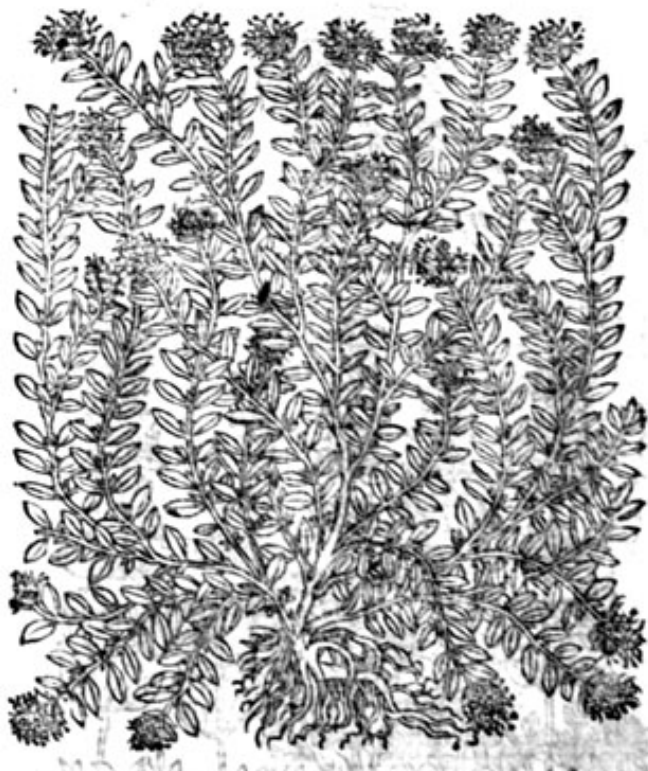

* The defcription.

r Oth Diofcorides and Plimie make two kindes of Serpollum, that is, of creeping or wilde Time, $B$ wherefof the firft is our conmon creeping Time, which is fo well knowen, that it needetlino defcription; yet this ye f ball vnderftand, that it beareth flowers of a purple colour, as euerie bodie knoweth. Of which kinde I found another fort, with flowers as white as fnowe, and have planted it in my garden, where it becommeth an herbe of great beautie.

2 This wilde Timethat bringeth footh white flowers, differeth not from the other, but onely in the colotir of the flowers.

There is another kinde of serpillum, which groweth in gardens, in finell and fauour refem. bling Marierom. It hath leaues like Organie, or wilde Marierome, but fomewhat whiter, putring foorth many finall italkes, fet full of leaues like Rue, but longer, narrower, and harder. The tlowers are of a biting tafte, and pleafant imell. The whole plant groweth vpright, wheteas the other creen peth along vpon the carth, catching hold where it groweth, and fpreading it felfe far abroad. 
3 Serpillwom ma ius fore purpur co Clusij \& L'Obely. Great purple wilde Time.

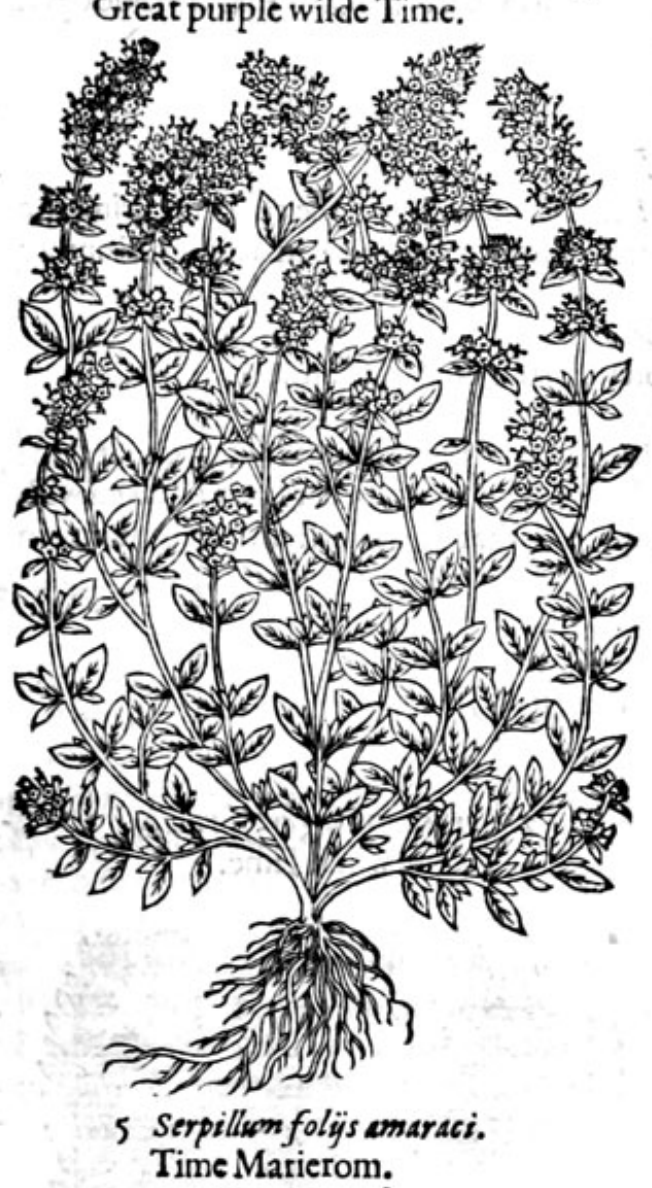

4 Serpillum mains fore albo. Great white wilde Time.
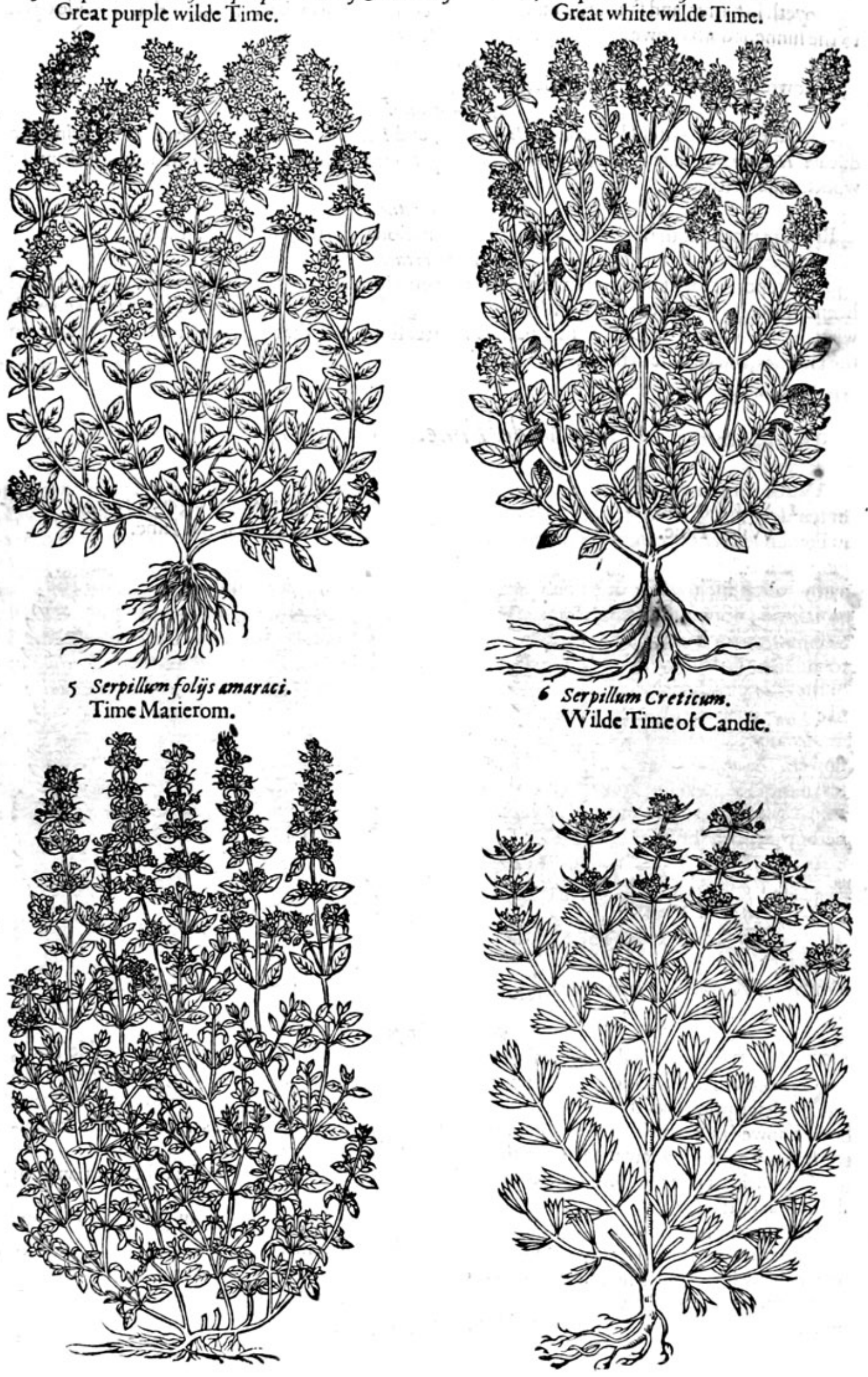
* The defription.

3 This great wilde Time creepeth not as the others do, but ftandeth vpright, and bringeth forth little flender branches full of leaues like thofe of Rue; yet narrower, longer, and harder. The flowcrs be of a purple colour, and of 2 twinging biting tafte : it groweth vpon rocks, and is hotrer than any of the others

4 This other great one with white flowers differeth not from the precedent, hauing many knaps or heads, of a milke white colour, which fetteth foorth the difference.

5 This wilde Time creepeth vpon the ground, fet with many leaues by couples like thofe of Marierom, but leffer, of the fame fmell : the flowers are of a reddifh colour. The roote is very threddie.

6 Wilde Time of $\mathrm{C}_{2}$ ndie is like vnto the other wilde Times, fauing that his leaues are narrower and longer. The fmell is more aromaticall than any of the others, wherein is the difference.

There is a kinde of wilde Time growing vpon the mountaines of Italie called Serpillum Citratum, that is, hauing the fmell of 2 Pome Citron, or 2 Limon, which giueth it the difference from the other wilde Times.

a $*$ The piace.

The firt groweth vpon barren hils, and vntoiled foiles, the fecond groweth in gardens. The white kinde I found at Southfleete in Kent, in a barren field belonging to one Mafter William Sram.

They flower from May to the end of fommer. $*$ I he time.

* The nomes.

Wilde Time is called in Latine serpillum, à ferpendo, of creeping: in high and lowe Dutch Quten.

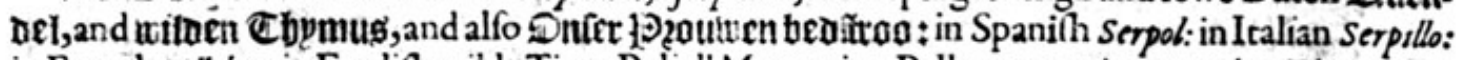
in French Pillolet : in Englifh wilde Time, Puliall Mountaine, Pclla mountzine, running Time, creeping Time, Mother of Time, and our Ladies Bedftrawe. Yet there is another herbe hauing the fame name, called alfo Galliwm: it is doubtles Serpillum voterum : of fome Apothecarics named Fulegium montanum; notwithftanding it anfwereth not fo well to the wilde Times, as to Diofcorides his Saxifrasga : for if it be diligently compared with the defcription of Time and Saxifrangt, it fhall be found to be little like the wilde Times, but very mutch like to Saxifranga, being none of the hindes of the olde phifitions wilde Time, but Saxifranga Diofcoridis: for faith he, Saxufranga is an herbe like Time, growing on rocks where our common wilde Time is oftentimes found.

Aelianis in his ninth booke of his fundrie hiftories, feemeth to number wilde Time among the flowers. Dionyfus Iunior, faith he, comming into the citie Locris in Italie, poffeffed moft of the houfes of the citie, and did ftrewe them with rofes, wilde Time, and other fuch kindes of flowers. Yet $V$ ir gil in the fecond Eglog of his Bucolicks, doth moft manifeftly teftifie, that wilde Iime is an herbe, and not a fhrubbie plant, in thefe wordes,

$$
\begin{aligned}
& \text { The Stylis of rapido fefis me ßoribus aftu } \\
& \text { Alloa, ferpillumgue, ber bas contundit olentes. } \\
& \text { Theftylis, to eafe men wearied with parching heate; } \\
& \text { Garlick, wild Time and holfome herbes protides to eate. }
\end{aligned}
$$

Out of which place it may be gathered, that common wilde Time is the true and right Serpillwers or wilde Time, which the Grecians call ipmuM. Marcellews an olde ancient author among the French men, faith it is called Gilarwes, as P liniwu Valerianus faith it is called of the fame Lawrio. * 7 be temperature.

Wilde Time is of temperature hot and dric in the third degree: it is of thinne and fubtill partes, cutting, and much biting.

$*$ It bringeth downe the defired ficknes,
prouoketh vrine, applied in bathes and fomentations it A procureth fweate: being boiled in wine, it belpeth the ague, it eafeth the ftrangurie, it faieth the hicket, it breaketh the ftones in the bladder, it helpeth the Lythargie, frenfie, andmadnes, and ftai-
eth the vomiting of blood.

Wilde Time boiled in wine and drunke, is good againft the wambling and gripings of the bellie, B ruptures, conuulfions, and in flammations of the liuer.

It helpeth againft the bitings of any venemous beaft, either taken in drinke, or outwardly ap. C
plied. 


\section{$45^{8}$ THE SECOND BOOKE OF THE}

D SEtius writeth, that Serpillum infufed well in vineger, and then fodden and mingled with rofe water, is a right fingular remedie to cure them that hauc had a long phrenfie or lythargie.

E Galen prefcribeth one dram of the iuice to be giuen in vineger againft the vomiting of bloud, and helpeth fuch as are greeued with the fpleene.

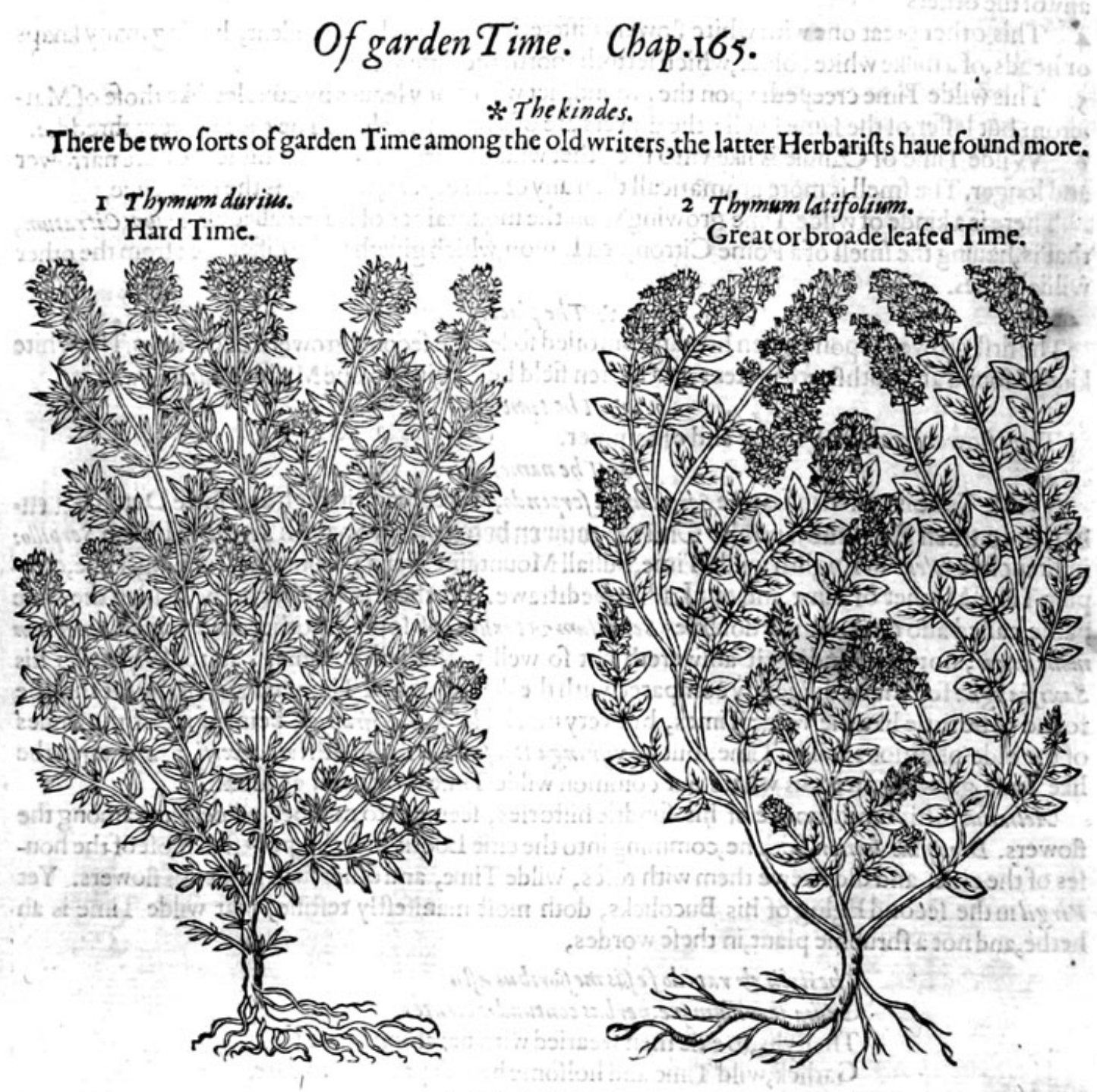

* The defcription.

I Hefirft kinde of Time is fo well knowen, that it needeth no defcription, bicaufe there is not any which are ignorant what $T$ hymum durius is, I meane our common Garden Time.

2 The feconde kinde of Time with broade leaues, hath many wooddie braunches rifing from a threddie roote, befet with leaues like Myrt us. The flowers are fet in rundels about the ftalke like Horehounde. The whole plant is like the common Time in tafte and fmell.

3 Time of Candie is in all refpects like vnto common Time, but differeth in that, that this kinde hath certaine knoppie tufts like vnto the fmall eares of $\mathrm{Phalaris}$, and not much vnlike the fpikes or knops of stacades, but much leffer, befet with flender flowers of a purple colour. The whole plant is of a more pontick and gratious fmell then any of the Times, and of another kinde of tafte, as it were
fauoring like fpice. The roote is brittle, and of a woodie fubftance.

4 D rubtleffe that kinde of Time whereon Epithymum doth growe, (and is called for that caufe Epithymum, and vifed in (hoppes,) is nothing elfe then Dodder that groweth vppon Time; and is all one with ours, though Mat hiolus makes a controuerfie \& difference therof: for Penatra-

uelling ouer the hils in Narbone neere the fea, hath feene not onely the garden Time, but the wilde 
Time likevife, loden and garnifhed with this Epithymom. So that by his fight and mine owne know. ledge, I am affured that it is not another kinde of Time that beareth Epithymam, but is common Time: for I haue often founde the fame in Englande, not onely vpon our Time, but vpon Sauorie, and other herbes alfo: notwithitanding, thus much I may coniecture, that the clymate of thofe countries doth yeelde the fame foorth in greater abundance then ours, by reafon of the intemperance of colde, whereunto our countrey is fubiet.

3. Thymem Creticum. Time of Candie.

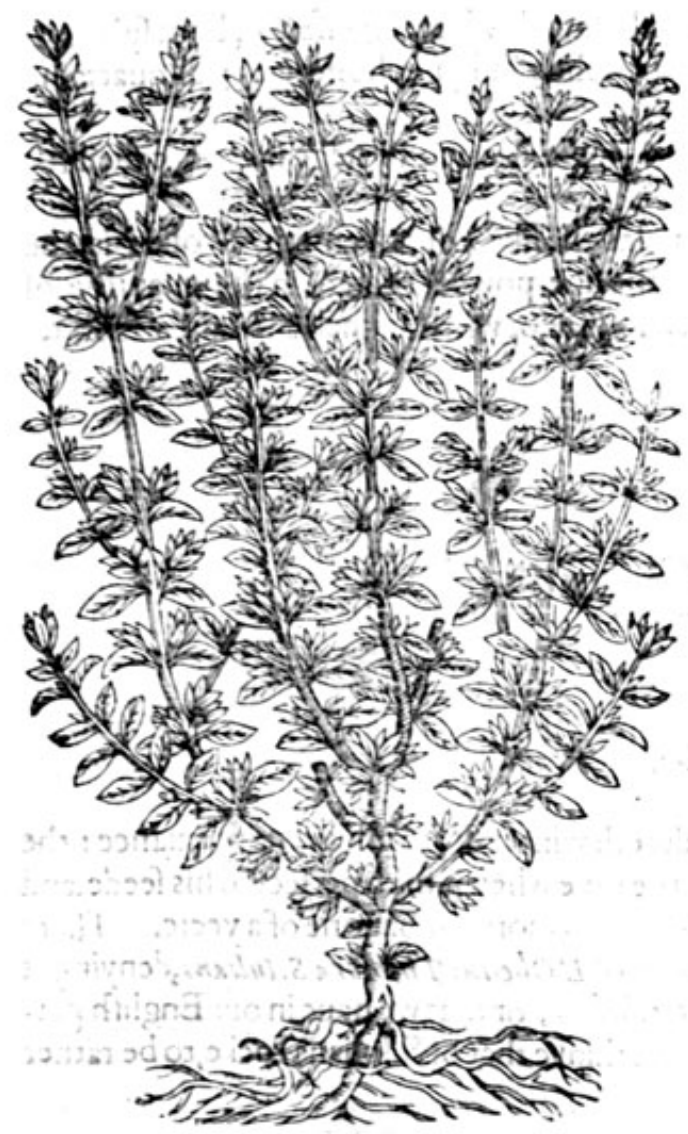

4 Epithymum Gracorum.
Laced'Time.

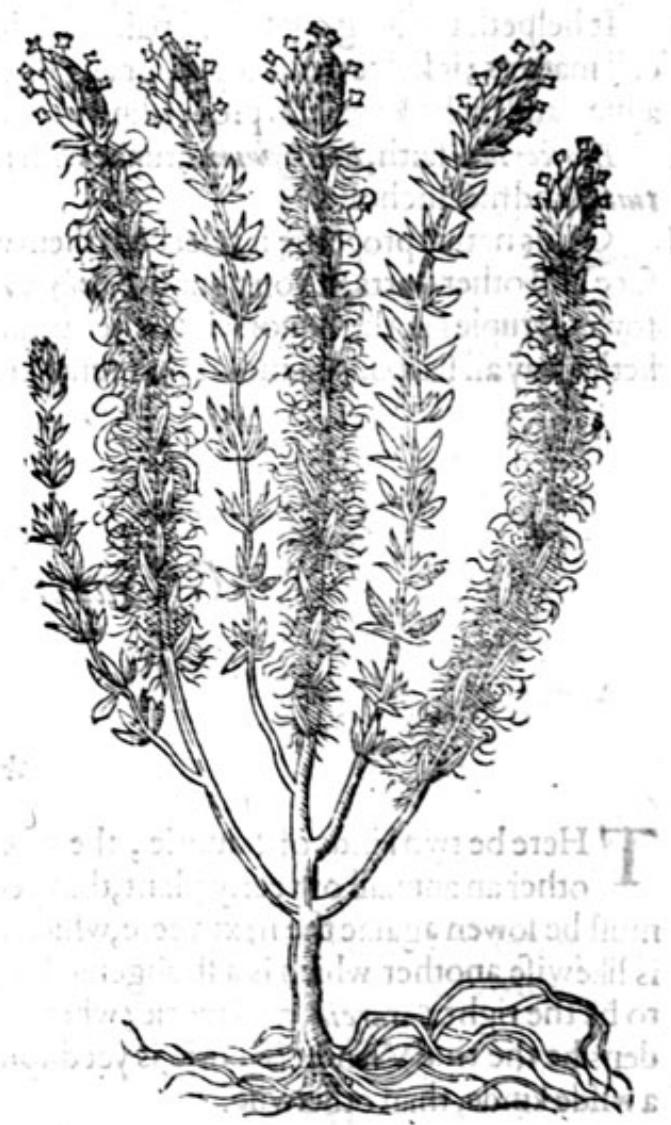

* The place.

Thefe kindes of Time growe plentifully in England euery where, except that with broad leaues; and $T$ ime of $C$ andic, which $I$ hauc in my garden.

They flourifh from Maie vnto September.

* The time.

* The names.

unstionriog $\quad \cdots$

The firft may be called harde Time, or common garden Time: the feconde broadeleafed Time: the thirde Time of $C_{2 n}$ dic; our Englilh women callit Muske Time: the laft may be called Dodder Timc. Time

$$
\text { Thith }
$$

Thefe kindes of Time are hot and drie in the thirde degree.

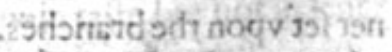

Jume boiled in watet and hionic and drunken, is good againft the cough and hortnefle of the $\mathbf{A}$ breath;it prouoketh vine, expelleth the fecondine or a fterbirth, and the dead childe; and diffolueth clotted orcongealed bloud in the bodic.

The Eme drunke with vineger end falt, purgeth tlegme: and boiled in Mezde or Metheglin, B clenfeth the bict, luings, reines, and matrix, and killeth wormes.

Made into powder and taken in the waight of three drams with Meade or honied vineget, called C 
Oximell, and a little falt, purgeth by ftoole tough and clammie flegme, fharpe cholericke htmours, and all corruption of blood.

D The fame taken in like fort, is good againft the Ifchiatica, the paine in the fide and breft, againft tbe winde in the fide and bellic, and is profitable alfo for fuch as are fearefull, melancholike, and
troubled in minde.

E It is good to be gituen vnto thofe that haue the falling fickneffe to fmell vnto.

F Epithymum, after $G$ alen, is of more effectuall operation in Phificke then Time, being hot \& dry in the third degree, more mightily clenfing, heating, drying, and opening then Cufcuta, hauing righe good effect to eradicatemelancholie, or any other humour in the fplecne, or other difeafe,firong by occafion of the fpleene.

G It helpeth the long continued paines of the head, and befides his fingular effeets about fpleneticall matters; it helpeth the lepry, or any difeafe of melancholie, or hypochondriaes; all quartaine agues, and fuch like griefes proceeding from the fpleene. H Diofcorides faith, Epithymum drunke with honied water, pulleth downe by fiege flegme, called $P$ i-
tuita, and inelancholie.

I Of his natiue propertie it relecueth then which be melancholike, or houen vp, fwollen in the face and other parts, if you pound Epithymuse and take the fine powder thereof in the quantitic of fower fcruples in the liquor which the apothecaries call Paffum, or with Oximell and falt, which taketh away all Aatuous humours and ventofities.

\section{Of Samorie. Chap.165.}

\section{* The kindes.}

$\mathrm{T}$ Here be two kinds of Sauorie, the one that endureth winter \& is of long continuance: the other an annuall or yeerly plant, that perifheth at the time when it hath perfected his feede, and muft be fowen againe the next yeere, which we call Sommer Sauorie, or Sauorie of a yeere. There is likewife another, which is a ftranger in England, called of L'Obeitus Thymbra S.Inliani, denying ic to be the right Saturein, or Sauorie; whether that of L'Obelisw, or that we haue in our Englinh gardens be the true Winter Sauorie, is yet difputable : for we thinke that of S. Iulians rocke, to be rather a wildekinde, than otherwife.

\section{$\therefore$ The defcription.}

I \ل Inter Sauorie is a plant refembling Hyffope, but lower, more tender, and brittle it bringeth foorth very many branches, compaffed on eterie fide with narrowe and harpe pointed leaues, longer than thofe of Time; among which growe the flowers, from the bottom to the top, out of fmall huskes, of co.our white, tending to a light purple. The roote is bard and wooddie, as is the reft of the plant.

2 Sommer Sauorie growetb yp with a flender brittle ftalke a foote high, diuided into little branches : the leaues are narrow, leffer than thofe of Hyfope, like the leaues of Winter Satiorie, but thinner fet vpon the branches. The flowers ftand hard to the branches, of a light purple tending to whitenes. The roote is f mall, full of ftrings, and peritheth when it hath perfected his feede. 3 This fmall kinde of Sauorie, which L'Obel hath fer foorth vnder the title Thymbra S.Imliani, bicaufeit groweth plentifully vpon the rough cliffes of the Tyrrhenian fea in Italie, called Saint Iulians rocke, it hath tender twiggie branches an handfull high, of a wooddie fubitance, fet full of leaues from the bottom to the top, very thicke thruft togither like vnto thofe of Time, fauing that they be finaller and narrower, bringing foorth at the top of the fprigs a round fpikie tuft, of finall purplith flowers. The whole plant is whitifh tending to 2 bleake colour, and of a hot and harpe taft-, and well fmelling. 


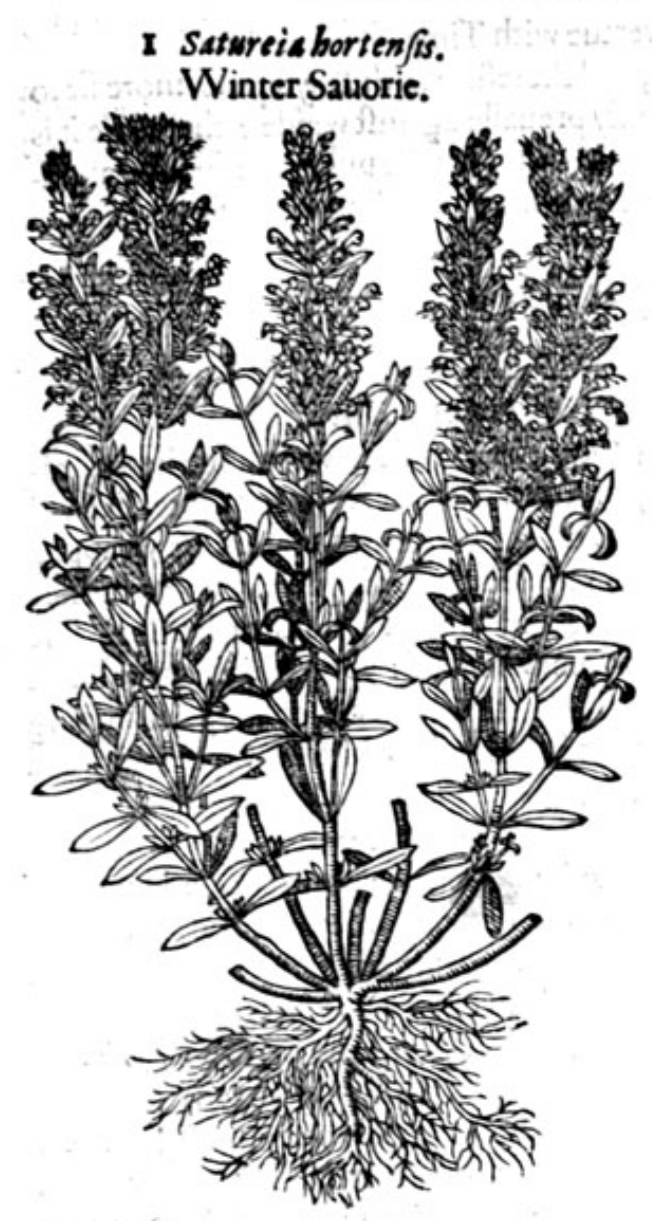

3 Satureia Sancti Iuliani. Rocke Sauorie.

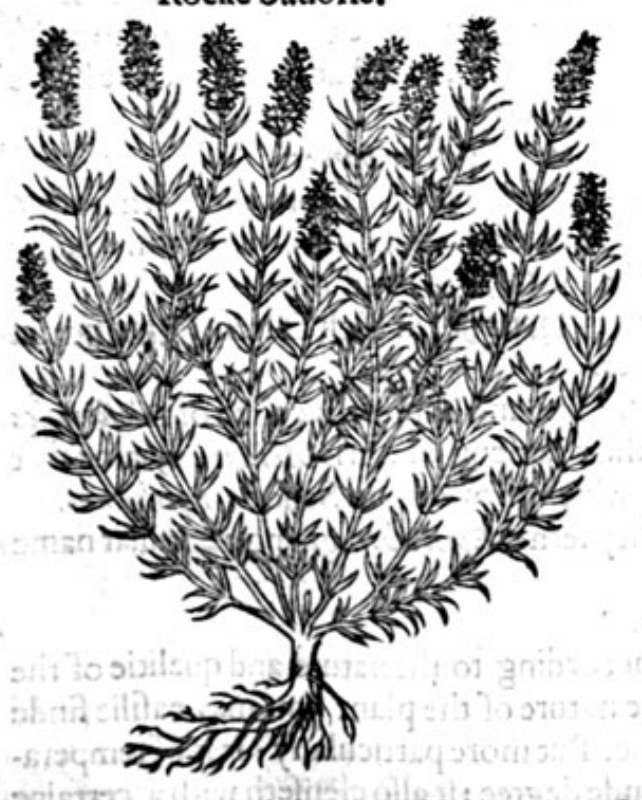

2 Saturcia bortenfs eltius. Sommer Sauoric.

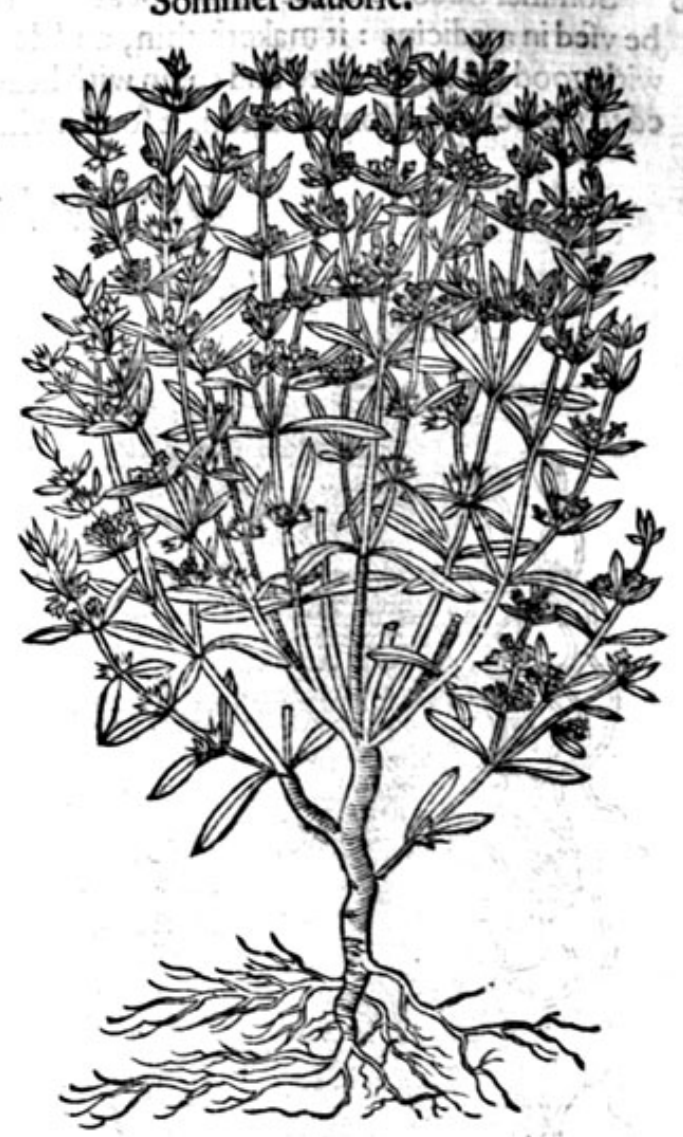

* The place.

They are fowen in gardens, and bring foorth their flowers the firft yeere of their fowing. * The time.

They flower in Iuly and Auguft. $*$ The nomes.

Sauoric is called in Greek ripsez, neither hath it any other true name in Latine than Thymbrs. The interpreters would haue it called Satureia, wherin they are repugnant to Colsmella a Latine writer, who doth thew 2 manifelt difference betweene $T$ bymbra and Satwreia, in his tenth book where he writeth, that Sauorie hath the tafte of Time, and of $T$ bymbra, or Winter Sauorie.

Et Satureia Thymi referens Thymbreg.japor em.

Sauorie is like Thyme in tafte, but not in ient:

So winter Sauorie from it is different.

Notwithitanding the contradietion of Columella, or whofoeuer, our Winter Sauoric may be that Thymbra,called alfo Cunila : in high Dutch litunet Satturep, and Sadantey: in lowe Dutch Cetilen: which name, as it feemeth, is drawen out of Cumila :in Italian Saworeggia : in Spanifh Axedrea, and Sagorids; in French Sarriette: in Englifh Sauorie, Winter Sauorie, and Sommer Sauorie:

bas: vlam * Thetemperatione and vertwes.

Winter Sauoric is of temperature hor and dicie in the third degree, it maketh thinne, curtech; it A $c^{2 t}$ clenfeth 


\section{2 THE SECOND BOOKE OF THE}

clenfeth the paffages, to be briefe, it is altogither of like vertue with Time.

B Sommer Sauoric is not full fo hot as Winter Sauorie, and therefore faith Diofrorides, more fit to be vfed in medicine : it maketh thin, and doth maruelloufly preuaile againft winde : therefore it is with good fucceffe boiled and eaten with beanes, peafon, and other windie pulfes, yea if it be applied to the belly in a fomentation, it foorthwith helpeth the mother proceeding of winde.

\section{Of Dodder. Chap.166.}

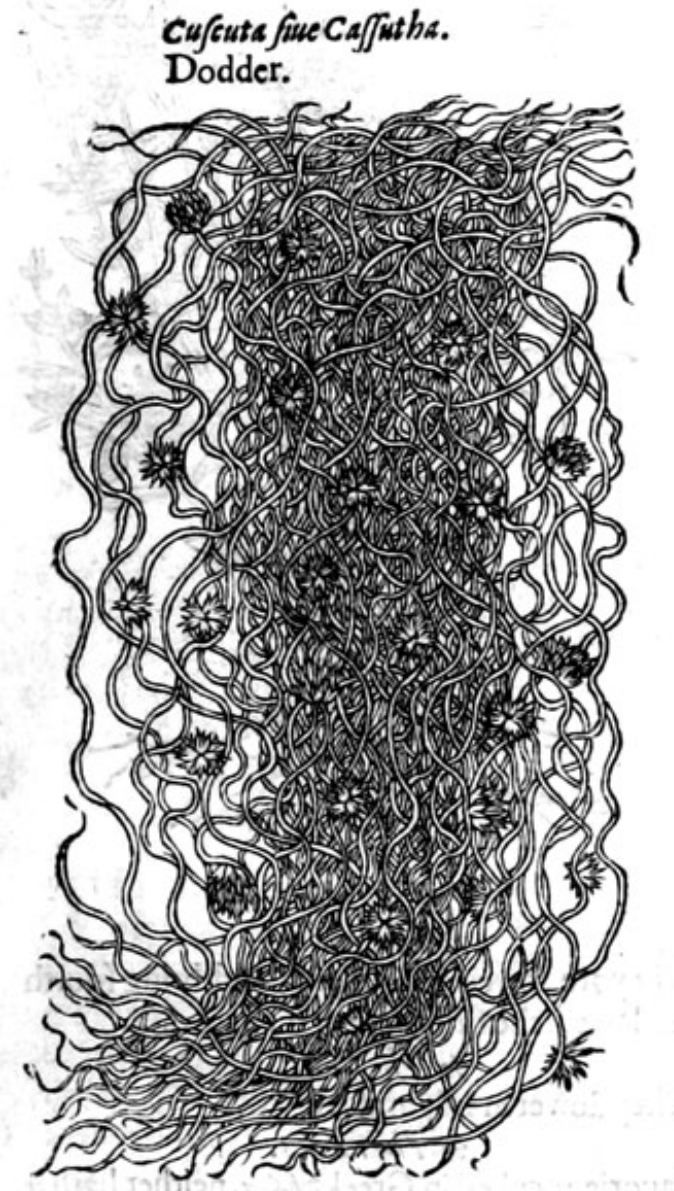

* The defcription.

C V cuta, or Dodder, is a ftrange herbe, altogither without leaues or roote, like vnto threds very much fnarled or wrapped togither, confufedly winding it felfe about bufhes and hedges, and fundrie kindes of herbes. The threds arefomewhat red: vpon which grow heere and there little rounde heads or knops, bringing foorth at the firft llender white flowers, afterward a fmall feed.

$$
\text { * The place. }
$$

This herbe groweth vpon fundrie kindes of herbes, as vpon Time, Winter Sauorie, Germander, and fuch like, taking his name from the herbe whereupon it doth growe, as that vpon Time is called Epithymum, vpon Line or flaxe Epilinum, and fo of others, as Dodonews fetteth foorth at large: yet hath he forgotten one among the reft, which groweth very plentifully in Sommerfetfhire vpon nettles:neither is it the leaft among manie, either in beautic or operation, but comparable to the beft Epithymum : following therefore the example of Diofcorides, I haue thought good to call it Epiurtica, and fo of the reft according to the herbe whereon they do growe.

\section{* The numes.}

The greateft is called in fhops euery where Cufcuta: and of diuers bicaufe it groweth vpon flaxe or

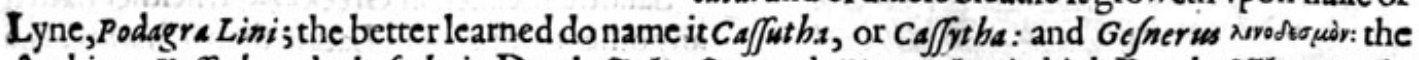
Arabians Keffuth, and Chafuth: in Dutch chofte, and watzangbe : in high Dutch follktaut : in French Goute d' Lin, and Tigne de Lin : in Englifh Dodder.

That lefler and flenderer which wrappeth it felfe vpon Time and Sauorie, is called of Diogcorides ansurv, the apothecaries keepe the name Epithymum: others, among whom is ACtwarisus, name that Epithymom which groweth vpon Time onely, and that which groweth on Sauorie Epithymbrum, and that alfo which hangeth vpon Staba, or Scabious, they terme Epistaben, giuing a peculiar name to euery kinde.

\section{\& The nature.}

The nature of this herbe changeth and altereth, according to the nature and qualitie of the herbes wherupon it groweth: fo that by fearching of the nature of the plant you may eafilie finde out the temperament of the laces growing vpon the fame. But more particularly: it is of temperature fomewhat more drie then hot, and that in the feconde degree : it alfo clenfeth with a certaine aftrictiue or binding qualitie, and efpecially that which is founde growing vpon the bramble: for it alfo receitieth 2 certaine nature from his parents on which it groweth; for when it groweth vpon the hotter herbes, as Time and Sauoric, it becommeth hotter and drier, and of thinner parts: that which commeth of Brome protoketh vrine more forcibly, and maketh the bellie more foluble : and that is moifter which groweth vpon tlaxe : that which is founde vpon the bramble hathioined with 
it as we haue faide a binding qualitic, which alfo by reafon of this facultie iogned by good right cure other infirmities of the liuer and milt : for feeing that it hath both a purging and binding $f_{2}$ : cultie vnited toit, it is molt fingular good for the entrals: for Gaien in his 13 : booke of the imethode of curing, doth ac large declare that fich medicines are fitteft of all for the liver and inile.

\section{* The vertwes.}

$\therefore$

This kinde of Dodder remooueth the ftoppings of the liucr and of the milt or ffleene, dit çisbur- $\grave{A}$ deneth the veines of flegmatike, cholericke, corrupt and fuperflyous humouirs: prouoketh vrine, gently, and in a meane openeth the kidneies, cureth the yellower raundife whicfrare iớned with the itopping of the liter and galli it is a remedie againft lingring agues, corrupt and long tertians, quartains alfo, andproperly agues in infants and yoong children, as Mejues faith in Serapio: who alfo teacheth, that the nature of Dodder is to purge choler by the ftoole, and that more effectually if it haue Wormewoode ioined with it ; but too much vfing of it, is hurtfull to the ftomacke: yet Asicen writeth that it doth not hurt it, but ftrengtheneth a iveake or feeble ftomacke; which opinion alfo wedo better allowe of.

Epithymem, or the Dodder which groweth vpon Time, is hotter and drier then the Dodder that B groweth vpon flaxe, that is to faie, euen in the thirde degree, as Galen faith. Ichelpeth all the infirmities of the milte: it is a remedie againft obftruetions and hard wennie fivellings: it taketh awaie olde head aches, the falling fickneffe, madneffe that commeth of melancholie, and efpecially that which proceedeth from thefpleene and parts thereabout : it is good for thofe that haue the French difeafe, and fuch as be troubled with contagious vicers, the leprofie, and the fcabbie euill.

Itpurgeth downwards blacke and melancholicke humours, as Aetinus, Netuarizus, and Mefwes C write; and alfo flegme as Diofcorides noteth : that likewife purgeth by ftoole which groweth vpon Sauorie and Scabious, but more weakely, as AZtuaritus faith.

Cafcuta, or Dodder that groweth vpon flaxe, boiled in water or wine and drunk, openeth the ftop- D pings of the liver, the bladder, the gall, the milt, the kidneies and veines, and purgeth both by fiege and vrine cholericke humours.

It is good againft the ague which hath continued a long time, and againft the iaundife, Imeane $\mathrm{E}$ that Dodder efpecially that groweth vpon brambles.

Epiurtica or Dodder growing vpon nettles, is a moft fingular and effectual medicine to prouoke F vrine,and to loofe the obftruetions of the body, and is prooued oftentimes in the weft parts to haue good fucceffe againft many maladies.

\section{Of Hy/Jope. Chap.167.}

* The kindes.

Here be diuers fortes of Hyffope, fome greater, others leffer, fome with whice flowers, others
of a purplifhblew colour, as fhall be declared in this prefent chapter. * The dejcription.

1 Joferrides that gaue fo many rules for the knowledge of fimples, hath left Hyffope altogither without defcription, as being a plant fo well knowen, that itneeded none: whofe example I follow not onely in this plant, but inimany others which becominon, to auoide tedioufnes to the reader.

2 The fecond kinde of Hyffope is like the former, which is our common Hyffope, and differeth in that, that this Hyflope hath his fmall and flender branches decked with faire red tlowers. 
I HyCopses Lirabum.

Hyllope with blew flowers.
$2 \mathrm{Hy}$ Jopus Labuon flore rubro. Hyflope with reddifh flowers.

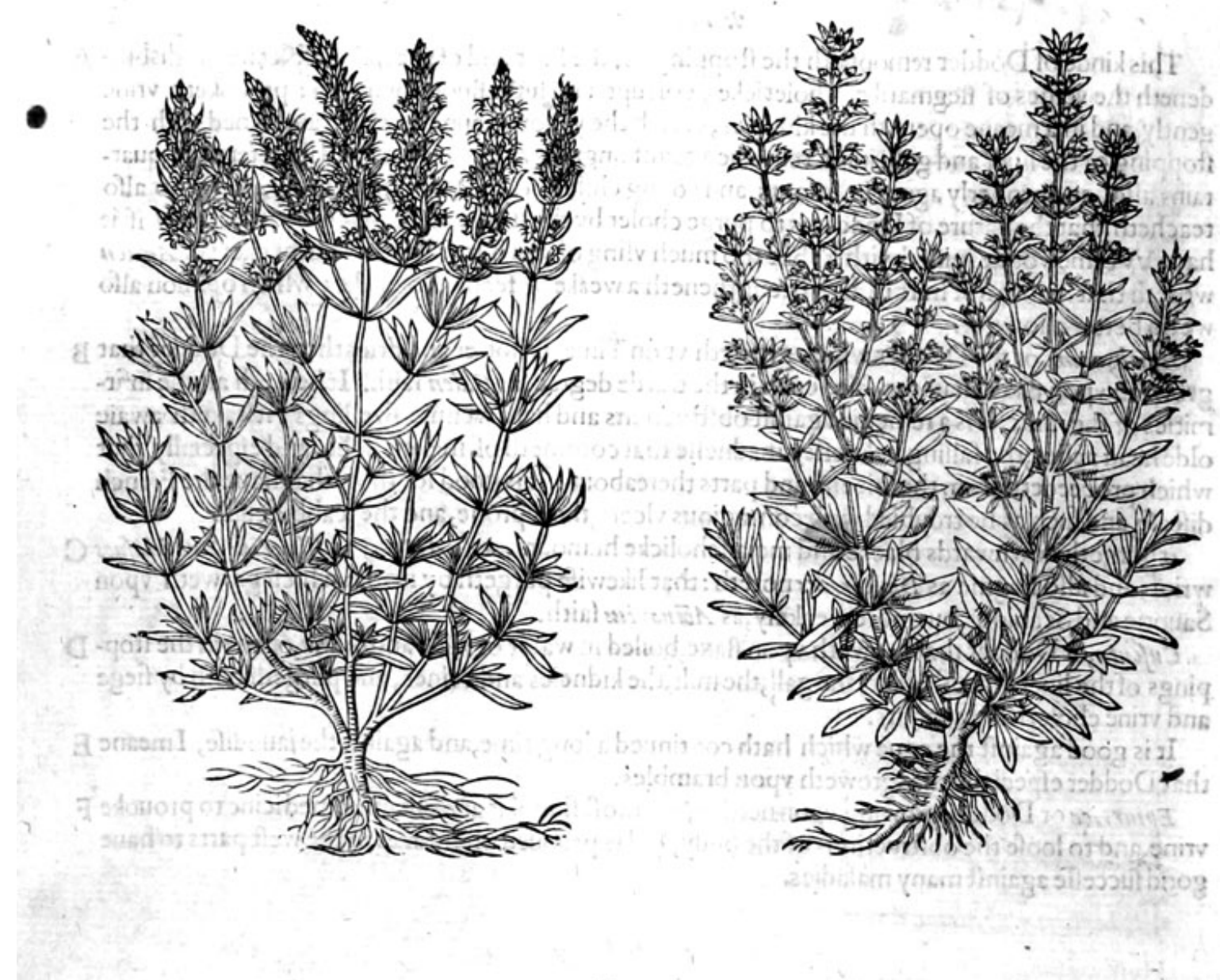

* The defcription.

3 The third kinde of Hyffope hath leaues, ftalkes, branches, feede, and roote, like the common Hyffope, and differeth in the flowers onely, which are as white as fnowe.

4 This kinde of Hyffope of all the reft is of the greateft beautie; it hath a wooddie roote, tough, and full of ftrings; from which rife vp fmall, tough, and flender flexible ftalkes, whereupon do grow infinite numbers of fmall Fenell-like leaues, much refembling thofe of the finalleft grafle; of a pleafant fweet fmell, and aromaticke tafte, like vnto the reft of the Hyffopes, but much fweeter : at the top of the ftalkes do growe among the leaues fmall hollow flowers, of a blewifh colour tending to purple. The feedes as yet I could neuer obferue.

We haue in England in our gardens another kind, whofe picture it thall be needleffe to expreffe, confidering that in few words it may be delinered. It is like vnto the former, but the leaues are forne of them white, fome greenc, as the other;and fome greene and white, mixed and potted, very good-
ly to beholde.

Of which kinde we haue in our gardens moreouer another fort, whofe leaues are woonderfully curled, rough, and hairie, growing thicke thruft togither, making as it were a tuft of leaues; in tafte and fmell, and in all other things like vnto the common Hyffope.

I haue likewife in my garden another fort of Hyffope, growing to the forme of a fmall wooddie Nhrub, hauing very faire broad leaues like vnto thofe of 2 (umula ria, or Money woort, but thicker, fuller of iuice, and of a darker greene colour; in tafte and fmell like the common Hyffope. 


\section{HISTORIE OF PLANTS.}

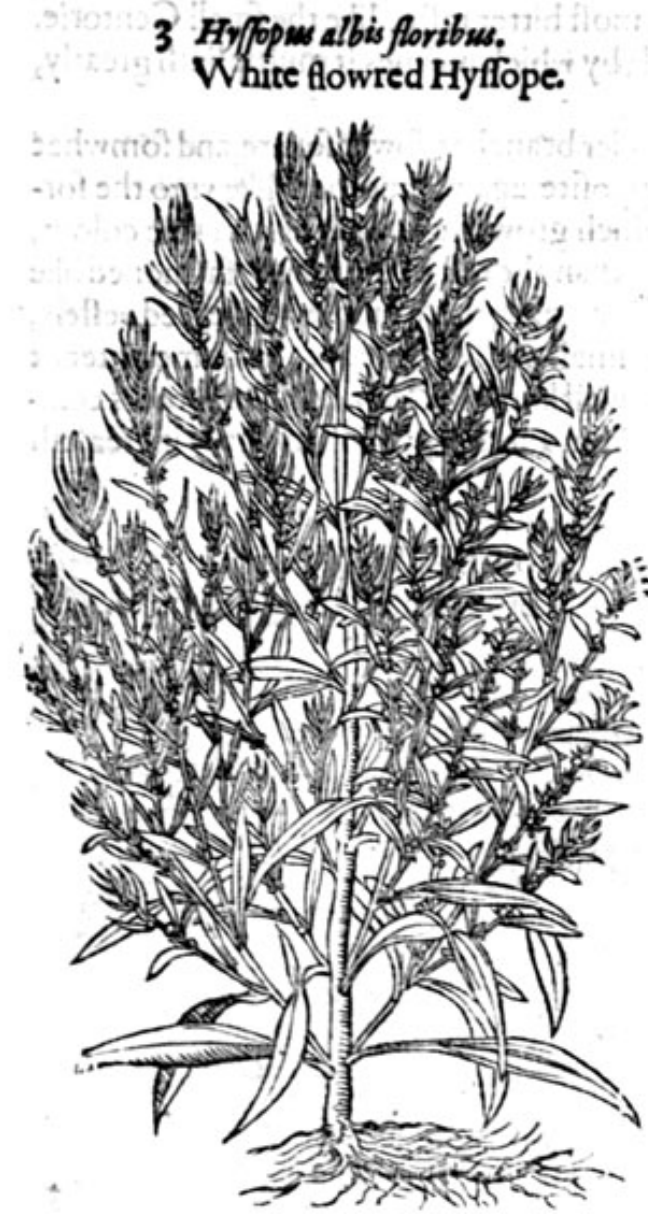

4 Hy) Sopmistenuifolic. Thinleafed Hyffope.

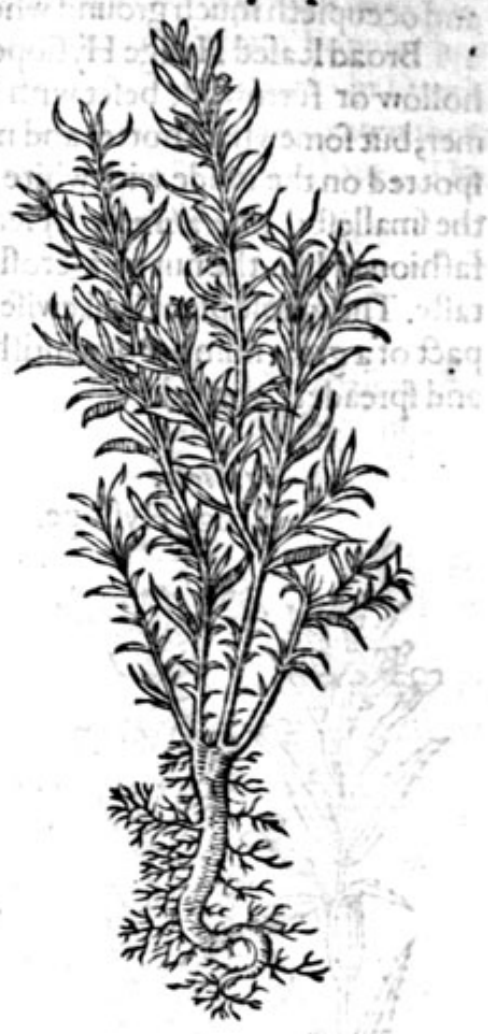

* The plase.

All thefe kindes of Hyffope do growe in my garden, and in fome others alfo.

They flower from Iune, to the end of Augutt.

$$
\text { * The time. }
$$

* The names.

Hyffope is called in Latine Hy/fopus: the which name is likewife retained among the Germans; Brabanders, French men,Italians, and Spaniards. Thetefore that thall fuffice, which hath beene fet downe in their feuerall titles.

\section{* The temperature and vertwes.}

A decoction of Hyflope made with figs, and gargled in the mouth and throte, ripeneth and brea- $\mathbf{A}$ keth the tumors and impoltymes of the mouth and throte, and eafeth the difficultie of fivallowing,
comming by cold rheumes.

The fame made with figs, water, honie, and rue, and drunken, helpeth the inflammation of the $B$ lungs, the olde cough, and fhortnes of breath, and the obftructions or ftoppings of the breaft.

The firupe or iuice of Hyffope taken with the firupe of vineger, purgeth by ftoole tough and C clammic tlegme, and drineth foorth woormes, if it be earen with figs. force.

The diftilled water drunke, is good for thole difeales before named, but not with that fpeede, and D

\section{Of Hedge HyJjope. Chap.168.}

T Edge Hyffope is a loweplant or herbe about a fpan long, very like vnto the common hyffope, with many fquare ftalkes or flender branches, befet with leaues fomwhat larger than Hyffope, but very like. The flowers growe betwixt the leaues vpon fhort ftems, of 2

$$
\text { Gg I white }
$$


white colour declining to blewnes. All the herbe is of a moft bitter tafte, like the fmall Centorie. The roote is little and threddie, dilating it felfe far abroad; by which meanes it multiplieth greatly, and occupieth much ground where it proweth.

2 Broad lcafed Hedge Hyffope hath many finall and tender branches, fower fquare, and fomwhat hollow or furrowed, befet with leaues by couples one oppofite againft another, like vnto the former, but fomewhat fhorter and much broader : among which grow the flowers of a purple colour, fpot ted on the infide with white, and of a brighter purple than the reft of the flower, farhioned like the fmalleft Antirrbinum, or leaft Snapdragon; which being paft, there fucceed litele feed veffels, fafhioned like the nut of a croffebowe, which conteine fmall yellowifh feede, extreme bitter of tafte. The whole plant is likewife bitter, as the common or well knowen Gratiola. The roote is compact of a great number of whitifh ftrings, intangled one within another, which mightily increafeth and fpreadech abroad.

1 Gratiola. Hedge Hyffope.

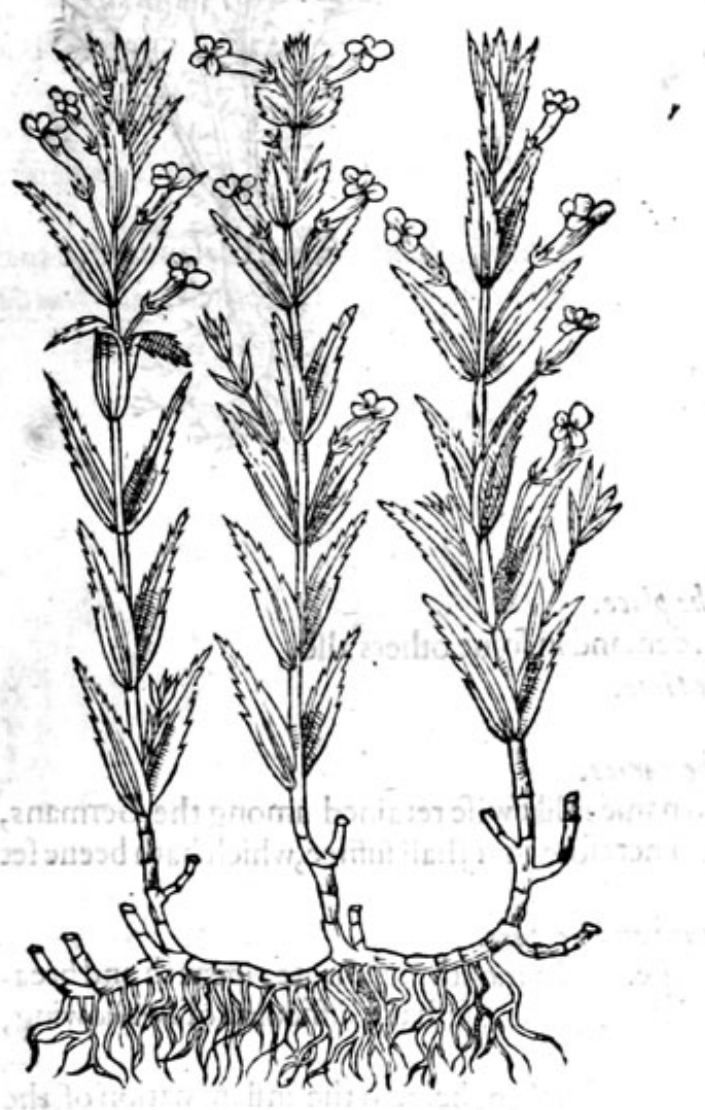

2 Gratiola latifolia. Broad leafed Hedge Hyffope.

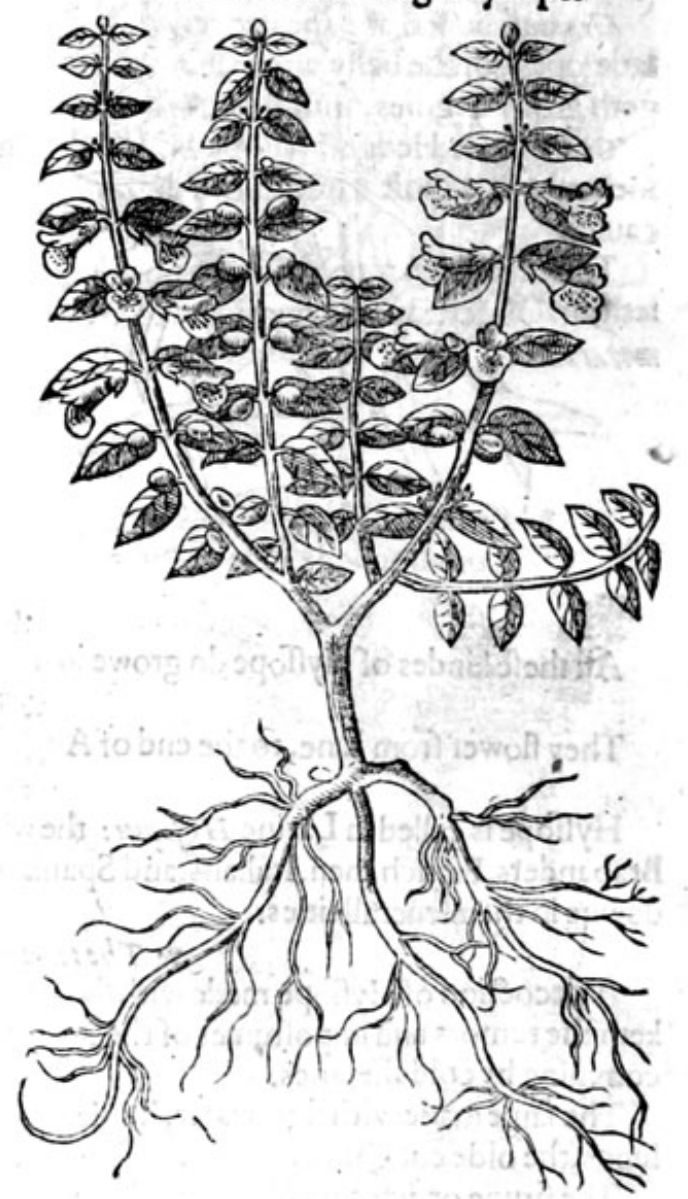

* The piace.

The firft groweth in lowe and moift places naturally, which I haue planted in my garden. The fecond groweth likewife in moift places. I found it growing vpon the bog or marrifh ground at the further end of Hampiteed heath, and vpon the fame heath towards London, neere vnto the head of the fprings that were digged for water to be conueied to London 1590 . attempted by that carefull citizen fir Iohn Hart Knight, Lord Maior of the Citie of London : at which time my felfe was in his Lordhips company, and viewing for my pleafure the fame goodly fprings, I found the faid plant, not heretofore remembied.

The firft flowreth in May, the fecond in Auguft.

* The time. 
$*$ The names.

Hedge Hyfiope is called in Latine Gratiola, and Gratia Dei, or the Grace of God; notwithftanding there is a kinde of Geranium, or Storkes bill, called by the fame name. Of Cordus Limnefium, and Centauris of Anguillara and Diofcorides, and allo Fapauer Jpumeum, or Spatling Poppic: bue there is another herbe comprehended vnder the fame name, which we call Behen album : in Dutch it is called Jonto gratie: in Italian Stanca canallo, bicaufe that horfes when they haue eaten therof,do waxe leane and languifh thereupon : and in Englifh Gratia Dei, and Hedge Hyffope. The feede hereof is calied Gibenech, which name the Arabians do retcine vnto this day.

Hedge Hiffope is hot and drie of temperature.

$$
\text { * The temperature. }
$$

Who fo taketh but one fcruple of Grat sola bruiled, thall perceiue enidently his effectuall opera- A tion \& vertue, in purging mightily, and that in great abundance, watrifh, groffe, \& flimie humors. Conradus Gefnerus experimented this, and found it to be true, and fo haue I my felfe and many others.

Gratiols boiled, and the decoction drunke or eaten with anykinde of meate, in manner of a fal- B lade, openeth the belly, and caufeth notable loofencs, and to fowre freely, and by that meanes purgeth grofle flegmes, and cholerike humors.

Gratiols, or Hedge Hyffope boiled in wine and giuen to drinke, helpeth feuers of what fort C foeuer, and is moft excellent in dropfies, and fuch like difeafes proceeding of colde and waterie caufes.

The extraction giuen with the powder of cinamom and a little of the iuice of $\mathrm{C}_{2}$ lamint, preuai D lethagainft tertian and quotidian feucrs, fet downe for molt certaine by the learned loachimm $\mathrm{Ca}_{\text {- }}$ meraritum.

\section{Of Lauander pike. Chap.169.}

1 Leseandalaftore cieruleo. Common Lauander fpike.

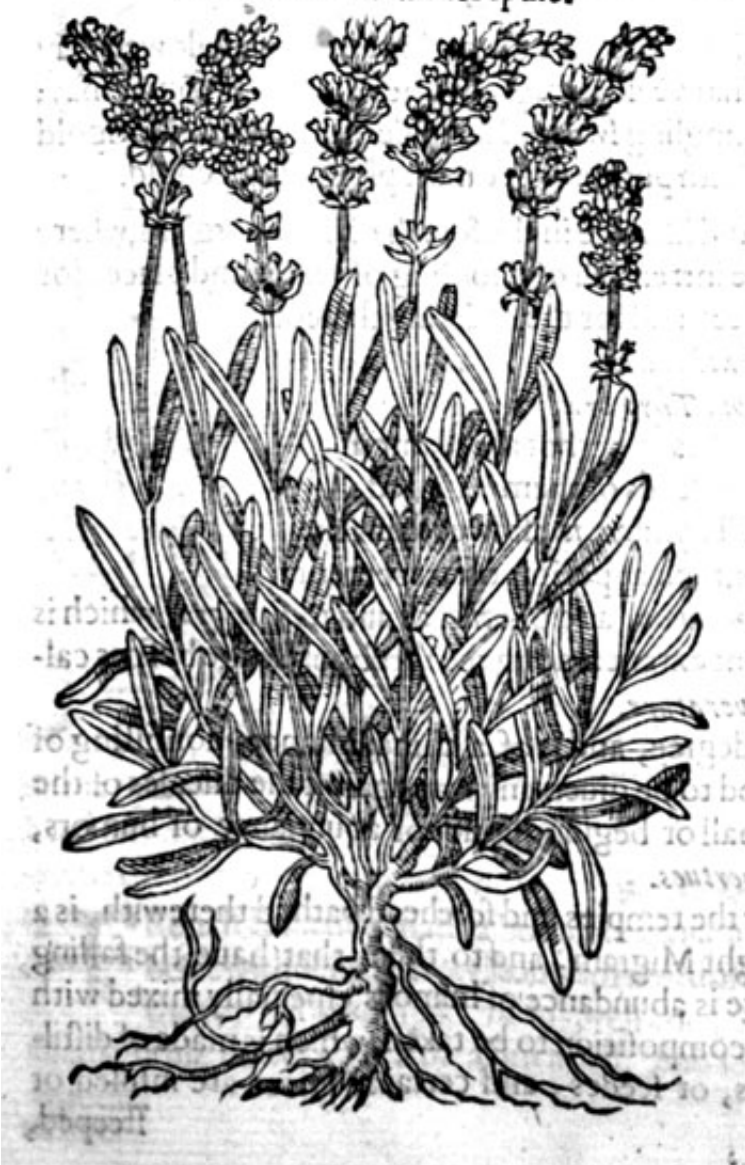

\section{Lassadula flore albo.}

White flowred Lauander fpike.

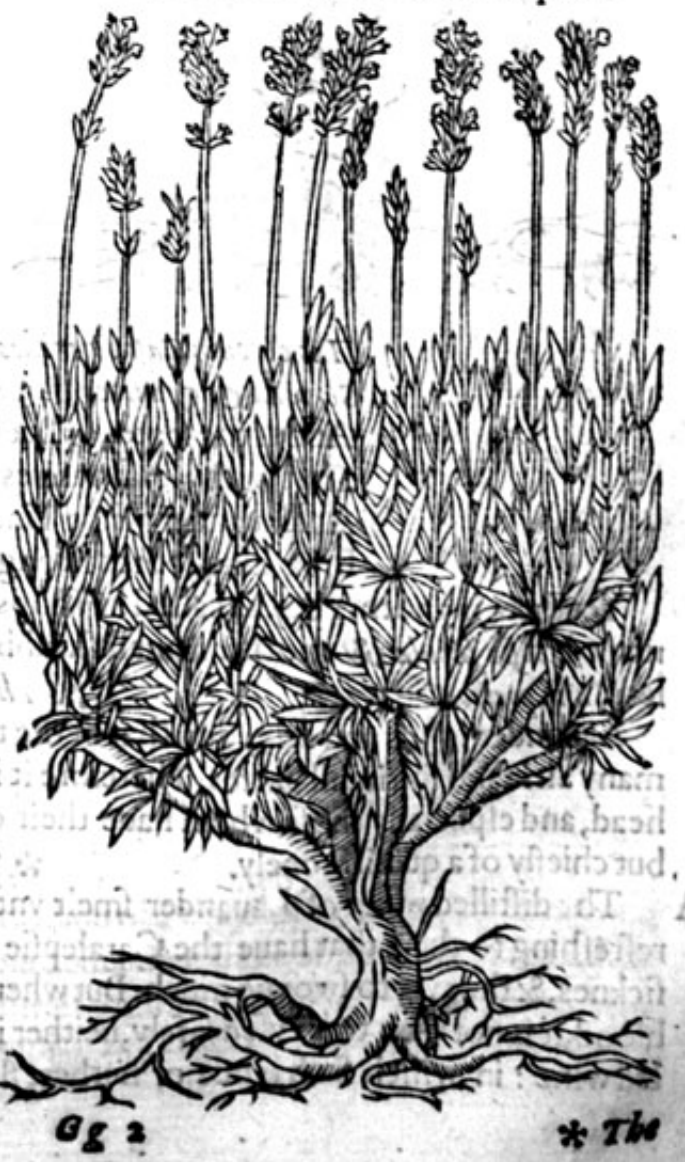


I Auander f pike hath many ftiffe branches of a wooddie fubltance, growing vp in manner of afhrub, fee with many long hoarie leaues, by couples for the moft part; of a ftrong finell,yet pleafant ynough to fuch as loue ftrong fauors. The flowers growe at the top of the bran. ches fpike ?afhion, of a blew colour. The roote is hard and wooddie.

2 The fecond differeth not from the precedent, but in the colour of the flowers ; for this plant bringeth milke white flowers;and the other blew, wherein efpecially confifteth the difference.

3 Lauandula bortenfis minima.

The Smalleft Lauander.

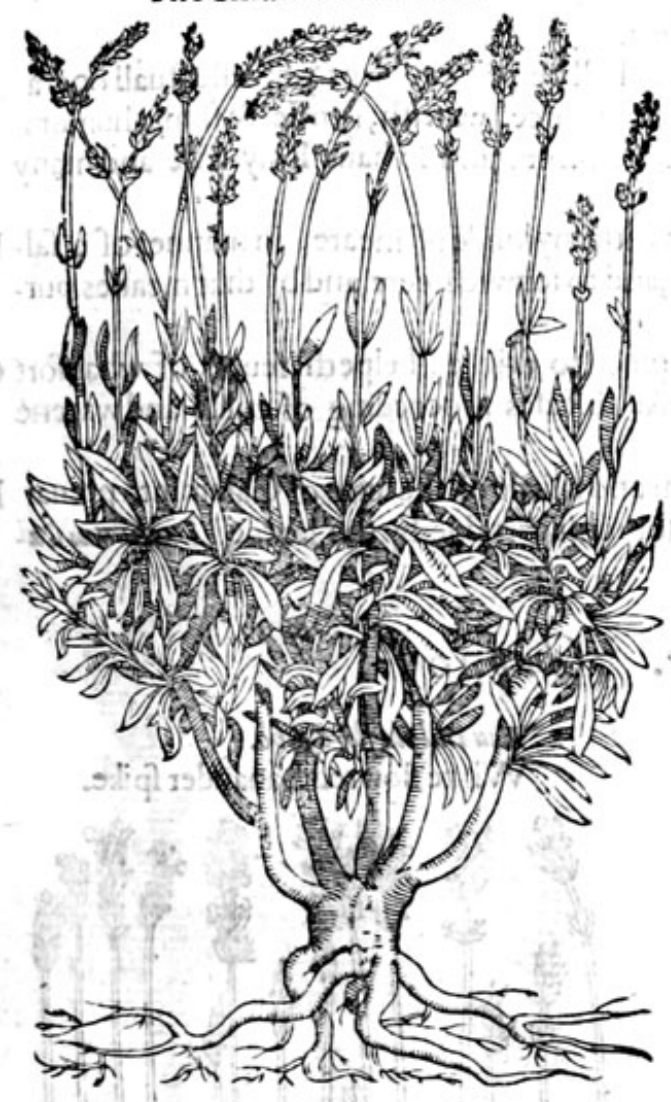

* Thedefeription.

3 We haue in our Englifh gardens a fmalkinde of Lauander, which is altogither leffer than any of the other of his kinde, wherein confifteth the difference. * Theplace.

In Spaine, and Languedocke in France, moft of the mountaines and defert fieldes, are as it were couered ouer with Lauander. In thefe cold countries theỹ are planted in gardens. * The time.

They flower and flourifh in Iune and Iuly. * The names.

Lauander fpike is called in Latine Lusandula, and Spica $\%$ in Spanifh Spigo, and Languds. The firt is the male, and the feconde the females It is thought of fome to be that fweete herbe Cafia, whereof $V$ irgil maketh mention in the feconde Eclog of his Bucolicks.

Tum Cafin a: que alÿs intexiens Juawibas ber bis, Mollia luseola pingit vacirria Caltba.?

The maidẽ faire hir garläd decks with flowers gay That yeeld a fragrant fmel as frefh as fōmer may; Mingling fwcete Lauander and yellow Marigold With purple violet, moft pleafant to behold.

And likewife in the fourth of his Georgicks, where he intreateth of chioofing of feates and places for Bees,and for the ordering thereof.

\section{Hec circum Cafie virides, ó olentia late}

Serpilla, o grauiter fpirantis copia Thymbra,

About the feates of Bees many braue berbes are planted

That with pleafant aires fill the places of them haunted,

As Lauander, wilde Tine and Thymber, moft fweete in fent

Breathing foorth ftrong fmels, their appetites oft to content.

Yet thete is another Cafat, called in fhops Cinamomum, arid Canella, as alfo Cafia nigra, which is named Cafia fistule; \& another a fmall Mhrubbie plant extant among the ihrubs or hedge bufhes called cafia poctica. * 7 be temperature.

Lauander is hot and drie, and that in the third degree, and is of a thin fubftance, confifting of many airie and fpirituall partes. Therefore it is good to be giuen any way againft the difeafes of the head, and efpecially thofe which hauc their originall or beginning not of abundance of humors, but chiefly of a qualitie onely. * The vertues.

A Th: diftilled water of Lauander fmelt vnto, or the temples and forehead bathed therewith, is a refrefhing to them that haue the Catalepfie, a light Migram, and to them that haue the falling ficknes, \& that vfe to fwoune much. But when there is abundance of humors, efpecially mixed with blood, it is not then to be vfed fafely, neither is the compofition to be taken, which is made of diftilled wine : in which fuch kinde of herbes, tlowers, or feedes, and certaine fpices are infufed or 


\section{HISTORIE OF PLANTS.HT}

fteeped, though moft men do rafhly and at aduenture giue them without making any difference at all. For by ving fuch hot things that fill and ftuffe the head, boththe difeafe is made greater, and the ficke man alfo brought into danger, efpecially when letting of blood, or purging hauenotgone before. This much by way of admonition, bicaufe etery where diuers rafh and onerbold Apothecaries, and other foolifh women, do by and by giue fuch compofitions, and others of the like kinde, not onely to thofe that haue the Apoplexie; but alfo to thofe that cannot fleepe, \& haue alfo an ague; to whom they can giue nothing worfe, feeing thofe things do very much hurt, and oftentimes bring death it felfe.

The flowers of Lauander picked from the knaps, I meane the blew part, and not the huske, mixed B with Cinamom, nutmegs, and cloues, made into fowder, and giuen to drinke in the diftilled water thereof, doth helpe the panting and paffion of the hart, preuaileth againft giddineffe, turning, or fwimming of the braine,and members fubiect to the palfie.

Conferue made of the flowers with fugar, profiteth much againft the difeafes aforefaid, if the $\mathbf{C}$ quantitie of a beane be taken thereof in the morning fafting.

It profiteth them much that have the palfie, if they be wafhed with the diftilled water of the $D$ flowers, or annointed with the oile made of the flowers and oile oliue, in fuch manner as oile of rofes is, which fball be expreffed in the treatife of Rofes.

\section{Of French Lauander, or Stickadoue. Chap.170.}

I Stachas fue jpica bortulina. Sticadoue and Sticados.

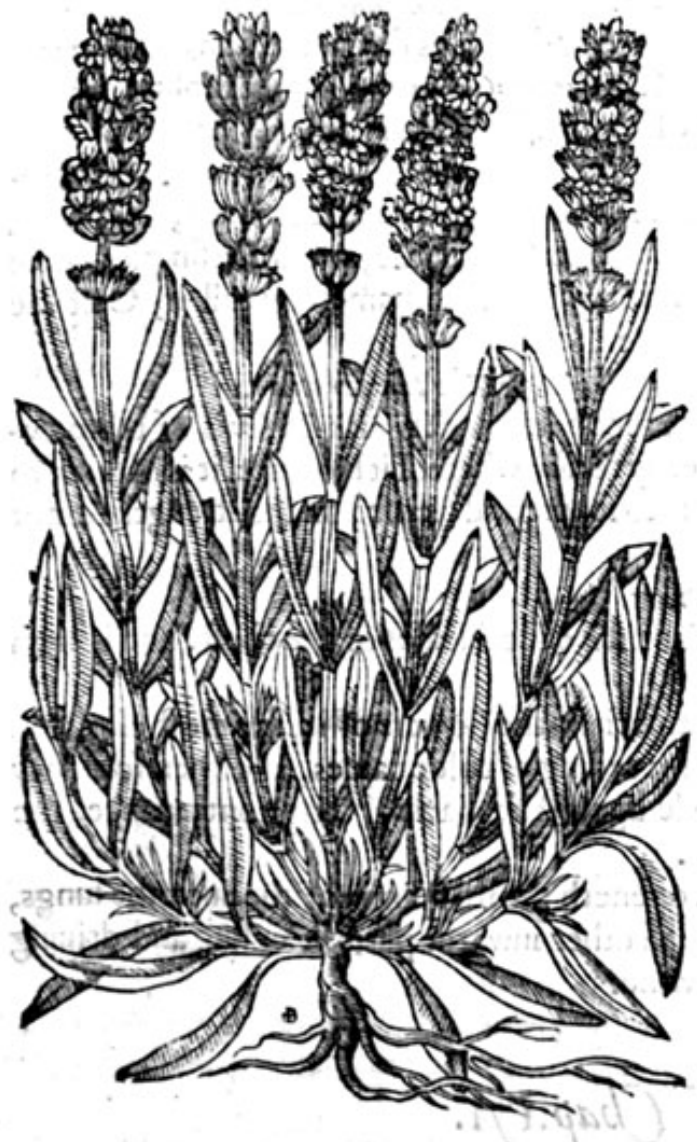

2 Staechas multifida. Iagged Sticados.

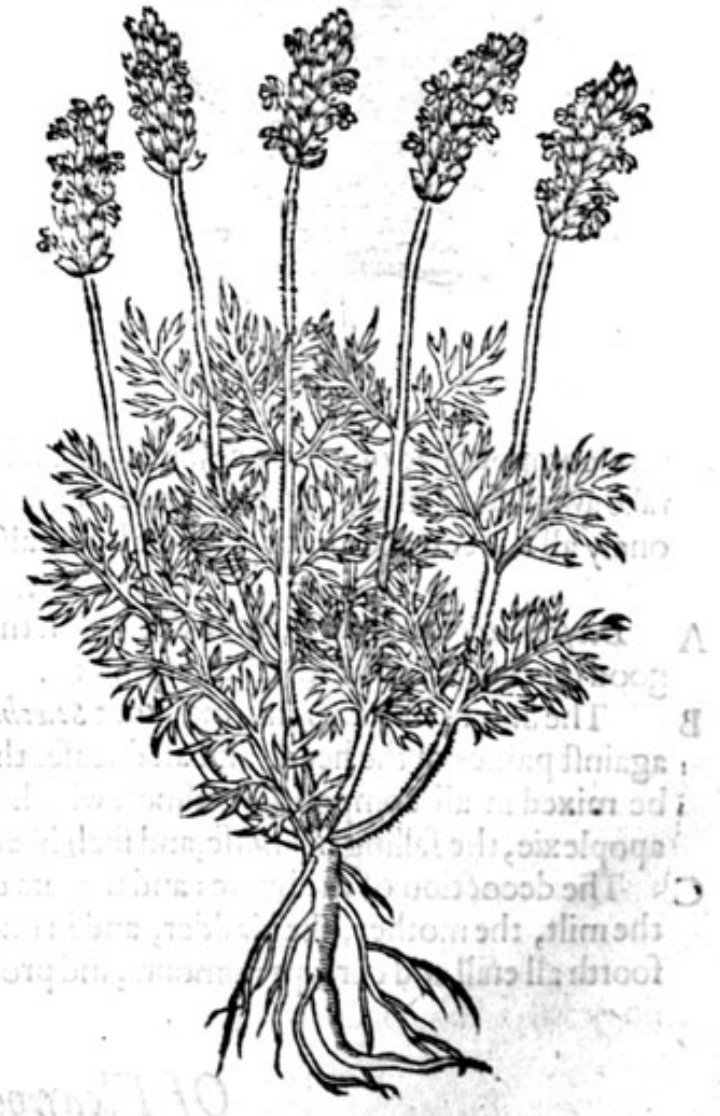

* The defcription.
Rench Lauander hath a body like Lauander, thort, 作, befet with long narrow leaues, of a whitifh colour, leffer then thofe of Lauander: it hath in the top bufhie or fikie heads, well compact or thruft togither;out of the which grow foorth Imall purple flowers, of a pleafant finell. The feede is fimall and blackifh : the roote is harde and woodie. 


\section{$47^{\circ}$ THE SECOND BOOKE OF THE}

2 This iagged Sticadoue hath many fmall ftife ftalkes of a woody fubftance; whercupon do grow iagged leaues in fhape like unto the leaues of Dill, but of an hoarie colour: on the top of the italks do growe fike flowers of a blewifh colour; and like vnto the common Launander fpike. The roote is likewife woodie.

\section{Stacbas folio Jerrato.} Toothed Sticadoue.

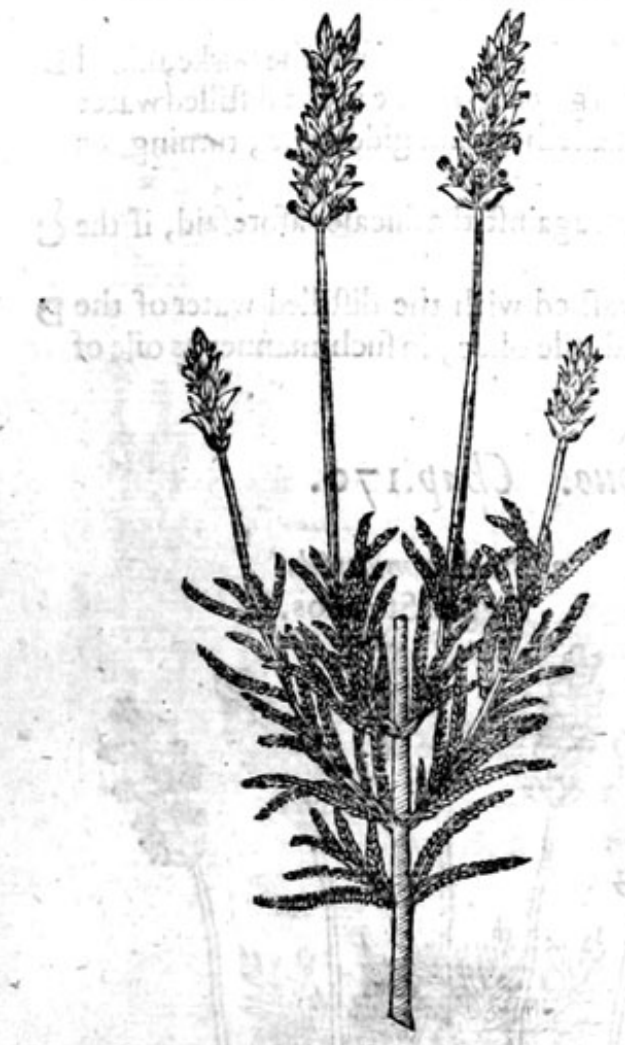

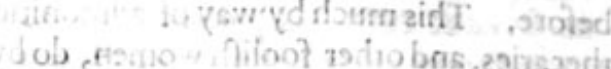

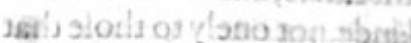
* The defoription.

3. There is alfo a certaine kinde heereof dife ring in fmalnefie of the leaties onely, which are rounde about the edges nicked or toothed like a fawe, refembling thofe of Lauander cotton. The roote is likewife woodie.

$$
\text { * The place. }
$$

The e herbs do grow wilde in Spaine, in Languedock in Fraunce, and the Ilandscalled Stœchades ouer againft Maffilia: we haue them in our gardens, and kept with great diligence, from the iniuric of our colde clymate.

$$
\text { * The time. }
$$

They are fowen of leede in the end of Aprill, and couered in the winter from the colde, or clfe fet in pots or tubs with earth, and caried into houfes.

* The names.

The apothecaries do cal the flower Staecado: Diofcorides rizas: Galen solzas, by the diphthong or in the firft fillable: in Latin Staechas: in High Dutch Sticbas ktatt: in Spanifh Tomani, and Cantweffo: in Englifh French Lauander, Steckado, Stickadoue, Caffidonie, and fome fimple people imitating the fame name doecall it, Caft me downe.

\section{* The temperature.}

French Lauander faith Galen is of temperature compounded of a little colde earthie fubftannce, by reafon where of it bindeth: it is of force to take away obftructions, to extenuate or make thinne, to fcoure and clenfe, and to ftrengthen not onely all the entrailes, but the whole bodie alfo.

\section{* The vertues.}

A Diofcrides teacheth that the decoction thereof doth helpe the difeafes of the cheft, and is with good fucceffe mixed with counterpoifons.

B The later phifitions affirme, that Stachas, and efpecially the flowers of it, are moft effectuall againft paines of the head, and all difeafes thereof proceeding of coldecaufes, and therefore they be mixed in all compofitions almoft which are made againft headach of long continuance, the apoplexie, the falling fickneffe, and fuch like difeafes.

C The decoction of the huskes and flowers drunke, openeth the ftoppings of the liuer, the lungs, the milt, the mother, the bladder, and in one worde all other inwarde parts, clenfing and driuing foorth all euill and corrupt humours, and procureth vrine.

\section{Of Fleawoort. Chap.izi.}

* The defcription.

1 Syllium, or the common Fleawoort, hath many round and tender branches, fet full of long and narrow leaues fome what hairie. The top of the ftalkes are garnifhed with fundric round chaffie knops, befet with fmall yellow flowers; which being ripe, containe many littlefhining feetes, in proportion, colour, and bignes like vnto tleas. 
2 The fecond kinde of $P$ f $y$ !tum, or Fleawoort, hath long and tough branches, of a wooddie fubftance like the precedeit, but longer $\&$ harder, with leaues refembling the former, but much longer \& narrower. The chaffie tuft which containeth the feed is like the other, but more like the eare of Phalaris, which is the eare of $A$ lpift $i$, the Canarie feede which is neate for birdes, that come from the Ilands of Canarie. The roote hercof lafteth all the winter, and likewilc keepeth his greene leaues, whereof it tooke his name.

I $P$ fyllium fiue pulicaris berbi. Fleawoort.

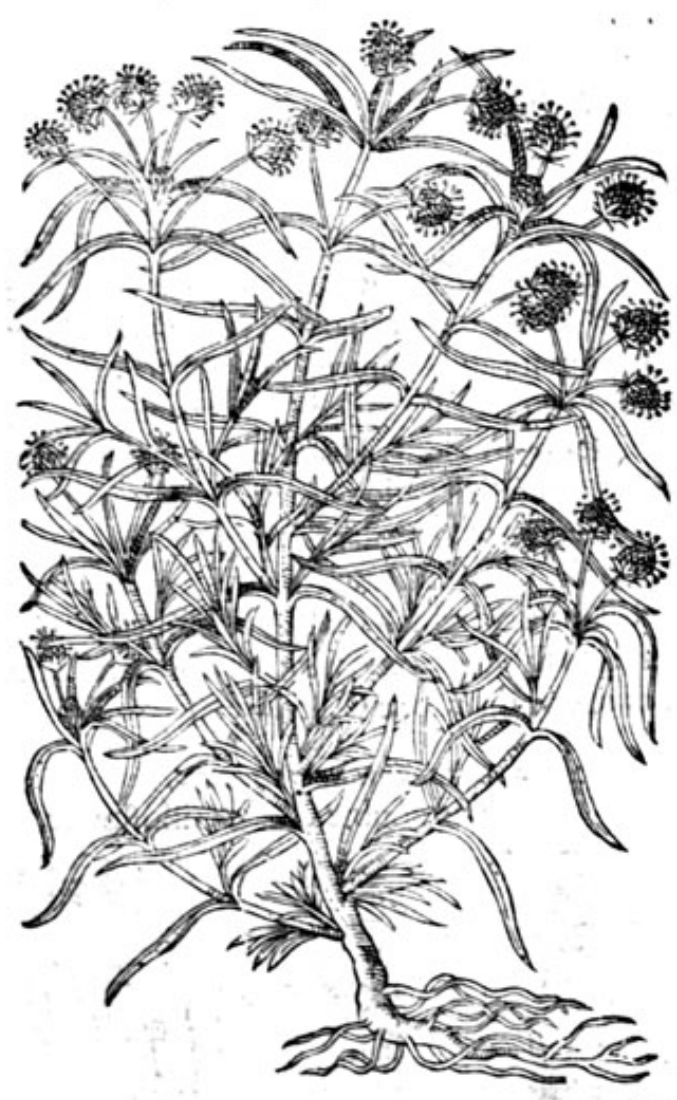

2 Pfylltarm emper virens L'Obelij. Neuer dying Flezwoort.

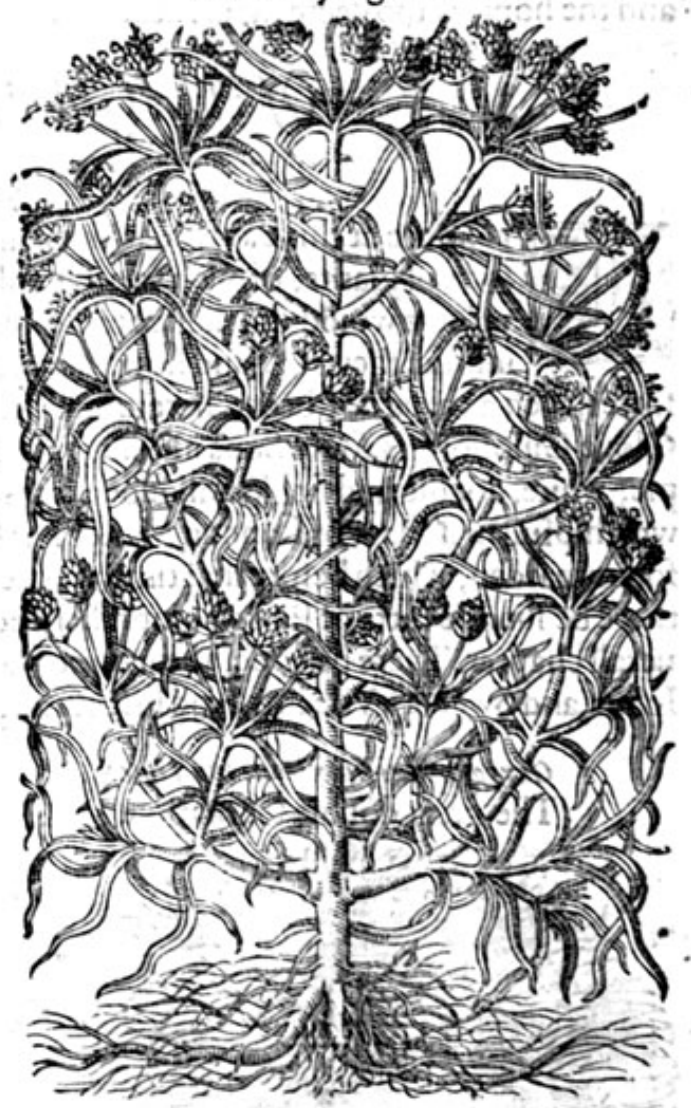

$*$ The place.

Thefe plants are not growing in our fieldes of England, as they do in France and Spaine, yet I haue them growing in my garden.

They flower in Iune and Iuly. * Thetime.

* 7 he names.

Fleawoort is called in Greeke forseor: in Latine Pulicaria, and Herba Pulicaris : in fhops Pfylliwom: in Englih Fleawoort, not bicaufe it killeth fleas, but bicaufe the feeds are like fleas: and of fome Fleabane, but voproperly. in Spanifh Zargatona : in French L'berbe ass pulces: in Dutch Đupls bloze-truet.

\section{* 7 . he temperature.}

Galen and Serapio record, that the feede of Pfyllium, which is chiefly vfedin medicine, is coppo in the fecond degree, and temperate in moifture and drineffe.

\section{* The vertues.}

The feede of Fleawoort boiled in water, or infufed, and the decoction or infufion drunke, pur- A geth downwardes aduft and cholericke humors, cooleth the heate of the inward partes, hor feuers, burning agues, and fuch like difeafes proceeding of heate, and quencheth drought and thirft.

The feede ftamped, and boiled in water to the forme of a plaifter, and applied, taketh away all B fwellings of the ioints, efpecially if you boile the fame with vineger and oile of roles, and applieit as aforefaid. 


\section{$47^{2}$ THE SECOND BOOKE OF THE}

$C$ The fame applied in maner aforefaid, vnto any burning heate, called $S$. Anthonies firc, or any hot and violent flaming impoftume, affwageth the fame, and bringeth it to ripenes.

D Some hold that the herbe ftrowed in the chamber where many fleas be, will driuc them away; for which caufe it tooke the name Fleawoort: but I thinke it is rather bicaufe the feede doth refemble a fleafo much, that it is hard to difcerne the one from the other.

\section{if The danger.}

Too much Fleawoort feede taken inwardly is very hurt ful to mans nature; fo that I wifh you not to follow the minde of Galen and Diofcorides in this point, being a medicine rather bringing a maladie, than taking away the griefe : remembring the olde prouerbe, A man may buie gold too deere: and the honie is too decre that is lickt from thornes.

\section{OfClowe Gilloflowers. Chap.172.}

* The kindes.

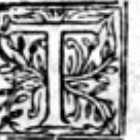

Here are at this day vnder the name of Caryophyllsus, comprehended diuers and fundrie forts of plants, of fuch variable colours, and alfo feuerallihapes, that a great and large volume would not fuffice to write of euery one at large in particular; confidering how infinite they are, and how enery yeere, euery climate and countric bringeth foorth new fortes, fuch as haue not beene heretofore written of; fome whereof are called Carnations, others Cloue Gilloflowers, fome Sops in wine, fome Pagiants or Pagion colour, Horfeflefh,blunket, purple, white, double and fingle Gilloflowers, as alfo a Gilloflower with yellow flowers, The which a worfhipfull marchant of London Mafter Nicholas Lete, procured from Poland, and gaue me therof for my garden, which before that time was neuer feene nor heard of in thefe countries. Likewife there be fundrie forts of Pinks, comprehended vnder the fame title, which fhall be defcribed in 2 feverall chapter. There be vnder the name of Gilloflowers alfo thofe flowers, which we do call Sweet Iohns, and Sweete Williams.And firft of the great Carnation and Cloue Gilloflower.

1 Caryophyllus maximus multiplex. The great double Carnation.

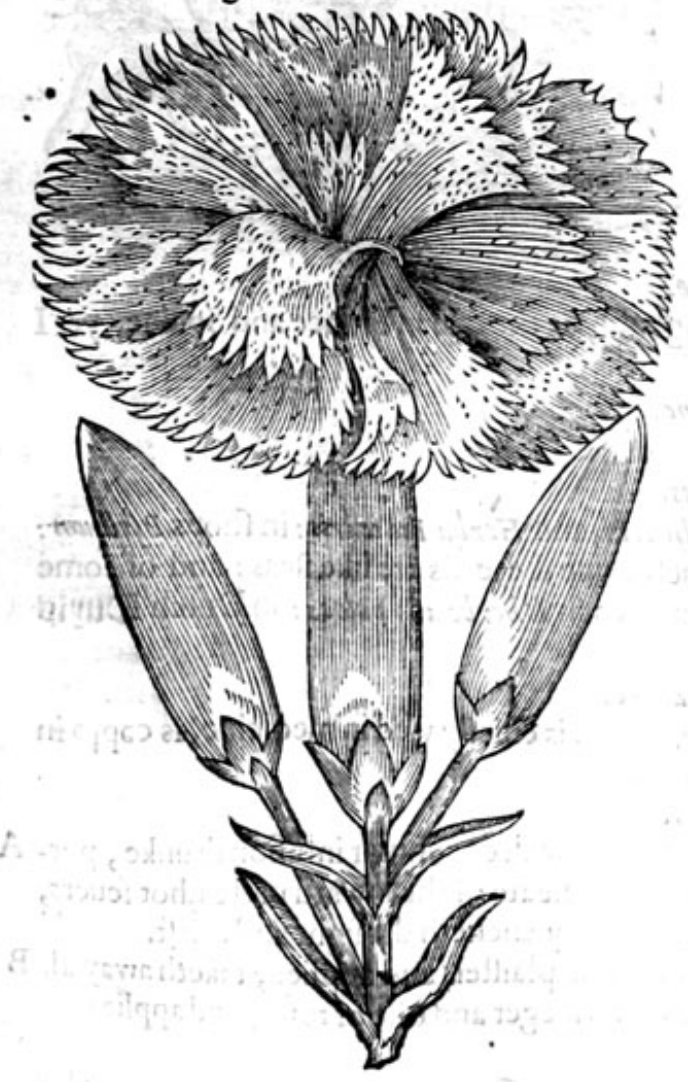

2 Caryophyllisus multiplex. The double Cloue Gilloflower.

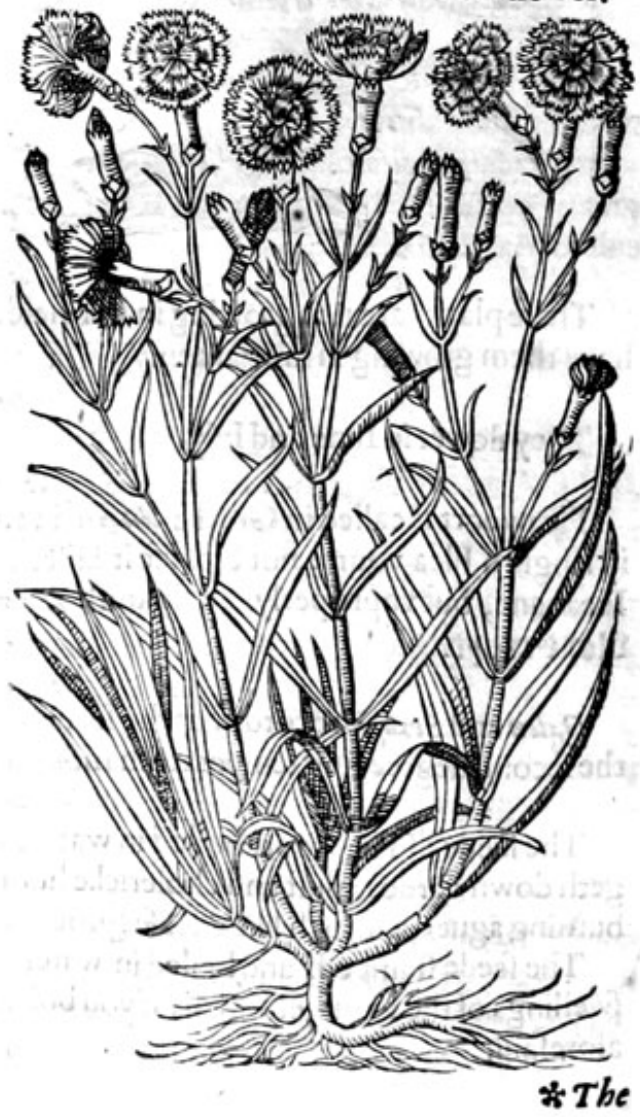


* The defcription.

I The great Carnation Gilloflower hath a thicke wooddie roote, from which rifeth vp many ftrong iointed ftalks, fet with long greene leaues by couples: on the top of the ftalkes do growe very faire flowers of an excellent fweete fmell, and pleafant Carnation colour, whereof it tooke his name.

i The Cloue Gilloflower differeth not from the Carnation, but in greatnes as well of the flowers as leaues. The flower is exceeding well knowen, as alfo the Pinks and other Gilloflowers, wherfore I will not ftand long vpon the defcription.

* The place.

Thefe Gilloflowers, efpecially the Carnations, are kept in pots from the extremitic of our colde winters. The Cloue Gilloflower endureth better the cold, and therefore is planted in gardens. It

They flourith and flower moft part of the time.

* The time.

* The names.

The Cloue Gilloflower is called of the later Herbarilts Caryophyllesw flos, of the fmell of Cloues, wherewith it is poffeffed : in Iralian Garofoli : in Spanilh Clamel: in French OeNllet $x$ : in low Dutch Gmoffelbloenien: in Latine of moft Ocellus Damafcenus, Ocellses Barbarices, and Barbarica: in Englinh Carnations, and Cloue Gilloflowers.Offome it is called Vetomica, and Herba Twnica. The which Bernurdus Gor donizus hath fet downe for Diofcorides his Polemonie.

That woorthie Herbarift and learned phyfition of late memorie,Mafter Doctor Turner, maketh Caryophyllews to be Cantabrica, which Plinie in his 23 .booke 8.chapter, writeth to haue been found out in Spaine about Angustus time, and that by thofe of Bifcay.

Jobannes Ruelliws thought, that the Gilloflower was vnknowen to the olde writers, whofeiudgement is very good, efpecially bicaufe this flower is not like to that of Vetonica, or Cantabrica. It is maruell, faith he, that fuch a famous flower, fo pleafant and fweete, hould lie hid, and not be made knowen by the olde writers, which may be thought not inferior to the Rofe in beautie, fmell and varietic.

The Gillo * The temperature.

The Gilloflower, with the leaues and rootes for the moft part are temperate in heat and drineffe. $*$ The vertues.

The Conferue made of the flowers of the Cloue Gillotlower and fugar, is exceeding cordiall, and $A$ woonderfully aboue meafure doth comfort the hart, being eaten now and then.

It preuaileth againft hot peftilentiall feuers, expelleth the poifon and furie of the difeafe, and B greatly comforteth the ficke, as hath of late been found out by a learned gentleman of Lee in Effex,
called Mafter Rich.

\section{Of Pinks, or wilde Gilloflowers. Chap.173:}

$*$ The defcription. 17 He double purple Pinke hath many graffic leaues, fet vpon fimall iointed ftalks by coaples, wooddie. moft fragrant finell, not inferiour to the Cloue Gilloflower. The roote is Imall and $^{-}$ 2 The fingle red Pinke hath likewife many fmall graffie leaues, leffer then the former. The flowers growe at the top of the fmall ftalkes fingle, and of a fiveete brightred colour,

3 The white iagged Pinke hath a tough woodie roote: from which rife immediately many graffie leaues, fet vpon a fmall ftalke full of joints or knees, at euery ioint two, one againf another, euen tothe top; whereup on do growe faire double purple flowers of a fweete and fpicie fmell, confifting of fiue leaues, fometimes more, cut or deepely iagged on the edges, refembling a feather; whereupon I gave it the name Pliwnar ius, or feathered Pinke. The feede is foft,blackifh, and like vn. 4 This purple coloured Pinke is very likethe precedent, in ftalkes, rootes, and leaues. The flowers growe at the top of the braunches leffer then the laft defcribed, and not fo deepely iagged; of a pur-
ple colour tending to bleivneffe, wherein confifteth the difference. 
I Caryophyllus fyluestris multiplex. DoublepurplePinkes:

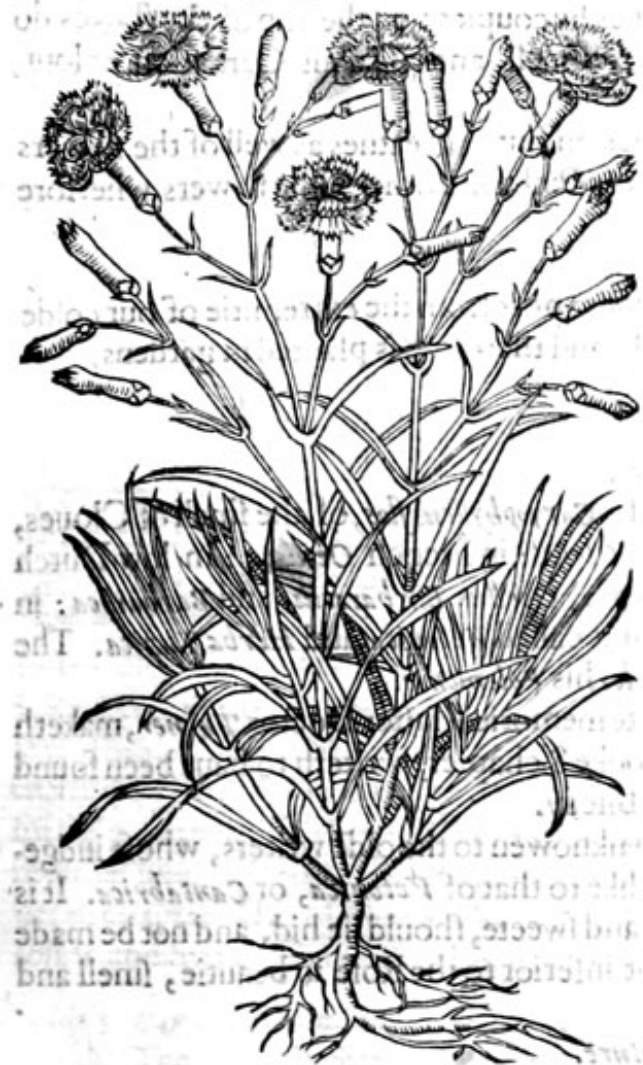

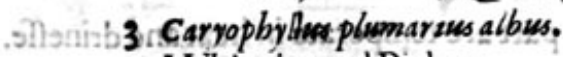
White iagged Pinkes.
2 Caryophyllius fyluestris fimplex, fuaue rabens. Single red Pinkes.
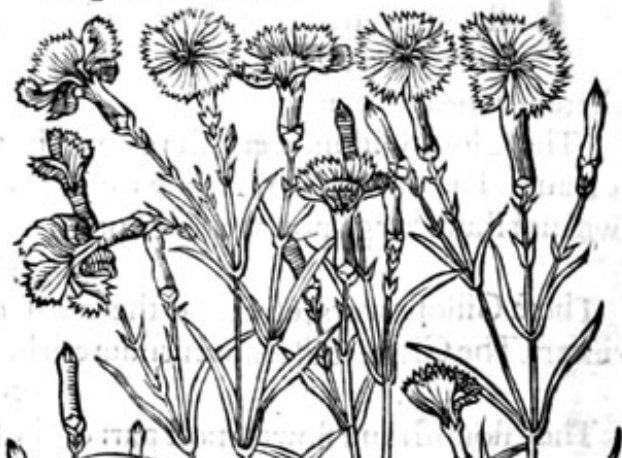

\&

Nive
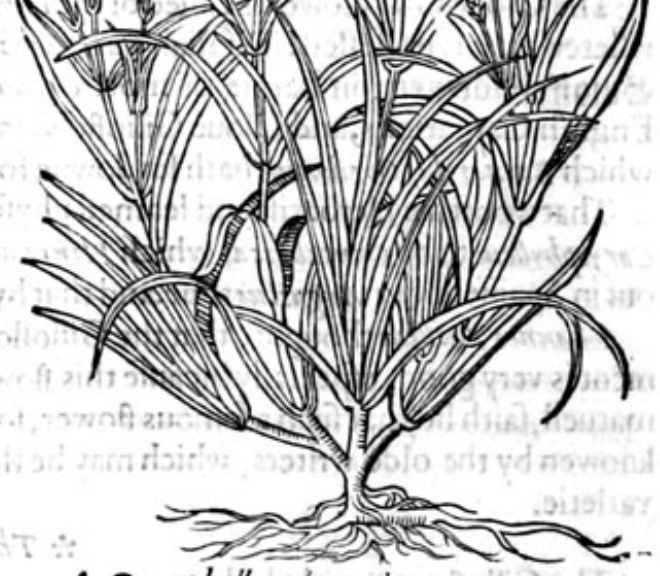

4 Caryophyllus plumarius pur purewo. Purple iage ed Pinkes.

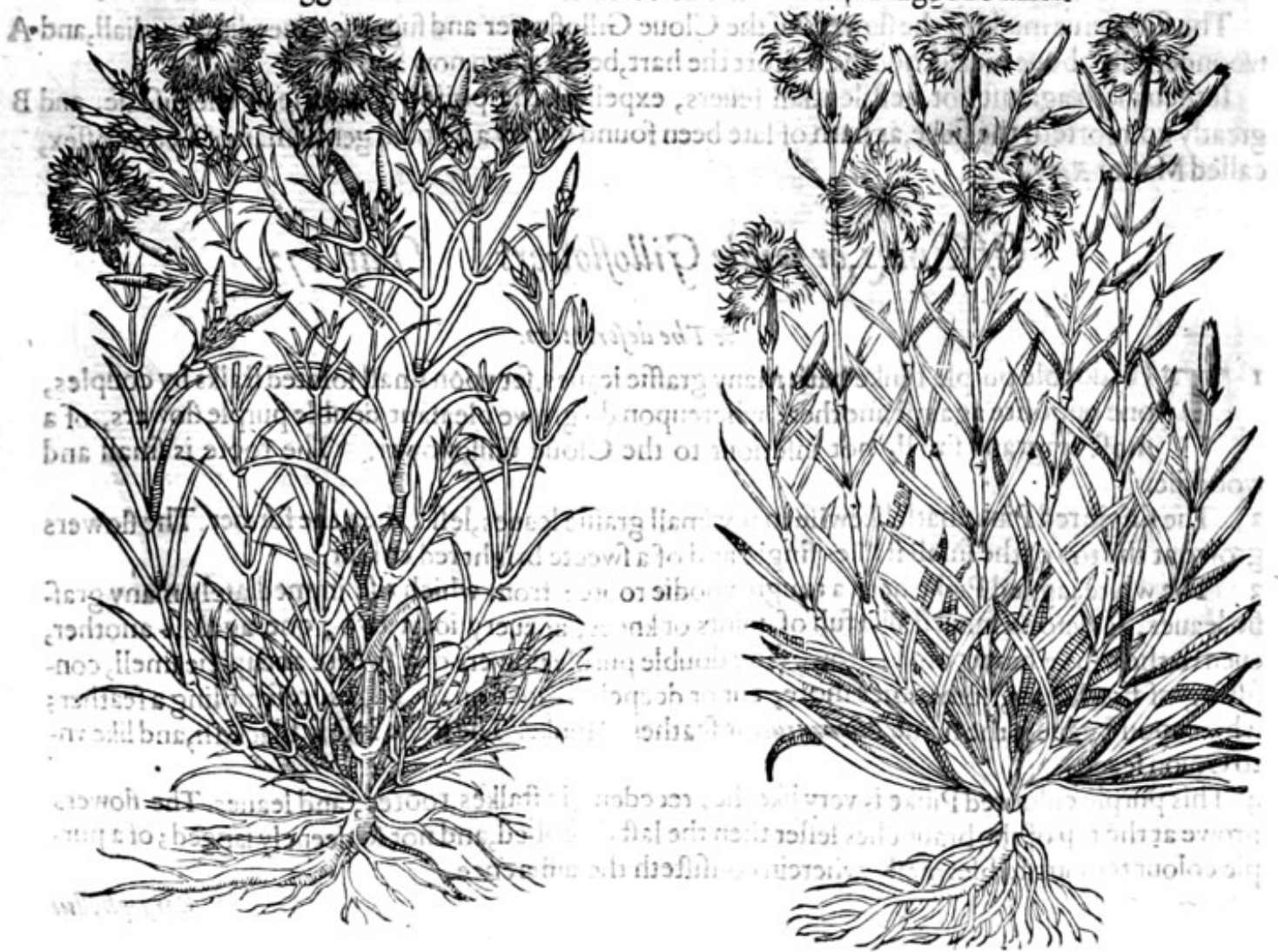




\section{BH TH IST QR IEO O FOBLANATS. 3 H T}

There be diuers forts of Pinkes more, whereof to write particulsrly were to fmall purpofe, confidering they are all wett thownd torthe moft, if not to all. Thereforo thefefeumeftial fertieat this time, for thofe that we do keppeih our gardens : notwithftanding I thibke irconueniene troplace thefe wilder forts in this fame chapter; confidering their nature and vertues do agree, and feive or none of themare vfed in phificke, Eefides their neerenefie in kindred and neighbourhoode.

5 Caryophyllows plimarinus flue ftris albus. White wilde iagged Pinkes.

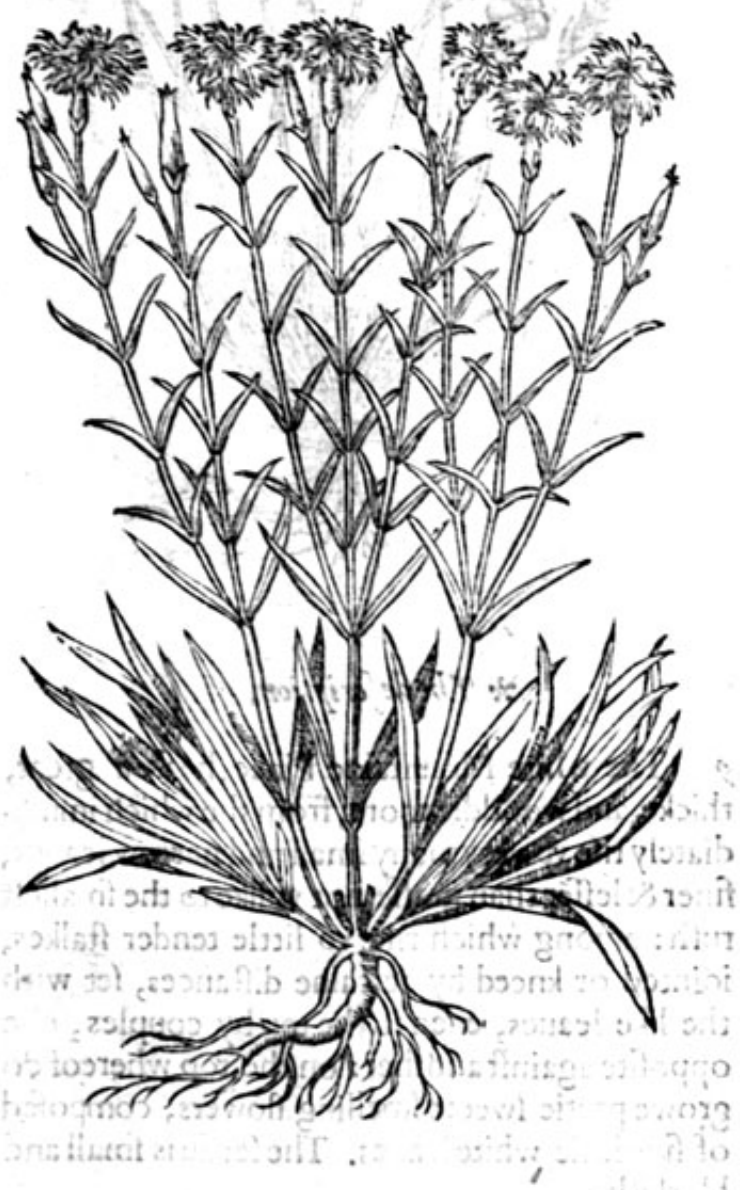

6 Caryophyllias montanus purpareus. Wilde purple iagged Pinkes.

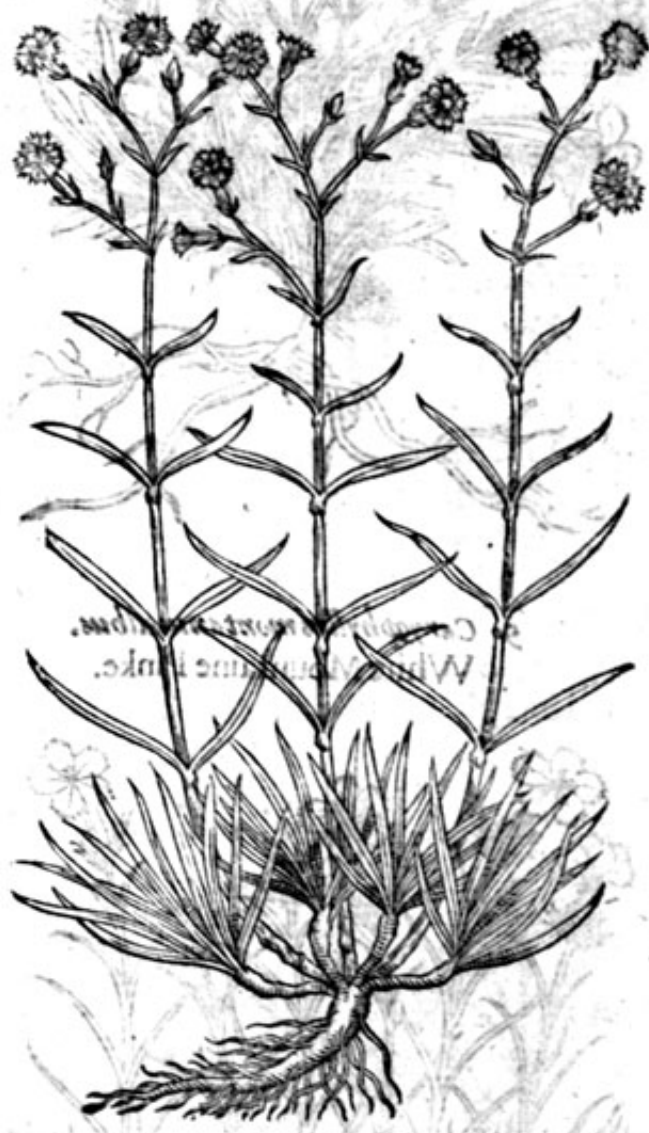

* The defcription.

5 This:wilde iagged Pink hath leaues, ftalks, and flowers like vnto the white iagged Pinke of the garden, but altogither leffer, wherein they efpecially differ.

6 The purple mountaine or wilde Pinke hath many fmall graffie leaues;among which rife vp flender ftalkes, fee with the like leatues, but leffer: on the top whereof do growe fmall purple flowers, muchleffer then any of the others before defcribed.

7 The mountaine Pinke of clufues defcription, hath many leaues growing in a tuft like vnto thofe of Thrift, and of a bitter tafte: among which rifevp fmall tender foote ftalkes, rather then ftalkes or ftems themfelues, of the height of two inches; whereupon do growe fuch leaues as thofe that were next the grounde, but leffer, fet by couples one oppofite to another :at the top of each fmall footeftalke doth ftande one red flower without fmell, confifting of fiue little leaues, fet in a rough hairie huske, or hofe, fiue cornered, of a greenifbicolour tending to purple. The roote is tough and thicke, cafting abroade many fhootes, whereby it greatly increafeth.

8 This leafeles Pinke, as the Greeke worde doth feen e to import, hath many finall rufhie or bentic leaues, rifing immediately from a fough rufhy roote; among which rile vp italkes like vinto rufhes of a fan bigh, without any joint at all, but fmooth and plaine: on the top whereof groweth a fmall Alower of $x$ blewith or skie colour, confifting of fowser liecte deaues formeivhat iagged inctic edges, not vnlike thofe of wilde taxe. The whole plant is very bitter and of a hot tafte. 
7 Caryophyllew mont anus Clufit. Clinguw mountaine Pinke.

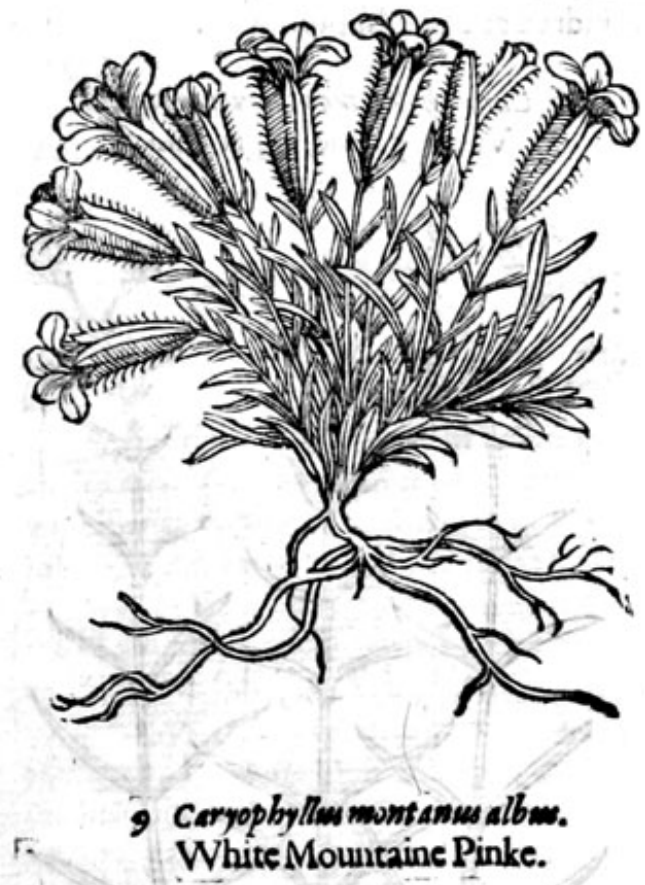

8 Caryophyllwow cerwlens five Aphylanthos. Leafeles Pinke,or ruíhie Pinkew its not

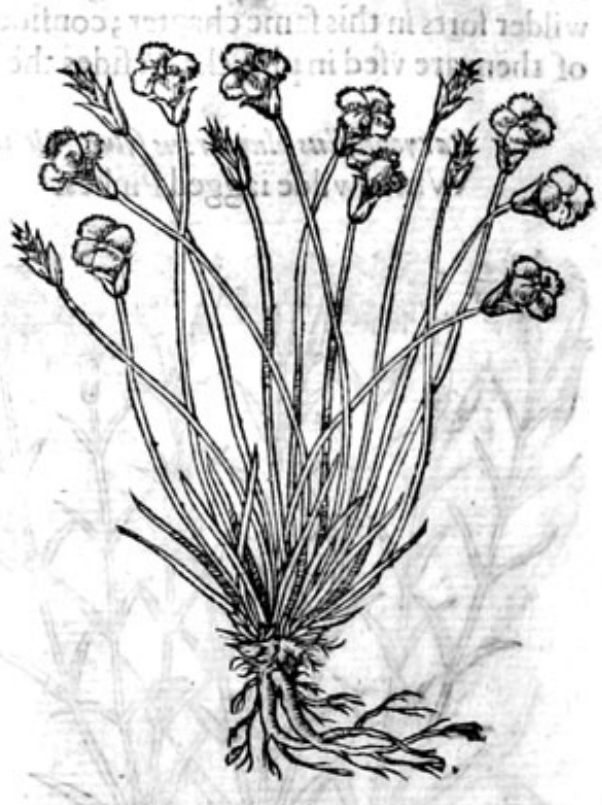

* The de cription.

9 The white Mountaine Pinke hath a great, thicke, and wooddie roote, from the which immediately rife vp very many fmall and narrow leaues, finer \& leffer than graffe, not vnlike to the fmalleft rurh: among which rife vp little tender ftalkes, iointed or kneed by certaine diftances, fet with the like leaues, even to the top by couples, one oppofite againft another: on the top whereof do growe pretie fweete fmelling flowers, compofed of fiue little white leaues. The feede is fmall and blackirh.

There is a Wilde creeping Pinke, which grow: eth in our paftures neere about London, and other places, but efpecially in the great field next to Detford, by the path fide as you go from Redriffe to Greenewich, which hath many fmall tender leaues, fhorter than any of the other wilde Pinkes; fet vpon little tender ftalks, which lie flat vpon the ground, taking holde of the fame in fundrie places, whereby it greatly encreafeth; whervpon doth growe little reddifh flowers. The roote is fmall, tough, and long lafting.

10 This Virginlike Pinke is like vnto the reft of the garden Pinkes in ftalkes, leatues, and rootes. The flowers are of a blufh colour, whereof it tooke his name, which heweth the difference from che other. 


\section{HISTORIE OF PLANTS.}

10 Caryophyllus Virginesu.

Maidenly Pinkes.

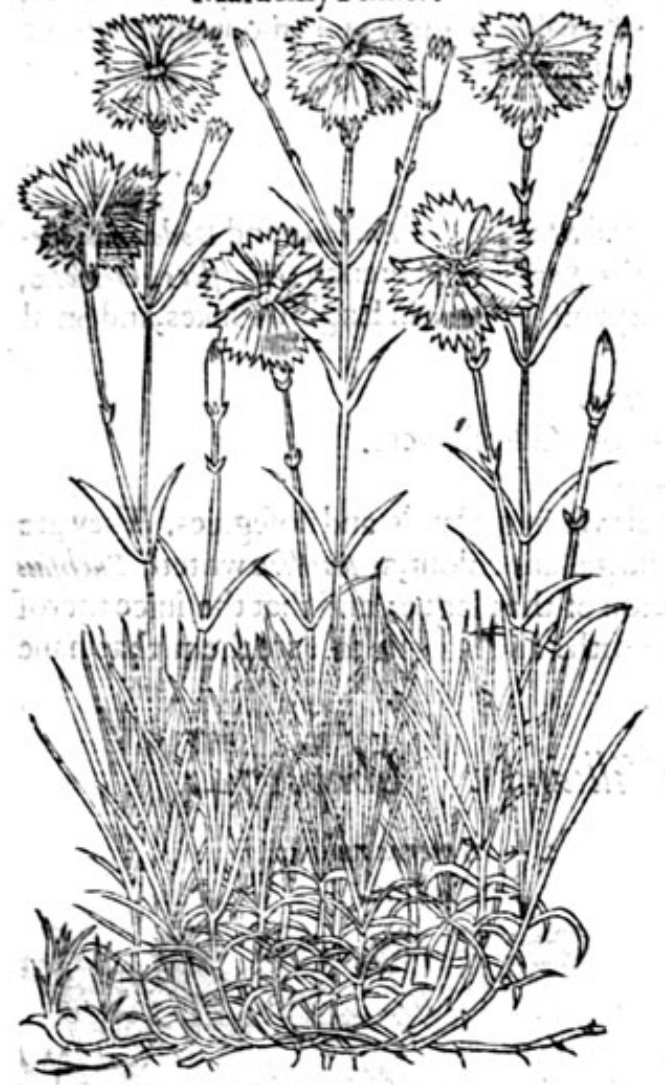

* The defcription.

II This wilde Sea.Pinke hath divers fmail tender weake braunches, trailing vopon the ground; whereupon are fezleaues liketholk of our fmalleft garden Pinke, biti of anoldehoary. colour, tending to whitenefle, as ate inoft of the Sea plants. The flowers growe av rhe top of the ftalks in thape like thofe of Stitchwoort, and of a reddifh colour. The feedes; raeither the feede veffels, I haue not as yet obferued. The root $c$ is tough and fingle.

12 There is another of thefe Wilde Pinkes, which is found growing in plowed fieldes; yot in fuch as are neere vntothie fea : it hath vęry many leaues fpred vpon the groundej] of ain ouerworn hoary colour, like thofe of the Campion; among which rife yp tendet ftalkes of the height of two foote, fet with the like leates by couples at certaine diftances. The flowers growe at the top many togither, in maner of the Sweete William, of a red colour tending to purple. The roote is fmall, tough, andlong lafting.

II Caryopholles Holostinus.

Wilde Sea Pinke.

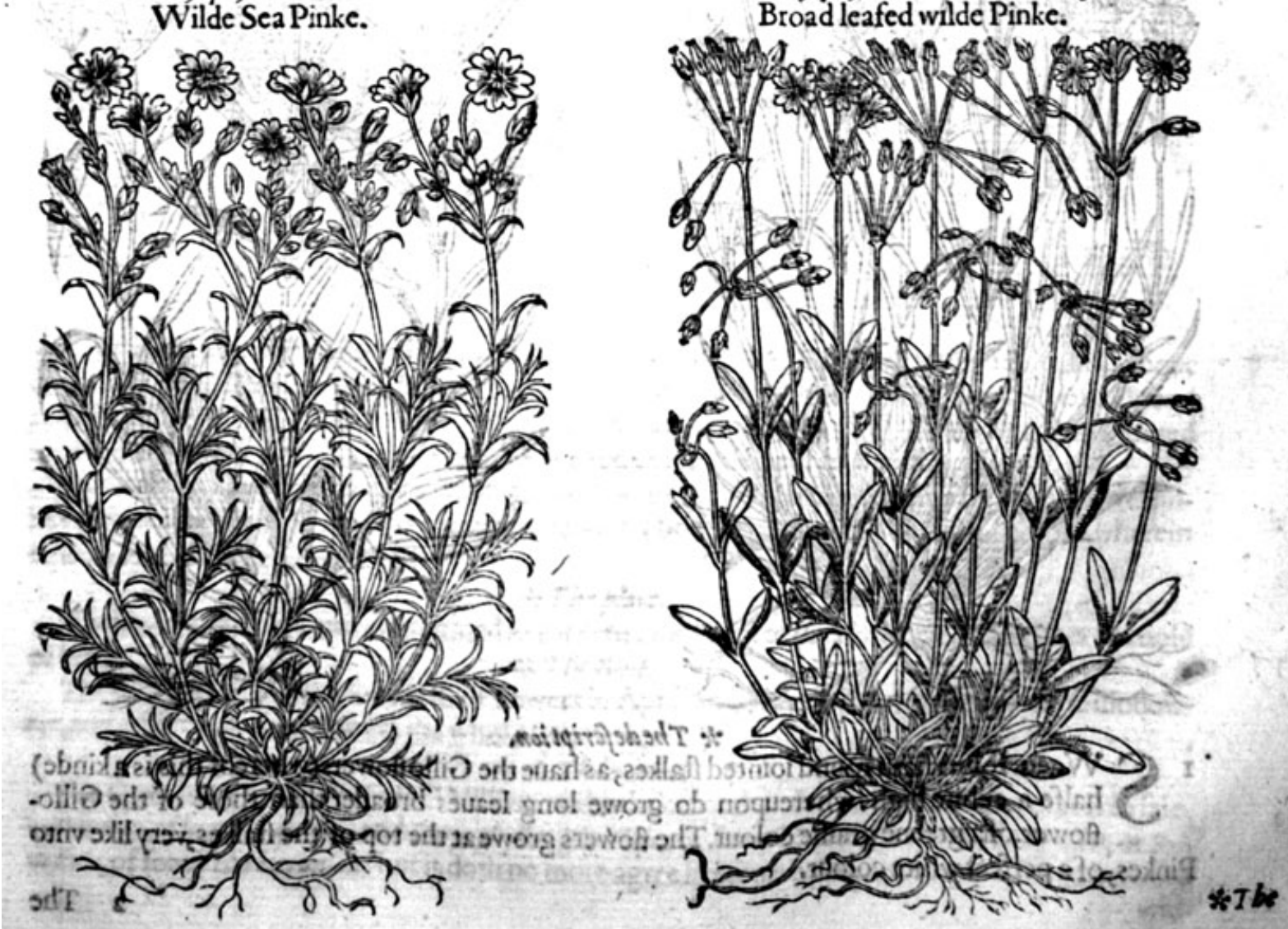

12 Caryophyllus Holostites arven/sis. Broad leafed wilde Pinke. 
* Theplace.

Thefe kindes of Pinkes do growe for the moft part in gardens, and likewife many other fortes, which were oucrlong to write of particularly. Thofe that be wilde do grow vpon mountaines, ftonie rockes, and defart places. The reft are fpecified in their defcriptions.

$$
* \text { The time. }
$$

They flower with the Cloue Gilloflower, and often after. * The names.

The Pinke is called of Plinie and Turner,Cant.abrica, and Stactice: of Fuchfius and Dodonaus, Vetonicalatter 4 , and Vetonica altilis: of L'Obelius and Fuchfius, Superbs : in French Gyrofflees, Oeilletz, and Viokettes herbues: in Italian Garofoli and Garoni : in Spanifh Clawis : in Englifh Pinkes, and Smal Honefties.

\section{* Thetemperature.}

The temperature of the Pinkes is referred vnto the Cloue Gillotlowers.

\section{b o $20 \mathrm{~T}$ Thevertues.}

A Thefe are not vfed in phificke, but efteemed for their vfe in garlands and nofegaies. They are good to be putinto vineger, to giue it a pleafant tafte, and gallant colour, as Ruellinw writeth.F uchfius faith, that the rootes are commended againft the infection of the plague; and that the iuice therof is profitable to wafte away the ftone, and todriue it foorth: and likewife to cure them that haue the falling fickneffe.

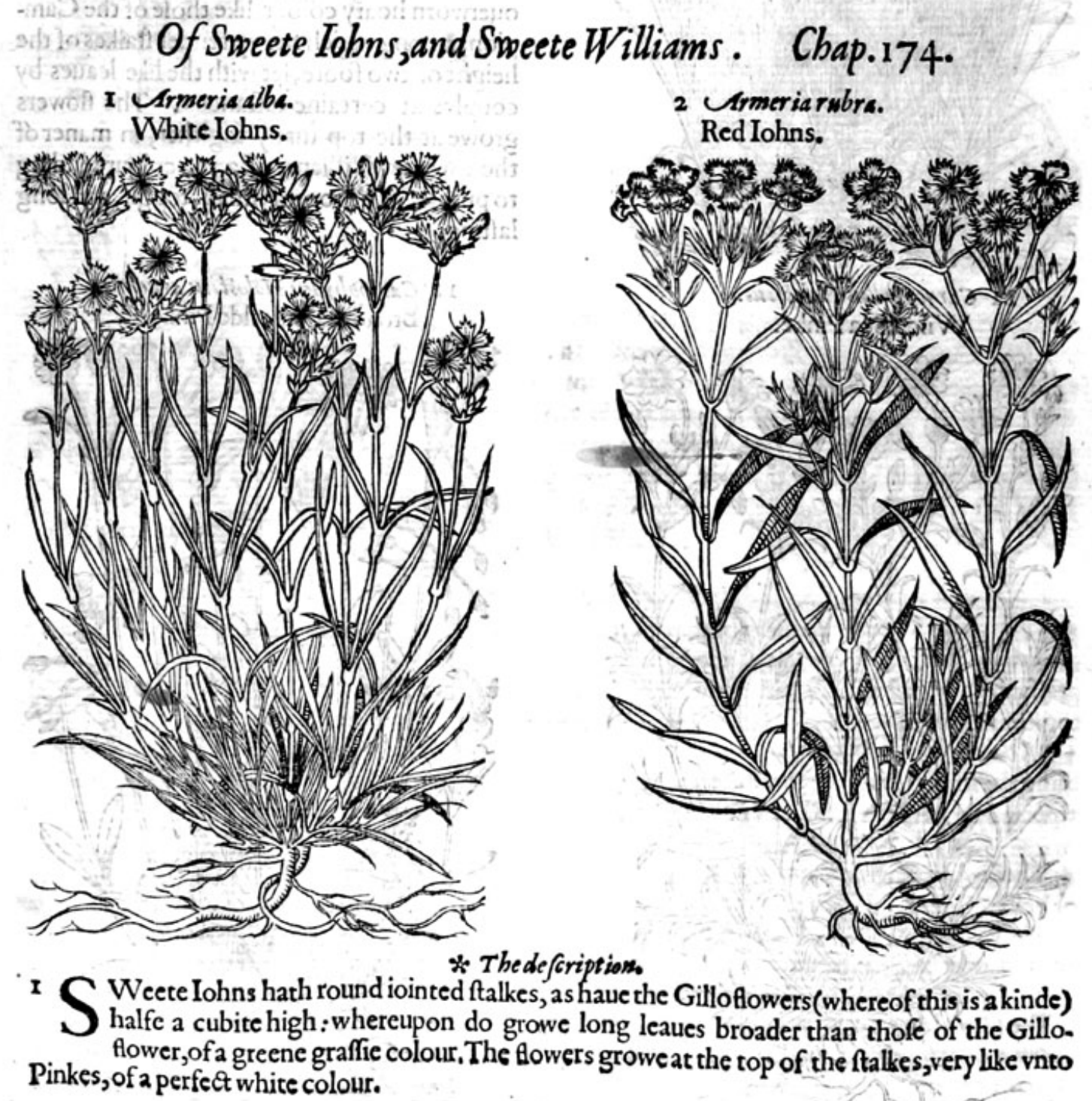

flower, of a greene graffie
Pinkes, of a perfect white colour. 
2. The feconid differeth not from the other, but in that, that this plant hath redde flowers, and the

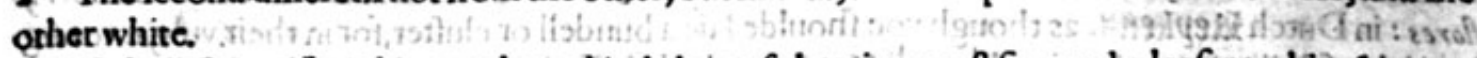
:- We hade in our London gardensakinde hereof, bearing moft fine and pleafant white téowers, fpotted very confufedly with reddifh fpots, which fetteth foorth the beautie thereof, anid hazhi beene taken of fome to bethe plant called of the later writers Superba Auftriata, or the pride of Auftrich.

kinde, bringing foorth moft double flówèrs, and yet verywithe We hane likewife one of the fame kinde,
of colour.

3 Armeris rubralatifolia. Broad leafed Sweete Williams.

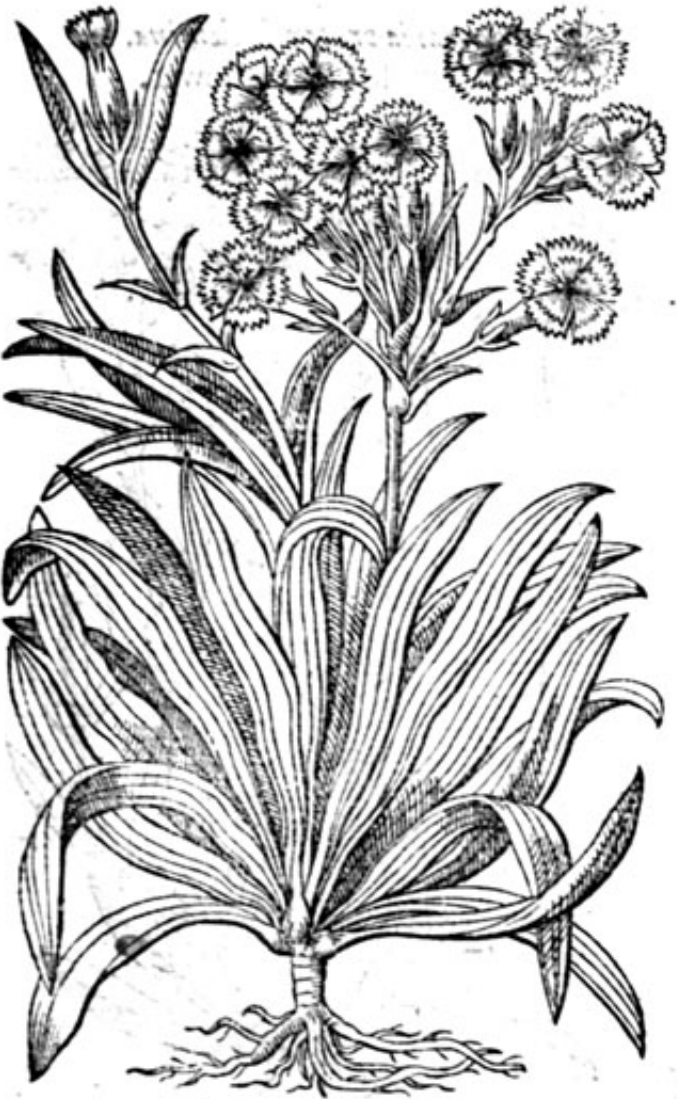

4 Limeria fuame rubens. Narrow leafed Sweore Williams.

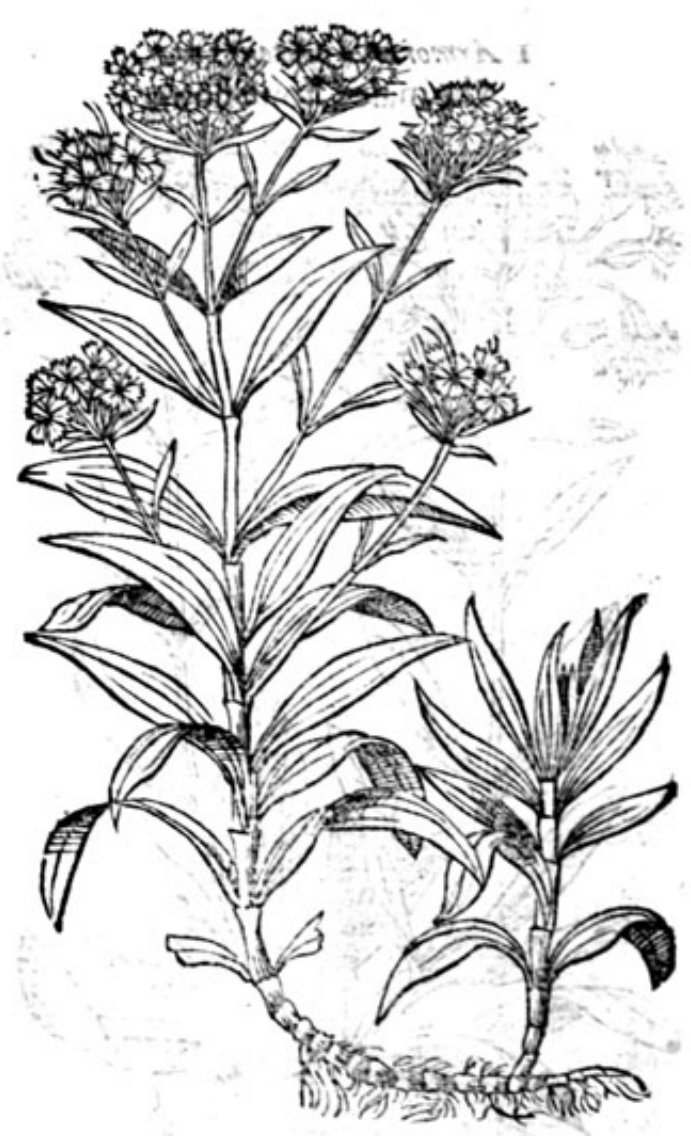

* The defcription.

3 The great Sweete William hath round iointed ftalkes, thicke and fat, fomwhat reddifh about the lower iointes, a cubite high, long,broad, and ribbed leaues as thofe of the Plantaine, of a greene graffie colour. The flowers at the top of the ftalkes are very like to the finall Pinkes, manyiorined togither in onetuft or fpokie vmbell, of a deepe red colour. The roote is thickeand rooddie.

4 The narrow leafed Sweete William groweth yp to the height of two cubites, very well refembling the former, but leffer, and the leaues narrower. The flowers are of a bright red colour, wherein efpecially confifteth the difference.

Thefe plants are kept and maintained in gardens, more for to pleafe the cie, than either thenofe or belly. * The time.

They flourilh and bring foorth their flowers in Aprill and May, fomewhat before the Gillotlow: ers, and afe beare their flowers the whole fommer.

The fweet Iohn $\&$ alfo the fweet Willia * The names. eet William are both comprehended ynder one title, that is to faie, Armeria, of fome Superba, and Caryophylluw flueftris ; of fome Herbarifts Vettonica agreftis, or Syl. weftris, of fome Herbetunica : but it doth no more agrec heerewith then the cloue Gilloflowet doth 
with Vettonica alters, or Polemonium: in French Armoires, heereupon Ruellises nameth iv Uirmer flores : in Dutch Kaevkenti, as though you fhoulde faic a bundell or clufter,for in their.vulgar toong bundels of flowers or nofegaies they call ftepkent; doubtleffethey are wildekinds of Gilloflowers: in Englifh the firft two are called fweete Iohns; and the two laft fweete Williams, Tolmeiners, and London Tuftes,

* Thetemperature and vertues.

rbinglinat

5:Thefe plants are nót vifed either in meate or medicine, but efteemed for their beautic to decke vp gardens, the bofomes of the beautifull,garlands and crownes for pleafure.

\section{Of Crowe flowers, or wilde Williams. Cbap,175.}

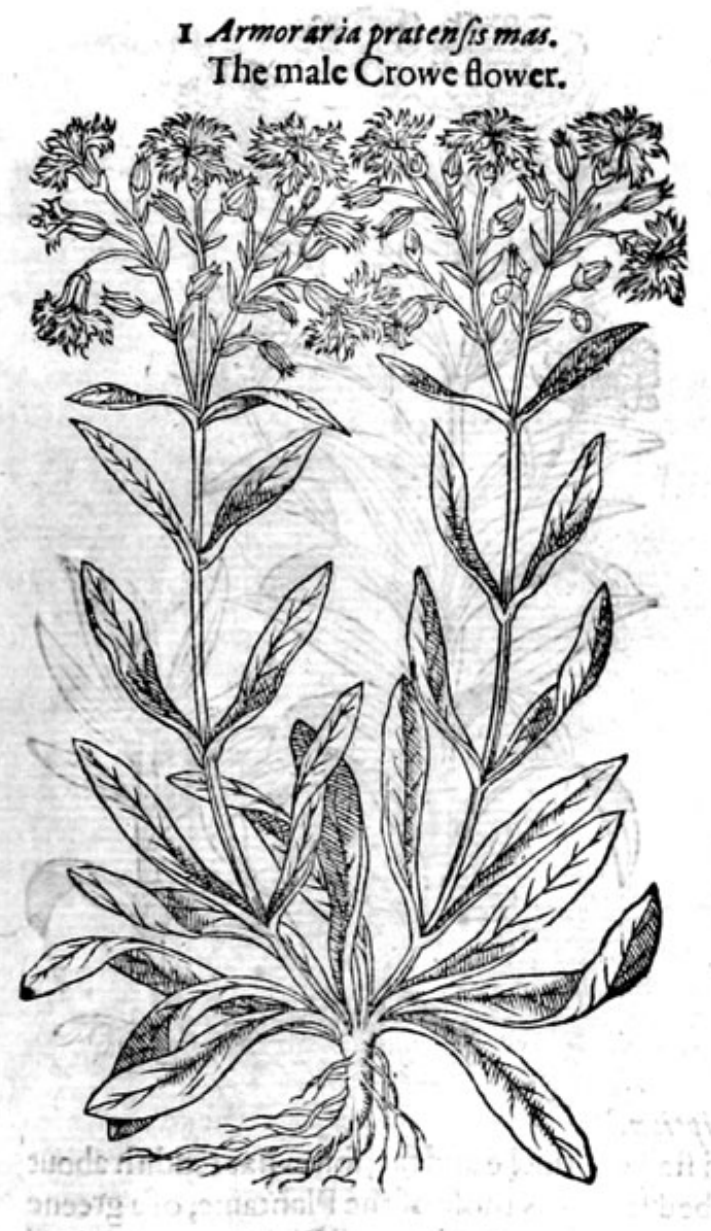

2 Armoraria pratenfis famina.

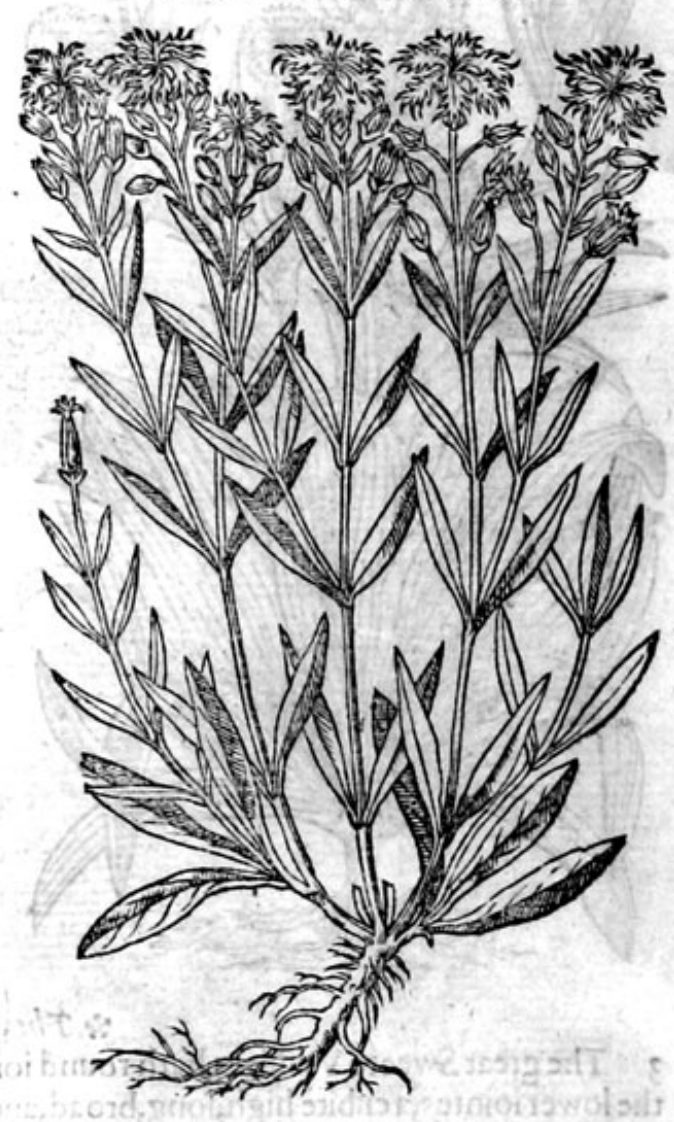

* The defaription.

I Efides thefe kindes of Pinkes before defcribed, there is a certaine other kinde, either of the Gilloflowers or elfe of the fweet Williams, altogither and euery where wild, which of fome hath been inferted amongft the wilde Campions, of others taken to be the true Flos Cuswit: notwithftanding I am not of any of their mindes, but do holde it for neither: but rather a degenerate kinde of wilde Gilloflower. The Cukowe flower I haue comprehended vnder the title of Sifom briwn, Englifhed Ladies finocks, which plant hath beene generally taken for Flos Cucali. It hath ftalkes of a fan or a foote high, whereupon the leanes do ftand by couples out of eueryioint; they are final \& bluntly pointed, very rough $\&$ hairy. The fowers are placed on the tops of the ftalks, many in one tuft, finely and curioufly fnipt in the edges, leffer then thofe of Gilloflowers, very well re2. This the fweete William (whereof no doubt it is a kinde) of a light red, or fcarlet colour. 2. This female Crowe flower differeth not from the male, fauing that this plant is leffer, and the

Of thefe Crowe flowers we haue in our gardens one that doth not differ from the former of the
and 


\section{HISTORIE OF PIANTS. IHT}

fielde, fauing that the plant of the garden hath very faire red double flowers, and thofe of the fielde fingle.

Thefe growe all about in medowes and paftures, and dankifh places.

They begin to flower in Maie, and ende in Iune. * The rine.

*. The names.

The Crow flower is called in Latine Armor aria / vluestris, \& Armoratix, of fome Flos Cuculi, but not properly; it is alfo called Tunix: of fome Armeria, Armerius flos primus of Dodonesw; and likewile Caryophylles minor/yluestris folys latioribus: in Dutch Craepnblocmkents, that is tofaie Cornicis flo. res: in French Cuydrelles: in Englifh Crowe flowers, wilde Williams, marth Gilloflowers, and Cockowe Gillotlowers.

\section{* The temperature and vertues.}

Thefe are not vfed either in medicine or in nourithment:but they ferue for garlands and crowns, and to decke vp gardens.

\section{OfCatch Flie, or bird-Lime woort. Chap.176.}

I. Vifaria.

Lime woort.

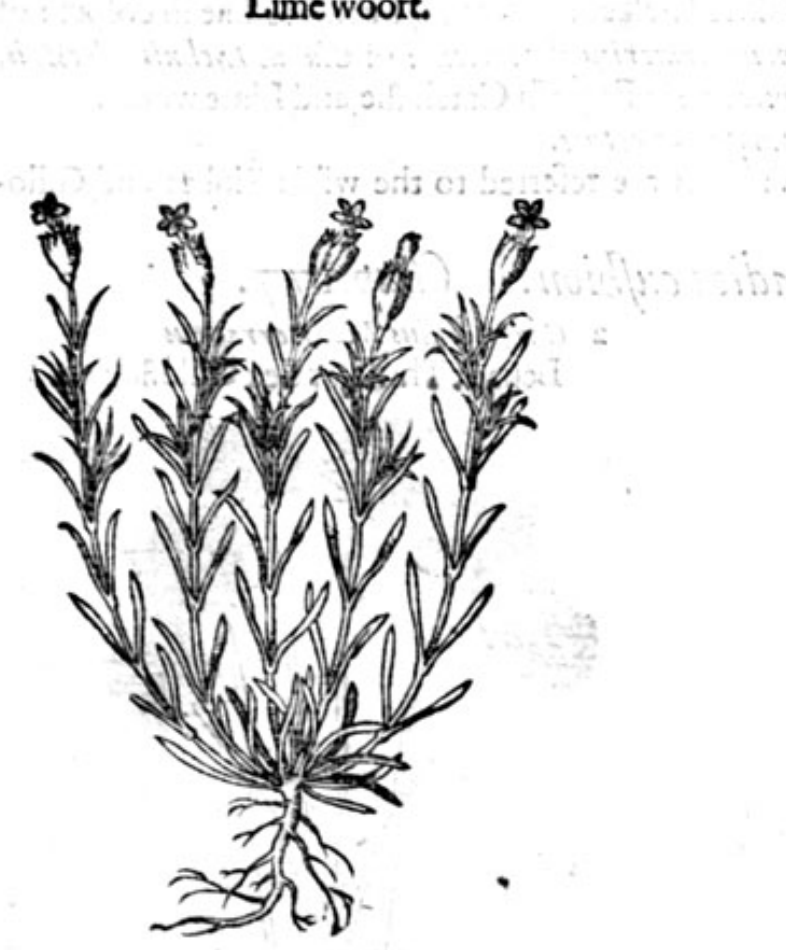

2 Mufcipula L'Obelg. Catch Flic.

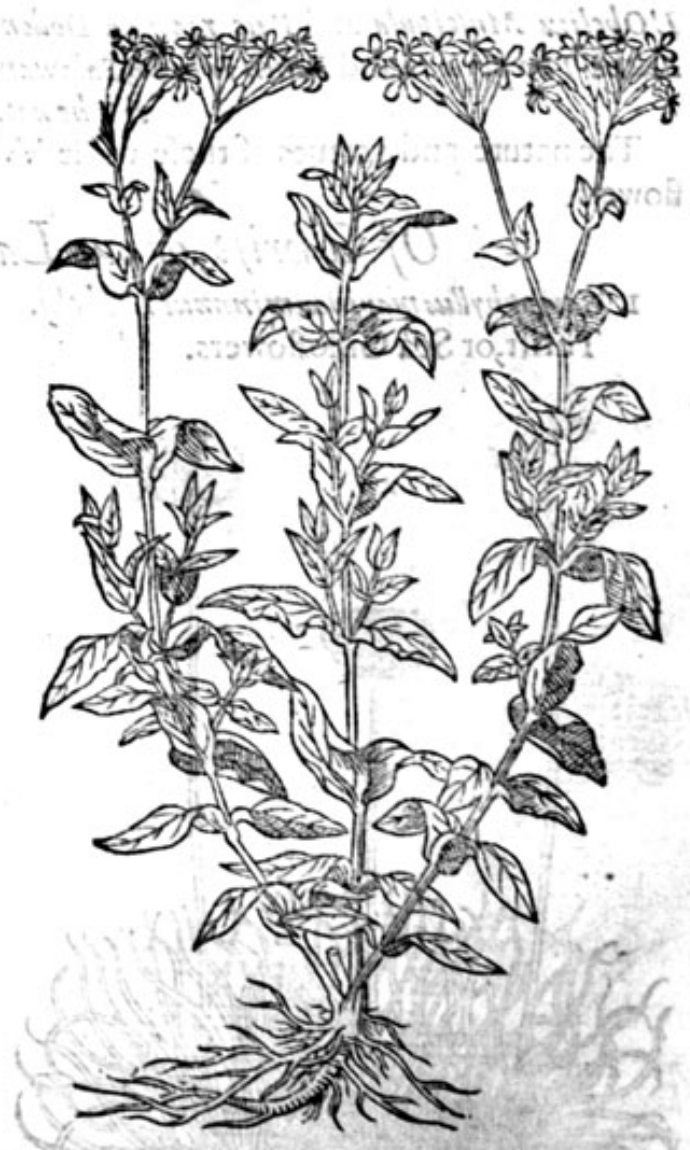

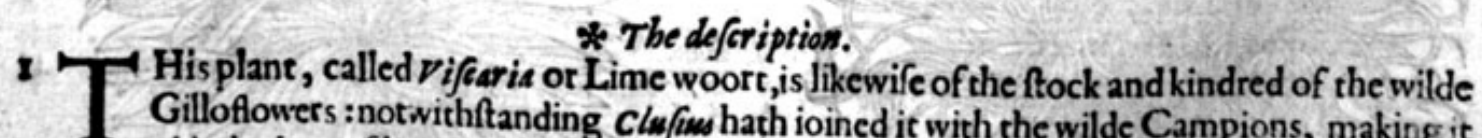
Gilloflowers :notwithftanding clufiws hath ioined it with the wilde Campions, making it a kinde thereof, but not properly; L'Obelsus among the fiveete Williams, whereof doubtleffe it is a kinde. It hath many leaues rifing immediately from the roote like thofe of the Crowe flower, or wilde fweete William: among which rife vp many reddith ftalkes iointed or kneed at certainefpaces, fer with leaues by couples one againft another: at the toppe whereof come foorth 


\section{THE SECOND:BOOKE OF THE}

pretie little red flowers, which being paft there commeth in place fmail blackith feede. The roote is fmall and threddie. The whole plant, as wel leaues \& ftalkes, as alfo the flowers, are couered ouer dimynefe is fucl, and clammie matter like vnto Birde lime, which if you take in your handes, the himerfe is fuch, that your fingers will fticke and cleaue togither, as it your hand touched birdelime: \& furthermore, if flies do light vpon the plant,as they do vpon other herbs, they wil be fo intangled with the limyneffe, that they cannot flie away; infomuch that in fome hot day or other, you Shall fee manie flies caught by that meanes : whercupon I hauc called ir Catch flic, or Lime woort. 2 This plant hath many broad leaues like the great Sweet William, but fhorter(wherof it is likewile a kinde) fet vpon a ftiffe and brittle ftalk; from the bofome of which leaues fpring forth fmaller branches than the aforefaide, clothed with the like leaues, but much leffer. The fowers grow at the rop of the ftalkes many togither tuft fathion, of a bright red colour. The whole plant is allopofferfed with the like limyneffe, as the other is, but leffe in quantitie.

*The place.

Thefe plants do growe wilde in the fieldes in the weft partes of England, among the corne : we haue them in our London gardens rather for toyes of pleafure, than any vertues they are poffeffed with, that hath as vet been knowen. * Thetime.

They flower and flourifh molt part of the fommer.

$$
\text { * The names. }
$$

Catch flies hath beene taken for Beben, commonly fo called, for the likeneffe that it hath with Beben rubentisfloris, or with Beben that hath the red flower, called of fomeValeriania rubra, or red Valerian; for it is fomething like vnto it in iointed ftalkes and leaues, butmore like in colour: of L'Obeliss Mufcipula and Vifcaria : of Dodonem Armerius flos tertius: of Cluf fus Lychnis fyluestr is, Silene Theophrasti, and Behen rubrum Salamanticum : in Englifh Catch flie, and Lime woort.

$$
\text { * } T \text { he nature and vertues. }
$$

The nature and vertues of thefe wilde Williams are referred to the wilde Pinkes and Gilloflowers.

$$
\text { Of Thrift, or our Ladies cu/bion. Chap.177. }
$$

$x$ Caryophylleus marinusminimus L'Obely. Thrift, or Sea Gilloflowers.

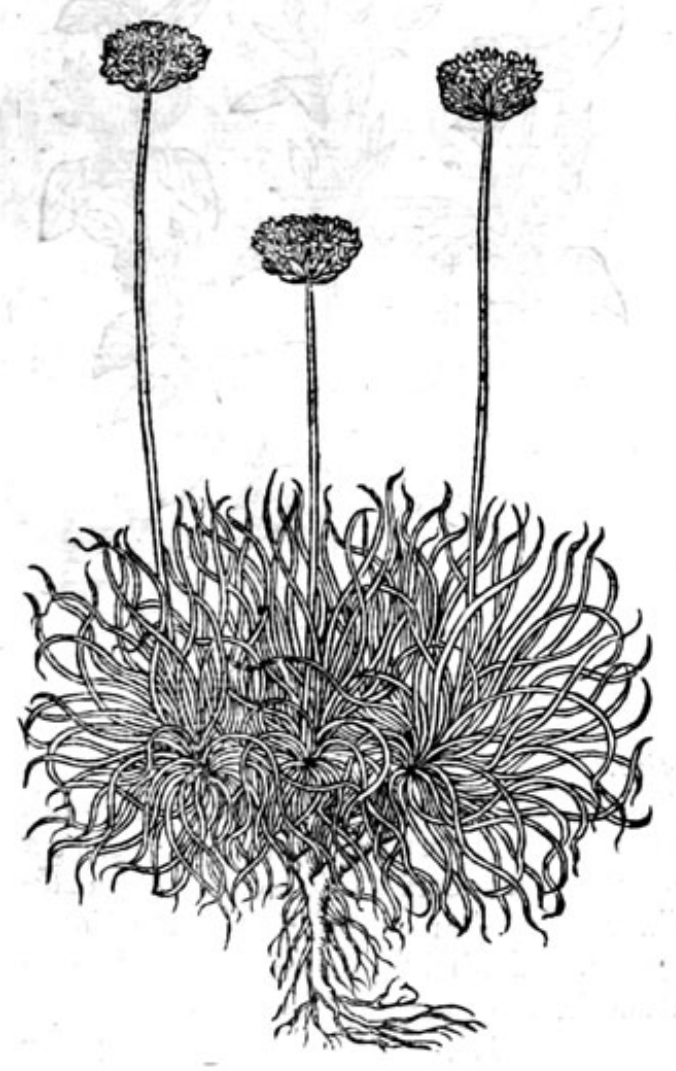

2 Caryophyllus Mediterraneus. Leuant Thrift, or Sea Gilloflower.

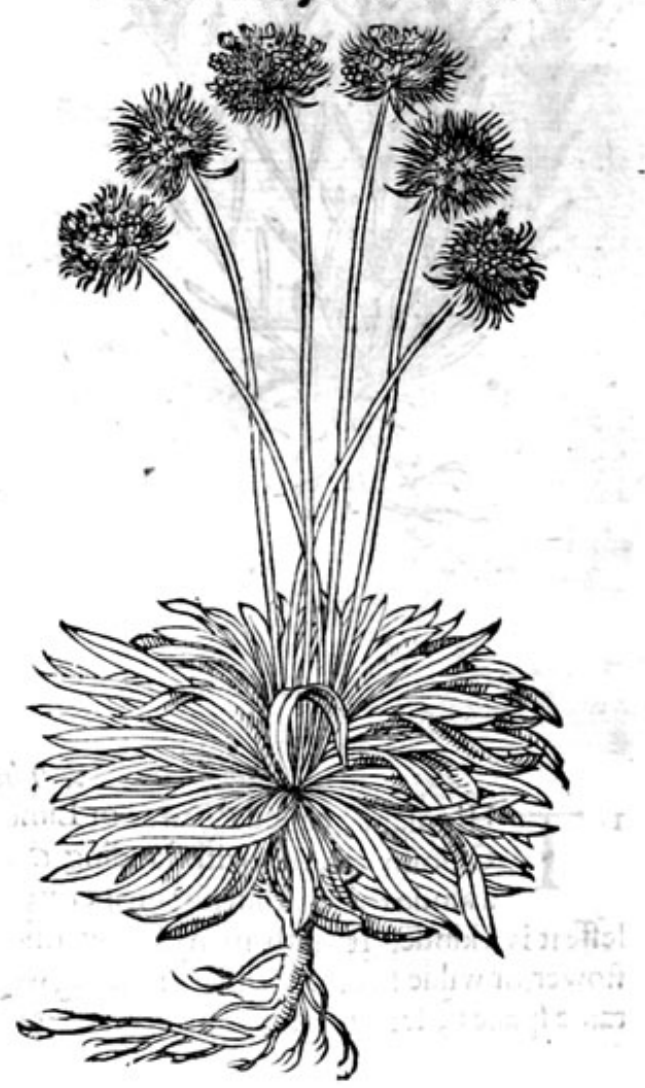




\section{HISTORIE OF PLANTS. HT \\ * The defcription.}

I Hrift is alfo a kinde of Gilloflower, of Dodonews reckoned among graffes, which bringeth foorth leaues in great tuftes, thicke thruft togither; fmaller, flenderer, and fhorter than graffe : among which rife vp fmall tender ftalkes of a f pan high, naked and without leaues; on the tops whereof ftand litele flowers in a fpokie tuft, of a white colour tending topurple. The roote is long and threddie.

2 The other kind of Thrift, found vpon the mountaines neere vnto the Leuant or Mediterranean fea, differeth not from the precedent in leaues; ftalkes, or flowers, but yet is altogither greater, and the leaues are broader.

$$
\text { * The place. }
$$

The firft is found in moit falt marfhes in England, as alfo in gardens, for the botdeting vpofbed's and bankes, for the which it ferueth very fitly. The other is a ftranger in thefe nortliren regions.

They flower from May till fommer be far fpent.

$$
\text { * The time. }
$$

$$
\text { * The nomes. }
$$

Thrift is called in Latine Gramen Polyant hemam, of the multitude of the flowers: of fome Gramen mariveon : of L'Obelizu Caryopbylles marinus : in Englifh Thrift, Sea graffe, and our Ladies Cufhion. * The temperature and vertues.

Their vfe in phificke as yet is not knowen, neither doth any feeke into the nature thereof, but efteeme them onely for their beautic and pleafure in gardens.

$$
\text { Of Sneele woort. Chap.178. }
$$

I Ptarmica.

Sncefewoort,

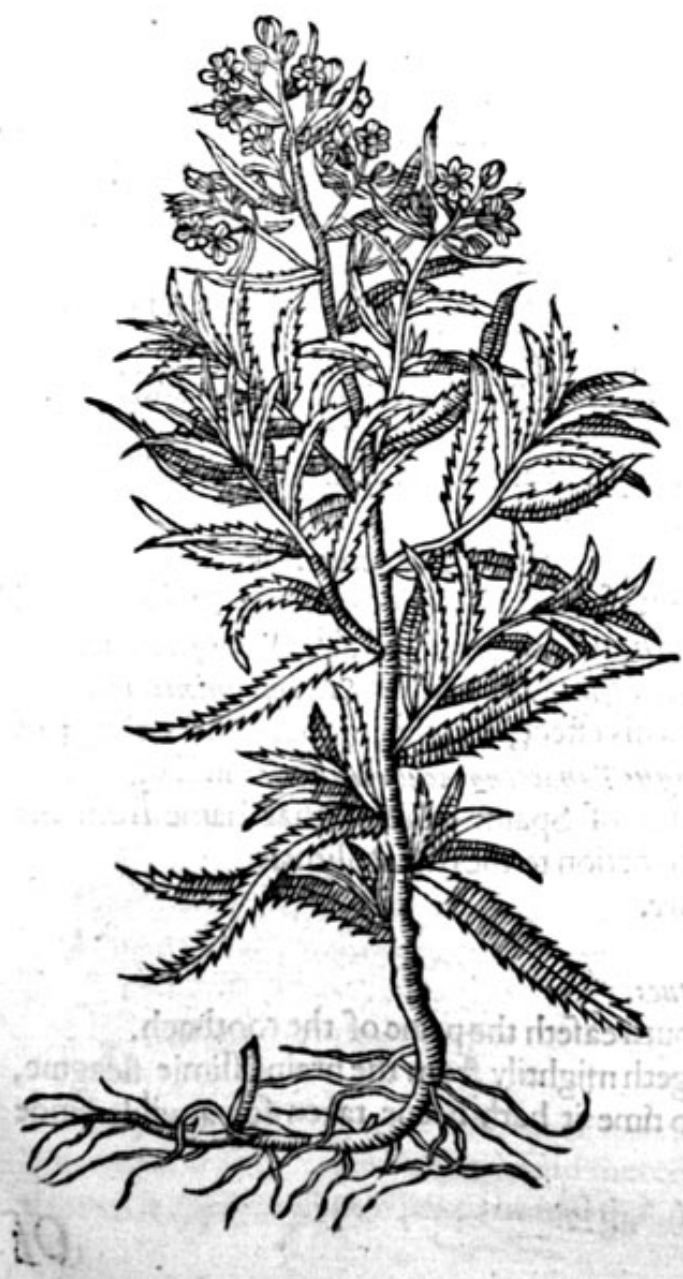

2 Ptarmicadupliciflore.

Double tlowred Sneefe woort.

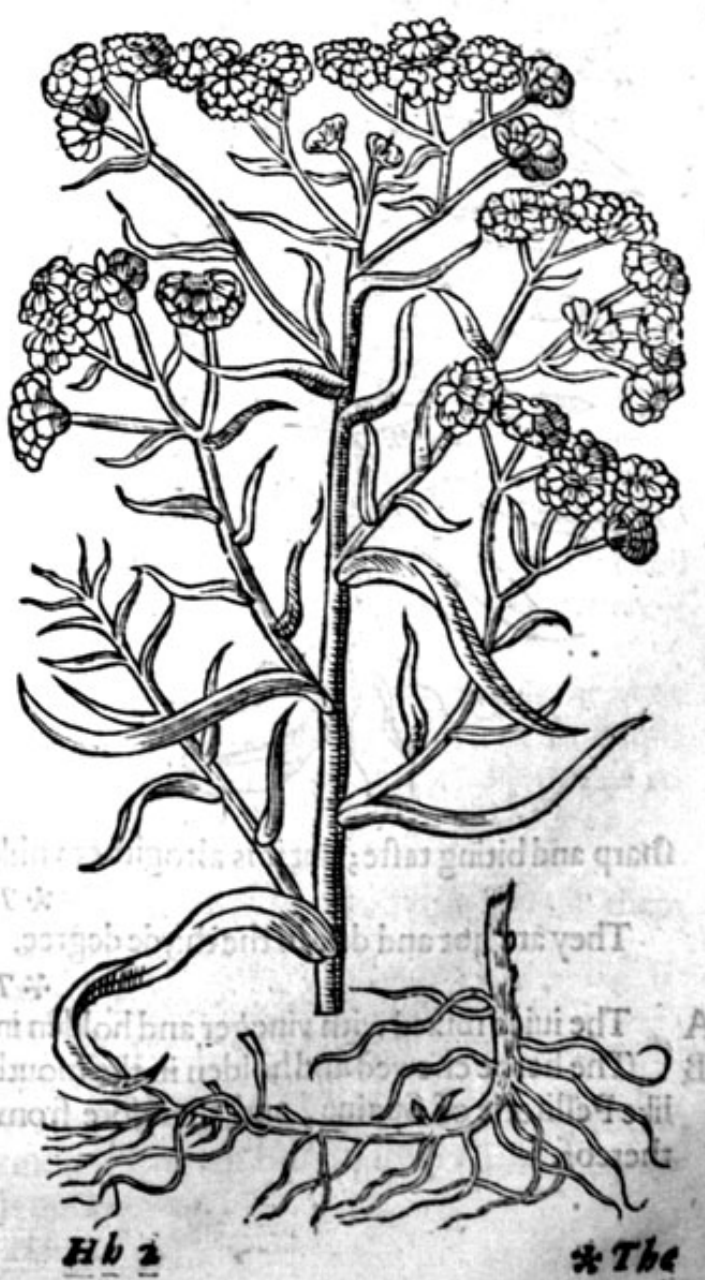




\title{
$4^{8} 4$ THE SECOND BOOKE OF THE
}

\author{
$*$ The defcription.
}

I He fmall Sneefe woort hath many rounde and brittle braunches, befet with long and narrowe leaues, hackt about the edges like a fawe; at the top of the ftalkes do grow fmal fingle flowers like the wilde fielde Daifie. The roote is tender and full of ftrings, creeping farre abroade in the earth, and in thort time occupieth very much grounde: the wholeplant is harpe, biting the toong and mouth like Pellitorie of Spaine, for which caufe fome haue called it wilde Pellitoric. The fmell of this plant procureth fneezing, whereof it tooke the name Sternutamentoria, that is the herbe which doth procure Sneefing, or Neefewoort.

2 Double flowred Sneefewoort, or Ptarmica, is like vnto the former in leaues, ftalks, and rootes, fo that vnleffe you behold the flower, you can not difcerne the one from the other, and it is exceeding white, and double like vnto double Fetherfew. This plant is of great beautie, and if it be cut downe in the time of his flowring, there will come within a moneth after a fupplie or crop of flowers fairer then the firft.

\section{Ptarmica Auftriaca.}

Sneefewoort of Auftrich.

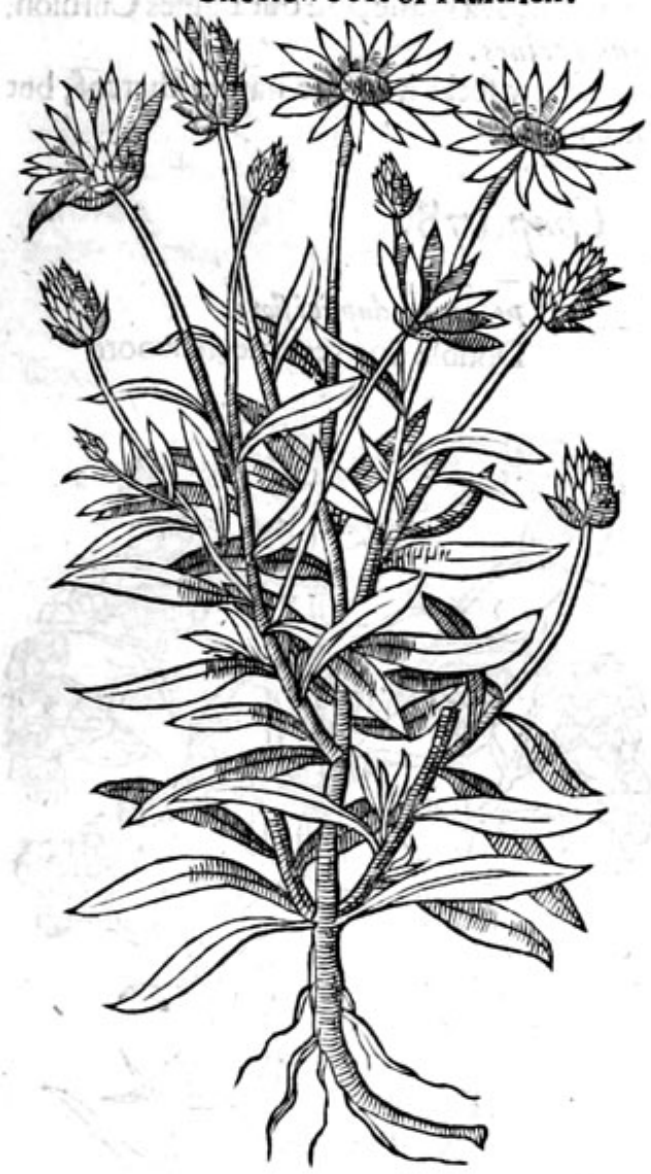

* T Thedefription.

3. There is alfo another kind heerof, of exteeding great beautic, hauing long leaues fomwhat narrow like thofe of the Oliue tree : the ftalkes are of a cubite high, on the top wherof do grow very beautiful towers of the bigneffe of a fmall fingle Marigold, confifting of fifteene or fixteene large leaues, of a bright thining red colour tending to purple; fet about a ball of thrummie fubftance, fuch as is in the middle of the Daifie, in manner of a pale, which flowers ftand in fcalie knops like thofe of Knapweede, or Matfellon. The roote is ftraight, and thrufteth deepe into the ground.

$$
\text { * Theplace. }
$$

The firft kinde of Sneefewoort groweth wilde in dric and barren paftures in many places, and in the threc great fieldes next adioining to a village neere London called Kentifh towne, and in fundry fieldes in Kent about Soutbfleete.

The fecond groweth in my garden, and in fome others alfo.

$$
\text { * The teme. }
$$
ber.

They flower from May to the ende of Septem.

\section{* The names.}

Sneefewoort is called of fome Ptarmica, and Pyrethrum fyluestre, and alfo Draco fyluestris, or Tarcon fylueftris, of moft Sternut umentoria, taken from his effect, bicaufe it procureth fneefing; of Tragu Tanacetum acutum album: in Englifh Pellitorie of Spaine, taking that name from his Tharp and biting tafte; but it is altogither vnlike in proportion to the true Pellitorie.

$$
\text { * The nature. }
$$

They are hot and drie in the thirde degree.

$$
\text { * The vertues. }
$$

A The iuice mixed with vineger and holden in the mouth eafeth the paine of the toothach.

B The herbe chewed andholden in the mouth, bringeth mightily from the braine flimie fleagme, like Pellitorie of Spaine, and therefore from time to time it hath beene taken for 2 wilde kinde
thereof. 


\section{Of Hares eares. Chap.179.}
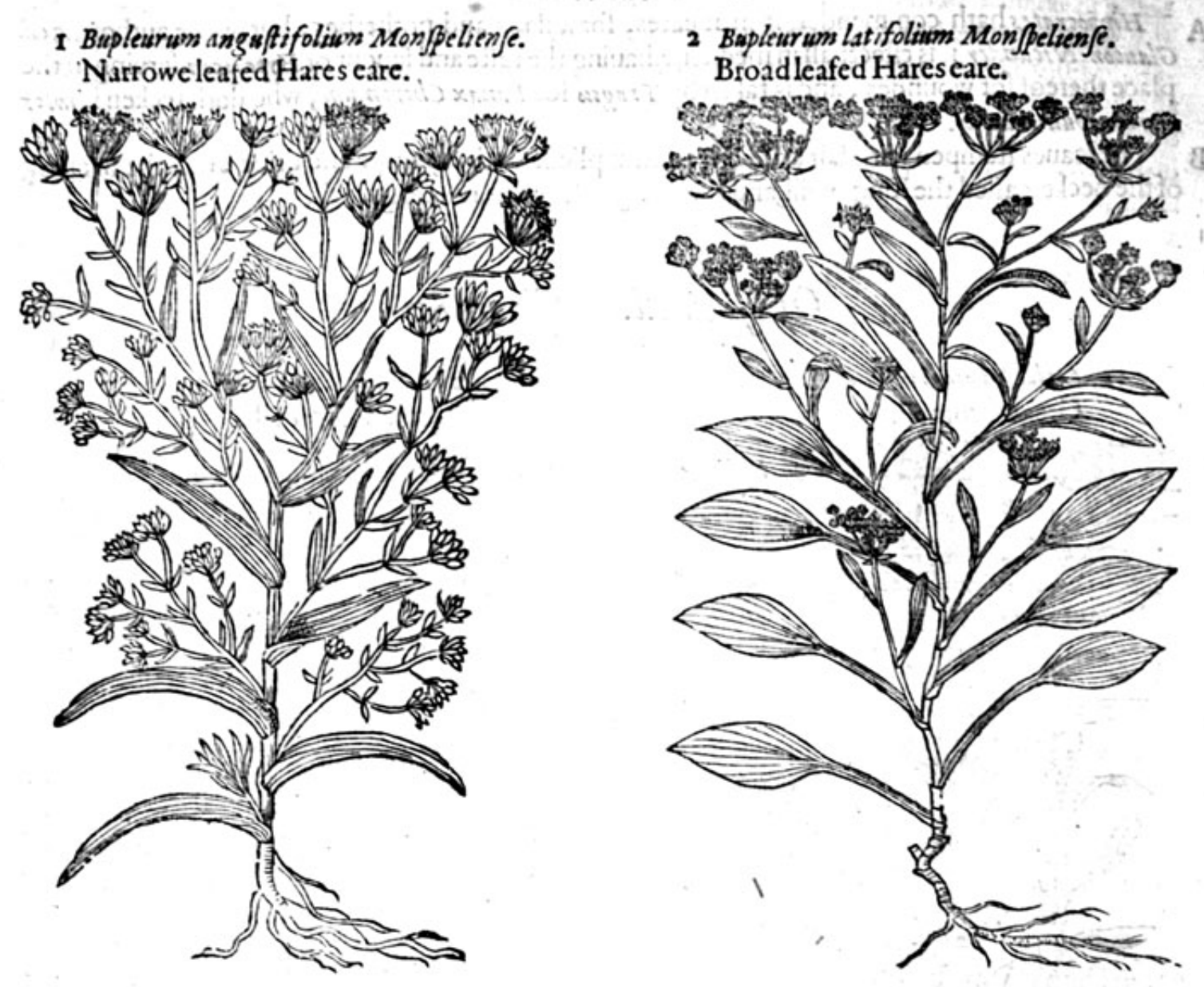

* The defcription.

I T Arrowe leafed Hares eares is called in Grecke Búrdes, and is reputed of the Latine wri-

N ters to be Buplearum Pling, from which the name or figure difagreeth notit hath the long, narrow and graffie leaues of Lachryma Iob, or Gladiolwe, ftreaked or balked as it were with fundrie ftiffe ftreakes or ribbes running along euery leafe, as $P$ liny fpeaketh of his Heptapleurum : The ftalkes are a cubite and a halfe long, full of knots or knees, very rough or ftiffe, fpreading themfelues into many braunches : at the tops whereof growe yellow flowers in rounde tufts or heads like Dill. The roote is as bigge as a finger, and blacke like $P$ eucedanum, whereunto it is like in tafte, fmell and refemblance of feede, which doth the more perfivade me that it is the true Buplewrum, whereof I now fpeake, and by the authoritic of 2 icander and $P$ liny confirmed.

2 The feconde kinde called broade leafed Hares eares, in figure, tufts, and flowers, is the verie fame with the former kinde, faue that the leaues are broader \& ftiffer, and more hollow in the midit: which hath caufed me to call it Hares eares, hauing in the middle of the leafe fome hollowneffe refembling the fame. The roote is greater and of a woodie fubftance.

\section{* Theplace.}

They growe among oken woods in ftonie and harde grounds in Narbone. Thaue founde them growing naturally among the bufhes vpon Beiftone caftell in Chefhire.

$$
\text { * The time. }
$$

They flower and bring foorth their feede in Iulie and Auguft.

$$
\text { * Thenames. }
$$

Hares eare is called in Latine Bupleurum : in Greeke Bundeen: the Apothecaries of Montpelier in Fraance do call it Auricula leporis, and therefore I terme it in Englifh Hares eares: Valerius Cor des namethit IJophyllon, but whence he had that name, it is not knowen. 
They are temperate in heate and drineffe.

\author{
$*$ The temperature.
}

* The vertues.

A Hippocrates hath commended it in meates, for fallads and potherbes: but by the authoritic of Glaucon, Nicander, it is effectuall in medicine, hauing the tafte and fauour of Hypericon,feruing in the place thereof for woundes, and is taken by Tragus for $P$ anax Chironium, who doth recken it inter Herbas vulnerarias.

B The leaues ftamped with falt and wine, and applied, doth confume and driue away the fwelling of the necke, called the Kings euill, and is vfed againft the ftone and grauell.

\title{
OfGromell. Chap.180.
}

I Lithofpermum mains. Great Gromell.

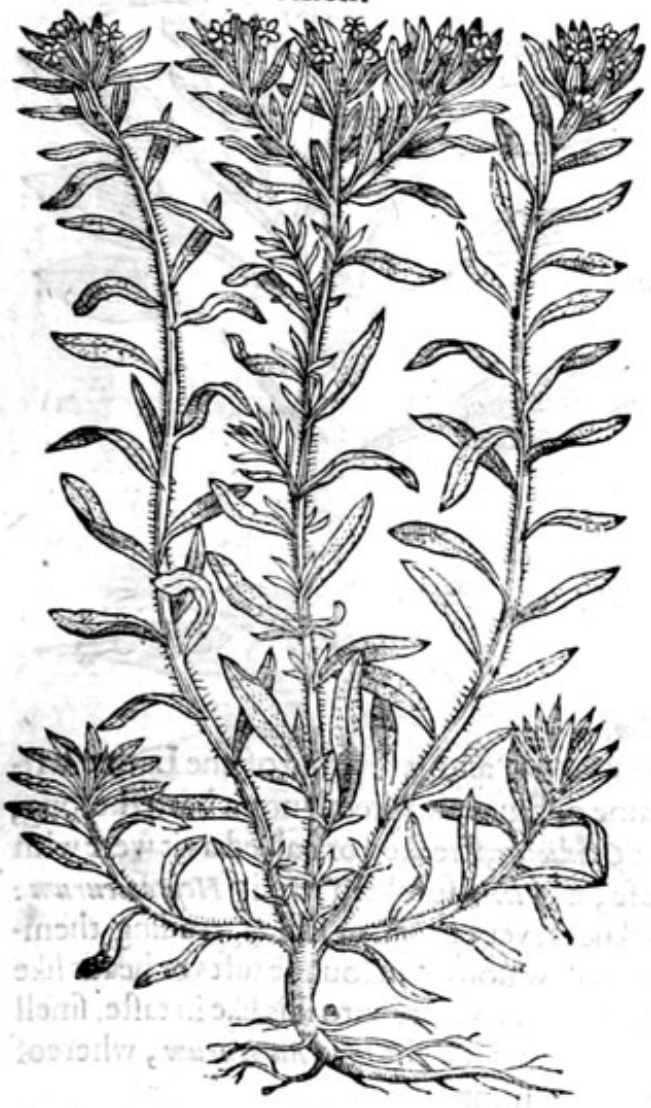

2 Lithopermum minus. Small Gromell.

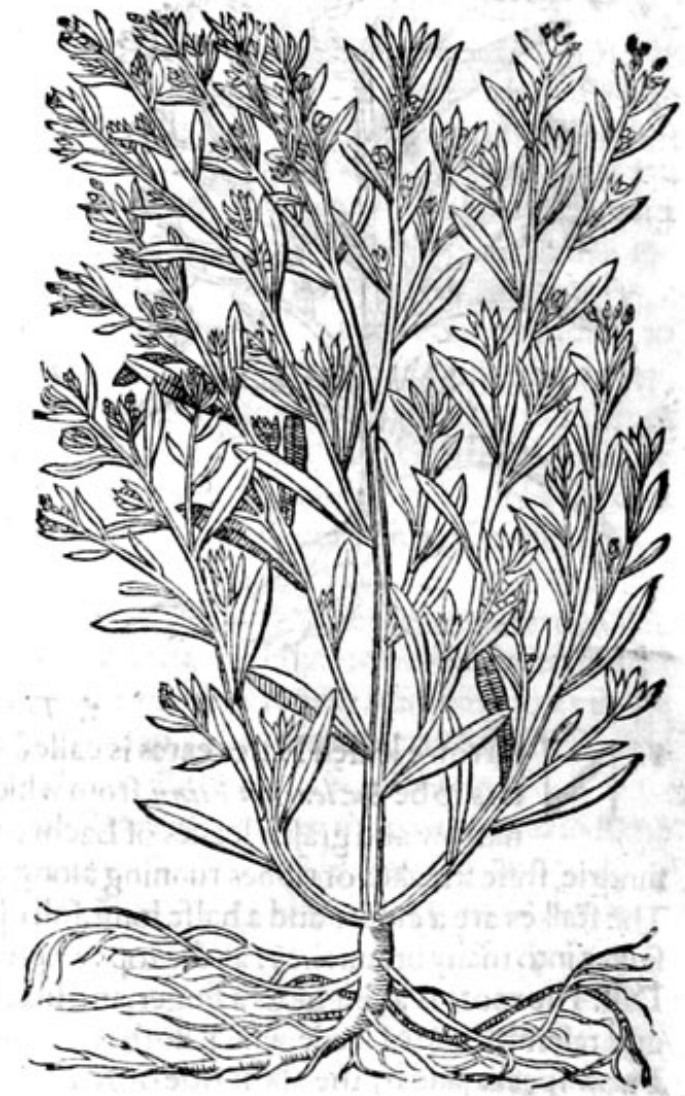

1 He great Gromell hath long, 1 thender and cription.

leaues; among which growe cerrainc beard thalkes, befet with long, browne and hoarie ers; which being paft, there fucceedeth a ded huskcs, bearing at the firft fmall blew flowis hard, and of a wooddie fubftance. 2 The fecond kinde of Gromell hath ftraight, round, wooddie ftalks, full of branches: the leaues which come foorth little white flowcrs; colour; fmaller than the leaues of great Gromell : among mer hath, but fmaller. is not fo white, neither fo fmooth and plaine, but fomes and ftalkes like the finall kinde; the feede fomcwhatrougher, like vnto a wilde kinde of Bugloffe, called Anchufa, for which caufe it carrieth 


\section{HISTORIE OF PLANTS.}

that additament Anchufa facie. The flowers are like vnto the former, that is, of a white colour,grow. ing in tufts at the top of the ftalkes, like vnto Sopewoort.

There is alfo a degenerate kinde hereof called Anchufa degener, being either a kinde of wilde Bugloffe, or a kinde of wilde Gromell, or elfe a kinde of neither of both, but a plant participating of both kindes : it hath the feeds and ftalkes of Milivem folis, or Gomell; the leaues and rootes of An$\operatorname{chafa}$, which is Alkanet, and is altogither of a red colour like the fame.

* Theplace.

The two firft kindes do growe in vntoiled places, as by the high waies fides, and barren places, in theftreete at Southfleete in Kent, as you go from the church vnto an houfe belonging to a genteman of worfhip,called Mafter Willsam $S$ wan, and in fundrie other places.

The two laft kindes growe vpon the fands and bach of the fea, in the yle of Thanet neere Reculvers, among the kinds of wilde Bugloffe there growing.

$$
\text { * The time. }
$$

They flower from the fommer Solftice, or from about the twelfe day of Iune euen vnto Autumne, and in the rueane feafon the feede is ripe.

$$
\text { * } 7 \text { he names. }
$$

Gromell is called in Greeke regoerpuspr, of the hardneffe of the feede: of diuers Gorgonium: of others Legonychon, Leontion, or Dio/poron, or Dio/pyron, as Plinie readeth it, and alfo Heracleos: of the Arabians Milium foler : in thops, and among the Italians Milium folis: in Spanifh Mijo del fol: in French Gremil, and Herbe asx perles : in Englifh Gromell : of fome Pearle plant, and of others Lichwale.

\section{* The temperature.}

The feede of Gromell is hot and dric in the fecond degree. * The vertues.

The feede of Gromell pound, and drunke in white wine, breaketh, diflolueth, and driueth foorth $A$ the ftone, and prouoketh vrine, and efpecially breaketh the ftone in the bladder.

\section{Of Cbickweede. Chap.18r.}

\section{* The kindes.}

$T$ Here be divers forts of Chickweedes, among which one is greater and other leffer and lower: and other fome there be alfo which we may call baftarde Chickweedes: and firft of the beft knowne Chickweedes.

\section{* The defcription.}

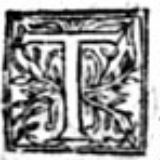
He great Chickweede rifeth vp with ftalkes a cubite high, and fome time higher, a great many from one roote, long and rounde, flender, full of ioints, with a couple of leaues growing out of euery knot or ioint aboue an inch broade, and longer then the leaues of Pellitorie of the wall,whereunto they are very like in fhape, but finooth with. out haires or downe, and of a light greene colour : the ftalkes are fome thing cleere, and as it were tranfparent or thorow fhining, and about the ioints they be oftentimes of a very light red colour, as be thofe of Pellitory of the wal: the flowers be whitim on the top of the branches like the flowers of Stitchwoort, but yet leffer: in whofe places fucceedeilong knops, but not great, in which the feede is conteined. The roote confifteth of fine little ftrings like haires.

2 The feconde Chickweede for the moft part lieth vpon the grounde : the ftalkes are finall, flen. der, long, and rounde, and alfo iointed; from which flender braunches do fpring leaues refembling the precedent, but much leffer, as is likewife the whole herbe, which in no refpeet attaineth to the greatneffe of the fame: the flowers are in like fort little and white; the knaps or feede heads are like the former. The roote is alfo full of little ftrings.

3 The third is like the fecond, but farre leffer: the ftalkes be moit tender and fine: the leaues are very fmall: the flowers very little; the rootes maruellous flender.

4 Alfo there is a fourth kinde which groweth by the fea; this is like to the feconde, but the ftems are thicker, thorter, and fuller of ioints. The leaues in like fort be thicker : the knaps or feede heades benotlong and rounde, but fomewhat broade, in which are three or fower feedes contained: 
1 Alfme maior.

Great Chickweede.
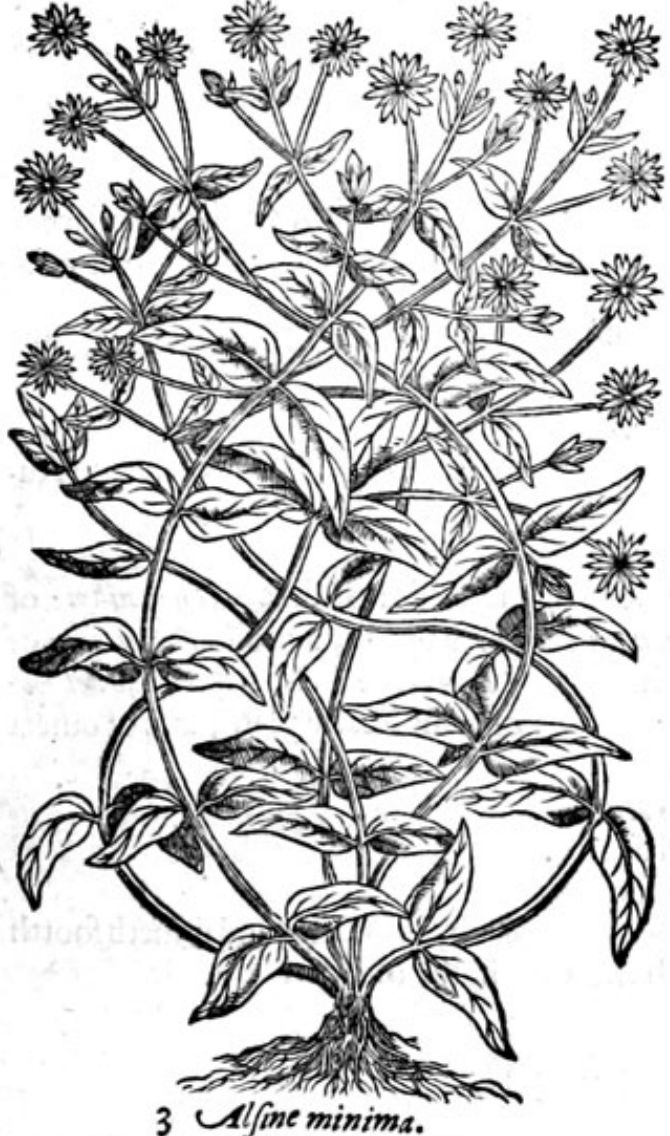

Fine Checkeweede.

-

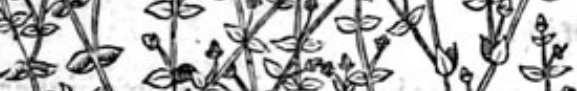
on 2 of is is की

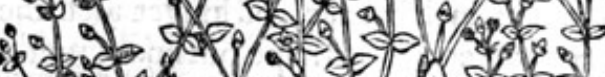

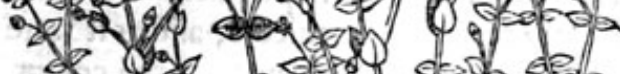
- a d a d o opo op

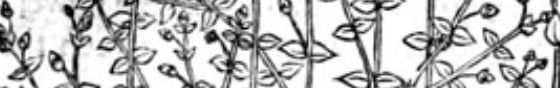

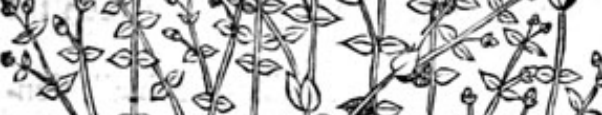

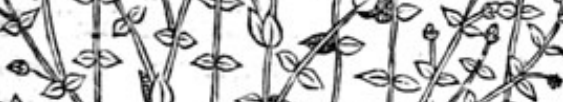

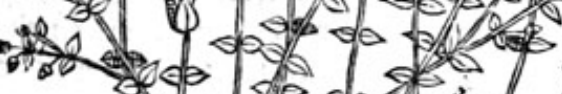
- of ase as of of

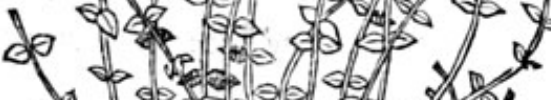
$<$ opes.

$$
\text { त्रा }
$$

2 valineminor. Small Chickweede.

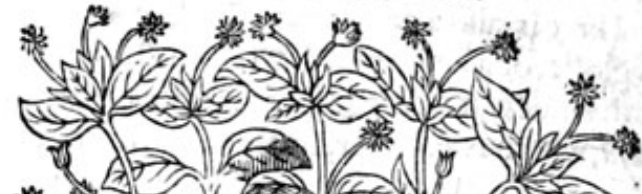
诰 (4)

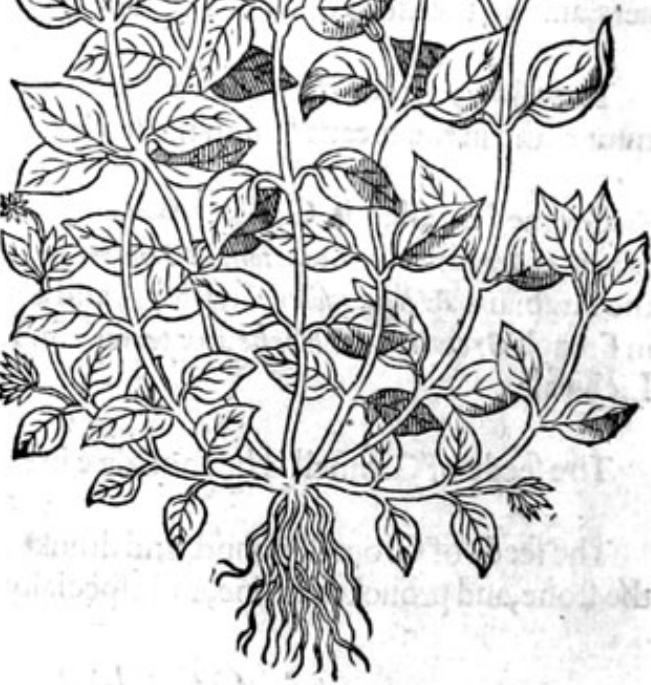

4 - slfine marina. Sea Chickweede.

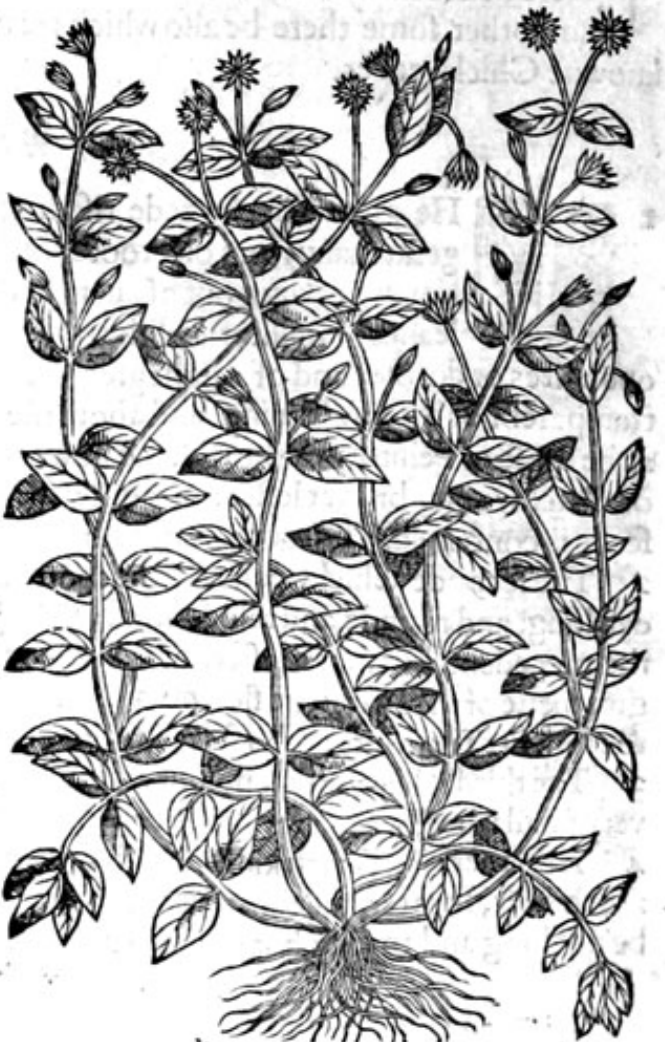


HISTORIE OF PLANTS.

5 - Alfomemedia. Middle Chickweede.

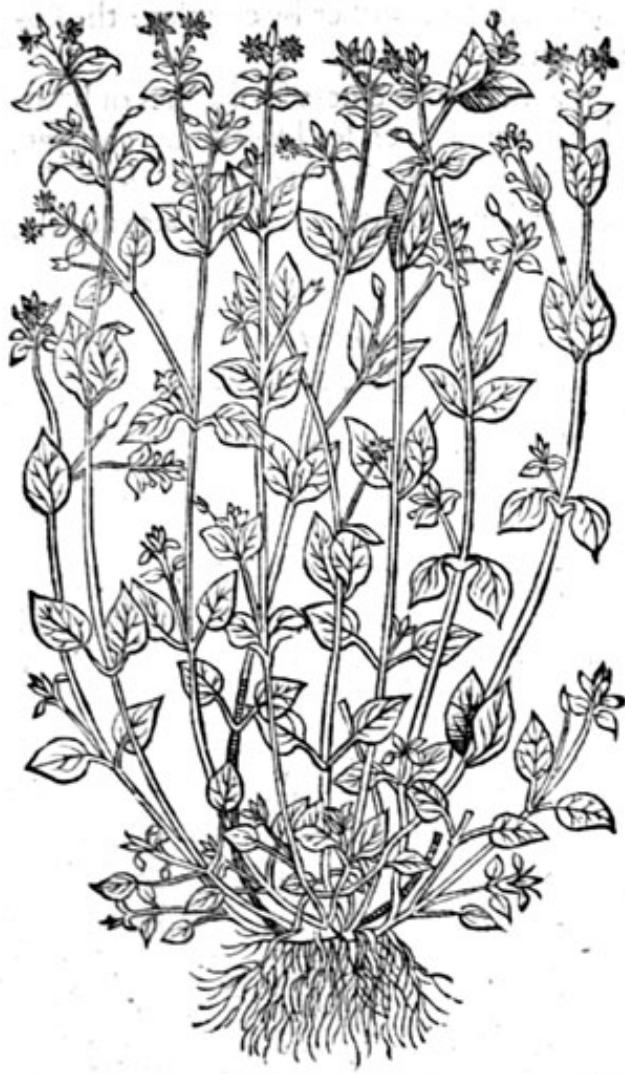

6 - alfine recita.

Right Chickweede.

$*$ The defription.

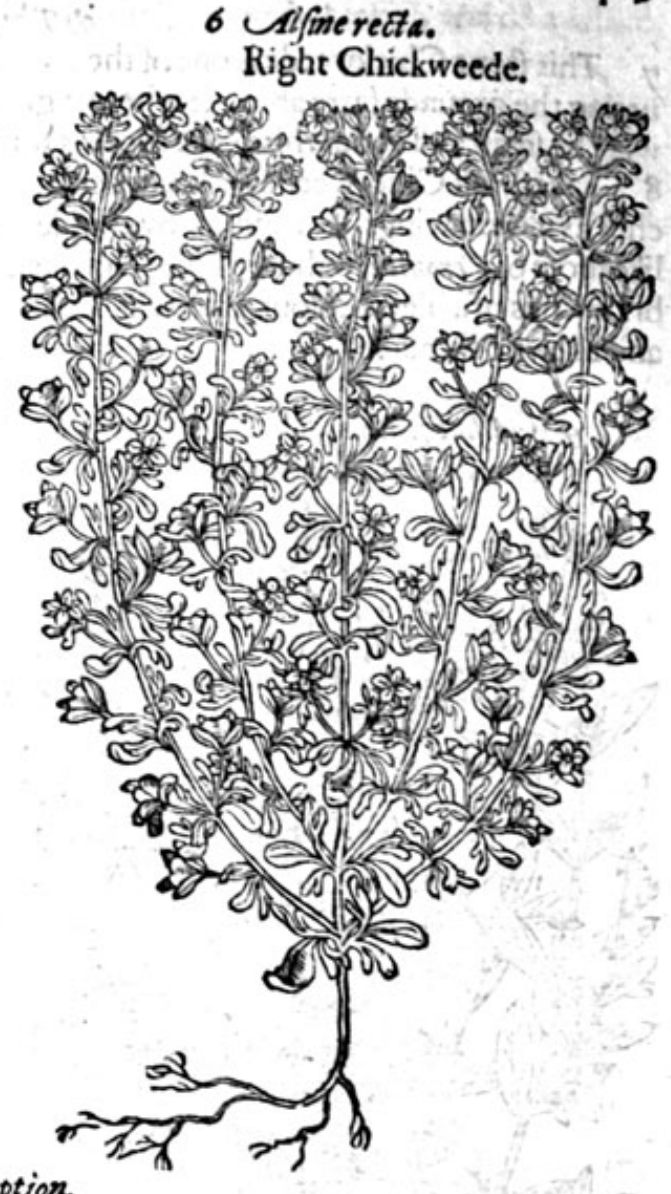

5 The middle Chickweede hath long trailing braunches, difperfed heere and there ypon the ground; whereupon are fet by couples fmall leaues like thofe of $V$ uluaria. The flowers are very little, and white of colour; after which come rounde knops wherein is the feede. The roote isflender and threddie.

6 The vpright Chickweede hath a very fmall fingle threddie roote, from which rifeth vp a flender ftem, diuiding it felfe into diuers braunches, euen from the bottome to the top; whereon do growe fmall leaues, thicke and fat in refpect of the others, in thape like thofe of Rue or Herbe grace. The flowers grow at the top of the branches confirting of fower fmall leaues of a white colour.

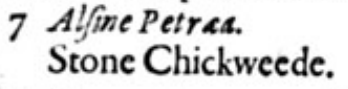

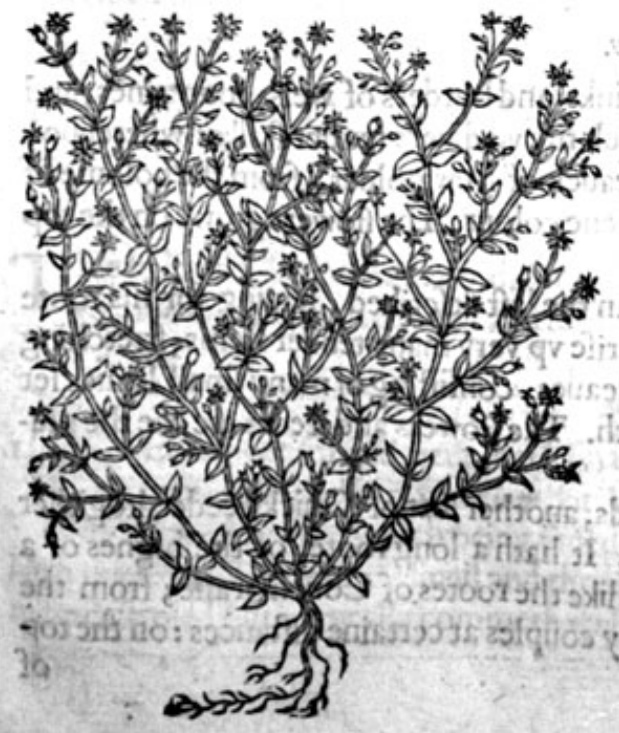

8 Al/pine folys vetonica.

Speedwell Chickweede.

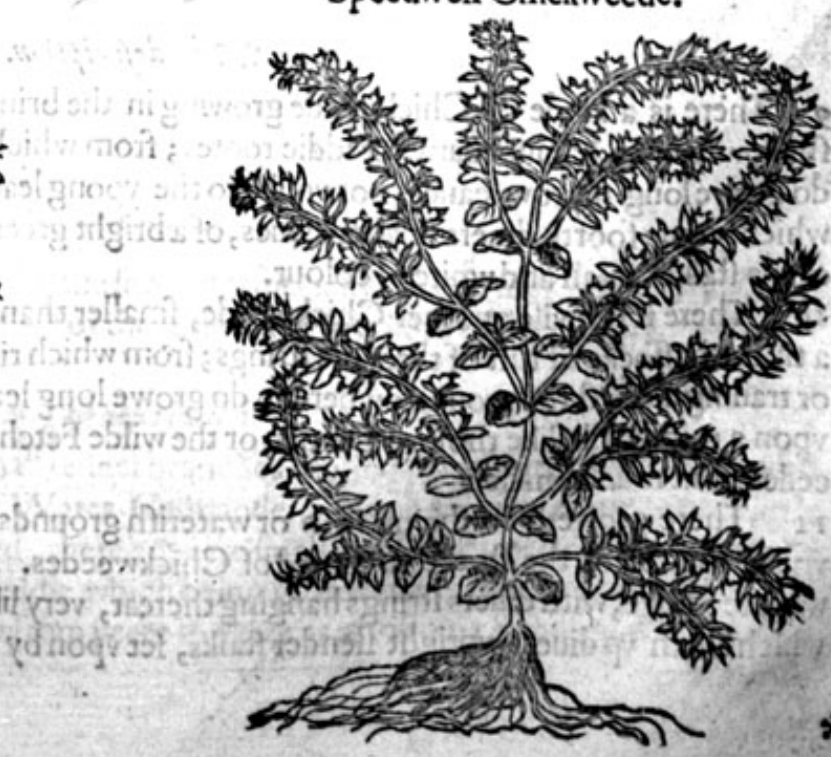


* The defcription.

7 This ftone Chickweede is one of the common Chickweeds, hauing very threddie branches co uering the grounde farre abroade where it groweth : the leaues be fet togither by couples; the flowers be fmall and verie white : the roote is tough and very flender.

8 Speedwell Chickweede hath a little tender ftalke, from which come diuers final armes or branches asit were wings, fet togither by couples: whereon doe growe leaues fet likewife by couples, like thofe of Veronica, or herbe Fluellen, whereof it tooke his name. The flowers growe along the braunches of a blewe colour, after which come little pouches wherin is the feed. The roote is fmall, and likewife threddie.

9 Nifme fontana.

Fountaine Chickweede.

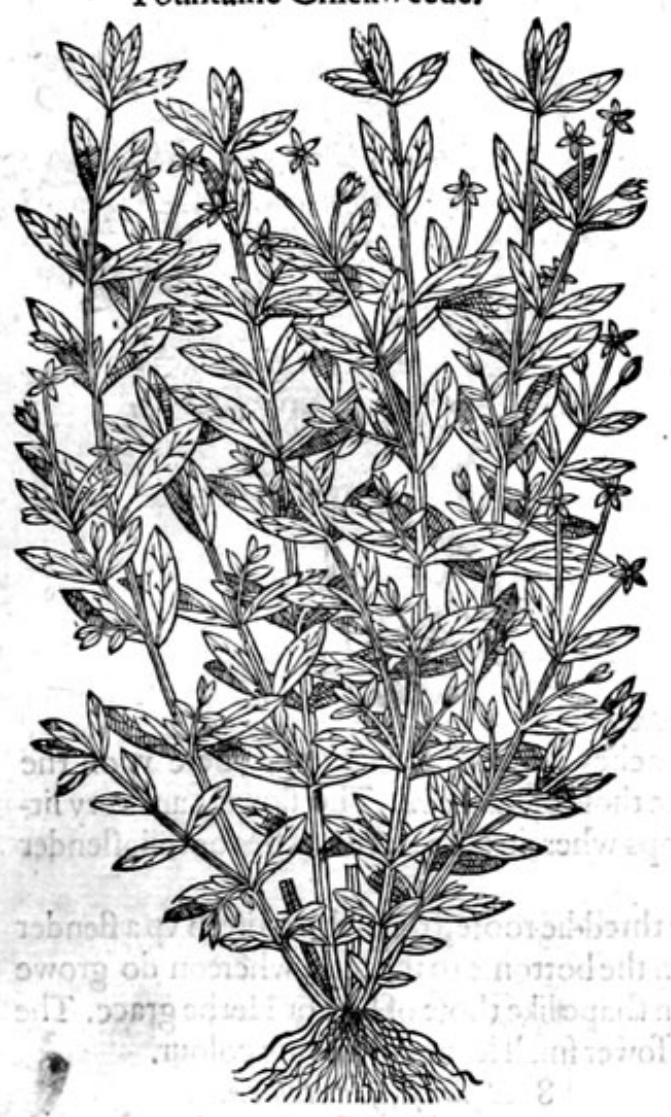

10 Alfme fluniatilis. Riuer Chickweede.

\section{* The defcription.}

9 There is a kinde of Chickweede growing in the brinks and borders of wels, fountaines, and Thallowfprings, hauing many threddie rootes; from which rife vp diuers tender ftalkes, whereupon do growe long narrow leaues, not vnlike to the yoong leaues of Marigoldes: from the bofome of which, come foorth diuers fmaller leaues, of a bright greene colour. The flowers growe on the top of the ftalkes, frmall and white of colour.

io There is likewife another Chickweede, fmaller than the laft defcribed, hauing for his roote a thicke haffocke or tuft of thieddie ftrings; from which rife vp very many tender ftems, ftretching or trailing alongt the ground; whereon do growe long leaues, confifting of many fmall leaues fet vpon a middle rib, like thofe of Lentils, or the wilde Fetch. The flowers and feedes are like the precedent, but much fmaller.

If There groweth in the marrifh or waterifh grounds, another fort of Chickweede altogither vnlike the reft of the ftocke or kinred of Chickweedes. It hath a long roote, of the bignes of a wheate frawe, with diuers ftrings hanging thereat, very like the rootes of Couch graffe; from the which rifeth vp diuers vpright flender ftalks, fet vpon by couples at certaine diftances : on the top 
of the ftalkes do grovve fmall white flowers like thofe of Stitchwoort, but leffer, and of a white: colour. .

it Cilfine palustris. Marifh Chickweede.

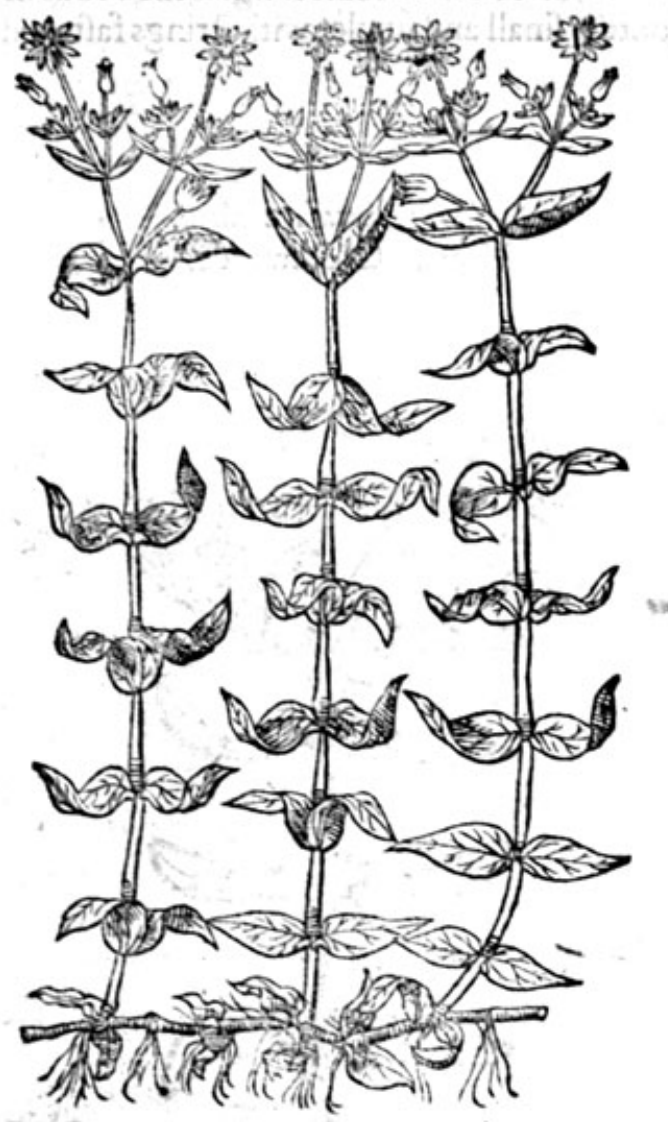

* Theplace.

Chickweedes, fome growe among bufhes and briers, olde wals, gutters of houfes, and fhadowic ; places. The place is fet foorth in the feueralldefcriptions of the other forts.

\section{* The time.}

The Chickweedes are greene in winter, they flower and feede in the fpring. * The names.

Chickweede or Chickenweede, is called in Greeke ainoim: in Latine it retaineth the fame name Alfane: of fome of the ancients it is called Hippia, the greater and the lefier. The reft of the plants are diftinguifhed in their feuerall titles, with proper names, which likewife fettech foorth the place of their growings.

$$
\text { *. The temperature. }
$$

Chickweede is colde and moift, and of a waterifh fubftance; and therefore it cooleth without aftriction or binding, as $G_{s} l c n$ faith.

$$
\text { * The vertwes. }
$$

The leaues of Chickweede boiled in water $\mathrm{A}$ very foft, adding thereto fome hogs greace, the powder of Fenugrecke and Linefeede, and a few rootes of Marrh Mallowes, ftamped to the forme of a Cataplafma or pultus, taketh away the fwellings of the legs; or any otherpart; bringeth to fuppuration or matter, hot apoftemes;

diffolueth fwellings that will not willingly yeeld to fuppuration; eafeth members that are fhrunke VR; comforteth wounds in finewie partes; defendeth foule maligne and virulent vicers from inflammation during the cure : in a word, it comforteth, digefteth, defendeth, and fuppurateth very notably.

The leaues boiled in vineger and falt, is good againft mangyneffe of the hands \&legs, if they be B bathed therewith.

Little birdes incages (efpecially Linets) are refrefhed with the leffer Chickweed, when they C loath their meate; whereupon it was called of fome $P$ afferina.

\section{Of the baftard Chickweeds. Chap.182.}

* The kindes.

Te baftard Chickweedes do differ from the former, efpecially bicaufe they be rough and hairie : fome alfo differ in forme and faftion of the leaues, and in colour of the flowers.

$$
\begin{aligned}
& \text { To }
\end{aligned}
$$

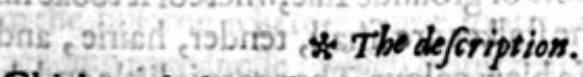

I Ermander Chickweede hath friall tenderbranches trailing vpon the ground, bèfetwith leates like thofe of Scordiwm, or Water Germander. Among which come foorth litede blew flowers; which being faded, there appeere fmall flat huskes orpouches, wherein lieth the feede. The roote is fmall and threddie, which being gotten into a garden ground, it is hard to be deftroied, but naturally commeth vp from yeere to yeere as a noifome weede. 
2 Clufins, a man fingular in the knowledg of plants, hath fet down this herbe for one of the Chickweedes, which doth very well refemble the Storks bill, and might haue been there inferted. But the matter being of fmall moment I let it paffe; for doubtleffe it participateth of both, that is, the head or beake of Storks bill, and the leaues of Chickweed,which are long \& hairy, like thofe of Scorpion Moufe eare. The flowers are fmall, and of an herbie colour; after which come long horned cods or feede veffels, like vnto thofe of the Storks bill. The roote is fmall and fingle, with ftrings faftened thereto.

I Alfune folÿs Trifjaginis. Germander Chickweede.

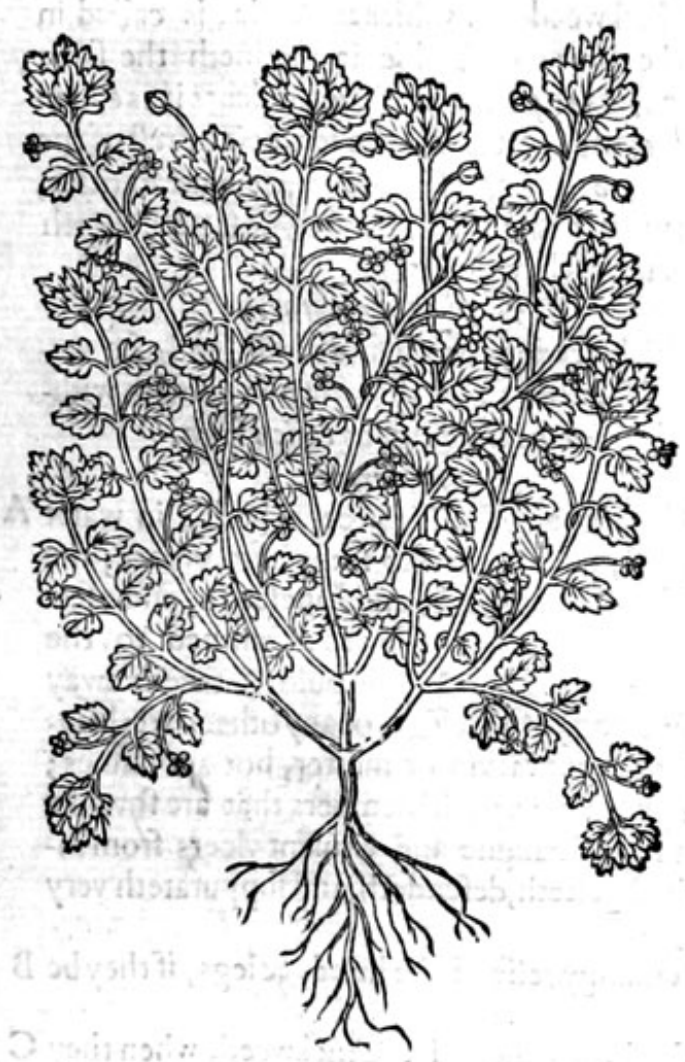

2 Alfine corniculata Clusj. Horned Chickweede.

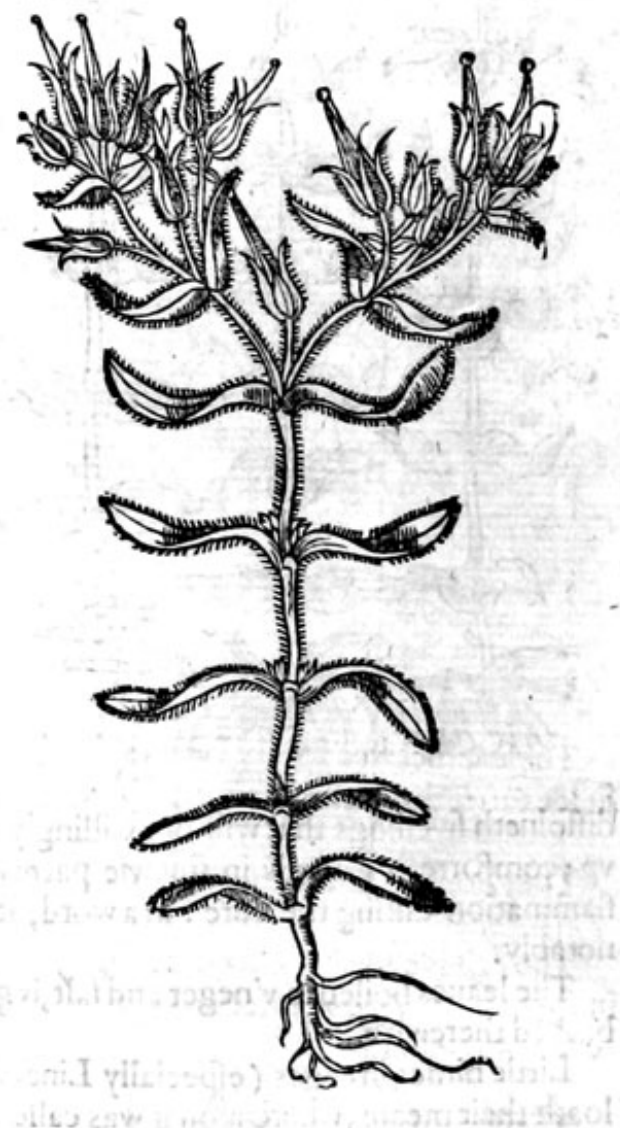

\section{* The defcription.}

3 IuieChickweede or fmall Henbit, hath thinne hairie leaues fomewhat broade, with two cuts ot gaf hes in the fides, after the maner of thofe of grounde Iuie, whereof it tooke his name, refembling the backe of a Bee when fhe flieth. The ftalkes are fmall, tender, hairic, and lying flat vpon the grounde. The flowers are flender and of a blew colour. The roote is little and threddie.

taine difteat Henbit hath feeble ftalkes leaning towarde the grounde, whereon do grow at cerderblew fles letell; from the bofome whereof come foorth flenfingle and a fewe ftrings hanging ejereape like thofe of the fimall dead Nettell. The roote is tough, 


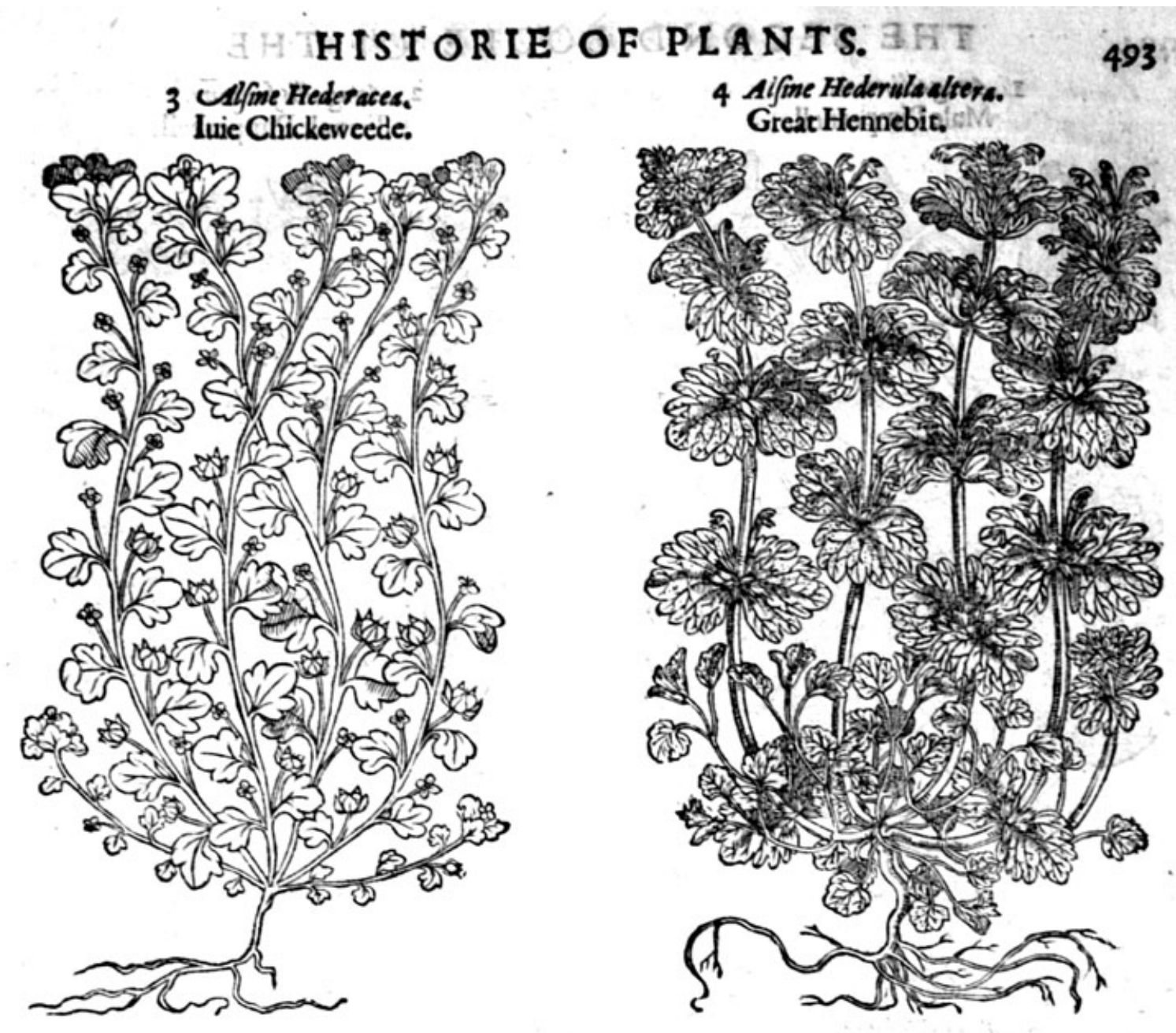

* Theplace.

Thefe Chickweedes are fowen in gardens among potherbes, in darke fhadowie places, and in the fieides after the corne is reaped.

\section{* The time.}

They flourilh and are greene when the other Chickweedes are.

$*$ The nanies.

The firft is called Morjous Gallina, Hens bit, Al/me Hederula, and Hederaces : in high punetbfiz: in French Mor/gelen, and CMorgeline : in low Du.tch Đoendetcbàt: in Englifh Henne bit the gre2ter and the leffer.

* The temperature and vertues.

Thefe are thought alfo to be colde and moift, and like to the other Chickweedes in vertue and $\mathbf{A}$ operation.

\section{Of Timpernell. Chap.183.}

* The de cription.

I. Imperpell is like vnto Chickweede; the ftalkes are fower fquare, trailing heere and there vpon the grounde, whereupon do growe broad leaues, and harpe pointed, fet togither by couples: from the bofome whereof come foorth flender tendrels, whereupon do growe fimall purple flowers tending to redneffe: which being paft there fucceede fine rounde bullets, like vnto the feede of Corianders, wherein is conteined fmall duftic feede. The roote confifteth of flender ftrings.

2 The female Pimpernell differeth not from themale in any one point, but in the colour of the flowers; for like as the former hath reddifh flowers, this plant bringeth foorth flowers of a molt perfect blew colour, wherein is the difference. 
THE SECOND BOOKE OF THE

I Amagallismas. Male Pimpernell.

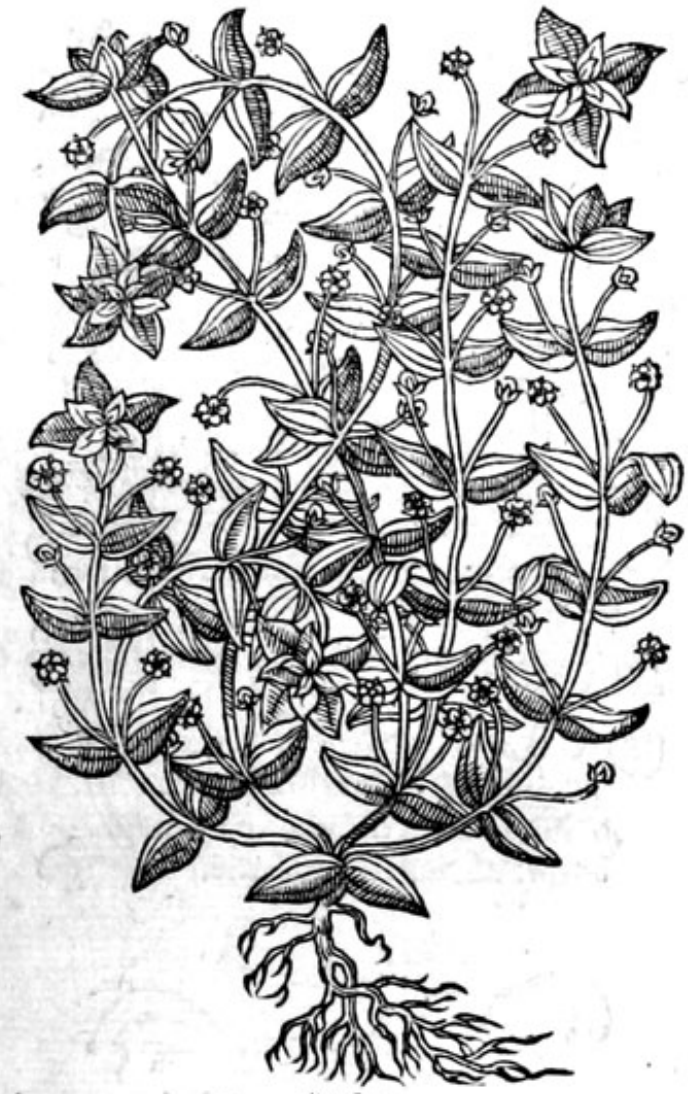

3 Anagallis lutea. Yellowe Pimpernell.

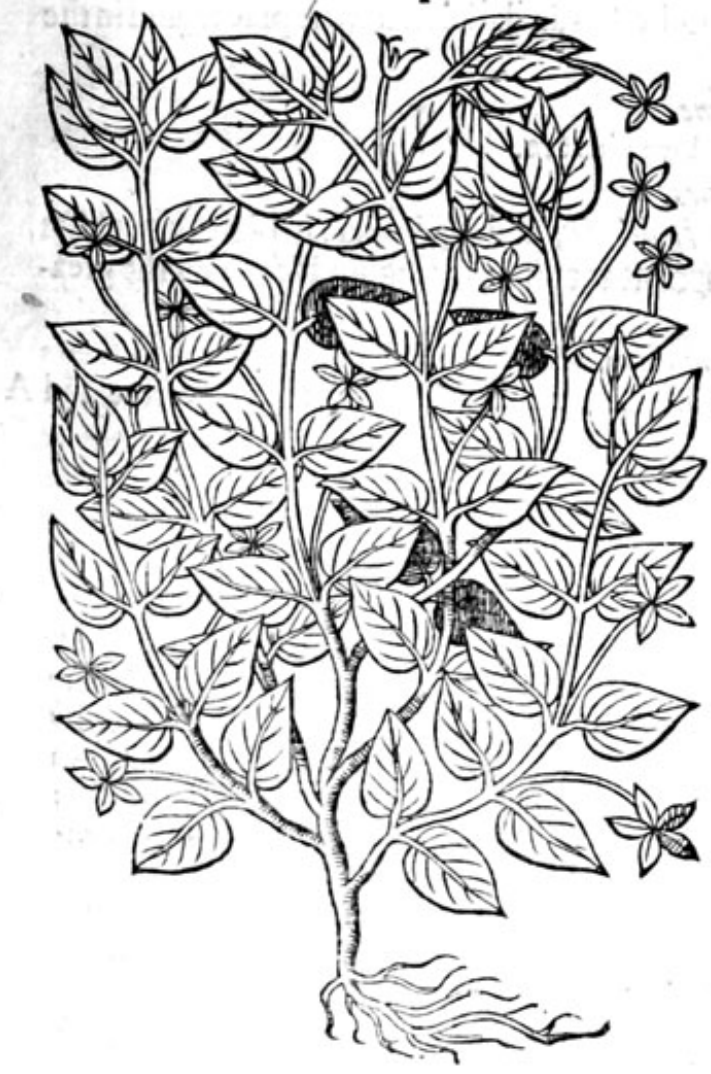

2 Anagallis famina. Female Pimpernell.

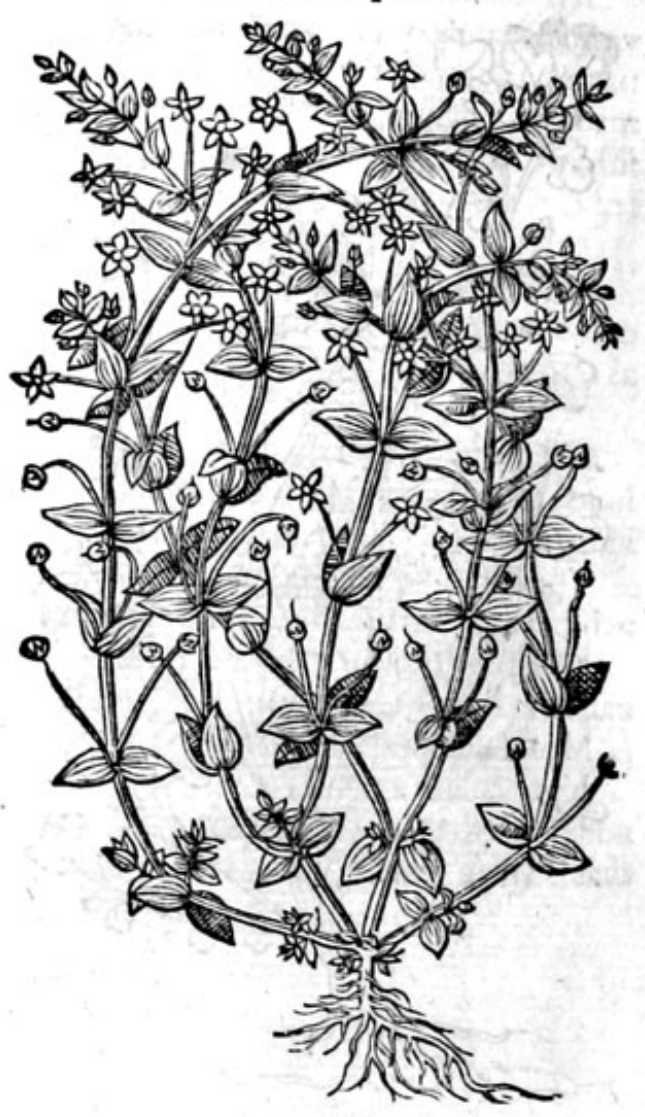

* The defcription.

3 The yellowe Pimpernell hath many-weake and feeble braunches trailing vpon the ground, befet with leaues one againft another like the great Chickweed, not vnlike to Nummuleria, or Money woorte; betweene which and the ftalkes, commeth foorth one fingle and fmall tender. ftalke, bearing at the toppe thereof one yellowe flower and no more. The root is fmall \& threddy.

$$
\text { * Theplace. }
$$

They grow in plowedfieldes neere path waies, in gardens and vineyards, almoft euery where.I founde the fernale with blewe flowers in a chalkie corne fielde in the way from mafter William Swaines houfe of Southfleete to Long fielde downes, but neucr any where elfe. * The time.

They flower in fommer, and efpecially in the month of Auguft, at what time the husbandmen hauing occafion to go vnto their harueft worke, will firft behold the flowers of Pimpernell,wherby theyknow the weather that fhall followe the next day after,as for example: if the flowers be Shut clofe vp, it betokeneth rain \& foul weather; contrariwife, if they bee fpread abroade, faire sveather. 


\title{
HISTORIE OF PIANTS.
}

\author{
* The names.
}

It is called in Greeke dragedws: in Latine allo Anagallis, of diuers as (Plinie reporteth) Corchorm but vntruely; of Marcellew an olde writer Macia, the worde is cxtant in Dicfcorides among the baftarde names. That with the crimfon flower being the male, is named P benticion, and Curallion; of this is made the compofition or receipt called Liacorallion that is vfed againft the gout, which compofition Paulues UEgineta fetteth downe in his 7 . booke. Among the baftarde names it hath been called Netitis,egitis, and Sawritis: in Englifh red Pimpernell, and blew Pimpernell.

$$
\text { * The tempersture. }
$$

Both the forts of Pimpernell are of a drying facultie without biting, and fometwhat hot, with a certaine drawing qualitie; infomuch that it doth drawe foorth fplinters, and things fixed in the et $t$ efh, 2s Gakn writeth.

\section{$*$ The vertues.}

Diogcorides writeth that they are of power to mittigate paine, to cure inflammations or hot fwel- A lings, to drawe out of the bodie and flefh, thornes, fplineers or fhiuers of woode, and to helpe the kings enill.

The itice purgeth the head by gargarifing or wafhing the throte therewith : it cureth the tooth- B ach, being fnift vp into the nofthrils, efpecially into the contrary nofthrill.

It helpeth thofe that be dim fighted, the iuice mixed with honie, clenfeth the vlcers of the eie, C called in Latine Argema.

Moreouer he affirmeth that it is good agàinft the ftinging of vipers, and other venemous beafts. D

It preuaileth againft the infirmities of the liter and kidneies, if the iuice be drunke with wine. He $\mathrm{E}$ addeth further, how it is reported that Pimpernell with the blew flower helpeth vp the fundament that is fallen downe; and that red Pimpernell applied, contrariwife bringeth it downe.

\section{OfBrookelyme, orwater Pimpernell. Chap.184.}

\section{* The kindes.}

$\mathrm{T}$

Here be fower forts of Water herbes comprehended vnder the name Anagallis aquatica, or water Pimpernell,or water Chicken weede, whereof fome are in vfe both in Phificke and chirurgeric; the others not fo much vfed, nor fo well knowne.

\section{* The defeription.}

$\mathbf{I}$

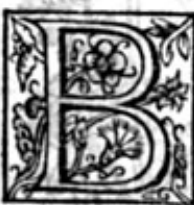
Rookelime or Brooklem, hath fat, thicke ftalkes, rounde and parted into diuers braunches. The leaues be thicke, fmooth, broad, and of a deepe greene colour. The flowers growe ypon fmall tender footeftalkes, which thruft foorth of the bofome of the leaues, of a perfect blew colour, not vnlike to the leaues of lande Pimpernell. The roote is white, lowe creeping, with fine ftrings faftned thereto; out of the root fpring many other ftalks, whereby it greatly increafeth.

2 The great water Pimpernell is like vnto the precedent, fauing that this plant hath fharper pointed and larger leaues, and the flowers are of a paler blewe colour, wherein confilteth the difference.

3 Small water Pimpernell hath for his roote a great bufh of threddie ftrings, from which rifeth vp a fat, thicke, ftraight ftalke, fetwith longer and fmaller leaues then thote of Brookelem, of an ouerworne green colour, placed togither by couples: from the which leaues clofe by the ftalk come foorth fmal tender footeftalks fet by couples with like leaues, but leffer: whereupon toward the top come foorth little foolifh or idle flowers, of a faint ouerworne bley colour.

4 The other differeth not írom the laft defcribed, in leaues, ftalkes, flowers, or rootes, fauing that the leaues heereof are rounder, broader, and more blunt at the points, wherein is the tifference. 
THE SECOND BOOKE OF THE

I Ana zallis /eu Becabunga.

Brooke lime.

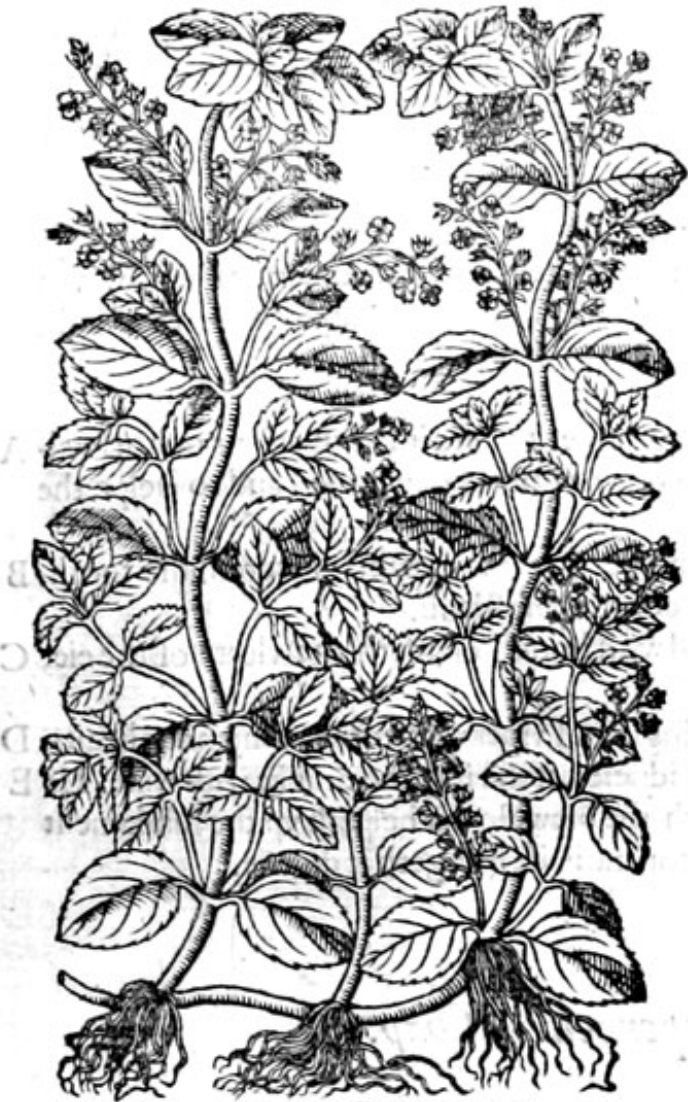

2 Anagallis aquatica.

Water Pimpernell.

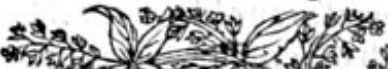

1 51 \%
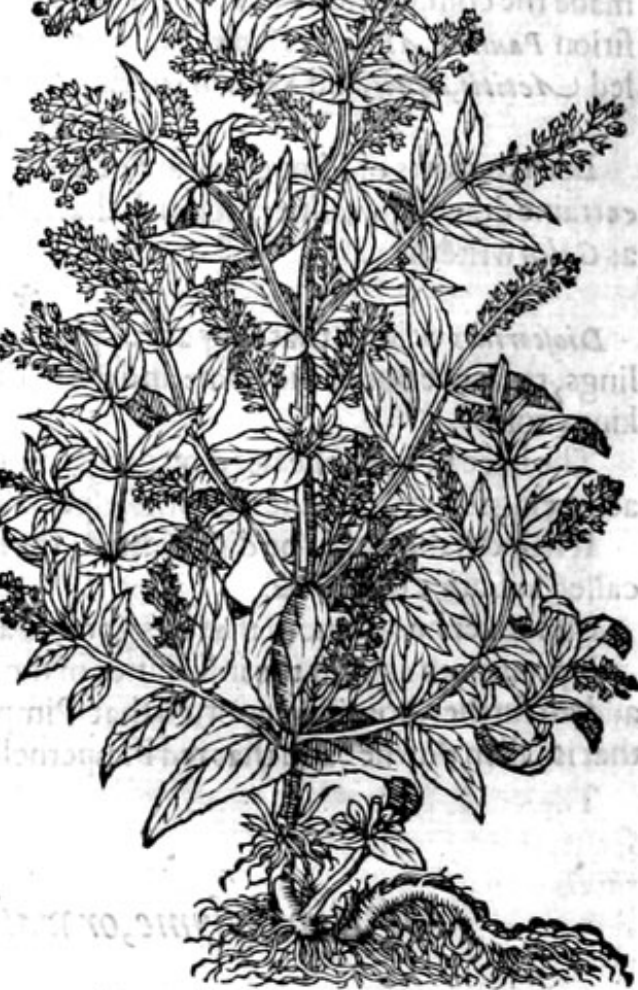

3 Limagallis aquatica minor.

4 Anagallis aquatica minor flore pallsdo. Small water Pimpernell.

Pale tlowred water Pimpernell.
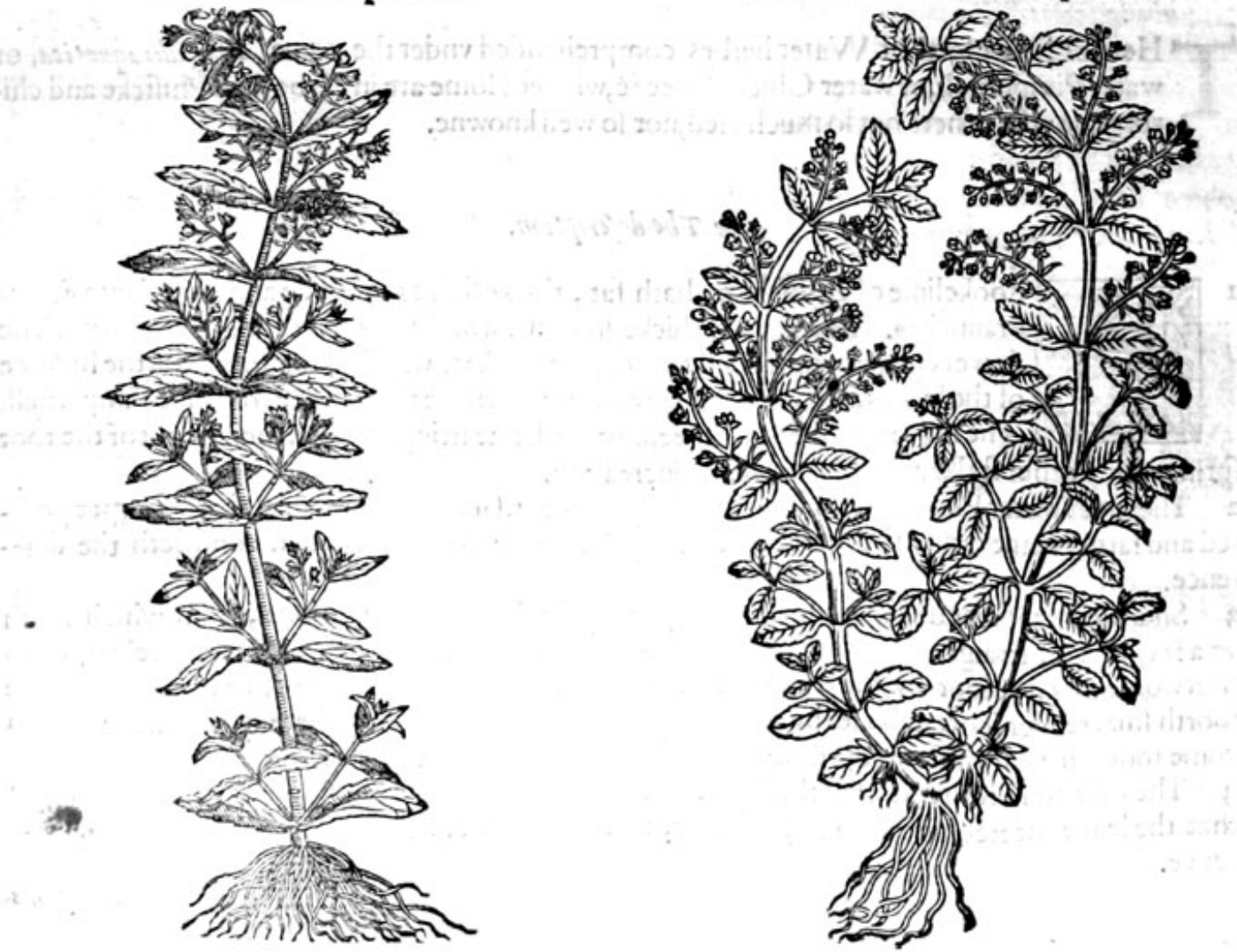


\section{* Theplace.}

They growe by riucrs fides, fmall running brookes, and waterie ditches. The yellow Pimpernell I found growing in Hampiteed wood neere London, and in many other woods and copfes. * The time.

They bring foorth their flowers and feede in Iune, Iuly and Auguft. * The names.

Water Pimpernell is called Anagallis aguatica : of mot Becabunga; which is borrowed of the Germane word 23acbptugben: in lowe Dutch 23 eeckpuntyben: in French Berle, wherupon fome do call it Berula; notwithiftanding Marcellues reporteth that Berula is that which the Grecians call xypsauin, or rather Creffes: it is thought to be Cepea, that is to fay, of the garden; which Diofcorides writeth to be like vnto Purlaine, whereunto this Brookelime doth very well agrec. But if it be therefore faid to be xmenia, bicaufe it groweth either onely in gardens, or for the molt part; this Pimpernell or Brookelime fhall not be like vnto it, which groweth no where leffe than in gardens, being altogither of his owne nature wilde, defiring to grow in waterie places, and fuch as be continually ouerflowen : in Englifh the firftis called Brookelime, and the reft by noe generall name, Water Pimpernell, or Water Chickweede, being likewife a kinde thercof.

* The temperature.

Brookelime is of temperature hot and drie like Water Creffes,yet not fo much. * The vertues.

Brookelime is eaten in fallads, as Water Creffes is, and is good againft that om zierer malum, of $\mathbf{A}$ fuch as dwell neere the Germaine feas, which they call encucrbupcke, or as we terme it the Scuruie or Skirbie, being vfed after the fame maner that Water Creffes and Scuruic graffe is vfed, yet is it not of fo great operation and vertue.

The herbe boiled maketh a good fomentation for fwollen legs, and the dropfie.

The leaues boiled, ftrained, and ftamped in a ftone mortar with the powder of Fenugreeke, Line- $\mathrm{C}$ feede, the rootes of marn Mallowes, and fome hogs greace, vnto the forme of a Cataplafma or pultis, taketh away any fwelling in leg or arme, woundes alfo that are ready to fall into apoftemation, itdefendeth mightrily that no humor nor accident thall happen vnto it.

Theleaues of Brookelime ftamped, ftrained, and giuen to drinke in winc, helpeth the ftrangurie D and griefes of the bladder.

The leaues of Brookelime, and the tendrels of $A$ parages, eaten with oile, vineger and pepper, $\mathrm{E}$ helpeth theftrangurie and ftone.

\section{Offinking Ground Pine. Chap. 185 .}

$*$ The kindes.

$T$ Here be diuers fortes of Ground Pines growing neere vnto the fea, the which may be numbred among the wilde kindes of Sea Chickweedes.

* Thedefoription.

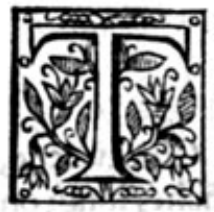
Here hath beene much adoe among writers about the certaine knowledge of the true Ant hyllis of Diofsorides: I will therefore fet downe that plant, which of all others is found moft agreeable thereunto. It hath many fmall branches full of ioints, not aboue a cubite high, creeping fundry waies, befer with fmall leaues of 2 pale colour, refembling Lenticula, or rather Alfine minima, the fmall Chickweede. The flowers growe at the top of the ftalke, ftarfafhion, of an herbie colour like Boxe, or Sedion minsus : it foftereth his fmall feedes in a three comered huske. The roote is fomewhar long, flender, knottie, and deepely thruft into the ground like Soldanella : all the whole plant is faltifh, bitter in talte, and fome-
whatheating.

There is anotherkind of Ant hyllis, that hath been taken for Chamefice of ancient writers, which is not poffible to agree with truth, bicaufe that this plant yeeldeth no milkie iuice at all, and chamefice
hath great plentie of milke like the Tithymales; fo that of neceffitiethis phuft needes be (as Ihaue Gaid)onekinde of Anthyllis, or Sea Pine, which in fhew refembleth Herniaris, or Chameefice. The whble plant is very falt and fharpe in tafte : the towers fmall, of a white purple colour; and vinder the leaues the feede is inclofed in litcle huskes, much lefler than Clinogodiun, or the baftard Bafill. 
1 Antbyllis lentifolia. Stinking Ground Pine.

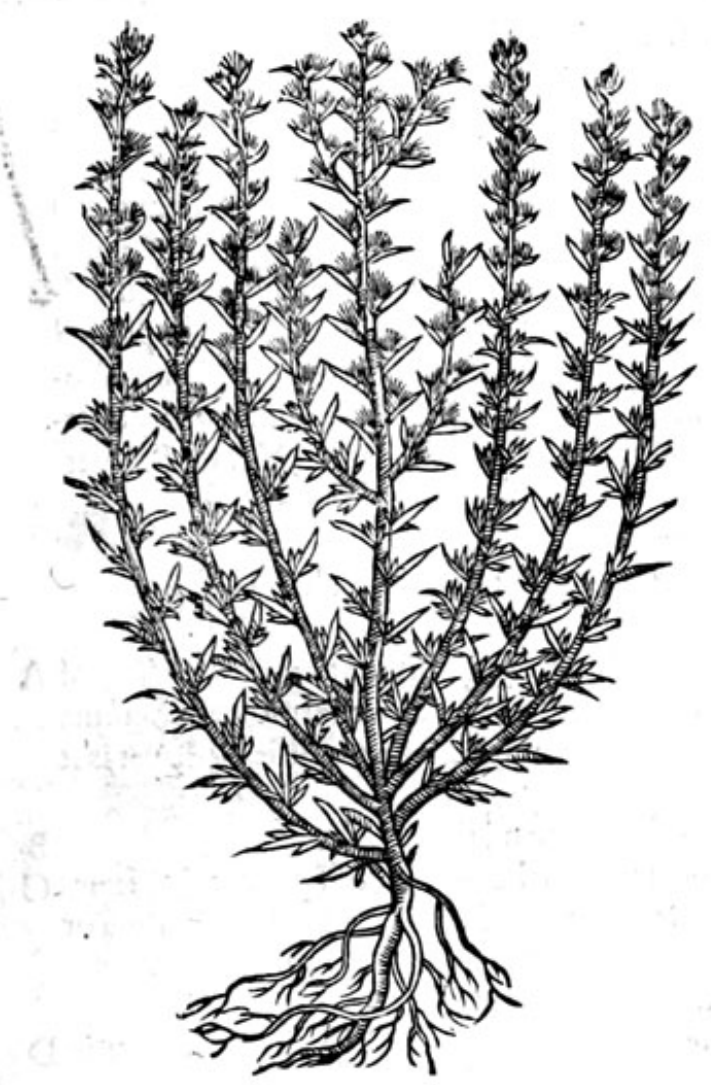

* The defcription.

There is likewife another fort of Anthyllis or Sea Ground-Pine, but in truth nothing elfe than a kinde of Sea Chickweede, hauing fmall branches trailing vpon the ground of two handes high; whereupon do growe little leaues like thofe of Chickweede, not vnlike to thofe of Lenticula marina, or Sea Lentils : on the top of the ftalks itand many fmall flowers of an herbie or moffie white colour. The whole plant is of a bitter and faltifh tafte.

$$
\text { * The place. }
$$

Thefe do growe in the fouth yles belonging to England, efpecially in Portland in the grauelly and fandie foordes, which lie lowe and againft thefea; and likewife in the yle of Shepey neere the water fide.

$$
\text { * The time. }
$$

They flower and flourifh in Iune and Iuly. * The names.

Their titles do fufficiently fet foorth their feuerall names: in Englifh they may be called Hoaric Salt woort,Sea ground Pine and Stinking ground Pine, bicaufe their fmell ftinketh in refpect of thofe of the Champion ground.

\section{* The temperature.}

Thele Sea herbes are of a temperate facultie betweene cold and drines.

* The vertwes.

A Halfe an ounce of the dried leaues drunke,preuaileth greatly againft the hot piffe, the ftrangurie, or difficultie of making water, and purgeth the reines.

B The fame taken with Oximell or honied water is good for the falling ficknes, giuen firft at morning,and laft at night.

\section{OfWhiteblowe, or Whitlowegrafje. Chap.186.}

\section{* The defcription.}

I $\mathrm{He}$ firft is a very flender plant hauing a fewe fmall leaues like the leaft Chickweede, growing in little tufts, from the midit whereof rifeth vp a fmall ftalke, nine inches long; on whofe top do growe verie little white flowers; which being paft, there come in place fmall flat pouches compofed of three filmes; which being ripe, the two outfides fall away, leauing the midale part ftanding long time after which is like white Sattin, as is that of Bulbonacke, which our women call white Sattin, but much fmaller : the tafte is fomewhat fharpe.

2 This fmall plant hath a flender tough roote, from which rife vp a tuft of leaues fpred vpon the grounde, very like vnto thofe of the greater Chickweede, but not altogither fo broade: from the midit of which tuft fpringeth vp a fmal vpright ftalk, on the top wherof doth grow litle idle flowers, of an herbic colour tending to whiteneffe; after which there come in place fmall flat coddes or feede veffels bright fhining, and as it were made of a peece of the whiteft fattin, wherein is the feede. 
1 Parongchia vulgaris.

Common Whitlowe graffe.

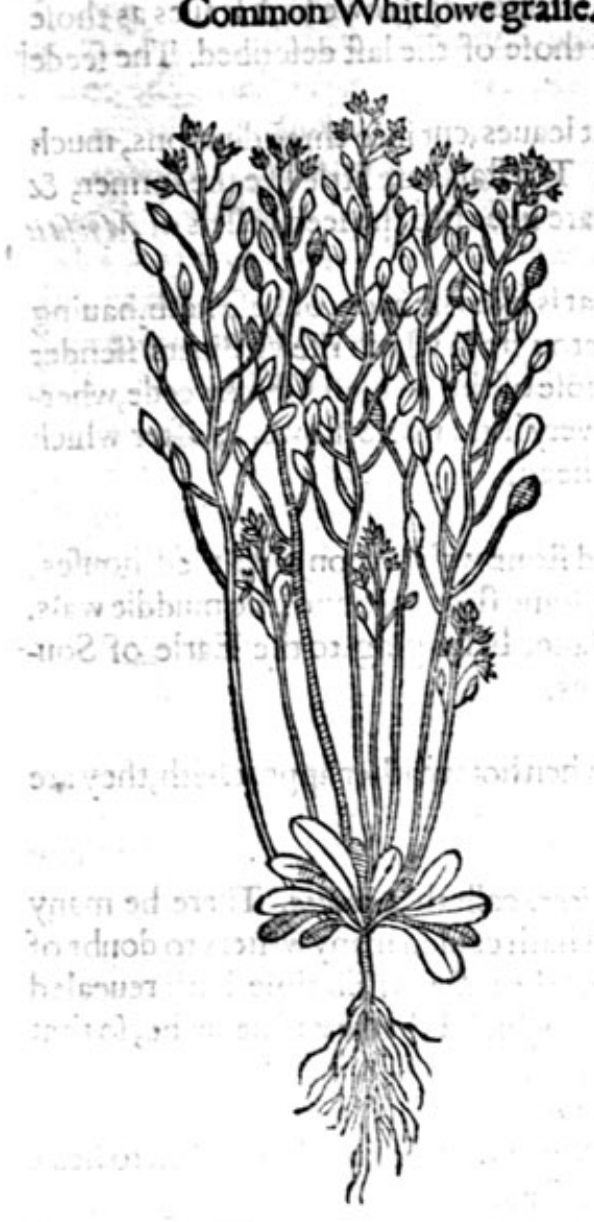

3 Parongchis Rutaceo folio.

Rewe leafed Whitlowe graffe.
2 Parangebialutifolia.

Broad leafed Whiclowe graffe.

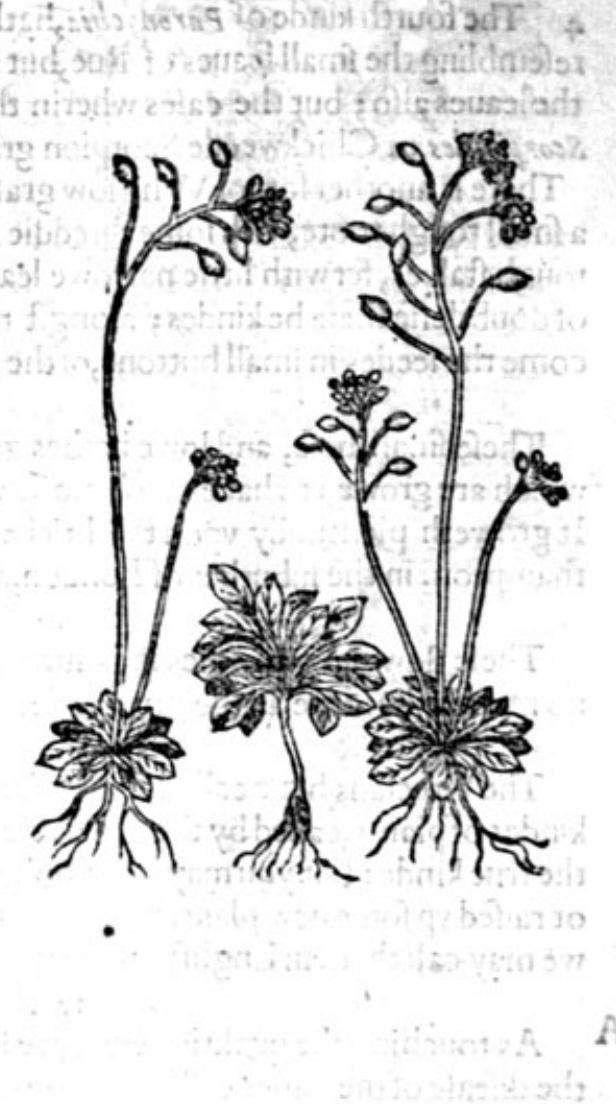

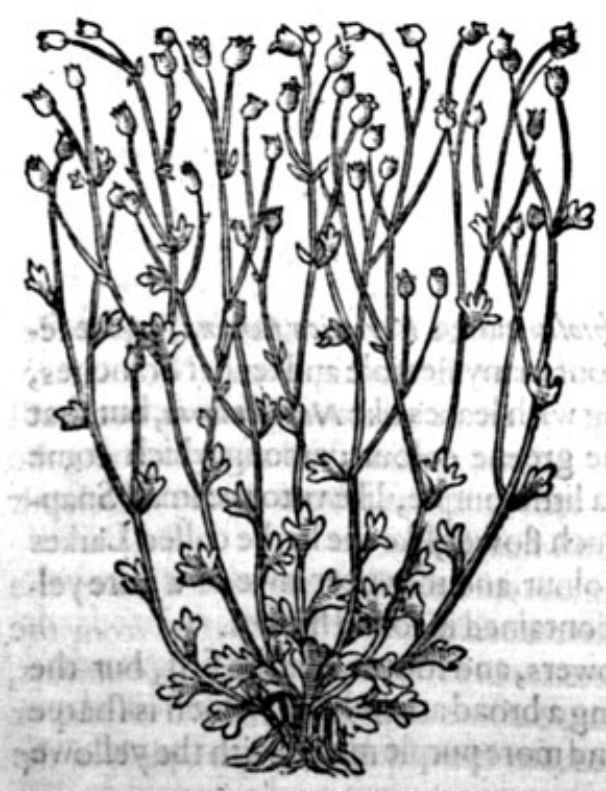

thivan: 1

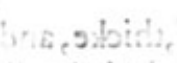

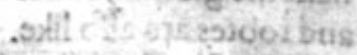

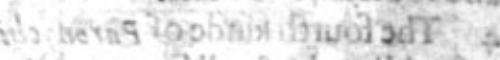

A.

4 Paronyehic Laciniate.

Iagged Whitlowe grafte.

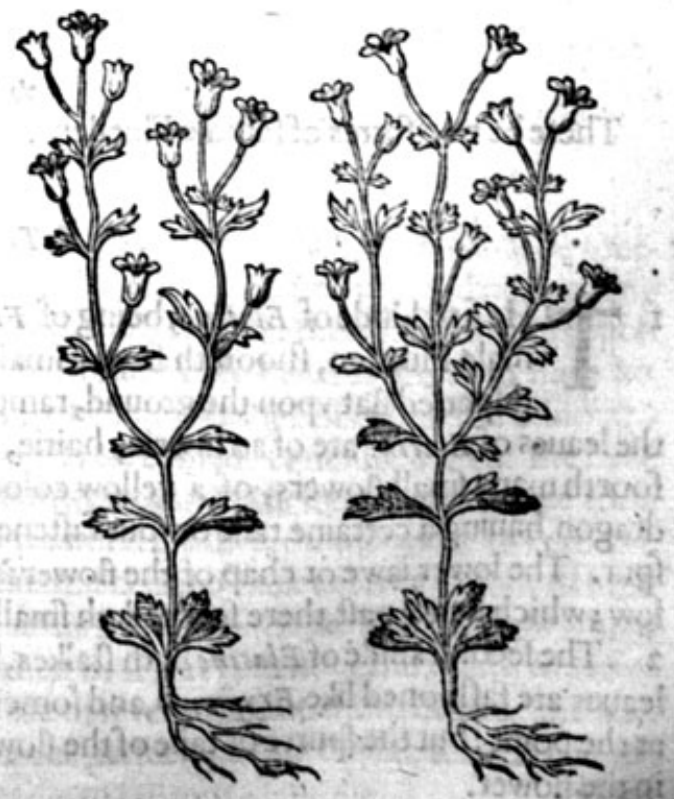

Ii $\underline{2}$

* rise 
$*$ The defoription.

3 This Whitclowe graffebath froll iagged leaues deepcly cut, lying flat vpon the wall or earth wheic it groweth: among which rifeth r 2 aflender ftem, whereupon do growe fuch leaues as thofe next the ground, but leffer. The flowers growe at the top like thofe of the laft defcribed. The feede and rootes are alfo like.

4 The fourth kinde of Par onychia, hath finall, thicke, and fat leaues, cut into three diuifions, much refembling the fmall leaues of Rue, but a great deale fmaller. The ftalks are little like the former, \& the leaues alfo; but the cafes wherin the feed is contained, are like vnto the feed veffels of Myofitis Scorpioides, or Chickweede Scorpion graffe.

There is another fort of Whitlow graffe or Naile woort, that is likewife a low or bafe herb, hauing 2 fmall tough roote, with fome threddie ftrings annexed thereto: from which rife vp diuers flender tough ftalkes, fet with little narrowe leaues confufedly like thofe of the fimalleft Chickweede, wherof doubtleffe thefe be kindes; alongt the ftalkes do growe very litcle white flowers, after which come the feedes in fmall buttons, of the bigneffe of a pinnes head.

* Theplace.

Thefe finall, bafe, and lowe herbes growe vpon bricke and ftone wals, vpon olde tiled houfes, which are growen to haue much moffe vpon them, and vpon fome hadowie and drie muddie wals. It groweth plentifully vpon the bricke wall in Chauncerie lane, belonging to the Earle of Southampton, in the fuburbes of London, and fundrie other places.

$*$ The time.

Thefe flower many times in Ianuarie and Februarie, and when hot weather approcheth, they are no more to be feene all the yeere after.

\section{* The names.}

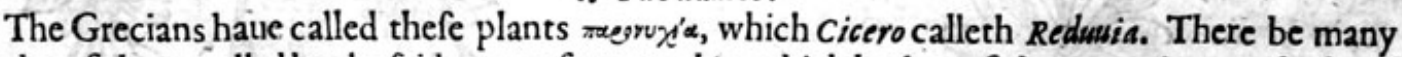
kindes of plants, called by the faid name of Paronychia, which hath caufed many writers to doubt of the true kinde: but you may very boldly take thefe plants for the fame, vntill time hath reuealed or raifed vp fome new plant, approching neerer vnto the truth: which I thinke will neuer be, fo that we may call them in Englifh Naile woort, and Whitlowe grafie.

$\dot{*}$ Thesemperature and vertucs.

A As touching the qualitie hereof, we haue nothing to fet downe: onely it hath been taken to heale the difeafe of the nailes called a Whitlowe, whereof it tooke his name.

\section{of Fluellen the female, or Speedwell. Chap.187.}

There be two fortes of female Fluellens.

* The kindes.

* The defcription.

I T Hefirft kinde of Elatine, being of Fuch/fus \& Mathiolus called Veronica famina, or the female Fluellen, thooteth from a fmall and fibrous root many flexible and tender branches, difperfed tlat vpon the ground, ramping \& creeping with leaues like Nummularia, but that the leaues of Elatine are of an hoarie, hairie, and ouerworne greene colour; among which come foorth many fmall flowers, of a yellow colour mixed with a little purple, like vnto the fmall Snapdragon, hauing a certaine taile or four faftened vnto euerie fuch flower, like the herbe called Larkes fpur. The lower iawe or chap of the flower is of a purple colour, and the vpper iawe of a faire yellow; which being paft, there fucceedeth fmall blacke feede contained in round huskes.

2 The fecond kinde of Elat ine hath ftalkes, braunches, flowers, and rootes, like the firft, but the leaues are fafhioned like Eryfomum, and fomewhat refembling a broad arrow head, which is fharpe at the point : but the fpurre or taile of the fower is longer, and more purple mixed with the yellowe in the Hower. 


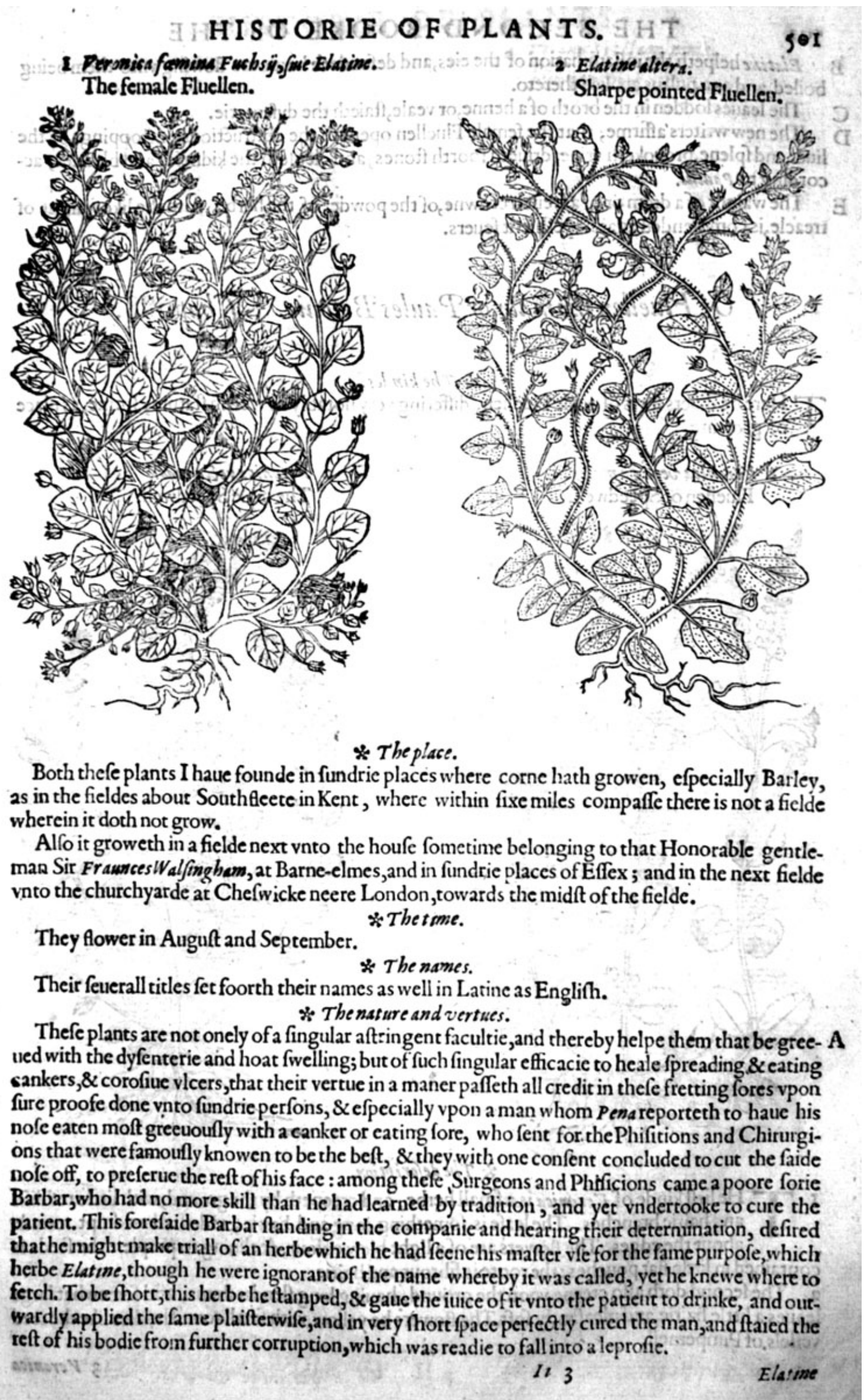




\section{THE SECOND BOOKE OF THE}

B Elatire helpeth the inflammation of the eies, and defendech humours flowing vnio thembeing boiled, and as a pulcus applied thereto.

C Thie leatues fodden in the broth of a henne, or veale, ftaieth the dyfenterie.

D The new writers affirme, that the female Fluellen openeth the obftructions or ftoppings of the liuer and fplene, prouloketh vrine, driueth foorth ftones, and clenfeth the kidneies and bladder, according to Paulus.

E The ivaight of a dram or of a french crowne, of the powder of the herbe, with the like waight of treacle, is commended againft peftilent feuers.

\section{Of Fluellen the male, or Paules Betonie. Chap. 188.}

* The kindes.

$T^{\prime}$ Here be diuers forts of male Fluellen, differing very notably as well in ftature, forme, as place of growing.

I Veronisa vera $\sigma$ maior.

Fluellen or Speedwell.

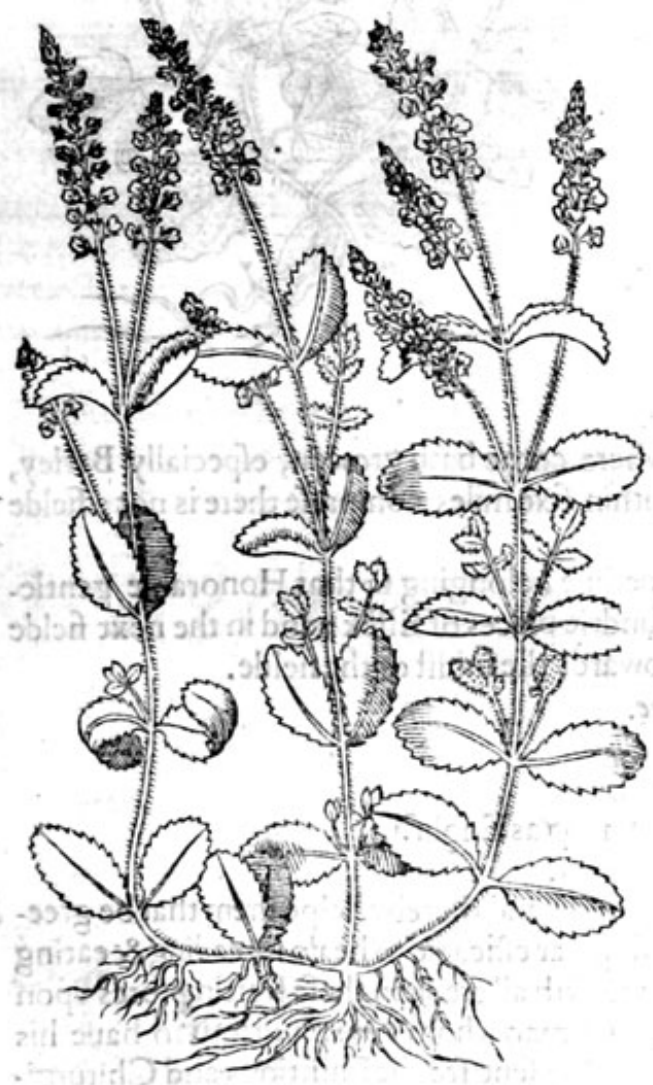

2 Veronica recta mas. The male Speedwell.

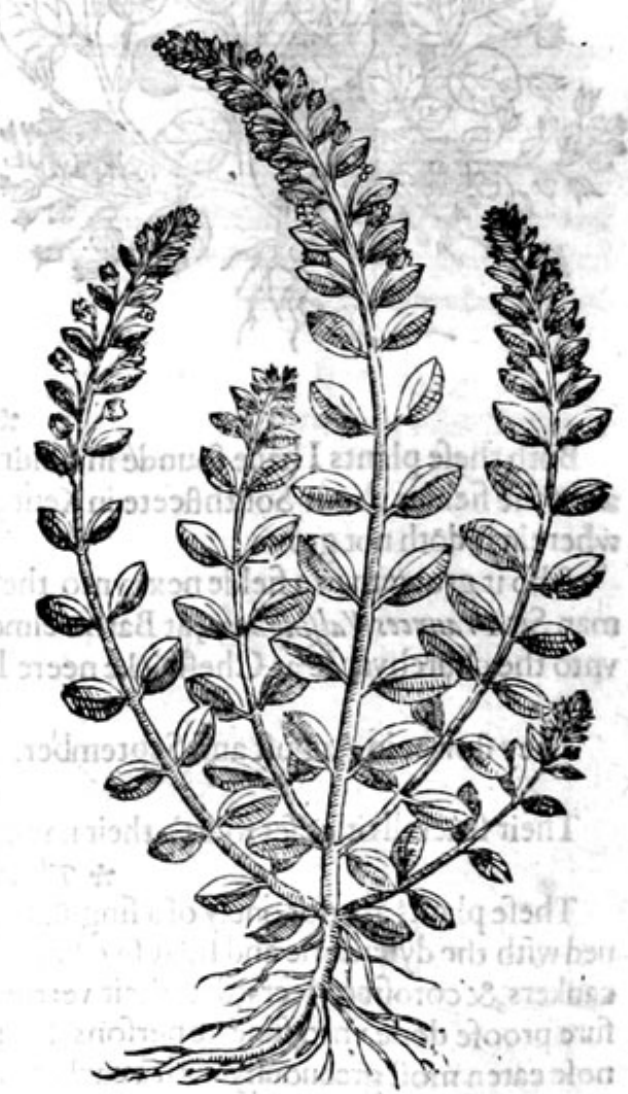

* The defcription.

I 7 He firft kinde of Veronica is a fmall herbe, and creepeth by the ground, with little reddifh and hairie branches. The leafe is fomething long and hairie, indented or fnipt rounde about the edges. The flowers are of a light blew colour, declining to purple : the feede is contained in little flat pouches: the roote is fibrous and hairie.

2 The fecond doth alfo creepe vpon the ground, hauing long flender ftems, and fomewhat large leaues a little hairie, and pleafantly foft.The flowers be yellow, with fimall round huskes like the ieed vefiels of Pimpernell. 


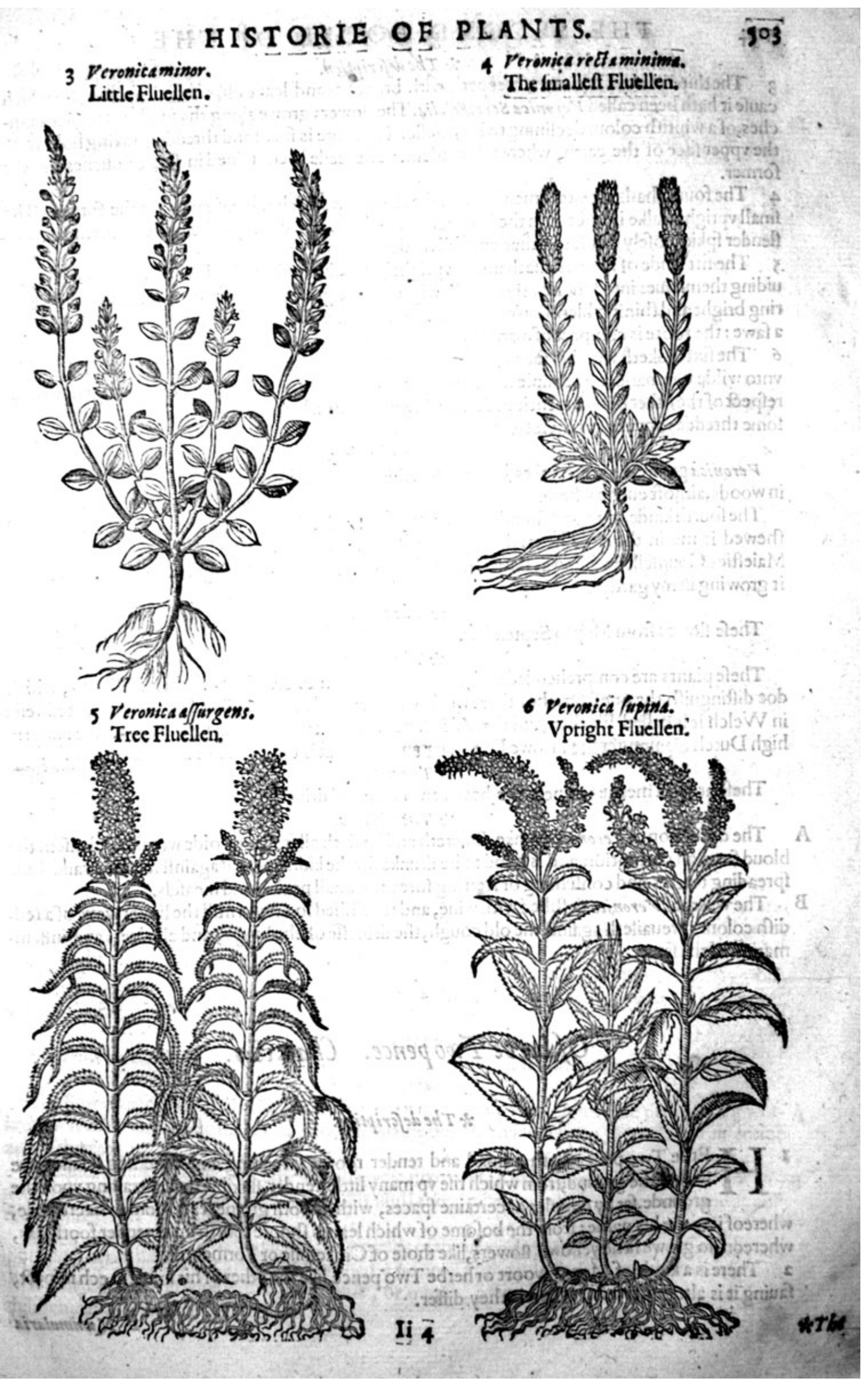


* The defcription.

3 Thethird kinde of $V$ eronica creepeth with branclicsand leaues like vnto Serpillam, for which caufe it hath been called $V$ eronica Serpillifolia. The flowers growe along the fmal and tender branches, of a whitifh colour declining to blewneffe. The roote is fmall and threddie, taking hold vpon the vpper face of the earth, where it fpreadeth. The feede is contained in fmall pouches like the former.

4 The fourth hath a roote fomewhat woodie, from the which rife vp leaues like the former. The fmall vpright ftalke is befet with the like leaues but leffer; at the top whereof commeth foorth a flender f pkie clofely thruft togither, and full of blewifh flowers.

5. The fift kinde of Veronica hath many vpright braunches a foote high and fomtimes more, diuiding themfelues into fundrie other fmall twigs; at the top whereof do growe faire fpikic tufts, bearing bright and fhining blew flowers. The leaues are fomewhat long, indented about the edges like 2 fawe : the roote is compact of many threds or ftrings.

6 The fixt looketh with his face vpright, hauing fundrie flexible braunches, fet with leaues like vnto wilde Germander by couples, one right againft another, deepely iagged about the edges, in refpect of the other before mentioned. The flowers are of a blewe colour, the roote is long, with fome threddes appendant thereto.

* The place.

Veronica groweth vpon bankes, borders of fieldes, and graffie mole hils, in fandie groundes, and in woods, almoft euerie where.

The fourthkinde, my good friende mafter Stephen Bredirell, practicioner in phificke founde and Thewed it me in the clofe next adioining to the houfe of mafter Bele, cheefe of the clarkes of hir Maiefties Counfell, dwelling at Barnes neere London. The fift is a ftranger in England, but I haue it growing in my garden.

Thefe flower from May to September.

$$
\text { * The time. }
$$

* The names.

Thefe plants are comprehended vnder this generall name Veronica, with their additions, which doe diftinguifh the onefrom the other: we do call them in Englifh Paules Betonie, or Speedwell : in Welch it is called Fluellen, and the Welch people do attribute great vertues vnto the fame: in

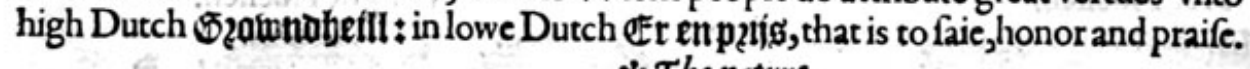

$$
\text { * The nature. }
$$

Thefe are of a meane temperature, betweene heate and drineffe.

* The vertues.

A The decoction of Veronica drunke, fodereth and healeth all freth and olde wounds, clenfeth the bloud from all corruption, and is good to be drunke for the kidneies, and againft fcuruines and foule fpreading tetters, and confuming or fretting fores, the fmall pockes and meafels.

B The water of Veronica deftilled with wine, and redeftilled fo often vntill the liquor waxe of a reddifh colour : preuailech againft the old cough, the drineffe of the lungs, and all vlcers and intlammation of the fame.

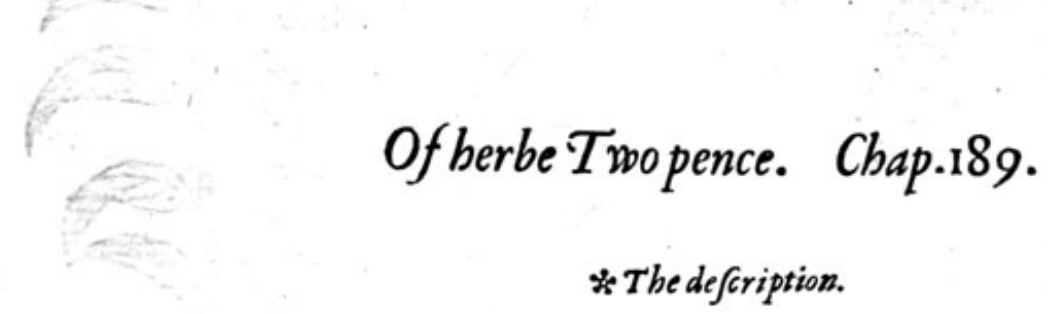

' $\mathrm{H}$ Erbe Two pence hath a frmall and tender roote, fpreading and difperfing it felfefarre within the ground;from which rife vp many little,tender, flexible ftalkes trailing vpon the grounde, fet by couples at certaine fpaces, with fmooth greenc leaues fomewhat rounde, whereof it tooke his name : from the bofome of which leaues thoote foorth fmall tender footfalks, whereon do growe little yellowe flowers, like thofe of Cinkefoile or Tormentill.

2 There is a kinde of Money woort or herbe Two pence, like the other of his kinde in ech refpeet, fauing it is altogither leffer, wherein they differ.

I Nemmularie 


\section{A H THSTORTE OE PLANTS. IHI}

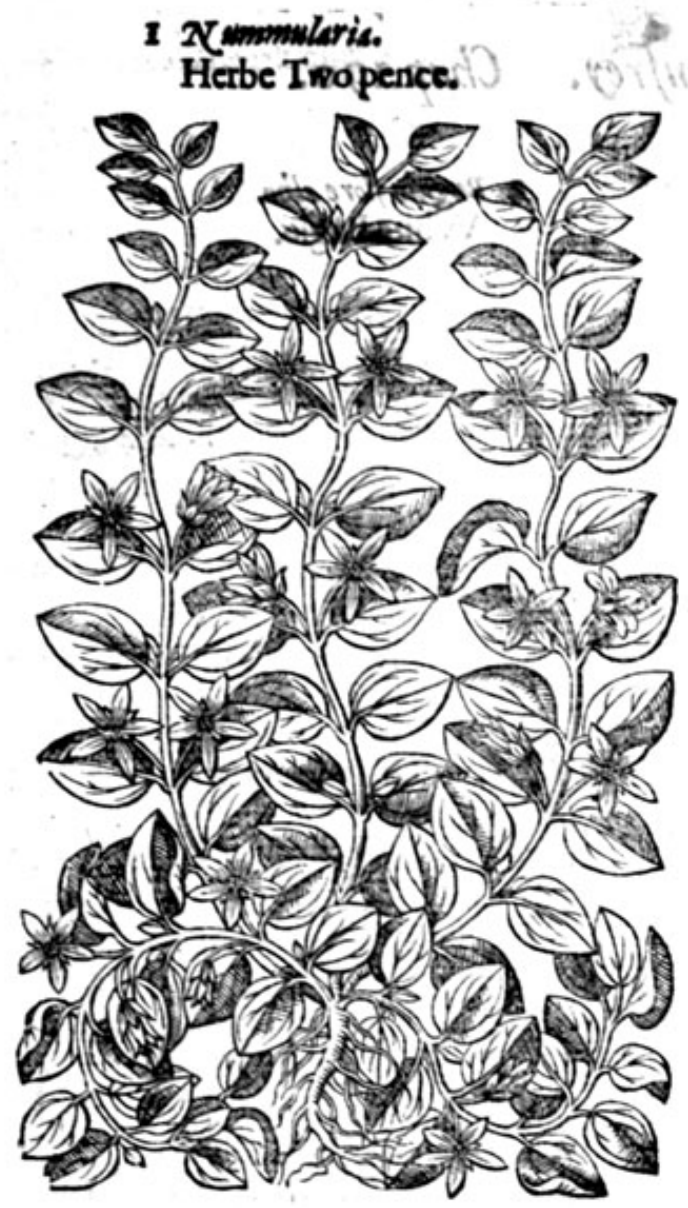

22 commlarie minor:

2 rumomularis. Swall Money woort.

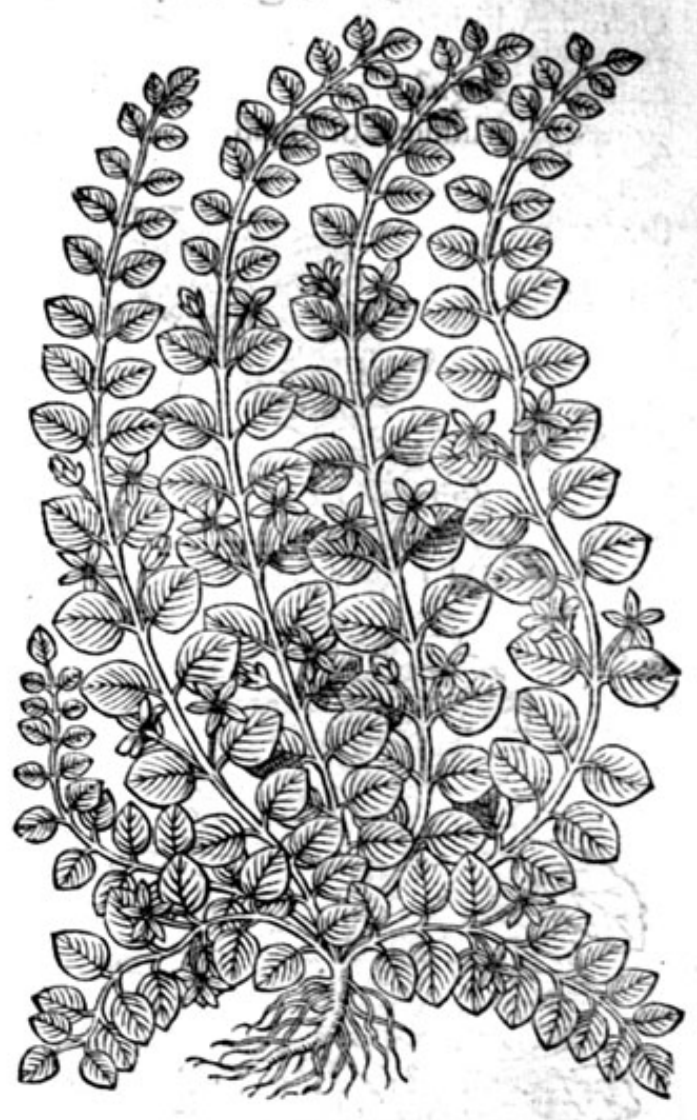

* Theplace.

It groweth neere vnto ditches and ftreames, and other waterieplaces, and is fometimes founde in moift woods: I founde it vpon the bancke of the riuer of Thames, right againit the Queenes pallace of White hall; and almoft in euery countrey where I haue trauelled.

It flowreth from May till fommer be well fpent.

$$
\text { * The time. }
$$

* The names.

Herbe Two pence is called in Latine Nummularia, and Centwomorbia : and of diuers scrpentaria. It is reported that if ferpents be hurt or wounded, they do heale themfelues with this berbe, whereupon came the name Serpentaria : it is thought to be called Centummorbia, of the woonderfull effect which it hath in curing difeafes; and it is called Nummularis, of the forme of money, wherunto the leaues are like : in Dutch joenunckctupt: in Englifh Money woort; berbe Twopence, and Two pennie graffe.

\section{* The temperature.}

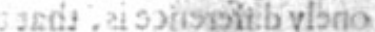

That this herbe is drie, the binding tafte thereof doth fhewe : it is alfo moderately colde. * The vertwes.

The flowers and leaues ftamped and laide vpon wounds and vlcers doth cure them : but it wor- A keth moft effectually being ftamped and boiled in oile oliue with fome rofen, waxe, and turpentine
added thereto.

The iuice drunke in wine, is good for the bloodie flixe, and afl other iffues of blood in man or wo-B man. The weakneffe and loofeneffe of the belly and laske; it helpeth thole that vomite blood, aud the Whites in fuch as have them,

Boiled with wine and honie it cureth the wounds of the inwarde parts, and vicers of the lings, C and in a worde, there is not a better wound herbe, no not Tabaco it felfe, nor any other whatfocter.

The herbe boiled in wine with a little honic, or meade, preuaileth much againft the cough in D children, called the Chinne cough. 
I Bugula. Middle Confound.

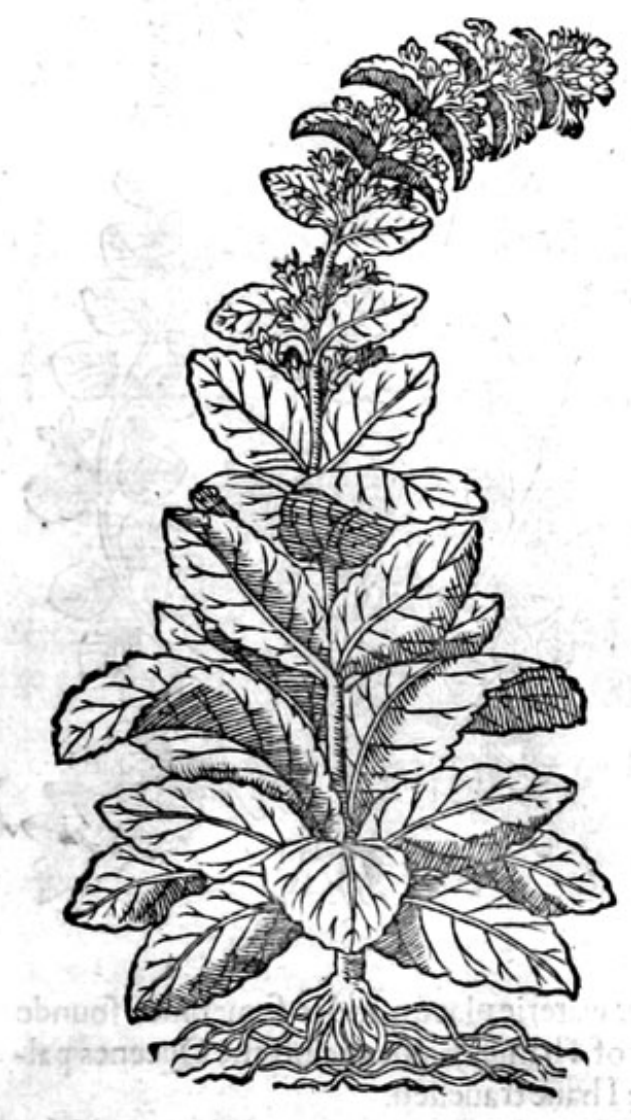

2 Bugula flore albo. White Bugle.

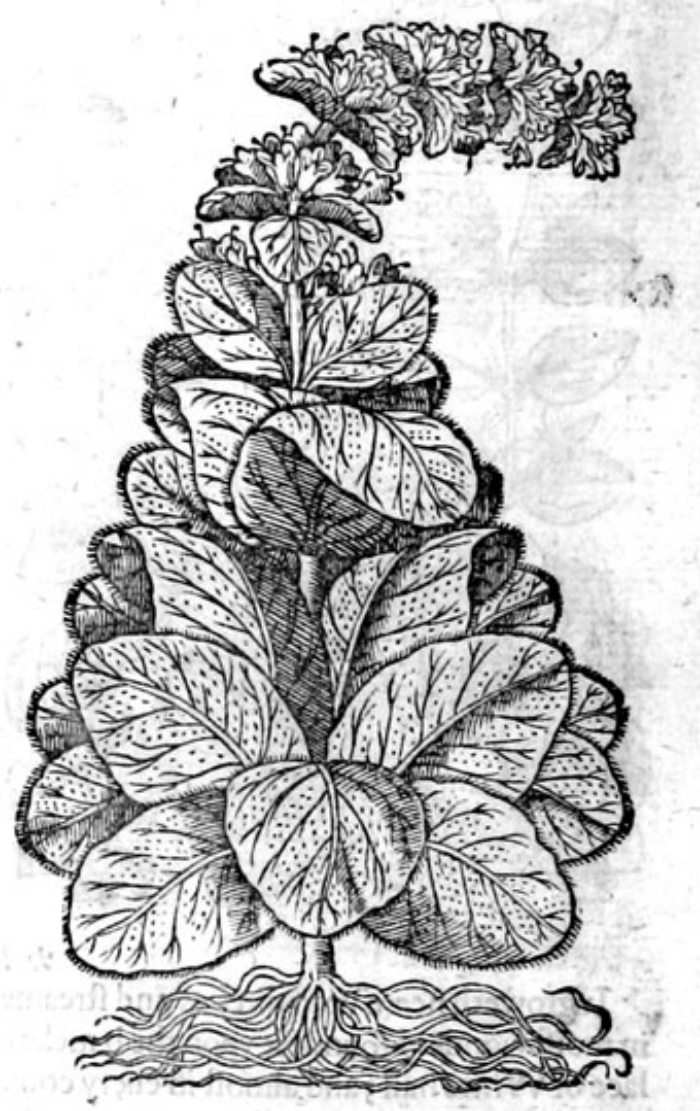

* The defcription.

I $V$ gula fpreadeth and creepeth alongtt the ground like Monie woort; the leaues be long; fat, and oleous, and of a browne colour for the moft part. The flowers growe about the ftalkes in rundles, compaffing the ftalke, leauing betweene euerie rundle bare or naked fpaces; and are of a faire blew colour, and often white. I found many plants of it in a moift ground vpon Blacke heath necre London, faft by a village called Charleton, but the leaues were greene, and not browne at all like the other.

2 Bugle with the white flower differeth not from the precedent, in rootes, leaues, and ftalkes; the onely difference is, that this plant bringeth foorth faire milke white flowers, and the other, thofe that are blew.

* The place.

Bugula groweth almoft in euerie wood and copfes, and fuch like fhadowie and moift places, and is much planted in gardens.

Bugula flowreth in Aprill and May.

* The time.

Bugle is reckoned among the Confoundes or wound herbs : calléd of fome confolida media, bw-

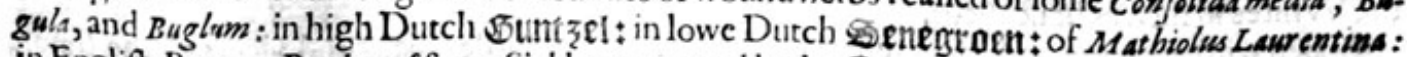
in Englift Browne Bugle: of fome Sickle woort, and herbe Carpenter, but not truly.

$*$ Bugle is of a meane temperature, betweene heate and drineffe.
. 
* The vertues.

Itis commended againft inwarde burftings, and members torne, rent, andbrufed: and therefore $\mathrm{A}$ it is put mto potions that ferue for nodes, in which it is of fuch vertue, that it can diffolue and wafte away congealed and clotted blood. Ruellisu writeth that they commonly faie in Fraunce, howe he needeth neither phificion nor furgeon that hath Bugle and Sanickle, for it doth not onely cure woundes being inwardly taken but allo applied to them outwardly; it is good for the infirmities of the liuer; it taketh away the obftructions, and ftrengthneth it.

5. The decoction of Bugle drunken, diffolueth clatted or congealed bloode within the bodie, hea- B leth and makech founde all woundes of the bodie, both inward and outwarde.

The lane openeth the ftoppingsof the liuer and gall, and is good againft the iaundife and feuers C ef long continuarice.

The fame decoction cureth the rotten vicers and fores of the mouth and gums.

Bugala is excellent in curing wounds and feratches, and the iuice cureth the wounds, vlcers and $\mathrm{E}$ Bres of the fecretparts, or the herbe brufed and laide thereon.

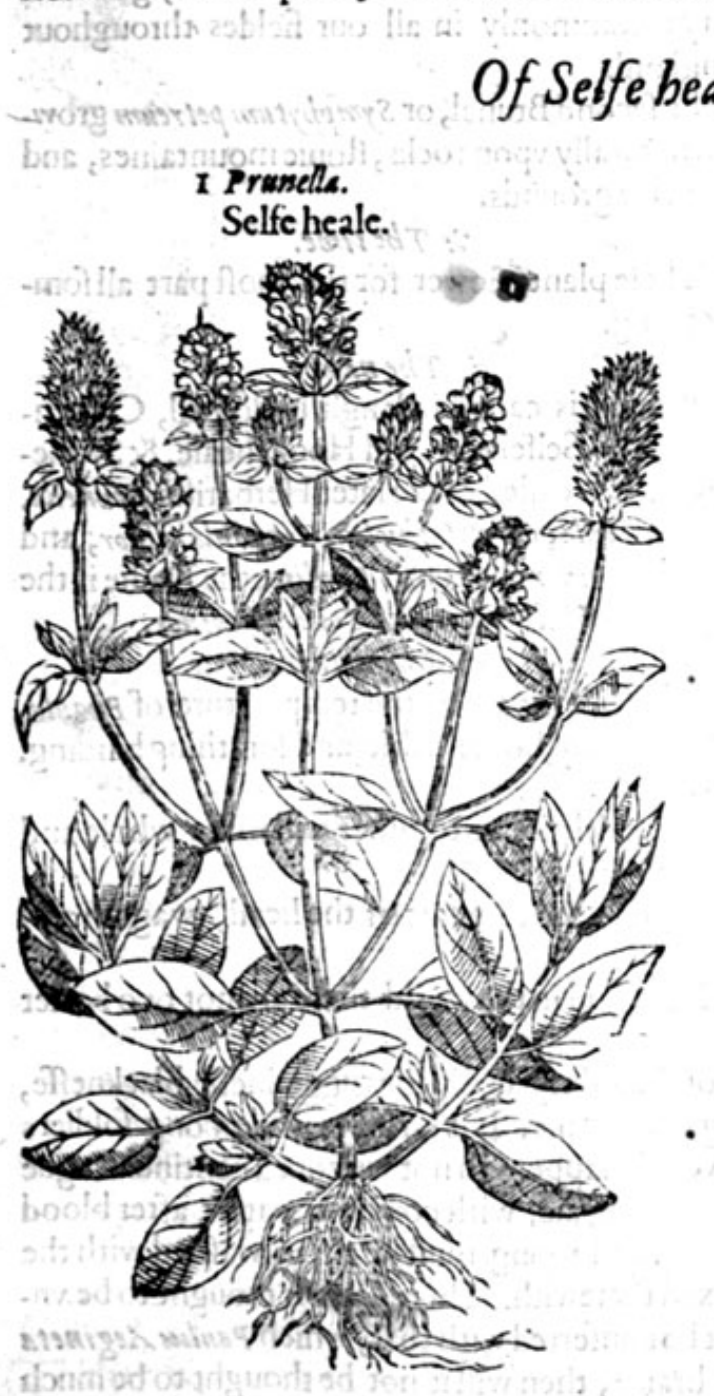

\section{Chap.191.}

2 Prunella L'Obely.

The fecond Selfe heale.

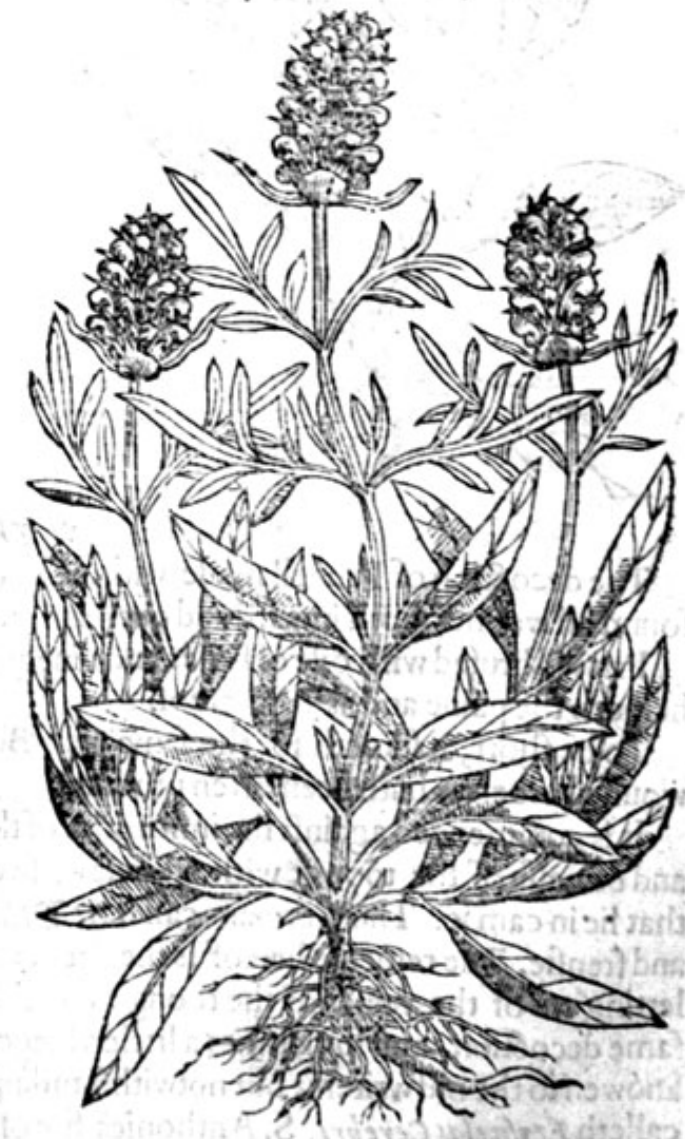

* The defeription.

I Runell or Brunell, hath fquare hairie ftalks of a foote high, befet with long hairie and tharpe pointed leaties, and at the top of the ftalkes growe flowers thicke fet togither, like an care or fpikie knap, of a browne colour mixed with blew colours, and fometimes white, of which kinde I founde fome plants in Effex neere Henningham caftell. The root is fmall and verie threddy. 2 Prunelli altera, or after L'Obeliwa and Pena Symphytum petrem, (many plsnts hauing like vertue in fodering, confolidating of wounds and fractures.) Is woodie, full of twigs and well fmelling, hauing the braunches of Origanum, with fmall leaues, and the tufts of Time :the roote is long, a 
finger big, of a purpie cclour. To be fhort, I cannot find that any of our new writers haue affuredly found this plant as yet, though Mathiolus triumpheth before victorie : but the neereft plant thereto (in mine opinion) is Coris cilon/pellienfium, and yet in fome points they differ; and therefore I leaue this plant to a better confideration.

3 Prunella flore albo.

White flowred Selfeheale.

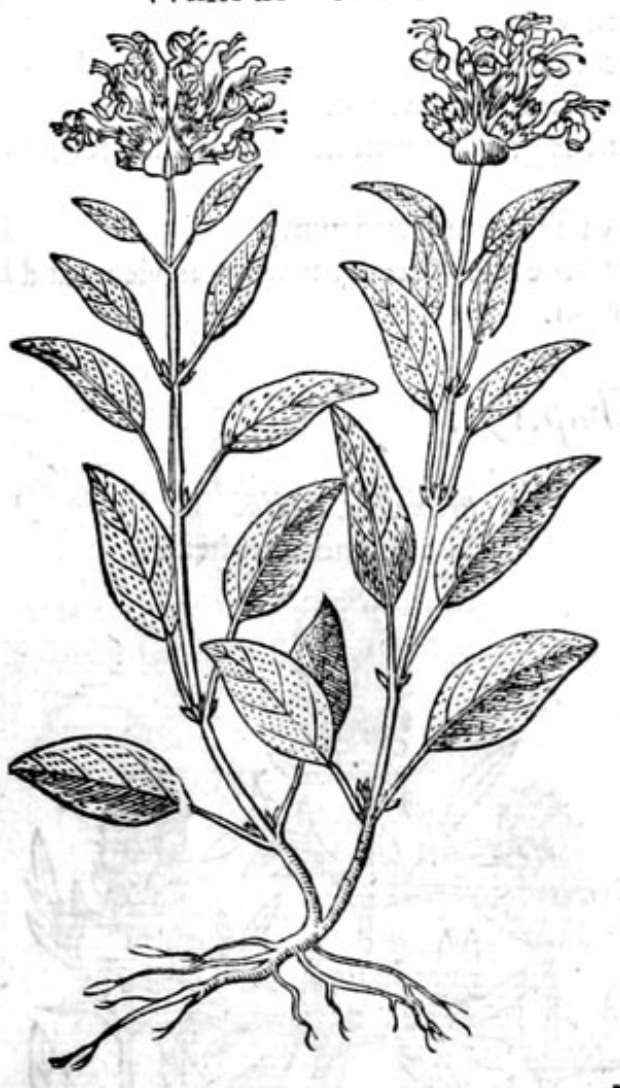

\section{* The defcripsion.}

3 The third fort of Selfeheale is like vnto the laft defcribed in roote, ftalke, and leaues, and in euery other point, fauing that the flowers hereof are of a perfect white colour, Scthe others not fo; which maketh the difference. * Theplace.

The firft kinde of Prunell or Brunell, groweth verye commonly in all our fieldes throughout England.

The fecond Brunel, or Symphytum petreum groweth naturally vpon rocks, ftonic mountaines, and grauellie grounds. * The time.

Thefe plant fower for the moft part allfommerlong.

$$
\text { * The names. }
$$

Brunell is called in Englifh Prunell, Carpenters herbe, Selfeheale, and Hookeheale, \& Sicklewoort. It is called of the later Herbarifts Brwnelle, and Prunella, of crathiolso, Confolida minor; and Solidagominor; but faith Ruelliws, the Daifie is the right Confolida minor, and Solidagominor.

$$
\text { * The nature. }
$$

Thefe herbs are of the temperature of Bugule, that is to fay, hot and drie, and fomthing binding. * The vertues.

A The decoetion of Prunell made with wine or water, doth ioine togither and make whole and found all wounds, both inward and outward, euen as Bugle doth.

B Pruncll brufed with oile of Rofes and vineger, and laid to the forepart of the head, fwageth and helpeth the paine and aking thereof.

C To be fhort, it ferueth for the fame that Bugle doth, and in the world there are not two better wound herbes,as hath been often prooued.

D It is commended againft the infirmities of the mouth, and efpecially the ruggedneffe, blackneffe, and drineffe of the toong, with a kinde of fwelling in the fame. It is an infirmitie among foldiers that lie in campe. 'The Germans call it de $2 B_{2}$ aun, which happeneth not without a continuall ague and frenfie. The remedie hereof is the decoction of Selfeheale, with common water, after blood letting out of the veines of the toong : and the mouth and toong muft be often wafhed with the fame decoction, and fometimes a little vineger mixed therewith. This difeafe is thought to be vnknowen to the old writers: but notwithftanding if it be conferred with that, which Pawles Aegimeta calleth Erysipelas Cerebri, S. Anthonies fire of the braine, then will it not be thought to be much differing, if it be not the very fame.

\section{Of the great Daifie, or Maudelen woort. Chap.igz.}

*. The defoription.

I He great Daifie hath very many broade leaues fpred vpon the grounde, fomewhat indented about the edges, of the breadth of a finger, not vnlike thole of groundfwell : among which rife vp ftalks of the height of a cubite, fet with the like leates, but lefler, in the top whereof 


\section{ZHHISTOO REECOF RUANTS. FHT}

whereof doe growe whire flowers wirh yellswe thrums in themiddle like thofe of the fingle fielde

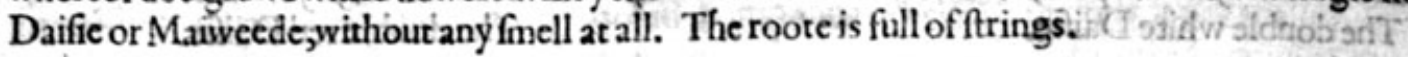
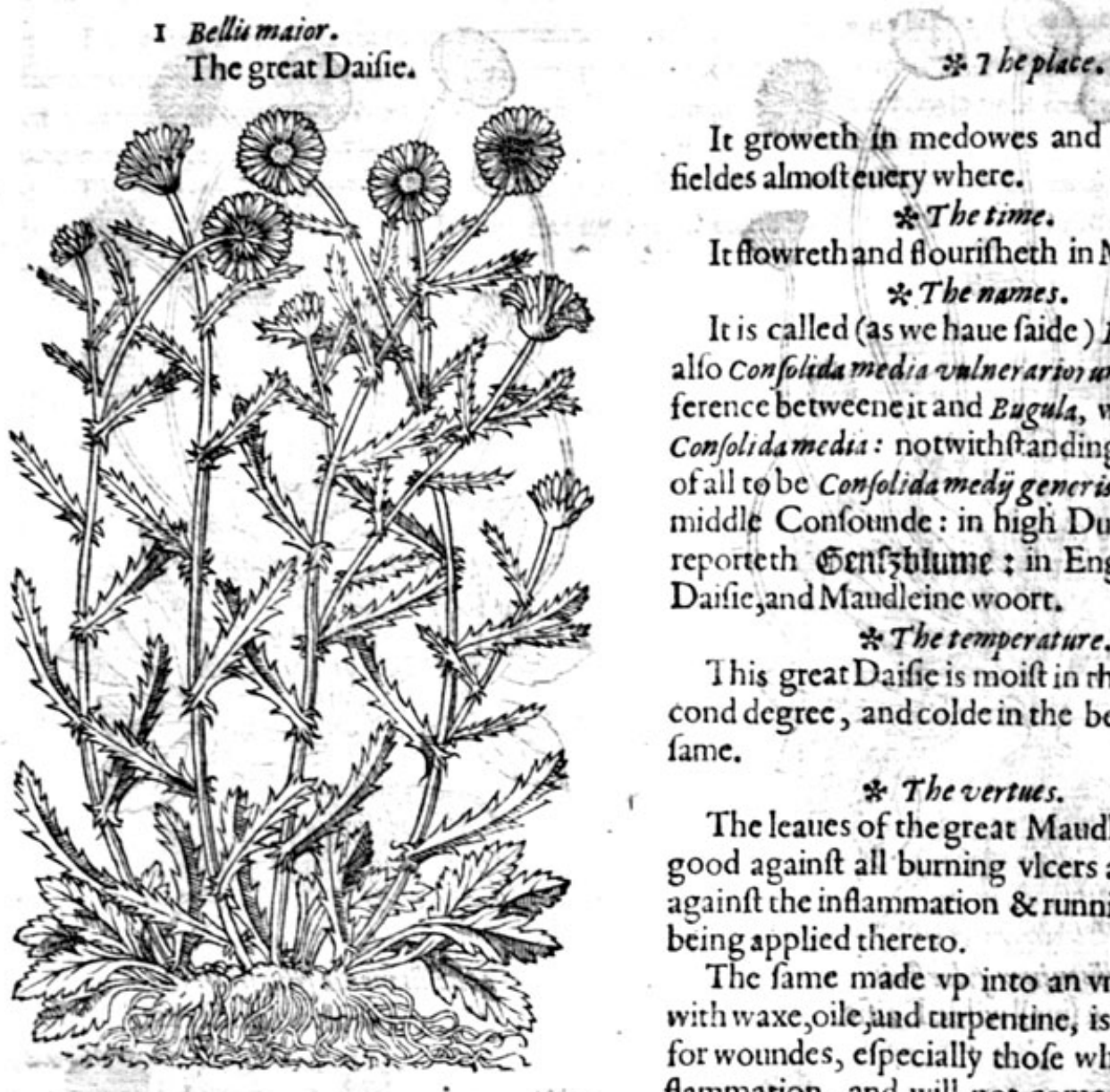

It groweth in medowes and the borders of fieldes almofteuery where.

$$
\text { से The time. }
$$

It flowreth and flourifheth in Maie arid Iune. $*$ The names.

It is called (as we haue faide) Bellismaior, and alfo confolida media vilnerarivi um, to make a difference betweene it and Eagula, which is thetrue Confolidamedia : notwithtanding this is holden of all to be Confolida medy generis, or a kinde of middle Confounde: in high Dutch as Fuchfius reporteth Entizblume : in Englifh the great Daifie, and Maudleine woort.

\section{* The temperature.}

This great Daifie is moilt in the end of the fecond degree, and colde in the beginning of the fame.

\section{* The vertues.}

The leaues of the great Maudleine woort are A good againft all burning vlcers and apoftemes, againft the inflammation \& running of the cies, being applied thereto.

The fame made vp into an vinguent or falue $B$ with waxe, oile, and curpentine, is moft excellent for woundes, efpecially thofe wherein is any inflammation, and will not come to digeftion or maturation, as are thofe weeping wounds made in the knees, elbowes, and other ioints.

The iuice, decoction, or deftilled water, is drunke to very.good purpofe againft the rupture or any $\mathbf{C}$ inward burftings.

The herbe is good to be put into Vuliterarie drinkes or potions, as one fimple belonging thereto D moft neceffarie, to the which effect the beft practifed do vfe it, as a fimple in fuch cafes of great
effect.

It likewife affwageth the cruell torments of the gout, vfed with a fewe Mallowes and butter, boi- E led and made to the forme of a pultis.

The fame receipt aforefaid vfed in clyfters, profiteth much againft the vehement heat in agues, $F$ and ceafeth the torments or wringing of the guts and bowels.$$
\text { Of little Daifies. Chap.193. }
$$ \\ * The kindes.} Here be diuers of the fmall Daifies differing in colour of the flowers, and alfoin the dou-
bleneffe thereof.

$x$ He Daifie bringeth foorth many leaues from a threddie roote, fmooth, fat, long,and fomwhat rounde withall, very fleightly indented about the edges, for the moft part lying flat vpon the groundetamong which rife vp the flowers, euery one with his owne flender ftem, like almoft to thofe of Camomill, but leffer, of a perfect white colour, and very double. 2 The double red Daifie is like vnto the precedent in euery refpeet, fauing in the colour of the flowers:for this plant bringeth foorth flowers of a red colour, and the other white as aforefaid. 
I Bellis Hortenfismultiplex flore albo. The double white Daifie.

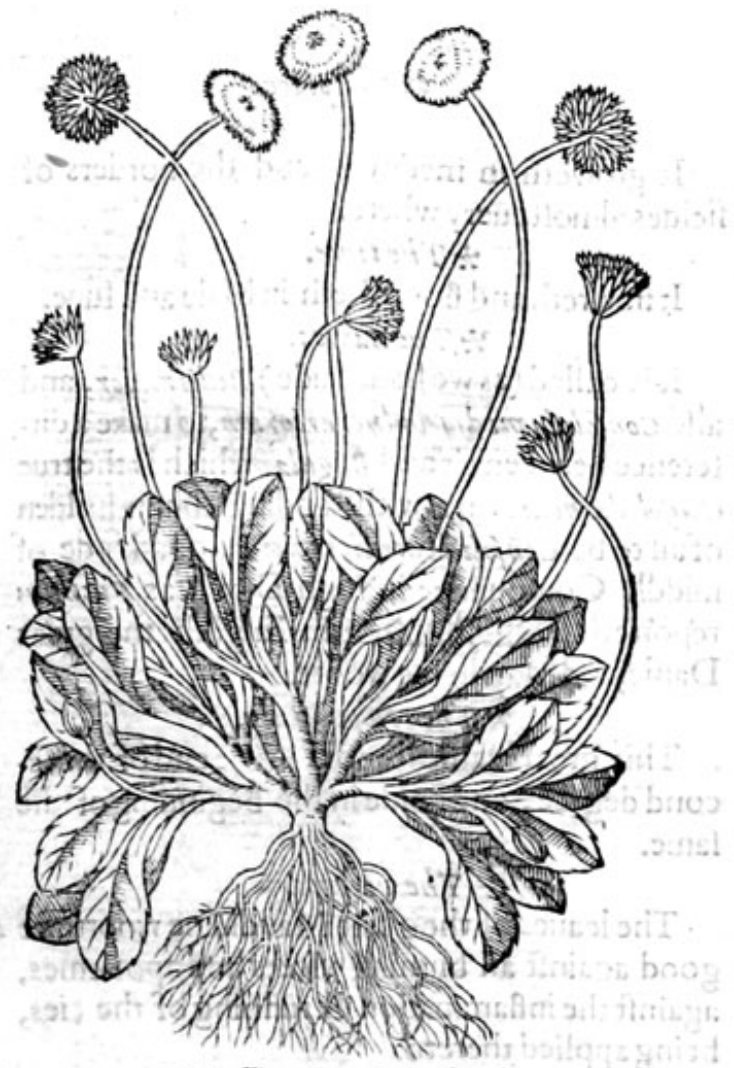

3 Bellisminor fylueftris.

The fmall wilde Daifie.

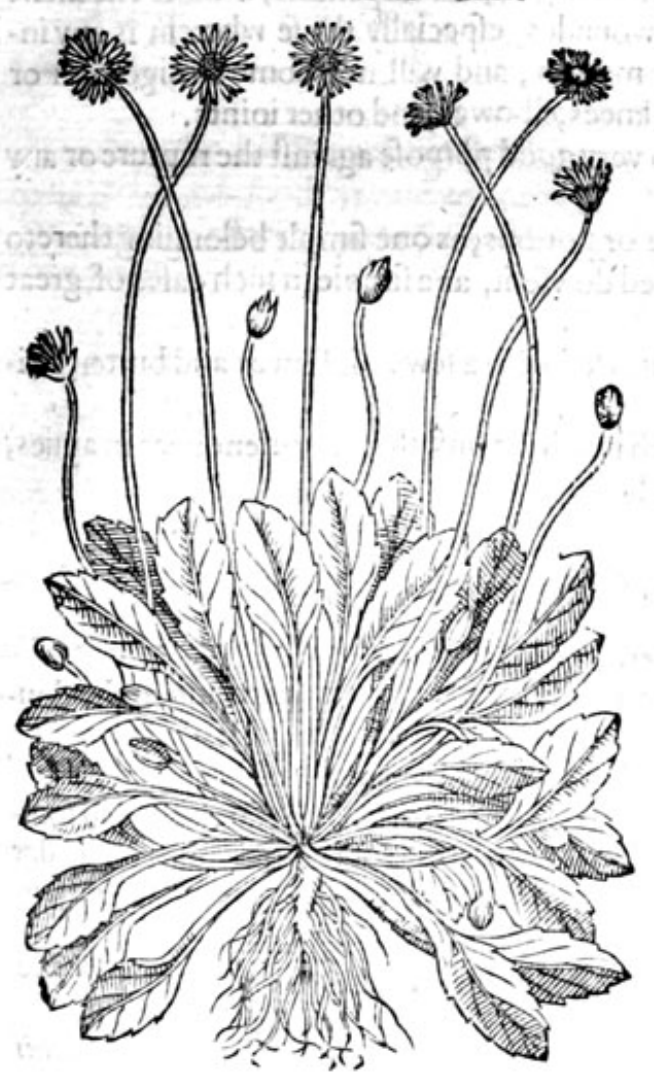

2 Bellis Hortenfis flore rubro. The double red $D_{\text {aifie. }}$

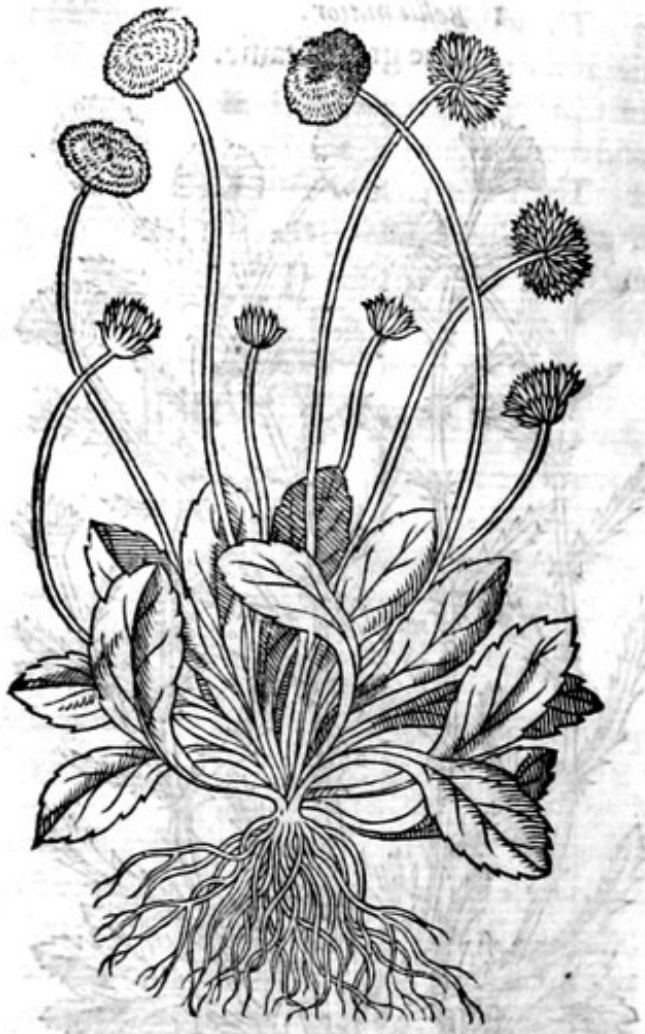

4 Bellis media fylueftris.

The middle wilde Daifie.

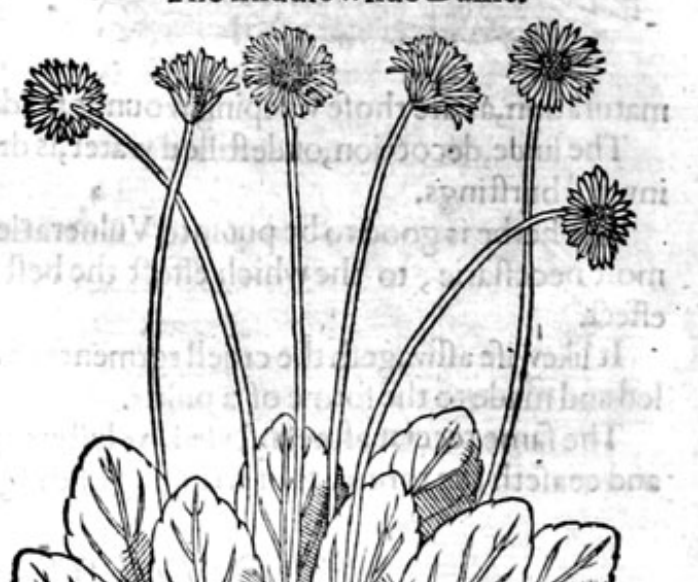

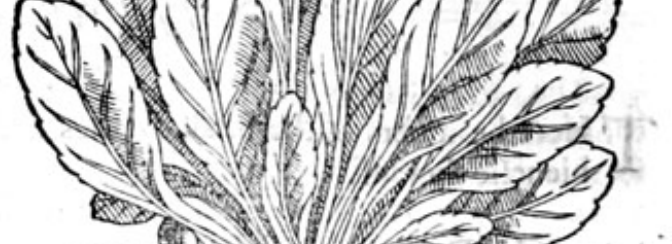

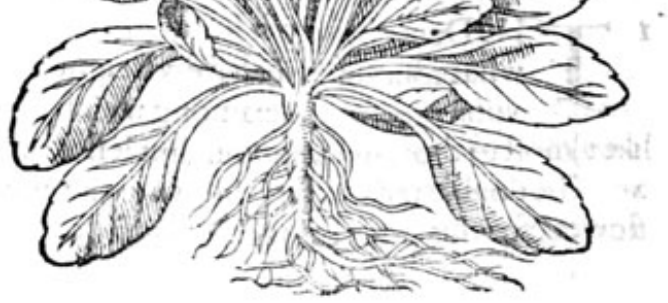




\section{* Thedefoription.}

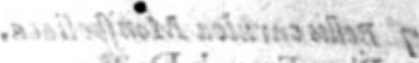 \\ this Chionaturif}

3 The wilde fielde Daifie hath many leaues fpred vpon the grounde, like thofe of the garden Daifie: among which rife vp flender ftems, on the top whereof doth grow fmall fingle flowers like thofe of Camomill,fet about a bunch of yellow thrums, with a pale of white leaues, fomtimes white, now and then red,and often of both mixed togither. The roote is threddie.

2 There doth likewife growe in the fields another fort of wilde Daifie, agreeing with the former in each refpeet, fauing that it is fomewhat greater then the other, and the leaues are fomwhat more cut in the edges.

5 Bellis ceralea fue globularis. The blewe rounde Daifie.

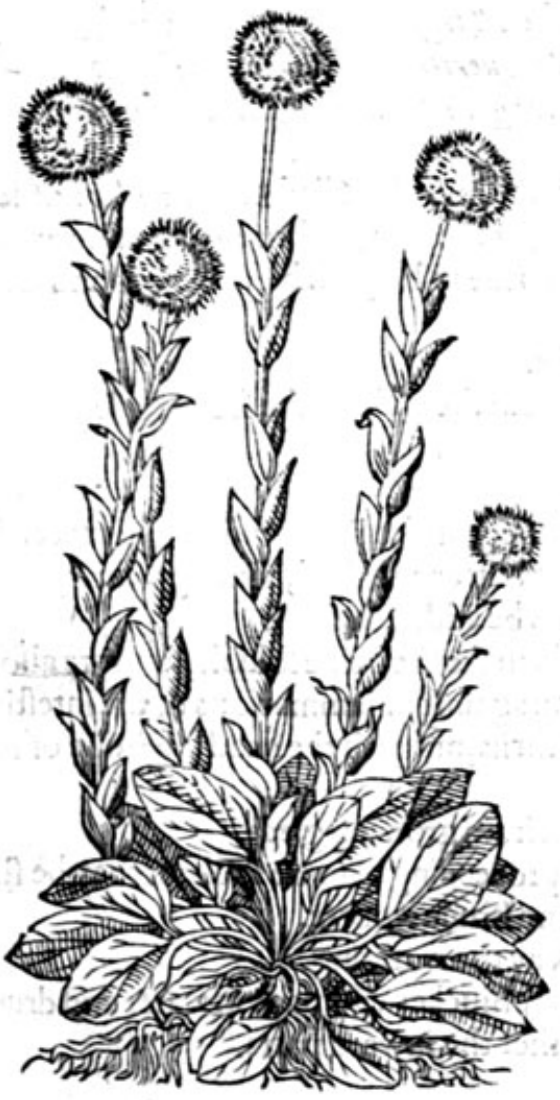

6 Bellis cerulea Apulea. The Blewe Italian Daifie.

\section{* The defaription.}

5. The blewe Italian Daifie hath manie fmall threddie rootes, from which rife vppeleaues like thofe of the common Daifie, of a darke greene colour, among which commeth vp a fat ftemme fet rounde about with like leaues, but leffer. The flowers growe at the toppe globe fafhion, that is, rounde like aball, of a perfect blewe colour, verie like vnto the flowers of Mountaine Scabious.

6 This Italian blew Daifiehath many leaues fpred vpon the ground like vato the former, but fomwhat broader and more hollowed in like 2 fpoone, among which rife vp flowers rounde as a ball, and of a blew colour. The roote is threddie. 7. The French blew Daifie is like vnto the otherblewe Daifies in eche refpeet, fauing it is altogither leffer, wherein confifteth the difference. 


\section{THE SECOND BOOKE OF THE}

7 Bellis carulea Monfpeliaca. Blew French Dailies.

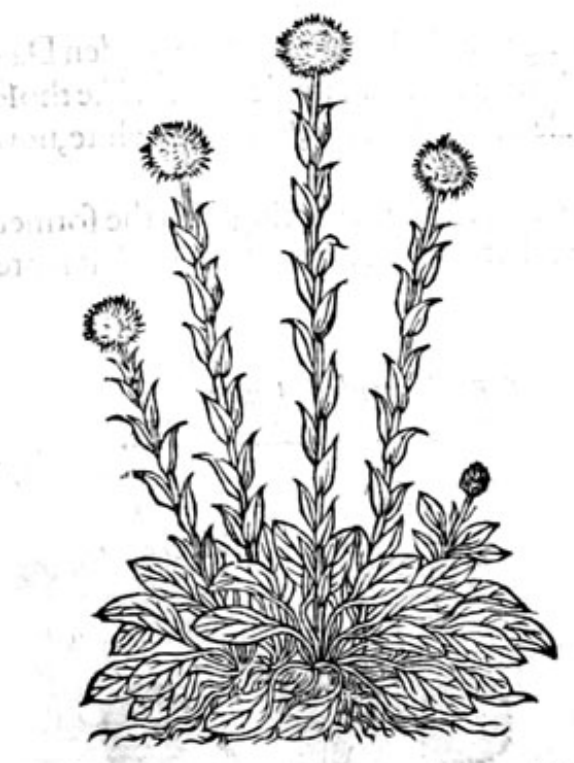

* The place.

The double Daifies areplanted in gardens : the others growe wilde euery where.

The blew Daifies are ftrangers in England, their naturall place of abode is fet foorth in their feverall titles.

\section{* The time.}

The Daifies do flower moft part of the fommer. * The names.

The Daifie iscalled in high Dutch $\mathscr{M a f z}$ líeben: in lowe Dutch Matgrieten: in Latin Bellisminor, and Confolidaminor, or the middle Confound: of Plinie Primula veris: but that name is more proper vnto Primrofe, or certaine kindes of Mulleines; of fome Herba Margarita: or Margarites berbe: in French Marguerites, and Caffaudes: in Italian Fiori diprima verigentili : in Englifh Daifies and Bruife woort.

The blewe Daifie is called Bellis carulea : of fome Globularia, of the rounde forme of the flower: it is alfocalled aphyllanthes and Frondiflora : in Italian Bot anaria : in Englifh blew Daifies and Globe Daifie.

* The temperature.

The leffer Daifies are colde and moift,and they are moift in the ende of the feconde degree, and colde in the beginning of the fame.

\section{$*$ The vertues.}

A The Daifies do mitigate all kinde of paines, but efpecially of the ioints and goute proceeding from a hot and drie humour, if they beftamped with newe butter vnfalted, and applied vpon the painfull place : but they worke more effectually if mallowes be added thereto.

B The leaues of Daifies vfed among other potherbes, do make the bellie foluble, and are alfo put into clyfters with good fucceffe, in hot burning feauers, and againft inflammations of the inteftines.

C The iuice of the leaues and rootes fnift vp into the nofthrils, purgeth the head mightilie of foule and filthy flimie humours : and helpeth the Megrim.

D The fame giuen to little dogs with milke, keepeth them from growing great.

E The leaues ftamped, taketh away brufes and fwellings proceeding of fome ftroke, if they be ftamped and laide thereon, whereupon it was called in olde time Bruife woorte.

F The iuice pur into the eies cleereth them, and taketh away the watering.

G The decoetion of the fielde $\mathrm{Daifie}$ (which is the beft for phifickes vfe)made in water and drunke, is good againft agues, in flammation of the liuer, and all other the inward parts.

$$
\text { Of Moufeare. Chap.194. }
$$

* Thekindes.

$T$ Here be diuers forts of Moufeare : whereof to write apart were to fmall purpole, confidering they may be diftinguifhed, and yet comprehended in one chapter.

* The defaription.

$\mathbf{I}$

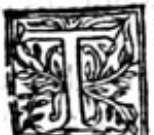

He great Moufeare hath grcat and large leaues, greater then our common Pylofelle, or Moufeare, thicke, and full of fubftaunce. The ftalkes and leaues be hoarie and white, with a filken moffines in handling like filke, pleafant and faire in view.It beareth three or fower quadrangled ftalkes, fomewhat knottie, a foote long. The rootes are harde, woodie and full of ftrings:the flowers come foorth at the top of the ftalkes, like vnto the fmall Piffeabed,or Dandelion, of a bright yellowe colour. 


\section{H IST ORIE O FAPLA N TS. $\exists H T$}

2 The fecondkinde of Pilofella is that herbe which we call Auricula muris, or Moufeare, being a very common herbe (but fewe more woorthy of confideration) bicaufe of his good effeet : and yet cleane vnremembred of the old writers. It is called Pilofella of the rough, hairie, and whitith fubftance growing on the leaues, which are fomewhat long like the little Daifie, but that they haue a fmall hollowneffe in them, refembling the eare of a moufe : vpon which confideration the Gracians haue called it Myofotis, wherein they were greatly deceiued, for it is nothing like vnto $M y$ fotis of Dio/corides : his fmall ftalkes are likewife hairic, flender, and creeping vpon the ground, his flowers are double, and of a pals yellowe colour, much like vnto Sonchis, or Hieracium, or Haukeweede.

I Pilofella major. Great Moufeare.

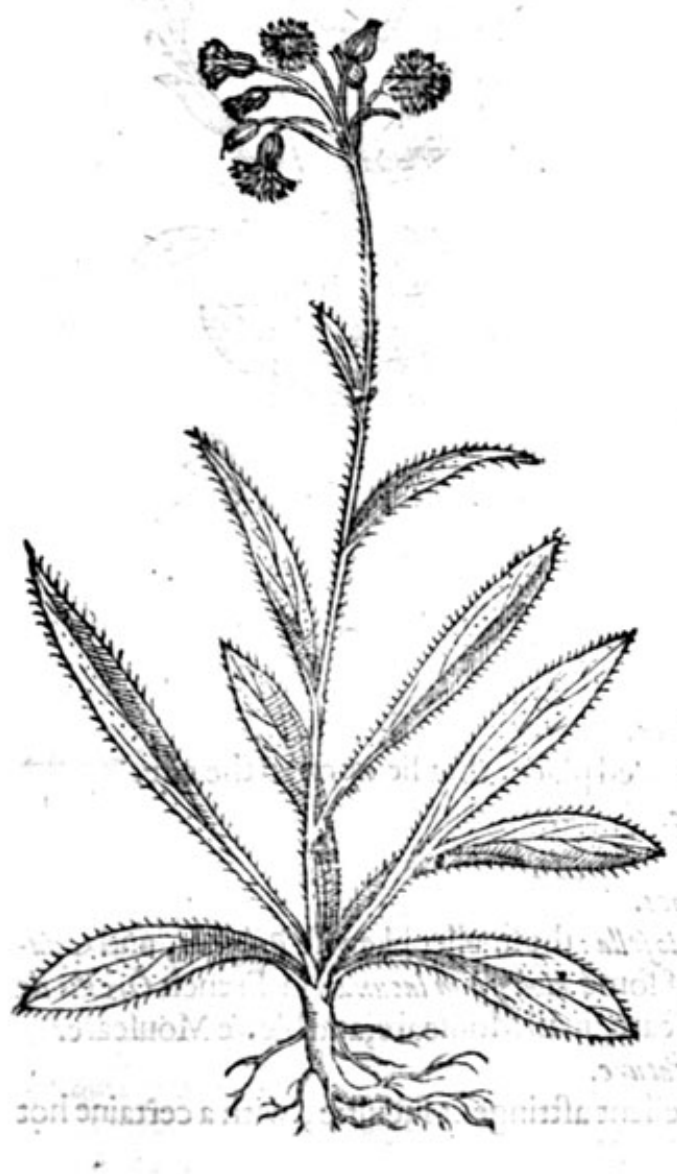

2 Pilofella repens.

Creeping Moufeare.

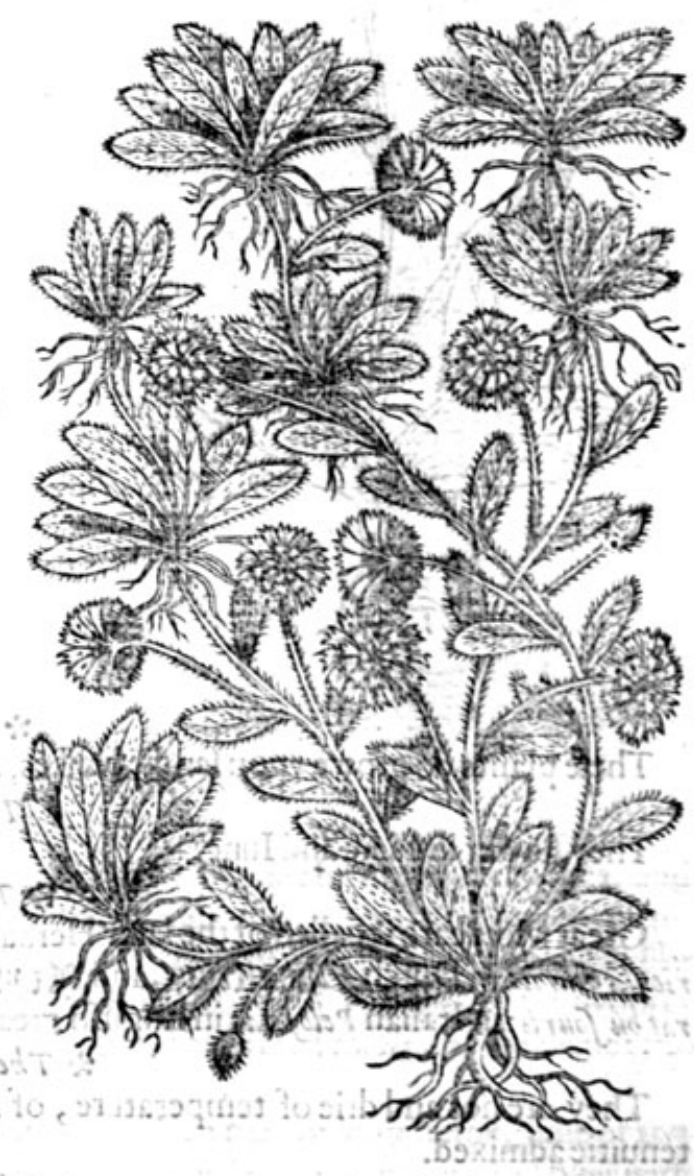

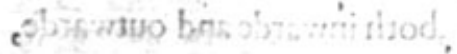

* The defoription.

3 The fmall Moufeare with broade leaues hath a fmall, tough rooke; from which rife vp manie hairie, and hoarie broade leaues fpred vpon the grounde: among which groweth vp a fender Item; at the top whereof ftande two or three fmall yellowe flowers, which being ripe turne vnto downe that is caried away with the winde.

4 Theblewe Moufeare hath a fmall threddie rooce, from which rife vp many rongh hairie leaues, of an ouerworne ruffet colour. The ftalke is likewife hairie, as is euery part of the plant:the flowers ate very fmall, of a blewe colour after which followe little hairie pouches or feede veffels, like thofe of Shepheards purfe. 
3 Pilofella minor latifolia.

Broad leafed Moufeare.

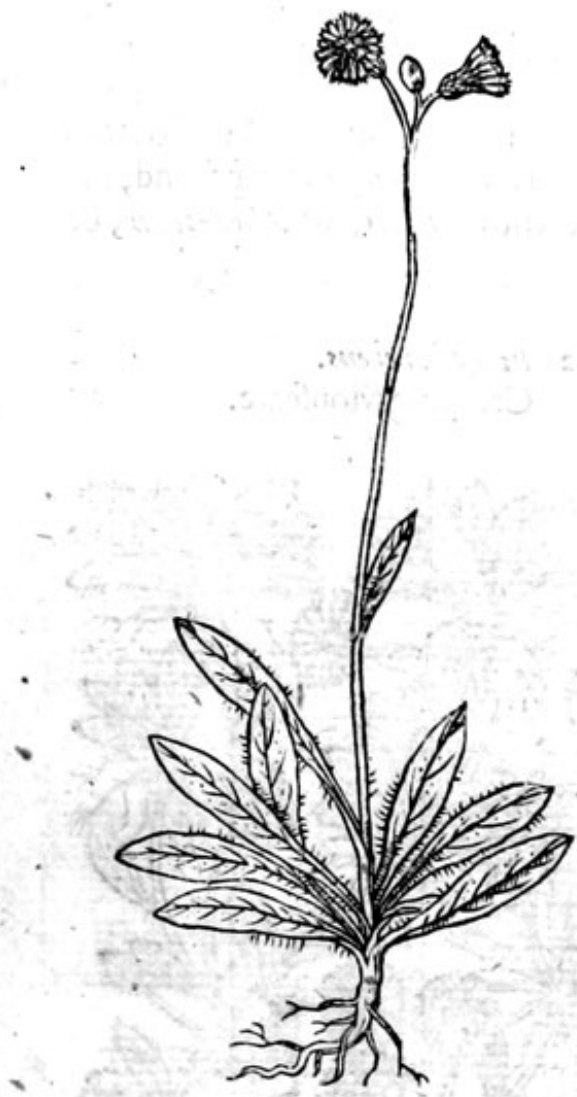

4 Pilofella flore caruleo. Blewe Moufeare.

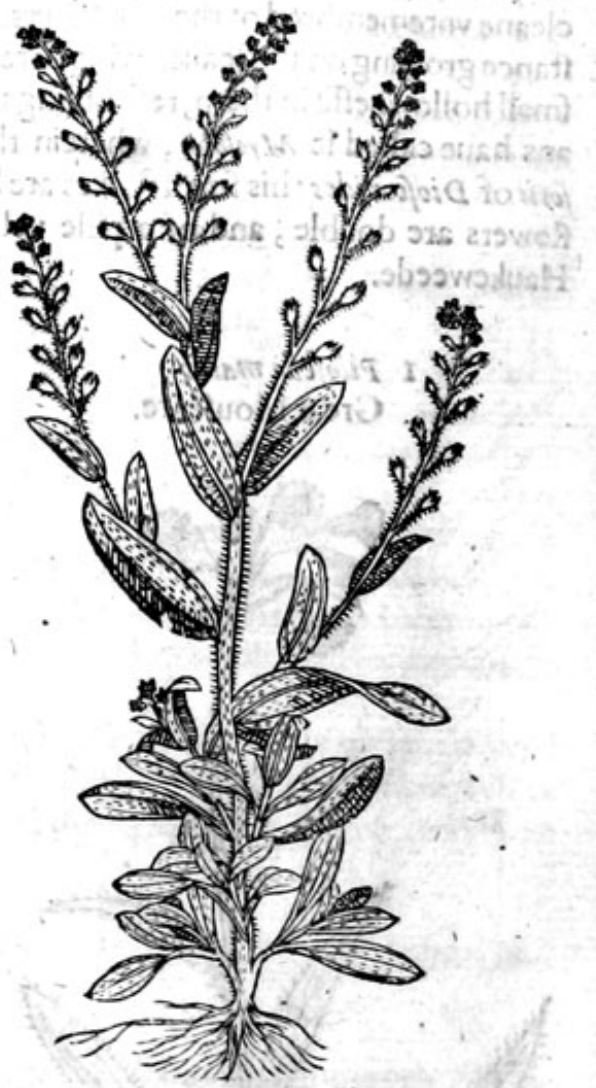

Thefe plants do growe vpon fandie bankes, and vntoile

They flower in Maie and Iune.

\& The time.

\section{* T the names.}

Great Moufeare is called of the later Herbarifts Pilofella : the frnaller likewife Pilofella, and LA

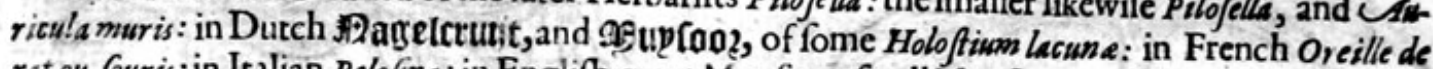
rat ou fouris: in Italian Pelofina : in Englifh great Moufeare,fmallMoufeare,andblewe Moufeare.

They $*$ The temperature.

$*$ The temperature.
re, of an excellent aftringent facultie, with a certaine hot tenuitie admixed.

$*$ The vertues.

A The decoction of Pilo fella drunke, doth cure and he.ie all wounds, both inwarde and outwarde, it cureth hernies, ruptures or blirftings.

B The leanes dried and made into powder, profite much in healing woundes being ftrawed therevpon.

C The decoetion or theinice is of fuch excelfencie, that if fteele edged tooles glowing hot be drenched and cooled therein of tentimes, it maketh them fo hard, that they will cut ftone or iron, be it neuer fo hard without turning the edge or waxing duill.

D This herbe being vfed in gargatifmes, cureth the loofeneffe of the Vuula.

i Being taken in drinke it healeth the fuxes of the wombe 2 as allo the difeafes called Dyfenteria, and Enterocele: it glueth and confoundeth wounds, ftalteth the fwelling of the folcene, and the bloudiecxcrements procured thereby.

F The Apothecaries of the lowe cothtries make a fyrupe of the iuice of this herbe, which they vee for the cough, confumption, and ptificke. 


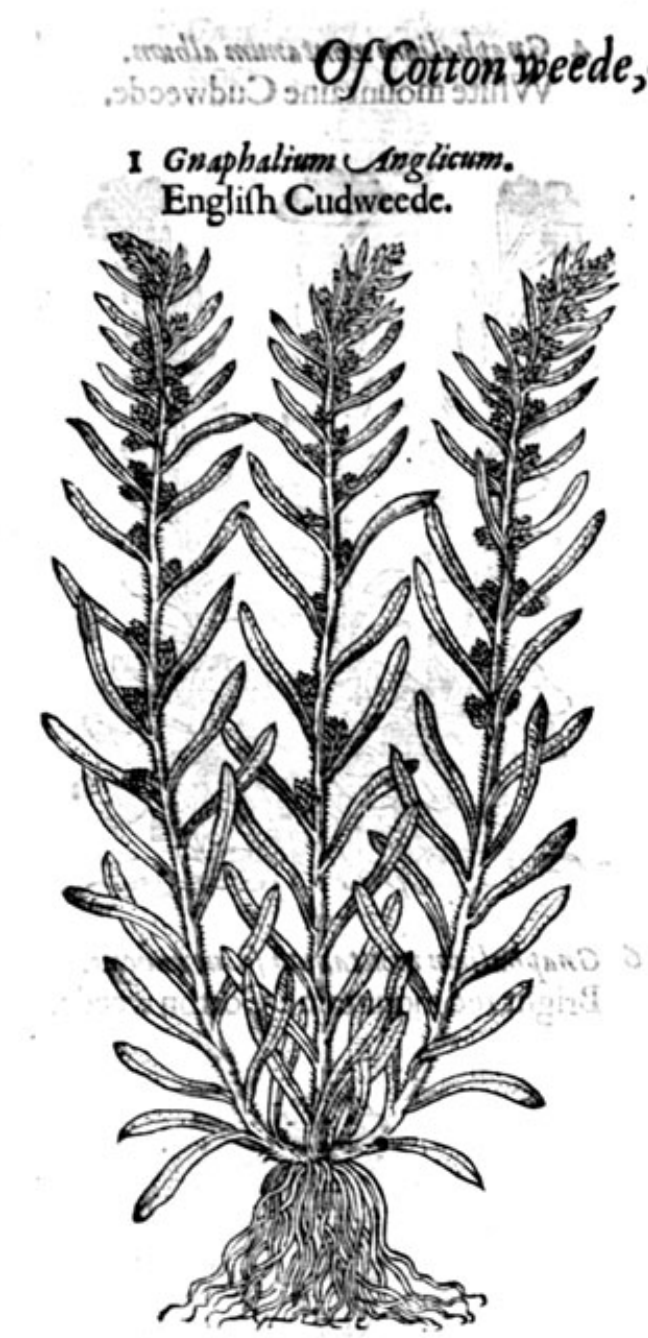

\section{or Cudweede.}

CBap:195:

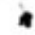

2 Gnapbalien vulgarie.

Common Cudweede.

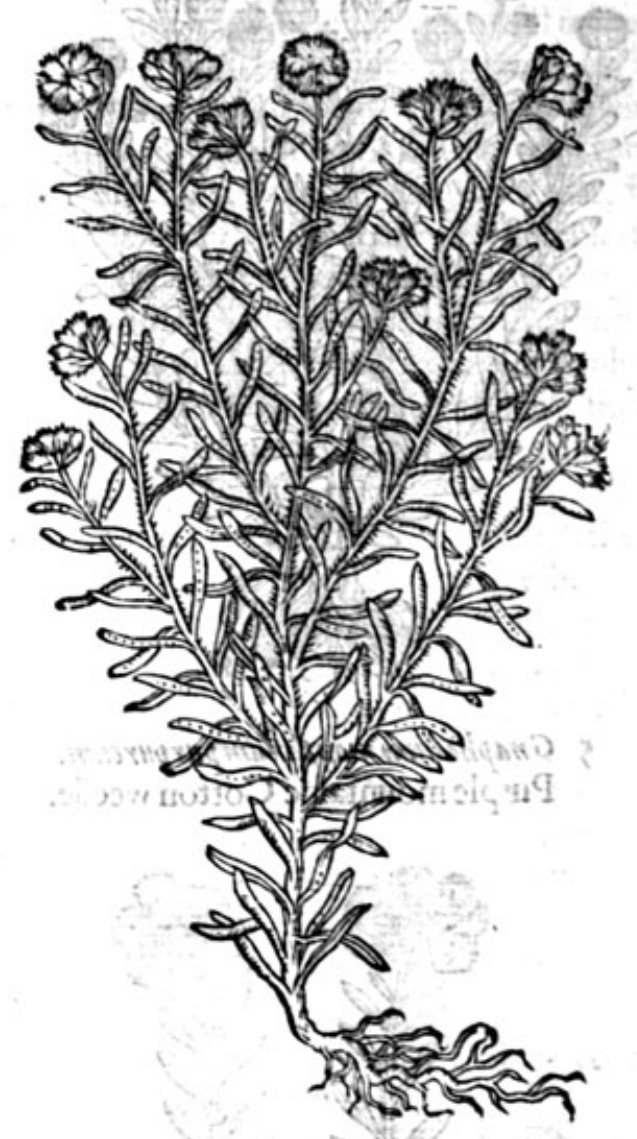

* The defcription.

I $\mathrm{C}$ Nlifh Cudweed hath fundrie flender and vpright ftalks, diuided into manybranches, and C groweth as high as common Wormwood, whofe colour and hape it doth much refemble. The leaues hoote from the bottome of the turfe full of haires, in thape fomewhat like a Willow leafe belowe, but aboue they be narrower, and like the leaues of $P$ fyllium, or Fleawoort; among which do grow fmall pale coloured flowers, like thole of the fmall conies or Fleabane : the whole plant is of a bitter tafte.

2 The fecond being our common Gnaphaliven, or Cudweede, is a bafe or lowe herbe, nine or ten inches long, hauing many fmall ftalkes or tender branches, and little leaues, coucred all ouer with a certaine white cotton, or fine wool, and very thicke. The flowers be yellow, and growe like buttons at the top of the ftalkes.

3 The thirde kinde of Cudweede, or Cotton weede being of the fea, is like vnto the other Cudweede laft recited, in ftalkes and white cotton leaues, but is altogicher fmaller and lower, feldome growing an handfull high. The flowers growe at the top of the ftalkes in fmall round buttons, of colour and fafhion like the other Cudweede.

4 The fourch being the Cotton weede of the hils and fonie mountaines, is fo exceeding white and hóarie, that one would thinke it to be a plant made of wooll, which may very eafily be knowen by his picture withotit other defcription.

5 The fiftkinde of Cotton weede hath leaues and talkes like the other of his kinde, and differeth in that, that this plant beareth a bufh or tuft of penple flowers, otherwife it is very like.

6 The fixt is like vnto the laft recited, but greater 8 the flowers are of an exceeding bright red co. lour, and of an aromaticall fweete fincll.

criaidadone

$K k=$

3 Gnaphalium 
3 Gnaphalium marinuar. Sea Cudwecde."

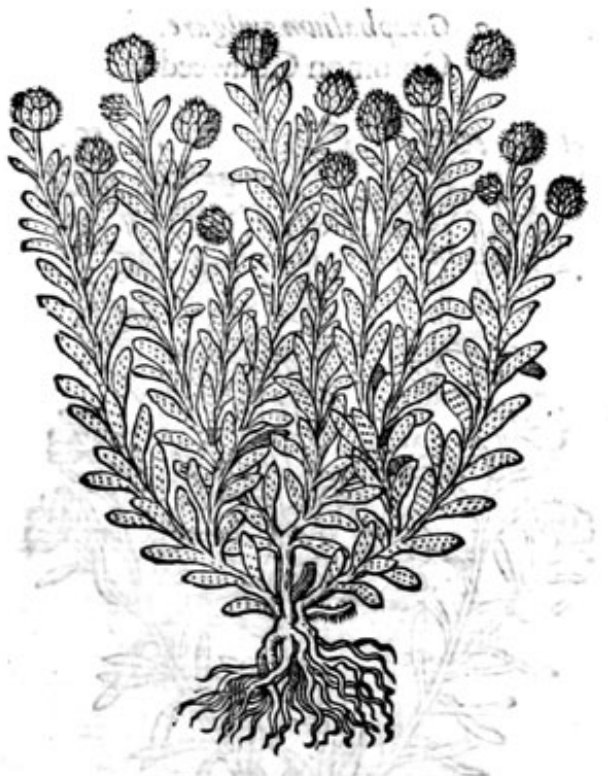

5 Gnaphalium montasum purpureum. Purple mountaine Cotton weede:

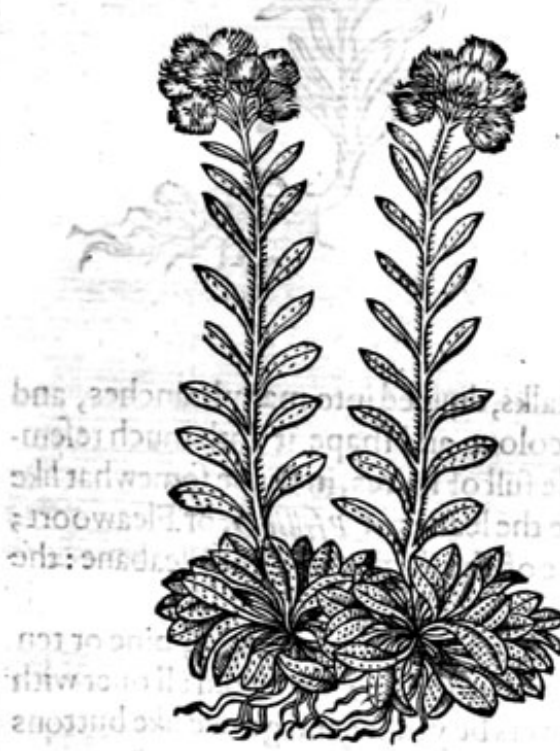

4 Gnapbalipon montanum albuem. White mountaine Cudweede.

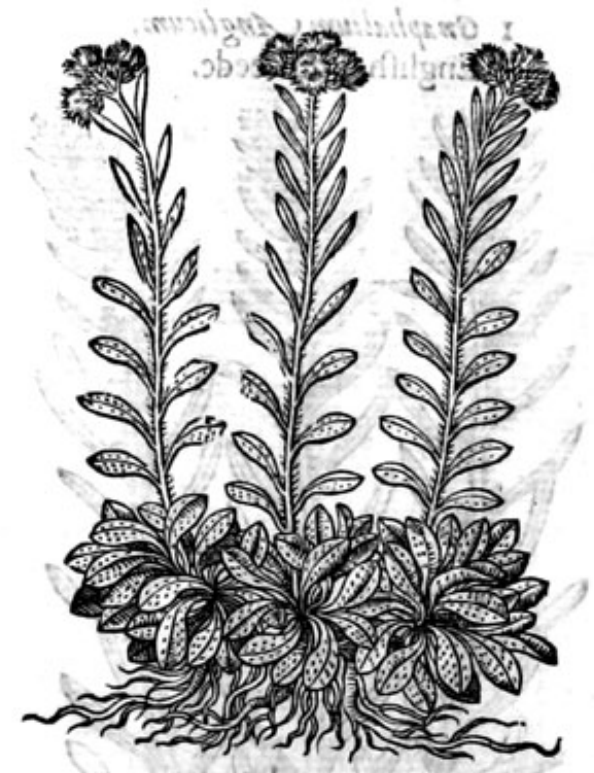

6 Gnaphalium montanum fuave rubens. Bright red mountaine Cotton weede.

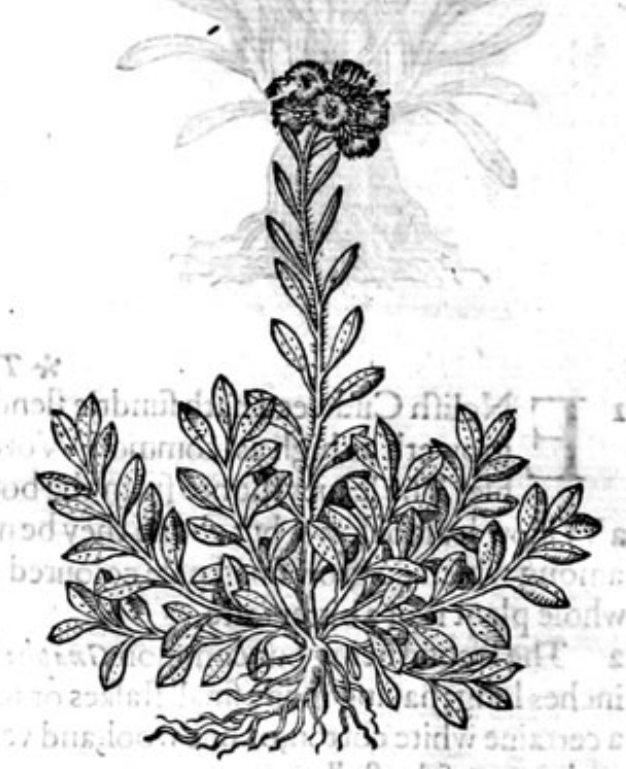

* The defcription.

7. The feuenth kinde of Gnaphaliwm, or Cotton weede of Clus fus his defcription, groweth to the height of nine or ten inches, hauing little long leaues, like the fmall Moufeare; woollie within, and of an hoarie colour on the outfide. The ftalkes in like manner are very woollie; at the top whereof commeth foorth a faire flower and a ftrange, hauing fuch woollie leaues bordering the flower about, that a man would thinke it to be nothing elfe but wooll it felfe : and in the middeft of the flower come foorth fundrie fmall heads of a pale yellow colour, like vnto the other of thiskinde.
The roote is blacke, and fomewhat fibrous. 


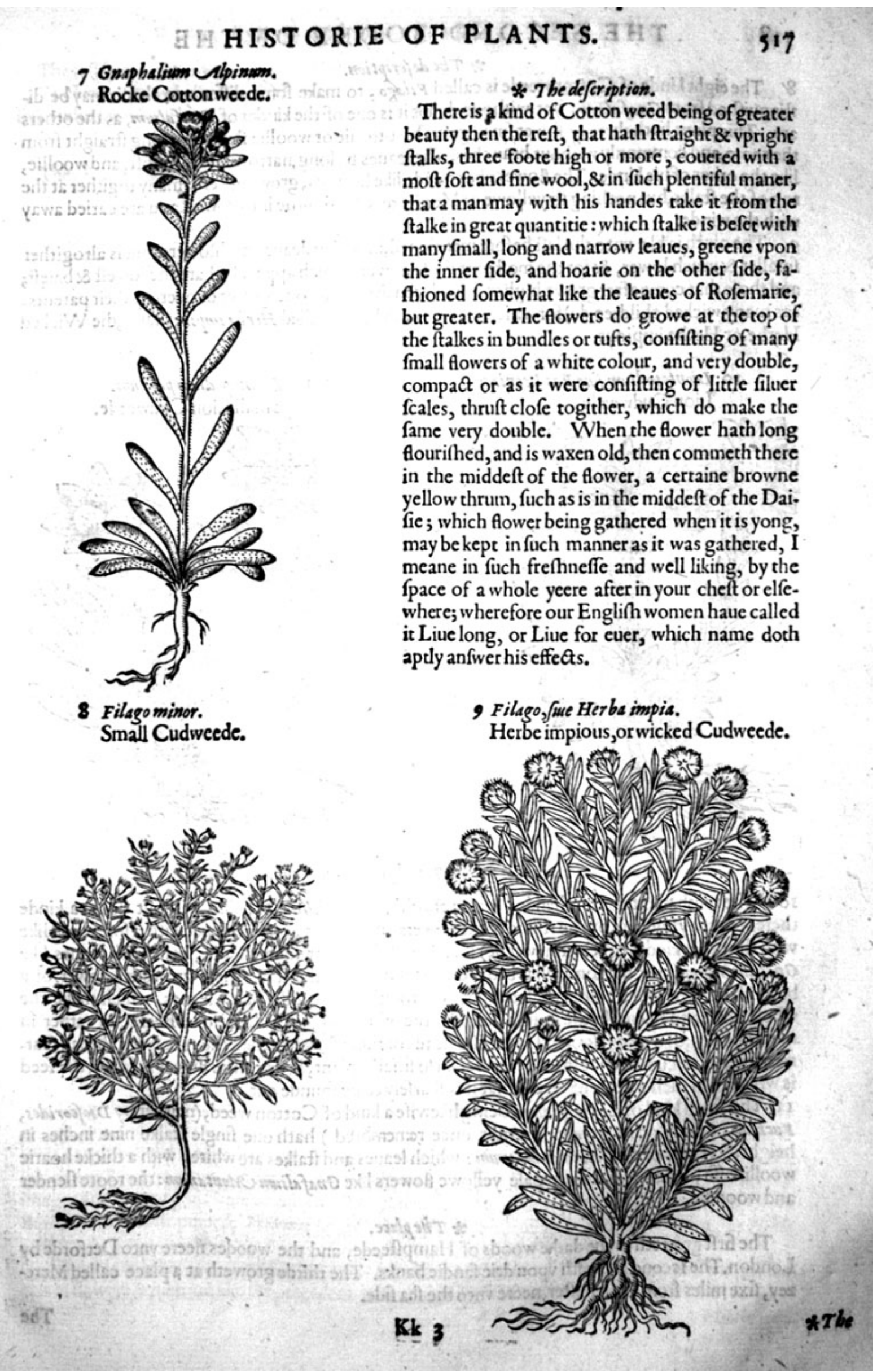




\section{* The defeription.}

8 The eight kinde of Cottonweede is called Filago, to make fome difference that it may be diftinguifhed from Gnafalium: yet without doubt it is one of the kindes of Gnafalium, as the others are. This plant hath three or fower fmall grayifh, cottonie or woollie ftalks, growing ftraight from the roote, and commonly without branches. The leaues be long, narrow, whitifh, foft, and woollie, like the other of his kinde. The flowers be rounde like buttons, growing verie many togither at the top of the ftalks, but nothing fo yellowe as Moufeare, which turne into downe, and are caried away with the winde.

9 The ninth is like vnto the laft before mentioned, in ftalkes, leaues, and flowers, but is altogither fmaller \& much lower, \& for the moft part thofe flowers which appeer firft are the loweft \& bafeft; and thofe that come after growe higher, as children feeking to ouergrowe or ouertop their parents, (as many wicked children do)for which caufe it hath beene called Herba impia; that is, the Wicked Herbe, or Herbe impious.

10 Leontopodium fue Pes Leoninus. Lion Cudweede.

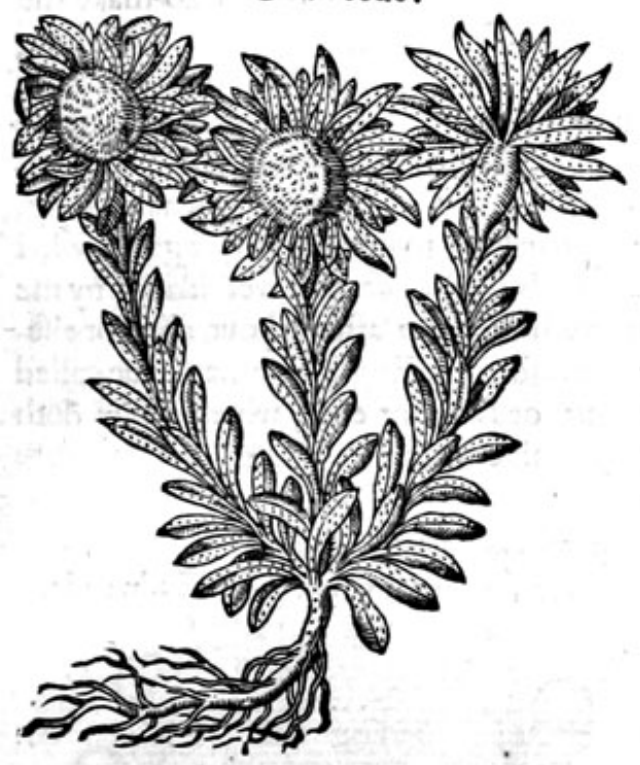

II Leontopodium paruum. Small Lion Cudweede.

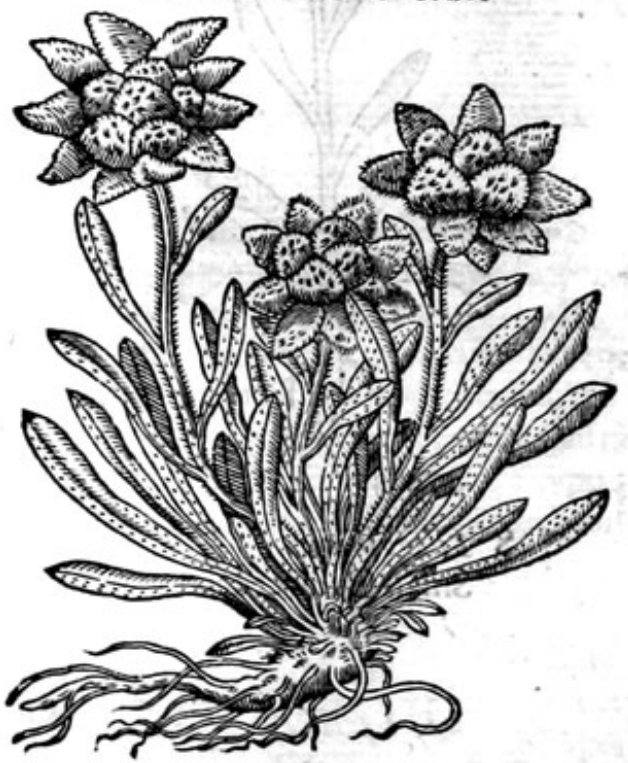

\section{* The defcription.}

10 The tenth plant comprehended vnder the title of $G$ nafaliwm, (being without doubt a kinde thereof,as may appeere by the fhape of his flowers and ftalkes, couered ouer with a foft wooll like vnto the other kindes of Cotton weede) is an handfull high or thereabouts, befet with leaues like Gnafaliam anglicum, but fomewhat broader. At the top of the ftalke there groweth a flower of a blackifh browne violet colour, befet about with rough, and woollie hairie leaues, which make the whole flower to refemble the rough haired foote of a Lion, of a Hare, or a Beare, or rather in mine opinion, of a rough footed Doue. The heads of thefe flowers when they are fpred abrcad, carrie a greater circumference then is required in fo fmall a plant, \& when the flower is faded, the feed is wrapped in fuch a deale of wooll, that it is fcarfely to be founde out.

I i This fmall kind of Leontopodium being likewife a kind of Cotton weed, (neither by Diofcorides, Fuch fius, or any other auncient writer once remembred) hath one fingle ftalke nine inches in height, S leaucs of Gnafaltum montanum : which leaues and ftalkes are white, with a thicke hoarie woollineffe, bearing at the top pale yellowe flowers like Gnafalium CMontanum: the rooteflender and wooddie.

$$
\text { * T heplace. }
$$

The firft groweth in the darke woods of Hampftecde, and the woodes neere vnto Detforde by London. The fecond groweth vpon drie fandie banks. The thirde groweth at a place called Merezey, fixe miles from Colchefter, neere vnto the fea fide. 
The reft grow vpon mountaines and hillie grounds, and barren paftures.

The kind of Grapbslitum newly fet foorth, groweth naturally neere vnto the Mediterianean fea, from whence it hath beenc brought and planted in our Englifh gardens.

\section{* The time.}

They flower for the moft part, from Iune to the end of Auguft.

* The names:

Cotton weede is called in Greeke vraparier; and it is called Gnaphalion, bicaufe men vfe the tender leaues of it in fteed of Bumbafte or Cotton, as Paulus 1 Eg ginet a writeth; Plinie faith it is called Chimexylon : as though he fhoulde fay lowe Cotton; for it hath a foft and white cotton like vnto. bumbafte, whereupon alfo it was called of diuers Tomentitit, and Cotonaria : of others Centunculus, and Centuncwlaris, and Albinwm, which worde is founde among the baftarde names.But the later worde by reafon of the white colour doth reafonably well agree with it. It is alfo called Eombax, bunilis filago, and Herba Impia , bicaufe the yonger, or thofe flowers that fpring vp later, are higher, and ouertop thofe that came firft, as many wicked children do vnto their parents, as before touched in the defcription : in Englifh Cotton weede, Cudweede, Chaffe weede, and petie Cotton.

\section{* The nature.}

Thefe herbes be of an aftringent or binding and drying qualitie.

\section{$*$ The vertues.}

Gnaphalinom boiled in ftrong lee, clenfeth the haire from nits and lice: alfo the herbe being laid in A wardrobes and preffes, keepeth apparell from mothes.

The fame boiled in wine and drunken, killeth wormes, and bringeth them foorth, and preuaileth $B$ againft the bitings and ftingings of venemous beafts.

The fume or fmoke of the herbe dried, and taken with a funnell, being burned therin, \& receined C in fuch maner as we vfe to take the fume of Tabaco, that is, with a crooked pipe made for the fame purpofe by the potter, preuaileth againft the cough of the lungs, the great ache or paine of the head, and clenfeth the breft and inward parts.

\section{OfGolden Mothwoort,or Cudweede. Chap.196.}

* The kindes.

Therebe diuers fortes hereof, conteined vnder diuers titles, yet of one ftocke or kinred, and all of them Cudweedes, or Chaffeweedes, or Cotton weedes.

\section{* The defcription.}

$\mathbf{I}$

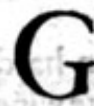
Olden Mothwoort bringeth foorth flender ftalkes fomewhat hard and wooddie, diuided into divers fmall branches: whereupon do growe leaues fomewhat rough, and of a white colour, very much iagged like Southernwood, which the grauer hath omitted in the picture. The flowers ftand on the top of the ftalkes ioined togither in tuftes of a yellow colour, glittering like golde, in forme refembling the fcalie flowers of Tanfie, or the middle button of the flowers of Camomil, which being gathered before they be ripe or withered, remain beautifull long time after, as my felfe did fee in the handes of Mafter Wade, onc of the Clerks of hir Maiefties Counfell, which was fent him among other things from Padua in Italic. For which cauffe of long lafting, the images and carued gods were woont to weare garlands therof, wherupon fome haue called it Gods flower. For which purpofe Ptolemie king of Aegypt did moft diligently obferue them, as Plinie writerh.

2 There is another fort of golden Mothwoort, which L'Obelies calleth Coma aures, of the golden tuft of lowers, which are like the precedent,as is all the reft of the plant. 
I Eliochryfon,fiue aur eus flos.

Golden Mothwoort.

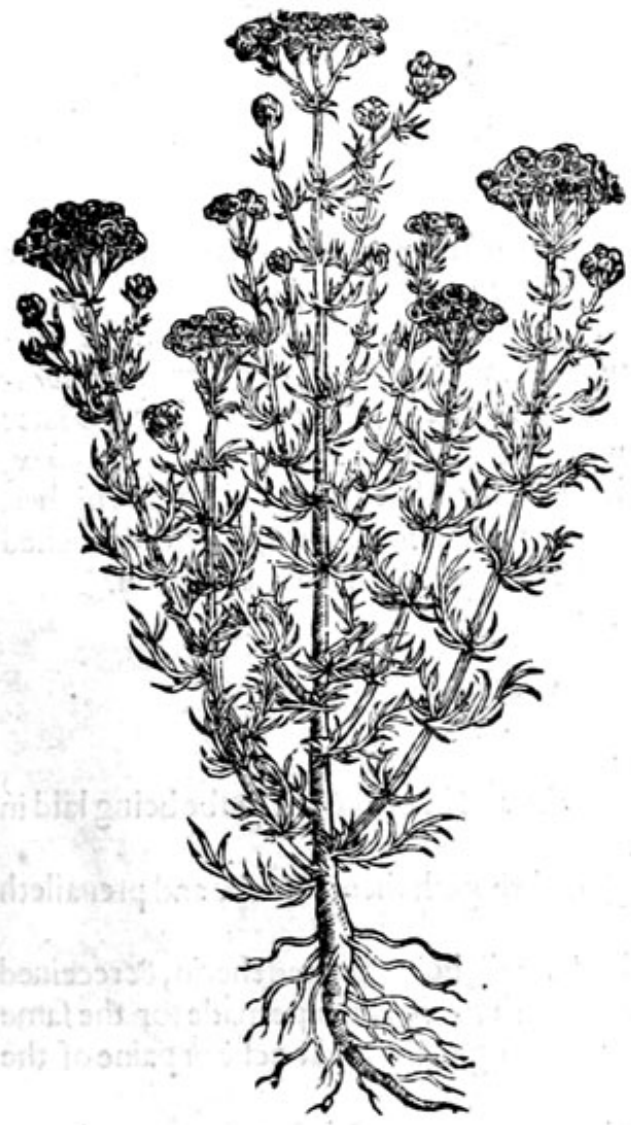

2. Coma aurea. Golden tuft.

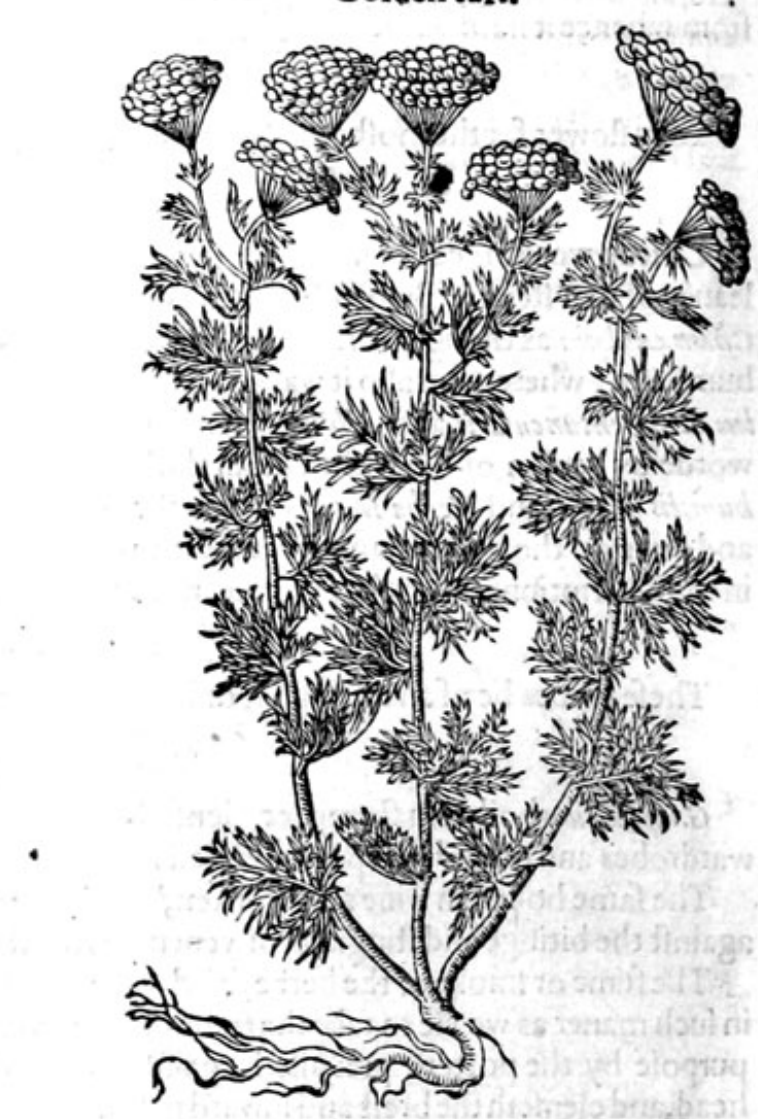

* Theplace.

They growe in moft vntilled places of Italic and Spaine, in medowes where the foile is barren, and about the banks of riuers. They are ftrangers in England.

* The time.

They flower in Auguft and September, notwithftanding $T$ heophrait $w$ and Plinie do number them among the flowers of the fpring.

\section{* The names.}

GoldenMothwoort is called of Diofcorides inizgurov: Plinie calleth it Helioshryfon, and likewife Theophriftus : Gazs tranlatethit Aurelia : in Englifh Gold flower, Golden Mothwoort, or Golden Cudweede; being doubtleffe a kinde of Gnaphaliwm, or Cudweede.

It is (faith Galen) of power to cut and make thin. * The temperature.

\section{* The vertues.}

A Diogcorides teacheth, that a branch thereof drunke in wine, is good for them that can hardly make water; againft ftinging of ferpents, paines of the huckle bones : and taken in fweete wine it diffolueth congealed blood.

B The branches and leaues laid among clothes keepeth thein from moths, whereupon ithath bene called of fome Mothweede, or Mothwoort.

$$
\text { Of Golden flower Gentle. Chap.i97. }
$$

* The defcription.

I His orenge coloured Cudweede or Flower gentle, called of the latter herbarifts Yellow Stœecados, is a plant that hath ftalks of a f pan long, and flender, wherupon do grow nariow leaues white and downie, as are alfo the ftalkes. The flowers ftand on the tops of the ftalks, confilting 


\section{HISTORIE OF PLANTS. AHT}

confifting of a feattered, or difordered fcalie tuft, of a reafonable good finell, and of a bright yellowe colour, which being gathered before they be ripe, do keepe their colour and beaurie long time twithout withering,as do moft of the Cotton weedes, or Cudweedes, whereof this is a kinde. The roote is blacke and flender.

2. This Cbryfocome, or Floramore (which maybe englifhed Goldilockes, of his golden chaffie; of fcalie locks) is altogither leffer than the former, wherein confifteth the difference.

I Stachas Citrins. Golden Stoechas.

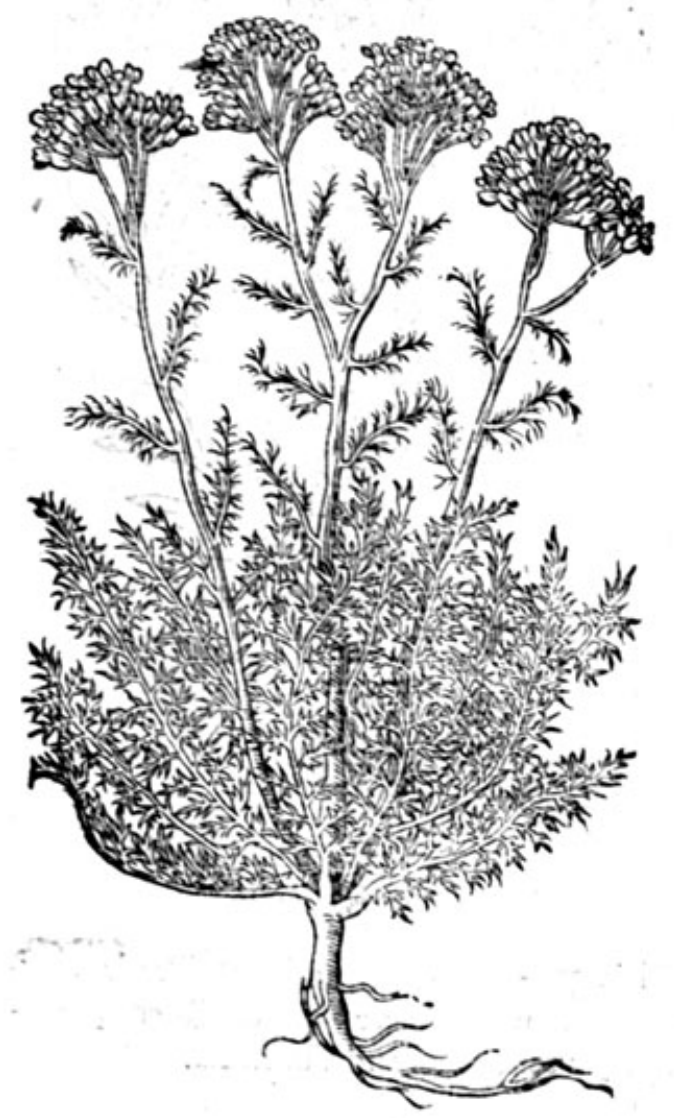

2 Chryfocome, fue Amarant hos lutew. Goldilockes Mothweed.

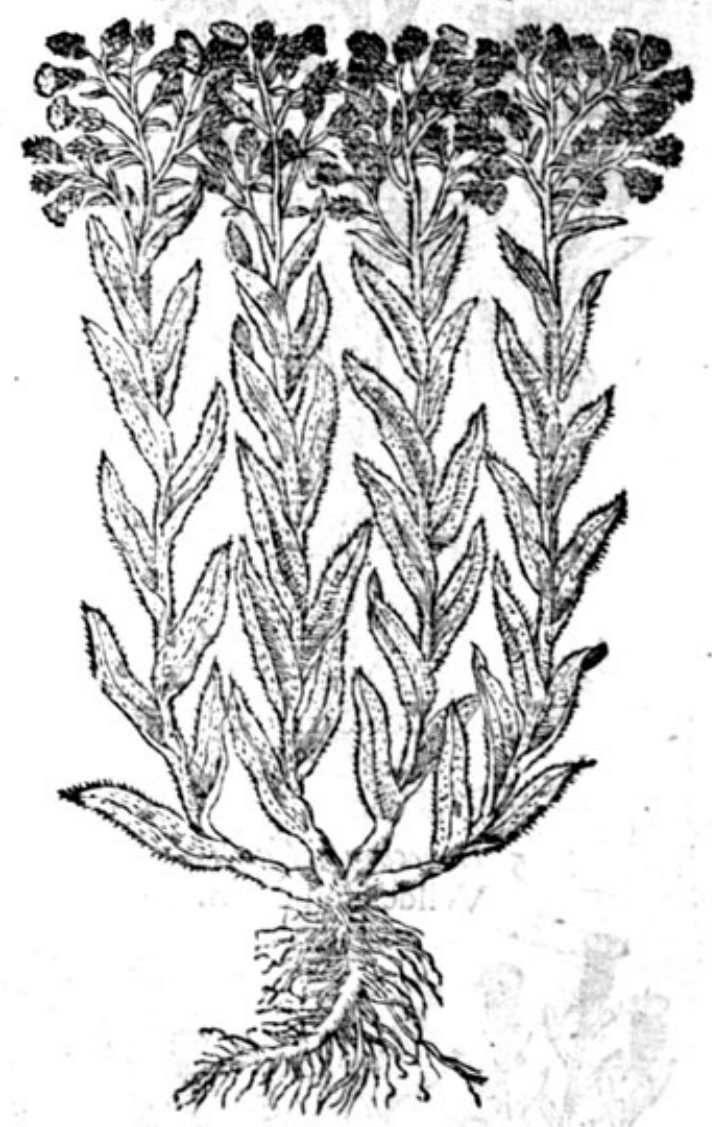

* The defcription.

3 About Nemaufium and Mountpellier, there groweth another kinde of Chryfocome, or as it may be called Stachas Citrina alsera, but that as this plant is in all points like, fo in all refpects it is leffer $\&$ ilenderer,blacker, \& not of fuch beautie as the former, growing more neer vnto an afhie colour, confifting of many fmall twigs a foote long. The roote is lefler, and hath fewer ftrings annexed thereto: and is fejdom found but in the cliffes and crags of rubbilh, $\&$ on wals of cities. This plant is browne, without fent or fauour like the other; euery branch hath his owne bunch of flowers, but not a number heaped togither, as in the firft kinde. It profpereth well in our London gardens. 4 There is a kinde hereof being a very rare plant, and as rare to be founde where it naturally groweth, which is in the woods among the okes betweene Omers and Mountpellier. It is a fine and beautifull plant, in hewe paffing Staechas Citrina altera : but the leaues of this kinde are broade; and. fomewhat hoarie, as is all thereft of the whole plant; the ftalke 2 foote long, and beareth the verie flowers of Stacbar Citrina altera, but bigger and longer, and fomewhat like the flowers of Lactuca agreftis. The roote is like the former, without any manifeft fmell, little knowne, hard to finde, whofe faculties be yet vnknowne.

5 This is a wilde kinde (which L'Obellin his obferuations fetteth foorth) that heere may be in:ferted, called Eliochryfos flueftris of Tragus; which CWathiolus calleth Pfoudoleontopodium. I he woolly or flockey leafe of this plant refembleth $G$ naphalium vulgare, they be of a pale colour, which growe with their feede vnder the wings of the leaues: the roote is very threddy. 
3 Chryfocome Galeni. Galens Goldilocks.

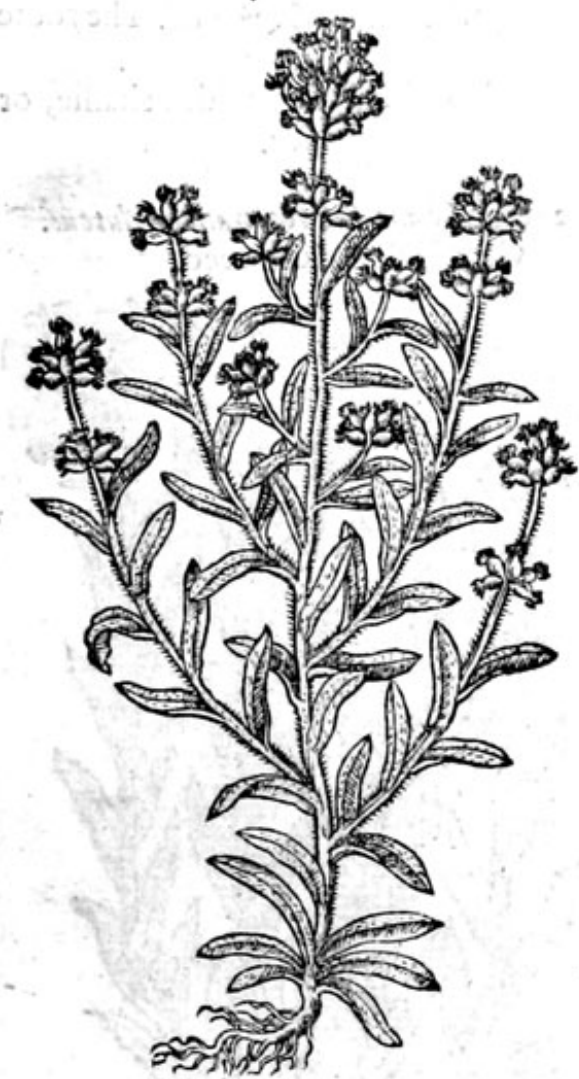

5 Heliochry fos flueftris. Wilde Goldilocks.

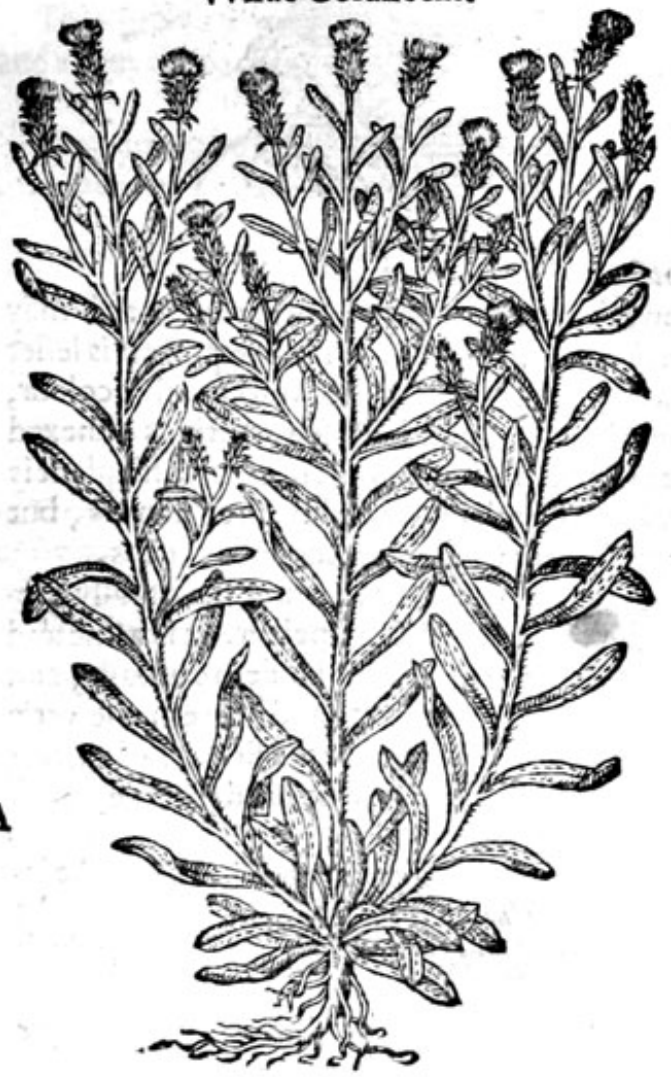

4 . Amaranthus Galeni. Galens Mothwoort.

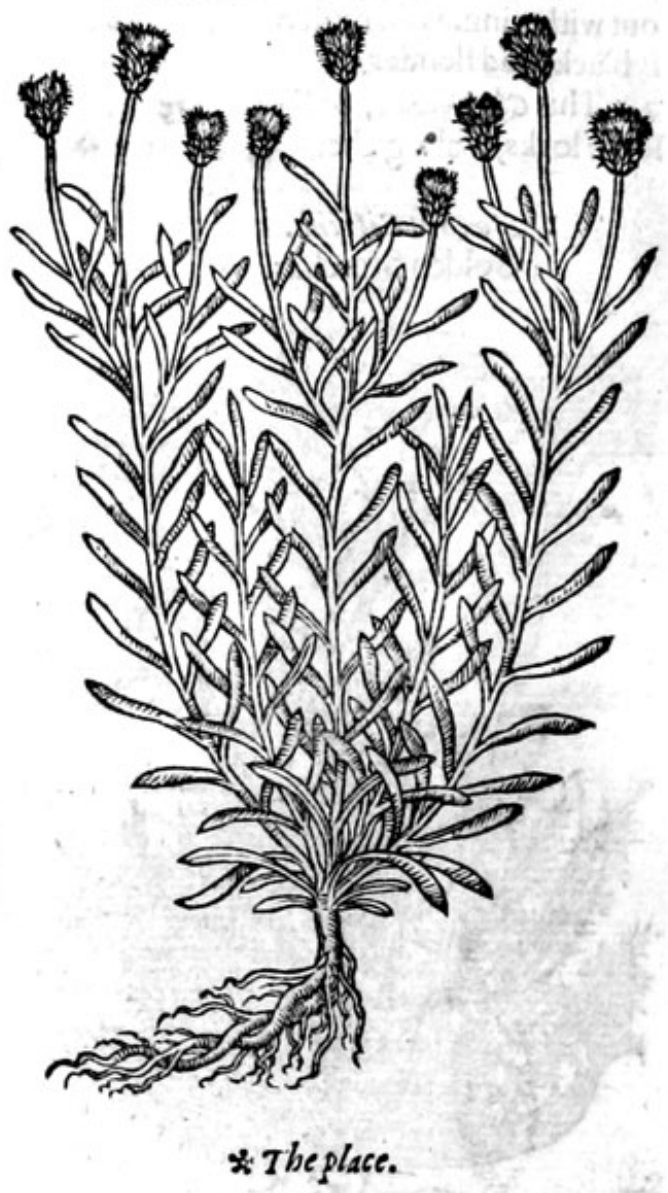

Theygrowe in rough and grauellie places almoft euerie where neere vnto the Rhene, elpecially betweene Spira and Vormacia.

\section{They flower in Iune and Iuly.}

\section{* The names.}

Golden Flower is called in Latine Coma aures, of his golden lockes or beautifull bufh, and allo Tineraria : in fhops Stachas citrina, Amaranthis luteus Fuchfii, \& 7 ragi : of fome Linaria al es, but not truely: in Greeke Chryfocome : in Dutch KRepnbloemen, and gotten crupt : in Italian Amarantho Giallo: in Englifh Golde Flower, Gods Flower,and Golden Stœcados.

\section{* Thetemperature and vertues.}

The flowers of Golden Stnechados boiled in wine and drunke, expell wormes out of the bellie; and being boiled in lee made of ftrong ahes doth kill lice and nits, if they be bathed there. with. The other faculties are referred to the former plants mentioned in the laft chapter. 


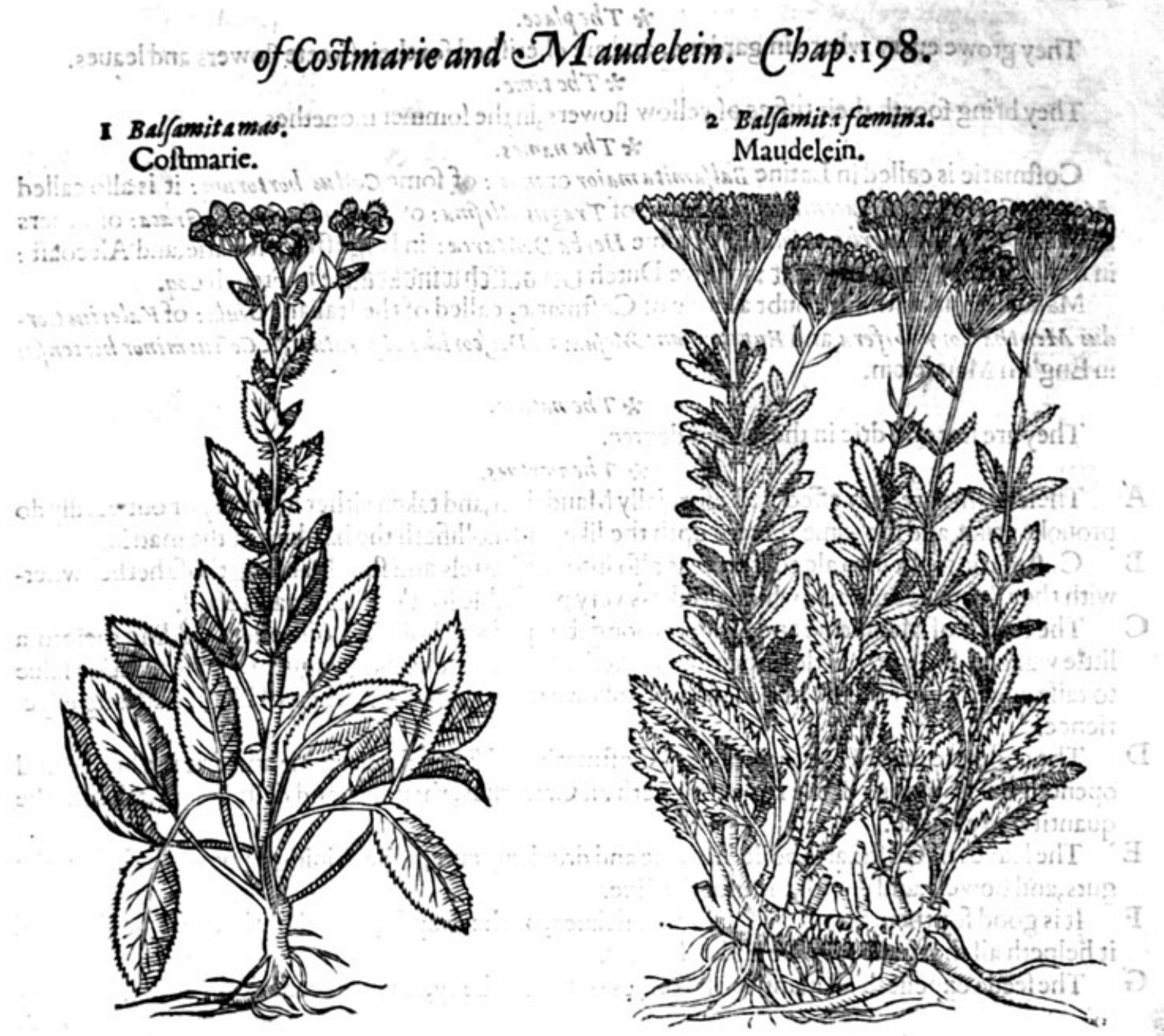

* The de cription.

I Oftmarie groweth vp with round hard ftalks two foote high, bearing long broad leaues finely nicked in the edges, of an ouerworne whitifh greene colour. The tuft or bundle is of a golden colour, confilting of many little flowers like clufters ioined togither in 2 rundle, after the maner of Golden Stœchados. The roote is of a wooddie fubftance, by nature very durable, not without a multitude of little ftrings hanging thereat. The whole plant is of a pleafant fmell,fauour and tafte.

2 Maudelein is fomewhat like vnto Coftmarie (whereof it is a kinde) in colour finell, tafte, and in the golden flowers, fet vpon the tops of the ftalks in round clufters. It bringeth foorth a number of ftalkes, flender, and round. The leaues are narrow, long, indented, and deepely cut about the edges. The clufter of flowers is leffer than that of Coltmarie, bur of a better fmell and yellower colour. The rootes are long lafting and many.

There is another kinde of Balfamita, which we haue called Ageratiom, as alfo that other withthe white flowers, that is all one with Baljamita, \& youmay cal them at your pleafure either Ageratum or Balfamita : the Grecians call it A riexrov, which is in Latine Ageratum, vel non fenejcens : called in fhops (though vntruly) Eupatorium. The flowers are of a beautifull and feemely fhew, which will not loofe their excellencie of grace in growing, vntill they be very olde, and therefore called of Mefwe 2 on fenefeens, as before; and are like in tufts to Eliochryfon, but of a white colour, and is the true and right U Aeratwm of Digcorides, although there hath beene great controuerfie which fhould be the true plant. 


\author{
* Theplace.
}

They growe euiery where in gardens, and are cherihedfoj their weete fowers and leaues. * The time.

They bring foorth their tuftes. of yellow flowers, in the fommer monethes. wiven the

$$
* \text { The namies. }
$$

Coftmaric is called in Latine Ballamita maior or mas : of fome Custus hortorum: it is alfo called M: ntha Greca, and Saracenica officinarium ; of Tragus Alifma: of Mathiolius HerbaGraca: of others Saluia Romana, and Herba tafjulats: of fome He, ba D. Marte: in Englifh Coftmarie, and Alecoaft: in high Dutch frautwentraut : in lowe Dutch i)epouffeb windaraut : in French Cog.

Maudelein is without doubs a kinde of Coftmarie, called of the Italians Giula : of $V$ alerius Cordus Mentha Corymbifera, and Eupatorivm CMefue: of Diofcorides Ageration, \& Costus minor horten $/ 1$ : in Eng'ilh Maudelcin.

They are hot and dric in the fecond degree.

$$
\text { * The nature. }
$$

\title{
* The vertues.
}

A Thefe plants are very effectuall, efpecially Maudelein, and taken either inwardly or outwardly do prouoke vrine, and the fume thereof doth the like, and mollifieth the hardnes of the matrix.

B Coftmarie is put into ale to fteepe,as alfo into the barrels and ftands among thofe herbes wherwith they do make fage ale; which drinke is very profitable for the difeafes aforefaid.

C The leaues of Maudleine and Adders toong ftamped and boiled in oile oliue, adding thereto $a$ little waxe, rofin, and a little turpentine, maketh an excellent healing vnguent, or incarnatiue falue to raife or bring vp fleth from a deepe and hollowe wounde or vlcer, whercof I haue had long experience.

D The conferue made with the leaues of Coftmarie and fugar, doth warme and drie the braine, and openeth the ftoppings of the fame: ftoppeth all Catarrhes, rheumes, and deftillations, taken in the quantitic of a beane.

E The leaues of Coftmarie boiled in wine and drunken, cureth the griping paine of the bellie, the guts, and bowels, and cureth the bloodie flixe.

F It is good for them that haue the greene ficknes, or the dropfie, efpecially in the beginning, and it helpeth all that haue a weake and cold liuer.

G The feede expelleth all manner of wormes out of the belly, as wormfeede doth.

$$
\text { Of Tanfie. Chap.199. }
$$

\section{* The deficrption.}

I Anfie groweth vp with many ftalkes, bearing on the tops of them certaine cluftered tufts, with flowers like the rounde buttons of yellow Romaine Cammomill,or Feuerfewe(without any leaues paled about them) as yellowe as golde. The leaues be long, made as it were of a great many fet togither vpon one ftalke, like thofe of Agrimonie, or rather wilde Tanfie, verie like to the female Ferne, but fofter and leffer, and euerie one of them flafhed in the edges as are the leaues of Ferne. The roote is tough, and of a wooddie fubftance. The whole plant is bitter in tafte, and of a ftronge fmell, but yet pleafant.

2 The double Englinh Tanfie hath leaues infinitely iagged and nicked, and curled withall, like vnto a plume of feathers:it is altogither like vnto the other, both in fmell and tafte, as alfo in flowers, but more pleafantly finelling by many degrees, wherin efpecially confifteth the difference.

3 The thirdekinde of Tanfie hath leauss, rootes, ftalkes, and braunches like the other, and differech from them, in that this hath no fmell or fauour at all, and the flowers are like the common fingle Fetherfewe.

4 The fourth kinde of Tanfie hath broad leaues much iagged and wcll cut, like the leaues of Fetherfew, but fmaller and more deepely cut. The ftalke is fmall, a foote long, whereupon dogrowe little tufts of little white flowers, like the tuft of Milfoile or Yarrow. The herbc is in fmell and fauour like the common Tanfic, but not altogither fo ftrong. 
I Taractum.

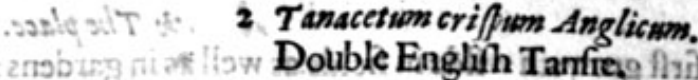

Tanfic.
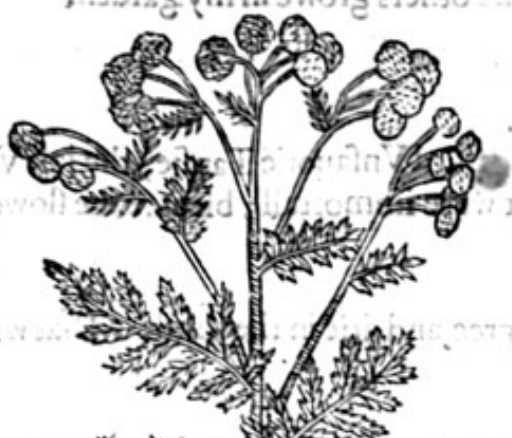

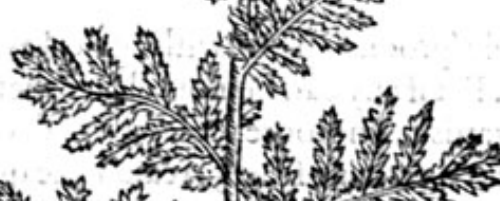
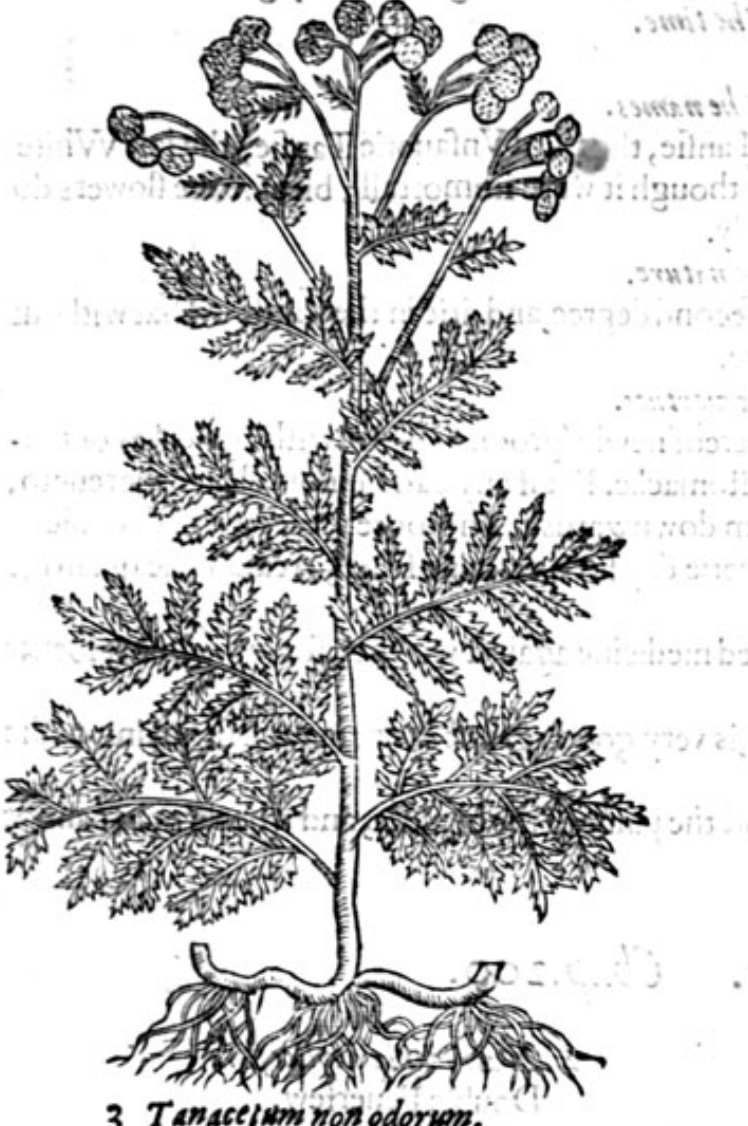

की
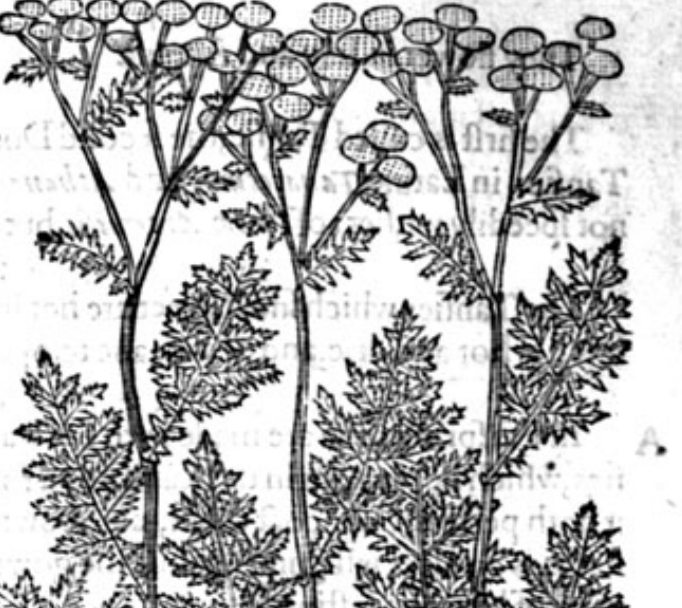

Vnfauorie Tanfie.
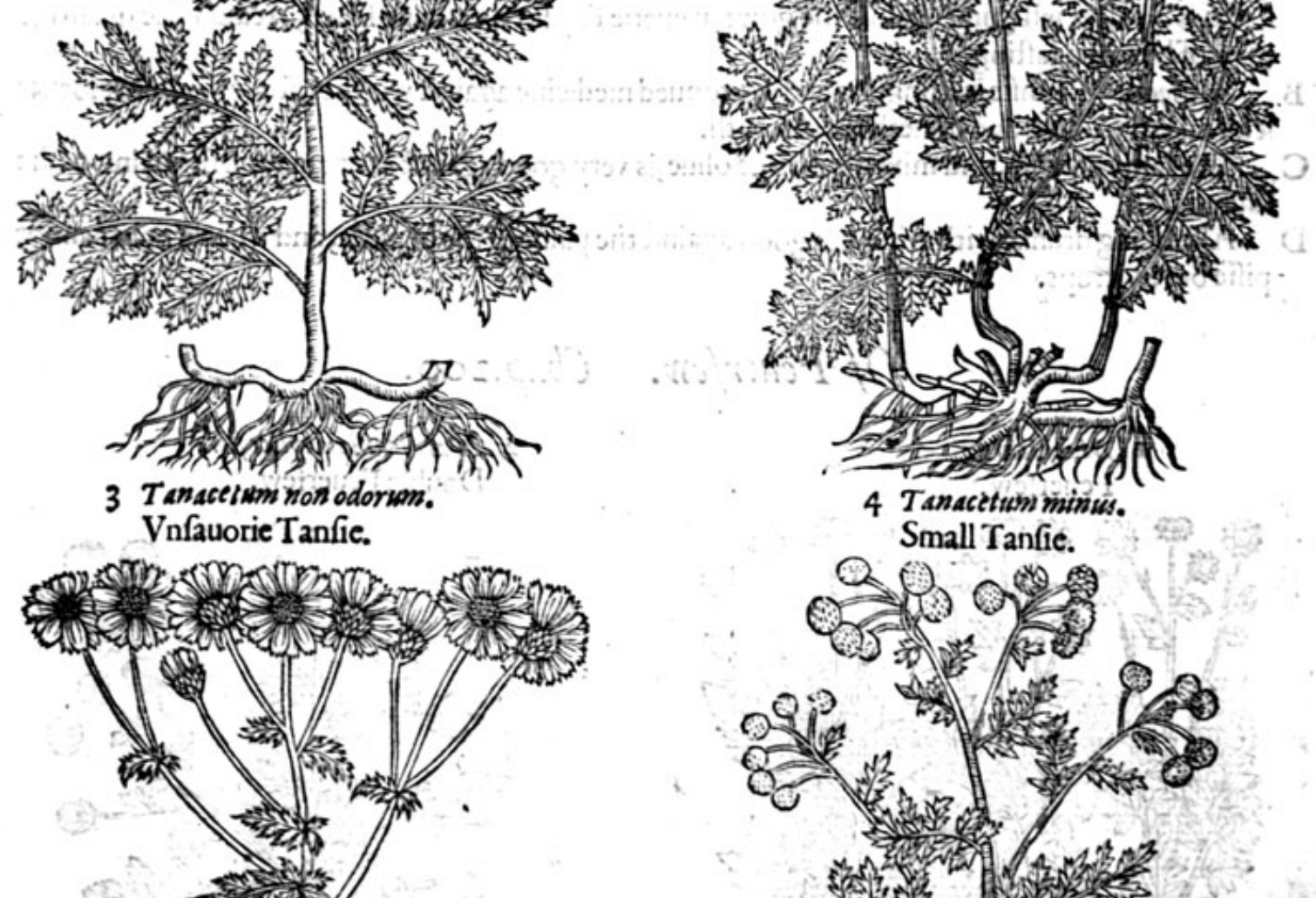

4 Tanacetuon minisus.

Small Tanfie.
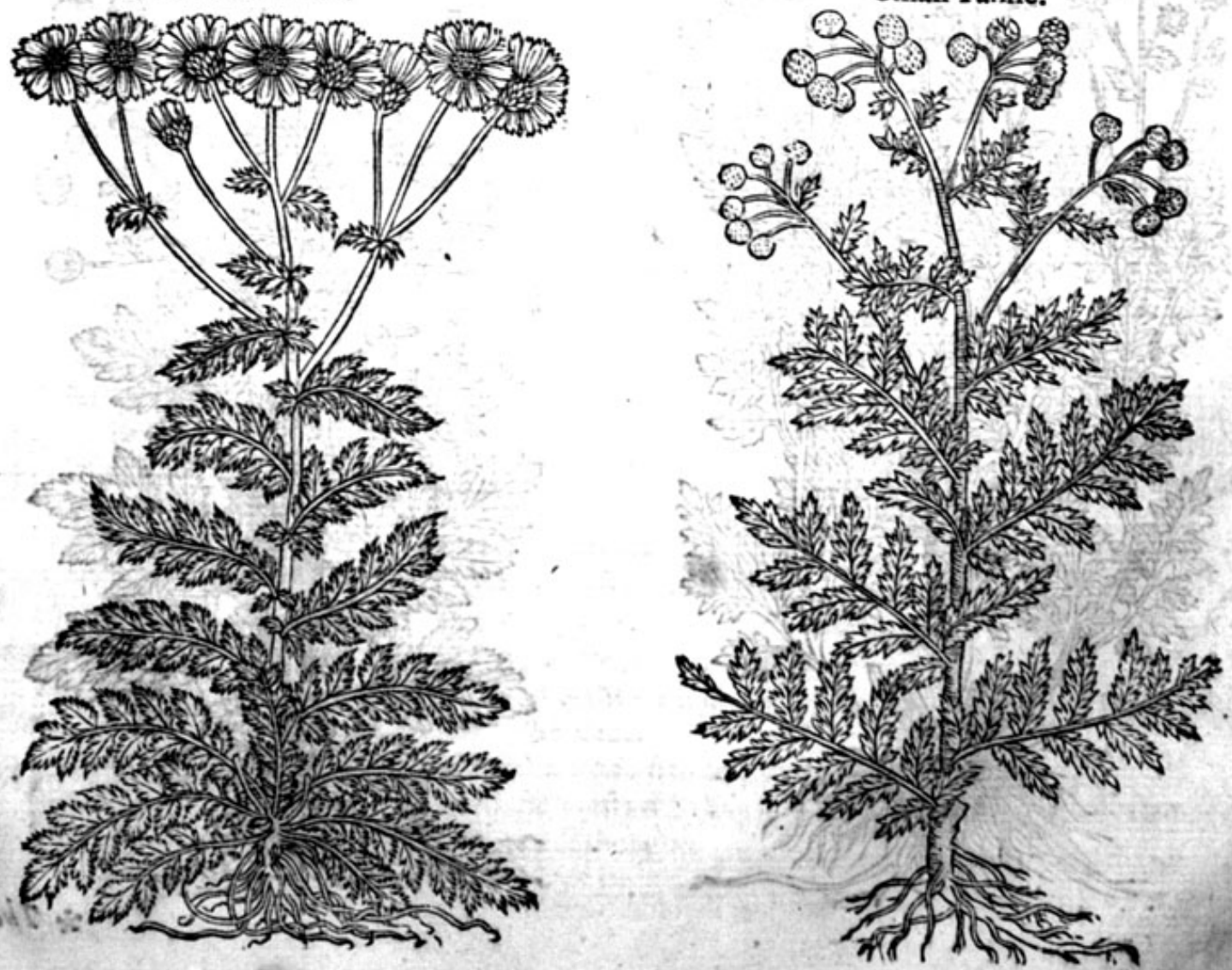
The firft groweth wilde in fields as well as in gardens : the others growe in my garden.

They flower in Iuly and Auguft. * The time.

* T he names.

The firft is called Tanfie, the fecond Double Tanfie, therehird Vnfauorie Tanfie, the laft White Tanfie: in Latine Tanacetum, and At banafia, as though it were immortall; bicaufe the flowers do not fpeedily wither: of fome Artemifa, but vntruly. * The nature.

The Tanfies which fmell fweet are hot in the fecond degree, and drie in the third. That without fmell is hot and drie, and of a meane temperature.

$*$ The vertues.

A In the fpring time are made with the leaues hereof newly fproong vp,and with egs, cakes or tanfies, which be pleafant in tafte, and good for the ftomacke. For if any bad humors cleaue thereunto, it doth perfeetly concoet them, and fcowre them downwards. The roote preferued with honie or fugar, is an efpeçiall thing againft the gowt, if euerie day for a certaine fpace, a reafonable quantitie thereof be eaten fafting.

B The feede of Tanfie is a fingular and approoued medicine againft wormes, for in what fort foeuer it be taken, it killeth and driueth them foorth.

C The fame pownd, and mixed with oile oliue, is very good againft the paine and fhrinking of the finewes.

D Alfo being drunke with wine, it is good againft the paine of the bladder, and when a man cannot piffe but by drops.

\section{Of Fenerfew. Chap.200.}

I. Matricara. Feuerfew.

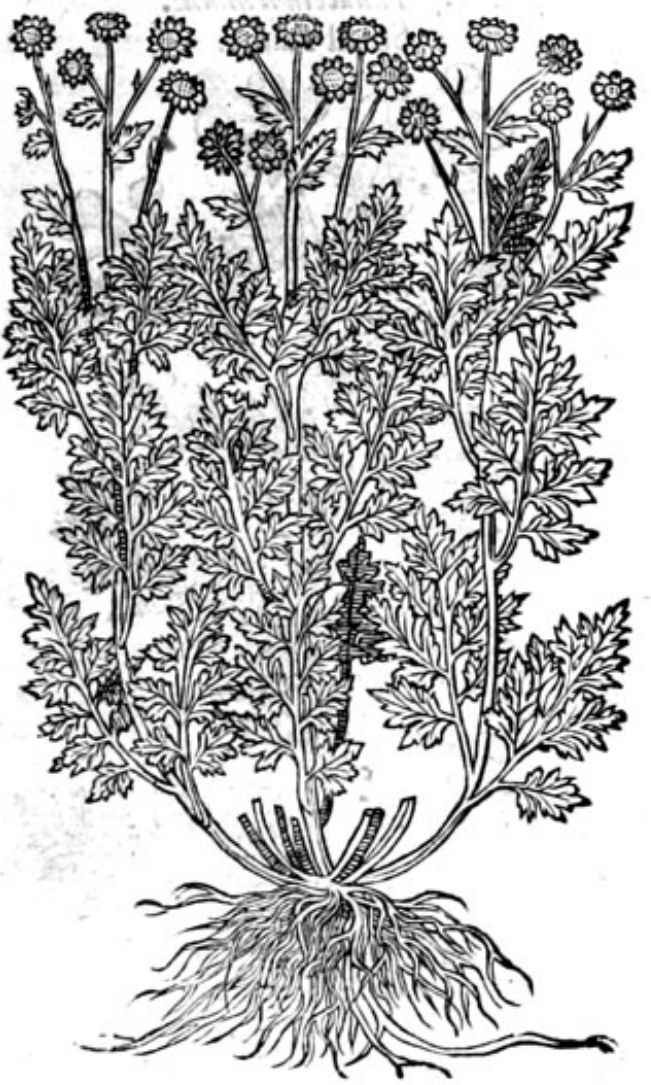

2 Matricaria dopliciflore. Double Feuerfew.

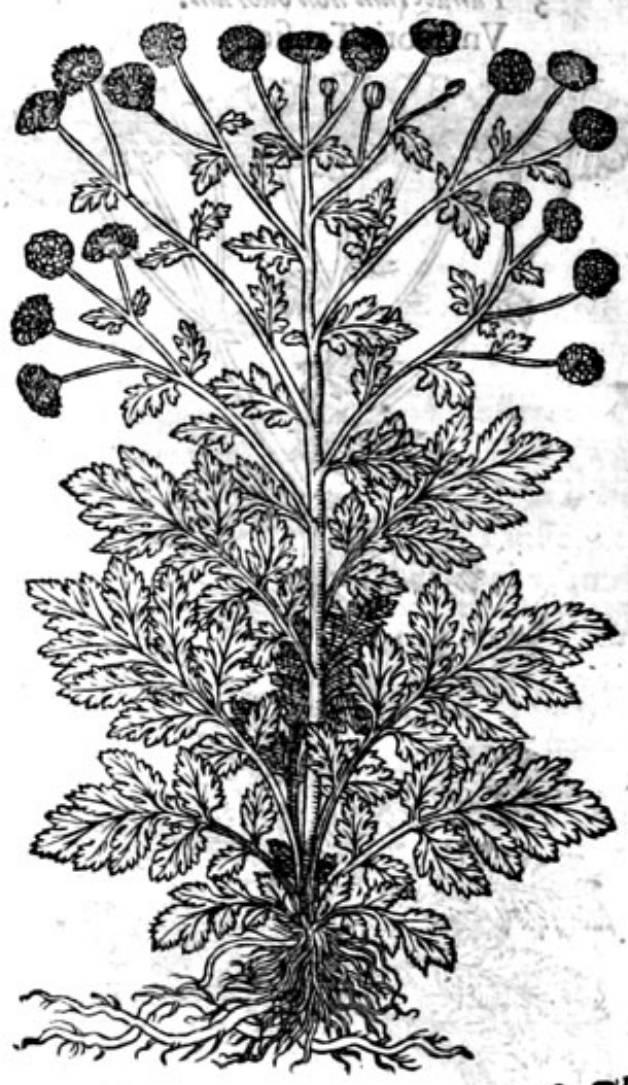




\section{\& The defoription.}

Euerfew bringeth foorth manylittle round ftalkes, diuided iato certaite branches. The leaues are tender, diuerfly torne \& iagged, and nickt on the edges like the firit and neathermoft leaues of Coriander, but greater. The fowers ftand on the top of the branches, with a fmall pale of white leaues; fet round abont a yellow ball or button, like the wilde field Daifie. The roote is hard and tough : the whole plant is of a light whitifh greene colour, of a ftrong fmell and bitter calte.

2 The fecond kinde of Feuerfew, Matricaria, or Partheniwm, differeth from the former, in that it hath double flowers; otherwife in fmell, leaues, and branches, it is all one with common Feuerfew.

There is a third fort called Mountain Feuerfew, of Carolus Clasfues his defcription, thac hath finall and fibrous rootes; from which proceed flender wooddie ftalkes, a foote high and fomwhat more, befet or garnilhed about with leaues like Cainmomill, deepely iagged or ctit, of the fauour or fmell of Fenerfew, but not fo ftrong; in tafte hot, but not vnpleafant. At the top of the ftalkes there come foorth fmall white flowers not like vnto the firft, but rather like vnto Ab/yntbium album, or White Woormwood.

Of which kinde I haue growing in my garden another fort, like vnto the firft kinde, but of a moft pleafane fiveete fauour, in refpect of any of the reft.

\section{$\because$ Theplace.}

The common fingle Feucrfewe groweth in hedges, gardens, and about olde walles. It ioyeth to growe among rubbih. There is eftentimes founde when it is digged vpa littie coale vnder the itrìngs of the roote, and neuer without it, wherof Cardane in his booke of Subtilities fetteth downe diuers vaine and triting things.

$$
\text { * The time. }
$$

They flower for the moft part all the fornmer long.

$$
\therefore \text { The names. }
$$

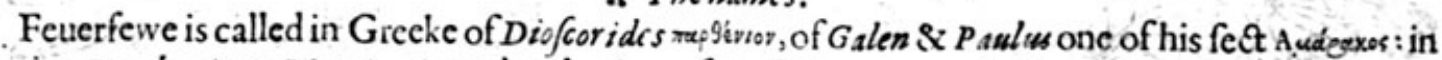

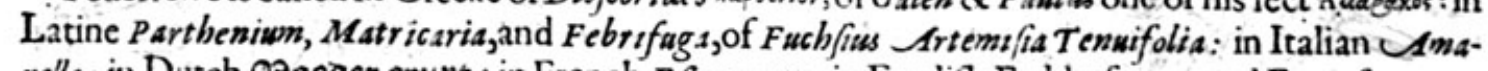
rella : in Dutch 9 ocoer crupt : in French EJpargouta: in Englifh Fedderfewe, and Feuerfewe, ta$\mathrm{ken}$ from his force of driting awaie agues.

Fene * * Therature.

Feuerfewe doth manifeftly heate : it is hot in the thirde degree, and drie in the fecond; it clenfeti, purgeth,or foureth,openeth and fully performeth all that bitter things can do.

\section{* The vertuss.}

It is a great remedie againft the difeafes of the matrix; it procureth womens ficknes with fpeed; $A$ it bringeth foorth the afterbirth, and the dead childe, whecther it be drunke in the decoution, or boiled in a bath and the woman fit ouer it; or the herbes fodden and applied to the priuie part, in manner of a cataplafmebrpultis.

Diofcorites alfo tedacheth, that it is profitablie applied to Saint Anthonies fire, to all intlammati- B ons, and hot fwellings, if it be laide vnto both flowers and leaties.

The fame author affirmeth, that the powder of Feuerfewe drunke with oximell, or fyrupe of vine-C ger, or wine for want of the others, draweth away flegme and melancholy, and is good for them that are purfiejand haue cheirlungs ftuffed with flegme; and is profitable likewife to be drunke againft

Feuerfew dried andinade into powder, and two drams of it taken with honie or fweete wine, D purgeth byfiege melancholieand fiegne; wherefore it is very good for thenthat are gidde in the head, of which haucthe tumingcalled $V$ ertigos, that is a fwimming and turning in the head Alfo it is goodforfuch asbemelancholike, fad, penfite jatid without fpeech.

The herbe is good againft the fiffocation of the mother, that is, the hardnes and ftopping of the $\mathrm{E}$ fame, being boiled invime, arid applied to the place.

b! Thedecoction of the fame is good for women to fit outer, for the purpofes aforefaid. F ol It is vfed both indridlss, and bound ro the wrefts with bay falt, and the powder of glaffe ftamped $\mathrm{G}$
togither, as a moft fingular experiment againft the ague.

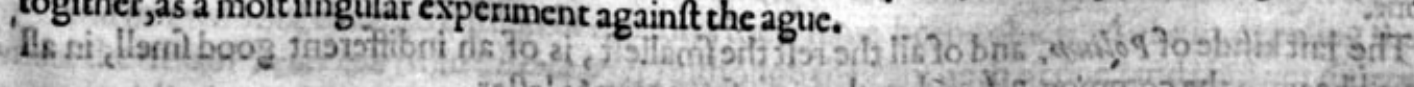


Of Poley, or Pellamountaine. Chap.201.

* The kindes.

Of Pellamountaine there be diuers forts, as fhall be declared in this prefent chapter.

I. Polium montasum album.

White Poley mountaine.

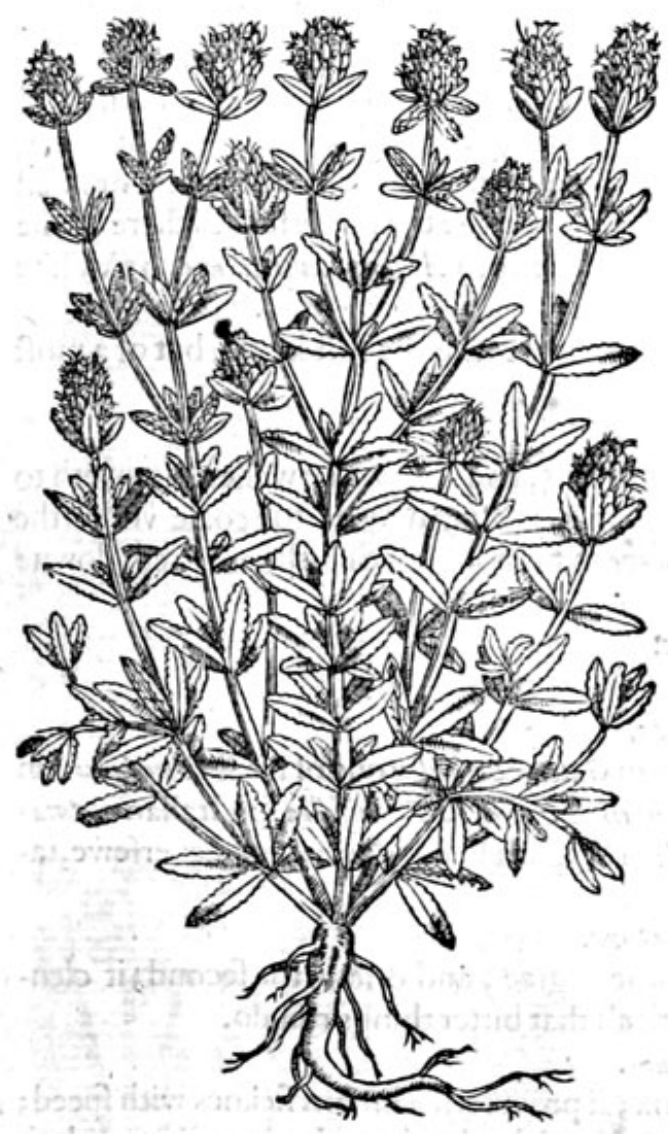

2 Polium montanum luteum. Yellowe Poley mountaine.

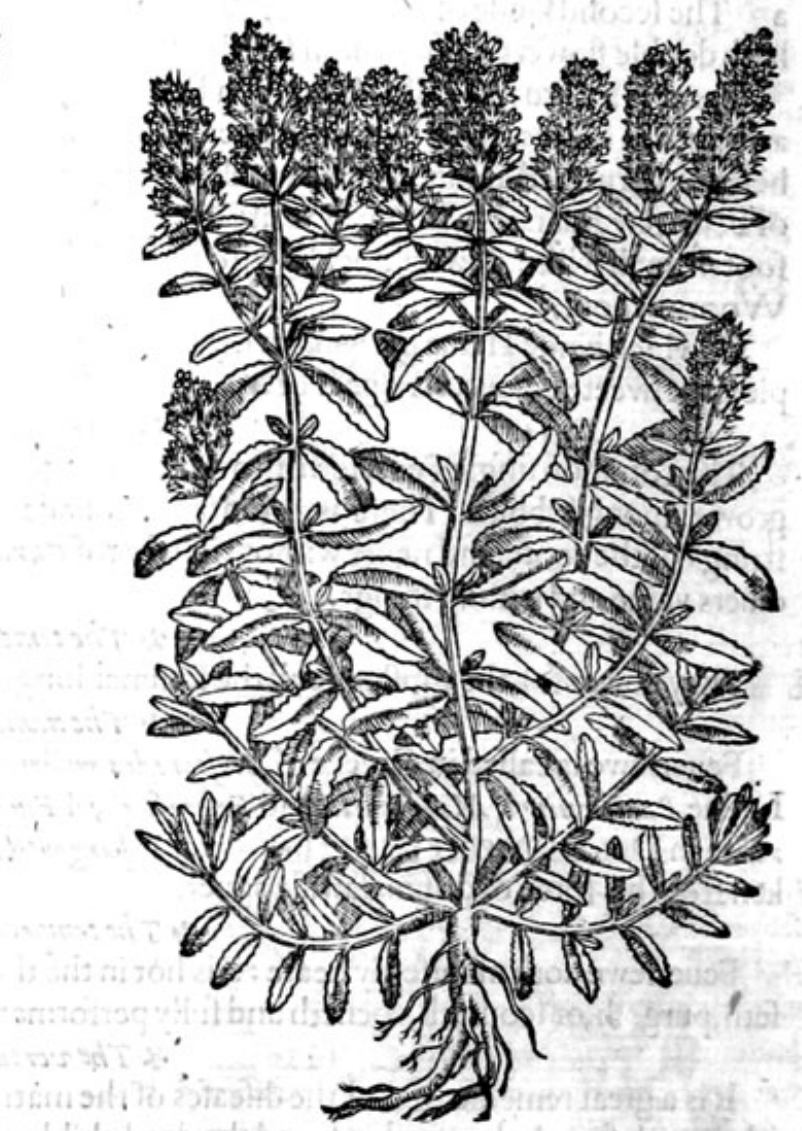

* The defcription.

I He firft kinde of Polium,or in Englifh Poley of the mountaine, is a little tender and fweete fmelling herb,verie hoaric, wherupon it tooke his name:for it is not only hoarie in part, but his hoarie flockineffe poffeffeth the whole plant, tufts and all, being noleffe hoarie then Gnaphaliwn, efpecially where it groweth neere the fea at the bending of hils, or neere the fandie Thores of the mediterranean fea : from his wooddie and fomewhat threddie roote, fhooteth foorth ftraight from the earth a number of fmall round it alkes nine inches long, and by certaine diftances from the ftalke proceed fomewhat long leaues like Gnaphalium, which haue light nickes about the edges, that ftand one againft another, inclofing the ftalke : in the toppe of the ftalkes ftande fpokie tufts of flowers, white of colour like Serpillum. This plant is ftronger of fent or fauour then any of the reff following, which fent is fomewhat tharpe and affecting the nofe with his fweeteneffe.

2 The tuftes of the fecond kind of Polium, are longer then the tufts or flowers of the laft before mentioned, and are of a yellowe colour, otherwife they are very like.

3 From the wooddie rootes of this thirde kinde of Poliwin, proceedea great number of fhootes like vnto the laft rehearfed, lying flat vpright vpon the grounde, whofe flender braunches take hold vpon the vpper part of the earth where they creepe. The flowers are like the other, but of a purple
colour.

4 The laft kinde of poliwm, and of all the reft the fmalleft, is of an indifferent good fmell, in all points like vinto the common Polium, but that it is fower times lefler. 

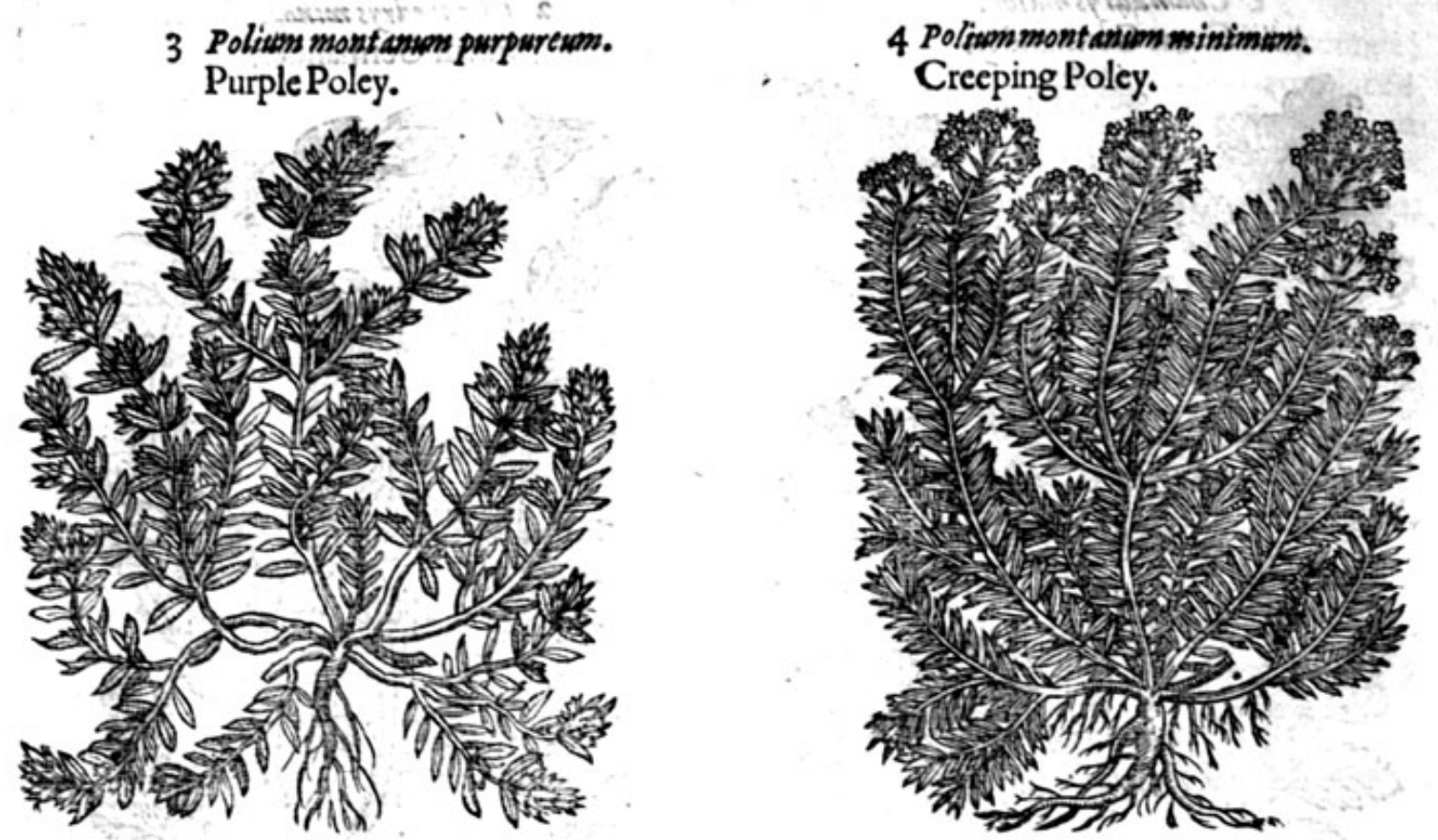

* Theplace.

Thefe plants do growe naturally vpon the mountaines of Fraunce,Italie, Spaine, and other hot regions. They are ftrangers in England; notwithftanding I haue plants of that Poley with yellowe flowers, by the gift of L'Obelius.

* The time.

They fower from the ende of Maie, to the beginning of Augurt.

$*$ Thenames.

Poley mountaine is called in Greeke $\pi^{2} \lambda \circ$, of his hoarineffe, and in Latine alfo Politom. Diuers fufpect that Politem is Lewcas, and that Diofcorides hath twife intreated of that herbe, vnder diuers names; the kindes, the occafion of the name, and likewife the faculties do agree. There be two of the Leucaides, one ipumi, that is, of the mountaine; the other numess, which is that with the broader leafe: it is called Leucazs of the whitifh colour; and Polion of the hoarineffe, bicaufe it feemeth like to a mans hoarie head; for whatfoeuer waxeth hoarie, is faid to bewhite.

$*$ Thetemperature.

Poley is of temperature drie in the thirde degree, and hot in the end of the fecond.

* The vertues.

Diofcorides faith, it is a remedie for them that haue the dropfie, the yellowe iaunders, and that are troubled with the fpleene.

It prouoketh vrine, and is put into mithridate, treacle, and all counterpoifons.

It profiteth much againft the bitings of venemous beafts, and driueth away all venemous beafts from the place where it is ftrowed or burnt.

The fame drunke with vineger, is good for the difeafes of the milt and fpleene; it troubleth the ftomacke, and aftliteth the head, and prouoketh the loofenes of the bellie.

\section{Of Germander. Chap.202.}

* The kindes.

He olde writers haue fet downeno certaine kindes of Germander,yetwe haue thought it good and not without caufe, to entreat of mo forts then haue beene obicrued of all, deuiding thofe vider the title of $\tau$ eucriwn from Chamadries : although they are both of one kind; but yet differing very notablie. 
THE SECOND BOOKE OF THE

I Chamadrysmaior.

Great Germander.

2 Chamadrys minor. Small Germander.
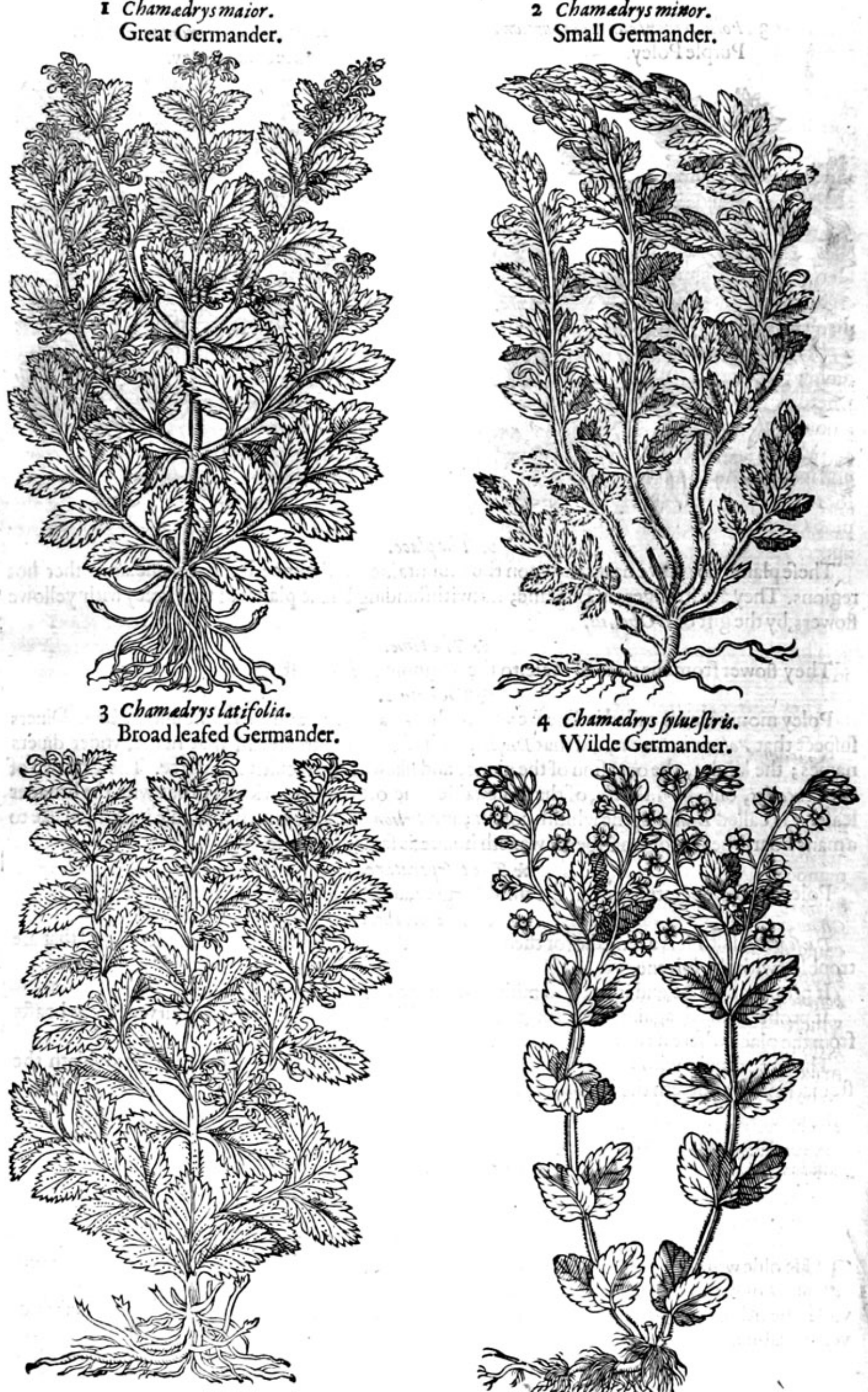

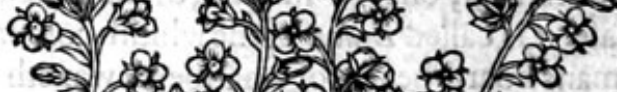
- 50 - $10.5 \%$ 3

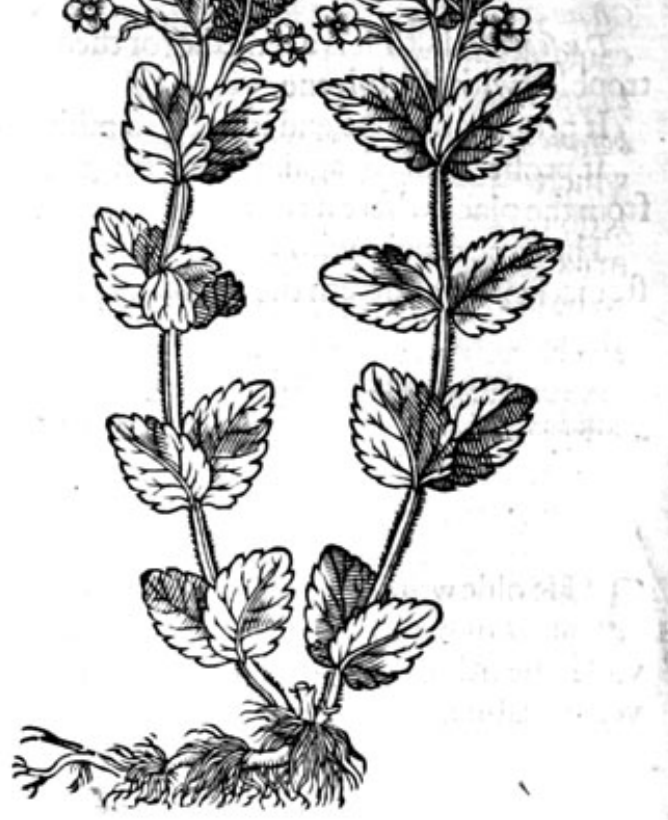



He firft Germander groweth lowe, with very many braunches lying vpon the grounde; sough, harde, and wooddie, fpreading is felfe becie and there: whereupon are placed fmall leaues fnipt about the edges tike the teeth of a fawe, tefermbling the fhape of an oken leafe. The towers are of a purple colour, very friall, ftanding clofe trithe leaues towarde the top of the braunches. The feede is licte and blacke. The rooteflender atid fablofftrings, creepingy and alwaies fpreading within the ground, whereby it grcatly increafeth.

2 The feconde Germander rifeth vp with a little ftraight ftalke a f pan long, and fometimes longer, woodie $\&$ hard like vnto a little fhrub : it is afterwards diuided into very many little fmall braunches. The leaues are indented and nicked about the edges, greater then the leaues of the creeping Germander : the flowers likcwife ftande neere ta the leaues, and on the vpper oarts of the fprigs, of colour fometimes purple, and of tentimes tending to blewneffe: the roote is diuernly difperfed with many ftrings.

3 The thirde Germander hath many threddie rootes, from which rifeth vps fttiffe and tough ftalk, diuiding it felfe from the ground to the top into diuers brawe hess grene fot op poffite againftainother; wherupon are placed by couples broad leaucs, fnipt or toothed about the edges. The flowers grow among the leaues of a bright res colour, in thape like thofe of red Archangell, but leffer.

4 Wilde Germander hath little ftalkes, weake and feeble, edged or cornered, fomewhar hairie, and fetas it were with ioints of a cubite long: about the which by cerraine diftances there come foorth leaues fomething broad, nicked in the edges, and formewhat greater than the leaues of creeping Germander, and fofter. The flowers be of a gallant blew colour, made of fower fmall leaues apeece, ftanding orderly on the tops of the tender foriggie foraies; after which come in placelittle huskes or feede veffels. The roote is fimall a ad threddie.

\section{$*$ The place.}

Thefe plants do growe in rockie and rough grounds, and in gardens they do eafily profper.

The wilde Germander groweth in many places about London in medowes and fertill fieldes, and in euerie place wherefocuer I haue trauelled in England.

\section{* 7 be time.}

They fower and flourif from the ende of Maie, to the later end of Auguit. * The names.

Garden Germander is called in Greeke \%ucuiofus, Chamedrys : of fome Triffago, and Trixago, and likewife Quercula minor; notwithftanding molt of thefe names do more properly belong to scortiupn, or water Germander: in Italian Querciuola : in Englifh Germander, or Englifh Treacle: in French Germandre. Before creeping Germander was knowne, this wilde kind bare the name of Germanderamong the apothecaries, $\&$ was vfed for the right Germander in the compofitions of medicines: but after the formerwere brought to light, this began to be named Syluestris, and spuria Chamedrys, that is wilde andbaftard Germander:of fome Teucrium paluftre, and without errour; bicaufe all the forts of plants comprehended vnder the title of Tencrivm, are doubtleffe kindes of Germander. Of fome it hath beene thought to be the plant that Diofcorides called iersorem, Hierabotane; that is to faic, the Holic herbe, if fo be that the Holie herbe, and Verbenaca, or Veruaine, which is called in Greeke messpeìr, be fundrie herbes. Diofcorides maketh them fundrie herbes, de-
fcribing them apart, the one after the other: but other authors as P.uulus Aetrius, and Oribafius, make no mention of Herba Sacra, the Holie herbe; but onely of Peristereun, and this fame is founde to be liketwife called Hierabotane, or the Holic herbe; and therefore it is euident that it is one, and the felfe fame plant, called by diuers names: the which things confidered, if they faie fo, andfaie truely, this wilde Germander can not be Hier abotaneat all, as ditiers hate written and faide it is a kinde of Veruaine; whereunto it hath becne referred.

\section{* 7 betemperature.}

Garder Germander is of thinne parts, and hath a cutting faculcie: it is hot and drie almoft in the thirde degree, euen as Galen doth write of Teucriwon, or wilde Germander.

The wilde Germander is likewife hot and drie, and is not altogither without force or power to open and clenfe : it may be counted among the number of them that do open the liuer and fpleene.

Germander boiled in water and drunke, deliuereth the bodie from all obitructions or ftoppings, A 
532

THE SECOND BOOKE OF THE

diuideth and cutteth tough and clammic humours : being receiued as aforefaide, is good for them that haue the cough, and fhortnefie of breath, the ftranguric or ftopping of vrine, and helpeth thofe which are entring into a dropfie.

B The leaues ftamped with hony and ftrained, and a drop at fundrie times put into the eies, taketh 2way the web, and hawe in the fame, or any dimneffe of fight.

C It prouoketh mightely the termes, being boiled in wine, and the decoction drunke with a fomentation or bathmade alfo thereof,and the fecret parts bathed therewith.

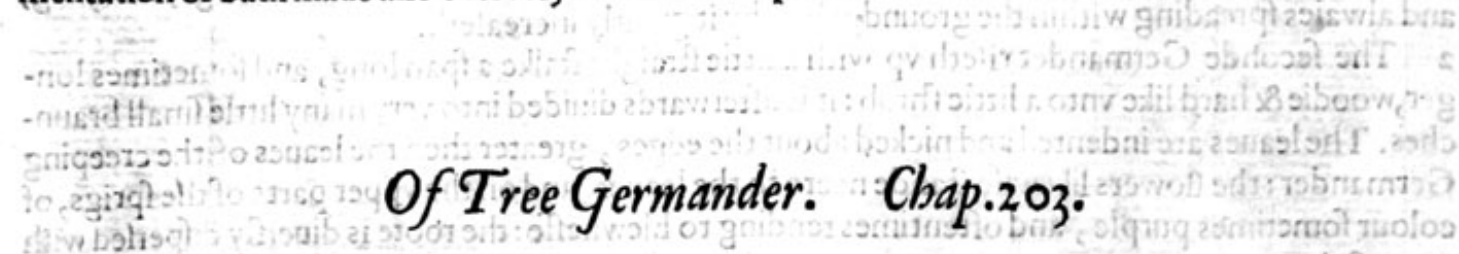

I Tewcriun latifolium.

Tree Germander with broade leaues.

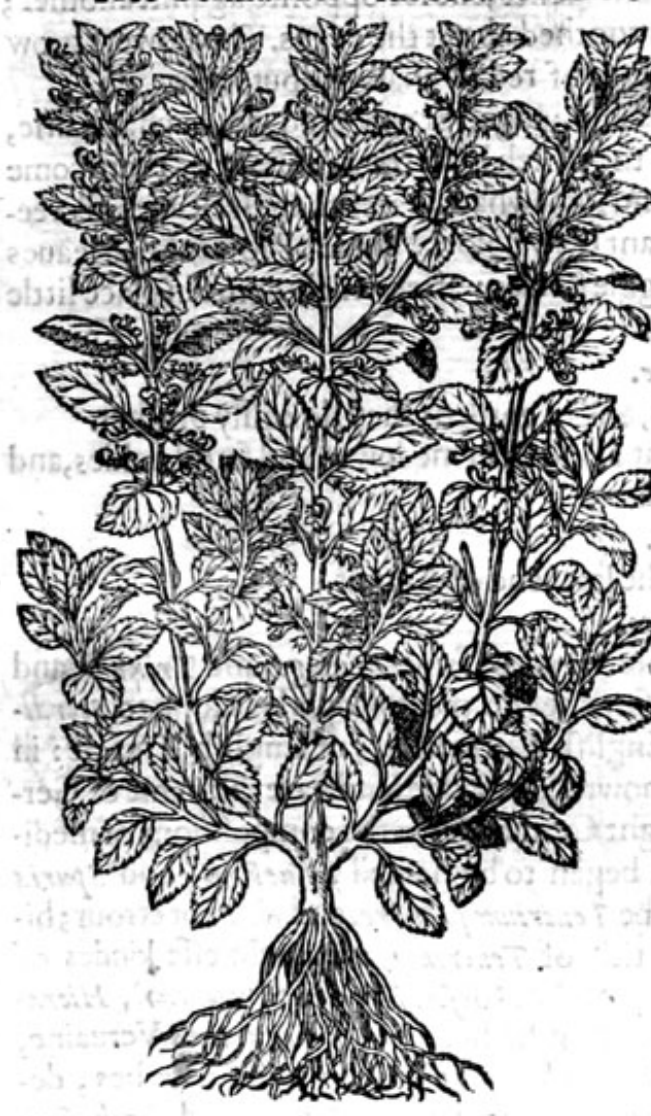

(2) Tevarium P annonicum. Hungarie Germander.

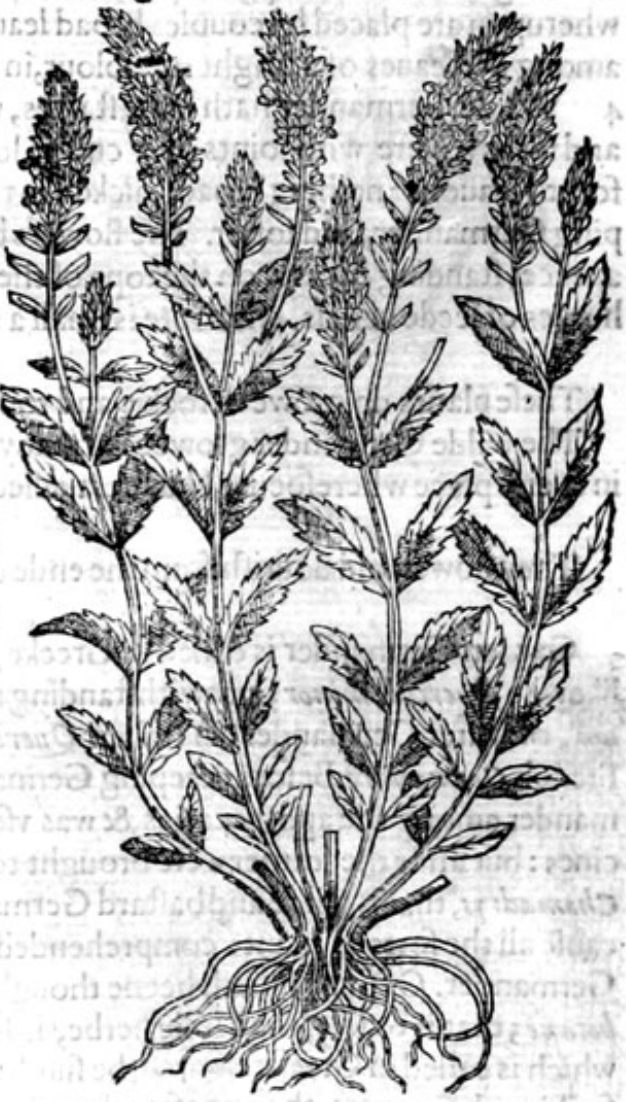

\section{$*$ The defcription.}

I He firft kinde of Tree Germander rifeth vp with a little ftraight ftalke a cubite high, wooddie and harde like vnto a fmall wooddie fhrubbe. The ftalke diuideth it felfefrom the bottome to the top into diturs braunches, wheron are fet indented leaues nickt about the edges, in hape not vnlike the oken leafe. The flowers growe among the leaues of a purple colour. The roo: $e$ is wooddie, as is all the reft of the plant.

2 The Tree Germander of Hungarie hath many tough, threddie roots, from which rife vp diuers weake and feeble ftalkes, reeling this waie and that waie; whereupon are fet togither by couples long leaues iagged in the edges, not vnlike thofe of the vpright Fluellen: on the toppes of the ftalkes ftande the flowers f pike farhion thicke thruft togither, of a purple colour tending to bleweneffe. 
3 Teucriun Bö̈ticuen.

Tree Germander of Boëria.

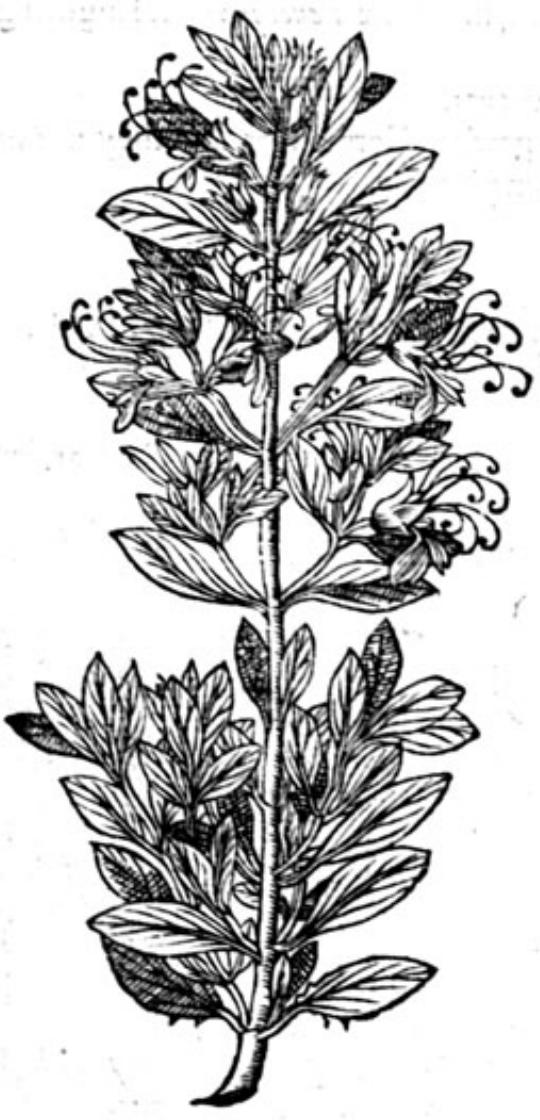

4 Tescrium Alpinum Ciffiflore. Tree Germander with Sage rofe flower.

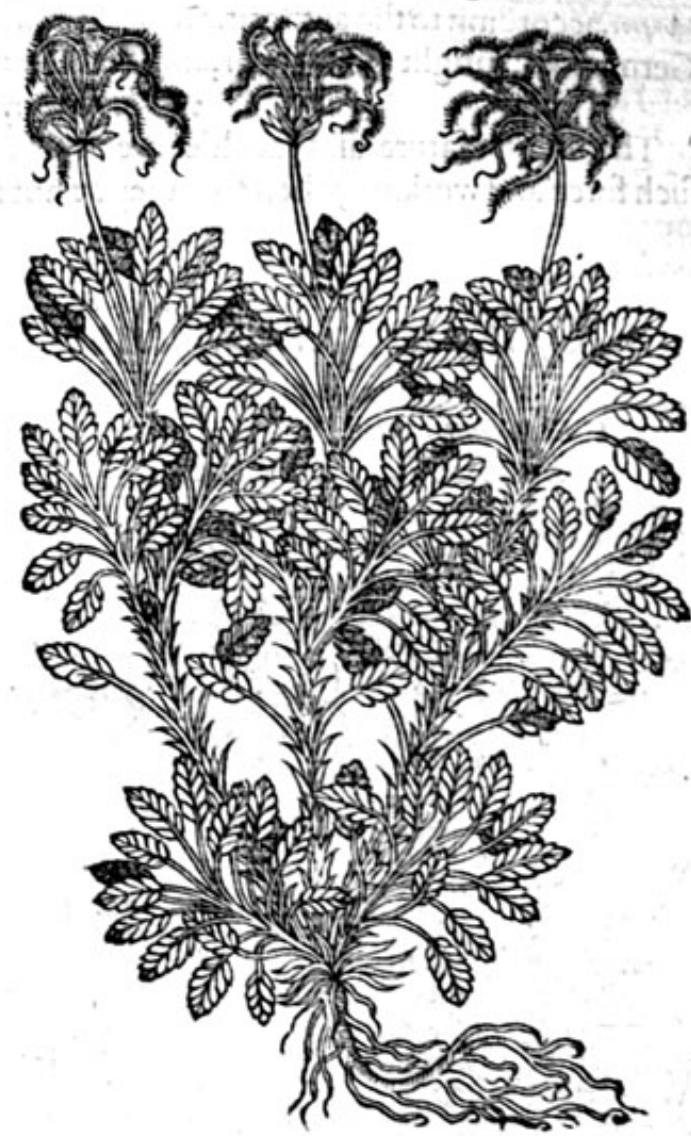

* The defcription.

3 This Germander of Boëtia rifeth vp oftentimes to the height of a man, in maner of a hedge bufh, with oneftiffe ftalke, of the bigneffe of a mans little finger, couered ouer with a whitifh barke, deuided fomtimes into other braunches which are alwaies placed by couples, one right againt an other, of an ouerworne hoarie colour, and vpon them are placed leaues not much vnlike the common Germander. The vpper parts whereof are of a grayinh hoare colour, \& the lower of a deepe greene; of a bitter tafte, and fomewhat crooked, turning and winding themfelues after the manner of a welt. The flowers come foorth from the bofome of the leaues, ftanding vpon fmall tender tootftalkes of a white colour, refembling the thape of a little helmet, hauing in the middle that ftandeth foorth many threddie ftrings. The whole plant keepeth greene all the winter long.

4 Among the reft of the Tree Germanders, this is not of left beautic and account, hauing many weake and feeble branches trailing vpon the ground, of a darke reddifh colour, hard and wooddie; at the bottome of which ftalkes come foorth many long, broad, iagged leaues, not vnlike the precedent, hoarie vnderneath,and greene aboue, of a binding and drying tafte. The flowers growe at the top of the ftalkes, not vnlike to thofe of Cist us famina, or Sage role, white of colour, confifting of eight or nine leaues; in the middle whereot do growe many threddie chiues, without fmell or $\mathrm{fa}_{\mathrm{a}}$ vour : which being paft, there fucceedeth a tuft of threddie or flockie matter, not vnlike to thofe of the great Auens, ot $P$ ulfatilla. The roote is wooddie, and fet with fome few hairie rootes faftened to the fame.

tThefeplants do ioy in toplace.

作 the funne and aire, and profper well in gardens. And of the fecond fort defcribed, Ihaue recei. tued of Mafter Garret Apothecaric one plant for my garden.

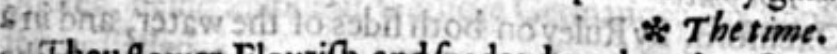

Fil They flower, Elourifh, and feede when the other Germanders da. 


\section{$\approx$ The names.}

Tree Germander is called in Greeke xaurits pus, retaining the name of the former Chamedrys, and rivecior, according to the authoritic of Diofcortdes and Plinie : in Latine Teucrium : in Englifh great Germander, vpright Germander, and Tree Germander. $*$ The temperature and vertues.

Their temperature and faculties are referred vnto the garden Germander, but they are not of fuch force and working, wherefore they be not much vfed in phificke.

\section{Of Water Germander, or Garlicke Germander. Chap.204.}

\section{Scordiummaim.}

Great Garlicke Germander.

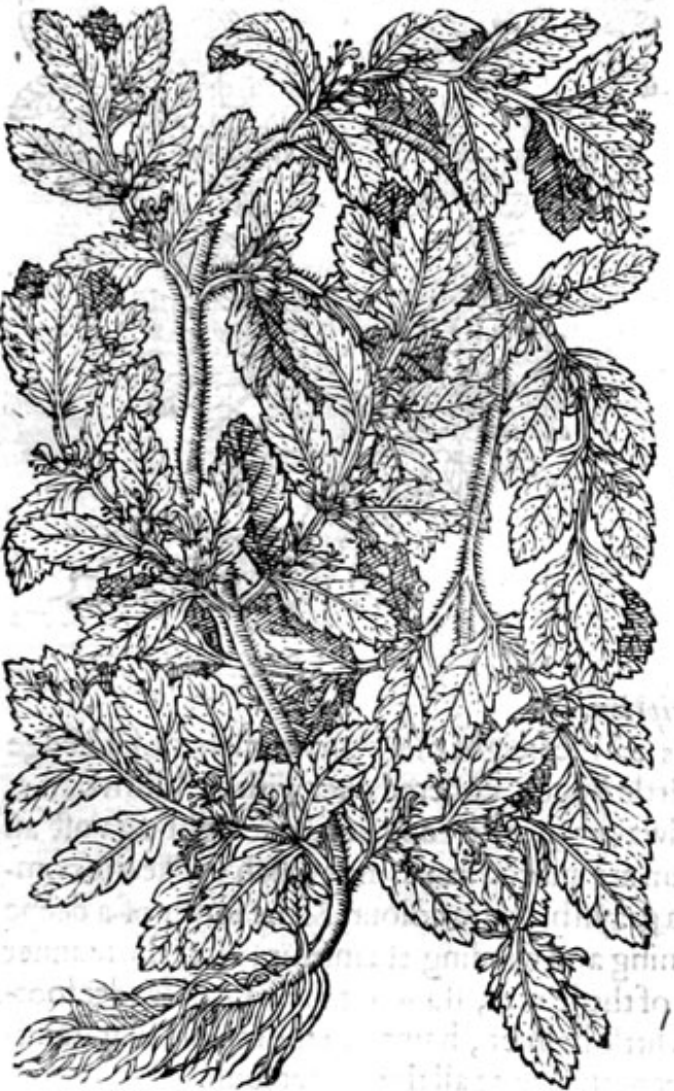

2 Scordivm minus. Small Garlicke Germander.

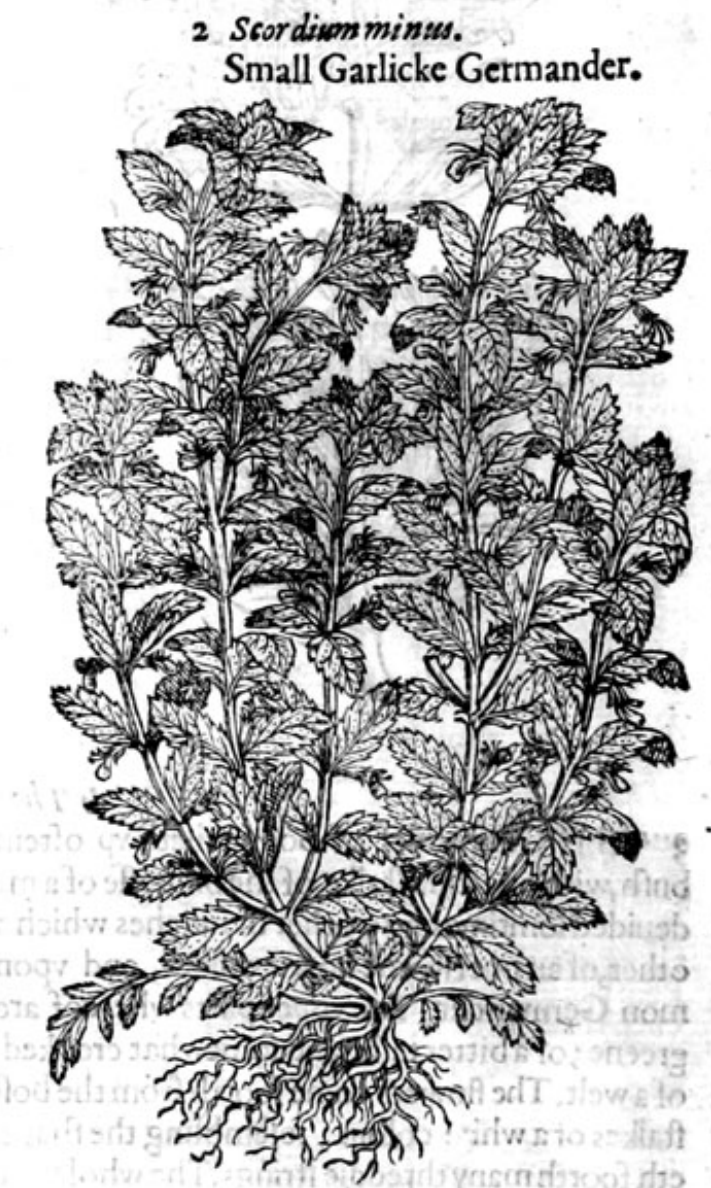

* The defcription.

I.

Cordiven or water Germander, hath fquare hairie ftalkes, creeping by the ground,befet with foft whitifh crumpled leaues, nickt and fnipt rotind about the edges like a fawe : among which growe fmall purple flowers, like the flowers of dead Nettle. The roote is fmall and threddie, creeping in the ground very deepely. The whole plant being bruifed fmelleth like Garlicke, whereof it tooke that name Scordium.

2 Thiskinde of Germander of Plinies defcription, hàth great broad leaues like unto the great water Germander, but much fmaller, fet vpon flender ftems; at the top whereof groweth foorth 2 ftalke, branching it felfe into fundric other twigs, garnifhed with fmallpendulous flowers like vnto Sage. The roote is threddie and fpreading. This plant being bruifed doth fmell like Garlicke, as the other kinde doth, but is not fo common.

$$
* \text { Theplace. }
$$

Water Germander groweth neere to Oxenford, by Ruley on both fides of the water, and in 2 medowe by Abington called Nietford, by the relation of a learned Gentleman of S Iohtins in the 


\title{
BHAISTORIE COF PLANTS. IH T
}

faid towne of $\mathrm{xenford}$, a diligent otnocoverìn my very good friend, called Mafter Richard slater.Alfo it groweth in great plentie in the yle of Elie, and in a medow by Harwood in Lancalhite, and diuers other places. milogit

* The time.

.ogse giblis J ${ }_{0}$ ogse booW

- The flawers appeerie in Iune and Holieg it is beft to gather the herbe in Auguft; it perifheth in winter, it commeth vpagaine in fomitier the robte remaineth frein all the yeere.

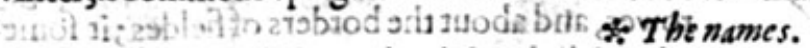

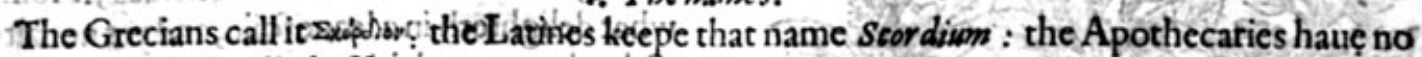
other name. It is called of fome $T$ rivigo Palaffris, Q wercula, and alfo Mithridatum of Mithridates the finder of it out. It tooke the name of Scordinm from the fimell of Garlicke, which the Grecians call ox sesosr and sionqur, of the ranknes of the fmell : in high Dutch veraftier battentig : in French Scordion : in Italian Cbalamandr ina pslustre : in Englifh Scordium, Water Germander, \& Garlicke Germander.

\section{* The temperature.}

Water Germander is hot and drie : it hath a certaine bitter tafte, harfh and harpe, as Galen witnefieth.

\section{- What emad mordat olls ayms * The vertues.}

Water Germander clenfeth the intrals, and likewife olde vicers, being mixed with honje accor- A ding toart : it prouoketh vrine, and bringeth downe the monethly ficknes: it draweth ont of the cheit thicke flegme androtien matter. It is good for an olde cough, paine in the fides, which commeth of ftopping and cold, and for burftingsand inward ruptures.

The decoction niade in wine and druinke, is good againft the bitings of ferpents, and deadly poi- B fons : and is vfed in Antidotes or counterpoifons with good fucceffe.

It is reportcd to mitigate the paine of the gowt, being ftamped and applied with a little vineger C and water.

Some affirme, that rawe flef heing Jaid among the leaues of Scordium, may be preferued a long D time from corruption.

Bcing drunke with wine, it openeth the ftoppings of the liuer, the milt, kidneies, bladder, \& ma- E trix, prouoketh vrine, helpeth the ftrangurie, that is, when a man cannot piffe bur by drops, and is 2 moft fingular cordiall, to comfort and make merrie the hart.

The powder of Scordion taken in the quantitie of two drams in meade or honied water, cureth $\mathbf{F}$ and ftoppeth the bloodie flixe, and comforteth the ftomacke. Of this Scordium is made a moft fingular medicine, called $D$ iafcordium, which ferueth very notably for all the purpofes a foref.jid.?

The fame medicine made of Scordium is giten with good fucceffe vinto childten and igged peo- $G$ ple, that haue the fmall pockes, mealles, or the purples, or any other peltilent ficknes iwhatfocuer, euen the plague it felfe,giuen before the ficknes have vniuerfally poffeffed the whole bodie:

\section{OfWood Sage,ar Garlicke Sage. Chap.2o5.}

\author{
* The defaription.
}

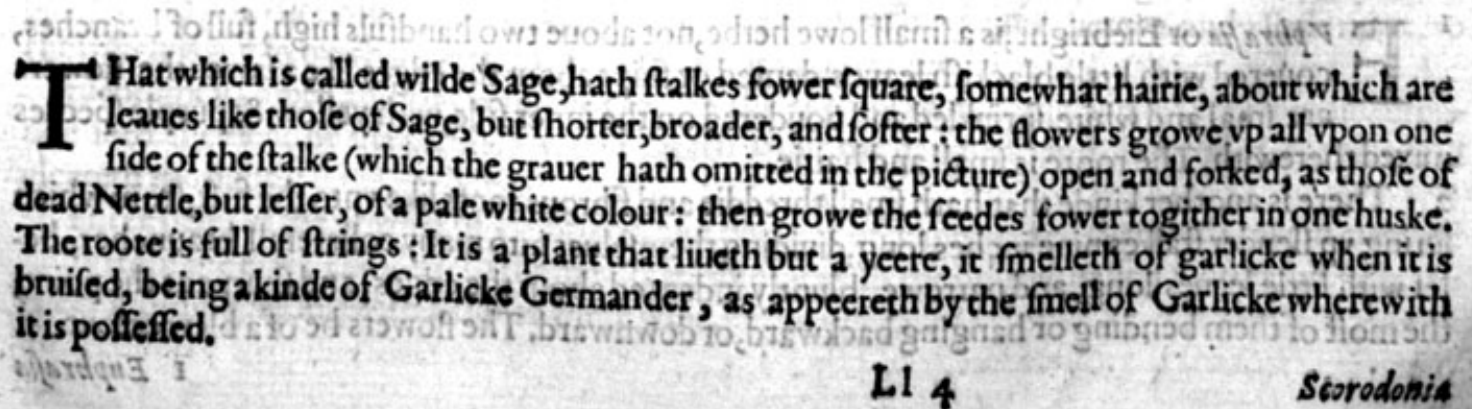


Scorodonia fume Saluia agrestio.

Wood Sage,or Garlicke Sage.

\author{
* Tkeplace.
}

to stworbid

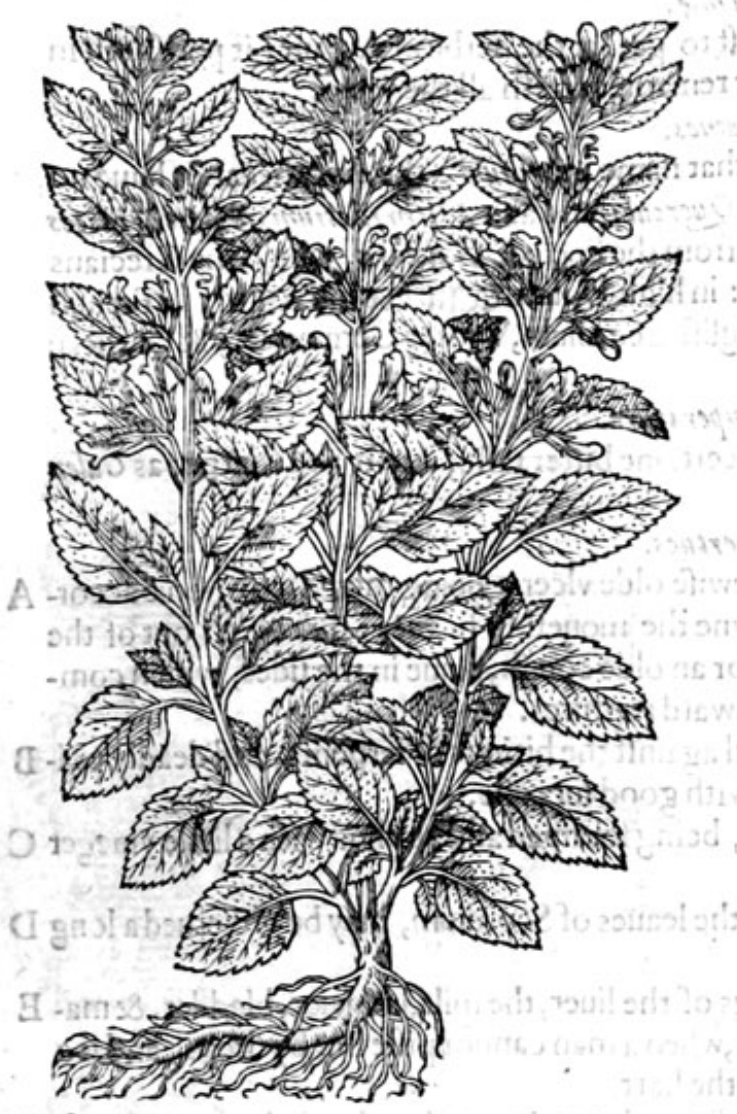

It groweth vpon heathes and barren places: it is alfo foundin woods, and neere vnto hedgerowes, and about the borders of fieldes; it fomewbat delighteth in a leane foile, and yet not altogither barren and driek bilis zi Ji . smsen isho

\title{
* Thetime.
}

It flowreth and feedeth in Iune, Iulie, and Ath guft, and it is then to be gathered and laid vp.

It is called of the later Herbarilts Salwia agrefus: of diuers alfo Ambrofa, but true Ambrofia, which is oke of Cappadocia differeth from this: Valeries Cordm namethit Scordonis; or Scorodo. mia, and Scordium alteruen. Ruellizu faith it is cal. led Bofcifaluia; or Salwia Bofai ; in high Dutch crabat falbep: in Englifh Wilde Sage, Wood Sage, and Garlicke Sage.

It feemeth to be T boophraft un his aéruvos, Sphacelus, which is alfo taken for the fmall Sage, but not rightly.

* The temperatura.

Wilde Sage is of temperature hot and-drie, yet leffe than common Sage; therefore it is hot and drie in the fecond degree.

* The vertmes.

A $^{-1}$ It is commended againft burftings, drie beatings, and againft wounds : the decoction thereof is giuen to them that fall and are inwardly bruifed.I alfo prouoketh vrine.

B Some likewife giue the decoction hereof to drinke with good fucceffe to them that are infected with the French poxe: for it caufeth fweate, drieth vp vicers, digeiteth humors, wafteth away and confumeth fwellings, if it be taken thirtic or fortie daies togither, or put into the decoction of Gwiacum infteed of Epithimum, and other adiutories belonging to the faid decoction.

\section{Of Eiebright. Chap:206.}

\section{* Thedefription.}

I $V$ phrafia or Eiebright, is a fmall lowe herbe, not abouc two handfuls high, full of branches, E couered with little blackinh leaues, dented or fnipt about the edges like a fawe : the flowers are fmal and white, fprinkled and poudered on the inner fide, with yellow \& purplespeckes mixed therewith. The roote is fmall and hairie.

2 There is another kinde that hath fmall threddie and fibrous roots like vnto the firft,from which fpring vp flender ftalkes nine inches long, diuiding themfelues into many collaterall braunches, befet with little leaues, long, and narrowe, bluntly indented a bout the edges, and fharpeat the point, the moft of them bending or hanging backward, or downward. The flowers be of a blew colour. 


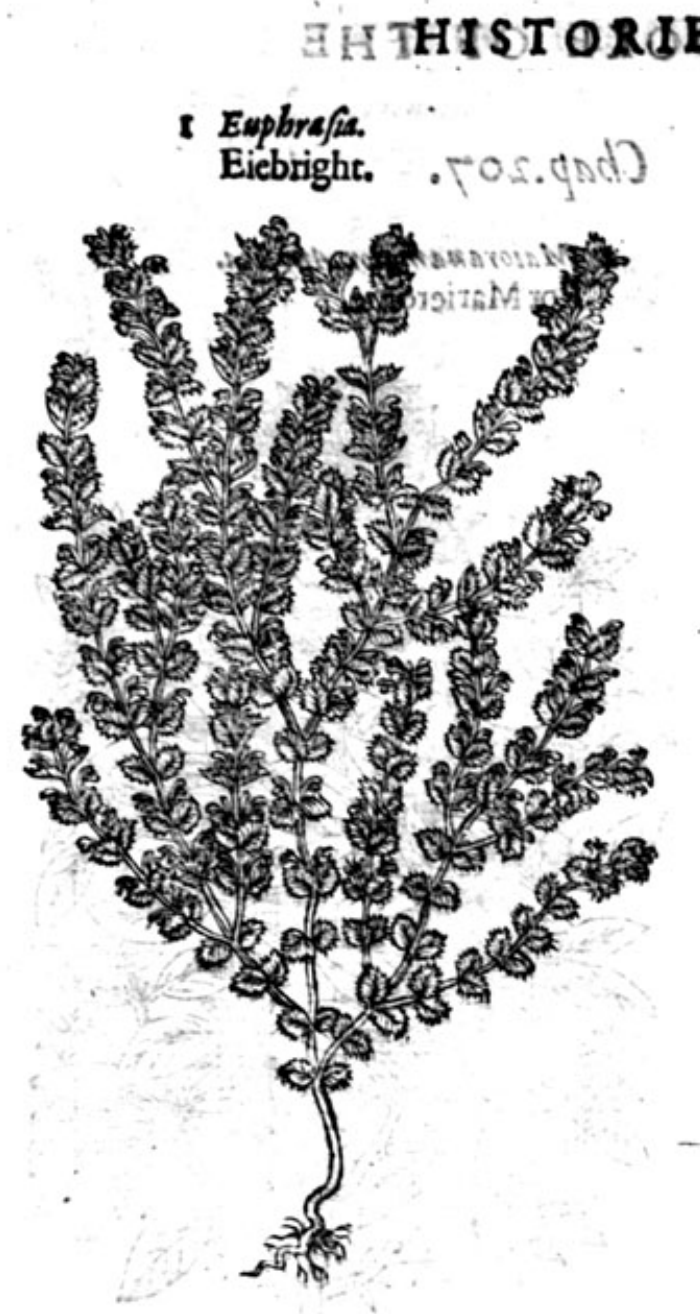

\section{OEI PLANTSATT}

Euphrafis. Einghe

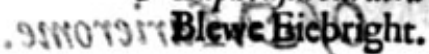

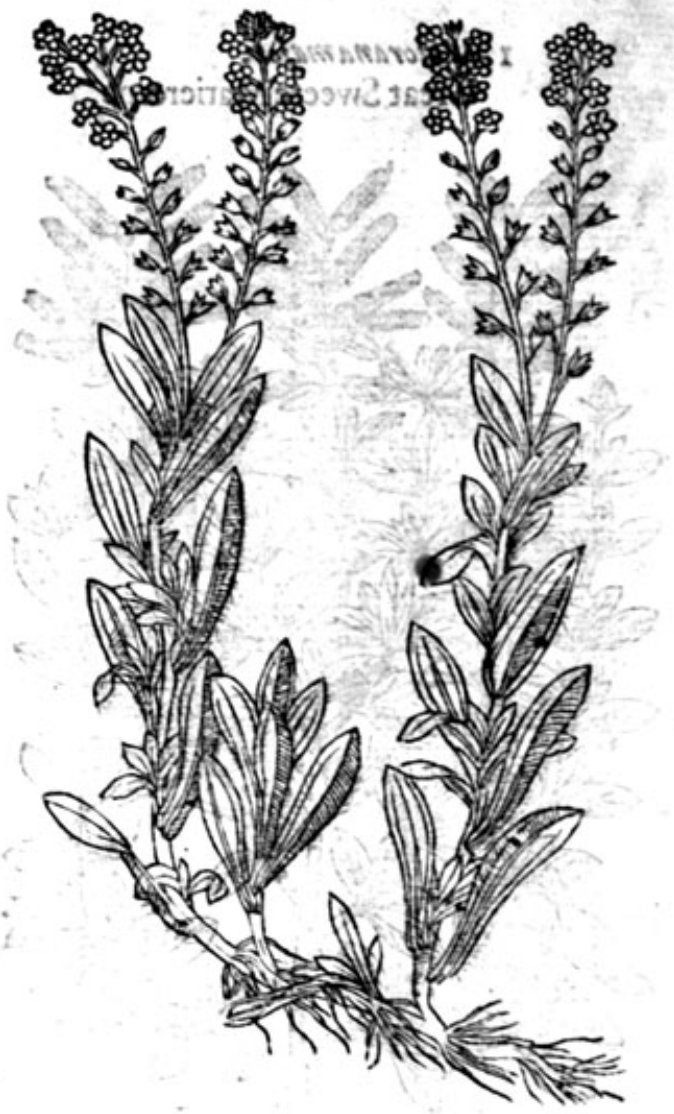

$*$ Theplace.

Thefe plants growe in drie medowes, in greene and graffie waies, and paftures ftanding againft the funne.

* The time.

Eiebright beginneth to flower in Auguft, and continueth vnto September, and muft be gathered while he flowreth for phificks vfe.

* The names.

It is commonly called Eaphrafue, and alfo Euphrofyne: notwithftanding there is another Euphrofyne, and that is Buglofle: it is named of fome Ocularis, and Opht balmica, of the effect: in high Dutch Gugen troff : in low Dutch Dagben traoft : in Italian; Spanilh, and French, Eufrafia, after the L2, tine name : in Englifh Eiebright.

* Thenature.

Thefe herbes are hot and dric, but yet more drie then hot.

* The vertues.

It is very much commended for the eies, being taken it felfe alone, or any waie elfe, it preferueth $\mathbf{A}$ the fight, increafeth it, and being feeble and loft it reftoreth the fame. It is giuen moft ficly being beaten into powder: oftentimes a like quantitie of Fenell feed is added thereto, and a little mace, to the which is put fo much fugar as the waight of themall commeth to.

Eiebright ftamped and laid vpon the eies, or the ivice thereof mixed with white wine and drop-B ped into the eies, or the deftilled water; taketh awaic the darkneffe and dimneffe of the eies and cleereth the fight.

Three parts of the powder of Eicbright, and one part of maces mixed therewith, taketh away all C hurts from the eies, conforteth the memorie, and cleereth the fight if halfe a fpoonefull be taken euery morning fafting with a cup of white wine. 


\section{OfoMarierome.}

I Maioranamaior.

Great Sweete Marierome.

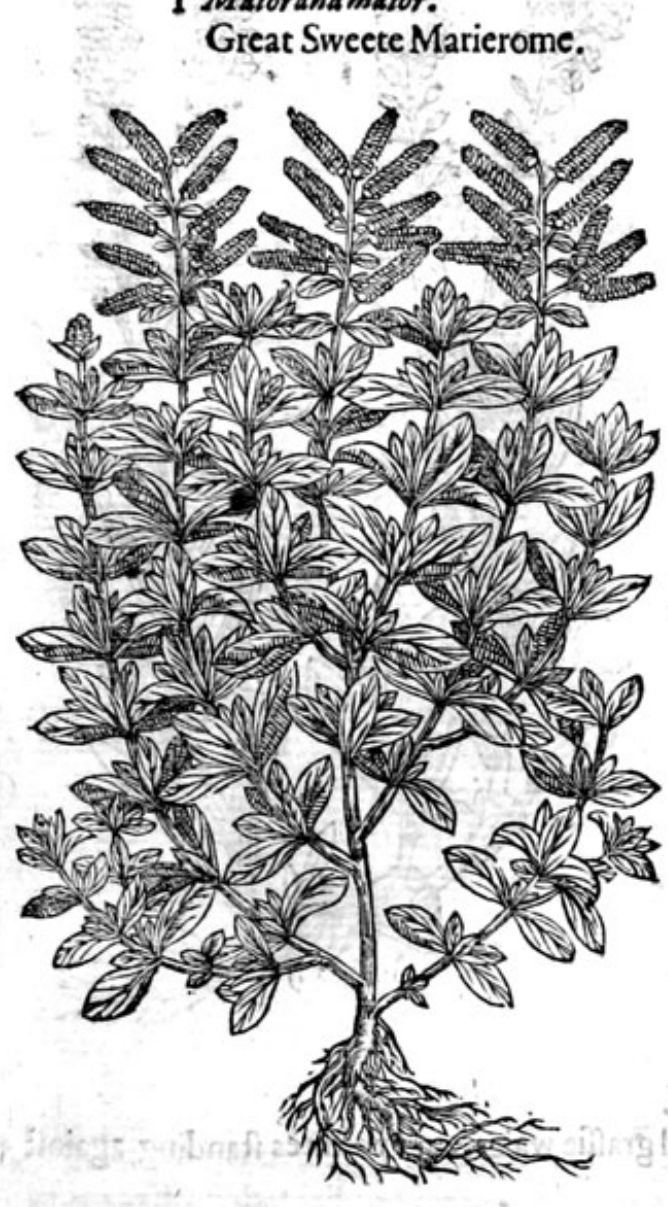

Chap.207. silgitoig 2

2 Maiorensmaior Anglica. Pot Marierome.

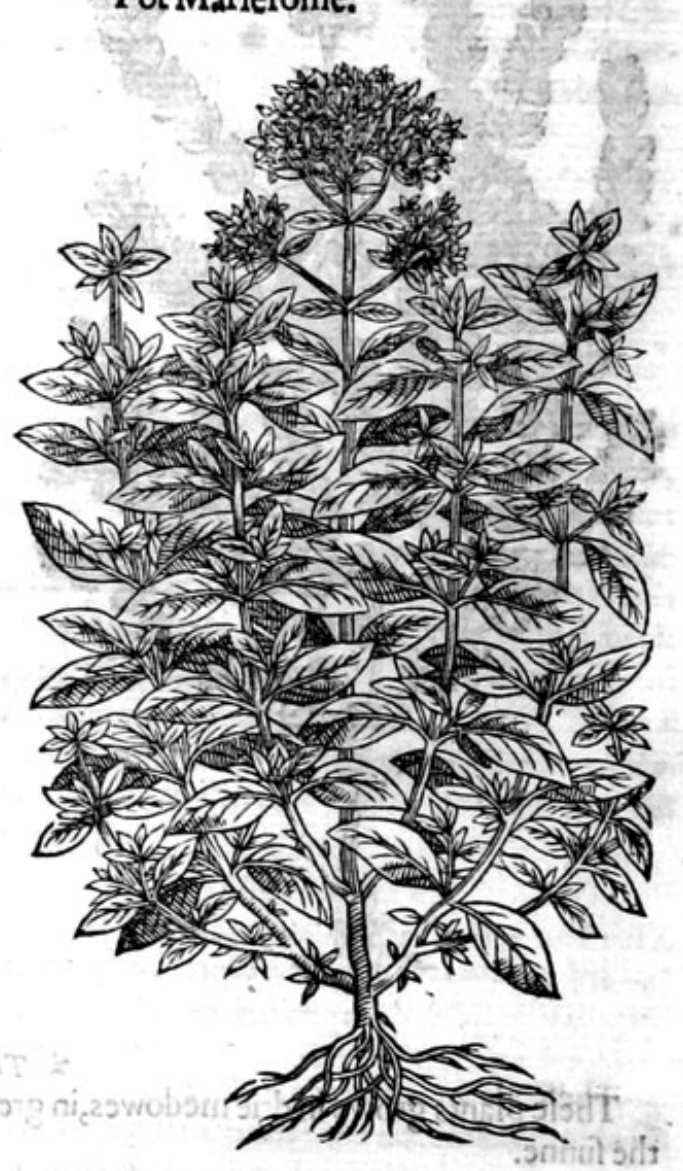

Thedefoription.

I Weete Marierome is a lowe and fhrubbie plant, of a whitifh colour and maruellous fweete

$O$ fmell, a foote or fomewhat more high. The ftalkes areflender, and parted into diuers braunches: about which, growe foorth little leaues, foft, and hoaric. The flower's grow at the top in fcalie or chaffie fpiked eares, of a white colour like vnto thofe of Candie. Organie. The roote is compact of many fmall threds. The whole plant and euery part thereof is of a moft pleafant tafte, and aromaticall fmell, and peritheth at the firft approch of winter.

2 Pot Marierome or winter Marierome, hath many threddie tough rootes, from which rife immediately diuers fmall braunches, whereon are placed fuch leaues as the precedent, but not fo hoarie, nor yet fo fweete of fmell, bearing at the top of the braunches tufts of white flowers tending to purple. The whole plant is oflong continuance, and keepeth greene all the winter, whereupon our Englifh women haue called it,and that very properly, winter Marierone.

3 Marierom gentle hath many branches rifing from a threddie root, wherupori do grow foft and fweete fmelling leaues, of an ouerworne ruffet colour. The flowers ftand at the top of the ftalkes, compact of diuers fmall chaffie fcales, of a white colour tending to a blufh. The whole plant is altogither like the great fwcete Marierome, fauing that it is altogither lefler, and far fweeter, wherin efpecially confifteth the difference.

4 Epimaiorana is likewife a kinde of fine Marierome, differing not from the laft defcribed, fauing in that, that this plant hath in his naturall countrie of Candia, and not elfewhere fomelaces, ot threds faftened vnto his branches, fuch and after the fame manner as thofe are, and dogrow vpon Sauorie, wherein is the difference. 
3 Maioramatennifolid. Marierome gentle.

4 Eprimaiorana. bib plitic lopoth Laced Marierome.
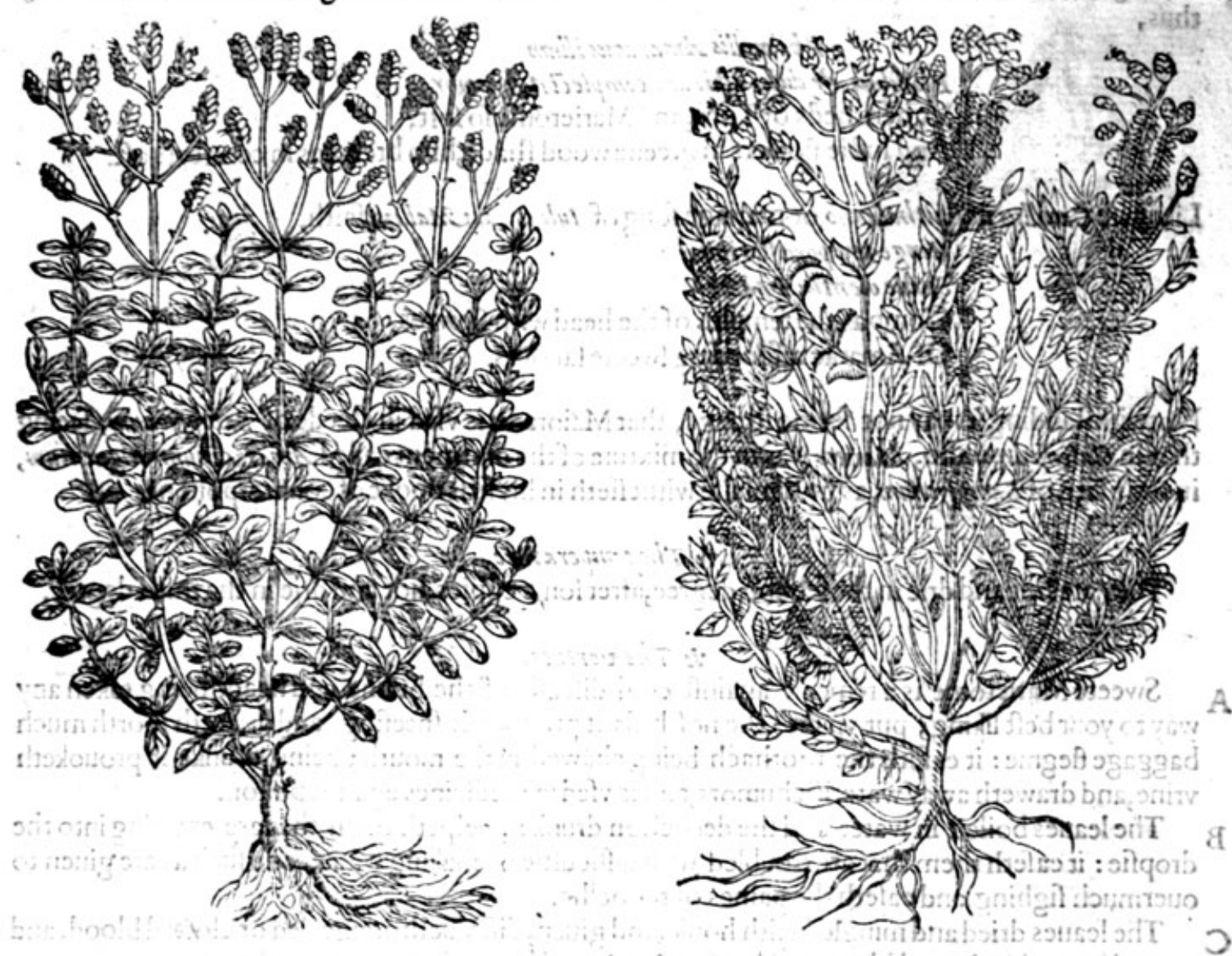

* The piace.

Thefe plants do gtowe in Spaine, Italie, Candia, and othet Ilandsthereabout, wilde, and in the field 5 ; from whence we haue the feedes for the gardens of our cold countries.

* The time.

They are fowen in May, and bring foorth theirf $f_{2}$ lic, or chaffie huskes orcarcs in $A$ ugurf. They

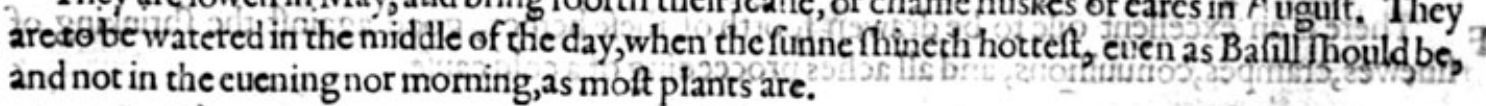

\section{* 7 he names.}

Marierome is called in Latine Maiorana, and Amarasus, and alfo sampfychum of others: in high Dutch 99apozan: in Spanifh chlayorana, Moradux, and Almoradux : in French Mariolaine: in Englifh Sweete Marierome, Fine Marierome, and Marierome gentle; of the beft fort Maioranc. The pot Marierome is alfo called WHinter Maxierome. Thecruife of the hame of thismoft fweete and pleafant herbe is not determined, except it came through tie faining of the Poets, who report that thofe of Cypres fawning vpon their king Cinara, imagining to pleafe his humor, faid that his fonne in time of his youth, caried a boxe full of fragrant ointment, ouer the fieldes of moft pleafant herbes, which by mifchance he fpilt vpon, tbefidid berbos, which being moiftened therewith,yeelde vnto this day that excellent fauour, wherein we do fo much delight, This boy mourning for the

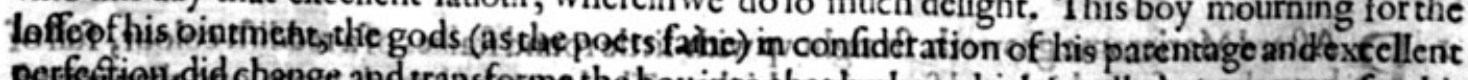

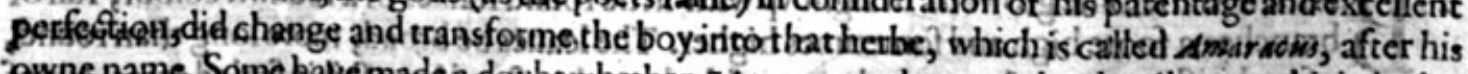

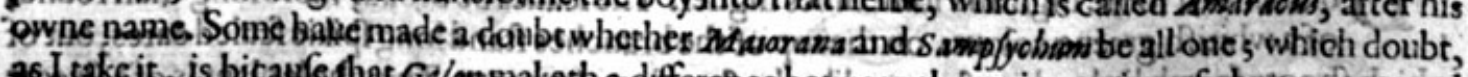

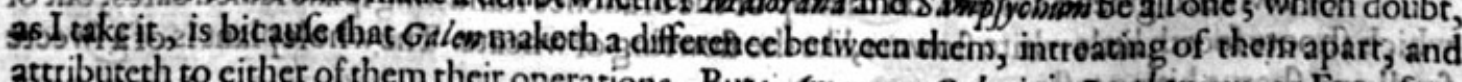
attributeth to cither of them their operations. But Umaracus Galeni, is Particiniwn, or Fonetfew.

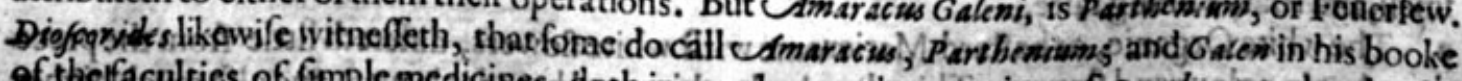

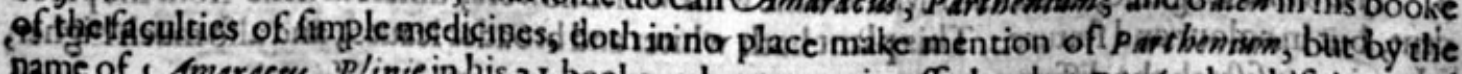

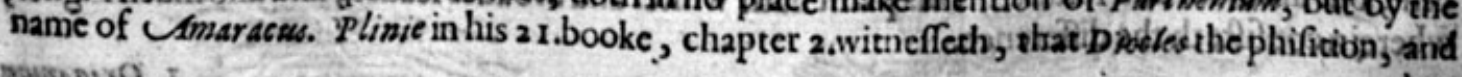

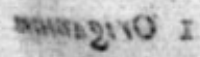
they 


\title{
$54^{\circ}$ THE SECOND BOOKE OF THE
}

they of Sicily did call that Lmaracus, which the Acgyptians and the Syrians did call samp fychume. thus,

$V$ irgil in the firft of his Aeneidos fheweth, that the fhrub Lmaracus beareth flowers, writing

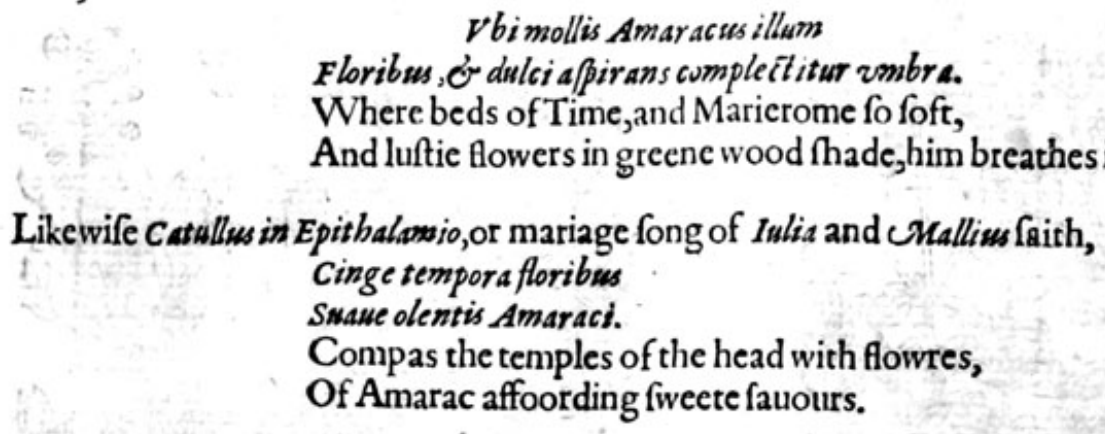

Notwithftanding it may not feeme ftrange, that Maiorane is vfed in fteede of Samp $p$ ychoom, feeing that in Galens time alfo, Marwm was in the mixture of the ointment called Amaracinum vngwentwom, in the place of Sampfychum, as he himfelfe witneffeth in his firft booke of counterpoifons.

\section{* The temperature.}

They are hot and drie in the fecond degree, after fome copies, hot and drie in the third degree.

* The vertues.

A Sweete Marierome is a remedie againft cold difeafes of the braine andhead, being taken any way to your beft liking; put vp into the nofthrils it prouoketh fneefing, and draweth foorth much baggage flegme: it eafeth the toothach being chawed in the mouth; being drunke it prouoketh vrine, and draweth away waterifh humors, and is vfed in medicines againft poifon.

B The leaues boiled in water and the decoction drunke, helpeth them that are entering into the dropfie: it eafeth them that are troubled with difficultie of making water, and fuch as are giuen to ouermuch fighing, and eafeth the paines of the bellie.

C The leaues dried and mingled with honie, and giuen, diffolueth congealed or clotted blood, and putteth away blacke and blew markes after ftripes and brufes, being applied thereto. D The leaues are excellent good to be put into all odoriferous ointments, waters, powders, broths;

E The dried leaues powdered, and finely fearced, are good to be put into Cerotes, or Cereclothes, and ointments, profitably againft colde fwellings, and members out of ioint.

F There is an excellent oile to be drawen foorth of thefe herbes, good againft the Thrinking of finewes, crampes, conuulfions, and all aches proceeding of a cold caufe.

\section{Of wilde Marierome. Chap.208.}

\author{
* The defcription.
}

${ }^{2} \mathrm{~B}$ Aftard Marierome groweth ftraight vp with little round ftalkes of a reddifh colour, full of branches, a foote high and fometimes higher. The leaues be broad, more long than round, of a whitith greene colour: on the top of the branches ftand long fpikie fcaled eares, out of which hoote foorth little white flowers, like the flowring of wheate. The whole plant is of 2 f weete
fmell, and tharpe biting tafte.

2 The white Organie, or baftard Marierome with white flowers, differeth little from the precedent, but in colour and ftature. This plant hath whiter and broader leaues, and alfo much higher,
wherein confifteth the difference. 
HIS T ORIE OF PLANTS. BHT .

1 Origanum Herasleoticam.

2 Origanum album.

BaftardMarierome.

White baftard Maricrome.

औx. *

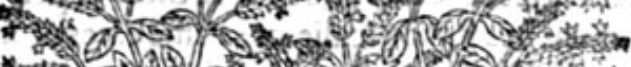
1. 5 (n) P. 2. -

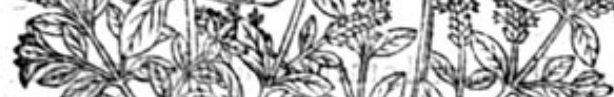

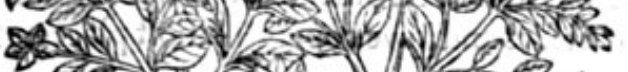

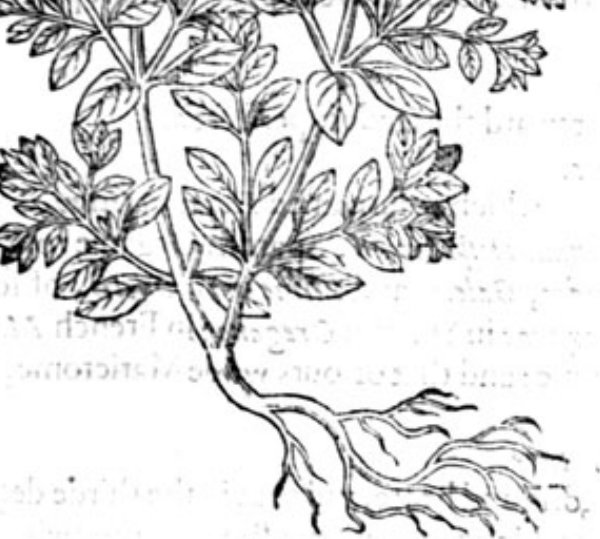

3 Origanum Creticum.

Wilde Marierome of Candie.
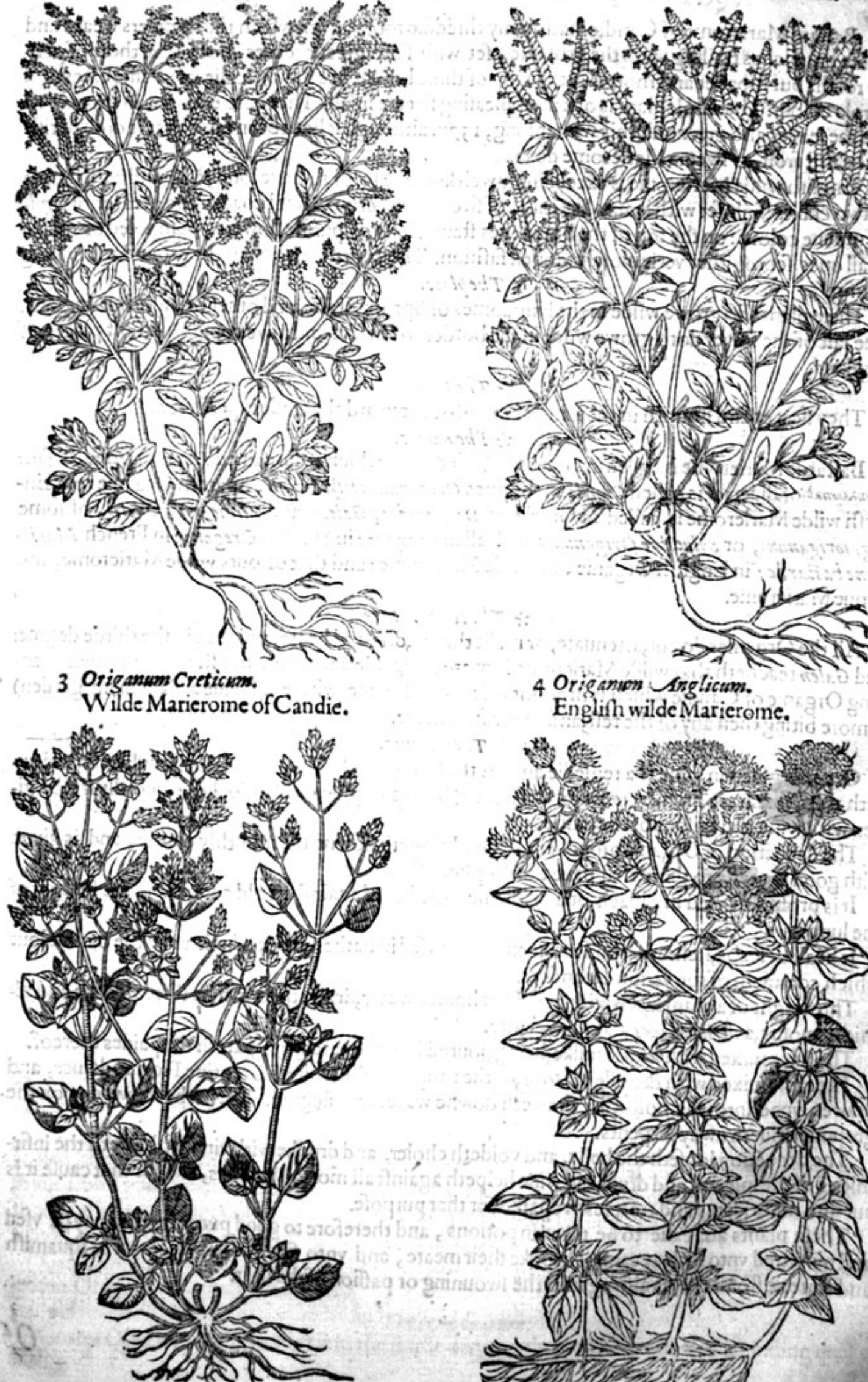

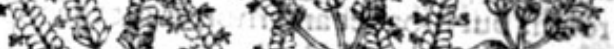

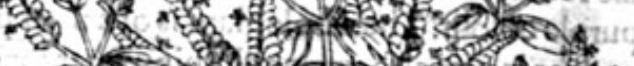
(1)

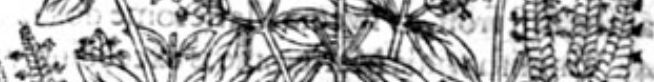

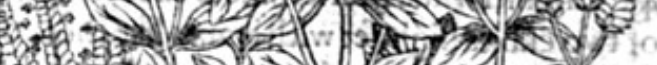

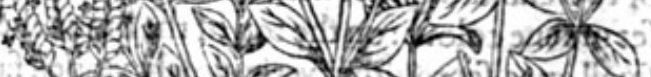

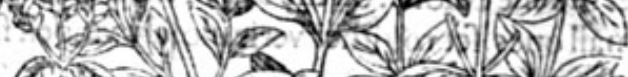
ater

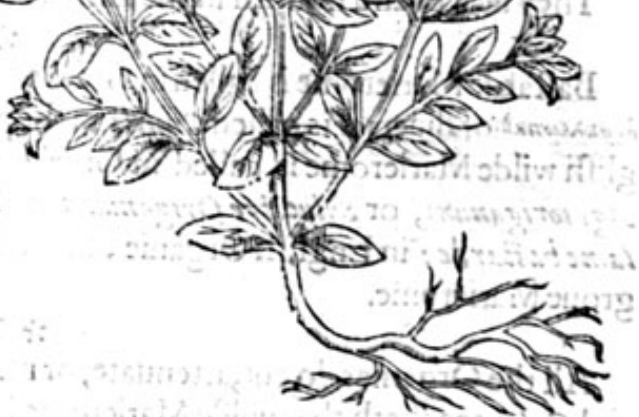

4 Origamion Anglicum.

Englirh wilde Marierome.

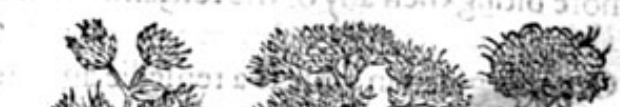

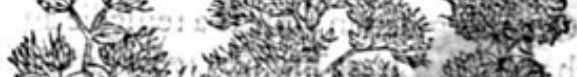

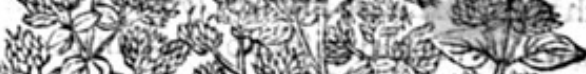
a
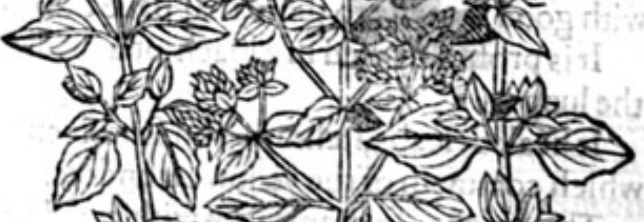

e) $\rightarrow 03$
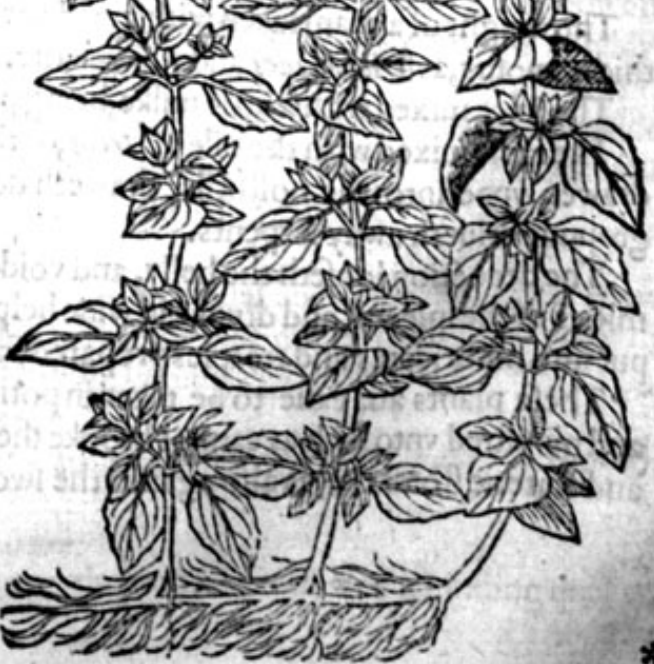


$$
* \text { The defcription. }
$$

3 Baftard Marierone of Candie hath many threddie roots; from which rife vp diuers weake and fecble braunches trailing vpon the grounde, fet with faire greene leaues, not vnlike thofé of pennie roiall, but broader and thorter : at the top of thofe braunches ftande fcalie or chaffie eares of a purple colour. The whole plant is of a moft pleafing fweete frnell. The roote endured in my garden and the leaues alfo greene all this winter long, 1597 . although it hath been faide that it doth perifh at the firt froft, as fweete Marierome doth.

4 Englifh wilde Marierome is exceedingly well knowne to all, to haue long, ftiffe, and hard ftalkes of two cubits high, fet with leaues like thofe of fweete Marierome, but broader and greater, of a ruffer greene colour : on the top of the braunches ftande tufts of purple flowers, compofed of manie finall ones, fet togither verie clofely vmbell fafhion. The roote creepeth in the groundand is long lafting.

* Theplace.

Thefe plants do growe wilde in the kingdomes of Spaine, Italie, and other of thofe hot regions. The laft of the fower doth growe wilde in the borders of fieldes and lowe copfes, in moft places of England.

\section{They flower and flourifh in the fommer months, afterward the feede is perfected. * The names.}

Baftarde Marierome is called in Greeke: óeizaros, \& that which is furnamed Heracleoticum, iéjaros

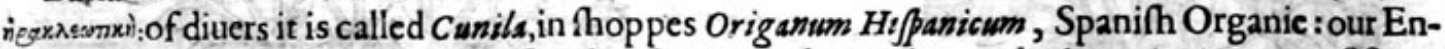
glifh wilde Marierome is called in Greeke of Dioferides, Galen, and Plinie ovins, Onitis, of fome Agrioriganum, or Syluestre Origanum: in Italian Origano: in Spanifh Oregano: in French Mariolaine bastaride: in Englifh Organie, baftarde Marierome : and that of ours wilde Marierome, and grone Marierome.

\section{* The temperature.}

All the Organies do cut, attenuate, or make thinne, drie and heate, and that in the thirde degree: and Galen teacheth that wilde Marierome is more forceable and of greater ftrength; notwithitanding Organie of Candic which is brought drie ott of Spaine (whereof I haue 2 plant in my garden) is more biting then any of the reft, and of greateft heate.

\section{* The vertues.}

A Organie giuen in wine is a remedie againft the bitings and ftingings of venemous beafts, and cu. reth them that haue drunke $O$ pium, or the iuice of blacke Poppie, or Hemlockes, efpecially if it be giuen with wine and raifons of the funne.

B The decoction of Organie prouoketh yrine, bringeth downe the monthly courfe, and is giuen with good fucceffe to thofe that baue the dropfie.

C It is profitably vfed in a loach, or a medicine to be licked againit an old cough, and the ftuffing of the lungs.

D It healeth $\mathrm{fcabs}$, itchings, and fcuruinefle being vfed in bathes, and it taketh away the bad colour which commeth of the yellowe iaunders.

E The weight of 2 dram taken with meade or honied water,draweth foorth by ftoole blacke and filthic humours, as Dio/corides and $P$ linie write.

F The iuice Inixed with a little milke, being poured into the eares, mitigateth the paines thereof.

G The fame mixed with the oile of Ireos, or the rootes of the white Florentine Flower-deluce, and drawen vppe into the nofthrils, draweth downe water and flegme. The herbe ftrowed vpon the grounde driueth away ferpents.

$\mathrm{H}$ The decoction loofeth the belly, and voideth choler, and drunke with vineger helpeth the infirmities of the fpleene, and drunke in wine helpeth againft all mortall poifons, and for that caufe it is put into mithridates and treacles prepared for that purpofe.

I Thefe plants are cafie to be taken in potions, and therefore to good purpofe they may be vfed and miniftred vnto fuch as cannot brooke their meate, and vnto fuch as haue a fower or fquaminh and waterie ftomacke, as alfo againt the fwouning or paffion of the hart. 


\section{OfGoates Marierome, or Organie. Chap.209.}

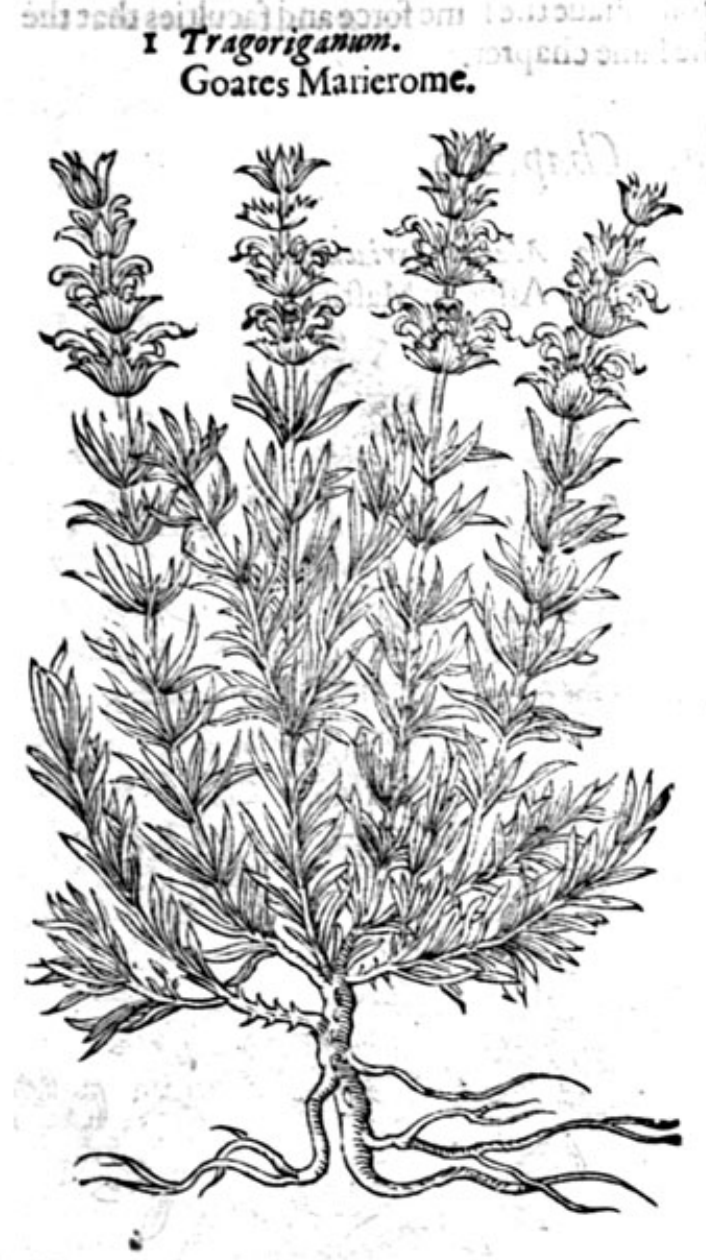

2 Tragoriganum Clufiu. Candie Goates Marierome.

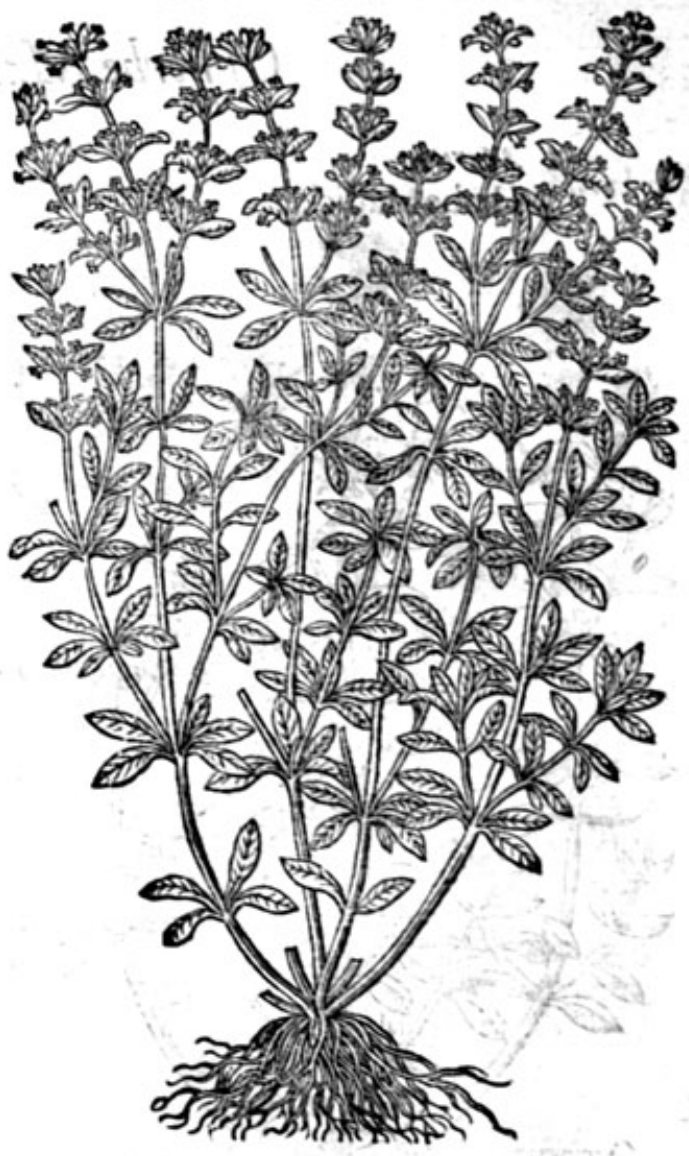

I 7 He ftalkes of Goates Organie are flender, hacde and wooddie ; of a blackinh colour, whereon are fet long leates, greater then thofe of the wilde Time, fweete of fmell, rough, and fomewhat hairie. The flowers be fmall and growe out of little crownes, or wharles, rounde about the top of the ftalkes, tending to a purple colour. The roote is fmall and threddie.

2 Carolus Clufins hath fet foorth in his Spanifh obferuations another fort of Goates Marierome, growing vp like a fmall fhrub. The leaues are longer and more hoarie then wilde Marierom, and alfo narrower, of a fharpe fower tafte, but of a fweete fmell, though not verie pleafant. The flowers ftande at the top of the ftalkes in fpokie rundles, of a white colour. The roote is thicke and wooddy.

Thele plants do growe wilde in Spaine, I * The place.

growing in diuers barren and chalkie fields and high waies nec countries. The firft of thefe I founde in Kent, and alfo neere vnto Cobham houfe, and Southflecte in the Sittingburne and Rochefter * T The time.

They fower in the month of Auguft: I remember faith Dodon eus that once I fawe Tragoriganum in the Lowe countries in the gardens of einoportrovr; that is, of thofe that applie their whole ftudie to the knowledge of plants, or as we may faie, in the gardens of cunning Herbarifts.

Goates Organie is called in Greeke rgaperjavos: in Latine likewife Tragoriganum : in Englifh goates Organie, and goatcs Marierome.

Goates Organies arehot and * The temperature.

Goates Organies are hot and drie in the thirde degree: they are faith Galen of a binding quality. 
* The vertues.

Tragoriganum or Goates Marierome, is very good againft the wambling of the ftomacke, and the fower belchings of the fame, and ftaieth the defire to vomite, efpecally at fea.

Thefe baftarde kindes of Organic or wilde Marieroms, haue the fame force and faculties that the other Organies haue for the difeafes mentioned in the fame chapter.

\section{Of berbe Masticke. Chap.210.}

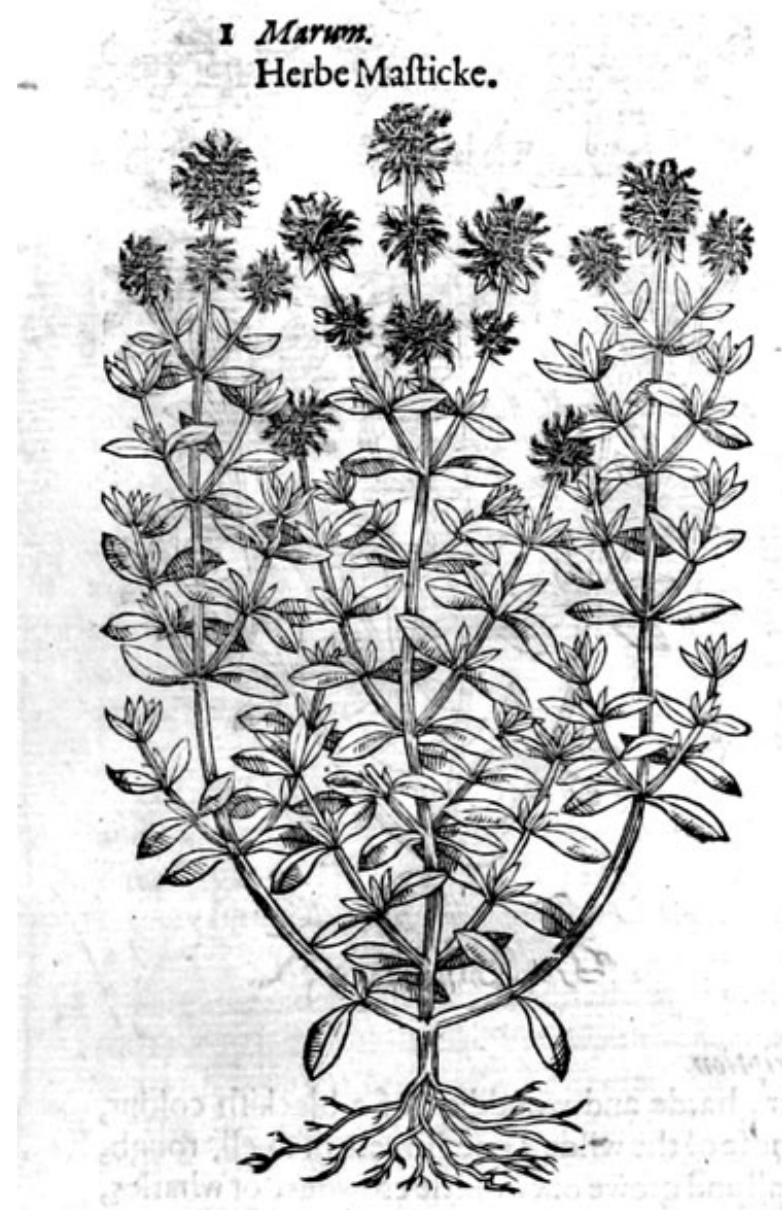

2 Marum Syriaciom.

Affyrian Mafticke.

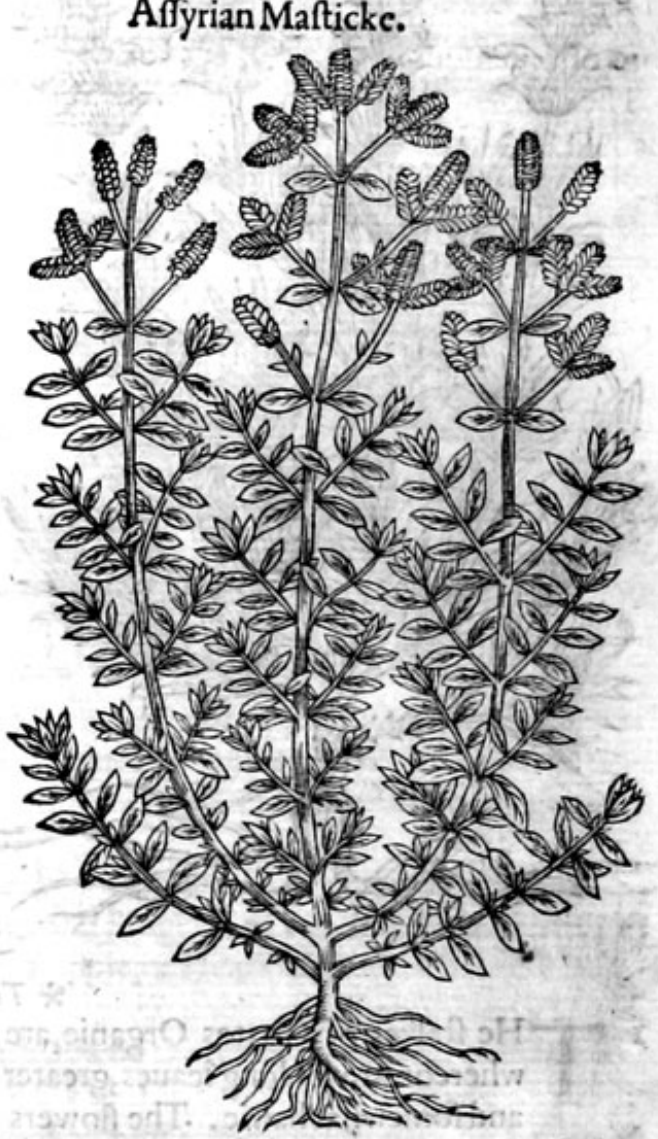

* The defcription.

I He Englifh and French Herbarifts at this daie do call this plant Mafticke or Maftiche, taking this name Marum, of Maro king of Thrace; though fome rather fuppofe the name corruptlie to be deriued of this worde Amar at hum, the one plant being fo like the other that many learned haue taken them to be one, and the felfe fame plant; others haue taken Marwm for Sampfuchus, which doubtleffe is a kinde of Marierome. Some, as Dodoneus, haue called Marum by the name of Clinopodium, which is alfo another plant and not Mafticke.

2 If any bee defirous to fearch for the true M.rum, let them be affured that the plant laft mentioned is the fame : but if any do doubt of the fame, for nouelties fake, heere is prefented voto your viewe a plant of the fame kinde (which cannot be reiected) for a fpeciall kinde thereof, which hath a moft pleafant fent or fmell, \& in fhewe refembleth Marierome and Origanum, confifting of fmall twigs 2 foote and more long : the heads tufted like the common Marierome, but the leaues leffer and like CMyrtus: the toote of a wooddie fubftance, with many ftrings hanging thereat.

There is another kinde heere of fet foorth by L'Obelius, which I haue not as yet feene, nor himfelfe hath well defcribed, which I leauc to a better confideration.

$$
\text { * The place. }
$$

Thefe plants are fet and fowen in gardens of England,and there mainteined with great care and diligence from the iniurie of our cold climate. 


\section{HISTORIE DF PLANTS:}

* The time.

They flower about Augut, and fomewhat later in colde fommers.

* The names.

Mafticke is called of the new writers Mirum : of Dio/corides Clinopodium. Diofcorides theweth that Clixopodium is sicurios, that is to fay, a little fhrub: of fome it is called cleonicwm, and of the $\mathrm{L}_{2}$ tines Letipes.

Thefe plants are hot and drie in the third degrec. * The nature.

* The vertues.

Diofcorides writeth, that the herbe is drunke, and likewife the decoction thereof, againft the bi- A tings of venemous beafts, crampes and conuulfions, burftings and the ftrangurie.

The decoction boiled in wine till the third part be confumed, and drunke, ftoppeth the laske, in B them that haue an ague, and vntoothers in water.

\section{Of Pennic royall, or Tudding grafje. Chap.2II.}

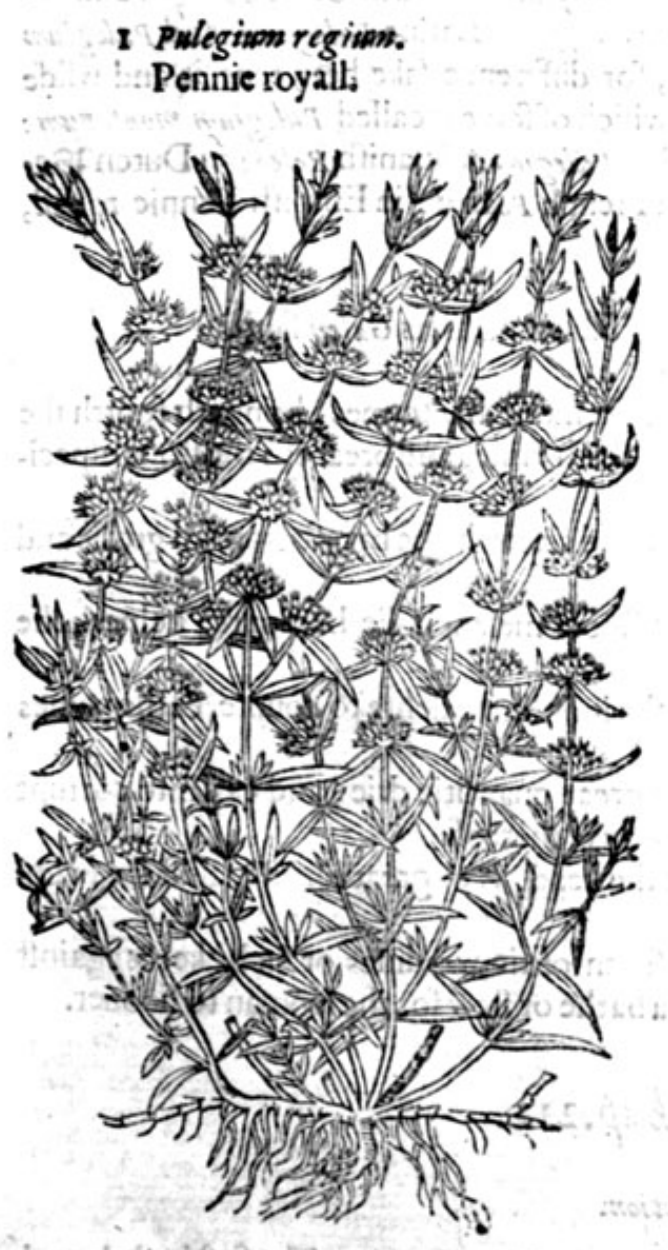

2 Puleginm mai.

Vpright Pennic royall.

* 7 he defription.

1 D Ylegiven region vulg atwm, is fo exceedingly well knowne to all our Englifh nation, that ix needeth no defcription, being our common Pennic roiall

2 The fecond being the male Pennic roiall is like vnto the former, in leaues, flowers, and fmell, and differeth in that this male kinde groweth vpright of himfelfe without creeping, muchlike
in fhewe vnto wilde Marierome.

3 The thirde kinde of $P$ ennie roiall groweth like vnto Time, and is of a wooddie fubftance, fomewhat like vnto the thinne leafed Hyflope, of the fauour of common Pennie royall. 
3 Frlegium angustifolium. Narrowe leafed Pennic royall.

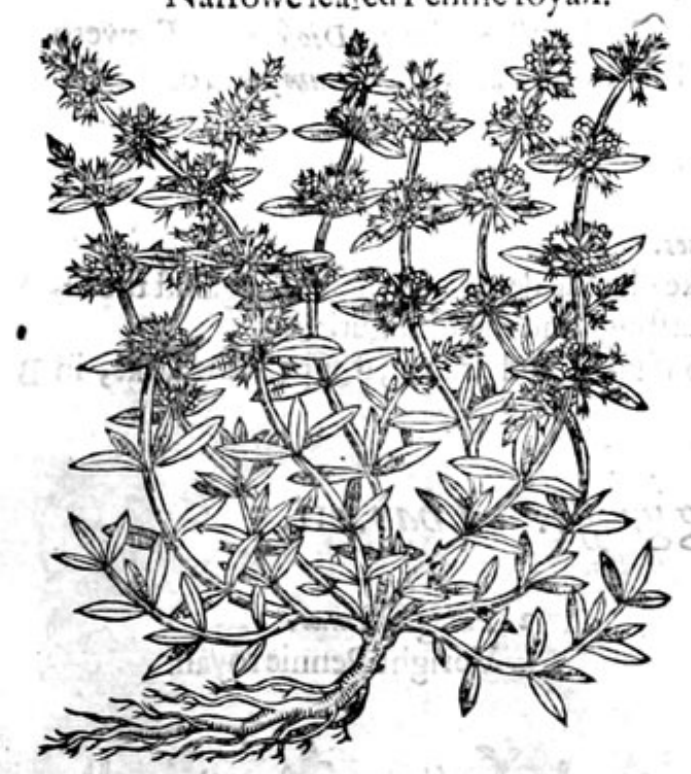

* The place.

The firft and common Pennie royall, groweth naturallie wilde in moift and oucrflowen places, 2s: in the Common neere London called Milesende, about the hoies and pondes thereof in fundrie places, from whence poore women bring plentie to fell in London markets, and it groweth in fundrie other commons neere London likewife.

The fecond groweth in my garden : the thirde L haue not as yet feene.

\section{* Thetime.}

They flower from the beginning of Iune to the ende of Auguft.

$$
\text { \& The names. }
$$

Pennie royall is called in Greeke 2xiner, and oftentimes Brin $\chi^{o v}$ : in Latine Pulegium, and Palegium regale, for difference fake betweene it and wilde Time, which of fome is called Pulegium montanum: in Italian Palegia : in Spanifh Poleo: in Dutch $1 \mathrm{~Pa}$. lep: in French Pouliot: in Englifh Pennie royall,

\section{Pudding graffe, Puliall royall, and of fome Organic.} $*$ The nature.

Pennie royall is hot and drie in the third degree, and of fubtile parts,as Galen faith. $*$ The vertues.

A Pennie royall boiled in wine and drunken, prouoketh the monethly termes, bringeth foorth the fecondine, the dead childe and vnnaturall birth : it prouoketh vrine, and breaketh the ftone efpecially of the kidneis.

B Pennie royall taken with honic, clenfeth the lungs, and cleereth the breaft from all groffe and thicke humours.

C The fame taken with honie and Aloes, purgeth by ftoole melancholie humours; helpeth the crampe and drawing togither of finewes. D The fame taken with water and vineger, affwageth the inordinate defire to vomite, \& the paines.
of the ftomacke.

E If you haue when you are at the fea Pennic royall in great quantitie drie, and caft into corrupt water, it helpeth it much, neither will it hurt them that drinke thereof.

F A Garland of Pennie roiall made and worne about the head, is of great force againft the fwimming in the head, the paines and giddines thereof.

G The decoction of Pennic royall is verie good againft ventofitie, windines, or fuch like, \& againft the hardnes and ftopping of the mother being vfed in a bathe or ftew for the woman to fit ouer.

\section{OfBafll. Chap.212.}

\section{8* Thedefoription.}

I Arden Bafill is of two fortes, differing one from another in bignes. The firft hath broad, thicke, and fat leaues, of a pleafant fwcete fmell, and of which fome one here and there are of a blacke reddifh colour, fomewhat fnipt about the edges, not vnlike the leaues of French Mercuric. The ftalke groweth to the height of halfe a cubite, diuiding it felfe into diuers branches, whereupon do ftande fmalland bafe towers fometimes whitifh, and often tending to 2 darke purple. The roote is threddie, and dieth at the approch of winter.

2 The middle Bafill is very like vnto the former, but it is altogither leffer. The whole plant is of a moft odoriferous fmell, not vnlike the fmell of a Limon,or Citron, whereof it tooke his fur-
name. 


\section{HISTORIE OF PLANTS.}

I Ocimum magnem.

Great Bafill.

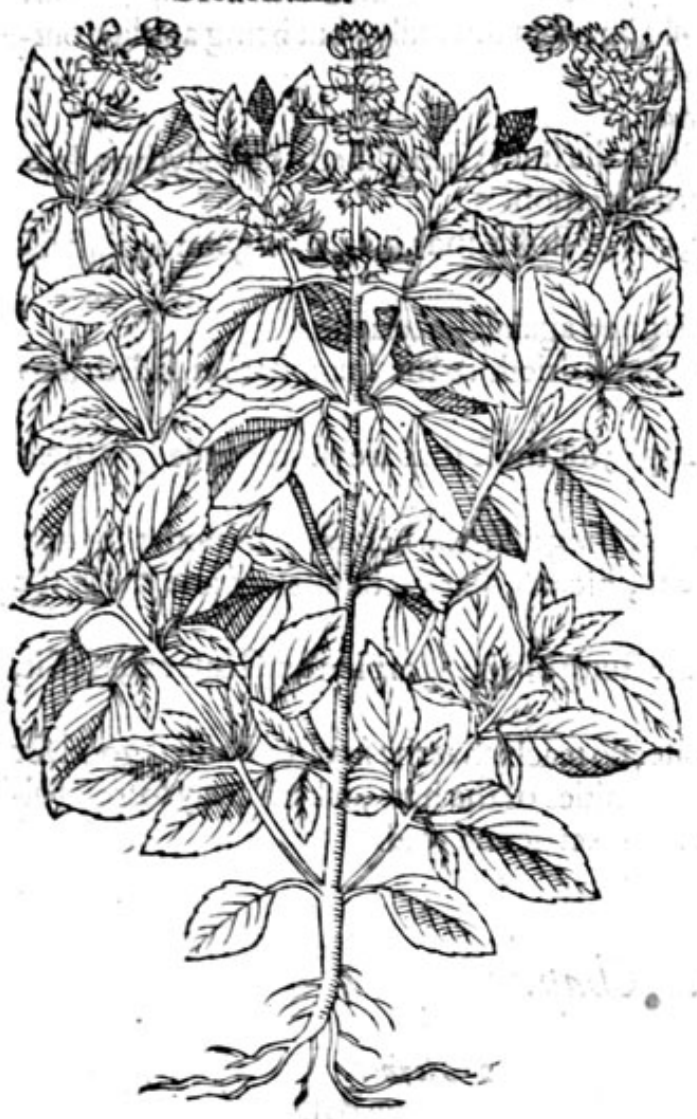

2 Ocimum medium citratam. Citron Bafill.

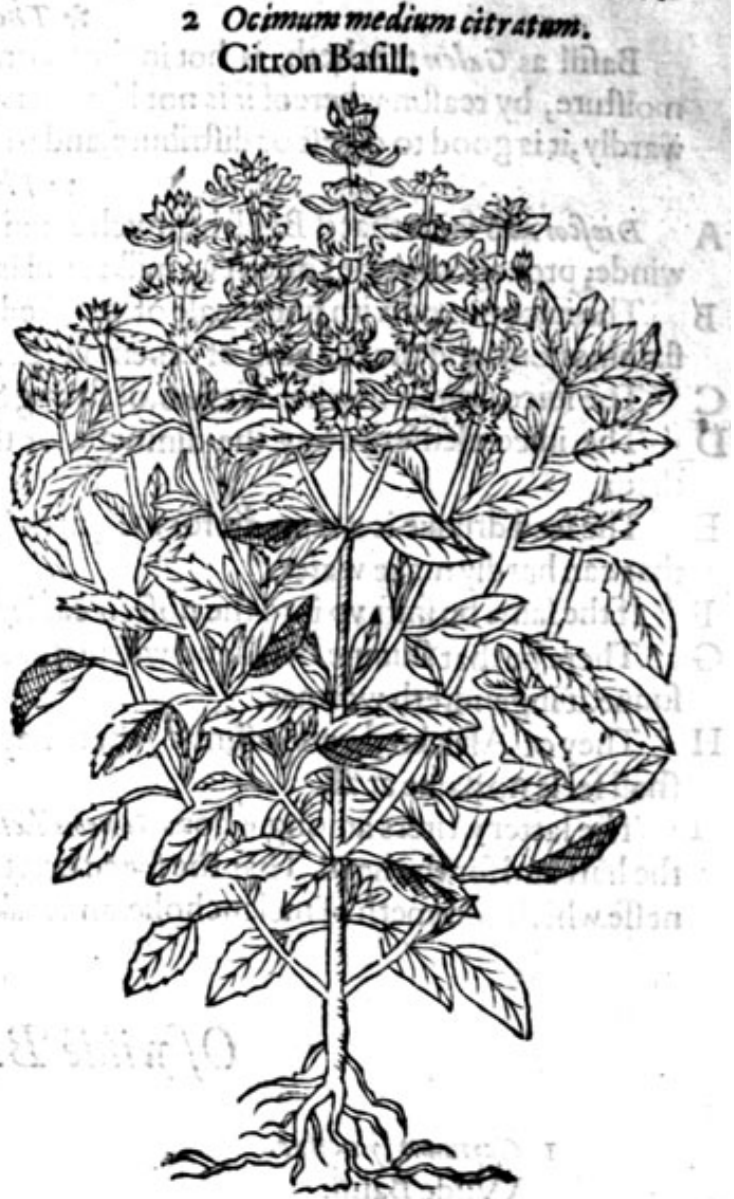

3 Ocimum minew Gariophyllatuon. Bufh Bafill.

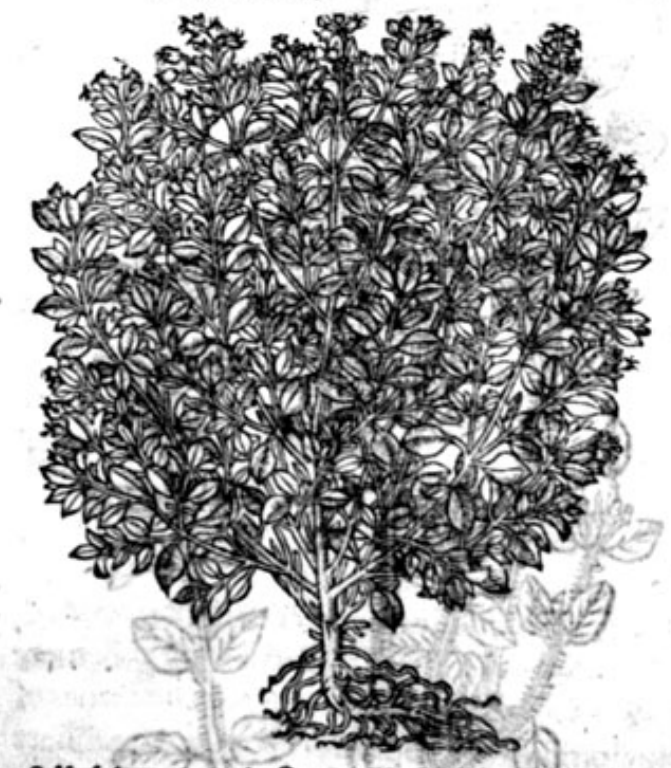

* The defoription.

3 Burh Bafill, or fine Bafill, is a low and bafe plant, hauing a threddie roote, from which rife vp manie fmall and tender ftalkes, branched into diuers armes or boughes, wherupon are placed many little leaues, leffer than thofe of Pennie royall. The whole plant is of a moft pleafing fivecte fmell.

\section{* The place.}

Bafill is fowen in gardens, and in earthen pots. It commeth vp quickly, and louech little moifture, except in the middle of the day $;$ otherwife if it bee fowen in rainie weather, the feede will putrifie, and growe into a iellic or flime, and come to nothing.

\section{* The time.}

Bafill fowretbin Iune and Iny, and that by little and little, whereby it is long a flowring, beginning firft at the top.

Bafill is called in Greckebuen, and $*$ in the firft
fyllable axumos in Latine Ocjmum. It differeth from Ocymum which we have called cereale, as we haue fhewed in the Hiftoric of Graine. The latter Grecians haue called it Ranjexir: in thops likewife Eaflicum, and Regiven: in Spanifh-Albahaca: in French Baflic : in Englifh Bafill, Garden Bafill, the greater Bafill royall, the leffer Bafill gentle, and Bufb Bafill: of fome Baflicam Gariophygestum, or Cloue Bafill. 
* The temperature.

Bafill as $G_{a l e n}$ teacheth, is hot in the fecond degree, but it hath adioined with it a fuperfluous moifture, by reafon whereof it is not like, that it fhould be taken inwardly; but being applied outwardly, it is good to digeft or diftribute, and to concoct.

$$
* \text { The vertues. }
$$

A Diofcorides faith that if Bafill be much eaten, it dulleth the fight; it mollifieth the belly; breedeth winde; prouoketh vrine; drieth vp milke, and is of hard digeftion.

B The iuice mixed with fine meale of parched Barly, oile of Roles and vineger, is good againft inflammations, and the ftinging of venemous beafts.

C The iuice drunke in wine of chios, or ftrong Sacke, is good againft head ache.

D The iuice clenfeth away the dimneffe of the eies, and drieth vp the humour that falleth into them.

E The feed drunke is a remedie for melancholicke people; for thofe that are fhort winded, \& them that can hardly make water.

F If the fame be fnift vp into the nofe, it caufeth often neefing :alfo the herbe it felfe doth the fame.

G There be that thunne Bafill and will not eatc thereof, bicaufe that if it be chewed and laid in the funne, it ingendreth wormes.

H They of Africke do alfo affirme, that they who are ftung of the Scorpion and haue eaten of it, thall feele no paine at all.

I The latter writers among whom Simeon Zethy is one, do teach, that the fmell of Bafill is good for the hart and for the head. That the feede cureth the infirmities of the hart, taketh away forrowful: neffe which commeth of melancholie, and maketh a man merrie and glad.

\section{Of wilde Bafill. .Chap.213.}
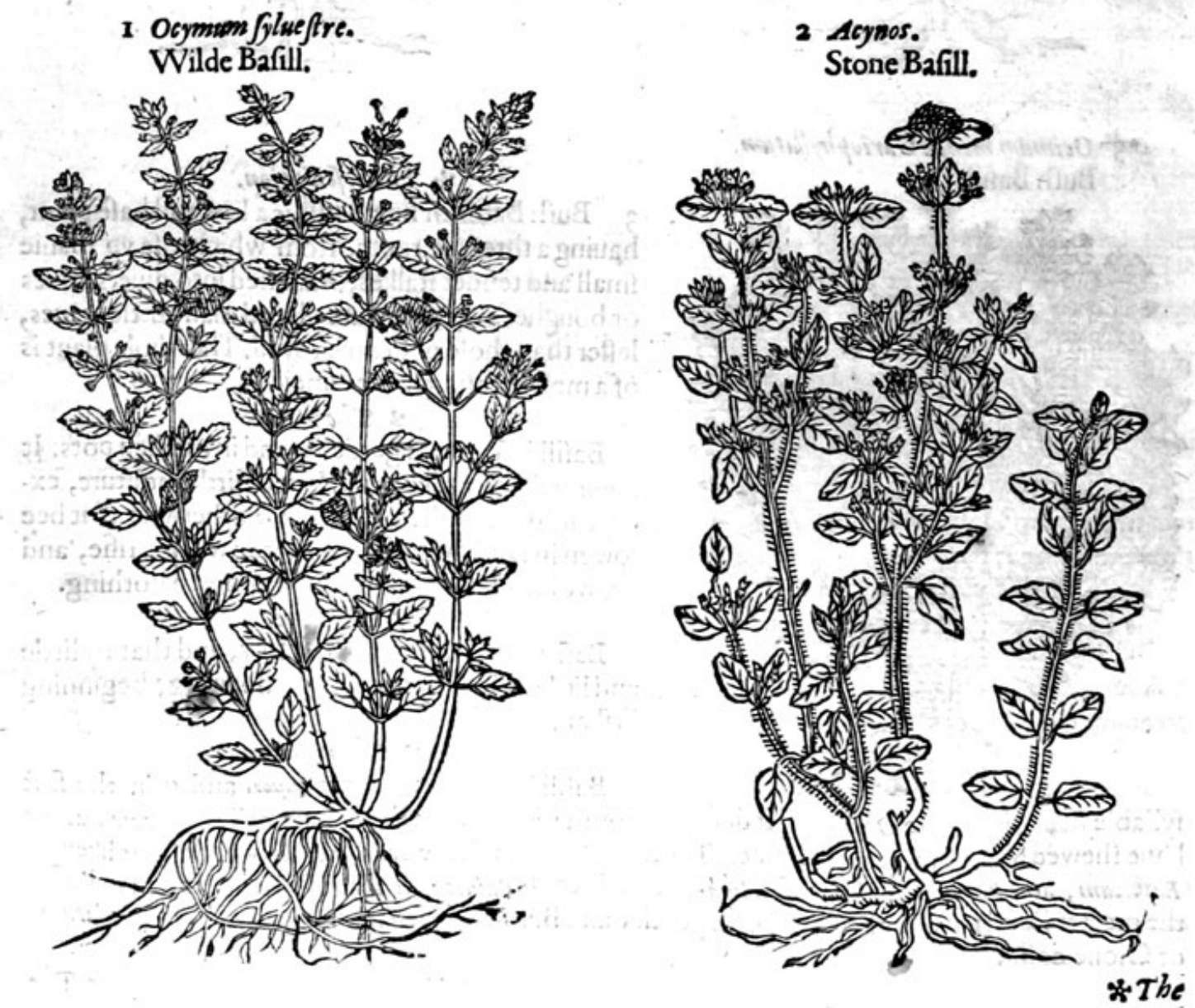


\section{HISTORIE OFILANTS.}

* The defcriotion.

17 He wilde Bafill or Acynos, called of Pena Clinopodium vulgare, hath fquare hairie ftems, befet with little leaues likeivnto the fmall Bafill, burmuch fmaller, andmore bairie, and flowers of a purple colour,farhioned like vnto the garden Bafill. The roote is full of hairie threddes, and creepeth along the grounde, and fpringech vpi yeerely anewe of it felfelwithout fowing.

2 This kinde of wilde Bafill called among the Græcians axxu $\vartheta$, which by interpretation is Sine femine, or Sterilis, hash caufed fundrie opinions and great doubts concerning the words of $p$ linie and Theophraftess, affiemitig that this herbe hath no flowers nor feeds, which opinions I am fure of mine owne knowledge to be without reafon: but to omit controuerfies; this plant beareth purple towers, wharled about fquare ftalkes, rough leaues and hairie, very like in fhape vnto Bafill.

3 Ocymoides repens. Creeping Cowe Bafill.

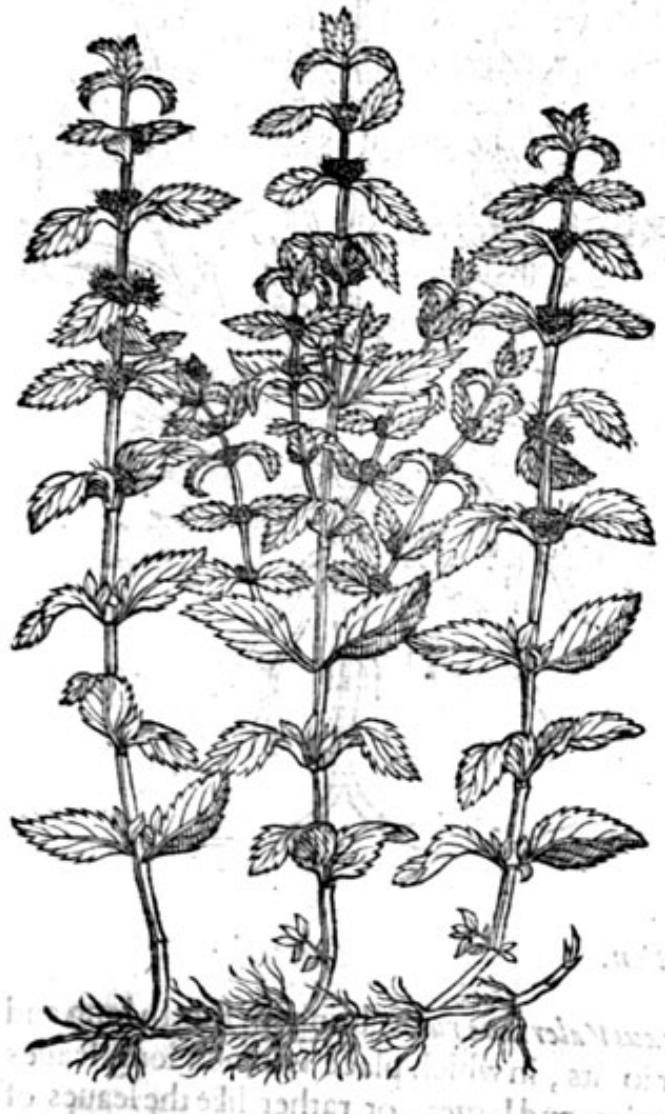

$*$ The defoription.

3 Creeping Ocymoides groweth not onely in the thadowie and wooddic valleies of Candie, about hedges, but euen in the graffie places and hadowie waie fides about rituers and fouds, and in the cliffes of rockes, with thinne ftalkes iointed, creeping in the grounde, tender and crooked like the grcat Chickweede; out of which come two leaues right oppofite one againft the other: the flowers are in thape like vnto Fleawoort, and of the fame colour, but much fraller. The roote is thiane; and the vfe thercof not found out.

Serapio and others have fet foorth another wilde Bafill vinder the title of Molochin; and L'Obelites after the minde of Iolon Brancion, calleth it Corcoros, which we haue Englifhed Fifh Bafill, the feedes whereof the faide Brancion receitued from Spaine, faying that Corcoros Plinij hath the leaues of Bafill. The ftalks are two handfuls high, the flowers yellowe, growing clofe to the ftalkes, bearing his feede in fmall bullets. The roote is compact and made of an innumerable companic of ftrings, creeping farre abroade like running Time.

* The place.

The wilde kindes doe growe ypon grauelly grounds by waterfides, and efpecially I found the three laft in the barren plaine by an houfe in Kent, two miles from Dartfordecalled Saint Iones, in a village called Sutton; and Climopodijm vulgare growethín great plentie rpon Long fielde downes in Kent. * Tbetime.

Thefe herbes flower in Iune and Iuly.

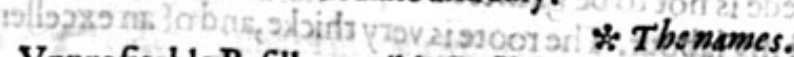

Vnprofitable Bafill, or wilde Bafill, is called of fome clinopodimo

creeping Cowe Bafill:

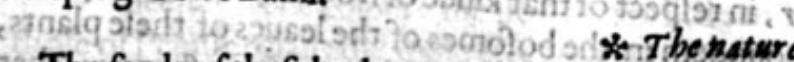

The feede of thefe herbes are of complexion hiot and drie.

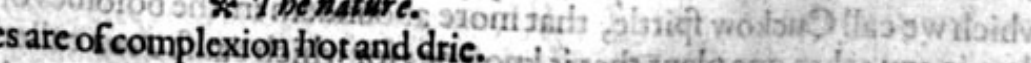

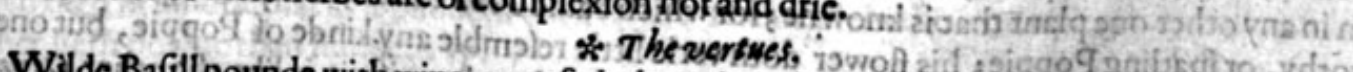

Wilde Bafill pounde with wine appeafeth the paineof the eies, and the iuice doth mundifie the A fame, and putteth awaicall obfouritie anid dimneffe, all catarthes and flowing humours that fall into the eles, being often dropped into the fame.

The wilde Bafill howfoeuer it be taken ftoppeth the laske. unithigurpo : 


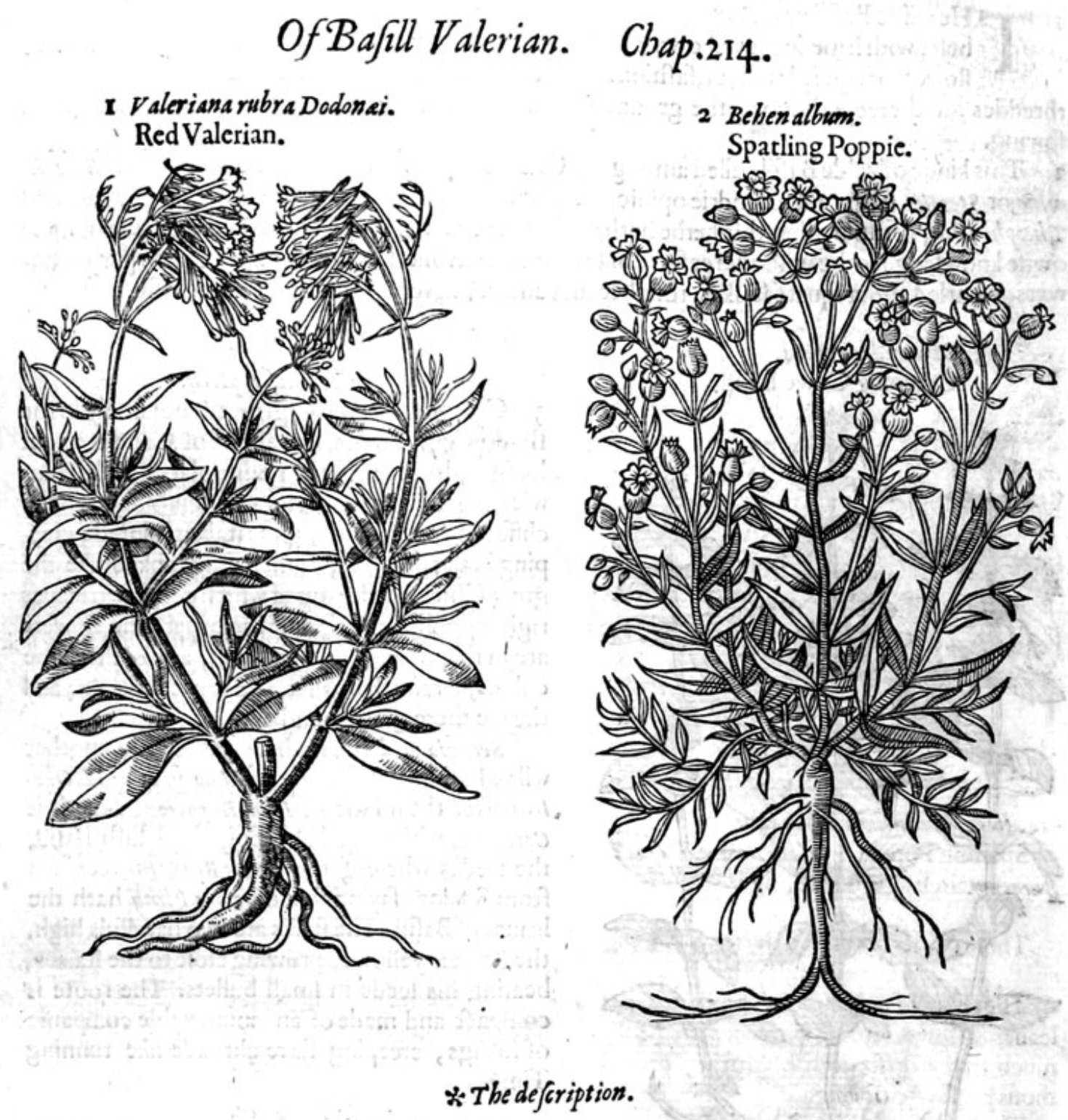

I THe firft kinde of Ocymaftrum, called of Dodonaus Vaieriana rubra, bringeth foorth long and brittle ftalkes two cubits high, full of knots or ioints, in which place is ioined long leates much like vnto great Bafill, but greater, broader, and larger, or rather like the leaues of Woade. At the toppe of the ftalkes do growe verie pleafant and long redde flowers, of the fa. Thion of the flowers of Valerian, which hath caufed Dodon ens to call thefe plants redde Valerian; which being paft, the feedes are caried away with the winde being few in number, and litele in quantitic, fo that without great diligence the feede is not to be gathered or preferued: formufelfe haue often indeuorued to fee it, and yet haue loft my labour. The roote is very thicke, and of an excellent fweete fauour.

2 The fecond is taken for Spumerm papauer, in refpect of that kinde of frothie fpattle, or fpume, which we call Cuckow fpittle, that more aboundeth in the bofomes of the leaves of thefe plants, then in any other one plant that is knowne; for which caufe Pena calleth it Papauier fpioneion, that is frothy, or fpatling Poppie; his flower doth verie little refemble any kinde of Poppie, but onely the feede and cod or bowle wherein the feede is contained, otherwife it is like the other Ocymafrum; the flowers growe at the top of the ftalkes hanging downwards, of a white colour, and is taken generally for Beben albom: the roote is white, plaine, andlong, and very tough and harde to breake. 
3 Ocymaflyom imultiflorwio.

Double Spatling poppic.

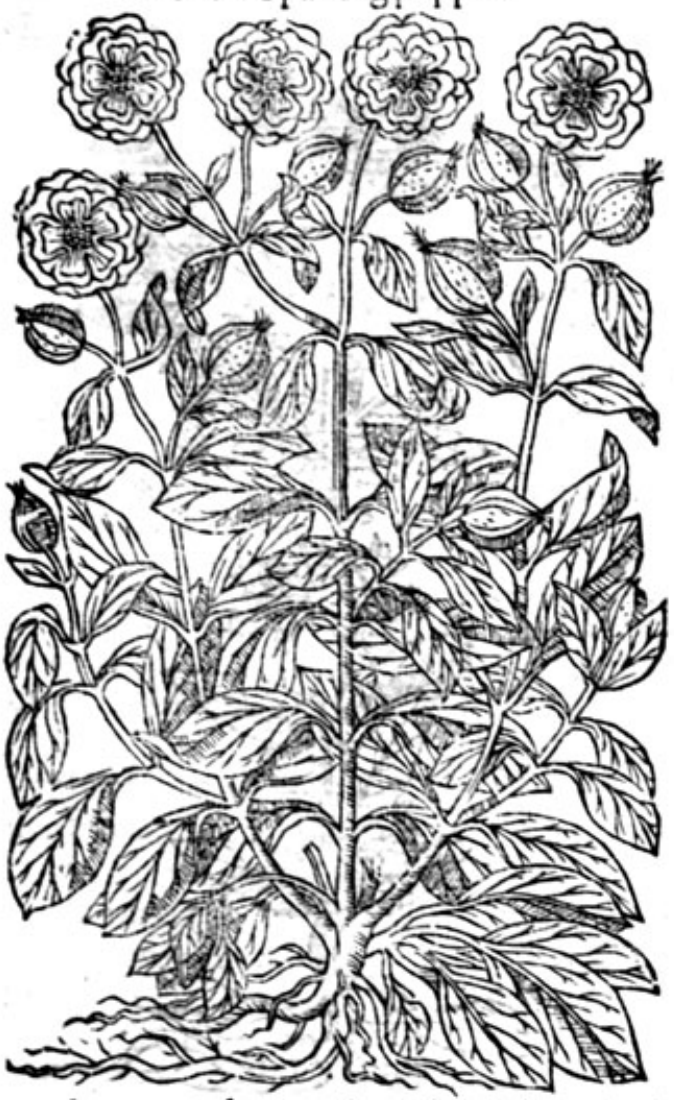

* The defcriptian.

3 There is founde in Germanie another fort of Ocym:frwm, or Valerianthon (which Taher montomus hath fet foorth) in leates, ftalks, and rootes, like the precedent, onely it hath double white flowers, dathe ouer with a little blufh colour; which naketh the difference.

$$
\text { * Theplace. }
$$

The firft groweth plentifully in my garden, being a great ornament to the fame, and not com. mon in England.

Thefecond groweth almoft in euery pafture,

$$
\text { * The time. }
$$

Thefe plants do fower from Maie to the ende of Auguft. *The names.

Red Valetian hath beene fo called of the likeneffe of the flowers, and fpoked rundles with $\mathrm{Va}$ lerian, by which name we had rather have is called, then rafhly to laie vpon it an vnptoper name. There ate fome alfo who would haue it tobe a kinde of Beben of the later Herbarifts, naming the fame Behen rubrem, for difference betweene it and the other Beben album, that of fome is called Otymiftrwn, and Papawer Bumeum, which I haue Englifhed Spatling Poppie; and is in truth another plant, much differing from Beben of the Arabians: It is alfo called Valeriantbon, Sapona. ria altera, Struthiom Aidroandz, and Condurdum : in Englifh red Valerian, andred Cowe Bafill.

Spatling Poppie is called Behen album, Ocymaftrum alterum; of fome Polemonium, and Papauer foumenm: in Englifh Spatling Poppie, frothie Poppic, and white Ben.

Thefe plants are dric in the fecond degrce.

$$
* \text { The nature. }
$$

\section{* The vertues.}

The rootc of Eehen albuen drunke in wiue, is good againft the bloudie fluxe: and being pounde $\mathbf{A}$ leaues \& towers, and laide to, cureth the ftingings of Icorpions \& fich like venemous beaifts; info. much that who fo doth folde the fame in his hande, can receiue no damageor hurt by any vene-
mous beaft whatfoeuer.

The decotion of the roote made in water and drunke, prouoketh vrine, it helpeth the ftrangu- B rie, and painés about thic backe and huckle bone.'

$$
\text { Of OMints. Chap.215. }
$$

*The thindes.

Here be diuers forts of Mintes; fome of the garden; others wilde, or of the fielde; andalfo
fome of the watet.

I He firft tame or garden Mint, commeth vp with ftalks fower quare of an obfcure red colour fomwhat hairie, which are couered with round leaues nicked in the edges like a fave, of a deepe greene colour: the flowers are little and red, and grow about the ftalks circlewife as thofe of Pennie roiall: the roote creepeth aflope in the ground, hauing fome frings on it, and now and then in fundrie places it buddeth out a frefh: The wholeherbe is of a pleafant finell, andit ra-
ther lieth downe than ftandeth yp.

2 The fecond is like to the firft in hairie ftaikes fomething round, in blackifh leaues, in creeping rootes, and alfo in fmell, but the flowers do not at all compafie the ftalke about, but ftand vp in the tops of the branches being orderly placed in little cares, or rather catkines or aglets. 
I Mentha fatima rubra. Red Garden Mints.
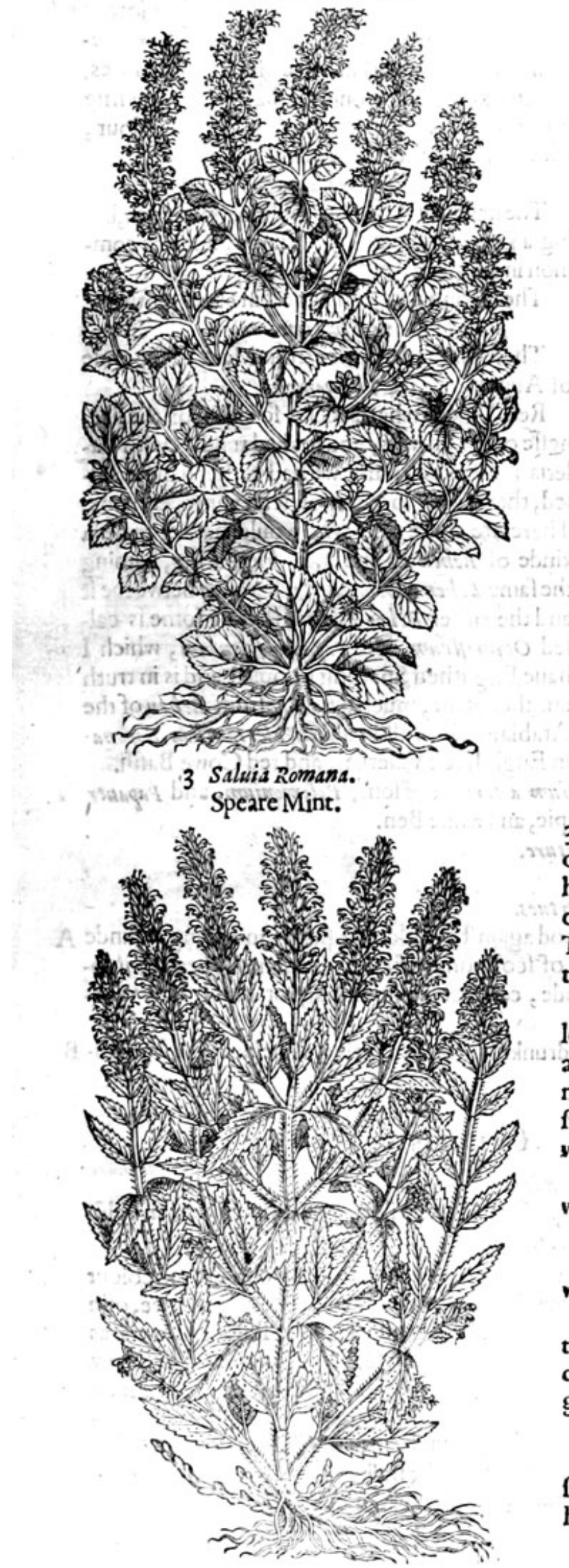

2 Mentha cruciata.

Croffe Mint, or curled Mint.

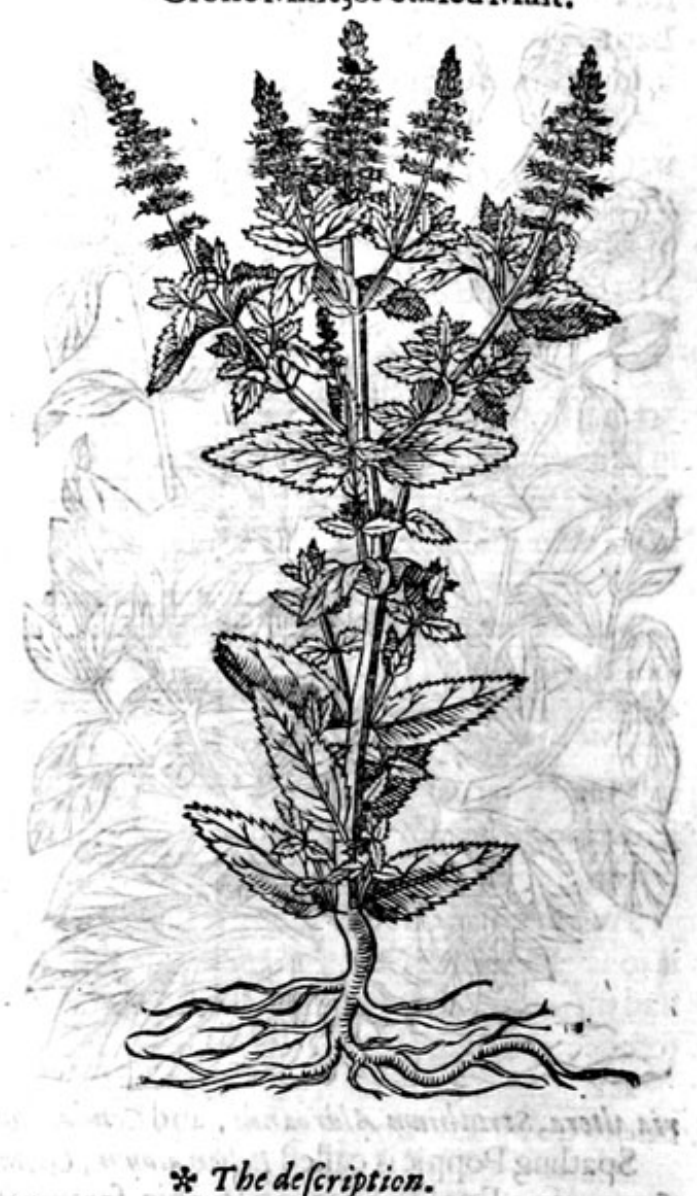

3 The leaues of Speare Mint are longlike thote. of the Willow tree, but whiter, fofter, and more hairie: the flowers are orderly placed in the tops of the ftalkes, and in eares like thofe of the fecond. The roote heereof doth alfo creepe no otherwife than doth that of the firft, vnto which it is like.

There is another fort of Mint which hath long leaues like to the third in little ftalkes, yet in leaues and in rootes leffer; but the flowers heereof ftand not in the tops of the braunches, but compafle the ftalkes abolit circlewife as doe'thofe of the firft, which be of a light purple colour.

Likewife there be many other forts, whereof to write it wcre to fmall purpofe. * The place.

Moft vfe to fet Mints in gardens almoft euerie where. * The time.

Mints do flower and flourifh in fommer, in winter the rootes oncly remaine: being once fet they continue long, and remaine fure and faft in the ground.

* Thenames.

Mint is called in Greeke risjooms and mivon: the fweete fmell (faith Plinie in his 19.bookechap.8.) hath changed the name among the Grecians, when 


\section{HISTORIE OF PLANAS. IHT}

when as otherwife it thould be called $M$ int ha, from whence our old ivriters hatue deritied the name: for iss fignificth fweet, and oomos fmell : The Apothecaries, Italians, and Frenchmen do keepe the

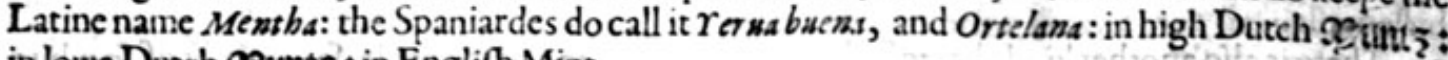
in lowe Dutch 9 gunte : in Englifh Mint.

The firt Mint is called inhigh Dutch Diement : in low Dutch 23zupn bevlinbe: he that would tranflate it into Latine, muft call it Sacra nigricans, or the holy blackin Mint: in Englifh browne Mint, or red Mint.

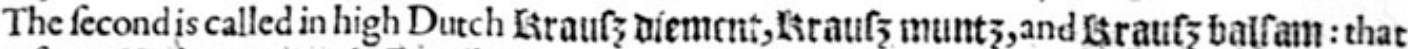
is to fay, Mentha critciats: in French Beaume cre/pw : in Englith crofle Mint,or curled Mint.

The third is called of diuers Mentha Sarracenca, Mentba Romana, Salais Romana, or ber ba Sant.e

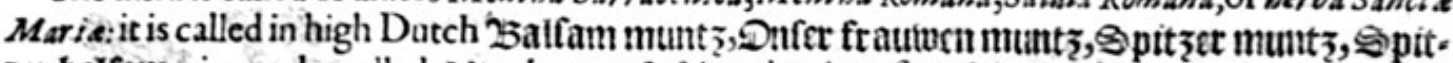
zer balfam: it maybecalled Mentha anguftsfolis: that is to fay, Mint with the narrow leafe: and inEnglifh Speare Mint, common Garden Mint, o! tr Ladies Mint, Browne Mint, and Macrell Mint.

The fourth is called in high Dutch pert 3 hat aut, as though it were to be named Cardiaca; or Cardiacs Mentba : in Englifh Hart Woolt, or Hart Mint.

$$
\text { * The temperatione. }
$$

Mint is hotanddrie in the third degree. It is faith Galen, fomewhat bitter and harfh, and it is inferidr to Cajamint. The fmell of Mint faith Plinie doth fturre vp the minde, and the taft a greedie defire to ineate.

$$
\text { * The vertues. }
$$

Mint is maruellous wholfome for the ftomacke, it ftaieth the hicket, parbraling, vomiting and A fcowring inthe cholerike paflion, ifit be taken with the inice of a fow re pomegranatc.

It ftoppeth the cafting yp of blood, being giuen with water and vineger, as Galen teacheth.

And m broth, faich Plinic, it ftaieth the flowers, and is fingular good againft the whites, that $\mathrm{C}$ is to fay, that Mint which is defcribed in the firft place. For it is found by experience, that many ha:!e had this kinde of fluxe ftaied by the continuall vife of this onely Mint : the fame being applied to the forehead,or to the temples, as Plinie teacheth, doth take away the headache.

It is good againft watring cies, and all manner of breakings out in the head, and againft the iufir- D mities of the fundament :it is a fure remedie for childrens fore heads.

It is powred into the eares with honie water. It is taken inwardly againft Scolopenders, Beare E wormes, Seafcorpions and ferpents.

It is applied with falt to the bitings of mad dogs.It will not fuffer milketocruddle in the ftomack, F (Plinieaddeth to waxe fower.) Therefore it is put into milke that is drunke for feare that thofe who haue drunke thereof fhould be ftrangled.

It is thought, that by the fame vertue it is an enimie to generation, by ouerthickening the feede. G

Diofcorides teacheth, that being applied to the fecret part of 2 woman before the act, it hindreth conception.

Garden Mints taken in meatc or drinke warmeth and ftrengtheneth the ftomacke, and dricth vp $\mathrm{H}$ all fuperfuous humors gathered in the fame, and caufeth good digeftion.

Mints mingled with the meale of parched barlie, confumeth tumors and hard fwellings.

The water of Mints is of like operation in diuers medicines, it cureth the trenchings and griping $\mathrm{K}$ paines of the bellie and bowels, it appeafeth headach, ftaieth yexing and yomiting.

It is fingular againft the grauell and ftone in the kidneies, and againft the ftrangury, being boiled $L$ in wine and drunke.

They laie it to the ftinging of watpes and bees with good fucceffe,

\section{Of $(e p$, or Cat Mint. Cbip.216.}

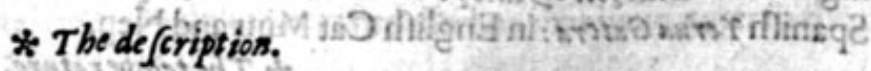

$I$ At Mint or Nep groweth hig

chamfered a follkes aboue a cubitelong, cornered, chamfer, and full of branches: the leaues are broad, nicked in the edges like thofe of Bawme, or of Horehound, but longer. The flowers are of a light yellow, and whitifh withall, they partly compas about the vppermoft fprigs, and partly in the very top, they are fet in manner like an eare, or cakkin : the roote is diuernly parted, and full of ftrings, and endureth a long time. The 
wholc herbe togither with the leaucs and ftalkes is foft,and cotiered with a white downe leffer than Horle Mint; it is of a harpe fincll, and pearfeth into the head : it hath a hot tafte with a certaine bitternefie.

2 There is al fo another kinde hereof, that hath a longer and narrower leafe, and not of fo white a colour : theftalkes hereof are fower fquare; the flowers be more plentifull, of a red light purple colour inclining to blew, fprinkled with little fine purple fpeckes: the finel hereof is ftronger, but the tafte is more biting.

I Mentha Felina, feu Cattaria. Nep,or Cat Mint.

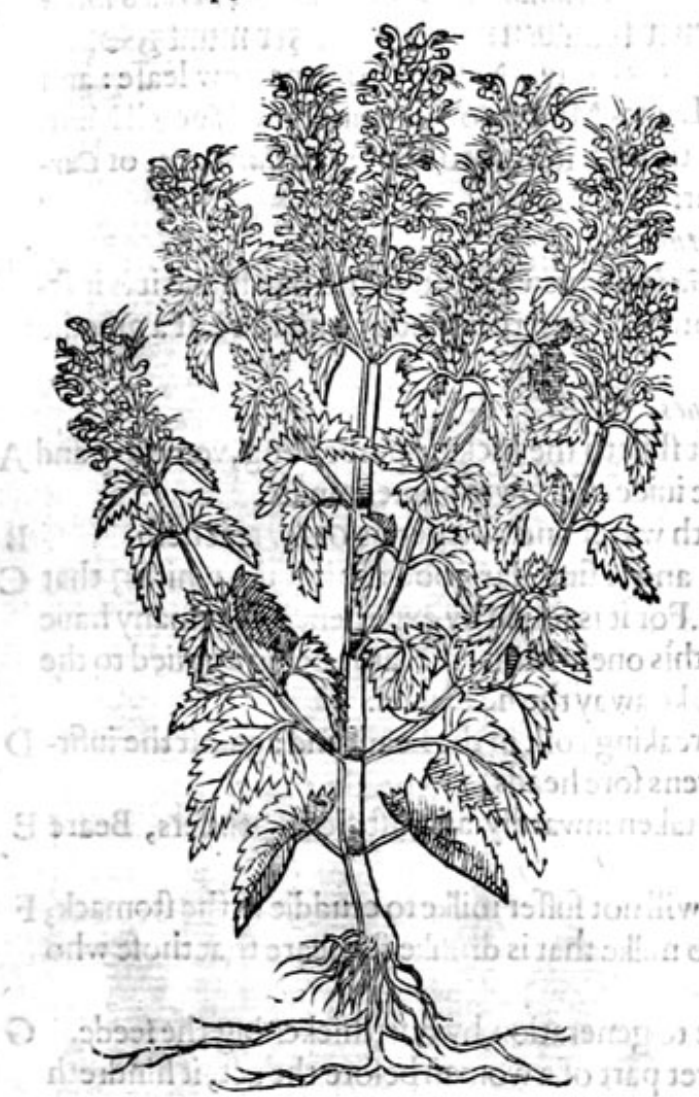

2 Menta Cattaria altera. Great Cat Mint.

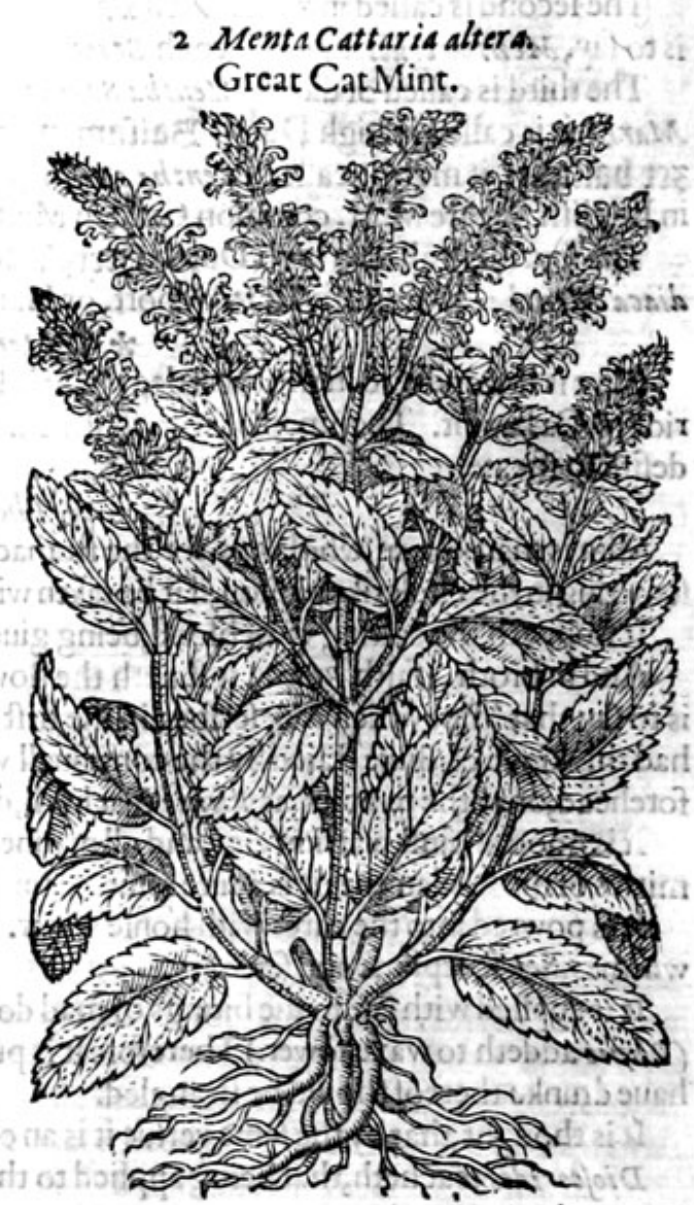

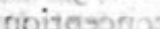

* Theplace.

They growe about the borders of gardens and fieldes, neere to rough bankes, ditches, and common waies: it is delighted with moift and wateric foiles; it is brought into gardens. * Thetime.

The Cat Mints flourin by and by after the fpring : they flower in Iuly and Auguft. * The names.

The latter herbarifts do call it Herba Cattaria, and Herba Catti, bicaufe the cats are very much delighted herewith; for the fmell thereof is fo pleafant vnto them, that they rub themfelues vpon it, and wallow or tumble in it, and alfo feede on the branches and leaues very greedily. It is named of the Apothecaries 2 (epeta ; but Nepeta is properly called (as we haue faid) wilde Pennie royall : in

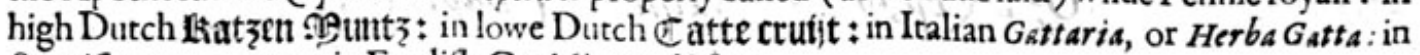
Spanifh rerua Gatera : in Englifh Cat Mint and Nep. $*$ The temperature.

Nep is of temperature hot and drie, and hath the faculties of the $C_{a}$ lamints.

$*$ The vertues.

A It is commended againf oldepaines of the head, ftomacke, and matrix, and thofe difeafes that growe of flegme, and rawe humors, and of winde. It is a prefent helpe for them that are burften in- 


\section{HISTORIE OF PLANTS. AHT}

wardly, by meanes of fome fall receiued from an high place, and that are very much bruifed, if the iuice be giuen with wine or meade.

It is vfed in bathes and decoctions for women to fit ouer, to bring downe their ficknes, and to $B$ make them fruitfull.

\section{Of Horfe Mint,orWater Mint. Chap.217.}

I CMenthía aguatica.

Water Mint.

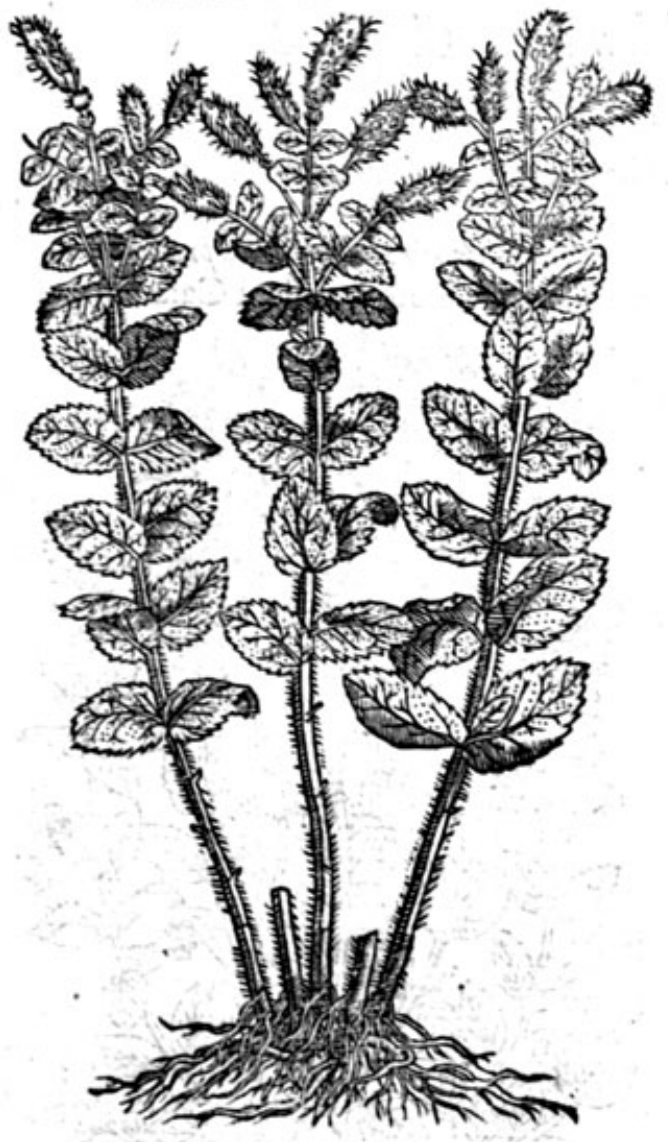

2 Sifymbria Mentha. Sweete Water Mint.

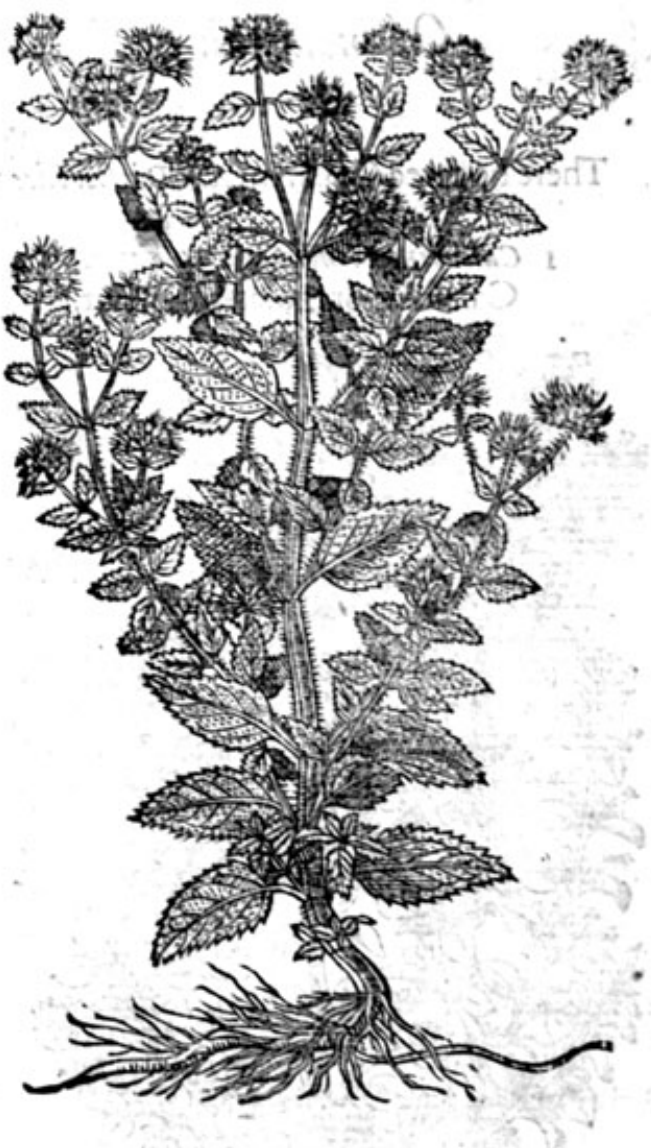

* The defcription.

I \ 7 Ater Mint is a kinde of wilde Mint, it is like to the firft garden Mint, the leaues thereof are round, the ftalkes cornered, both the leaues and ftalkes are of a dârke red colour: the rootes creepe far abroad, but euery part is greater, and the herbe it felfe is of a ftronger fmell: the flowers in the tops of the braunches are gathered togither into a long fikie eare, in thape like the red Mace, of a purple colour.

2 The fecond kind of water Mint in eche refpect is like the others, fauing that the fame hath a more odoriferous fauour, being lightly touched with the hand; otherwife being hardly touched, the fauour is ouer hoetofinell vnto, and beareth his flowers in fundrie tufts towardthe toppe, of a light purple colourinas to jus,

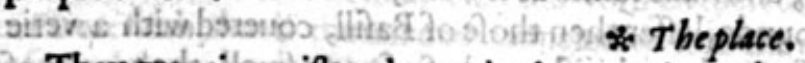

They grow in moift and waterie places, as in medows neer vnto ditches that haue water in them, and by riuers.

* The time.

They flower when the other Mints do, and reuine in the fpring.

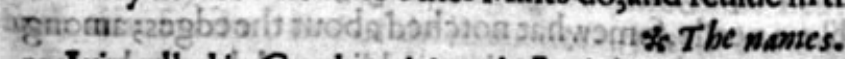

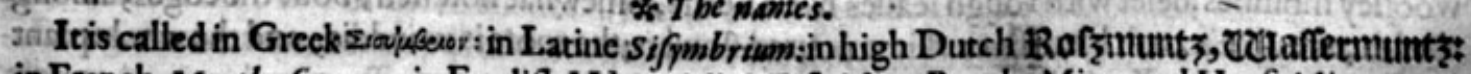
in French Ment be faunage : in Englifh Water Mint, Fißh Mint, Brooke Mint, and Horfe Mint. 


\title{
556 THE SECOND BOOKE OF THE
}

\author{
* Thetemperature.
}

Water Mint is hot and drie as is the garden Mint, but it is of a ftronger fmell and operation.

A It is commended to haue the like vertues that the garden Mint hath: and alfo to be good againft the ftinging of Bees and Wafpes, if the place be rubbed therewith.

B The fauour or fmell of the water Mint reioiceth the hart of man, for which caufe they ftrowe it in chambers and places of recreation, pleafure, and repofe, and where feafts and banquets are made.

C There is no vfe hecreof in Phificke, whileft we may haue the garden Mint, which is fweeter, and more agreeing to the nature of man.

\section{Of mountaine CMint, or Calamint. Chap.218.}

There be three Calamints, as Diofcorides teacheth. The later writers haue found more.

1 Calamintha montana vulgaris. Calamint,or mountaine Mint.

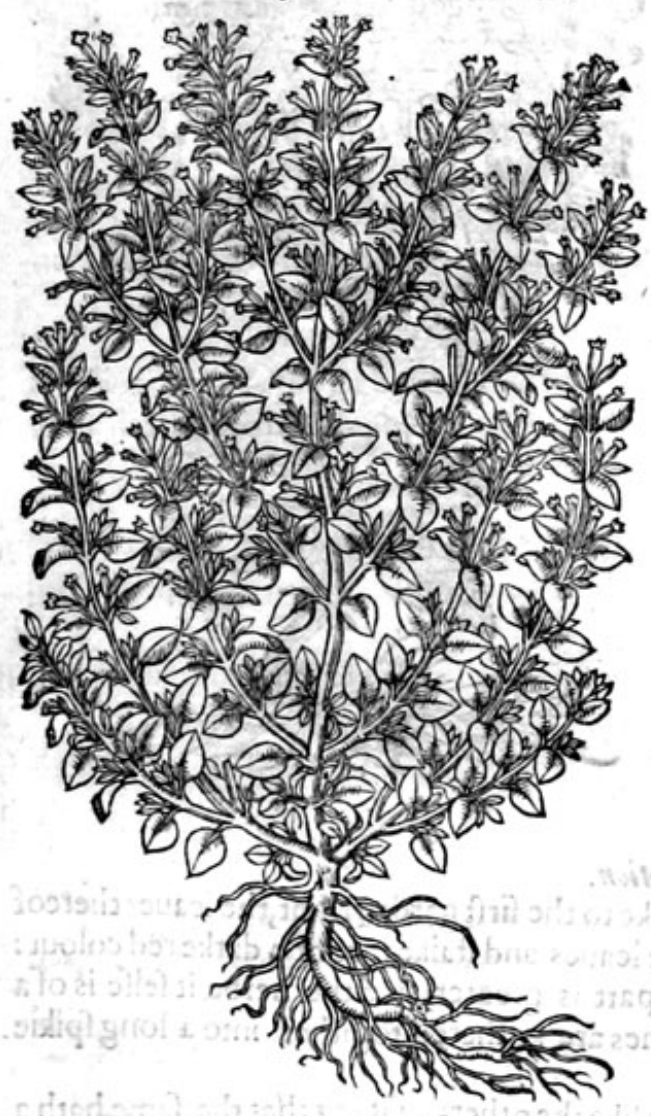

2 Calamintha montana preftantior. The more excellent Calamint.

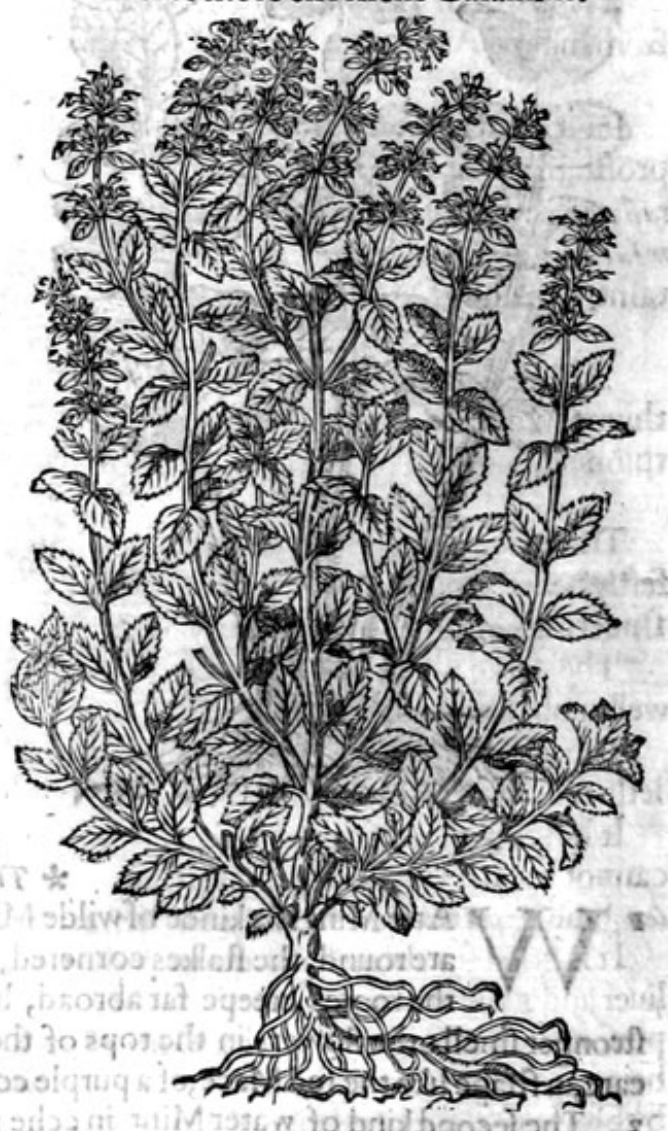

* The defoription.

I Ountaine Calamint is a lowe herbe, feldome aboue a foote high, parted itito many ches : the ftalkes are fower fquare, and haue ioints as it were, out of euerie one whiereof growe foorth leaues fomething rounde, leffer then thofe of Bafill, couered with a verie thinne hairie downe, as are alfo the ftalkes; fomewhat whitifh, and of a fweete finell: the toppes of the branches are gallantly deckt with flowers, fomewhat of a purple colour, then groweth the feede which is blacke : the rootes are full of ftrings, and continue.

2 This moft excellent kinde of Calamint hath vpright ftalkes a cubite high, couered ouer with a woolley moffines, befet with rough leaues like a nettle,fomewhat notched about the edges; among the leaues come foorth blewifh or skie coloured floivers; the roote is wooddie, and the wholeplant is of a very good fmell. 
There is another kinde of $\mathrm{Calamint}$ which hath harde fquare ftalkes, couered in like manner as the other, with a certaine hoaric or fine cotton. The leaues be in fhape like Bufill, but that they are rough; and flowers groming onely by one fide of the ftalke among the leaues, fometimes three or fower vpon a ftemme, of a blewifh colour. The roote is threddie.

There is a kind of ftinking Calamint, that hath alfo fquare ftalks couered with foft cotton,and al . moft creeping by the grounde, hauing euermore two leaues ftanding one againft another, fmal, and foft, not much vnlike the leaues of Penny roiall, faung that they are larger and whiter: the flowers growe about the ftalkes like wharles or garlands, of a blewifh purple colour; the roote is fmall and threddie: the whole plant of a bad finell.

* The place.

It delighteth to growe in mountaines, and in the ihadowie and gratuelly fides thereof: $\mathrm{it}$ is found in many places of Iraly and Fraunce, and in other countries: it is brought into gardens where it profpereth maruellous well, and very eafily foweth it felfe.I haue founde thefe plants growing vpon the chalkie grounds and high w.ies leading from Graues end vnto Canterburie, in molt places, or
almoft euery where.

$$
* \text { The time. }
$$

It flourifheth in fommer, and almoft all the yeere thorowe : it bringeth foorth flowers and feede from Iune to Autumne.

t Thenames.

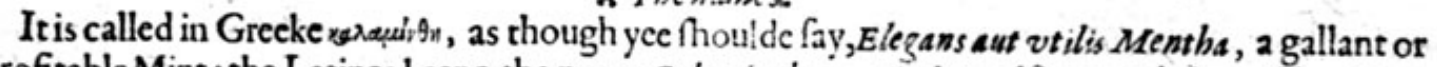
profitable Mint : the Latines kecpe the name Calamintha: Apuleisus alfo nameth it amiffe, Mentaftrum, and confoundeth the names one with another: the apothecaries do call it Montana Calamintha, Calamentum, and fometime Calamentum montanum: in French Calament : in Englifh Moun-
taine Calamint.

Thisetemperature.

This Calamint which groweth in mountaines, is of a feruent tafte and biting, hotte, and of a thinne fubftance, and drie after a fort in the third degree, as Galen faith: it digefteth or wafteth away
thinne humours, it cuttech and maketh thicke humours thinne.

$$
* \text { The vertues. }
$$

Therefore being inwardly taken by it felfe, and alfo with meade, or honied water, it doth mani- A feftly heate, prouoketh fweate, and confumeth fuperfluous humours of the bodie, it taketh away the
fhiuerings of agues that come by fits. The fame alfo fallet oyle performeth, in which it is boiled, if the bodie bee annointed and B
well rubbed and chafed therewith.

The decoction thereof drunke prouoketh vrine, bringeth down the monthly fickenes, and expel- C leth the childe, which alfo it doth being but onely applied.

It helpeth thofe that are brufed, fuch as are troubled with cramps and conuulfions, and that D cannot breath vnleffe they holde their neckes vpright(that haue the wheafing of the lungs faith $G_{2}$ len ) and it is a remedie faith Diofcorides for a cholericke paffion, otherwifecalled the Felonie.

It is good for them that have the yellowe iaunders, for that it remooueth the ftoppings of the $E$ liuer and gall, and withall clenfeth:being taken aforehande in wine, it keepeth a man from being poifoned : being inwardly taken, or outwardly applied, it cureth them that are bitten of ferpents: by blowes or drie beatings, making the skin faire and white, but for fuch things ( fats that come better to be laide to greene then dric. Ir killet all o to greene then dric. into the eares doth in like maner kill the wormes thereof. Plinie faith, that if the iuice be conucied vp into the nofthrils, it ftancheth the bleeding at the G
nofe, and the roote (which Diofcorideswriteth to begood for nothing) helpeth the fquincie if it be
gargarized,or the throate wafhed herewith gargarized, or the throate wafhed therewith, being vfed in Cute, and Myrtle feede withall.
It is applied to thofo

It is applied to thofe that haue the Sciatica, or ache in the huckle bone, for it draweth the humor $\mathbf{H}$ from the very bottome, and bringeth a comfortable heate to the whole ioint; P.sulis UEgineta Fith, that for the paine of the hauncles or huckle bones, it is to be vfed in glifters. Being much eaten, it is good for them that hauc the leprofie, fo that the patient drinke whaie af. I
ter is, 25 Diofcorides witneffeth. 


\section{THE SECOND BOOKE OF THE}

$\mathrm{K}$ Apuleius affirmeth, if the lcaues be often eaten, they are a fure and certaine remedie againft the leprolie.

L There is made of this an antidote, or compofition, which $G_{\text {alen }}$ in his fourth booke of the gouernment of health, defcribeth by the name of Diacalamint hos, that doth not onely notablie digeft or wafte awaie, but alfo is maruellous good for yoong maidens that want their courfes, if their bodies be firft well purged, for in continuaunce of time it bringeth them downe verie gently without force.

\section{Of Bawme. Chap.219.}

* The kindes.

Tere be diuers herbes comprehended vnder this generall title Melsfa, or Bawme, taking their

1 Meliffa. Bawme.

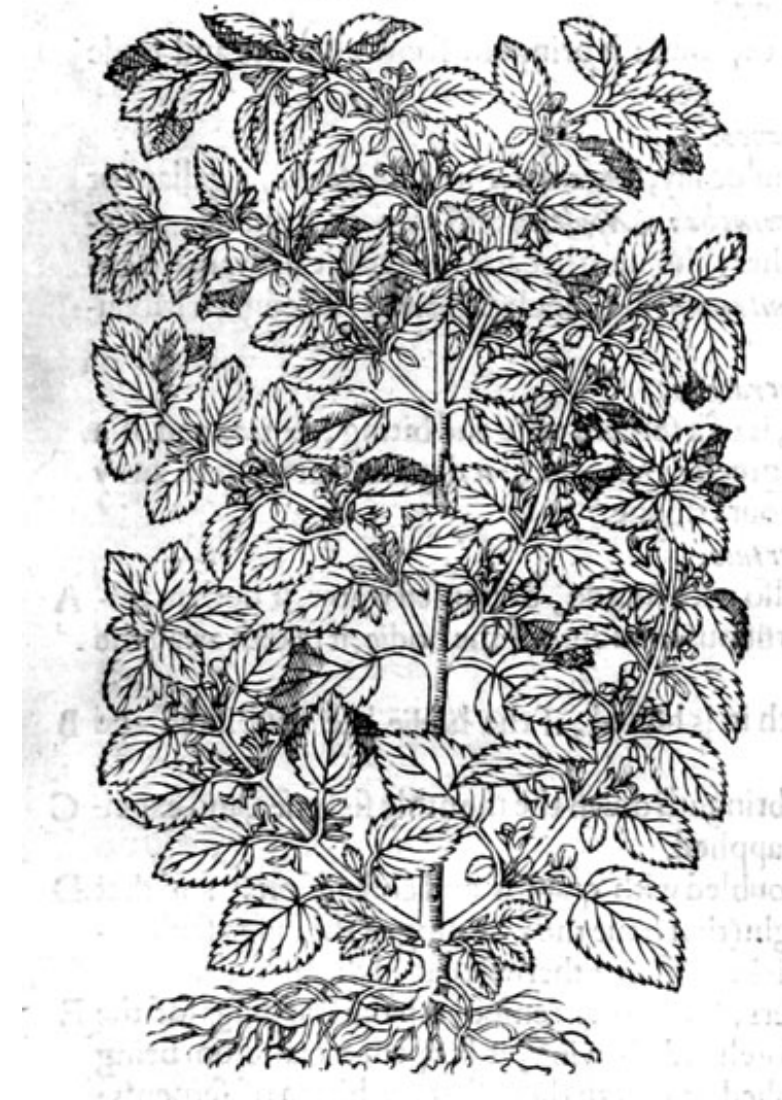

2 Meliffa Turcica. Turkie Bawme.

* The defcription.

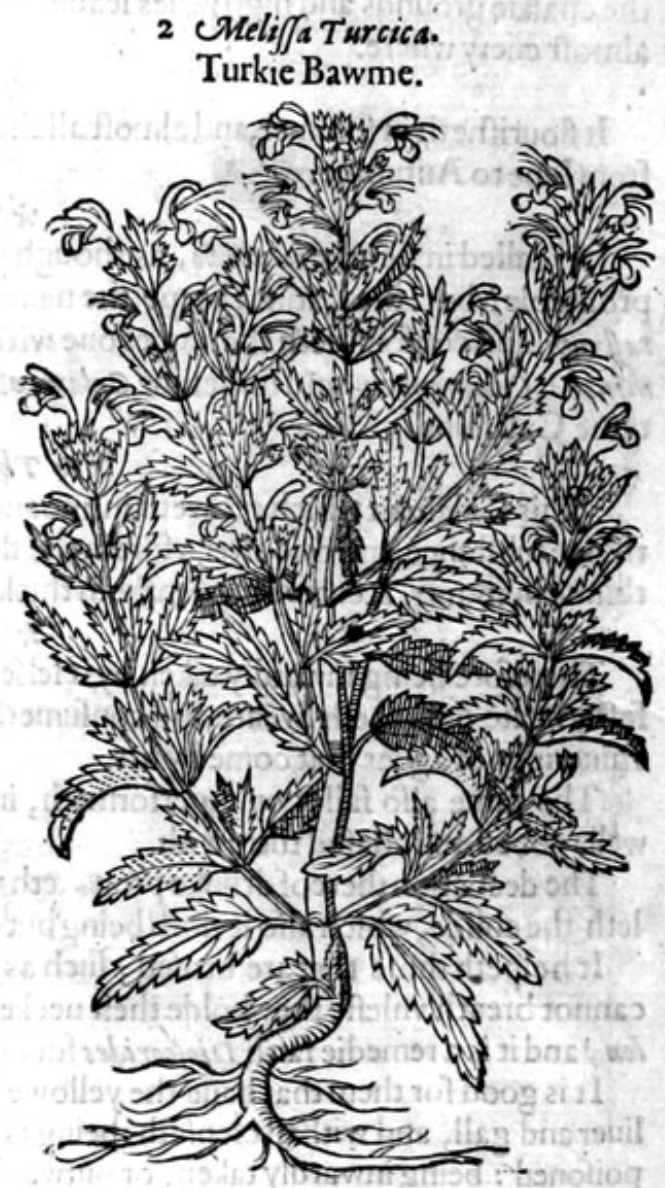

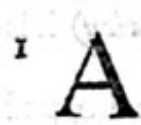
Piaftrum, or Meliffa, is our common beft knowne Balme, or Baume, hauing many fquare fmell,drawing neere in fmell and Ballote, or blacke Horehound, but larger, of a pleafaunt lour; the roote of a wooddie fubftance.

2 The feconde kinde of Bawme was brought into my garden and others by his feedefrom the parts of Turkie,wherefore we haue called it Turkie Balme: it excelleth the reft of the kindes if you my rude pen can deliuer. This rare plant hath fundre and deferueth a more liuely defcription then braunches, mounting to the height of a cubite andrie fmall, weake, and brittle fquare ftalkes and mander, or scordium to the height of a cubite and fomewhat more, befet with leaues like to Gerted at the top. The fowers growe in finall very bluntly about the edges, but fomwhat fharpe poinmall 


\section{HISTORIEOF PLANTS.}

and threddie, and diech at the firft approch of winter, and muft be fowen anewe in the beginning of Maie,ingood and fertill ground.

Fuchfous fettech foorth a kinde of Balme hauing a fquare ftalke, with leaues like vnto cemmon Bawne, but larger and blacker, and of an cuill fauour; the flowers white, and much greater then thofe of the common Bawne : the roote hard and of a woodie fubitance

There is a kind of Balme called Herbs Iud tica, which L'Obelius calleth Tetrabit, that hath many weake \&etender fquate hairic branches; fome leaning backward, \& others turning inward, diuiding themfelues into fundric other fmallarmes or twigges, which ate befet with long rough leaties dented about, and fmaller than the leaues of Sage. And growing in another foile or climate; you hall fee the leaues like to the oken leafe; in other places like GMrrubium creticum, verie hoarie, which caufed Diofcorides to defcribe it with fo many fhapes, and alfo the flowers, which are fometimes blew and purple, and oftentimes white : the roote is fmall and crooked with fome hairieftrings $\mathrm{fa}$ ftened thereto. All the irhole plant dr aweth to the fauour of Balme, called Meliffa.

3 creliffa molucca leuis. Smooth Molucca Baume.

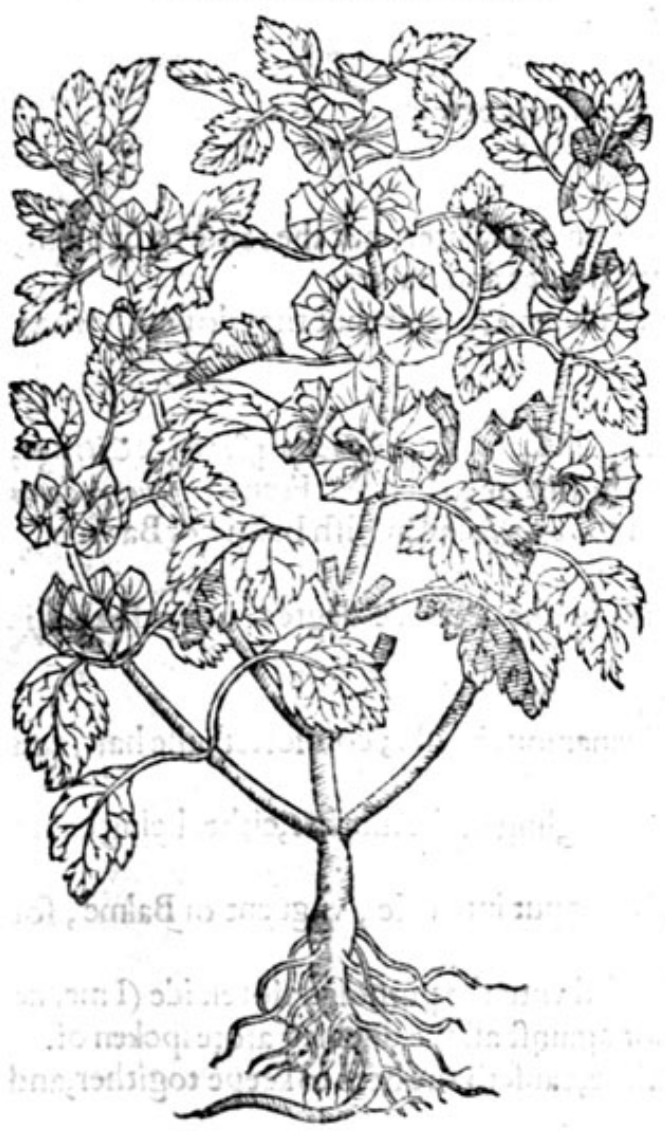

4 Molucca pinofa. Thornie Molucca Baune.

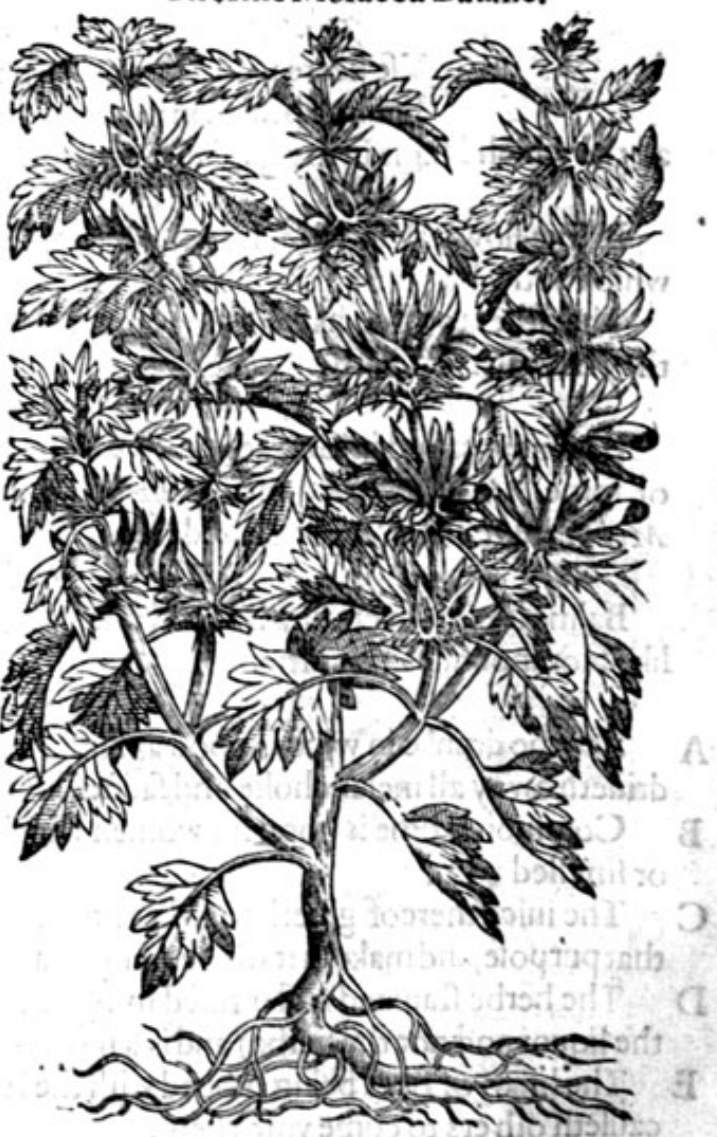

* The defaription.

3 There be alfo two other plants comprehended vnder the kinds of Balme, the one very like vnto the other, although not knowne to many Herbarifts, and haue beene of fome called by the title of Cardieca; the firft kinde Pena calleth Cardiaca Melica, or Molucca Syriaca, fo called for that it was firft brought out of Syria: it groweth three cubits high, and yeeldeth many fhootes from a wooddie roote, full of many whitifh ftrings: the ftalkes be rounde, fomewhat thicke, and of a reddith colour, which are hollowe within, with certaine obfcure prints, or fmall furrowes along the ftalkes with equall fpaces halfe kneed or knotted, and at euery fuch knee or ioint ftand twoleaues. one againft another, tufted like Melifa, but more rough and deepely indented, yet not fo deepely as our common Cardrac4, called Motherwoort, nor fo hharpe pointed:about the knees there come foorth fmall little prickles, with fixe or eight fmall open wide bels, hauing many corners, thinne like parchment, and of the fame colour, fomewhat ftiffeand long; and at the top of the edge of the 


\section{THE SECOND BOOKE OF THE}

bell, it is cornered and pointed with hharp prickles; \& out of the middle of this prickley bell, rifetha flower fomwhat purple tending to whiteneffe, not vnlike cur L.mium, or Cardiaca, which bringeth foorth a cornered fecde, the botiome flat and fmaller toward the top like a fteeple: the fatiour of the plant draweth toward the fent of Lamium.

4 The other kinde of Melica, otherwife called Molucca a perior, (whereof Pcna writeth) differeth from the laft before mentioned, in that the cups or bels wherein the flowers growe are more prickly then the firft, and much fharper, longer, and more in number : the ftalke of this is fowerfquare, lightly hollowed or furrowed: the feede three cornered, tharpe vpwarde like a wedge ; the tunnels of the flowers brownifh, a nd not fo white as the firft.

* Theplace.

Bawme is much fowen and fet in gardens, and oftentimes it groweth of it felfe in woods and mountaines, and cther wilde places; it is profitablie planted in gardens as Plinie writethin his $2 \mathbf{r}$. booke $\mathrm{I} 2$.chap.about places where Bees are kept, bicaufe they are delighted with this herbe aboue others, whereupon it hath beene called Apiastrum: for faith he, when they are Itraied away, they do finde their way home againe by it : as Virgill writeth in his Georgicks:

Huc tu iufjos a perge liquores, Trita Meliphylla, of Cerinthe ignobile gramen.

Vfe becre fuch helpe as husbandrie do vfually prefcribe,

Baulme brufed in a mortar and bafe Honic woort befide.

all the which I haue in my garden from yecre to yeere.

\section{ithe tome.}

Balme flowreth in Iune, Iulie, and Auguft; it withereth in the winter, but the roote remaineth, which in the beginning of the fpring bringeth foorth frefh leaues and ftalkes.

The other forts do likewife flower and Aourilh in Iune, Iuly, and Auguft; but they doperifh when they haue perfected their feede.

$* 7$ be names.

Bawme is called in Grecke uerawooumey, of $P$ liny Melittis : in Latine Meliffa Apiaftrum, \& Citrago, of fome Meliffophyllon, and Meliphyllon: in Dutch Confille ie greenn: in French Pougrade os Melffe: in Italian Cedronella, and Crantinta : in Spanifh Torongtl: in Englifh Balme, or Bawme.

$$
\text { * T hętemperature. }
$$

Balme is of temperature hot and drie, as Uutcen faith in the feconde degree: $G_{a}$ len faithit is like Horehounde in facultie.

\section{$*$ The vertues.}

A Bawme drunke in wine, is good againit the bitings of venemous beafts; comforteth the hart, and driueth away all melancholie and fadneffe.

B Common Balme is good for women which haue the ftrangling of the mother, either being eaten or fmelled vinto.

C The iuice there of glueth togither greene woundes, being put into oile, vnguent or Balme, for that purpofe, and maketh it of greater efficacie.

D The lierbe ftamped and infufed in Aqua vit a, may be vfed vnto the purpofes aforefaide (I meane the liquor and not the herbc) and is a moft cordiall liquor againft all the difeafes afore fpoken of.

E The hiues of Bees being rubbed with the leaues of Balme,caufeth the bees tokeepe togither,and caufeth others to come vnto them.

F The later age togither with the Arabians and Mauritianes, affirmeth Balme to be fingular good for the hart, and to be a remedie againft the infirmities thereof; for Muicen in his booke written of the infirmities of the hart, teacheth that Bawme maketh the hart merrie \& ioiful,and ftrengtheneth the vitall fpirits.

G Serapio affirmeth it to be comfortable for a moift and colde ftomacke, toftirre vp concoction, to open the ftopping of the braine, and to drite awaic forrowe and care of the minde.

H Diofcorides writeth that the leaues drunkc with wine or applied out wardly, are good againft the ftingings of venemons beafts, and the bitings of madde dogs; alfo it helpeth the toothach the mouth being wafhed with the decoction, and is likewife good for thofe that cannot take breath vnlefie they hoide their neckes vpright.

I It helpeth (faith the fame author) the leaues being mixed with falt, the kings euill, or any other hard fwellings and kerneis, and mitigatech the painc of the gout. 


\section{HISTORIE OF PLANTS.}

Smithes Bawme, or carpenters Bawme, is moft fingular to heale vp green wounds that are cut $K$ with iron; it cureth the rupture in fhort time; it ftaieth the whites: Diofcorides and Plimy haue attributed like vertues vnto this kind of Bawme, which they call Iron woort. Theleaues faic they being applied, clo e vp wounds without any perill of in flammation: Flivie faith that it is of fo great vertue, that though it be but tied to his fworde that hath giuen the wounde, it ftancheth the bloode.

\section{Of Horebound. Chap.220. \\ * The kiniles.}

D Iofourides and others of the auncient writer s haue fet downe two forts onely of Horehoundes, theone white Horebounde, and the other blacke; notwithitanding the later writers haue difcouered and founde out more forts, as well wilde as tame, as shallbe declared.

I Marrabium albam.

White Horehound.

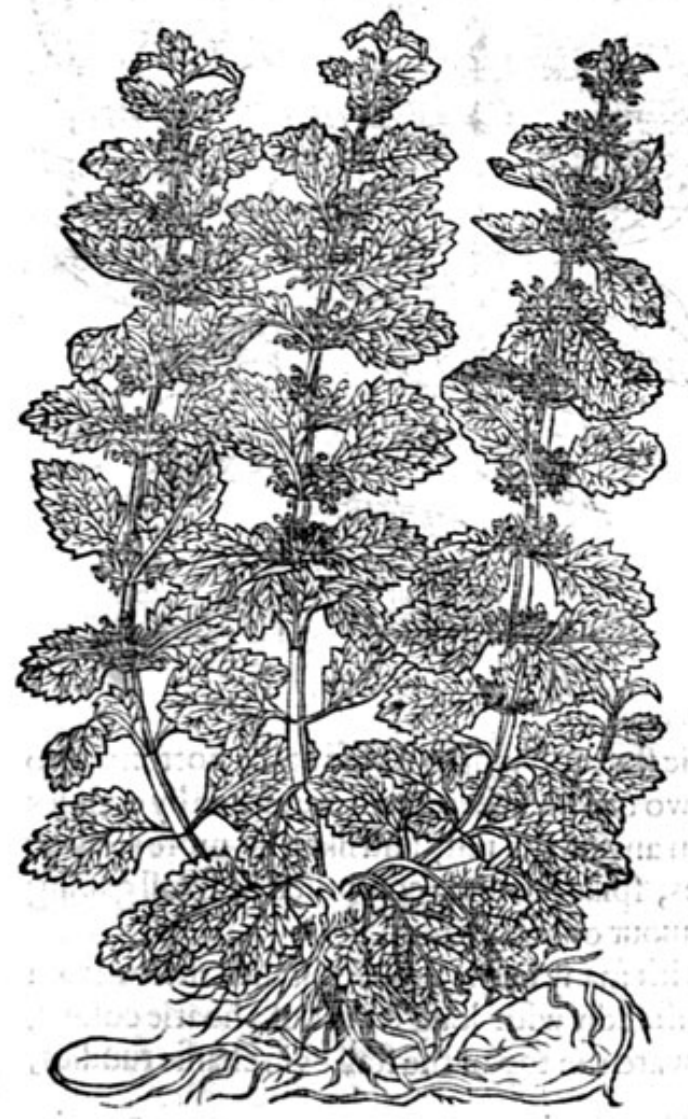

2 Marrubiamicandidam.

Snowe white Horehound.

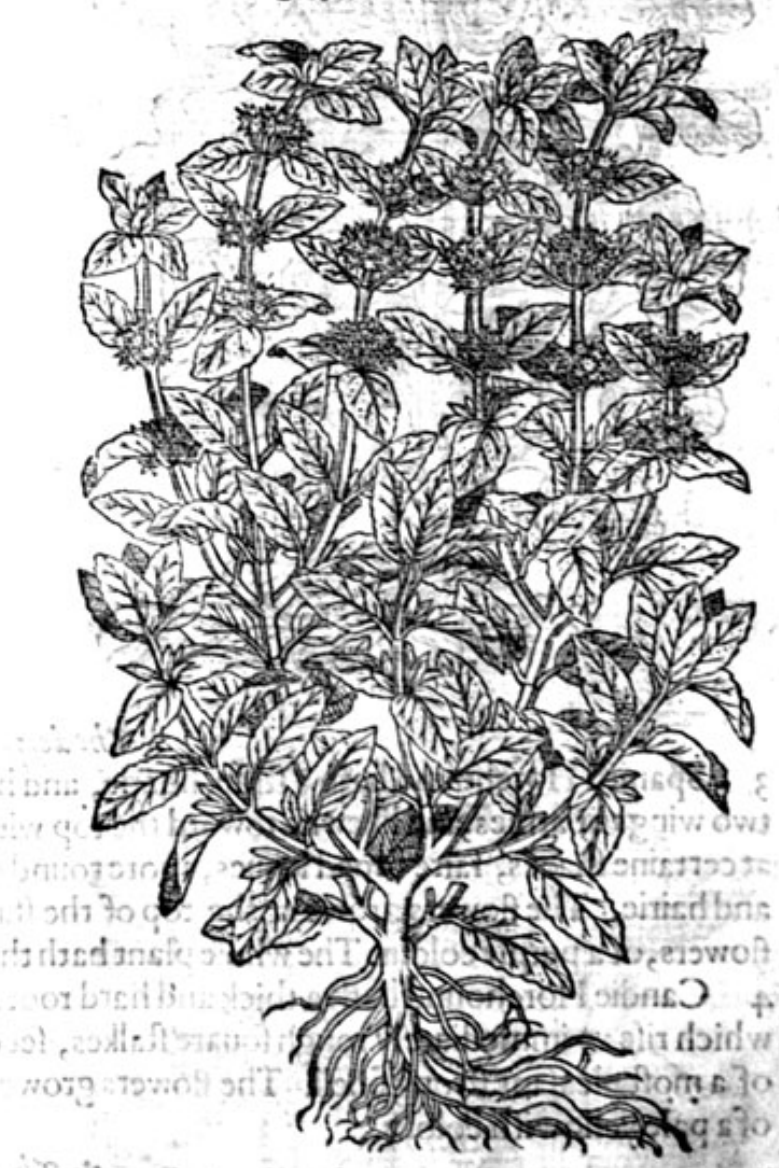

Tite Horehound bring * The defcriptjon.

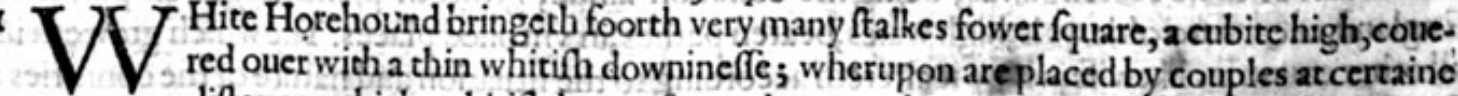
diftances, thicke whitifh leaues fomewhat round, wrinkled, and nicked on the edges, and couered ouer with the like downinefle:-from the bofomes of which leaves come foorth tmall flowers, of 2 faint purplifh colour, fet round about the ftalke in round wharies, which turne into Sharpe prickley huskes after the flowers be paft. The whole plantis of a ftrong fauour, buit not vn. pleafant. The roote is threddie.

2 The fecond kinde of Horehound hath fundric crooked flender ftalkes, diuided intomany finall branches, coucred ouer with 2 white hoarineffe, or cotronie downe. The leatues are likewife hoaric and cottonie, longer and narrower than the precedent, lightly indented about the edges, and harp: ly pointed like the Turkie Bawme, and of the fame bigneffe, hauing finall wharles of white flowers 
and prickly rundles or feede veffels : about the ftalkes be certaine diftances. The roote is likewife threddie.

3 Marrubium Hi.panicum. Spanifh Horehound.

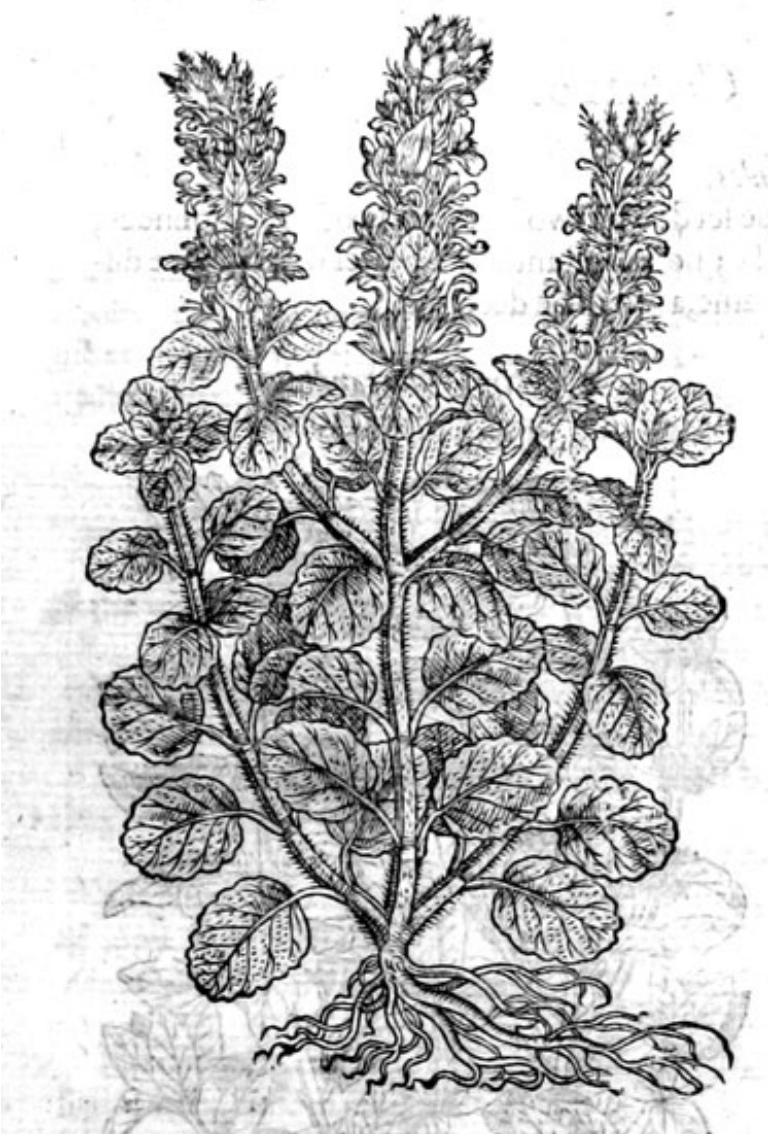

4 Marrubium Creticum.

Candie Horehound.

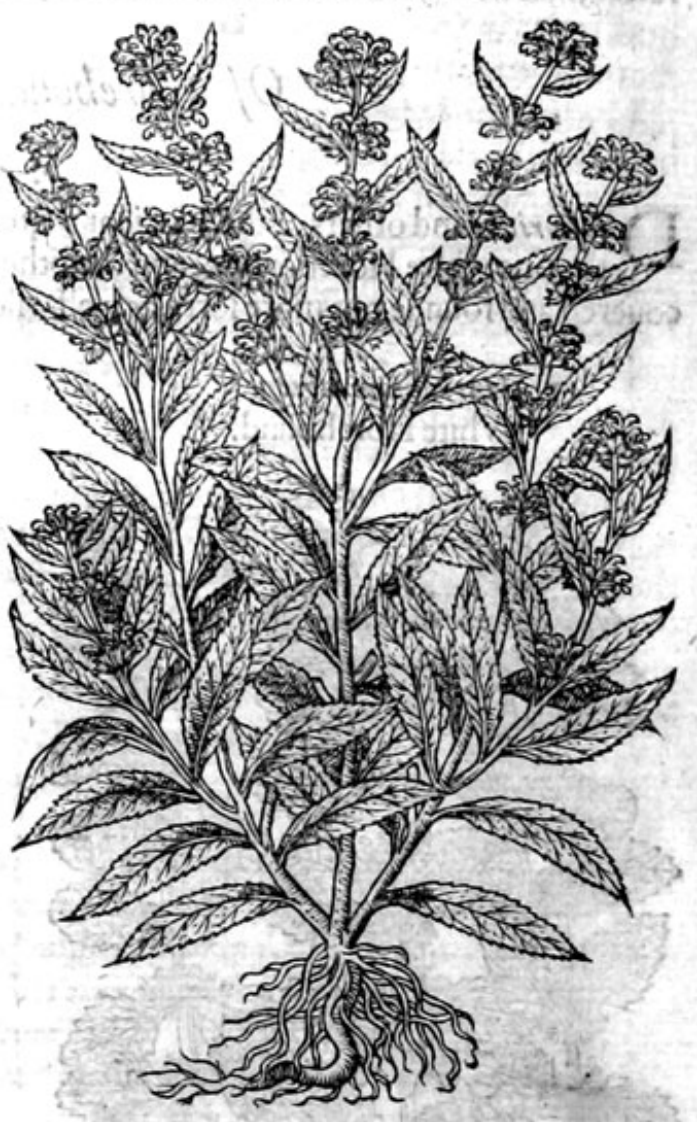

* The defcription.

3 Spanith Horehound hath a ftiffe, hoarie, and hairie ftalke, diuiding it felfe at the bottome into two wings or armes, and likewife toward the top with two others, whereupon are placed by couples at certaine fpaces, taire broad lezues, more round than any of the reft, and likewife more woollie and hairie. The flowvers growe at the top of the ftalkes, f pike fafhion, compofed of fmall gaping flowers, of a purple colour. The whole plant hath the fauour of Stœechados.

4 Candie Horehound hath a thick and hard roote, with many haírie threds faftened therto, from which rife vp immediately rough fquare ftalkes, fet confufedly with long leaues of a hoaric colour, of a moft pleafant ftrong finell. The flowers growe toward the top of the ftalkes in chaffic rundles, of a pale yellowith, colour.

The firft of the place.

Finde, groweth plentifully in all places of England, neere vrrto olde wals, high waies, beaten pathes, in vntoiled places. The which groweth in all other countries likewife, where it altereth according to the fituation and nature of the conntries: forcommonly that which groweth in Candie, and in Hungaric, is much whiter, and of a fweeter fmell, and the leates oftentimes narrower, and leffer than that which groweth in England, and thefe northren regions. $*$ The time.

They flower in Iuly and Augut, and that in the fecond yecre after the fowing of them.

$$
* \text { The names. }
$$

It Horehound is called in Greeke weginov: in Latinc Marrubium : in fhops Praßsum, and often Marrubium. Therebe certaine baftard names found in Apuleius, as Melitten., Labeonia, and Vleeraria : in Italian Marrubio : ir Spanifh Marratio: in Dutch TPattotie : in French Marubin: in
Englifh Horehound. 


\section{HISTORIE OF PLANTS.}

* Tietemperature. tafte.

Horehound, as Galen teacheth, is hot in the fecond degree, and drie in the third, and of a bitter

* The vertues.

Common Horehound boiled in water and drunke, openeth the liuer and fpleene, clenfeth the $\mathbf{A}$ breft and lungs, and preuaileth greatly againft an old cough, the paine of the fide, fpitting of blood, the ptificke, and vlcerations of the lungs.

The fame boiled in wine and drunke, bringeth downe the termes, expelleth the fecondine, after B birth,or dead childe, and alfo eafeth thofe that haue fore and hard labour in childbearing.

Sirupe made of the greene frefh leaues and fugar, is a moft fingular remedie againft the cough, C and wheefing of the lungs.

The fame firupe doth woonderfully and aboue credit, cafe fuch as haue lien long ficke of any D confumption of the lungs, as hath beene often prooued by the learned Phifitions of our London Colledge.

It is likewife good for them that haue drunke poifon, or that haue beene bitten of ferpents. The $\mathrm{E}$ leaues are applied with honie to clenfe fowle and filthle vicers. It ftaieth and keepeth backe the pearle or web in the eies.

The iuice preffed foorth of the leaues, and hardened in the funne, is very good for the fame F things, efpecially if it be mixed with a little wine and honie, and dropped into the eies it helpeth them, and cleereth the fight.

Being drawen vp into the nofthrils, it clenfeth the yellownes of the eies, and ftaieth the running $\mathbf{G}$ and watering of them.

\section{Ofwilde Horebound. Chap.221.}

I Stachys.

Wilde Horehound.

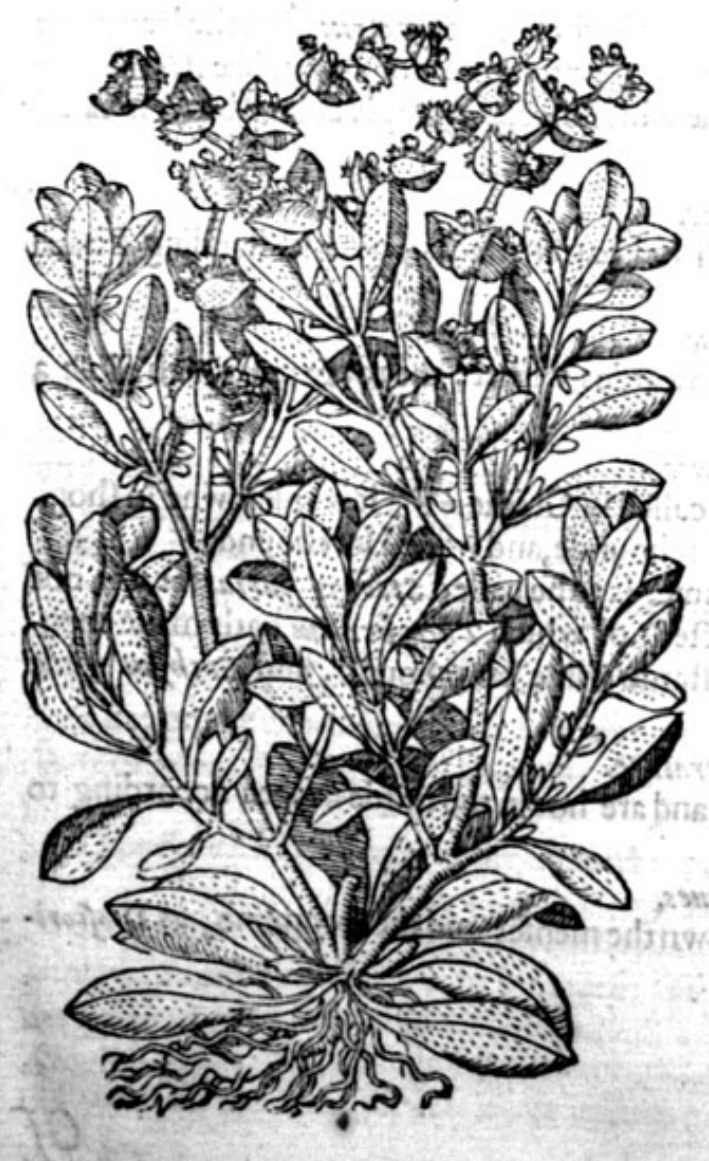

2 Stacbys Fuchfit. Wilde ftinking Horehound.

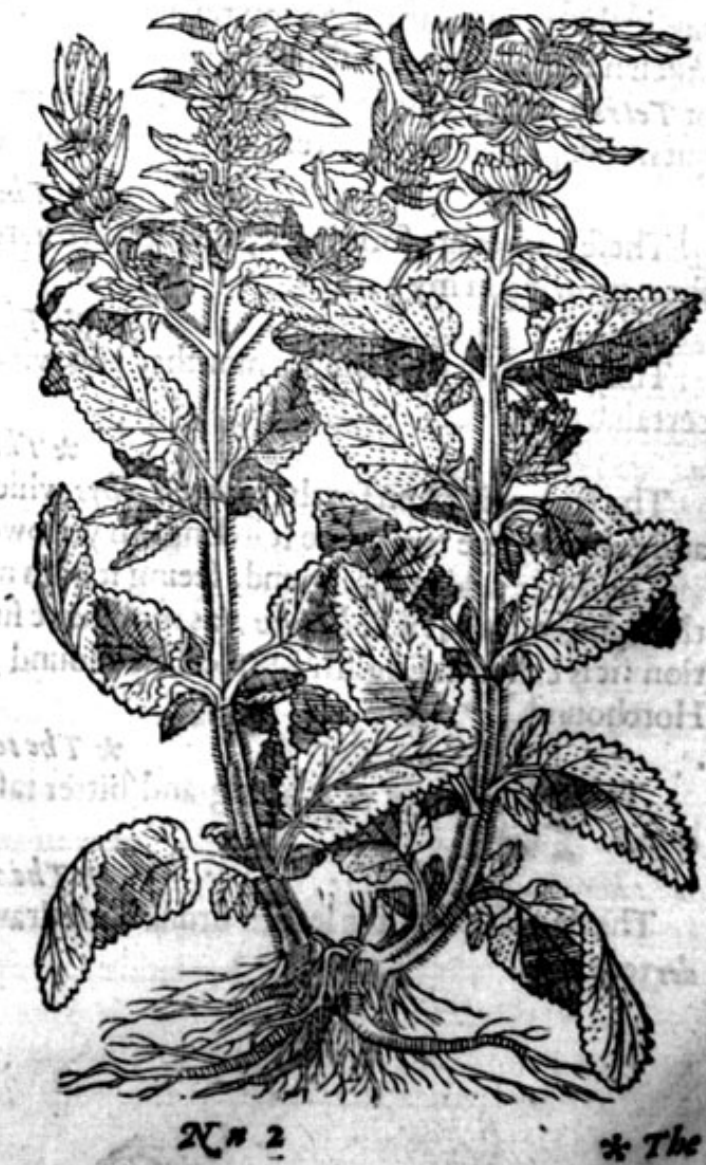




\subsection{THE SECOND BOOKE OF THE}

$$
\text { * The defcription. }
$$

1 Ilde Horchound is alfo like to common Horehound: there rife from the roote heerof a great number of ftalkes, high or iointed, and out of euery ioint a couple of leaues oppofite or fet one againft another, fomewhat harde, a little longer then thofe of common Horchound, and whiter, as alfo the ftalkes are fet with foft haires, and of a fweete finell: the flowers do compaffe the ftalke about as thofe do of common Horehound, but they are yellow, and the wharles be narrower : the roote is wooddie and durable.

2 Befides this there is alfo another defcribed by Fuchfrus; the ftalkes heereof are thicke, fower fquare, nowe and then two or three foote long:the leaues be broad, long, hoarie, nicked in the edges, hairie as are al fo the ftalkes, and much broader then thofe of common Horehound: the flowers in the whories which compaffe the ftalke about,are of a purple colour; the feed is round and blackifh: the roote hard and fomthing yellowe.

There is a kinde of wilde Horehound, called Stachys Spuria Flantlrorum, which doctor Pensie the phifition brought firft into England out of the clifts of the moumatnes Iura and Salana : this herbe beareth braue skie-coloured flowers ftanding in thrummie, prickley, fcaley or fhellie crownets, diuiding it felfe towarde the top into fundry little braunches, fet full of leaues like to Scabious, two togither one againft the other, with a thin film or peele between them clofing the ioints, which make a finall three cornered difh, as in the Teafill, but much lefler, to hold the dewe and water that falleth.

There is another wilde Horehound of Mountpelier, called Sideritis Mon/pelliaca Scordicides, fuse Scordy folvo: being that kinde of Siderițis, wilde Horehound which is like vnto Scordivem, or water Germander, which groweth to the height of a Palme and a halfe, with many Imall branches rifing vpright, of a wooddie fubftance, hauing the tops \& fpokie cronets of Hyffope, but the leaues do refemble Diofcorides S6ordism, faue that they be fomewhat leffer, ftiffer, more wrinckledor curled and hairie, then Tetrabit, or Iudaical herbe: the flowers do refemble thofe of common Sauorie, in tafte bitter, and of an aromaticall fauour.

Mountaine Sideritis being alfo of the kindes of Horehound, was firf founde by $V$ alerandus Don$r_{a z}$, in the mountaines of Sauoy, refembling very well the herbe Ferruminatrix, but the leaues are much narrower, otherwife like, hauing fmall rough rundlets or tufts, pale of colour like Marrubium or Tetrabit: the roote long and bending, of a wooddie fubftaunce, and purple colour, bitter intafte, but not vnpleafant, whofe vertue is yet vnknowne.

\section{* Theplace.}

Thefe herbes are forreiners, they growe in rough and barren places, notwithftanding I haue themgrowing in my garden.

\section{* The time.}

They flower in the fommer months, and wither towardes winter: the roote remaineth aliue a certaine time.

The former is taken for the right Stachys, which is called in Greeke saxis: it is vnknowne in thops and euerie where : we name it in Englifh yellowe Horehounde, and wilde Horehounde.

The other wilde Horehound, feeing it hath no name, is to be called Stachys _puria : for it is nor the right, neither is it Sphacelus, (as moft haue fufpected) of which Theopbrastus hath made mention :it is called in Englifh purple Horehound, baftarde wilde Horehound, and Fuchfirm wilde Horehound. Galen.

Thefe herbes are of a biting and bitter tafte, and are hot in the thirde degree according to

* The vertues.

The decoction of the leaues drunk doth draw down the menfes and the fecondine, as Diofcori- : des teacheth. 


\section{Of water Horebound. Chap.222.}

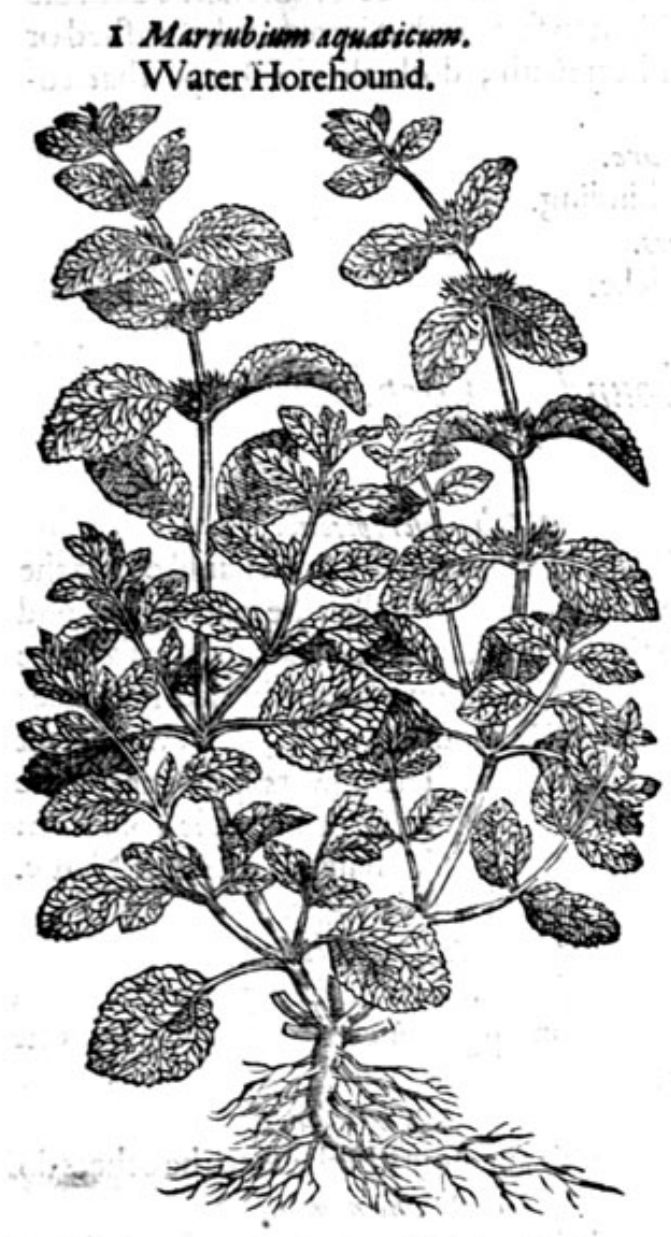

2 Marribium aguaticum acutum. Sharpe pointed water Horehound.

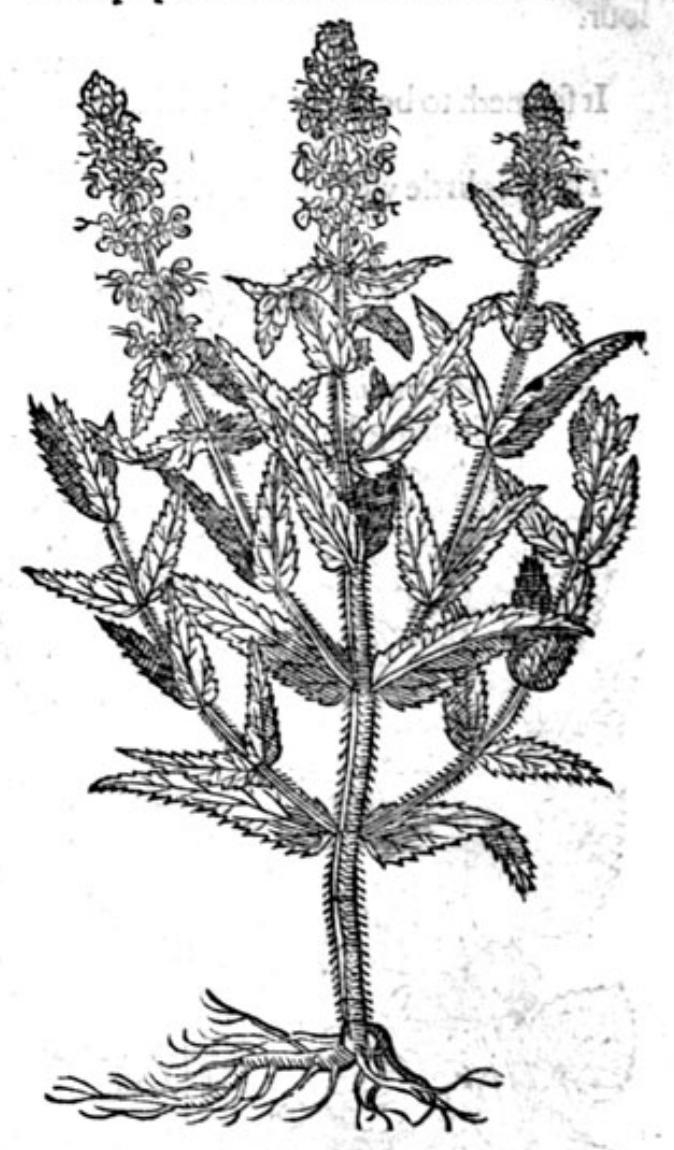

* The defcription.

1 T Ater Horehound is very like to blacke or ftinking Horehound in ftalke and flowred cups, which are rough, pricking, and compaffing the ftalkes rounde about like garlandes: the leaues thereof be alfo blacke, but longer, harder, more deepely gaf hed in
the edges then thofe of ftinking Horehound, yet not hairic at al, but wrinkeled: the flowers be fmal and whitifh: the roote is faftned with many blacke ftrings.

2 Sharpe pointed water Horehound hath an vpright rough ftalke, and hairie, which diuideth it felfe towarde the top into other branches, whereon do growe broade rough leaues, fharpe pointed, of a ftrong fmell. The flowers growe at the top of the ftalkes of a purplifh colour : the root is tough
with fome threds annxed thereto.

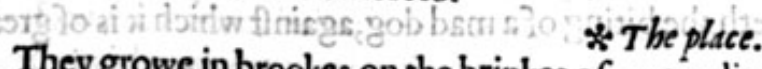

They growe in brookes on the brinkes of water ditches, and neere vntomotes, for it requireth ftore of water, and groweth not in drie places.

They flourilh and flower in the fommer $*$ The time.

The

It is called Squatile ahd Palustre Marrubium : in Englifh water Horehound, and marrifh Horehound. Matbiolus taketh it to be Species Sideritidis; or a kinde of Iron woort, which Diofcorides hath defcribed in the firft place; but with this doth better agree that which is called Herba Iudaica, or: Glidewoort; itmuch leffe agreeth with sider itis fecunda, or the feconde Ironwoort, which thing
atio hath his fauorers, for it is like in leafe to none of the Fernes. Some alfo thinke good to call it 
Herba AEgptia, bicaufe they that counterfet themfelues Egyptians (fuch as many times wan-" der like vagabonds from citie to citie in Germanie)do vfe with this herbe to giue themfolues a fwart colour,fuch as the Egyptians and the people of Afrike are of; for the iuice of this herbe doth die euerie thing with this kinde of colour, which alfo holdeth fo faft, as that it cannot be wafhed or wiped awaic: in fo much as linnen cloth being died heerewith, doth alwaies keepe that colour.

\title{
* Thetemperature.
}

It feemeth to be colde, and withall very aftringent or binding.

\author{
* The vertues.
}

There is little yfe of thefe water Horehounds in Phificke.

\section{Of blacke orftinking Horebound. Chap.223.}

- Marrubitum nigrum. Stinking Horehound.

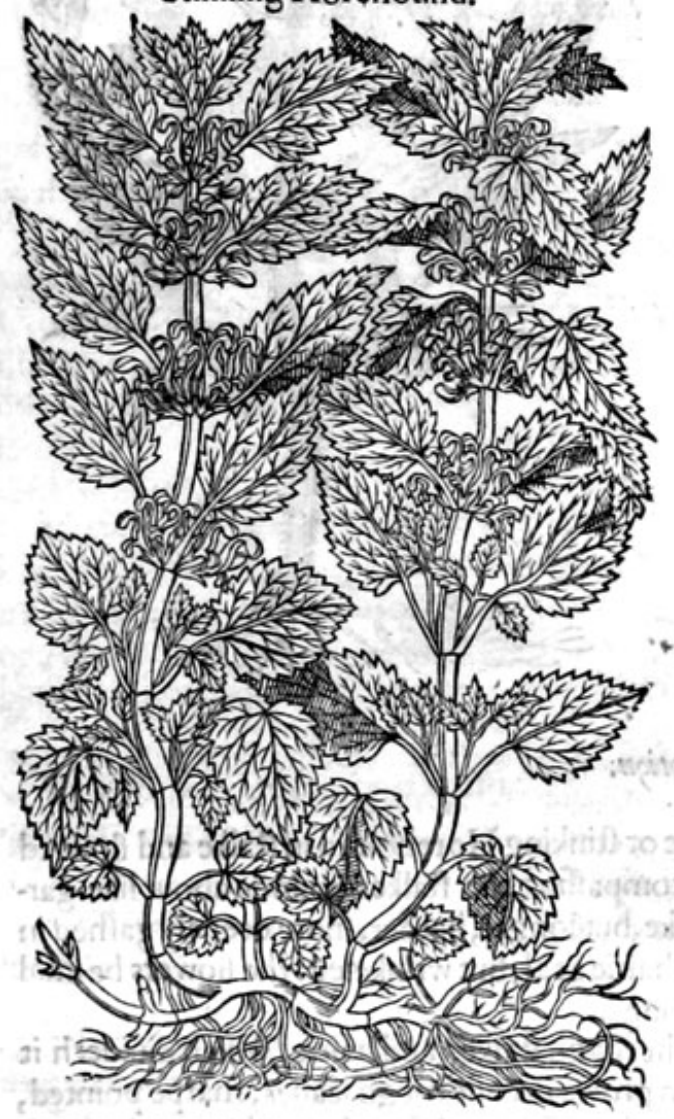

* The defoription.

D Lacke Horehound is fomewhat like vnto the white kinde. The ftalkes be alfo fquare and hairie. The leaues fomwhat larger, of a darke fwart or blackifh colour, fomewhat like the leaues of Nettles, fnipt about the edges, of an vnpleafant and ftinking fauour. The flowers growe about the ftalkes in certaine fpaces, of a purple colour, in Thape like thofe of Archangell or dead Nettle. The roote is fmall and threddie.

$$
* \text { Theplace. }
$$

It is found in gardens among pot herbes, and of entimes among ftones and rubbirh in drie foiles.

\section{* The time.}

It flowreth and flourifheth when the others do: * The names.

It is called in Grecke farswrin, and winav wediror,as Plinie teftifieth in his 27.booke, 8 chapter: of fome Marrubiaftrum, or Marrubium purium, or baftard Horehound: in fhop' Prafium fat tidum, and Ballote: in Italian Marrubiastro: in Spanifh cMarratuio negro: in French Marubin noix \& puant : in Englifh itinking Horehound.

* The temperature.

- Stinking Horchound is hot and die Paulus Aegineta tea facultic.

* The vertues.

(19) efficacie, as Diofcorides writeth.

The leaues rofted in hot embers do wafte and confume away hard lumpesor hit the fundament.It alfo clenfeth fowle and filthie vlcers, as the fame author teacheth.

$$
\text { Of Archangell, or dead Nettle. Chap.224. }
$$

*The kindes.

Here be diuers fortes of dead Nettles, or kindes of Horchound, differing in many notable
points,as fhall be declared. 

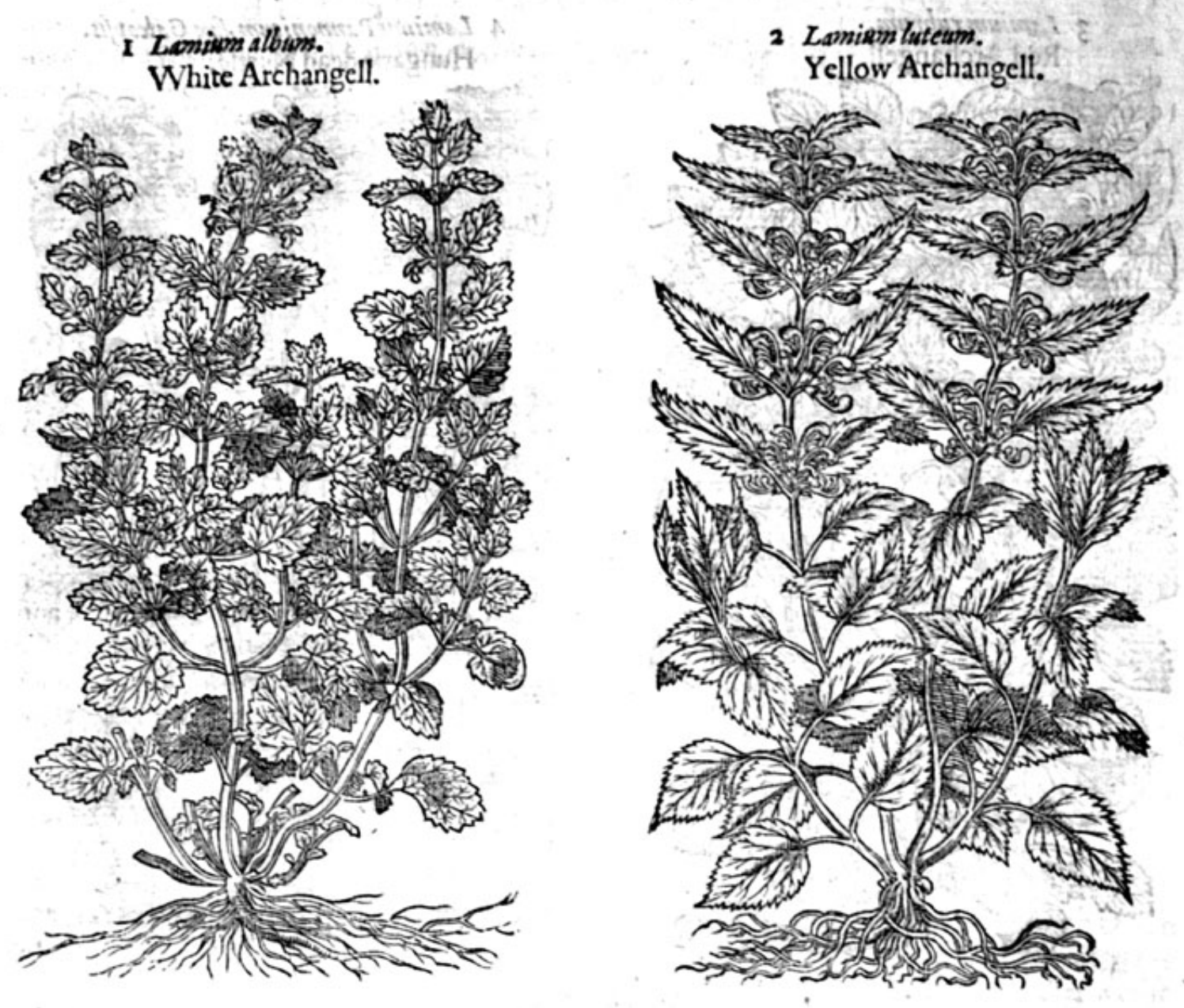

* The defoription.

IT Hite Archangell hath fower fquare ftalkes, a cubitchigh, leaning this way and that way, by reafon of the great waight of his ponderous leaues, which are in fhape like thofe of Nettles, nicked round about the edges, yet not ftinging at all, but foft, and as it were downie. The flowers compaffe the ftalkes round about at certaine diftances, euen as thofe of Horehound do, whereof doubtleffe this is a kinde, and not of Nertles, as hath beene generally holden, which flowers are white of colour, fafhioned like to little gaping hoods or helmets. The roote is very threddie.

2 Yellow Archangell hath fquare ftalkes rifing froma threddic roote, fet withileaties by couples, very much cut or hackt about the edges and harpe pointed. The vppermoft whereof are oftentimes of a faire purple colour. The flowers growe among the fame leaues of a gold yellow colour, fafhioned like thofe of the white Archangell,but greater, and more wider gaping open. 3 Red Archangell being called V rtica non mordax, or dead Nettle, hath many leaues fpred vpon the ground; among which rife vp ftalkes hollowe and hairie, whereupon do growe rough leaues of an ouerworne colour, among which come foorth purple flowers, fet about in round wharles, or rundles. The roote is fmall, and perifheth at the firft approch of winter.

4 Dead Nettle of Hungarie hath many rough leaues yery much curled or crumpled, dike thofe of the ftinging Nettle, of a darke greene colour, fnipt about the edges like the teeth of a fawe 5 fet ypon a fower fquare ftalke by coupless from the bofome of which leaues come foorth the flowers clofe to the ftalkes, of a perfect purple colour, in hape like thofe of the white Archangell, gaping like a dragons mouth, the lower chap where of is of a bright purple fpetted with white, which being paft, there doth follow feedeinclofed in rough husks, with fine fharpe points fticking out. The roote is thicke, tough, confifting of many threds and long ftrings. 


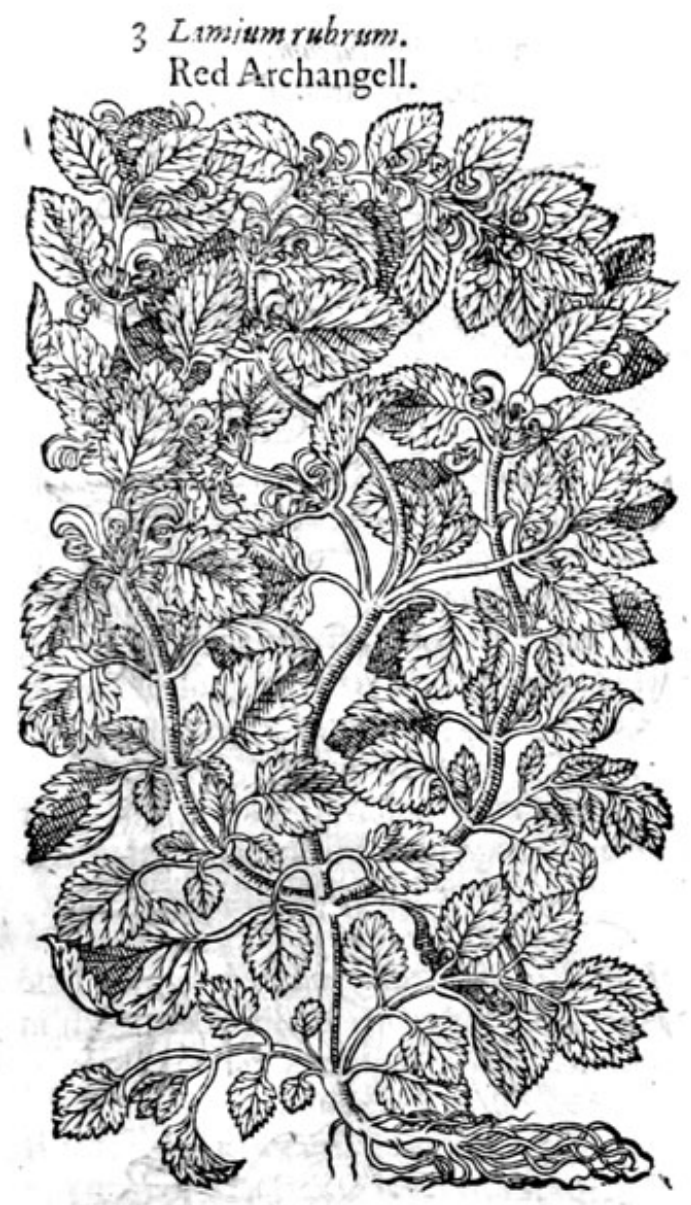

4 Lamium Pannonicum, fiue Galeop/is. Hungarie dead Nettle.

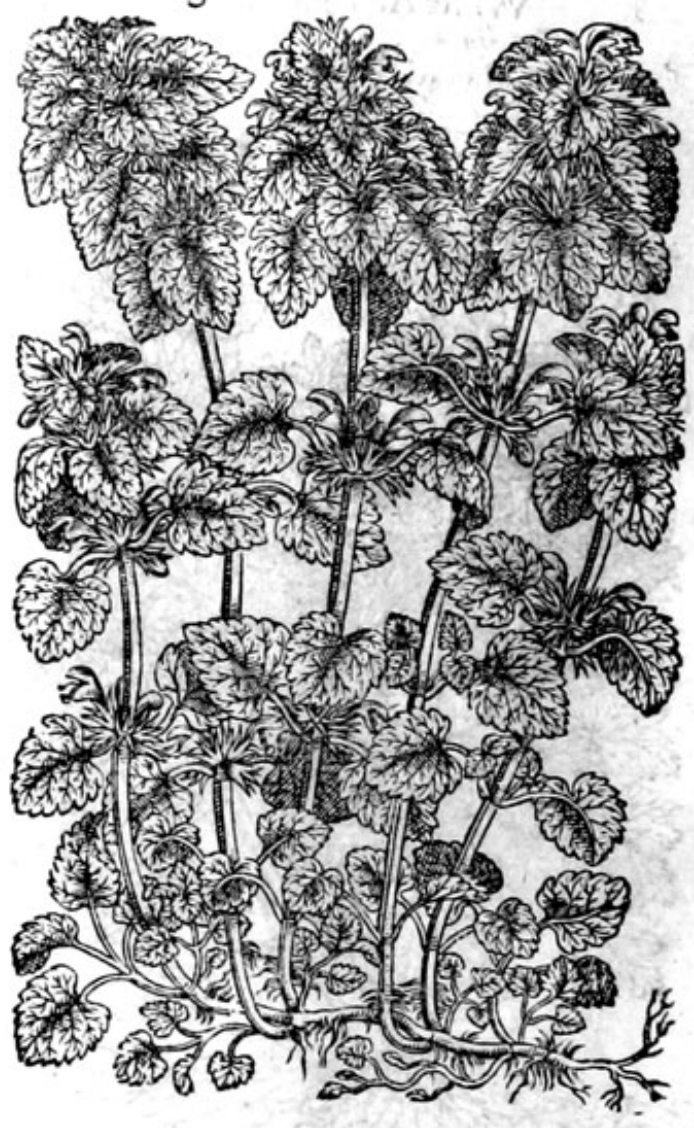

* The place.

Thefe plants are founde vnder hedges, olde wals, common waies, among rubbilh, in the borders of fields, and in earable grounds, oftentimes in gardens ill husbanded.

That with the yellow flower groweth not fo common as the others. I hate found it vnder the hedge on the left hand as you go from the village of Hampfteed neere London to the church, and in the wood thereby, as alfo in many other copfes about Lee in Effex, neere Watford and Bufhic in Midlefex, and in the woods belonging to the Lord Cobham in Kent.

The The time.

$*$ The time.
Tommer long.

* The names. Archangell is called of fome $V$ rtica iners, and Mortua, of fome Lamiven : in Englifh Archangell,
blinde Nettle, and dead Nettle.

They archoter and drier than $\%$ The temperature.

$\div$ The temperature.
ttle, approching to the temperature of Horehound.

* The vertues.

A Archangell ftamped with vineger, and applied in manner of a pultis, taketh away Wens and hard fwellings, the Kings cuill, inflammation of the kernels vnder the eares and iawes, and alfo hot fieric inflammations of the kernels of the necke, armeholes, and flanks.

B It is good to bathe thofe parts with the decoction of it as Dio/cordes and Plinie faie.

C The later Phifitions thinke that the white flowers of Archangell do ftaie the whites, and for the fame purpofe diuers do make of them a conferue, as they call it, of the flowers and fugar,which they
appoint to be taken for certaine daies togither.

D The flowers arc baked with fugar as rofes are, which is called fugar Rofet : as alfo the diftilled water of them, which is vfed to make the hart merrie; to make a good colour in the face, and to make the vitall firits more trefh and liucly. 


\section{HISTORIE OF PLANTS.}

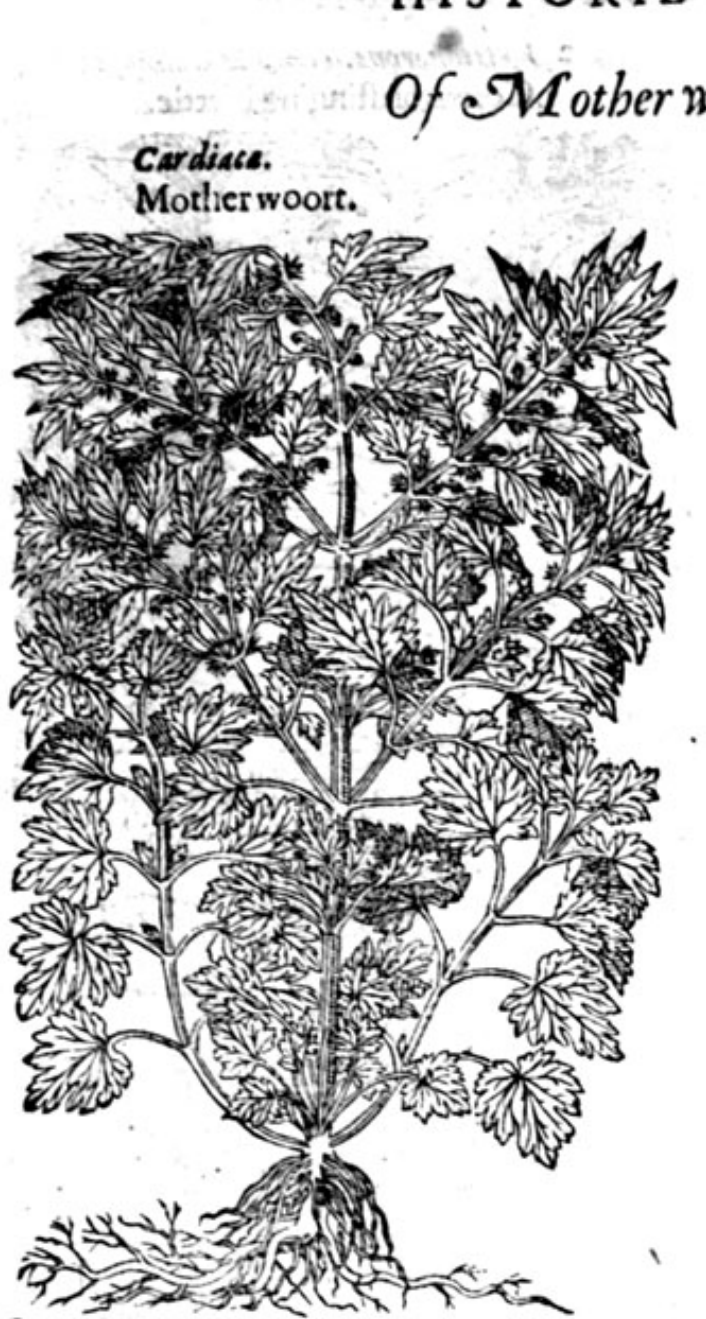

feemeth that it may alfo be referred to Sideritis Herculana, or Hercules Iron woort.

* The defcription.

Other woort bringeth foorth ftalks fower

VI fquare, thicke, harde, two cubits high, of an obfcure or ouerworne red colour.

The leaues are fomewhat blacke, like thofe of Nettles, but greater and broader then the leaues of Horehound, deepeiy indented or cut on the edges. The huskes are harde and pricking which do compaffe the ftalkes about like wharles, or little crownets, out of which do growe purplifh flowers, not vnlike to thole of dead Nettle, but leffer. The roote is compact of mang fmal ftrings; the whole plant is of a verie ranke fnell andbitter tafte.

*t the place.

It ioieth among rubbirh, in ftonic and other barren and rough places ; efpecially about $\mathrm{Ox}$ ford; it profiteth well in gardens. * The time.

It flourifheth, flowreth, and feedeth, from Iune to September: the leaues and ftalkes perifh in winter, but the roote indureth.

\section{* The names.}

It is called in our age Cardiaca : in high Dutch pert3gefpoze : in low Dutch yettegeipan: in French Agripaulme: in Englifh Mother woort. Some there be that make it a kinde of Baume; it * The temperature.

Mother woort is hot and drie in the fecond degree, by reafon of the clenfing and binding qualitie that it hath. * The vertues.

Diners commend it againft the infirmities of the hart: it is iudged to be fo forceable, that it is $\mathbf{A}$ thought it tooke his name Cardiaca of the effect.

It is alforeported to cure conuulfions and cramps, and likewife the palfie : to open the obftructi- B ons or ftoppings of the intrailes : to kill all kindes of wormes of the bellie.

The powder of the herbe giuen in wine, prouoketh not onely vrine, or the monthly courfe; but $\mathbf{C}$ alfo is good for them that are in hard traucll with childe.

Moreouer, the fame is commended for green wounds: it is alfo a remedie againft certaine difea- D fes in cattell,as the cough, \& murren, \&\& for that caufe diuers husbandmen oftentimes much-defireit.

\section{Of Stinging $\mathcal{N}$ (ettle. Cbap.226.} There be diuers forts of Nettles as fhall be declared.

* The defcription.

I He ftalkes of the firft be now and then halfe a yarde high, round, and hollow within: the leaues ate broad, tharpe pointed, cue round a bour like a fawe, they be rough on both fides, and couered with a ftinging downe, which with a light touch onely caulech a great burning, and raifeth hard knots in the skin like blifters, and fometimes maketh it red. The feede commeth from the rootes of the leaues in round pellets, bigger than Peafe; it is flipperie, glittering like Line feede, but yet leffer and rounder.The roote is fet with ftrings. 
I Vrtica Romana.

Romane Nettle.

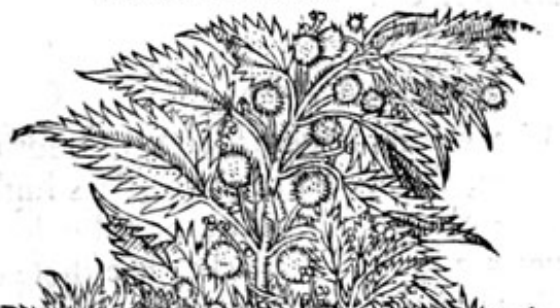

(1) 专 \%

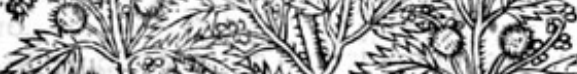
370 Q

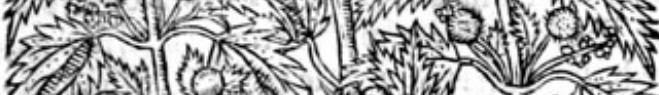
结 1 (6) 3 , 3 in 3.0.

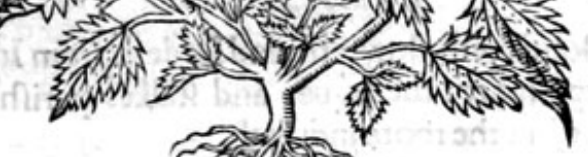

3 Vrticaminor.

Small Nettle.

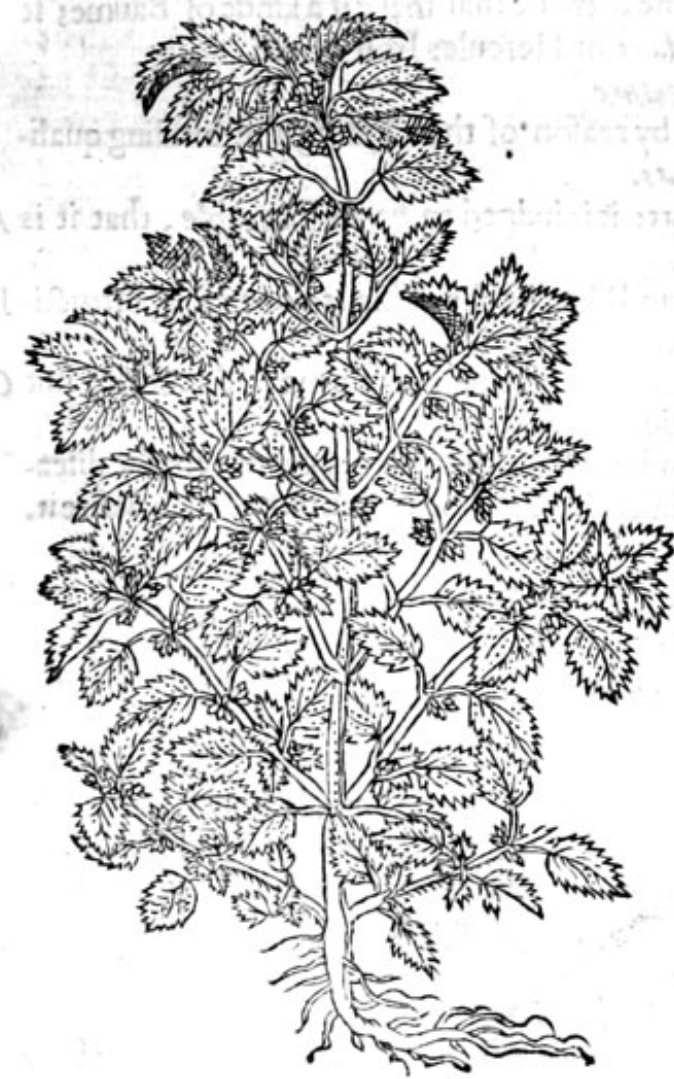

2 Vrtich vrens.

Common ftinging Nettle.
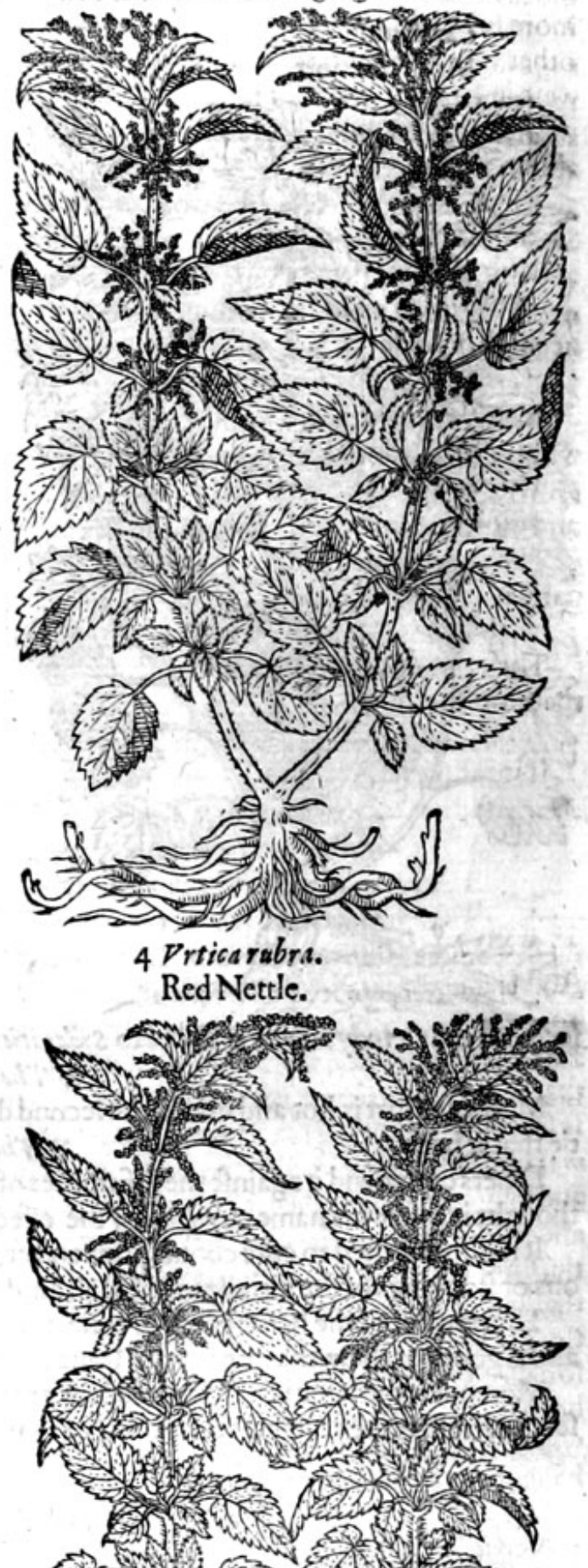

$\rightarrow$ V
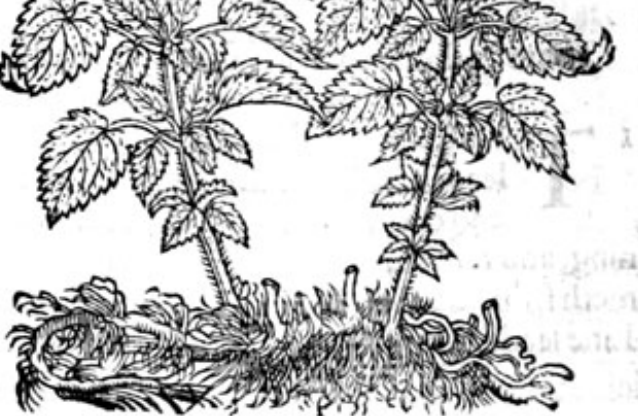


\section{HISTORIE OF PLANTS.}

2 The fecond Nettle is like to the former in leaties and ftalkes, but yet now and then higher and more full of branches : it is alfo couered with a downe that ftingeth and burneth as well as the other; the feede hereof is fmall, and groweth not in round bullets, but onlong flender ftrings, as ic were in clufters, as thofe of the feriale Mercurie, which growe along the ftalkes and branches aboue the leaues, verymany. The roote is full of ftrings, of colour fomething yellow, and creepeth all about.

3 The thirde is like to the feconde in ftalks, leaues, and feede, that groweth by clufters, but leffer, sccommonly more full of branches, of a light greene, more burning and ftinging; the roote is fmal and not without ftrings.

4 The fourth being our common red Nettle, is knowne better to fome thien defired, and therefore needeth no defcription.

\section{* $\quad *$ The place.}

Nettles growe in vntilled places, and the firit in thicke woods, and is a ftranger in England; notwithftanding it growethin my garden.

The fecond is more common and groweth of it felfe neere vnto hedges, bufhes, and brambles, and olde wals.

The thirde and fourth alfo commeth vp in the fame places, which notwithintanding groweth in gardens, and moift earable groundes.

* Thetime.

They allflourifh in fommer, the leffer fuffereth the winter colde; the feede is ripe and maybe gathered in Iuly and Augurt.

It is called in Grecke Avere⿰n: in Latine Vrtic., of his burning and ftinging qualitie:whereupon, as Macer faith:

\section{-nec immerito nomen funto ife videtur,}

Talta quod exurat digitos vrticatenentis.

The Nettle feemes her name to take of no vndeferued thing,

Which hurtes the hand of him that toucheth her, with a piercing fting.

And of diuers alfo xviss, bicaufe it ftingeth with hurtful down:in high Dutch Pefiel in Italiã Ortica: in Spanifh Hortiga : in French Ortie : in Englifh Nettle. The firft is called in low Dutch Roomictbe Retelen, that is Romina Vrtica, or Romain nettle : \& likewife in high Dutch veralfcbe Jeffiten: that is, Italica vrtica, Italian Nettle, bicaufe it is rare and groweth but in fewe places, and the feed is fent from other countries and fowen in gardens for his vertues : it is alfo called of diuers Vrtica mas : and of Diofcorides Vrtica fylueftris, or wilde Nettle, which he faith is more rough, with broader and longer leaues, and with the feede of Flaxe, but leffer. Plinie maketh the wilde Nettle the male, and in his 2 r.booke, chap.1 s.faith, that it is milder \& gentler: it is called in Englifh Romane Nettle, Greeke Nettle, male Nettle. The fecond is called Vrtica famima, and oftentimes $V$ rtica maior, that itmay differ fromithe thirde Nettle : in Englifh female Nettle, great Nettle, or common Nette. The thirde is named in high Dutch Devter fitfiel: in the Brabanders fpeech ivetite Jeteien, focalled of the ftinging qualitic: in Englifh fmall Nettle, fmall burning Nettle: but whether this be that or no swhich Plinie calleth Camia, or rather the firf, let the Students confider. There is in the wilde nettle a more ftinging qualitie, which, faith he, is called Cania, with a.ftalke more ftinging, hauing nickedleaues,

$$
\text { .rolg xit * * The temperature. }
$$

Nettle is of temperature drie, a lickle hot, fcarce in the firft degree, it is of thinne and fubtile parts, for it doth not therefore burne andiftinge by reafon it is extreme hot: but bicaufe the downe of it is ftiffe and hard, pearcing hike fine little prickles, or ftings, and entring into the skin : for if it be withered orboiled, it ftingethnotatall, by reafon that the itiffeneffe of the downe is fallen away.

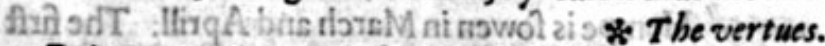

Beingeaten, or as Diofcorides faich, boiled with Pèrywinkles, it maketh the bodie foluble, and A doth it by a kinde of clenfing qualitic : it alfo prouoketh vrine, and expelleth ftones out of the kidneies; being boiled with barly creame, it bringethwp tough humors that ticke in the cheft, as it is

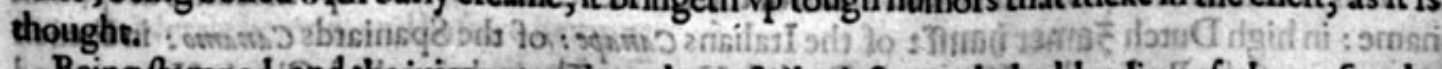
Being ftamped, and shic juice putsplinto the rioftrils, it ftoppech the bleeding of the nofe: the B iuice is good againft the inflammation of the Vutalas ? 


\section{$57^{2}$ THE SECOND BOOKE OF THE}

C The feede of Nettle ftirreth vp luft, efpecially drunke with Cute: for (as Galen faith) it hath in it a certaine windineffe.

It concocteth and draweth out of the cheft raw humors.

E It is good for them that cannot breath vnleffe they hold their neckes vpright, and for thofe that haue the Pleurifie, \& for fuch as be ficke of the in flammation of the lungs, if it be taken in a loache or licking medicine, and alfo againft the troublefome cough that children haue, called the chinne cough.

F Nicander affirmeth, that it is a remedie againft the venemous qualitic of Hemlocke,Mufhroms, and Quickfiluer.

G And Apollodoris faith, that it is a counterpoifon for Henbane, ferpents, and fcorpions.

H As P linie witneffeth, the fame author writeth, that the oile of it taketh away the ftinging which the Nettle it felfe maketh.

I The fame groffely powned, and drunke in white wine, is a moft fingular medicine againft the ftone either in the bladder, or in the reines, as hath beene often prooued to the great eafe and comfort of thofe, that have been grieuoufly tormented with that maladie.

$\mathrm{K}$ It expelleth grauell, and caufeth to make water.

I. The leaues of any kinde of Nettle, or the feedes, do worke the like effeet, but not with that good fpeede, and fo affuredly as the Romane Nettle.

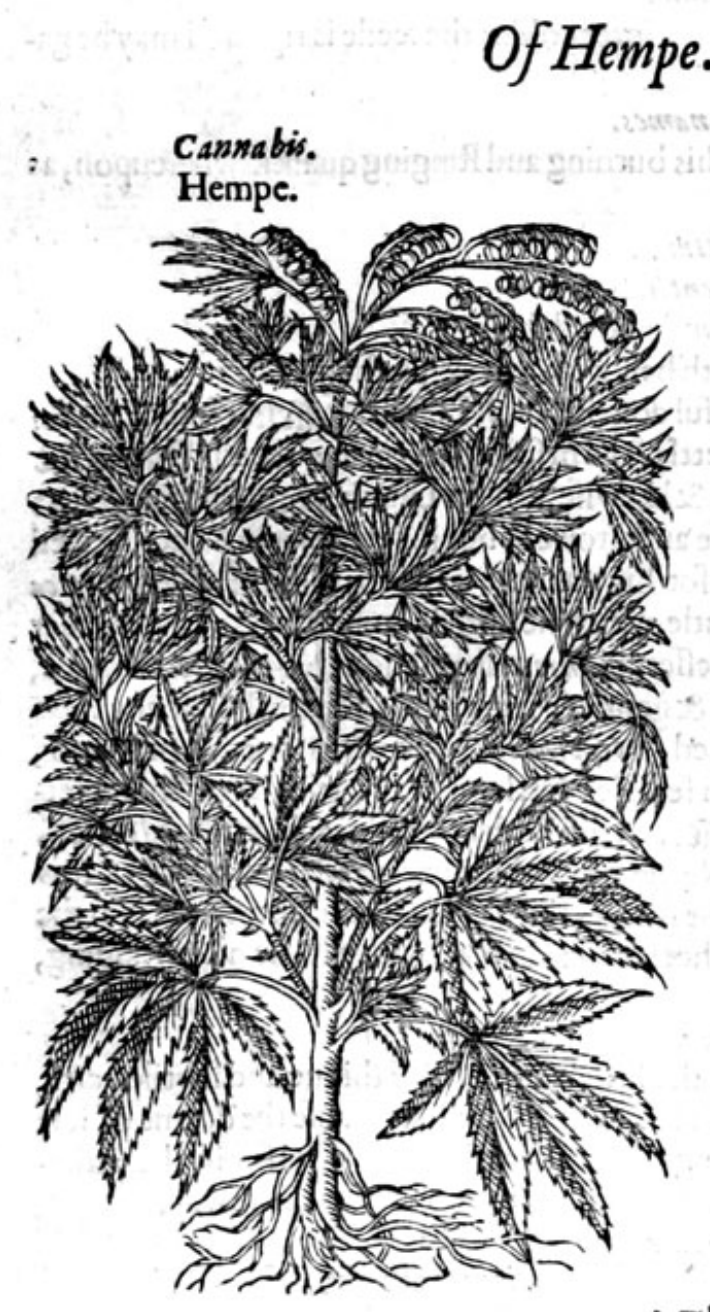

* The names.

Cbap.227.

This is named of the Grecians xivrocis, alfo of the Latines Cannabis: the Apothecaries keepethat name: in high Dutch zamet banff : of the Italians Canape : of the Spaniards Canamo: in French Chanure: of the Brabanders Kitemp ₹ in Englifh Hempe. Themale is called Charle Hempe, and Winter Hempe. The female Barren Hempe, and Sommer Hempe. 
$*$ Thetemperature and vertues.

The feedc of Hempe, as Galen writeth in his bookes of the faculties of fimple medicines, is hard A of digeftion, hurtfull to the ftomacke and head, and conteineth in it an ill iuice, notwithftanding fome do vfe to eate the fame parched, cum alÿs tragematis, with iunkets.

It confumeth winde, as the faid author faith in his booke of the faculties of medicines, and is fo B great a drier, as that it drieth wp the feede, if too much be eaten of it.

Diofcorides faith, that the iuice of the herbe dropped into the eares, affwageth the paine thereof, $\mathrm{C}$ proceeding as I take it, of obftruetion, or ftopping, as Galen addeth.

The inner fubftance or pulpe of the feed preffed out in fome kinde of liquor, is given to thofe that $D$ haue the yellowe iaunders, when the difeafe firft appecreth, and oftentimes with good fucceffe if the difeafe come of obftruction without an agewe, for it openeth the paffage of the gall, and difperfeth and conco teth the choler through the whole bodie.

Matbiolus faith, that the feed given to hens, caufeth them to laie egges more plentifully.

\section{Of wilde Hempe. Chap.228.}

* The kindes.

Tere be diuers forts of wilde Hempes, it fhall fuffice to giue you the figure of one, with the defcription of mo.

Cannabis Sparia.

Wilde Hempe.

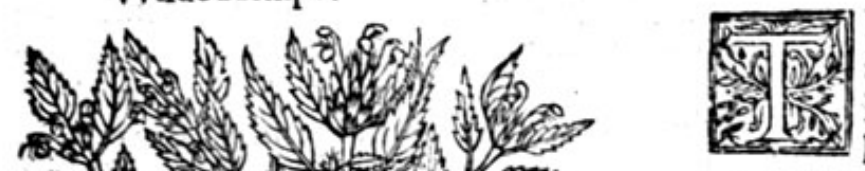
ioint with two leaues, fmallie indented about the edges, fomewhat like a netrle. The flowers growe in rundles about the ftalkes, of a purple colour : the roote is little and threddie.

There is likewife another kinde of wilde Hempe which hath hairie ftalkes and leates like the former, but the flowers are greater, gaping wide open like the flowers of Lamivm, or dead Nettle, whereof this hath beene taken for a kinde: but hee that knoweth any thing may eafily difcerne the fauour of hempe from the fmell of dead Nettle. The flowers are of a cleere and light carnation colour,declining to purple.

There is alfo another kinde of wilde hempe, like vnto the laft before mentioned; fauing that it is fmaller in eche refpect \& nor fo hairic : the leafe is fomewhat rounder. The roote fmall and thredcie.

\section{* The place.}

Thefe kindes of wilde or baftarde hempe, doe growe ypon hilles and mountaines, and barcen hilly grounds, efpecially in earable lande, as I haue often feene in the corne fieldes of Kent, as about

Graues ende, Southtleete, and in all the tract from thence to Canterburie. * The time.

Thefe herbes do flower from Iulie to the end of Auguft. * The names.

It fhall fuffice what hath beene fet downe in the title for the Latine name: in Englifh wilde hempe, Nettle hempe, and baftard hempe.

The temperature and faculties a te temperature and vertwes.

notvfed the manured hempe, nọtwithftanding they are not vifed in phificke, where the other may be had. 


$$
\text { Of Water Hempe. Chap.229. }
$$

\section{Eupatorium Cannabinum.}

Water Hempe, or water Agrimonie.

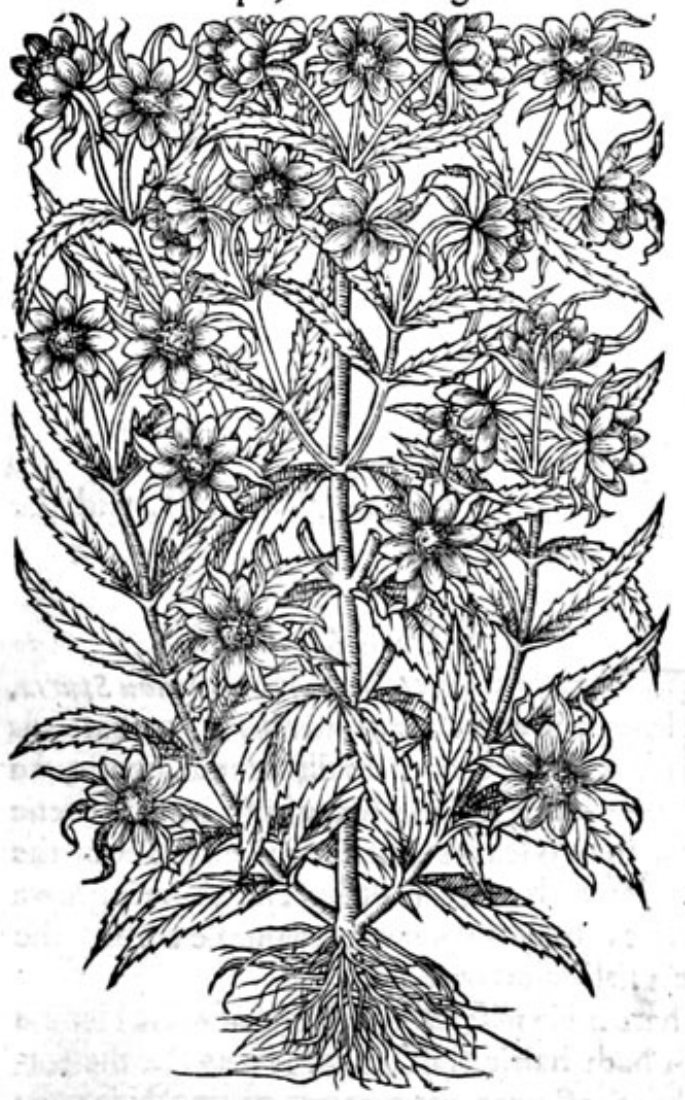

* The defription.

TT Ater Hempe, or water Agrimonie, is feldome founde in hot regions, for which caufe it is called Expatorium Cannabinum famina Septent rionalitum, and groweth in the colde northerne countries in moift places, and in the midft of ponds, flowe running riuers, and ditches. The roote continueth long, hauing many long and flender ftrings, after the nature of water herbes. The ftalkes growe a cubite and a halfe high, of a darke purple colour, with many braunches ftanding by diftaunces one from another. The leaues are more indented and leffe hairie than the male kinde, the flowers growe at the top, of a browne yellowe colour, fpotted with black fpots like Aster atticus, which confifteth of fuch a fubftaunce as is in the midft of the Daifie, or the Tanfie flower, \& is fet about with fmall and fharpe leaues, fuch as are about the rofe, which caufeth the whole flower to refemble a ftarre and fauoureth like gum Elemprii, Rofine, or Cedar woode when it is burned. The feede is long like Pyrethrum, clofely thruft togither, and lightly cleaueth to any wollen garment, that it toucheth by reafon of his roughnes.

There is another wilde hempe growing in the water, whereof there be two forts more delighting to grow in the like ground, in fhew differing verie little. This fpringeth vp with long rounde ftalkes, and fomewhat reddifh, about two cubits high, or fomething higher, they are befet with long greeneleaues indented vpon the edges, wherof you thall fee commonly fiue or feauen of thofe leaues hanging vpon one ftem like the leaues of hempe, but yet fofter. The flowers are little, of a pale reddith colour, confifting of foft rounde tufts, and ftand perting vpon the top of the fprigs, which at length vanifh away into downe: the roote vnderneath is full of threddie ftrings, of a meanc bigneffe.

* Theplace.

They growe about the brinkes of ditches,running waters, and ftanding pooles, and in waterie places almoft euerie where.

They flower and fourif in The time. wither away in winter.

uguft: the roote continueth, but the ftalkes and leaues

* The names.

The baftarde or wilde Hempes, efpecially thofe of the water, are called commonly Hepatoriwo Cannabinum, of diuers alfo Eupatorium, Leonhar. Fuchfous nameth it Eupatorium adulterium, of moft Cannabina, of the likenes it hath with the leaues of Cannabis, Hempe, and Eupatorium Auicenna. It is thought alfo to be that which Baptifta Sardus doth terme Terzola: in high Dutch . Batuti= gund ktaut, that is to faie in Latine Sanct e Cunigunde Herba, S. Cunigundes herbe: in low Dutch Boelkens httlift: in Englifh water Hempe, baftard and water Agrimonie. It is called Hepatorium, of the facultie, whercby it is good for Hepar, the liuer.

* 7 he temperature.

The leaues and rootes of thefe herbes are bitter,alfo hot and drie in the fecond degree, they hate vertue 


\section{HISTORIE OF PLANTS.}

vertue to fcoure and open, to attenuate or make thinne thicke and groffe humours, and toexpell or driue them foorth by vrine : they clenfe and purifie the blood.

* The vertues.

The decoction heerof is profitablie giuen to thofe that be fcabbed and haue filthy skinstand like- A wife to fuch as haue their fpleene and tiuer ftopped or fwolne; for it taketh away the ftoppings of both thofe intrailes; and alfo of the gall: wherefore it is good for them that haue the iaundife, efpe: cially fomewhat after the beginning.

The herbe boiled in wine or water, is fingular good againft tertian feuers.

The decoction drunke, and the leaues outwardly applied, doe heale all wounds both inwarde $\mathbf{C}$ andoutward.

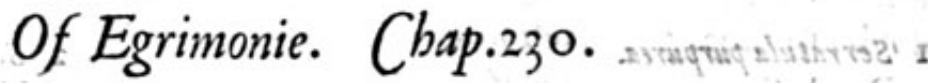

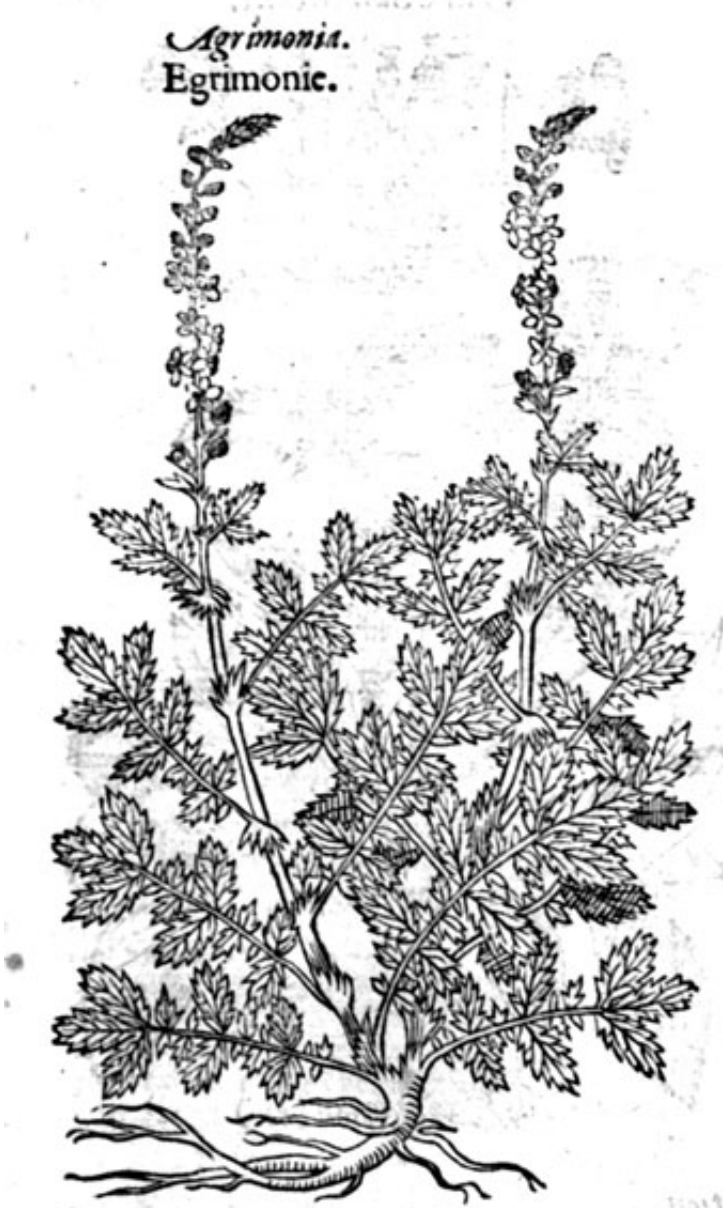

* The defoription.

7 Heleanes of Ugrimonia, are long and hairie, greene abouc, and fomewhat grayifh vaderneath, parted into diuers other finall leaues, fnipt rounde about the edges, almoft like the leaues of hempe. The ftalke is two foote and an halfe long, rough, and bairic; whereupon grow manie fmall yellowe flowers one aboue another vpwards towarde the top: after the flowers come the fecdes fomewhat long and rough, like to fmall burs hanging downwards, which when they be ripe, do catch holde vpon peoples garments which paffe by it. The roote is great,long, and blacke.

$$
\text { * Theplace. }
$$

It groweth in barren places by high waies, inclo fures of medowes, and of corne fieldes, and oftentimes itr woodes and copfes, and almoft enerie where.

$$
\text { * The time. }
$$

It flowreth in lune, and fomewhat later, and feedeth after that, a great part of fommer.

$$
\text { * Tbenames. }
$$

The Grxcians call it oumereerovi and the Latihes alfo Eapatoriwn. Plinie Eupatoria, yet there is another Eupator ium in LApuleims, and that is Marrubium, Horehound: in like manner the Apothecaries haue another Hepatorium that is commonly vfed, which alfo is named Hepatorism aduiterinum: the fhops call it baftarde Agrimonic, of diuers it is named Ferraris, of others Concordia, or $\mathrm{Alarmorella:}$ In Oribafius his olde tranflation in the fourth booke of fimples, Agrimonie is named Lappa inuer/a: and it is named Lapps inuer fa bicaufe the feedes which are rough like burres, do hang downwardes; of fome Pbilant hropos, of the cleauing qualitie of the feedes hanging to mens garments:the Italians

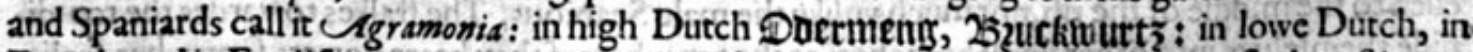
French, and in Englifh, Cgrimonie: Eupatoriwon beareth his name of Eupasor the finder of it out; and(faith Plinie) it hath a roiall and priicely authoritie.

\% The temperature.

It is hot, and doth moderately binde, and is of a temperate drineffe: Galen teacheth, that Agrimo. nie is of fine and fubrill parts, that it cuttech and f coureth, therefore faith he, it remooueth obftructions or ftoppings out of the liuer, and doth likewife ftrengthen it, by reafon of the binding qualitie that is in it. 
* The vertues.

A The decoction of the leaues of Egrimonie is good for them that haue naughtie liuers, and for fuch as piffe bloud vpon the difeafes of the kidneis.

B The feedebeing drunke in wine (as Pliny affirmeth) doth helpe the bloudie flixe.

C Diofcorides addeth, that it is a remediefor them that haue bad liuers, and for fuch as are bitten with ferpents.

D The leaues being ftamped with oldfwines greafe, and applied, clofeth yp vlcers that be hardly healed,as D iofcorides faith.

\section{Of Samenoort. Chap.231.}

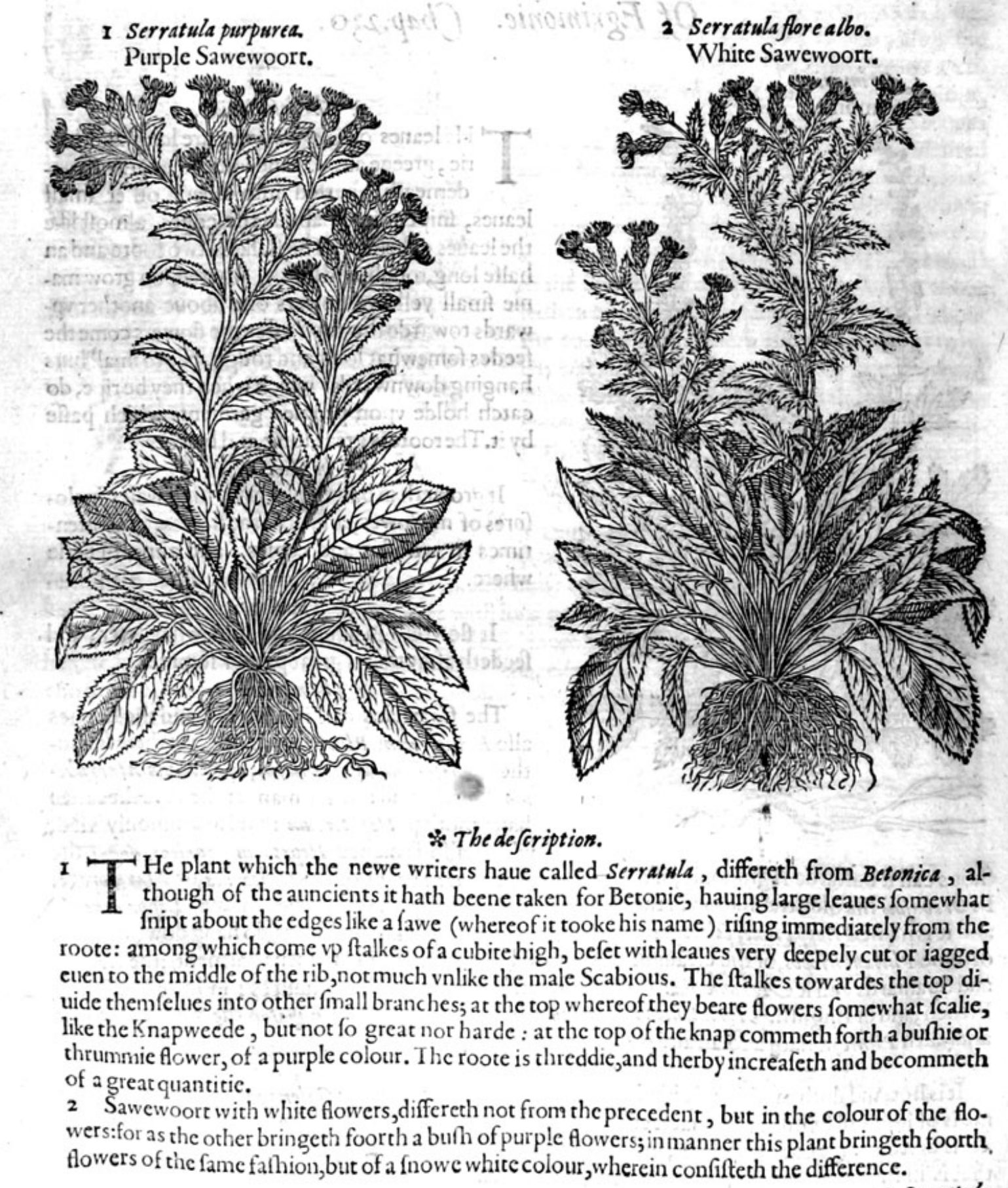




\section{HISTORIE OF PLANTS.}

3 Serratula flore rubro. Red Sawewoort.

* T be defcription.

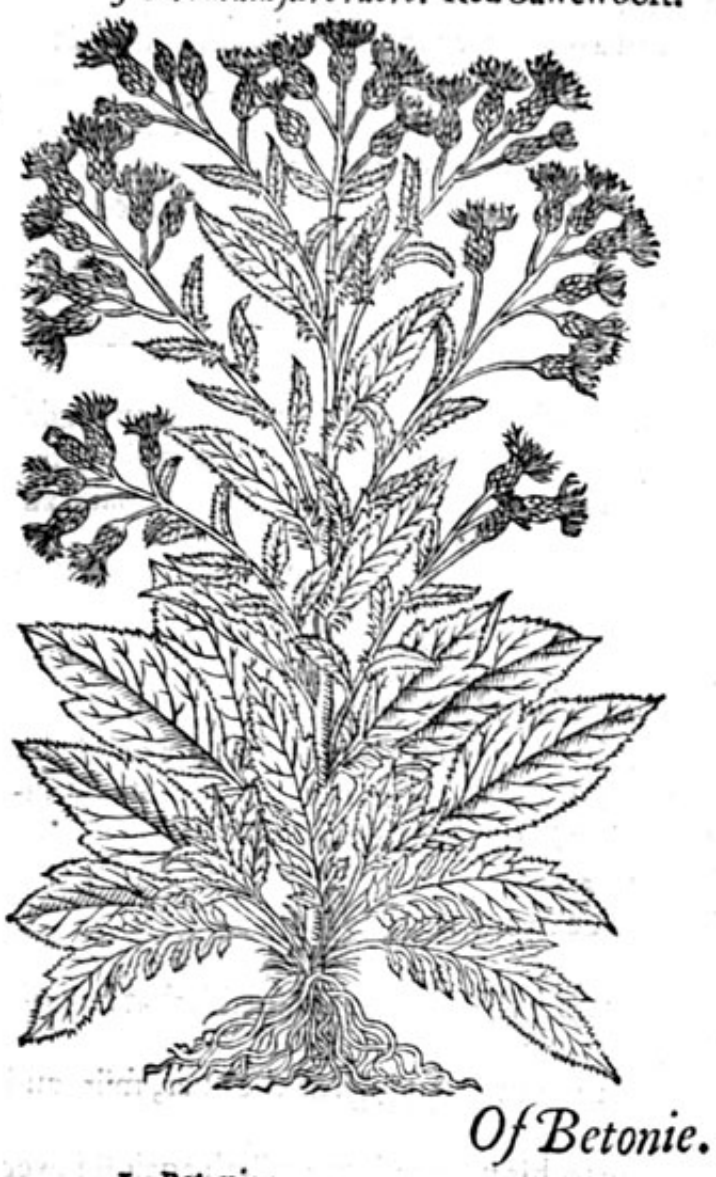

3 We have founde in our woods another fore of Sawewoort, differing from the others of his kinde, anely in the colour of his flowers, without any other difference at all,for this piant bringeth foorth red flowers, and the others not fo. * The place.

Sawcwoort groweth in woods and Thadowie places, and fometimes in medowes. They grow in Hamfteede woode : likewife I haue feene it growing in great abundance in the woode adioining to Iffington, within halfe a mile from the farther ende of the towne, and in fundrie places of Effex and Suffolke. * The time.

They flower in Iuly and Augut. * T Te names.

The later age doth call them Serratula : it differeth as we hauefaide from Betonic, which is alfo called Serratula: other names if it haue any we knowe not : it is called in Englifh Sawewoort. $*$ The temper ature and vertues.

Serratula is woonderfully commended to be moft fingular for woundes, ruptures, burftings, hernies and fuch like: and is referred vnto the temperature of Sanicle.

I Betonica.

Chap.232. Betonie.

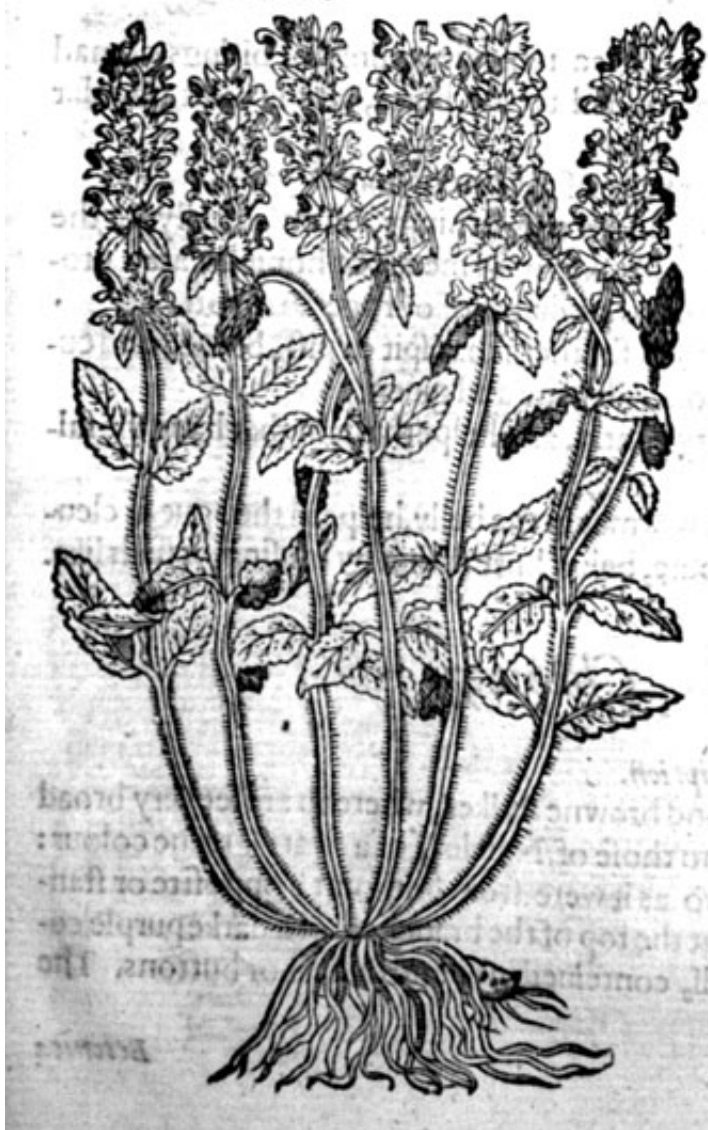

2 Bctonicafore albo.

Betonic with white flowers.

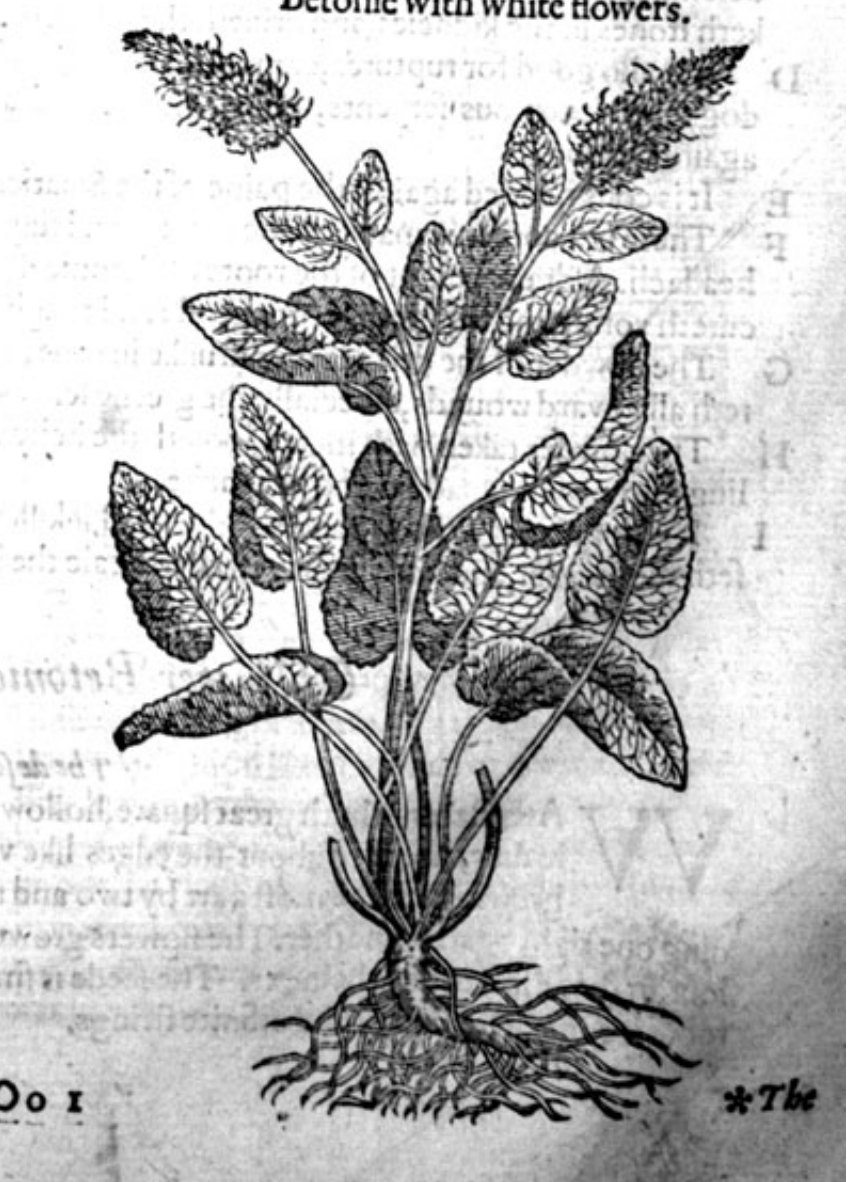




\title{
$57^{8}$ THE SECOND BOOKE OF THE
}

\author{
* The defcription.
}

1 Etonie groweth vp with leaucs long and broad, of a darke greene colour, flightly indented about the edges like a fawe. The ftalke is flender, fower fquare, fomewhat rough, a foote high more or leffe.It beareth eared flowers, of a purplifh colour, and fomtimes reddifh;after the flowers, cummeth in place long cornered feedc. The roote confifteth of many ftrings.

2 Betonie with white flowers is like the precedent in each refpect, fauing that the flowers of this plant are white, and of greater beautie, and the others purple or red, as aforefaid.

* The place.

Betonie loueth hadowic woods, hedgerowes, and copfes, the borders of paftures, and fuch like places.

Betonie with white flowers is feldome feene. I found it in a wood by a village called Hampiteede neer vnto a worhhipfull Gentlemans houfe, one of the Clarks of the Queenes counfell called Ma. fter Wade, from whence I brought plants for my garden, where they flourifh as in their naturall place of growing.

$$
\begin{gathered}
* \text { The time. } \\
\text { They flower and flourifh for the moft part in Iune and Iuly. } \\
* \text { The nomes. }
\end{gathered}
$$

Betonie is called in Greeke risegv : in Latine Betonica : of diuers Vetonica, but vnproperly. There is likewife another Betonica, which Paulus Aegineta defcribeth, and $G$ alen in hisfirft booke of the gonernment of health, fheweth that it is called xiserv, that is to fay, Betunica, Betonie, and alfo Sarxiphagon: Diofcorides notwithiftanding doth defcribe another Sarxiphagon.

Betonie is hot and drie in the fecond degree : it hath force to cut,as Galen faith.

$$
\text { \& The vertues. }
$$

A Betonie is good for them that be fubiect to the falling fickneffe, and for thole alfo that haue ill heads vpon a cold caufe.

B It clenfeth the lungs and cheft, it taketh away obftructions or ftoppings of the liuer, milt, and gall: it is good againit the yellow iaundies.

C It maketh a man to have a good, ftomacke and appetite to his meate: it preuaileth againft fower belchings: it maketh a man to piffe well : ir mitigateth paine of the kidneies and bladder : it breaketh ftones in the kidneies, and driueth them foorth.

D It is alfo good for rupture's, crampes, and conuulfions: it is a remedic againft the bitings of mad dogs and venemous ferpents, being drunke and alfo applied to the hurts, and is moit fingular againt poifon.

E It is commended againft the paine of the Sciatica,or ache of the hucklebone.

F There is a conferue made of the flowers and fugar good for many things, and efpecially for the headach. A dram weight of the roote of Betonie dried and taken with meade or honied water, procureth vomit, and bringeth foorth groffe and tough humors, as diuers of our age do report.

G The powder of the dried leaues drunke in wine, is good for them that fit or piffe blood, and cureth all inward wounds, efpecially the greene leaues boiled in wine and giuen.

H The powder taken with meate, looleth the belly very gently, and helpeth them that haue the falling ficknes,with madnes and headache.

I It is fingular againft all paines of the head, it killeth wormes in the belly, helpeth the ague, it clenfeth the mother, and hath great vertue to heale the bodie, being hurt within by brufing,orfuch like.

\section{OfWater Betonie. Chap.233.}

* The defcription.

VJ Ater Betonie hath great fquare, hollow, and browne ftalkes, whereon are fet very broad leaues, notched about the edges like vnto thofe of Nettles, of a fwart greene colour: growing for the moft part by two and two as it were from one ioint, oppofite or ftanding one right againt another. The flowers growe at the top of the branches, of a darkepurple colour, in thape like to little helmets. The feede is fmall, conteined in round bullets or buttons. The roote is compact of many and infinite ftrings. 


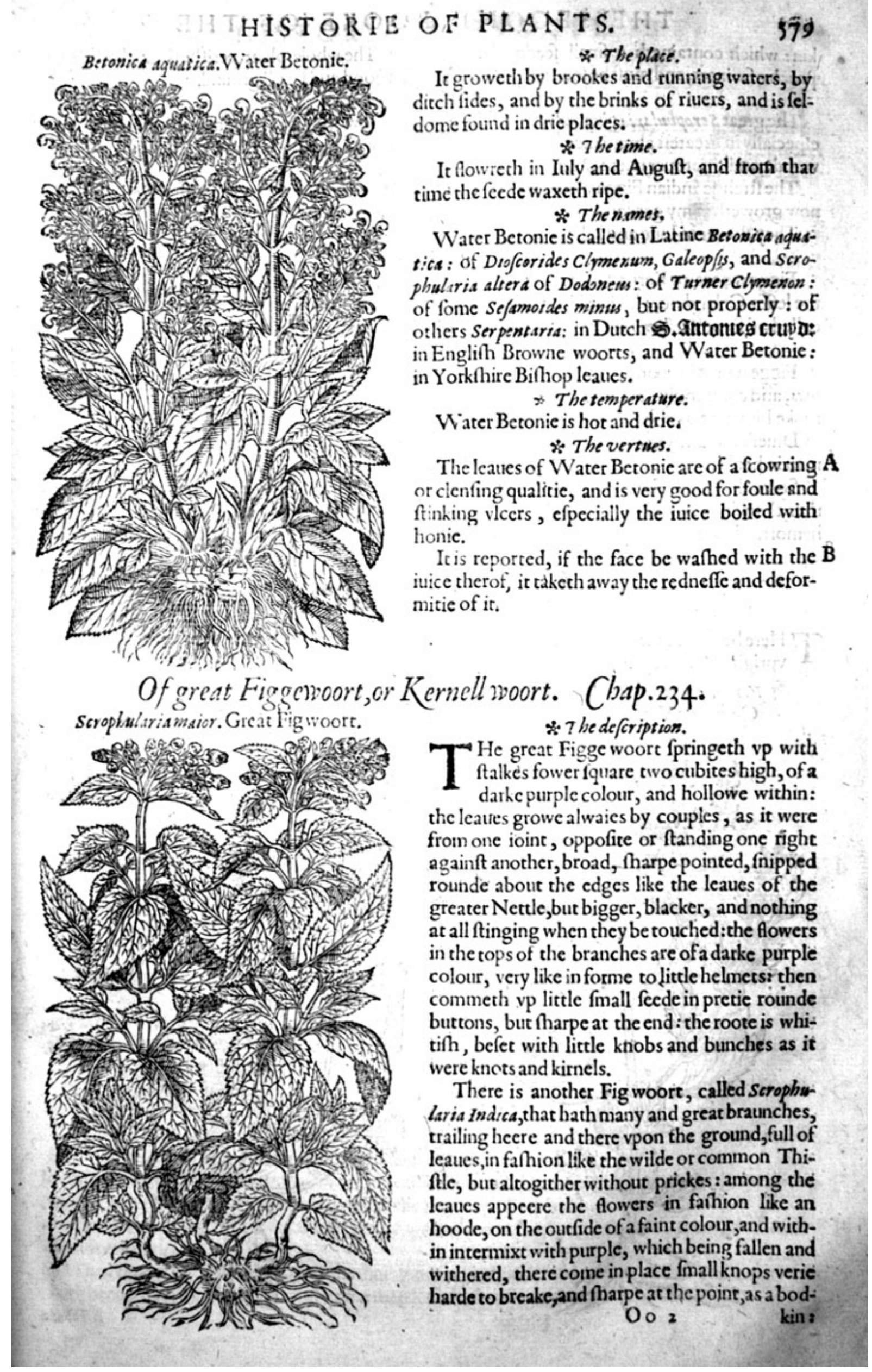




\section{THE SECOND BOOKE OF THE}

kin: which containeth a fimall fecde like vntoTime. The whole plant perifheth at the firft approcis of winter, and muft be fowen againe in Aprill, in good and fertill ground.

$$
\text { * The place. }
$$

The great Scroplularia groweth plentifully in fhadowie woods, and fomtimes in moilt medowes, efpeciallv in greateft abundance in a woode as you go from London to Harnefey, and alfo in Stowe woode, and Shotouer necre Oxenforde.

The ftrange Indian Figge woort, was fent me from Paris by Ioln nobin, the Kings Herbarilt, and now groweth in my garden.

They flower in Iune and Iulic.

* The time.

$*$ The names.

Figge woort or Kernell woort, is called in Latine Scrophularia maior, that it might differ from the leffer Celandine, which is likewife called Scrophularia, with this addition minor, the leffer: it is called of fome Millemorbia, and Caftrangula : in Englifh great Figge woort, or Kernell woort.

$*$ The vertues.

Figge woort is good againft the hard kernels, which the Græcians call peréses: the Latines Strum.ts, and commonly scrophulas, and it is reported to be a remedie againft thofe difenfes whereof it tonke his name, as alfo the painfull piles and fwelling of the hemorihcides.

Diuers do rafhly teach, that if it be hanged about the necke, or elfe caried about one, it keepeth a Amanin health.

Some do ftampe the roote with butter, and fet it in a moilt thadowie place fifteene daies togither, then do they boile it, ftraine it, and keepe it, wherewith they annoint the hardekernels, and the hemorrhoide veines, or the piles which are in the fundament, and that with good fucceffe.

\section{Of Veruaine. Chap.235.}

* The kindes.

$T$ Here be two kindes of Veruaine as pliny faith, the male, and the female; or as others affirme, vpright, and creeping.

I Verbena communis.

Common Veruaine.

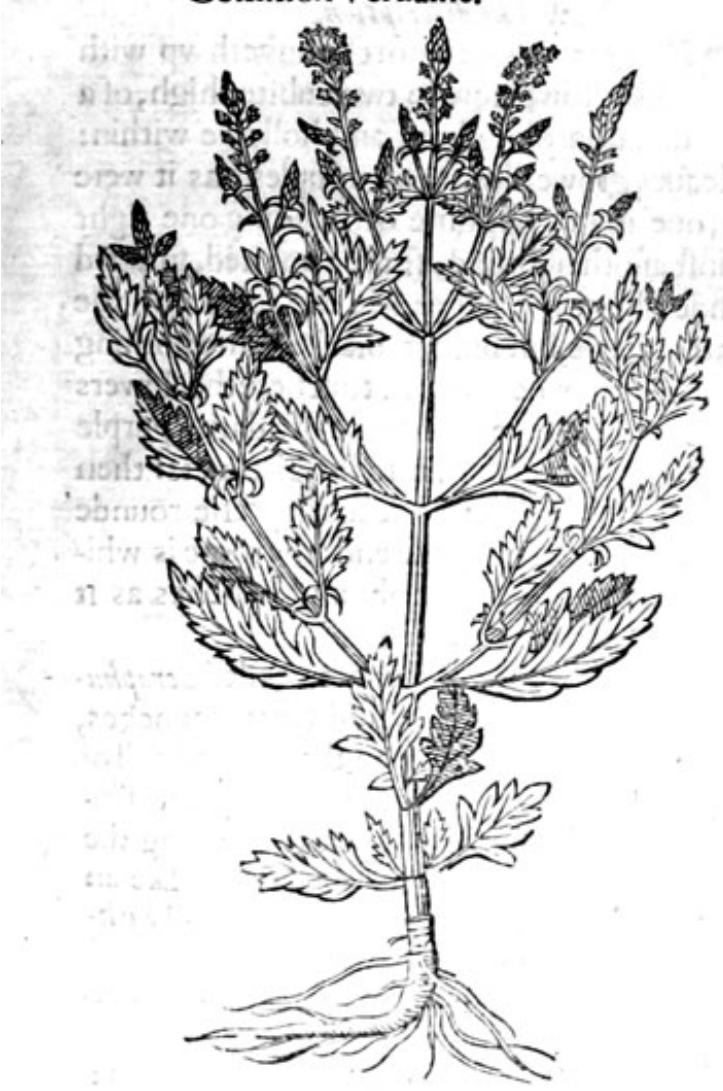

2 Verbena facra. Holie Veruaine.

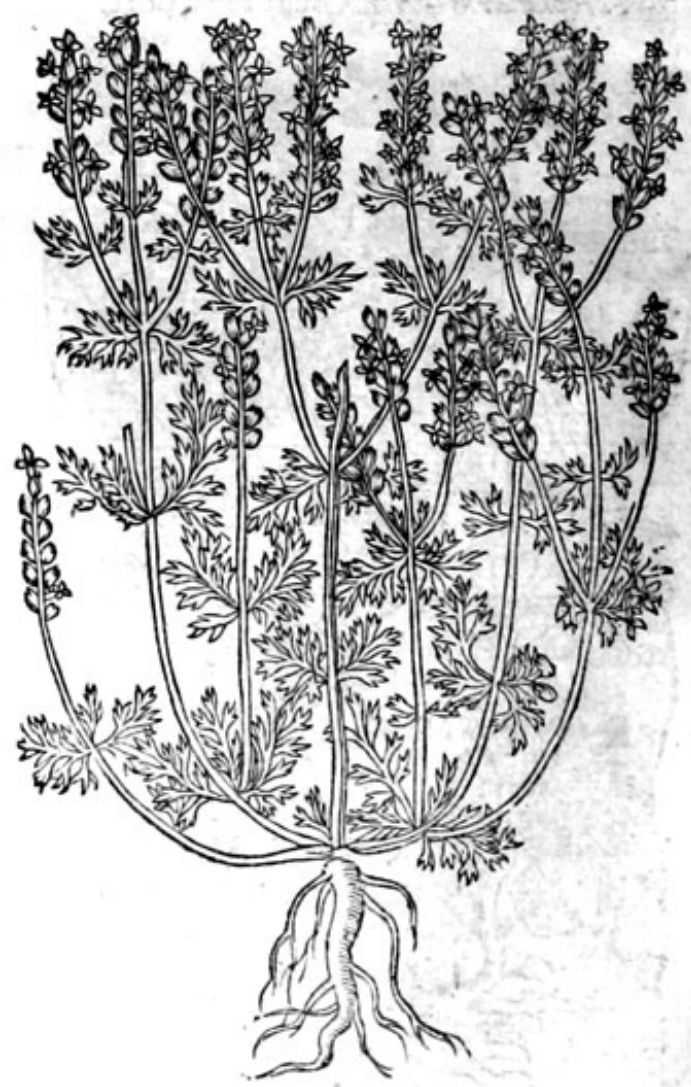




\section{* Thedefaripition.}

I He italke of vpright Veruaine rifeth from the roote fingle,cornered, a foothigh, feldome aboue a cubite, and afterwards diuided into many braunches: the leaues are long, greater then thofe of the oke, but with bigger cuts and decper: the flowers along the fprigs are little, blewe, or white, orderly placed the roote is long, with ftrings growing on it.

2 Creeping Veruaine fendeth foorth ftalkes like the former, now and then a cubite long,cornered, moreflender, for the moft part lying vpon the grounde : the leaues alfo are as the former, but with deeper cuts, and mo in mumber: the flowers in the tops of the fprigs are blewe, and purple withall, verie fmall as thofe of the other, and placed after the fame manner and order: the roote groweth ftraight downe being flender andlong, as is the roote of the former.

$$
\text { * The place. }
$$

Both of them grow in vntilled places neere vnto hedges, high waies, and commonly by ditches almoftenery where.

The Veruaines flower in Iuly and Auguft.

$$
\text { * Thetime. }
$$

* I he names.

Veruain is called in Greek mess ptár: in Latin Verbena, \& Verbenaca, He rculania, Ferraria, \& Exupera, of fome Matricalis, \& Hierabotane, of others Veruena, \& Sacra berba. Verbena are herbs that were taken from the altar,or from fome holie place, which bicaufe the Conful or Prætor did cut vp, they were likewife called Sagmina, which of tentimes are mentioned in Liuie to be graftie herbs cutvp in the capitol. $r$ limie alfo witneffeth in his 22 .bóok, $I 1$.chap.that Verbene \& Sagmina be all one, \& this is manifeft by that which we read in Andria in Terence: $E x$ ara ver benas hinc fume; Take herbs here from the altar; in whicl place Terence did not meane Veruaine to be taken from the altar, but fome certaine herbe: for in Mensuder, out of whom this Comedie was tranflated, is read $\mu$ poorn, or Myrtle, as Donatus faith. In Spanifh it is called V rgebaom : in Italian Verminaculs: in Dutch Jeter ctutiit: in French Veruayne : in Englifh Iunos teares, Mercuries moift bloude, Holie herbe, and of fome Pigeon's graffe, or Columbine, bicanfe Pigeons are delighted to be amongtt it, as alfo to eate thereof,as Apuleiw writeth.

\section{* Thetemperature.}

Both the Veruaines are of temperature very drie, and do meanely binde and coole.

$$
\text { * The vertues. }
$$

The leaues of Veruaine pounde with oile of rofes, or $A x u n g$ is, that is, hogs greafe, doth mitigate A and appeare the paines of the mother, being applied thereto.

The leaues of Veruaine and rofes ftamped witli a little newe hogs greafe, and emplaiftered. after $B$ the manner of a pultis, doth ceafe the inflammation and greenous paines of woundes, and fuffereth them not to come to corruption: and the greene leaues ftamped with hogges greafe, taketh away the fwelling and paine of hot impoftumes and tumours, and clenfeth corrupt and rotten vlcers.

It is reported to be of fingular force againft the tertian and quartaine feuers: but you muft ob- $C$ ferue mother Bumbies rules to take iuft fo many knots or fprigs, and no more, leaft it fall out fo that it do you no good, if you catch no harme by it. Many odde olde wiues fables are written of Veruaine tending to witehcraft and forcerie, which you may reade elfe where, for I amnot willing to trouble your eares with reporting fuch trifles, as honeft eares abhorre to heare.

Lrchigenes maketh a garlande of Veruaine for the headach, when the caufe of the infirmitic C proceedeth of heate.

The herbe ftamped with oile of rofes and vineger, or the decoction of it made in oile of rofes, D keepeth the haires from falling, being bathed or annointed therewith.

It is a remedie againft purrified vlcers, ic healeth vp wounds, and perfeotly cureth fiftulaes, it wa- E fteth awaic olde fwellings, and taketh away the heate of inflammations.

The decotion of the rootes and leaues, fwageth the toothach, and faftneth them, andhealeth F the vicers of the mouth.

They report faith $P$ limie, that if the dining roome be fprinckled with water in which the herbe $G$ hath beene fteeped, the guefts will be the merrier, which alfo Diofcorides mentioneth. 


\section{THE SECOND BOOKE OF THE}

$\mathrm{H}$ Moft of the later Phificions do give the iuice or decoction hecrof to them that haue the plague; but thefe men are decsiued, not onely in that they looke for fome truth from the father of fallhood and leafings, but alfo bicaufe in fteede of a good and fure remedie they minifter no remedie at all;for it is reported, that the diuell did reucale it as a fecret and diuine medicine,

Of Scabious. Chap. 236 .

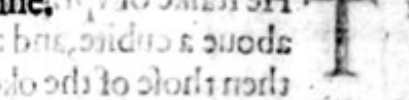

* The kindes. $T$ Here be many kinds or forts of Scabious, euery onefor the molt part takng his denomination from his foile or countrie.

I Scabiofa maior vulgaris. Common Scabious,

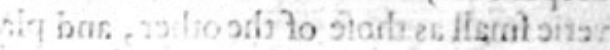

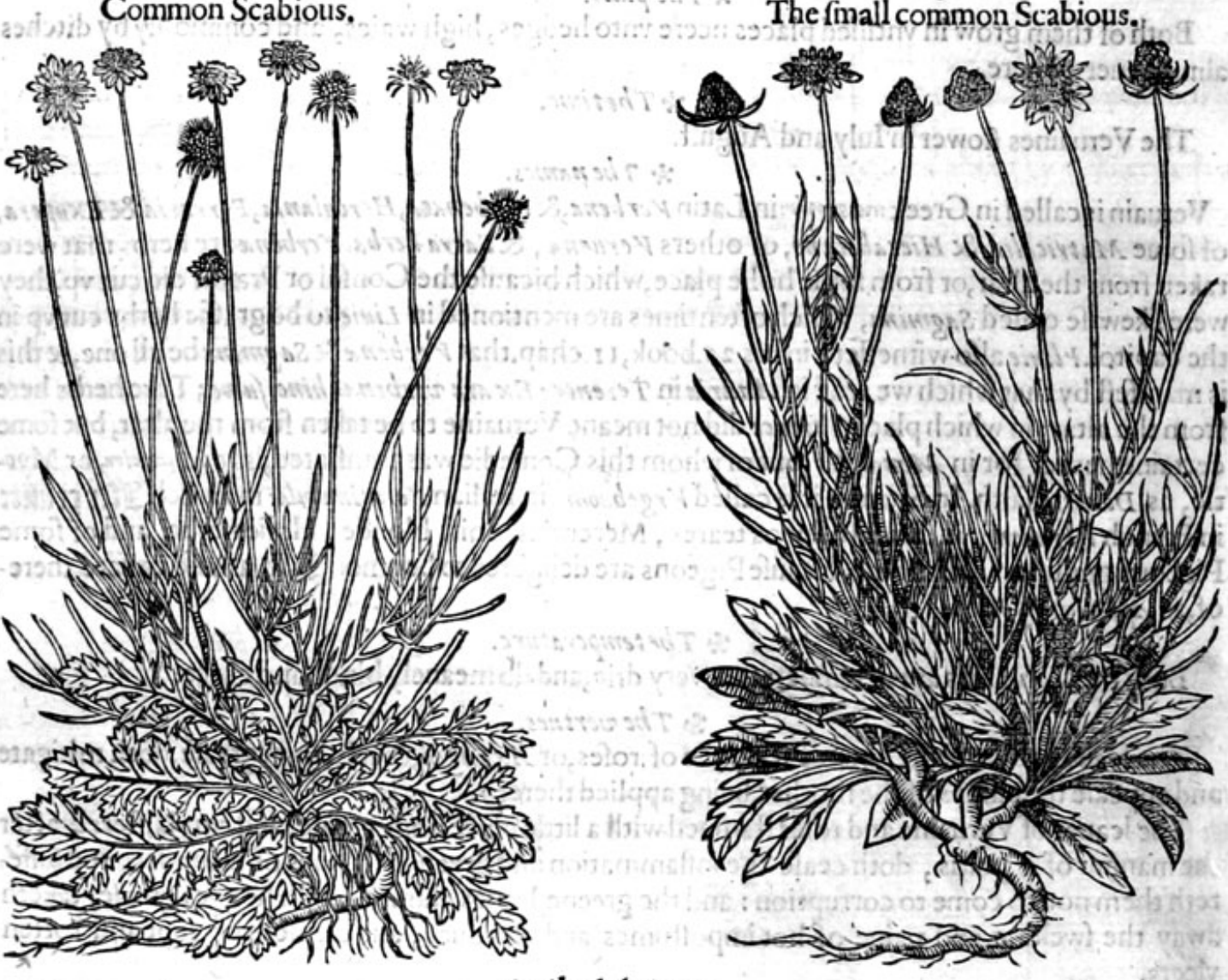

$7 \mathrm{He}$ firftkinde of Scabious be $*$ The defcription. - 2 Scabiofa minor yuve Columbaria. 


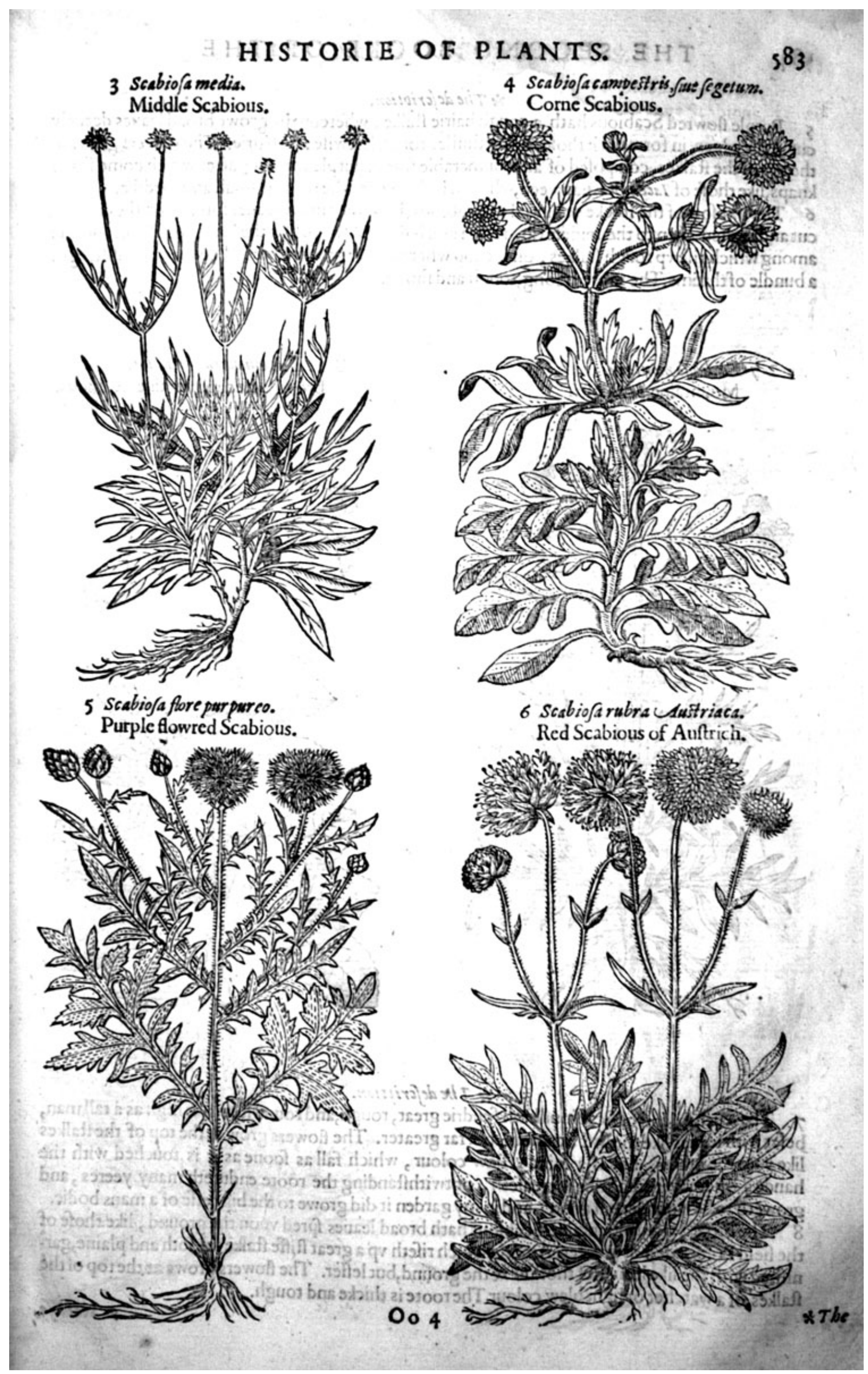


* The defcription.

5 Purple flowred Scabious hath a rough hairic ftalke, whereon do growe broad lcaues deepely cut in the edges, in forme like thofe of Sowthiftle, rough likewife and hairie. The flowers growe at the top of the ftalkes, compofed of an innumerable fort of purple thrums; after which come fcalie knaps, like thofe of Iacea, or Knapweed, wherein is the feede. The roote is fmall and theddie.

6 The fixt fort of the ftocke or kinred of Scabious, hath very many leaues fpred vpon the ground, cut and iagged euen to the middlerib, rough and hairie, in fhape like the leaues of Buckes horne: among which rife vp rough ftalkes, on the top whereof doe growe faire red flowers, confifting of a bundle of thrums. The roote is long, tough and fingle.

7 Scabiofa montana.

Mountaine Scabious.

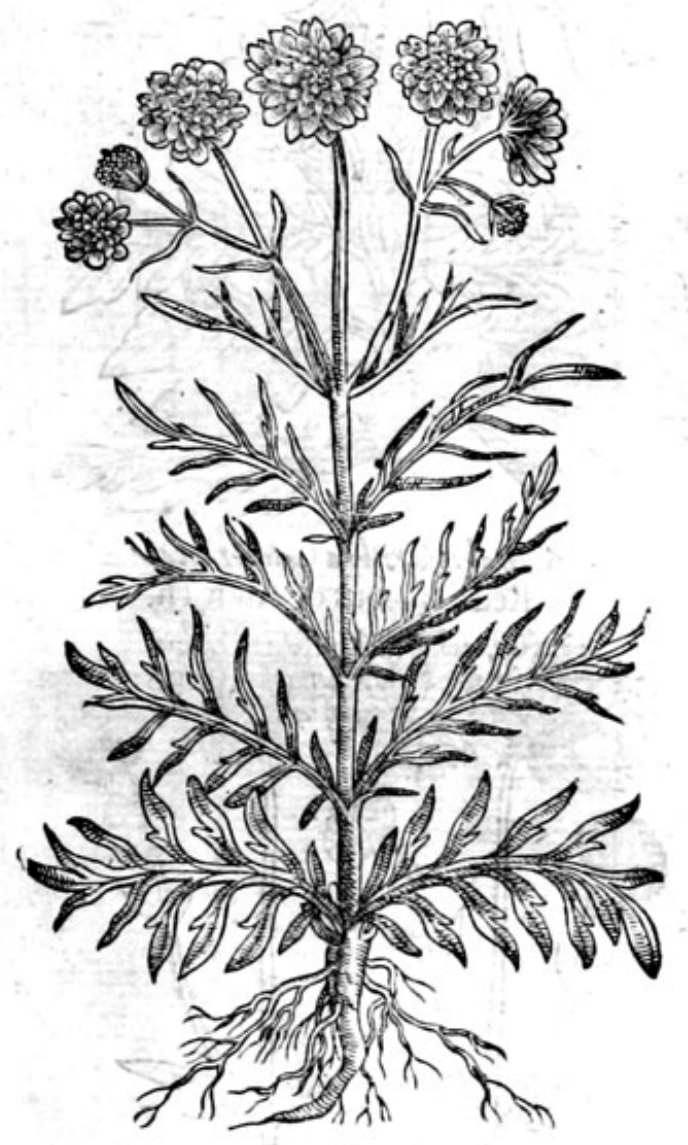

8 Scabiofa montana latifolia.

Broad leafed mountaine Scabious.

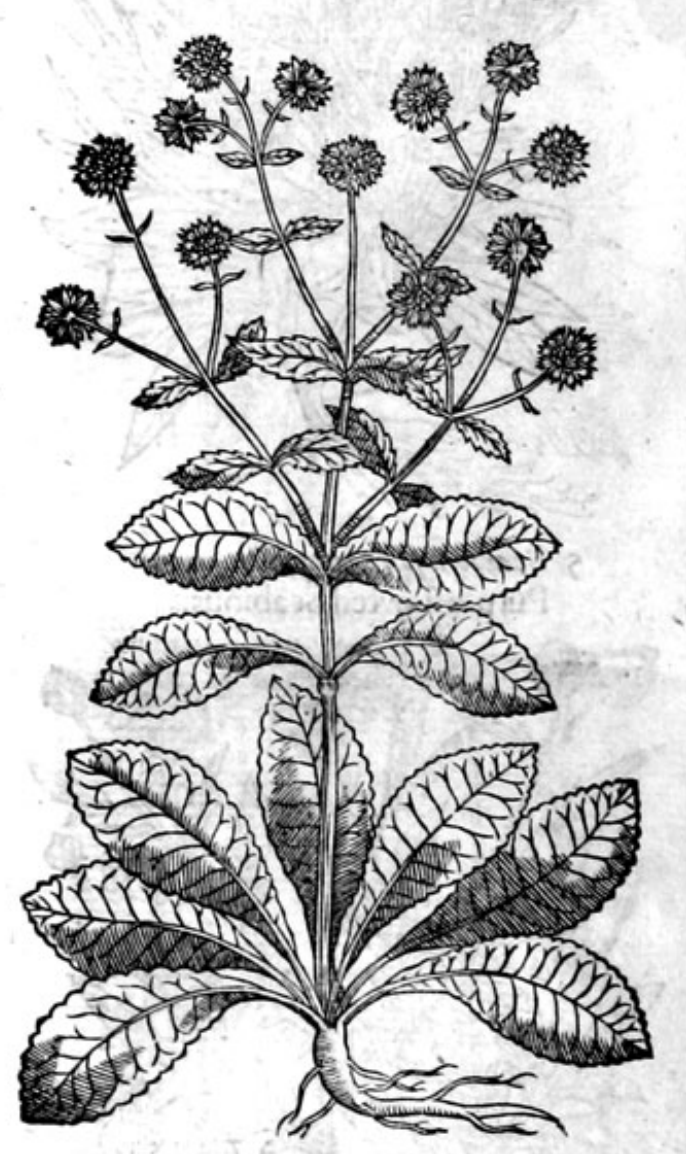

* The defcrittion.

7 The feuenth kind of Scabious hath fundrie great, rough, and round ftems, as high as a tall man, befet with leaues like the firft Scabious, but far greater. The flowers grow at the top of the ftalkes like vnto the others, but of a faint yellow colour, which fall as foone as it is touched with the hande, whereby it mightilie increafeth, notwithitanding the roote endureth many yeeres, and groweth to be woonderfull great: and in my garden it did growe to the bigneffe of a mans bodie. 8 The broad leafed mountaine Scabious hath broad leaues fpred vpon the ground, like thofe of the field Primerofe, but greater. Among which rifeth vp a great ftiffe ftalke fmooth and plaine,garnifhed with the like leaues of thofe next the ground, but leffer. The flowers growe at the top of the ftalkes, of a watchet or light blew colour. The roote is thicke and tough. 
HISTORIE OF PLANTS.

9 Scabiofamaior Hafpanica. Spanith Scabious.

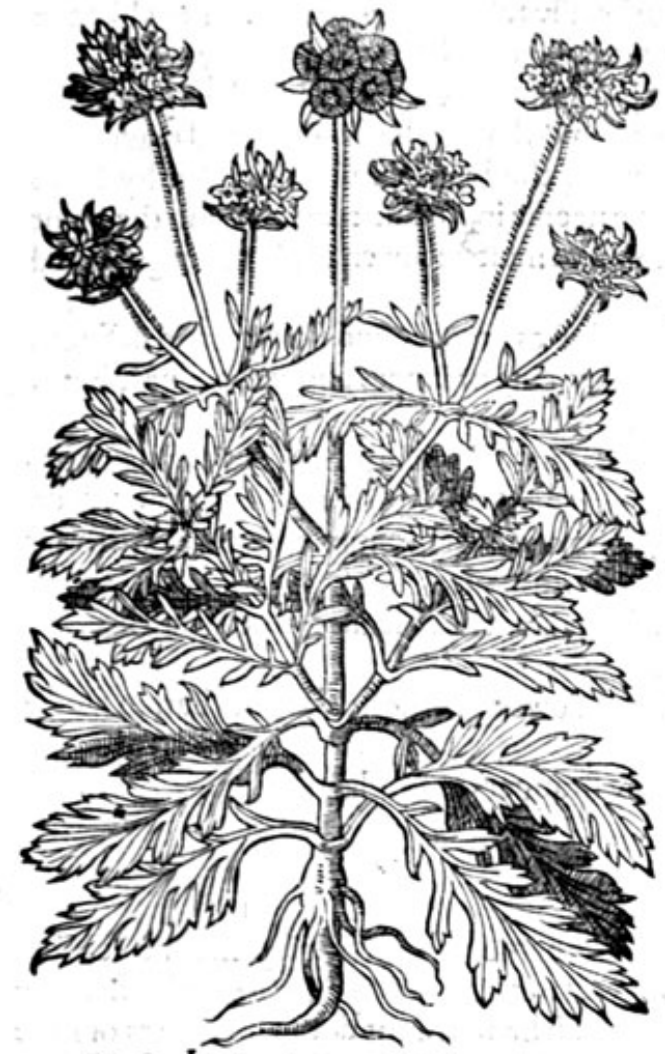

II Scabiofa omnivan minima. Sheepes Scabious.

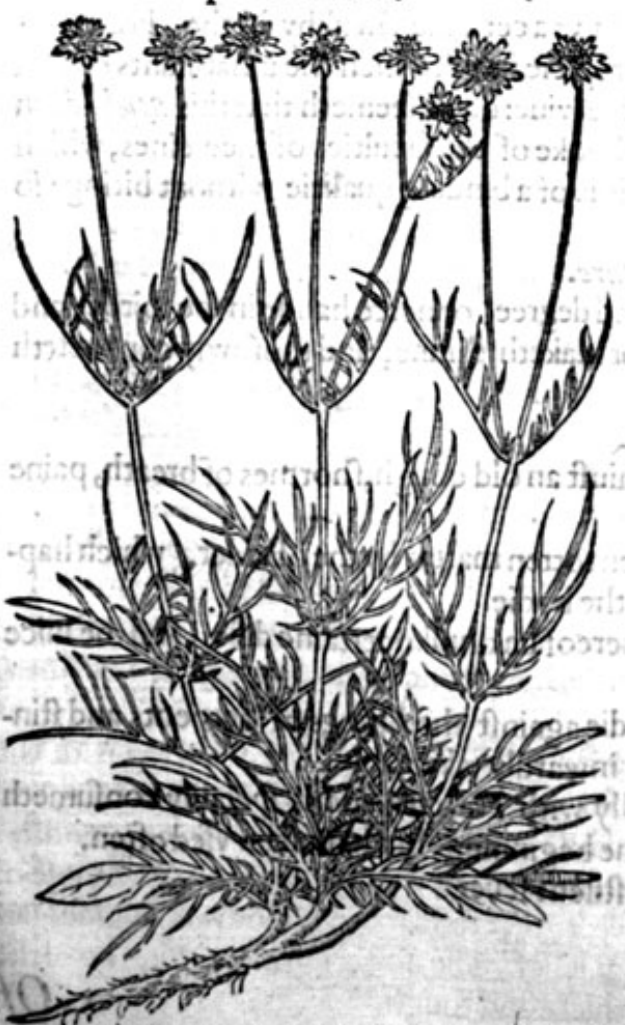

10 Scabiofa feregrina: Strange Scabious.

589

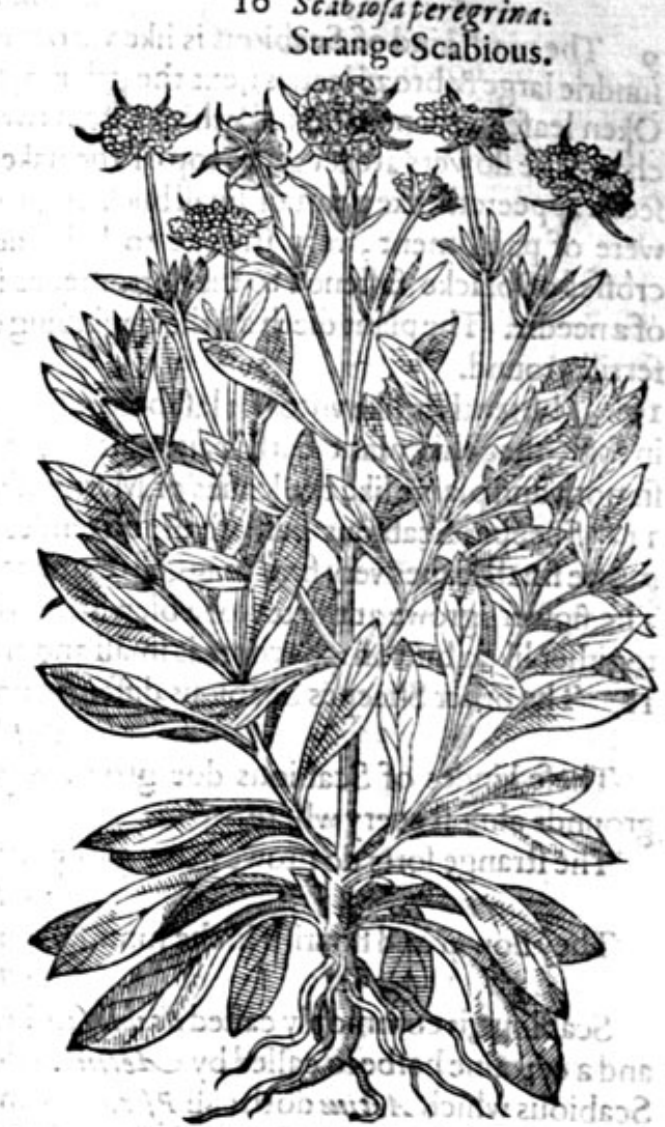

12 Scabiofa minimic Hirfuta.

Hairic fheepes Scabious jlob ath

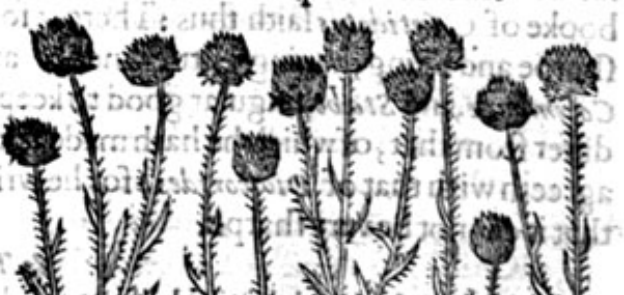
(1) 1.

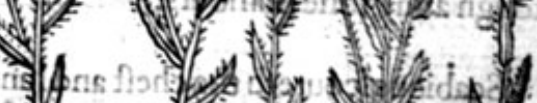

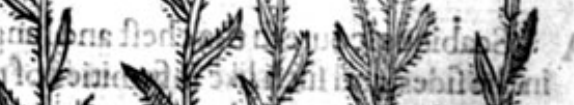

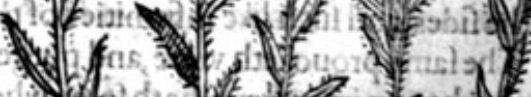

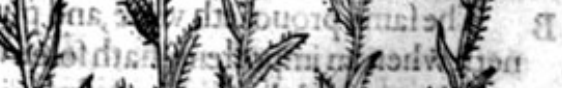

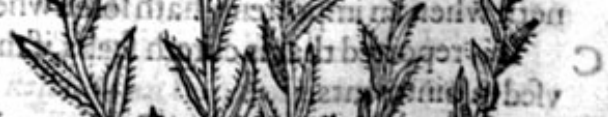

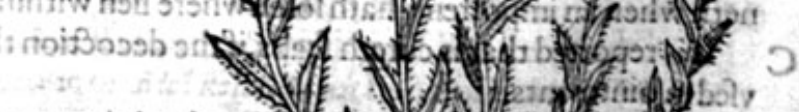

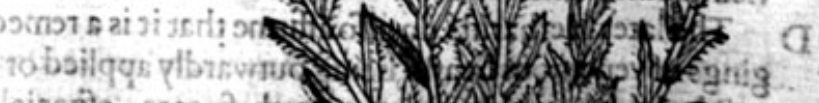

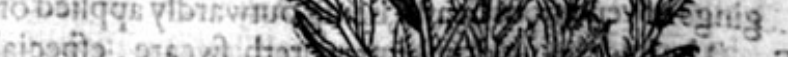

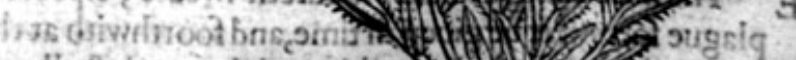

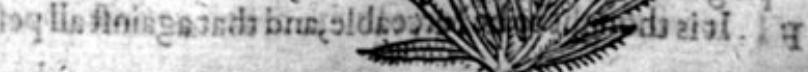

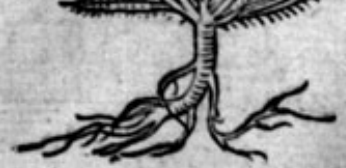


* The defeription.

9 The ninth kind of Scabious is like vnto the mountaine Scabious, but lower and fmaller, hauing fundrie large \& broad leaues next the ground, fnipt confufedly \& out of order at the edges like the Oken leafe; among which rifeth vp a ftem two cubits high, diuiding it felfe into fundry other branches. The flowers are fet at the top of the naked ftalkes, of a whitifh colour; which being paft, the feede appecreth like a tuft of fmall bucklers, round, and fomewhat hollow within, and made as it were of parchment, very ftrange to beholde : and within the bucklers there are fundry fmall croffes of blacke faftened to the bottome, as it were the needle in a diall, running vpon the point of a needle. The plant dieth at the beginning of winter, and muft be fowen in Aprill, in good and fertill ground.

ro The tenth is like vnto the laft before mentioned, in ftalkes, roote, and flowers, and differeth in that, that this plant hath leaues altogither without any cuts or iagges about the edges, but is fmooth and plaine like the leaues of Marigolds, or Diuels bit.

II Sheepes Scabious hath fmail and tender branches trailing vpon the grounde, whereupon do growe fmall leaues very finely iagged or minced etien to the middle ribbe, of an ouerworne colour. The flowers growe at the top of a blewifh colour, confifting of much thrummie matter, hard thruft togither like a button : the roote is fmall and creepeth in the grounde.

12 The other Sheepes Scabious differeth not but in the hairienefle of leaues, otherwife a like. * The place.

Thefe kindes of Scabious doe growe in paftures, medowes, cornefieldes, andbarren fandie grounds almoft euery where.

Theftrange forts do growe in my garden, yet are they ftrangers in England.

They flower and flourith in the fommer moneths.

$$
\approx \text { The time. }
$$

\section{T The names.}

Scabious, is commonly called scabio fa, diuers thinke it is named wiee which fignifieth a fcabbe; and a certaine herbefo called by Netius. I do not knowe, faith Hermolaus Barbarus, whether it be Scabious which Aetinus dothcall P fora, the fmacke of which being burnt doth kill cankers or little wormes. Theaurhor of the Pandeds doth interpret Scabiofa to be Diofcorides his Stabe: Diofcorides defcribeth strebeby no markess at all, being commonly knoyne in his time; and $G_{a} l e n$ in his firft booke of Antidotes faith thus: There is founde amongft vs a certaine fhrubby herbe, hot, verie fharpe and biting, hauing a little kinde of aromaticall or fpiciefmell, which the inhabitants do call Colymbade, and Stabe, fingular good to keepe and preferue wine: but it feemeth that this Stabe doth differ from that, of which he hath made mention in his booke of the facultics of medicines, which agreeth with that of Divfcorides; for he writeth that this is of a binding qualitie without biting: $f 0$ that it cannot be very harpe.

\section{* The temperature.}

Scabious is hot and drie in thelatter end of the fecond degree, or neere hande in the thirde, and of thinne and fubtile parts: it cutteth, attenuateth, or maketh thinne, and thorowly concoeteth tough and groffe humours. 5

A Scabiousfcoureth the cheft and lungs, it is good againft an old cough, fhortnes of breath, paine in the fides, and fuch like infirmities of the chelt.

B The fame prouoketh vrine, and purgeth now and then rotten matter by the bladder, which hapneth when an impofteme hath fonse where lien within the bodie.

C It is reported that it cureth fcabs, if the decoction thercof be diunke certaine daies, and the iuice vfed in ointments.

D The later Herbarifts do alfoaffirne that it is a remedie againft the bitings of Serpents and ftingings of venemous beafts, beingoutwardly applied or inwardly taken.

$\mathrm{E}$ The iuice being drunke procureth fweate, efpecially with Treacle; and it fpeedily confumeth plague fores, if it be given in time, and foorthwith at the beginning: but it muft be vfed often.

F It is thought to be forceable, and that againft all peftilent feuers. 


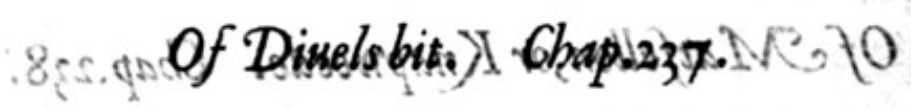

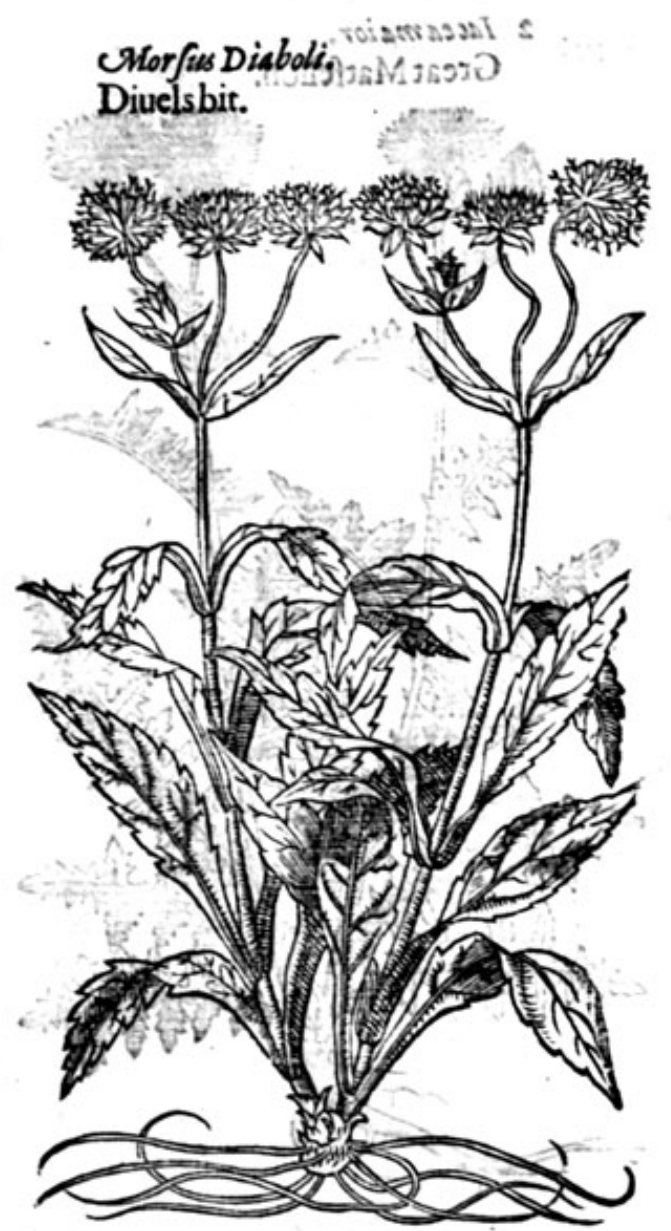

.2. noliojsin odsald * The defaription.

$\mathrm{D}$ Iuels bit Hath finall vpright roundef talkes of a cubite high, befert with long leaues fomewhat broade, very litule of nothing fnipt about the edges, fomewhar hairie and euen. The flowers are of a darke purple colour, fathioned like the tlowers of Scabions, which being ripe are caried away with the winde. The root is black, thicke, harde, S Thort, with many threddicitrings faftned thereto. The greatpart of the roore feemeth to be bittenaway, old fantafticke chamers report, that the dinell did bite it for enuie, bicanfe it is an herbe that hath fo many good vertues, and is fo beneficialt to mankinde.

$$
\text { * Theplase. }
$$

Diuels bit groweth in drie medowes \& woods, and about waies fides. I haue founde great ftore of it growing in Hampiteede woode neere London, at Lee in Effex, and at Raleigh in Effex, in a woode called Hammerell, and fundric other places.

\section{* The time.}

It flowreth in Auguft, and is harde tobe known from Scabious, fauing whenic fowreth.

\section{* The names.}

It is commonly called Mlorfus Diaboli, or Diuels bit, of the root (as it feemeth)that is bitten off.For the fuperftitious people hold opinion, that the diuell for the enuie that he beareth to mankind bit it off, bicaufe it woulde be otherwife good for many vfes: it is called of Fuch/mus Saccifa; in high Teufiets abbitz; in lowe Dutch Dupuelles beet : in French Mors du Diabte: in Englifh Dinels Bit, and Fore bit.

\section{* The temperature.}

Diuels bit is fomething bitter, and of a hot and drie temperature, and that in the latter end of the fecond degree.

\% The vertues.

* The vertues. There is no beter thing againft old fwellings of the almonds, and vpperparts of the throte that $A$
be hardly ripened.

It clenfeth away flimie flegme that fticketh in the iawes, it digefteth and confumeth it: and it B quicklie taketh away the fwellings in thofe partes, if the decoction thereof be often helde in the mouch and gargarized, efpecially if a little quantitie of Mel Ro artum, or honie of Rofes be put into it.

- It is reported to be good for all the infirmities that Scabious ferueth for, and to be of noleffe $C$ forceagaint the ftingings of venemous beafts, poifons, and peitilent difeafes, and to confume and wafte away plague fores, being ftamped and laide vpon them.

And alfo to mitigate the paines of the matrix or mother, and to driue foorth winde if the decoc-D tion thereof be drunke. 


\section{Of Matfellon, or Knapweede. Chap.238.}
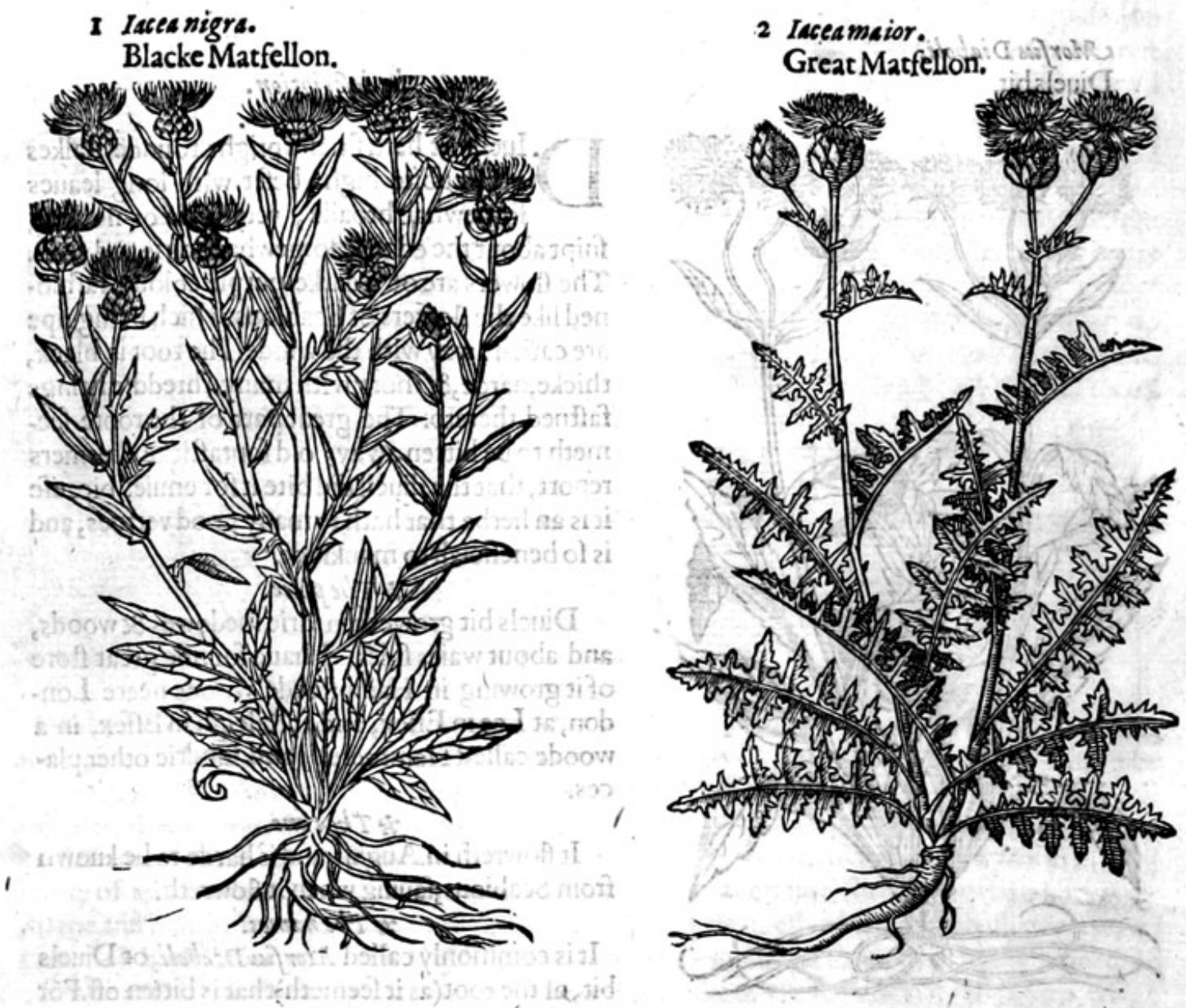

* The defcription.

$\mathrm{M}$ Atfellon or blacke Knapweede, is doubtleffe a kinde of Scabious, as all the others are, intituled with the name of Iacea; yet for diftinction, I haue thought good tofet them down in a feuerall chapter, beginning with that kinde which is called in Englifh Knapweede, and Matfellon, or Materfilon. It hath long and narrowe leaues, of a blackifh greene colour, in hape like Diuels bit, but longer, fet vpon ftalkes two cubits high, fomewhat bluntly cut or fnipt about the edges: the flowers do grow at the top of the ftalks, being firft fmall fcaly knops, like to the knops of Corne flower, or blew bottles, but greater, out of the midft thereof groweth a purple thrummie or threddie flower. The roote is thicke and hort.

2 The great Knapweede is very like vnto the former, but that the whole plantis much greater, the leaues bigger and more deepely cut, euen to the middle rib: the flowers come foorth of fuch like fcaly heads, of an excellent faire purple colour, and much greater.

3 The thirde kinde of Matfellon, or Knapweede, is very like vnto the former great Knapweed laft before mentioned, fauing that the flowers of this plant are of an excellent faire yellowe colour,proceeding foorth of a fcaly head or knop, befet with moft fharpe prickes, not to be touched without hurt; the flower is of a pleafing fmell and very fweete; the roote is long and lafting, and creepeth farre abroad, by meanes whereof it greatly increafeth.

4 The mountainc Knapweede of Narbone in Fraunce, hath a ftrong ftemme, of two cubits high, and is verie plentifull about Couentrie among the hedges and bufhes: the leaues are very much iagged, in forme of Lonchitis, or Spleene woort; the flowers are like the reft of the Knapweeds, of a purple colour. 
3 Iacea miaior letet.

Yellowe Knapweds.

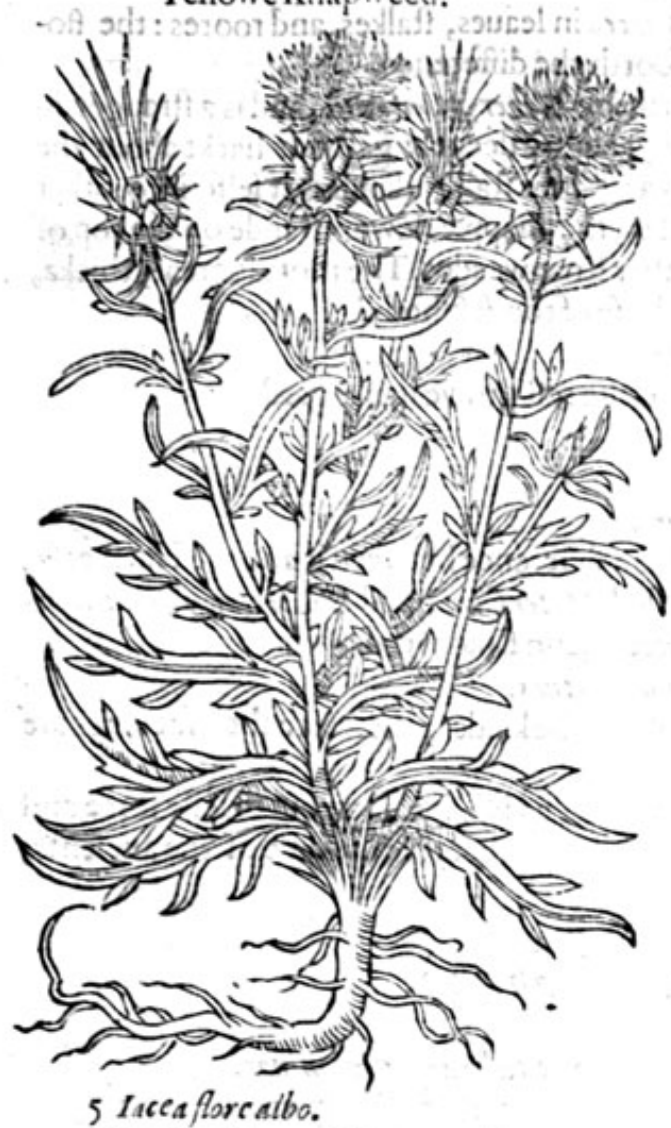

White fiowred Knapweed.

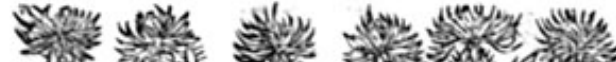
तै 2 - 10 B. i) 7 o m s n - 1501250 w ide * $3<N$ 3)

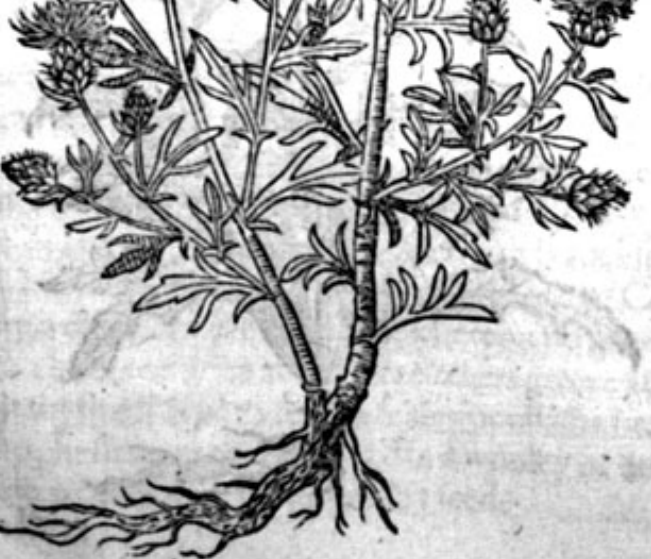

4 Itcea montana.

(5i) Mountaine Knapweed.

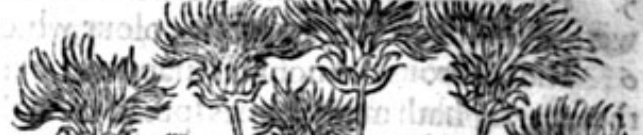

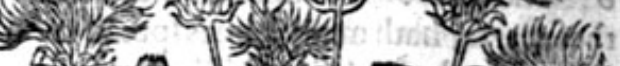

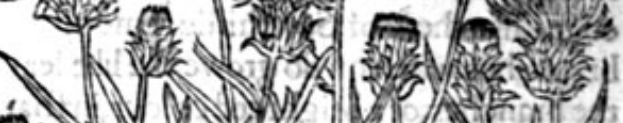
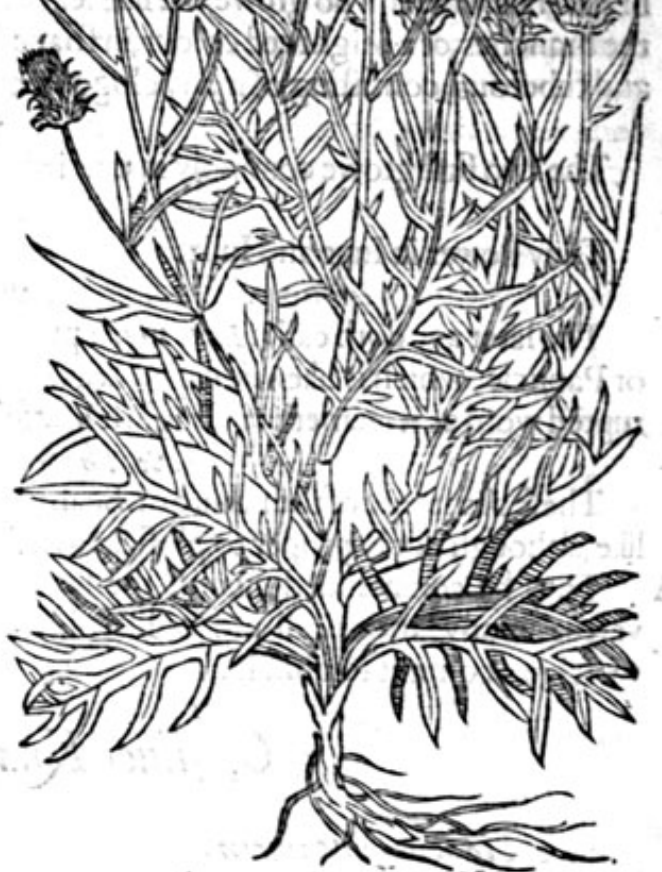

6 Jasestuberefa.

Knobled Knapwecd.
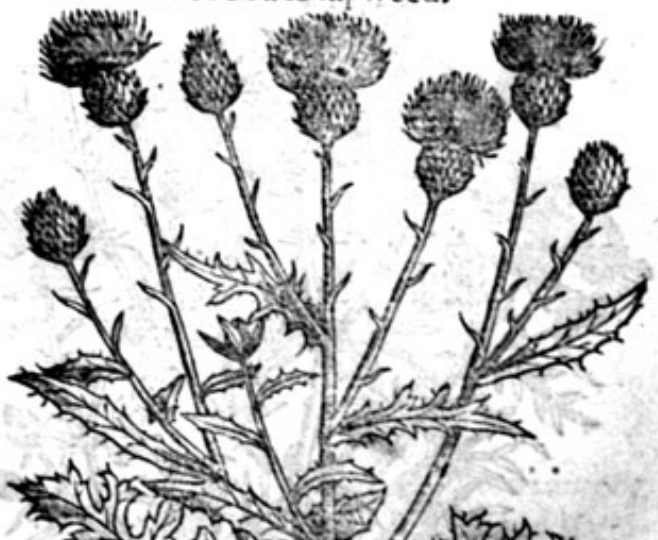

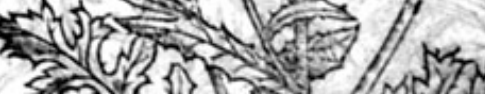

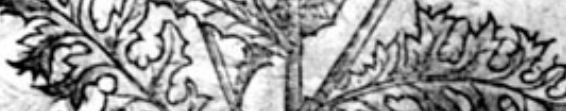

ind 230

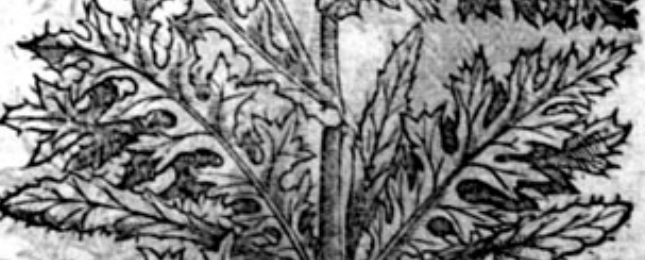

nd $m{ }^{3}$

35. (3) 
* Thedefription.

5 The white fowred Knapwced is like vnto the great Iacea in leaucs, ftalkes, and rootes: the flowers of this plant are of a white colour, which fetteth foorth the difference.

6 The tuberous or knobbie Knapweed being fet foorth by Taber Montanus, and is a ftranger in thefe parts, hath many leaues fpread vpon the grounde, rough, deepely gahtor hackt about the edges, like thofe of Sowthifle: among which rifeth vp a ftraight ftalke, diuiding it felfe into other braunches, whereon do growe the like leaues, but fmaller; the knappie flowers ftande on the top of the branches, of a bright red colour, in hape like the other Knapweedes. The roote is great, thicke, and tuberous, confifting of many cloggie parcels, like thofe of the Afphodill. * The place.

The two firft growe commoly in euerie fertill palture, the reft growe in my garden.

They flower in Iune and Iulie. $*$ The time.

* The names.

The later age doth call it Iacea nigra,putting nigra for a difference between it and the Harts eafe, or Pauncie, which is likewife called Iacea: it is alfo called Mater fillon, and CMatrefillon, of a corrupted word as it feemeth : in Englifh Matfellon, Bulweede, and Knapweed.

$$
\text { * The temperature and vertues. }
$$

Thefe plants are of the nature of Scabious, whereof they bekindes, therefore their faculties are like, although not fo proper to phifickes vfe.

A They be commended againft the fwelling of the Vuula, as is Diuels bit, but of leffe force and vertue : many fantafticall and foolifh old wiues tales haue beene reported by forne of the ancients, which we commit to obliuion.

\section{Of filuer Knapweed. Chap.239.}

I Stabe argentea maior.

Great filuer Knapweed.

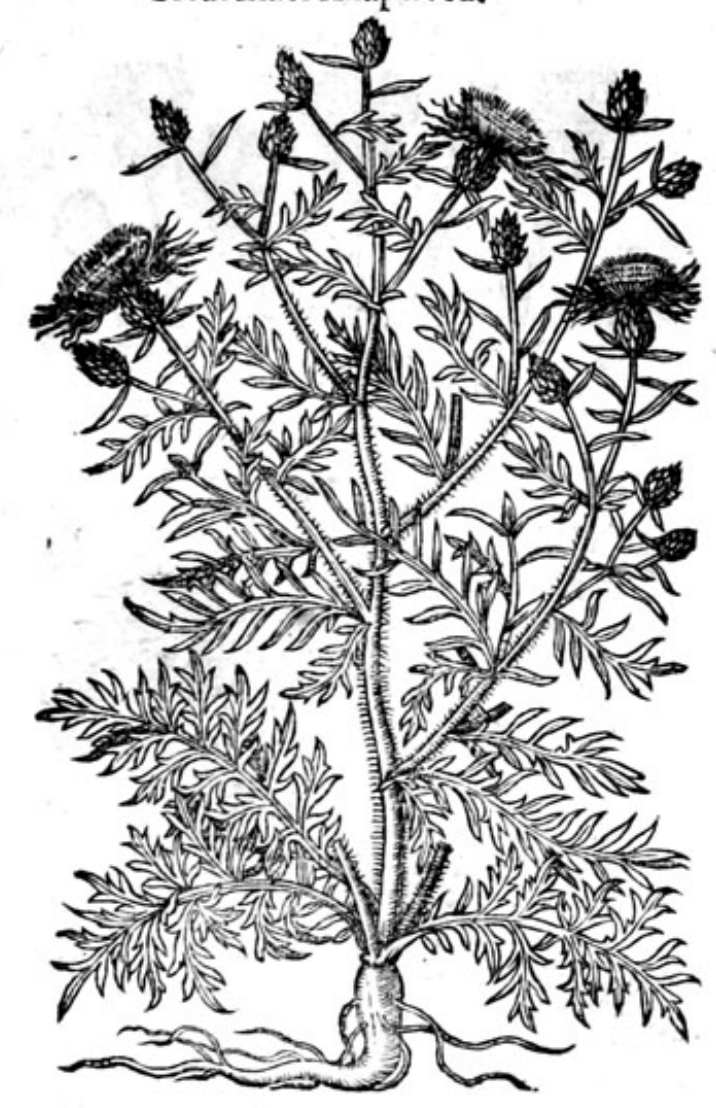

2 Stabe argentea minor. Little filuer Knapweed.

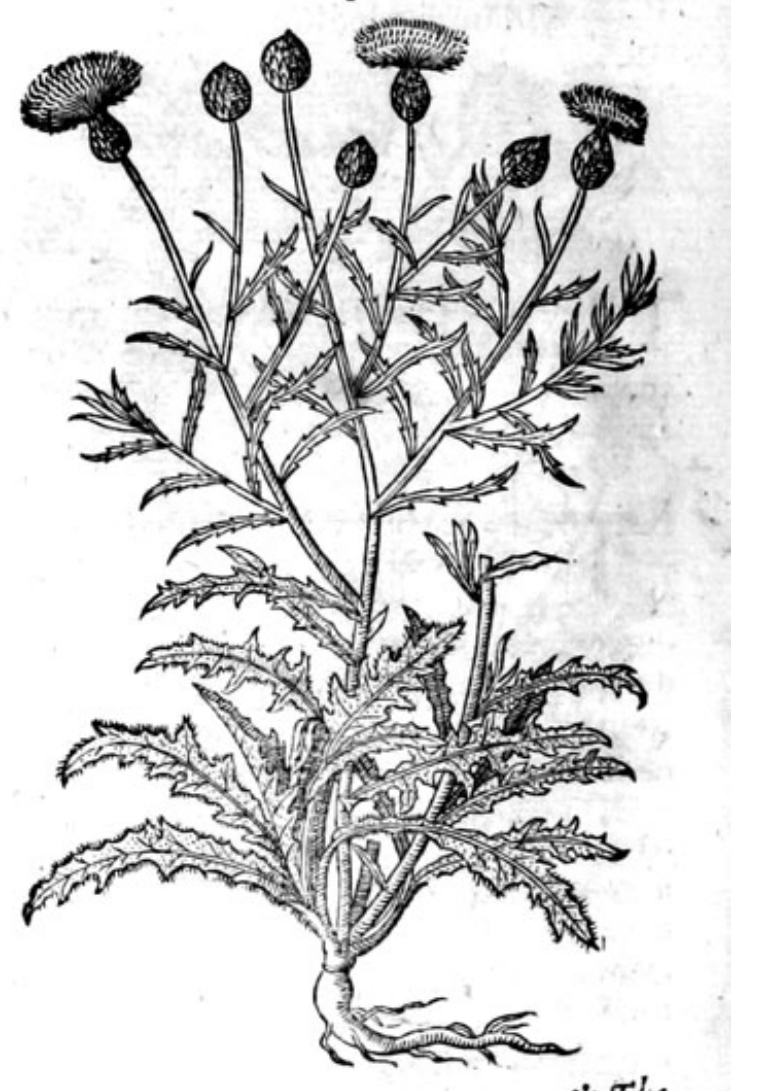


* Thedefcription.

I He great filuer Knapweed hath at his firft comming vp diuers leaves fpred vpon the grounde, of a deepe greene colour, cut and iagged as are the other Knapweeds, Itraked heere and there with fome filuer lines downe the fame, where of it tooke his furname, $\mathrm{Nr}$ gentea among which leaues rifeth vp a ftraight ftalke, of the height of a cubite, fomewhat rough and brittle, diuiding it felfe towarde the top into other twiggie branches, on the tops whereof doe grow flowers fet in fcaly heades or knaps like the other Mattellons, of a gallant purple colour, confifting of a number of threds or thrums thicke thruft togither $;$ after which the feedes appeere, 1lipperie, fmooth at one end, and bearded with blacke haires at the other end, which maketh it toleape and skip away when a man doth but lightly touch it. The roote is fmall, fingle, and perifheth when the feede is ripe.

2 The fecond agreeth with the firft in eche refpect, fauing that the leaues heereof are more iag. ged, and the filuer lines or ftrakes are greater and moe in number, wherein confifteth the difference.

* Theplace.

Thefe do growe of themfelues in fieldes neere common high waies, and in vntilled places, but they are ftrangers in England,neuertheleffe I haue them in my garden.

\section{* The time.}

They fpring vp in Aprill, they flower in Auguft, and the feede is ripe in September. * T the names.

Siluer Knapweed is called of L'Obelines Stabe jalamantica, of Dodonens Lphyllant bes, that is, without leaues, for the flowers confift onely of a number of threddes without any leaues at all: in Englifh filuer Knapweed, or filuer Scabious, whereof doubtles they be kindes.

* The temperature and vertues.

The faculties of thefe Matfellons are not as yet founde out, neither are they vfed for meate or A medicine.

\section{Of blewe Bottle, or Corneflower. Chap.24o.}

* The kindes. Here be diuers forts of blew Bottles, differing onely in the colour of the flowers, as fhall be
(hewed.

\section{* The defcription.}

$1-$ Hegreat blewe Bottle hathlong leaues, fmooth,foft, downie, and tharpe pointed: among the leaues rife up crooked, weake, and feeble braunches, chamfered, furrowed, and garniThed with fuch leaues as are next the ground: on the tops whereof ftande taire blewe flowers tending to purple, confifting of diuers little flowers, fet in 2 fcaley huske or knap like thofe of the Knapweeds; the feed is rough or bearded at one end, fmooth at the other and (hining. The root is tough, and long lafting (contrarie to the reft of the Corne flowers) and increafetly yeerely into newe thootes and fprings, whereby it greatly increafeth.

2 The common Corne flower hath leaues fpred vpon the ground, of a whitimgtene colour, fomwhat hackt or cut in the edges like thofe of Corne Scabious : among which rifeth vp a ftalk diuided into diuers's Imall braunches, whereon do growe long leaues, of an ouerwornegreene colour, with fewe euts or none at all. The flowers growe at the top of the ftalks, of a blewe colour, confifting of many finall flowers fer in a fcaley or chaffic head, like thofe of the Knapwẹeds : the feede is fmooth, bright fhining,and wrapped in a wooley or flockie matter. The roote is fmall and fingle, and perifh- 
I Cyanusmaior.

Great blewe Bottle.

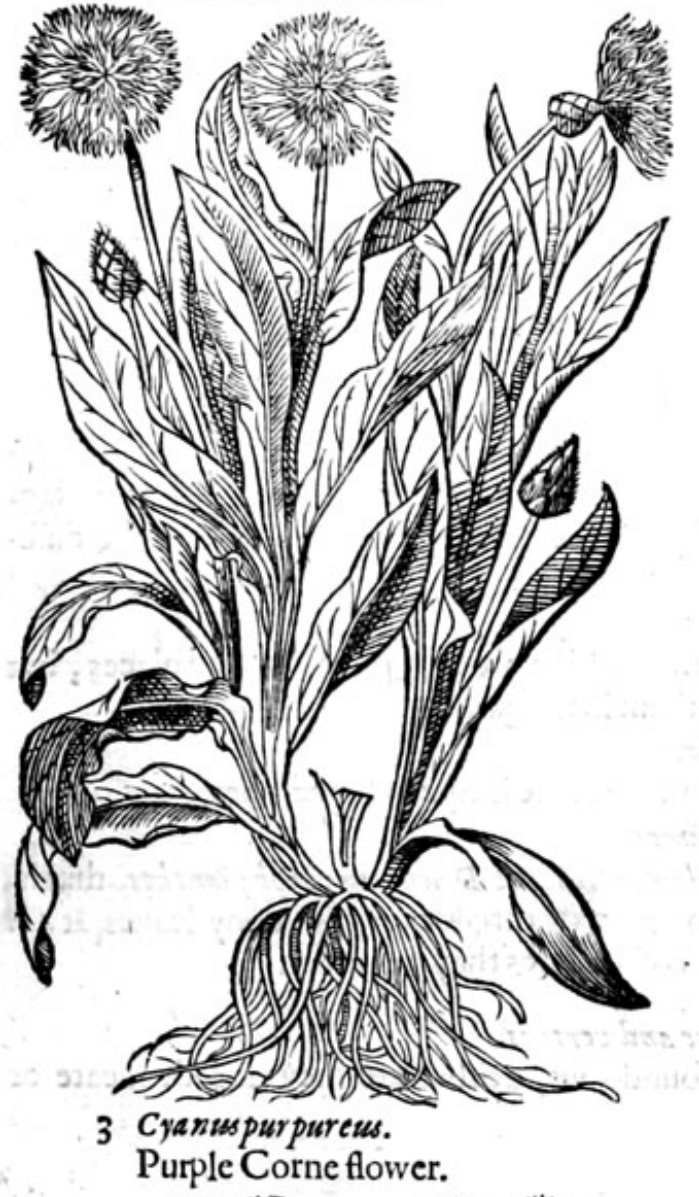

2 Cyanusvulgaris.

Common blewe Bottle.
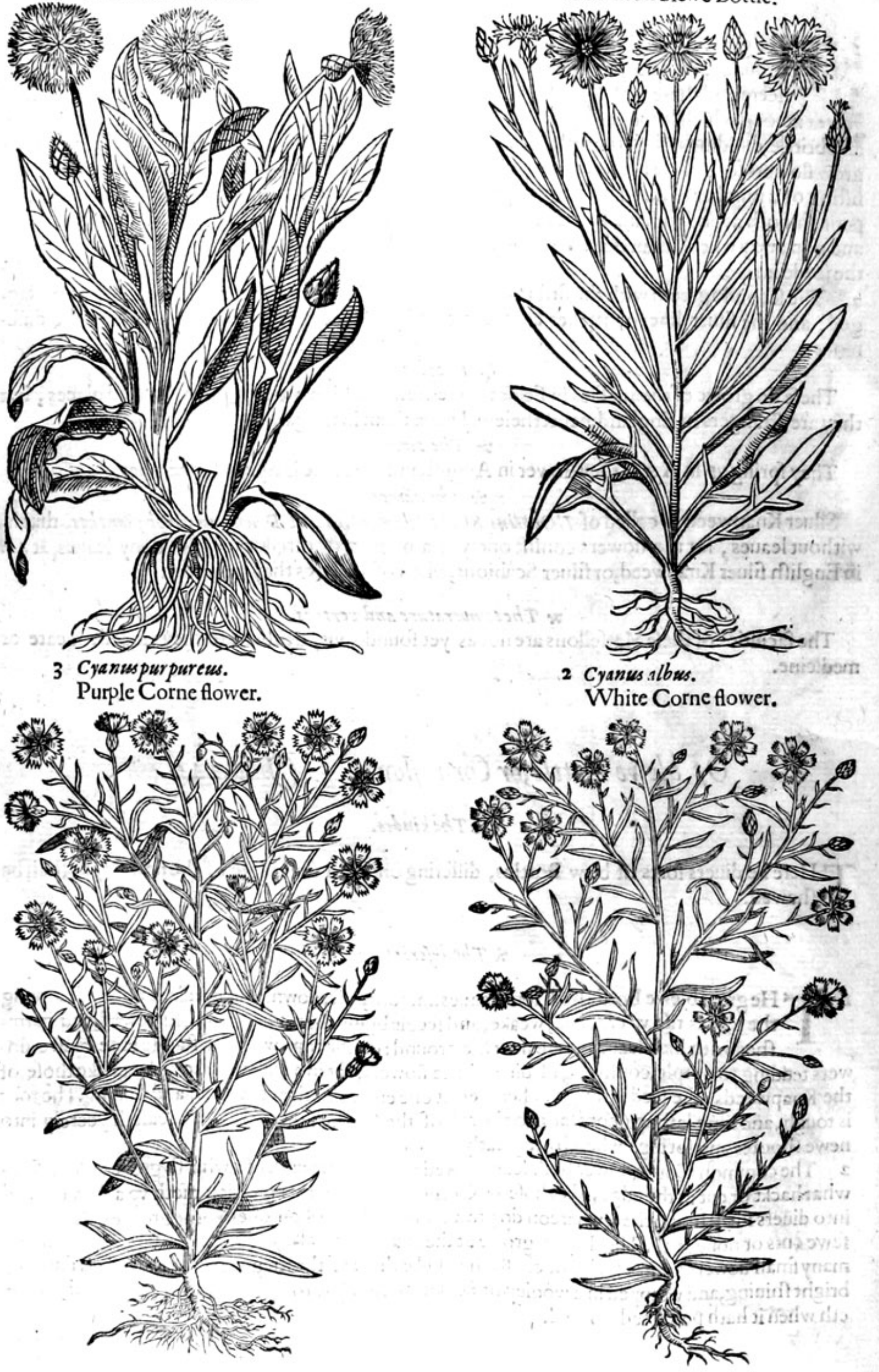


\section{马HTHIST ORIE OF PLANTS. HII}

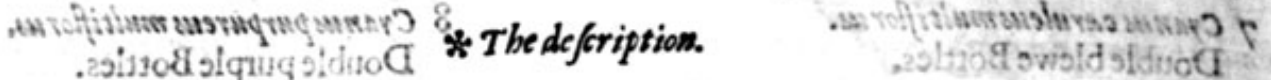

3 This Bottle is like the laft defcribed in eche refpect, fauing in the colour of the flowers, which are of a purple colour, wherein confifteth the difference.

4 The fourth bottle is alfo like the precedent, not differing in any point but in the flowers, for as the laft before mentioned are of a purple colour: contrariwife thefe are of a milke white colour, which fetteth foorth the difference.
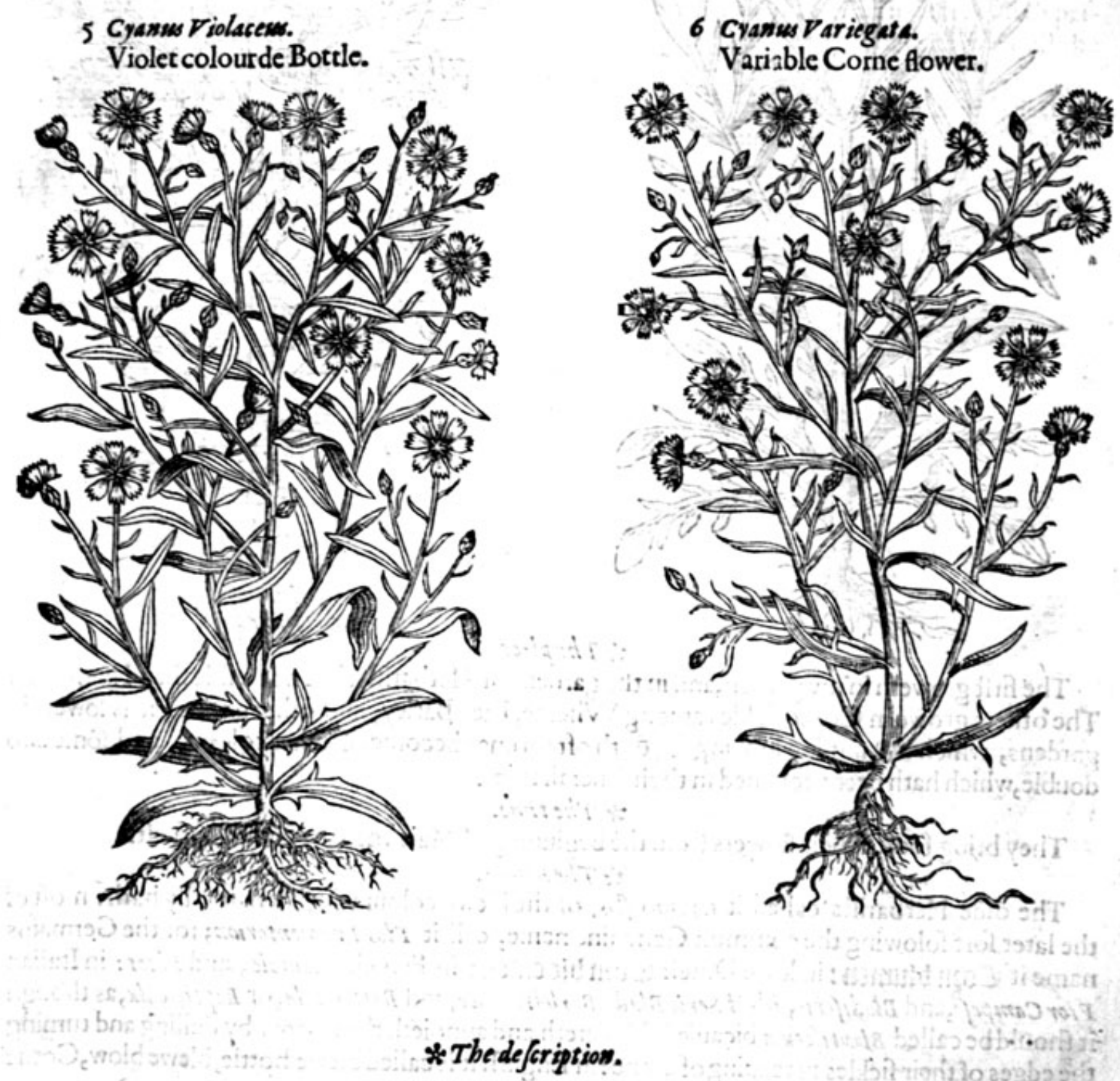

5 The violet coloured Bottle or Corne flower, is like the precedent, in ftalkes, leaues, feedes, and rootes. The onely difference is, that this bringeth foorth fowers of 2 violet colour, and the others not fo.

6 Variable Corne flower is fo like the others, in ftalkes, leaues, and proportion, that it cannot be diftinguifhed with wordes, onely the flowers heereof are of two colours mixed cogither, that is, purpleand white, wherein it differeth from the reft.

7 There is no difference to be founde in the leaues, ftalkes, feede, or rootes of this Corne flower from the other, but onely that the flowers heereof are of a faireblewe colour and verie double.

8 The eight Come flower is like the precedent, without any difference at all, fauing in the colour of the flowers, the which are of a bright purple colour, that fetteth foorth the difference: 


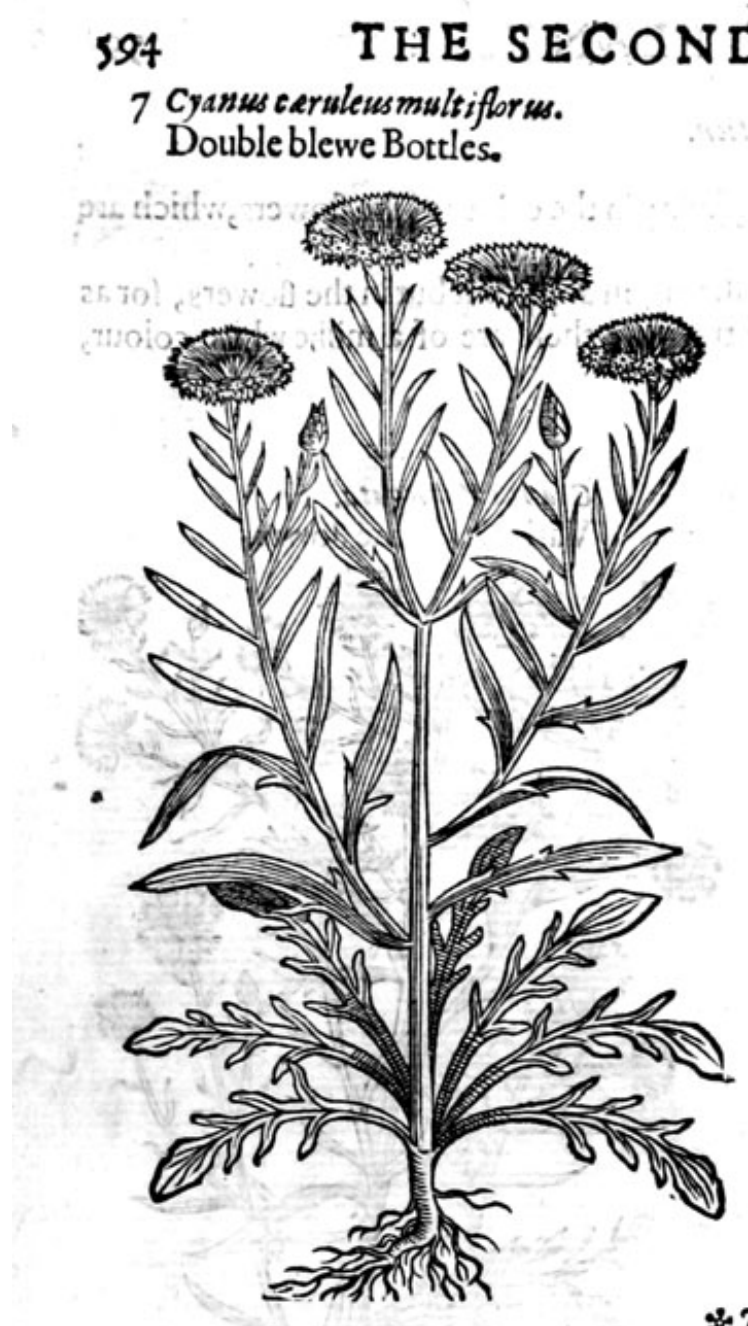

* The place.

BOOKE OF THE

8 cyanuspurpuresusmultiflorew.

Double purple Bottles.

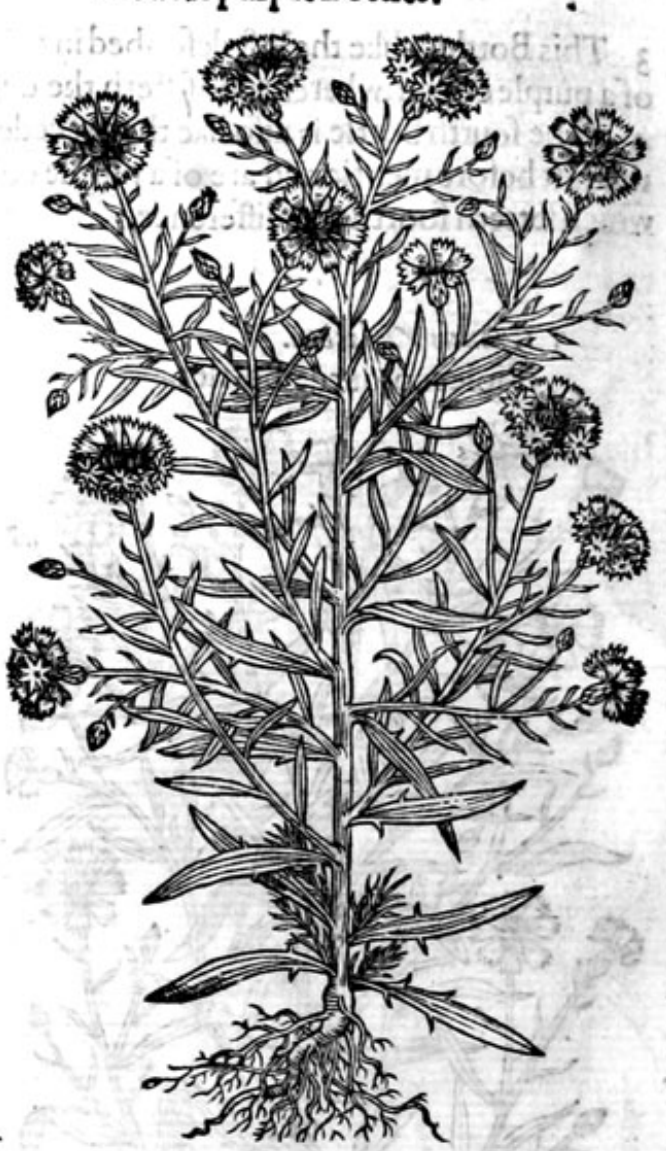

The firft groweth in my garden, and in the gardens of Herbarifts, but not wilde that I knowe of. The others growe in Corne fieldes among Wheate, Rie, Barley, and other graine: it is fowen in gardens, which by cunning looking to, doth oftentimes become of other colours, and fomealfo double, which hath beene touched in their feuerall titles.

\section{* The timie.}

They bring foorth their flowers from the beginning of Maie vnto the end of harueft. * The names.

The olde Herbarifts called it Cyannes flos, of the blewe colour which it naturally hath: moft of the later fort folowing the common Germaine name, call it Flos Frumentornm; for the Germains name it Coen blumen: in lowe Dutch Coun bloemen: in French slaueole, and Bluet : in Italian Fior Campefe, and Bladiferis, idest Seris Bladi,Barbar a voce, and Battifecula, or Baptifecula, as though it fhould be called Blaptifecula bicaufe it hindereth and annoieth the reapers, by dulling and turning the edges of their fickles in reaping of corne: in Englifh it is called blewe Bottle, bleweblow, Corne flower, and hurt fickle.

\section{$*$ The temperature and vertues.}

A The faculties of thefe flowers are not yet fufficiently knowen. Sith there is no ve of them in $\mathrm{Phi}$ ficke, we will leaue the reft that might be faid to a further confideration: Notwithftanding fome haue thought the common Blew bottle tobe of temperaturefomething colde, and therfore good againift the inflanmations of the eies, as diuers do thinke.

$$
\begin{gathered}
\text { Of Goates beard, or Go to bed at noone. Chap.24r. } \\
\text { * The decription. }
\end{gathered}
$$

I Oates beard or Go to bedde at noone, hath hollow ftalkes, fmooth, and of a whitilh

I greene colour, whereupon do grow long leaues crefted downe the middle with a fwelling ribbe, harpe pointed, yeelding a milkic iuice when it is broken, in fhape like thofe of Gar- 


\section{HISTORIE OF PLANTS.}

licke: from the bofome of which leaues, thruft foorth finall tender ftalkes fet with the like leaues, but leffer. The flowers grow at the top of the ftalkes confifting of a number of purple leaues, dafhe ouer as it were with a little yellowe duft, fet about with nine or ten tharpe pointed greene leaues; the whole flower refembleth a ftarre when it is fpred abroade: for it thutteth it felfe at twelue of theclocke, and fheweth not his face open vntill the next daies funne do make it flower anew, wherupon it was called Go to bed at noone, when thefe flowers become to their fullmaturitic and ripeneffe, it groweth into a downic blowe ball like thofe of Dandelion, that is caried awaic with the winde. The feede is long, having at the ende one peece of that downie matter hanging at it. The roote is long and fingle, with fome fewe threds thereto annexed, which perifheth when it hath perfeeted his feede, yeelding much quantitie of a milkic iuice when it is cut or broken, as doth all the reft of the plant; and perifheth when the feede is ripe.

2 Theyellowe Goates beard hath the like leaues, ttalkes, roote, feede and downie blow bals, that the other hath, and alfo yeeldeth like quantitic of milke, infomuch that if the pilling while is is greene be pulled from the ftalkes, the milkie iuice followeth; but when it hath there remained a little while, it waxeth yellowe. The flowers heereof are of a golde yellow colour, and hath no fuch greene leaues to garnifh it withall, wherein confifteth the difference.

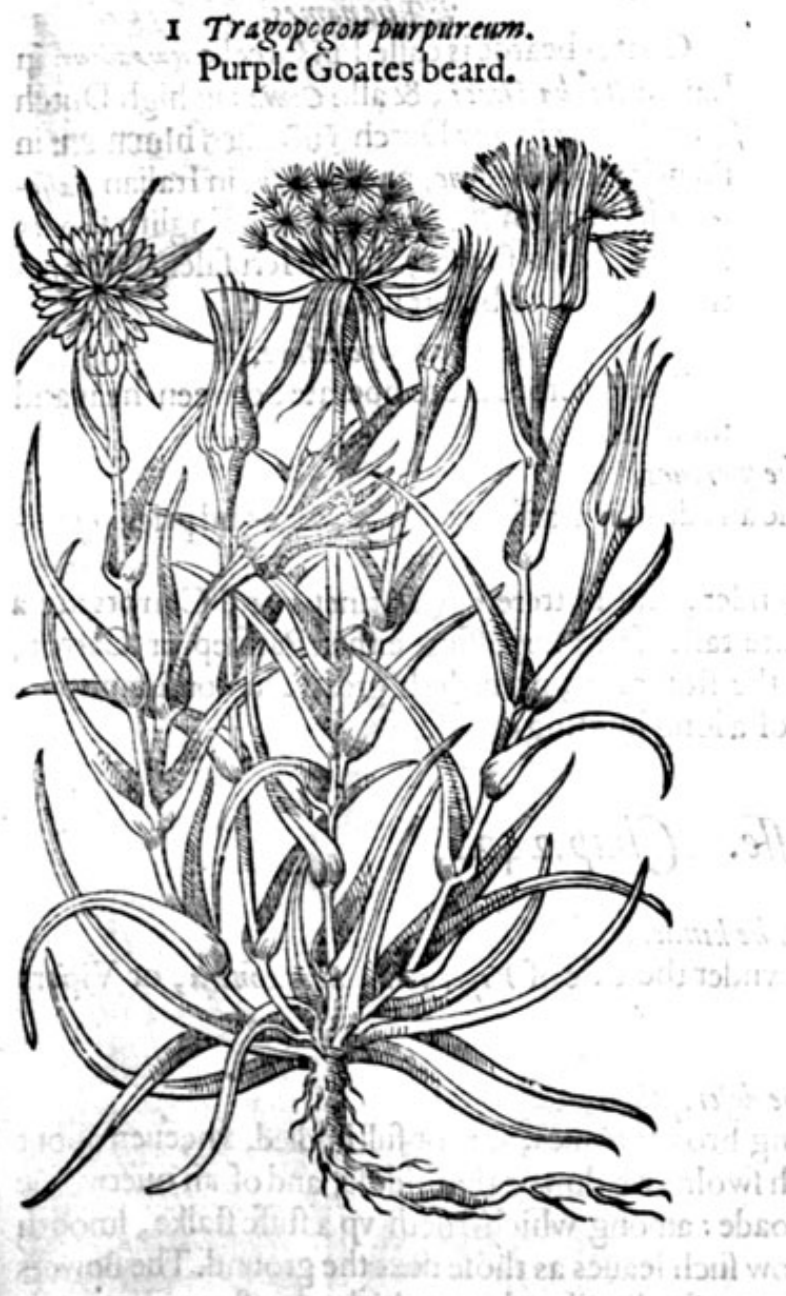

\section{Tragopogon luteum. \\ Yellow Goates beard.}

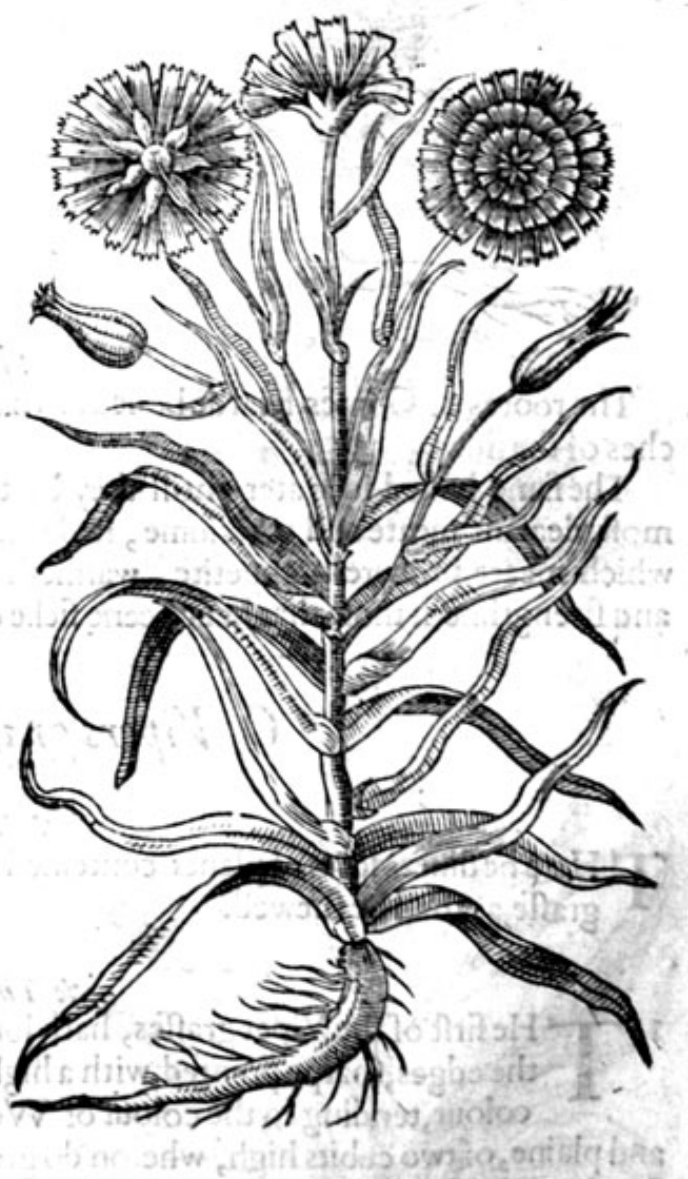

\section{* The defaripsion.}

3 This fmall fort of Goates bearde, or Go to bed at noone, hath a thicke roote full of a milkie fap, from which rife vp many leaues fpread vpon the grounde, very long, narrowe, thinne, and like vnto thofe of graffe, but thicker and groffer : among which rife vp flender ftalks, on the tops whereof do ftande faire double yellowe flowers like the precedent, but leffer. The whole plant yeeldeth a milkie fapor iuice as the others do: it perilheth like as the other, when it hathperfected his feede. 
3 Trazopagonminus.

Little Goates beard.

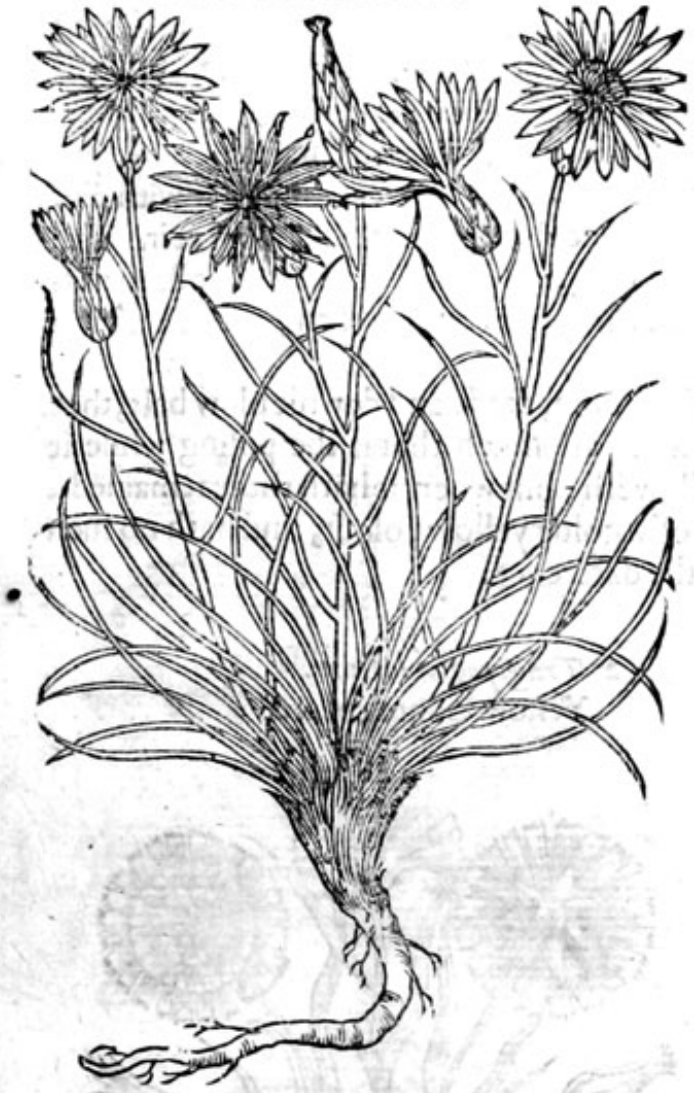

$$
\because \text { The place. }
$$

The firft groweth not wilde in England that I coulde euer fee or heare of, except in Lancafhire vpon the bankes of the riuer Chalder, neere vnto my Ladie Hesketh hir houfe, two miles from Whawley: it is fowen in gardens for the beautie of the flowers, almoft euery where. The others growe in medowes and fertill paftures in moft places of England. It groweth plentifully in moft of the fielde's about London, as at Iflington, the medowes by Redreffe, Detforde, and in the medowes neere vnto Putney and diuers other places.

$$
\text { - : The time. }
$$

They flower and flourith from the beginaing of Iune to the ende of Augurt.

$$
\text { * T thenames. }
$$

Goates bearde is called in Greeke rsaremajav: in Latine Barba Hirci, \& allo Coma : in high Dutch 2sactbaett: in low Dutch Jofephes bloement in French Barbe de bouc, and $S_{a} \beta a f y$ : in I talian $S_{a j f e-}$ frica: in Spanifh Barba Cabruna in Englifh Goats beard,Iofephs flower, Star of Ierufalem, Noonetide, and Go to bed at noone. * The temperature.

Thefe herbes aretemperate between heat and moifture.

\section{* The vertues.}

A The rootes of Goates bearde boiled in wine and drunke, affwageth the paine and pricking ftitches of the fides.

B The fame boiled in water vntill they be tencer, and buttered as Parfneps and Carrots are a moft pleafant meate and wholfome, in delicate tafte farre furpaffing either Parfnep or Carrot, which meare procureth appetite, warmeth the ftomacke, preuaileth greatly in confumptions, and ftrengthneth thole that haue beene ficke of a long lingring difeafe.$$
\text { OfVipers grafJe. Chap.242. }
$$

* The kindes. Here be diuers forts of plants conteined vnder the title of $v$ iperaria, scorzonera, or Vipers
graffe,as Thall be fhewed.

* The defcription.

I $\mathrm{He}$ firft of the Viper graffes, hath long broade leaues, fat, or full bodied, vneeuen about the edges, tharpe pointed, with a high fwolne rib downe the middle, and of an onerworne colour, tending to the colour of Woade : among which rifeth vp a ftiffe ftalke, fmooth and plaine, of two cubits high, wheron do grow fuch leaues as thofe next the ground. The flowers ftande on the top of the ftalkes, confifting of many fimall yellow leaues thicke thruft togither, verie double, as are thofe of Goates beard, whereof it is a kinde, as are all the reft that doe follow in this prefent chapter : the roote is long, thicke, verie brittle, continueth many yeeres yeelding great intreafe of roots, blacke without, white witlin, and yeeldeth a milkie inice, as do the leaues alfo, like vinto the Goates beardes.

2 The dwarffe Vipers graffe differeth not from the precedent, fauing that it is altogither leffer, wherein efpeciaily confifteth the difference. 


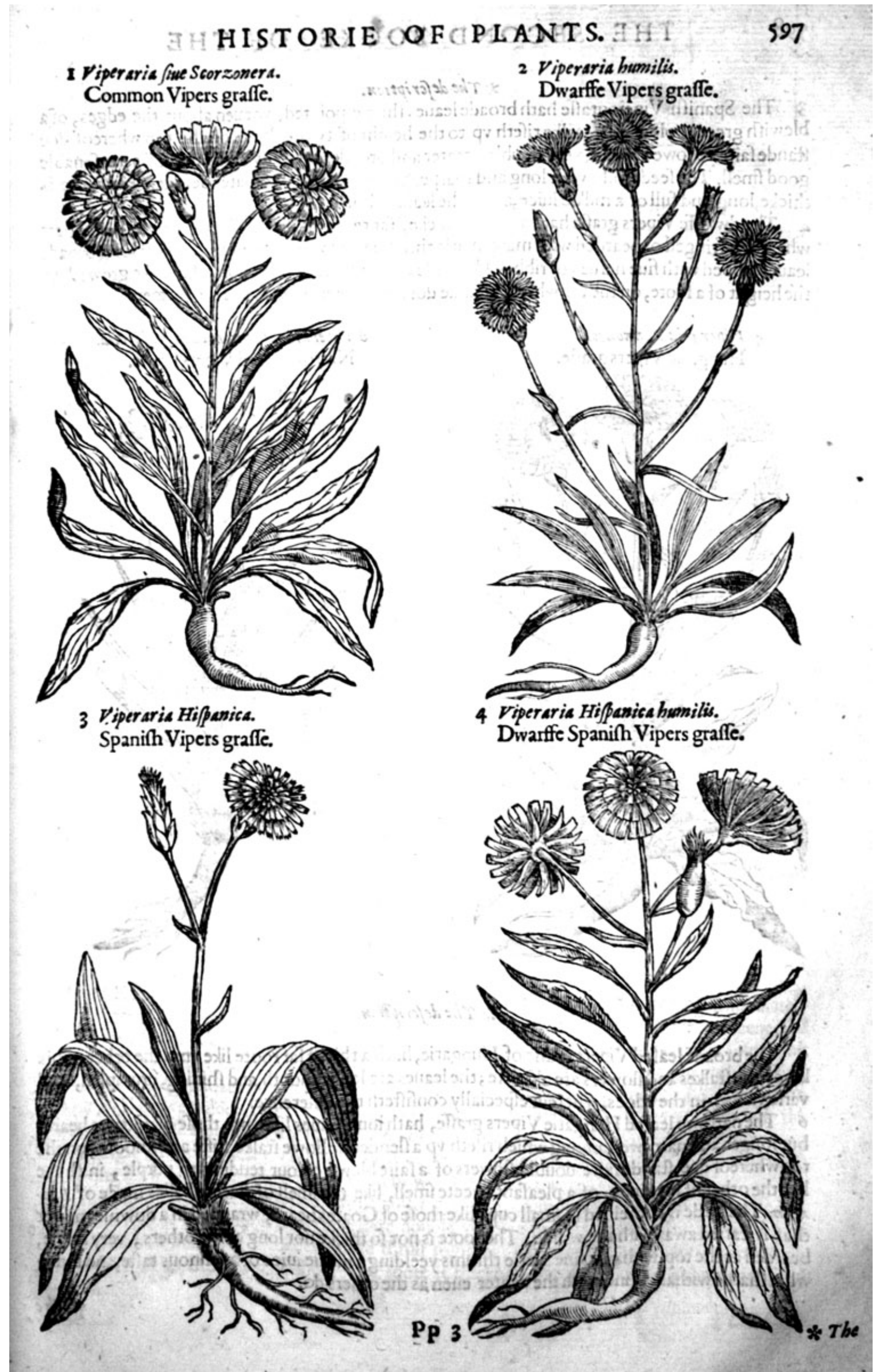



\$The defoription.

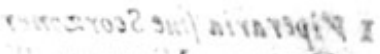

3 The Spanifh Vipers grafie hath broade leaties tharpe pointed, vneuen about the edges, of 2 blewifh greene colour: the !talke rifcth vp to the height of two cubits; on the top whereof doe ftande faite ycllowe flowers, very double, greater and broader then any of the reft, of a reafonable good fmell. The feede followeth long and fharpe, like vnto thofe of Goates bearde. The roote is thicke,long,and full of a milkie iuice, as are the leaues alfo.

4. The dwarffe Vipers graffe hath a great, thicke, fat roote, full of milkie fappe; the vpper part whereof is fringed or bearded with many hairie threds : from which fpring vp diuers long broade leaues, ribbed with fiue nerues or ribbes, like thofe of Plantaine or Ribwoort; the ftalke groweth to the height of a foote, on the top whereof itande double yellowe flowers like the former.

5 Viperaria Pannonica. Hungarie Vipers grafle.

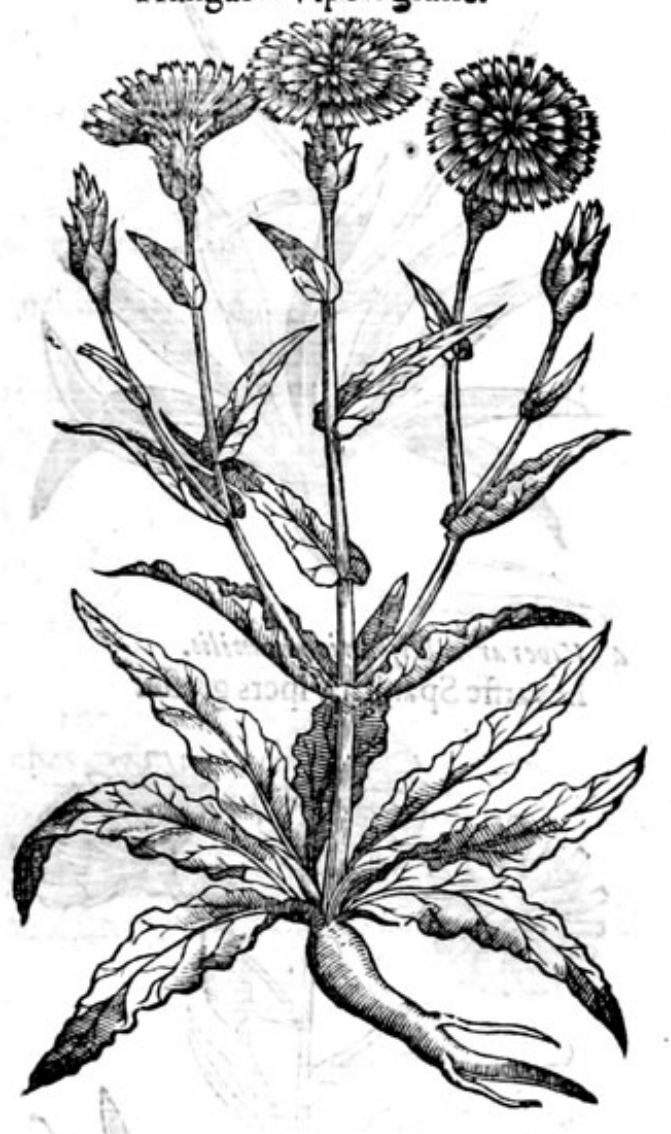

6 Videraria Pasnonica ang fififolia. Narrow leafed Vipers graffe.

8

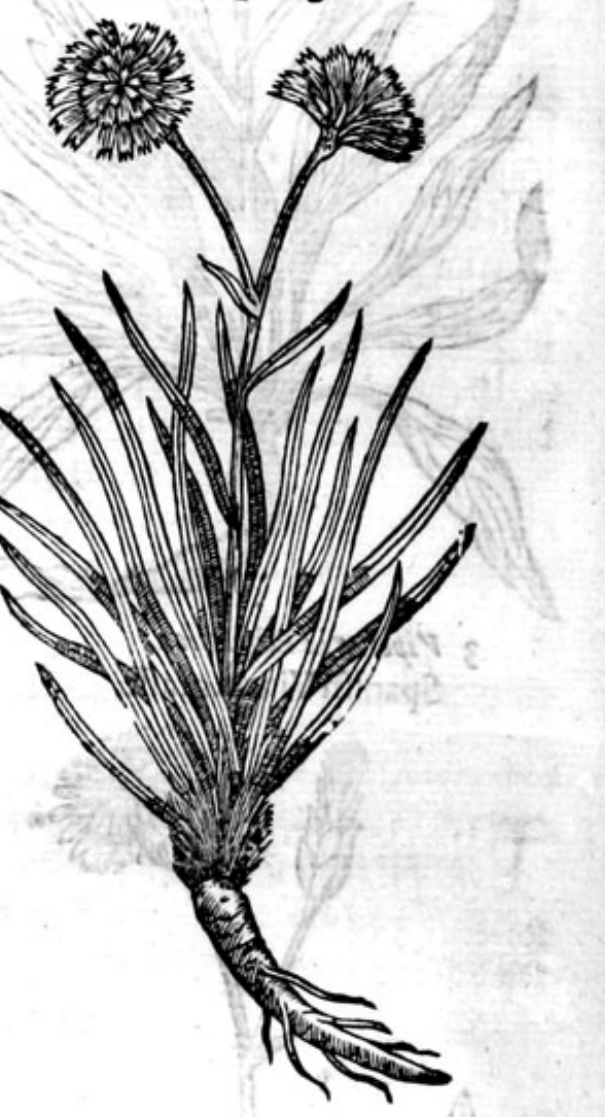

* The defeription.

5 The broade leafed Vipers graffe of Hungarie, hath a thicke fat roote like vnto the other of his kinde; the ftalkes and flowers are alfo like; the leaues are long,fmooth,and fhining, crumpled, and
verie vneten in the edges, wherein efpecially confifteth the difference.

6 The narrowe leafed Hungarie Vipers graffe, hath long leaues like vnto thofe of Goates beard, but longer and narrower, among which ri ceth vp a flender hollowe ftalke, ftiffe and fmooth, on the top whereof doe ftande faire double flowers of a faire blewe colour tending to purple, in hape zorn. The feede is conteined in fmall cups like fhell, like the fmell of fweete balles made of Benthat is caried away with the winde. The roote is of Goatesbeard, wrapped in a downie matter bearded at the top, with certaine hairie thrums yeelding a milkie long as the others, very fingle, what tharpe withall. indureth the winter cuen as the a milkie itice of a refinous tafte,and fome- 


\section{HIST ORIE OF PLANTS.}

* The place.

Moft of thefe are ftrangers in England. The two firt defcribed do growe in my garden. Thereft are touched in their feuerall titles.

$$
\text { * The time. }
$$

They flower and flourifh from May to the cnd of Iulie.

$$
\text { * The names. }
$$

Vipers graffe is called of the Spaniards Scorzonera, which foundeth in Latine Viperaris, or Viperima, or Serpenta ria, fo called bicaufe it is accounted to be of force and efficacie againt the poifons of Vipers and ferpents, for Vipera or a viper is called in Spanifh Scurzo: it hath no name either in the high or lowe Dutch, nor in any other more then hath beene faide that I can read: in Englifh we may call it Scorzoner after the Spanifh name, or Vipers graffe.

They are hot and moift as are the Goates beards.

$$
\text { * } 7 \text { he temperature. }
$$

$$
\text { * The vertues. }
$$

It is reported by thofe of great iudgement, that Vipers graffe is moft excellent againft the $\mathbf{A}$ infections of the plague, and all poifons of venemous beafts, and efpecially to cure the bitings of vipers, (of which there be very many in Spaine and other hot countries, yet haue I hearde that they haue beene feene in England) if the iuice of the rootc or herbe be drunke.

It helpeth the infirmities of the hart, and fuch as vie to fwoune much, it cureth alfo them that $\mathbf{B}$ haue the falling fickneffe, and fuch as are troubled with giddineffe of the head.

The roote being eaten, either rofted in embers, fodden or rawe, doth make a man merric, and re-C moouethall forrow.

The rootes condited with fugar,as are the rootes of Eringos and fuch like, worke the like effectes: D but more familiarly being thus dreffed.

\section{Of Marigoldes. Chap.243.}

\section{* The kindes.}

$T$ Here be diuers forts of Marigolds, differing in many notable points, fome are great and verie double; fome fmaller, and yet double; fome of the garden likewife and fingle, although it was fowen of double feede, fol lift nature to plaie with hir little ones; others wilde, or of the fielde, and fome of the water, which fhall be diftinguifhed in feucrall chapeers.

\section{* The defcription.}

1 He greateft double Marigold hath many large, fat, broade leaues, fpringing immediately from a fibrous or threddic roote; the vpper fides of the leaues are of a deepe greene, and the lower fide of a more light or thining greeneramong which rife vppe ftalkes fomewhat hairie, and alfo fomewhat iointed, and full of 2 pungious pith. The tlowers in the top are beautifull, rounde, verie large and double, fomething fweete, with a certaine ftrong fmell, of a light faffron colour, or like pure golde: fromthe which followe a number of long crooked feedes, efpecially the butmoft, or thofe that ftande about the edges of the flower, which being fowen cornmonly bring foorch fingle flowers, whereas contrariwife thofe feedes in the middleare leffer, and for the moft

2 The common double Marigolde hath manie fat, thicke, crumpled leaues fet vpon a groffe and fpungious ftalke: whereupon do growe faire double yellowe flowers, hauing for the moft pare in the middlea bunch of threddes thicke thruft togither, which being paft there fucceede fuch crooked feedes as the firft deferibed. The roote is thicke and harde, with fome threds annexed
thereto. 


\section{THE SECOND BOOKE OF THE}

I Calendula multiflora maxima. The greateft double Marigold.

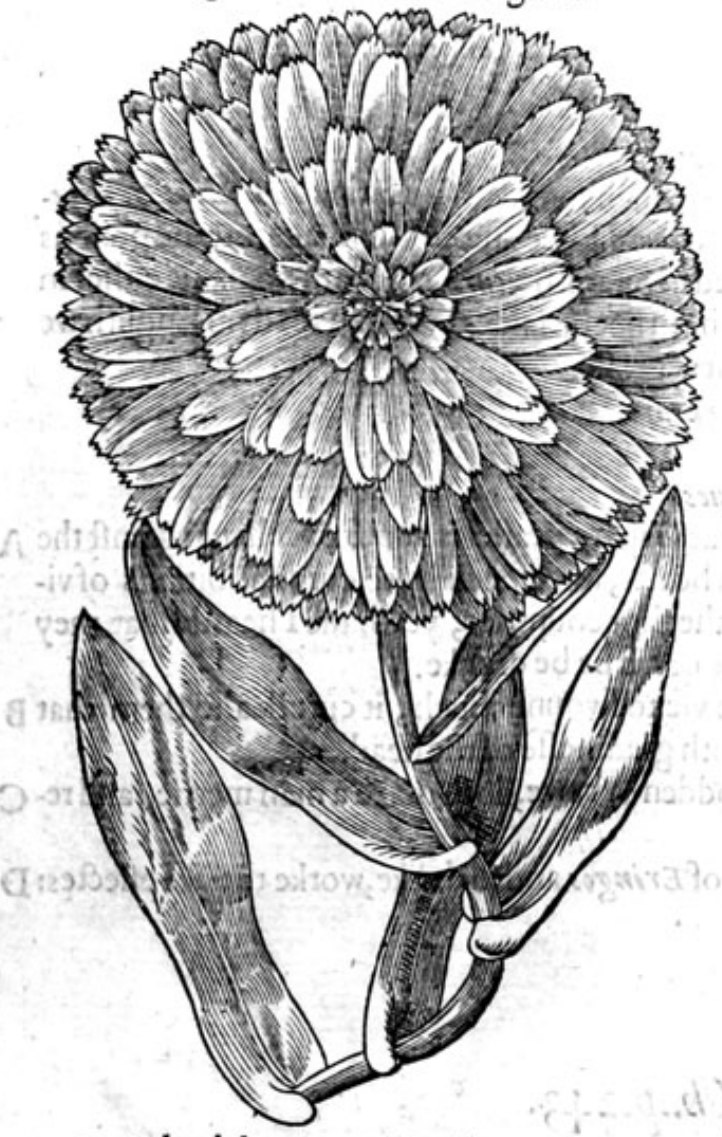

3. Calendula minor polyanthos.

The fmaller double Marigold.

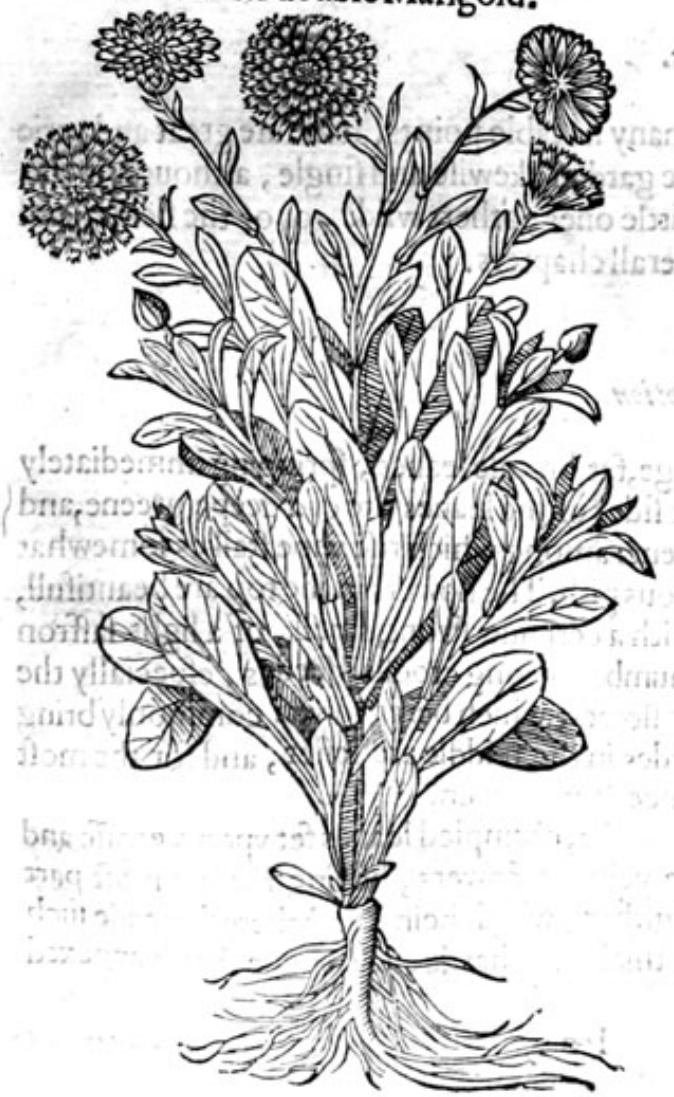

2 Calenduia maior polyanthos. The greater double Marigold.

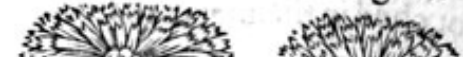
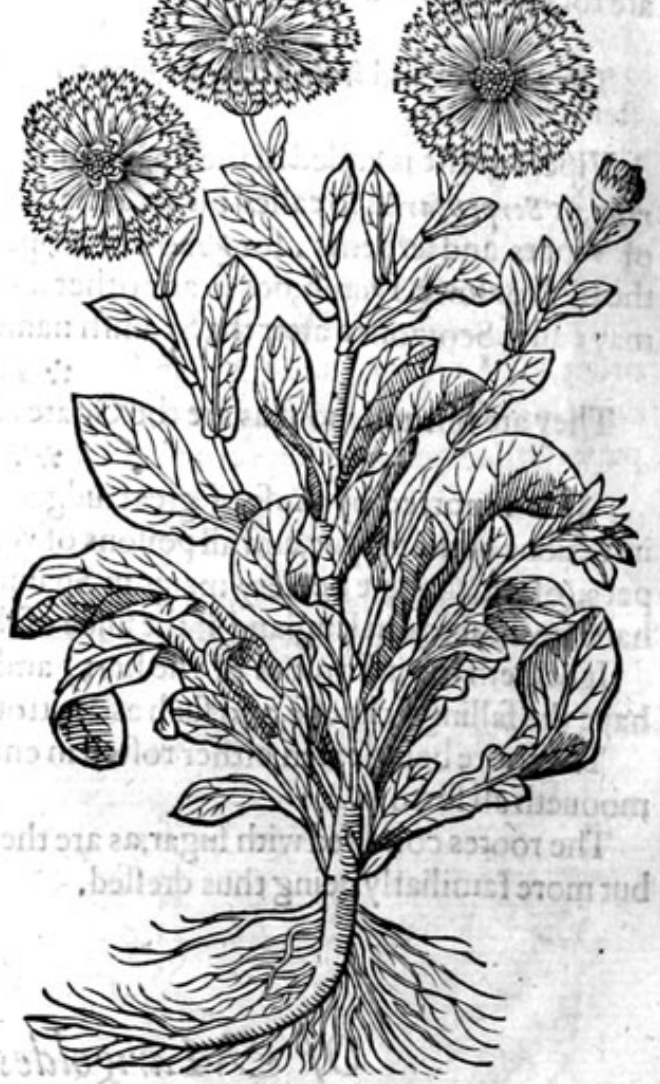

4 Calendula multiflora orbiculata. Double Globe Marigolde.

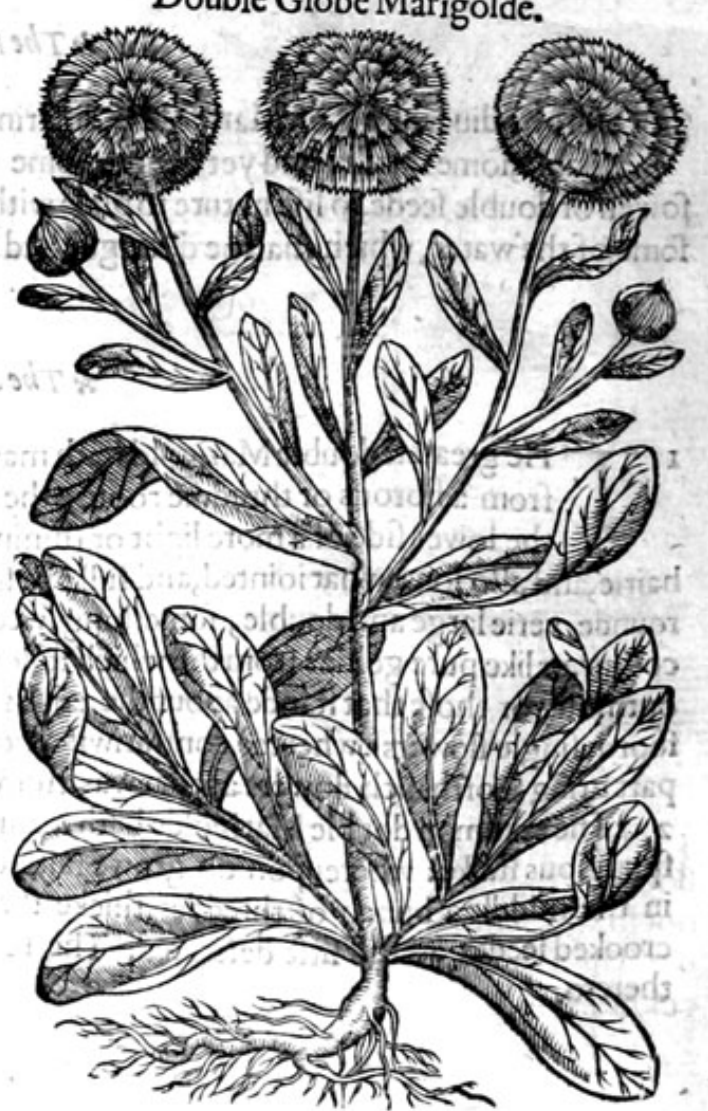




\author{
* The defoription.
}

3 The frialler or finer leafed double Marigolde groweth vpright, hauing for the moft part one ftem or fat fpungious ftalke, garnifhed with finooth and fat leaues confufedly. The flowers grow at the top of the fimall branches, veric double, but leffer then the other, confifting of a more finer iag. gedneffe, and of a faire yellowe gold colour; the roote is like the precedent.

4 The Globe flowring Marigold hath many large broadeleaues, rifing immediately foorth of the grounde: among which rifeth vp a ftalke of the height of a cubite, diuiding it felfe towarde the top into other fmaller branches, fet or garnifhed with the like leaues, but confufedly or without order. The flowers growe at the top of the ftalks verie double; the fmall leaues whereof ate fet in comely order by certaine rankes or rowes, as fundrie lines are in a globe, trauerfing the whole compaffoof the fame, whereupon it tooke the name Orbiculata.

5 Calendula polyanthosmelina.

Straw coloured double Marigold.

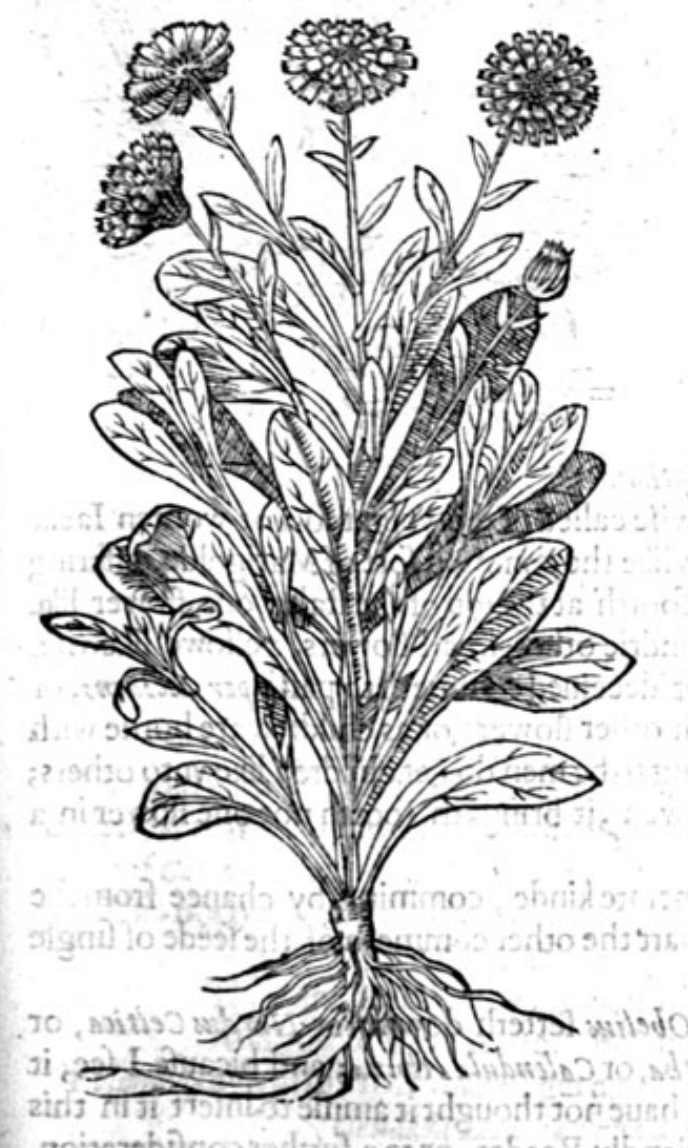

6 Calcendula fimplici fore.

Single Marigold.

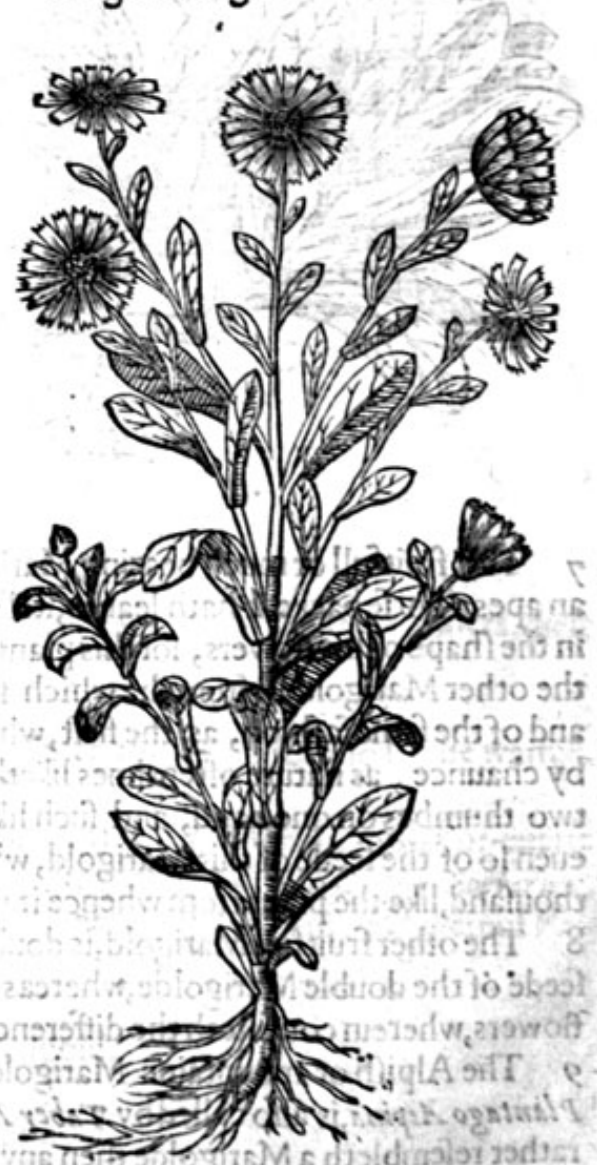

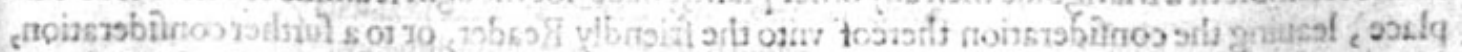

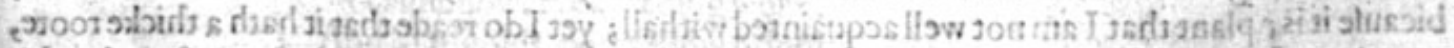

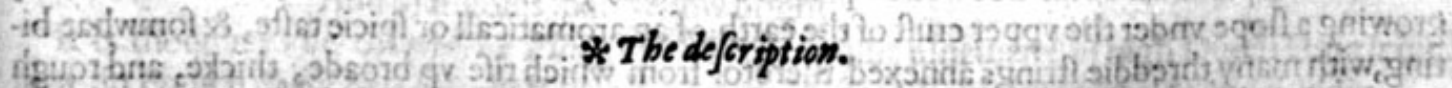

5. The fift fort of double Marigold differeth not from the laft defcribed, fauing in the colour of the towers, for this plant bringeth foorth flowers of a frawe or light yellow colour, and the others not fo, wherein confifteth the difference.

6 The Marigold with Single flowers differeth not from thafe with double fowers, but in that it confifteth of fewer leaues which we terme Single, that maketh the difference. 
7 Calendula prolifera.

Fruitfull Marigold.

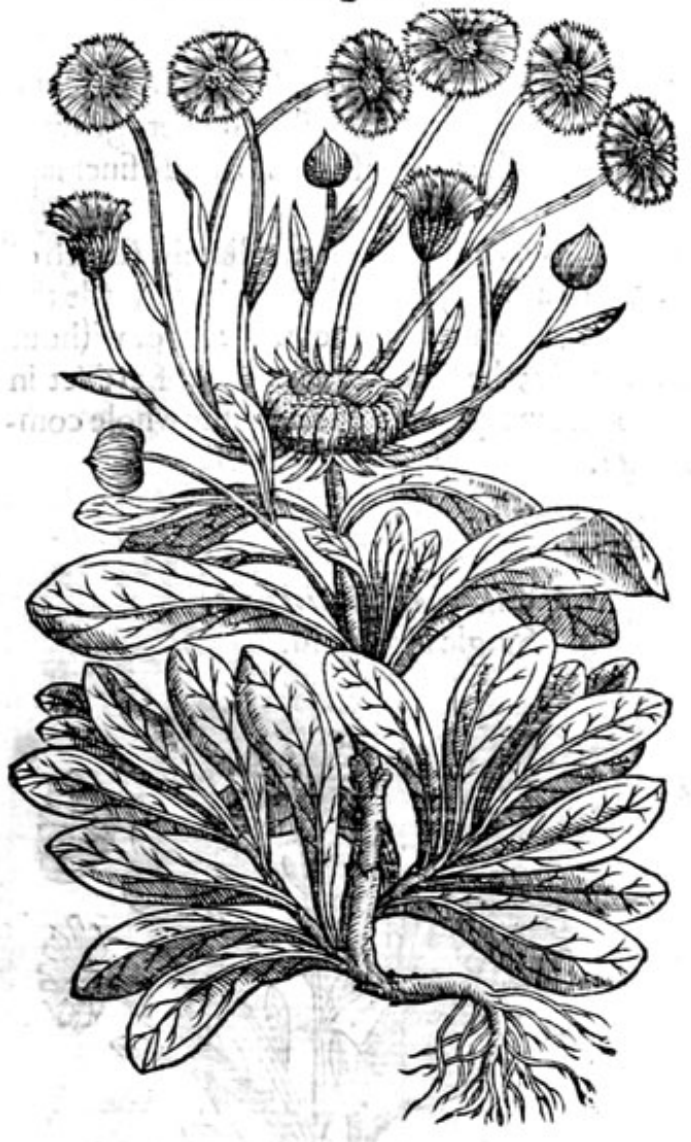

8 Calendula maior prolifera. Iacke an apes a horfe backe.

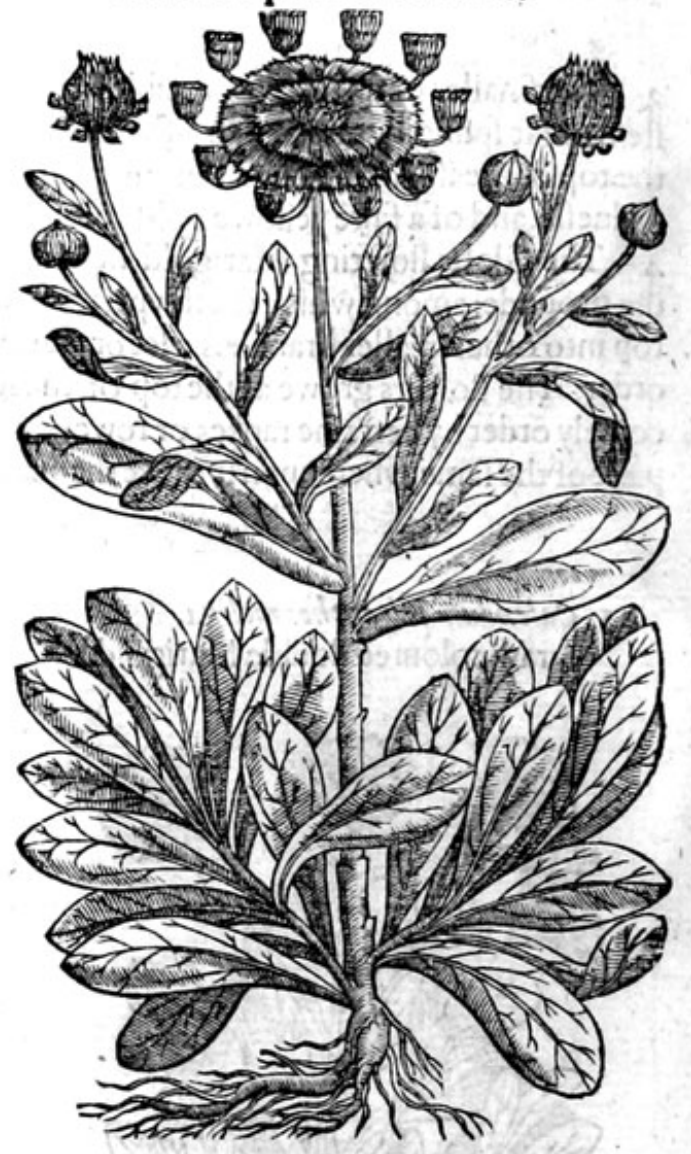

* The defcription.

7 This fruitfull or much bearing Marigolde, is likewife called of the vulgar fort of women Iacke an apesa'horfe backe:it hath leaues, ftalkes and rootes like the common fort of Marigolde, differing in the fhape of his flowers, forthisplant doth bring foorth at the top of the ftalke one flower like the other Marigoldes, from the which ftart foorth fundrie other fmall flowers, yellowe likewife, and of the fame fafhion, as the firft, which if I be not deceiued commeth to paffe per accidens, or by chaunce, as nature oftentimes liketh to plaie with other fowers, or as children are borne with two thumbes on one hand, and fuch like, which liuing to be men do get children like vnto others; enen fo of the feede of this Marigold, which if it be fowen, it bringeth foorth not one flower in a thoufand, like the plant from whence it was taken.

8 The other fruitfull Marigold, is doubtleffe a degenerate kinde, comming by chance from the feede of the double Marigolde, whereas for the molt part the other commeth of the feede of fingle flowers, wherein confilteth the difference.

9 The Alpirh or mountaine Marigolde, which L'Obelius fetteth downe for Nardus celtica, or Plantago Alpina, is alfo calledby Taber Montanus Caltha, or Calendula Alpina; and bicaufe I fee, it rather refembleth $a$ Marigolde then any other plant, I haue not thought it amiffe toinfert it in this place, leauing the confideration thereof vnto the friendly Reader, or to a further confideration, bicaufe it is a plant that I am not well acquainted withall; yet Ido reade that it hath a thicke roote, growing a flope vnder the vpper cruft of the earth, of an aromaticall or fpicie tafte, \& fomwhat biting, with many threddie ftrings annexed thereto: from which rife vp broade, thicke, and rough leaues, of an otcrworne greene colour, not vnlike vnto thofe of Plantaine: among which there rifeth vp a rough and tender ftalke, fet with the like leaues ; on the top whereof commeth foorth a fingle yellow flower paled about the edges with fmall leaues of a light yellow, tending to a frawe co. lour; the middle of the flower is compofed of a bundle of threds, thicke thruft togither, fuch 2 s is in the middle of the fielde Daific, of a deepe yellowe colour. 
Io The ivilde Marigold is like vnto the fingle garden Marigold, but altogither leffer, \& thewhole plant perifheth at the firft approch of winter, and reconereth it felfe againe by falling of the féede.

- Calendula alpina.

Mountaine Marigold.

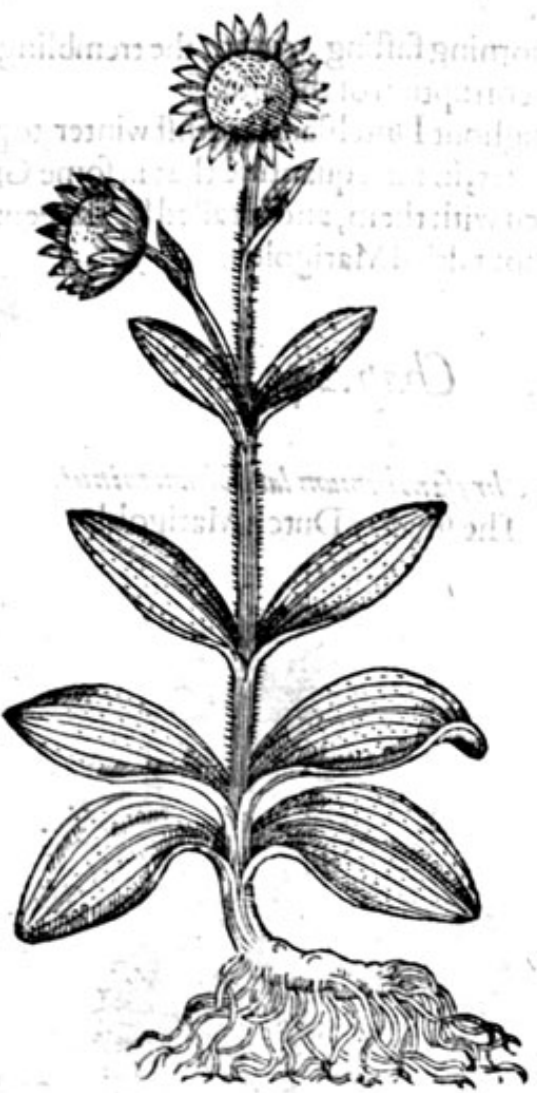

Io Calendeila arwenfis. Wilde Marigold.

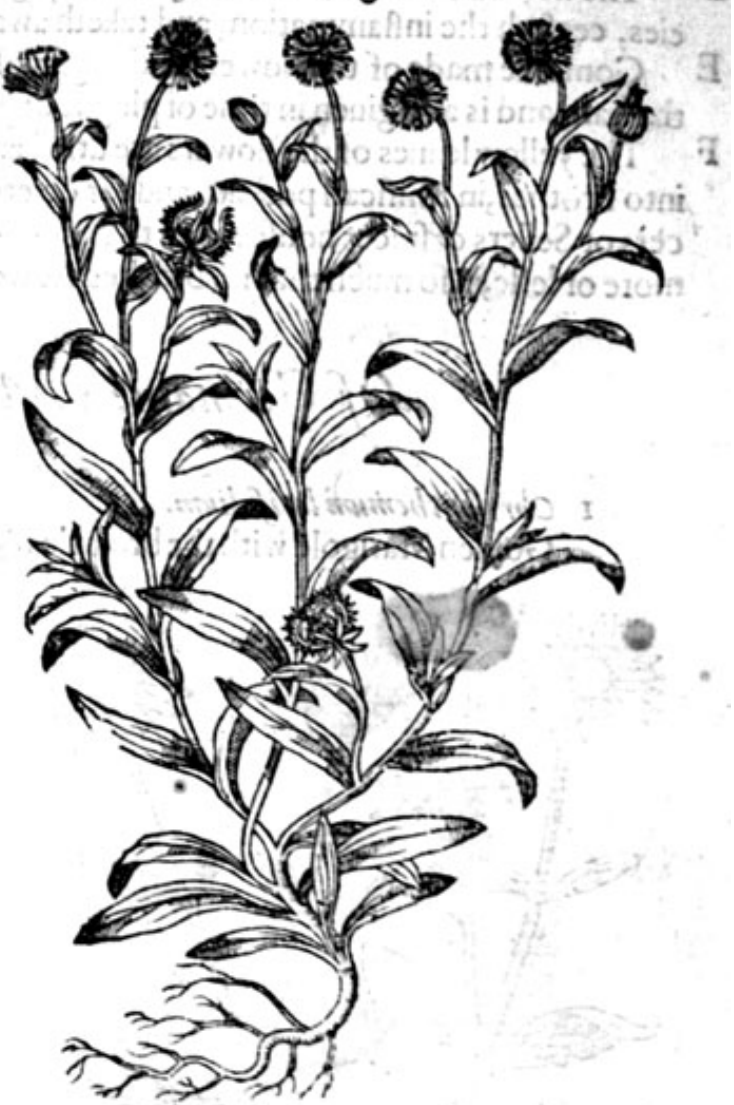

* Theplace.

Thefe Marigolds with double flowers efpecially, are fet and fowen in gardens; the others, their titles do fet foorth their naturall being. * The time.

The Marigold flowreth from Aprill or Maie, euen vntill winter, and in winter alfo if it be warme. * 7 he names.

The Marigolde is called Calendala : it is to be feene to flower in the Calends almoft of euerie moneth: it is alfo called Chry fant hemum, of his golen colour, of fome Caltha, and Calt ha Puetarwm, whereof colwmells and $V$ irgilldo write, faying : that $C a l t h a$ is a flower of yellow colour, whereof $V$ ire gill in his Bucolicks, the fecond Egloge, writeth thus : Mollia Luteola pingit vacinis Calt hs.

The wench trms vp her garland with yellow Marigold,

And purple Violets molt delightfull to behold.

Colvemells allo in his 10. booke of gardens hath thefe words :

Candila Leacoia of fluent is Lwmina Calsha.

Stockgilliflowers exceeding white, And Marigolds mott yellow bright.

It is thought to be Gromphema Pliny : in Dutch Goubt blaetinen: in high Dutch ritusledulu. men :in French Soiffi $\&$ Goude : in Italian Fior tognimefe: in Englifh Marigolds and Ruddes. \% The temperature and vertues.

The flower of the Marigolde is of temperature hot, almoft in the fecond degres, efpecially when $A$ it is drie :it is thought to ftrengthen \& comfort the hart, \& to withftand poifon, 25 alfo to be good againift peftilent agues, being taken any waie : Fuch ficu hath written, that being drunke with wine, it bringeth downe the termes, \& that the fume thereof expelleth the fecondine or afterbirth. 


\section{THE SECOND BOOKE OF THE}

B But the leaucs of the berbe are hotter, for there is in them a certaine biting : but by reafon of the moifture ioined with it, it doth not by and by fhewe it felfe, by meanes of which moifture they mollifie the bellie, and procure folubleneffe if it be,vfed as a potherbe.

C Fuch/ins writeth, that if the mouth be warhed with the iuice, it helpeth the toothach.

D The flowers and leaues of Marigolds being diftilled and the water dropped into red and waterie eies, ceafeth the in flammation, and taketh away the paine.

E Conferue made of the flowers and fugar taken in the morning fafting, cureth the trembling of the hart; and is alfo giuen in time of plague or peitilence, or corruption of the aire.

F The yellow leaues of the flowers are dried and kept throughout Dutchland againft winter, toput into brothes, in Phificall potions, and for diuers other purpofes, in fuch quantitie that in fome Grocers or Sellers of fpices houfes, are to be found barrels filled with them, and retailed by the pennic more or lefle, in fo much that no brothes are well made without dried Marigolds.

\section{Of Germaine Marigolds. Chap.243.}

I Chryfanthemum latifolium.

Golden Marigold with the broad leafe.

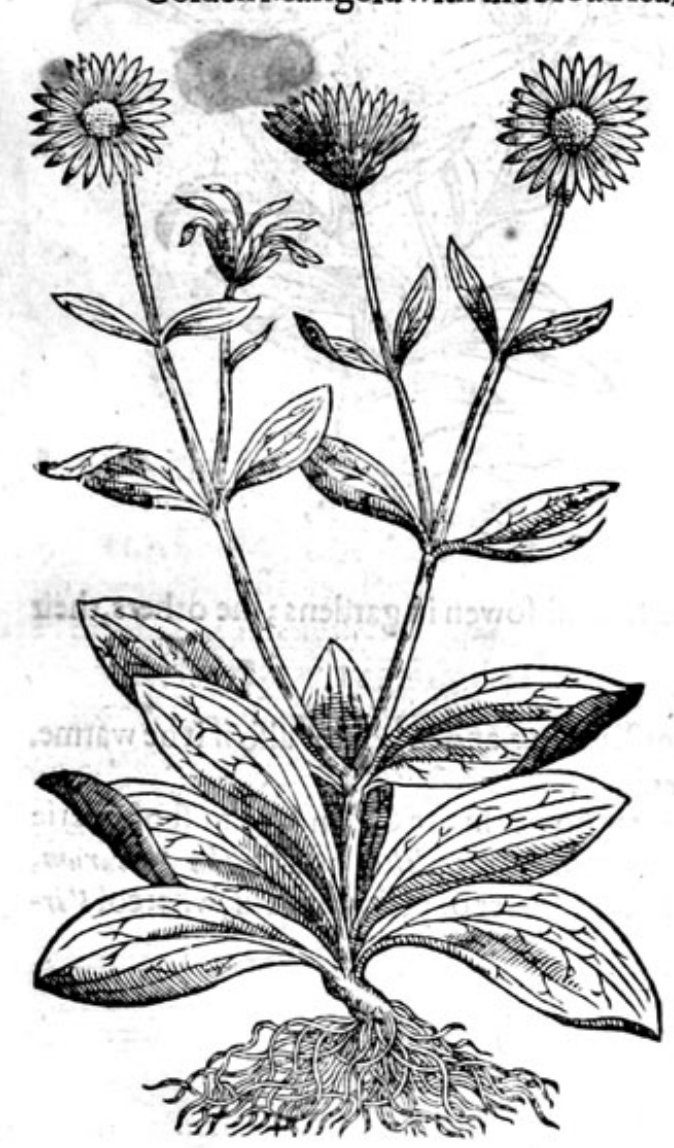

2 Chryfanthemwom latifoliwmminus. The fmaller Dutch Marigold.

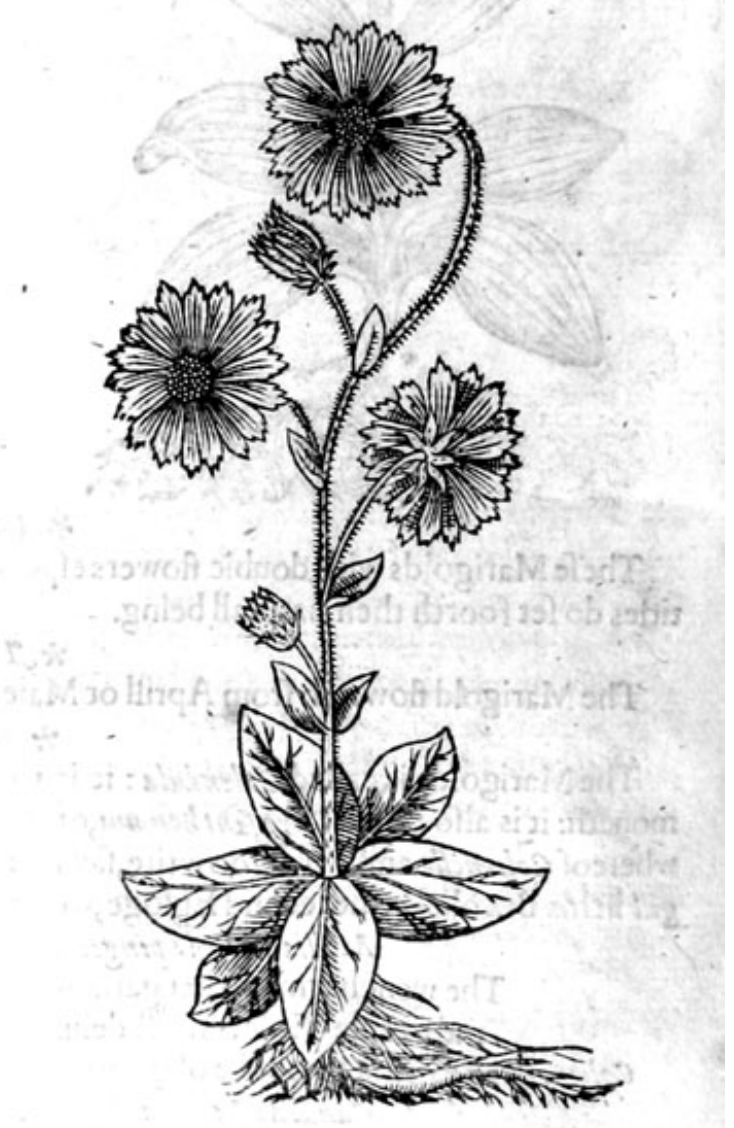

* The defcription.

1 Olden Marigold with the broad leafe doth foorthwith bring from the roote long leaues f pred vpon the grounde, broad, greene, fomething rough in the vpper part, vnderneath finooth, and of a light greene colour : among which fpring vp flender ftalks a cubitehigh, fomething hoarie, hauing three or fower ioints, out of euery one whereof grow two leaues, fec one right againft another, and oftentimes little flender ftems, on the tops whereof ftande broad round tlowers like thofe of Oxeic, or the corne Marigolde, hauing a rounde ball in the middle (fuch as is in the middle of thole of Camomill)bordered about with a pale of bright yellow leaues. The whole 


\section{HISTORIE OF PLANTS.}

flower turech into downe that is caried away with the winde, among which downe is founde long blackifh feede. The roote confifteth of threddie ftrings.

2 The leffer fort hath fosver or five teaues fpred vpon the grounde tike vnto thofe laft defcribed but altogither lefier and ffiorter:among which rifeth vp aflen der ftalke two hands high, on the top whereof ftand fuch flowers as the precedent, but fairer and greater.

s. They befounde eucry where in vntilled places of Germanie, and in woodes, but are ftrangers in England.

They are to be feene ivith their flowers in Iune, in the gardens of the low countries.

* The nomes.

Golden Marigolde is called in high Dutch velalifbltume. There are that woulde have it to be Alifma Diofcoridis, which is alfo called Damafoniam, but vnproperly; therefore we muft ratber call it Chrysant bemwn latifolitum, then rafhly attribute vnto it the name of Alijwa. I

$*$ The temperature anid vertues.

Touching the faculties hecteof, there is nothing certaine.

\section{Of corne Marigold. Chap $2+4$.}

I Chryfanthemsm fegetwon.

Corne Marigold.

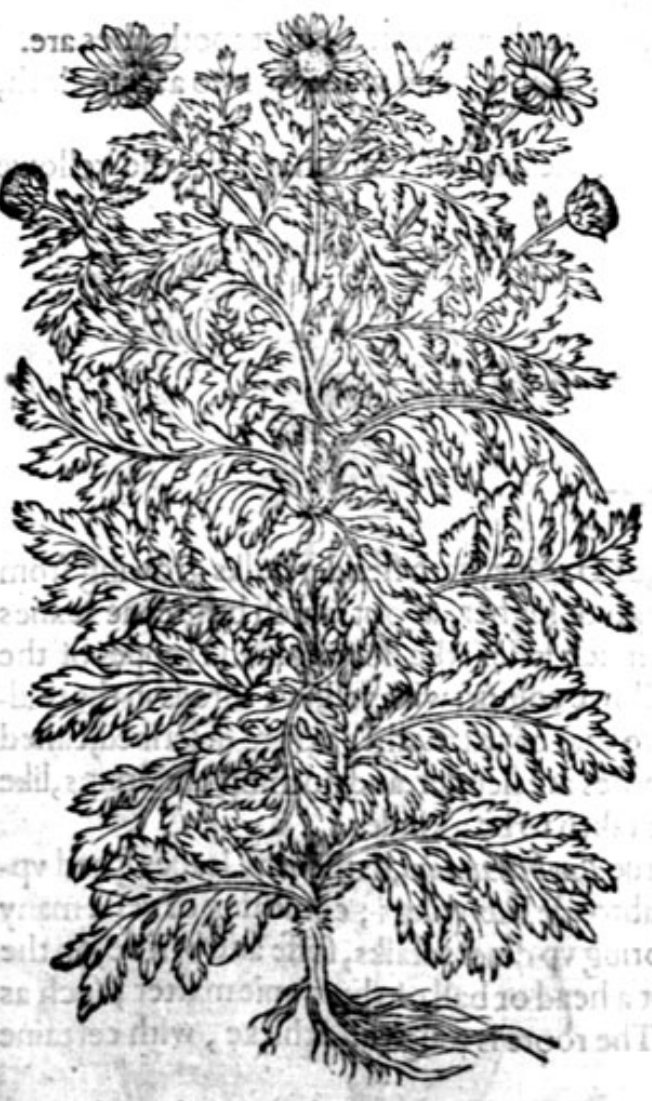

2 Chryfanthemuon Valentinuss.

Corne Marigold of Valentia.

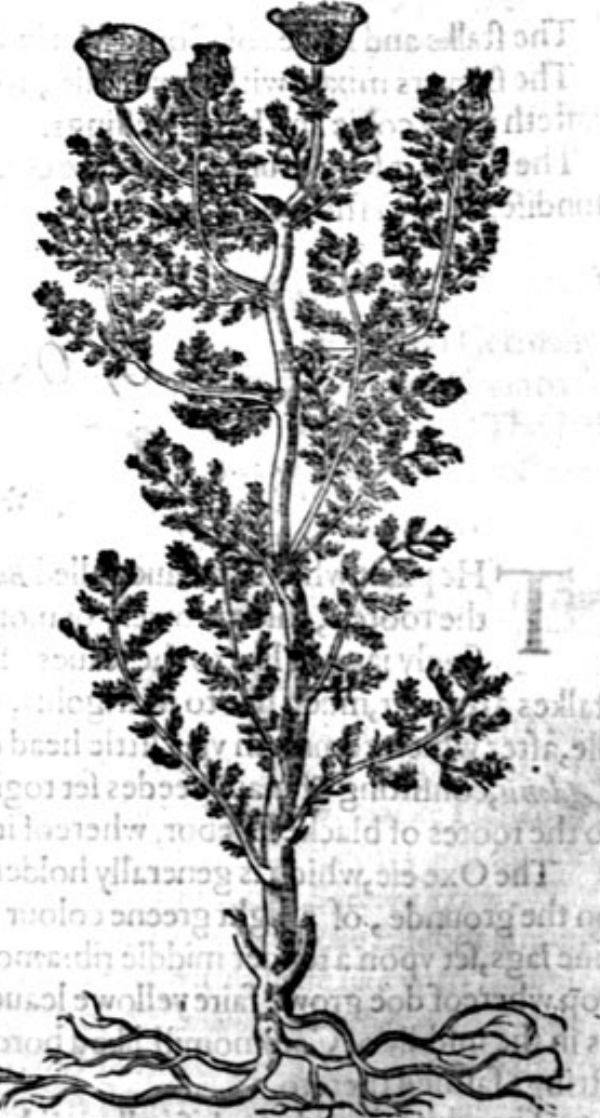

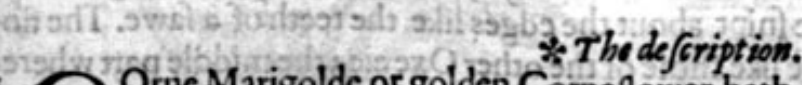

i Orne Marigolde or golden Comeflower, hath a foft ftalke, hollow, and of a greene colour; whereupon doe growe great leaues, very much hackt and cut into diuers feetions, like an Oftrich feather, confufedly or out of order placed.vpon the top of the branches do ftande faire Searlike flowers,yellowe in the middlejand likewife thepale or border of leaues that compaffe 
the foft ball in the middle like that in the midd!c of Camomill flowers, of a reafonable pleafaunt finell. The rootes are full of ftings.

2 The golden fower of Valentia hath a thicke fat ftalke, rough, vncuen, and fomewhat crooked, whercupon do grow long lea:ıes, confifting of a long middle rib, with diters little fetherlike leauest fet thercon without order. The flowers growe at the top of the ftalks, compofed of a yellow thrummie matter, fuch as is in the middle of the Camomill flowers, and is altogither like the corne Marigolde laft defcribed, fauing it doth want that border or pale of little lealies that do compaffe the ball or head, the roote is thicke, tough, and difperfeth it felfe farre abroade.

* Theplace.

The firt groweth among corne, and where corne hath beene growing; it is found in fome places with leaues more iagged, and in others leffe.

The fecond is a ftranger in England.

They flower in Iulie and Auguft.

* Thetime.

* 7 he names.

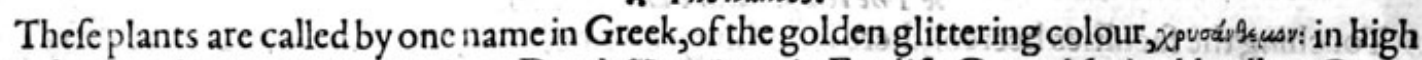
Dutch s ant 3/obants blum: in lowe Dutch Clokelaet: in Englifh Corne Marigold, yellow Corne flower, and golden Corne flower.

There be diuers other flowers called Chry]anthemum allo, as Batrachion, a kinde of yellow Crowfoote, Aelicbryfos, and Heliochryfon, but thele golden flowers differ from them.

* The temperature.

They are thought to be of a meane temperature betweene heat and moifture. * The vertues.

A The ftalks and leaues of Corne Marigolde as Diofcorides faith, are eaten as other potherbes are.

B The flowers mixed with waxe, oile, rofin, and frankencenfe, and made vp into afeare cloth, $B$ wafteth away colde and hard fwellings.

C The herbe it felfe drunke, after the comming foorth of the bath of them that haue the yellowe iaundife, doth in fhort time make them well coloured.

\section{Of Oxe eie. Chap.245.}

s. The defcription.

I Heplant which we haue called Bupht halmum, or Oxe eie, hath flender ftalks growing from the rootes, three, fower, or more, a foote high or higher, about which be greene leaues finely iagged like to the leaues of Fenell, but much lefler : the flowers in the toppes of the ftalkes are great, much like to Marigolds, of a light yellowe colour, with yellowe threds in the middle, after which commeth vp a little head or knap like to that of red mathes before defcribed, called Adonis, confifting of many feedes fet togither. The rootes are flender, and nothing bur ftrings, like to the rootes of blacke Ellebor, whereof it hath beene taken to be a kinde.

2 The Oxe eie, which is generally holden to be the true Bupht halmum, hath many leaues fpred vpon the grounde, of a light greene colour laide farre abroade like wings, confifting of verie many fine iags, fet vpon a tender middle rib:among which fpring vp diuers ftalks, ftiffe and brittle, on the top whereof doe growe faire yellowe leaues, fet about a head or ball of thrummie matter, fuch 25 is in the middle of Cammomill, like a border or pale. The roote is tough and thicke, with certaine ftrings faftned thereto.

3 The white Oxe eie, hath fmall vpright ftalkes of a foote high, whereon do growelong leaues, compofed of diters fmall leaues, and thofe fnipt about the edges like the teeth of a fawe. The flowers growe on the top of the ftalks, in hape like thofe of the other Oxe eie; the middle part whereof is likewife made of a yellowe fubftance, but the pale or border of little leaues, are exceeding white, like thofe of great Daifie, called Confolidamedia vulnerariorum. The roote is long, creeping alongtt vinder the vpper cruft of the carth, whereby it greatly increafeth. 


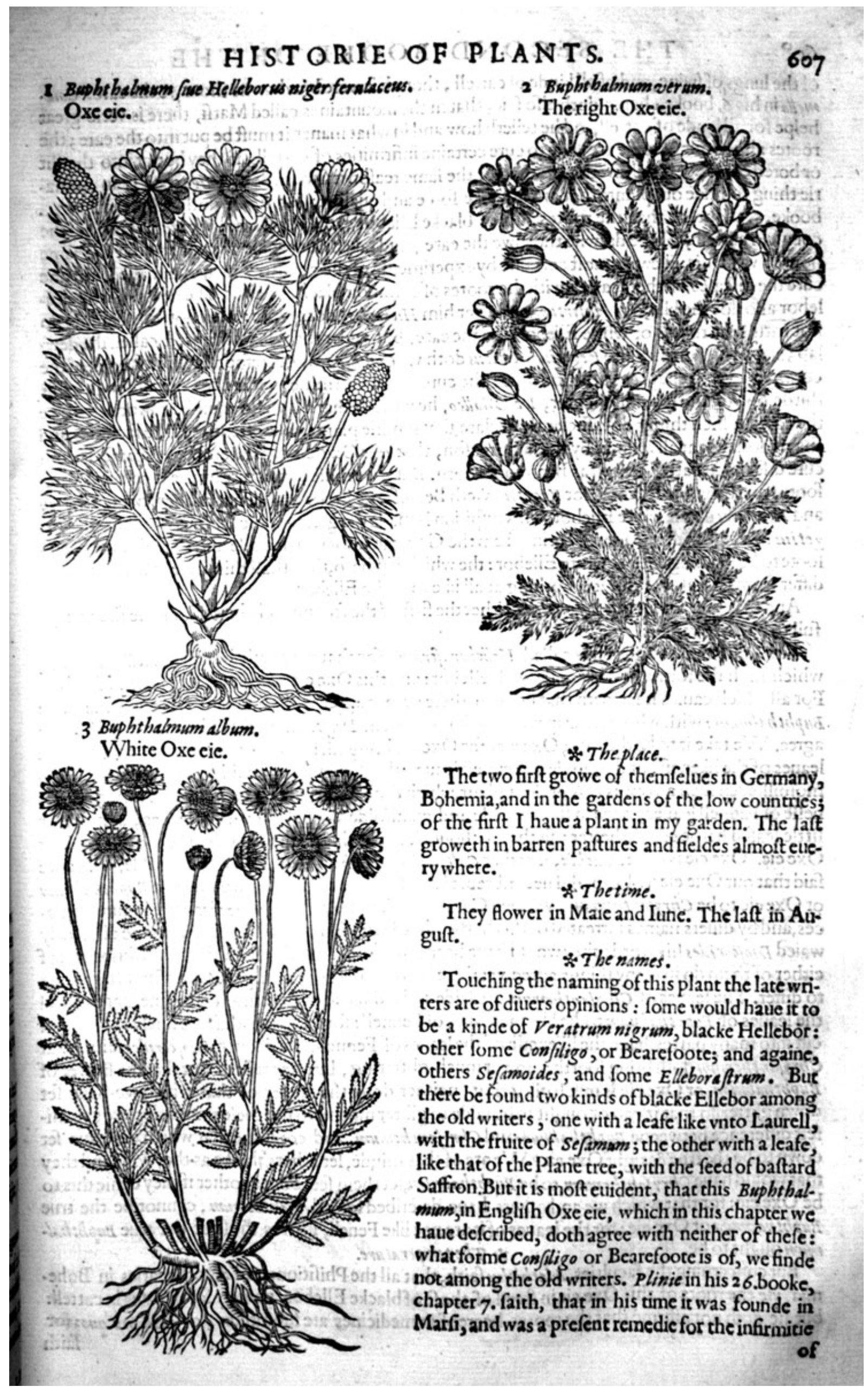




\section{8 \\ THE SECOND BOOKE OF THE}

of the lungs off wine, and of all kinde-of cattell , though it were but drawhe thorowe the eare. Colsmella in his 6. booke, chap.5. doth alfo faie, that in the mountaines called Marfi, there is verie great helpe for all kinde of cattell, and he teileth how and in what maner it muft be put into the eare; the rootes alfo of our Oxe eie are faide to cure certaine infirmities of cattell, if they be put into the flit or bored eare : but it followeth not, that fot the fame reafon it fhould be Confligo; \& it is an ordinarie thing to finde out plants that are of a like force and qualitie: for Plinie doth teftifie in his 25 . booke, 5 . chapter, that the rootes alfo of blacke Ellebor cando the fame; it cureth (faith he) the cough in cattell, if it be drawne thorowe the eare, and taken out againe the next daie at the fame houre: which is likewife moft certaine byexperiments of the countrey men of our age; who doe cure the difeafes of their cattell with the rootes of common blacke Ellebor. The roots of white EIlebor alfo doe the like, as Ab fyrtus, and after him Hierocles, doth write: who notwithitanding do not thruft the rootes of white Ellebor into the eare, but vnder the skin of the breft called the dewlap; after which maner alfo Vegetius Renatus doth vfe Confligo, or Bearefoot, in his firft book of the curingof cattell, chapter 12 .intituled, Of the cure of the infirmities vnder the skin: although in his thirde booke and fecond chapter, De CMalleo, he writeth that they alfo muft be faftned thorowe the eare. Which things do fufficiently declare, that fundrie plants haue oftentimes like faculties:and that it doth not at all followe by the fame reafon, that our Oxe eie is Bearefoote, bicaufe it doth cure difeafes in cattell as well as Bearefoote doth. But if we muft coniecture by the faculties, Bearefoote hall be white Ellebor : for Veget isis vfeth Bearefoote in the very fame manner that 16 /yrtw and Hierocles do vfe white Ellebor. This fufpition is made the greater, bicaufe it is thought that $V e$ get ius hath taken this maner of curing from the Grxcians, for which caufe alfo moft do take Bearefoote to be nothing elfebut white Ellebor : the which if it be fo,then fhall this prefent Oxe eie much differ from Bearefoote: for it is nothing at all like to white Ellebor.

And that the fame is not Sefamoides, either the firft or the fecond, it is better knowne then needfull to be confuted.

This fame alfo is vnproperly called Helleboraftrum, for that may aptly be called Helleboraftrum, which hath the forme and likeneffe of Hellebor: and this Oxe eie is nothing at all like to Ellebor. For all which caufes it feemeth that none of thefe names agree with this plant, but onely the name Buphthalmum : with whofe defcription which is extant in Diofcorides, this plant doth moft aptlie agree. We take it to be the right Oxe eie; for Oxe eie bringeth foorth fender foft ftalkes, and hath leaues of the likeneffe or fimilitude of Fennell leaues: the flower is yellow, bigger then that of $C_{2 m}$ moinill, euen fuch an one is this prefent plant, which doth fo exquifitely expreffe that forme or likeneffe of Fennell leaues, both in flenderneffe and manifolde iaggedneffe of the leaues, as no other little leafed herbe can do better; fo that without all doubt this plant feemeth to be the true \& right Oxe eie. Oxe eie is called Cacbla, or rather Caltba; but Caltha is Calendula, or Marigolde, which we faid that our Oxe eie in flower did neereft reprefent. There are fome who would haue Buphthalmam or Oxe eic to be Chryfant bemum, yellowe Cammomill, and fay that Dzofcorides hath in fundry pla. ces, and by diuers names intreated of this herbe; but if thofe men had fomewhat more diligently waied Diofcor ides his words, they would haue beene of another minde : for although defcriptions of either of them do in many things agree, yet there is no propertie wanting that may fhew the plants to differ. The leaues of cbryfant bemwm are faide to be diuided and cut into many fine iagges: and the leaues of Buphthalmum to be like the leaues of Fennell: for all things that are finely iagged and cut into many partes, haue the likeneffe of theleaues of Fennell. Moreouer, Diofcorides faith, that Chryfant hemum doth bring foorth a flower much glittering, but hee telleth not that the flower of Buphthalmsm, or Oxe cie is much glittering, neither doth the flower of that which we have fet down glitter, fo that it can or ought to be faide to glitter much. Do not thefe things declare a manifeft difference betweene Buphthalmum and Chryfant hemum, and confirme that which we haue fet down to be the true \& right Oxe eie? We are of that minde, let others thinke as they will: and they that would haue Chry fant hemum, to be Buphthalmum, let them feeke out another if they denie this to be Oxe eie: for that which we and others haue defcribed for Chryfanthemum, cannot be the true Buphthalmum or Oxc eie; for the leaues of it are not like Fenell, fuch as thofe of the true Buphthabmam ought to be. $*$ The temperature.

But concerning the faculties, Mat hiolus faith, that all the Phifitions and Apothecaries in Bohemia, vfe the roots of this Oxe eie in fteed of thofe of blacke Ellebor, namely for difeafes in cattell: but he doth not affirme that the rootes heereof in medicines are fubltitutes, or quid pro quo; for 


\section{HISTORIE OE PLANTS. IT}

faith he, Idoe remember that Ionce fawe the rootes heereof in a fufficient bigge quantitic put by certaine phifitions into decoctions, which were made to purge by fiege, but they purged no more then if they had not beene put in at all; which thing maketh it moft plaine, that it cannot be any of the Ellebors, although it hath beene vfed to be faftned through the eares of cattell for certaine difeales, \& doth cure them as Ellebor doth. The rootes of Gentian do mighti: ly open the orifices of fiftulaes which be too narrow, fo do the roots of Ariflolocbia, or Birthivoort, or Brionie, and peeces of fpunges, which notwithftanding do much differ one from another in other operations: wherefore though the rootes of Oxe eie can doe fomething like vnta blacke Ellebor, yet for all that, thev cannot performe al! thofe things that the fame can. We knowe that thornes, finges, fplinters of woode, and fuch like bring paine, caufe inflammáticns, drawe vinto them humours from the parts neere adioining, if they be faftned in any part of the bodie; no part of the bodie is hurt without paine; the which is increafedif any thing be thruft throtigh, or putinto the wounde: peraduenture alfo if any other thing befide be put into the flit or bored eare, the fame effeet would followe, which hapned by the roote of this plant thruft in; notwithftanding we heere affirme nothing, we onely make way for curious men to make more diligent fearch touching the operations heereof.

$$
* \text { The vertues. }
$$

Dio/corides faith, that the flowers of Oxe eie made vpin a fearecloth, doth aflwage and wafte $\mathbf{A}$ awaie colde hard fwellings : and it is reported that if theybe drunke by and by after bathing, it maketh them in thort time well coloured that hauebeene troubled with the yellowe iaundife.

\section{Of French Marigold, or A frican Marigold. Chap.246.}

\section{(i) $*$ Thekindes.}

Terobe extant at this day fiue forts of Turkie Gilloflowers or African Marigolds; fome with double flowers, and other verie fingle, as fhall be declared.

I Flos L Apricaniu maior Polyanthos.

The great Africane do:able Marigold. :

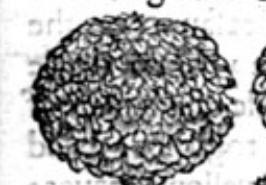

12

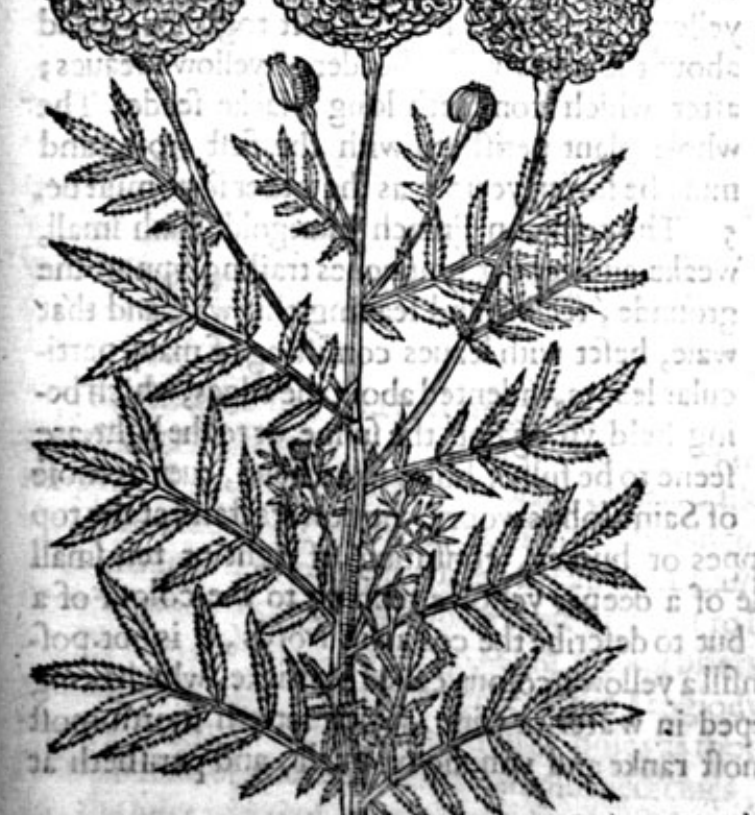

2 Flos Aphricanas maior maltifornes. The fmaller double Africane Marigold.

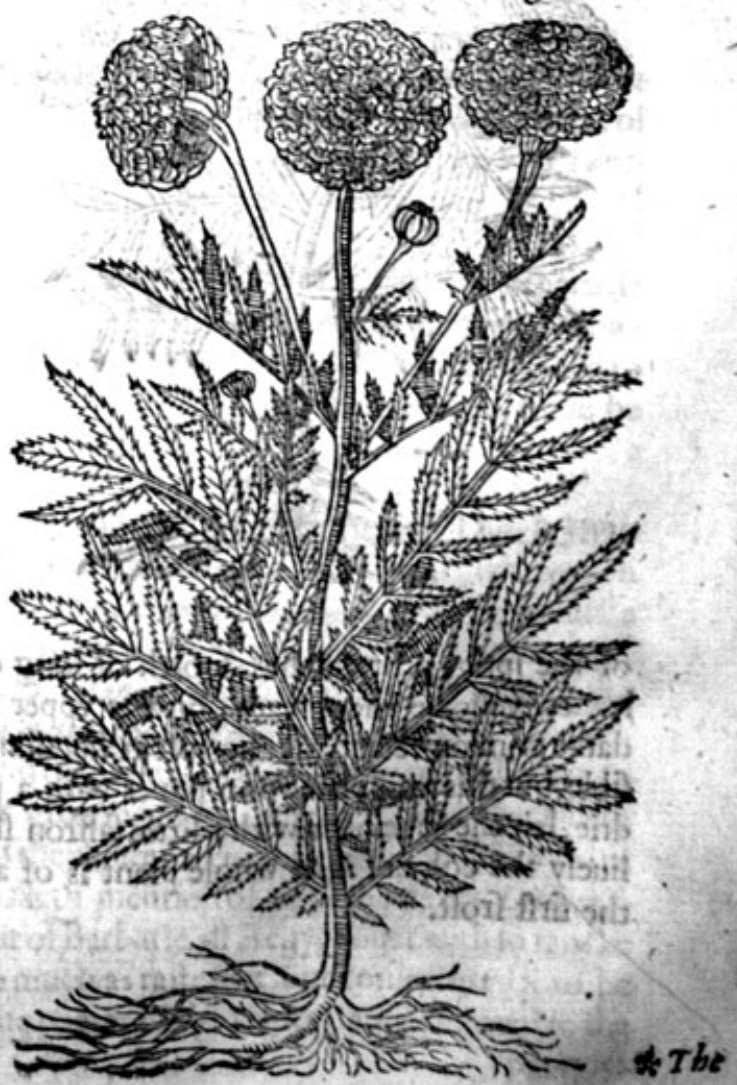




\author{
* The defcription.
}

1

He great double Africane Marigold hath a great, long, browne reddifh ftalke, crefted, furrowed, and femewhat knobbic, diuiding it felfe toward the top into other branches; wherupon do grow leaues compofed of many fmall leaues fet vpon a middle ribbe by couples, much like vnto the leaues of wilde Valerian, bearing at the top verie faire \& beautifull double yellow flowers, greater and more double than the greateft Damaske Rofe, of a ftrong fmell, but not vipleafant. The flower being paft, there fucceedeth long blacke flat feede: the whole plant periNheth at the firft approch of winter.

2 The fecond differeth not from the firft, fauing that this plant is altogither lefler, wherein confifteth the difference.

3 Flos Aphricanus minor multiflorus. The fmaleft double Africane Marigold.

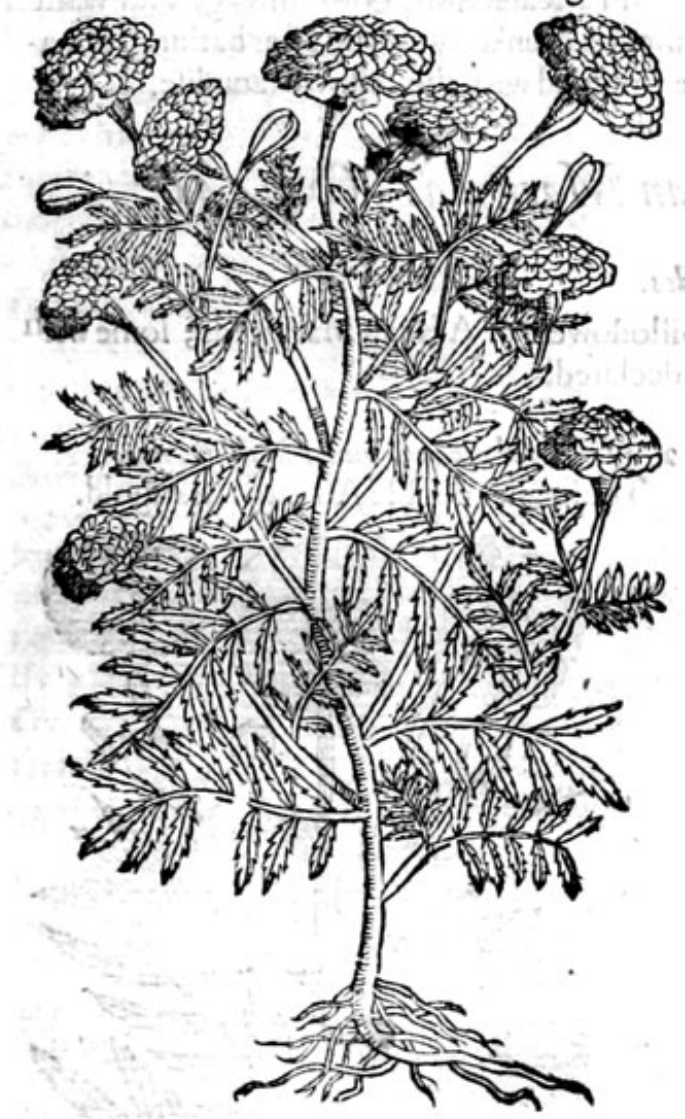

\section{$\therefore$ The defaription.}

3 There is little difference between this and the precedent, or laft defcribed, fauing that this plant is much leffer, and bringeth foorth more ftore of flowers, which maketh the difference.

4 The fingle great Africane Marigolde, hath 2 thicke roote, with fome fibres annexed thereto; from which rifeth vppe a Atiffe ftalke chamfered and furrowed, of the height of two cubits, diuided into other finall braunches; whereupon are fet long leaues, compact or compofed of many little leaues like thofe of the Alhe tree, of a ftrong fmell, yet not verie vnpleafaunt: on the top of the braunches doe growe yellowe fingle flowers, compofed in the middle of a bundle of yellowe thrummes harde thruft togither, paled about the edges with a border of yellowe leaues; after which commeth long blacke feede. The whole plant perifheth with the firlt froft, and muft be fowen yeerely as the other forts muft be. 5 The common French Marigolde hath fmall, weake and tender braunches trailing vppon the grounde, reeling and leaning this waie and that waie, befet with leaucs confifting of many particular leaues, indented about the edges, which being held vp againtt the funne, or to the light, are feene to be full of holes like a fieue, euen as thofe

of Saint Iohns woort : the flowers ftand at the top
of the friggie braunches foorth of long cuppes or huskes, confifting of eight or ten fmall leaues, yellowe vnderneath, on the vpper fide of a deeper yellowe tending to the colour of a darke crimfon veluet, as alfo foft in handling: but to defcribe the colour in words, it is not poffible, but this waie; laie vpon paper with a penfill a yellowe colour called Mafticke, which being drie, laie the fame ouer with a little faffron fteeped in water or wine, which fetteth foorth molt liuely the colour. The whole plant is of a molt ranke and vnholfome fmell, and perifheth at
the firft froft. 4 Flos 


\section{HISTORIE OF PLANTS. I}

4 Flos Aphricanum misior fmplici flore. The great fingle French Marigold.

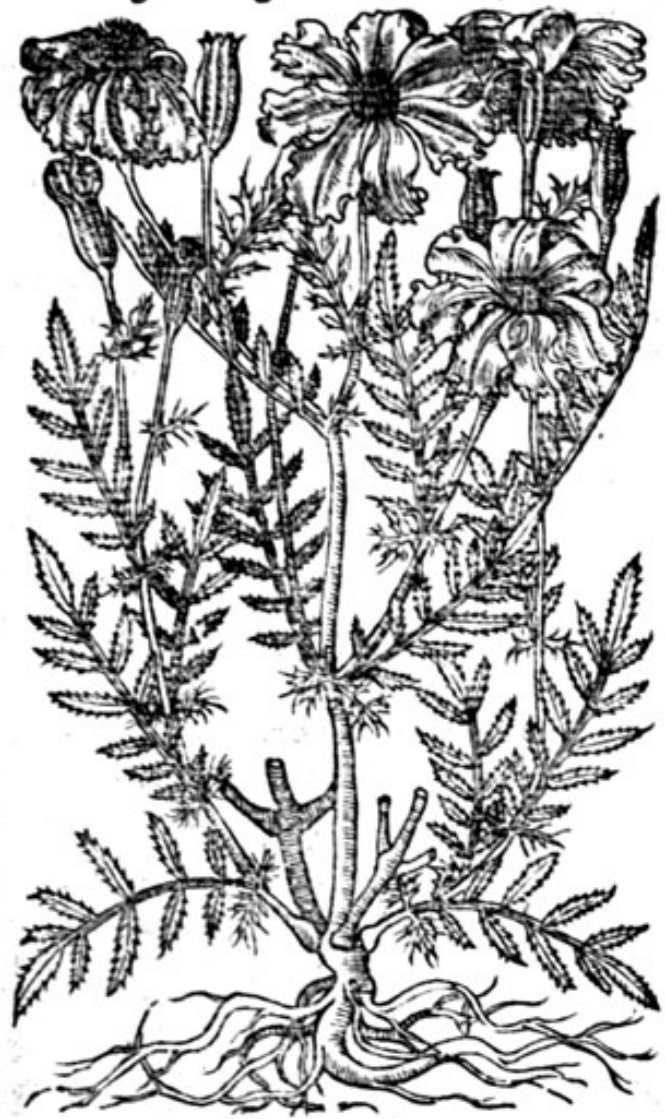

5 Flos Aphricansus mimor fomplici flore.

The fimall French Marigolde.

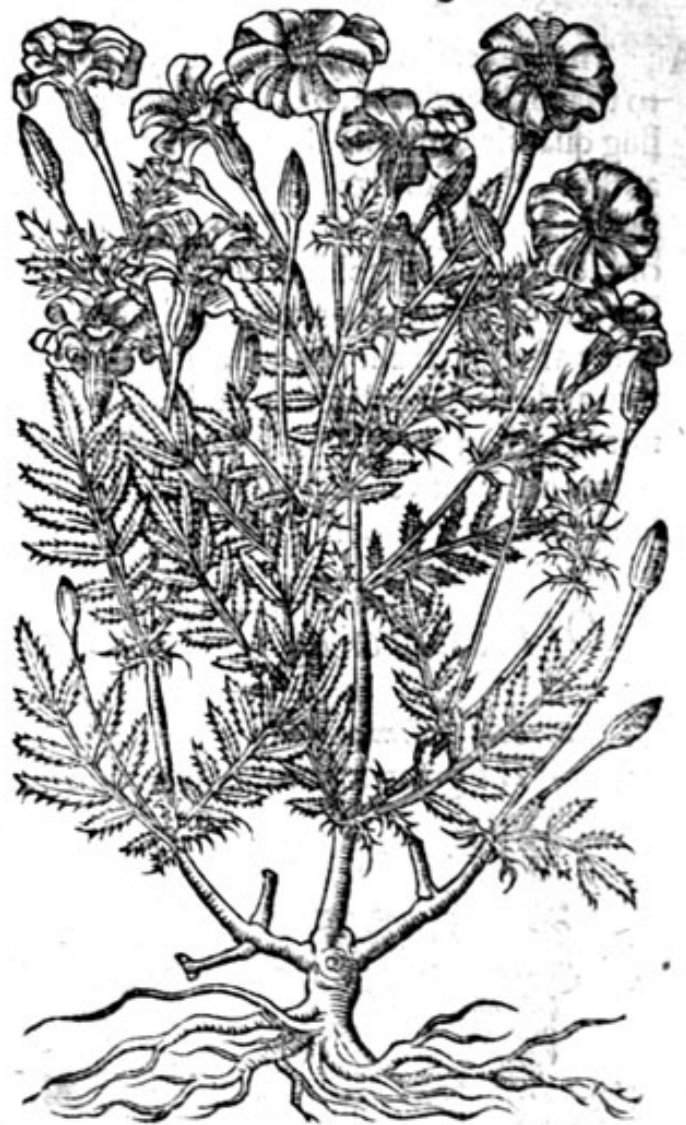

* The place.

They are cherifhed and fowen in gardens euery yeere : they grow euery where almoft in Africke of themfelues, from whence we firft had them, and that was when Charles the firft Emperour of Rome made a famous conqueft of Tunis; whereupon it was called Flos Aphricenus, or Flos Tunetenfis.

\section{* The time.}

They are to be fowen in the beginning of Aprill if the feafon fall out to be warme, otherwife they muft be fowen in 2 bed of dung, as fhall be fhewed in the chapter of Cucumbers. They bring foorth their pleafant flowers very late, and therefore there is the more diligence to be vfed to fowe them very earely, bicaufe they fhall not be ouertaken with the froftes before their feede be ripe.

The Africane or French Marigold is called in Dutch Thtnis bloement: in high Dutch Tnof. anffebunegelin, that is the flower or Gilloflower of India : in Latine Caryophyllus Indicus, whereupon the Frenchmen call it Oeillet $z$ d' Inde. Cordsus calleth it Tanacctum Peruuianum, of the likencfie the leaues haue with Tanfie, and of Peru a Prouince of America, from whence it was firfterotght to be brought into Europe. Gefnerus calleth it Caltha Aphricana, and faith that it is called in the Carthaginian toong Pedua : forne would haue it to be Petilizus flos Plinij, but not properly: for Petilius fos is an Autumne flower growing among briers and brambles. Andress Lacuna galleth it $O$. thonna, making it a certaine herbe of the Troglodytes growing in that part of Arabia which lieth toward Aegypt, hauing leaues full of holes as though they were eaten with prothes. 6.ten in his fourth booke of the faculties of Simple medicinics, inaketh mention of an Kerbe called $L y c o p e r / 2$ wow: the iuice whereof, a certaine Centurion did caric out of Barbarie all Aegyprouer with fo rancke a fmell, and fo lothforne, as $G$ ilen himfelfe durft not fo much as tafte of it, but conicctured it to be deadly ; yet that Centurion did vie it againft the extreme paines of the ioints, and it feemed to the 
612

THE SECOND BOOKE OF THE

patients themfelues, to be of a very colde temperature; but doubtleffe of a poifonfome qualitie, very neere to that of Hemlockes.

\author{
* The temperature and vertues.
}

A The vnpleafant fmell, efpecially that common fort with fingle flowers (that ftuffeth the head like to that of Hemlocke, fuch as the iuice of Lycoperfum is ) doth thew that it is of a poifonfom \& cooling qualitie; and alfo the fame is manifefted by diuers experiments: for I remember faith the fame author, that I did fee a boie whofe lippes and mouth when hee began to chewe the flowers did fwell extrencly; as it hath often happened vnto them, that playing or piping with quils or kexes of Hemlockes, do holde them a while betweene their lippes: likewife he faith, we gaue to a cat the flowers with their cups, tempered with freith cheefe, fhee foorthwith mightely fwelled, and a little while after died: alfo mice that haue eaten of the feede there of haue beene founde dead. All which thingsdodeclare that this herbe is of a venemous and poifonfome facultie; and that they are not to be harkened vnto, that fuppofe this herbe to be an harmeleffe plant: fo to conclude, thele plants are moft venemous and full of poilon, and therfore not to be touched or fmelled into, much leffe vfed in meate or medicine.

\title{
Of the flower of the Sunne, or the Marigolde of Peru. Chap.247.
}

1 Flos Solismaior.

The greater Sunne flower.

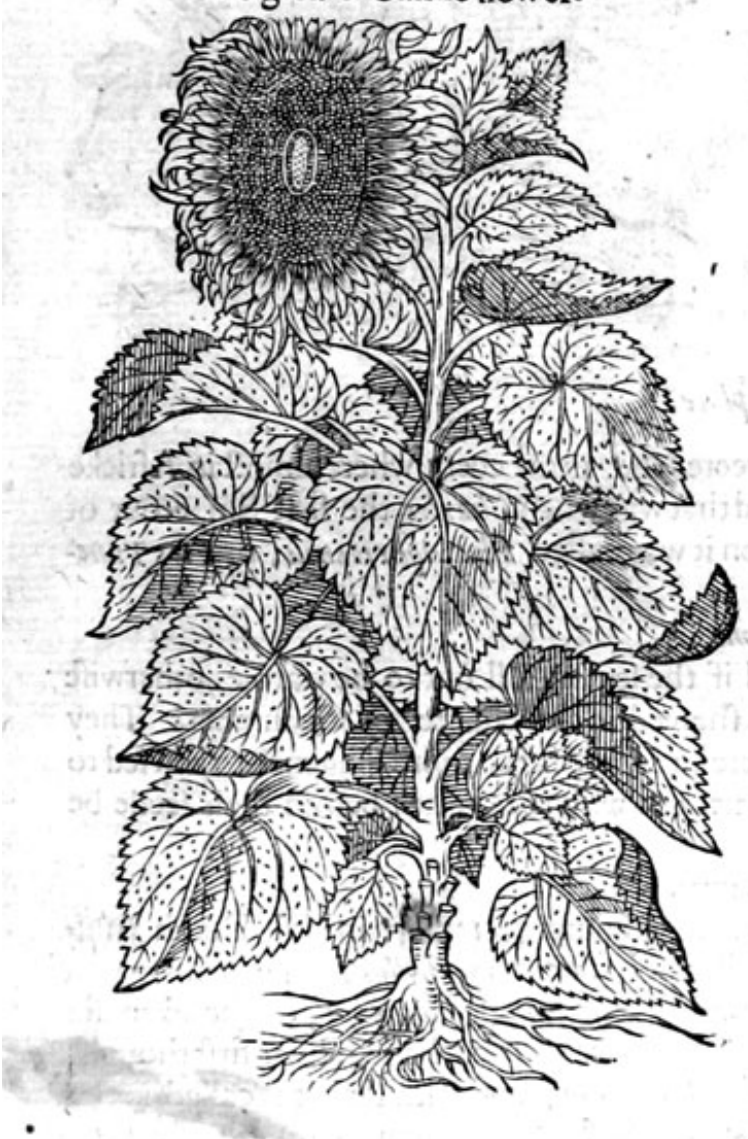

2 Flos Solisminor. The leffer Sunne flower.

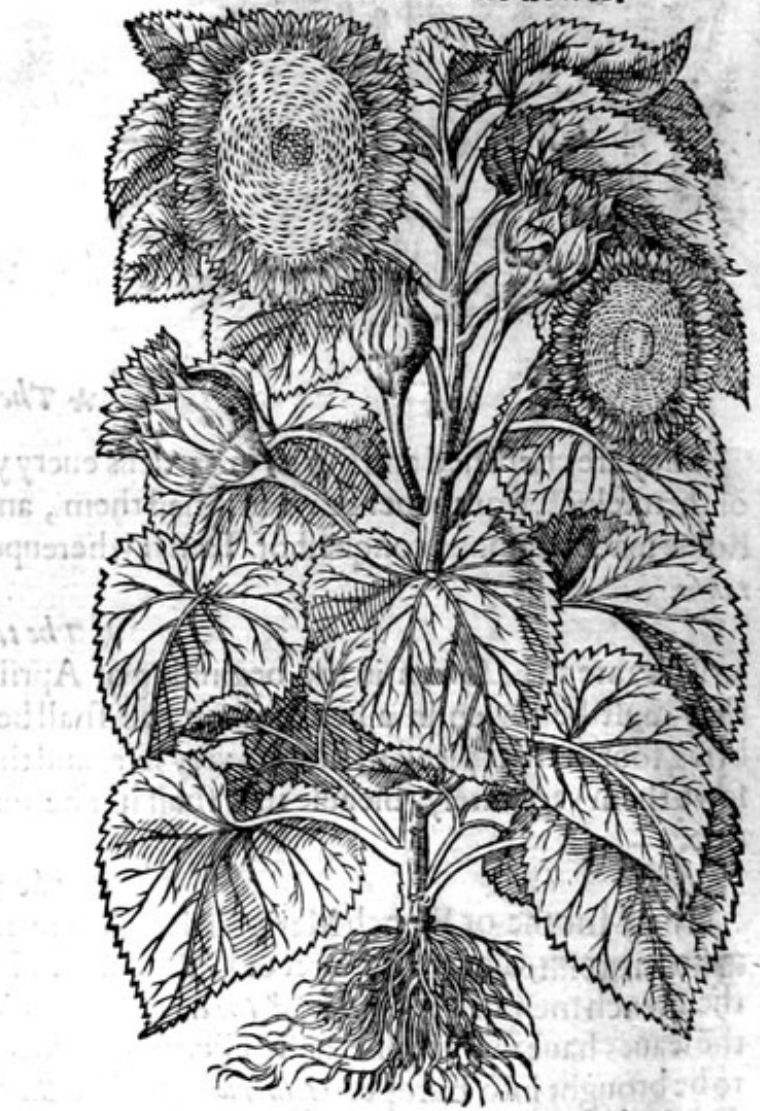

* The defcription.

I He Indian Sunne or the golden flower of Peru, is a plant of fuch ftature and taleneffe, that in one fommer being lowen of a feede in Aprill, it hath rifen vp to the height of fourteene foote in my garden, where one flower was in waight three pounde and two ounces, and croffe ouerthwart the flower by meafure fixteene inches broade. The ftalkes are vpright and fraight, of the bigneffe of a ftrong mans arme, befet with large leaues euen to the top, like vnto the 
great Clote, or Burre: at the top of the ftalke commeth foorth for the moft part one flower, yet many times there fpring out fucking buddes, which come to no perfection : this great flower is in thape like to the Cammomill flower, befet rounde about with a pale or border of goodly yellowe leaues, in Thape like the leaves of the flowers of white Lillies: the middle part ovhereof is made as it were of vnfhorne veluet, or fome curious cloth wrought with the needle, which braue worke, if you do throughly view and marke well, it feemeth to be an innumerable fort of fmall flowers, refembling the nofe or nozell of a candlefticke, broken from the foote thereot : from which finall nozell fweateth foorth excellent fine and cleere Venice Turpentine, in fight, fubftance, fauour, and tafte. The whole plant in like maner being broken, fmelleth of Turpentine : wv hen the plant groweth to maturitie, the flowers fall away, in place whereof appeereth the feede, blacke, and large, much like the feede of Gourds, fet as though a cunning workeman had of purpofe placed them in very good order, much like the honie combes of bees : the roote is white, compact of many ftrings, which perifhat the firft approch of winter, and muft be fet in moft perfect dunged grounde : the maner how fhall be fhewed, when vpon the like occafion I thall fpeake of Cucumbers and Melons.

2. Theother golden flower of Peru is tike the former, fauing that it is altogither lower, and the leaues more iagged, and verie fewe in number.

3 Flos Solisminor mis. The male Sunne flower.

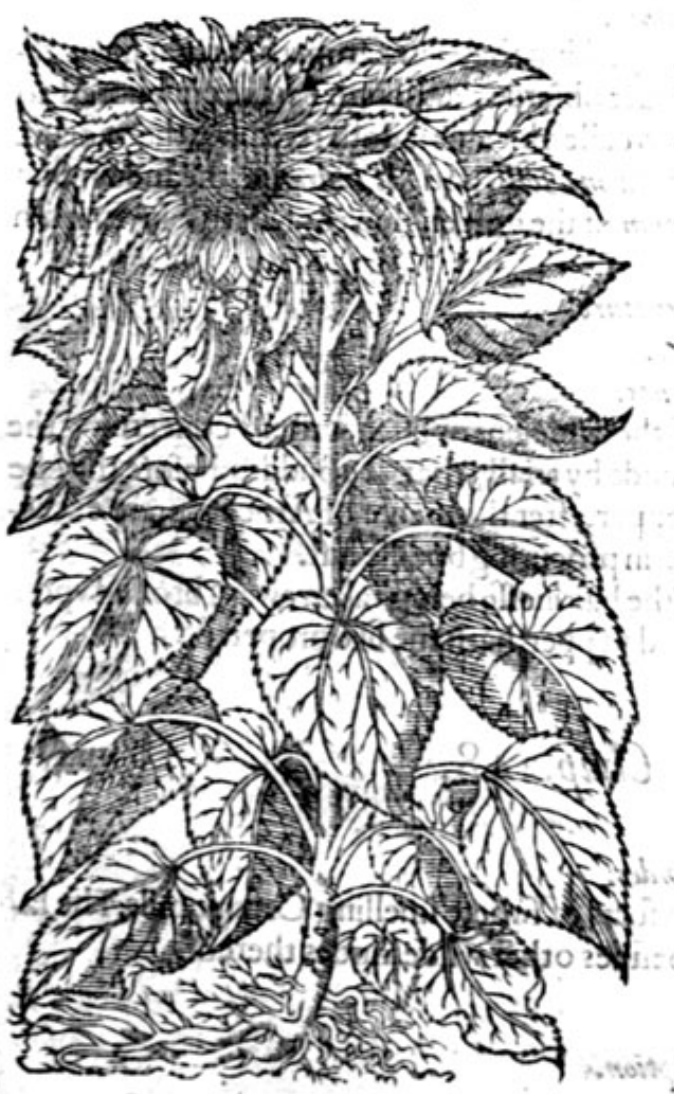

4 Flos Solis minor famina. The marigold Sunne flower.

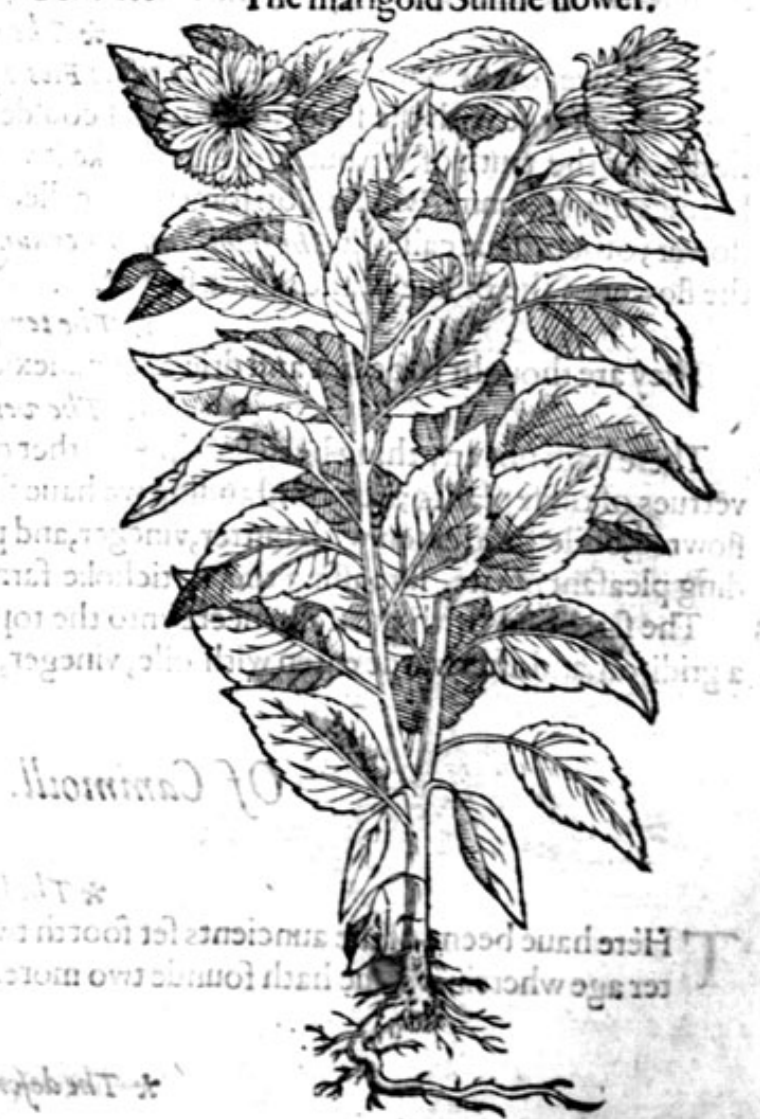

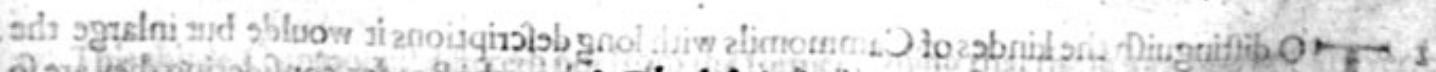

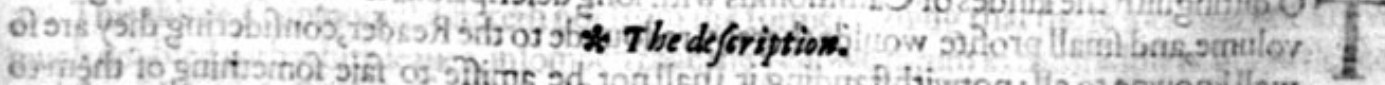
2 The male flowero f the Sunne of thefmaller fort, hath a thieks roote, harde, andof a wogddie fubftance, with mahy threddic ftrings annexed thereto, from whicb afeth yp a graic or ruffet ftylk to the height offige on fixecubits, of the bigneffe of ones arme, whereupon are fer great broade leaves with long foote ftalkes; very fragill or eafie to breake, of an ouerworne greene colour, harp pointed;and fomewhatcur or hacksabout she edgeslike a fawe s the flower groweth at the top of the italke, bordered about with a paleof yellowaleaules; the thrummed middle part is blacker then 
that of the laft defcribed. The whole flower is compafied about likewife with diuers fuch ruffet leaues, as thofe are that do growe lower vpon the ftalkes, but leffer and narrower. The plant and every part thereof doth fmell of Turpentine, and the flower yeeldeth foorth moft cleere Turpentine, as my felfe hate noted diuers yeeres. The feede is alfo long and blacke, with certaine lines or ftrakes of white running alongtt the fame. The roote and euery part thereof perifhech when it hath perfected his feed.

4 The female or Marigolde Sunne flower hath a thicke and wooddie roote, from which rifeth vp a ftraight ftem, diuiding it felfe into one or more branches, fet with fmooth leatues fharpe pounted, flightly indented about the edges. The flowers growe at the top of the braunches of a faint yellow colour, the middle part is of a deeper yellow tending to blacknes, of the forme and hape of a fingle Marigolde, whereupon I haue named it the Sunne Marigold. The feede as yet I haue not obferued. * The place.

Thefe plants do growe of themfelues without fetting or fowing in Peru, and in diuers other prouinces of America, from whence the feedes haue beene bronght into thefe parts of Europe. There hath beene feene in Spaine and other hot regions a plant fowen and nourifhed vp fromfeede, to at: taine to the height of 24 . foote in one yeere.

\section{* Thetime.}

3 he feede mult be fet or fowen in the beginning of Aprill if the weather betemperate, in the moft fertill grounde that may be, and where the Sunne hath moft power the whole daie.

\section{* The names.}

The flower of the Sunne is called in Latine Flos Solis, taking that name from thofe that haue reported it to turne with the funne, the which I couldeneuer obferue, although I haue endeuored to finde out the truth of it; but I rather thinke it was fo called bicaufe it doth refemble the radiant beames of the Sunne, whereupon fome haue called it Corona Solis, and Sol Indianus, the Indian Sun flower; orhers haue called it Chry fant hemum Pernuianum, or the golden flower of Peru; in Englith the flower of the Sunne, or the Sunne flowet.

* The temperature.

They are thought to be hot and drie of complexion.

$$
\text { * The vertues. }
$$

A There hath not any thing been fet down either of the auncient or later writers concerning the vertues of thefe plants; notwithftanding we haue founde by triall, that the buddes before they be flowred, boiled and eaten with butter, vineger, and pepper, after the maner of Artichoks, are excee. ding pleafantmeate, furpaffing the Artichoke farre, in procuring bodilie luft.

B The fame buds with the ftalks neere vnto the top(the hairineffe being taken away) broiled vpon a gridiron, and afterwarde eaten with oile, vineger, and pepper, hath the like property.

\section{Of Cammoill. Chap.248.}

* The kindes.

$T$ Here haue beene of the auncients fet foorth two forts of fweete fmelling Cammomils. The l2ter age wherein weliue hath founde two more, befides other wilde kindes thereof.

$$
\text { * Thedefcription. }
$$

$17 \mathrm{O}$ diftinguif the kindes of Cammomils with long defcriptions it woulde but inlarge the volume, and fmall profite woulde thereby redounde to the Reader, confidering they are fo well knowne to all; notwithftanding it fhall not be amiffe to faie fomething of them to keepe the order andmethod of the booke, hitherto obferved. The common Cammomillhath manieweake and feeble braunches trailing vpon the grounde, raking holde vpon the top of the earth, as it runneth, whereby it greatly increafeth. The leaues are very fine and much iaggedor deepcly cut, of a ftrong fweete fmell: among which come foorth the fowers like vato the fielde Diafie, bordered about the edge with a pale of white leaues; the midlle part is yellowe compbfed of fuch thrums; clofe thruft togither, as is that of the Daifie. The roote is verie fmall and threddic. oxls sit if 


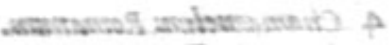 \\ * The defaription.}

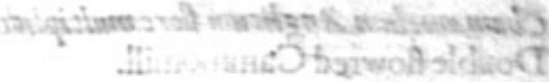

2. The fecond kinde of Cammomill hath leaues, rootes, ffalkes, and creeping branches, like vinto the precedent: the flowers grow at the tops of fmall tender ftemmes, which arenothing elfe but fuch yellowe thrummie matter, as is in the middle of the reft of the Cammonils, without any pale or border of whire leaues, 25 the others haue; the whole plant is of 2 pleafing fiveete finell, whereupon fome have given icthis addition Odoratsum.

\section{1 chamenelian. Cammomill.}

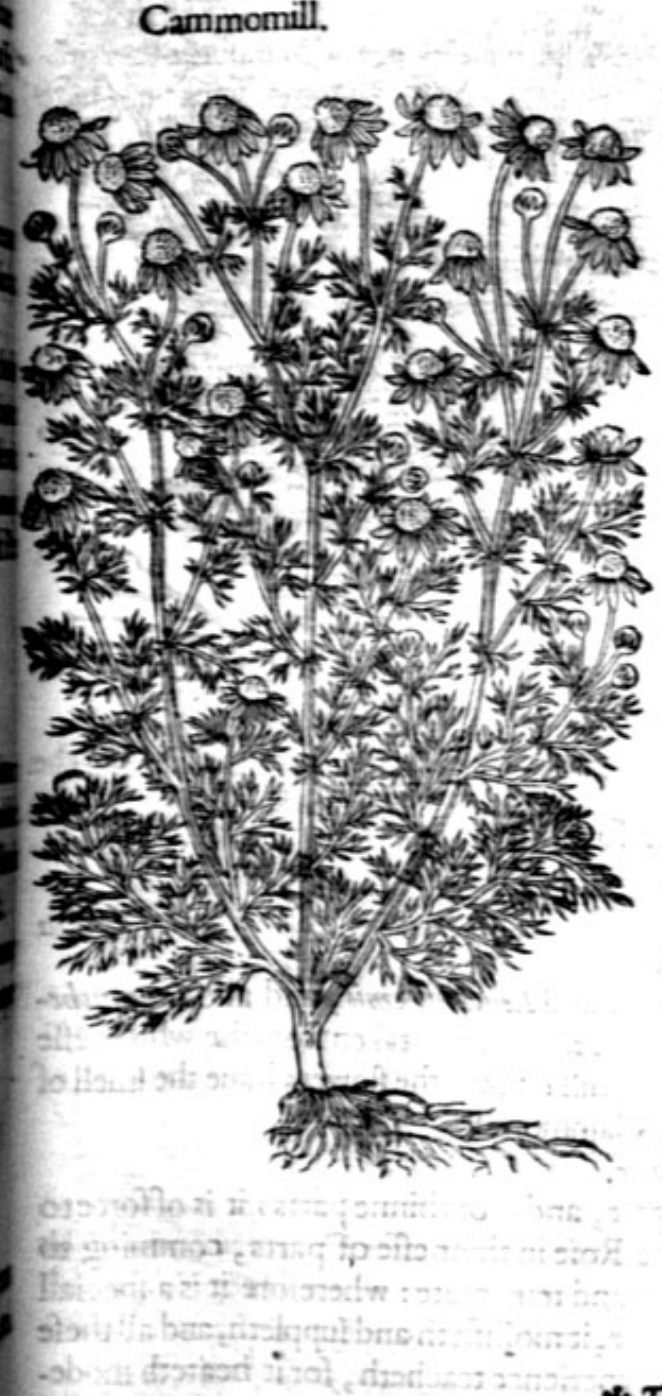

2 Chsemencion nadienodoratien. Sweetenaked Cammomill.

* The defcription.

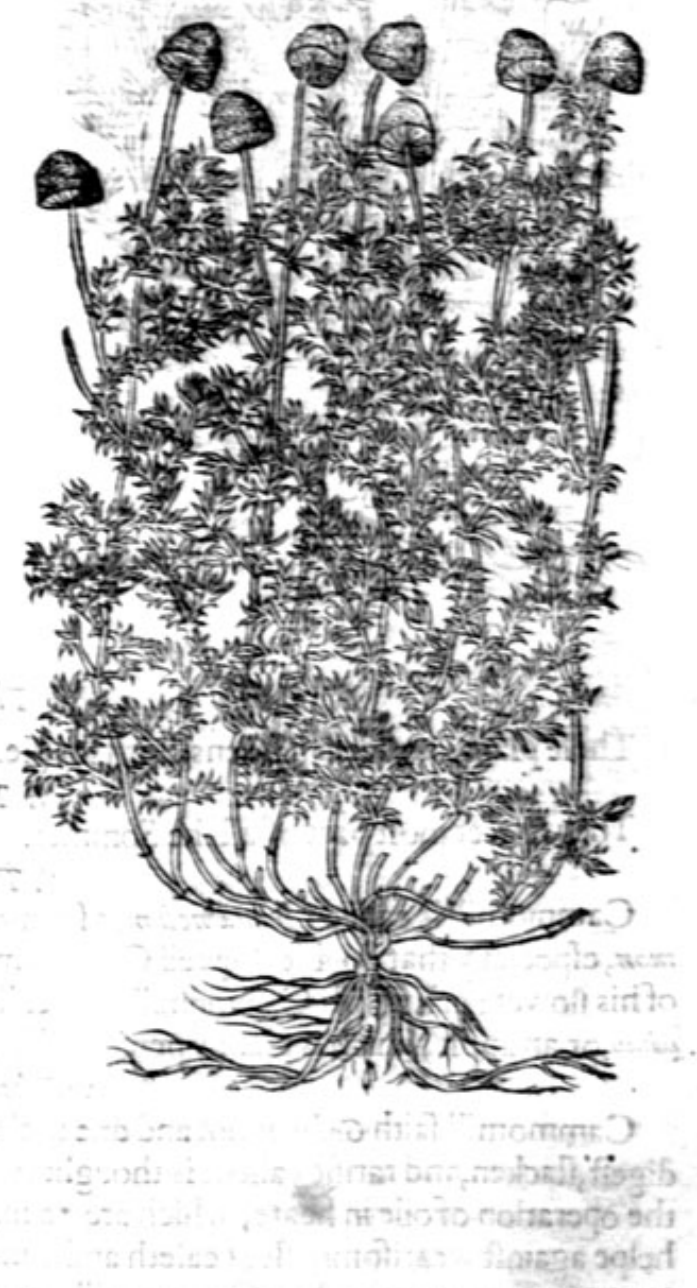

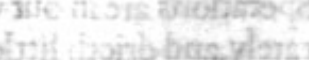

3 This thirde Cammomill differeth potfrom the former, fauing that the leaves heereof are verie much doubled with whiteleaues, infomuch that the yellowe thrum in the middle is but little feene, and the other verie fingle, wherein confiiteth the difference.

4 Romifh Cammomill hath many flender ftalkes, yet ftiffer and ftronger thent any of the others, by reafon whereof itftandech more vpright, and doth not creepevppon the earth as the ochers doe. The leaues are of a more whitith colour tending to the colour of the leaues of Woade. The flowers belikewile gellowein themiddle, and paled about with a border of fmall white flovers. 
3 Chamemelum Anglicum fore multiplici.

Double flowred Cammomill.

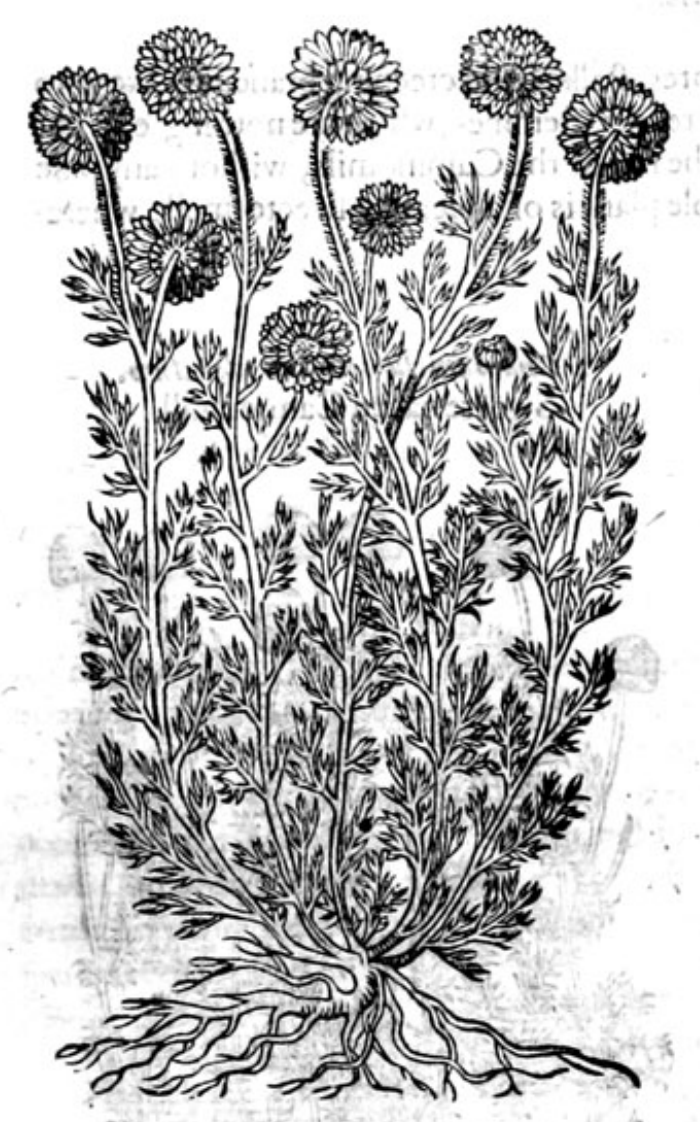

BOOKE OF THE

4 Chamamelum Romanwom. Romirh Cammomill.

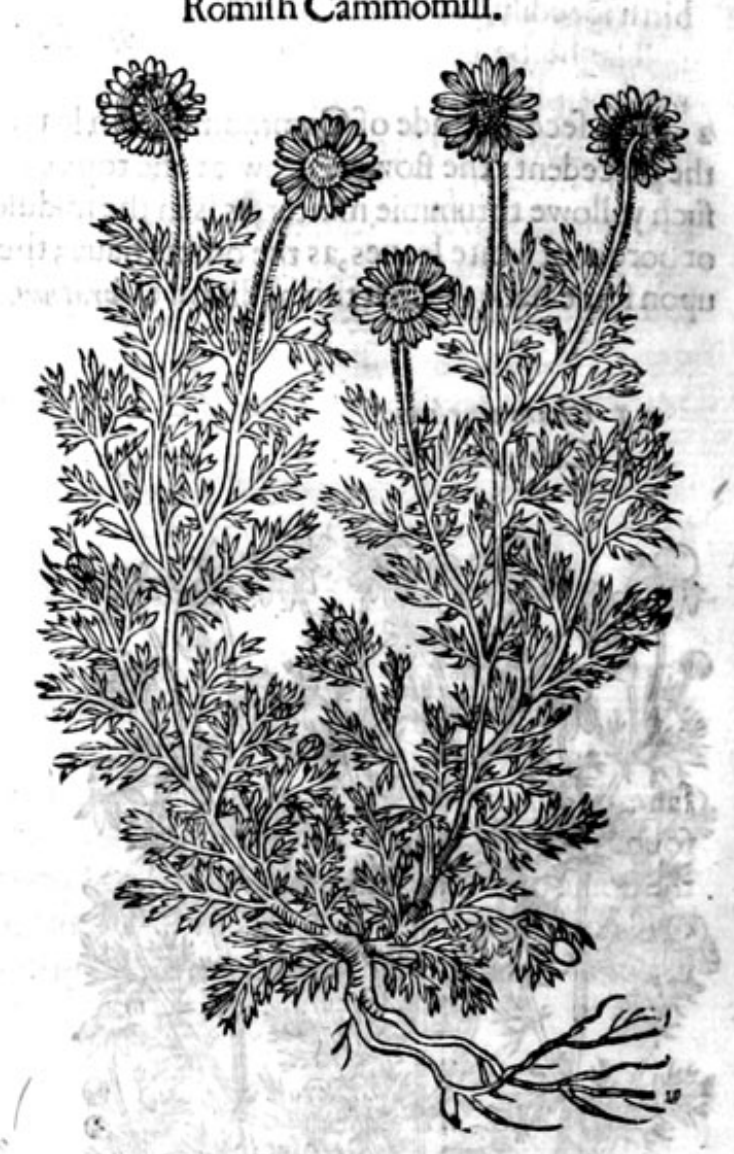

- * Theplace.

Thefe plants arefetin gardens, both for pleafurc and alfo profite.

They flower moft part of all the Sommer. * The time.

* The nonses.

Cammomill is called chamamelum, of fome Anthemis, and Lewcanthemis, and alfo Lewsanthemon, efpecially that double fowred Cammomill, which Greeke name is taken from the whiteneffe of his flower : in Englifh Cammomill : it is called Cammomill bicaufe the flowers haue the fmell of u'vov, or an apple, which is plainly perceitued in common Cammomill.

C Thetemperature.

Cammomill faith Galen is hot and drie in the firft degree, and is of thinne parts: it is of forceto digeft, flacken, and rarifie; alfo it is thought to be like the Rofe in thinneffe of parts, comming to the operation of oile in heate, which are to man familiar and ternperate: wherefore it is a fpeciall helpe againft wearifomneffe, it eafeth and mitigateth paine, it mollifieth and fuppleth, and all thefe operations are in our vulgar Cammomill, as common experience teacheth, for it heateth moderately, and drieth little.

A Cammomill is good againft the collicke and ftone, prouoketh vrine, is moft fingular inglifters which are made againft the forefaid difeafes.

B Oile of Cammomill is exceeding good againft all maner of ache and paine, brufings, fhrinking of finewes, hardneffe, and colde fivellings.

C The decoction of Cammomill made in wine and drunke, is good againft coldnes in the ftomack, fower belchings, voideth winde, and mightily bringeth downe the montly courfe.

D The Egyptians haue vfed it for a remedie againft all colde agues : they did therefore confecrate it, as $G_{a l e n}$ faith. 


\section{HISTORIE OF PLANTS. I IAT}

The decoction made in white wine and drunke, expelleth the dead childe and fecondine, or after- $\mathrm{E}$
birth fpecdily, and clenfeth thofe parts:

The herbe boiled in poffet ale, and giuen to drinke, eafeth the paine in the cheft comming of $\mathrm{F}$ winde, and expelleth tough and clammie fiegme, and helpeth children of the ague.

The herbe vfed in bathes prouoketh fweate, rarifieth the skin' and openeth the pores, briefely $G$ is mitigateth gripings and gnawings of the belly, it alaieth the paines of the fides, mollifieth hard fwellings, and wafteth awaic rawe and vndigefted humours.

The oile compounded of the flowers, performerh the fame, and is a remedie againft all weari- $H$ fomneffe, and is with good fucceffe mixed with all thofe things that are applied to mitigat e paine.

\section{Of Maieweede, or wilde Cammomill. Chap.249.}

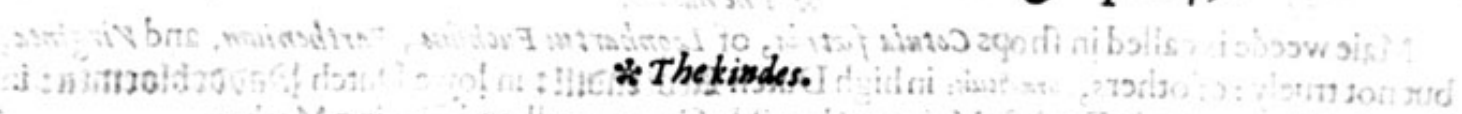

Herebe three kindes of wilde Cammomils which are generally called in Latine Cosule; one 1 ftinking, 2nd two other not ftinking: the one hath his tiower all white throughout the compaffe, as alfo in the middle; and the other yellow. Befides thefe, there is another wich ver ie faire double flowers voide of finell, which a Kentifh gentleman called Mafter Bartilmerve Line found growing wilde in 2 fieide in the Ile of Thanet neere vnto a houfe called Queakes, fometime the houfe of Sir Henrie Gri/pe. Likewife Malter Hesketh before remembred, found it in the garden of his Inne at Barnet (if my memoric faile me not) at the figne of the red Lion,or elfe neere vnto it,
in a poore womans garden, as he was riding into Lancafhire.

1 Cotuls fatita. Maie weede.

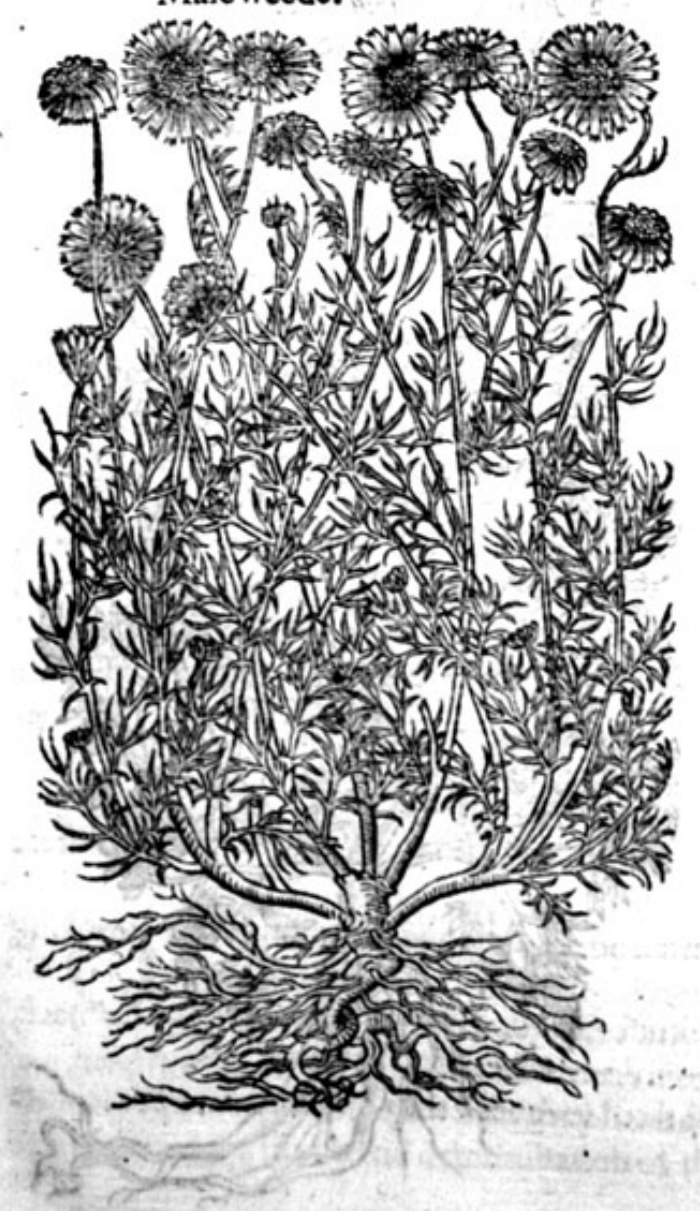

2 Cotula lutes.

Ycllow Maie weede.

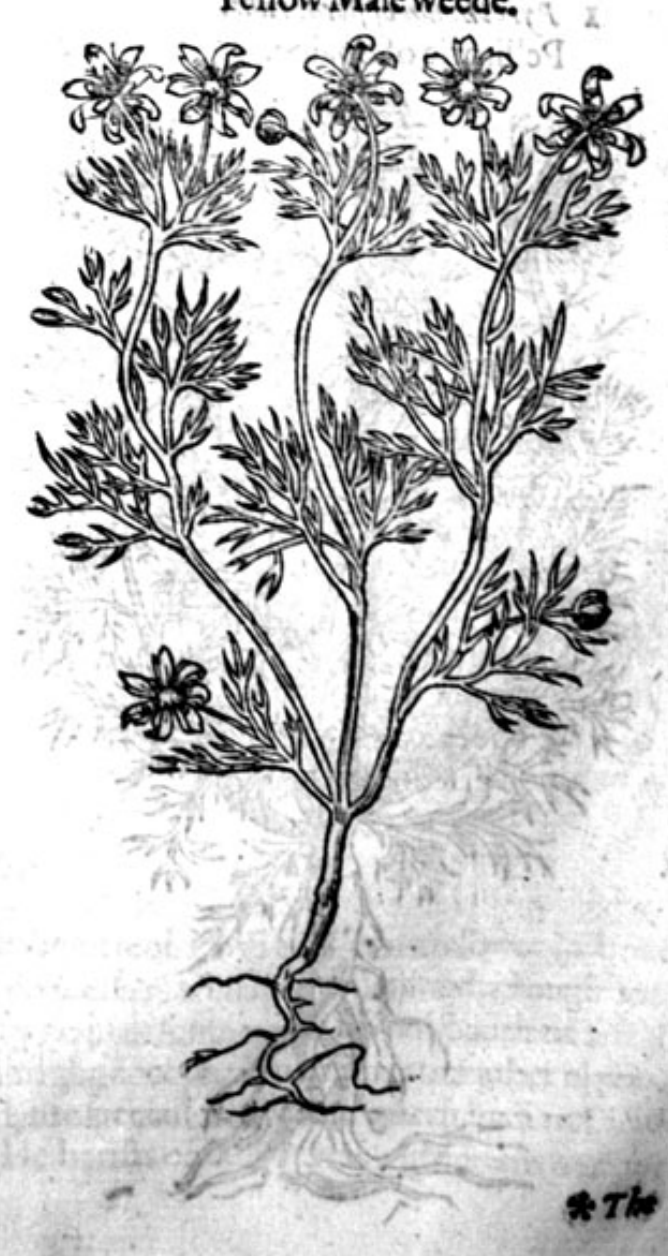




\section{* The defcription.}

I Aic weede bringeth foorth rounde ftalkes, greene, brittle, and full of iuice, parted into manie branches, thicker, and higher then thofe of Cammomill; the leaues in like maner are wider, and of a blackinh greene colour, the flowers like in forme and colour. The whole plant ftinketh, and giueth a rankeimell.

2 The yellowe Maie weede hath a fmall and tender roote, from which rifeth vp a feeble ftalke, diuiding it felfe into many other branches, whereupon do grow leaues not vnlike to. Cammomill, but thinner, and fewer in number. The flowers grow at the top of the ftalkes, of a golde yellowe colour.

$$
\begin{aligned}
& \text { * The place. } \\
& \text { to path waies, and in the borders of fieldes. }
\end{aligned}
$$

They growe in Corne fieldes, neere vnto path waies,
$*$ The time.

They flower in Iuly and Auguft.

$$
\text { *. The names. }
$$

Maie weede is called in fhops Cotwla fatida, of Leonhartw Fuchfous, Parthenium, and Vir ginea;

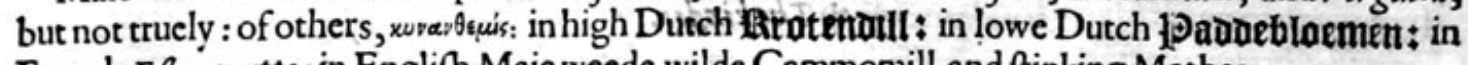
French E/pargostte : in Englith Maic weede, wilde C2mmomill, and finking Mathes.

$$
\text { * The temperature and veriaks. }
$$

A Maie weede is not vfed for meate nor medicine, and therefore the faculties are vnknowne, and not founde out, yet all of them are tho:ight to be hot and drie, and like after a fort ih operation to Cammomill, but nothing at all agreeing with mans nature; notwithitanding it is commended a: gainft the infirmities of the mother, feeing allftinking things are good againft thofe difeafes.

B It is an vnprofitable weede among corne, and raifech blifters vpon the handes of the weeders, and reapers.

\section{Of Pellitorie of Spaine. Chap.250.}

\section{Pyrethrum of ficinaruem.}

Pellitorie of Spaine.

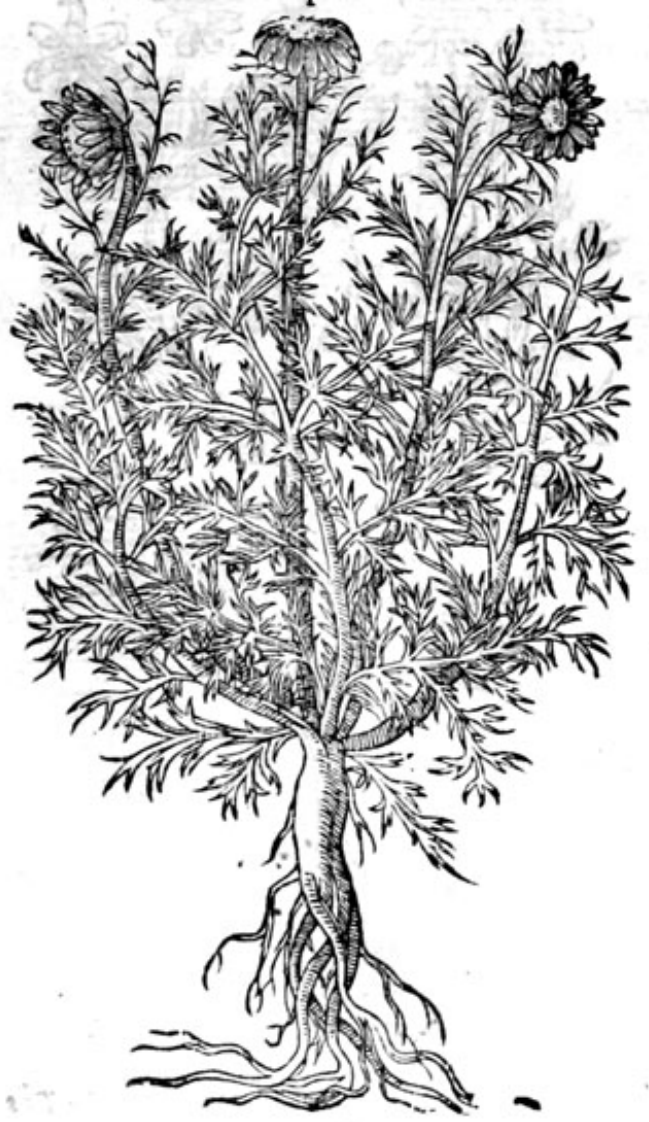

2 Pyrethruen fylueftre. Wilde Pellitorie.

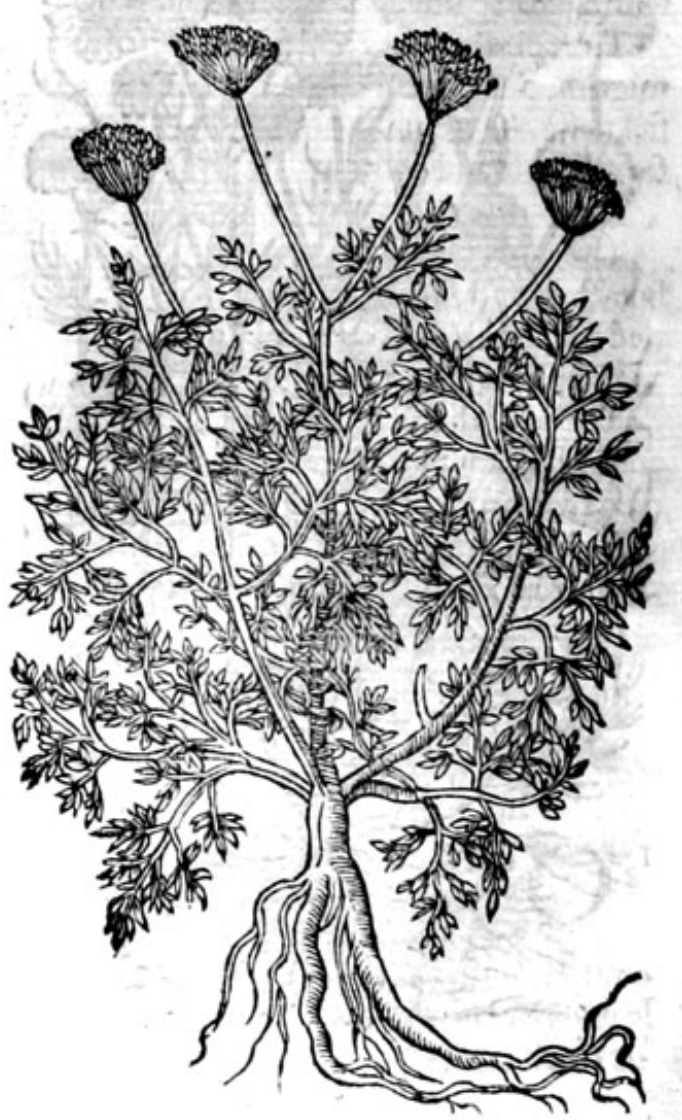




\section{* Thedefcription.}

1 D rrethrum, in Englifh Pellitoric of Spaine(by the namé whereof, fome do vnproperly call an other plant, which is indeede the true Imperatoriz, or mafter wort, and not Peilitotic) is hath great and fat leaues, like vnto Fennell, trailing vpon the grounde:among which immediately from the roote, rifeth vp a fat greene ftem, bearing at the top a goodly flower, firhioned like the great fingle white Daifie, whofe bunch or tnob in the midft is yellowe like that of the Daifie, and bordered about with a pale of fmall leaues, exceeding white on the vpperfide, and vnder of a faire purple colour : the roote is long, of the bignes of a finger, verie hot, and of a burning tafte.

2 The wilde Pellitorie groweth vp like vnto wildeCheruile, refermbling the leaues of Castalis, of a quicke and nipping tafte, like the leaues of Dittander or Pepper woort; the flowers growe at the top of flender ftalkes in fmall tufts or fpokie vmbles, of a white colour : the roote is tough, and of the bigneffe of a little finger, with fome threds thereto belonging, and of a quicke biting tafte.

It groweth in my garden very plentifully. * The place.

It flowreth and feeceth in Iuly and Auguft.

$$
\text { * The sime. }
$$

\section{* The names.}

Pellitorie of Spaine is called in Giceke mipeser, by reafon of his hot and fierie tafte: in hops alfo Pyretbrum : in Latine Salimaris : in Italian Pyret bro : in Spanifh Pclitre: in French Pred a Alexandre, that is tofaie, Pes Nlexandrinus, or Alexanders foote: in high and lowe Dutch zertram ; in Englith Pellitorie of Spaine,and of fome Bertram after the Dutch name; and this is the right Pyrethruen, or Pellitorie of Spaine, for that which diuers take to be the right, is another"kinde of herbe, commonly called Imperatoria, or Mafterwoort, but vntruly, being decciued by Diofsorides his corript copies, reading one thing for another.

\section{* The temoerature and vertues.}

The roote of Pellitorie of Spaine is very hot and burning, by reafon whereof it taketh awaie the $\mathbf{A}$ colde fhiuering of agues that haue beene of long continuance, and is good for thofe that are taken with a dead palfie, as Dio/corides writeth.

The fame is with good fuccefle mixed with antidotes or counterpoifons, which ferue againft the B migrim, and continuall paine of the head, the diffineffe called Vertigo, the apoplexie, the falling fickneffe, the trembling of the finewes, and palfies, for it is a fingular good and etfectuall remedie for all colde and continuall infirmities of the head and finewes.

Pyret hrom, taken with honie, is good againft all colde difeafes of the braine.

The root chewed in the mouth, draweth foorth great ftore of rheume, flime, and filthie waterioh humours, and eafeth the paine of the teeth, efpecially if it be ftamped with a little Staphifagria, and tied in a fmall bagge and put into the mouth,and there fuffered to remaine 2 certaine pace.

If it be boiled in vineger and kept warme in the mouth it hath the fame effect.

The oile wherein Pellitorie hath beene boiled, is good to annoint the bodie toprocure fweating, $\mathbf{F}$ and is excellent good to annoint any part that is brufed and blacke, al though the member be declining to mortification: it is good alfo for fuch as are ftriken with the palfie.

It is moft fingular for the Chirurgians of the Hof pitals, to put into their vnctions contra 2 Leapo-G it anum mor bum, and fuch other difeales that be cofin germaine thereunto.

\section{Of Leopards bane. Chap.251.}

\section{* The dejcription.}

I F this plant Doronicum there be fundric kindes, where of I will onely couch fower, whom Dodonems vnproperly calleth Aconit wm pardelianches, which hath hapned through the negligence of Diofcorides and Theophraftess, who in defcribing Doromicum, have not onely omitted the flowers thereof, but haue committed that negligence in many and diuers other plants, leauing out in many plants which they haue defcribed, the fpeciall accidents, which hath not a litte troubled the ftudie and determination of the beft Herbarifts of late yeeres, nor knowing cer- 


\section{0 \\ THE SECOND BOOKE OF THE}

tainly what to determine and fet downe in fo ambiguous a matter, fome taking it one waie, fome another, and fome efteening it to be Aconitum : but for better vnderftanding heereof, knowe that this worde Aconttum as it is a name attributed to diucrs plants, fo it is to be confidered that all plants called by this name, are malignant and venemous, as with the iuice and roote whereof, fuch as hunted after wilde and noifome beafts, were woont to imbrue and dippe their arrowes, the foo. ner and more furely to difpatch and flea the beaft in chace. But for the proofe of the goodneffe of

- this Doronicum and the reft of his kinde : knowe alfo that $L^{\prime} O$ Obelius writeth of an excellent learned man called Iohn de Vroede, who did eate verie many of the rootes at fundric times, and founde them verie pleafant in tafte and veric comfortable. But to leaue contronerfies, circumftances, and obiections which heere might be brought in and alleaged, affure your felues that this plant Doronicuen minus off tcinaruon (whofe rootes Pena reportcth to haue found plentifully growing vpon the Pedemountaine hils and certaine hie places in Fraunce)hath many great leaues fpread vpon the ground, fomwhat round, \& rough haired like Plantainc: among which rife vp manie tender rough ftalks two cubites and an halfe high bearing at the top certaine fingle yellow flowers; which when thcy vade, change into downe, and are caried away with the winde: the rootes are thicke and manie, very clookedly croffing and tangling one within another, refembling a fcorpion, and in fome yecres do grow in our Englifh gardens into infinite numbers.

2 The fecond kinde of Doronicum hath larger leaues then the former, but rounde and broader,almoft like the great Clot or Burre; among which rifeth vp a ftalke two cubits high : the flowers are like the former:the roote is longer and bigger then the former, barred ouer with many fcalie barks, in colour white, and fhining like white marble, hauing on eche fide one arme or finne, not vnlike to the fea fhrimpecalled Squills marina, or rather like the ribbes or fcales of a fcorpions bodie, and is fweet in tafte.

\section{Doronicum maius of ficinarum.} Great Leopards bane.
2 Doronicum minu. Small Leopards bane.

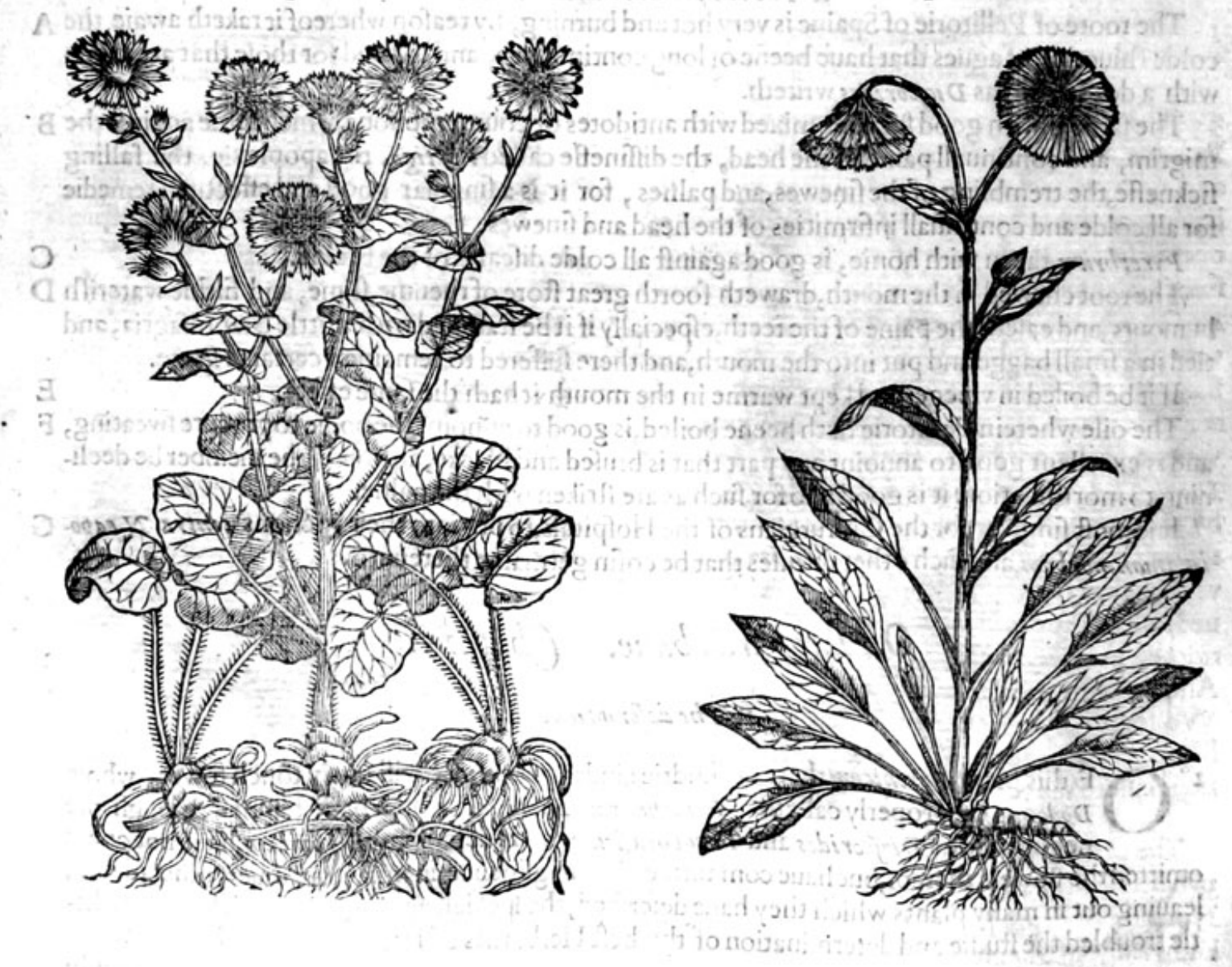

3 Doronicums 


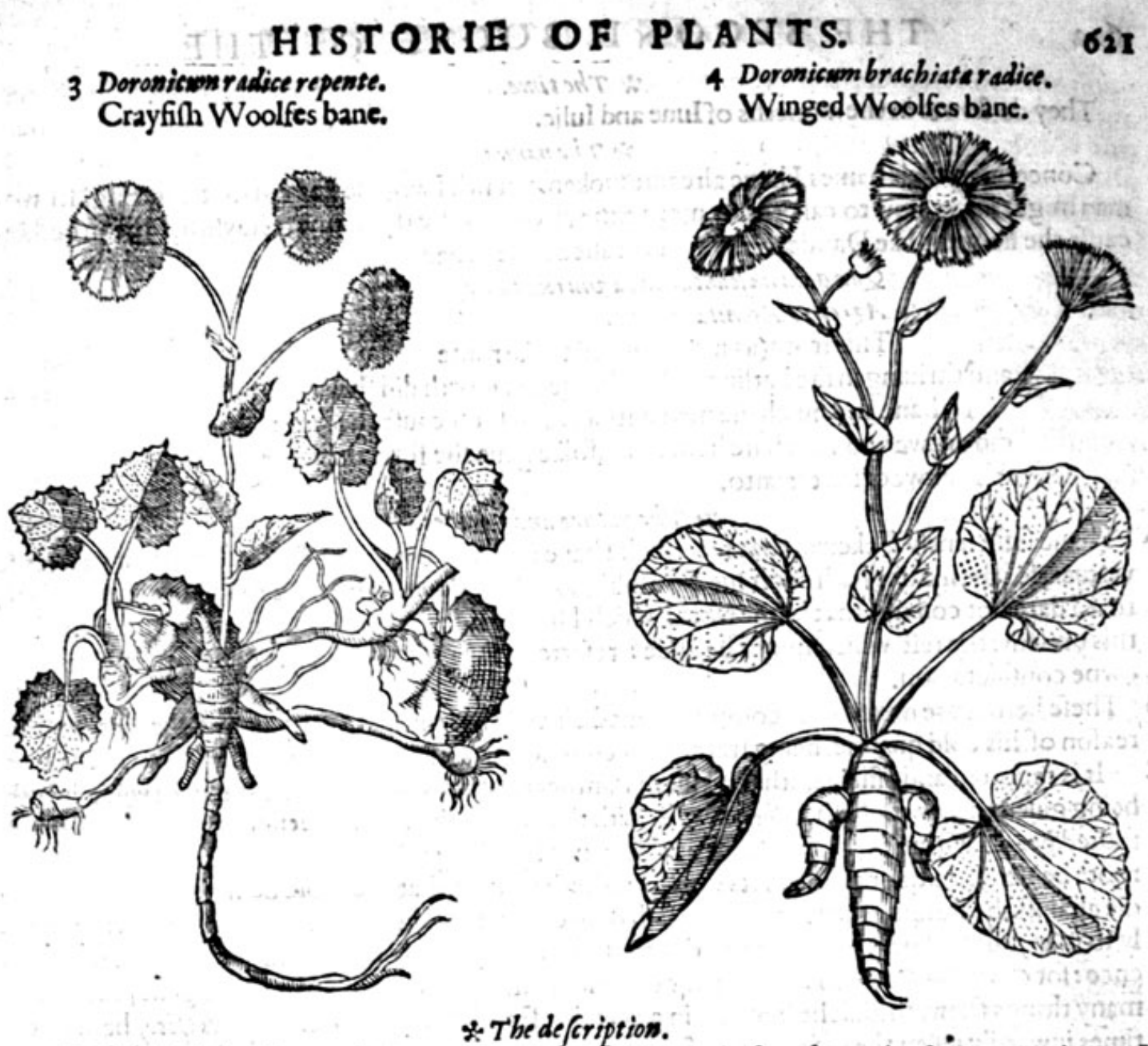

* The defcription.

3 The thirde kinde of Doronicum, growing naturally in great abundance in the mountaines of Fraunce, is alfo brought into, and acquainted with our Englifh groundes, bearing very large leaues of a light yellowirh greene, and hairie like Pilo/ell.t, or Cucumis a grefts. The ftalkes are a cubite high, hauing at the top yellowe flowers like Buphthaimus, or Confolida media vulner arioram : all the roote oucr is barred \& welted with fcales like the taile of a fcorpion, white of colour, \& in tafte fweet, with fome bitternes, yeelding foorth much clamnineffe, which is very aftringent.

4 The fourth kinde heereof is founde in the woodie mountaines about Taurinum and Sauoie, very like ynto the former, fauing that the leaues are fomwhat rougher, the flowers greater, and the ftalks higher. But to be fhort, eche of thefe kinds are fo like one another, that in fhew, tafte, fmel, 8 maner of growing, they feeme to be as it were al one; the Ifore it were fuperfluous to ftand vpon their varietic of names, Pardalianches, $M$ rodtonupe, $T$ heliphonum, Camor un, andfuch like, of $T$ heophrastus, Diofcorides, Plinie, or any of the newe writers, which names they hate giuen vnto Dorowicum, for by the opinion of the moft skiliull in plants, they are but Symonymies of onle kinde of plant. And though thefe olde writers fpeake of the hurtfull qualities of thefe plants : yet experience teacheth ys, that they haue written what they haue heard and read_and not what they hane knowne and proued : for it is apparant that Doronicum by the confent of the olde and newe witiers, is vfedas an antidote, or certaine treacle, as well in the confections de Geminis Me fue, as in electivario Utromat tum. And thoughe Mathiolus difclaimeth againft the vfethereof, and calleth it Pardilianches, that is, Wolfes bane: yet let the learned know, that Quantitas non qualitias nccet: for as Saffron is comforta ble to the hart; yet if you giue thereof, or of muske, or any fuch cordiall thing, too great a quantitie, it killech the partic which receiuethit.

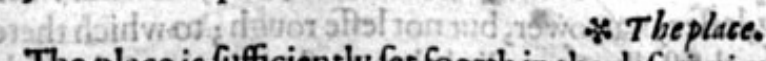

The place is fufficiently fet foorth in the defcription, yet you nall vnderfande that I have the tivo firft in ny garden, and the thirde hath beene founde and gathered in the colde mountaines of Northumberlande, by doctor Pennie, lately of London decealed, a man of much experience and knowledge in Simples, whofe death my felfe and many others do gteatly bewaile. 
They do flower in the moneths of Iune and Iulie.

* T The names.

Concerning their names I hauc alreadie fpoken, yet fith I woulde be glad that our Englinh women migbt know how to call it, they may terme Doronicum by this name, Crayfirh, Piffe in bed,bicaufe the flower is like Dandelion, which is called Piffe in bed.

\section{Qua quia na fountur dara vimacia caute, Agreftes Aconita vocant.}

This froth(as men fuppofe) tooke roote

and thriuing in the batling foile in burgcons foorth did hoot,

To bane and mifchiefe men withall: and for bicaufe the fame

did growe vpon the bare hard fints, folke gaue the forrefaid name

of Fintwoort thereunto.

* The nature and vertues.

A I haue fufficiently fpoken of that for which I haue warrant to write, both touching their natures \& vertues, for the matter hath continued fo ambiguous $\&$ fo doubtfull; yea, i $x$ fo full of controuerfies, that I dare not commit that to the world which I haue read : thefe few lines therfore fhal fuffice for this prefent : the reft which might be faide I referre to the great and learned doctors, and to your owne confideration.

B Thefe herbes are mixed with compound medicines, that mitigate the paine of the eies, and by reafon of his cold qualitie, being frefh \& green, it helpeth inflammations, or fierie heat of the eies.

C It is reported and affirmed, that it killeth Panthers, fwine, wolues, and all kindes of wilde beafts, being giuen them with fle? . Theophraftm faith that it killeth cattle, fheepe, oxen, and all fower footed beafts, within the compaffe of one daie, not by taking it inwardly onely, but if the herbe or roote be tied vnto their priuie parts : yet he writeth further, that the roote being drunke, is a remedie againft the ftingings of f corpions: which fheweth that this herbe or the root thetof is not deadly to man, but to diuers beafts onely, which thing alfo is found out by triall, and manifeft experience : for Conradus Ge/nerus a man in our time fingularly learned, and a moft diligent fearcher of many things fheweth, that he himfelfe in a certaine Epiftle written to 1 dolphes Occu, hath oftentimes inwardly taken the roote heereof greene, drie, whole, preferued with honie, and alfo beaten to powder, and that euen the very fame daie in which he wrote thefe things, he had drunke with warme water two drams of the rootes made into fine powder, neither felt he any hurt therby; and that he oftentimes alfo had giuen the fame to his ficke patients, both by it felfe \& alfo mixed wirgh other things, and that very luckelie. Moreouer, the Apothecaries in fteedeo Doronicum, do vfe (though amiffe) the rootes thereof without any manifeft danger.

D That this Aconite killeth dogs, it is very certaine and founde out by triall, which thing Mathio. lus could hardly beleeue, but that at length he founde it out to be true by a manifeit example, as he confeffeth in his Commentaries.

$$
\text { Of Sage. Chap.252. }
$$

7 Here be diuers forts of Sage, two efpecially oblerued of the auncients. Thelater writers haue found more. $*$ The defcription.

f 7 He great Sage is very full of ftalks, fower fquare, of a woodie fubftance, parted into bran-

4. ches, about the which grow broad leaues, long, wrinckled, rough, whitioh, very like to the lcaucs of wilde Muliein, but rougher, and not fo white, like in roughnes to woollen cloth thread bare; the flowers ftande forked in the tops of the branches like thofe of dead Nettle, or of Clarie, of a purple blewe colour, in the place of which groweth little blackifh feede in fmall husks. The roote is hard and woodie, fending foorth 2 number of little ftrings.

2 The leffer Sage is alfo a fhrubby plant, fpred into braunches like to the former, but leffer : the ftalks hecreof are tenderer : the leaues be long, leffer, narrower, but not leffe rough; to which there do growe in the place wherein they are fixed to the ftalke, two little leaues ftanding on either fide one right againft another, fomewhat after the maner of finnes or little eares, the flowers are eared blewe like thofe of the former : the roote alfo is woodie, both of them are of a certaine ftrong fmel, but nothing at all offenfiue, and that which is the leffer is the better. 


\section{HISTTORIE OF PLANTS.}

I Sa'wia maior.

Great Sage.

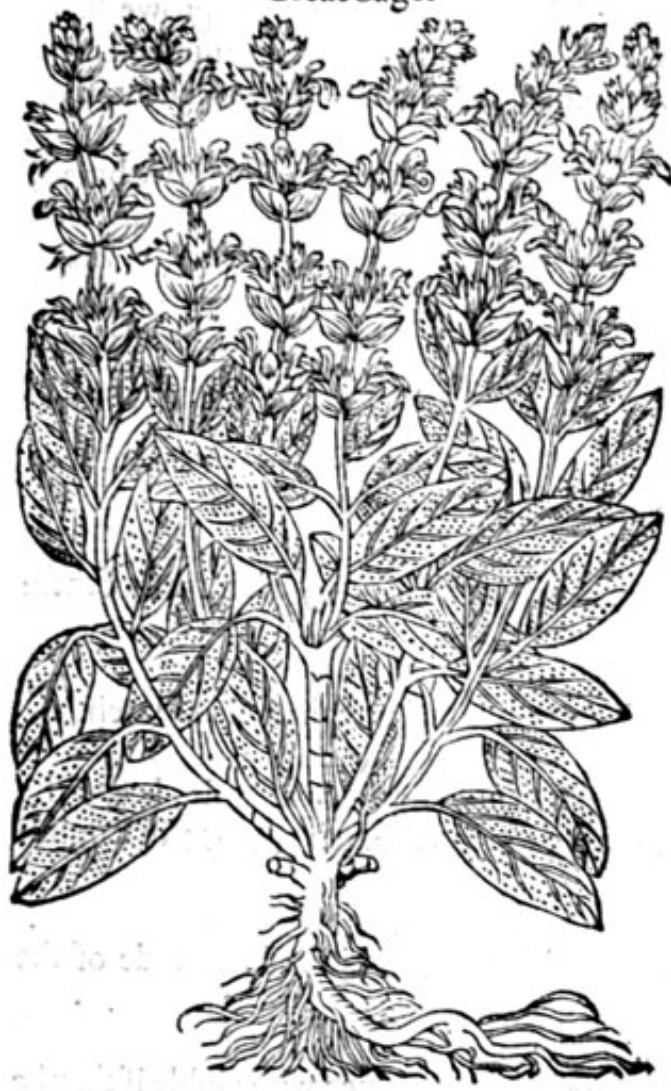

3 Salwia Indica.

Indian Sage.

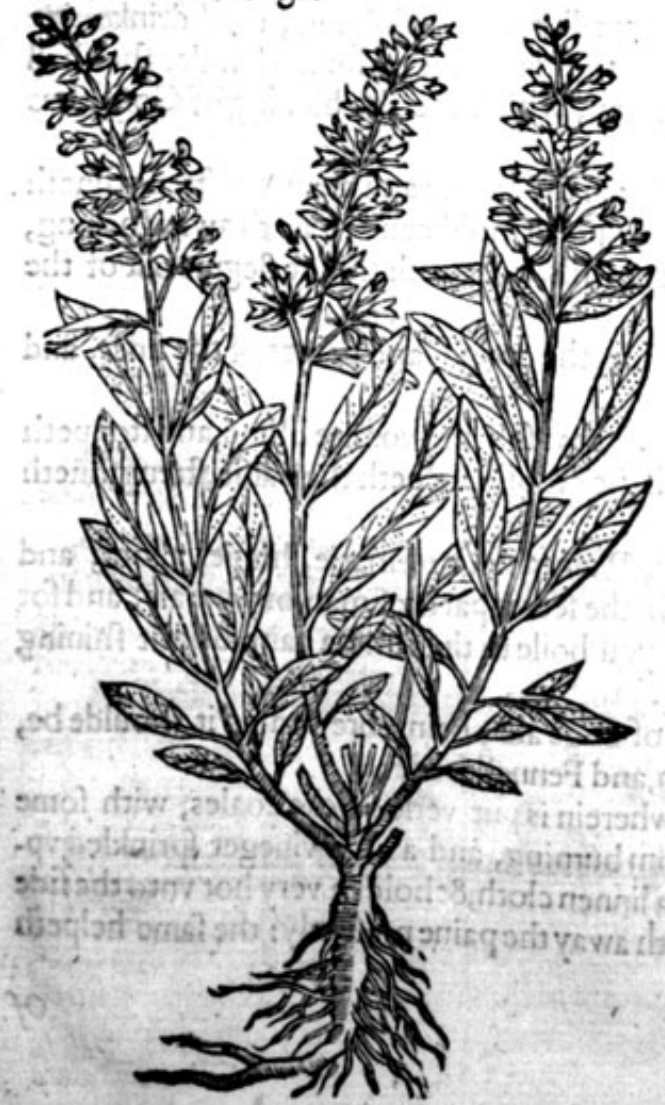

2 Saluia minor. Small Sage.

* in \%

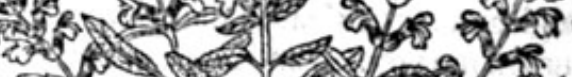
a 10 की 2 1

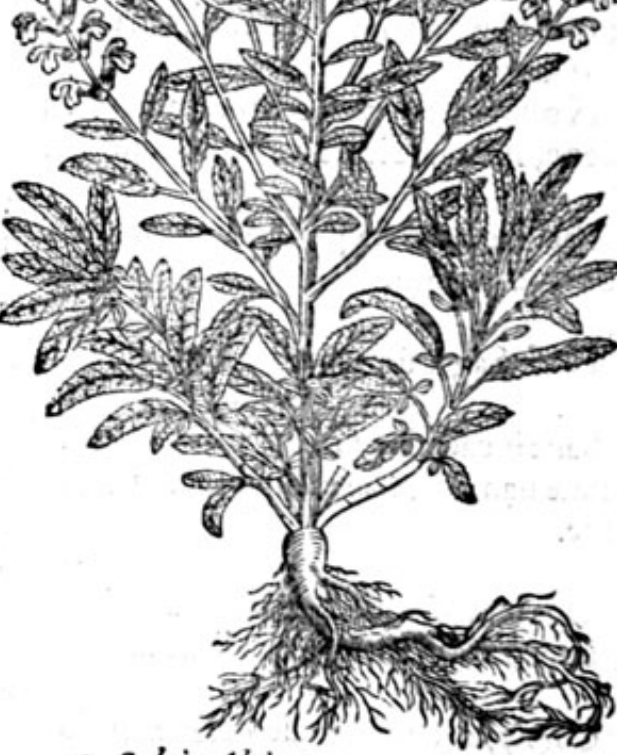

4 Saluia Alpina. Mountaine Sage.

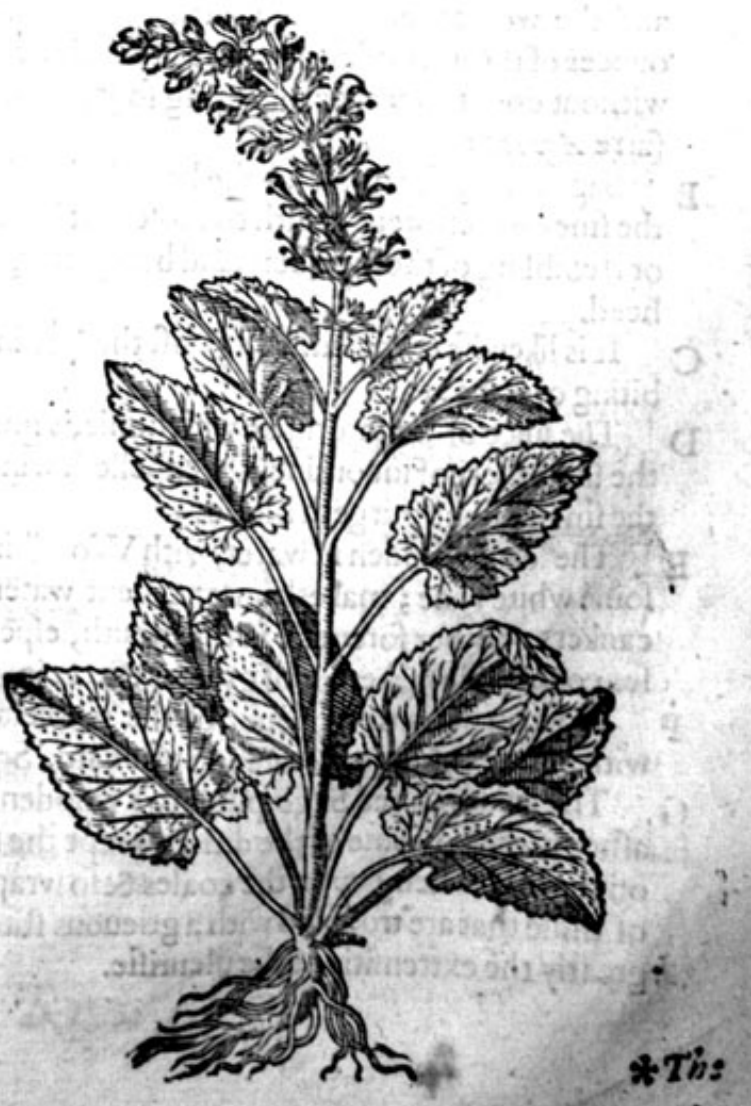




\section{4 \\ THE SECOND BOOKE OF THE}

\section{* The defcription.}

3 This Indian Sage hath diuers braunches of a woodie fubftaunce, whereon do growe finall lcaues, long, rough, $\$$ narrowe, of an oucrworne colour, \& of a molt fweet and fragrant finell. The flowers grow alongtt the top of the braunches of a white colour, in forme like the precedent. The roote is tough and wooddie.

4 The mountaine Sage hath an vpright ftalke, fmooth and plaine, whereupon doe growe broad, rongh and rugged leaues, flightly nicked, and vneeuenly indented about the edges, of a hoarie colour, fharpe pointed, and of a ranke fmell. The flowers growe alongtt the top of the ftalke, in thape like thofe of Rofemarie; of a purplith colour tending to blewneffe. The roote is likewife woodie.

Wc hauc in our gardens a kinde of Sage, the leates whereof are reddith,part of thofe red leaues areftriped with white, other mixed with white, greene and red, even as nature lift to plaie with fich plants.

We hate alfo another, the leaues whereof are for the moft part white, fomewhat mixed with greenc, often one leafe white, and another greene, euen as nature lift, as we haue faide.

* The place.

Thefekinds of Sage do not growe wilde in England, I haue them all in my garden,moft of them are very common.

$*$ The time.
Thefe Sages flower in Iune and Iuly, or later : they are fitly remooued and planted in March.
$*$ The names.

Sage is called in Greeke inerisodros: the Apothecaries, the Italians, and the Spaniards, keepe the Latine name Saluia : in high Dutch Salben: in French Sauge: in lowe Dutch gaute : in Englifh Sage.

\section{* 7 be temperature.}

Sage is manifeftly hot and drie in the beginning of the third degree, or in the later ende of the feconde, it hath adioined no little aftrittion or binding.

\section{* The vertues.}

A Agrippa, and likewife Aetius, called it the Holie herbe, bicaufe women with childe if they be like to come before thair time, \& aretroub'ed with abortments do eate thercof to their great good; for it clofeth the matrix, and maketh them fruitefull; it retaineth the birth, and giueth it life: and the woman about the fourth daie of hir going abroade after hirchilding, thall drinkenine ounces of the iuice of Sage with a little falt, and then vfe the companie of hir husbande, the fhall without doubt conceaue and bring foorth ftore of children, which are the bleffing of God: thus farre Agrippa.

B Sage is fingular good for the head and braine, quickneth the fences and memorie, ftrengthneth the finewes, reitoreth health to thofe that haue the palfie vpon a moift caufe, taketh away haking, or trembling of the members, and being put vp into the noftrils, it draweth thinne flegme out of the head.

C It is likewife commended againft the fpitting of bloode, the cough, and paines of the fides, and biting of ferpents.

D The iuice of Sage drunke with honie, is good for thofe that fpit and vomite blood, and ftoppeth the fluxe there of incontinently, expel!eth winde, drieth the dropfie, helpeth the palfie, ftrengthneth the finewes, and purgeth blood.

E The leaues fodden in water, with Woodbinc leaues, Plaintaine, Rofemarie, honie, allom, and fome white wine; maketh an excellent water to wath the fecretparts of man or woman, and for cankers or other foreneffe in the mouth, efpecially if you boile in the fame a faire bright fhining fea cole, whichmakcth it of greater efficacie.

F Noman needeth to doubt of the wholefomneffe of Sage ale, being brewed as it rhoulde be, with Sage,Scabious, Betonic, Spikenard, Squinanth, and Fennell feedes.

G The leaues of red Sage put into a wooden dilh, wherein is put verie quicke coales, with fome athes in the bottome of the difh to keepe the fame from burning, and a little vineger fprinkled vp. on the leaues lieng vpon the coales \& fo wrapped in a linnen cloth, \& holden very hot vnto the fide of thofe that are troubled with a grieuous ftitch, taketh away the paine prefendly: the fame helpeth greatly the extremitic of the pleurifie. 


\section{Of French Sage, or woodie Mullein. Chap.253.}

Verbafcum Mathioli.

French Sage.

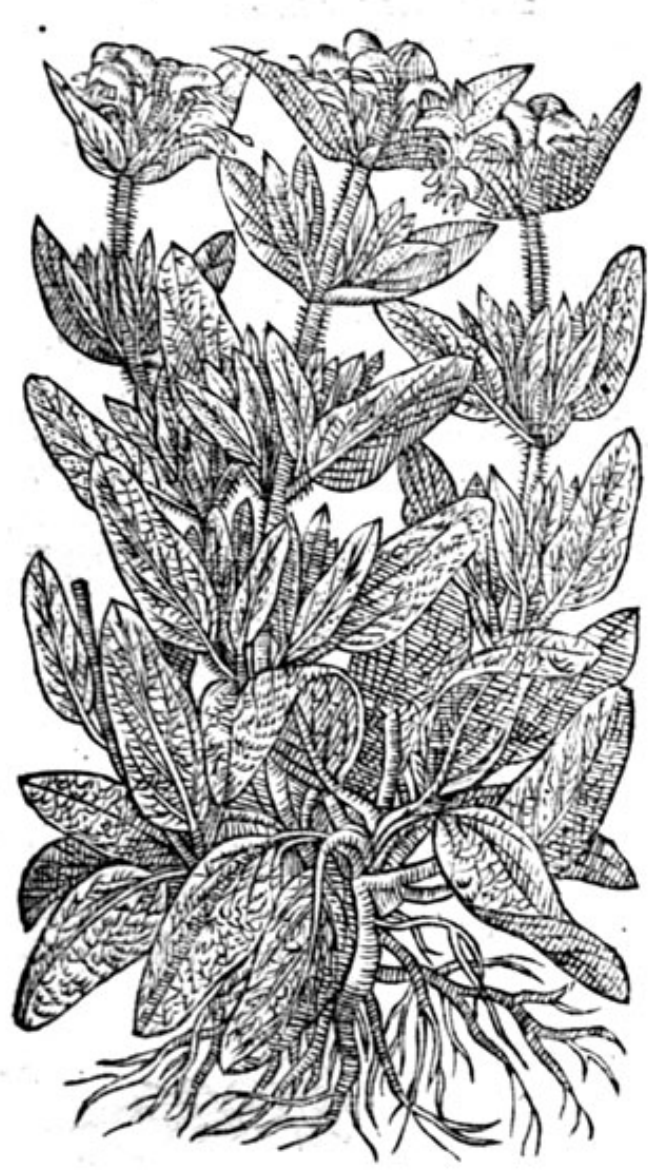

\section{* The defription.}

$\mathrm{VV}$ Ilde Mullein, woodie Mullein, cMa. thiolws his Mullein, or French Sage, groweth vpe like a fimall woodie fhrub, hauing manie woodie braunches of a wol. lic and hoarie colour, foft \& downic; wherupon arc placed thicke hoarie leaues, of a ftrong ponticke fauour, in thape like the leaues of Sage, wherupon the vulgar people call it French Sage: towarde the toppe of the braunches are placed roundels, or crownets, of yellow gaping flowers like thofe of dead Nettle, but much greater. The rootc is thicke, tough, and of a woodie fubftance, as is all the relt of the plant.

There is another fort heerof that is very fweet like the other, fauing that the leaus \& euery other part of this plant, hath a moft fweet and pleafant fmell, and the other more ftrong and offenfiue.

$$
\text { * Theplace. }
$$

Thefe wilde Mulleins do growe wilde in diuers prouinces of Spaine, and allo in Languedoc, vp. on drie banks, and ftony places: I haue them both in my garden, and many others likewife.

$$
\text { * The time. }
$$

They flower in Iune and Iulic.

$$
\approx T \text { the names. }
$$

They are called of the learned men of our time, Verbafca fylueftria : the firft is called of the Gre-

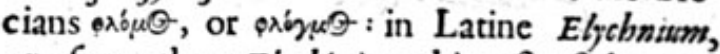
or after others Elychinisom; bicaufe of the cottonie fubftaunce thereof, matches, or weekes weremade to keepe light in lamps: Verbafcom Lychnitis, as Diofcorides himfelfe teftifieth, is named alfo Thryallis, or Rofe Campion; but the flower of $\boldsymbol{T}$ bryallis is red of colour, as Nicander in his verfes of counterpoifons doth hewe, but the flowers of thefe are yellowe: therefore they are neither Thryallio nor Lychnit is : but Syluestre Verbafcum, or wilde Mullein, as we haue alreadie taught in the

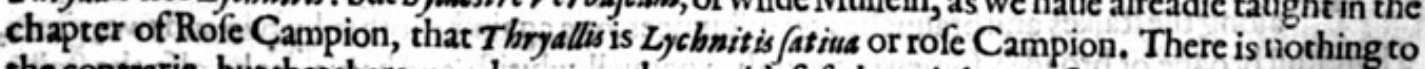
the contrarie, but that there may be many plants with foft downie leaues fit to make candle weeke of : in Englifh it is generally called French Sage, we may call it Sage Mullein.

$$
\text { * Thetemperature. }
$$

As thefe be likein vertues to the others going before, fo they be likewife drié in tempera.

$$
\text { wo stcure. }
$$

Digfcorides flith, that the leauesare ftamped and laide in maner of a pultis vpon burnings and $\mathbf{A}$ fcaldings.

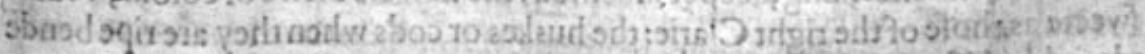

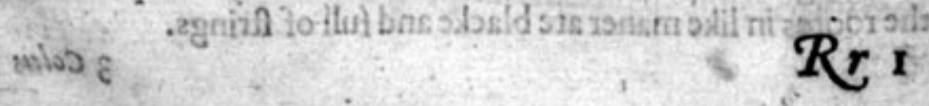




\section{Of Clarie. Chap.254. \\ * The kindes.}

There be diuers kindes of Clarie, fome wilde, others of the garden, as fhall be declared.

I Gallitricum. Common Clarie.

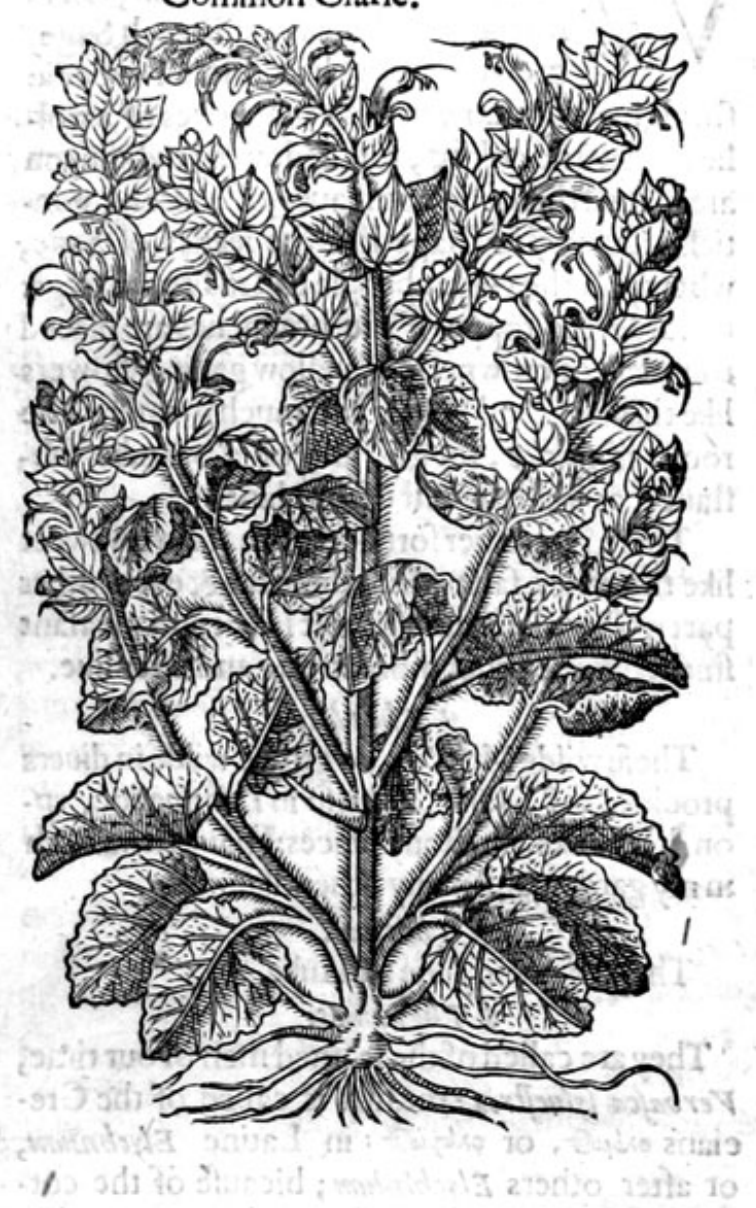

2 Gallitricum alserum. Small Clarie.

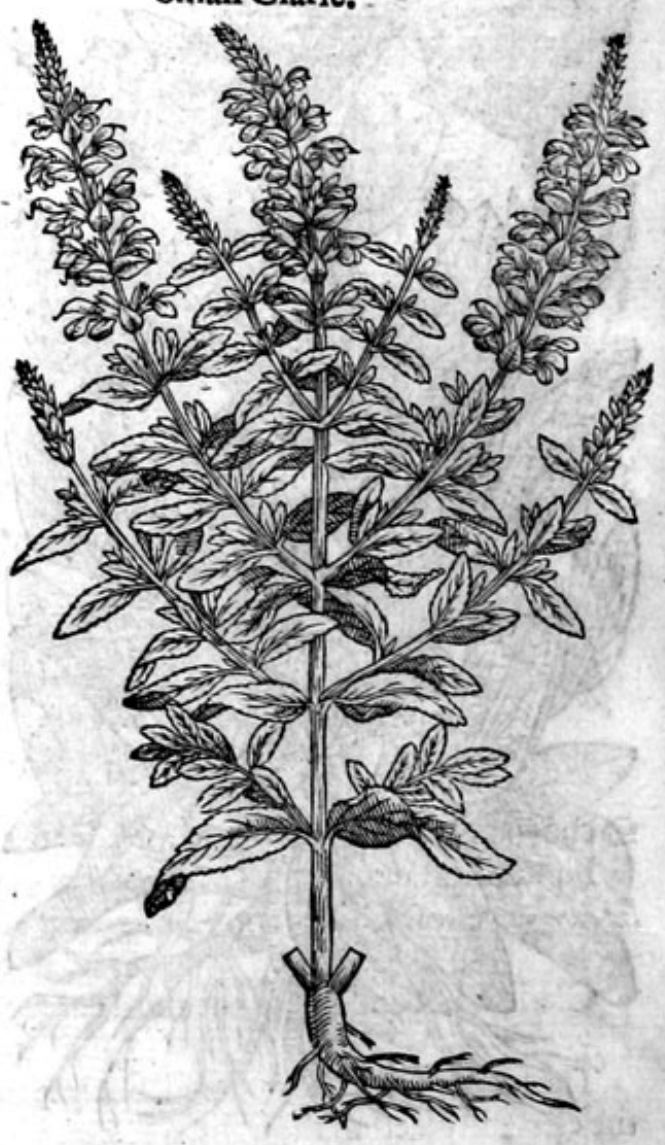

* The defcription.

$\mathbf{I}$

$\mathrm{T}$

He firft kinde of Clarie which is the right foote long, diuided in where fwo along the ftalkes and braunches: it hath many leaues growing both from the roots, and a handfall broade or broader, fomewhat by diftaunces, one againit another by țo and two, great, The flowers are like the which grow vp long toothed huskes in dead Nettle, of colour white, out of alight blewe : after fring er f ripe, which is in the fecond yeere after it is fowen. $12 \%$ aig tolstij ef? 2 The feconde kinde of Clarie hath likewife ftalkes fower fquare, a foote and a halfe high: the leaues alfo be rough and rugged, leffer, and not fo white. The flowers be alike, of colour purple or blewe : the rootes be as thofe of the former are. This hath not fo ftrong a fent by a great deale.

There is a kind of Clarie which Fuch/ums pictureth for wild Clarie, thathath horrer ftalks, hatirie alfo and fower fquare: the leaues leffer, long,deeper indented : the flowers blewe of colour, fweete downwards; not fo fweete as thofe of the right Clarie: the huskes or cods when they are ripe bende downwards; the feede is blackifh; the rootes in like maner are blacke and full of ftrings. 


\section{HISTORIE OF PLANTS.}

3 Coleus Jomis. Iupiters diftaffe.

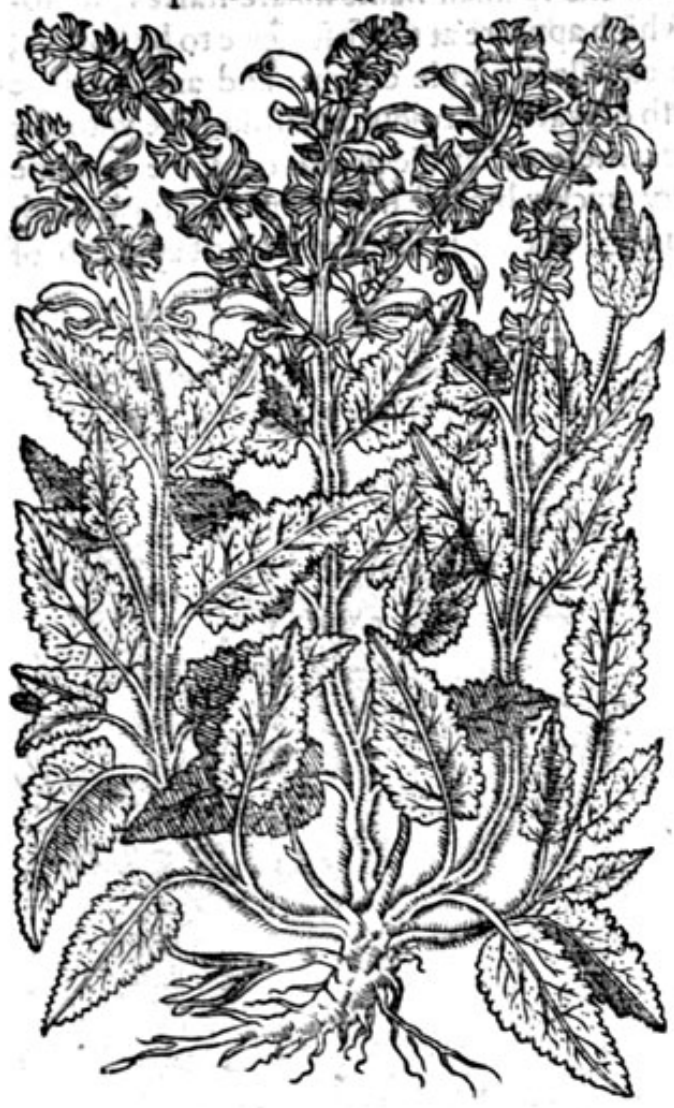

*The deforiotion. 3 The thirde kinde of Horminum, called Ionts Colses, reprefenteth in the higheft top of the ftalke a diftaffe, wrapped about with yellow flaxe, wherof it tooke his name, hauing knobbie rootes, with certaine ftrings annexed thereto like Galeopfis, of like vnto the rootes of $\mathrm{Clarie}$, which doe yeelde foorth fundrie fower fquare rough ftalkes, two cubits high; whereon do growe leaues like thofe of the Nettle, rough, fharpe pointed, and of an ouerworne greene colour: the flowers do growe alongft the top of the ftalkes, bycertaine fpaces, fet rounde about in fmall coronets, or wharles, like thofe of Sage in forme, but of a yellowe colour.

\section{* The place.}

Thefe do growe wilde in fome places, notwithftanding they are manured and planted in gardens almoft euery where, except Iupiters diftaffe, being a kinde thereof, which I haue in my garden. $*$ Thetime.

They flower in Iune, Iuly, and Auguft. * Thenames.

Clarie is called of the apothecaries, Gallitrictum; it is likewife named Oruala, of fome Tots bona but not properly: of others Scarlea, Sclarea, Centrum Galli, and Matrifaluia:in Italian Sciaris:in French Oruale: in high Dutch Os crbarlacb: in low Dutch

Qshatietet in Englifh Clarie, or Clecre eie.

Iupiters diftaffe, is called Colus Iouis, of fome Galeop /s lutea, but not properly, of divers Horminam lut eum,or yellow Clarie, and Horminum Tridentinum, or Claric of Trent.

Clarie is hot and drie in the third degree. * The temperature.

$*$ The vertues. The feede of Clarie poudered, fincly fearced and mixed with honie, taketh away the dimneffe of $\mathbf{A}$
the cies, and cleereth the fight.

The fame ftamped, infufed, or laide to fteepe in warme water, the muffilag or flimiefuftaunce ta- $B$ ken and applied plaifterwife, draweth foorth iplinters of woode, thornes, or any other thing fixed in the bodie : it alfo fcattereth and diffolueth all kindes of fwellings, efpecially in the ioints.

The feede poudered and drunke with wine, ftirreth vp bodily luft.

The leanes of Clarie taken anic maner of waie, helpeth the weaknes of the backe proceeding of the ouermuch flowing of the whites, but moft effectually if they be fried with egges in manner of 2 tanfie, either the leaues hole or ftamped.

\section{Of wilde Clarie, or Oculus Chrifti. Chap.255.}

$1 \bigcirc$ culus Chrifti, is alfo a kinde of Clarie, but leffer : the ftalks aremany, a cubite high, fquared, * The dejaription. and fomewhat hairie: the leaues be broade, rough, and of a blackifh greene colour. The flowers growe alongft theiftalks, of a blewifh colour. The feede is rounde, and blackifh, the roote is thicke and tough, with fome threds annexed thereto. 


\section{THE SECOND BOOKE OF THE}

2 The purple Clarie hath leaues fomewhat rounde, laide ouer with a hoare cottonie fubftaunce, not much vnlike Horchounde : among which rife vp fmall hairie fquare ftalkes, fet towarde the top with little leaues of a purple colour, which appeere at the firft viewe to be flowers, and yet are nothing elfe but leaues, turned into an excellent purple colour : and among thefe beautifull leaues come foorth fmall flowers of a blewilb or watched colour, in fafhion like vnto the flowers of Rofemarie, which being withered, the huskes wherein they did growe containe certaine blacke feede, which falleth foorth vpon the ground very quickly, bicaufe that euery fuch huske doth turne and hange downe his head towarde the grounde. The roote dieth at the firft approch of winter.

I Horminum fylwestre.

Wilde Clarie, or Oculus Cbrifti.

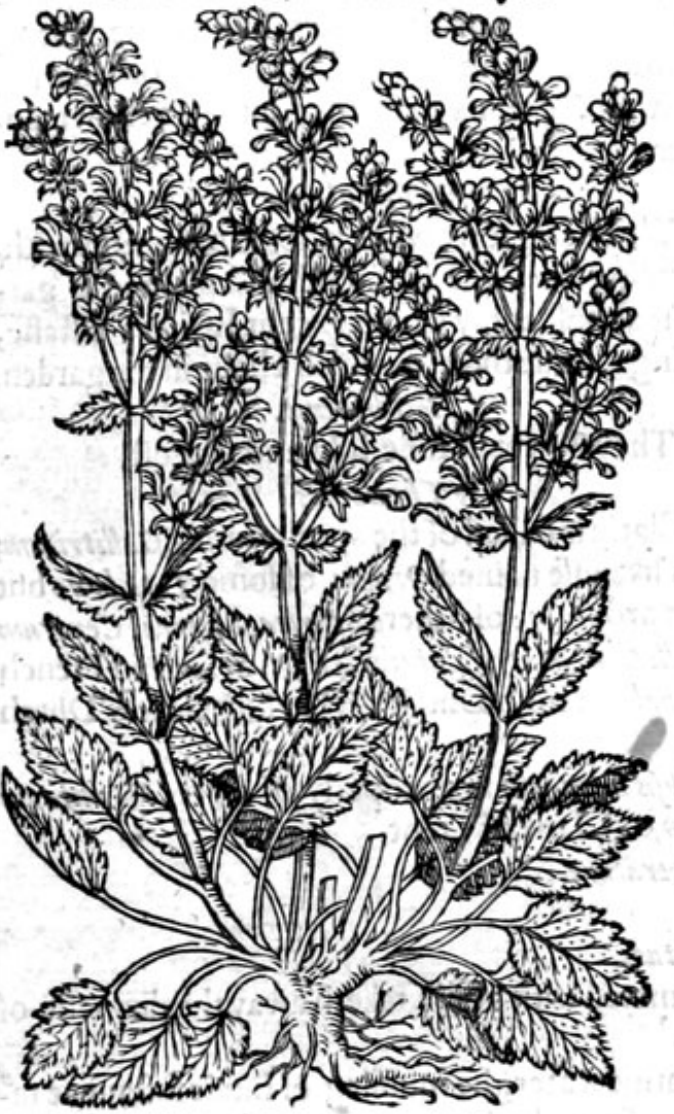

2 Horminum fylueftre folys spurpureis. Clariewith purpleleaues.

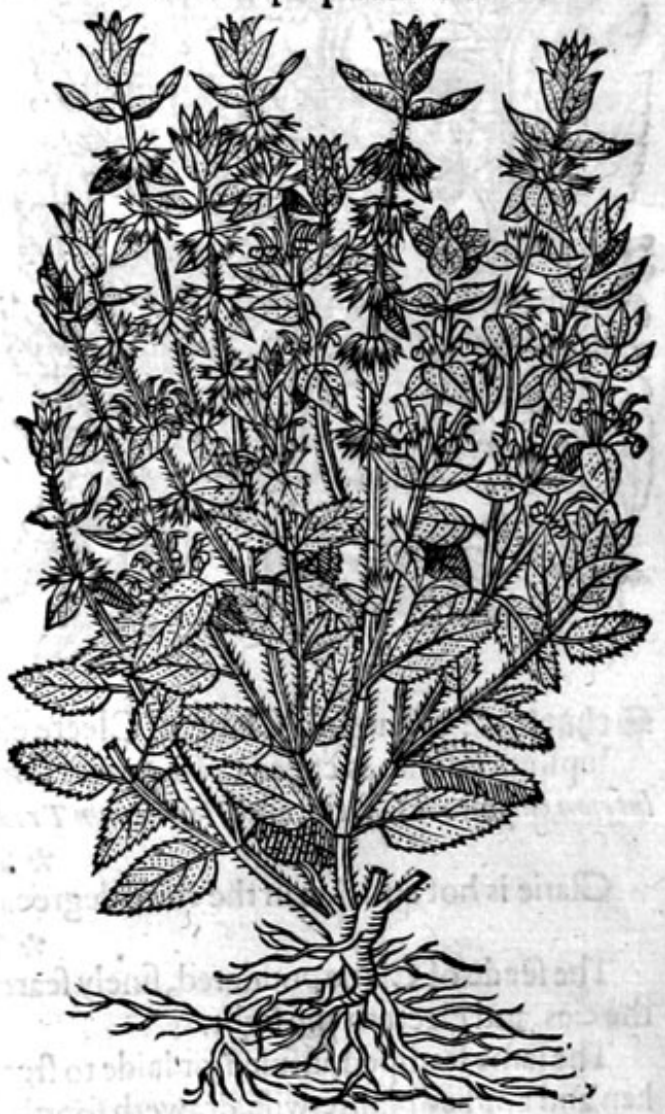

* Theplace.

The firft groweth wild in diuers barten places, almoft in euery countrey, efpecially in the fields of Holburne neere vnto Graies Inne, in the high way by the end of a bricke wall: at the ende of Chelfey next to London, in the high way as you go from the Queenes pallace of Richmond to the water fide, and diucrs other places.

The other is a ftranger in England: it groweth in my garden.

$$
\text { * T The time. }
$$

They flower and flourifh from Iune to the ende of Auguit.

$$
\text { * The names. }
$$

Wilde Clarie is called after the Latine name Oculus Christi, of his effect in helping the difeafes of the eies, in Greeke öpurvor: and likewife in Latine Horminwm, of fome Geminalis: in Englifh wilde Claric, and Oculus Chrifti.

Thefecond is thought of fome to be the right Clarie, and haue called it Horminum verwom, bue with greater error : it may be called in Latine Horminiom fylueftre folÿs o foribus pur pureis, Clarie with leaues and flowers of a purple colotir. 


\section{* The temperature and vertwes.}

The temperature and faculties are referred vnto the garden Claries, yet Pawlus UEginata faith, A it is hot and moderately drie, and it alfo clenfeth.

The feede of wilde Clarie as Dio/corides writeth, being drunke with wine, ftirreth vp luft, it clen-B feth the eies from filmes and other imperfections being mixed with honie.

The feede put whole into the eies, clenfeth and purgeth them exceedingly from waterifh hu-C mours, redneffe, inflammation, and diuers other maladies, or all that happen vnto the eies, and taketh away the paine and fmarting thereof, efpecially being put into the eies one feede at one time, and no more, which is a generall medicine in Chefhire and other countries thereabout, knowne of all, and vfed with good fucceffe.

The leaues are good to be put into pottage and brothes among other pot herbes; for they fcat- D ter congealed bloud, warme the ftomacke, and helpe the dimnes of the eies.

\section{Of Mullein. Cbap.256.}

*Thekindes.

$T$ Here be two kindes of Mullein, one white, another blacke; of the white there are two forts, one 1 with broad leaues, and another with narrow leaues: Diofcorides, and Galen after him haue added wilde Mulleins, Primrofes, Cowllips, and Rofe Campions, and firft of the true Mullein.

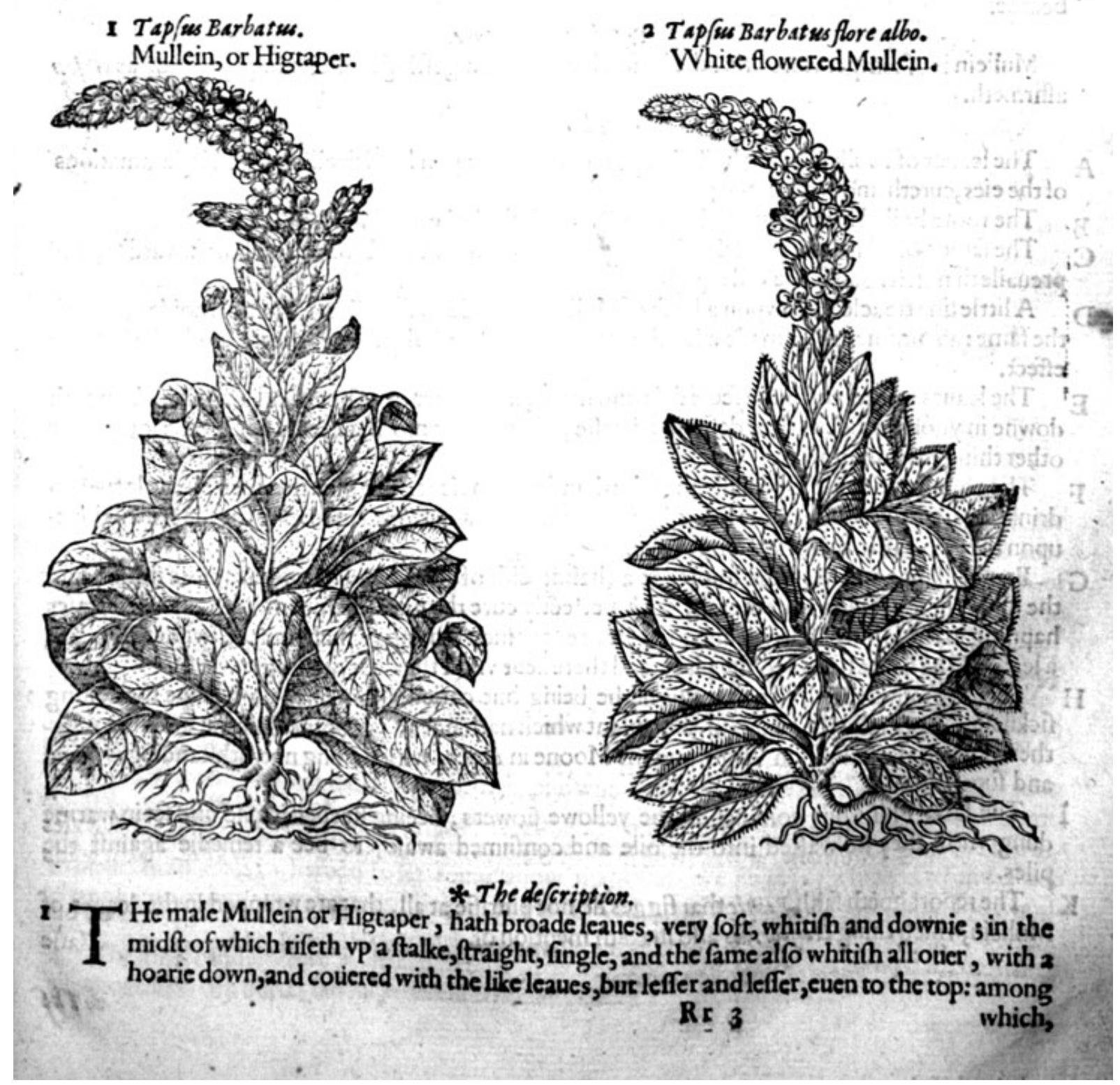




\section{THE SECOND BOOKE OF THE}

which, taperwife are fet a multitude of yellowe flowers, confifting of fiue leaues a peece: in the place's where of come vp little round veffels, in which is conteined verie fmall feede. The roote is long, a finger thicke, blacke without and full of ftrings.

2 The female Mullein hath likewife many white woolley leaues, fet vpon an hoarie cottonie vpright ftalk, of the height of fower or fiue cubits : the top of the ftalks refembleth $a$ torche decked with infinite white flowers, which is the fpeciall marke to know it from the male kinde, being like in etuerie other refpect.

$$
\text { * Theplace. }
$$

Thefe plants do growe of themfelues neere the borders of paftures, and plowed fieldes, or caufies, and drie fandy ditch bankes, and in other vntilled places. 'They grow in great plentieneere vnto a lyme kill vpon the end of blacke Heath next to London, as alfo about the Queens houfe at Eltham, neere vnto Dartford in Kent: in the high waies about Hicgate neere London, and in moft countries of England that are of a fandic foile.

$$
\text { * Thetime. }
$$

They are found with their flower from Iuly to September, and bring foorth their feede, the feconde yeere after the feede is fowen.

\section{* The nawes.}

Mullein is called in Greeke 9 rouss, in thops Tapfus Barbatus, of diuers Candela Regia, Candelaria, and Lamaria : Diofcorides, Plinie, and Galen, do call it Verba foum: in Italian Verbafco, and $T a f f o$ Bar-

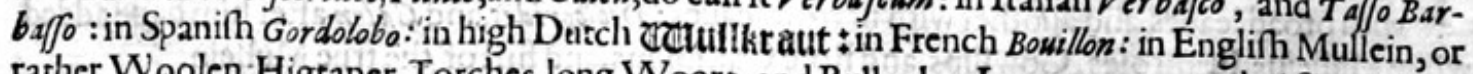
rather Woolen; Higtaper, Torches, long Woort, and Bullockes Longwoort, and of fome Hares
bearde.

\section{Mullein * The temperature.} affirmeth.

\section{* The vertwes.}

A The leaues of Mullein being boiled in water, and laide vpon hard fwellings, and in flammations of the eies, cureth and ceafeth the paine.

B The roote boiled in red wine and drunke, ftoppeth the laske and bloudie flixe. C The fame boiled in water and drunke, is good for them that are broken and hurt inwardly, and
preuaileth much againft the old cough.

D A little fine treacle fpred vpon a leafe of Mullein, \& 8 laide to the piles or Hemorrhoides, cureth the fame : an ointment alfo made with the leaues thereof and old hogges greafe, worketh the fame effect.

E The leaues worne vnder the feete daie and night, in manner of a fhoe fole, or focke, bringeth downe in yoong maidens their defired fickneffe, being kept vnto their feete with fome fockes, or
other thing for falling away.

F The countrey people, efpecially thofe husband men in Kent, doe give their cattell the leaues to drinke againft the cough of the lungs, being an excellent approoued medicine for the fame, whereupon they do call it Bullocks Longwoort.

G Frankenfence and Mafticke burned in a chafing difh of coles, and fet within a clofe ftoole, and the fume thereof taken vnderneath, doth perfectly cure the piles, hemorrhoides, and all difeafes hapning in thofe lower parts, if alfo there be at euery fuch fuming (which muft be twife euerie day) a leafe of the herbe bound to the place, and there kept vntill the next dreffing.

H There be fome who thinke that this herbe being but caried about one, doth helpe the falling ficknefle, efpecially the leaues of that plant which hath not as yet borne flowers, and that is gathered when the funne is in Virgo, and the Moone in Aries, which thing notwithftanding is vaine
and fuperftitious.

I The later Phifitionis commende the yellowe flowers, beeing fteeped in oile and fet in warme dung vntill they be wafted into the oile and confumed awaie, to bee a remedie againft the piles.

\footnotetext{
K The report goeth faith $P$ (inie that figges do not putrifie at all, that are wrapped in the leaues of Mullein,which thing Diofcorides alfo maketh mention of.
} 


\section{HISTORIE OF PLANTS. BHT}

\section{Ofbafe onullein. Chap.257.}
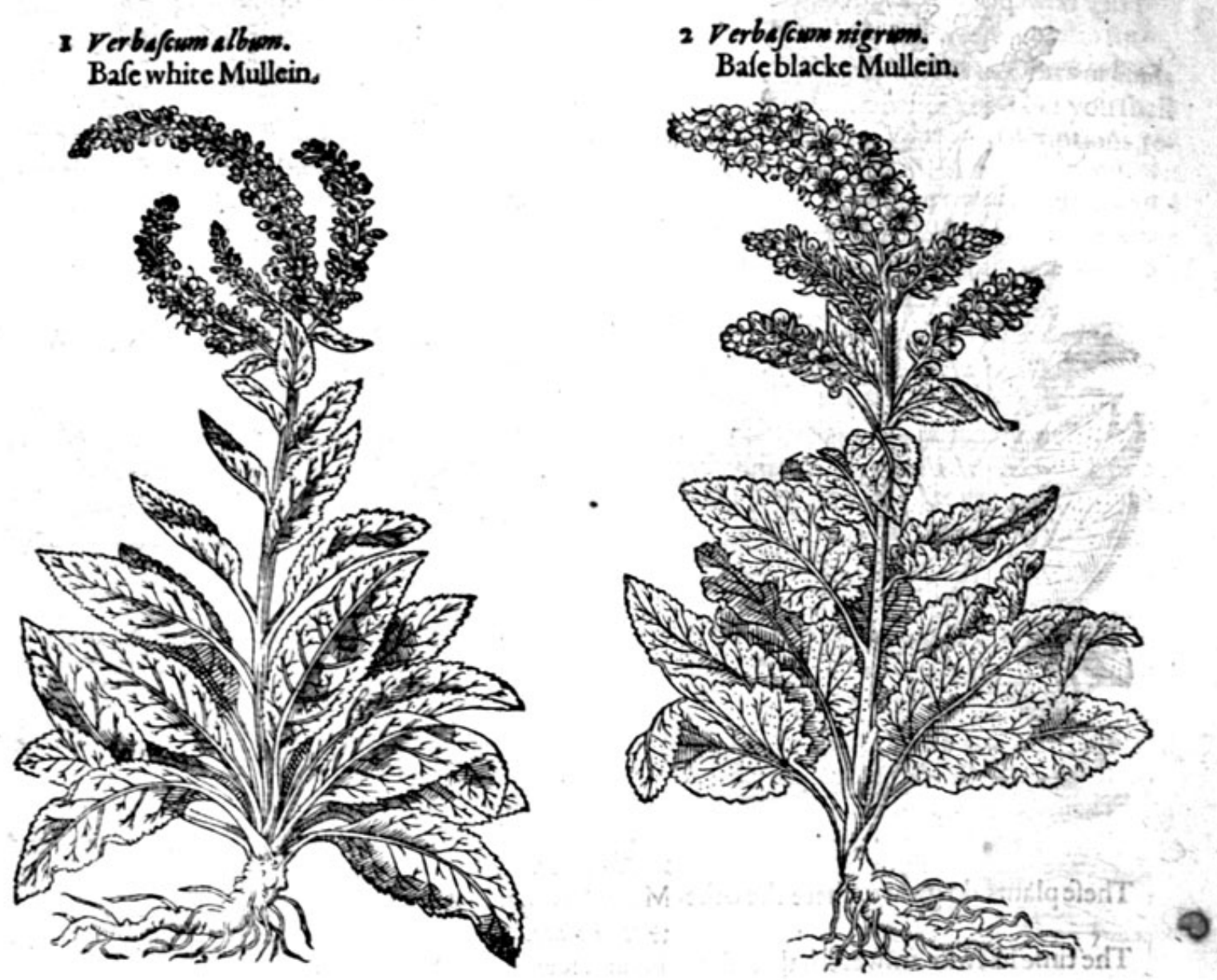

\section{* The defaription.}

$1-1 \mathrm{He}$ Bafe white Mullein hath a thicke woodie roote, from which rifeth vp a ftiffe and hairy ftalke, of the height of fower cubits, garnifhed with faire grayifh leaues like thofe of Elecampane, but lefier : the flowers growe rounde about the italkes taper or torch fafhion, of a white colour, with certaine golden thrums in the middle: the feede followeth, fmall, and of the colour of duft.

2. Blacke Mullein hath long leaues, not downie at all, large and (Marpe pointed, of an ouerworne blackirh greene colour, fomewhat rough,and ftrongly fmelling : the flowers grow at the top of the ftalks, of a golden yellow colour, with certaine threds in the middle therof. The root differerhnot from the precedent.

3 Candleweeke Mullein hath large, broade, and woollie leaues, like vito thofe of the common Mullein:among which rifeth vp a ftalke couered with the like leaues, euen to the braunches wheron the flowers do growe, but leffer and leffer by degrees. The ftalke diuideth it felfe toward the top in to diuers braunches, whereon is fet round about many yellowe flowers, which of tentimes doe change into white, varying according to the foile and climate. The roote is thicke and wooddie.

4. The fimall candle weeke Mullein differeth little from the laft rehearfed, fauing that the whole plant of thisis of a better fauour, wherein efpecially confifteth the difference.

Rr 4 V verbajow 
3 Verbafcam Lychnite Matbioli. Candle weeke Mullein.

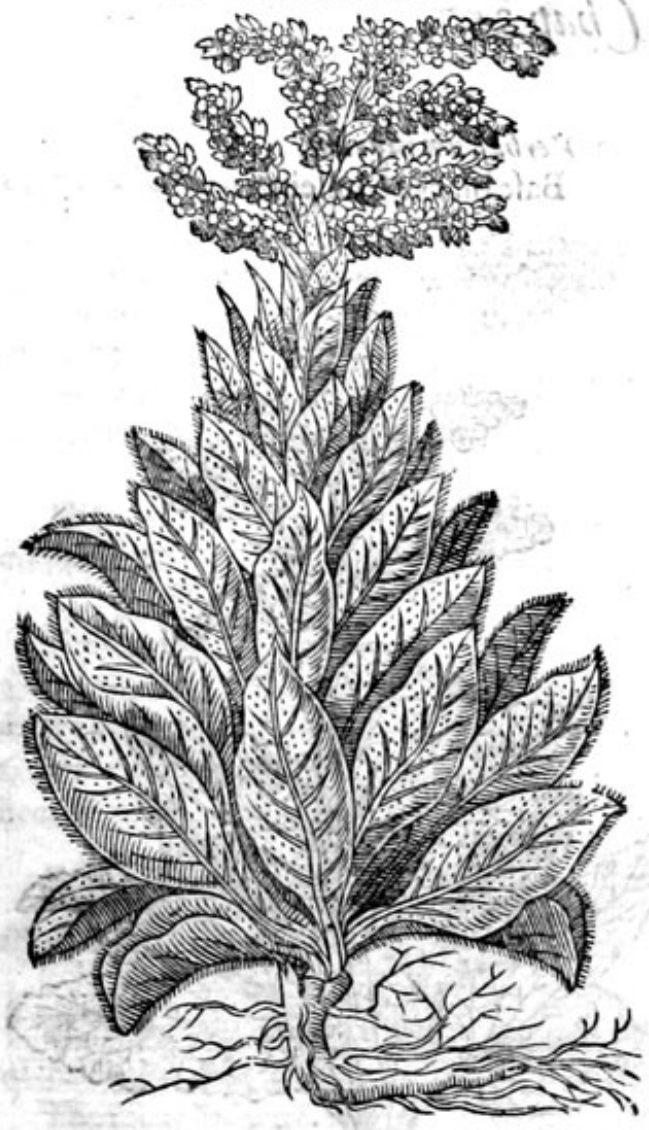

4 Verba/cum Lychnite minus. Small Candle weeke Mullein.

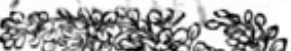
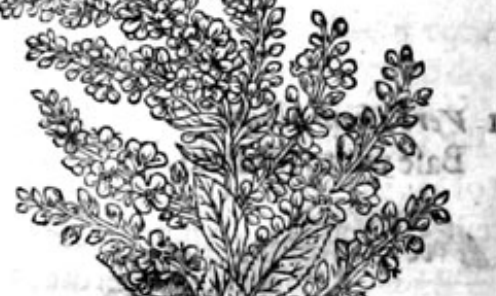

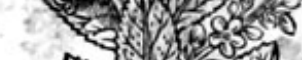

minger.
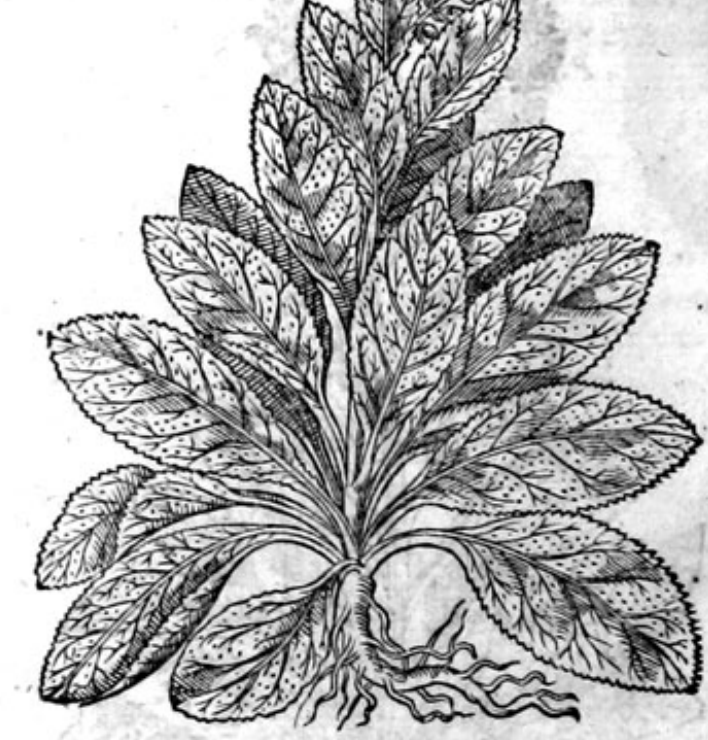

Thefe plants do growe where the other $*$ The place.

* 7 he time.

Mulleins do,and in the like foile.

The time likewife anfwereth their flowring and feeding.

Their capitall names expreffed in the $*$ The names. are all, and euery of them kinds of Mulleins.

Thefe Mulleins are dry without $*$ The temperature. mon Mullein or Hygtaper.

A The blacke Mullein, $*$ The vertues. good againft the difeafes of the leafant yellowe flowers, boiled in water or wine and drunken, is B The leaues boiled in water, ftamped lungs, and againft all fpitting of corrupt rotten matter. mita) and alfo vpon the vlcers anped and applied pultis wife vpon colde fwellings (called OedeC The flowers of black Mand inflammations of the eies, cureth the fame.

列

end

with fire or water. E spuleius reporteth a tale of $V$ lyfes, Mercurie, and the inchauntreffe Circe and their ve of thefe herbes in their incantations and witchcrafts. 


\section{HIST ORIE O FCPLANTS. IHT \\ Of Motb Mullein. Chap.258

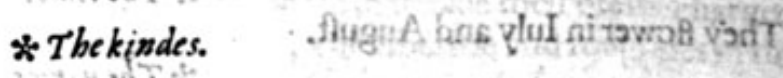

Ike as there be diuers forts of Mulleins, \& bafe Mulleins; fo is there likewife many forts or kinds of Moth Mulleins, differing efpecially in the colour of their flowers, of whiéthumber yourhall receiue two figures or piQtures, for the reft you muft content your felues with their-defcriptions, teferring their formes vnto a furcher confideration, or a fecond edition.

\section{Blatteris Pliny.}

Plinies Moth Mullein.

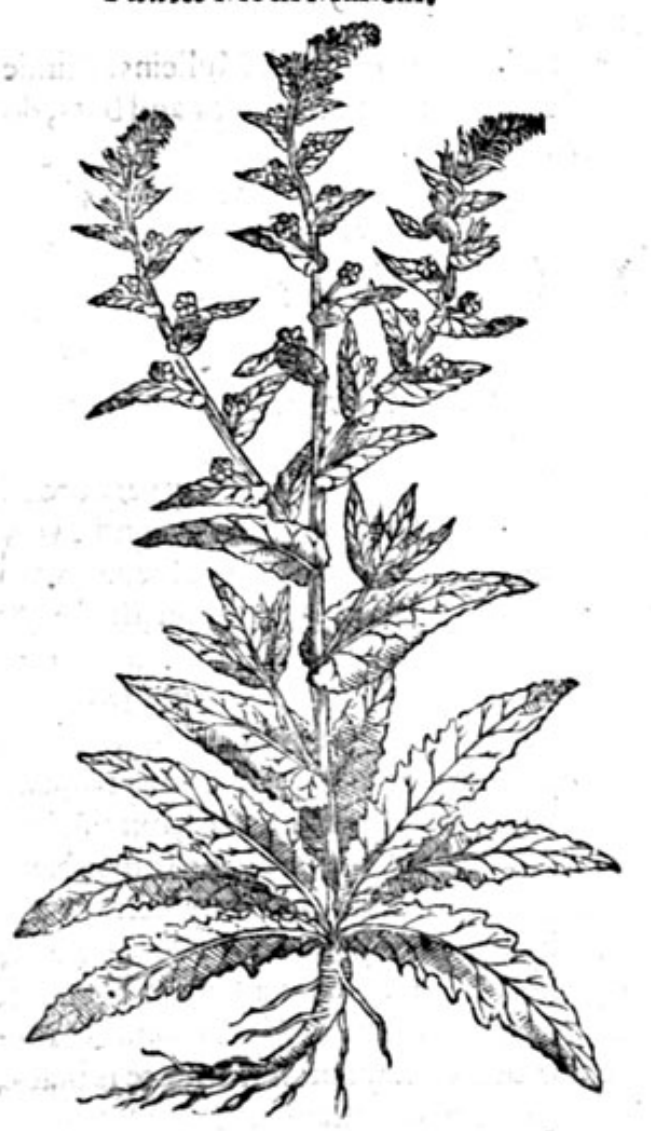

2 Blattaria flore purpureo. Purple MothMullein.

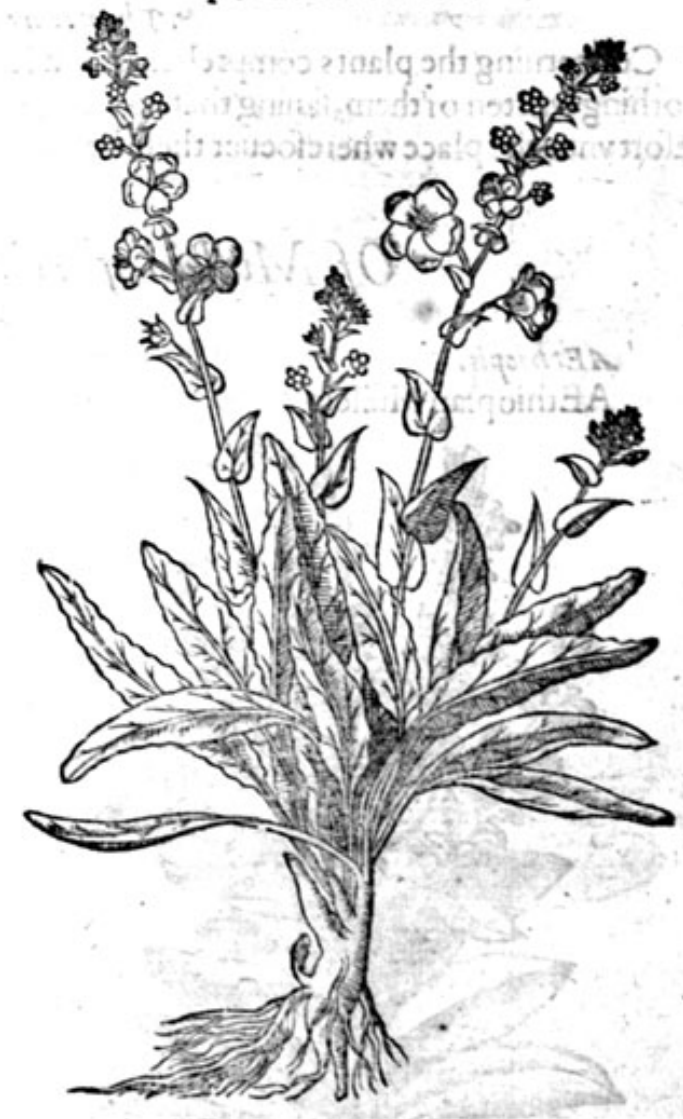

\section{* The defcription.}

1 Linie hath fet foorth a kinde of Blattaria, which hath long and fmooth leaues, fomewhat felfe towarde about the edges: the ftalke rifeth vp to the height of three cubits, diuiding it

blacke Mullein. 2 Blattiria with purple flowers hath broad blacke leaues, without any manifeft fnips or notches by the fides, growing flat vpon the ground: among which rifeth vp a ftalke two cubits high, garnifewe threds or chiues into the common Blattaria, but that they are of a purple colour, andthole with fome threds hanging thereat, , of a golden colour: the roote is as thicke as a mans thumbe,

There is another kinde like vat, and it endureth from yeere to yeere.

fpeets, fauing that his finall flowers are blacke Mullein, in ftalkes, rootes, andleaues, and other re-

There is anorher like vnto the lat be a greene colour.

about the edges,and that the fmall tlowers written, fauing that his leaues are not fo decpely cur 
* Theplace.

The firft,fecond and fourth growe in my garden :the third I haue not as yet feene.

They flower in Iuly and Auguft. * The time.

The later Herbarifts call Morh Mullein by the name of Blattaria, and doe truely take it to be that which Pliny defcribeth in his 22. booke, 9. chapter, in thefe wordes: There is an herbe like Mullein, or Verbafcum nigrum, which oftentines deceiueth, being taken for the fame, with leaues not fo white, mo ftalkes, and with yellowe flowers(as we haue written) which do agree with blacke Mullein; but we haue not as yet learned by obferuation that they do gather mothes and fleas vnto them, as we haue faid. Valerius Cordses nameth it Verbafcum Leptophyllon, or narrowe leafed Mullein: their feuerall titles do fufficiently fet foorth their Englifh names.

t: The nature and vertues.

A - Concerning the plants comprehended vnder the titles of Blattaria, or Moth Mulleins, I finde nothing written or them, fauing that mothes, butter flies, and all maner of fmaller flies and bats, do refort vnto the place wherefoeuer thefe herbes be laide or ftrowed.

\section{Of Mullein of Etbiopic. Cbap.259. \\ *Thedejaripsion.}

AEthiopis.

AEthiopian Mullein.

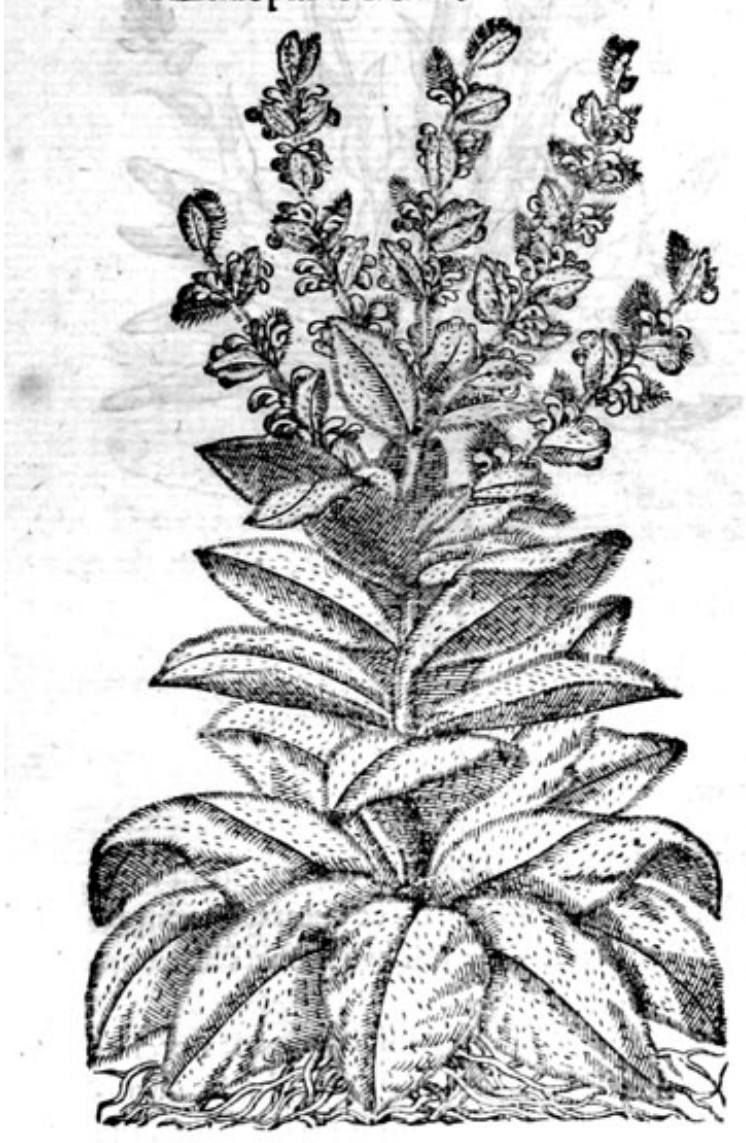

Vllein of Aethiopia hath many very broad hoarie leaues fpred vpon the ground, very foft and downie or rather woollie, like vnto thole of Hygtaper, but far whiter, fofter, thicker,\& fuller of woollineffe, which wooll is folong, that one may with his fingers pull the fame from the leaues, euen as wooll is pulled from a heepesskin: among which leaues rifeth vppe a fower fquare downie ftalke, fet with the like leatues, but fmaller, which ftalke is diuided at the topinto other bran. ches, fet about and orderly placed by certaine diftaunces, hauing many flowers like thofe of Archangell, of a white colour tending to blewnes, which being paft, there fucceedeth rounde blacke feed, like thole of Colewoorts : the roote is black, hard, and of a woodic fubitance. * The place.

It groweth naturally in AEthiopia, and in Ida, a hill hard by Troie, and in Meffenia, a prouince of Morea, as Pliny fheweth in his 27 .booke 4. chapter : it alfo groweth in Meroë, an Iland in the riuer Nilus, hauing a citie of the fame name in AEthiopia, which lieth vnder Eegypt:it likewife groweth in my garden.

\section{* The time.}

It flowreth and fourifheth in Iune, and perfeeteth his feede toward the end of Auguft.

$*$ The names.

It is called in Greeke Aigromis : and in Latine AEthropis, of the countrey in which it groweth: and for that caufe it is likewife called Meroides, of UMeroë, as Plinie writeth: of fome bicaufe the Greeke worde Ai9or, fignificth in Latine Fauilla adufta, or Cinere a Jperfa, or couered with afhes : in Englifh we may call it Mullein of AEthiopia, or woolly Mullein. 


\section{HISTORIE OF PLANTS.}

* The nature.

AEthiopis is dric without any manifeft heate.

* The vertues.

AEtbiopis is good for thofe that haue the pleurifie, and for thofe that have their breits charged A with corrupt and rotten matter, and for fuch as are greeued with the afperitie and roughnes in the throate, and ag ainft the Sciatica, if one drinke the decoction of the roote thereof.

For the difeafes of the breft and lungs, it is good to licke oftentimes of a confection made with B the roote heereof and honie, and fo are the rootes condited with fugar, in fuch maner as they condite the roots of Eringos.

\section{Of Cow/lips. Chap.260.}

1 Primals veris masior.

Field Cowllips.

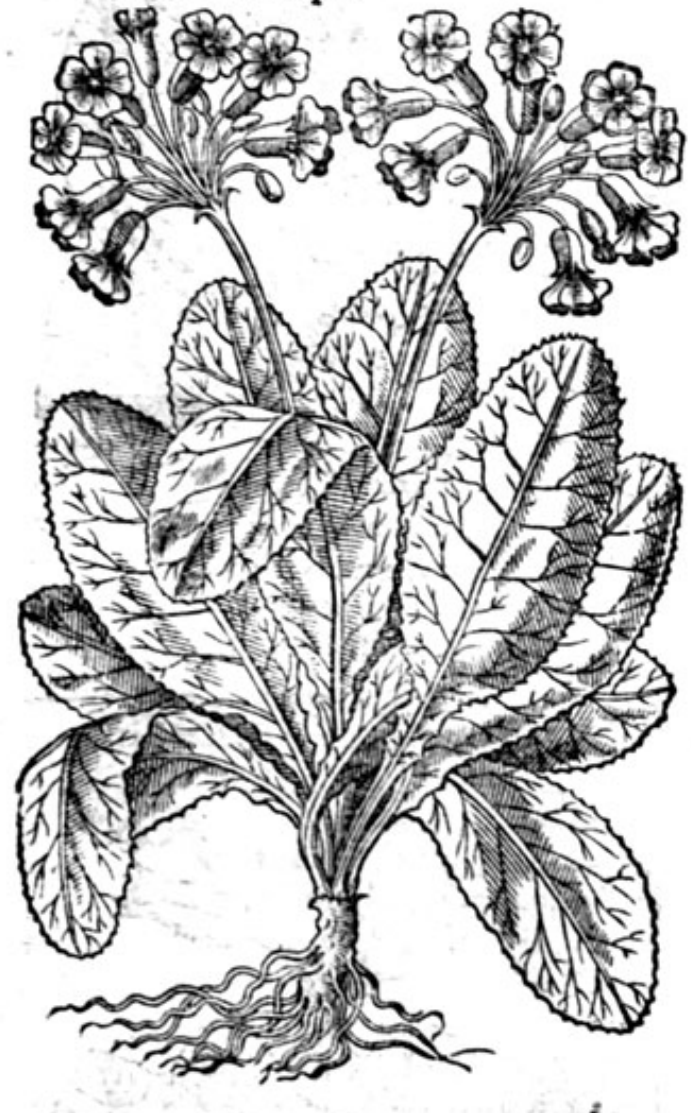

2 Primulapratenfis inodora Iutea. Field Oxelip.

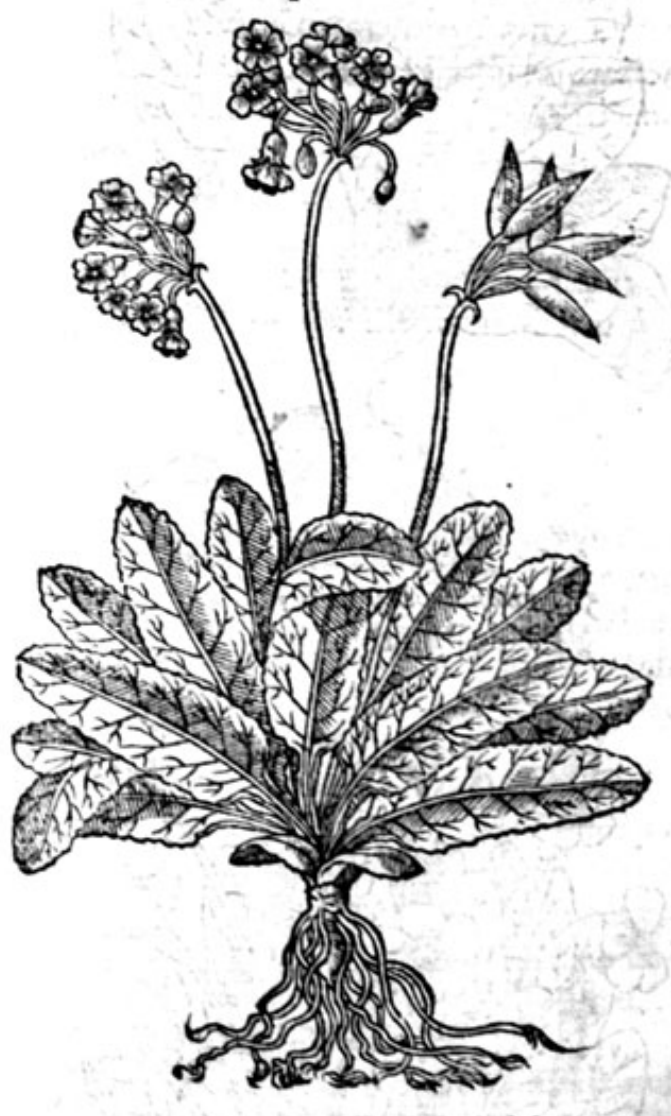

* The defaription.

17 Hofe herbes which at this day are called Primrofes, Cowflips, and Oxelips, are reckoned among the kinds of Mulleins, notwithftanding fordiftinctions fake, I hauemarMulleins, for that the ancients haue named them Verba /culi, that is to faie, fmall Mulleins. The firt which is called in Englith the field Cowllip, is as common as the reft, therefore I fhall norneed to fpend much time about the defcription.

2 The fecond is likewife weil knowne by the name of Oxelip, and differeth not from the other, faue that the flowers are not fo thicke thruft togither as the former, and they are fairer and fewer in number, and do not finell fo pleafantly as the other; of which kinde, we haue one lately come into our gardens, whofe flowers are curled and wrinckled after a moft ftrange maner, which our women haue named, lacke an apes on horfebacke. 
3 Primula hortenfis Anglica.

Double Paigles.

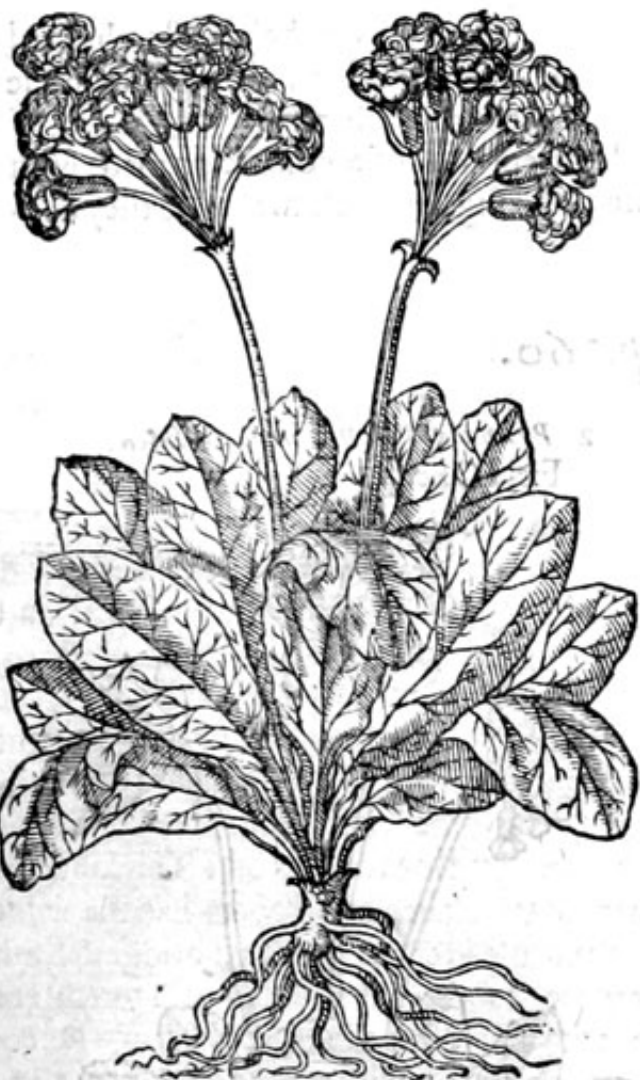

5 Primula veris minor.

Fielde Primrofe.

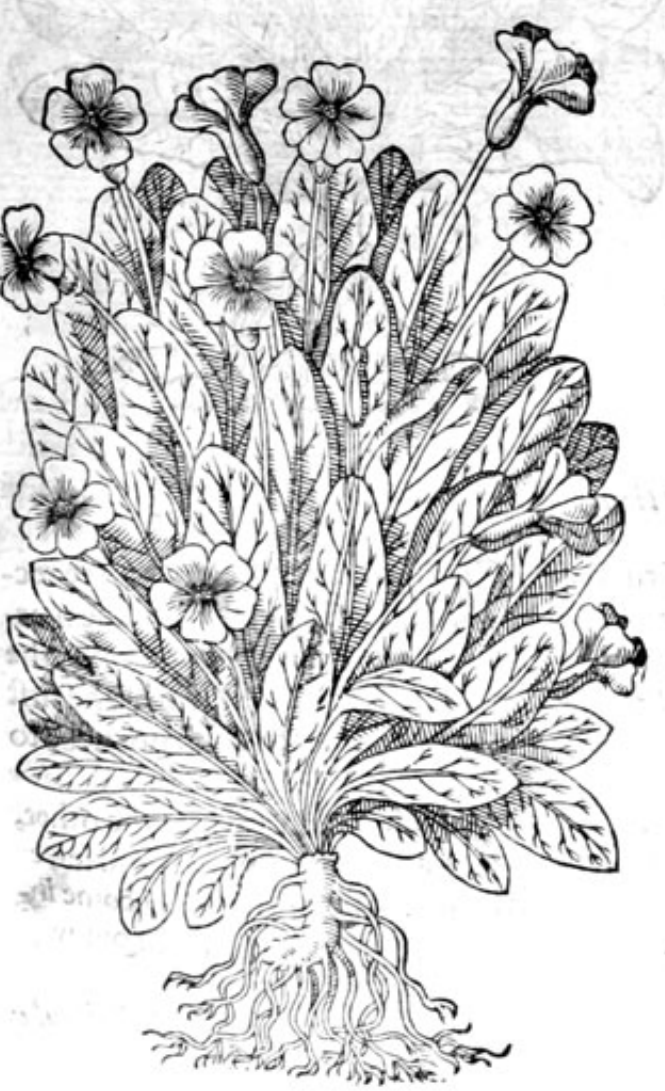

4 Primula veris flore geminato.

Collips two in a hofe.
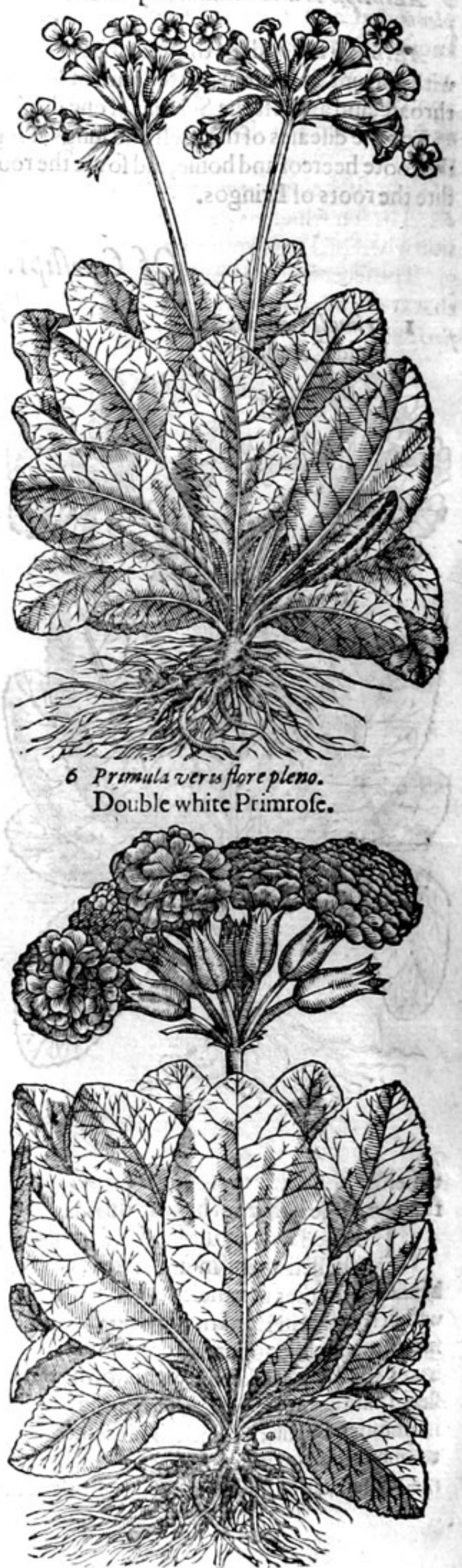


\section{HIST ORIE OF PLANTS. \\ * The def criotion.}

3 Double Paigle, called of $P$ ena, Primula hortenfis Anglica amniwm maximis, \& ferotima foribua plenis, that is, the greateft Englifh garden Cowflip with double yellowe flowers, is fo commonly knowne, that it needeth no defcription.

4 The fourth is likewife knowne by the name of double Cowflips, hatuing but one flower within another, which maketh the fame once double, whete the other is many times double, called by $P_{\text {e- }}$ na Geminata, for the likeneffe of the flowers, which are brought foorth as things againft nature, or twinnes.

5 The fift being the common white fielde Primrofe, needeth no defcription.

6 The fixt which is our garden double Primrofe, of all the reft is of greateft beautie,the defcription where of I refervnto your owne confideration.

7 The feuenth kinde is alfo verie well knowen, which is a Primrofe that hath greenifh flowers that are fornewhat welted about the edges: for which caufe Pena hath called it Siluarum primalt, floribus ob foure virentibus fimbriatis.

7 Primula fore virids. Greene Primrofe.

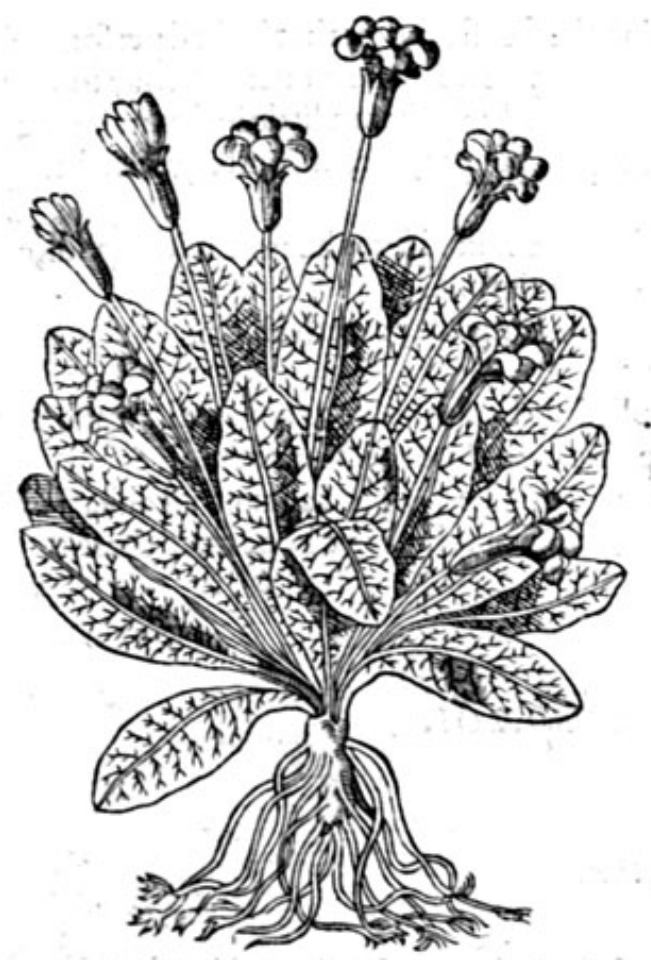

* The defcription.

There is a ftrange Prmtofe founde in a wood in Yorkefhire, growing wifde, by the trauell and induftry of alearried gentleman of Lancalhire, called mafter $T$ bomas Hesket $b$, and a diligent fearcher of Simples, who hath not only brought to light this amiable and pleafant kind of Primrofe, but many others likewife, neuer before his time remembred or founde ont. This kinde of Primrofe hath leaues and rootes like the wilde fielde Primrofe in eche refpeet ; it bringeth forth among the leaues a naked ftalke of a grayifh or ouerworne greenifh colour: at the top whereof doth growe in the winter time one flower and no more, like vnto that fingle one of the fielde; but in the fommer time it bringeth foorth $a$ foft ruffet huske or hofe, wherin are conteined many fmal flowers, fometimes fower or fiue, and oftentimes more, very thicke thruft togither, which maketh one entire flower, feeming tobe one of the common double Primrofes, whereas indeed it is one double flower made of a number of fmal fingle flowers, neuer ceaffing to beare flowers winter nor fommer, as before is fpecified.

\section{* The place.}

Cowlips and Primrofes ioie in moift and dankifh places, but not altogither couered with water; they are found in woods and the borders
of fields: the Primrofe found by mafter Hesketh, groweth in 2 woode called Clapdale, three miles from a towne in Yorkefhire called Settle.

* The time.

They flourifh from Aprill to the end of May, and fome one or other of them do flower all the win. terlong.

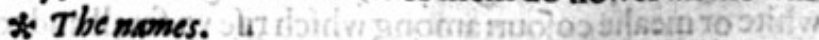

They are commonly called Primule verus,bicaufe they are the firft among thofe plants that do flower in the fpring,or bicaufe they flower with the firft. They are alfo named Srrthretice, and Herbe Paraly is, for they are thought to be good againft the paines of the ioints and finewes; they are called in Italian Brache Cuculs : in Englifh pettie Mulleins,or Palfie woorts, of moft Cowllips.

The greater fort called for the moft part Oxeflips and Paigles, are named of diuers Herba S.P F tri : in Englifh Oxeflip and Paigle.

The common Primrofe is vfially called Primula veris, moft Herbarifts do refer the Primrofes 


\section{THE SECOND BOOKE OF THE}

to the 9xópuss, called in Latin Ver bafcula, or pettie Mulleins;but feeing the leaues are neither woollie nor rounde, they be hardly drawne vnto them : for Phlomides are defcribed by leaues, as Plinie hath interpreted it, Hir/ut is and Rotundis hairie and round, which Plinie in his 25.booke, 10. chap. tranflateth thus; Sunt \& Phlomides duc Hir fut a, rotundis folys, bumiles, which is as much to faie in Englifh, as there be alfo two pettie Mulleins, hairie, rounde leafed, lowe, or thort.
The Cowllips and Primrofes are in temperature drie, and a little or nothing hot. * The vertues.

A The Cowflips are commended againft the paine of the ioints, called the gout, \& flacknes of the finewes, (which is the palfie.) The decoction of the roots is thought to be profitablie giuen againft the ftone in the kidneies and bladder: and the iuice of the leaues for members that are loofe and out of ioint, cr inward parts that are hurt, rent, or broken.

B Adram \& a halfe of the powder of the dried roots of field Primrofe gathered in Autumne, given to drinke in ale or wine, purgeth by vomite very forcibly, (but fafely)waterifh humours, choler, and flegme, in fuch maner as Azarum doth, experimented by a learned and skilfull Apothecarie of Colchefter, mafter $\tau$ bomas Buckftone, and fingular in the knowledge of fimples. C A conferue made with the flowers of Cowflips and fugar, preuaileth woonderfully againft the
palfie, conuulfions, cramps,and all the difeafes of the finewes.

D Cowflips or Paigles do greatly reftraine and ftop the bellie in the time of a great laske or bloudie flixe, if the decoction thereof be drunke warme.

E A practitioner in London, who was famous for curing the frenfic, after that he had performed his cure by the due obferuation of Phificke, accuftomed euery yeere in the moneth of May to diet his patients after this fort. R. Theleaues \& flowers of Primrole, boile them a little in fountaine water, and in fome Rofe \& Betonie waters, adding thereto fugar, pepper, falt, and butter, which being
ftrained, he gaue them to drinke thereof firft and laft.

F The rootes of Primrofe ftamped and ftrained, and the iuice fniffed into the nofe with a quill,or fuch like, purgeth the braine, and qualifieth the paine of the migrime.

$G$ An vnguent made with the iuice of Cowllips, and oile of Linfeede, cureth all fcaldings or burnings with fire, water or otherwife.

$H^{-T h e ~ f l o w e r s ~ o f ~ P r i m r o f e s ~ f o d d e n ~ i n ~ v i n e g e r, ~ a n d ~ a p p l i e d, ~ d o ~ h e a l e ~ t h e ~ k i n g s ~ c u i l, ~ h e a l e t h ~ a l f o ~ t h e ~}$ almonds of the throte and vuula, if you gargarife the partic with the decoction thereof.

I The leaues and flowers of Primrofes boiled in wine and drunke, is goodagainft all difeafes of the breft andlungs, and draweth foorth of the flefh any thorne or fplinter, or bone fixed therein.

\section{Of Birds eine. Chap.261.}

\section{$*$ The defcription.}

'S Ome Herbarifts call this plant by the name of Sanicula anguffifolia, making thereof two kinds, and diftinguifhing them by thefe termes, mator, 8 minor, five media : others call them Paralytica alpina, which without controuerfie are kindes of Cowllips, agreeing with them afwell in thape as in their nature and vertues, hauing leaues much like vnto Cowflips but fmaller, growing flat vpon the grounde, of a faint greenifh colour, on the vpperfide and vnderneath of $\mathbf{a}$ white or mealie colour: among which rife vp fmall and tender ftalks of a foote high, hauing at the top of euerie ftalke a burh of fmall flowers, in thape like the common Oxelip, fauing that they are of a faire ftammell colour tending to purple: in the middle of euery fmall fower appeereth a little yellowe fpot, refembling the eie of a bird, which hath mooued the people of the north parts (where it aboundeth)to call it Birds cine. The feed 6 is fmall like duft, and the roote white and threddie. 2 The fecond is like the firft,fauing that the whole plant is greater, in eche refpect, and that the flowers are of a whitifh colour. 


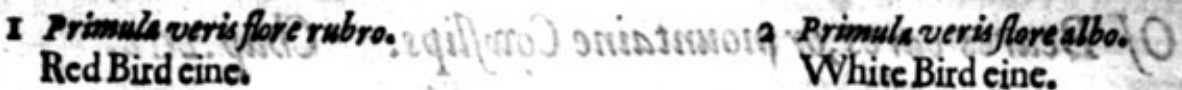

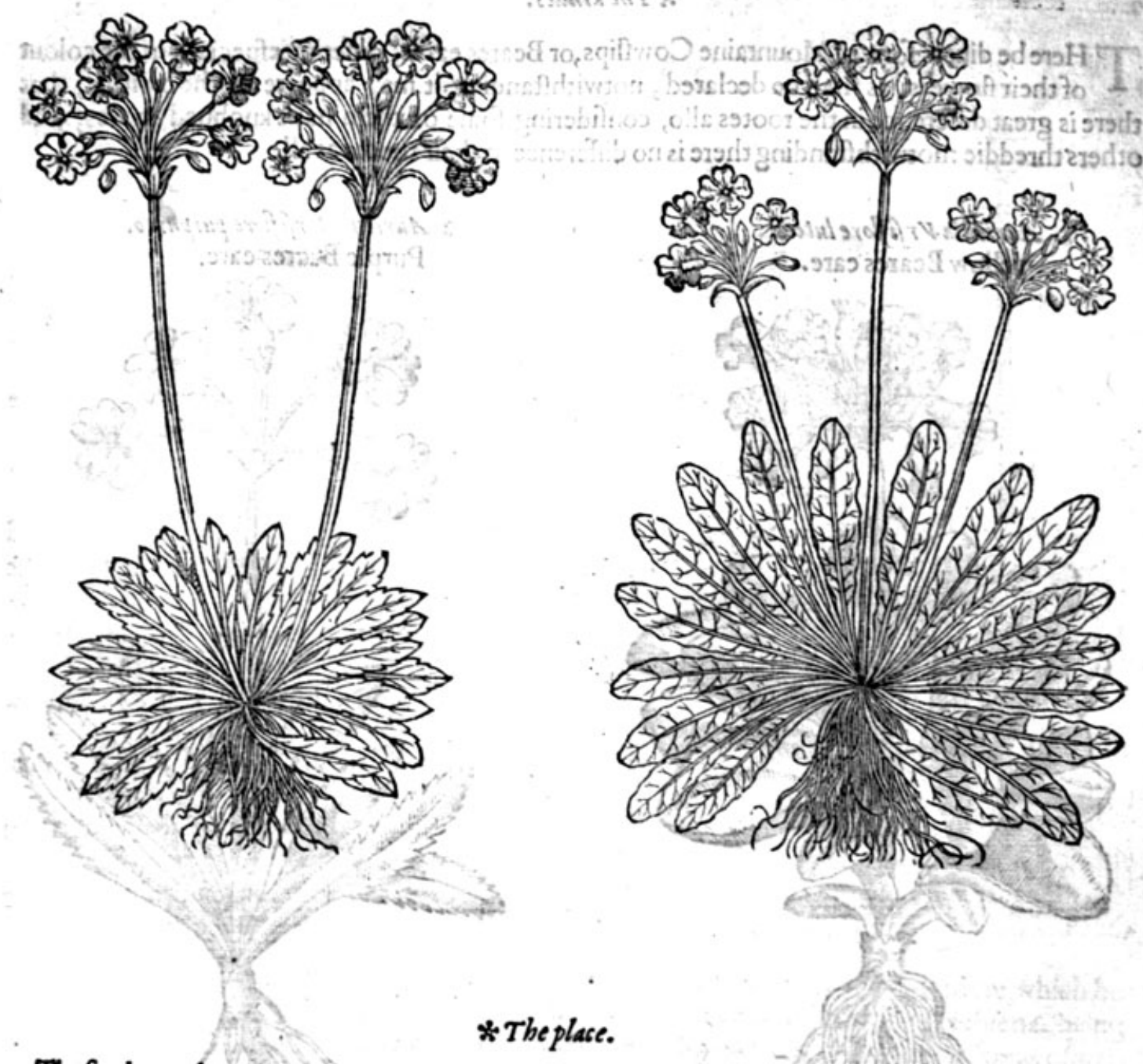

Thefe plants do grow very plentifully in moift and fquallie grounds, in the north parts of England; as in Harwood neere to Blackburne in Lancafhire, and xen miles from Prefton in Aunderneffe, alfo at Crosbie, Rauenfwaith, and Cragge clofe in̉ Weftmerland.

They likewife growe in the medowes belonging to 2 village in Lancafhire neere Maudfley called Harwood, and at Hesketh not farre fröm thence, and many other places of Lancafhire, but not

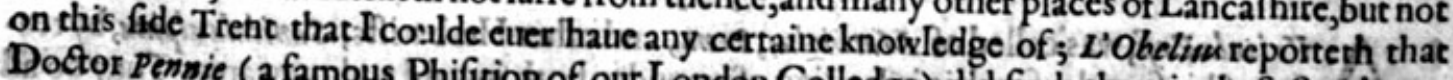
Doetor Pennie (a famous Phifition of our London Colledge) did finde them in thefe Souttherne

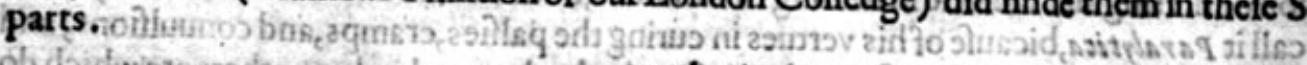

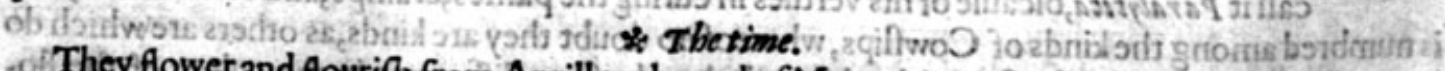

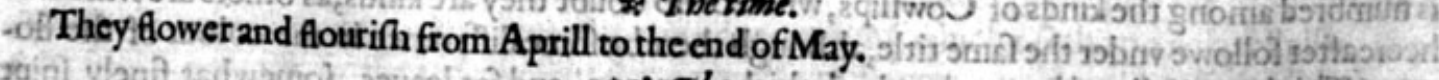

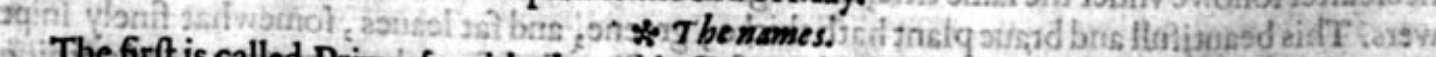
27. The firt is called Primrole with the redde flower: the fecond Primrofewith the white flower

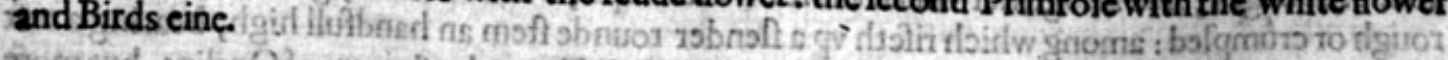

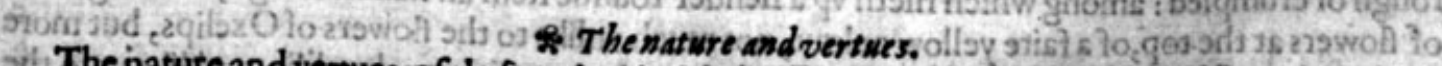
Thenatuteand vertues of thefe red and white Primrofes, miuft be foughe out amonget thofe
abouenamed.

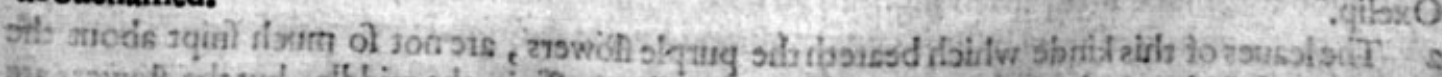

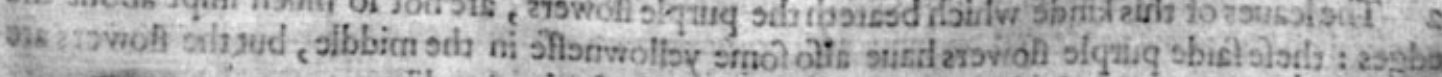

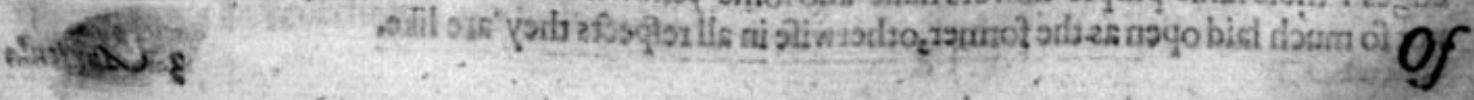


* The kindes.

$T^{\top}$ Here be diuers forts of Mountaine Cowllips,or Beares eares, differing efpecially in the colour 1 of their flowers, as fhall be declared, notwithtanding it may appeere to the curious, that there is great difference in the rootes alfo, confidering forme of them haue knobbed rootes, and others threddie : notwithftanding there is no difference in their rootes at all.

I Auricula Vrfiflore luteo. Yellow Beares eare.

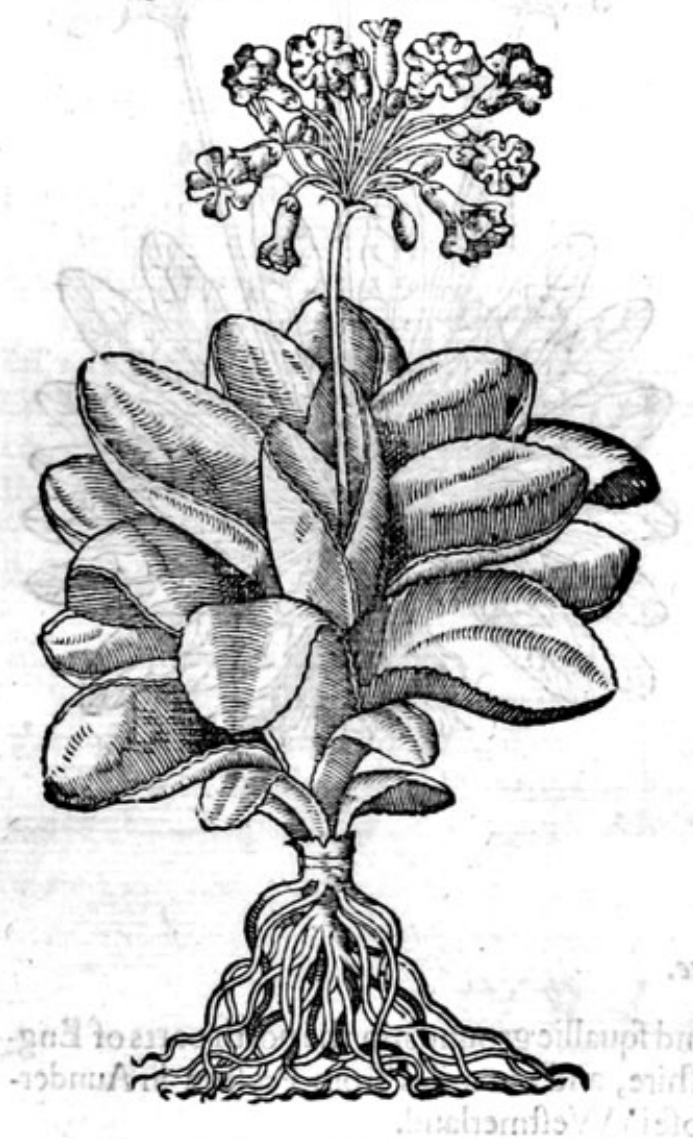

2 Auricula Vrfiflore purparco. Purple Beares eare.
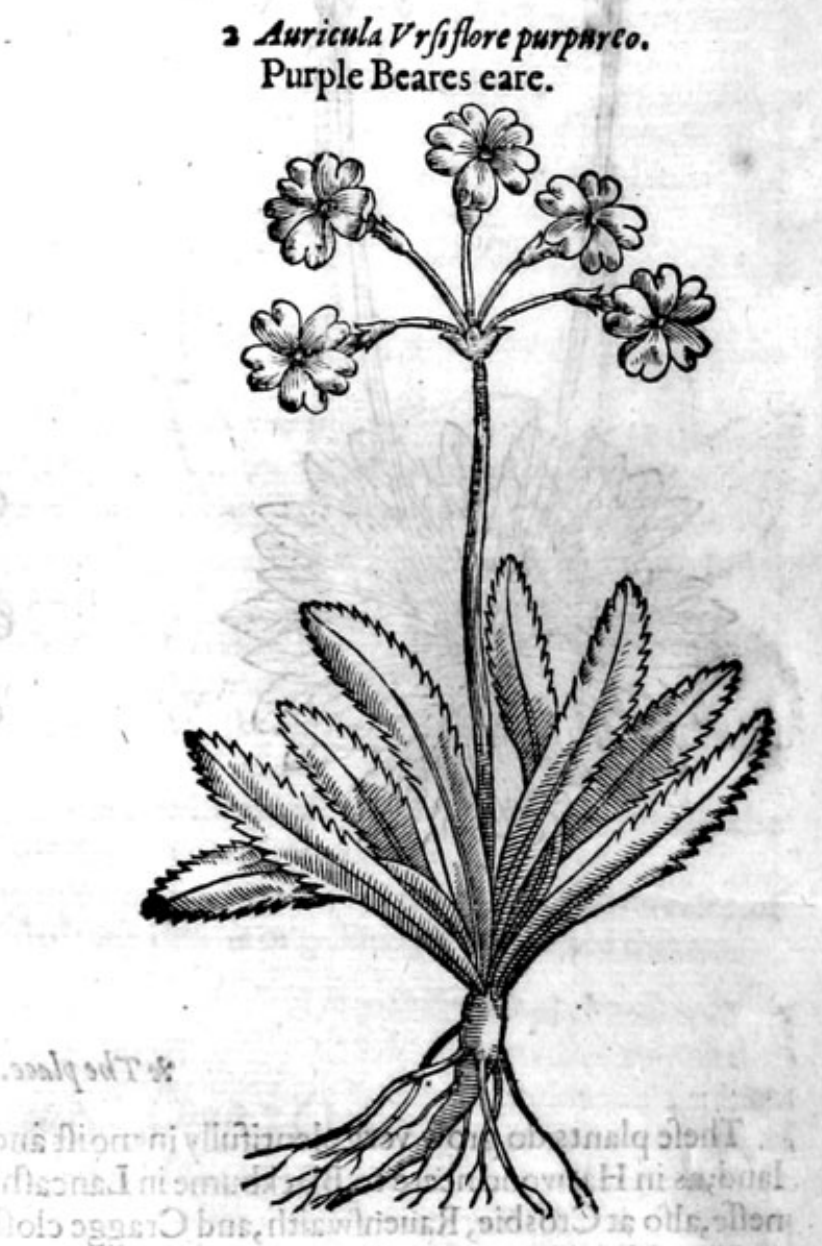

*Thedefaription.

owolis (3 ris smoxgotivishlil port

\section{$A$}




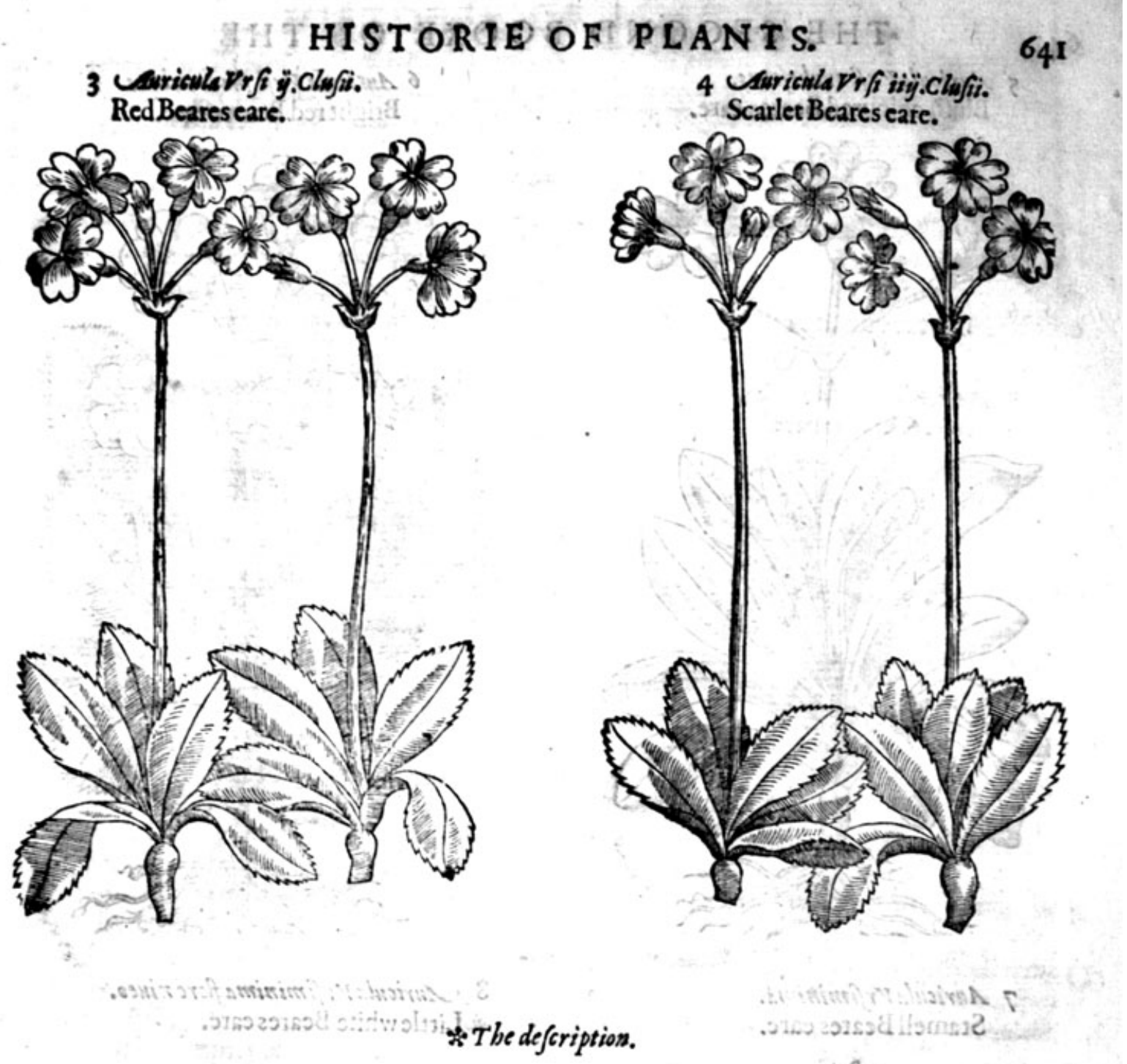

3 Carolus Clufins fetteth foorth in the booke of his Pannonicke trauels two kinds more, which he hath founde in his trauell ouer the Alpes, and other mountaines of Germanie and Heluetia, being the third in number, according to my computation: it hath leaues like the former, but longer, fmaller, and narrower toward the bottome, greene abouc, and of a pale colour vnderneath. The flowers are in faf hion like ynto the former, but of a moft hining red colour within; and on the outfide, of the colour of a Mulberie; in the middle or eie of the flower, it is of a whitilh or pale colour: the
roote is like the former.

4 The fourth is a fmaller plant then any of the forefaid, whofe leaues are thicke and fat, nothing at all fnipt about the edges, greene aboue, and grayifh vnderneath : the flowers are like the former, fhining about the edges, of an ouerworne colour toward the middle, and in the middle commeth 2 forke couered with an hiairineffet the roote is blacke and threddie.

5 The blufh coloured Beares eare hath diuers thicke, fat, leaues, fpred vpon the grounde, of a whitifh greene coloiri, lleightly indented in the edges :among which rifeth vp a naked ftalke, likewife hairie or whitifh, on the top whereof ftande very faire flowers, in fhape like thofe of the common Cowflip, butof a whitith colour tending to purple, which we terme blufh colour. The roote is tough and threddie, as areall the reft, although the grater haue omitted them in the cutting of the figure, it mult be vnderftoode, that their rootes are all alike.

6 The bright fhining red Beares eare of Matbiolus defcription, feemeth to late Herbarifts to be rather a figure made by conceit or imagination, then by the fight of the plant it felfe, for doubtleffe we are periwaded that there is no fuch plant, but only a figure foifted for of tentations fake, the deneither do we beleeue there is any fuch, confideration, bicaufe we hame not feene any fuch plant, 


\section{THE SECOND BOOKE OF THE}

5 Auricula Vrfierubefcens.

Blufh coloured Beares eare.

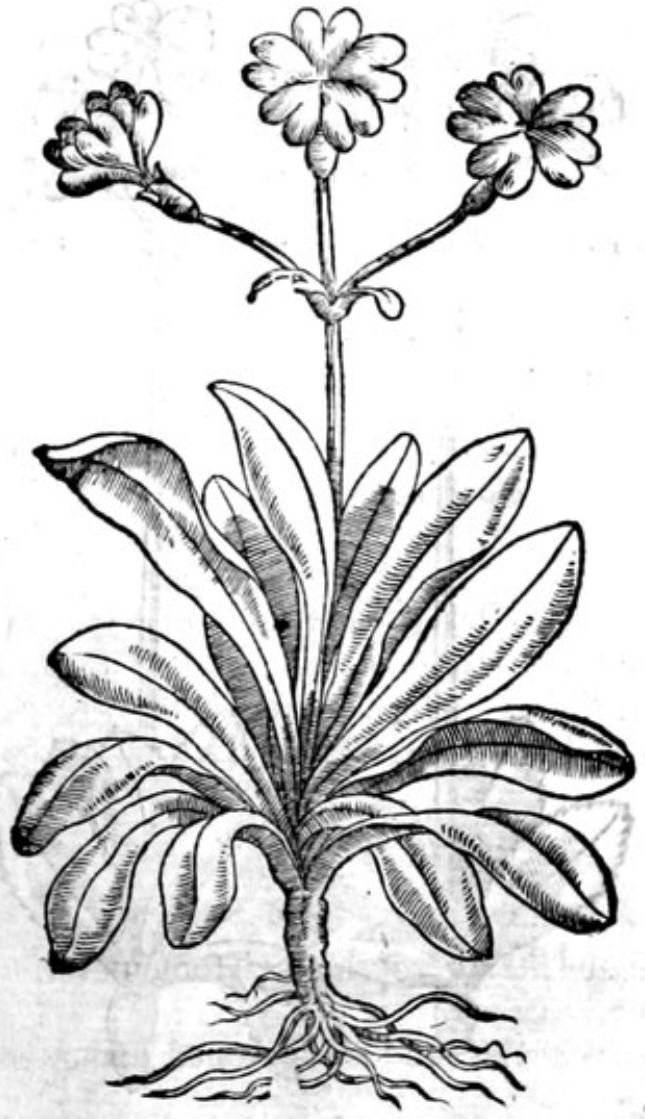

7 AuriculaVrfominima.
Stamell Beares eare.
6 Auricula $V x / a$ funcerubens. Bright red Beares eare.

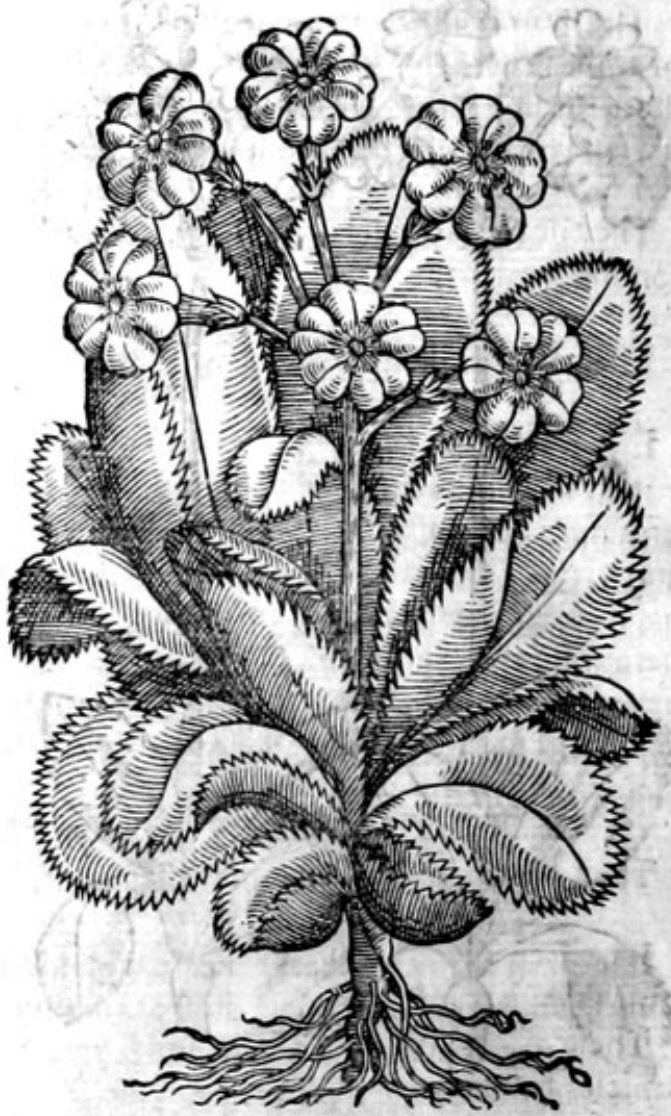

8 curicula Vrfiminima flore niveo. Little white Beares eare.

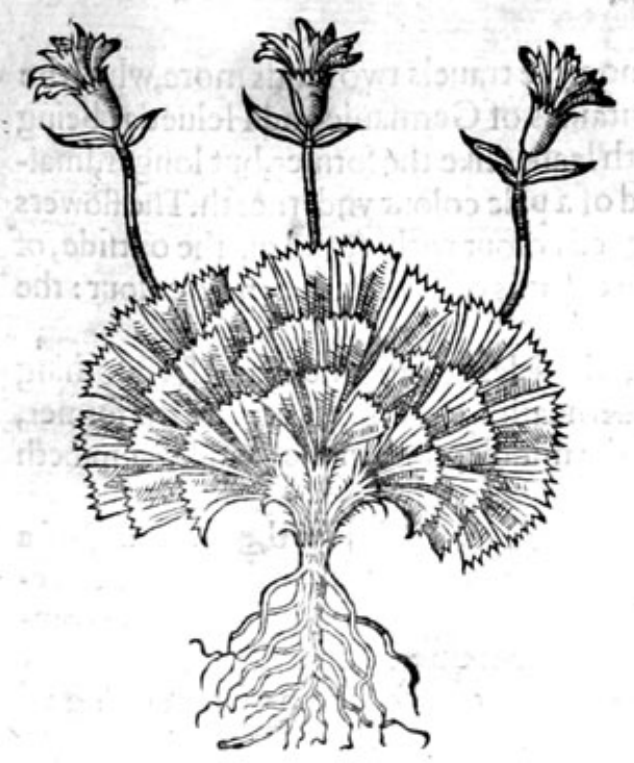

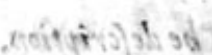

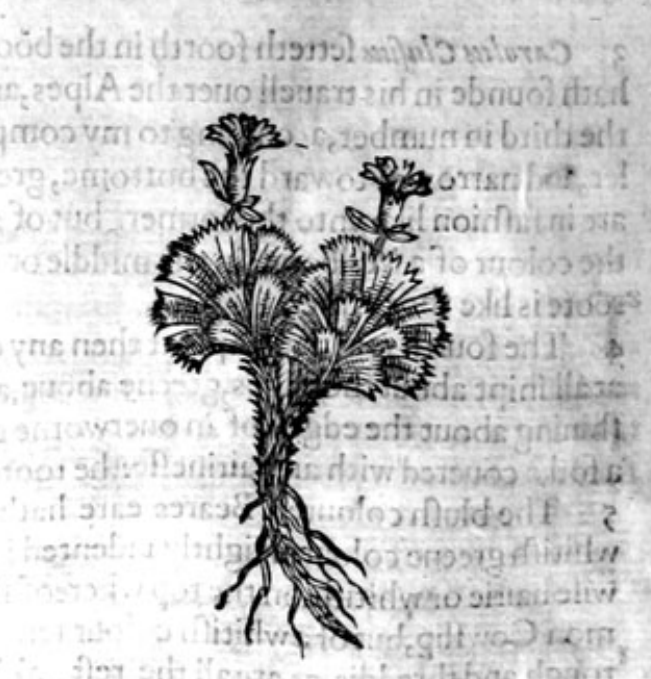

* The defaription.

2. Pena fetteth forth a kind of Beares eare vnder the name of Sanicula alpina, hauing his vppermof leaues an inch long, fomewhat iagged and hemde at the endes, and broade before like a fhouel; the 
lower leaves next the ground, fomewhat Thorter, but df the fame forne, among which tifeth a finat flender foote ftalke of an inthe long, whereon doth ftainde a fmall flower, confifting of frue tittle leaues, of a bright red or ftammell colour.

8 The fnow whire Beares eare differeth not from the laft deferibed but in the collour of the flower, for as the others ate red, contrary thefe are very white, and the whole plant is leffer; whereiniconfifteth the difference. The roote is long, rough, with forne fibres thereto belonging, nieither $b$ f thefe swo laft written of will be content to growe in gartens.

$$
\text { * The place. }
$$

They grow naturally vpon the Alpifh, and Heluetian mountaines, moft of them do grow in our London gardens.

Thefe herbes do flower in Aprill and Maie.

$$
\text { * The time. }
$$

$$
\text { * The names. }
$$

Either the auncient writers knewe not thefe plants, or elfe the names of them were not by them or their fucceffors diligently committed vnto pofteritic; Mathiolus and other later writers, haue giuennames according to the fimilitude, or of the fhape that they beare, vnto other plants according to the likenefle of the qualities and operations: you may call it in Englifh Beares eare: they that dwell about the Alpes do call it Dafaftktawt, and @ibwimiteitraint, by reafon of the effects thereof,for the roote is among them in great requeft, for the ftrengthning of the head, that when they are on the tops of places that are high, giddines, and the fwimming of the braine may not affliet them : it is there called the rocke role, for that it groweth ipon the rocks, and refembleth the braue colour of the rofe.

Thefe herbes are drie and veric aftringent.

$$
\text { * The nature. }
$$

* The vertues.

It healeth all outward and inward wounds of the breft, and the enterocele alfo, if for fome reafo- $A$ nable fpace of time it be put in drinkes, or boiled by it felfe.

Thefe plants are of the nature and temperature of Primula veris, and are reckoned among the $B$ Sanicles, by reafon of their vertue.

Thofe that hunt in the Alpes \& high mountaines a fter Goats and Robucks, do as highly efteeme $C$ heereof as of Dorowicum, by reafon of the fingular effects that it hath, but(as I faid before) one efpecially, euen in that it preuenteth the lofle of their beft ioints (I meane their necks) if they take the
roots heerof before they afcend the rocks, or other high places.

\section{Of mountaine Sanicle. Chap.263. \\ *The kindes.}

$\mathrm{T}$ Here be fundrie forts of herbs conteined vnder the name of Sanicle, and yet not one of them
agreeing with our Sanicle,called Diapen fis, in any one refpect, except in the vertues, whereof no doubt they tooke that name, which number doth dailly increafe by reafon that the later writers. haue put downemore new plants, not written of before by the auncients, which hall be diftingui-
fhed in this chapterby feuterall titles.

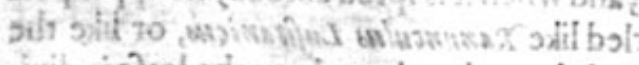

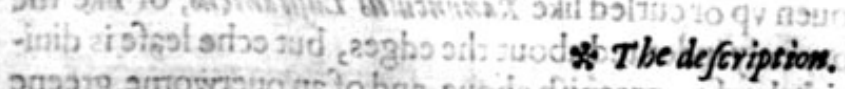

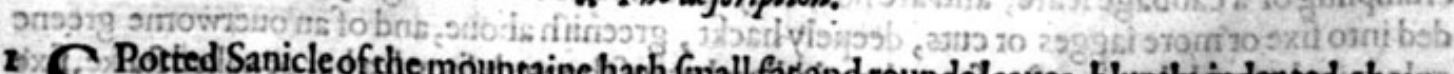

$\mathrm{S}$ the edges and the edges, and faftiòned like vnto theleaues of Saxif raggra air ea, or rather Cyclamen folio fundric ftalkes, of a datke with like leaues colour, ond fomewhat hairic vriderrieath, amiong which rite vp fundrie ftalkes, befet with like leaues ig burfinaller, atid of a cubiochigh, diuiding themfelues into

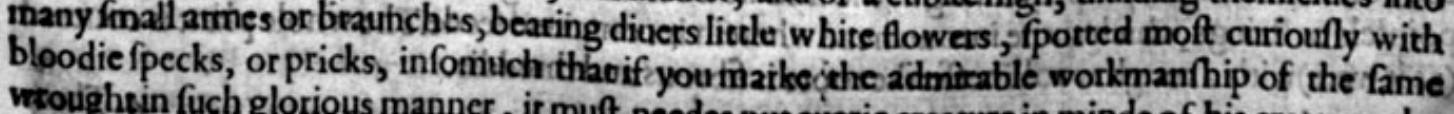
veroughtin fuch glorious manner, it muft needes puteierie creature in minde of his creator: the 


\section{THE SECOND BOOKE OF THE}

flowers are in fmell like the Maie flowers, or Hawthorn: the feede is fmall and blacke, contained in fmall pointels, like vnto white Saxifrage. The roote is fcalie and full of ftrings.

2 The fecond kinde of Sanicle, which Clufius calleth P inguicula, not before his time remembred, hath fundrie fmall thicke leaues, fat and full of iuice, being broad towards the roote, and harpe towards the point, of a faint greene colour, and bitter in tafte: out of the middeft whereof fprouteth or Shooteth vp a naked flender ftalke, nine inches long, euery ftalke bearing one flower and nomore, fometimes white, and commonly of a blewifh purple colour, fafhioned like vnto the common Munkes hoods, called Con folida rega lis, hauing the like fpur or Larkes heele annexed thereto.

I Sanicule guttata.

Spotted Sanicle.

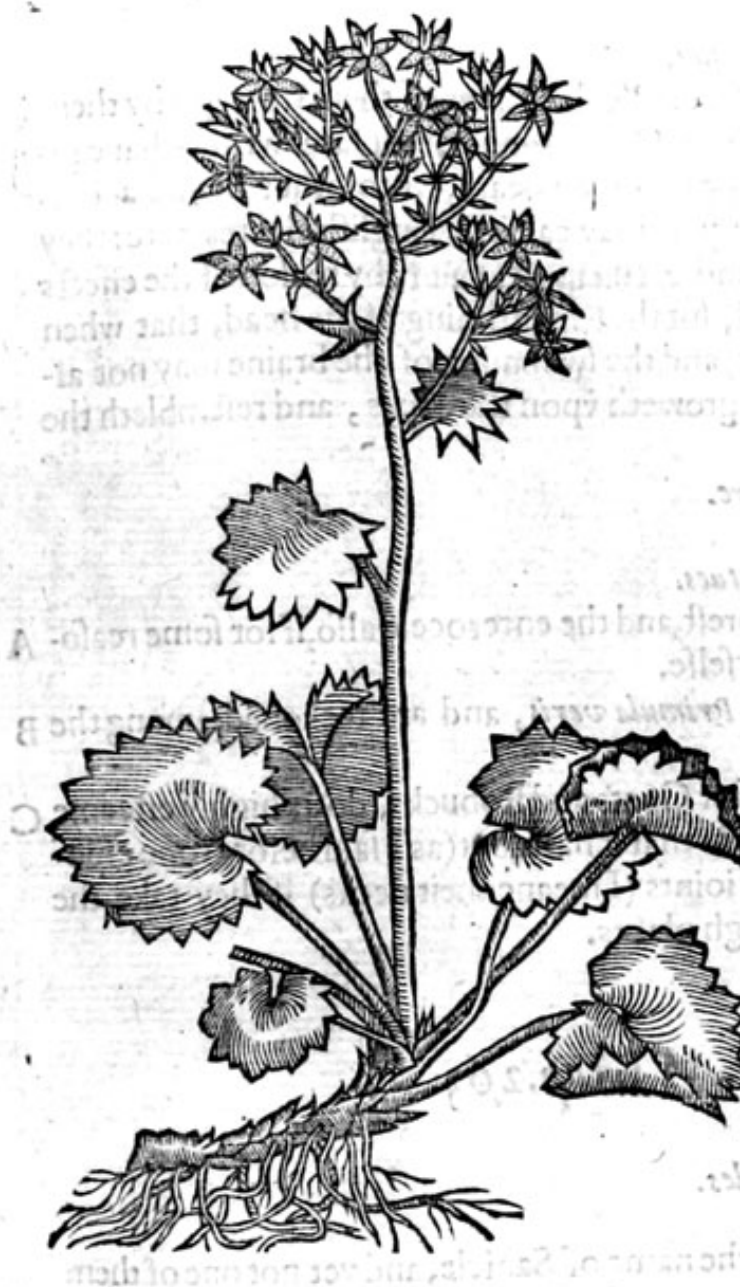

2 Pingwicula fume Sanicula Eboracenfis. Butterwoort,or Yorkfhire Sanicle.

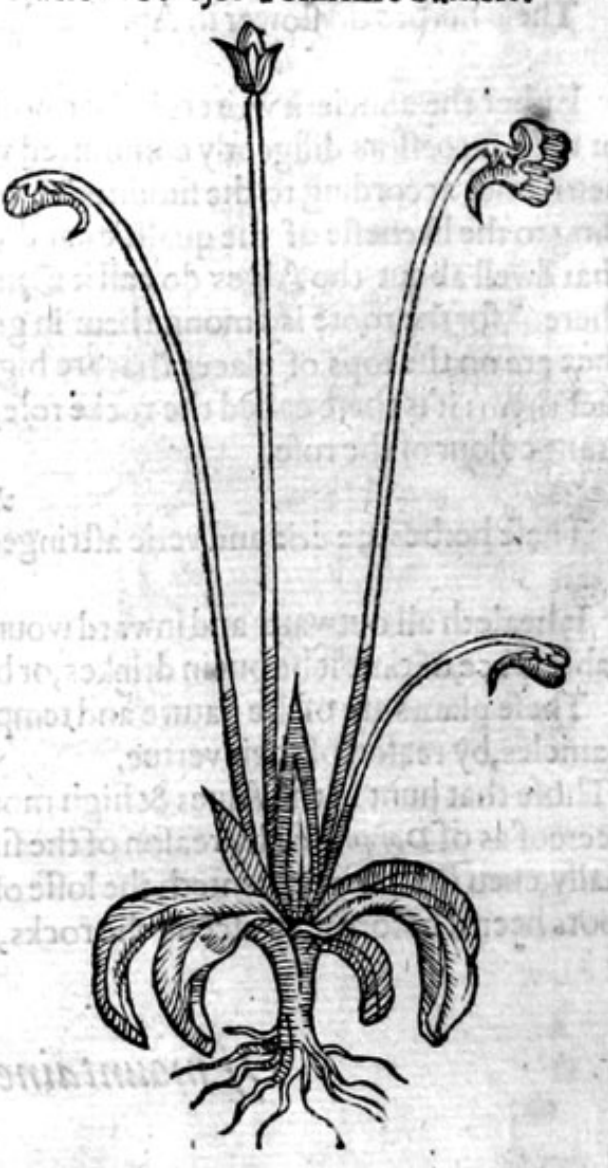

* Thedefoription.

3 The thirde kinde of mountaine Sanicle, fone Herbarifts haue called Samiculs alpina flore rmbros the leaues thoote foorth in the beginning of the fpring, very thicke and fat, and are like a purfe or rounde lumpe, at their firft comming out of the ground; and when it is fpred abroad, the vpper part there of is full of vaines or finewes, and houen vp or curled like Ranunculus Lufitanicus, or like the crumpling of a cabbage leafe, and are not oncly indented about the edges, but eche leafe is diuided into fixe or more iagges or cuts, deepely hackt, greeniih aboue, and of an ouerworne greene colour vinderneath, hot in tafte: from the middle whereof hooteth foorth a bar or naked ftalke, fixe inches long, fomewhat purple in colour, bearing at the top a tuft of fmall hollow flowers, looking or hanging downwards like little bels, not vnlike in forme to the common Cowflips, but of a fine deep red colour tending to purple, hauing in the middle a certaine ring or circle of white, \&ealfo certaine pointels or ftrings, which turne into an head wherein is contained feede. The whole plant is couered (as it were)with a rough woollineffe: the roote is fibrous and threddie. 


\section{HISTORIE OFIPLANTS.}

4 There is another figure fet foorth which may feeme vinto the ignorant to be one of the fame kinde, but differing in fome points, whereas in truth they are but one and the felfe fame plant; one of the which I would willingly haue left foorth of our volume, but fearing that fome not knowing that they be one, might aske the caufe why we left it out; but hencefoorth I doubt not but thole that fhall fuccede will leaue it out as needeleffe, confidering they know that one pieture was made by a drie and withered plant, and the other by the liuely herbe it felfe.

3 Sanicula Alpina Clufrir,jue Cortunga Matbioli. Beares eare Sanicle.

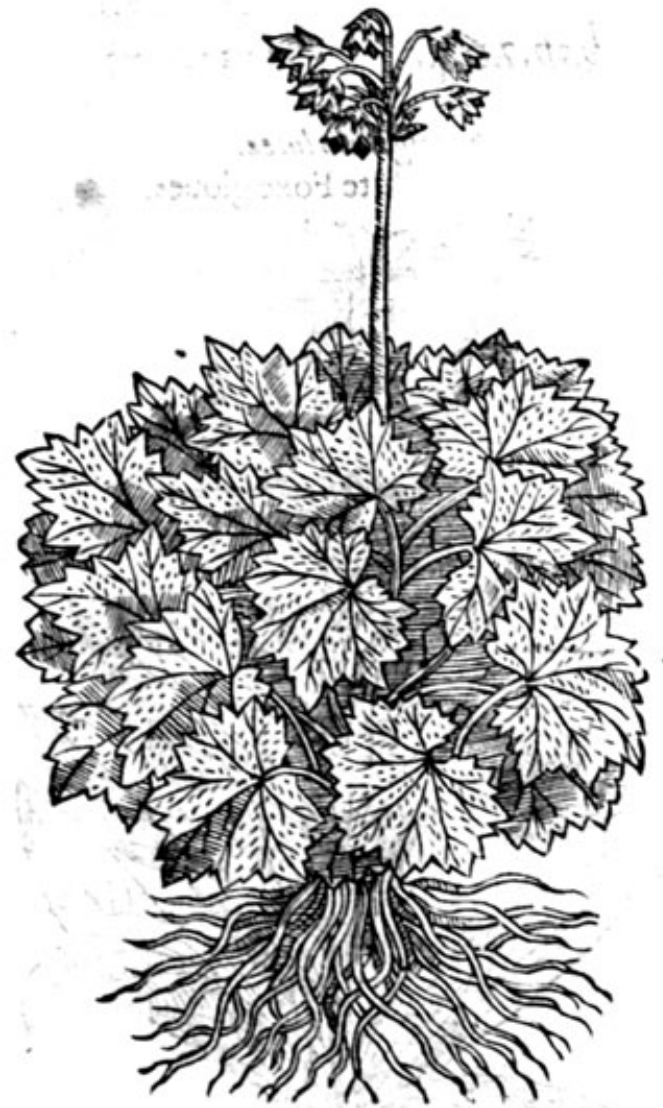

4 Cortufaveriori Icon.

Beares eare Sanicle the true figure.

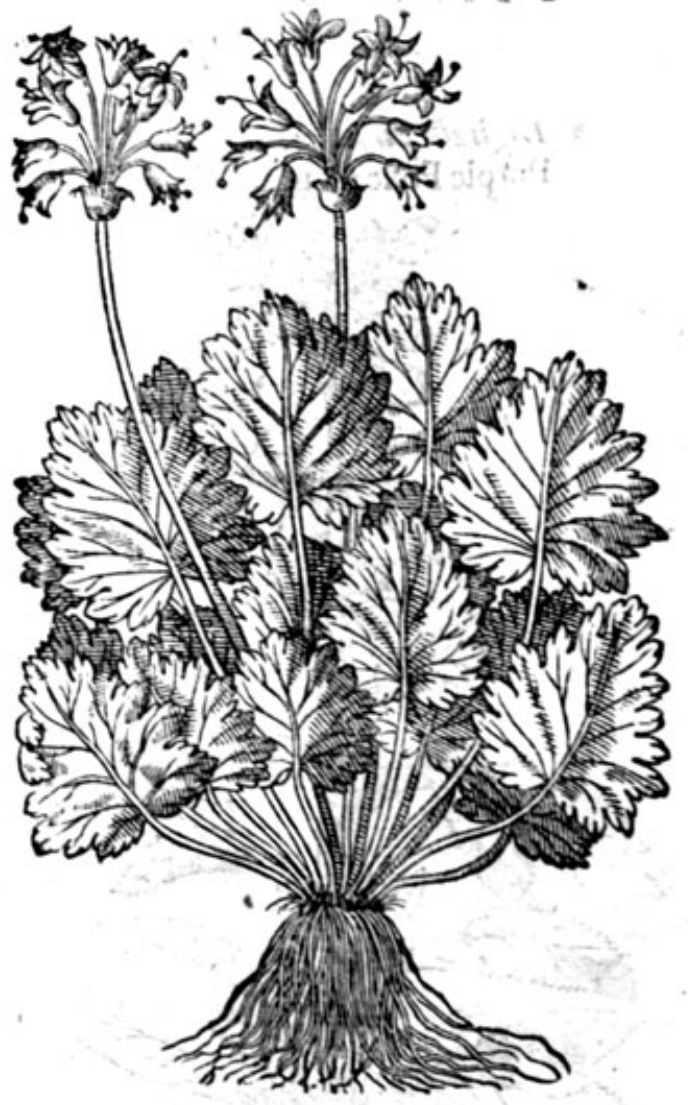

* Theplace.

Thefe plants are ftrangers in England, their naturall countrie is the alpifh mountaines of Heluetia. They growe in my garden, where they flourith exceedingly, except Butterwoort which groweth in our Englifh fqually wet grounds, and will not yeelde to any culturing or tranfplanting: it groweth efpecially in a field called Cragge clofe, and at Crosbie, Rauenfwaith in Weftmerland, vpon Ingleborough fels, twelue milcs from Lancafter, and in Harwoode in the fame countie neere to Blackburne, ten miles from Prefton in Anderneffe vpon the bogs $\$$ marifh grounds, and in the boggiemedowes about Birhops Hatfielde; and alfo in the fens, in the waie to Wittles mearefrom London, in Huntingdon?hire.

\section{$*$ the time. \\ They flower and flourifh from Maie to the ende of Iulie.}

The firft is called sanicula guttata; taken from the fpots wherewith the flowers are marked, of L'Obeliwe Geven Alpinwm, makingit a kinde of Auens: in Englifh fpotted Sanicle; of our London dames pratling Parnell.

The fecond is called Pinguicula, of thefatnes or fulnes of the leafe, or of fatning, in Yorkthire where it doth efpecially growe, and in greateft abundance, it is called Butterwoorts, Butter roote, and white roote, but that name belongeth more properly vnto Salomonsfeale. . 


\title{
646 THE SECOND BOOKE OF THE
}

They are hot and drie in the third degree.

\author{
* Thetemperature.
}

* The vertues.

A The husbandmens wiues of Yorkhire, do vfe to annoint the dugs of their kine with the fat and oilous iuice of the herbe Butterwoort, when they are bitten with any venemous worm, ot chapped, rifted, and hurt by any other meanes.

B They fay that it doth rot their theepe, when they are for want of other food conftrained to eate thereof.

\section{Of Foxe gloues.}

I Digitalis purpurea.

Purple Foxe gloues.

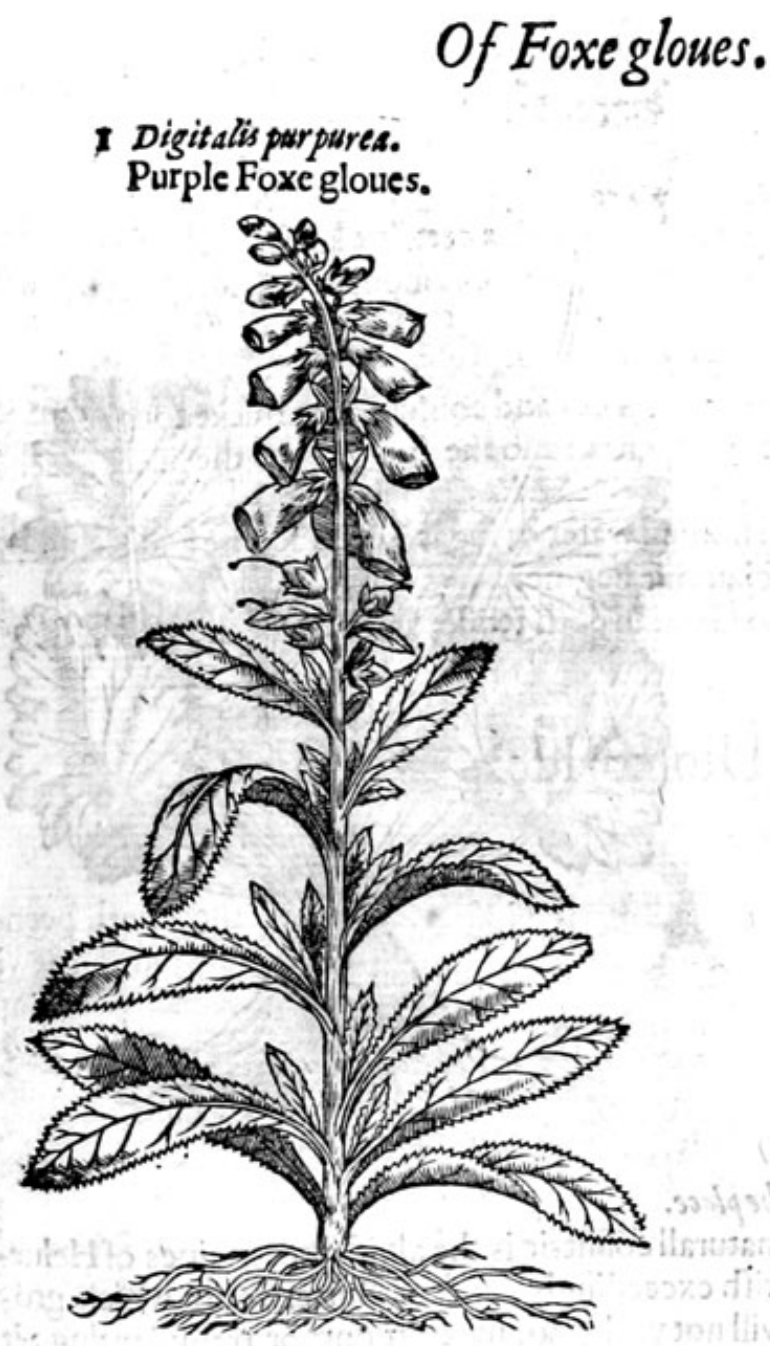

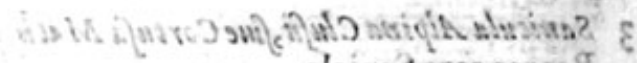
गुinte jus? 29 ins

\section{Chap.264.}

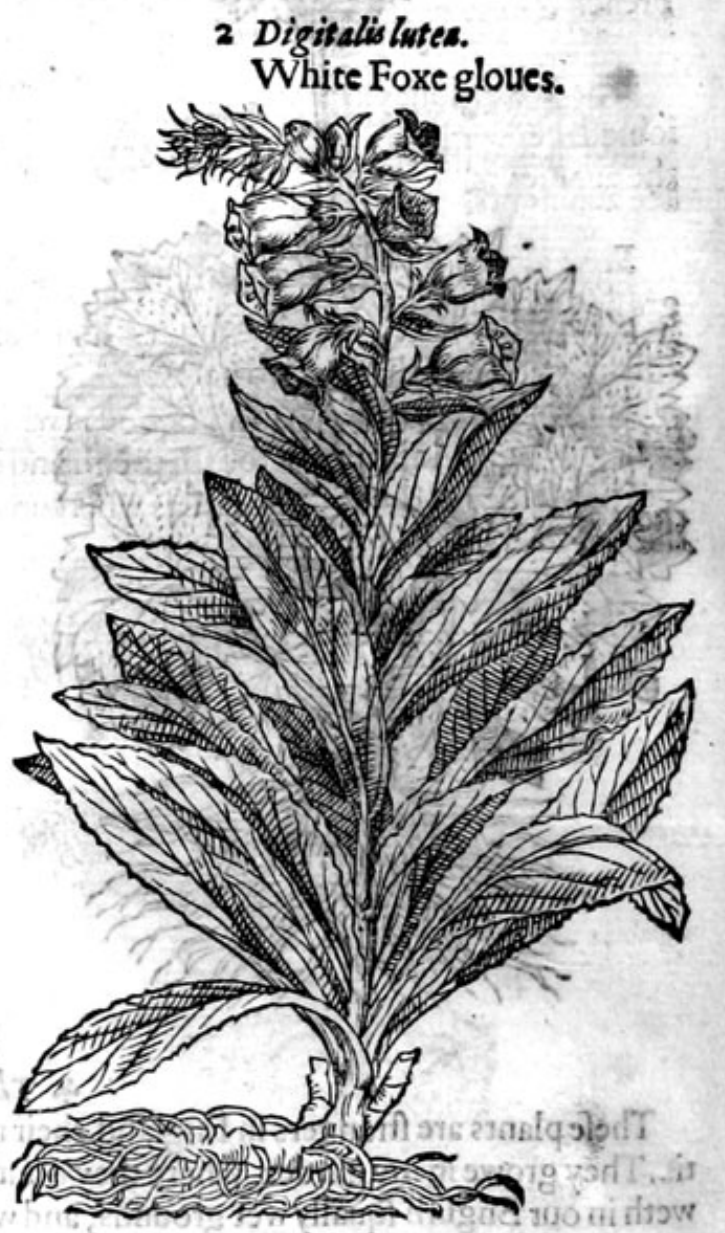

$*$ Thedefcription.

1 Oxe gloues with the purple tower, is moft common; the leaues whereof are long, nicked in -1 the edges, of a light greene, in manner like thofe of Mullein, but leffer, and not fo downie: the ftalke is ftraight, from the middle whereof to the top ftande the flowers, fet in courfe one by another vpon one fide of the ftalke, hanging downwardes with the bottome vpwarde, in forme long, like almoft to finger ftals, whereof it tooke his name Digitalis, of a red purple colour, with certaine white fpots dafht within the flower, after which come vp round heads, in which tieth the feed, fomwhat browne, and as fmall as thofe of Time. The roots are many flender frings. 2 That Foxe glones with white flowers differeth not from the precedent, but in the colour of the flowers, for as the others were purple, thefe contrariwife are of a milke white colour.

We haue in our gardens another fort heereof, which bringeth foorth molt pleafant yellow flowers, and fomewhat leffer then the common kinde, whercin they differ. 
We have alfo another fort, which we call Digitalin ferraginea, whofe flowers are of the colour of ruftic iron; whereof it tookc his name, and likewife makech the difference.

Foxe gloue groweth in barten fandie grounds, and vnderhedges almoft enery where.

Thofe with white flowers do grow naturally in Landefdale, and Crauen, in a field called Cragge clofe, in the north of England: likewife by Colchefter in Effex; neere Excefter in the weft parts, and in fome fewe other places. The other two are ftrangers in England, neuertheleffe they do grow
with the others in my garden. $\quad$ * The time.

They flower and flourifh in Iune and Iuly.

\section{* The names.}

Foxe gloues fome callin Greek opverus, \& make it to be Verbafci /peciem, or a kind of Mullein: in Latine Digitalis : in high Dutch fingberbut, and fingber ktaut ; in lowe Dutch, Citnget beet:
French Gantes noftre deme : in Engliih Foxe gloues.

\section{* Thesempcrature.}

The Foxe gloues in that they are bitter, are hot and drie, with a certaine kinde of clenfing quality ioined therewith,yet are they of no vfe, neither haue they any place among medicines,according to
the auncients.

$*$ The vertues.

Foxe gloue boiled in water or wine, and drunken, doth cut and confume the thicke toughneffe of $\mathbf{A}$ grofie and flimie flegme and naughtic humours; it openeth alfo the ftopping of the liuer, fpleene,
and milt, anid of ocherinward parts. The fame taken in like maner, or boiled with honied water or fugar, doth fcoure and clenfe the B
brelt, ripeneth and bringeth foorth tough and clammie flegme. They ferue for the fame purpofes whereunto Gentian doth tende, and hath beene vfed in fteade $\mathbf{C}$
thereof,as $G$ alen faith.

\section{Of Baccbaris out of Diofcorides. Chap.265.}

Beccharis CMon/pelienfiwm.

Plowinans Spiknard.

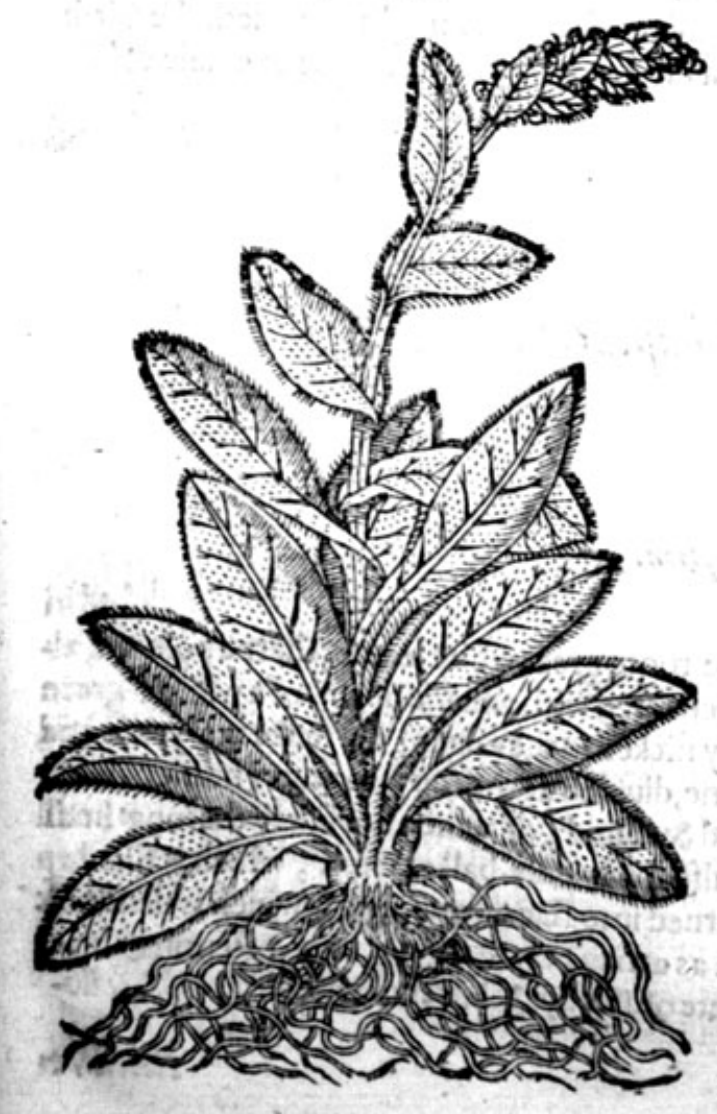

* The defcription.

$\mathrm{A}$ Bout this plant Baccharis, there hath beene great contention among the old and newe writers; Mathiolies and Dodonew have miftaken this plant, for Coviza masior, or Coniza Helenitis Cordi; Virgill and wibensws have confounded Baccharis, and Srizarwm togither : but following the auncient writers, it hath manyblackith rough leaues, lomewhat bigger then the leaues of Primrofe:among which rifeth vp a ftalk two cubits high, bearing at the top little chaffic or fcalie flowers in fimall bunches, of a darke purple colour, which turne into downe,and are caried away with the winde, like vnto the kinds of Thiftles: the root is thicke, groffe, andfat, fpreading about in the carth, full of ftrings : the fragrant fmell that the roote of this plant yeeldeth, may well be compared vnto the fauour of Cinnamom, Helenutum, or rie many or mott forts of people: I meane in moft parts of England.

*Theplace.

Baccharis delighteth to growe in rough $\$$ crag. gie places, and in a leane foile where nomoifture is : it groweth very plentifully about Montpellier
in France, aud diuers places in the Weft parts of England, 


\section{$64^{8}$ THE SECOND BOOKE OF THE}

It fpringeth vp in Aprill, it flowreth in Iune, and perfecteth his feede in Auguft. * The names.

The learned Herbarifts of Montpellier, haue called this plant Bacchar is sthe Gracians Eargieas, or

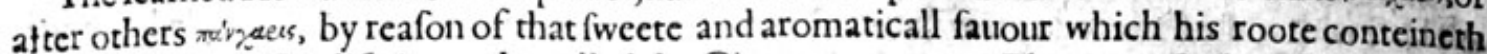
and yeeldeth $:$ in Englifh it may be called the Cinamom roote,or Plowmans Spiknarde: $V$ irgill in his feuenth ecloge of his Bucolicks, maketh mention of Baccluaris, and doth not onely fhew that it is a garland plant, but alfo fuch 2 one as preuaileth againft inchantments, faying,

\section{-..-Bacchare frontem}

Cingite, ne vati noceat mala lingua futwro.

Decke the forehead of the Prophet with plowmans Spiknard,

To keepe him from an ill toong that hurtes withoutregard.

Baccharts is likewife an ointmen t in Atheneus, in his 15.booke, which may take his name of the fweete herbe Bacchar is: for as Plinie writeth, Ariftophanes of olde, being an ancient comicall poët, witnefleth, that ointments were woont to be made of the roote thereof: to be briefe, Cratewas his Afarum, is the fame that Diofcorides his Baccharis is.

\section{Baccharis or Plowmans Spiknard is of temperature very aftringent or binding. \\ * The vertwes.}

A Baccharis, or the decoction of the roote, as Paulus AEg ineta briefly fettech downe, doth open the pipes and paffages that are ftopped, prouoketh vrine, and bringeth downe the defired fickneffe: the leaues thereof for that they are aftringent or binding, ftop the courfe of fuxes and rheumes.

B Baccharis is a fingular remedie to heale inflammations and Saint Authonies firc, called Ignio facer, and the fmell thereof prouoketh fleepe.

C The decoction of the roots of Baccharis, helpeth ruptures \& conuulfions, thofe alfo that haue fal. len from an high place, and thofe that are troubled with the fhortnes of breath.

D It helpeth alfo the old cough, and difficultie to make water.

E When it is boiled in wine, it is giuen with great profite againft the bitings of fcorpions, or anivenemous beaft, being implaittered and applied thereto. '

F A bath made thereof, and put into a clofe ftoole, and receiued hot, mightily voideth the birth, and furthereth thofe that haue extreme labour in their childing, caufing them to have eafie deliue: rance.

\section{Of Elecampane. Chap.266.}

\section{* The defeription.}

$\mathrm{E}$

Lecampane bringeth foorth prefently from the roote great white leaues, tharpe pointed, 21moft like thofe of great Comfrey, but foft, and couered with a hairie down, of a whitith green colour,and are more white vnderneath, llightly nicked in the edges : the ftalke is a yarde and a halfe long, aboue a finger thicke, not without downe, diuided at the top into diuers branches, vpon the top of cuerv fprig ftande great flowers, broad $\&$ round, of which not onely the long fmall leaues that compafic round about are yellow, but alfo the middle ball or circle, which is filled vp with an infinite number of threds, \& at length is turned into fine downe; vnder which is flender \& long feed: the roore is vneeuen, thicke, and as much as a man may gripe, not long, cftentimes blackifh without, white within, and full of fubftance, fweete of fmell, and bitter of tafte. 


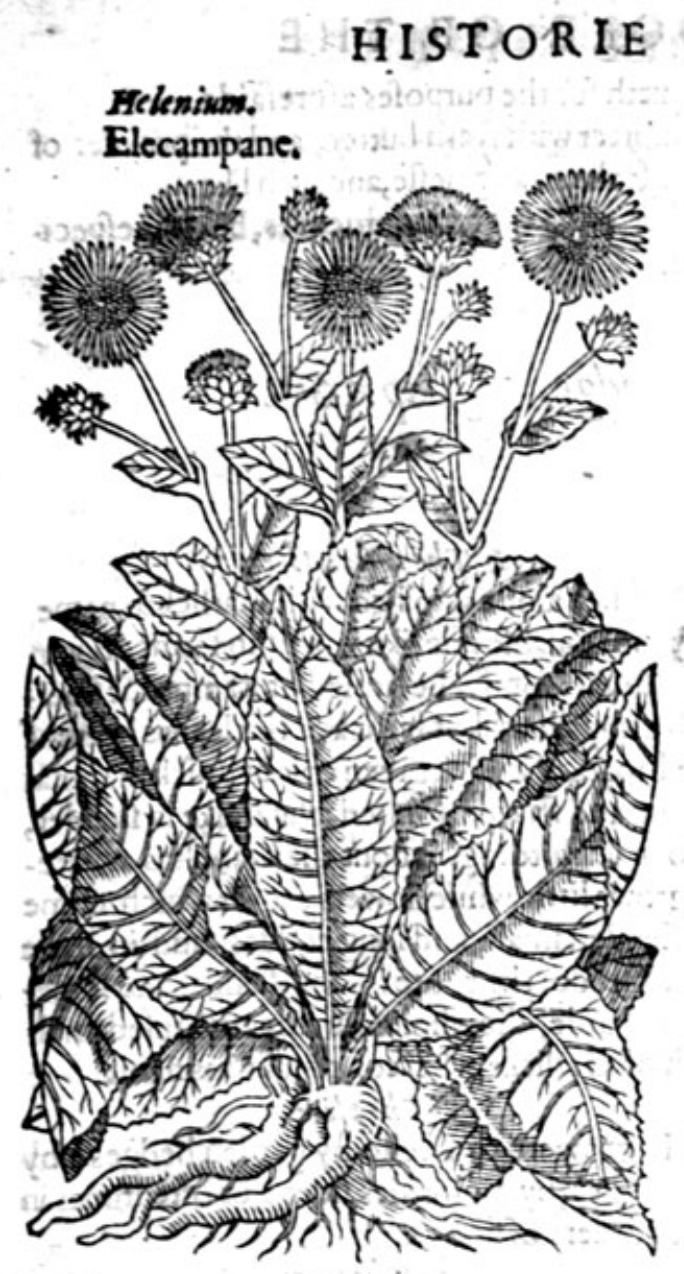

OF PLANTS.

*The place.
It groweth in medowes that are fat and fruitfull: it is allo oftentimes founde vpon mountaines, $\mathrm{h}_{2}$ dowie places, that be not altogither dry:it groweth plentifully in the fieldes on the left hande as you go from Dunftable to Puddle hill : alfo in an orcharde as yee go from Colbrook to Ditton ferrie, which is the way to Windfore, and in fundrie other places, as at Lidde, and Folke?tone, neere to Douser by the fea fide.

\section{* The time.}

The flowers are in their brauerie in Iune and Iulie: the rootes be gathered in Autumne, and oftentimes in Aprill and Maic.

$*$ The names.

That which the Gracians name ixinor, the Latines call Inuls; and Enula : in Thops Enula compans: in high Dutch Glantutitz $:$ in lowe Dutch $\mathfrak{a}$. lanot unotele :in Italian Enos, and Enols: in Spanifh Raiz del alla: in French Enula Campane: in Englifh Elecampane, and Scabwoort, and horfeheale: fome report that this plant took the name Heleniwm of Holeva, wife to Menelase, who had hir hands full of it when Paris ftole hir awaie into Phrygia. $*$ The temperature,

The roote of this Elecampane, is maruellous good for many things, being of nature hot and drie in the third degree, efpecially when it is drie: for being greene and as yet full of iuice, it is full of fuper fuous moifture, which fomewhat abateth the hot and dry qualitie thereof.

*The vertues.

It is good for thortnes of breath,and an old cough, and for fuch as cannot breath valeffe they A hold their necks vpright.

S. It is of great vertue both giuen in a looch, which is a medicine to be licked on, \& likewife prefer- B ued, as alfo otherwife giuen to purge and voide out thicke, tough, and clainmie humours, which
fticke in the cheft and lungs.

The roote preferued is good and holfome for the ftomacke: being taken after fupper it doth not $\mathrm{C}$ onely helpe digeftion, but alfo keepeth the belly foluble.

The inice of the fame boiled, driueth foorth all kinde of wormes of the bellie, as Plinie teacheth: D who alfo writeth in his twentie booke and fift chapter, the fame being chewed fafting, doth faften
the teeth.

The root of Elecimpane is with good fucceffe mixed with counterpoifonstit is a remedy againft $\mathbf{E}$ the bitings of ferpents: it refifteth poifon: it is good for them that are barften, and troubled with
cramps and conuulfions.

Some alfo affirme, that the decoction thereof, and likewife the fame beaten intopowder and F mixed with honic in maner of an ointment, doth clenfe and heale vp old vlcers.

Galen faith, that heerwith the parts are to be made red, which be vexed with long \& cold greefes: G as are diuers paffions of the hucklebones, called the Sciatica, and little and continuall bunnies and loofenes of certaine ioints, by reafon of ouermuch moifture.

The decoetion of Enula drunken, prouoketh vrine, and is good for them that are grieued with $\mathrm{H}$ inward burftings, or haue any member out of ioint.

The roottaken with hony or fugar, made in an electuary, clenfeth the breft,ripeneth tough flegm, I and maketh iteafie to be fpet foorth, and preuaileth mightily againft the cough and fhortneffe of breach, comfortech the ftomacke alfo, and helpeth digeftion. 


\section{0 \\ THE SECOND BOOKE OF THE}

$\mathrm{K}$ The rootes condited after the maner of Eringos, ferueth for the purpofes aforefaide.

L The roote of Enula boiled very foft, and mixed in a morter with frefh butter, and the powder of Ginger,makcth an exccllent ointment againft the itche,fcabs, mangineffe, and fuch like.

M The rootes are to be gathered in the end of September, and kept for fundrie vfes, but it is efpeci. ally preferued by thofe that make fuccade and fuch like.

\section{Of Sauce alone, or fack by the bedge. Chap.267.}

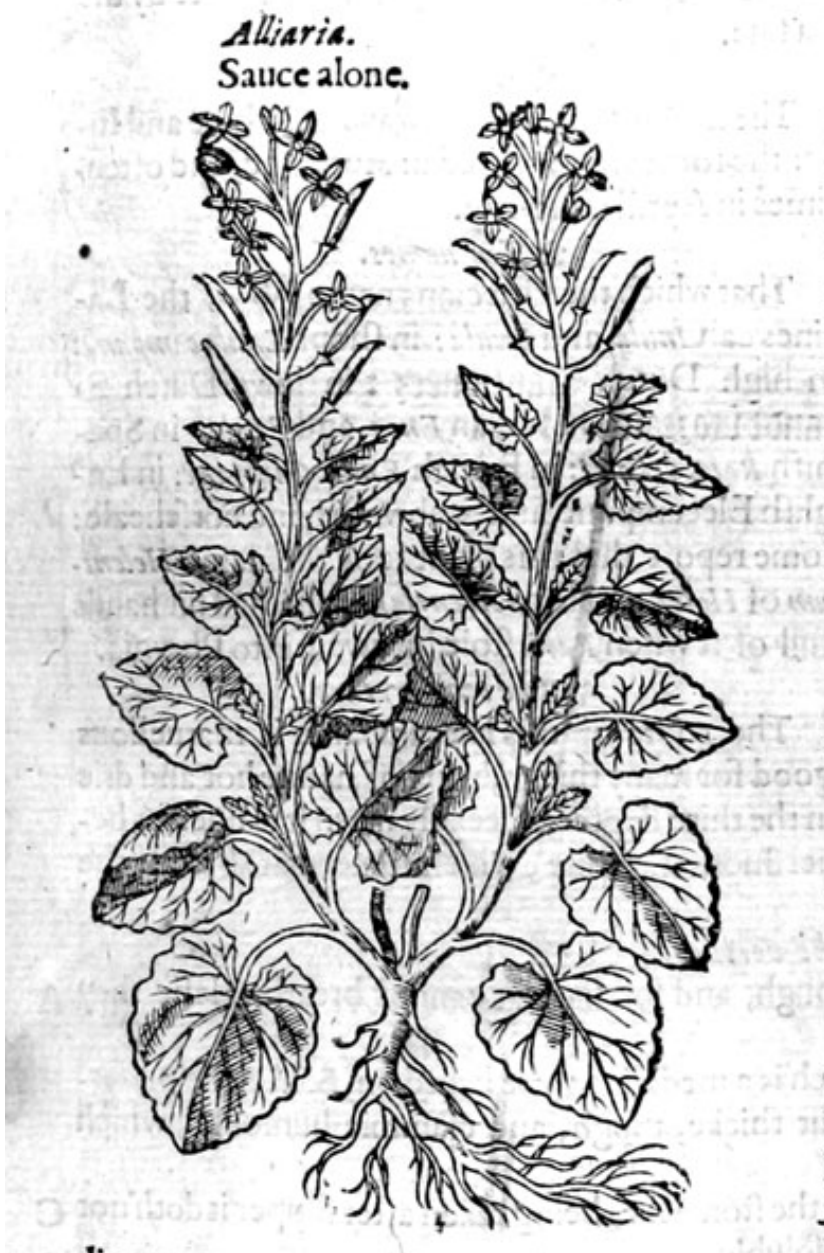

C Auce alone is ioined with Garlick in name,

* The defcription.

not bicaufe it is like vnto it in forme, but in fmell : for if it be brufed or ftamped, it fmel. leth altogither like Garlicke : the leaues heereof are broad, of a light green colour, nicked round about, and tharpe pointed : the ftalke is flender, about a cubite high, about the branches whereof growe little white flowers, after which come vp flender, fmall, and long coddes, and in thefe black feede: the roote is long, flender and fomething harde, the whole plant being brufed fmel. leth of Garlicke, whereofit tooke his name. * The place.

It groweth of it felfe by garden hedges, by old walles, by highwaies fides, or oftentimes in the borders offieldes. * Thotime.

It flowreth chiefely in Iune and Iuly, the feede waxeth ripe in the meane feafon. The leaues are ved for a fauce in March or Aprill.

$*$ Thenames.

The later writers call it UAlliaria and Alliarin, of fome Rima Maria : it is not Scordium, orwater Germander; which the apothecaries in times paft miftooke for this herbe; neither is it Scordij pecies, or a kind of water Germander, wherof diuers, Pes A Sininas: it.is called in high Dutch we haue written: it is reported to benamed of knobiaucb ktaut, Leucbel, and saf ktaut: in

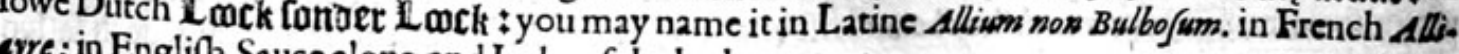
ayre : in Englifh Sauce alone, and I acke of the hedge.

Iacke of the hedge is hot and drie, but $\%$ he temperature. Iacke of the hedge is hot and drie, but much leffe then Garlicke, that is to faie, in the ende of the
fecond degree, or in the beginning of the thirde.'

A Weknow notwhat vfe $\%$ The vertues.

for for 2 fauce,as they do thofe of Ramfons.

B Some alfo boile the leaues in glifters which are vfed againft the paine of the collicke and ftone, much eafed. 


\section{HISTORIE QF PLANTS. IHT GSI Of Dittanie. Chap.268.}

I Diltamum Creticum. Dittanic of Candie.

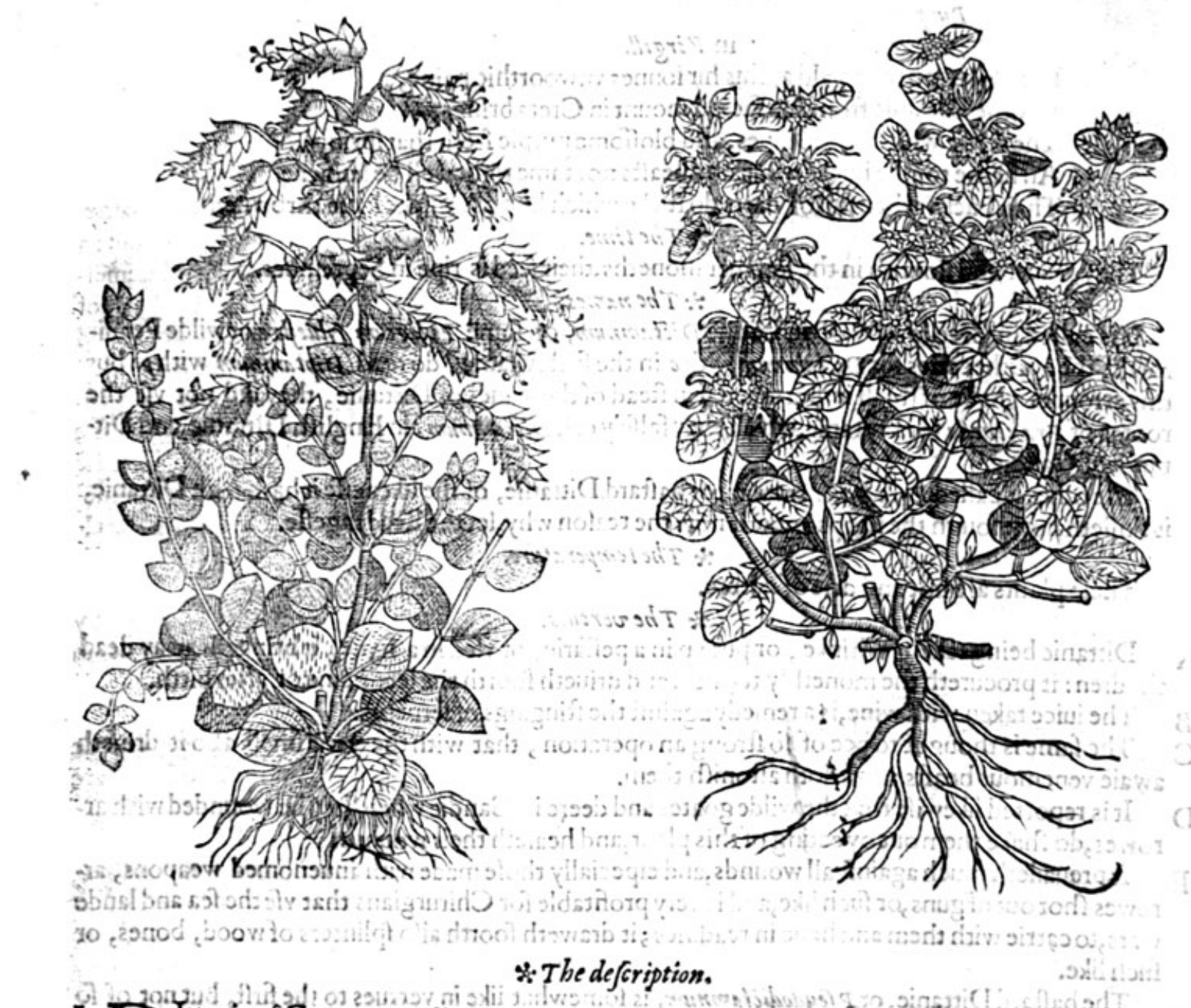

2. Pfendodict animien. Baftard Dittanic.

${ }^{7} \mathrm{D}$ Ittanie of Crete now called Candie (as D iofcorides faith) is a hot and fharpe herbe, much
like vnto Peniroiall, fauing that his leaues be greater and fomewhat hoarie, couered ouer
with a foft downe or white eares or fcaley aglets, hanging by little fimall fton: at the top of the branches growe fmall fpikie white colour; among which fcales thete do of a red purple colour; which being for the flown the wheate, ing of Diofcorides, who faith, it neither the knop is founde full of fmall feede, contraric to the fayboth in my garden : the whole plant perilhed inther, nor feede, but my felfe hauefeene it beare 2 The fecond kinde called $P$ fewdodict amnum, that winter following. fauing that it is not fweete of fmell, neither dothat is, baftard Dittanie, is much like vntothe firft, ftalks, with knots and ioints, and at eueric knot two leaues fomewhat hauing rounde, foft, woolley whar bjter : the flowers be of a lighepurp not two leaues fomewhat round, foft, woolley, and fomgarlands or wharles, and tike the fourple colour, compaffing the ftalkes by certaine fpaces like whole plantgroweth to the height fowers of Peniroiall. The roote is of a woodie fubftance : the The firt Ditranie commeth from Coc $\%$ Theplace.

Ily: firft Dittanie commeth from Crete, andland which wecall Candie, where it groweth natuton of the iniuric of our extreten, where it hath flowred and borne feede; but it perifhed by teaoghis? ? writeth 


\section{2}

THE SECOND BOOKE OF THE

writeth againft all truth, that it neither beareth flowers nor feede : after $T$ beophraFim, Virgil witneffeth that it doth beare flowers, in the 12 .of his AEneidos:

\section{Dicfamnum genitrix Cretea Carpit ab Ida, Puberibus caulem folys, of flore comantem Purpureo.}

in Virgill.

But $V$ enus much appald at this hir fonnes vnwoorthie paine,

Greene Dittanie from Ida facred mount in Creta brings,

The ftalke with tender leaues, and bloffome purple frem that fprings.

An herbe to Roe bucks wilde, and beafts not tame right well be knowne

Their backs when full of darts do fticke which hunters thicke haue throwne. * The time.

They flower and flourifh in the fommer moneths, their feed is ripe in September. * The nanies.

It is called in Greeke dixrauvos : in Latine Dictamnwm, of fome Pulegium fylueftre, or wilde Penniroiall: the apothecaries for Dictamnum with $c$ in the firft fyllable, do read Diptamnum withp: but this errour might be of fmall importance, if in ftead of the leaues of Dittanie, they did not vie the rootes of Fraxinella for Dittanie, which they falfely call Dictamnum : in Englih Dittanie, and Dittanie of Candie.

The other is called $P$ feudodict amnum, or baftard Dittanic, of the likeneffe it hath with Dittanis, it skilleth not, though the fhops know it not: the reafon why, let the Reader geffe.

Thefe plants are hot and drie of nature. * The temperature.

* The vertues.

A Dittanie being taken in drinke, or put vp in a peffarie, or vfed in a fume, it bringeth away dead children: it procureth the monethly termes, and driueth foorth the fecondine or after birth.

B The iuice taken with wine, is a remedy againft the ftingings of ferpents.

C The fame is thought to bee of fo ftrong an operation, that with the veriefmell alfo it driueth awaie venemous beafts : and doth aftonifh them.

D It is reported likewife that the wilde goates and deere in Candie when they be wounded with arrowes, do thake themout byeating of this plant, and healeth their wounds.

E It preuaileth much againit all wounds, and efpecially thofe made with inuenomed weapons, arrowes fhot out of guns, or fuch like, and is very profitable for Chirurgians that vfethe fea and lande wars, tocarrie with them and haue in readines; it draweth foorth alfo fplinters of wood, bones, or fuch like.

F The baftard Dittanie, or $P$ feudodictannom, is fomewhat like in vertues to the firft, but not of fo great force, yet it ferueth exceeding well for the purpoles aforefaid.

\section{Of Borage. Chap.267.}

* The kindes.

There is found at this day fower forts of Borage,as (hall be declared in this prefent Chapter.

\section{* The defoription.}

${ }^{2} \mathrm{~B}$ Orage hath broad leaues, rough, lying flat vpon the ground, of a blacke or fwart greene colour : among which rifeth vp a ftalke two cubits high, diuided into diuers branches, whereupon do growe gallant blewe flowers, compofed of fiue leaues a peece, out of the middle of which growe foorth blacke threds, ioined in the top, and pointed like a broch or pyramide: the root is threddie, and cannot away with the colde of winter.

2 Borage with white flowers is like vnto the precedent, but differeth in the flowers, for thofe of this plant are white, and the others of a perfect blewe colour, wherein is the difference. 
I Borago bortenfss. Garden Borage.

40

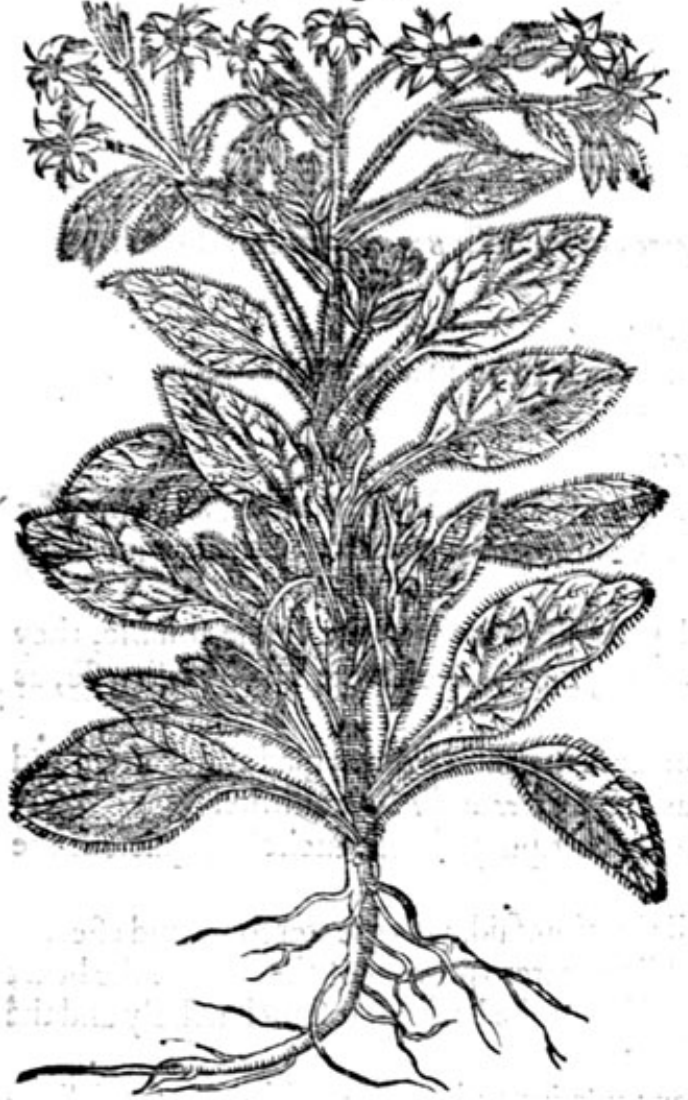

3 Borago femper virens.

Neuer dying Borage,

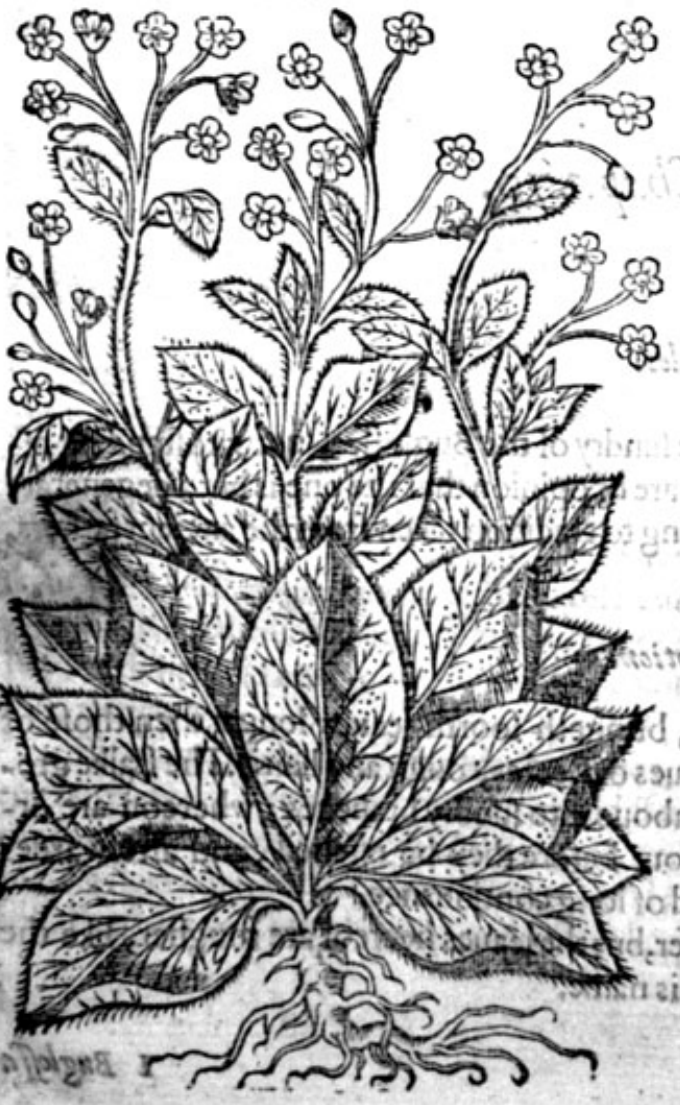

2 Boragofore albo. White towred Borage.

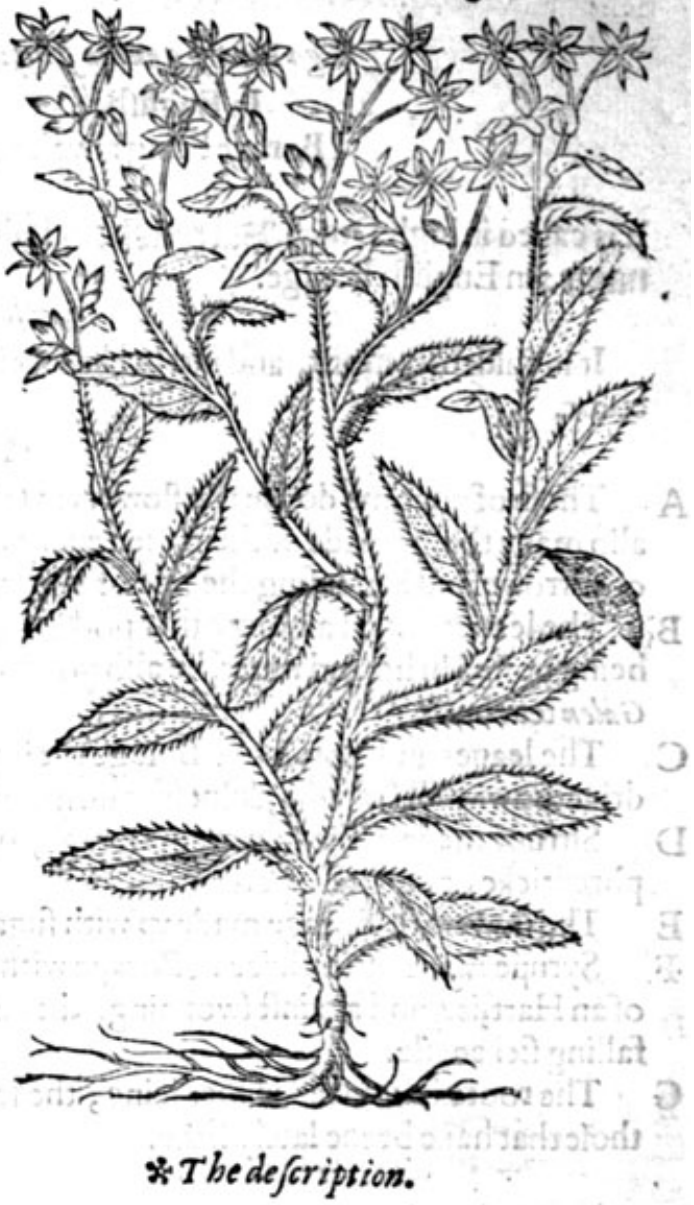

3 Neuer dying Borage hath many verie broade leaues, rough and hairie, of a blacke darke greene colour : among which rife vp ftiffe hairie ftalkes, whereupon do growe faire blew flowers, ripe feed, and buds for newe flowers, allat once; whereupon it was called Semper virens, and that veryproperly, bicaufe it is not to be feen neither winter nor formmer, but alwaies at one time, with greene leaues, faire flowers, buds, ripe and vnripe leed, wherby it greatlyincreafeth. The roote is very durable.

There is a fourth fort of Borage, that hath leaties like the precedent, but thinter \& leffer, rough and hairie, diuiding it felfe intobranches at thebottom of the plant, whereupon are placed fairered flowers, wherein is the chiefeft difference betwcene this and the laft defcribed.

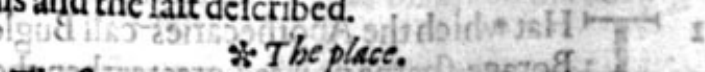
Thefe grow in mygarden, and in others alfo. * The trome.

Borage flowreth and flourifheth moft part of allfommer, audd till Autumne be far fpent.

$\approx$ The natres.

Borageis called in thops Borago: of the old writers Poo' jaewor, which is called in Latine LingaA BU- 
bula : Pliny calleth it Euphrofonum, bicaufe it maketh a man merrie and ioyfull : which thing alfo the olde verfe concerning Borage doth teftifie:

Ego Borago gandia femper ago.

In Englifh.

I Borage bring alwaies courage.

It is called in high Dutch 23utretfty: in Italian Boragine : in Spanifh Boraces: in low Dutch 26eto nagie : in Englifh Borage.

\section{* The temperature.}

It is euidently moift, and not in like fort hot, but feemeth to be in a meane betweene hot and colde.

* Thevertues.

A Thofe of our time do vfe the flowers in fallads, to exhilarate and make the minde glad. There be alfo many things made of them, vfed euery where for the comfort of the hart, for the driuing away of forrowe, and increafing the ioie of the minde.

B The leaues boiled among other potherbs, do much preuaile in making the bodie foluble, they being boiled in honied water, be alfo good againft the roughnes of the throte and hoarfeneffe, as Galen teacheth.

C The leaues and flowers of Boragepurinto wine, maketh men and women glad and merrie, and driueth away all fadneffe, dulneffe, and melancholie, as Dio corides and $P$ linie affirme.

D. Sirrupe made of the flowers of Borage, comforteth the hart,purgeth melancholie, quieteth the phrenticke or lunaticke perfon.

E The flowers of Borage made vp with fugar, doth all the aforefaid, with greater force and effect.

- F Syrupe made of the iuice of Borage with fugar, adding thereto powder of the bone in the heare of an Hart, is good againft fwouning, the cardiacke paffion of the hart, againit melancholy and the falling fickeneffe. G The roote is notvfed in medicine, the leaues eaten rawe ingendreth good bloode efpecially in
thofe that haue beene lately ficke.

\section{Of Bugloffec: Chap.270. \\ *Thekindes.}

Ike as there be diuers forts of Borage, fo are there fundry of the Bugloffes, notwithftanding af ter Diolsorides, Bugloffe is the true Borage; many are of opinion that the one is but a degenerate kinde from the other, yet will we diuide them according to tradition taken from the ancientfathers, Diofcorides, Plimie, and others.

\section{* The defoription.}

I Hat which the Apothecaries call Bugloffe, bringeth foorth leaues longer then thofe of Borage, tharpe pointed, greater then the leaues of Beetes, rough and hairie. The ftalke groweth vp to the height of tivo cubits, parted aboue into fundry branches; whereon are orderly placed blewifh flowers tending to a purplc colour before they be opened, and afterwardes more blewe. The roote is long, thicke, and groffe, and of long continuance. 2 Lang de Beefe is a kinde heereof, altogither leffer, but the leaues heereof are rougher, like the rough toong of an Oxe or Cowe, whereof it tooke his name. 


\section{Buglofavalgaris.}

Common Buglofie, or garden Bugloffe.

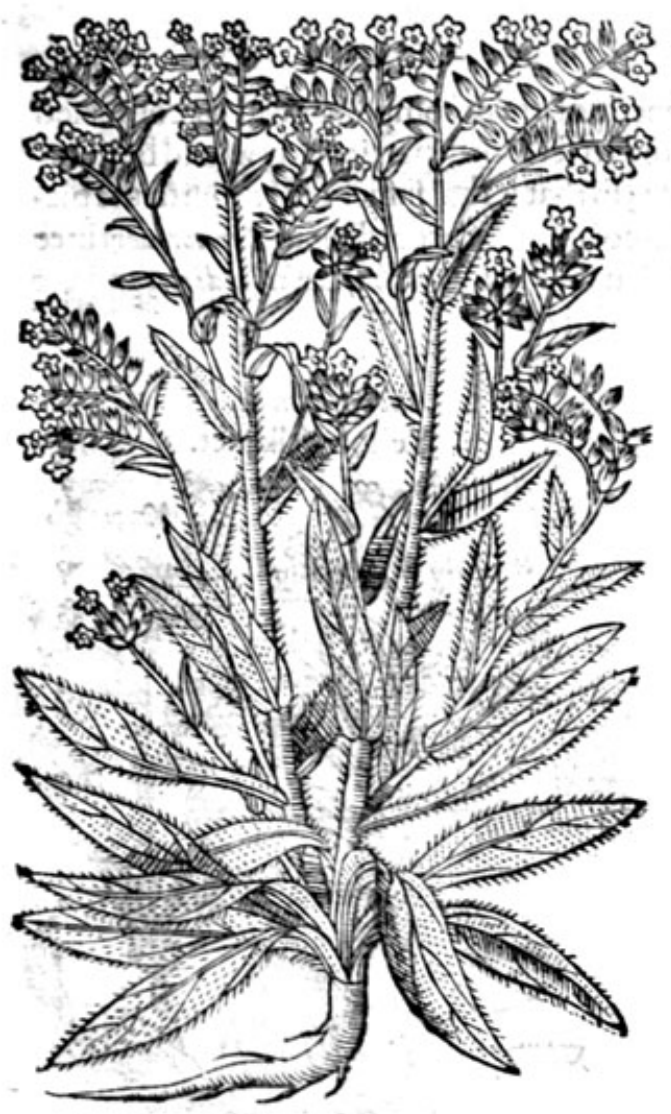

2 Bugloffunluteum. Lang de beefe.

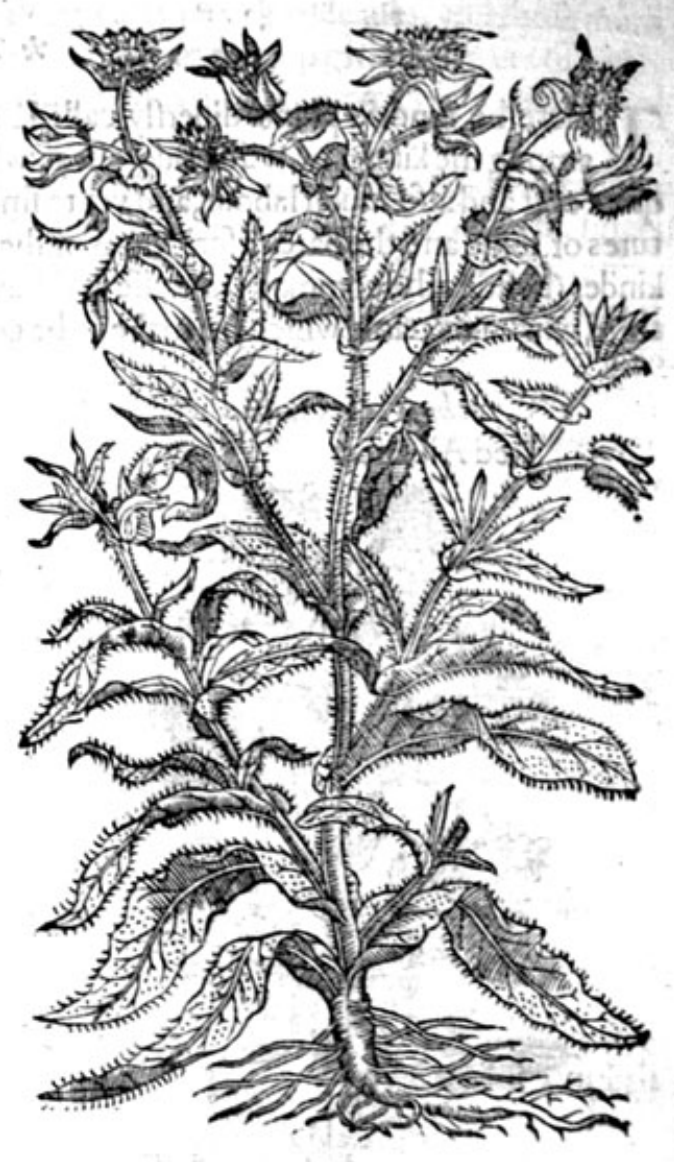

Thefe do growe in gardens euery where.

* The plase.

They time. They flower from Maic, or Iune, euen to the ende of Sommer. The leaues perifh in winter,and
newe come vp in the fpring.

Garden Buglofle is called of the later $*$ The names. gloffe. Lange de beefe, is called in Latine, Lingua bouts, and Bugloffum luteum, of fome Hieracio cognation,
and alfo Bugloffa fylueffris, or wilde Bugloflc.

$*$ The temperature and vertues.

Theroote faith Diofcorides mixed with oile, cureth greenewounds, and adding therto a little bar- A ley meale, itis a remedie againft Saint Anthonies fire. It caufech fweat in agues, as $P$ linie faith, if the iuice be mixed with a little a gus vite, and the body B
rubbed therewith. The Phifitions of the later time vfe the leaves, flowers, and rootes, in fteede of Borage, and put C
them both into alldkindes of medicines indiffer awaie forrowe and penfiueneffe of the minde, andently, which are of force and vertue to drive ate of like operation with thofe of Borage, and to comfort and ftrengthenthe hart. The leaues as vell Bugloffe,as Lang debeefe, and alfo to keepe the bellie foluble.

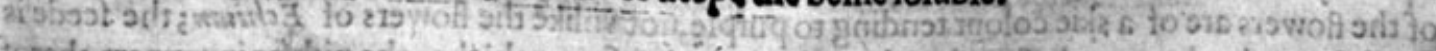

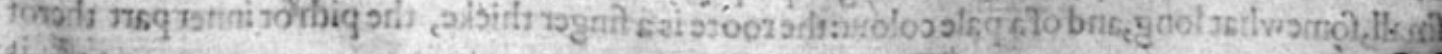

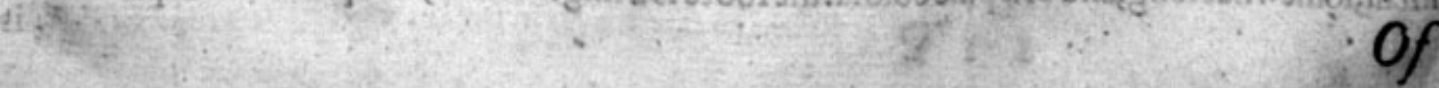




\section{Of Alkanet or wilde Bugloffe. Chap.271.}

* The kindes.

$T$ Here be fundrie plants diuerfly called, and yet euerie of them comprehended or conteined

among the kindes of wilde Bugloffes, whofe figures to fetfoorth particularly would both require coft and alfo much labour, and yet to fmall purpofe; fo that it thal fuffice to fet foorth the pictures of fome and the bare defcriptions of the reft : whereof there be according to Diofcorides three kindes (befides the common Buglofie and Landebeuf) that is to fay, Onoclia, cllcibiadion, and the third without a name which we make to be Onofma. And firft of

I Anchnsa Alcibiadion Red Alkanet.

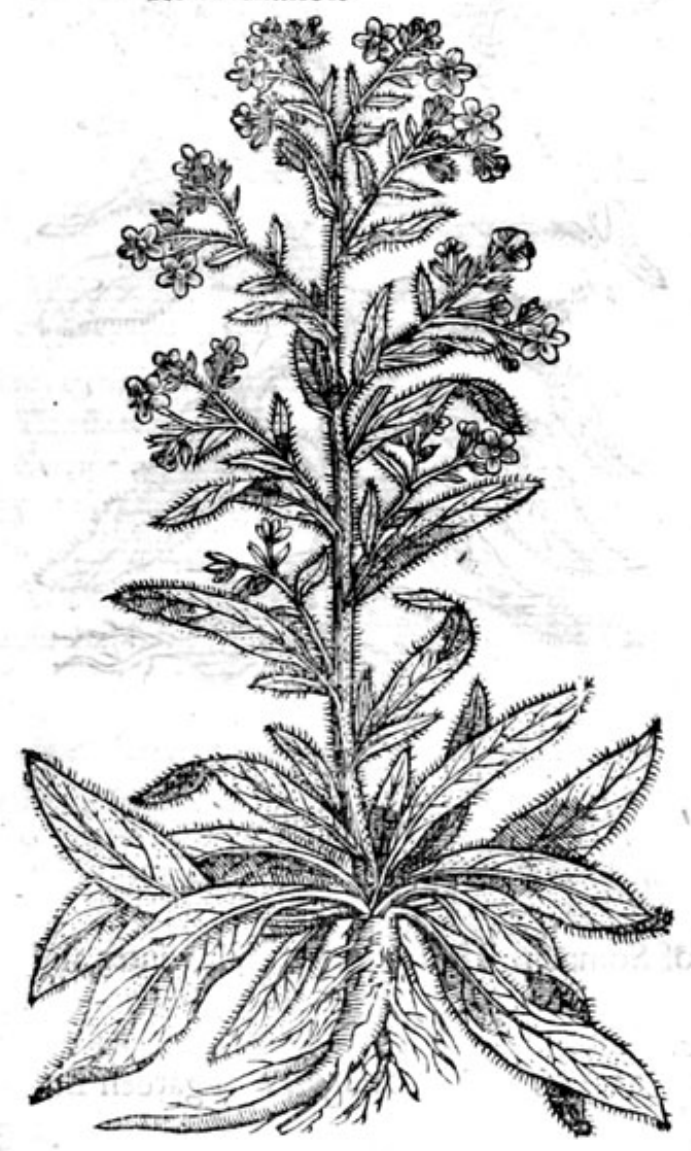

2 Anchugalutea. Yellow Alkanet.

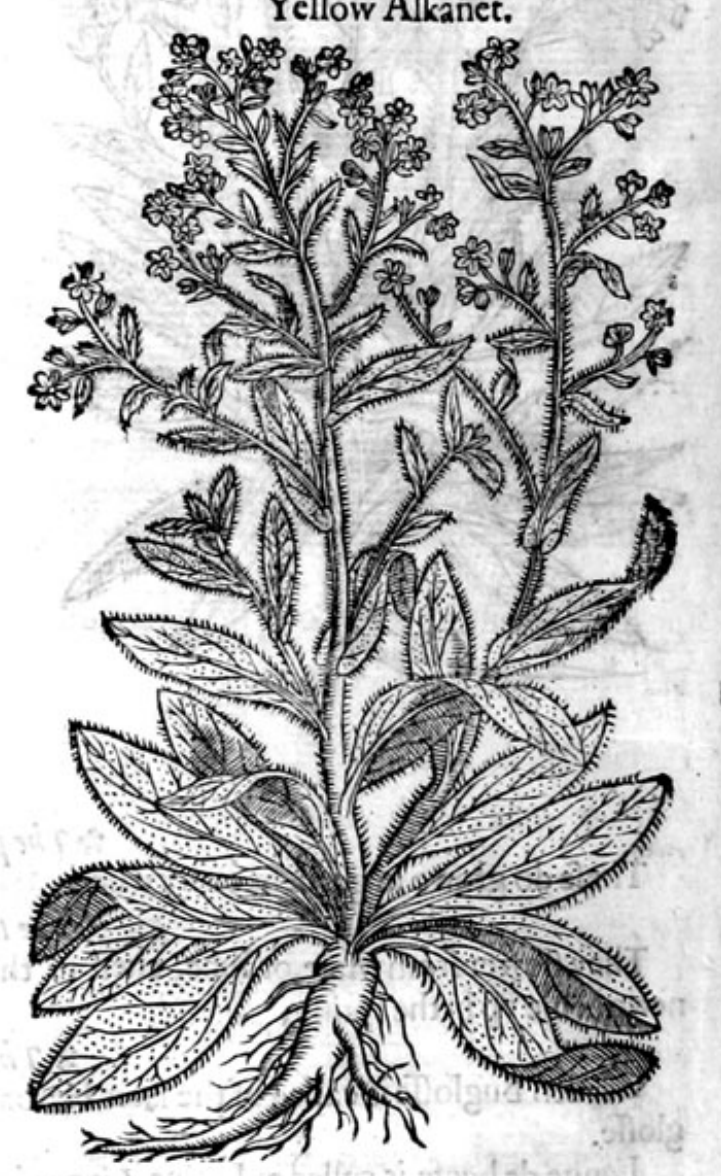

* The defoription.

7 Hefe herbes comprehended vnder the name of Anchufa were fo called of the Greeke word ànevou: i.illinere /acco, vel pigmentis, that is to colour or paint any thing:wherupon thefe plants were called Anchufa of that flourifhing and bright red colour which is in the roote, euen as red as pure and cleere blood: for that is the onely note or marke whereby to diftinguifh thefe herbes from thofe which be called Echï, Lycop/ss, and Buglof $f_{a}$, whereof they make a great refemblance: I haue therefore cxpreffed fowcr differences of this plant Aischufa or Alkanet from the other kinds, by the leaues, flowers, and bigneffe.

I The firft kinde of Alkanet hath many leaues like Echium, or fmall Bugloffe,couered ouer with a prickly hoarines, hauing commonly but one ftalk, which is round, rough, \& a cubite high. The cups of the flowe is are of a skie colour tending to purple, not vnlike the flowers of Echism; the feede is fmall,fomewhat long, and of a pale colour: the roote is a finger thicke, the pith or inner part therof 


\section{GH HIST ORIE OFI PDANTS:HT}

is of woodie fubftance, dying the hands or whatfoeuer toucheth the fame, of abloodie colour, or of the colour of faunders.

2 The fecond kinde of $A n c h u / A$ or Alkanet, is of greater beautie and eftimation then the firft, the branches are lefte and more bufhie in the top: it hath alfo greater plentie of leaues, and thofe more woolly or hairie : the ftalke groweth to the heiglit of two cubits : at the top growe flowers of a yellowe colour, farre different from the other : the roote is more fhining, of an excellent delicate purplifh colour, andmore full of iuice then the firft.

There is a fmall kinde of Alkanet, whofe roote is greater and more full of iuice and fubftaunce then the rootes of the other kinds; in all other refpects it is leffe, for the leaues are narrower, fmaller, tenderer, and in number more, very greene like vnto Borage, yeelding foorth many little tenderftalks: the flowers are leffe then of the fmall Bugloffe, and red of colour : the feede is of an afhe colour fomewhat long and flender, hauing the tafte of Bugloffe.

There is alfo another kinde of Alkanet, which is as the others before mentioned, a kind of wilde Bugloffe, notwithftanding for diftinction fake, I haue feparated and feuered them. This laft Anchusa hath narrowe leaues, much like vnto our common fommer Sauorie. The ftalkes are two handfuls high,bearing very fmall flowers, and of a blewifh or skie colour : the roote is of a darke brownifh red colour, dying the hands little or nothing at all, and of a woodie fubftance.

$$
\text { *The place. }
$$

Thefe plants do grow in the fieldes of Narbone, and about Montpelier, and many other parts of Fraunce: I found thefe plants growing in the Ile of Thanet neere vinto the fea, betwixt the houfe fometime belonging to Sir Henrie Crippe, and Margate: where I founde fome in their naturall ripenes, yet fcarcely any that were come to that beautifull colour of Alkanet :but fuch as is folde for very good in our Apotkecaries fhops, I found there in great plentie.

\section{$*$ Thetime.}

The Alkanets flower and flourifh in the fommer moneths : the rootes doyeelde their bloody iuice in harueft time, as Diofcor ides writeth.

$$
\text { \& } 7 \text { be names. }
$$

Alkariet is called in Greeke inesor: in Latine alfo Anchufa, of diuers Fuces berba, and Onosleia, Bugloffa Hi/panica, or Spanilh Bugloffe: in Spanilh Soagem: in French Orchanets : and in Englifh likewife Orchanet, and Alkanet.

\section{* The temperatare.}

The rootes of Alkanet are cold and drie as Galen writeth, and binding, and bicaufe it is bitter it clenfeth awaie cholericke humours, the leaues be not fo forceable, yet do they likewife binde and drie.

\section{* The vertues.}

Diofcorides faith, that the roote being made vp into a cerote, or ferecloth with oile, is very good for old vlcers; that with parched barley meale it is good for the leprie,\& for tetters or ring wormes. That being vfed as a peffarie it bringeth foorth the dead birth.

The decoetion being inwardly taken with meade or honied water, cureth the yellowe iaund:fe, difeafes of the kidneies, the fpleene and agues. laske.

It is ved in ointments for womens paintings: and the leaues drunke in wine is good againft the D

Diuers of the later Phifitions do boile with the roote of Alkanet and wine, fiveete butter; fuch $\mathbf{E}$ as hath in itno falt atall, vntill fuch time as it becommeth red, which they call red butter, \& giue it not onely to thofe that haue fallen from fome high place, but alfo report it to bee goud todriue foorth the mealels and fmall poxe, if it be drunke in the beginning with hot beere.

The rootes of thefe plants are vfed to colour firups, waters, geilies, and fuch like confections, as F Turnfole is.

Iobn of Arderne hath fet downe, a compofition called Sanguis veneris, which is moft fingular in G deepe punctures or wounds made with thrufts, as followeth: Take of oile Oliuez pint, the rootes of Alkanet two ounces, earth woormes purged, in number twentie, boile them togither and keepe it to the vfe aforefaid.

The gentlewomen of Fraunce do paint their faces with theferootes, as it is faid. 
I Lycop/is Anglica.

Vipers Buglofle, or wall Bugloffe.

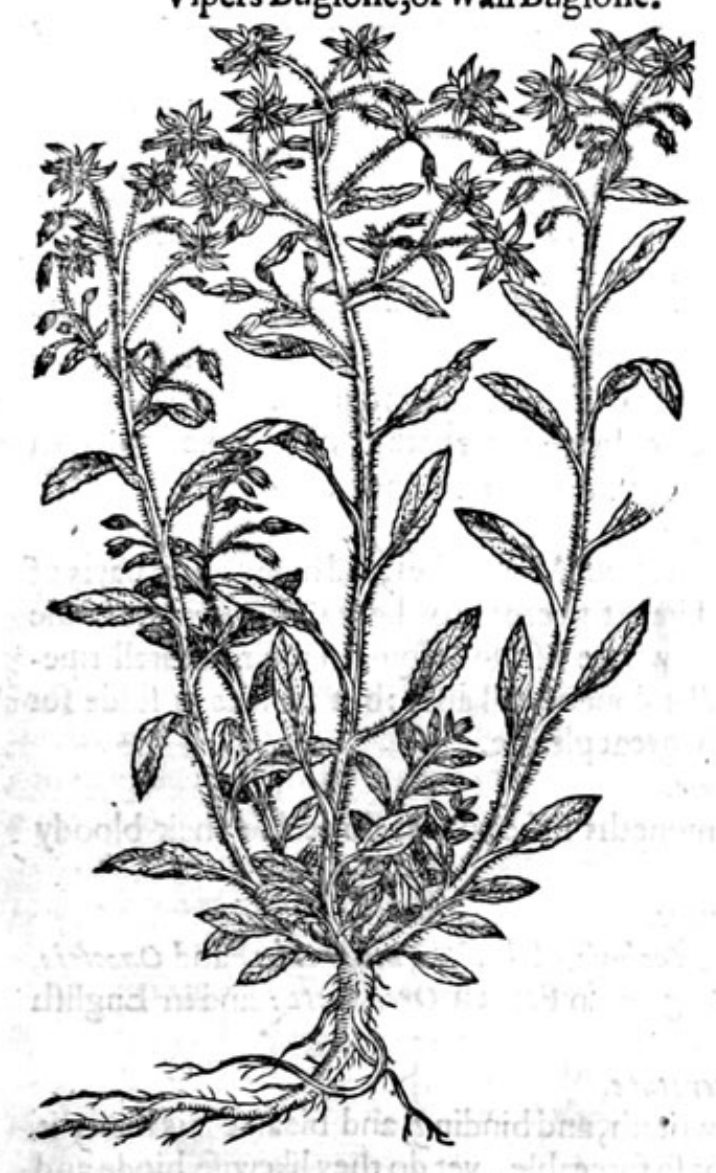

2 Onofma.

Stone Bugloffe.

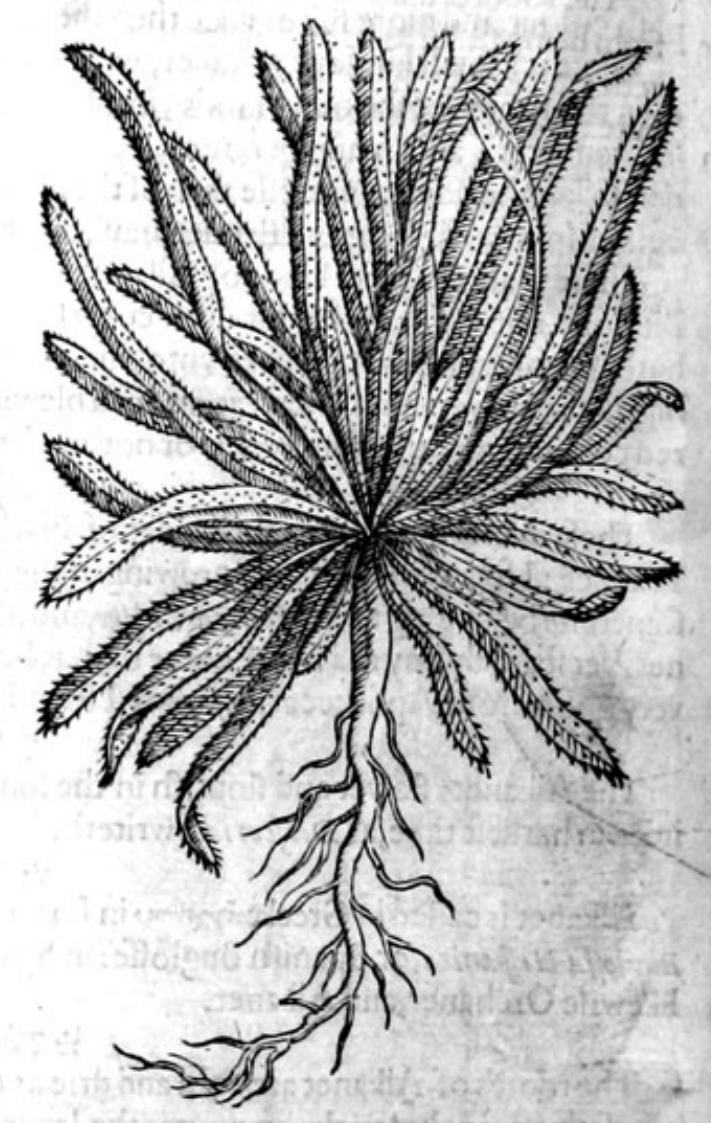

* The defcription.

${ }^{2} \mathrm{~L}$ $r$ copfis Anglica, or wilde Bugloffe, fo called for that it doth not growe fo commonly elie where, hath rough and hairie leaues, fomewhar leffer then the garden Bugloffe: the flowers grow for the molt part vpon one fide of the flender ftalke, in fal hion hollow like a litcle bel, के whereof fome be blew, and others of a purple colour.

2 There is another kind of Ecbutum that hath rough \& hairie leaues likewife, much like vnto the former : the ftalke is rough, charged full of little branches, which are laden on euery fide with diuers fmall narrowe leaues, tharpe pointed, and of a browne colour, fcattered or fpred like little feathers: among which leaues growe the flowers, of a $\mathrm{ad}$ biew or purple colour at the firft, but when they are open they thewe to be of an azure colour, long, and hollow, hauing certaine fmallblewe threds in the middle : the feede is fmall and blacke, fafhioned like the head of a fnake or viper: the roote is. long, and red without.

\section{* Theplace.}

Lycop/is groweth vpon ftone wals, and vpon drie barren ftonie grounds.

Echivon groweth where Alkanet doth groive, in gieat abundance.

$$
\approx \text { The time. }
$$

They flourith when the other kinds of Buploffes do fower.

$$
\text { * The names. }
$$

It is called in Greekeixo", Ecbitum, and eivutictor: Alcibiadion, of alcibiades the finder of the vertues thereof: of fome thought to be Anchufa pecics, or a kinde of Alkanet: in high Dutch wilde Debfenzintingen + in Spanifh Yerua de la Btwora, or Chupamel; in Italian Bugloffa faluatica: in French 


\section{HISTORIE OF PLANTS. BNT}

Rugloffe fausage : in Englifh vipers Bugloffe, Snakes Bügloffe, and of fome vipers herbe, and wilde Buglofle the leffer.

Thefe herbes are colde and drie of conplexion.

\section{* The temperature.}

* 7 he vertues.

The roote drunke with wine is good for thofe that be bitten with ferpents, and it keepeth fich $\mathbf{A}$ from being ftung as haue drunke of it before; the leaues and feedes cothe fame, as Diofcorides writeth : 2 icander in his booke of Treacles, maketh vipers Bugloffe to be one of thofe plants, which cure the biting of ferpents, and efpecially of the viper, and that drite ferpents away.

If it be drunkc in wine or otherwife, it caufeth plentic of milke in womens brefts.

The herbe chewed, and the iuice fwallowed downe, is a moft fingular remedie againft poifon, and the bitings of any venemous beafts, and the roote fo chewed, and laide vpon the fore worketh the fame effect.

\section{Of Houndestoong. Chap:273.}

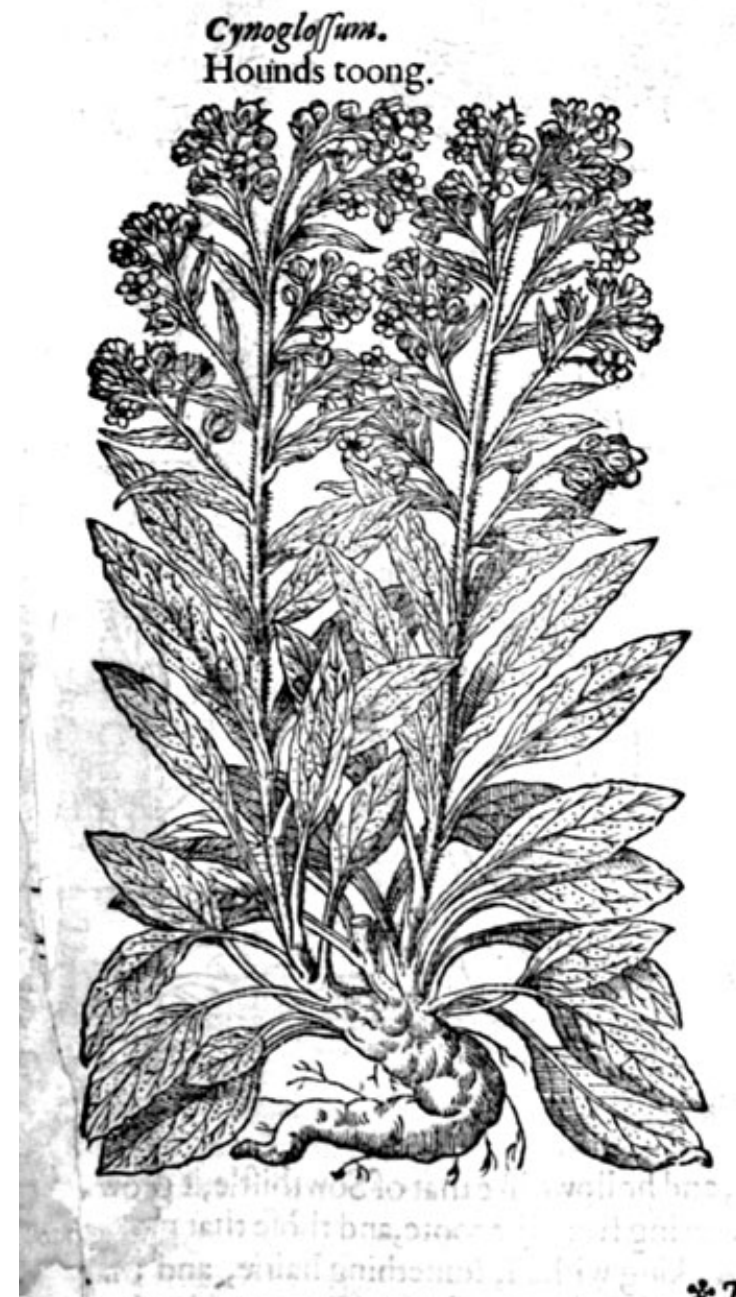

They flower in Iune and Iulie.

\section{*The time.}

* The names.

Houndes toong is called in Grecke xurizanosor: in Latine Lingua Caris, of Pling Cymogloffos, and heweth twokindes thereof: in Englifh Hounds toongs; but rather Hounds piffe, for in the world here is not any thing fmelleth fo like vnto dogs piffe, as the leaues of this plant do.

Hot inds toong but efpecially his roote, is colde and drie. 
* The vertues.

A The rootes of Houndes toong rofted in the embers and laide to the fundament, healeth the hemorrhoides, and the difeafe called Ignis Sacer, or wilde fire.

B The inice boiled with honie of rofes and Turpentine, to the forme of an vringuent, is moft fingulat in wounds and deepe vilcers.

C Diofcorides faith, that the leaues boiled in wine and drunke, do mollifie the bellie, and that the leaues ftamped with old fwines greafe, are good againt the falling away of the haire of the heade, which proceedeth of hot Tharpe humours.

D Likewife they are aremedie againft fcaldings or burnings, and againft the bitings of dogs, as the fame author addeth.

\section{Of Comfrey, or the great Confound. Chap.274.}

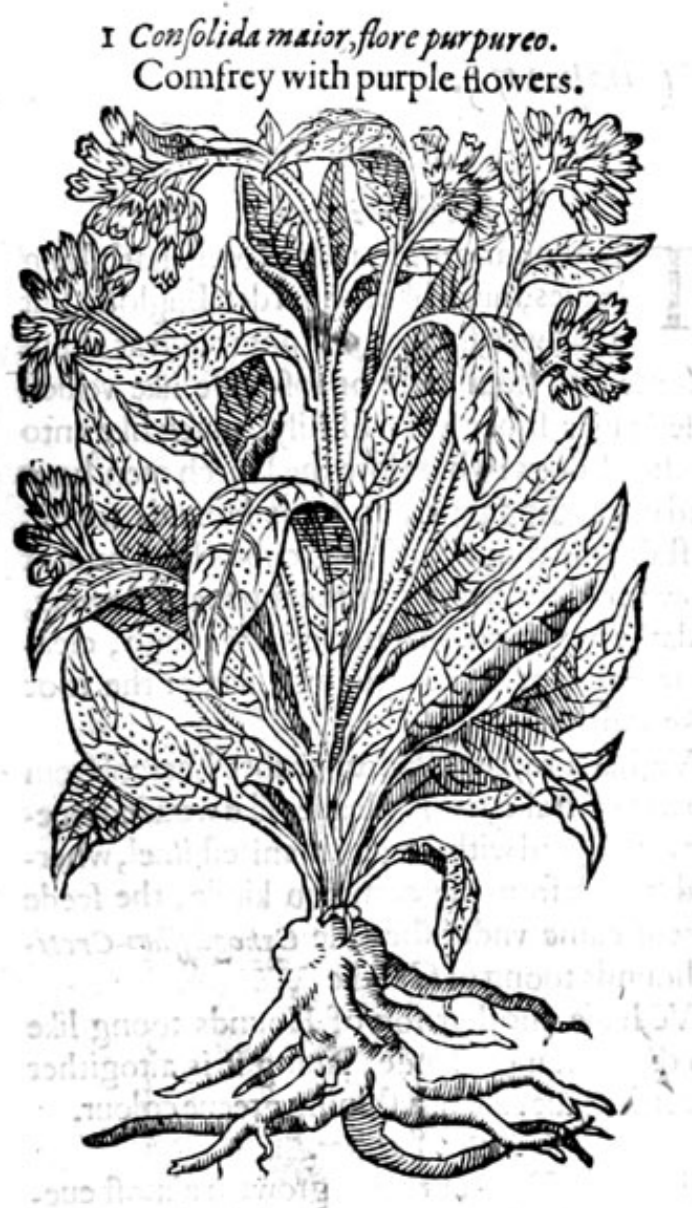

2 Conjolida maior, flore albo. Comfrey with white flowers.

* Thedefoription:

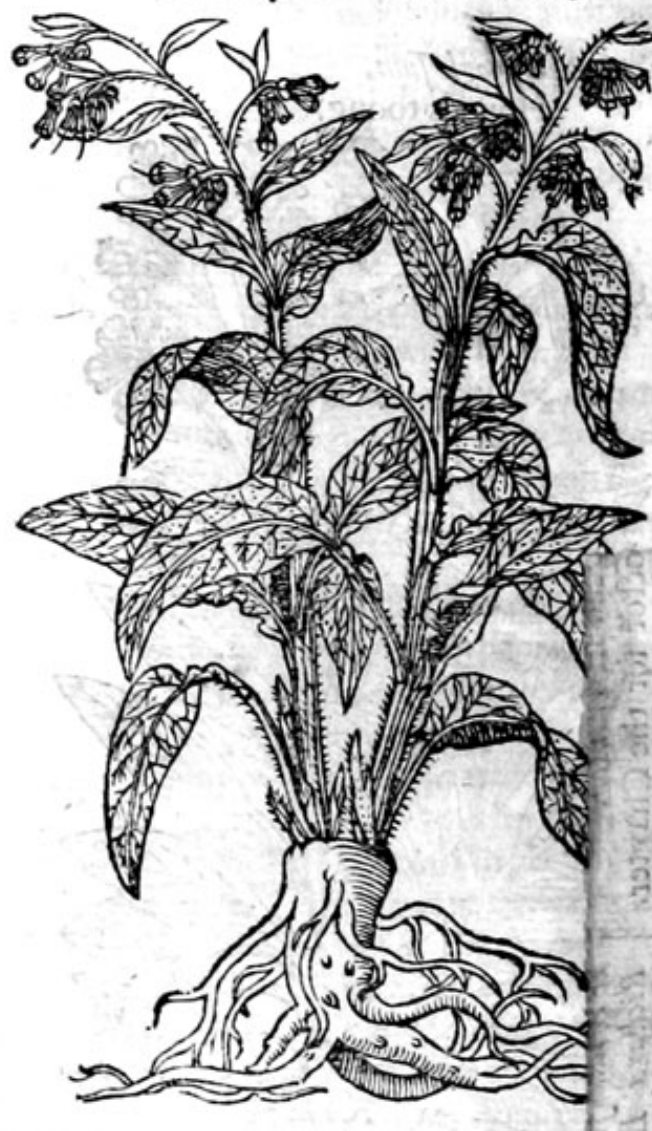

1 He ftalks of this Comfrey is cornered, thicke, and hollowe like that of Sowthiftle, it $\mathrm{g}$ eth two cubits or a yarde high:the leaues that f pring from the roote, and thofe that g vpon the ftalks are long, broade, rough, and pricking withall, fomething hairie, and tirat being handled, make the hands itch, very like in colour and roughnes to thofe of Borrage, but longer and harpe pointed, as be the leaties of Elcc.ampane : from our the wings of the ftalkes appeere the flowers,orderly placed, long, hollowe within, of a light redde colour: after them groweth the feed which is blacke: the roote is long and thicke, blacke without, white within, hauing in it a clarng mie iuice, in which roote confifteth the vertue.

2 The great Confrey hath rough hairie ftalks, long rough leaues, much like the garden Buglofiz, but greater and blacker: the flowers be round and hollowe like little bels, of a white colour:ther rooe is blacke without, and white within, and veryflimie. 


\section{HISTORIE OF PLANTS:}

There is another kinde of Comfrey that hath leaues like the former, fauing that they belefler: the ftalks are rough and tender ; the flowers are like the former, but that they be of an ouerworne yellow colour : the rootes are thicke, (hort, blacke without, and tuberous.

$$
\text { * Theplace. }
$$

Comfreyioyeth in watrie ditches, in fat and fruitfull medowes; they grow all in my garden.

They flower in Iune and Iuly. * T be time.

* The names.

It is called in Greeke súpurur :in Latine Symphytum, and Solidago: in thops Confolida maior, and Symphytum maizus : of Scribonius Largus, Inula rustrca, and Alus Gallica, of others Ofteocollon: in high

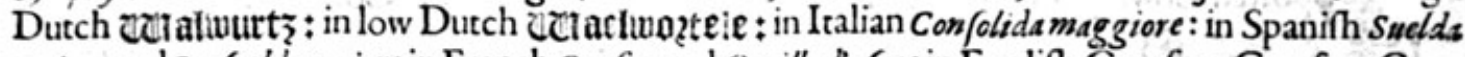
maiore, and confwelda maior: in French Confree, and Oreille d's $s n e$ : in Englifh Comfrey, Comfrey Confound, of fome Knit backe, and Blackwoort.

\section{*ै The temperature.}

The roote of Comfrey hath a colde qualitie, but yet not much:it is alfo of a clammie and gluing moifture, it caufeth no itch at all, neither is it of a fharpe oi biting tafte, vnfauorie, and without anie qualitie that may be tafted, fo farre is the tough and gluing moifture from the fharpe clammineffe of the fea Onion, as that there is no comparifon betweene them. The leaues may caufe itching not thorow heat or fharpneffe, but through their ruggednes, as we haue alreadic written, yet !effe then of Nettle.

\section{* The vertues.}

The rootes of Comfrey ftamped, and the :uice drunke with wine, helpeth thofe that fpit bloude, A and healeth all inward wounds and burftings.

The fame brufed and laide to in manner of a plaifter, doth heale all frefh and greene woundes, B andare fo glutinatiue, that it will fodder or glewe togither meate that is chopt in peeces feething in a pot, and make it in one lumpe.

Therootes boiled and drunke, doth clenfe the breft from Alegme, and cureth the greefes of the $\mathbf{C}$ lungs, efpecially if they be confect with fugar in fyrupe, it preuaileth much againft ruptures or burftinges.

The flimie fubftance of the roote made in a poffet of ale, and giuen to drinke againft the paine in D the backe, gotten by any violent motion, as wraftling,or ouermuch vfe of women, doth in fower or fiue daies perfectly cure the fame: although the inuoluntarie flowing of the feed in men be gotten thereby.

The rootes of Comfrey in number fower, Knotgraffe, and the leaues of Clarie, of eche an handfull, being ftamped altogither, and ftrained, and a quart of Mufcadell put thereto, the yolkes of three egges, and the powder of three Nutmegs, drunke firt and laft, is a moft excellent medicine againft Gonorrhæa or running of the raines, and all paines and confumptions of the backe.

There is likewife a fyrupe made heere of to be vfed in this cafe, which ftaieth voiding of bloude: F tempereth the heate of agues; allaicth the fharpneffe of flowing humours: healeth vp vlcers of the lunges, and helpeth tbe cough : the receit whercof is this : Take two ounces of the rootes of great Comfrey, one ounce of Lyquorice; two handfuls of Folefoot rootes and all; one ounce and a halfe of Pine apple kernels; twentic iuiubes; two drams or a quarter of an ounce of Mallowe feede ; one dram of the heads of Poppie; boile all in a fufficient quantitic of water, till one pint remaine, ftraine it, and adde to the liquor itrained fixe ounces of very white fugar, and as many of the beft honie,and
make hecreof a fyrupe that muft be throughly boiled.

The fame fyrupe cureth the vicers of the kidneies, though they haue been of long continuance : $G$ and ftoppeth the bloud that commeth from thence.

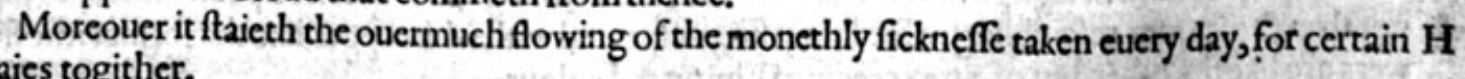
daies togither.

It is highly commended for wounds or hurts of al the reft alfo of the intrailes and intward parts, I and for burftings or ruptures.

The rootes itamped and applied vnto them, taketh arvay the inflammation of the fundament, and $\mathbb{K}$ ouermuch flowing of the hemorrhoides. 


\title{
Of Complips of ferufalem. Chap.275.
}

\author{
* Thekindes.
}

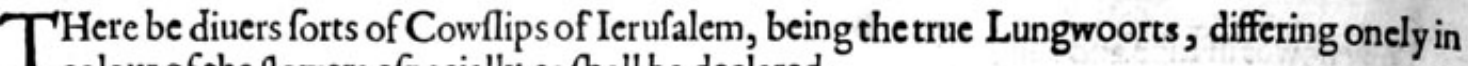
colour of the flowers efpecially, as fhall be declared.

I Pulmonaria maculoja. Spotted Cowllips of Ierufalem.

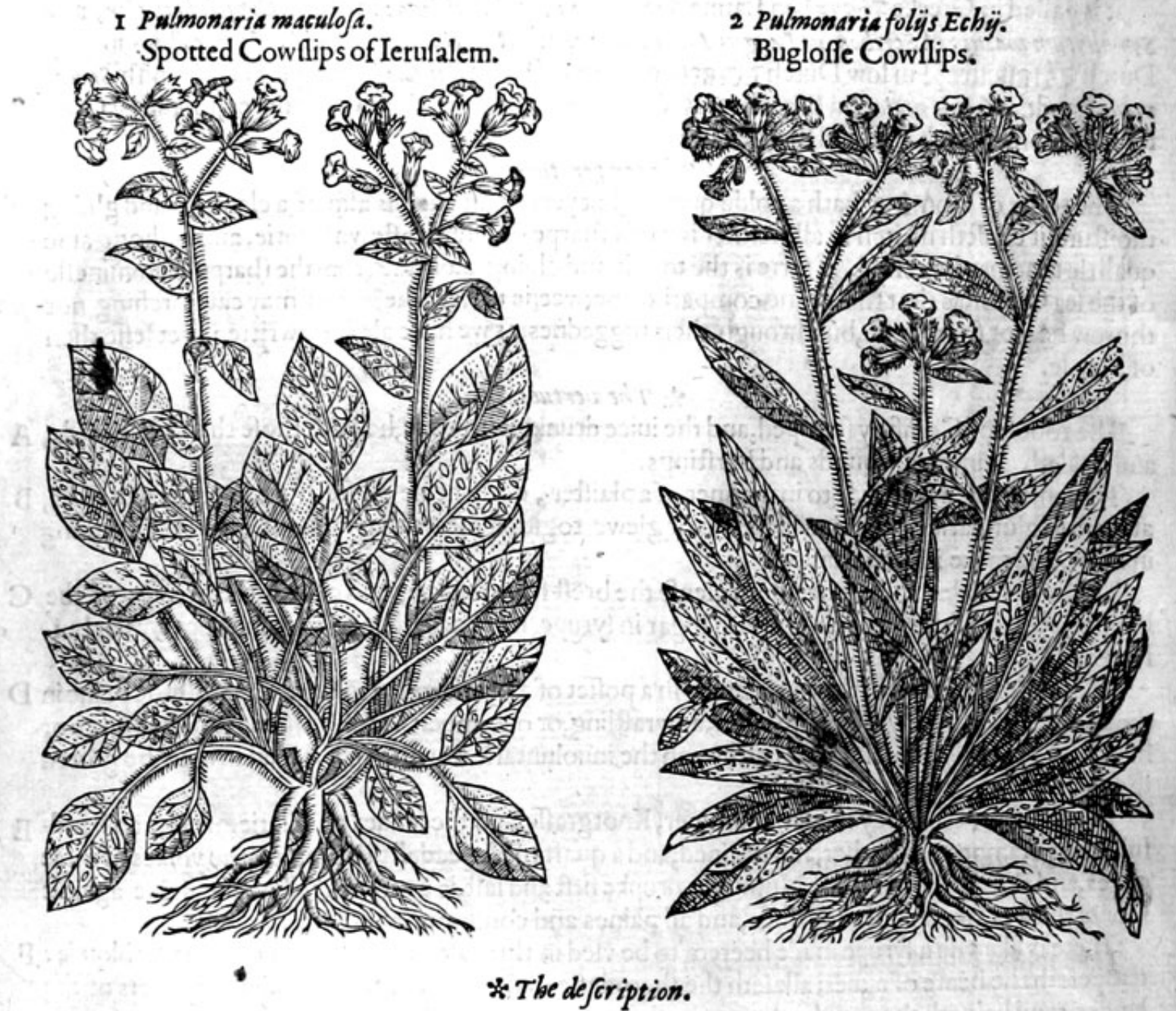

2 Pulmomaria folÿs Echï. Bugloffe Cowflips.

I Owflips of Ierufalem or the true and right Lungwoort, hath rough, hairie, \& large leaues, of a browne greene colour, confufedly fpotted with diuers fpots, or droppes of white: amongft which fpring vp certaine ftalks, a fpan long, bearing at the top many fine flowers, growing togither in bunches like the flowers of Cowflips, fauing that they be at the firft red or purple, and fomtimes blewe,and of tentimes of all thefe colours at once. The flowers being fallen, there come fmall buttons full of feed. The roote is blacke and threddie.

2 The fecond kind of Lungwoort is like vnto the former, but greater in ech refpect: the leaues bigger then the former, refembling wilde Buglofie,yet fpotted with white fpots like the former: the flowers are like the other, but of an exceeding fhining red colour.

3 . Carolus Clus/rus fetteth foorth a thirde kinde of Lungwoort, which hath rough and hairie leaues, top a bundlde Bugloffe, but narrower : among which rifeth vp a ftalke a foote high, bearing at the 4 Pena fete of blew flowers, in fafhion like vnto Sopewoort.

leaucs are like fourth likewife a kinde of Lungwoort which naturally groweth in Fraunce, whofe no vfe in Phificke. Enditie: the flowers yellowe, and like vnto the Haukeweedes, both which haue 
3 Pulwonaria ongufiffoliay. Clufa.

Narrow leafed Cowllips of Ierufalem.

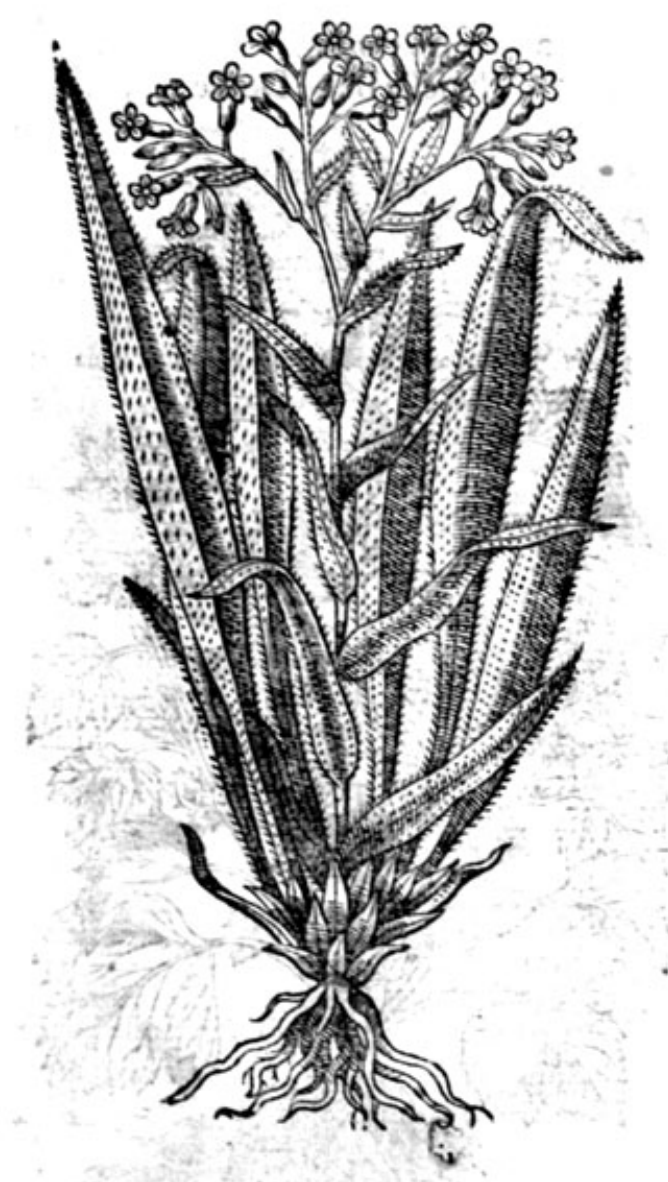

4 Pulmomatia Gallorwon?

French Cowllips of Ierufalem,

\& The place.

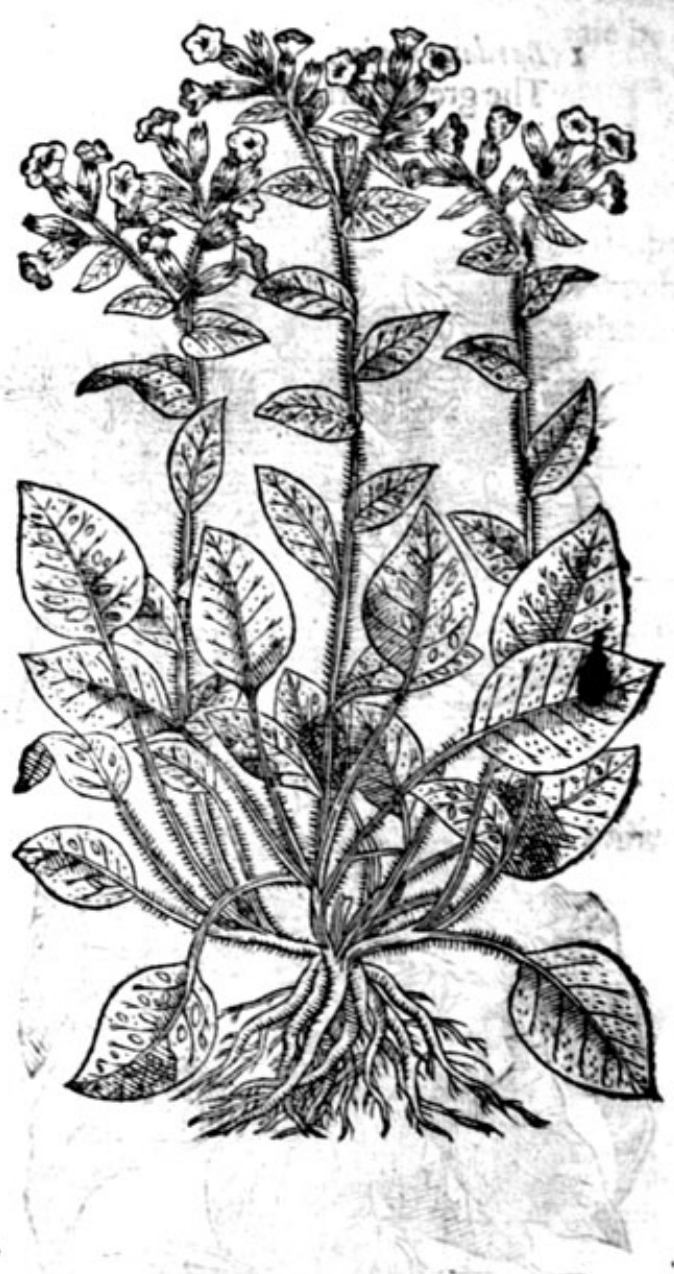
dens.

Thefe plants do growe in moift hadowic woods, and are planted almoft euery where in gatdens.

* The time.
They flower for the moft part in March and Aprill.

\section{* 7 be names.}

Cowllips of Ierufalem, or Sage of Ierufalem, is called of the Herbarifts of our time, pulbronaria, and Palmonalas; of Cordses, Symphytsm fylueftre, or wilde Comfrey : but feeing the other is alfo of nature wilde, it may aptly be called Symphytum maculofuw, or Maculation: in high Dutch

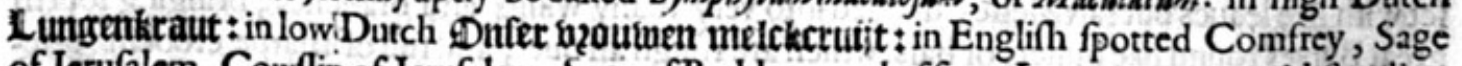
of Ierufalem, Cowflip of Ierufalem, Sage of Bethlem, and of fome Lungwoort; notwitbitanding there is another Lungwoort, of which we will intreat among the kindes of Moffes.

Pulmonaria, thould be of like temper ature.

mie but feeing hat it is have temperature with the great Comfrey if the roote of this were clammie : but feeing that it is hard and woodie, it is of a more drying qualitic, and more binding.

* Thevertues.

The leaues are vfed among pot herbs. The roots are alfo thought to be good againft the infirmi- A ties and vicers of the lungs, and to be of like force with the grear Comfrey.

$$
\text { T } 4
$$




\section{Of Clote Burre, or Burre Docke. Chap. 276 .}

1 Bardana maior. The great Burre Docke.

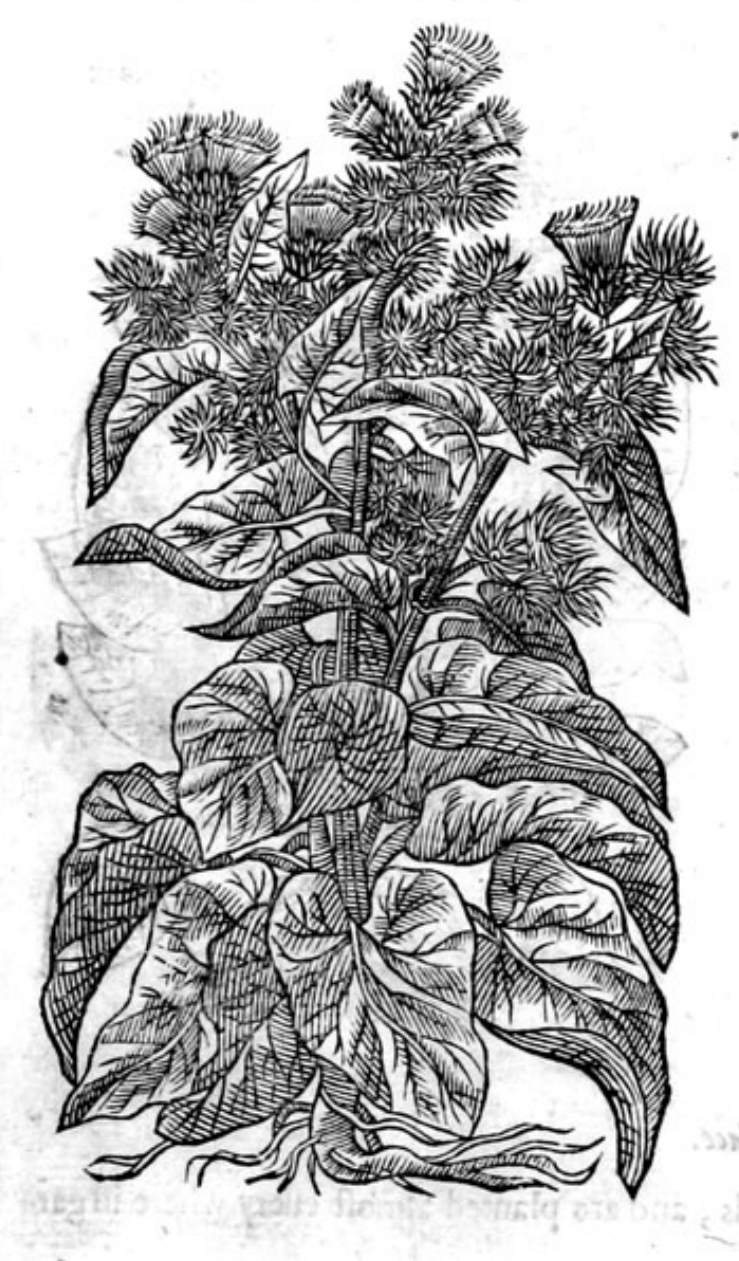

2 Bardana minor. Theleffe Burre Docke.

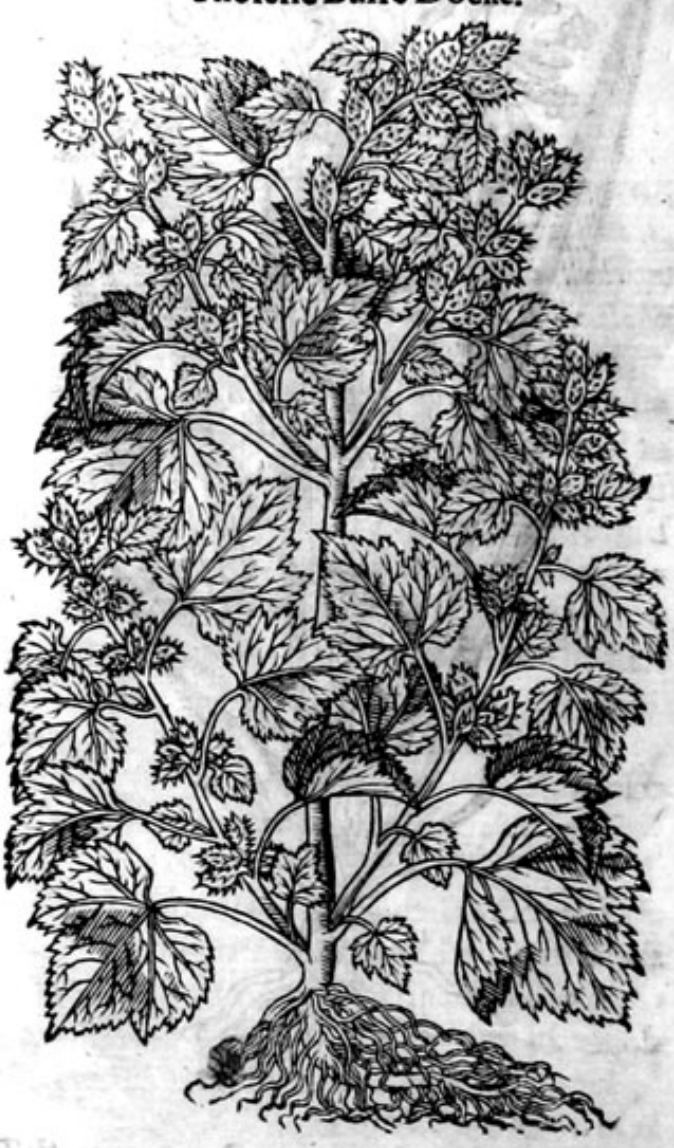

\section{* The defoription.}

C Lot Burre bringeth foorth broad leaues and hairie, far bigger then the leaues of Gourde and of greater compaffe, thicker alfo, and blacker, which on the vpper fideare of 2 darke greene colour, and on the neather fide fomewhat white : the ftalke is cornered, thicke, befet with like leaues but farre leffe, diuided into very many wings and branches, bringing foorth great Burres round like bullets or bals, which are rough all ouer, and full of harpe crooking prickles, taking holde on mens garments as they paffe by; out of the tops whereof groweth a Hower thrummed, or all of threds, of colour purple: the feede is perfected within the round ballor bullet, and this feede when the burres open, and the winde bloweth, is caried away with the winde : the roote is long,white within, and blacke without.

2 The leffer Burre hath leaues farre fmaller then the former, of a light green colour like to thofe of Orach, nicked round about the edges : the ftalke is a foote and a halfe high, full of little blacke pots, diuiding it felfe into many branches : the flowers before the Burres come foorth do compaffe the fmall ftalkes round about, they are but little and quickly vade aw ay: then followe the Burres or the fruit out of the bofome of the leaues, in forme long, on the tops of the branches, as bigge as an Oliue or a Cornell berrie, rough like the bawles of the Plane tree, and being touched cleaue 
faft vnto mens garments; they do not open at all, but beingkept clofe fhut bring foorth long

feedes. The roote is faftned with very manie ftrings, and groweth not deepe.
of the place.

The firft growech enerie where: the feconde I founde in the high waie leading from Draiton to Iuer, two miles from Colbrooke, fince which time I haue founde it in tbe hightwaie be. tweene Stanes andEgghim.

Their feafon is in Iulie and Auguft.

$$
\text { * The time. }
$$

* The names.

The great Burre is called in Greeke apxior : in Latine Perforata, per fovatia, and Lrcium: in thops

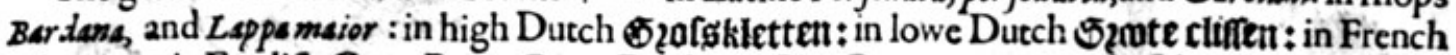
Glouteron : in Englifh Great Burre, Burre Docke, or Clot Burre: Apaleises befides thefe doth alfo fet downe certainc other names belonging to Clot Burre, as Dardana, Bacchion, Elephanto/is, Nephelion, Manifolisom.

The leffer Burre Docke is called of the Grxcians zijgror: in Latine Xantbium : in fhops Lapps minor, Lappa inuerfa, and of diuers Strumaria: Galen faith it is alfo called Pha/ganion, \& P hafsanon, or herbe Victorie, being but baftarde names, \& therefore not properly focalled : in Englifh Loufe Burre, Ditch Burre, and leffer Burre Docke; it feemeth to be called Xint bism of the effeet, for the Burre or fruite before it be fully withered being ftamped and put into an earthen veffell, and a ferwards when need requireth the weight of two ounces thereof and fomewhat more, being fteeped in warme water and rubbed on, maketh the haires of the head red; yet the head is firft to be dreffed or rubbed with niter,as Diofsori.tes writeth.

\section{* The temperature.}

The leaues of Clot Burre are of temperature moderately drie and wafting; the roote is fomething hot.

The feede of the leffer Burre as $G_{a l}$ es faith, hath power to digeft, therefore it is hot and drie. * The vertues.

The rootes being taken with the kernels of Pine apples, as Dijferides witneffeth, are good for $\mathbf{A}$ them that fpit bloud and corrupt matter.

Apuleizs faith, that the fame being ftamped with a little falt and applied to the biting of a madde $\mathbf{B}$ dogge, cureth the fame, and of fpecdily fetteth free the ficke man.

He alfo teacheth, that the iuice of the leaues giuen to drinke with honie, procureth vrine, and ta- C keth away the paines of the bladder, and that the fame drunke with olde wine doth woonderfully helpe againft the bitings of ferpents.

Coliomella declareth, that the herbe beaten with falt and laid vpon the fcarifying, which is made D with the launce or rafor,draweth out the poifon of the viper; and that alfo the roote being ftamped is more auaileable againft ferpents, $\&$ that the roote in like maner is good againft the kings cuil.

The ftalk of Clot Burre before the burs come foorth, the rinde pilled of, being caten rawe with $\mathrm{E}$ falt and pepper, or boiled in the broth of fat meate, is pleafant to be eaten : being taken in thatiman-
ner, it increafeth feed and ftirreth vp.luft.

Alfo it is a good nourihment, efpecially boiled, if the kernell of the Pine apple be likewife ad- F ded it is the better, and is no leffe auaileable againft the vlcer of the lungs, and fpitting of bloud then the roote is.

The roote ftamped and ftrained with 2 good draught of ale, is a moft approoued medicine for a G windie and colde ftomacke.

Treacle of Andromachus, and the whites of egges, of eche a like quantitie, laboured in 2 leaden $\mathbf{H}$ mortar, and fpred vpon the Burre leafe, and fo applied to the gout, haue beene prooned oftentines moft miraculoufly to appeafe the paine thereof.

Digfcortdes commendeth the decoction of the rootes of Ar cion with the feed, againft the tooth-I ache if it be holden a while in the mouth: alfo that it is good to foment therewith both burnings \& kibed heeles, and affirmeth that it may be drunk with wine againft the ftrangury, $\&$ paine in the hip.

Diofcerides reportech, that the fruit is very good to be laid vnto hard fivellings.

The roote cleane picked, wafhed, ftamped and ftrained with Malmfey, helpeth the running $\mathbf{K}$ the raines, the whites in women, and ftrengthneth the backe, if there be added thereto the yolkes of egges, the pouder of acornes, and nutmegs brued or mixed togither, and drunk firft and laft. 


\section{Of Coltesfoote, or Horre foote. Chap. 277 .}

I TuSlagoflorens.

Coltes foote in flower.

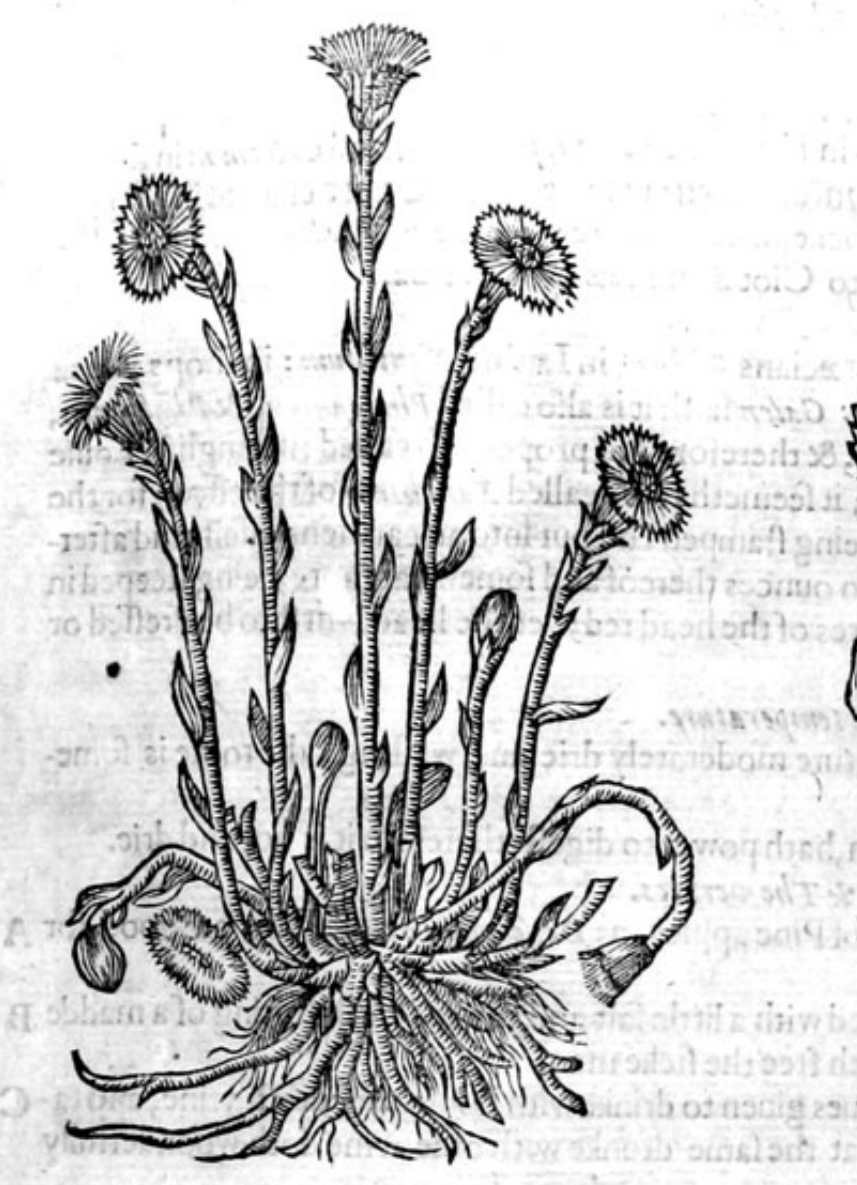

2 Tusalaginis folic. The leaues of Coltes foote.

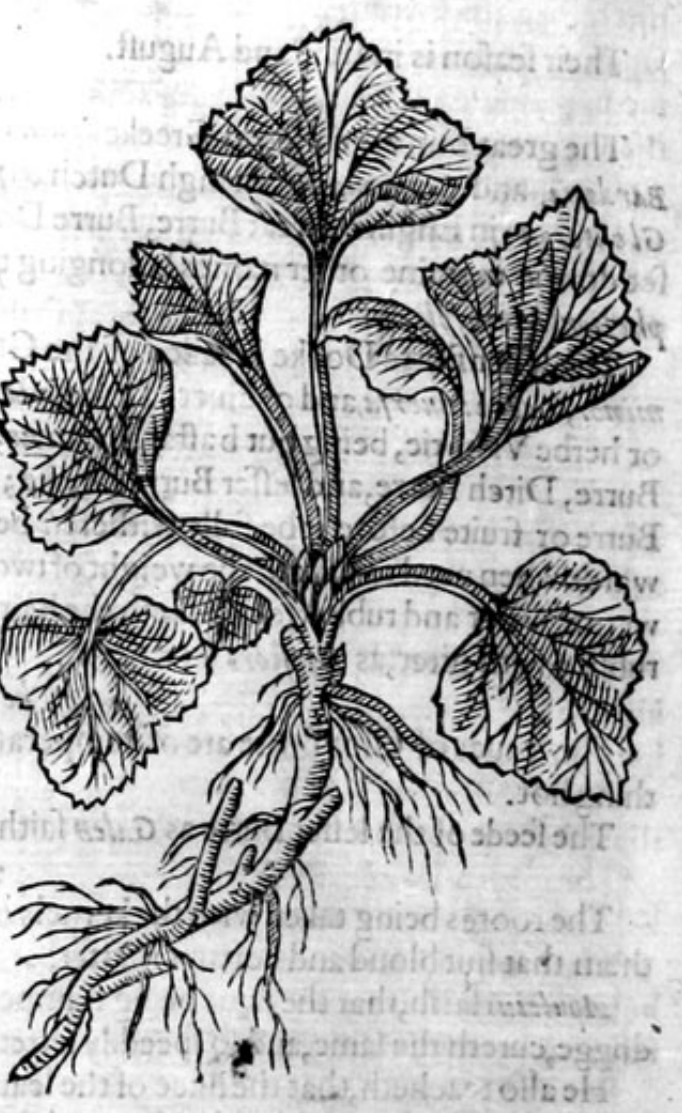

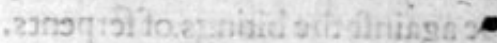

\section{* The defcription.}

1 r silago or Folefoote, hath many white and long creeping rootes, fomewhat fat: from which rife vp naked ftalkes(in the beginning of March and Aprill)about a fpan long, bearing at the top yellow flowers which change into downe, and are caried awaie with the winde; when the ftalke and feede is perifhed, there appeere fpringing out of the earth many great broad leaues, greene aboue, and next the ground of a white hoarie or grayifh co'our, fafhioned like an horfe foote, for which caufe it was called Folefoote, and Horiehoofe; feldome or neuer thal you finde leaues and flowers at once, but the fiowers are paft before the leaues come out of the ground, as may appeere by the firft picture, which fetteth foorth the naked ftalkes and flowers: and by thefecond which pourtraiteth the leaues onely.

$$
\dot{*} \text { The plase. }
$$

This groweth of it felfe neere vnto fprings, and on the brinkes of brookes and riuers, in wet furrowes, by ditches fides, and in other moift and watrie places neere vnto the fea almoft euery where.

$$
\therefore \text { The time. }
$$

The Bowers which quickly fade, are to be feene in the end of March, and about the Calends of Aprill,which fpeedily wither togither with the ftems, after them growe foorth the leaves, which remaine greene all fommer long : and heereupon it came that Colsfoote was thought to be without Alowers, which thing alfo Plinie hath mentioned in his fixe and twentie booke, and fixt
'Chapter. 


\section{HISTORIE OE PLANTS.}

* The names.

2ustoft (2stiोats 3

Folefoote is called in Greeke Bíner : of the Latines likewife Becbion, and Tupitago : infhops Farfara, and Vngula Caballina, of diuers Pata equima: in Italian onghia di Casuallo: in Spanifh vnhad a/no: in French pas d'a/ne: in Engliih Folefoote, Coltes foote, Horfehoofe, and Bulfoote. The fame is alfo Chamaleuce, which Plinie in his 28 .booke 15 .chap.reporteth to be likewife called Farfugium, and Farr anum, (if there be not an errour in thecopie) which thing alfo Netious in his firft booke affirmeth,pretermitting the name of Bechiom, and attributing vnto it all the vertues and faculties of Bechism, or Coltsfoot, whofe opinion Oribafius feemeth to be of in his 15 . booke of his medicinable collections, making mention of Chameleuce: onely Plinie alfo agreeth with them, fhewing that fome thinke, that Bechium is called by another name Chameleuce, in his 26 . booke 6.chap.and it may be that Dioferides hath written of one and the felfefame herbe in fundrie places, and by diuers names. Bechram and $T u \beta$ Slago (which may alfo be Englifhed Coughwoort) focalled of the effect,'and Farfara, of the white poplar tree, to whofe leaues it is like, which was named of the ancients Farfarus,as Pliut us writeth in his Comedie called Panulus:

-..-vifcum legioni dedi

funda/que, cos proffernebam vt folia Farfari:

To the company I gaue both lime bufh and fling,

That to the ground as Poplar leaues I might them fling.

The white Poplar tree is called in Greeke $\lambda^{\prime}$ is $x$, and heereupon Bechion or Coltes foote, was alfo called Chamalewce.

$$
\text { * The temperature and vertwes. }
$$

The leaues of Coltes foote, as yet frefh and greene, are fomething cold, and have withalla dry- A ing qualitic : they are good for vlcers and inflammations : but the dried leaues are hot and drie, and fonwhat biting.

A decoction made of the greene leaues and rootes, or elfe a fyrupe therof, is good for the cough, B that proceedeth of a thine rheume.

The greene leaues of Folefoote pound with honie, docure and heale the hot inflammation cal- C led Saint Anthonies fire, and all other inflammations.

The fume of the dried leaues taken through a funnell or tunnell, burned vpon coales, effectually D helpeth thofe that are troubled with the fhortneffe of breath,and fetch their winde thicke and often, and breaketh without perill the impoftumes of the breft. faide.

Being taken in manner as they take $\tau_{a} b a c 0$, it mightuly preuaileth againft the difeafes afore- $\mathbf{E}$

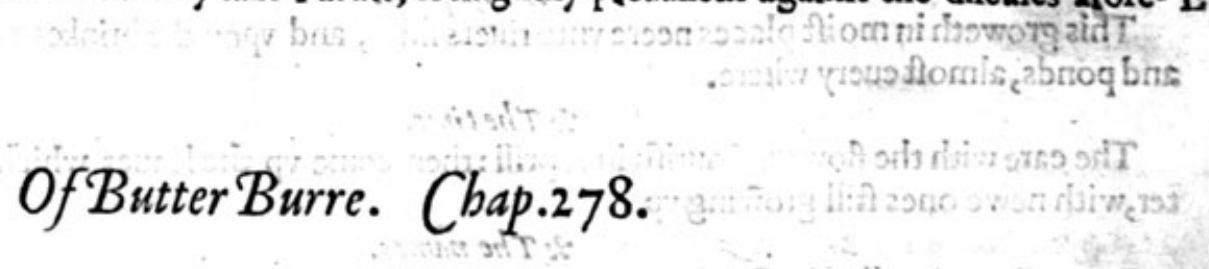

$$
\text { * Thedefcription. }
$$

I Vtter Burre doth in like maner bring foorth flowers before the leaues, as doth Coltesfoot; but they are fmall, moffie, tending to a purple colour, which being made vp into a big eare, as it were,do quickly togither with the ftem which is thicke, full of fubftaunce and brickle, wither and fall away : the leaues are verie great like to a rounde cap or hat,called in Latine Peta fus, of fuch a wideneffe, as that of it felfe it is bigge and large inough to keepe amans headfrom raine, and from the heate of the funne; and therefore theybe greater then the leaues of the Clot Burre, of colour fomething white, yet whiter vnderneath,euery ftemme beareth his leafe:the ftemme is of tentimes a cubite long, thicke, full of fubftaunce; spon which ftandeth the leafe in the center or middlemoft part of the circumference or verie neere, like to one of the greateft Mufhroms (but that it hath a cleft that ftandeth about the ftem, efpecially when they are in perifhing and withering away : at the firft the vpper fuperficiall, or outfide of the Mufhroms ftandethout, and when they are in withering ftandeth more in,and euen fo the leafe ofButter Burre hath on the outfidea certaine ihallow hollownes : the roote is thicke, long, blacke without, white within, of tafte fomewhat bitter, and is oftentimes woorme eaten. 
1 Petafites forens. Butter Burre in flower.

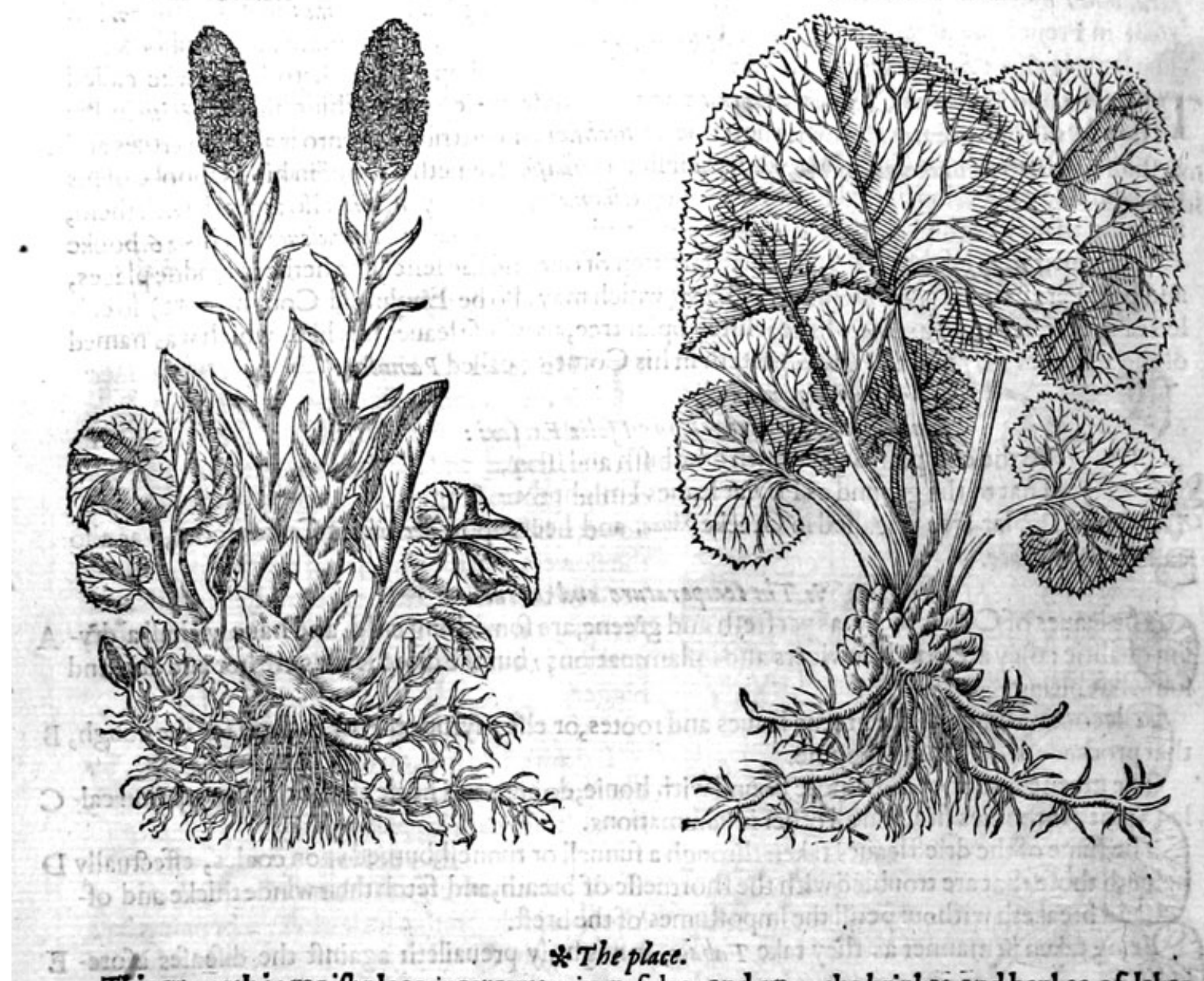

This groweth in moift places neere vntoriuers fides, and vpon the brinkes and bankes of lakes and ponds, almoft euery where.

The eare with the flowers flourih in Aprill : then come vp the leaues which continue till winter, with newe ones ftill growing vp.

Butter Burre is called in Greeke mactims, of the hugeneffe of the leafe that is like to mireonr, ora hat : the Latines do alfo call it Petaftes: in high Duch 1Peffitentzinurts : in low Dutch Docke bladerent: in Englifh it is named Butter Burre; it is very manifeft that this is like to Coltes foote, and of the fame kinde.

$\%$ The temperature.

Butter Burre is hot and drie in the fecond degree, and of thinne parts.

$*$ The vertues.

A The rootes of Butter Burre ftamped with ale, and giuen to drink in peftilent and burning feauers, mightily cooleth, and abateth the heate thereof.

B The rootes dried and beaten to powder and drunke in wine, is a foueraigne medicige againft the plague and peftilent feauers, bicaufe it prouoketh fweat, and driueth from the hart all vechome and ill heat; killeth wormes, and is of great force againft the fuffocation of the mother.

C The fame cureth all naughtie filthie vlcers, if the powder be ftrowed therein.

D The fame killeth wormes in the belly; prouoketh vrine, and bringeth down the monechly termes. 


\section{HISTORIE OF PLANTS. $¥ H$ T}

\section{Of fmall Celandine, or Pilewoort. Chap.279. \\ *T The kindes.}

$T$ Here be two kindes of Celandine,according to the olde writers, much differing in forme and

figure : the one greater, the other leffer, which I intende to deuide into two diftinct chapters, marhalling them as neerc as may be with their like, in forme and figure, and firft of the fimall $\mathrm{Ce}_{e}$ landine.

Chelidonivom minus.

Pile woort.

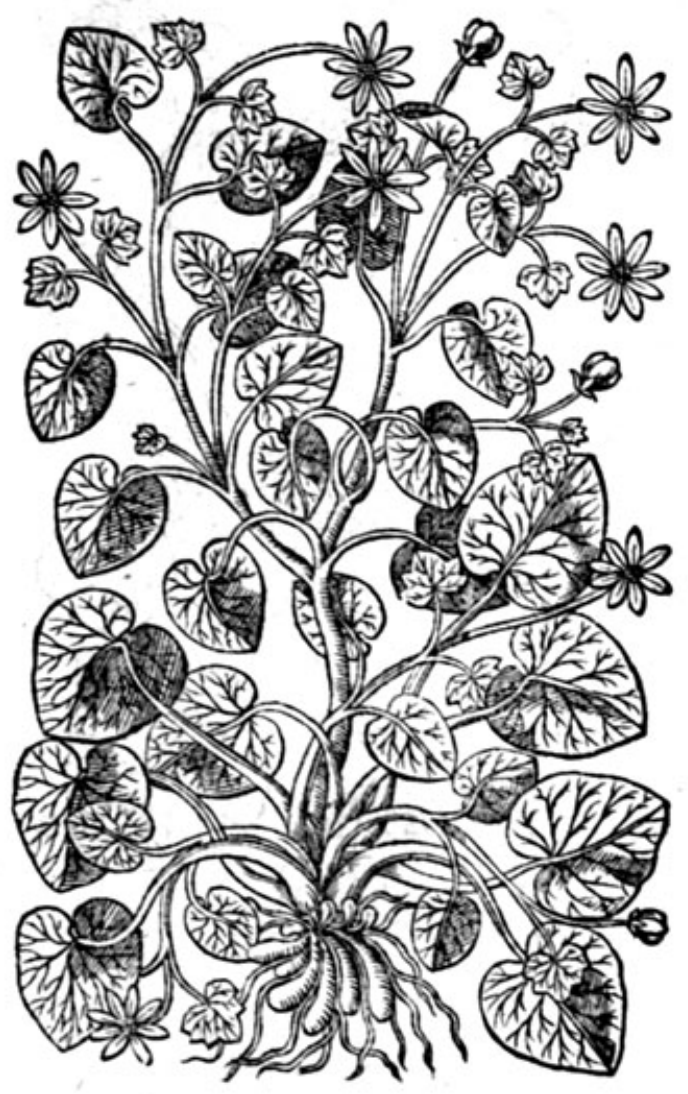

* The defoription.

7 He leffer Celandine bath greene rounde leaues, fmooth, flipperie, and fhining, leffe then the leaues of the luic : the ftalkes are flender, fhort, and for the moft part creeping vpon the ground: they bring foorth little yellowe flowers like to thofe of Crowfoote, and after the flowers there fpringeth vp a littie fine knop or head full of feede: the roote confiftech of flender ftrings, on which do hang as it were certaine graines, of the bigneffe of Wheate cornes, or bigger.

$$
\text { * Tbeplace: }
$$

It groweth in medowes, by common waies, by ditches and trenches, $\&$ is common euery where, in moift and dankifh places.

$$
* \text { The time. }
$$

It commeth foorth about the Calends of March,and flowreth a little after : it beginneth to fade away in Aprill, it is quite gone in May, afterwards it is harde to be founde, yea fcarfely the roote.

$$
\text { * The names. }
$$

It is called in Grecke yerestrior : of the Latines Chelidonium minus, and Hirundimaria minor, of diuers Scropbula ria minor, Ficaria minor: of SerapixeMemiren : in Italian Fawo fello:in high Dutch

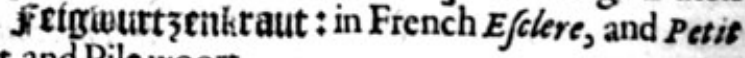
Bafseret : in Englifh little Celandine, Figgewoort,2nd Pile woort.

\section{* The temperature.}

Ir is hot and drie,alfo more biting and hotter then the greater: it commeth neereft in facultic to the Crowfoote.

It prefently as Galen and Diofcorides a The vertues. rough and corrupt nailes to fall awaie.

The iuice of the roots mixed with honie, and drawne up into the nofthrils, purgeth the head of $B$
foule and filthie humours.

The later age vfe the rootes and graines for the piles, which being often bathed with the iuice $\mathbf{C}$ mixed with wine, or with the fickmans vrine, are drawne togither and dried vp,and the paine quite
taken away. There be alfo who thinke, that if the herbe be but caried about one that hath the piles, the paine $D$
forthwith ceafeth. 


\section{Of mar/h Marigolde. Chap.280.}

Here be founde at this daie three forts of marfh Marigolds; the auncients haue defcribed but
one.

I Calthapaluftris maior.

The great marfh Marigolde.

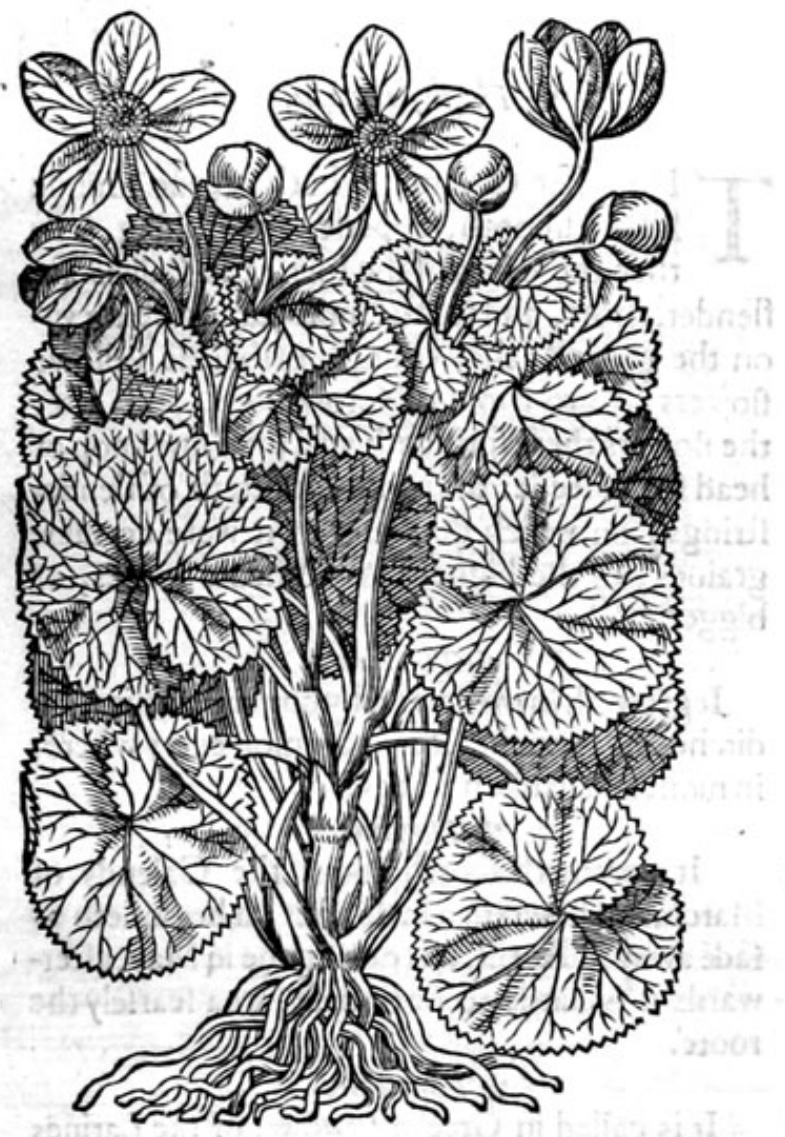

2 Caltha paluftrisminor. The fmall marnh Marigold.

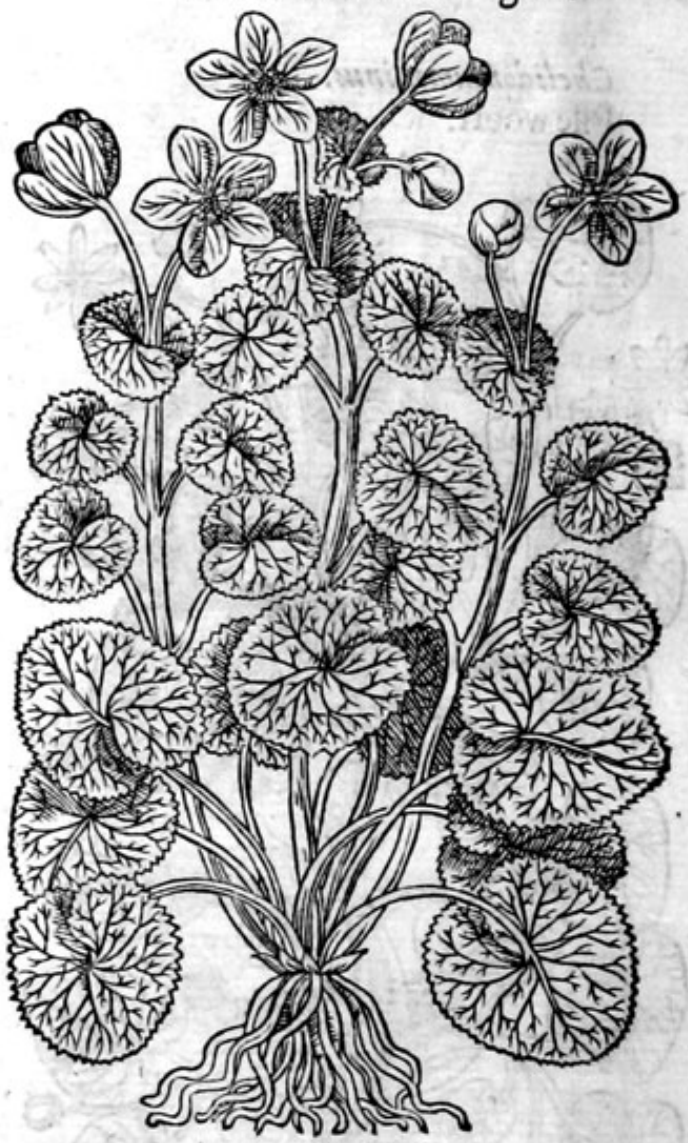

* Thetemperature.

$\mathbf{N}$ Arh Marigold hath great broad leaues fomewhat round, fmooth, of a gallant greene colour,flightly indented or purlde about the edges, among which rife vp thicke fat ftalkes, likewife greene; wherupon do growe goodly yellow flowers, glittering like gold, and like to thofe of Crowfoote, but greater : the roote is fmall,compofed of verie manie ftrings.

2 The fmaller marfh Marigold hath manie rounde leaues fpred vpon the grounde, of a darke greene colour: among which rife vp diuers braunches, charged with the like leaues : the flowers growe at the top of the braunches, of a mat fhining yellowe colour: the roote is like the former.

3 The great marfh Marigolde with double flowers is a ftranger in England, his natiuecountrey 1hould feeme to be in the furtheft parts of Germanie, by the relation of a man of thofe countries that I hauc had conference withall, the which he thus defcribed: it hath faith he, leaues, rootes, and ftalkes, like thofe of our common fort, and hath double flowers like thofe of the garden Marigold, wherein confifteth the difference. 
OF PLANTS.

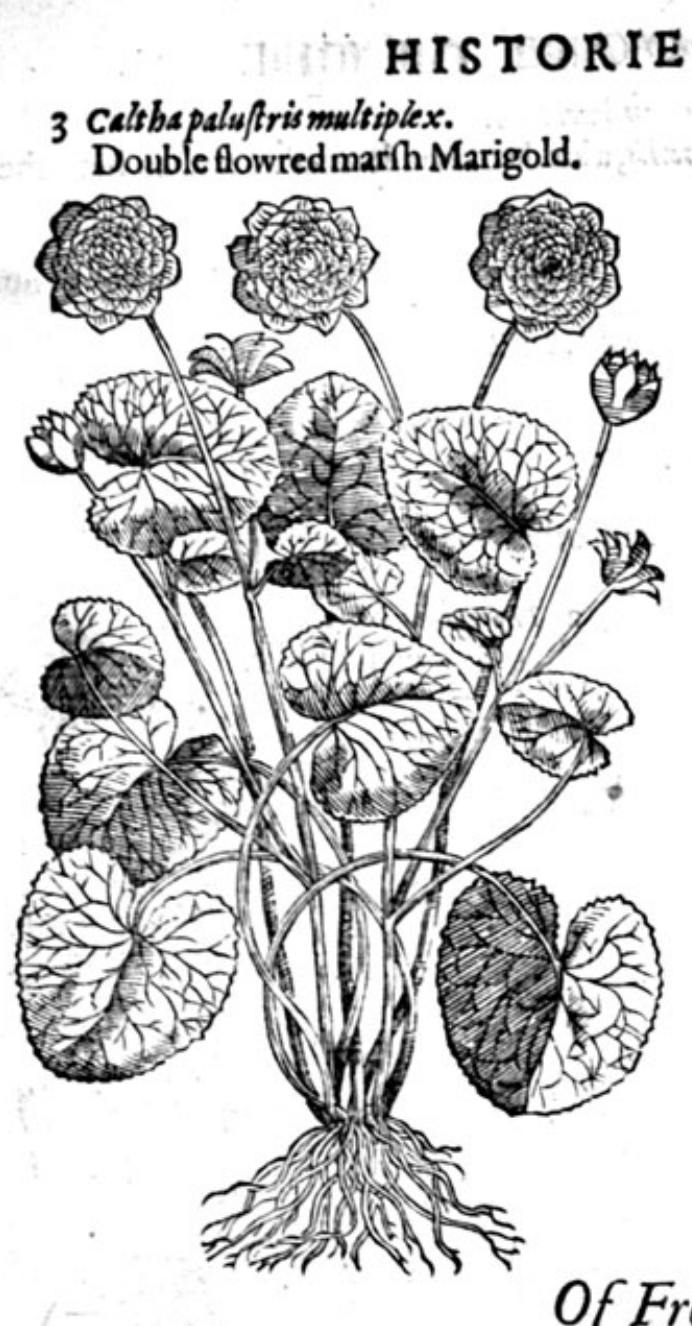

Morfus Rana. Frogge bit.

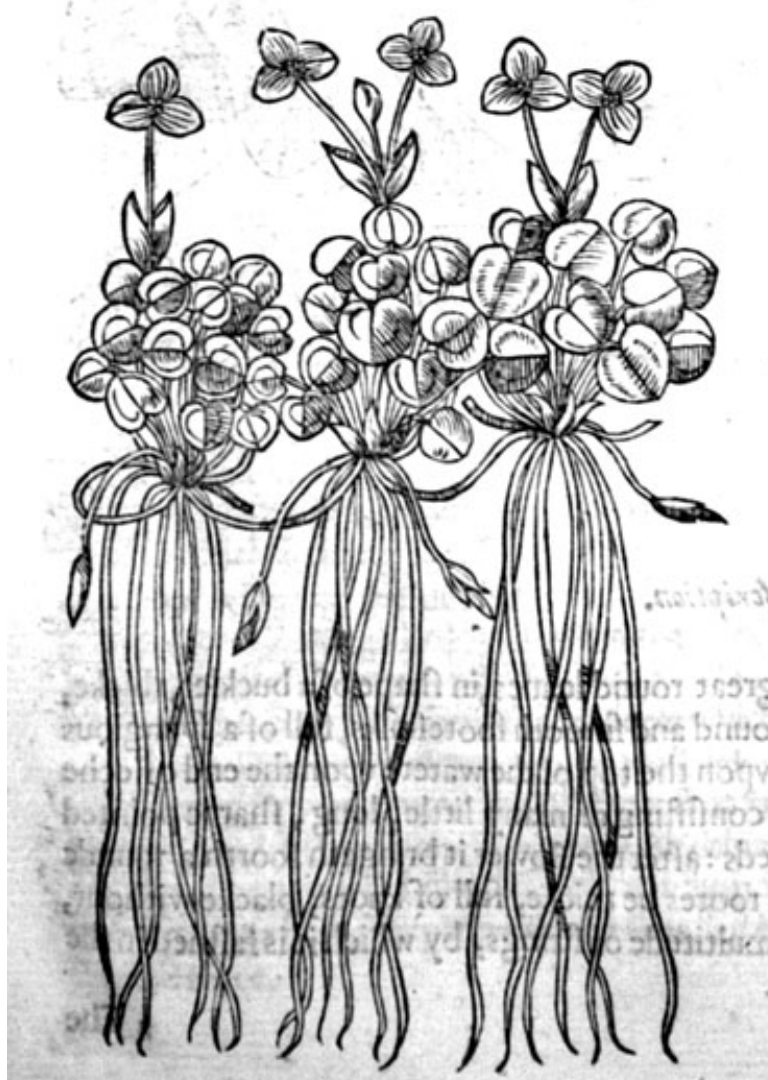

Calsha palufiris mult iplex.
* The place. Jiा

They ioy in moift and marilh groundes, and in watery medowes.

\section{* The time.}

They flower in the fpring when the Crowfoots do, but fomewhat later, oftentimes in fommer; the leaues keepe their greeneneffe all the winter long.

* 7 he names. $I$

Marfh Marigold is called of Valerius Cordes, Calt ha paluftr is; of 7 aber CMontanus, Populago, but not properly: in Englifh Marfh Marigoldes, in Chefhire and thofe parts it is called Bootes.

\section{\&. The temperature and vertues.}

Touching the faculties of thefe plants, we haue nothing to faie, either out of other mens writings, or our owne experience. $\rightarrow$ Here flotectscription. per parts of the water a fill which we vfually cal Frogge bithaning litle round leaues, thick \& ful of inice, very like to the leaues of wall Peniwoort: the flowers grow vpon long ftemmes among the leaues of a white colour, with a certaine yellow thrum in themiddle, confifting of three leaues : in ftead of rootes it hath fléder ftrings, which grow out of a fhort $\&$ fmall head,as it were, from whence the leaues fpring, in the bottom of the water: from which head alfo come forth flopewife certaine ftrings, by which growing foorth, it multiplieth itfelfe. * The place.

If is founde fwimming or floting almoft in euery ditch, pond, poole, or itanding water, in all the ditches about Saint Georgehis fieldes, and in the ditches by the Thanes fideneere to $\mathrm{Lam}$ beth marfh, where any that is difpoled may Iee it. * Thesime.

It flourifheth and flowreth most part of al the yeere.

It is called of fome Rane mor fous, and Morgin Rane, and 2 Cymphea parwa. 
* The temper ature and vertues.

It is thought to be Species fontalis, or Potamogeitonis, a kinde of Ponde weede, and to haue the fame faculties that belong vnto it.

\section{Of water Lillie. Chap.282.}

\section{*The kindes.}

There be diuers forts of water Lillies, fome greater, and others leffer.

I Nymphas alba. White water Lillie.

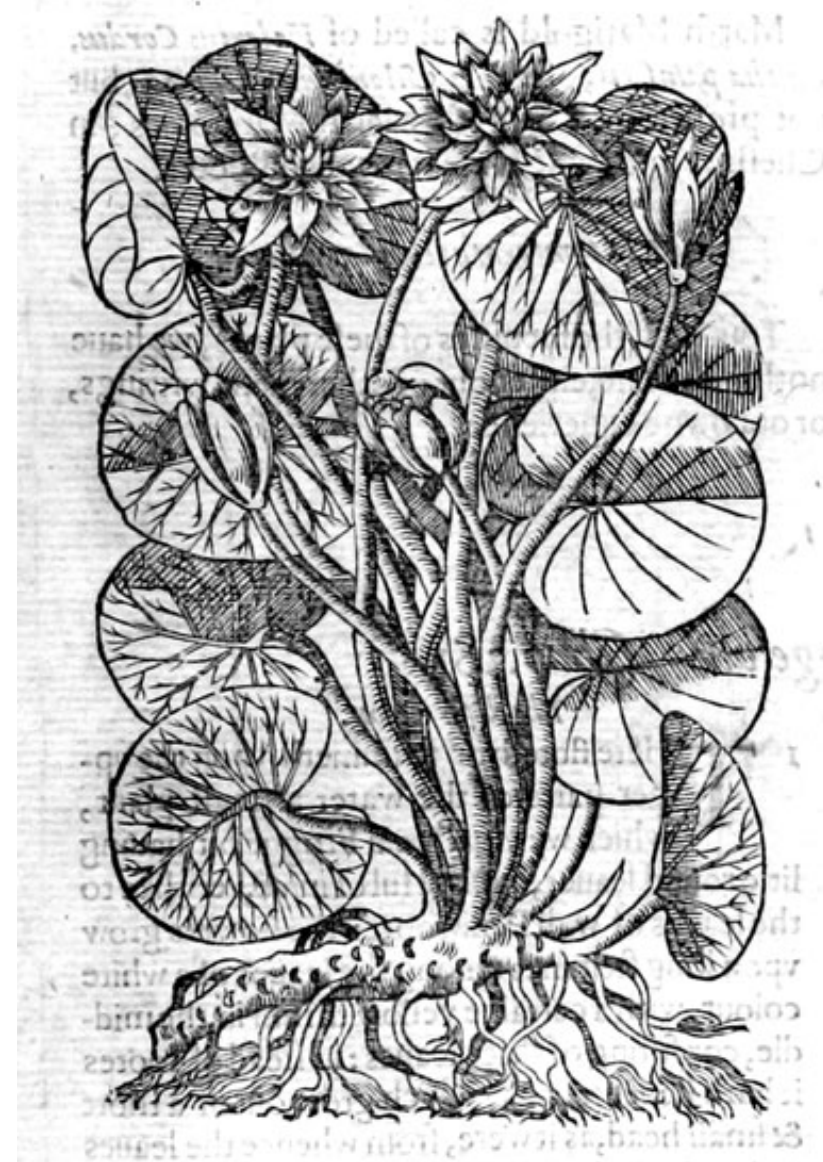

2 Nymphas lutea. Yellow water Lillie.

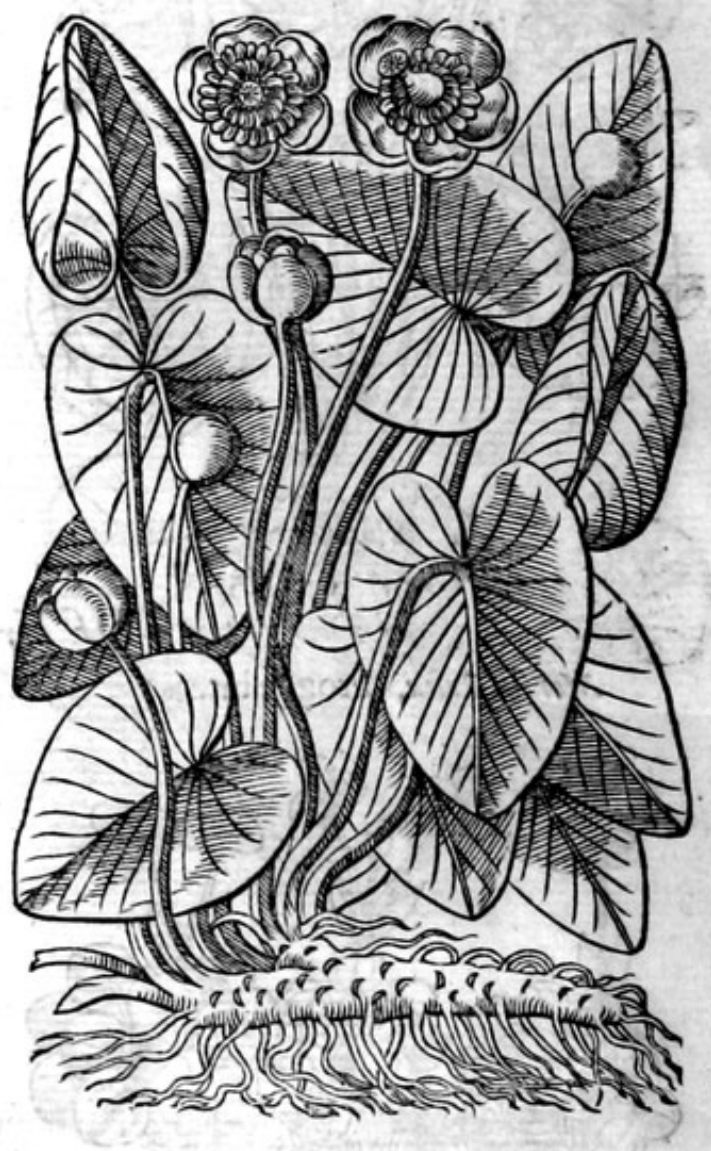

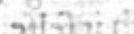

ai flom is a risch to * The defcription.

I $\mathrm{T}^{-4} \mathrm{He}$ white water Lillie or Nenuphar, hath great round leaues, in Thape of a buckler, thicke, fat, and full of iuice, ftanding vpon long round and fmooth footeftalks, full of a fpungious fubftance, which leaues do fwim or flote vpon the top of the water: vpon the end of eche ftalke groweth one flower onely, of colour white, confifting of many little, long, fharpe pointed leaules, in the middeft whereof be many yellow threds : after the flower it bringeth foorth a rounde head, in which lieth blackifh glittering feede. The rootes be thicke, full of knots, blacke without, white and fpungis within, out of which groweth a multitude of ftrings, by which it is faftened in the
bottome. 


\section{HISTORIE OF PLANTS.}

2 The leaues of the yellow water Lillie be like to the other, yet are they a little longen. The ftalkes of the flowers and leaues be like: the flowers be yellowe, confifting onely of fiue little fhort leanes fomething round; in the middeft of which groweth a fmall round head, or button, Tharpe towards the point, compaffed about with many yellowe threds, in which, when it is ripe, lie alfo glittering feedes, greater then thofe of the other, and lefier then Wheat cornes. The roots be thick, long, fet with certaine dents, as it were white both within and withour, of 2 fpungious fubftance.

3 Nymphesalbs minor.

The imall white water Lillie.

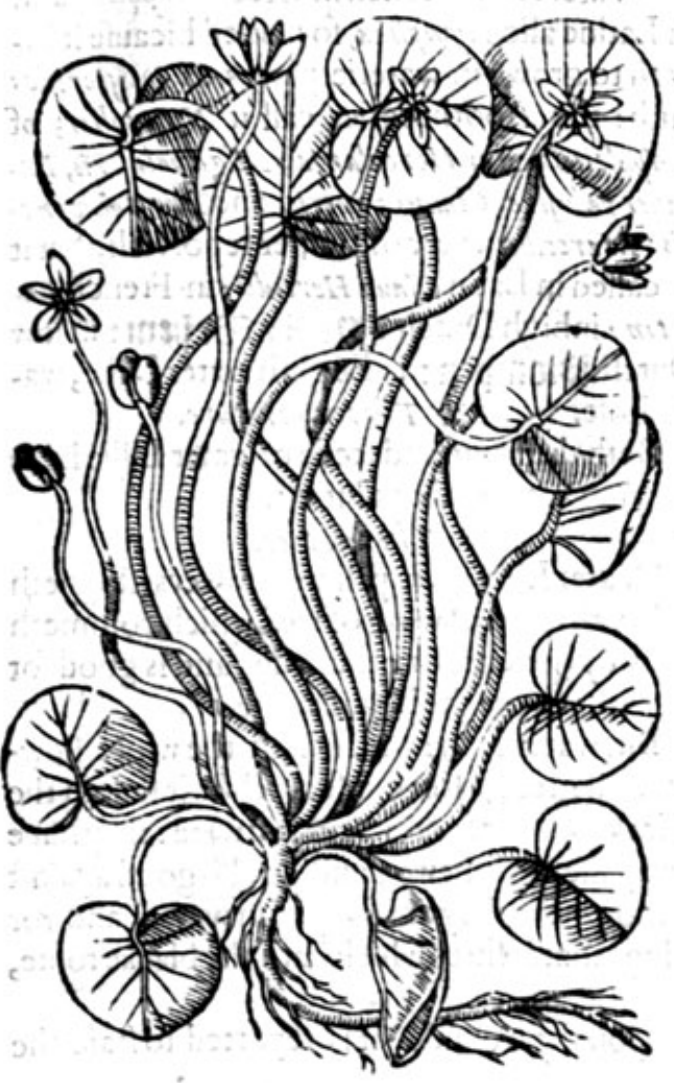

4 Nymphea minor lutes.

The fmall yellow water Lillie.

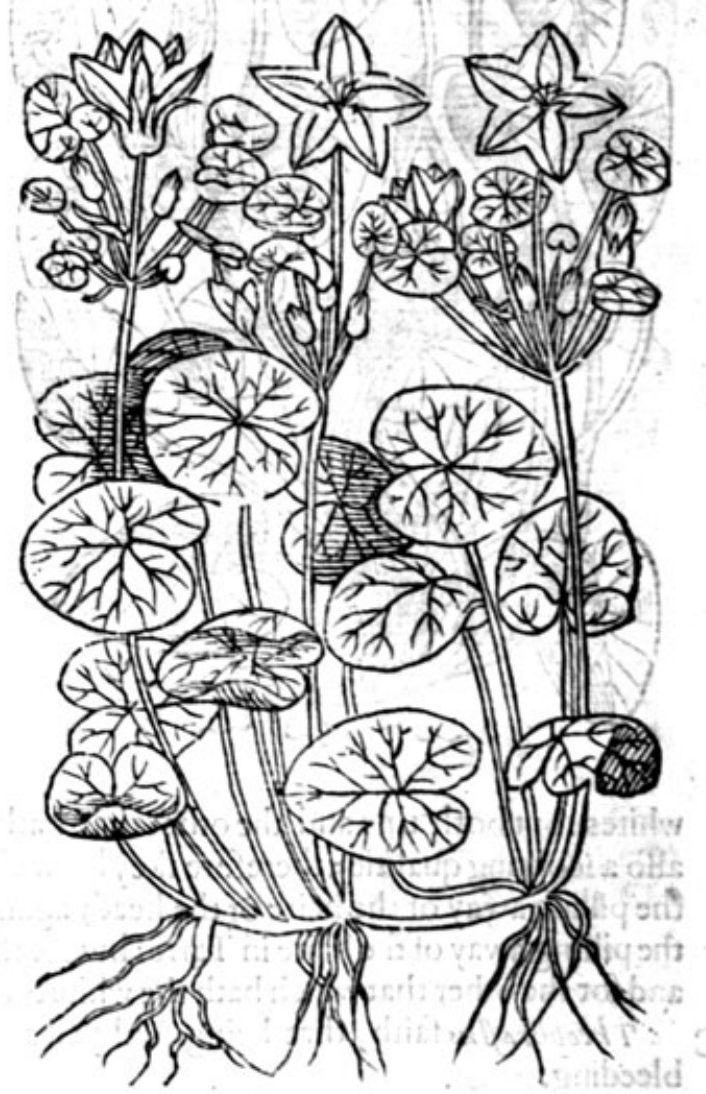

iritite

* Thedefcription.

3 The fmall white water Lillie floteth likewife vpon the water, hauing a fingle roote, with folne fewe fibres faftned thereto:from which rifeth vp many long, rounde, fmooth, and foft footeftalkes, fome of which do bring foorth at the ende faire broad rounde buckler leaues like vnto the precedent, but leffer: on the other footeftalkes ftande pretic white flowers, confifting of fiue finall leaues a peece, hauing a little yellowe in the middle thereof.

4 The fmall yellowe water Lillie, hath a little threddic roote, creeping in the bottome of the was ter, and difperfing it felfe farre abroad; from which rife fmall tender ftalkes, fmooth and foft, whereon do grow littie buckler leaues like the laft defcribed; likewife on the other fmall ftalke ftandeth 2 tuft of many flowers, contrarie to all the reft of his kinde, of a hining yellow colour: the leaues and flowers likewife flote vpon the water as the others do.

5 This dwarfe water Lillie, differcth not from the other finall yellowe water Lillie, fauing that, that this kinde hath fharper pointed leaues, and the whole plant is altogither leffer, wherein lieth the difference. 
5 Nymphas luteaminima.

Dwatfe water Lillie.

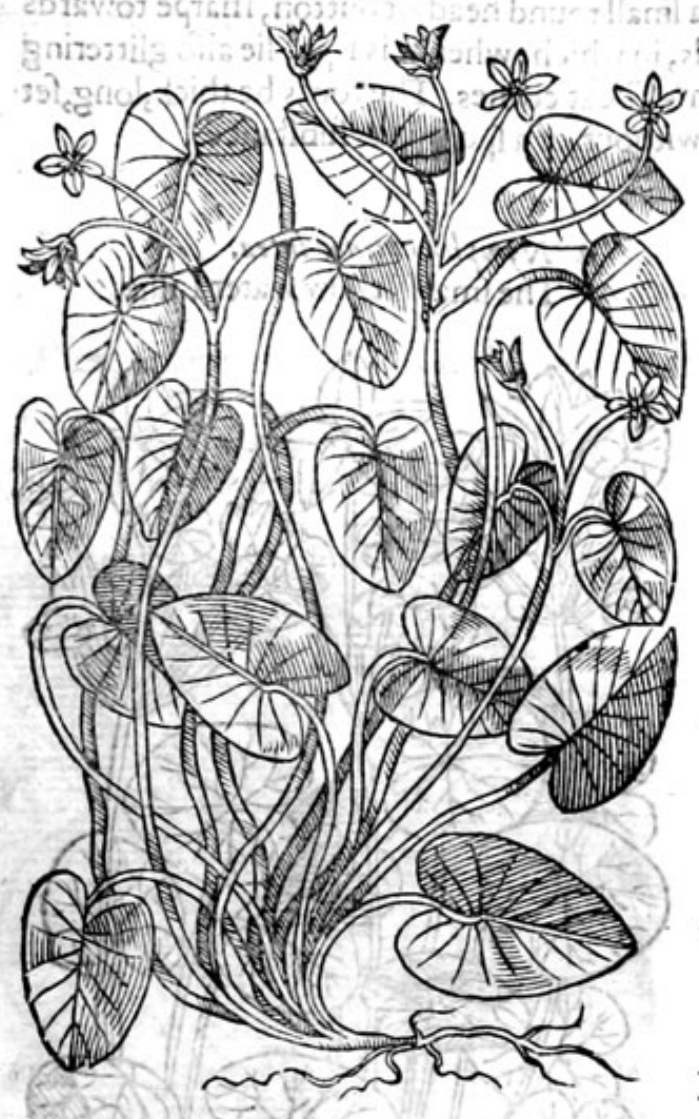

* The place. Thefe herbes do growe in fennes, ftanding waters, broad ditches, and in brooks that rumne flowly, andfomtimes in great riuers. 903 , 25 hos?

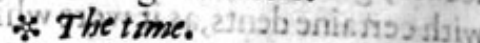

They flower and flourin moft of the fommer moneths.

$*$ * The names.
Water Lilly is called in Greeke Numpaic : and in Latine alfo Nymphas, fo named bicaufe it loueth to growe in waterie places as Diogsorides faith: the Apothecaries call it 2Eexusphar; of Apuleisus mater Herculania, Alga paluf tr is, $\mathrm{P}$ apawer painftre, Clausus voneris, and Digitiw veneris: Marcellus a very old writer reportech, that it is called in Latin Clawa Herculis : in French Baditun; inhigh Dutch rotafler PGabem: in low Dutch folompen : in Englifh water Lillie, water Rofe. $\quad$ * Tletemperature.

Both the roote and feede of water Lillie haute a drying force withouc biting.

* The vertues.

A Water Lilly with yellowe flowers ftoppeth laskes, the ouerflowing of feed which commeth away by dreames or otherwife, and is good for them that haue the bloudie flixe.

B But water Lillie which hath the white flow. crs is of greater force, infomuch as it ftaicth the whites: but both this and the other that hath the blacke roote are drunke in redwine :they have alfo a fcouring qualitic; therefore they both clenfe away the morphewe, and be alfo good againft the pilling away of the haire of the head; againft the morphew they are fteeped in water, and for the pilling away of the haire in Tarre : but for thefe things that is fitter which hath the blacke roote,
and for the other that which hath the white roote. Theophriftus faith, that being ftamped and laide vpon the wounde, it is reported to taie the
bleeding.

D The Phifitions of our age do commende the flowers of white Nymphea againft the infirmities of the head, which come of a hot caufe : and do certainly affirme, that the roote of the yellowe cureth hot difeafes of the kidneies and bladder, and is fingular good againft the running of the
raines.

E The roote and feede of the great water Lillie, is verie good againft venerie or flefhly defire, if one do drinke the decoction thereof,or vfe the feede or roote in powder in his meates, for it drieth vp the feede of generation, and fo caufeth a man to be chafte, efpecially vfed in broth with $\mathrm{fle}$ h. F The conferue of the flowers is good for the difeafes aforefaid, and is good alfo againt hot burn-
ing feauers.

G The flowers being made into oile, as yee do make oile of rofes, doth coole \& refrigerate, caufing fweat and quiet fleepe, and putteth away all venereous dreames : the teinples of the head \& $\&$ palmes of the hands and feete, and the breft being annointed for the one, and the genitors vpon and abous
them for the other.

H The greene leaues of the great water Lillie, either the white or the yellow laide vpon the region of the backe in the finall, mightily ceafeth the inuoluntarie flowing away of the feedecalled $G 0$ norrbea, or running of the reines, being two or three times a day remooued, and frefh applied ther-
to. 


\section{HIS TORIE OF PLANTS.}

\section{Of Pondweede, or water Spike. Chap.283.}

1 Potamogetion latifolivem.

Broadleafed Pondweed.

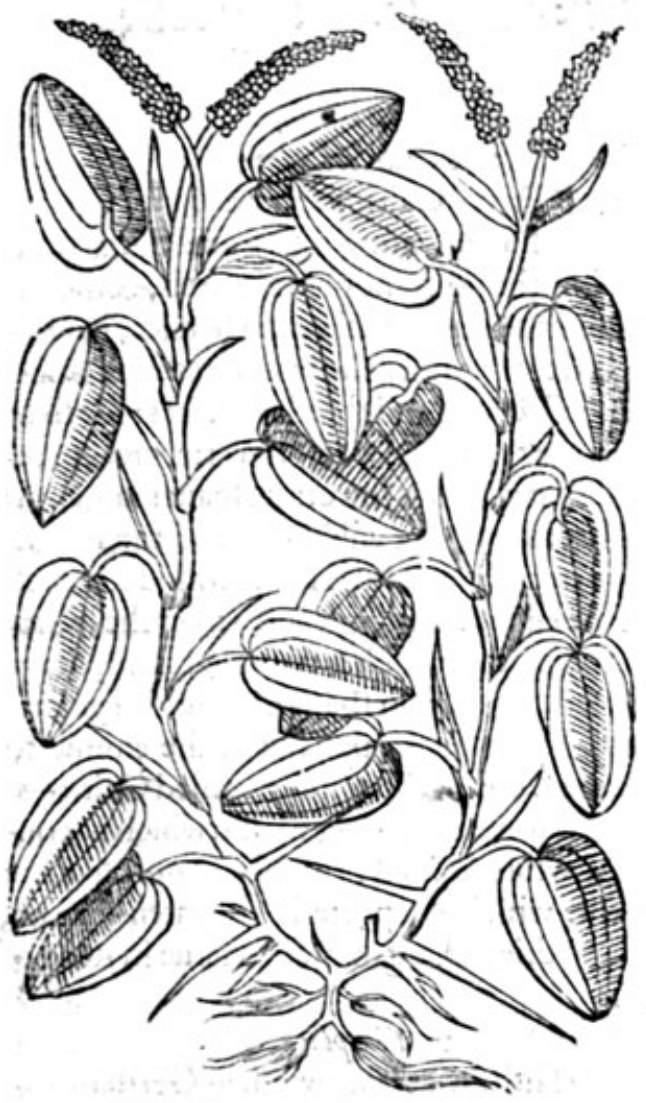

2 Potamogeiton anguftifolivm. Narrow leafed Pondweed.

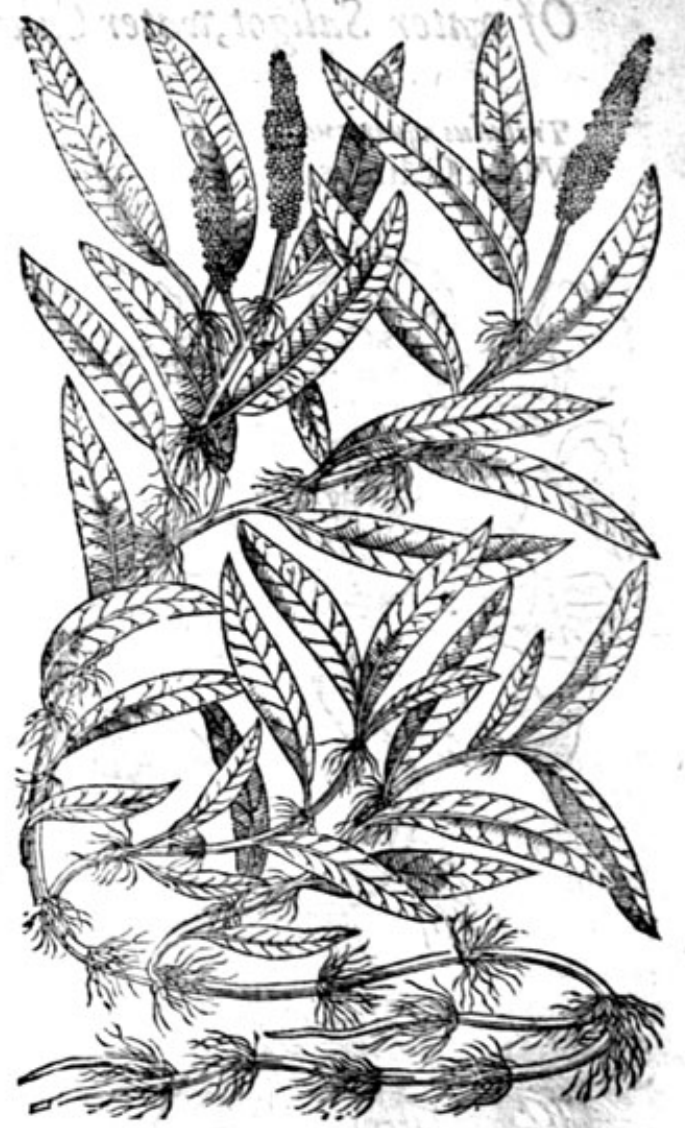

* The defoription.

D Ondweed hath litcle ftalks, flender, fpreading like thofe of the vine, and iointed: the leaues be long,fmaller then the leaues of Plantine, and harder, which ftanding vponflender and long ftems or foote ftalks, thewe themfelues aboue the water, and lie flat along vpon the fuperficiall or vpper part thereof, as do the leaues of the water Lillie: the flowers growe in thore eares, and are of a light red purple colour,like thofe of Redhankes: the feede is hard.

2 There is another Pondweed defcribed thus; it thooteth foorth into many flender and rounde ftems, which are diftributed into fundrie branches: his leates are broad, long, and tharpe pointed, yet much leffe then the firft kinde: out of the bofemes of the branches and leaues there fpring eertaine little ftalkes, which beare fundrie fmall white moffie fiowers, which do turne into plaine and round feeds, like the common Tare or Vetch: his roote is fibrous, throughly faftned in the ground.

Theic herbes do grow in ftanding waters, pooles, ponds, and ditches, almoft euery where.

They do flower in Iune and Iuly. * The time.

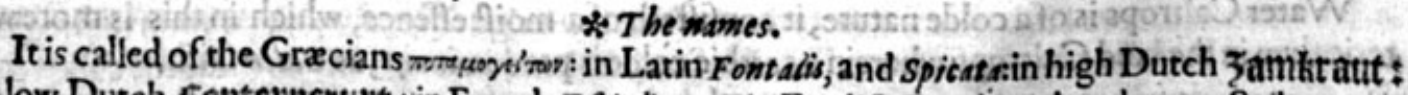
in low Dutch fontevnctupt : in French $E / \beta i$ d' eaves in Englifh Ponciveed, and water Spike.

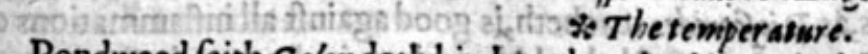

Pondweed faith Galen doth binde'and coole, like as doth Knotgraffe, but his effence is thicker then that of Knotgraffe. 
* The vertues.

A It is good againft the itch, and confuming or eating vlcers, as Diofcorides writeth.

B Alfo it is good being applied to the inflammation of the legges, wherein Ignis facer hath gotten the fuperioritie.

\section{Of water Saligot, water Caltrops, or water Nuts. Chap.284.}

\section{Tribulsus aquaticus.}

Water Caltrops.

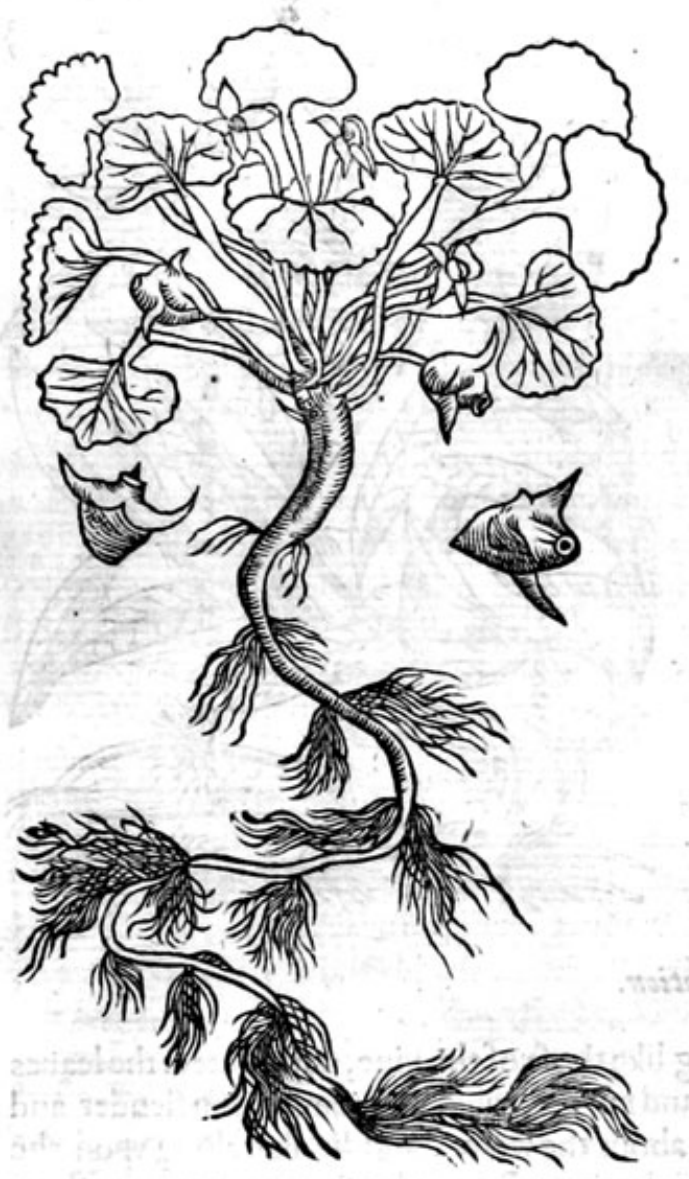

* The defcription.

$\mathrm{VV}$ Ater Caltrops hath long flender ftalkes, growing vp and rifing from the bottome of the water, \& 2 moun. ting aboue the fame, weake, and flender, hauing heere and there vnder the water certaine taffels full of fmall ftrings and threddic haires: the ftem towards the top of the water is verie great in refpect of that which is lower:the leaues large and fomewhat round, not vnlike thofe of the Poplar or Elme tree leaues, a little creuifed and notched about the edges: amongft and vnder the leaues groweth the fruit, which is triangled, hard, tharp pointed and prickly, in thape like hurtfull engins in the wars, caft in the paffage of the enimie to annoy the feete of their horles, called Caltrops, whereof it tooke his name; within which is conteined a white kernell, in tafte almoft like the Chefnut, which is reported to be eaten greene, and being dried and grounde to ferue in ftead of bread.

$$
\text { * The place. }
$$

Cordus faith, that it groweth in Germanie in mirie lakes, and in citie ditches which haue mud in them; in Brabant and in other places of the low countries, it is found oftentimes in ftanding waters, and fprings. Mathioles writeth, that it groweth not onely in lakes of fweete water, but alfo in certaine ditches by the fea neer vnto Venice.

\section{It flourifheth in Iune,Iuly, and Auguft.}

* The time.

* The names.

The Grxecians call it reísonos êrudes : the Latines Tribulus aquatilis, and aquaticus, and Tribulus lacustris: the Apothecaries 7 ribulus marinus: in high Dutch orotaffer nuf ; : the Brabenders vella: ter noten $:$ and of the likeneffe of iron nailes Binckiffers: the French men Macres: in Englifh it is named Water Caltrops, Saligot, and water Nuts, moft do call the fruite of this Caltrops, Cafta nea aquatiles, or water Chefnuts.

\section{* The temperature.}

Water Caltrops is of a colde nature, it confitteth of a moift effence, which in this is morewaterie then in the land Caltrops, whercin a earthie colde is predominant, as Galen faith.

$$
* \text { The vertues. }
$$

A The herbe vfed in maner of a pultis, as Diofcorides teacheth, is good againft all inflammations or hot fwellings: boiled with honie and water, it perfectly healeth cankers in the mouth, fore gums, and the almonds of the throte. 


\section{HIS T ORAE OFI PLANITS.IHT}

The Thracians faith plinie that dwell in Strymona, do fatten their horfes with the leaues of Sa- B ligot, and they themfelues do feede of the kernels, making very fweete bread therof, which bindeth the belly.

The greene nuts or fruit of $T$ ribulise a quatices, or Saligot, being drunke in wine, is good for them C which are troubled with the ftone and grauell.

The fame drunke in like maner, or laid outwardlie to the place, helpeth thofe that are bitten with D any venemous beaft, and refifteth all venome and poifon.

The leaues of Saligot be giuen againft all in flammations and vlcers of the mouth, the putrifac- $E$ tion and corruption of the iawes, and againift the Kings euill.

Apowder made of the nuts, are giuen to fuch as piffe bloud, and are troubled with grauell, and F do binde the belly very much.

\section{Of water Sengreene, or fre/h water Soldier. Chap.285.}

Militaris Lizoides.

Frefh water Soldier.

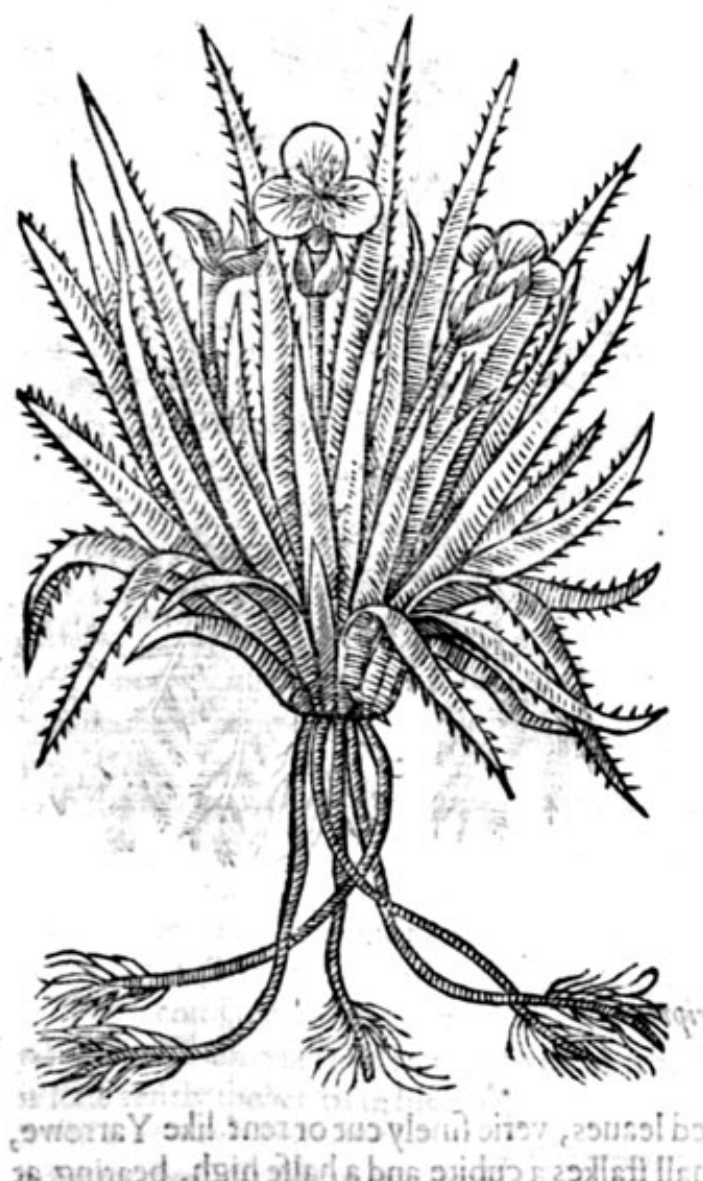

- * Thedefcription.

Refh water Soldier or water Houfleeke, hath - leaues like thofe of herbe Aloe, or Semper viusm, but fhorter \& lefler, fet round about the edges with certain ftiffe and fhort prickles: among which come foorth diters cafes or huskes, very like to crabs clawes;out of which when they open growe white flowers, confifting of three leaues, altogither like thofe of Frogs bit, hauing in the middle little yellowifh threds; in fteade of rootes there be long ftrings, rounde, white, verie like to great harpe ftrings, or tolong woormes, which falling downe from $a$ fhort head that brought foorth theleaues, go to the bottome of the water, and yet be they feldome there faftned: there alfo growe from the fame other ftrings aflope,by which the plant is multiplied after the maner of Frogs bit.

$$
\text { * Theplace. }
$$

This is founde inlakes or ftanding waters, and ditches, in veriemanie riuers in the lowe countries, the greateft part of the leaues togither with the flowers ftandeth aboue the water: the other parts of the plant are vnder the water. * The time.

Ir flowreth in Iune, and fomtimes in Angurt. $*$ The narres.

It may becalled Sedem aquatile, or water Sengicene, that is to Faiej of thelikenefie of berbe Aloë, which is alfo called in Latine Seduon; of fome concri chels, or canori for fitwla: in Englith water. Houfleeke, Krights Pondwoort, and of fome Knights water Sengreene, freh ivater Soldier, or wading Pondweed a it feemeth to bE Striatiotesiaguatilis, or Stratiotes pot amios, or Knights water Woundwoort, which imay likewife bonamed in La-

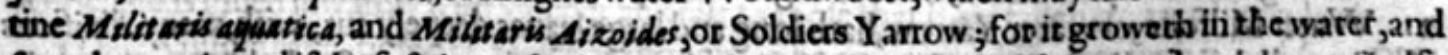
floteth vponit,and if thofe ftrings which irfendeth to the bottome of the water be na toots, it alfo

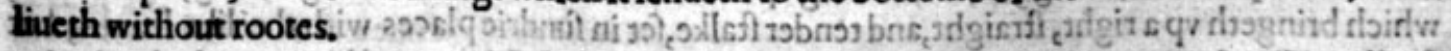

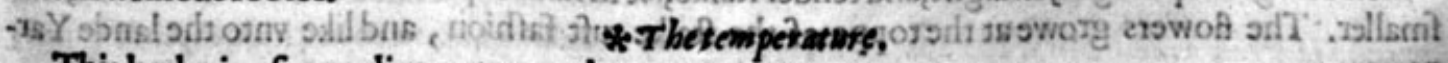
This herbe is of a cooling nature and temperament.

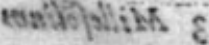


* The vertues.

A This Houfleeke ftaieth the bloud which commeth from the kidneies, it keepeth green woundes from being inflamed, and it is good againft Saint Antonies fire and hot fwellings, being applied vnto them : and is equall in the vertues aforefaid with the former.

\section{Of water Yarrow, and water Gilloflower. Chap.286.}

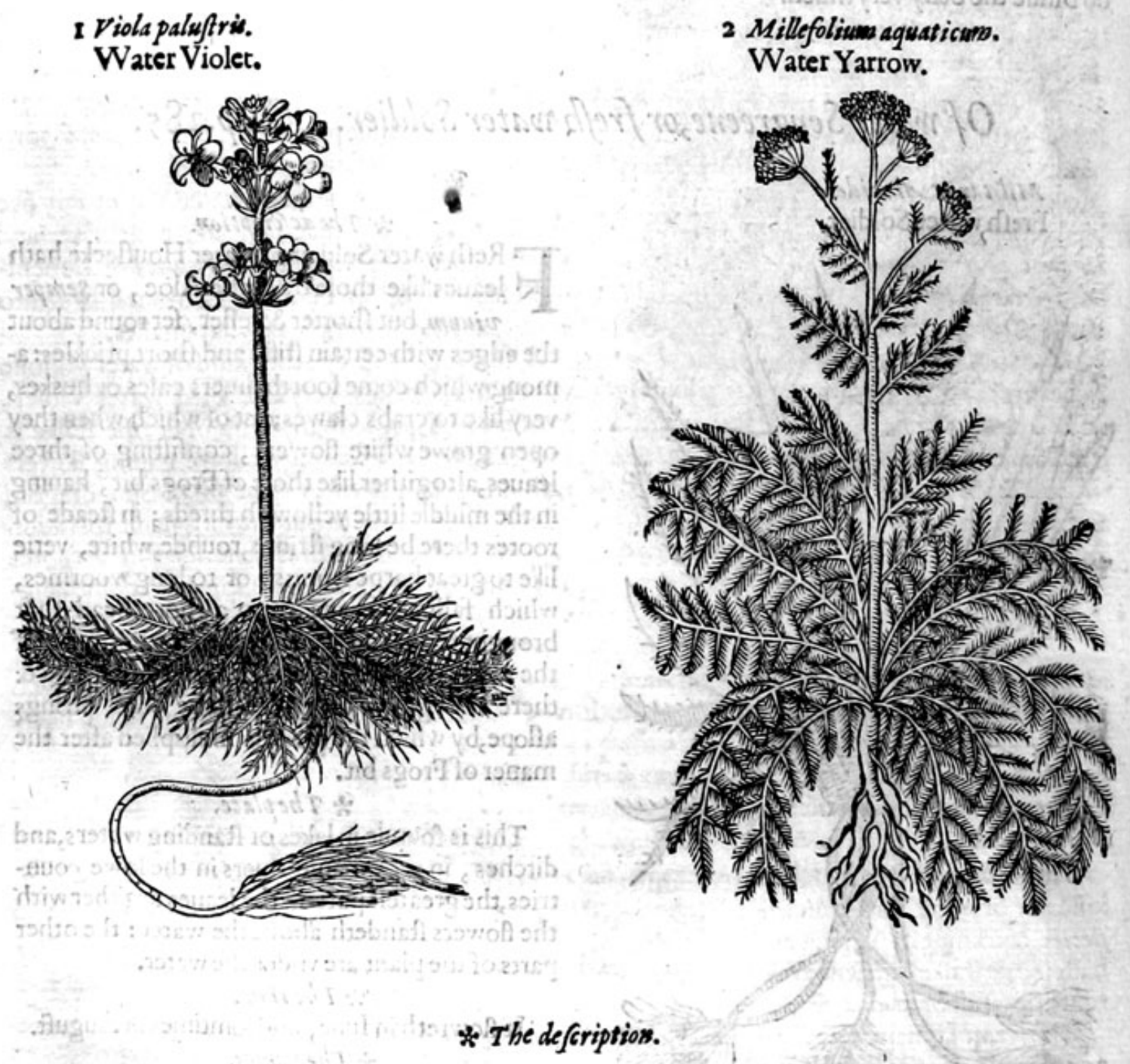

I T 7 Ater Violet hath long and great iagged leaues, verie finely cut or rent like Yarrowe, but fmaller: among which come vp fmall ftalkes a cubite and a halfe high, bearing at the top fmall white flowers like vnto ftocke Gillotlowers, with fome yellowneffe in the middle. The rootes are long and fmall like blackethreds sand at the ende whereby they are fait: ned to the ground they are white, and hining like Chryftall.

2 Water Milfoile, or water Yarrow, hath long and large leaues deepely cut, with-many diuifions like Fennell, but finelier iagged, fwimming vpon the water. The rooteis fingle, long, and rounde, which bringeth vp a right, ftraight, and tender ftalke, fet in fundrie places with the like leaues, but fmaller. The flowers growe at the toppe of the ftalke tuft falhion, and like vnto the lande Yarrowe. 


\section{HISTORIE OF PLANTS.}

3 Millefolian fue Maratriphyllon flere o femine Kanunsuli aquatici, Hepatic a facie.

Crowfootc, or water Milfoile.

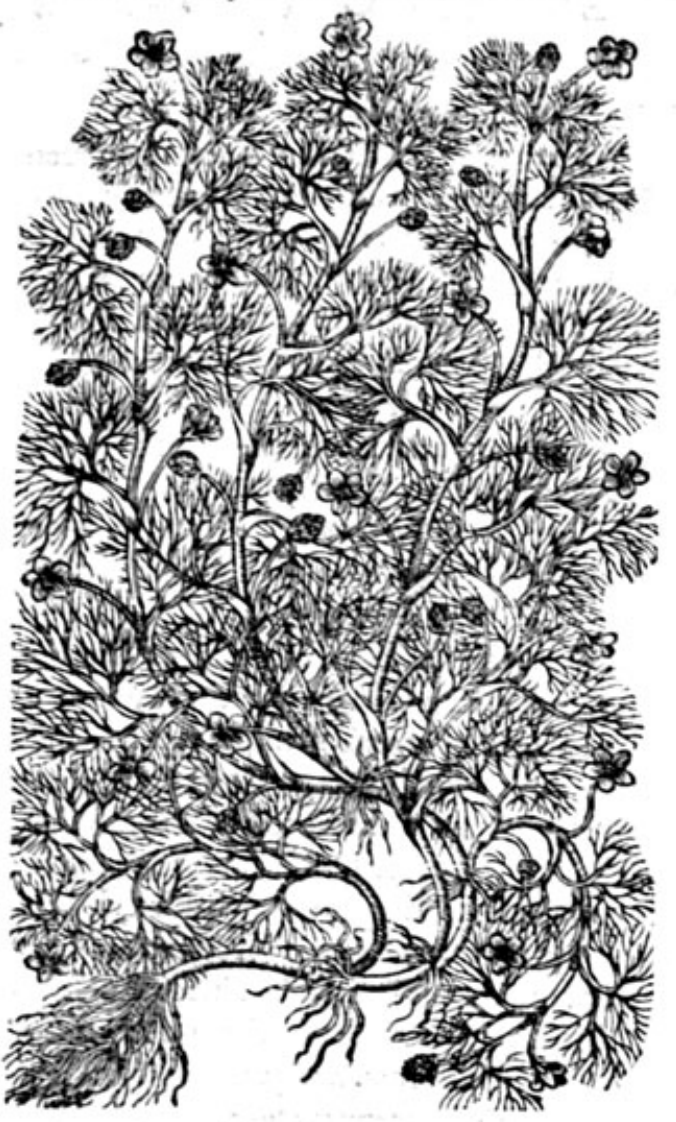

$* T$ be deforipsion.

3 This water Milfoile, diffeteth from all the kinds aforefaid, hauing a roote in the bottome of the water made of many hairie ftrings, which yeeldeth vp a naked flender ftalke withn the water, and the reft of the ftalke which loteth vpon the water diuideth it felfe into fundry other branches \& wings, which are be dafhe with fine fmall iagged leates like vnto Cammomill, or rather refembling hairie Taffels or fringe, then leaues: from the bofomes where of come foorth fmall and tender braunches, euery braunch bearing one fower like vnto water Crowfoote, white of colour,with a little yellowe in the midft; the whole plant refembleth water Crowfoote in all things fate in thebroadc leaues.

There is another kind of water Violet very like the former, fauing that hisleaues are thicker and fatter, fomewhat refembling the leanes of Lonchitis, but as fmall as Fennell, fafhioned like vnto wings, and the flowers fomewhat fmaller.

There is likewife another kind of water Milfoile which hath leaves very like vnto water Violet, fmaller, and not fo many in number :the ftalke is fmall and tender, bearing yellowe gaping flowers fafhioned like a hood, or the fmall Snapdragon, which caufed Pena to put vnto his name this additament Galericulatum, that is, hooded. The rootes are fmall and threddic, with fome few knobs hanging thereat, like the founds of finh.

* Theplace.

They be found in lakes and ftanding waters,or in waters that run flowly, Ihate not founde fich plentie of it in any one place as in the water ditches adioining to Saint George his fielde neere London.

\section{They flower for the moft part in Maie and lune.}

* The time.

* The names.

The firft is called in Dutch water Citolieren, that is to faie, Diols agwatilis: in Englifh water Gilloflower, or water Violet : in French Gyrofiees d' eauc : Matbiolus maketh this to be alfo Myriophyllis Jpecies, or a kinde of Yarrow, although it doth not agree with the defcription thereof: for neither hath it one ftalke onely, nor one fingie roote as Myrtophyllon or Yarrow is defcribed to haue:for the rootes are full of ftrings, and it bringeth foorth many ftalks.

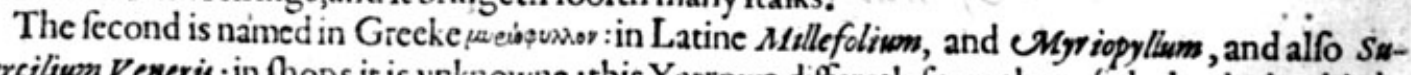
perciliwn Veneris : in fhops it is vnknowne : this Yarrowe differeth from that of the land: the thirde is fufficiently fpoken of in his title.

\section{Water Yarrow as De temperature and vertwes.} Water Yarrow as Dio/corides faith, is of a drie facultie: and by reafon that it taketh away hot in- A Yarrow is a remedie againft inflammations in greene wounds, if with vineger it be applied greene or drie, and is giuen inwardly with vineger and falt to thofe that haue fallen froman high place. Water Gilloflower, or water Violet, is thought to be colde and drie, yet hath it no ve in Phi- B
fickeat all.

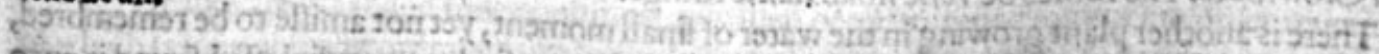

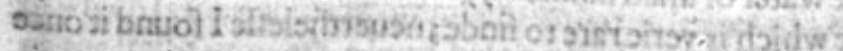
nil

$$
V \vee 4
$$




\section{of Duckes meate, and other Jwimming berbes. Chap.287.}

\section{Lens paluftris. .}

Duckes meate.

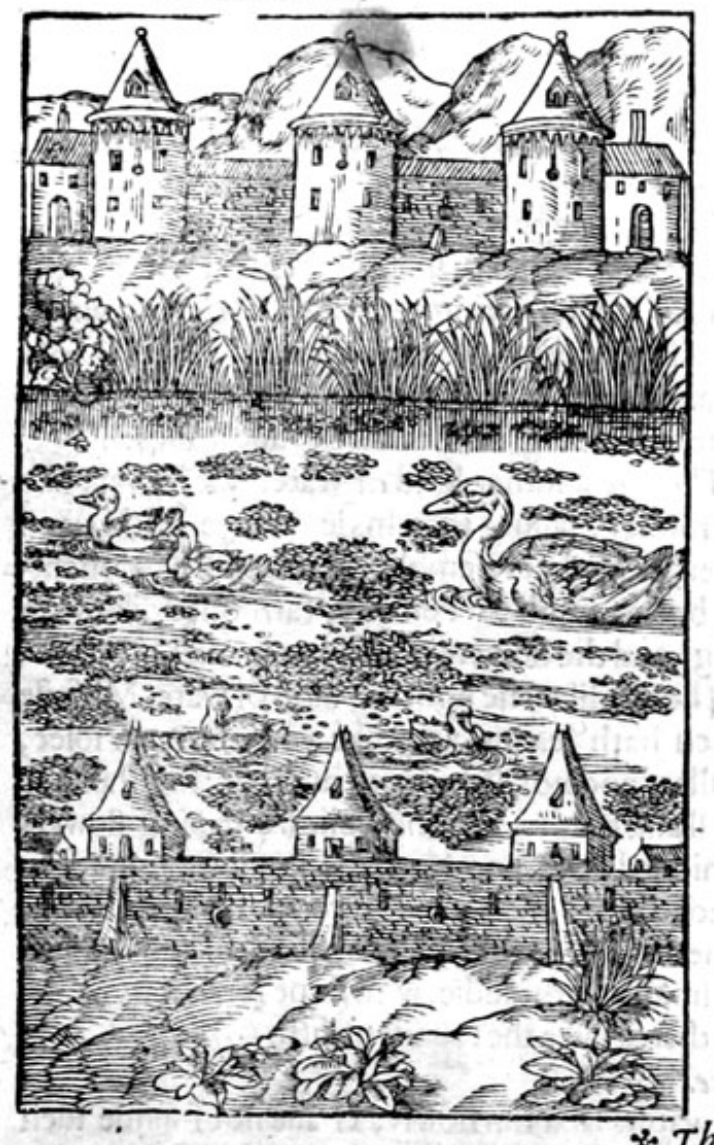

* The defoription.

Vckes meate is as it were a certaine green mofie, with very little round lgaues of the bignes of Lentils : out of the middle wherof on the neather fide growe downe verie fine threds like haires, which are to them in fteede of rootes:it hath neither ftalke, tlower nor fruite.

$$
\text { *Theplace. }
$$

It is found in ponds, lakes, citie ditches, and in other ftanding waters euery where. * The time.

The time of Duckes meate is knowne to all. * T The names.

Duckes meat is called in Latine Lens lacuftris, Lens aquatilis, \& Lens paluftris: of the Apothecaries named aqua Lenticula: in high Dutch פger. Iinfeit: in lowe Dutch wetatrtinien, \& more vfually Endon gruen, that is to fay Anat um ber$b a$, Ducks herbe, bicaufe Ducks do feede thereof: whereupon alfo in Englifh it is called Ducks meate:fome terme it after the Greek water Lentils, and of others it is named $G$ raines : the Italians call it Lent di Palude: in French Lentille d' eaue : in Spanifh Lenteias de agua. * T he temperature.

Galen iheweth that it is cold and moift,after 2 fort in the fecond degree.

A Diofcorides faith that it is a remedie againft all manner of inflammations, Saint Anthonies fire and hot agues, if they be either applied alone, or elfe vfed with parched barly meale : It alfo knitteth ruptures in yoong children.

B Duckes meate mingled with fine wheaten flower and applied, preuzileth much againft hot fwellings, as Phlegmons, Erifipelas, and the paines of the ioints.

C The fame dorh helpe the fundament gutte fallen downe in yoong children.

\section{Of water Crowfoote. Chap.288.}

\section{* The defcription.}

I T Ater Crowfoote hath flender braunches trailing farre abroade, whereupon do grow leaues vnder the water moft finely cut and iagged like thofe of Cammomill. Thofe aboue the water are fomwhat round, indented about the edges in forme not vnlike the finall tender leaues of the mallow, but leffer : among which do grow the flowers fmall and white of colour,made of fine little leaues with fome yellowneffe in the middle like the flowers of the Straberie, and of a fweete fmell : after which there come rounde, rough and prickly knaps like thofe of the field Crowfoote. The rootes be verie fmall hairie ftrings.

2 There is another plant growing in the water of fmall moment, yet not amiffe to be remembred, called Hederula aguatica or water Iuie, the which is verie rare to finde; neuercheleffe I found it once 
in a ditch by Bermondfey houfe neer to London, and nener elfe where : it hath final threddie ftrings in fteed of rootes and ftalkes, rifing from the bottome of the water to the top, whereunto are fafte. ned fmall leaues fwimming or floting vpon the water, triangled or three cornered like vnto thofe of barraine Iuic, or rather noble Liuerwoort : barraine of tlowers and feeds.

There is likewife another herbe of fmall reckoning that floteth vpon the water called stelleris equstics or water Starwoort, which hath many fmall graffie ftems like threds, comming from the bottome of the water vnto the vpper face of the fame: whereupon do grow final double flowers of a greenifh or herbie colour.

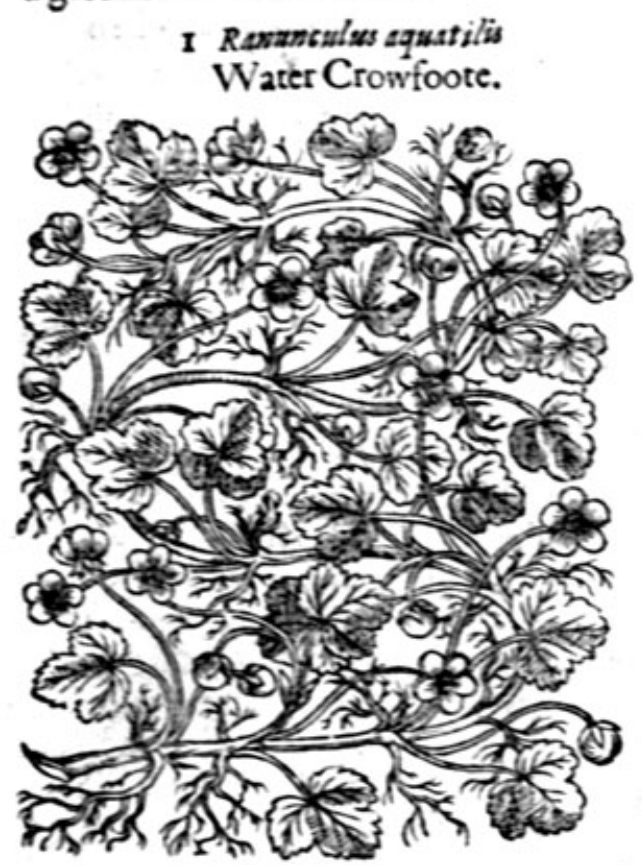

2 Hederalsagustics. Water Inic.

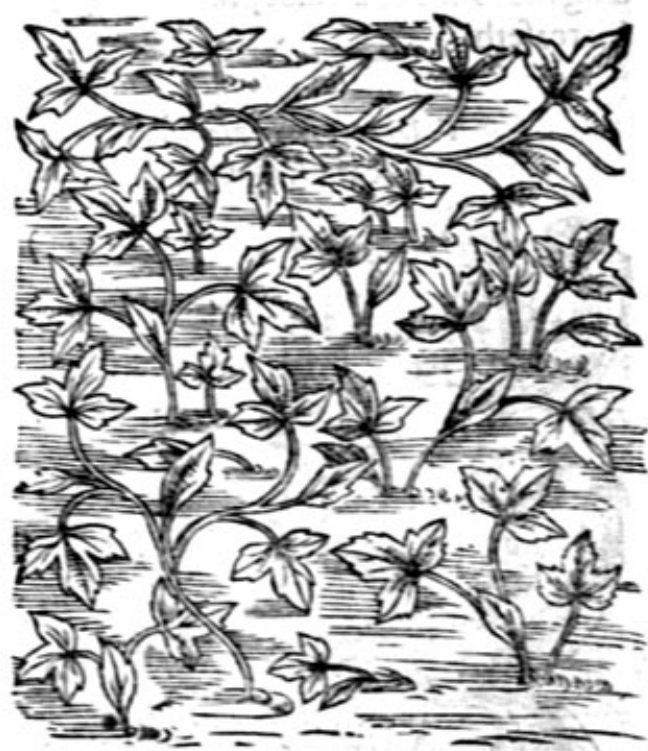

$*$ Theplace.

Water Crowfoote groweth by ditches and fhallow fprings, and in other moift and plafhie places.

It flowreth in Aprill and May, and fometimes in Iune.

$*$ The time.
$*$ The nemes.

Water Crowfoote is called in Latine Rsusnculsws aquatilis, and Polyenthemum aquatile: in Englifh water Crowfoote, and white water Crowfoote: moft Apothecaries and Herbarifts doe erronioufly name it Hepatica agaat ics, and Hepatses alba, and with greater error they mixe it in medicines in fteede of Hepatics albi or graffe of Parnaffus.

* The temperature and vertues.

Water Crowfoote is hot and like to common Crowfoote.

$$
\text { Of Dragons. Chap.289. }
$$

\section{*The kimdes.}

THere be two forts of Dragons, the greater and the lefier : and befides thefeathird one which groweth in waters.

\section{* The defaription.}

I - He great Dragon rifeth vp with 2 ftraight ftalke a cubitand a halfe high or higher, thicke, round, finooth,fprinckled with fpots of diuers colors like thofe of the adder or fnalkes. The leaves ate great and wide confifting offeauen or more ioined rogither in order : eueric one of which is long and narrow muchilike to the leaues of Docke, fmooth and lipperie :out of the rop of the ftallie growech a long hofe or huske greater then that of the Cockow pintle, of a greenifh 


\section{2}

THE SECOND BOOKE

OF THE

colour without, and within crimfon, with his peitell which is blackifh, long, thicke, and pointed like a horne: the skin or filme where of when the feede waxeth bigge being ftretched and broken in funder there appeereth the fruite, like to a bunch or clufter of grapes: the berries whereof at the firft be greene, afterwards red and full of inice, in which is conteined feede that is fomewhathard: the root continueth freth, thick, like to a knob, white, cotered with a thinne pilling, oftentimes of the bignes of a meane apple, full of white little threds appenden thereto.

2 The leffer Dragon is like Aron, or wake-Robin in leaues, hofe, or huske, peftell and berries yet are not the leaucs fprinckled with blacke, but with whitifh fpots, which perifh not fo foone as thofe of wake-Robin, but endure togither with the berries, euen vatill winter : thefe berries alfo be not of a deepe red, but of a colour inclining to faffron. The roote is not vnlike to the Cuckowpint, hauing the forme of a bulbe, full of ftrings, with diuers rude fhapes of newe plants, whereby it greatly increafeth.

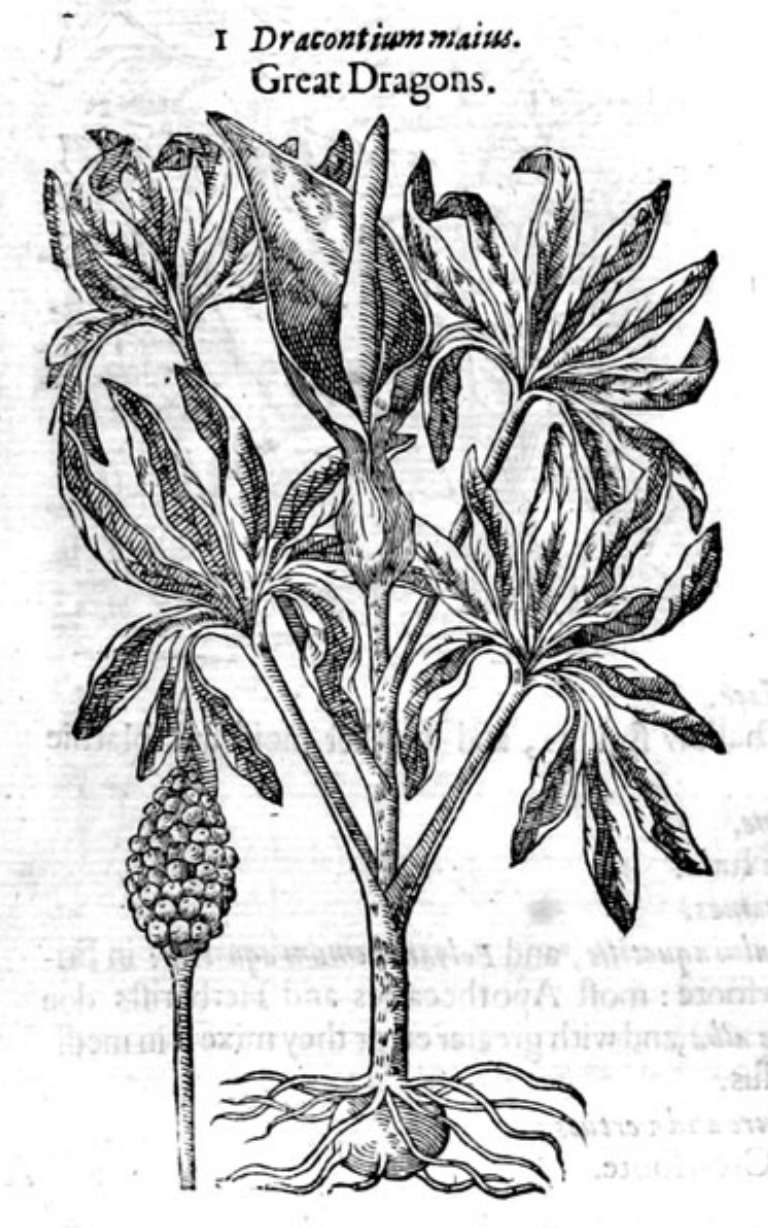

\section{Dracontium minus. Small Dragons.}

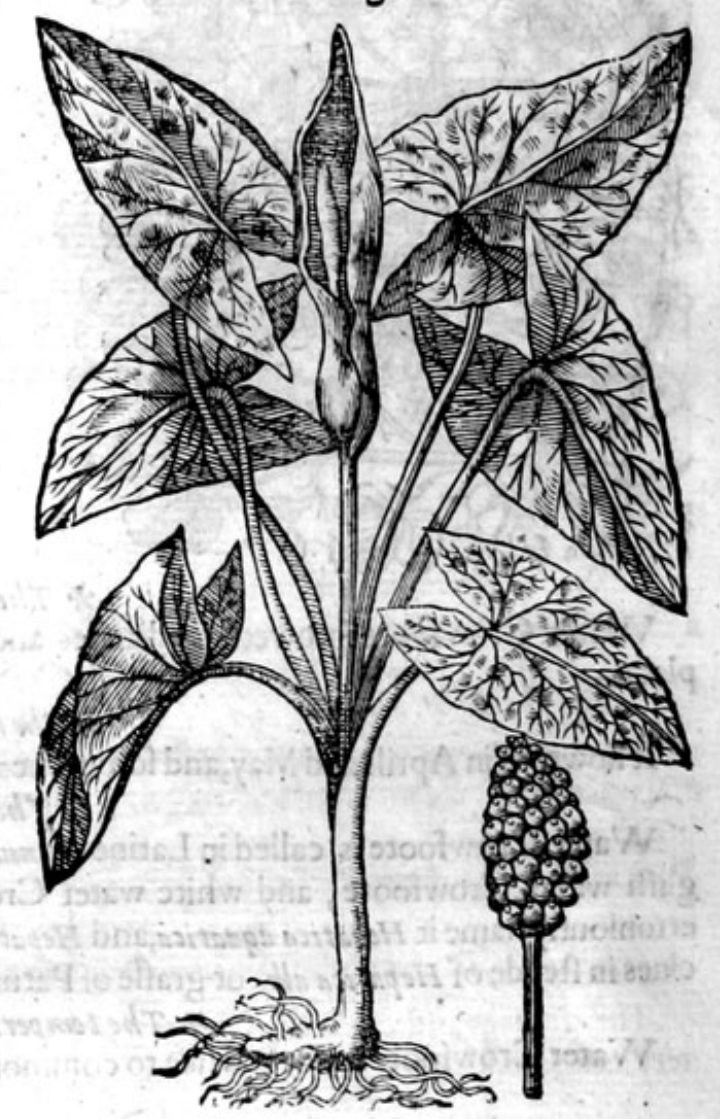

\section{* Thedefription.}

3 The roote of Water Dragon is not round like a bulb, but very long,creeping and iointed, and of meane bignes : ont of the ioints where of arife the ftalkes of the leaues which are round, Imooth, and fpungie within, and there grow downwards certaine white and flender ftrings: the fruit fpringeth forth at the top vpon a fhort ftalke togither with one of the leaues, being at the beginning couered with little white threds, which are in fteede of the flowers; after that it groweth into 2 bunch or clufter, at the firft greene, and when it is ripe, red, lefier then that of Cuckowpint, but not leffe biting : the leaues are broad, greenifh, glib and mooth, in fafhion like thofe of Iuie, yet leffer then thofe of Cuckowpint, but that thing whereunto the cluftered fruite groweth is alfoleffer, and in that part shich is towards the fruite, that is to fay, the vpper part is white. 


\section{AHISTORIE OF PLANTS. NT}

4 The great Dragon of Mathiolys defcription is a ftranger, not onely in England, but elfewhere for any thing that we can learn of the ancient writers, or thofe liuing in my timesmy felfe have diligently inquired of moft ftrangers skilfull in plants that haue reforted vnto me for conference fake, but no man can giue me any certaintie thereof: and therefore I thinke it not amiffe to give yoti his figure without any further defcription, referring what might be faid to a furcher confideration ; for as yer I take it for a fained picture.

3 Dracunculus agmaticus. Water Dragons.

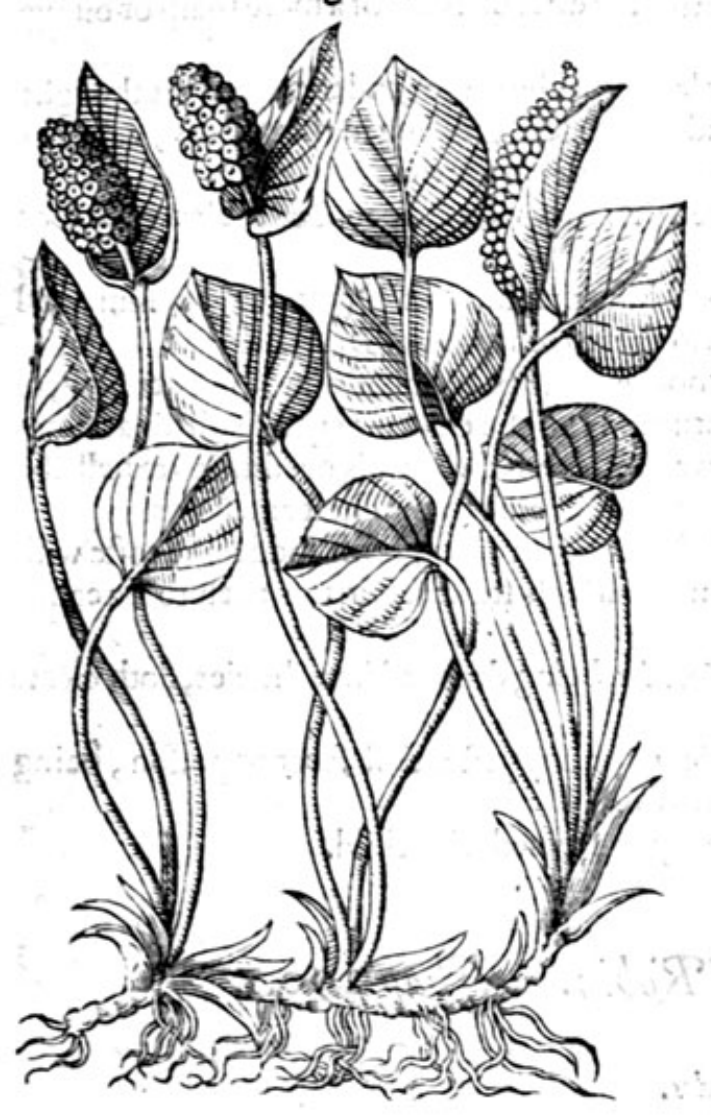

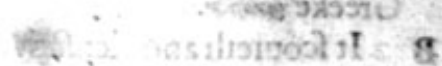

4 Dracontium mains Matbioli. Spikie Dragons.

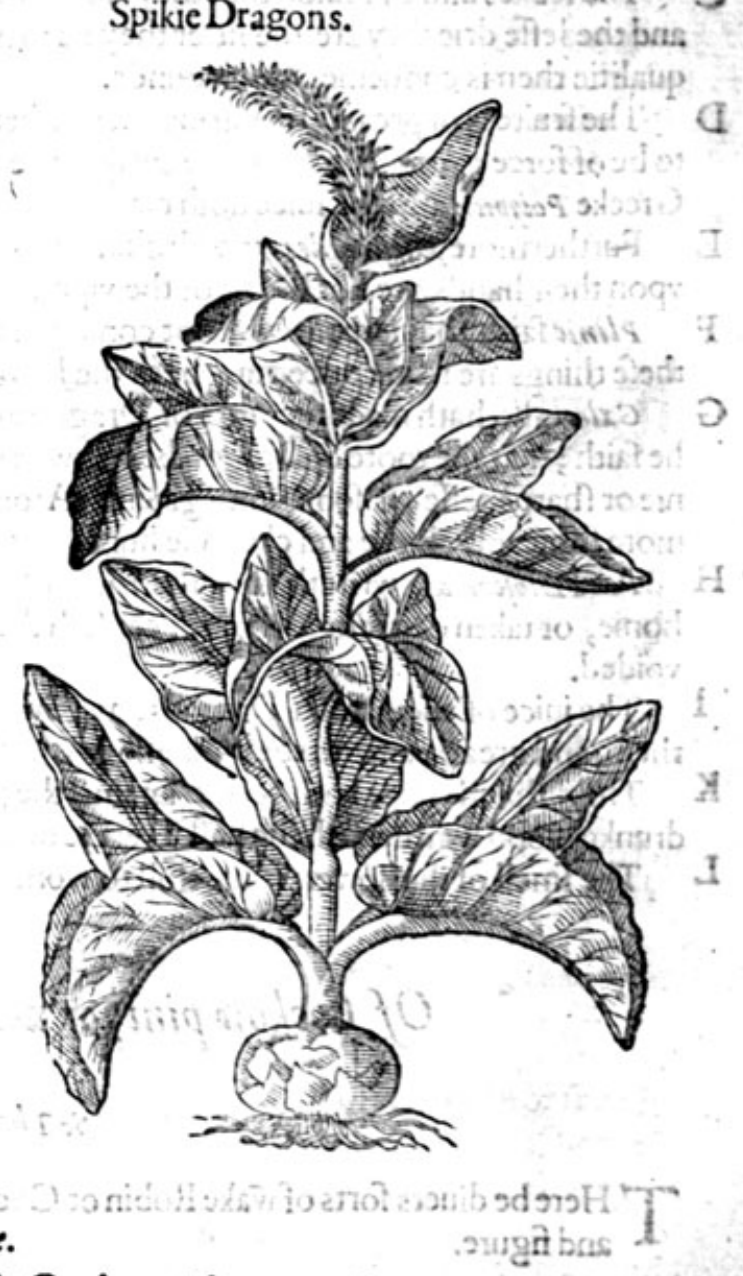

* The place.

The greater and the leffer Dragons are planted in Gardens. The water Dragons grow in watery and marrifh piaces, for the moft part in Fennie and ffanding waters.

* The the berries of thefe plants are ripe in Autumne.
* The names. sise-Dragon is called in Grecke dexximon: in Latine pracknculus. The greater is named, ser.

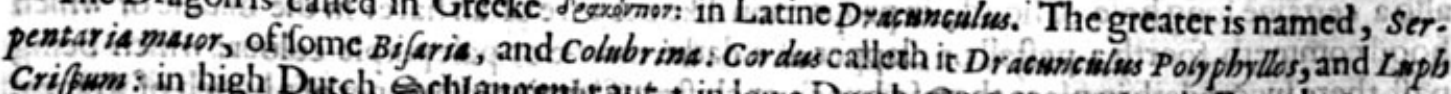

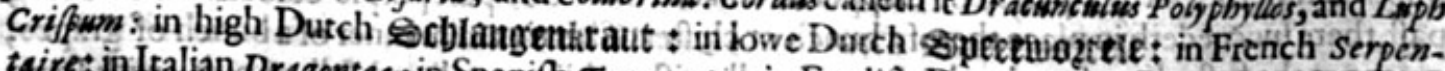
tairst in Italian Dragontea : in'Spanifh Taragontids : in Engliph Dragons, and Dragon woort. Apter leiws calleth Dragon Dracontea, and fetteth downe many ftrange names thereof, which whether they, agrece with the greater or theleffer, or both of them he doth not expound: as Pytbonion, 1 in.

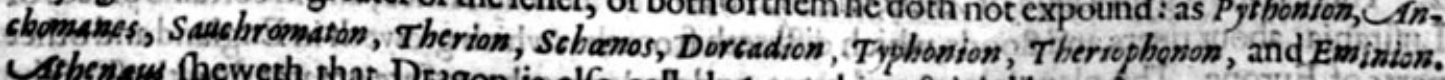
uspenew fheweth that Dragon is alfo called Aronia, bicaufe it is like to Aron.

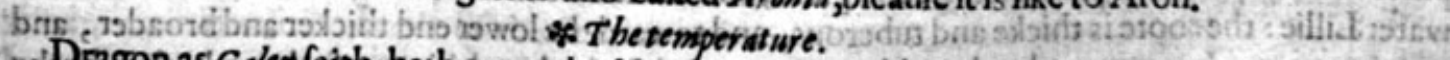

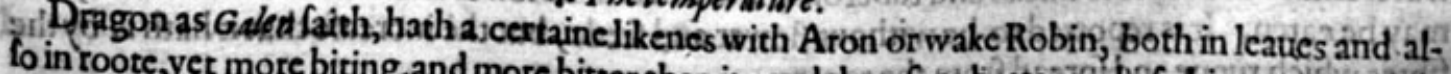
10 in roote,yet more biting, and more bitter then it, and therefore hotter atd dof thinrer parts: it is stit se 


\section{THE SECOND BOOKE OF THE}

alfo fomthing binding, which by realon that it is adioined with the two former qualities, that is to faic, biting and bitter,it is made in like maner a fingular medicine of very great efficacie.

$$
\text { * The vertues. }
$$

A The roote of Dragons doth clenfe and fcoure all the entrailes, making thinne, efpecially thicke and tough humours; and it is a fingular remedic for vlcers that are harde to be cured, named in Greeke raxouism.

B It fcoureth and clenfeth mightily, afwell fuch things as haue neede of fcouring,as alfo white and blacke morphewe, being tempered with vineger.

C The leaues alfo by reafon that they are of like qualitie, are good for vicers and greene woundes: and the leffe drie they are, the fitter they be to heale; for the drier ones are of a more fharp or biting qualitie then is conuenient for wounds.

D. The fruite is of greater operation then either the leaues or the roote : and therefore it is thought to be of force to confume and take away cankers and proud tlefh growing in thenoftrils, called in Greeke Polypus: alfo the iuice doth clenfe away webs and fpots in the eies.

E Furthermore Diofcorides writeth, that it is reported that they who haue rubbed the leaues or root vpon their hands, are not bitten of the viper.

F Plinie faith,that ferpents will not come neere vnto him that beareth Dragons about him, and thefe things are read concerning both the Dragons in the two chapters of Diofcorides.

G Galen allo hath made mention of Dragon in his booke of the faculties of nourifhments, where he faith ; that the roote of Dragon being twife or thrife fod, to the ende it may lofe all his acrimonie or harpeneffe, is fometimes giuen as Aron or wake-Robin is, when it is needfull to expell the more forceably thicke and clammie humours that are froublefome to the cheft and lungs.

H And Diofcorides writeth that the roote of the leffer Dragon being both fodde and rofte with honie, or taken of it felfe in meate, caufeth the humours which fticke faft in the cheft to be eafilie voided.

I The iuice of the garden Dragons, 25 faith Diofcorides, being dropped into the cies, doth clenfe them, and greatly amend the dimneffe of the fight.

$\mathbf{K}$ The diftilled water hath vertue againft the peftilence or any peftentiall feuer or poifon, being drunke blood warme with the beft Treacle or mithridate.

L The fmell of the flowers is hurtfull to women newly conceiued with child.

\section{Of Cockow pint, or wake Robin. Chap.290.}

\section{* The kindes.}

Here be diuers forts of wake Robin or Cockow pint differing in names, titles, and alfo in forme
and figure.

\section{* The defaription.}

I rum or Cockow pint hath great, large, fmooth, fhining, (harpe pointed leaues, befpotted heere and there with blackilh fpots, mixed with fome blewneffe: among which rifeth vpa ftalke nine inches long, befpecked in manyplaces with certaine purplefpots. It beareth alfo a certaine long hofe or hood, in proportion like the eare of an hare: in the middle of which hood commeth foorth a peftell or clapper of a darke murrie or pale purple colour: which being paft, there fucceedeth in place therof a bunc's or clufter of berries in manner of a bunch of grapes, greene at the firft, but after they be ripe of a yellowilh red like corall and full of pith, with fome threddie additaments annexed thereto.

2 There is in Aegypt a kind of Arum, which alfo is to be feene in Africa, and in certaine places of Lufitania, about riuers and floods, which differeth from that which groweth in England and other parts of Europe. This plant is large and great, and the leaues thereof are greater then thofe of the water Lillie: the roote is thicke and tuberous, and toward the lower end thicker and broader, and may be eaten. It is reported to be without flower and feede, but the increafe that it hath is by the fibres which runne and fpread from the rootes. 


\section{HISTORIE OF PLANTS.}

1 Arnm maius.

Great Cockowipint.

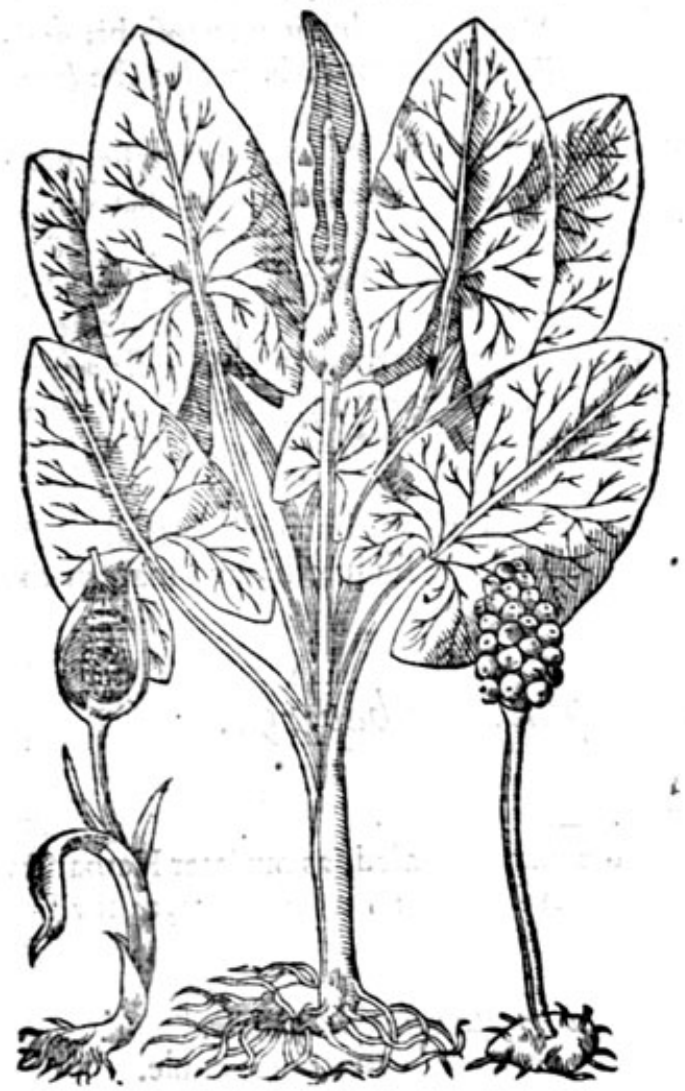

Lrwom minese.

Little Cóckow pint.

* The place.

Cockow pint groweth in woods neere vnto ditches vnder hedges, euerie where in thadowic places.

\section{* T The time.}

The leaues appecre prefently after winter : the peftell heweth it felfe out of his huske or fheath in Iune whileft the leaues are in withering; and when they are gone, the bunch or clufter of berries becommeth ripe which is in Iuly and Auguft.

$$
\text { * The names. }
$$

There groweth in A egypt a kinde of Aron or Cockow pint which is found alfo in Africa, and likewife in certaine places of Portingall neere vnto riuers and ftreames, that differeth from thofe of our countries growing, which the people of Caftile call Manta de muestra fenora : moft would haue it to be called Colocaf fia, but Diofcor ides faith that Colocafia is the roote of Faba Aegyptit, or the Beane of Aegypt.

The common Cockow pint is called in Latin Arum: in Greek äer : in fhops Iarm, \& Barba-Aron: of others Pes vituli : of the Syrians Lupha: of the men of Cyprus Colocafat, as we finde among the baftard names. Plinie in his 24 . booke 16 . chapter doth witneffe that there is great difference between Aron \& Dracontivn, although there hath bin fome controuerfie about the iame among the old writers, affirming them to beall one : in high Dutch it is called jPaffen pent : in Italian Gigaro: in Spa-

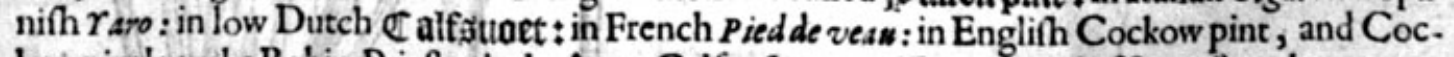
kow pintle, wake Robin, Priefts pintle, Aron, Calfes foote, and Rampe, and of fome Starch woort.

$$
\text { * The temperature. }
$$

The faculties of Cockow pint doe differ according to the varietic of countries: for the roote heereof as Galen in his booke of the faculties of nourifhments doth affirme, is fharper or more biting in fome countries then in others almoft as much as Dragons, contrariwife in Cyren a citic in Africke,yet is it generally in all places hot and drie, at the lealt in the firft degree. 


\author{
* The vertues.
}

A If any man would haue thicke and tough humours which are gathered in the cheft and lungs to be clented and voided out by coughing, then that Cuckowpint is beft that biteth moft.

B It is eaten being fodden in two or three waters, and frefh put to, whereby it may lofe his acrimonie, which being fo eaten they cut thicke humours meanly, but Dragons is better for the fame purpofe.

C Diofcorides fheweth that the leaues alfo are preferued to be eaten, and he fheweth that they muft be eaten after they be dried and boiled, and writeth alfo, that the roote hath a peculiar vertue againft the gout, being laide on ftamped with Cowes dung.

D Beares atter they haue lien in their dens forty daies without any maner of fuftenance (but what they get with licking and fucking their owne feete)do affoone as they come foorth, eate the herbe Cuckowpint; through the windie nature whereof the hungrie gut is opened and made fit againe to receiuc fuftenaunce; for by abfteining from foode fo long a time, the gut is fhrunke or drawen fo clofe togither, that in a maner it is quite fhut vp, as Ariftutle, NElianies, Pluterch, Plinie, and others do write.

E The moft pure and white ftarch is made of the rootes of Cuckowpint; but moit hurtfull for the hands of the laundreffe that hath the handling of it; for it choppeth, bliftereth, and maketh the hands rough and rugged, and withall fmarting.

\title{
Of Friers Coule, or booded Cuckompint. Chap.291.
}

* The kindes.

FRiers hood is of two forts, the one broad leafed, the other narrow leafed, as our later Herbarifts Faue obferued : notwithftanding Methiolus hath fet foorth the figure of a thirde fort, 2 s fhall be declared.

I Urifarum latifolium.

Broad leafed Friers coule.
2 Arifarum anguftifolivem. Narrow leafed Friers conle.

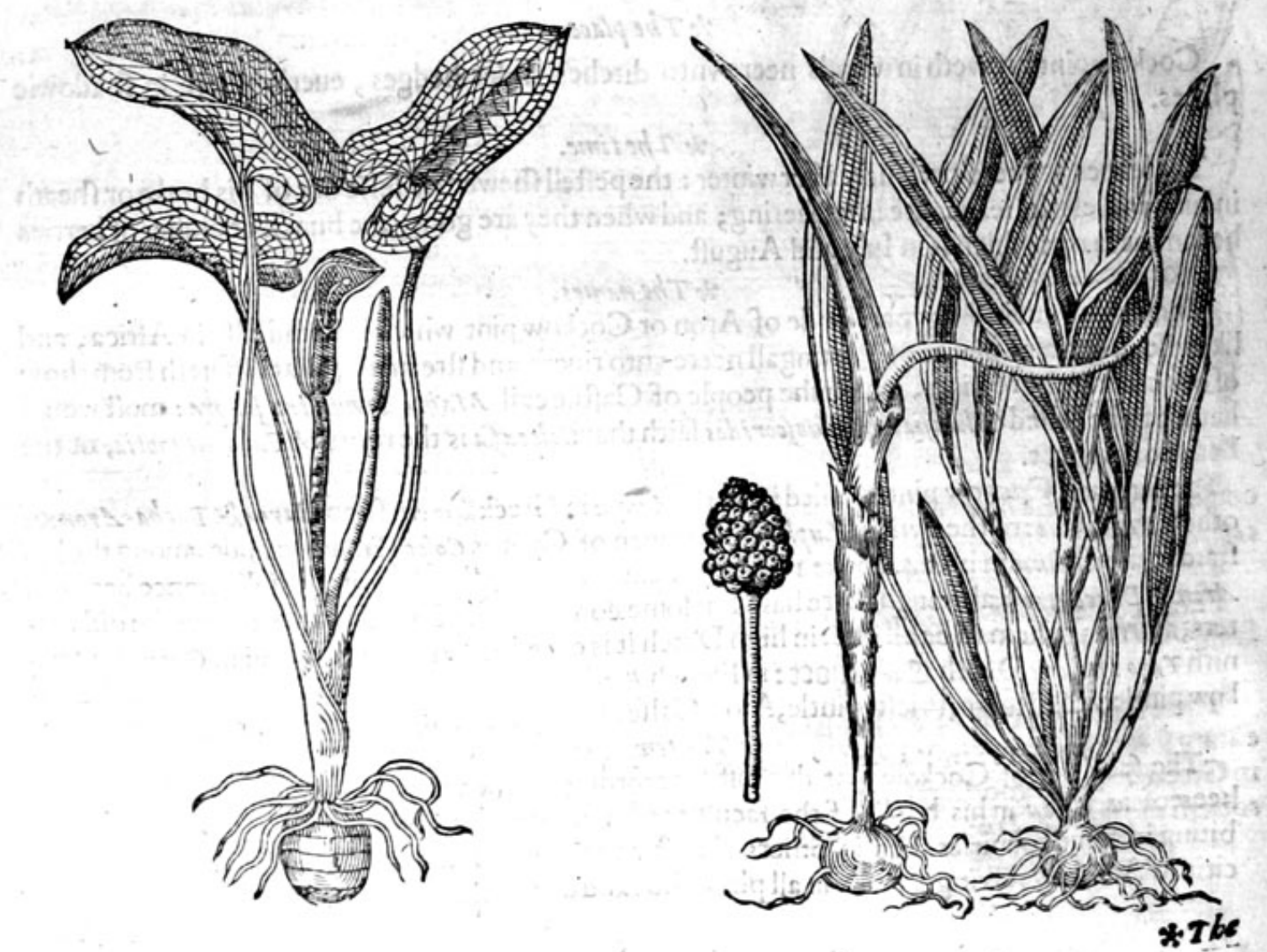




\section{HISTORIE OF PLANTS.}

' $\mathrm{B}$

*The defcription. Road leafed Friers hoode hath a leafe like Iuie, broade, and harpe pointed : but far leffer, approching neere to the forme of thofe of Cuckowpint. The ftalke thereof is fmall and flender. The huske or hofe is little; the peftell fmall, and of a blacke purplifh colour ; the clufter when it is ripe is red; the kernels fmall. The roote white, hauing the forme of Aron or Cuckowpint, but leffer, whereof doubtleffe it is a kinde.

2 The fecond Friers hood hath many leaues, long and narrowe, fmooth, and glittering: the huske or hofe is narrowe and long; the peftell that commeth foorth of it is flender, in forme like a great earth worme, of a blackith purple colour, as hath alfo the infide of the hofe;vpon which hard to the ground, and fomtimes a little within the grounde, groweth a certaine bunch or clufter of berries, greene at the firft,and afterwards red. The roote is round and white like the others.

3 Arifarwen latifolium Mathioli. Italians Friers hood.

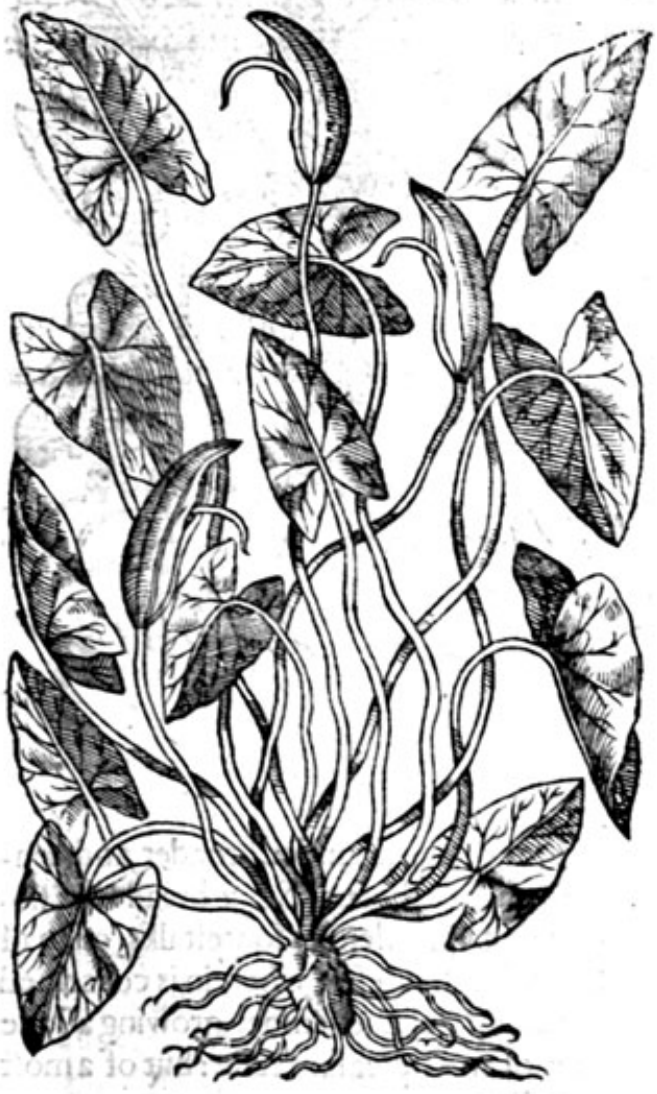

* The defcription.

3 The Friers hood of Mashiolus defcription hath a knobbed thicke roote, fet with diners fmal ftrings: from whieil rifeth vp fundrie weake and tender footeftalks, wheron do grow broad leaues fharpe pointed, of a perfect greene colour, not vnlike thole of forrell; the hood and peftell grow. eth at the ends of the like footeftalks, which turn into a bunch or clufter of redde berries like the others.

$$
\text { * Theplace. }
$$

Thefe plants are ftrangers in Englande : but common in Italy, \& efpecially in Tufcane about Rome, and in Dalmatia, as Cloifises Angaillsra witnefieth; notwithftanding I haue two of the firft in my garden.

$$
\text { * The time. }
$$

The flowers and fruit of thefe come to perfection when thofe of Cuckowpint \& Dragons do

\section{* The names.}

Friers hoode is called of Diofcorides abioney : in Latine Arifarum : but $P$ liny calleth it A"eus or Ar is, for in his 24 . booke 16 .chapter, he faith that $A r$ is which groweth in AEgypt is like Aron or Crickowpint: it may be called in Englifh after the $\mathrm{La}_{2}$ tine name Arifarsen, but in mine opinion it may be more fitly Englifhed Friers hood, or Friers
coule, to which the flowers feemeth to be like, whereupon the Spaniards name it Frailillos, as Dale-
noteth. campius noteth.

Friers coule is like in power and facultie temperature. faith.

There is no great $*$ The vertues.

eating fores or vicers : and likewife thats in Phificke; but it is reported that they ftaie running or A in Greeke Collyria, good againft fiftulaes, and is made of the rootes certaine compofitions called rottech the fame, as Diogcorides writeth.

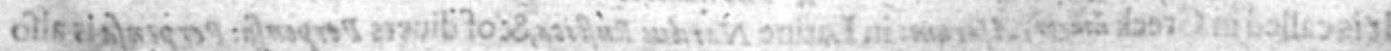
xindewe 


\section{of eAftrabacca. Cbap.292.}

I Alarum.

Afarabacca.

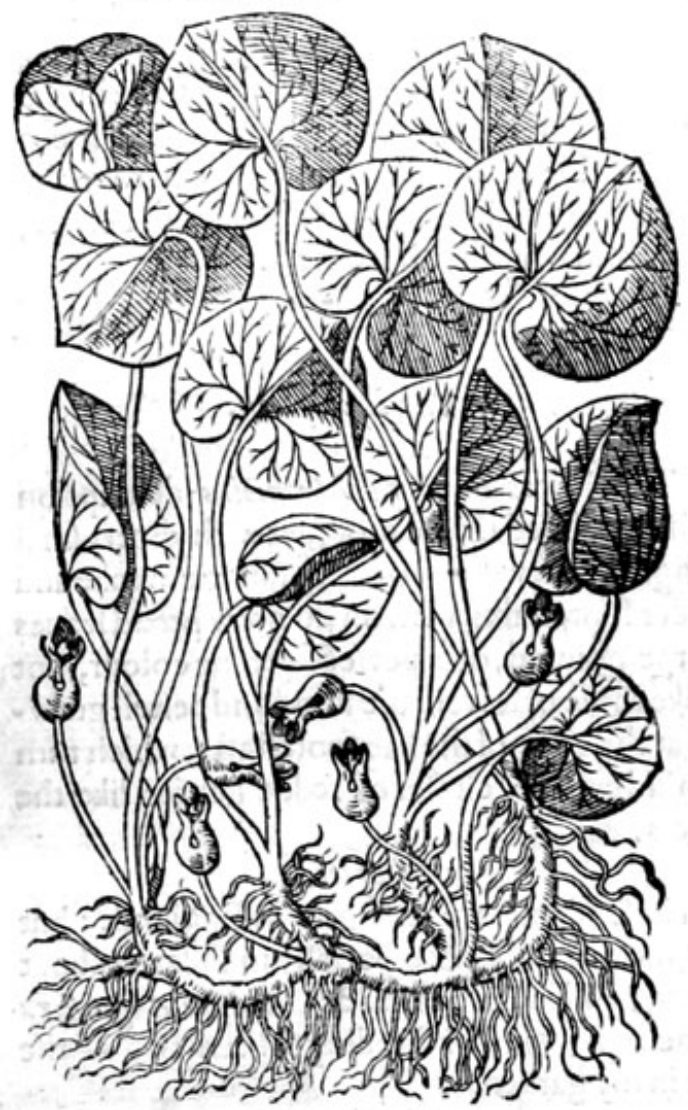

2 Afarina Mathioli. Italian Afarabacca.

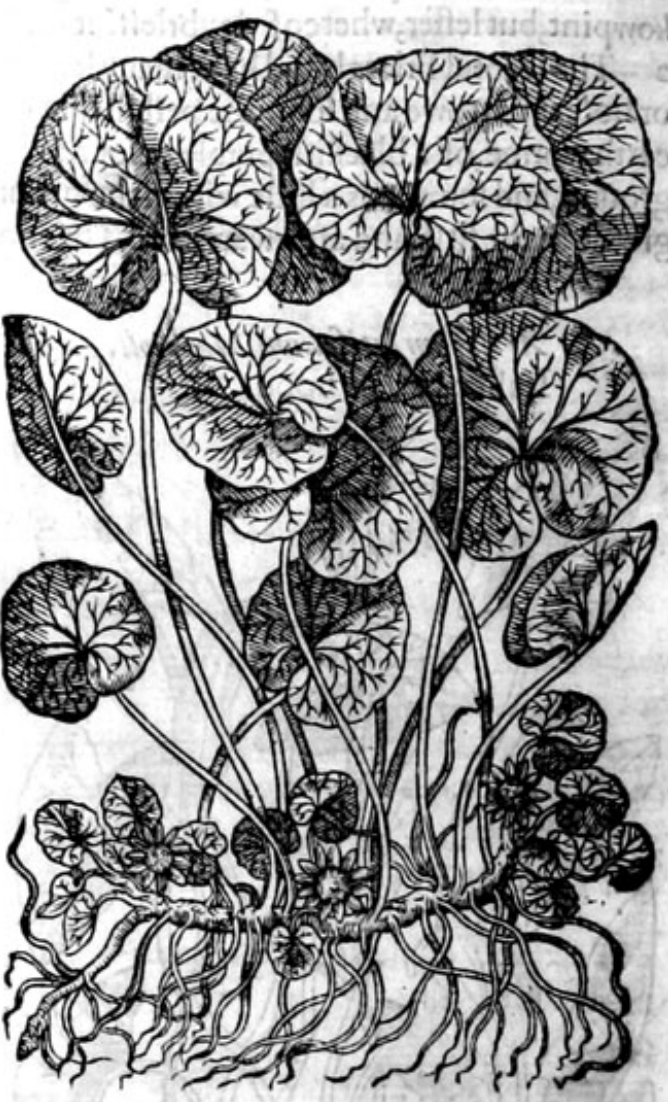

\section{* The defcription.}

I Theleaues of Afarabacca, are fmooth, of a deepe greene colour, rounder, broader, and tenderer then thofe of Iuie,and not cornered at all, not vnlike to thofe of Sowe bread: the flowers lie clofe to the rootes, hid vnder the leaues, ftanding vpon flender footeftalks, of an ill fauoured purple colour, like to the flowers and huskes of Henbane, but leffer, wherein is conteined fmall feedes, cornered and fomewhat rough: the rootes are many, fmal, and flender, growing aflope vnder the vpper cruft of the earth,one folded within another, of an vnpleafant tafte: but of a molt fweete and pleafing finell, hauing withall a kinde of biting qualitie.

2. This ftrangekind of Afarabacca which CMathiulus hath fet foorth creepeth vpon the grounde, in maner of our common Aftrabacca : the leaues are fomewhat rounder and rougher, flightly indented about the edges, and fet vpon long flender footftalks: the flowers growe harde vnto the ground like vnto thole of Cammomill, but much leffer, of 2 mealie or duftie colour, and not without fincll. The rootes arc long and flender, creeping vnder the vpper cruft of the earth, of a tharpe tafte, and bittcr withall.

$$
\text { * The place. }
$$

It delighteth to growe in thadowie places, and is very common in moft gardens.

$$
* \text { Thetime. }
$$

The herbe is alwaies greene,yet doth it in the fpring bring foorth newe leaues and lowers. $\therefore$ T be names.

It is called in Greek čzegy, 1 farum: in Lacine Nardus Ruflica, \& of diuers Perpenfa: Perpenfa is alfo Baccharis 


\section{HISTORIE OF PLANTS.}

Baccharis in Plinie in his $2 \mathrm{r}$.booke, $2 \mathrm{r}$.chapter, Macer faith, that $\triangle \mathrm{Afarom}$ is Vulgago.

Est Afaron Grecè (faith he) Vulgago dicta Lasine.

This herbe 1 aron, do the Gracians name,

Whereas the Latines $V$ algago clepe the fame.

It is found among the baftard names that it was called of the great learned Philofophers muma apous, that is Martis fanguis, or the bloud of Mars : and of the French men Baccar, and thereupon it feemeth that the word $A$ Jarabasca came, which the apothecaries vfe, and likewife the common people: but there is another Bascharis differing from 1 Jarum, yet notwithiftanding Cratesadoth alfo call Baccbaris is,Afarum.

This confufion of both the names hath been the caufe, that moft could not fufficiently expound themfelues concerning 1 farum $\&$ Baccharis: Sx that many things haue been written amiffe in many copies of Diofcorides, in the chapter of Afarum: for when it is fet downe in the Greeke copies a fweete fmelling garland herbe, it belongeth not to the defcription of this 1 farum, but to that of Baccharis: for Afarim (as Pliny faith) is fo calledbicaufe it is not put into garlands; and fo by that meanes it came to paffe, that oftentimes the defcriptions of the old ivriters were founde corrupted and confufed: which thing, as it is in this place manifeft, fo oftentimes it cannot fo eafily be marked in other places. Furthermore $A$ faram is called in French Cabaret: in high Dutch Đarelivurtz: in lowe Dutch 9ang aozen: in Englifh Afarabacca, Folefoote, and Hafell woort. *T The semperature.

Theleaues of Afarabacca are hot and drie, with a purging qualitie ioined thereunto: yet not withouta certaine kinde of attriction or binding. The rootes are alfo hot and drie : yetmore then the leaies: they are of thinne and fubtill parts: they procure vrine, bring downe the defired fickneffe, and are like in facultie, as $G_{\text {ales faith }}$, to the rootes of $A$ cor mw, but yet more forceable : and the rootes of Acorw are alfo of a thinne effence, heating, attenuating, drying and prouoking vrine, as heiffirmeth: which things are happely performed by taking of the rootes of Afarabacca, either by themfelues, or mixed with other things.

$*$ The vertues.

The leaues draw foorth by vomit thicke, phlegmaticke, and cholericke humours, and withall $\mathbf{A}$ mooue the belly, and in this they are more forceable, and of greater effect then the rootes themfelues.

They are thought to kcepe in hard fwelling cankers that they increafe not, or come to exulcera- B tion,or creepe any farther if they be outwardly applied vpon the fame.

The rootes are good againft the ftoppings of the liuer, gall, and fpleene, againft wens and harde $\mathbf{C}$ fwellings, and agues of long continuance : but being taken in the greater quantitie, they purge flegme and choler not much leffe then the leaues, (though Galen faith no,)by vomite efpecially, and alfo by fiege.

One dram of the powder of the rootes giuen todrinke in ale or wine,groffely beaten, prouoketh $D$ vomite for the purpofes aforefaide. But being beaten into fine powder, and fo giuen, purgeth verie little by vomite, but worketh moft by procuring much vrine; therefore the groffer the powder is, fo much the better.

But if the rootes be infufed or elfe boiled, then muft there be two, three, or fower drams put to $\mathrm{E}$ the infufion; and of the leaues eight or nine be fufficient: the iuice of which ftamped with fome liquid thing, is to be giuen. The rootes may be fteeped in wine, but more effectually in Whaie or honied water, as Mefwes teacheth.

The fame is good for them that are tormented with the Sciatica,or gout in the hucklebones, for F thofe that haue the dropfie, and for fuch alfo that are vexed with a quartaine ague, who are cured andmade whole by vomiting. 


\title{
Of Sea Bindweede, Chap.293.
}

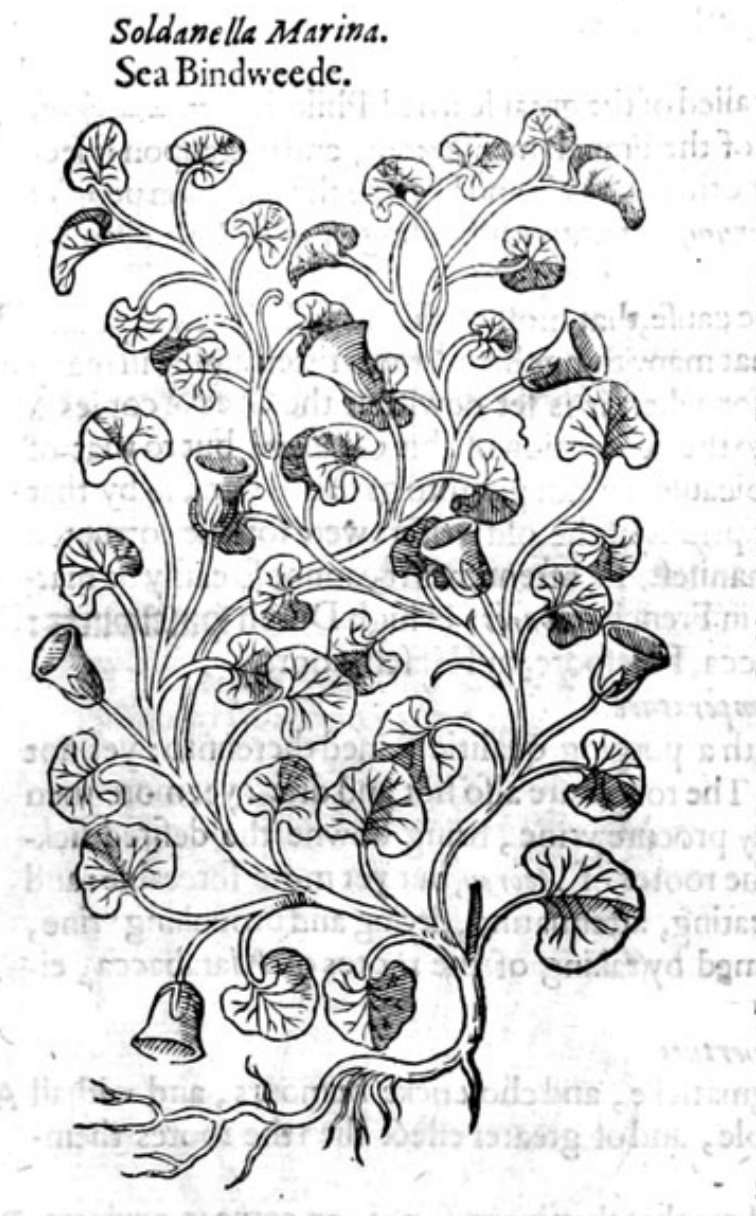

\author{
* The defcription.
}

S oldanells or Sea Bindweede, hath many fmal braunches, fomewhat red, trailing vpon the ground, befer with finall round leates, not much vnlike Afarabacca, or the leaues of Ariftolochia, but fmaller; betwixt which leaues and the ftalks come foorth flowers formed like 2 bell, of a bright red incarnate colour, in euery refpect an. fwering the fmall Bindweed, whereof it is a kind, albeit I haue heere placed the famefor the reafons rendred in my Proeme. The feede is black, and groweth in tound husks : the roote is long \& fmal, thrufting it felfe farreabroad, and into the earth like the other Bindweeds.

Soldanella or mountaine Bindweed, hath many round leaues Ipred vpon the ground, not much vnlike the former, but rotunder and more full of veines, greener, of a bitter taft like Sez Bindweed: among which commeth foorth a fmall \& tender ftalke a handfull high, bearing at the top little flowers like the fmall Gentianella, of a skie colour: the roote is friall and threddie.

$$
\text { * Theplace. }
$$

The firft groweth plentifully by the fea fhore in moft places of Englande, efpecially neere vnto Lee in Effex, at Merfey in the fame countie, in moft places of the Ifle of Thanet, and Shepie, and in many places along the northren coaft.

Thefecond groweth vpon the mountaines of Germanie, and the Alpes; it groweth vpon the mountaines of Wales, not farre from Cowmers Meare in Northwales.

$$
\text { * The time. }
$$

Thefe herbes do flower in Iune, and are gathered in Auguft, to be kept for medicine. * The names.

The firtt called Soldanells is of the Apothecaries and others called Marina BraSsca, that is to fay, Sea Colewoort; but what reafon hath mooued them fo to doI cannot conceiue, vnleffe it be penurie and fcarfitie of names, and bicaufe they know not otherwifc how to terme it: of this Iam fure, that this plant \& Braßscta are no more alike then things which are moft vnlike, for Brnßsica Man rima is the' $\mathrm{Sez}_{2} \mathrm{Colewoort}$; which doth much relemble the garden $\mathrm{Cabbage} \mathrm{or} \mathrm{Cole}$, both in fhape and in nature, as I haue in his due place expreffed. A great fault and ouerfight ther fore it hath been of the old writers and their fucceffors which haue continued the cuftome of this error, not taking the paines to diftinguifh a Bindweed from a Colewoort. But to auoid controuerfies, the truth is as I haue before fherved, that this Soldanella is a Bindweed,\& cannot be efteemed for a Brafisca, that is 2

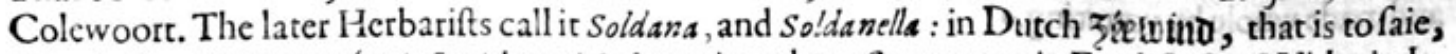

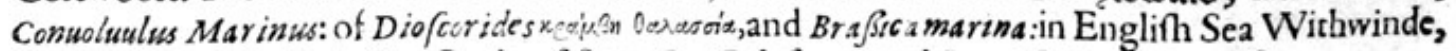
Sea Bindweed, Sea bels, Sea Coalc, of fome Sea Folefoote, and Scottith Scuruie graffe.

The fecond is called Soldanells montana : in Englifh Mountaine Bindweed. $\approx$ The nature.

Sea Bindweed is hot and drie in the fecond degree: the fecond is bitter and verie aftringent. $*$ The vertues.

A Soldanella purgeth downe mightily all kinde of watrith humours, and openedh the ftoppings of 


\section{IH THIST OR IE ORI PLANTS. HT}

the liuer,and is given with great proficte againft the dropfie: butit muft be boiled with the broth of fome fatmeate or flefh jand the brotbidrunke, orelforthe berberaken in powder worketh the like effect.

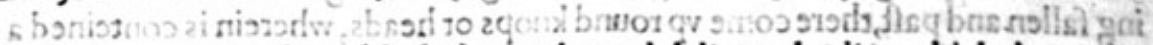

Soldanells hurtcth the ftomacke, and troubleth the weake and delicate bodics wbich doteceite B it in poivder, wherefore aduice muft betaken tomixe the faide powder with innife feedesy ionna-

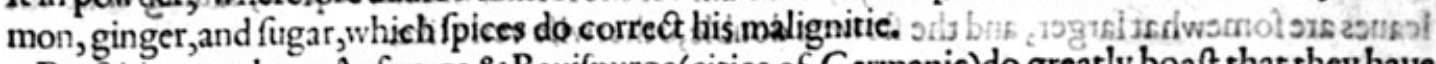

Practitioners about Aufpurge \& Rauifpurge(cities of Germanic)do greatly boaft that they haue C done woonders with this herbe Soldanelia montaina, traying, that the leaues taken andempiaiftred vpon the napell and fomewhat lower, draweth footh water from their bellies that are hydroptike, that is, tronbled with water or the dfopfie:this effect it worketh in other parts withoutheating $\frac{1}{\text {. }}$

If dothaffo woonderfully bring fleflim wounds thid healeth them. Dibforiaks witneffeth, thiat the whole herbe is an enimie to the ftomacke, biting andexiffefnely $\mathbf{E}$ purging (both fodden, and taken with meate) and bringeth troublefome gripings thereunto, and doth oftentimes more hurt then good.

\section{Of the graffe of Parnaffus. Chap.294.}

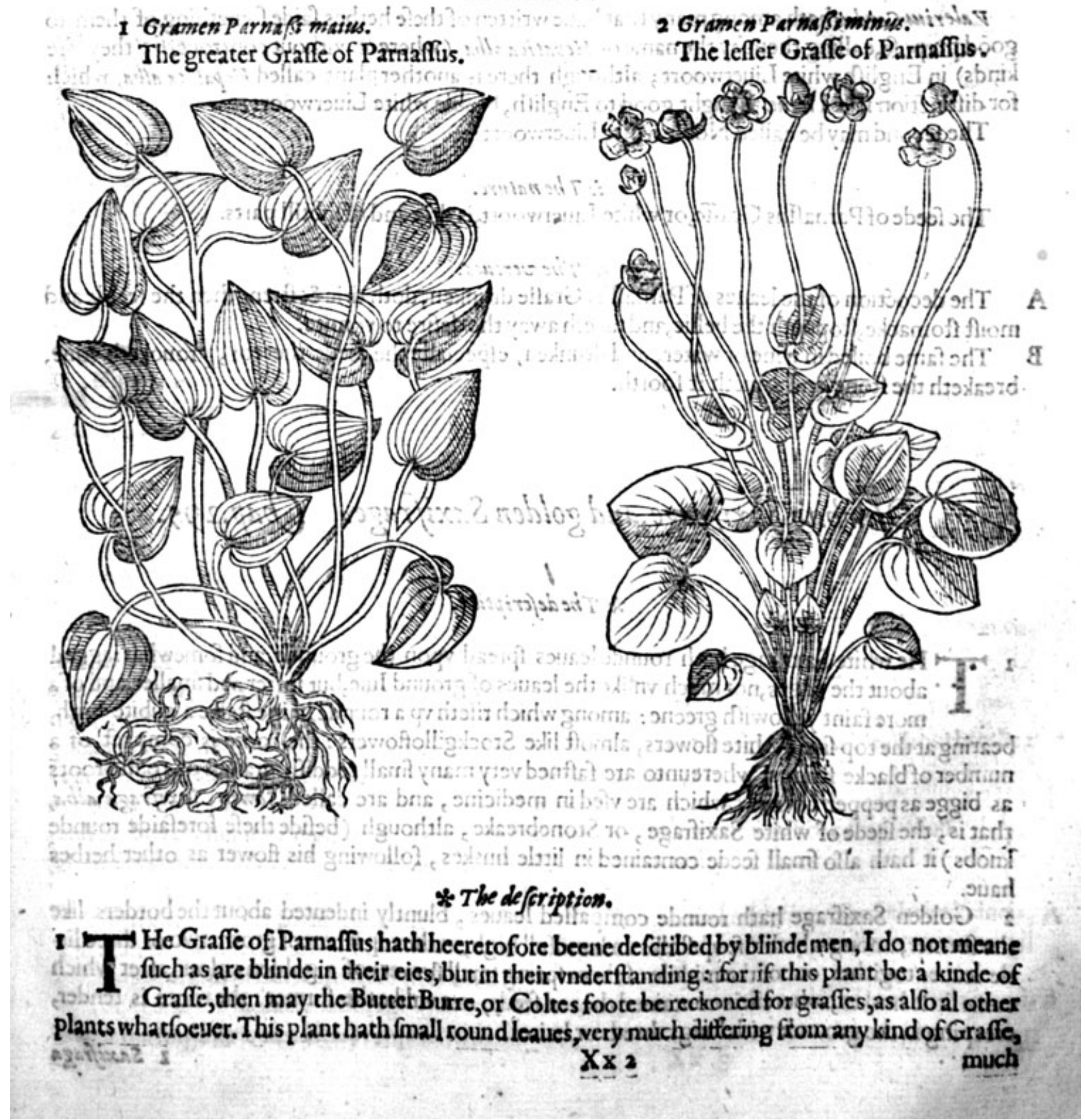


much refembling the leaues of Iuie, or A farabacca, but fmaller, and not of fo darke a colour: among thefe leaues fpring vp fmall ftalkes a foote high, bearing little white towers at the top, which being fallen and paft, there come vp round knops or heads, wherein is conteined 2 reddifh feede. The

2 The fecondkinde of $G$ ramen Parna $\beta$, doth anfwer theformer in eche refpect, fauing that the leaues are fomewhat larger, and the flowers double, otherwile verie like.

\section{* The place.}

Thefirft groweth very plentifully in Lanfdall and Crauen, in thenorth parts of England;at Doneafter, and in Thorneton fieldes in the fame countrie: moreouer in the Moore neere to Linton, by Cambridge, at Heffet alfo in Suffolke, at a place named Drinkitone, in the medowe called Butchers
meade.

The fecond is a franger as yet in England.

* The time.

Thefe herbes do flower in the end of Iuly, and their feede is ripe in the end of Auguft.

\section{* The names.}

$V$ alerim Cordws hath among many that haue written of thefe herbes faide fomething of them to good purpofe, calling them by the name of Hepatica alba (whereof without controuerfie they are kinds) in Englifh white Liuerwoort; although there is another plant called Hepatica alba, which for diftinction fake I haue thought good to Englifh, Noble white Liuerwoort.

The fecond may be called Noble white Liuerwoort.

\section{The feede of Parnaffus Graffe, or white Liuerwoort, is drie and of fubtill parts.}

* The vertues.

A The decoction of the leaues of Pamaffus Grafle drunken, doth drie \& ftrengthen the feeble and moift ftomacke, ftoppeth the bellie, and taketh away the defire to vomite.

B The fame boiled in wine or water, and drunken, efpecially the feede thereof, prouoketh vrine, breaketh the ftone, and driueth it foorth.

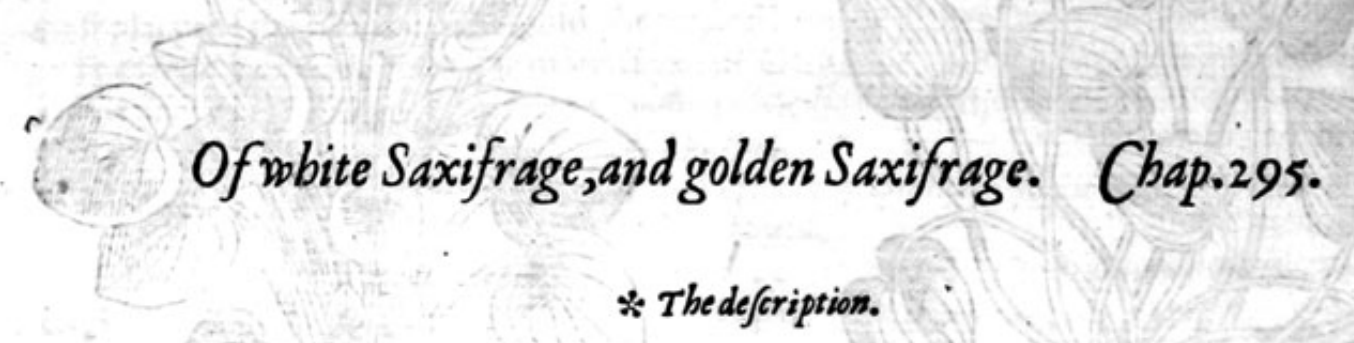

1 Hewhite Saxifrage hath roundeleaues fpread vpon the grounde, and fomewhat iagged about the edges, not much vnlike the leaues of ground Iuie, but fofter and fmaller, and of a more faint yellowilh greene: among which rifeth vp a rounde hairie ftalke a cubite high, bearing at the top frill white flowers, almoft like Stockgilloflowers : the roote is compact of $\mathbf{a}$ number of blacke ftrings, whereunto are faftned very many finall reddifh graines or round roots as bigge as pepper cornes, which are vfed in medicine, and are called Semien Saxifrage alba, that is, the feede of white Saxifrage, or Stonebreake, although (befide thefe forefaide rounde knobs) it hath alfo fmall feede contained in little huskes, following his flower as other herbes haue.

2 Golden Saxifrage hath rounde compaffed lcaues, bluntly indented about the borders like the former, among which rife vip ftalks an handfull high, at the top whereof growe two or three little leaues togither, out of the middle of them fpring imall flowers of a golden colour, after which come little huskes, wherein is contained the red feede, not vhlike the former : the roote is tender, creeping in the grounde with longs threds or haires. 


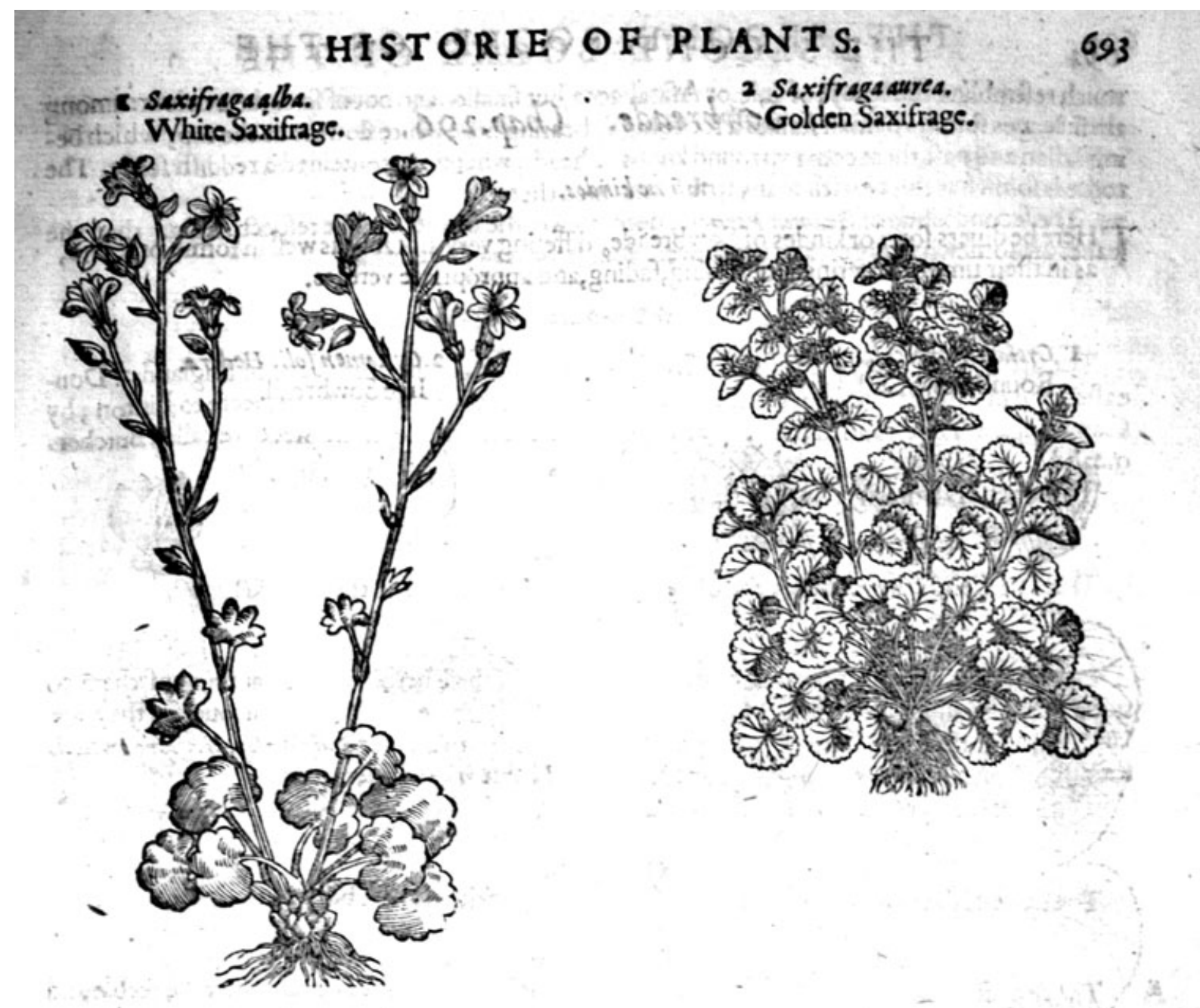

* The place.

The white Saxifrage groweth plentifully in fundrie places of England, and efpecally in a ficlde on the left hand of the high way, as you go from the place of execution called Saint Thomas Waterings vnto Dedford by London. It groweth alfo in the great fielde by Iflington called the Mantels; alfo in the greene places by the fea fide at Lee in Effex, among the rufhes, and in fundrie other places thereabout and eife where.

The Golden Saxifragegroweth in the moift and marrifh grounds about Bath and Wels; alfo in the Moores by Bofton and Wisbich in Lincolnthire.

* The time.

The white Saxifrage flowreth in Maie and Iune : the herbe with his flower are no more feen vntill the next yeere.

The golden Saxifrage flowreth in March and Aprill.

* The names.

The firft is called in Latine Saxifraga alba : in Englifh white Saxifrage, or white Stonebreake: The fecond is called golden Saxifrage, or golden Stonebreake.

\section{* The nature.}

The firft of thefe efpecially the roote and feede thereof, is of a warme or hot complexion.

6. Golden Saxifrage is of a cold nature, as the tafte dothmanifeftly declare.

* The vertues.

The roote of white Saxifrage boiled in wine and drunken, prouoketh vrine, clenfeth the kidneis, A and bladder, breaketh the ftone, and driucth it foorth,and is fingular againft the ftrangurie and all other griefes and imperfections in the raines.

The vertues of golden Saxifrage are yet vnto vs vnknowne, notwithiftanding I am of this mind, B that ir is a fingular wound herbe, equall with Sanicle. 


\section{Of Sombreade. Chap.296.}

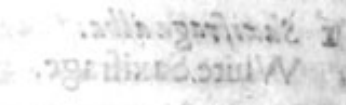

*The kindes.

THere be diuers forts or kindes of Sowbreade, differing very notably as well in forme or figure, as in their time of lowring, flourifhing, fading,and appropriate vertues.

i cyclamen orbicalat of folio. Round Sowbread.

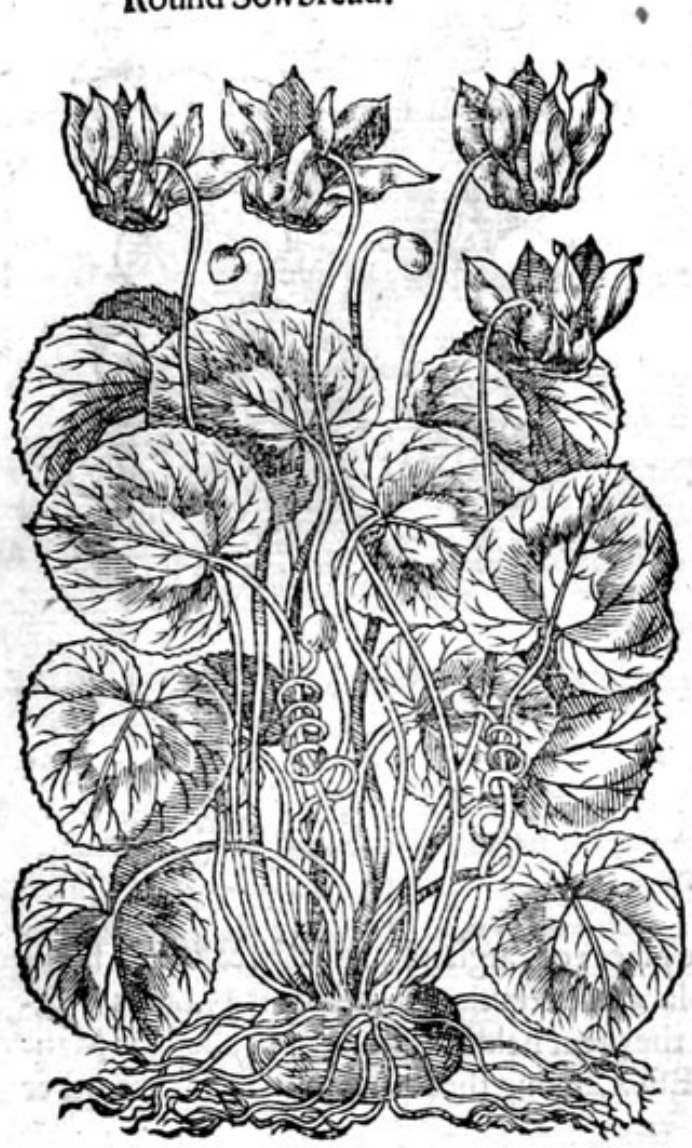

\section{Cyclamen folio Hedere.} Iuic Sowbread.

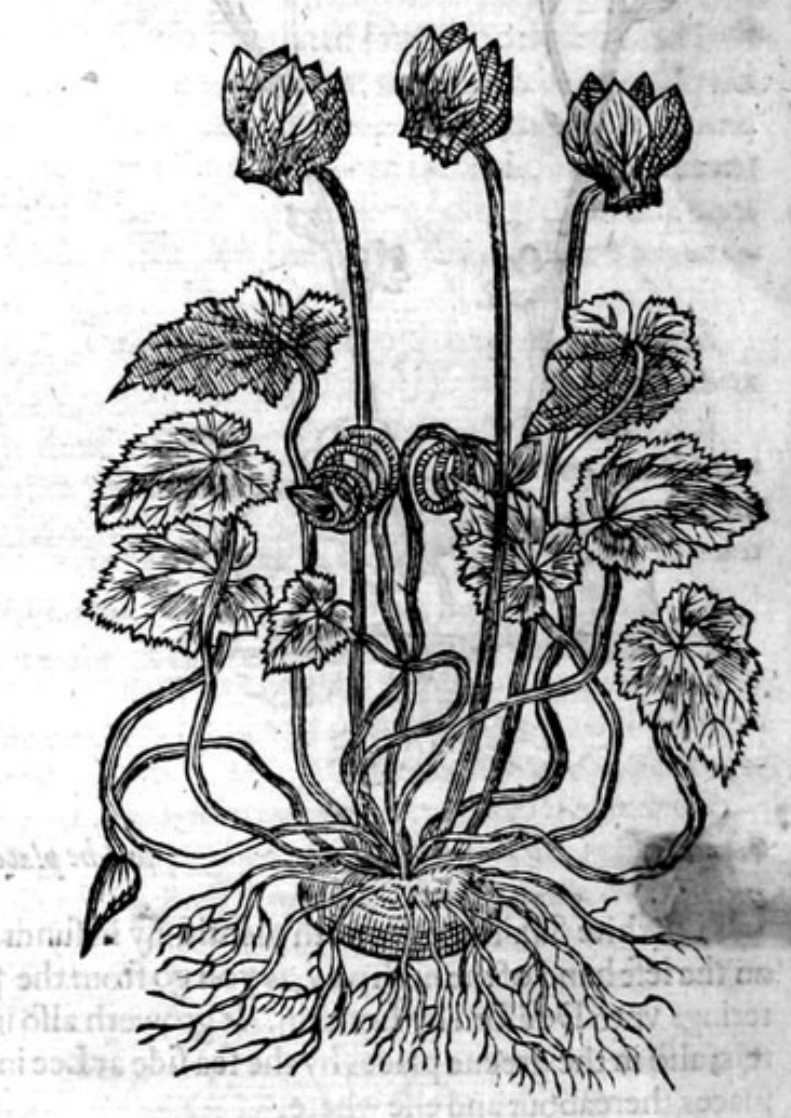

* The defcription.

1 He firt being the common kinde of Sowbread,called in thops Panis porcinu, and Arthenita, hath many greene and round leaues like vnto Afarabacca, fauing that the vpper part of the leaues are mixed heere and there confufedly with white fpots, and vnder the leaues next the ground of a purple colour: anong which rife vp little ftems like vnto the ftalkes of violets, bearing at the top fmall purple flowers which turne themfelues backward (being full blowen) like 2 Turkes cap, or Tolepan, of a fmall fent or fauour, or none at all: which being paft there fucceede little rounde knoppes or heades which conteine flender browne feedes : thele knops are wrapped after $a$ fewe daies in the fmall ftalkes, as thredde about a bottome, where it remaineth fodefended from the inurie of winter clofe vpon the ground, couered alfo with the greene leaues aforefaide, by which meanes it is kept from the froft, euen from the time of his feeding which is in September, vntill Iune; at what time the leaues do fade awaie, the ftalkes and feede remaining bare and naked, wher eby it enioieth the funne (whereof it was long depriued) the fooner to bring them vato maturitic: the roote is rounde like 2 Turnep, blacke without and white within, with many fmall ftrings ainexcd thereto. 
2 The fecond kinde of Sowbread, hath broad leaues fpred vpon the ground, (narpe pointed, fomwhat indented about the edges, of a darke greene colour with fome little lines or ftrakes of white on the vpper fide, \& of a darke reddifh colour on that fide next the ground : among which rife vp flender footeftalks of two or three inches long; at the tops wherof ftand fuch flowers as the precedent; but of a fweeter fmell and more pleafant colour. The feed is alfo wrapped vp in the fta'ke for his further defence againft the iniuric of winter.' The root is fomwhat greater and of more vertue, as thall be declared.

There is a thirde kind of Sowbread that hath round leaues without peaked corners, as the laft before mentioned, yet fomewhat fnipt about the edges and fpeckled with white about the brims of the leaues, and of a blackifh colour in the middle: the flowers are like vnto the reft, but of a deeper purple: the roote alfo like, but fmaller.

There is a plant which I haue fet foorth in this place that may very wel be called into queftion,se his place alfo, confidering that there hath beene great contention about the fame, and not fully determined on either part, which hath mooued me to place him with thofe plants that moft doe refemble one another, both in thape and name : this plant hath greene cornered leaues like vnto Iuie; long and fmall gaping flowers like the fmall Snapdragon: more hath not beene faid of this plant, either of ftalke or roote, but is left vnto the confideration of the learned.

$$
\text { * The place. }
$$

Sowbread groweth plentifully about Artois, \& Vermandois in Fraunce, in the forreft of Arden, and in Brabant : but the fecond groweth plentifully in manic places of Italie, being the beft of all.

It is reported vnto me by men of good credite, that Cyclamen or Sowbread groweth vpon the mountaines of. W/ales; on the hils of Lincolnhire, and in Somerfethile by the houfe of a gentleman called Mafter Hales; ypon a foxe burrough alfo not farre from Mafter Bamfrelds neere to a towne called Hardington. The firft two kinds do grow in my garden, where they profper well, * The time.

Sowbread flowreth in September when the plant is without leafe, which do afterwards fpring vp, continuing greene all the winter, couering and keeping warme the feede vntill midfommer next, at what time the feede is ripe as aforefaid. The third flowreth in the fpring, for which caufe it was called cyclamen vernum. $\quad *$ The names.

Sowbread is called in Greeke xuxaduesos : in Latine $T$ uber terre, and Torr e rapum: of Marcellus Orbicularis; of Apuleius Palalia, rapum Porcinum, and Terre malum : in thops Cyclamen, Panus Porcinus, and Arthanita : in Italian Pan Porcino in Spanifh Mazan de Pucrco: in high Dutch cbucinto bzot : in lowe Dutch Cierckitis bzoot: in French Pain de Porceau : in Englifh Sowbread, Plinie calleth the colour of this flower in Latine Cóloßinus color : in Englifh Murrey colour.

\section{Sowbread is hot and drie in the third degree.}

$$
\text { * The nature. }
$$

$$
\text { * T hevertues. }
$$

The roote of Sowbread dried into powder, and taken inwardly in the quantitic of a dram and a A halfe,witlrmeade or honied water;purgeth downwarde tough and groffe flegme, and other tharpe humotrs.

The fame taken in wine as aforefaid, is very profitable againft al poifon, and the bitings of vene- B mous beafts, and to be outwardly applied vnto the hurt place.

The powder taken as aforefaide, cureth the iaundies and ftoppings of the liuer, taketh aivay the $\mathbf{C}$ yellow colour of the bodie, if the patient after the taking thereof be caufed to fiveat.

The leaues ftamped with honie, and the iuice put into the eies, cleereth the fight, taketh away all D fpots and webs, pearleor hawe, and all impediments in the fight, and is put into that excellentointment called $V$ nguentum Arthanita.

The roote hanged aboutwomen in their extreme trauell with childe, caufeth them to be deliue- $\mathrm{E}$ red incontinent, and vaketh aw ay much of their paine.

The leaves put into the place hath the like effect, as my wife hath prooued fundrie times vpon $\mathrm{F}$. diuers women, by my aduife and commandement, with good fucceffe.

The juice of Sowbread doth open the hemorrhoides, and caufech them to flowe being applied G withwoollor flocks:

It is mixed with medicines that confurne or wafte away knors, the kings eull, \& other hard fwel- H lings:moreoueris elenfeth the head by the noftrils, it purgeth the belly being annointed therewith, 
and killeth the childe. It is a ftrong medicine to deftroie the birth,being put vp as a peffarie.

I. It fcoureth the skin, and taketh away funne burning, and all blemifhes of the face, pilling of the haire, and markes alfo that remaine after the fmall pockes and mefels: and giuen in wineto, drinke, it maketh a man drunke.

$\mathrm{K}$ The decoction thereof ferueth as a good and effectuall bath for members out of ioint, the gout, and kibed heeles.

L The roote being made hollowe and filled with oile, clofed with a little waxe and rofted in the hot embers, maketh an excellent ointment for the griefes laft rehearfed.

M Being beaten and made vp into trofchies, or little flat cakes, it is reported to be a good amorous medicine to make one in loue if it be inwardly taken.

* The danger.

It is not good for women with childe to touch or take this herbe, or to comeneere vnto it,or ftride ouer the fame where it groweth, for the naturall attractiue vertue therein contained is fuch, that without controuerfie they that attempt it in maner abouefaid, fhall be deliuered before their time : which danger and inconuenience to auoide, I haue (about the place where it groweth in my garden ) faftened fticks in the ground, and fome other ftickes I haue faftned alfo croffewaies ouer them, leaft any woman fhould by lamentable experiment findemy words to betrue, by their ftepping ouer the fame.

\section{Of Birtbrooorts. Chap.297.}

\section{* The kindes.}

B Irthwoort, as Dio/corides writeth, is of three forts, long, rounde, and branched: Plinie hath added a fourth kinde called $P$ isfolochia, or little Birth woord. The later writers haue ioined vnto them a fift named Saracens Birchwoort.

I Sristolochia longa. Long Birthwoorc.

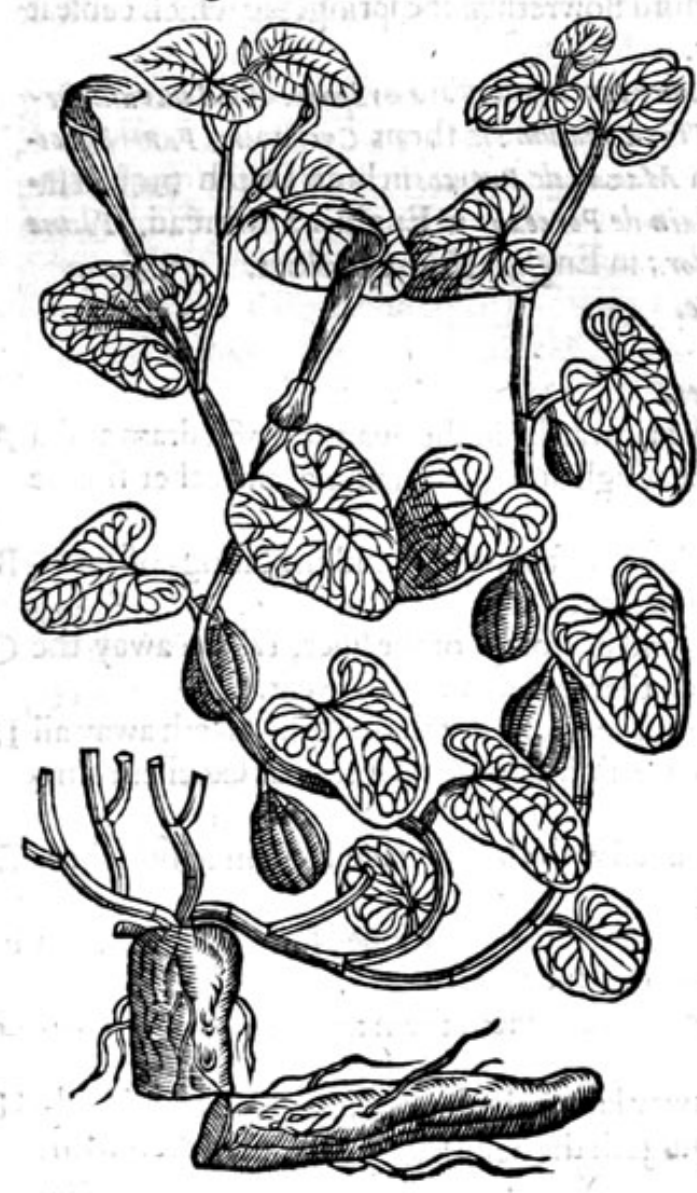

2 Siffolochic rotweda. Round Birthwoort.

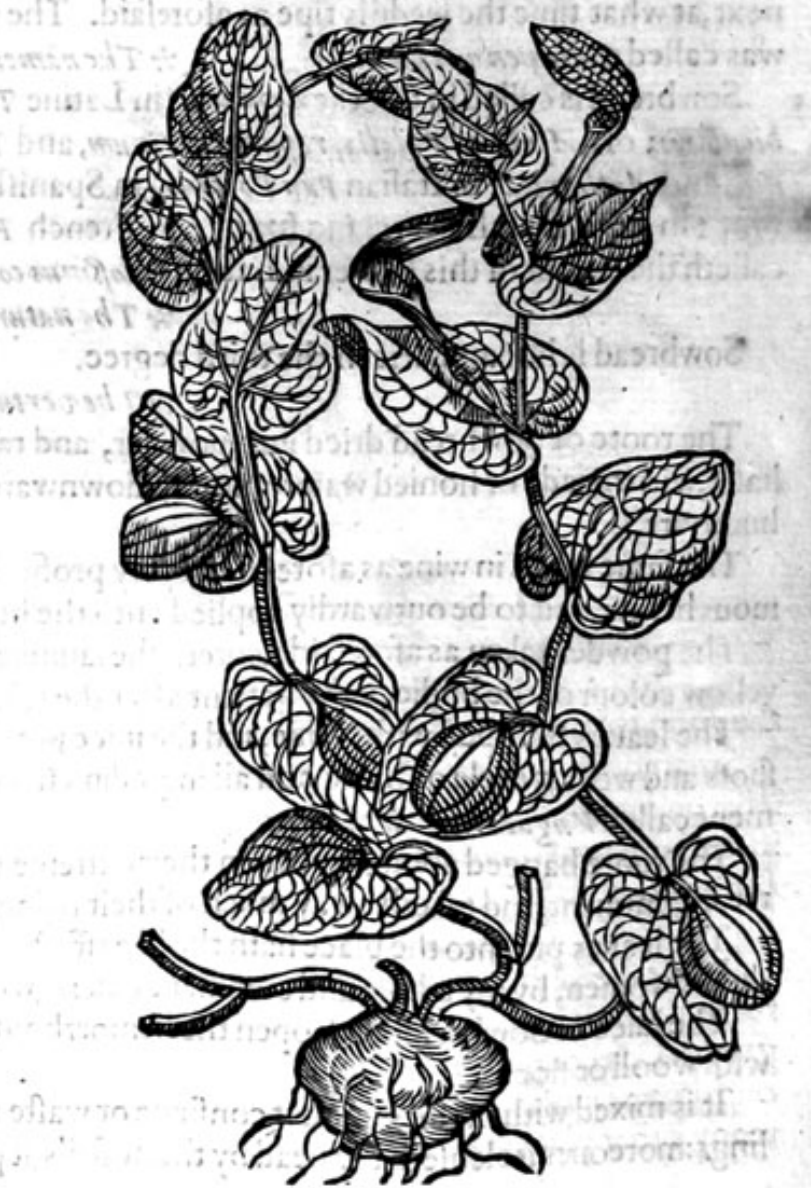


* The defaription.

I Ong Birthwoort hath many fmall, long, ilender ftalks creeping vpon the ground, tangling one within another very intricately, befet with round leaues not much vnlike Sowbread or Iuie, but larger, of a light or ouerworne greene colour, \& of a greeuous or lothfom fmel and fauour : among which come foorth long hollow flowers, not much vnlike the flowers of Aron,bir without any peftell or clapper in the fame; within of a darke purfle colour, and without of agreenifh or herby colour:atter which do follow fmall fruite like vntolitcle peares, containing triangled feedes of a blackifh colour. The roote is long, thicke, of the colour of boxe, of a ftrong fauour and bitter tafte.

2 The rounde Birthwoort in ftalkes and leaues is like the firft, but his leaues are rounder : the flowers differ onely in this, that they be fomewhat longer and narrower, and of a faint yeilowith colour, but the fmall flap or point of the flower that turneth backe againe, is of a darke or blacke purple colour. The fruite is formed like a peare, fharpe towarde the top, more rubbed and fuller then the former : the roote is round like vnto Sowbread, in tafte and fauour like the former.

3 Sriftolochis clemat is. Climing Birthwoort.

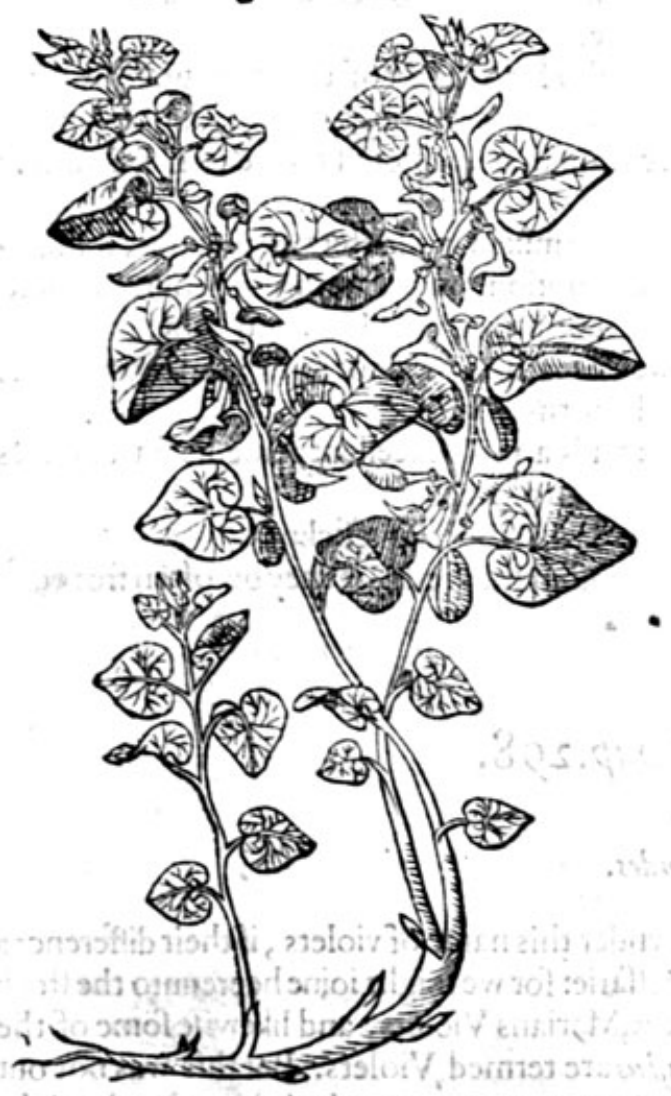

*The defeription.

3 Clining Birthwoort takech holde of any thing that is next vnto it, with his long and clafping ftalkes, which be ofteritimes branched, \& windeth it felfe about like Bindweede : the ftalkes of the leaues are longer, whofe leaues be fmooth, broad, fharpe pointed, as be thofe of the others: the flower is likewife hollow, long,yellow, or of a blackifh purple colour: the fruit differeth not from that of the others: but the roots be flender, and very long, fometimes creeping on the top of the earth, and fometimes growing deeper, being of like colour with the former ones.

There is a fourth kind of Birthwoort refembling the reft in leaues, and branched ftalks, yet higher, and longer then either the long or the rou inde: the leaues thereof be greater then thofe of Folefoote: the flowers hollowe, long, and in one fide hanging ouer, of a yellowith colour : the fruite is round and long like a peare, in which the feedes lie feuered, of forme three fquare, of an ill fauoured blackifh colour : the roote is fomewhat long, oftentimes of a meane thickneffe, yellowe like vnto the colour of Boxe, not inferior in bitternes either to the long or to the rounde Birthwoort, and fometimes thefe are found to be fmall and flender, and that is when they were but lately digged $\mathrm{vp}$ and gathered: for by the little parcels of the rootes which are left, the yoong plants bring foorth at the beginning tender and branched rootes.

Small Birthwoors is like to the long and round Birthwoort, both in ftalkes and leaues, yet is it leffer and tenderer; the leaues thereof are broad; and like thofe of Iuie : the fower is long, hollowe in the vpperpart, and onthe outfide blackifh: the fruite fomthing rounde like the fruite of rounde Birthwoors: in fteed of rootes there growe foorth a multitude of flender ftrings. $20 x$ is

Plinje heweth, that the Birthwoorts grow in fat and championplaces, the fields of Spaine are ful of thefe three long and round Birthwoorts; they are alfo found in Italie and in Narbonc or Languedock; a countrey in Fraunce. Petrus Bellomias writeth, that he found branched Bitthwoort vpon Ida a mountaine in Candie: Corolou Clusfur faith, that he found this fame about Hifpalis, and in many other places of Granado in Spaine,among bufhes and bramblesthey grow all in iny garden. 28

* The 


\title{
698 THE SECOND BOOKE OF THE
}

\author{
They flower in Maie, Iune, and Iuly. \\ * The time. \\ * T The names.
}

Birthwoort is called in Greeke desseno jia: in Latine likewife Ariffolochia, bicaufe it is deisa teis abyors, that is to faie, good for women newly brought a bed, or deliuered with childe :in Englifh Birth. woort, Hartwoort, and of fome Ariftolochia.

The firft is called Ariftolocbia longa, or long Birthwoorte, of the forme of his roote: and likewife Ariftolochia mas, or male Birthwoort : the fecond is thought to be Famina, or female Birthwoort, and is called Rotunda Ariffolochia, or round Birthwoort: of diuers alfo Terre Malum, the Apple of the earth: yet Cyclaminus is alfo called Terre Malum, or the apple of the earth.

\section{$\dot{x}$ The temperature.}

All thefe Birthworts are of temperature hot and drie, and that in the thirde degree, hauing befides apower to clenfe.

\section{r * The vertues.}

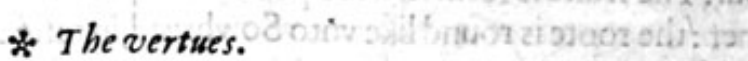

A Diofcorides writeth, that a dram waight of long Birthwoort drunke with wine and alfo applied, is good againft ferpents and deadly things : and that being drunk with myrrhe and pepper, ir expelleth whatfoeuer is left in the matrix after the childe is deliuered, the flowers alfo \& dead children: and that being put $\mathrm{vp}$ in a peffarie, it performeth the fame.

B Round Birthwoorth ferueth for all thefe things, and alfo for the reft of the other poifons: it is likewife auaileable againft the ftuffing of the lungs, the hicket, the fhakings or ihiuerings of agues, hardnes of the milt or fpleene, burftings, cramps, and conuulfions, paines of the fides, if it be drunk with water.

C It pluckethout thornes, fplinters, and thiuers, and being mixed in plaifters, or pultefes, it draweth foorth fcales or bones, remooueth rottenneffe and corruption, mundifieth and fcoureth foule and filthie vlcers, and filleth them vp with newe flefh, ifit be mixed with Ireos and hony.

D Galen faith, that branched Birthwoort is of a more fweete and pleafant fmell : and therefore is vfed in ointments; but it is weaker in operation then the former ones.

E Birthwoortas Plinie writeth being drunke with water is a molt excellent remedie for crampes and conuulfions, brufes, and for fuch as haue fallen from high places.

F It is good for them that are fhort winded, and troubled with the falling ficknes.

G The rounde Ariftolochia doth beautifie, clenfe, and faften the teeth, if they be often froted or rubbed with the powder thereof.

\section{Of Violets. Chap. 298 . \\ * The kindes.}

$T$ Heremight be defcribed many kinds of flowers vnder this name of violets, if their differences fhould be more curioufly looked into then is neceffarie: for we might ioine heereunto the ftock Gilloflowers, the Wall Flowers, Dames Gilloflowers, Marians Violets, and likewife fome of the bulbed Flowers, bicaufe fome of them by Theophraftusare termed Violets. But this was not our charge, holding it fufficient to diftinguifh and diuide them as neere as may be in kinred and neighbourhood ; addreffing my felfe vnto the Violets called the blacke or purple Violets, or March Violets of the Garden, which have a great prerogatiue abouc others, not onely bicaufe the minde conceiueth acertaine pleafure and recreation by fmelling and handling of thefe moft odoriferous flowers, but alfo for that very many by thefe Violets receiue ornament and comely grace: for there be made of them Garlands for the heade, nofegaies and poefies, which are delightfull to looke on and pleafant to fmell to, fpeaking nothing of their appropriate vertues; yea Gardens themfelues receiue by thefe the greateft ornament of all, chiefeft beautic, and moft gallant grace; and the recreation of the minde which is taken heereby, cannot be but verie good and honeft: for they ad. monifh \& ftir vp a man to that which is comely \& honeft; for flowers through their beatitie, varietie of colour, and exquifite forme, do bring to a liberall and gentle manly minde, the remembraunce of honeftic, comelineffe, and all kindes of vertues: For it would be an vnfeemely and fitchie thing, 
as a certaine wife man faith for him, that doth looke vpon and handle faire and beautifull things; and who frequenteth and is conuerfant in faire and beattifull places, to hatue his minde not faire, but filthic and deformed.

I Viols migra fine parpures. Thepurple garden Violet.

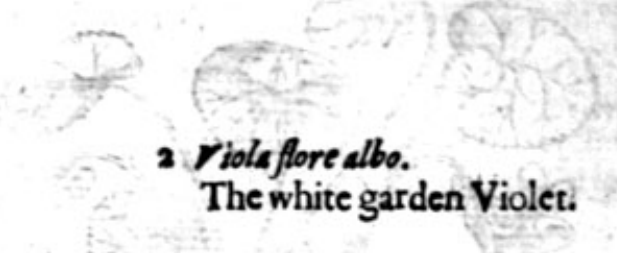

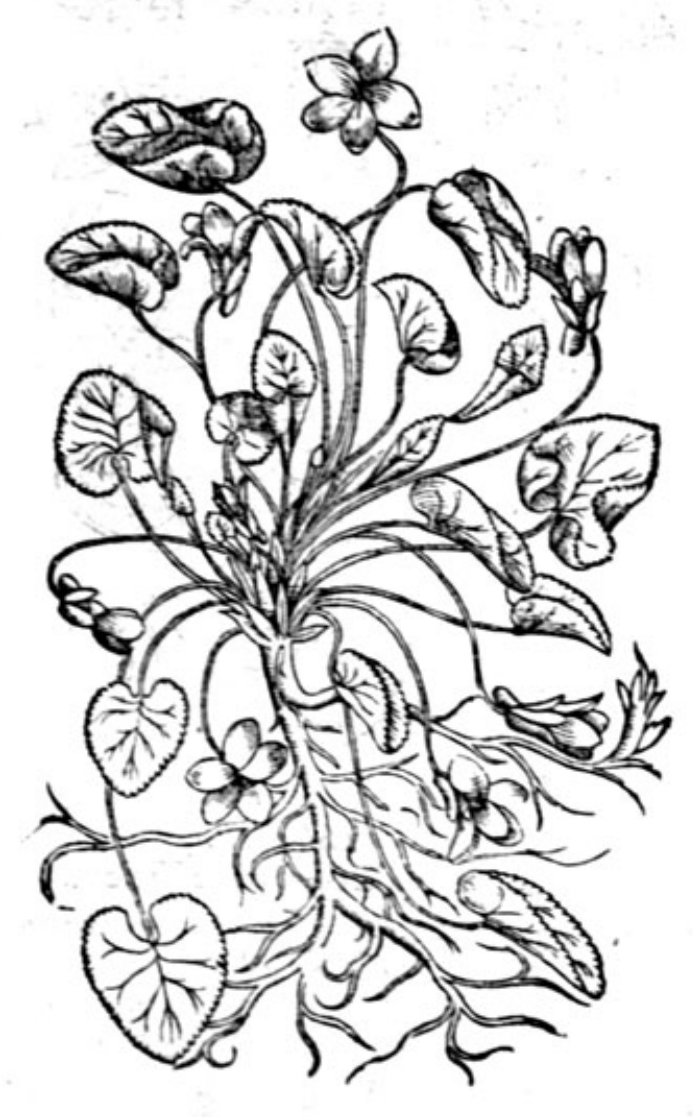

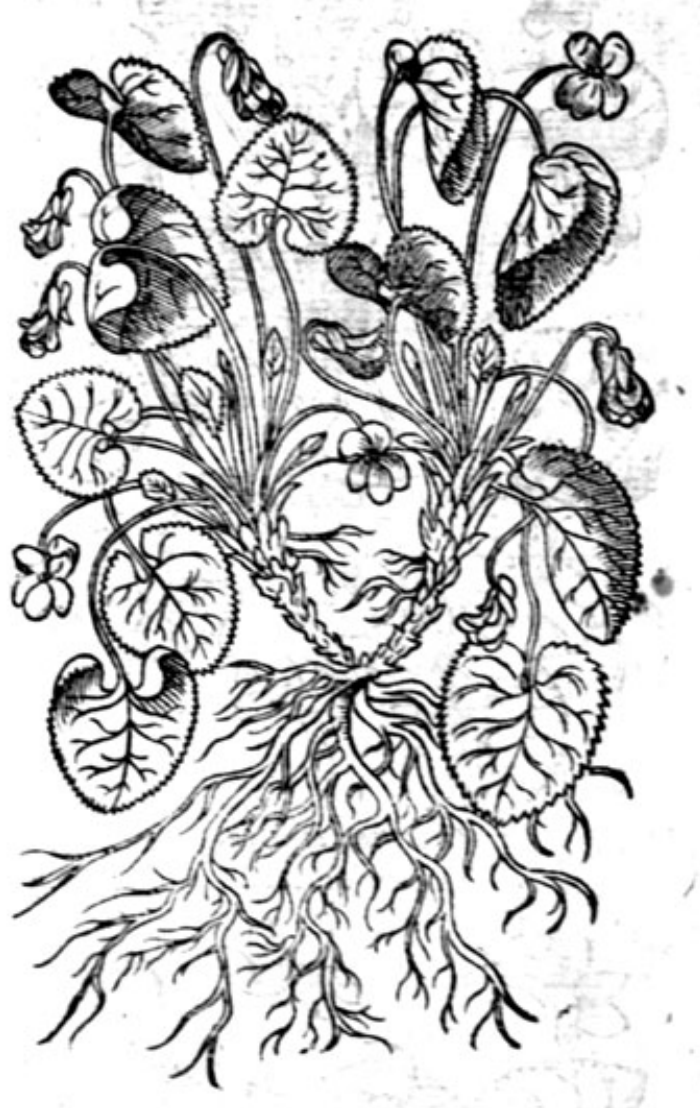

* The defcription.

I Heblacke or purple Violetdoth foorthwith bring from the roote many leaues, broade, fleightly indented in the edges, rounder then the leaues of Iuie : among the middeft wherof lpring vp fineflender ftemmes, and vppon euerie one a beautifull tower fweetely fmelling,of a blew darkih purple, confifting of fiue little leaues, the loweft whereof is the greateft; and after them do appeere little hanging cups or knaps, which, when they be ripe, do open and dituide themfelues into three partes. The feede is fmall,long,and fomewhat round withall. The roote confifteth of many threddie ftrings.

2 The white garden Violet hath many millke white flowers, in forme and figure like the precedent. The colour of whofe flowers efpecially fetteth foorth the difference.

3 The double garden Violet hath leaues, creeping branches, and rootes like the garden fingle Violet; liffering in that, that this fort of Violet bringeth foorth moft beautifull fweete double flowers, and the other fingle.

4 The white double Violet likewife agreeth with the other of his kinde, and onely differetb in the colour. For as the laft defcribed bringeth double blew or purple flowers: contrariwife, thisplant bearteth doub!e white flowers, which maketh the difference. 
3 Viola martia purpurea multiplex. The double garden purple Violet.

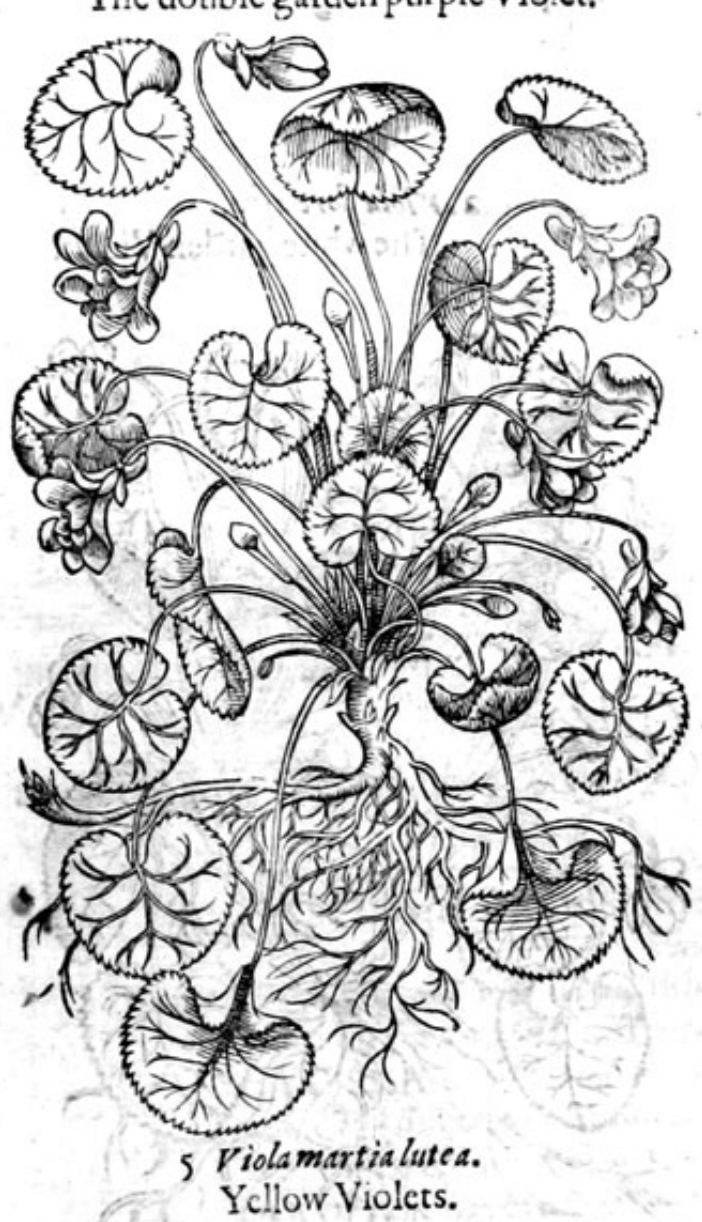

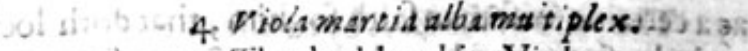

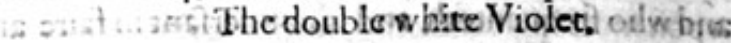
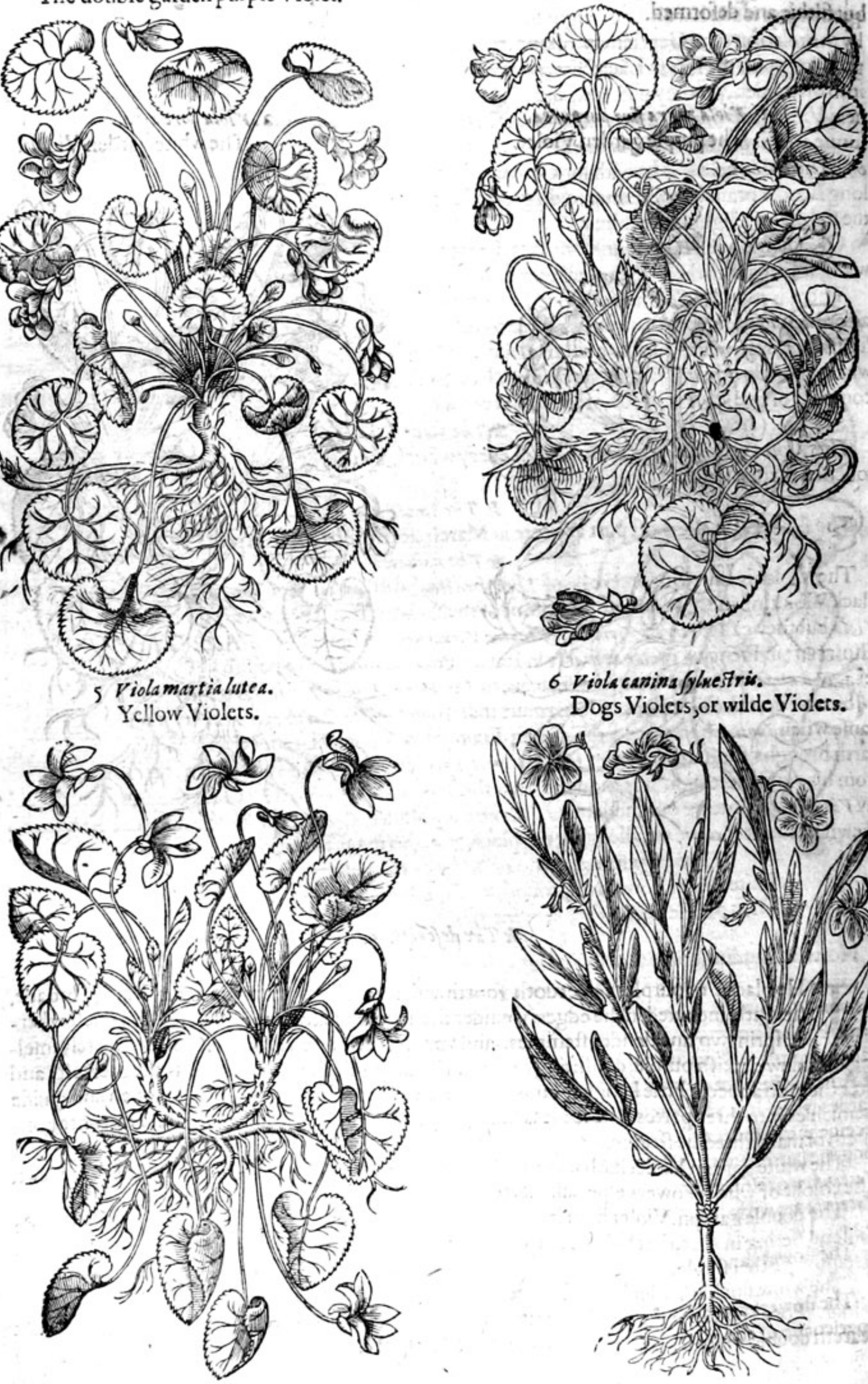
Dogs Violets, or wilde Violets.

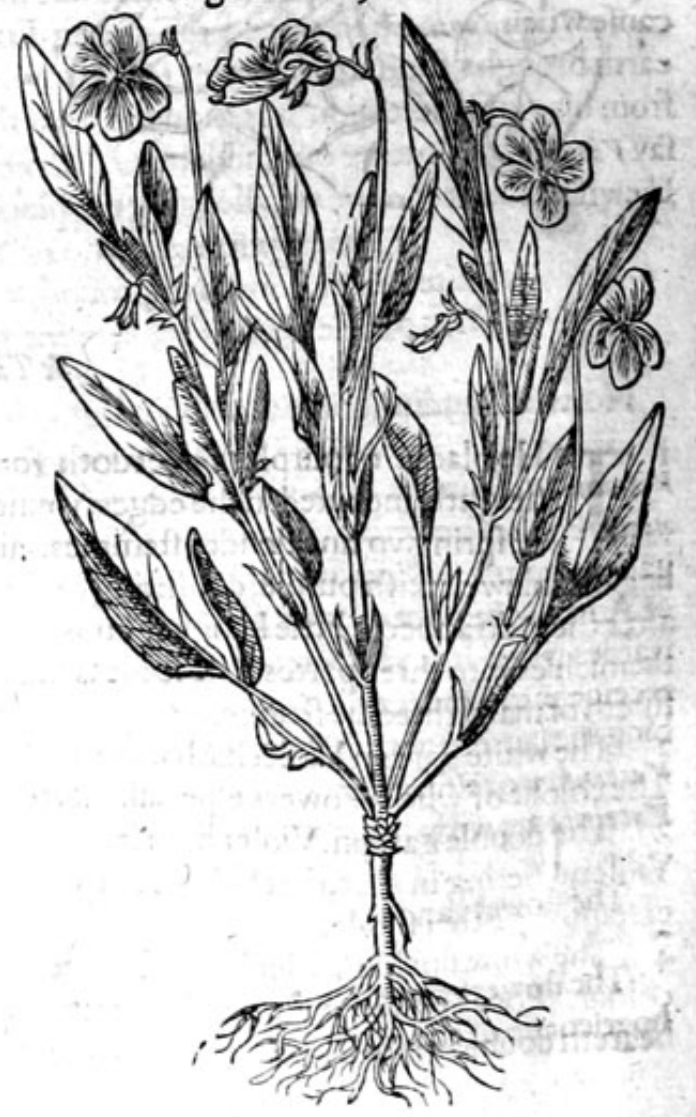




\section{HIS TORIE OF PLANTS.}

5. The yellow Violec is by nature one of the wilde Violets, for it groweth feldome any where but vpon moft high and craggic mountaines, from whence it hath beene diuers times brought into the garden, but it can hardly be brought to culture, or growe in the garden without great induftric. And by the relation of 2 Gentleman often remembred, called Mafter $T$ homas Hesketh, who found it growing ypon the hils in Läcafhire, neer vnto a village called Latham, \& though he brought them into his garden,yet they withered and pined away. The whole plant is defcribed to be like vnto the field Violet, and differeth from it, in that that this plant bringeth foorth yellow flowers, yet like in forme and figure, but without fmell. ' 19

6 The wilde field Violet with long leanes, rifeth foorth of the ground from a fibrous roote, with long flender branches, whereupon da growe long fmooth leates. The flowers growe at the top of the italkes, of a light blew colour.

Of which kinde I haue found another fort growing wilde neere vnto Blackeheath by Greenewich, at Eltham parke,with flowers of a bright reddifh purple colour.

There is found in Germanie about Noremberg and Strasborough, a kinde of Violet which is altogither a ftranger in thefe parts. It hath faith my author, a thicke and tough roote, of a woodie fubftance, from which rifeth vp a ftalke diuiding it felfe into diuers branches, of a woody fubftance, where upon do growe long iagged leaues, like thofe of the Panfey. The flowers growe at the top compact of fiue leaues apeece, of a watchet colour. * The plase.

The Violet groweth in gardens almoft euery where; the others which are ftrangers, haue beene touched in their defcriptions.

* The time.

The flowers for the moft part appeere in March,at the furtheft in Aprill. * The nanses.

The Violet is called in Greeke isr, of Theophrastus bothior udar \& undairor, in Latine Nigra Viola, or black Violet, of the blackifh purple colour of the flowers. The Apothecaries keepe the Latin name Viola, but they call it Herba Violaria, o mater Violarwm : in high Dutch 2 Blan Uliel : in lowe Dutch Citoleten: in French Violette de mars: in Italian Viola mammols : in Spanifh Violets : in Englifh Vio. let. 2 icanter in his Geoponickes beleeueth (as Hermolam fheweth) that the Grxecians did call it ior, bicaufe certaine Nimphes of Ionia gaue that flower firft to Iupiter; others fay it was called ior, bicaufe when Iupiter had turned the yoong Damfell 10 whom he tenderly loued into a Cow, the earth brought foorth this flower for hir foode : which being matelfor hir fake, receiued the name from hir : and thereupon it is thought, that the Latines alfo called it $V$ iola, as though they fhould fay $V$ itula, by blotting out the letter $t$. Servisus reporteth, that for the fame caufe, the Latines do likewife name it $V$ accinium, alledging the place of $V$ ir gil in his Bucolicks:

Alba ligustra cadunt, vaccinia nigra leguntur.

White Priuct flowers to ground do fall,fade and oftimes fterue,

When purple Violets are kept for vfes good to ferue.

Notwithftanding Virgill in his 10. Eclog heweth that Vaccinivem and $V$ iola do differ. Et nigra viole funt, o vaccinis xigra.

$V$ itrusius alfo in his feauenth booke of Architecture or building, doth diftinguifh $V$ iola from $V$ acci. nimm. For he fheweth that the colour of yellow Oker of Athens is made ex Viols or Violet, and the gallant purple ex Vaccinio or of Priuet. The diers faith he when they would counterfeit yellow Oker of Athens, they put the dried Violets into a fat, kettle or Cawdron \& boile them with water, after. svardes when it is tempered they powre it into a linnen ftrainer and wringing it with their handes, receiue into a mortar liquor coloured with the Violets, and fteeping bole of Erethrias in it, and rub. bing the fame, do make the colour of yellow Oker of Athens. After the fame manner they temper $V$ accinium or Priuet betries, and putcing milke vnto it doe make a gallant purple colour. But what Vaccinia are we will elfe where declare, and that in their proper place.

\section{The flowers and leaves of the Viplets The temper ature.} $*$ The temper ature.
The cold and moift.

\section{Thig 1025 iniligass}

The flowers are good for all inflammations efpecially of thefides and lungs, they take away the $A$ hoarfeneffe of the cheft, the ruggedneffe of the winde pipe and iawes, alaieth the extreme heate of 


\section{2}

THE SECOND BOOKE OF THE

the liuer, kidneies, and bladder, mitigateth the firie heate of burning agues, tempereth the fharpneffe of choler, and taketh away thirft.

B There is an oile made of Violets, which is likewife colde and moift. The fame being anniointed vpon the tefticles, doth gently prouoke fleep, which is hindered by a hot and drie diftemper: mixed or laboured togither in a wooden dirh with the yolke of an eg $\dot{g}_{x}$ it affwageth the paine of the fund2ment and hemorrhoides: it is likewife good to be put intog cooling clifters, and into pultifes that coole and eafe paine.

13 sdi

C But let the oile in which the Violets are fteeped, be cither of vnripe olities, called Omphacine, or of fweete almonds, as Mefwes faith, and the Violets themfehies mift be frefh and moift: For being drie and hauing loft their moifture, they do not coole, but feemie to haue gotten a kinde of heate.

D The latter phifitions do thinke it good to mixe drie Violets with medicines, that are to comfort and ftrengthen the hart.

E The leaues of Violets inwardly taken do coole, moifter, and make the bodie foluble. Being outwardly applied, they mitigate all kinde of hot inflammations, both taken by themfelues, and alfo applied with barly flower dried at the fire, after it harhlien foking in water. They are likewife laide vpon a hot ftomacke, and on burning eies, as Galen witneffeth. Diofcorides writeth, that they be moreouer applied to the fundament that is fallen out.

F They may helpe the fundament that is fallen out, not as a binder keeping backe the fundament, but $2 s$ a fuppler and a mollifier. Befides Plinie faith, that Violets are as well vfed in garlands as fmelt vnto; and are good againft furfetting, heauineffe of the head, and being boiled in water and drunke, remoue the fquinancie, or inward fwellings of the throte. They do cure the falling fickneffe,efpecially in yong children, and the feede is good againft the ftinging of Scorpions.

$G$ There is a firupe made of Violets and fugar, called in Greeke seowisv, or as Netwariws nameth it redmov, whereof three or fower ounces being taken at one time, it fofteneth the bellie, and purgeth choler.Themanner to make it is as followeth.'

H Firlt make of clarified fugar by boiling a fimple firupe, of a gocd confiftence, or meane thicknes, whereunto put the flowers cleane piked from all manner of filth, as alfo the white endes nipped away, a quantitie, according to the quantitie of the firupe, to your owne difcretion, wherin let them infufe or fteepefower and twenty howers, and fet vpon a few warme embers; then ftraine it, and put more Violets into the fame firupe: thus do three or fower times, the oftener the better : then fet them vpon a gentle fire to fimper, but not to boile in any wife; fo haue you it fimply made of 2 moft perfect purple colour, and f the fmell of the flowers themfelues. Some do adde thereto a little of the iuice of the flowers in the Joiling, which maketh it of better force and vertue. Likewife, fome do put a little quantitic of the iuice of Limons in the boiling, that doth greatly increafe the beautie thereof, but nothing at all the vertue.

I There is likewife made of Violets and fugar, certaine plates called SugarViolet, or Violet tables, or plate, which is moft pleafant and wholefome, efpecially it comforteth the hart, and the other in: ward parts.

$\mathrm{K}$ The decoetion of Violets is good againft hot feuers, and the inflammation of the liuer, and all other inward partes; the like propertie hath the inice, firupe or conferue of the fame.

L Sirupe of Violets is good againft the in flammation of the lungs and breft, againft the pleurifie and cough, againit feuers and agues in yong children,efpecially if you put vnto an ounce of firupe eight or nine drops of oile of Vitrioll, and mixe it togither, and giue vnto the childe a fpoonefull $2 t$ once.

M The fame giuen in manner aforefaid, is of great efficacie in burning feuers, and peftilent difeafes, greatly cooling the inward parts : and it may feeme ftrange to fome that forharpe 2 corrofiue, as oile of Vitriol, thould be giuen into the bodie, yet being delaied and giuen as aforefaid, fucking children may takeit without any perill.

$\mathrm{N}$ The fame taken as aforefaid, cureth all inflammations of the throte, mouth, vuula, fquinancie, and the falling euill in children.

o Sugar Violet hath power to ceafe inflammations, roughneffe of the throte, and comforteth the hart, affwageth the paines of the head, and caufeth fleepe.

P The leaues of Violets are vfed in cooling plaifters, oiles, \& comfortable cataplafmes or pultifes; and are of greater cfficacie among other herbs, as Mercurieand. Mallowes and fuch like, in clifters, for the purpoles aforelaid. 


\section{Of Harts eafe, or Paunfies. Cbap.299.}

$*$ The kindes.

As there be diuers fortes of March Violets, fo are there likewife fundrie kindes of Paunfies.

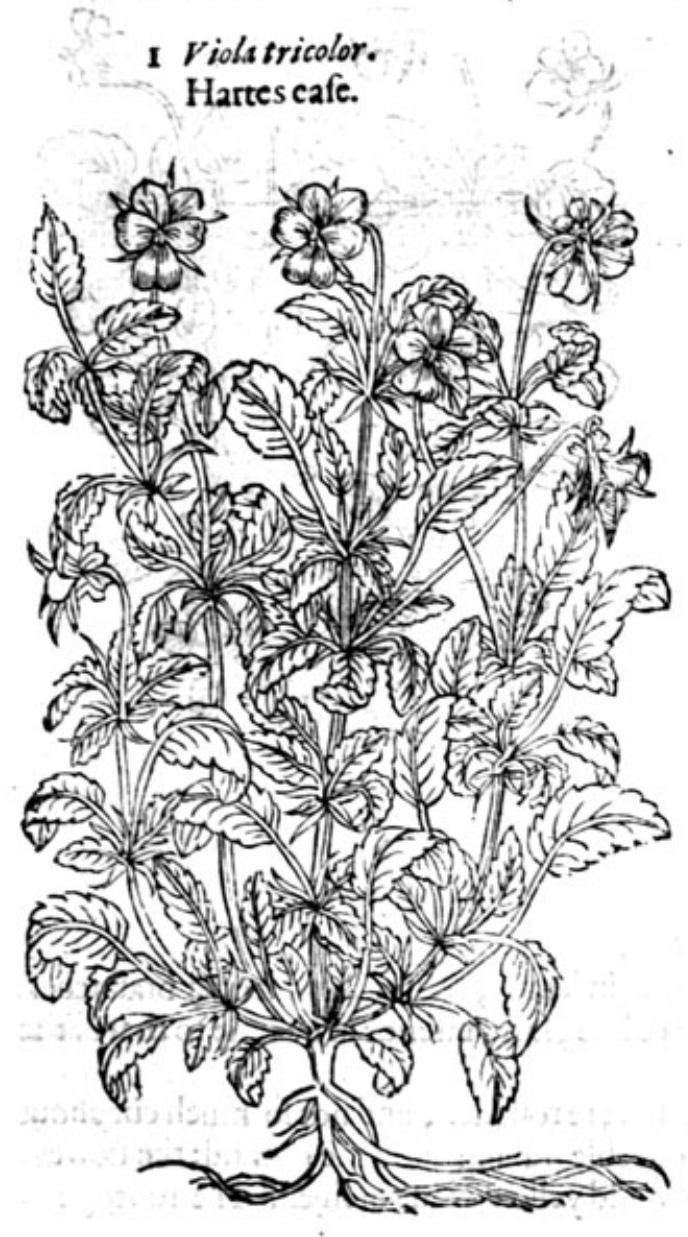

2 Viola affirgens tricolor. Vpright Hartes eafe.

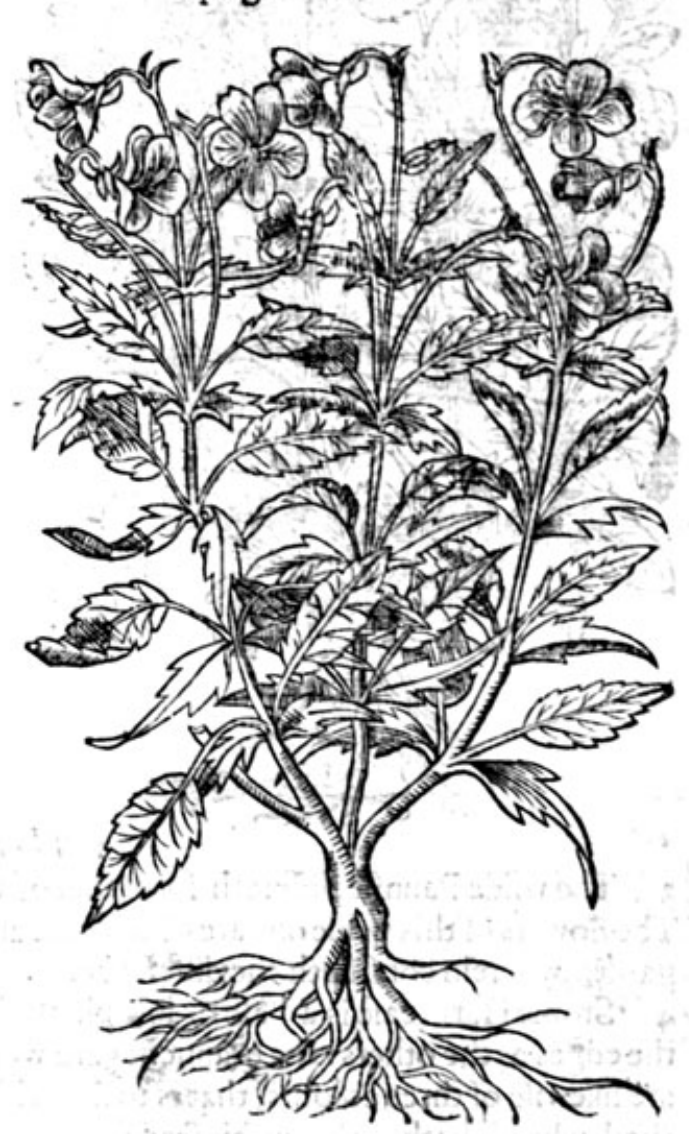

* The defcription.

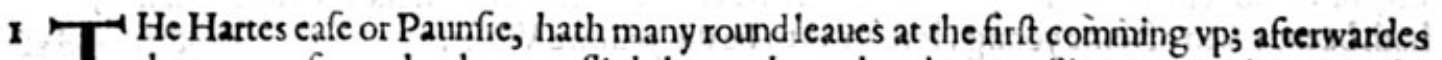
they growe fomewhat longer, flightly cut about the edges, trailing or creeping vpon the ground. The ftalkes are weake and tender, where upon do growe fiowers in formeand figure like the Violet, and for the moft part of the fame bigneffe, of three fundrie colours (whereof it tooke the furname Tricolor) that is to fay, purple,yellow, and white or blew : by reafon of the beuatie \&brauerie of which colours, they arc very pleafing to the cie; for finell they hauc little, or none at all. The feede is contained in little knaps, of the bigneffe of a tare, which come foorth after the flowers befallen, and doopen of themfelues when the feede is ripe. The roote is nothing elfe, but as it were a bundle of threddie ftrings.

2 The vpright Paunfic bringeth foorth long leaues deepely cut in the edges, Tharpe pointed, of ableake or pale greene colour, fet vpon flender vpright italkes, cornered, iointed, or kneed, 2 foote high or higher; whereupon do grow very faire towers of three colours, that is, of purple, blew and yellow, in hape like the common Hartes eafe, but greaterand fairer; which colours are fo excellently and orderly placed, that theybring great delectation to the beholders, though they have little or no fmell at all. For oftentimes it liappeneth, that the vppernoft flowers are differing from thofe thargrowe vpon the middle of the plant, and thofe yarie from the lowermoft,as nature lift to dallie with things of fuch beautic. The feede is like the precedent, 
3 Violatricolor/vluestris. Wilde Paunfies.

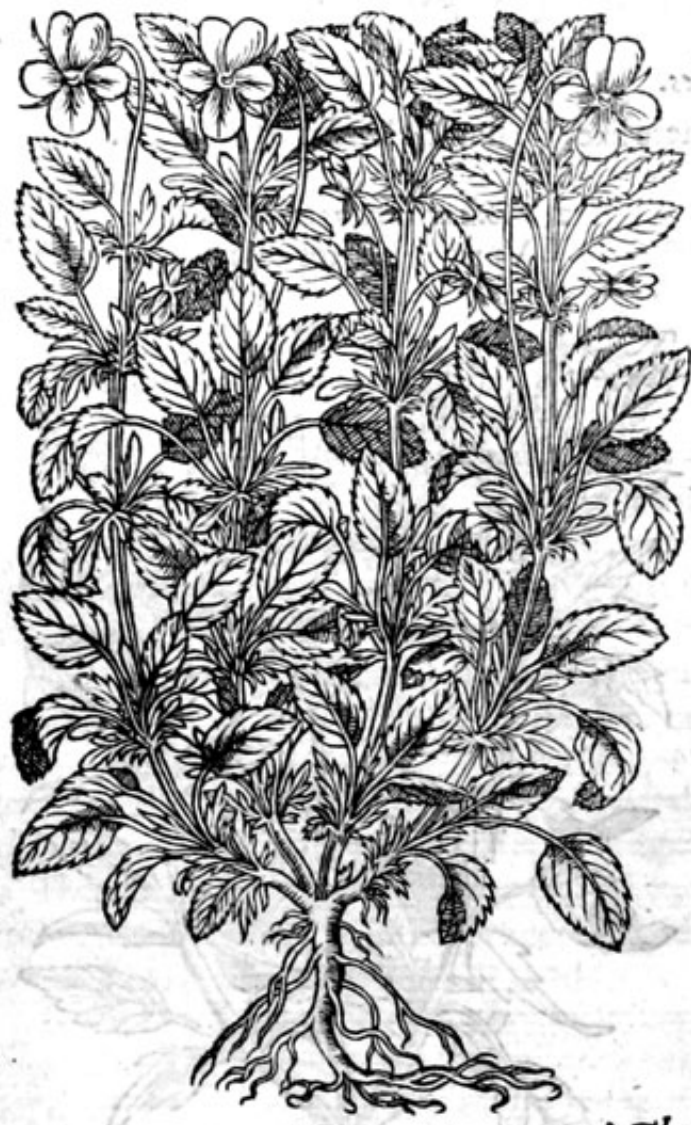

4 Viola tricolor petraa. Stonie Hartes cafe.

\section{* The defcription.}

3 The wilde Paunfie differeth from that of the garden in leaues, rootes, and tender braunches. The flowers of this wilde one are of a bleake and pale colour, farre inferior in beautic to that of the garden, wherein confifteth the difference.

4 Stonie Harts eafe is a bafe or low plant. The leaues are rounder, and not fo much cut about the edges as the others : the braunches are weake and feeble trailing vpon the ground: the flowers are likewife of three colours, that is to fay, white, blew, and yellow, voide of fmell. The roote periTheth when it hath perfected his feede.

There is found in fundrie places of England a wilde kinde hereof,bringing flowers of one yel ow colour without mixture of any other colour, wherein it differeth from the other wilde kithde, which hath beene taken of fome yoong Herbarifts to be the yellowe Violet.

\section{* Theplace.}

The Harts eafe groweth in fieldes in many places, and in gardens alfo, and that ofttentimes of it $\mathrm{felfe}:$ it is more gallant and beautifull then any of the wilde ones.

Mathiolss reporteth that the vpright Paunfie is founde on Mount Baldus in Italie. L'Obeliws faith that it groweth in Langudocke in Fraunce, and on the tops of fome hils in England, but as yet I haue not feene the fame.

Thofe with yellow flowers haue beene found by a village in Lancafhire called Latham, fower miles from Kyrckam by Mafter $T$ homas Hesketh before remembred.

$$
\text { * The time. }
$$

They flower not onely in the fpring, but for the moft partall fommer thorowe, euen vntill Autumne. * $T$ he names.

Harts eale is named in Latine Viola tricolor or the three coloured Violet, and of diuers Isces : yet there is another Iacea furnamed Nrgra : in Englirh Knapweede, Bull weede, and Matfellon, of others Her ba Trinitat is or Herbe Trinitie, by reafon of the triple colour of the flowers, of others fome Herba Clauellata : in French Penfees; by which name they became knowen to the Brabanders and thofe of the Lowe countries that are next adioining. It feemeth to be riola flammea, which 


\section{HISTORIE OF PLANTS.}

Theophraftus calleth orija, which is alfo called exísyon: in Englifh Harts eafe, Panfies, Liue in İdlenes; Cullme to you, and three faces in a hood.

The vpright Pancic is called not vnproperly Viola a/Jurgens, or Surrecta, and withall Tricolor, that is to fay Straight, or vpright Violet three coloured; of fome Vio's arborefeens, or waxing to 2 tree, but without any reafon, for as much as it hath not attained to the height or likenes, no not of a fhrub, much lefie of a tree.

\section{* The temperature.}

It is of temperature obfcurely cold, but more euidently moif, of a tongh and flimie iuice, as that of the Mallowe, for which caufe it moiftneth and fuppleth, but not fo much as the Mallow doth.

$$
\text { * The vertwes. }
$$

It is good as the later Phifitions write, for fuch as are ficke of an agewe, efpecially children and $\mathbf{A}$ infants; whofe conuulfions and fits of the falling ficknes it is thought to cure.

It is commended againft in flammations of the lungs and chelt, and againft fcabs and itchings of $B$ the whole body, and healeth vlcers.

The diftilled water of the herbe and flowers ginen to drinke, for ten or more daies togither, three $\mathrm{C}$ ounces in the morning, and the like quantitie at night, doth woonderfully eafe the paines of the French difeafe, and cureth the fame if the patient be caufed to fiveate fundrie times, as reporteth Cofteiw in his booke De natura vniserf. ftirp.

$$
\text { Of ground fuic, or Aleboofe. Chap. } 300 \text {. }
$$

Hederaterreftris.

Alehoofe.

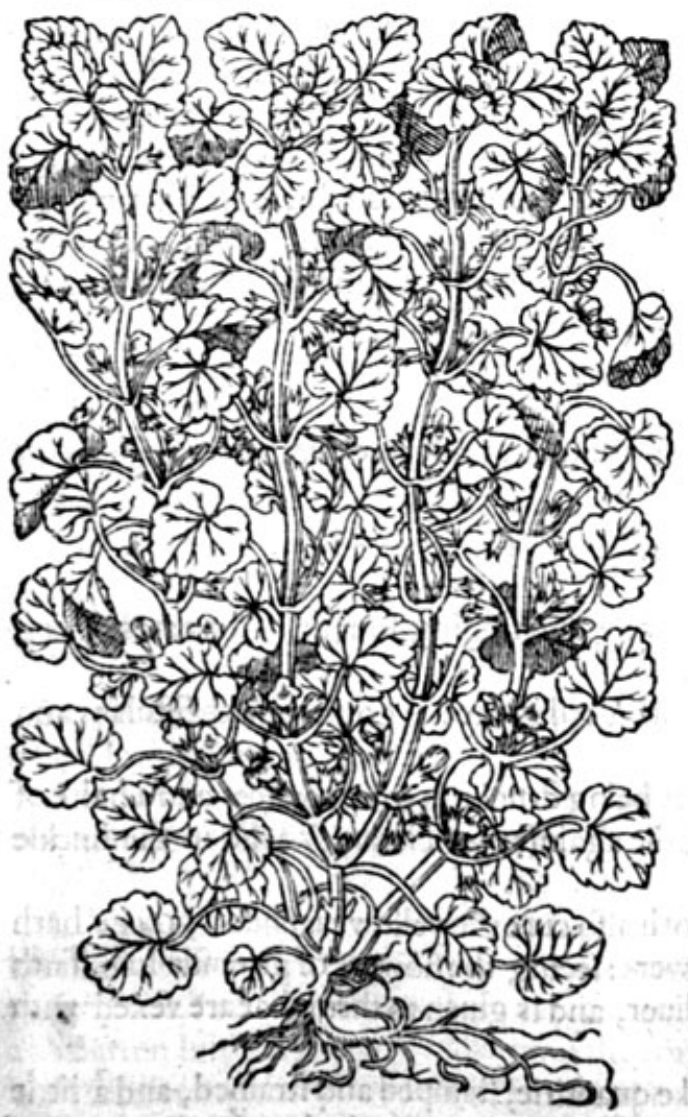

\section{* The defcription.}

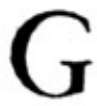
Round Inie is a low or bafc herbe, itcreepeth and fpreadeth vpon the grounde hither and thither all about, with manie ftalkes, of an vncertaine length, flender, and like thofe of the vine, fom thing cornered, and fome. times reddith : whereupon do grow leaues fomething broad and round, wrinckled, hairie, nicked in the edges, for the moft part two out of euerie ioint: among which come foorth the flowers gaping like little hoods, not vnlike to thofe of Germander, of a purplifh blew colour : the roots are very threddie. The whole plant is of a ftrong fmell, and bitter tafte.

\section{* The place.}

It is founde as well in tilled, 2 in vntilled places, but moft commonly in obfcure, bafe \& darke places, vpon dunghils, and by the fides of houfes, where the eues do drop.

$$
* \text { The time. }
$$

It remaineth greene not onely in fommer, but alfo in winter at any time of the yeere: it flowreth from Aprill till fommer be farre fpent.

\section{* The names.}

It is commonly called Hedera terreftris, in Greeke xemunitotes: alfo Corona terre : in high Dutch कैutuelteb: in low Dutch Dnaerbaue:

in French Lierreterreftre; Hedera bumilis of fome, and chamacif we : in Englifh ground Iuie, Alehoof, Gill creepe by ground, Tunehoofe, and Cats foore.

Moft of the later Herbarifts will not fuffer it to be Chamecif veterim: or the olde Herbarifts Y y 1 
ground Iuie:for the fafhion of the leaues, the length of the ftalkes, the forme of the flowers, and alfo the talte are repugnant. For Chamect/fus (as the copics haue that are cuery where extant) hath the leaues of Iuie, but thinner \& longer; the ftalks of a fpan long, \& flowers like thofe of the ftockeGilloflowers, but whiter and flenderer, in tafte very bitter. But the leaues of this Iuie are rounder, and not finooth at all, as be thofe of common Iuie: the ftalks be long and creepe all about; the flowers differ from ftocke Gilloflowers, and much leffe the leates : which defcription of Diofcorides may be corrupted, and the words falfely read, as oftentimes fuch an error as this may eafily happen by miftaking one letter for another, and certaine wordes alfo altered by thofe that write foorth the copies. And this is prooued, bicaufe Dioforides commendeth the leaues to be good for the Sciatica,\& write th that they fcoure away the yellow iaundifc; for if the flowers be bitterer, then are thefe of greater force then the leaues, efpecially to feoure away the yellow iaundife, as we read that $G$ alen did, who might haue beene deceiued by Diofcorides his corrupt text: if the defcription wonld haue fuffered this correction, the common ground luie might be Veterum Chameciffes or the old Herbarifts ground Inie. The leaues will be anfwerable being lefier then thofe of Iuie, thinner, and verie bitter. The ftalks are full of leaues, which ftaiks though they feeme long,yet are they fcant aboue a fpan long, for that they fo faften themfelues in their trailing or running at euery ioint with newe rootes, as that from the very roots indeed they are not aboue a f pan long. The flowers likewife, although vnlike in forme to ftocke Gilloflowers, may notwithftanding allo be compared vnto them: For the colour or the beautie of the flower offereth at the firft fhew, occafion of comparifon; although beheld with iudgemét, no more like then thofe things that are moft vnlike, which maner of comparifon among the ancients hath been a fault hereditary or taken by tradition, as for example. The flower of Calues fnout, or Snapdragon, faith Diofcorides, is like to ftocke Gillotlowers, the yellow flower of Spanifh Broome is as that of ftock Gilioflowers. The white flower of fmooth Withwinde is not vnlike to the Lillie. as Plinie writeth :there is a flower(faith he) in his $2 \mathrm{r}$. booke 5. chapter, not vnlike to the Lillie, which they call Conuoluulus or Withwinde, growing among fhrubs, without fmell,without yel lowe chiues within, onely reprefenting a white colour, and as it were a rude thape of nature, as now going about to learn how to make Lillies. Thefe \& fuch like haue caufed much corruption and errours among writers. If the curious pleafe to read the 15.chap.of Plinies 24. booke, he fhall there finde fuch a defcription of grounde luie(as alfo in his 25. booke 3.chapter) that he fhall haue no iuft caufe to blame me for thefe fewe aduertifements which do offer matter difputable for fchollers, wanting iudgement in Herbarifme, but not woorth the fpeaking of among thofe that haue but the leaft tafte in the knowiedg of plants, leauing the reft vnto the curious Reader.

\section{* The temperature.}

\section{Ground Iuic is hot and drie, and bicaufe it is bitter it fcoureth, and remooueth ftoppings out of} the entrailes.

\section{* 7 bevertues.}

A Ground luie is commended againft the humming noife and ringing founde of the eares, being pur into them, and for them that are hard of hearing.

B Mathiolus writeth, that the iuice being tempered with Verdigreace, is good againft fiftulaes and hollow vlcers.

C Diofcorides te acheth, that halfe a dram of the leaues being drunke in fower ounces and 2 halfe of faire water for fortie or fiftie daies togither, is a remedie againft the Sciatica or ache in the huckle bone.

D The fame taken in like fort fixe or feauen daies, doth alfo cure the yellowe iaunders, Galen hath attributed(as we haue faid)all the vertue vnto the flowers: feeing the flowers of grounde luie, faith he, is verie bitter, it remoouth ftoppings out of the liner, and is giuen to them that are vexed with the Sciatica.

E Ground Iuie, Celandine, and Daifies, of eche a like quantitie, ftamped and frained, and a little fugar and rofewater put thereto,and dropped with a feather into the eies, taketh away all manner of inflammation, fpots, webs, itch, fmarting, or any griefe whatfoeuer in the cies, yea although the fight were nigh hand gone it is prooued to be the belt medicine in the world.

F The herbes ftamped as aforefaid, and mixed with a little ale and honie, and ftrained, caketh away 


\section{HISTORIE OF PLANTS IHT fot}

the pinne and web, or any griefe out of the eies of horfe or cowe, or any othet beaft, being fquirted into the fame with firing, or I night haue faid the liquor iniected into the eies with a firing:but I lift
not to be ouer eloquent among gentlewomen, vnto whom efpecially my works are moft neceffary.

The women of ournorthien parts, efpecially about Walesand Chefhire, do tun the herbe Ale. H hoouc into their ale, but the reafon theref I know not, notwithttanding without all controueific it is moft fingular againit the griefes aforefaid; being tumed vp in ale and drunke, it allo purgeth the head from rheunaticke humours flowing from the braine.

Hedcraterreftrisboiled in water ft aieth the termes i andboiled in mutron broth helpeth weake I and aking backs.

They haue vifd to put it into ointments againft burning with fire, gunpowder, or fuch like. $\mathrm{K}$

Hederaterreftris being bound in a bundell, or chopt as herbes for the pot, and caten or drunke $\mathrm{L}$ as thinnebroth, ftaiect the Auxe in women.

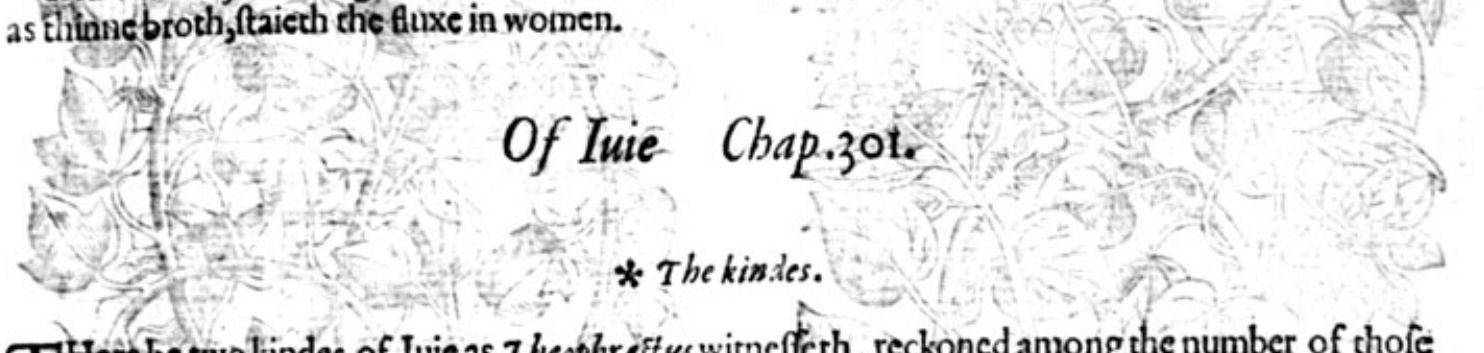

There be two kindes of Iuic as 7 heophrast us witneffeth, reckoned among the number of thofe plants, which haue neede to be propped vp:for they itande not of themfelues, but are faftned to. ftone wals, erees, and fuch like, and yet notwithift anding both of a woodie fubftance, and yet not to be placedamong the trees, thrubs, or bufhes, bicaufe of the affinitie they haue with climing herbes, as alfo agreeing with many other herbes in forme and figure that clime, and are indeed fimply to be reckoned amongtt the herbes that clamber vp. But if any will cauill or charge me with nhy promife madeat the beginining of this Hiftoric, where we made ot: deuifion, promifing to placeecheplane as neereas may be inkindred and neighbourhood: the which promile I have fulfilled, if the curious cie can be content to vicw without ralhnes thofe plants folorving in order, and not onely this climing luic that lifteth hirfelfe vnto the tops oftrees, bat alfo the other Iuie that creepeth vpon the ground.

Of the greater or the climing Iuic there are alfo many forts, but efpecially three, the white, the blacke,and that which: is called Hedera Helix, or Heder a fterilis.

\section{$*$ The defcription.} He greater Iuie climeth on trecs, olde buildings and wals: the ftalkes thereof are woodie, and now and then fo great, as it feemeth to become a tree, from which it fendeth a multitude of little bowes or branches enery waie, whereby as it were with armes it creepethand wandreth farre about : it a!fo bringeth foorth continually fine little tootes, byswhich it faftneth it felfe and cleaucth woonderfull hard vpon trees, and ypon the imootheft ftonewals. The leates are fimooth, fhining efpecially on the ypper fide, cornered with fharpe pointed corners. The flowers are veric fmall and moflic, after which fucceede bundels of blacke berries, etiery one hauing a fmall tharpe pointle.

There is another fort of great Iuie that bringeth foorth white fruite, which fome call Acharnicam irriguam: and alfo another leffer, the which hath blacke berries. This Plinie callech selinitium.

We alfo finde mentioned another fore heercof fpread abroad with fruite of a yellow faffron colour, called of diuers Diony fis as Diofcorides writeth : others Bascbikn, which the Poets vfed to make garlands of, as Pliny reftifieth in his 16. booke 34 , chapter. 2 Barren Iuic is not much vnlike vnto the common luic aforefaid, fauing that his braunches are both fmaller and tenderer, notlifting or bearing it felfe vpward, but creeping along by the grounde vinder moift and thadowie ditch bancks. The leaues are moft cominonly three fquare, corneted, of a blackifh greene colour, which at the ende of fummer become brotvnifh red vpen the lowier fide. The whole plant beareth neither flowers nor fruitc, but is altogither barren and fruitleffe. 


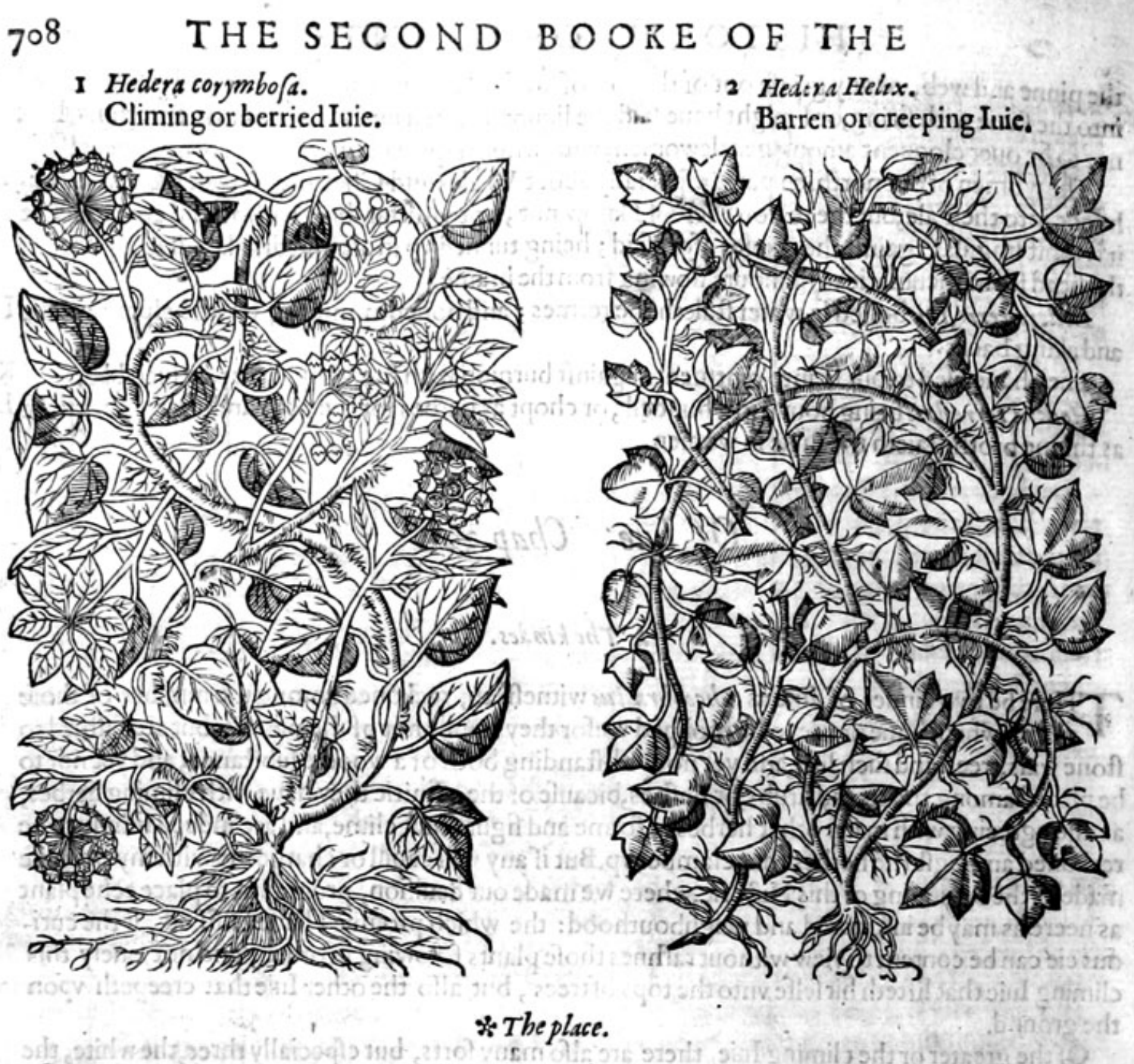

Iuic groweth commonly about wals and trees: thewhite Iuie groweth in Greece; and the barren Iuie groweth vpon the ground, in ditch bankes and fhadowie woocs.

Iuie flourifheth in Autumne; the berries are ripe afterithe winter Solltice.

\section{* The names.}

Iuie is called in Latine Hedera : in Greeke xitros, and xiaros : in high Dutch epbeuः in low Dutch đeple : in Spanifh redr $t$ : in French Liarre.

The greater Iuie is called of Theophraft wes in tos xiaros: in Latin Hedesa attollens, or Hedera affargens: Gaza interpreth it Heder a excelfa. The later Herborifts would haue it to be Hedere arborea, or tree Iuic, bicaufe it groweth vpon trees, and Heder a mur alis which hangeth vpon wals.

Creeping or barren Iuie is called in Greeke bisyos xiaros in Englifh ground luiejyet doth it much differ from Hedera terreftrus, or ground Iuie before defcribed:of fome it is called Clauicula, Heders Helix, and Hedera fterilis; and is that herbe wherein the Boare delighteth,according to Johannis Khueviy.

\section{* The temperature.}

- Iuie as Galen faith, is compounded of contrarie faculties: for it häth a certaine binding, earthie and cold fubftance, and alfo a fubftance fomewhat biting, which euen the very tafte doth fhew to be hot. Neither is it without a third facultie, as being of a certaine warme waterie fubfance, and that is if it be greene. For whileft it is in drying, this waterie fubftance being earthie, colde, and binding, confumeth away; and that which is hot and biting remaineth.

A The leates of Iuie frefh and greene, boiled in wine, do heale olde vlcers, and perfectly cure
thofe that haue a venemous and malitious qualitie ioined with them : and are a remedie likewife againtt burnings and fcaldings.

B Moreouer the leaues boiled with vineger, are good for fuch as haue bad fpleenes: but the flowers 
or fruit are of more force, being very finely beaten and rempered with vineger, ofpecially fo vied they are commended againft burnings.

The inice drawne or fnift vp into the nofe, doth effectually purge the head, ftaieth the running $\mathbf{C}$ of the eares that hath been of long continuance, and healeth old vicers both in the eares, and alfo in the nofthrils : but if it be tôo tharpe, it is too be mixed with oile of Rofes, or fallad oile.

The gum that is found vpon the trunke or body of the old ftocke of luie, killeth nits, and lice, and D taketh away haire: it is offo hot 2 qualitic, as that it dothobfcurely burne; it is as it were a certaine waterim liquor, congealed of thofe gummie drops. Thus farre Galen.

The veryfatie almoft hath Diofcorides, but yet alfo fomewhat more : for ouer and befides, he $\mathrm{E}$ faith, that flue of the berries beaten fmall and made hot in a Pomegranate rinde with oile of Rofes, and dropped into the contraric eare, doth eale the toothach, and that the clufter berries make the haire blacke.

Iuic in our time is very feldome vfed, faue that the leaues are laidévpon little vicers made in the $F$ thighes, legs, or other part of the bodie(they are called iflues) for they draw humours and waterifh fubitance to thofe parts, and remooue out of them hot fwellings or inflimmations, that is to faic, the leaues newly gathered, and not as yet withered or dried.

Some likewife affirme, that the clufter berries are effectuall to procitre vrine: and are giten to $G$ thofe that be troubled with tlie ftone, and difeafes of the kidneies.

The leaues laide to fteepe in water for 2 day and a nights ipace, helpeth fore and fmarting $\mathrm{H}$ waterifh eies, if they bebathed and wafhed with the ivater, whererin they haue beene infufed.

\section{Of rough Bindweed. Chap.jo2.}

* The kindes.

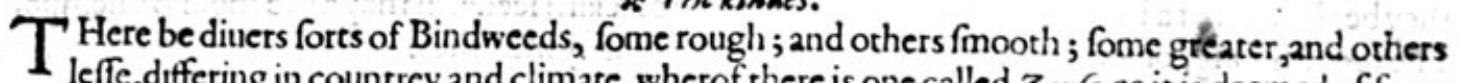

leffe, differing in countrey and climate, wherof there is one called $Z_{\Delta r}$ a as it is deemed of fome new writers: the which we intend to comprehend vader one chapter.

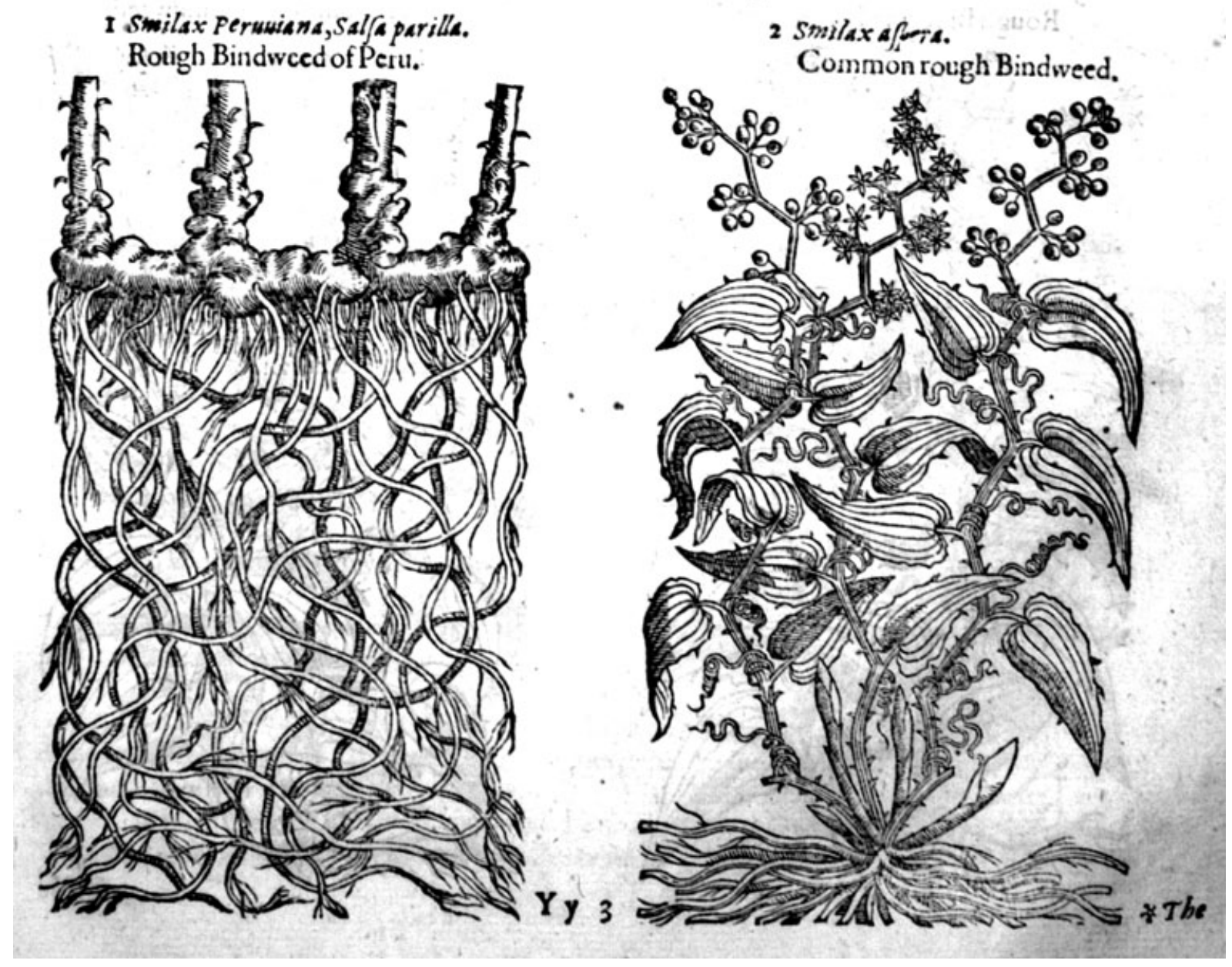


$*$ The defcription.

i Lthough we hate great plentie of the rootes of this Bindweed of Peru, which we vfuallie thefe rootes are very well knowne to all; yet fuch hath beene the careleffenes and that prouidence of fuch as haue trauelled into the Indies, that hitherto not any haue giuen vs inftruction fufficient, either concerning the leaues, flowers, or fruite, onely Monardms faith, that it hathlong rootes deepe thruft into the ground, which is as much, as if a great learned man fhould tell the fimple, that our common carrion Crowe were of a blacke colour : for who is foblinde that leeth the - root it felf,but can eafily affirme the roots to be very long? notwithiftading, there is in the reports of fuch as faie they haue feene the plant it felfe growing, fome contradiction or contrarietie; fome report that it is a kind of Bindwecd, and efpecially one of thefe rough Bindweeds; others, as one mafter White an excellent painter who caried very many people into Virginia (or after fome Norembega) there to inhabite, at which time he did fee thereof grcat plentie, as himfelfe reported vnto me, with this bare defcription; It is faith he, the roote of a fmal fhrubbie tree, or hedge tree, fuch as are thofe of our countrey called Hawthornes, hauing leaues refembling thófe of luie: but the flow crs or fruite he remembreth not.

2 The common rough Bindweede bath many branches fet full of little fharpo prickles, with certaine clafping tendrels, whcrewith it taketh hold vpon hedges, Mrubs, and whatfoeuer ftandeth next vnto it,winding \& clafping it felfe about from the bottom to the top, wheron are placed at euerie ioint one leafe like that of Iuie, without corners, fharpe pointed, leffer and harder then thofe of fmooth Bindweed; oftentines marked with little white fpots, and garded or bordered about the edges with crooked prickles. The flowers grow at the top of crooked ftalkes of a white colour, and fweet of fnell : afeer commeth the fruite like thofe of the wild Vine,green at the firf, and red when they be ripe, and of a biting tafte, wherein is contemed blackifh feede, in thape like thofe of hempe. The roote is long, fomewhat hard, and parted into very many branches.

3 Smilax affera Lafftanica.

Rough Bindweed of Portugall.

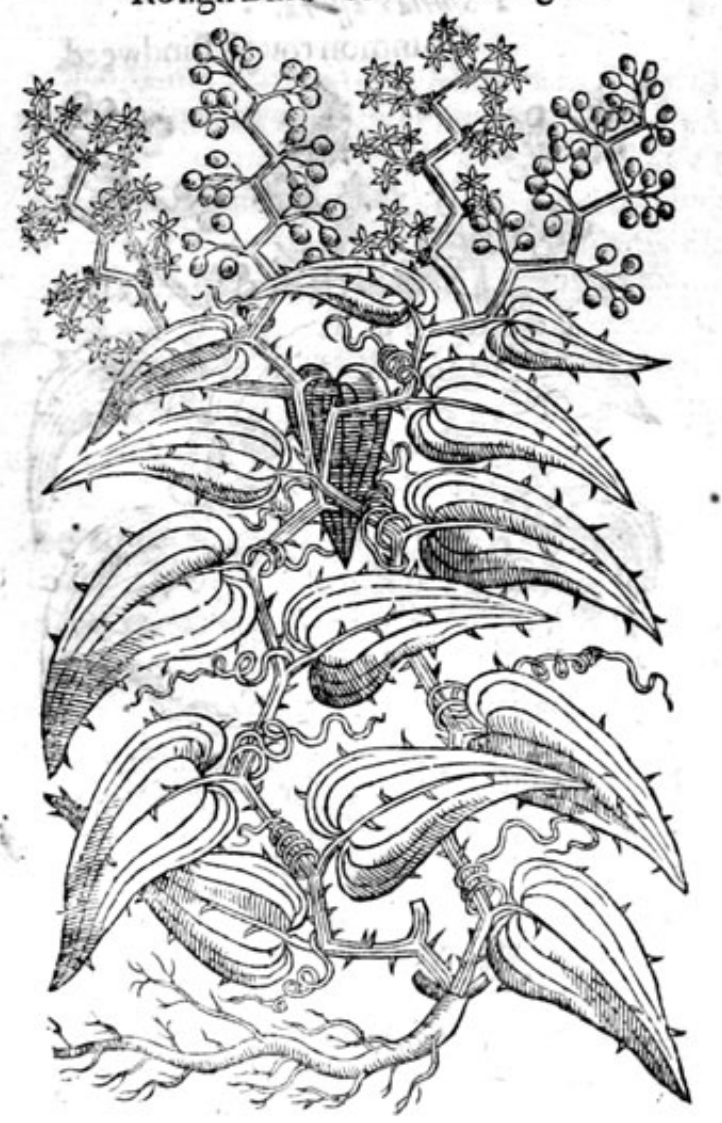

4 Smilax a pera Germanica. Germanie rough Bindweed.

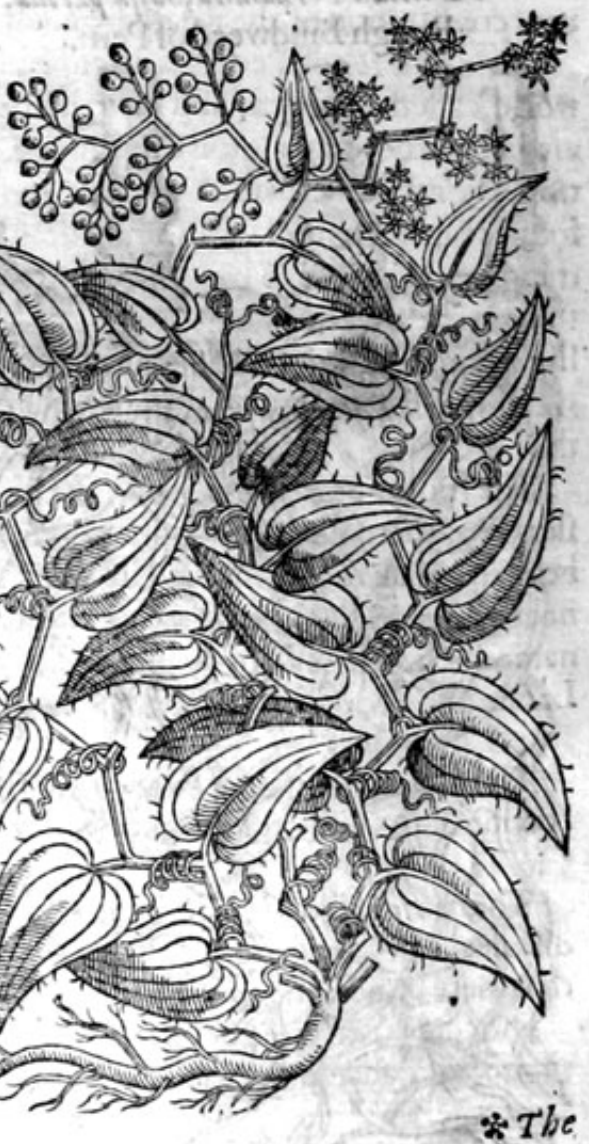




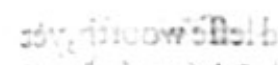

3 This rough Bindweed found for the moft part in the barren mountains of Portingale, differeth not from the precedent, in italkes, leaues, flowers or fruite. The roote heereof is one fingle roote of a woodie fubftance, with forne fibres annexed thereto, wherein confifteth the difference.

4 This Bindweed of Germanic hath many rough,prickly it alks, garnifhed and fet rounde about with diuers thorns, like thofe of the brier or bramble, winding and wrapping it felfe with his téndrels about thofe things that do ftande neere vnto it, like the common Bindweed, whereof this is 2 kinde. The leaties are like thofe of the Ituie: but tharper at the point, vpon the middle tibbe whereof do ftand diuers fhat pe prickles of a black green colour : the flowers grow at the tops of the ftalks in tufts, of a white colour; after commeth the fruite in clufters like thole of the red fmall raifons, called Ribes, and of the fame bignes. The roote is like the former.

$$
\text { * The place. }
$$

Zarza parills, or the prickley Bindweede of America, groweth in Peru, a prouince of America, in Virginia, and diuers other places both in the eaft and weft Indies.

The others growe in roughand vntilled places, about the hedges and borders of fieldes, on mountaines and vallies, in Italie, Languedock in Fraunce, Spaine, and Germanie.

$$
\text { * The time. }
$$

They flower and tlourith in the fpring,their fruit is ripe in Autumne, or a little before. $*$ The names.

It is named in Greeke 5 uirazer rexxĩa. Gaza Theoplirast us his tranflator nameth it Hedera Cilicia, 2s likewife Plinie, who writeth in his 24 .booke 10 .chapter, that it is alfo furnamed 2 icophoron. Of the Hetrufcians Heders /pinofa, and Rubus ceruinus: of the $\mathrm{C}_{2}$ ftilians in Spaine, as Lacuna faith, Zarzapartla, as though they hould fay, Kubus viticu/a or Bramble little vine. Parra as Matthiolus interpreteth it, doth fignific a vine, and $P$ arr $\mathbf{l} / \mathrm{k}$, a fimall vine, or little vine.

Dituers affirme, that the roote (brought out of Peru a prouince in America) which the latter herbarilts do call $Z_{a r} z a$, is the roote of this Bindweede. Garcias Lopins Lufit anu granteth it to be like therunto, but yet he doth not affirme that it is the fame.Plants are oftentimes found to be like one another, which notwithftanding are prooued not to be the fame, by fome little difference. The diuers conftitution of the weather and of the foile,maketh the difference.

Zarza partlls of Peru is a ftrange plant, and is brought vnto vs from the countries of the new world,called America, and fuch things as are brought from thence, although they alfo feeme and are like to thofe that growe in Europe, notwithftanding they do often differ in vertue andoperation. For the diuerfitie of the foile and of the weather, doth not onely breede an alteration in the forme, but doth moft of all preuaile in making the qualities and vertues greater or leffer. Such things as do grawe in hot places be of more force and greater fincll ; and in cold, of leffer. Some things that are deadly and pernitious, being remoued waxe milde, and are made wholefome: fo in like manner, although $Z_{a r z s}$ par rlla of Peru be like to rough Bindweede, or to Spanifh $Z_{a r} z a$ parille, notwithitanding by reafon of the temperature of the weather, and alfo through the nature of the foile, it is of a great deale more force than that which groweth either in Spaine, or in Afrike.

The rootes of Zarzaparilla of Peru (which are brought alone without the plant) te long and flender, like to the leffer rootes of common Liquorice, very many oftentimes hanging from one head, in which roores the middle ftring is hardeft. They haue little tafte and fo fmall a finell; as it is not to be perceiued. Thefe are reported to growe in Honduras, a prouince of Peru. They had their name of the likeneffe of rough Bindweede, which among the inhabitants it keepeth, fignifying in Latine alfo a rough or prickley vine,as Garcias Lopius doth witneffe.

* The temperature.

The rootes are of temperature hot and drie, and of thin and fubtill partes, infomuch as their de. coction doth veryeafily procure fweate.

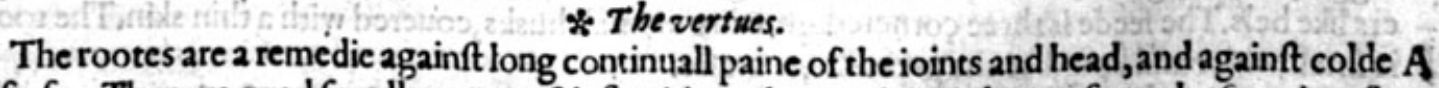
difeafes. They are good for all manner of infirmities, wherein there is hope of cure by fweating, fo that there be no ague ioined.

The cure is perfected in few dais, if the difeafe be not old or great; but if it be, it requireth a longer $B$ time of cure, mening, as I take it, the roots of Zarza parilk, wherof this Smilax a/pera, or rough Bind 


\section{$7: 2$ THE SECOND BOOKE OF THE}

weede is holden for a kinde; notivithftanding this of Spaine, though it be counted leffe woorth,yet it is commended of Diofcorides and Plinie againft poifons. The leaues hereof, faith Diofcorides,are a counterpoifon againft deadly medicines, whether they be drunke before or after.

\section{Offmootborgentle Bindweede. Chap.303.}

* The kindes.

$T$ Here be diuers forts of Bindweedes, differing as well in countrie,2s in forme and figure,2as hall be declared in this prefent Chapter.

I Smilax lenis fine leuis maior.

Great fmooth Bindweede.

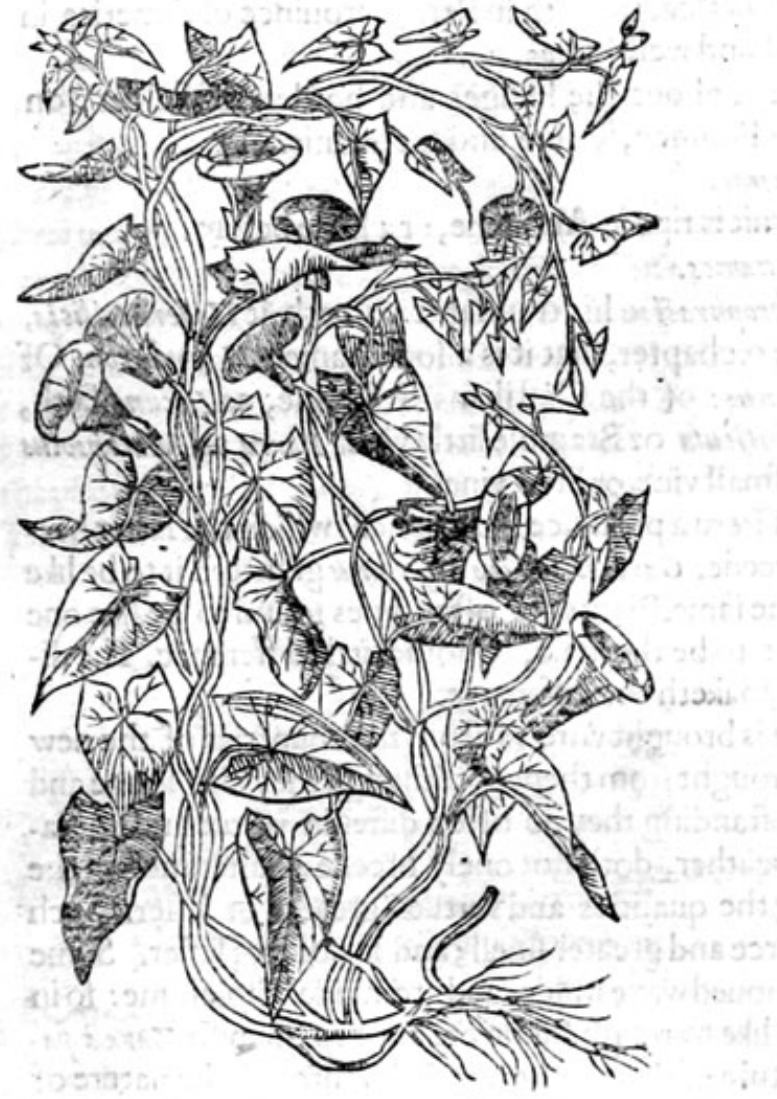

2 Smilax lenisminor. Small gentle Bindweede.

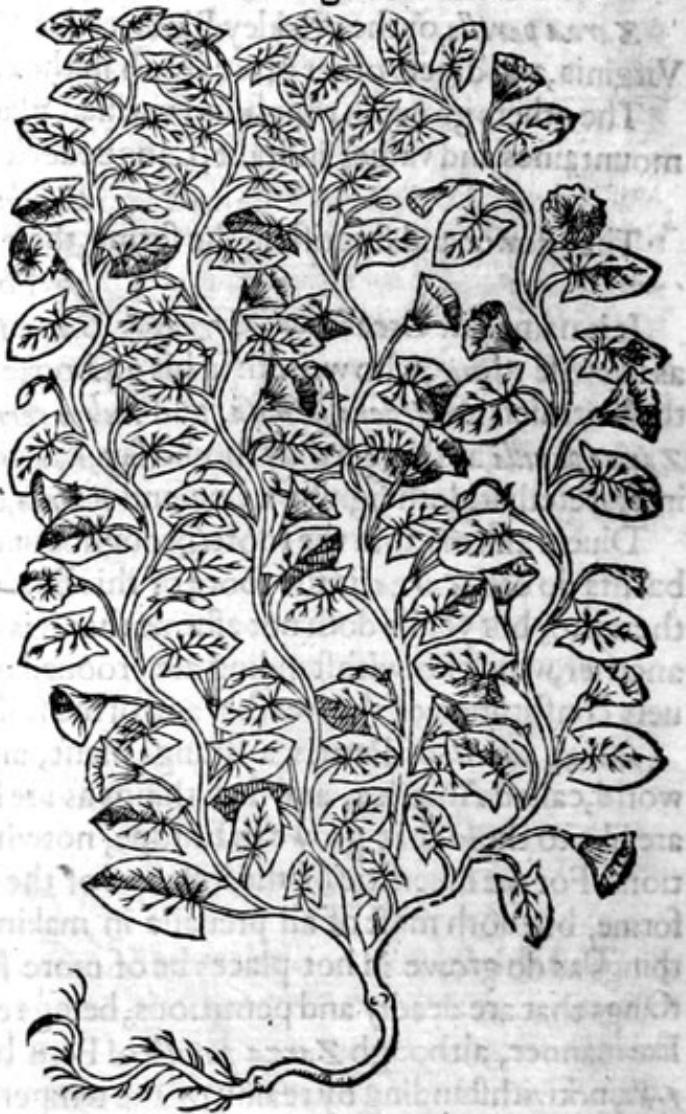

* The defcription.

$T$ is a ftrange thing vnto me, that the name of Smilax fhould fo largely be extended, as that it fhould be affigned to thofe plants, that come nothing neere the nature and fcarfly vnto any part of the forme of Smilax indeede. But we will leaue controuerfies to the further confideration of fuch asloue to daunce in quagmires, and to come to this our common fmooth Smilax, called and knowen by that name among vs, or rather more truly by the name of Conuoluulus maior or Volvbilis maior: It beareth the long branches of a vine, but tenderer, and for the length and great fpreading thereof, very fit to make thadowes in arbors. The leaues are fmooth like Iuie, but fomewhat bigger, and being broken full of milke; amongft which come foorth great, white and hollow flowers like bels. The feede is three çornered, growing in fmall husks, couered with a thin skin. The roote is fmall, white and long, like the great Dogs graffe.

2 Smilax lenis minor, is much like vnto the former, in ftalkes, leaues, flowers, feede and rootes, $f_{2}$ uing that in all refjects it is much fmaller, and creepeth vpon the ground. The branches are fmall and fmooth: the little leaues tender and foft: the flowers like vnto little bels, of a purple colour. The feede three cornered like vnto the others. 
Of which fmall Bindweede there are founde other forts which onely yaric in the colour of the Alowers.

3 Connolualus minimus fica folino.

Lauender leafed Bindweed.
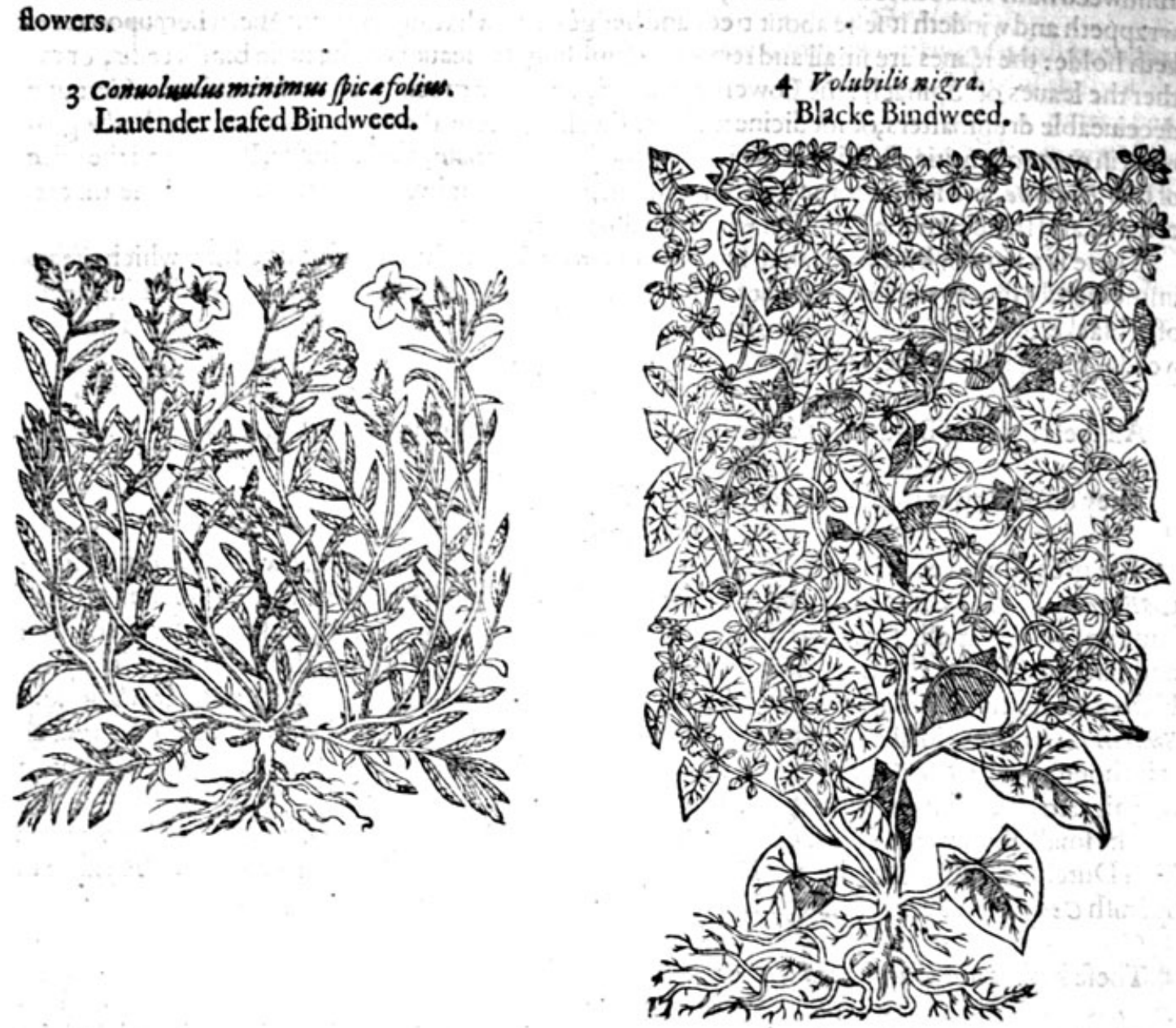

* The defcription.

3 This thirde kinde of Bindeweede, $P$ ens faith he neuer fawe but in the brinks of quickfets, and Oliuets in Prouence, Sauoy, and Narbone, notwithftanding I found the fame growing in the corn fields about great Dunmow in Effex in fuch abundaunce, that it doth very great hurt voto their corne. This kinde of Bindweed or $\boldsymbol{V}$ olubilis is like vnto the fmall Bindweed before mentioned, but it hath a more delicate flower, plaited or foulded in the compaffe of the bell, very orderly, efpecially before the funne rife(for after it openeth it ielfe, the welts are not fo mech perceitied) and is of a darke purple colour. The feede is not vnike the reft, cornered and flat, growing out of flender braunches, which ftande vpright and thicke togither,proceeding out of a woodie white roote. The leaues are long and narrow, refembling Linaria, both in colour and hairineffe, in tafte drying, and fomewhat heating.

4 The fourth kind of Bindweed called Helxine of the Greek word inxwin, which fignificth to draw, to cleaue, or to pull to him; being conferred with the forefaide kindes of Bindwcedes togitlier with his nature and effect of purging, may yeelde manifelt reafons why $C i$ /ampelos houldbe alfa of the kindes of Comuoluulus which Dodoneus calleth Conuolualum nigrum. But for as much as there be fower differences to beconfidered in the herbe Consoluulus, or as the conmon people tearme it Volubilis, whofe vertues hauenot as yet by any one beene fet foorth: I have therefore thought it good to account this Volubilis for the right Ciffampelos, which agreeth moft with him as well in place of growing, as alfo in his euident propertic of purging, which is the onely qualitic tha: Diof corides notethand applieth vnto him, which the ftudents of Padua call Broeggis, and of Pliny Scam. monestenwis, and doth thinke it to be akinde of the true Scammonie. This cyfampelos, or blacke 


\section{4 \\ THE SECOND BOOKETOF THE}

Bindweed hath fmooth red branches, and verie fmall, like the tendrels of a vine, wherewith it wrappeth and windeth it felfe about trees and hedges, and whatfoçuer thing elfe, whereupon it ra. keth holde: the leaues are fmall and tender, refembling the leaues of the little Bindweede, or rather the leaues of Spinach : the flowers are fmall, and of a greenifh or herbie colour. Certaine deceiueable drugmafters, or medicine makers, dwelling neere the fea coafts where this herbe gro. weth in great quantitic, do mingle the iuice of the fea Tithymale, Colophonie, Rofin, and the iuice of this Heixize, and fell it for the beft Scammonic, to the great hurt and detriment of thofe that receine it, and flander to the Phifition which minifteth it.

There is a kind of Bindweed that hath a tough root full of threddie ftrings, from which rife vp immediately diuers trailing branches, wherupon do grow leaues like the common field Bindweed, of a blacke greene colour, whereofit tooke his name. The whole plant is not onely a hurefull weede, but ofan euill fmell alfo.

\section{* Theplace.}

All thefe kinds of Bindweeds do grow very plentifully in moft parts of England. * The time.

They do all tlower from Maic to the end of Auguit. * T The names.

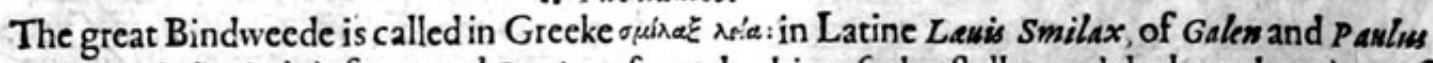
MEgineta $\mu i \lambda \alpha \xi$ reid : it is furnamed Lenis or fmooth, bicaufe the ftalkes and the branches thereof hauenoprickles at all. Dolichus called alfo Smilax hortenfis; or kidney Beane, doth differ from this: and likewife Smilax the tree, which the Latines call Taxus, in Englifh the Yewe tree. The later Herbarifts do call this Bindweed Volubelis maior, Campanella, funis arborum, Consoluslos albus, and Smilax leais mazor: in like maner Plinie in his 21 . booke 5 .chapter, doth alfo name it Conuolnaulus. It is thought to be Ligustrum, not the fhrubbe priuet, but that which Martialio in his firft booke of Epigrams fpeaketh of, writing againft Procilles.

The fmall Bindwcede is called Comioluutus minor, and Smilaxlanis minor, Volubilis minor : in

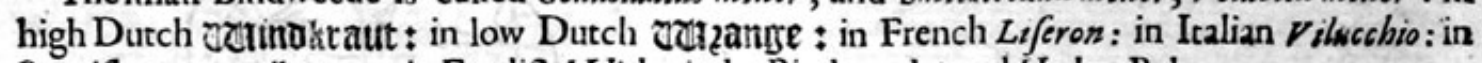
Spanifh Campanilla rerus : in Englifh Withwinde, Bindweede, and Hedge Bels.

Thefe herbes are of an hot and drie temperature. * The vertues.

The leaues of blacke Bindweedecalled Helxine Ciffampelos, ftamped and frained, and the iuice A drunken, doth loofe and open the bellic exceedingly.

The leaues pounde and laid to the greeued place, diffolueth, wafteth, and confumeth hard lumps $B$ and fwelling,as Galen faith.

The reft of the Bindweedes are not fit for medicine, but vnprofitable weedes and huirtullivnto Ceche thing that groweth next vnto them.

\section{Of Blew Bindweed. Cbap.304.}

\section{* The dejcription.}

$\mathrm{B}$ Lewe Bindweed bringeth foorth long, tender, and winding branches, by which it climeth vpon things that ftand neere vnto it, and fouldeth it felfe about them with many turnings and windings, wrapping it felfc againft the funne contraric to al other things whatfoeuer, that with their clafping tendrels do imbrace things that ftand neere vnto them; whereupon do grow broad cornered leates very like vnto thofe of luie, formething rough and hairic, of an ouerworne ruffer greene colour : among which come footth moft pleafant flowers bell fafhion, fomething cornered as are thofe of the common Bindweede, of a moft hining azure colour tending to purple: which being paft, there fuccede rounde knobbed feed veffels, wherein is contained long blackifh feede of the bigneffe of a Tare, and like vnto thofe of the great hedge Bindweede. The roote is threddie, and perifheth at the firft approch of winter. 
Consolualas Cerulews.

Blew Bindweed:

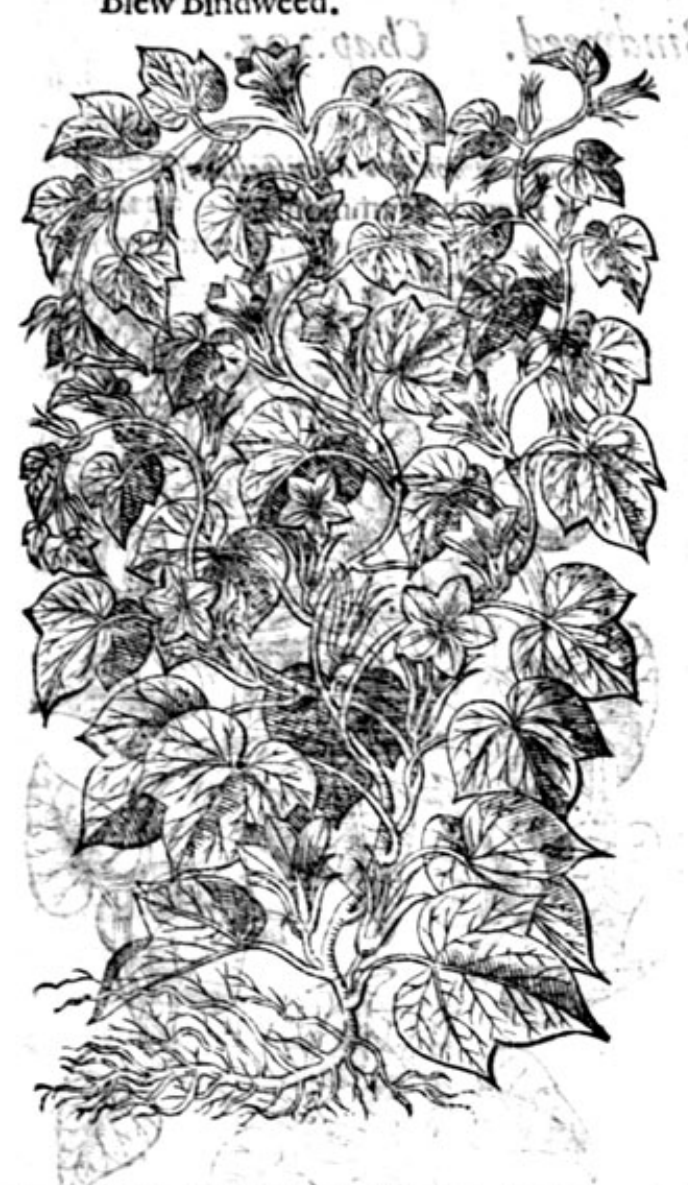

* Theplace.

The feede of this rare plant was firft brought from Syria and other remote parts of the world, and is a ftranger in thefe northren parts, yee haue I brought vp and nourilhed it inmy garden vnto tlowring, but the whole plantperithed before it could perfect his feed. * The time.

The feede muft be fowen as Melons and $\mathrm{Cu}$ cumbers are, and at the fame time: it flowred with me in the end of Auguft. $*$ T he names.

It is called Campans Lazula, and Lazura, of the later Herbarifts Compana Cerwlea, and alfo Conmolusitan Carulesm: it is thought to be Liguftrum nigruem, (but not truely) of which Colunells in his 10. bookchath made mention:

\section{Fer calat bis violem, \& nigro permiftaliguftro}

Balfama cum Ca fia nedtens, Ore.

In baskets bring thou Violets

And blew Bindivced withall;

But mixed with pleafant Baulme And Caffia medicinall.

For if the greater fmooth Withwinde, or Bind: weede be Liguftram, then may this be not vnproperly called Liguftrom nigrwm: for a blewe purple colour is oftentimes called black, as hath beene faide in the blacke Violet. But there be fome that would haue this Bindeweed to be Granum Nil Aurcenne, of which he writeth in the 306.chapter; the which differeth from that Nil that is defcribed in the 51 2.chapter. For this is 1 fat is Grecorwm, or the Græcian Woadesbut that is a ftrange plant, and is brought from India, as both Luicenne and Serapio do teftifie : Nuicenne in this manner; what is grasum Nd? it is Chartamuon Indum : and Serapio thus; $\mathrm{Habal}_{\mathrm{Nil}}$, is granum Indicum, in the 283 .chapter, where the fame is defcribed in thefe words: the plant therof is like to the plant of Leblab,that is to faie of Cowolwulus, or bindweed, taking hold on trees with his tender ftalks it hath both greene branches \& leaues, and there commeth out by euery leafe a purple flower, in fafhion of the Bell flowers : and when the flower doth fall away, it yeeldeth a feede in fmall coddes(I read little heads) in which are thee graines, leffer then the feedes of Statiefaker, to which defcription this blew Bindweed is anfwerable.

There be alfo other forts of Bindweeds, which be referred to Nil Awicenne which ro doubemay be kinds of $\mathrm{Nil}$; for nothing gainfaieth it why they fhoulde not be fo. Therefore to conclude, this beautifull Bindweed, which we call Comolunlus Cerwlesw, is called of the Arabians Nil: of Serapio Hab almil: about Alepo and Tripolis in Syria, the inhabitants call it $\mathrm{Ha}_{4}$ mifen: the Italians Campans azures, of the beautifull azured fowers, and alfo Fior de notte, bicaufe his beautie appeerech moft in the night.

\section{$\approx$ The temperature.}

Conyoluulus Caruleus, or 2 il as waicenne faith, is hot and dric in the firft degree, but Serapio maketh it to be hot and drie in the third degree.

*The vertues.

It purgeth and voideth foorth rawe, thicke, flegmaticke, and melancholicke humours :it dritueth A out allkinde of wormes, but it troubleth the belly and caufeth a readines to vomite, as Asicen faith: it workech flowly as Ser apjo writeth, in whom more heer of may be found, but to litlepurpofe, wherfore we thinke good topaffe it ouer. 
I Scammoniven Syriacum. Syrian Scammonie.

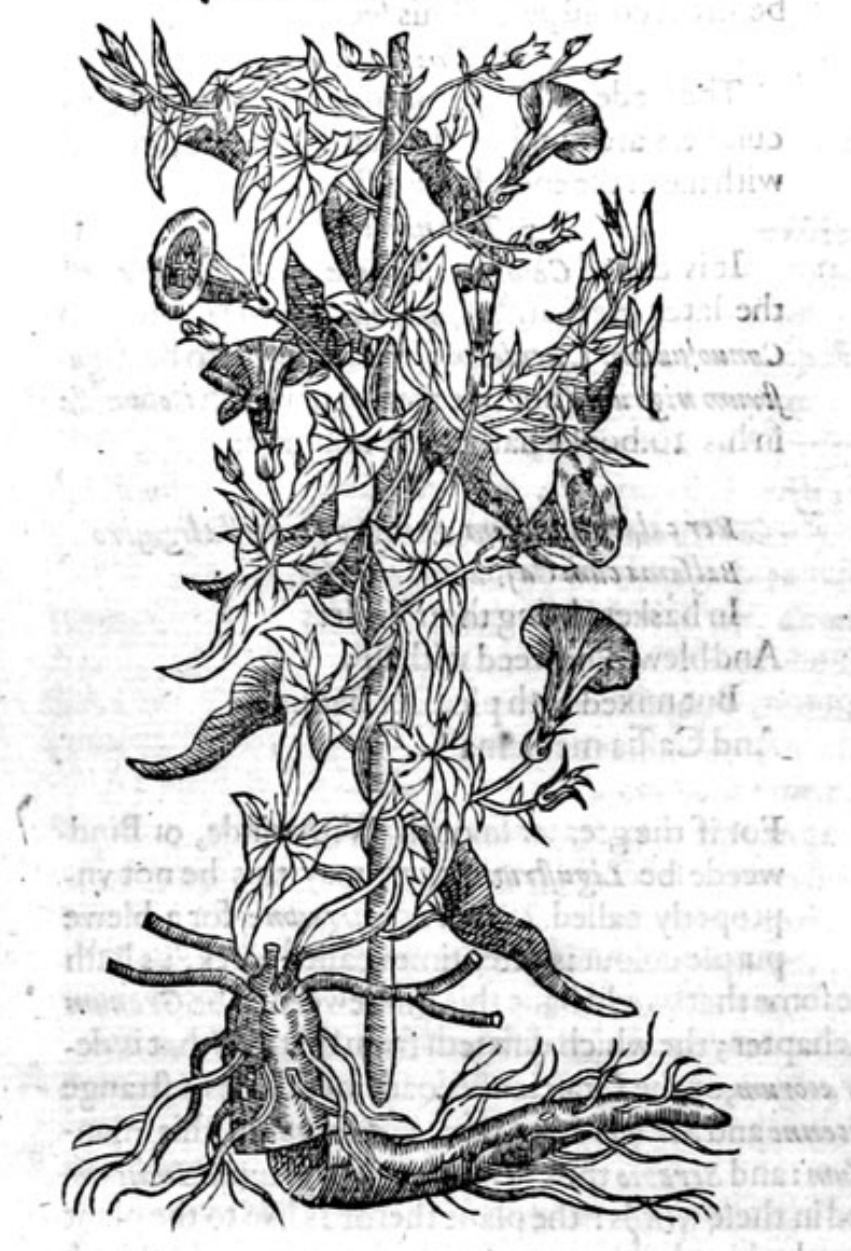

2 Scammonivem Monfpellienfe. French Scammonic.

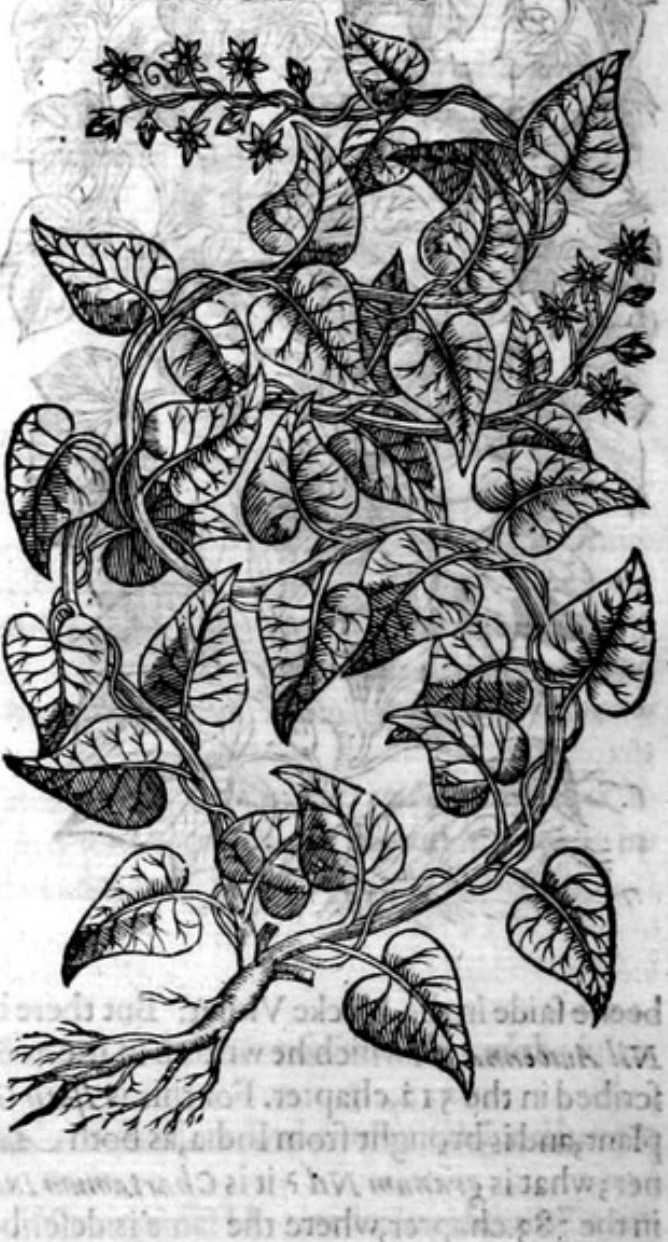

Po retconitaristalis lio

\section{$*$ The defcription.}

I Cammonie of Syria hath many ftalkes rifing from one roote, which are long, flender, and like the clafping tendrels of the vine, by which it climeth and taketh holde of fuch things as are next vnto it. The leaues be broade, tharpe pointed like thofe of the finooth or hedge Bindweed : among which come foorth very faire white flowers tending to a blufh colour, bell fafhion. The roote is long, thicke, and white within; out of which is gathered a iuice, that being hardned, is greatly ved in Phificke : for which confideration, there is not any plant that groweth on the earth, the knowledge whereof more concerneth 2 Phifition, both for his fhape and properties, then this Scammonie, which Pena calleth Lactaria feanforiague voluuba, that is milkie and climbing Windweed, where of it is a kinde; although for diftinction fake, I haue placed them as two fundrie kinds. And although this herbe be fufpeeted, and halfe condemned of fome learned men, yet there is not any other herbe to be founde, whereof fo fmall a quantitie will do fo much good : neither could thofe which haue carped at it, and reproned this herbe, finde any fimple in refpect of his vertues to be put in his roome: and heereof infueth great blame to all practitioners who haue not indeuored to bee better acquainted with this herbe, chiefely to auoide the deceite of the craftie drugfeller and medicine maker of this confected Scammonie, brought vs from farre 
places, rather to be called I feare infeeted Scammonic, or poifoned Scammonic, then confeEted. But to auoide the inconueniences heercof, by reafon of the counterfaiting and ill mixing there of: I haue therefore thought good to fet downe what I haue taken out of the diligent, and no leffe learned obferuations of Pena, concerning this plant, Anno 1561 . or 1562 .

Sequinus Martinellises, an apothecarie of Venice, being a moft diligent fearcher of Symples, to the end he might haue the right Scammonie of Antioche, tranelled into Syria, where from the citic of Alepo, he fent an hundreth waight of the iuice of Scammonie of Antioche, prepared and hardned into a lumpe, at the making whereof he was prefent himfelfe. This man fent alfo of the feedes thereof, which in all points anfwered the cornered feed of $V$ olubilis : which being fowen in the beginning of the fpring at Padua, and Venice, grew vp to the forme of a braue and goodly Conuolunlus, in leaues, flowers and thewe like vnto our Ciffampelos, that a man woulde haue taken it for the fame without controuerfie, fauing that the roote was great, and in bigneffe equall to the great Brionie,as alfo in tenderneffe. The outwarde batke of the roote was of a pukie colour, and white within: the inner pith being taken foorth feemeth in all mens iudgements to be the fame and the beft allowed Turbith officinartem : and yet it differeth from Turbith, in that, that it is more bstetle, and willmore eafily be broken, though the pith in Scammonie be no leffe gummie, and full of milkie iuice then Turbith. Further Pena reporteth that afterward he fent of this feede vnto Antwerpe, where it grewe very brauely, the climing ftrings and braunches growing vp to the height of fuie or fixe cubits, not differing from that which was fowen in Italie. Alfo William D ries of Antwerpe, a moft excellent apothecary, did cut off the branches of this Antwerpian Scammonie from the roote, and dried them, planted the feedes in his garden, and conferred the fuperfluous branched rootes with the Turbith of Alexandria, and coulde not finde them to differ or difagree, the one from the other in any point. But he that will knowe more concerning Scammonie (I meane what apothecarie foeuer, vnto whom efpecially it belongeth ) either concerning the right choife thereof, his difference from Opium, and how the counterfaiting thereof may be knowne, of the vfe of Scammonie, and the reafon that the dofes which are giuen in thefe daies, will not anfwer the quantitie which was prefcribed to be giuen in Galen his time, and how Scammonie is to be corrected and mixed with other purging medicines, as Diaphenicon, Catholicom, Succus rofarum, Braßsca marima, and $T$ ithrmale: let him read $P$ ena his learned obferuations in his chapter of Scammonic, where he fhall finde many excellent fecrets woorthie the noting of thole, as know how to vie fuch rare and excellent medicines.

2 Scammonie of Montpellicr(whereof I haue plentie in my garden) is alfo a kinde of Bindweed, growing naturally by the fea'fide vpon the grauely fhore, by the mouth of the riuer Rhodanus, at the waters called Aquas marianas, where the apothecaries of Montpellier gather of it in great pleatie, who haue attempted to harden the milkie iuice thereof, to vfe it in fteede of Scammonic of Antioch. This plant bringeth foorth manie flender branches, which will climbe and verie well runne vpon a pole, as being fupported therewith, and mounteth to the height of fite or fixe cubits, climbing and ramping like the firft kinde of Scammonie. The leaues are greene, fmooth, plaine, and Tharpe pointed, which being broken do yeelde abundance of milke: the flowers are white, fmall, and ftarre fafhion: the rootes white and manic, thooting foorth fundrie other rootes, whereby it mightily increafeth.

$$
\text { * The defoription. }
$$

3 This ftrange kinde of Scammonic, which $C l$ fus founde in the marfhie grounds neere vnto the fea in the Prouince of Valentia, being one of the Bindweeds, as are likewife all the reft of Scammonies: neuertheleffe hemaketh this to be Periploca pecies, making Periploca and Scammonieto be of, kinred. This plant hath a verie long branch ramping and taking hold vpon fuch things as do growe neere ynto it, of a darke ruffet colour which we call afh colour, whereupon do grow leaues tharpe pointed, crooked at the fetting on of the ftalk like thofe of the blacke Brionie, and likewife of an afh colour fet tog ither by couples: from the bofome wherof thrufteth foorth fmall tender foote ftalks, whereon are placed fmall white flowers ftarre fafhion. The roote hath not as yet beene difcouered by any that hath written heereof. 
3 Scamonea Valentina.

Scammonie of Valentia.

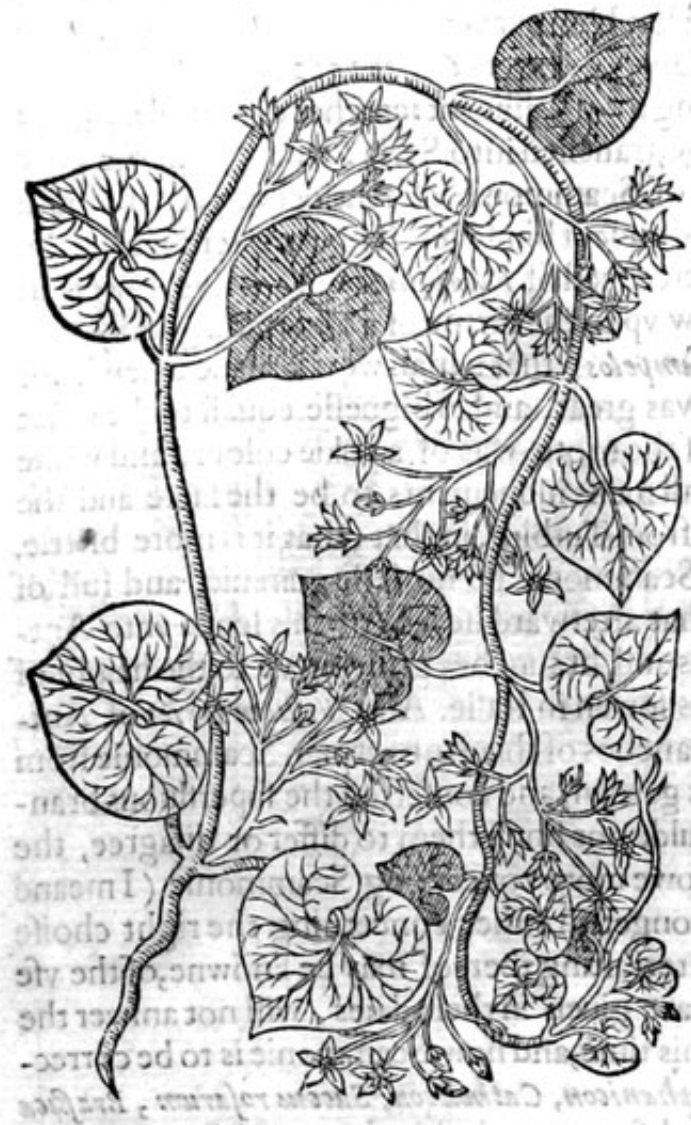

* Theplace.

It doth grow in hot regions, in a fat foile, as in Mifia,Syria, and other like countries of Afia ; it is likewife found in the Iland of Candia,as Bellonius witneffeth, from whence I had fome feedes, of which feed I receiued two plants that profpered exceeding well, the one whereof I beftowed vp. on a learned apothecarie of Colchefter, which continueth to this daic, bearing both flowers and ripe feede. But an ignorant wiceder of my garden plucked mine vp, and caft it away inmy abfence, inftecde of a weede, by which mifchance I am not able to write hecreof fo abfolutely as. I determined: it likewife groweth necre vnto the fea fide about Tripolis in Syria, where the inhabifotants do call it Meudhendi.

\section{$*$ Thetime.}

It flowred in my garden about Saint Iames tide, as I remember; for when I went to Briftow faire, Il left it in flower; but at my recurne itwas deltroiedas aforefaid.

\section{*. The names.}

The Greekes call it orquevía : the Latines Scammonium, fo naming not onely the plant it felfe, but alfo the hard and congealed iuice: of the apothecaries Scamonea, and when it is boiled in 2 Quince Diagradium; as though they fhoulde faie, saxptritov: which fignifieth a litule teare, both the

berbe and iuice are named Scamony, of Rhafis Coriziola. $\because$ The temperature.

This iuice doth mightily purge by the ftoole, and is the ftrongeft purge whatfoeuer; for as Oribafius faith, it is in no part ouercome by thofe things which ftirre and mootie the bodie. It worketh thefame not vehemently by any hot qualitie, but by fome other hid \& fecret propertic of the whole fubltance; for there is no extremitic of heat perceiued in it by tafte: for with what liquor or thing foever it is mixed, it giueth vato it no bitterneffe, biting, or other vnplea ant tafte at all, and therefore it is not to be accounted among the extreme hotmedicines, but among thofe that are moderately hot and drie.

A $*$ The vertues.

ime times flegme, yet is it as Paulus teacheth more hurtfull to the ftomacke then any othermedicine.

B Mefues thinketh that it is not onely troublefome and hurtfull to the itomacke, but alfo that it thaueth the guts, gnawing and fretting the entrailes; openeth the ends of the vaines;and through the effence of his whole fubitaunce, it is enimie to the hart, and to the reft of the inward parts: if it be vfed immoderately and in time not conuenient, it caufeth fwounings, vomitings, and ouerturnings of the ftomacke, fcouring the bloodic fluxe and vleers in the lower gut, which bring a continuall
defire to the ftoolc.

C Thefe mifchiefes are preuented if the Scammonie be boiled in a Quince and mixed with the flime or mucilage of $P$ fillium, called Fleawoort, the pappe or pulpe of Prunes, or other things that hate a flimie iuice, with a little Mafticke added, or fome other eafie binding thing.

D plinie affirmeth that the hurt thereof is taken away if Aloës be tempered with it; Scammonie faith he, ouerthroweth the ftomacke, purgeth choler, loofeth the belly vnleffe two drams of Alcës be put vinto one fcruple of it, which alfo Oribafius alloweth of in the firft bocke of his Symopfes, and the 7 booke of his medicinall Collections.

E Theold Phificions were alfo woont to boile Scammonic in a Quince, and to give the Quince to 


\title{
HISTORIE OF PLANTS.
}

be eaten, hauing caft away the Scammonie: and this Quince fotaken doth mooue the belly with. out any hurt vnto the ftomacke, as Galen in his firft booke of the faculties of no:arifhments doth fer downe, and likewife in bis third booke of the faculties of fimple medicines.

The apothecaries do vfe Scammonie prepared in an apple, which as we haue faide, they name F Dia gridum, and do mixe it in diuers compofitions.

They kcepe vfually in their fhops two compofitions, or electuaries, the one of Pfillinm or Flez-G woort, fet down by Mefues : the other of Prunes fathered vpon 2 icholazes, which were deuifed for the tempering and correction of Scammonie, and be commended for hot burning agues, and tertianș, and for what dieafes foeuer that proceed of choler.

Galen hath taken Mafticke and Bdellitom out of the pilles called Cochie, which alfo conteine in $\mathrm{H}$ them a great \& fufficient quantitie of Scammonie, as we may reade in his firft booke of medicines according to the places affected, which alfo we meane to touch in the chapter of Coloquintida, where we intend to intreat at large concerning Mafticke, and other binding things, that are accuftomed to be mixed for the correction of itrong and violent purgers.

The quantitic of Scammonie, or of Diagridium it felfe, as $\mathrm{Me}_{\mathrm{e}}$ /us writeth, is from fiuc graines to I ten or twelue : it may be kept, as the fame authour fheweth, fower yeeres: Plinie iudgeth it to be after two yeeres little woorth: It is to be vfed faith he when it is two yeeres old, and it is notgood before, nor after. The mixing or otherwife the vfe thereof, more then is fet downe, I thinke it not expedient to fet foorth in the Phificall vertues of Scammonie, vpon the receipt wherof, many times death infueth: my reafons are diuers, for that the fame is very dangerous, either if too great a quantitie thereof be taken, or if it be gitien without correction; or taken at the hands of fome runnagate phificknonger, quackfaluer, old women leaches, and fuch like abufers of Phificke, and deceiuers of people. The vfe of Scammonie I commit to the learned, vnto whom it efpecially and onely belong. eth, who very carefully and curioufly vie the fame.

\section{Of Brionie, or the whiteVine. Chap.306.}

\author{
* The kindes.
}

$T_{\text {the one white, the other blacke, of the white Brionie as followeth. }}^{\text {Here be two kindes of Brionie(befides the wilde one, called Brionis orwilde Brionie) }}$

* The defcription.

W Hite Brioniebringeth foorth diuers long and flender ftalkes, with many clafping tendrels like the Vine, wherewith it catcheth holde of thofe things that are next vnto it. The leaues are broad, fiue cornered, and indented like thofe of the Vine; but rongher, more hairie, and whiter of colour. The flowers be fmall, white, growing manie togither. The fruite confifteth inlittie clufters, the berries whereof are atthe firtt greene, and red when they be ripe. The roote is verie great, long, and thicke, growing deepe in the earth, of a white yellowifh colour, extreme bitter, and altogither of an vnpleafant tafte. The Queenes chiefe Chirurgion, $\mathrm{Ma}$ fter William Goodorows, a very curious and learned gentleman fhewed me a roote heereof, that waied haife an hundred waight, and of the bigneffe of a childe, of a yeere olde. 
Bryonia alba.

White Bryonie.

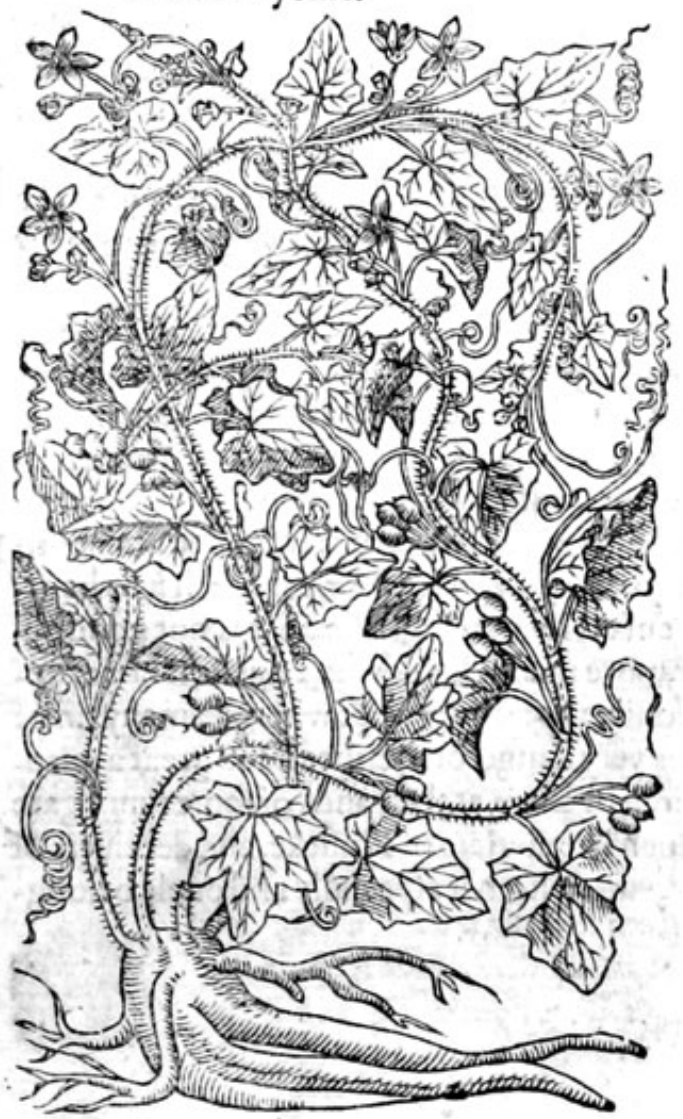

* T the place.

Brionie groweth almoft euery where among pot herbes, hedge bufhes, and fuch like places. $*$ The time.

It flowreth in Maie, and bringeth foorth his grapes in Autumne.

\section{* The names.}

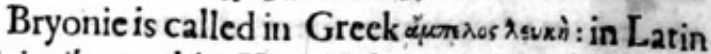
Vitis alba, or white Vine, and it is named ajun ios bicaufe it is not onely like the Vine in leaues, but alfo for that it bringeth foorth his fruite made vp after the likeneffe of a little clufter, although the berries ftande not clofe togither : it is called of Plinie Bryonia and Madon: of the Arabians $\mathrm{Al}$ phefere : of Matheeus Syluaticus Viticella : in the poore mans Treafure Roraftrum: of Apuleiws Apiaftellum, vitis 7 aminua, Vitis alba, and Vitalba: in high Dutch ucbwuttz: in low Dutch 28tionie: in Englifh Bryonie, white Bryonie, and tetter Betrie : in French Conleuree : in Italian $Z$ woces faluatica: in Spanifh Nueza blawen. * The temperature.

White Brionic is in all his parts hot and drie, exceeding the thirde degree, efpecially of heate, with an exceeding great force of clenfing and fcouring, by reafon whereof it purgeth and draweth foorth, not onely cholericke and flegmatike humours, but alfo warric.

\section{$*$ The vertues.}

A Diofcorides writeth that the firft prings or fproutings being boiled and eaten, do purge by fiege and vrine. Gales faith, that all men vfe curtomably to eate of it in the fpring time, and that it is 2 nourithment holfome, by reafon of the binding qualitie that it hath; which is to be vnderftood of thofe of the wilde Vine, called in Latine T amos; and not of the fproutings of this plant; for the fproutings or the firft fprings of white Bryonie are nothing binding at all, but do mightily purge the belly, and torment the ftomacke.

B Diofcorides alfo affirmeth, that the itice of the roote being preffed out in the fpring, and drunke with ineade or honied water, purgeth flegme: and not onely the iuice,but alfo the decoction of the roote draweth foorth flegme, choler, and waterifh humours, and that very ftrongly; and is withall oftentimes fo troubleforne to the ftomacke, as it procureth vomite.

C This kinde of ftrong purgation is good for thofe that haue the dropfie, the falling ficknes, and the difinefle and fwimming of the braine and head, which hath continued long, and is hardly to be remooued :yet notwithftanding it is not daily to be giuen (as Diofcorides admonifheth) to them that haue the falling ficknes, for it wil be troublefome inough being taken now \& then:\& it is (as we haue faid)an exceeding ftrong medicine, purging with violence, \& very forceable for mans nature.

D The roote put vp in manner of a peffarie bringeth foorth the deadchilde and afterbirth: being boiled for a bath to fit in, it worketh the fame effect.

E Itfcoureth the skin, and taketh away wrinckles, freckles, funne burning, blacke marks, fpots, and fcars of the face, being tempered with the meale of vetches or Tares, or of Fenugreeke: or boiled in oile till it be confumed; it taketh away blacke and blewe fpots which come of fripes: it is good againft Whitlowes: being ftamped with wine and applied it breaketh biles; and fmall apoftumes, it draweth foorth fplinters and broken bones if it be ftamped and laid thereto.

F The fame is alfo fitly mixed with eating medicines as Dio/corides writeth. G The fruit is good againft fcabs and the leprie, if it be applied and ánnointed on, as the fame au-
thor afimeth. 
Galen writeth that it is profitable for Tanners to thicken their leather hides with. $\quad$ H

Furthermore an electuarie made of the rootes and hony or fugar, is fingular good for them that I are fhorte winded, troubled with an old cough, paine in the fides, and for fich as are hurt and burften inwardly : for it diffolueth and fcattereth abroad congealed and clottered blood.

The roote ftamped with falt, is good to be laide vpon filthie vlcers and fcabbed legs. The fruite $\mathrm{K}$ is likewife good to the fame intent if it be applied in manner aforefaide.

The roote of Bryonie and of wake-Robin ftamped with fome fulphur or brimftone, andmade vp $L$. into a maffe or lump and wrapped in a linnen clout, taketh away the morphewe, freckles, and Ipots of the face, if it be rubbed with the fame being dipped firft in vineger.

\section{Of blacke Bryonie, or the wilde vine. Chap.307.}

I Bryonis vigra. Blacke Bryonie.

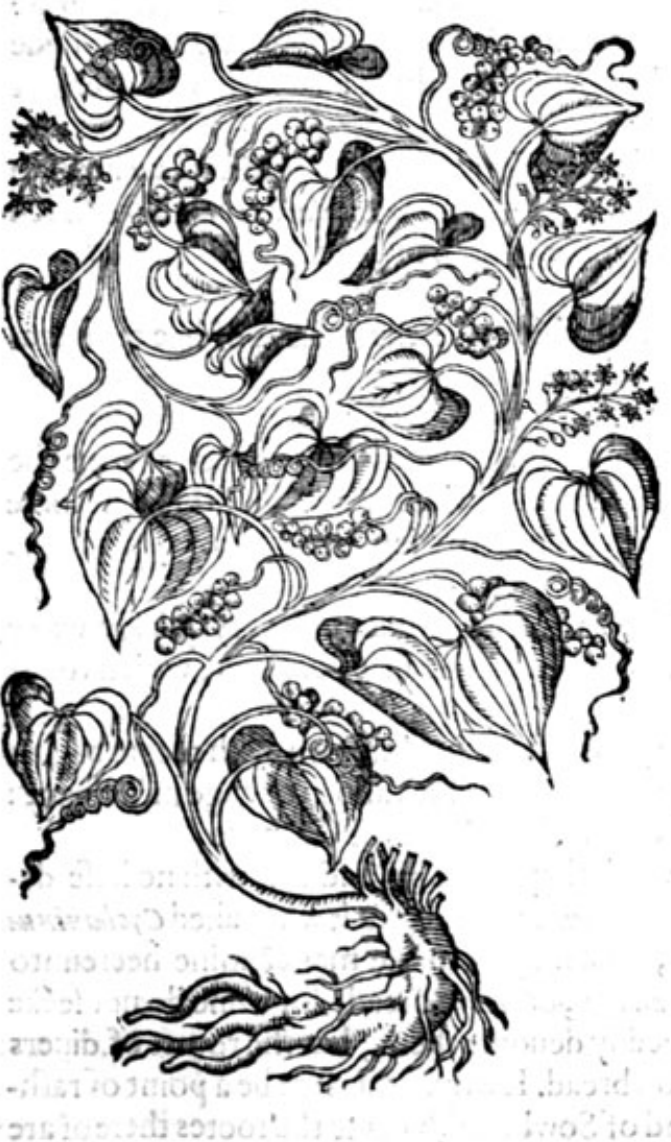

2 Bryonia nigra fyluestris. Wilde blacke Bryonie.

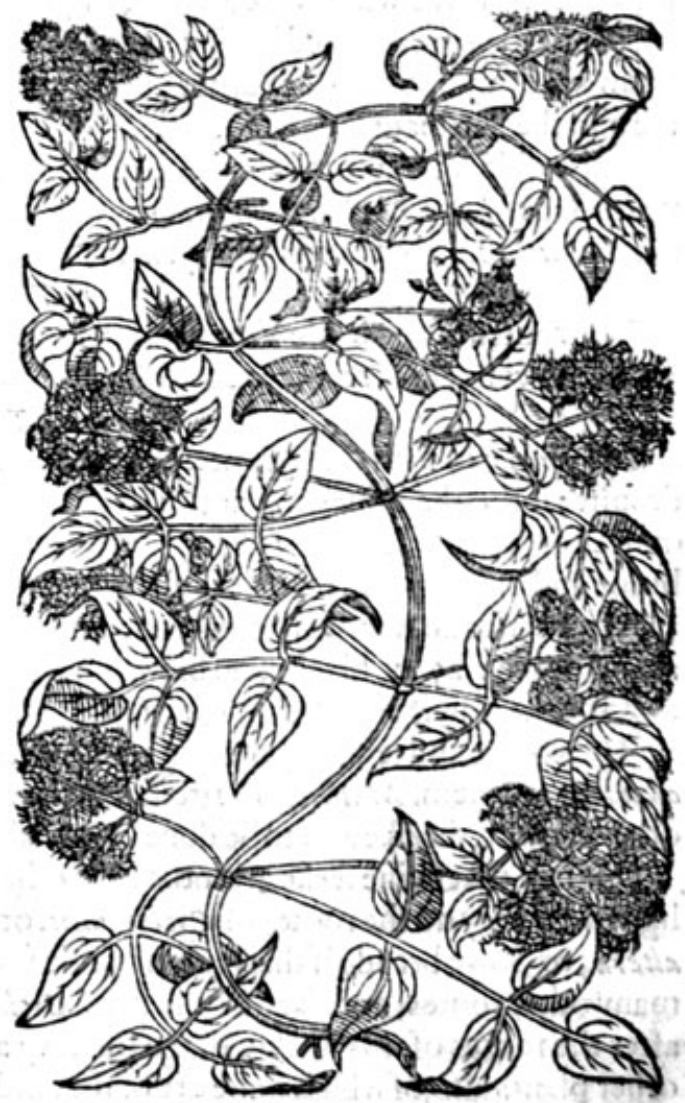

* The dejeription.

27 He blacke Bryonie hath long flexible branches of a woodie fubftance, couered with a ga*

1 ping or clouen barke growing very farre abroad, winding it felfe with his fmatl tendrels about trees, hedges, \& what elfe is next vnto it, like vnto the branches of the Vine. The leaues are like vnto thofe of Iuic or garden Night?hade, tharpe pointed, andof a fhining greene colour:the flowers are white, fimall and moffieswhich being paft, there fucceede little clufters of red berries, formewhat bigger then thofe of the fmall Raifons, or Ribes, which we call Currans or fmall Raifins. The roote is very great and thicke, oftentimes as bigge as a mans legge, blackith withour, and very clammic or flimy within; which being but fcraped with a knife, or any other thing fit for that purpofe, it feemeth to be a matter fit to f pread vpon cloth or leather in maner of a plaifter or feare cloth; which being fo fpred and vfed, it ferueth to laie vpon many infirmities, and to very good pupoles, as fhall be declared in the proper place. 


\section{2}

\section{THE SECOND BOOKE OF THE}

2 The wilde blacke Bryonie refembleth the former, as well in flender Vinie ftalkes as leaues; bue clafping tendrels hath it none, neuertheleffe by realon of the infinite braunches, and the tendernes of the fame, it taketh holde of thofe things that ftand next vnto it, although eafie to be loofed, contrarie to the other of his kinde. The berries heere of are blacke of colour when they be ripe. The roote alfo is blacke without, and within of a pale yellowe colour like boxe. * Theplace.

The firft of thefe plants doth grow in hedges and bufhes almoft euery where.

The fecond groweth in Heffia, Saxonie, Weftphalia, Pomeriand,\& Mifnia, where white Bryony doth not growe, as $V$ aler ius Cordus hath written, who faith that it groweth vnder Hafell trees, neer vnto a citic of Germanie called A rgentine, or Strawsborough.

\section{$*$ The time.}

They fpring in March,bring foorth their flowers in Maie, and their ripe fruite in September. $*$ The names.

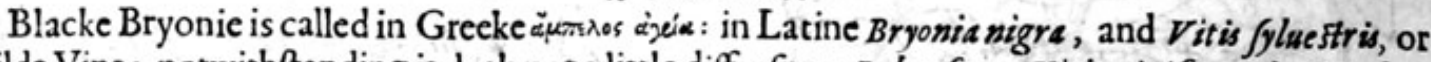
wilde Vine; notwithftanding it doth not a little differ from Labrufca, or Vitis vinifera Jyluestris, that is to faie, from the wilde Vine, which bringeth foorth wine, which is liketvife called Ampelos agria : why both thefe were called by one name, Plinie was the caufe, who could not fufficiently expounde them in his 23 . booke firft chapter; but confounded them, and made them all one, in which errour are alfo the Arabians.

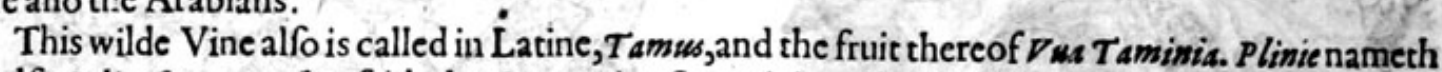
it alfo Salicaftrum. Ruelius faith that in certaine fhops it is called Sigillwom B. Marie: it is alfo called Cycliminus altera, but not properly: in Englifh blacke Bryonie, wilde Vine, and our Ladies Seale.

\section{$*$ The temper ature.}

The rootes of the wilde Vine are hot and drie in the third degree : the fruite is of like temperature, but yet not fo forceable: both of them fcower and waft awaie.

* The vertues.

A Diofcorides faith that the rootes do purge waterifh humours, and are good for fuch as haue the dropfie; if they be boiled in wine, adding vnto the wine a little fea water, and be drunke in three ounces of faire frefh water : he faith furthermore, that the fruit or berries doth take away the funne burne and other blemilhes of the skinne.

B The berries do not onely clenfe and remooue fuch kinde of fpots, but do alfo very quickly wafte and confume away blacke and blewe marks that come of brufes and drie beatings, which thing alfo the roots performe being laid vpon them.

C The yoong and tender fproutings are kept in pickle, and referued to be eaten with meate as $D$ iofcorides teacheth. Mat biolus writeth that they are ferued at mens tables alfo in our age in Tufcane: others report, the like alfo to be done in Andalofia,one of the kingdomes of Granado.

D It is faid that fwine feeke after the rootes heerof, which they digge vp and eate with noleffe delight then they do the rootes of Cyclaminus, or Panisforcinus, whereupon it was called Cyclaminus altera, or Sowe bread; if this reafon ftande for good, then may we in like maner ioine heereunto many other rootes, and likewife call them Cyclamenus altera, or Sowe bread: for fwine do not feeke after the rootes of this onely, digge them vp and greedily deuoure them, but the rootes of diters other plants alfo, of which none are of the kinds of Sowbread. It would therfore be 2 point of rafhneffe to affirme $T$ amus or our Ladies Seale to be a kind of Sowbread, bicaufe the rootes therefo are pleafant meate to Swine.

E The roote fpred vpon a peece of theepes leather, in maner of a plaifter whileft it is yet freth and greene, taketh away blacke or blewe markes, all fcarres and deformities of the skin, breaketh harde apoltemes, draweth foorth fplinters and broken bones, diffoltieth congealed bloud; and being laid on and vfed vpon the hippe or huckle bones, thoulders, armes, or anyother part where there is great paine and ach; it taketh it away in fhort fpace,and worketh very effectually. 


\section{THISTORIE OF PLANTS. HT}

\section{Of Bryonice of Mexico. Chap.308.}

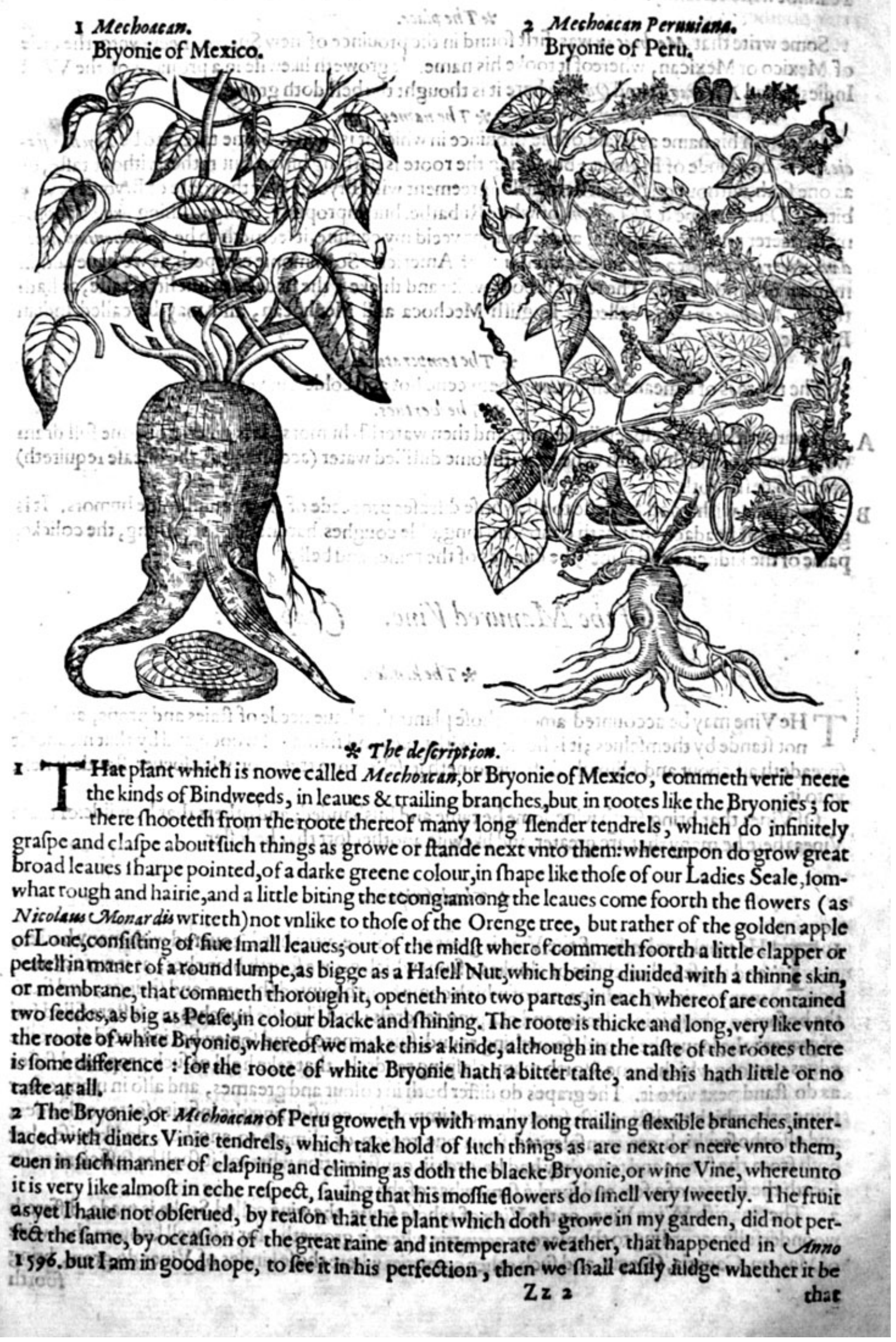


that right Mechoacan that hath beene brought from Mexico, and other places of the Weft Indies or no? The roote by the figure hould feeme to anfwere thatoff the wilde Vine, but as yet thereof I cannot write certainly.

\section{*Theplace.}

Some write that Mecbosean was firft found in the prouince of new Spaine, neere vnto the citie of Mexico or Mexican, whereof it tooke his name. It groweth likewife in a prouince of the Weft Indies called Nicaragus and Quito, where it is thought the beftdoth growe.

$$
\text { * T the names. }
$$

It beareth his name as is faid, of the prouince in which it is found. Some take itto be Bryonie ge. cies, or to be a kinde of Bryonie : but feeing the roote is nothing bitter, but rather without tafte, or as one faith,without qualitie, it hath little agreement with Bryonie; for the roote of Bryonie is very bitrer. Diuers name it $R$ ha album, or white Rubarbe, but vnproperly, being nothing like. It commech neerer vnto Scammonie, and if I might yeeld my cenfure, it leemerh to be Scammoniun quoddom Americanum, or a certaine Scammonie of America. Scammonie creepech, as we have faid, in manner of Bindweede. The roote is both white and thicke : the iuice hath but little tafte, as hath this of Mechoacan : it is called in Englifh Mechoca and Mechocan, and may be called Indian
Bryonie.

\section{The roote is of a meane temperature betweene hot and colde, but yet drie. \\ * The vertues.}

A It purgeth by fiege,efpecially flegme, and then waterifh humors. It is giuen from one full dram weight to two, and that with wine, or with fome diftilled water (according as the difeafe requireth)
or elfe in flefhbroth.

B It is giuen with good fucceffe to all, whofe difeafes proceede of flegme and colde humors. It is good againft headach that hath continued long,olde coughes, hardneffe of breathing, the colicke, paine of the kidneies and ioints, the difeafes of the reines and belly.

\section{Of the Manured Vine. Chap.309.}

* The kindes.

$T$ He Vine may be accounted among thofe plants that haue neede of ftaies and props, and cannot ftande by themfelues ;it is helde yp with poles and frames of woode, and by that meanes it Ipreadech all about and climeth aloft: it iomethit felfe vnto trees, or whatfoever fandech next vnto it.

OfVines that bring forth wine, fome be tame and husbanded; and others that be wilde:of tame Vines there be many that are greater, and likewife another fort that be leffer.

$$
17
$$$$
\text { * Thedefription. }
$$
He trunke or bodie of the Vine is great and thicke, very hard, couered with many barkes,
and thofe full of cliffes or chinkes; from'which growefoorth branches; as it were armes, many waies fpreading; out of which come foorth iointed fhootes and Pprings; and from the bofome o: thofe ioints, leaues and clafping tendrels; and likewife bunches or clufters filled full of grapes: the leaues be broad, fomething round, fue cornered, and fomew bat indented abour che edges; among which come foorth many clafping tendrels, that take hold of fuch props and ftaies as do ftand next vnto it. The grapes do differ both in colour and greatnes, and alfo in many orher things, the which to diftinguifh feucrally were impoffible, confidering the infinite fortes or kindes; and alfo thofe which are tranfplanted from one region or climate to another, do likewife alter both from the forme and tafte they had before; in confideration whereof, it fhall be fufficient to fer foorth the figures of a few, and fpeake fomewhat of the reft.

2 The Spanifh Wine Vine, or the Vine of whofe fruite the wine called Secke is made, differecth woonderfully according to the place or countrie where it groweth: for it is well knowen that wine of Madera, Canaria, Grecia, and fuch other countries where thofe kindes of Vines do grow, bring 
forth wine differing very notably one fromanother in diuers refpects, and yetal and dénetyrof thiem kindes of Seekes and therefore it fhall be'to fmall purpofe to vfo further fpeech as touchipg this Vine, morethen to let you know the thing that the fimpleft doth khowe, that is ta faie: it is likevife 2 Vine of a woodie fubitance, it bringeth foorth bunches of grapes like vnto the commoin Vines differing onely in tafte.

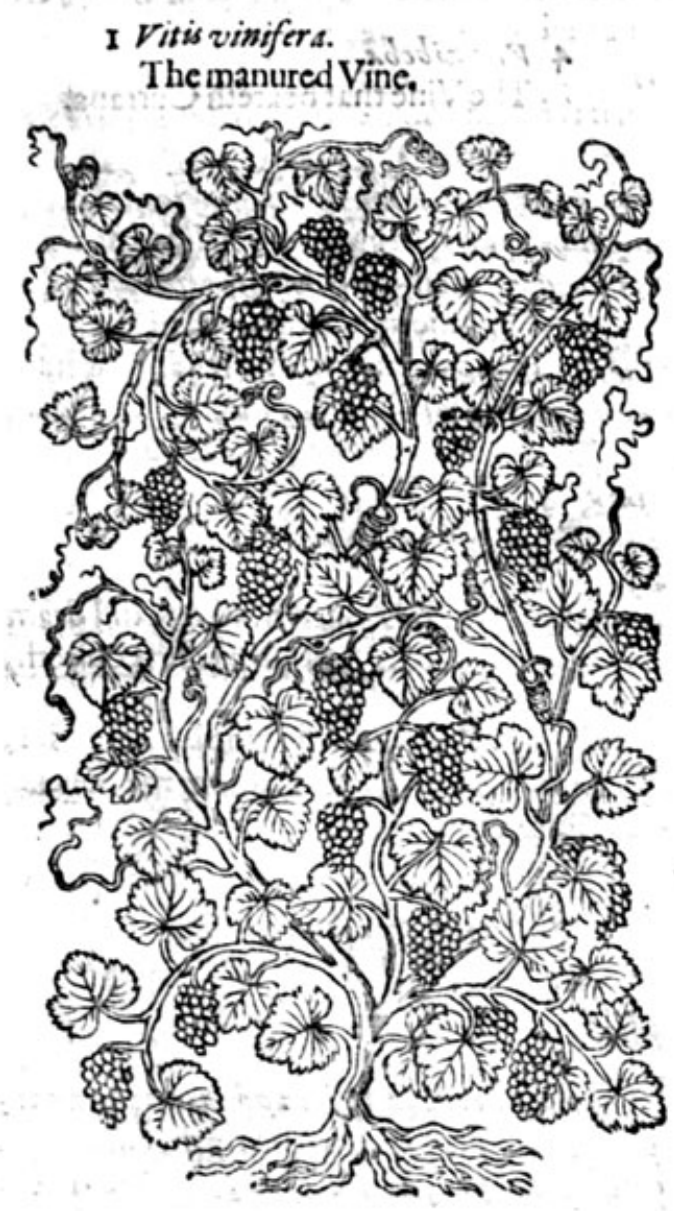

2 Vitisvinifera Hißpanica. The Spanifh manured Vine.

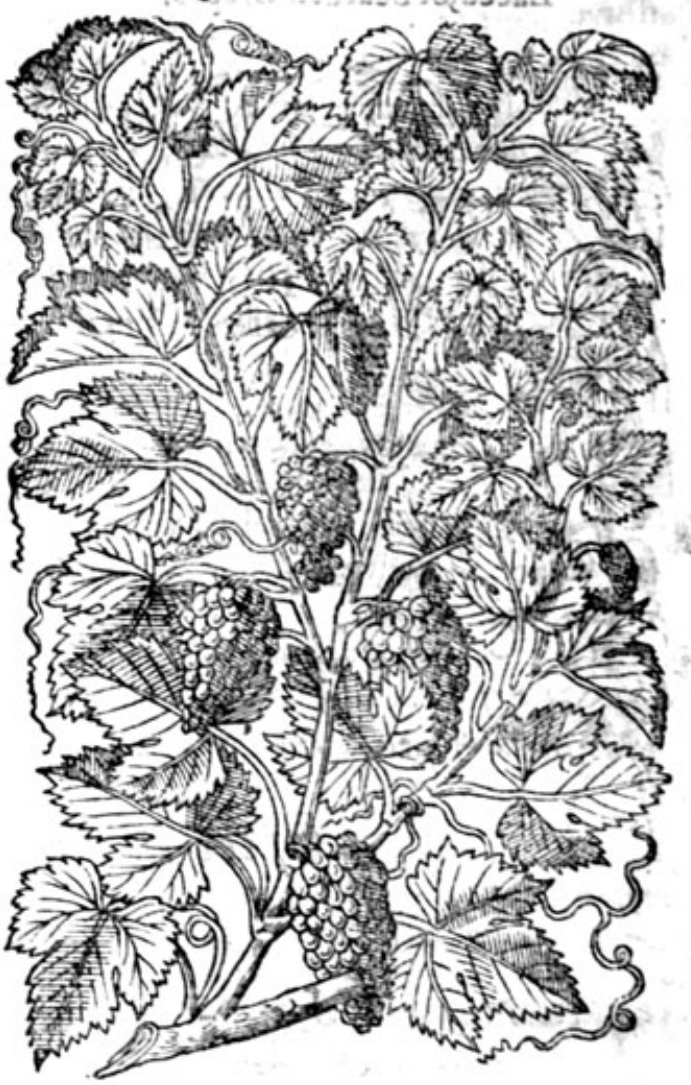

\section{* The defcription.}

3 There is found in Grecia and the parts of Morea, as Pantalarea, Zante, Sapholonia, and Petras, (whereof fome are Ilands, and the other of the continent) a certaine Vine that hath a trunke or body of a woodie fubftance, with a fcalie or rugged barke, of a grayith colour; whereupon do growe faire broad leaues, flightly indented about the edges, not vnlike vnto thofe of the Marfh Mallow: from the bofome whereof come foorth many fmall clafping tendrels, and alfo tough and pliane footeftalks, whereon do grow very faire bunches of grapes, of a watchet blewifh colour; from the which fruite commeth foorth long tender laces or ftrings, fuch as is found among Sauorie; wherupon we call that plant which hath it, laced Sauorie, not vnlike vnto that that groweth among and vpon Flaxe, which we call Dodder, or Podagra lini, whereof is made a blacke wine, which is called Greeke Wine,yet of the tafte of Secke.

4 The plant that beareth thofe fmall Raifons which are commonly called Corans or Currans, or rather Raifins of Corinth, is not thatplant which among the vulgar people is taken for Currans, being a fhrubbe or bufh that bringeth foorth fmall clufters of berries, differing as mitich as may bee from Corans, hauing no affinitie with the Vine, or any kinde thereof. The Vine that beareth fimall Raifins or Corans, hath a bodie or ftocke as other Vines bate, braunches and tendrels likewife. The leaues are larger then any of the others, fnipt about the edges like the teeth of a fawe; among which come foorth clufters of grapes, in forme like the other, but fmaller, of a blewifh colour; which being ripe are gathered and laid vpon hurdels, carpets, mats, and 
fuch like, in the funine to drie : then are they caried to fome houfe and laid vpon heapes, as we laie apples, or corne in a garner, vntil the marchants do buie them:then do they put them into Buttes other wooden veffels, and treade them downe with their bare feete, which they call Stiuing, and fo are they brought into thefe parts for our vfe.

\section{3 ruabarbata.}

Laced, or bearded Grapes.

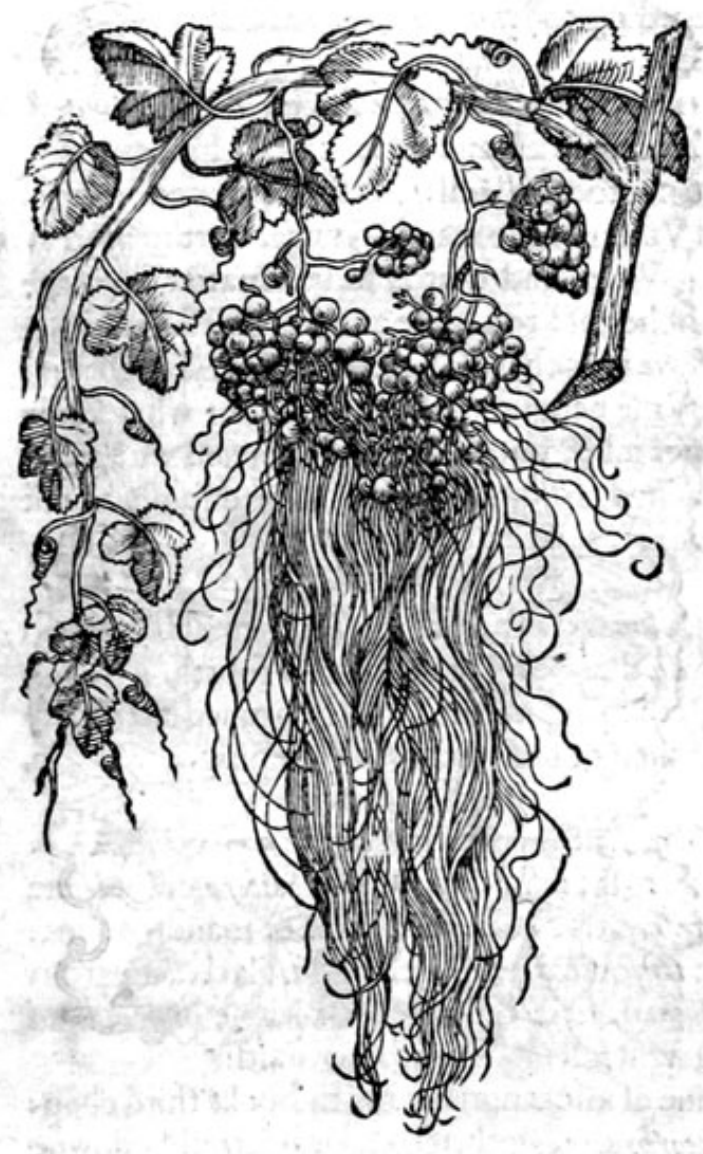

4 Vua zibeba. The Virle that beareth Currans.

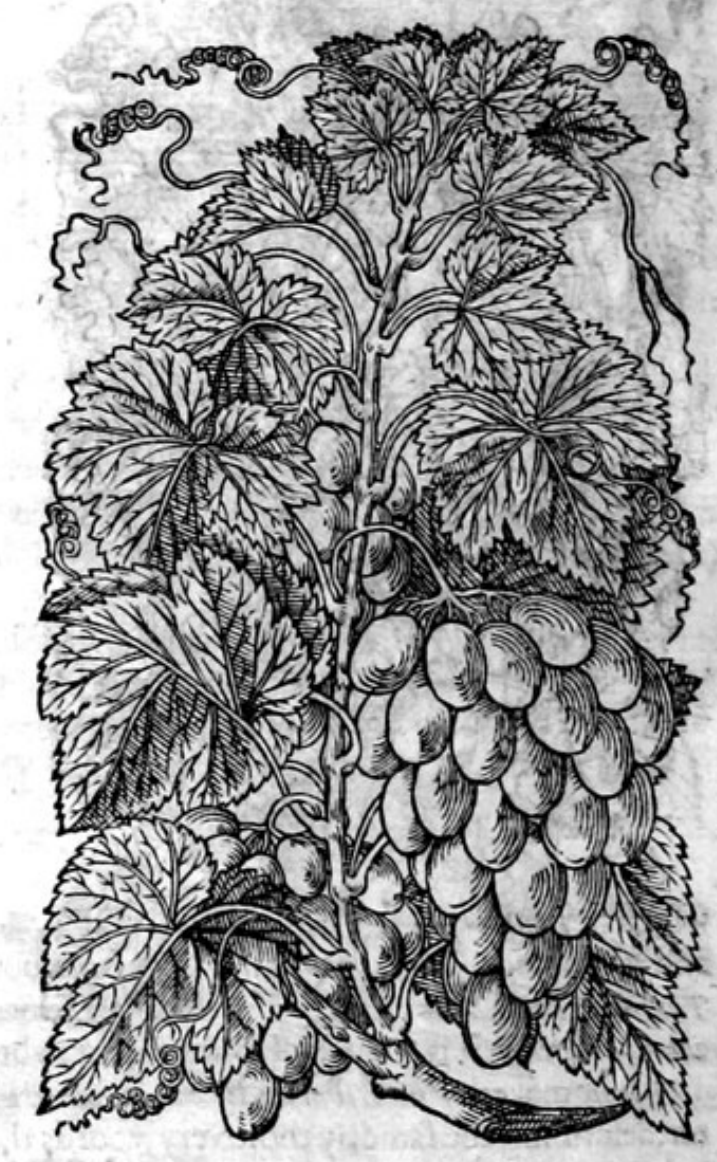

* The defaription.

5 This kinde of Vine hath great leaues, very broad, of an ouerworne colour, wherupon do grow great bunches of grapes, of a blewifh colour. The pulpe or meate whereof fticketh or cleaueth fo hard to the graines or little ftones, that the one is not eafily diuided from the other, refembling fome ftarued or withered berric that hath beene blafted, whereof it tooke the name Duracine.

There be fome Vines that bring foorth grapes of a whitilh or reddilh yellowe colour; others of 2 deepe red, both in the outwarde skin, pulpe and iuice within.

There be others whofe grapes are of a blewe colour,or fomthing red, yet is the iuice like thoie of the former. Thefe Grapes do yeeld forth a white Wine before they areput into the prefie, and a reddifh or pallet wine when they are troden with the huskes, and foleft to macerate or fernent, with which if they remaine too long, they yeeld foorth 2 wine of a higher colour.

There be others which make a blacke and obfcure red wine, whereof fome bring biggerclufters, and confift of greater grapes; others of leffer : fome growe more cluftered and clofer togither, others loofer; fome haue but one ftone, others moe; fome make a more auftere or harfh wine, others a more fweete; of fome the old Wine is beft, of diuers the firft yeeres Wine is moft excellent; fome bring foor th fruitc fower fquare, of which forts or kinds, we haue great plentie. 


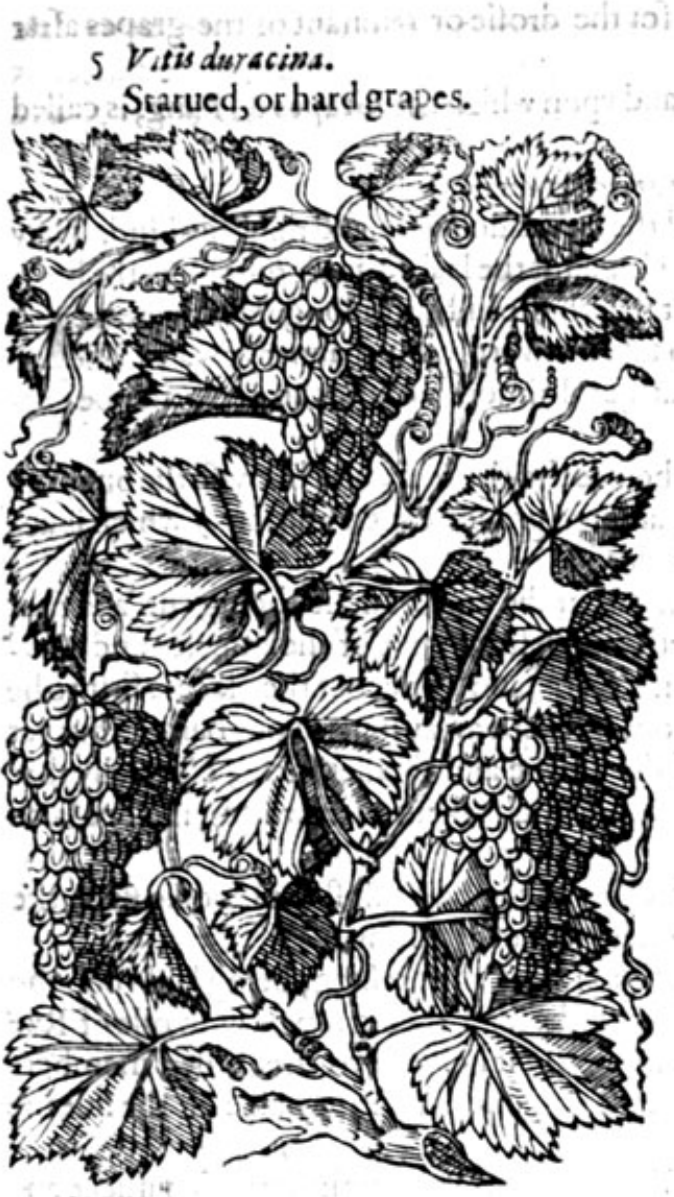

* Theplace.

A fit foile for Vines, faith Florentinw, is every blacke earth, which is not very clofe norclammie, hauing fome moifture;notwithftanding $\mathrm{Ca}$ lumella faith, that gicat regarde is to be had, what kinde or fort of Vine you woulde nourifh, according to the nature of the countric and foile.

A wife husbandman will commit to a fat and fruitfull foile a leane Vine, and of his owne nature not too fruitfull: to a leane grounde a fruitfull Vine: to a clofe and compact earth, a fpreading Vine, and that is full of matter to make branches of: to a loofe and fruitfull foile, a Vine of fewe branches. The lame Coluonella faith, that the Vine delighteth not in dung, of what kinde focuer it be; but frefh moulde mixed with fome thauings of horn is the beft to be difpofed about the rootes, to caufe fertilitie. * The time.

Colume lla faith, that the Vines muft be pruned before the yoong branches bud foorth. Palladites writech in Februarie:if they be pruned later, they lofe their nourifhment with weeping. * The names.

The Vine is called in Greeke äur ros dorbooess, as much to fay in Latin, as Vitis vinifera, or the Vine which beareth wine, and aurros äusees, that is, Vit is man/wefscta, /we cultita, tame or manured Vine: and it is called aurosees, that it may differ from both the Bryonies, the white and the blacke, and from $T$ amus, or our Ladies feale, which be likewife named äpmat: It is called $V$ it is, bicaufe inuitatur ad vaus pariendas. It is cherifhed to the intent to bring foorth full clufters, as Varro faith.

Plinie maketh $V_{w a} Z t b e b a$, Alexandrina vitis, or Vine of Alexandria, in his 14 .booke third chap. ter, defcribing the fame by thofe very woords that $T$ heophrast sus doth. Diofcorides fetteth it downe to be aliera ßpecies Vitis fyluestris, or a fecond kinde of wilde Vine, but we had rather retaine it among the tame Vines. We may name it in Englith fmal Raifin Vine. The fruits are hereof called in thops by the name of $P$ affularwm de Corint ho : in Englifh Currans, or fmall Raifins.

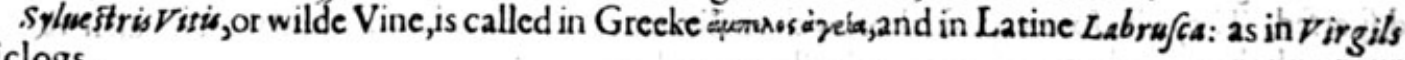
Eclogs.

Syluest ris raris parfit labrufca racemis.

The wilde Vine with her branches few and clufters thinne

Adornes our countrey Bowre, a feemely thing I winne.

To this wilde Vine do belong thofe, which Plinie in his 16. booke 27. chapter, reporteth to becal led $T$ rtfere, or that bring three fundrie fruites in one yeere, as infane, and mad bearing Vines, bicaufe in thofe fome clufters are ripe and full growen, fome in fwelling, and others but flowring.

The fruit of the Vine is called in Greeke, sorgev and saquati : in Latine Racemes and $V_{u s}$ : in Englifh a bunch or clufter of Grapes.

The clutter of Grapes that hath beene withered or'dried in the funne, is named in Grecke sadis, in Latine Vas pa $\int a$ : in hops Pafjula: in Englifh Raifins of the funne.

The bertic or giape it felfe is called in Latine Acinus, and alfo Gramen, as Democritus faitb, peaking of the berrie.

The feede or ftones contained within the berries, are called in Latine Vinacea, and fometimes Nuslei : in fhops arilli, as though they fhould fay Ariduli, bicaufe they are drie, and yeeld no iuice, 
notwithftanding Vinacea are alfo taken in Columella for the droffe or remnant of the grapes after they be preffed.

The ftalke, which is in the middle of the clufters, and vpon which the Grapes do hang, is called of Galcn ßórsues, of Varro, Scapus vuarum.

* The temperature andvertues.

A The tender and clafping branches of the Vine and the leaues do coole, and mightily bind. They ftay bleeding in any part of the bodie. They are good againft the laske, the bloodie fixe, the hart. burne, or heate of the ftomacke, readines to vomit. It ftaieth the lufting or longing of women with child, though they be but outwardly applied, and alfo taken inwardly any manner of waies. They be morcouer a remedie for the inflammation of the mouth, and almonds of the throte, if they be gar. galed,or the mouth wafhed therewith.

B Of the fame facultie be alfo the cluitters gathered before they be ripe; and likewife the bunches of the wilde grape ( that we accept for one of the manured grapes called Currans) which is accounted to be more effectuall againft all thofe infirmities.

C Diofcorides faith, that the liquor which falleth from the bodie and branches being cut, and that fomtime is turned as it were into a gum (which driueth foorthftones out of the kidneies and bladder, if the fame be drunke in wine ; ) healeth ringworms, fcabs, and leprie, but the place is fir?t to be rubbed with Niter; being often annointed or laide on, it taketh away fuperfluous haires : but yet he faith that the fame is beft which iffueth foorth of the greene and fmaller fticks, efpecially that liquor that falleth away whileft the branches are burning, which taketh away wartes, if it bee laide on them.

D The ftones and other things remaining after the preffing, are good againft the bloodie flixe, the laske of long continuance, and for thofe that are much fubiect to vomiting.

E The afhes made of the fticks, and droffe that remaineth after the preffing, being laid vpon the piles, and hard fwellings about the fundament, doth eure the fame : being mixed with oile of Rue or Herbegrace and vineger, as the fame author affirmeth, it helpeth to Atrengthen members

$\checkmark$ out of ioint, and fuch as are bitten with any venemous beaft, and eafeth the paine of the fpleene or milt, being applied in manner of a plaifter.

F The latter age do vfe to make a lie of the afhes of Vine fticks, in compofitions of cauftickeand burning medicines, which ferue in fteede of a hot iron : the one we call a potentiall cauterie, and the other actuall.

\section{Of Grapes.}

G Of Grapes thofe that are eaten rawe do trouble the belly, and fill the ftomacke full of winde: efpecially fuch as are of a fower and auftere tafte, fuch kinde of grapes do very much hinder the concoetion of the ftomacke, and while they are difperfed through the liuer and veines, they engender cold and tawe iuice, which cannot eafily be changed into good blood.

H Sweete grapes and fuch as are thorow ripe, are leffe hurtfull: their iuice is hotter, and is eafilier difperfed; They alfo foonerpafte thorow the belly, efpecially being moift, and moft of all if theliquor with the pulpe be taken without the ftones and skin, as $G$ alen faith.

I The fubftance of the ftones, although it be drier,and of a binding qualitic, doth defcend thorow all the bowels, and is nothing changed : as alfo the skins, which are not altered in the bodie atall, or very little.

$\mathrm{K}$ Thofe grapes which haue a ftrong tafte of wine, are in a meane betweene fower and fweete.

L Such grapes as haue little iuice do nourifh more, and thofe leffe that haue more iuice : but thefe do fooner defcend; for the bodie receiueth more nourifhment by the pulpe, than by the iuice; by the ruice the belly is made more foluble.

M Grapes hatie the preheminence among the Autumne fruits, and nourith more than they all, but yet nat fo much as figs : and they haue in thein little ill iuice, efpecially when they be thorowe ripe.

$N$ Grapes may be kept the whole yeere, being ordered after that maner which Toachimus Camerarins nowe liuing in Noremberg reporteth. You fhall take (faith he) the meale of muftard feede, and ftrow in the bottome of any earthen pot wehi leaded; whereupon you fhall lay the faireft bunches of the ripeft grapes, the which you hall coner with more of the forefaid meale, and lay vpon 
that another fort of grapes, fo doing vintill the potbe full. Then fhall you fill ip the pot to the brim with a kinde of f weete wine called Muft. The por being very clofe couered thall be fet into, fome celler,or cold place. The grapes may you take foorth at your pleafure, wathing them with faire water from the powder.

\section{Of Raifons.}

Of Raifons moft arefweete; fome haue an auftere or harfhrtafte. Sweete Raifons are hotter, A auftere colder; both of them do moderately binde, but the auftere fomwhat more, which do more ftrengthen the ftomacke: The fweete ones do neither flacken the ftomacke nor make the belly foluble, if they betaken with their ftones which are of a binding qualitie: otherwife the ftones taken foorth, they do make the belly loofe and foluble.

Raifors do yeeld good nourifhment to the bodie; they haue in them no ill itice at all, but doin- B gender fomewhat a thicke iaice, which notwithftanding doth nourith the more.

There commeth of fweete and fat Raifons moft plentie of nourifhment; of which they are the $C$ beft that haue a thinne skin.

There is in the fivecte ones a temperate and fmoothing qualitic with a power to clenfe mode- D rately. They are good for the cheft, lungs, winde pipe, kidneies, bladder, and for the ftomacke: for they makes imooth the roughnes of the winde pipe, and are good againft hoarfneffe, fhortneffe of breath,or difficultic in breathing : they ferue to concoct the fpettle, and to caufe it to rife more eafilie in any difeafe whatfueder of the cheft, fides and lungs, and doth mitigate the paine of the kidneies andbladder, which hath ioined with it heate and fharpeneffe of vrine: they dull and allaie the malice of fharpe and biting humours that hurt the mouth of the ftomacke.

Moreouer Raifons are good for the liner, as Galen writeth in his 7 .booke of medicines according E to the places affected: for they be of force to concoct rawe humours, and to reftraine their malignitie, and they themfelues do hardly putrefie: befides they are properly and of their owne fubftance familiar to the entrailes, and curc any diftemperature, and nourifh much, wherein they are chiefely to be commended, for Raifins nourifh, ftrengthen refilt putrefaction, and if there be any diftemperature by reafon of moifture and coldneffe, they helpe without any hurt, as the faide Galen affirmeth.

The olde Phifitians haue taught vs to take foorth the ftones, as we may fee in diuers compofiti- F ons of the auncient writers, as in that compofition which is called in Galen Urteriaca Mithridatis, which hath the feedes of the Raifins taken foorth: for feeing that Raifins containe in them a thicke fubftance, they cannot eafily paffe through the vaines, but are apt to breede ob ftructions and ftoppings ot the entrailes, which things happen the rather by reafon of tho feeds :for they fo much the harder paffe through the body,and do quicklier and more eafily caufe obftructions, in that they are more aftringent or binding. Wherefore the feedes are to be taken outs for forhall the iuice of the Raifins more eafily paffe, and the fooner be diftributed through the entrailes. Diogcorides reportech that they Raifins being chewed with pepper, draweth flegme and water out G
of the head.

Of Raifins is made a pultis good for the gout, rottings about the ioints, gangrenes and morti- $H$ fied vlcers, being ftamped with the herbe Alheale, it quickly, taketh away the nailes that are loofe in the fingers or toes, being laid thereon.

\section{Of Murt.}

Muft, called in Latine MuStum, that is to fay, the liquor newly iffuing out of the grapes when I they be troden ot preffed, doth fill the ftomacke and entrailes with winde, it is hardly digefted, it is of a thicke itrice, and if io do not fpeed dily paffe through the bodie, it becommeth more hurtfull.

That which is fweeteft and preffed out of ripe Grapes doth fooneft paffe through; but that $\mathrm{K}$ which is made of fower and auftere Grapes is woorft of all: it is more windie, it is hardly concocted, it ingendreth rawe humours ; and althoughit doth defcend with a loofeneffe of the belly, notsvithftanding it oftentimes withall bringeth the colicke, and paines of the ftone; but if the bellie be riot wooued, all things are the woorfe, and more troubleforne, and it oftentimes bringeth an extreme laske, and the bloodie flixe. 
A That firft part of the wine that commeth foorth of it felfe before the grapes behard prefled, is anfwerable to the grape it felfe, and doth quickly defcend: but that which iffueth forth afterwards, hauing forme part of the nature of the ftones, ftalke, and skins, is much woorfe.

\section{Of Cute.}

B Of Cute that is made of Muft, which the Latines call Supa, and Defrutum is that liquor which we call in Englifh Cure, which is made of the fweeteft Muft, by boiling it to a certaine thickneffe, or boiling it to a third part, as Colvmella writeth.

C Ptimie affirmeth, that Saps and Defrutum do differ in the manner of the boiling: and that Sapa is made, when the new wine is boiled away, till onely a third part remaineth : and Defrutum till halfe be boiled.

D Sir ewm, faith he in his 14 .booke 17 .chap. which others call itmma, and we Sapa, the worke of wit \& not of nature, is made of new wine boiled to 2 3.part:which being boiled to halfe, we cal Defrutum.

E Palladius ioineth to thefe Carenwm, which as he faith, is made when a third part is boiled away, and two remaine.

F Leontius in his Geoponickes, heweth that Hep/ema mult be made of eight parts of new wine, roo. of wine it felfe boiled to a third.

G Galen teftifieth that inmua is newe wine very much boiled. The later Phifitions do call Hepfema or Sapa boiled wine.

H Cute or boiled wine is hot,yet not fo hot as wine, but it is thicker; yet not fo eafily diftributed, or caried through the body, and it flowlier defcendeth by vrine, but by the belly oftentimes fooner, for it moderately maketh the fame foluble.

I It-nourifheth more and filleth the body quickly, yet doth it by reafon of his thicknes fticke in the ftomacke for a time, $\mathrm{S} \times$ is not fo fit for the liuer, or for the fplene. Cute alfo doth digeft raw humors that fticke in the cheft and lungs, and raifeth them vp fpeedily. It is therefore good for thecough and fortnes of breath.

$\mathrm{K}$ The Vintners of the low countries (I will not fay of London)do make of Cute and wine mixed in a certaine proportion, a compounde \& counterfaite wine, which they fell for Candie wine, commonly called Malmfey.

L Plinie faith in his 8 4. booke 9 .chapter, that Cute was firft deuifed for a baftard honie.

\section{Of Wine.}

M To fpeake of Wine, the iuice of grapes, which being newly preffed foorth, iscalled as we haue faid Muftum, or new wine. After the dregs and droffe are fetled, and now it appeereth pure \& cleer, is called in Greeke aivos, in Latine $V$ inum: in Englifh Wine, and that not vnproperly. For certaine other iuices, as of apples, pomegranates, quinces, peares, medlers, or feruices, or fuch as are otherwife made ( for example fake) of barlie and graine, be not at all fimply called wines, but with the name of the thing added, whereof they do confilt. Hereupon is the wine, which is preffed foorth of the pomegranate berries named Rhoites, or wine of pomegranates: out of quinces $C y d$ donites, or wine of quinces: out of peares Upyites, or perrie : and that which is compounded of barlie is called $z$ th hum, or barlie wine : in Englifh Ale or Beere.

$\mathrm{N}$ And other certaine wines haue borrowed furnames of the plants that hạe beene fteeped, or infufed in then: and yet all wine sof the vine, as Wormwood wine, Mirtle wine,Hyflope wine, and thefe are called artificiall wines.

O That is properly and fimply called wine which is preffed out of the grapes of the Vine, and is without any maner of mixture.

P The kinds of wines are not of one nature, nor of one facultie or power; but of many differing one from another: for there is one difference therof in tafte, another in colour; the third is referred to the confiftence or fubftance of the wine; the fourth confifteth in the vertue \& Atrength thereof. Galen addeth that which is found in the fmel, which belongeth to the vertue \& Atrength of the wine.

$Q$ That may alfo be ioined vnto them which refpecteth the age: for by age wines become hotter and harper, \& do withal change oftentimes the colour, the fubittance $\&$ the fmel:for fome wines are fweete of tafte, others auftere or fomthing harfh, diuers of a rough tafte, or altogicher har $h, \&$ inoft of them fufficient fharpe: there be likewife wines of a middle fort, inclining to one or other qualitie.

$\mathbf{R}$ Wine is of colour either white or reddifh, or of a blackifh deepe red, which is called blacke: or of fome middle colour betweene thefe. 


\section{HIST ORIE OF PLANTS.}

Some wineis of fubftance altogither thinne: other thicke, fat; and many alfo of a middle con-A fiftence.

One wine is of great ftrength, and another is weake, which is called a waterifh wine s a full wine B is called in Latine $V$ ino $\mathrm{wm}$. There be alfo among thefe, very many that be of a middle ftrength:

There is in all wines be they neuer fo weake, a certaine winie fubftance thin and hot. There be $\mathrm{C}$ likewvife waterie partes, and alfo diuers earthic. For wine is not fimple, but, as $G \times$ len teftifieth inhis fourth booke of the faculcies of medicines, confifteth of partes that haue diuers faculties. fif stis bos

Of the fundrie mixture and proportion of thefe fubitances one with another, there rife diuers D and fundrie faculties of the wine.

That is the beft and fulleft wine, in which the hor and winie partes do moft of all abound: and $E$ the weakeft is that, wherein the waterie haue the preheminence.

The ear thie fubftance abounding in the mixture, caufeth the wine to be auftere, or fornething $\mathbf{F}$ harfh, as a crude or rawe fubftance doth make it alrogither harfh. The earthie fubftance being fetered falleth downe, andin continuance of time finketh to the bottome, and becommeth the dregs or lees of the wine; yet it is not alwaies wholy feucred, bur hath both the tafte and other qualities of this fubftance remaining in the wine.

All wines haue their heate, partly from the proper nature and inwarde or originall heate of the $G$ vine, and partly from the funne. For there is a double heate which ripeneth not onely the grapes, but alfo all other fruits, as Gaien teftifieth. The one is proper and naturall to euery thing: the other is borrowed of the funne, which if it be perceiued in any thing, it is vadoubtedly beft and efpecially in the ripening of grapes.

Fo: the heate which proceedeth from the funne, concoeteth the grapes and the iuice of the $\mathrm{H}$ grapes, and doth efpeciallyripen them, ftirring vp and increafing the inward and naturall heate of the wine, which otheiwife is fo ouerwhelmed with abundance of rawe and waterifh partes, as it feemeth to be dulled, and almoft without life.

For vnleffe wine had in it a proper and originall heate, the grapes could not be fo concoeted by I the force of the fun, as that the wine fhould become hot, no leffe then many other things naturally cold, which although they be ripened and made perfect by the heate of the funne, do not for all that lofe their originall nature, as the fruits, iuices, or feedes of Mandrake, Nightfhade, Hemlocke, Poppie, and of other fuch like, which thoughı they be made ripe, and brought to full perfection, yet itill retaine their owne cold qualitie.

Wherefore feeing that wine through the heate of the funne, is for the moft part brought to his $K$ properheate, and that the heate and force is not all alike in al regions and places of the carth: therfore by reafon of the diuerfitic of regions and places, the wines are made not a lirtle to differ in facultic.

The ftronger and fuller wine groweth in hot countries and places that lie to the fun : the rawer $L$ and weaker, in cold regions and prouinces that lie open to the north.

The hotter the lommer is, the ftronger is the wine: the leffe hot or the moifter it is, the leffe ripe $\mathrm{M}$ is the wine. Notwithftanding not onely the manner of the weather and of the funne, maketh the qualities of the wine to differ, but the natiue propertic of the foile alfo. For both the tafte and other qualities of the wine, are according to the manner of the foile. And it is very well knowen, that not onely the colour of the wine, but the tafte alfo dependeth on the diuerfitie of the grapes.

Wine, as Galen writeth, is hot in the fecond degree, and that which is very old in the thirde: but $N$ new Wine is hot in the firft degree; which things are efpecially to be vnderftood concerning the meane betweene the ftrongeft and the weakeft: for the fulleft and mightieft being but Horma, (that is as I take it of one yeeres old) are for the moft part hot in the fecond degree: the weakeft and the moft waterifh Wines although they be old, do feldome exceed the fecond degree.

The drines is anfwerable to the heat in proportion (as Galen faith in his booke of Simples:) but $O$ in his bookes of the gouernment of health he fheiveth, that wine doth not onely heate, but alfo moiften our bodies, and that the fame doth moiften and nourifh fuch bodies as are extreme drie: and both thefe opinions be true.

For the faculties of winc are of one fort as it is a medicine, and of another as it is a nourifhment, $P$ which Galen in his booke of the faculties of nourifhments doth plainiy fhew, affirming that thole qualities of the wine, which Hippocrates writeth of in his booke of the manner of diet, be not as a nourifhment, but rather as of a medicine. For wine as it is a medicine doth drie, efpecially being 
outwardly applied; in which cafe, for that it doth not nourifh the bodie at all, the drineffe doth more plainly appecre, and is more manifeftly perceiued.

A Wine is a fpeciall good medicine for an vlcer, by reafon of his heate and moderate drying, 28 Galen teacheth in his fourth booke of the methode of healing.

B Hippocrates writeth, that vlcers what manner of ones foeuer they are, muft not be moiftned, vnleffe it be with wine:for that which is dry, as Galen addeth, commeth neerer to that which is whole, and the thing that is moift, to that which is not whole.

C It is manifeft that wine is in power or faculty dry, and not in a 0 : for wine actually is moift and liquide, and alfo colde: for the fame caufe it likcwife quencheth thirft, which is an appetite or defire of colde and moift, and by this actuall moyfture(that we may fo terme it) it is if it be inwardlytaken not a medicine, but a nourifhment; for it nourifheth, and thorowe his moifture maketh plenty of bloud, and by increafing the nourifhment, it moiftneth the body, vnleffe peraduenture it be old and very ftrong: for it is made fharpe and biting by long lying, and fuch kinde of wine doth not onely heate, but alfo confume and dry the body; for as much as it is not nowe a nourifhment, but a medicine.

D That wine which is neither fharpe by long lying nor made medicinable, doth nourith and moiften, feruing as it were to make plenty of nourifhment and bloud, by reafon that through his actuall moifture it more moifteneth by feeding, nourifhing and comforting, then it is able to dry by his power.

E Wine doth refrefh the inward and naturall heate, comforteth the ftomacke, caufeth it to haue an appetite to meate, mooueth concoction, and conueyeth the nourifhment through all parts of the body, increafeth ftrength, inlargeth the body, maketh flegme thinne, bringeth foorth by vrine cholericke and watery humours, procureth fweating, ingendreth pure bloud, maketh the body well coloured, and turneth an ill colour into a better.

F It is good for fuch as are in a confumption by reafon of fome difeafe, and that haue need to haue their bodies nourifhed and refrefhed (fo they be not fick of an agewe) (as Galen faith in his feuenth booke of the methode of curing: ) it reftoreth ftrength moft of all other things, and that fpeedily: it maketh a man merry and ioiefull: it putteth away feare, care, troubles of minde, and forrowe : it mooueth pleafure and luft of the body; and bringeth ileepe gently.

G And thefe things proceede of the moderate sfe of wine; for immoderate drinking of wine doth altogither bring the contrary. They that are drunke are diftraughted in minde, become foolifh and opprefled with a drowfie fleepines, \& be afterward taken with the apoplexie, the gout, or altogither with other moft greeuous difeafes:the braine, lituer, lungs, or fome other of the entrailes, being corrupted with too often and ouer much drinking of wine.

H Moreouer, wine is a remedie againft the taking of Hemlocke, or greene Coriander, the iuice of blacke Poppie, Wolfes bane, and Leopards bane, Todeftooles, and other colde poifons, and alfo againft the biting of ferpents, and ftings of venemous beafts, that hurt and kill by cooling.

I Wine alfo is a remedie againft the ouerfulneffe and ftretching out of the fides, windy fwellings, the greene fickneffe, the dropfie, and generally all cold infirmities of the ftomacke, liuer, milt, and alfo of the matrix.

$\mathbf{K}$ But wine which is of colour and fubftance like water, through fhining, bright,pure, of a thinne fubftance, which is called white, is of all wines the weakeft; and if the fame fhould be tempered with water, it would beare very little : and hereupon Hippocrates calleth it 'irgópoer, that is to fay, bearing little water to delay it withall.

L This troubleth the head, and hurteth the finewes leffe than others do, and is not vnpleafant to the ftomacke: it is eafily and quickly difperfed through all partes of the bodic: it is giuen with far leffe danger than any other wine, to thofe that haue the ague (except fome inflammation or hot fwelling be fufpected ) and of tentimes with good fucceffe to fuch as haue intermitcing feuers: for, as $G_{\text {alen }}$ in his 8 booke of method faith, it helpeth concoction, digefteth humours that be halfe rawe, procureth vrine and fweate : and is good for thofe that cannot lleepe, and that be full of care and forrow, and for fuch as are ouerwearied.

M Blacke wine, that is to fay, wine of a deepe red colour, is thicke, and hardly difperfed, and doth not eafily paffe through the bladder:it quickly taketh hold of the braine, and maketh a man drunke, it is harder of digeftion; it remaineth longer in the body; it eafily ftoppeth the liuer and fpleen; for the moft part it bindech; notwithftanding it nourifheth more, and is moft fit to engender blood: it 
Ellech the bódy withetefhsfooner than others do.

That which is of a light crimfon red colour, is for the moft part more delightfull to the tafte, fit- $A$ ter for the ftomacke, it is fooner and eafier difperfed, it troubleth the head leffe, it remaineth not fo long vnder the fhort ribs, and eafier defcendeth to thebladder then blacke wine doth : it doth allo make the belly contiuc, if fo be thiâit be ripe:Eor finch crudeandrough wines, do oftentimes moleft weake ftomacks, and are troublefome to the belly.

Reddifh gellow wine fecmiectu to be in a meane betweene a thin and thicke fubftance: otherivife B it is of all wines the hoticefteind fuffenethinoft wine tobe mixed with it, as Hippocrates writerh.titin

The old dwine of thiskihde, boing of a thin fubltance and good finell; is a fingular medicune for C

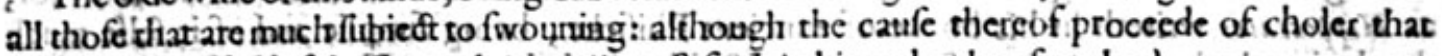

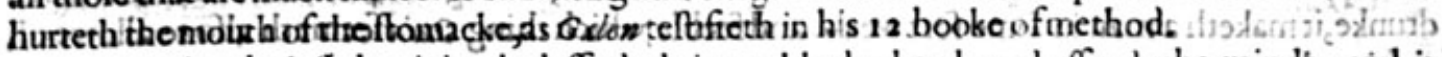

Sweete wine the leffe hot it is, the leffe doch it trouble the head, and offende the minde; aed it D better paffeth through the belly, making it ofturcimes foluble: but-itdotix norfo eafily paffe, or defcend by vrine.

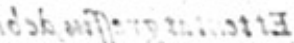

Againe, the thicker it is of fubftance, the harder and flowlier it paffeth through: it is good for $\mathrm{E}$ the lungs, and for thofe that haue the cough. It ripebech-awohnowots thateticsic in the cheft, and

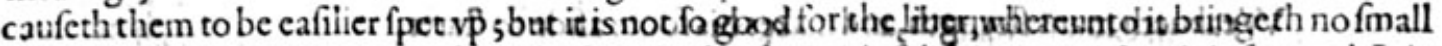
hurt, when ether it is intamed, or hath in it a had wennic fub?tance, or whenit is ftopped.It is

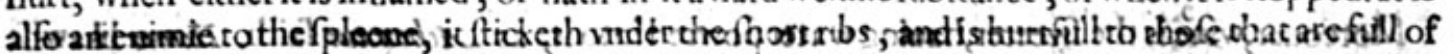

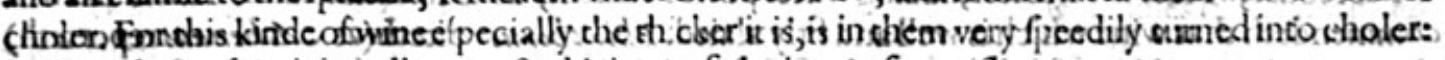

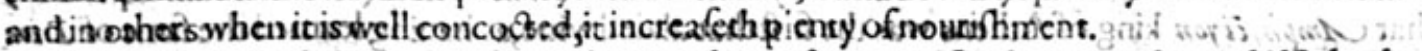
sidufteresvine; or that which is fomew it be thin and white, it is ape to prouoke vxine, it jeffe troubleth the head, it is notquickly digefted, for which aure it is the more to be stawned, as Gales faich in his r 2 . booke of mathod.

That wine which i6.airogither hath or rough in tafte, the leffe ripe it is, theneerer it commeth $G$ to the qualitics of Veriuice made of fowre grapes being euidently binding. It fteengthneth a weakes ftomacke; ic is good aginint the vnisindeiy bifting or longing of women with childe; it flaieth the laske, but it fticketh in the bowels tit breccietb froppings in théliver and milt; irolowly defoendeth

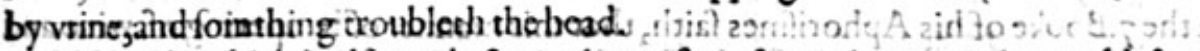

Oldewine which is alfo made fhatpe by reafoul ofage, is notonely troublefome to the braine, $H$ but alfohortech rhe fineives; it is an enimie to the intrailes, and maketh the body leane.

Newe wine, and wine of the firft yeere, doth eafily make the body to fwel, and ingendreth wiade, I it daufeth rroublefomedreames, efpecially that which is not throughly refined, or thicke, or very fwetete: fot fuch,dófoóner fticke iu the entrailes thenothers do. Other wines that are in a meane, in

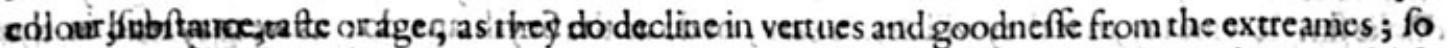
alfo they be free from their faults and difcommodities. They come neere in faculties to thofe wries swhireuntotk ey be riext, either in colour, tafte or fubftance, or elfe in fruell or in age.

Wine is fittelt for thofe that be of riature coldand dry; and alfo for oldmen; as Galen theweth $\mathrm{K}$ in his 5 .booke of thegourernment of healch: for icheatedi all themembers of their bodies, and purgeth away the waterie part of the bloud if there be any. Jigosy

The beit wines are: thofe that be of a fat fubftance:for thofeboth increafe bloud and nourith the $L$ body, both which commodities it bringeth to oldmen, efpecially at fuch time as they haue no wat tery humour in their vaines, and haue neede of much nourifhment. It hapneth that oftentimes there doth abound in their bodies a waterifh excrement, and then ftande they in moft neede of all of fuch wines as do prouoke vrine.

As wine is beft for old men, fo is it woorft for children: by reafon that being drunke, it both moi. $\mathrm{M}$ fteneth and drieth ouermuch, and alfo filleth the head with vapours, in thole who are of a moift \& hot complexionjot whofebodies are in a meane betweene the extremes, whom Galen in his book I of the gavernment efthealch doth perfwade, that they fhoulde not fo much as tafte of wine for a very long time: for neither is it good for them to haue their heads filled, nor to be mademoit and hot, more then is fufficient, bicaufe they are already offuch a heat and moifture, as if yout fhould but litcle increafe erther sualities, they would foorth with fall into the extreme.

And feeing that euery exceffe is to bef hunned jt is expedient moft of all to thun this, by which $\mathbf{N}$ not onely the body, but allo the minde receiueth burt. 2.

Wherefore we muft thinke, that wine is neither fit for men that be already full of age, vnleffe $\mathrm{O}$ 
it be mocerately taken, bicaufe it carieth them headlong into fury and luft, and troubleth and dul. leth the reafonable part of the minde.

\section{Of the delaying,or tempering of Wine.}

A It was an auncient cuftome, and of long continuance in oldetime, for wines to bee mixed with water, as it is plaine and euident not onely by Hippocirites, bit alfo by other olde mens writings. Wine firt beganne to be mixed with water for health and wholefomneffe fake: for, as Hippocrates writeth in his booke of auncient Phificke, being fimplie and of it felfe much drunke, it maketh $2 \mathrm{man}$ in forne fort weake and feeble, which thing Owidfeemeth alfotoallowe of, writingthus:

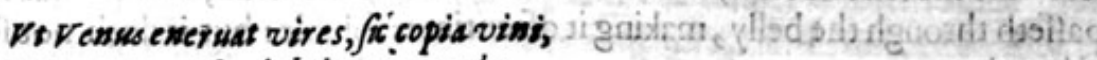

$$
\begin{aligned}
& \text { Et tentat greffow, de bilitatque pedes. }
\end{aligned}
$$

Immoderate vfe of Bacchusiuice and V enew Arre

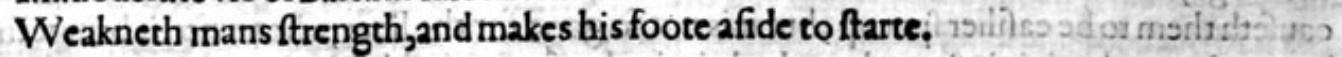

B Moreouer, wine is the fweeter, hauing water powred intoit, as Ua heneing faith, Homarlikewife commenderh that wine which is well and fitly alaied. P hiloc bor w writect (as vabemeins reporteth) that Amphicityon king of Athens wasthe firfthat alaied wine, as hauing learned the fame of Dion) fius: wherefore he faith, that thofe, who in that imaner dranke $i t$, remained in health, that before had their bodies feebled and ouerweakened with pure and vsmixed wine.

C The manner of mingling or tempering of wine was diuers : for fometimes to one part of wine; there were added two, and fometimes three or fower of water; or to two parts of wine, three of water : ofaleffe delaie was that, which confifted of equall parts of wine and water.

D The olde Comedie writers did thinke that this leffer mixture was fufficient to make men mad,

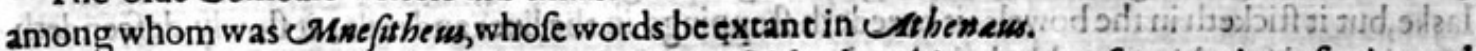

E Heppocrates in the 7. Booke of his Aphorifmes faith, that this manner of tempering of wine and water by equall parts, bringech as it were a light pleafant drunkenneffe, and that it is a kinde of $r e-$ medie againft difquietnes, yawnings, and (hiuerings; and this mingling belongeth toothe ftrongeft wines.

F Such kinde of wines they might be which in times paft the Scythians were reported of the olde writers to drinke, who for this caufe do call vnmixed winethe Scythians drinke. And they that drinke fimple wine fay, that they will scythizere, or doas thie Scythians do: as wemay read in the 10.Booke of Uthenasu.

G The Scythians as Hippocrates and diuers other of the olde writers affirme, be people of Germanie beyonde the floud Danubius, which is alfo called Ifter $:$ Rhene is a riuer of Scythia : and Cyrus hauing paffed ouer Ifter is reported to haue come into the borders of the Șcythians.

H And in this our age all the people of Germanie do drinke vnmixed wine, which groweth in their owne countrey, and likewife other people of the north parts, who make no fcrupleat all to drinke of the ftrongeft wines without any mixture;

\section{Of the liquor which is deftilled out of the Wine, commonly called Water of life.}

I There is drawne out of Wine a liquor, which the Latines commonly call Agaa vite, or water of life, and alfo Aqus ardens, or burning water, which as diftilled waters are drawne out of herbes and other things, is after the fame manner diftilled out of ftrong wine, that is to fay, by certaine inftruments made for this purpofe, which are commonly called Lembickes.

K This kinde of liquor is in colour and fubftaunce like vnto waters diftilled out of herbes, and alfo refembleth cleere fimple water in colour, but in facultie it farre differeth.

L It beareth the furname of life, bicaufe that it ferueth to preferue and prolong the life of man. 


\section{HISTORIE OF PLANTS.}

It is called Ardens, burning, for that it is eaffly tumed into a burning flame: for feeing it isnot any other thing then the thinneft and ftrongeft part of the wine, it being put tothe tlame of fire, is quicklie burned.

This liquor is very hot, and of molt fubtill and thinne parts; hot and drye in the later ende of A the thirde degree, efpecially the pureft fpirits thereof; for the purer it is, the hotter it is, the dryer, and of thinner parts : which is made more pure by often deftilling.

This water diftilled out of wine, is good for all thofe that are made cold either by a long difeafe, B or through age, as for olde and impotent men : for it cherifheth and increafeth naturall heate; vpholdeth ftrength, repaireth and augmenteth the fame : it prolongeth life, quickneth all the fenfes, and doth not onely preferue the memorie, but alfo recouereth itwhen it is loft : it fharpnech the fight.

It is fit for thofe that are taken with the Catalepfie, (which is a difeafe in the braine, proceeding $\mathbf{C}$ of drines and colde) and are fubiect to dead fleepes, if there be no agewe ioined; it ferueth for the weakenes, trembling, and beating of the hart; it ftrengtheneth and heateth a feeble ftomacke; it confumeth winde both in the ftomacke, fides, and bowels; it maketh good concoction of meate, and is a fingular remedic againft colde poifons.

It hath fuch force and power in ftrengthning of the hart, and ftirring vp the inftuments of the D fenfes, that it is moft effectuall, not onely inwardly taken to the çuantitic of a little fpoonefull, but alfo ontwardly applied : that is to fay, fet to the nofthrils, or laide vpon the temples of the head, \& to the wrefts of the armes; and alfo to foment or bathe fundry hurts and griefes.

Being held in the mouth it helpeth the toothach: it is alfo good againft colde cramps and con-E unlfions, being chafed andrubbed therewith.

Some are bold to giue it in quartaines before the fit, efpecially after the height or prime of the F difeale.

This water is to be giuen in wine with great iudgement and difcretion, for feeing it is extreme $\mathbf{G}$ hot, and of moft fubtill parts, and nothing elfe but the very fpirite of the wine, it moft fpeedily pearceth thorough, and doth eafily affault and hurt the braine.

Therefore it may be giuen to fuch as haue the apoplexie, and falling fickneffe, the megrim, the $\mathbf{H}$ headach of long continuance, the Vertigo or giddineffe proceeding through a colde caufe,yet can it not be alwaies fafely giuen : for vnleffe the effectuall matter of the difeafe be fmall, and the ficke man of temperature very colde, itcannot be miniftred without danger: for by reafon that it fpredeth and difperfeth the humours, it filleth or ftuffeth the heade', and maketh the fickemen worfe: but and if the humours be hot, as bloud is, it doth not a little increafe in flammations alfo.

This water is hurtfull to all that be of nature and complexion hot, and moft of all to cholericke I men : it is allo offenfiue to the liuer, and likewife vnprofitable for the kidneies, being often and pler-: tifully taken.

If I hould take in hande to write of euery mixture, of each infufion; of the fundry colours, and euery other circumftance that the vulgar people do giue vnto this water, and theirdiuers ve, I fhould fpende much time but to fmall purpofe.

$$
\text { Of Argall,tartar, or wine Lees. }
$$

The Lees of wine which is become hard like a cruft, and fticketh to the fides of the veffels, and wine casks, being dry, hard, found and well compact, and which may be beaten into powder, is called in fhops Tartarion : in Englifh Argall,and Tartar.

Thefe Lees is vfed for many things; the filuer Smiths polifh their filuer heerewith : the Diers K vfe it : and it is profitable in medicine.

It dōth greatly dry and wafte away, as $P$ auluw $U$ Eg ginet a faith : it hath withall a binding facultie, $L$ proceeding from the kinde of wine, of which it commeth.

1t The fame ferueth for moift difeafes of the body; it is good for them that haue the greene fick-M nes and the dropfie, efpecially that kinde which lieth in the flef, called in Latine Lewcophlegmaticas being taken euery day fafting halfe a penny waight or a full penny waight(which is a dram and nine graines after the Romaines compuration) doth not onely dry vp the waterifhexcrements, and voi. deth them by vrine, but it preuaileth much ta clenfe the belly by fiege.

Itwould workemore effectually, ifit were mixed either with hor fpices, or with other things that $\mathbf{N}$ (8) 


\section{6}

\section{THE SECOND BOOKE OF THE}

breake winde, or elfe with diuretickes, which are medicines that prouoke vrine; likewife to be mixed with gentle purgers, as the ficke mans cafe fhall require.

A The fame of it felfe, or tempered with oile of Myrtles, is a remedie againft foft fwellings, as Diof corides teacheth : it ftaicth the laske, and vomiting, being applied outwardly vpon the region of the ftomacke, in a pultis; and if it be laide to the bottome of the belly and fecret parts, it ftoppeth the whites, wafteth away hot fwellings of the kernels in the flankes and other places, which be not yet exulcerated : it affwageth great brefts, and drieth vp the milke, if it be annointed on with vineger.

B This Lees is oftentimes burnt: if it become all white it is a figne of right and perfect burning, for till then it muft be burned : being fo burnt, the Grecians terme it roiknn, as UEgineta faith : the A pothecaries call it Tartarum vstum, and Tartarum calcinatum : that is to fay, burnt or calcined Tartar.

C It hath a very great caufticke or burning qualitie: it clenfeth and thiroughly heateth, bindeth, eateth,and very much drieth as Diofcorides doth write: being mixed with Rofin, it maketh rough and ill nailes to fall away: $P$ aulus faith, that it is mixed with caufticks or burning medicines to increafe their burning quality: it muft be vfed whileft it is newe made, bicaufe it quickly vanifheth : for the Lees of wine burned, doth foon relent, or waxe moift,\&k is fpeedily refolued into liquor:therfore he that would vfe it drie, muft haue it put in a glaffe, or glaffed veffell well ftopped, and fet in a hot and dry place. It melteth and is turned into liquor if it be hanged in 2 linnen bagge in fome place in a celler vnder the ground.

D The Apothecaries call this liquor that droppeth away from it, oile of Tartar. It retaineth 2 caufticke and burning quality, and alfo a very dry facultie :it very foone taketh away leprie, fcabs, tetters, and other filth and deformitie of the skin and face : with an equall quantity of Rofe water added, and as much Cerufe as is fufficient for 2 liniment, wherewith the blemifhed or fpotted parts muftbe annointed ouer night.

\section{The briefe fumme of thathath been faid of Wine.}

E The itice of the greene leaues, branches, and tendrels of the Vine drunken, is good for thofe thas vomite or fpit bloud, for the bloudie flixe, and for women with childe that vomite ouermuch. The kernell within the grapes boiled in water and drunke, hath the fame effeet.

F Wine moderately drunke profiteth much, and maketh good digeftion, but it hurteth and diftempereth them that drinke it feldome.

G White wine is good to be drunke before meate, preferueth the body, and pearceth quickly into the bladder:but vpon a full ftomack it rather maketh oppilations or ftoppings, bicaufe it doth fwifly driue downe meate, before nature hath of hirfelfe digefted it.

H Claret wine doth greatly nourifh and warme the body, and is wholfome with meate, efpecially vnto flegmatike people: but very vnwholfome for yoong children,as Galen faith, bicaufe it heatech aboue nature, and hurteth the head.

I Red wine ftoppeth the belly, corrupteth the bloud,breedeth the ftone, is hurtfull to oldepeople, and good or profitable to fewe, faue to fuch as are troubled with the laske, bloudy flixe,or any other loofeneffe of the body.

K Seckeor Spanilh wine hath been vfed of a long time to be drunke after meate, to caufe the meate the better to digeft : but common experience hath founde it to be more beneficiall to the ftomacke, to be drunke before meate.

L Likewife Malmefie, Mufcadell, Baftard, and fuch like fweete wines haue been vfed before meat, to comfort the colde and weake ftomacke, efpecially being taken fafting; but experience teacheth, that Sccke drunke in fteede thereof, is much better, and warmeth more effectually.

Almighty God for the comfort of mankind òrdeined wine; but decreed therwith, that it fhoulde be moderately taken, for fo it is holfome and comfortable; but when meafure is turned into exceffe, it becommeth vnwholfome and a poifon moft venemous, relaxing the finewes, bringing with it the palfie and falling ficknes: to the aged it bringeth hot feuers, frenfie, and lecherie, confumeth the liuer and other of the inward parts:befides, how little credence is to be giuen to drunkards it is euidtent, for though they be mighty men, yet it maketh them monfters, and woorfe then brute beafts. Finally in a word to conclude: this exceffue drinking of wine difhonoreth noblemen, beggereth the poore, and morc haue beene deftroied by furfeiting therewith, then with cruell battell. 
Of Hops. Chatp.310.

\author{
* The kindes.
}

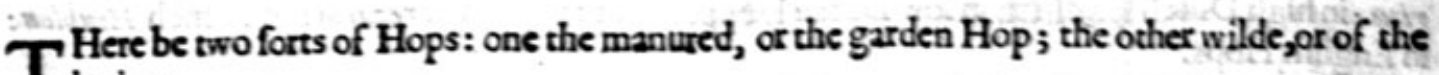
hedge.

I Lopenfatiarian.
Hops.

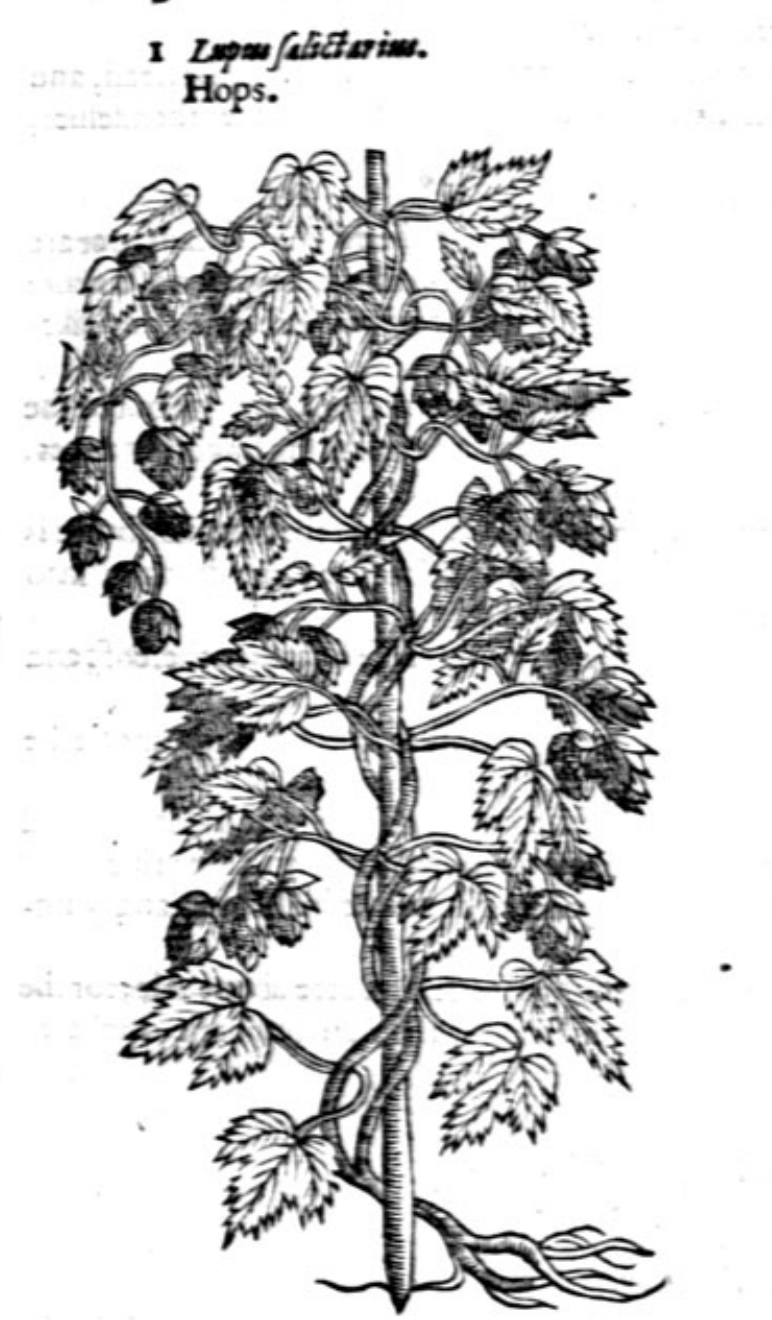

2 Lopulaw fluesifiti. Wilde Hops.

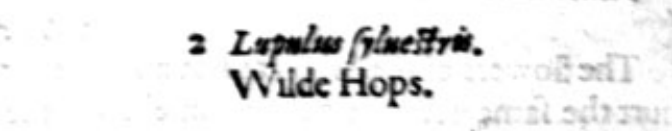

\title{
* The defoription.
}

I He Hop doth live and flourifh by imbracing and taking bolde of poles, pearches, and other things, vpon which it climeth. It bringeth foorth very long ttalkes, rough and hairic; alfo tugged leaues, broad, like thofe of the Vine, or rather of Bryonie, bur yetblacker, and with fewer dented diuifions. The flowers hang downe byclufters from the tops of the branches puffed vp, fet as it were with fcales the little canes, or fcaled Pineapples, of a whitifh colour tending to yellowneffe, ftrong of fmell. The rootes are flender and diuerily folded one within another.

2 The wilde Hop differeth not from the manured Hop in forme or fal hion, bat is altogither !ef. fer, as well in the clufters of towers, as alfo in the franke fhootes, and doth not buing foovith fuch ftore of tlowers, wherein efpecially confifteth the difference.

*T Theplace.

The Hop ioyeth in a fat and fruitfull ground:itprofpereth the better by manuing : alfo it groweth among briers and thomes, about the borders of fields, fpeaking of the wilde kinde.

The tlowers of Hops are gathered in Auguft and September, and referved to be vfed in beere: 


\section{THE SECOND BOOKE OF THE}

in the fpring time come foorth new fhootes or buds. In the winter onely the rootes remaine aliue.

* The names.

It is called in thops, and in all other places Lupulus: of fome Lupus falictarim, or Lupulus falictarius : in high Dutch fopffen: in low Dutch foppe: in Spanifh Hombrezillos: in French Houblon: in Englifh Hops.

Plinie maketh mention of Hops in his $2 \mathrm{t}$.booke, $\mathrm{I}$ 5.chapter among the prickley plants. * The temperature.

The flowers of the Hop are hot and drie in the fecond degree; they fill and ftuffe the head, and hurt the fame with their ftrong fmell. Of the fame temperature alfo are the leaues themfelues, which do likewife open and clenfe.

* The vertues.

A The buds or firft fprouts, which come foorth in the fpring are vfed to be eaten in fallads: yet are they as Pliny faith, more toothfome then nourifhing, for they yeeld but very fmall nonrifhment: notwithftanding they be good for the entrailes, both in opening and procuring of vrine, and likewife in keeping the body foluble.

B The leaues and little tender ftalks, and alfo the flowers themfelues, remooue ftoppings out of the liuer and fpleene : purge by vrine, clenfe the bloud, and be profitable againft long lingering agues, fcabs, and fuch like filth of the skin, if they be boiled in Whaie.

C The iuice is of more force, and doth not onely remooue obftructions out of the entrailes, but it is alfo thought to auoide choler and flegme by the ftoole. It is written that the fame dropped into the eares taketh away the ftench and corruption thereof.

D The flowers are vfed to feafon Beere or Ale with, and ouermany docaufe bitternes thereof, and are ill for the head.

E The flowers make bread light, and the lumpe to be fooner and eafilier leuened, if the meale be tempered with liquor, wherein they haue beene boiled.

F The decoction of Hops drunke, openeth the ftoppings of the liuer, the fpleene, and kidneies, and purgeth the bloud from all corrupt humours, caufing the fame to come foorth with the vrine.

G The iuice of Hops openeth the belly, and driueth foorth yellow cholericke humours, and purgeth the bloud from all filthines.

H The manifold vertues in Hops do manifeftly argue the holfomneffe of Beere aboue Ale; for the Hops rather make it a Phificall drinke to keepe the body in health, then an ordinarie drinke for the quenching of our thirft.

\section{Of the Traueilorsioy. Chap.311.}

\section{* The defcription.}

I He plant which L'Obeliw fetteth foorth vnder the title of Viorna, Dodomaus maketh Vitis alba, but not properly, whofe long woody and Vinie bianches, extende themfelues verie farre, and into infinite numbers, decking with his clafping tendrels and white ftarrelike flowers (being very fweete) all the burhes, hedges, and hrubbes that are neere vnto it. It fendeth foorth many braunched ftalkes, thicke, tough, full of fhootes and clafping tendrels, wherewith it foldeth it felfe vpon the hedges, and taketh holdc and climeth vpon fuch things as ftande neere vito it. The leaues are faftned for the moft part by fiucs vpon one rib or ftemme, two on either fide, and one in the midft or point ftanding alone, which leaues are broade like thole of Iuie, but nor cornered at all, among which come foorth clufters of white flowers, and after them great tufts of flat feedes, each feede hauing a fine white plume like a fether faftned to it, which maketh in the winter a goodly fhewe, couering the hedges white all ouer with his fetherlike tops. The root is long, tough and thicke, with many ftrings faftned thereto.

2 Clusiues hath fet foorth a kinde of Clemat is, calling it Clemat is Batica, hauing a marueilous long fmall branch full of ioints, with many leaues indented about the edges, like thofe of Goofefoote, but ftiffer and broader, comming from cuery ioint, from whence alfo proceede fimall clafping tendrels, as alfo the finall footeftalks whereon the feeds do ftand, growing in great tufted plumes or fethers, 
H IS T ORIE OF PLANTS.

like vnto the precedent, which is 2 kinde heereof. The flowers are not expreffed in the figure, nor feene by the author and therefore what hath beene faid fhall fuffice.

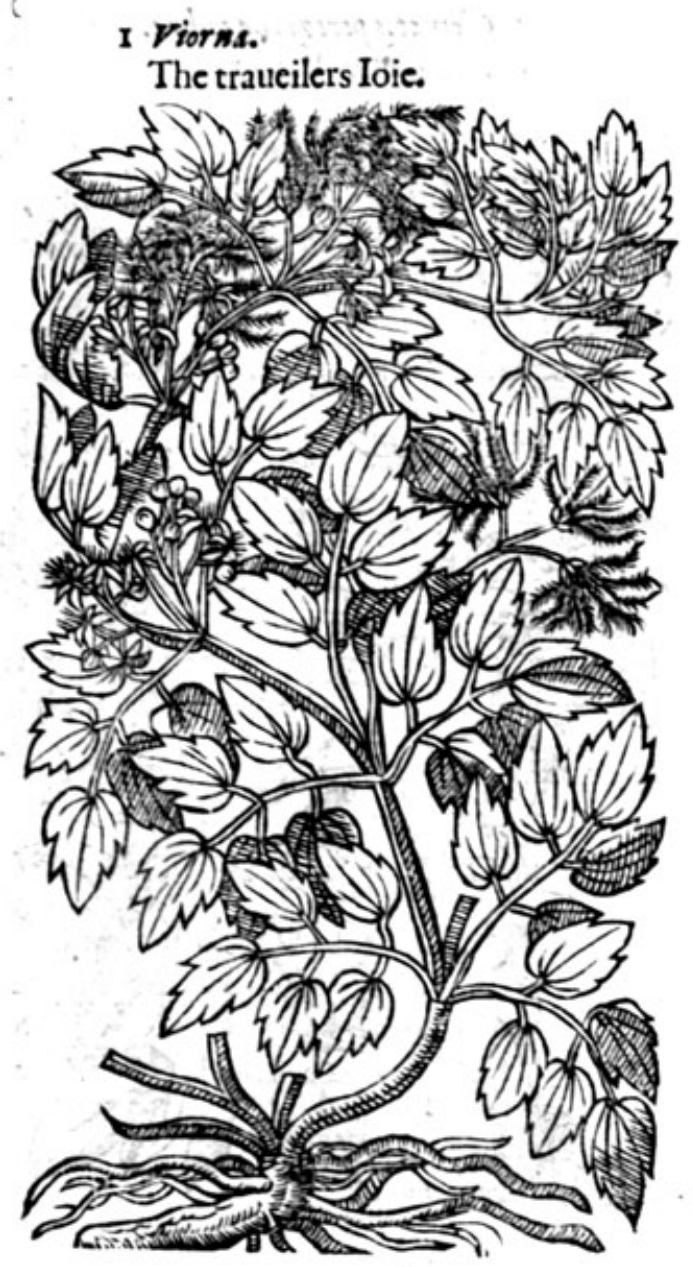

2 Clematis Batica.

The traucilers Ioie of $\mathrm{C}_{2}$ ndie.

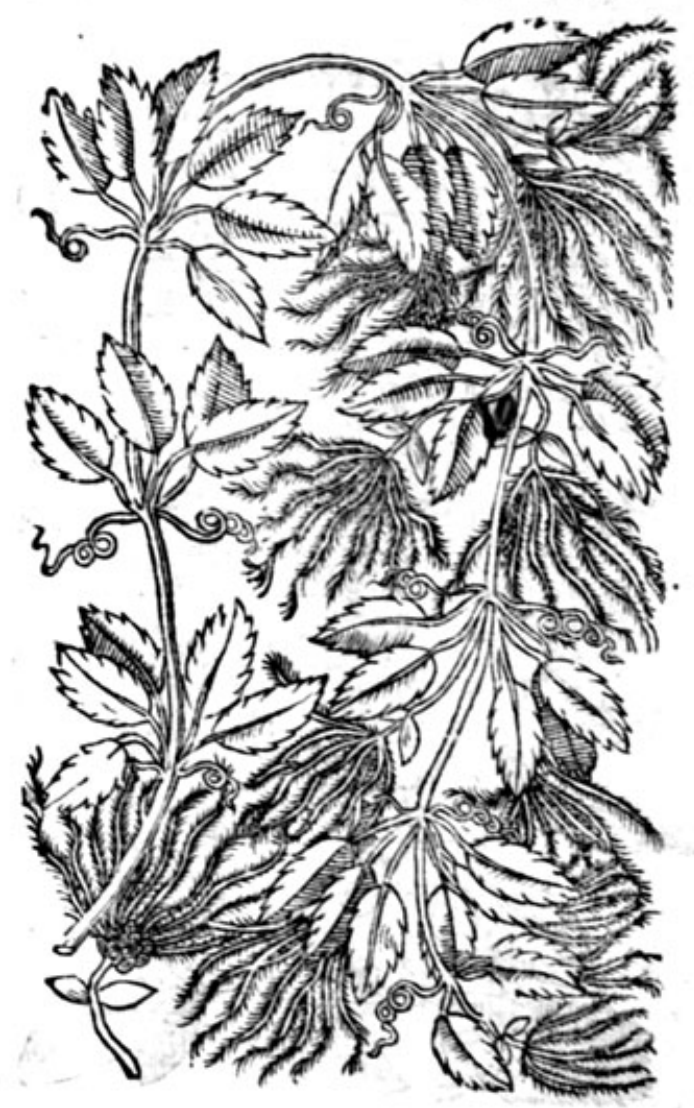

* Theplase.

hedge, as youg gofrom Graueferi the borders of ficldes among thornes and briers, almoft in euery thefe Soutberly parts aboit London, buterbury in Kent; in many places of Eflex, and in moft of Thefecond is a ftranger in thicfe parts, not in the North of England that I can heare of.

Walthamabbey.

The flowers comefoorth in Iulie: the $*$ The fime.

$*$ The fime.

appeereth in Nouember and December.

The firit is called commonly Viorna qua fovias orvians, of decking and adorning waies and hedgé, whete pieopletrauell ${ }_{\text {sand }}$ thereupon 1 hauenamed it the Traueilers Ioie; of Fuch fius it is called

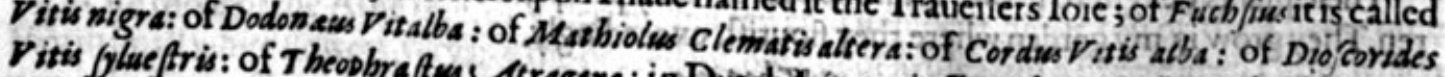
Thefe plants haue no vfe in $\$ T$ hereinperatiene and vertwes.

Fon of the goodly fhadowe which beautic of she flowers,and the pleafant fent or fauour of the fame. 


\section{Of Ladies Bower, or Virgins Bower. Chap.312.}

I Clematis peregrina Carmlea.

Blewe Ladies Bower.

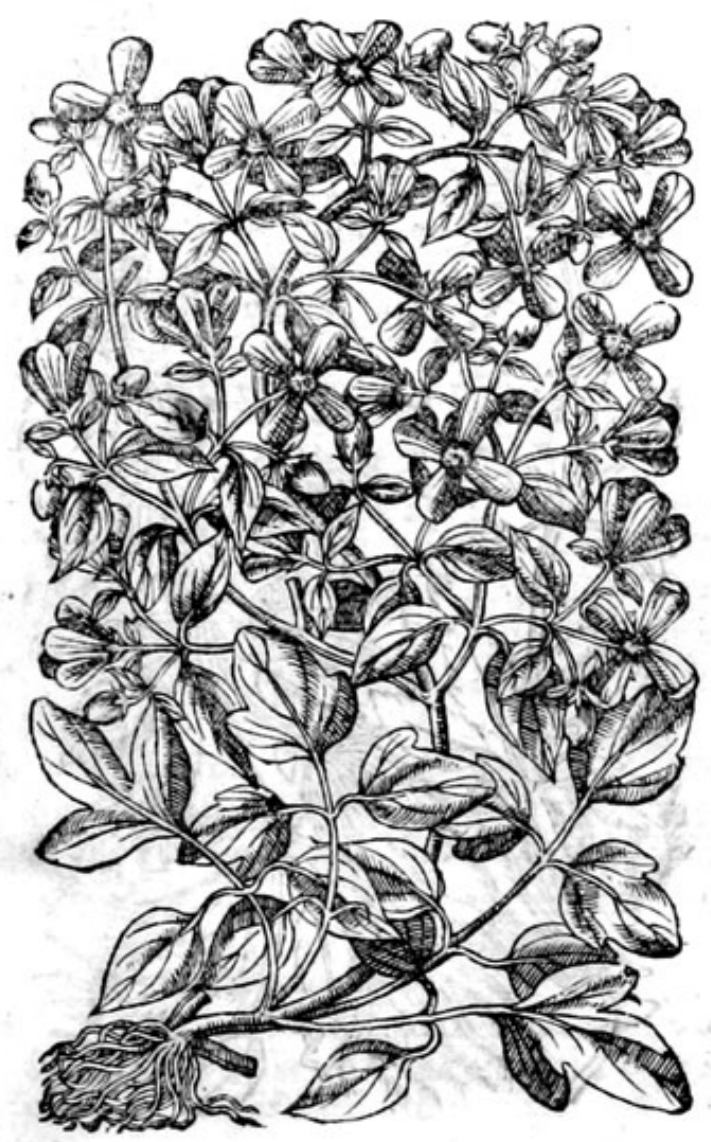

3 Clematis peregrina rubra.

Red Ladies Bower.

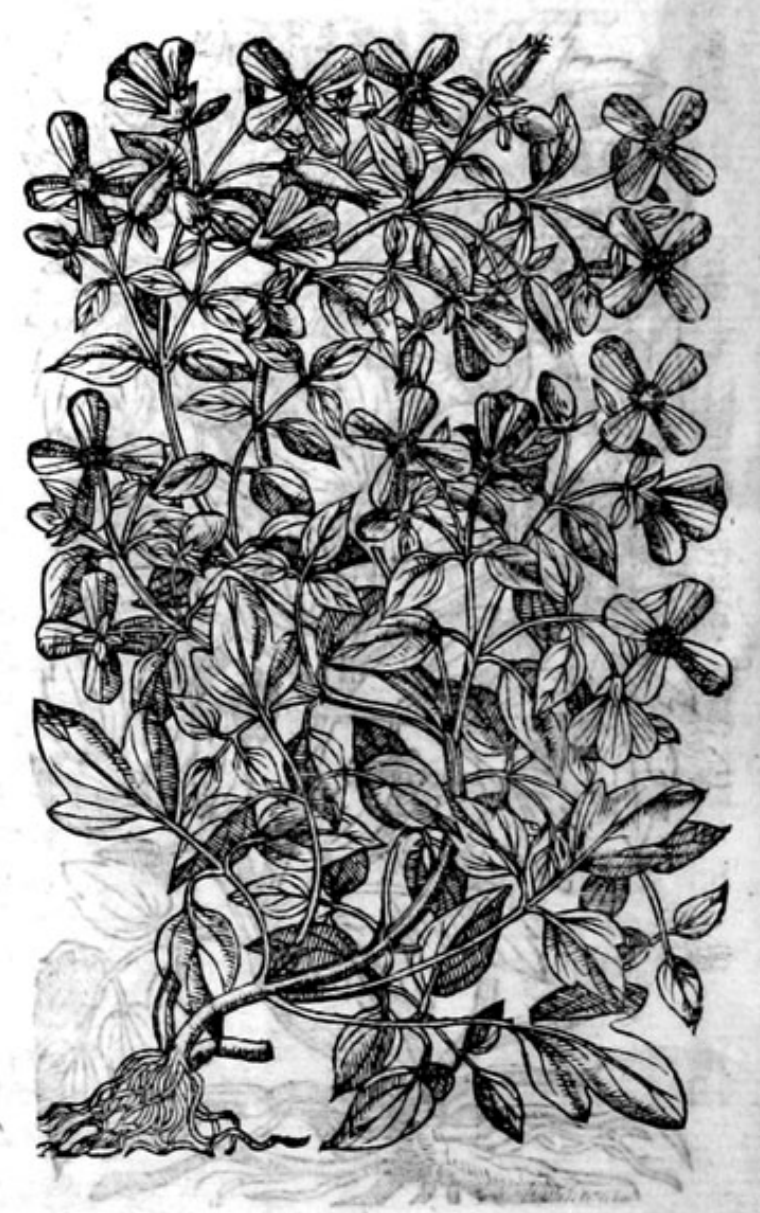

* The defoription.

I Hat which L'Obel defcribeth by the name Clemas is peregr ina, hath very long and flender ftalkes like the Vine, which are iointed, of a darke colour; it climethalof rand taketh holde with his crooked clafpers vpon euery thing that ftandeth neere vnto it: it hath manie leaues diuided into diuers parts, among which come the flowers that hang vpon flender footeftalks, fomething like to thofe of Peruinckle, confifting onetyrof fower leaues, of a blewcolour, and lometimes purple, with certaine threds in the middle: the feedes be Alat, plaine, and tharpe poirted. The rootes are flender, and preading all aboutt.

2. The fecond differeth not from the other, in leaues, ftalkes, branches nor feede. Theonely difference confiftech in that, that this plant bringeth foorth red flowers, and the other blewe. rence confletho * Tbeplace.

Thefe plants delight to growe in funnie places : they profpor better in a'fruitfull follę thei a batren. They grow in my garden where they flourifh exceedingly. $*$ The time.

They flower in Iuly, and perfeet their feede in September.

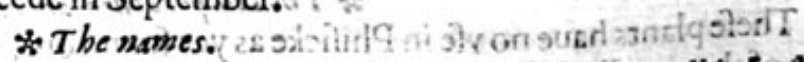

Ladies Bower is called in Greeke xaxueris; in Latine Ambuxum :in Englifhyou may callfte Ladies Bower, which I take from his aptnes in making of Arbors, Bowers, and foradie coliertires in Gate dens. * The temperature and vertues.

The faculties and the vfe of thefe in Phificke is not yet knowne. 


\section{HISTORIE OF PLANTS.}

\section{Of purging Peruinkle. Chap.313.}

\section{Clematis vrens. Virgins Bower.}

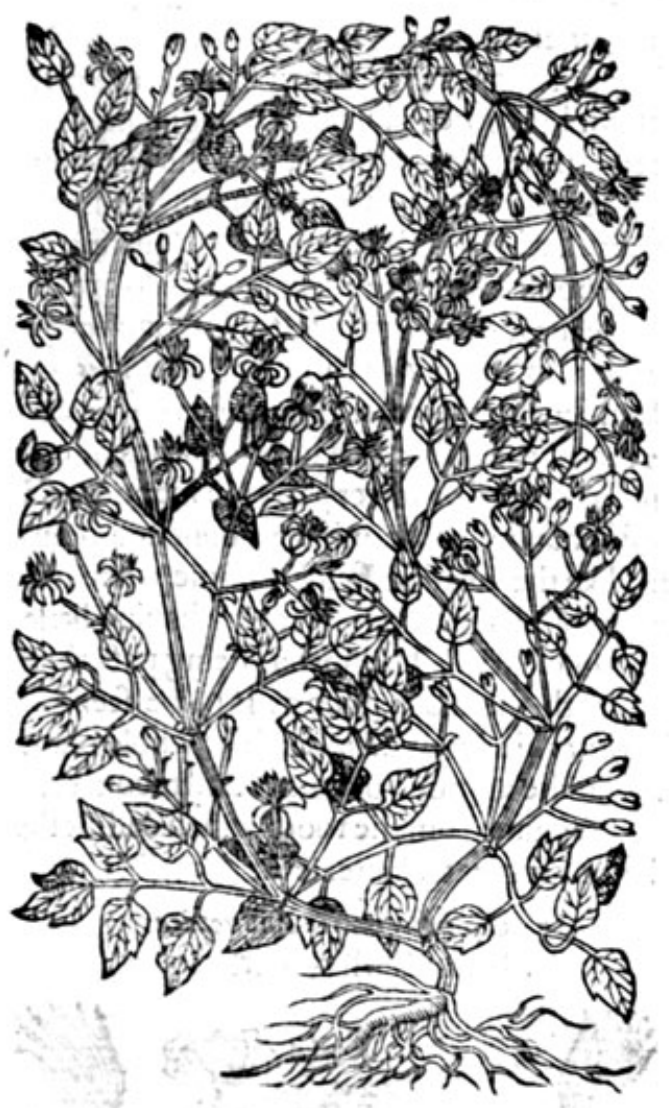

2 Flammula Iowisfarredia.

Vpright Virgins Bower.

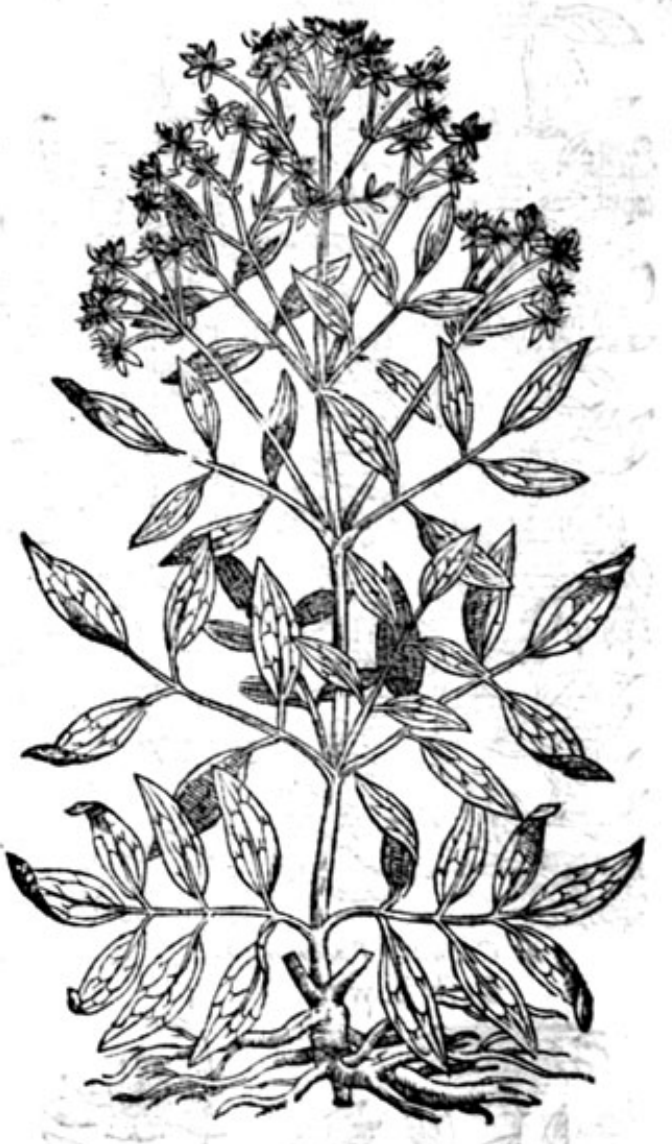

$*$ The defcription.

I Mong thofe plants which are called clem ttides, thefe are alfo to be numbred, as hauing a A certaine affinitic, bicaufe of the fpreading, branching and femblance of the Vine, and is called Flammula vrens, by reafon of his firie and burning heate, bicaufe that being laide von the skin, it burneth the place, \& maketh an efchare, euen as our common cauftick or corrofiue medicines do. The leaues hereof anfwere both in colour and fmoothneffe, $V$ inca Peruincs, or Peruinkle, growing vpon long clambring tender branches, like she other kindes of climing plants. The flowers are very white, ftar fafhion, and of an exceeding fweete finell, much like vnto the finell of Hawthorne flowers, butmore pleafant, and leffe offenfiue to the head; hauing in the iniddle of the flowers certaine fmall chiues or threds. The roote is tender, and difpeffeth it felfe farre vnder
the ground. 2. Vpright Clamberer or Virgins Bower, is al fo a kinde of clematis, Jauing long tough rootes, not vnlike to thofe of Licorife; from which rifeth vp a ftraight vpright ftalke, of the height of fixe ot feuen cubits, fet about with winged leaues, compofed of diuers fmall leaues, fet vpon a middle rib,as are thofe of the Afhe tree, or Valerian, but fewer in number: at the top of the ftalkes come foorth fmall white flowers, very like the precedent, but not of fo pleafant a fiveete fmell; after which come the feedes flat and harpe pointed.

3 There is another clematis, of thekinde of the white clemdsis or burning clemati, which thaue recouered from feede, that hath beene fent me from a curious and learned citizen of Argentine now called Strawsborough, which is like vnto the others in each refpect, fauingthat, that the flowers
heereof are very double, whercin confilteth the efpeciall difference. 
3 Clematis vrensmultifora.

Double flowred Virgins Bower.
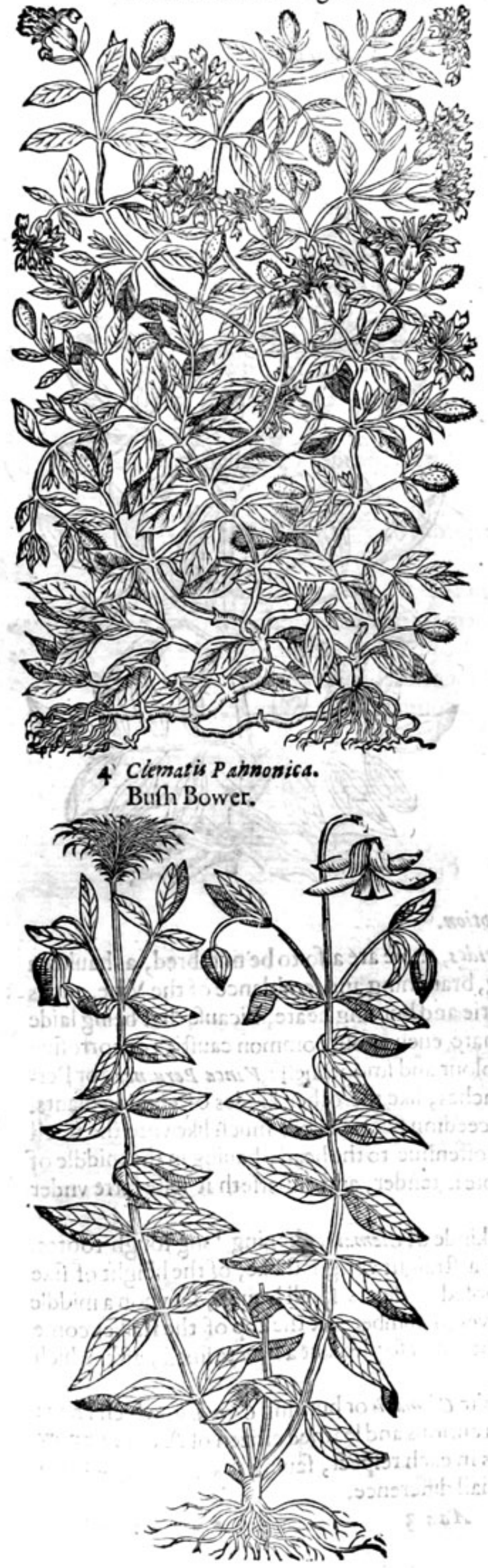

* 7 hedefcription.

4 Amongtt the kindes of climing or clambering plants, Carolus $\mathrm{Clu}$ fusus, and likewife $L^{\prime} O$. belius haue numbred thele two, which approch neere vato them in leaues and flowers, but far different in clafping tendrels, or climing otherwife, being lowe and bafe plants in refpect of the others of their kinde. The fiift hath for his rootes a bundle of tough tangling threds, in number infinite, and thicke thruft togither; from which rife vppe manie fmall ftalkes, of a brownifh colour, fower fquare, and of a woodie fubftance : whereupon do growe long leaues, of 2 biting tafte, fet rogither by couples, in thape like thofe of Usclepias, or Silken Swallow woort. The flowers groweat the top of the ftalks, of a faire blew or skie colour, confinting of fower partes in manner of $a$ croffe, hauing in the middle a bunched pointell, like the head of fielde Poppie when it is yoong, of a whitifh yellow colour, hauing little or no fmell at all. The flowers being pait, then commeth the feede, fuch as is to be feene in the other kindes of Clematis. The whole plant dieth at the approch of winter, and recouereth it felfe againe from the roote, which endureth; whereby it greatly increaleth.

\section{Clematis maior Pannonica. Great Bufh Bower.}

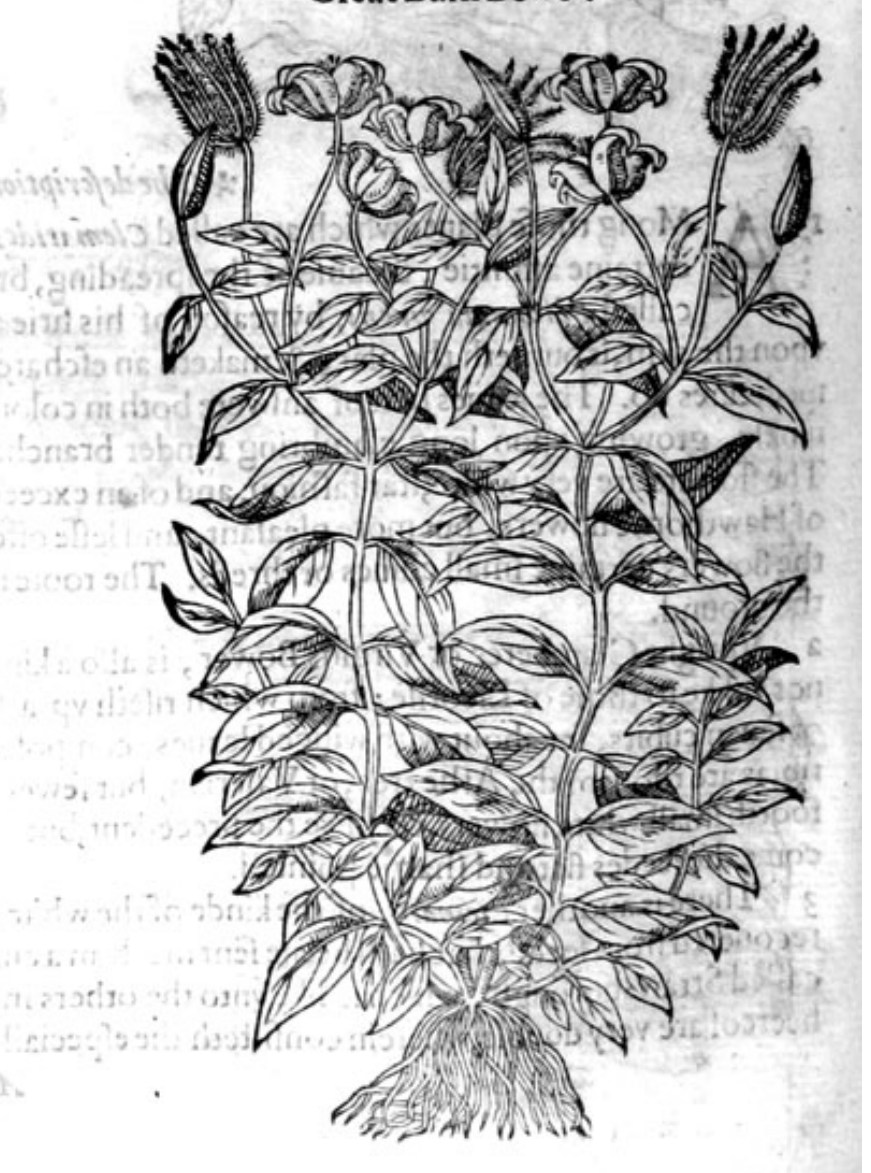




\section{HIST ORIE OF PLANTS.}

5 The great Bufh Bower differeth not from the former laft defcribed, but in greatneffe: which name of greatneffe fetteth foorth the difference.

Thefe plants do not growe wilde in England, that I can as yet learne; notwithiftanding I haue them all in my garden, where they flourifh exceedingly.

Thefe plants do fiower from Auguft to the end of September.

$*$ The names.

There is not much more founde of their names than is expreffed in their feuerall titles, notwithiftanding there hath beene fornewhat faid, as I thinke, by heare fay, but nothing of certaintie: wherefore let that which is fet downe fuffice. We may in Bnglifh call the firft, Biting Clematis, or white Clematis, biting Peruinkle, or purging Peruinkle, and Ladies Bower, and Virgins Bower.

\section{* The temperature.}

The leafe hereof is biting, and doth mightily blifter, being as $G_{a}$ len faith, of a caufticke or burning qualitie : it is hot in the beginning of the fourth degree.

$*$ The vertues.

Diofcorides writeth, that the leaues being applied doe heale the fcurfe and leprie, and that the $A$ feede beaten and the powder drunke with faire water or with Meade, purgeth flegme and choler by the ftoole.

\section{Of Woodbinde, or Honifuckle. Chap.314.}

* The kinies.

$T$ Here be diuers fortes of Woodbindes, all of them fhrubs with winding ftalkes, and that wrap themfelues vnto fuch things as are neere about them. Likewife there be other fortes or kindes there of, found out by the later herbarifts, that clime not at all, but ftand vpright, the which Phall be fet foorthamong the fhrubbie plants. And fiuft of the common Woodbinde.

I Periclymenum.

Woodbinde or Honifuckles.

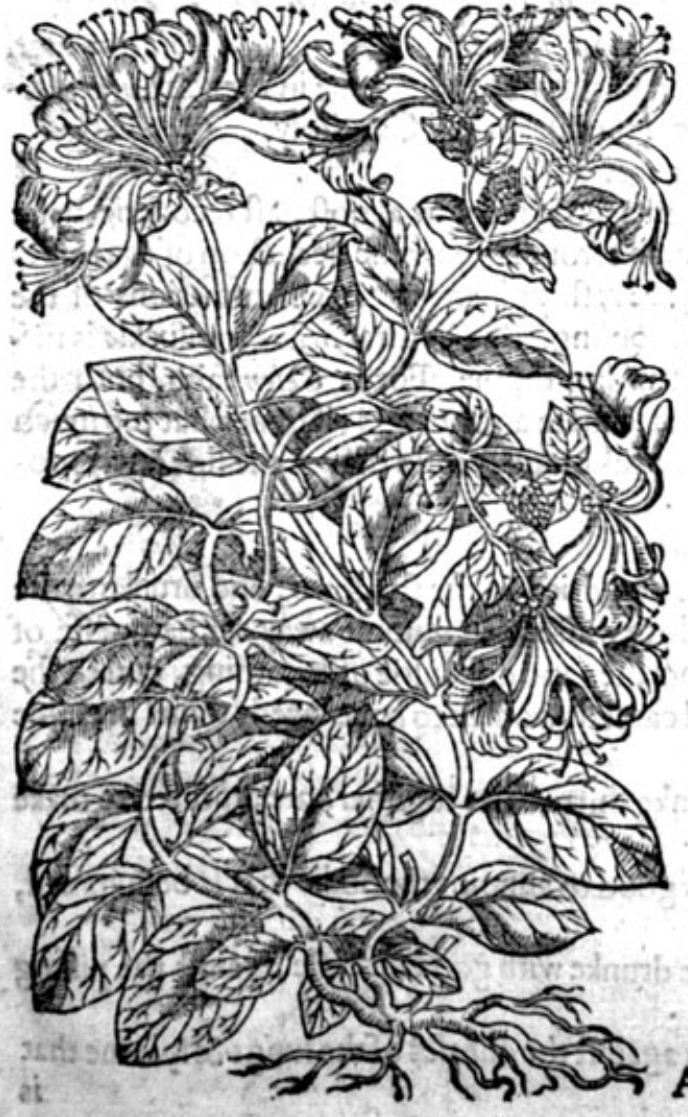

2 Periclymenumperfoliatiom. Italian Woodbinde.

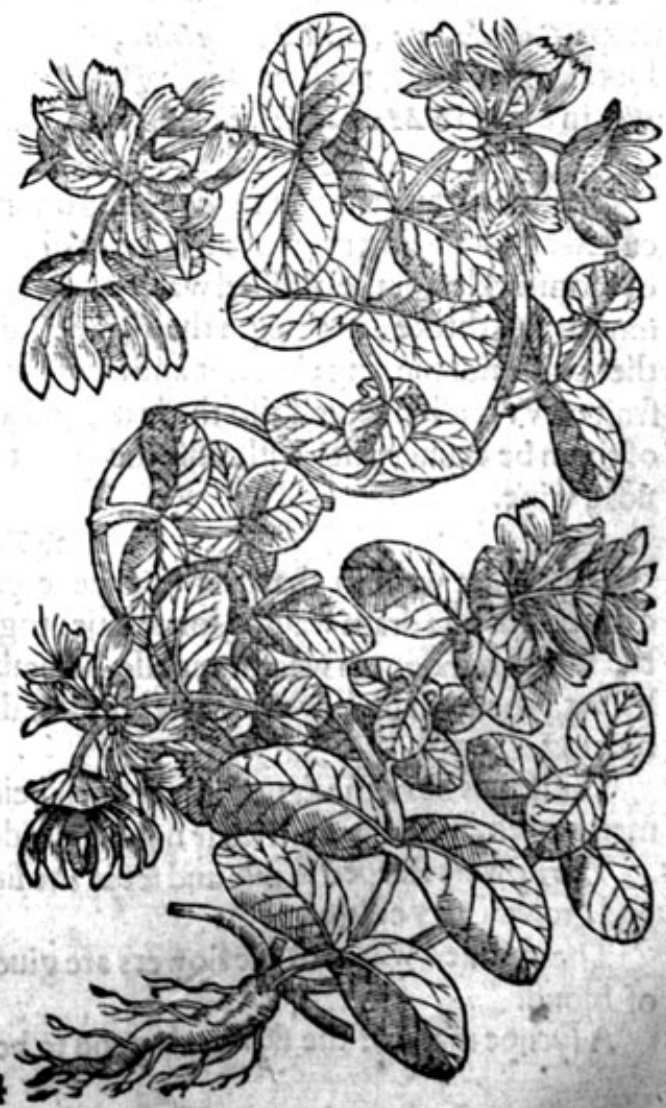




\section{* The defaription.}

I T Oodbinde or Honifuckle climeth vp aloft, hauing long flender noodieftalkes, parted into diuers branches: about which ftand by certaine diftances fmoothleaues, fet togither by couples one right againft another; of a light greene colour aboue, vnderneath of a whitilh greenc. The flowers thew themfelues in the tops of the branches many in number, long, white, fweete of fmell, hollow within; in one part ftanding more out, with certaine threds growing out of the middle. The fruite is like to little bunches of grapes, red when they be ripe, wherin is conteined frmall hard feede. The roote is woodie, and not without ftrings.

2 This ftrange kinde of Woodbinde hath leaues, ftalks and rootes like vnto the common Woodbinde or Honifuckle, fauing that neere vnto the place where the flowers come foorth, the ftalkes do growe thorough the leaues, like vnto the herbe Thorow waxe, called Perfoliata, which leaues do refemble little fawcers : out of which broad round leaues proceedefaire, beautifull, and weHl fmelling flowers, fhining with 2 whitifh purple colour, ix form what dafht with yellow, by littleand little ftretched out like the nofe of an Elephant, garnifhed within with fmall yellow chites or threds: and when the flowers are in their flourifhing, the leaues and flowers do refemble lawcers filled with the flowers of Woodbinde; many times it falleth out, that there is to be found three or fower fawcers one aboue another, filled with flowers as the firft, which hath caufed it to be called double Honifuckle, or Woodbinde.

\section{* The place.}

The Woodbinde groweth in woods and hedges, and vpon fhrubs and bufhes, oftentimes winding it felfe fo ftreight and hard about, that it leaueth his print vpon thofe things fo wrapped.

The double Honifuckle groweth now in my garden, and many others likewife in great plenty, although not long fince, very rare and hard to be found, except in the garden of forne diligent Herbarift.

\section{* 7 be time.}

The leaues come foorth betimes in the fpring: the flowers budde foorth in Maie and lune: the fruite is ripe in Autumne.

It is called in Greeke mexaviueror: in Latine Volucrum maim, of Scribonim Largus Sylue muter : in fhops Caprifolium, and Matrifylus, of fome Lilium inter pines: in Italian Vincibofco: in high

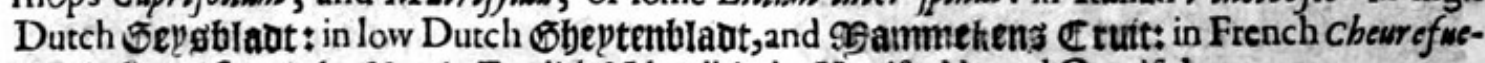
jlle: in SpaniR Madrefelwa : in Engliih Woodbinde, Honifuckle, and Caprifoly.

\section{* T The temperature.}

There hath an errour in times paft growen amongft a fewe, and now almoft paft recouerie to be called againe, being growen an errour vniuerfall, which errour is, how the decoction of the leaues of Honifuckles, or the diftilled water of the flowers, are rafhly giuen for the inflammations of the mouth and throte, as though they were binding and cooling. But contrariwife Honifuckle is neither colde nor binding; but hot and attenuating or making thinne. For as Galen faith, both the fruit of Woodbinde, and alfo the leaues, do fo much attenuate and heate, as if fomewhat roo much of them be drunke, they will caufe the vrine to be as red as bloud, yee do they at the firt onely proúoke vrine.

\section{$\approx$ T bevertues.}

A Diofcorides writeth that the ripe feede gathered and dried in the fhadowe, and drunketo the quantitie of one dram waight, fortie daies togither, doth wafte and confume away the hardineffe of the fpieen, remooueth wearifomneffe, helpeth the fhortnes and difficultie of breathing, cureth the hicket,procureth bloudy vrine after the fixt day, and caufeth women to haue fpeedy trauel in childe bearing.

B The leaues be of the fame force: which being drunke thirty daies togither, are reported to make men barren, and deftroieth their naturall feede.

C The flowers fteeped in oile and fet in the funne, is good to annoint the bodie that is benummed, and growen very colde.

D The diftilled water of the flowers are giuen to be drunke with good fucceffe againft the piffing of bloud.

E A fyrupe made of the flowers is good to be drunk againft the difeafes of the lungs \& fpleene that 


\section{BHSTORIE OF PLANTS.}

is ftopped, being dnunke with a little wine.

Notwithitanding thewords of Galen, it is certainly found by experience, that the watet of Ho: F fifuckles is good againit the forefieffe in the throte and Vutla? and with the fame eleautes boiled, of the leaues and flowers diffilled, are made diuers good medicines ag ainit eankers, and fore motiths, as well in children as elder people, and likewife for vilcerations and fealdings in the prituie parts of man or woman: if there be added tôthe decoction heerof fome hony and alfome or Verdigreace: if the fore require greater clenfing outwardly, prouided alwaies that therc be no Verdigreace put into that water that muft be iniected into the fecret parts.

\section{Of fafmine, or Gelfemine. Chap.315.}

\section{* The kindes.}

Tere be found at this day fower forts of Iafmine, differing as well in colour of the flowers, as

- in greatnes of the fame, as ihall be declared in their fenerall defcriptions.

\section{Infminum altum.} White Geffemine.

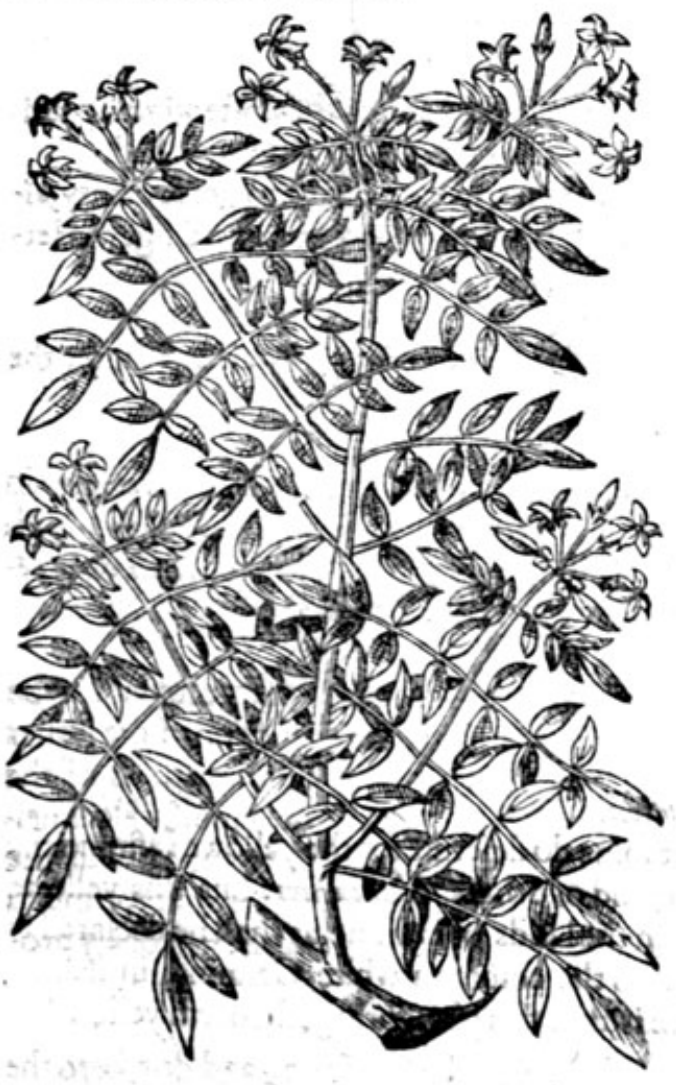

2 Isfminien Candiflorwonmaim. Grẹat white Geflemine.

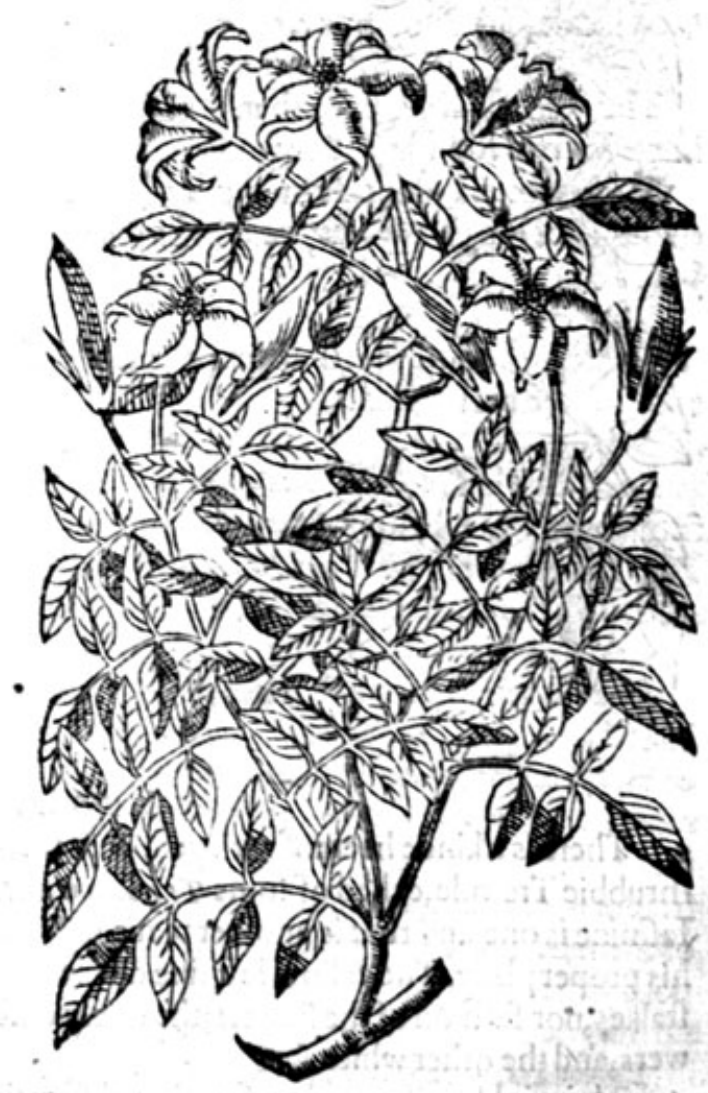

* Thedefcription.

I Afmine, or Gelfemine, is of the number of thofe plants, which haue neede to be fupported or propped vp; and yet notwith ftanding of it felieclafpeth not or windeth his ftalks about fuch things as ftandneer vntoik, but only leaneth and lieth vpon thofe things, that are prepared to fuftaine it about arbors and banqueting houfes in gardens, by which it is held vp. The ftalks therof are long, round, branched, iointed or kneed, and of a greene colour, hauing within a white fpungeous pith. The leaues ftande vpon a middle rib,fet togither by couples like thofe of the afh tree, but finaller, of a deepe greene colour. The flowers growe at the vppermoft part of the branches, ding in a fmall tuft, farre fet one from another, fweete in finell, of colour white. The feede is tat and broade like thofe of Lupines, which feldome come to ripenes. The roote is tough and threddic, 


\section{THE SECOND BOOKE OF THE}

2 L'Obeliw reporteth that he fawe in a garden at Bruxels, belonging to a reuerend perfon called mafter Iohn Boifot, a kinde of Gelfemine, very much differing from our common Iafmine, which he nourifhed in an earthen pot: it grew not aboue (faith he) to the height of a cubit, diuided into diuers branches, whereupon did growe leaues like thofe of the common white Iafmine, but blacker and rounder. The flowers to the fhew were moft beautifull, in fhape like thofe of the common Iafmine, bur fower times bigger, gaping wide open, white on the our fide, and of a bright red on the infide.

Infminum luteum.
Yellowe Iafmine.

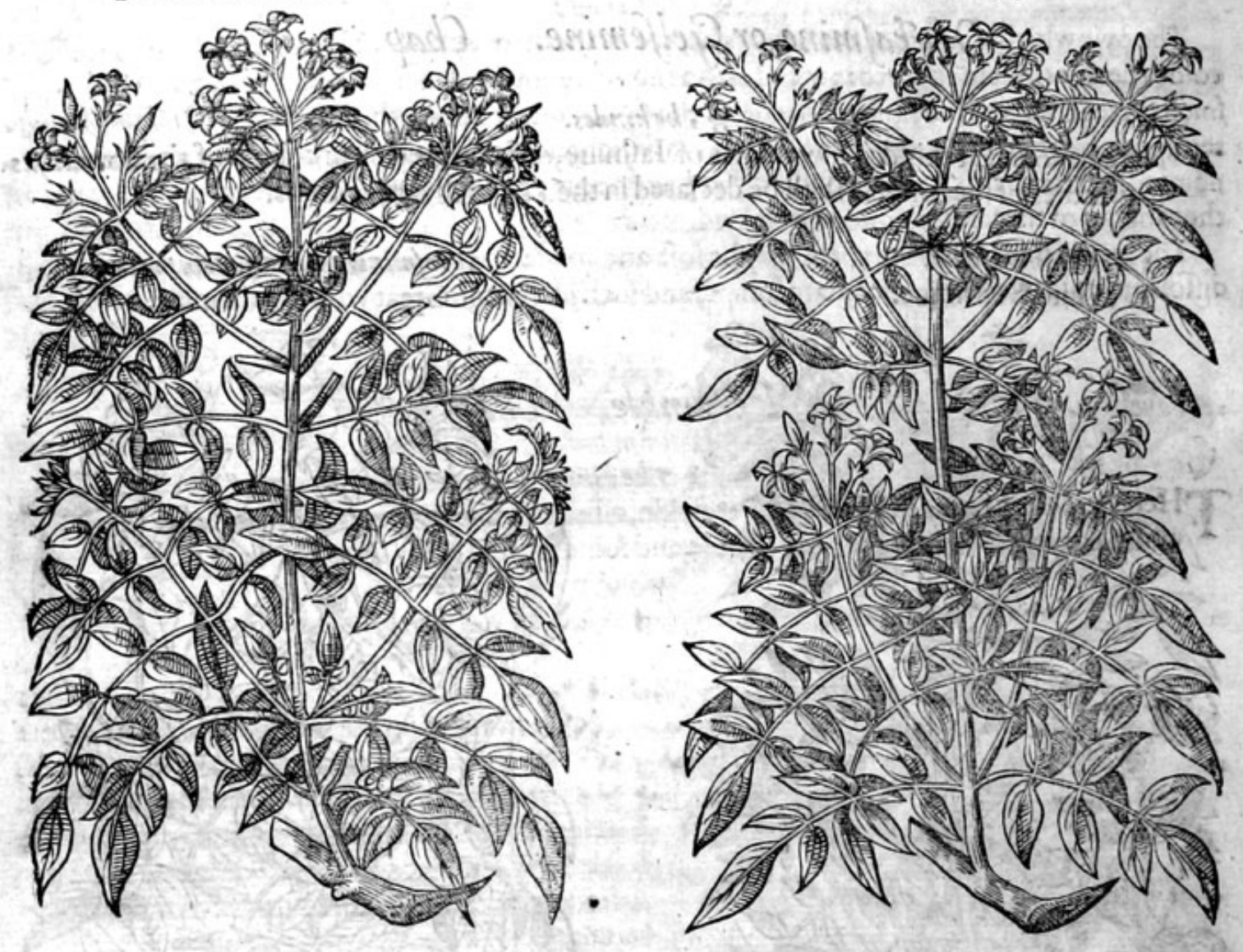

* The defcription.

3 There is a kinde heereof with yellow flowers : but fome do defcribe for the yellowe Iafmine, the fhrubbie Trefoile,called of fome Trifolium fruticans; and of others Polernonium: but this yellowe Iafmine is one, and that is another plant, differing from the kinds of Iafmine, as fhall be declared in his proper place. Theyellow Iafmine differeth not from the common white Gefmine, in leaues, ftalkes, nor fathion of the flowers; the onely difference is, that this plant bringeth foorth yellow flowers, and the other white.

4 There is likewife another fort that differeth not from the former in any refpeet, but in the colour of the flower; for this plant hath flowers of a blewe colour, and the others not fo, wherein confifteth the difference.

$$
\text { *The place. }
$$

Gelfemine is foftered in gardens, and is vfed for arbors, and to couer banquetting houfes in gardens: it groweth not wilde in England that I can vnderftande of, though mafter Lyse be of another opinion: the white Iafmine is common in moft places of Englande: the reft are ftangers and not feene in thefe parts as yet.

\section{* The time.}

They bring foorth their pleafant flowers in Iuly and Auguft.

$$
\text { * The names. }
$$

Among the Arabians, Serapio was the firft that named Geffemine, $z_{a m b a c h}$; it is called 10 fint- 
nom, and $\mathrm{le}^{\prime}$ emsinum, and alfo Geffeminkm: in Englifh Lafmine, Geffemine, and Ieffe.

There is in Diofcorides a compofition of oile of Iafmine, which he faith is made in Petfia of the white flowers of Violets, which Violets feeme to be none other then the flowers of this Geffeminei. for Diofsorides oftentimes hath taken one plant for another; fo that it muft not feeme ftrange that he calleth the flowers of Geffemine Violets, efpecially feeing that the plant it felfe was vnknowne vnto him, as it is euident.

\section{* The temperature.}

Geffemine, and efpecially the flowers thereof be hot in the beginning of the fecond degree, as: Serapio reporteth out of Mefue.

\section{* The vertues.}

Theoyle which is made of the flowers heerof, wafteth away rawe humours, and is good againft $\mathbf{A}$ colde rheumes, but in thofe that are of an hot conftitution, it caufech headach, and the ouermuch fmell thereof maketh the nofe to bleede,as the fame author affirmeth. It is vfed(as Diofcoridesswritech, and after him (1etims ) of the Perfians in their banquets forpleafure fake: it is good to be annointed on after baths, in thofe bodies that haue neede to be fuppled and warmed, but by reafon of
theranknes of the fmell, it is not much vfed.

The leaues boiled in wine vntill they be loft and made vp to the forme of a pultis, and applied, B diffolueth cold fwellings,wens, hard lumps, and fuch like outgoings.

\section{OfPeruinkle. Chap.j16.}

* The kindes.

There be diuers fortes or kindes of Peruinkle, whereof fome be greater, others leffer, fome with white flowers, others purple and double, and fonc of a faire blew skic colour.

1 Vincs Perwincs. Peruinkle.

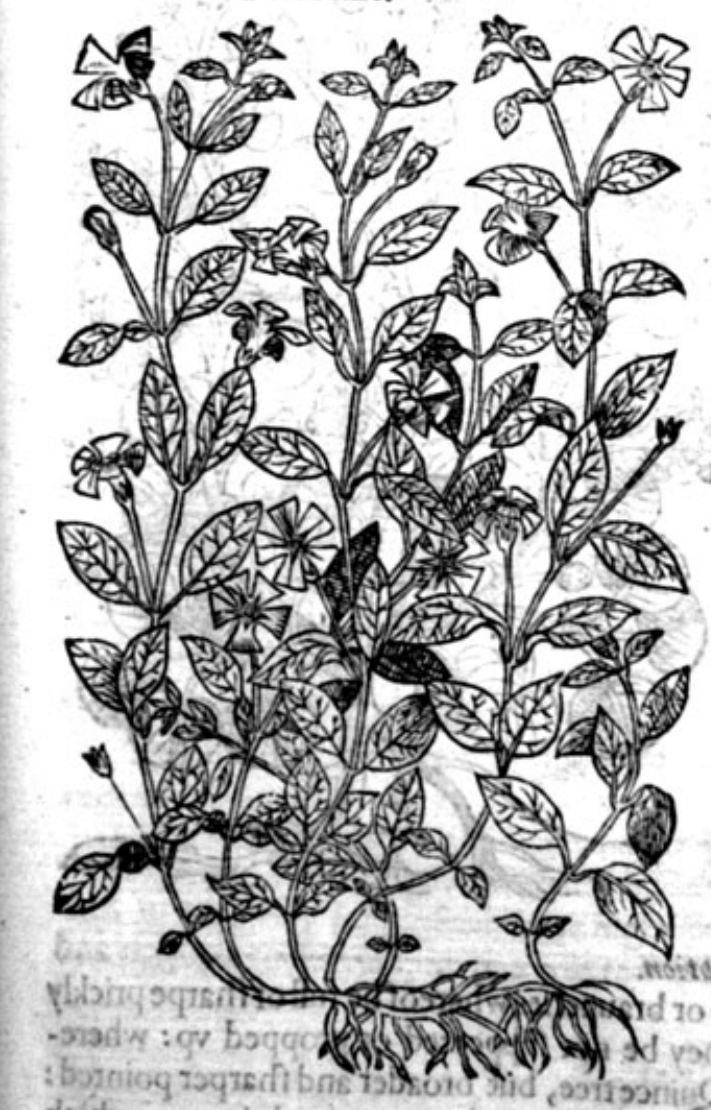

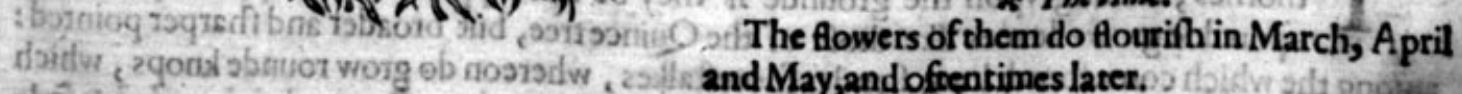
ob?
* The defcription.

1 Eruinkle hath flender and long branches trailing vpon the ground, taking holdhere and there as it runneth, fmall like to rufhes, with nakedor bare fpaces betweene ioint and ioint. The leaues are fmoothe, not vnilike to the Bay leafe but leffer. The flowers growe harde by the leaues, fpreading wide open, compoled of fiue finallblew leaues.

We haue in our London gardens a kinde hereof bearing white flowers, which maketh it to differ from the former.

There is another with purpleflowers, doubling it felfe fomewhat in the middle, with fmaller leaves, wherein is the difference.

There is another fort, greater than any of the reft, which is called of fome clematis Daphnoides, of the fimilitude the leaues baue with thofe of the Bay. The leaues and flowers are like vnto the precedent, but altogither greater 3 wherein confifteth the difference.

* Theplace.

They growe in moft of our London gardens; they lovea moift and fhadowie place: the branches remainealwaiks greene. * $T$ be 
$*$ The names.

Peruinkle is called in Greeke xas uatis dxevouidis, bicaufe it bringeth foorth ftalkes, which creepe like thofe of the Vine, and Daphnoides by reafon that the leaues are like thofe of the Bay, as aforefaide. Pliny calleth it Vinca Perwinca, and Cham adaphne : notwithitanding there is another Chamadaphne, of which in his place. The fame auchor likewife calleth it Centunculus: in high Dutch Ingrunt: in lowe Dutch Cincoozte, maegoen crupt: in French Pucellage, Vauche of Peruauche : in Italian Promence : in Spanifh Peruingua : in fhoppes Clematis peraincla : in Englifh Peruinkle, Pervinkle, and Periwinkle. * The temperature.

Peruinkle is fomething hot,but within the fecond degree, fomething drie and aftringent. $*$ The vertues.

A The leaues boiled in wine and drunken, ftoppech the laske and bloudie fixe.

B An handfull of the leaues ftamped and the iuice giuen to drinke in red wine, ftoppeth the laske and bloodie flixe, fpetting of blood, which neuer faileth in any bodie, either man or woman: it likewife ftoppeth the inordinate courfe of the monethly fickneffe.

\section{OfCapers. Chap. 317.}

* The kindes.

$T$ Here be two fortes of Capers efpecially, one with broad leaues fharpe pointed: the other with rounder leaues. The Brabanders haue alfo another fort, called Capparis fabago, orbeane Capers

1 Capparis folio acuto. Sharpeleafed Capers.

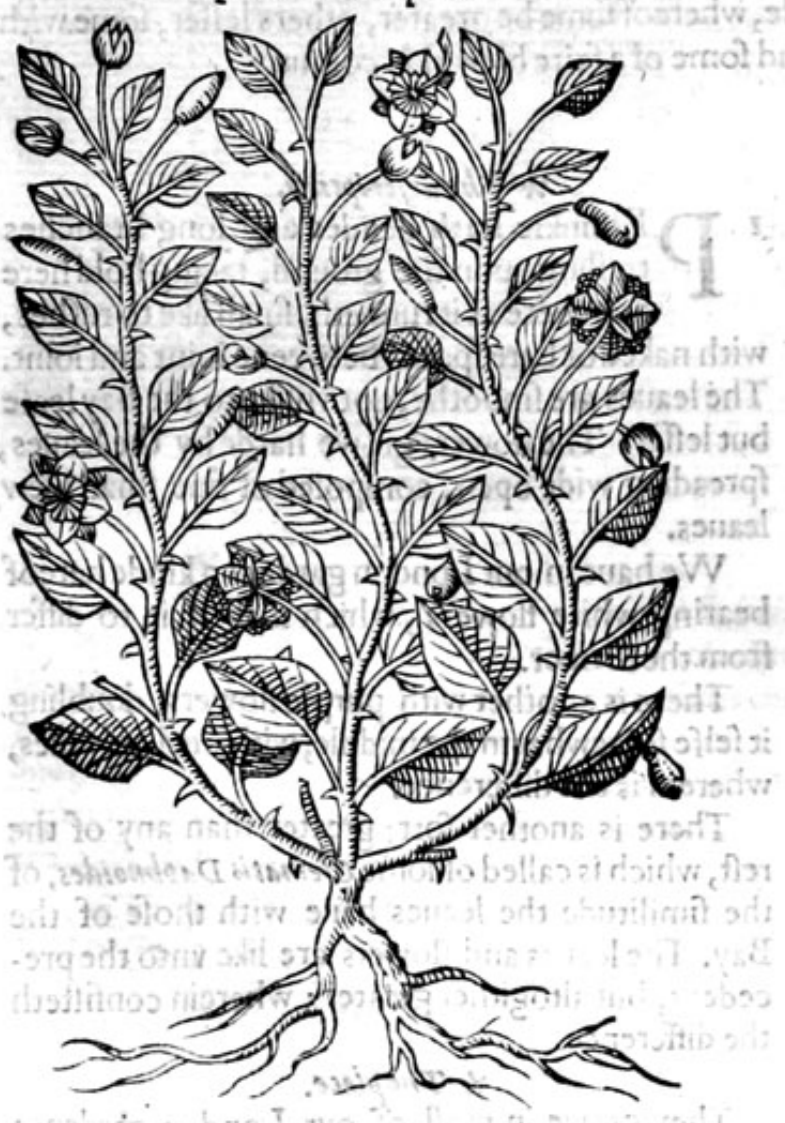

2 Capparis rotandiore folio. Round leafed Capers.

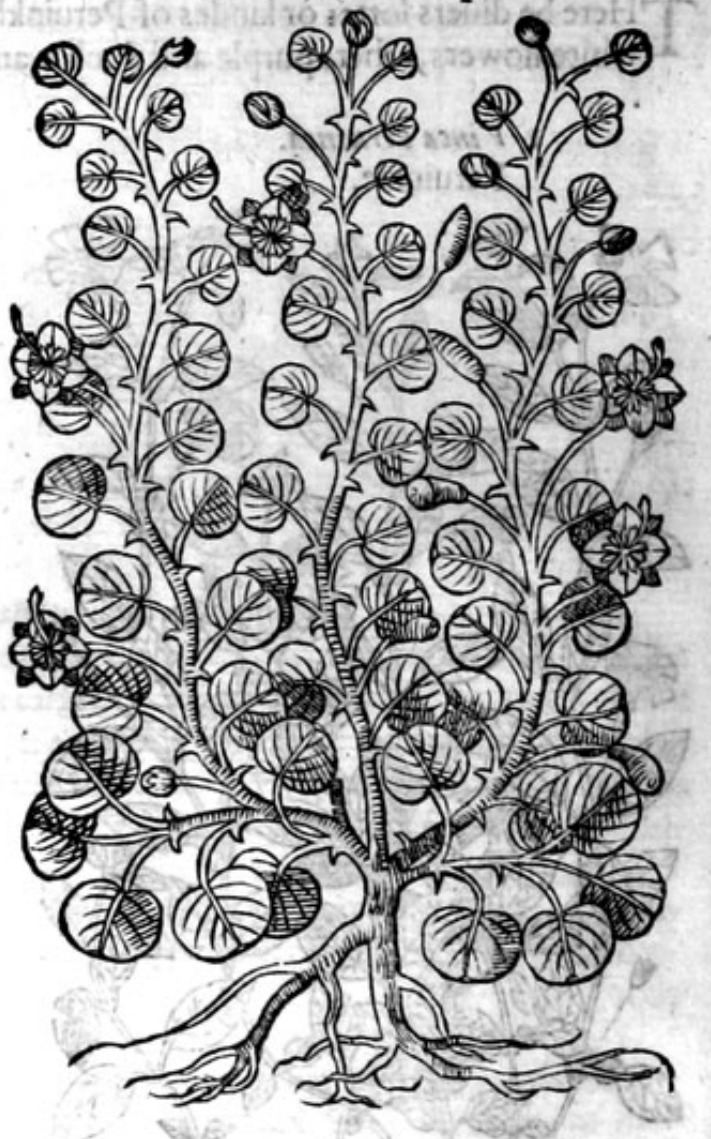

* The defoription.

$1-\mathrm{He}$ Caper is a prickly fhrubbe, the fhootes or braunches whereof be full of fharpeprickly thornes, trailing vpon the grounde if they be not fupported or propped vp: whereupon doe growe leaues like thofe of the Quince tree, but broader and fharper pointed: among the which come foorth long flender footeftalkes, whereon do grow rounde knops, which 
do open or fpead abroad into faire flowers, after which commeth in place long fruite, like to an oliue, and of the fame colour, wherin is conteined flat rough feedes, of a duftie colour. The roote is woody and conered with a thicke barke or rinde, which is much vfed in Phificke.

2 The fecond kinde of Caper is likewife a prickly plant, much like the Bramble bufh, hauing many flender branches fet full of tharpe prickles. The whole plant traileth vpon the place where it groweth, befet with round blackifh leaues diforderly placed, in fhape like thofe of Aftrabacca, but greater, approching to the forme of Folefoote : among which commeth foorth 2 fmall and tender naked twigge, charged at the end with a fnall knap or bud, which openeth it felfe to 2 fmall ftarrelike flower, of a pleafant fweete finell, in place whereof comes a fmall fruite, long and rounde like the Comell berry, of a browne colour. The roote is long and woody, and couered with a thicke barke or rinde, which is likewife vied in medicine.

The Caper groweth in Italy, Spaine, and other hot regions without manuring, in a leane foile,
The in rough places among rubbih, and vpon old wals, as Diofcorides reporteth.

Theoplir aftes ivriteth, that it is by nartire wilde, and refufeth to be husbanded, yet in thefe our dieies ditiers vfe to cherifh the fame, and to fer it in dry and ftony places: my felfe at the impreffion heereof,planted fome feedes in the bricke wals of my garden, which as yet doe fpring and growe greene, the fucceffe I expect.

\section{$*$ The time.}

The Caper flowreth in fommer, euen vntill Autumne. The knops of the flowersbefore they open, are thofe Capers or fauce that we eate, which are gathered and preferued in pickle or falt.

* T The names.

It is called in Grecke nar meers : and in Latine alfo Capparis : but properly Cynosbatos, or Canirubus, which is alfo taken for the wilde Rofe; it is generally called Cappers, in moft languages: in Englifh Cappers, Caper, and Capers.

\section{* Thetemperature.}

Capers, or the flowers not yet fully gtowen, be of temperature hot and of thinne parts; if they be eaten greene, they yeeld very little nourifhment, and much leffe if they be falted. And therfore they be rather a fauce and medicine, then a meate.

\section{$*$ The vertues.}

They flitre vp an appetite to meate; theybe good for a moift stomack, and itaicth the rvatering A thereof,and clenfeth ay ay the flegme that cleauerh vnto it. They open theftoppings of the liuer and mile, with meatexhey are good to be taken of thofe that haue a quartaine agew, and ill fpleenes. They are eaten boiled, (the falt firft wafhed off, ) wittf oile and vineger, as other fallads be, and fomtimes arc 8 olled witlinicate.

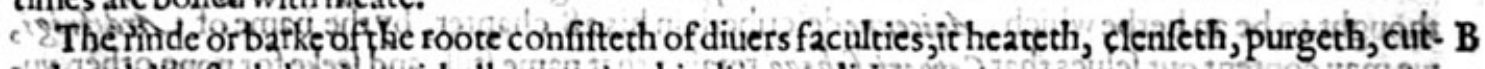
teth and affefteth, liaung withall a certaine binding qualitie.

This batke is a fingnilar remedie for tiard fpleenes, being outwardly applied, and alfo in wardly $\mathbf{C}$ taken, and the fame boiled in vineger or oxymel, orbeing beaten and mixed with other fimples: for afterthis maher it expellettr thicke and groffehumburs, and conucieth away the fimetintxed with bloud,by vrine and alfo by fiege, whereby the milt or fpleene is helped, and the paine of the huckle bonestaken away: moreouer it bringeth downe the defired ficknes, purgeth and draweth

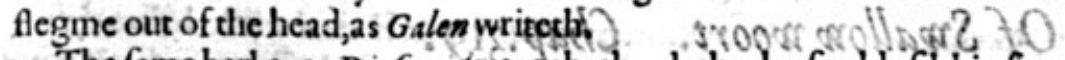

The fame barke, as Diofcorides teacheth, doth clenfe olde filthie fores, and fcoureth away the D thicke lips and crufts about the edges, and being gbewed it taketh away the toothach.

Being ftamped with vineger, it fcoureth away tetters or Ringwoormes, hard fwellings, and cu- E

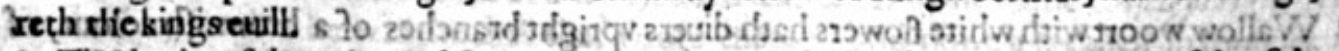
- boTlie barkeof thiorodtes of Capersis goodagainft the hardnes and ftopping of the Iplecpe, and $\mathbf{F}$

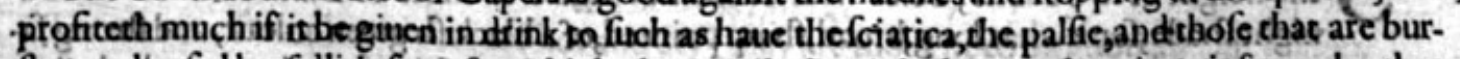
ften onbrufed by falling from fome high place it doth mightilyprouoke vxine, infomuch, that

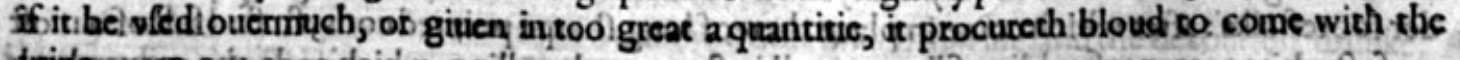

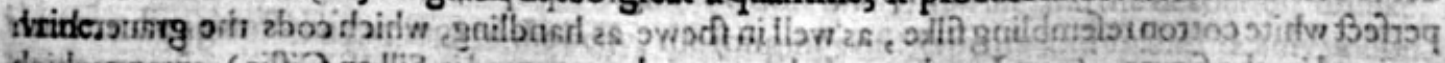

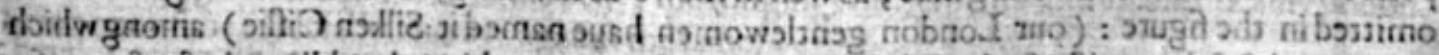

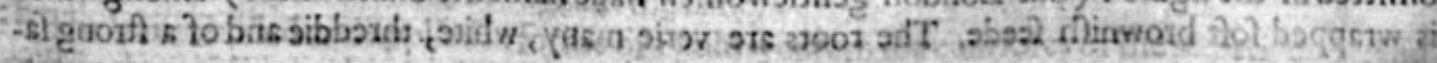




\section{Of Beane Capers. Chap.318.}

Catparis fabago.

Beane Capers.

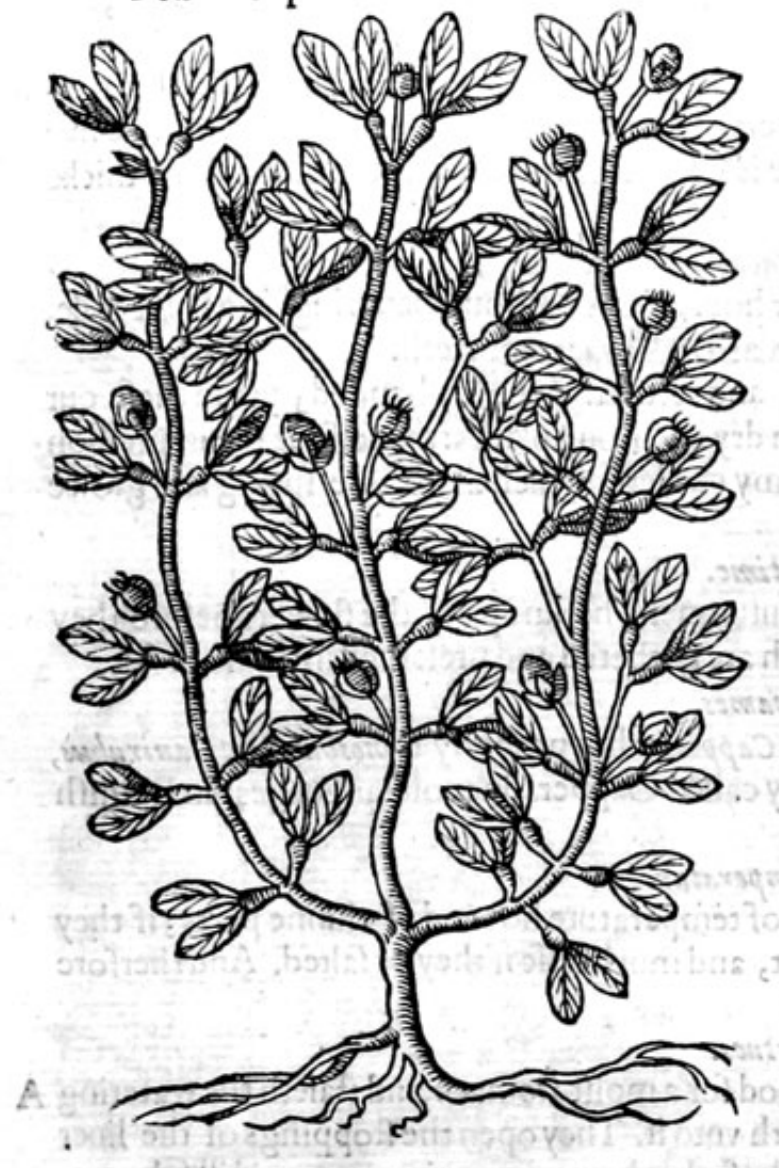

* The defcription.

7 His plant which the Germaines call fo. bagso, and Dodowess fauoring of Dutch, calleth it in his laft Edition Capparis $F_{a} b_{a-}$ go, and properly: L'Obelises calleth it Capparis Legumino/a: betweene which there is no great difference, who labour to referre this plant vnto the kinds of Capers, which is but a lowe \& bafe herbe, and not 2 fhrubbie bufh, as are the true Capers. It bringeth foorth fmooth ftalkes, tender and branched, whercupon doe growe long thick leaues, leffer than thofe of the true $\mathrm{C}_{\text {apers, }}$ \& not vnlike to the leaues of Purflane,comming out of the branches by couples, of a light greene colour. The flowers before they be opened are like to thofe of the precedent, but when they are come to maturitie and full ripeneffe, they waxe white, with fome yellowe chives in the middeft, which being paft, there appeere long coddes, wherein is contained fmall flat feede. The roote is tender, branching hither and thither. t The place.

It groweth of it felfe in the corne fieldes of the lowe countries, from whence I haue receiued feeds for my garden, where they flourifh. * The time.

It flowreth when the Caper doth.

* The names.

It is called in Latine of the later Herbarifts Capparis fabago, of moft Capparis Legmaminofa : it is thought to be an herbe which Anicenne defcribeth in his 28 . chapter, by the name of Uirdifrigi, we may content our felues that Capparis fabago retaine that name ftill, and feeke for none other, vuleffe it be for an Englifh name, by which it may be called after the Latine, Beane Caper.

$$
\text { * The temperature and vertues. }
$$

Touching the faculties thereof we haue nothing left in writing woorth the remembrance.

\section{Of Swallow woort. Cbap.319.}

\section{* The defcription.} Wallow woort with white flowers hath diuers vpright branches of a brownifh colour, of the height of two cubits, befet with leaues not vnlike to thofe of Dulcamara or Woodnight thade, fomewhat long, broad, fharp pointed, of a blackifh green colour, and ftrong fauor: among which come forth very many fmall white flowers ftarfathion, hanging vpon little llender footeftalks : after which come in place thereof long fharpe pointed cods; ftuffed full of a moft perfect white cotton refembling filke, as well in fhewe as handling, which cods the grauer hath omitted in the figure : (our London gentlewomen haue named it Silken Ciflie) among which is wrapped foft brownifh feede. The roots are verie many, white, threddie and of a ftrong faiюur. 
2 The fecond kinde is oftentimes founde with ftalkes much longer, climing vpon props or fuch things as ftande neere vntoit, attaining to the height of fue or fixe cubits, wrapping it felfe vpon them with many and fundry foldings : the flowers heereof are blacke : the leaues, cods, and rootes, be like thofe of the former.
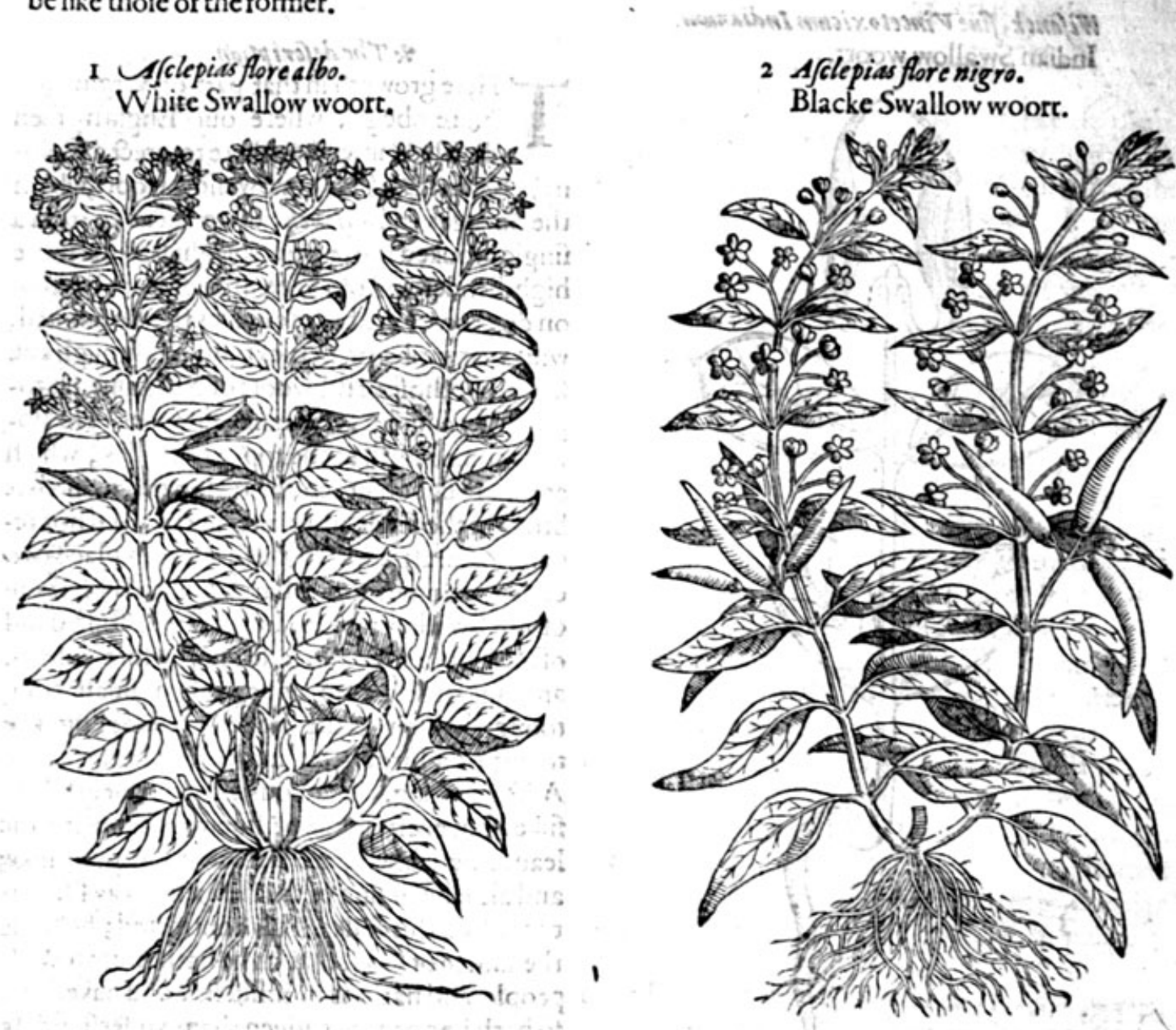

* The place.

Both thefe kinds do growe in my garden, but not wilde in England; yet haue theard it reported, that it groweth in the fieldes about Northampton, but as yet I am not certaine of it. * The time.

They flower about Iunc, in Autumne the downe hangeth out of the cods, 2 ad the feede falleth to the ground.

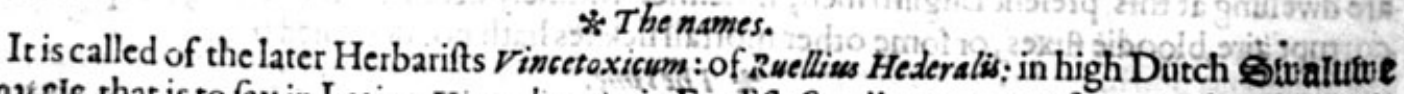
wotele, that is to fay in Latine Hirundinaria; in Englifh Swallow woort, of our gentlewomen it is called Silken Cillie; AE/culapin (who is faide to be the firft inuenter of Phificke, whom therefore the Greekes and Gentiles honored as a God)called it after his owne name 1 /clepias, or $A E /$ culspius herbe, for that be was the firft that wrote thereof, and nowe itis called in hoppes Hirwndivaria. * The temperisture.

The rootes of Swallow woort are hot and dry; they are thought to begood ag inft poifon.

Diogcorides writeth, that the rootes of Swallow woort boiled in wine, and the decoction drunke, A is a remedie againt the gripings of the belly, theftingings of Serpents andagainft deadly poifon, being one of the efpecialleft herbes againft the fame

The leaues boiled and applied in forme of a pultis, cureth the cuill fores of the paps or duggs, and B matrix, that are hard to be cured. 


\section{Of Fndian Swallow woort. Cbap.320.}

Wifanck, fune Vincetoxicum Indianum. Indian Swallow woort.

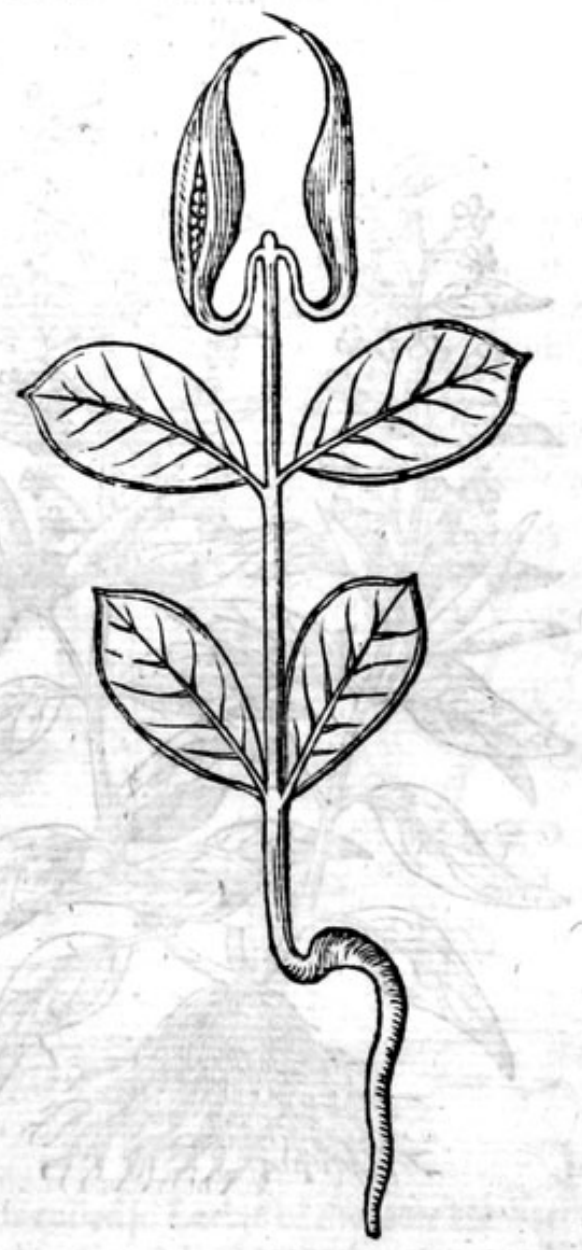

\section{$*$ The defcription.}

7 Here groweth in that part of Virginia,or Noreinbega, where our Englith men dwelled (intending there to ereet a Colony)a kind of Afclepias, or Swallow woort, which the Sauages call Wifenck: there rifeth vp from 2 fingle crooked roote one vpright ftalke a foote high, llender, and of a greenifh colour:whereupon do growe faire broade leaues fharpe pointed, with many ribs or nerues running through the fame, like thofe of Ribwoort or Plantaine, fet togither by couples at certaine diftances. The flowers come foorth at the top cfthe ftalks, which as yet are not oblerued, by reafon the man that brought the feeds and plants heereof did not regard them: after which, there come in place two cods (feldome more) fharpe pointed like thofe of our Swallow woort, but greater, ftuffed full of moft pure filke, of a fhining white colour: among which filke appeereth a fnill long toong (which is the feede) refembling the toong of a birde, or that of the herbe called Adders toong. The cods are not onely full of filke, but euery nerue or finewe wherewith the leaues be ribbed, are likewife moft pure filkc; and alfo the pilling of the ftems, euen as Flaxe is torne from his ftalks. This confidered; beholde the iuftice of God, that as he hath fhut vp thole people and nations in infidelitic and nakednes; fo hath he not as yet giuen them vnderftanding to couer their nakednes, nor matter wherewith

to do the fame;notwithftanding the earth is couered ouer with this filke, which daily they tread vnder their feete, which werefufficient to apparell many kingdomes if they were carefully manured, and cherifhed. * The place.

It groweth, as before is rehearfed, in the countries of Norembega, and now called Virginia by the H.fir Walter Raleigh, who hath beftowed great furmmes of monie in the difcouerie therof, where are dwelling at this prefent Englíh men, if neither vntimely death by murdering, or peftilence, corrupt aire, bloodie flixes, or fome other mortall ficknes hath not deftroied them.

\section{* Thetime.}

It fpringeth vp, flowreth, and flourifheth both winter and fommer, as do many, or moft of the plants of that countrie.

\section{* The names.,}

The filke is vfed of the people of Pomeioc, and other of the prouinces adioining (being parts of Virginia ) to couer the fecret parts of maidens that neuer tafted man, as in other places they vfea white kinde of moffe Wifanck : we hauc thought Afclepias Virginiana, or $V$ incetoxicum Indienem, fit and proper names for it : in Englifh Virginia Swallow woort,or the filke woort of Norembega. * it he nature and vertues.

A We finde nothing by report or otherwaies of our owne knowledge, of his phificall vertues, bue onely report of the abundance of moft pure filke, wherewith the whole plant is poffeffed. 
Gosipium fue Xylon.

The Cotton buih.

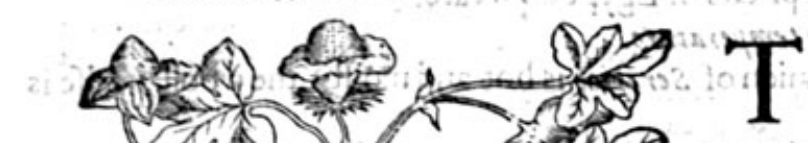

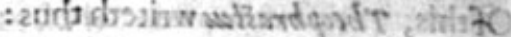

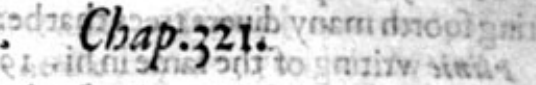

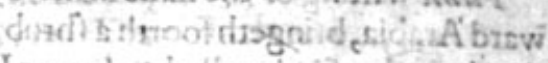

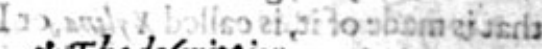
* Thesefcription sil diworiorio

He Cotton bufh is a lowe and bafe plant, haung fniall italkes of a cubite hight, and fometimes a little higher; dituided from the loweft part to the top into fundrie fmall branches, whereuponare fefconfufedly bo without order, a A fearbroadlealies, curtfot the moft part intorditeet fections, and fonetintes more, as nature fint to be- 8 ftow, fomwhat inderted about the edges, not yn- $O$

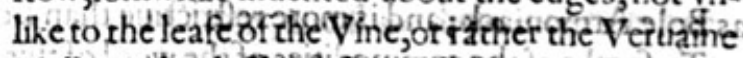
Mallowe, bot Icteet, fofter and of a grayifh colour:

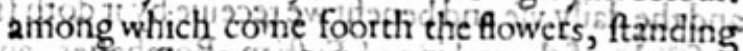
vpon'flerder footeftalkes, the brimnies or etges where of are of 2 yellow co'our, the middle partpurpie : after which appeereth the fruit, round, and of the bignefle of a Terinife ball, wherein is thruft to. gither a great quantity of fine white Cotton wool; among which is wrapped vp blacke feede of the bignefle of Peafow; in fhape like the cretules or dung of a conie. The fruit being come to maturitic or ripeneffe, the huske or codopeneth it felfe into fower partes or diuifions, and cafteth foorth his - wooll and feeda vpon the gtound, if it be nor gathered in his rime and feafon. The roote is fmall and fingle, with ew threds annexed thereto, and of a woodie fubftance, as is all the reft of the plani.

* The place.

It groweth in India, in Arabia, Aegypt, \& in certaine Ilands of the Mediterranean fea, as Cyptus, Candia,Melita,Sicilia, and in other prouinces of the continent adiacent. It groweth about Iripolis,and Alepo in Syria, from whencethe Factor of a worhipfull merchant in London, Mafter $\mathrm{Ni}$ cholas Lete before remembred, did fend vnto his faid Mafter diuers pounds weight of the feecte, wherof fome were committed to the earth at the impreffion hereof: the fincceffe we leaue to the Lord. Notwithiftanding my felfe three yeeres paft did fowe of the feedes, which did grow very frankly, but perifhedbefore it came to perfection, by reafon of the coldefroftes that ouertooke it in the time of flowring. * The time.

Cotton feede is fowen in the plowed fields in the fpring of the yeere, and reaped or cut downe in haruett, eyen as corne with vs, and the ground muft be tilled and fowen new againe the next yeere, and $v$ fed in fuch fort as we do the tillage for corne and graine: for it is a plant of one yeere,and perifheth when it hath perfected his fruit,as many other plants do.

\section{* The names.}

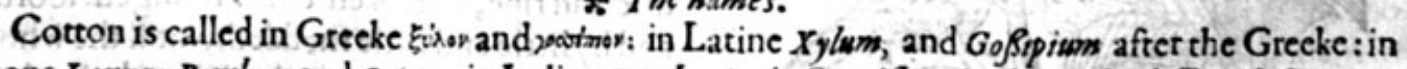
fhops Linugo,Bombax, and Cotum: in Italian Bombagis : in Spanifh Algodon : in high Dutch 23 atum: wool: in Englifh and French Cotton, Bombafte, or Bombace.

Theophrastus hath made mention hereof in his fourth booke 9 . chapter, but without a name; and be faith it is a tree in Tylus which beareth wooll: neither is it any maruell if he tooke an vnknowen thrub or plant, and that groweth in countries far off, for a tree; feeing alfo in this age, in which very many things come to be better knowen than in times paft, the Cotton or wooll heereof is called of the Germanes, as we haue faid 23 aumumpll, that is, wooll of a tree : Whereas in truth it is rathera fmall hrub(and not to be numbred among herbes.) 


\section{THE SECOND BOOKE OF THE}

Of this, Theophrestus writeth thus: It is reported, that the fame Ilande, that is to fay $T$ ilus, doth bring foorth many diuers trees that beare wooll, whereof fome haue leaues like thofe of the Vine.

Flinie writing of the fame in his 19. booke chapter 1 . faith thus; The vpper part of Aegypt toward Arabia, bringeth foorth a fhrub, which is called Go Sapion and $X y l o n$, and therefore the linnen that is made of it, is called $X y$ lina, or Linfie woolfic. It is faithhe, the plant that beareth that wooll, wherewith the garments are made, which the prielts of Egypt do weare.

\section{* The temperatsere.}

The feede of Cotton 2 according to the opinion of Serapio, is hot and moift : the wooll it felfe is hot and drie.

\section{$*$ Thevertwes.}

A The feede of Cotton is good againt the cough, and for them that are fhort winded, italfo ftirreth vp luft of the body, by increafing naturall feede, wherefore it furpaffeth.

B The oile preffed out of the feede, taketh away freckles, fpots, and other blemines of the skin.

C - The afhes of the wooll burned, ftancheth the bleeding of wounds, vfed in reftrictiue medicines as Bole Armoniack; and is more refrietiue than Bole it felfe.

D To fpeake of the commodities of the wool of this plant it werefuperfluous, Common experience and the daily vfe and benefit we receiue by it doth hew. So that it were impertinent to our hiftory, to fpeake of the making of Fuftian, Bombafies, and many other things that are made of the wooll thereof.

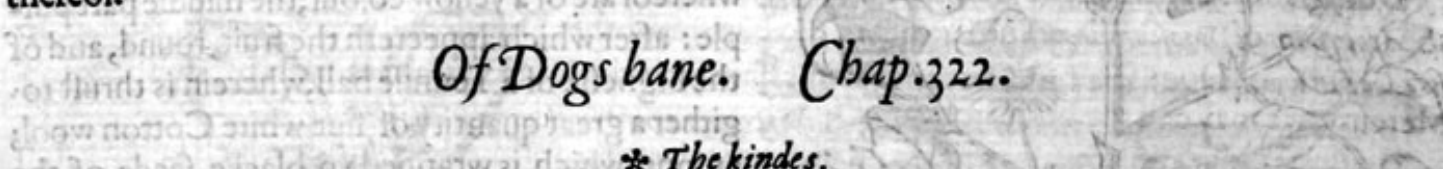

There be two Dogs banes : the one a climing or clambering plant; the other an vpright fhrub.:
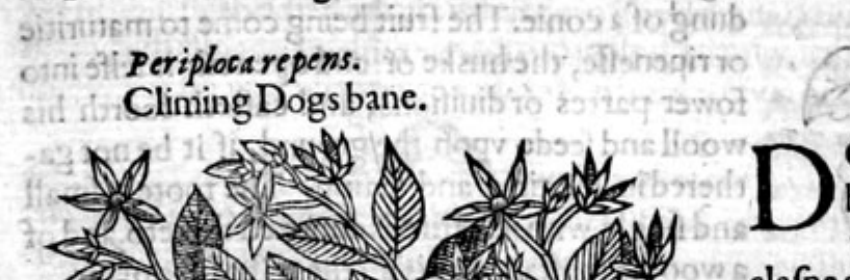

\section{* The defaription.}

Ogsbane rifeth vp like vnto a fmall hedge bufh, vpright and ftraight, vntill it haue attained to a certaine height; then doth it clafpe and clime with his tender branches as do the Bindweeds, taking hold vpon props or poles, or whatfoever ftandeth next vnto it: whereupon do growe faire broad leaues tharpe pointed like thofe of the Bay tree, of a deep green colour. The flowers come foorth at the top of the ftalks, confifting of fiue fmall white leaues, which being paft, there fucceede long coddes fet ypon a flender footeftalke by couples, ioyning themfelues togither at the extreme point, and likewife at the Italke, making of two peeces knit togither one entire cod; which cod is ful of fuch downie matter \& feed as that of $A$ fclepias, but more in quantitic by reafon the cods are greater, which being drie and ripe, the filken cotton hangeth foorth, and by little and little fheddeth, vneill the whole be fallen vpon the grounde. The whole plant yeeldeth that yellowe ftincking milkie iuice that the other doth,and fometimes it is of a white co. lour, according to the climate where it groweth; for the more colde the countrey is, the whiter is the iuice, and the nore hot, the yellower. The roote is long and fingle, with fome threds annexed thereto. 


\section{HISTORIE OF PLANTS.}

There is another Dogs bane, that hath long \& flender ftalks likethofe of the Vine, bur of a brown reddifh colour, wherwith it windeth it felfe about fuch things as ftande neere vnto it, in maner of 2 Bindweede: wherupon are fet leaues not vnlike to thofe of the Iuie, but not fo much cornered, of $\mathbf{a}$ darke greene colour, and of 2 ranke fmell being brufed betweene the fingers, yeelding foorth a ftinking yellowe milkie iuice when it is fo broken : among which come foorth little white flowers, ftanding fcatteringly vpon little husks:after the flowers come long codş,very like vnto Asclepias, or Swallow woort, but greater, ftuffed with the like foft downie filke, among which downe is wrapped vp flat blacke feede. I he rootes are many and threddie, creeping all about within the grounde, budding foorth newe fhootes in fundry places, whereby it greatly increafeth.

$$
* \text { The place. }
$$

They do grow naturally in Syria, and alfo in Italy as Matbiolus reporteth: my louing friend Iobn Robin Herbarift in Paris, did fende me plants of both the kindes for my garden, where they flower and flotrifh; but whether they do grow in Fraunce, or that he procured them from fome other region, as yet I haue no certaine knowledge.

\section{* 7 be time.}

They begin to bud foorth their leaues in the beginning of Maie, and fhew their fowers in September.

\section{* I he names.}

Dogsbane is called by the learned of our age Periplose: it is euident that they are to be referred to Apocynum of Dio/corides. The former of the two hathbeen likewife named xuroxeduen, and Braf fica Caniss, or Dogs Cole : notwithftanding there is another Dogs cole, which is a kinde of wilde Mercury:we may call the firft Creeping Dogs bane, and the other vpright-or Syrian Dogs bane.

$$
\text { * The temperature. }
$$

Thefe plants are of the nature of that peftilent and poifonfull herbe $T$ hora, which being eaten of dogs, or any other liuing creature, doth certainly kill them, except there be in readines an Anti. dote, or preferuatiue againft poifon and giuen, which by all probabilitie is the herbe deferibed in the former chapter, called $V$ incetoxicum, euen as Anthora is the Antidose or remedie againft the poifon of $T$ bora, and Herba Paris againit Pardalia nebes.

\section{* The vertues.}

Dogs bane is a deadly and dangerous plant, efpecially to fower footed beafts, for as Diogcorides writeth, the leaues heereof being mixed with bread and giuen, killeth dogs, woolues, foxes and leopards, the vie of their legs and huckle bones being prefently taken from them, and death it felfe followeth incontinent, and therefore not to be vfed in medicine.

\section{Of Salomons Seale. Chap.323.}

* The kindes.

$T$ Here be diuers fortes of Salomon his feale, differing in leaues and fruit very notably, but in rootes there is fmall difference.

\section{* The defcription.}

$x$ Hefirft kinde of Salomons feale hath long round ftalkes, fet for the moft part with long leaues, fomewhat furrowed and ribbed, not much vnlike Plantaine, but narrower, which for the moft part ftand all vpon one fide of the ftalke, and hath fmall white flowers refenbling the flowers of Lillic Conuall : on the other fide when the flowers be vaded,there come foorth round berries, which at the firft are greene, and of a blacke colour tending to blewneffe; and when they be ripe, be of the bignefle of luie berries, of an exceeding fweete and pleafant tafte. The roote is white and thicke, full of knobs or ioints, which in fome places refemble the marke of a feale, wherof I thinke it tooke the name Sigillum Salomonis, and is fweete at the firft, but afterwarde of a bitter tafte, with fome rharpneffe.

2 The fecond kinde of Polygomatum doth not much varie from the former, fauing in the leaues. which be narrower, and growe round about the ftalke like a fpur, in fafhion like vnto Woodroofe, or red Madder; among the leaues come foorth flowers like the former, but of a greener white colour : which being paft, there fucceede berries like the former, but of a reddifh colour. The rootes are thick and knobbie like the former, with fome fibres annexed chereto. 
THE SECOND BOOKE OF THE

I Polygonation.

Salomons Seale.

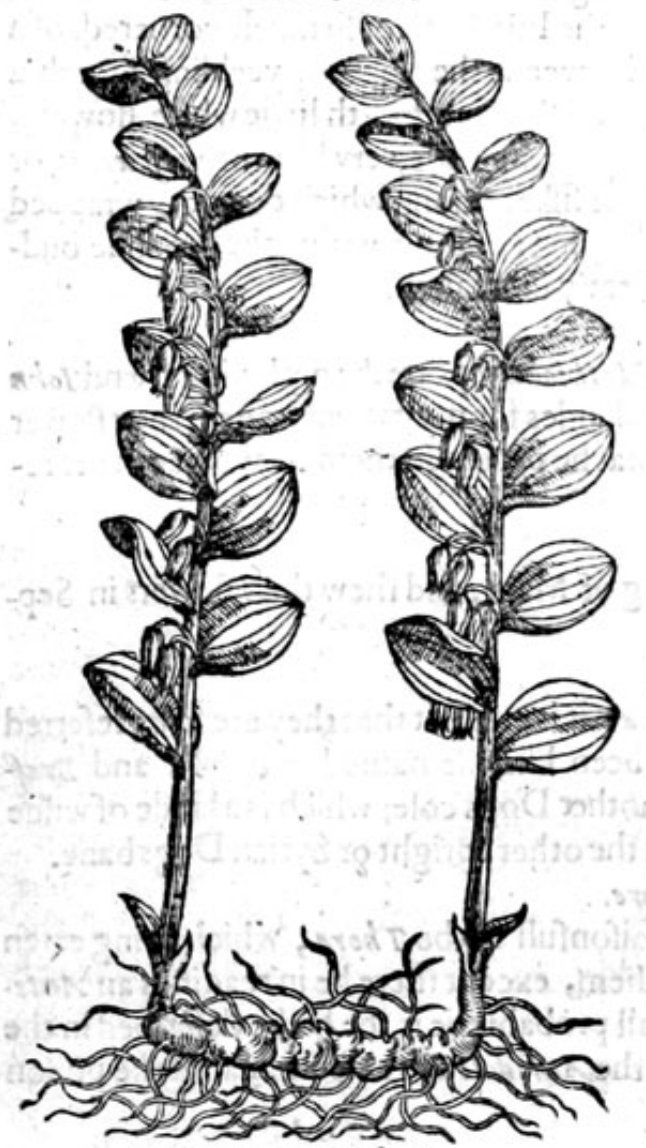

3 Polygonatum I.Clusy.

Sweetefmelling Salomons Séale.

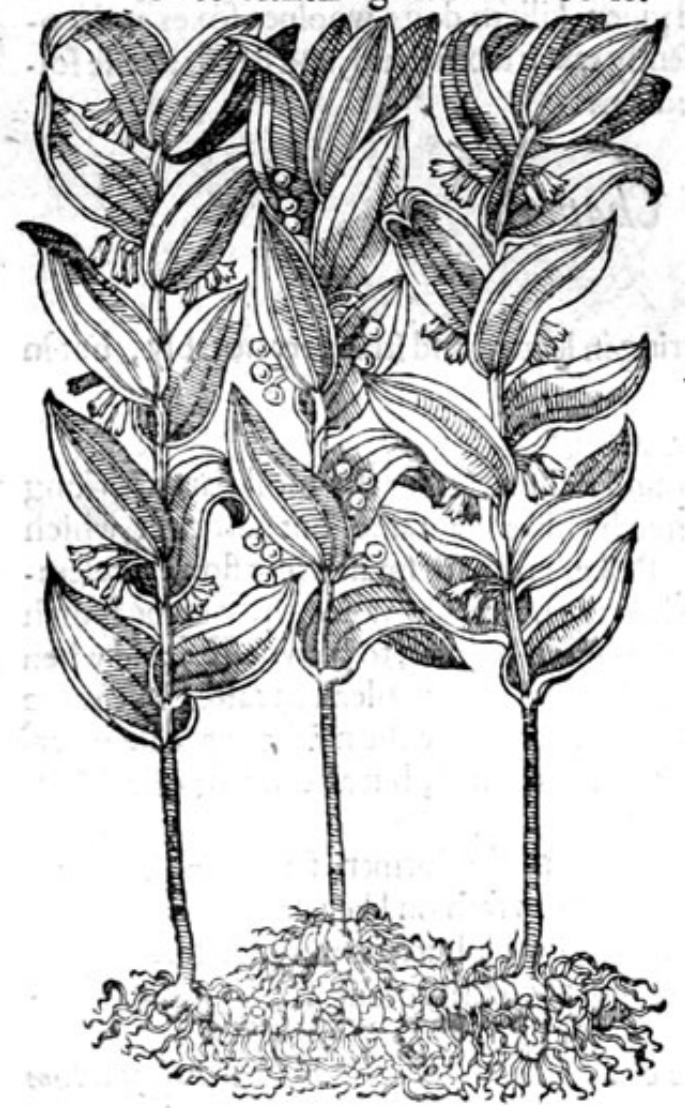

2 Polygonation miniw. Small Salomons Seale.
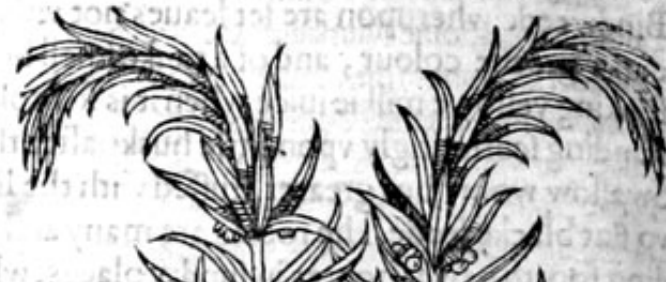
ov $\Rightarrow$
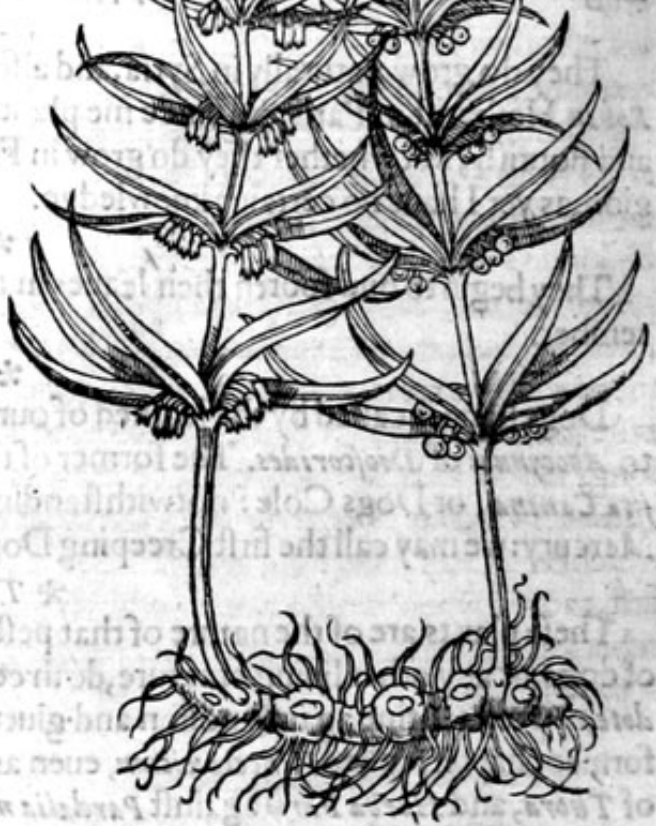

4 Polygonatum ramofum.

Branched Salomons Seale.

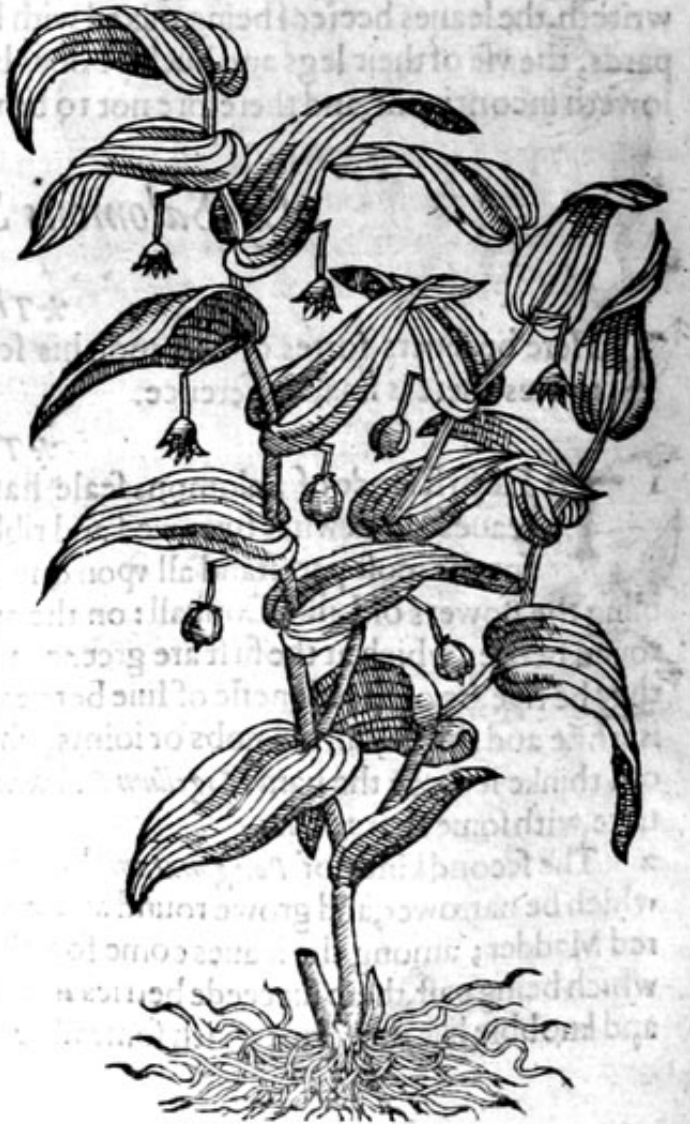




\section{HISTORIE OF PLANTS.}

* The defcription.

3 Thethird kinde of Salomons feale, which Carolus Cluffus founde in the woodie mointaines of Leitenberg,aboue Manderftorf, and many other mount ains beyond the rituer Danubius, efpecially among the ftones: he fent to London vnto Mafter Garth a worfhipfull Gentleman, and one that greatiy delighteth in ftrange plants, who very louingly imparted the fame vnto me. This plant hath ftalkes very like vnto the common Salomon his feale, a foote high, befet with leaues vpon one fide of the ftalke, like the firft and common kinde, but larger and more approching to the bigneffe of thebroad leafed Plantaine, the tafte whereof is not very pleafant : from the bofome of whichleaues come foorth finall well fmelling greenifh white flowers, not much vnlike the firft; which being paft, there follow feedes or berries, that are at the firft greene, but afterward blacke; containing within the fame berries a fmall feed, as big as a Vetch, and as harde as a ftone. The rootes are like vnto the other of his kinde, yet not fo thicke as the firft.

4 The fourth kinde according to my account, but the third of clufius (which he found alfo in the mountaines aforefaid) groweth a foote high, but feldome a cubite, differing from all the others of his kinde: for his ftalkes diuide themfelues into fundric other branches, which are garnifhed with goodly leaues, larger and fharper pointed than any of the reft, which do imbrace the ftalkes about, after the manner of Perfoliats or Thorow waxe, yet very like vnto the kindes of Salomons Seale in fhew, faue that they are fomewhat hoarie underneath the leaues, which are fweete at the firf, in tafte fomewhat faltifh towards the latter end. From the backe part of the leaues fhoote foorth fmall, long, tender and crooked ftems, bearing at the ende little gaping white flowers, not much vnlike Lilium conutllism, fauouring like Hawthorne flowers, fpotted on the inner fide with blacke fpots; which being paft, there come foorth berries like the narrow leafed Salomons feale; greene at the firft, and red when they be ripe, containing many white hard graines. The rootes differ from all the other kindes, and are like vnto the crambling rootes of 7 haliatrum, which the grauer hath omitted in the picture.

\section{Polygonstum acatuon Clus ÿ.} Sharpe pointed Salomons Seale.

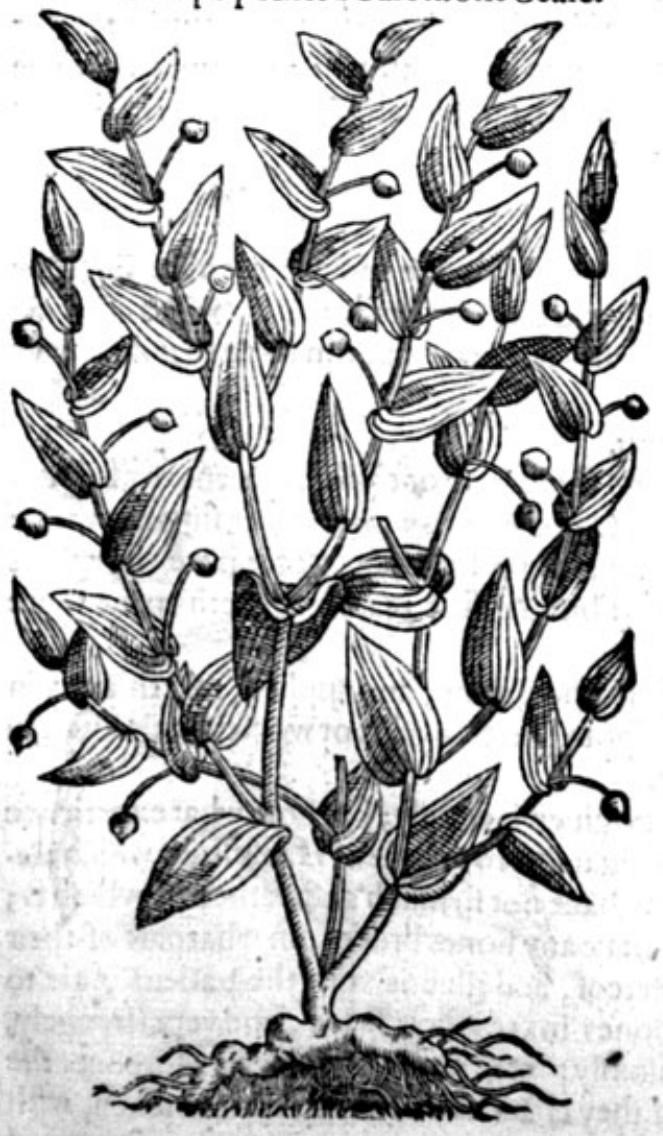

6 Polygonatum angustifolivem. Narrow leafed Salomons Seale.

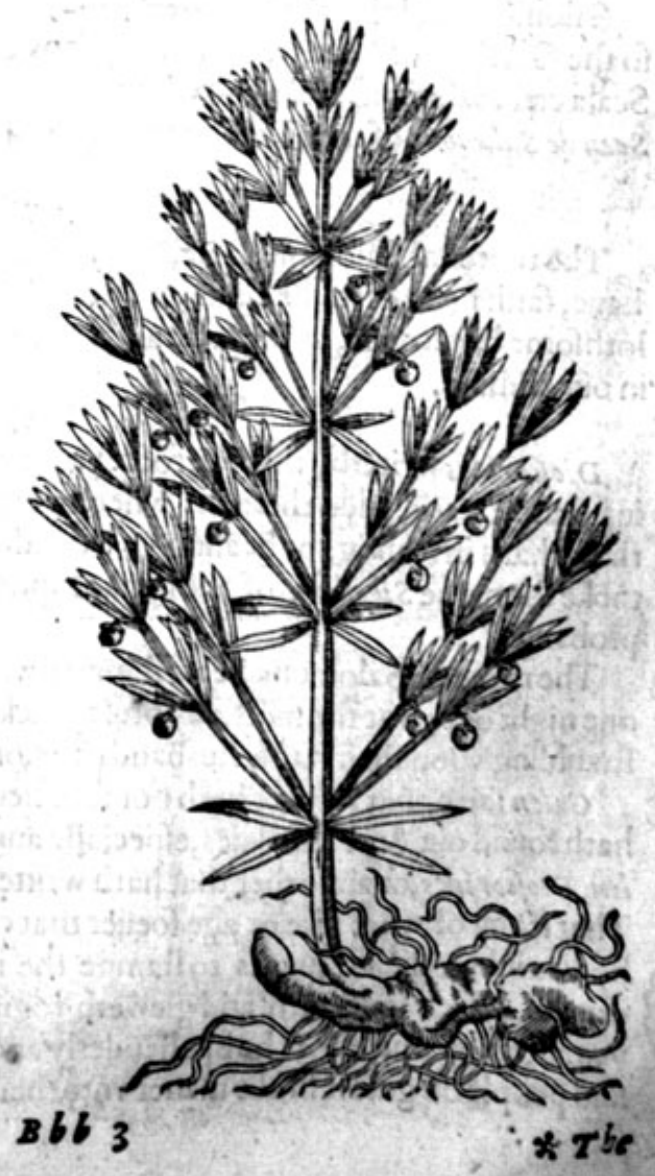




\author{
* The defcription.
}

5 The fift kinde of Salomons feale hath a thicke knobbed roote, voide of fuch markes as the firft kinde hath, white both without and within, and of a fweete tafte; from which rifeth vp diuers ftalks, which diuide themfelttes into fundrie branches; whereupon are fet at certaine ioints or knees one fingle broad leafe, with certaine nerues or finewes running thorough the fame like Ribwoort, very finoothe and hining; from the bofome of which leaues commeth foorth a flender footeftalke, whereon doth growe little foolifh idle flowers of fmall moment, which turne into red berries when they be ripe.

6 This rare fort of Salomons feale rifeth vp from his tuberous or knobbie roote, with a ftraight vpright ftalke, iointed at certaine diftances, leauing betweene each ioint a bare or naked fțalke, fmoothe and of a greeni?h colour tending to yellowneffe : from the which iointes, thruft foorth diuers fmall branches, with fower narrow leaues fet about like a ftar, or the herbe Woodroofe:vpon which tender branches are fet about the ftalkes by certainefpaces, long narrow leaues, inclofing the fame round about : among which leaues come foorth frmall whitifh flowers of little regarde. The fruit is finall, and of a red colour, full of pulpe or meate; among which is contaned a hard ftonie feede like thofe of the firft Salomons feale.

* The place.

The firft fort of Salomons feale groweth naturally wilde in Somerfethire vpon the north fide of a place called Mendip, in the parifh of Shepton Mallet; alfo in Kent by a village called Crayforde vpon Rough or Rowe hill; alfo in Odiam parke in Hampfhire, in Bradfords wood neere to a towne in Wilthire fower miles from Bathe; in a wood neere to a village called Horfley fiue miles from Gilford in Surrey, and diuers otherplaces.

That fort of Salomons feale with broad leaues groweth in certaine woods in Yorkfhire called Clapdale woods, three miles from a village named Settle.

The firft,fecond, and third I haue growing in my garden; the reft are ftrangers in England.

* The time.

They fpring vp in March, and fheiv their flowers in May: the fruit is ripe in September. * The names.

Salomons feale is called in Greeke xoneyóra:s : in Latine likewife Polygonatum, of many knees; for fo the Greeke word doth import : in Thops, Sigillum Salomonis, and Scala celi : in Englifh likewife Scala cxli,Salomons feale, and white woort or white roote : in high Dutch चzieifinututz : in French Seau de Sabomon : of the Hetrurians Frafinella or Fraxineda.

\title{
* The temperature.
}

The rootes of Salomons feale, as Galen faith, haue both a mixt facultie and qualitie alfo. For they haue, faith he, a certaine kinde of aftriction or binding, and biting witha!l, and likewife a certaine lothfome bitterneffe, as the fame author affirmeth : which is not to be found in thole that do growe in our climate.

\section{* The vertues.}

A Diofcorides writeth, that the rootes are excellent good for to feale or clofe vp greene wounds being ftamped and laide thereon: whereupon it was called Sigillum Salomonis, of the fingular vertue that it hath in fealing, or healing vp wounds, broken bones, and fuch like. Some haue thought it tooke the name Sigillum, of the markes vpon the rootes: but the firft reafon feemeth to me more probable.

B The roote of Salomons Seale ftamped while it is fref $\mathrm{h}$ and greene, and applied, taketh away in one night or two at the moft, any brufe, blacke or blew fpots gotten by falls or womens wilfulnes, in ftumbling vpon their haftie husbands fifts, or fuch like.

C Galen faith, that neither herb nor toot hereof is to be giuen inwardly; but note what experience hath found out, \& of late daies, efpecially among the vulgar fort of people of Hampfhire, which $G_{A-}$ len, Diofcorides, or any other that hath written of plants, haue not fo much as dreamed of, which is; That if any of what iexe or age foeuer that chance to haue any bones broken, in what part of their bodies it be; theirrefuge is toftampe the rootes heereof, and give it vnto the patient in ale to drinke, which foddereth and gleweth togither the bones in very fhort fpace, and very ftrangely, yea, al though the bones be but nlenderly and vninandfomly placed and wrapped vp. Moreouer the iaid people do giue it in like maner vnto their cattle, if they chance to haue any bones broken, with 
good fosceffe, which they do alfo ftampe,and apply ot:twardly in maner of a pultis, as well vinto themfelues as their cattle.

The rootes ftamped and applied in maner of a pultis, and laide vpon members that haue beene D out of ioint, and newly reftored to their place, it driueth away the paine and knitteth the ioint very firmely, and takerh aivay the intammation if there chance to be any.

The fame ftamped, and the iuice giuen to drinke with ale or white wine, as aforefaide, or the de- $\mathbf{E}$ coction thereof made in wine, helpeth any inwarde brufe, difperfeth the congealed and clotted bloud, in very fhort fpace.

That which might be written of this herbe, as touching the knitting of bones (and that true. F ly) woulde feeme vnto fome incredible, but common experience teacheth, that in the worlde there is not to be found another herbe comparable to it for the purpofes aforefaide: and therefore in briefe, ifit be for brufes inward, the rootes muft be ftanped, forne ale or wine put therto, ftrained, and given to drinke.

It murt be giuen in the fame maner to knit broken bones, againft brufes, blacke or blewe markes $G$ gotten by ftripes, falles or fuch like, againft in tammation, tumors or fwellings, that happen vnto members, whofe bones are broken, or members out of ioine afterreftauration: the rootes are to be ftamped fmall, and applied pultis or plaifter wife, wherewith many great workes haue beene performed beyond credite.

Mathiolus teacheth that a water is drawen out of the rootes, wherewith the women of Italic vie H to fcoure their faces from funne burning, freckles, morphew, or any fuch deformitic of the skin.

\section{Of Kneebolme, or Butchers Broome. Chap.324.}

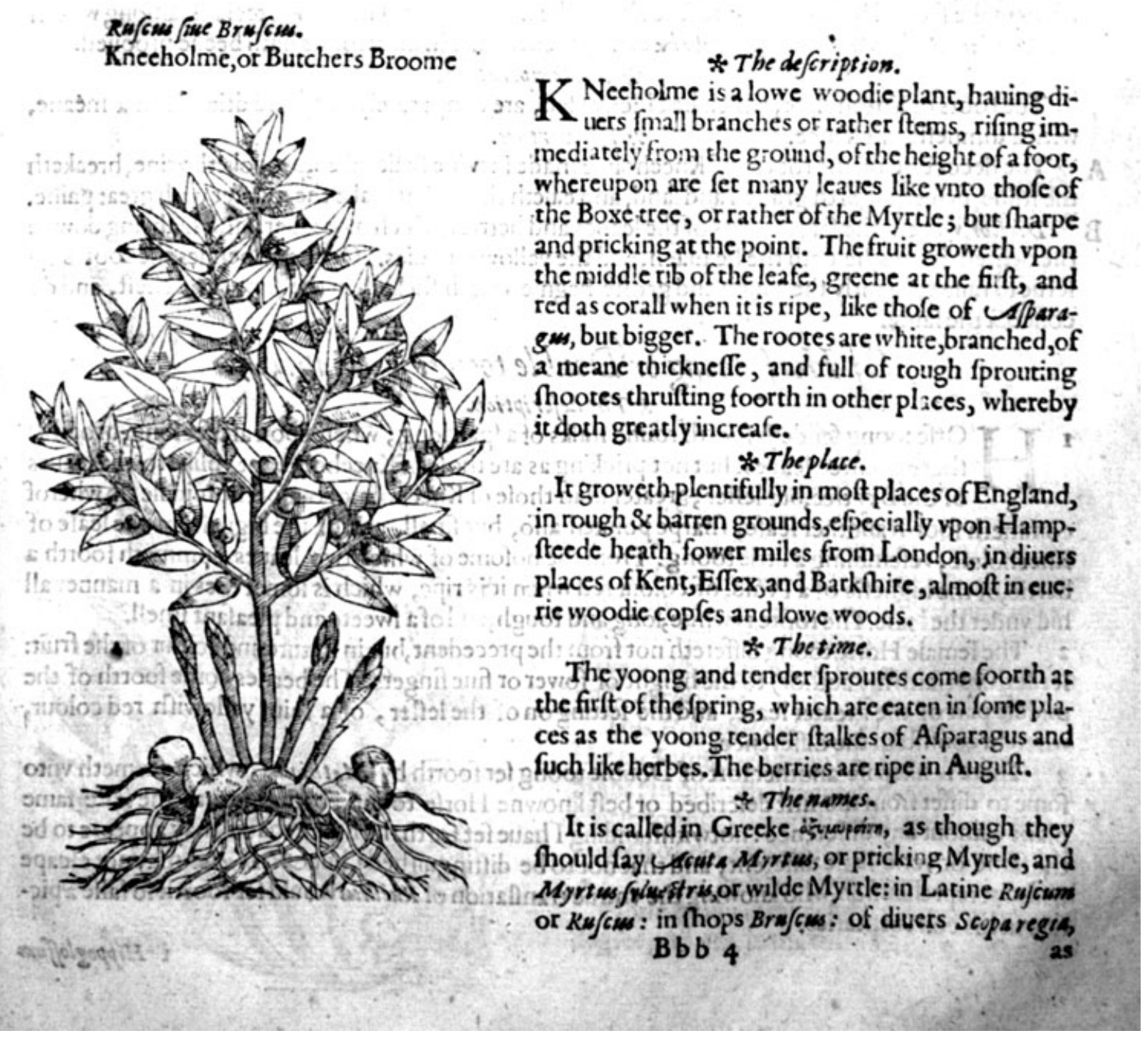


as teftificth Miscellses Empericses an olde writer : in high Dutch Qviefinozn: in lowe Dutch ote kenor palm: in Italian Rufco, and Pontogopi: in Spanifh Gilbarbeyra : in Englilh Kneeholme,Kneehulme, Kneehuluer, Butchers broome, and Petigree.

There be fome faith Plinie in his 25 .booke 13 .chap.that call it $O x y m y r$ fine.

Serapro in his 288. chapter fuppofeth that Myrtus agria or wilde Myrtle is the fane that Cabeba are : he alleageth a reafon, bicaule Galen hath not defcribed Myrtsuagria, or Kneeholme, neither Diofcorides Cubebe : which as it is a reafon of no account; fo is it alfo without truth. For $G_{z}$ len doth no where make mention of Cubebs: and be it that he had, it fhould not therefore follow, that Kneeholme is Cubebe. Galen fpeaketh of Carpefum, which visicen in his 137. chapter maketh to be Cubeba: and that Carpefurn doth much differ from Knecholme, thofe things declare which Galen hath left written hereof in his firft booke of counterpoifons.

Carpe/fum, faith he, is an herbe like in kinde to that which is called $P$ bor or Setwall, but of greater force, and more aromaticall or f picie. This groweth very plentifully in Sida a citic of Pamphilia: alfo he faith further, that fome of the ftickes of Carpefium are like to thofe of Cinnamom. There be two kindes thereof : one which is named Lärtium, and another thatis called ponticum. They both take their names of the mountaines on which they growe : but Ponticum is the better, which is put into medicines, in which the herbe Phu ought to be put. For Carpeffum, as I haue faid, is like vnto $P$ bu or Setwall,yet is it ftronger, and yeeldeth a certaine aromaticall qualitie, both in tafte and fmell. Thus far are Galens words.

By which it plainly appeereth, that Kneeholme is not Carpefoum, that is to fay, exicentia his $\mathrm{CM}$ beba, as thall be further declared in the chapter of Cubeba. Herein serapio was likewife deceiued, whofufpected it to be fuch a like thing : faying, there be certaine fruites or graines (called cubeb.e) not fticks : yet do they neither agree with Kneehılme, neither yet were they knowen vnto Galen.

Ifacs in the fecond booke of his practife doth number it among the graines: and likewife Haliabbas in the fecond booke of his praetife alfo, in the number 162. The later Grecians, among whom is Nicholaus M Yrep/as, call them Cubebie; and yet euery one in an error, as hath becne prooued.

$$
\text { * Thetemperature. }
$$

The roots of Knecholme, which be chiefly vfec, are temperately hot, and drie allo in a meane, with a thinneffe of effence. * The vertues.

A The decoction of the rootes of Knecholme made in wine \& drunken, prouoketh vrine, breaketh the ftone, driueth foorth grauell and fand, and eafech thofe that make their water with great paine.

B Diofcor writeth the fame things of the leaues and berries, which moreouer, faith he, bring downe the defired ficknes, helpeth the headach, and the yellow iaundies. Ouer and befides the rootes do ferue to raife vp gently the tough and groffe flegme which fticketh in the lungs and cheit, and do concoet the fame.

\section{Of Horfe toong or Double toong. Chap. 325.}

' $\mathrm{H}$ Orfe toong fendeth foorth round ftalks of a fpan long; whereupon are fet long, broad \& fharp pointed leatues, but not pricking as are thofe of Kneeholm, not vnlike to the leaues of the Bay tree, but leffer; greater than thofe of Kneeholme: out of the middle rib wherof commeth foorch another leafe, tharpe pointed alfo, but fmall, and of the bigneffe of the leafe of Kneeholme, refembling 2 little toong. From the bofome of which two leaues eommeth foorth a berrie, of the bigneffe of a Peafe, of colour redwhen it is ripe, which is fomerimes in a manner all hid vnder the leafe. The roote is white, long and tough, and of a fweete and pleafant fmell.

2 The female Horfe roong differeth not from the precedent, but in ftature and colour of it rifeth $\mathrm{vp}$ (faith my author) to the height of fower or fiue fingers. The berries come foorth of the middie part of the greater leafe, and the fetting on of the leffer, of 2 faint yellowifh red colour, wherein confifteth the difference.

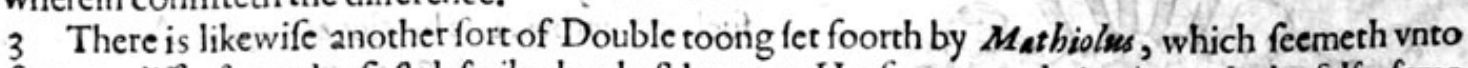
- fome to differ from the firft defcribed or beft knowne Horfe toong, being in truth the felfe fame plant without any difference : notwithiftanding I haue fet forth the figure that it may appeere to be the fame or verie little different, and that not to be diftinguifhed: but CMathiolus maynot efcape without reprehenfion, who knowing the vntrue trantation of Rxelliws would fet foorth fo falle a picture in his commentaries. 
1 Hippogloffeon mas. 6.

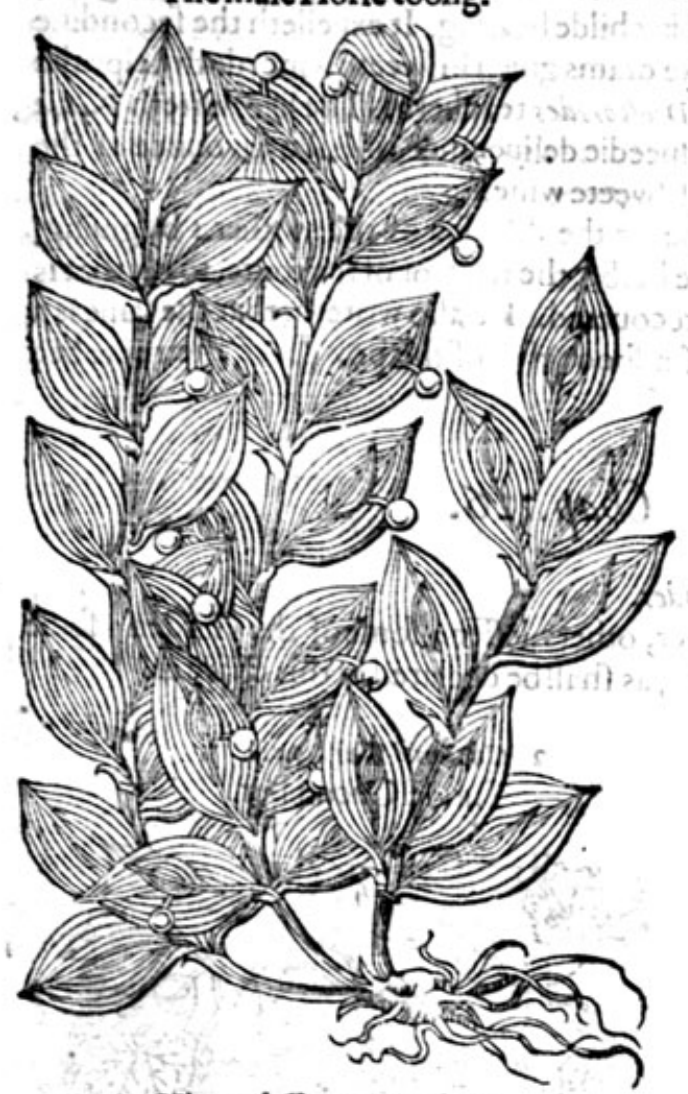

3 Hipooglof foen CMatthioli. Italian Horfe toong.

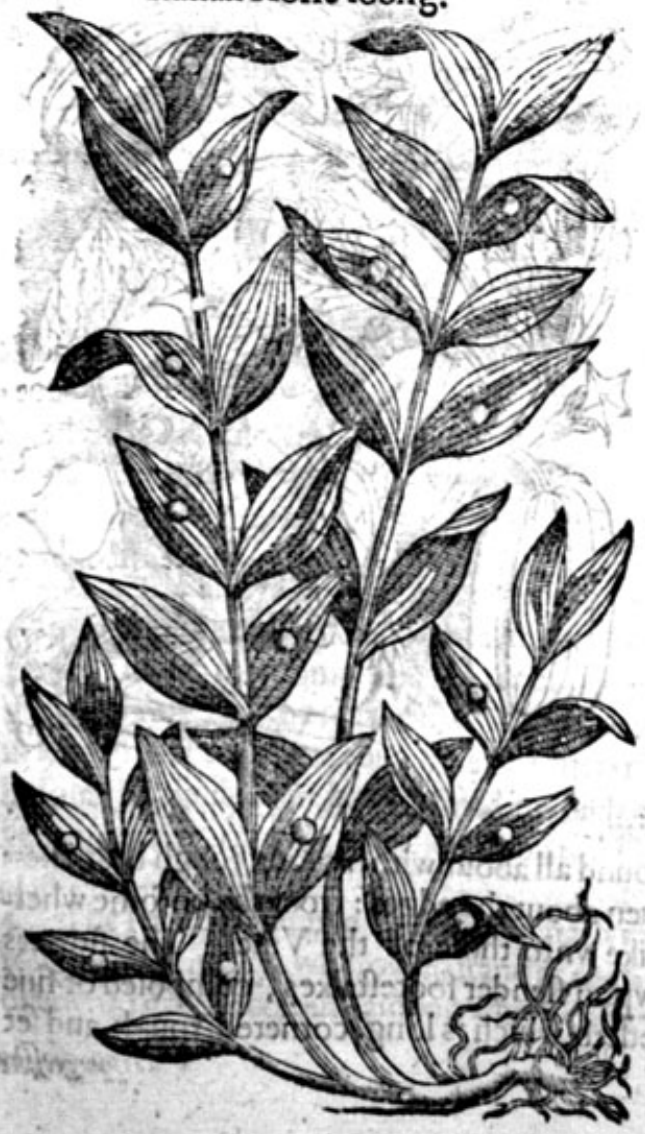

2 Hippoglojam femine.

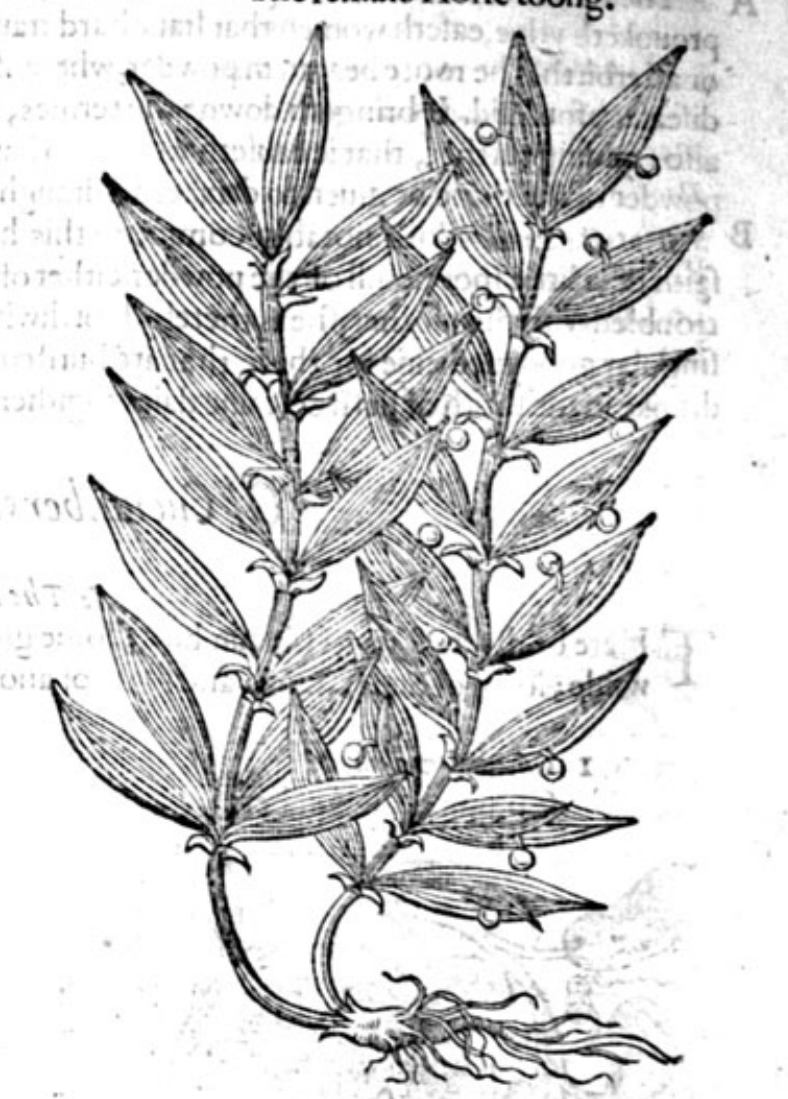

* The place.

They are founde on the Alpes of Liguria, and on the mountains of Auftria. Belloniss writeth, that they do growe very plentifully about the hill Athon.

The firft of the Horfe toongs groweth in my garden very plentifully.

\section{$*$ Thetime.}

Thatwbich groweth in my garden flowred in the beginning of May. The fruitis ripe in the fall of the leafe.

\section{* 7 henemes.}

Horfe toong is called in Greeke irrey rearer, of the later Herbarifts Bontf acia, Vwalgria, Biff lingua, Lingua Pagama, and Victoriols. The lame is alfo named dism isãe, of Ida a mountaine of Troy which is called Alexanders Troy: of fome Lawrus Alexandrima, or the bay of Alexandria, and Lastrus Ites.

This Hrppoglorjam Bonifacis is called in high Dutch zapflintratut: in low Dusch Tongbin. btabt: in Spanifh Lengus de Cawallo: in Englifh Horfe toong, Toong blade, Double toong, and Laurell óf Alexandria.

\section{* Thetemperature.}

Horfe toong is cuidently hot in the feconde degree, and drie in the fiot. 
* The vertues.

A The rootes of Double toong boiled in wine, and the decoction drunke, helpeth theftrangurie, proucketh vrine, eafeth women that have hard traucll in childe bearing, It expelleth the fecondine or afterbirth. The roore beaten in powder, wher ef fixe drams giuen in fweete wine, doth helpe the difeafes aforefaid. It bringeth downe the termes, as Diofcorides teacheth. The like writeth $P$ linie alfo: adding further, that it caufech women to haue fpeedie deliuerance, if halfe an ounce of the powder of the roote be giuen to drinke in a draught of fweete wine.

B Baptista Sardus doth notably commend this herbe for the difeafes of the mother : by gituing, faith he, a little fpoonefull of the powder, either of the herbe, the fruit, or of the roote, to hir that is troubled with the mother, the is thereby foorthwith recouered. He alfo writeth, that the fame is 2 fingular good medicine for thofe that are burften, if a fpoonefull of the powder of the roote bee drunke in the broth of Aefh certaine daies togither.

\section{OfCucumbers. Chap. 326 .}

* The kindes.

THere be diuers forts of Cucumbers; fome greater, others leffer; fomeof the Garden; fome wilde; fome of one fahion; and fome of another, as fhallbe declared in this chapter.

I Cucmmis vulgaris.

Common Cucumber.

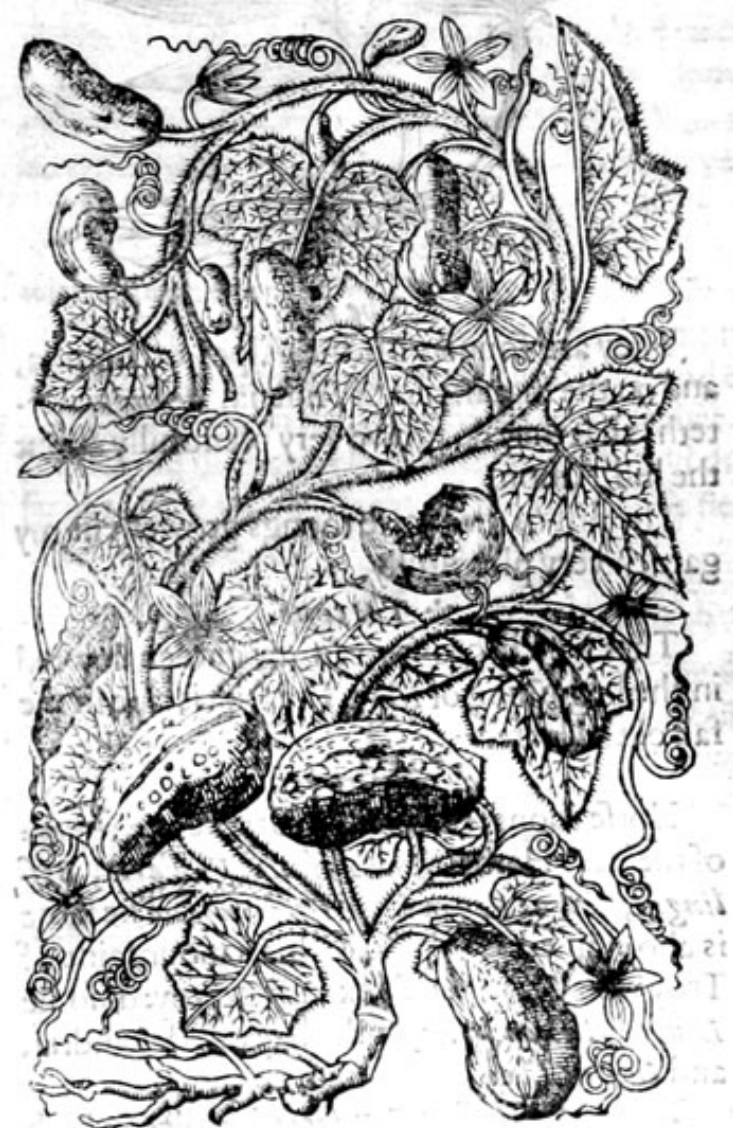

2 Cucwmis Turcicus. Turkie Cucumber.

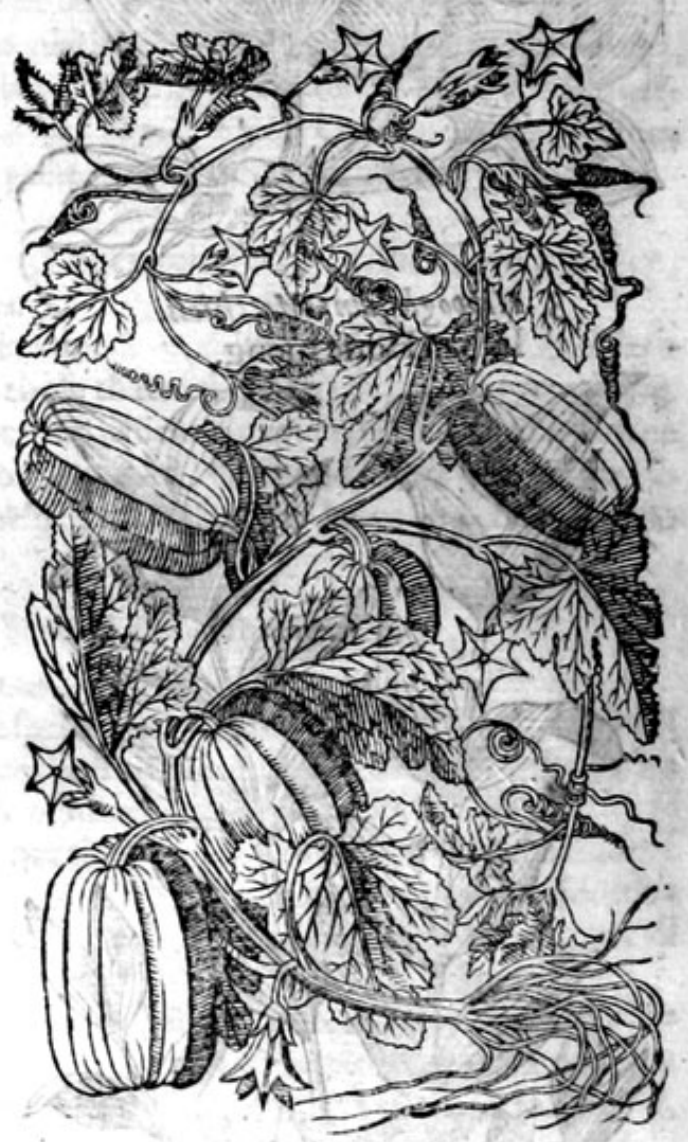

* The defcription.

- He Cucumber creepeth along t vpon the ground all about with his long rough branches; whereupon do grow broad rough leaufes vneuen about the edges: from the bofome wherof come foorth crooked clafoing tendrels like vnto thofe of the Vine. The flowers thoote foorth betweene theftalkes and the leaues fet vpon flender footeftalkes, compofed of fiue fmail yellow leaues : which being paft, the fruite fucceedech, which is long, cornered, rough, and et with 


\section{HISTORIE OF PLANTS.}

with certaine bumpes or rifings, greene at the firft, and yellow when they be ripe; wherein is con* tained a firme and folide pulpe or fubitance, tranfparent or thorow fhining; which togicher with the feede is eaten, a little before they be fully ripe. The feeds be white, long and flat:

2 The Turkie Cucumber hath many long flexible branches trailing vpon the ground, fethero and there by certaine diftances, at cueric ioint with one leafe and no more, verybroad, deepely cue about the edges, not vnlike to thofe of the Pompion; among which come foorth the clafping ten-. drels, wherewith it taketh hold of weedes or other herbes that are in his way; as alfo may be fet to clime vpon poles, arbors, and fuch like, for the hadowe fake, as well as for the fruite: from the faid ioint likewife commeth foorth a fmall tender footeftalke, whereon doth growe a little pale yellow flower, bell fafhion; after which commeth the fruit crefted,chamfered, or furrowed like the Pompion. The meate or pulpe is more firme and folide than that of the common Cucumber. The feede is long,very white, in fhape like thofe of the common Cucumber, but greater.

3 Cucumis Anguina. Adders Cucumber.

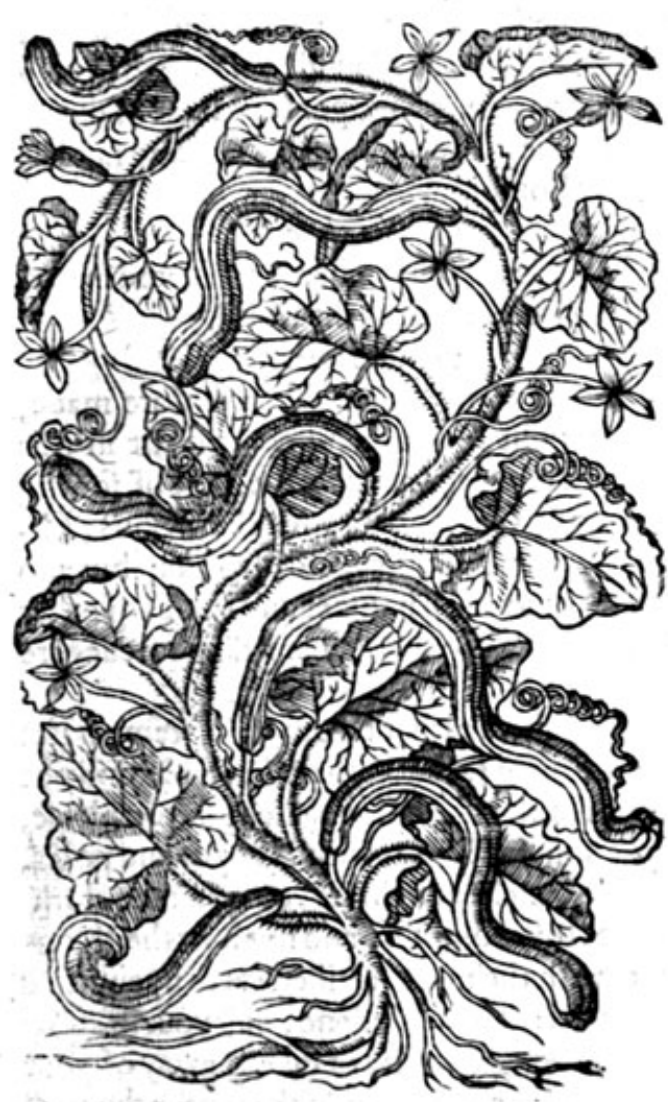

4 Cacionis Pyriformis. Pearefahion Cucumber.

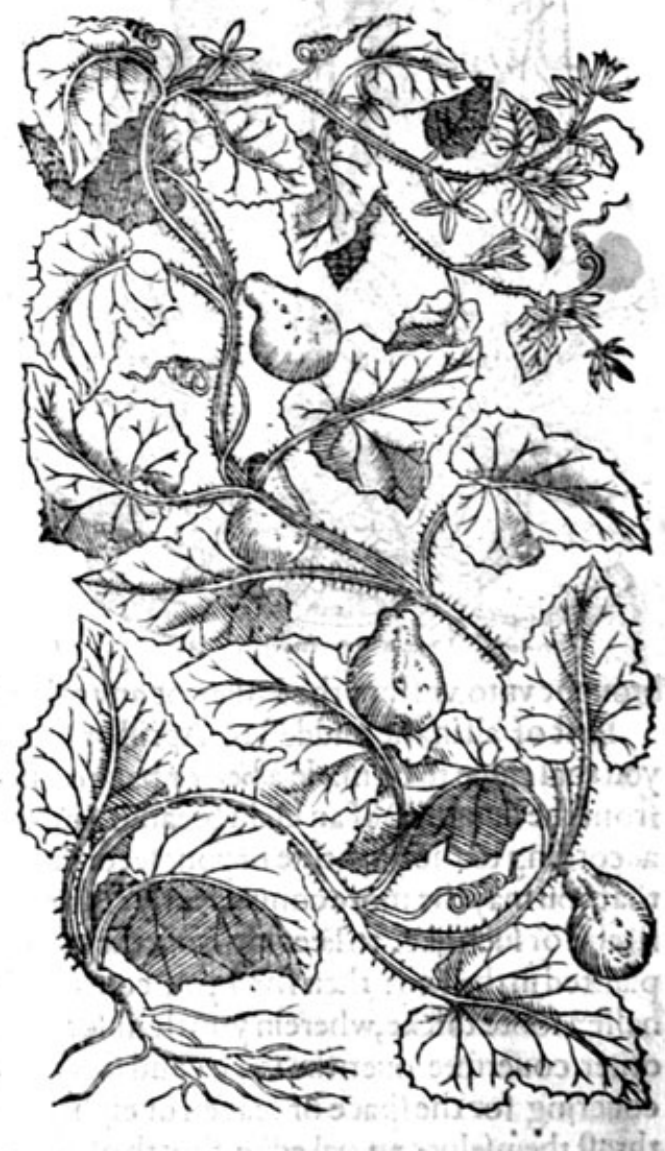

* The defcription.

3 There be alfo of this kinde certaine long Cucumbers, which were firft made (as it is faide) by art and manuring, which nature afterwards did preferue. For at the firt, when as the fruit is very little, it is put into fome hollow cane, or other thing made of purpofe, in which the Cucumber groweth very long, by reafon of that narrow hollowneffe being filled vp, the Cucumber increafeth in length. The feede of this kinde of Cucumbers being fowen, bringeth foorth not fuch as were before, but fuch as art hath framed : which of their oivne growth are found long, and oftentimes very crookedly turned; and thereupon they have beene called Angumi, or long Cucumbers, and crooked Cucumbers.

4 The Peare fafhioned Cucumber hath many trailing branches, lying flat vpon the grounde, rough and prickley, wheron doftand at each ioint one great rough leafe, tharpe pointed, and of an ouerworn greenecolour ; among which come forth clafping tendrels, \& likewifeilender foorftalks; 
whereon do growe fmall yellow ftarlike flowers. The fruite fucceedeth, fafhioned like a Peare, and of the bignes of a great Warden. The roote is threddie.

5 Cucumis ex Hifpanico femime natus. Spanifh Cucumber.

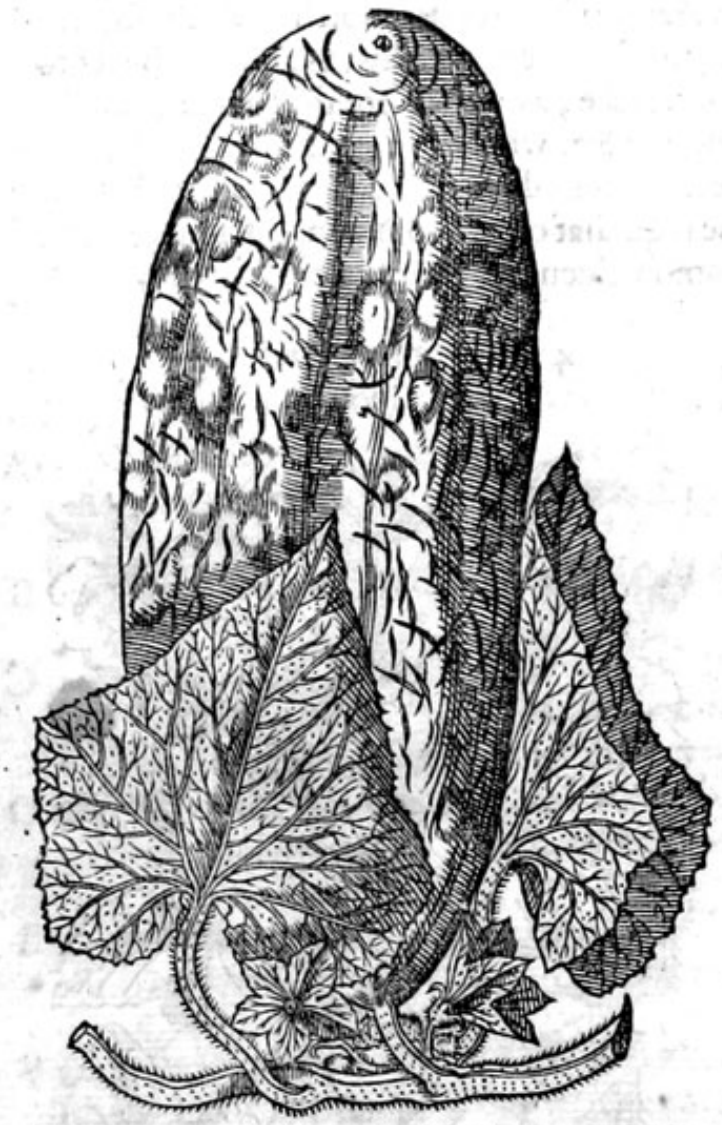

\section{* The defoription.}

5 Here hath been not long fince fent out of Spaine fome feeds of a rare and beautifull Cucumber, into Argentine a citic of Ger. manie, otherwife called Strawsborough, which there brought foorth long trailing braunches, rough and hairy, fet with very large rough leaues, Tharpe pointed, fafhioned like vnto the leaues of the great Burre docke: among which come forth faire yellow flowers growing nakedlie vpon their tender footeftalkes : the which being paft, the fruite commeth in place, of 2 foot in length, green on the fide toward the ground, yellowe to the fun warde, ftraked with manie fpots and lines of diuers colours. The pulpe or meate is hard and faft like that of our Pompion.

$$
\text { * The place. }
$$

Thefe kindes of Cucumbers are planted in gardens in moft countries of the world.

$$
\text { * The time. }
$$

According to my promife heeretofore made, I haue thought it good and conuenient in this place to fet downe, not onely the time of fowing and fetring of Cucumbers, Muskemelons, $\mathrm{Ci}_{\mathrm{i}}$ truls, Pompions, Gourdes, and fuch like; but alfo how to fet or fowe all manner and kindes of other cold feedes, as alf q whatfoever ftrange feedes are brought vnto vs from the Indies, or any other hot regions, videl.

Firft of all in the middeft of Aprill or fomwhar fooner (if the weather be any thing temperate) you fhal caufe to be made a bed or bank of hot $\&$ new horfe dung taken forth of the ftable (and not from the dunghill) of an ell in breadth, and the like in depth or thicknes, of what length you pleafe, according to the quantitic of your feed: the which bancke you fhall couer with Hoopes and poles, that you may the more conueniently couer the whole bed or bancke with Mats, olde painted cloth, ftrawe or fuch like, to keepe it from the iniurie of the colde froftie nightes, and not hurt the things planted in the bed: then fhall you couer the bed all ouer with the moft fertilleft earth finely fifted halfe a foote thicke, wherein you h $\mathrm{h}$ ll fet or fowe your feedes : that being done, caft your ftraw or other couerture ouer the fame; and fo let it reft withour looking vpon it, or taking away of your couering for the fpace of feauen or eight daies at the moft, for commonly in that fpace they will thruft themfelues vp nakedlie foorth of the grounde : then muft you caft vpon them in the hoteft time of the daie fome water that hath ftoode in the houfe or in the funne a daie before, bicaufe the water fo caft vpon them newely taken foorth of a well or pumpe, will fo chill and coole them being brought and nourifhed vp in fuch a hot place, that prefently in one daie you haue loft all your labour; I meane not onely your feede, but your bancke alfo; for in this fpace the great heat of the dung is loft and fpent, keeping in memorie that euerie night they muft bee couered and opened when the daie is warmed with the fun beames: this muft be done from time to time vntill that the plants haue fower or fixe leaues a peece, and that the danger of the cold nights is paft : then muft they be replanted verie curioufly with the earth fticking to the plant as neere as may be vinto the moft fruitfull place, and where the funne hath moft force in the garden; prouided that vpon the remoouing of them you moft couer them with fome Docke leaues or wilpes of ftraw, propped vp with forked ftickes, as well to keepe them from the cold of the night, as allo the heate of the funne: 


\section{HTHISTORIE OFIPLANTS.}

for they stannot whilet they be yoong and newly planted, indure neicher ouermuch cold nor much heate, vntill they are well rooted intheirnew place or dwelling.

Ofteritines is falleth out that forne feedes are more franker and forwarder thanthereft, which commonly do rife vp verie nakedile with long necks not vnlike to the ftalke of a fmall mufhrome, of a nightolde. This naked ftalke muft you coner with the like fine earth euen to the greeneleaves,

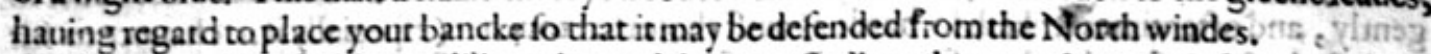

Obierue thefe initruetions ditigently, and then you fhall nothauecaufe to corbplaine fhat your feedes were not good, nor of the intemperancie of the climate (byreafon whereof yourcangerno fruire) although it were in the furtheft partes of the North of Scotland.

$$
\approx \text { T be names. }
$$

- The Cucumber is named generally Cucumis: in thops Cucumer: and is taken for that which the Grecians call anver ineses : in Latin Cucwnis fatrass or garden Cucumber: in high Durch surumern: in Italian Concomero: in Spanifh Cogombro: in French Concombre : in lowe Dutch Concentumeten: in Englifh Cowcumbers and Cucumbers.

\section{* The temperature and vertues.}

All the Cucumbers are of temperature cold and moitt in the fecond degree. They putrifie foone A in the ftomacke, and yeelde vito the body a cold and moift nourifhment, and that vecie little, and the fame not good.

Thofe Cucumbers muft be chofen which are greene and not yet ripe: for when they are ripe and $B$ yellow they be vnfic to be eaten.

The feede is colde, but nothing fo much as the fruit. It openeth and clenfeth, prouoketh vrine, $\mathbf{C}$ openerh the ftoppings of the liver, helpeth the cheft and lungs that are inflammed: and being ftamped and outwardly applied in fteede of a Clenfer, it maketh the skin fmooth and faire.

Cucumber(faith my Author) taken in meats, is good for the ftomacke and other partes troubled D with heate. It yeeldeth not any nourithment that is good, in fo much as the vnmeafurable vfe therof filleth the vaines with naughtie colde hurnours.

The feede ftamped and made into milke like as they do with Almonds, orftrained with milke or $\mathbf{E}$ fweere wine and drunke, loofeth the bellie gently, and is excellent againft the exulceration of the bladder.

The fruite cutte in peeces or chopped as herbes to the pot and boiled in a fmall pipkin with a $\mathbf{F}$ peece of mutton, being made into potage with Otemeale, euen as herbe potage aremade; whereof a meffe eaten to breakefaft, as much to dinner, and the like to fupper : taken in this manner for the fpace of three weekes togither without intermiffion; doth perfeetly cure all manner of fawceflegme and copper faces, red and fhining firie nofes (as red as red Rofes) with pimples, pumples, rubies, and fuchlike pretious faces.

Prouided alwaies that during the time of curing you do vfe to wafh or bathe the face with this $\mathbf{G}$ liquor following.

Take a pinte of ftrong white wine vineger, powder of the rootes of Ireos or Orrice three $\mathrm{H}$ dragmes, fearced or bolted into moft fine duft; Brimftone in fine pouder halfe an ounce, Camphire two dragmes, ftamped with two blanched Almondes, fower Oke, apples'cut thorowe the middle, and the iuice of fower Limons : put them all togither in a ftrong double glaffe, shake them togither verie ftrongly, ferting the fame in the funne for the fpace of tenne daies: with which let the face be wafhed and bathed daily, fuffering it to drie of it felfe without wiping it away. This doth not onely heipe firie faces, but alfo taketh away lentils, fpots, morphew, funneburne, and all other deformities of the face.

\section{of Wilde Cucumber. Chap.327.}

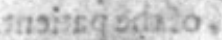

\section{* Thedefription.}

He wildeCucumber hath many fat hairic braunches, verie rough and ful of iuice, creeping or trailing vpon the ground; whereupon are fet verie rough leaves, hairic, fharpe pointed, and of an ouerworne grayilh greene colour: from the bofome of which, some foorth long ten. der footeftalks : on the ends whereof do grow fmall flowers compoled of figef fmall leaues of a pale thised 
yellowe colour: after which commeth foorth the fruite of the bignes of the fmaleft pullets egge, but fomewhat longer, verie rough and hairie on the outfide, and of the colour and fubftance of the ftalkes, wherein is contained verie much water and finall hard blackifh feedes alfo, of the bignes of tares; which being come to maturitie or ripenes, it cafteth or fquirteth foorth his water with the feedes, either of it owne accord, or being touched with the moft tender or delicate hande neuer fo gently, and oftentimes ftriketh to harde againft thofe that touch it (efpecially if it chaunce to hit againft the face) that the place fmarteth long after; whereupon of fome it hath beene called Nols me tangere, Touch me not. The roote is thicke, white, and long lafting:the whole plant,as alfo the fruit, is verie bitter.

Cucsomis afinions.

Wilde Cucumber.

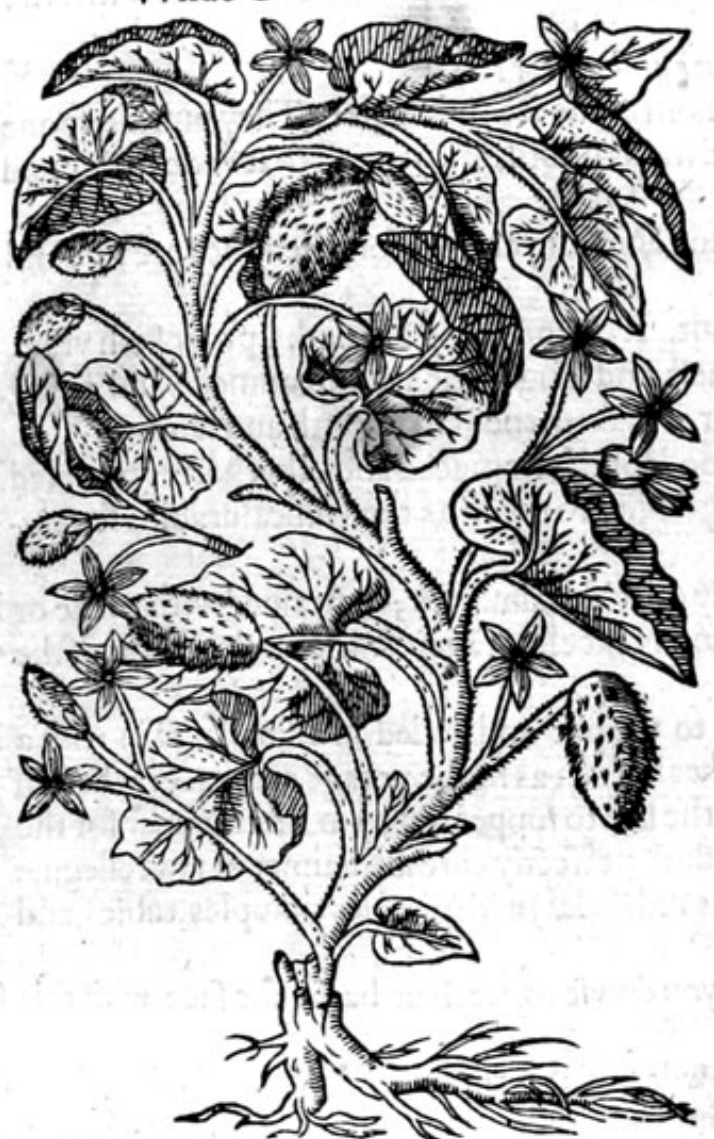

*The place.

It is found in moft of the hot countries, among rubbifh, grauell, and other vntilled places: it is planted ingardens in the lowe countries, and being once planted, faith Dodonesw, it eafily com. meth vp againe many yeeres after (which is true) and yet faith he further, that it doth not fpring againe of the roote, but of the feedes fpirted or caft about: which may likewife be true where he hath obferued it, but in my garden it is otherwife, for as I faide before, the roote is long lafting, and continueth from yeere to yeere. * The time.

It fpringeth vp in Maie, it flowreth and is ripe in Autumne,and is to be gathered at the fame time, to make that excellent compofition of called Elaterivan.

* The names.

It is called in Greeke rixus àyeess : in Latine Agrefis, and Erraticus Cucumis: in fhops Cucumer afmimos : in Italian Cocomero falustico: in Spanifh cogumbrillo amargo : in Englifh wilde Cucumber, fpircing Cucumbers, \& Touch me not:in French Concombres Jasuages.

* The temperature.

Theleawes of wild Cucumbers, rootes \& their rindes as they are bitter in talte; fo they belikewife hor and clenfing. The iuice is hot in the fecond degree, as Galen witneffeth, and of thin parts. It clenfeth and wafteth away.

* The vertues.

A The iuice called Elaterium, doth purge foorth choler, flegme, and watery humours, and that with force, and not onely by fiege, but alfo by vomit.

B The quantitie that is to be taken at one time, is from fiue graines to ten, according to the ftrength of the patient.

C The iuice dried or hardned, and the quantitie of halfe a fcruple taken, driueth foorth by fiege groffe flegme, cholericke humours, and preuaileth mightily againft the dropfie, and fhortnes of breath.

D The fame drawne vp into the nofthrils mixed with a little milke, taketh away the rednes of the eies.

E The iuice of the roote doth alfo purge flegme, cholericke and waterifh humours, and is good for the dropfie, but not of fuch force as Elateriwm, which is made of the iuice of the fruite : the making where of I commend to the learned and curious apothecaries, among which number mafter William Wright in Bucklers Burie my louing friend, hath taken more paines in curious compofing of it, and 


\section{HISTORIE OF PLANTS. IHT}

hath more exactly performed the fame then any other whatfoetuer, that I hauehad any knowledge of.

\section{Of Citrull Cucumbers. Chap.328.}

\section{Citrulus officinarum. \\ Citrull Cugumber.}

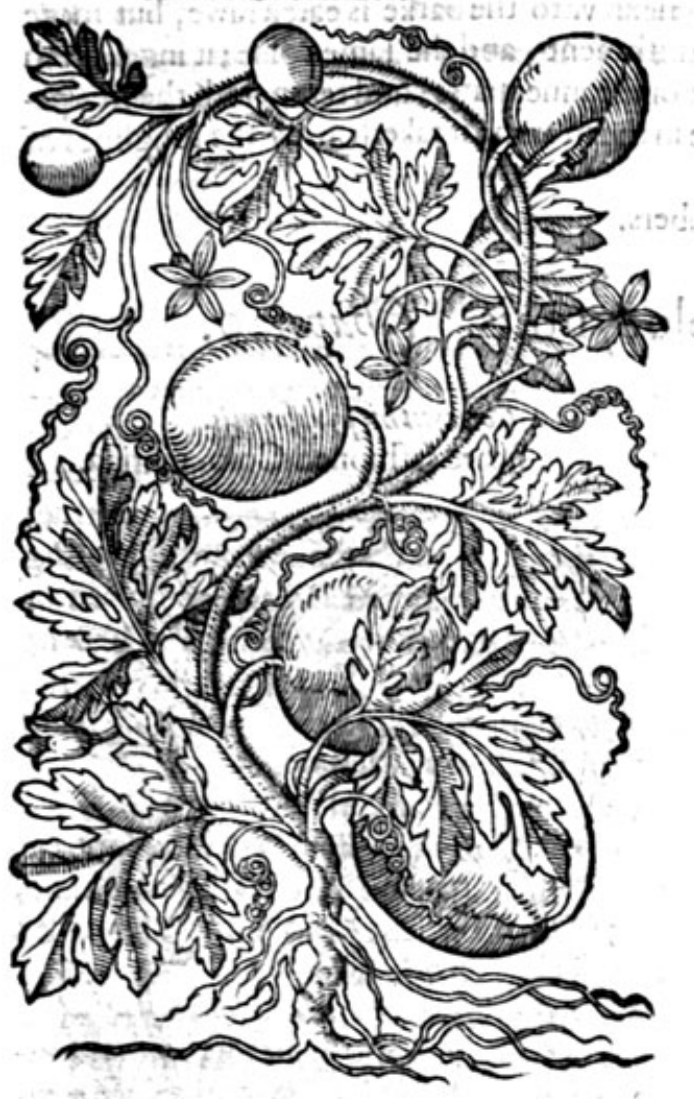

2 Citrutusminor. Small Cirrul.

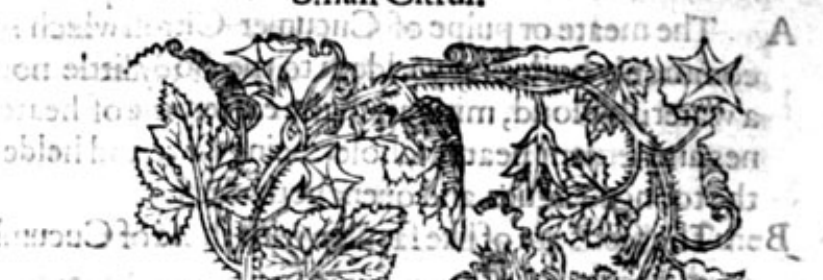

\section{* Thedefcription.}

I Te Citrull Cucumber hath many long,flexible, \& tender ftalks, trailing vpon the ground, branched like vnto the Vine, fet with certaine great leaues deepely cut, and veriemuch iagged: among which come foorth long clafping tendrels, and alfo tender footftalkes, on the endes whereof do growe flowers of a golde yellowe colour: the fruite is fomewhat rounde, ftreaked or ribbed with certaine deepe furrowes alongtt the fame, of a greene colour aboue, and vnderneath on that fide that lieth vpon the grounde fomething white: the outwarde skin whereof is very fmooth; the meate within is indifferent harde, more like to that of the Pompion therrof the Cucumberor muske Melon : the pulpe wherein the feede liech, is fpungie and of a flimie fubftance: the feede is long, flat, and greater then thofe of the Cucumbers: the fhell or outward barke is blackifh, fometimes of an ouerworne reddifh colour. The fruite of the Citrull doth not fo eafily rot or putrifie as doth the Melon, which being gathered in a faire dry day, may be kepta long time, efpecially being couered in a heape of Wheate, as Mathioles faith, bur according to my practile you may keepe them much longer and better, in a heape of dry fande. 2 The fecond kinde of Citrull differeth not from the former,fauing that it is altogither leffer, and the leaues are not fo deepely cut or iagged, wherein confifteth the difference.

The Cirull profperech $* 7$ he place and time. The Citrull profpereth beft in hot regions as in Sicilia, Apulia, Calabria, and Syria, about Alepo in planting of Cucumbers, but they neuer came to zipenes. 
*. The names.

The later Herbarifts co call it Anguria : in fhops Citrulus, and Cucumiu Citrulus : in Englith Ci-: truls, Cucumber Citruls, and Pome Citruls, and is knowne by the name of Semen Citruli or Citrull feede. But if Cucsmis Citrulus be fo called of the yellow colour of the Citron, then is the common Cucumber properly Cucumis Catrulus, which is knowne vnto all to be contrarie. Afo situritio I

$*$ The temperature and vertues.

A The meate or pulpe of Cucumer Citrull which is next vnto the barke is eaten rawe, but more conmonly boiled: it yeeldeth to the body little nourifhmenth and the fame colde; it ingendteth a waterifh bloud, mitigateth the extremitic of heate of the inner parts, and tempereth the thatpenesand feruent heat of choler: being rawe and helde in the mouth, it taketh away the roughnes of the toong in agues, and quencheth thirft.

B Ihe feeds are of like faculie with thofe of Cucumbers.

\section{Of the wilde Citrull,called Colocynthis. Cbap.329.}

1 Colocynthis.

The wilde Citrull, or Coloquintida.

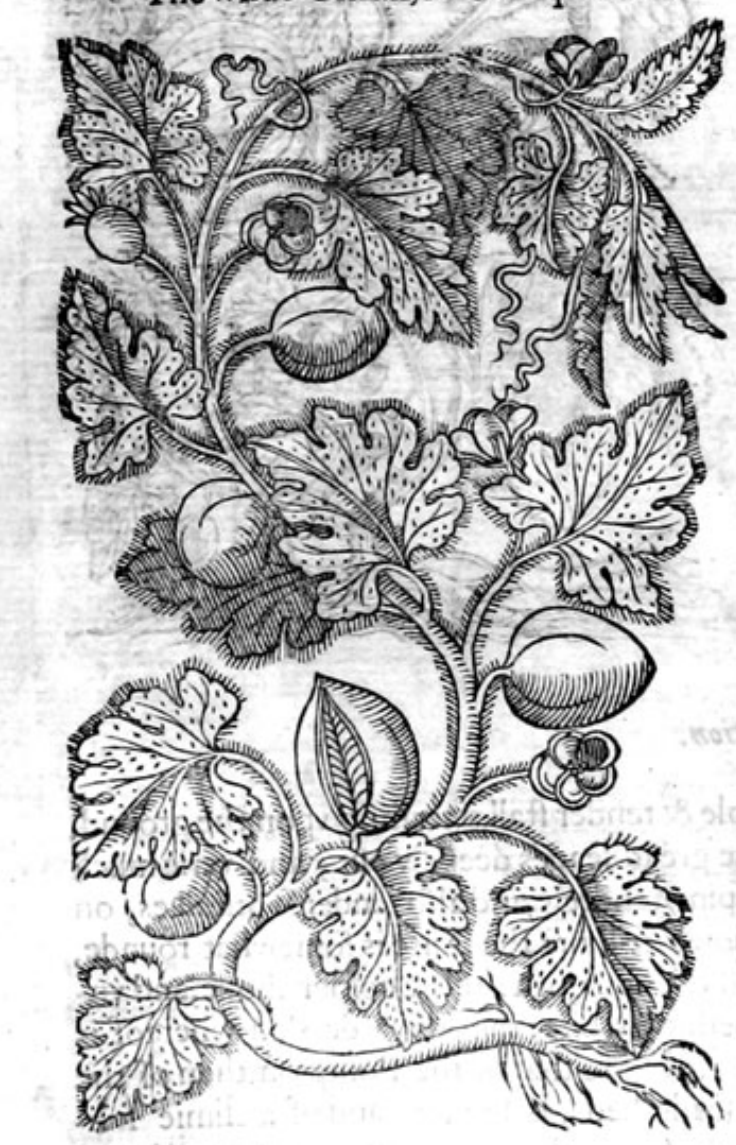

2 Colocynthispyriformis. Peare fathioned Colog uintida.
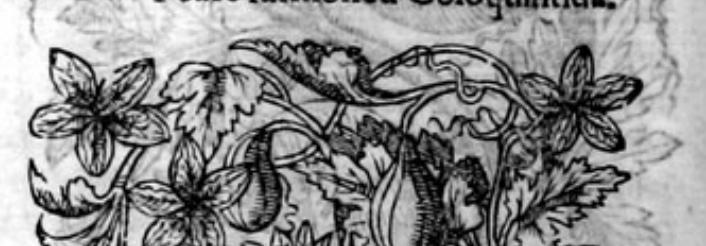

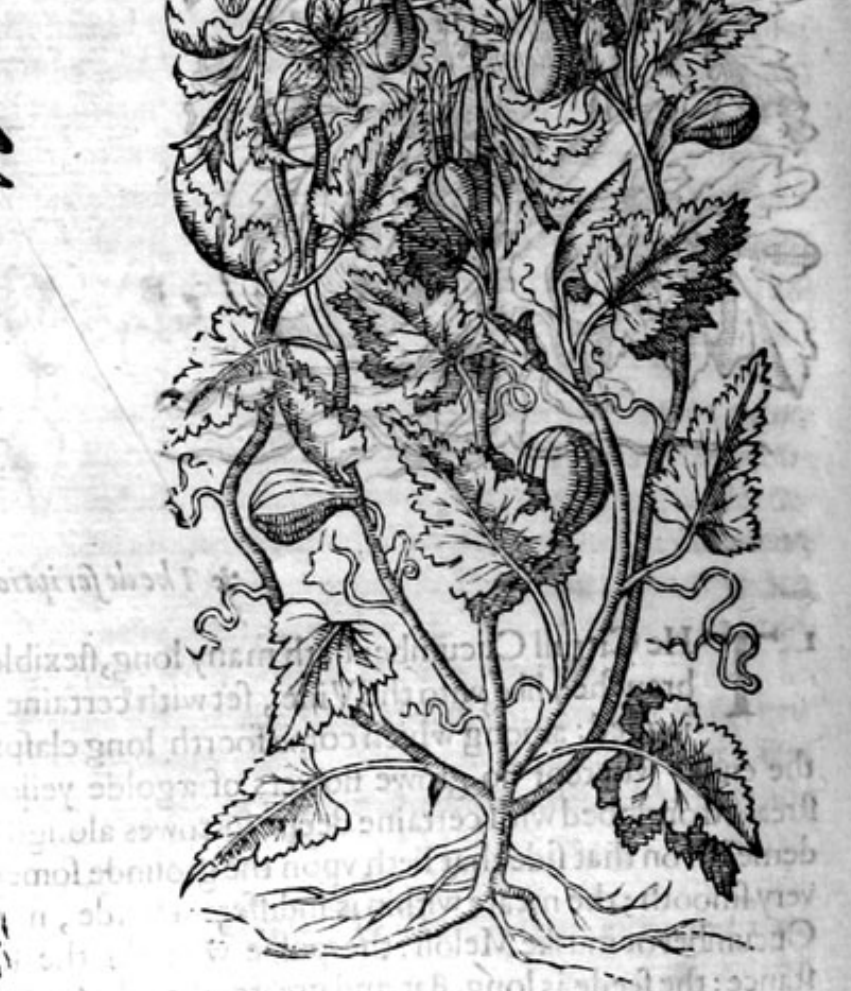

* The defcription.

I

Oloquintida hath been taken of many to be a kinde of the wilde Gourde, but not truely: it lieth along creeping on the grounde as do the Cucumbers and Melons, comming neereft of all to the Muske Melons, which in thefe daies of fome Herbarifts is called Citrull Cucumber, but with the greater errour: It bringeth foorth vpon his long braunches fmall crooked tendrels like the Vine, and alfo very great broad leaues deepely cut or iagged: among which come foorth fmall flowers of a pale yellowe colour; then commeth the fruite, roundeas a boule, couered with a thinne rinde, of a yellowe colour when it is ripe, which when it is pilled or pared off, the white pulpc or fpungie fubstance appeereth full of feedes, of an ouerworne browne colour; the 
fruite fopared or pilled, and dried for medicine; the which is moft extreme bitter, and likewife the feede, and the wholeplant it felfe in all his parts.

2 The feconde kinde of Cologuintids hath likewife many lor.g braunches and clafping tendtels; wherwith it taketh hold of fuch things as ate neet vnro it. It bringeth foorth the like leaves, but hot fo much iagged. The flowers are fmall and yellow : the fruit is falhioned like a peare, and the othet fort rounde, wherein the efpeciall difference confiftech.

Cologaintids is fowen and commeth to pertection in hot regions, but feldome, or neuer in thefe nottherly and cold countries.

\section{\&. The time.}

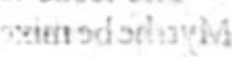

It is fowen in the fpring and bringeth his fruite to perfection in Auguft.

It hath beene diuers times deliuered vnto me for a truth that they do growe in the Sands of the Mediterfanean fea fhore, or verie neer vnto it, wilde, for euerie man to gather that lift, efpecially on that fide of Barbarie; as alfo without the mouth of the Streights neere to Sanda Crux and other places adiacent; from whence diuers Chirurgians of London that haue traueiled thither, for the curing of ficke and hurt men in the hip, haue brought great quantities thereof at their returne.

$$
* 7 \text { be names. }
$$

F is called of the iguorant Apothecaries Coloquint ids : in Greeke xoroxuras : the Latine tranflators

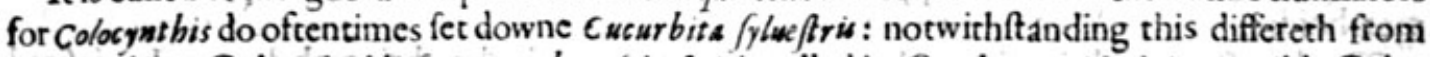
colocynt his, or Cologuintidasfor Cucurbuta fylmeftris is called in Grecke rexardisadyia, or wilde Coloquintida, whereof thall be fet foorth a peculiar Chapter next after the Cacurbita or Gourde : in Englith it is câiled Coloquintida,or apple of Coloquintida.

$$
\text { * The temperature. }
$$

Coloquintida as it is in his whole nature and in all his parts bitter, fo is it likewife hot and dry in the later ende of the fecond degree: and therefore it purgeth, clenfeth, openeth and performeth all thofe things that moft bitter things do: but that the ftronge qualitic which it hath to purge by the ftoole, is yas $G$ alen faith, of more force then the reft of his operations.

$$
\text { * The vertues. }
$$

Which operation of purging it worketh fo violently, that it dorh not onely draw foorth tegme $\mathbf{A}$ and choler marueilous fpeedily, and in very great quantity : but oftentimes fetchech foorth blotd and bloudie excrements, by fhauing the guts, and opening the endes of the meferaicall veines.

So that therefore the fame is not to be vfed either rathly, or without forne dangerous and ex- B treme difeafe conftraine thereunto : neither yet at all vnleffe fome tough and clammie thing be mixed therewith, whereby the vehemencie thereof may be repreffed, the hurffull force dulled, and the fame fpeedily paffing through the belly, the guts be not fret nor fhaued. Mefwes teacheth to mixe with it either Maftich,or gum Tragacanth.

There be made of it Trochifes, or little tlat cakes, with Maftich, gum Arabick, Tragacanth and D Bdellium, of thefe, Maftich hath a manifeft binding qualitic: but tough and clammie things are much better,which haue no aftrietion at all in them, or very little.

For by fuch binding or aftringent things, violent medicines being reftrained and bridled, doe $\mathrm{E}$ afterwarde worke their operation withmore violence and trouble : but fuch as hauenotbinding thingsmixed with them, du eafilier worke and with leffer paine, as be thofe pilles which $R$ hafis in hisg.booke of LAmenzor, calleth Illiats, which are compounded of Coloquintida and Scamony, twoof the ftrongeft medicines that are: and of a thirde called gumme Sagapene, which through his clainmines doth as it were daube the entrailes and guts, and defende them from the harme that might haue come of eicher of them.

The which compofition, although it be woonderful ftronge \& not to be vfed without very great $F$ neceffitie vrge thereunto, doth notwith fanding eafily purge, and without any great trouble, and with leffer torment, then moft of the mildeft and gentleft medicines which haue Maftich, 32 other things mixed with them that are aftringent.

And for this caufe it is yery like that Galem in his firt booke of medicines according to the pla- G cesaffected, would not fuffer Maftich and Bdellium to be in the pilles, which are furnamed Cochie, the which notwithftanding his fchoolemafter Quntw was alfo woont before to adde vnto the fame.

But Coloquintida is not oncly good for purgations, in which it is a remedie for the diffines or $\mathbf{H}$ dist: 2 Ccc s. 
the turning ficknes, the megrim, continuall headach, the apoplexie, the falling ficknes, the ftuffing of the lurigs, the gnawings and gripings of the guts and entrailes, and other moft dangerous difeafes, but allo it doth outwardly worke his operations, which are not altogither to be reiected.

I Common oile wherein the fame is boiled, is good againft the finging in the eares, and deafenes: the fame killeth and driueth foorth all maner of wormes of the belly, and doth oftentimes prouoke to the ftoolc, if the nauell and bottome of the belly be therewith annointed.

$\mathrm{K}$ Being boiled in vineger, and the teeth wafhed therewith, it is a remedie for the toothach, $25 \mathrm{Me}$ fues teacheth.

L The feede is very profitable to keepe and preferue dead bodies with; efpecially if Aloes and Myrrhe be mixed with it.

$M$ The white pulpe or f pungious pith taken in the waight of a cruple, openeth the belly mightily, and purgeth groffe tlegme, and cholericke hum ours.

$\mathrm{N}$ It hath the like force if it be boiled and laide to infure in wine or ale, and giuen to drinke.

O Being taken after the fame maner it profiteth the difeafes before remembred, that is the apoplexie, falling ficknes, giddines of the head, the colicke, loofenes of finewes, and places out of ioint, and all difeales proceeding of colde.

$P$ For the fame purpofes it may be vfed in glifters.

Q. The fame boiled in oile and applied with cotton or wooll, taketh away the paine of the Hemorrhoides.

$R$ The decoction made in wine, and vfed as a fomentation or bathe, bringeth downe the defired ficknes.

\title{
Of Muske Melon, or Million. Cbap.329.
}

\author{
* The kindes.
}

There be diuers forts of Melons found at this day, differing very notablie in fhape and propor. tion, as alfo in tafte,according to the climate and countrie where they growe: but of the ancients there was onely one and no more, which is that Melopepo called of Galen Cucumis, or Galens Cucumber; notwithiftanding fome haue comprehended the Muske Melons vnder the kinds of $\mathrm{Ci}$ truls, wherein they haue greatly erred: for doubtleffe the Muske Melon is a kinde of Cucumber, according to the beft approoued authors.

\section{* The defoription.}

17 Hat which the later Herbarifts do call Muske Melons, is like to the common Cucumber in ftalkes, lying flat vpon the grounde, long, branched, and rough. The leaues be much a like, yet are they leffer, rounder, and not fo cornered : the flowers in like maner be yellowe: the fruite is bigger, at the firit fomewhat hairie, fomthing long, now and then fomewhat round; oftentimes greater, and many times leffer : the barke or rinde is of an ouerworne ruffet greene colour, ribbed and furrowed very deepely, hauing often chappes or chinkes, and a confufed roughnes: the pulpe or inner fubftance which is to be eaten, is of a faint yellow colour. The middle part whereof is full of a flimie moifture, among which is conteined the feede, like vnto thofe of the Cucumber, but leffer, and of a browner colour.

2 The fugar Melon hath long trailing ftalkes lying vpon the grounde, whereon are fet fmall clafping tendrels like thofe of the Vine, and alfo leaues like vnto the common Cucumber, but of agreener colour : the fruite commeth foorth among thofe leaues, ftanding vpon flender footeftalkes, rounde as the fruite of Coloquintidt, and of the fame bigneffe, of a moft pleafant taftelike Sugar, whereof it tooke the furname Saccharat us. 
I Melo.

2 Melo Saccharimses.

The Muske Melôn.

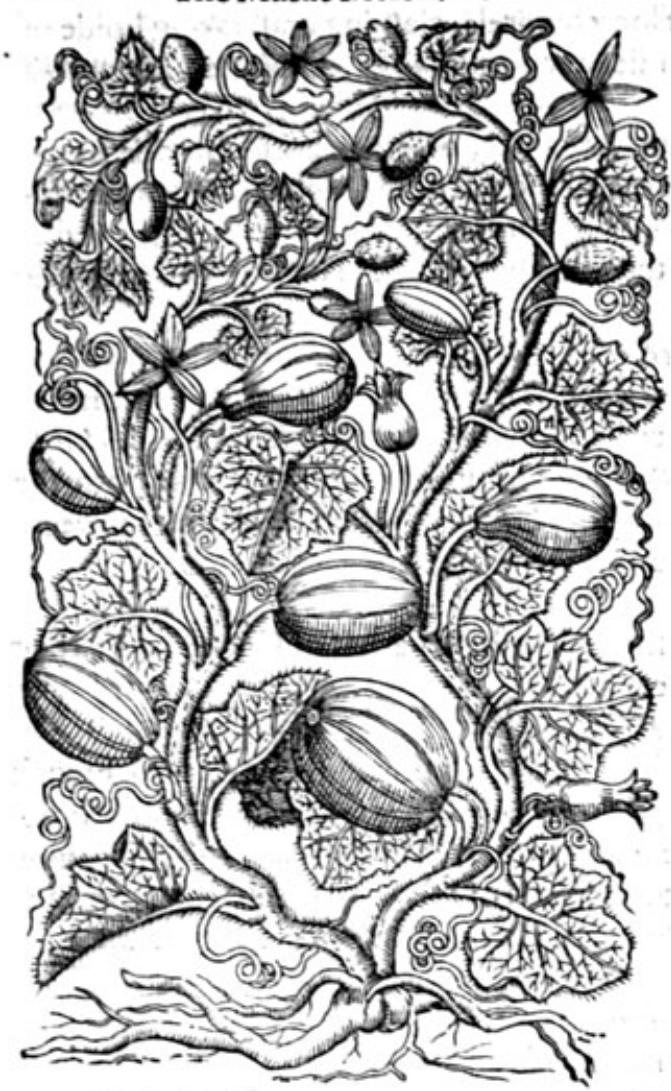

3 Prromelo.

Peare fafhion Melons.

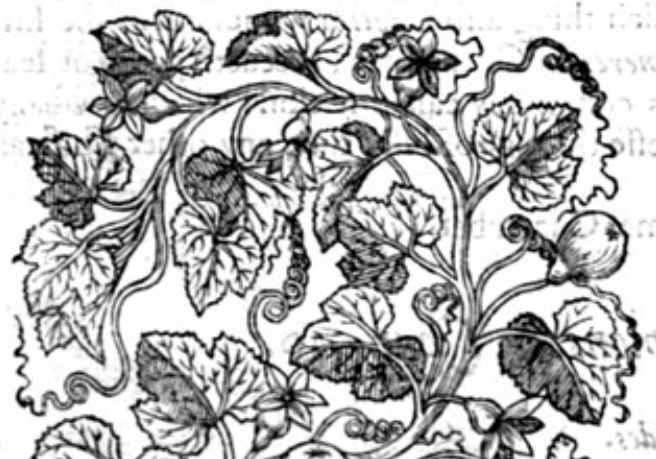
Sugar Melon.

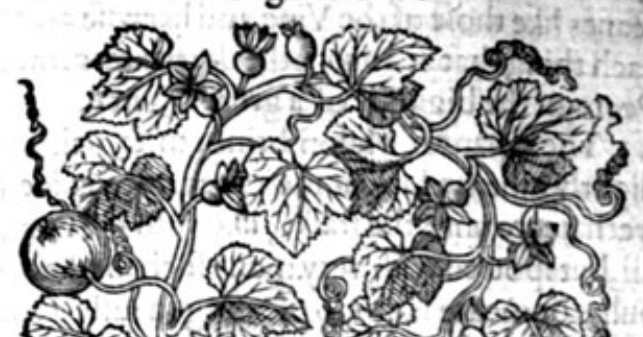

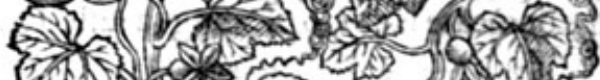

in

(3)
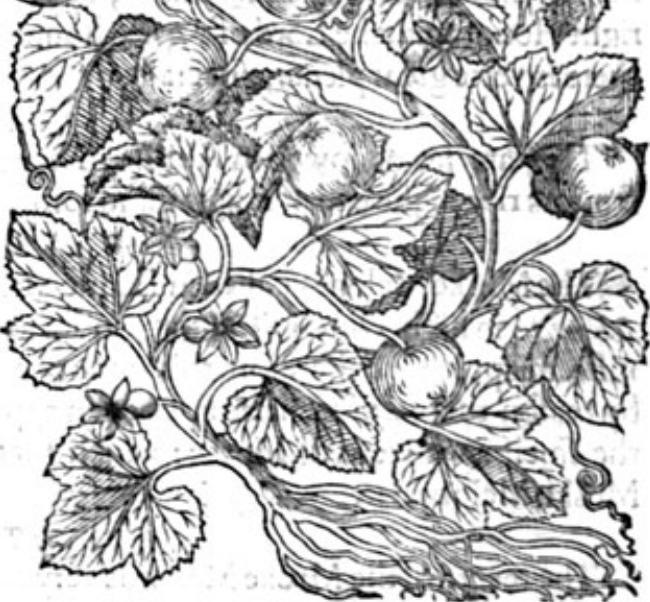

4 cMelo Hiparicass.

SpanifhMelons. Paticis A

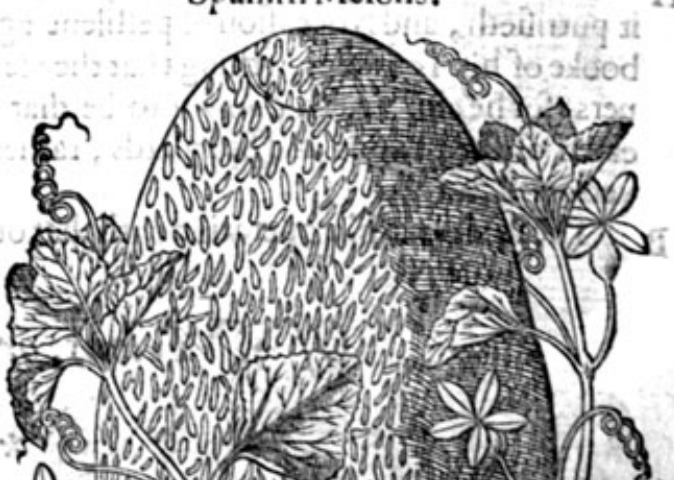

(5)

Q 30 ?

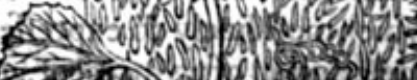

(10)

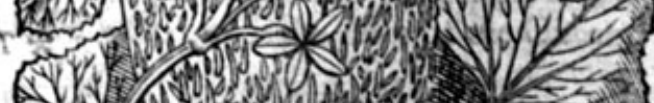

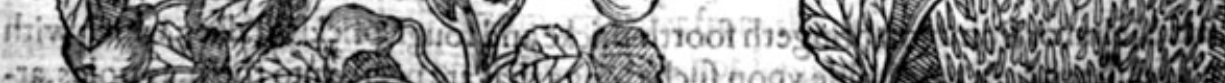

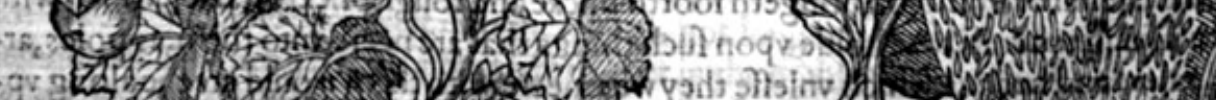

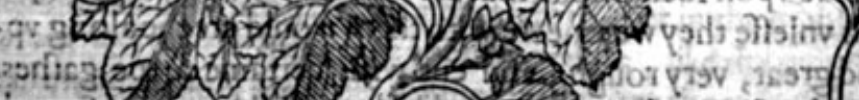
iorice (20)

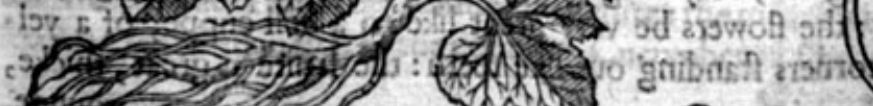


* T The defcription.

3 The Peare falhioned Melon hath many long Vinie braunches, whereupon do grow cornered leaues like thofe of the Vine, and likewife great ftore of long tendrels, clafping and taking holde of each thing that it toucheth: the fruite groweth vpon flender footeftalkes, fafhioned like vnto 2 Peare, of the bigneffe of a great Quince.

4 The Spanifh Melon bringeth foorth long trailing branches, whereon are fet broade leaues flightly indented about the edges, not deuided at all, as are all the reft of the Melons. The fruit groweth neere vnto the ftalke, like vnto thę common Pompion, very long, not crefted or furrowed at all, but fpotted with very many fuch markes as are on the backefide of the Harts toonglehfe. The pulpe or meate is not fo pleafing in tafte as the others.

$*$ The place.

They delight in hot regions, notwithiftanding I haue feene at the Queenes houfe at Saint Iames very many of the firft fort ripe, through the diligent \& curious nourifhing of them by a skilful Gentleman the keeper of the faid houfe, called Mafter Fovvle; and in other places neere vnto the right Honorable, the Lord of Suffex houfe of Bermondfey by London, where from yeere to yeere there is verie great plenty, efpecially if the weather be any thing temperate.

$$
\text { * The time. }
$$

They are fet or fowen in Aprill as I haue already fhewed in the Chapter of Cucumbers: their fruite is ripe in the end of Auguft, and fomtimes fooner.

* The names.

The Muske Melon is called in Latine Melo: in Italian Mellone : in Spanifh Melon : in French Melons : in high Dutch Telaun: in lowe Dutch Tgeloenen: in Greeke ainov, which doth fignifie an apple; and therefore this kinde of Cucumber is more truely called unnonitivon, or Melopepon, by reafon that $P$ e po hathithe fmell of an apple, whereto the fmell of this fruit is like; hauing withall the fmell as it were of Muske: which for that caufe are alfo named Melones Mogabatellint, or Muske Melons.

\section{* Thetemperature.}

The meate of the Muske Melon, is very colde and moift.

$$
\text { * The vertues. }
$$

A It is harder of digeftion then is any of the reft of Cucumbers:\& if it remaine long in the ftomack it putrifieth, and is occafion of peftilent agues, which thing alfo setius witneffeth in the firft booke of his Tetrables, writing that the vfe of Cucumeres, or Cucumbers, breedeth peftilent feauers : for he alfo taketh Cucumis to be that which is commonly called Melon: which is vfually eaten of the Italians and Spaniards, rather to repreffe the rage of luft, then any other Phificall vertue.

B The feede is of like operation with that of the former Cucumber.

$$
\text { Of Melons, or Pompions. Chap. } 33^{\circ} \text {. }
$$

\section{* The kindes.}

Here be founde diuers kindes of Pompions which differ either in bignes or forme: it thall be 1 therefore fufficient to defcribe forme one or two of them, and referre the reft vnto the viewe of their figures, which moft liuely do expreffe their differences; efpecially bicaufe this volume waxeth great, the defcription of no moment, and I haften to an end.

\section{* The defcription.}

I He great Melon or Pompion bringeth foorth thicke and rough prickly ftalkes, which with their clafping tendrels take holde vpon fuch things that are neere vnto them, as poles, arbors, pales, and hedges, which vnleffe they wereneere vnto them would creepealong vfon the grounde : the leaues be wide and great, very rough, and cut with certaine deepe galhes, nicked alfo on the edges like a fawe ; the flowers be very great like to a bell cuppe, of a yellowe colour like golde, hauing fiue corners ftanding out like teeth: the fruite is great, thicke, rounde, 


\section{HISTORIE OF PLANTS.}

round, fet with thicke ribbes like edges fticking foorth. The pulpe or meate where of which is nexe vnder the rinde is white, and of a meane hardnes : the pith or fubftance in the middle is fpungie and flimic : the feede is great, broade, flat, fomething white, much greater than that of the Cucumber, otherwife not differing at all in forme. The colour of the barke or rinde is oftentimes of an obfcure greene, fometimes graie. The rinde of the greene Pompion is harder, and as it were of a woo. die fubitance : the rinde of the graie is fofter and tenderer.

2 The fecond kinde of Melons is like vnto the former in ftalkes and leaues, and alfo in clafping tendrels : but the gathes of the leaues are not fo deepe, and the ftalkes be tenderer: the flowers are in like manner yellowe, gaping, and cornered at the top, 25 be thofe of the former : but the fruite is fomewhat rounder; fometimes greater, and manie times leffer: and oftentimes of a green colour with an harder barke: nowe and then fofter and whiter. The meate within is like the former: the feedes haue alfo the fame forme, but they be fomewhat leffer.

1 Peponaximus oblonges. The great long Pompion.

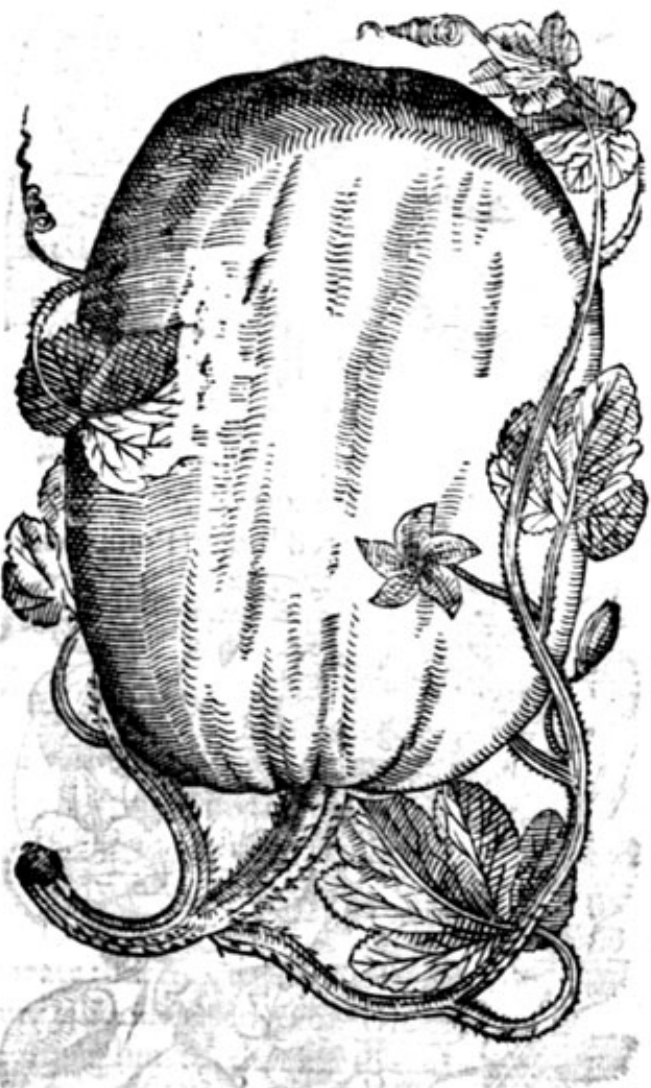

2 Pepomaxinus rotundius. The great tound Pompion.

\section{* The defcriptios.}

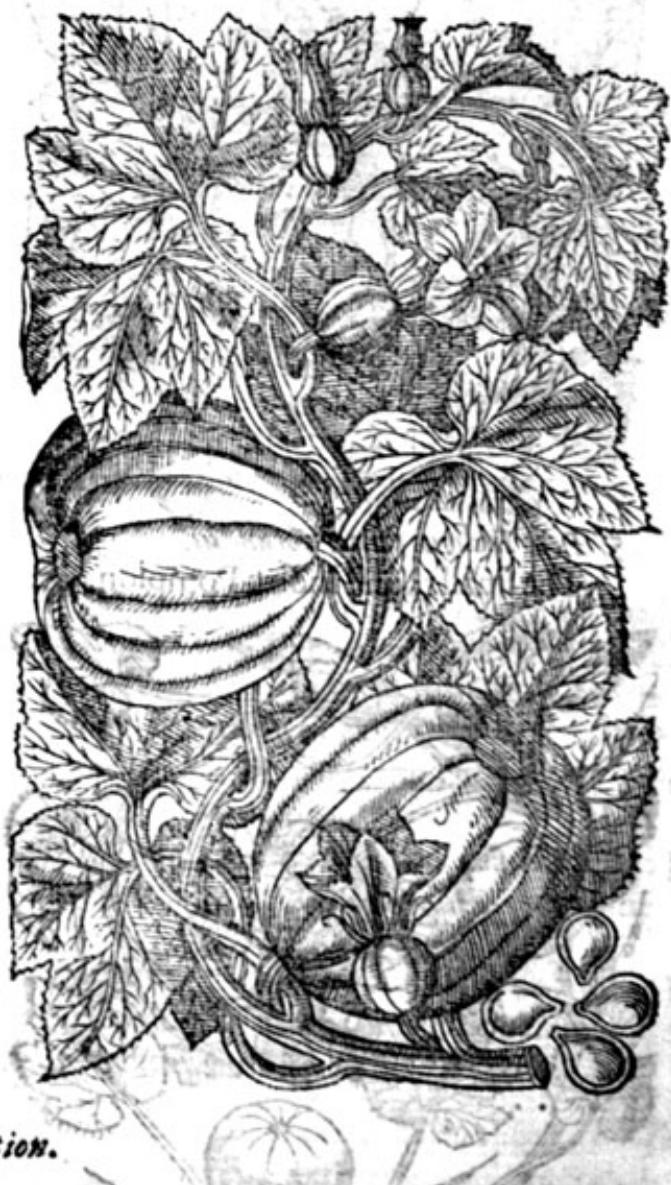

3 Of this kinde there is alfo another Pompion like vnto the former in rough ftalks, and in gafhed and nicked leaues: the flower is alfo great and yellowe, like thofe of the others: the fruite is of a great bignes, whofe barke is full of little bunnies or hillie welts, as is the rinde of the Citron, which is in likemanner yellow when it is ripe.

4. The fourth Pompion doth verie much differ from the others in formesthe ftalkes, leaues, and flowers are like thofe of the reft: but the fruite is not long or rotnd, but altogither broade, and in a manner flat like vnto a fhield or buckler; thicker in the middie, thinner in the compaffe, and curled or bumped in certaine places aboutehe edges, like the rugged or vneuenbarke of the Pomecitron; the which rinde is verie foft, thinne, and white: the meate wirhin is meetely hard and durable. The feede is gteater than that of the common Cucumber, in forme and colour allone. 
3 Pepomaximus comprefus.

The great flatbottom'd Pompion.

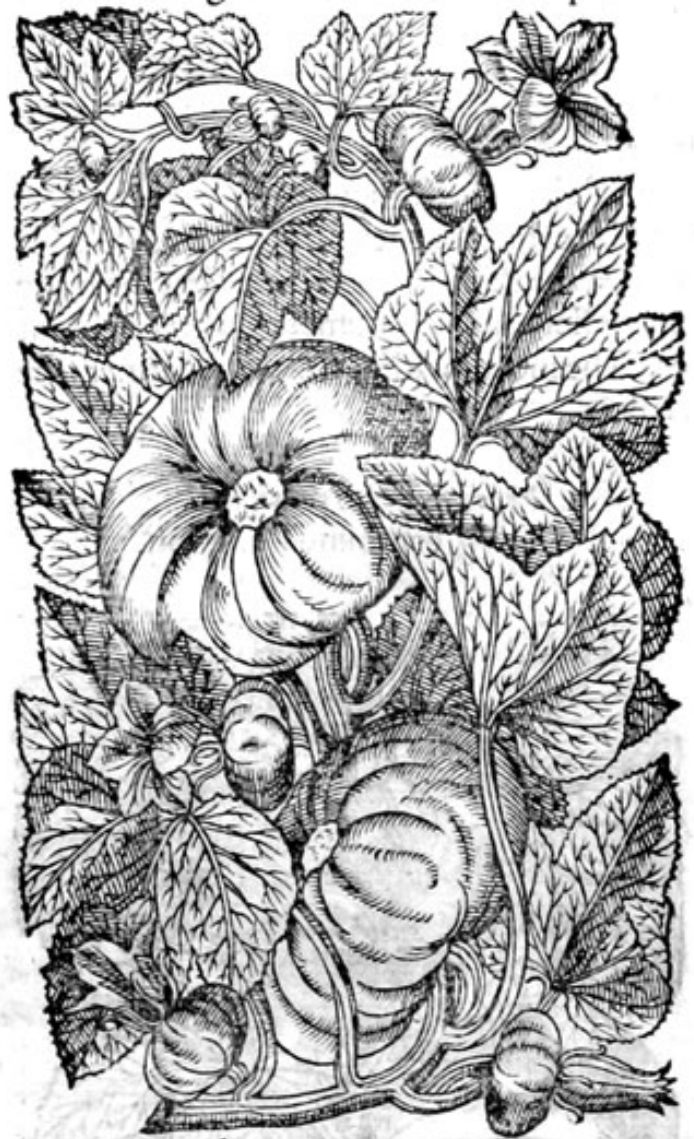

5 Pepo Indicus minor rotundus.

The finall round Indian Pompion.

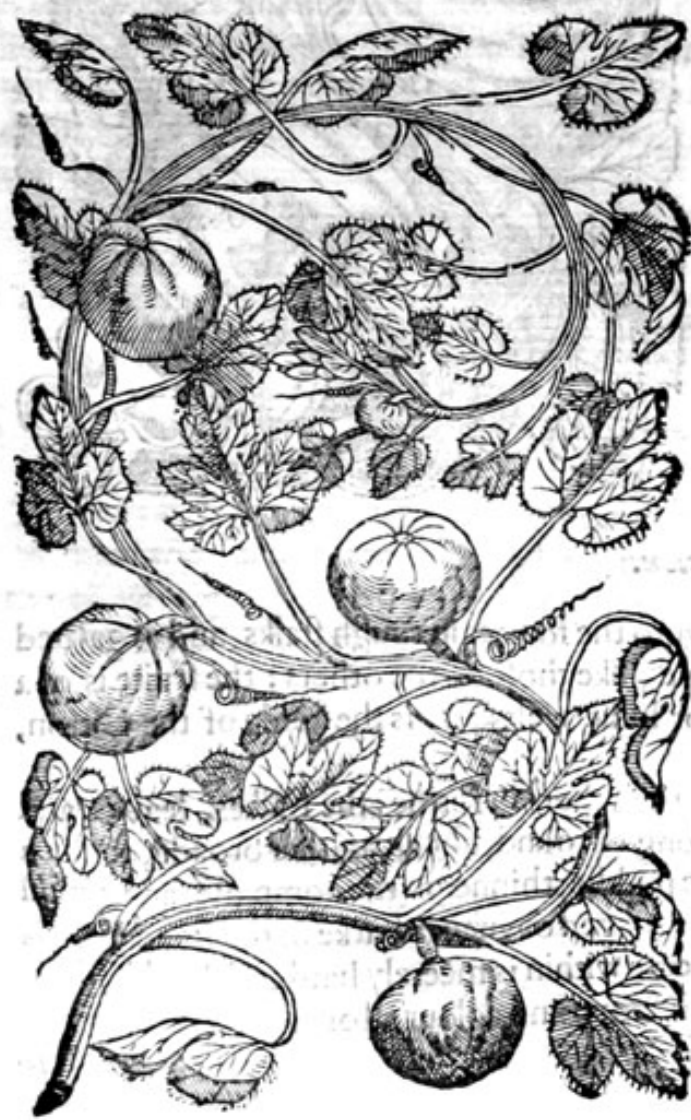

4 Pepomaximus clypeatiss.

The great buckler Poimpion.

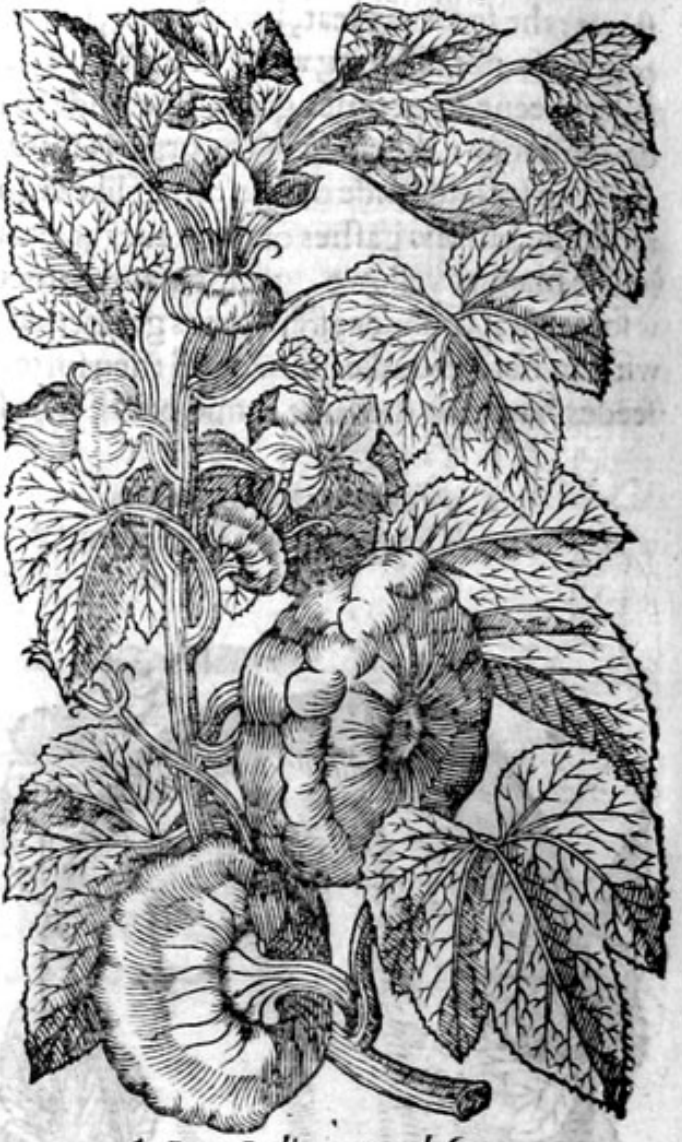

6 Pepo Indicsus angulorw.

The cornered Indian Pompion.

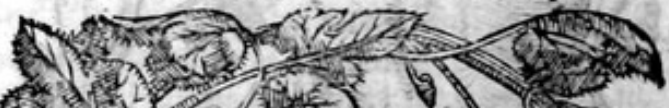

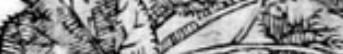

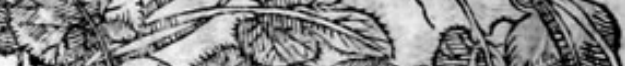

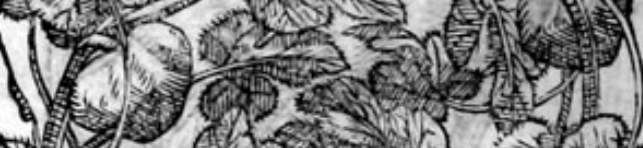

5110 (1)

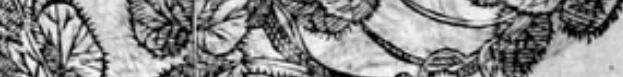

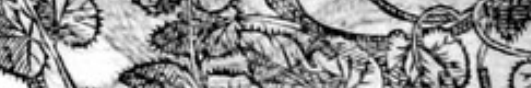

m.

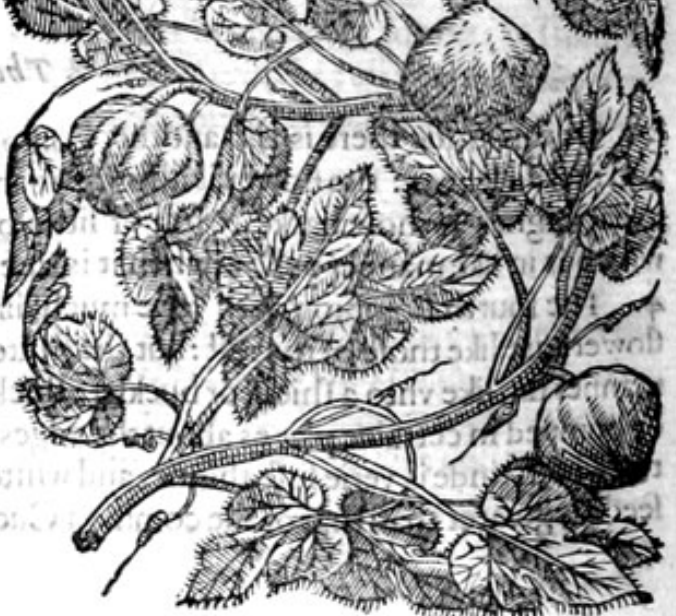




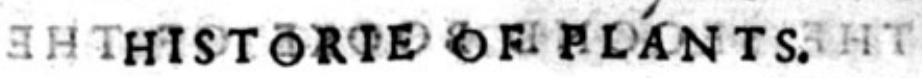

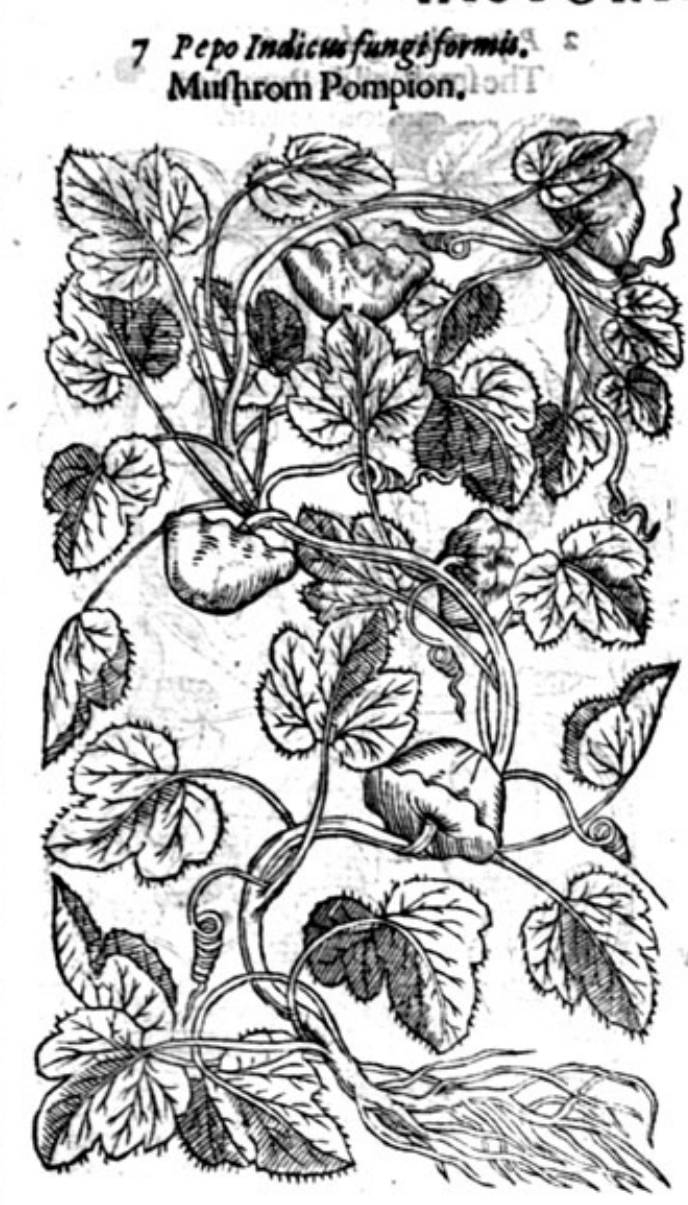

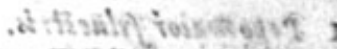

acic $x$ Theplace.

All thefe Melons or Pompions bee garden plants: they joy beft in a fruitfull foile, and are common in England; except the laft defcribed, whichis as yer a ftranger in England.

\section{* The time.}

They are planted at the beginning of Aprill: they flower in Auguit: the fruite is ripe in Sep. tember.

\section{* The names.}

The Melon or Pompion is named in Greeke mimor: in Latine likewife Pepo. The fruites of them al when they be ripe are called by a common name in Greeke mirops: in Englifh Millions or Ponpions. Whereupon certaine Phifitions faith Galen have contended, that this fruit ought to be called axvo. Tizw, that is to fayin Latine, Pepo Cucumeralis, or Cucumbor Pompion. Plimy in his 9 booke 5.chap. ter writeth, that Cuctumeres when they exceede in greatncffe, are named $P$ epones. It is called in high Dutch 1Oltiket: in lowe Dutch Joepoetten : in French Pormpons.

* The temperature and vertwes.

All the Melons are of a cold nature, withplen- $\mathbf{A}$ tic of moifture : they haue a certaine clenfing qualitic, by meanes whereof they prouoke vrine, and do more fpcedily paffe through the bodie, than do cither the Gourd, Citrull, or Cucumber, as Galen hath written.

The pulpe of the Pompion is neuer eaten raw, but boiled. For fo it doth more eafily defcend, ma- B king the belly foluble. The nourithment which commeth hereof is little, thin,moitt and colde (bad, faith Galen') and that efpecially when it is not well digefted: by reafon whereof it maketh a man apt and readie to fall into the difeafe called the Cholerike paffion, and of fome the Felonie. The feede clenfeth more than themeate, it prouoketh vrine, and is good for thofe that are trou- C
bled with the ftone of the kidneies.

The fruit boiled in milke and buttered, is not onely a good wholefome meate for mans bodie: D but being fo prepared, is alfo a moft phificall medicine for fuch as haue an hot ftomacke, and the
inward parts inflamed.

The flefh or pulpe of the fame fliced and fried in a pan with butter, is alfo a good and whole ${ }^{i}$ ome $\mathbf{E}$ meate : but baked with apples in an ouen, it doth fill the bodie full of flatuous or windie belchings, and is foode vtterly vnwholefome for fuch as liue idly; but vnto robuftious and rufticke people,
nothing hurtect that filleth the belly.

\section{Of wilde Pompions. Chap.331.}

* The defcription. A certaine wilde Melons, Cucumbers, of Melons, Citruls and Gourds, folikewife there be fet with fharpe rough prick be fo of their owne nature. Thefe bring foorth rough ftalkes, of the garden Melon, but euery part is l. The leaues be likewife: roughthe flowers yellow as be thofe a hard greene rinde. The pulpe or meate where fruite is thicke, round, and fharpe pointed, hauing of the garden Pompion, but very bitter whereof, and the middle pith, with the feede are like thofe 2 The fecond is like vnto the forter in tafte. 2 The fecond is like vnto the former, but it is altogither leffer, wherein confilteththe difference] 
I Pepomaior fyluest, is.

The great wilde Pompion.

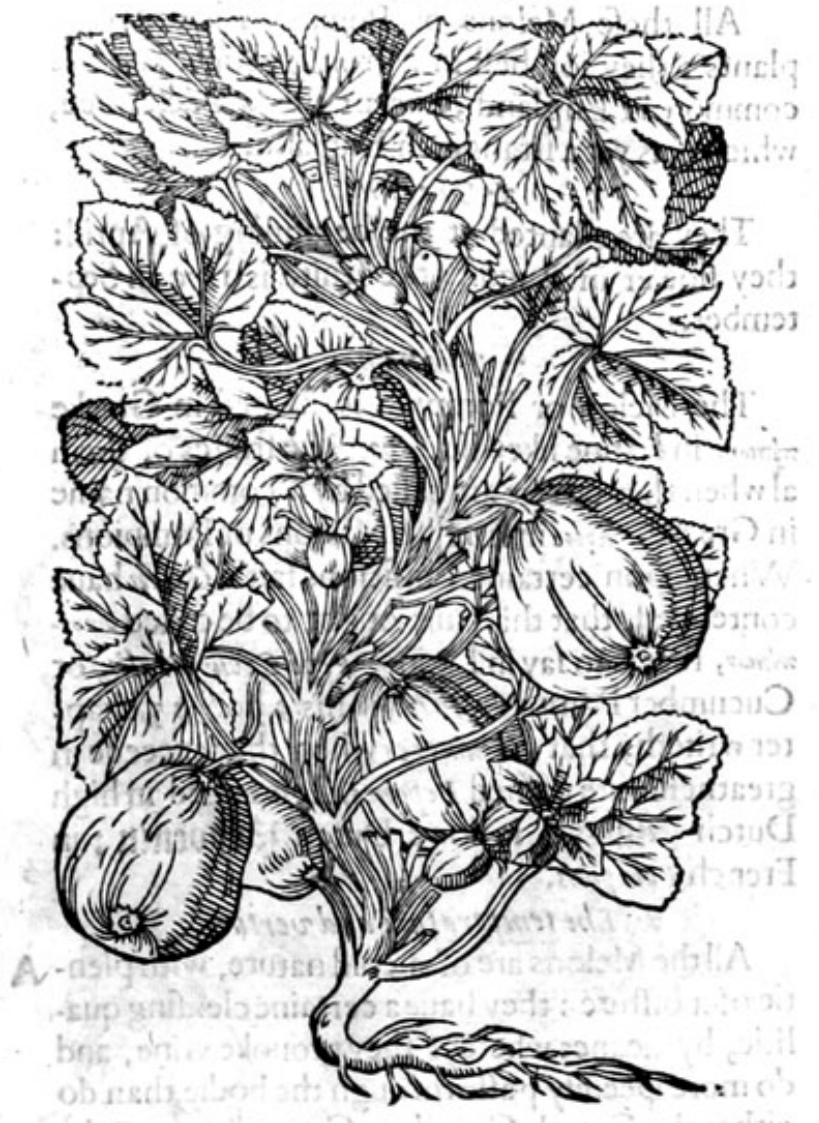

2 Pepaminor Gluestris. cang : The fmall wilde Pompion.

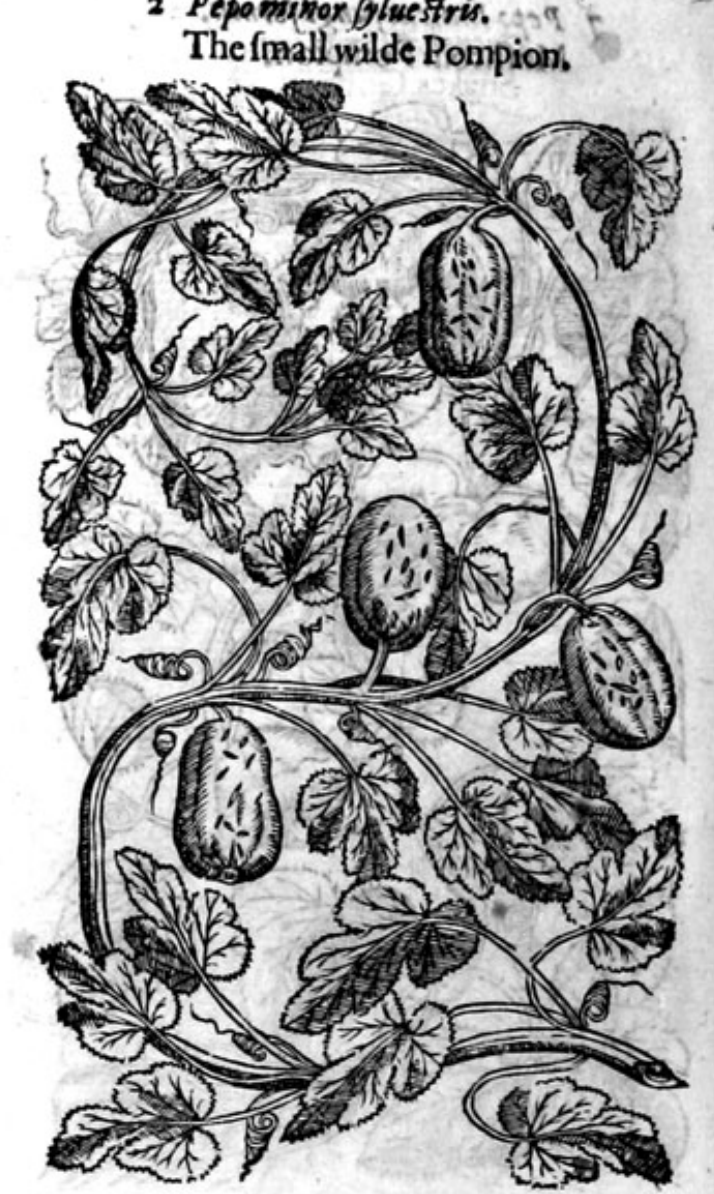

Thefe Melons do growe wilde in Barbarie, Africa, and moft partes of the eaft and weft Indies. They growe not in thefe partes, except they be fowen.

Their time of tlowring and flourifhing anfwereth that of the garden Pompion.

\section{* The names.}

Although the ancient Phifitions haue made no mention of thefe plants, yet the thing it felfe doth fhew, that there be fuch, and ought to be called in Greeke misorsäryect: in Latine Pepones Jybueftres; in Engliih wilde Melons or Pompions.

\section{$*$ The temperature.}

Like as thefe wilde Melons be altogither of their owne nature very bitter, fo be they alfo of temperature hot and drie, and that in the latter end of the fecond degree. Theyhaue likewife a clenfing facultie, not inferior to the wilde Cucumbers.

* 7 hevertues.

A The wine, which when the pith and feede is taken foorth, is powred into the rinde, and hath remained fo long therein till fuch time as it becommeth bitter, doth purge the belly, and bringeth foorth flegmatike and cholericke humors. To be briefe, the iuice heereof is of the fame operation that the wilde Cucumber is of ; and being dried it maybe vfed in fteede of Elaterium, which is the dried iuice of the wilde Cucumber.

\section{Of Gourdes. Chap.332.}

* The kindes.

There be diuers forts of Gourds, fome wilde, and others tame or of the garden; fome bringing foorth fruite like vnto a bottle; others long, bigger at one end, keeping no certaine forme or fafhion; fome greater, others leffer. 


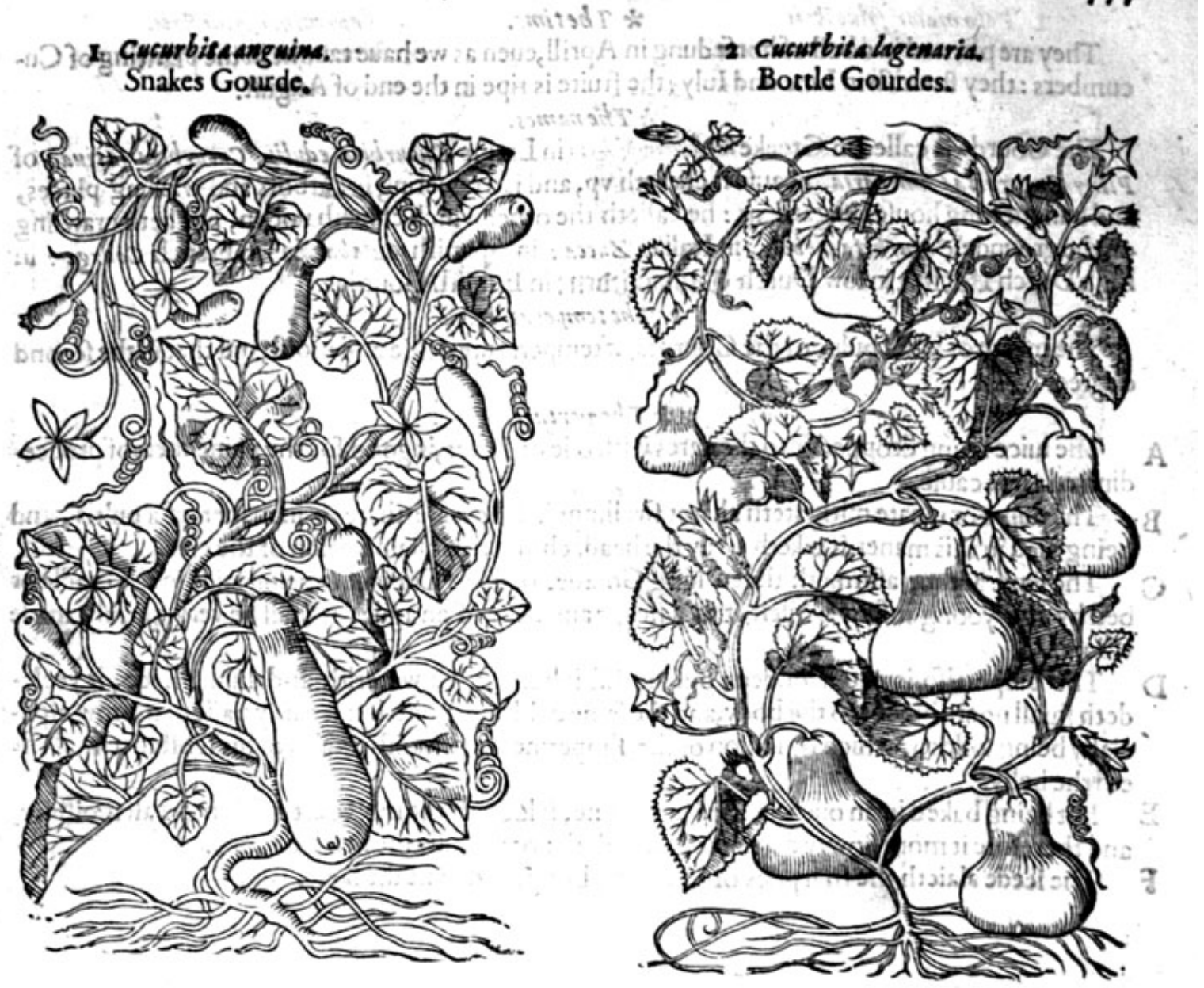

\section{* The defcription.}

I T He Gourde bringeth.foorth very long ftalks, as be thofe of the Vine, cornered and parted into diners branches, which with his clafping tendrels taketh holde and climeth vp vpon fuch things that thande neere vnto it: the leaues be very great, broad, and fharpe pointed, almoft as great as thofe of the Clote Burre, but fofter, and fomewhat couered as it were with a white freeze, as be alfo the ftalks and branches, like thole of the Marfh Mallowe : the flowers be white, and growe foorth from the bofome of the leaues: in their places come vp the fruite, which are not all of one fafhion; for oftentimes they haue the forme of $\mathrm{fl}_{1}$ gons, or bottles, with a great large belly, and a finall necke. The Gourd faith Plinie in his 19.booke 5.chapter, groweth into anie forme or fafhion that you would haue it, either like vnto a wreathed dragon, the legge of a man,or any other thapeaccording to the moulde wherein it is put whileft it is yoong; being fuffered to climbe vpon an arbor where the fruite may hang, it hath beene feene to be nine foote long, by rea: fon of his great waight which hath ftretched it out to the length :the rinde when it is ripe, is verie hard, woody, and of a yellow colour : the meate or inner pulpe is white: thefeedelong, flat, pointed at the top, broade belowe, with two peakes ftanding out like hornes, white within, and fweete
in tafte.

2 The fecond differeth not from the precedent in ftalkes, leaues, or flowers :the fruite heercof is for the moft part fafhioned like a bottle or flagon, wherein efpecially confifteth the difference. fit, in the hot countries where they come to ripeneffe, they are fometimes eaten (but with finall delighe) efpecially they are kept for the rindes, wherein they put Turpentine, Oile, Honie, and alfo ferue them for pailes to fetch water in, and many other the like vfes. 


\section{* Thetime.}

They are planted in a bed of horfe dung in Aprill,euen as we haue taught in the planting of $\mathrm{Cu}$ cumbers : they flourifh in Iune and Iuly : the fruite is ripe in the end of Auguft.

\section{* The names.}

The Gourde is called in Greeke Kudóxurgec inusess : in Latine Cucurbita edulis, Cucurbita fativa : of Pliny Cucurbita Camer aria, bicatife it climeth vp, and is a couering for arbors and walking places, and banquetting houfes in gardens : he calleth the other which climeth not vp, but lieth crawling on the grounde, Cucurbita plebeia : in Italian Zucca : in Spanifh Calabazza ; in French Courge : in high Dutch Nurbs: in low Dutch Taumoożen: in Englifh Gourdes.

$$
\text { * The temperature. }
$$

The meate or inner pulpe of the Gourd is of tempcrature colde and moift,and that in the fecond degree.

\section{* The vertues.}

A The iuice being dropped into the eares with oile of Rofes, is good for the paine thereof proceeding of a hot caufe.

B The pulpe or meate mitigateth all hot fwellings if it be laide thereon in maner of a pultis, and being vied in this maner, it taketh away the headach and the inflammation of the eies.

C The fame author affirmeth that a long Gourde, or elfe a Cucumber being laide in the cradle or bed by the yoong infant whileft it is a lleepeand ficke of anague, it Thall be very quickly made whole.

D The pulpe alfo is eaten fodden; but bicaufe it hath in it a waterifh and thinne iuice, it yeeledeth fmall nourifhment to the body, and the fame cold and moift; but it eafily paffeth thorow,efpecially being fodden, which by reafon of the flipperines and moiltnes alfo of his fub tance mollifieth the belly.

E But being baked in an ouen,or fried in a panne, it loofeth the moft part of his naturall moifture, and therefore it more flowly defcendeth, and doth not mollifie the belly fo foone.

F The feede alaieth the fharpnes of vrine and bringeth downe the fame.

\section{Of the woilde Gourde. Chap.333:}

\section{*The defcription.}

1 Here is befides the former ones, a certaine wilde Gourde: this is like the garden Gourde in climing ftalkes, clafping tendrels, and foft leaues, and as it were downie, all and euerie one of which things being farre leffer; this alfo climeth vpon arbors and banquetring houfes : the fruite doth reprefent the great bellied Gourde, and thofe that be like vnto bottles in forme, but in bignes it is very far inferior; for it is fmall \& fcarfe fo great as an ordinary Quince,and may be held within the compaffe of a mans hande : the outwarde rinde at the firft is greene,afterwards it is as harde as woode, and of the colour thereof; the inner pulpe is moilt and very full of iuice, in which lieth the feede: the whole is as bitter as Coloquintida, which hath made fo manie errours, one efpecially in taking the fruit Coloquintida for the wilde Gourde.

2 The feconde wilde Gourde hath likewife many trailing branches and clafping tendrels, wherewith it taketh holde of fich things as be neere vnto it: the leaues be broad, deepely cut into diuers fections, like thofe of the Vine, foft and very downy, wherby it is efpecially known to be one of the Gourdes : the flowers be very white, as are alfo thofe of the Gourdes : the fruite fucceedeth growing to a rounde forme, flatte on the top like the head of a Murhrome, whereof it tooke his furname. 
- Cucurbita lagenaria fyiw:ftris.

Wilde bottle Gourde.

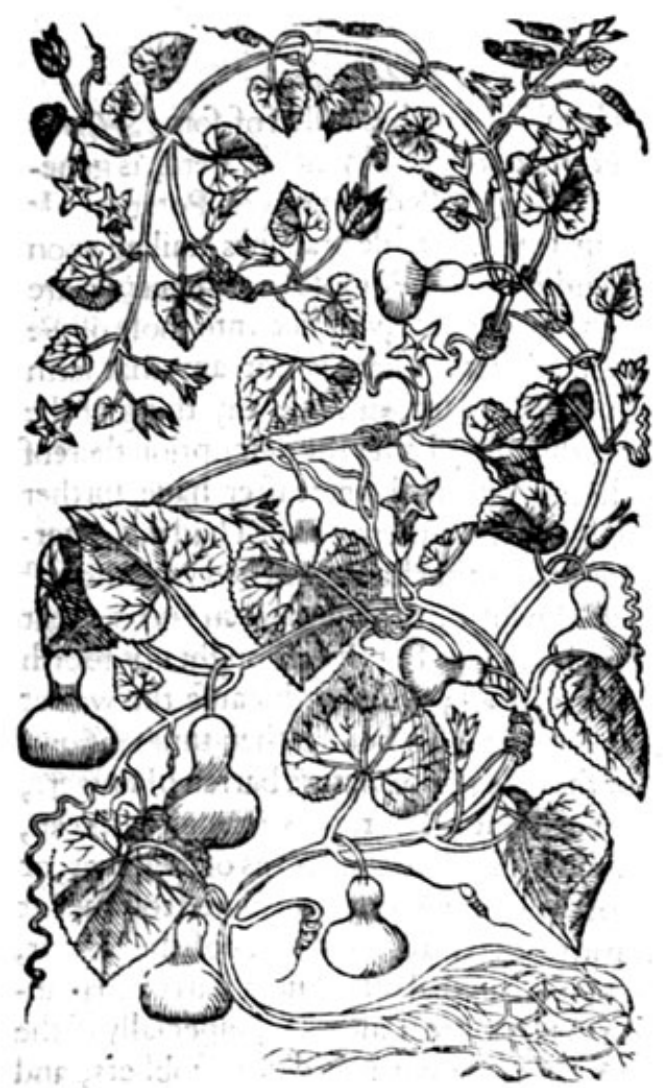

2 Cucurbita fylueftris fungiformis. Muihrome wilde Gourde.

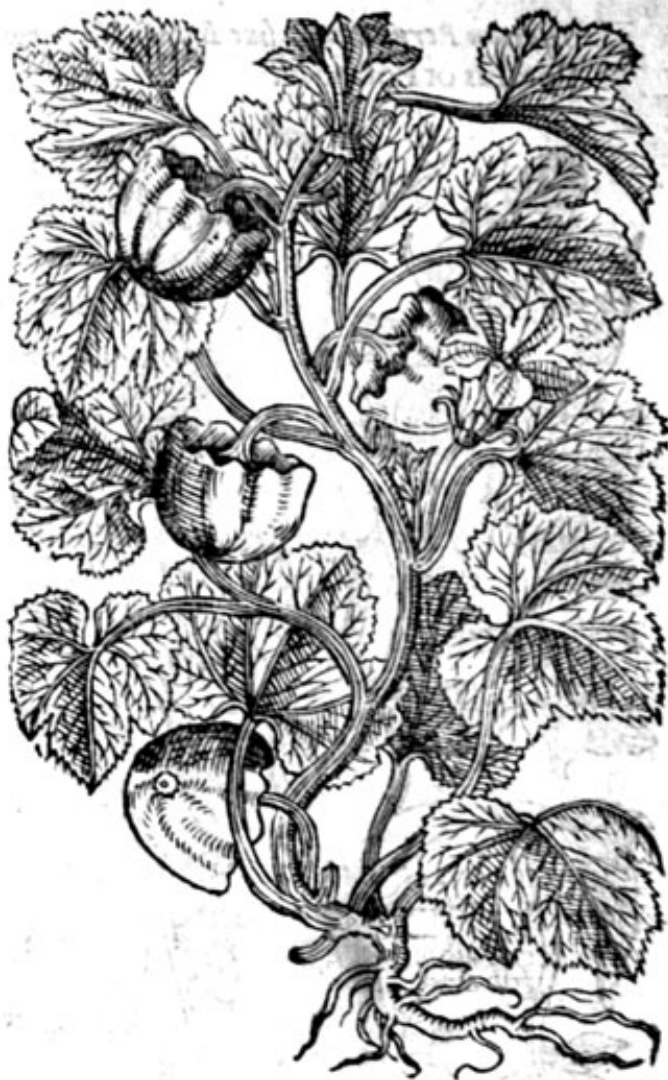

* The place.

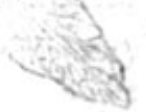

They do grow of themfelues wilde in hot regions, they neuer come to perfection of ripenes in thefe cold countries.

The time anfwereth thofe of the garden.

$$
\text { * The time. }
$$

* The names.

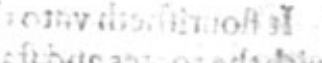

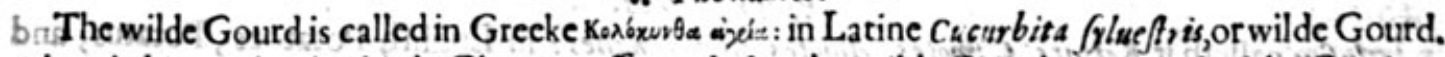
Plinie in his 20. booke thirde Chapter, affirmeth that the wilde Gourde is named of the Grecians riupos, which is hollowe, an inch thicke, not growing but among ftones, the iuice whereof beng chewed, is fingular good for the ftomacke. But the wilde Gourd is not that which is fo deferibed; for it is aboue an inch thicke, neither is it hollow, but full of iuice: and by rearon of the extreame bitterneffe, offenfiue to the ftomacke.

- Some therebe alfo that take this for Coloquintida, but they are farre deceiued. For Colocynthis is the wilde Citrull Cucumber, whercof we haue intreated in the chap. of Citruls.

\section{Isrivamot ingoris \\ as: The wilde Gourde is as hot and drie as Coloquintida, that is to fay, in the fecond degtee. * The vertues.}

The wilde Gourd is extreme bitter, for which caufe it openeth and fcowreth the ftopped paffa. A ges of the bodie, it al fo purgeth downwards, as do wilde Melons.

Moreouer, the wine which hath continued all night in this Gourd, doth likewife purge the belly B mightily, and bringeth forth cholericke and Alegmaticke humors. 


\section{Of Potatoes. Chap.334.}

Sifarum Ferwwianum, fue Batata Hifpanorum. Potatus or Potatocs.

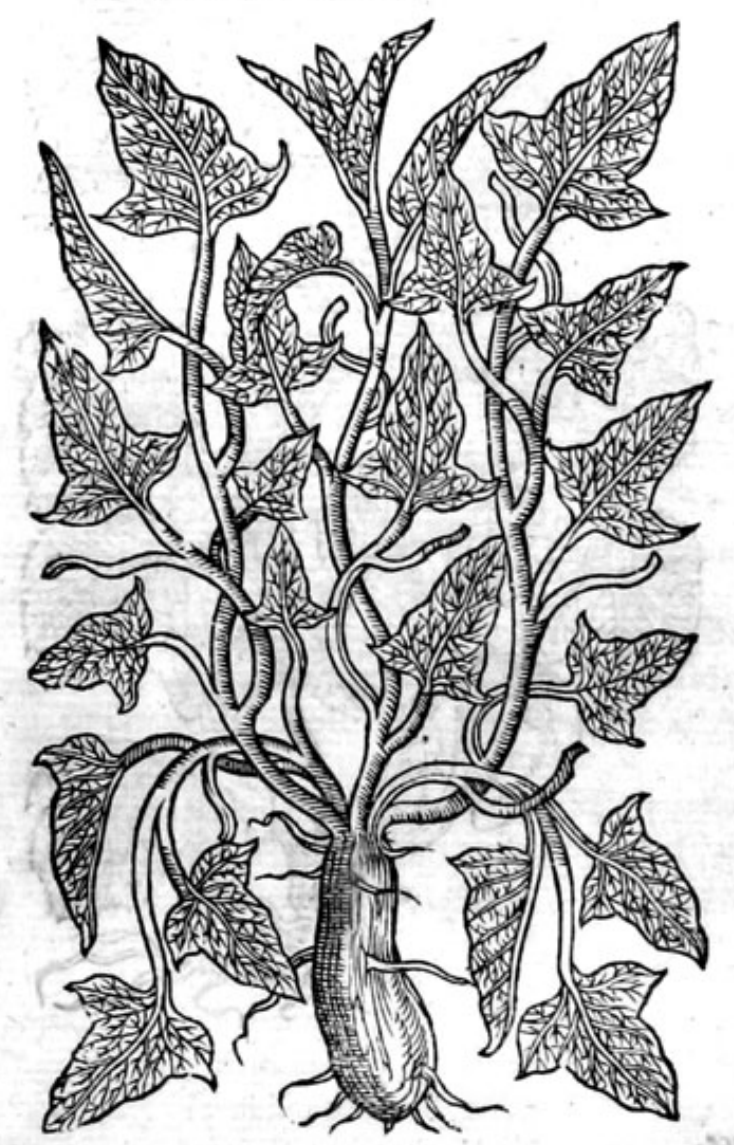

* $\mathrm{T}$ be defription.

His plant which is called of fome Sifarwom Peruuismum, or Skyrrits of Peru, is generally of vs called Potatus or Potatoes. It hath long rough flexible branches trailing vpon the ground, like vnto Pompions; whereupon are fet rough hairie leaues, very like vnto thofe of the wilde Cucumber. There is not any that hath written of this plant, or faide any thing of the flowers, therefore I refer the defcription thereof vnto thofe that fhall heereafter haue further knowledge of the fame:yet haue I had in my garden diuers roots that haue florifhed vnto the firft approch of winter, \& haue growen vnto a great length of branches, but they brought not foorth any flowers at all; whether bicaufe the winter caufed them to perilh before their time of flowring, or that they be of nature barren of flowers, I am not certaine. The rootes are many, thicke, and knobbie, like vnto the rootes of Peionies, or rather of the white Afphodill, ioined togither at the top into one head, in manner of the Skyrrit, which being diuided into diuers parts and planted, do make a great increafe, efpecially if the greateft rootes be cut into diuers gobbets, and planted in good and fertill ground.

$$
\text { * Theplace. }
$$

The Potatocs grow in India,Barbarie,Spaine, and other hotte regions, of which I planted diuers rootes (that I bought at the exchange in London) in my garden, where they flourifhed vntill winter, at which time they perifhed and rotted.

$$
\text { * The time. }
$$

It flourifheth vnto the end of September: at the firft approch of great frofts, the leaues togither with the rootes and italkes do perifh.

\section{* The names.}

Clufues calleth it Battata, Camotes, Amotes, and Ignanes: in Englifh Potatoes, Potatus, and Potades.

\section{* T he nature.}

The leaues of Potatoes are hot and drie, as may euidently appeere by the tafte. The rootes are of a temperate qualitic.

A The Potatoe rootes are among the Spaniards, Italians, Indians, and many other nations common and ordinarie meate, which no doubt are of mightie nour:fhing parts, and do ftrengthen and comfort nature, whofe nutriment is as it were a neanc betwcene fle? and fruit, though fomewhat windie; but being rofted in the embers, they do lofe much of their windineffe, efpecially being eaten fopped in wine.

B Of thefe rootes may be made conferues, no leffe toothfome, wholefome, and daintie, than of the flefh of Quinces. And likewife thefe comfortable and delicate meates, called in fhops Mor felli, rlacentule and divers other fuch like.

C Thefe rootes may ferue as a ground or foundation, whereon the cunning confectioner or Sugar baker may worke and frame many comfortable delicate conferues, and reftoratiue fweete meates. 


\section{HESTORIE, OFIPLANTS.}

They are vfed to be eaten rofted in the afhes; fomewhen they be fo rofted, infufe them, and fop D them in wine $:$ and others to giue them the greater grace in eating, do boile them with prunes,and fo eate them. And likewife others dreffe them (being firft rofted) with oile, vineger and falt, euery man according to his owne tafte and liking : notwithftanding howfoeuer they be dreffed, they comfort,nourim, and ftrengthen the bodie, procure bodily luft,and that with greedineffe.

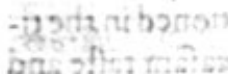

\section{Of Potatoes of Virginia. Chap:335.}

Battata Virginians fue Virginianorum, \& Papposs. Potatoes of Virginia.

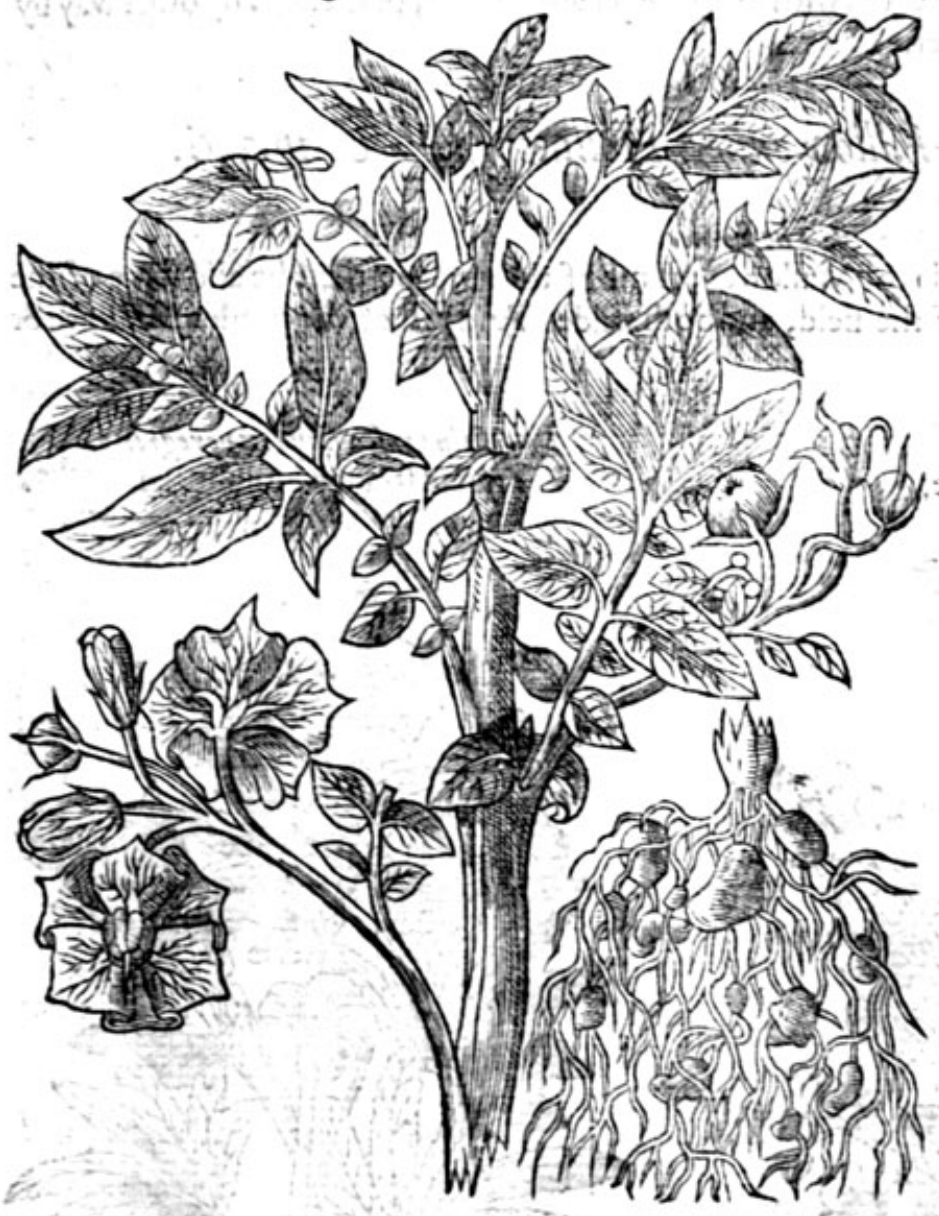

* The defcription.

Trginia Potatoes hath many hollowe flexible branclies, trailing vppon the grounde, three fquare, vnetien, knotted or kneed in fundry places at certaine diftances; from the which knots commeth foorth one great, leafe made of diuers leaues, fome fumt: ler, \& others greater, fet togither vpon a fat mieddle rib by couples; of a fivart greene colour tending to rednes. The whole leafe refembling thofeof the Parfnep, in tafte at the firt like grafle, but afterward fharp \& nipping the toong: from the bofome of which lezues come foorth long rounde flender footitalks, whereon do grow yery faire and pleafant flowers, made of onie entire whole leate, which is folded or plaited in fuch frange fort, that it feemeth to be a tower made of fixe fundrie fmall leaves, which cannot eafily be perceived, except the fame be pulled open. The colour whereof it is hardeo expreffe. The whole flower is of a light purple color, ftripped doyn the middle of euery folde orwelt, with a light thew of yellownes, as though purple and yellow were mixed togitber: in the middle of the flower thrufteth foorth a thicke fat pointell, yellow as golde, with a fmall tharpegreene pricke or point in the middeft thereof. The fruite fucceederth the flowers, round as a ball, of the bignes of a little bulleffe or wilde Plum, greene at the firt, andblacke when it is ripe; wherein is contained fmall white feede, lefier than thofe of Multarde. The roote is thicke, fat, and tuberous; not much differing either in fhape, colour or tafte from the common Potatoes, fauing that the tootes hereaf are not fo great nor long; fome of them round as aball, fome ouall or eggefathion, fome longer, and others horter : whichknobbie rootes are faltened vnto the ftalkes with an infinite number of threddie ftrings.

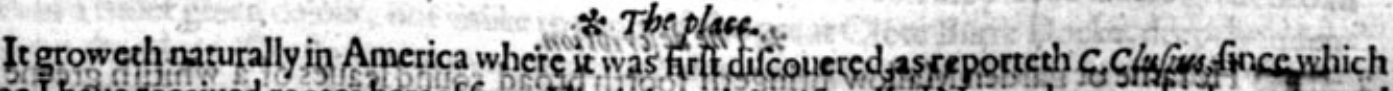

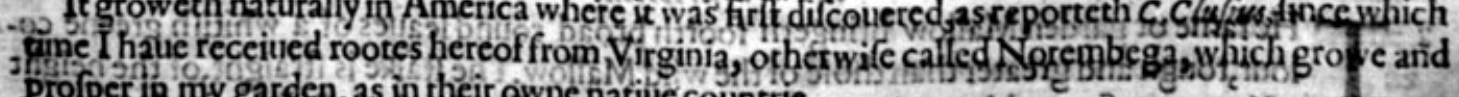

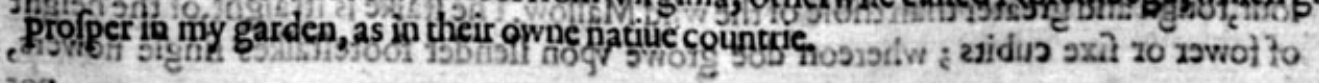


* $T$ be time.

The leaues thruft foorth of the ground in the beginning of May: the flowers bud foorth in Allguft.The fruit is ripe in September.

\section{* The names.}

The Indians do call this plant Papus (meaning the rootes) by which name alfo the common $\mathrm{Po}$ tatoes are called in thofe Indian countries. We haue the name proper vnto it, mentioned in the title. Bicaufe it hath not onely the fhape and proportion of Potatoes, but alfo the pleafant tafte and vertues of the fame, we may call it in Englifh Potatoes of America, or Virginia.

\section{* The temperature and vertues.}

The temperature and vertues are referred vnto the common Potatoes; being likewife 2 foode, as alfo a meate for pleafure, equall in goodneffe and wholefornneffe vnto the fame, being either rofted in the embers, or boiled and eaten with oile, vineger and pepper, or dreffed any other way by the hand of fome cunning in cookerie.

\section{Of the garden Mallow called Hollibocke. Chap.336.}

* The kindes.

$T$ Here be diuers fortes or kindes of Mallowes; fome of the garden : there be alfo fome of the marfh or fea fhore; others of the field, and both wilde. And firt of the garden Mallowe or Hollihocke.

I Malua hortenfis. Single garden Hollihocke.

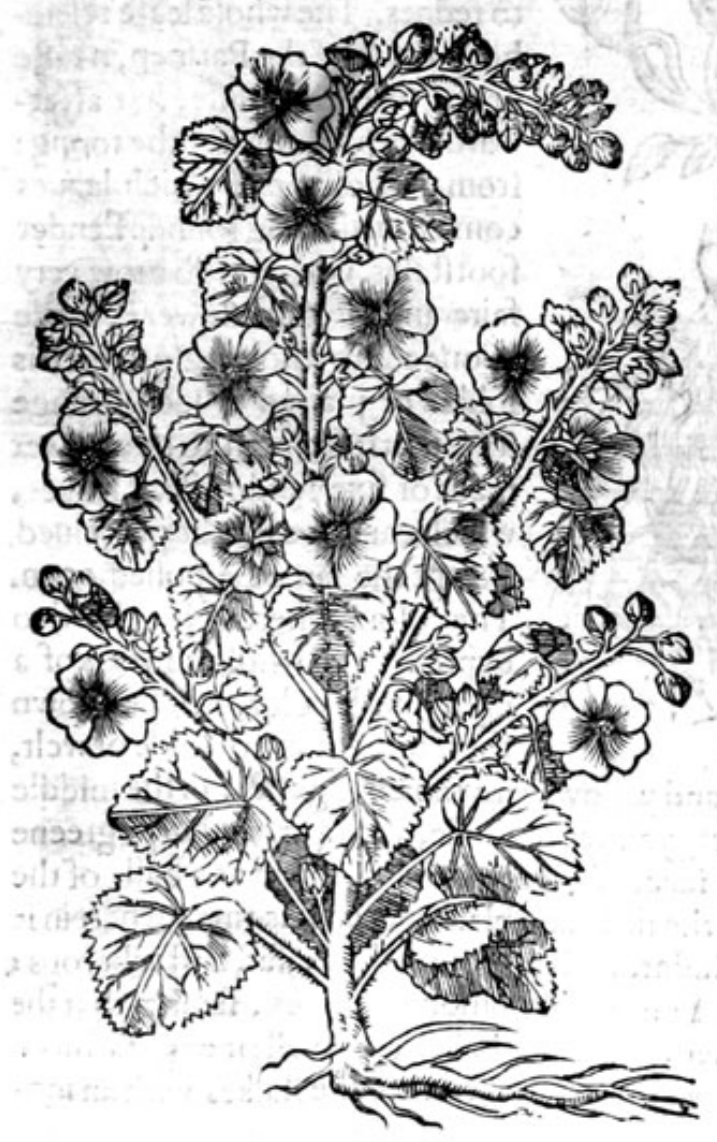

2 CMalua rofea fimplex peregrina. Iagged ftrange Hollihocke.

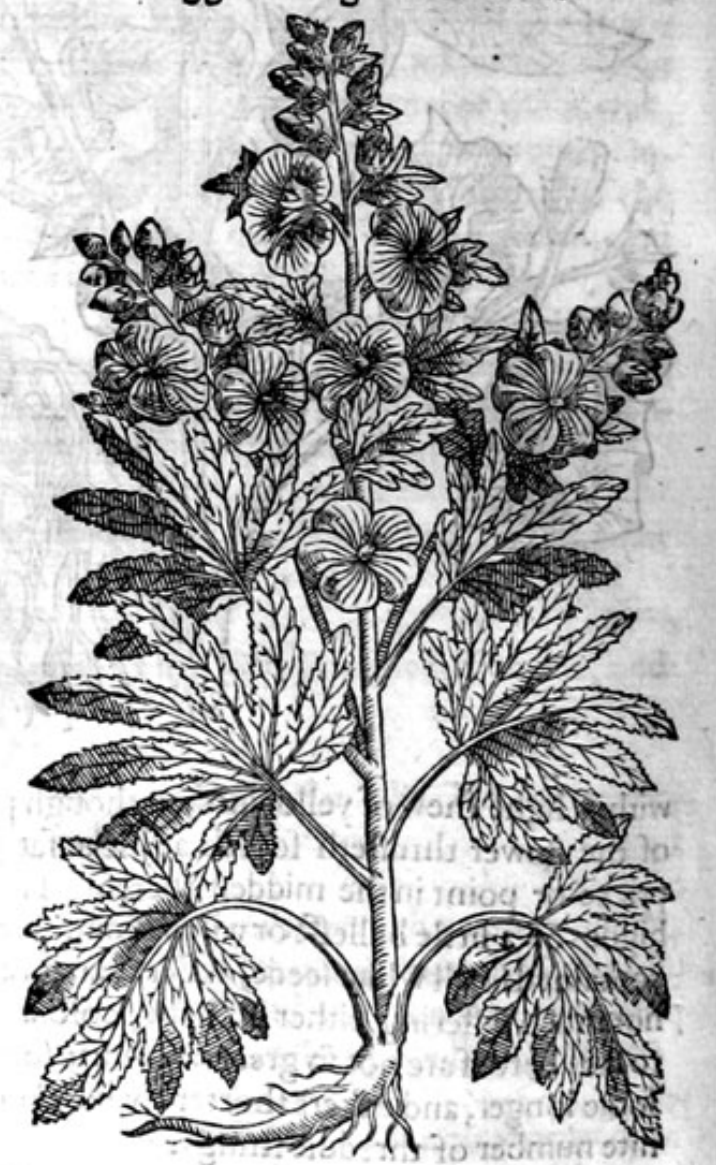

* The defcription.

- He tame or garden Mallow bringeth foorth broad round leates of a whitin greene colour, rough and greater than thofe of the wild Mallow. The ftalke is ftraight, of the height of fower or fixe cubits; whereon doe growe vpon flender footeftalkes fingle flowers,

not 
not much vnlike to the wilde Mallow, but greater, confifting onely of fiue leaues, fometimes white, or red;now and then of a deepe purple colour, varying diuerfly as nature lift to play with it : in their places groweth vp a round knop like a little cake, compact or made vp of a multitude of flatfeedes like little cheefes. The roote is long,white, tough, eafily bowed, and groweth deepe in the ground. 2 Thefecond being a ftrange kind of Hollihock, hath likewife broad leaues, rough and hoarie, or of an ouerworne ruffet colour, cut into ditiers fections euen to the middle rib, like thofe of Palma Chrifti. The flowers are very fingle, but of 2 perfect red colour, wherein confifteth the greateft difference.

3 Malwa purpures multiplex. Double purple Hollihocke.
4 Mslus bortenfis multipliciflore.

Double Scarlet Hollihocke.
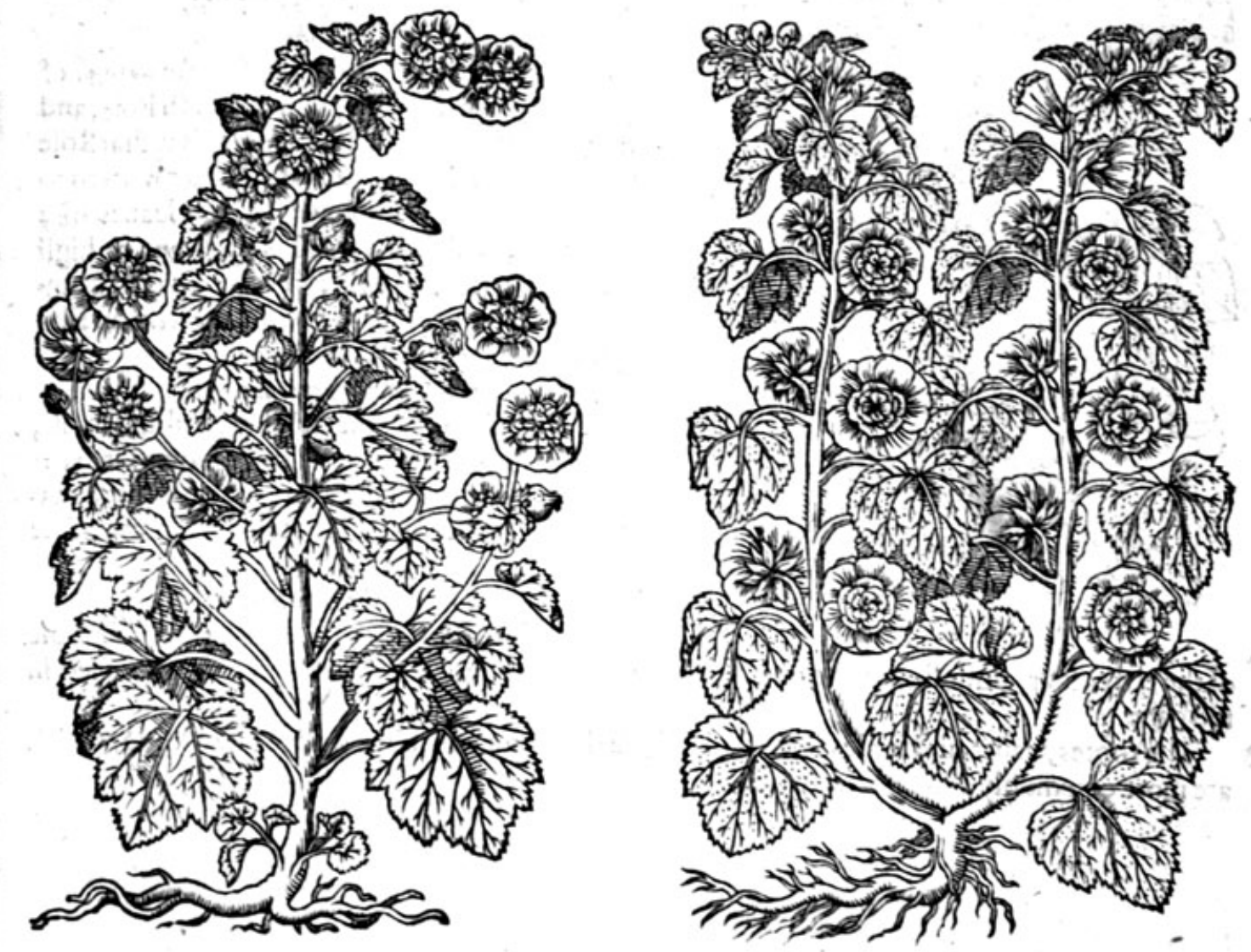

\section{* The defcription.}

3 The double Hollihocke with purple flowers hath great broade leaues, confufedly indented about the edges, and likewifetoothed like a fawe. The ftalke groweth to the height of fower or fiue

4. The garden Hollihocke with double flowers of the colour of fcarlet, groweth to the height of precedent.
ples, hauing many broad leaues cut about the edges. The italke and roote is tike the

5. The tree Mallow is likewife one of the Hollihocks ; it bringeth forth a great ftalke of the height leaues of a ruffet green colour to the forme of a fmall tree, whereon are placed diuers great broad ted about the edges. The flowers vnlike to thofe of the great Clote Burre Docke, deepely indenof a deep red colour tending to blackneffereat and double as the greateft Rofe, or double Peionie, is the reft of the plant. 
Malua arborca fore nigro multiplici.

Tree Hollihocke with double flowers.

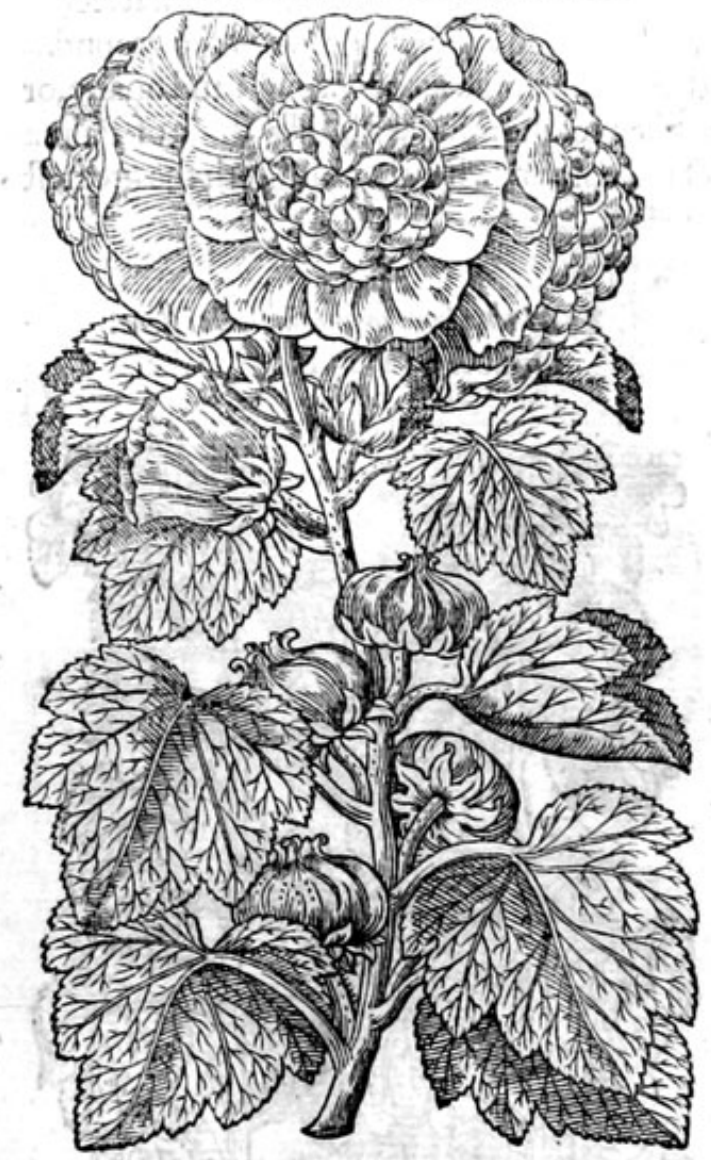

A of the red colour, doth ftoppe the ouermuch flowing of the monthly courfes, if they be boyled in red wine.

B The rootes, leaues, and feedes ferue for all thofe things for which the wilde Mallowes do, which are more commonly and familiarly vfed.

\section{Of the wilde Mallowe. Chap.337.}

* Thedefcription.

I

He wilde Mallowe hath broade leaues fomewhat rounde and cornered, nickt about the edges, fmooth, and grcene of colour : among which rife vp many flender tough ftalkes, clad with the like leaues, but fmaller. The flowers growe vpon little footeftalks of a reddifh colour mixed with purple ftrakes, farhioned like a bell: after which commeth vpaknap or round button, like vnto a flat cake, compact of many fmall feedes. The roote is white, tough, and ful of a flimie iuice, as is all the reft of the plant.

2 The divarfe wilde Mallowe creepeth vpon the grounde: the ftalkes are flender and weake, yet tough and fexible. The leaues be rounder, and more hoarie then the other. The flowers are imall and of a white colour. The roote and feede is like the precedent. 


\section{EHHISTORIEO FI RDANTS. HT}

1 Malua fluefris. The ficlde Mallowe.

2 Malius flueforis puonila.

S1)

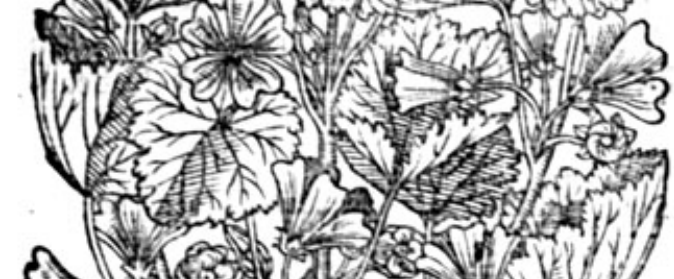

S. 1 ( (n)

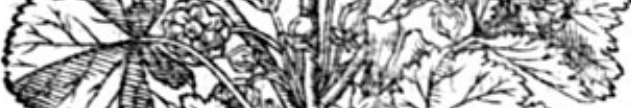
(1) 1 - $10-3 y^{2}$
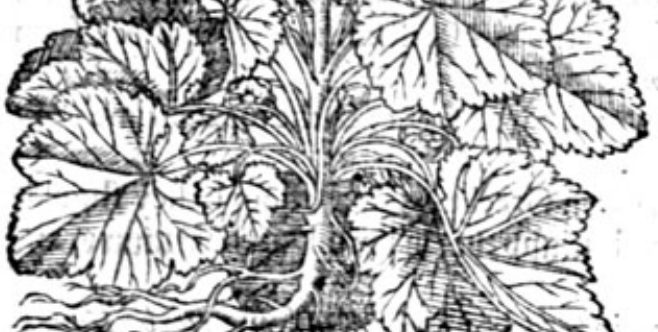

3 Maluacripa.

The French curled Mallowe.
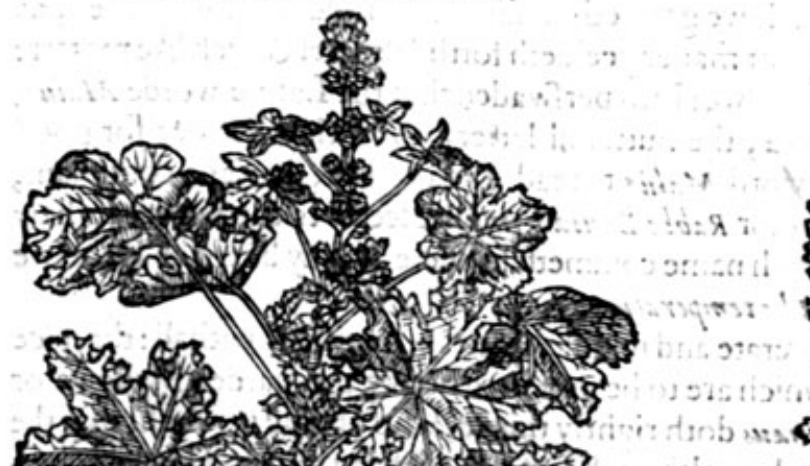

ob the wilde dwanfe Mallowe T

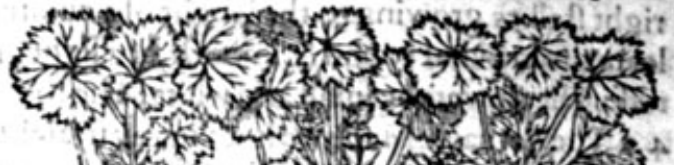

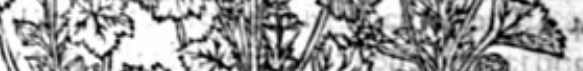

(4)

6. 201 .

(1)

ind

(1)

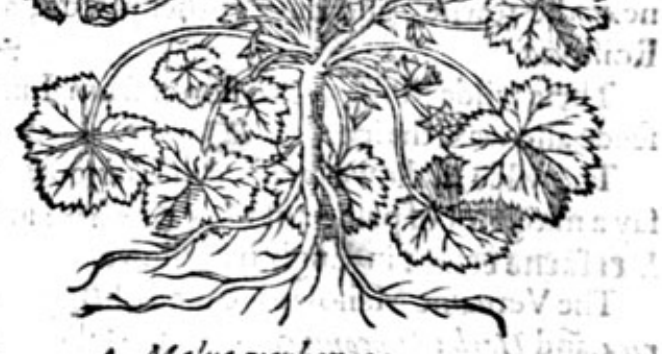

4 Malua verbersica.

Veruaine Maliowe.

Non
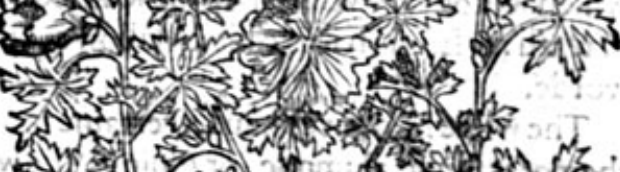

5.

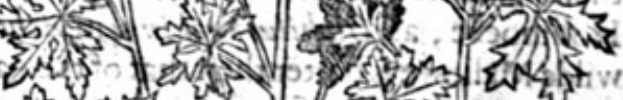
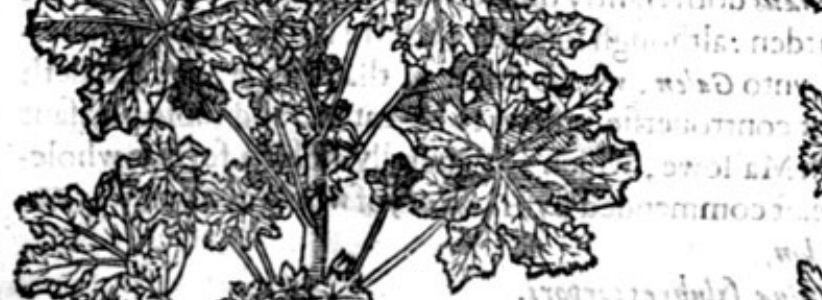
(n)
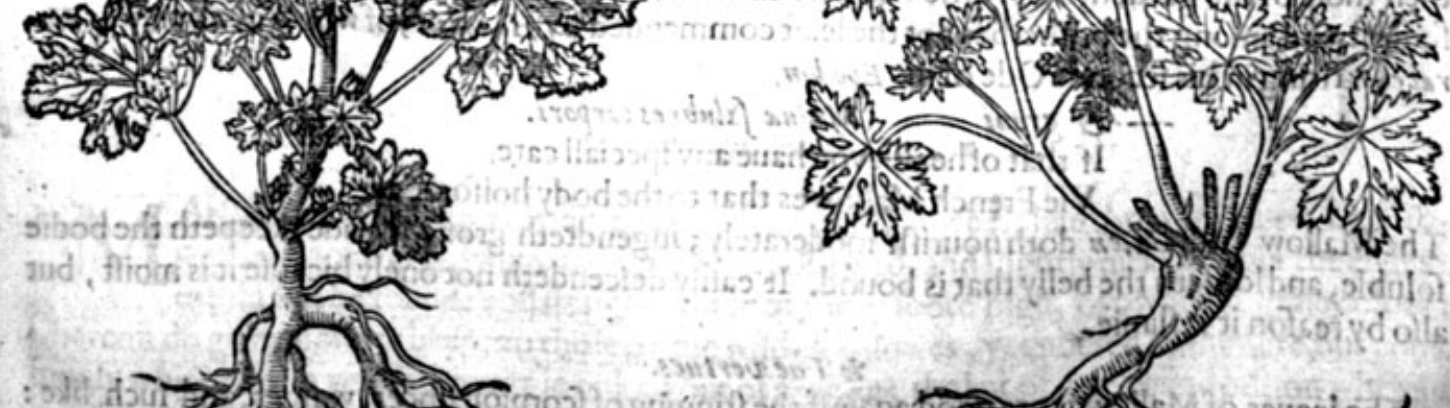

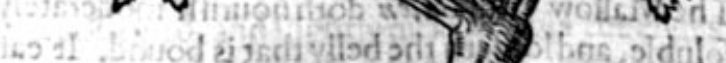

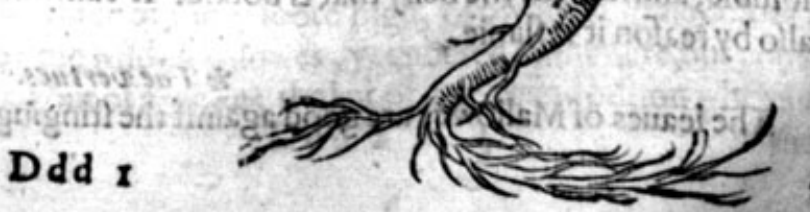


The crifpe or curled Mallowe, called of the vulgar fort French Mallowes, hath many fmall vptight ftalkes, growing to the height of a cubite, and fometimes higher; whereon do growe brozde leaues fomewhat round \& fmooch, of a light greene colour, plaited or curled about the brims like 2 ruffe. The flowers be fmall and white. The roote perifheth when it hath perfeeted his feede.

4 The veruaine Mallowc hath many ftraight ftalks, whereon do growe duers leaues deepely cut, and iagged euen to the middle rib, not vnlike to the leaues of Veruaine, whereof it tooke his name: among which come foorth faire and plcafant flowers like vnto thofe of the common Mallowe in forme, but of a more bright red colour, mixed with ftripes of purple, which fetteth foorth the beau. tie. The roote is thicke and continueth many veeres.

* The place.

The two firft Mallowes growe in vntoiled places among potherbes, by high waies, and the borders of fieldes.

The French Mallowe is an excellent potherbe, for the which caufe it is fowen in gardens, and is not to be found wilde that I know of.

The Veruaine Mallowc groweth not euery where; it groweth by the ditch fides, on the left hand of the place of execution by London, called Tyborne: alfo in a fielde neere vnto a village fourteene miles from London called Buthey, on the backfide of a gentlemahs houfe named mafter Robert Wylbrabam; likewife among the bufhes and hedges as you go from London to a bathing place called the Old Foorde; and in the bufhes as you go to Hackney a village by London in the clofes next the towne, and diuers other places, as at Baffingburne in Hartfordhire three miles from Roifton. * The time.

Thefe wilde Mallowes doflower from Iune till fommer be well fpent : in the meane time their feede alfo waxeth ripe. $D^{\prime}$ * The numes.

The wilde Mallowe is called in Latine Malua fylueftris: in Greekex̃xoms, as though they fhoulde fay a mitigator of paine : of fome Ofiriaca : in high Dutch 1Dappelt : in lowe Dutch 9 aluwe, and treeftien cruit : in Englifh Mallowe.

The Veruaine Mailowe is called of Diofcorides Alcea: in Greeke alfo inxie, of fome Her ba Hungarice, and Herba Simeones, or Simons Mallowe: in Englifh Veruaine Mallowe and cue Mallowe.

The name of this herbe Malua, feemeth to come from the Hebrewes, who call it in their toong mino, Malluach, of the faltneffe, bicaufe the Mallowe groweth in faltifh and olde ruinous places, as dunghils and fuch like; which in moft abundant maner yeeldeth forth faltpeter \& fuch like matter: for nto. Melach, fignifieth falt as the learnec knowe: I am perfwaded that the Latine worde Malua, commeth from the Chaldee name Mallucha, the gutturall letter $n, C h$, being left out for good foundes fake: fo that it were better in this yord Malija to read $u$ as a vowell, then as a confonant, which wordes are vttered by the learned doctor Rabbi Dauid Kimbi, \& feeme to carrie a great thew of truth : in Englirh it is called Mallowe, which name commeth fo neere as may be to the Hebrewe worde. * The temperature.

The wilde Mallowes haue a certaine moderate and middle heate, and moiftnes withall : the iuice there of is flimie, clammie, or gluing, the which are to be preferred before the garden Mallowe or Hollihocke, as Diphilus Siphinus in Athenases doth rightly thinke, who plainly fheweth, that the wilde Mallowe is better then that of the garden : although fome do preferre the Hollihocke, wherunto we may not confent, neither yet yeeld vnto Galen, who is partly of that minde, yet ftandeth he doubtfull : for the wilde Mallowe without controuerfie is fitter to be eaten, and more pleafant then thofe of the garden,except the French Mallowe, which is generally holden for the wholeforne $\mathrm{ft}$, and among the potherbes not the leaft commended by $\mathrm{He}_{\mathrm{e}}$ fodus; of whole opinion was Horace, writing in his feconde Ode of his Epodon,

$$
\text { -... o graui Malua falubres corpori. }
$$

If that ofhealth you haue any fpeciall care,

Vfe French Mallowes that to the body holfome are.

The Mallow faith Galen doth nourifh moderately; ingendreth groffe bloude: keepeth the bodie foluble, and loofeth the belly that is bound. It eafily defcendeth not onelybicaufe it is moift, but alfo by reafon it is flimic.

A The leaucs of Mallowes are good againft the ftinging of fcorpions, bees, wafpes, and fuch like: and 


\section{HISTORIE OF PLANTS.}

and if a man be firft annointed with the leaues ftamped with a little oile, he fhall not be ftung atall 2s Diogcorides faith.

The decoction of Mallowes with their rootes drunken, are good againft all venome and poifon; B if it be incontinently raken after the poifon, fo that it be vomited vp againe. $1.175 \%$ s thonswo

The leanes of Mallowes boiled till they be foft and applied, domollifie tumours and harde fwel. C lings of the mother, if they do withall fit ouer the fume thereof, and bathe themfelues therewith.

The decoetion vfed in glifters is good againft the roughnes and fretting of the guts, bladder; $D$ and fundament.

The rootes of the Veruaine Mallowe do heale the blondie flixe and inward burftings, if they be $\mathrm{E}$ drunke with wine and water, as Diofcorides and Paulus AEginet a teftific.

$$
\begin{gathered}
\text { Of Marge Mallowe. Chap. } 338 \text {. } \\
\text { * The kindes. }
\end{gathered}
$$

There be diuers forts of Marfh Mallowes, differing very notably as fhall be declared.

1 Althea Ibifcers.

Marfh Mallowe.

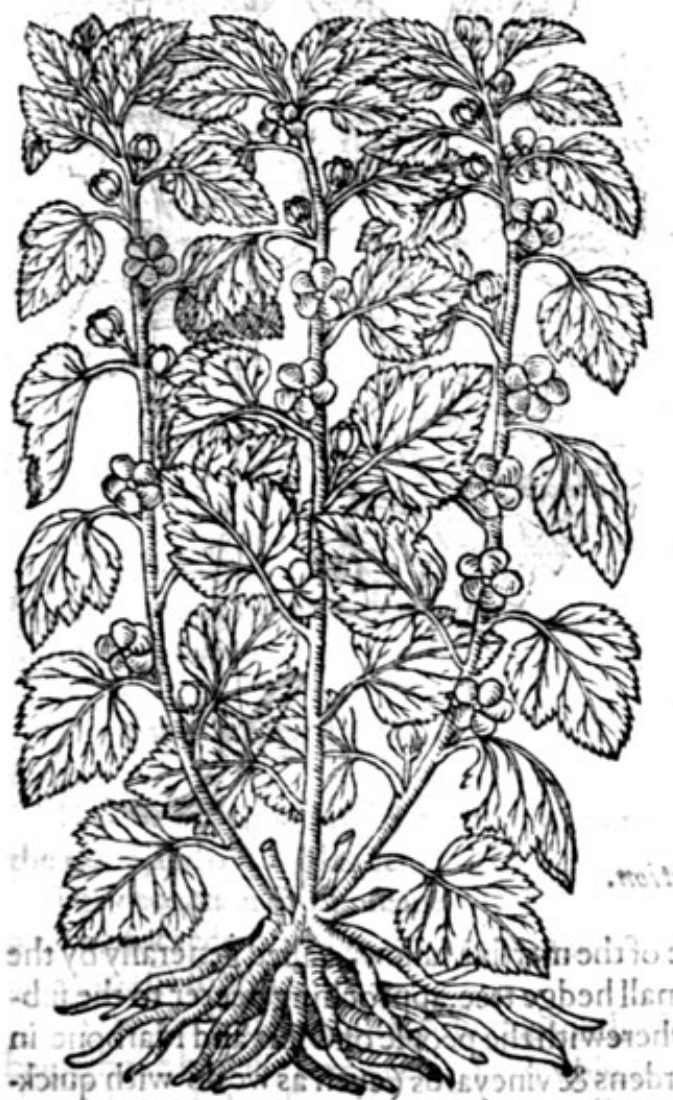

2 Altheapaluftris. Water Mallowe.

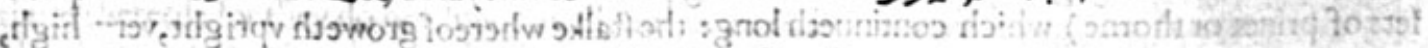

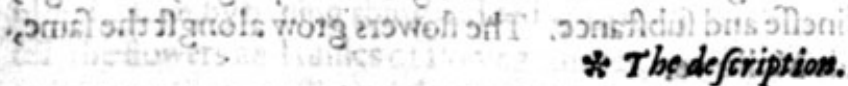

1. Arr. Mallowe is alfo a certaine kinde of wilde Mallowe : it hath broade leaues, finall totheft alkes be rounde and ftraight, three or fower foote high, of a whitifh graie colour: Whereon do graw flowers like vnto thoíc of the wilde Mallowes, yet not red as they are, but cont. monly white, or of a very light purple colour out of 2 white; the knoppe or round button wherein oWV 
the feedes lie, is like that of the firft wilde Mallowe. The roote is thicke, tough, white within, and containeth in it a clammic and flimie iuice.

2 This ftrangekinde of Mallowe is holden amongft the beft writers to be a kinde of marth $\mathrm{Mal}_{2}$. lowe: fome excellent in Herbarifme, haue fet it downe for Sida 7 heophrafti, whereunto it fully anfwereth; it hath ftalkes two cubits high, whereon are fet without order many broade leaues, hoarie and whitifh, not vnlike to thofe of the other marnh Mallow, of a purple colour tending to rednes, that is of a Citrine colour, or the colour of the Porngranate flowers : after which there come round bladders of a pale colour, in thape like the fruite or feed veffels of round Ariftochia, or Birth woort, wherein is conteined round blacke feede. The roote is thicke and tough, much like thofe of the common Mallowe.

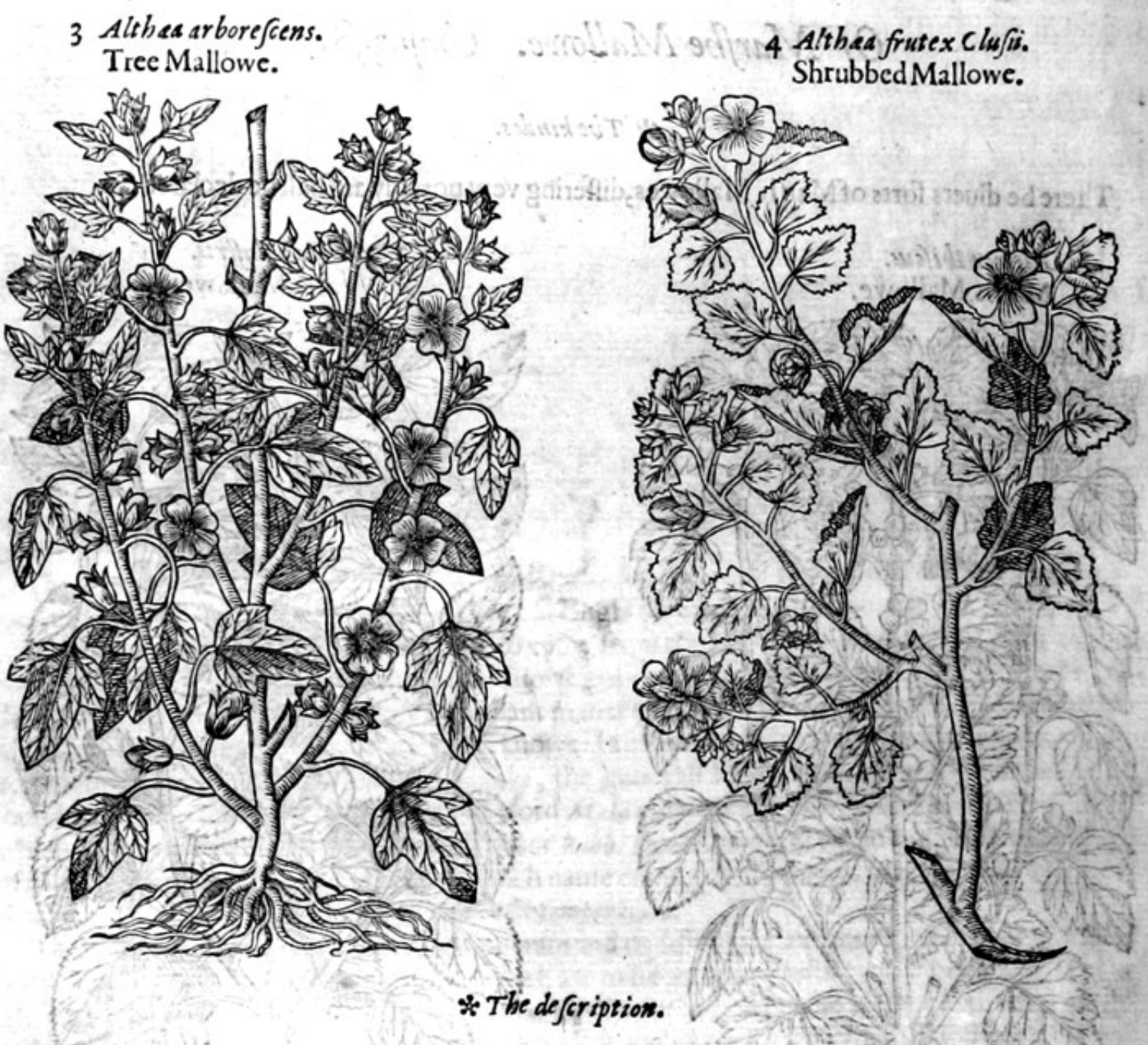

3 This wilde Mallow is likewife referred vnto thofe of the marn Mallow, called generally by the name of Ult bet, which groweth to the forme of a finall hedge tree, approching neerer to the fubftance or nature of woode then any of the other, wherewith the people ofOlbia and Narbone in Fraunce do make hedges, to fether or ditide their gardens \& vineyards (euren as we do with quickfets of prituet or thorne) which continucth long: the ftalke whereof groweth vpright, very high, comming neere to the Willowe in woodineffe and fubftance. The flowers grow alongft the fame, in fafhion and colour of the common wilde Mallowe. I :

4 The fhrubbie Mallowe rifeth vp like vnto a hedge bufh, and of a woodie fubtance, diuiding it felfe into diuers tough and limiber branches, couered with a barke of the collour of antes , whereupon doe growe rounde pointed leaues, fome what nickt about the efiget, very foft, not unlike to thofe of the common marfh viallow, and of an ouerworne hoarie colourf; the fow ers do growe at the top of the ftalkes, of a purple colour, confifting of five leaues, verty tike to the common wilde Mallowe, and the icede of the marfh Mallowe. 


\section{A H IST ORIE OOF PLADTS. 3HT}

We haue aniother fort of Mallow called of Pens Fraticofior trentaplylla folios it bringeth fodrth in my garden many twiggie braunches, fet spon ftiffe ftalkes; of the bignes of a mansthoinbe, growing to the height of ten or twelue foote: s whereupon are fet very many leaues decpely cut, etien to the middle ribbe, like vnto the leaues of Hempe, or rather chofe of the redde Cinquefoile, called Pentaphy lum rubium, whereofiotooke this additament Pentaphylls: the flowers and feed sare like vnto the common Mallow : the roore is exceeding great, thicke; and of a moodie fubitance.

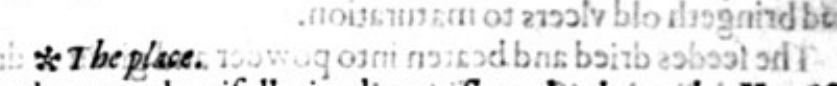

The common marh Mallowe groweth very plentifully in the marthess, both on the Kentifh and Effex fhore alongt the riuer of Thames, about Woolwich, Erith, Greenehyth, Grauefend, Tilburie, Lee, Colchefter, Harwich, and in mott falt marlhes about London; being planted in gardens it profpereth well, and continueth long.

The fecond groweth in the moilt and fennie grounds of Fetratia, betweene Padua in Italie and the riuer Eridanus; Atheneus alleaging Theophraftus fheweth that it groweth in the lake Orchomenitum, where their cattle feede on the branches therof, \& the fwine on the tenderbuds. Theophraftics Theweth that three things do growe in this lake, Sida, Boutomon, and Phlron, that is, water Lillic faie fome authors (making this kinde of marh Mallowe, a kinde of water Lillie) Reede Graffe, and Cats taile,or Reede Mace.

The others are Itrangers likewife in England, notwithiftanding at the impreffion heereof, I haue fowen forrefeedes of them in my garden, expecting the fucceffe,

\section{\& Thetime.}

They flower and fourifh in Iuly and Auguft; the roote fpringeth foorth a frefh euery yeere in the beginining of March, which are then to be gathered, or in September.

$*$ The names.

The common marth Mallowe is called in Greeke dateras, and idroos: the Latines retaine the names Altbea, and $I b_{i} f$ cus : in fhops Bifmalus, and Malmavifcus, as though they fhoulde faic, Malus

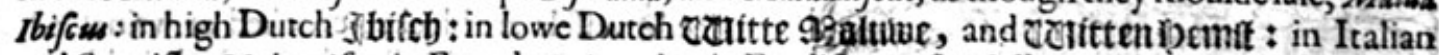
and Spanifhercaluswifoo : in French Guimaulue : in Englifh marfh Mallow, moorifh Mallowe, and white Mallowe.

The fecond marh Mallow is called of Theophrastus Sida, of the Greeke worde sion, by reafon that the Alower thereof is like, or of the colour of Balauftitum, or the flowers of Pomegranates.

The reft of the Mallowes retaine the names expreffed in their feuerall titles. * The temperature.

Marfh Mallowe is moderately hot, but drier then the other Mallowes: the rootes andfeedes heereof are more drie, and of thinner parts, as Galen writeth; and likewife of a digefting, foftning,or. mollifying nature.

The leaues of marn Mallowe are of power to digeft, flacken, to mittigate paine, and to con- $A$ coet.

They be with good effect mixed with fomentations and pultefes againt paine of the fides, of B the ftone, and of the bladder; in a bath al (o they ferue to take away any maner of paine.

The decoction of the leaues drunke doth the fame, which alfo doth not oncly affwage paine, C which proceedeth of the ftone, but alfo is verie good to caufe the fame to defcende mose eafily,
and to paffe foorth.

The rootes and feeds are profitable for the fame purpofe: morcouer the decottion of the rootes D helpech the bloudie flixe, yet not by any binding qualitie, but by mitigating the gripings and frettings thereof: for they do not binde at all, although $G$ alen otherwife thought; but they cure the bloudie flixe, by hauing things added vnto them, as the rootes of Fisfort, called Patience, Tormentill, the flowers and ruides of Pomegranates, and fuch like.

Thermucilage or flimie iuice of the rootes, is mixed very effeetually with all oiles, ointments, E and plaifters that flacken and mitigate paine.

The rootes boiled in wine, and the decoction helpeth the bloudie flixe, fciatica, crampes, and conuulfions.

The roots of marfh Mallowes, the leaues of cōmon malluwes, and the leaues of violets, boiled in G water vntil they be very foft, S that litlc water that is left drained away, ftamped in a ftone morter, Ddd.3 
adding thereto a certaine quantitic of Fenugreeke, and Linefeede in powder; the roote of the blacke Brionic,and fome good quantitic of Barrowes greafe, ftamped altogither to the forme of a pultis, and applied very warme; it mollifieth and foftneth apoftemes and hard fwellingssfwellings in the ioints, and fore of the mother : it confumeth all colde tumours, blaftings, and windie ontgoings; it cureth the riftes of the fundament; it comforteth, defendeth, and preferueth dangerous greene wounds from any maner of accidents that may happen therto; it helpeth digeftion in them
and bringeth old vlcers to maturation.

The feedes dried and beaten into powder and given to drinke, ftoppeth the bloudie flixe and laske, and all other iffues of bloud.

\section{Of theyellow Mallowe. Cbap.339.}

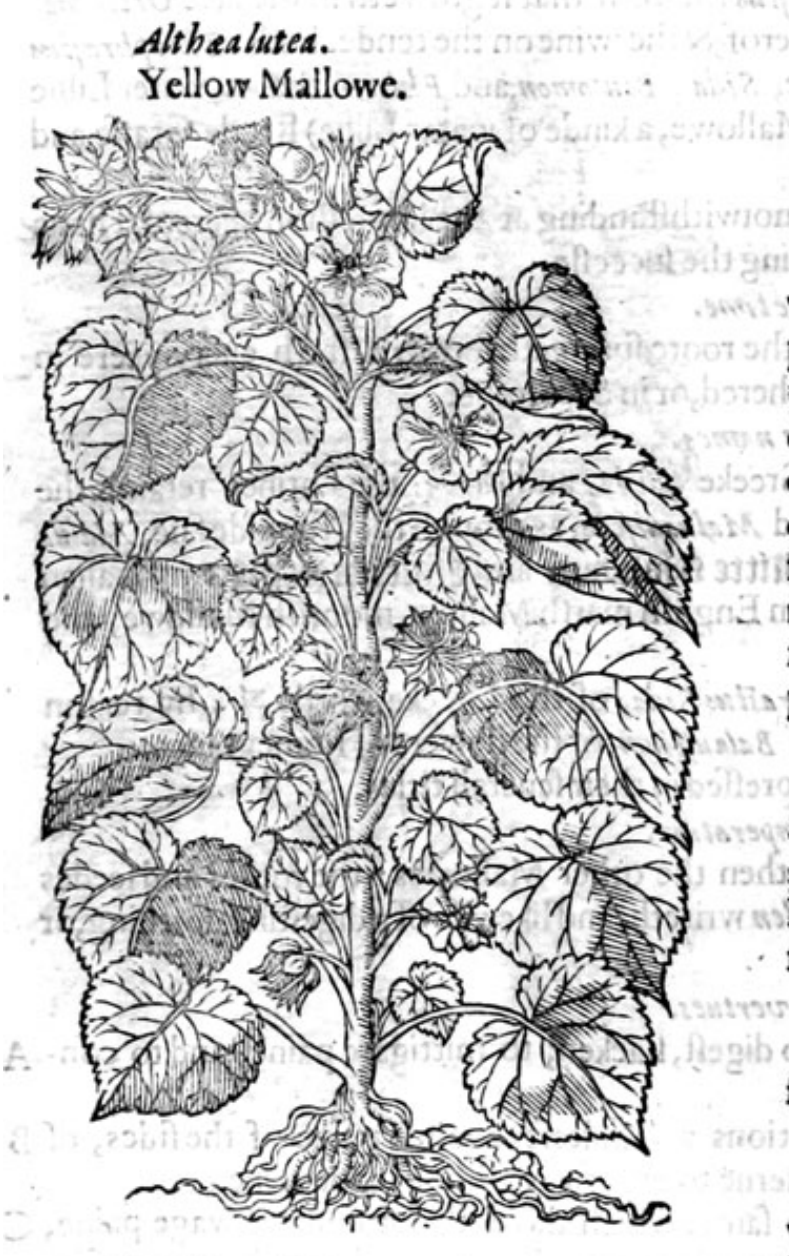

'T

* 1 be defoription.

7 He yellowe Mallowe rifeth yp with a round ftalke, fomerhing hard or wooddie, three or fower cubits high, couered with broade leaues fomthing rounde, but harpe pointed, white, foft, fet with very fine haires like to the leaues of Gourds, hanging vpon long tender footitalks; from the bofome of which leaues come foorth yellow flowers, not vnlike to thfoe of the common Mallowe in forme : the knops or feedo veffels are blacke, crooked or wrinckled, made up of many fmall cods, in which is blacke feede : the roote is fmall, and dieth when it hath perfected his feede.

to The place.

The feede heereof is brought vnto vs from Spaine and Italy, we do yeerely fowe it in our gardens, the which feldome or neuer doth bring his feede to ripenes; by reafon whereof, we are to feeke for newe feedes againft the nexr yeere. $\checkmark$ The time.

It is fowen in the midit of Aprill, it bringeth foorth his tlowers in September. * The names.

It is called Abutilon, whereunto that agreeth which Uivicen writeth to be like the Gourd, that is to fay in leafe, and to be named Abutilon, and Arblutilon: diuers take it to be that Althea, or marh Mallowe vnto which Theophraftus in his 9. booke of the Hiftorie of Plants doth attribute Florem uirumor, or a yellow flower: for the flower of the common marn Mallowe is not a yellowe, but white; yet may Theophrastus his copie, which in dituers places is faultie, and hath many emptie and vnwritten places, be alfo faultic in this place; therefore it is hard to faie, that th:is is Theophraftus marfh Mallowe, efpecially feeing that Theophraftus feemeth alfo to attribute vnto the roote of marfh Mallowe fo much flime, as that water may be thickned therewith, which the rootes of common mar?h Mallowe can very well do: but the roote of Abutilon or yellowe Mallowe not at all: : t may be called in Englifh yellow Mallowe, and Auicens Mallow.

* Thetemperature.

The temperature of this Mallow is referred vnto the tree mallow. 


\section{HISTORIE OF PLANTS. $\exists H T$}

* The vertues.

Aavis en faith that Cabitilon or yellow Mallow, is helde to be good for greenewounds, and doth $A$ prefently glew togither, and perfectly cure the fame.

The feede drunke in wine preuaileth mightily againft the ftone.

Bernardus Paludanus of Anchufe, reporteth that-the Turkes do drinke the feede to prouoke $\mathbf{C}$ fleepe and reft.

\section{Of Venice Mallowe, Gor Goodight at noone. Chap.340.}

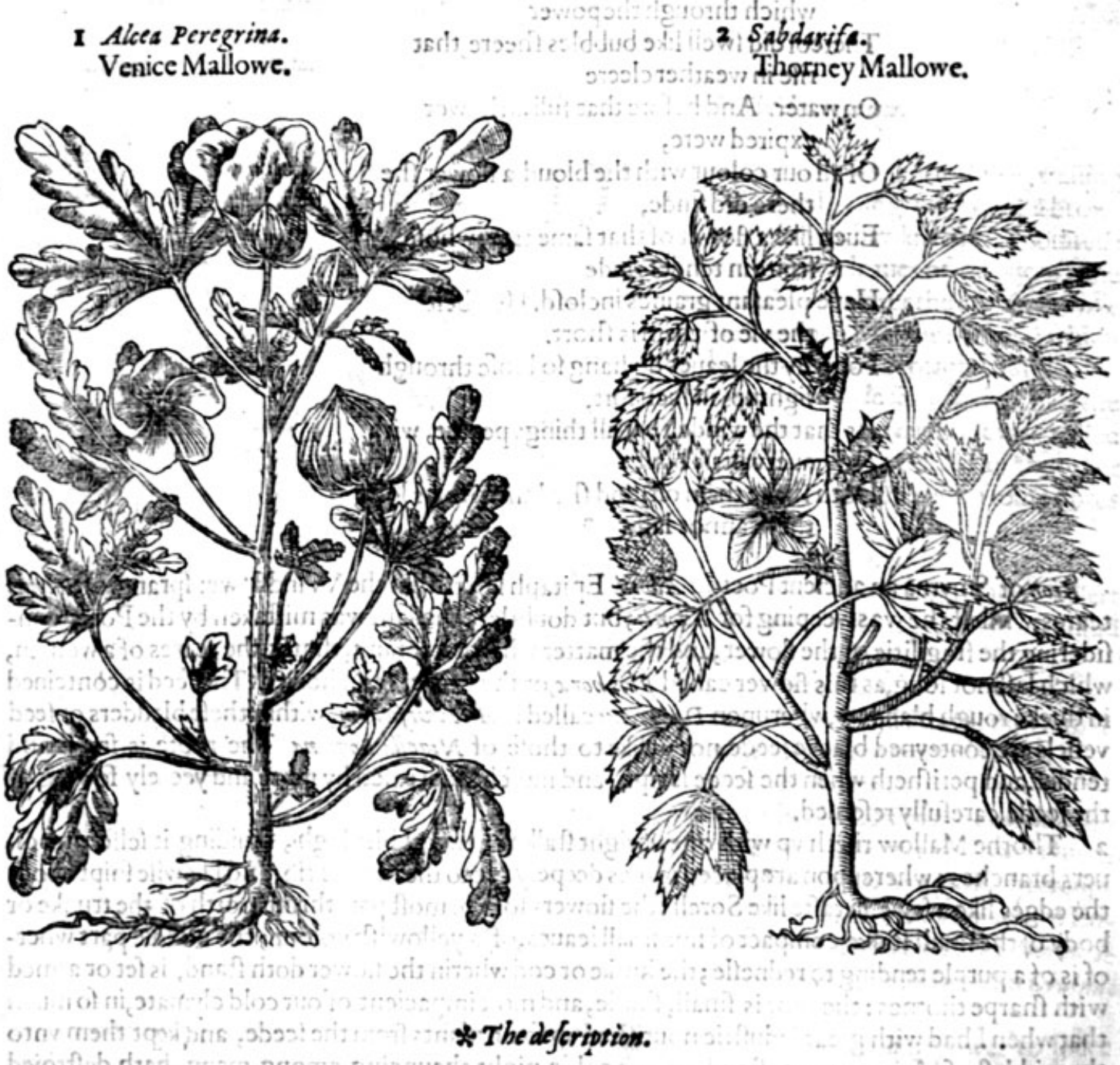

I 7 He Venice Mallow rifeth vp with long, rounde, feeble ftalkes, whereon are fet vponlong fender footeftaikes, broade iagged leaues, deepely cut euen to the middle ribbe : among which come foorthvery pleafant and beautifull flowers, in thape like tbofe of the common Mallowe, fomthing white, dafht ouer with a thinne wath of purple; in the midale of which flower ftandeth foorth a knap or peftell as yellowr as golde: it openeth it felfe about eight of the clocke, and fhutteth yp againe at nine, when ithath receiued the beames of thefunne, whercon it fhould feeme to refufe to looke, whereupon it might more properly be called chalus herarifs or the Mallow of an hower, which Colvemells feemeth to call Molochen in his verfe:

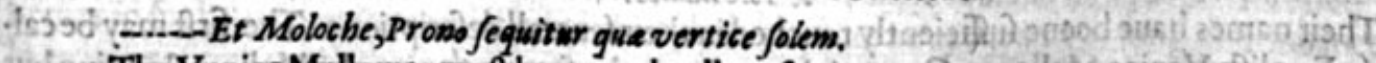

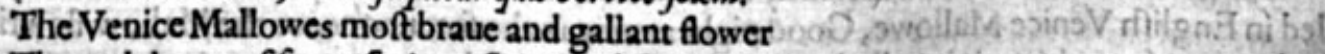
Through heate of funne fprings, fhuts, and dies in an hower. 
Ouid fpeaking of Adonis flower, is thought to defcribe Anemone or Windflower, in the ro.booke of his Metamorphofis, which we rather deeme to be this quicke fading Mallowe; for it is eurident, that Adonis flower and all thofe vnder the title of Winde flowers, laftemoe then one day 3 but this

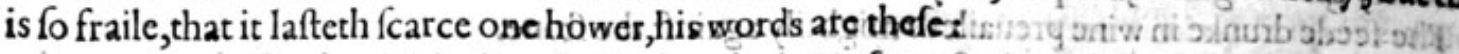

Nectare odorato parfit, guitactus abillo

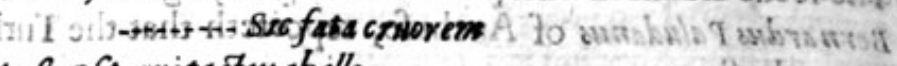
Intumuit,ficut, \&c.

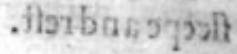

\section{In Eughifhithiso ?}

This faide, The fprinckled Nectar on the bloud, which through the power

Thereof did fifell like bubbles rheere, that

swolisiverife in weather cleere

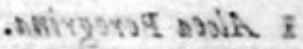

Onwatec. And before that full an hower expired were,

Of all our colour with the bloud a flower the there did finde,

Euen like a flower of that fame tree, whofe - fruite in tender rinde

Haue pleafant graines inclofd. Howbeit the $y$ fe of them is hort.

For why the leaues do hang fo loofe through lightnes in fuch fort,

As that the winde, that all things pearce, with euery little blaft

Doth fhake them off, and fhed them fo, as long they cannor lait.

Bion of Sinyrma an ancient Poet, in Adonis Epitaph Faith, that the Windflower fprang of Venus teares; whileft the was weeping for Adonis; but doubtles the plant was miftaken by the Poet, confidering the fragilitic of the flower, and the matter wherot it f prang, that is, the Efares of a woman, which laft not laigg, as this flower called $F$ los hore, or the flower of an hower. The feed is conteined in thicke rough bladders, wherupon Dodon eus called it Alcea veficaria, withih thefebladders or feed veffels are conteyned blacke feede, not vnlike to thofe of Nigella Romana. The roote is finall and tender, and perifheth when the feede is ripe, and mut be increafed by newe and yeerely fowing of the feede, carefully referued.

2 Thorne Mallow rifeth vp with one vpright ftalke of two cubits high, diuiding it felfe into diuers branches; whereupon are placed leaues deepely cut to the middle rib, and likewife fnipt about the edges like a fawe, in tafte like Sorell : the flowers for the moft part thruft foorth of the trunke or body of the fmalliftalke, compact of fiue fmall leaues, of a yellowifh colour; the middle part wherof is of a purple tending to rednefie ; the huske or cod wherin the flower doth ftand, is fet or armed with fharpe thornes: the root is fmall, fingle, and moft impacient of our cold clymate, in fo much that when I had with great induftrie nourifhed vp fome plants from the feede, and kept them vnto the middeft of Maie; notwithftanding one colde night chauncing among many, hath deftroied them all.
तigras:
* The place.

The feedes heerof haue beene brought out of Spaine and other hot countries. The firf profpereth well in my garden from yeere to yeere.

* The time.

They are to befowen in the moft fertilleft grounde and finnie places of the garden, in the beginning of Maie, or in the end of Aprill.

* The names.

Their names haue beene fufficiently touched in their feuerall defcriptions. The firft may becalIed in Englifh Venice Mallowe, Good night at nine in the forenoone, or the Mallow flowring but an hower, of Mathiolus it is called Hypecoon, or Rue Poppie, but vnproperly. 
There is a certaine clammic iuico inchelgaueş of the Venice Mallowe, whereupon it is thought to come neere vnto the temperature of the common Mallowe, and to be of 2 mollifying facultie: but his vfe in Phificke is not yet knowne, and therefore can there be no certainty affirmed.

$$
\text { Of Gramesbilt Chap.34r. }
$$

I) 25 is

THere be many kindes of Cranesbill, whereof two were knowne to Diofcorides, one with the I. knobby roote, the other with the Mallowe leafe.

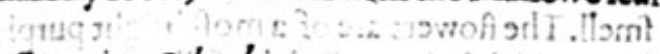

Geraniwn Columbiniom.

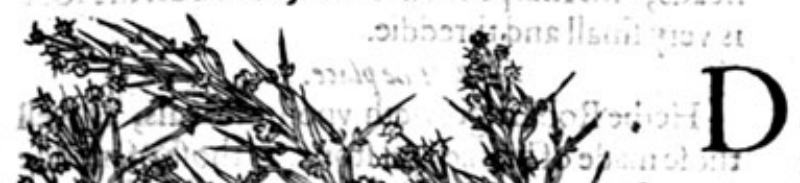

Doutes foote, or Cranes bill.

\section{* The defcription.}

Ques foote hath manie hairie ftalks, trailing or leaning towarde the grounde, of a brownifh colour, fomewhat kneede of iointed; whereupon do grow rough leaues of an ouenworne greene colour, rounde, cut about the edges, and like vito thole of the common Mallow s amons which come foorth the Alowers of \& bright purple colour : after which is the feede fer togither kike the heed and bifl of a birde, whercupon it was called Cranes bill, or Storkes bill, as are atfo all theother of hiskinde. The roote is flender with fome fibres annexed thereto.

$$
\text { * Tbeplace. }
$$

It is found necre to common high wales, cefert places, vntilled grounds, and efpecially vpon mud wals almoft eueric where.

$$
\text { * The time. }
$$

It fpringeth vp in March and Aprill : flowreth in Mays and bringeth his feede to ripenes in Iune.

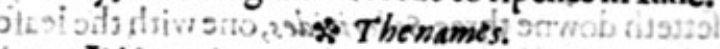

It iscommonly catled in Latine Pes Colmonbinus: in high Dutch catter kraut : in lowe Dutch Du uen boet 8 in Fitench Pied ide Pigeon : hecreuponirmay be called Geranium Columbinum : in Englifh Doues foote, and Pigeons foote: of D:ofcorides Geranium alterwon; of fome Polmonia and Gruind. $*$ The temperature. Douiesifoote is cold and fomewhat drie, with fome aftrietion or binding, hauing power to foder
oribine sogither.

It feemeth, faith my author, to begood fortwes.

It feemeth, faith my author, to be good for greene and bleeding woundes, and affwageth inflam- $\boldsymbol{A}$
mations or hot fwellings.

The herbe and rootes dried, beaten into moit fine pówder, and giugen halfe a f poonefull fafting, B and the like quantitic to bedwards in red wine, or olde claret, for the fpace of one and twenty daies
togither; cureth miraculoufly ruptures or burfings, as my felfe haue often prooued, wherby I haue gotten crownes and credite : if the ruptures be in aged perfons, it fhall be needfull to adde thereto the powder of red fnails (thofe without (hels)dried in an ouen, in number nine, which fortifieth the herbes in fuch fort, that i neuer faileth, although therupture be great and of long continuance : it likewife profiteth much thofe that are wounded into the body, \& the decoction of the herbe made in wine, preuailect mightily in healing inward wounds, as my felfe have likewife prooued. zetowol? 


\section{Of Herbe Robert. Chap. $34^{2}$.}

Geranium Robertianum.

Herbe Robert.

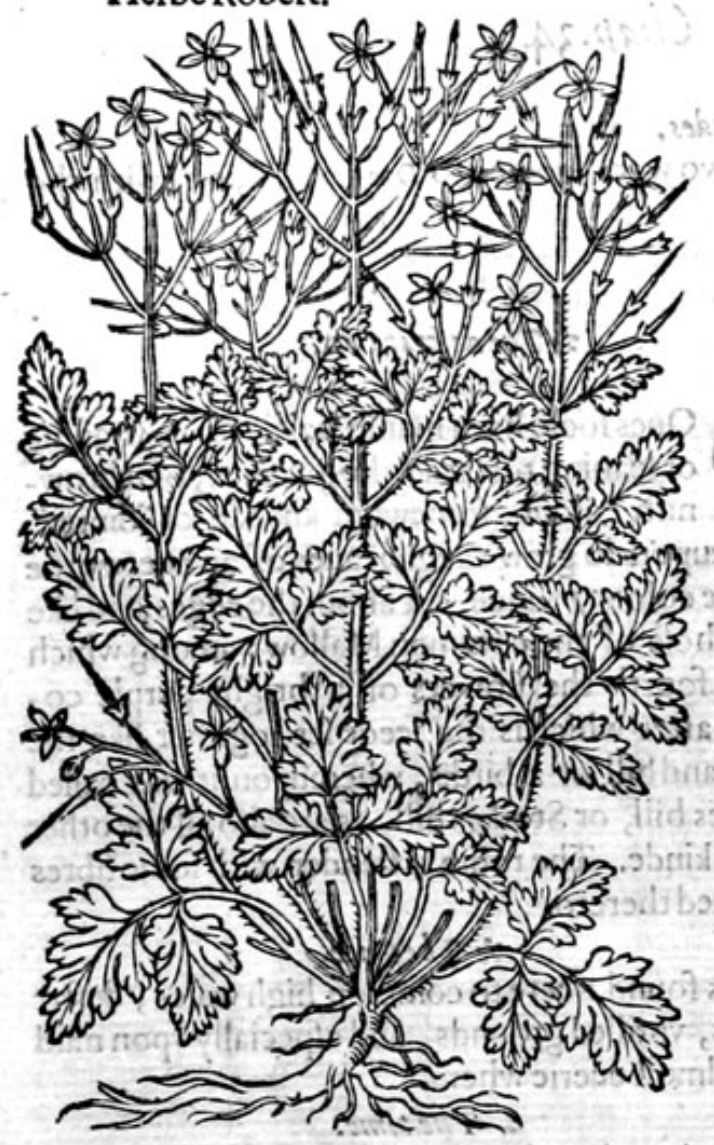

* The defription.

F EtbeRobert bringeth foorth flender, weake, and brittle ftalkes, fomewhat hairie, and of a reddirh colour, as are oftentimes the leaues alfo, which areiagged and deepely cut; Jike vinto thofe of Cheruile j of a moft lothfomé ftinking fmell. The flowers are of a moft bright purple colour; which being pait, there follow certaine fmall heads, with fharpe beakes or bils of birds: the root is very finall and threddie.

\section{* The place.}

Herbe Robert groweth vpon old wals, as well thofe made of bricke and ftone, as thofe of mudde or earthsit groweth likewife among rubbißh, in the bodies of trces that are cut downe, and in moift and Thadowie ditch banks.

\section{* The time.}

It fowreth from Aprill till fommer be almoft fpent : the herbe is greene in winter alfo, $8 \mathrm{c}$ is hardly hurt with colde.

\section{* The names.}

It is calledin high Dutch iRtipeectits hraut : in low Dutch Robzechts ktutit, and thereupon it is Inamed in Latine Ruberta, and Roberti Herba: $\mathrm{Ru}$ ellusus calleth it Robertiana, and we Robertianum; of Taber Montanus, Rupertianum : in Englifh Herbe Robert. He that conferreth this Cranes bill with Diofcorides his thirde sideritis, thall plainly perceiue, that they are both one, and that this is moft apparently Sideritis 3 . Diofcoridis; for Diofcorides fetteth downe three Sideritides, one with the leafe of Horehound; the next with the leafe of Fearne; and the thirde groweth in wals and vineyardes: the natiue foile of Herbe Robert agree thereunto,and likewife the leaues, being like vnto Cheruile, and not vnlike to thofe of Corianders, according to Diofcorides defcription.

\section{* The temperature.}

Herbe Robert is of temperature fomewhat colde: but yet both fcowring and fomwhat binding, participating of mixt faculties.

\section{$*$ The vertues.}

A It is good for wounds and vlcers of the dugges and fecret parts; it is thought to ftanch bloude, which thing Diofcorides doth attribute to his thirde Sideritis : the vertue of this (faith he) is applied to heale vp bloudy woundes.

\section{Of knobbed Cranes bill. Chap.343. \\ * The defcription.}




\section{H HIST ORIEOOFCPLANTS. TH TY}

flowers, of a bright purple colour, and like vnto the fmalleft brier Rofe in forme : which being paft, there fucceede fuch heads and beakes as the reft of the Cranes bill haue: the roote is thicke, bumped or knobbed, which we call tuberous.

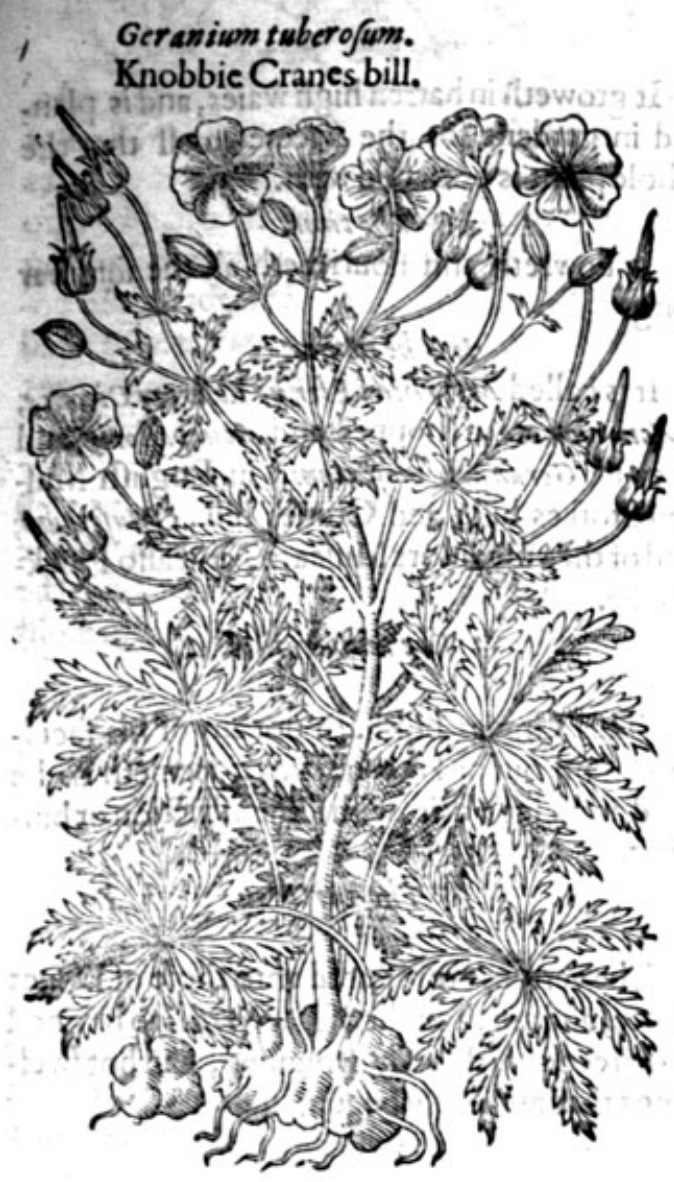

ill d astor O bolewik * The plase.

This kinde of Cranes bill is a ftranger in England, notwithftanding I haue it growing in my garden.

\section{* Thetime.}

The time anfwereth the reft of the Cranes billes.

\& The nomes.

Cranes bill is called in Grecke regonor in La. tine Grainalis, commonly Ruftrum Grais, or Rofrum Crconie, of the likenes of a Cranes bill, or Storkes bill : of fome Acus mo ocata, but that name doth rather belong to another of this kinde: it is alfo called Acus Paftor is : in Italiä Roftrodegrua: in French Bec de Grue : in Spanifh Pucodiciguena, pico del grou : in high Dutch Stozckentchitablet in lowe Dutch Di et.aerg teck : in Englifh Storks bill, Cranes bill,Hearons bill, and Pinckencedle: it is alfo called of fome Gerantum tuber ofiom, and Geranium bulbofum: it is likewife Geraniuen Diofcoridis primum, or Diofcorides his firft Eranes bill, which is founde to be called by certaine baftardenames, as Ouchinaftrum, or Echinastrum, miavoris, and fuch like.

* The temierature.

The rootes of this Cranes bill have a little kinde of heat in them

* Thevertues.

Diofcorides faith that the rootes may be eaten, and that a dram waight of them drunke in wine, $\mathbf{A}$ doth wafte and confume away the windines of the matrix.

Alfo Plinie affirmeth, that the roote heereof is fingular good for fuch as after weaknes craue to B be reftored to their former ftrength.

The fame auth or affirmet hethat the waight of a dram of it drunke in wine three times in a daie, is $\mathbf{C}$ excellent good againft the Ptificke, or confumption of the lungs.

\section{of chusked Cranes bill. Chap.344.}

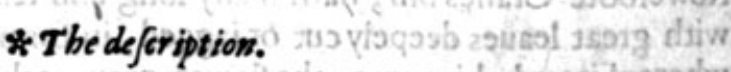

$\mathrm{M}$ Vsked Cranes bill hath many weake and feeble branches trailing vponthe groumde, whereon do growe long leaues, made of many fmaller leaues, fet vpon a middle rib, fniptor cut about the edges, of a pleafant fwete fmell, not vnlike to that of Muske, among which come foorth the flowers fet vpon tender footeitalks, of ared colour, compaet of fiue fmall leaues apeece, after which appeere fmall heads and pointed beakes or bils like the other kindes of Cranes bils: the roote is finalland threddie. 
Geraniom mofchatum. Musked Cranes bill.

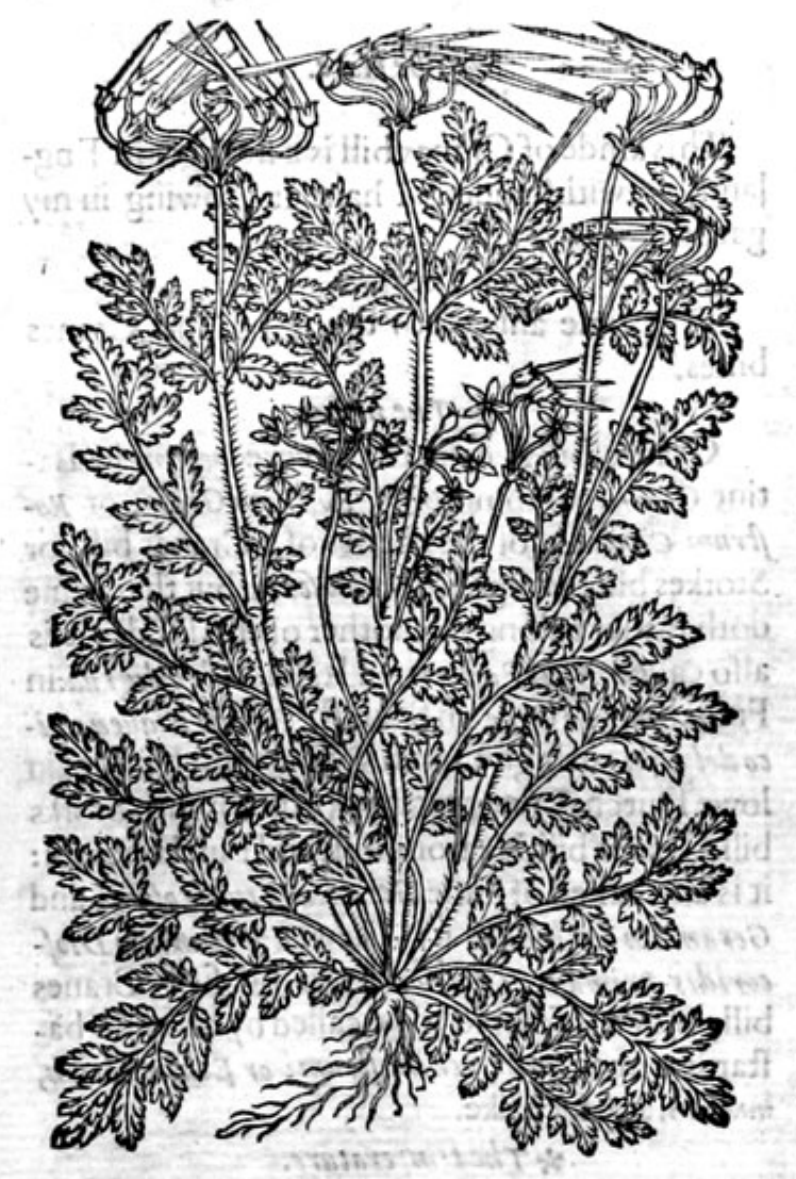

$$
\text { * The place. }
$$

It groweth in barren high waies, and is plan. ted in gardens for the fweete fmell that the whole plant is poffeffed with.

* The time. long.

It flowreth and flourifheth all the formet

* The names.

It is called Mirrhide Plinï, Roftrum Ciconie, Lcus mofcata in fhoppes, and Acuspaftoris, and likewife Geranium mof catum : in Englifh Mufked Storkes bill, and Cranes bill, CMufcation, and of the vulgar fort Mufcata, and alfo Pinckneedle.

\section{* The temperature.}

This Cranes bill hath not any of his facultiesfound out or knowne: yet it feemeth to be cold and a little drie, with fome aftriction or binding.

\section{* The vertues.}

The vertues are referred vnto thofe of Doues foote, and are thought of Diofcrides to be good for greene and bloudy woundes, and hot fivellings that are newly begun.

\section{Of Crowe foote Cranes bill, or Gratia Dei. Chap.345.}

\section{* Thedefcription.}

1 Rowefoote Cranes bill, hath many long and tender branches tending to redneffe, fet with great leaues deepely cut or iagged, in forme like thofe of the fielde Crowfoote, whereof it tooke his name : the flowers grow at the top of the ftalkes vpon tender footeItalks, of a perfect blew colour, which being paft, there fucceede fuch heads, beakes, and bils as the other Cranes bils.

2 I haue in my garden another fort of this Cranes bill, bringing foorth very faire white flowers, which maketh it to differ from the precedent; in other refpeets there is nodifference
atall. 


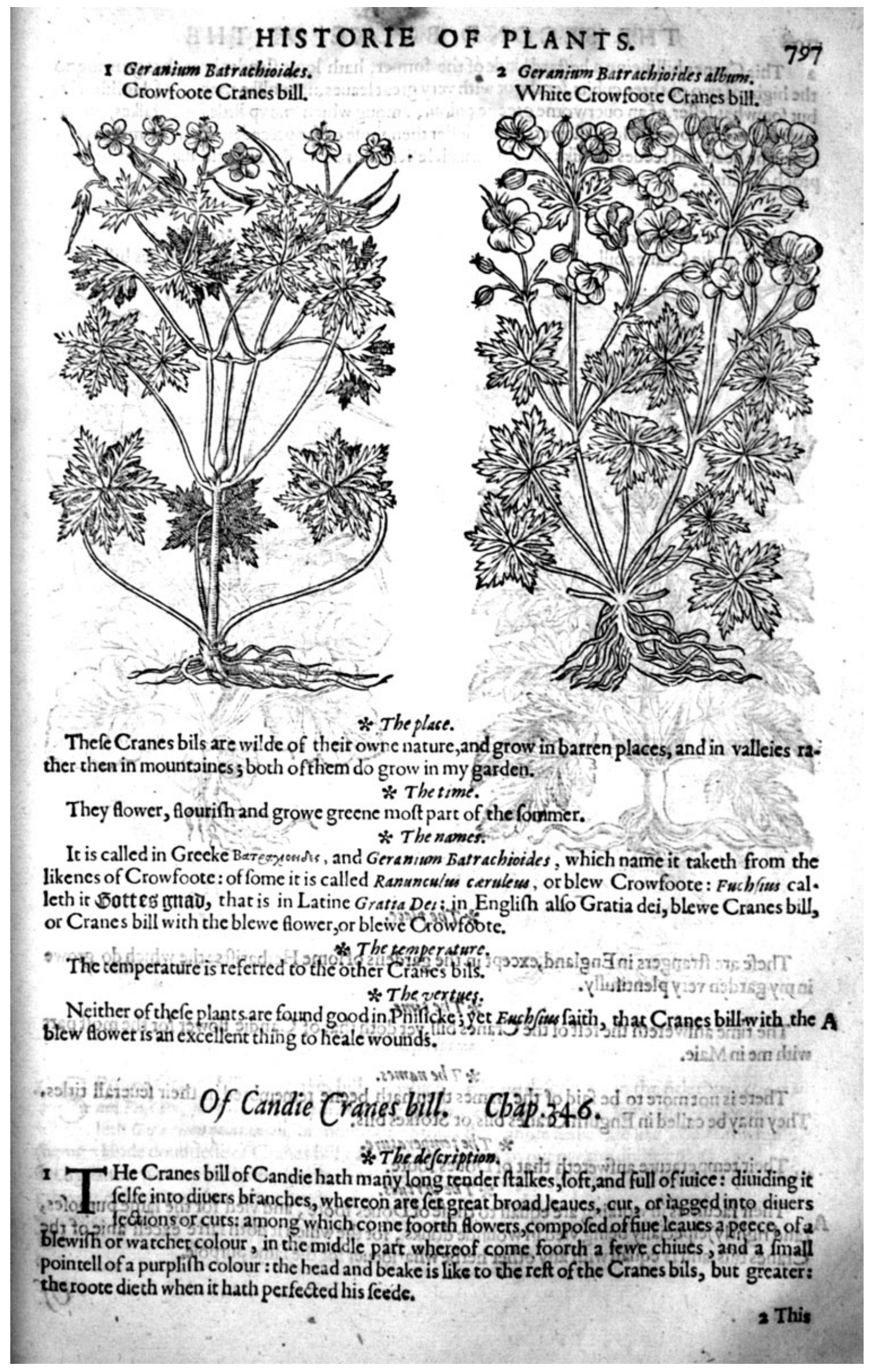


2 This Cranes bill, being a baftard kinde of the former, hath long flender branches growing to the hight of two or three cubits, fet about with very great leaues, not vnlike to thofe of Hollihocks, but fomwhat leffer, of an ouerworne greene colour, among which rife vp little footeftalkes, on the endes whereof do grow finall flowers, much leffer then thofe of the precedent, and of a murrey colour : the head and feedes are like allo, but much leffer: the rootes do likewife die at the firft approch of winter.

\section{Geranium Creticum.}

Candic Cranes bill.

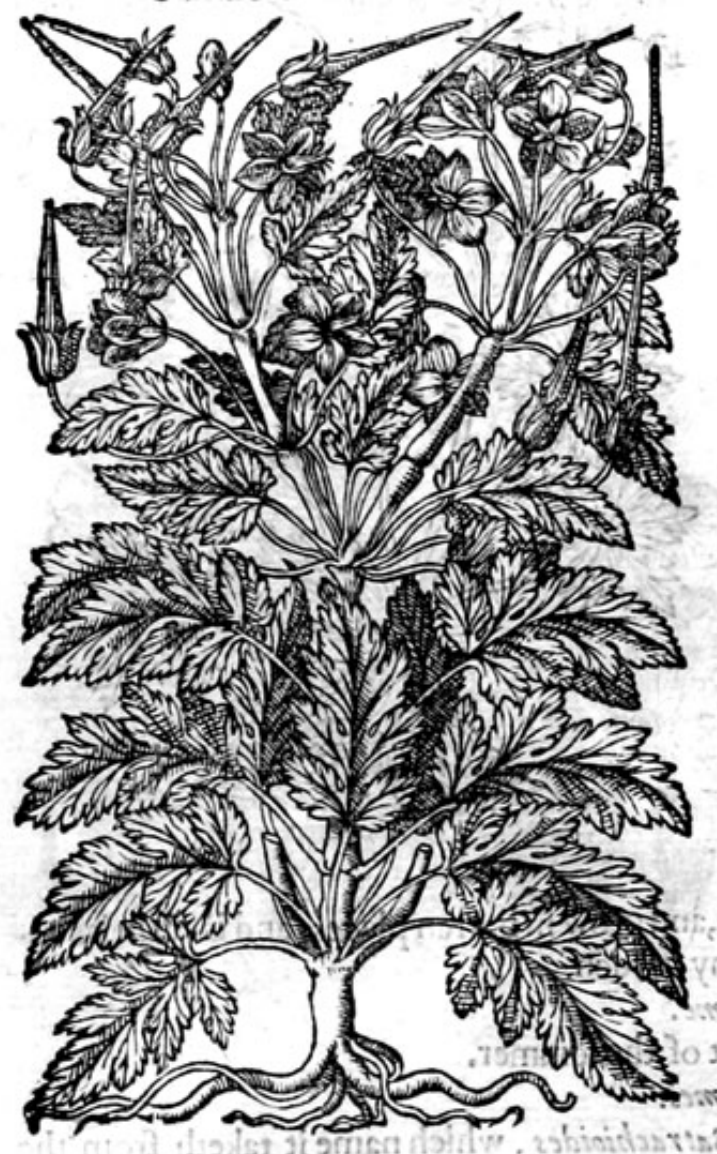

2 Geranium Malacoides. Baftard Candie Cranes bill.

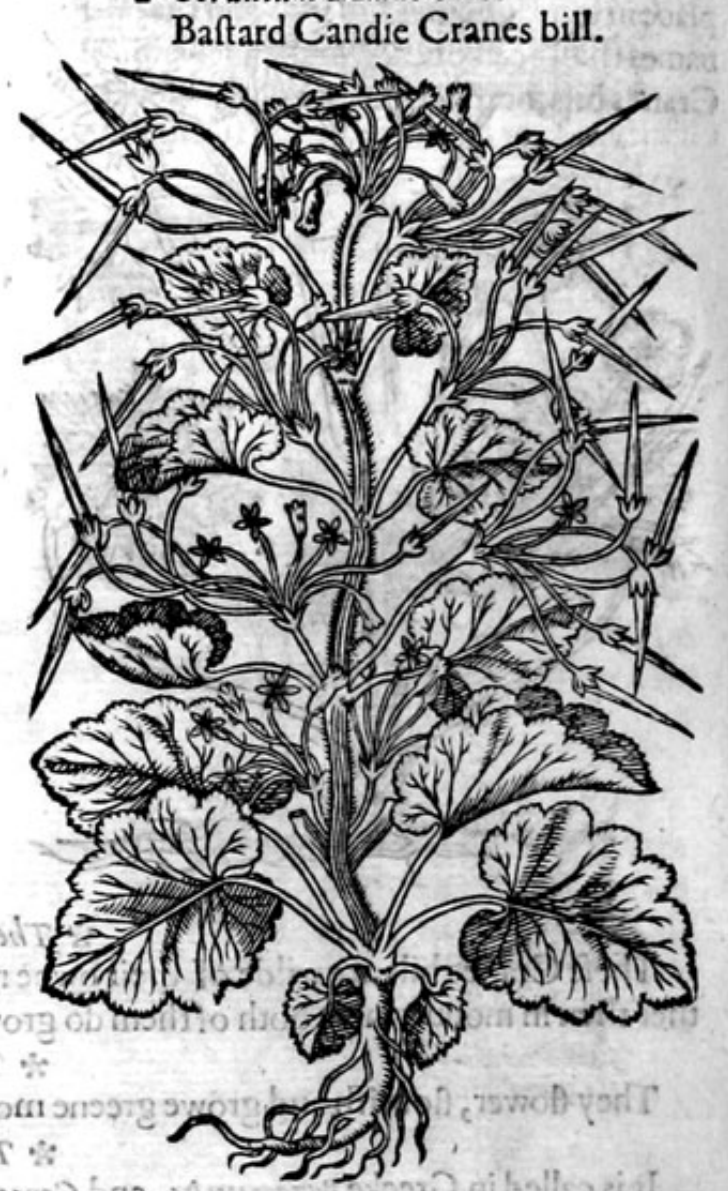

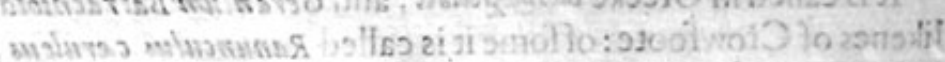
* The place.

Thefe are ftrangers in England, except in the gardens of fome Herbarifts : the which do growe in my garden very plentifully.

The time anfwereth the reft of the Cranes bill,yet doth that of Candie flower for the moft part with me in Maie.

\section{* The names.}

There is not more to be faid of the names then hath beene remembred in their feuerall titles. They may be called in Englifh Cranes bils, or Storkes bils.

\section{* The temperature.}

Their temperature anfwereth that of Doues foote.

$$
\text { * Thevertues. }
$$

Their faculties in working are equall to thofe of Doues foote, and vfed for the fame purpoles; A (and rightly)efpecially being vfed in wounde drinks, for the which it doth farre excell anie of the Cranes bils,and is equall with any other herbe what foewer for the fame purpofe. 


\section{Of diuers wilde Cranes bils. Chap 347 . daria \\ * The kindes.}

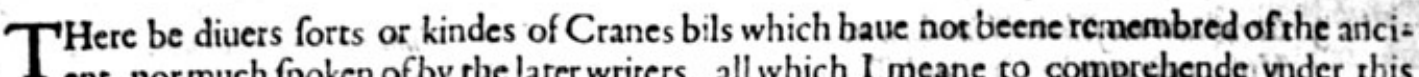

ent, nor much fpoken of by the later writers, all which I meane to comprehende vinder this

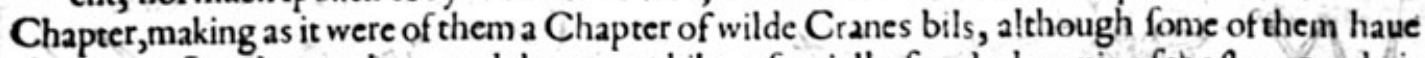
place in our London gardens, and that woorthily, efpecially for the beautie of the flowers, thcir names fhall be expreffed in their feuerall titles, their natures and faculties are referred to the othet Cranes bils, or if you pleafe to a further confideration.

1 Geranivom maculatum frue fun cawn. Spotted Cranes bill.

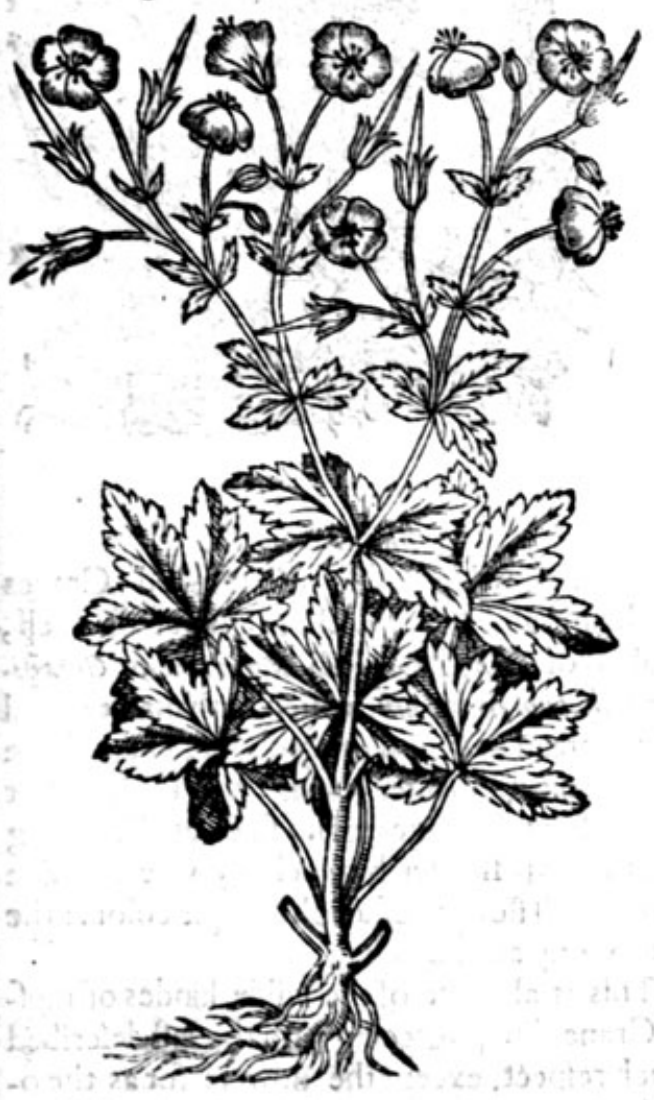

2 Geranitum fanguinarisem. Bioudie Cranes bill.

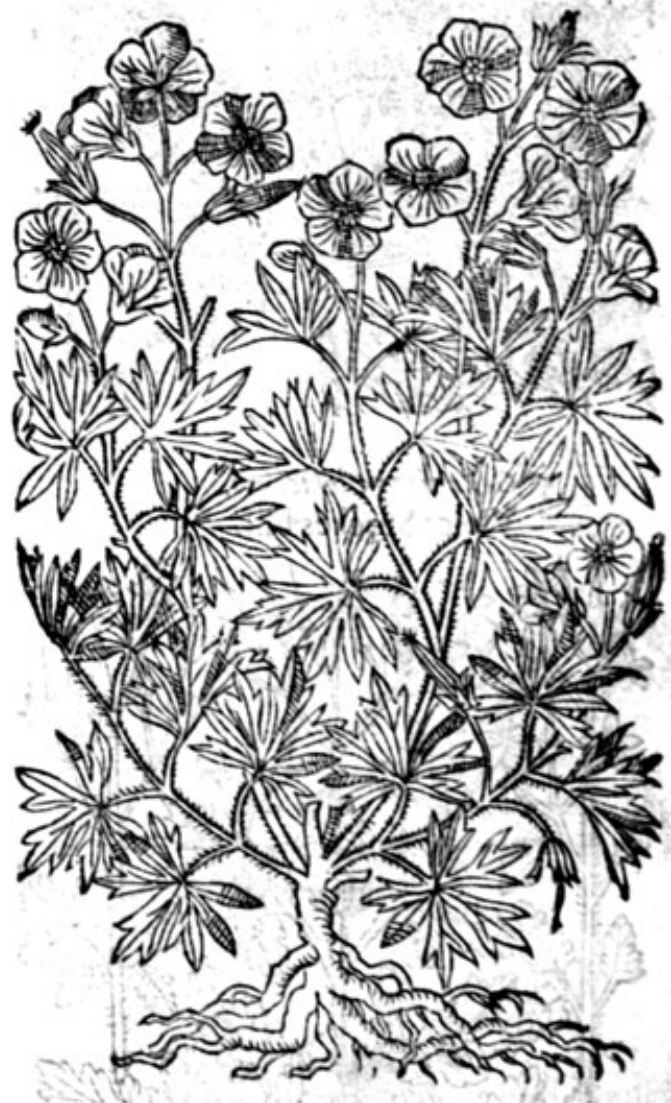

* The defcription.

$\mathbf{I}$

$S$

Potted Cranes bill, or Storkes bill, the which L'Obeline defcribeth in the title thus, Geraniwom Fu/cum, flore liwido, purpur ante, \& medio Candicante, is the fanc that Dodoneius calleth Ger aniwom montanum, or mountaine Storks bill, whofe leaues are like vnto Crowfoote, (being a kinde doubtleffe of Cranes bill, called $G$ ratis d $i$ ) of an ouerworne duftie colour, and of $\mathbf{a}$ ftrong fauour, yet not altogither vnpleafant : the ftalkes are dry and brittic, at the tops wherof doe growe pleafant flowers of an exceeding fairepurple colour, the middle part whercof tending to whitenes : from the ftile or pointell thereof, commeth foorth a tuft of fmall purple hairie threds. The roote is thicke and very brittle, lifting it felfe foorth of the ground, infomuch that many of the faide rootes lie abotic the ground naked without earth, euen as the rootes of Flower Deluces doe. 
2. The fecond of thele wilde ones rifeth foorth of the ground to the height of a foote, fomtimes more : the ftalkes are dry and brittle, with many knees or knobbed ioints of a bloudic colour, wher. of it tooke his name, called for the molt part Hemathodes : the leaties, fowers and feedes are like vnto thofe of Gratia Dei, or blew Cranes bill, wherin efpecially it differech from the precedent.

3 Geranium mo fohatum ivodorum. Vnfauorie muske Cranes bill.

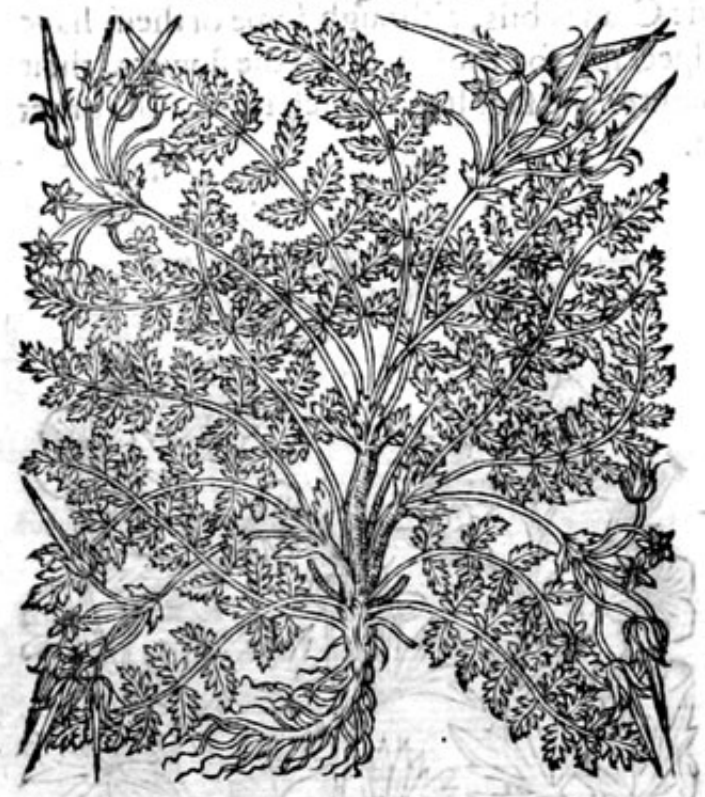

5 Geranism violaceum.

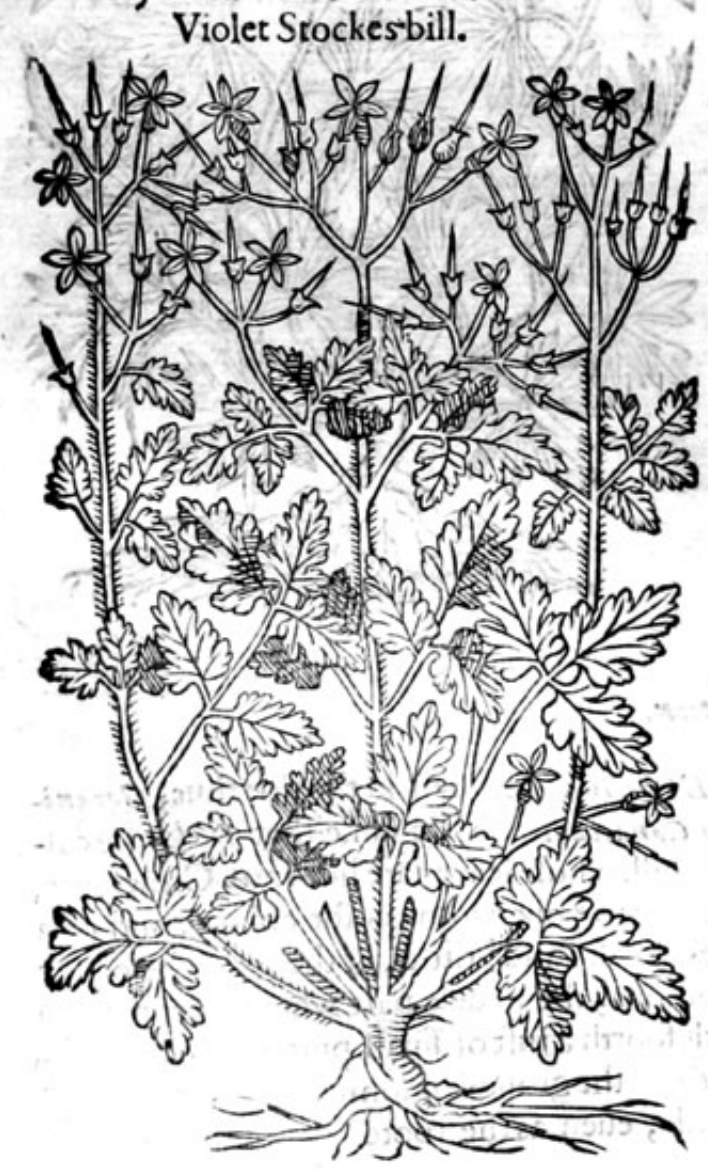

4 Geranium inodorum allum. White flowred Pinckneedle.

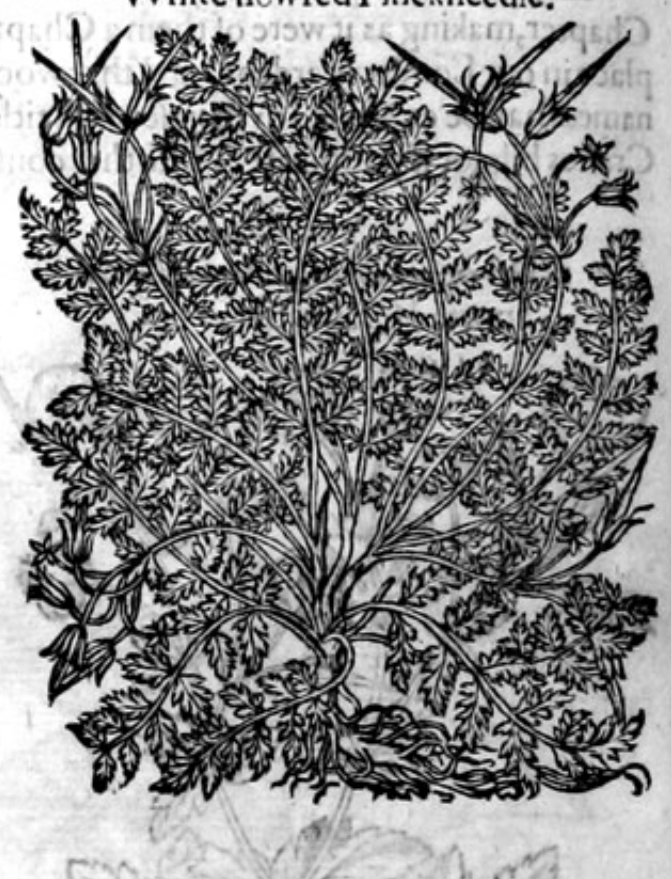

* The defcription.

3 This wilde kunde of musked Cranes bill, being altogither without fauour or fmell, is called of Fliny Myrrhida inudorum, or Geraniwm nooschatum inodorum, which hath manie broad leaues fpíead tat vpon the grounde, everie leafe mace of diuers finaller leaues, and thole cut or iagged about the edges, of no finell at all: among which rife vp flender braunches, whereon doe growe fmall flowers of a light purple colour: the roote is long and fibrous.

4 This is alfo one of the wilde kindes of mufked Cranes bils, agreeing with the laft defcribed in each refpeet, except the flowers, for as the other hath purple flowers, this plant bringeth forth white flowers, other difference there is none at al. 5 The Cranes bill with violet coloured flowers, hath a thicke woodie roote, with fome few ftrings annexed thereto : from which rife inmediatelie foorth of the grounde diuers ftiffe ftalkes, which dinide themfelues into other finall braunches, whereupon are fet confuledly broad leanes, made of three leaues a peece, and thofe iagged or cut about the edges; the flowers growe ar the top of the braunches of 2 perfect violet colour, wherof it tooke his name, after which come fuch beakes or bils, as the other of hiskinde. 


\section{HISTORIE OF PLANTS.}

Of thefe wilde ones I haue another fort in my garden, which $\mathrm{Clnf} /$ fus in his Pannonicke obferuations hath called Geranivom Hematodes, or fanguine Cranes bill, and L'Obelinus Geranium Giruinuon, or Gruinale: it hath many flexible branches creeping vpon the grounde: the leaues are much like vnto Doues foote in forme, but cut euen to the middle rib: the flowers are like thofe of the wildemallowe, and of the fame bigneffe, of a perfect bright purple colour, which if they be fuffered to growe and ftande vntill the next day, will be a murrey colour; and if they ftand vito the third daie, they ivill turne into a deepe purple tending to blewneffe; their changing is fuch, that you fhall finde at one time vpon one branch, flowers like in forme, but of diuers colours. The rooteis thicke and of a woodie fubftance.

I haue likewife another fort that was fent me from Robinus of Paris, whofe figure was netuer fet footth,neither defcribed of any : it bringeth from a thicke tough roote manybranches, of a brownifh colour : whereupon do growe leaues not vnlike to thofe of Gratia dei, but not fo deepely cut, fomewhat cornered, and of a fhining greene colour : the flowers grow at the top of the tender branches, compofed of fixe fmall leaues, of a bright icarlet colour.

* The place.

Thefe Cranes bils do growe of themfelues about olde wals, the borders of fieldes, woodes and copfes, and moft of them we haue brought into our gardens.

$$
* \text { Thetime. }
$$

Their time of flowring and feeding anfwereth the reft of the Cranes bils. * 7 he names.

Their feuerall titles fhall ferue for their names, referring what might be faidemore to a further confideration. $* 7$ be nature and vertues.

There hath not as yet any thing beene founde cither of their temperature orfaculties, but may be referred vnto the other of theirkinde.

\section{Of Sanicle. Chap. 348.}

Sanicula füe Diapenfia.

\section{Sanicle.}

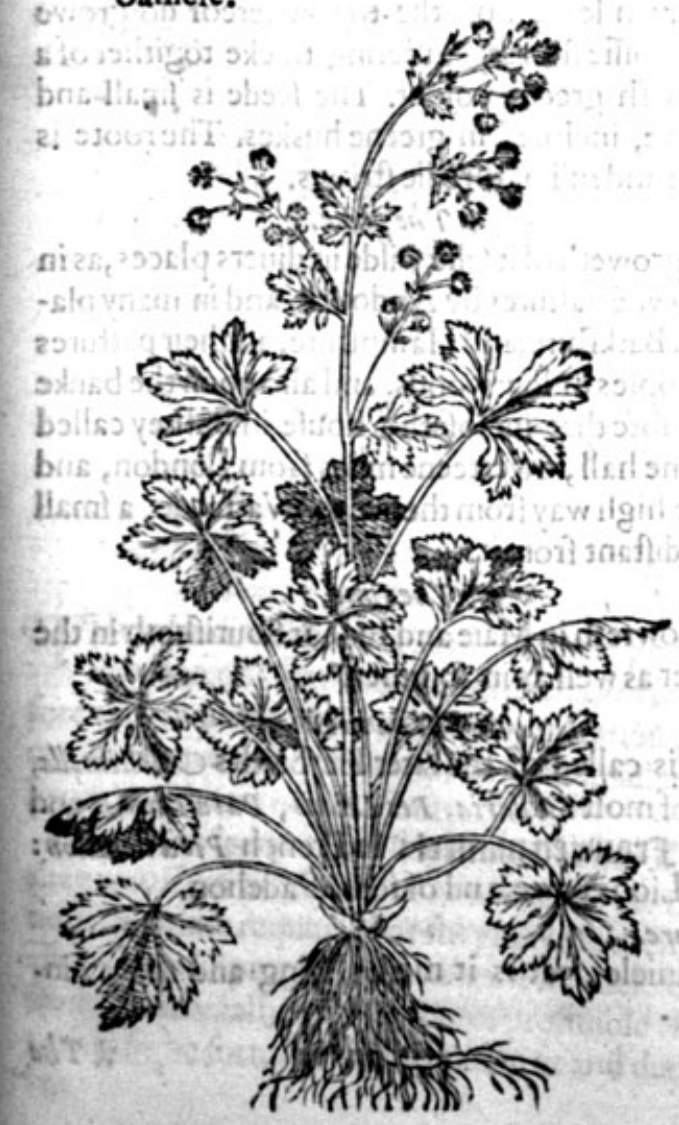

* The defoription.

Anicle hath leaues of a blackirh greene co: lour, finooth and fhining, formwhat round, diuided into fiue parts like thofe of the vine, or rather thofe of the maple: among which rife vp flender ftalkes of a browne colour; on the toppes whereof ftande white moffie flowers, in their places come vp rounde feede, rough, cleauing to mens garments as they paffe by, inmaner of little burs : the roote is blacke and full of threddie-ftrings.

\section{* The place.}

It groweth in thadowie woods and copfes almolt euery where, it ioieth in fat and fruitefull moilt foile.

\section{* Thetime.}

It flowreth in Maic and Iunc: the feed is ripe in Auguft : the leaues of the herbe are greene al the yeere, and are not hurt with the colde of winter.

$$
\text { * The names. }
$$

It is commonly called Sanicula, of diuers Dispenfia: in high \& low Dutch $\&$ anikeltin French Sanicle: in Englifh Sanickle, or Sanikel : it is fo called d samandis vulneribus, or of healing of woundes as Ruelliw faith : there be alfo other 
Sanicles fo named of moft Herbarifts, as that which is defcribed by the name of Dentaria, or Coral woort, and likewife Aurtcula or f, or Beares eare, which is a kinde of Cowllip, and likewife another fet foorth by the name of Sanicula guttata, wherof we haue intreated among the kindes of Beares eares.

\section{*. The temperature.}

Sanicle as it is in tafte bitter, with a certaine binding'qualitie; fo befides that it clenfeth, and by the binding qualitic ftrengthneth, it is hot and dry, and that in the feconde degree, and after fome authors hot in the third degree, and aftringent.

\section{$*$ The vertues.}

A The inice being inwardly taken is good to heale wounds.

B The decoetion of it alfo made in wine or water, is giuen againft petting of bloud, and the bloudy flixe; alfo foule and filthie vlcers are cured by being bathed or wafhed with it. The herbe boiled in water, and applied in maner of a pultis, doth diffolue and wafte away cold fwellings; it is vied in potions, which are called Vulnerarie potions, or wounde drinkes, which maketh wholeand found all inward wounds, and outward hurts : it alfo helpeth the vlcerations of the kidneies, ruptures or burftings.

\section{Of Ladies mantle, orgreat Sanicle. Chap.349.}

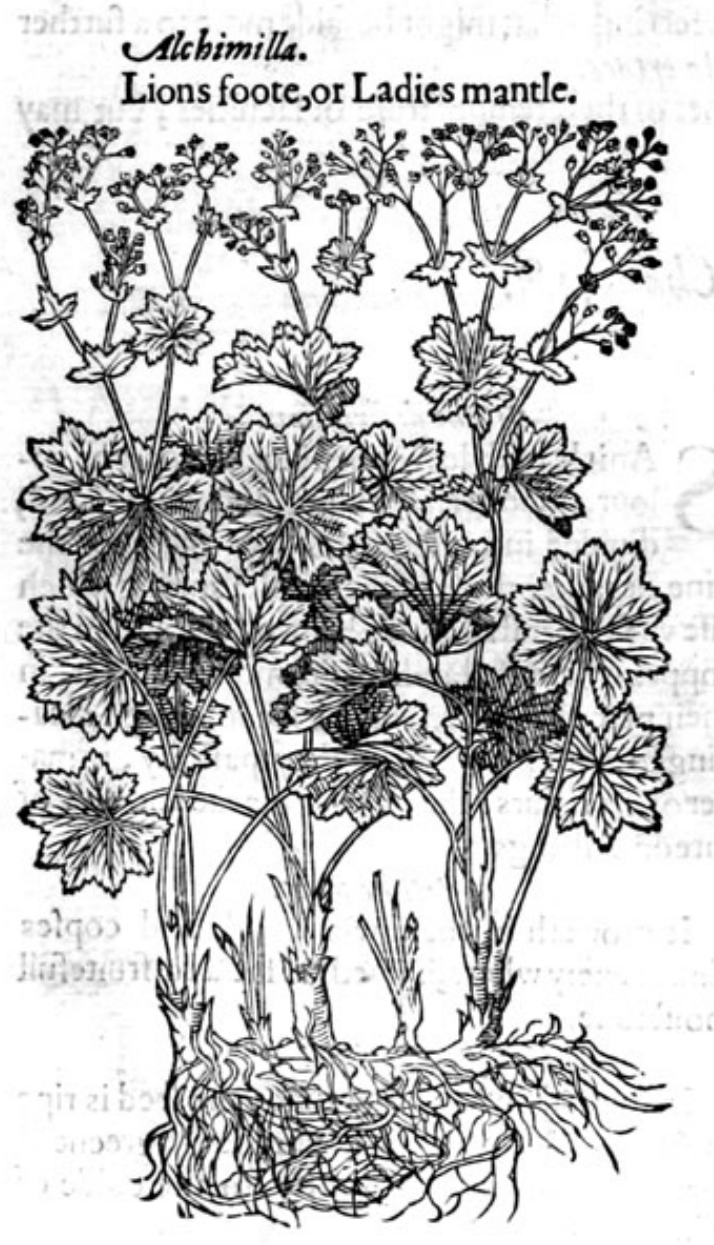

\section{* The defcription.}

T Adies mantle hath many round leaues, with fiue or fixe corners fiaely indented about the edges, which before they be opened are plaited and foulded togither, not vnlike to the leaues of Mallowes, but whiter and more curled: among which rife vp tender ftalks fet with the like leaues, but much leffer : on the tops whercof do growe fmall moffie flowers cluftering thicke togither of a yellowifh greene colour. The feede is finall and yellowe, inclofed in greene huskes. The roote is thicke and full of thredie ftrings. * The place.

It groweth of it felfe wilde in diuers places, as in the towne paftures by Andouer, and in many places in Barkfhire, and Hamplhire, in their paftures and coples or low woods, and alfo vpon the banke of a mote that inclofeth a houfe in Bufhey called Bourne hall, fowerteene miles from London, and in the high way from thence to Watforde, a fmall mile diftant fromit. * The time.

It flowreth in Maie and Iune, it flourifheth in the winter as well as in fommer. * The names.

It is called of the later Herbarifts Alchimills, and of molt Stellaria, Fes Leonis, Pata Leonis, and Sanicula maior : in high Dutch Spunautu, and Dnier frautuenmantet : in French Pied de Lion: in Englifh Ladies mantle,great Sanicle, Lions foote, Lions pawe, and of fome Padelion. * The temperature. ding.

Ladies mantle is like in temperature to little Sanicle, yet is it more drying and more bin* The 


\section{HISTORIE OF PLANTS. $3 H$ I}

It is applied to wounds after the fame manerthat thefmaller Sanicle is, being of like efficacic: it A dens paps or dugs, and when they be too great and laggie, it maketh themleffer and harder. $-25 d$

$$
\text { of } \mathcal{N} \text { eefewoort Sanicle. Chap.350. }
$$

Alpona Elleborine.

Neefewoort Sanicle.

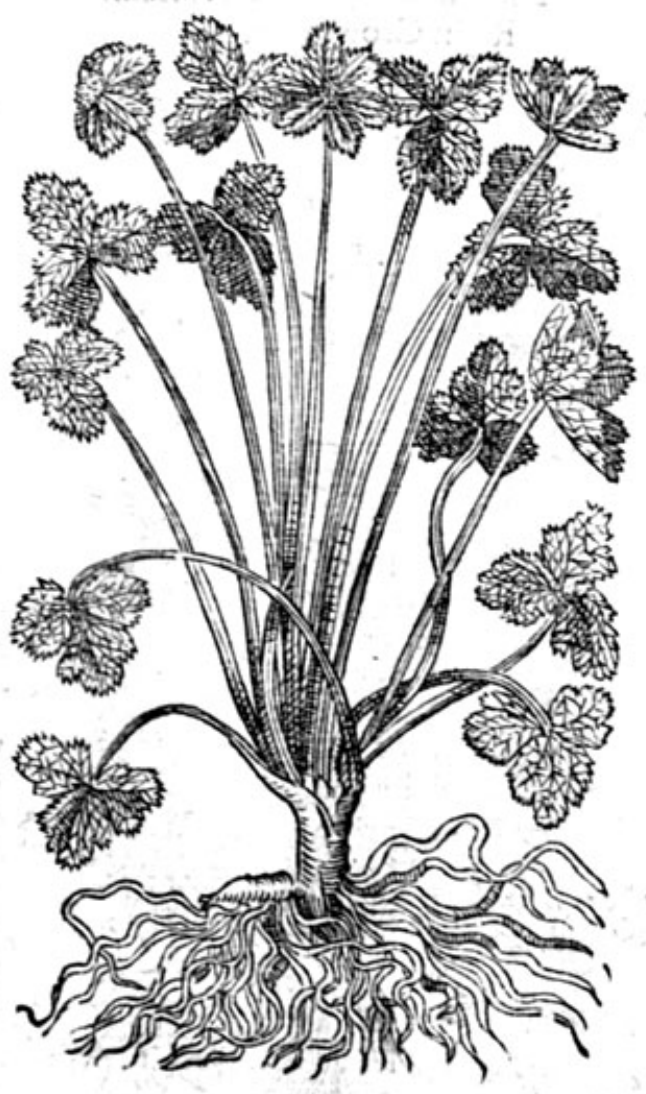

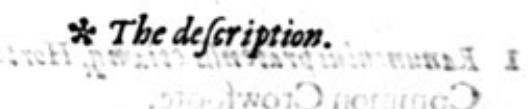

T 7 Hen I made mention of HeDeborras al. bus, I did alfo fet downe my cenfure concerning Elleborine or, Epipactis : but this Elleborine of the alpes I put in this place bicaufe it approcheth neerer vnto Sanicle and RAnunculss, as participating of both; it groweth in the mountaines and higheft parts of the alpin hils, and is a ftranger as yet in our Englifh gardens: the roote is compzet of manie fmall twifted ftrings, like vnto black tellebore: from thence arife imall tender ftalks, fmooth and eafie to bend, in whofe tops growe leaues with fiue diuifions, fomewhat nickt about the edges like vnto Sanicle: the flowers confift of fixe leaues, fomewhat thining, in tafte harpe, yet not vnpleafant. Some would account this plant to be that Hellebores ni. ger which Pena found in the forreft of Efens, not farre from Iupiters mount.

I haue not as yet found any thing of his nature or of his vertues.

$$
\text { Of Crowfootes. Cbap. } 351 \text {. }
$$

\section{* Tbe kindes.}

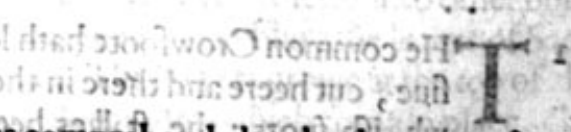

$T$ Here be diuers forts or kinds of thefe pernitions herbes comprehended vider the natne of $\mathrm{R}$ masculis, or Crowfoote, whereor moft are very dangerous to be taken into the body, and there. fore theyrequire a very exquifite mbderation, with a mof exact and due maner of tempering, not

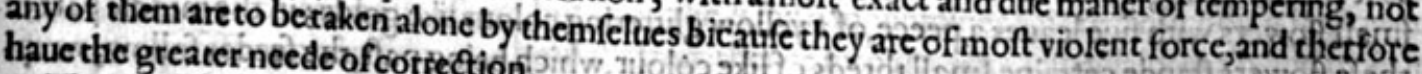
The knowledge of thefe plants is as neceftatie to the Phich they may fhan the fame, as sstribonitus $t$. tie at any time require, that they may or gis faith, and nor take them ighotantly: or alfo, if idceffiand with their proper correetiues, Fer thefe ; and that with forite deliberation and fpecial choife, felues beneficiall, and óftentimes profitable: for foner of timples are likewic many times of theernmay in fome fort,and oftentimes in fit and due feafon profit and dogood, if temperature and inio-
AT I 


\section{THE SECOND BOOKE OF THE}

deration be vfed; of which there be fower kindes as Diofcorides writeth, one withbroadeleaues, another that is downie; the thirde very fmall; and the fourth with a white flower : the later Herbaritts haue obferued alfo many mo: all thefe nay be brought into two principall kindes, fo that one bee a garden or tame one, and the other wilde: and of thefe fome are common, and others rare; or foraine. Moreouer there is a difference both in the rootes and in the leaues: for one hath a bumped or knobbie roote, another a long leafe as Spearewoort; and firft of the wildeor fielde Crowfootes, referring the Reader vnto the ende of the ftocke and kind red of the fame, for the temperature and vertues.

I Ranunculuspraten/ss, etiamós, Hortenfis. Common Crowfoote.

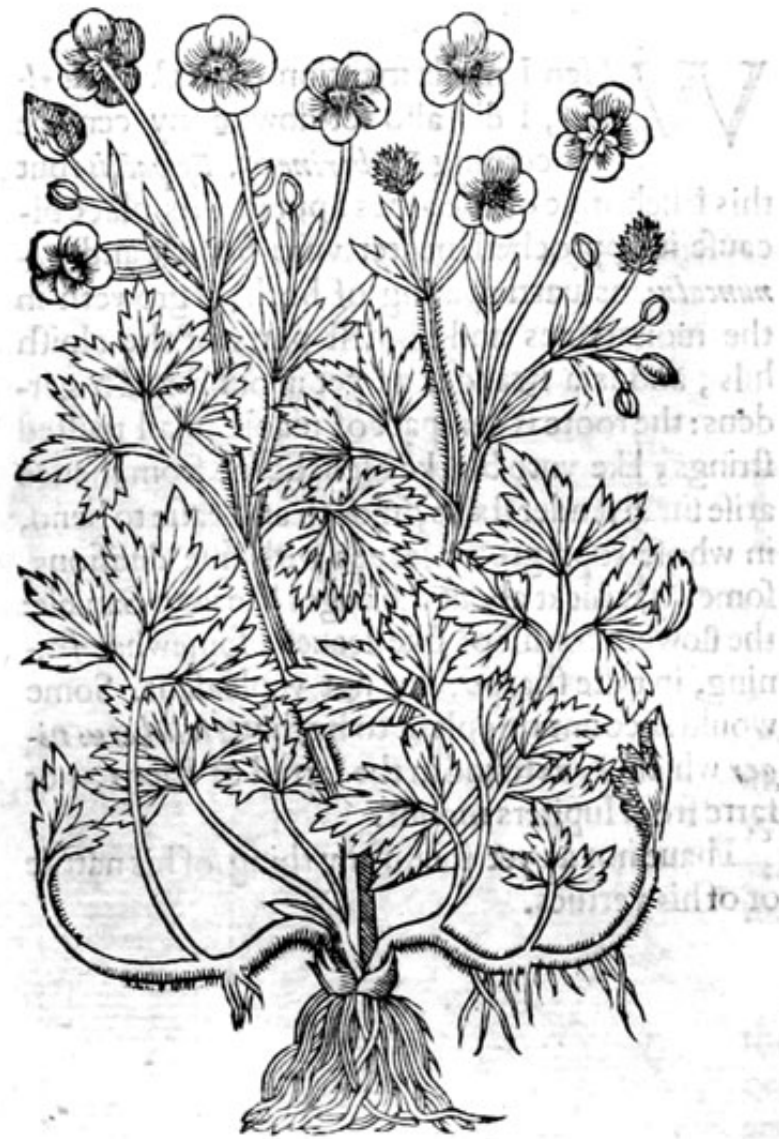

2 Ranunculus furrectis cauliculis. Right Crowfoote.

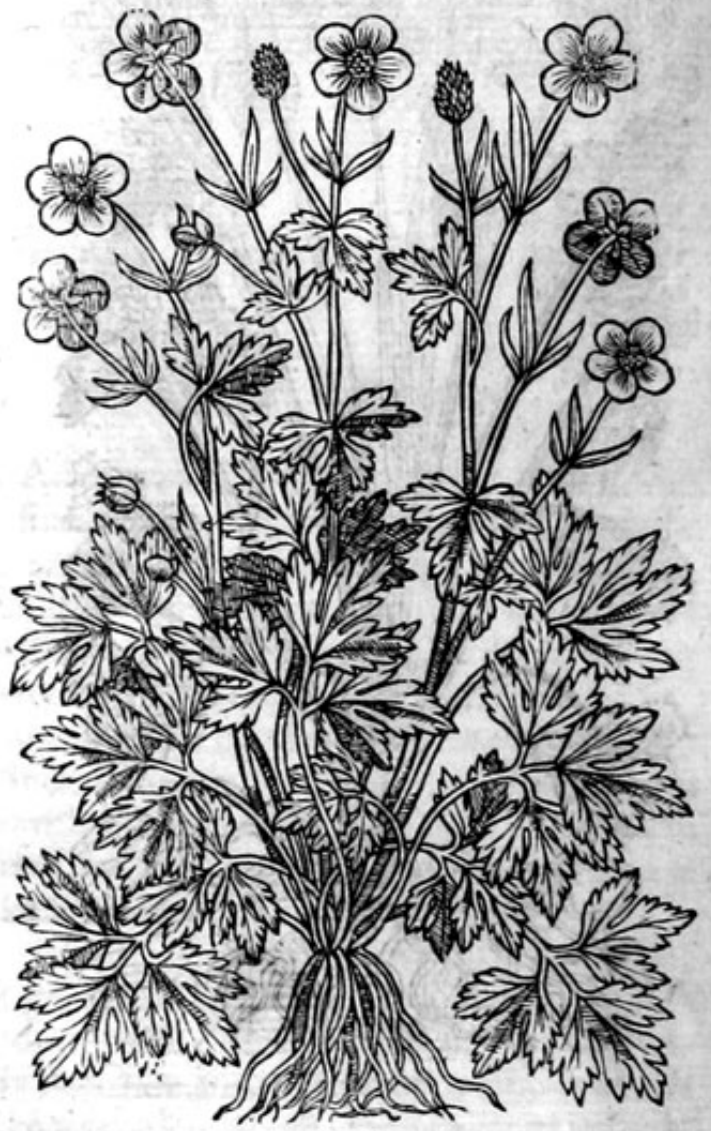

* The defcription.

I

He common Crowfoote hath leaues diuided into many parts, commonly three, fomtimes fiue, cur heere and there in the edges, of a deepe greene colour, in which ftande diuers whitifh fpots : the ftalkes bee rounde, fomething hairie, fome-of them bowe downe towarde the grounde, and put foorth mante little rootes, whereby it takech holde of the grounde as it traileth along: fome of them ftande vpright a foote high or higher; on, the tops heereof growe fmall flowers with fiue leaues a peece, of a yellow glittering colour like golde; in the middle part of thefe flowers ftande certaine f mall threds of like colour, which being paft, the feedes follow, wrapped vp in a rough ball: the rootes are white and threddie.

2 The fecond kind of Crowfoot is like vnto the precedent, fauing that his leaues are fatter, thic$\mathrm{ker}$, and greener, and his fmall twiggie ftalkes ftand vpright, otherwife it is like : of which kinde it chanced, that walling in the fielde next vnto the Theater by London, in company of a worfhipfull marchant named matter Nicholas Lete, I founde one of this kinde there with double flowers, which before that tine I had not feene. 
They growe of themfelues in paftures andmedonves almoft euery where

They flower in May, and many monethes afteradt

$*$ Tbetime.
hes aftersit
$\star$ T The nomes.

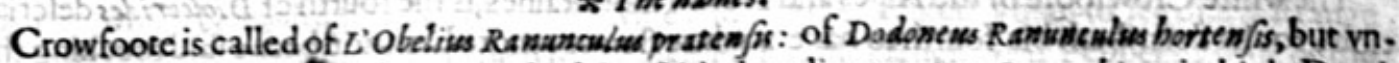

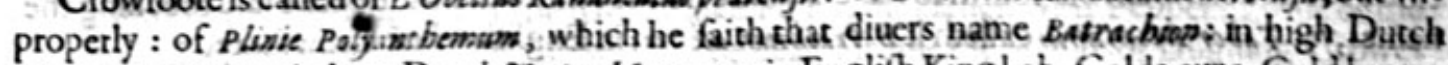
Orbnalabiuan: in lowe Dutch Zater bioement in Englifh King kob, Goldecups, Gold lonops, Crowfoote, and Butcen flowers.

3 Renuncuisus arsorion.

Crowfoote of the fallowed field.

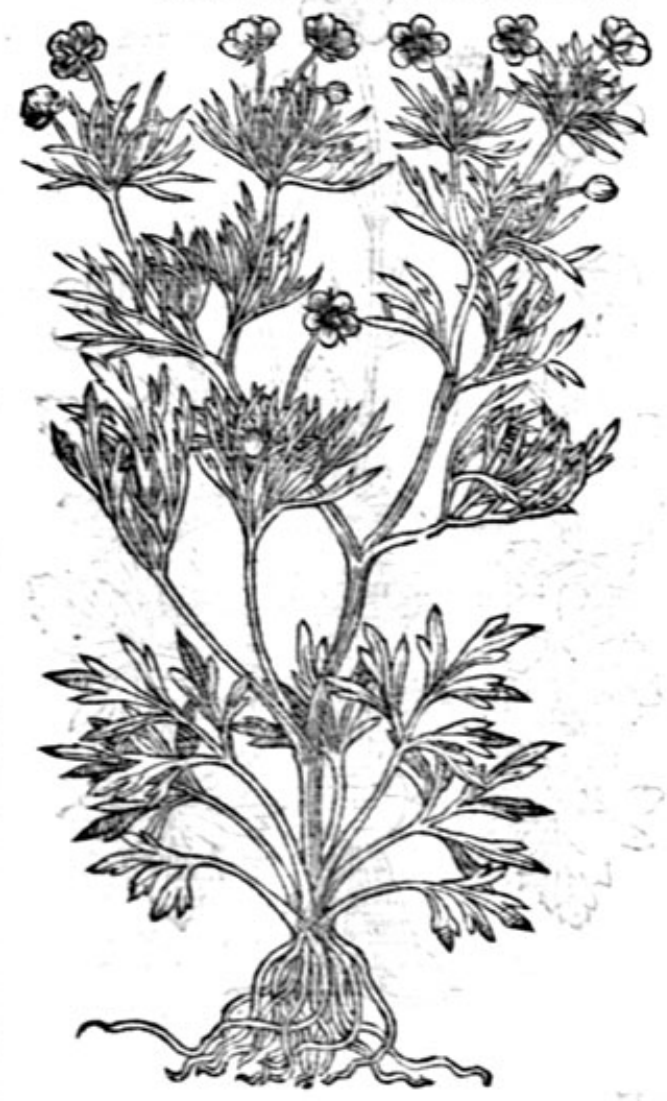

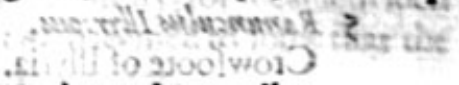

4 Raminculas Calpinsus albew.

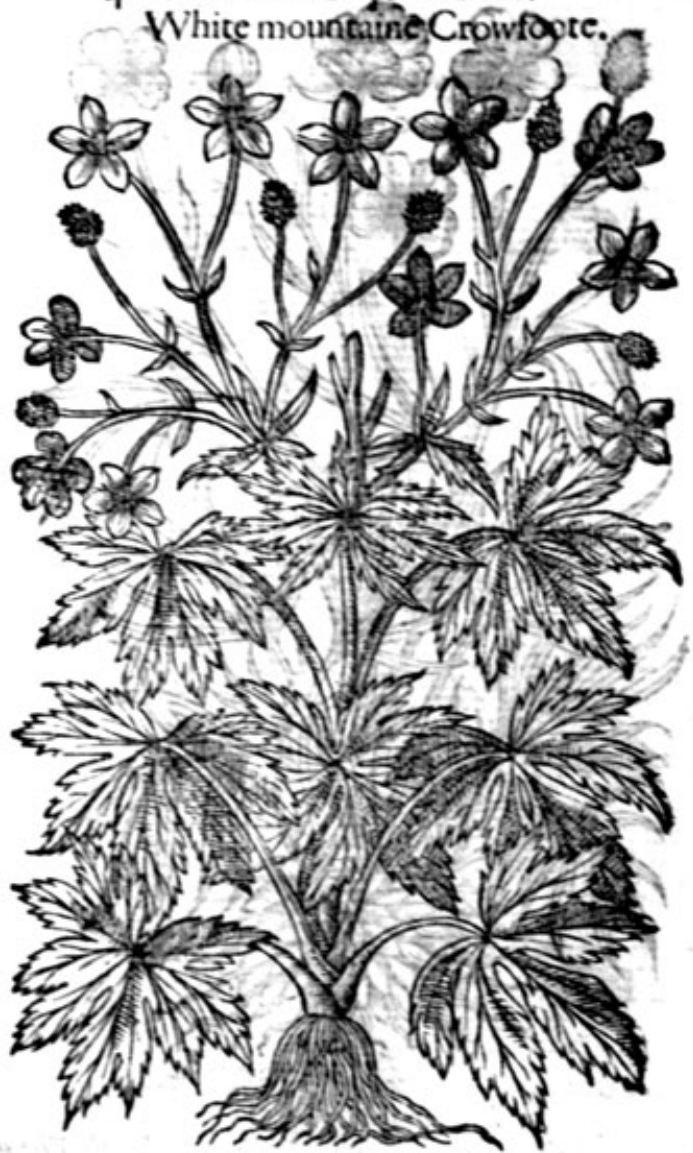

* The defcription.

3 The third kinde of Crowfoote called in Latine Ranunoulw aruorsom, bicaufe it groweth com monly in fallow fieldes, where corne hath beene lately fowen, and may becalled Corne Crowfoote. It hath for the molt part an vpright ftalke of a foote high, which diuideth it felfe into other branches, whereon do growe fat thicke leaues very much cut and iagged, refembling the leanes of Sampire, but nothing fo greene, but rather of an ouerworne colour. The flowers growe at the top of the braunches compact of fiue fmall leaues, of a faint yellowe colour; after which come in place, clufters of rough and fhappe pointed feedes, like thofe of Hounds toong. The roote is fimall \& threddie. 4 The fourth Crowfoote which is called Ranunculus Alpinus, bicaufe thofe that haue fift written hereof, haue not found it elfe where, but vpon the Alpifh inountaines : notwithiftanding it gtoweth plentifully in England wilde, and brought from thence into gardens, efpecially in a wood by London called Hampiteed wood. It hath diuers great fat branches, two cubites high, fet with large leaues, like the common Crowfoote, but greater, of a deepe greene colour, much like to thofe of the yellowe Aconite, called scomitum luteum Ponticum. The flowers confift of fite white leaues, with fmall yellowe chiues in the middle, fimelling likethe flowers of May or Hawthorne, but more pleafant. The rootes are greater than any of the ftocke of Crowfootes. 


\section{* 7 be place and time.}

Their place of growing is touched in their defcriptions : their time of flowring and feeding anfwerech the other of their kindes.

* Thenumes.

The white Crowfoote of the Alpes and French mountaines, is the fourth cf Diofcorides defcrip. tion; for he defcribeth his fourth to haue a white flower : more hath not beene faid toviching the names, yet Taber Montsonus calleth it Batrachiom allews : in Englifh white Crowfoote.

5 Ranunculaw Illyricuse Crowfoote of Illyria.

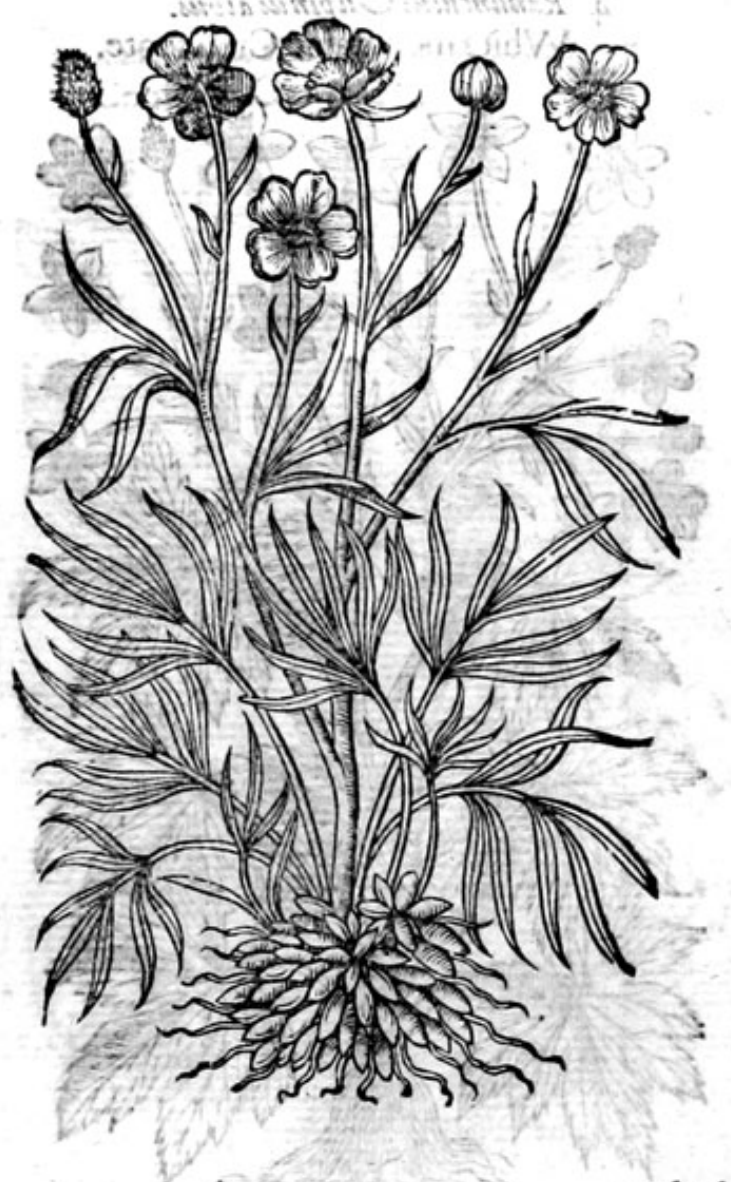

\section{Ranunculises bulbo/rus.} Round rooted Crowfoote.

* The defoription.

5 Among the wilde Crowfootes there is one that is furnamed silyricus, which bringeth foorth flender ftalkes, round, and of a meane length: whereupon dogrowe long narrow leaties, cut into many long gafhes, fomething white, and couered with a certaine downyneffe. The flowers be of a pale yellow colour. The roote confiteth of many fmall bumpes, as it were graines of corne, or little long bulbes growing clofe togither, like vnto thofe of Pilewoort. It is reported, that it was firft brought out of Illyria into Italie, and from thence into the lowe countries; notwithftanding we haue it growing very common in England.

6 The fixt kinde of Crowfoot called Ranunculus bulbofus, or Oinion rooted Crowfoot, and round rooted Crowfoote, hath a round knobbic or Oinion fafhioned roote, like vnto a fmall Turnep, and of the bignes of a great Oliue berrie : from which riferh vp many leaues fpred vpon the ground, like thofe of the fielde Crowfoote, but finaller, and of a ruftie or ouerworne greene colour, among which rife vp ilender ftalks of the height of a foote, whereupon do growe flowers of a faint yellowe colour.

$$
\because \text { The place. }
$$

It is alfo reported to be found not onely in Illyria and Sclauonia, but alfo in the Iland Sardinia, ftanding in the midlund, or Mediterranean fea. 


\section{HISTORIE COF PLANTS.}

\section{* The names.}

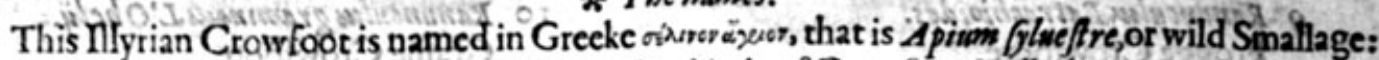

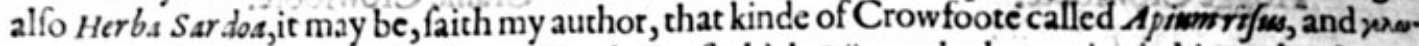
7:qvì, and this is thought to be that Gelotophyllis, of which Pling maketh mentionin his 24 booke 17. chapter: which being drunke, faith he, with wine and myrthe, caufeth a man to fee diuers ftrange fights, and not to ceafe laighing till he hath drunke Pine apple kernels with Pepper in wine of the Date tree, (I thinke be woulde hate faid vntill he be dead)bicaufe the nature of laughing Crowefoote is thought to kill laughing, but without doubt the thing is cleane contrary; for it caufech fuch conuulfions, crampes and wringings of the mouth and iawes, that it hath feemed to fome thar the partics hatie died laughing, whereas in truth they haue died with great torment.

\section{Ranunculses asricomas.}

Golde haire Crowfoote.

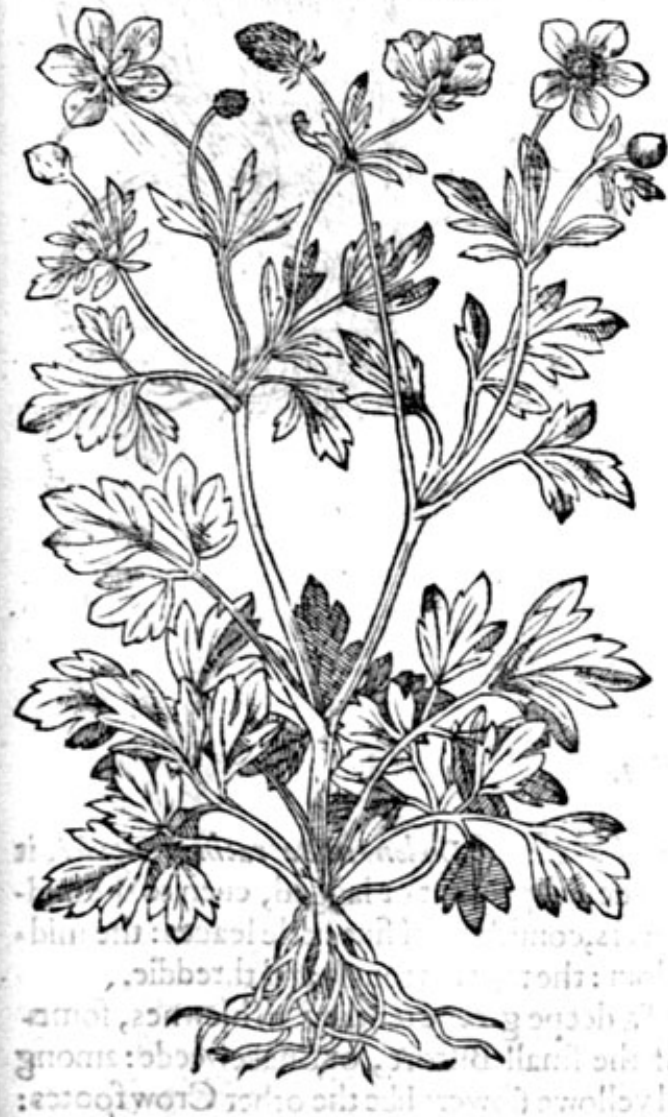

8 Ranunculas nemorofese. Wood Crowfoote.

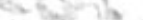

\section{政}


I Ranuneulsu Batrachioides. Frogge Crowfoote.

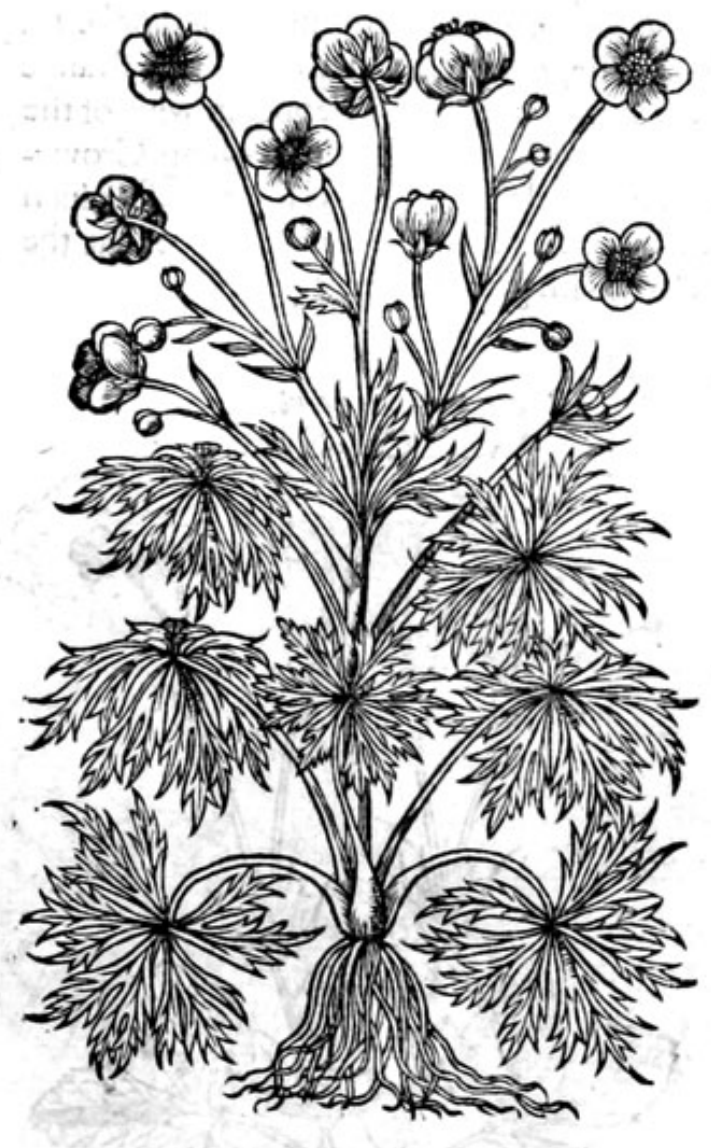

I0 Ranunaulm grominew L'O bely.
Graffie Crowfoote.

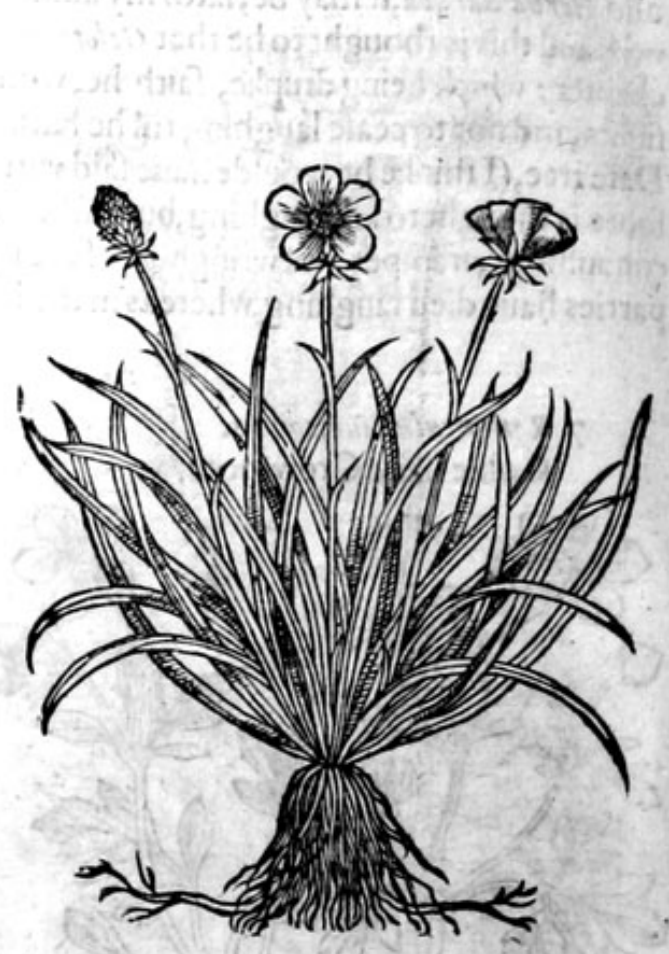

* The defcription.

9 Frogge Crowfoote called of Pena Aconitum Batrachioides, of Dodonean Batrachion Apwlej, it groweth to the height of two cubits : the leaues are broade, deepely cut or iagged, euen to themiddle rib: on the top of the ftalks itande fmall yellowe flowers, confifting of fiue little leaues: the mid. dle part is of a deepe yellowe, as it were of a faffron colour : the roote is tough and threddie. 10 The tenth Crowfoote hath many graffie leaues, of a deepe greene tending to blewnes, fomewhat long,narrow and fmooth, very like vnto thofe of the fmall Biftort, or Snakeweede: among which rife vp flender ftalkes, bearing at the top fmall yellowe flowers like the other Crow footes: the roote is fmall and threddie.

II The autumne or winter Crowfoot, hath diuers broadleaues fpred vpon the ground, fnipt about the edges, of a bright thining green colour on the vpper fide, and hoarie vnderneath, full of ribs or finewes, as are thofe of Plantaine, of an vnpleafant tafte at the firft, afterwarde nipping the toong: among which leaues rife vp fundrie tender footeftalkes, on the tops whereof ftand yellow flowers, confifting of fixe Imall leaues apeece : after which fucceede little knaps of feede like vnto a drie or withered Strawberie. The roote is compact of a number of limber rootes, rudely thruft togither in manner of the Alphodill.

12 The Portingale Crowfoote hath many thickeclogged rootes, faftened vnto one head, very like vnto thofe of the yellow Afphodill; from which rilc vp three leaues, feldome more, broad, thick, and puffed vp in diuers places, as if it were a thing that were bliftered, by meanes whereof it is very vneuen. From the middle of which leaues rifeth yp a naked ftalke, thicke, fat, but yet tender, and very fragile, or cafie to breake: on the end whercof ftandeth a faire fingle yellow flower, hauing in the middle a naked rundell of a golde yellow, tending to 2 Saffron colour. 


\section{ALATHISTORIE OF PLANTS.}

II Rowonoulaw autumnalie Clusp. Winter Crowfoote.

12 Ranunculas Luffranicum Cluss.;.

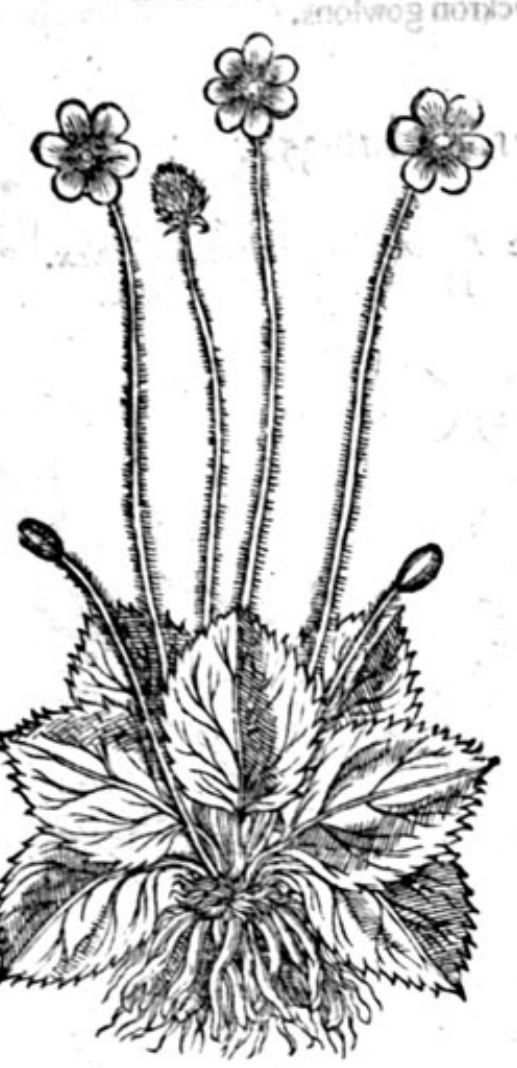

13 Remuscsulus globofus.

Locker Goulons, or globe Crowfoote.

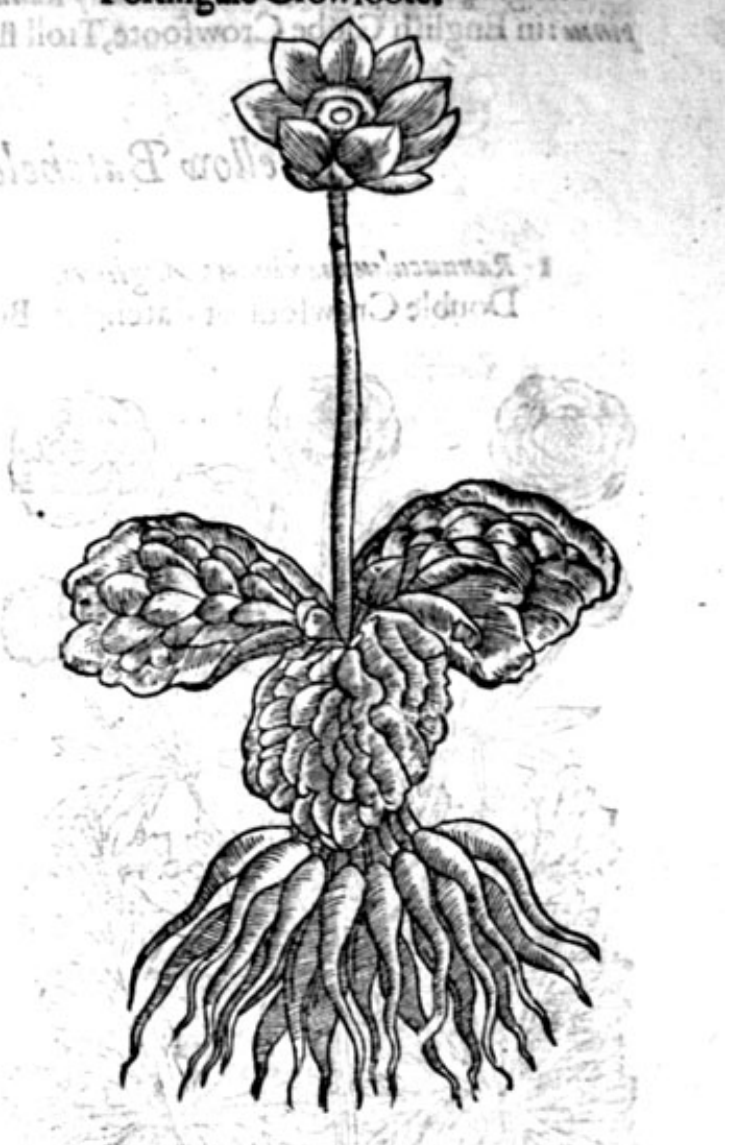

* The defcription.

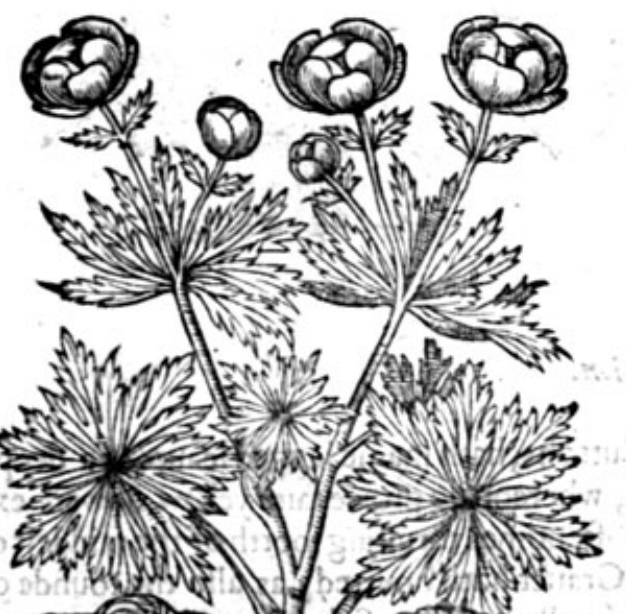

I3 The globe Crowfoote bath verie manie leaues deepely cut and iagged, of a bright green colour, like thofe of the field Crowfoot tamong which rifeth yp a ftalke, diuided towarde the top into other branches, furnifhed with the like leaues of thofe next the grounde, but fmaller: on the tops of which branches growe very faire yellowe flowers, confifting of a fewe leaves, folded or rowled vp togither like a round ball or globe; whereupon it was called Ramusculus globo fous, or the globe Crowfoote, or globe flower, Which being paft, thete fucceede rough knaps, whereiv is blackinh fee d:theroote is mall and threddy;

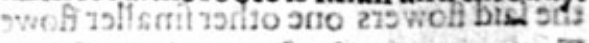

$$
\text { ind tor * T heplace. }
$$

This kinde of Crowforte groweth in hioft places of Yorke fhire, andLancalhire, 3nd othe thof b ordering fhires of the North coufirfey,

alnoft in etery medowe, butnot found wilde in it si thefe foutherly or wefterly parts of Elfiglande,

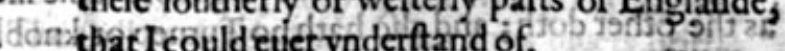
* The time. 2 arijutib jios

If flowreth in Maicand Iune. The feed is ripe in Augurt: 
The globe flower is called generally Ranunculsus globofus, of fome Flos Trolliub, and Ranunculuw $A t$. pinus : in Englifh Globe Crowfoote, Troll flowers, and Lockron gowlons.

\section{Of yellow Batchelers Buttons. Chap.352.}

I Ranuacules maximus Anglicus.

Double Crowfoot, or Batchelers Buttons.
2 Ranunculus maximus multiplex. Double wilde Crowfoote.
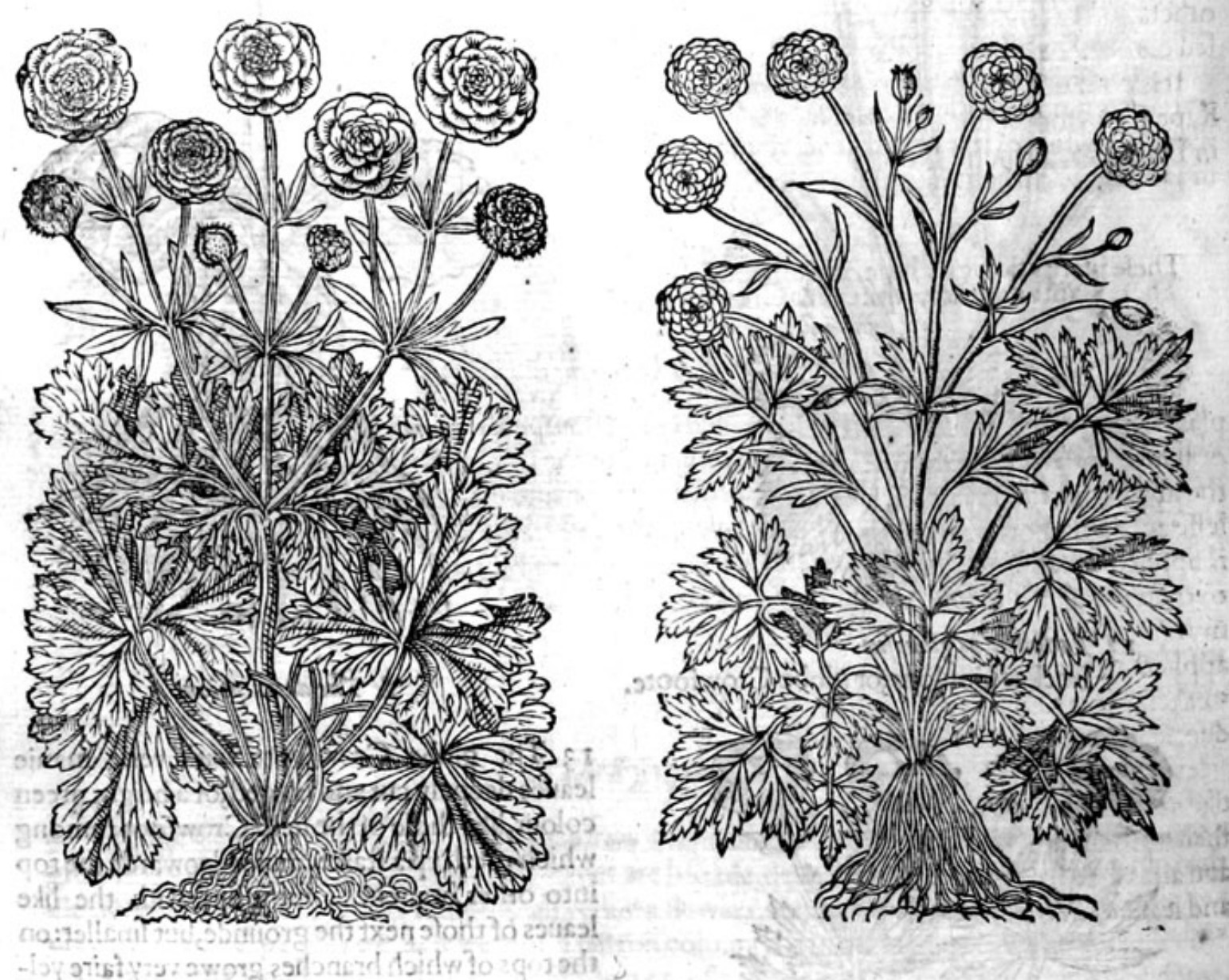

bovicis $1 c^{2}$ i odolg:

\section{$*$ The defoription.}

2 IT He great double Crowfoote or Batchelers Buttons, hath manie iagged leaues of a deepe -19d greene colour : among which rife vp ftalkes, whereon do growe faire yellow flowers exceeding double, of a hining yellow colour, oftentimes thrufting foorth of the middeft of the Laid flowers one other finaller flower, which the Grauer hath omitted, as alfo the rounde or Turnep roote, the forme where of hath caufed it to be called of fome Saint Antonies Turnep, or Rape Tumep. The feede is wrapped in a clufter of rough knops, as are moft of the Crowfootes. 2 The double ycllow wilde Crowfoote hath leaues of a bright greene colour, with manie weake braunches trailing vpon the grounde, whereon do grow verie double yellow flowers like vnto the precedent, but altogither lefler. The whole plant is likewife without anie manifeft difference, $\mathrm{f}_{2}$ uing that - thefe flowers do neuer bring foorth anie fmaller flower out of the middle of the greater, as the other doth; and alfo hath no Turnep or knobbed roote at all, wherein confifteth the greateft difference.

The firt is planted in Gardens for the beauty

the towers, and likewife the fecond, which hath 
of Jatebeerie brought foorth of Lancafhire vnto our London Gardens, by acurious gentlemianin the ferching foorth of Simples Mafter 2 bomas Hesketh, who found it growing wilde in the towas ficlds of a fmall village called Hesketh, not far from Latham in Lancalhire.

\section{* Thetime.}

They fower from the beginning of May to the end of Iune.

?

* The names.

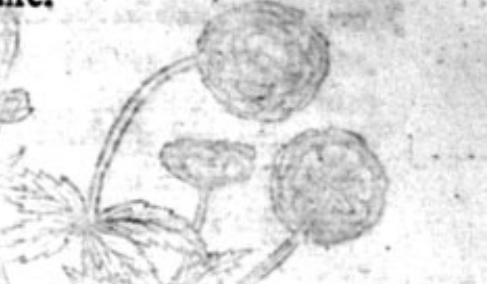

Diofcorides hath made no mention here of : but Apule ims hath feparated the firt of thefe from the others, intreating of it apart, and naming it by a peculiar name Baty achion, whereupon it is alfocalled Lipuley Eatracbion, or Apuleitus Crowfoote.

It is commoniy called Rapum D.Antbonì, or Saint Anthonies Rape : it may becalled in Englifh, Rape Crowfoote; it is called generally about London, Batchelers buttons, and double Crowfoote: in Dutch os. Antbonp Rapkin.

\section{* The temperature.}

Thefe plants do bite as the other Crowfootes do.

$$
\text { * Tle vertues. }
$$

The chiefeft vertue is in the roote, which being ftamped with falt is good for thofe that haue a A plague fore, if it be prefently in the beginning tied to the thigh, in the middle betweene the groine or thanke, and the knec : by meanes whereof, the poifon and malignitie of the difeafe is drawen from the inward partes, by the emunctorie or clenfing place of the tlanke, into thofe outwarde partes of leffe account. For it exulcerateth and prefently raileth a blifter to what part of the bodie foeuer it is applied. And if it chance that the fo:e happeneth vnder the arme, then it is requifite to applie is to the arme a little aboue the elbowe : my opinion is, that any of the Crowfootes will do the fame: my reafon is, bicaufe they all and euery of them do blifter, and caufe paine wherefoeuer they be applied, and paine doth drawe vnto it felfe more paine : for the nature of paine is, to refort vnto the weakeft place,and where it may finde paine; and likewife the poifon and venemous qualitie of that difeafe, is to refort mito that painfull place.

Apuleissfaith further, that if it be hanged in a linnen cloth about the necke of him that is luna- B tike in the waine of the moone, when the figne fhall be in the firft degree of Tawr wo or Scorpio, that then he fhall foorthwith be cured. Moreouer, the herbe Batracheon ftamped with vineger, roote and all, is vied for them that haue blacke fcars, or fuch like marks on their skins, is eateth them out, and leaueth a colour like that of the bodic.

\section{Of white Batcbelers Buttons, or double Crowfoote. Chap.353.}

\section{* The defoription.}

17 He white double Crowfoote hath many great leaues, deepely cut with great garhes; and thofe fnipt about the edges. The ftalkes diuide themfelues into diuers brittle branche, on the tops whereof do growe very double flowers as white as fnowe, and of the bigneffe of our yellow Batchelers Button. The roote is tough, limber, and difperfeth it felfe far abroad, whereby it greatly encreafech. 
I Ranunculusalbus multiflorus.

Double white Batchelers Buttons, or double white Crowfoote.

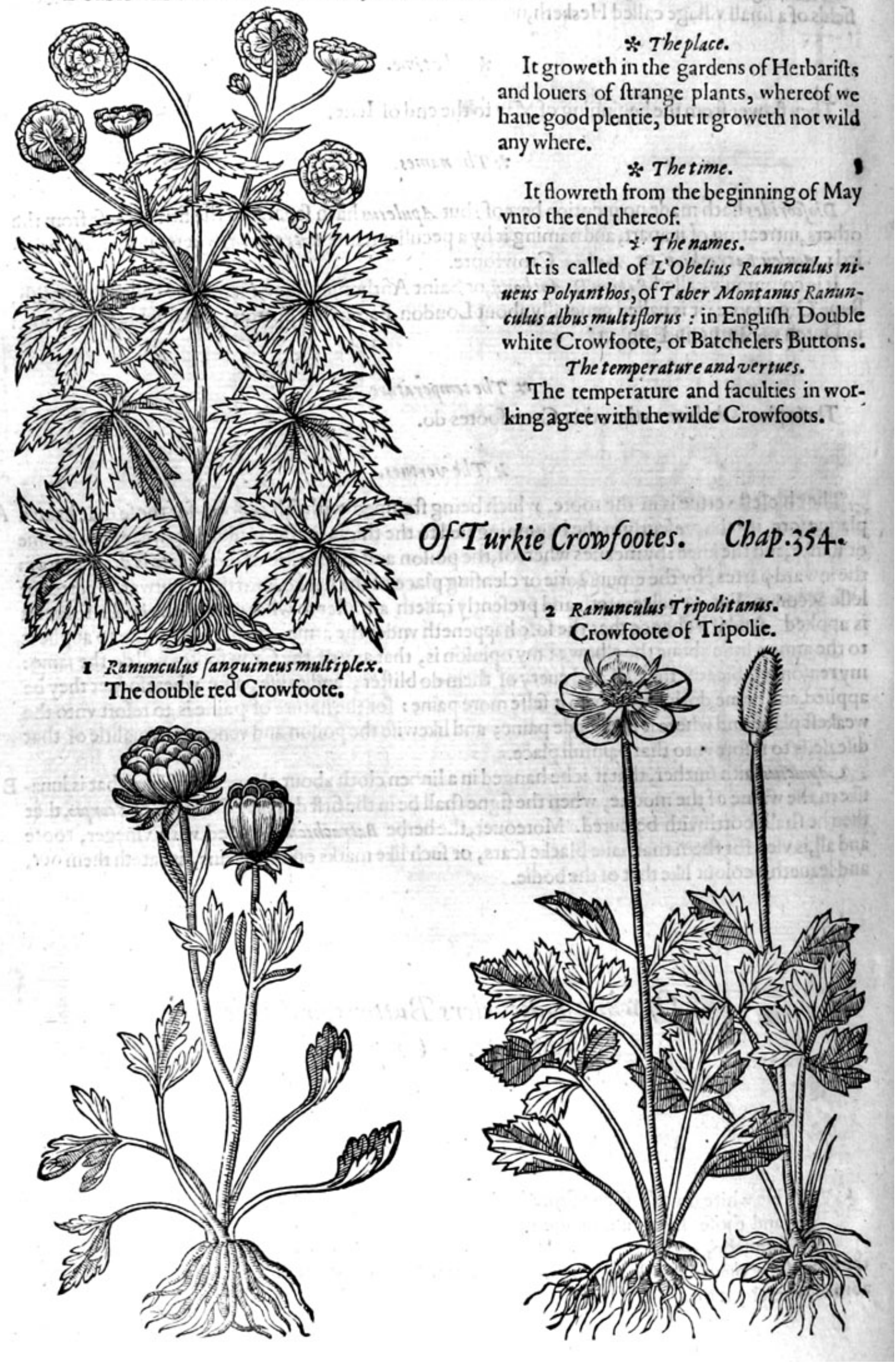




\section{H HIST OR IE OF PLAN T S. HT \\ * The defcription.

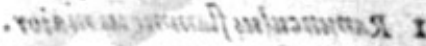

He double red Crowfoote hath a fewe leaues rifing immediately foorth of the ground, cut in the edges with deepe gafhes, fomewhat hollow, and of a bright fhining greene dolour. The ftalke rifeth vp to the height of a foote, fmooth, and very brittle, diuiding ir felfe into other branches, formetimes two, feldome three; whereon do grow leaues confufedly fetwithout order: the flowers growe at the tops of the ftalks very double, and of great beaurie, of a perfeetefarlet colour tending to rednes. The roote is compact of many long tough rootes like thofe of the yellow Afphodill.

2 The Crowfoote of Tripolis or the fingle red Ranunculus, hath leanes at their firftcomming vp like vnto thofe of Groundfivell: among which rifeth vp a ftalke of the height of halfe a cubire,fomwhat hairie, whereon do growe broad leaues deepely cut, euen to the middle rib, like thofe of $\mathrm{Hem}$ locks : the flower groweth at the top of the ftalk, confifting of fiue leaues, on the out fide of a dark or ouerworne red colour, on the infide of a red lead colour, or Phœniceus colour, in thape bike the wilde corne Poppie, the knop or fttle in the middle which conteineth the feede, is garnithed or bedeckt with very many fmall purple thrums tending to blacknes: the roote is as it were a bundell of little bulbes or graines like thofe of the fmall Celandine or Pilcwoort.

$$
\text { * The place. }
$$

The firft groweth naturally in and about Conftantinople, and in Afia, on the further fide of Bofphorus, from whence there hath beene bronght plants at diuers times, and by diuers perfons, but they haue perifhed by reafon of the long iourney, and want of skill of the bringers, that haue fuffered them to lie in a boxe or fuch like fo long, that when we haue receiued them, they haue beene as drie as ginger; notwhichftanding Cluf fus faith he receiued a plant frefh and greene, the which a domefticall theefe ftole foorth of his garden; my Lord and Mafter the right Honorable the Lorde Treafurer, had diuers plants fent him from thence which were dric before they came-as aforefaide. The other groweth in Alepo and Tripolis in Syria naturally, front whence we haue receiued plants for our gardens, where they flourith as in their owne countrey.

They bring foorth their pleafant flowers in Maic and Iune, the feede is ripe in Auguft.

$$
\text { * The names. }
$$$$
\text { nicow jusag boggal }
$$

The firft is called Ranunculus Conftant inopolitanse, of $L^{\prime} O$ belises Ranunculus fanguinesus muitiple $x$, $R$. Anunculas Bizantionus, fuue Afuticus : in the Turkifh toong Tarobolos Catsmer lale: : in Englifh the double redRantinculus, or Crowfoote.

Thefecond is called Ranunculas Tripolitanus, of the place from whence it was firft brought into thefe parts: of the Turkes Tarobolos Cat amer, without that addition lale, which is a proper yourde vnto all flowers that are double.

\section{* The temperature and vertues.}

Their temperature and vertues are referred to the other Crowfootes, whereof they are thotight to be kindes.

\section{Of Spearewoort, or Banewoort. Chap.35.}

\section{* The defcription.}

$\mathbf{r}$

Pearewoort hath an hollowe ftalke full of knces or ioints, whereon da growe long fmooth leaues, not vnlike thofe of the Willow, of a fhining greethe colours the Howers gtosy at the tops of the ftalkes, confifting offiue leaues, of a pale yeltowe colour, very like vato the field gold cup, or wilde Crowfoote : afier which come round knops or feede veffels, wherein is the feed: the roote is compact of diuers bulbes or long clogs, mixed with an infinite number of hairy threds. 2 The common Spearewoort being that which we callthe lefler hath leaues, flowers and ftalks like the precedent, but altogither leffet : the roote confiftethof 20 infinite oumber of threddie ftrings. 
I Ranunculus flammesus maior.

Great Spearewoort.

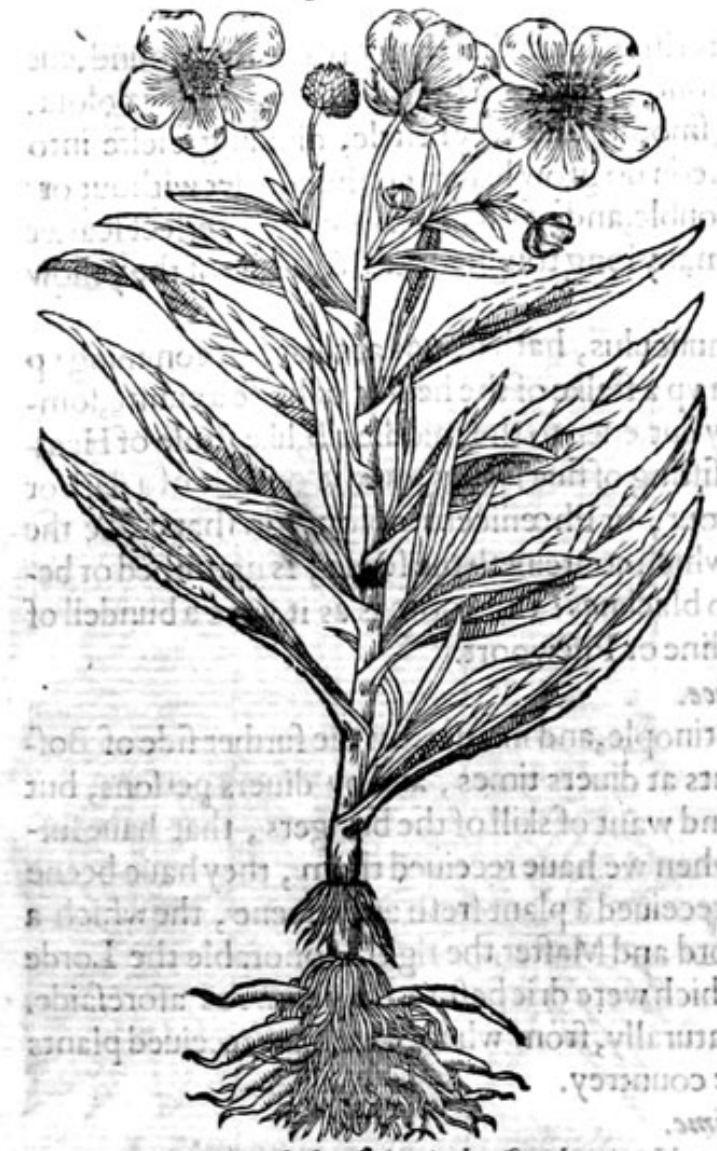

3 Ranunculicis flammesus forratus.

lagged Spearewoort.
2 Ranunculus flanmeus minor. The leffer Spearewoort.
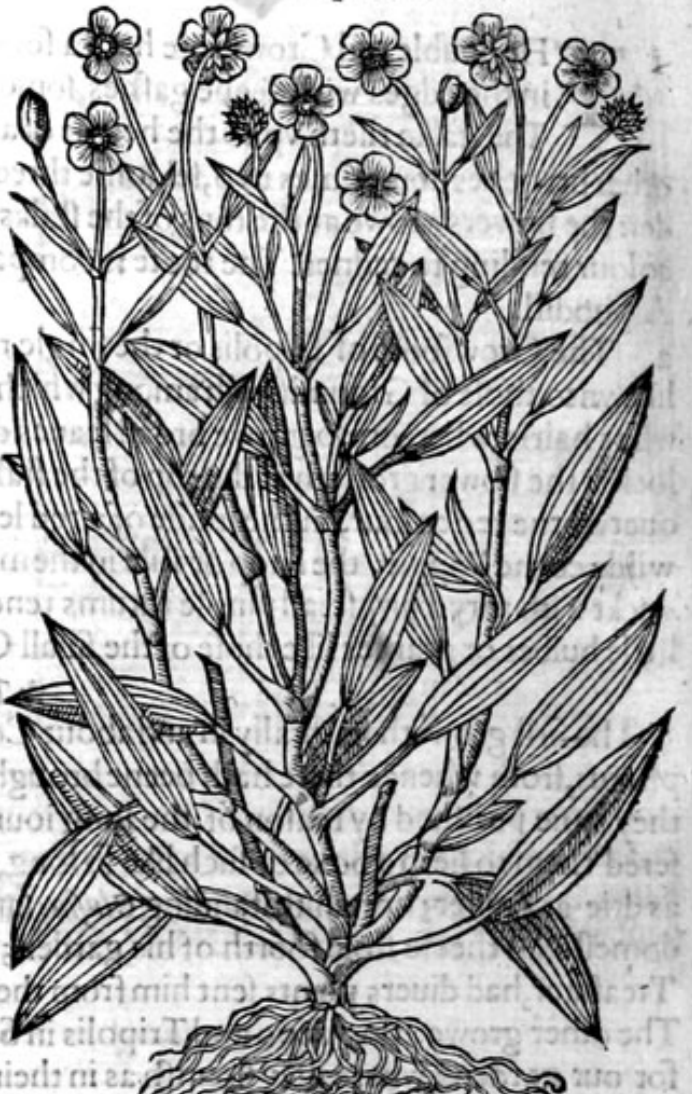

.

4 Rasunculus Palinftris.

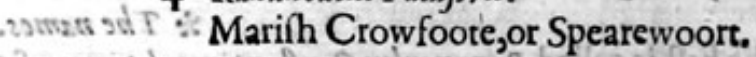

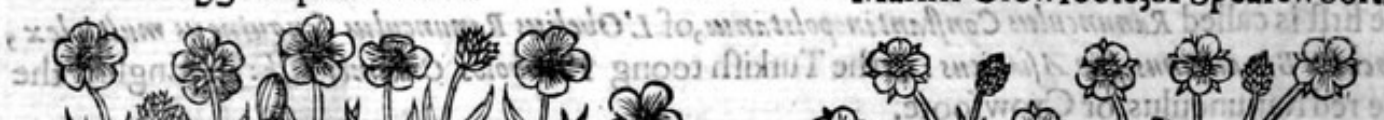

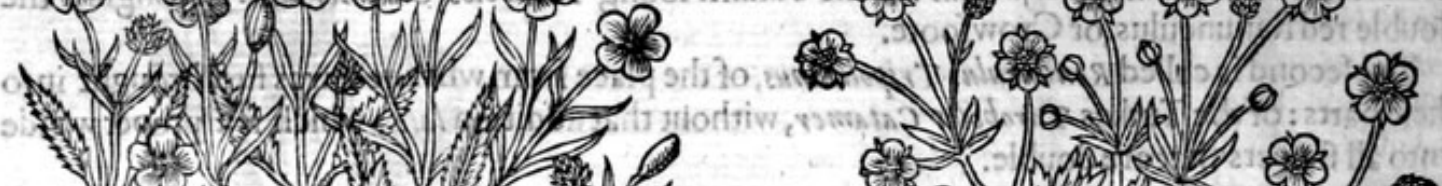
1. (1) (1) 1 (3)

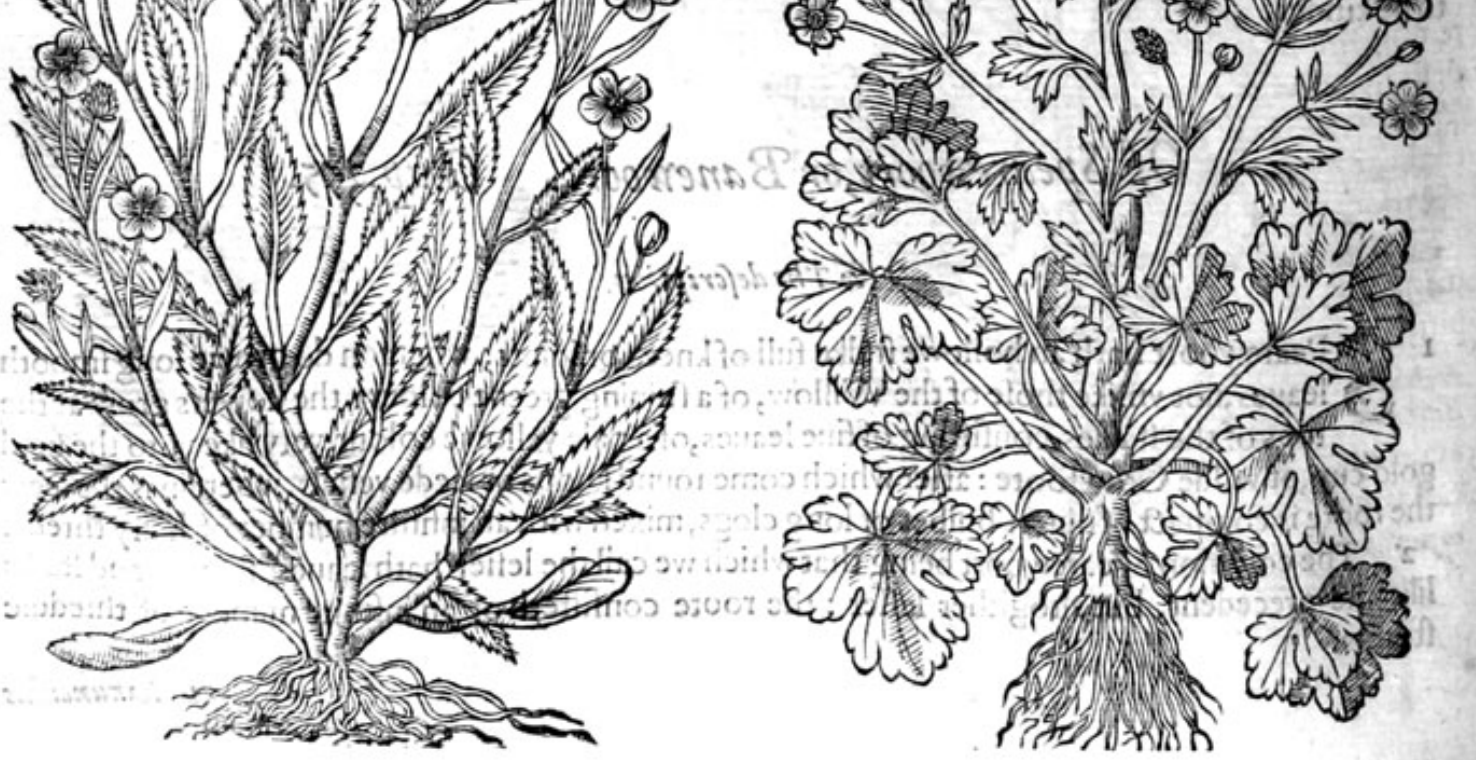




\section{HISTORIE OF PLANTS.}

\section{* The defaription.}

3 Iagged Spearewoort hath a thicke fat hollowe ft alke, diuiding it felfe into diuers branches, whereon are fet by couples at euery ioint two long leaues, (harpe pointed and cut about the edges like the teeth of a fawe. The flower's grow at the top of the branches of a yellow colour, in forme like thofe of the fielde Crowfoote : the roote confilteth of a number of hairie ftrings.

4 Marfh Crowfoote, or Spearewoort (where of it is a kinde, taken of the beft approoued authors to be the true Apium Rifm, although diuers report that Fulfat /lla is the fame: of fome it is taken to bee Apiom Emorodiar rum ) rifeth foorth of the mudde or waterifh mire from a threddie roote, to the height of a cubite, fometimes higher. The ftalke diuideth it felfe into diuers branches, whereupon dogrowe broade leaues deepely cut round about like thofe of Doues foote, andnot vnlike to the cur Mallowe, bur fomewhat greater, and of a moft bright fhining greene colour: the flowers grow at the top of the branches of a yellowe colour, like vnto the other water Crowfootes.

$$
\text { * The place. }
$$

They growe in moift and dankifh places, in brinkes or water courfes, and fuch like places almoft euery where.

* Tie time.

They flower in Maie when the other Crowfootes do. * 7 be names.

Spearewoort is called of the later Herbarifts Flammula, and Ranumculies Flammeses, of Curdue Ranunculus atatieunsos, Platyphyllos, or broad leafed Crowfoote, others Ranunculus long folmus, or long leafed Crowfoote : in lowe Dutch Escienlen: in Engliih Speare Crowfoote, spearewoort, and Banewoort, bicaufe it is dangerous and deadly for heepe; and that if they feede of the fame it inflameth their liuers, fretteth and bliftereth their guts and entrailes.

\section{* The temperature of allthe Crovvfootes.}

Spearewoort is like to the other Crow footes in facultie, it is hot in the mouth or biting, it exulcerateth and raifeth blifters, and being taken inwardly it kulleth remediles.Generally all the Crow. footes, as Galen faith, are of a very fharp or biting qualitie, infomuch as they raife blifters with pain: and are hot and drie in the fourth degree.

$$
\text { The vertipes of all the crovvfootes. }
$$

The leaues or rootes of Crowfoote ftimped and applied vnto any part of the body, caufeth the $\mathbf{A}$ skin to Iwell and blifter, and raifech vp wheales, bladders, caufeth fcars, crufts, and vglie vlcers : it is laide vpon cragged warts, corrupt nailes, and fuch like excrefcence, to caufe them to fall away.

The leaues ftamped and applied vnto any peftelentiall or piague fore, or carbuncle, ftaieth the B fpreading nature of the fame, and caufeth the venemous or peftlentiall mater to breach foorth, by opening the pores and paffages in the skin.

It preuaileth much to draive a plague fore from the inwarde parts, being of danger, vnto other $\mathbf{C}$ remote places further from the hart, and other of the foirituall parts, as hath beene declared in the defcription.

Many do vfe to tie a little of the herbe ftamped with falt vnto any of the fingers againft the paine D of the teeth, which medicine feldome faileth; for it caufeth greater patine in the finger then was in the tooth, by the meanes whereof, the greater paine taketh aw ay the lefier.

Cunning beggets da vie to ftampe the leaues, and lay it vnto their legs and armes, which caufeth $\mathbf{E}$ fuch filthy vicers as we dally lee(annong fuch wicked vagabondes) to mooue the people the more to pittie.

The kinde of Crowfoote of Illyria, being taken to be Apiem Rif fus of fome, of others CAconitum F Batracbeotdes. This plant f poileth the fences and vnderftanding, and drawerh togither the finewes and mufcles of the face in fuch ftrange manner, that thofe who beholding fuch as died by the taking heereof, haue fuppofed that they died laughing; fo forceably hath it drawne and contracred the nerues and finewes, that their faces haue beene drawne awry, as though they laughed, whereas contrariwife they haue died with great torment. 


\section{Of Woolfes bane. Chap.356.}

* The kindes.

THere be diuers forts of Woolfes bane : moft of them bring foorth flowers of a yellow colour; others with a blew, or tending to purple: among the yellow ones there are fome greater,others leffer,fome of broader leaues, and others of narrower.

I ThoraValdenfismas.

Broad leafed Woolfes bane.

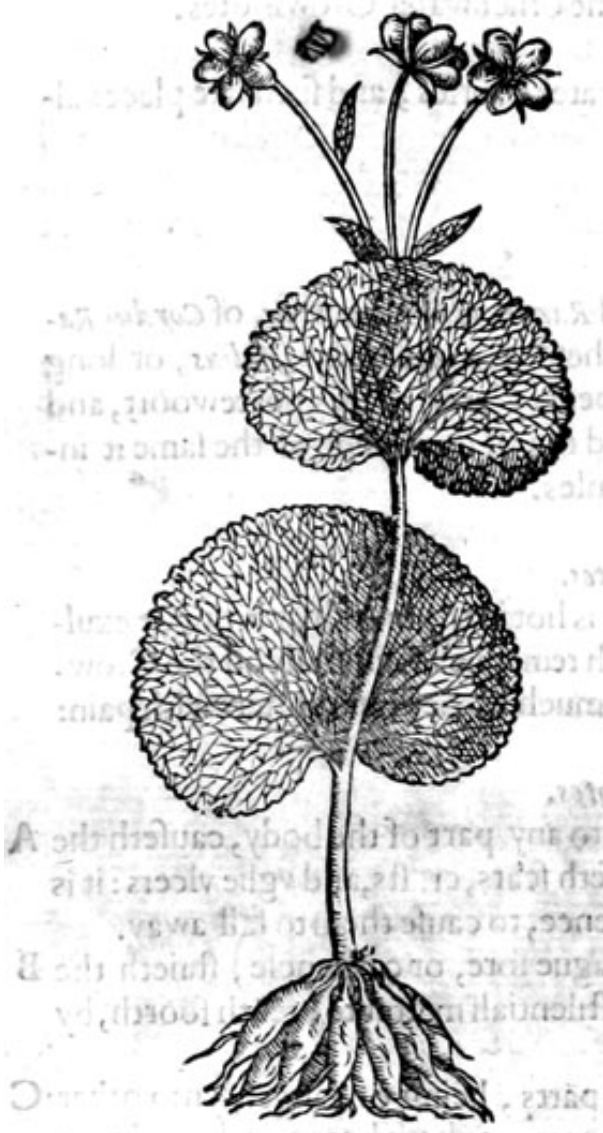

$*$ The defcription.
2 Thora Valden is famina. Broad leafed female Woolfes bane.

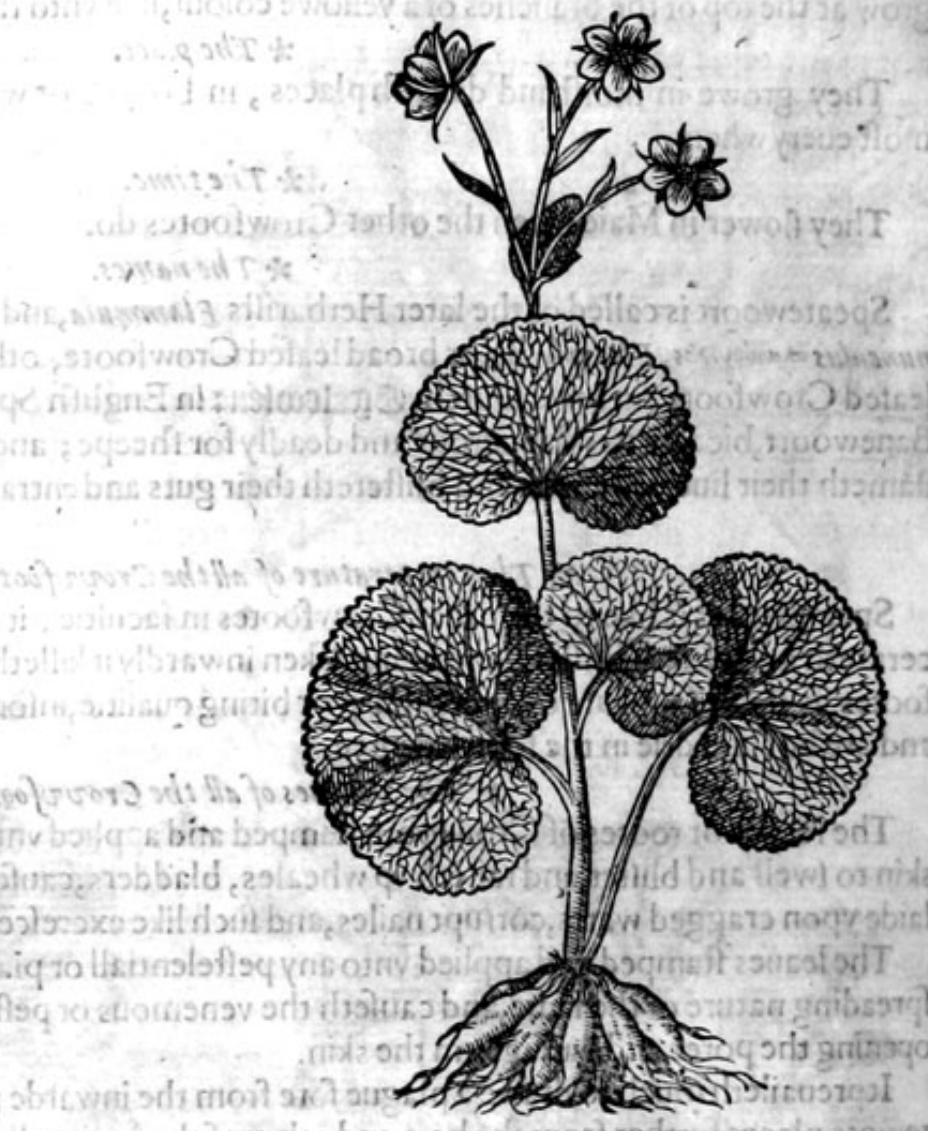

trotsqints He firft kinde of Aconite, of fome called $T$ hora, others adde thereto the place where it groweth in great abundance, which is the Alpes, \& call it Thora Valdenfium. This plant tooke his name of the Grecke worde êtoeg, fignifying corruption, murther, poifon, or death, which are the certaine effeets of this pernicious plant: for this they vfe very much in poifons, and when they meane to infect their arrowe heads, the more fpeedily and deadly to difpatch the wilde and fauge bealts, which do greatly annoy thofe mountaines of the Alpes : to which purpofe alfo it is brought into the mart townes neere vnto thofe places to be folde vnto the hunters, who prepare the iuice there of by preffing it foorth in hornes and hoofes of beafts, referuing it for the moft fpeedie poifon of all the Aconitcs; for an arrowe touched therewith, leaueth the wounde vncureable (if it fetch bloude where it entreth) except rounde about the wound the flefh be cut away ingreat quantitie : this plant therefore may rightly be accounted as firft and chiefe of thofe that becalled Sagittarie or Aconites, by reafon of the malignant qualities aforefaide. This that hath beene faide argueth 


\section{HISTORIE OF PLANTS. I}

arguech alfo that Mathiolus hath vnproperly called it $P$ feudoaconitsom, that is, falfe or baftard Aconite; for without queftion there is no woorfe or more fpeedie venoine in the worid, nor no Aconite or toxicall plant comparable heereunto. And yet let vs behold the fatherly care and prouidence of God, who hath prouided a conquerour and triumpher ouer this lant fo venemous, namely his $A n$ tigonift, Ant it bora, or to fpeake in fhorter and fewer fyllables, Anithor $a$, which is the very antidore or remedre againft the kinds of Aconites. The ftalke of this plant is fmall and rufhie, verie fmooth, two handfuls high, about the middle whereof, and towarde the top, commeth forth ofren one leafe alone, fomtimes two, and very feldome three or fower, which are fomewhat rounde of compaffe, and a little nickt about the edges, like the combe of a cocke. The leafe is $\mathrm{ft}$ tffe and fomwhat finooth on the vpper fide, and not much vnlike the leaues of Cyclsmen: the flowers grow at the top of the ftalke, in colour and fafhion like the flowers of Cinkefoile, or fiue leafed graffe: the rootes are fmall, hauing many round and thiche trunchcons, harpe and flender at the bottome, but next the ftalke it is knottie, not vnlike the rontes of Antbora or Aphodeles. Dodon.ews hath more truelie defcribed this plant in his laft edition, then Pena hath, who hath faulted in two notable refpects; firft in the rootes, and fecondly in the flowers, both which are much varying, yeanothing neere the true picture.

2 Thefecond broad leafed Woolfes bane of the Valdenfes (or of thofe people fometimes called Sclauonians) hath one onely ftalke, and the fame rounde, two handes high: whereupon do growe three or fower leaues, feldome more, which be fornething harde, rounde, fmooth, of a light greene colour tending to blewnes, like the colour of the leaues of Woad, nicked in the edges. The flowers grow at the top of the ftalkes, of a yellow colour, leffer then thofe of the fielde Crowfoote,otherwife alike : in the place thereof groweth a knop or rounde head, wherein is the feede: the roote con: fifteth of nine or ten clogs; faftned togither with little ftrings vnto one head, like thofe of the white Asphodill.

3 Thor a mont is Baldi. Mountaine Woolfes bane.

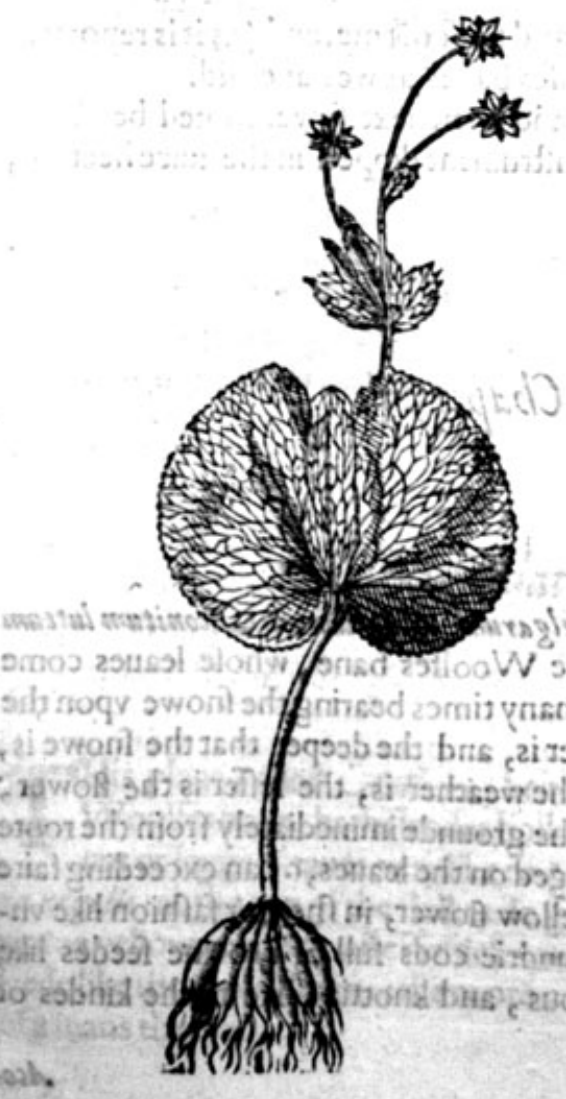

4 Thora Sabaudica. Sauoie Woolfesbane:

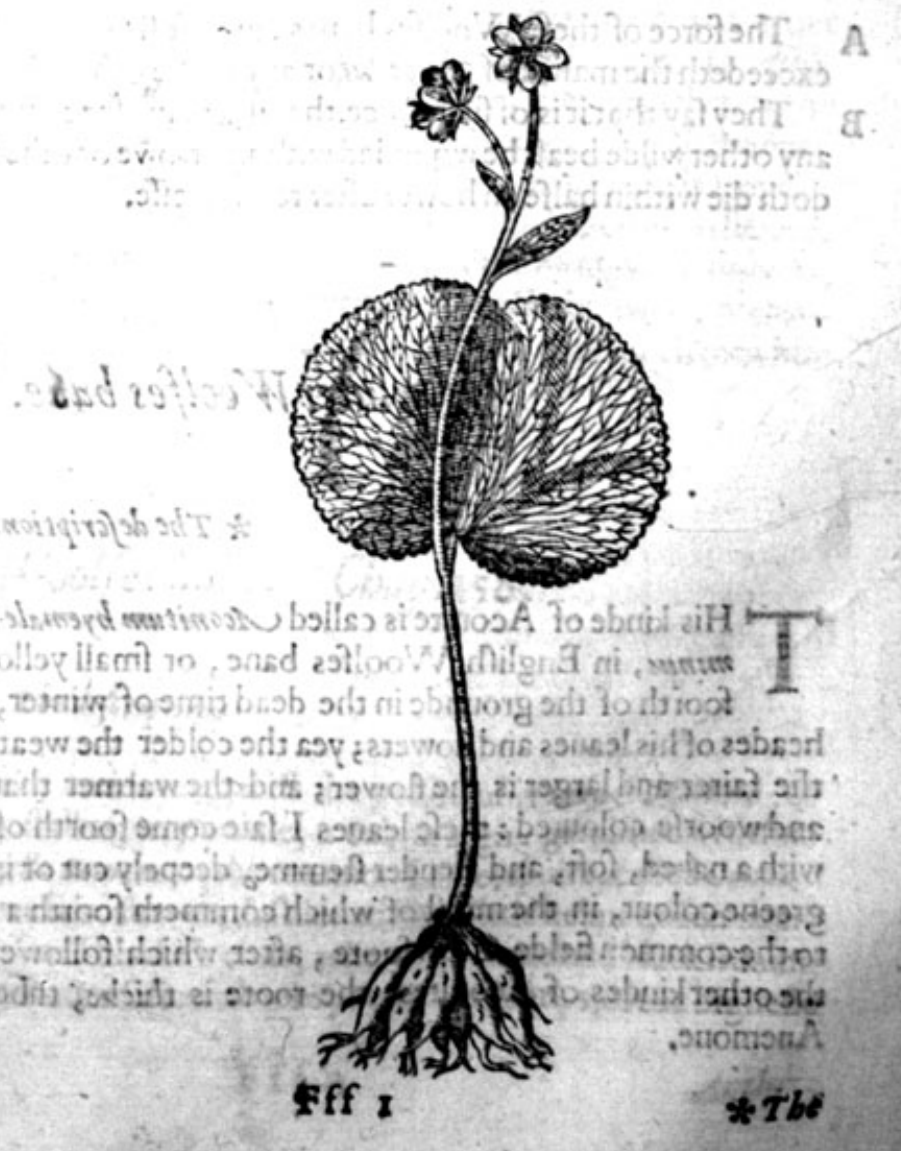




\author{
* The defcription.
}

3 Woolfes bane of the mount Baldus hath one ftalke, fmooth and plaine, in the middle whereof come foorth two leates and no more, wherein it differeth from the other of the Valdens, hauing likewife three or fower tharpe pointed leaues, narrowe and fomewhat iagged at the place where the ftalke diuideth it felfe into fmaller bianches; whereon do growe fmall yellowe flowers like the precedent, but much leffer.

4. That of Sauoic hath likewife an vpright ftalke, fmooth, and of a greene colour, in the middle whereof growe two leaues, of an ouerworne blewilh colour: the flowers are fomewhat bigger then the precedent, and of the fame colour.

$$
\text { * The place. }
$$

Thefe venemous plants do grow on the Alpes, and the mountaines cf Sauoic and Switzerland: The firft grow plentifully in the countrey of the Valdens, who inhabite part of thofe mountaines towards Italie. The other is found on Baldus, a mountaine of Italy. They are ftrangers in England.

* The time.
They flower in March and Aprill, their feede is ripe in Iune.

* The names.

This kinde of Aconite or Woolfes bane is called $\tau$ bora, Tasra, and Twra, it is fumamed Valden: fos, that it may differ from Nepellus, or Munckes hoode, which is likewife named Thora.

Awicen maketh mention of a certaine deadly herbe in his fourth booke, fixt Fen. called Farfiwn; it is harde to affirme this fame to be $T$ ior a Vaiden fis, or Munkes hoode of Valdenfia: in Englifh we may call it round leafed Munkes hood,and to of the reft,as is fet downe in their feuerall titles.

\title{
* The temperature and vertues.
}

A The force of thefe Woolfes banes, are moft pernicious and poifonfome, and (as it is reported) exceedeth the malice of 2 apellses, or any of the other Woolfes banes, as we haue faid.

B They fay that it is of fuch force, that if a man efpecially, and then next fower footed bea?ts or any other wilde beaft be wounded with an arrowe or other inftrument dipped in the iuice heercof, doth die within halfe an hower after remedileffe.

\section{Of minterWoolfes bane. Chap:357.}

\section{* The defaription.}

$\mathrm{T}$ His kinde of Aconite is called Aconitum byemale Belgarum, of Dodonasu Aconitum luteum minus, in Englifh Woolfes bane, or fmall yellowe Woolfes bane, whofe leaues come foorth of the grounde in the dead time of winter, many times bearing the fnowe vpon the heades of his leaues and flowers; yea the colder the weather is, and the deeper that the fnowe is, the fairer and larger is the flower; and the warmer that the weather is, the leffer is the flower, and woorfe coloured : thefe leaues I faie come foorth of the grounde immediately from the roote with a naked, foft, and flender ftemme, deepely cut or iagged on the leaues, of an exceeding faire greene colour, in the midit of which commeth foorth a yellow flower, in hew or farhion like vinto the common fielde Crowfoote, after which followe fundrie cods full of browne feedes like the other kindes of Aconites: the roote is thicke, tuberous, and knotric, like to the kindes of Anemone. 


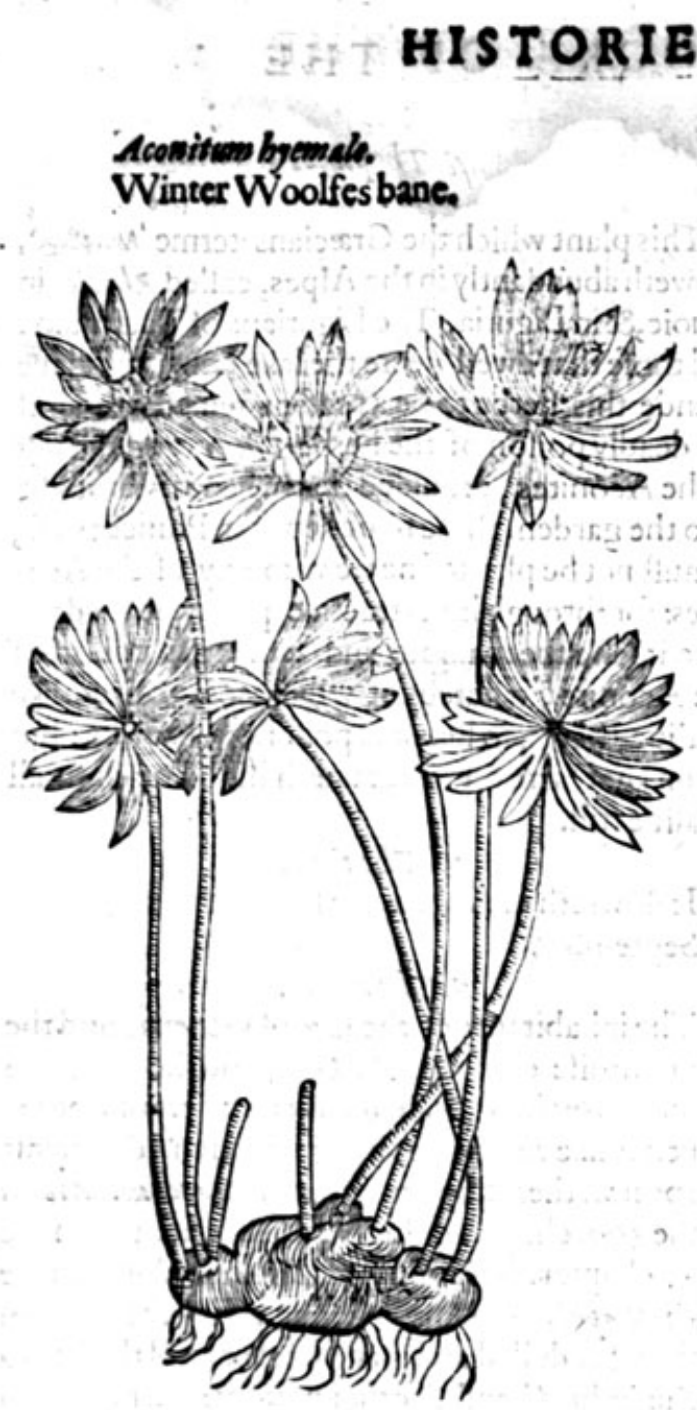
moft poifoneft herbe of all others, which mooned It groweth vpon themountaines of Grrmanie: we haue great quantitie of it in our London gar: dens.

1) It flowreth in Ianuarie; the feede is ripe in the end of March.

* The names.

It is called Aconitum hyemale, or Hibernum, or winter Aconite: that it is a kinde of Aconite or Woolfes bane, both the forme of the leaues and cods, and alfo the dangerous faculties of the herbe it felfe do declare.

It is much like to Aconitum Theophrafti, which he defcribeth in his 9. booke faying, it is a fhort he:be, hauing no meridy, or fuperfluous thing gro. wing on it, and is without branches as this plant is : the roote faith he is like to vapu , or to a nut, or elfe to xquvin, a drie figge, onely the leafe feemeth to make againft it, which is nothing at all like to that of Succory, which he compareth it vnto. .

* The temperature and vertues.

This herbe is counted to be very dangerous and $\mathbf{A}$ deadly : hot \&drie in the fourth degree, as 7 beoph. in plaine wordes doth teftitie concerning his owne Aconite; for which he faith that there was neuer founde his antidoteor remedie : whereof ctibenews and $T$ heopompus write, that this plant is the vertues. Joac bimus Camer arius now liuing in Noremberg faith, the water dropped into the eves ceafeth the paine and burning : it is reported to preuaile mightily againft the bitings of fcorpions, and is of fuch force, that if the fcorpion paffe by where it groweth and touch the fame, prefently he becommeth dull, heauie, and fenceleffe, and if the fame fcorpion by chance touch thewhite Helleb or, is prefently deliuered from his drowfines.

\section{Of Mitridate Woolfes bane. Chap.358.}

\section{* The defcription.}

7 His plant called Anthora, being the antidote againft the poifon of it hors, Usconite, or Woolfes baue, hath flender hoilowe ftalkes, very brittle, a cubite high, garnifhed with fine cut or iagged leaues, very like to Nigella Romama, or the common Larkes spurre, called Con foliLa Regalis : at the top of the ftalkes do growe faire flowers, fafhioned like a litele helmet, of an ouerworne yellowe colour; after which come fmall blackifh cods, wherein is conteined black fhining feede like thofe of Oinions : the roote confiftech of diuers knobs or tuberous lumps, of the bigneffe
of a mans thumbe. 


\section{THE SECOND BOOKE OF THE}

Anthora fune Acunitum falut iferum. Holfome Woofes bane.

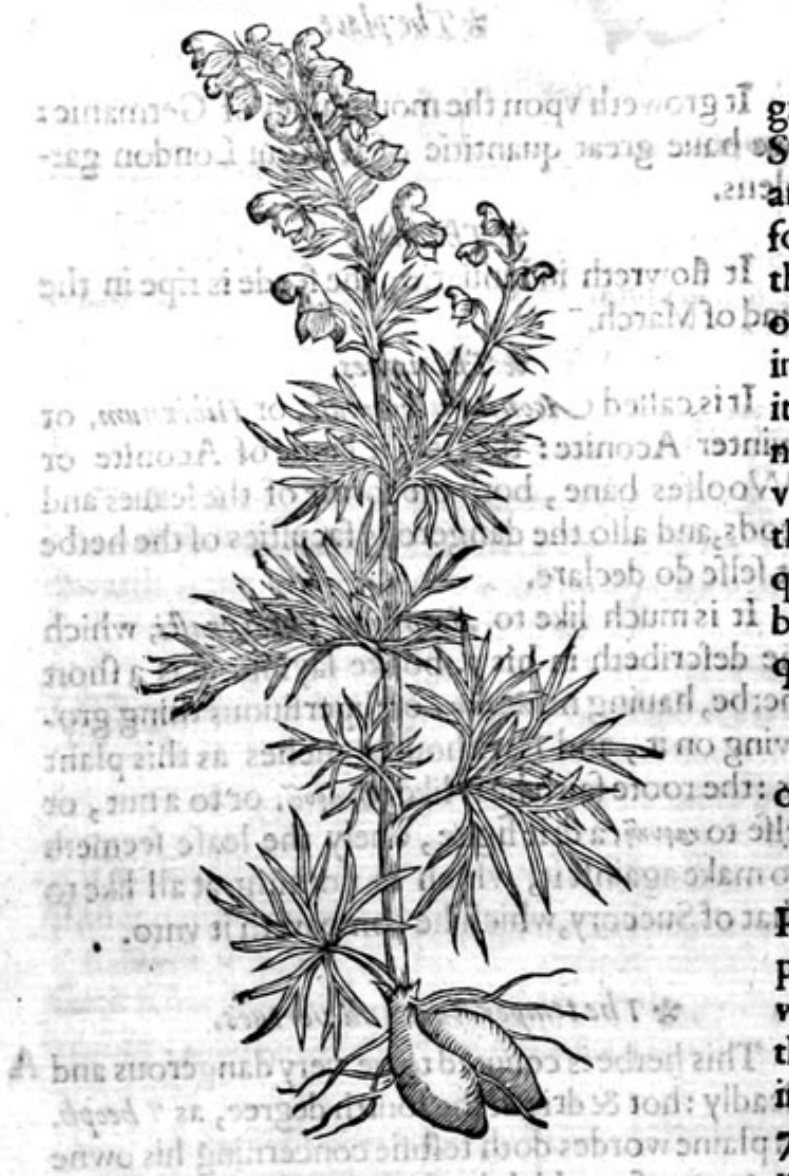

\section{x Thephace. At ronition}

This plant which the Græcians terme Arme日oed, groweth abundantly in the Alpes, called Rhetici,in Sauoie,\$ in Liguria. The Ligurians of Taurinum, and thofe that dwell neere the lake Lemanus, haue founde this herbe to be a prefent remedie againt the deadly poifon of the herbe $T$ hora, and the reft of the Aconites, prouided that when it is brought into the garden, there to be kept for Phifickes vfe, it muft not be planted neere vnto any of the Aconites: for through his attractive quality, it wil draw vnto it felfe the maligne and venemous poifon of the Aconite, whereby it will become of the like qualitie, that is, to become poifonous likewife : but being kept farre off, it retaineth his owne naturall qualitie ftill.

* The time.

It flowreth in Auguit, the feed is ripe in the end of September.

* The names.

The inhabitants of the lake of Geneua, and the Piemontoife do call it Anthora, and the common people Anthoro. Avicen calleth a certaine herbe which is like to Munkes hoode, as a remedy againft the poifon therof, by the name of Napellies. Moy/is in the 500. chapter of his fecond booke, and in the 745. chapter, he faith, that Zedoaria doth growe with 2 apelles or Mnnks hoode, and that by reafon of the neerenes of the fame, the force and ftrength therof is dulled and made weaker, and that it is a Treacle, that is, a counterpoifon againft the viper Munks hood,and all other poifons:and heerupon it followeth, that it is not onely Moyfis Napelliws, but alfo Zedoaria Avicenne, notwithitand ing the apothecaries do fell another Zedoaria differing from Anthora, which is a roote of a longer forme, that not without caufe is thought to be Uavicens and Serapios Zerwembeth, or Zurwmbeth.

It is called Anthora, as though they fhould faie Antithora, bicaife it is an enimie to $T$ bora, anda connterpoifon to the fame. Thora and Antbors, or Tura and Antura, feeme to be newe wordes, but yet they are vfed in Marcellus Empericus, an old writer, who teacheth a medicine to be made of Tiv. $r a$ and Antura, againft the pin and webbe in the eies: in Englifh yellowe Munkes hoode, yellowe Helmet flower, and Aconites mithridate.

* The vertues.

A The roote of Anthora is woonderfull bitter, it is an enimie to all poifons: it is good for purgations; for it voideth by the ftoole both waterie and flimy humours, killeth and driueth foorth all mancr of wormes of the belly.

b Hugo Solerius faith, that the rootes of Anthora do largely purge not onely by the ftoole, but alfo by vomite: and that the meafure thereof is taken to the quantitie of Fafelus, (which is commonly called 2 beane) in broth or wine, and is gituen to ftrong bodies.

C Antonius Guanerius doth thew, that Anthora is of great force, yea and that againft the plague, in his treatie of the plague; the feconde difference, the thirde chapter: and the roote is of like yertues, giuen with Dittanie, which I haue feene faith he by experience: and further faith, it is an herbe that groweth hard by that herbe $T$ hora, of which there is made a poifon, whercwith they of Samoy and thofe parts adiacent, do enuenome their arrowes, the more fpeedily to kill the wilde Goates, and other wilde beafts of the Alpifh mountaines. And this roote Anthora is the Bezosr or counterpoifon to that $T$ hora, which is of fo great a venome, as that it killeth all liuing creatures with Hils poifonfome qualitie, and thus much Guanerius. 
Simon Itmuen fss hath alfo made mention of Anthora, and Urnoldew Villenowanws in his treatie of D poifons : but their writings do declare that they did not well knowe Unt hora.

\section{Ofyellow Woolfes bane. Chap. 359 . \\ * The kindes.}

$T^{\top}$ Here be diuers forts of Woolfes bane, moft of them bring foorth flowers of a yellowe colour, others blew, or tending to purple : among the yellowe ones there is one greater, another leffer.

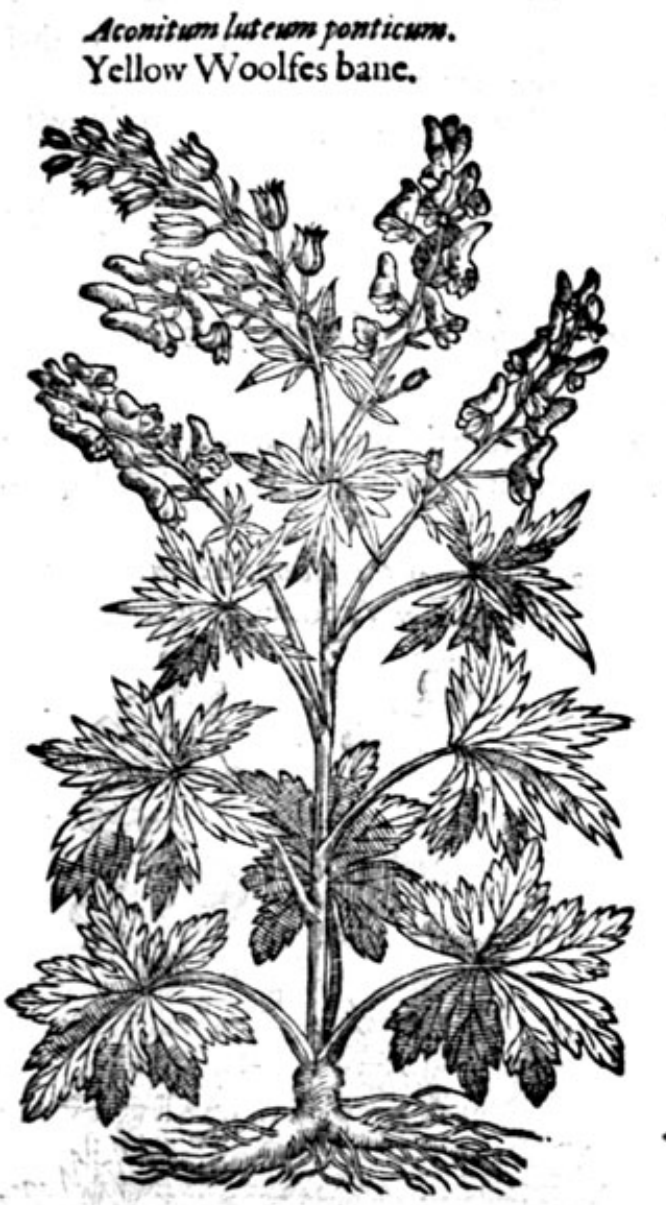

\section{* The defcription.}

He yellowe kinde of Woolfes bane called
Acontsom lut eum ponticum, or according to
Dodoneas, Aconttwon Lycoctonon latewn miins : in Englifh yellowe Woolfes bane, (whereof this our age hath founde out fundrie forts not known to Diojcorides, although fome of the forts feeme to ftande indifferent betweene the kindes of Ranuncu/us, Helletor us, and 2 (apellus :) this yel. lowe kinde I faic hath large fhining greene leaues fafhioned like a vine, and of the fame bigneffe, deepely indented or cut, not much vnlike the leates of Geranium Fufctom, or blacke Cranes bill, the ftalks are bare or naked, not bearing his leaues von the fame ftaikes, one oppofite againft anoth:r, as in the other of his kind: his ftalks growvp tc the hight of three cubits, hearing very fine yellow flowers, fantaftically fafhioned \& in fuch maIrr fhaped, that I can very hardly defcribe them vito you. They are fomewhat like vnto the helmet Munkes hoode, open and hollow at one end, fime and fhut vp at the otber : his rootes are manis compact of a number of threddie or blacke ftrigs, of an ouerworne yellow colour, fpreading fare abroade euery way, foulding themfelues oncwithin another very confufedly. This plant groreth naturally in the darke hillie forreits, and fhaowic woods, which ate not trauelled nor haunted, but by wilde and fauage beafts, and is thougt to be the ftrongeft and next vnto $T$ hora in his poifoning qualitie, of all the reft of the Aconites, oN Voolfes banes; infomuch that if a ferve of the flowers be chewed in the mouth, and fpet foorth agine prefently, yet foorthwith it burnetly the iawes and toong,caufing them to fwell, and making a crtaine fwimming or giddines in the head. This calleth to my remembrance an hiftoic of a certaingentleman dwelling in Lincolnfhirc, called Mahevve, the rrue report whereof my very good friend zafter Nucholas Bel fon, fometimes fellowe of Kings Colledge in Cambridge, hath deliuered vnto or: Mafter Mabevve divelling in Bofton, a ftudent in Phificke, hauing occafion to ride through thFennes of Lincolifhire, founde a roote that the hogs had turned vp, which feemed vnto him vo ftrange and vnknowne, for that it was in the fpring before the leaues were out : this roote he taft, and it fo inflamed his mouth, toong, Bofton he coulde not fpeake, and no doubthad loft his ke, if that the Lord God had notbleffed thofe good remedies which prefently he procured and vfei I haue heere thought goad to expreffe this hiftorie, for twoefpecially caufes; the firft is, that fore induiftrious and diligent obferuer of nature, may be prouoked to feeke foorth that venemous plit, or fome of his kindes; for I am certainly perfwaded that it is either the $T$ bors $V$ aldens swom, or Anitwon Lutewon, whereof this gentleman

$$
\text { Ff } 3
$$




\section{$8: 2$ \\ THE SECOND BOOKE OF THE}

tafted, which two plants haue not at any time beene thought to growe naturally in Englande: the other caufe is, for that I would warne others to beware by that gentlemans harme.

* The place.

This vellowe Woolfes bane groweth in my garden, but not wilde in Englande, or in any other of thete northerly regions. * The time.

Ir Aowreth in the end of Iune,formewhat after the other Aconites.

* The names.

This yellow Woolfes bane is called of L'Obelius, Aconitum lateum ponticum, or Pontick Woolfes banc. There is mention made in Diofcorides his copies of three Woolfes banes, of which the hunters vfe one, and Phifitions the other two. Marcelles Vergilius holdeth opinion that the vfe of this plant is vtterly to be refufed in medicine. $*$ The temperature and vertwes.

A The facultie of this Aconite, as alfo of the other Weolfes banes, is deadly to man, and likewife to all other liuing creatures.

B It isvfed among the hunters which fecke after Woolfes, the iuice whereof they put intorawe Alefh, which the Woolfes deuoure and are killed.

\section{Of otber Woolfes banes that are notyellow. Chap.360. \\ * The kindes.}

THere be alfo other kindes of Woolfes banes, whici differ from the fornier in colour of the flowers; amongtt the which our common Munks hoode might be taken, but it is defcribed apart, forgood and efpeciall caufes.

I Lycoctonon fore Delphinï.

Larkes heele Woolfes bane.

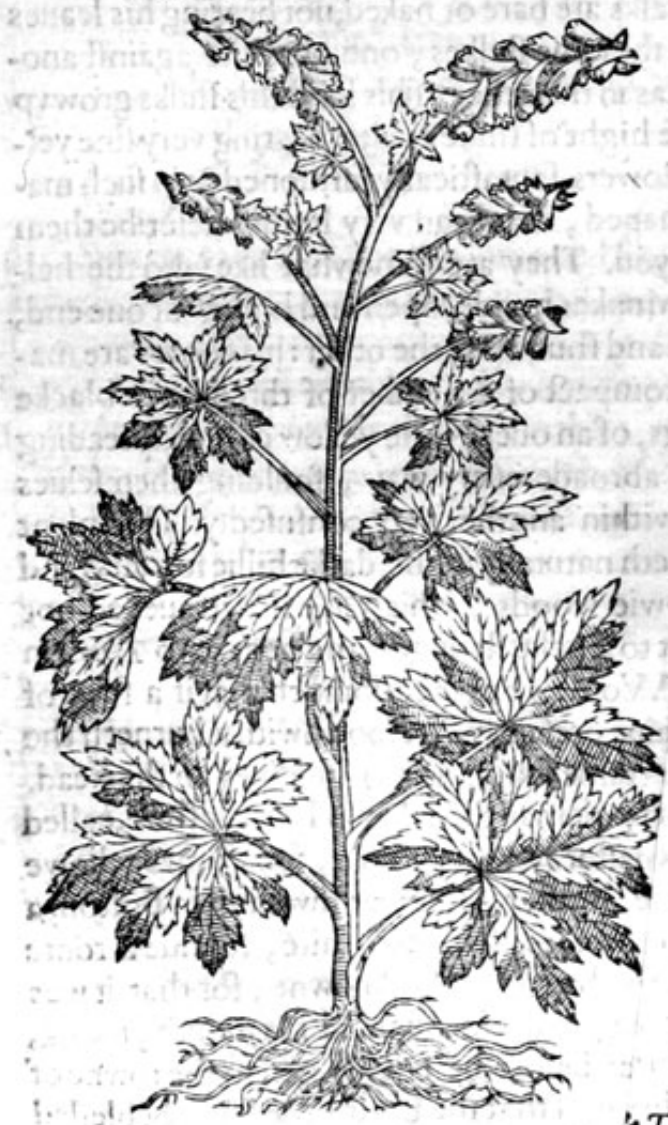

2 Lycortonon Cerwleum parmens. Small blew Woolfes bane.

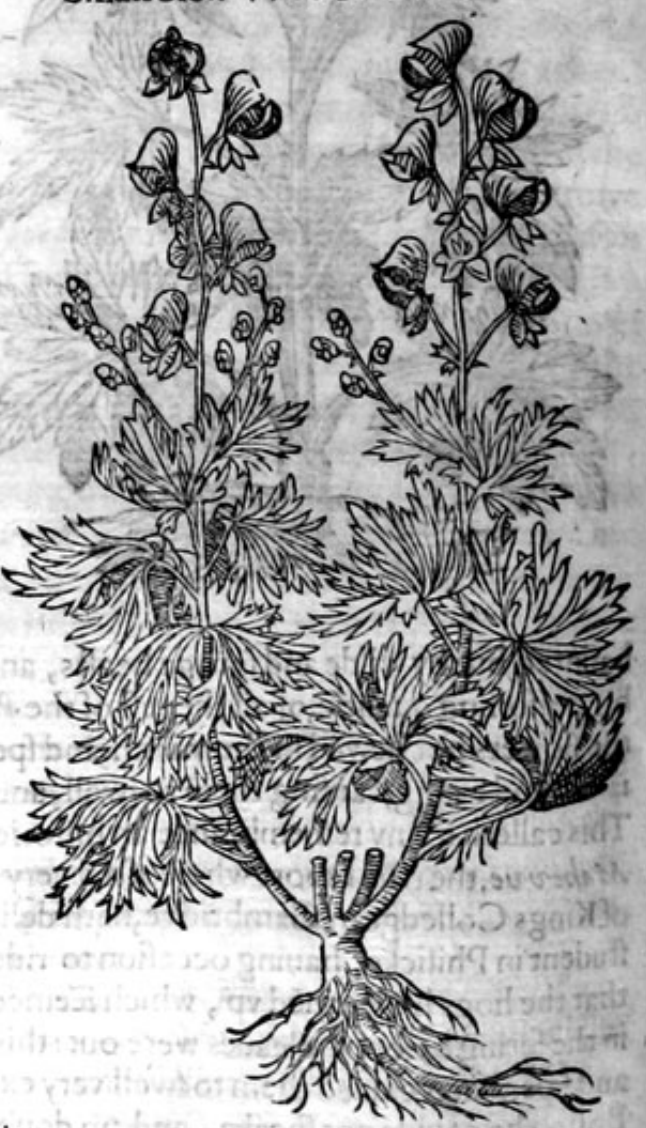

7 Hiskind of Woolfes bane (cald The defcription.

His (cald Aconitum Lyco Zlonum, and of Dodonasus Lycoctonon Delphinï, by reafon of the fhape all likenes that the flower hath with Delphinium, or Munkes hoode, and in Englifh it is cald blacke Woofes bane:) hath many large leaues, of a ieric decpe grecene, or oucrworne colourery deepely cut or iagged: among which rifech vp a ftalke, 


\section{HH HISTORIEOOF PLANTS.}

two cubits high, whereupon do grow flowers fafhioned like an hoode, of a very ill fauoured blewith colour, and the thrums or threds within the hoode are blacke, the feede alfo blacke and thice cornered, growing in frnall huskes: the roote thicke and knobbie,

2 This kinde of Woolfes bane, called Lycuctonon Caruleum parnwm, facie 2 (apelli, in Englith fmall Woolfesbane, or round Woolfes bane, hath many flender brittle italkes two cubits high, befet with leaues, very much iagged and like vnto Napellws,called in Englith Helmet fower: tha flowers growe at the top of the ftalkes, of a blewifh colour, fafhioned alfo like an hoode, but wider open then any of the reft; the cods and feed are like vato the other:the roote is rounde and frmall, fafhioned like a Peare,or fmallRape, or Turnep, which mooued the Germaines to call the fame גiapen: : bloemen, that is in Latine, Flos rapacews : in Englifh Rape fower.

3 2Capellus verus Coruleus. Blew Helmet flower.

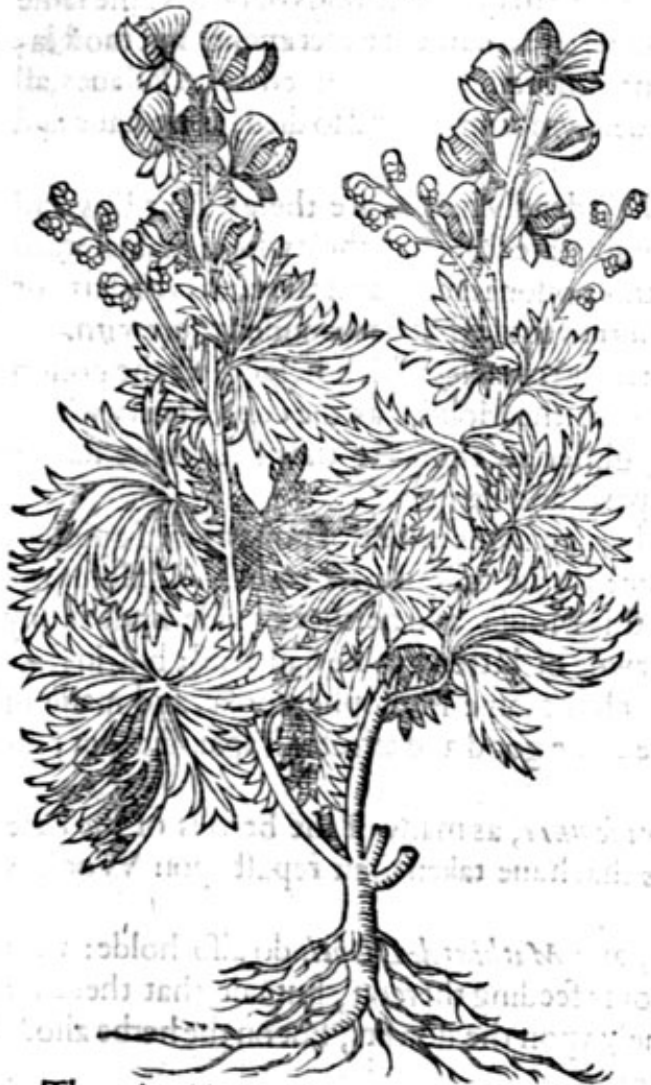

* The defcription.

3 This kind of Woolfs banecalled Napellus vews, in Englith Helmet flower, or the great Munks hood, beareth very faire and goodly blew flowers, in thape like an helmet, which are fo beautifull that a man would thinke they were of fome excellent vertue, but Non eft femper fuiles haliends fronti. This plant is visiuerfally knowne in our London gardens, and elfe where; but naturally it groweth in the mountaines of Rhetica, and fundrie places of the Alpes, where you thall finde the grafie that groweth rownd it eaten vp with cattle, butno part of the herbe it felfe rouched, except bycertaine fies, who in fuch abundant meafure fwarmabout thelame, that they couer the wholeplant: and (which is very ftrange) although thefe flics doe with great delight feede beereupon, yet of them there is confected an antidote or moltauaileable medicine againft the deadly bite of the beatt or worme called Taranta, or any other venemous beaft whatfoener; yea, an cxcellent remedie not onely againftue poifon of the Aconites, but all other poifons whatfoeuersthemedicinc of the fore faid flies is thusmade. Take of the tlies which have fedde themelues as is aboue mentioned, in number twenty $x$ of Arifolochin roturida, andbole Armoniack of ech a dram.

There is a kinde of Woolfes bane, which Dodon ew $r$ eportecth he found in an old writteg Grecke

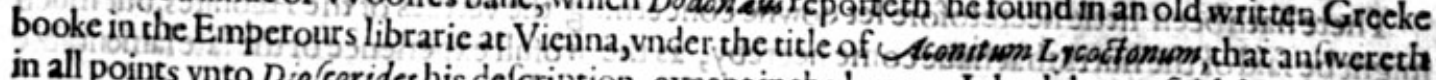
in all points vnto Dio corides his defcription, except in the leaues. It hath leaus faith he, like vinto the Plane tree, but lefler, and more full of iagges, and diuifions, a llender ftalke as Ferne, of a cubite the Emperours feede in long ceds: it hath black roots, in fbape like Creauifes. Heerunto agreeth the Emperours pieture in all things faving in theleaties, whicharencither 10 large, nor fo much di-
uided, but notched or toothed like the teth of a faw.

All the kinds of Woofes bane * Theplace.

of the Emperours booke.

Thele plants do flower from Maic vnto $*$ The time.

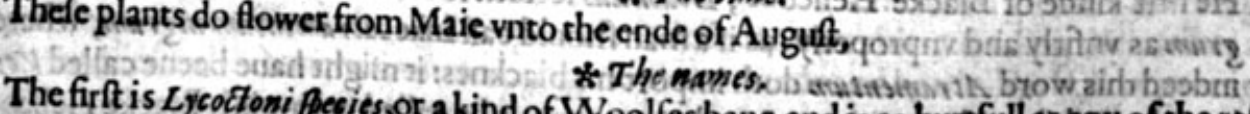

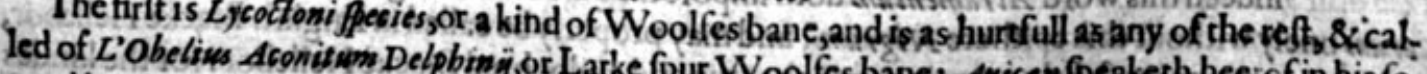

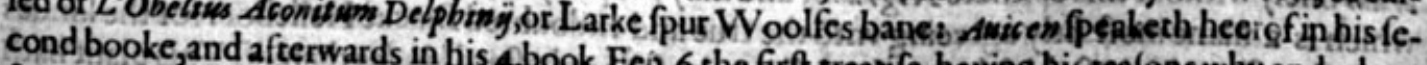
fore he harh feparated this frô 


\section{THE SECOND BOOKE OF THE}

The later and barbarous Herbarifts do call this laft. Woolfes bane in Latine Napellus, of the figure and Thape of the roote of Napus, or $\mathcal{N}$ auet, or Nauewe gentle, which the grauer hath omitted in the figure: it is likewife Lycoctoni ßecies, or a kinde of Woolfes bane, which is alfo called Toxicum; for Toxicum is a deadly medicine, wherewith the hunters poifon their fpeares, darts,and arrowes, that bring prefent death: fo named of arrowes which the Barbarians call Toxeumata, and Toxa. Diofcorides fetting downe the fymptomes or accidents to Toxicum, togither with the remedies, reckoneth vp almoft the very fame that Awicen doth concerning Napelliw : notwithftanding Awicen writeth of Napellus and Toxicum feuerally, but not knowing what Toxicum is (as he himfelfeconfeffeth) fo that it is not to be maruelled that hauing written of 2 (apellus, he fhoulde
afterwards intreate againe of Toxicum.

$\therefore$ The nature and vertues.

A All thefe plants are hot and dry in the fourth degree, and of a moft venemous qualitie.

B The force and facultic of Woolfes bane is deadly both to man and all kinds of beafts: the fame was tried of late in Anwarpe, and is as yet frefh in memorie by an euident experiment, but moft lamentable, for when the herbes heereof were by certaine ignorant perfons ferued vp in fallades, all in the former chapter.

C The fymptomes that followe thofe that do eate of thefe deadly herbes are thefe; their lips and toongs fwell foorthwith, their eies hang out, their thighes are ftiffe, and their wits are taken from them, as Anicen writeth in his 4 . booke. The force of this poifon is fuch, as if the points of darts or arrowes be touched with the fame, it bringeth deadly hurt to thble that be wounded therewith.

D Againit fo deadly a poifon, Auicen reckoneth vp certaine remedies which helpe after the poifon it felfe is vomited vp, 8 among thefe he maketh mention of the Moufe (as the copies euery where haue)nourifhed and fed vp with Napellus, which is altogither an enimie to the poifonfome nature thereof,and deliuereth him that hath taken it from all perill and danger.

E Antoniws Guaneriws of Pauia, a famous Phificion in his age, in his treatic of poifons is of opinion, that it is not a moufe that Assicen peaketh of, but a Flie: for he telleth of a certaine Philofopher that did very carefully and diligently make fearch after this Moufe, and neither coulde findeat any time cither Moufe, or the roote of Woolfes bane gnawne or bitten, as he had read; but in fearching he founde manie flies feeding on the leaues, which the fame Philfopher tooke, and made of them an antidote or counterpoifon, which he founde to be good and effectuall againft other poifons, but ef pecially the poifon of Woolfes bane.

F This compofition confifteth of two ounces of Terra lemnia, as many of the berries of the Baie tree, and the like waight of inithridate, 24 . Of the flies that haue taken their repaft vpon Woolfes bane, of hony and oile Oliue a fufficient quantitie.

G The fame opinion that Guanerises is of, Petrus Pena, and Mathias de L'Obel, do alfo holde: who affirme that there was neuer feene at any time any Moufe feeding thereon, but faie that there be flies which refort vnto it by fwarmes, and feedenot onely vpon the flowers, but on the herbe alfo.

$$
\text { xit Thendanger. }
$$

Therehathbeen little heeretofore fet downe concerning the vertues of the Aconites, but much might be faid of the hurts that haue come heereby, as the wofull experience of the latelamentable example at Anwerpe, yet fref $\mathrm{h}$ in memorie doth declare, as we haue faide.

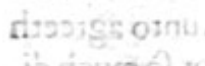

\section{Of blacke Hellebor. Chap.36r.}

\section{* The defcription.}

I. He firt kinde of Blacke Hellebor, Dodorieus fetteth foorth vnder this title Veratrim ni: grum as vnfitly and vnproperly, as if a man fhould call Inke Atramentum nigrum, whereas indeed this word Atramentum doth import his blacknes: it might haue beene called Verstrum onely without this epithete Nigrum, and may properly be called in Englifh Blacke Hellebor, which is 2 name moft fitly agreeing vnto the true and vndoubted Blacke Hellebor: for the kindes and other forts thereof which heereafter follow, are falfe or baftard kindes thereof. This plant hath thicke and fat leaues, of a deepe greene colour : the vpper part whereof is fomewhat bluntlynicked 


\section{HISTORIE OF PLANTS.}

or toothed, hauing fundrie diuifions or cuts ; in fome leafe manie, in others fewer, like vnto the female Peonie, or Smirnivm Creticum. It beateth Rofe fafhioned tiowers vpon flender ftemmes, growing immediately out of the grounde an handful high, likethe flowers of Cyclamen, fometimes verie white, and often mixed with a little fhewe of purple, which being vaded, there fucceede fmall huskes full of blacke feedes: the rootes are manie with long blacke ftrings comming from one head.

2 The fecond kinde of Blacke Hellebor called of Pena Hellebor aftruon, and of Dodonesus Veratrum fecundum : in Englinh Baftarde Hellebor, hath leaues much like vnto the former, but narrower and blacker; each leate beingmuch iagged or toothed about the edges like a fawe. The ftalkes grow to the height of a foote or more, diuiding themfelues into other branches towardes the top ; whereon do grow flowers not much vnlike to the former in fhew, faue that they are of a greenifh herbie colour. The rootes are fmall and threddie, but not foblacke as the former.

I Helleborus niger verws. The true blacke Hellebor.

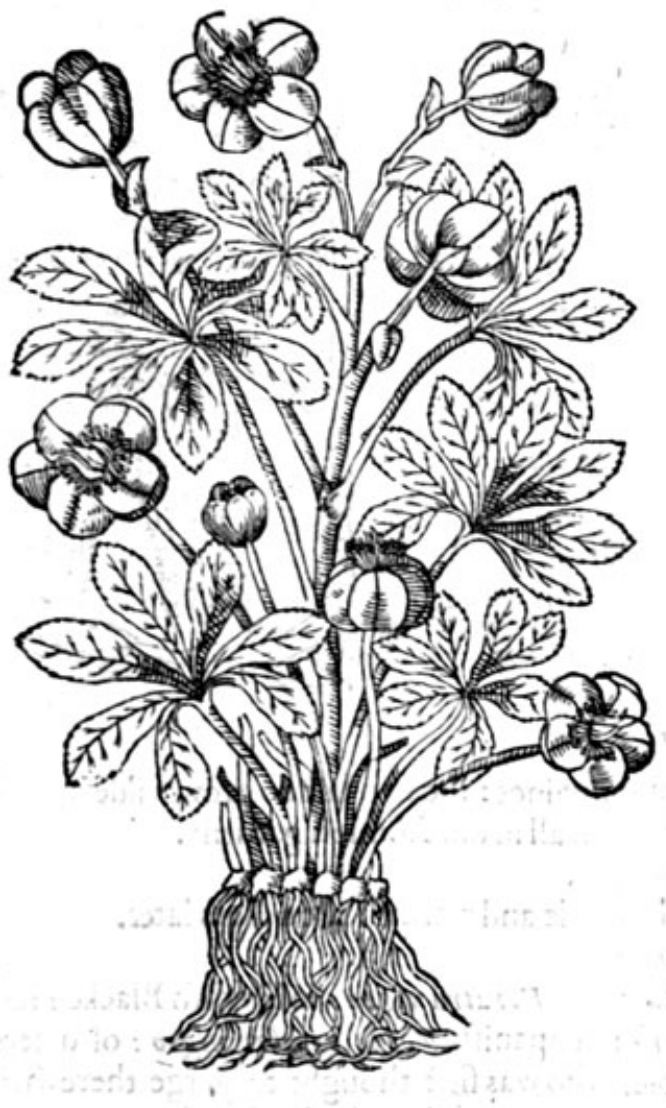

2 Helleboraftrum. Wilde blacke Hellebor.

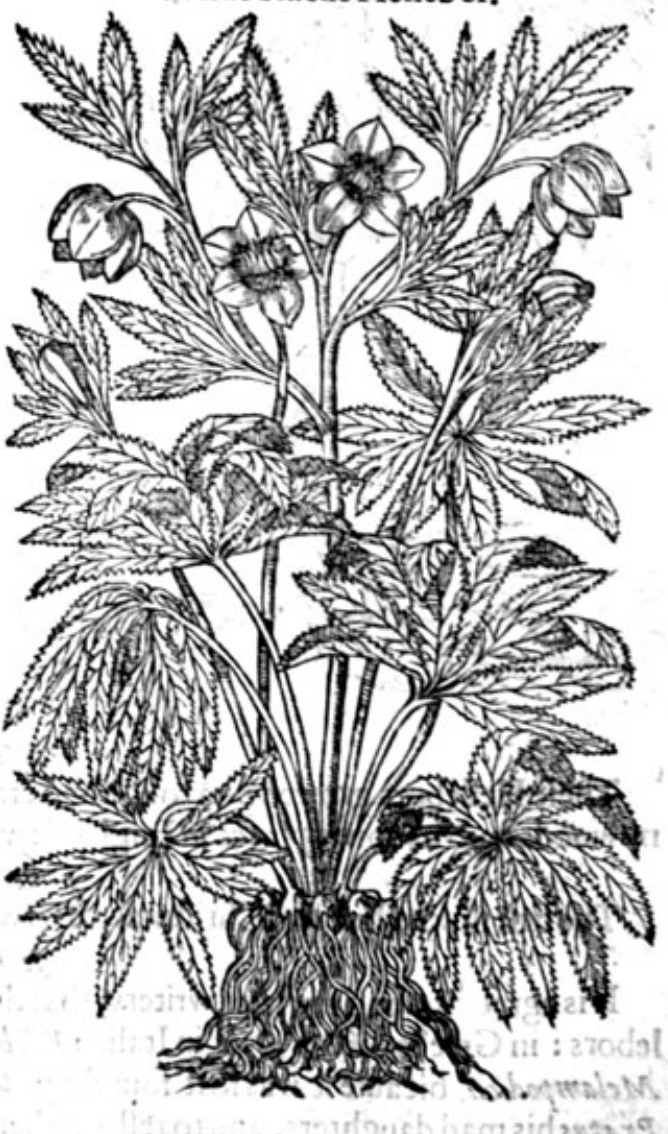
abroduan

3. The third kind of Black Hellebor called of Pens Hellebor after maximus, with this addition Flore 6 Jemine pregnians, that is bearing both flowers and feede (which the reft of the fame kind do not at all, or verie little) and may becalled in Englifh the great wilde Blacke Hellebor : hathleanes fomewhat like the former wilde Hellebor, faue that they be verie much greater, more iagged, and more deepely cut. The ftalkes grow vp to the height of two cubits, diuiding themfelues at the top into fundrie fimall braunches, whereupon grow little rounde and bottle-like hollow greene flowers: after which comefoorth feedes which come to perfect maturitic and ripenes. The roote confiftech of manie fmall blackeftrings, inuolued orwrapped one within another verie intricately. 4 The fourth kinde of BlackeHellebor called of Pens and L'Obelins (according to the defcription of Cor des and Ruelliw) Sefomoides magnum, and Comfiligo : in Englifh Oxchecle, or Setterwoort: 
which names are taken from his vertues, in curing oxen and fuch like cattell, as thall bee fhewed afterward in the names thereof : it is fo well knowen vnto the moft fort of people, by the name of Bearfoote, that I fhall not haue caufe to fpend much time about the defcription.

3 Helleboraster maximus. The great Oxeheele.

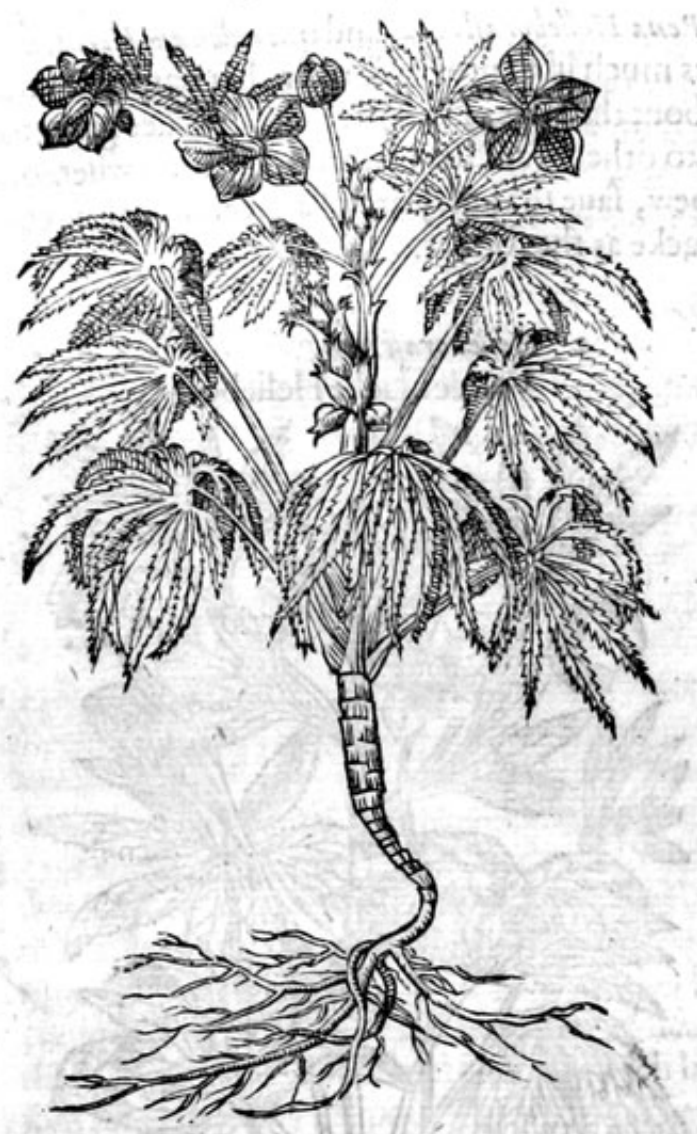

4 Confligo Ruellì \& Sefamoides magnum Cordi. Setterwoort, or Bearfoote.

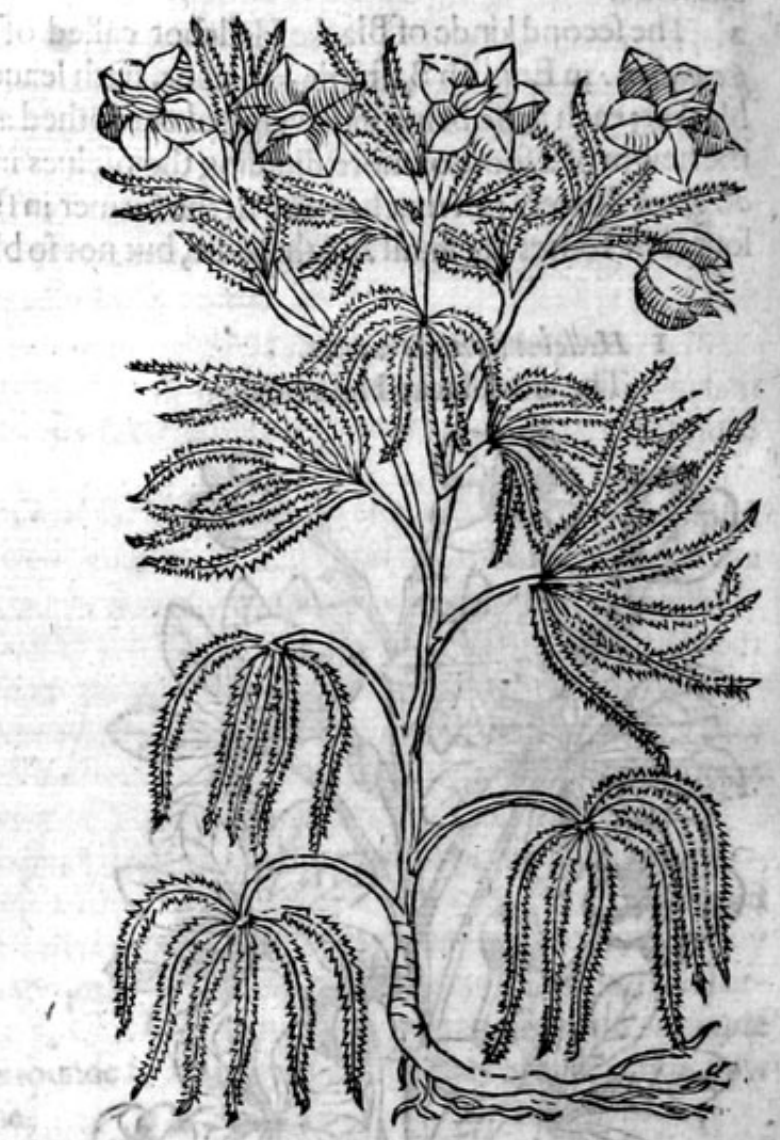

* The place.

Thefe Hellebors growe vpon rough and craggie mountaines : the two laft do grow wilde in many woods and fhadowie places in England : we haue thern all in our London gardens. * Thetime.

The firft flowreth about Chriftmas, if the winter be milde and warme : the others later. * The names.

It is agreed among the later writers, that thefe plants are Veratra nigra : in Englifh Blacke Hellebors: in Greeke iníboes ubuas: in Italian Elleboro nero : in Spanifh Verde gambre negro : of diuers Melampodion, bicaufe it was firft found by Melampos, whowas firft thought to purge therewith Pratus his mad daughters, and to reftore them to health. Diofcorides writeth, that this man was a Phepherd: others a foothfayer. In high Dutch it is called Ubeiffuurtz, that is, Chriftes herbe, or Chriftmas herbe: in low Dutch peplicblierff etuitt, and that bicaufe it flowreth about the birth of our Lord Iefus Chrift.

The fecond kind was c.lled of $F$ uch fius $P$ feudobelleborus, and $\nu$ erat rum nigrum adulterinsom, which is in Englifh, Falfe or baftard blacke Hellebor. Moft name it Confligo, bicaufe the husbandmen of our time do herewith cure their cattell, no otherwife than the olde Farriers or Horfeleeches were wont to do, that is, they cut a flit or hole in the dewlap, as they terme it (which is an emptie skin vnder the throte of the beaft) wherein they put a peece of the roote of Setterwoort, or Bearfoote, fuffering it there to remaine for certaine daies togither: which manner of curing they do call Settering of their cartell, and is a manner of rowelling, as the faide Horfeleeches do their horfes with horfe haire twifted, or fuch like, and as in Chirurgerie we do vfe with filke, which in fteede of the word Setow, a certaine Phifition called it by the name Rowell; a worde very viproperly fpoken of a 
learned man, bicaufe there would be fome defference betwixt men and beaftes. This maner of Settering of cattell, helpeth the difeafe of the ltings, the cough, and wheefing. Moreouer, in the time of pefti cuce or murraine, or any other difeafe affecting cattell, they put the roote into the place afore1.aid, which draweth vinto it all the venemous matter, and voideth it foorth at the wound. The which Ab/rtus and Hucrocies the Greche Hoteleeches haue at large fetdowne. And's called in Englith Beaifoote Setterwoort, and Settergiafic.

The thirde and fourth are named in the Germane toong Loweztraut, that is redensalar is, of Lowfie grafic : for it is thought to deftroy and killlyce, and not onelv lyce, but fheepe and other cattell:and may be reckoned among the Bearfootes, as kindes thereof.

\section{* The temperatarc.}

Blacke Hellebor, as Gilen holdeth opinion, ishotter and bitterer than the white Hellebor: in like. manner hot and drie in the third degrec.

$$
\text { * The vertues. }
$$

Blacke Hellebor purgeth downwardes tlegme, choler, and alfo blacke choler efpecialty, and all A melancholike humors,yet not without trouble and difficultie. Therefore it is not to be giuen but to robuftious and ftrong bodies, as $M$ efues teacheth. A purgation of blacke Hellebor is good formad and furious men, for melancholike, dull, and heauic perions, for thofe that are trotbled with the falling fickneffe, for lepers, for them that are ficke of a quartaine ague, and brictly for all thofe that are troubled with blacke choler, and molcfted with melancholie.

The maner of giuing it (meaning the firft blacke Hclicbor) faith Actuarius in his firft booke, is B threefcruples, little more or lefle.

It is giuen with wine of raifons and oxymel, but for pleafantnes fake, fome fweete and odorife- C rous feedes muft be put vnto it: but if you would hauc it itronger, adde thereunto a graine or two of Scamonic; Thus much Actusrius.

The firft of thefe kinds is beft, then the fecond; the reft are of leffe force.

The rootes take away the Morphew and blackefpots in the skin, tetters, ringwoormes, lepro- E fies, and fcabs.

The roote fodden in pottage with teef h,openeth the bellies offuch as haue the dropfie. F

The root of baftarde Hellebor, called among our Englifh women Bearefoote, fteeped in wine $G$ and drunken, loofeth the beliy, euen as the true blacke Hellebor, and is good againft all the difeafes whereunto blacke Hellebor feructh, and killeth wormes in children.

It doth his operation with more force and might , if it be made into powder, and a dram thereof $\mathrm{H}$ be receiued in wine.

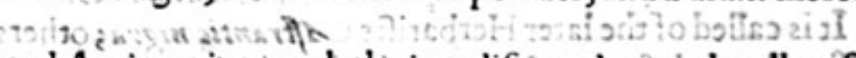

The fame boiled in water with Rue and Agrimonie, cureth the iaundife, and purgeth yellow fuis I perfluities by fiege.

Theleaues of baftard Hellebor dried in an ouen after the bread is drawneotit, and the powder $\mathbf{K}$ thereof taken in a figge or raifon, or @trawed vpon a peece of bread fpred with honic and eaten;kif leth wormes in children exceedingly.

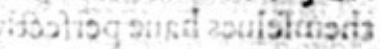

$$
\text { OfDioferides bis blacke Hellebor as Chap.362. }
$$

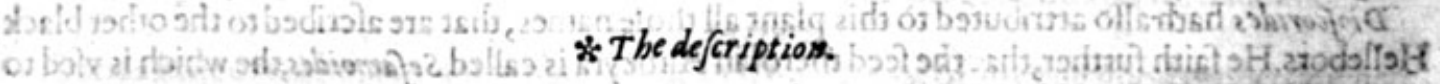

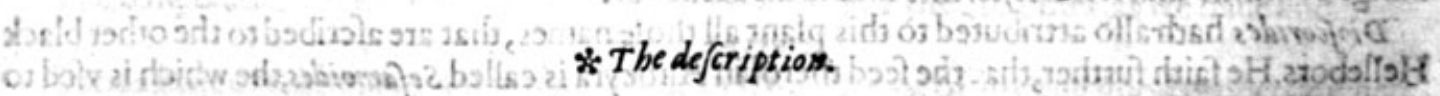
TpHis kinde of blacke, Hellebpr fet foorth by L'Obelius onder the name Affecentia nigrds 7. agreoth very well in hape with the true Afrantio, which is alfo called dopperesorias nenere theleffe by the confent of Diefsprides and other authors who hatic expreffed this plant for 2 kind of V erat rum nigrwom or black Hellebor, it hath many blackinh sweene leaues, patcedor cut into fower or fiue deepe cuts, after the maner of the Vine leafe, very like vnto thofe of Sanickle, both in greenges of solour, and alfo in proportion. The ftalke is cuen, imoeth, and plaine:atche: top whereof groy flowers in lictle tufts or vmbles, fer togicher like thofe of Scabious, of a wbitifh light greer colour, dafht ouer(as it were) with a little darke purple : after which come the feede like vnto cartase mis, or baftard $S_{2} f f r o n$. The rootes are many blackifh threds faltned vinto one heade, or mafter ropte. 
Aftrantianigra.

Blacke Mafterwoorts, or Diofcorides his blacke Hellebor.

* The defcripsion.

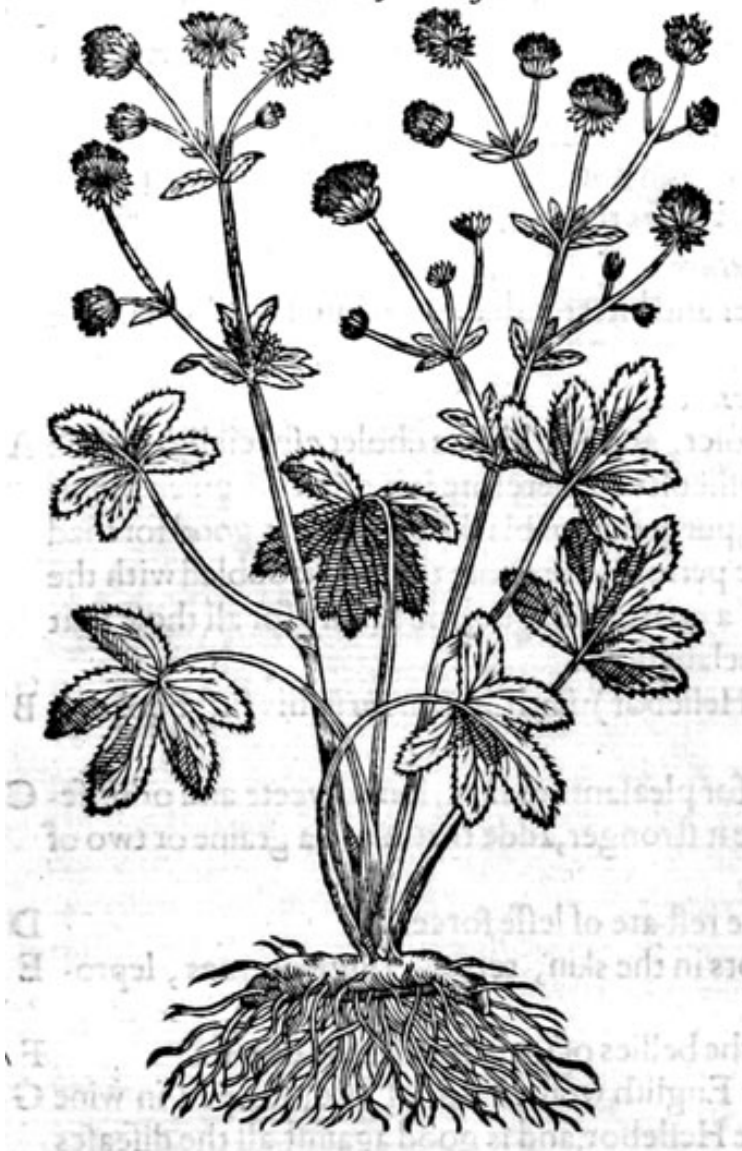

There is another plant which hath beene ac? counted of fome to be a kinde of blacke Hellebor, whofe figure we haue fet foorth for one of the Arfmarts, called of fome Impatiens Herba, and others $\mathcal{N}$ oli me tangere, defcribed thus. It hath rounde leaues tharpe pointed, not vnlike to thofe of Englifh Mercurie, verie tender, and of 2 lighe greene colour. The ftalke is fmall, full of knees or ioints; on the ends whereof ftande little yellowe flowers, fafhioned like a fpanifh Caruell, broade at one ende, and turning vp the other like a little horne, which being paft, there fucceede fmall cods, like the fmall Celandine. * The place.

Blacke Hellebor is found in the mountaines of Germanic, and in other vntilled and rough places: it profpereth in gardens, Dio/corides writeth that blacke Hellebor groweth alfo in rough high and dry places: and that is beft which is taken from fuch like places as is that faith he, which is brought out of Anticyra,a citie in Greece :it groweth in my garden. * The time.

This blacke Hellebor flowreth not in winter but in the fommer monethes. The herbe is greene all the yeere thorow.

It is called of the later Herbarifts 1 ftrentia nigra; others Sawicula famina :notwithftanding it differeth much from Aftrantia, an herbe which is alfo named imperatoria, or Mafterwoort: the vulgar people call it Pellitorie of Spaine, but vntruly; it maybe called blacke Mafterwoort, yet doubtlefle a kinde of Hellebor, as the purging facultie doth fhewe: for it is certaine that diuers expert Phifitions can witnes, that the rootes heereof dopurge blacke and other humours, and that they themfelues haue perfectly cured mad melancholicke people being purged heerewith: and that it hath a purging qualitie. Conradus Gefnersu doth likewife teftifie in a certaine Epiftle written to Adolphus Occo, in which he fheweth that Aftrantia nigra is almoft as ftrong as white Hellebor; and that he himfelfe was the firt that had experience of the purging facultie thereof by fiege, which things confirme that it is Diofcorides his blacke Hellebor.

Diofcorides hath alfo attributed to this plant all thofe names, that are afcribed to the other black Hellebors. He faith further, that the feed therof in Anticyra is called Sefamoides, the which is vied to purge with, if fo be that the text be true and not corrupted, but it feemeth not to be altogither perfeet.For if Sefamoides, as Plinie faith, and the word it felfe doth (hew, hath his name of the likenes of Sefamum, the feede of this blacke Hellebor fhall vnproperly be called sefamoides, not like to that of Sefamom; but of Cnicus or baftard Saffron: by thefe proofes we may fufpect, that thefe wordes are brought into Diofcoredes from fome other author.

* $T$ he nature and vertues.

The faculties of this plant we haue already written to be by triall found like to thofe of the other blacke Hellebor : notwithftanding thofe that are defcribed in the former chapter, are to be accoun: ted of greater force. 


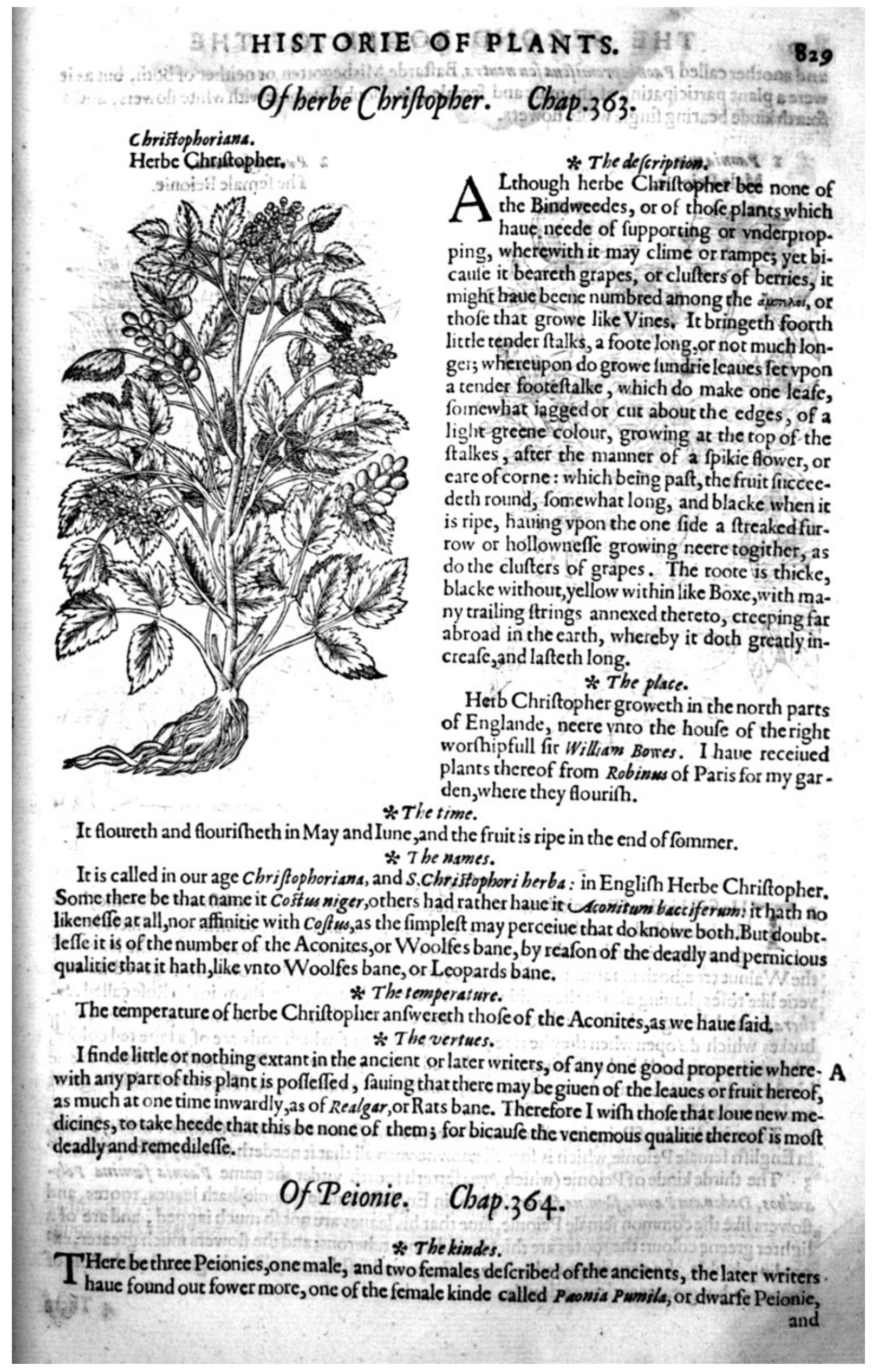


and another called P eonia promi / cua feu newt ra, Baftarde, Misbegotten, or neither of both, but as it were a plant participating of themale and female, one double Peionie with white flowers, and a fourth kinde bearing fingle white flowers.

I Peoniamas. Male Peionie.

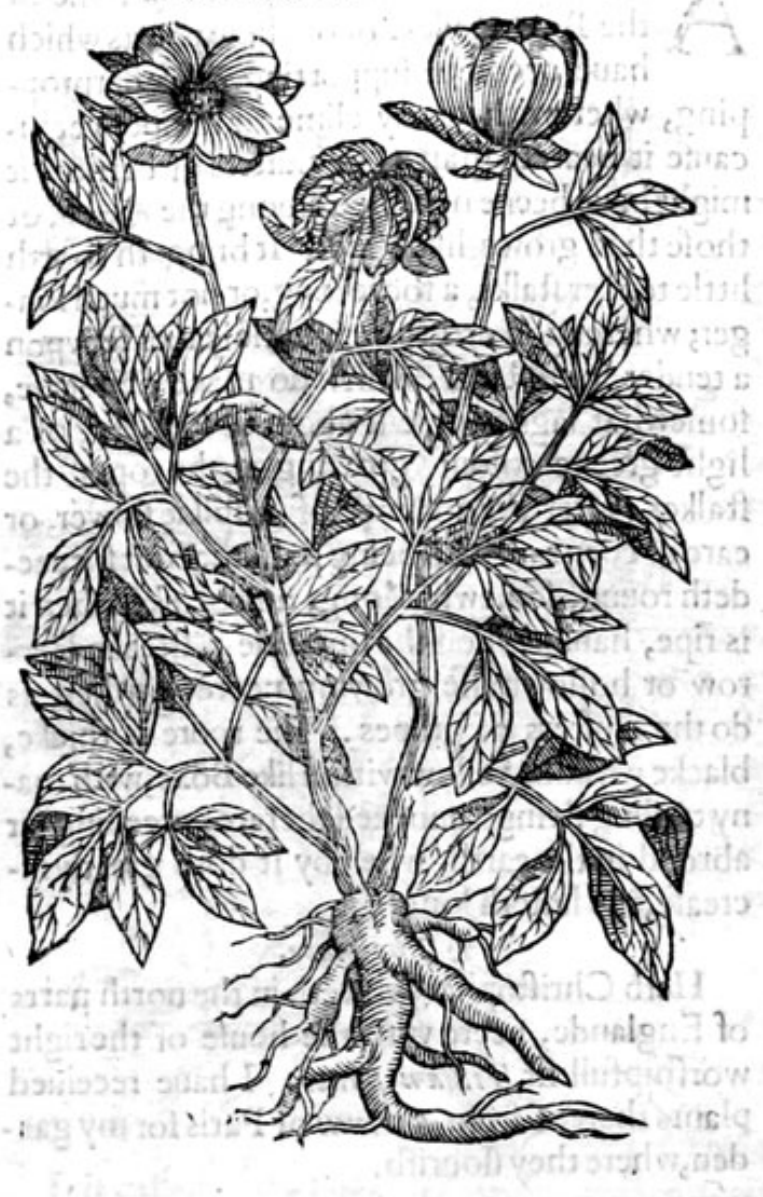

2 Pconia famina. pdistis The female Peionie.

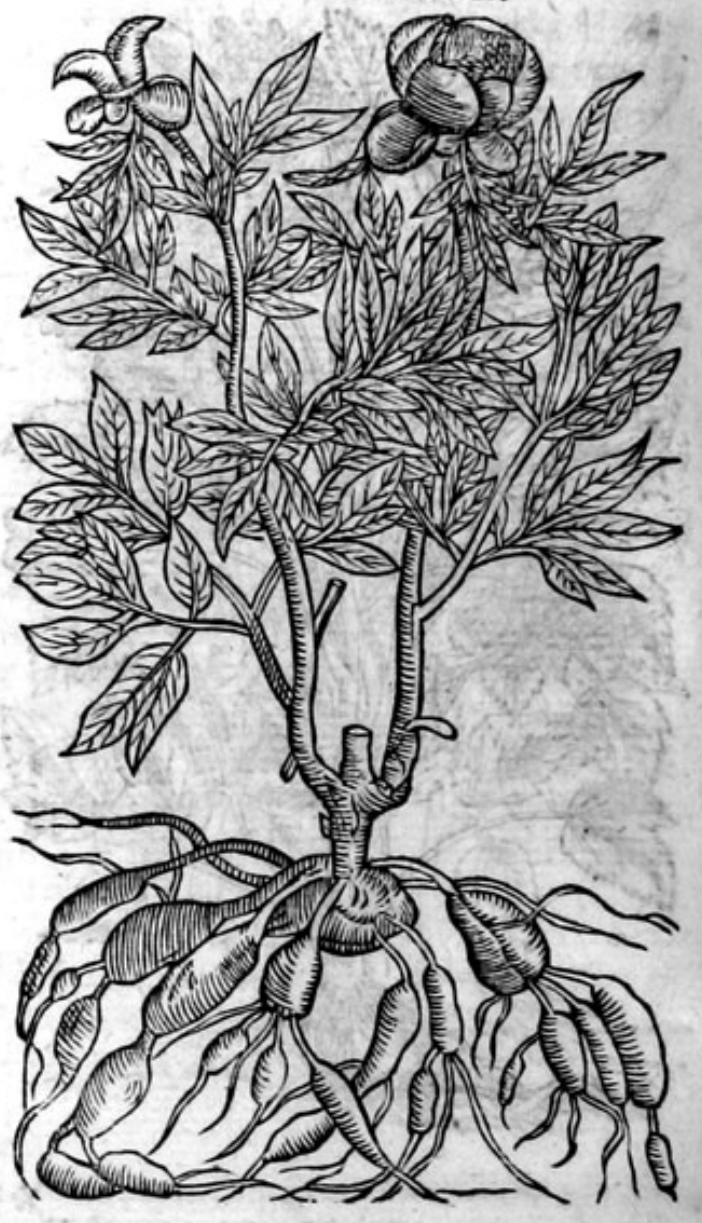

*The defcription.

I He firft kinde of Peionie(being the male, called $P$ eonia mas, in Englin male Peionie) hath thicke red ftalkes a cubite long: the leaues be great and large, confifting of diuers leaues growing or ioined togither vpon one flender ftem or ribbe, not much vnlike the leaues of the Walnut tree, both in fafhion and greatnes; at the top of the ftalks grow faire large red flowers verie like rofes, hauing alfo in the midit yellow threds or thrums, like them in the Rofe called $A$ thera; which being vaded and fallen away, there come in place three or fower great coddes or huskes which do open when they be ripe; the inner part of which cods are of a faire red colour, wherein is containedblacke fhining and polifhed feedes, as big as a Peafe, and betweene euerie blacke feede is couched a red or crimfon feed, which is barren and emptie. The roote is thicke,great and tuberous, like vnto the common Peionie.

2 There is a kinde of Peionie, called of Dodoneus Peonia famina prior, of $L^{\prime} O$ Obelius Pania famina, in Englifh female Peionie, which is fo well knowne vnto all that it needeth not any defcription.

3 The thirde kinde of Peionie (which Pena fetteth foorth vinder the name Peonia famina Poly: anthos, Dodoneus Peonia famins flos multiplex, in Englifh double Peionie)hath leaues, rootes, and towers like the common fernale Peionie, faue that his leaues are not fo much iagged, and are of a lighter greene colour: the rootes are thicker and more tuberous; and the flowers much greater, $\mathrm{ex}$ ceeding double, of a very deepe red colour, in fhape and falhion very like the great double Rofe of Proucnce, but greater and more double. 


\section{HIST ORIE OF PLANTS.}

4 There is found another fort of the dotble Peionie not differing from the precedent in ftallkes, leaues, or rootes: this plant bringeth foorth white flowers wherein confifteth the difference.
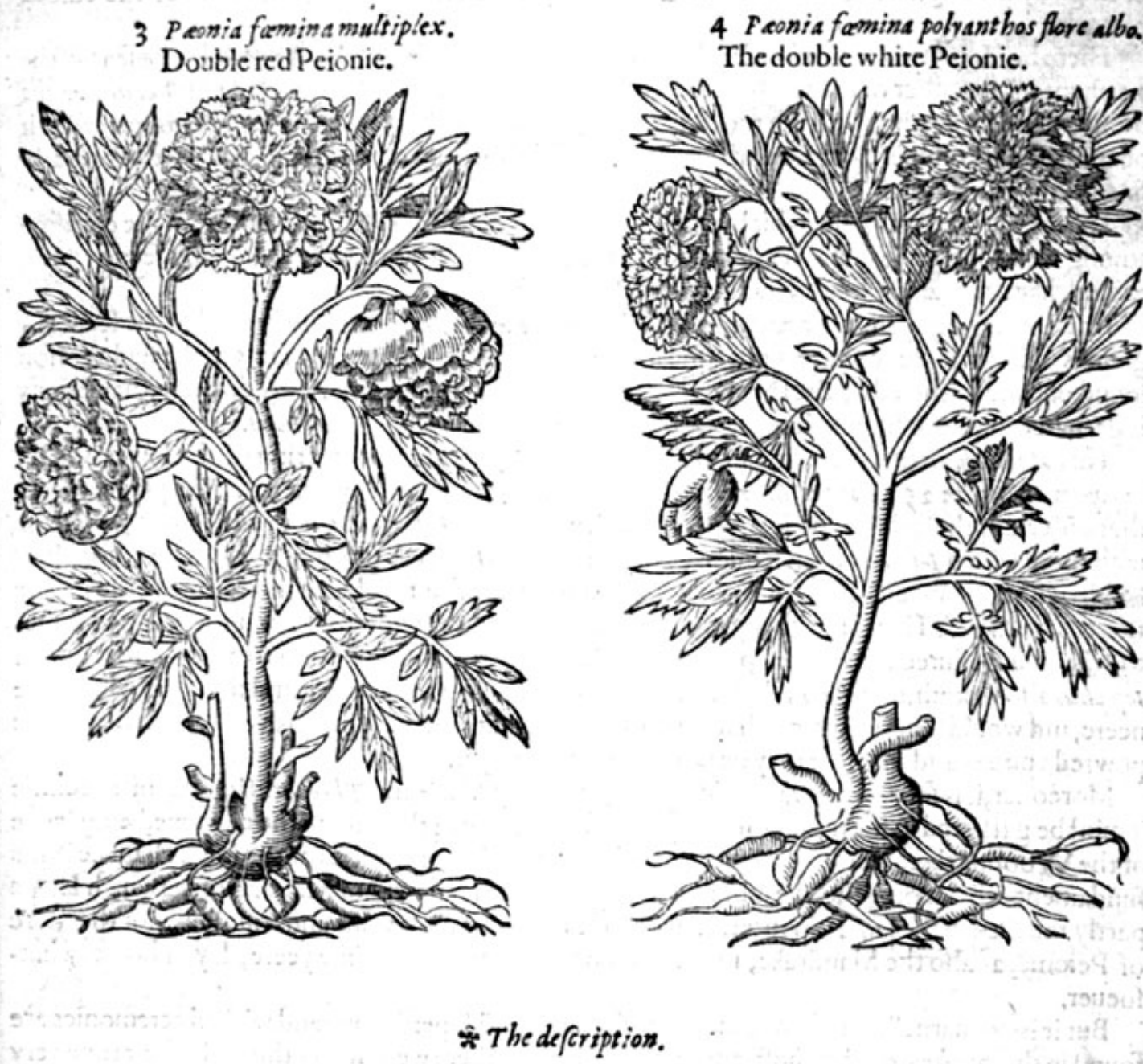

* The defription.

There is another kinde of Peionic (called of Dodonens Peonia famina altera, but of Pena Peonis Promiftus feu neutra: in Englifh Maiden or Virgine Pcionie) that is like vinto the common female Peronie, lauing that his leaues and flowers are much fmaller, and the ftalkes thorter, and beareth red Aowers, and feede alfo like the former.

We have likewife in our London gardens another fort bearing flowers of a pale whitifh colour, very fingle, refembling the female wilde Peionie, in other refpects like the double white Peionie:

An T Te place.
All the forts of Peionies do grow in onr London gardens, except that double Peionie with white flowers, which we do expect from the lowe countries of Flaunders.

The male Peionie groweth wilde vpon a conic berrie in Betfome, being inthe parifh of Southfleete in Kent, two miles from Grauefend, and in the grounde fometimes belonging to a Farmer
there called Iobn Bradiey.

They flower in May, the feede is ripein * The time.

They tower in May, che iecde is ripe in fuly.

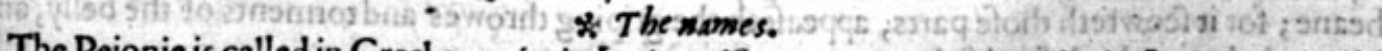
The Peionie is called in Grecke resoris: in Latine alfo P eomia, and Dulcifids : in hops P ionis : in high Dutch jeomien biumen: in low Dutch 99 aff bitoeinen: in French Pinuine : in Spanifh Rofa delmonte: in Englifh Peionie: it hath alfo many baltardenames, as Rofa fatwma, Herba Gafta, of fome Lunaris,or Lunaria Pania : bicaufe it cureth thofe that have the falling ficknes, whom mott men do call Lensasicos, or Lunaticke. It is called Idjew Dadjlew; which agreeth with the female 
Peionie, the knobbic rootes of which be like to Dactyli Idei, and Dactyli Idei are certaine precious ftones of the forme of a mans finger, growing in the Iland Candie: it is called of diuers Aglaoph tis, or Brightly thining, taking his name of the fhining and glittering graines, which are of the coluur offcarlet.

Therc be found two Aglaophotides, defcribed by AEliansus in his I 4 .booke; one of the fea, in the 24.chaptcr: the other of the carth, in the 27 . chapter. That of the fea is a kinde of Fucus, or fez mofic, which groweth vpon high rocks, of the bignes of Tamarisk, with the head of Poppie; which opening in the fommer Solltice doth yceld in the night time a certaine fierie, and as it were fparkling brightnes or light.

Ihat of the earth, faith he, which by another name is called cyno/pastus, lieth hid in the day time among the other herbes, and is not knowen at all, and in the night time it is eafily feene : for it fhineth like a $\mathrm{ftar}$, and glittereth with a firie brightneffe.

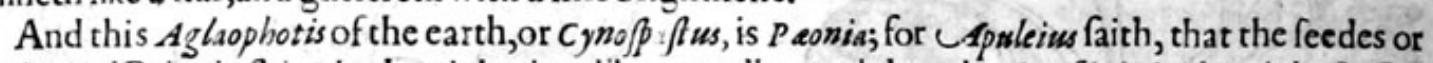
graines of Peionie fhine in the night time like a candle, and that plentie of it is in the night feafon found out and gathered by the fhepherds. Moreouer, $T$ beophraftus and Plinie do fhew, that Peiony is gathered in the night, which Aelianus alfo affirmeth concerning Aglaophot is.

This Aglasphot is of the earth, or Cyno/pastu, is called of Iofep hus the writer of the Iewes war, in his feuenth booke 25. chapter Basras, of the place wherein it is found; which thing is plaine to him that cöferreth thefe things which Aelianus hath written of Aglaophotus of the earth,or Cyno/pastus, with thofe which Iofephius hath fet downe of Baaras: for Aelianus faich, that Cyno/pastess is not plucked sp withour danger; and that it is reported how he that fiuft touched it, not knowing the nature there of, perifhed. Therfore a fring muft be faftned to it in the night, and a hungrie dog tied thereto, who being allured by the fmell of rofted fefh fet towards him, may plucke it vp by the rootes. Iofephus alfo writeth, that Baira doth fhine in the euening like the day ftar, and that they who come neere, and would plucke it vp, can hardly do it, except that either a womans vrine, or hir menfes be powred vpon it, and that fo it may be pluckt vp at the length.

Moreouer, it is fet downe by the faid aythor, as alfo by Plinie and $T$ heophrast us, that of neceffitie it muft be gathered in the night; for if any man fhall plucke of the fruit in the day time, being feene of the Woodpecker, he is in danger to lofe his eies; and if he cut the roote, it is a chaunce if his fundament fall not out. The like fabulous talc hath beene fet foorth of Mandrake, the which I haue partly touched in the fame Chapter. But all thefe things be molt vaine and friuolous: for the roote of Peionie, as alfo the Mandrake, may be remooued at any time of the yeere, day or hower whatfoetuer.

But it is no maruell, that fuch kindes of trifles, and moft fuperftitious and wicked ceremonies are found in the bookes of the molt ancient authors; for there were many things in their time very vainly fained and cogged in for oftentation fake, as by the Aegyptians and other counterfeit mates, as Plinie doth truly teftific, an imitator of whom in times palt, ivas one Andreas a Phifition, who as Galen faith, conueied into the art of phyfickelies, and fubtile delufions. For which caufe Galen commanded his fcholers to refraine from the reading of him, and of all fuch like lying and deceitfull fycophants. It is reported that thefe herbes tooke the name of Peionie, or P eon, of that excellent Phifition of the fame name, who firt found out and taught the knowledge of this herbe vnto pofteritie.

* The temperature.

The roote of Peionic , as Galen faith, doth gently binde with a kinde of fweeteneffe : and hath alfo ioined with it a certaine bitterifh fharpneffe : it is in temperature not very hot, little more than meanly hot; but it is drie and of fubtile partes.

\section{$*$ The vertues.}

A Diofcorides writeth, that the roote of the male Peionic being dried, is giuen to women that bee not well clenfed after their deliueric, being drunke in Meade or honied water to the quarititie of a beane; for it fcowreth thofe parts, appeafeth the griping throwes and torments of the belly, and bringeth downe the defired ficknes.

B Galen addeth, that it is good for thofe that haue the yellow iaundies, and paine in their kidneies and bladder, it clenfeth the liuer ąad kidneies that are ftopped.

C It is fouml by fure and cuident experience made by Galen, that the freih roote ried about the necks of children, is an effeetuall remedie againft the falling fickneffe; but vnto thofe that are 


\section{HISTORIE OF PLANTS. ZIIT}

growen vp in more yeeres, the roote thereof muft alfo be miniftred inwardly.

It is alfo ginen faith $P$ linie againtt the difeafe of the minde. The roote of the male Peionie is pre-D ferred in this cure.

Ten or twelue of the red berries or feeds drunke in wine that is fomething harfh or fower, and E red, do ftaie the inordinate fluxe, and are good for the ftone in the beginning.

The blacke graines (that is the feede) to the number of 15 .taken in wine or meade, helpeth the F ftrangling and paines of the matrix or mother, and is a peciall remedie for thole that are trotibled in the night with the difeafe called Ephialses, or night Mare, which is as though a heauie burthen were laidvpon them, and they oppreffed therewith, or as if they were ouercome of their enimies, or ouerpreft with fome great waight or burden;and are alfo good againft melancholike dreames.

Syrupe made of the flowers of Peionie helpeth greatly the falling ficknes, likewife the extracti- $G$ on of the rootes doth the fame.

\section{Of tootbed Violets, or Corall woorts. Chap.365.}

* The kindes.

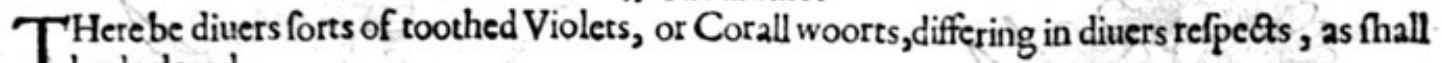
be declared.

I Dentaria bulbifera. Toothed Violec

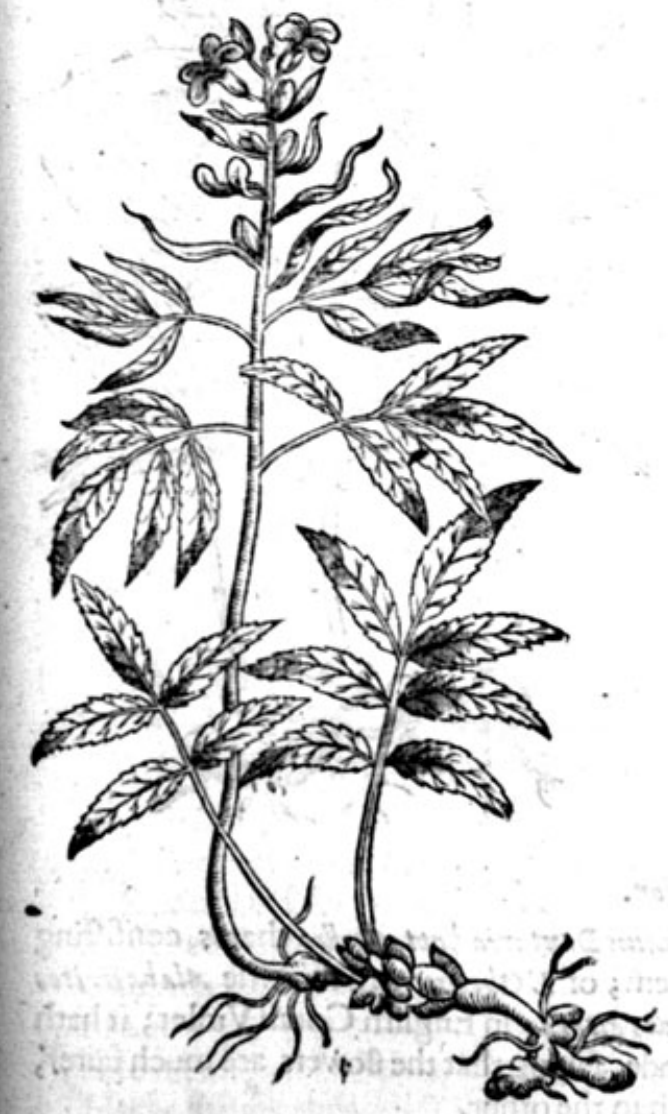

2 Dentaria Coralloide radice fine Dentaria Emeaphyllon. The Corall toothed Violet.

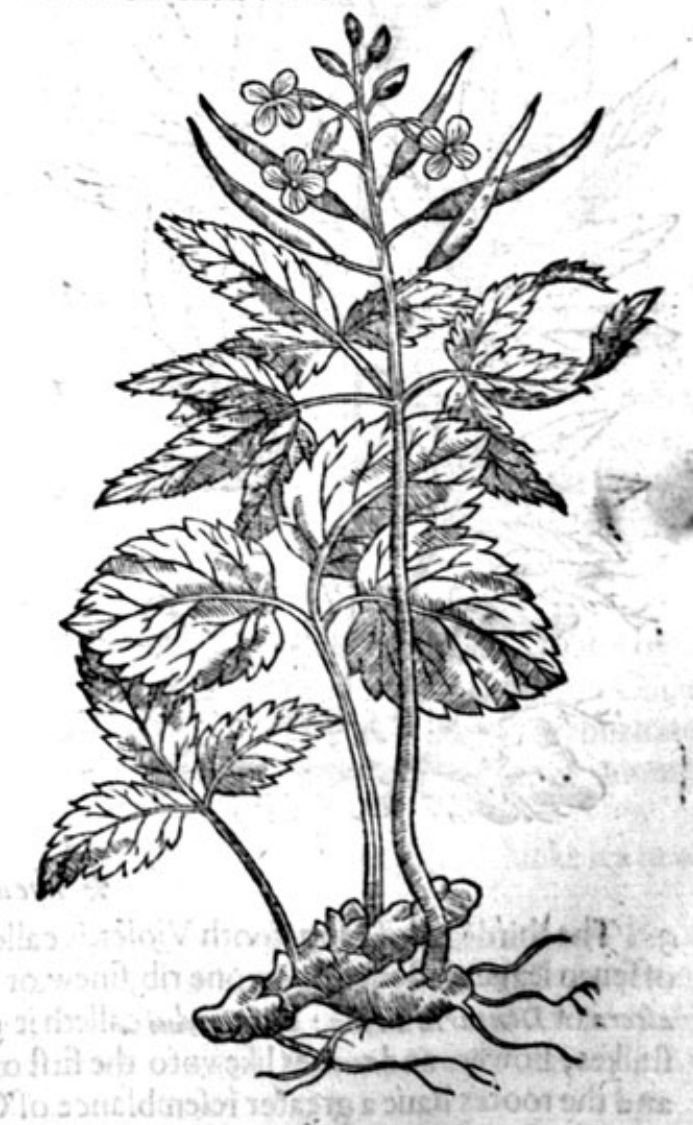

\section{* The defcription.}

I Hefirft kinde of Demtaria (called in Latine Dentaria baccifera, of Dodomems Viola Dentaria prior in Englifh Dogs tooth Violet) hath a tuberous and knobbie roote, toothed, or as it were kneed like vnto the crags of Corall, of an vnpleafant fauour, and fomewhat tharpe in tafte: from which fpring foorth certaine fmall and flender ftalkes a foote high, which haue leaues 
very much cut or iagged, like vnto thofe of Hempe; of the forme and fafhion of Afhen leaves: the top of the ftalkes do grow fmall white lowers, in Thape like Viole matromales, that is, Queenes Gilloflowers or rather like ftocke Gilloflowers, of a white colour, laid ouer with a light fprinkling of purple : among which come forth fmal knobs growing vpon the ftalks among the leaues, fuch as are to be feene vpon the Cymifts Martagon, which being ripe, do fall vpon the ground, whereof ma. nie other plants are ingendred.

2 The fecond kinde of Dogstooth Violet, bringeth foorth fmall round ftalkes, firme and ftiffe, 2 foote high, befet with leaues much broader, rounder, and greener then the former, bearing at the top many little flowers confifting of fower fmall leaues, of a pale herbie colour; which being paft, there fucceede long and flender cods, fomwhat like the cods of Queenes Gilloflowers, wherein is contained fmall blackifh feede: the roote is like the former, but not in euery refpeet much refembling Corall,yet white and tuberous notwithftanding.

3 Dentaria Heptaphyllos Clusij.

The feauen leafed toothed Violet.

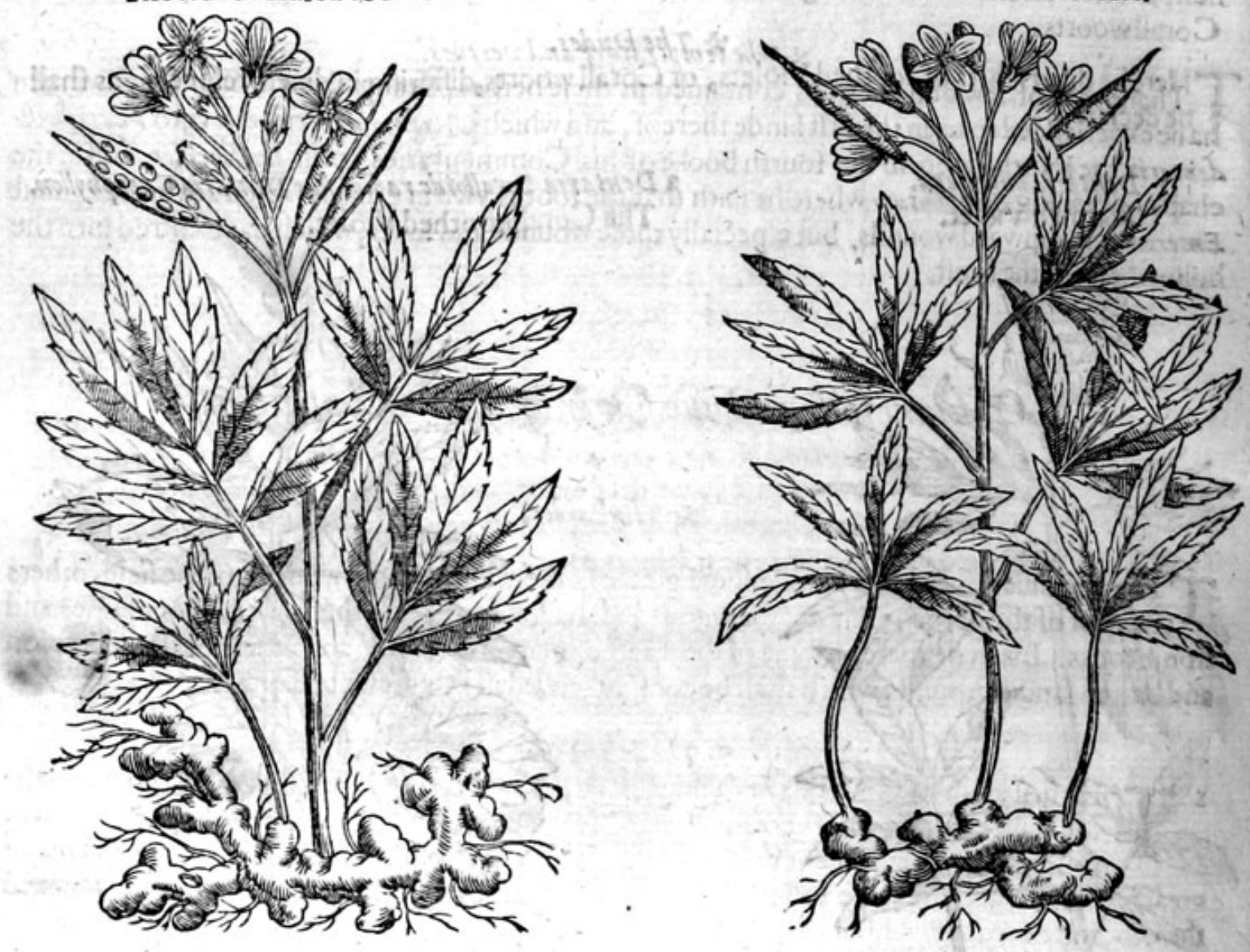

4 Dentiria Pentaphyllos Clusì. Fiue leafed toothed Violer.

\section{* Thedefoription.}

3 The third kindof Dogstooth Violet, is called of Clufums Destaria heptaplyyllos, that is, confifting of feuen leaues faftened vpon one rib, finew, or fmall ftem; of 'L'Obelius with this title Alabastrites altera, or Dentaria altera : but Cordnes calleth it Coralloides altera : in Englin Corall Violet; it hath ftalkes, flowers and rootes like vnto the firft of his kinde, fauing that the flowers are much fairer, and the rootes haue a greater refemblance of Corall than the other.

4 The fourth kinde of Dogs tooth Violet, called in Englith Codded Violet, which Clmfius fetteth foorth vnder the title Dentaria Mathioli Pentaphyllos, which Pena doth alfo expreffe vnder the title of 2 emoralis Alpina; Cordus calleth it Alabastrites Coralloides, and may very well becalled in Englifh Cinkfoile Violet:it hath leaues fo like the greater Cinkfoile, that it is hard to knowe one from another ; thercfore it might very well haue beene reckoned among the herbes called Pentaphyllat that is fiue lea'ed herbs. This plant groweth in the fhadowic forreft about Taurinum and the 


\section{HISTORIE OF PLANTS.}

mountaine Samena, called Calcaris, and by the Rhene not far from Bafill. The ftalkes grovive to the height of a cubite, befet with a tuft of flowers at the top, like vnto Sopewoort, which being vaded there fucceede long and fat cods like vnto Rocket, or the great Celandine, wherein is contained a fmall feede. All the whole plant is of a hot and bitter tafte. The rootes are like vnto Corall,of a pale whitifh colour.

$$
\text { * The place. }
$$

They growe on diuers Thadowie and darke hils. Valerisus Cordus writeth, that they are founde about the forreft Hercinia, not far from Northufium, molt plentifully in a fat foile, that hath quarries of ftone in it. The firft I haue in my garden.

$$
\text { \& Thetime. }
$$

They flower efpecially in Aprill and May: the feede commeth to perfection in the end of Auguft.

$$
\text { * The names. }
$$

The Toothed Violet, or after fome Dogs tooth Violet, is commonly called Dentaris, of Cordas Coralloides, of the roote that is in forme like to Corall. Mathiolus placech it inter Sulidagines $b-$ Symphyta among the Confounds and Comfreies. We had rather call them Viole Dentarie, of the likeneffe the flowers haue with Stockgilloflowers. They may be called in Englifh Toothed Violets, or Corallwoorts.

\section{\&.The temperature and vertues.}

I haue read of few or no vertues contained in thefe herbes, fatuing thofe which fome women $\mathbf{A}$ ha ue experienced to be in the firt kinde thereof, and which CWathioliss afcribeth ynto Pextaphy the dentaris the fourth kinde, in the fourth booke of his Commentaries vpon Dioferides, and in the chap.concerning Symphrtum, where he faith that the root is vfed in drinkes which are made againft Enteroceleand inward wounds, but e.pecially thofe wounds and hurts, which haue entred into the hollowneffe of the breft.

\section{Of Cinkefoile, or Fine finger graffe. Chap.366.}

\section{* The kindes.}

$T^{+}$Here be diuers forts of Cinkfoile, fome greater, others leffer; fome wilde or of the field, others tame or of the garden; fome of the woods and hhadowie places, others of the mountaines and ftonie rocks. Likewife there be forne of the water or marrifh ground, and others of the champion and barren fandie grounds, which thall be comprehended in this prefent chapter.

\section{* The defaription.}

I He firft kinde of Cinkfoile or Quinquefoile, hath round and fmall ftalkes of a cubite high : the leaues are large, and very much iagged about the edges, very like the common Cinkefoile : the flowers grow at the top of the ftalks, in fafhion like the common kind, butmuch greater, and of a pale or bleake yellowe, the roote is blacke without, and full of ftrings annexed thereto, and of woodic fubftance.

2 The fecond kind of Cinkefoile, is fo common and fo vniuerfally knowne, that I thinke it a needleffe tranell to ftand about the defcription.

3 The thirde kinde of Cinkefoile I haue named Album of Purpureum, (not that it is two kindes comprehended vnder one figure) but bicaufe his leaues are whitifh vnderneath, and his fowers are of a purple colour; which being paft, there fucceedeth a rounde knop of feed like a Strawbertic, before it be ripe: the ftalks are creeping vpon the ground : the roote is of a woodie fubftance, full of blacke ftrings appendant thereto.

4 The fourth kinde of Cinkefoile is verie like vnto the other, efpecially the firft and great kitde: the ftalkes are a cubite high, and of a reddifh colour: the leaues confift of fiue parts, fomewhat finipe about the edges: the flowers grow at the top of the ftalkes like vnto the other Cinkefoiles, fauing that they be of a darke red colour : the roote is of a woodie fubitance with fome fibres or threddie ttrings hanging thereat. 
I Quinquefolism maiso. Great Cinkfoile.
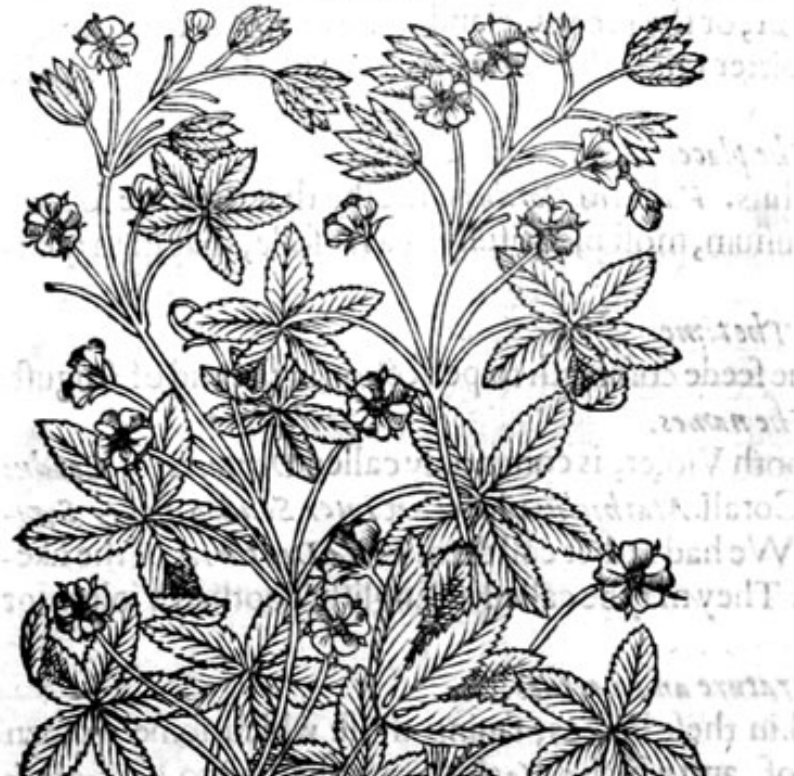

a

12 (1)
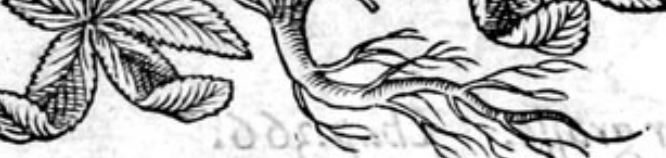

3 Pentaphyllum parpureum. Purple Cinkfoile.

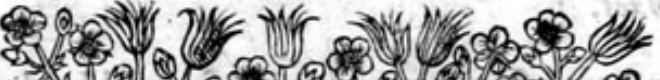

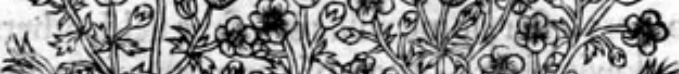

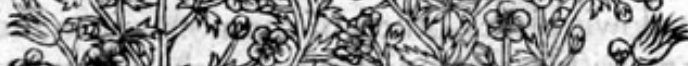
8. 003 on

tont

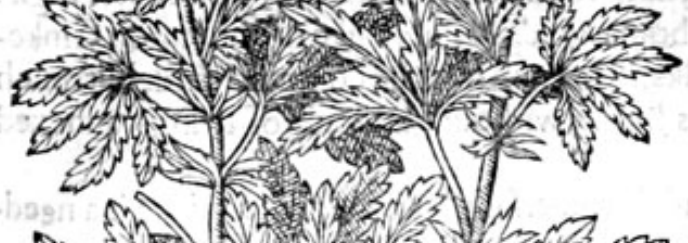

th ins (D)

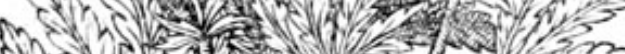

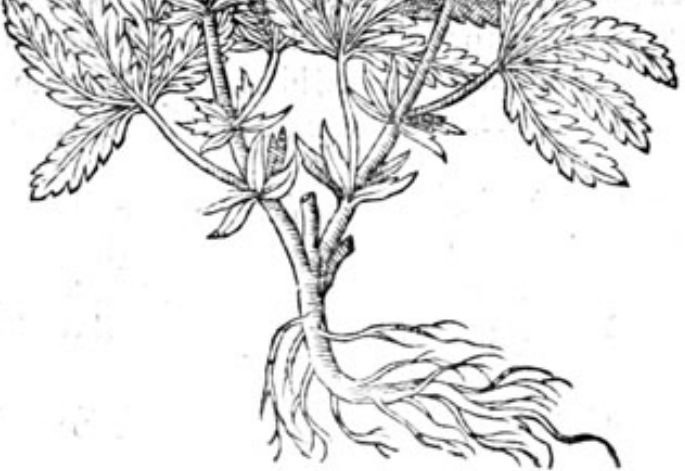

2 Quinguefolivon vulgare. Common Cinkfoile.

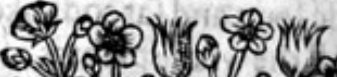
\& 1 (2)

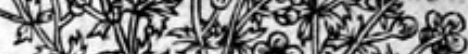
किता है। Exiv
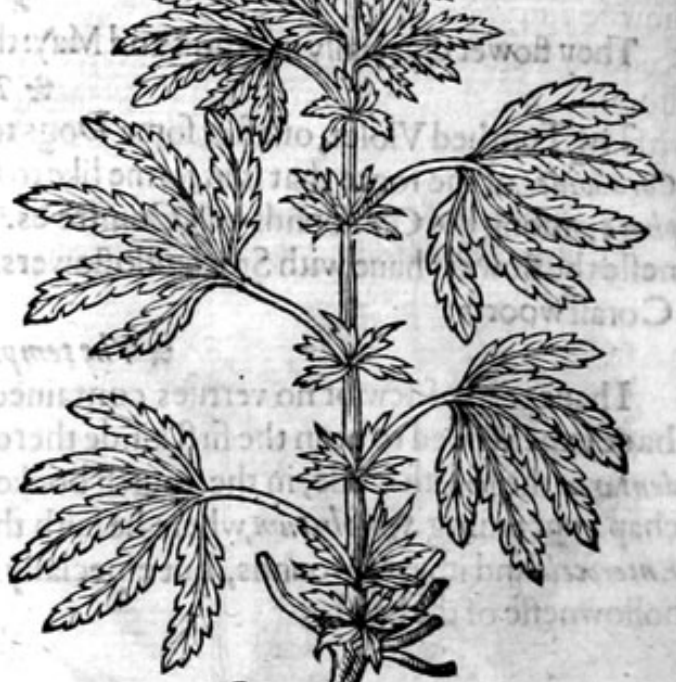

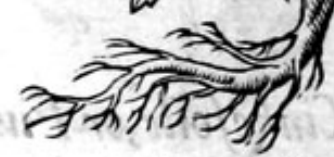

4 Pentaplyllum rubrum paluftre. Marifh Cinkfoile.

散

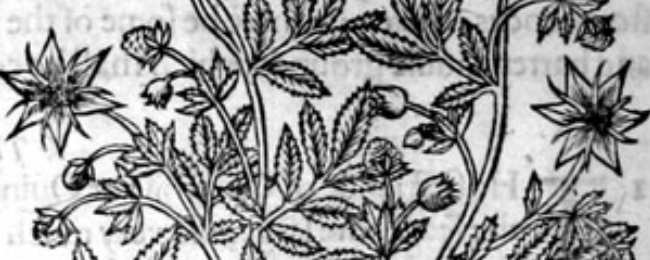
(2)

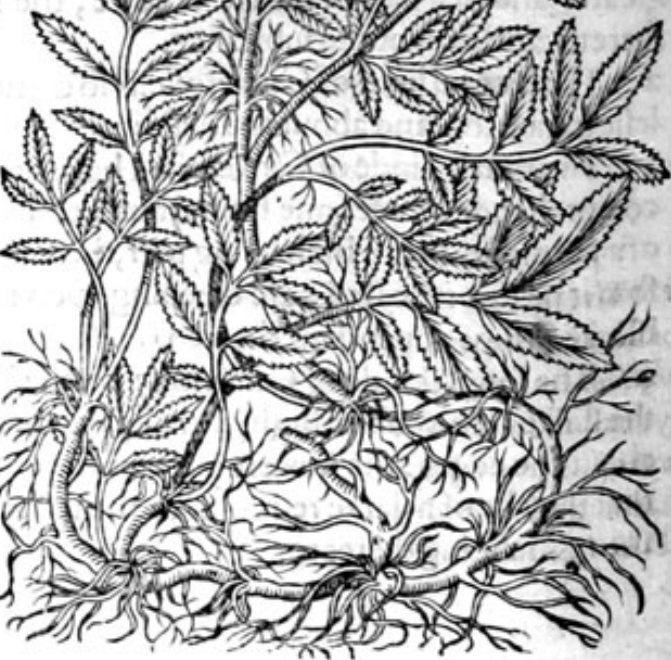




\section{J HISTORIE OF PLANTS.}

5 The fift kinde of Cinkefoile groweth vpon the coldemointaines of Sauoie, and in the valley of Auftenfie, and in Narbone in France (and if memorie faile not) I haue feene the fame growing vpon Beefton caftle in Chefhire: the leaues heerof are fewe and thinne fet, confifting of fiue parts like the other Cinkefoiles, oftentimes fixe or feauen fet rounde about the ftalke likeMadder, not fnipt about theedges as the others, but plaine and fmooth; that fide of the leafe which is next the grounde, is of a fhining white colour, but the vpper part greene, refembling Sanicle: the flowers grow likeftars vponflender ftalks, by tufts and bunches, of a white colour, and fometimes purple, in fafhion like the flowers of Alchimils, or Ladies Mantle: the roote is full of ftrings, and of a browne purple colour.

6 The fixt kinde of Cinkefoile growing commonly in moft barren groundes, called Supimum, is altogither like the common garden Cinkfoile, faue that it is much leffer, which Pens fetteth foorth with this addition, Torments lle facie, bicaufe it doth very much refemble Tormentill.

\section{Pentaphylluon petrofum Heptaphyllawom Clusï.} Stone Cinkfoile.

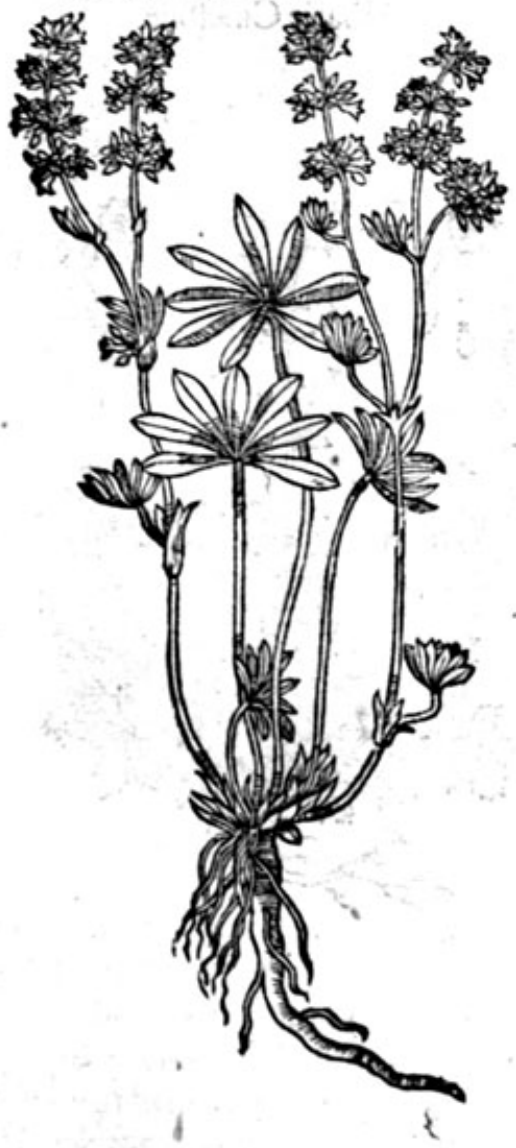

6 Pentaphylliom fapinam. Vpright Cinkfoile.

\section{* The defcription.}

7 The feuenth kinde of Cinkefoile, Pens that diligent fearcher of Simples, founde in the Alpes ofRhetia, neere Clauena, and at the firit fight fuppofed it to be a kinde of Tormentilla, or Fentaphyllum, faue that it had a more threddie roote, rather like Geranivm; it is of a rufhie colour outwardly, hauing fome fweete fmell, reprefenting Gariophyllata in the fauor of his rootes, in leaues and flowers Cinkefoile and Tormentilla, and in the fhape of his ftalkes and rootes Awens or Gariophillate, participating of them all: notwithftanding it approcheth neereft ynto the Cinkefoiles, hauing ftalkes a foote high, whereupon grow leaues diuided into fiue parts, and iagged rounde about the edges like the teech of a lawe, hauing the pale yellowe flowers of Pentaphyllow or Tormentilla; 


\section{THE SECOND BOOKE OF THE}

within which are little moffie or downie threddes, of the colour of faffron, bat lefier then the com: mon Auens.

8 The eight kinde of Cinkefoile(according to the opinion of diuers learned men, who haue had the vicw thereof, and haue iudged it to be the true Leucas of Drofcorides, agreeable to Drofcorides his defcription) is all hoarie, whereupon it tooke the addition Incans. The ftalkes are thicke, woo. die and fomwhat red, wrinckled alfo, and of a browne colour, which rife vnequally from the roote, fpreading themfelues into many branches, fhadowing the place where it groweth, befet with thick and notched leaues like Scordium, or water Germander, which according to the iudgement of the learned is thought to be of no leffe force againft poifon then Pentaphyllon, or Tormentilla,being of a aftringent and drying qualitic. Heerupon it may be that fome trying the force heereof, havie yeelded it vp for Leucas Dio/corides. This rare plant Ineuer founde growing naturally, but in the hollownes of the peakifh mountaines, and drie grauellie valleies.
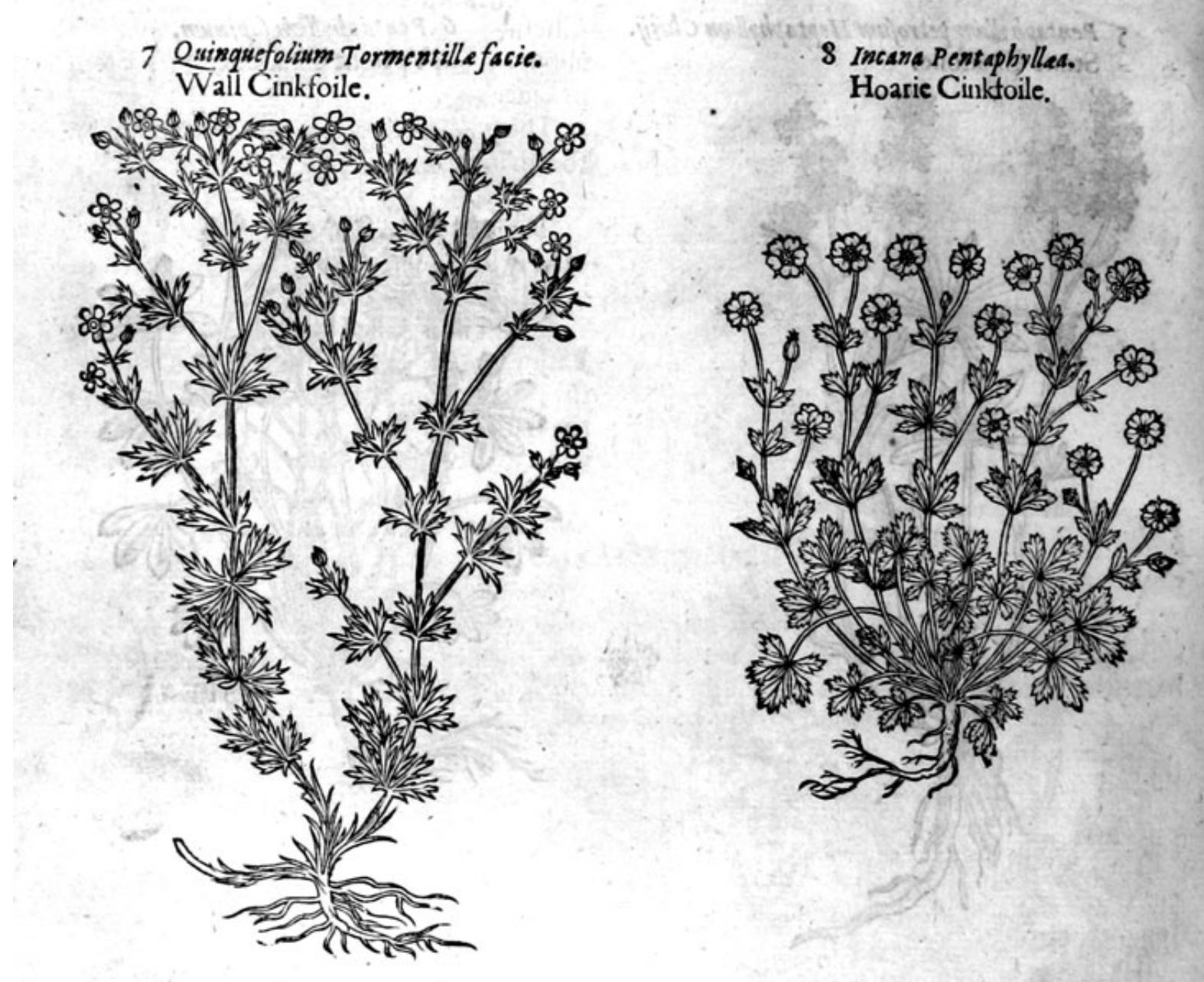

\section{* The defcription.}

- The wood Cinkfoile hath many leaues fpred vpon the ground, confifting of fiue parts : among which rife vp other leaues, fet vpon very tall footftalkes, and long in refpect of thofe that did grow by the ground, and fomewhat fnipt about the edges. The flowers grow vpon flender ftalks, confifting of fiuc yellow leaues. The roote is verie threddie.

There is one of the mountaine Cinkefoiles that hath diuers flender brittle ftalks, rifing immediately foorth of the ground; whereupon are fet by equall diftances certaine iagged leaues, not valike to the fmalleft lcaues of Auens : the flowers growe at the top yellowe of colour, and like to the other Cinkfoiles, but altogither leffer : the roote is thicke, tough, and of a woodie fubftance. 


\section{HISTORE OF PLANTS. HT}

9 Qningwefoliwom fyluaticum. Wood Cinkfoile.

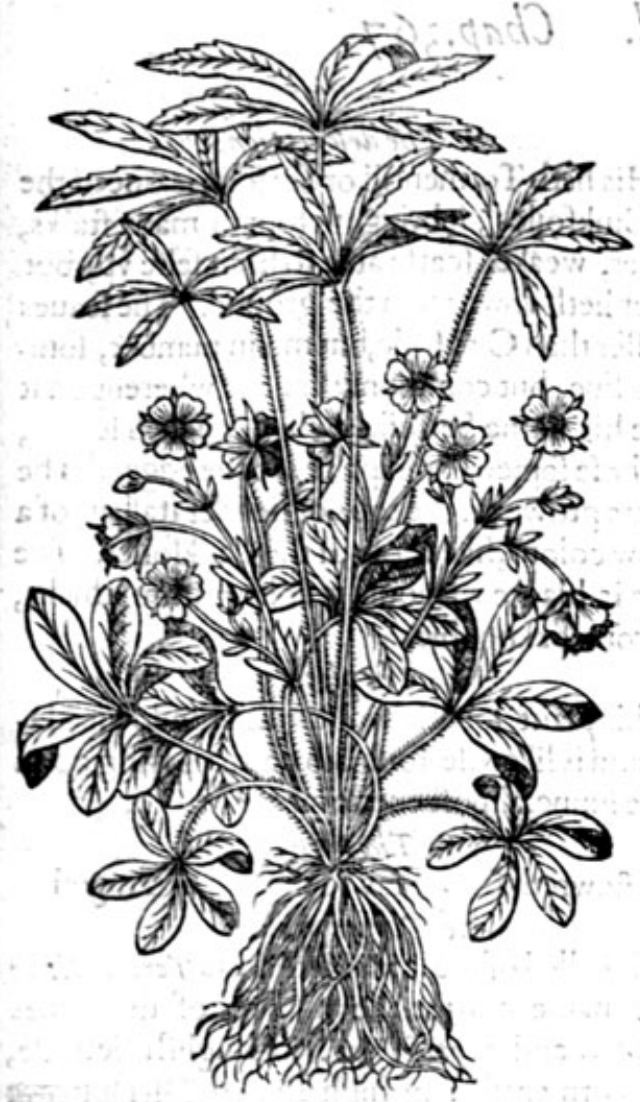

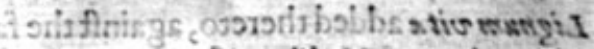
* The place.

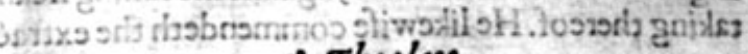

8. Tha firt groweth 10 my garden, but not wilde in England; the fecond groweth in lowe and moift medowes. Allitws ther $T$

The third groweth in the woods of Sauena ind Narbon, bus not in England: the fourth roweth in a marrilb ground adioming to the Iadcalled Bourne pondes halfe gruile ffom $\mathrm{C}_{\text {chefter } \text {; from whence I brought Home }}$ plars for iny garden, wbere they flourithand probr wefl.

$T_{1}$ fift groweth vpon Beeftone cittell in Chen re: the fixt vpon bricke and ftome wals about hiadon, efpeciafly ypon the bricke wall in Liuer ine.

The pice of the feaventh and eight is fet foorth in neirdefcriptions.

$$
\text { * T Tetime. }
$$

Thefe plints do flower from the beginning of May to the end of Junc.

$$
\text { * Thinames. }
$$

Cinkfoile is called in Greeke morianor in Latine Quingueflitom the Aporhecaries vfe the Greeke name Pentapby llow, and founetime the Latine name. There be yery many baftard names, wherwith I will nor trouble yourceares: in high Dutch Ituff finserktant t in Lowe Dutch đatiff đangerktuit : in Italia cingue-

foglio: in French Quinte f neille : in Spanifh Cinco en rama ; in Englin Cilikfoile, Farc finger graffe, Fiuc leafed graffe, and Sinkfield.

\section{* The temperature.}

The rootes of Cinkfoile, efpecially the two laft, do vehemently drie, and that in the third degree, but without biting : for they haue very little apparant heatc or fharpnes.

* Tlevertues.

The decoction of the rootes of Cinkfoile drunke, cureth the bloodie flixe, and all other atuxes of $\mathbf{A}$ the bellie, and ftancheth all exceffuc bleeding.

The iaice of the rootes while they be yoong and tender, is giuen to be drunken againft the dif- B eafes of the liuer and lungs, and all poifon.

The fame drunke in meade or honied water, or wine wherein fome pepper hath beene mingled, C cureth the tertian and quartaine feuers $:$ and being drunken after the fame manher for thirtie daies togither, it helpeth the falling ficknes. The leaues vfed among herbes appropriate for the fame purpofe, cureth ruptures and burfting $D$
of the rim, and guts falling into the cods.

The iuice of the leaues drunken doth cure the iaundies, and comforteth the ftomack and liter. E

The decoction of the rootes held in the mouth, doth mitigate the paine of the teeth, ftaieth pu- $\mathbf{F}$ trifaction, and all putrified vlcers of the mouth, helpeth the inflammations of the almonds, throte, and the partes adioining, it ftaieth the laske, and helpeth the bloodie flixe.

The roote boiled in vineger is good againft the fhingles, appeafeth the rage of fretting fores, $G$ and cankerous vicers.

It is reported, that fower branches hereof cureth quiattaine agues, three tertians, and onc branch $\mathbf{H}$ quotidians: which things are moft vaine and friuolous, as tikewife many other fuch like, which are not onely found in Diofcorides, but alfo in other authors, which we willingly withftand.

Orislpho Morolto a learned Phifition, commended the leaues being boiled with water, and fome I 
Lignwm vite added thereto, againft the falling fickn, if the patient be caufed to fweate vpon the taking thereof. He likewife commendeth the extra on of the rootes, againfte the bloodie flixe.

\section{Of Setfoile, or Tormitill. \\ Chap.367.} Tormentilla.

Setfoile,

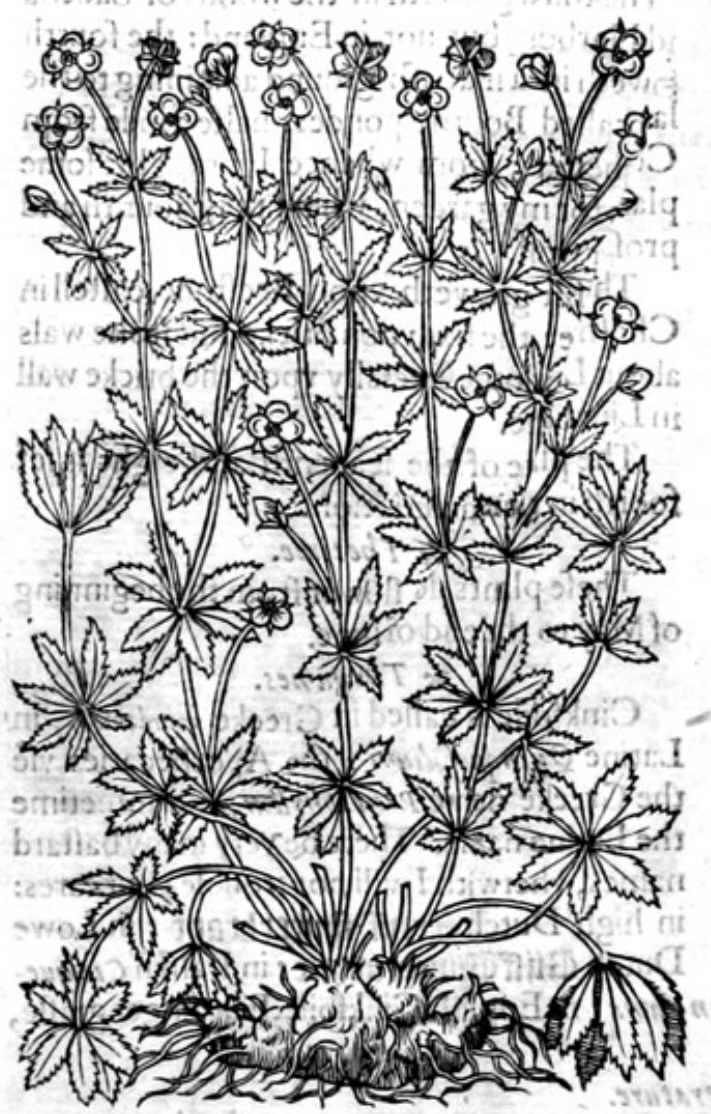
tuberous, or knobbie.

\section{* The place.} to the funne, almoft euerie where.

$$
\text { * The time. }
$$
* The names.

* The defcription.

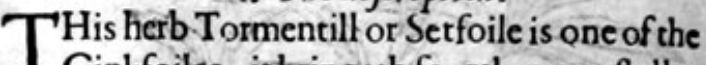
Cinkfoiles, itbringeth foorth many ftalks, flender, weake, fcarfe able to lift itfelfe vp, but rather lieth down vpon the ground. The leaues be leffer than Cinkfoile, but mo in number, fomtimes fiue, but commonly feuen, whereupon it tooke his name Setfoile; which is feuen leaues, and thofe fomewhat fnipt abour the edges. The flowers growe on the tops of flender ftalkes, of a yellow colour, like thofe of the Cinkfoiles. The roote is blacke without, reddifh within, thicke,

This plant loueth woods and (hadowieplaces, and is likewife found in paftures lying open

It flowreth from May to the end of Auguif.

It is called of the later Herbarifts Tormentills : fome name it after the number of the leaues imadounrov, and Septifolivon : in Englifh Setfoile, and Tormencill : in high Dutch 2Bitkwurt3: moft take it to be Chryfoganow, whereof D iofcorides hath made a briefe defcription to fmall purpofe, comparing Chryjoganon and Tormentill togither, making them one and the felfe fame plant; whereas in truth they are no more like, than thofe things that are moft vnlike. * T The temperature.

The roote of Tormentill doth mightily drie, and that in the third degree, and is of thinne parts: it hath in it very little heate, and is of a binding quality.

\section{* T be vertues.}

A Tormentill is not onely of like vertue with Cinkfoile, but alfo of greater efficacie: it is much vfed againft peftilent difeafes : for it ftrongly refifteth putrifaction, and procurech fweate.

B The leaues and rootes boiled in wine, or the iuice thereof drunken prouoketh fweate, and by that meanes dritueth out all venome from the hart, expelleth poifon, and preferueth the bodie in time of peftilence from the infection thereof, and all other infectious difeafes.

C The rootes dried, made into powder and drunke in wine, hath the fame vertue.

D The fame powder taken as aforefaid, or in the water of a fmithes forge, or rather the water wherin hot fteele hath been often quenched of purpofe,cureth the laske and bloudie flixe,yea although the patient haue adioined vnto his fcouring a greeuous feuer.

E It ftoppeth the fitting of bloud,piffing of bloud, and all other iffues of bloud, as well in men as women.

F The decoction of the leaues and rootes, or the iuice thereof drunke, is excellent good for all wounds, both outward and inwarde: it alfo openeth and healeth the ftoppings of the liuer \& lungs,

$G$ The root beaten into powder, tempered or kneaded with the white of an egge and eaten, ftaieth the defire to vomite, and is good againft choler and melancholie. 


\section{HIST ORIE OF PLANTSETT \\ Of wilde Tanfre, or Siluerweede. Cbap.368 rezrias}

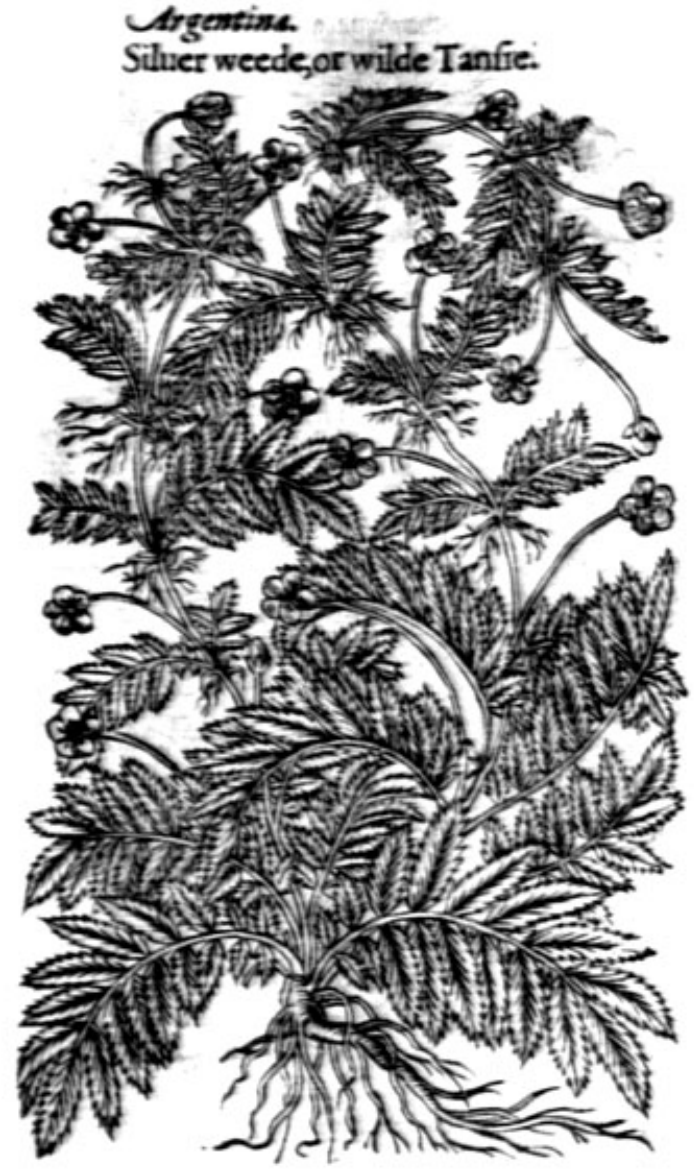

binding facultie.

\section{*The defoription -} Vل grounde with finctlender italke ond clafping tendrels: the leaves ar elong, made vp of many inaller leaves, like vneo thofe of the garden Tanfie, bur lefier, on the vpper fide greene, and vndervery white. The flowers toeyellow, and ftand vpon flender ftemis, as do thofe of Cinkfoile.

$$
\text { 35. *Tbeplace. }
$$

Ir groweth in moift places neere vitio high waies and running brookes euery where. * The time.

Ir flowreth in Iune and luily.

$$
\approx \tau \text { be nomes. }
$$

The later Herbarifts docall it C gr gentine, of the filuer drops that are to be feene in the diftilled water thereof when it is put into a glaffe, which you thatl eafely fee rowling and tumbling vp \& down in the bottoms it is likewife called Potent: las, of diuers Agrimonia frlueftris, Arf fercma, \& Tascetiom fylueftre: in high Dutch Genietich: in lowe Dutch Ganfertck : in French Argentine: in Englifh wiIde Tanfie, and Siluer weede.

$$
\text { * The tomperature. }
$$

It is of temperature moderately cold, and drie almoft in the thirde degree, hauing withall a

*Thevertwes. Wilde Tanfie boiled in wine and drunke, ftoppeth the laske, the bloudie flixe, jand all other fuxe A
of bloud inman or woman. The fame boiled in water and falt and drunke, diffolueth clotted and congealed bloud if fuch $\mathbf{B}$
as are hurt or brufed with falling from fome high place.

The decoction heerof made in water, cureththe vicers and cankers of themouth, if fome fionie $\mathbf{C}$ and allome be added thereto in the boiling.

Wilde Tanfie hath many other good vertues, efpecially againft the ftone, inwarde wounds, and D wounds of the privie or fecret parts, and clofeth vp all greene and frefh wounds.

The diftilled water taketh away freckles, fpots, pimples in the face and funburning, but the herbs $\mathrm{E}$ laide infufe, or fteeped in white wire is farre better: but the beft of all is to fteepeit in ftrong white wine vineger, the face being often bathed or wafhed therewith.

\section{Of ef uens, or berbe Bennet. Chap. 369 .} IIf ataman

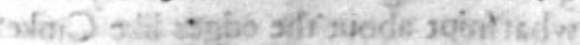
Herebe diuers forts of Auens, fome of the garden, others of the fielde and champion grounds,
andfome of the mountaines, as thall be declared in their feuerall titles. 
I Caryophyllata.

Auens or herbe Bennet.

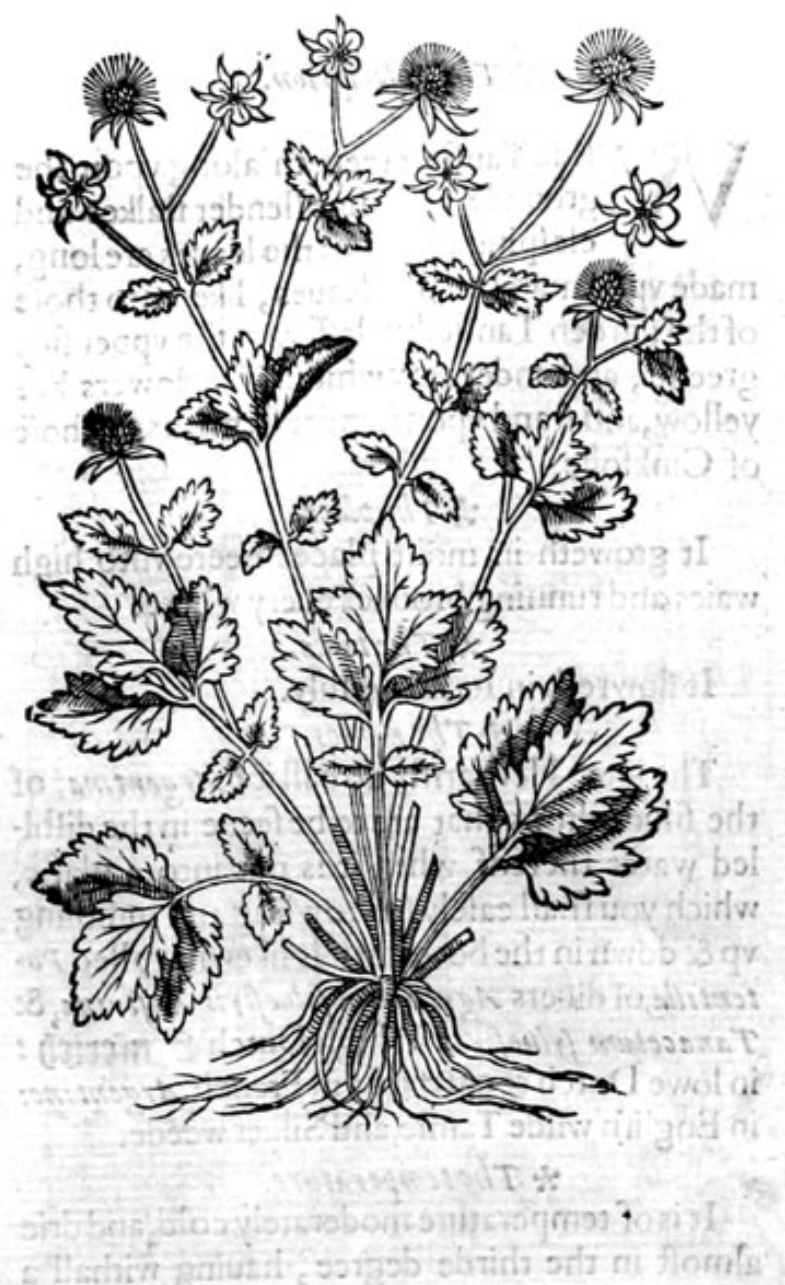

2 Caryophyllata montana. Mountaine Auens.

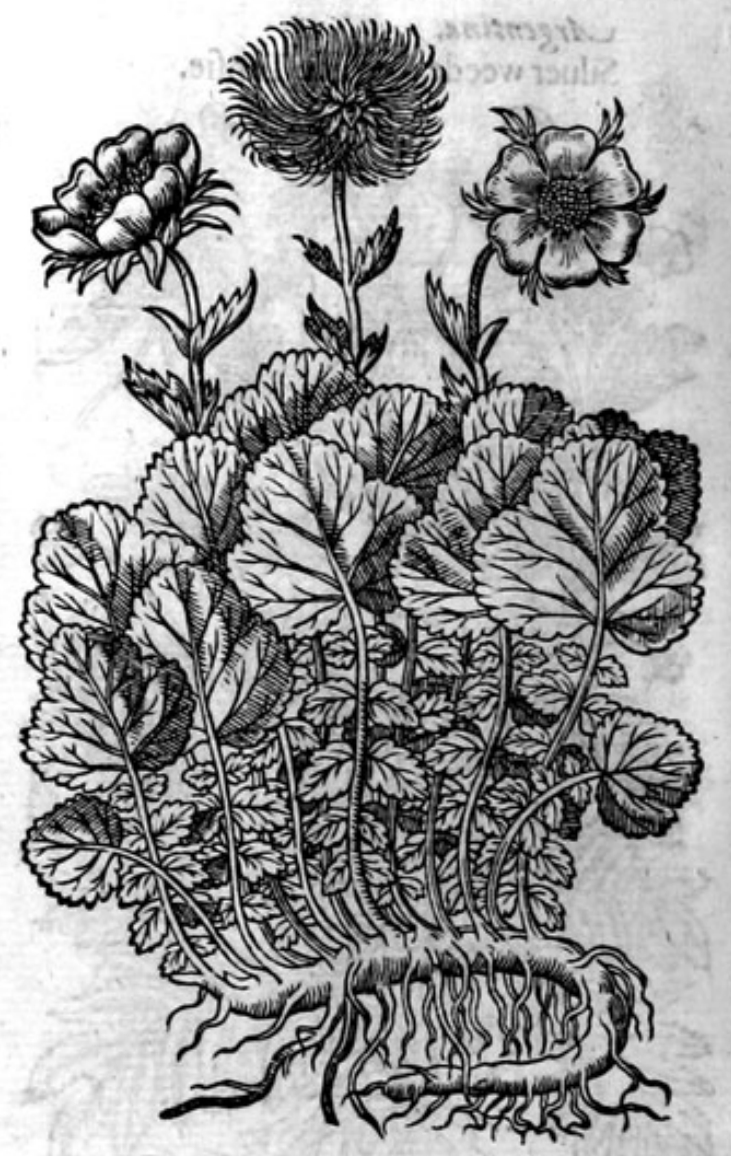

* The defcription.

1. He common garden Auens hath leaues not vnlike to Agrimonie, rough, blackißh, and much clouen or deepely cut into ditiers gafhes: the ftalke is rounde and hairy, a foot high, diuiding it felfe at the top into diuers branches, whereupon do grow yellow flowers, like thofe of Sinkfielde or wilde Tanfie, which beingpaft there followe rounde rough heads or knops full of feede: which being ripe will hang vpon garments as the Burs do. The roote is thicke, reddifh within, with certaine yellowe ftrings faftried thereto, fmelling like vnto cloues or the rootes of Cyperus.

2 Themountaine Auens hath greater and thicker leaues then the precedent, rougher, and more hairie, not parted into three, but rather round, nicked on the edges:among which rifeth vp flender ftalks, whereon do grow very little leaues like thofe of Chickweede, on the top of the ftalkes doth grow one flower, greater then that of the former, which confifteth of a number of little leaues as yellow as golde; after which groweth vp a round circle, confifting as it were of little feathers. The roote is long, growing a flope,fomwhat thicke, with ftrings annexed thereto.

3. Fiue finger Auens hath many fmall leaues fpred vpon the grounde, diuided into fiue parts, fomwhat fnipt about the edges like Cinkefoile, whereof it tooke his name: among which rife vp flender ftalkes diuided at the top into diuers branches, whereon do growe fmall yellow flowers like thofe of Cinkfoile: the roote is compofed of many tough ftrings, of the fmell of Cloues, which maketh it a kinde of Auens, otherwife doubtleffe it muft of neceffitie be one of the Cinkfoiles. 


\section{HIST ORIE OF PLANTS.}

3 Caryophyllata alpinapentaphyllea. Fiue leafed Auens.

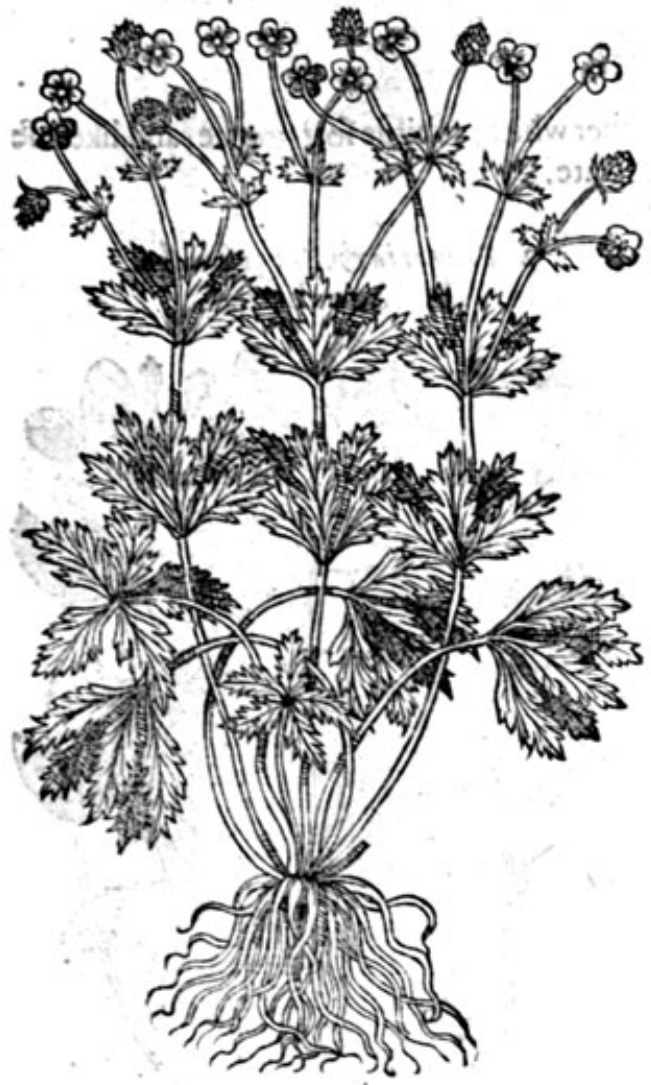

* 7 be place.

Thefe kinds of Auens are found in high mountaines and thicke woods of the north parts of England:we haue them in our London gardens, where they flourifh and increafe infinitely.

* The time.

They flower from the beginning of Maie, to the end of Iuly.

\section{* The names.}

Auens is called Caryophyllata, fo named of the finell of cloues which is in the rootes : and diuers call it Sanamunda, Herba Benedicta, and 2 ardisu refteca : in high Dutch 2Bentoteten motiz: in French Galiot: of the Walons Gloris files : in Englifh Auens and herbe Bener: it is thought to be Geum Plinÿ, which mott do fufpect, by reafon he is fo briefe: Geum faith Plinie in his 26 . booke 7 . chapter, hath little flender roots, black, and of a good fmell.

The other kinde of Auens is called of the later Herbarifts, Caryopbyllat a montans, mountaine Auens: it might agree with the defcription of Baccharis, if the flowers were purple tending to whitenes, which as we have faide are yellow, and likewife differ in that, that the rootes of Auens do fimell of cloues, and thofe of Bacchars haue the fmell of Cinamom. Spotted Auens hath beene called Sanicula guttata, or fpotted Sanicle, but not properly; it hath alfo beene called SanicuLa Alpina, or mountaine Sanicle : of L'Obel Gewm Alpinum : and of vs Caryophyllats Alpina guttata, or fpotted Auens of the mountaines.

\section{* The temperature.}

The rootes and leaues of Auens are manifeftly drie, and fomthing hot, with a kinde of fcowring qualitic.

* The vertues.

The decoction of Auens made in wine, is commended againft cruditie or rawneffe of the fto- $\mathbf{A}$ macke, paine of the collicke, and the biting of venemous beafts.

The fame is likewife a remedie for ftitches and griefe in the fide, for ftopping of the liver; it con- B cocteth rawe humours; fcoureth away fuch things as cleaue to the entrailes, wafteth and diffolueth winde, efpecially being boiled with wine : but if it be boiled in pottage or broth, it is of great efficacie, and of all other pot herbes is chiefe, not onely in phificall brothes, but commonly to be vfed in all.

The loques and rootes taken in this maner, diffolue and confume cluttered bloud in any inwarde $\mathbf{C}$ part of the body : and therefore they are mixed with potions, which are drunke of thofe that be brufed, that are inwardly broken and that haue fallen from fome high place.

The rootes taken vp in Autumne and dried, do keepe garments frombeingeaten with -Mothes, D and make them to haue an excellent good odour, and ferue for all the Phificall purpofes that
Cinkefoiles'do. 


\section{Of Strawberries. Chatp.370. \\ * The kindes.}

THere be diuers forts of Strawberrries, one red, another white, a thirde fort greene, and likewife a wilde Strawberrie, which is altogither barren of fruite.

I Fragaria d Fraga. Red Strawberries.

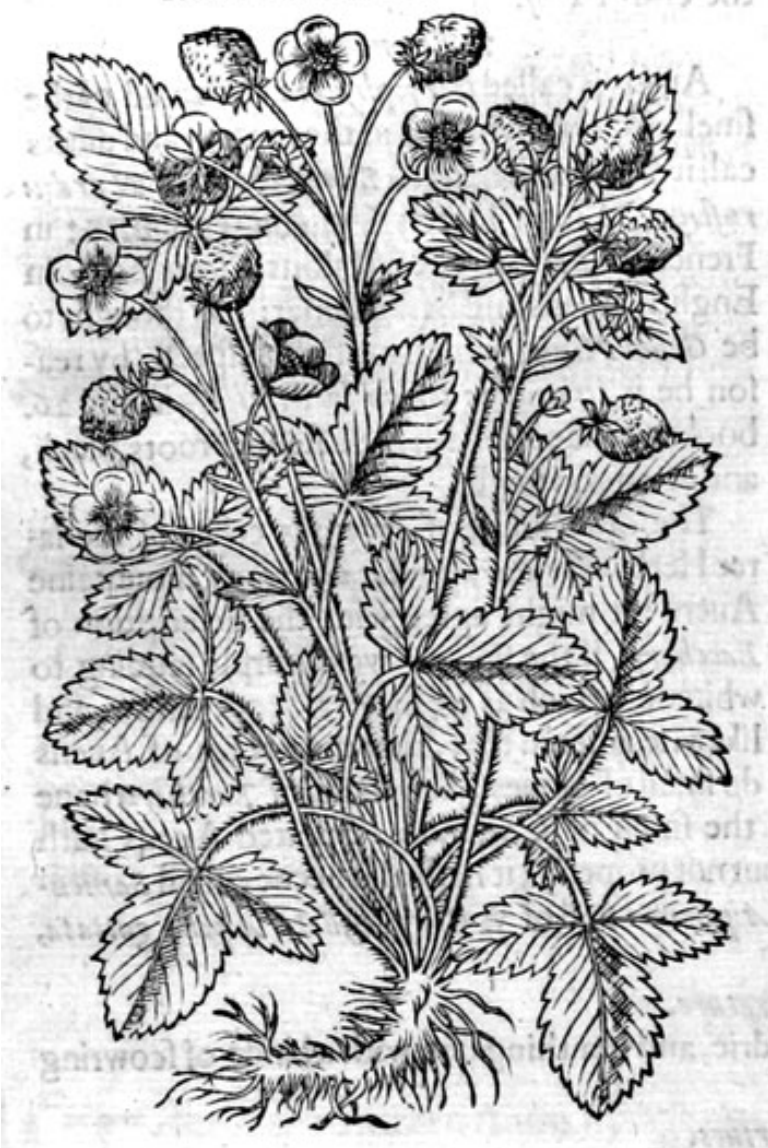

2 Fragaria \& Fragafubalba. White Strawberries.

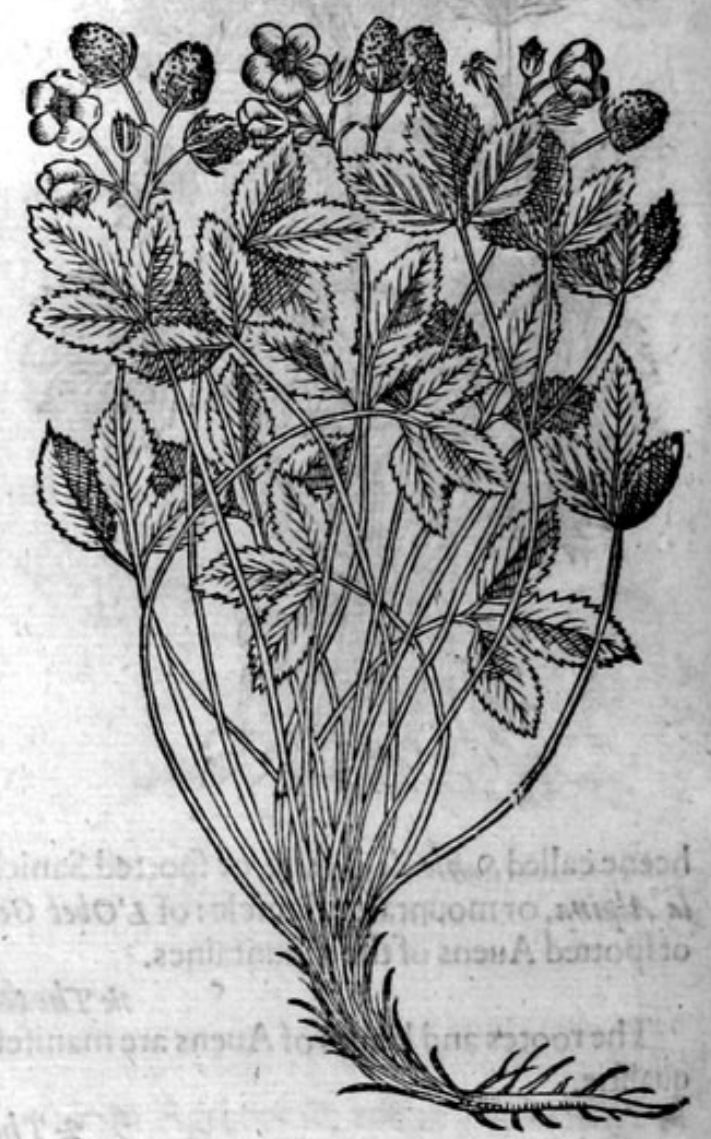

* The defcription.

I He Strawberrie hath leaues fpred vpon the ground, fomwhat fnipt about the edges, three fer togither vpon nne flender footeftalke like the Trefoile, greene on the vpperfide, and on the neather fide more white: among which rife vp flender ftems, whereon do growe fmall flowers, confifting of fiue little white leaues, the middle part fomewhat yellowe, after which commeth the fruit not vnlike to the Mulberie, or rather the Rafpis, red of colour, hauing the taft of wine, the inner pulpe or fubftance whereof is moift and white, in which is conteined little feedes: the roote is threddie, of long continuance, fending foorth many ftrings, which difperfe themfelues farre abroad, whereby it greatly increafeth.

2 Of thefe there is alfo a fecond kinde which is like to the former in ftemmes, ftrings, leaues and flowers. The fruite is fomething greater, and of a whitifh colour, wherein is the difference.

There is an other fort which bingeth forth leaues, flowers, and ftrings like the other of his kind. The fruite is greene when it is ripe, tending to redneffe vpon that fide that lieth to the funne, cleauing fafter to the ftems, and is of a fweeter tafte, which maketh the difference. 
3 Fragaria vefca, fuve fteriliss.

Wilde or barren Strawberrie.

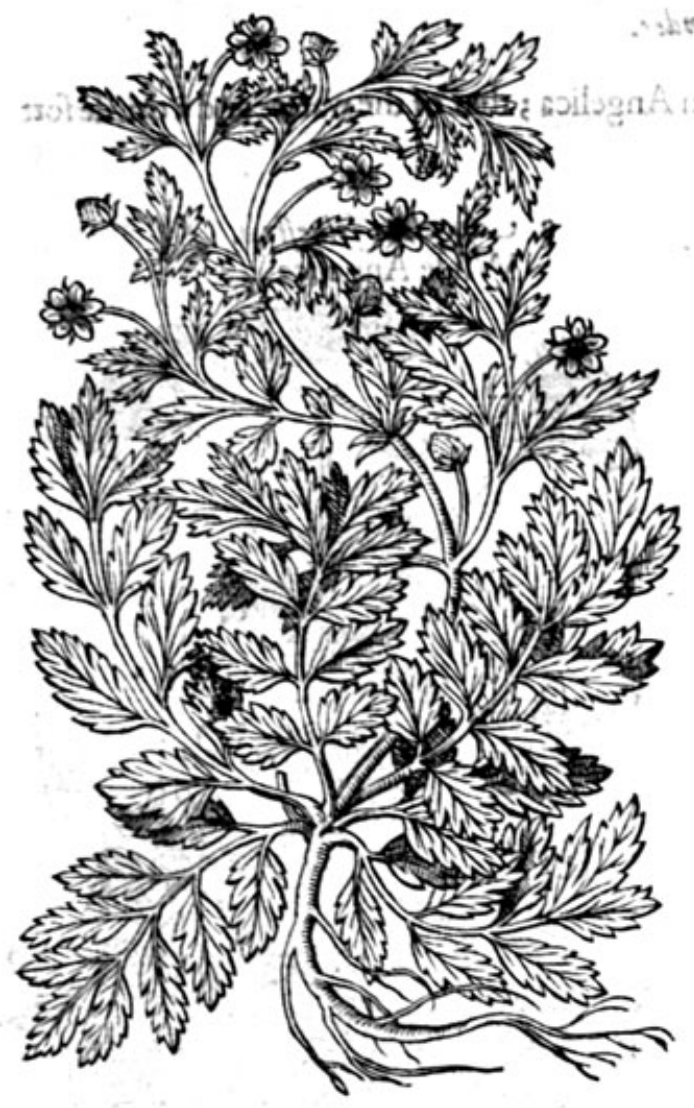

\section{* T he defcription.}

3 This wilde Strawberric hath leanes fpred ypon the grounde, compofed of fixe or feaven fimall leaues, fet ypon a middle ribbe, flightlyindented about the edges, and of a ruffet greene colour : among which rifevBflender ftems bearing fuch flowers as the common Strawberries do,but leffer, which do wither away, leauing behinde a barren or chaffie head, in hape like a Strawberrie, but of no wootth or yalue : the root is like the others.

$$
\text { * The place. }
$$

Strawberries do grow vpon hils and valleies, likewife in woods and other fuch place s that bee fomething fhadowic: they profper wellin gardens, the firft euery where, the other two more rare ; and are not to be foundefauc onely in gardens.

\section{* The time.}

The leaues continue greene all the yeere: in the fpring time they fpred further with their ftringes, and flower afterwarde, the berries are ripe in Iune and Iuly.

$$
* \text { The nimes. }
$$

The fruite or berries are called in Latine by Virgil and Ouid Fraga, neither haue they anie other name commonly knowne: they are called in high Dutch Erobexten : in lowe Dutch eetthefien: in French Fraifes: in Englifh Strawberries.

\section{* The temperature.}

The leaues and rootes do coole and drie, with an aftriction or binding qualitic: but the berries be colde and moift.

\section{* The vertues.}

The leaues boiled \& applied in maner of a pultis, taketh away the burning heate in wounds : the A decoction thereof ftrengthneth the gums, faftneth the teeth, and is good to be helde in the mouth both againft the inflammation or burning heate therof, and alfo of the almonds of the throat : they
ftaie the ouermuch flowing of the bloudie flixe, and other iffues of bloud.

The berries quench thirft, and do alaie the inflammation and heate of the ftomacke, the nou-B rifhment which they yeelde is little, thinne, and waterifh, and if they happen to putrific in the ftomacke, their nourifhment is naught. The diftilled ivater drunke with white wine, is good againft the paffion of the hart, reuiuing the $\mathrm{C}$
fpirits, and maketh the hart merrie.

The diftilled water is reported to fcower the face, to take away fots, and tomake the face faire D and fmooth; and is likewife drunke with good fucceffe againft the ftone in the kidneies.

The leaues are good to be put into lotions or wafhing waters for the mouth and the priuie $\mathbf{E}$ parts.

The ripe Strawberries quench thirft, cooleth heate of the ftomacke, and inflammation of the F liuer, taketh away (ifit be often vfed) the rednes and heate of the face. 


\section{Of Angelica. Chap.371.}

$*$ The kindes.

THere be diuers kinds of Angelicaes; the garden Angelica; that of the water, and a thirde fort wilde growing vpon the land.

$x$ Angelica fatiun. Garden Angelica.

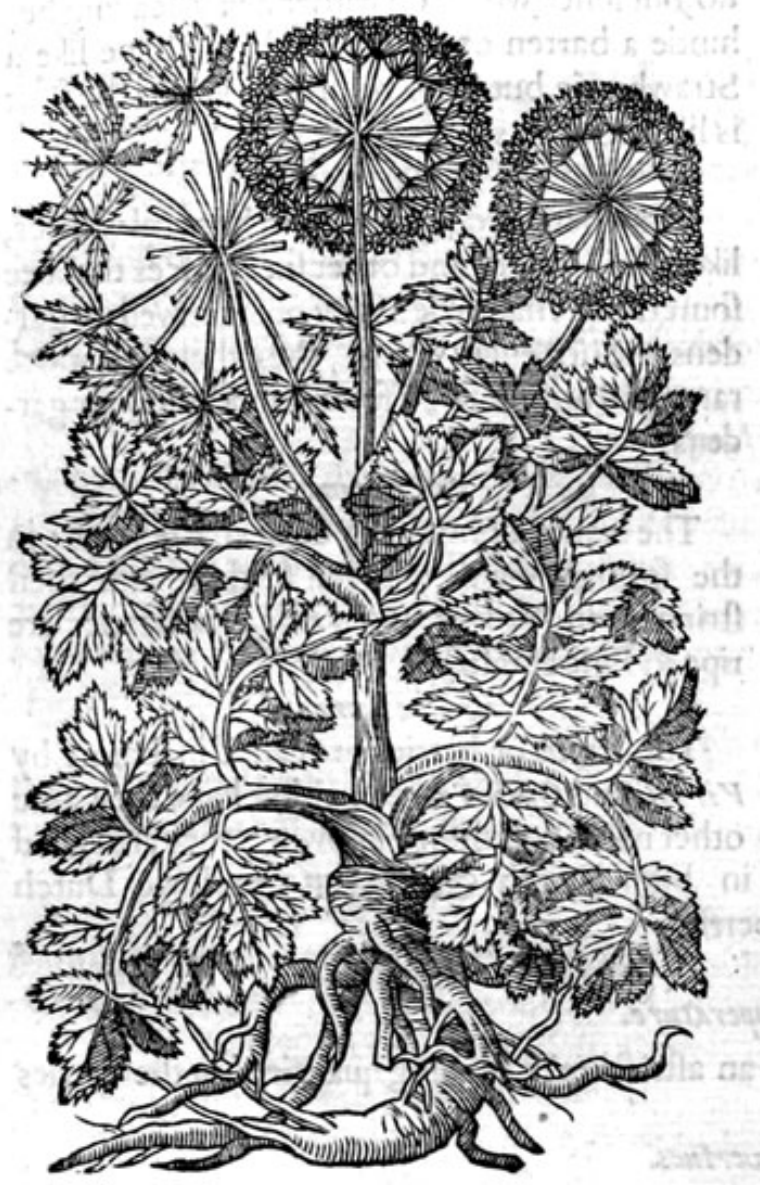

2 Angelica fylmeftrin. Wilde Angelica.

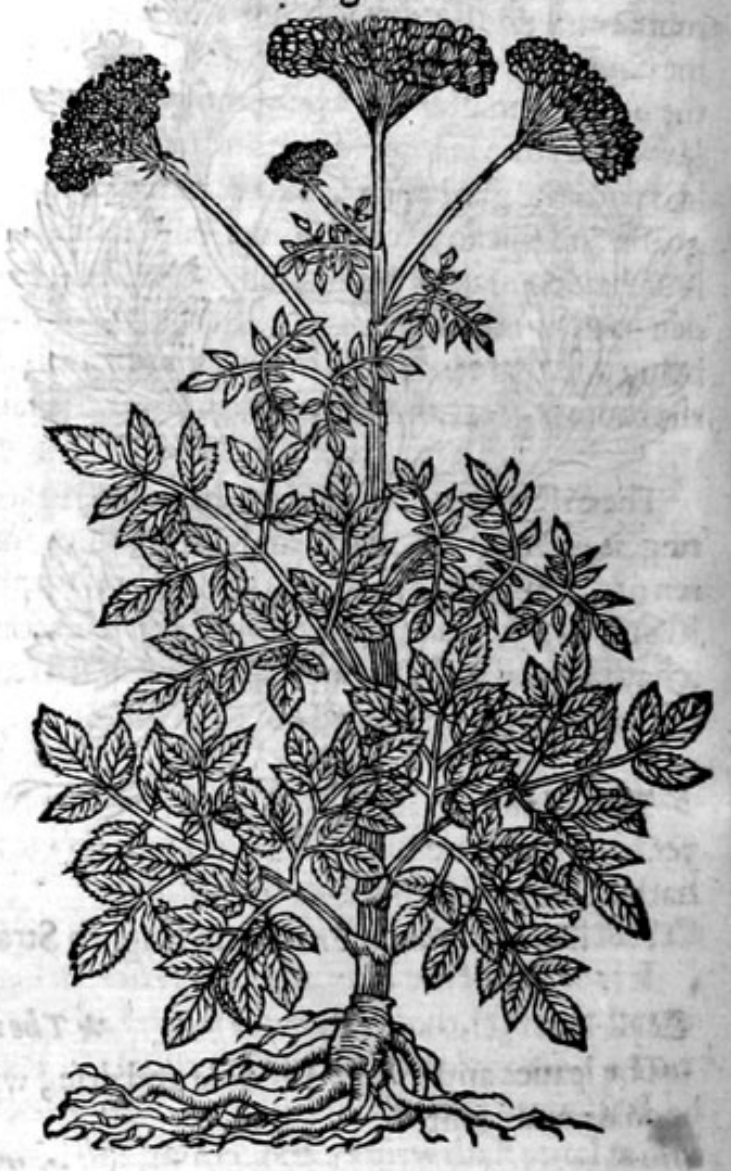

* The defcription.

$\mathbf{x}$

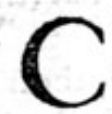
Oncerning this plant Angelica, there hath beene heeretofore fome contention and controuerfie, Cordus calling it Smyrnium, fome later writers Costus niger: but to auoide cauilling, the controuerfic is foone decided, fith it, and no other, doth affuredly retaine the name Angelica. It hath great broad leaues, diuided againe into other leaues, which are indented or fript about, much like to the vppermoft leaues of spondilliwm, but lower,tenderer, greener, and of a ftronger fauour : among, which leaues fpring vp the ftalkes, very great, thicke and hollowe, fixe or feauen foote high, iointed or kneed; from which ioints proceede other armes or branches, at the top where of grow tufts of whitih flowers, like Fennell or Dill : the roote is thicke, great, and oileous, out of which iffueth (it it be cut or broken)an oilie liquor:the whole plant as well leaues, ftalkes, as rootes, are of a reafonable pleafant fauour, not much vnlike Petroleum.

There is another kinde of true Angelica founde in our Englifh gardens (which I haue obferued) being like vnto the former, fauing that the rootes of this kinde are more fragrant, and of a more aro. maticke fauour, and the leaues next the grounde of a purplifh red colour, and the whole plant leffer. 


\section{HISTORIE OF PLANTS.}

\section{* The defcription.}

2 The wilde Angelica which feldome groweth in gardens, but is founde to growe plentifully it water foken grounds, and cold moift medowes, is like to that of the garden, fave thiar his leaves are not fo deepely cut or iagged, they be alfoblacker and narrower : the ftalkes are much fenderer and fhorter;and the flowers whiter; the roote much fmaller, and hath more threddie ftrings appendant thereunto, and is not fo ftrong of fauour by a great deale.

Matbiolus and Ge/nerus haue made mention of another kinde of Angelica, but we are veryflen:derly inftructed by their infufficient defcriptions : notwithftanding for our betterknowledge, and more certaine affurance, I muft needs record that which my friende mafter Bredevell related vinto ine concerning his fight heereof; who founde this plant growing by the mote which compaffeth the houfe of mafter Munke of the parifh of Iuer, two miles from Colbrooke, and fince that I haue teene the fame in lowe fennic and marfhie places of Effex, about Harwich : this plant hath leaues like vnto the garden Angelica, but fmaller, and fewer in number, fet vpon one ribbe, a great ftalke, grofie and thicke, whofe ioints, and that fmall rib whereon the leafe groweth, is of a reddifh colour, hauing many long branches comming forth of an huske or cafe, fuch as is in the common gardell parfnep : the towers grow at the top of the branches, of a white colour and tuft fafhion, which being palt there fucceede broad, long, and thicke feeds, longer and thicker then garden Angelica: the roote is great, thicke, and white, of little fauour, with fome $\mathrm{ftrings}$ appendant thereto.

$$
\text { * The place. }
$$

The firft is very common in our Englinh gardens: in other places it groweth wilde without planting, as in Norwaie, and in an Iland of the north called Ifland, where it groweth very high, it is eaten of the inhabitants, the barke being pilled off, as we vnderftande by fome that haue trauelled into Illand, who were fomtimes compelled to cate heereof for want of other food; and they report that it hath a good and pleafant tafte to them that are hungrie : it groweth likewife in diuers mountaines of Germany, and eipecially of Bohemia.

$$
\text { * The time. }
$$

They flower in Iuly and Auguft, whofe rootes for the moft part do perifh after their feed is ripe: yet haue I with often cutring the plant kept it from feeding, by which meanes the roote and plant hath continued fundrie yeeres togither.

\section{* 7 he names.}

It is called of the later age Angelics : in high Dutch anjelick, 23zuffuturt3, or mes beiligben Bepeft wuttz 3 el, that is, Spiritus fancti radix, or the roote of the holic Ghoft, as witnefieth Leonhartus Fuchfius : in lowe Dutch Aniselifica: in French Angelic : in Englifh alfo Angelica.

It fecmeth to be a kinde of Laferpitiom, for if it be compared with thofe things which Theophrafius at large hath written concerning Silphium, or Laferpitium, in his fixt booke of the hiftorie of plants, it thall appeere to be anfwerable thereunto. But whether wilde Angelica be that which Theopbraftus callech Maguduris, that is to faic, another kinde of Lajerpitium, ive leaue it to be examined and confidered of by the learned Phificions of our London Colledge.

\section{* The temperature.}

Angelica, efpecially that of the garden, is hot and dric in the thirde degree, therefore it openeth, attenuateth,or maketh thinne, digefterh and procureth fweate.

$$
\text { * The vertues. }
$$

The rootes of garden Angelica is a fingular remedie againft poifon, and againft the plague, and $\mathbf{A}$ all infections taken by euill and corrupt aire, if you dobut take a peece of the roote and holde it in your mouth,or chew the fame betweene your teeth, it doth molt certainly driue away the peftivrine and fweate, as Rue and Treacle doth, and fuch like Antipharmace.

Angelica is an enimie to poifons: it cureth peftilent difeafes if it be vfed in feafon:a dram waight $\mathbf{B}$ of the powder hereof is giuen with thin wine, or if the feauter be vehement, with the diftilled water of Cardiens benedict ws, or of Tormentil, and with a little vineger, and by it felfe alfo, or with Treacle
of Vipers added.

Itopeneth the liuer and fpleene : draweth downe the tearmes, driteth otit or expelleth the fe- $G$ condine. 


\section{$84^{8}$ THE SECOND BOOKE OF THE}

D The decoction of the roote made in wine, is good againft the colde fhiuerings of agues.

E It is reported that the roote is auaileable againft witcheraft and inchantments, if a man carrie the fame about him as Fuchfous faith.

F dextenuateth and maketh thinne, groffe and tough legme: the roote being vfed greene, and while it is full of iuice, helpeth them that be afthmaticke, diffoluing and expectorating the ftuffings therein, by cutting off and clenfing the parts affected, reducing the bodie to health againe; but when it is dry it worketh not fo effectually.

G It is a molt fingular medicine againft furfeiting and lothfomnes to nieate: it helpeth concoction in the ftomacke, and is right beneficiall to the hart : it cureth the bitings of mad dogs, and all other venemous beafts.

H The wilde kinds are not of fuch force in working, albeit they haue the fame vertues attributed vnto them.

\section{Of Mafterwoorts and berbe Gerard. Chap: $37^{2}$.}

\section{Imperatoria.}

Mafterwoorts, or Falfe Pellitory of Spaine.

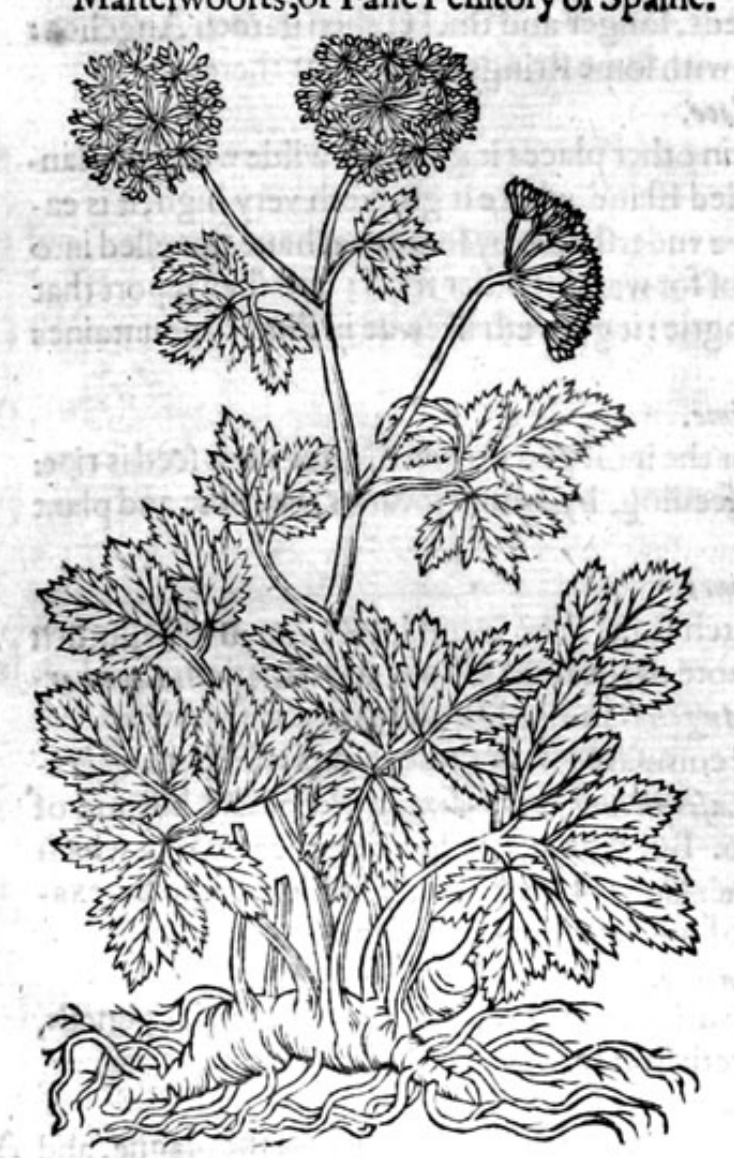

2 Herba Gerardi. Herbe Gerard, or Aifhweed.

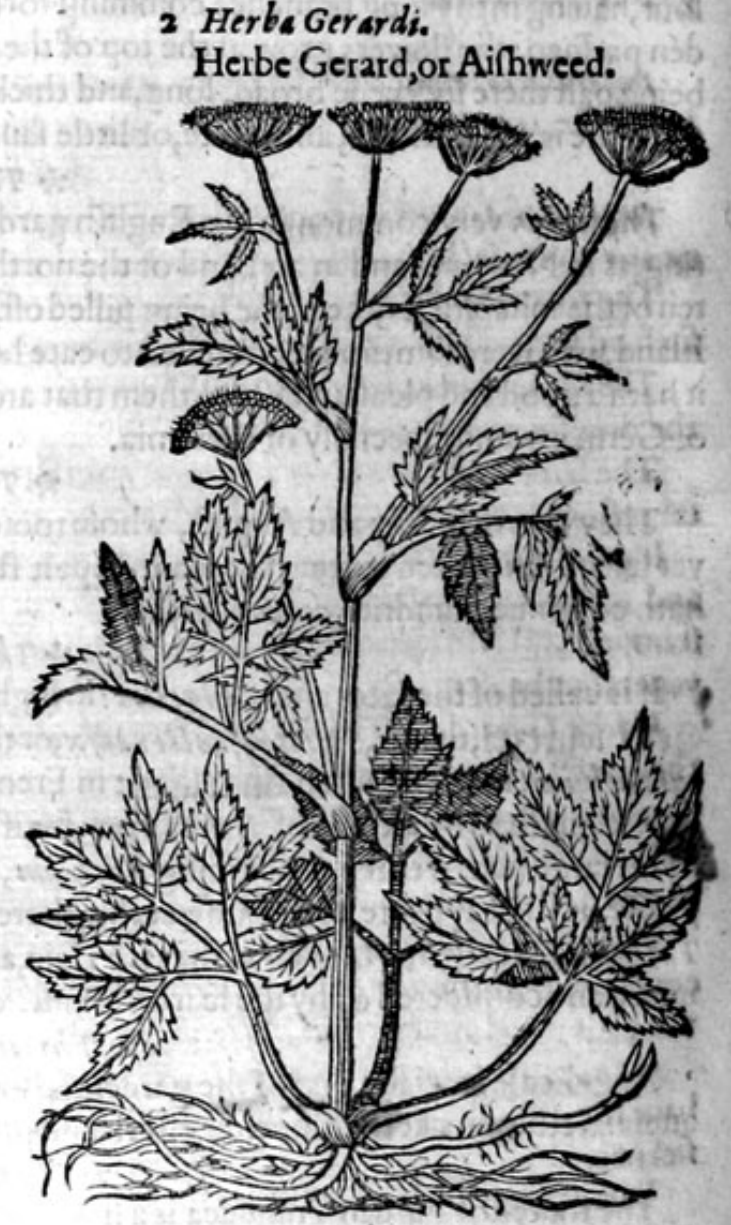

- $\quad$ \& The defcription.

I Mperatoria or Mafterwoort, hath great broad leaues not much vnlike wilde Angelica, bue finaller \& of a deeper green colour, in fauor like Angelica, \& euery leafe diuided into fundrie other little leaues: the tender knottie ftalkes are of a reddifh colour, bearing at the top round fpokic tufts with white flowers : the feede is like the feede of Dill : the roote is thicke, knottie, and tubersic, of a good fauour, and hot or biting vpon the toonge, which hath mooued the vnskilfull to call it Pellitorie of Spaine, but very vnfitlie and vntruely. 
2 Herba Gerardi, which Pena doth alfo call Imperatoric, \&Oftrutiwm, the Germaines Podagraris, that is gout wcort, iniEnglimh herbe Gerard, ortwilde Mafterwoort, and in fome places after Lyte Aifhweed; is very like the other in leaues, flowers, and rootes, fauing that they be finaller, growing vpon longer ftems: the rootes tenderer, whiter, and not fo thicke or tuberous. The whole plant is of a reafonable good fauour, but not fo intông as Mafterwoort.

$$
\text { * The plate. }
$$

Imperaforia groweth in darke woods and defarts; in my garden and fundry others verie plentis fullic.

Herbe Gerarde groweth of it felfe in gardens without fetting or fowing, and is fo fruitfull in bis increafe, thatwhere it hath once taken roote, it will hardly be gotten out againe, fpoiling apd getting euery yeere more ground, to the annoying of better herbes.

$$
\text { * The time. }
$$

They flower from the beginning of Iune to the beginning of Augurt.

$$
\text { * The names. }
$$

Imperatoris,or Affrantia, is called inEnglinh Mafterwoort, or falfe Pellitoric of Spaine.

Herba Gerardi, is calledin Englifh Herbe Gerard, Airhweed, and Goutwoort, in Latine Poda- . graria Germanica.

$$
* \text { The nature. }
$$

Imperaturia, efpecially the roote, is hot and drie in the thirde degree. The wilde Imperatoria, or herbe Gerarde, is almoft of the fame nature and qualitie, but not fo ftrong.

$$
\text { * } 1 \text { be vertues. }
$$

Imperatoria, is not onely good againft all poifon, but alfo fingular againft all corrupt and naugh. A tie aire and infection of the peftilence, if it be drunken with swine.

The rootes and leaues ftamped, doth diffolue and cure peftilentiall carbuncles and botches, and B fuch other apoftemations and fwellings, being applied thereto.

The roote drunke in wine cureth the extreme and rigorous fits of old feuers, and is good againft C the drop fie, and prouoketh fiveate.

The fame taken in maner aforelaid comforteth and ftrengthneth the ftomacke, helpeth digefti- D on, reftoreth apperite, and diffolueth all ventefities or windineffe of the ftomacke and other parts.

It greatly helpeth fuch as haue taken great fquats, brufes, or fals from fome high place, diffoluing E and cattering abroad congealed and clotted bloud within the body : the roote with his leaues ftamped and laid vpon the members infected, cureth the bitings of madde dogs, and of all other yénemous beafts.

Herbe Gerard with his rootes ftamped, and laid vpon membets that are troubled or vexed with $F$ the gout, fwageth the paine, and taketh awray the fwelling and infammation thereof, which occafoned the Germaines to giue it the name Poda graria, bicaufe of his vertues in curing the gout.

it cureth alfo the Hemorrhoids, if the fundament be bathed with the decoction of the leaues and $\mathbf{G}$ rootes, and the foft and tender fodden herbes laid thereon very hot.

Falfe Pellitoric of Spaine attenuatetior maketh thinne, digefteth, prouoketh fweate and vrine, $H$ concoteth groffe and colde humours, watteth away windines of the entrailes, ftomacke and ma-
tix: it is good againft the colicke and ittone.

One dram of the the roote in powder giuen certaine daies togither, is a remedie for them that $I$ haue the dropfie, and alfo for thofe that are troubled with conuulfions, crampes, and the falling
ficknes.

Being giuen with wine before the fit come, it cuteth the quartaine ague, and is a remedy againft $K$ peftilent difeafes.

The fame boiled in fharpe or fower wine, eafeth the toothach, if the mouth be wafhed therwith $L$ verichot.

Being chewed it draweth foorth water and flegme out of the mouth (which kinde of reme-M dies in Latine are called Uspopblegmatifmos) and disburdeneth the braine of phlegmatike humours, and are likewife vfed with good fucceffe in apoplexies, drowfiefleepes, and other like in-
firmities.

vront 6 i toghot 9

(volisitio lint 


\title{
Of Hercules Woundwoort, or Albeale. Chap. 373 .
}

\author{
* The kindes.
}

P Amax is of fundrie kindes,as witneffeth Theophraftws in his 9.booke, one groweth in Syria, and Plikewife other three, that is to faie Chironitum, Heraclium, and $A E$ culapium, or Chirons Alheale, Hercules Alheale, and AE/culapius Alheale; befides thefe there is one Platyphyllon, or broad leafed, fo that in $i$ heop hr aftus there are fixe kinds of Panax : but Diofcorides defcribeth onely three, Heracicum, Afcleptum, and Chironium; whereunto we haue added another fort, whofe vertues we founde out by meanes of a husbandman; and for that caufe haue named it Panax Coloni, or Clownes woort.

I Panax Heracleum. Hcrcules Alheale.

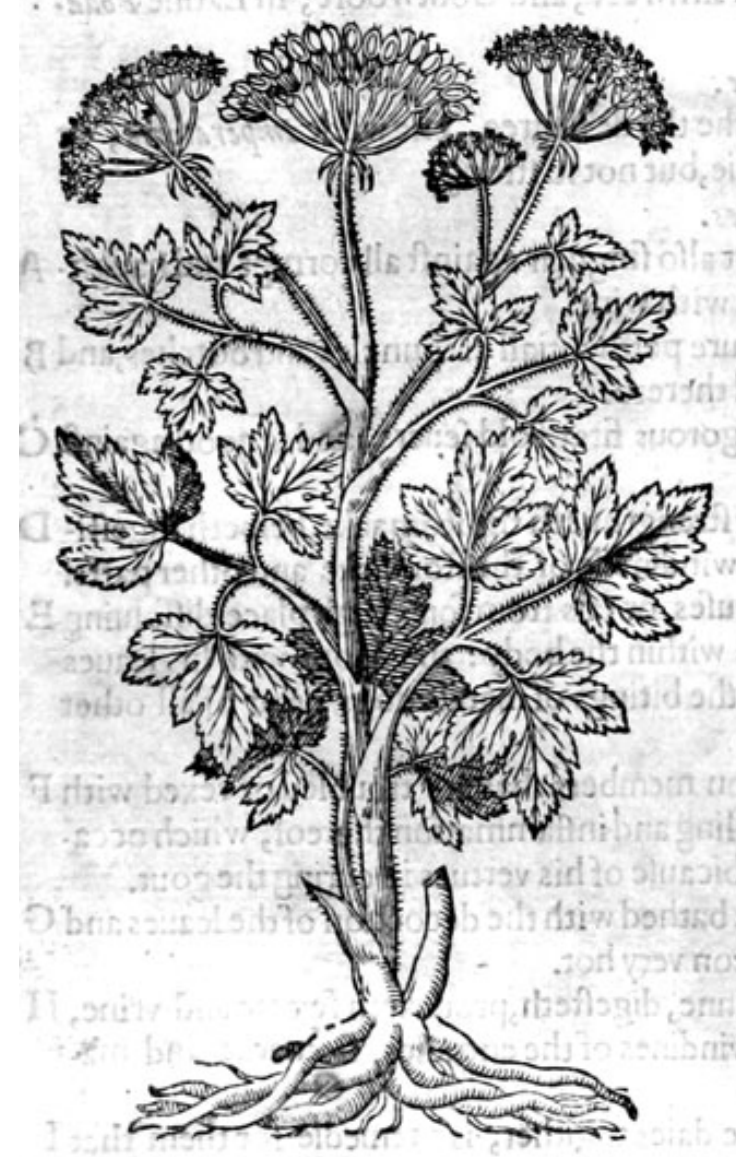

2 Panax Heraclesom maino. Hercules great Woundwoort.

\section{* Thedefoription.}

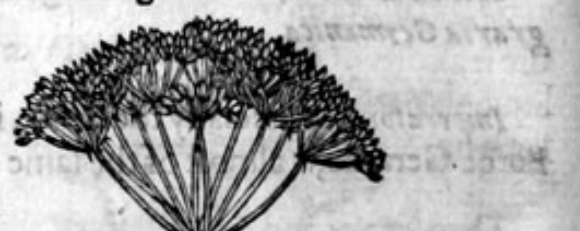

1 Ercules Alheale or Woundwoort, hath many broad leaues fpred vpon the grounde, very rough and hairie, of an oterworne greene colour, and deepely cut into diuers fections, like thofe of the Cowparfnepe, and not vnlike to the figge leaues: among which rifeth vp a very ftrong ftalke, conered ouer with a rough hairineffe, of the height of fower or fiue cubites: being wounded it yeeldeth foorth a yellowe gummie iuice, as doth euery part of the plant, which is that precious gum, called opopanax : at the top of whichoftalkes do ftand great tufts or vmbles of yellowirh flowers, fet togither in fpokie rundles like thofe of Dill, which turne into feede of a fraw colour, tharpe and hot in tafte, and of a pleafing fat:our : the roote is very thicke, fat, full of iuice, and of a white colour. 


\title{
HISTORIE OF PLANTS.
}

* The defcription.

2 The great Woundwoort, which the Venetians nourifh in their gardens, hath great large leaues, fomewhat rough or hairie, confifting of diuers fmall leaues fet togither vpon a middle ribbe, which make one entiteleafe iomed togither in one, whereof each collaterall or fideleafe is like thecommon Docke: among which rifeth vp a knottieftalke three or fower cubits high, diuiding it felfe into diuers branches; on the tops where of do growe fpokie tufts or rundles like the precedent: the feede is flat and plaine: the rootelong, thicke, and wbite, which being broken or wounded yeeldeth foorch that liquior of the former, of an hot and warmingtafte.

"g The place.

Thefe plants do growe in Syria, the firft of them alfo in my garden; but what Panax of Syria is, Theophraftus doth not exprefle: Plmy in his 12 . booke 26. chapter faith, that theleaves are rounde, and of a great compaffe : but it is fufpected that thefe are drawne from the defcription of Hercules Panax.

Broad leafed Panax is thought to be the gteat Centorie: for Pliny witnefieth, that Panax which chiron found out, is furnamed Centaur ium, Centorie, as we hall more at large write heereof.

Mathiolw faith it groweth of it felfe in the tops of the hils Apennini, in the Cape Argentario, in the fea colts of Siena, and it is cherifhed in the gardens of Italie, but he cannot affurme that the liquor is gathered heereof in Italie: for the liquor Opopanax which is folde in Venice, is broughe faith he, out of Alexandria, 2 citic in Egypt ; in Syria,Bœtia, and in Phocide, cities of Arcadia. * The time.

They flowe and flourith from the firft of Maie vnto the end of September. * The names.

That which is called nivers in Greeke, is likewife named Panaces in Latine; and that Panaces Hea raclium which Dio/sorides fetteth downe, is called in Latine Panaces Herculanum, or Herculewm, or Hercules Panax: it may be called in Englifh Hetcules his Woundwoort,or Atheale, or Opopanax woort, of the Greeke name.

Some thinke it tooke his name of Heraclites that weeping Philofopher, who continually wept as Democritus alwajes laughed: for in regard of the teares or drops that iffue out of the ftalkes and roores of this piant(which is called Opopanax) when they are brufed or wounded: but whether of Hercules, bicaufe he vfed the fame in healing of his foldiers wounds, or of the the weeping of Heraclit w, it refteth difputable, and yet nothing pertinent to our hiftorie.

* The temperature.

The barke of the roote of Hercules Woundwoort is a Symple hot and drie, yet leffe then the iuice, as Galen teacheth.

*Thevertwes.

The feedebrought into powder and drunke in Wormwood wine, is good againft poifon, the bi- $A$ ting of madde dogs, and the ftinging of all maner of wilde beafts.

The leaues or rootes ftamped with honie, and brought to tho forme of an vinguent or falue, cu- B reth woundes and vlcers of great difficultie, and couereth bones that are bare or naked without fle?h.

\section{Of Clownes Woundwoort,or Albeale. Chap.374.}

\author{
* Thedefription.
}

Lounes Alheale, or the husbandmans Woundwoort, hath long flender ftalkes, of the height of two cubits, furrowed or clamfered along the fame, as it were with fmall gutters, and fomewhat rough or hairie; whereupon are fet: by couples one oppofite to another, tong rough leaues, fomewhat narrowe, bluntly indented about the edges like the teeth of a fawe, of the forme of the leaues of Spearemint, and of an ouerrworne greene colour : at the top of the ftalkes do growe the flowers fpike fathion, of a purple colour mixed with fome fewe fpots of white, in forme like to little hoods. The roote confifteth of many fmall threddie ftrings, whereunto are annexed or tied diuers knobbie or tuberous lumpes, of a white colour, tending to yellewnes : all the whole plant is of an vnpleafant fauour like Stachis, or ftinking Horehound. 
Panax Coloni.

Clounes Alheale.

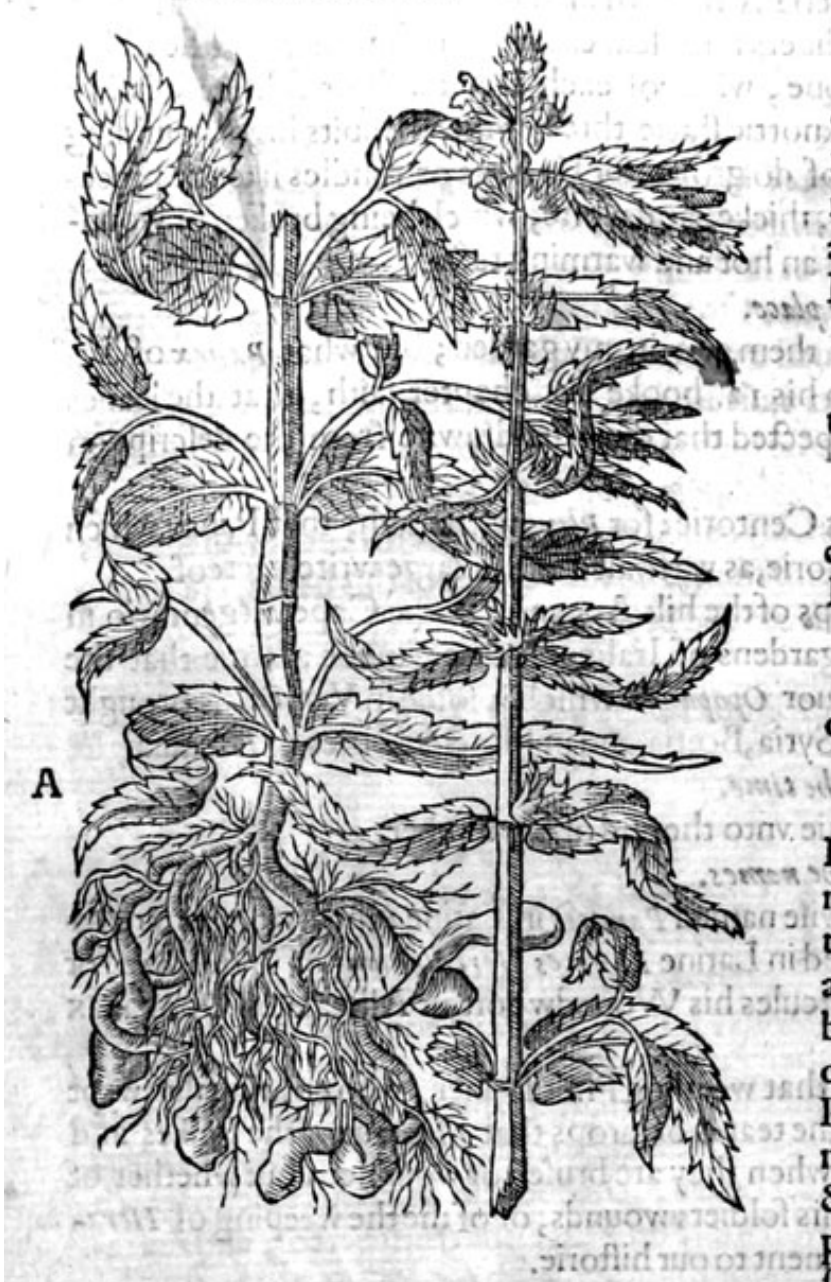

\author{
* The place.
}

It groweth in moif nedowes by the fides of ditches, and likewife in fertill fieldes that are fomwhac moirt, almoft euerie where, efpecilly in Kent about South feete neere to Grauefend and likewifo in the medows by Lamberh neere London.

I. Thesime.

It flowreth in Auguft, and bringeth his feede to perfection in the end of September. * The names.

It Thall fuffice what hath beene faide in the defeription as touching the names, as well in Latine as Englifh.

This plant is Thetemperature. drie in the firit.

$* T$ be vertues.

The leaues heerof ftamped with Axung ia ; or Hogs greafe, and applied vnto green wounds in maner of a pultis, doth heale them in fuch thort time \& in fuch abfolute maner, that it is hard for any that hat h not had the experience thereof to beleeve: for being in Kent about a Pacient, is chanced that a very poore man in mowing of Pealon did cut his leg with the Sieth, wherinhe made a wound to the bones, \& withal yery large \& wide, \& alfo with great effufion of bloud, the poore man crept vnto this herbe which he brufed in his hands, \& tied a great quantitic of it vntothe wound with a peece of his thirt; which prefently ftanched the bleeding and ceafed the pain, infomuch that the poore man prefently went to his daies worke againe, \& $\mathrm{fo}$ did from daie to daie, without refting one day vntill he was perfectly hole, which was accomplifhed in a fewe daies by this herbe ftamped with a little. Hogs greace, and folaid vpon in maner of a pultis, which phe as it were glewe or foder the lips of the wounde togither, and heale it according to the firft intentis on (aswe tearme it) that is without drawing or bringing the wonnde to fuppuration or matter, which was fully performed in feauen daies, that woulde haue required fortie daies with Balfam it felfe: If awe the wounde, and offered to heale the fame for charitie, which he refufed, faying, that I coulde not heale it fo well as himfelfe ; a clownish anfwer I confefle without thankes for my good will,whereupon I hauenamed it Clounes Woundwoort as aforefaide. Since which time my felfe haue cured many greeuous wounds, and fome mortall, with the fame herbe, one for exainple done vpon a gentlemä of Graies Inne in Holburne, matter Edmund Cartvvright, who was thruft into the lungs, the wound entring in at the lowermoft part of Thorax or the breft plate, euen through that cartilaginous fubftance, c alled Mucronat a Cartilago, infomuch that from day to day, the frothing and puffing of the lung's did fpewe foorth of the wound fuch excrements as it was poffeffed of befides the gentleman was moft dangeroufly vexed with a double quotidian feauer, whom by Gods permiffion I perfectly cured in very fhort time, and with this Clounes experiment, and fome of my foreknowne helpes, which were as followeth.

B Firft I framed a flight vnguent hereof, thus; I tooke fower handfuls of the herbe ftamped, and put them into a pan, whertinto I added fow er ounces of Barrowes greafe, halfe a pint of oile oliue, waxe three ounces, which I boiled vinto the confumption of the iuice (which is knowen when theftuffe doth not bubble at all) then did I ftra ine it, putting it to the fire againe, adding therto two ounces of Turpentine, the which I fuffered to boile a little, referuing the fame for my ve. 


\section{THST OR DEO OFCD LANFTS. BHT}

853

The which I warmed in a fawcer, dippingtherein finall foft tents, which I put into the wound, $C$ defending the partes adioining with a plaitter of Chalsiseos relented with oile of Rofes, which manner of dreffing or preferuing I ved euen vncilt the wound wasperfectly whole : notwithitanding once in a day I gaue him two f poonefuls of this dectoction follogiving.

I tooke a quart of good Claret wine, wherin I boiled an handfull of the leaues of Solidago Sara-D

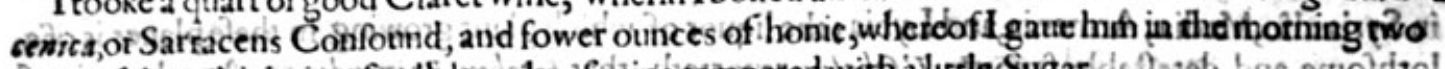

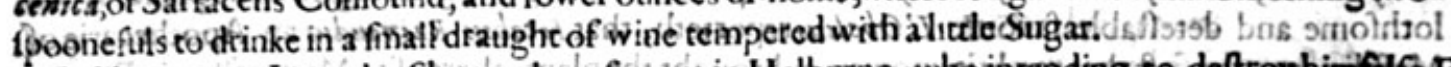

In like manner I cured a Shoomakers fertaant in Holburne, whio ibcending to deftroy himfelfe:E for caufes knowen vito many now liting, and therefore deeming it bettentradower the faulorthany to put the fame in print, which might mooue fuch a graceleffo feltowe watberiptitici likedihis? attemptwas thus; Firft he gaue himfelfe a moft morrall wound in the throte, in fucbufory thato when I gaue him drinke it came forth at the wound, which likewife did blowe outa candle; another deepe and greeuous wound in the breft with the faid dagger, andalfo tivo ochersinishaborivition the nicather belly: fo that the $Z$ ir bus or fat, commonily called the Caule, iffued foorth, with the guts likewife. The which mortall wounds, by Gods permiffion, and the verrues of this tierbo, I lperfeetly

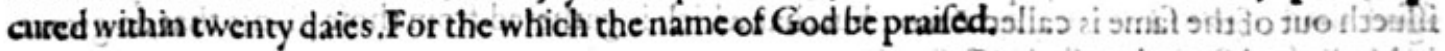

$$
\begin{aligned}
& \text { Of Magydare or Laferwoort. Chap } 375 \text {. } \\
& \text { * Thedefription. }
\end{aligned}
$$

Laferpitium.

$\mathrm{L}_{2}$ fer, woort.

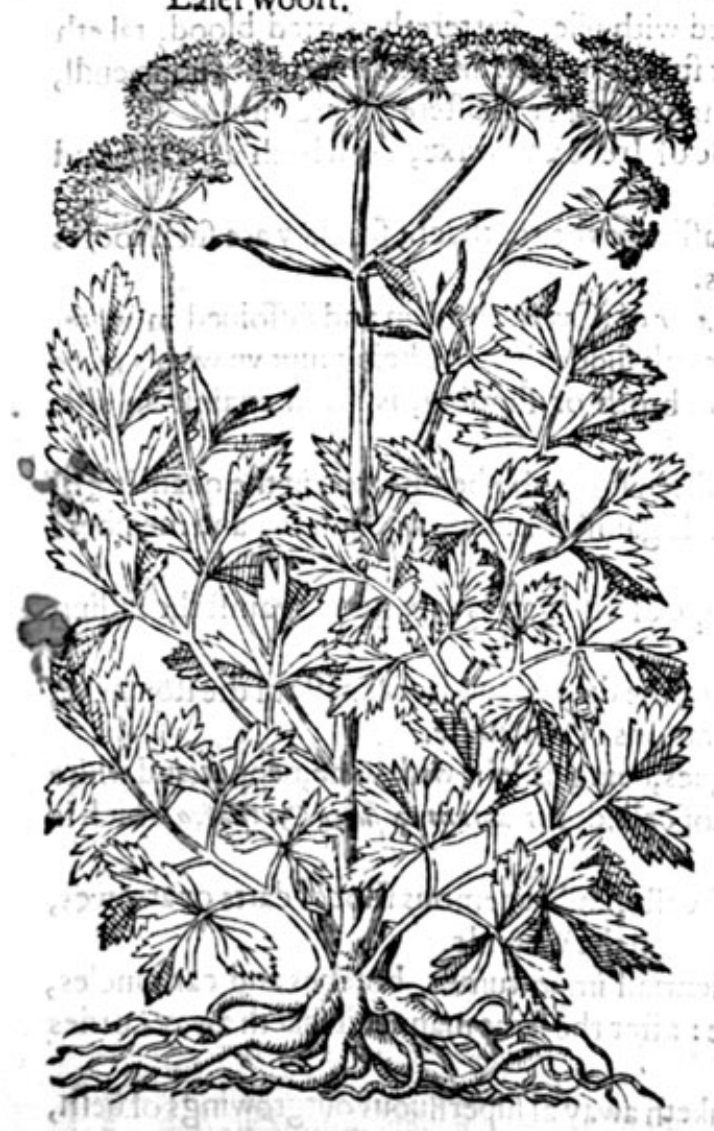

T Teemeth that neither Defocinides, not 'yet Theophrastias hate euer feene Laferpition, Sas: gapewu'n, or any other of the ${ }^{2}$ gummifetots: rootes, but haue barely and naskedly fet downe their cenfares or judgements vpon the fane, either by hearefay, or by readiag ef ether mene 0 works. Now then feeing the old wtiters be vapers. fect herein', it behoouteth vs in this cafe to featch with more diligence the truth hereof, and the ratherfor that very few haue fet foorth the truede fcription of that plant which is called Laforpitidiom? that is indeede the right Laferpitiom, from the rootes whereof floweth that fap of liquor called Lacer. This plant, as Pena and L'Cbelins themfelues fay, was founde out not far from the lle which Dio_corides calleth Strecados (ouer againft Maffilia) among fundrie other rare plants. His ftalke is great and thicke like Ferula, or Fennell gyant; the leaues are like vnto the common Smallage, and of an vnpleafant fauour. The flowers growe at the top of the ftalkes tuft farhion tike Ferula or Fennel;; which being paft, there fuceeed broad and flat leaues like Angelica, of 2 goodfauour and of the colour of Boxe. The rootes are many, comming from one head or chieferoote, and are couered ouer with a thicke and fat barke. Thefe rootes and ftalkes being icarified or eut, I there floweth out of them 2 ftronge liquor, which being dried is very medicinable, and is called Lacer.

$$
\text { * The place. }
$$

There be fundrie fortes of Lacer flowing from the rootes and ftalkes of $L$ eferpitiwn, the goodnes or qualitie whereof, varieth according to the countric or climate wherein rhe plant groweth. For the beft groweth vpon the high mountaines of Cyrene, and A frica,and is of a pleafant finell, where. of Catulliw doth truely write, 


\section{THE SECOND BOOKE OFTHE \\ Laferpiciferis iaces Cyrenis. \\ In Englith thus, \\ Asfand dothlie on Cyren fhore, \\ Which beareth Gacerpife good ftore,}

in Syria alfo,Media; Armenia, and Lybia; the liquor of which plant growing in thefe places is of a

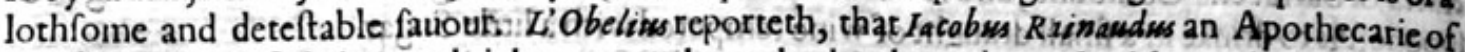
Malstiay ivas the firtt thatmadeirknowen, or brought the plants thereof to Montpellier in France, vnoolthelestndd - Rondeletins, whoright weell beholding the fame, concluded thas, of all the kindes of Ferlibawhirhthe had euer feene, shere wasnot any fo anfwerable vnto the true LAforpitivon as this:

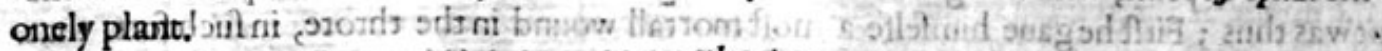

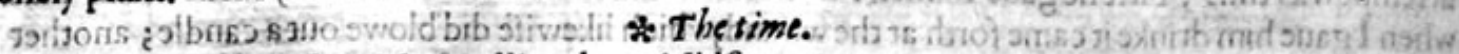

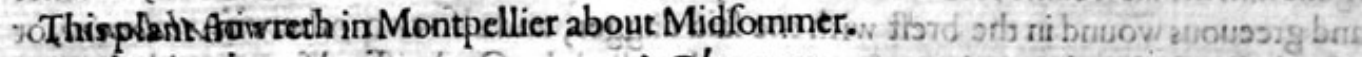

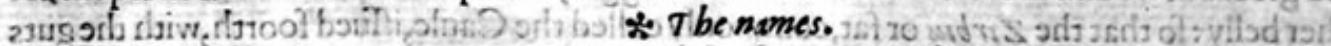

It is calle dabollatihe Laferpition : in Englifh Laferwoort and Magydare: the gam or liquor that: iffueth out of the fame is called $E$ ixcer, but that which is gathered from thofe plants that do growe in Media and Syria, is called Afs fatids.

Laferpitium elpecially the roote, is hot and drie in the third degree: La er is alfo hot and drie in the third degree, but it exceedech much the heate of the leaues, ftalkes, and rootes of Laferpitivm.

$$
\text { moitgina sh st } \mathrm{T} \text { * The vertues. }
$$

A ${ }_{25}$ Tharootes of Lesferpit twm well pouned, or ftamped with oile, fcattereth clotted blood, taketh away blacke and blewmarkes that come of bruifes or ftripes, cureth and diffolueth the Kings euill, and all hard fwellings and botches, the places being annointed or plaiftered therewith.

B Thefame rogres made into a plaifter with the oile of Ireos and waxe, doth both a flivage and cure the Sciatica, or goute of the hip or hucklebone.

C a The fane holden in the mouth and chewed, doth affwage the toothach; for they are fuch rootes as drawe from the braine a grezt quancitie of humors.

D The liquor or gum of $L_{1}$ ferpitium, efpecially the $L_{A}$ fer of Cyrene broken and diffolued in water and drunken, sakech away the hoarfeneffe that commeth fuddenly: and being fupt vp with a reare egge, eureth the cough : and taken with fome good broth or fupping, is good againft an olde pleurifie.

E Lacer cureth theiaundies and dropfie taken with dried figs : alfo being taken in the quantitie fo a cruple, with a little pepper and Myrrhe, is very good againft fhrinking of finewes, and members out of ioint.

F The fame taken with honie and yineger, or the firupe of vineger, is very good againft the falling

fickneffe.

G It is good again?t the fluxe of the bellie comming of the debilitie and weakneffe of the ftomacke, (called in Latine Caliacus mor bus) if it be taken with raifons of the funne.

H It driueth away she thakings and fhiucrings of agues, being drunke with wine, pepper, and whire Erankincenfe. Alfo there is made an electuarie thereof called Antidotum ex fucco Cyrensico, which is a fingular medicine againft feuer quartaines.

I It is excellent 2gainit the bitings of al venemous beafts, and venemous thot of darts or arrowes, not onely taken inwardly, but alfo applied outwardly vpon the wounds.

$\mathrm{K}$ Itbringeth to maturation, and breaketh all peftilentiall impoftumes, botches and carbuncles, boing applied thereto with Rue, Salt peter and honie : after the fame manner it taketh away cornes after they haue beene fcarified with a knife.

L Beinglaid to with Copperas and Verdigreafe, it taketh away al fuperfluous outgrowings of fleh, the Polypus that bapperieth in the nofe, and all fcuruie manginefle.

$M$ If it be applied with vineger,pepper and wine, it cureth the naughtie fcurfe of the head, and fal. ling off of the haire.

$\mathrm{N}$ The gum or liquor of Ls/er pitium which groweth in Armenia, Lybia, and fundry other places, is that ftinking and lothfome gum called of the Arabian Phifitions $L / A$ and $A \int f a$, as alfo with vs in fizops Affa fatidn: but the LAferpitsum growing in Cyrene is the beft, and of a reafonable pleafant fmell, and is called Lacer, to diftinguifh and make difference betweene the two iuices; though $A$ Ifo. 


\section{HISTOR HE OE PLANOTS EHI}

835 is

fatida be good for all purpofes aforefaid, yet is it not fo good as Lacer of Cyrene: it is good alfo to fmell vnto, and to be applied vnto the nauels of women vexed with the choking ot unfingot the mother.

\section{Of common Louage.}

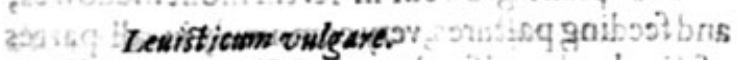 siand Common Louagedst. St. 70 bras'gnit to}

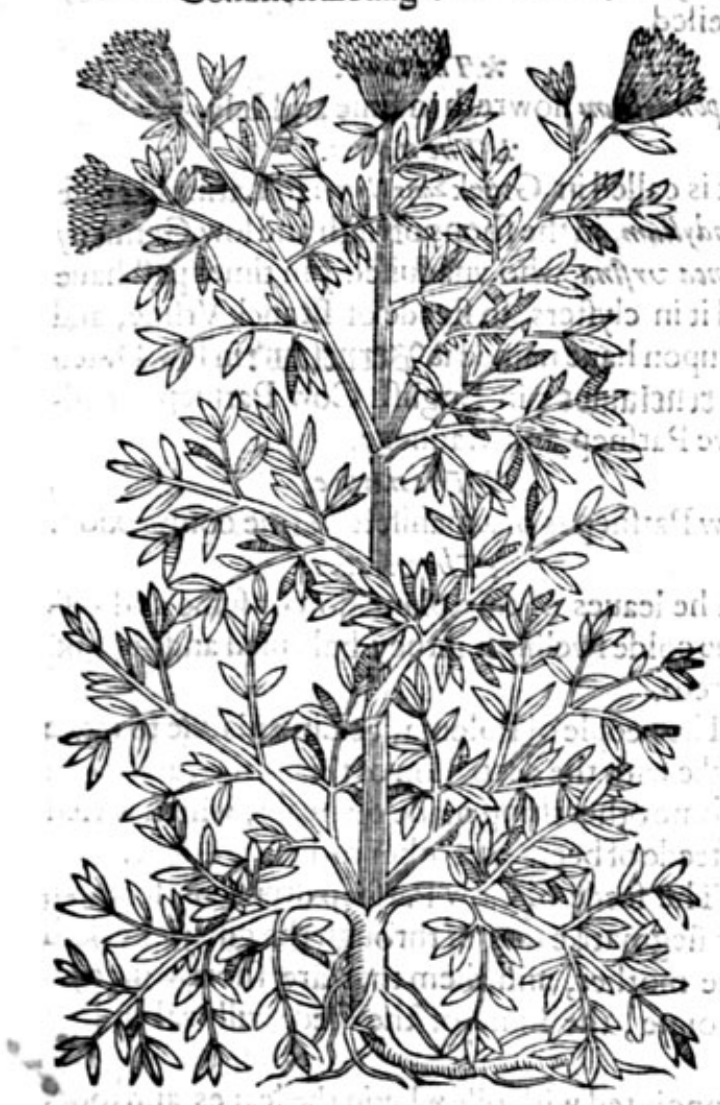

$\mathrm{A}$<smiles>[14CH3]</smiles>
.99nोs 9 woS true silic mont anam, and not Levisticion, though others alfo haue deemed it $L_{3}$ ferpitium. Thefe two fuppofitions are eafily antweted, fith they be fundrie kindes of plants, thongh verie neere in fhape and faculties one vnto another. This plane being our commion garden Louage, hath large and broad leaues, almoft like to Smallage. The ftalkesare round, hollow and knottie, chree cubits high, hauing f pokietuftes, or bufhie rundles, and at the topot theitalks of a yellow colour, a round, flat and brownefeede, like the feede of Angelica: the foote is long and thicke, and bringeth foorth cuery yeere new fterns.

$$
\text { * The place. }
$$

The right Leuisticum or Louage groweth in fundry gardens, and not wilde(as far as I knowe)in England. $\%$ T betrme.

Lounge flowreth moft cormmonly in Iuly and Aunghif. * The names.

It is called in Latin Leuffrcum \& Ligufticum: of fotne siler montastion butnot trily.in high Durch fibftecket: if Fench Linifbe: inlowe Datch

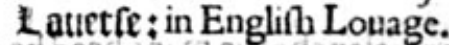
.inkos * The nature.

This plant is hot and drie in the third degree.

The rootes of Loulage are very good for all inward difeafes, driuing away ventofities or windy. $\mathbf{A}$ neffe,efpecially of the ftomacke.

The feede there of warmeth the ftomacke, helpeth digeftion, wherefore the people of Gennes, B in time paft, did vfe it in their meates, as we do pepper, according to the teftimonie of $A m$. Mufa.

The diftilled,water of Louage, cleereth the fight, and putteth away all fpots, lentiles; freckles, C and rednes of the face, if they be often wafhed therewith.

$$
\text { Of Cowe Parenep. Chap.377. }
$$

* Tbe defcription.

$T$ His plant Spondylisen groweth in all counuties and is knowne by the name of wilde $\mathrm{Parf}$ nep,or Spondylium, whereunto it effectually anfwereth, both in his grecuous and ranke fauour, as alfo in the likeneffe of the roote, whereupon it was called Spondylium, and of the Germaines Acanthus, but vntruly: the leaues of this plantare long and large, not much vnlike the leaues of wilde Parfneppe, or Panax Her aclium, decpely notched or cut about the edges like the teeth of a fawe, and of an ouerworne greene colour. The fowers grow in rufis or rundles, like vnto wilde Parfneps, the roote is like to Henbane: this herbe in eachpart thereof hath an euill layour, and differech frorn the right astanshium, not onely in faculties, buceuen in all qther things. 


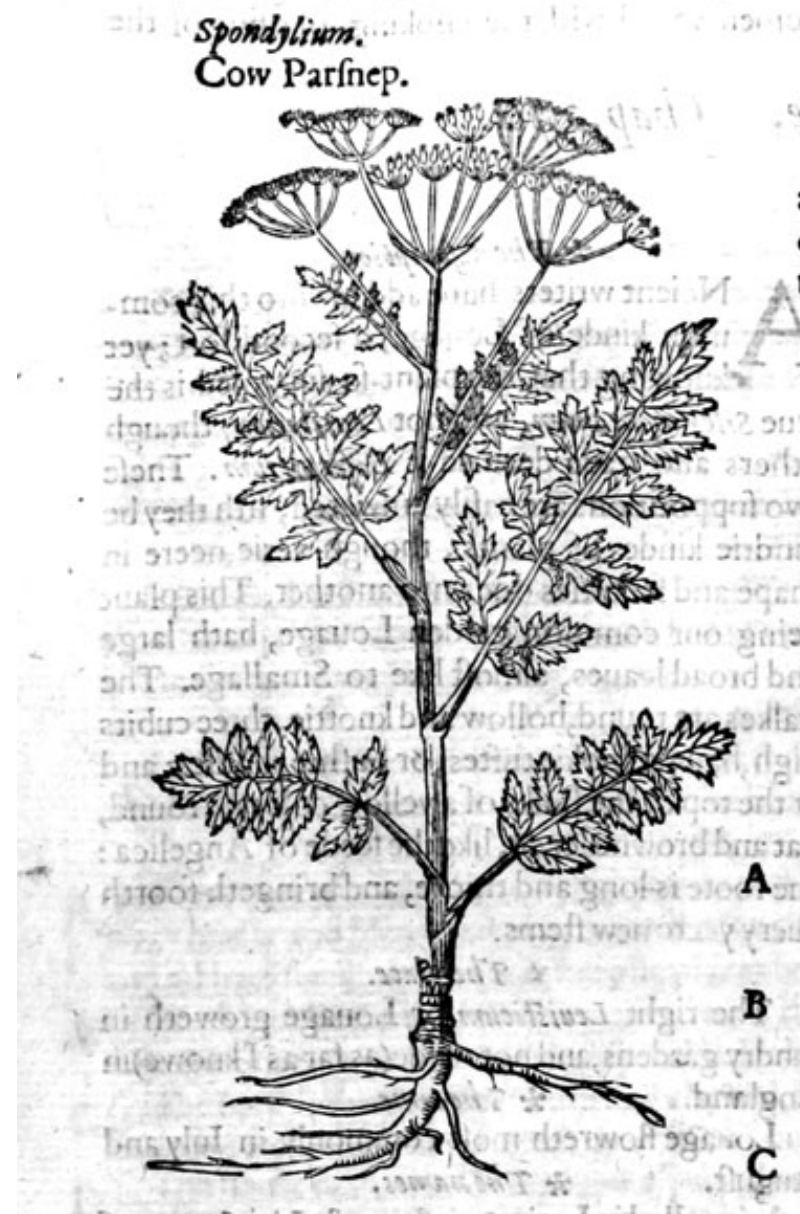

* The plase. * The place.

This plant groweth in fertill moift medowes, and feeding paitures, very commonly in all partes of England, or elfe where, in fuch places as I haue traueiled.

* The time.

spondylisum flowreth in Iune and Iuly. * The names.

It is called in Greek $\Sigma_{\pi x}$ Ninov: in Latine likewife spondyliwm, in the fhops of high and low Germany Branca vr/ina, who vnaduifedly in times paft haue vied it in clyfters, in fteede of Branck Vrfine, and therupon haue named it 2Betnclain: in low Dutch 23xrenciautue: in Englifh Cow Parfnep, meddowe Parfnep, and Madnepe.

* The nature.

Cow Parfnep is of a manifeft warme complexion. * The vertues.

A The leaues of this plant do confume and diffolue colde fwellings if they be brufed and applied thereto.

The people of Polonia, \& Lituania, vfe to make drinke with the decostion of this herbe, and leuen or fome other thing made of meale, which is vfed in fteede of beere, and other ordinarie drinke.

C The feede of Cow Parfnep drunken, fcoureth out Alegmatike matter through the guts; it healeth the iaundife, the falling ficknes, the ftrangling of the mother, and them that are fhore winded.

D Allo if a man befallen into a deadfleepe, or a fwoune, the fume of the feede will waken him againe.

$\mathrm{E}^{2 \mathrm{If}}$ If phrenetike or melancholike mans head be annointed with oile wherin the leaues and roots haue beene fodden, it helpeth him very much, and fuch as be troubled with the headach and the lethargie, or ficknes called the forgetfull euill.

\title{
Of berbe Frankincenfe. Chap. $37^{8}$.
}

\author{
* The kindes.
}

There be diuers forts of herbe Frankincenfe, as fhall be declared.

* Thedefription.

$\mathrm{T}$ Here hath beene from the beginning diuers plants of fundrykindes, which men haue termed by this glorious name Libanots, onely in refpect of the excellent and fragrant finell which they haue yeelded vnto the fenfes of man, fomwhat refembling Frankincenfe. The fent and fincll $D$ iofcorides doth afcribe to the roote of this firft kinde, which bringeth foorth a long ftalke with ioines like Fennell, whereon growe leaues almoft like Cheruil or Hernlocks, $\mathrm{fa}_{2}$ uing that they be greater, broader, and thicker: at the top of the ftalkes grow fpokie taffels bearing whitifh flowers, which do turne into fweete fmelling feede, fomewhat flat, and almoft like the feede of Angelica.The roote is blacke without, and white within, hairie aboue, at the parting of the root and Italke like vnto Mewm or Peucedanwm, and fauoreth like vnto Rofine, or Frankincenfe. 


\section{GH HISTORIEOF PLANTS. $7 \mathrm{HT}$}

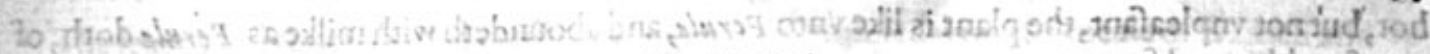
* The defcription.

.710 int boggaldistolsws

2 The fecond kinde of Libanotis hath alfo a ftraight ftalke, full of knots and ioints : the leaues are like vnto Smallaget the flowers growe in taffels like vnto the former, and bringe foorth great long, and vneuen feed, of a fharpe tafte: the roote is like the former, and fo is the whole plant very likebur leffer.
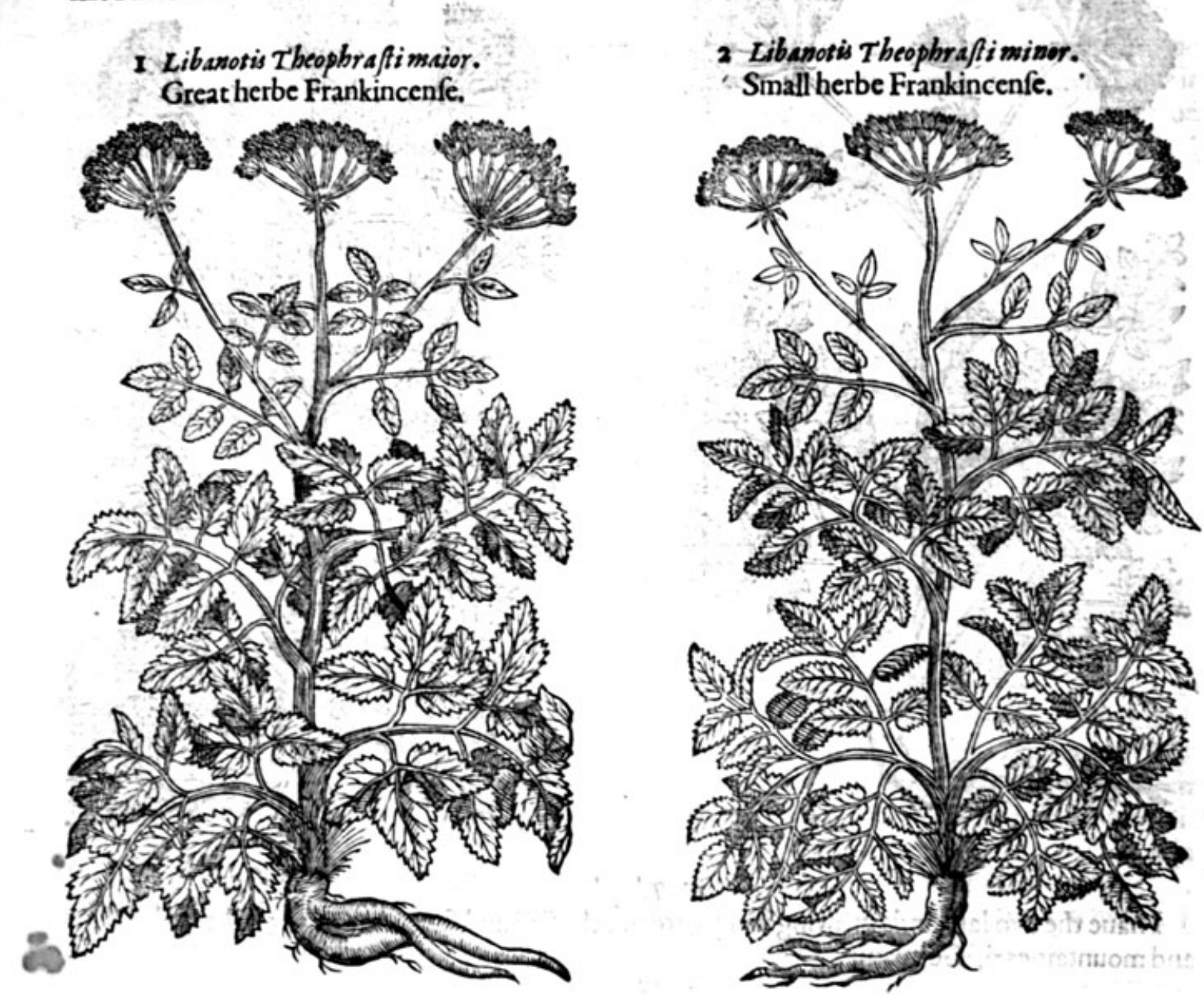

* The dejcription.

3 Thethirde' kinde of Libanotis differeth fomewhat from the others in forme and hape, yet it agrecth with them in fmell, which in fome fort is like Frankincenfe: the leaues are whiter and rougher then the leaues of Lactuca agreft is: the ftalkes do growe to the height of two cubits, bearing at the toppe the fpokie tufts of Dill, fomewhat yellowe: the roote is like the former, but thicker, and wanteth,the hairie taffels at the toppe of the roote, which the other haue, before rehearfed.

4 I cannot finde among all the plants called Libanotides, any one more agreeable to the true and right Libanotis of Diofeorides then this herbe, which arifeth vp to the height of fiue or fixe $\mathrm{Cu}$ bits, with the cleere fhining ftalks of Ferwla, diuiding it felfe from his knotcie ioints into fundrie armes or branches, fet full of leaues like Fennell, but thicker and bigger, and fatter then the leaues of Cotula fetida, of a grayinh greene colour, bearing at the toppe of the ftalkes the rufts of Ferula, or rather of Carrots, full of yellowe flowers: which being paft there fuccedethlong flat feed like the feed of the Afh tree, fmelling like Rofin, or Frankincenfe, which being chewed fillech the mouth with the tafte of Frankincenfe, but fharper:al the reft of the plant is tender, Sx fomwhat 
hot, but not vnpleafant, the plant is like vnto Ferula, and aboundeth with milke as Ferwla doth, of a reafonable good fauour.

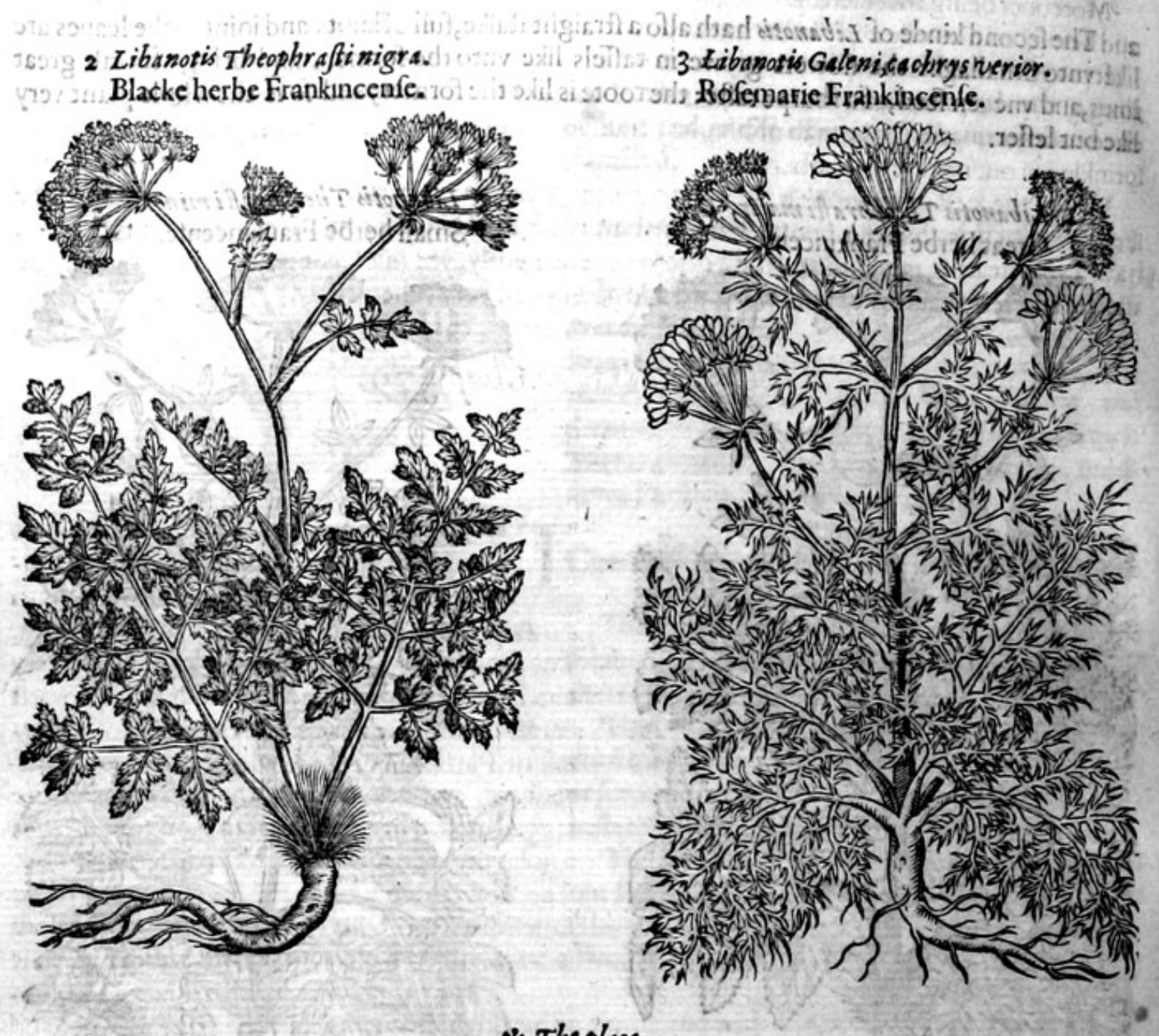

* The place.

Ihaue the two laft kinds growing in my garden; the firft and fecond grow vpon the high deferts and mountaines of Germanie.

Thefe herbes do flower in Iulie and A uguft.

\section{* The time.}

* The names.

Thefe plants are called in Greeke $A$ Gaveris, bicaufe their rootes do fmell like incenfe, which is called in Grecke $\lambda$ íavos: in Latine Rofmar inus; the firft may be Englifhed great Frankincenfe Rofemarie; the fecond fmall Frankincenfe Rofemarie; mafter Lite calleth the thirde in Englifh black Hart roote; the fourth white Hart roote : the feede is called Cachrys, or Canchrys. * The nature.

Thefe herbes with their feedes and rootes are hot and drie in the fecond degree, and are of a digefting, diffoluing, and mundifying nature.

\section{* The vertues.}

A The leaues of Libanotis pouned, do ftoppe the fluxe of the Hemorrhoides or piles, and do fupple the fwellings and inflammations of the fundament called Condilomat $a$, concocteth the fwelling of the throte called Strumas, and ripeneth botches that will hardly be brought to fuppuration or
ripeneffe.

B The iuice of the leaues and rootes mixed with honie, and put into the eies, doth quicken the fight, and clecreth the dimneffe of the fame. C The feede mingled with honie,doth fcoure and clenfe rotten vlcers, and being applied vnto cold
and hard fwellings confumeth and wafteth them. 
The leaues and rootes boiled vntill they befoft; and mingled with the meale of Darneli and vi-D neger,afwageth the paine of the gout, if they be applied thereto.

Moreouer being receiued in wine and pepper; it helpech Mor beem regizm, and prouoketh fiveate, E and being put intỏ oile and vfed as an ointinent, it cureth ruptures alfo.

It purgech the difeafe called in Greeké sipes: in Latine $V^{\prime}$ itilige,or Impot igo,that is the white fpot- F tines of the skin, chaps, or rifts in the palmes of the hands, and tioles of the teete, and by your patiencecofingermane to the icabof Naples, tranfported or transferred into France, and pretily well fprinkledin our northern coafts.

When the feed of Libanut is is put into receiptes, you muft vnderftand, that it is not meant of the $\mathrm{G}$ feede of Cachris; bicaufe it doth with his ibarpneffe exafperate or make rough the gullet, for it bath a very heating qualitic, and doth drie very vehemently, yea this feede being raken in wardly, or the herbeit felfe, cauieth to purge vpward and downward very vehemencly' $3 \operatorname{sic}^{2}$ moriti.

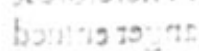

ib cis Coriundram.

Corianders.

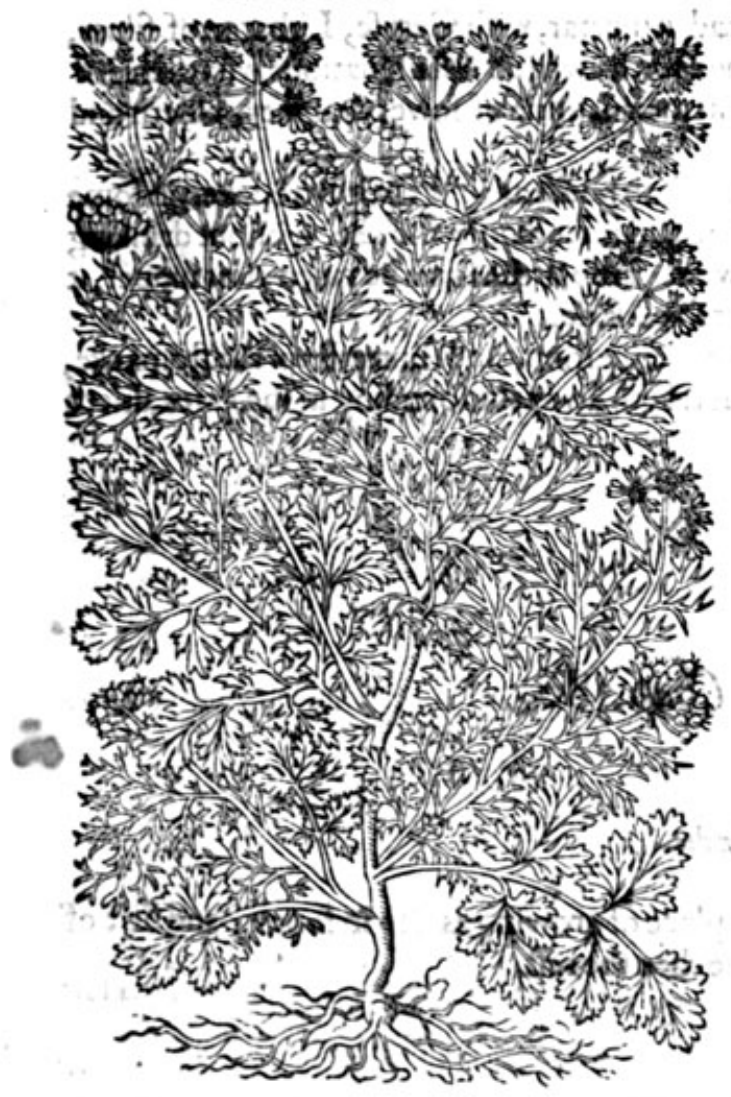

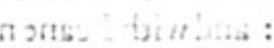

$*$ The defription.
+ He firt or common kinde of Coriander is The firt or coinmon kinde of Coriander is ? a very ftinking herbe, finelling like theftinking worme called in Latine Cmex. it hath a round ftalke full of branches, two foote long, The leaues are of a faint greene colour, very $H$ much cut or iagged: the leanes that growe loweft \&cfpring firft, are almoft like the leaues of Cheruill or Parfley, but thofo which come foorth afterward, and gtowe vpon the ftalkes; are more iagged,almof like the leaues of Fumitory, a great deale finaller, tenderer, and more iagged. The flowers are white, and do growe in rounde taffels like vnto Dill. The feede is round, hollow within, and of a pleafant fent and fauour when it is dric. The roote is harde, and of a woodie fub. ftance, which dieth when the fruite is ripe, and foweth it felfe from yecte to yeere, whereby it mightily increafeth.

There is a fecond kinde of Coriander very like vnto the former, fauing that the fruit thereof is greater, and growing togither by couples, is not fo pleafant of fauour nor tafte, being a wilde kinde thereof, vnfit either for meate or medicine.

$$
\text { * i be place. }
$$

Coriander is fowen in fertil fieids and gardens, and the firft doth come of it felfe from time to time in my garden, though I neuer fowed the fame but once.

* The time.

They flower in Iune and Iuly, and deliuer their feede in the end of Auguft.

* $t$ be names.

The fieft is called in Latine Coxiendruon: in Englifh Corianders. The fecond Corianidruni alteriem, wilde Corianders.

The greene and ftinking leaues of Corianders are of conplexion cold and dry, and very naught vnwholefome and hurtfull to the bodie.

The dric and pleafant well fauoring feede is warme, and very conuenient to fundrie purpofes.

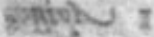


* The vertues.

A Coriander feede prepared and couered with fugar, as comfits, taken after meate clofeth vp the mouth of the ftomacke, ftaieth vomiting, and helpeth digeftion.

B The fame parched or rofted, or dried in an ouen, and drunke with wine, killeth and bringeth foorth wormes, ftoppeth the laske, and bloodie flixe, and all other extraordinarie iffues of blood.

The manner how to prepare Coriander, both for meate and medicine.

C Take the feede well and fufficiently dried, whereupon powro foine wine and vineger, and foleaue them to infufe or fteepe foiver and twenty howers, then take them foorth and drie them, and kecpe them for your vfe.

D No Apothecarie ought to fell the feede of Coriander to any perfon, except it be firft prepared in manner abouefaid, neither ought they to coter the fame with fugar in comfits, nor toput the fame in medicine: for although the feede well dried be of a good tafte, yet is it not altogither voide of fome of that filthie and venemous qualitie, which remaineth in the greene herbe. Wherefore it is not to be vfed in medicine without great care, for that there hath often great danger enfued vpon the immoderate and vndifcreete vfe thereof.

E The greene leaues of Coriander boiled with the crums of bread or Barly meale, confumeth all hot fwellings and intlammations: and with Beane meale diffolueth the Kings euill,wens, and hard lumpes.

F The iuice of the leaues mixed and laboured in a leaden mortar, with Cerufe, Litharge of filuer, vineger and oile of Rofes, cuteth S.Anthonies fire, and taketh away all inflammations whatfoeuer.?

G The iuice of the greene Coriander leaues, taken in the quantitie of fower dragmes, killeth and poifoneth the bodic.

H Thefeedes of Coriander prepared with fugar,preuaileth much againft the gowte, taken in fome fmall quantitie before dinner vpon a fafting ftomacke, and after dinner the like, without drinking immediately after the fame, or in three or fower howers. Alfo if the fame be taken after fupper, it preuaileth the more, and hath more fuperioritie ouer the difeafe.

I Alfo if it be taken with meate fafting, it caufeth good digeftion, and hutteth rp the ftoma cke, keeping away fumes from rifing vp out of the fame: it taketh away the founding in the eares, drieth vp the rheume, and eafeth the fquinancie.

\section{Of Parlley. Chap.380.}

* The kindes.

Therebe diuers forts of Parfley, differing in their place of growing as alfo in forme, and firft of 1 Garden Parlley, which is more familiarly knowne then the reft.

\section{* The defcription.}

I He leaues of garden Parlley are of a beautifull greene, confifting of many little ones fiftned togither, diuided molt commonly into three parts, and alfo fniptrounde about the edges: the ftalke is aboue one cubite high,flender,fomething chamfered, on the top wherof ftande fpoked rundles, bringing foorth very fine little flowers, and afterwards fmall feedes fomewhat of a fierie tafte:the roote is long and white, and good to be eaten.

2 There is another garden Parfley in tafte and vertue like vnto the precedent: the onely difference is, that this plant bringeth foorch leaues verie admirablie crifped or curled like fannes of cur:led feathers, and the other not fo. 


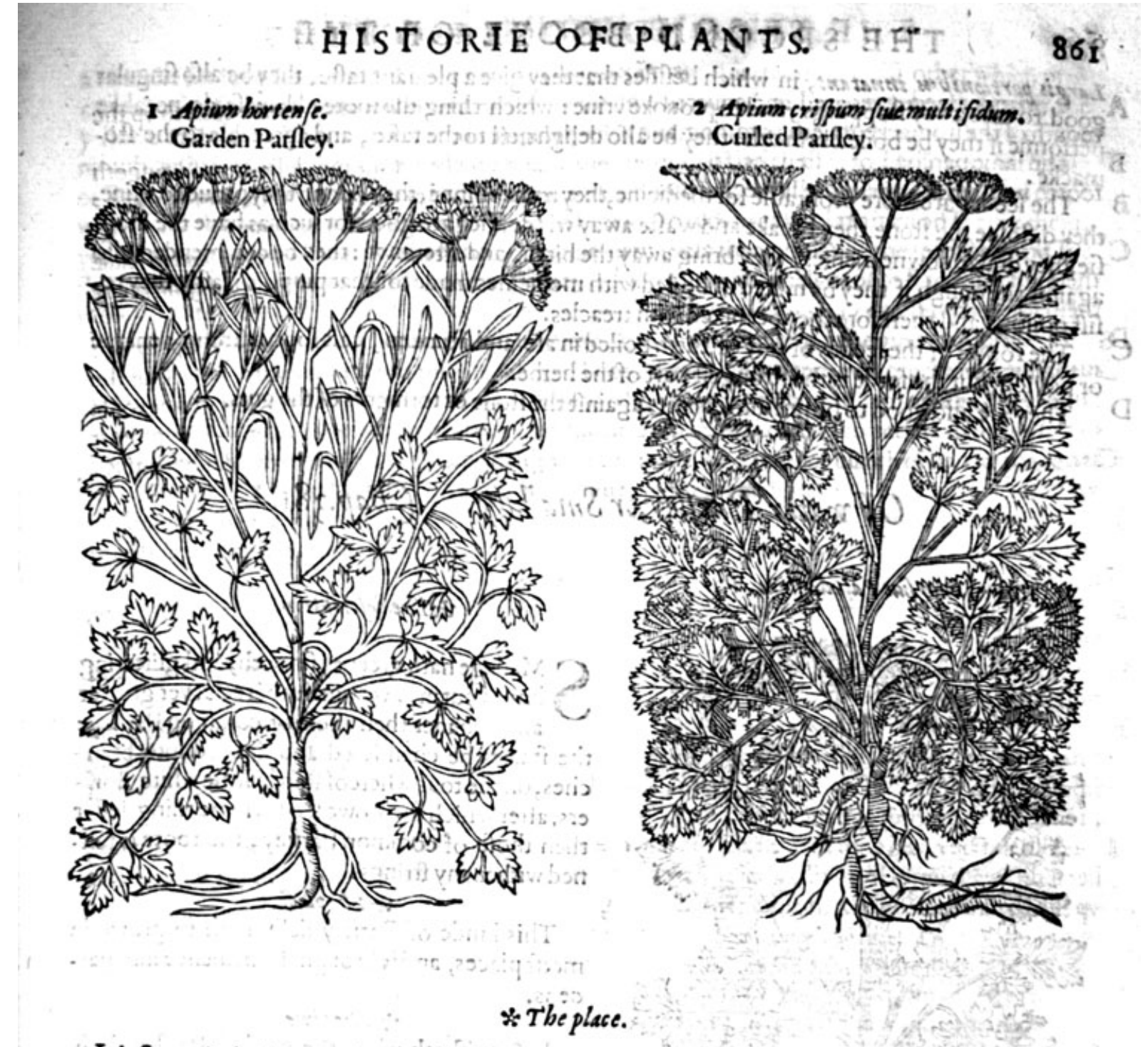

It is fowen in beds in gardens; it groweth both in hot and colde places, fo that the grounde be cither by nature moift,or be oftentimes watered: for it profpereth in moilt places, and is delighted with water, and therefore it naturally commeth vp neere to fountaines or fprings: Fuchfous writeth
that it is found growing of it felfe in diuers fennic grounds in Germanie.

It may be fowen betime, but it flowly * Thetime.

bringeth foorth his ftalkes the fecond yeere ; * the feedes be ripe in Iuly or Augut.
\[ \text { Thes. } \]

Euery one of the Parlleyes is called in $*$ The names.

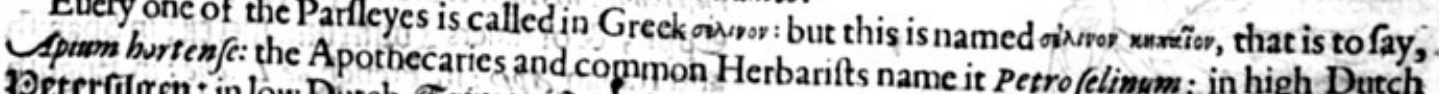
jeterfilyen: in low Dutch Ctimen jetetíelie: in French du Perft: and Salfa : in Italian Fetrofells: in Englifh Perfele, Parfely, common Parfely, and garden Parfley. tooke his name, and the beft is in Macedonich which groweth among rocks and ftones, wherupon it Parfley doth not differ from Stone Parflenia: therfore they are deceiued who thinke that garden is of leffe force then the wilde; for wilde herbes are the onely difference is, for that garden Parfley garden.

Garden Parfley is bot and dry, but the The temperature. gree, and dry almoft in the thirde: the roote is alfo of a moderate heate. The leaues are pleafant in fauces of $*$ The vertwes. The leaues are pleafant in fauces, with broth, as Plinie writeth in his 20 . booke Ir.chapter, A 
Largis portionibus innatant, in which befides that they give a pleafant tafte, they be alfo fingular good to take away ftoppings, and to prouoke vrine: which thing the rootes likewife do notablie performe if they be boiled in broth : they be alfo delightfull to the tafte, and agreeable to the fto.

B The feedes are more proficable for medicine, they make thinne, they open, they prouoke vrine, they diflolue the ftone, they breake and wafte away winde, they are good for fuch as haue the dropfie, they drawe downemenfes, they bring away the birth, and afterbirth: they be commended alfo againt the cough if they be mixed or boiled with medicines made for that purpole : lafty they refift poifons, and therefore they be mixed with treacles.

C The rootes or the feedes of any of themboiled in ale and drunken, calt foorth ftrong venoms or poyfon, but the feede is the iftongeft part of the herbe.

D They are allo good to be put into clyfters algainft the ftone or torments of the guts.

\section{Of water Tarfley, or Smallage. Cbap. 381 .}

Eliofelinum fine Paludapiun.

Smallage.

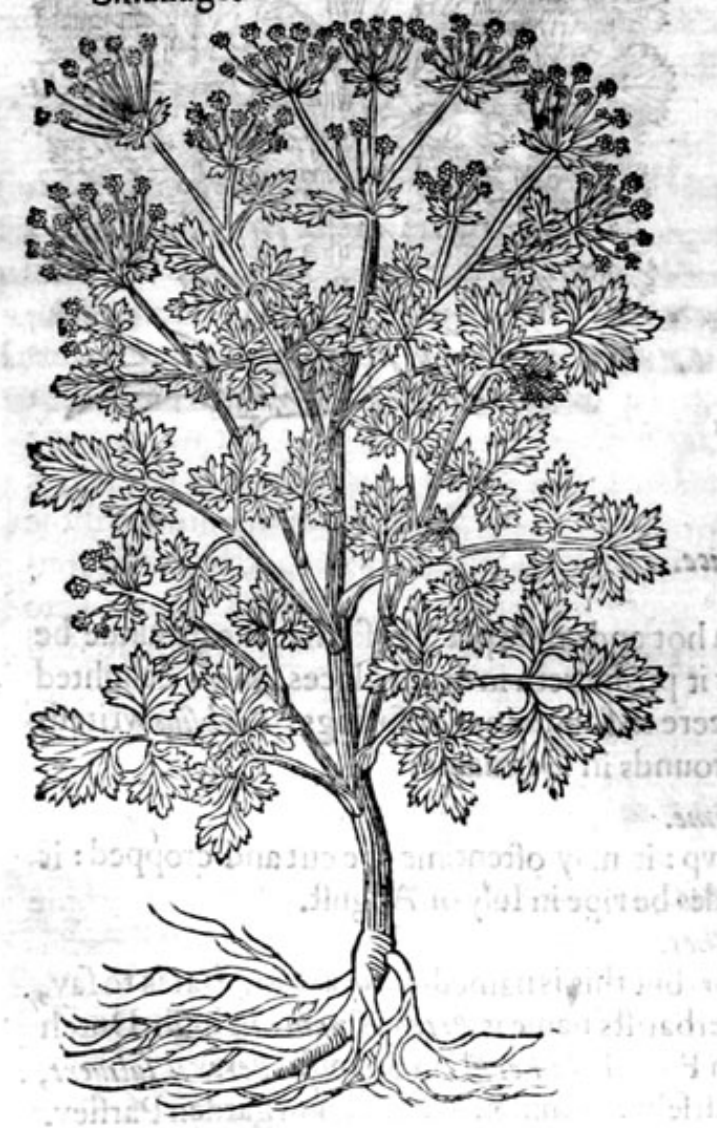

$*$ The temperature.

This Parlley is like in temperature and vertues to that of the garden, but it is both hotter and drier, and of a more force in moft things : this is not woonted to be eaten, neither is it counted good for fauce, but it is not vnprofitable for medicine.

*. $T$ he vertues.

A The iuice thereof is good for many things, it clenfeth, openeth, attenuateth or maketh thinjit remoutcth obftructions, and prouoketh vrine, \& therfore thofe fyrups, which hath this mixed with them, as that which is called Syrupus bizantinu, open the ftoppings of the liuer and fplcene, and is 


\section{HISTORIE OF PLANTS.}

a vemedie for long lafting agues, whether they be tertians or quartains, and all other which proceede both of a colde caufe and alfo of obftructions or ftoppings, and are very good againft the yellowe iaundife : the fame iuice doth perfectly cure the malitious and venemous vlcers of the mouth, and of the almonds of the throte with the decoction of Barley and Mel Rofarkm, or honie of Rofes added, if theparts be wafhed therewith : it likewife helpeth all outwarde vlcers land foule woundsi with honie it is profitable alfo for cankers exulcerated, for although it can not cure them, yer it doth keepe them from putrifaction, and pteferueth them from ftinking : the feede is good for thofe things for which that of the garden Parlley is : yet is not the vee theteof fo fafe, for it hurteth thole that are troubled with the falling ficknes, as by euident proofes it is very well knowne.

Smallage as $P$ lingwriteth, hath a peculiar verttie àgainft the biting of venemous fpiders.

The iuice of Smallage mixed with honie and beane flower, doth make an excellent mudifica- C tiue for old vlcers and malignant fores, and ftaieth alfo the weeping of the cut or hurt finewes in fimple members, which are not very fattic or flefhie, and bringeth the fame to perfect digeftion.

The leaues boiled in hogs greafe and madeinto the forme of a pultis, takethaway the paine of $\mathbf{D}$ felons and whitlowes in the fingers, and ripeneth and healeth them.

\section{Of Mowntaine Parfley. Chap.382. A}

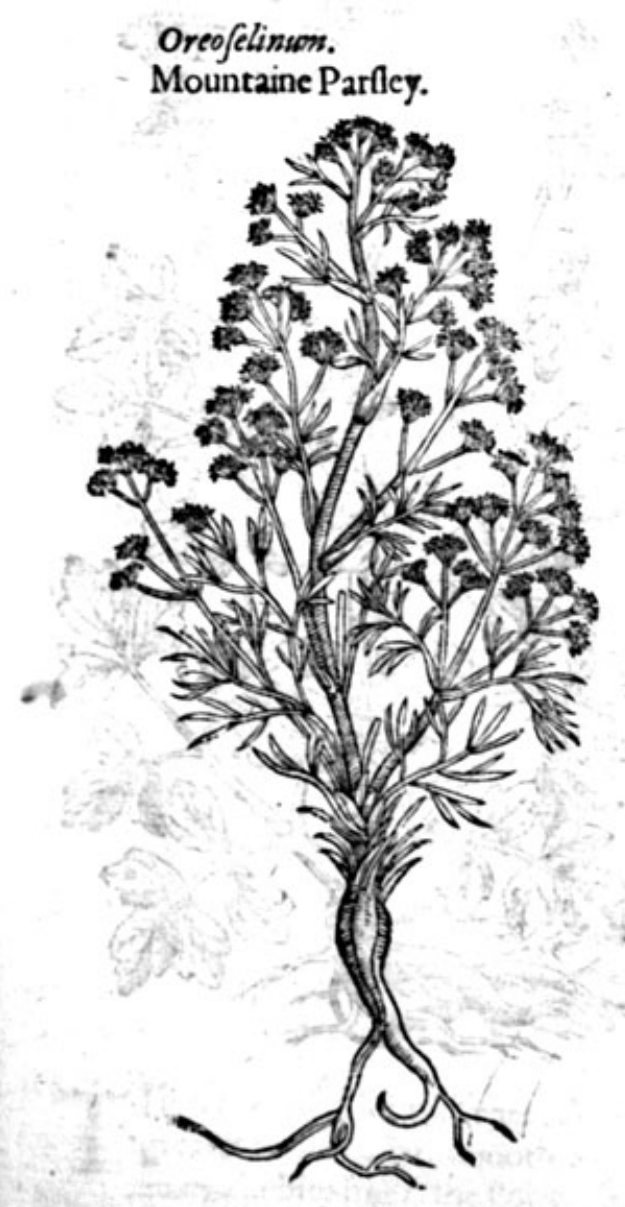
coldiffer from Diofcorides maketh Petrofelimum or ftone Parfley to to be that which groweth on rockes : for rocke Parfley is another plant, of fome it is called đitel. Butta : in Latine Mwiriboms (in Englifh Much good:) for it is fo named bicaufe it is good \& profi. table for many things, and this is not altogither vnproperly termed Oreofelimom, or mountaine Parfley; for'tit growethas we haue faide on mountaines, and is not vnlike to ftone Parfley : the feede is 
864

\section{THE SECOND BOOKE OF THE}

not like to that of Cumin, for if it were fo, who woulde denie it to be Oreofelinwn, or Diofcorides mountaine Parley.

\section{* The temperature and vertwes.}

A Oreofelinum, or mountaine Parfley is as $G$ alen faith, like in faculty vnto Smallage,but more effec. tuall; Diogcorides writeth that the feede and roote being drunke in wine prouoketh vine, bringeth downe the menfes, and that it is mixed with counterpoifons, piffing medicines, and medicines that are hot.

B The roote of Veelgutta, or Much Good, is alfo hot and drie, and that in the latter ende of the fecond degree, it maketh thin, it cutteth, openeth, prouoketh, breaketh the ftone, and expelleth it, openeth the ftoppings of the liuer and fpleene, and cureth the yellowe iaundife, being chewed it helpeth the toothach, and bringeth much water out of the mouth.

\section{Of ftone Parfley of Macedonie. Chap. 383 .}

I Petrofelinum Macedonicum Fuchsy. Baftard ftone Parfley.

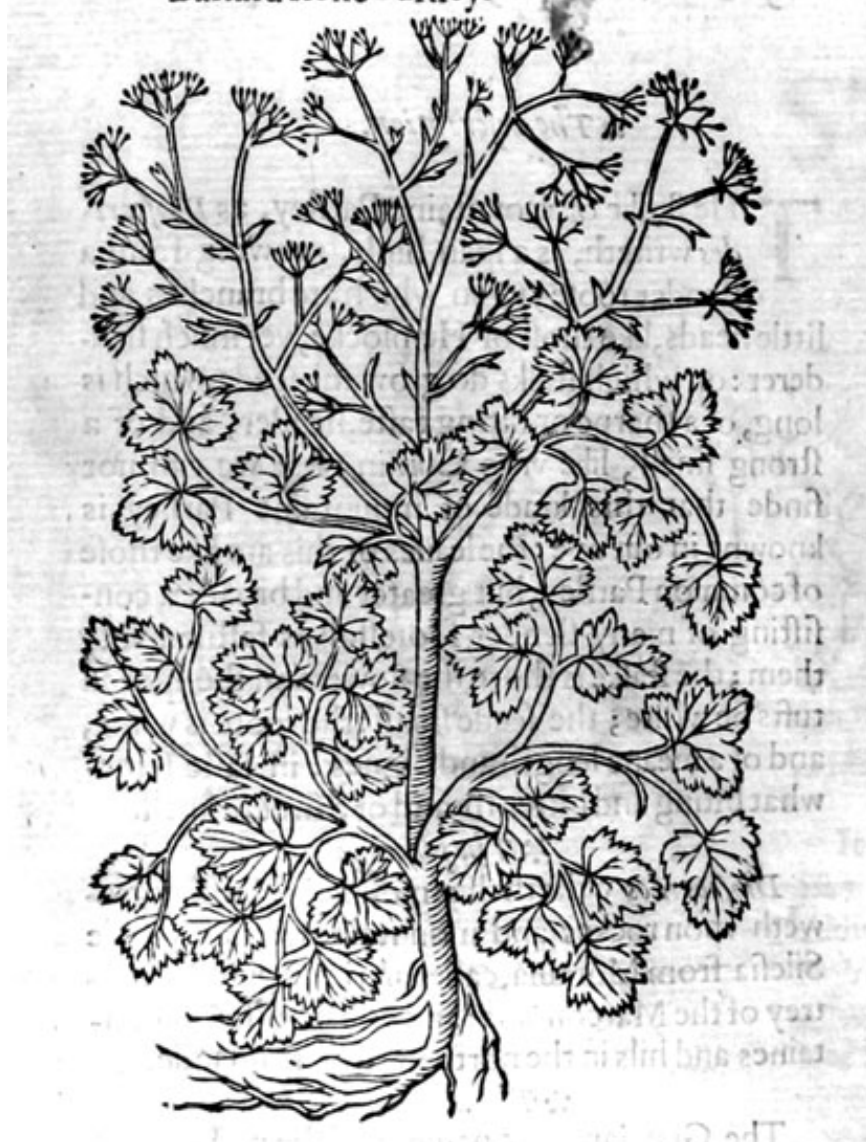

1 Petrofelinum Macedonicum verum. The true Parfley of Macedonia.

\section{* The defoription.}

Fiftone Parfley very little is written by the olde writers, Diofcorides onely faith that this hath feede like to that of Ameos, but of a more pleafant fmell, Mharpe, aromaticall, ot fpiced : touching the forme of the leaues, the colour of the flowers, and farhion of the roote he writeth nothing at all :and $P$ linie is more breefe; as for $T$ beophraftus he doth not fomuch as name i, making mention onely of Paraley, Alexanders, Smallage, and mountaine Paraley. 
I For fton: Parfley Leonhart ius Fuchfius hath fet downe a plant, hauing leaues not fpred and cue after the maner of garden Parfley, but long, and inipped round about, made vp and faftuted to a rib or ftem in the midit, fornthing like, but yet not altogither to the firft leanes of the leffer Saxifrage; the ftalke is flender, and a cubite high; the fowers on the fpoked tufts are white: the feed fomthing blacke, like to that of Ameos, and garden Parnley, very fwecte of finell, fomthing fharpe or biting: the roote is flender and full of ftrings.

2 L'Obelins alfo in fteede of the r:ght ftone Parfley defcribeth another, which the Venetians call Atone Parfley of Macedonia, this hath le aues tike thofe of garden Parfley, or of Saxifrage rather:the ftalke is a cubite high; the fpoled tufts fomething white : the feede friall, quickly vading (as he faith)inferior to that of garden Parfley in temperature and vertues: but whether this be the true and right ftone Parfley, he addeth, hẹe iș ignorant.

$$
\text { * The place. }
$$

It groweth on craggie rocks, and among ftones: but the beft in Macedonia whercupon it beareth the furname Macedontciun, of Macedonia.

It Aowreth in the fommer moneths,

$$
\text { * The time. }
$$

\section{* 7 henames.}

It is called in Greeke nororitaror, of the ftonie places where it grotieth $:$ in Latine Petrapitom, \& Petrofelinwom Macedonicum : in Englifh ftone Parfley: the Apothecaries know it not: they are farre deceiued that would haue the herbe which Fuchyius pictureth to be Anomom: for Amomom differetb from this, as it is very plaine by the defeription thereof in Dio/corides: but we holde this for the trueftone Parfley, till fuch time as we maylearne fome other more like in leafe to the Parfeies and in feede, fuch as that of ftone Parfley ought to be : and the very feede it felfemay caufe vs to holde chis opinion, being fo agreeing to the defctiption as no herbe more ; for it is tharpe \& biting, and of a fweeter fmelt then is that of Ameos, and of a more fpicie fent; yet do not the leaues gainfaie it, which though they haue not the perfect forme of other Parfleyes, yet notwithftanding are
not altogither vnlike.

The feede of ftone Parfey which * Thetemperature. ting qualitic.

\section{* Tle vertues.}

and colick gut, and gripings in confuner of winde stis a remedie againit paine in the fides, aith, afuor, that is to fay, awalter or A in counterpoifons: Diojcorides.
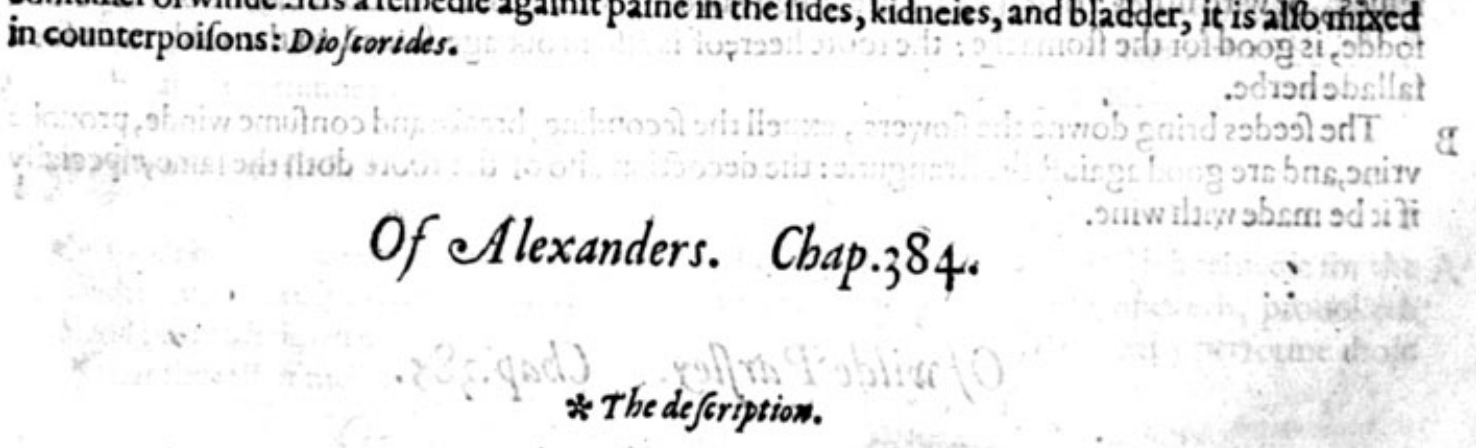

$\mathrm{T}$ Heleaues of Alcxander are cut into many parcels like thofe of Smallage, but they be much greater and broader, fmooth alfo, and of a deepe greene colour : the ftalke is thicke often times a cubite high : the flowers be white, and growe ypon fpoked tufts : the feede is thicke,
long, blacke, fomething bitter, and of an aromaticall or fpicie fnell: the roote is thicke, blatke
without, white within, like to a litle Radif without, white within, like to a litle Radifh, \& is good to be eaten, out of which being broken or cut, tafte vnto Myrrhe: which thing alfo theopheth thieke, hauing in it a fharpe bicterneffe, like in inice like Myrrhe. 


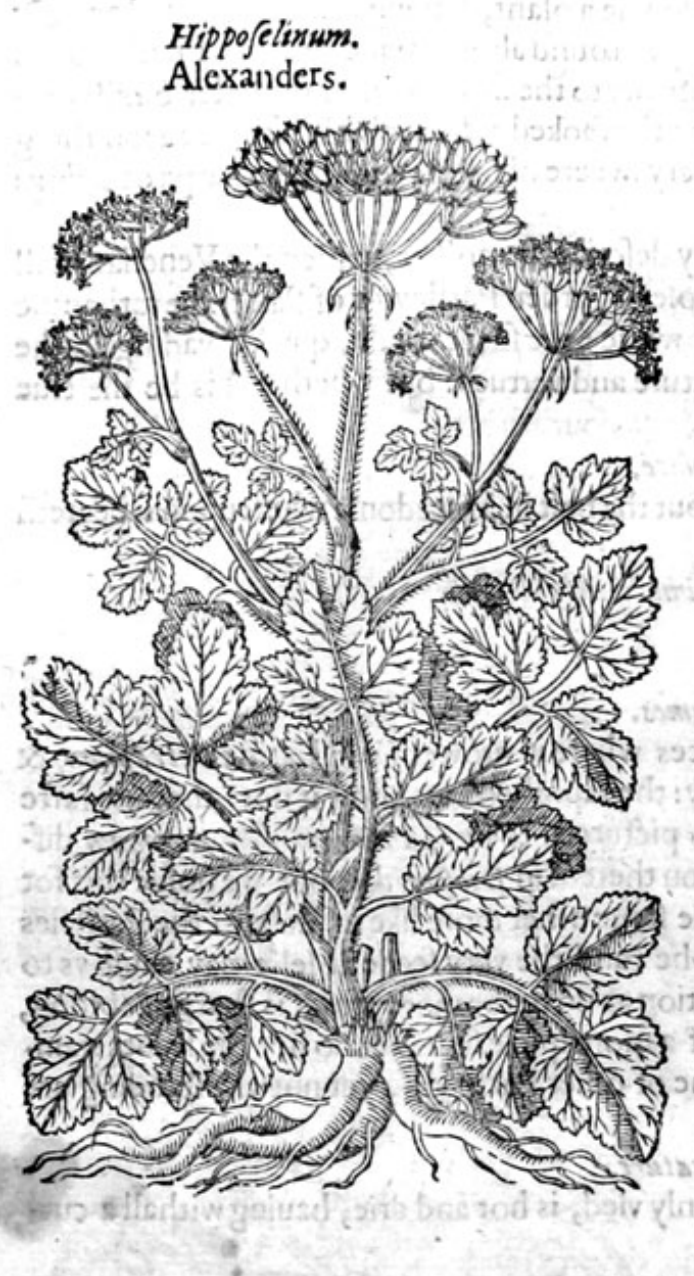

* Theplace.

Alexanders or great Parlley, groweth in moft places of England.

* 7 be time.

The feede waxech ripe the fecond yeere, in the month of Augurt.

* The names.

It is called in Greeke of the greatnes, wherein it excelleth the other Parfleyes izmoineson, or gteat Parlley; of Gaza Eguapium : it is alfo named Oltus atrum, or blacke Potherbe, and of diuers Sylueflre apium, or wilde Parfley; of Galen and certaine others ousprior, by reafon of the inice that iffueth foorth thereof, that is, as we havie faide, like vnto-Myrrhe, which is called in Greeke ovepipiov: there is alfo another Smyrnium of mount Aman, of which we doe write in the Chap. 387 . the Apo, thecaries cal it Petrofelinum Ma cedonicum: others Petrofelinum Ullexandrimum: the Germaines 5zol3 Epfich: thelowc Countrie men 1 Peterfelie bam 29 atrionion: in Spanifh Perexil Macedonico: the French and Englifhmen Alexandre, Alexander.

\section{* The temperature.}

The feede and roote of Alexanders, is no leffe hot and drie then are thofe. of the garden Parfley, they clenfe and make thinne, beinghot and drie vatros in the thirde degree.

* The vertues.

A Diofcorides faith, that the leaues and ftalkes are boiled and eaten, and dreffed alone by themfelues, or with filhes: that they are preferued rawe in pickle: that the roote eaten both rawe and fodde, is good for the ftomacke: the roote heereof is alfo in our age ferued to the table rawefora falladeherbe.

B The feedes bring downe the flowers, expell the fecondine, breake and confume winde, prouoke vrine, and are good againft the ftrangurie: the decoction alfo of the roote doth the fame, efpecially if it be made with wine.

\section{Of wilde Parfley. Chap.385.}

\section{$*$ The defcription.}

$\mathrm{T}$ His is like to the kindes of Parfleyes in the fundrie cuttes of the leaues, and alfo in thebig. neffe; for they be broad, and cut into diuers parcels : the ftalkes are round, chamfered,'fet with certaine ioints, hollow within, a cubite high or higher, two or three comming foorth togither out of one roote, and in the neather part many times of a darke reddifh colour. The flow: ers be white, and growe vpon fpoked tuftes : the feede is round, flat, like that of Dill : the roote is white within, and diuided into many branches and ftrings. This plant in what part focuer it be cut or broken,yeeldeth foorth a milkie iuice. 


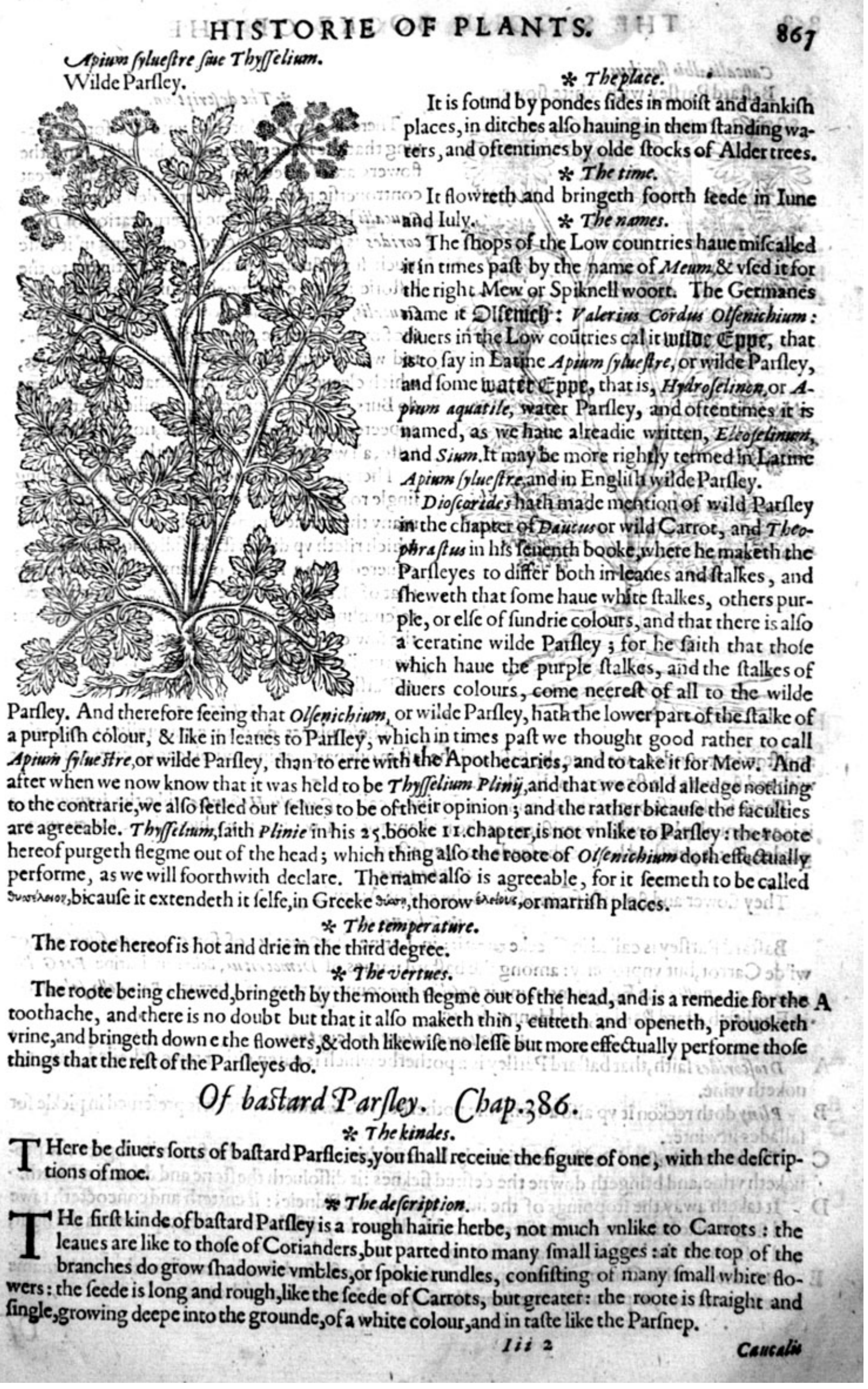


Callcalisalbis floribus.

Baftard Parfley with white flowers.

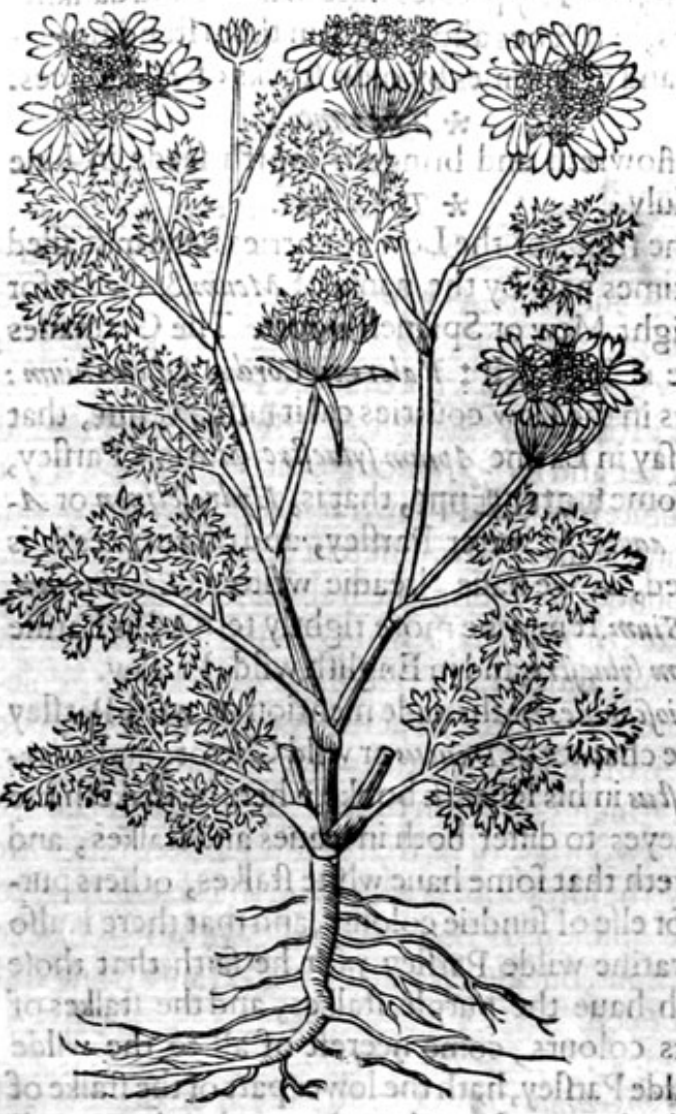

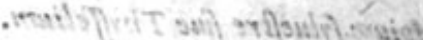 \\ * The defcription.}

There is another fort like vnto the former, $\mathrm{fa}_{\mathrm{a}}$ uing that the leaues heereof are broader, and the flowers are of a reddifh colour: there hath great I controuerfic rifen about the true determinationiof I G Gucalis, bicaufe the Latine interpretation of Diof corides is greacly fufpected, conteining in it felfe much fuperfuous matter, not pertinent to the hiftorie : but we deeme thate this plant is the true Quncalis, the notes fet downe declare it fo in be: the flowers, faith he, are reddith: the feedes couc. sf ord with a rough huske fer abour with prickles, t b mhich cleauc vnto garments that it touchethias de Burs, which roughnes being pilled off, the feed appeereth like vned hulled Otes, not vnpleafant in tafte, all which do Thew it to be the fame.

There is bikewife another fore that hath a long a fingle roote, thrummed about the vpper ende with grismany thrummic threds, of a browne colour: from which rifeth vp diüers ftalks full of ioints or knees, couered witha fheath or skinnie filme, like vnto that of Meins : the leaues are finely cut or iagged, tefembling the leaues of our Englifh Saxifrage: the flowers growe ac the top of the ftalkes in fpottie rundles fike Fennell: the feede is fmall like that ofParley.

\section{isjilo is $\%$-Theplase.}

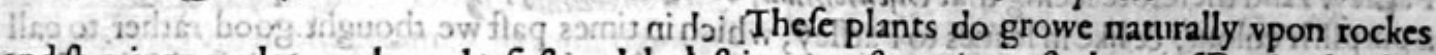
and fton iegroundes, we haue the furf and thelaft in our paftures in moft places of England: that with red flowers is a ftranger in Eugland.

There is likewife one of thefe founde in Spaine, calied Causalis Hifpanica, like the former; but it is an annuall plant; which perifheth at the firft approch of winter, the which I haue fowen in my garden, but it perilhed before the feede was perfected.

30 d a

They flower and flourilh from Maie to the end of Augurt.

$$
\text { * } 7 \text { he names. }
$$

Baftard Parfley is called in Greeke vevoris : in Latine alfo Caucalis, of fome Daucus fylweftris, or wilde Carrot, but vnproperly: among the baftard names of Democrits, Beisr: in Latine Pes GalliA. naceus, Pes Pulli: the Egyptians name it Sejelis; the countrey men of Hetruria Petrofelle falmatico: in Englifh baftard Parfley, and Hennes footc.

\section{stoth $\quad *$ The tempcrature and vertues.}

A Diofcorides faith, that baftard Parfley is a potherbe which is eaten either rawe or boiled, and prouoketh vrine.

B Pliny doth reckon it vp alfo among the potherbes: Galen addeth, that it is preferued in pickle for failades in winter.

C The Ieede of baftard Parfley is cuidently hot and drie, and that in the feconde degree: it prouoketh vrine, and bringeth downe the defired ficknes : it diffolueth the ftone and driuethit foorth.

D It taketh away the itoppings of the liuer, fpleene, and kidneies: it cutteth and concoeterh rawe and Aegmatike humours : it comforterh a colde ftomacke, diffolueth winde, it quickneth the fight, and refrefheth the hart, if it be taken fafting.

E Muthroius in his Commentaries vpon Diofcorides, the feconde booke, attributeth vnto it manie excellent vertues, to prouoke venerie and bodily luft, and erection of the parts. 


\section{HISTORIE OF PLANTS!}

\section{of Candie Alexanders. Chap.387.}

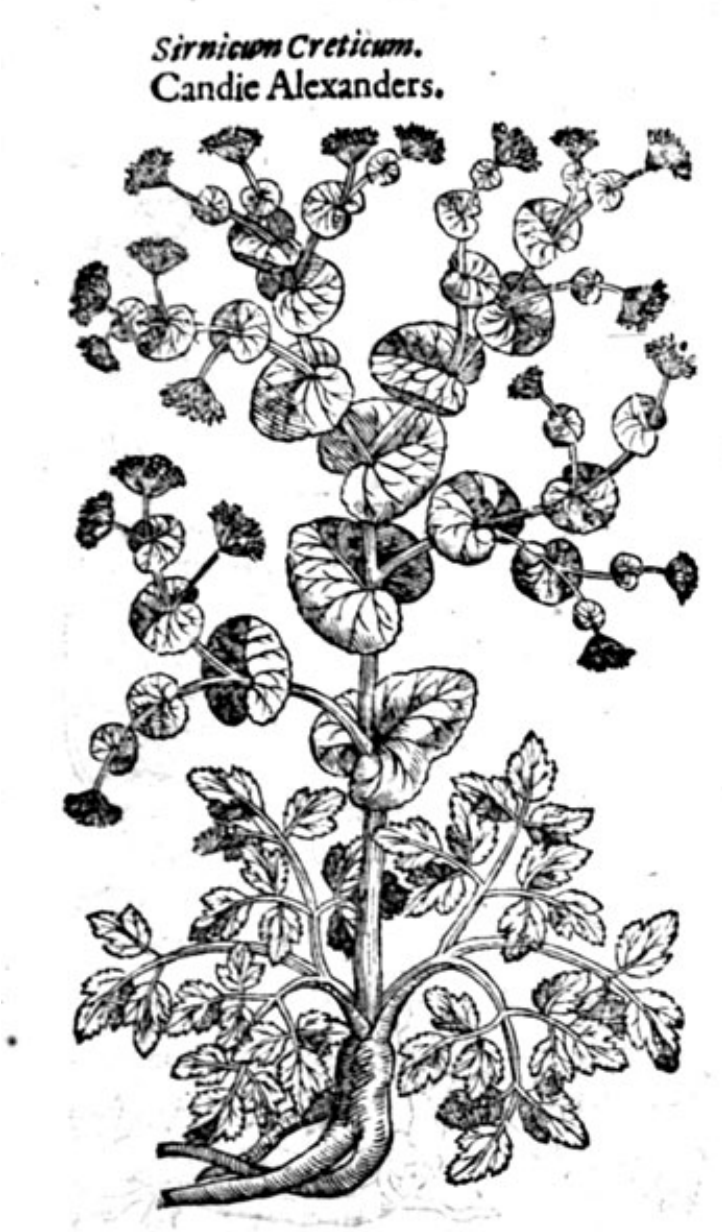

Sirnicwen Creticum.

Candie Alexanders.

* The names.
* The defoription.

Iofcorides and $P$ limie haue reckoned Smyrni. um among the kindes of Parley, whofe iudgements while this plant is yoong and not growen vppe to a ftalke, may Itande with very good reafon, for that the yoong leaues next the grounde are like vnto Parlley, But fomewhat thicker and larger:among which rifeth vp a ftalke a cubite high, and fomwhat more, garnifhed with round leaues, farre different from thefe next the grounde, inclofing the ftalke about like Thorow waxe, or Perfoliata; which leaues are of a yellow colour, and do rather refemble the leaues of Folefoote then Parfley : at the top of the ftalkes doe growe round fpokie tufts of a yellowe colour, after which commeth rounde and blacke feede like Colewoorts, of a fharpe and bitter tafte like Myrrhe: the roote is white and thicke, contrary to the opinion of Dodonews, who faith, it is blacke without, but I fpeake that which I haue feene and prooued.

\section{นิ The place.}

Smyrnitum groweth naturally vpon the hils and mountaines of Candie, and in my garden alfo in great plentie: alfo vpon the mountaine Amanus in Cilicia.

\section{* The time.}

Smyrnium flowreth in Iune, and the feede is ripe in Auguft.

This plant is called in Latine Smyrnium : in Greeke oueipvior: in Cilicia Petrcfelinon, and as Galen teftifieth, fome haue called it Hippofelinum agrefe: : in Englifh Candie Alcxanders, or Thorowbo. red Parlley.

\section{* The natwre.}

Smyrnium is hot and drie in the thirde degree.

Theleaues of Smyrniuen do diffolue wens, and hard fwellings, drieth vp vicers and excoriations, and gleweth wounds togither.

The feeds are good againft the ftoppings of the fpleene,kidneies,and bladder.

Candie Alexanders hath force to digett and wafte away hardfwellings, in other things it is like $\mathbf{C}$ to garden Parley, and ftone Parfley, iand therefore we vfe the feede thereof to prouokethe defired ficknes, vrine, and to helpe thofer hatare ituffed in the lungs, as Galen writerh.

Theroote is hor, fo is the herbe and feede, which is good to be drunke againft the bitings of fer: D pents : it is a remedy for the cough, and profitable for thofe that cannot rake their breath, vnleffe chey do fit or ftande vpright : it helpeth thofethat can hardly make their water: the feede is good againft the infirmitic of the fpleene or milt, the kidneies and bladder: it is likewife a good medicine for thofe that haue the dropfie as Diofcorides writeth.

$$
f_{i i} 3
$$




\section{Of Parneps. Chap. 388 . \\ $*$ The kindes.}

There be two forts of Parfneps, the tame and the wilde.

I Paftinacalatifolia fation. Garden Parfneps.

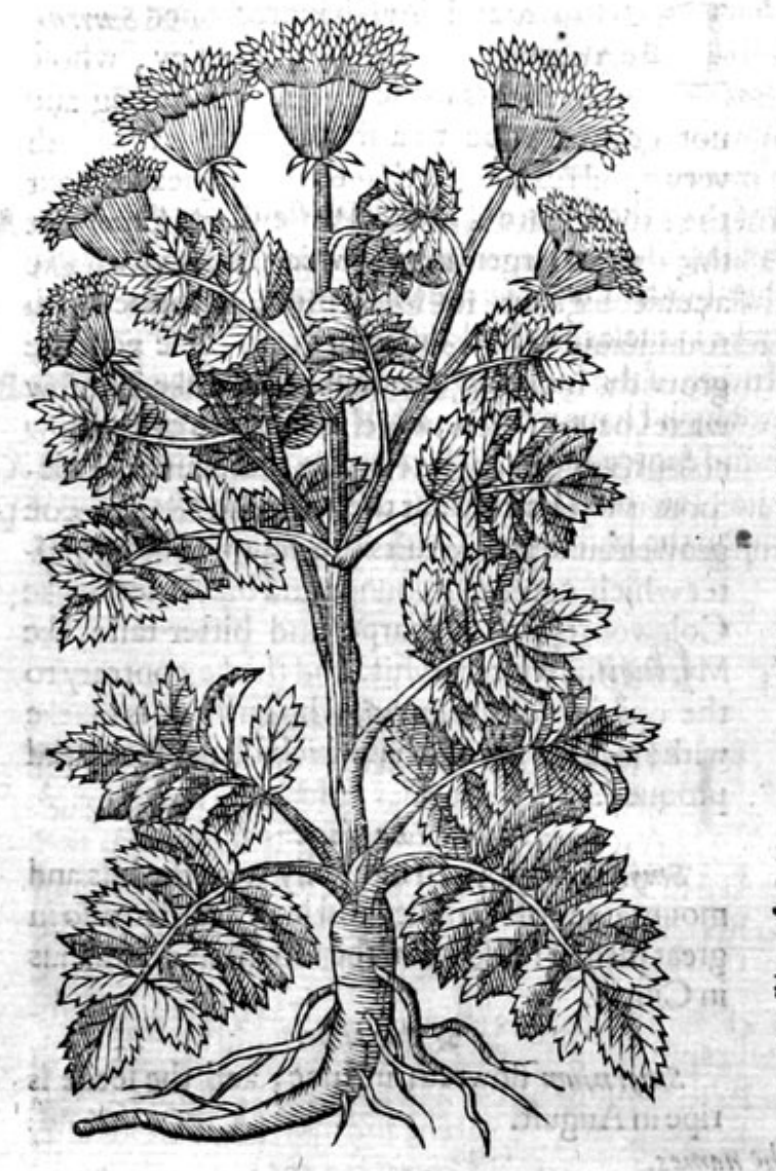

2 Paftinaca latifolia fylueftrus. Wilde Parfneps.

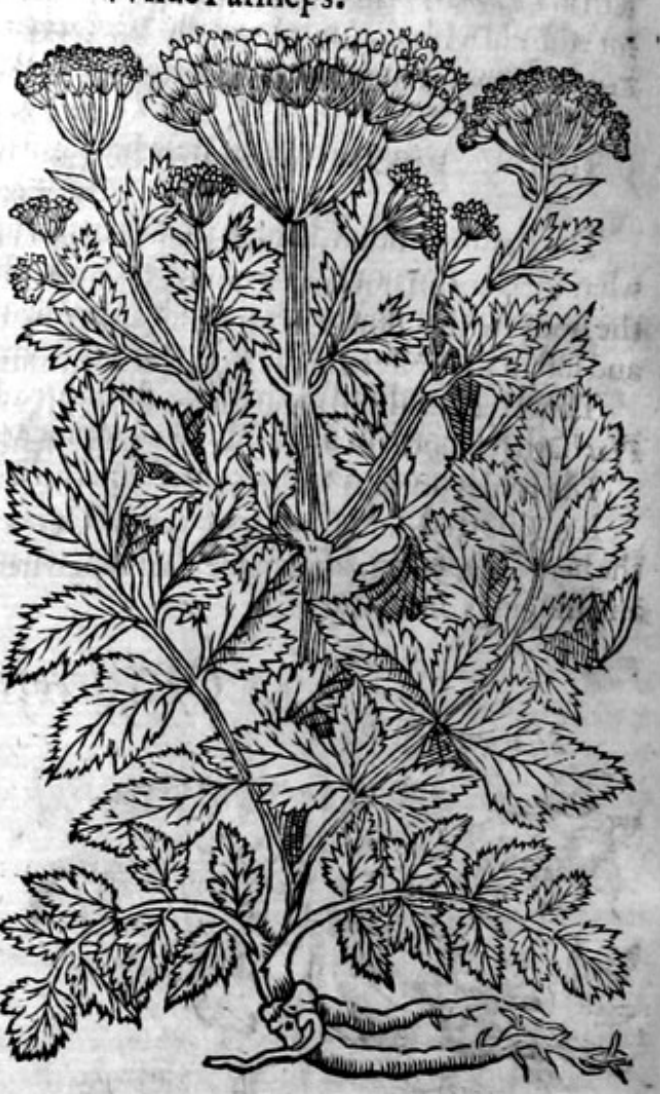

*Thedefcription.

*The defcription.

17 He leaues of the tame or garden Parfneps are broade, confilting of many fmall leaues faitned to one middle rib like thofe of the Alh tree: the ftalke is vpright, of the height of a man: the flowers itande vpon fpokic tufts, of colour yellowe; after commeth the feede flat and rounde, greater then thofe of Dill: the roote is white, long, fweete, and good to be eaten. 2 The wilde Parfnep is like to that of the garden, in leaues, ftalke, tnft ;yellowe flowers, flat and round feede, but altogither leffer: the ronte is fmall, hard, woodie, and not fit to be eaten.

$$
\text { The place. }
$$

The garden Parfnep requireth a fat and loofe earth,and that, that is digged deepe.

The wilde Parfnep groweth in vntoiled places, efpecially in the falt marrhes, vpon the bankes and borders of the fame : the feed whereof being gathered and brought into the garden, and fowed in fertill ground, do prooue better rootes, fweeter, and greater, then they that are fowen of feedes gathered from thofe of the garden.

They flower in Iulie and Augut, and feede the fecond yeere after they be fowen.

$$
* \text { The names. }
$$

A The names.
A Therbariftes of our time do call the garden Parfneps sapunivos, and Paftizaca, and therefore we haue furnanied it La $t_{\text {folia }}$, or broad leafed, that it may differ from the other garden Parfnep with narrow leaues, which is truely and properly called Staphyinises, that is the garden Carrote. 


\section{HISTORIE DOF PLANTS.}

Some phyficions doubting and not knowing ta what herbe it fhoulde be referred, havefained the wilde kind heerof to be Panacis pecies, or a kind of Alheale, as fhall be declared in his proper place: diuers haue named it Baucis, others haue called it Brarica Leonina, which if you diligently marke and confer with Elaphobo/cwon Dio/coridis,you thal hardly find any difference at all : but the plant called at Montpelier Pabulam Ceruinum, in Englifh Harts fodder, fuppoled there to be the true Elaphobofcum, differeth much from the true notes of wilde Parfneps: But Baucia, as Iacobos Manlius reporteth in Luminari maiore, is D sofcorzies and the old writers Paftinaca, that is to fay, Tenuifolia, or Car. rot : the old writers, andefpecially Diofcorides haue called this wilde Parfnep by the name alfo of Elsphobofiwn: that of the garden we do call Parfneps and Mypes.

* 7 he temperature.

The Parfnep roote is moderately hot, and more drie then moift. * The vertues.

The Parfneps nourifh more then do the Turneps or the Carrots, and the nourifhment is fome- $\mathbf{A}$ what thicker, but not faultic nor bad;notwithintanding they be fomwhat windie:they paffe thorough the body neither flowly nor fpeedily : they neither binde nor loote the bellie: they prouoke vrine, and luft of the body : they be good for the ftomacke, kidneies, bladder and lungs.

Thereisa good and pleafant foode or bread made of the rootes of Parfineps as my friendmafter B Plathath fer foorth in bis booke of experimenes, which I haue made no triall of, nor meane to do.

The feed is hotter and drier eten vnto the fecond degree, it mooueth vrine, and confumeth wind. C

It is reported, faith Diofcorides, that Beere are preferued from bitings of Serpents, by eating of $D$ the herbe Elaphobo/cum, or wilde Parfinep, wherupon the feed is gituen with wine, againft the bitings. and ftingings of ferpents.

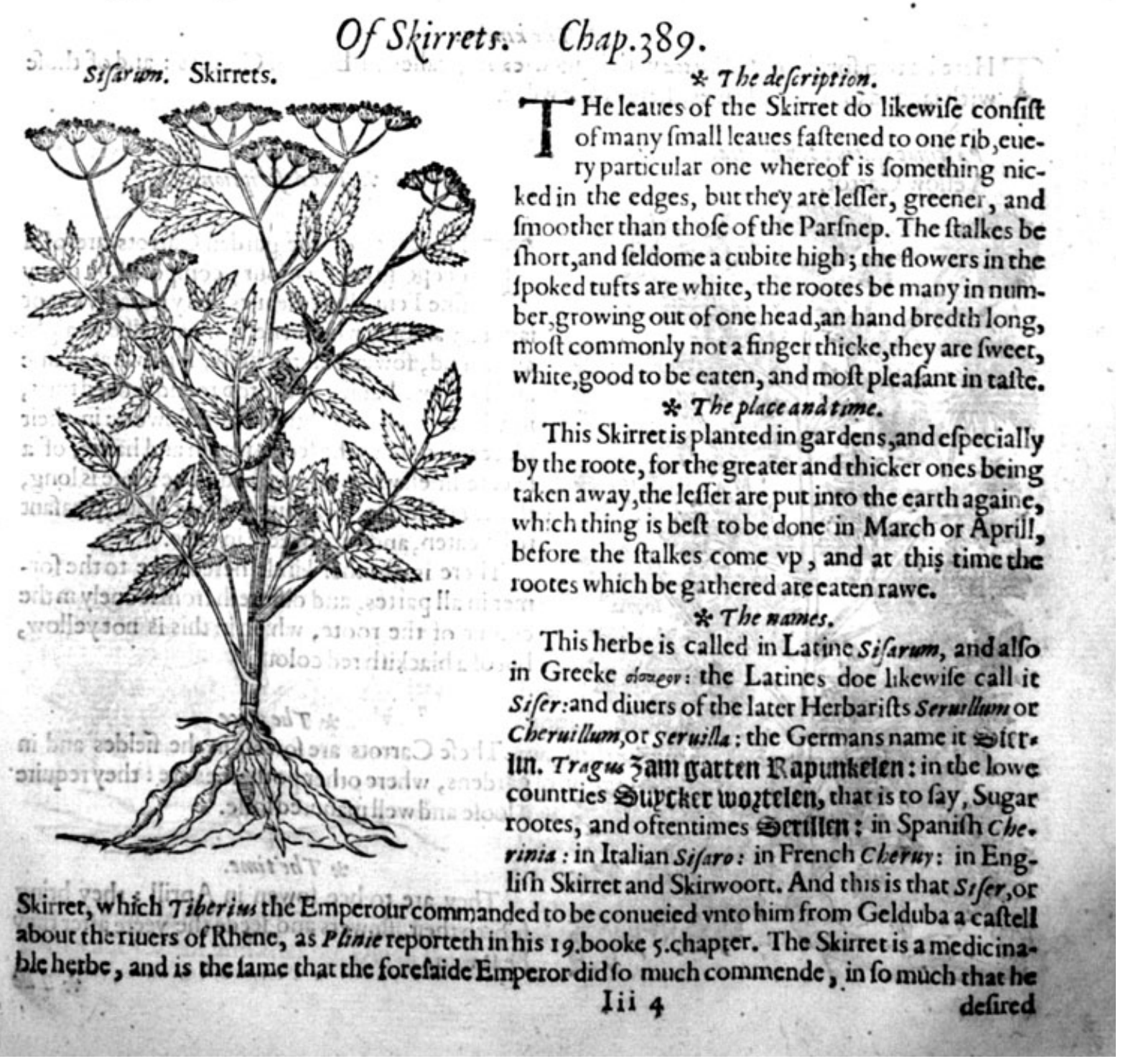




\section{THE SECOND BOOKE OE THE}

defired the fame to be brought vnto him euery yeere out of Germanie. It is not, as diuers fuppofe, Serapto his Secacul, of which he hath written in his 89.chapter: for Secacal is deferibed by the leafe of Iulben, that is to fay, of the Peafe, as CMathiolus Syluaticus expoundeth it: and it bringeth foorth a blacke fruit of the bigneffe of 2 Ciche peafe, full of moifture, and of a fweete tafte, which is called Granum Culcul. But the Skiret hath not the leafe of the peafe, neither dorh it bring foorth fruit like to the Ciche peafe, whereupon it is manifeft, that the Skirret doth very much differ from Serapio
his Secacul: fo far is it from being the fane.

\section{: The nature and vertues.}

A The rootes of the Skirret te moderately hot and moift; they be eafily concocted; they nourin meanly, and yeeld a reafonable good inice: but they are fomething windie, by reafon whereof they a!fo prouokeluft.

B They be eaten boiled, with vineger, falt, and a litcle oile, a fter the manner of a fallad, and oftentimes they be fried in oile and butter, and alfo dreffed after other fafhions, according to the skill of the cooke, and the taite of the eater.

C Thewomen in Sweuia, faith Hierongmus Heroldus, prepare the roots hereof for their husbands, and knowe full well wherefore and why, \&rc.

D The iuice of the rootes drunke with goates milke ftoppeth the laske. The fame drunke with wine puttech away windineffe out of the ftomacke, and gripings of the belly, and helpeth the bicket or yeoxing. They ftir vp appetite, and pronoke vrine.

\section{OfCarrots. Chap. 390 .}

* The kindes.

$T$ Here be two fortes of Pastinaca with iagged leaues, called in Englifh Carrots : and of thofe with iagged or narrow leaues, there is one wilde.

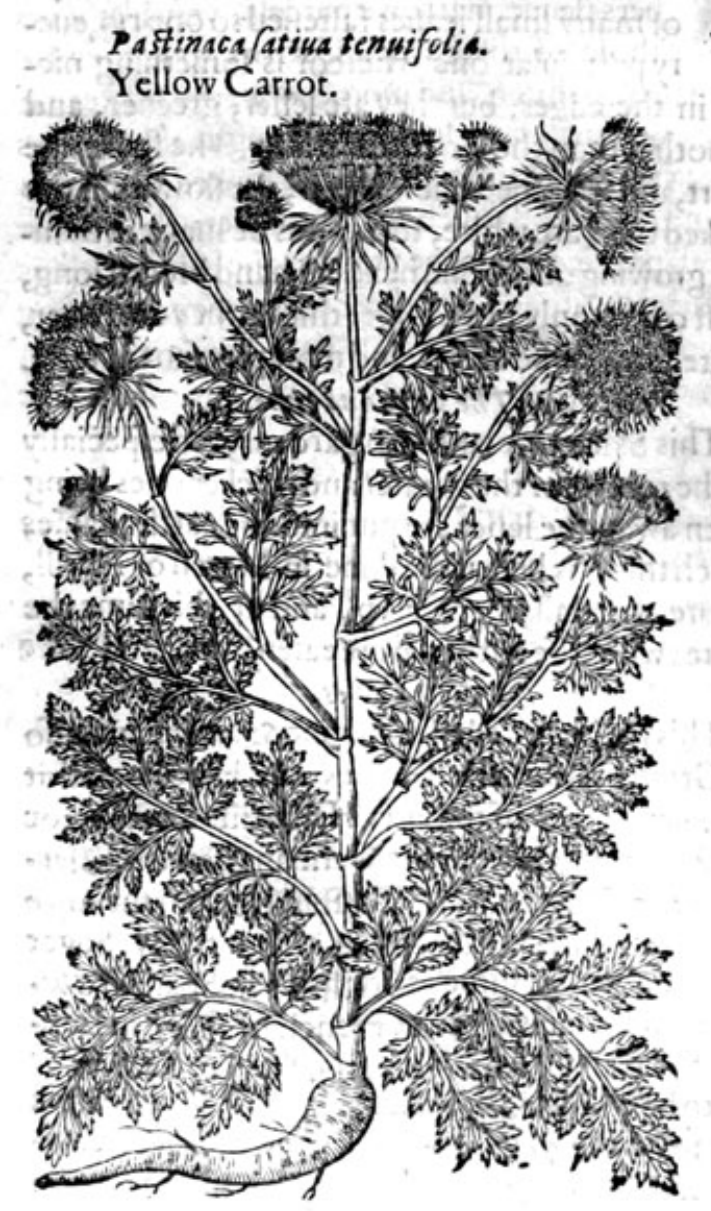

\section{*. Thedefoription.}

5 He leaues of the garden Carrots are of a deepe greene colour, compofed of many fine Fennell-like leaues, very notably cut or iagged; among which rifeth vp a ftalke ftraight and round, fower cubites high, fomewhat hairic and hollow, hauing at the top round fpoked tufts, in which do growe little white flowers: in their places commeth the feede rough and hairie, of $a$ fweete fmell when it is rubbed. The roote is long, thicke and fingle, of a faire yellow colour, pleafant to be eaten, and veryf wreete in tafte.

There is atother kinde hereof like to the former in all partes, and differeth from it onely in the colour of the roote, which in this is not yellow, but of a blackifh red colour.

\section{* The place.}

Thefe Carrots are fowen in the fieldes and in gardens, where other potherbes are : they require a loofe and well manured foile.

\section{* The time.}

They are to bee fowen in Aprill; they bring foorth their flowers and feede the yeere after they be fowen. 


\section{HISTORIE ZOF PLANTS.}

\& The names.

The Carrot is properly called in Greekesut $x$ inos, for that which we have termed in Latine by the name of Paffisica La tioris folg, or the garden Parfnep, is defcribed of the olde writers by another name: this Carrot is called in Latine likewife, Paftin :ca fatius, but with this addition tensifolia, that it may differ from the garden Parfnep with broad leaues, and white roote. Theophraftses in the 9. booke of his hiftory of plants nameth this Staphylanies, or Carrot, savias, and writeth that itgroweth in Arcadia, and faith that the beft is founde in sparten/i Achata, but doubtieffo hement that Dances which we call Creten fis, that may be numbred ainong the Car rots; $G_{3}$ lenin his booke of the faculties of Simple medicines doth alfo make it to be Dausws, but yet not finplie Dasesn, but with a compound name Daucus paftemaca : in high Dutch it is called forel tubsa: in lowe Datch feel

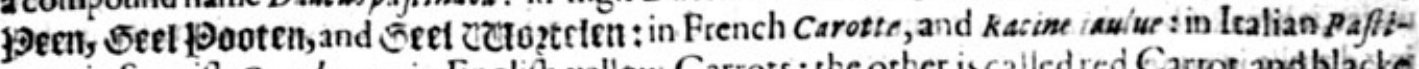
naca : in Spanifh Canahoria. in Englifh yellow Carrots: the other is called red Carrot, and blacke Carrot. * The temperatureand vertwes.

The roote of the yellow Carrot is moft commonly bojied with fat ficth andeaten: it is tempe- $\mathbf{A}$ rately hot and fomething moilt. The nourifhment which commeth therot is not witch, and not verie gond: it is fomething windie, but not fo much as be the Turne?s: and doth not fo foone as they paffe throvgh the bodie.

The red Carrot is of like facultie with the yellow. The feede of them both is hot and drie, it B breaketh and confumeth windineffe, prouoketh vrine, as doth that of the wilde Carrot.

$$
\text { Of wilde Carrot. Chap.j9r. }
$$

PeIt inacs fy'mestristenuifolia. Wilde Carrot.

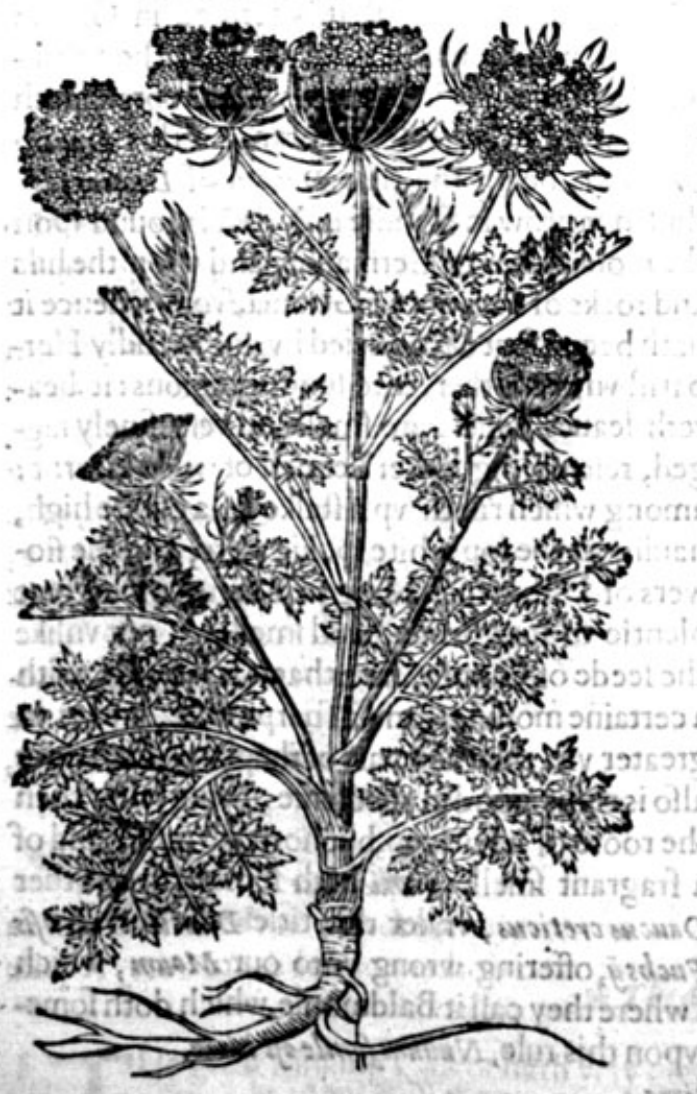

* Tle defcription.

7 He leaues of the wild Carrot are cut into diuers flender narrowe parcels, very like vnto thofe of the garden Carrots, but they be fomewhat whiter, and more hairie: the ftalkes be likewife hairie and fomewhatrough: the flowers are little, and ftande vpon broad fpoked tufts, of a white colour, of which ruft of tlowers the middle moft part is of a deepe purple, the whole tuft is drawne togither when the feedeis ripe,refembling a birdes neft; whereupon it hath beene named of fome Birds neits the roote flender, and of a meane length.

$$
\text { * The place. }
$$

It groweth of it felfe in vntoiled places, in fields and in the borders thereof, almoft euery where.

$$
* 7 \text { he tume. }
$$

They flower and flourifh in Iune and Iuly, the feede is ripe in Anguft.

The wilde Carrot is called in Greeke eepuiños E)eos: in Latinc Paftinaca glueftris remeifolia : in fhops Daucsw: \& is vfed infteed of the crue Dasycous, and not amiffe, nor vnprefitablie: for $G_{A} / e_{m}$ alfo in his time doth teftific that it was taken fot Dawisw, or baftard Parfley, andl is wictiout doubs Dewoi fylueftris genow, or a wildelande of baftarde Partley, fo called of $T$ heophraftses : in high Dutch

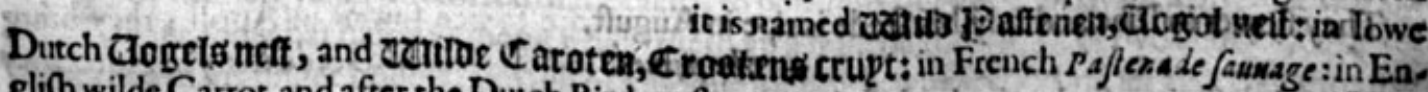

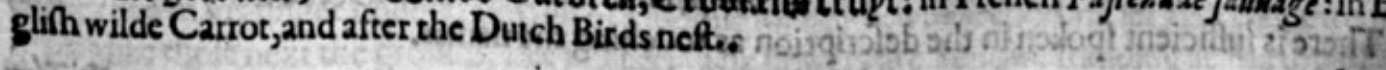




\section{THE SECOND BOOKE OF THE}

At benews citing Diphilus for the author, faith, that the Carrot is called pirssor, bicaufe it fenueth for loue matters, and Orpheus, as Pliny writeth, faide, that the vfe heereot winneth lone, which things be written of wilde Carrot, the roote whereof is more effectuall then that of the garden, and conteineth init,as Galen faith, a certaine force to procure luft.

* The temperature and vertues.

The feede of this wilde Carrot, and likewife the roote is hot and drie in the feconde degree, and doth withallopen.

The roote boiled and eaten, or boiled with wine, and the decoction drunke, prouoketh vrine, expelleth the ftone, bringeth foorth the birth; it alfo procureth bodily luft.

The feede drunke bringeth downe the defired ficknes, it is good for them that can hardly make water, it breaketh and diffolueth winde, it remedieth the dropfie, it cureth the colicke and ftone, being drunke in wine.

It is alfo good for the paffions of the mother,and helpeth conception : it is good againft the bytings of all maner of venemous beafts : it is reported faith Diofcorides that fuch as haue firft taken of it are not hurt by them.

\section{Of Candie Carrots. Chap. 392.}

Daucus Cretenfis verm.

Candic Carrots.

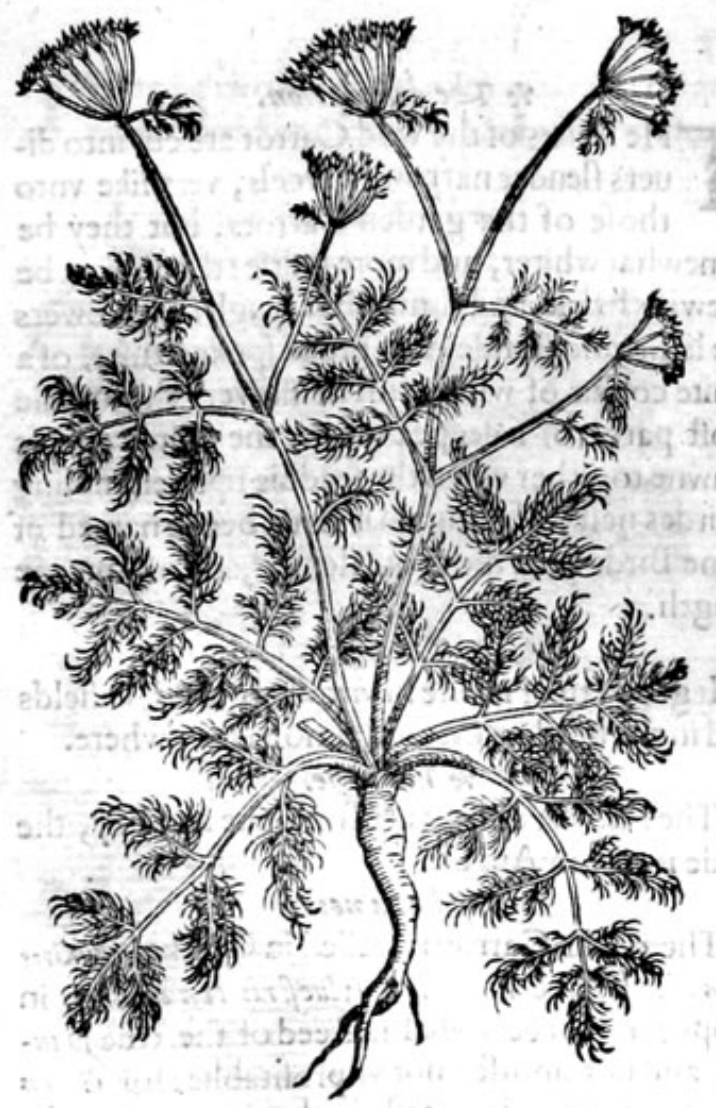

\section{* Thedefcription.}

His kinde of Dawcm feemeth to beparta: ker both in name \& nature with the herbe called Caucslis, that is termed in Greeke noxysior, which name is taken from the refernblance of the feed in the tuft, which reprefenteth (as it were) the fcales of branne : this Danems Cretenfis, being the true Daucus of Diofcorides, doth not grow in Candie only, but is found vpon the mountaines of Germanie, and vpon the hils and rocks of Iura about Geneua, from whence it hath beene fent \& conueied by one friendly Herbarift vnto another, into fundrie regions: it beareth leaues which are fmall and very finely iagged, refembling either Fennell or wilde Carrot: among which rifeth vp a ftalke of a cubite high, hauing at the top white fpokie tufts, and the flowers of Dill, which being paft there come great plentic of long feede, well fmelling, not vnlike the feede of Cumin, fane that it is whitifh, with a certaine moffines, and a fharpe tafte, and is in greater vfe, then any part of the plant. The roote alfo is right good in medicine, being leffer then the roote of a Parfnep, but hotter in tafte, and of 2 fragrant fmell. Pena hath fet foorth another Daucus creticus, vnder this title Dawcus cretenfis Fuchs $\ddot{y}$, offering wrong vnto our Meum, which groweth plentifullyin the north parts of England, where they call it Baldmonie, which doth fome: what refemble Daucus, yet he might haue thought vpon this rule, Nullum frmile oft idem. * The time.

They flower in Iune and Iuly, his feede is ripe in Auguft. * The mames.

There is fufficient fpoken in the defcription as touching the names. 


\section{HISTORIE OF PLANTS.}

* The nature.

Thefe plants are temperate in heate and drineffe, efpecially the feede of Dascus Creticm, which is hot and drie in the thirde degree : but the feede of the wilde Carrot, is hot and dry in the feconde degree.

The feede of Dascus drunken is good againft the ftrangurie, and painfull making of water, it pre- A uaileth againftrthe grauell and ftone, and prouoketh vrine.

It affwageth the torments and gripings of the bellie, diffolueth windines, cureth the colicke, and B ripeneth an old cough.

The fame taken in wine, is very good againft the bitings of beafts, and expelleth poifon. C

The feede of Dancus Creticus is of great efficacie and vertue, being put into Treacle, Mithridate, D or any antidotes,againft poifon or peftilence.

The roote thereof drunke in wine ftoppeth the laske, and is alfo a foueraigne remedie againft $\mathbf{E}$ venome and poifon.

\section{Of finking and deadly Carrots. Chap.393.}

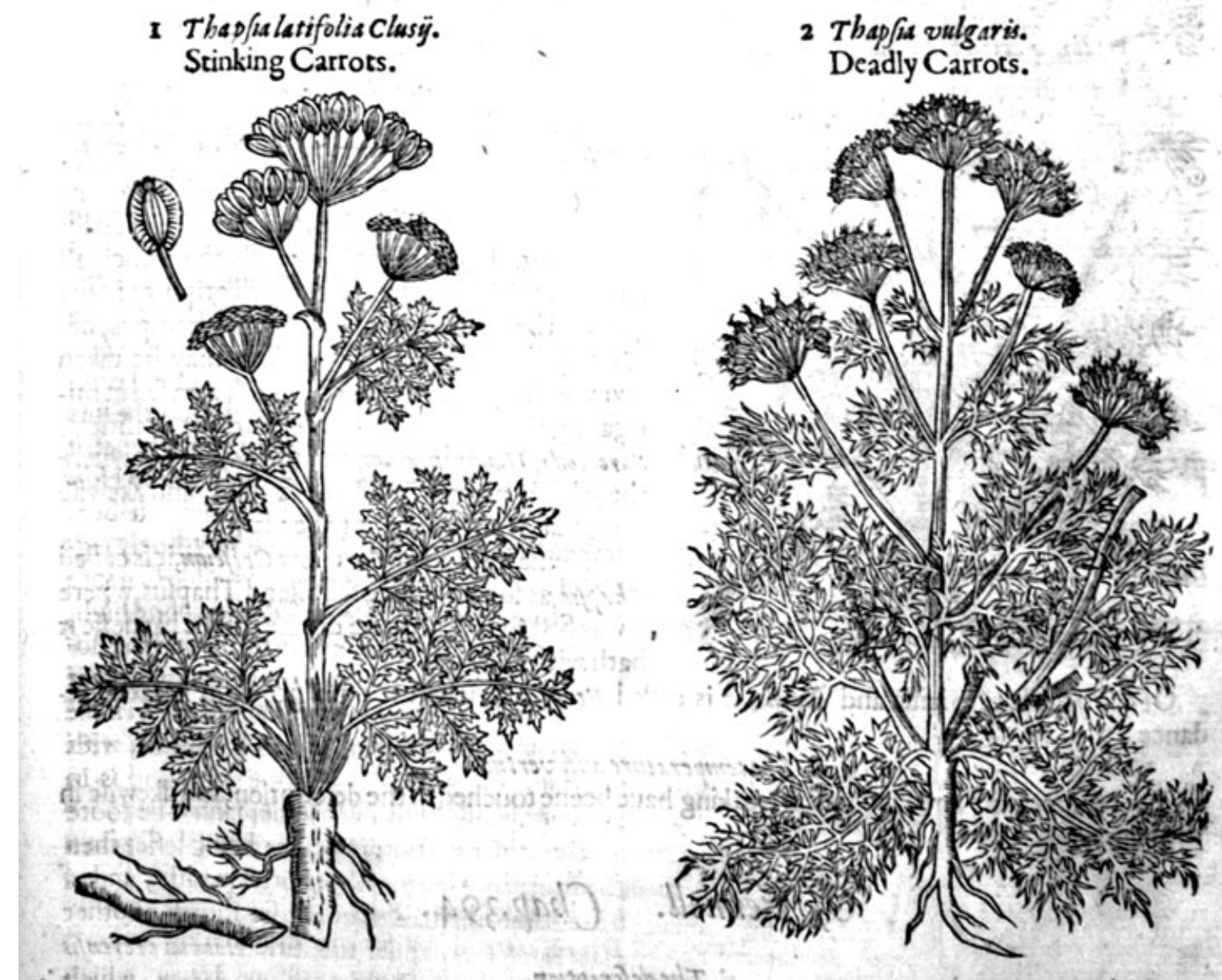

2 Thapfat vulgaris. Deadly Carrots.

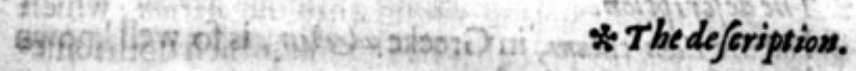

I The great ftinking Carrot hath very great leaues, fpred abroad like wings, refembling thofe tar I f Fennelgyant (wherof fom haue take it to bea kind, but vnproperly) of a bright gieen co1) lour, fomwhat hairie; among which rifeth vp a ftalk of the height of two cubites, $\&$ of the bignes of a mans finger, hollow, and full of a foongious pith; whereupon are fet at certaine iointes; leaues likethofe next the ground, but finaller. The flowers are yellow, ftanding at the top of the 
ftalkes in fpokie rundles, like thole of Dill ; after which commeth the feede flat and broad like thofe of the Parfinep, but much greater and broader. The roote is thicke, garnifhed at the top with certaine capillaments or hairie threds, blacke without, white within, full of milkie iuice, of a moft bitcer, tharpe, and lothfome tafte and fmell, in fo much that if a man do ftande where the winde doth blowe from the plant, the aire doth exulcerate and blifter the face, and euery other bare or naked place that may be fubiect to his yenemous blafts, and poifonous qualitie.

2 The common deadly Carrot is like vnto the precedent, fauing that he doth more neerely refemble the ftalkes and leaues of the garden Carrot, and is not garnifhed with the like buth of haire about the top of the ftalkes: otherwife in feede, roote, and euill fmell,tafte and qualitie like.

3 Thapfis tenuifolia.

Small or thin leafed ftinking Carrot.

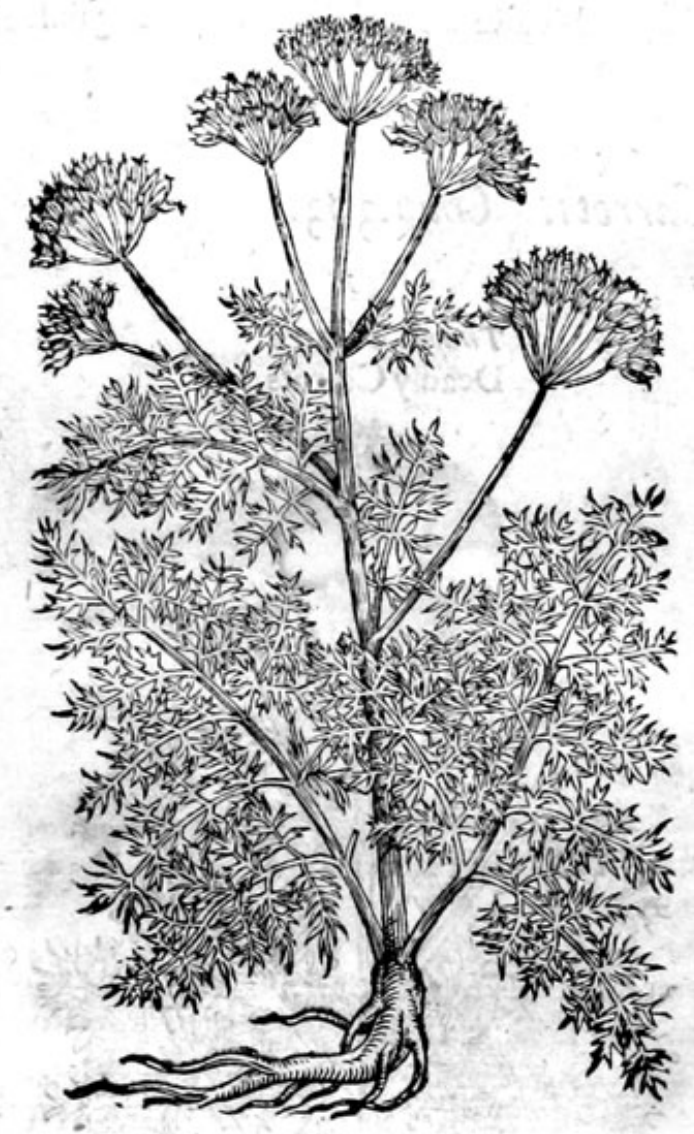

\section{* The defcription.}

3 This frnall kinde of ftinking or deadly $\mathrm{Carrot}$ is like vnto the laft defcribed in each refpect, $f_{2}$ uing that the leaues are thinner \& more finely minced or iagged, wherin confifteth the difference. * The place.

Thefe pernicious plants delight in ftonie hils and mountaines : they are ftrangers in England. * The time.

They flower in Auguft or fomewhat after. * The names.

The French Phifitions haue accepted the roote of Thap fis for a kinde of Turbith, calling it Turpetum Cineritium, notwithftanding vpon better confideration they haue left the vfe thereof, efpecially in purging. For it mightily hurteth the principall partes, and doth often caufe cruell gripings in the guts and bellie, with conuulfions and crampes, neuertheleffe the venemous qualitie may be taken away with thofe correctiues, which are vfed in mitigating the extreme heate and virulent qualitic of Sarcocolla, Hammoniacum, and Turpetum, but where there be fo many wholefome fimples, and likewife compounds, they are not to be vfed.

Of forne it is called $\tau$ urpetum Grifum, it is called Thapfus, as fome thinke of the iland Thapfus, where it was firt found, or as we deeme, of the likeneffe it hath with Carrots. dance.

Of the people of Sicilia and Apulia it is called Ferulacoli, where it doth growe in greatabun-

$*$ The temperature and vertues.

The temperature and faculties in working haue beene touched in the defcription, and likewife in the names.

\section{Of Fennell. Cbap.394.}

\section{$\checkmark$ The defaription.}

I 7 He firft kinde of Fennell called in Latine Fanisulwm, in Greeke $\mu$ dealer, is fo well known among ft vs, that it were but loft labour to defcribe the fame.

2 The fecond kinde of Fennell is likewife well knowne by the name of fweete Fennell, fo called bicaufe the feedes thereof are in tafte fweete like vnto Annife feeds, refembling the com: mon Fennell, furing that the leaues are larger and fatter, or more oileous: the feede greater and whiter, and the whole plant in each refpect greater. 


\section{AH HISTORIE OOF VPLATS.HT}

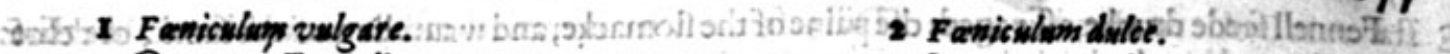
Common Fennell.

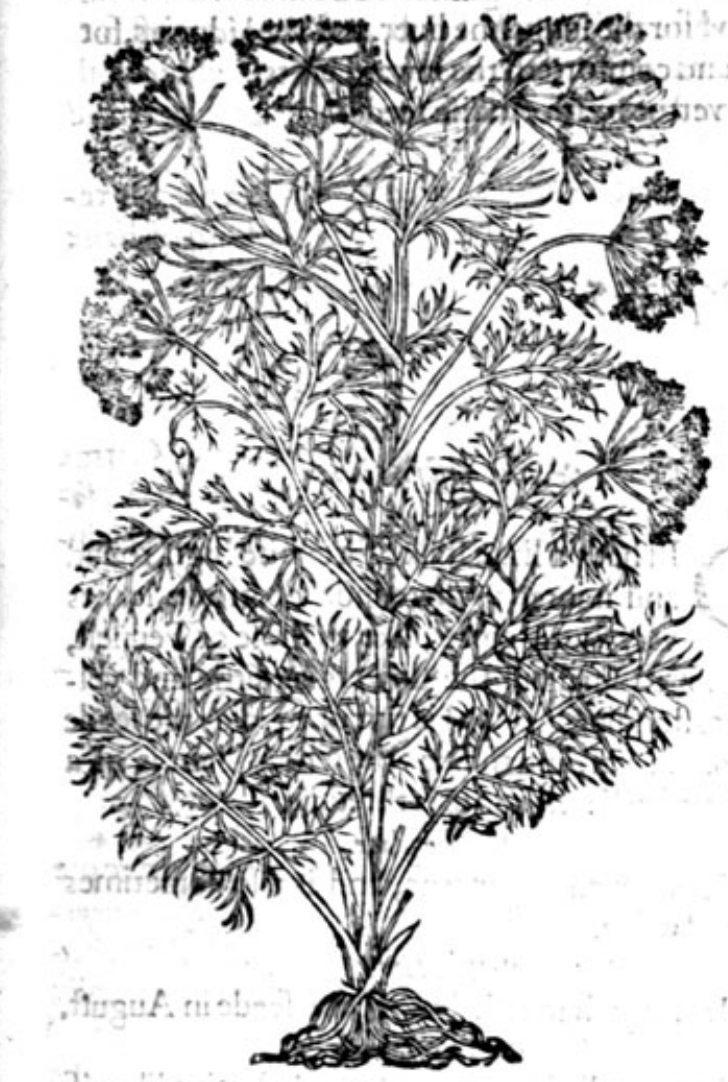

Sweete Fennell. sid bocessimovioa

* The place.

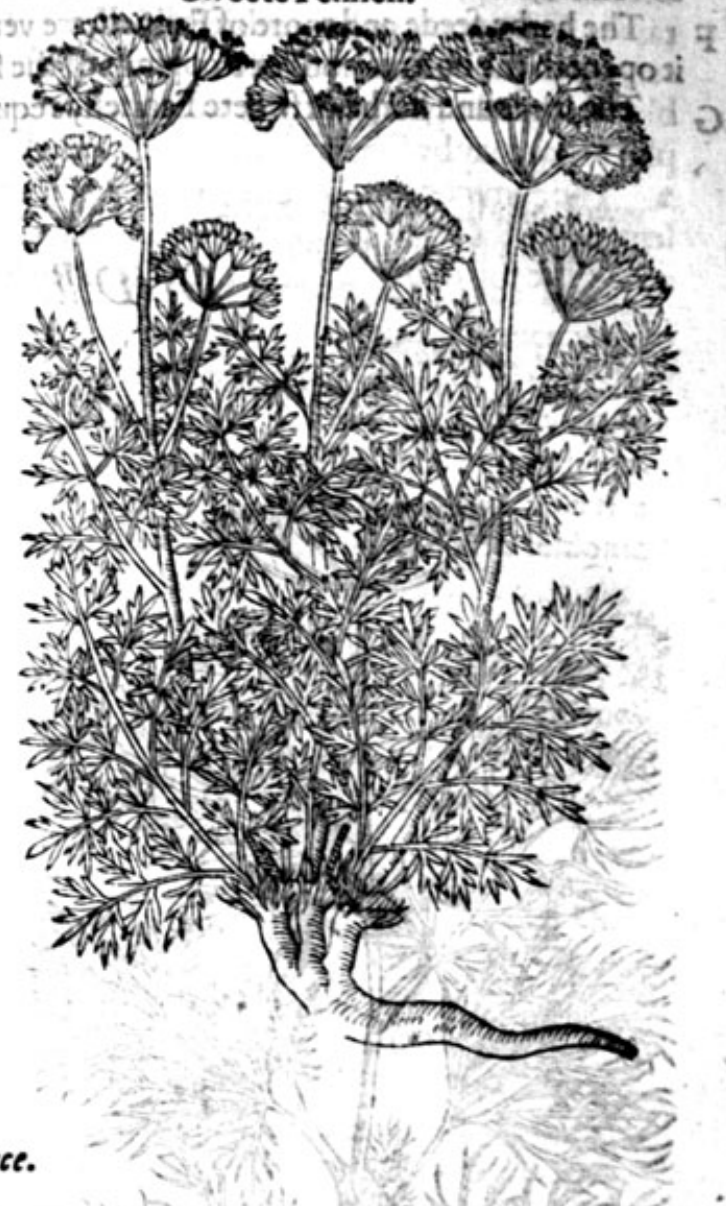

Thefe herbes are fet and fowen in gardens: but thefeconde doth not profper well inthis coun. trey, for being fowen of good and perfect feede, yet in the fecond yeere after his fowing it will dege-
nerate from theright kinde, and become common Fennell.

They flower in Itue and Iuly, and the feede is ripe in the end of Augurt.

* The names.

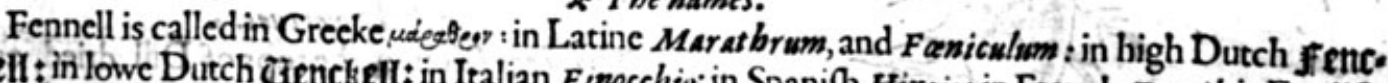
Befl! in lowe Dutch Cienckell: in Italian Finocchio: in Spanifh Hinoio: in French Fenoil: in Englifh
Fennell,and Fetickell.

The feede of Fennell is $*$ The nature.

The feede of Fennell is hot and drie in the thirde degree.
$*$ T be vertues. The pow der of the feede of Fennell, drunke for certaine daies togither fafting, preferueth the $\mathbf{A}$
eiefight, whereof was written this diftichon following,

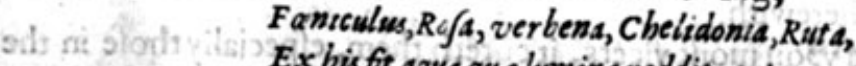

Ex his fir a gua gue lumina reddit acuts.

Of Fennel, Rofes, Verueine, Rue and Celandine,
Is made a water good to cleere the fight of cyne.

The greene leaves of a water good to cleere the fight of cyne.

brefts with milke.

The deccetion of Fennell drunke, eafeth the paines of the kidncies, caufeth one to auoice the $\bar{C}$

The roo es are as effectuall, and not oncly good for the intents aforefaid, but againft the dropfie D al:o, being boiled in wine and drunken. 


\section{THE SECOND BOOKE OF THE}

E Fennell feede drunke, affwageth the paine of the ftomacke, and wambling of the fame, or defire to vomite, and breaketh winde.

F The herbe,feede, and roote of Fennell, are very good for the lungs, the liuer,and the kidneies, for it openeth the obftructions or ftoppings of the fame, and comforteth the inward parts.

G The feede and herbe of fweete Fennell, is equall in vertues with Annife feede.

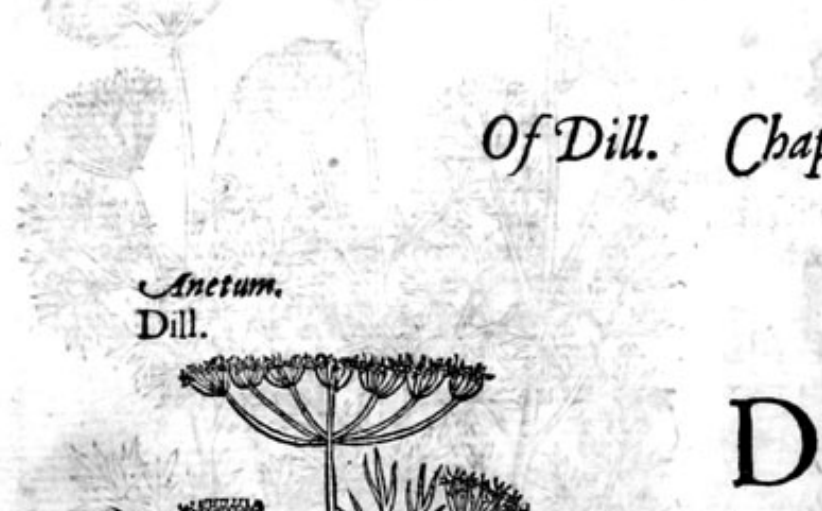

\section{* The defaripsion.}

Ill hath a little ftalk of a cubite high, round and iointed; whereupon do growe leaues very finelie cutte, like to thofe of Fennell, but much fmaller: the flowers be little and yel. lowe, ftanding in a f pokie tuft or rundle : the feede is round, flat, and thinne : the whole plant is of 2 ftrong fmell: the roote is threddie.

$$
\text { * The place. }
$$

It is fowen in gardens, and is alfo fometimes found wilde.

\section{* Thetime.}

It bringeth foorth flowers and feede in Auguft. * The names.

Dill is called in Greeke ámpov : in Latine likewife Anet bum, and Anetum : in high Dutch Dptien: in lowe Dutch Dille: in Italian Anetho: in Spanifh Eneldo: in French Anet: in Englifh Dill and Anet.

\section{* The temperature.}

Dill, as Galen faith, is hot in the ende of the feconde degree, and dry in the beginning of the fame, or in the end of the firft degree.

$$
* \text { The vertwes. }
$$

The decoction of the tops of Dill dried, and likewvife of the feede being drunke, ingendereth milke in the brefts of nurfes, alaieth gripings and windineffe, prouoketh vrine, increafeth feede, ftaieth the yeox, hicket, or hicquet, as Diofsorides teacheth.

B The feede likewife if it be finelled vnto, ftaieth the hicket, efpecially being boiled in wine, but chiefely if it be boiled in Wormewood wine, or wine and a fewe branches of Wormwood, and red Rofe leaues, and the ftomacke bathed therewith.

C Galen faith, that being burnt and laid vpon moift vlcers, it cureth them, efpecialiy thofe in the fecret parts: and likewife thofe $\int u b$ P raputio, though they be old and of long continuance.

D Common oile, in which Dill is boiled or funned, as we do oile of Rofes, doth digeft, mitigate paine, procure fleepe, and bringeth rawe and vnconcocted humours to perfect digeftion, and prouoketh carnall luft.

E Dill is of great force and efficacie againft the fuffocation or ftrangling of the mother, if the woman do receiue the fume thereof being boiled in wine, and put vnder a clofe ftoole or hollowe feat fit for the purpofe. 


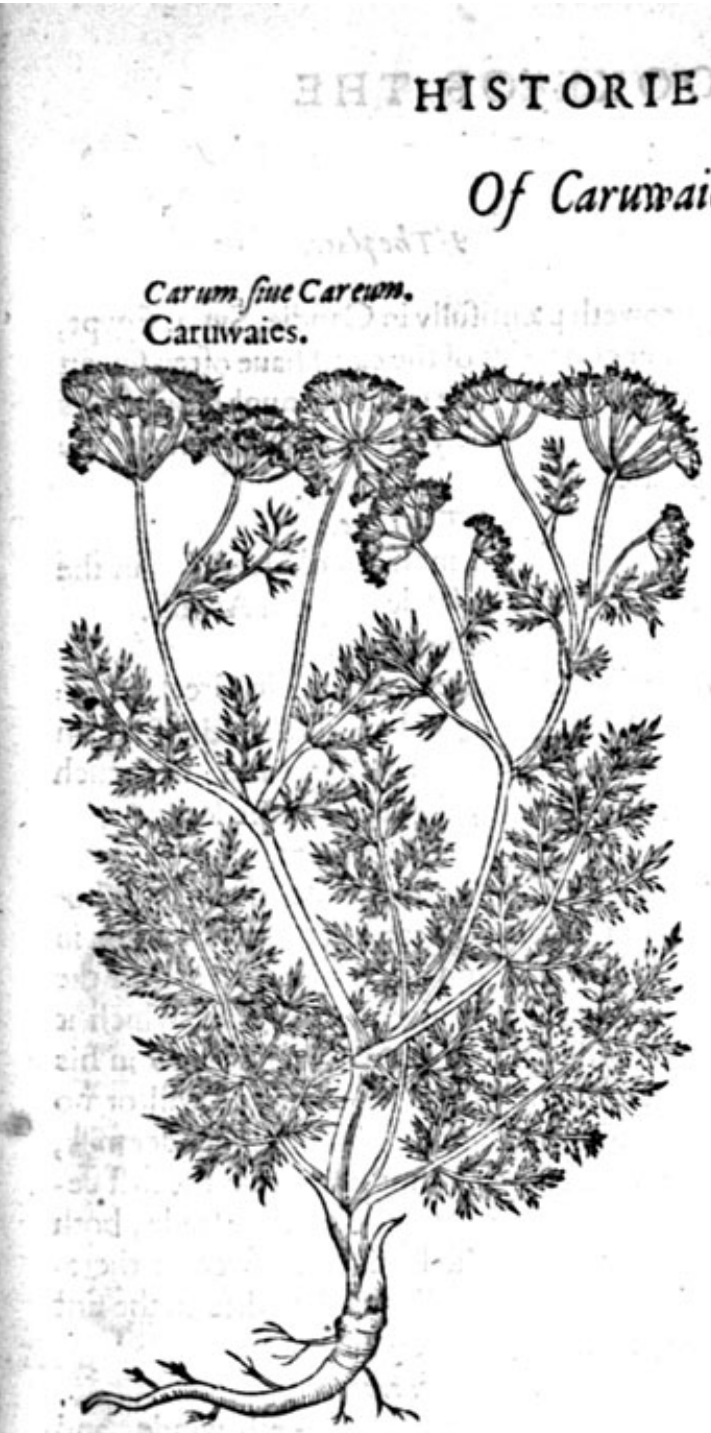

waie, and the feede is called Caruwaie feede.

Carum, fiue Car eion,

Caruwaies.

The Themperature.

The feede of Caruwaies (2s $G$ alen faith)is hot and drie in the thirde degree, and hath a moderate biting qualitie.

\section{* The vertues.}

It confumeth winde, it is delighfull to the ftomacke and tafte, it helpeth concoction, prouoketh A vrine, and is mixed with counterpoifons: the roote may befodden and eatenas the Parfnep or Carrot is.

The feedes confected or made with fugar into Comfits, are very good for the ftomacke, they B helpe digeftion, prouoke vrine, affwage and diflolue all windines : to conclude in a worde, they are anfiverable to Anile feede in operation and vertues.

\section{Of Anife. Chap.397, shisgringollig?o \\ * T he defcription.}

$\mathrm{T}$ He ftalke of Anife is rounde and hollowe, diuided into diuers fmall branches, fet.with leaues next the ground fomwhat broad and rounde; thofe that growe higher are more iagged, like thofe of yoong Parfley, but whiter;on the top of the ftalkes do ftande fpokie rundles ortufts of white flowers, and afterward feede, which hath a pleafant tafte as all do knowe. 
Axifum.

Anife.

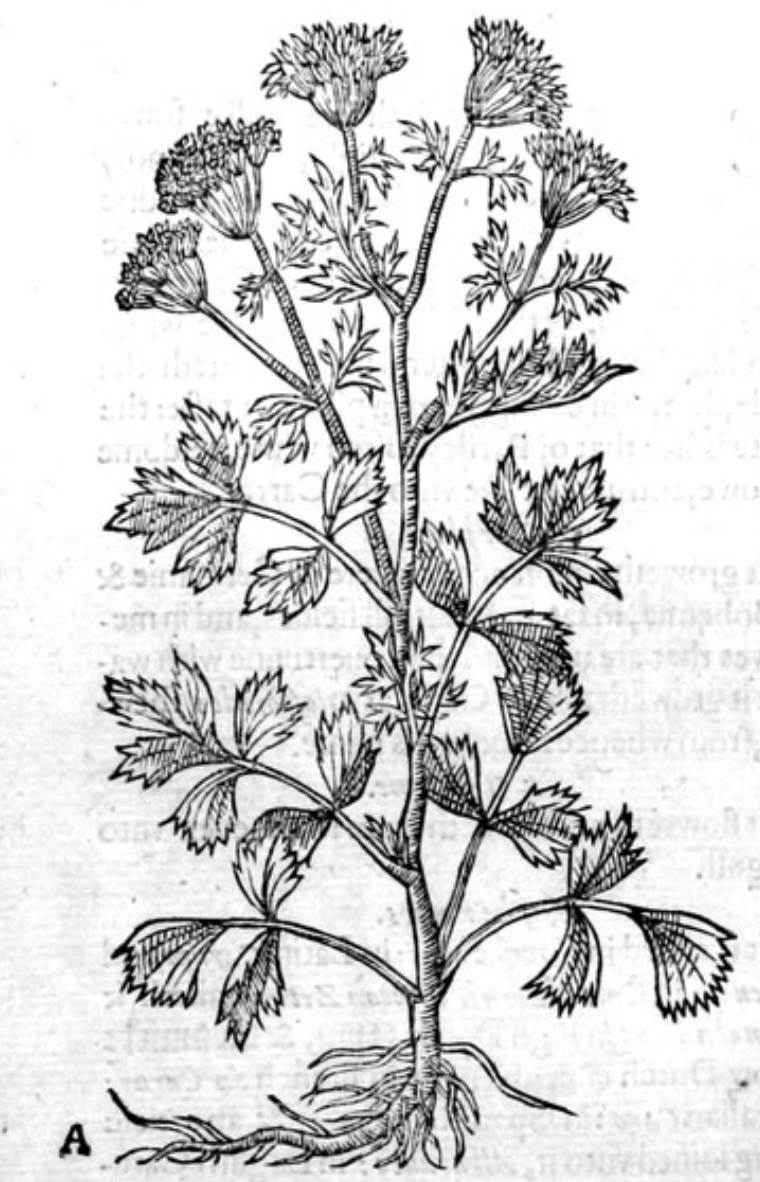

* The place.

It groweth plentifully in Candie, Syria, Egypt, and other countries of the eaft:I haue often fowen it in my garden, where it hath brought foorth his ripe fecde, when the yeere hath fallen out to be temperate.

$$
\text { * The time. }
$$

It is to be fowen in thefe colde regions in the moneth of Maie, the feede is ripe in Auguft. * The names.

It is called in Latine Anifum: in Greeke ayıon: in high Dutch Gnt?z: in lowe Dutch gutflaet : in Italian Anifo: in Spanifh CMatabalus : in French Anis : in Englifh Anife, and Annife feede.

$$
* 7 \text { be temperature. }
$$

Galen writeth, that the feede of Anife is hor and dry in the third degree, after othersit is hot in the fecond degree, and much leffe then drie in the fecond degree; for it ingendreth milke, which it coulde not do if it were very drie, as Galen in his Chapter of Fenell doth whether hee will or no declare and teftifie; in that it doth ingender milk, his opinion is, that it is not hot aboue the firft degree, which thing alfo may be in Anife feede, both by this reafon and alfo bicaufe it is fweete: therefore to conclude, Anife feede is drie in the firft degree, and hot in the fecond.

$$
\text { * The vertwes. }
$$

The feede waftech and confumeth winde, and is good agaimt belchings and vpbraidings of the
ftomacke, alaieth gripings of the belly, prouoketh vrine gently, maketh abundance of milke, and ftirreth vp bodily luft: it ftaiech the laske, and alfo the white fuxe in women.

B Being chewed it maketh the breath fweete, and is good for them that are fhort winded, and quencheth thirf, and therefore it is fit for fuch as hauc the dropfic:it helpeth the yeoxing or hicket, both when it is drunken or eaten drie : the fmell thereof doth alfo preuaile very much.

C The fame being dried by the fire and taken with honie, clenfeth the breft from flegmatike fuper. fluities, and if it be eaten with bitter almonds, it doth helpe the old cough.

D It is to be giuen vnto yoong children and infants to eate which are like to haue the falling ficknes, or fuch as hauc it by patrimonie, or fucceffion.

E It taketh away the fquinancie, or quincie(that is, a fwelling in the throte) being gargled with honie, vineger, and a little Hyoffpe gently boiled togither.

\section{Of Bifhops weede, herbeWilliam, or A meos. Chap.398.}

* The kindes.

$T_{\text {the later age hathobferued two kindes of Ameos, one greater with the broadeleafe, which is }}^{\text {He }}$ ing the common Ameos, and the other the le
ingarfe or lowe plant of the fame kinde. 


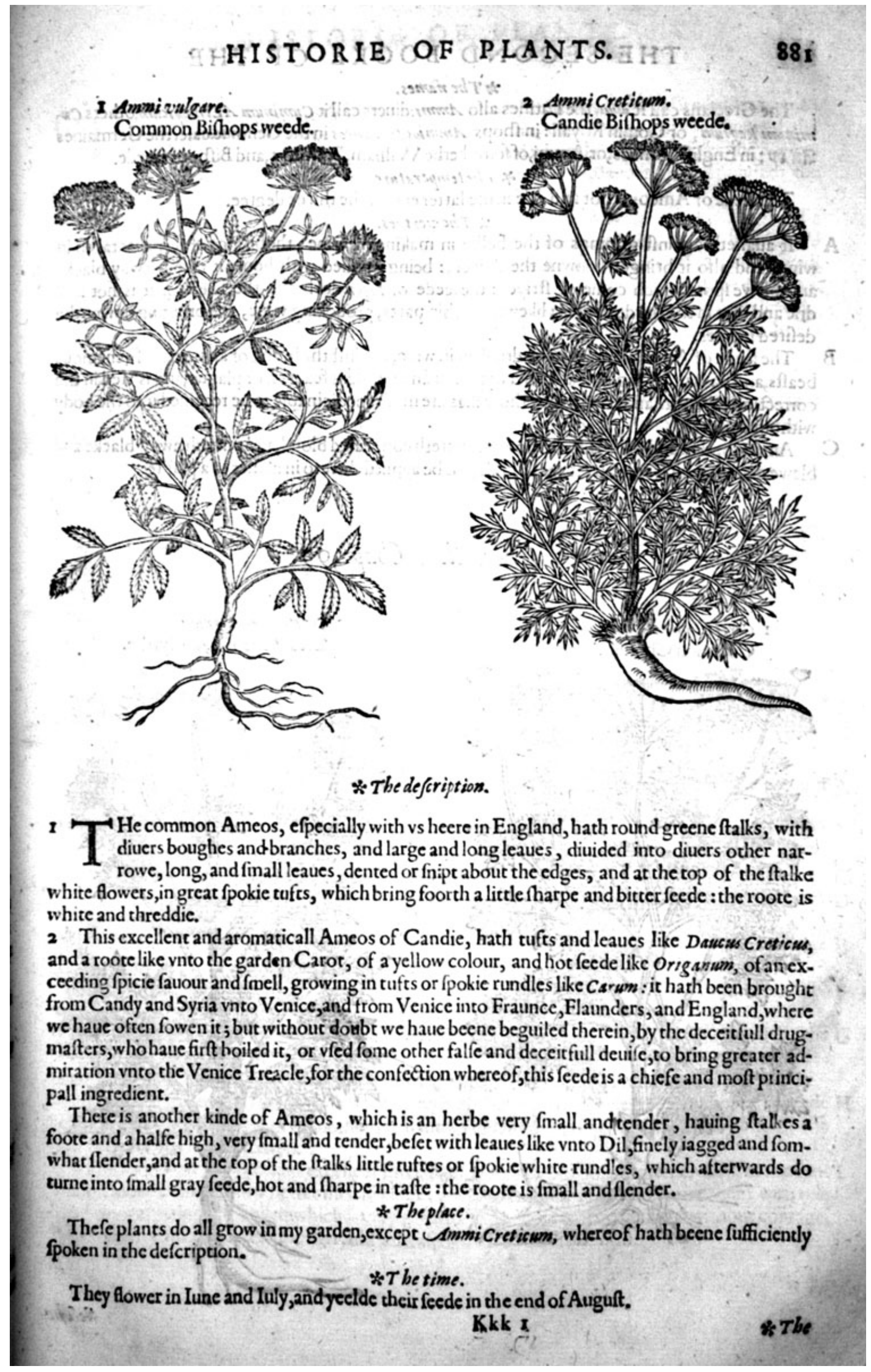


$*$ The names.

The Grecians call it aum, the Latines alfo Ammi diuers call it Cuminum AEthiopicum others $C m$ minum Regium, or Comin Royall: in fhops Ammios, or Ameos in the Genitiue cafe:the Germaines An $\mathfrak{A}$ : in Englifh Ameos, or Amm;, of fome herbe William, Bulwoort, and Birhops weede.

* The temperature.

The feede of Ameos is hot and dric in the latter end of the thirde degree.

$*$ The vertues.

A It auaileth againft gripings of the bellie in making of vrine, the bitings of ferpents taken in wine, and alfo it bringeth downe the flowers: being applied with honie it taketh away blacke and blewe fpots which cone of ftripes: the feede of $\mathrm{St}$ Jon doth alfo the like : for it is hot and drie and that in the thirde degree; likewife of thin parts, prouoking vrine, and bringing downe the defired ficknes.

B The feede of Ameos is good to be drunken in wine, againft the biting of all maner of venemous beafts, and hath power againft al maner of poifon and peftilent feauers, or plague, and is vfed in the correcting of Cantharides, whereby thofe flies are made medicinable to be receiued into the body without danger.

C Ameos braied and mingled with hony fcattereth congealed bloud, and putteth away blacke and blewe markes which come by ftripes or fals, if it be applied thereto in maner of a plaifter.
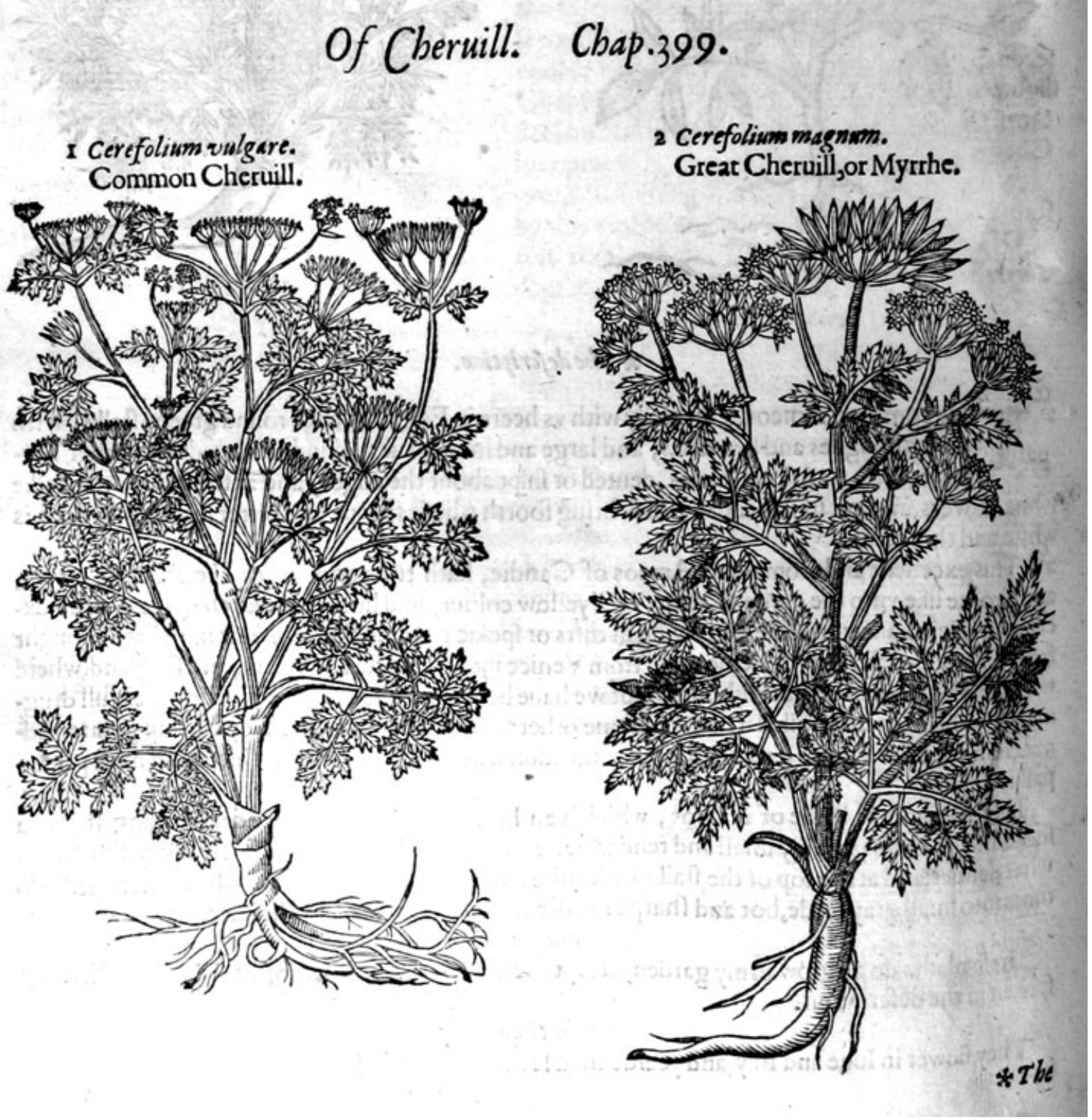


\section{HISTORIE OF PLANTS. $H$ HT}

He leaues of Cheruill are flender, and dituerly cur, fomething hairic, of a whitith greene:
the ftalkes be fhort, flender, round and hollow within, which at the firft togither with the

$\mathbf{I}$ the ftalkes be fhort, flender, round and hollow within, which at the firft togither with the leaues are of a whitilh greene, but tending to a red when the feedes be ripe : the tiowers be white, and growe vpon fcattered tuftes. The feede is long, narrow, llender, fharpe pointed: the roote is full ot ftrings.

2 Great Cheruill hath large learies, decpely cut or iagged, in fhew very like vnto Hemlocks, of a very good and plealant fmell and tafte like vnto Cheruill, and fomething hairie, which hath caufed vs to call it fweete Cheruill. Among thefe leaues rifeth vp aftalke fomewhat crefted or furrowed, of the height of two cubites; at the top where of growe fpokie tuftes or rundles with white flowers, which doturne into long, browne and ihining feede, one feede being as big as fower Fennellfeeds, which being greene, do tafte like Annis feede. The roote is great, thicke andlong, as big as Enula Campana, exceeding fweete in fmell, and tafting like vnto Annis feedes.

* 7 be place.

The common Chertill groweth in gardens with other pot herbes: it profpereth in a ground that is dunged and fomething moilt. The great fweete Cheruill groweth in my garden, and in the gardens of other men, who haue beene diligent inthefe matters.

* The time.

Thefe herbes do flower in May, and their feed is ripe in Iuly. * The names.

Cheruill is commonly called in Latine cerefoliwn, and as diuers affirme Cerofoliwon, with o in the fecond fyllable. Columella nameth it Cherephyllum, and it is thought to be fo called bicaufe it delighteth to growe with many leaues; or rather in that it caufeth ioy and gladneffe: in high. Dutch Sioffelkraut : in Lowe Dutch fiertiell : in Italian Cerefoglio: in French Du Cerfueil: in Englifh Cheruell, and Cheruill.

Myrrbis is alfo called Myrha, taken from his pleafant fauour of Myrrhe : of fome Conila, as it is found noted among the baftard names.

Of this Plinie maketh mention in his 24 .booke 16 .chapter, where he reporteth that it is called smyrrbiza : in Englifh great Cheruill, and Sweete Cheruill.

\section{* The temperature and vertues.}

Cheruill is held to be one of the pot herbes; it is pleafant to the ftomacke and tafte; it is of a A temperate heate, and moderate dryneffe, but nothing fo much as the Parfleies.

It prouoketh vrine, efpecially being boiled in wine, and applied hot to the fhare or nethermoft $B$ part of the belly, and the wine drunke in which it was boiled.

It hath in it a certaine windineffe, by meanes whereofit procureth luft.

It is vfed very much among the Dutch people in a kinde of loblollie or hotch potch, do eate, called Warmus.

The leaues of fweete Cheruill are exceeding good, holfome, and pleafant among other fallade E herbes; giuing the tafte of Anife feede vnto the reft. ftance.

The roote, as, Galen writeth, is hot in the fecond degree, and hath ioined with it a thinneffe of fub- F

Diofcoridesteacheth, that the roote being drunke in wine, is a remedy againft the bitings of the $G$ venemous fpiders called in Latine P balangia, and that it bringeth down the menfes \& fecondines:

and being boiled and drunke, it is good for fuch as haue the ptificke or confumption of the lungs.
The feedes eaten as a fallade whileft they arc yer greene, with oile, vineger, tand pepper, cxceede $\mathbf{H}$ all other fallads by many degrees, both in pleafantnes of tafte, fiveeteneffe of fimell, and holfomneffe for the cold and feeble ftomacke.

The rootes are likewife moft excellent in a fallade, if they be boiled, and after dreffed, as the cun-I ning Cooke knoweth how better then my felfe; notwithitanding I do vfe to eate them with oile
and vineger, being firft boiled,which is very good for old people that are dull and without courage,
it reioiceth and comfortech the it reioiceth and comfortech the hart, and increafecth their luft and ftrength. 


\section{Of Shepheards $\mathcal{N}$ (eedle, or wilde Cheruill. Chap.40o.}

Pecten Veneris, fiue Scandix.

Shepheards Needle, or Venus combe.

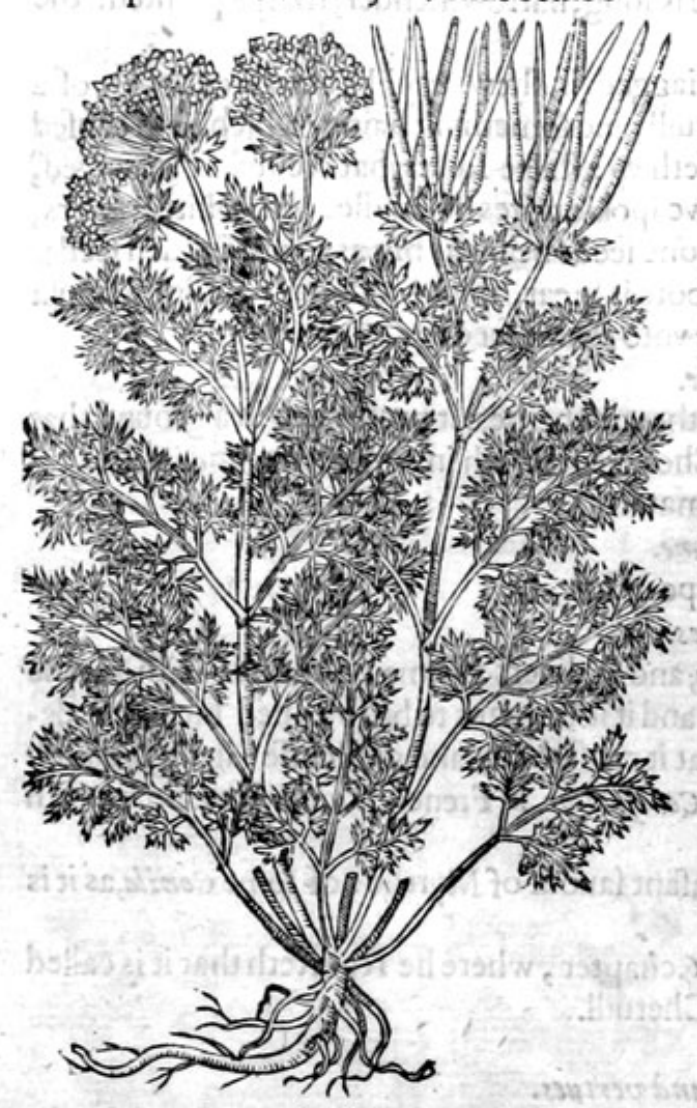

* The defaription.

Candix, or Pecten Veneris, doth notmuch differ in the quantitic of the ftalkes, leaues and flowers from Cheruill, but Scandix hath no fuch pleafant fmell as Cheruill hath: the leaues be greater,more finely cut, and of a browne green colour: the flowers grow at the top of the ftalkes in fmall white tufts, after which come vppe long feedes, very like vnto packneedles, orderlie fet one by another like the great teeth of a combe, whereofit tooke the name Pecten Veneris, Venus Combe, or Venus Needle: the roote is white, 2 finger long.

*T Teplace.

It groweth in moft corne fieldes of England, efpecially among wheate and barly.

\section{* Thetime.}

It flowrethin Maie, the feede is ripe in Auguft with corne.

\section{* The names.}

The Latines call it Scandix, hauing borowed

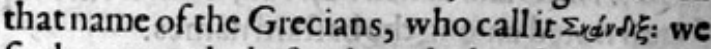
finde among the baftard words that the Romains didname it Scanaria, and Ucula, of the feede that is like vnto a needle : Ruellims defcribeth it voder the name Pecien Veneris, of others Wrow Veneris, and LAcus Paftoris, or Shepheards Needle, wilde Cheruill, Mock-Cheruill, and Ladies Combe: in high Dutch Jactae Karnel:this is faith Pliny in his 22.booke 22.chapter, that herbe which Arrftophanes obiected in.fport to the Poet Euripudes, that his mother was woont to fell not any right potherbe but scandix, or Shepheardes needle: meaning as I take it $V_{t}$ /naga, wherewith the Spaniards do picke their teeth when they haue eaten no meat at all, except a few Orenges or fuch alike trifle, called allo Scandix.

\section{* 7 hetemperature.}

Shepheards Needle, as Galen faith, is a potherbe fomewhat binding,and bitter in tafte, infomuch that it is hot and drie, either in the latter ende of the fecond degree, or in the beginning of the thirde.

\section{$*$ The vertues.}

A Digfcoridesfaith,that it is eaten both raw and boiled, and that it is an holfome potherb among the Greekes, but in thefe dares it is of fmall eftimation or value, and taken but for a wilde woort, 25 appeereth by Araftophanes taunting of Euripides, as aforefaid.

B The decostion thereof is good for the bladder, kidneies and liuer; but as I deeme, he ment Cheruill, when he fet the fame downe to be vfed in Phificke.

\section{Of Toothpicke Cheruill. Chap.4or.}

* The defcription.

I $T$ He firft of thefe Toothpicke Cheruils beareth leaues like wilde Turneps, a round ftalke furroived, icinted, blackifh and hairie, diuided into many branches; on the tops whereof growe tpokic tuites, befet round about with many fmall leaues. The flowers thereof are whitih 


\section{HISTORIE OF PKANTS.}

whitifh; after commeth the feede, which being once ripe do clufter and are drawen togither, in round thicke tuft like a fmall birdes neft, as be thofe of the wilde Carrot, which feedes who fo toucheth, they will cleaue and fticke to his fingers, by reafon of the glutinous or flimie matter they are poffeffed with. The roote is fmall and whitifh, bitter in tafte, as is all the reft of the plant.

2 The Spanifh Toothpicke hath leaues, flowers, and knobbie ftalkes like vnto wilde Carrots, fauing that the leaues are fomewhat finer, cut or iagged thicker, and tenderer; but not rough or hairie at all,as is the former : of a bitter tafte, and a realonable good fmell : among which rife vp bufhie roundles or fpokie tuftes, like thofe of the wilde Carrot or Birdes neft, clofely drawen togither when the feed is ripe; at what time alfo the fharpe needles, which are the feed vefiels, are hardened, fit to make Toothpicks, and fuch like, for which purpole they do very fitly ferve.

I Gingidium latifolinom.

Broade Toothpicke Cheruill.

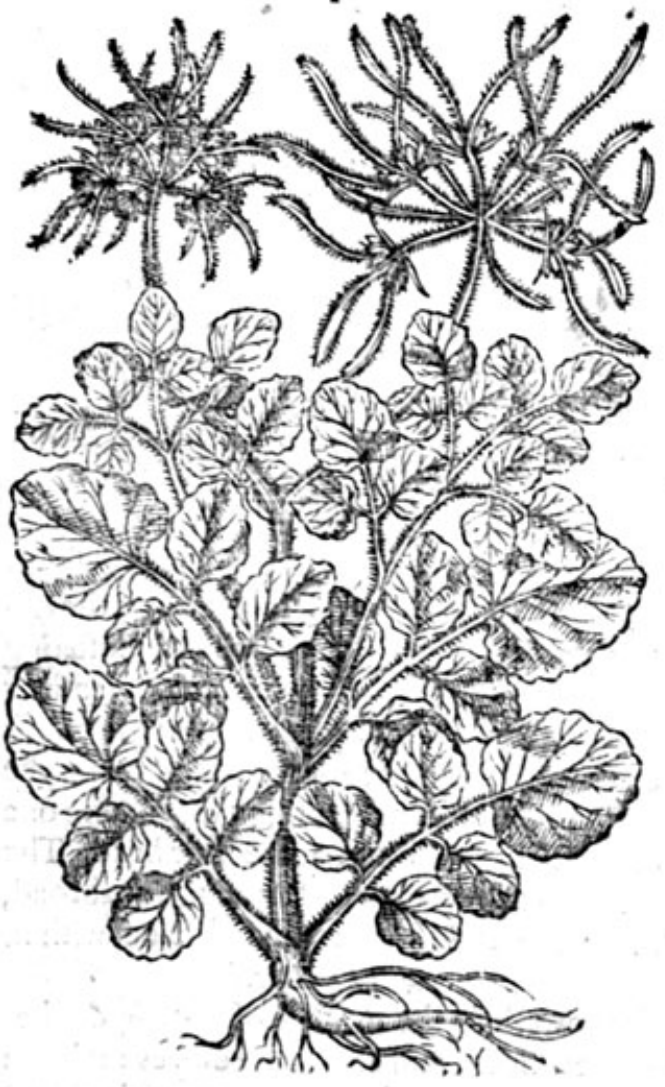

2 Gingiditum Hipanicumi. Spanifh Toothpicke Cheruill.

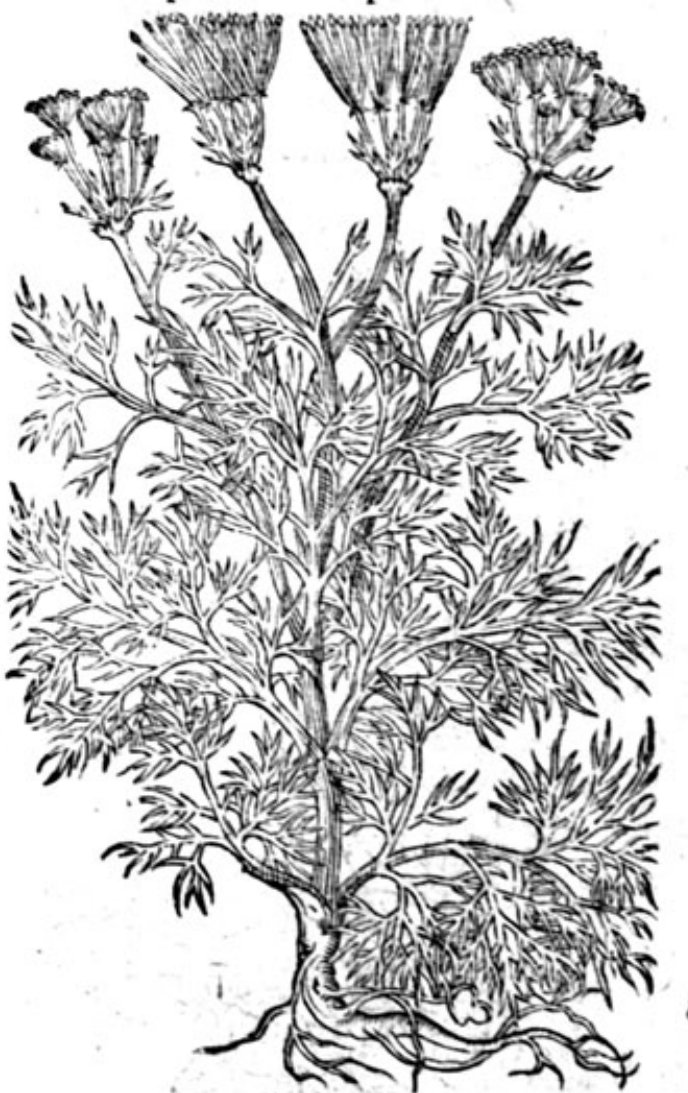

* The place.

Both of them dogrowe in Syria, and moft commonly in Cilicia : the later is to be found likewife in Spaine almoft euery where; and $I$ haue it likewife in my garden in great plenty.

* The time.

They flower in my garden about Auguft, and deliter their feede in October. * The names.

That which the Grecians call $r$ ritsoy, the Latines do likewife name Gingidium : and it is called in Syria Lepitivom; yet is there another Lepidium, of which we will intreate hereafter. It is reported among the baftard names to be called by the Romanes Bifacutim, of which name fome fhew re-

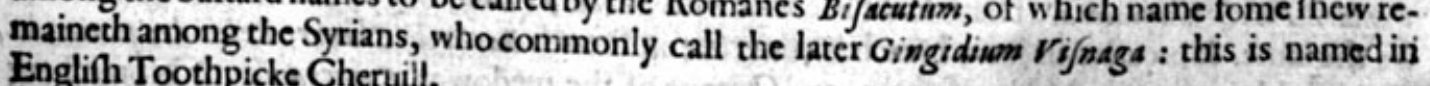
Englifh Toothpicke Cheruill.

\section{$*$ The temperature and vertwes.}

There is, faith Galen, great increafe of Gingidiun in Syria, and it is eaten no otherwife than is $\mathbf{A}$ Shepheards needie of Troy with vs, making a difference between Cerefolium, which is called of fome Shepheards needle, and Gingidium, which is called Toothpicke Cheruill. It is, faith he, very whole- 


\section{THE SECOND BOOKE OF THE}

fome for the ftomacke, whether it be eaten rawe or boiled; notwithftanding it is euident that it is a medicine rather than 2 nourifhment. As it is bitter and binding, fo is it likewife of a temperate heate and dryneffe. The heate is not very apparant, but it is found to be drie in the latter end of the fecond degree, as alfo the faid author alledgeth in his difcourfe of the faculties of fimple medicines.

B Diofcorides doth alfo write the fame: This potherbe, faith he, is eaten rawe, fodden, and preferued with great good to the ftomacke, it prouoketh vrinc: and the decoction therof made with wine and drunke, is profitable to fcowre the bladder, prouoketh vrine, and is good againft the grauell and ftone.

C The hard quils whereon the feedes did growe, are good to clenfe the teeth and gums, and doe eafily take aivay all filth and baggage fticking in them, without any hurt vnto the gums, as follow. eth a fter many other Toothpicks,and leaueth a good fent or fauour in the mouth.

\section{Of Medefweete, or Queene of the medowes. Chap.402.}
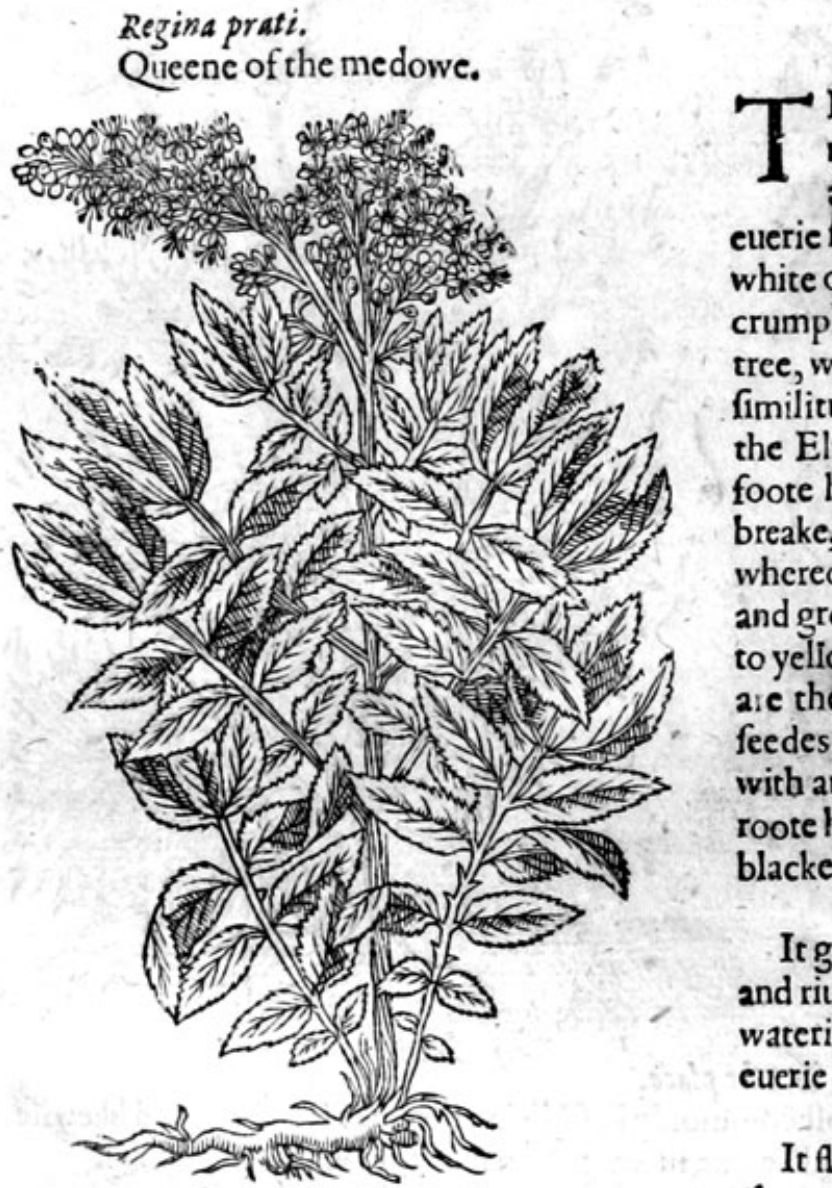

\section{* Thedefcription.}

His herbe hath leaues like thofe of Agrimonie, confifting of diuers leaues fet vpon a middle rib, like thofe of the Afhe tree, euerie fmall leafe flightly fript about the edges, white on the inner fide, and on the vpper fide crumpled or wrinkled like thofe of the Elme tree, whereof it tooke the name Vlmaria, of the fimilitude or likeneffe that the leaues hatue with the Elme leaues. The ftalke is three or fower foote high, rough and very fragile, or eafie to breake, of a reddifh purple colour; on the top whereof are very many little flowers, cluftering and growing togither, of a white colour tending to yeliowneffe, and of a pleafant fweet fmell, as aic the leaues likewife : after which come the feedes, fmall, crookedly turning or winding one with another, made into a fine little head. The roote hath a fweete fmell, preading far abroad, blacke without, \& of a darkifh red colour within. * The place.

It groweth in the brinkes of waterie ditches and riuers fides, and alfo in medowes : it liketh waterie and moift places, and groweth almoft euerie where.

\section{* The time.}

It flowreth and flourifheth in Iune, Iuly, and Auguft.

\section{$*$ The names.}

It is called of the later age Regina prati, and Barba Capri, of fome Vlmaria, a foliorum Vlmi fomilitudine taken from the likeneffe it hath with the Elme tree leafe: in high Dutch cifz̧atat. It iscalled Barba Hirci, which name belongeth to the plant which the Grecians do call $\tau$ ragopogon, of $A n$. guillar a, Potentilla maiora. It hath fome likeneffe with Rhodora Plinü, but yet we cannot affirmeticto be the fame. It is called in lowe Dutch Reiinette: in French Barbe de Cheure, Reine des praiz: in Englifh Maidefwcete, Medow fwecte, and Queene of the medowes. Camerarizus of Noremberg faith it is called of the Germanes his countrimen, veriutme braut, bicaufe the rootes, faith he, feeme to be eaten with wormes. I rather fuppofe they call it fo, bicaufe the ancignt hackneymen, and horfe leaches, doe giue the decoetion thereof to their horfes andaffes; againit the bots and wormes, for the which it is greatly commended. 


\title{
HISTORIE OF PLANTS.
}

Medefweete is cold and drie, withan cuident binding qualitie adioined.

\author{
* T be vertaes.
}

The roote boiled, or made into powder and drunke, helpeth the bloodie flixe; ftaieth thelaske, $A$ and all other fluxes of blood in man or woman.

It is reported, that the flowers boiled in wine and drunke, do take away the fits of a quartaine B ague, and maketh the hart merrie.

The leaues and flowers far excell all other ftrowing herbes, for to decke vp houfes, to ftrowe in C chambers, hals, and banketting houfes in the fommer time; for the finell thercof maketh the trait merrie, delighteth the fenfes : neither doth it caufe headach, or lothfomneffe to meate, as fome other fweete finelling herbes do.

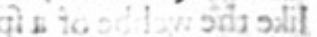

The diftilled water of the flowers dropped into the eies, taketh away the burning and itching $D$ thereof,and cleereth the fight.

\section{Of Burnet Saxifrage. Chap 404 .}

1 Pimpinella Saxifrage.

Burnet Saxifrage.

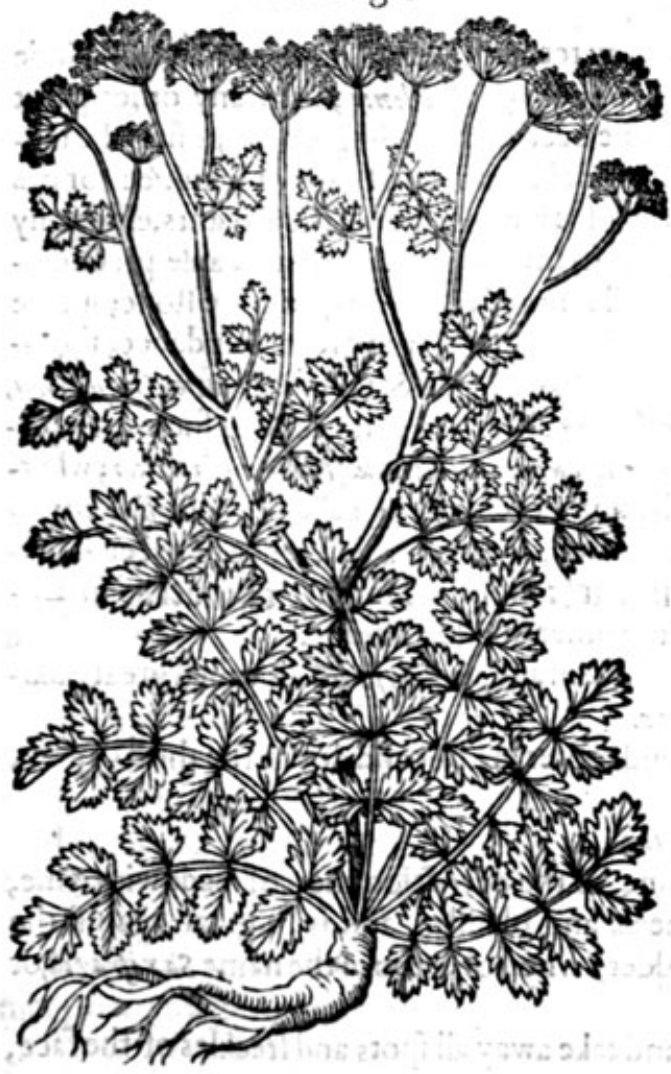

2 Bipinella, fue Saxifraga minor. Small Burnet Saxifrage.

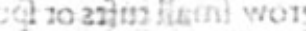

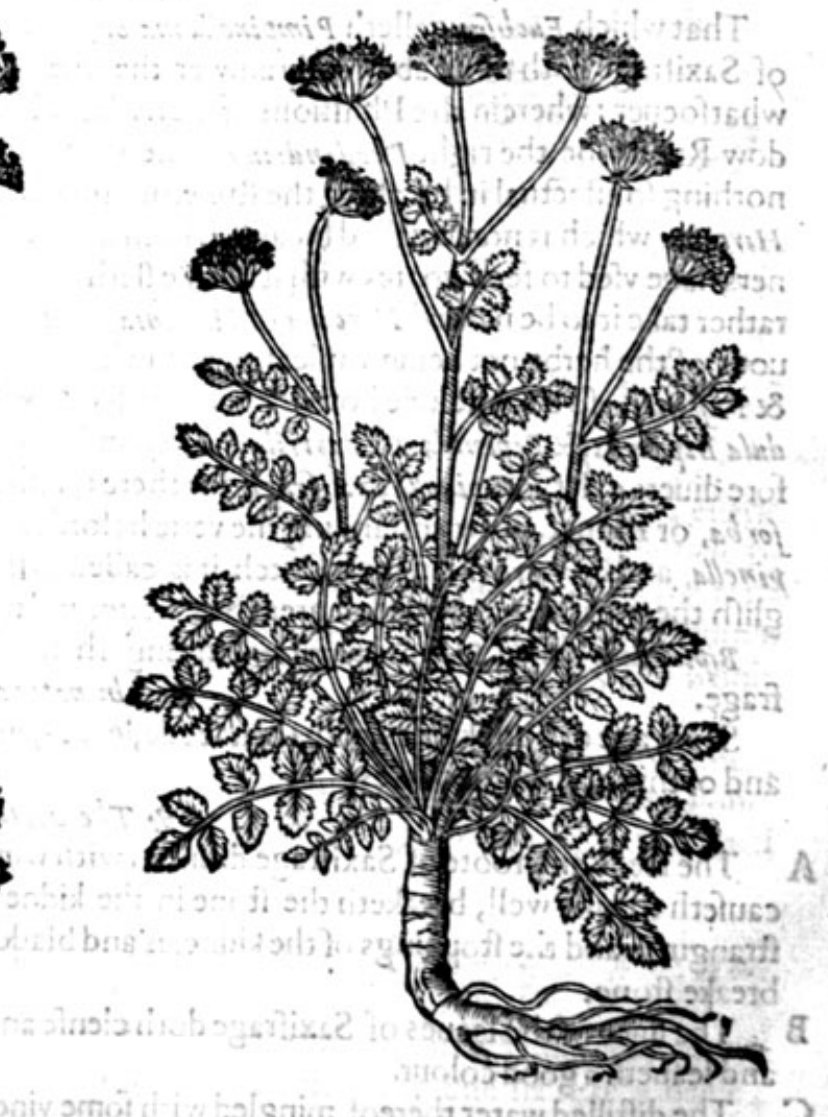

* The defaription.

' $\mathrm{T}$ His great kinde of Pimpinell, or rather Saxifrage, hath great and long rootes, fafhioned like a Parfnep, of an hot and biting tafte like Gingerffrom which rifeth vp an hollow ftalke prefent Smallage then Pimpernell, cubits high, befet with large leavies; which do more neerely refmall leaues growing vpon one ftem, or rather the garden Parfinep. This plant confifteth of many grow at the top of the ftalks in whitere, fnipt or dented about the edges like a fawe : the flowers do it is hotter and biting vpon the toong round tufts, the fecde is like the common Parfley, fauing that 2 Bipinella is likewifg a kinde of Burnet or Pimpinell, vpon which Pena hath beflowed this additi. 4hes. ratis $x$ 
on Saxifraga winor, vnder which name Saxif ragia are comprehended diuers herbes of diuers kinds, and the one very vnlike vnto the other: for fome of thofe herbes called Saxifrage ; dono more agree with the Saxifrages of Diofcorides, then in fhewe like vnto the diureticall herbes called Ruf-
cus Polygonatum; and Alparagus: but that kinde of Saxifrage which is called Hircina, which is rough or hairie Saxifrage, of others Bipinella, is beft knowne, and the beft of all the reft, like vnto the fmath Burnet, or common Parfley, fauing that it is voide of haires, as may appeere by the old Latin verfe: Pimpinella habet pilos, Saxtfraga non babet villos.

Pimpinell hath haires fome : but Saxifrage hath none.

Notwithftanding, I have founde a kinde heereof growing in our paftures adioining to London, the leaues whereof it you take and tenderly breake with your hands, yec may draw foorthifmall threds like the webbe of a fpider, fuch as yee may draw from the leaues of Scabious. The ftalke is hollow, diuiding it felfe from the ioints or knees, intofundrie other fimall branches; at the top whereof do grow fmall tufts or fpokie rundles, of a white colour, after which commeth the feed like vnto Carui, or Caruwaies, of a tharpe tafte: the roote is alfo harpe and hot in tafte.

* The place.

Thefe plants do grow in dry paftures and medowes, in this countrey veryplentifully.

They flower from Ine to the end of Augut. * The time.

\section{* The names.}

That which Fucb fus calleth P impinella maior, Dodonaus termeth Saxifragia maior, which kinde of Saxifrage doth more abfolutely anfwer the true Phell indrium of Plime, then any other plane what foeuer : wherein the Phifitions of Paris haue beene deceiued, calling or fuppofing the medow Rue to be the right $P$ hellandrium, whereunto it is not like either in fhape or faculte: : for it is nothing fo effectual in breaking the ftone, or prouoking of vrine, as either of thefe plants, ef pecially Hircinia, which is not fo called bicaufe it hath any raminifh fmell of a goate, but bicaufe practicioners haue vfed to feed goates with it, whofe flefh \& blotit is fingular good againft the ftone;bur we rather take it to be named Hircina, of Hircinia fylua, where it doth grow in great abundance; the 1auour of the herbe not being vnpleafant, fomwhat refembling the finell \& tafte of Daucus, Liguftrum, \& Paft inaca:fo to conclude both thefe are called Saxifragia: the fmaller is called of fome Pctrafundula, Bipinella, \& Bipenula: of Baptista Sardus, and alfo of Lconardus Fuchfous, Pimpinella maicr; wherfore diuers cal it P mpinella Saxifraga: for there is alfo another Pimpinella, called Pimpinella Sangui, for $b a$, or Burnet, notwithftanding the verfe before rehearfed, Theweth a difference betweene $F$ in. pinella, and Saxifraga: in high Dutch it is called 2bibernel : in lowe Dutch 2Bettenaett: in Englifh the greater may be called great Saxifrage, and the other fmall Saxifrage.

Bipinella is called Saxifragia minor, in Englifh fmall Saxifrage, as P impinell. is called great Saxifrage. * Ihe nature.

Saxifrage of both kindes, with their feede, leaues, and rootes are hot and drie in the third degree, and of thin and fubtile partes.

A The feede and roote of Saxifrage drunken with wine, or the decoction thercof made with wine, caufeth to piffe wcll, breaketh the ftone in the kidneies and bladder, and is fingular againft the Itrangurie, and the ftoppings of the kidneies and bladder: whereof it tooke the name Saxifragia,or breake ftone.

B The iuice of the leaues of Saxifrage doth clenfe and take away all fpots and freckles of the face; and leaueth a good colour.

C The diftilled water thereof mingled with fome vineger in the diftillation, cleerech the fight, and taketh away all obfcuritie and darkneffe of the fame.

\section{Of Burnet. Chap:403.}

* The kindes.

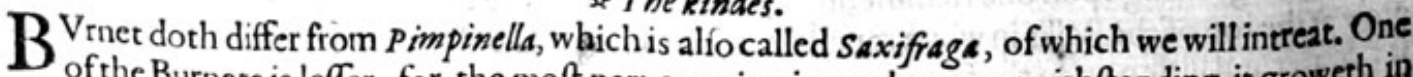
of the Burnets is leffer, for the moft part growing in gardens, notwithiftanding it groweth in barren fieldes, whe re it is much fmaller: the other greater, is altogither wilde. 

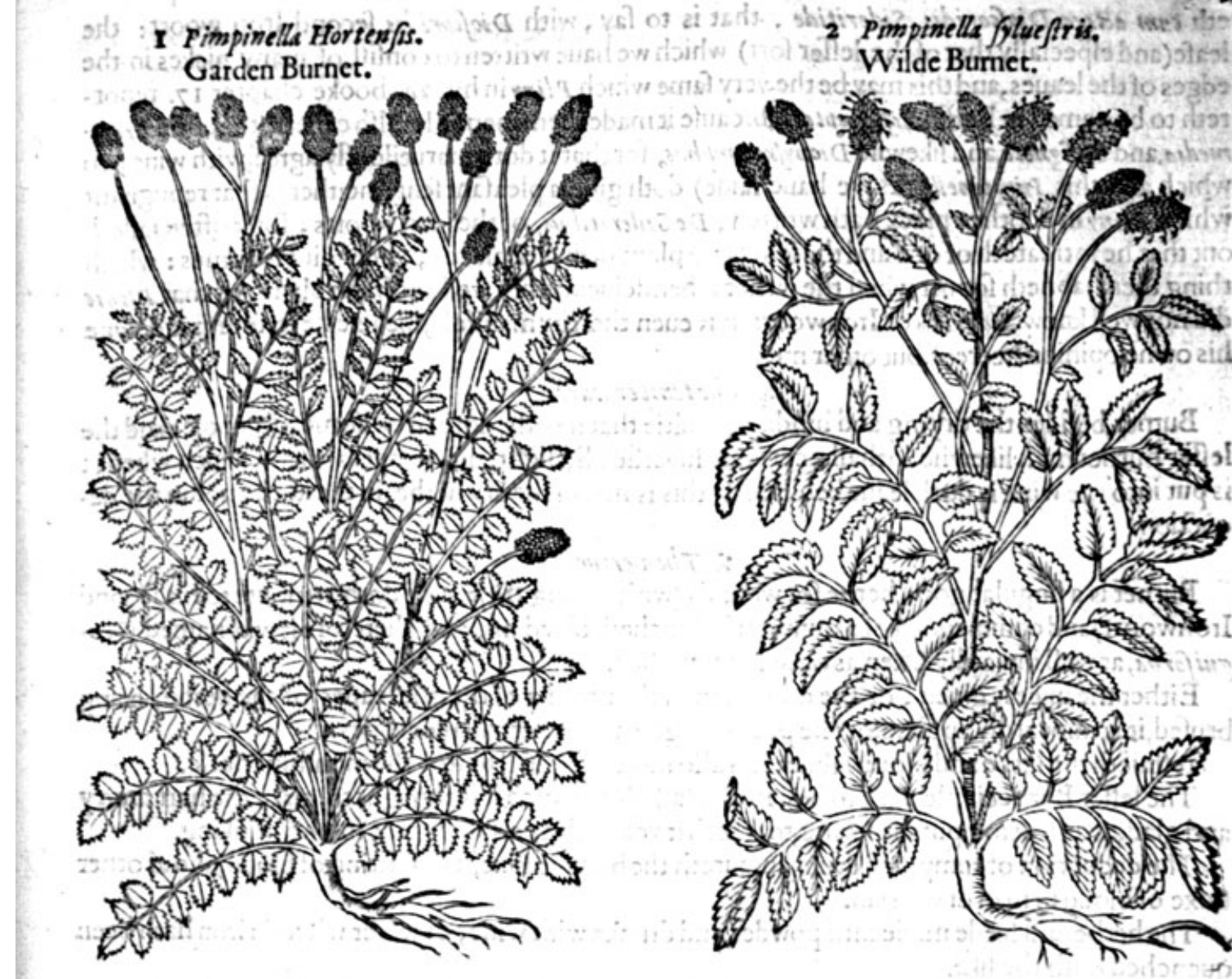

the taes its?

$*$ The defcription.

I Arden Burnet hath long leaues made vp togither of a great many vpon one ftem, euerie

$\mathbf{J}$ one whereof is fomething rounde nicked on the edges;, fomewhat hairic : among thefe rifeth a ftalke that is not altugither without leaues, fomething chamfered: vpon the tops where of growe little round heads or knaps, which bring foorth imail flowers of a browne purple colour, and after them cornered feedes, which are thruft vp togither. The roote is long: the whole plant doth fmell fomething like a Melon, or Cucumber.

2 Wilde Burnet is greater in all parts, it hath wider and bigger leaues then thofe of the former: the ftalke is longer, fometimes two cubits high: the knaps are greater, of a darke purple colour: the feede is likewife cornered and greater: the roote longer, but this Burnet hath nopleafant finell atall.

* The Dlace.

The finall Pimpinell is commonly planted in gardens, notwith fanding it doth grow wilde vpon many bar en heathes and paftures.

The great wilde Burnet groweth (as mafter $L$ ste faith) in dry medowes about Viluorde, and my felfe haue founde it growing vpon the fide of a carvfey which croffeth the one halfe of a fielde, whercof the one part is earable grounde, and the other part medowe, lying betweene $\mathrm{Paddington}$ and Lyfon greene, neerevnto London, vpon the high way.

They flower from Iune, vnto the end of Auguit. * Thetome.

\section{* The names.}

The later Herbarifts do call Burnet Pimpinella sanguifor ba, that it may differ from the other, and yet it is called by leuerall names, Sanguifor ba, and Sangumaria : Ge fner had rather it houlde be cal. led Peponella of the fmell of Melons or Pompions, to which it is like as we haue faide: of others it is named Pmpinella, or Bipennula, of moft men Solbaftrells: in high Dutch Itolbieskraut, ber Sots

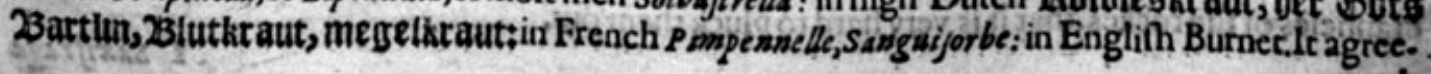


eth tum alisera Diofcoridis Sideritide, that is to fay, with Diofcorides fecond Iron woort: the leafe(and efpecially that of the leffer fort) which we haue written to confift of many' nickes in the edges of the leaues, and this may be the very fame which Pliny in his 24 booke chapter 17 . repor, teth to be named in Perfia Si sitiepter is, bicaufe it made them merry; he alfo calleth the fame Proso-

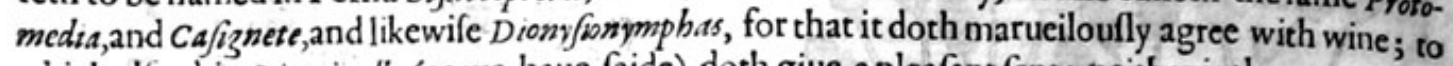
which alfo this Pimpinella (as wc haue faide) doth giue a pleafant fent: neither is that repugnant which Pliny in another place hath written, De Sideritibus, of the Iron woorts; for it often falleth out that he intreateth of one and the felfefame plant in diuers places, vnder diuers names: which thing then hapnech fooner when the writers themfelues do not well know the plant, as that Plinie did not well know Sideritis or Ironwoort, it is euen thereby manifeft, bicaufe he fettech not downe his owne cpinion heereof, but other mens.

* The temperature.

Bumet, befides the drying and binding facultie that it hath, doth likewife meanly coole : and the leffer Burnet hath likewife withall a certaine fuperficiall, flight, and temperate fent, which when it is put into the wine it dothleaue behinde it: this is not in the dry herbe, in the iuice, nor in the decoction.

A Burnet is a fingular good herbe for wounds (which thing Diofcorides doth attribute to his fecond Ironwoort)and commended of a number: it ftancheth bleeding, and therefore it was named Sanguiforba, as well inwardly taken as outwârdly applied.

B Either the iuice is given, or the decoction of the powder of the dric leaves of the herbe, being brufed, it is outwardly applied,or elfe put amongft other externall medicines.

C It ftaieth the laske and bloudy flixe: it is alfo moft effectuall to ftop the monthly courfe.

D The leffer Burnet is pleafant to be eaten in fallads, in which it is thought to make the hart merry and glad, as alfo being put into wine, to which it yeeldeth a certaine grace in the drinking.

E The decoction of Pimpinell drunken, curcth the bloudie flixe, the fpitting of bloud, and al other fluxe of bloud in man or woman.

F The herbe and feede made into powder,and drunke with wine, or water wherein iron hath been quenched doth the like.

G The leaues of Pimpinell are verie good toheale woundes, and are receiued in drinkes that are made for inward wounds.

H The leaues of Burnet fteeped in wine and drunken, doth comfort the hart, and maketh it merrie, and is good againft the trembling and fhaking thereof.

\section{Of Englifh Saxifrage. Chap.405.}

\section{* Thedcfoription.}

His kinde of Saxifrage our Englifh women Phifitions haue in great vfe, and is familiarly knowne vnto them, vouchfafing that name vnto it of his vertues againft the fone: it hath the leaues of Fennell, but thicker and broader, very like vnto sefelipraten $f e$, Mox/felienfium, (which addition Pens hath beftowed vpon this our Englifh Saxifrage) among which rileth vp a ftalke, of a cubite high or more, bearing at the top f pokie rundles befet with white flowers: the roote is thicke, blacke without, and white within, and of a good fauour.

There is another Saxifrage, fet foorth by Mathiolus, which he calleth Saxifraga maior, that groweth naturally on the flope cliffes and rockes of the mountaine Baldus in Italy, neere vnto the citie Verona confifting of a great number of fmall twigs, fomewhat tough and woodie; whereon do growe little leaues like thofe of winter Sauorie, growing for the moft part by couples, fet one againft another: the flowers grow at the top of the twigs, of a white colour, fafhioned like little cups, after which commeth fmall red feede: the roote thrufteth it felfe fo deepe into the clifts and. cranueies of the rockes, that it is very hard to pluck them out. 


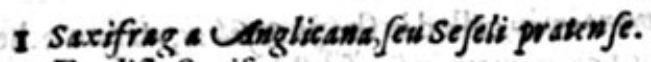
Englifh Saxifrage.

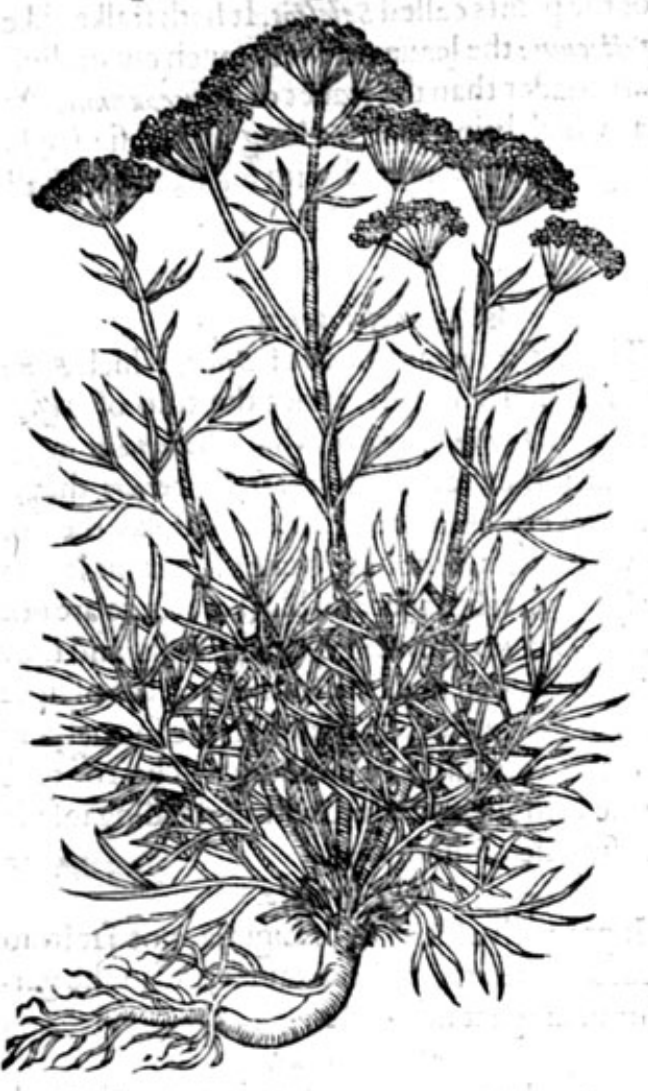

* The defription.

There is another Saxifrage altogither lefler then the former, wherof the dric coults , chalkie hils, ftonie and barren groundes, which bring foorth Serpillym or wilde Tinte in England, doe yeelde alfo great plentie : this finaller Saxifrage (which of L'Obetimu is called Saxifraga antiguto. rwn, or the ancient Saxifrage, ) hath many thicke branches fpreading vpon the grounde, like Serpilium or wilde Time, fee with the like leaues of wilde Time, but fomewhat leffer: among which come foorth finall flowers of an herbie colour, after comneth a little red feed: the roote is flender and groweth deepe into the ground: of the firft of the fe two laft defcribed, the Italians do make great account, calling it Lithontrima, gmafi terens ls jitem: in Englifh wemay call is Rocke Breakeftone.

$$
\text { * The plase. }
$$

,Saxifrage groweth in moft fields 8 medowes, euery where throughout this our countrey of England.

\section{*Thetime.}

It flowreth from the beginning of Maie to the end of Augult.

\section{* The names.}

Saxifraga Anglicana, is called in our mother toong Stone breake, or Englifh Saxifrage : Pena and L'Obel call it by this name Saxifraga Anglicame, for that it groweth more plentifully in England then in anyother countrey.

$$
\therefore \text {. The nuture. }
$$

Stone breake is hot and drie in the thirde degree.

$$
\leqslant \text { The vertues. }
$$

A decoction made with the feedes and rootes of Saxifrage, breaketh the ftone in the bladder $A$ and kidneies, helpeth the ftrangurie, and caufeth one to piffe freely.

The roote of Stonebreake boiled in wine, and the decoetion drunken, bringeth downe womens B ficknes, expelleth the fecondine and dead childc.

The roote dried and made into powder, and taken with fugar,com fortech and warmeth the fto- $\mathbf{C}$ macke, helpeth digeftion, cureth the gnawings and griping paines of the belly.

It helpeth the colicke, and driueth away ventofities or windines.

Our Englifh women vfe to put it in their running D (where I was borne) where the beft their ringing or renuector cheefe, exfpecially in Chefhire $\mathbf{E}$

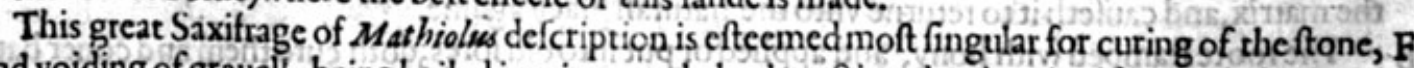
and voiding of grauell, being boiled in wine, and the decoction drunke; it alfo curech rhe ague, eafeth the ftranguric, helpeth the difeafe Singultsus, or yeoxing: finally, whatfocuermay beexpected of any herbe for the breaking of the ftone, the famemay be fooked for in this plant.

\section{Of Siler mountaine, or baftarde Lonage. Chap.406.}

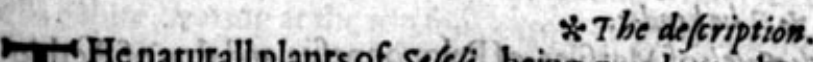

He naturall plants of sefeli, being now better kpowne then in times paft, efpecially among oir Apothecaries, is called by them siler mont antom, and sefeleos : this plant they haue retained to very good purpofeand confideration; but the erfour of the name hath caufed diuers 


\section{2}

\section{THE SECOND BOOKE OF THE}

of our late writers to erre, and to fuppofe that Siler montanum, called in fhops sefeleos, was no other

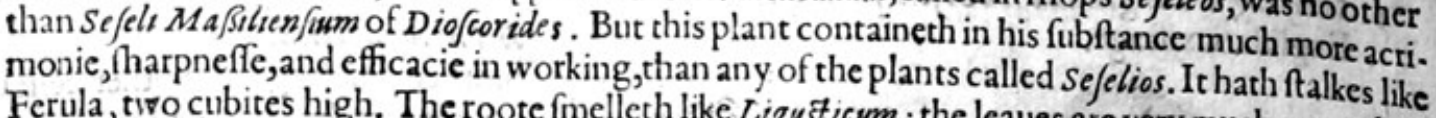
Ferula, tiro cubites high. The roote fmelleth like Ligusticum: the leaues are very much cut or diujded, like the leaues of Fennell or Sefeli Ma Britienfe, and broader than the leaues of Peucedanum. At the top of the ftalkes growe fpokie tufts like Angelica, which bring foorth a long and leafie feede
like Cumine, of a pale colour; in tafte feeming as though it were condited with fugar, but withall fomewhat Tharpe, and harper than Sefelipratenfe.

Siler monta num of ficinarum.

Baftard Louage.

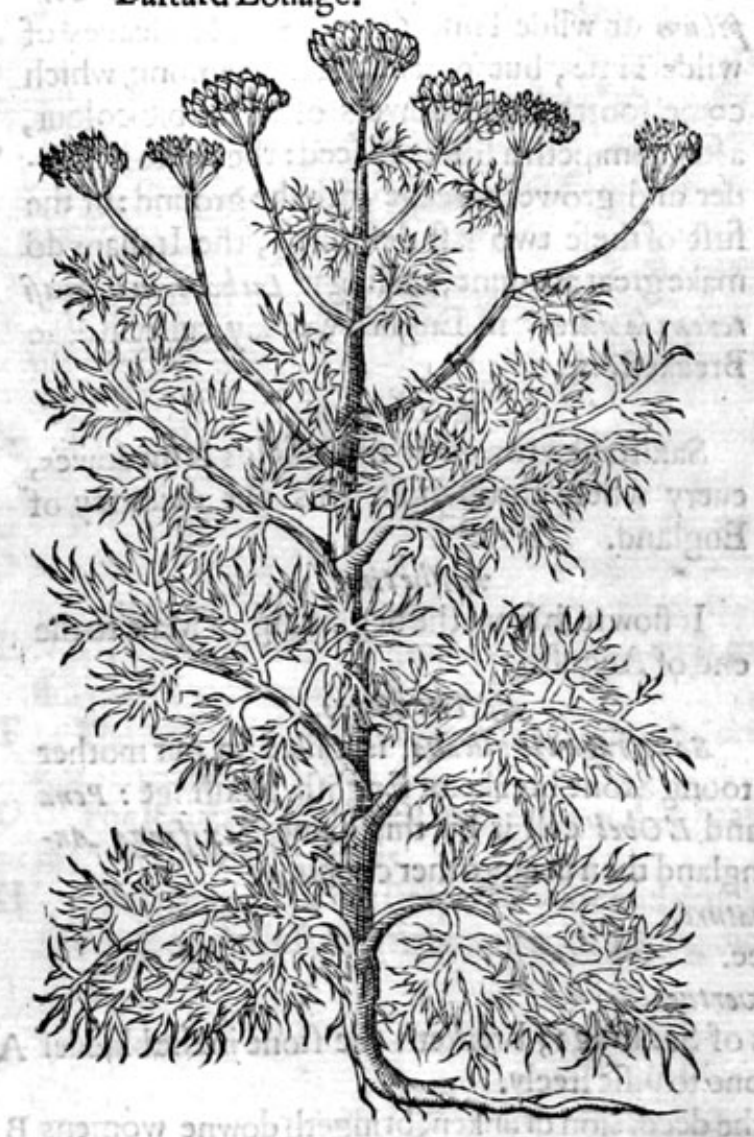

\section{* The defcription.}

There is a fecond kinde of siler, which Pena and L'Obel fet foorth vnder the title of sefeli pratenfe Mon/pellienfum, which Dodonaus in his laft edition callech Siler pratenfe alterum, that is in fhew very like the former. The ftalks thereof growe to the height of two cubits, but his leaues are fomewhat broader and blacker : there are not fo many leaues growing vpon the ftalk, and they are leffe dituided than the former, and are of little fatour. The feede is fmaller than the former,and fauoring very little or nothing. The roote is blacke without, and white within, diuiding it felfe into fundrie diuifions.

\section{* The place.}

It groweth of it felfe in Liguria, not farfrom Genua in the craggy mountaines, and in the gardens of diligent herbarifts.

\section{$*$ The time.}

Thefe plants do flower from Iune to the ende of Auguft.

It is called commonly Siler montanum : in Fiench and Ditch by a corrupt name Ser-Mon. twin: in diuers fhops Sefeleos, but vntruly: for it is not Sefeli, nor a kinde thereof : in Englifh Siler mountaine after the Latine name, and baftarde Louage.

\section{* The nature.}

This plant with his feede is hot and dry in the third degree.

$*$ I he vertues.

A The feedes of siler drunke with Wormewood wine, or wine wherein Wormwood hath beene

A fodden, mooueth womens difeafes in great abundance : cureth the fuffocation and ftrangling of the matrix, and caufeth it to returne vnto the naturall place againe.

B The roote ftamped with hony, and applied or put into old fores, doth cure them and coucr bare and naked bones with fleth.

C Being drunke it prouoketh vrine, eafeth the paines of the guts or entrailes proceeding of cruditic or rawneffe, it helpeth concoetion, confumeth winde, and fwelling of the ftomacke.

D The roote hath the fame vertue or operation, but not fo effectuall, as not being fo hot and drie.

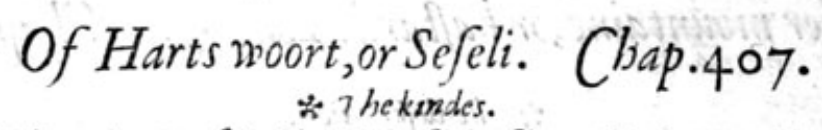

DIofcorides maketh three fortes of Sefelt, Sifelt of Marfiles, of Peloponnefus, and that of Aethiopia being a fhrubbie or hedge plant, wher of we will intrea te in the laft part of this our hiftorie. The later writers haue found more, as fhall be fhewed in this ptefent chapter. 


\section{A H HISTORIE OF PLANTS. HT}

Sefeli peloponnefiacum.

Harts woort of Peloponnefus.

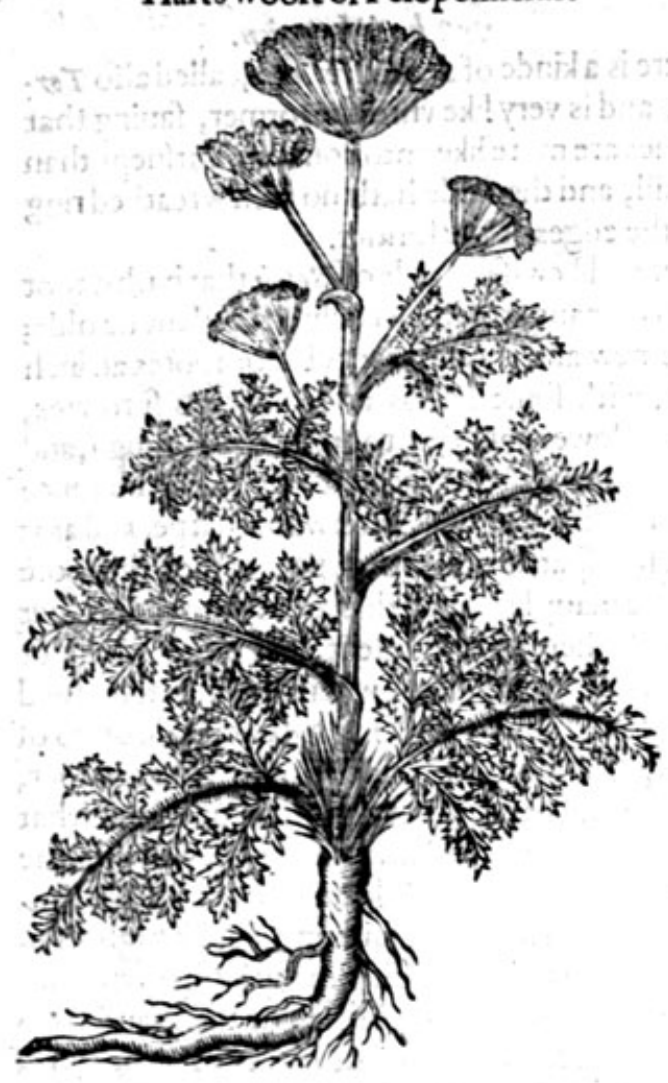

* The defcription, wo listor.

Efeliof Peloponnelus or of Greece, hath a thicke great roote, white within and blacke without, of the bignes of a Parfnep.growing ftraight downe, and deepe in the ground like that of Ferula, of a good mell and fharpe in tafte; from which rifeth vp an vpright ftalke two cubits high; whercupon doth grow heere and there at certaine fpaces one great leafe at euery ioint, confifting of many fmall iagged leaves fet vpon a rough and hairie middle $\mathrm{nb}$, verymuch curled, hairy,\& ful of wrinckles,greater then thofe leaues of Hemlocks: at the top of the ftalke do ftande great tufts or fpokie rundles of yellowe flowers like thofe of Dill, after which followeth the feed fomewhat flat and broade, of a darke yellowe colour and pleafant finell, in fhape like thofe of $\mathrm{Fe}$ rula, or the Parfinep feede.

$$
\text { * Theplace. }
$$

It groweth in rough and waterifh mountaines, in diuers places of $\mathrm{Grecce}$,Morea, and the mount Ida : it is a ftranger in Englande.

$$
\text { * The time. }
$$

It flowreth and flourifheth in the fommer months.

* The names.

It is called sefeli Peleponne/m, taken from the natiue iöile, diuers alfo call it Sphagnon, and of fome Feniciulum tortuofum, or writhed Fennell, in Shops Sefeleos : in Englifh Hartwoort of Peloponnefus, or of Greece.

\section{* The temperature.}

* The vertues.

It prouoketh vrine, and belpeth the ftrangurie, bringeth downe the ficknes and dead birth : it $A$ heipeth the cough and thortnes of breath, the fuffocation of the mother, and helpeth the falling
fickneffe.

The feede drunke with wine concocteth rawe humours, taketh away the griping and torments of $B$ the belly, and helpeth the ague as Diofcorides faith.

The iuice of the leaues is giuen to goates and other cattle to drinke : that they may the fooner be C deliuered of their yoong ones : as the fame author reporteth.

\section{Of Sefelios, or Hartewoorts of Candie. Chap. 408.}

\section{* The defcription.}

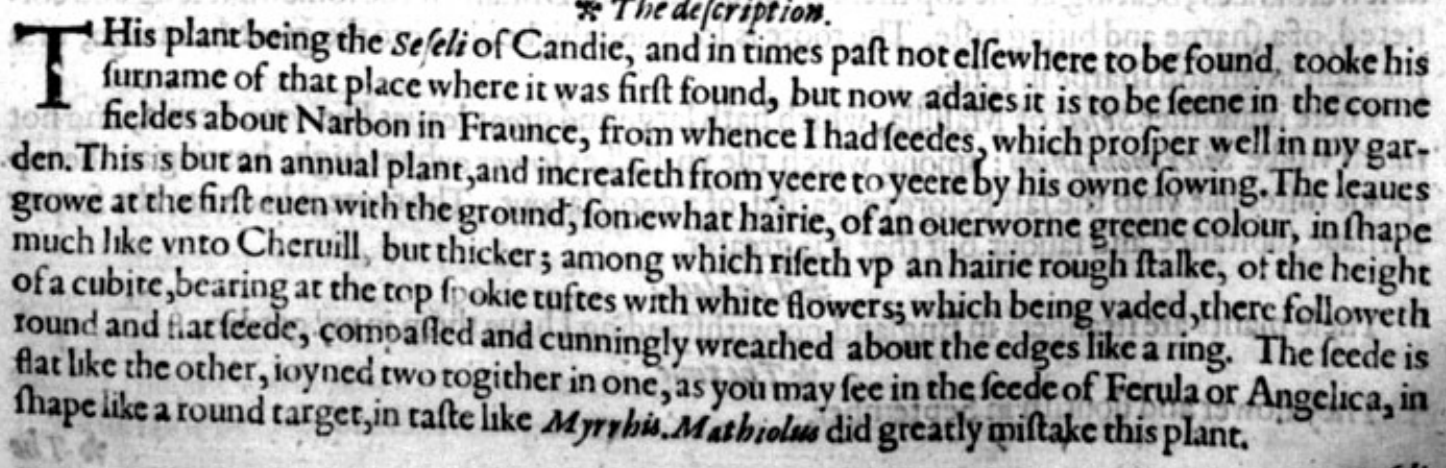




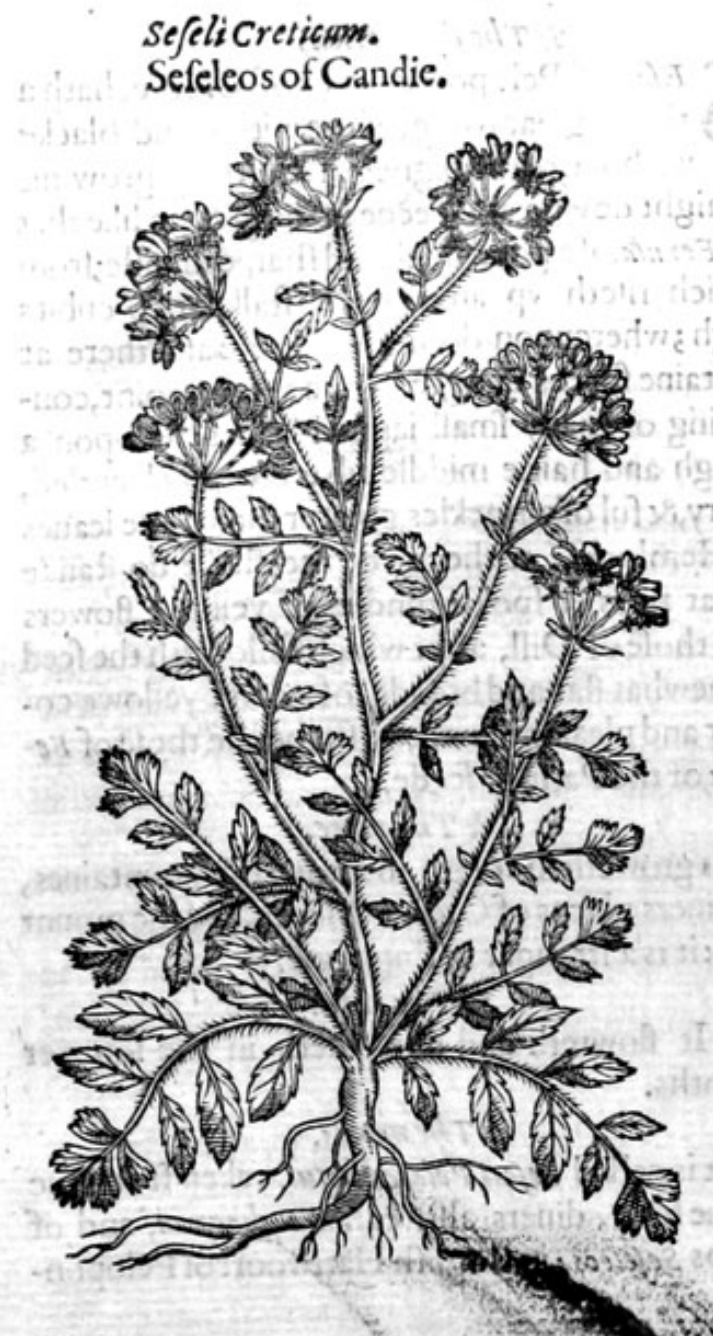

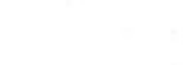

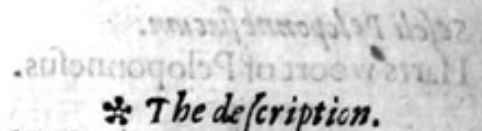

There is a kinde of Sefeli Creticum, called alfo $\boldsymbol{T}_{\text {or- }}$ dylion, and is very like vnto the former, fauing that his lcaues are more like vnto common Parfneps than Cheruill, and the feede hath no fuch wreathed ring about the edges as the former.

irt There is likewife a kinde of Sefeli that hath a root as big as a mans arme, efpecially if the plant be olde; but the new and yoong plants beare rootes an inch thicke, with fome knobs and tuberous fprowtes, about the lower part; the roote is thicke, rough, and couered ouer with a thicke barke, the fubiftance whereof is firft gummie, afterward fharpe, and as it were full of fpattle; from the vpperpart of the roote proceede many knobs or thicke fwelling rootes, out of which there iffueth great and large wings or branches of leaues, fome whereof are notched and dented round about, growing vnto one fide or rib of the leafe, ftanding alifo one oppofite vnto another, of a darke and delaied greene colour, and fomewhat Phining aboue, but vnderneath of a grayilh or Afhe color:from amongft thefe leaues there arifeth $a$ ftraked or guttered ftalke, a cubite and a halfe high,fomtimes an inch thicke, hauing many iointes or knees, and many branches growing about them, and vpon each ioint leffer branches of leaues. At the top of the ftalkes, and vpper endes of the branches growe little cups or bottles of pale flowers; which being vaded, there commeth in place a feede, which is very tike siler montanum.

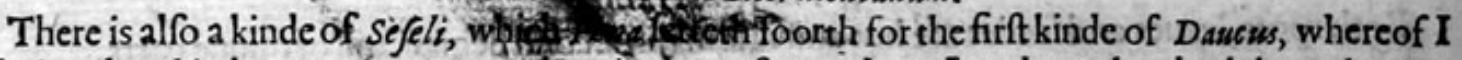
rake it to be a kinde, growing euery whiere in the paftures about London, that hath large leaues, growing for a time euen with the earth, and fpred thereupon, and diuided into many parts, in maner almoft like to the former for the moft part in all things, in the round fpokic tuftes or vimbles, bearing ftiffe and faire white flowers in fhape like them of Cinkfoile, in fmell like Sambucus or Elder. When the flower is vaded, there commeth in place a yellow guttered feede, of a ficie and very hot tafte. The roote is thicke and blacke without, which rotteth and perifheth in the ground (as we may fee in many gummic or Ferulous plants) after it hath feeded, neither will it flower before the fecond or third yeere after it is fowen.

There is likewife a kinde of Sefeli called Sefeli Maßslienfe, which hath leaues very much clouen or cut, and finely iagged, very much like vnto the leaues of fweete Fennell,greater and thicker than the common Fennell. The ftalke groweth to the height of three cubites, hauing knottie iointes, as it were knees; bearing at the top thereof tuftes like vnto Dill, and feede fomewhat long and cornered, of a tharpe and biting tafte. The roote is long and thicke like vnto the great Saxifrage, of 2 pleafant fmell and $\mathrm{fharpe}$ in tafte.

There is another Sejelt of Maffilia, which hath large and great leaues like vnto Ferula, and not much vilike Siler montanum : among which rife vp ftalkes fower cubites high, bearing at the top pokie tuftes like vnto the laft before rehearfed, of a good fauour. The roote is like vnto the former in fhape, fubftance, and fauour, but that it is greater.

$$
\text { * Theplace. }
$$

Thefe plants are ftrangers in England, notwithftanding I haue them in my garden.

They flower and flourith in September. $*$ The time. 
Their names haue beene toughed in their feuerall defcriptions. * The temper ature and ver tues.

Their temperature and faculties in working are referred to the other Sefeleos.

$$
\text { Of Spignell, Spicknell, or cMeme. Chap.409. }
$$

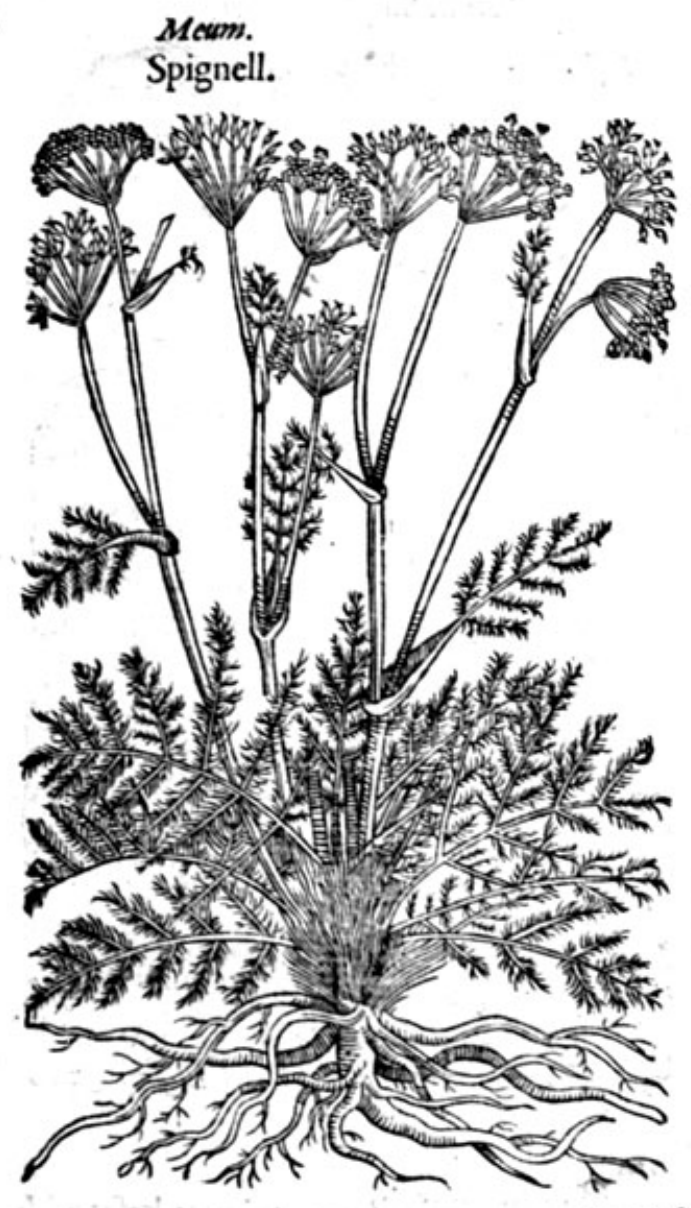

* The names.

* 7 be defeription.

Pignell hath ftalkes rifing vp to the height of a cubite and an halfe, befet with leaues refembling Fennel or Dill, but thicker, more burhie, and more finely iagged; and at the top of the ftalkes do growe fpokie tufts like vnto Dill. The rootes are thicke and full of an oleous fubftance, fmelling well, and chafing or heating the toong, of a reafonable good fauour.

There is a baftarde kinde of Spignell like vn. to the former, fauing that the leaues are not fo finely cut or iagged: the flowers are tufted more thicker then the former : the rootes are manie, thicke, and full of fappe.

$$
\text { * The flace. }
$$

Mewe, or Meon, groweth in Weftmerland,at 2 place called Round-thwait betwixt Aplebie and Kendall, in the parith of Orton.

Baftarde Mewe, or Meum, groweth in the wafte mountaines of Italy, and the Alpes, and(as it hath beene tolde me) vpon Saint Vincents rocke by Briftowe, where I fpent two daies to feeke it, but it was not my hap to finde it, therefore I make fome doubt of the truth thereof.

$$
\text { * The time. }
$$

Thefe herbes do flower in Iune and Iuly, and yeelde their feede in Auguft.

It is called of the Grecians uñov, or uñov, likewife of the Latines Meum : of the Italians Cateo: in Apulia, as Mathiolus declareth, it is called Imperatrix: in diuers places of Spaine Siftra, in others Pinello: in high Dutch 2Bateinutz: in French Siftre: Ruellitus faith that it is named in France Imet hwon tortwo fum, and fylueftre, or writhed Dill, and wilde Dill : alfo it is called in Englifh Spig:
nell,or Spicknell,of fome Mewe, or Baldmony, and Bearewoort.

The fecond may be called baftard Baldmony, or baftard Spicknell. Thefe herbes efpecially the temper ature. cond.

The rootes of Meon $\quad$ * The vertues.

of the kidneies and bladder, prouoke vrine in water and drunke, mightily openeth the ftoppings A

fumeth all windines and belchings of the ftomacke.

The fame taken with honie doth appeafe the griefe of the belly, and is excellent againft all Ca- B
tarrhes,rheumes, and aches of ioints, as alfo any

If the fame be laide plaifterwife vpon the any phlegme falling vpon the lungs.

If the fame be laide plaifterwife vpon the bellies of children, itmaketh them to piffe well. 
D They clenfe the entrailes, and deliuereth them of obftructions or ftoppings: they prouoke vrine, driue foorth the ftone, and bring downe the flowers: but if they be taken more then is requifite, they caufe the headach; for feeing they haue in them more heate then drines, they carric to the head raw moifture and windy heate, as $G$ alen faith.

\section{Of Horefrange, or Sulpburwoort. Chap. 4io.}

I Pescedanum.

Sulphurwoort.

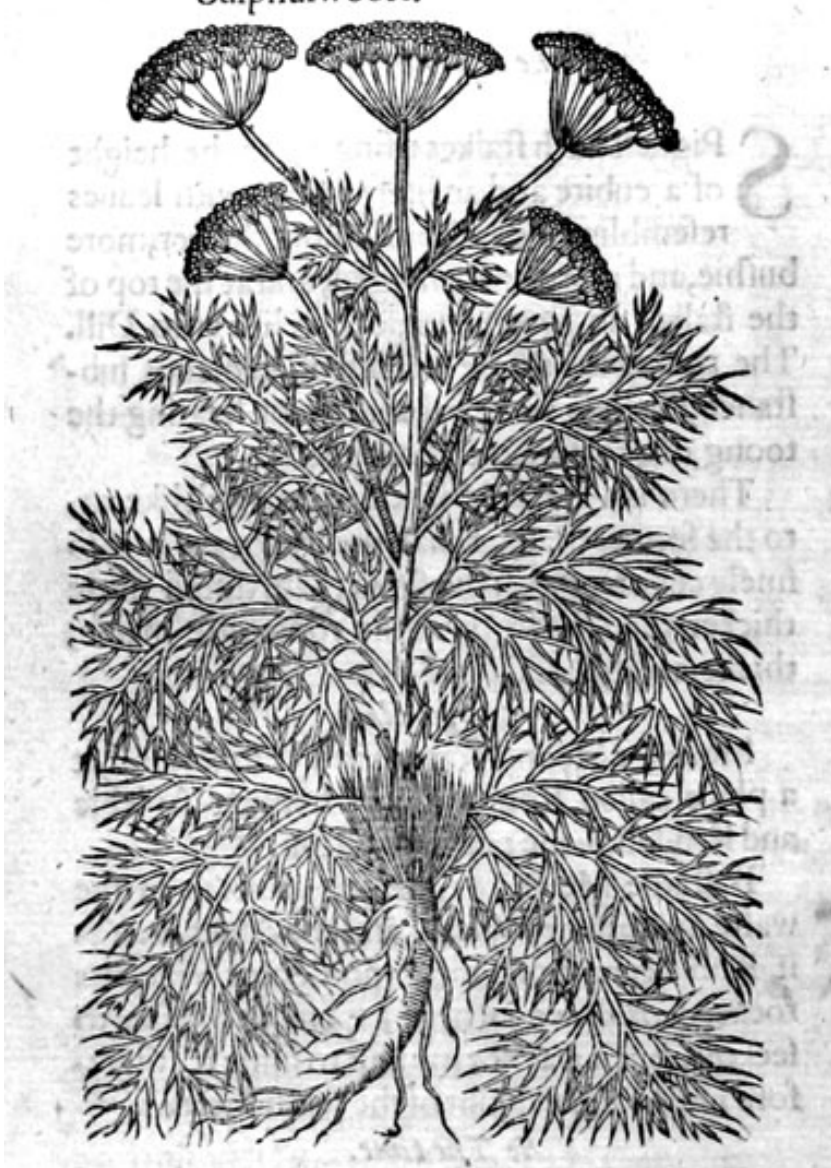

2 Peucedanum maius. Great Sulphurwoort.

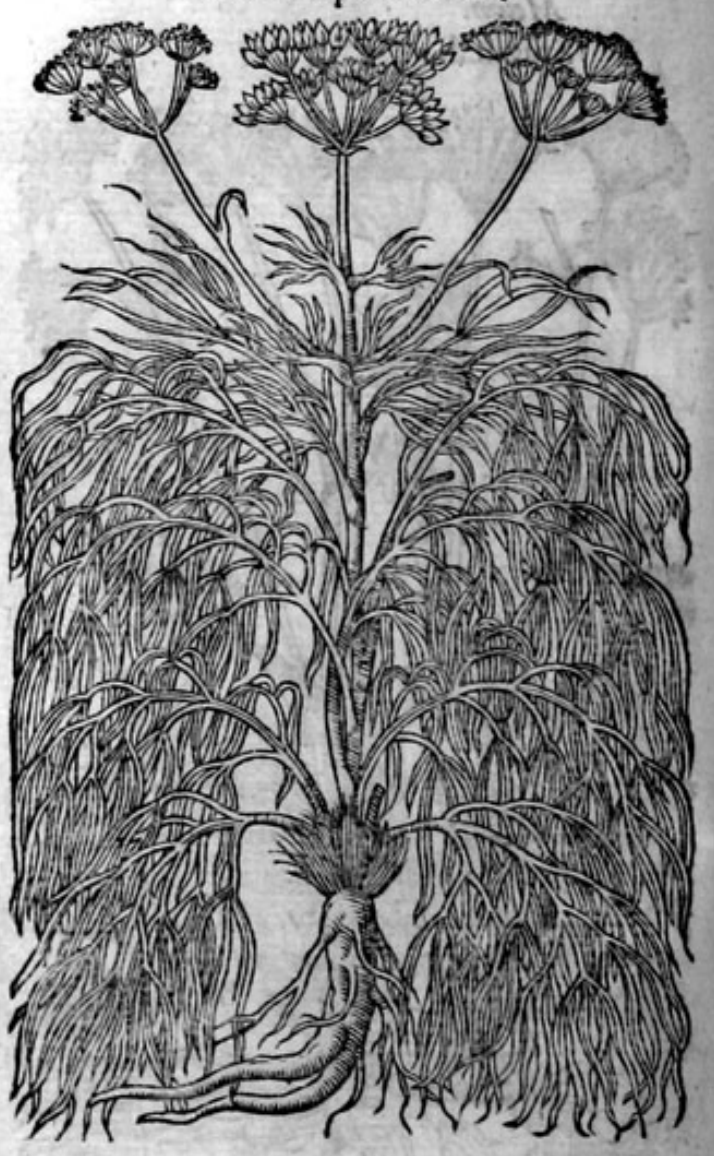

* 7 be defcription.

I Vlphurwoort or Hogs Fennell, hath a ftiffe and hard ftalke full of knces or knots, befet with leaues like vnto Fennell, but greater, comming neerer vnto Ferula, or rather like the leaues of wilde Pine tree; and at the top of the ftalkes round fpokie tuftes full of little yellow flowers, which do turne in to broad browne feede. The roote is thicke and long; I baue digged vp rootes thereof as big as a mans thigh, blacke without, and white within; of a ftrong and greetuous fmell, and full of yellow fap or liquor, which quickly waxech hard or drie, fmelling not much vnlike Brim. ftone, called Sulphor, which hath induced fome to call it Sulphurwoort; hauing alio at the top toward the vpper face of the carth, a certaine burh of haire, of a browne colour, among which the leaues and talkes do fpring foorth.

2 The fecond kinde of Pescedanum or Hogs Fennell, is very like vnto the former, faung that the leaues be like Ferula : the rootes are nothing fo great as the former, but all the reft of the plant doth far exceede the other in greatneffe.

There is an ther kinde of Peacedanum, or Hogs Fennell, which Pems found vpon Saint Vincents recke by Briftow, whofe pieture he hath fet foorth in his Aduer/aride, which that famous Englifh Phifition of late memorie D. Turner found there alfo, fuppofing it to be the right and true Peusedsnum, where of nodoubt it is a kinde: it groweth not aboue a foote high, and is in thape and leatues like the right Peucedanum, buc they be fhorter and leffer, grow ing fomewhat lik the writhed Feunell 


\section{HISTORIE OF PLANTS. IHT}

of Maffilia,but the branches are more largely writhed, and the leaves are of the colour of the branches, which are of a pale greene colour. At the top of the branches growe fmall white tuftes, hauing feede like Dill,but fhorter and flenderer, of a good tafte, fomewhat tharpe. The roote is thicker than the fmalneffe of the herbe will well beare. Among the people about Briftowe, and the rocke aforefaid, this hath beene thought to be good to eate.

\section{$*$ The place.}

The firft kinde of Pesuedanum, or Hogs Fennell, groweth very plentifully on the fouth fide of a wood belonging to Waltham, at the Nafe in Effex by the high way fide, allo at Whitfable in Kent in a medow neere to the fea fide, foncetime belonging to Sir Henrie Criffe, and adioining to his houfe there.

legroweth alfo in great plentie at Feuerfham in Kent, neere vnto the hatien vpon the baakes thereof, and the medowes adioining.

The fecond kinde groweth vpon the fea coalts of Montpellier in Fraunce, and in the coaftes of Italie.

Thefe plants do flower in Iune, Iuly and Auguft.

$$
* \text { Thetime. }
$$

$*$ ibenames.

The Grecians call it $\pi$ dxidzeos: the Latines in like manner Pencedanos, and alfo Pinastillom : moft of the thops, and likewife the common people name it Fenicutom Porcinion: of diuers Stataria : of the Prophets ajagis saiuv, that is to fay, a good Angellor ghoft : in high Dutch batftan!,

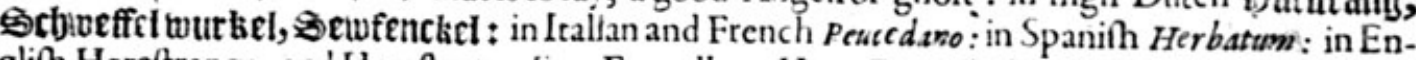
glifh Horeftrange, and Horeftrong, Sow Fennell, or Hogs Fenrell, Sulphurwoort, or Brimftone woort. It is called Pewcedanum, and Pinestellum, of the Greek and Latine words múxn, and Pinuw.

\section{* T he temperature.}

Thefe herbes, efpecially the yellow fap of the roote, is hot in the fecond, and drie in the beginning of the third degree.

\section{$\therefore$ The vertues.}

The yellow fap of the roote of Hogs Fennell,or(as they call it in fome places of England) Hore- A ftrange, taken by itfelfe, or with bitter Almonds and Rue, is good againt the fhortneffe of breth, it affwageth the griping paines of the belly, diffolueth and driucth away ventofitie or windinefle of the ftomacke, it wafteth the fwelling of the milt or fpleene, loofeth the belly gently, and purgeth by
fiege both flegtne and choler.

The fame taken in manner aforefaid, prouoketh vrine, eafeth the paine of the kidneies and blad- B der, caufeth eafie deliuerance of childe, and expelleth the fecondine or afterbirth, and dead childe.

The fap or iuice of the rootmixed with oile of Rofes and vineger, and applied, cureth the palfie, C crampes, contraction or drawing togither of finews, s all old cold difeafes, efpecially the Sciatica. It is vfed with good fucceffe againift the rupewre or burftings in yoong children, and is very good D
to be applied vnto thenauels of chitdren thate ftand out ouermuch. The decoetion of the poote drunke is of liko vertue vnto the iuice, but not altogither fo effectuall E
againft the forefaid difeafes.

Thetootedricdandmade into powder, doth mundifie and clenfe olde ftinking and corrupt $\mathbf{F}$ fores and vicets,andhealeth thein bitralfodraweth forth the corrupt and rotten bones (that hinder the fame from bealing)and draweth foorth fplinters, and other things fixed in the flefh. dy be anfiointed therewinh of the roote mixed/ with oile of Rofes, caufeth one to fweate if the bo- $G$ French difesfe.

Thecongealed liquor remperodivith

ointment, is good forthem that hatie the oileofRofes \& applied to the head, after the manner of an $\mathbf{H}$ that are troubled withithe falling ficknes; thathiaue the palfie, that are vexed with conuulfions and
cramps, and generallyitis a remsedy for allinfirmitics of corides teacheth.

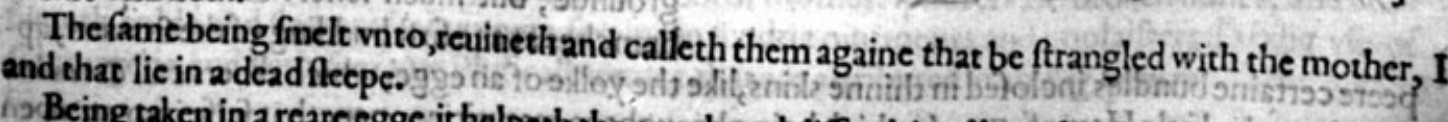

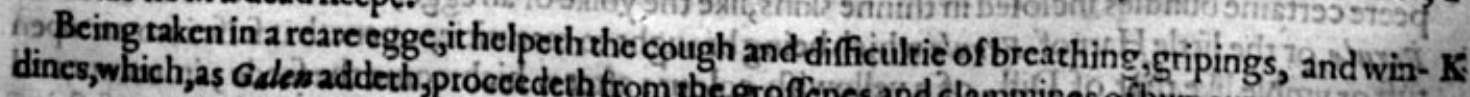
hoines, 
L It purgeth gently, it diminifheth the fpleene, by cutting, digefting, and making thinne humours that are thicke : it caufeth eafie trauaile, and openeth the matrix.

M A fmall peece of the roote holden in the mouth, is a prefent remedie againft the fiffocation of the mother.

\section{Of berbe Ferula, or Fennell Giant. Cbap:4II.}

\section{* The kindes.}

DIofcorides maketh mention of a Ferula, out of which is gathered the Gum Sagapene, \& alfo he declareth that the Gums Galbanum, and Ammoniacum, are liquors of this herb Ferula:but what difference there is in the liquors, according tothe climate or countrey where it groweth, he doth not fet downe; for it may be that out of one kinde of Ferula fundry iuices may be gathered, that is to fay, according to the diuerfitie of countries where they grow, as we haue faide: for as Lafer, the iuice of Laferwoort that groweth in Cyrene, doth differ from that liquor which groweth in Media, and Syria : fo it is likely that the herb Ferula doth bring forth in Media Sagapenum, in Cyrene Ammoniacum, and in Syria Galbanum. Theophraftus faith, that the herbe Ferula is diuided into mo kinds, and he calleth one great, by the name of Ferula, and another little, by the name Ferulago.

Ferula.

Fennell Giant.

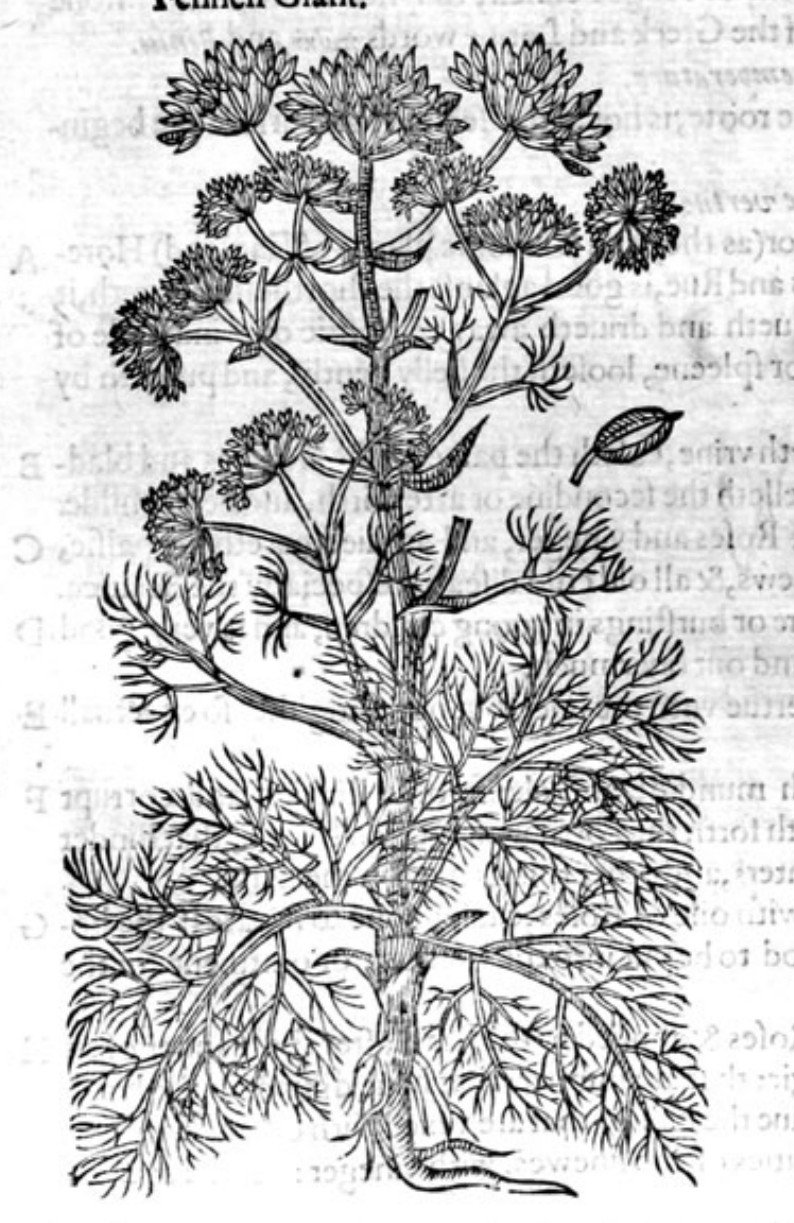

*. The defoription.

C Erula or Fennell Giant, hath very great \&large leaues of a deep green colour, cur and iagged like thofe of Fennell, fpreading themfelues abroad likewings : among which rifeth vp a great hollow ftalke, fomwhat reddifh on that fide riext the funne, diuided into certain fpaces, with ioints or knees like thofe of Hemlockes or Kexes, of the bignes of a mans arme in the wreft, of the height of fower or fine cubites where it groweth naturally, as in Itralie, Greece, and other hot countries: notwithitanding it hath attained to the height of 14. or 15. foote in nylgarden, and likewife groweth fairer and greater then from whence it came, as it farech with other plants that come hither from hot regions; as for example, our great Artichock, which firft was brought out of Italie into England, is become (by reafon of the great moifture which our councrey is fubiect vato) greater, and better then thofe of Iraly, infomuch that diuers Italians haue fent for fome plants of our Artichockes, deeming them to be of another kinde ; neuercheleffe in Italie they are fmall and dry, as they were before; euen fo it hapneth vnto this Ferala, as we haue faid. This forefaid ftalke diuidech it felfe towarde the top into diuers other fmaller branches, wheron are fet the like leaues that growe next the grounde, but much leffer: on the top of the branches at the firt budding of the flowers, appecre certaine bundles inclofed in thinne skins, like the yolke of an egge, which diuers call corculan
Ferule, or the little Hart of Fersla, which being brought to matiritie, openeth it felfe into an open Ferule, or the little Hart of Fersla, which being brought to matiuritie, openethitfelfe into an open
tuft or vmble like that of Dill, of a yellowifh colour: after $w$ wich cone the feede, in colour and fafhion 


\section{马 $\mathrm{H}$ HISTORIE DF PDANT S: HT}

fafhion like thofe of the Parfnep, but longer and greater, alwaies growing two togither foclofely ioined, that it cannotbe difcerned to bewore thein one feedevntili they be dipided : the roote is verie thicke and great, full of a certaine gumntie ulice, that floweth foorth the roote being brufed, broken or cur, which being dried or hardned, is that Gum which is called Sagapenum, and in thops Serapinom.

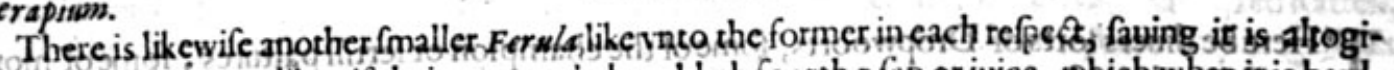
ther leffer : the roote likewife being wounded,yeeldech foorth B fipariuice, which whenis is hardned is called Galba num : of the Aflyrians Metopium.

I haue likewife another fort fentme from Paris, with this title, Ferula nigra, , which profpereth exceeding vell in my garden; but difference I cannot finde any from the former; fauing the leaues are of a more blacke or fwart colour.

$$
\text { * The place. }
$$

Thefe plants are not growing wilde in England; I haue them all in my garden.

$$
\text { * The time. }
$$

They flower in Iune and Inly, they perfect their feede in September, not long after the ftalk with his leaues perifh: the roote remaineth frefh and greene all winter.

$$
* \text { The names. }
$$

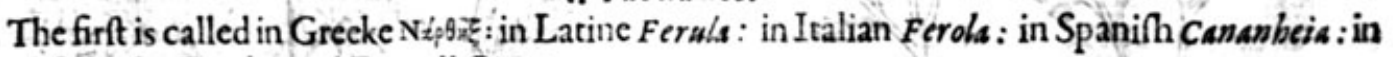
Englinh herbe Ferula, and Fennell Giant.

$$
* \text { The temperature. }
$$

Thefe plants with their Gums are hot in the thirde degree, and dric in the fecond. * T.be vertues.

The pith or marrowe called corculiom Ferule, as Galen teacleth, is of an aftringent of binding A quality, and therefore good for them that fpet bloud, and that are troubled with the flixe.

Diofcor ides faith, that being put into the nofthrils it ftaicth bleeding, and is giuen in wine to thofe $\mathbf{B}$ that are bitten withvipers.

It is reported to be caten in Apulia rofted in the embers, firft wrapped in leaues or in old clouts, C with pepper and falt, which as they fay, is a pleafant fweete foode, that firreth vp luft as they report,

The feede doth beate and attenuate or make thinne : it is a remedic againft colde fits of an ague, D by procuring fweate, being mixed with oile, and the body annointed therewith.

A dram of the iuice of Ferula, which beareth Sagapenum, purgeth by ficge tough and flimie hu- $\mathbf{E}$ mours,and all groffe flegme and choler: and is alfo good againft all old and colde difeafes, which are hard to be cured; it purgeth the braine, and is very good againft all difeafes of the head, againft the Apoplexie andEpilepfie. finewes.

Being taken in thefame maner it is good againft cramps, palfies, fhrinkings, and paines of the $F$

It is good againft the fhortnes of breath, the colde and long cough, the paine in the fide and $G$ breft, for it mundificth and clenfeth the breft fromall cold flegme, and rheumatike humors.

Sagapenum infufed, or ftecped in vineger all night, and fpred vpon leather or cloth, fcattereth, dif- $\mathbf{H}$ folueth,and driueth away all hard and colde fwellings, tumors, botches, and harde lumpes growing about the ioints or elfe where, and is excellent good to be put into or mingled with all ointunents or emplaifters, which are made to mollifie and foften.

The iuice of Ferula Galbanifera, called Galbanum, drunke in wine with a little Myrrhe, is good I againft all venome or poifon that hath beene taken inwardly, or fhot into the bodie with venemous darts, quarrels, or arrowes.

It helpeth womens painfull trauell, if they do take thereof in a cup of wine the quantitic of a $\mathrm{K}$ beane.

The perfume of Galbanion, helpeth women that are grieued with the rifing of the mother, and is $\mathbf{L}$ good for thofe that haue the falling ficknes.

Galbanum foftneth, mollifieth, and draweth foorth thornes, fplinters, or broken bones, and con- $\mathbf{M}$ fumeth colde and flegmatike humours, feruing in fundrie ointments and implailters, for the vfe of Chirurgerie, and hath the fame Phificall vertues, that are attributed vnto Sag apenwm. 


\section{Of Dropwoort, or Filipendula. Chap.412,}

* The kindes. Thesgaraz Here be diuers forts of Dropwoorts, fone of the champion or fertili paftures's forme of more
moint and dankifh grounds, and fome of the water.

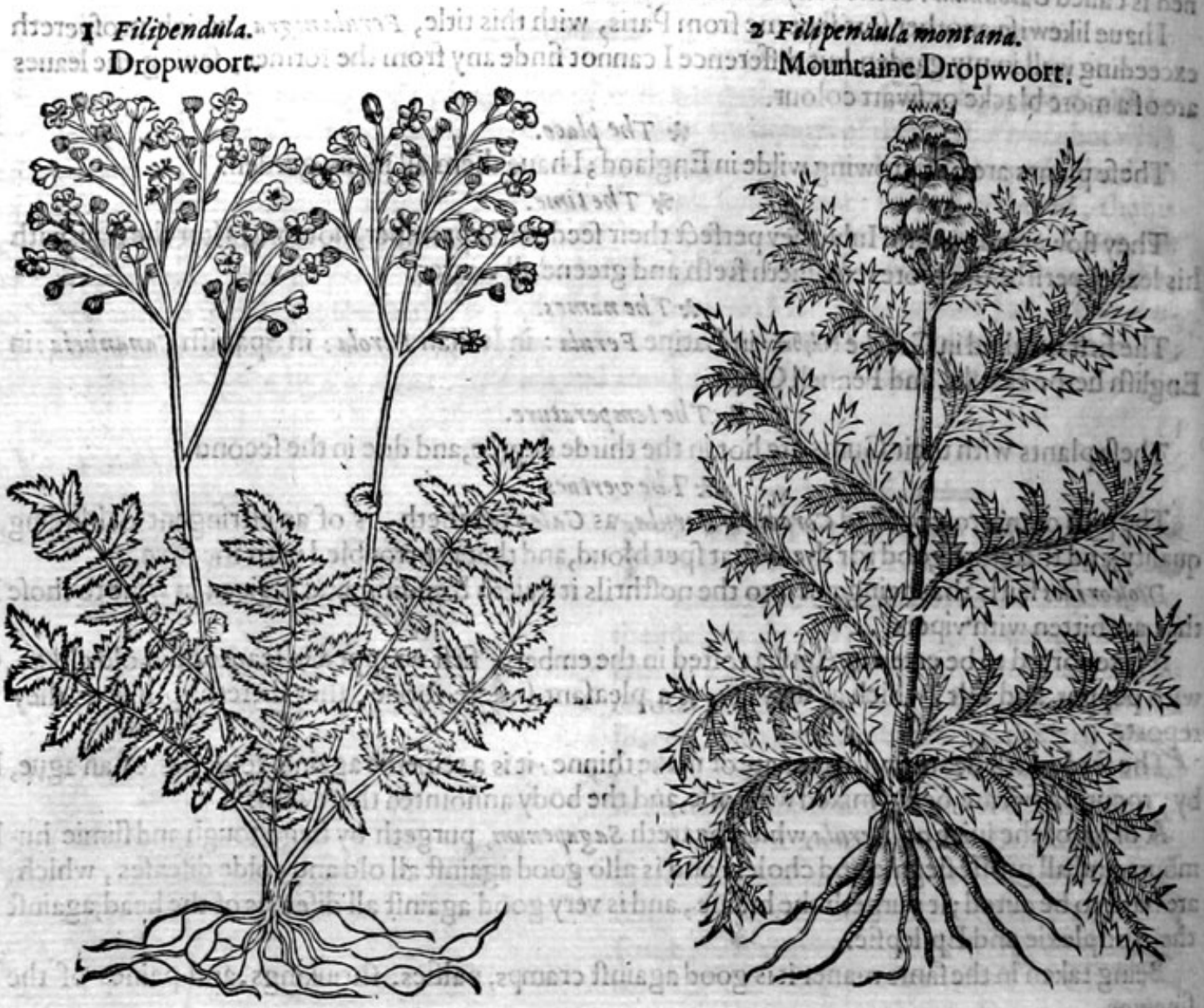

\section{* Thedefeription.}

I He firft kinde of Filipendula hath leaties growing and fpred abroad like feathers, ech leafe confifting offundry fmall leaues, dented or fnipt rounde about the edges, growing to the ftalke by a fmall and flender ftemme; thefe leaues refernble wilde Tanfie or Burner, but that they be longer and thicker, fer like feathers as is aforcfaid: among theferife vp ftalks a cubite \& an halfe high, at the top wher of grow many faire white flowers, each fmall flower confifting of fixe flender leaues, like a little ftarre, bufhing togither in a tuft like the flowers of Meadfiweete, of a foft fweet fmell: the feed is fmal and groweth togither like a button: the roots are fmal and blacke, wherupon depend many little knops or blacke pellets, much like the rootes of the female Peonie, fauting that they be a great deale fmaller.

2 The fecond kinde of Filipendula, called of Pena in his Obferuations Oenanthe fute P hilipenduls alter a montan , is neither at this day very well knowne, neither did the old writers heeretofore once write or fpeake of it: but Pena that painfull Herbarift founde it growing naturally in Narbone in Fraunce, neere vnto Veganium, on the top of the high hils called Paradifus Des, and necre vnto the mountaine Calcaris : this rare plant hath many knobbie long rootes, in hape like to $A$ pphodeles los teus, or rather like the rootes of Corruda, that is, wilde Afparagus: from which rifeth vp aftalke a 
fooce highand more; which is thicke, round,arichchañneled; befet full of leaues likic thofe of common Filipendu a, bur they benot fo thicke for, or winiged, but morelike vnto the leaues of a Thiftle,

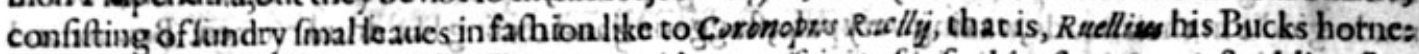
roundeabout the top of the italke thene groweth a tery faire tufte of white flowets, refembling fine

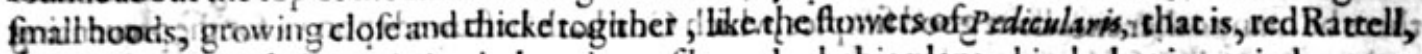
called of Car olus Clufius Mlectorulophos, where of he maketh this plant a kinde, busin myiudgement and opinion rather like Cynofor cbiss, a kinde of Satyrion.

3 Filipendulengigiffifolia:

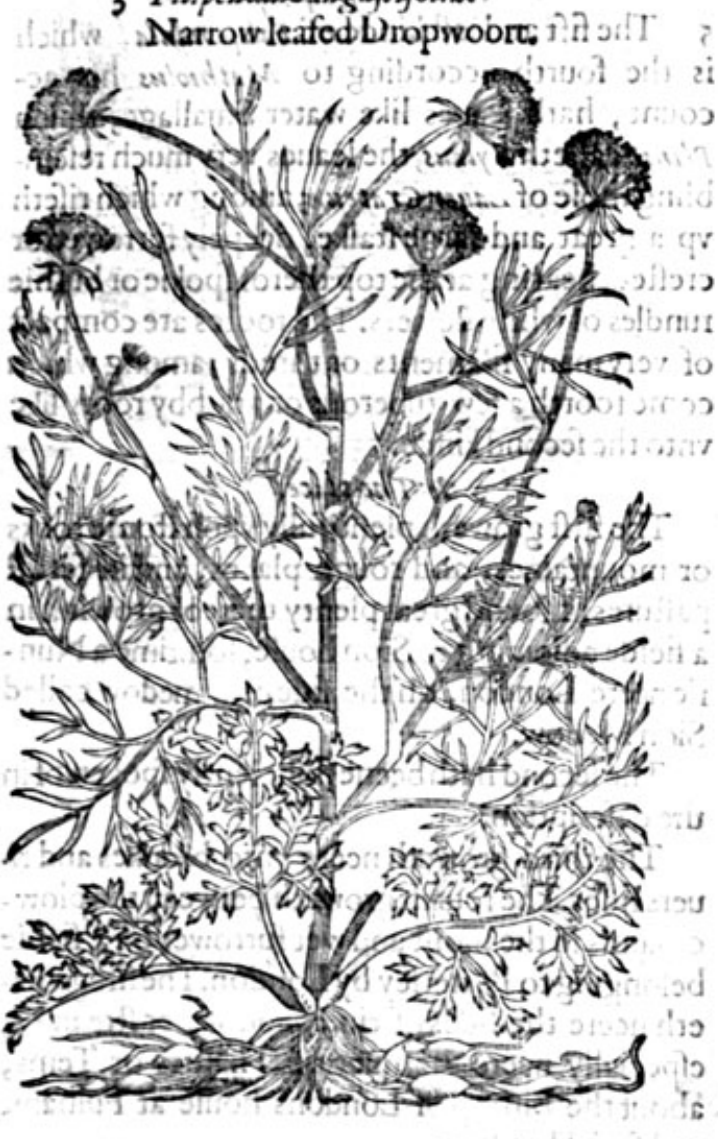

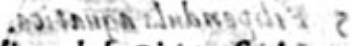
4. Filipendula Cieutrefacia. Homlacke Dropwoort.

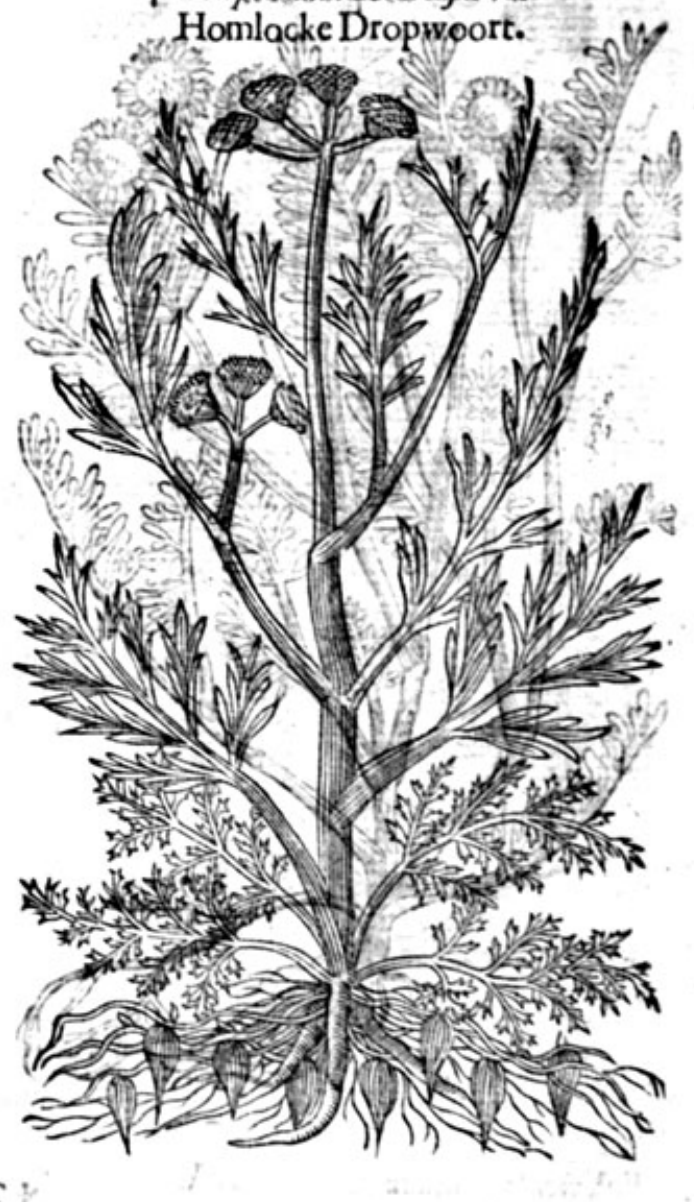

* The deficiftion.

3 There is another kind of Filipendula fer forth vrider the riame of Oenunt be, that hath many tuberous \& thicke rootes like the male Peionic; and every one of tbofe knobs hath t kettaine ftring or fibre annexed thereto; from whence anfeth a crefted ftalke tivo foote high, dutuiding it felfe to ward the top into fundry armes or branches; from the hollowe place or bofome of encry ibint $Y$ ont of which dogrow thofe bratnches) the leaties do alfo proced, very nuch cut or riagted like Fetinel, euery fmall leafe for the molt part refembling the forkes of the herbe called Harts horne, or Bucks horne: at the top of thofe branches come foorth fpokie rundles of white flowers, fafhioned like 4 The fourth kinde of Filipendula; is as ftrange a plant as the former, efpecially with vs heere in England,except in the watery places and rilles in the north, where Paludapiem or water Smallage groweth, whereunto in leaues it is not vnlike, but more like Ruta praten/s, it hath many plumed twocubites hightie fauour, and in colour and hape like Cicuta, that is Homlocke. The ftalkes are Af bodeliow aibres. Thefe ftalks are permate, which exceedingly multiplieth it felfe into bulbes, like The fpokie tufts or rund!es growing at the top are like Cicuta, yea it much referubleth Homlocke in 
propertie and euill qualitics, and fo do they affirme that haue prooucd and feene the experience of it. For being tahen in tharpe fawces, it doth well nigh poifon, and thofe which eare ofit have beene made giddie in their heads, waxing very pale; ftaggering and reeling like drunken men. Beware and take good heede of this and tuch like fimples; for there is no Phifition that will giue it: bicaufe there be many orlier excellent good fimples, which God hath beftowed vpon vs, for the preuenting and cung of difeafes,

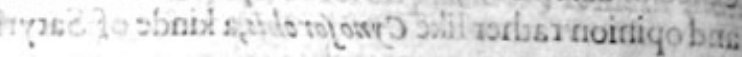

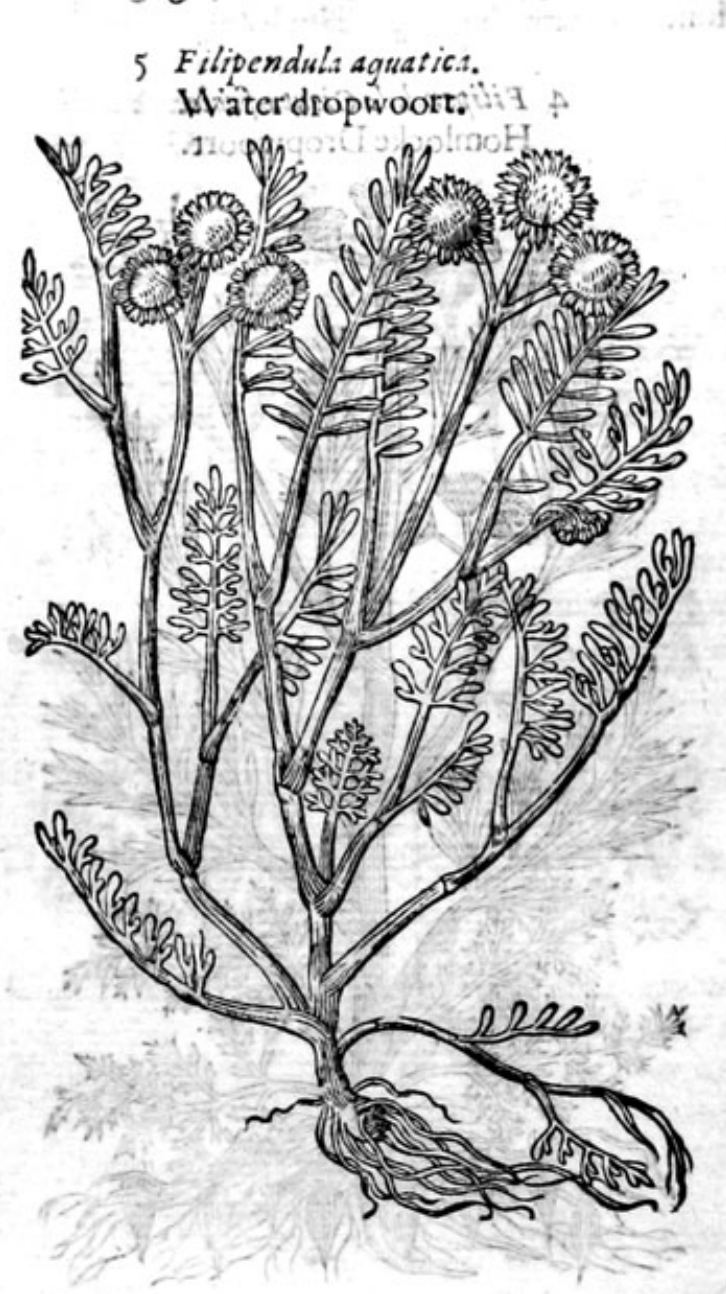

Filipendula aquatic.t.

Whaterdropwoort:
* Thedefoription:uitis \&

5 The fift and lalt kinde ot Fitupendula, which is the fourth according to Mathrolus his account, hath leaues like mater Snallage, which Plinze calleth Sylaus, the leaues very nuch refemblingthófe of Layer Cratewe; anong which rifeth vp a great and large ftalke, deepely furrowed or crefted, bearing at the top therof pokic or bufhie rundles of white flowers. The rootes are compat of verymany filaments or threds ; among which come foorth a few tuberous or knobby roots like vnto the fecond kinde.

\section{* The place.}

The firft groweth plentifully vpon ftonie rocks or mountaines, and rough places, and in fertill paftures. I found great plenty thereof growing in a fielde adioining to Sion houle, fomtime a Nunrie neere London, on the fide of a medow called Sion Medow.

The fecond hath beene fufficiently fpoken of in the defeription.

The third groweth neere vnto brookes and riuers fides. The fourth groweth between the plowed lands in the moilt and wet furrowes of a fielde belonging to Batterfey by London. The fift groweth neere the fides of riuers and water ftreames, efpecially neere the riuer of Thames or Tems, about the Bifhop of Londons houfe at Fulham, and fuch like places.

\section{* The time.}

Thefe plants do flower from May to the end of Iulie.

* The names.

They are commonly called Filipendule. The firft is called of 2 icolaus Mirepfus Philipenduls: of fome Saxifragarubra, and Millefolium fyluefre: of Plimie Molon : in Italian and Spaninh Filipendula: in Englifh Filipendula and Dropwoort. Water Philipendula is called Philipendula aguatica, Oenant be squatici, and Silaus Plinij.

The fourth whofe leaues are like to Homlocks, is called of Cordus Olfenichium:in Englifh Home locke Filipendula.

\section{* The nature.}

Thefe kindes of Philipendula are hot and dric in the third degree, opening and clenfing, and yet with a litcle aftriction or binding. All the kindes of Oenanthes haue the fame facultie.

\section{$* 7$ be vertues.}

A The roote of common Philipendula boiled in wine and drunken, is good againft all paines of the bladder, caufeth one to make water, and breaketh the ftone. The like Diofcorides hath written of Oenanthe; the roote, faith he, is good for them that piffe by drops.

B The powder of the rootes of Philipendula often vfed in meate, will preferte a man from thefalling ficknefic. 


\section{Of Homlocks, or berbe Bennet. Chap.413.}

1 Cicuta.

Hemlocks.

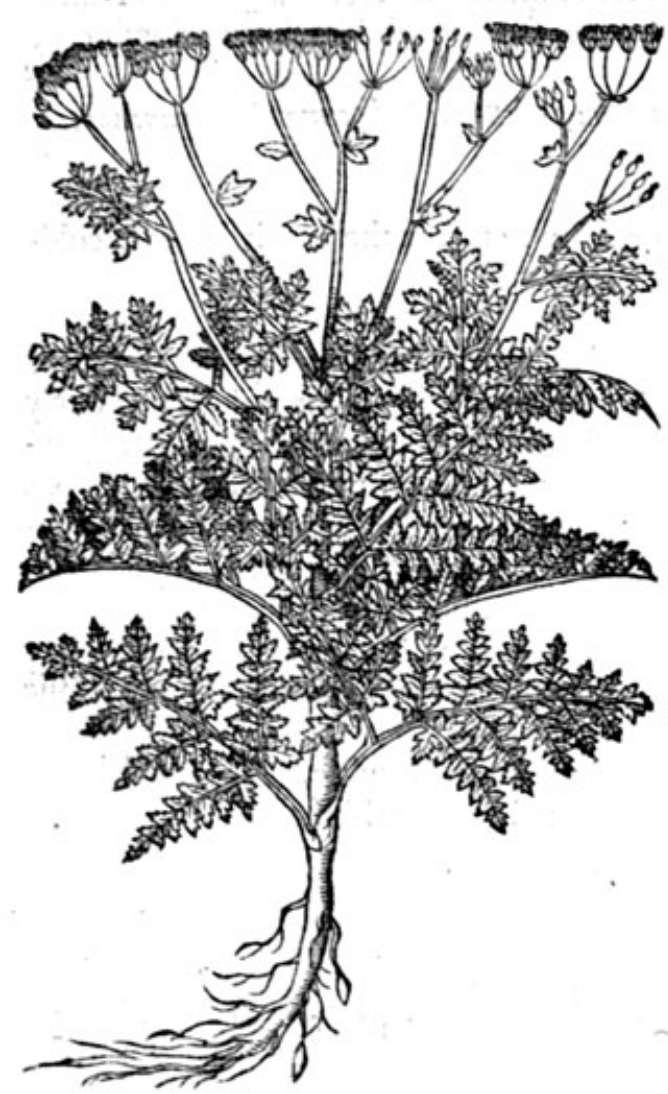

2 Cicuta latifolia fatidisoma.

Broad leafed ftinking Homlocks.

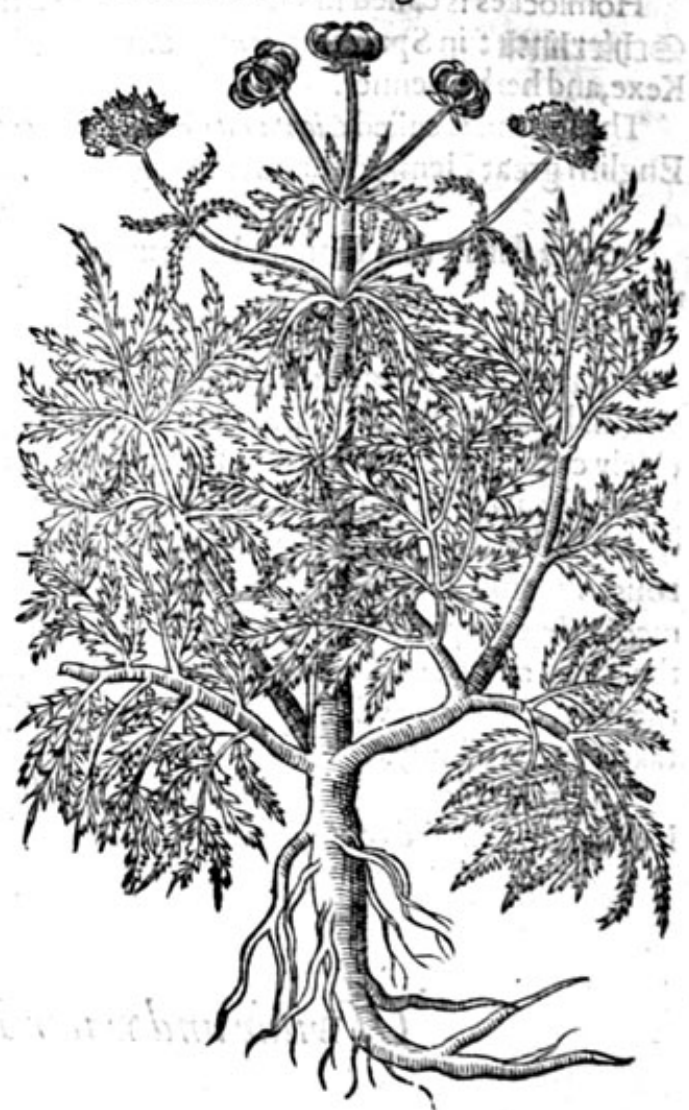

\section{* The defcription.}

17 He firft kinde of Hemlocke hath a long ftalke, fiue or fixe foote high, great and hollow, full of ioints like the ftalkes of Fennell, of an herbie colour; powdered with fmall red fpots, almoft like the ftems of Dragons. The leaues are great, thicke, and fmall cut or iagged like the leaues of Cheruill,but much greater, and of a very ftrong and vnpleafant fauour. The flowers are white,growing by tuftes or fpokic tops, which do change and turne into a white flat feede: the roote is fhort, and fomewhat hollow within.

2 The Apothecaries in times paft not knowing the right Sefeli Peloponmenfe, haue erronioully thken this Cicuta latifolia for the fame. The leaues whereof are broad, thicke, and like vnto cicutaria, yet not thefame; they called it Sefeli Peloponnen fe cum folio Cicuta, the faculties whereof denie and refute that affertion and opinion, yea and the plant it felfe, which being touched, yeeldeth or breatheth out a moft virulent or lothfome fmell: thefe things fufficiently argue, that it is not a kinde of Sefeli,befides the reafons following. Sefeli hath a reafonable good fauour in the whole plant, the roote is bare and fingle, without fibres like a Carrot: but Cicuta hath not onely a lothfome fmell, but his rootes are great, thicke, and knobbie, like the rootes of $M y r r b i s$ : the whole plant doth in a manner refemble the leaues, ftalkes and flowers of Myrrhis odorata, whofe fmall white flowers do turne into long and crooked feedes, growing at the top of the branches three cubites high.

Common Hemlocks groweth plentifully a place. Common Hemlocks groweth plentifully about towne wals and villages in ihadowy places, and
fat foiles neere ditches. 
The feconde groweth vpon mountaines and defart places, and is a ftranger in Eniglande; yet I haue plants thereof in my garden.

They flourifh and feede in September.

$$
\text { * Thetime. }
$$

* The names.

Homlockes is called in Greeke váverov : in Latine Cicata : in high Dutch ocbitlingt in low Dutch bebixtlintk : in Spanifh Cegutay Canahera : in French Cigue : in Englifh Hemlocke, Homlocke, Kexe, and herbe Bennet.

The fecond is called Cicuta latifolia, and Cicutaria lat ifolia, and Sefeli Peloponnenfe quorundam : in Englifh great Hemlocks, and ftinking Homlock.

* Thetemperature. neffe.

Galen faith, that Homlocke is extreme colde in operation, euen in the fourth degree of cold-

$* T$ be vertues.

A It is therefore a very rafh part to laie the leaues of Homlockes to the ftones of yoong boies or virgins brefts, and by that meanes to keepe thofe parts from growing great : for it doth not oneiy eafely caufe thofe members to pine away, but alfo hurteth the hart and liuer being outwardly applied; then muft it of neceffitie hurt more being inwardly taken; for it is one of the deadly poifons which killeth by his coldequalitie, as Diofcorides writeth, faying, Homlocke is a very euill, dangerous, hurtfull, and poifonous herbe, infomuch that whofoeuer taketh of it into his body dieth remedileffe, except the partie drinke fome wine that is naturally hot, before the venome haue taken the hart, as Plinie faith :but being drunke with wine the poifon is with greater fpeedecarried to the hart, by reafon whereof it kulleth prefently; therefore not to be applied outwardly, muchleffe taken into the body.

B The great Hemlocke doubtleffe is not poffeffed with any one good facultie, as appeereth by his lothfome fmell, and other apparant fignes, and therefore not to be vfed in Phificke.

\section{Of wilde and water Homlocks. Chap.414.}

\section{* The kindes.}

THere be diuers forts of wilde Homlocks, two figures Shall be fet foorth vnto you, one of the land, another of the water, with the defcription of moe.

\section{* The defcription.}

I 7 His wilde kinde of Hemlocke hath a thicke tough roote, from which rife vp diuers ftiffe ftalkes, hollowe, fomewhat reddifh toward the funne, iointed or kneed at certaine diftances, from which ioints fpring foorth long leaues very grcene, and finely minced or iag. ged like the common Cheruill: the flowers ftande at the tops of the ftalkes in fmall fpokie vmbles : the feede followeth like thofe of Parfley, but leffer : the whole plant is of a naughtie finell. 2. Water Homlocks, which L'Obelius calleth Cicutaria paluftris; Clufius and Dodoneus Phellsn. drium, rifeth vp with a thicke, fat, and emptie hollowe ftalke, full of knees and ioints, crefted, chamfered, or furrowed, of a yellowifh greene colour : the leaues thoote foorth of the ioints and branches like vnto wilde Homlocks, but much thicker, fatter, and oileous, very finely cut or iagged, almoft like thofe of the fmalleft $V i$ /naga or Spanifh Toothpickes : the flowers ftande on the top of the ftalkes in fmall whitifh tufts: the feede followeth blackifh, of the bignes of Anife feede, and of a fwecte fauour : the roote is thicke, and long within the water, very loft and tender, with very many ftrings faftned thareto. 


\section{HIST ORIE OF PLANTS. IHT}

1 Cicutariatenuifolia.

Thinne leafed wilde Hemlocks.

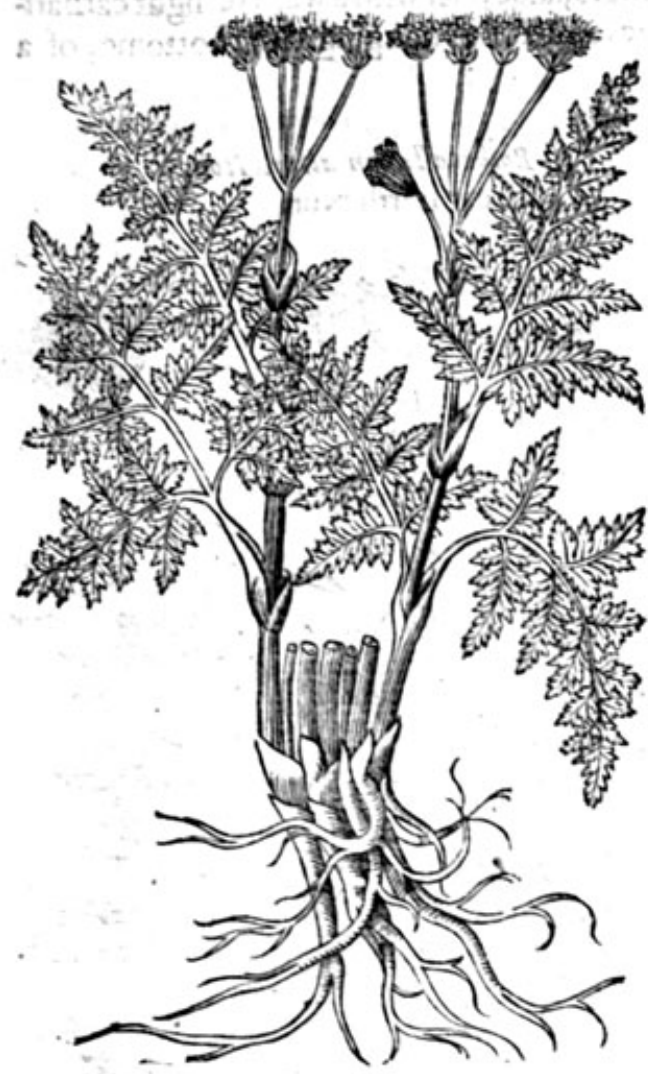

2 Cicutaris paluftris. Wilde water Hemlocks: smit rivatis

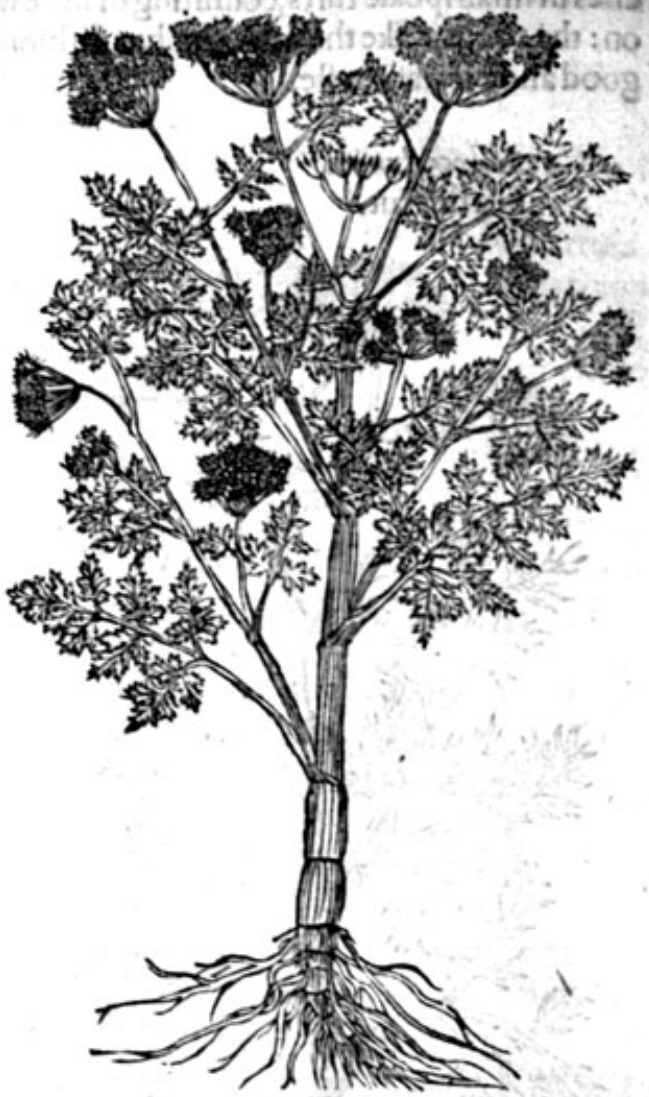

* The place.

The firft groweth among ftones, rubbirh, by the wals of cities and townes almoft euery where.

The other groweth in the midft of water ditches, and ftanding pooles, and ponds, in moft places of England : it groweth very plentifully in the ditches by a caufey, as you go from Redreffe to Det* forde neere London, and many other places.

They flower and flourifh in Iuly and Auguit. * The time.

* 7 be names.

There is not more to be faide of the names, then is expreffed in their ticles and defcription. * The temperature and vertues.

Their temperature and faculties are anfwerable to the common Homlocke, which haue no vfe in Phificke as we haue faid.

\section{Of Earth $\mathcal{X}$ ut, Earth Cheftnut, or Kipper. Nut. Chap.415.

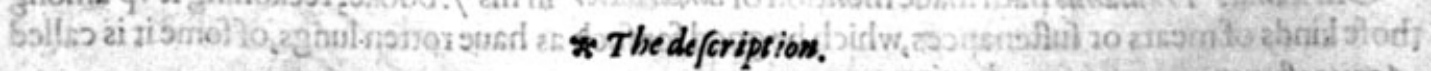

1 Arth Nut; or Kipper Nut, called after L'O belius, Nucula terreftris, hath fingll cuen crefted 5 D. Atalkes, a footeand fomewhat more high, whereon do growe next the groundeleaues like thofe of Parfley, and thofe that do grolve higher like thofe of Dill : the white flowers do ftande on the top of the ftalks in f pokje rundles like the tops of Dill, which turne into fniallfeede, of a very good fmell, not vnlike to thofe of Fennell, but fmallets the roote ismande, ktrobbed with cerraine eminences on bunchings out; browne without, white within; of a firme and fOlide fib. ftance, and of a tafte like the Cheffenut, or Cheftnut, whereof it tooke his name. 
2 There is alfo another Earth Nut, that hath ftalks a foote high, wheron do grow iagged leaues like thofe of Englirh Saxifrage, of a bright greene colour : the flowers growe at the top of the branches in fmall fpokie tufts, confifting of little whitifh flowers, laide ouer with a wafh of light carnation: the roote is like the other, bulbus falhion, with fome fewe ftrings hanging at the bottome, of a good and pleafant tafte.

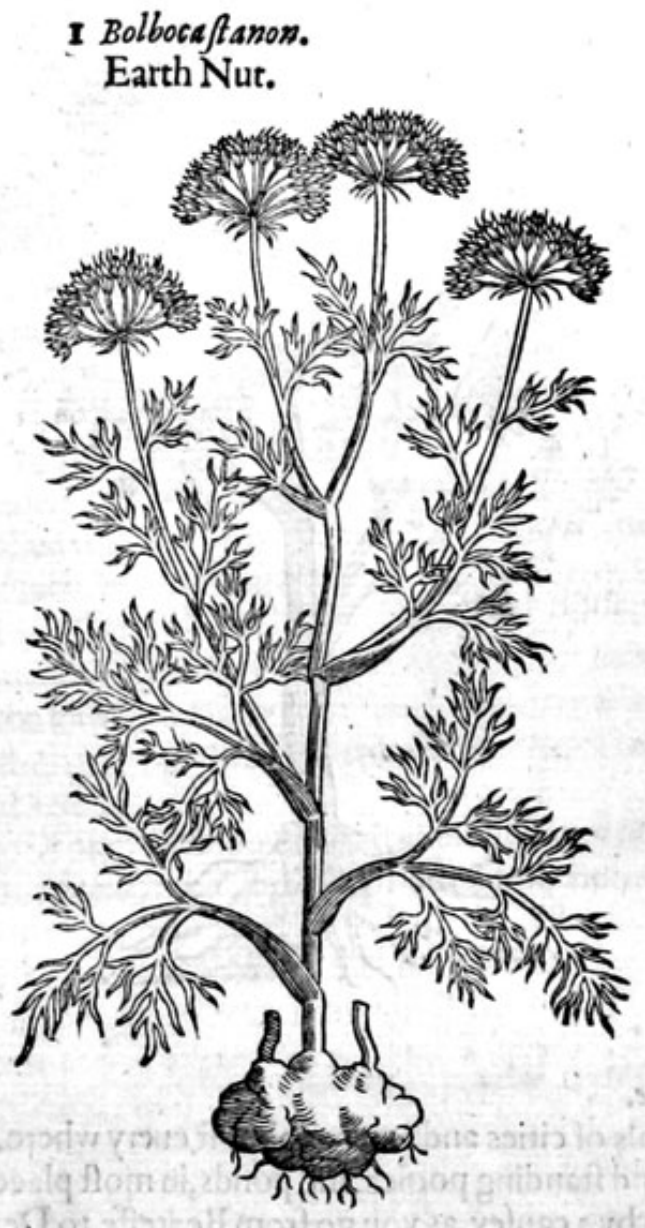

\section{Bolbocaftanon altera Icon. Great Earth Nut.}

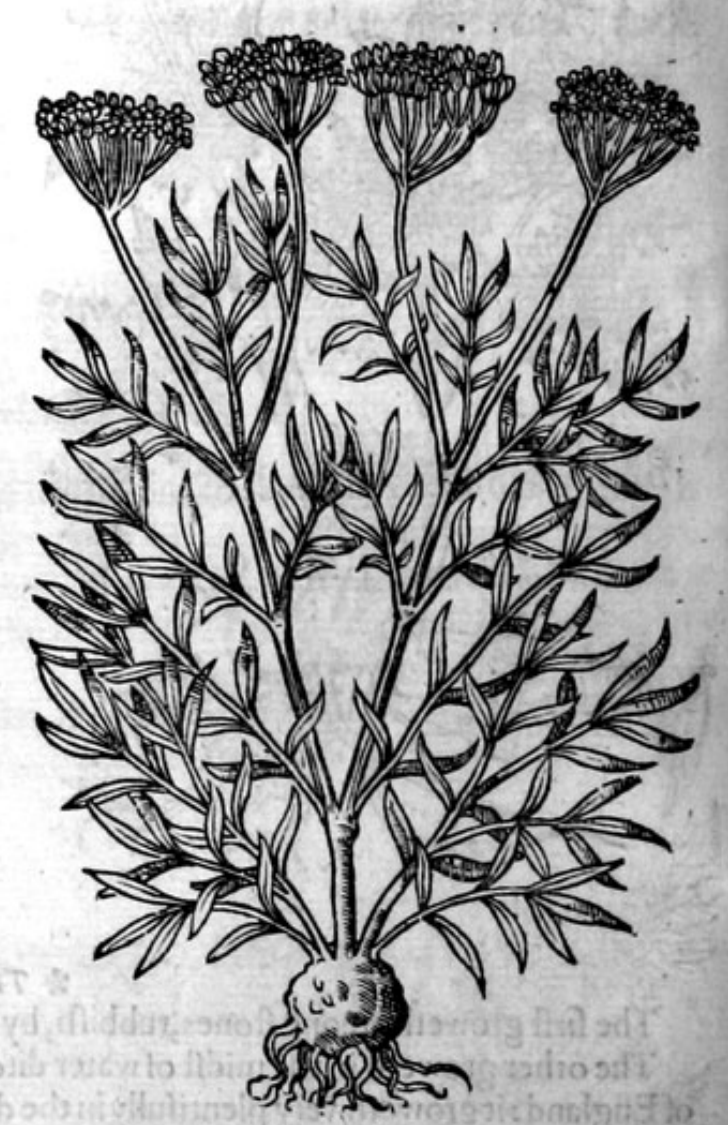

\section{* The place.}

Thefe herbes do growe in paftures and corne fieldes almoft euery where: there is a field actioining to Highgate, on the right fide of the middle of the village, couered ouer with the fame : and likewife in the next fielde vnto the conduit heads by Maribone, neer the way that leadeth to Paddington by London, and in ditiers other places.

They flower in Iune and Iuly : the feede commeth to perfection afterwards.

\section{* The names.}

slexander Trallianus hath made mention of Boxkoxdsavor in his 7. booke, reckoning it vp among thofe kinds of meats or fuftenances, which be good for fuch as haue rotten lungs, of fome it is called Agriocaftanon.

Guinterins thought the worde was corrupted,and that Balanocaftanon fhould be read, but this is as ftrange a worde as Bolbocaftanon, which was deriued of the forme of a bulbe, and the tafte of $a$ Cheffenut : of fome Nucula Terreftris,or the little Earth Nut: it is thought to be Bunium Diofcoridis of fome, but we thiske not fo; of Doctor Turner LApios, yet there is another Apios, being a kind of Tithymale: of Mathiolus Oenanthe, making it a kinde of Filipendula : in high Dutch ererontuf: in lowe Dutch Eertnoten: the people of Sauoycall it Fawerottes : in Englifh Earth Nuts, Kipper 


\section{HISTORIE OF PLANTS. \\ * The temperatare.}

The roote of Earth Nuts are moderately hot and dry, and alfo binding : but the feed is both hotter and drier.

The feede openeth and prouoketh vine, and fo doth the roote likewife.

The roote is good for thole that fpetand piffe bloud, if the roote be eaten rawe, or rofted in the $\mathbf{A}$ embers. div. pous

The Dutch people do yfe to eate them boiled and tuttered, as twe do Parfneps and Carrots, B which fo caten comfort the ftomacke, and yeelde nourifhment that is good for the bladder and .kidneies.

There is a plaifter made of the feedes heereof, whereof to write in this place, were impertinent to $\mathrm{C}$ our biiftorie.

\section{Of Cumin. Clsap.416. \\ * $T$ be kindes.}

Diofcorides maketh one kinde of the garden or tame, and orthers wilde.

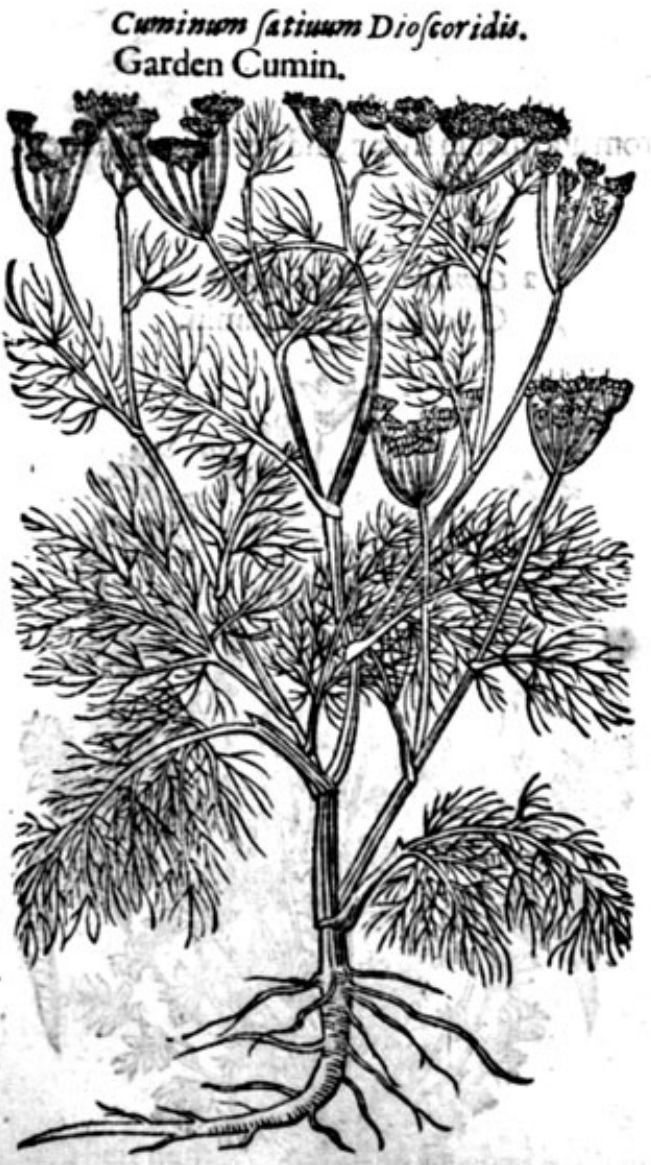

Ir is called in Greckexumoos $*$ The names.

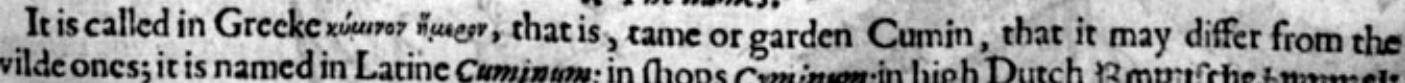

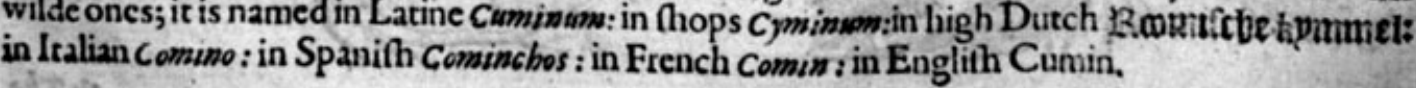

* The defcription.

7 He garden Cumin is a fowe or bafe heibe, of a foote high: the ftalke diuideth it felfe into diuers fmall branches, whereon do grow lit. tle iagged leaues very finely cut into fmall parcels like thofe of Fennell, but more finely cut, thorter and leffer : the fpokie tufts growe at the top of the branches and ftalkes, of a daike purplifh colour, after which come the fecde, of a ftrong or rancke finell, and a biting tafte: the roote is flender, which perifheth when it hath brought his feede to ripenefle.

\section{* Theplase.}

Cumin is husbanded and fowen in Italie and Spaine, and is very common in other hot countries, as in AEthiopia, AEgypt, Cilicia, and all the leffer Afia.

It delighteth to growe efpecially in patrified and hot loiles: I haue prooued the feeds in my gardert, where they haue brought foorth ripefeede much fairer and greater then any that commeth from beyond the leas.

$*$ It is to be fowen in the middle of the fpring, a
a Phewer of raine prefently following doth much hinder the growing thereof, as Ruellisus faith.

My felfe did fowe It in the midit of Maie, which . 


\title{
908
}

\section{THE SECOND BOOKE OFITHE}

\section{* The temperature.}

The feede of garden Cumin, as Galen faith, is hot and dry irthe thirde degree: Diofcorides faith, that it hath in it alfo a binding qualitic.

\author{
* The vertues.
}

rubbritios?

A The feedes of Cumin feattereth and brcaketh all the windines of the fomarke, belly, guts, and matrix: it is good againft the griping torments, gnawing or fretting of the belly, not, opely receiued inwardly by the mouth, but alfo in glifters, and outwardly applied to the belly with wine and barly meale boiled togither to the forme of apultis.

B Being handled according to Art either in a Cataplafme, pultis \& plaifter, orboiled in wine and fo applied, taketh away blaftings, fwellings of the cods, or genitors: it confumeth windy fwellingst in.

the ioints and fuch like.
C Being taken in a fupping broth, it is good for the cheft, and for colde lungs, and fuchassare ops preffed with abundance of rawe humours.

D . It ftancheth bleeding at the nofe, being tempered with vineger and fmelt vnto.

Being quilted in a little bagge with fome fmall quantity of baie falt, and made hot vpon abed I pan with fire, or fuch like,and iprinckled with good wihe vinoget, and applied to the fide very hor, taketh away the ftitch and paines therof, and eafeth the pleurifie verymuch. olisisistis

\section{Of wilde Cumin. Cbap.4rio.}

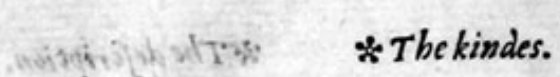

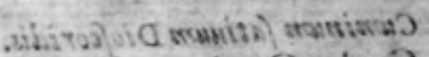

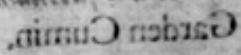

THere be diuers plants differing very notably one from another in thape, and yet all comprehen?

1 ded vnder the title of wilde Cumin.

I Cuminum fylueftre. Wilde Cumin.

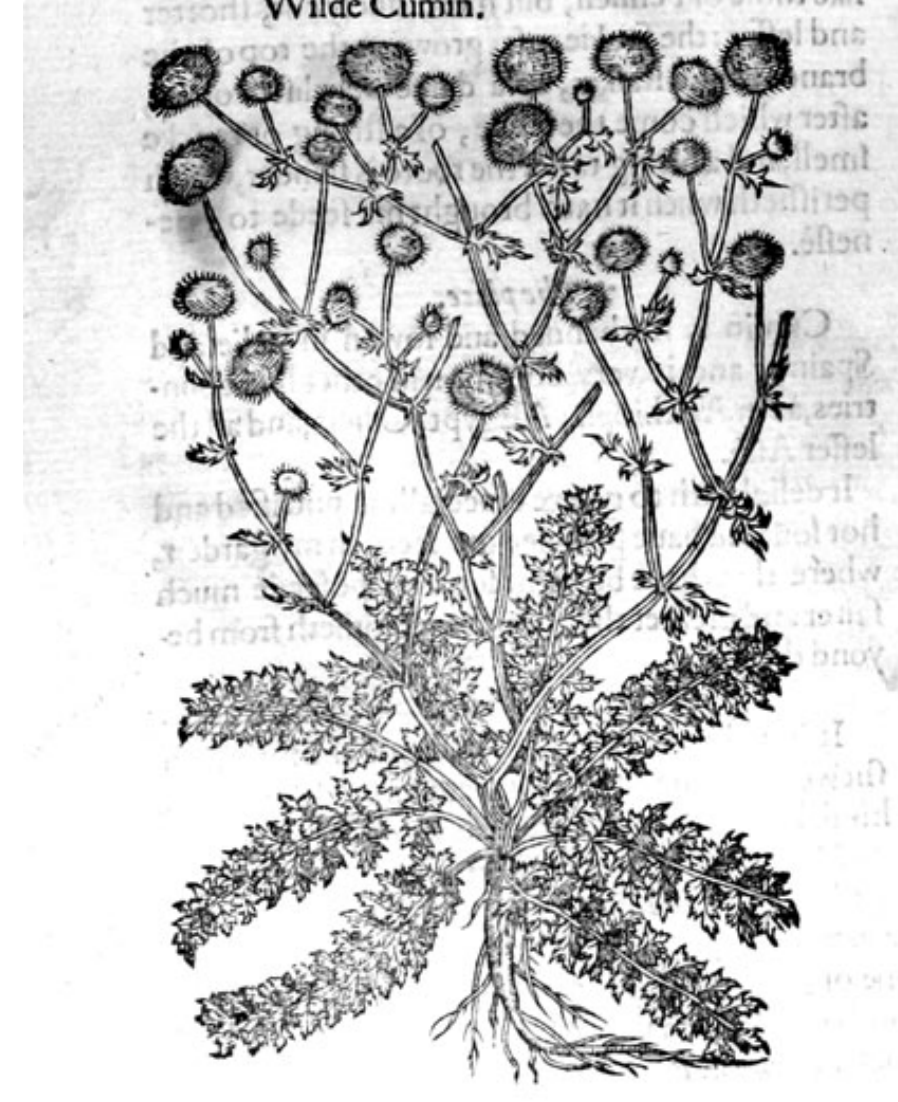

2 Cominum fliguofum.

Codded wilac Cumin.

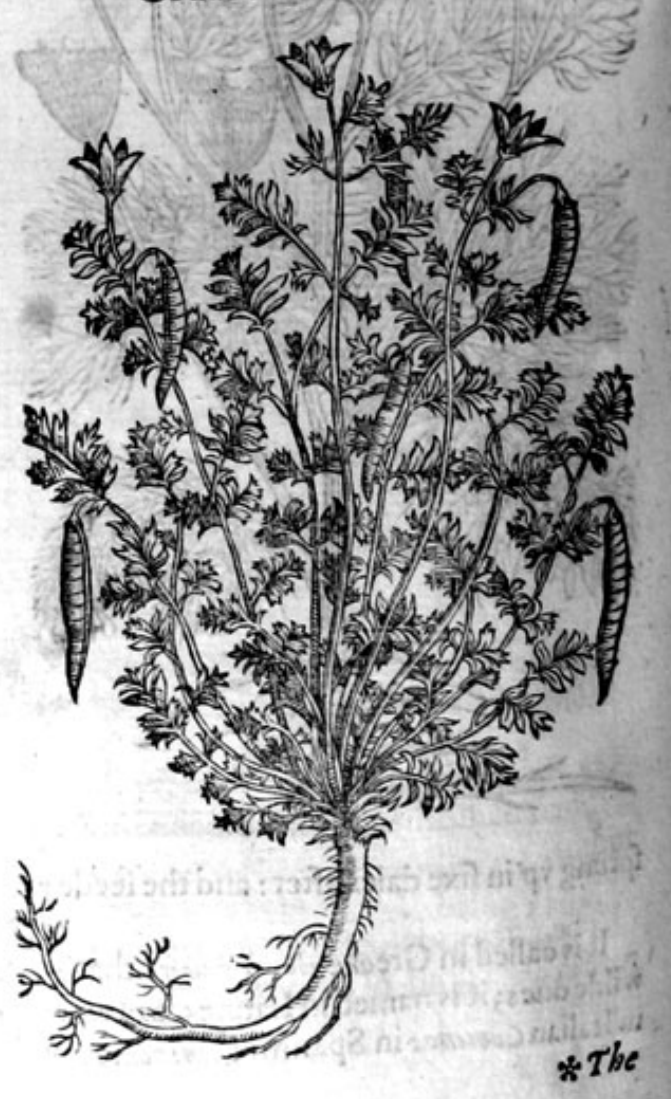

* The 


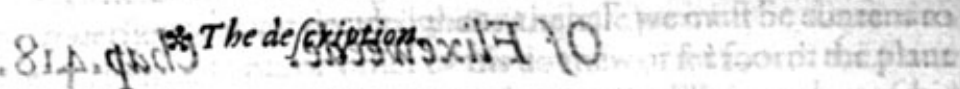

I

$T^{H e}$ wilde Cumin hath fmall white rootes; with fome fibres thereto appendant; from which arife fundrie litcle agged lezues, confifting of many lefier leaues fipflydenated about the edges, in fintion lite the fmalleft leaues of wilde Parfnep:among which Spripgeth vp a flender bending rtalk 2 foote high, like ynto Pecten Veneris, bearing at the top therof white, round, and hairie buttons or knops, tike Arction as Diofcorides hath right welloblernedawithin which knops is conteined a tender downie fubltance, among which is the feede, like the feedeof Dens zeonis, But

2 The fecond kinde of Cumin is yery like vnto the aforéfide yifde Cuning, fate that it beareth a number of horned or crooked cods, after the maner of scorpess ss bur thick ef and leffec cookked, and the feedes within the cods are feucrally diftinct andfevarated one from another by equnl partitions, in finall croffes; yellow of colour, and fomewhat long athe italkes are litule and tender, befet with leanes muchlike vnto the finall leaues of Carui, or Pelfen V encris; and at the top of the ftalkes there do grow pretic yellowe flowers, like thofe of great Celandine or Rocket, fauing that they be fomwharleffer.

$$
\text { ㄱ. }
$$

3 Cumisum Corniculatum, fine Hypeceum Clusij. Hómed wilde Cumin,

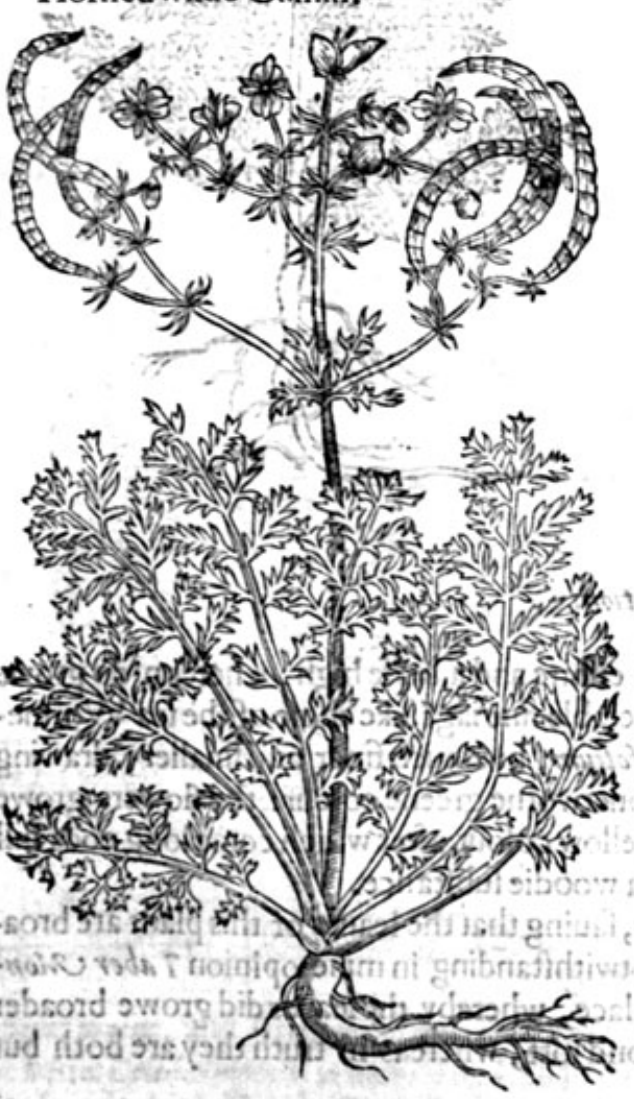

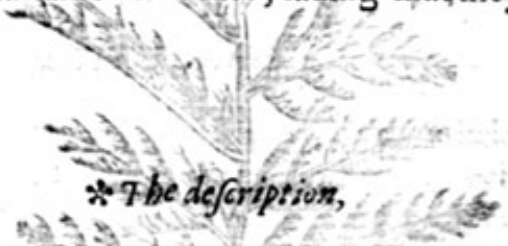

3 The thirdkinde of Cumin is very like vnto the laft before mentoped, but the leaues are much greater, morc flender, and more finely cut, or iag-

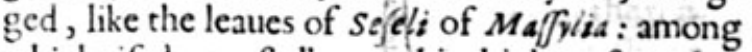
which rifeth vp a ftalke a cubite high or formwhat more, very fmogth and whitith, at the top whereof fpring foorth fine yellow flowers, like the former, but in my opinion more like the Paunfey or Harts eafe : thefe flowers being vaded, there fucceede crooked eods, greater, and more full of knots or divifions then the former, wherein is conteined a fmall and flat yellowe feede like Galega: the roote is long, thicke, and fingle.

\section{The $*$ Theplace.}

Thefe wilde. Gumins do growe in Lycia, $\& \mathrm{G}_{2}$ latia, a prouince of Afia, and in Carthage a vitie of Spaine; feldome feene in thefe northern pars; notwithit anding at the impreffion heerof, the laft did flower and fourifhin my garden.

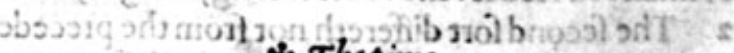
( They fower in Auguft, andperfect their feede in September.

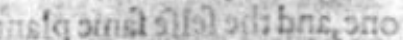

ob/Theirnaines hauebeene rouched $*$ The romes. author.

*The temperiture end vertucs.
Their temperature and vertues are referred

read in any author of their vfe in phificks.

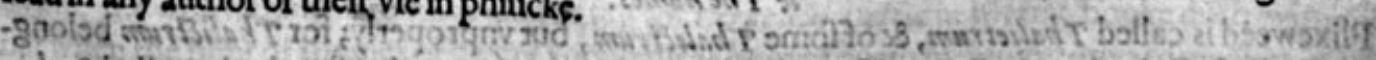

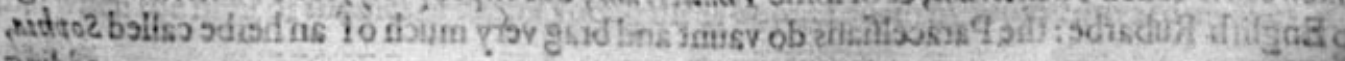
griiblos 


\section{Of Flixeweede. Chap.418.}

1 Sophia Chirurgorum. Flixeweede.

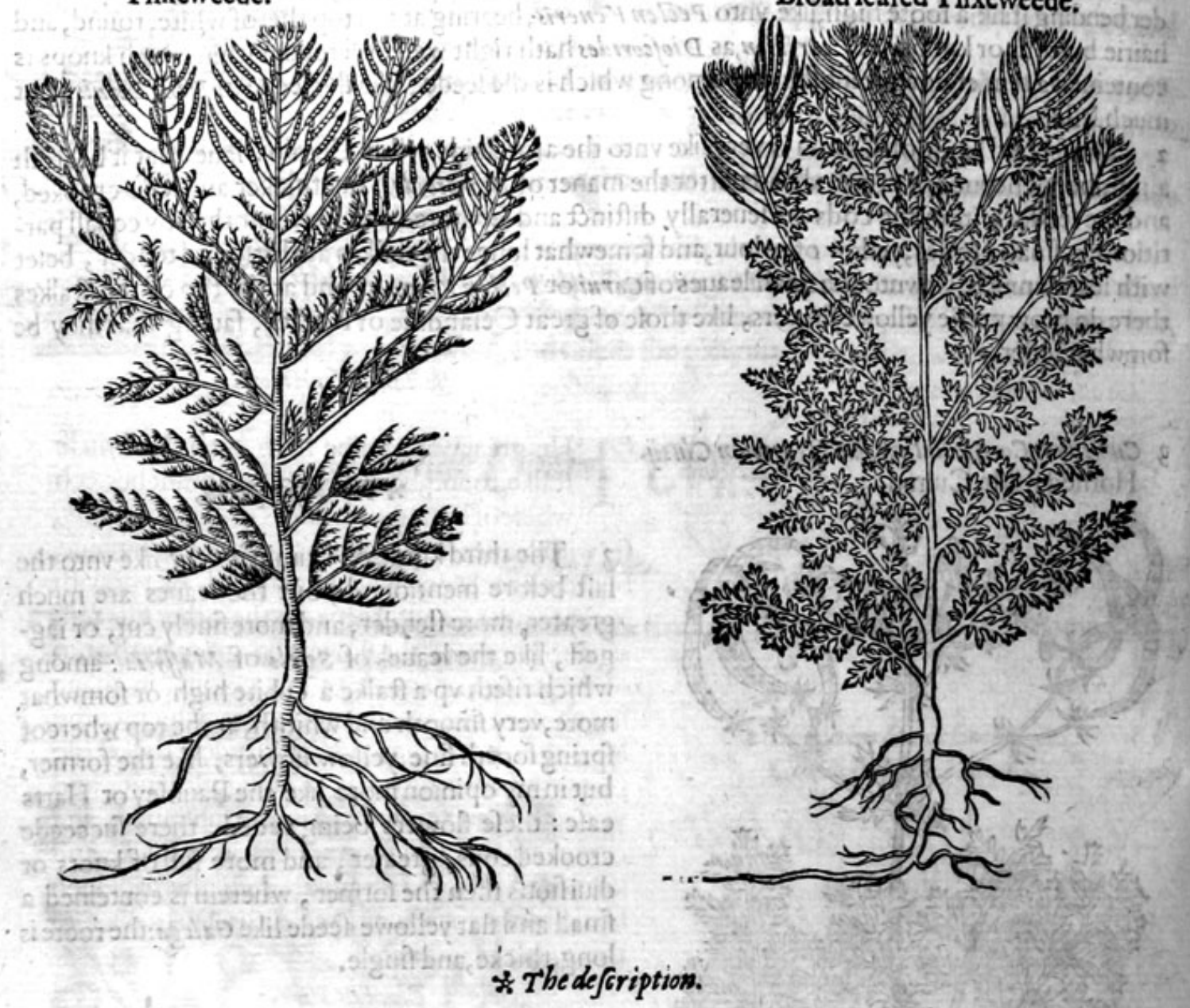

1 Lixeweede hath rounde and harde ftalkes, a cubite and a halfe high, whereon do growe leaues moft finely cut and diuided into innumerable fine iags, like thofe of the fea Wormewood called Seriphium or Abfinthium tenuifolium, but much finer and fmaller, drawing necre vnto the fmalleft leaues of Corianders, of an ouerworne greene colour: the flowers growe alongft the tops of the fpriggie branches, of a darke yellow colour:after which come long cods full of fmall red feedes: the roore is long, ftraight, and of a woodie fubftance.

2 The fecond fort differeth nor from the precedent, fauing that the leaues of this plant are broader, wherein efpecially confifteth the difference; notwithitanding in mine opinion 7 aber calontanus found this fecond fort growing in fome fertill place, whereby theleaues did growe broader and greater, which mooued him to make of this a fecond fort, whereas in truth they are both but one, and the felfe fame plant.

* Theplace.

This Flixeweede groweth in moft places of Englande, almoft euery where in the ruines of olde buildings, by high waies, and in filthy obfcure bafe places.

$$
* \text { The time. }
$$

It fowreth and feedeth from Iune to the end of Scptember.

$$
\text { * The names. }
$$

Flixeweed is called Thalietrum, \& of fome Thalictrum, but vnproperly; for Thalictram belong: eth to Englin Rubarbe : the Paracelfians do vaunt and brag very much of an hexbe called Sophis, 
adding thereto the furname Paracel/s, wherewith they imagine to do woonders, whether this be the fame plant it is difputable, the controuerfie not as yet decided ;neuertheleffe we muft be content to accept of this for the true Sophia, vntill fome difciple or other of his do fhew or fet foorth the plant wherewith their mafter Faracelfues, did fuch great matters: in Englifh we call it Flixeweede, of his facultie againft the flixe.

Sophia drieth without any manifeft fharpeneffe or heate.

* The vertues.

The feede of Sophia or Flixeweede drunke with wine, or Smithes water, ftoppeth the bloudic A flixe, the laske, and all other iffues of bloud.

The herbe brufed or put into vnguents, clofeth and healeth vlcets, or olde fores and woundes, as B $P$ aracelfyes faith, and that bicaufe it driech without acriponie or fharpenes.

\section{Of the great Celandine, or Swallow woort. Chap.410.}

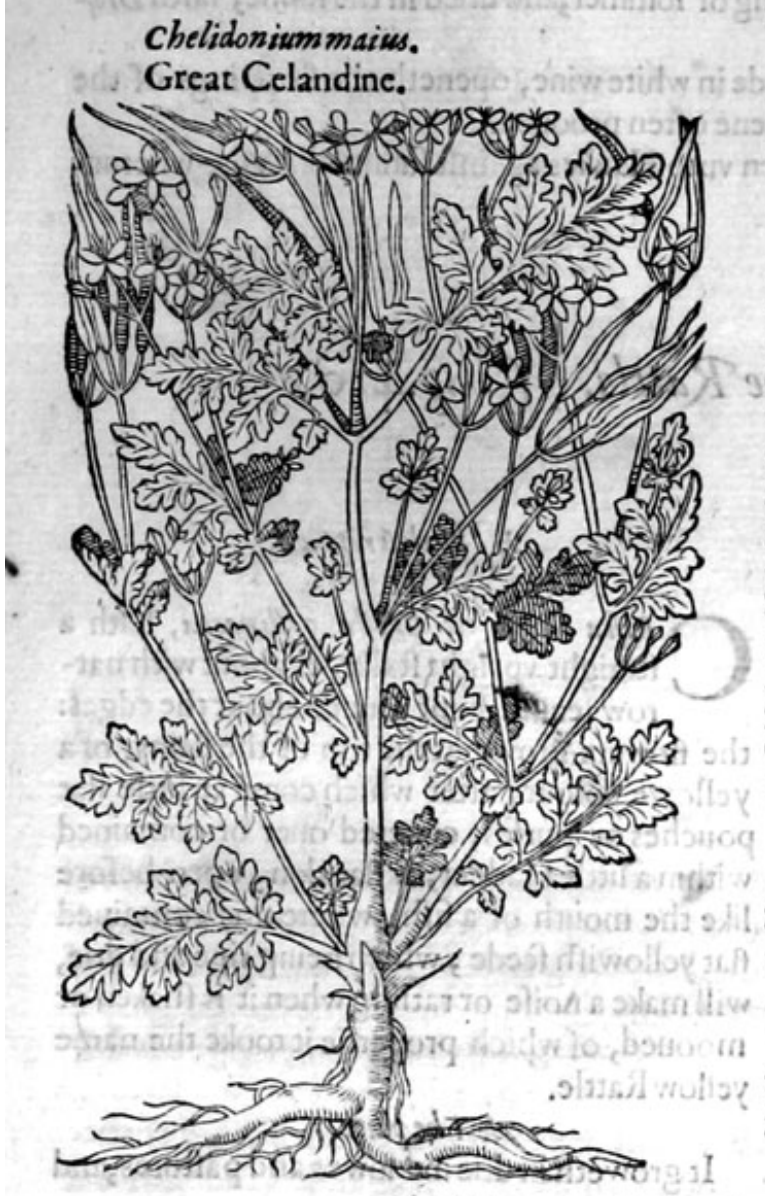

7 He great Celandine hath a tender brittle 1 ftalke, round, hairie and full of branches, ech where of hath diuers knees or knottie ioints, fet with leaues not vnlike to thofe of Columbine, but tenderer \& deeper cut or iagged, of a grayifh greene vnder, and greene on the other fide tending to blewnes: the flowers do grow at the top of the ftalkes, of a golde yellow colour, in thape like thofe of the Wall flower; after which come long cods, full of bleake or pale feedes ; the whole plant is of a ftrong finell, nothing pleafant, and yeeldeth a thicke iuice of a milkie fubitance, and of the colour of Saffron: the roote is thicke and knobbie,with fome threds annexed therto, which being broken or brufed, yeeldeth a fap or iuice of the colour of golde.

$$
\text { * The place. }
$$

It groweth in vntilled places, by common way fides, among briers and brambles, about old wals, and in the fhade rather then in the funne.

$$
\text { *Thetime. }
$$

It is greene all the yeere, it flowreth from April to a good part of fommer, the cods are perfected in the meane time.

It is called in Greeke xenuobrov: in Latine Chelidonium maius, and Hirundinaria maior: among the Apothecaries Chelidonia, diuers mifcall it by the name Celidonium; it is named in Italian Celidonia: in Spanifh celiduenha, rerua de las golun-

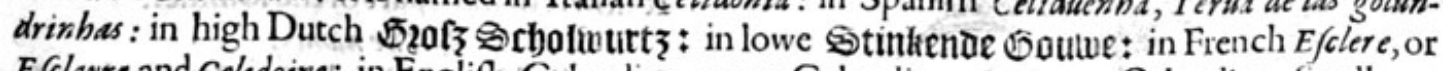
Efclayre, and Celidoine: in Englifh Celandine, great Celandine, common Celandine, Swallowe

It is called Celandine, not bicaufe it then firft fpringeth at the comming in of the Swallowes, or dieth when they go away; for as we haue faide, it may be founde all the yecre, but bicaule fome holde opinion, that with this herbe the dains reftore fight to their yoong ones when their eies beout, the which things are vaine andfalfe: for Corneizus cel/us in his fixt booke doth witneffe, that when the fight of the cies of diuers yoong birds be put foorth by fome outward meanes, it will 


\section{2}

\section{THE SECOND BOOKE OF THE}

after a time be reftored of it felfe, and fooneft of all the fight of the Swallow, whereupon (as the fame author faith) that the tale or fable grew, how thorow an herbe the dams reftore that thing, which healeth of it felfe: the very fame doth Ariftotle alleadge in the fixt booke of the hiftorie of liuing creatures : the eies of yoong Swallowes, faith he, that are not Aledge, if a man dopricke them out, do grow againe, and afterwards do perfectly recouer their fight.

$$
\text { * The temperature. }
$$

The great Celandine is manifeftly hot and dry, and that in the thirde degree, and withall fcourech and clenfeth effectually.

\section{* The vertues.}

A The iuice of the herbe is good to tharpen the fight, for it clenfeth and confumeth awaie flimie things that cleaue about the ball of the eie, and hinder the fight, and efpecially being boiled with hony in a brafen veffell, as Diofcorides teacheth.

B The roote cureth the yellowe iaundife, that commeth of the ftopping of the gall, efpecially when there is no ague ioyned, for it openeth and deliuereth the gall and liuer fromitoppings.

C The roote being chewed, is reported to be good againft the toothach.

D . The iuice muft be drawne foorth in the beginning of fommer, and dried in the funne, faith Diof corides.

E The roote of Celandine borled with Annife feede in white wine, openeth the ftoppings of the liuer, and cureth the iaundife very fafely, as hath beene often prooued.

F The roote cut in fmall peeces is good to be giuen vnto Haukes againft fundry difeafes, wherunto they are fubiect, as wormes, craie, and fuch like.

\section{Of Coxcombe, or yellowe Rattle. Cbap.420.}

Crifta Galli.

Yellow Rattle, or Coxcombe.

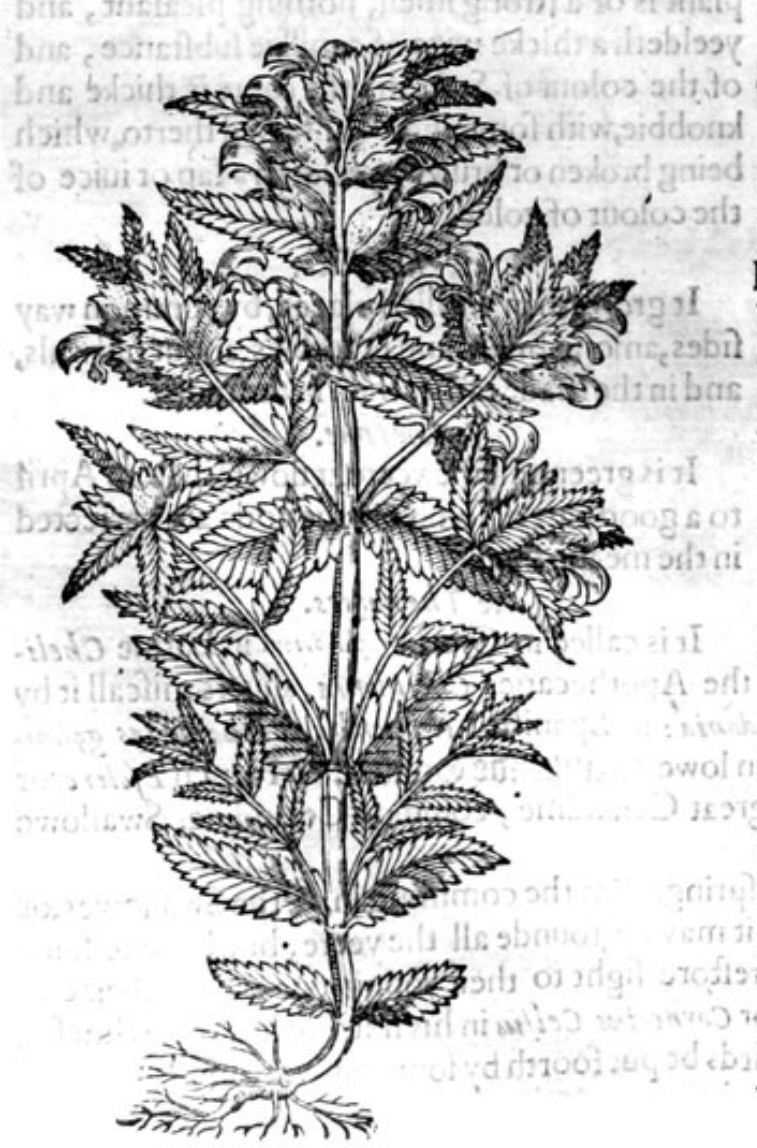

\section{*The defription.}

Rifta Galli, or Criffa gallinaces, hath a ftraight vpright ftalke, fer about with narrow leaues, fnipt rounde about the edges: the flowers growe at the top of the ftems, of a yellowe colour; after which come vp little flat pouches or purfes, couered ouer or contained within a little bladder, or flat skin, open before like the mouth of a fifh, wherein is contained flat yellowifh feede, which being ripe and drie, will make a noife or ratling when it is fhaken or mooued, of which propertie it tooke the name yellow Rattle.

$*$ It groweth in drie medowes and paftures, and
It is to them a great annoiance.

\section{* The time.}

It flowreth moft part of the fommer.

It is called in low Dutch 1Ratelen, and geele Rateien: commonly in Latine Crifta Galli, and Gallinacea Crifta : in Englifh Coxecombe,Penie graffe,yellow or white Rattle : in high Dutch it is called geet Rodel: in French Creffede Cos: diuers take icto be the olde writers silectorolophos. * The 
But what temperature or vertue this herbe is of, men haue not as yet beene carefull to knowe, feeing it is accounted vnprofitable.

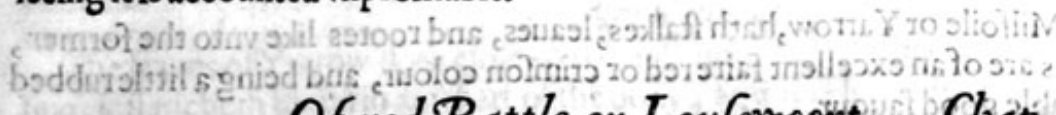

\section{Of red Rattle, or Loufewoort. Cbap.421.}

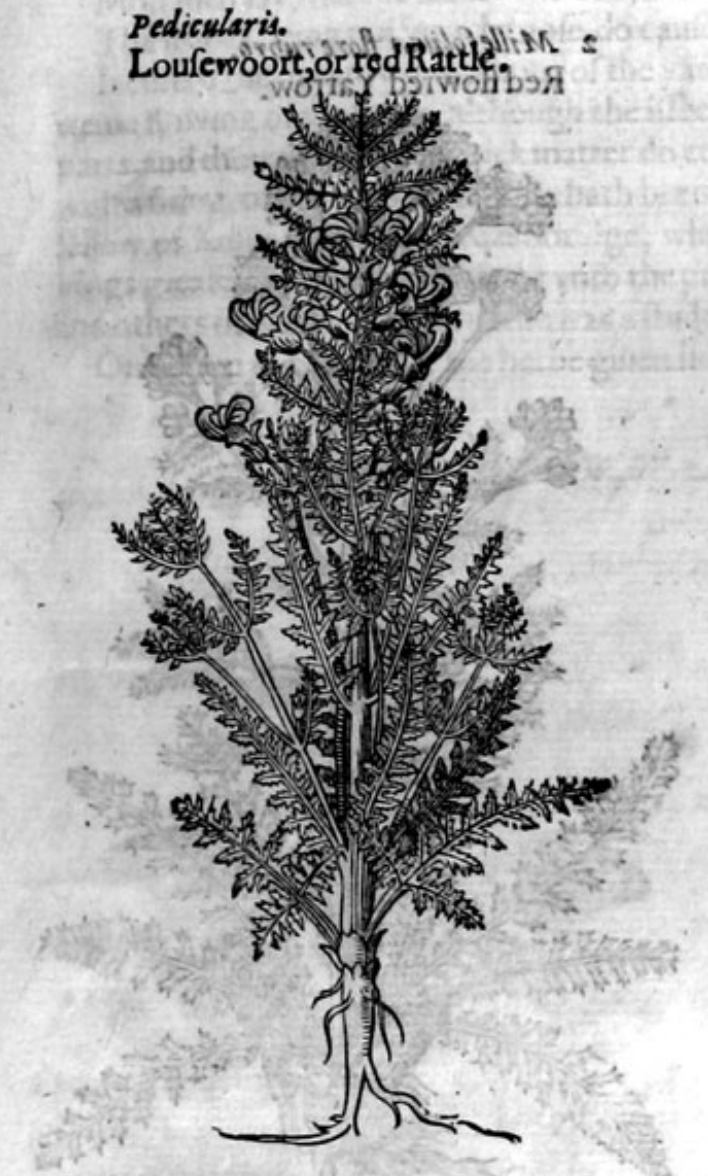

\%The defcription.
EdRattle (of Dodoneus called Fiftularia, and
according to the opinion and cenfure of
Carolue Cluf fuss, Pena and others, the true Alectorolophos) hath very fmall, rent, or iagged leaues, of a browne redde colour, and weake; fmall and tender ftalkes, whereof fome lie along trailing vpon the grounde; within verie moorifh medowes they grow a cubite high and more, but in moift and wet heathes, and fuch like barren grounds not aboue an handfult high $;$, the flowers grow round about the ftalke, from the midft therof euen to the top, and are of a browne red colour, in Thape like the flowers of dead Nettle; which being paft, there fucceede little flat pouches, wherein is contained flat and blackifh feede, in Thewe very like vnto the former: the root is fmall, white, and render. *T Teplace.

It groweth in moift and moorifh medowes, the herbe is not onely vnprofitable, but alfo hurffull, and an infirmitic of the medowes.

\section{* The time.}

It is founde with his flowers and ftalks in Maie and Iune.

\section{* The names.}

It is called in Greek 9 9icorr: in high Dutch 23 atun Rodel : in Latine Pedicularis of the effect, bicaufe it filleth theepe and other cattle that feede in medowes where this groweth full of lice: diuers of the later Herbarifts cal it Fiftularia, of fome Crifta Gallis, and diuers take it to be Mimmulus herba: in Englifh Rattle graffe, red Rattle graffe, and Loufewoort.

\section{Xo}

- It is colde and drie and aftringent.

\section{* The vertues.}

It is helde to be good for fiftulaes and hollowe vlcers, and to ftay the ouermuch flowing of the $\mathrm{A}$ menfes, or any other fluxe of bloud, if it be boiled in red wine and drunke.

\section{Of Yarrowe, or Nofebleede. Chap. 422 .}

\section{* The defcription.}

12 Ominon Yarrowe hath very many ftalkes comming vp a cubite high, round, and formshat hard :about which ftande long leaues, cut in the fides fundrie wife, and as it were made vp of many fmal iagged leaues, cuery one of which feeme to come neere to the flender leaues 
of Coriander : there ftande at the top tufts or fpoked rundles, the flowers whereof are either white

or purple, which being rubbed do yeelde 2 ftrong fmell,but vipleafant; the roote fendeth downe
many ftringes. many ftringes. 2 The fecond kinde of Milfoile or Yarrow, hath ftalkes, leaues, and rootes like vnto the former, fauing that his fpokie tufts are of an excellent faire red or crimfon colour, and being a littlerubbed in the hand, is of a reafonable good faugur.

I Millefolium terreftre vulgare. Common Yarrow.

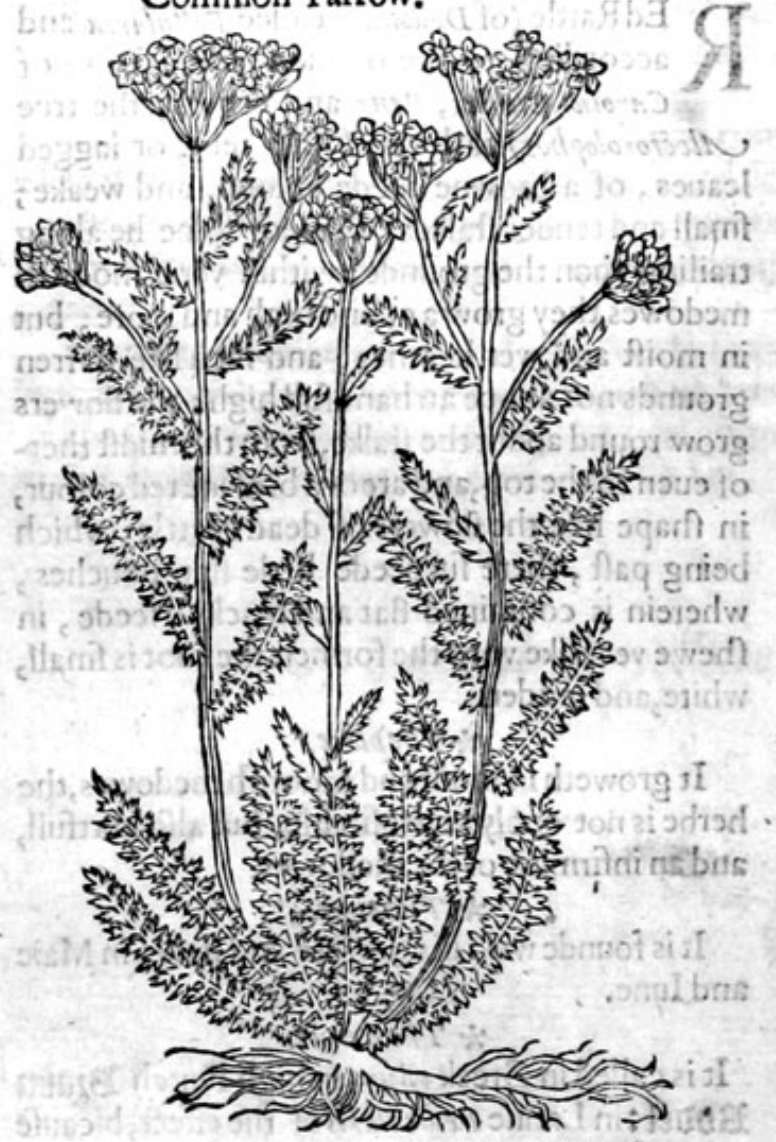

2 Millefoliven flore rubrolusihs Red'flowred Yarrow,

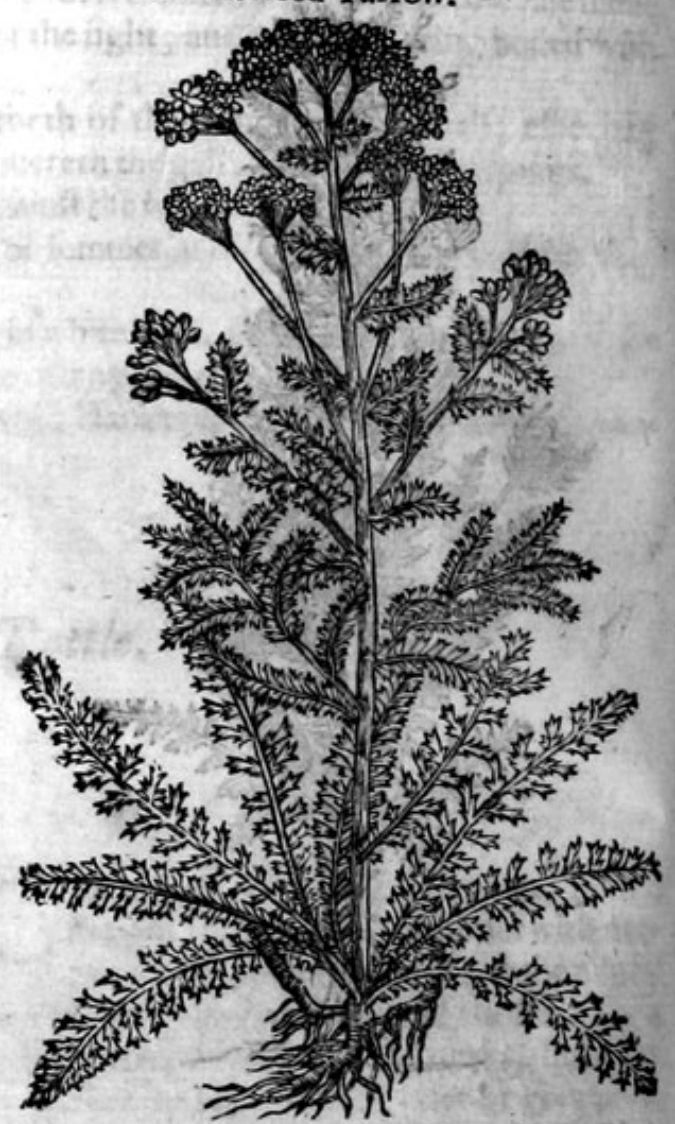

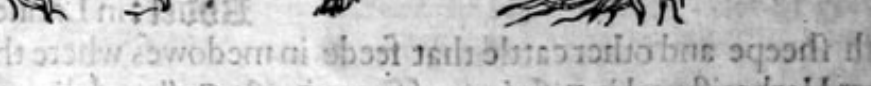

* The place. Iis in.

The firft groweth euery where in driepaftures and medowes: red Milfoile groweth in a fieldby Sutton in Kent, called Holly Deane, from whence I brought thofe plants that do growe in my gar: den ; but it is not common euery where as the other is:

They flower from Maie to the end of October. * The time.

* $T$ he names.

Yarrow is called of the later Herbarifts Millefolium, it is Diofcorides his a jimeros: in Latin Achillew, and Acbillea fiderttis, which thing he may very plainly fee that will compare it with that defcription which Diofcorides hath fet downe: this wasfounde out faith $P$ liny in his 25 . booke chapter 5 . by Achilles Chirons difciple, which for that caufe is named Achilleios, of others Sideritis, among vs Millefolium : yet be there other Sideritides, and alfo another Panaces Heracleion; whereof wc will intreat in another place: Apuleius fetteth downe diuers heerof, fome of which are alfo found among the baftard names in Diofcorides : in Latine it is called Militaris, Supercilium Veneris, Acrum, or Ac0. ram fyluaticum: of the French men Mallefueille: in high Dutch Jatben, fcjarffistagt in low Dutch Jeruwe: in Italian Millefoglio : in Spanifh Milhoyas yerua : in Englifh Yarrow, Nole bleed, common Yarrow, red Yarrow, and Milfoile. 
* The temperature.

Yarrow,as Galen faith, is not vnlike in temperature to the Sideritides, or Iron worts, that is to fay, clenfing, and meanly colde, but it moft of all bindeth.

*T The vertues.

The leaues of Yarrow doth clofe vp wounds, and keepeth them from inflammation, or fiery fwel- A ling: it ftanchech bloud in any part of the body, and it is likewife put into bathes for women to fir in: it ftoppeth the laske, and being drunke it helpeth the bloudy flixe.

Moft men fay, that the leaues chewed, and efpecially greene, are a remedie for the toothoch. B

The leaues being pur into the nofe, do caufe it to bleede, and eafeth the paine of the megrim. C

It cureth the inward excoriations of the yarde of a man comming by reafon of pollutions or extreme flowing of the feede, although the iffue do caufe inflammation and fwelling of thofe fecret parts, and though the fpermatick matter do come downe in great quantitie, if the iuice be iniected with a firing, or the decoction. This hath beene prooued by a certaine friende of mine, fometimes a fellow of Kings Colledge in Cambridge, wholightly brufed the leaues of common Yarrowe with Hogs greafe, and applied it warme vnto the privie parts, and therby did diuers times helpe himfelfe, and others of his fellowes, when he was a ftudent, and a fingle man liuing in Cambridge.

One dram in powder of the herbe giuen in wine, prefently taketh away the paine of the colick D

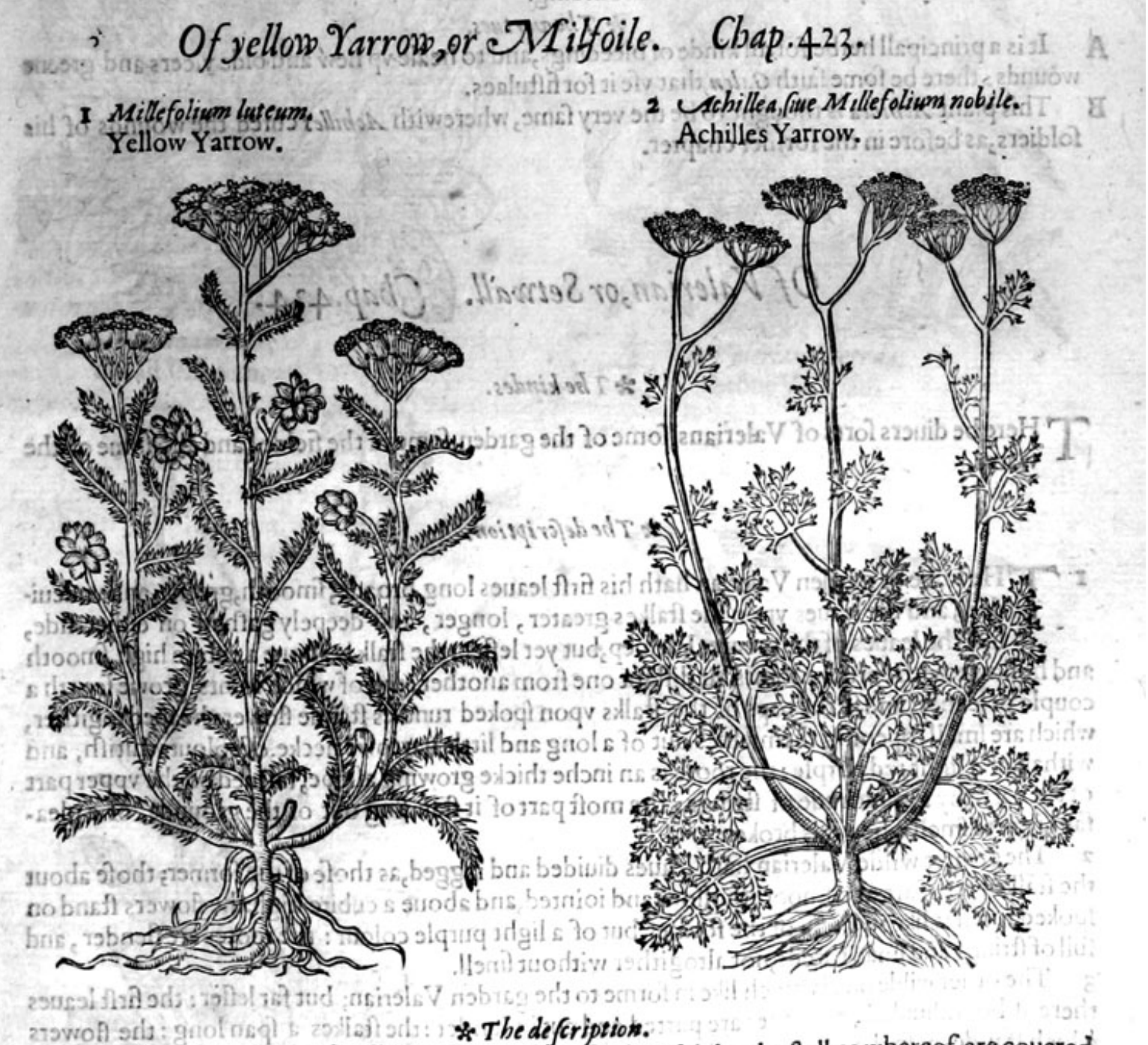

1 Ellowe Yarrow is a fmall plant, fcarce atouc a fpan high : the ftalkes whereof are couered with long leaues, very finely cut in the edges like feathers in the wings of little birds : the -irst 1 iniftes or fpokedrundles, bring foorth yellow flowers, of the fame fhape and forme of the common Yarrow : the roote confifteth of threddie ftrings. 


\section{THE SECOND BOOKE OF THE}

2 Achilles Yarrow or noble Milfoile, hath a thicke tough roote, with ftrings faftned thereto; from which immediately rife vp diuers ftalkes, very greene and crefted, whereupon do growe long leaues compofed of many fmall iagges, cut euen to the middle rib : the flowers ftande on the top of
the ftalkes in fpokie vmbles or tufts, of a yellowifh colour, and pleafant fmell.

* The place.

Thefe kinds of Yarrow are feldome found : they grow in a fat and fruitfull foile, and fomtimes in medowes, and are ftrangers in England.

* The time.

They flower in Maic efpecially, in the moneth of Auguft they are likewife feene.

* The names.

Diofcorides defcription doth fufficiently declare, that this herbe is Stratiotes Millefoliwm : in Greeke seenéns ynsopunios: the height of the herbe fheweth it, the forme of the leaues agree; there is fome ambiguitie or doubt in the colour of the flowers, which Dioforides defcribeth to be white, as the vulgar copies haue; but Lindreas Lacuna addeth out of the old booke, of a yellow colour: it is named of the later age Millefolium minus, or little Yarrow, and Millefolisam luteum, yellowe Yarrow, or Nole bleede: the Apothecarics and common people know it not.

Yarrow is meanly colde, and fomewhat binding. $*$ Thetemperature.

* The vertues.

A It is a principall herbe for all kinde of bleedirigs, and to heale vp new and olde vlcers and greene wounds: there be fome faith $G$ alen, that vfe it for fiftulaes.

B This plant Achillea is thought ro be the very fame, wherewith Achilles cured the wounds of his foldiers,as before in the former chapter.

\section{Of Valerian, or Setwall. Chap.424.}

* 1 he kindes.

$T^{3}$

Here be diuers forts of Valerians, fome of the garden, fome of the fielde, and alfo fome of the water.

\section{\$ The defcription.}

- The tame or garden Valerian hath his firft leaues long, broade, fmooth, greene, and yndeuided; and the leaues ypon the ftalkes greater, longer, and deepely gafhed on either fide, like the leaues of the greater Parfnep, but yet leffer : the ftalk is aboure a cubite high, fmooth and hollowe, with certaine ioints far diftant one from another: out of which ioints growe foorth a couple of leaues, and in the tops of the ftalks vpon fpoked rundles ftande flowers heaped togither, which are Imall, opening themfelues out of a long and little narrowe necke, of colour whitifh, and withall of a light red purple : the roote is an inche thicke growing allope, faftned on the vpper part of the earth by a multitude of ftrings, the moft part of itftanding out of the grounde, of a pleafant fweete fmell when it is broken.

2 The greater wilde Valerian hath leaues diuided and iagged, as thofe of the former; thofe about the ftalke hereof are alfo fmooth, hollow, and iointed, and aboue a cubite high:the flowers ftand on fpoked rundles like to thofe of the former, but of a light purple colour : the rootes are flender, and full of ftrings and finall threds, not altogither without finell.

3 The other wilde one is much like in forme to the garden Valerian, but far leffer : the firft leaues there of be vndiuided, the other are parted and cart in funder : the ftalkes a fpan long: the flowers which ftande on foked rundles are like to thofe of the others, of a light whitith purple colour ; the rootes be flender, growing aflope,creeping, and.full of fine fmall threds, of little fmell. ! isim 4 There is a fmall Valerian growing vpon rocks and iftonie places, that is like vnto the laft defcribed, faung it is al togither lefler. 


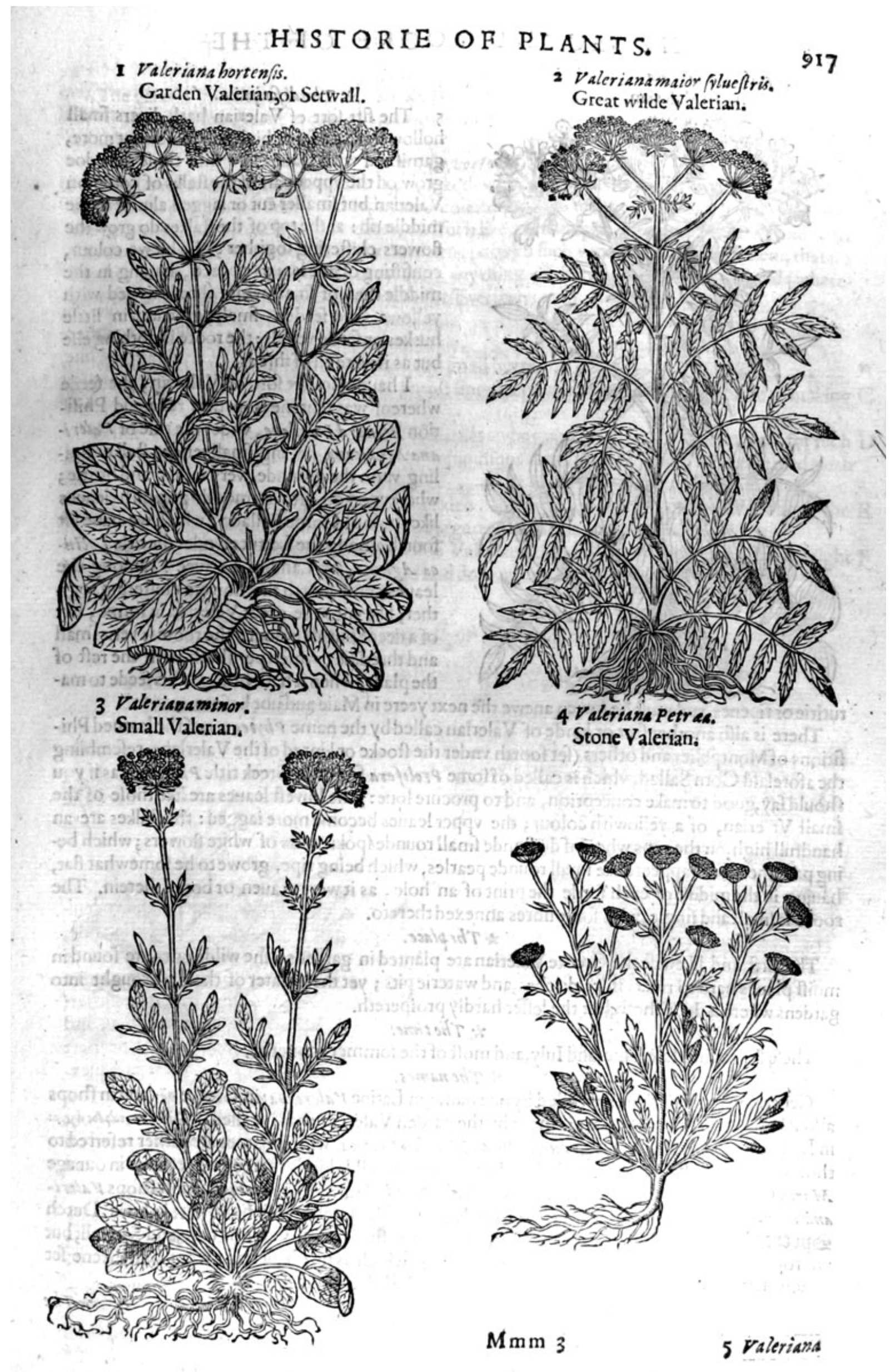


5 Valeriana Graca.

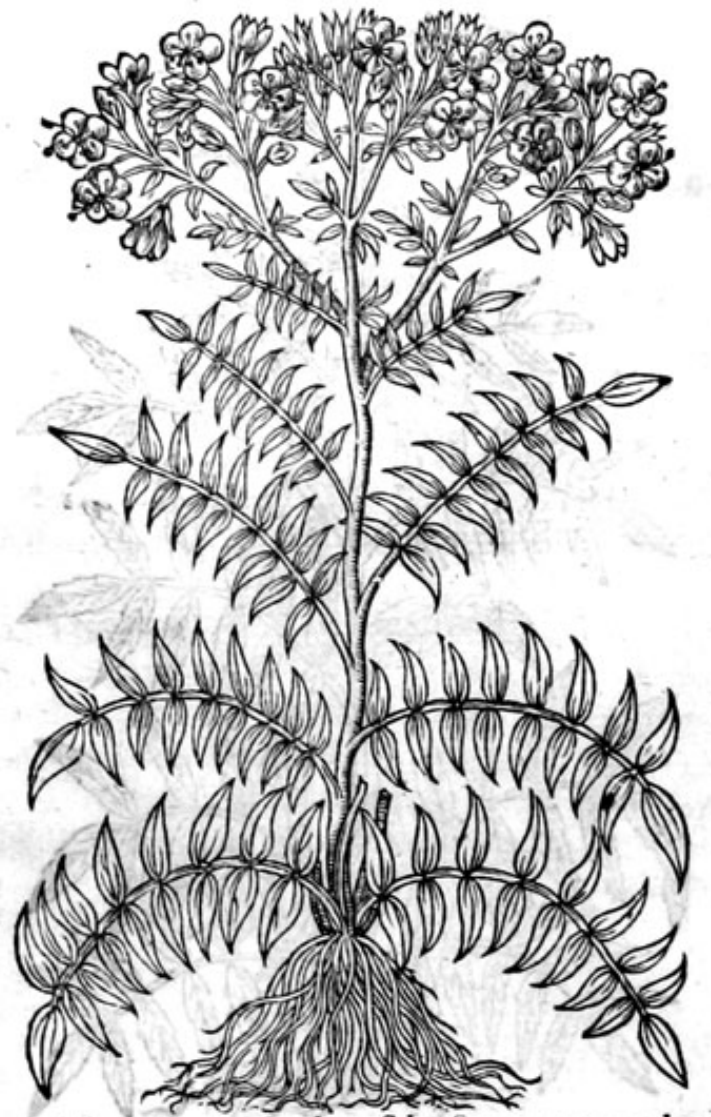

Greekinh Valerian.

* The defoription. I lita

5 The fift fort of Valerian hath diuers fmall hollow ftalks, a foote high and fomewhat more, garnifhed with leaues like vnto thofe that doe grow on the vpper part of the ftalks of common Valerian, but fmaller cut or iagged almoft to the middle rib: at the top of the ftalkes do grow the flowers cluftering togither, of a blewe colour, confifting of fiue leaues a peece, hauing in the middle thereof fmall white threds tipped with yellowe : the feede is fmall, growing in little huskes or feede veffels: the roote is nothing elfe but as it were all of threds.

I hate another fort of Valerian, the feede whereof was fent me from that reuerend Phifition Bernard Paladane, vnder the title of Valer;ana Mexicana, hauing fmall tender ftalkes trajling vpon the grounde, very weake and brittle; whereupon do growe fmooth greenifh leaues like thofe of Corne Sallade (which we haue fet foorth among the Lettuce, vnder the title Lactuca Agnins, or Lambes Lettuce :) among the leaues come foorth the flowers cluftering togither, like ynto the great Valerian in forme, but of a deepe purple colour: the roote is veriefmall and threddie, which perifheth with the reft of the plant, when it hath brought his feede to maturitie or ripenes, and muft be fowen anewe the next yeere in Maic and not before.

There is alfo another fort or kinde of Valerian called by the name Phytewma, of the learned Phifitions of Montpelier and others (fet foorth vnder the ftocke or kinred of the Valerians, refembling the aforefaid Corn Sallad, which is called of fome Prolifera from the Greek title P hyteuma as if you Thould fay, good to make conception, and to procure loue: ) the loweft leaues are like thofe of the finall Valerian, of a yellowifh colour; the vpper leaues become more iagged: the ftalkes are an handfull high, on the tops whereof do ftande fmall rounde fpokie tufts of white flowers; which being paft, the feedes appeere like fmall rounde pearles, which being ripe, growe to be fomewhat fat, hauing in the middle of each feede the print of an hole, as it were grauen or bored therein. The roote is fmall and fingle, with fome fibres annexed thereto.

\section{* The place.}

The firft and likewife the Greeke Valerian are planted in gardens; the wilde ones are found in moift places hard to riuers fides, ditches, and waterie pits; yet the greater of thefe is brought into gardens where it flourifheth, but the leffer hardly profpereth.

* The time.

Thefe flower in Maie, Iune, and Iuly, and moft of the fommer moneths.

$*$ The names.

Generally, the Valerians are called by one name, in Latine Valeriana : in Greeke oz: and in fhops

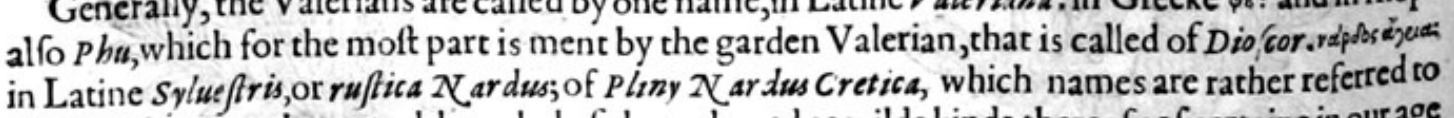
thofe of the next chapter, although thefe be reckoned as wilde kinds thereof:of certaine in our age Marinella, Amantilla Valentiana, Genicula ris, Herba Benedicta, and Theria caria: in moft thops Valeri-

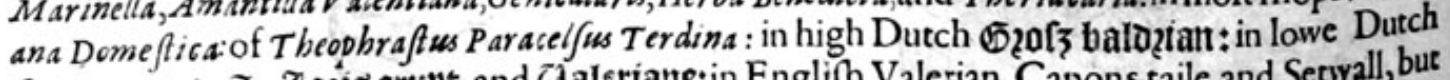
sepercrupt, $D$. Toz̨is ctupt, and Caleriane: in Englifh Valerian, Capons taile, and Setwall, but vnproperly; for that name belongeth to Zedoxria, which is not Valerian: what hathbeene fet downe in the titles fhall ferue for the diftinctions of the other kinds. 
Seite

fehlt

\author{
Page \\ missing
}




\section{$*$ The dejcription.}

17 He Nardus named Celtica, but now Liguftica 2 ardus, flourifheth in high mountaines. The Vallefians in their mother toong call it Selliga, thatis Saliunea; neither do I doubt, but that it is the fame which Virgil doth fpeake of in thefe verfes,

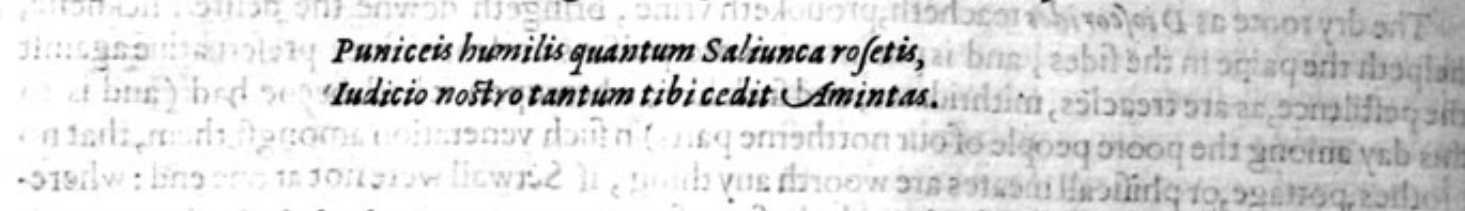

For it is a very little herbe creeping on the ground, and afterward lifting vp it felfe with a ftalke of a handfull high; whereupon from the lower part growe mall thin leaues, like thofe of Gnaphalivm or Cottonweede, whitifh and fomewhat yellowifh: vpon the roughneffe of the roote, there are

I many fcales, platted one vpon another ; but vnder the roote there are many browne ftrings and hairie thireds, in fmell like the rootes of $A$ St rabacca, in tafte fharpe and bitter. The flowers growe along the vpper branches, white and very frnall.

(1) The fecond fort of Spikenard hath many threddic rootes, from the which rife vp many fcalie, rough, and thicke ftalkes, hauing at the top certaine flat hoari-leaues, growing vpon fmall and tender footeftalkes. The whole plant is of a pleafant fweete fmell.

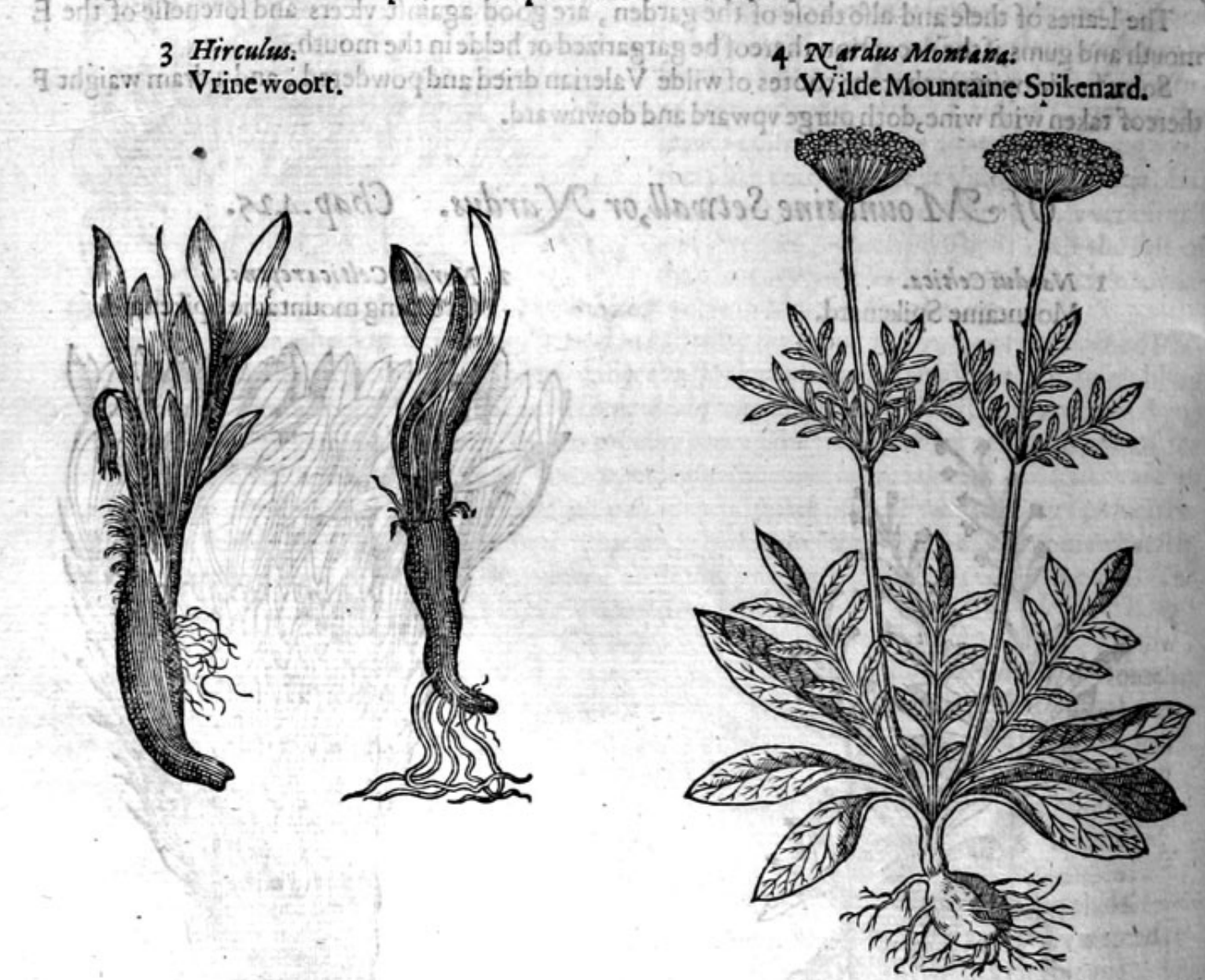

$*$ The defcription.

3. Hirculus is a plant very rare, which as yer I neuer fawe, notwithitanding we are greatly beholding to Ca rolses clufuses, the father of forren fimples, who finding this plant among inany bunches of handfuls of Spikenard, hath made it knowen vnto pofterity, as he hath done many other rase plants, in tranflating of Garcia the Lufitanian phifition, he fetteth it forth with a light defcription, faying it is a bafe and lowe herbe two hands high, bringing foorth leaues without any ftalkes at all. 
4 Mountaine Spikenard hath a great thicke knobbed roote, fet here and there with fome tender fibres, of a pleafant fweet imell : from the which come forth three or fower fmooth broad leaues, \& likewife iagged leaues deepely cut, euen to the middle rib ; among which rife vp naked ftalkes, garnifhed in the middle with a tuft of fmall iagged leaues. The flowers growe at the top of the ftalke, vmble or tuft fafhion, like thofe of Eennell. The feede is fmall and chaffie.

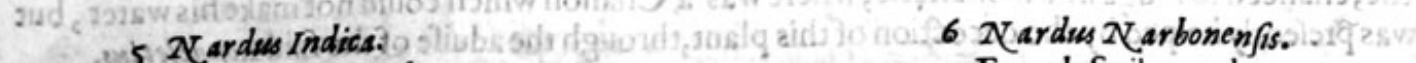

Indian Spikenard.

French Spikenard.

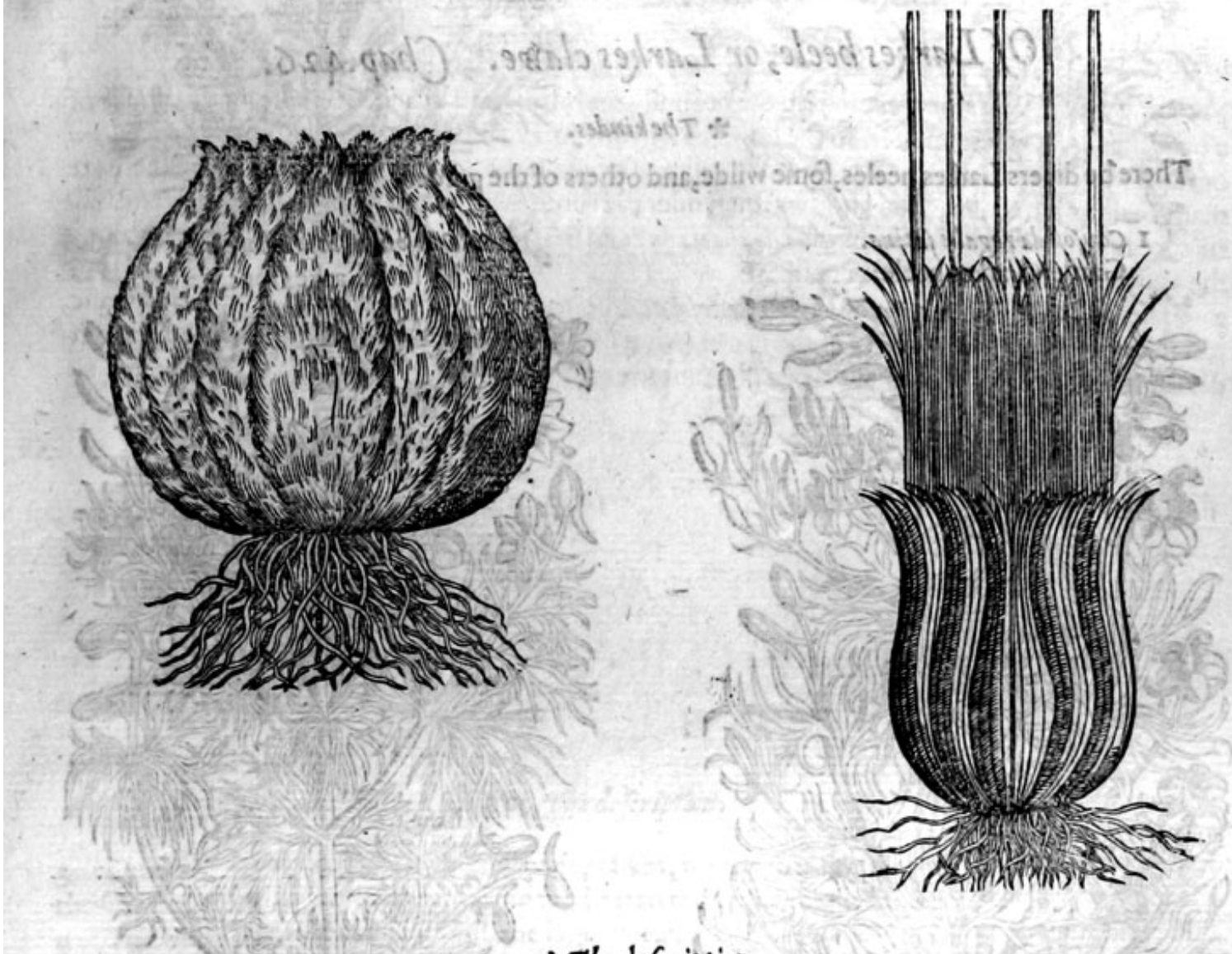

* The defcription.

5 The Spikenard of India is a lowe plant, growing clofe vnto the grounde (as doth our Thiftle; which we call cardurs acaulis ) compoled of many rough fcalie cloues, of a pleafant fmell. The roote is fmall and threddie.

6 The French Spikenard, being a baftard kinde, groweth clofe vpon the ground like the precedent,compact of fcalie rough leaues:in the middle whereof commeth foorth a great bufh of rough graffe, fharpe and cutting; among the which thoote vp diuers round ftalkes. The roote is fmall and threddie. The whole plant is altogither without fmell,which fheweth it to be abaftard kinde of Spikenard.

Thefe plants are ftrangers in England, growing in great plentie vpon the mountaines by Ludenberge and Heluetia, on the rocks among the mofle.

The firft and fecond, if my memoric faile me not, do growe in a field in the north part of England called Crag clofe, and in the foote of the mountaine called Ingleborrow Fels.

* Thetime.

The leanes growe to withering in September, at which time they fmell more pleafantly, than when they flourifhed and were greene.

$*$ The names.
2 ardess is called in Pannonia or Hungarie, of the countrey people Spcick, of fome Betzfin, that
is, 
is, the herbe of Vienna, bicaufe it doth growe there in great abundance, from whence it is brought into other countrics: of Gejner sus Saliunca : in Englifh Spikenard : of the Valletians Selliga, and
Nardus Celtica.

\& T The temperature and vertues.

It mightily prouoketh vrine, as recordeth Rondeletius, who trauelling thtough the defart coun. trie, chanced to lodge in a monafteric, where was a Chanon which could not make his water, but was prefently helped by the decoction of this plant, through the aduife of tre faid Rondektivo.

\section{Of Larkes beele, or Larkes clawe. Chap.426.}

* The kindes.

There be diuers Larkes heeles, fome wilde, and others of the garden.

I Confolida regalis fatiua. Garden Larkes heele.

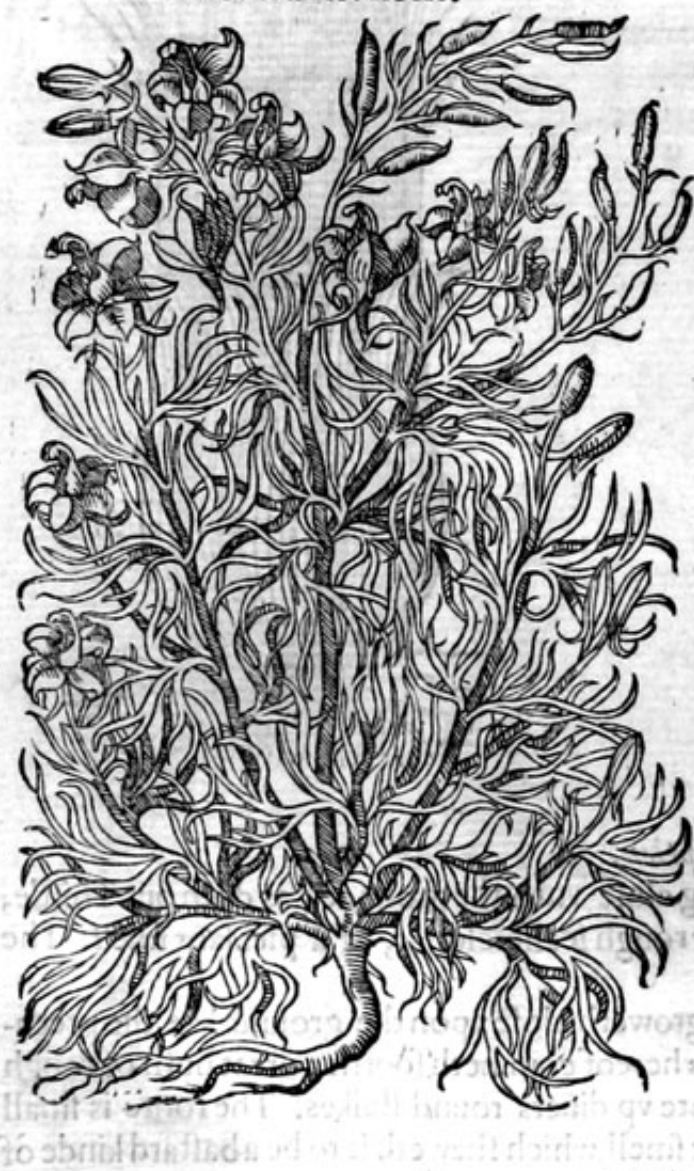

2 Confolida fatiua flore albo. White Larkes fpur.

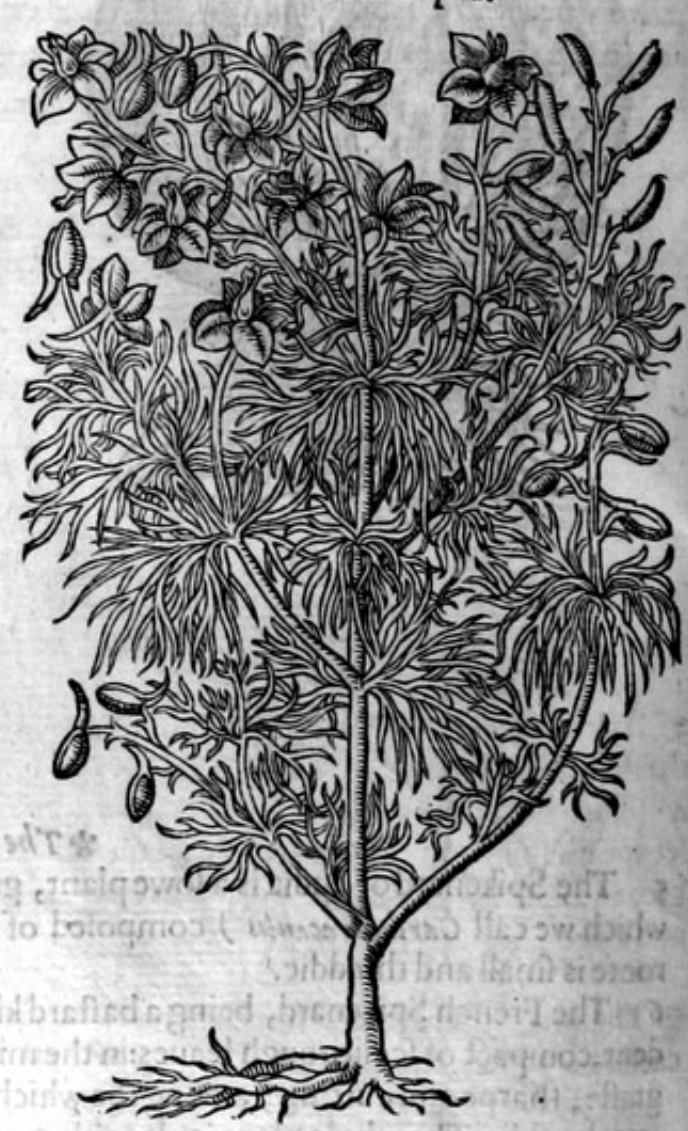

* The defoription.

I Te garden Larkes fpur hath a rounde ftem full of branches, fet with tender iagged leaues, very like vnto the fmall Sothernwood: the flowers grow alongft the ftalks toward the tops of the branches, of a blewe colour, confifting of fiue little leaues which grow togither and make one hollowe flower, hauing a taile or fpur at the ende, turning in like the fpur of Toade flaxe. Thefe flowers are fometimes of a purple colour, fomtimes white, murrey, carnation, and of fundry other colours, varying infinitely, according to the foile or countrey wherein they liue: after come the feede very blacke, like thofe of Leekes: the roote perifheth at the firf approch of winter.

2 The fecond Larke fpur is like the precedent, but fome thing frvaller in ftalkes and leaues: the flowers arc allo like in forme, but of a white colour, wherein efpecially is the diffetence. 


\section{HISTORIE OF PLANTS.}

\section{Con olida regalis flore rubro. \\ Red Larkes fpur.}

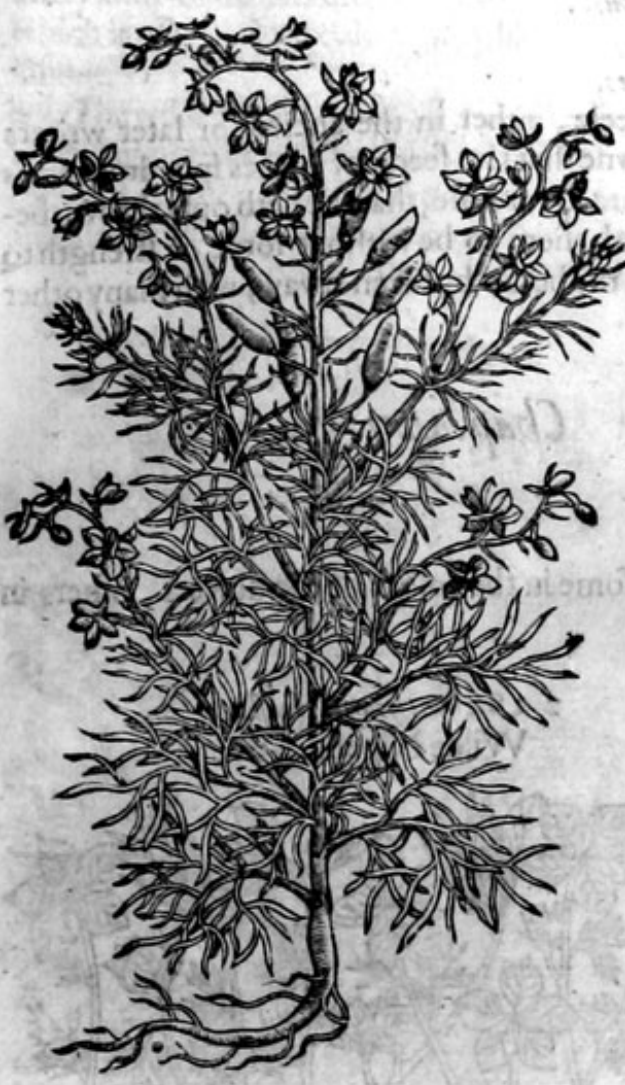

4 Confolida regalis fylueftris. Wilde Larkes heele.

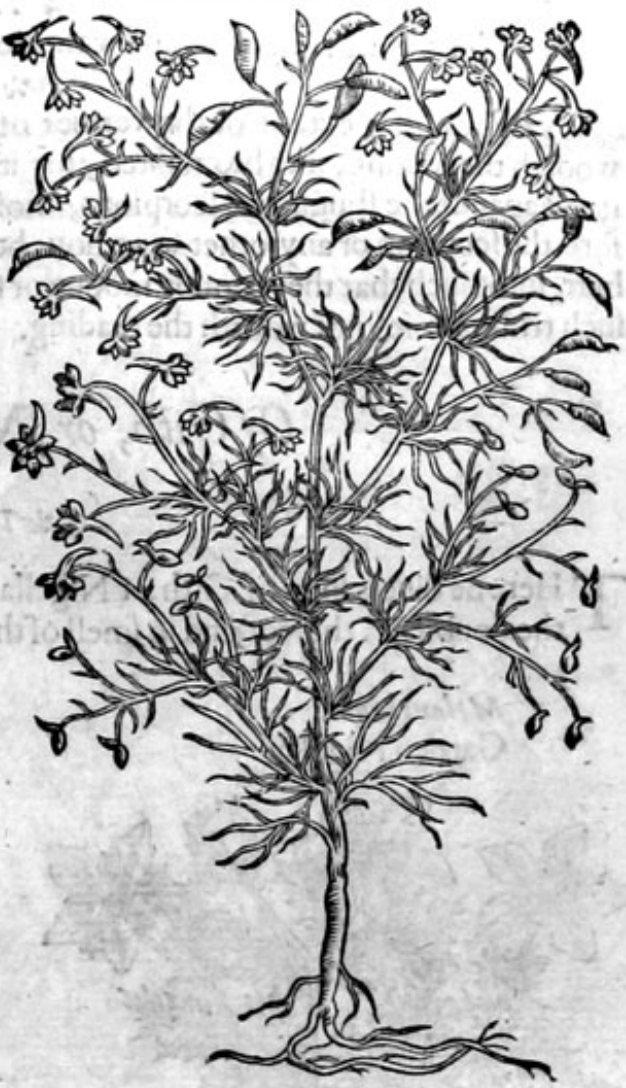

* The defcription.

3 Larkes fpur with red flowers hath leaues, ftalkes, rootes, and feedes like the others, fauing that the flowers heerof are of a brightpurple tending to rednes, wherein confifteth the difference. 4 The wilde Larkes fpur hath moft fine iagged leaues, cut and hackt into diuers parts, confufedly fet vpon a fmall middle tendrell : among which growe the flowers, in fhape like the others, tut $a$ great deale lefier, fomtimes purple, otherwhiles white, and often of a mixt colourthe roote is fmall and threddie. corne hath growen.

$$
\text { *Theplace. }
$$

Thefe plants are fet and fowen in gardens: the laft groweth wilde in corne fieldes, and where

They flower for the moft part all fommer long.

\section{* The time.}

$*$ The names.

Larkes heele is called Flos Regius, of diuers Confulida regalis, who makeit one of the confounds or Comfreies: it is alfocalled Delphinum, which Diofcorides defcribeth in his thirde booke, wherewith it may agree: it is reported by Gerardus of Veltwijck, who remained Leger with the great Turke from the Emperour Charles the fift, that the faide Girardfawe at Conitantinople a copie which had in Delphinio, not leaues, but flowers like Dolphines; for the flowers, and efpecially before theybe perfected, haue a certaine thewe and likenes of thofe Dolphines, which old pietures and armes of certaine ancient families, haue exprefied with a crooked and bending figure or thape; by which figne allo the heauenly Dolohin is fer foorth: And it skilleth not, though the Chapter of Delphiniwm be thought to be fallified and counterfeited: for although it be fome other mans and not Diofcerides, it is notwithftanding fome one of the olde writers, out of whom it is taken, and 


\section{THE SECOND BOOKE OFTTHE}

foifted into Diofcorides his bookes; of fome it is called Bucinus,or nomum: in Englinh Larkes fpur,
Larkes hecle, Larkes tocs, Larkes clawe, and Munkes hoode. In high Durch Larkes hecle, Larkes tocs, Larkesclawe, and Munkes hoode. in high Dutch iRtouer fpoozen, that is, Equit is calcar, Knight fpur: in Italian Sperone: in Freach Pied d'alosette.

Thefe herbesare temperite, and warme of nature.

$$
\text { * The temperature. }
$$

$*$ The vertues.

We finde little extant of the vertues of Larkes heele, either in the ancient or later writers woorth the writing,or to be credited, for it is fet downe that the feede of Latkes fpurdrunken is good againft the ftinging of fcorpions, whofe vertues are fo forcible, that the herb only thrown be. fore the fcorpion or any other venemous beaft, caufeth them to be without force or ftrength to hurt, infomuch that they carnot mooue or ftirre vntill the herbe betaken away, with many other fuch trifling toics not woorth the reading.

\section{OfGith, or Nigella. Chap.427.}

* The kindes. Here be divers forts of Gith,or Nigella, differing fome in the colour of the flowers, others in
the doublenes thereof, and in fmell of the feede.

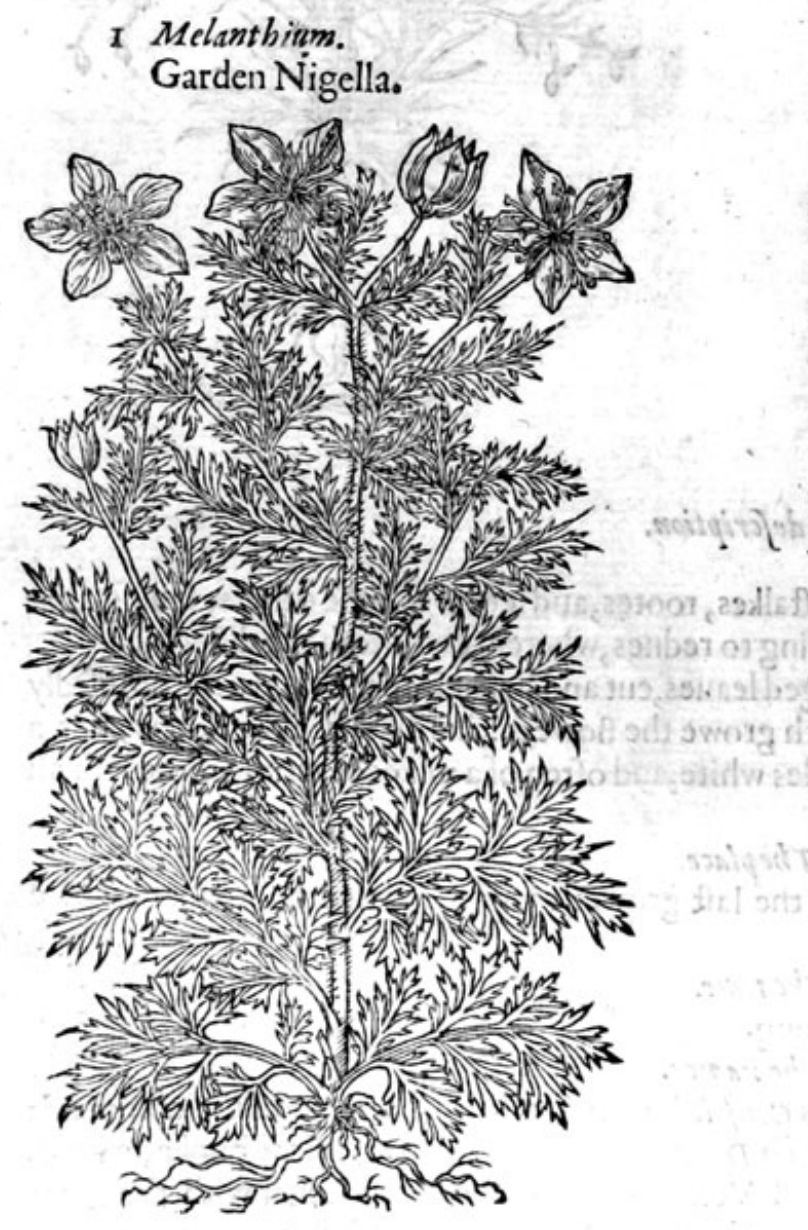

$$
\begin{aligned}
& 2 \text { Ulelanthiom fylueftre, } \\
& \text { Wilde Nigella. }
\end{aligned}
$$

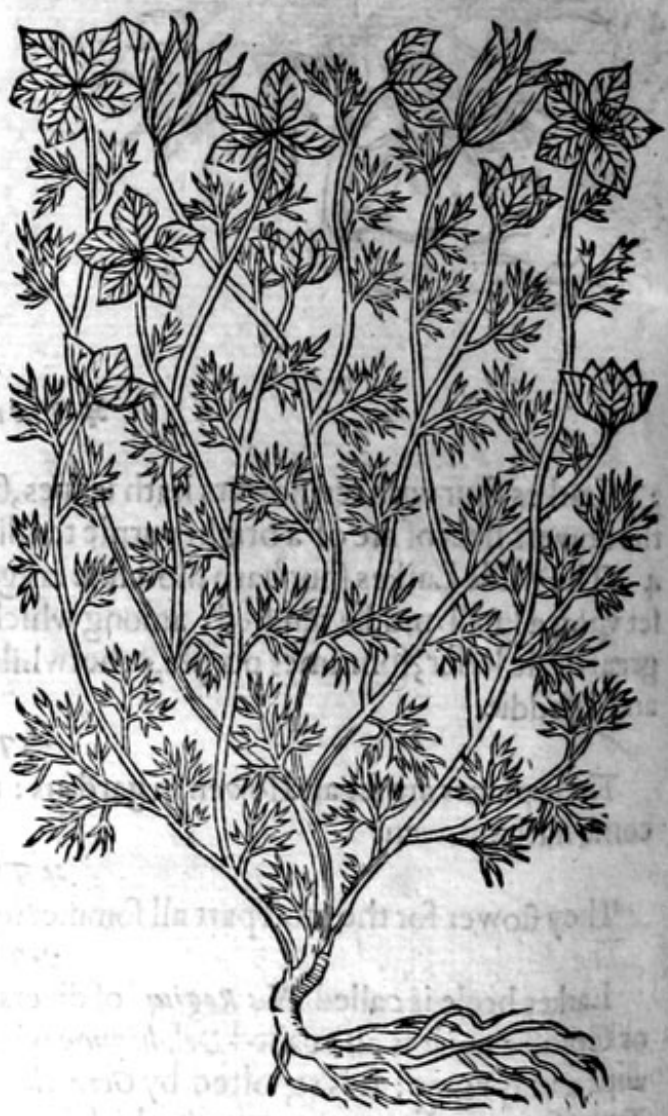

\&: The defcription.

I THe firft kind of Nigella hath,weake and brittle ftalkes, of the height of a foote, full of branches, befet with leaues verie much cut and iagged, refembling the leaues of Fumiterr $x$, but much greener : the flowers grow at the top of the branches, of a whitifh blew colour, each 


\section{HISTORIE OF PLANTS.}

flower being parted into fite frall leaues, ftarre fafhion: the flowers being vaded, there come vp fmall knops or heads, hauing at the end there of fiue or fixe little fharpe hornes or pointels, and euery knop or head is diuided into fundrie fmall cels or partitions, wherein the fecde is contcined, which is of a blackith colour, very like vnto Oinion feede, in tafte tharpc, and of anexcellent fivect fauour.

2 The wilde Nigella hath a ftreaked ftalke a foote or more high, befet full of grayinh leaues, verie finely iagged,almoft like the leaucs of Dil: the flowers are like the former, fauc that they are blewer:

f the cods or knope are like the heads or huskes of Columbines, wherem is conteined the fweete and pleafant feede, like the former.

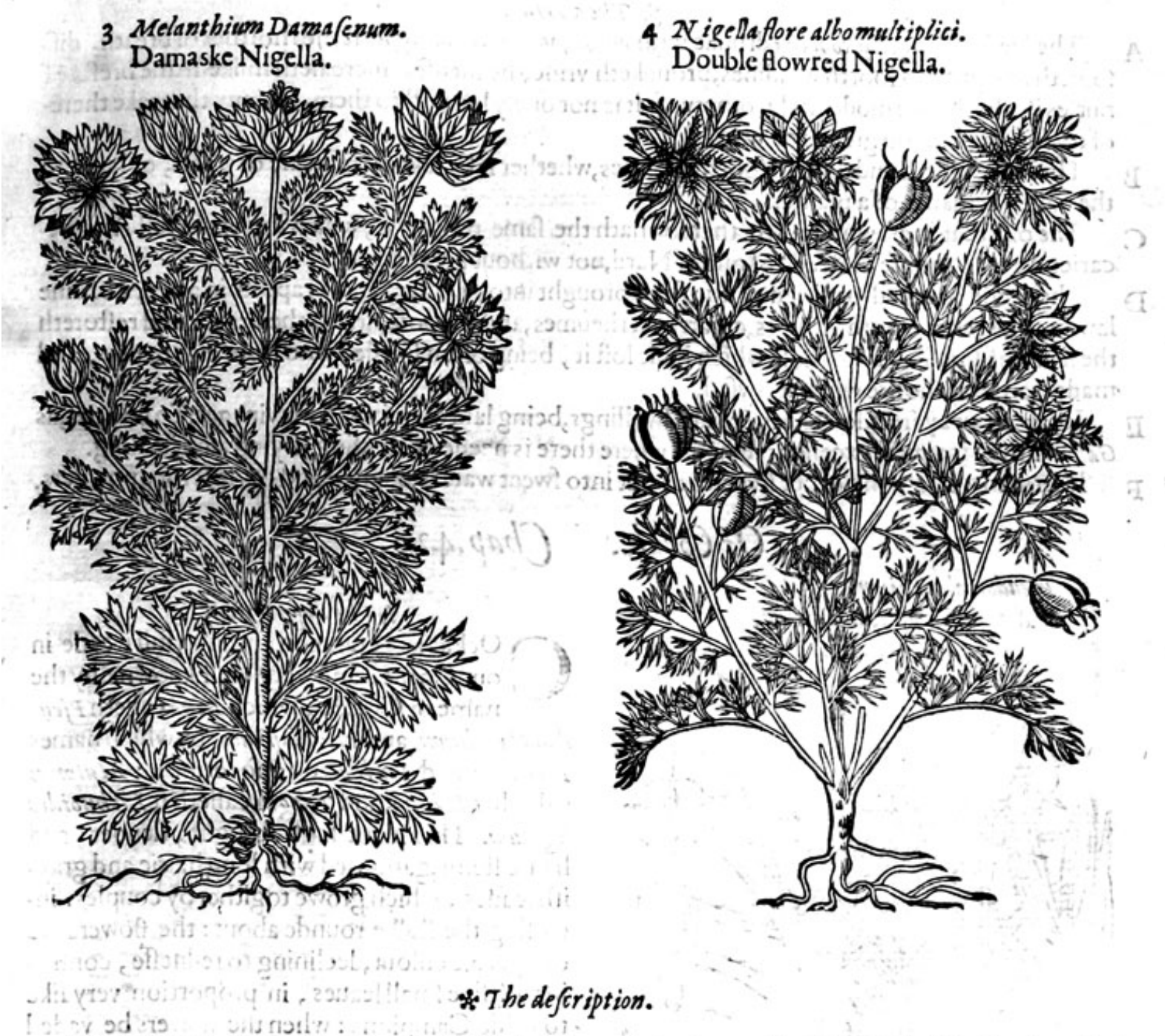

3 The thirde kinde of Nigella, which is both färe and pleafant, called Damaske Nigella, is verie like vinto the wilde Nigella in his fmall cut and jagged leaues, but his ftalke is longer : the flowers are like the former, but greater, and euery flower hath fiue fmall greenc leaues vnder him, as it were to fupport and beare himvp: which fowers being gone, there fucceede and follow knops and feede like the former, but without fmell or fauour.

4 The fourth kinde of Nigella hath many fmall and flender ftalkes, fet full of flender and thinne leaues deepely cut or iagged, of a faint yellowifh greene colour : the flowers grow at the top of the ftalkes, of a whitifh colour, and excecding double, which being vaded, there fucceede bowles or knobs, full of fweetéblacke feede like the former: the rootc is fmall and tender.

$$
* \text { The place. }
$$

The tanic are fowen in gardens: the wilde ones do grow of themfelues among Corne and other graine, in diuers countries beyond the feas. 
* Thetime.

The fcede muft be fowen in Aprill : it flowreth in Iuly and Auguft. * The names.

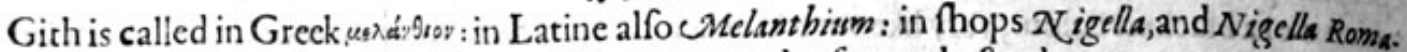
$n a$ : of diuers Gith, and Salusandria, and fome among the former baftard names Papauer nigriam:

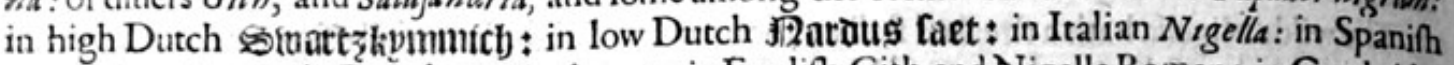
Axenuz, Alpiture: in French Nielle odorante : in Englifh Gith,and Nigella Romana, in Cambridg. fhire Bilhops woort : and alfo Drue Catbarine flos, Saint Katherines flower.

* The temperature.

The feede of the garden Nigella is hot and dry in the third degree, and of thinne parts,

$*$ The vertues.

A The feed of 2 igella Romana drunke with wine, is a remedie againft the fhorenes of breath, diffolueth and putteth foorth windines, prouoketh vrine, the menfes, increafeth milke in the brefts of nurfes if it be drunke moderately, otherwife it is not onely hurtfull to them, but any that take thereof too often, or in too great a quantitic.

B The feede killeth and dritieth foorth wormes, whether it be taken with wine or water, or laide to the nauell in maner of a plaifter.

C The oile that is drawne foorth thereof hath the fame propertie, which the vnskilfull Apothecaries do take and vfe in fteede of oile of Nard, not without great crrour.

D The feede parched or dried at the fire, brought into powder, and wrapped in a peece of fine lawne or farcenet, cureth all murs, catarrhes, rheumes, and the pofe, drieth the braine, and reftoreth the fence of fmelling vnto thofe which hate loft it, being often finelled vnto from day to day, and made warme at the fire when it is vfed.

E It taketh away freckles, fcurfs, \& hard fwellings, being laid on mixed with vineger. To be brief,as Galen faith, it is a moft excellent remedie where there is neede of clenfing,drying, and heating.

F - It feruerh well among other fweetes to put into fweet waters, bagges, and odoriferous powders.

P feudomelanthium.

$$
\text { Of Cockle. Cbap. } 428 \text {. }
$$

Baftard Nigella, or Cockle.

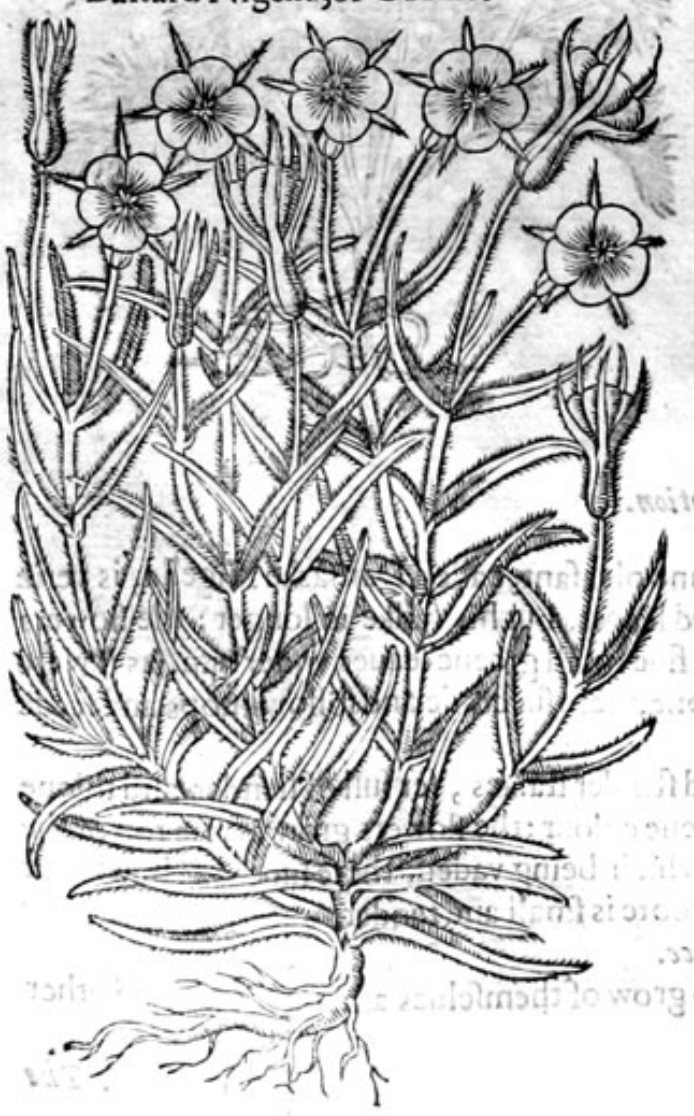

* The defcription.

Ockle is a common and hurrfull weede in our Corne, and very well knowne by the name, of Cockle, which Pena calleth $P$ few. domelanthiom, and Nigelleftrum, by which names Dodonesus and Fuch fros do alfo terne it; Mutomus calleth it $L o$ lism; and Tragus calleth it Lichnoides jegetwm. This plant hath ftraight, flender; and hairie ftems, garnifhed with long hairic and grayifh leaues, which growe togither by ceuples, inclofing the ftalke rounde about : the flowers are of a purple colour, declining to redneffe, confifting of fiue fmall leaues, in proportion very like to wilde Campions: when the flowers be vaded there follow round knops ò heads ful of blackifh feede, like vinto the feede of a igell, bir without any fmell or fauour at all. ins

$$
\text { \&-Theplace and time. }
$$

The place of his growing, and cine of his towring, are better knowine then defired.

Cockle is called Preudo-medunt buim, and 2 igellaftrumb, wilde or baftarde' Nigella; of Fuchfour Lohium: of Moston Lichnoides/egetum, of Tragas Githago: in high dutch lionnegele: in low Dutch

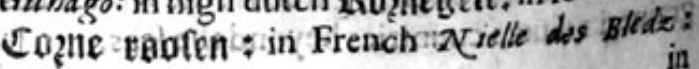




\section{HISTORIE OF PLANTS.}

in Englifh Cockle, fielde Nigella, or wilde Nigella : in I w.ian Githone, whercupon moft Herbarift being mooued with the likenes of the word, baue thought it to be the true Gith or Melanthium; but how far they are deceiued, it is better knowne then needfull to be confuted: for it doth not onely diffece in leaues from the true Gith, but alfo in otheriproperties, and yet it is called Gith or Melan thinow, and that is of the blacknes of the feede; yeenot properly, but with a certaine addition, that it way differ from the true Melonthium : for Hippocrates calleth it Melant hism ex Tritico, of wheate: Ottamines Horatianus calleth that Gith which groweth among corne, and for the fame caufe it is named of the learned of this our tinne Nigellaftrum, Git hago, and P feudomelanthium : Ruelliws faith, it iscalled in French Nielesand Flos wicancalies.

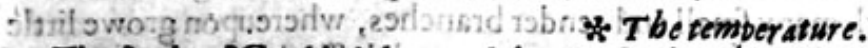

The feede of Cockle is hot and dry about the later end of the fecond degree.

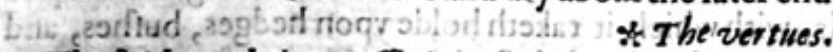

7. Tho feedemade in a peffatic or inother fuppofitorie with honie put vp, bringeth downe the de- $\mathbf{A}$ firedficknes, as Hippoctates in his böoke of womeris difeafos doth witnes.

Octavius Hrratianus giueth the feede parched and beaten to powder to be drunke againit the B yellow iaundife.

Some ignorant people haue vfed the feede heereof for the feede of Darnell, to the great danger C of thofe who haue receiued the fape $:$ what hurt it doth among corne, the f poile vntobread, as well in colour, tafte, and vnholfomnes, is better knowne then defired.

\section{Of Fumitorie. Chap.429.}

* The kindes.

Here be diuersherbes comprehended vnder the title of Fumitorie, fome wilde, and others of the garden;fome with bulbous or tuberous rootes, and others with fibrous or threddie rootes: and firft of thofe whole rootes are nothing but ftrings.

1 Fuenaria porpurea. Common or purple Fumitorie.

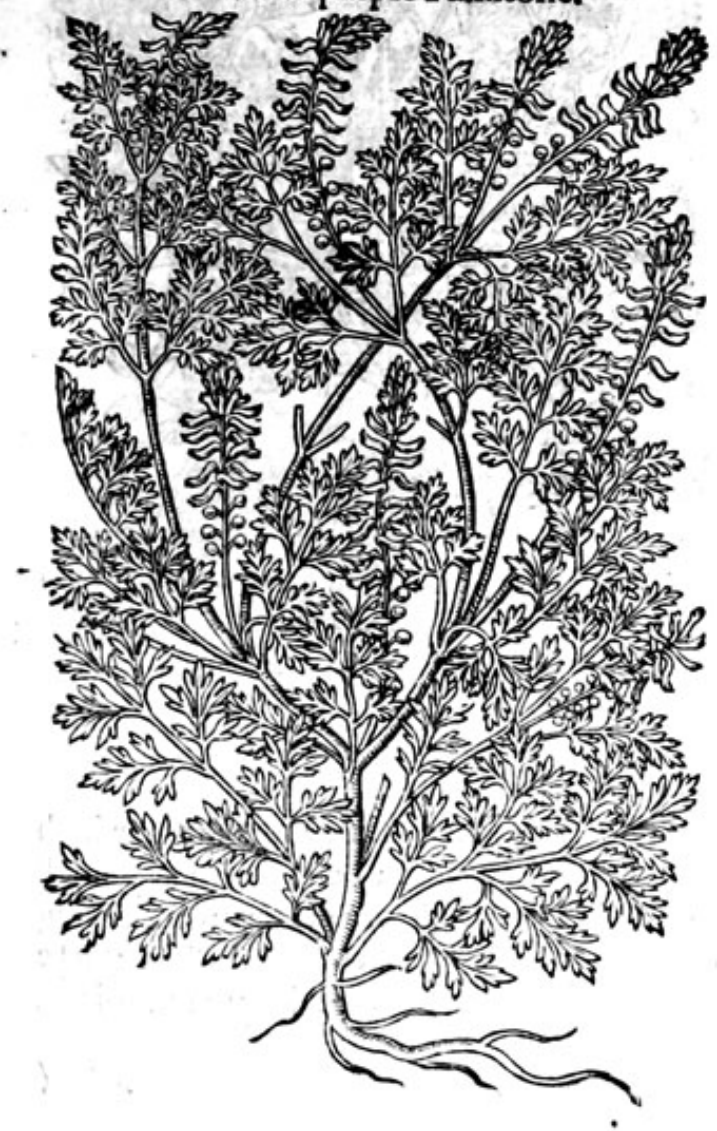

2 Fumariaflore albo. White flowred Fumitorie,

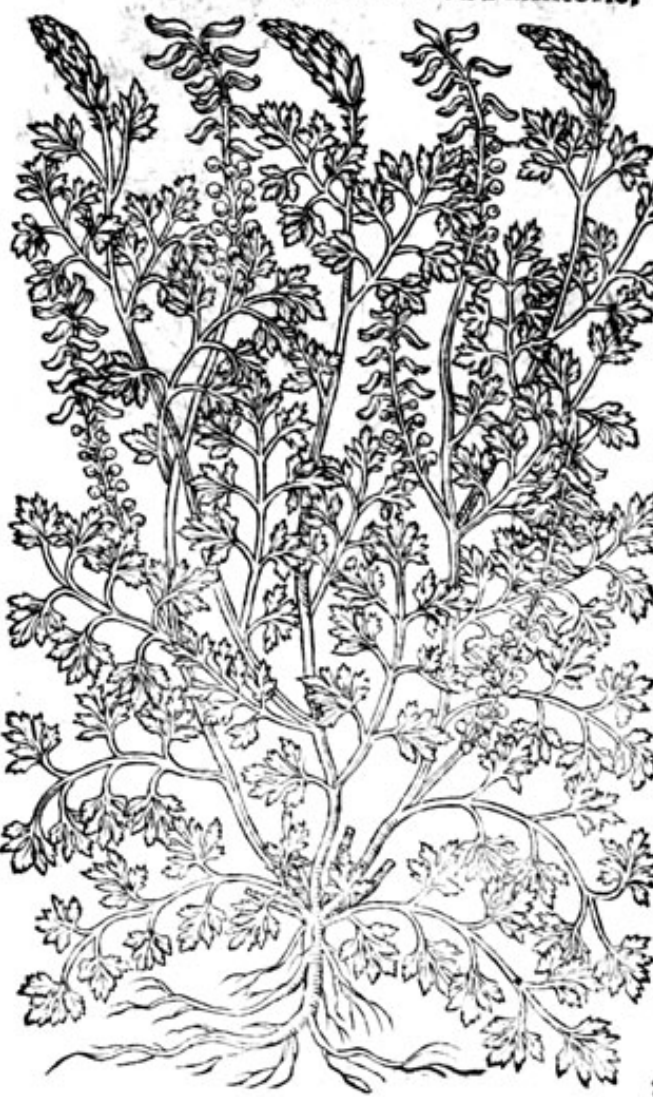




\section{* The defcription.}

I Vmitorie is a very tender little herbe; the ftalkes thereof are flender, hauing as it werelittle

-1 knots or ioints full of branches, that fcarce grow yp from the grounde without proppings, but for the moft part they growe fidelong : the leaues roundeabout are fmall, cut on the edges as thofe of Coriander, which as well as the ftalkes are of a whitifh greene : the flowers be made vp in clufters at the tops of the fmall branches, of a red purple colour : then rife vp huskes, round and little, in which lieth the fmall feede: the roote is flender, and groweth ftraight downe.

2 The fecond kinde of Fumitoric hath many fmall and tender branches, whereupon growe little iagged leaues, in colour, tafte and fafhion like vinto the former, but muchi leffer, haung at the top of the branches many fmall clafping tendrels, with which it taketh holde vpon hedges, burhes, and svbatfoeuer groweth next vnto it: the flowers are fmall and cluftering togither, of a white colour, mixed with a little blew, after which do fucceede cods, conteining the feede: the roote is finigle, and of a finger length.

3 Fumaria tenuifolia. Fine leafed Fumitorie.
4 Fumarialutes. Yellow Fumitorie.

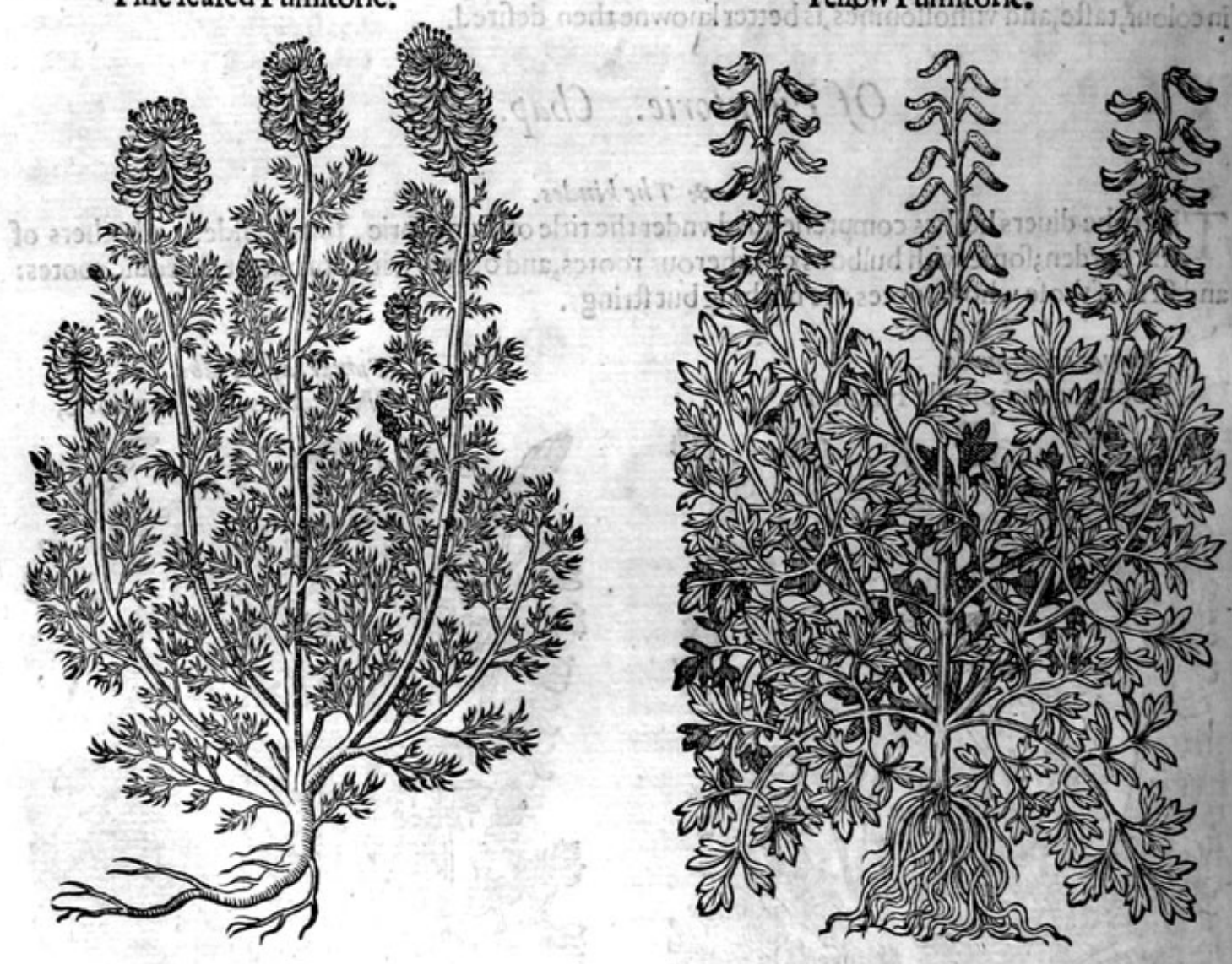

* Thedefription.

3 The third kind of Fumitorie hath a very fmall root, confifting of diuers little ftrings, from which arife fmall and tender branches, trailing heere and there vpon the grounde; befet with many finall and tender leaues, moft finely cut and iagged, like the little leaues of Dill, of a deepe greene colour tending to blewnes : the flowers ftande on the tops of the branches, in bunches or clufters thicke thruft togither, like thofe of the medowe Clauer, or three leafed graffe, of a moft bright red colour, and very beautifull to behold: the roote is verie fmall and threddic. 


\section{HISTORIE OF PLANTS.}

4 The yellow Fumitorie hath many crambling thred die rootes, fomewhat thicke, groffe, and fat, like thofe of $A$ paragm: from which rife diners vpright ftalkes a cubite high, diuiding themfelues towarde the top into other fmaller branghes, wheregon are confufedly placed leaues like thofe of Thalictrum or Englifh Rubarbe, bus beller and thinner:alongft the tops of the branches grow yellow flowers, refembling thofe of Sage, which bejigg palt there followeth fmall feede like vnto duit.

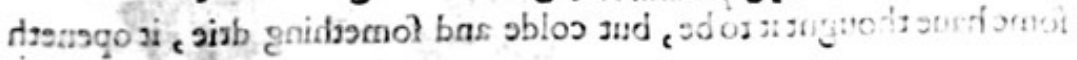

5 Fumaria alba latifolia. .23utros dT: 6 Fumarialatifoliaminor.

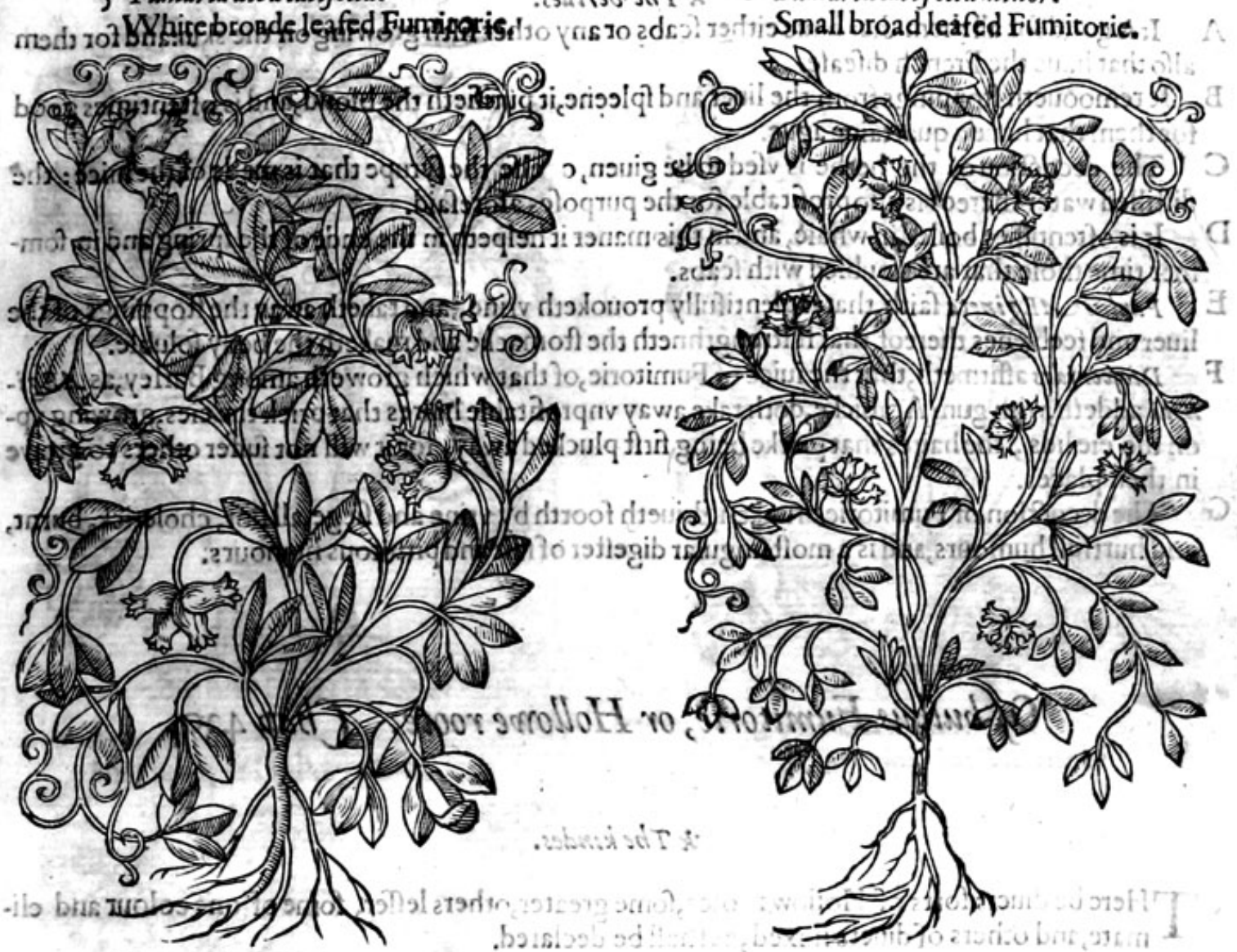

\section{*. Thedefoription:}

5 The white Fumitorie with broad leaues hath a very finall roote, deepely thruft into the ground, from which rarife fmall tegder branches trailing heere and there vpon the grounde; garnifhed with diuerslezues confufedly, fet vpon thort tendrels or footeftalks, fmooth, very greene of colour, and fes rogither by three and three, like vnto the Trefoiles or three leafed graffe : among the leaucs come foorth clufters of swhite flowers, fet togither in bunches, refembling a clufter of filberd nuts when they are but yoongiof a white colour, tipped at the points with 2 little light blufh of purple hard to be difcerned; except it be aduifedly looked vpon.

6 The fmaller broade leafed Fumitorie is like vnto the laft defcribed in each refpect, fauing it is altogitherleffer, wherein onely confifteth the difference.

\section{* The place.}

The Fumitories do grow in corne fieldes among Barley and other graine, in vincyards, gardens, and fuch like manured places; I founde the laft and thirde in number growing in a corne fielde betweene a fmall village called Charleton and Greenwich.

$$
\text { * The time. }
$$

Fumitorie is fowen with his flower in the beginning of Maic, and fo continucth to the ende of fommer, then is it the beft time to be gathered to keepe drie or diftill. 


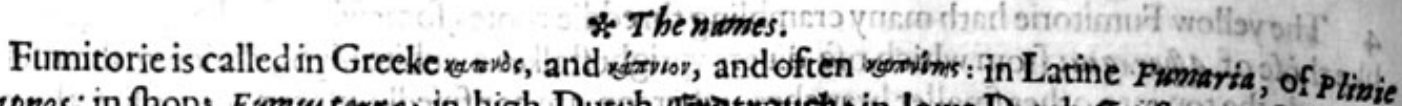

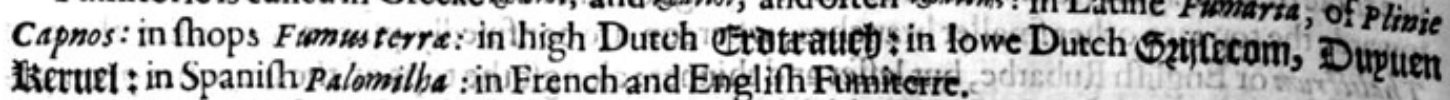

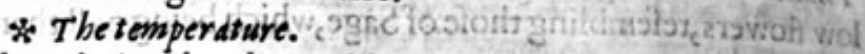

Fumitorie is not hot as fome haue thought it to be, but colde and fomething drie, it openeth and clenfeth by vrine.

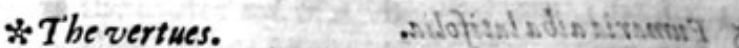

A It is good for all them that haue either fcabs or any other frith growing on the skintand for them alfo that haue the French difeafe.

B It remooueth ftoppings from the liuer and fpleene, it purifieth the bloud, and is oftentimes good for them that have a quartaine igue.

C The decoction of the herbe is vfed to be giuen, or elfe the fyrupe that is made of the iuice: the diftilled water thereof is alfoprofitable forthe purpofes aforefaid.

D It is oftentimes boiled in whaie, andin this maner it helpeth in the ende of the fpring and in fommer time thofe that are troubled with fcabs.

E Paulus 1Eg ineta faith, that it plentifully prouoketh vrine, and taketh away the ftoppings of the liuer and feeblenes thereof, that it ftrengthneth the ftomacke and maketh the belly foluble.

F Diofcorides affirmeth, that the iuice of Fumitorie, of that which groweth among Barley,as $\triangle E \mathrm{~g} i$ neta addeth, with gum Arabicke, doth take away vnprofitable haires that prick the eies, growing vpon the eie lids, the haires thatpricke being firft plucked away, for it will not fuffer others to growe in their places.

G The decoction of Fumitorie drunken, driueth foorth by vrine and fiege, all hot, cholerick, burnt, and hurtfull humours, and is a moft fingular digelter of falt and pituitous humours.

\section{Of bulbus Fumitorie, or Hollowe roote. Cbap $43^{\circ}$.}

* The kindes.

THere be diuers forts of Hollow rootes, fome greater, others leffer, fome of one colour and climate, and others of diuers mixed, as shall be declared.

\section{* The defoription.}

17 He leaues of great Hollow roote are iagged and cut in funder, as be thofe of Coriander, of a light greenifh colour, that is to fay, like the gray colour of the leaues of Columbine, whereunto they be alfo in forme like, but leffer : the ftalkes be fmooth, rounde, andflender, an handfull long; about which, on the vpper part ftande little flowers orderly placed, long, with 2 little horne at the ende, like the flowers of Toade flaxe, of a light redtending to a purple colour: the feede lieth in flat cods, very foft and greenith when it is ready to yeelde vp his blacke fhining ripe feede : the roote is bumped or bulbus, hollowe within, and on the vpper part preffed downefom: what flat, couered ouer with a darke yellow skin or barke, with certaine ftrings faftned thereto, and of a bitter and auftere tafte.

2 The fecond is like vnto the firft in each refpeet, fauing that it bringeth flowers of 2 white colour, and the othernot fo.

3 The fmall purple Hollow roote, hath rootes, leates, ftalkes, flowers, and feedes, like vnto the precedent, the efpeciall difference is, that this plant is fomwhat leffer.

4. The fmall white Hollowe roote likewife agreeth with the former in eacb refpeet, fauing that this plant bringeth white flowers, and the other not fo. 
HISTORIE OF PLANTS.

I Radix cath maior pur purca. Great purple Hóllow roote.
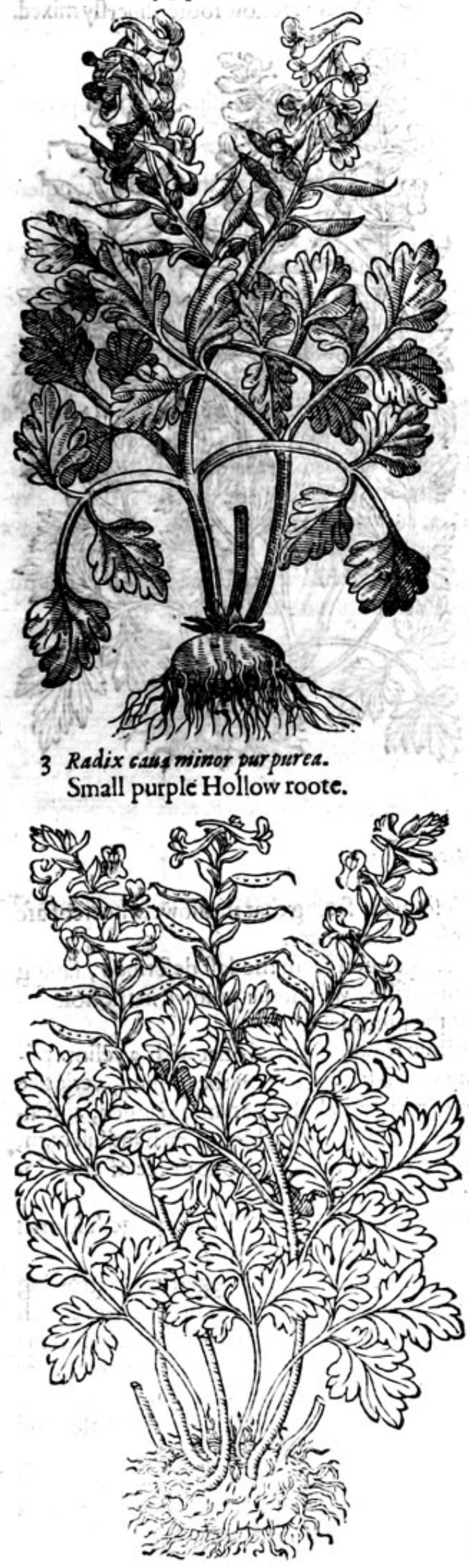

2 Ratix catuamitior alba. Great white Hollow roote.

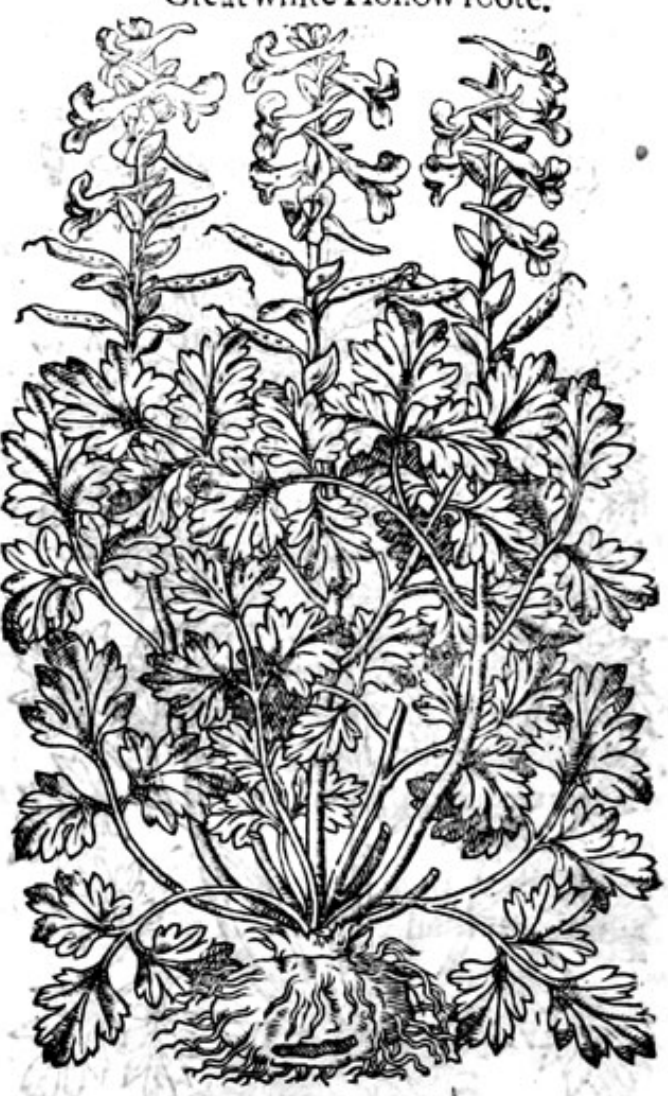

4 Radix caua minor alba.

Small white Hollow roote.

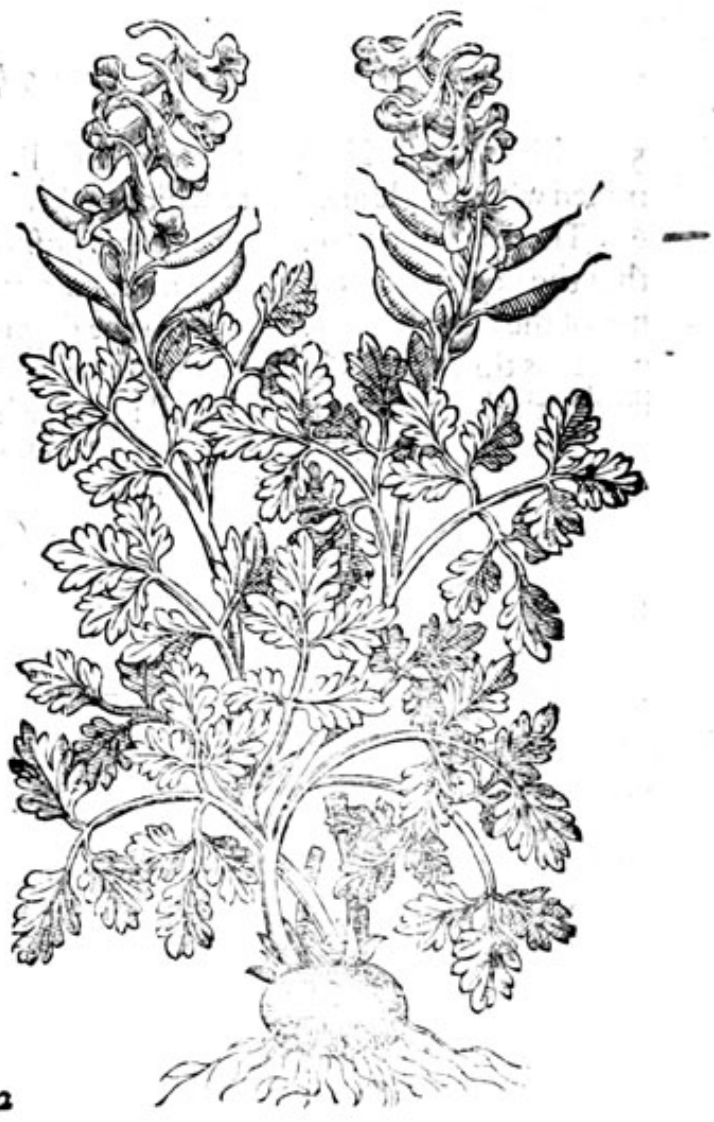


5 Radix cauta purpurea variegata.

Purple Hollow roote of two colours.

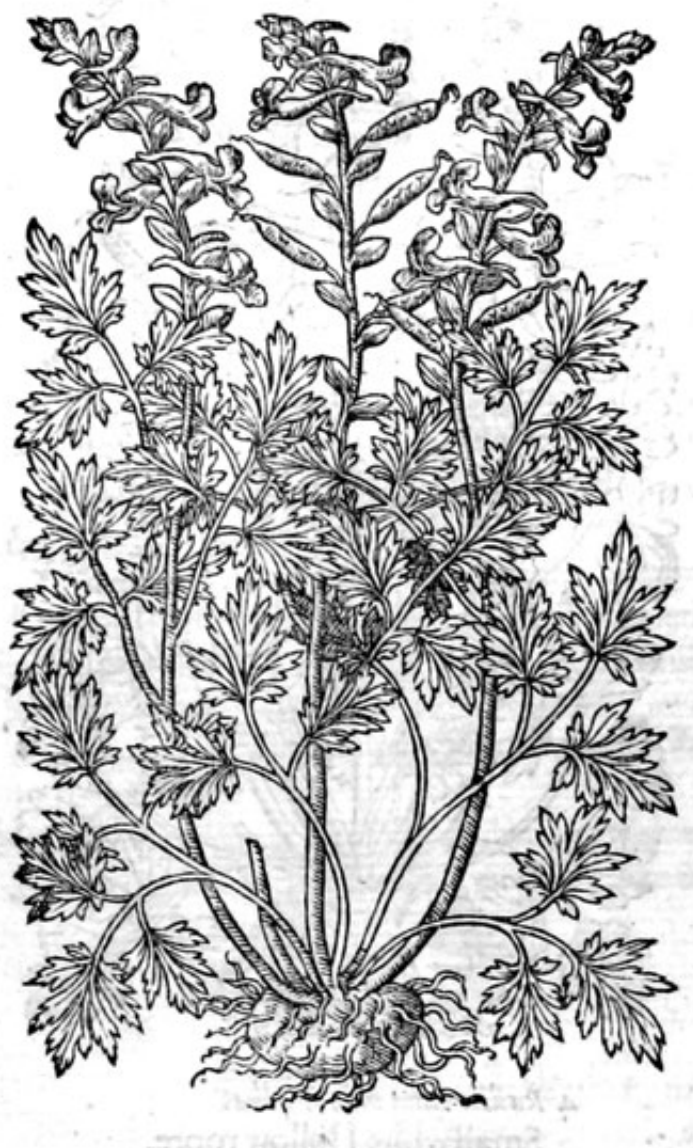

6 Radix caua alba variegata. White Hollow roote diuerlly mixed.

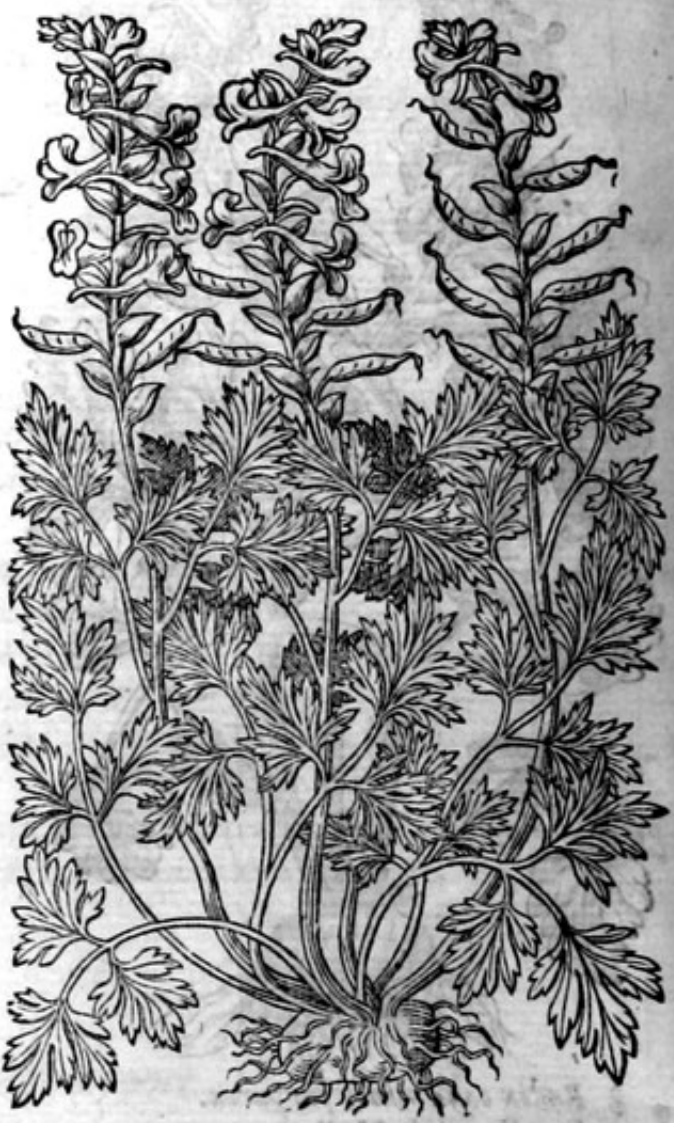

\section{*The defcription.}

5 This kinde of Hollow roote is alfo like the laft defcribed, fauing that the flowers heereofare mixed with purple and white, which maketh it to differ from the others.

6 There is not any difference that is poffible to be diftinguifhed from the laft defcribed, fauing that the flowers heereof are of a mixt colour, white and purple, with fome yellowe in the hollownes of the fame, wherein confifteth the difference from the precedent.

7 This thin leafed Hollow roote, hath likewife an hollow roote, couered ouer with a yellow pilling, of the bignes of a tennice ball : from which fhoote vp leaues fpred vpon the ground, verie like vnto the leaues of Columbines, as well in forme as colour, but much thinner, more iagged, and altogither leffer: among which rife vp fmall tender ftalkes, weake, and feeble, of an handfull high, bearing from the middle thereof to the top very fine Howers, fafhioned vnto one peece of the $\mathrm{Co}_{0}$ lumbine flower, which refembleth a little birde of a purple colour.

8 This other thin leafed Hollow root is like the precedent, fauing that this plant bringeth foorth white flowers tending to yellownes, or as it were the colour of the field Primrofe.

9 Lummpken boliwoztele, as the Dutch men do call it, hath many fmall iagged leaues growing immediately from the ground:among which rife vp very flender ftalkes, whereon do growe fuch leaues as thofe next the ground:on the top of the branches ftand faire purple flowers, like vnto the others of his kinde, fauing that the flowers heere of are as it were fmall birdes, the bellies or lower parts wherof, are of a white colour, wherein it differeth from all the reft of the Hollow rootes.

is The laft and finall Hollow roote is like the laft defcribed, fauing that it is altogither leffer, and the flowers heerof are of a greene colour, not vnlike in fhape to the flowers of Cinkfoile. 
HISTORIE OF PLANTS.

7 Radix ciua tennifolia purpur ea.

Purple Hollow roote with thin leaues.

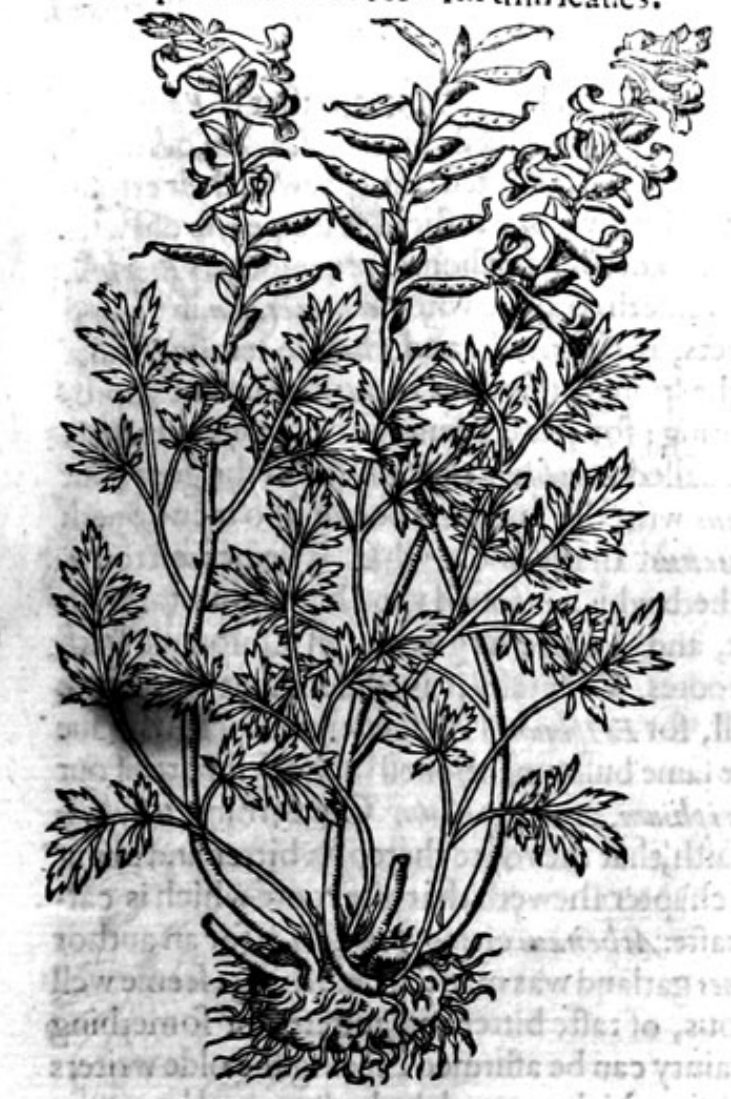

Radix cavia minor.

Buninikens Holwort, or Hollow roote.

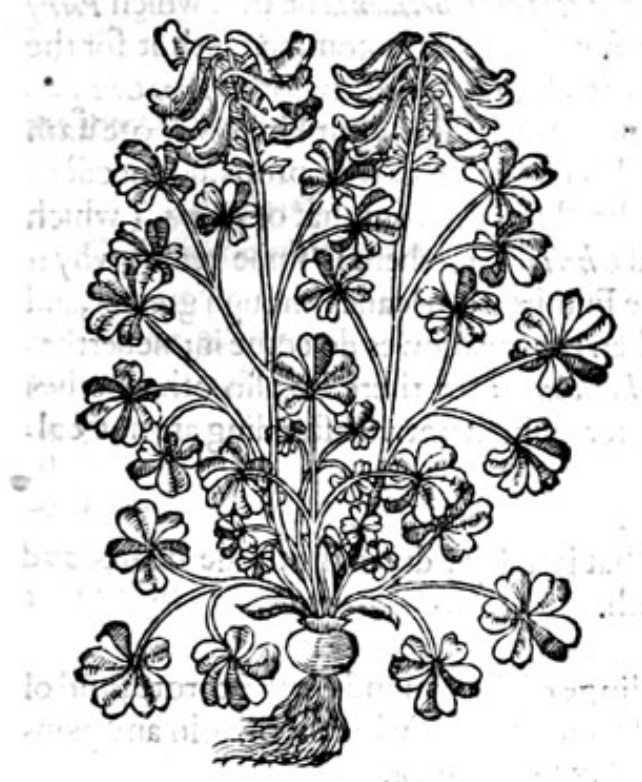

9 Radixcauztcnuifolat alba.

White Hollow roote with thin leates.
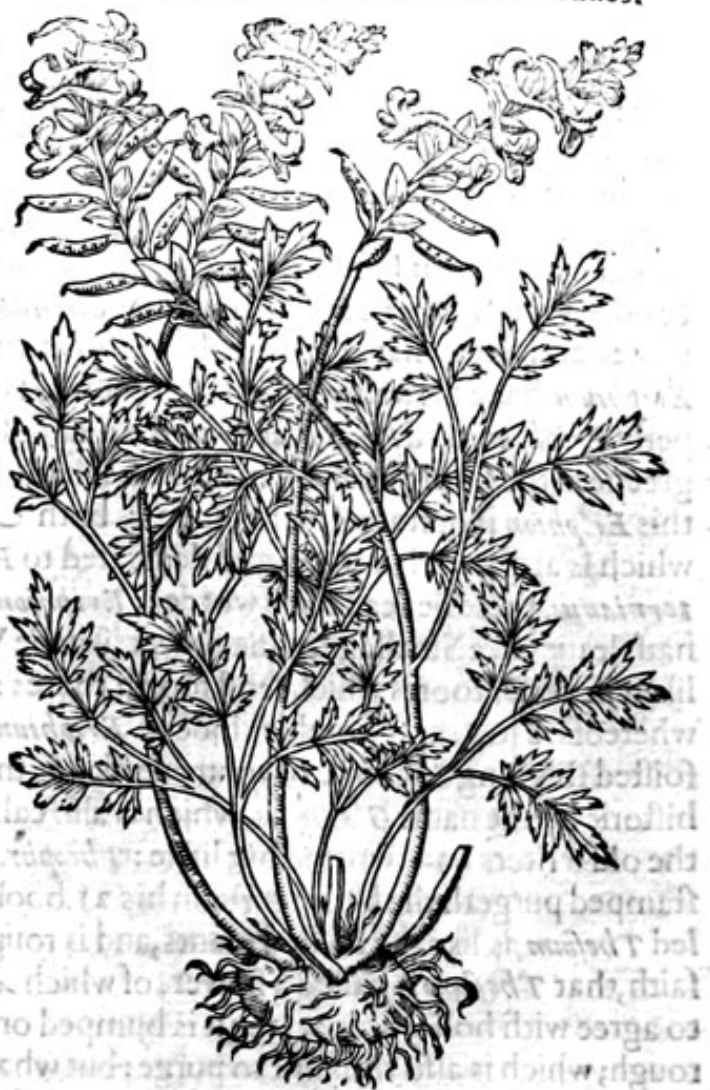

Io Radix caus minima viridi fore.

Sinal Bunnikens Holwort with green flowers.
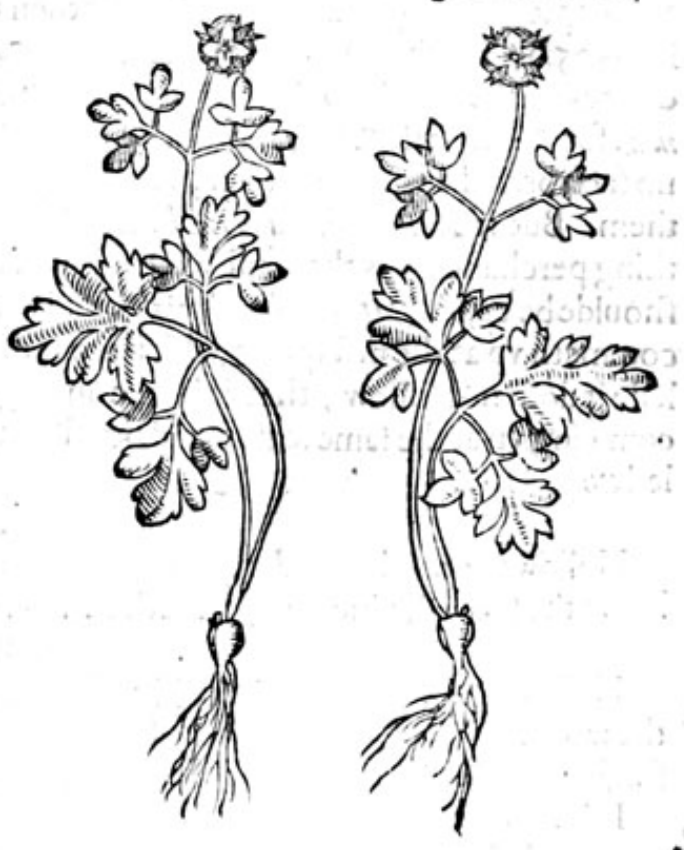

* The place.

Thefe plants do grow about hedges, brambles, and in the borders of fieldes and vineyardes, in low and fertill grounds, in Cermanie and the lowe countrics, neuertheleffe the two firft, and allo the two laft deficribed do grow in my garden. 
* Thetime.

Thefe do flower in March, and their fecde is ripe in Aprill : the leaues and ftalkes are gone in Maie, and nothing remaining faue onely the rootes, fo little a while do they continue.

$*$ The names.

Hollow roote is called in high Dutch Đolwutt3: in low Dutch Đoolwoetele, that is, Radix ca$\boldsymbol{u} \boldsymbol{a}$ : in Englih Hollow roote, and Holewoort: it is vfed in hops in fteede of Uriftolochia, or round Birthwoort, which errrour is better knowne then needfull to be confuted: and likewife their errour is apparant, who rafhly iudge it to be Piffolochia, or little Birthwoort. It fhoulde feeme the old writers knew it not, for fomc haue made it Leontopet ali ßpeciem, or a kind of lions Turnep;others Eriphiž, \& others fom $T$ hefrum, moft merr Capnos Chelidonia: it feemeth to agree with Leontipefalon, in bulbed rootes, and fonewhat in leaues, but in no other refpects, as Diofcorides and Pliny do teftifie. And if Eriphium haue his name $\dot{\alpha} \pi \dot{\tau} \tau \tilde{x}$ ives, that is to fay, of the fpung, then this roote may be not vnpro. perly Eriphium, and Veris Plant a, or the plant of the fpring: for it is euident that it appeereth and is greene in the fpring onely: fome thinke it hath beene called Eripbitom ab Haedo, or of the goat; but this Eriphion is quite another plant, as both Apuleius writeth, and that booke alfo mentioneth which is attributę to $G$ alen, and dedicated to $P$ aterniansus. In the booke which is dedicated to $P a$ ternianus, there be read thefe wordes; Eriphion is an herb which is found vpon high mountaines, it hath leaues like Smallage, a fine flower like the Violet, and 2 roote as great as an Onion : it hath likewife other rootes which fend foorth rootes after rootes. Whereby it is euident that this roote whereof we intreat is not this kinde of Eriphium at all, for Eriphium howfoeuer the ancients haue foifted this long difcourfe of controuerfies, is the felfe fame bulbe mentioned in the firft part of our hiftorie by the name Gladio'us, which is alfo called Eriphium, and $Z$ yphium. Concerning Thefiwm the old writers haue written but little: T heophraftus faith, that the roote thereof is bitter and being ftamped purgeth the belly: Pliny in his 2 r.booke 17 . chapter fheweth that the roote which is called $T$ hefum, is like the bulbed plants, and is rough in tafte:Athenews citing Timachida for an author faith, that $T$ be fum is called a flower, of which Ariadnes garland was made. Thefe things feeme well to agree with hollow roote ; for it is bumped or bulbous, of tafte bitter and auftere, or fomething rough; which is alfo thought to purge: but what certainty can be affirmed, feeing the olde writers are fo bricfe? What maner of herbe Capnos Chelidonia is, which groweth by hedges, and heerupon is furnamed peryuris, Nitius doth not expounde, onely the name thereof is founde in his feconde Tetrab. the thirde booke, Chapter r10. in Martianus his Colyrium, and in his Tetrab. 3.booke 2. Chapter,arnong fuch things as ftrengthen the liuer. But if Capmos Chelidonia be that which Pliny in his 25 . booke, chaper 13. doth call Prima Capnos, or the firft Capnos, and commendeth it for the dimnes of the eies, it is plaine inough that Radix caua, or the Hollow roote, is not Capnos Chelidonia : for Plinies firft Capnos is branched, and fouldeth it felfe vpon hedges; but Hollow roote hath no fuch branches growing on it, and is a lowe herbe, and is not helde vp with props, nor needeth them. But if Aetines his Capnos Chelidonia be an other herbe differing from that of Plinie, (which thing perchance was the caufe why it fhould be furnamed Chelidonia) there is fome reafon why it fhoulde be called Capros Chelidonia, for it is fomewhat like Fumitorie in leaues, though greater, and commeth vp at the firft fpring, which is about the time when the Swallowes do come in; neuertheleffe it doth not follow, that it is true and right Capnos Chelidowia; for there be alfo other herbes comming vp at the fame feafon, and perifh in fhort time after, which notwithftanding are not called Chelidonia.

\section{* The temperature.}

Hollow roote is hot and dry, yet more drie then hot, that is to fay, dry in the thirde degree and hot in the fecond; it bindeth, clenfeth and fomwhat wafteth.

$*$ The vertues.

Hollow root is good againft old and long lafting fwellings of the alnionds in the throte, and of

A the iawes:it likewife preuaileth againft the paines of the Hemorrhoides, which are fwoln and painfull, being mixed with the ointment of Popular buds, called $V$ ng. Populeon.

B It is reported, that a dram waight heereof being taken inwardly, doth purge by fiege, and draweth foorth flegme.

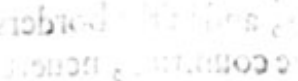




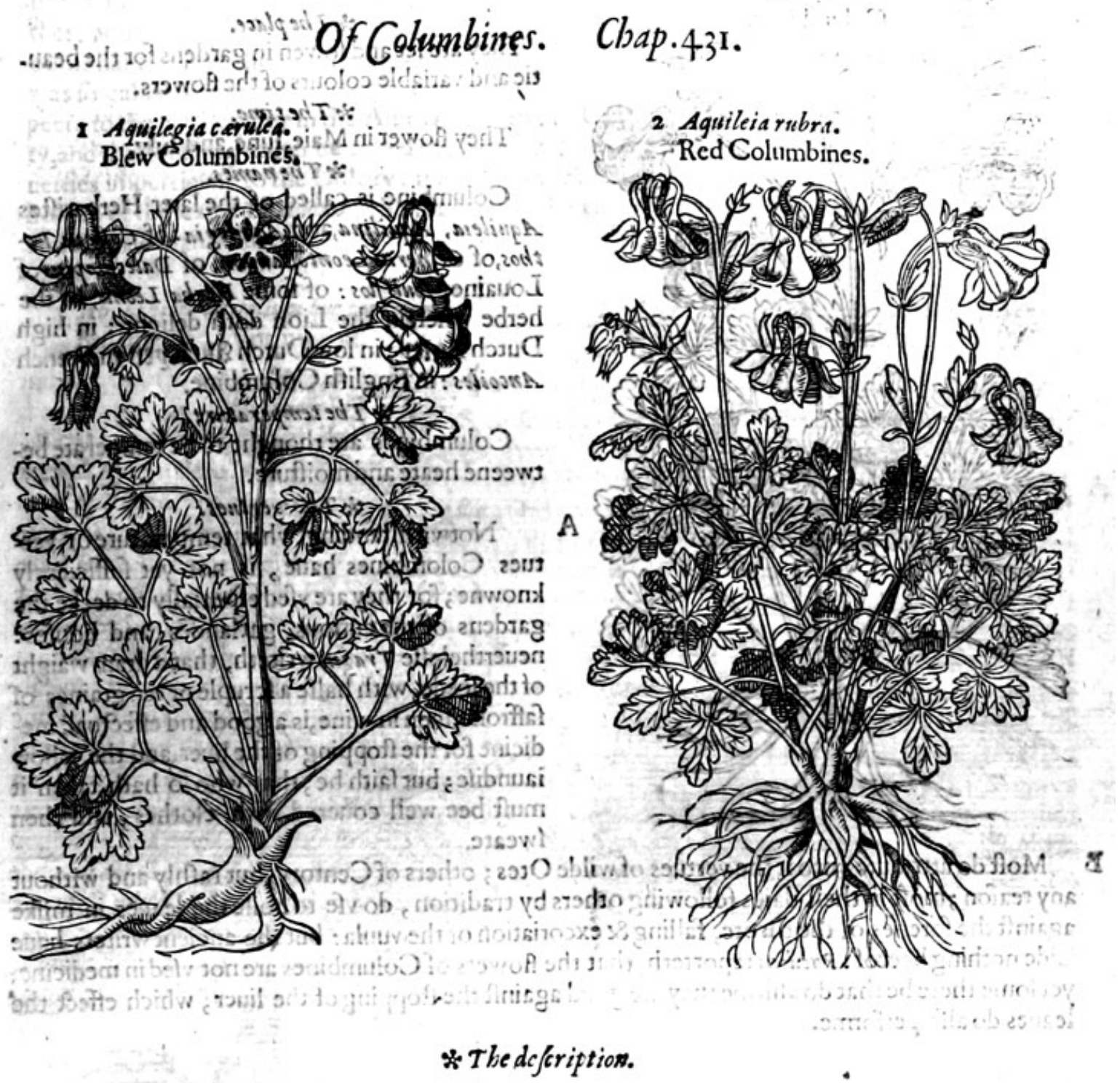

1 He blew Columbine hath leaues like the great Celandine, but fomwhat rounder, indented on the edges, parted into diuers fections of a blewifh greene colour, which being broken yeelde foorth little itice or none at all : the ftalke is a cubite and a halfe high, flender, reddifh, and Aleightly haired : the flender fprigs whereof bring foorth euery one, one flower with fiue little hollowe hornes, as it were hanging foorth, with fmall leaues ftanding vpright, of the fhape of litclebirds : thefe flowers are of colour fometines blewe, at other times of a red or purplc, often white, or of nixt colours, which to diftinguin feuerally woulde be to fmall purpofe, being things fo familiarly knowne to alf; after the flowers growe vp coddes, in which is conteined little blacke and glittering feede : the rootes arc thicke, with fome ftrings thereto belonging, which continue many yeeres.

2 The fecond doth not differ fauing in the colour of the flowers, for like as the others are defcribed to be blew, fo thefeare of a purple red, or horfe flefh colour, which maketh the difference.

3 The double Columbine hat'i ftalkes, leaues, and rootes like the former : the flowers hecrof are very double, that is to fay, many of thote little flowers (hauing the forme of birds) are thruft one into the belly of another, lomtimes b!ew, of ten white, and otherwhiles of mixt colours, as nature litt to plaie with hir little ones, differing to infinitely that to difting tith them apart, woulde requtice moie tine then were requifite to leefe: and chere ore it inall fuffice what hath beenefaide for their defcriptions. 


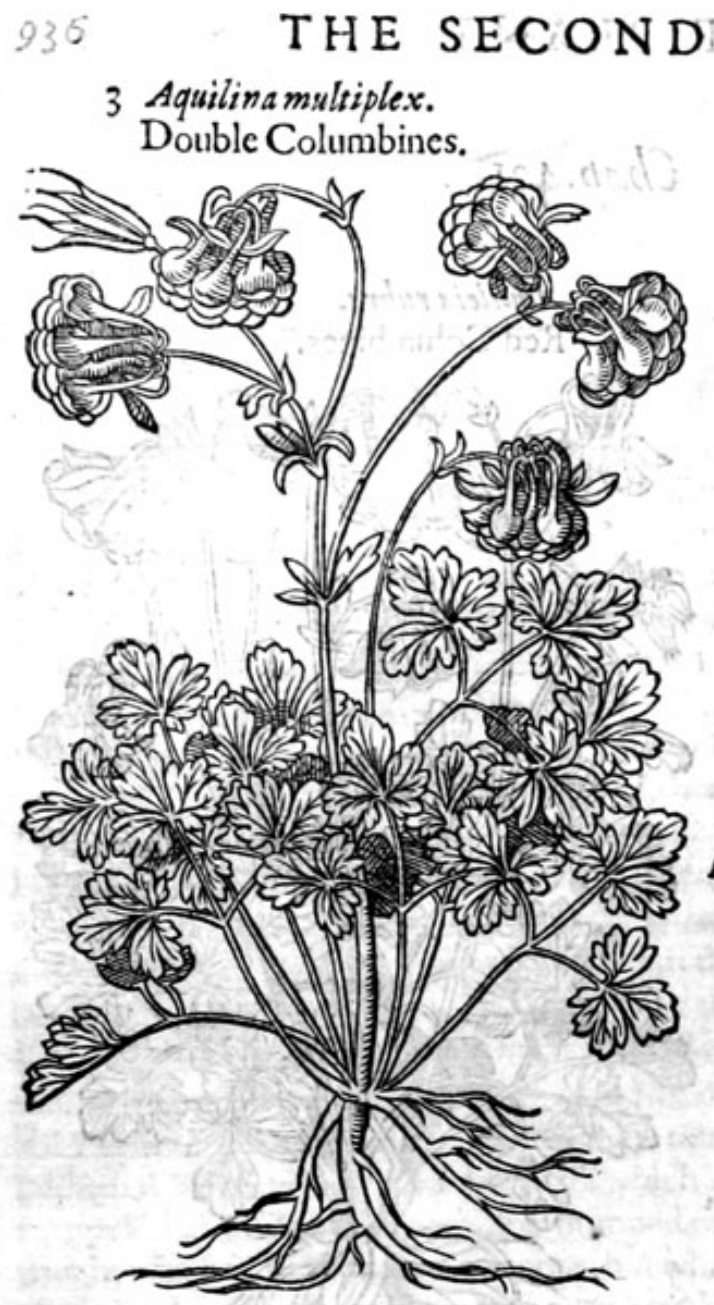

\section{B OOKETOFITHE}

They are * The place.

- They are fet and fowen in gardens for the beau. tie and variable colours of the flowers. * The time.

They flower in Maie; Itune, and Iuly. I *Thenames.

Columbine is called of the later Herbariftes Aquileia, Aquilina, and Aquilegia of Cofters Po thos, of Gefnerus Leonto fasmom, of Dalecampins of Louaine, Lovisflos: of fome Berba Leomis, of the herbe wherein the Lion doth delight: in high Dutch Agler: in low Durch gteleventin French Ancoiles:in Englifh Columbine.

* The temperature.

Columbines are thought to be temperate betweene heate and moifture.

* The vertues.

A Notwithiftanding what temperatureor vertues Colombines haue, is not yet fufficiently knowne; for they are vfed efpecially to decke the gardens of the curious, garlandes, and houfes: neuertheleffe Tragus writech, that a dram waight of the feede, with halfe a fcruple or ten graines of faffron giuen in wine, is a good and effectuall medicine for the ftopping of the liuer, and the yellow iaundife; but faith he, that who fo hath taken it muft bee well couered with clothes, and then iweate.

B Moft do attribute vnto it the vertues of wilde Otes; others of Centory, but rafhly and without any reafon; moft in thefe daies following others by tradition, do vfe to boile the leaues in milke againft the forenes of the throte, falling \& excoriation of the vuula: but the ancient writers haue faide nothing heerof: Ruelliws reporteth, that the flowers of Columbines are not vfed in medicine, yet fome there be that do affirme they are good againft the ftopping of the liuer, which effect the leaues do alfo performe.

\section{Of Wormewood. Chap.432.}

* Thekindes.

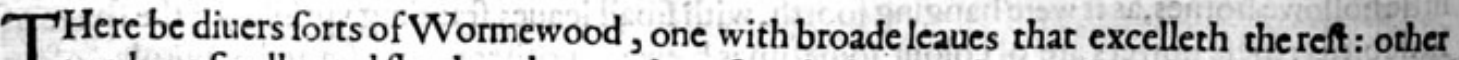
two haue fmaller and flenderer leaues; the reft are baftard kinds: Diof corides maketh mention of three forts of Wornewood, Ponticum, Seriphium, and Santonicum, which are to be referred to the formerkindes.

\section{s: The defoription.}

1 He firft kinde being our common and beft knowne Wormewood, hath leaues of a grayilh colour,very much cut or iagged, and very bitter : the ftalkes are of a woodie fubftance two cubites high, and full of branches, alongft which do grow little yellowim bottons, wherein is found fmall feede like the feede of Tanfey, but fmaller: the roote is likewife of a woodie fubftance, and full of fibres.

2 The fecond kinde of Wormwood bringeth foorth flender ftalkes about a foote high or fome. what more,garnifhed with leaues like the former, but much leffer, and cut or iagged into moft fine and finall cuts or diuifions : the flowers are like the former, hanging vpon fmall ftems with their 
heads downward: the rootes are whitifh, fmall and nrany, crawling and crambling one ouer another, and thereby infinitely do increafe, of fauour leffe pleafant then the common Wormewoode. Some haue termed this plant 1 b fint hium fantonicum, but they had flender reafon fo to do : for if it was fo called bicaufe it was imagined to growe in the prouince of Santoinge; it may very well appecte to the cobitratyyforin the Alpes of Galatia a cointrey in Afia minor, it groweth in greatplen. ty, and therforemay rather be called Galatiom Sardonicum, and no: Santonicum : but leauing controuerfies impertinent to the Hiftory, it is the Ponticke Wormewood of Galens defcription, and fo holden of the learned Padudke, who for his fingularknowledge in plants, is woorthie triple honor, and likewife manic others.

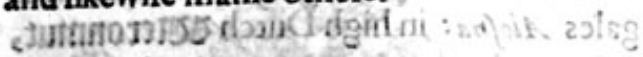

I Abfint bium latifolium frue ponticum.

Broadlealed Wormwood.

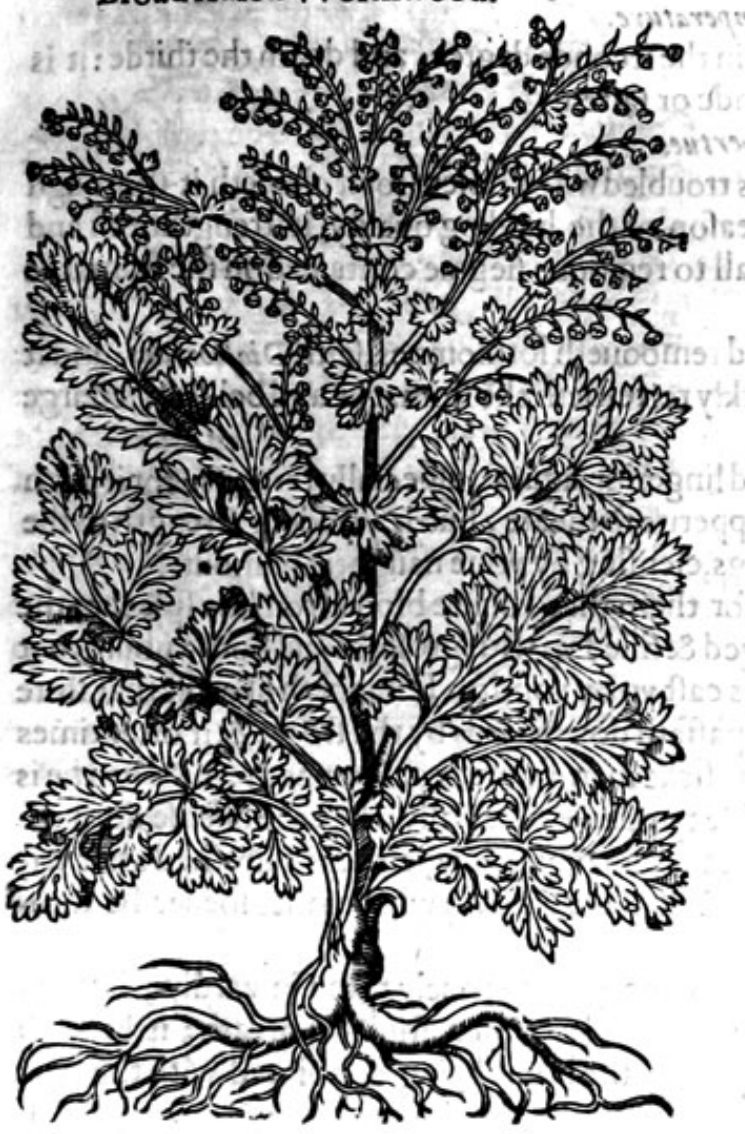

2 Abfintbium tenuifolium ponticum $G$ aleni. Small Ponticke Wormilood. 
* Thetime.

The little flowers and feedes are perfited in Iuly and Auguft, then may Wormwood be gathered and laid $\mathrm{vp}$ for profitable vfes.

* The names.

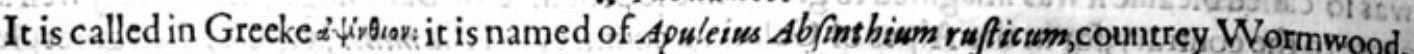
orpefants Wormwood;we haue named it 16 fint hium latifolium, broad leafed Wormwood, thas it may differ from the reft: the interpretors of the Arabians call the better fort, which Diofso rides nameth Ponticke Wormwood, Romsnum Abfinthium, Romaine Wormwood, and after thefe the barbarous Phifitions of the later age : the Italians name Wormwoode Affenfo: the Spariards Axenxios, Afenfios, moft of them Donzell: the Portingales Alofma: in high Dutch VCereronmut, oriermut: in French Alune: in Englifh common Wormwood.

Victor T rincauella, a fingular Phifition, in his practife tooke it for Abfinthiom Ponticum.

* 7 betemperature.

Wormwood is of temperature hot and dry, hot in the feconde degree, and dry in the thirde: it is bitter and clenfing, and likewife hath power to binde or faften.

* The vertues.

A It is very profitable to a weake ftomacke that is troubled with choler, for it clenfeth it thorough his bitternes, purgeth by fiege and vrine: by reafon of the binding quality, it ftrengthneth and comforteth the ftomacke, but helpeth nothing at all to remooue flegme contained in the ftomacke as $G$ alen addeth.

B If it be taken before a furfeit itkeepeth it off,and remooueth lothfomnes, faith Diofcorides: and it helpeth not onely before a furfeit, but alfoit quickly retrefheth the ftomacke and belly after large eating and drinking.

C It is oftentimes a good remedie againft long and lingering agues, efpecially tertians : forit doth not onely ftrengthen the ftomacke and make an appetite to meate, but it yeeldeth ftrength to the liuer alfo, and riddeth it of obftructions or ftoppings, clenfing by vrine naughtie humowrs.

D Furthermore Wormwood is excellent good for them that vomite bloud from the f pleene, the which hapnech when the fleene being onercharged \& filled vp with groffe bloud doth vnburden it folfe, and then great plenty of bloud is oftentimes caft vp by vomite. It hapneth likewife that ftore ofblack \& corrupt bloud mixed with excrements paffeth downwards by the ftoole, \& it of tentimes hapheth that with violent and large vomiting the ficke.man fainteth or fwouneth, or when he is reuiued doth fall into a difficult and almoft incurable tympanie, eipecially when the difeafe doth of ten happen; but from thefe dangers Wormwood can deliter him, if when he is refrefhed after vomite and his itrength any way reconered, he fhall 2 good while vfe it, in what maner foever he himfelfe fhall thinke good.

E Agaifie,Wormewood voideth awy the wormes of the gits, not onely taken inwardly, but applied outwardly: it withitanderh all putrifactions; it is good againit a finking breath; it keepech garments alfo from the Mothes; it driueth away gnats, the bodie being annointed with the oyle thereof.

F Likewife it is fingular good in pultefies and fomentations to binde and to dry.

G Befides all this Diofcorides declareth, that it is good alfo againft windines and griping paines of the ftomacke and belly, with Sefeli and French Spikenard: the decoetion cureth the yellowe iaundife or the infufion, if it be drunke thrife a day fome ten or twelue fponfuls at a time.

H It helpeth them that areftrangled with cating of mufhrumes, or toad ftooles, if it be drunke with vineger.

I And being taken with wine, it is good againft the poifon of Mifletow, and of Hemlocke, and againft the biting of the fhrcw motife, and of the fea Dragon, it is applied to the fquincie or intlammations of the throte with hony and niter, and with water to night wheales, and with hony to fwartih markes that come vpun brufes.

$\mathrm{K}$ Ir is applied after the fame maner to dim eies, and to mattering eares.

L Ioachemus Camerarius of Noremberg commendeth it greatly againit the iaundife, giving of the flowers of Wormwood, Rofemaric, Sloes, of each a fmall quantitic, and a little Saffron, boiled in wine, the body firt being purged and prepared by the learned Phifition. 


\section{Of fmall leafed Wormwood, which is called Romane Wormwood. Chap.433.}

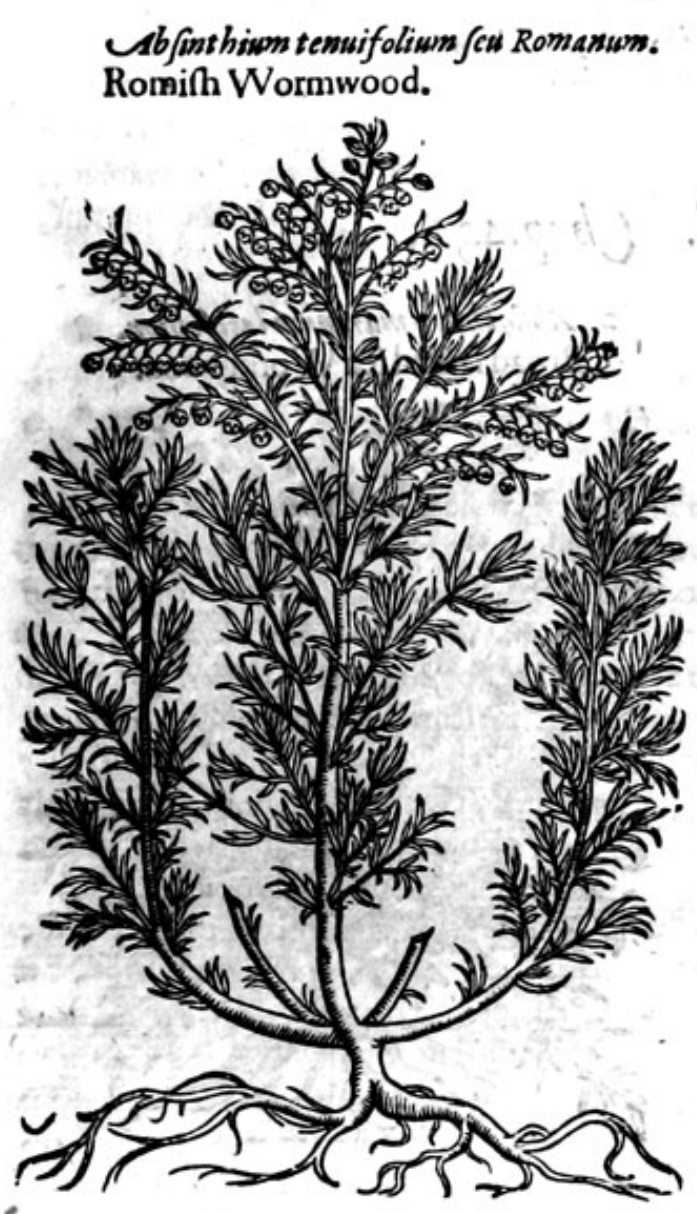

\begin{abstract}
* Thedefcription.
Mall leafed Wormwood bringeth foorth very many little branches, flender, a fpan or 2 foote high, full of leaues, leffe by a great deale, and tenderer then the former, mott finelie and nicely minced : the flowers like thofe of the former, hang vpon the little branches and fprigs : the rootes are fmal creeping ouerthwart, from whence do rife a great number of yoong fprouts : this Wormwood alfo is fomewhat white, and leffe bitter a good deale then the broad leafed one, and hath notfo ranck, or fo vnpleafant a fmell, but rather delightfuil.
\end{abstract} * The place.

It groweth plentifully in Mylia, Thracia,Hungarie, and Auftria, and in other regions neere adioining; it is alfo founde in Bohemia, and in many vntilled places of Germanie; it is a garden plantin the low Countries, and in England.

\section{* Thetinte.}

It bringeth foorth flowers and feede in Autumne:a little while after when winter commeth the herbe withereth away, but the roote remai. neth aliue, from which, leaues and ftalkes do come againe in the fpring.

\section{* The names.}

It is commonly called $A b$ forthium Romanum : \& in low dutch 1 Roomicbe alftene, by which name it is known to very many Phifitions\& apothecaries, who vfe this in fteed of Pontick Wormwood: furthermore it hath a leafe and flower farre leffe then the other Wormwoods : likewife the fmell of this is not onely pleafant, but it yeeldeth alfo a fjicie fent, whereas all the reft haue a ftrong an d lothfome fmell : and this Pontick Wormwood doth differ from that which Dio/corides commendeth, for Diofcorides his Pontick Wormwood is accounted among them of the firft kinde, or of broad leafed Wormwood; which thing alfo Galen affirmeth in his fixt booke of the factilties of medicines, in the chapter of Sothernwood. There be three kinds of Wormwood(faith he) whereof they vfe to call one by the generall name, and that is efpecially Pontick: whereby it is manifeft that Galen in this place hath referred Pontick to no other then to the firft Wormwood; and therefore inany not without caufe maruell, that Ga len hath written in his booke of the method of curing, how Pontick Wormwood is leffe in flower \& leafe; manie cxctife him, and lay the fault vpon the corrtuption of the booke, and in his $g$. booke of Methode the leffer they would have the longer. Therefore this Wormcwood with the leffer leafe is not the right Ponticke Wormwood, neithier againe the Arabians Romaine Wormwood, who haue no other Romaine theriPonticke Wormwood of the Grrecians. Alfo many belceue that this is called Santonicum, but this is not to be fought for in Myfia, Thracia, or other countrics Eaftward, but in Fraunce beyond the Alpes, if we may beleeue Diofcurides his copics: there be that woulde haue it growe not beyond the Alpes of Italy, but in Galatia a countrey in Afia, and in the region of the Sardines, which alfo is theleffer Afia, whereuponit was called in Greeke $\Sigma x$ \&inow, which was changed into the name Santonicum through the errour of the tranflators: Diofcorides his copieskeepe the word Sardmiun, and Galens copies Santonicum, which came to pofterity as it feemeth. It is cal- 


\section{THE SECOND BOOKE OF THE}

led in Engliph fmall leafed Wormwood, Romaine Wormwood, garden or Cypres Wormwood,

$*$ Thetemoerature. Small leafed Wormwood is of facultie hot and dry, it is bitter alfo, but leffe a good deale then
the bioad leafed one, the greateft forceit hath is in binding.

The facultics are referred vnto the common Wormwood.

\section{OffeaWormwood. Chap.434.}

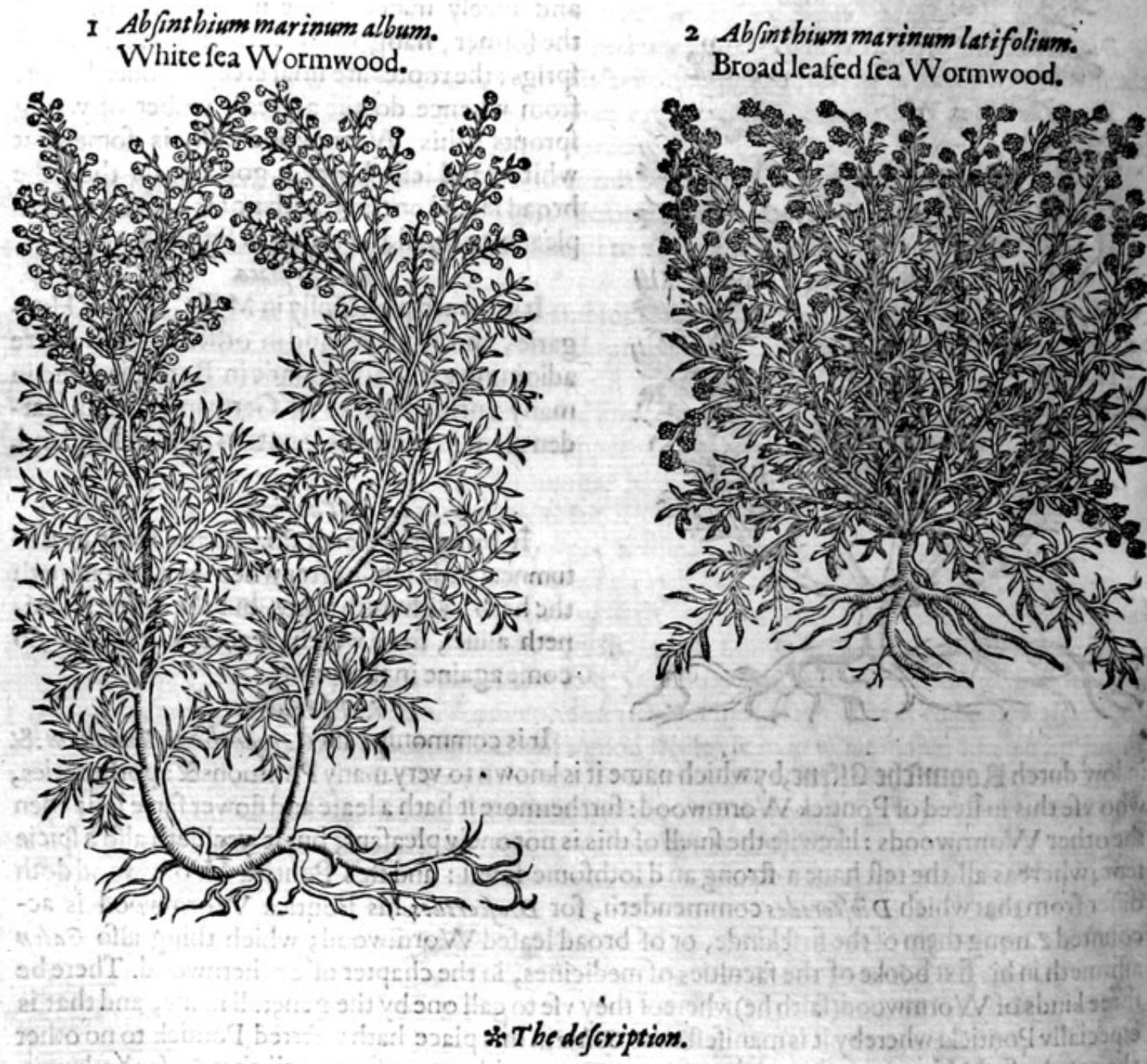

I Tewhite fea Wormwood (which Pena and $L^{\prime}$ Obelius call $A b$ finthium Ponticum, or Triden: tinum, Dodonesus in his laft Edition Seriphison ) hath many leaues cut and diuided into infinite fine iagges, like thofe of Sothernwood, of a white hoaric colour and ftrong fmell, but not vnpleafant : anuong which rife vp tough hoarie ftalkes fet with the like leaues, on the top where of do grow finall yellowifh flowers : the roote is tough, and creepeth farre abroad, by meanes whereof it greatly increafeth.

2 The broad leafed fea Wormwood hath very many foft leaues, growing clofe by the grounde, of a darke fwart colour, nothing fo fincly cut or iagged as the other of his kinde: the flowers growe ypon the tops of the ftalkes of a yellowifh colour: the roote is tough and creeping.

$$
\text { * Theplace. }
$$

Thefe Woormwoods do growe vpon the railed grounds in the faltmarnhes neere vnto the fea, 
in moft places of England; which being brought into gardens doth there flourith as in his naturall place, and retaineth his fmell, tafte, and naturall qualitie, as hath beenc often prootied.

$$
\text { * The time. }
$$

Thefe bring foorth fowers and feedes, when the other Wormwoods do.

* T he names.

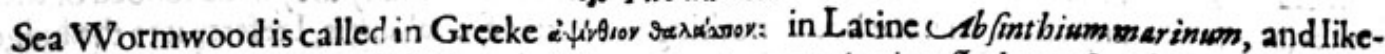
wife Seriphiwm: in Dutch bóx alfene : of diuers Santontcum, as witneffeth Dio/sorides: neuertheleffe there is another Santunitum differing from fea Wormwood : in Englifh of forme women of the countrey,garden Cypreffe.

Sea Wormwood is of nature hot and dry.

$$
\text { * The temperature. }
$$

* Thevertwes.

Diofcorides affirmeth, that being taken' of it felfe, or boiled with Rice,and eaten with hony, killeth $\mathbf{A}$ the fmall wormes of the guts, and gently loofeth the belly; the which Pliny alfo doth affirme.

The iuice of fea Wormwood drunke with wine refitteth poifon, efpecially the poifon of $\mathrm{Hem}$ - B lockes.

The leaues ftamped with figs, faltpeter, and the meale of Darnell, and applied to the bellie, fides, C or flanckes, helpeth the dropfie, and fuch as are fplenitike.

The fame is fingular againft allinflammations, and heate of the ftomackeand liuer, exceeding D all the kinds of Wormwood for the fame purpoles that common Wormwood ferueth.

It is reported by fuch as dwell neere the fea fide, that the cattle which do feed where it groweth $\mathbf{E}$ become fat and lufty very quickly.

The herbe with his ftalkes laid in cheftes, preffes, and wardrobs, keepeth clothes from mothes $\mathbf{F}$, and other vermine.

Of bolieWormwood. Cbap-435.

Sementina.

Holie Wormwood.

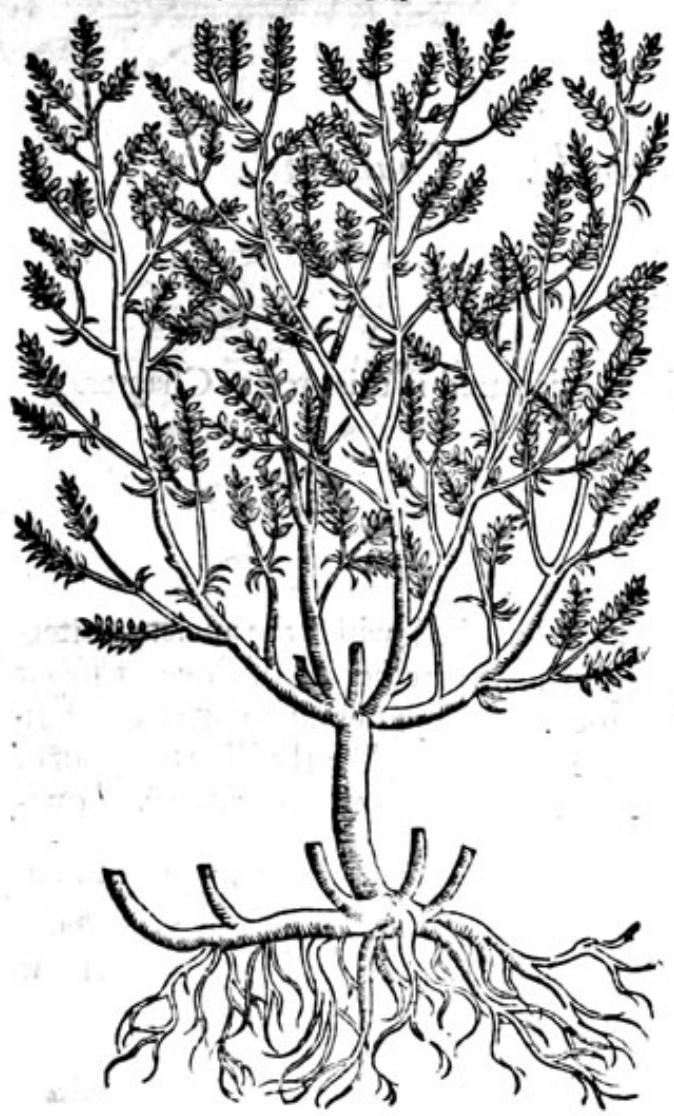

\section{* The defription.}

7 His Wormwood called Sementina, \& semen fanctum, which we haue Englifhed Holie, is that kinde of Wormwood which beareth that feede which we haue in vfe, called Wormfeede: in thoppes Semen fantolinum : about which there hath been great controuerfie amongtt writers, fome holding that the feede of Santonicsem Galatium to be the true Wormfeede, others deeming it to be that of Romanum Ab/unthizm :it doth muche refemble the firfte of the fea Wormwoods in Shape and proportion : it rifeth vp with a woodie ftalke, of the height of a cubite, dituided into diuers branches and wings; whereupon are fet very fmall leaues, among which are placed clufters of feede in fuch abundance, that to the firft view it fcemeth to be a plant confifting all of feede.

$$
* \text { Theplace. }
$$

It is a foraine plant, the feedes being fowen in the gardens of hot regions do profer well; in thele colde countries it will not growe at all. Ne. uerthefic there is one or two companions about London, who hauc reported vnto me that they had great ftore of it growing in their gardens yeerely, which they folde at a great price vntoour London 
London Apothecaries, and gained much money thereby; one of the men dwelleth by the Bagge and Bottle neere London, whofe name is Cornwale, into whofe garden I was brought to fee the thing that I would not beleene; for being of fen tolde that there it did growe, Iftill perfifted it was not truc : but when I did behold this great quantitie of Wormwood, it was nothing elfe but common Aneos. How many Apothecarics haue beene deceiued, how many they haue robbed of their money, and how many children haue beene nothing the better for taling it, I referre it to the iudge. ment of the fimpleft, confidering their owne report, to haue folde manie hundreth poundes waight of it ; the more to their Shame be it fpoken, and the leffe wit or skill in the Apothecaries: therefore haue I fet downe this as a caueat vnto thofe that buie of thefe feedes, firft to tafte and urie the fame before they giue it to their children,or commit it to any other vfe.

\title{
* The time.
}

It flowreth and bringeth foorth his feede in Iuly and Auguft.

* The names.

The French men call it Barbotine : the Italians Semen zena: whereupon alfo the Latines name it Sementina: the feede is called euery where Semen fanctum, Holie feede, and Semen contra Lim. bricos: in Englifh Wormfeed; the herbe it felfe is alfo called Wormfeed, or Wormfeedwoort: fome name it Semen Zedoarie, Zedoar feed.

\section{* The temperature.}

This feed is very bitter,and for that caufe of nature hot and dry.

\section{* The vertwes.}

A It is good againft wormes of the belly and intrailes, taken any way, and better alfo if a little Rheubarbe be mixt withall, for fo the wormes are not onely killed, but likewife they are driuen downe by the fiege, which thing muft alwaies be regarded.

B The feed mixed with a little cloes fuccotrine, and brought to the forme of a plaifter, and applied to the nauell of a childe doth the like.

\section{Of forrein and bastard Wormwoods. Chap. 436 .}

\author{
* The kindes.
}

There be diuers forts of forrein Wormwoods, as fhall be declared in this prefent Chapter.

\section{* The defcription.}

Ree Wormwood, Pena that painfull Herbarift hath defcribed, which the ancient writers haue not mentioned, to haue a truncke or ftocke growing to the height of three or fower cubits, of a woodie fub tance like vnto the Hollihocke, diuiding or branching it felfe into fundry armes tow ərd the top, fet full of fmall iagged leaues, not much vnlike the Pine tree, but of an hoarie colour, and ranke fmell: the flowers and feedes are like vnto the common Wormewoode.

2 Ab/ixthium album hath ftraight and vpright ftalkes, a cubite and a halfe high, befet with broad leaues, but verie deepely cut or clouen, in hewe like vnto Mugwoort: at the top of the ftalks do growe fimall flowers ftarre fafhion, compact of fixe fmall leaues: the roote is long with fome fibres annexed vnto it. 
HISTORIE OF PLANTS.

1 Abfonthium arborefcens.

2 Ublinthitum album.

Tree Wormwood.

White Wormwood.

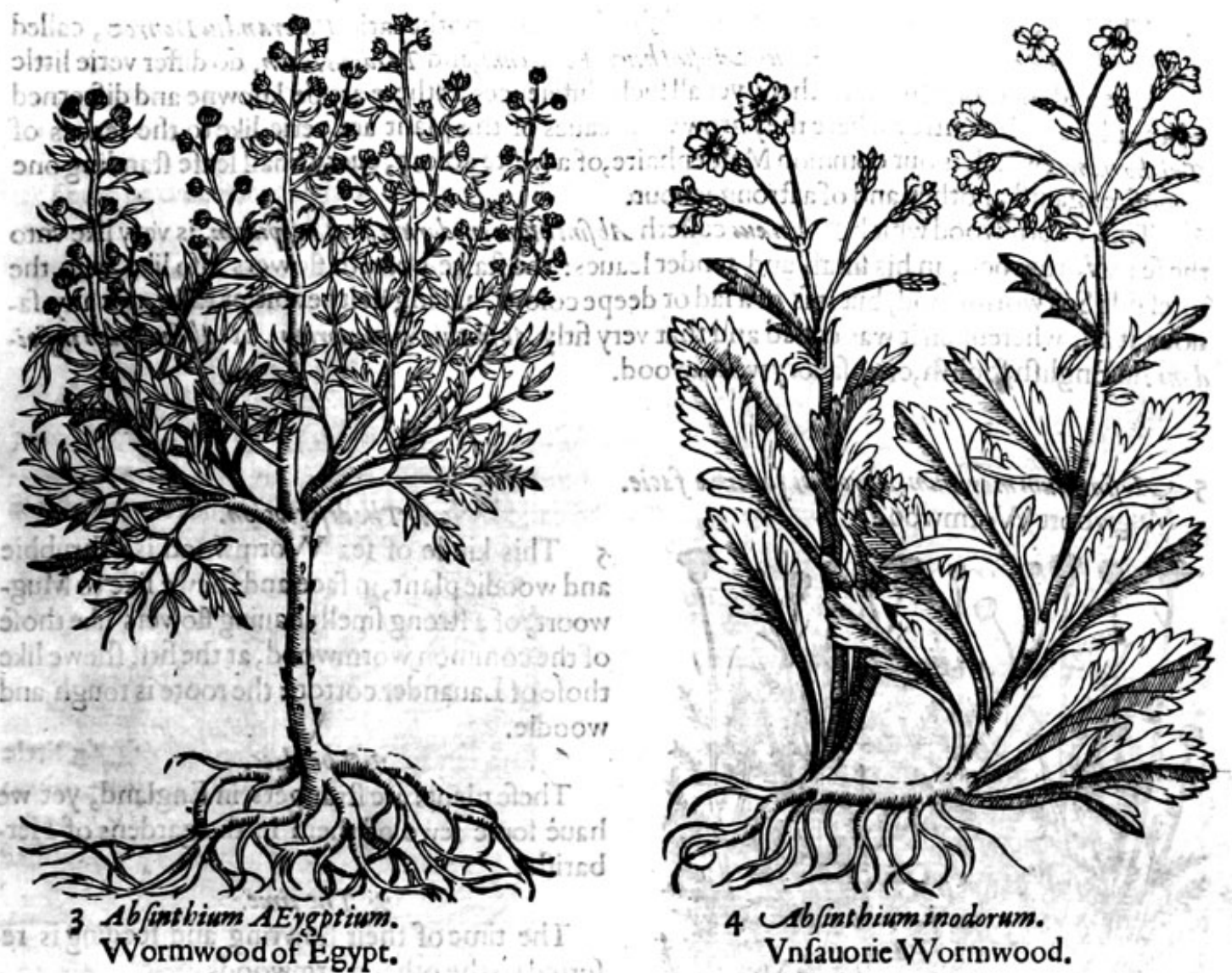

Egyp

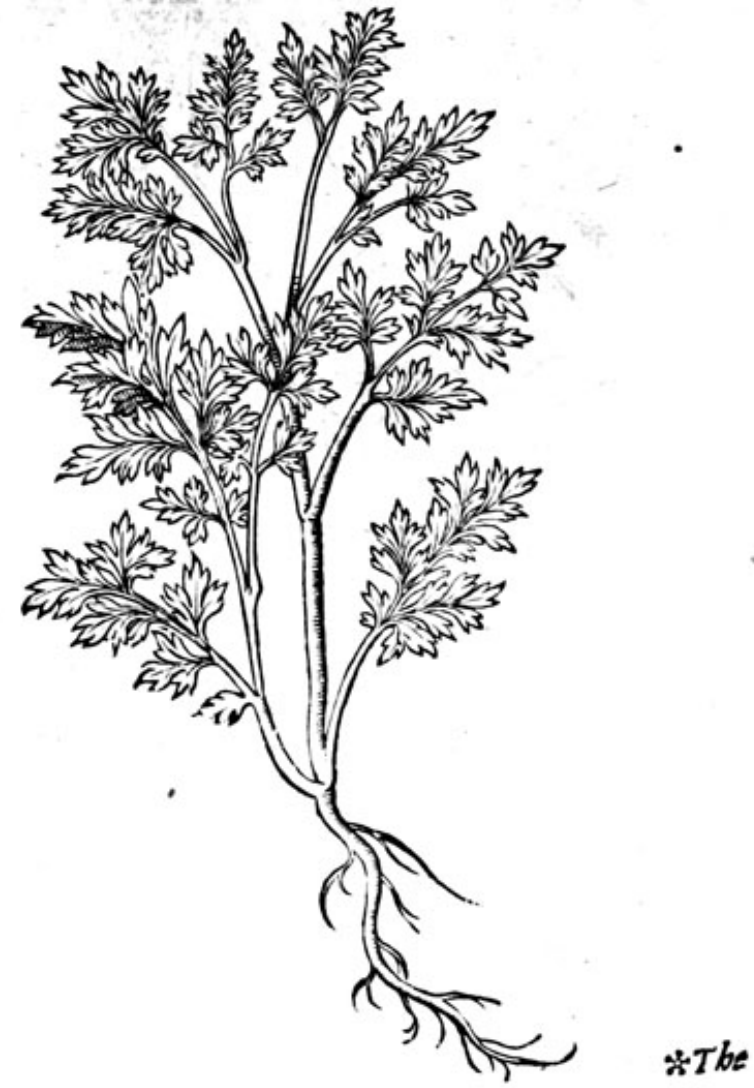




\author{
* The defcription.
}

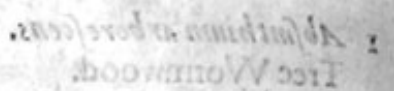

3 This kinde of Wormwood Gefnerus and that learned A pothecarie Valerandus Donroz, called Ab inthium Egvptium, but L'Obelins Ab fint hum Ponticum, and Trident iunm, do differ verie little in thape and hew one from nnother, yet all fuch differences as there are be knowne and difcerned by the place and countrey where they grow: the leaues of this plant are verie like to the leaues of Trichomanes, which is our common Maidènhaire, of a white colour, euery fmall leafe ftanding one oppofite againft another, and of aftrong fauour.

4 This Wormwood which Dodoneus calleth $A b$ fint hium inodurum, and Infpidum, is very like vnto the fea Wormwood, in his fmall and tender leaues: the ftalke beareth flowers alfo like vnto the forefaide Sea wormwood, but it is of a fad or deepe colour, having neither bitter tafte, nor any $\mathrm{fa}_{\text {- }}$ nour at all, whereupon it was called and that very fitly $A b$ finthium inodorum, or Ab finthium ing (rpidum : in Englith foolifh, or vnfauory wormwood.

5. Abfunthium marinum, Abrotoni farmina facie. Mugwoort Wormwood.

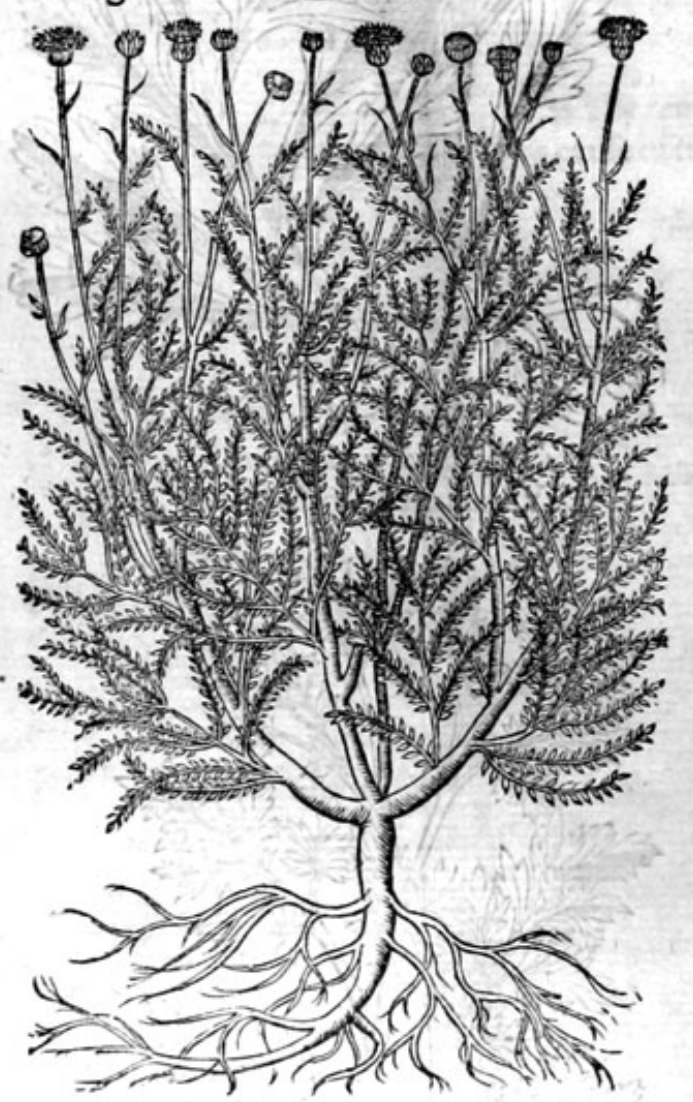

* Thedefaription.

5 This kinde of fea Wormwood is a fhrubbie and woodic plant, in face and fhewe like to Mugwoort, of a ftrong fmell; hauing flowers like thofe of the common wormwood, at the firft fhewe like thofe of Lauander cotton: the roote is tough and woodie.

\section{* Theplace.}

Thefe plants ate ftrangers in England, yet we haue forne fewe of them in the gardens of Herbaritts.

\section{* The time.}

The time of their flowring and feeding is referred to the other wormwoods.

$$
\text { * The names. }
$$

The white Wormwoode Conradas Gefnerws nameth Seriphium famina, and faith, that it is commonly called Herba alba, or white Herbe ; an other had rather name it Santonicum, for as Diofcorides faith, Santonicüm is founde in Fraunce beyonde the Alpes, and beareth his name of the countrey where it groweth: but that part of Swifferland which belongeth to Fraunce is zecounted of the Romaines to be beyond the Alpes; and the prouince of the Santons is far from it: for this is 2 part of Guines fcituated vpon the coaft of the Ocean, beneath the floude Gerond northward: therefore Santon wormwood if it haue his name from the Santons, groweth farre from the Alpes; but if it growe neere adioining to the Alpes, then hath it not his name of the Santons.

\section{$\approx$ The temperature and vertues.}

White wormwood is hot and fomewhat drie.

A Vnfauorie Wormwood as it is without fmell and tafte, fo is it fcarfe of any hot qualitie, much leffe hath it any fcouring facultie; thefe are not vfed in Phificke where the othersmay be had, being as it were wilde or degencrate kindes of Wormwood, fome of themparticipating both of the forme and fmell of other plants. 


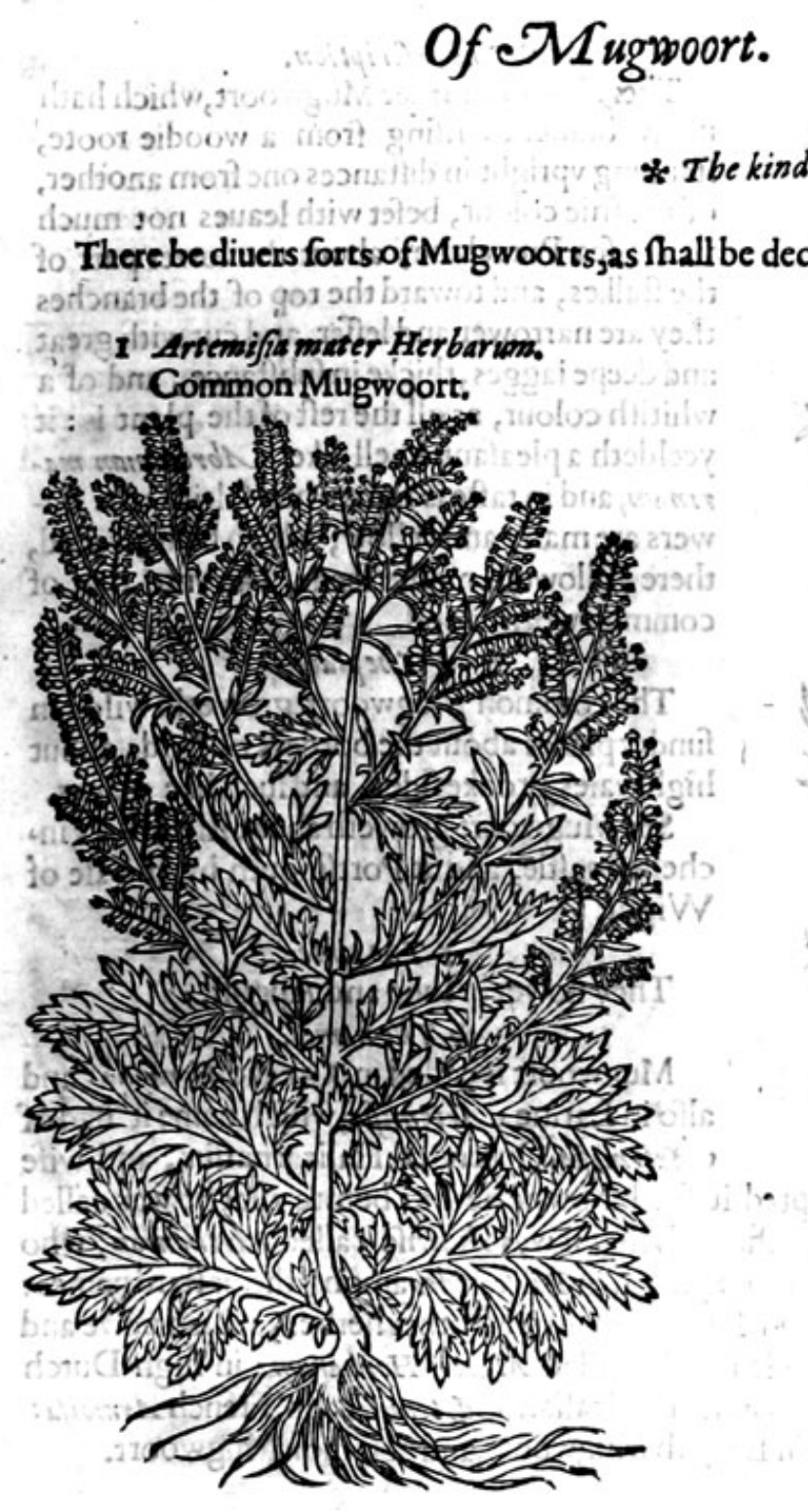

\title{
Chap. 437.
}

$\therefore$

des.

\author{
.
}

2 Utremifiatenuifolia.

Thinne leafed Mugwoor.

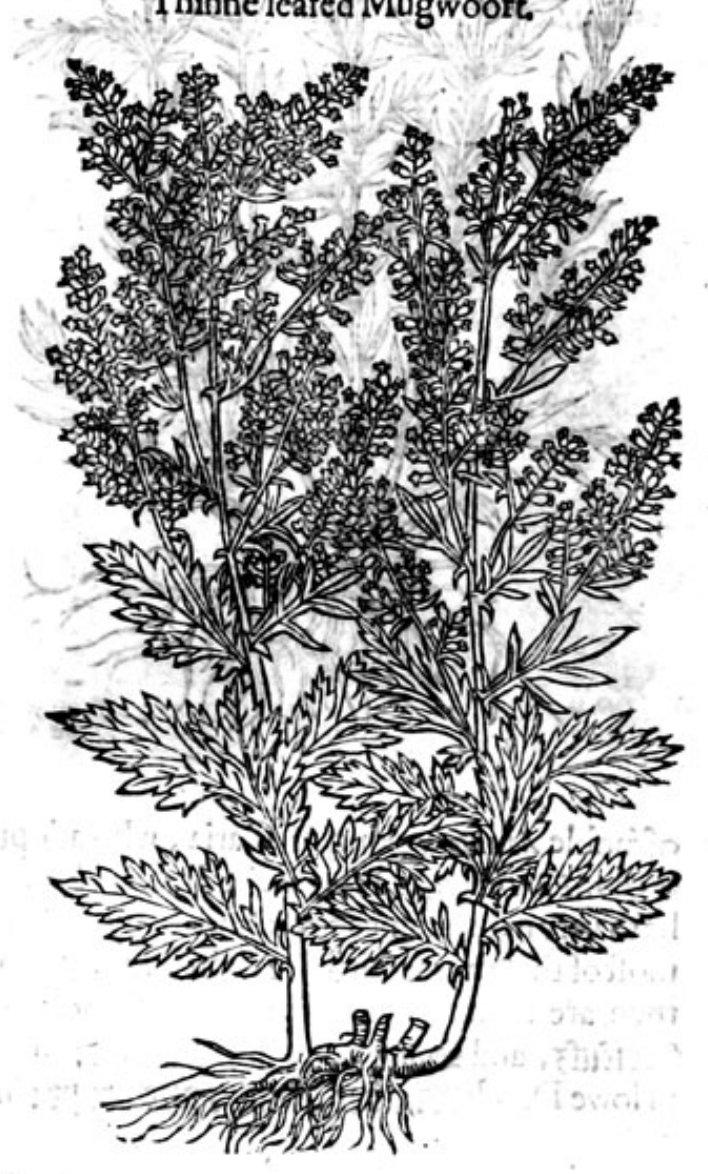

\section{\% The defcription.}

1 He firft kinde of Mugwoort hath broad leaues, very much cut or clouen, like the leaues of common wormwood, but fmaller, of a darke greenc colour aboue, and hoarie vnderneath: the ftalkes are long and ftraight, and full of branches, whercon do grow fmall rounde but-
tons which are the flowers, fmelling like Marierome when they waxe ripe : the roote is great and
of a woodie fubttance. of a woodie fubstance.

2 The feconde kinde of Mugwoort hath a great thicke and woodie roote: from whence arife fundric braunches of a reddifh colour, befet full of fmall and fine iagged leaues, very like vnto fea Sothernwood: the feed groweth alongt the finall twiggie branches, like vnto little berries, which fall not from their branches, in a long time after they be ripe.

3 There is another Mugwoort of the fea,that hath leatucs likc vnto fea Puiflane,thick, fat, and oileous, of a grayifh colour:among which rifeth vp a ftalke two cubits high, diuiding it felfe into fundrie
branches, befet full of fmall and barren tlowers, like fea wormwood : the rootc is thicke and of a
woodiefubftance. woodiefubftance. 
3 Artemifia marina. Sea Mugwoort.

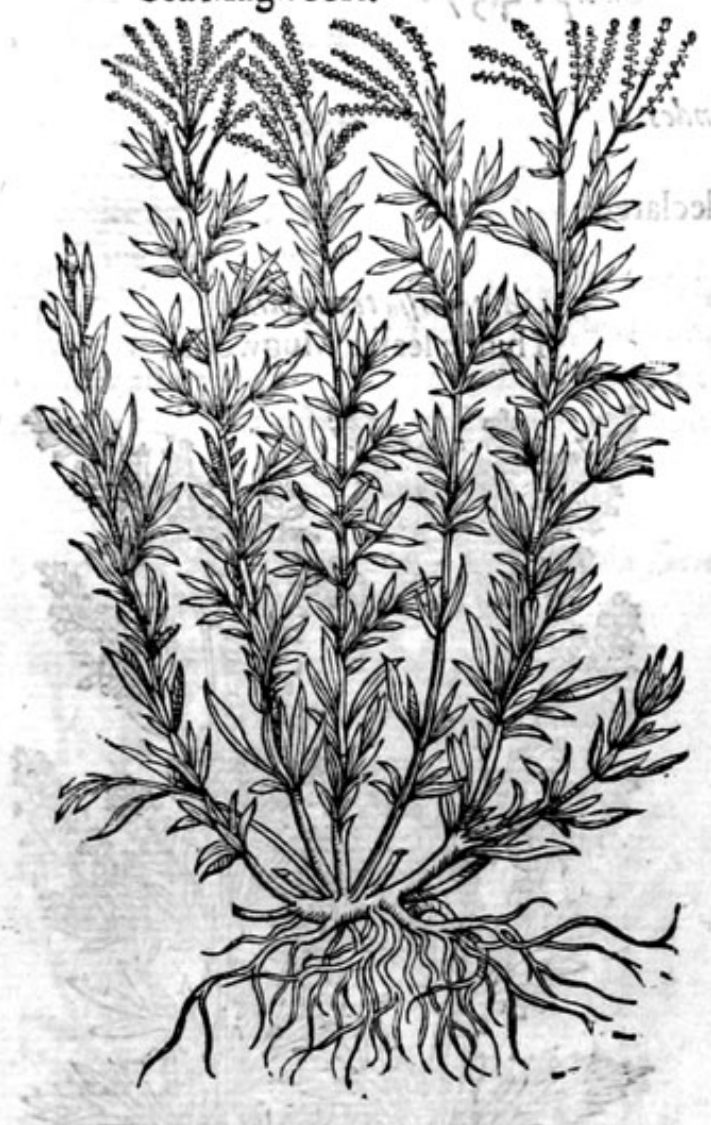

4] $*$ Thedefoription.

There is alfo another Mugwoort, which bath many branches rifing from 2 woodie roote, Itanding vpright in diftances one from another, of an afhie colour, befet with leaues not much vnlike fea Purcelane; about the lower part of the ftalkes, and toward the top of the branches they are narrower and leffer, and cut with great and deepe iagges, thicke in fubftance, and of a whitifh colour, as all the reft of the plant is : it yeeldeth a pleafant fmell like Ubrotonum marinum, and in tafte is fomewhat faltifh : the flowers are many and yellow, which being vaded, there followeth moffie feede, like vnto that of common wormwood.

$$
\text { * Theplase. }
$$

The common Mugwoort groweth wilde in fundry places about the borders of fields, about high waies, brooke fides, and fuch like places.

Sea Mugwoort groweth about Rie and Winchelfey caftle, and at Portinouth by the Ile of Wight.

$$
\text { * The time. }
$$

They flower in Iulie and Auguit.

$$
\text { * The names. }
$$

Mugwoort is called in Greeke Aprumia : and alfo in Latine Artemifra, which name it had of Artemifia Queene of Halicarnaffus, and wife of noble Maufolus king of Caria, who adopted it for hir owne herbe: before that it was called nap9ivis, Parthenis, as $P$ liny writeth. Lpuleius affirmeth that it was likewife called Parthenion, who hath very many names for it,and many of them are placed in Divfcorides among the baftard names: moft of thefe agree with the right Artemifia, and diuers of them with other herbes, which nowe and then are numbred among the Mugwoorts : it is alfo called Mater Herbarwm: in high Dutch 2Beifuif, and Sant Jobamus 5urtelt: in Spanifh and Italian Artemifas : in French Armoiss: in lowe Dutch 23ijuaet, Sint Jang ktupt : in Englifh Mugwoort, and common Mugwoort.

\section{* Thetemperature.}

Mugwoort is hot and dry in the fecond degree, and fomwhat aftringent.

\section{* The vertues.}

A Pliny faith that Mugwoort doth properly cure womens difeafes.

B Diofcorides writeth that it bringeth downe the termes, the birth and the afterbirth.

C And that in like maner it helpeth the mother, and the paine of the matrix, to be boiled as bathes for women to fit in;and that being put vp with myrrh, it is of like force that the bath is of; and that the tender tops are boiled and drunke for the fame infirmities, and that they are applied in manner of a pultis to the fhare to bring downe the monthly courfe.

D Pliny faith, that the trauailer or waifaring man, that hath the herbe tied about him, feeleth no wearifomnes at all, and that he who hath it about him can be hurt by no poifonfome medicines, or by any wilde beaft, neither yet by the funne it felfe; and alfo that it is drunke againft opium, or the iuice of blacke Poppie. Many other fantafticall deuifes inuented by Poets are to be feene in the workes of the auncient writers, tending to witchcraft and forcerie, and the great difhonor of God: wherefore I do of purpole omit them as things vnwoorthie of my recording or your teujewing. 


\section{HISTORIE OF PLANTS.}

Mugwoort pound with oile of fweetc Almonds, and laid to the ftomacke as aplaifter, cureth all $\mathrm{E}$ the pairies and griefes of the fame.

It cureth the thakings of the ioints declining to the palfie, and helpeth the contration aud $F$ drawing togither of the nerues and finewes.

\section{Of Sothernwood. Chap. $43^{8}$.}

* The kindes.

D I0, corides affirmeth that Sothernwood is of two kindes, the female and the male, which are thirde kinde, which is of a fweeter fmell, and lefier then the others; and alfo others of a bafteris kinde.
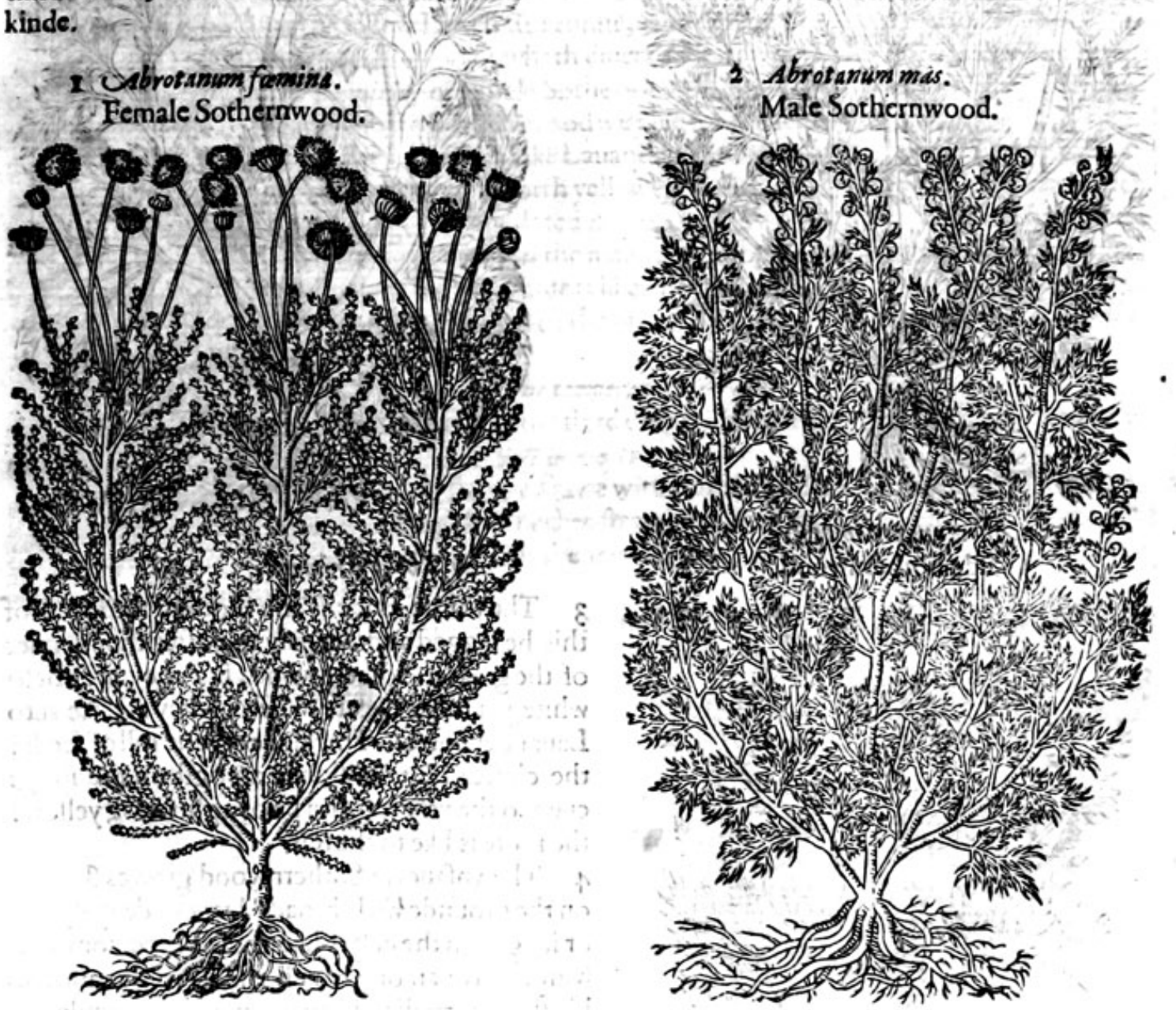

\section{* Thedefription.}

1 He greater Sothernwood by carefull manuring, doth oftentimes grow vp in maner of a fhrub, and commeth to be as high as a man, bringing foorthftalkes an inch thicke or more: out of which fpring very many fprigs or branches fet about with leaues, diterfly iagged and finely indented, fomewhat white, and of a certaine ftrong fmell : in fteede of tlowers little imall clufter buttons do hang on the fprigs from the middle to the very top, fcolour yellow, and at the length turne into feede: the roote hath diuers ftrings.

2 The leffer Sothernwood groweth lowe, full of little flender fprigs, of a woody fibftance : the leaues are more indented then thofe of the former, not fo whitc; it beareth no clufter blittons: the roote is made of many ftrings. 
3 Abrotanum humile.

Dwarfe Sothernwood.

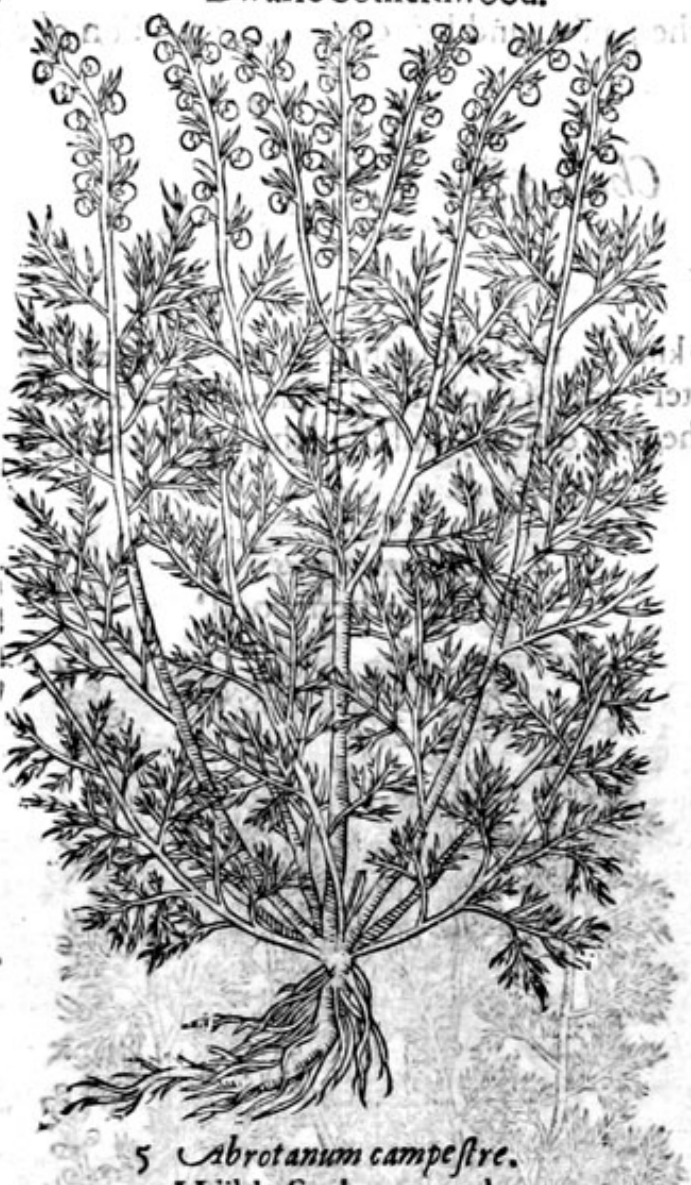

Wilde Sothernwood.

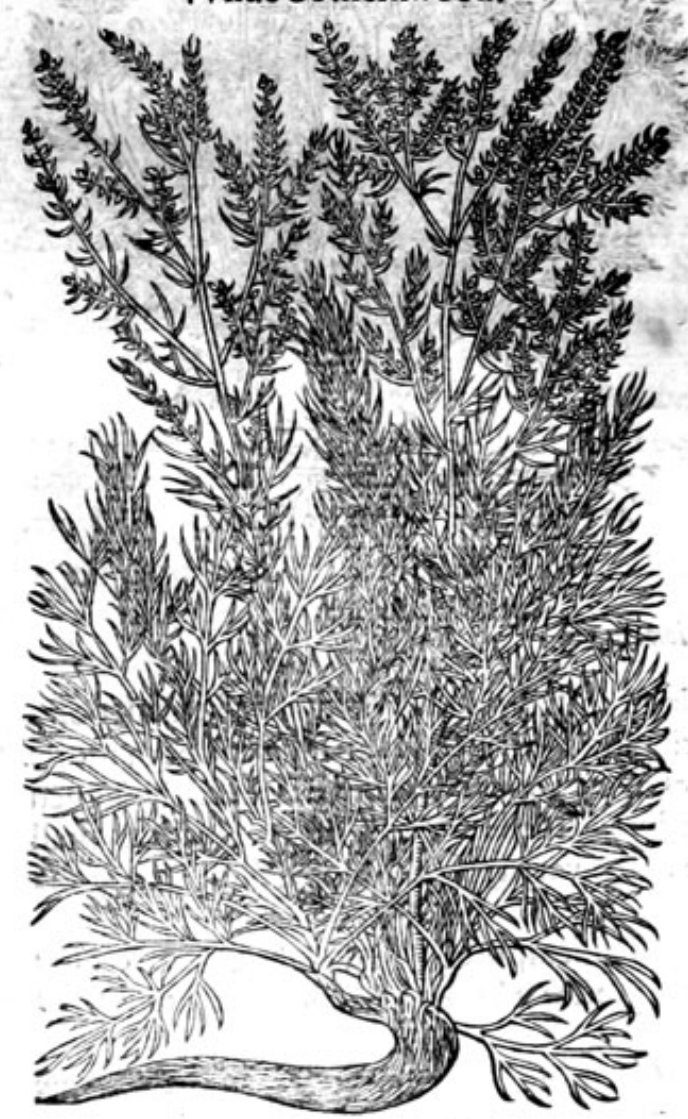

4 Abrotaniom Inodoram, own uM

Vnfatorie Sothernwood,

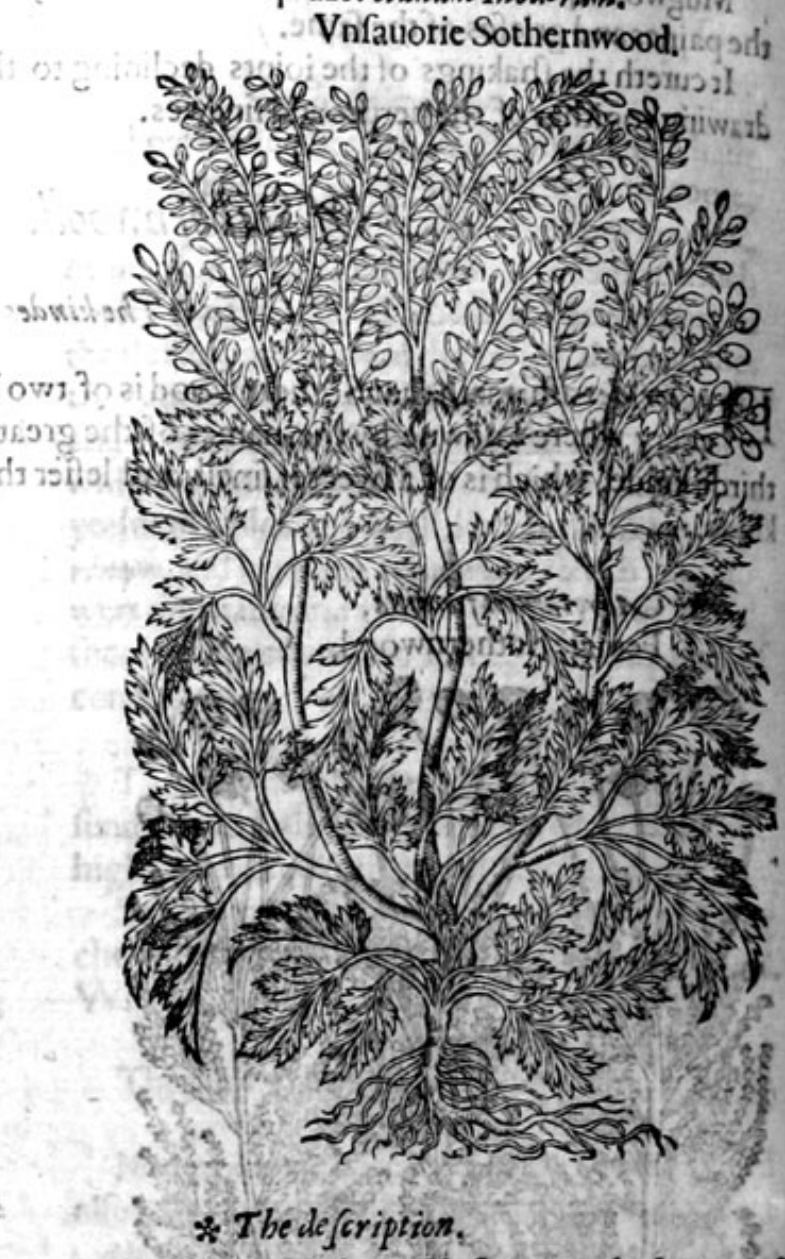

3 The thirde kinde is alfo thorter : theleaues of this be iagged and deepely cut after the manner of the greater Sothernwood, but they are not fo white, yet more fweete, wherein they are like vnto Lauander cotton. This kinde is verie full of feede: the clufter buitons ftande alongft on the forigs euen to the very top, and be of a glittering yellow: the roote is like to the reft.

4 The vnfauorie Sothernwood growes flat vpon the grounde with broade leaues, deepely cut or iąged in the edges like thofe of the common Mugwoort : among which rife vp weake and feeble ftalkes, trailing likewife vpon the grounde, fet confufedly heere \& there with the like leaues that grow next the ground, of a grayinh or hoary color, altogither without finell, The flowers growe 2 Jongeft the ftalkes of a yellowifh colour, imal and chaffie: the roote is tough and woodie with fome ftrings annexed thereto.

5 This wilde Sothernwood hath a great long thick roote, tough and wcodic ; conered ouer with a Icalie barke like the fcalie backe of an adder, and of the fame colour : from which rile verie many Ieaues like thofe of Fennell, , f an ouerworne green colour: among which grow finall twiggie braun- 
ches on the tops, and alongft the ftalkes do grow fmall cluftering nowers of a yellow colour : the whole plant is of a darke colour, as ivell leaues as ftalkes, and of a itrong vnfauoric fmell.

$$
* \text { The place. }
$$

Theophraftus faith, that Sothernwood delighteth to grow in places o? en to the funne: Diofcorides affirmeth that it groweth in Cappadocia, and Galatia a countrey in Afia, and in Hicrapolis a citie in Syria : it is planted in gardens almoft euery where; that of Sicilia and G.2latia is molt commended of Plsmie.

\section{* The time.}

The clufter buttons of Sothernwood do flourih and be in their prime in Auguft, and now and then in September.

It is called in Greeke A'Go'rovi: the Latines and the Apothecarios keepe the fame name Abrotomum : the Italians and diuers Spaniards call it Abrut ano; and other Spaniards rerua lombriguers: in high Ditch Stnbiuutz : in low Dutch Guetonne, and auerctut $t$ t the French Asrose, and Auroefse : the Englifhmen Sothernwood; ithath diuers baftarde names in Digfcurides: the greater kinde is Digfcorides his Famina, or female Sothernwood, and Pliny his UMontaniom or mountaire Sothernwood; the mountaine Sothernwood we take for the female, \& the champion for the male. There be notwithiftanding fome that take Lauander Cotton to be the female Sothernwood, grounding thereupon, bicaufe it bringeth foorth yellowe flowers in the top of the fprigs like cufter buttons: but if rhey had more diligently pondered Diofcorides hiswords, they would not bagre been of this opinion:the Ieffer Sothernwood is Mas the male, \& is alfo Plinies champjon Sothernwood, in Latine Campeftre. The thirde as we haue faide is likewic the fenale, and is vfually called fiveete Sothernwood, bicaufe it is of a fweeter fent then the reft; Diof corides feemech to call thiskind Siculom, Sicilian Sothernwood.

Sothernwood is hot and dry in the end of the third degree : it hath alfo force to diftribute and to rarifie.

$$
\text { * The temperature. }
$$

The tops, flowers, or feed boiled or ftamped rawe with water and drunke, helpeth them that can $A$ not take their breath without holding their neckes ftraight vp, and is a remedie for the crampe, and for finewes fhrunke and drawne togither; for the fciatica alfo, and for them that can hardly make water, and it is good to bring downe the termes.

It killeth wormes and driueth them out : if it be drunke with wine, it is a remedic againft deadly B poifons.

Alfo ithclpeth againft the ftinging of fcorpions and fielde fpiders, but it hurteth the ftomacke. C

Stamped and mixed with oile it taketh away the fhiuering cold that commeth by the ague fits, D and it heateth the body if it be annointed therewith before the fits do come.

If it be pouned with barly meale and laide to puthes, it taketh them away.

It is good for inflammations of the cies, with the pulpe of a rofted Quince, or with crums of $\mathrm{F}$ bread, and applied pultis wifc.

The athes of burnt Sothernwood with fome kinde of oyle, that is of thinne parts, as of Palma G Chrifti, Radifh oyle, oyle of fwecte Marierome, or Organie, cureth the pilling of the haire of the head, and maketh the beard to grow quickly: being ftrowed about the bed or a fume made of it vpon hot embers it driueth away ferpents: if but a branch be laid vnder the beds head, they fay that it prouoketh venerie.

The feede of Sothernwood made into powder, or boiled in wine and drunke, is good againft the $\mathrm{H}$ difficultie and ftopping of vrinc, it cxpelleth, watteth, confumeth, and digefteth all colde humours, tough flime, and flegme, which do vfually ftop the fpleene,kidneies and bladder.

Sothernwood drunke in wine is good againft all venome and poifon. and barrowes greafe vnto the forme of a plaifter, diffolueth and wafteth all colde humours and fwellings, being applied or laide thereto.

Female Sothernwood or Lauander Cotton, drunk in wine, is good againft the bitings of ferpents, $L$ and expclling of poifon.

It killeth wormes in children, as daily experience prooueth, for women do vfe it to that purpofe $\mathrm{M}$ with good fuccefic. 


\section{OfOke of ferufalem, and Oke of Cappadocia. Chap.43\%.}

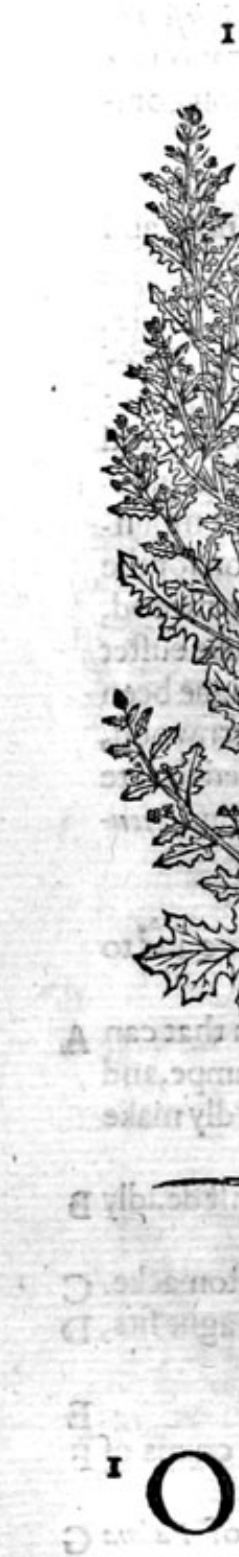

I Botrys.

Oke of Ierufalem.

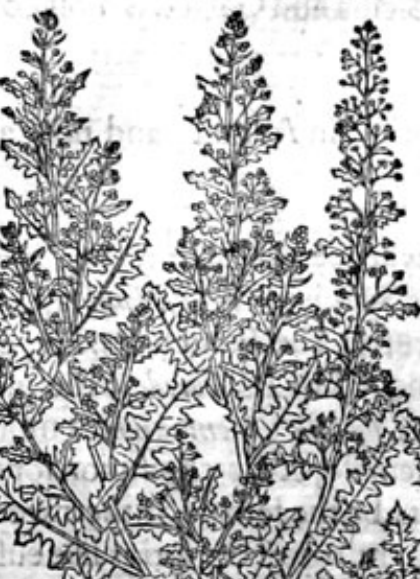

萢

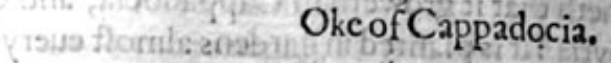

2 Ambrofia,

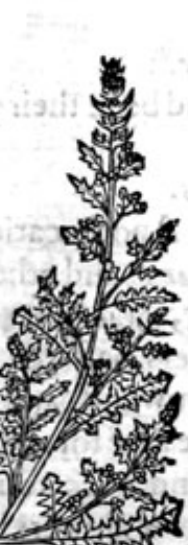

䗉

(n) sts

留
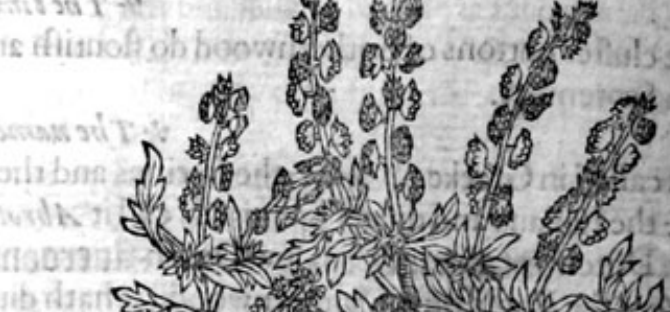

(2)
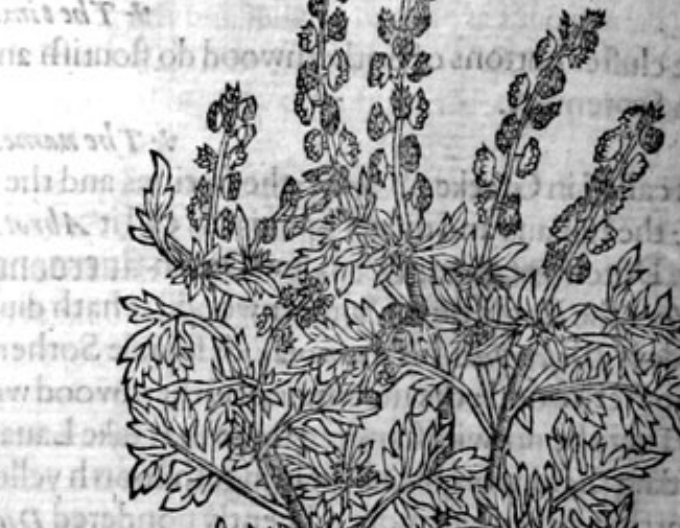

(n) 1 -

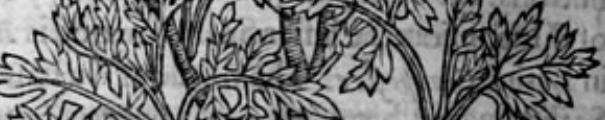

(1)

Nis sis
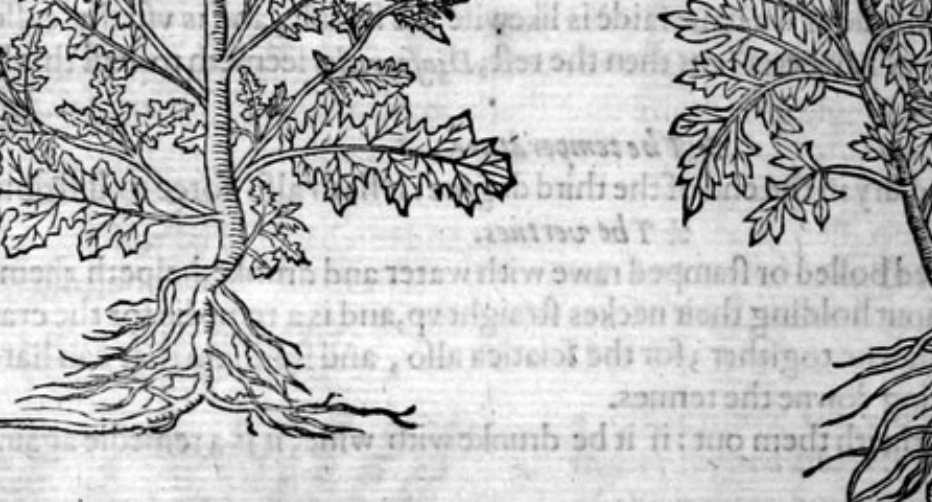

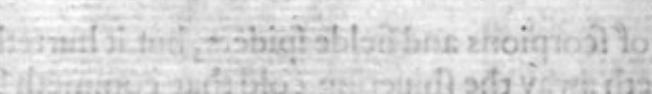

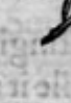

* The defcription.

Ke of lerufalem or Botrys, hath fundry fmall ftems, a foote and an halfe high, diuiding themfelues into many fmall branches, befet with fmall leaues, deepely cut or iagged, very much refembling the leafe of an Oke, which hath caufed our Englifh women to call it Okes of Ierufalem; the vpperfide of the leafe is of a deepe greene, and fomewhat rough and hairie, but vnderneath it is of a darke reddifh or purple colour: the feedie flowers do grow cluftring about the branches, like the yoong clufters or blowings of the vine : the roote is fmall and threddie; the whole herbe is of a pleafant fmell and fauour, and of a faint yellowifh colour; and the whole plant dieth when the feede is ripe.

2 The fragrant fmell that this kinde of Ambrofat, or Oke of Cappadocia yeeldeth, hath mooued the Poets to fuppofe that this herbe was meate and foode for the gods: Diofcorides faith it groweth three handfuls high; in my garden it groweth to the height of two cubits, yeelding many weake crooked, and ftreaked branches, dividing them/elues into fundry other fmall branches, hatuing from the midtt to the top there of, many moffie yellowifh flowers notmuch vnlike common Worm. wood, ftanding one before another in good order, and the whole plant is as it were coucred ourer with bran or a meal e dutt: the flowers do change into finall prickly cornered buttons, much like vnto Tribulusterreftrts, wherein is contained blacke round feede, not vnplcafant in tafte and fmell: the leaues are in thape like the leaues of Mugwoort, but thinner $\$$ more tender, all the whole plant is horie, \& yecldeth a plealant fauor:the whole plant perifhed with $\mathrm{me}$ at the firft approch of winrer. 
There is another kinde of Ambrofia, which hath a long fnall and flender roote, withra few fibres annexed thereto: from which rife vp diuers finall hoaric ftems of a cubite high; fet full of hoarie leaues a great deale lefter than the fotmer, and more finely cut or iagged: the flowers growe vpon fmall twigs without any leaues amọg them, in hew likc little rough berries, of a duskilh colour : the whole plant is very hatitie and of a good fmell.

There is likewifeanothet kinde of dmbrofia very like vnto the laft before mentioned, but that his leaues are thinner andsworefinely cut, refembling the fmall leaues of Englihh Saxifrage s the flowers and feedes are nugh finallex and the roote greater:

Thefe plants are bronght vnto vs from beyond the feas, efpecially from Spaine and Italie.

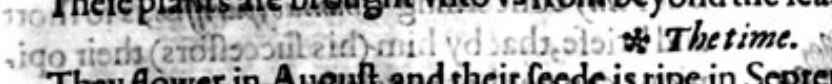

They flgwer in Augutt, and their feade is ripe in Seprember.

They thower in Auguh and heir

Oke of Ierufalem is calledin Grecke, for Tus : in Latine Botrys ; in Italian Botri, in Spaning Bient

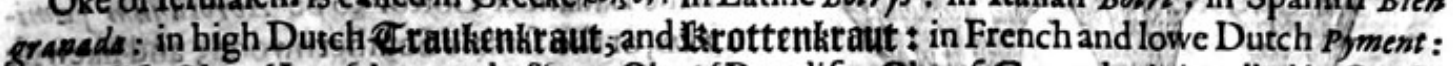
in Englinh Oke of Ierufalemb and of forme. Oke of Paradife. Oke of Cappadocia is called in Greeke

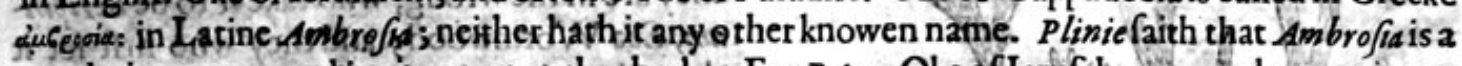
yandering name, andis gigen vgtonthex berbes. For Botrys Oke of Ierufalem, as we haue written, is of diuers alfo called Ueprofia in Englifbitis called Oke of Cappadacia.

is of diuers ilfocalled con

Thefeplanrs are hot and drie in the fecond degree, and confift of (ubtill partes. $*$ The vertues.

Thefe plants are good to be boiled in wine and miniftred vnto fuch as hane their breafts ftopped, A and are fhort winded, at d cannpt eafily drawe their breth; for it cuereth and wafteth groffe humors and tough flegme. The leaues are of thefame force being made vp with Sugar, they commonly call it a Conferue.

It giuctha pleafant tafte to flefh that is fodden with ityandeaten with the broth.

in Iris dried and laid among garmeists notonely to make them fmell fweetes, bakallo to preferue C them from moths and other vermine: which, thing it doth allo performe.

c2manow

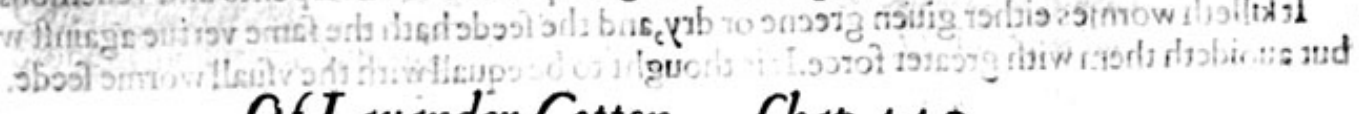

\section{Of Lauander Cotton. Chap.440.}

\section{* The kindes.}

C Hamecyparifus, or Lauander Cotton, whereof there be two fortes, of which one is very con-

mon in our Englifh gardens : the other leffe knowne, which the Italians call Santolina.

$$
\text { * T he defcription. }
$$

$\mathrm{L}$

Auander Cotton bringeth foorth cluftered buttons of a golden colour, and of a fiveete fmell, and is often vfed in garlands and decking vp of gardens and houfes. It hath a woodie ftocke', out of which grow foorth branches like little boughes, flender, very many, a cubite lorig, fet about with little leaues, long, narrow, purled or crumpled; on the tops of the branches ftande vp flowers, one alone on cuerybranch, made vp with hort threds thruft clofe togither, like to the flowers of Tanfie, and to the middle buttons of the flowers of Cammomil, but yet fomething broader, of colour yellow, which be changed into feede of an obfcure colour. The roote is of a woodie fubftance. The fhrub it felfe is white both in branches and leaues, and hath a ftrong fivcetc fnell.

There are fet foorth two figures, one by $T$ aber Mont anus, vnder the title 4 - lb fint hium marinum te: nuifolium: the fame is fet forth in diuers written copies for Abrotonum famina, differing very notably in kinde, yet fo like that they cannot be diftinguiihed: doubtleffe I take them to be one plant, Se therfore with the ancients we hold it for the female Sothernwood, or lauander Cotton. It agteeth with our common Lauander Cotton in cach refpect, fauing that it is altogither lefler, and the leaues more finely cut and hackt, and of a greener colour; yet whitifh as well leautes as branches.

$$
\mathrm{O} 004
$$

Chanse- 


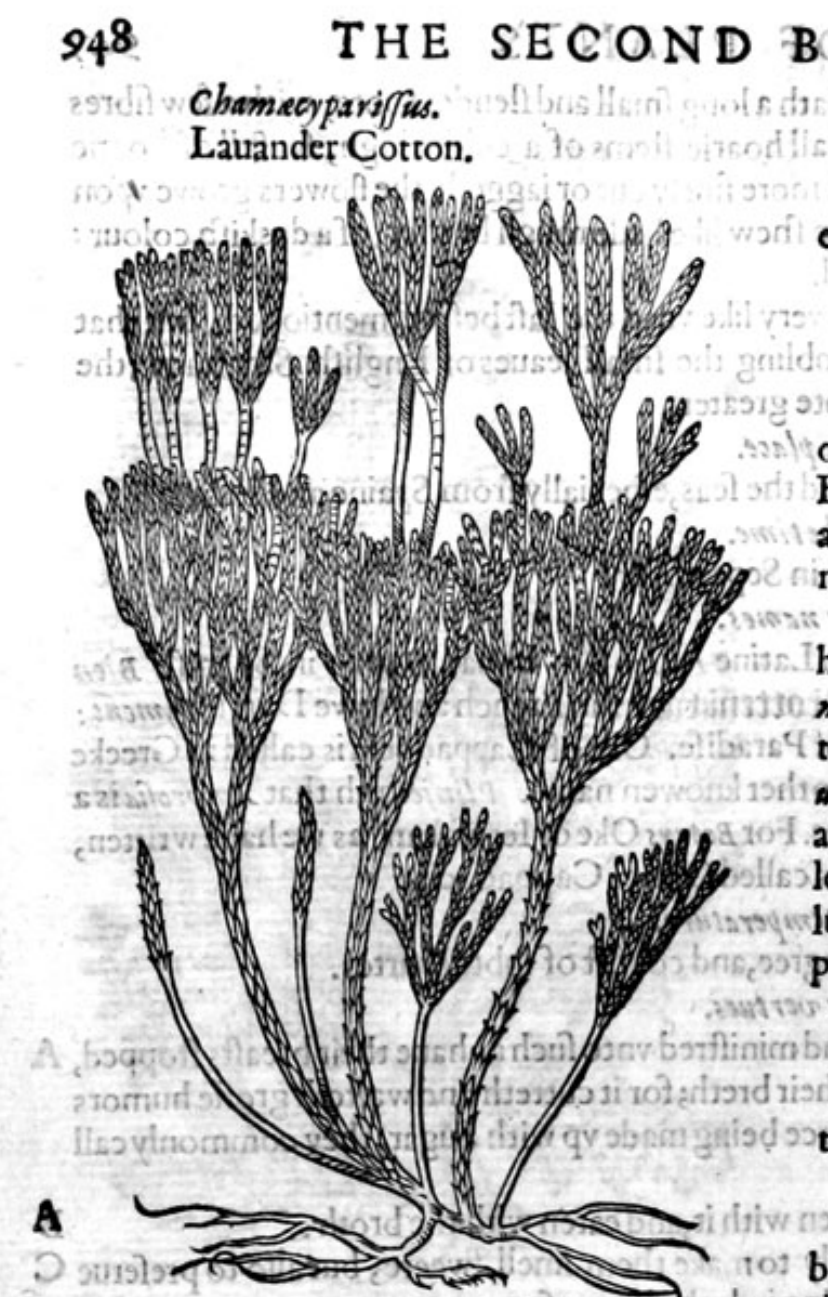

B Irkillech womies cither given

BOOKEOFITHE

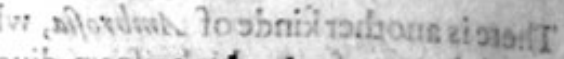

suth qrolin $*$ Theplace.

Lauander Cottongtoweth in gardens almoft

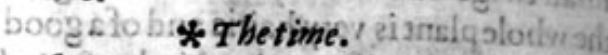

They flowerin Iuly and Auguft:i zi sradt siva vlaning The names.

They are both called by one name Santolina, or Lauander Cotton, of moft Chamecyparifius. But Plinjyconcerning Chamecypariffes, is fo fhort and briefe, that by him (his fucceffors) their opinions canneither be reiected, nor receilied.

They are doubtles much deceiued that would haue Lauarider Cottonso be Abrotaniom faminam, or the female Southernivood; and likewife they ate in the wrong, who take it to be seriphi. ans, Sea Wormwood; and they who firf fet it abroach tó be a kiade of Southernwiood, we leaue them totheir errors: bicaufe ic is not abfolutely to be referred to one, but a plant partici. pating of Wormwood and Soutiefnitood. sdis:

rive ail $*$ The temperature.

The feede of Latiander Cotton bath a bitter tafte,being hot and drie in the third degree.

$$
* 2 \text { be vertues. }
$$

Plinic faith, that the berbe chamecypariffous being drunke in wine, is a good medicine againft the poifons of all ferpents and venemotis beafts. dry, and the feede hath the fame vertue againft wormes, but auoideth them with greater force.It is thought to be equall with the vfuall worme feede.

$$
\text { Of Sperage, or Afparagus. Chap.44I. }
$$

moว

$T$ He ancients haue fet foorth two fortes of Sperage: the garden and the wilde Sperage. The later writers haue found more of the wilde kinde.

\section{* The defcription.}

I. He firft being the manured and garden Sperage, hath at his firft rifing foorth of the ground, thicke tender thootes, very foft and brittle, of the thicknes of the greateft fwans quill, in tafte like vnto the greene Beane, hauing at the top a certaine fcalie foftbud, which in time groweth to a branch of the height of two cubites, diuided into diucrs other finaller branches, wheron are fet many little leaues like haires, more fine than the leaues of Dill : anong which come forth fmall moffie yellowifb fowers, which yeeld foorth the fruit greene at the firft, after red as Corall, of the bignes of a fmall Peafe, wherein is conteined grofle blackifh feede exceeding hard, which is the caule that it lieth fo long in the ground after the fowing before it dofpring vp. The rootes are many, thicke, foft, and fpoongie ftrings hanging downe from one head, and fpread themfelues all about, whereby it greatly increafeth.

2 We hauc in our marrifh and lowe grounds neere vnto the fea, a Sperage of this kinde, which differeth little from that of the garden, and yet in kinde there is no difference at all, but onely in manuring: by which all things,or moft things are made more beautifull and larger. 


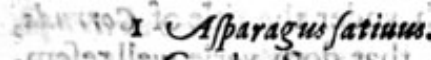

- frolozlle Garden'Sperage.

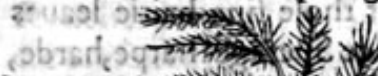

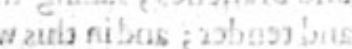
20m

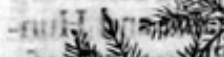

sit

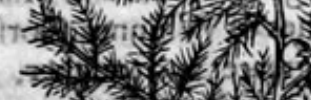

**1] ( ․

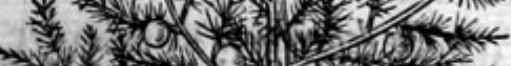

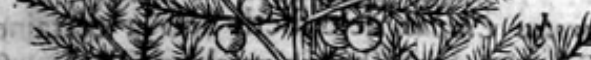

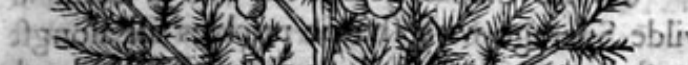

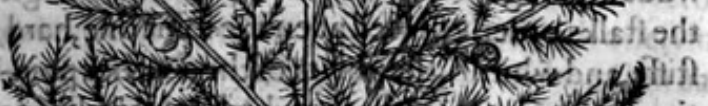
की

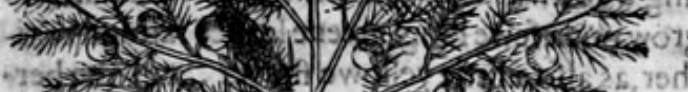
\% - MI : 210 物

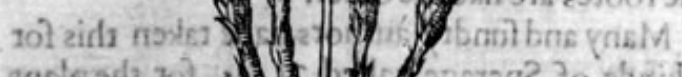

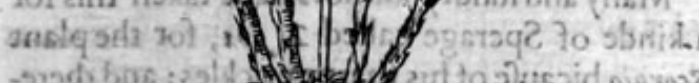

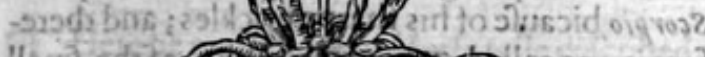

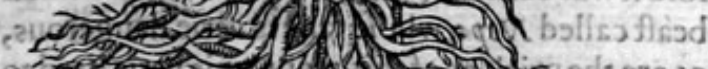
0 得 dof 3 Uparaguspetreus.

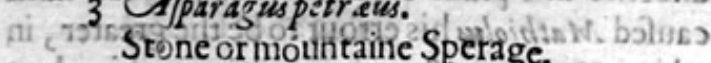

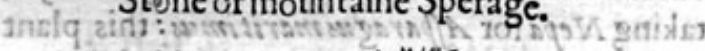

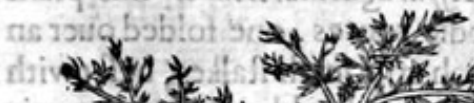

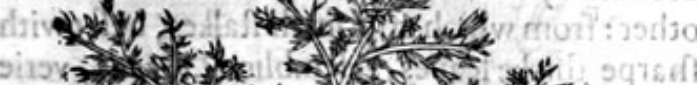

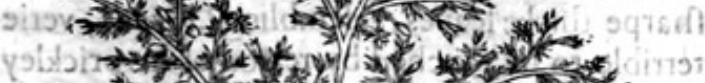

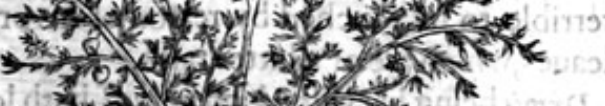

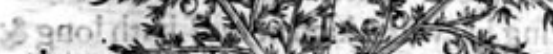
4 \%

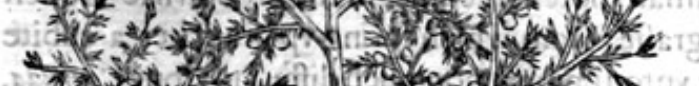

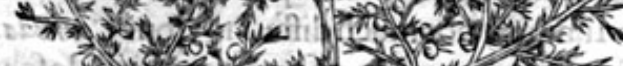

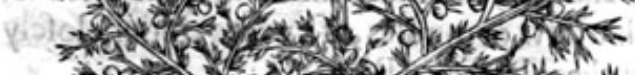
*

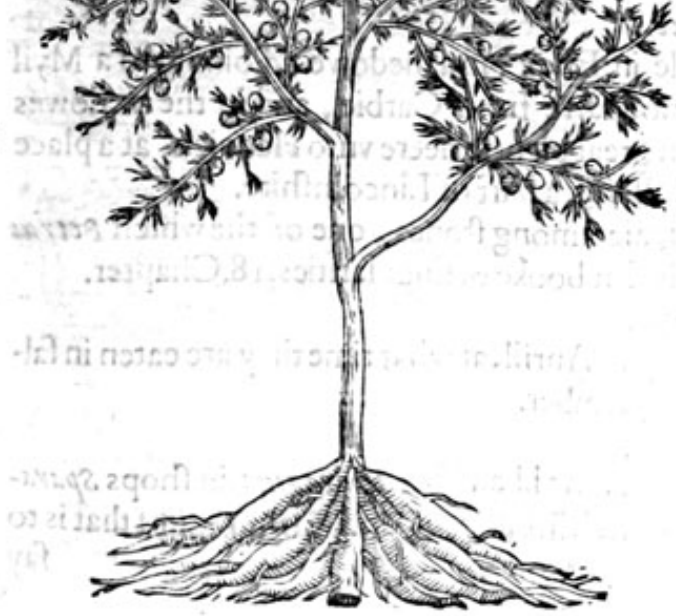

2 Aparagus pílustris. Marih Sperage.

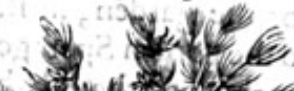

(3) in w w

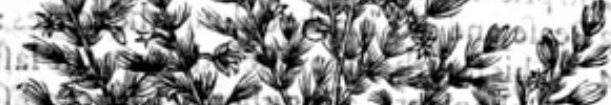

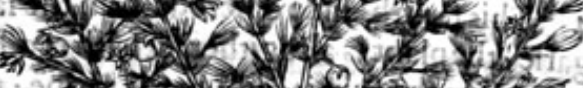
2010.

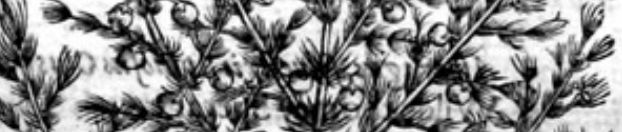

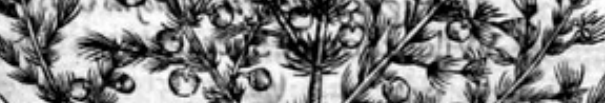
4. 10.0 .045

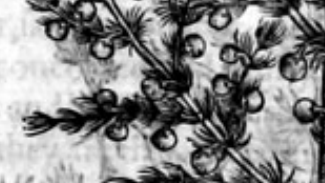
$20 y$ 1.01

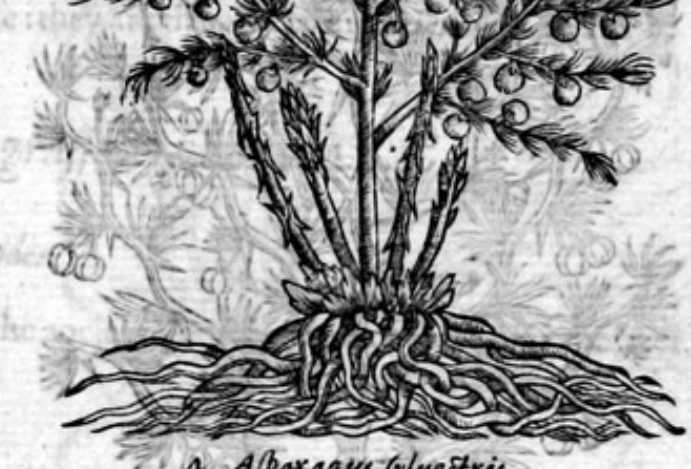
4. Afparagus jylwestris. , Wilde Sperage.

$* 1$ v , H.

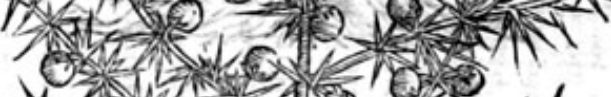
*2 * s.4.

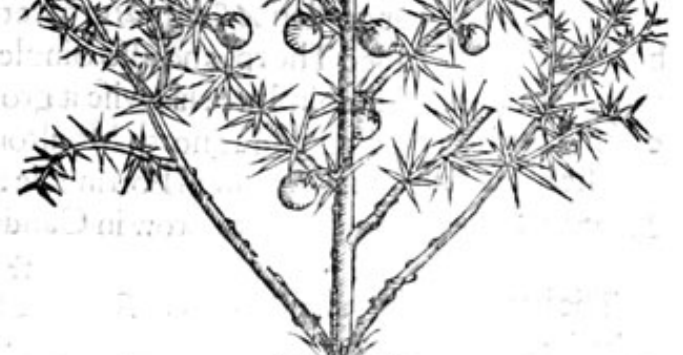


3 Stone or mountaine Sperage, is one of the wilde ones, fet foorth vnder the title of Corruda, which L'Obelcalleth 1 Paragus Petraus, and Galen Myacanthinus, that doth veric well referm. ble thofe of the garden, in ftalkes, rootes and branches, fauing that thofe fine hairie leaues which are in the garden Sperage, be foft, blunt, and tender; and in this wilde Speragefharpe, harde, and pricking thornes, though they be fmall and flender : the fruite heereof is round, of the bignes of a Peafe, and of a blacke colour: the rootes are long, thicke, fat, and very many.

4 This fourth kinde differeth from the laft defcribed, being a wilde Sperage of Spaine and Hungarie : the plant is altogither fet with moft fharpe thornes, as are she branches of Whinnes, Gorfe, or Furfen: the fruit is red when it is ripe : the rootes are like theorhers, butgreater and tougher.
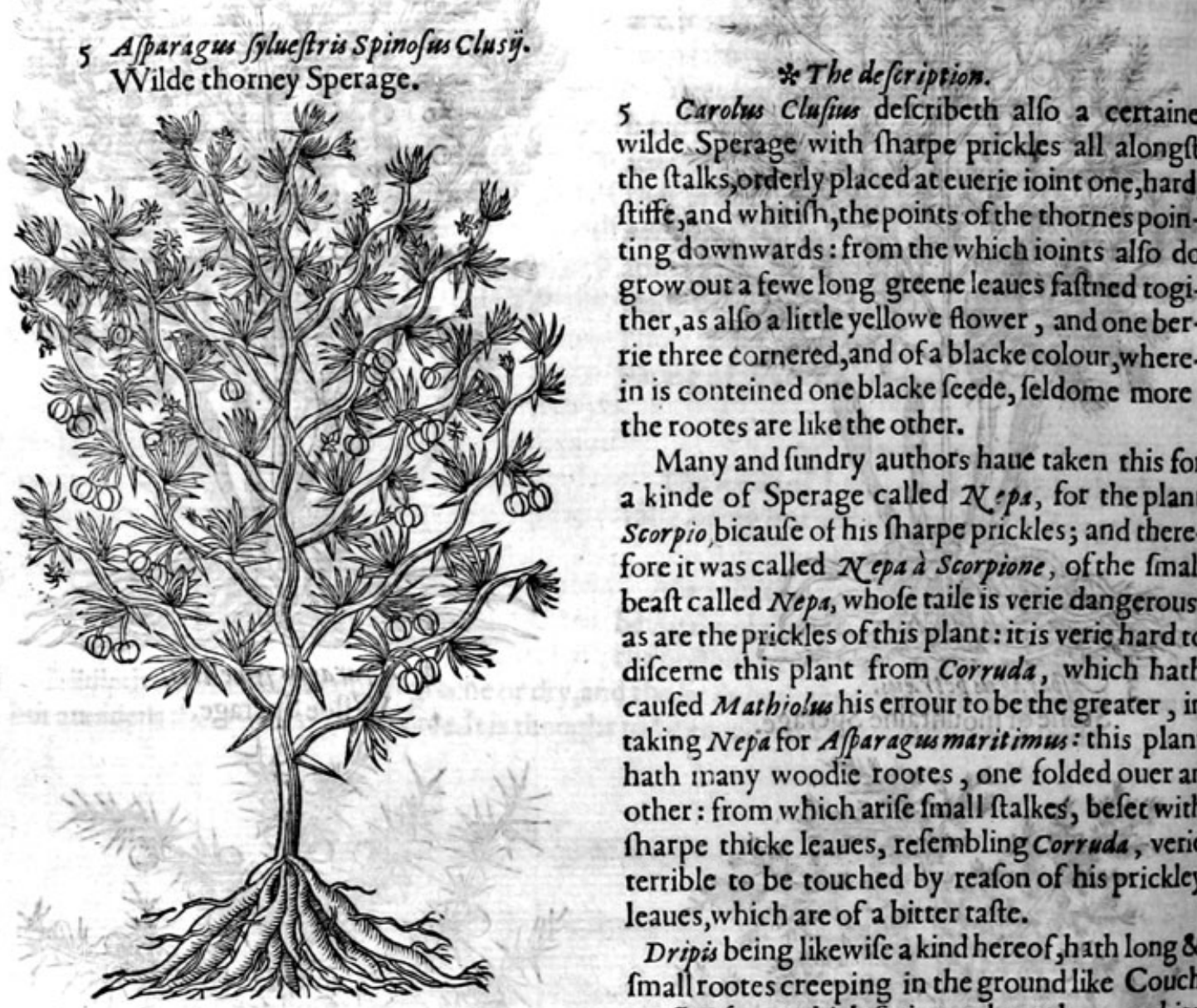

5. Caroleses Clufues defcribeth alfo a certaine wilde Sperage with tharpe prickles all alongtt the Italks, orderly placed at euerie ioint one, hard ftiffe, and whitin, the points of the thornes pointing downwards: from the which ioints alfo do grow out a fewe long greene leaues faftned togither, as alfo a little yellowe flower, and one berrie three cornered, and of a blacke colour, wherein is conteined one blacke feede, feldome more : the rootes are like the other.

Many and fundry authors haue taken this for a kinde of Sperage called $2<e p a$, for the plant Scorpio bicaufe of his fharpe prickles; and therefore it was called 2Nepa a Scorpione, of the finall beaft called Nepa, whofe taile is verie dangerous, as are the prickles of this plant: it is verie hard to difcerne this plant from Corruda, which hath caufed Matbiolsus his errour to be the greater, in taking Nepa for Aparagus maritimus : this plant hath many woodie rootes, one folded ouer an other: from which arife fmall ftalkes, befet with fharpe thicke leaues, refembling Corruda, verie terrible to be touched by reafon of his prickley leaues, which are of a bitter tafte.

Dripis being likewife a kind hereof, hath long \& fmall rootescreeping in the ground like Couch graffe: from which fpring vp branches a cubite high, full of knottie ioints : the leaties are fmall like vnto Iuniper, not much differing from Corruda, or Nepa: the flowers grow at the top of the ftalke in fpokic tufts or rundles, of a white colour, clofely chruft togither : the feede before it be taken out of the huske is like vnto Rice.

\section{* The place.}

The fift being our garden A paragus groweth wilde in Effex, in a medowe adioining to a Myll bevond a village called Thorp, and alfo Singleton, not farre from Carbie, and in themedowes neere Moulton in Lincolnfhire: likewife it groweth in great plentie neere vnto Harwich, at a place called Landamer lading, and at north Moulton in Holland, a part of Lincolnfhire.

The wilde Sperages do grow in Portingale and Bifcaie among ftones, one of the which Petrow Bellonius doth make mention to grow in Candie, in his firft booke of fingularities, 18 . Chapter.

$$
\text { * The time. }
$$

The bare naked tender fhootes of Sperage fpring vp in Aprill, at what time they are eaten infallads; they Hower in Iune and Iuly; the fruite is ripe in September.

$$
\text { * The names. }
$$

The garden Sperage is called in Greeke daróegros: in Latine likewife 1 1paragus: in fhops Spar.1. gus, and speragus: in high Dutch Spargent in low Dutchalpatogs, and Cozalctuit: that is to 
fay Herba Coralli, or Corall woort, of the red berries, which beare the colour of corall : in Spanith Aparragos:in Iralian Afparago: in Englith Sperage, \& likewife Afparagus after the Latine name: in

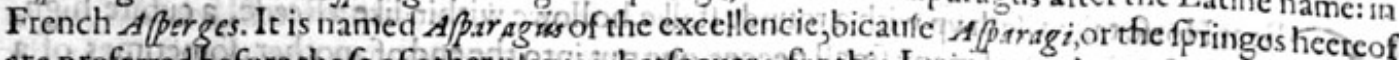
ate preferred before thofe of other plants whatfoever: for this Latine word Ajparages doth properly fignifie the firft fpring or prout of euery plant? efpecially whenit is tender, and before it do grow into an harde ftalke, as are the bilds, tendrels, or yoong furingsof wilde Vine, or Hóppes and tuch like. 2Wilde Sperage is properly called in Greeke avidyatd, which is as mich to fay as Moufe prickle? and aimaecos maseios, that is to fay, Petresus 1 paragus, or Stone Sperage: it is alfo named in Lative

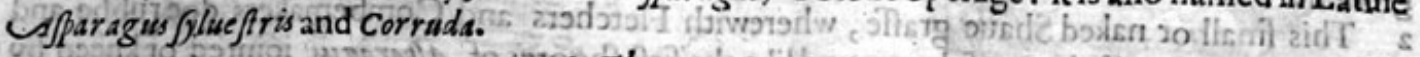
Y The rootes of the garden Sperage, and alfo of the wilde do ctenfe withont innenifelt heat amot drineffe.

The firft fprouts or naked tender hootes heerof be oftentimes fodden in flefh broth and eaten, A or boiled in faire water, and feafoned with oile, vineger, falt, and pepper, then are ferued at mens tables for a fallade; theyarepleafant to the taften eafily concocted, and gently loofen the belly

They fomwhat prouoke vrine, good for the kidneies and bladder, biut they yeeld vinto the bodie B little nourifhment, and the fame moift,yet not faultie : they are thought to increafe feede, and iftitre vpluft.

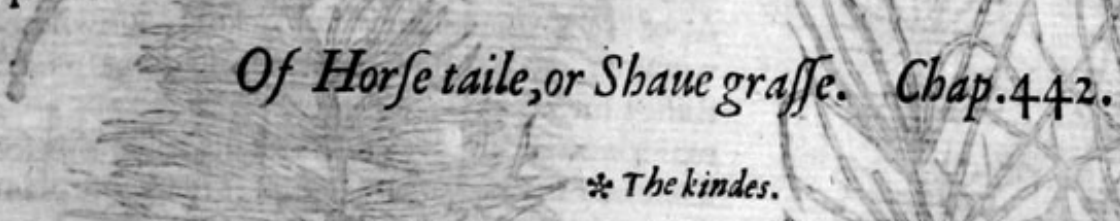
Here be two kindes off lorfe raile delcribed of the ancients, one great, the other little: thelater
age hath found more.

1 Equifetum mains. Great Horfe taile.

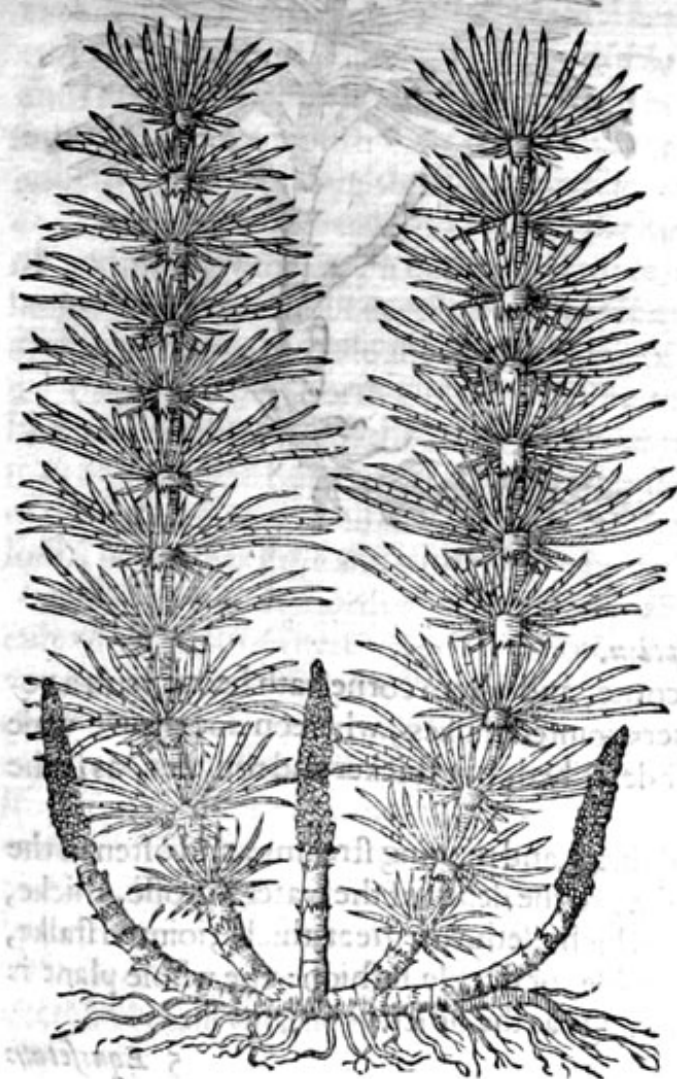

2 Equifetwm nudum. Naked Horfe taile.

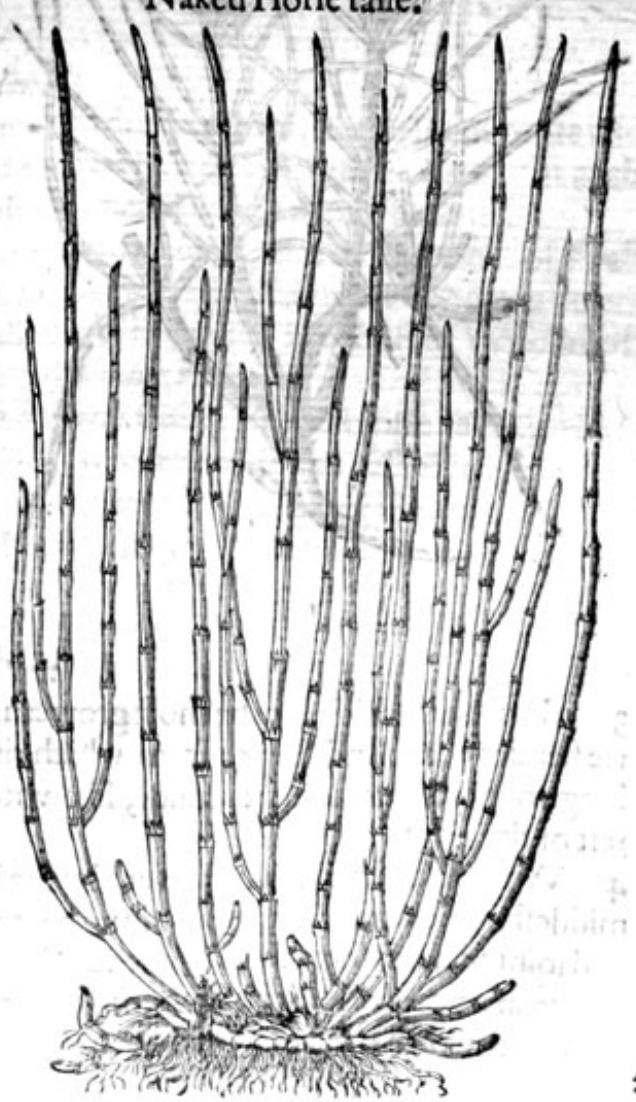

20 The 
* The defcription,

I Reat Horfe taile, rifeth vp with a rounde ftalke, hollowe within like a Reede, a cubite high,

compactas it were of many fmall peeces, one put into the endof another, fometimes of a reddifh colour, very rough, and fet at euery ioint with many ftuffe rufhlike leaues, or rough briftes, which maketh the whole plant to refemble the taile of a Horfe, whercofit tooke his name: on the top of the ftalke do ftand in fteed of flowers cluftered and thick Catkins, not vnlike vnto the fifft fhootes of Sperage, which is called Myatantba: the roote is iointed and creepeth in the grounde.

2 This fmall or naked Shaue graffe, wherewith Fletchers and Combemakers doe rubbe and polifh their worke, rifeth out of the ground like the firft fhootes of $A$ fparagus, iointed or kneed by certaine diftances like the precedent, but altogicher without fuch briftley leaues, yet exceeding rough and cutting: the roote groweth aflope in the earth like thofe of the Couch graffe.

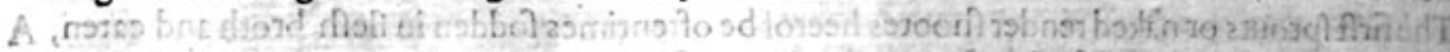

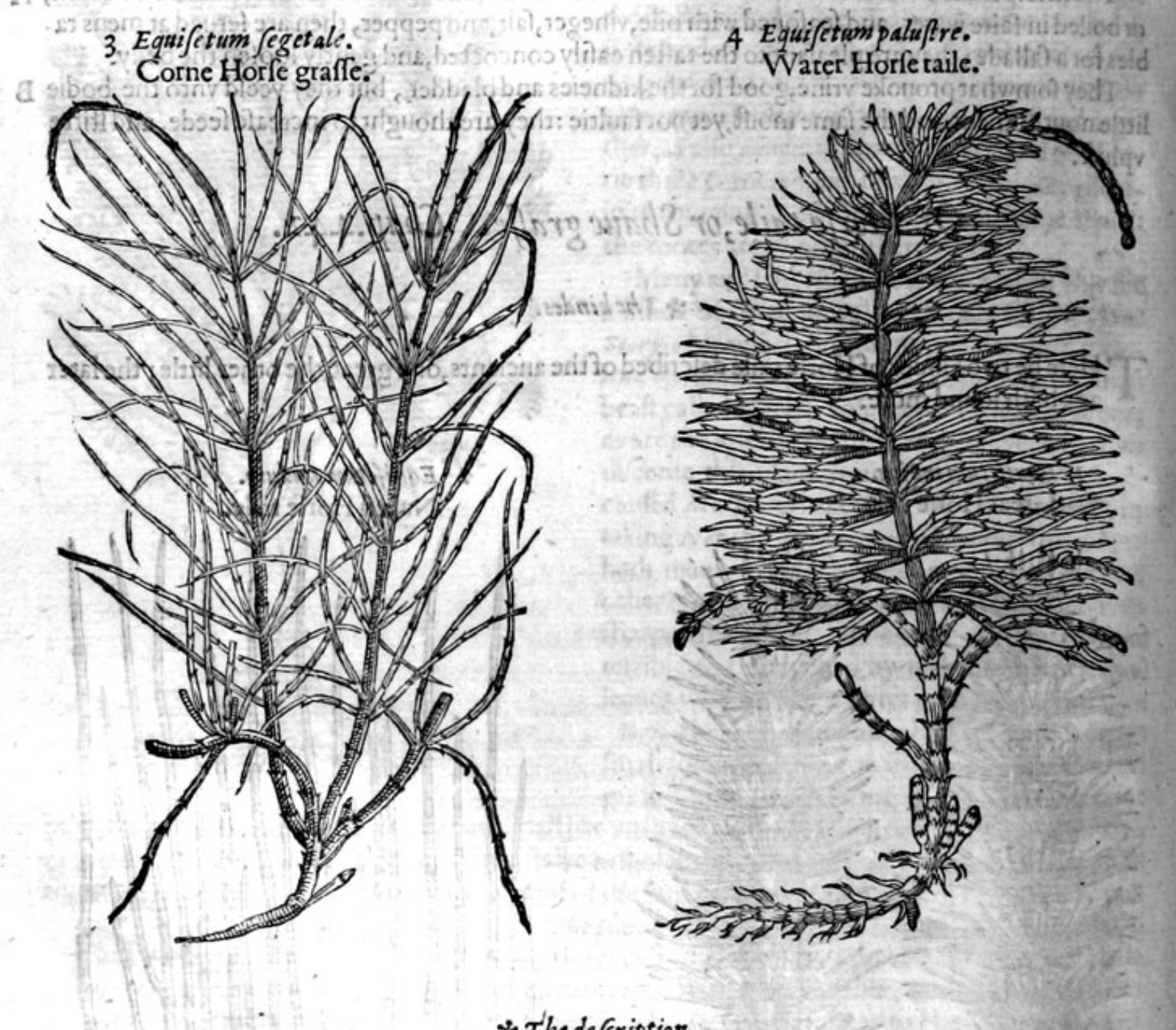

* The defcription.

3 Horfe taile which for the moft groweth among corne, and where corne hath beene, hath a verie flender roote and fingle: from which rife vp diuers iointed ftalkes, whereon doe growe verie long,rough, narrow iointed leaues, like vnto the firft defcribed, but thicker and rougher, as is the reft of the plant.

4 Watcr Horfe taile that groweth by the brinkes of riters, and running ftreams, and often in the middeft of the water, hath a very long roote, according to the depth of the water, groffe, thicke, and iointed, with fome threds annexed thercto: from which rifeth vp a great, thicke, iointed ftalke, whereon do growelong, rough, rufhic leaues, pyramides or fteeple fafhion: the whole plant is likewife rough, hard, and fit to thaue and rub wooden things as the other. 

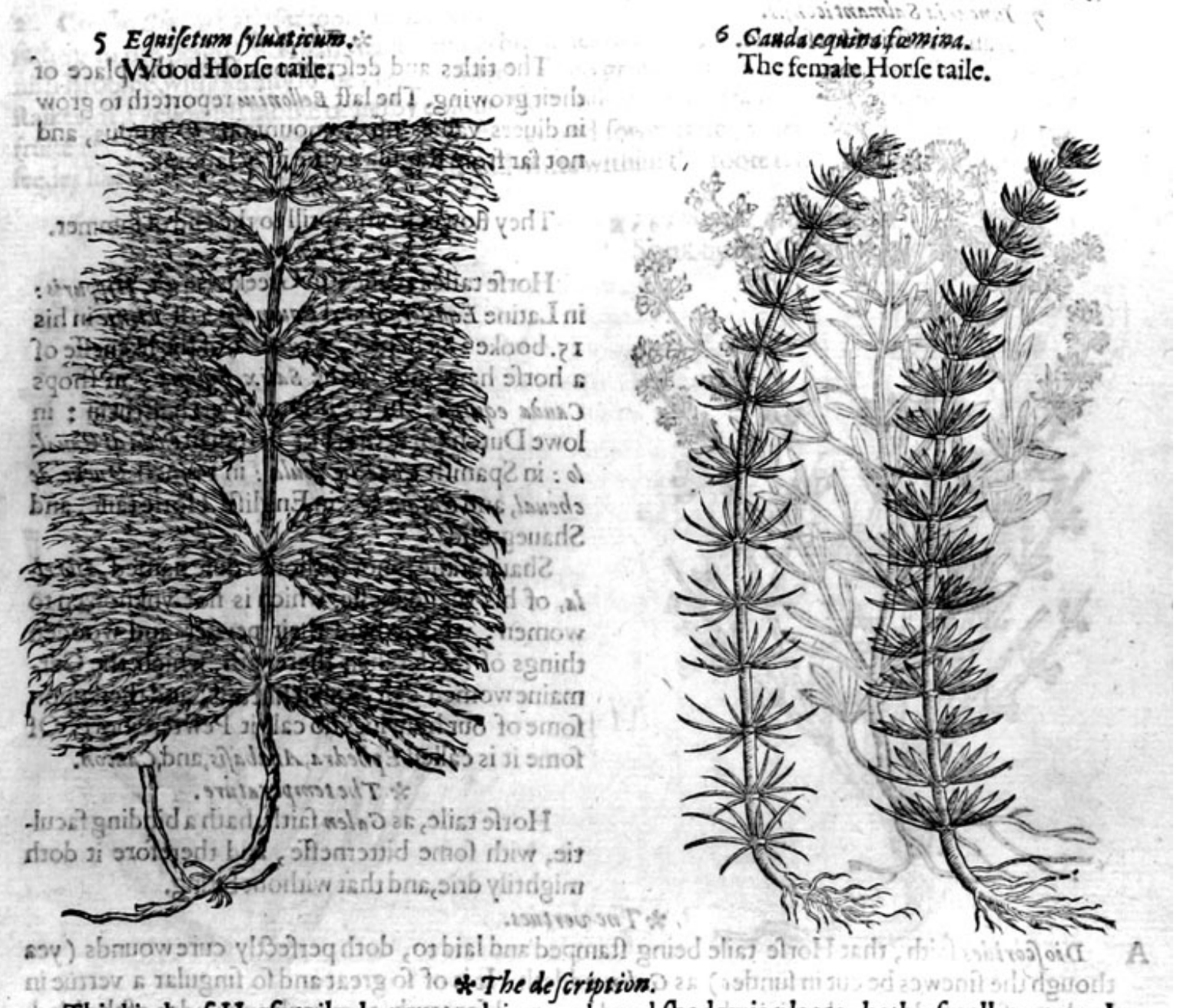

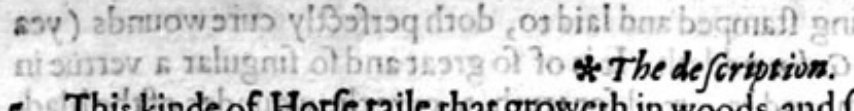

5 This kinde of Horfe taile that groweth in woods and fhadowie places, hath a fmall roote and fingle : from which rifech vp a rough chamfered ftalke iointed by certaine fpaces, hauing at each ioint two bufhes of roughbriftley leaties, fet one againft another like the other of his kind. 6. The female Horfe taile groweth for the moft part in waterifh places, and by the brinks of fmall rils and pirling brookes, it hath a long roote like that of Couch graffe; fromwhich rife vp diuers hollow ftalkess, fet abour arcertaine diftances, with fmall teaues in rundles like thofe of Woodroof, al togither barten of feede and flower, whereof it was called Semine vidua.

7 Clufus hath fet foorth a plant, that he referreth vnto the ftocke of the Horfe tailes which he thus defcribeth: It hath niany twiggie or rufhie fțalkes, whereupon it was called Iuncaria, and may be englifhed Ru?h weede. The leaues growe vponche branches like thofe of Flaxe; on the tops of the ftalkes growe finall chaffie flowers of a whitifh colour. The lecede is finall and blacke of colour. The roote is little and white. The whole plant is fweetifh in tafte.

Dodonems fetteth foorth another Horfe taile, which he colled Climing Horfe taile, or Horfe taile of Olyınpus. There is, ,aitli he, another plant like Horle taile, but greater and higher. It rifeth vp oftentimes with a ftalke as big as a mans arme, diuided into diuers branches; out of which there grow longflender fprigs very full of ioints, like to the firft Horfe taile. The flowers ftand about the iointes of a moffie fubitance, fmall as are thofe of the Cornell tree, in places where of growe vored fruite full of fower ruice, not vnlike to litele Mulberies, in which is the feede. The roote is hard and woodie. This groweth now and then to a grear height, and fometimes lower. Bellonius writeth in his Singularities, that it hath beene feene to be equall in height with the Plane tree :it commeth vp lower, neere to fhorter and leffer trees or hrubs, yet doth it not faften it felfe to the trees with any teindrels or clafping aglets;-much leffe doth it winde it felfe about them, yet doth it delight to ftand neere and clofe vnto them. 
7 Yuncarit Salmanticen/is.

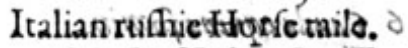

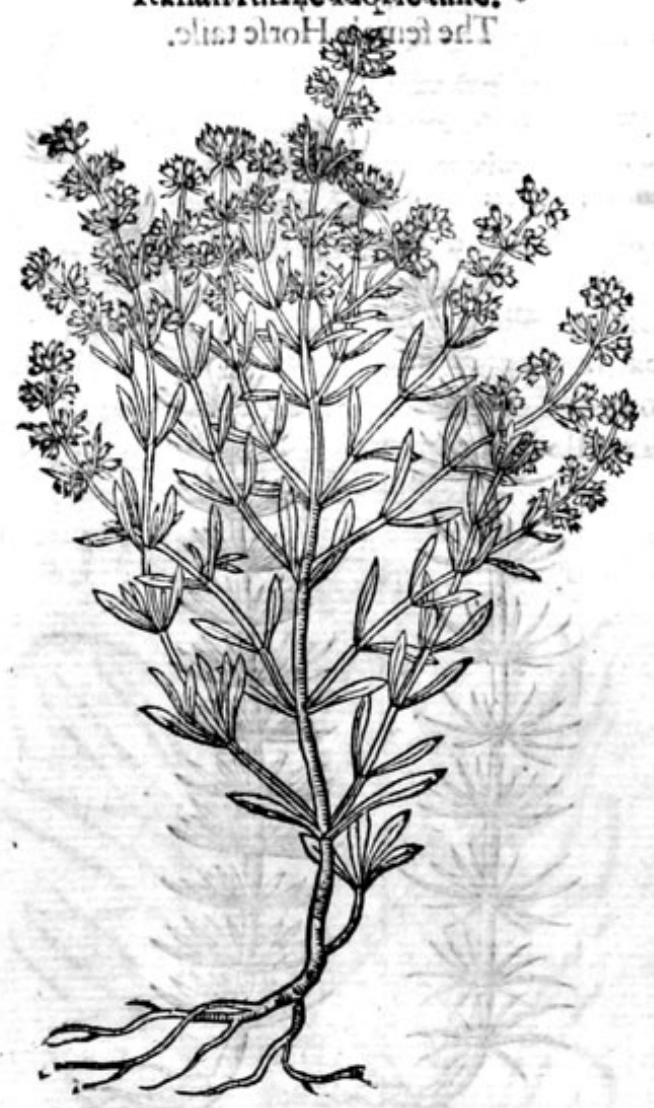

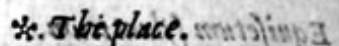

The titles and defcriptions abeivetie.place of their growing. The laft Bellonins reporteth to grow in diuers valties of themountaine Olympus, and not far fronrRagufa a cirie in Sclauonia.

$$
\text { * The time. }
$$

They flower from A prill to the end of fommer. $\rightarrow 7$ benames.

Horfe taile is called in Greeke inrreis, Hipparis: in Latine Equifetum and Equanalis : of Plinie in his 15. booke 28. chapter, Equz/etis, of the likeneffe of a horfe haire : of fome Salix Equina : in fhops Cauda equina : in high Dutch sebbafftbem: in lowe Duțch 1 peertffeett : in Italian Coda di Caual$10:$ in Spanifh code de soula : in French Queve de chewal, andCa-queue: in Englifh Horfe taile, and Shauegrafic.

Shauegrafie is not without caufenamed $A \beta$ rel. $l a$, of his ruggedneffe, which is not vnknowen to women, who fcowre their pewter and wooden things of the kitchen therewith, which the Germaine women call ftannenttraut, and thereupon fome of our hufiviues do call it Pewterwoort. Of fome it is called Ephedra, Amabafis, and Cascon. * Thetemperature.

Horfe taile, as Galen faith, hath a binding facultie, with fome bitterneffe, and therefore it doth mightily dric, and that without biting.

\section{*T The vertues.}

A Diofcorides faith, that Horfe taile being ftamped and laid to, doth perfeetly curewounds (yea though the finewes be cut in funder) as Galin addeth. It. is of fo great and fo fingular a vertue in healing of woundes, as that it is thoughtandicporced for truth, to cuirectio woundes of the blad

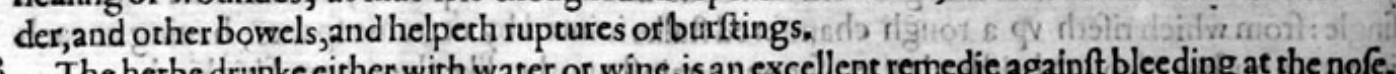

B The herbe drunke either with water or wine, is av excellent remedie againft bleeding at the nofe, and other Aluxes of blood. It ftaicth the ouernuch flowing of womens flowers, the bloodie flixe, and the other fluxes of the belly.

C The iuice of the herbe taken in the fame imanner can do the like, and more effectually.

D Horfe taile with his rootes boiled in wine, is very profitable for the vlcers of the kidneies and bladder, the cough, and difficultic of breathing.

$$
\text { Of Seaclufter, or SeaRaifon. Chap.443. }
$$

* Thedefcription.

$\mathbf{r}$

$S^{-1}$ Ea Grape is not vnlike to Horfe taile, but it is leffer and lower:it bringeth foorth little ftalks, flender, fmall, and round, almoft like rufhes, fet with very many little ioints, fuch as thofe are of the Horfetaile,and diuided into many wings and branches 3 the tops whereof are fharpe pointed, fomewhat hard and pricking: it is without leaues : the fowers growe in clufters out of the ioints with little Items, they are fmall and of a whitih green colour: the fruite confifteth of manie little pear les, like to the vnripe berrie of Rafpis, or Hindberry; when it is ripe it is red with a faffron colour, in tafte fweete and pleafant: the feede or kernell is hard, threefquare, fharpe on euerie fide, in tafte binding : the roote is iointed, long, and creepeth aflope: the plant it felfe alfo doth rather lic on the ground then ftande vp: it groweth all full of finall ftalkes and branches, cafting themfelues all abroad. 2 Carolies 
2 Carolus Clu fius hathier foorchianother fort of fea Grape, far different from the precedent; it rifeth vp to the heightofaman, hasing many branches of a woodieffubit arice, in forme like to Spanifh Broome, withotitany leaues at all : whereupon do grow clufters of flowers vpon flender footeftalkes, of a yellowith mofile or herby colour, like thofe of the Cornell tree : after which come the fruite like vnto the mulberie, of a reddifh colour and fower tafte, wherein lieth hid one or two feedes like thofe of Millet, blacke without and white within: the roote is hard, tough, and woodie.

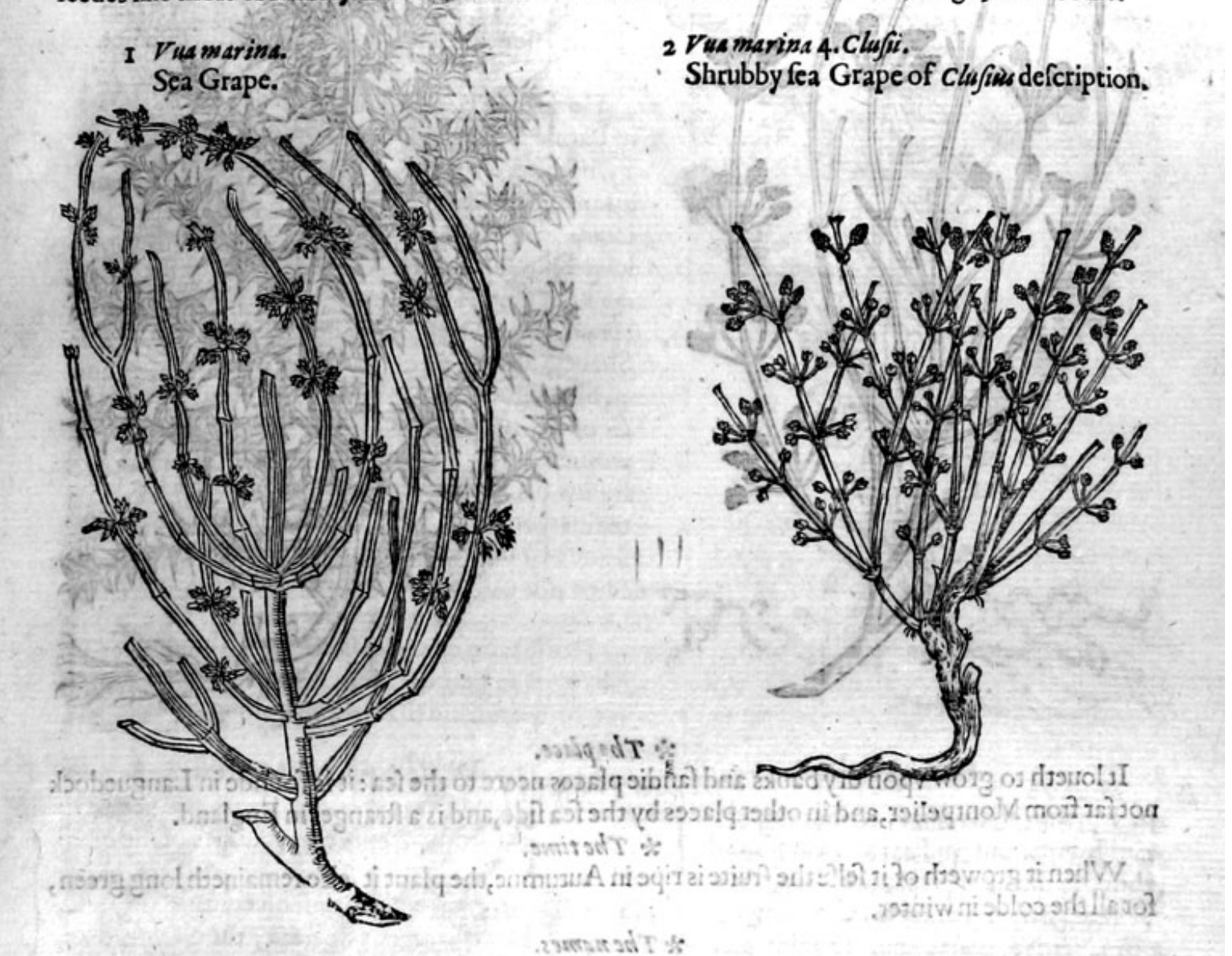

This kinde of fea Grape differeth not from the laft defcribed in any one point, fauing that it is altogither leffer, wherein efpecially confifteth the difference.

4 Tragon Matbioli, or rather Tragos improbus Mathioli, which he vnaduifedly called Tragon, is without controuerfie nothing elfebut a kinde of $\mathrm{Kali}$, or a kinde of Crithmim alterum, or eomming neere to the plant called Pastinaca marina, or Secacul: this plant rifeth vp out of the groundewith ftalkes a cubite high, diuided into fundry other groffe, thicke, and writhen branches, fer, or armed with many pricking leaues, of the colour and fhape of Aizoon, and fomewhat thicke and flefhie: among which come foorth fuch prickley burs, as are to be feene in Tribulo terreftri, as that it is harde for a man to touch any part thereof, without pricking of the handes: the flowers are of an herbie colour, bringing foorch flat feede like vnto $K a l t$ : the roote is flender, and fpreadeth vnder the turfe of the earth : the whole plant is full of clammie iuice, not any thing aftringent, but fomewhat faltih,and of no fingular vertue that is yet knowne : wherefore I may conclude, that this cannot be Tragos Diofcoridis, and the rather for that this Tragon of Mathiolus, is an herbe and not a fhrub, as I haue before fpoken in Vua marina, ncither beareth it any berries or graines like Wheate, ncither is it pleafant in tafte and fmell, or any thing aftringent, all which are to be founde in the righte Tragos before expreffed, which (as Diofcorides faith)is without leaues, neither is it thorney as $3 \mathrm{ra}$ gus improtus Mathioli : this plant I haue found growing in the Ile of Shepey, in the tract leading to the houfe of Sir Edward Hobbie, called Sherland. 
3 Vuamarinaminor.

Small ihrubbie fea Grape.
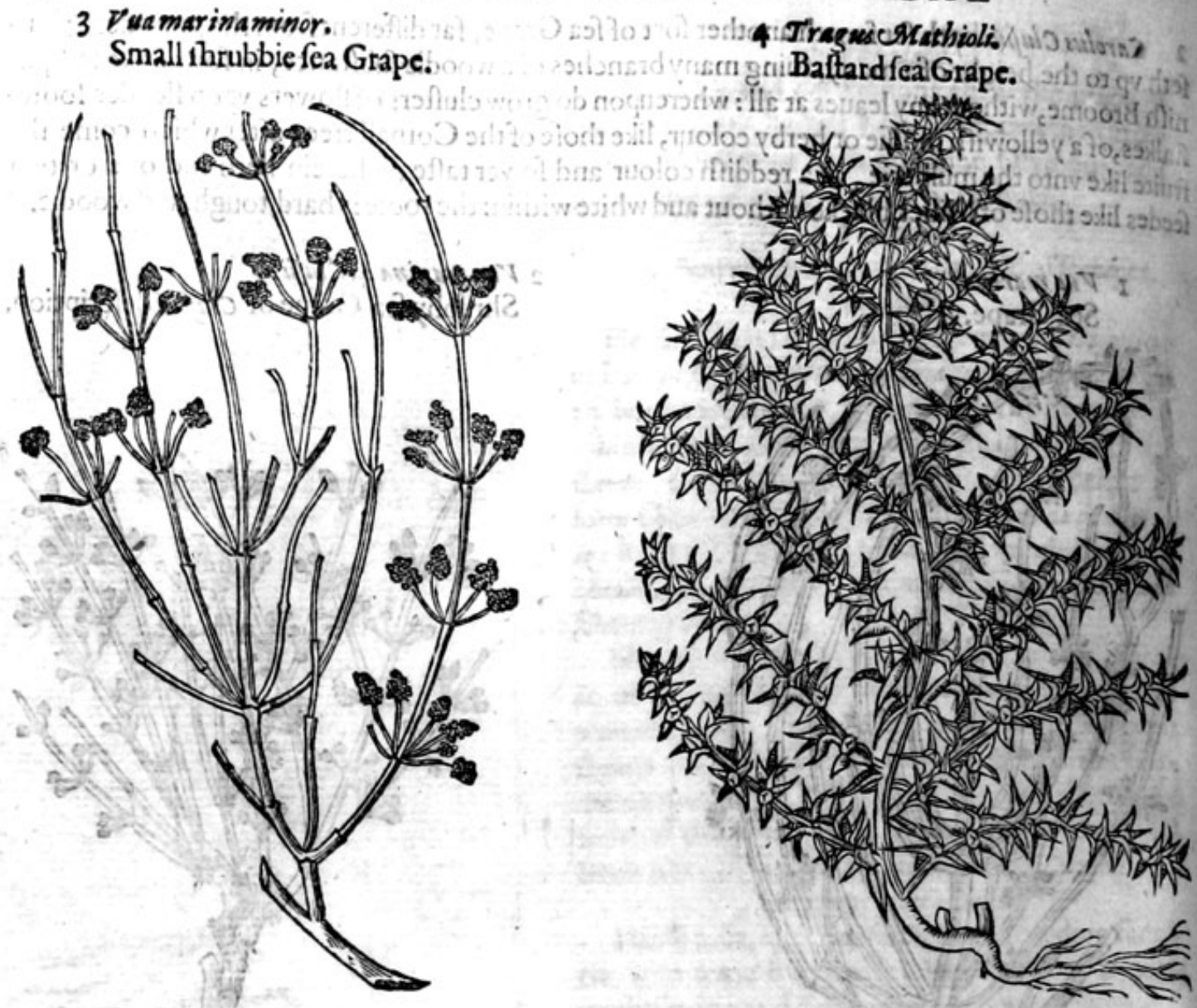

* The place.

It loueth to grow vpon dry banks and fandie places neere to the fea : it is founde in Languedock not far from Montpelier, and in other places by the fea fide, and is a ftranger in England. * The time.

When it groweth of it felfe the fruite is ripe in Autumne, the plant it felfe remaineth long green, for all the colde in winter.

\section{$*$ The names.}

It is called of the later Herbarifts Vua marima: in French Raifin de Mer, of the pearled fruite, and the likenes that it hath with Rafpis berrie, which is as it were a Raifon or Grape, confifting of many little ones: it is named in Greeke reses, but it is not called Tragus, or Traganos, of a Goate, (for fo fignifieth the Greeke word)or of his ranke and rammifh fmell, but bicaufe ittringeth foorth fruite fit to be eaten, of the verbe $\tau$ pess which fignifieth to eate : itmay becalled Scorpion, bicaufo the fprigs thereof are tharpe pointed like to the Scorpions taile.

* The temperature.

The berries or raifons, and efpecially the feede that is in them haue a binding qualitie, as we haue faide, and they are drie in the later end of the fecond degree.

$*$ The vertues.

A Diofcorides writeth, that the Raifons of fea Grape do ftaie the flixe, and alfo the whites in women,when they much abound.

\section{Of Madder. Chap. 444 . \\ $*$ The kinies.}

Here is but one kinde of Madder onely: but if all thofe that are like vnto it in leaues and manet

of growing were referred thereto, there Phoulde be many forts : as Goofe grafie, foft Cliuer, our Ladies Bedftraw, Woodroofe, and Croffewoort, all which are like to Madder in leaues, and therefore they be thought to be wilde kinds thereof. 
HISTORIE OF PLANTS.

1 Rubia tinctorum. Red Madder.

2 Rubiafylueftris. Wilde Madder.

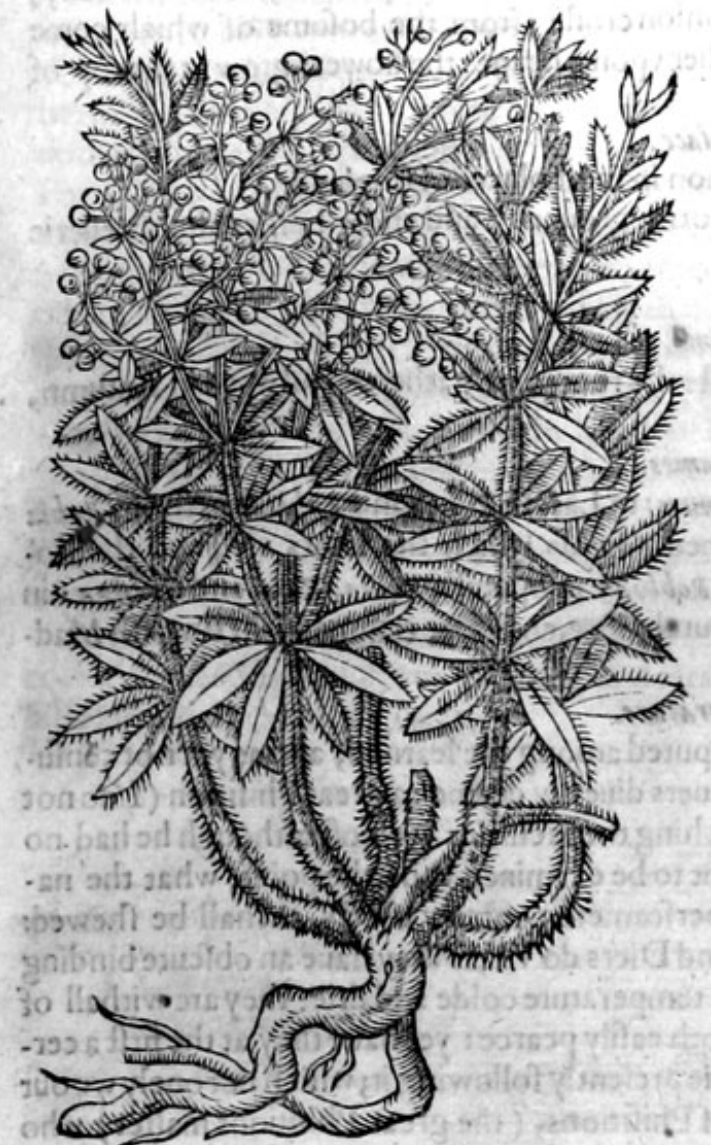

3 Rubiamarina. SeaMadder.

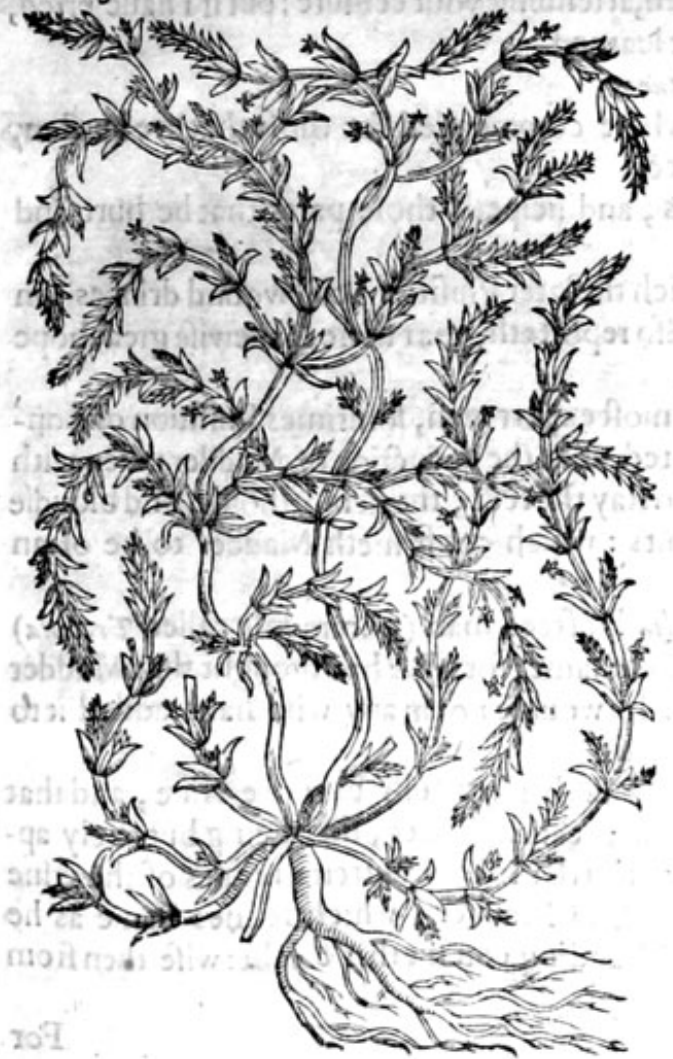

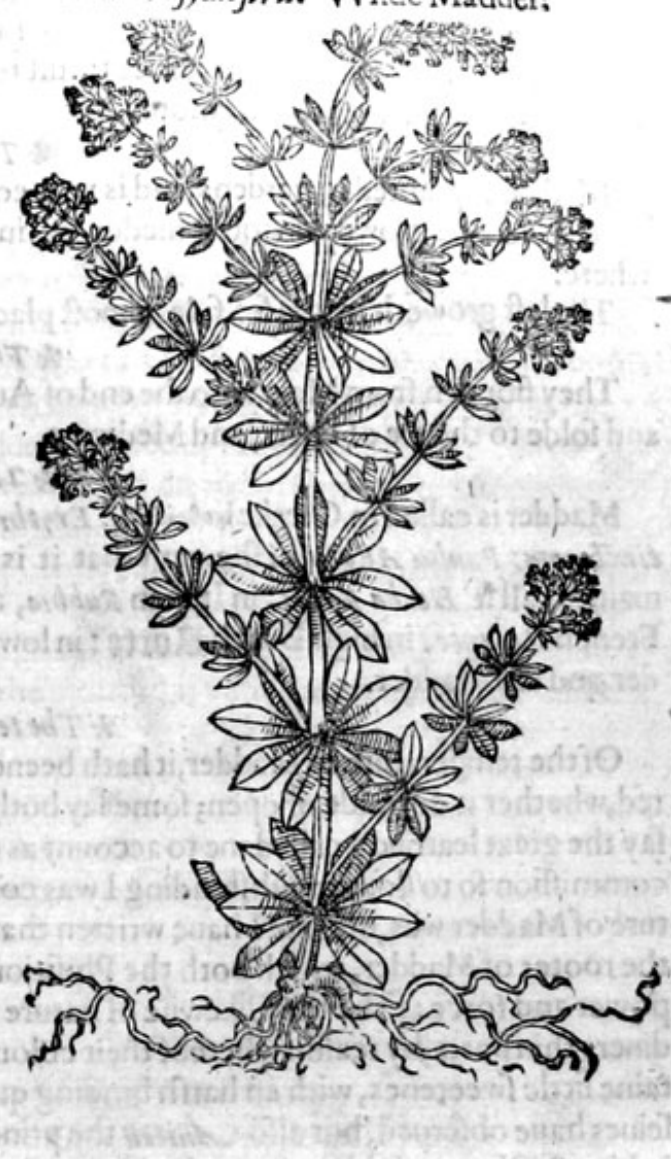

* The defoription.

I $T$ He garden or manured Madder, hath long ftalkes or trailing branches difperfed farre abroade vppon the grounde, fquare, rough, and full of ioints, at enery ioint fer rounde with greene rough leaues, in maner of a ftarre, or as thofe of Woodroofe: the flowers growe at the top of the branches; of a faint yellowe colour:after which come the feede, rounde, greene at the firf $;$ aftetwarde red, and laftly of $\mathbf{a}$ blacke colour : the roote long, fat, full of fubftance, creépeth farre abroade withinthe vpper cruft of the earth, and is of a reddifh colour, when it is greene and frefh.

2 Wilde Madder is like informe vnto that of the garden, but altogither fmaller, ard not fo rough: the flowers are white: the roote is verie finall and tender, and oftentimes of a reddifh co. lour.

3 Sea Madder hatl: a roote two foote long, with many dry threds hanging thereat, of a reddith colour like Alkanet, on the outfide of the fume forme and bigoes, but within it of the colour of the fcrapings of imper, or Cedar wood, fending foorth diue rs flender $\mathrm{A}$ thes rounde and $\mathrm{PP}_{\mathrm{P}} \mathrm{I}$ 


\section{THE SECOND BOOKE OF THE}

full of ioints: from which come foorth fmall thin leaues, ftiffe and fharpe pointed, fomewhat hairy in number commonly fower, ftanding like a Burgonion crofle ; from the bofome of which come foorth certaine tufts of fmaller leaues thruft togither vpon a heape : the flowers grow at the top of
the italkes of a pale yellowifh colour.

$$
\text { * Theplace. }
$$

Madder is planted in gardens, and is very common in moft places of England. where.

The feconde groweth in moift medowes, in moorifh grounds, and vnder bufhes almoft euerie

The laft groweth by the fea fide in moft places.

$$
\text { * The time. }
$$

They flourith from Maie vnto the end of Auguft : the rootes are gathered and dried in Autumn, and folde to the vfe of Diers, and Medicine.

* 7 he names.

Madder is called in Greeke ípuleásxyov, Erythrodanum : in Latine Rubia, and Rubeia : in fhops Rubia tinctorum: Paulus AEgineta heweth that it is named Thapfon which the Diers vfe, and the Ro: maines call it Fierba Rubia : in Italian Rubbia, and Robbia : in Spanifh Ruuia, Roya, and Granza : in French Garance : in high Dutch Rotte : in lowe Duteh $98 R$, and \$ॄe ctappen: in Eng lifh Madder, and red Madder.

\section{* The temperature.}

Of the temperature of Madder, it hath beene difputed among the learned, and as yet not cenfired, whe ther it do b:inde or open; fome fay both, diuers diuerly deeme : a great Phifition (I do not fay the great learned) called me to account as touching the faculties heereof, although he had no commiffion fo to do, notwithftanding I was content to be examined vpon the point, what the nature of Madder was, bicaufe I haue written that it performeth contrary effects, as Shall be thewed: the rootes of Madder, which both the Phifitions and Diers do vfe, as they hate an obfcure binding power and force; fo be they likewife of nature and temperature colde and drie: they are withall of diuers thin parts, by reafon whereof their colour doth eafily pearce: yer haue they at the firft a certaine little fweetenes, with an harh binding qualitie prefently following it; which not onely we our felues haue obferued, but alfo Auicen the prince of Phifitions, (the great Phifitions mafter) who in his 58. Chapter hath written, that the roote of Madder hath a rough and harfh tafte: nowe mafter Doctor, whether it binde or open I haue anfwered, attending your cenfure : but if I haue erred, it is with the multitude, and thofe of the beft, and beft learned.

\section{* The vertues.}

A The decoction of the rootes of Madder is euery where commended for thofe that are burften, brufed, wounded, and that haue fallen from high places.

B It ftancheth bleeding, mitigateth inflammations, and helpeth thofe parts that be hurt and brufed.

C For thefe caufes they be mixed with potions, which the later Phifitions call wound drinkes : in which there is fuch force and vertue, as Matbiolus alfo reporteth, that there is likewife greathope of curing of deadly wounds in the cheft and intrails.

D Our opinion and iudgement is confirmed by that moft expert man, fomtimes Phifition of London Iohannes Spiringus, who in his Rapfodes hath noted, that the decoction of Madder giuen with Triphera, that great compofition is fingular good to ftay thereds, the hemorrhoides and bloudie flixe, and the fame approoued by diuers experiments : which confirmeth Madder to be of an aftringent and binding qualitie.

E Of the fame opinion as it feemeth is alfo Eros Iulia hir freed man (commonly called Trotala) who in a compofition againft vntimely birth doth vfe the fame : for if he had thought that Madder were of fuch a qualitic as Diofcorides writeth it to be of, he woulde not in any wife haue added it to thofe medicines which are good againft an vntimely birth.

F For Diofcorides reporteth, that the roote of Madder doth plentifully provole vrine, and that groffe and thicke, and of tentimes bloud alfo, and it is fo great an opener, that being but onely applied, it bringeth downe the menfes, the birth, and afterbirth: but the extreme rednes of the vrine deceiued him, that immediately followeth the taking of Madder, which recines came as he thought, from bloud mixed therewith, which notwithftanding conmeth no other wife then from the colour of the Madder. 
HISTORIE OF PLANTS.

$\mathrm{SO}_{3}$

For the roote hereof taken any maner of way doth by \& by make the vrine extreme red: no other- $G$ wife then Rubarb doth make the fame yellow, not changing in the mean time the fubftance therof, nor making it thicker then it was before, which is to be vnderftoode in thofe which are in perfeet health, which thing doth rather rhew that it doth not open, but binde, no otherwife then Rubarbe doth; for by reafon of his binding qualitic the waterifh humours do for a while keepe their colour. For colours inixed with binding things do longer remain in the things colored, and do not fo foon vade : this thing they well knowe that gather colours out of the iuices of flowets and herbes, for with them they mixe allume, to the end that the colour may be retained and kept the longer, which otherwife woulde be quickly loft. By thefe things it manifeftly appeereth that Madder doth nothing vehemently cither clenfe or open, and that Diofcortds hath rafhly attributed vnto it this kinde of qualitie, and after him Galen and the reft that followed, ftanding ftiffely to his opinion.

plinie faith, that the ftalkes with the leaues of Madder, are vied againft ferpents. $\quad \mathrm{H}$

The roote of Madder boiled in Meade or honied water, and drunken, openeth the ftoppings of $\mathrm{I}$ the liuer, the milt and kidneies, and is good againft the iaundife.

The fame taken in like manerprouoketh vrine vehemently, infomuch that the often vfe thereof $\mathrm{K}$ caufeth one to piffe bloud, as iome haue dreamed.

Langius and other excellent Phifitions haue experimented the fame to amende the lothfome $\mathrm{L}$ colour of the Kings euill, and helpeth the vlcers of the mouth; if vats the decoction be added a little allume and honie of Rofes.

\section{Of Gooe graffe, or Clywers. Chap.445.}

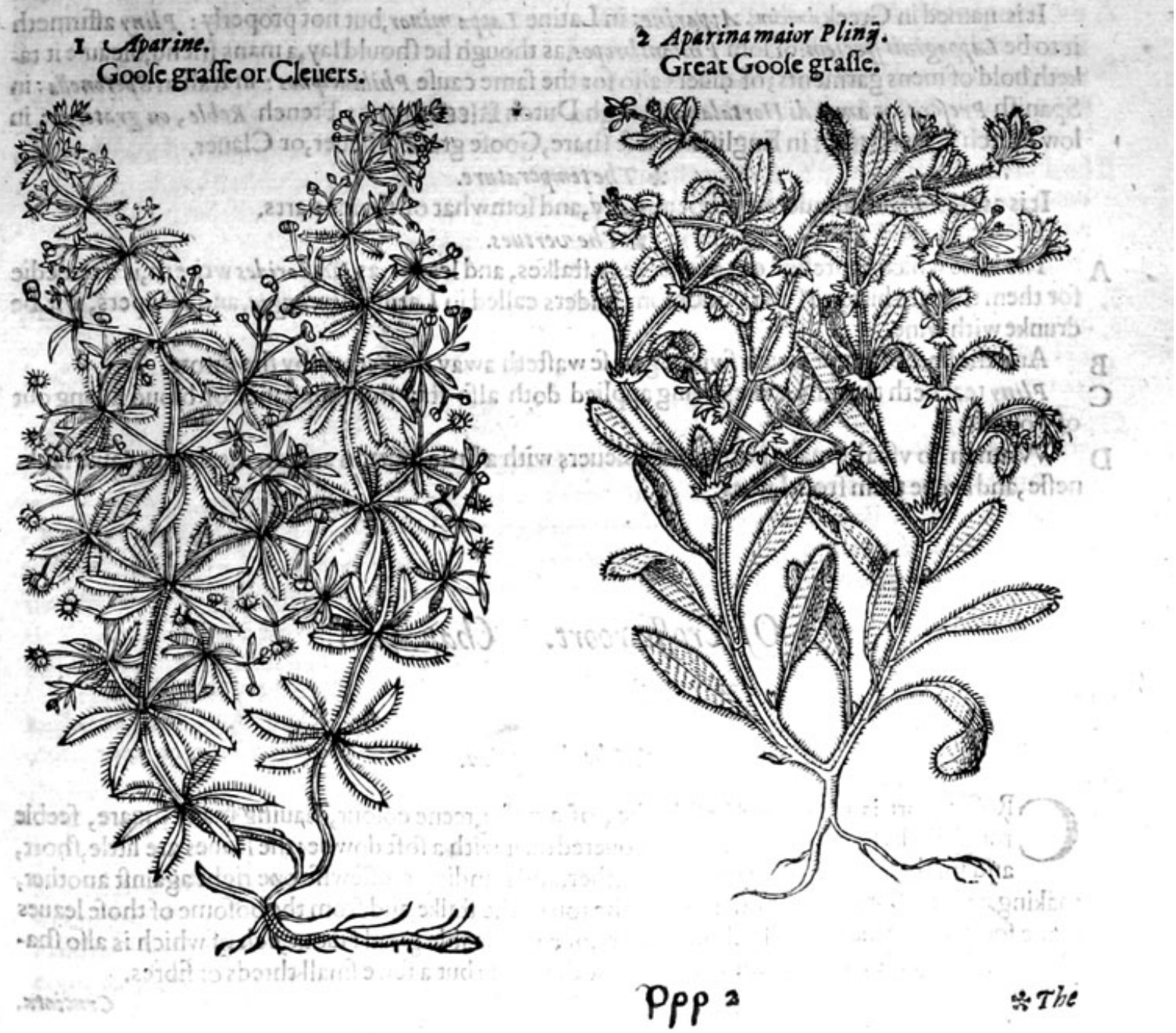




\author{
* Thedefcription.
}

I Parine, Cliuers or Goofe grafte, hath many fmall fquare branches, rough and fharpe,full - of ioints, befet at euery iont with fmall leaues ftarre fafhion, and like vnto fmall Madder: the flowers are very little and white, pearking on the tops of the fprigs: the feedes are finall,rounde, a little hollow in the midft in maner of a nauell, fet for the moft part by couples : the rootes flender and full of ftrings : the wholc plant is rough, and his ruggednes taketh holde of mens veftures and woollen garments as they paffe by: being drawne along the toong it fetcheth bloud: Diofcorides reporteth, that the Phepheards in fteede of a Cullander do vfe it to take haires out of milke, if any remaine therein.

2 The great Goofe graffe of Plinie, is one of the Moone woorts of $L^{\prime} O$ Obelisu, it hath a very rough tender ftalke, whereupon are fet broade leaues fomewhat long, like thofe of Scorpion graffe, or Alyffon Galent, Galens Moonewoort, very rough and hairy: the flowers growe at the top of the branches of an herbie colour; after which commeth rough cleauing feedes, that do fticke to mens garments which touch it: the roote is fmall and fingle.

* The place.

Goofe graffe groweth neere the borders of fieldes, and oftentimes in the fieldes themfelues mixed with the corne, alfo by common waies, ditches, hedges, and among thornes: Theopbraffem and Galen write, that it groweth among Lentles, and with harde imbracing it doth chokeit, and by that meanes is burdenfome and troublefome vnto it.

It is found plentifully cucry where in fom

$$
\text { * The time. }
$$

\title{
* The names.
}

It is named in Greek aimeeim, Apparine: in Latine Lappa minor, but not properly: Pling affirmeth it to be Lappaginis feciem: of fom P hilant hropos, as though he hould fay, a mans friend, bicaufeit t2. keth hold of mens garments; of diuers alfo for the fame caufe Philidelphos: in Italian Speronells: in Spanifh Prefera, or amor di Hortalano: in high Duten ntieeb traut : Freneh Reble, on graseron: in low Dutch lileefctupt : in Englifh Goofe hare, Goofe graffe, Cleuer, or Clauer.

$$
\text { * The temperature. }
$$

It is as Galen faith, moderately hot and dry, and fomwhat of thinne parts.

$$
\text { * The vertues. }
$$

A The iuice which is preffed out of the feeds, ftalkes, and leaules, 2s Dio/corides writerh, is a remedie for them that are bitten of the poifonfom fpiders called in Latine Phalangia, and of vipers, if it be drunke with wine.

B And the herbe ftamped with fwines greafe wafteth away the kernels by the throte.

C Pliny teacheth that the leaues being applied doth alfo ftay the abundance of bloud iffuing out of wounds.

D Women do vfually make potrage of Cleuers with a little mutton and otemeale, to caufe lankneffe, and keepe them fromfatnes.

\section{Of Croffewsoort. Chap. 446.}

\section{$*$ The defcription.}

Roffewoort is a lowe and bafe herbe, of a pale greene colour, hauing many fquare, feeble
rough ftalks full of ioints or knees, conered ouer with a foft downe; the leaues are little, fhort,
and fmal, alwaies fower growing togither, and ftanding croffewife one right againft another,
making a direet Burgunion croffe:toward the top of the ftalke, and from the bofome of thofe leaues
come foorth verie many fmall yellow flowers, of a reafonable good fauour, ech of which is alfo fha-
ped like a Burgunion croffe : the rootes are nothing elfe but a fewe fmall threds or fibres. 
Cruciata.

Croffewoort.

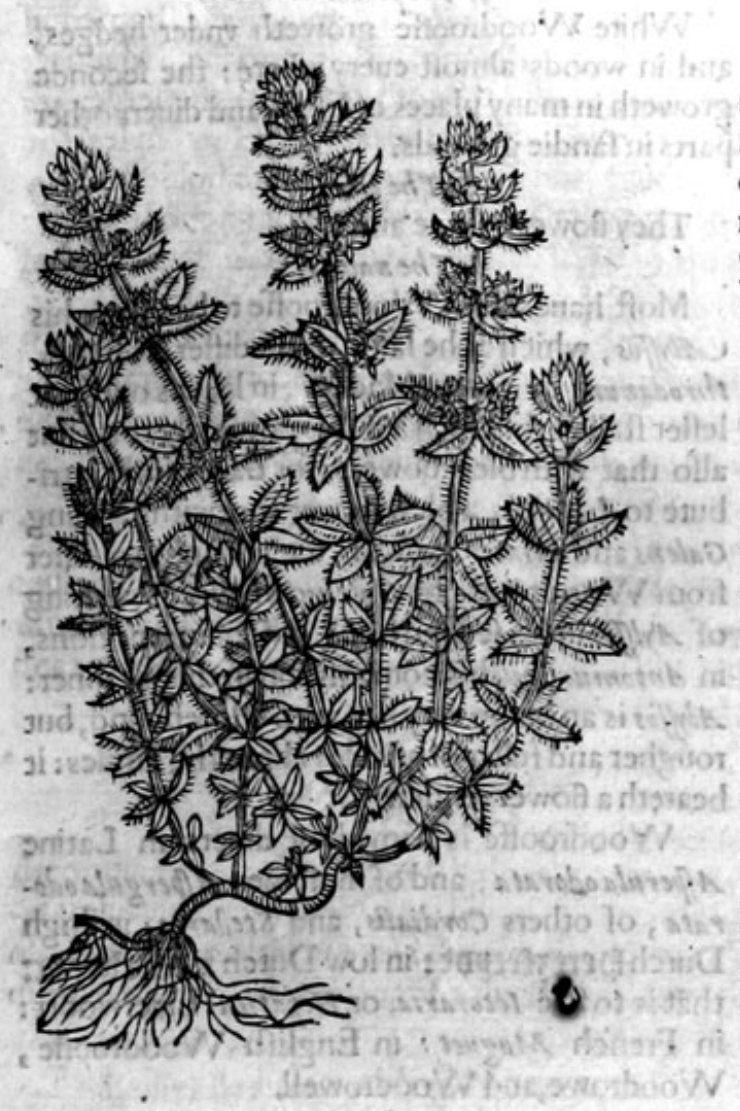

$\approx$ Theplace.

Cruciata, or Croffewoort, groweth in moift and fertill medowes: I found the fame growing in the churchyarde of Hamplteede neere London, and in a pafture adioining thereto by the mill: alfo it groweth in the lane or bigh way beyond Charleton, a fmall village by Greenwich, and in fundry other places.

\section{* The time.}

long.

It flowreth for the moit part all fommer * The names.

It is called Cruciata, and Crucistis, of the placing of the leaues in manner of a croffe: in Englinh Croffervoort, Golden Croffewoort; or Golden Mugweet.

\section{$*$ * Ce temperature.
Croffewoort feemeth to be of a binding and drying qualitie. \\ * The vertues.}

Croffewoort hath an excellent propertie, to $A$ heale, ioine, and clofe wounds togither, yea it is very fit for them, whether they be inwarde or outwarde, if the faide herbe be boiled in wine and drunke.

The decoction thereof is alfo miniltred B with good fucceffe to thofe that are burften: and fo is the herbe, being boiled vntill it be foft, and laide vpon the burften place in man: ner of a pultis.

\section{Of Woodrooffe. Cbap.447.}

* The defcription.

T Oodrooffe hath many fquare ftalkes full of ioirts, and at euery knot or ioint feauen or eightlong narrowe leaues, fet round about like a ftarre; or the rowell of a fpurre : the flowers grow at the top of the ftemmes, of a white colour, and of a very fweete fmell, as is the reft of the herbe, which being made vp into garlands or bundles, and hanged $\mathrm{vp}$ in houfes in the heate of fommer, doth very well attemper the aire, coole and make frefh the place, to the delight and comfort of fuch as are therein.

There is another fort of Woodrooffe called Aperula Cerulea, or blew Woodrooffe: it is an herbe of a foote high, foft, hairie, and fomething branched, with leates and ftalkes like thofe of white Woodrooffe: the flowers therof are blue, ftanding vpon fhort ftems on the tops of the ftalks: the feede is fmall,round, and placed togither by couples : the roote is long and of a red colour.

There is another herbe called Sagina fpergula, or fpurrie, which is fowen in Brabant, Hollande, and Flaunders, ot purpofe to fatten cattle, and to caufe them to giue much milke, and there called Spurrie, and franke Spurry : it is a bafe and lowe herbe, very tender, hauing many io inted ftalkes, whereupon do grow leaues fet in round circles like thofe of Woodrooffe, but leffer and fmoother, in forme like the rowell of a fpur, at the top of the ftalkes do grow finall white flowers, after which comeround feede like thofe of Turneps: the roote is fmall and threddie. 


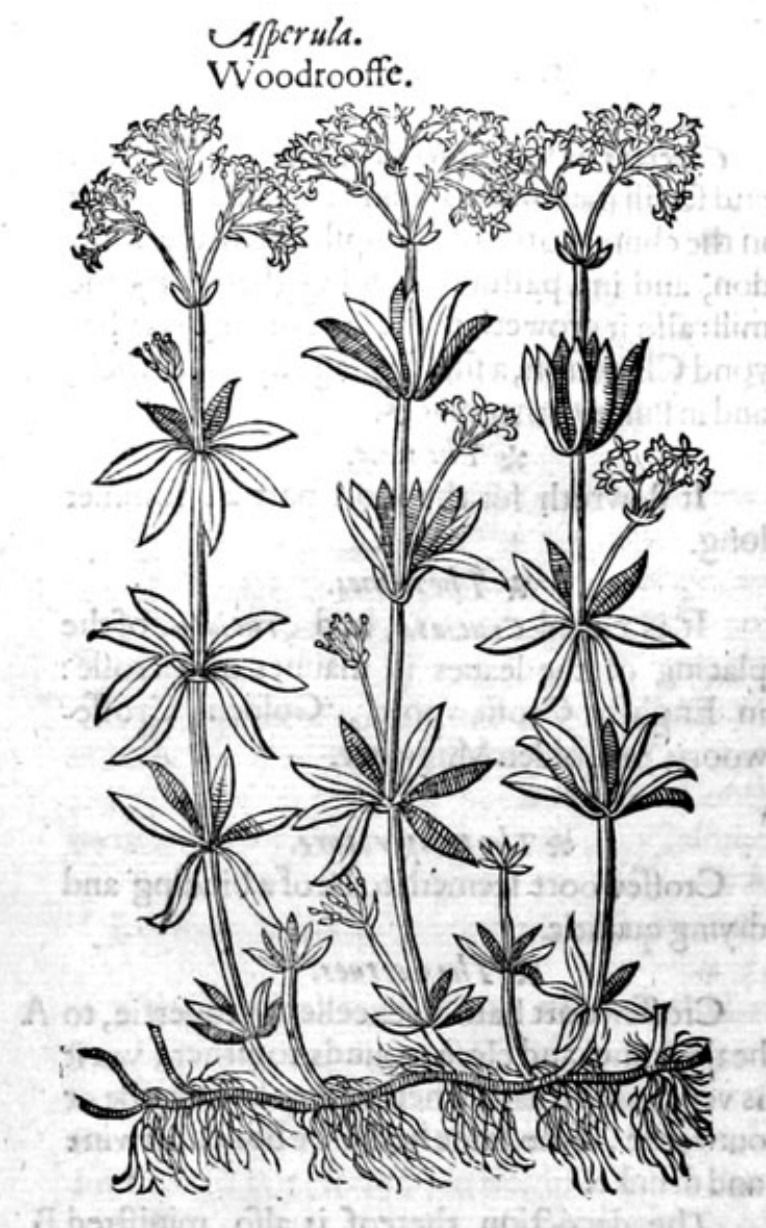

*Theplace.

White Woodrooffe groweth vnder hedges, and in woods almoft euery where: the feconde groweth in many places of Eflex,and diwers other parts in fandie grounds.

They flower in Iune and Iuly. * The names.

Moft haue taken Woodrooffe to be $P$ linie his Alyfos, which as he faith, doth differ from $E_{r}$ : throdanum, or garden Madder, in leaues onely, \& leffer ftalkes: but fuch a one is not onely this, but alfo that withblew flowers: for $G$ alen doth attribute to Lisyfos, a blew flower : notwithiftanding Galens and Plinies Aly]jos, are thought to differ from Woodrooffe, by Galensown words, writing of Aylfos in his fecond book of Counterpoifons, in Antonius Cous his compofition in this maniner: Alyfos is an herbe verylike vnto Horehound, but rougher and fuller of prickles about the circles: it beareth a flower tending to blew.

Woodrooffe is named of diuers in Latine Aperula odorata, and of moft men A/pergula odorata, of others Cordialis, and Stellaria: in high Dutch pertzfrepat : in low Dutch L euerbraut: that is to fte Iecorarie, or Hepatica Liuerwoort: in French Muguet : in Englifh Woodrooffe, Woodrowe, and Woodrowell.

\section{* The temperature.}

Woodrooffe is of temperature fomthing like vnto our Ladies Bedifraw, but not fo ftrong, being in a meane betweene heat and drines.

\&. The vertues.

A It is reported to be put into wine, to make a man merrie, and to be good for the hart and liuer: it preuaileth in wounds, as Cruciata, and other vulnerarie herbes do.

\section{Of Ladies Bedftraw. Chap. $44^{8}$.}

* The kindes.

THere be diuers of the herbes called Ladies Bediftraw, or Cheefe renning, fome greater, others leffe,fome with white flowers, and fome with yellowe.

\section{$*$ Thedefcription.}

I Adies Bedftraw hath fmall, round, euen ftalkes, weake and tender, creeping hither and thither vpon the ground: whereon doe growe very fine leaues, cut into fmall iags, finer then thofe of Dill, fet at certaine fpaces, as thofe of Woodrooffe: among which come foorth flowers of a yellow colour, in clufters or bunches thicke thruft togither, of a ftrong fweete fmell, but not vnpleafant : the roote is finall and threddie.

2 Ladies Bedftraw with white flowers is like vnto Cleauers or Goofe graffe, in lenues, ftalkes, and maner of growing, yet nothing at all rough, but fmooth and foft : the flowers be white, the feede round: the rootes flender, creeping within the grounde: the whole plant rampeth vpon bufhes, fhrubs, and allother fuch things as itande neere vito it, otherwife it cannot ftande, but muft reele and fall to the ground. 
HISTORIE OF PLANTS.

1 Gallium luteum.

Ladies yellow Bedftraw.

3 G.tlitum aibum.

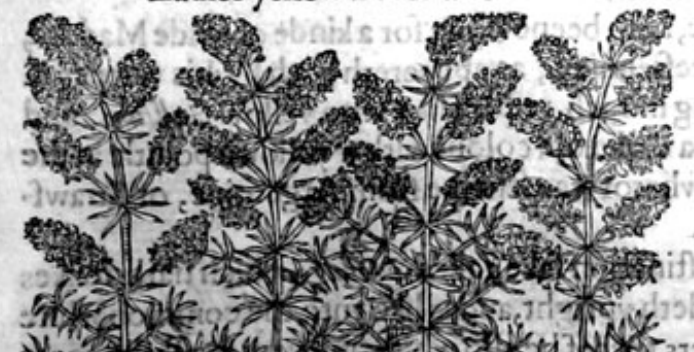

Ladics Bedftraw with white flowers.

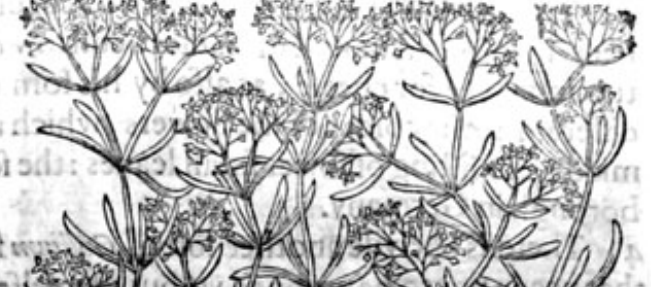

Nor

-7 (1)

*.7.

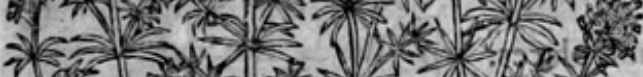

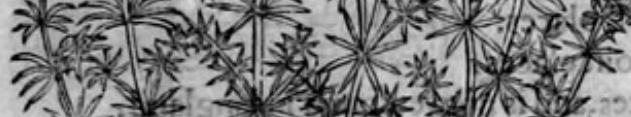

V.

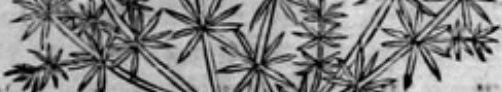

đsin wh

3. Gallium rubrum

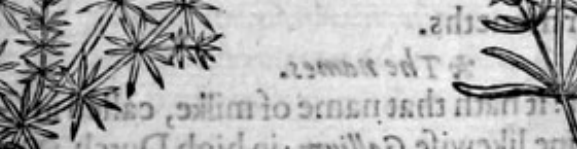
(1)

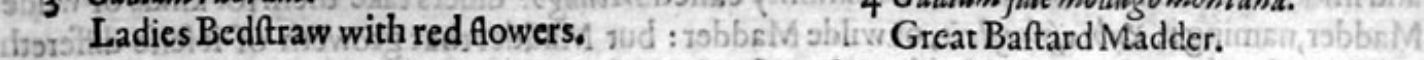

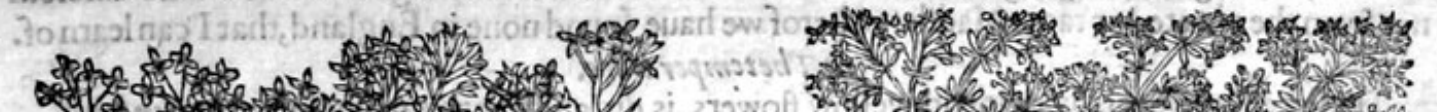

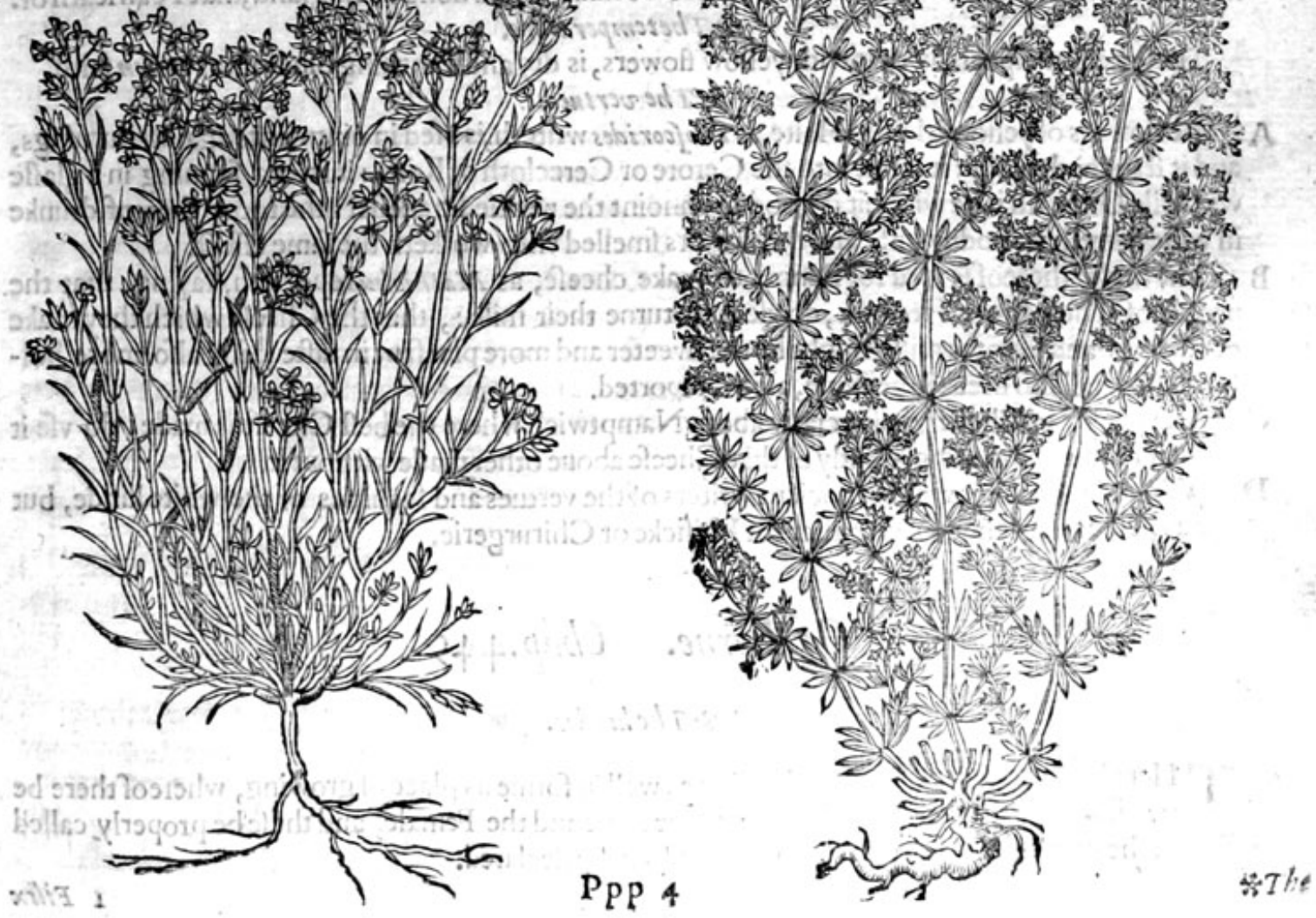


* The defription.

3 This fmall Gallium or ladies little red bedftrowe, hath beene taken for a kinde of wilde Madder; neuertheleffe it is a kinde of Ladies bedftrow or cheefrenning, as appeereth both by his vertues in turning milke for cheefe, as alfo by his forme being in each refpect like vnto yellow Galliwem, and differeth in the colour of the flowers, which are of a darke red colour with a yellowe pointle in the middle, confifting of fower fmall leaues : the feede wherof was fent me from Argentine, or Strawf borough in Germany.

4 There is likewife another fort of Gallium for diftinction fake called Mollugo, which hath ftalkes that neede not to be propped vp, but of it felfe ftandeth vpright, and is like vnto the common white Gallism, but that it hath a fmoother leafe : the flowers therof be alfo white, and very fmallethe roote blackifh.

I haue receiued from a citizen of Straws borough the feedes of a kind of $G$ alliven with red flowers, which hath not beene feene in thefe parts before this time.

\section{* $T$ be place.}

The firft groweth vpon funny bankes neere to the borders of fieldes, in fruitfull foiles almoft euerie where.

Thefecond groweth in hedges among bufhes in moft places.

The third groweth in marifh grounds, and other moift places.

The fourth groweth vpon mountaines and hilly places, and is not yet found in England.

They flower moft of the fommer moneths.

$$
\text { * Thetime. }
$$

* T he names.

The firft is called in Greeke zedrov : it hath that name of milke, called in Greeke $2 d^{2} \lambda a$, into which it is put as Cheefe renning: in Latine likewife Galliwm : in high Dutch פegrerktaut, vortalftron: in low Dutch roralften: in French Petit Muguet : in Italian Galio: in Spanifh coaja leche yerus: in Englifh our Ladies Bedftraw, Cheeferenning, Maides Haire, and petie Mugwet.

The others are Species Lappagini, a kinde of fmall Burre,fo taken of the ancients, of the foftnes and fmoothnes of the leaues, and is commonly called Mollugo: diuers take them for kinds of wilde Madder,naming it Rubia fylueffris, or wilde Madder : but Madder that groweth of it felfe differeth not from the planted or tame Madder, wherof we haue found none in England, that I can learn of. * Thetemperature.

Thefe herbes efpecially that with yellow flowers, is dry and fomthing binding, 25 Galen faith. * The vertues.

A The flowers ofyellow Maides Haire, as Diofcorides writeth, is vfed in ointments againft burnings, and it ftancheth bloud: it is put into the Cerote or Cerecloth of Rofes: it isfet a funning in a glaffe with oile Oliue till it be white:it is good to annoint the wearied traueiler: the roote thereof drunke in wine ftirreth vp bodily luft: and the flowers fmelled vnto worketh the fame effeet.

B The herbe thereof is vfed for Rennet to make cheefe, as Mathiolsw reporteth, faying, that the people of Thufcane or Hetruria, do vfe it to turne their milke, that the Cheefe which they make of fheepes and Goates milke might be the fweeter and more pleafant in tafte, and alfo more holfome, efpecially to breake the ftone, as it is reported.

C The people in Chefhire, efpecially about Namptwich where the beft Cheefe is made, do ve it in their Rennet, efteeming greatly of that Cheefe aboue other made without it.

D Wefinde nothing extant in ancient writers of the vertues and faculties of the white kinde, but are as herbes neuer had in vfe, either for Phificke or Chirurgerie.

\section{Of Ferne. Chap.449.}

* $\mathrm{T}$ be kindes.

Here be diners forts of Ferne, differing as well in forme as place of growing, whereof there be

two forts according to the old writers, the Male and the Female, and thefebe properly called Ferne : the others haue their proper names as fhall be declared. 


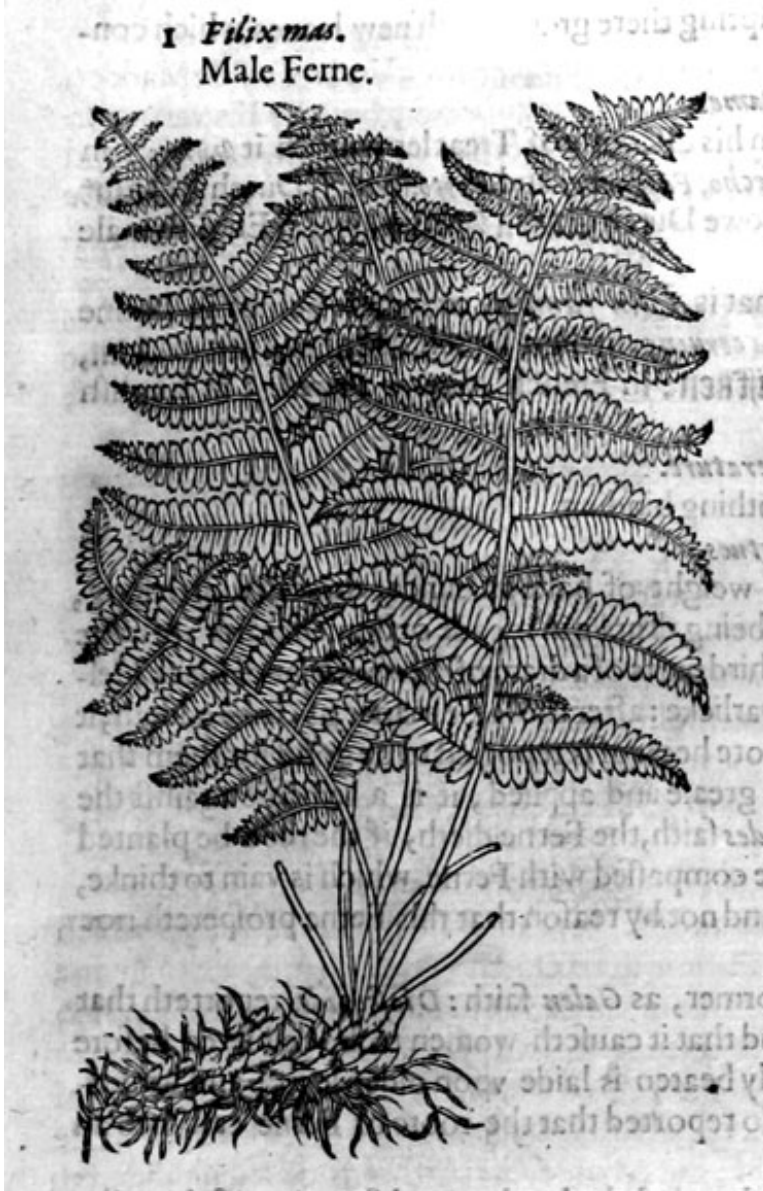

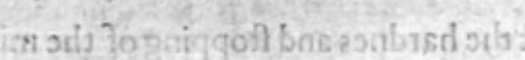

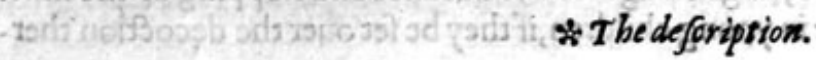

2 Filix famina. Femalc Ferne or brakes.
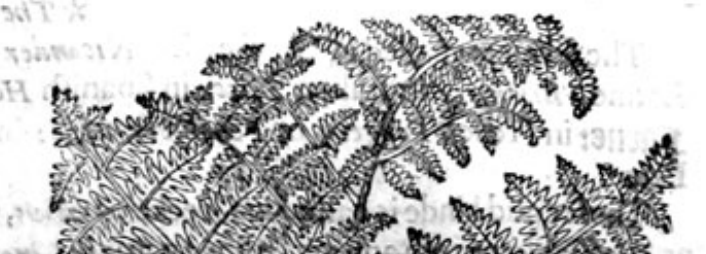

西
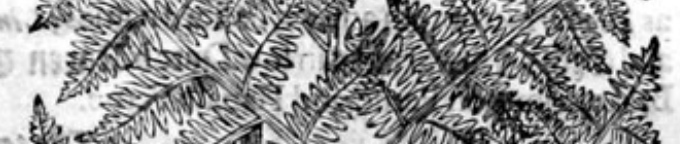

\section{s.}
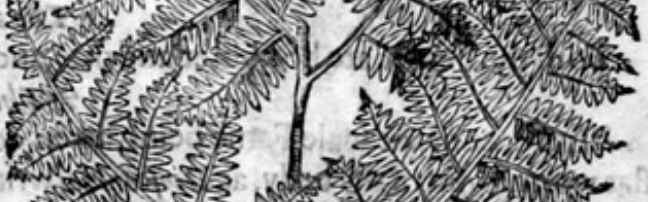
A 
* The time.

Both thefe Fernes wither away in winter; in the fpring there grow foorth new leaues, which con. tinue greene all fommer long.

\section{* Thenames.}

The former is called in Greeke miers: Nicander in his difcourfe of Treacles nameth it Bnireen : in Latine Filix mas : in Italian Felce : in Spanifh Helecho, Falguero, and Feyto:in high Dutch vretalot farne: in French Fongere, or Fenchiere mafe: in lowe Dutch Caren 9 gannekent in Englifh male Ferne:

Thefecond kinde is called in Greeke mnumates, that is, Filix famina, or female Ferne : in Latine as Diofcorides noteth among baftard names, Lingua ceruina: in high Durch corlalit f farn wethlin, and 5zof s atnktaut : in low Dutch đaren Jetifikent in French Fougere Femelle : in Englifh Brake, common Ferne, and Female Ferne.

\section{A}

Both the Fernes are hot, bitter and drie, and fomthing binding. * The temperature.
drie, and fomthing
$*$ The vertues.

The roote of the male Ferne being taken to the weight of halfe an ounce, dritech foorth long, flat wormes out of the belly, as Diofcorides writeth, being drunke in meade or honied water ; $8 \mathrm{more}$ effectually if it be giuen with two fcruples or two third parts of a dram of Scamonie, or of black Hellebor; they that will vfe it faith he, muft firft eate Garlicke : after the fame maner, as $G$ alen addech, it killeth the childe in the mothers wombe : the roote heereof is reported to be good for them that haue ill fpleenes: and being ftamped with fwines greafe and applied, it is a remedie againft the pricking of the reed; for proofe heereof as Diofcorides faith, the Ferne, dieth, if the reed be planted about it, and contrariwife, that the reed dieth if it be compaffed with Ferne, which is vain to thinke, that it hapneth by an antipathy or natural hatred, and not by reafon that this Ferne profpereth not

B in moift places, nor the Reede in drie.

The female Ferne is of like operation with the former, as Galen faith: Diofsorides reporteth that this bringeth barrennes, efpecially to women; and that it caufeth women to be deliuered before their time: he addeth that the pówder heereof finely beaten is laide vpon olde vlcers; and healeth the galled neckes of oxen and other cattle: it is alfo reported that the-rootc of Ferne caft into an

C Hogihed of wine keepeth the fame from fowring.

The roote of male Ferne fodden in wine, is good againft the hardnes and ftopping of the milt: and being boiled in water ftaieth the laske in yoong children, if they be fet ouer the decoetion therof to eafe their bodies by a clofe ftoole.

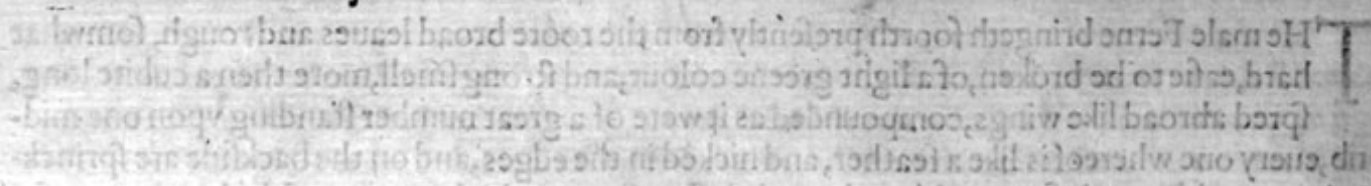

\section{Of water Ferne, or Ofmund the water man. Chap. $45^{\circ}$.}
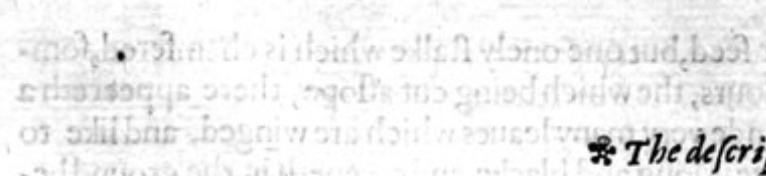

\section{\& The defcription.}

I $\ 7$ Ater Ferne hath a great triangled ftalke two cubits high, befet vpon each fide with large leaues fpread abroad like wings, and dented or cut like Polypodie : thefe leaues are like the large leaues of the Afh tree: for doubtleffe when I firt faw them a far off, it caufed me to woonder thereat, thinking that I had feene yoong Afhes growing vpon a bogge, but beholding it a little neerer, I might eafily diftinguifh it from the Afhe; by the browne, rough, and round graines that grewe on the top of the branches, which yet are not the feede thereof, but are verie like vnto the feede: the roote is great and thicke, folded and couered ouer with manic fcales and interlacing rootes, hauing in the middle of the great and hard woodie part thereof fome fmall whiteneffe, which hath beene called the hart of $O$ mund the water man. 


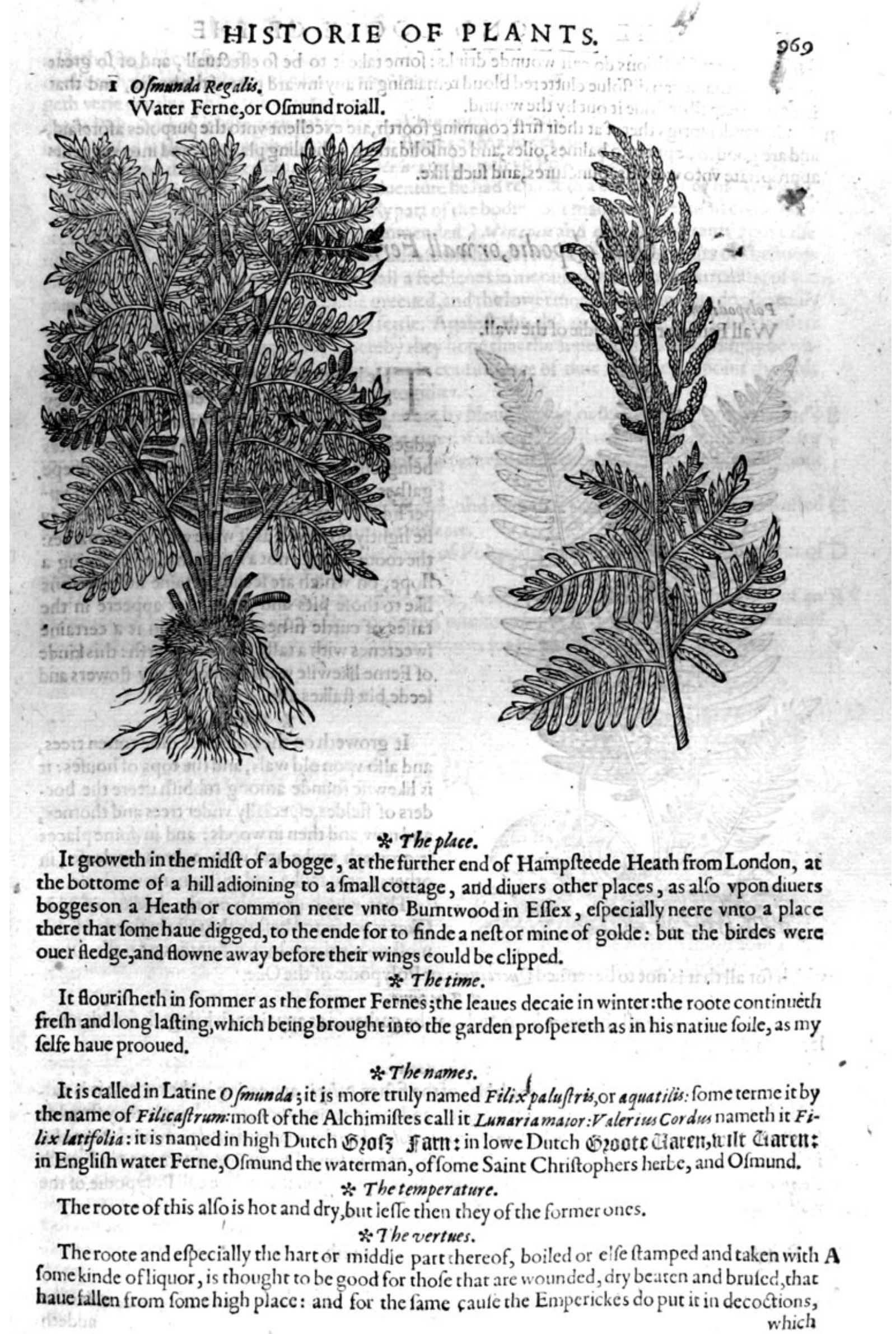




\section{THE SECOND BOOKEOOF THE}

which the later Phifitions do call wounde drinks: fome take it to be fo effeetuall, and of fo great a vertue, as that it can diffolue cluttered bloud remaining in any inward part of thic bodie, and that it alfo can expcll or driue it out by the wound.

Usior brismil 10 ,

$B$ The tender fprigs therof at their firft comming foorth, are excellent vnto the purpofes aforefaid, and are good to be put into balmes, oiles, and confolidatiues or healing plaifters, and into vnguents appropriate vnto wounds, punctures, and fuch like.

\section{Of Polypodie, or wall Ferne. Chap.451.}

Polypodivin.

Wall Ferne, or Polypodie of the wall.

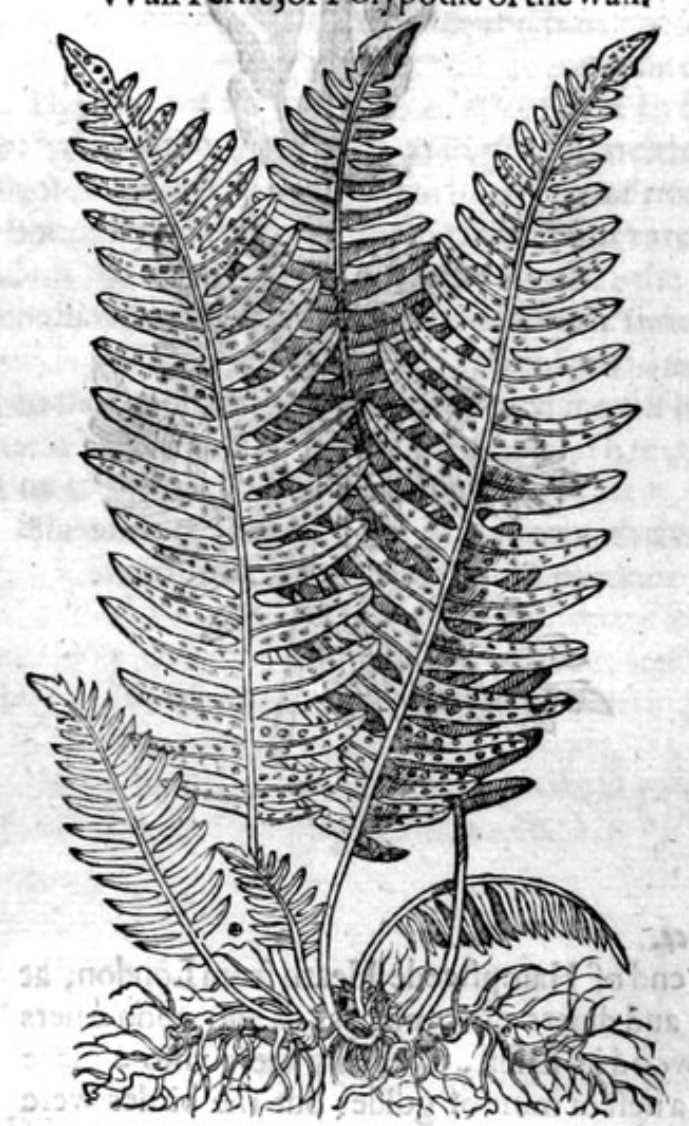

* The defcription.

The leaues of Polypody might be thought to be like thofe of male Ferne, but that they are farre leffer, and not nicked at all in the edges: thefe do prefently fpring vp frô therootes being cut on both the edges with many deepe gafhes, euen harde to the middle rib; on the vp. per fide they are finooth, on the ncather fide they be lightly powdred as it were with duftymarkes: the roote is long, not a finger thicke, creeping a flope, on which are feene certaine litele buttons like to thofe pits and dents that appeere in the tailes of cutcle firhes: this hath in it a certaine fweetenes with a tafte fomthing har $\mathrm{h}$ : this kinde of Ferne likewife wanteth not onely flowers and feede, but ftalkes alfo.

$$
\text { * The plase. }
$$

It groweth on the bodies of olde rotten trees, and alfo vpon old wals, and the tops of houfes: it is likewife founde among rubbilh neere the borders of fieldes, efpecially vnder trees and thornes, and now and then in woods : and in fome places it groweth ranke and with a broader leafe, in others not fo ranke, and with a narrower leafe.

That which groweth on the bodies of olde Okes is preferred before the reft : in fteede of this moft do vfe that which is foundevinder the Okes, which for all that is not to be termed Quercinum, or Polypodie of the Oke.

\section{\& Thetime. \\ Polypodie is greene all the yeere long, and may be gathered at any time; it bringeth foorth newe leaues in the firit lpring.}

\section{$*$ The names.}

The Græcians call it $\pi \lambda v \pi_{i}$ oor, of the holes of the fithes polypi, appeering in the rootes: it is called in Latine Polypodium, after the Grecke name, and many times Filicula, as though theyfhoulde fay Parm Filıx, or little Ferne: the Italians name it Pulipodio : the Soaniards Filipodio, and Polypodio:

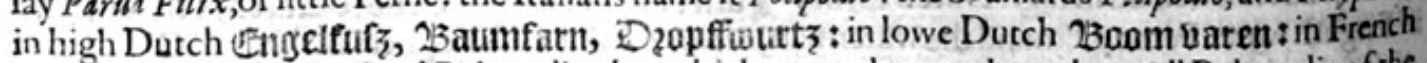
Polypode : and we of England Polypodie: that which groweth vpon the wal we call Polypodie of the wall, and that on the Oké,Polypodie of the Oke.

\section{$*$ The temberature.}

A. Polypodie doth drie, but yet without biting as Galen writeth.

$*$ The vertues.
A Diofcorides writeth that it is of power to purge and to drawe forth choler and flegme. Aatwowius
addech 
addeth that it likewife purgeth melancholy:others fuppofe it to be without any purging force at al, or elfe to haue verie little: of the fame minde is alfo Iohannes Monardus, who thinketh that it purgeth verie gently; which thing is confirmed by experience, the miftris of things. For in verie deede Polypodic of it felfe doth not purge at al, but onely ferueth a little to make the bellie foluble, being boiled in the broth of an old cockewith Beetes or Mallowes, or other like things that mooue to the ftoole by their flipperines. Loannes Mef/urs reckoneth vp Polypodie among thofe things that doeefpecially drie and make thinne : peraduenture he had refpett to a certaine kinde of Arthritis, or ache in the ioints : in which not one onely part of the bodie, but many togither moft commonly are touched: for which it is verie much commended 2 Mens pis and other inhabitants about the riuer Rhene, and the Maze. In this kinde of difeafe the hands, the feete, and the ioints of the knces and elhowes dofwell. There is ioined withall a feeblenes in moouing thorow the extremitic of the paine: fometimes the vpper parts are leffe greeued, and the lower more. The humours do alfo eafily runne from one place to another, and then fettle. Againft this difeafe the Geldres \& Cleuelanders do vfe the decoction of Polypodie, whereby they hope that the fuperfuous humours may be wafted and dried vp, and that riot by and by, but in continuance of time : for they appoint that this decoction fhould be taken for certaine daies togither.

But this kind of gout is fooner taken away either by bloud letting,or by purgations, or by both, \& B afterwardes by fweate; neither is it harde to be cured if thefe generall remedies be vfed in time : for the humours do not remaine fixed in thofe ioints, but are rather gathered togither then fetled about them.

Therefore the bodie muft out of hand be purged, and then that which remaineth is to be wafted $\mathbf{C}$ and confunied away by fuch things as procure fiveate.

Furthermore Dioferides faith, that the roote of Polypodic is verie good for members out of D ioint, and for chaps betweene the fingers.

The rootes of Polypodie boiled with a little honie, water, and pepper, and the quantitie of an E ounce giuen, emptieth the belly of cholericke and pituitous humuurs; fome boile it in water and wine, and giue thereof to the quantitic of three ounces for fome purpofes with good fucceffe.

\section{Of Polypodie of the O Oke, or Oke Ferne. Chap. 452.}

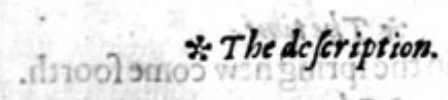

1. Olypodie of the Oke is much like vnto that of the wall, yet the leaues of it are more finelie cue, frnooth oh the vpper fide, of a pale greene colour, togither with the ftalke and the middle ribs 3 on the neather fide tough likethofe of Ferne ? this Ferne alfo litieth without a ftalk: it groweth without feede: the rodre hath many ftrings faftned to it, one folded within another, of a meanebignes, and weete in tafte: it fendech foorth heere and there new dodkins or fpringes, wherebyit increafech.

2 This kinde of Ferne called Dryopteris, or $F$ ilix quer na, hath leatues like vnto the female Ferne before fpoken of (called by the name Ferne or brakes) but much leffer, fmaller, and more finely cut or iagged, and is not aboue a foote high", being a verie flender and dclicate tender herbe. The leaues are fo finely iagged that in thewe they refemble feathers ferround about a fmall ribbe or finewe; the back fige being fprinckled, not with ruffet or brown marks or fpecks, as the other Fernes are, but as itweropainted with white fpets or matks, notwithftanding out of the leaues infcales, as the fpots in the male Ferne which are double vpon eache leafe, clofe vnto the middle rib or finew. The root is long, brown, \& fomwhat hairie, verie like vnto Polypodie, but much flenderer, of a fharp \& cauftick tafte. Sundrie ignorant apothecaries fuppofing that this was alfo a kind of Polypodie, haue vfed the fame in their medicines for Polypodie, greatly abufing the patients therein, for the roote of Diy, opteris is verie bitter in tafte, of a pernicious and naughtie qualitie, vtterly forbidden in media cine. 
I Polypudium Quercinnm. Polipodic of the Oke.

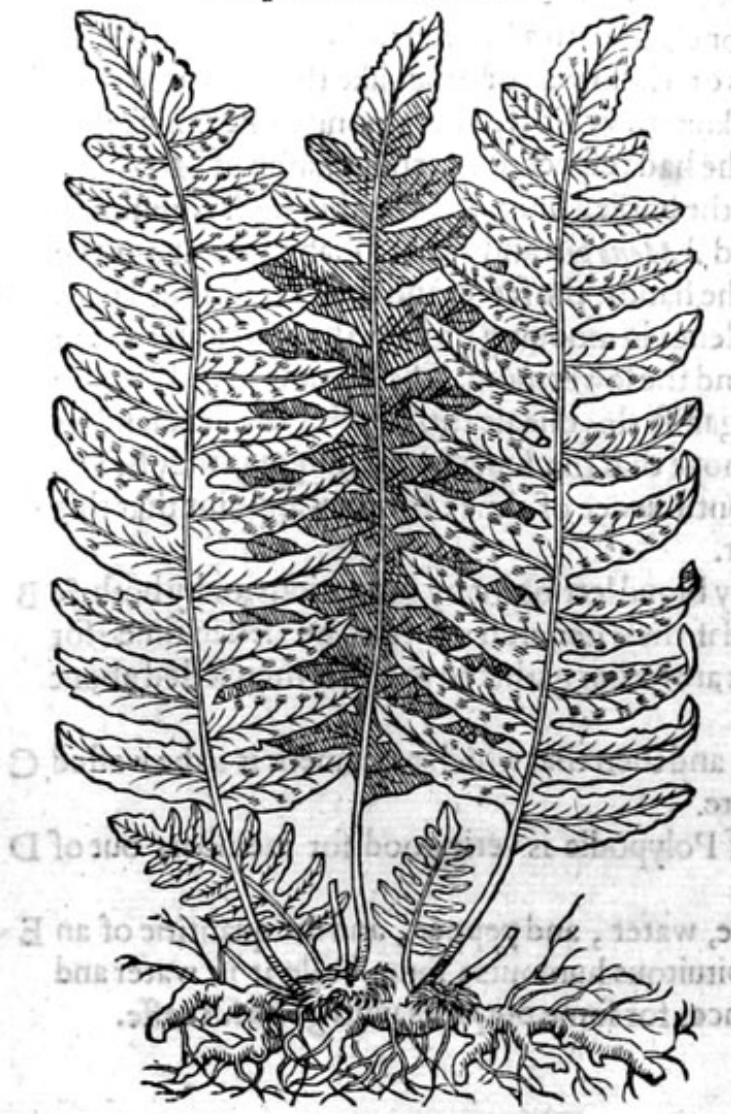

\section{Filix Querna, fune Dryopteri.} Small Oke Ferne.

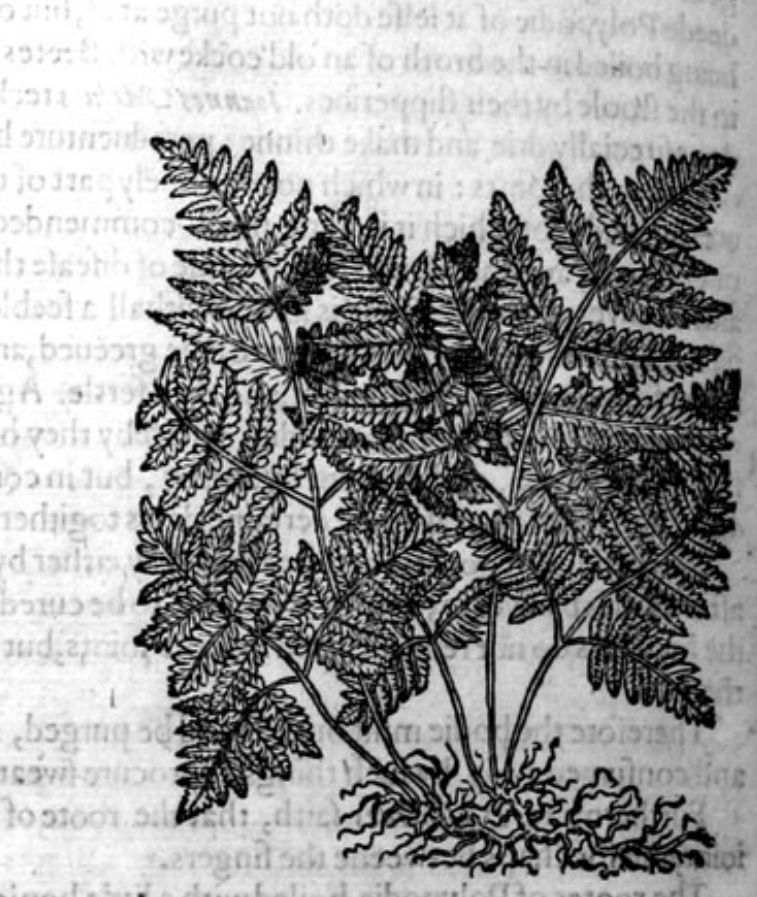

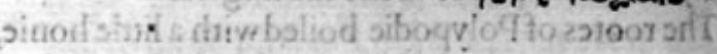

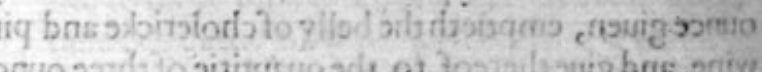

3brissoritu

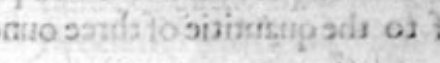

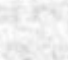

\section{*ै The place,}

It is oftentimes found in funnie places in the valleies of mountaines and littlehils, andin the rops of the trunks of trees of thicke woods.

* The time.

The leaues heereof perifh in winter; in the fpring new come foorth.

* The names.

This is called in Grecke spuomiseis: in Latine Querna Filix : Oribafues in his II. booke of Phificall collections calleth it Bryopter is of the moffe with which it is found: for as Digf6. writeth, it groweth in the moffe of Okes : the Apothecaries in times paft mifcalled it by the name of Udiansion: but

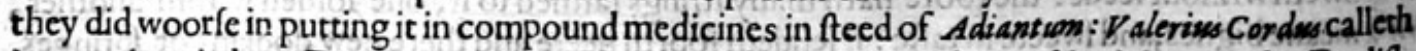
it Pteridion: in lowe Dutch Eticken baren : the Spaniards Helecho de roble: it is named in Englifb Oke Ferne, Pettic Ferne, and it may moft fitly be called Moffe Ferne.

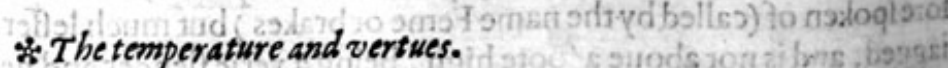

A Polypodie of the Oke hath manytaftes : it is fweete, biting,and bitter, it hath in the rootea harfh or choking tafte, and a mortifying qualitic, and therefore it taketh away haires. Dio/corides doth alfo report, that Oke Ferne ftamped rootes and all, is a remedie to roote vp haires, if it be applied to the body after fweating, and the fiveate wiped away.

B His other vertues and faculties in working, are referred vnto the Polypodie of the wall; but this Polypodie is not holden to be fo good nor holfome for Phifickes vfe as the other, although fome newe fanglers attribute more vinto this then is due. 


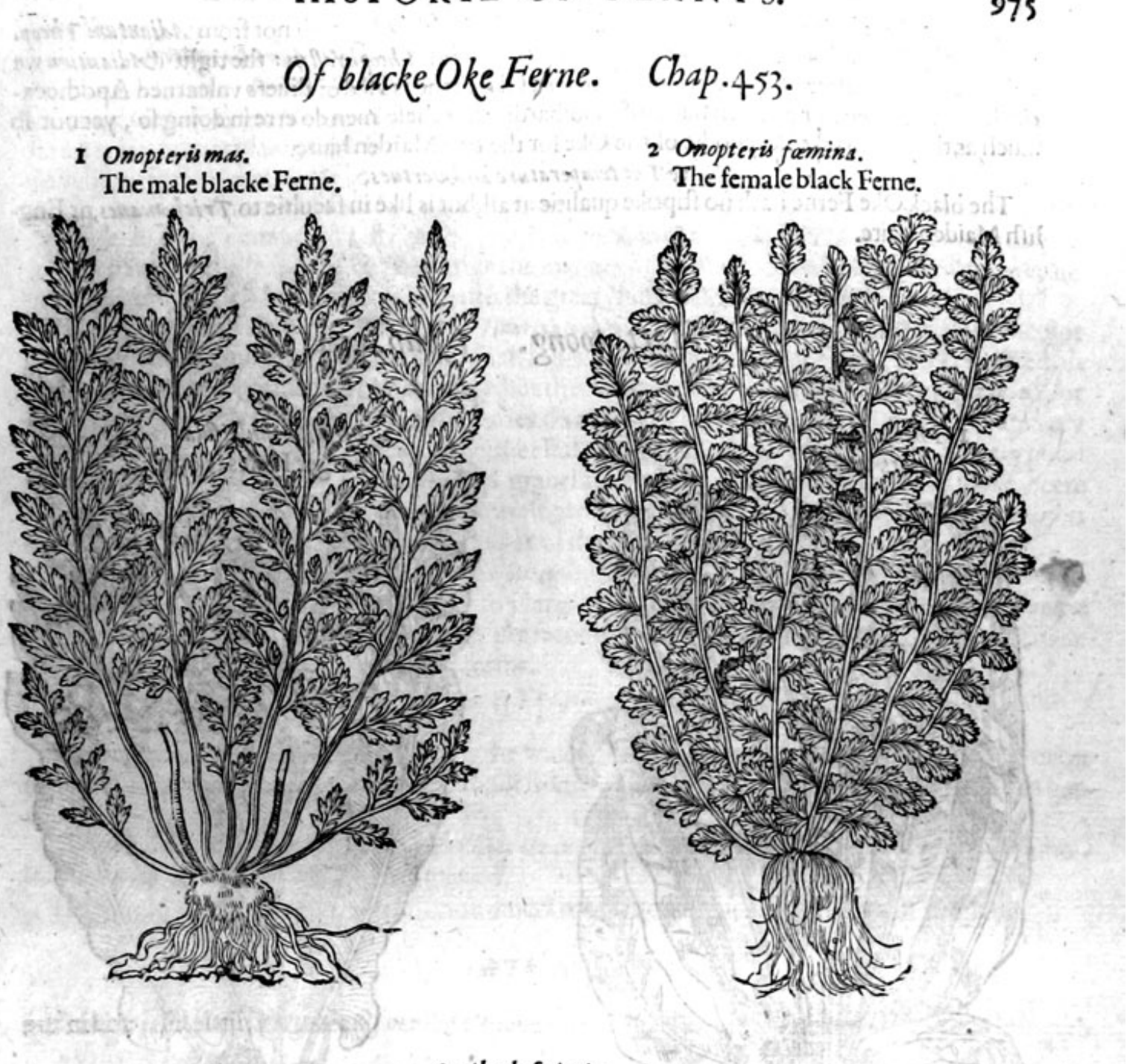

\section{* The defcription.}

1 Here is alfo a certaine other kinde of Ferne like to the former Oke Ferne; but the ftalkes and ribs of the leaues are blackifh, and the leaues of a deeper greene colour : this doth growe alfo out immediately from the root; and is likewife diuerlly, but not fo finely indented : the roote is made vp of many ftrings, not vnlike toPolypodie of the Oke, but much leffer. 2 The female blacke Ferne is like vnto the male, fauing his leaues are not fo tharpe at the points, more whiter and broader then the male, wherein confifteth the difference.

They grow likewife vpon trees in thadowie woods, and now and then in thadowie fandy bankes, and vnder hedges.

Thetime.

They remaine greene all the yeere long, otherwife then Polypodie and maidens haire do :yet do they not ceafe to bring foorth newe leaues in fummer : they are deftitute of flowers and feede, as is

- the former.

This is called of diuers of the later Herbarifts Dryopteris nigra, or blackę Oke Ferne, of the likenes that it hath with Dryopteris, which we haue called in Englifh Oke Ferne, or Moffe Ferne : of others undiantum nigrum, or blacke Maidens haire, that it may differ from the former, which is faliely called Adiantum: there are of the lacer Herbarifts who would have it to be Lonchitis a pera, or rough fpleenwoort : but what likenes hath it with the leaues of Scolopendrium? none at all : there- 
fore it is not Lonchitis a pera, much leffe Adiantum Pling̈, which differeth not from Adiant um 7 beop. for what he hath of Adiantum', the fame he taketh out of Theophraftus: the right Adiantum we will defcribe heerafter. Notwithftanding blacke Oke Ferne is vfed of diuers vnlearned Apothec2. ries for Utiaxtum, or Maiden haire of Lumbardie : but thefe men do erre in doing fo, yet not fo much as they, who take Polypodie of the Oke for the true Maiden haire.

\section{* T The temperature and vertues.}

The black Oke Ferne hath no ftiptike qualitie at all, but is like in facultie to Trichomanes, or Eng. lifh Maiden haire.

\section{OfHartstoong. Chap.454.}

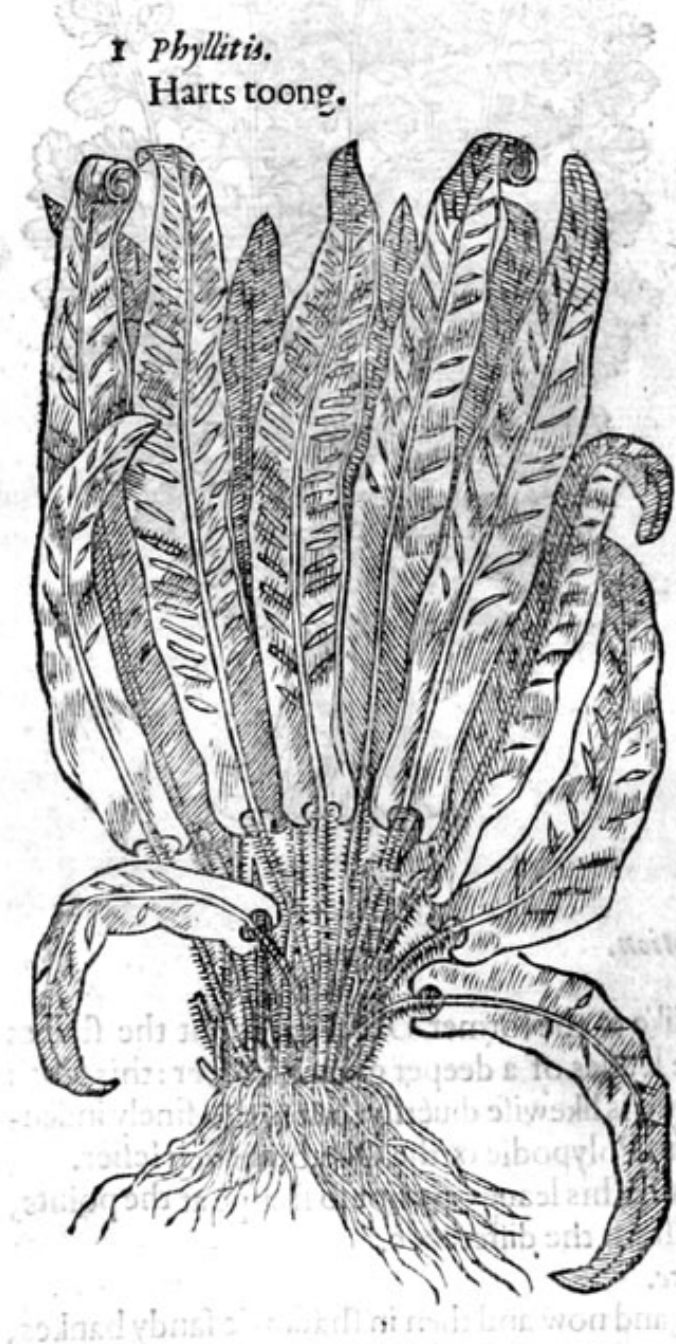

2 Phyllisis multifida. Finger Harts toong.

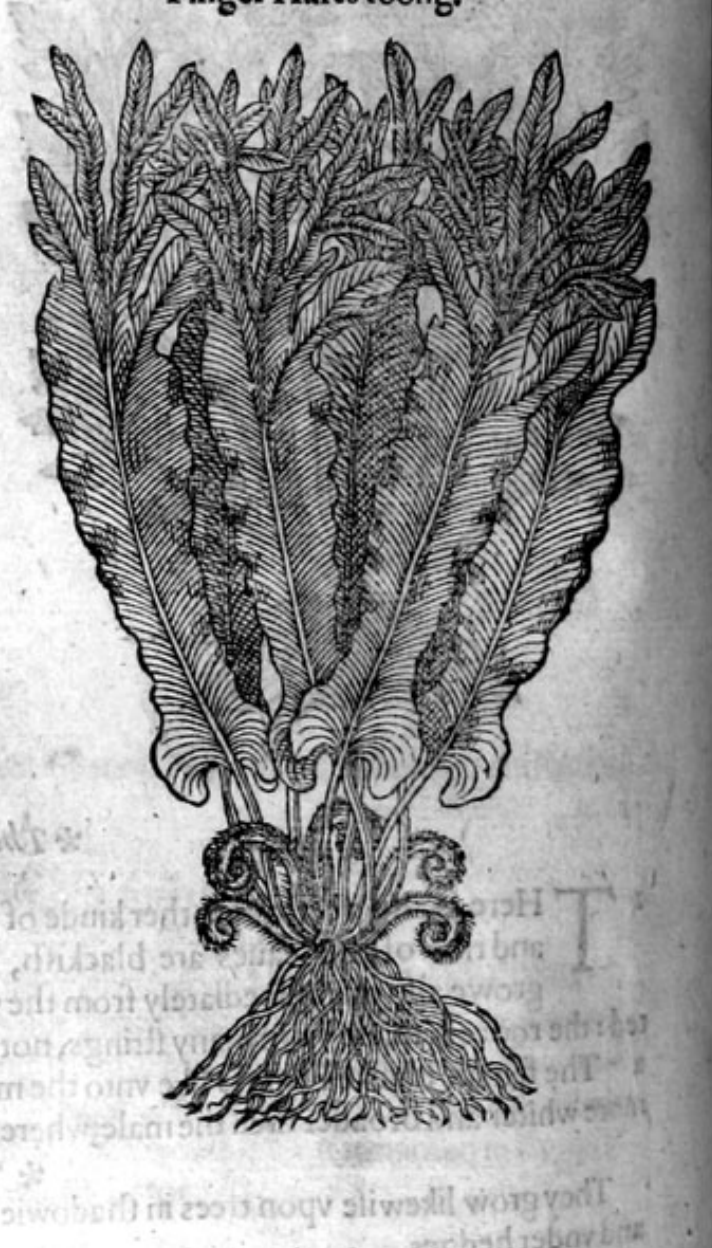

* The defcription.

I THe commonkinde of Harts toong called $P$ byllitis, that is to fay, a plant confinting onely of le.ues, bearing neither ftalk, flower nor feed refembling in fhew a long toong, wherofit hath beene and is called in thops Lingua ceruina that is Harts toong: thefe leaues are a foote long, fincoth and plaine vpon one fide, but vpon that fide next the ground, fraked ouerthwart with certaine long rough markes, like fmall wormes, hanging on the backfide therof: the roote is black, hairie, and twilted, or fo growing as though it were wound togither.

2 The other linde of Ferne called P bylibtis mu ty fida, or Laciniata, that is iagged Harts toong, is 
very like vnto the former, fauing that the leaues thereof are cut or ingged like a mans hand, or the palme and browantles of a Deare, bearing neither ftalke, flower, nor feede.

There is another kinde of Harts toong called Hemionitis, which hath bred fome controuerfie among ancient writers:for fomc hauc tooke it for a kinde of Harts toong, as it is indeed ; others defcribe it as a proper plant by it felf,called Hemiontt is, of nuelovos, that is Mulus, 2 Mule, bicatife Mulles do delight to feede thereon:ir is barren of feeds, ftalks, \& flowers, and in fhape agreeth very well with our Harts toong : the roores are compact of many blackifh haires : the leaues are fpotted on the backfide like the common Harts toong, and differeth in that, that this Hemionitis in the bafe or loweft parts of the leaues, is arched after the manner of a newe Moone, or a forked arrowe; the yoongeft and fmalleft leaues, being like vnto the great Bindweed, alled Volubilis.

There is a kind of Ferne, called likewife Hemionitis fterilis, which is a very fmall \& bafe herbe, not abouc a finger high, hauing fower or fiue fniall leaues of the fame fubltance and colour, fpotted on the backe part,and in tafte like Harts toong; but the leaues beare the fhape of them of Totabona, or good Henrie, which many of onr Apothecaries do abufuely take for Mercurie : the rootes are very fmooth, blacke, and threddie, bearing neither ftalke, flower, nor fecde : this plant my very good friende Mafter Nicholas Belfon founde in a grauellie lane in the way leading to Oxey parke neere vnto Watforde, fifteene miles from London : it groweth likewife on the ftone walles of Hampton Court, in the garden of mafter Hug gens keeper of the faide houlle or pallace.

There is a kinde of Ferne called al fo Hemjonits, but with this addition Perrgrina, that is very feldone founde, and hatb leaues verylike vnto Harts toong, but that it is palmed or branched in the partenext the grounde, almoft in maner of the fecond $P$ hyllitts, at the top of the leaues; otherwile they refemble one another, iz nature and forme.

* The place.

The common Harts toong groweth by the waies fides, as yee trauell from London to Exceter in great plextie, in fhadowie places, and moift ftonic valleies and wels, and is much planted in gardens.

Tbe fecond I found in the garden of maffor Cranwicha 2 Chirurgion, dwelling at Much-dunmow in Effex, who gaue me aplant for my garded.

Ir groweth vpon Ingleborough hils, and diuers other mountaiues of the north of England.

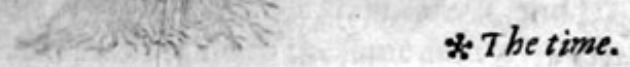

It is greene all the yeere long, yet leffe greene in winter: in fommer it nowe and then bringeth foorth newe leaues.

$$
\text { * The names. }
$$

It is called in Grecke quadins: in Latine alfo Phyllitis; in fhops Lingua cerwina, and falfely Scolopendria, for it differeth much from the right Scolopendria, or Stone Ferne: it is called in high Dutch pirfžtung: in lowe Dutch perffonge: in Spanith Lengur ceruina : in French Langue de Cerf: in Englifh Harts toong, offome Stone Harts toong: Upuleiss in his 83 . Chapter nameth it Radiolies.

It is of a binding and drying facultic.

\section{* Thetemperature.}

* The vertues.

This common Harts toong is commended againft the laske and bloudie flixe: Diofcorides tea- A cheth, that beingdrunke in wine it is a remedy againft the bitings of ferpents.

It doth open the hardnes and ftopping of the fpleene and liter, and all other griefes proceeding $B$. of oppilations or ftoppings whatfoeuer.

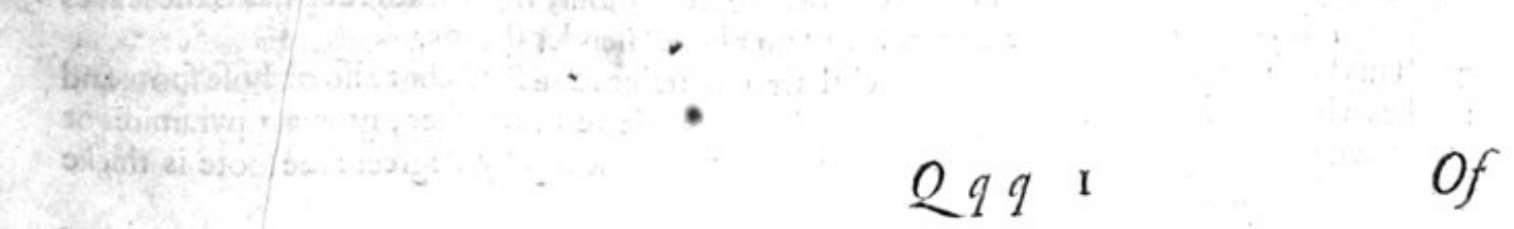




\section{Of Spleenewoort, or Mitt waste. Chap.455.}

s Aplenium fue Ceterach. Spleenewoort or Miltwafte.

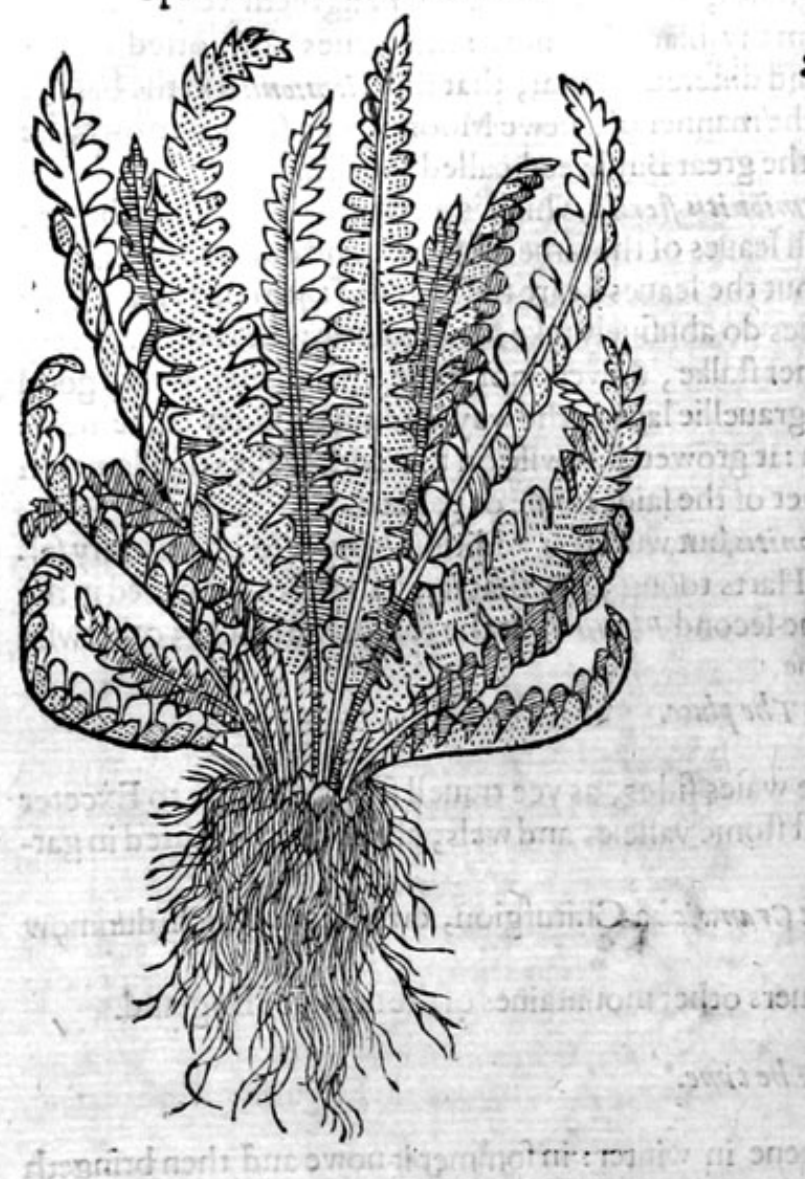

2 Lonchit is apera. Rough Spleenewoort.

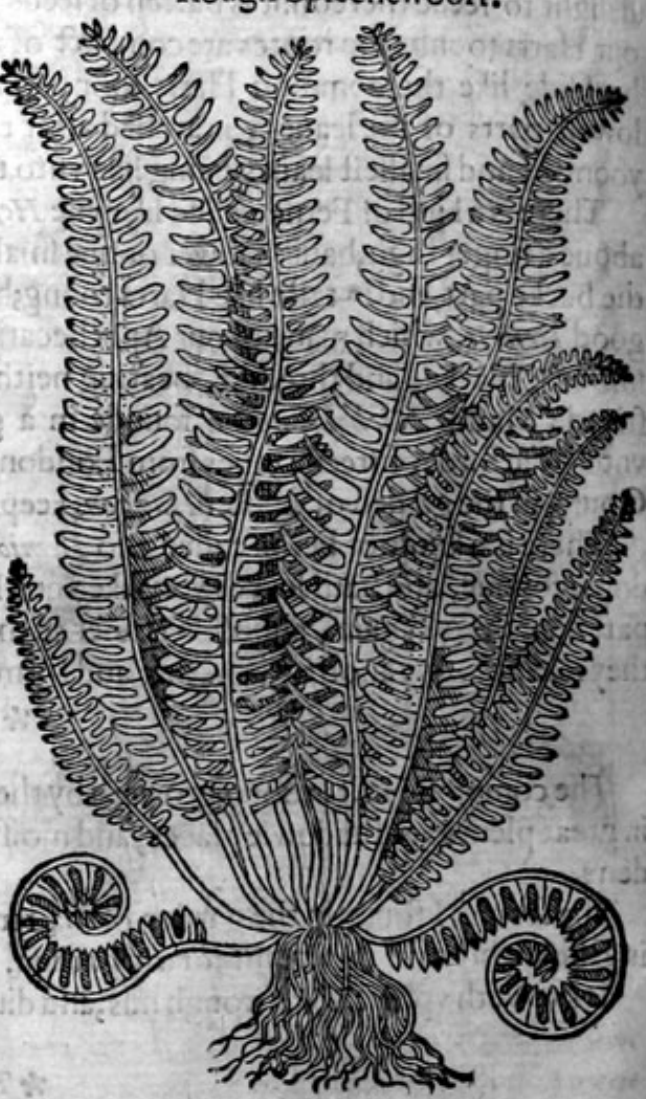

* The defoription.

i

Pleenewoortbeing that kinde ofFerne called Apleniwo or Ceterach, and the true Scolopendria, hath leaues a fpan long,iagged or cut vpon both fides, euen hard to the middle rib; euery cut or incifure being as it were cut halfe rounde ( whereby it is knowne from the rough Spleenewoort) not one cut right againft another, but onc befides the other, fet in feuerall order, being flippery and greene on the vpperfide, foft and downie vnderneath; which when they be withered are folded vp togither like a ftrole, and hairie without, much like to the rough Beareworme wherewith men baite their hookes to catch fifh : the rocte is fmall, blacke, and rough, much platted or interlaced, hauing neither ftalke, flower, nor feedes.

2 Rough Spleenewoort is partly like the other Fernes in fhewe; and bearethneither ftalke nor feede, hauing narrow leaues 2 foote long, and fomewhat longer, flafhed on the edges euen to the middle rib, fmooth on the vpperfide, and of a fivart green colour; vnderneath rough, as is the leaues of Polypodic: the roote is blacke, and fet with a number of flender ftrings.

3 This kinde of Spleenewoort is not onely barren of ftalkes and feeds, but alfo of thofe fpots and markes wherewith the others are fpotted: the leaues are fewe in number, growing pyramidis or fteeplewife,great and broad belowe, and harper towarde the top by degrees: the roote is thicke blacke, and bubaic, as it were a Crowes neft. 
I Lonchitis Maranthe.

Baftard Spleenewoort.

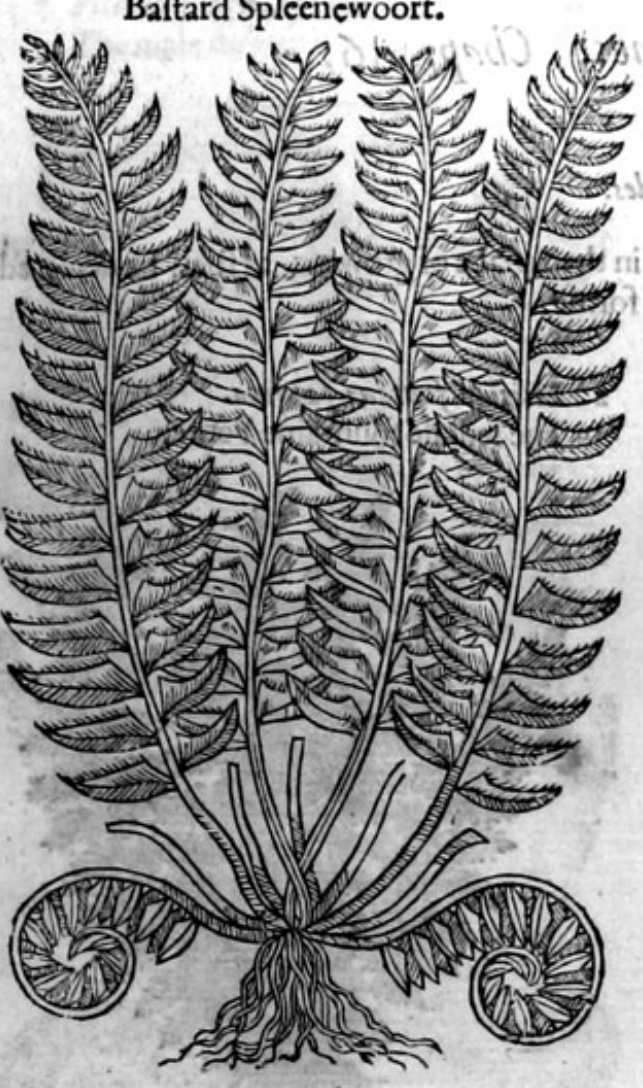

*T he place.

Ceterach groweth vpon old ftone wals \& rocks; in darke and fhadowie places throughout the weft part of Englande; efpecially vpon the ftone wals by Briftowe, as you go to Saint Vincents rocke, and likewife about Bathe, Wels, and Salisburie, where I haue feene great plenty thercof. The rough Spleenewoort groweth vpon barren heathes, dry fandie banks \& ?hadowie places in moft parts of Englande, but efpecially on a heath by London called Hampiteede heath, where ir groweth in great abundance.

\section{*. T he names.}

Spleencwoort, or Miltwafte, is called in Greok ciomtínor : in Latine likewife $\mathcal{A}$ plenitom, and alfo Scolopendria, of Gaza Mula berba : in fhops Ceterach: in high Dutch tevnfarn: in lowe Dutch Steen varen, \& geiltctupt : in Engiifh Splecilwoort, Miltwafte, Scale Ferne, and Stone Ferne. It is called $\cup$ plenion, bicaufe it is fpeciall good againft the infirmities of the Spleene or Milt, and Scolopendria of the likenes that it hath with the Beare worme, before remembred.

Rough Miltwafte, is called of diuers of the later writers A/plenium fylueftre, or wilde Spleenwoort: of fome Uplenium magnam, or great Spleene. woort :Valerizu Cordus calleth it Strutiopteris, and Diofcorides Lonchitis afpera, or rough Splcenewoort : in Latine according to the fame author, Longina, and Calabrina : in Englifh rough Spleenewoort, or Miltwafte.

$$
\begin{aligned}
& \text { Thefe plants are of thinne parts as Galen teftifieth, yet are they not hot, but in a meane. } \\
& \qquad \begin{array}{c}
* \text { The vertues. }
\end{array}
\end{aligned}
$$

Diofcorides teacheth, that the leaues boiled in wine and drunke by the fpace of fortic daies, doth $\mathbf{A}$ take away infirmities of the Spleene; helpeth the ftrangurie, and yellow iaundife, caufeth the ftone in the bladder to moulder and paffe away; all which are performed by fuch things as be of thinne and fubtill parts: he addeth likewife that they ftaie the Hicket, or yeoxing, \& alfo hindereth conception, either inwardly taken, or hanged about the partic; and therefore faith Plinie Spleenewoort is not to be giuen to women, bicaufe it bringeth barrennes.

2] There be Empericks or blinde practitioners of this age, who teach, that with this herbe not one- B ly the hardneffe and fwelling of the Spleene, but all infirmities of the liuer alfo may be effectuallie, and in verie thort time remooued, infomuch that the fodden liuer of a beaft is refto-red to his conftitution againe, that is, made like to a rawe liuer, if it be boiled againe with this

But this is to be reckoned among the old wiues fables, and that alfo which Dioforides telleth $\mathrm{C}$ of, touching the gathering of Spleenewoort in the night, and other moft vaine things, which are founde hecre and there fcattered in the old writers books: from which moft of the later writers do notabftaine, whomany times fill vp their pages with lies and friuolous toies, and by fo doing do nota little deccuic yoong ftudents.

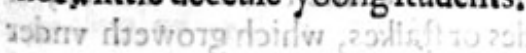




\title{
Of diuers fmall Fernes. Chap. 456.
}

\author{
* The kindes.
}

$T$ Here be diuers forts of dwarffe Fernes, differing in their place of growing, as fhall be declared in their feuerall titles and defcriptions, as alfo in forme.

1 Filicula fontana mas. The male fountaine Ferne.

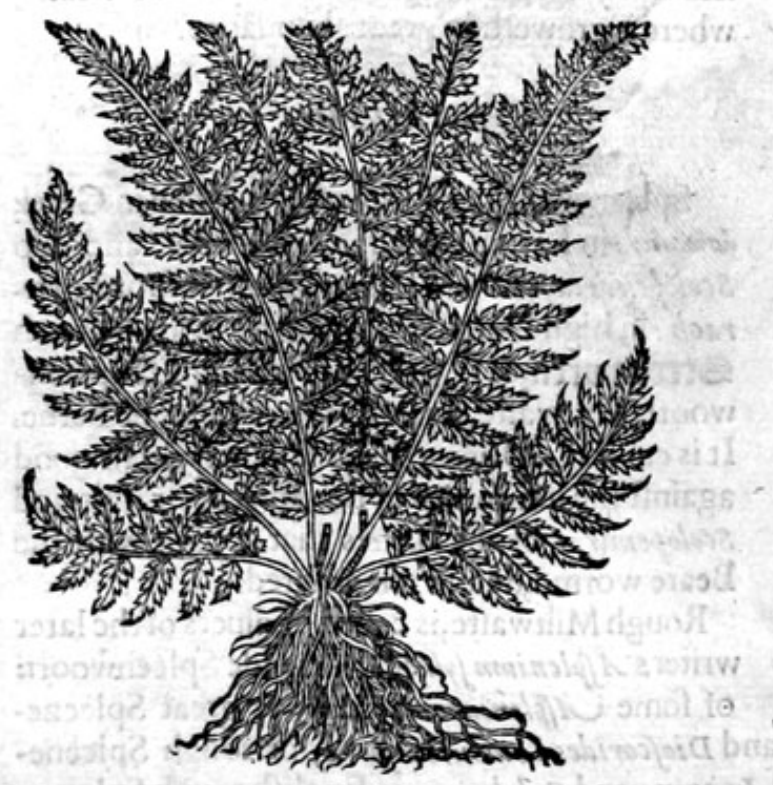

2 Filicula fontana femina. The female fountaine Ferne.

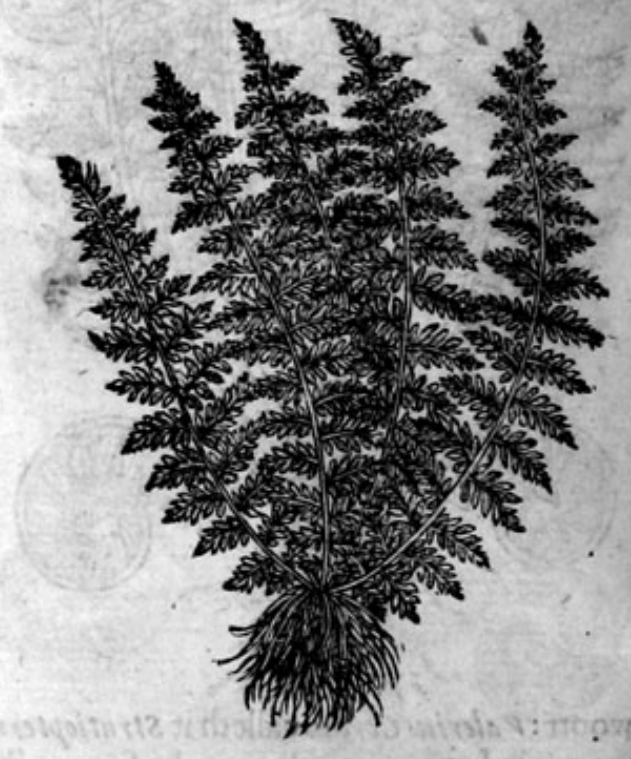

*T the defaription.

17 His fmal or dwarfe Ferne, which is feldome found except in the banks of ftonic fountaines, wels, and rocks bordering vpon riuers, is very like vnto the common Brakes in leaues, but altogither leffer : the roote is compofed of a bundle of blacke threddy ftrings.

2 The female which is found likewife by running ftreames, wels, and fountaines, vpon rocks and ftonieplaces, is like the precedent, but is a great deale fmaller, blacker of colour, fewer roots and horter.

3 The male dwarffe Ferne that groweth vpon the ftonie mountaines of the north and wett parts of Englande, efpecially toward the fea, and alfo in the ioints of ftone wals among the morter, hath fmall leaues deepeiy cut on both fides, like vnto Ceterach or Spleenewoort, barren both of feedes and ftalkes, as alfo of thofe fpots or marks that are to be feene vpon the backe part of the other Fernes: the roote creepeth along, fet with fome fewe hairie ftrings, refemblingthofe of the Oke Ferne, called Dryapteris.

4 The female ftone Ferne hath diuers long leaues rifing from a threddie roote, contrarie to that of the male, compofed of many fmall leaues finely minced or cutte like the teeth of a fawe, of a whitifh greene colour, without any fpots or marks at all, feedes or ftalkes, which groweth vnder thadowie rocks, and craggie mountaines in moft places. 
3 Filicula petrea mas.

The male dwarfe ftone Ferne.

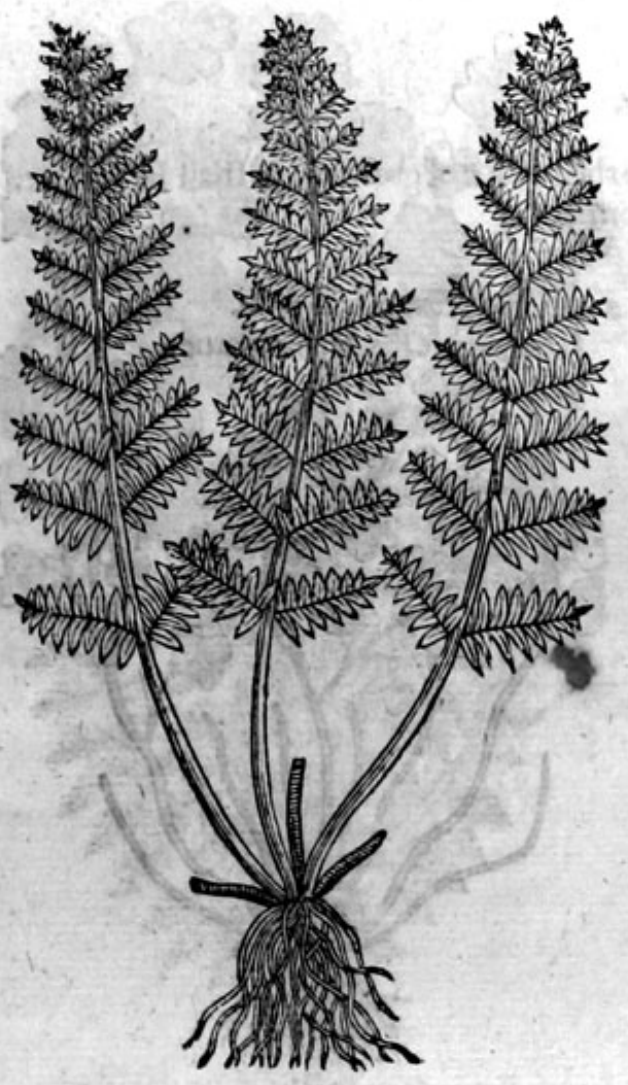

4. Filicula petraa foemina, fure Chamefilix marina The female dwarfe ftone Ferne. (Anglics.

\section{The place is touched in the defcription.}

* The place.

* The time.

They flourilh both winter and fommer, for when the leaues wither by reafon of age, there arife yoong to fupplie the place, fo that they are not to be feene without greene and withered leaues both at once.

* The names.

It fufficeth what hathbeene faide of the names in their feuerall titles: notwithftanding the laft . defcribed we hauecalled Cbamafilix marina Anglica, which groweth vpon the rockie cliffe neere Harwich,as alfoat Douer among the Sampire that there groweth.

$$
* \text { The temperatureand vertues. }
$$

Their temperature and faculties in working are referred to the kindes of blacke Oke Fernes ${ }_{j}$ cal: led Dropteris, and Onopteris.

\section{Of-true Maidentaire. Chap.457.}

\section{* The kindes.}

Theophrastus and Plinie haue fet downe two Maiden haires, the blacke and the white; whereunto may be added another called Rutamuraria, or wall Rue, equall vnto the others in facultie, whereof we will intreat. 
I Capillus Veneris verm. True Maiden haire.

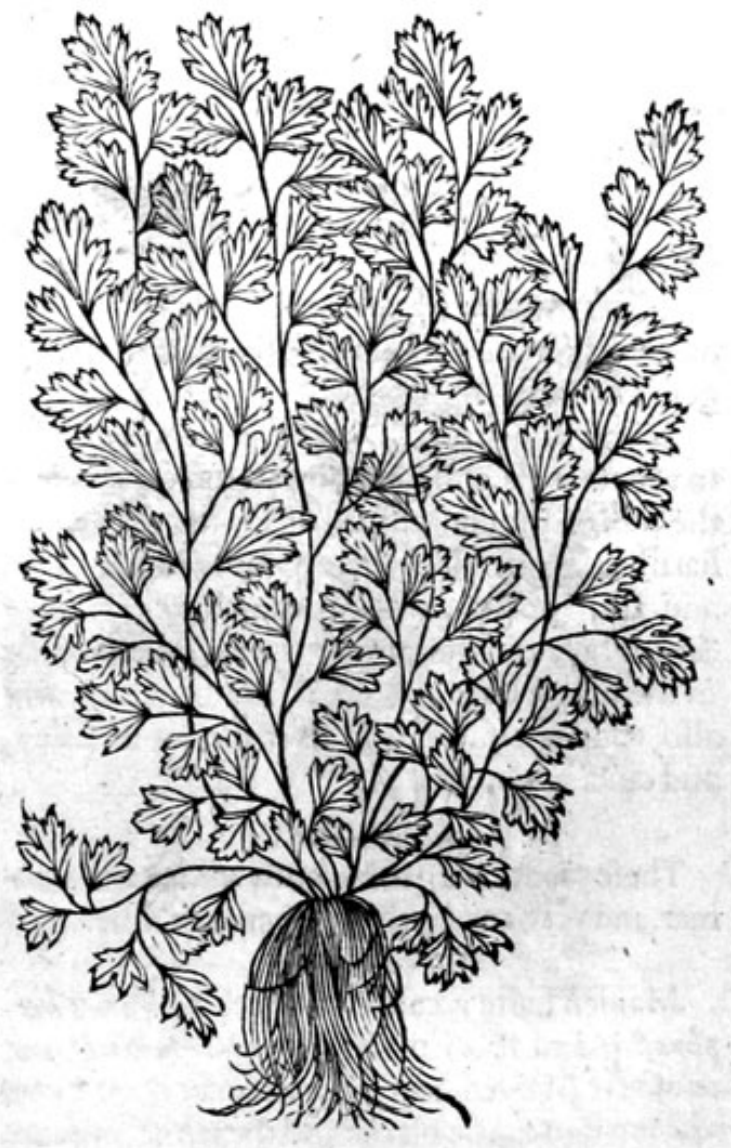

2 Capillso Veneris Syriaca. Affyrian Maiden haire.

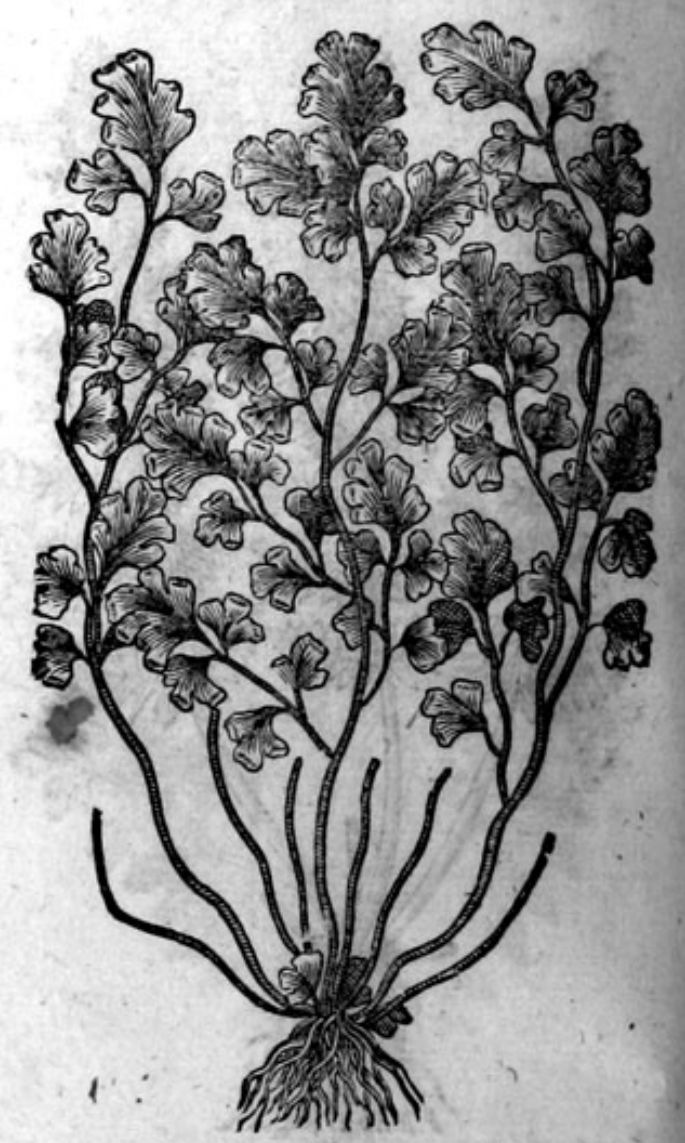

* Thedefcription.

VV Ho fo will followe the variable opinions of writers, concerning the Ferne called Adiantham verum, or Capillus vener is verus, muft of neceffitie be brought into a laby. rinth of doubts, confidering the diuers opinions thereof: but this knowe, that Venus haire, or Maiden haire, is a lowe herbe growing an hand high, fmooth, of a darke crimfon colour, and glittering withall: the leaues be fmall, cut in funder, and nicked in the edges fomthing like thofe of Coriander, confufedly or without order placed: the middle rib whereof is of a blacke fhining co. lour : the roote confifteth of many fnall threddie ftrings.

2 This Affyrian Maiden haire is likewife a bafe or lowe herbe, hauing leaues, flat, fmooth, and plaine, fet vpon a blackifh middle rib, like vnto that of the other Maiden haire, cut or notched in the edges, nature keeping no certaine forme; but making one leafe of this fafhion, and another far different from it : the roote is tough and threddie.

3 This plant which we haue inferted among the Adianthes as a kinde thereof, may without er* rour fo paffe, which is in great requeft in Flanders and Germanie, where the practitioners in Phificke do vfe the fame in fteede of Capillus Vener is, and with better fucceffe then any ci the Capil: lare herbes, although Mathiolus and Diofcorides himfelfe hath made this wall Rue $\mathrm{t}$, be a kinde of Paronychia, or Nailewoort : notwith ftanding the Germaines will not leaue the vfe. hereof, burreceive it as the true Adianth, efteeming it equall, if not farre better, then either Ceterach, Cafillus $V$ cneris ver us, \& Tricomanes, called alfo Folytrichon $:$ it bringeth foorth very many leaues, round and flender, cut into two or three parts, very harde in handling, fmooth and greene on the outfide, of an euill fauoured dead colour vnderneath, fet with little fine fpots, which euidently fheweth it to be a kinde of Ferne: the roote is blacke and full of ftrings. 
3 Ruta muraria, fue faluia vite. olls aud Wall Rue,or Rue Maiden haire.

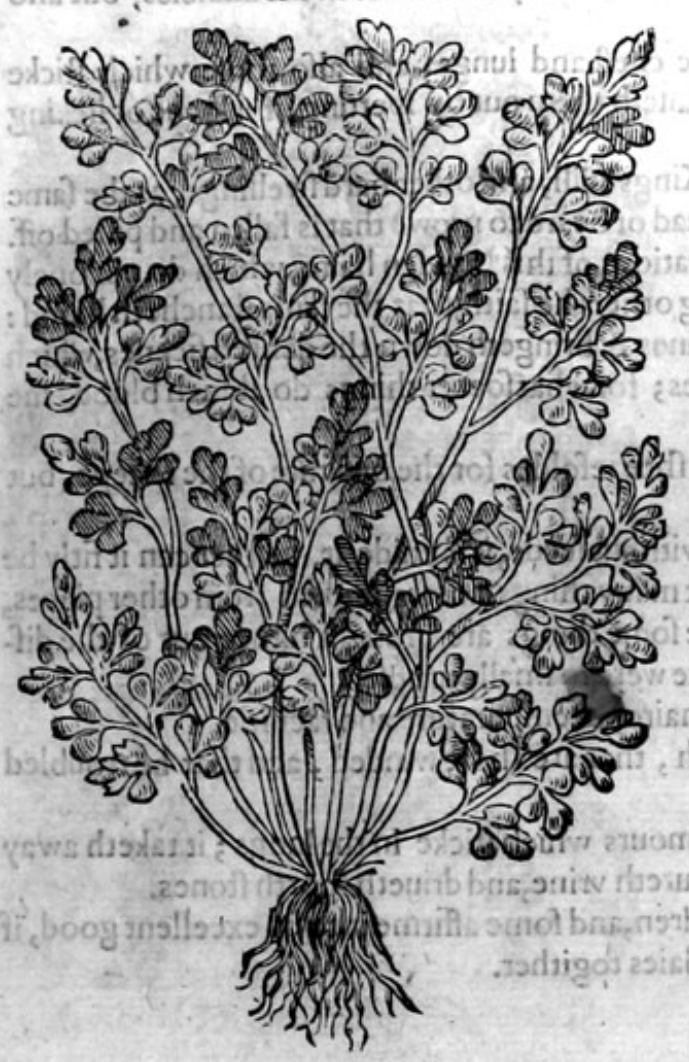

$\approx$ The place.

The right Maiden haire groweth vpon wals, in ftonie, fhadowie and moilt places, neerevnro fountaines, and where water droppeth: it is a ftranger in Englande; notwithftanding I haue heard it reported by fome of good credit, that it groweth in diuersplaces of the weft countrey of England.

The Affyrian Maiden haire taketh his furname of his natiue countrey Affyria, it is a ftranger in Europe.

Stone Rue groweth vpon old wals neere vn to waters, wels, and fountaines:I founde it vpon the wall of the churchyard of Dartford in Kent, hard by the riuer fide where people ride throgh, and alfo vpon the wals of the churchyarde of Sittingburne in the fame Countie, in the middle of the towne hard by a great lake of water, and alfo vpon the Church wals of Railey in Effex, and diuers other places.

\section{tosil * The time.}

Thefe plants are greene both winter and fommer, and yet have neither flowers nor feed. *Tlenumes.

Maiden haire is called in Greek Adivor: Thed: phraftus and Pliny name it Adiantum nigrum, or blacke Maiden haire : for they fet downe two Maiden haires, the blacke and the white, making this the black, and the Rue of the wall the white : it is called in Latine Polytrichsom,Callitrichum, Cin cinalis, Terr c Capillues, supercilium terra ; of LApleius, Capillus Vener is, Capillaris, Crintta, and of diuers Coriandrum putei : the Italians keepe the name Capillus Veneris: in Englifh black Maiden haire, and Venus haire, and may be called our Ladies haire.

It is called Adianton bienufe the leafe, as Theophraftus faith, is never wet, for it cafteth off water that falleth thereon, or being drowned and couered in water, it remaineth ftill as if it were dry, as Plinielikewife writeth; and is termed Callutrichon and Polytrichon, of the effect it hath in dying haire, and making it grow thicke.

Wall Rue is commonly called in Latine Ruta muraria, or Ruta muralis, of fome Saluia vite, but wherefore I knowe not, neither themfelues, if they were liuing: of the Apothecaries of the lowe countries Capillus Veneris, or Maiden haire, and haue vfed it a long time for the right Maiden haire; it is that kind of Adianturn which Theophraft us tcrmeth Adiantum Candidum, or white Maiden haire, for he maketh two, one blacke, and the othet white, as we haue faide. Plinie dothlikewife fet doivne two kinds, one he calleth Polytrichon, the other Trichomanes, or Englifh Maiden haire, whereof we will intreat in the Chapter following, which he hath falfely fet downe for a kinde of Adianium, for Trichomanes doth differ from Adiantum.

Some there be that thinke, Wall Rue is Paronychia Dioforidis, or Diofcorides his Whitlow woort, wherein they haue beene greatly deceiued: it is called in high Dutch $\$$ atuttanim: in low Dutch Stefucturt: in French Rue de Muraille: in Englifh Wall Rue, and white Maiden haire.

* 7 he temperature and vertues.

The truc.Maiden baire, as Gaien teftifieth, doth dric, make thin, wafte away, and is in a meane be - A twcene heate and coldries: Mefues fheweth that it confifteth of valike or difagrecing partes, and that fome are svateric and earthie, and the fame binding, and another fuperficially hot and thin. And that by this is taketh away obftruetions or ftoppings, makcth things thin that are thicke, loofeneth the belly, elpecially when it is freih and greene : for as this part is thin, fo is it quickly refol-

$$
\text { Q१q } 4
$$
t.ed, 


\section{THE SECOND:BOOKE OFITHE}

ued, and that by reafon of his binding and earthie partes: it ftoppeth the belly, and ftaieth the laske

B Being drunke it breaketh the ftone, and expelleth not onely the ftones in the kidneies, but alfo

C It raifeth vp grofle and flmie humors out of the cheft and lungs, and alfo thofe which fficke in the conduits of the winde pipe, it breaketh and raifeth themeut by fpecting, if a loclie or licking
medicine be made there of.

D Moreouer, it confumeth and wafteth away the Kings euill, and other hardfwellings, as the fame author affirmeth, and it maketh the haire of the head or beard to growd that is fallen and pilled off.

E Diofcorides reckoneth vp many vertues and operations of this Maiden haire, which do not onely differ,but are alfo contrarie one to another. Among others he faith, that the fame ftanclieth blood: and a litcle before, that it draweth away the fecondines, \& bringeth down the defired ficknes, which words do confound one another with contratieties; for whatfoeuer things do ftanch blood, the
fame do alfo ftay the termes.

F He addeth alfo in the end, that it is fowen about heepefoldes for the benefite of the fheepe, but what that benefit fhould be, he fheweth not:

G Befides, that it cannot be fowen, by reafon it is without feede, it is euident, neither can it fitly be remooued. Therefore in this place it feemeth that many things are tranfpofed from other places, and fally added to this chapter : and peraduenture fome things are brought hither out of the difcourfe of Cytifus, or Milke Trefoyle, whereof to write wereto fmall purpofe.

H Wall Rue is not much vnlike to blacke Maiden haire, in temperature and facultie.

I Wall Rue is good for them that haue the cough, that are fhort winded, and that be troubled with ftitches and paine in their fides.

$\mathrm{K}$ Being boiled, it caufeth concoction of rawe humours which fticke in the lungs; it taketh away the paine of the kidneies and bladder, it gently procureth vrine,and driueth foorth fones,

L It is commended againt ruptures in yoong children, and fome affirme it to be excellent good, if the powder thereof be taken continually for forty daies togither.

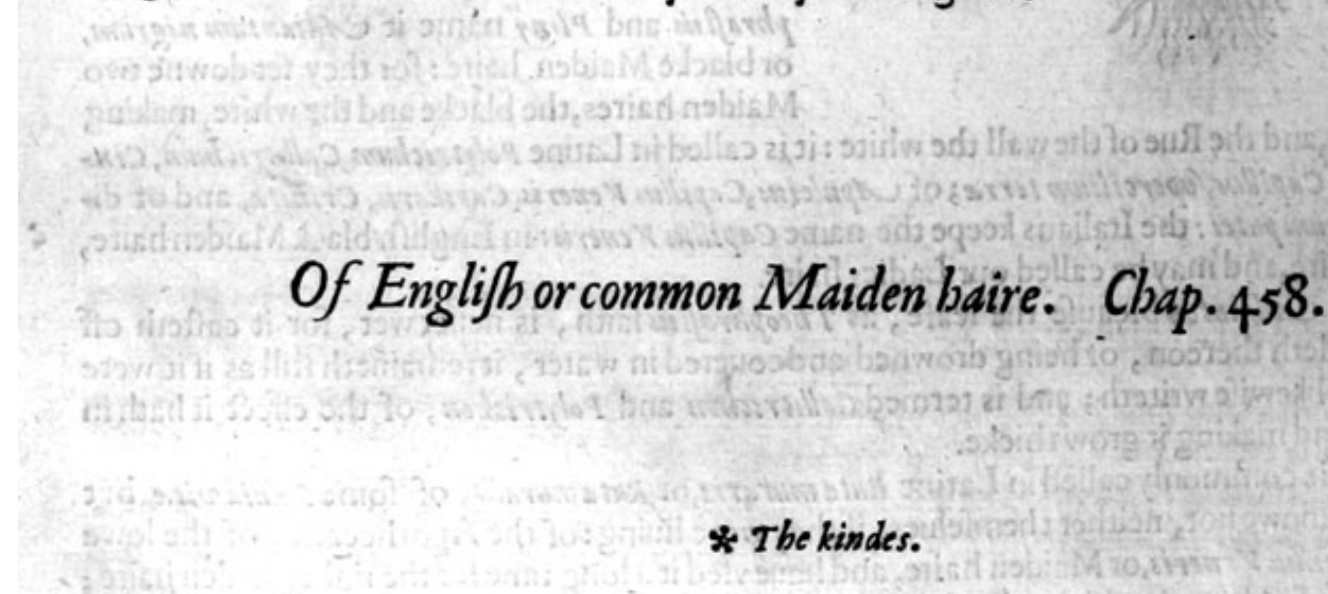

There be two fortes of our common Maiden haire, the greater and the leffer.

* The defcription.

E Nglifh Maiden haire hath long leaues of a darke greene colour, confifting of very many fnill round leaues fet vpon a middle rib, of a fhining blacke colour, dafhed on the neather fides with fmall rough markes or fpeckes, of an ouerworne colour; the rootes arefmall and threddie.

2 The female Englifh Maiden haire is like vnto the precedent, fauing that it is lefter, and wanteth thofe fpots' or markes that are in the other, wherein confifteth the difference. 


\section{HISTORIE OF PLANTS.}

Tricbomanesmas.

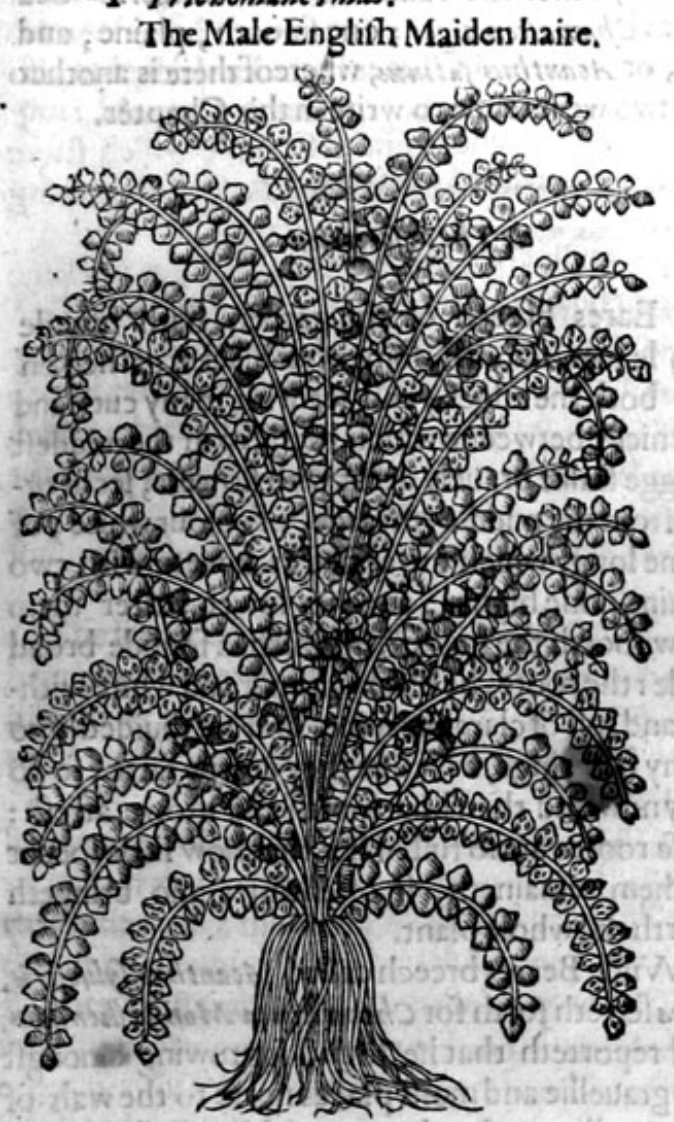

2 Trichomanesfarmina.

The Female Englith Maiden haire.

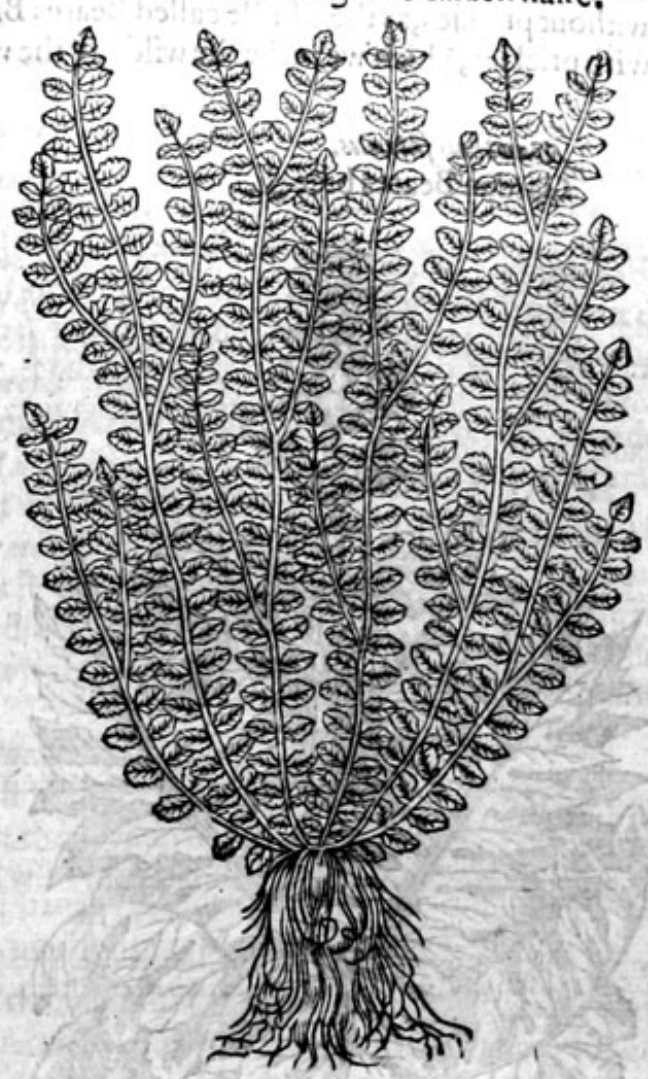

*-The place.

It groweth for the moft part neere vntof prings and brookes, and other moift places, vpon olde ftone wals and rockes: I founde it growing in a hadowie fandie lane in Betfome, in the parifh of South flecte in Kent,ypon the ground whereas there wa s no ftones or ftonie groundeneere vnto it, which before that time I did neuer fee; it groweth likewife vpon the ftone wals of hir Maiefties pallace of Richmond, and in moft ftone wals of the weft and norch parts of England.

$$
\text { * The time. }
$$

It continueth a long time, the coldnes of winter doth it no harme, it is barren as the other Fernes are, whereof it is a kinde. * The names.

It is called in Greeke rexópares: in Latine Frlicula, as though we fhould fay Parua Filix, or fittle Fernc; alfo Capillaris : Apuleius in his 5 r.chapter, maketh it all one with Callitrichon: of forne it is called Polgtrichum : in Englifh common Maiden haire.

\section{* The temper ature and vertues.}

Thefe, as Diofcorides and Galen do write, haue all the faculties belonging to Adiantum, or blacke A Maiden haire.

The decoetion made in wine and drunke, helpeth them that are fhort winded, it helpeth the B cough,ripeneth tough flegme, and auoideth it byfpetting.

The lie wherein it hath beene fodden, or laid to infufe, is good to wafh the head, caufing the $\mathbf{C}$ fcurffe and Icales to fall off, and haire to growe in places that are pild and bare.

\section{Of Thistles. Chap.45?.}

\section{* T he kindes.}

Thematter of the Thiftles is diuer, fome Thiftles ferue for nourifhment, as the Artichoke without prickles, and the Artichoke with prickles; other for medicines, as the roote of Carlinie 


\section{THE SECOND BOOKE OFTHE}

which is good for many things; the bleffed Thiftle alfo, otherwife called Carduses benedicteus: $\mathrm{Sea}$ Huluer, and diuers others : fome are poifonfome, as Chameleon niger; one fmooth, plaine, and without prickles, as the Thiftle called Beares Breech, or Acant bus jatzus, whereof there is another with prickles, which we make the wilde, of the which two we intende to write in this Chapter.

Acanthus fatiuns.

Garden Beares breech.

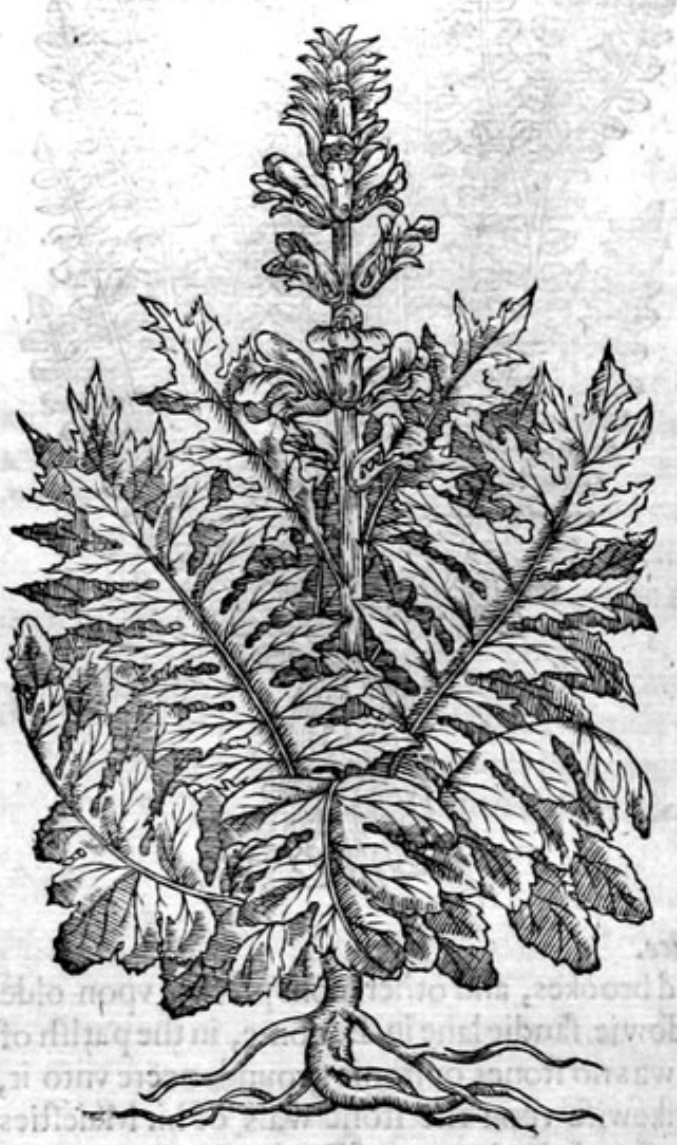

$*$ The defoription.

$\mathrm{B}$ Eares breech of the garden hath broade leaues, fmooth, fomewhat blacke, gathed on both the edges, and fet with many cuts and fine nicks:betweene which rifeth vp in the middeft a bigge ftalke brauely deckt with flowers, fet in order from the middle vpwarde, of colour white, of formelong, which are armed as it were with two catkins, one higher, another lower : after them grow foorth the huskes, in which is founde broad leede : the rootes be black without and white within, and full of clammie iuice, and are diuided into many ofsprings, which as they creepe farre, fo do they nowand then bud foorth and growe afreeh: thefe rootes are fo full of life, that how little foeuer of them remaineth, it oftentimes allo bringeth foorth the whole plant.

Wilde Beares breech called Acanthus fylueftri, Fess fetteth forch for Chameleonta Mompellien furm. and reporteth that he found it growing amongt the grauellie and moift places neere to the wals of Montpellier, and at the gate of AEgidia, betweene the fountaine and the brooke neere to the wall: this Thiftle is in ftalke, flowers, colour of leaues and feede like the firft kinde, but fhorter and lower, hauing large leaues, dented or iagged with manie cuts and incifions, not onely in fome fewe parts of the leaues, as fome other Thiftles, but very thicklie dented or clouen, and hauing many tharpe and harde prickles about the fides of the diuifions and cuts, not very eafie to be bandled or touched without danger to the hand and fingers. * The place.

Diofcorides writeth, that garden Branke Vrfine groweth in moift and ftonie places, and alfo in gardens: it were vnaduifedly done to fecke it in either of the Germanies any where, but in gardens onely; in my garden it doth growe very plentifully.

The wild was found in certaine places of Italie neer to the fea, by that notable learned man $A$ fon fus Pancius, Phifition to the Duke of Ferrara, and profeffor of fimples and Phificke, and is a ftranger in England.

\section{* The time.}

Both the Branke Vrfines do flower in fommer feafon, the feede is ripe in Autumme: the roote remaineth frefh; yet nowe and then it perilheth in winter in both the Germanies, if the weather be too cold : but in England it feldome or neuer dieth.

$$
* 7 \text { he names. }
$$

It is called in Greeke êvey 0 os : the Latines keepe the fame name Acanthus, yet doth Acanthws fignifie generally all kinde of Thiftles, and this is called Acantbus by the figure Antomoma/La: the Englifh name is Branke Vrfine, and Beares Breech.

The tame or garden Branke Vrfine is named in Latine Satiuus, or Hurten/s Acanthos,in Greeke

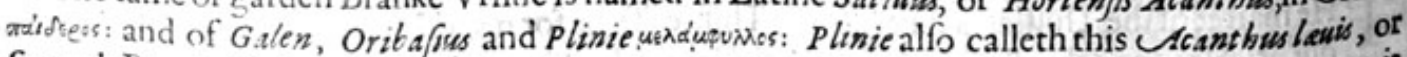
fmooth Branke Vrfine, and reporteth it to be a citic herbe and to ferue for arbors: fome name it 
Brance Vrfina, (others vfe to call Cowparfnep by the name of Branca Vrfima) the Italians call it Acantho, and Branca Orfints : the Spaniards Yerua Giguante: the ingrauers of old time were woont to carue the leaues of this Branke Vrfine in pillers, and other workes, and alfo vpon the eares of pots, as among others Virgtll teftufieth in the third Eclog of his Bucolickes.

\section{Et nobis idem Alcimedon duo pocula fecit, Et molli circum eft an fas amplexus Acantho.}

The other Branke Vrfine is named in Greeke ajeres àvypoos, and in Latine sylaefris Leantbus or wilde branke Vrfine, and they may be called properly dxay9a, or Spina a prickle; by which name it is found called of molt Herbarifts Acanthws: yet chere is alfo an other Acanthus a thornie fhrub: the liquor which iffueth foorth of it as Herodotus and Theophrastus affirme, is a gumme : For difference whereof peraduenture this kinde of Acantbus is named Herbacantha. There is likewife founde among the baftard names of Acant bus the worde CM amolaria, and alfo Crepula, but it is not expreffed to which of them, whether to the wilde or tame, it ought to be referred.

$$
\text { * The temperature. }
$$

The leatres of the garden Branke Vrfine confift as it were in a meane betweene hot and colde; being fomewhat moift, with a mollifying and gentle digefting facultie, as are thofe of the Mallow, and therefore they are profitably boyled in clifters, as wel as be Mallow leaucs. Theroote,as Galen teacheth, is of a more drying qualitie.

Diofcorides faith, that the rootes are a remedie for lims that are burnt with fire, and that be out $A$ of ioint, if they be laide thereunto : that being drunke they prouoke vrine, and ftop the belly : that they helpe thofe that be broken, and that be troubled with the crampe, and be in a confumption of the lungs.

They are good for fuch as haue the ptifike and fpet bloud withall, for thofe that hauc fallen from B fome high place, that are brufed and dry beaten, and that have ouerifrained themfelues, and they are as good as the rootes of the greater Comfrey, whereunto they are very like in fubftance, tough iuice, and qualitie. feete.

Of the fame roote is made an excellent plaifter againft the ache and numineffe of the hands and $\mathbf{C}$ It is put into clifters with good fucceffe againft fundry maladies,

\section{Of the cotton Thistle. Chap.460.}

* Thedefcription.

I The common Thifte, whereof the greateft quantitic of downe is gathered for diuers purpofes, as well by the poore to ftop pillowes, cufhions, and beds for want of feathers, as alfo bought of the rich Vpholiters to mixe with the feathers and downe they do fell, which deceit would be looked vnto: this Thiftle hath great leaucs, long and broade, garhed about the edges, and fet with harpe and ftiffe prickles all alongft the edges, couered all ouer with a foft cotton or downe: out from the middeft whereof rifeth vp a long ftalke about two cubites high, cornered, and fet with filmes, and alfo full of prickles: the heads are likewife cornered with prickles, and bring foorth flowers confifting of many whitifh threds: the feede which fucceedeth them is wrapped vp in downe; it is long, of a light crimfon colour, and leffer then the feede of baftard Saffron: the roote groweth deepe in the grounde, being white, harde, woodie, and not without ftrings.

2 The Illyrian cotton Thiltle hath a long naked roote, befet about the top with a fringe of manie fmall threds or iagges:from which arifeth a very large and tall ftalke, higher then any man, rather like a tree then an annuall herbe or plant: this ftalke is garnifhed with feroles of thin leaues, from the bottome to the top, fet full of moft horrible fharpe prickes, and fo is the ftalke and euery part of the plant; fo that it isimpoffible for man or beaft to touch the fame without great hurt or danger: bis leaues are very grear, farre broader and longer then any other thiftle whatfoeuer, couered with 
an horie cotton or downe like the former : the florvers do grow at the top of the Itallies, which is dis uided into fundrie branches, and are of a purple colour, fet or armed round about with the like, or rather fharper thornes then the aforefaid.

I Acanthiumalbum.

The white cotton Thiftle.

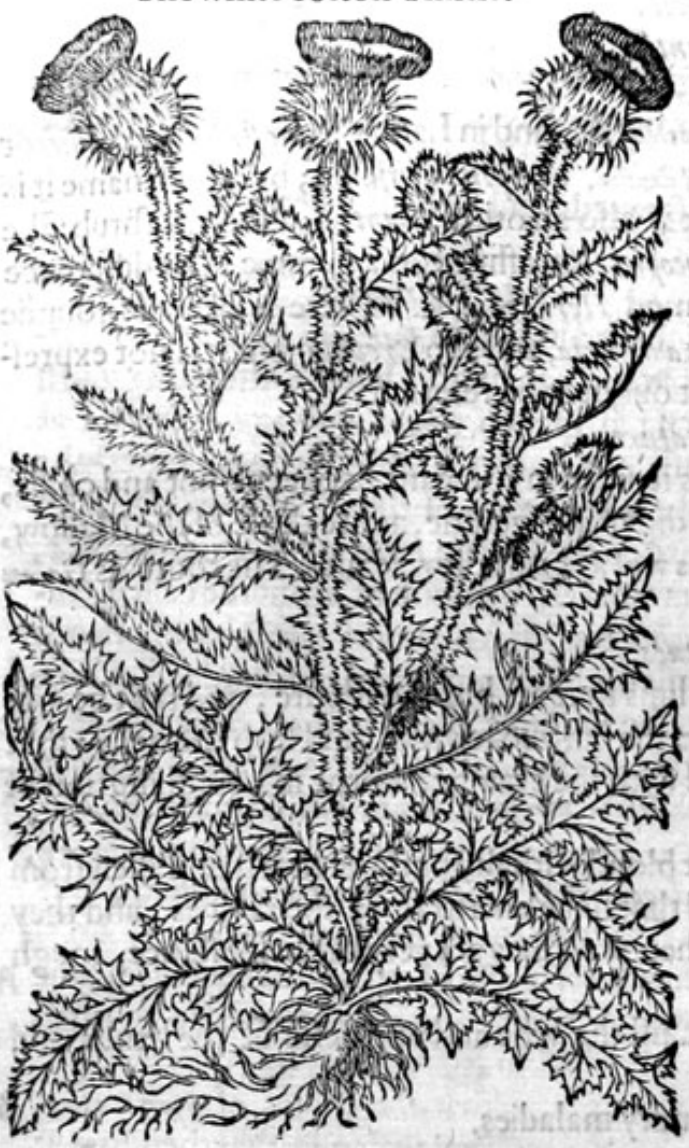

2 Ac unt hium Illyricum purpureum. The purple cotton Thiftle.

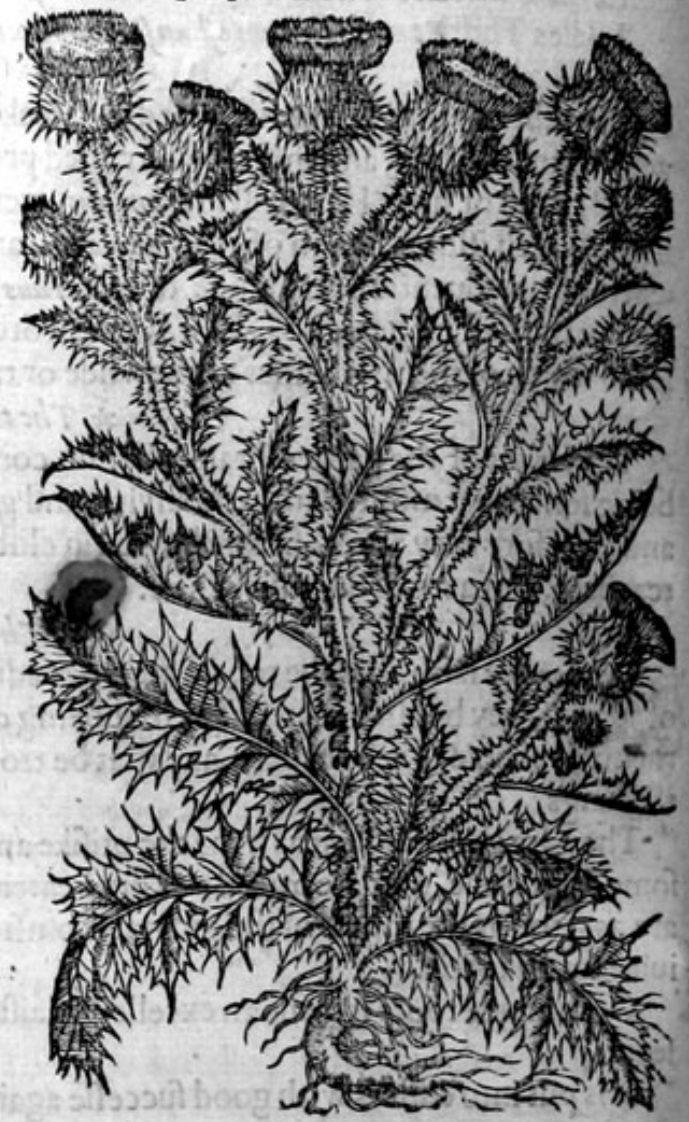

* Theplace.

Thefe Thifles grow byhigh waies fides, and in ditches almoft euery where.

* The time.

They flower from tune vntill Auguft, the fecond yeere after they be fowen:and in the mean time the feede waxeth, which being thorowe ripe the herbe perifheth, as doe likewife moft of the other Thittles, which liue no longer then till the feed be fully come to maturitie.

* The names.

This Thiftle is taken for that which is called in Greeke Axdvgsor: which Diofcorides defcribeth to haue Ieaues fet with prickles round about the edges, and to be couered with a thinne downe like 2 copweb, that may be gathered and fpun to make garments of, like thofe of filke : in high Dutch

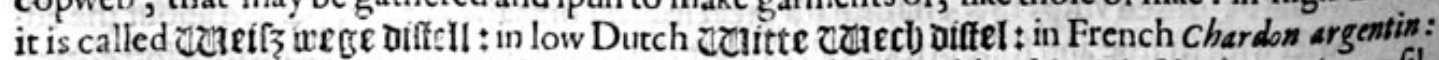
in Englifh ote Thiftle, or cotton Thiftle, white cotton Thiftle, wilde white Thiftle, Argentine or filuer Thiftle. * Thetemperature and vertues.

Diofcorides faith, that the leaucs and rootes heereof are a remedy for thofe that haue their bodies drawne backwards; thereby Galen fuppofeth that thefe are of temperature hot.

\section{Of our Ladies Thistle. Chap.46r.}

$*$ The defcription.

7 He leates of our Ladies Thifte are as bigge as thofe of white cotton Thiftle : for the leaues 1 thereof be great, broade, large gafhed in the edges, armed with a multitude of ftiffe and fharp prickles as are thofe of Ote Ihiftle; but they are without downe, altogither flippery, of a light 


\section{ILIS TORIE OF PLANTS.}

greenc and fpeckled, with white and milkic fpots and lines drawne diuers waies : the ftalke is high and as bigge as a mans finger : the flowers growe foorth of heads full of prickles, being threds of a purple colour : the feedeis wrapped in downe like that of cotton Thiftle: the roote is long, thicke, and white.

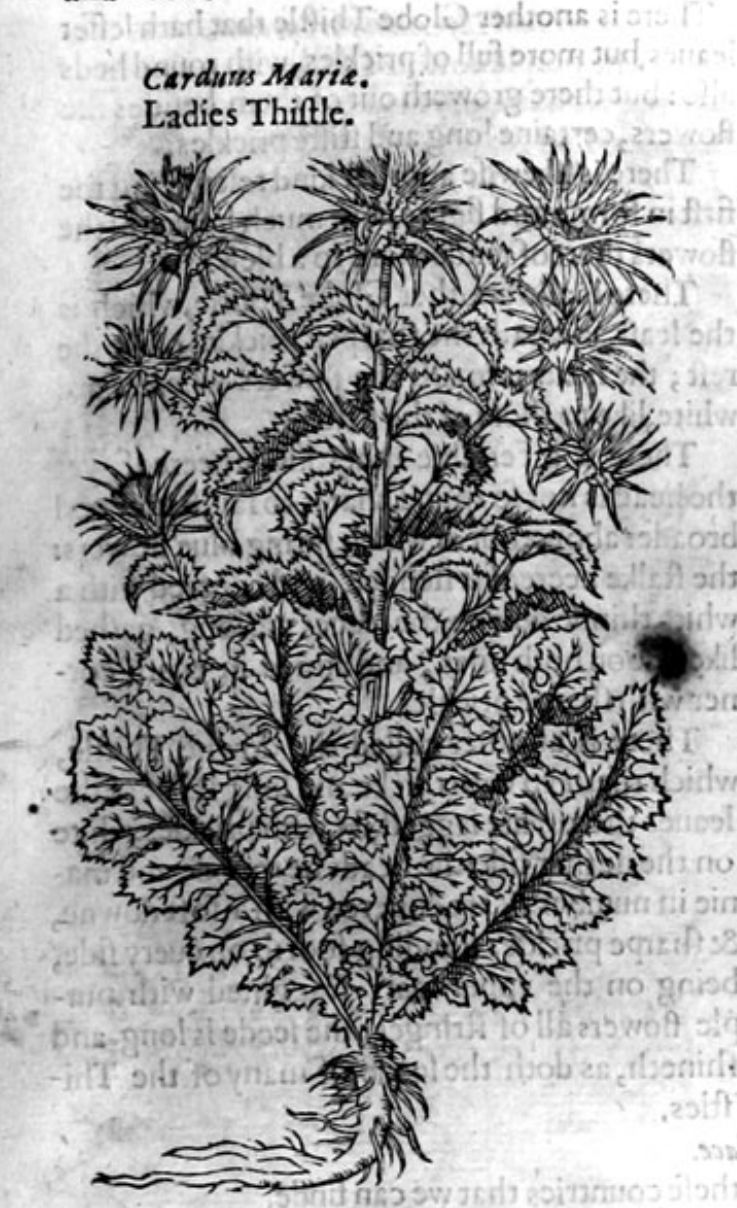

\section{* The place.}

It groweth vpon wafte and common places by high waies, and by dunghils, almoft euery where. * The time.

It flowreth and feedeth when cotton Thiftle doth.

\section{* The names.}

It is called in Latine Carduus Lacteus, and Cardusu CMaric : in high Dutch Dnfer Catoumen Diffell : in French Chardon de noftre Dame : in Englifh our Ladies Thiftle : it mayproperly be called Leucographess, of the white fyots' and lines that are on the leaues: Pliny in his 27 . booke 11 . chapter maketh mention of an herbe called Lencographis, but what maner of one it is he hath not expreffed; therefore it would be harde to affirme this to be the fame that Cardusu Lencographus is, and this is thought to be Spina alba, called in

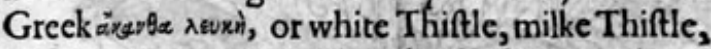
and Carduns Ramptariws, of the Arabians Bedoard, or Bedegusr, as Matthens Syluat icus teftifieth. * The temper ature and vertues.

The tender leaues of Cardusus Leucographsu, the $\mathbf{A}$ prickles taken off are fometimes vfed to be eaten with other herbes.

Galen writech, that the rootes of spina alba, B doth drie and moderately binde; that therefore it is good for thofe that be troubled with thelaske and the bloudie flixe, that it ftaieth bleedings, wafteth away colde fwellings; eafeth the paine of the teeth if they be wafhed with the decoction thereof.

The fecde thereof is of a thin effence and hot facultie, therfore hefaich that it is good for thofe C that be troubled with cramps.

Diofcorides affirmeth that the feeds being drunk are a remedie for infants that haue their fmewes D drawne togither, and for thofe that be bitten of ferpents : and that it is thought to driue awaie ferpents, if it be but hanged about the necke.

\section{of the globe Thistle. Chap.462.

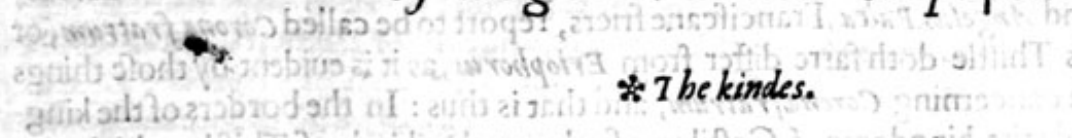

There are diuers kindes of Globe Thiftles.

$\cdot$

* The defcription.

Lobe Thiftle hath a very long ftalke, and leaues iagged, great,long, \& broad,deepely gahed, ftrong of fmell, fomwhat green on the vpper fide, and on the ncather fide whiter and downie: the flowers growe foorth of a rounde head like a globe, which ftandeth on the tops of the ftalkes; they are white and fmall, with blew threds in the midft : the feede is long, with haires of $\mathbf{a}$ meane length: the roote is thicke and branched. 
Cardusus Globofrus:

The Globe Thiftle.

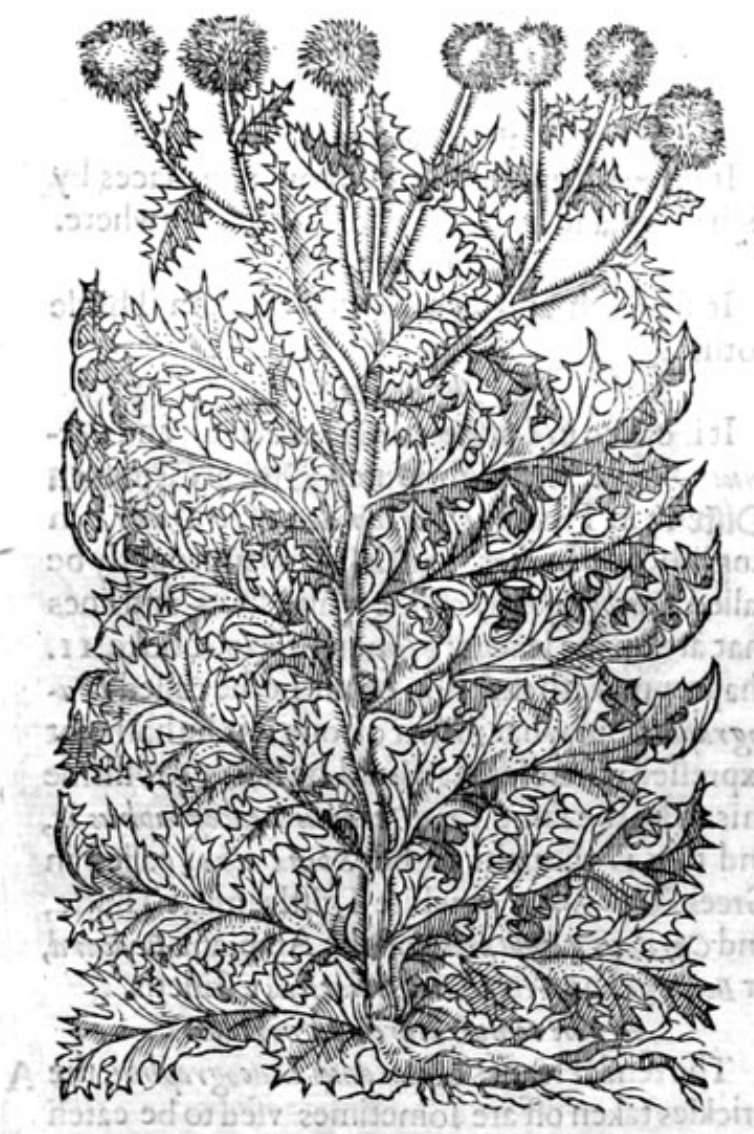

- * The defcription.

There is another Globe Thiftle that hath leffer leaues, but more full of prickles, with round heds alfo: but there groweth out of them befides the flowers, certaine long and ftiffe prickles,

There is likewife another kind refembling the firft in forme and figure, but much leffer, \& the flowers thereof tende more to a blew.

There is alfo another Globe Thiftle, which is the leaft, and hath the fharpeft prickles of all the reft; the head is imall; the flowers whereof are white, like to thofe of the firft.

There is a certaine other kindeheereof, yet the head is not fo round, that is to fay, flatter and broader aboue; out of which fpring hlue flowers: the ftalke heereof is flender, and couered with 2 white thinne downe; the leaues are long, gafhed likewife on both fides, and armed in cuery corner withfirarpe prickles.

There is another called the downe Thifte, which rifeth yp with thicke and long ftalkes: the Ieaues thereof are iagged, fet with prickles, white on the nether fide:the heads be rounde and manie in number, $\&$ are conered with a foft downe, \& fharpe prickles ftanding foorth on euery fide, being on the ypper part fraughted with purple flowers all of ftringes: the feede is long and Ahineth, as doth the feede of many of the Thiftles.

* The place.

They are fowen in gardens and do not growe in thefe countries that we can finde.

They flower and flourifh when the other Thiftles do.

* The names.

Fuchfins did at the firft take it to be chameleon niger, but afterwards being better aduifed namedit Spina peregrina, \& Carduus globofus : $V$ al Cordses doth fitly call it Sphar ocephalis: the fame name doth alfo agree with the reft, for they haue a rounde head like a ball or globe; molt woulde haue the firt to be that which Mathiolus fetteth downe for Spina alba: this Thiftle is called in Englifh Globe Thiftle, and Ball Thiftle.

The downe Thiftle is called in Latin being deftitute of another name Eriocep halus, of the woolly head: in Englifh downe Thiftle, or cotton Thiftle; it is thought of diuers to be that which Bartholomens $V$ rbeuenetanus and Angelus Palea, Francifcane friers, report to be called Corona fratrom, or Friers Crowne: but this Thiftle doth farre differ from Eriophorus, as it is euident by thofe things which they haue written concerning Corona fratrum, and that is thus: In the borders of the kingdome of Aragon towards the kingdome of Caftile we finde another kinde of Thiftle, which groweth plentifully there by common waies and in wheate fieldes.

$$
\begin{aligned}
& \text { * The temperature and vertwes. } \\
& \text { Concerning the temperature and vertues of thefe Thiftles we can alledge nothing at all. }
\end{aligned}
$$




\section{HISTORIE OF PLANTS,}

$$
\text { Of the Articboke. Chap.463. }
$$

* The kindes.

$\mathrm{T}^{\mathrm{H}}$

Here be three forts of Artichokes, two tame or of the garden;and one wrilde, which the Italian efteemeth greatly of as the beft to be eaten rawe, which he calleth Cardune.

1 Cinara maxima Anglica. The great red Artichoke.

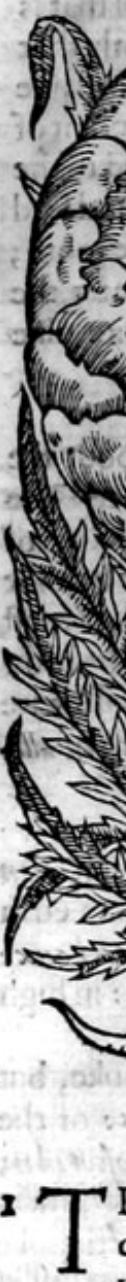

con

)

vanc aty

4(

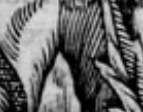

$(-2)$

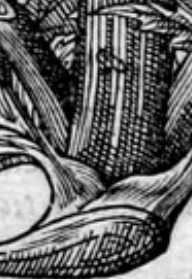

2 Cinaramaxima alba. The great white Artichoke.
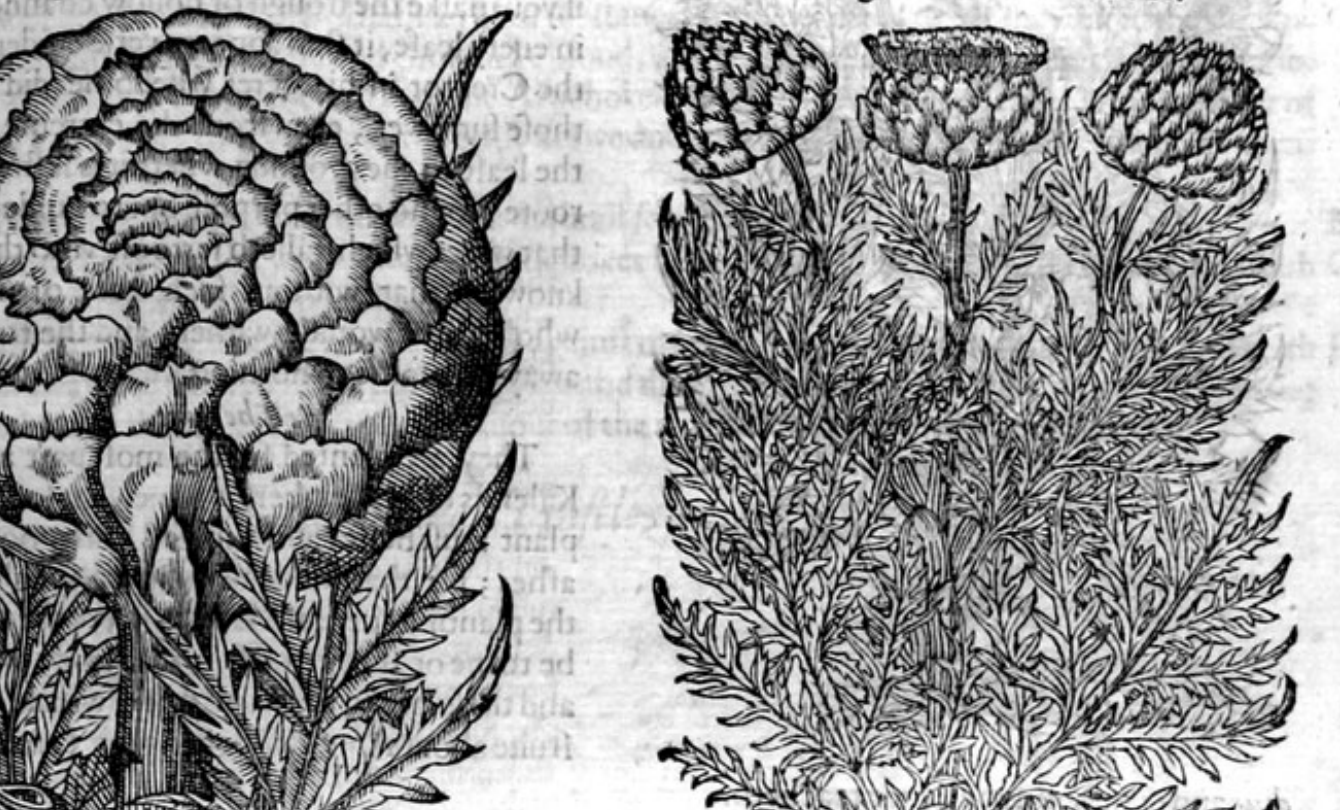

(1)
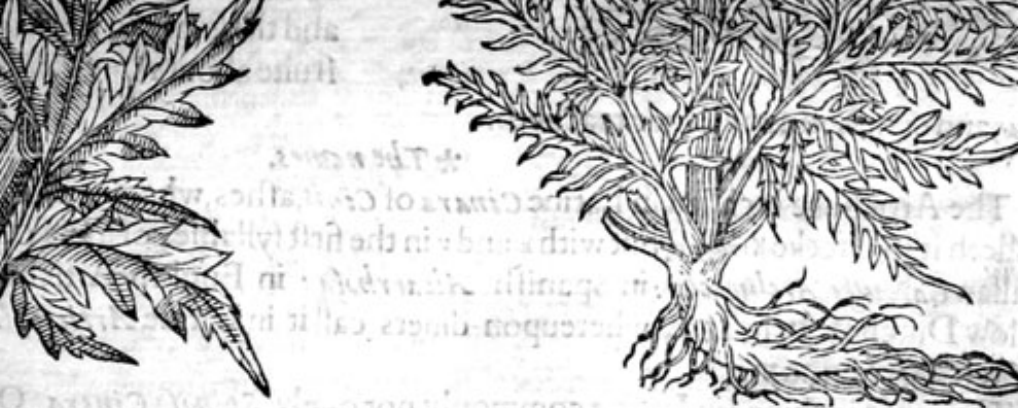

* The defcription.

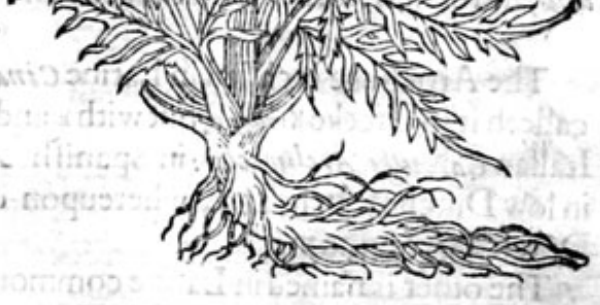

high, and bringer or verie few 3 and they be of a greene ath colour: the ftalke is aboue a cubite high, and bringeth foorth on the top a fruite like a globe, refembling at the firft a cone or Pine apple, that is to fay, made vp of many fcales; which is when the fruit is great or loofed, of a greenifh red colour within, and in the lower parte full of fubftance and white; but when it openeth it felfe there groweth alfo vpon the cone a flower al of threds, of a gallant purple tending to a blewe colour: the feede is long,greater and thicker then that of our Ladies Thittle, lying vnder foft and downie haires, which are contained within the fruite : the roote is thicke aid of a meane length.

2 The fecond great Artichoke differeth from the former in the colour of the fruite, otherwife there is little difference, except the fruite heereof dilateth it felfe further abroade, and is not fo clofely compact togither, which maketh the difference.

3 The prickely Artichoke called in Latine Cardunes or Spinofa Cinara, differeth not from the former, faue that all the corners of the leaues hereof, and the ftalkes of the cone or fruite are srmed with ftiffe and harpe prickles, whereupon it beareth well the name of Carduses or Thiftle. 
3 Cinara flowestris. Wilde Artichoke.

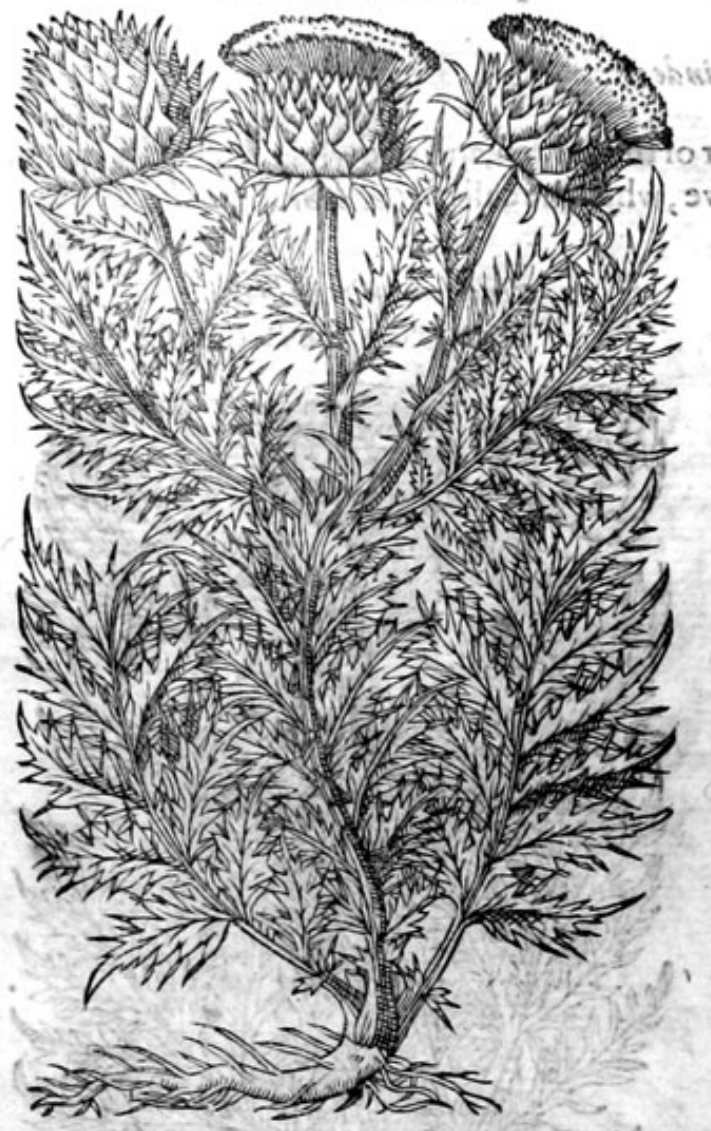

* The place.

The Artichoke is to be planted in a fat \& fruitfull foile : they do loue water and moilt grounde. The commit great errour who cut away the fide. or fuperfluous leaues that growe byl theifides, wsthinking thereby to increale the greatnos of the fruite; when as in truth they deprited the roote from much water by that meanes which fhould nourith the roote to the feeding of the fruite : for if youmarke the trough ochollow channel that is in euery leafe, it fhal appeere veric euidently that the Creator in hisfecret wiledome did ordaine thofe furrowes, enen from the extreme point of the leafe to the grounde where it is faftned to the roote, for no other purpofe but to guide and lead thatwater which falleth farre off vnto the roote; knowing that without fuch ftore of water thic whole plant woulde wither, and the fruite pine away and come to nothing.

$$
\text { * The time. }
$$

They are planted for the molt part about the Kalends of Nouember, or fomewhat fooner. The plant muft be fet and dunged with good ftore of afhes; for that kinde of dung is thought beft for the planting thereof. Euerie yeere the flips mult be torne or Alipped off from the body of the root: and thefe are to be fet in Aprill which will beare fruite about Auguft following, as Columells, $P_{\text {allt }}$.

dives, and common experience teachech.

\section{* The nomes.}

The Artichoke is called in Latine Cinars of $C$ in is, afhes, wherewith it loueth to be dunged. Galen calleth it in Greeke Kivaegy, but with $x$ and $v$ in the firft fyllable, of fome Cinar a cactos: it is nianed in Italian Carcioff, Arcbrocchi : in Spanifh Alcarrhofa: in Englifh Artichoke: in French Artichasx: in low Durch Grticbalen, whereupon diuers call it in Latine Articocalese, and Articoca : in high Dutch Gtrobildozm.

The other is named in Latine commonly not onely Spinua a Cinara, Ote prickly Artichoke, but alfo of Falladius, Cardurus: of the Italians Cardo, and Cardino: of the Spaniards Cardos: of the French men chardons: Leonhartus Fuchfius, and moft writers take it to be Scolymus Diofouridis; but Scolymus D tofcoridis hath the leafe of Chameleon or Spind alba, with a ftalkefull of leaties, and a prickly head: but neither is Cinara the Artichoke which is without prickles, nor the Attichoke with prickles any fuch kinde of herbe; for though the head hath prickles, yet the italke is not fullof leaues, but is many times without leaues, or elie hath not paft a leafe or two. Cinara doth better agree with that which Theophrast us and Pline call xixres, Cactus, and yet it dothnotbring foorth ftalkes from the roote creeping alongft the grourid ; it hath broad leaues fet with prickles, the niddle ribs of the leaues, the skin pilled off, are good to be caten, and likewife the fruite, the leede and downe taken away; and that which is vnder is as tender as the braine of the Date tree; which things Theophraf us and Plinie reporc of Cactus: that which they write of the ftalkes fent foorth inmediately from the roote vpon the grounde, which are good to be eaten, is peraduenture the ribs of leaues:euery fide taken away (as they be ferued vp at the table) may be like a ftalke, except euen in Sicilia, where they grew onely in Theophraft sus time: it bringeth foorth both certaine ftalkes thatlie on the ground, and another alfo ftanding ftraight vp; but afterwards being remooued and brought into Italy or England, it bringeth foorth no more but one ypright: for the foile and clime do much into ltaly or England, it bringeth foorth no more but one ypright: for the foile and clime de it felfe
prewaile in altering of plants, as not onely $T$ beophraftus teacheth, but alio euen experience declareth, 
declareth; and of Cactus Theophrafus writeth thus: vikns, Cactus, groweth oncly in Sicilia: is bringeth foorth prefently from the roote ftalks, lying along vpon the grounde, with a broade and prickly leafe; the ftalkes being pilled, are fit to be eaten, being fomewhat bitter, which may be pre ferued in brinesit bringeth foorth alfo a nother ftalke, the fame likewife is good to be eaten. * The temperature and vertues.

The nailes, that is the white $\&$ thick parts which are in the bottom of the outwardfcales or flakes $\mathbf{A}$ of the fruit of the Artichoke, \& alfo the middle pulpe, wheron the downy feed doth ftand, are eaten both rawe with Pepper and falt, and commonly boiled with the broth of fat $\mathrm{Alefh}$, with pepper ad. ded; and are accounted a dainty difh, being pleafant to the tafte, and good to procure bodily luft: fo likewifc the middle ribs of the leaues being made white \& tender by good chernhing and looking to, are brought to the table as 2 geat feruice togither with other iunkets: they are eaten with pepper and falt, as be the raw Artichokes; yet both of them are of ill iuice: for the Artichoke containeth plentie of cholericke iuice, and hath an hard fubftance; infomuch as of this is ingendred melancholike iuice, and of that a thinne and cholericke bloud, as Galen teacherh in his booke of the Faculties of nourifhments : but it is beft to cate the Artichoke boiled; the ribs of the leaues are altogither of an hard fubftance: they yeelde to the body a rawe and inclancholike iuice, and containe in them great ftore of winde.

It ftaich the inuohntary courfe of the naturall feede in man or woman.

Sone write that if the yoong buds of Artichokes be firft fteeped in wine and eaten, it prouoketh $\mathrm{C}$ vrine, and ftirreth vp the luft of the bodie.

I finde moreouer, that the roote is good againft the rank fmel of the arme holes, if when the pith $D$ is taken away, the fame roote be boiled in wine and drunke: for itfendeth foorth plentie of ftinking vrine, whereby the ranke and rammifh fauour of the whole body is much amended.

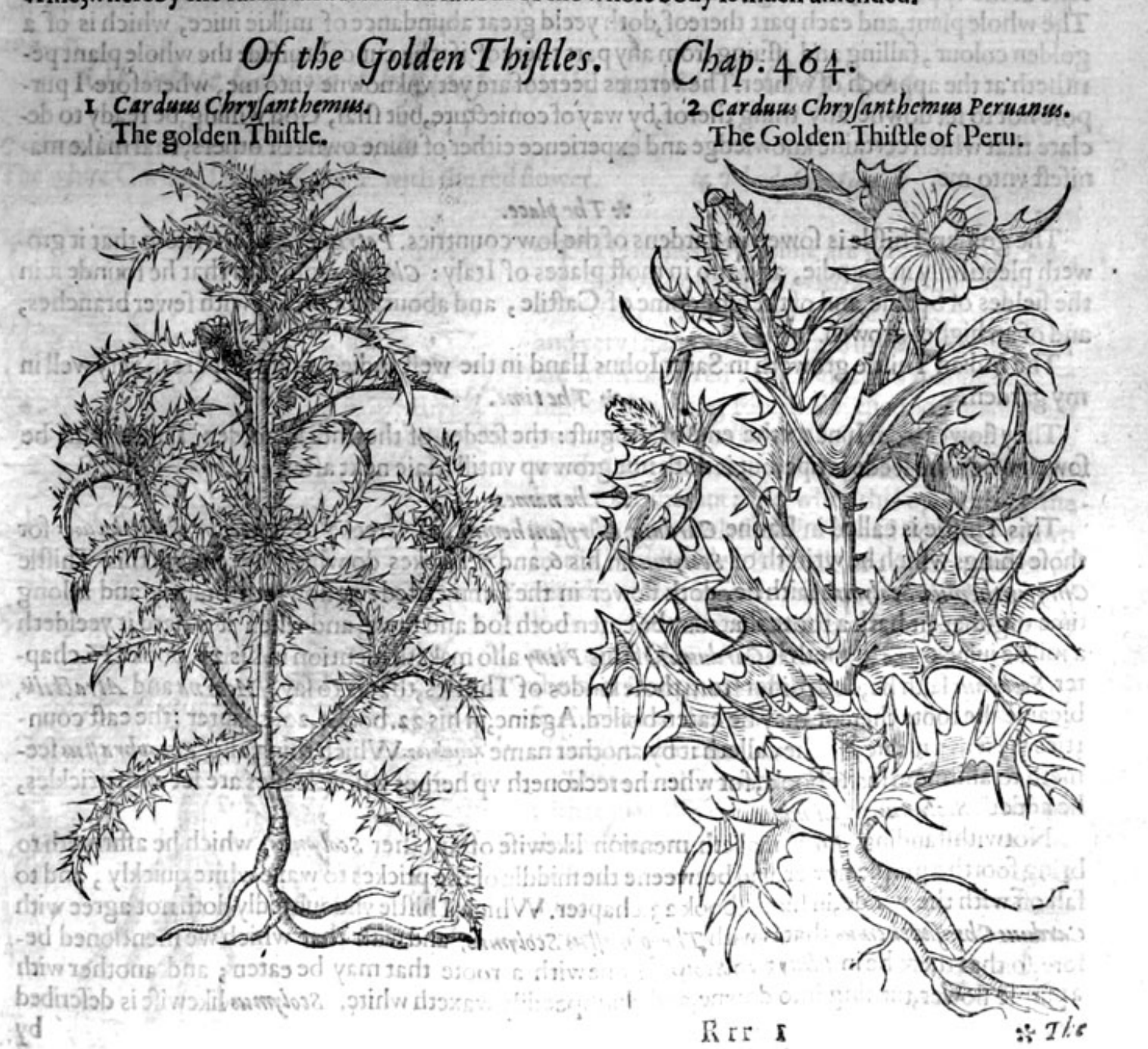


$*$ The defcription.

I T He ftalkes of golden Thiftle rife vp foorthwith from the roote,being many,rounde and branched:the leaties are long, of a beautifull greene, with deepe gafhes on the edges, and fet with moft fharpe prickles : the flowers come from the bofome of the leaues, fet in a fica. lie chaffic knap, very like to Succorie flowers, but of a colour as yellow as golde: in their places come vp broad, Alat, and thinne feedes, not great, nor wrapped in downe:the roote is long, a finger thicke, fwcet, fof $\mathrm{r}$, and good to be eaten, wherewith fwine are much delighted: there iffuerh foorth of this Thiftle in what part foeuer it is cut or broken, a iuice as white as milke.

2 The golden Thiftle of Peru,called in the weft Indies Fique del inferno, a friend of mine brought it vnto me from an Iland there, called Saint Iohns Iland, among other feedes:'what reafon the inhabitants there haue to call it fo, it is vnto me vnknown, vnleffe it be bicaufe of his fruite, which doth much refemble a figge in thape and bigneffe, but fo full of fharpe and venemous prickles, that who. foeuer had one of them in his throte, doubtleffe it woulde fende him packing either to heauen or to hell. This plant hath a fingle woodie roote, as bigge as a mans thombe, but fomewhat long: from which arifeth a brittle ftalke full of ioints or knees, diuiding it felfe into fundrie other finall branches, fet full of leaues. like vnto the milke Thiftle, b.ıt much fmaller,and ftraked with inanie white lines or ftreakes: and at the top of theftalks come foorth faire and goodly yellow flowers, very like vnto the fea Poppie, but more elegant and of greater beautie, hauing in the middle thereof a fmall knop or boll, fuch as is in the middle of our wilde Poppie, but full of tharpe thornes, andat the tip or end thereof a ftaine or fpot of a deepe purple : afterthe yellow flowers be fallen, this forefaide knop groweth by degrees greater and greater, vntill it come to full maturitie, which openeth it felfe at the vpper end, fhewing his feed, which is very blacke and round like the feedes of Muftarde. The whole plant, and each part thereof,doth yeeld great abundance of milkie iuice, which is of a golden colour, falling and iffuing from any part thereof, if it be cut or bruifed: the whole plantperifheth at the approch of winter. The vertues heereof are yet vnknowne vnto me, wherefore I purpofe not to fet downe any thing therof, by way of coniecture, but fhal, God willing, be ready to declare that which certaine knowledge and experience either of mine owne or others, fhal make manifeft vnto me.

* The place.

The golden Thiftle is fowen in gardens of the low countries. Petres Bellonizu writeth that it gro. - weth plentifully in Candie, and alfo in moft places of Italy: Clnfins reporteth that he founde it in the fieldes of Spaine, and of the kingdome of Caftile, and about Montpelier with fewer branches, and of an higher growth.

The Indian Thiftle groweth in Saint Iohns Iland in the weft Indies, and profpereth very well in my garden. * The time.

They flower from Iune to the end of Auguft: the feedes of the Indian golden Thiftle muft be fowen when the feede is ripe, but it doth not grow vp vntill Maie next after.

\section{* 7 he names.}

This Thiftle is called in Latine Carduns chryfanthemus, in Greeke of $T$ beophraftess oxdrupes: for thofe things which he writeth of Scolymus in his 6 . and 7 . bookes do wholy agree with this Thiftle Chry]ant bemus. Scolymus faith he, doth flower in the fommerfted: it flowreth brauely and a long time togither; it hath a roote that maybe eaten both fod and rawe, and when it is hard it yeeldeth a milkie iuice.Gaza nameth it Carduses. Of this Pliny alfo maketh mention in his 2 r. booke r 6.chapter, Scolymus faith he, doth differ from thofe kindes of Thiftles, that is to fay, Acarna and Atractilis, bicaufe the roote thereof may be eaten boiled. Againe, in his 22. booke, 22. chapter :the eaft countries vfe it as a meate, and he calleth it by another name nesusurvor. Which thing alfo $T$ heophraftus feemeth to affirme in his 6 . book, for when he reckoneth vp herbes whofe leaues are fet with prickles, he addeth Scolymus, or Limonia.

Notwithftanding, Pliny maketh mention likewife of another Scolymus, which he affirmeth to bring foorth a purple flower, and betweene the middle of the prickes to waxe white quickly, and to fall off with the winde, in his 20 .book 23 .chapter. Which Thiftle vndoubtedly doth not agree with Carduus Chryfanthemus, that is with Theophraftus Scolymks, and with that which we mentioned before, fo that there be in Pliny two Scolymi : one with a roote that may be eaten; and another with a purple flower, turning into downe, and that fpeedily waxeth white. Scolymus likewife is defcribed 


\section{HISTORIE OF PLANTS.}

by Dio fcorides, but this differeth from scolymus Theophrafti, and it is one of thofe which pling 975 koneth vp, as we willmoreat large declare heereafter. But let vs come againe to Chirvfant hemus, this the inhabitants of Candie keeping the markes of the old natne, do call it A/colymbi/os : the Italians name it Anconitani Rinci: the Romaines Spins borda : the Spaniards Cardon lechar: and of diuets icisalfo nained Glycgrnbizon, that is to fay Dulcis radrx, or fweete roote : it is called in Englifh golden Thiftle; fome would haue it to be that which Vegetzus in Zrte Veterinaria calleth Eryngzums but they are deceiued, for that Eryngium whereof $V$ legetius writeth, is Eryngium CNarinum, or fea Huluer: of which we will intreate.

The golden Thiftle of India, may be called Cardsus Chryfant hemus, of his golden colour, adding thereto his, natiue countrey Indsanus, or Perwanus, or the golden Indian Thiftle, bo the golderithifle of Peru: the feede came to my handes by the riame Frque del inferno: in Latine Eiciesinfernatis,

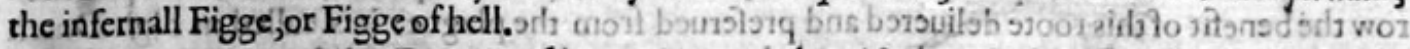

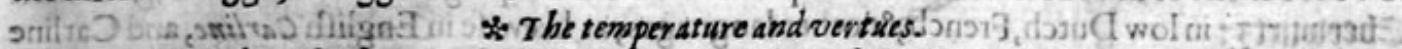
- The roote and tender leaues of this Scolymus, which are fornecimes cateri 3 are good for the fto; A macke, bue they containe very little nourifhment, and the fame thinne and watery; as Gaken teacheth. 2. Pliny faith, that the roote heer of was comimended by Eratosthenes, in the poore mants fapper, B and that it is.reportedalfo to prouoke yrane efpccially, to heale tecters and dry fourffe being taken with vineger;and with wine to ftirre vp Alefhly luft, as Hefrodus and Alceens teftifiejand to take away the ftenchof the arme hobles, if an cunce of the roote, the pith picked our, be boiled in three parts of wine, tillone part be wafted, and a gooßdraught taken fafting after a bath, and likewife after meat? which laser words Dio/corides likewife hath conceriing his Soolymess: out of whom Pliny is thoughe

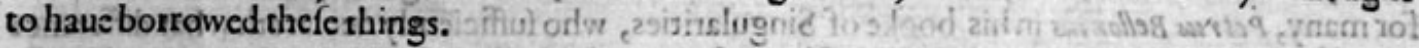

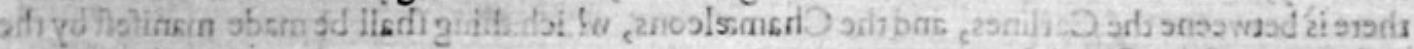

$$
\text { Of white Carline Thiftle of Diofcorides. }{ }^{21} \text { Chap.465. }
$$

Carlina, feu Chameleon albus Diofcoridis. The white Carline Thiftle of Diofo. with the red flower. Iis o $*$ Tiedefcription.

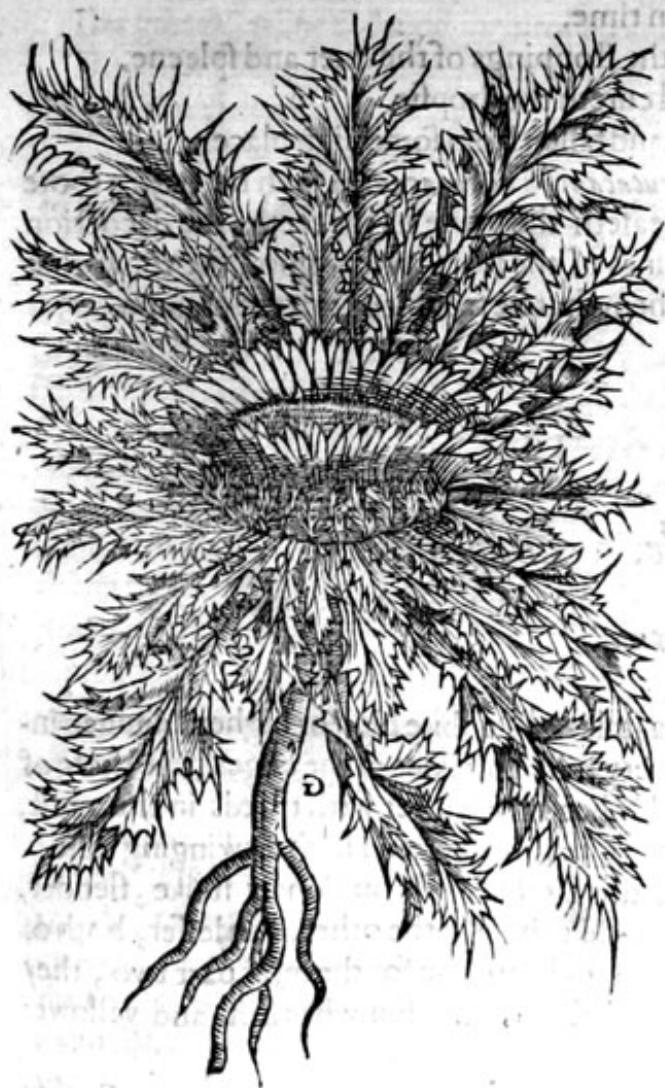
7 Heleaues of Carline are very full of prickles;
cut on both edges with a multitude of deepe gafhes, and fet alongft the corners with ftiffe and very fharpe prickles; the middle ribs whereof are fonsetime red : the ftalke is a fpanne high or higher, bringing foorth for the moft part onely one hed or knap being full ofprickles, on the outward circumference or compaffe like the Vrchin : huske of a chefnut: and when this openeth at the top, there groweth foorth a broad flower,made vp in the middle like a flat ball, of a great number of threds, which is compaffed about with little long leaues, oftentimes fomewhat white, very feldome red: the feede vinderneath is flender and narrowe, the roote long, a finger thicke, fomething blacke, fo chinked as though it were fplit in funder, fweete of fmell, and in tafte fomwhat bitter.

There is alfo another hecrof without a ftalke, with leaues alfo very full of prickles, like almoft to thofe of the other, lying flat on the ground on cuerie fide: among which there groweth forth in the middle a rounde head or knap, fet with prickles without after the fame manner, but greater : the flower whereof in the middlc is of ftrings, and paled rounde about with red leaues, and fometimes 
with white, in faire and calme weather the flower both of this and alfo of the other laieth themb. felues wide open,and when the weather is fowle and milty, are drawne clofe togither: the roote heereof is long, and fweetc of fmcll, white, found, not chinked or fplitted as the other.

$$
\text { * The place. }
$$

They both grow vpon high mountaines in delart places, and oftentimes by high way fides; but that which bringeth foorth a ftalk groweth euery where in Germany, and is a ftranget in England.

They flower and feede in Iuly and Auguft, and many times later.

$$
\text { * The time. In }
$$

\section{* T he names.}

The former is called in Latine Carlina prior, and Cardopativm, and of diuers Caroline, of charle. maine the firft Romain Emperor of that name, whofe armie (as it is reported)was in times palt thorow the benefit of this roote deliuered and preferued from the plagie: it is called in high Dutch Ebertwurtz : in low Dutch, French, \& other languages, as likewife in Englifh Carline, and Carline Thiftle: it is Diofcorides his Leucacanthe; the ftrong \& bitter rootes thew the fame; the faculties allo are anfwerable, as foorthwith we wil declare:Leacacant ha hath alfo other names, but they are coun. terfeit, as among the Romaines Gniacardus, \& among the Thufcans Spina alba, or white Thiftle,yet doth it differ from that Thiftle which Diofcorides calleth Spina alba, our Ladies Thiftle; of which he alfo writing apart, doch likewife attribute to both of them their owhe proper faculties and operations, and the fame differing.

The later writers do alfo call the other Carlina altera, and Carlina homilis, or minor, lowe or little Carline : but they are much deceiued who go about to refer them both to the Chamaleons; for in Italie, Germanie or Fraunce, Chamaleones, the Chamæleons, do neuer growe, as there is one witnes for many, Petrus Bellonius in his booke of Singularities, who fufficiently declareth what difference there is betweene the Carlines, and the Chamæleons, which thing thall be made manifelt by the defcription of the Chan elcons.

\section{* The temperature and vertues.}

A The roote of Carline which is chiefely vfed, is hot in the later end of the fecond degree, and drie in the thirde, with a thinnes of parts and fubftance; it procureth fiveat, it driueth foorth all kinde of wormes of the belly, it is an enimic to all maner of poifons, it doth not onely driue away infeetions of the plague, but alfo cureth the fame if it be drunke in time.

B Being chewed it helpeth the toothach; it openeth the ftoppings of the liuer and fpleene.

C It prouoketh vrine, bringeth downe the menfes, and cureth the dropfie.

D And it is giuen to thofe that haue beene dry beaten, and fallen from fome high place.

E The like operations Dio/corides hath concerning Leucacantha: Lencacant ha faith he, hath a roote like Galanga, bitter and ftrong, which being chewed eafeth the paine of the teeth, the decoction thereof with a draught of wine is a remedie againft paines of the fides, and is good for thofe that haue the Sciatica, or ach in the huckle bones, and for them that be troubled with the crampe.

F The iuice alfo being drunke is of like vertues.

\section{The wilde Carline Thifle. Chap. 466.}

\section{* The defcription.}

I $1 \begin{aligned} & \text { He great wilde Carline Thiftle rifeth v with a ftalke of a cubite high or higher, diuided in- } \\ & \text { to certaine branches:the leaues are long, and very full of prickles in the edges, like thofe of }\end{aligned}$ and paled round about with little yellowifh leaues: the roote is flender, and hath a twinging tafte. 2 Carolus Clufius, defcribeth 2 certaine other alfo of this kinde, with one onely ftalke, flender; fhort, and not aboue a handfull high, with prickly leaues like thofe of the other, but leffer, both o: them couered with a certaine hoarie downe : the heads or knaps are for the moft part two, they haue a pale downe in the midtt, and leaues ftanding round about being fomwhat ftiffe and yellowe: the roote is flen der and of a reddifh yellow. 
I Carlima fyluefris maior.

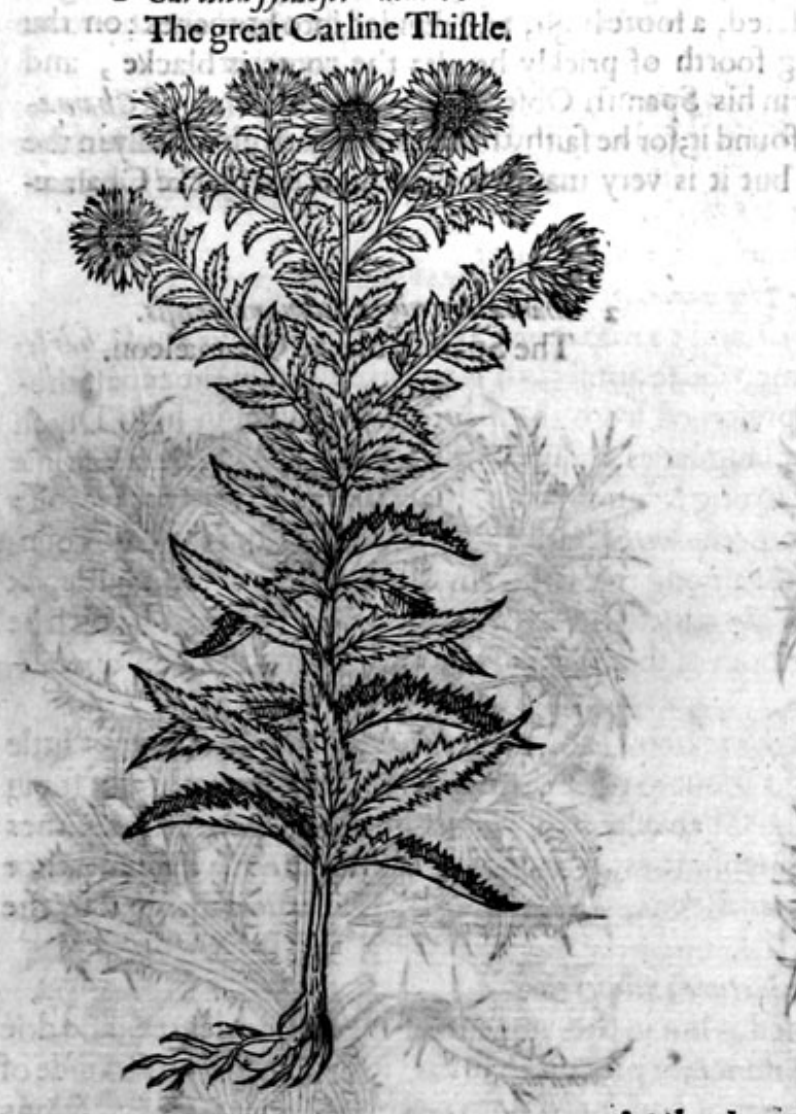

2 Carlina fylueftris minor. The littlc Carline Thiftle.

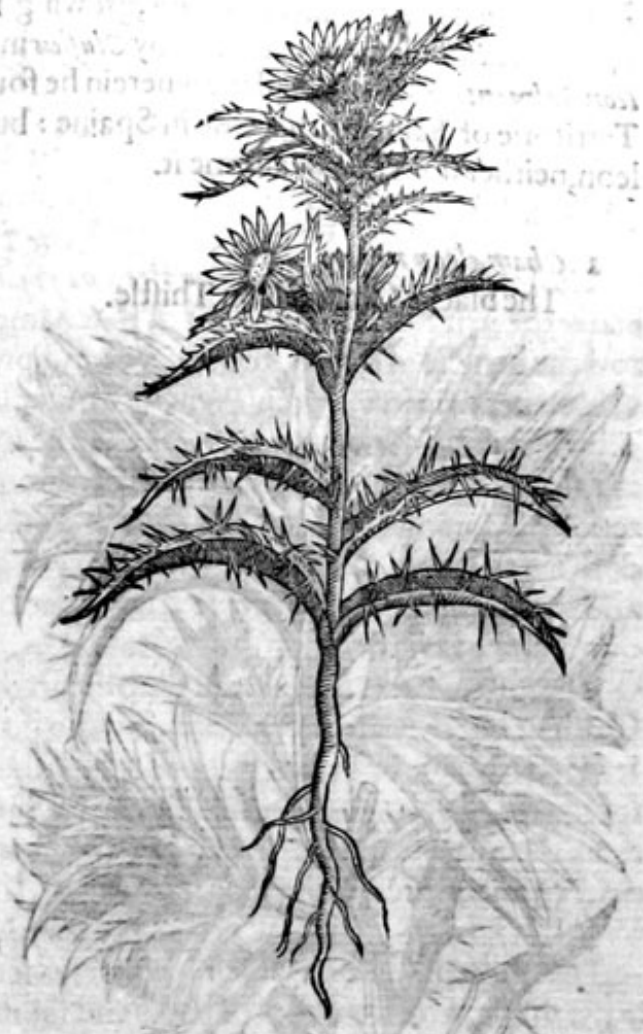

The grear $C$ arline is found in vntoiled and delart places, and oftentimes vpon hils.

The leffer Carline Carolus Clufus writeth that he found growing in dry ftony, and defart places about Salmantica a citie of Spaine.

They flower and flourith in Iune and Iuly.

It is commonly called in Latine and that not vnfitly Carlina Sylueftris : for it is like to Carline in flowers,atrd is not very vnlike in leaues. And that this is äxopm it is fo much the harder to affirme, by how much the briefer $T$ heophrast w hath written heerof: for he faith that this is like baftard Saffron, of a yellow colour and fat iuice : and Ucorva differeth from Acarna, for Acarna as Hefrebius faith,isthe Bay tree; but Acorma is a prickly plant.

20 gno slasol

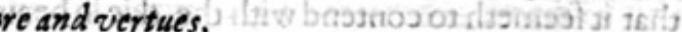
the is hocesecially in the roote, the twinging tafte thereof doth declare; but feeing it is of no vfe, earched out.

\section{Of Chamaleon Thifle. Cbap.467.}

* T be kindes.

7 Here be two Chamaleons, and both blacke; the vertues of their roots do differ; and the roots themfelues do differ in kinde, as Theophraftus declareth.

$*$ The defcription.

1. Heleaues of blacke Chamxleon are Ieffer and flenderer then thofe of theprickly Arti2al w choke, and fprinckled with red fpots: the ftalke is a cubite high, a finger thicke, and fomewhat red, it beareth a tufted rundle, in which are flender prickly fowers, of a blewe colour like the Hyacinth : the roote is thick, blacke without of a clofe fubltance, fometimes eaten awaie, which being cut is of a yellowifh colour within, and being chewed it biteth the toong. 


\section{8}

\section{THE SECOND BOOKEOF THE}

2 This blacke Chameleon hath many leaues, long and narrowe, very full of prickles, of a light greene, in a maner white: the ftalke is chanfered, a foote high, and diuided into branches : on the tops whereof flande purple flowers, growing foorth of prickly heads; the roote is blacke, and fweete in tafte. This is defcribed by Clufius in his Spanilh Obferuations by the name of chameleon Salmanticen /is, of the place wherein he found it; for he faith, that this groweth plentifully in the Territorie of Salmantica, a citie in Spaine : but it is very manifeft that this is not blacke Chamxleon, neither doth clufurs affirme it.

I Chamaleon niger.

Theblacke Chamæleon Thiftle.

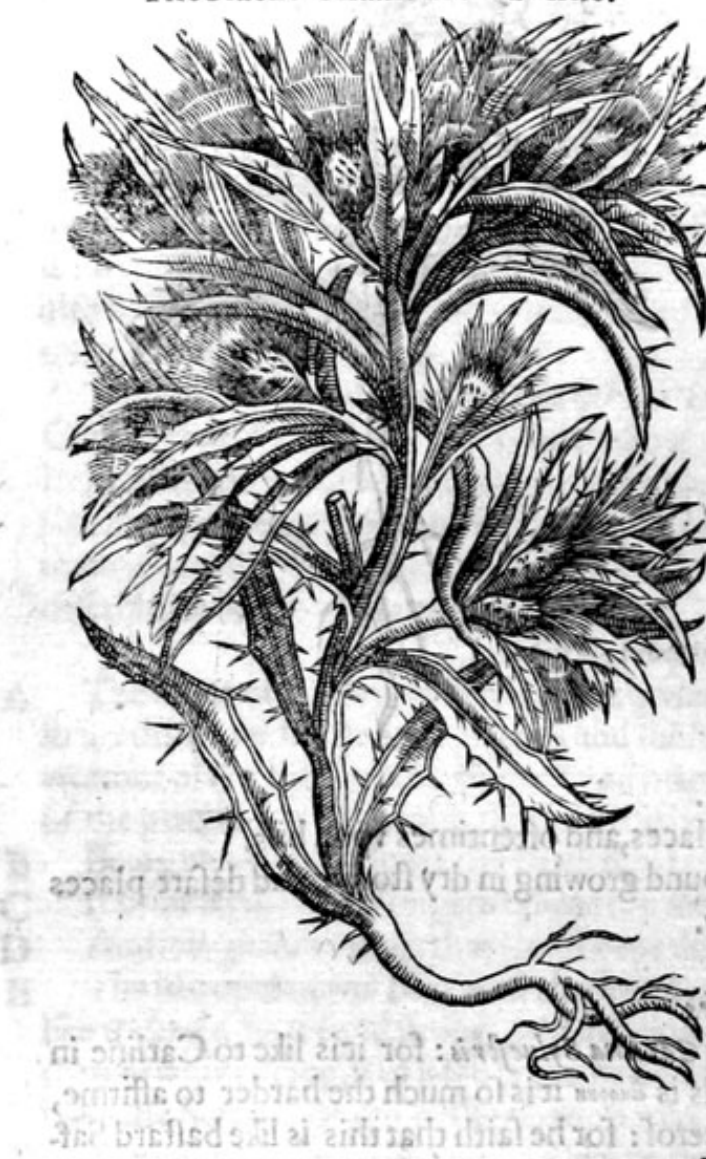

2 Chameleon nizer Salmenticenjis. The Spanifiblacke Chamaleon.

It is very conmon (faith Bellonises) in Lemnos, where it beareth a flower of fo gallantablew, as that it feemeth to contend with the skie in beautie, and that the flower of blewe Bottle being of this colour, feemeth in comparifon of it to bebut pale: it groweth alfo in the fieldes neere Aby$\mathrm{dum}$, and hard by the riuers of Hellefpont, and in Heraclea in Thracia.

Chamaleon Salmanticen/is groweth plentifully in the Territorie of Salmantica a citie in Spaine.

They flower and flourith when the other Thiftles do.

$$
\begin{aligned}
& * \text { The time } \\
& \text { her Thiftles do. }
\end{aligned}
$$

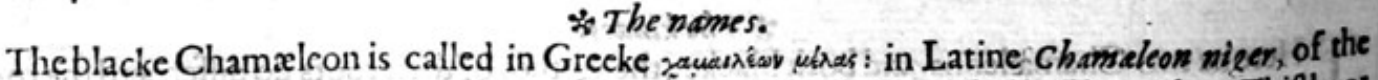
Romaines Carduus niger, and Vernilago, of fome Crocedilion : in Englifh the Chamaleon Thifle, ot the Thiftle that changeth it felfe into man y hapes and colours.

$$
\text { * The temperature and vertues. }
$$

A The roote heerof, as Galen faith, containeth in it a deadly qualitie; it is alfo numbred among the poifonous herbes by Nicander in his booke of Treacles; by Diofcorides in his 6.booke, and by Pulles AEgineta : and therefore it is vfed onely outwardly, as for fcabs, morphewes, tetters, and to be breefe for all fuch things as ftande in neede of clenfing: moreouer, it is mixed with fuch thing 25 do diffolue and mollifie, according to Galew. 


\section{HISTORIE OF PLANTS.}

\section{Of fea Hollie. Chap. 468 .}

* T the kindes.

DIofrorides maketh mention onely of one fea Hollic: $P$ liny in his $\mathbf{2 2}$. booke 7 . Chapter, feemeth to acknowledge two, one growing in rough places, another by the fea fide : the Phifitions after them haue obferued moe, one of the fea, and another of the maine land, and likewife certaine other baitard kinds.

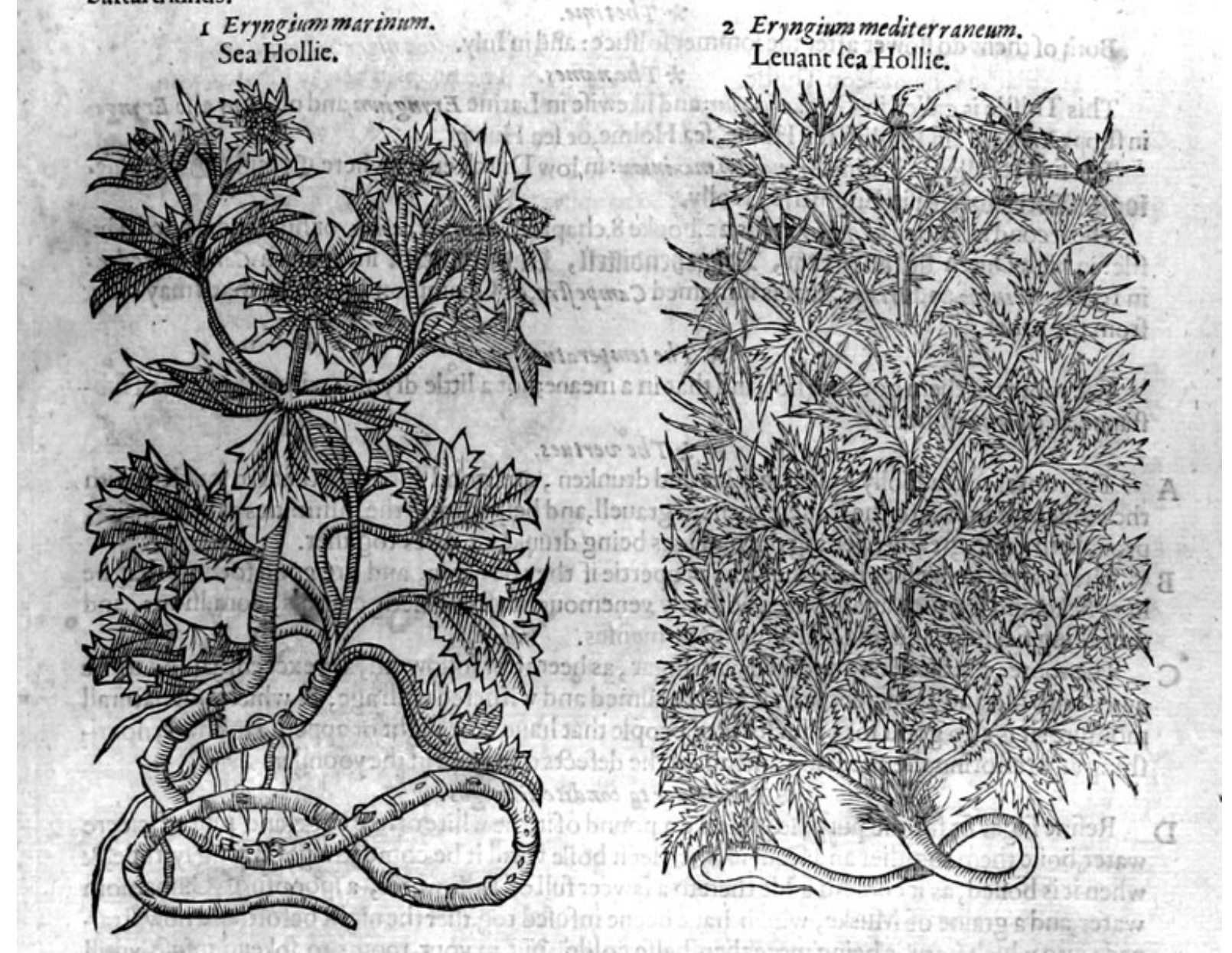

\section{Eryngium mediterraneum.} Leuant fea Hollie.

*. The defcription.

I Ea Holithath broad leaues, like almoft to Mallow leaues, but cornered in the edges, and 5 fet rounabout with hard prickles, fat, of a blewith white, 8 of an aromatical or fpicie tafte : the ftalkis thicke, aboue a cubite high, nowe and then fomewhit red below : it breaketh foorthon the tus into prickley and round heads or knops, of the bignes almolt of a Walnut, belde in for the moftart with fixe prickly leates, compaffing the top of the ftalke round about; which leaues as well ache heads, are of a glittering blew : the flowers foorth of the heads are likewife blew, with whit threds in the middeft : the roote is of the bignes of a mans finger, verie long, and folong, as th it can not be all plucked vp, vnles very feldome; fet heere and there with knots, and of tafte fwee and pleafant.

2 The leaues the fecond feca Hollie, are diuerfly cut into fundry parcels, being all full of prickles alongft the ges : the ftalke is diuided into many branches, and bringeth foorth prickly heads, but leffer then the of the other : from which there alfo grow foorth b/e:v flowers, feldome yellow; there ftand likew vnder euery one of thefe fixe rough and prickly leaties, like thofe of the other, but thinner and ther: the roote hecrof is alfo long, blacke without, white within, a finger thicke, of tafte and fmelte that of the other, as be alfo the leaues, which are likewife of an aromaticall or fpicie tafte, whicleing new fprung vp and as yet tender, be alfo good to be eaten,

$$
\text { Rrr } 4
$$


$*$ The place.

Eryngium marinum groweth by the fea fide vpon the baich and ftonie ground; I found it growing plentifully at Whitftable in Kent; at Rie and Winchelfey in Suffex, and in Effex at Landamer lading,at Harwich, and vpon Langtree point, on the other fide of the water, from whence I haue brought plants for my garden. wife.

Eryngium campeftre, groweth vpon the fhores of the Mediterranean fea, and in my garden like-

* Thetime.

Both of them do flower after the fommer folftice: and in Iuly. * The names.

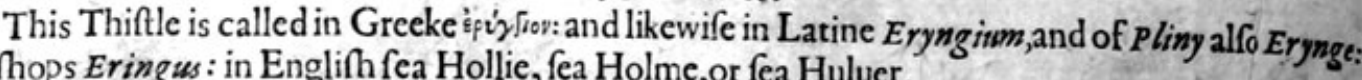
in Thops Eringus : in Englifh fea Hollie, fea Holme, or fea Huluer.

The firft is called in Latine Eryngium marinum: in low Dutch euery where ctpus diff, Einde. loog, 9eerinoztele : in Englifh fea Holly.

The fecond is named of Pliny in his 22 .booke 8.chapter, centum capita, or hundred headed Thiftle: in high Dutch velantztrew, 23zancbendiftefl, Ladenoiffell : in Spanifh Cardk corredor: in Italian Eringio, and Iringo: this is furnamed Campeftre, or Champion fea Holly, that i may differ from the other.

\section{* The temperature.}

The rootes of them both are hot, and that in a meane;not a little dry alfo, with a thimeffe of fubftance, as Galen teftifieth.

A The rootes offea Holly boiled in wine and drunken, are good for them that are toubled with the collicke, it breaketh the ftone, expelleth grauell, and helpeth alfo the infirmities othe kidneies, prouoketh vrine, greatly opening the paffages being drunke 15 . daies togither.

B The rootes themfelues haue the fame propertic if they be eaten, and are good forhofe that be liuer ficke, and for fuch as are bitten with any venemous beafts; cafeth cramps, conylfions, and the falling ficknes; and bringeth downe the menfes.

C The rootes condited or preferued with fugar, as heer after followeth, are exceedingood to be giuen vnto old and aged people that are confumed and withered with age, \& which ant naturall moifture : it is alfo good for other forts of people that haue no delight or appetite to enery, nourifhing and reftoring the aged, and amending the defeets of nature in the yoonger.

\section{* The maner to condite Eryngos.}

D Refine fugar fit for the purpofe, and take a pound of it, the white of one egge, and pint of cleere water,boile them togither and fcum it, then let it boile vntill it be come to a good fong fyrrupe,\& when it is boiled, as it cooleth adde thereto a fawcer full of Rofe water, a fpoonfulbf Cinnamom water, and a graine of Muske, which haue beene infufed togither the night before and now ftrained; into which fyrrupe being more then halfe colde, put in your rootes to foke ad infufe vneill the next day: your rootes being ordered in maner heerafter following.

E Thefe your rootes being wafhed and picked, muft be boyled in faire water by thfpace of fower howers, vntill they be foft, then muft they be pilled cleane, as ye pill Parfneps, ande pith muft be drawne out at the end of the roote; and if there be any, whofe pith cannot be dwen out at the end, then you muft flit them, and fo take out the pith : thefe you muft alfo keepe fm much handling, that they may be cleane, let them remaine in the firupe till the next day, andien fet them on the fire in a faire broad pan vntill they be very hot, but let them not boile at all : ithem thereremaine ouer the fire an hower or more,remoouing them eafily in the pan from ondace to another with a wooden flice. This done, haue in a readines great cap or royall papers,yhereupon you mutt ftrow fome Sugar, vpon which lay your rootes after that you haue taken the out of the pan. Thefe papers you muft put into a Stoue, or hot houfe to harden; but if you haue it fuch a place; lay them before a good fire. In this maniner if you condite your rootes, there not any that can prefcribe you a better way. And thus may you condite any other roote whatfaer, which will not onely be exceeding delicate, but very wholefome, and effectuall againft $t$ difeafes aboue named.

F A certaine man affirmeth, faith Letius, that by the continuall vfe of Sea Hol he neuer afterwards voided any ftone, when as before he was very often tormented with that dife. 


\section{HISTORIE OF PLANTS.}

dram.

It is drunke, faith Diofcorides, with Carrot feede againft very many infirmities in the weight of a $G$ The iuice of the leaues preffed foorth with wine is a remedie for thofe, that are troubled with the $\mathrm{H}$
running of the reines.

They report that the herbe Sea Holly, if one goate take it into hir mouth, it caufeth hirfirft to I ftand ftill, and afterwards the whole flocke, vntill fuch time as the fhepheard take it foorth of hir mouth,as Plutarch writeth.

\section{Of baftard Sea Hollies. Chap:469. \\ * The kindes.} Here be diuers Thiftles reckoned for wilde or baftard kindes of Sea Holly, as fhall be prefently
declared.

I Eryngium cerulewn. Blew Sea Holly.

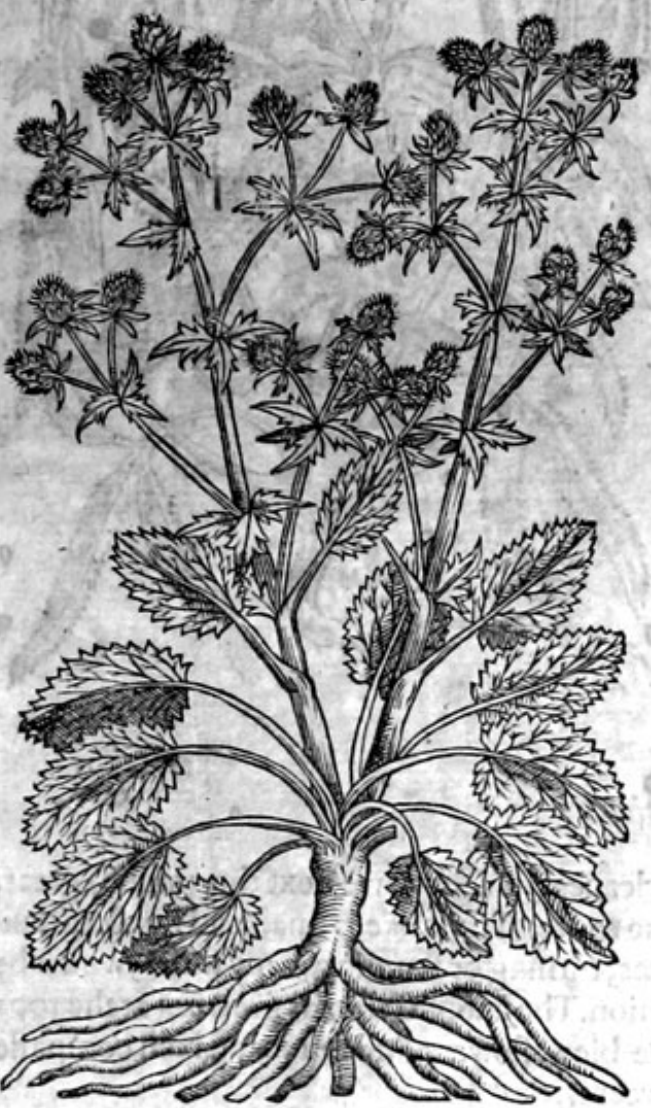

2 Eryngium fpurium primum Dodonai. Baftard Sea Holly.

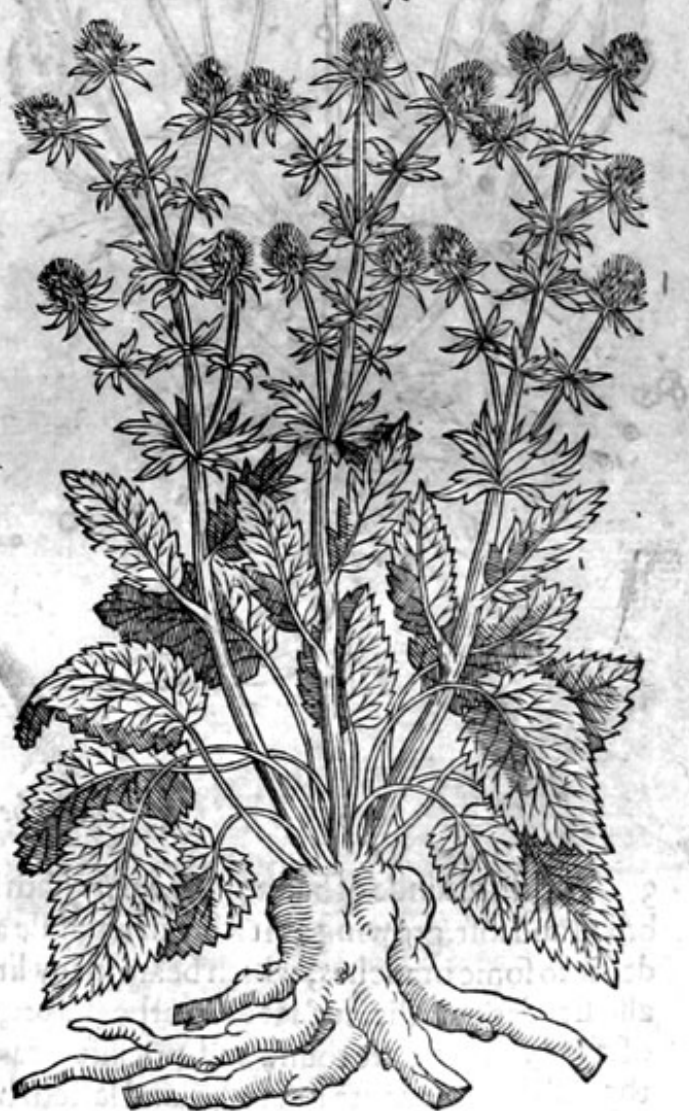

* Thedefcription.

I THis Eryngium, which Dodoneus in his laft edition calleth Eryngium planum, and Pena more fitly and truly Eryngium Alpinum caruleum, hath ftalkes a cubite and a halfe high, hauing fpaces betweene euery ioint. The lower leaues are greater and broader, and notched about the edges, but thofe aboue are leffer, compaffing or enuironing each ioint ftar fafhion, befet with prickles, which are foft and tender, not much hurtfull to the hands of fuch as touch them; the knobs or heads are alfo prickley, and in colour blew. The roote is bunchic or knottie, like that of Heleniwm,that is Elecampane, blacke without and white within, and like the Eringes in fiveeteneffe and tafte. 
2 The fecond baftard Sea Holly, whofe pieture is fet foorth in Dodonass his laft edition very gallantly, being alfo a kinde of Thittle, hath leaues like vnto the former Erynges, but broader next the rcotes than thofe which growe next the ftalkes, fomewhat long, greenifh, ioft, and not prickly, but lightly creuifed or notched about the edges, greater than Quince leaues. The ftalkes growe more than a cubite high; on the tops whereof there hang downwards fiue or fixe knobs or heads, in co. lour and flowers like the others; hauing three or fower whitilh rootes of a foote long.

3 Eryngium pumilum Clusï. Dwarfe Sea Holly.

\section{Eryngium Montanum.} Mountaine Sea Holly.

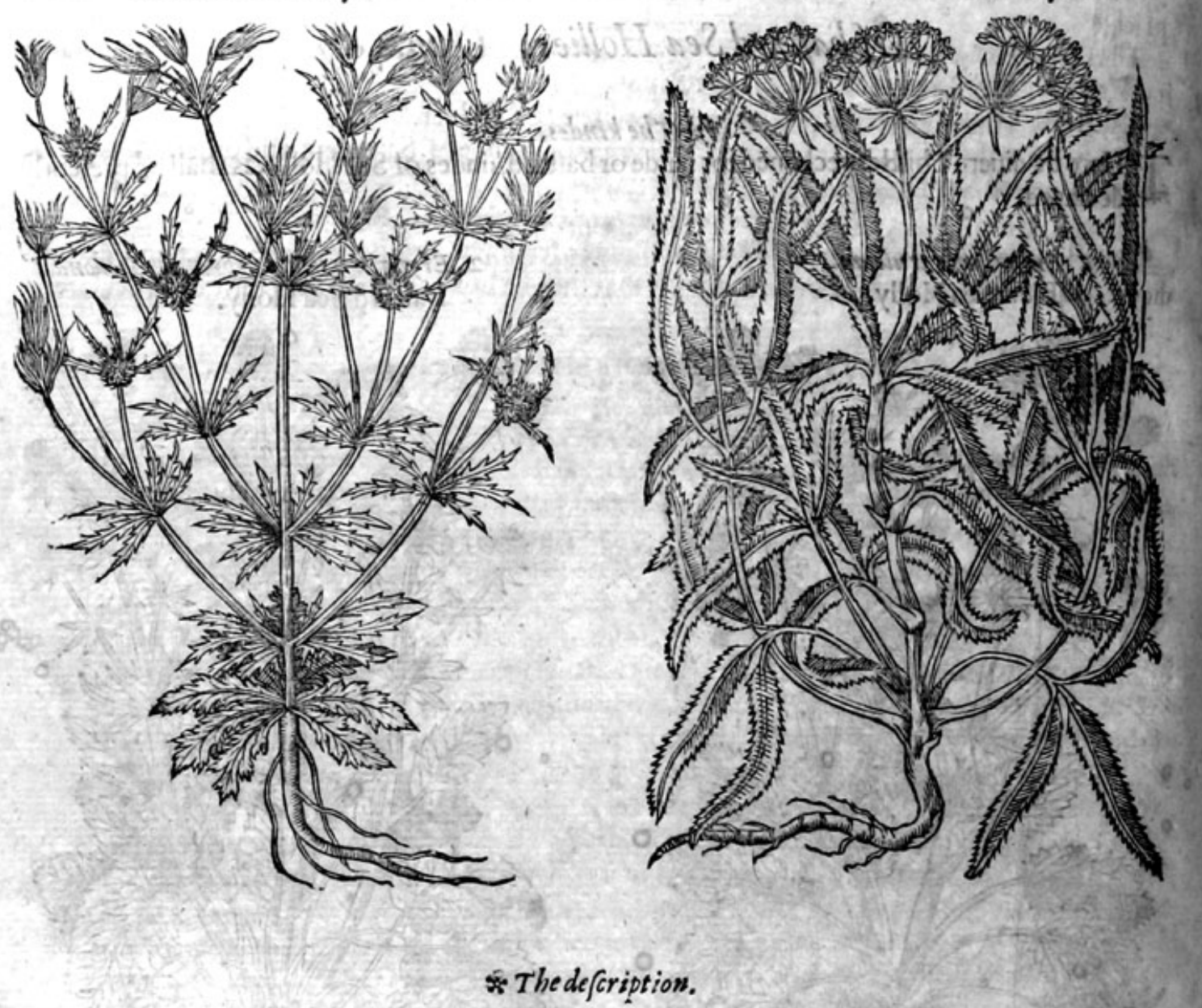

3 The third kinde of baftard Eryngium hath his firft leaues (which growe next the ground) great, broad and foft,growing as it were in a rundle about the roote. The ftalke is fmall and flender, diuided into fome branches, which beare many little leates, turning or ftanding many waies; which be alfo flender, pricklie, and fet about the ftalkes, ftar fafhion. The knops or heads growing at the tops of the branches, are round and pricklie bearing little blew flowers and leaues, which compaffe them about. The roote is flender, and lafteth but one yeere.

4 The fourth kinde of baftard Sea Holly, which Pens calleth Eryngium montanum recentionson,and is the fourth according to Dodon aus his account, is like vnto the Erynges, not in Thape but in tafte. This beareth a very fmall and flenc'er ftalke, of a meane height; whereupon do growe three or fower leaues, and feldome fitie, made of diuers leaues fet vpon a middle rib, narrow, long, hard, and of 2 darke greene colour, , dented on both edges of the leafe like a fawe. The ftalke is a cubite high, iointed or kncede, and diuiding it felfe into many branches; on the tops whereof are round tuftes or knops, wherein are contained the flowers, and (after they be vaded) the feedes, which are fmall,fomewhat long, well fmelling and fharpe in tafte. The roote is white and long, not a finger thicke, in tafte fweete, but afterwards fomewhat fharpe, and in fent and fauour not vnpleafant: when this roote is dried, it may be crumbled in peeces, and therefore quickly braied. 
Thefe kindes of Sea Holly are ftrangers in England: we haue the firft and fecond in our London gardens.

\section{*Thetime.}

They flower and flourifh when the Thiftles do.

Thefe plants be Ergngia jpuria, orbaftard Sea Hoflies, and are lately obferued : and therefore they haue no oldnames.

'The firt may be called in Latine Eryngium Borwsecum, or Non Spinofinm, Sea Holly without prickles,

The fecond is called by Mat biolus Eryngium planum, or flat Sea Holly; others had rather name it Alpinum Eryngium;or Sea Holly of the Alpes.

The chird is rightly calle d Exyngium pumilum, little Sea Huluer.

Matholym maketh the fourth to be Crithmi genis, or a kinde of Sampiere, and others Eryngÿ genus, or a kinde of Sea Huluer.

Toun a $*$ Thetemperature and vertues.

Touching the faculties hereof we haue nothing to fet down, eeing they liaure as yet no vee in medicine, and are neither vied to be eaten. But yet thaft they be hot onely, the very tafte doth declare.

sima zselq risurid nogv Of Star Thiftle. Chap.470.

I Carduus fello

The Star Thiftle.
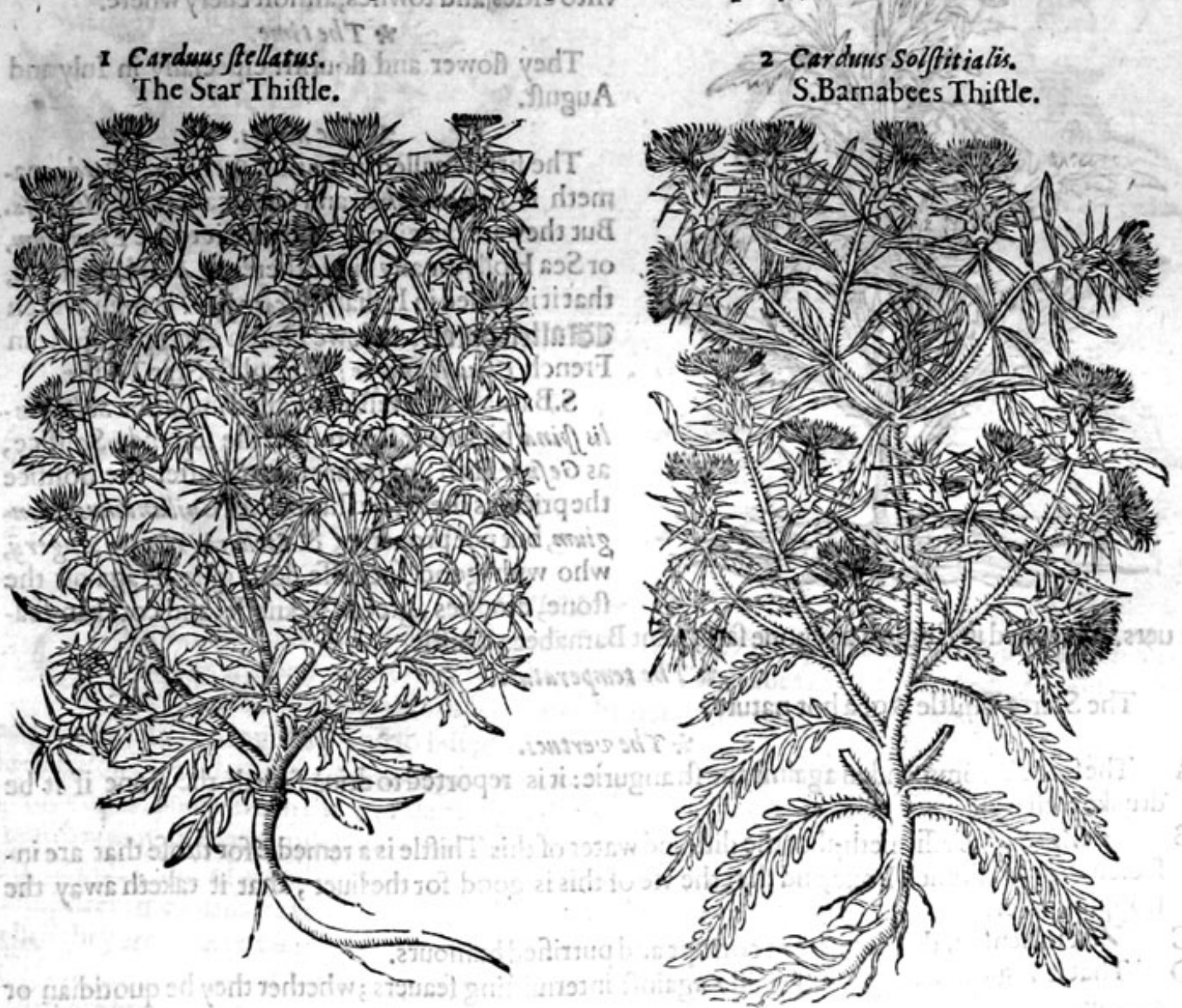

- *The defoription.

I He Star Thiftle, called Carduius ftellat ws, hath many foft frized leaues, deepely cut or gathe, altogither without prickles : among which rifeth vp a it $1 \mathrm{kc}$, diuiding it felfe into many other branches, growing two foote high; on the tops whercof are finall knops or heads 


\section{THE SECOND BOOKE OF+THE}

like the other Thiftles, armed round about with many fharpe prickles, fafhioned like a blafing ftar, which at the beginning are of a purple colour, but afterwardes of a pale bleake or whitithoolour, The feede is fmall,flat, and round: the roote is long,and browne without.

2 S.Barnabees Thiftle another kinde of Starr Thiftle; notwithftanding it hath prickles nowher fave in the head only, and the prickles of it ftand foorth in manner of a ftar: the ftalksare two cubits high,parted into diuers branches fofter than are thofe of ftar Thifle, which ftalkes have velmes or thin skins cleauing ynto them all inlength, by whish they fécroe to be fower fquarc. i Thelezues are fomewhat long, fet with deepe gathes on the edges: the flowers are yellowy;and confiftof threds: the feede is littlesthe roote long and fender.

3 Solftitialis lutea peregrina. The ftrange S.Barnabees Thiftle.

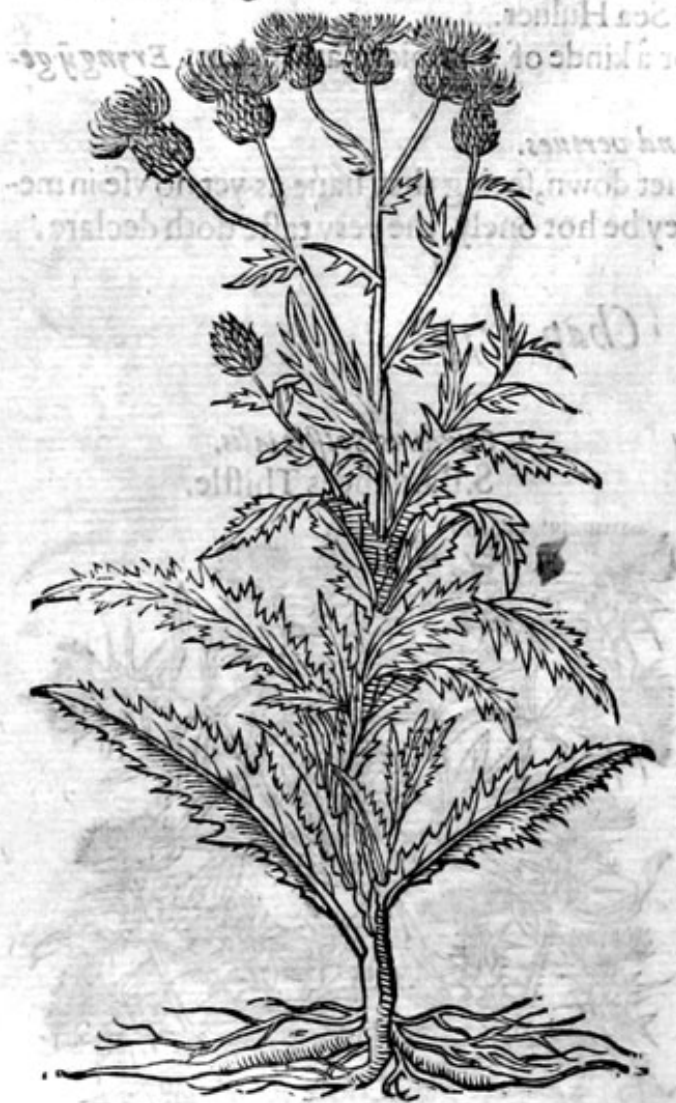

* The defcription.

3 This Thiltle hath leatues fet with deepe gafhes, hauing yellow flowers, with heads or knaps fill of prickles, but greater than the former, and with 2 ftalke without skins cleauing to it. Clufins writeth, that he found this in the territotic of Salmantica hard by the vineyards in a driefoile, * The place.

The two firft do growe vpon barren places neere vinto cities and townes, almoft euery where. * The time.

They flower and flourifh efpecially in Iuly and Auguft.

The firft is called in Latine Stellaria: Cordus nameth it Polyacantha, and Gaza calleth it LAculeofa. But they are deceiued, who take irto be Eryngiwm, or Sca Holly, or any kinde thereof. Mathiolus Iaith, that it is called in Italian Calcatrippa : in high Dutch vartailen diffeIl: in lowe Dutch sterte Diftell: in French chau/fetrappe: in Englifh Star Thiftle.

S.Barnabees Thiftle is called in Latine Solstitialis $\beta$ ina, bicaufe it flowreth in the fommer Solftice, as $G e$ fver faith, or rather bicaufe after the Solltice the prickles therofte fharpeit, of Guillan dinus Eryngium, but not properly, \& Stellaria Horatì Angeriy, who with good fucceffe doth giue it againtt the ftone, dropfies, greene fickneffe, and coridian fe2uers. It is called in Englifh as aboue faid, Saint Barnabees Thiftle.

The Starre Thiftle is of a hot nature. * The temperature.

\section{$*$ The vertues.}

A The feede is commended againft the ftrangurie: it is reported to driue foorth the ftone if it be drunke with wine.

B Baptista Sardus affirmeth, that the diftilled water of this Thiftle is a remedie for thofe that are infected with the French Poxe, and that the vfe of this is good for the liuer, that it taketh away the ftoppings thereof.

C That it clenfeth the bloud from corrupt and putrified humours.

D That it is giuen with good fucceffe againft intermitting feauers; whether they be quotidian of tertian.

E As touching the faculties of Saint Barnabees Thiftle, which are as yet not found out, we hay nothing to write. 


\section{OfTeafels. Chap.471.}

* The kindes.

Vrage hath fet downe two kindes of Teafels: the tame, and the wilde. Thefe differ not fave
onely inithe husbanding; for all things that are planted and manured do more tourifh and be.
come for the moft part fitter for mans vfe.

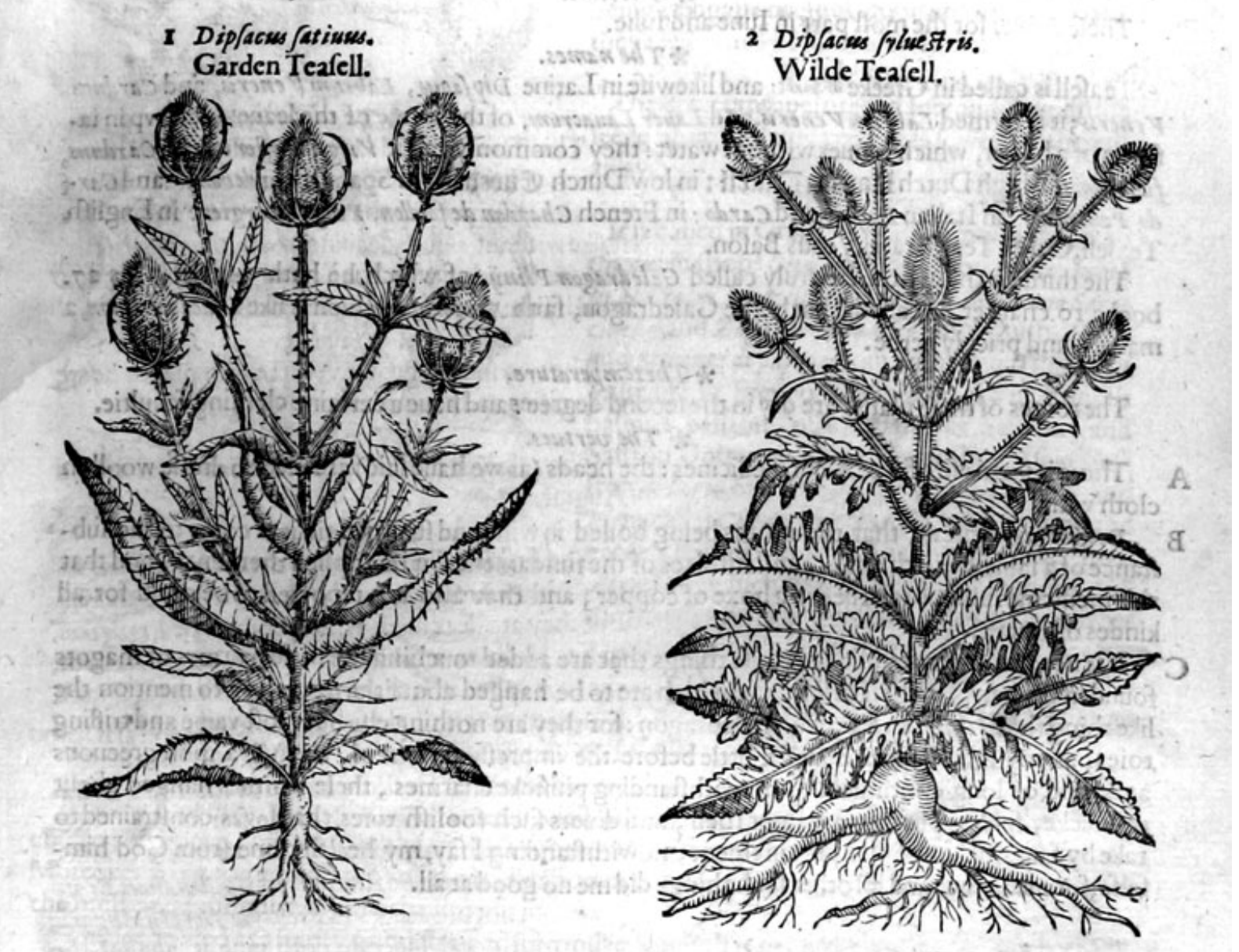

I

*Tbe defcription:

Arden Teafell is alfo of the number of the Thiftles; it bringeth foorth a ftalke that is ftraight, very long, iointed, and full of prickles. The leaues growe foorth of the iointes by couples, not onely oppofite or fet one right againft another, but alfo compaffing the ftalke about, and faftened togither; and fo faftened, that they hold deaw and raine water in manner of a little bafon: thefe be long, of a light greene colour, and like to thofe of Lettice, but full of prickles in the edges, and haue on the outfide all alongft the ridge ftiffer prickles : on the tops of the ftalkes ftand heads with tharpe prickles like thofe of the Hedgehog, and crooking backward at the point like hookes, out of which heades growe little flowers. The feede is like Fennell feede, and in tafte bitter: the heads waxe white when they growe old, and there are found in the middett of them when they are cut, certaine little magots. The roote is white, and of a meane length.

2 The fecond kinde of Feafell which is alfo a kinde of Thifte, is very like vnto the former; but his leaues are fmaller and narrower; his flowers of a purple colour, and the hookes of the Teafell nothing fohard nor fharpe as the other, nor good for any vfe in dreffing of cloth.

There is another kinde of Teafell, being a wilde kinde thereof, and accounted a mong the catalog of Thiftles, growing higher than the reft of his kindes, but his knobbed lieads are nobiggerthan a Nutmeg, in all other things elfe they are like to the other wilde kindes. 
The firlt called the tame Teafell, is fowen in this countrey in gardens, to ferue the vfes of Fullers and Clothworkers.

The fecond kinde groweth in moift places, by brookes, riuers, and fuch like places.

The third I found growing in moift places in the high way leading from Braintree to Henning. ham caltle in Effex, and not in any other place except heere and there a plant vpon the high waie from Much-Dunmow to London.

Thefe flower for the moft part in Iune and Iulie.

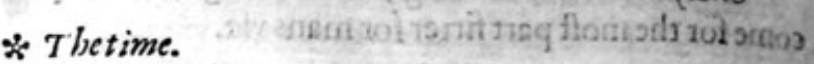

*The names. $\quad$ The bisilcid 1

Teafell is called in Greeke N/axos: and likewife in Latine Dipfacus, Labrum t eneris, and Cardums $V$ cner is ; it is termed Labram Veneris, and Lauer Lauacrum, of the forme of the leaues inade vp in fa. hion of a bafon, which is nuer without water : they commonly call it Virga Paftor is, and Carduses fullonum : in high Dutch fiarien Diffell : in low Dutch $\mathbb{C}$ aetren: in Spanifh Cardencha : and Car do Pentea dor: in Italian Diffaco, and Cardo: in French Chardon de foullon, Verge a bergier: in Englifh Teafell, Carde Teafell, and Venus Bafon.

The thirde is thought to be truly called Galedragon Plinï, of which he hath written in his 27 . booke ro chapter, he calleth that herbe Galedragon, faith Xenocrates, which is like Leucacanthum, 2 marrifh and prickly herbe.

\section{* Thetemperature.}

The rootes of thefe plants are dry in the fecond degree : and hatue a certaine clenfing facultie. * The vertues.

A There is fmall vfe of Teafell in medicines: the heads (as we haue faid) are vfed to dreffe woollen cloth with.

B Diofcorides writeth, that the rootes being boiled in wine and ftamped till it is come to the fubftance of 2 falue, healeth chaps, and fiftulaes of the fundament if it be applied thereunto, and that this medicine muft be referued in a boxe of copper, and that alfo it is reported tobe good for all kindes of warts.

C It is needleffe heere to alledge thofe things that are added touching the little wormes or magots found in the heads of the Teafell, and which are to be hanged abour the necke, or to mention the like thing that Plinie reporteth of Galedragon : for they are nothing elfe but moft vaine and trifling toies, as my felfe haue prooued a little before the impreffion heereof, hauing a moft greeuous ague and of long continuance : notwithitanding phificke charmes, thefe wormes hanged about my necke, fpiders put into a walnut fhell, and diuers fuch foolifh toies that I was conftrained to take by fantafticke peoples procurement; nowithftanding I fay, my health came from God himfelfe, for medicines and all other fuch things did me no gocd at all.

\section{Of baftard Saffron. Chap. 472 . \\ * The defcription.}

C Nicus, called alfo baftard Saffron, which may very well be reckoned among the Thiftles, $\mathrm{t}^{-}$feth vp with a ftalke of a cubite and a halfe high, traight, round, hard, and woodie, and branched at the top; it is defended with long leaues, fomething broad, fharpe pointed, and with prickles in the edges: from the tops of the ftalkes ftande out little heads or knops, of the bignes of an Oliue or bigger, fet with many fharpe pointed and prickly fcales : out of which come foorth tlowers like threds, clofely compact, of a deepe yellow fhining colour, drawing neere to the colour of Saffron;vnder them are long feedes, fmooth, white, fonewhat cornered, bigger then a Barly corne, the huske whereof is fomthing hard, the inner pulpe or fubftance is fat, white, fweete in tafte: the roote flender and vnprofitable.

There is alfo another kinde of baftard Saffron, that may very well be numbred among the kindes of Thiftics, and is verylike vnto the former, fauing that his flockie or threddie flowers, are of a blew colour: the roote is thicker, and the whole plant is altogither more fharpe in prickles.

Cartamus, 
Carthamns, fue Cnicus.

Baftard Saffron.

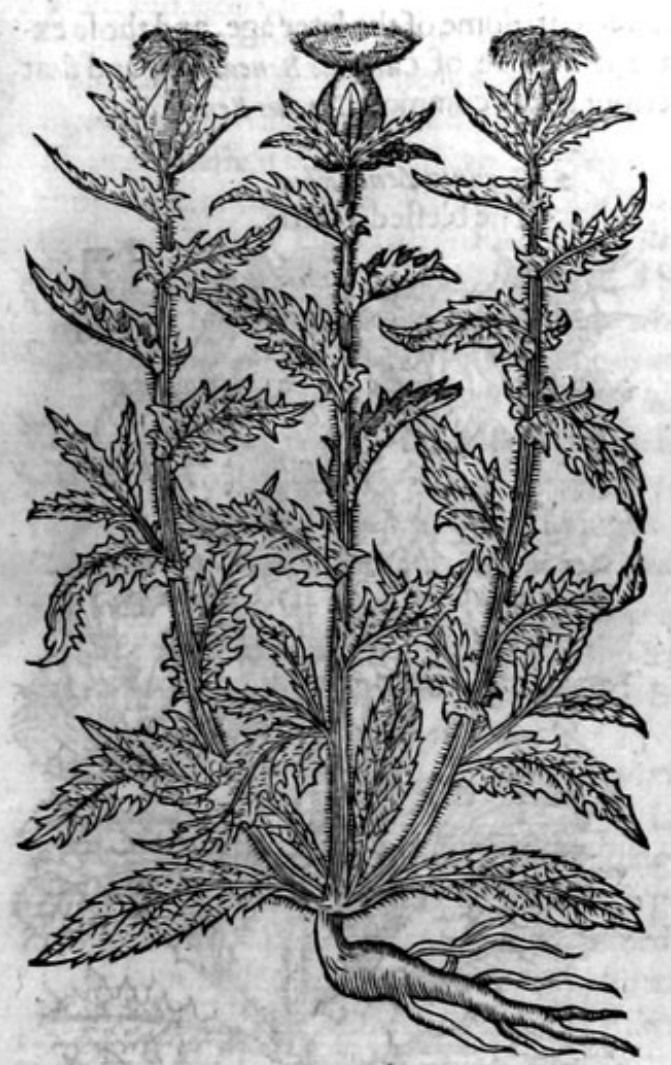

$$
\text { * The place. }
$$

It is fowen in diuers places of Italy, Spaine, and Fraunce, both in gardens and in fields, Plinie in his 25 . booke 15 . chapter faith, that in the raigne of $V e$ e $a$ /ian this was not knowne in Italie, being in Egypt onely of good account, and that they vfed to make oile of it and not meate.

$$
\text { * The time. }
$$

The flowers are perfited in Iuly and Auguft:the feede after the fame yeere it is fowen, withereth away.

\section{* The names.}

It is called in Greek xvixos in Latinalfo cnicus, or Cnecus: in fhops Chartamus, of divers Crocus hort $\vec{e}$ fis, \&e Crocus Saracenicus: in Italiā $Z$ affarano Saracinef co, and $Z$ affa rano faluatico : in Spanifh $A$ Alafor and semente depapagaios: in high Dutch valinturn zaftitan: in French Safran fanuage: in Englin baftard Saffron, of fome,mocke Saffron, and Saffron Dorte, as though you thould faie Saffron de horto, or of the garden. Theophraftus and Plinycall it Cnecus vrbana, and fatiua, or tame and garden baftard Saffron, that it may differ from Atract lis, which they make to be a kinde of $\mathrm{Cni}$ cus fylueftris, or wilde baftard Saffron, but rather aspecies of the Holie Thiftle.

$$
\text { * The temperature. }
$$

We vfe faith Galen, the feede onely forpurgations: it is hot and that in the firft degree, as Mefues writech.

\section{* The vertues.}

The iuice of the feede of baftard Saffron brufed and ftrained into honied water, or the broth of a A chicken $\&$ drunke, prouoketh to the ftoole, and purgeth by fiegeflimy flegme, and fharpe humors. Moreouer it is good againft the colicke, and difficultic of taking breath, the cough and ftopping of the breft, and is fingular againft the dropfie.

The feede vfed as aforefaid, and ftrained into milke, caufeth it to curdle and yeelde much cruds, B and maketh it of great force to loofe and open the belly.

The flowers drunke with honied water openeth the liuer, and is good againft the iaundife :and C the flowers are good to colour meate in ftead of Saffron.

The feede is very hurtfull to the ftomacke, caufing defire to vomite, and is of harde and flow di- D geftion, remaining long in the ftomacke and entrailes.

Put to the fame feede things comfortable to the ftomacke, as Annife feede, Galingale, or Ma- E fticke, Ginger, Sal gemmie, and it fhall not hurt the ftomacke at all, and the operation thereof hall be the more quicke and fpeedie.

Of the inwarde pulpe or fubftance heereof is made a moft famous and excellent compofition to $\mathrm{F}$ purge water with, commonly called Diachartamon, a moft fingular and effectuall purgation for thole that haue the dropfie.

The perfect defcription is extant in Guidothe Surgeon : in his firft doctrine, and fixt Tractate. G We haue not read of,or had in vfe that baftard Saffron with the blew flower, and therefore can $\mathrm{H}$ faynothing of his vertues.

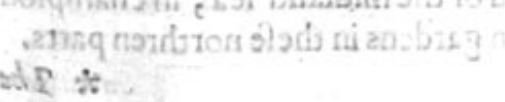




\section{Of wilde baftard Saffron. Chap. 473 .}

$\approx 7$ be kindes.

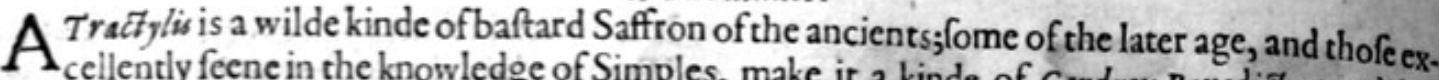

I Atractylis.

Wilde baftard Saffron.

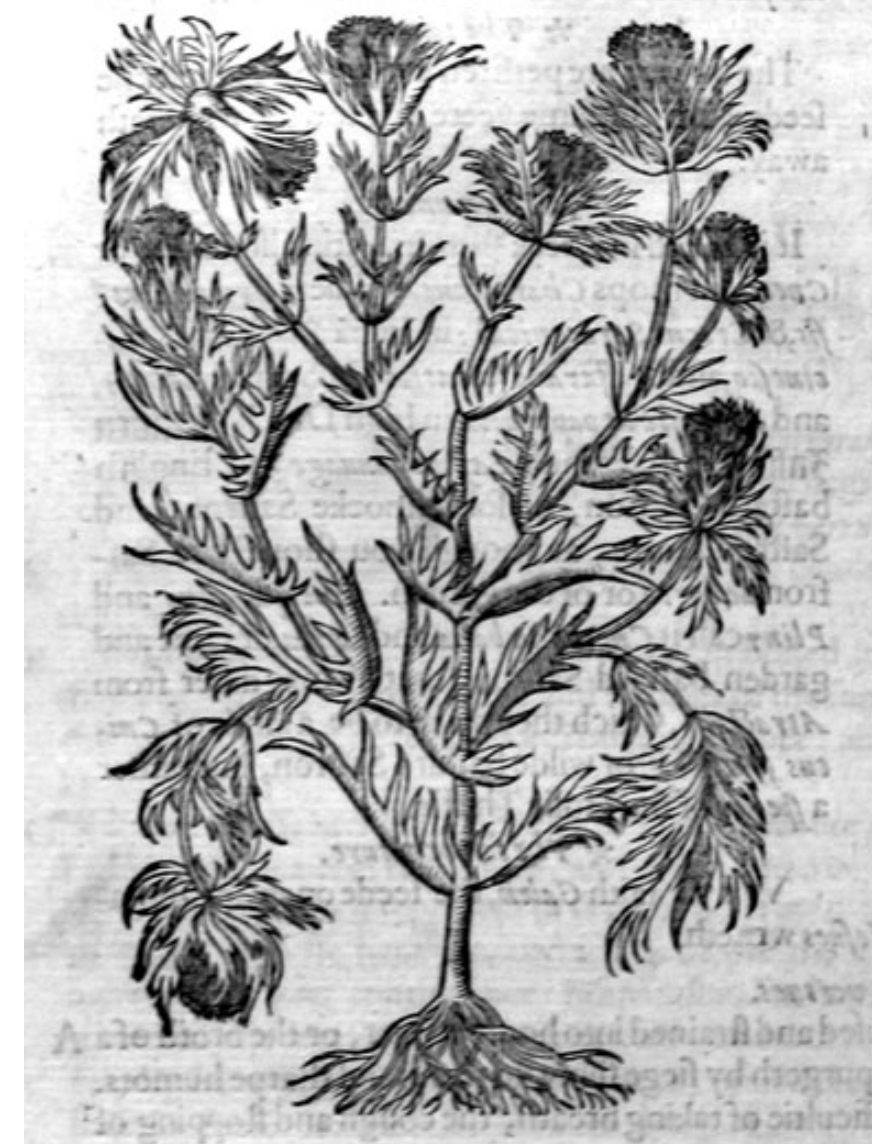

2 Carduus Benedittus. The bleffed Thiftle.

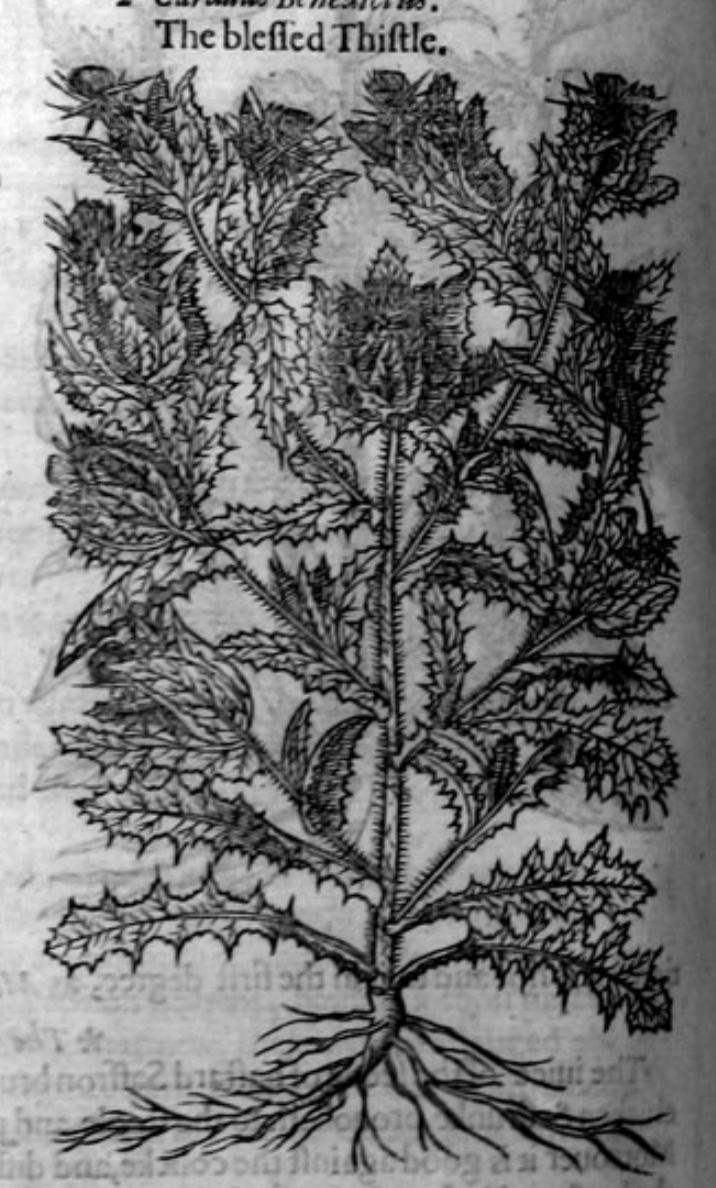

* T bedeforiotion.

I Tractylis, otherwile called wilde baftard Saffron, bringeth foorth a fraightand firme ftalke, very fragile or brittle, diuided at the top into certaine branches: it hathlong iagged leaues fet with prickles; the heads on the tops of the branch are very full of fhaipe prickles;out of which grow flowers al of thred's, like thofe of baiftard Saffron, but they are of a light yellow colour, and fomtimes purple: the feede is fomwhat grèat, browne, and bitter; otherwifelike that of baftard Saffron : the roote is of a meane bignes.

2 The ftalkes of Car dures Benedrat us or Bleffed Thiftle, are round, rough, and pliable, and being parted into divers branches, do lie flat on the ground: the leaues are iagged rounde about, and full of harmleffe prickles in the edges: the heads onthe tops of thic ftalks are fet with prickles, and inuironed with fharpe pricking leaues, out of which ftandeth a yellow flower: ehe feede is long, and fet with haires at the top like a beard : the roote is white, and parted into itrings: the whole herbe leaves and ftalkes, and alfo the beads, are couered with a fofs and thinne dowrie.

$$
\text { * T beplace. }
$$

Atraty lis groweth in Candie, and in divers prouinces and Ilands of Greece, and alfo in Lan. guedocke :and is an herbe growing in our Englifh garderis.

Carduses Benedi 7 wes is found every where in Lemnos, an Iland of the midland fea, in champion ground;, as Petr w Beilonist teftifiethat is diligently cherifhed in gardens in thefe northren parts. 


\section{HISTORIE OF PLANTS.}

* The time.

Astactyls is very late before it flowreth and feedeth.

Cardusu benedicfius flowreth in Iuly and. Auguit, at which cime it is efpecially to be gathered foz phifickematters.

$$
\text { * The names. }
$$

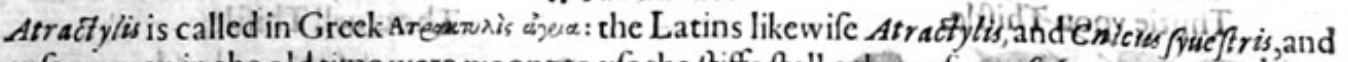
bicaufe women in the old time were woonoto vfe the itiffe ftalke theteof pro fulo aut colo, for a finindle or a diftaffe, it is named Fucus agreffes, and Colus ruftica, which thing Petrus Bellowius reporteth

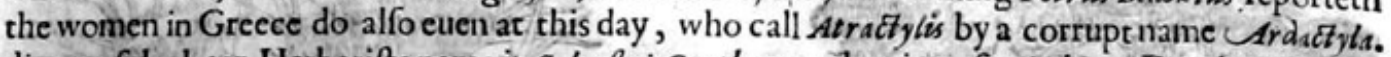
diuers of the later Herbarifts name it Svlueftris Carthamus, that is to fay in lowe Ditch, veituden Carthamus: and in Englifh wilde baftard Saffron.

Bleffed Thiftle is called in Latine euery where Cardus benedictus: and in thops by a compound worde, Cardobenedect us: it is moft plaineas we have faid, that it is Species Atractylis, or a kinde of wilde baftard Saffron :it is called Atractylis hirfutzor, hairie wilde baftarde Saffron, Valeriws Cordsus

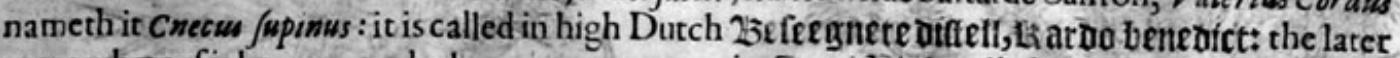
name whereof is knowne to the low countrey men : in Spanilhit is called Cardo Sancto: in French Chardion bonoift, or beneist, in thelle Lemnos Garderacantha : in Englifh Blefled Thiftle; but more commonly by the Latine name Cardurus Benedt ctus.

* * The temperature.

Wildebaftard Saffron doth dry and moderately digeit, as Galen teacheth.

As Carduses benediat us is bitter, fo it is alfo hot and dry in the fecond degree, and withall clenfing and opering.

\section{$*$ The vertues.}

The crop, feede, and leaues of L 1 ractylis, faith Dio, corides, being beaten aud drunke with pepper A and wine, are 2 remedie for thofe that are ftung of the fcorpion.

Blefled Thiftle taken in meate or drinke, is good for the forimming and giddines of the head, it $\mathbf{B}$ ftrengthneth memorie, and is a fingular remedie againft deafenes.

The fame boiled in wine and drunke hot, healeth the griping paines of the belly, killeth and ex- C pelletn wormes, caufeth/fweate, prouoketh vrine, and driueth out grauell; clenfeth the ftomacke, and is very good againft the feuer quartaine.

The iuice of the faide Cardus, is Gngular good againft all poifon, as Hierome Bock witueffech, in D what fort foeuer the medicine be taken; and helpeth the inflammation of the lituer, as reporteth Ioachimus Camerarius of Noremberge.

The powder of the tearcs, minutt edin the quantitie of halfe a dram, is verygogdagainf thege- $\mathbf{E}$ ftilerice, if it be receiued within 24 howers a ter the takjigg of the ficknes, and the parsy iveat ypon the fame: the like vertue has the,wine, wherein the herbe hath been fodden. wob sust gnisd

The greene herbe pouned, and laide to, is good againit all hor fyellings, as Fryfipelas, plagure E fores, and botches, ef pecially thote that proceede of thepeftilence, and is alfogesd ro bes laide vpohi the bitings of mad dogs, ferpents, fpiders, or any venemous bealt what foever; and fo it is likewife if it be inwardly taken.

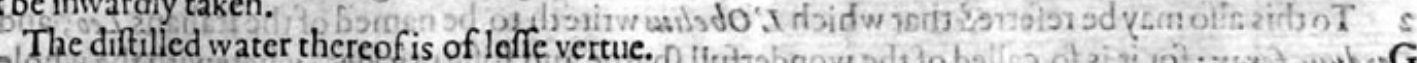

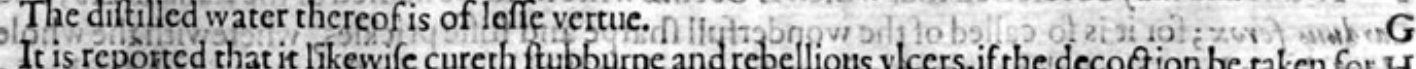
It is reponted that it likewife cureth fubburne and rebellions vicers, if the decoction be taken for $\mathrm{H}$

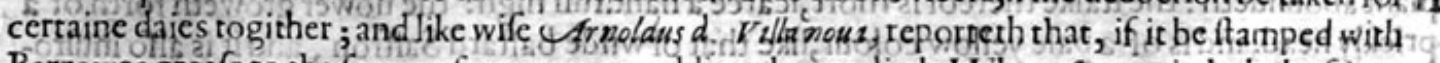

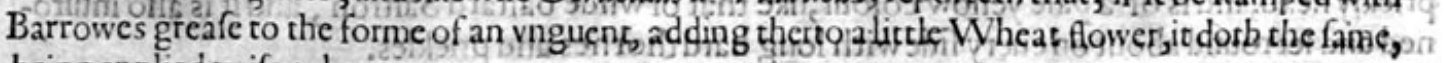

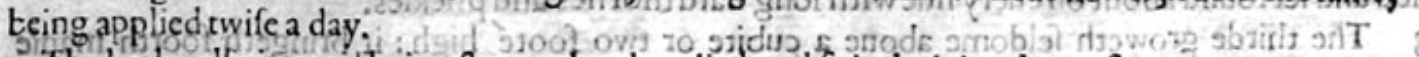

The herbe allo is gcodbeing fanped and applicd and fo is the iuice thereof

The extiaction of the leaues dravne afcarding to Ars jis excellent good againft the Erench dif $-\mathrm{K}$

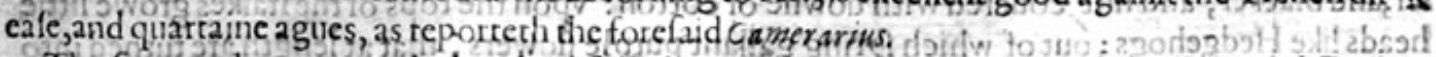

The fame ath of reporteth, that the diftitied water saken with the water of Lougag and Dodn 5 der, helpeth the fauceflegme face, if it be drunke for certaine daies togither.

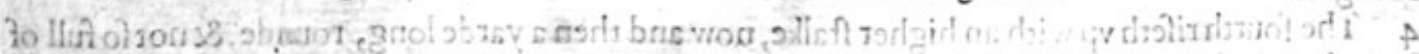

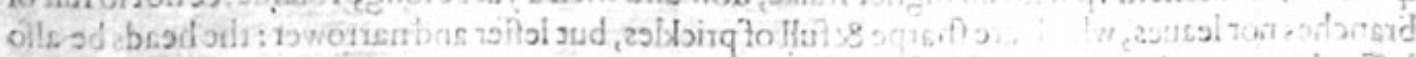

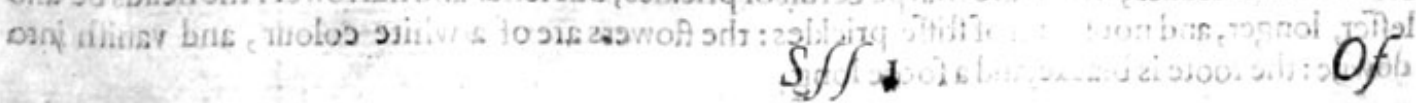

$$
\begin{aligned}
& \text { whincià \& }
\end{aligned}
$$




\section{of Thiftle upon $T$ biftle, and diuers other wilde Thistles. Chap.474.}

I Onopordon.

Thiftle vpon Thiftle.

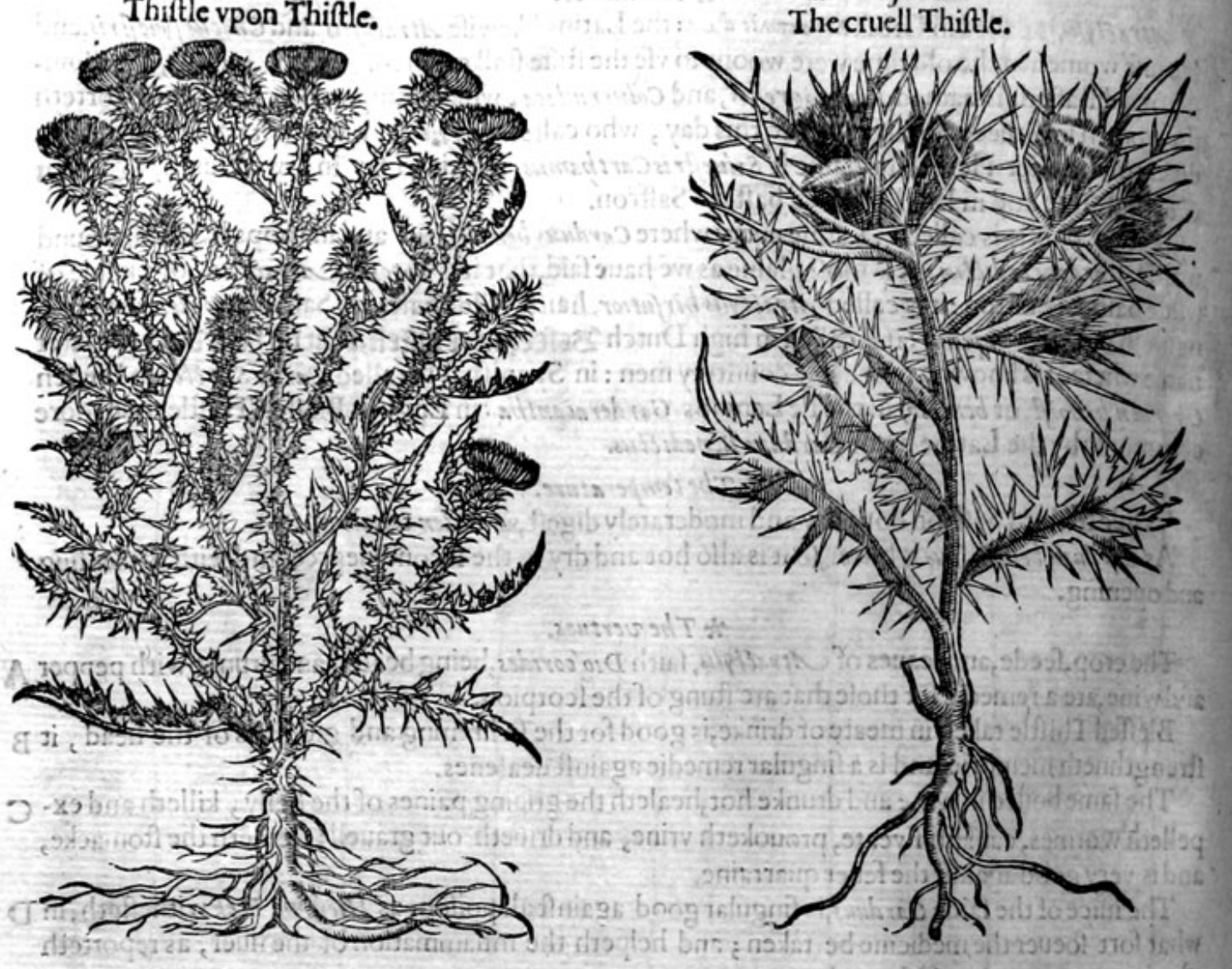

* The defcription.

I- Mongall the Thornes and Thiftles, this is molt full of prickles; the ftalkes thereofareveA rie long, and feeme to be cornered by reafon of certs.ine thinne skins growing vinto them, being fent downe foorth of the leaues : the leaves are fet rounde about with manie deepe gafhes, being very full of prickles as well as the ftalkes; the heads are very thicke fet in euery place with ftiffe prickles, \& confift of a multitude of fcales; ont of which grow purple flowers, as they do out of other Thintles, feidome white: the roote is almoft ftraight, but it groweth not deepe.

2 To this alfo may be referred that which L'Obeliess writeth to be named of the Italians Leo, and Cardus ferux; for it is fo called of the wonderfull marpe and ftiffe prickles, wherewith the whole plant aboundeth: che ftalke there of is fhort, fcarce a bandfull high: the flower groweth forth of 2 prickly head, and is of a pale yellow colour, like that of wilde baftard Saffron, and it is alfo inuironed and fet round about on euery fide with long hard thornes and prickles.

3 The thirde groweth feidome aboue a cubite or two foote bigh: it bringeth foorth manie round ftaiks,parted into diuer s branches; the leaues are like thofe of white cotton Thifte, butleffer,and blacker, and not coucred with downe or cotton: vpon the tops of the ftalkes growe little. heads like Hedgehogs; out of which foring gatlant purple flowers, that at length are turned into downe, leauing feedes behinde them like thofe of orher Thiftles: the roore confifteth of many fmall ftringes.

4 The fourth rifeth vp with an higher ftalke, now and then a yarde long, rounde, \& not fo full of branches nor leaues, which are tharpe \& full of prickles, but leffer and narrower: the heads be alfo leffer, longer, and not fo full of ftiffe prickles: the flowess are of a white colour, and vanith inta downe: the roote is blacke, and a foose long:

3 Cardues 
3 Carduius viarsem.

The way Thiftle.

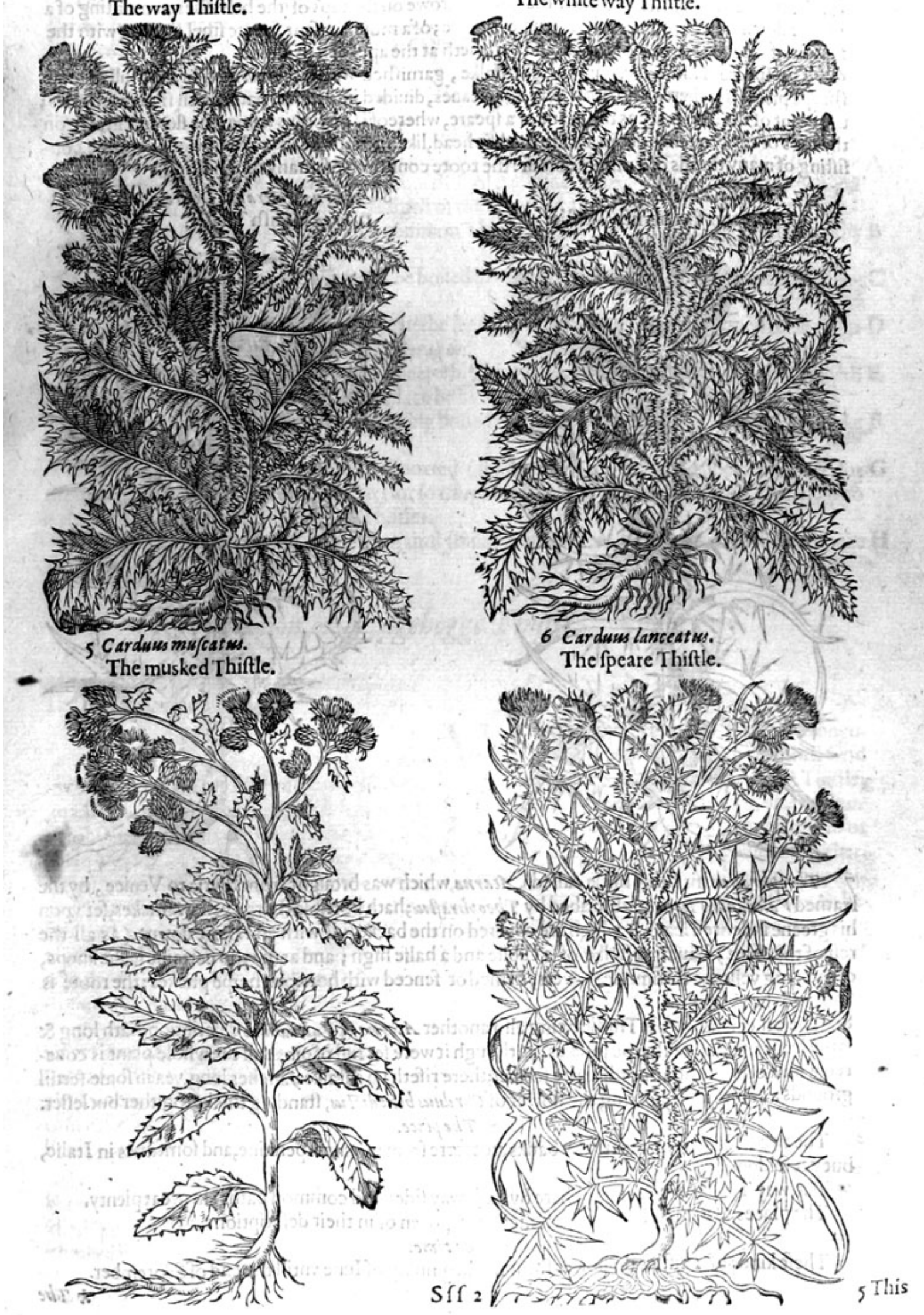


5 This wilde Thiftle which groweth in the fieldes about Cambridgc, hath anvpright ftalk, wheron do growe broad prickly leaues : the flowers growe on the tops of the branches y confifting of flockie downe, of a white colour tending to purple; of a moft pleafant fweete finel, ftriuing with the fauour of muske : the roote is fmall,and perifheth at the approch of winter.

6 The fpeare Thiftle hath an vpright ftalke, garnifhed with a skinnie membrane, full of moft tharpe prickles : whereon do grow very long leaues, diuided into diuers parts, with iharpe prickles; the point of the leaues are as the point of a peare, whereof it tooke his name: the flowers growe on the tops of the branches, fet in a fcaly prickliehead, like vnto the heads of Knapweed in forme, confifting of many threds of a purple colour: the roote confifteth of many tough ftrings.

7. Acarna Theophrafti.

Theophraftus his filh Thiftle.

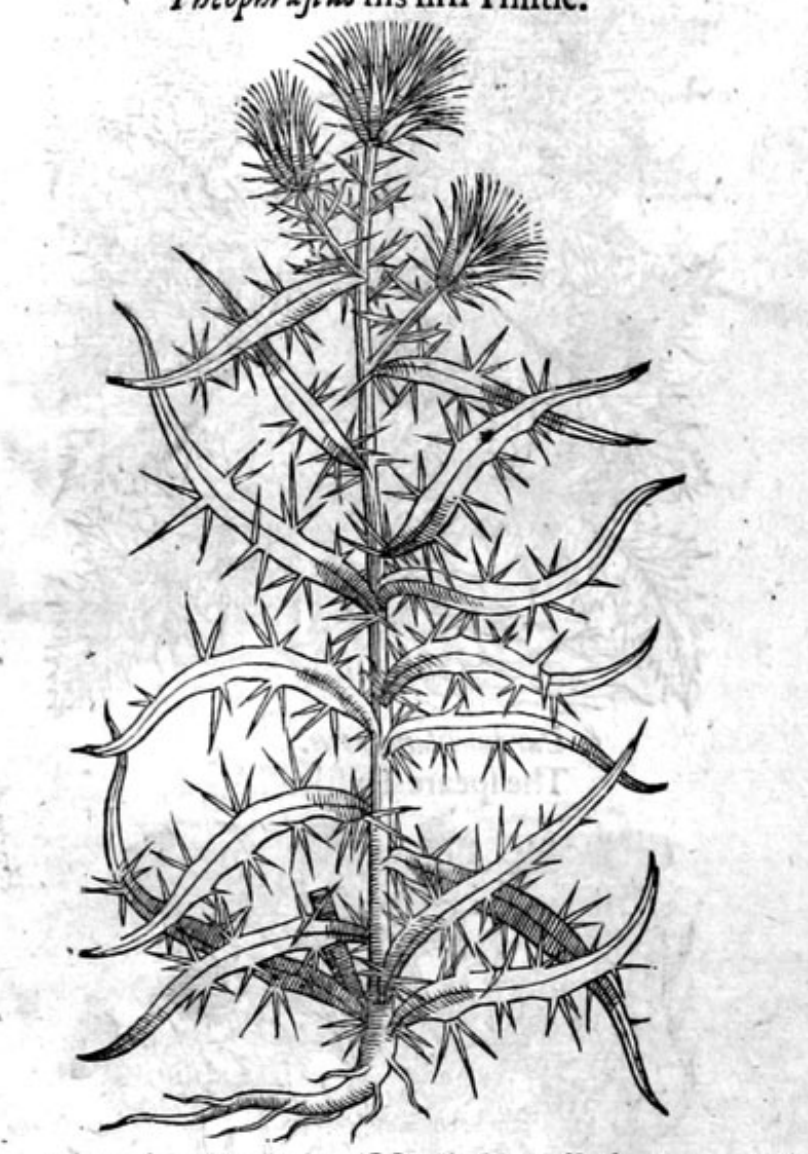
8 . AsarnaWalerandi Donrez.
Donrez his firh Thiftle.

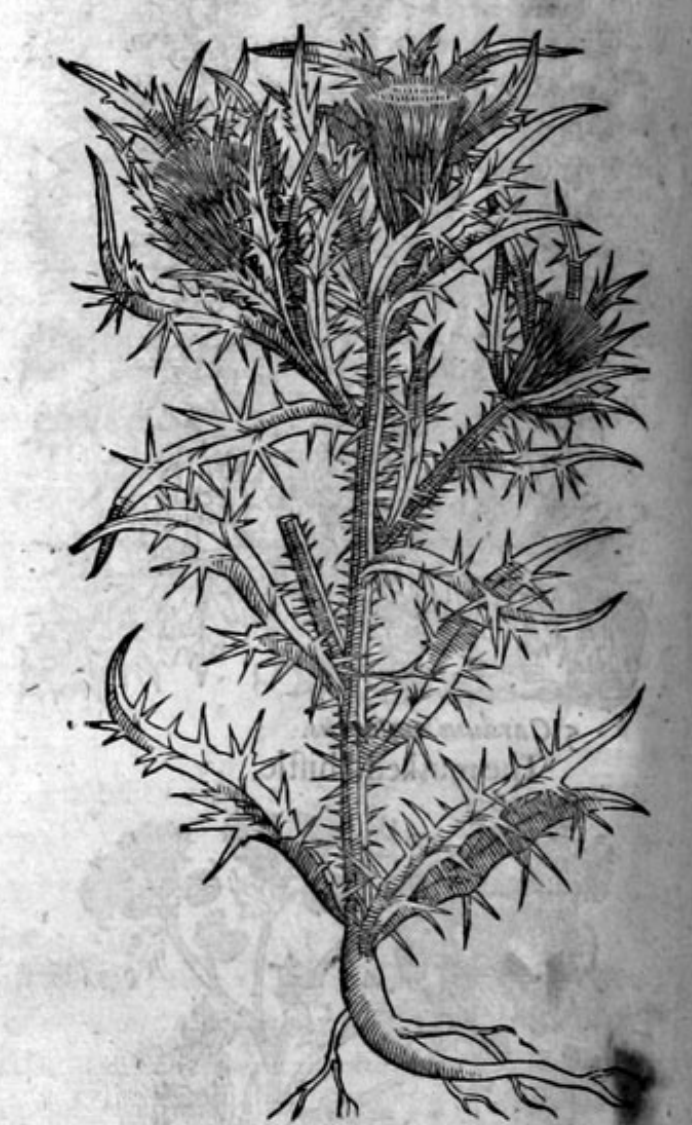

7 Theophraftus his fifh Thiftle called Ncarna,which was brought from Illyria to Venice, by the learned $V$ ale randus Donrez, defcribed by $T$ heophraftus; hath horrible fharpe yellow prickes, fet vpon his greene indented leaues, which are couered on the backe fide with an hoarie downe (as all the reft of the plant ) hauing a ftalke of a cubite and a halfe high; and at the top certaine fcalieknops, containing yellowe thrummie lowers, armed or fenced with horrible harpe prickes: the roote is long and threddie.

8 The other kind of fifh Thiftle being alfo another Acarna of $V$ aler andus defcription, hath long \& large lcaues, fet, full of fharpe prickes, as though it were fet full of pins : all the whole plant is couered with a certaine hoarines, like the former; there rifeth vp a ftalke 9 .inches long,yea in fome fertill grounds a cubite high, bearing the flower of Cardus benedictus, ftanding thicke togither butlefler.

$$
* \text { The place. }
$$

The two firft grow on diuers dry banks, not farre from mount Apennine, and fomtimes in Italie, but yet feldome.

The way Thiftles grow euery where by high way fides and common paths, in great plenty.

The places of the reft hate beene fufficiently fpoken of in their defcriptions. $*$ The time.

Thefe kinds of Thiftles do flower from the beginning of Iune vntill the end of September. 


\section{HISTORIE OF PLANTS.}

* The names.

Thefe Thiftes comprehended in this prefent Chapter are by one generall name called in Latine Cardui fylueftres, or wilde Thiftles, and that which is the fecond in order is named Scolymus; but not that Scolymm, which T heophraftess declareth to yeelde a milkie iuice, of which we haue written before, but one of thefe which $P$ liny in his 20 .booke 23 . chapter defcribeth: of fome they are taken for kindes of Chamaleon : their feuerall titles do fet foorth their feuerall Latine names, and alfo the Englifh.

* Thetemperature and vertues.

Thefe wilde Thiftles according to $G$ alen, are hot and dry in the fecond degtee, and that thotowe $A$ the propertic of their effence they driue foorth ftinking vine if the rootes be boiled in wine and drunke, and that they take away the ranke fmell of the body and arme holes.

Diofsorides faith, that the roote of the common Thiftle applied plaiftetwife, correcteth the filthy $\mathrm{B}$ finell of the armeholes and whole bodie.

Arid that it worketh the fame effect if it be boiled in wine and drunke, and that it expelleth plen- C ty of ftinking vrine.

The fame author affirmeth alfo, that the herbe being as yet greene and tender, is vfed to be eaten D among other herbes after the maner of $\mathcal{1}$ Aparagis.

This being ftamped before the flower appeereth, faith $P$ liny, and the iuice preffed foorth, caureth $\mathrm{E}$ haire to growe where it is pilled off, if the place be bathed with the iuice.

The roote of any of the wilde Thiftles being boiled with water and drunke, is reported to make $\mathbf{F}$ thein dry that drinke it.

It ftrengthneth the ftomacke, and it is reported (if we beleeue it) that the fame is alfo good for $\mathbf{G}$. the matrix, that boies may be ingendred; for fo chereas of Athens hath written, and Glaucias, who is thought to writemoft diligently of Thiftles.

This Thiftle being chewed, is good againft ftinking breath : thus farre Plinie in his 20 . booke $H$ 23.chapter.

\section{Of the Melon, or Hedgebogge Thifle. Chap.475.}

Melocarduns Echinatus Pena d L'Obely.

The Hedgehogge Thiftle.

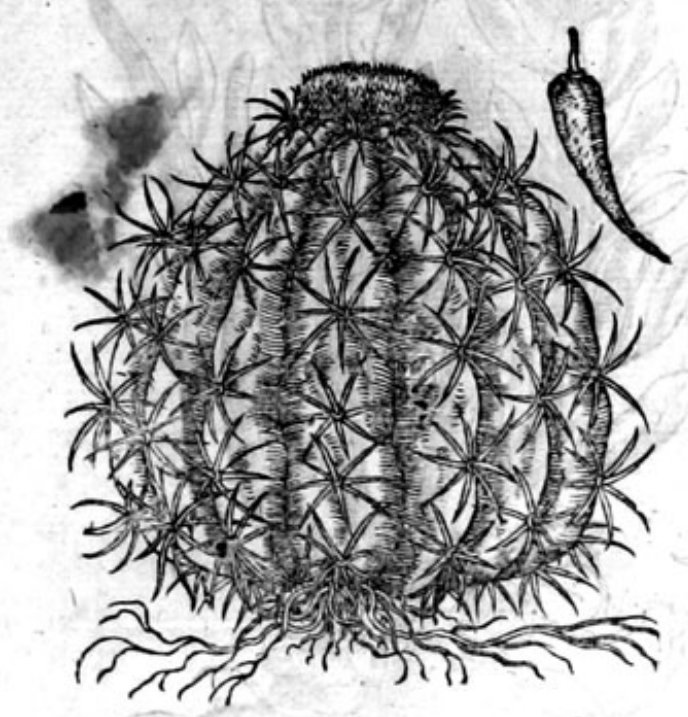

* The defcription.

$\mathrm{W}$ Ho can but maruell at the rare and fingtrlar workemanthip which the Lord God almightie hath fhewed in this Thiftle, called by the name Echino-Melocactos, or Melo-cardius Echinatus? This knobbie or bunchie maffe or lumpe, is itrangely compact and context togither, containing in it fundry fhapes and formes, participating of a Pepon or Melon, and a Thiftle, both being incorporate within one bodie; which is made after the forme of a cocke of haie, broade and flat belowe, but harpe toward the top, as big as a mans bodie from the belly vpward; on the outfide heereof are fourteene harde ribs, defcending from the crowne to the loweft part, like the bunchie or outfwelling rib of a Melon ftanding out, and chanineled betweene : at the top or crowne of the plant iffueth foorth a fine filken cotton, wherewith it is full fraught; within wl:ich cotton or flockes lie hid certaine fmall theathes or cods, tharpe at the point, and of a deepe fanguine colour, anfwering the cods of Capficum or Indian Pepper, not in fhew only, but in colour; but the cods are fomwhat fmaller: the furrowed or channeled ribs on the outfide are garnifhed or rather armed with many prickly ftarres, ftanding in a compaffe like fharp crooked hornes or hookes, ech ftarre confifting of ten or twelue prickes, wherewith the outwarde Sif 3 barke 
barke or peeling is garded, fo that without hurt to the fingers it cannot be touched: this rinde is harde, thicke, and like vnto Aloes, of the colour of the Cucumber: the flefh or inner pulpe is white,
fat, waterifh, of tafte fower, vnfauorie, and cooling, much like vnto the meate of a Pompion : this plant groweth without leafe or It alke, as our northren Thifle dof awe Melon, or ferme, and is bigger then the largeft Pompion: the rootes are fmall, fpreading doth, called Acaulis ground, \& confifting of black and tough twigs, which cannot indure the iniurie of abroade in the * The place.

This admirable Thiftle groweth vpon the clifts and grauelly grounds neere vnto the fea fide, in the Ilands of the weft Indies, called S.Margarets Ile, \& S.Iohns neer vnto Puertorico.or Portorico, \& other places in thofe countries, by the relation of diuers traucilers that haue iourneied into thofe parts, who haue brought me the plant it felfe with his feede; the which woulde not grow in my garden by reafon of the coldnes of the climate.

* The time.

It groweth,flowreth, and flourifheth all the yeere long, as do many other plants of thofe countries.

* T The names.

It is called Cardusu Ecbinatus, Melocarduess echinatus, and Echino-Melocactos : in Englin the Hedgehogge 'Thiftle,or prickly Melon Thiftle.

\section{*The temperature and vertwes.}

A There is not any thing extant fet foorth of the ancient, nor of the later writers, neither by any that hath trauciled from the Indies themfelues: therefore we leaue it to a further confideration.

\section{Of the gummie Thistle called Euphorbium. Chap. 476.}

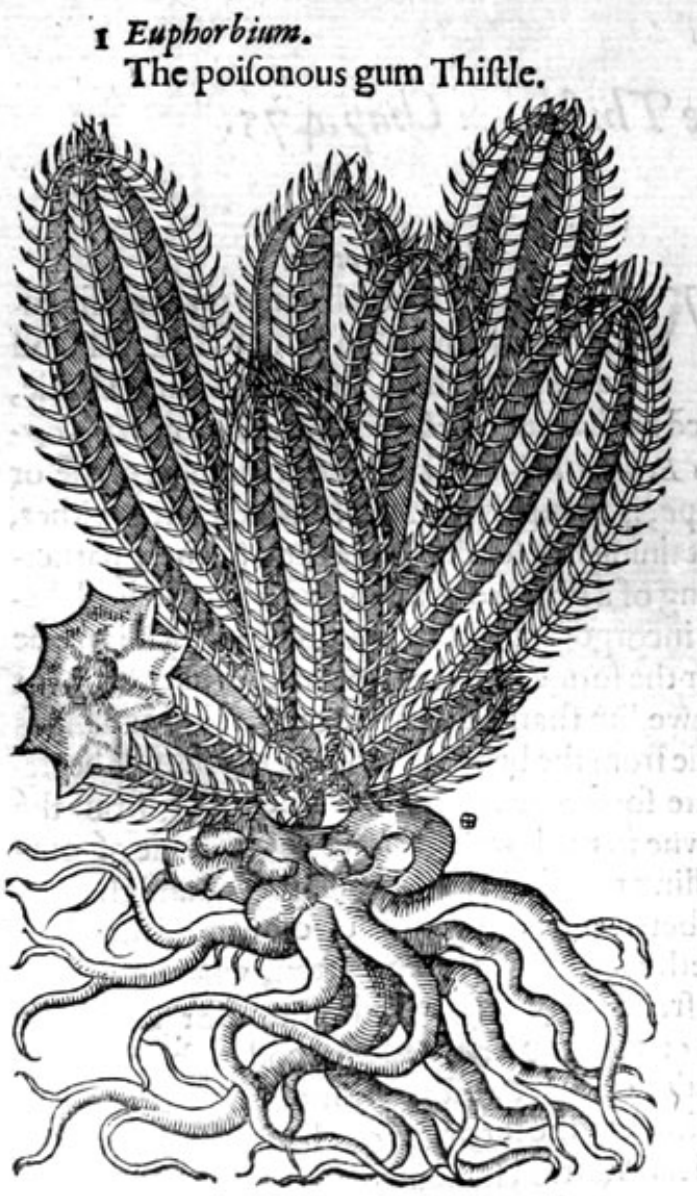

2 Anteuphorbium.

The Mithridate againft the poifonous Thiltle.

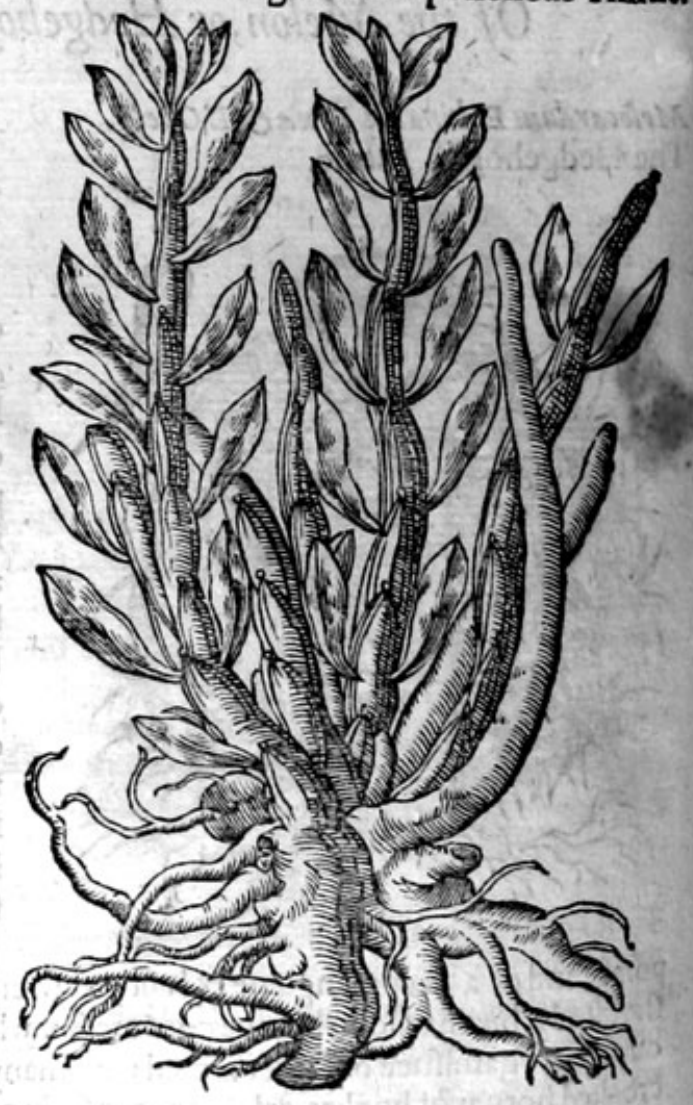

istke 


\section{HISTORIE OF PLANTS.}

$*$ Thedefcription.

T Vphorbium (whereout that liquor or gum, called in foops Euphorbitem, is cxtracted) hath - very great, thicke, groffe, and fpreading rootes, difperfed far abroad in the grounde: from which arife long and round leaues, almoft like the fruite of a great Cucumber, a foote and a halfe long, ribbed, walled, and furrowed like vinto the Melon : thefe bunched ribs are fet or armed for the molt part with certaine prickles ftanding by couples, the point or fharpe end of one garding one way, and the point of another looking directly a cleane contraric way; thefe pricks are often found in the gum it felfe, which is brought vnto vs from Libya and other parts : the leaues heereof being planted in the ground, will take roote wel, and bring foorth great increafe, which thing I haue prooued true in my garden;it hath perithed againe at the firft approch of winter:the fappe or liquor that is extracted out of this plant, is of the colour and fubftance of the creame of milke; it burneth the mouth extremely, and the duft or powder doth verie much anoie the head and the parts thereabout, caufing great and vehement fneezing, and ftuffing of all the pores.

2 This rare plant called Anteuphorbium, hath a very thicke, grofle, and farre fpreading roote, very like vnto Euphorbium:from which rifeth vp many round, greene, and flefhie ftalkes, whereupu on do grow thicke leaues like Purflane, but longer, thicker, and fatter: the whole plant is full of cold and clammie moifture, which repreffech the fcorching force of Euphorbium : and it wholic feemeth at the firft viewe to be a branch of greene corall.

3 Cereus Peruuianus pinofus L'Obely. The torch, or thornie Euphorbium.

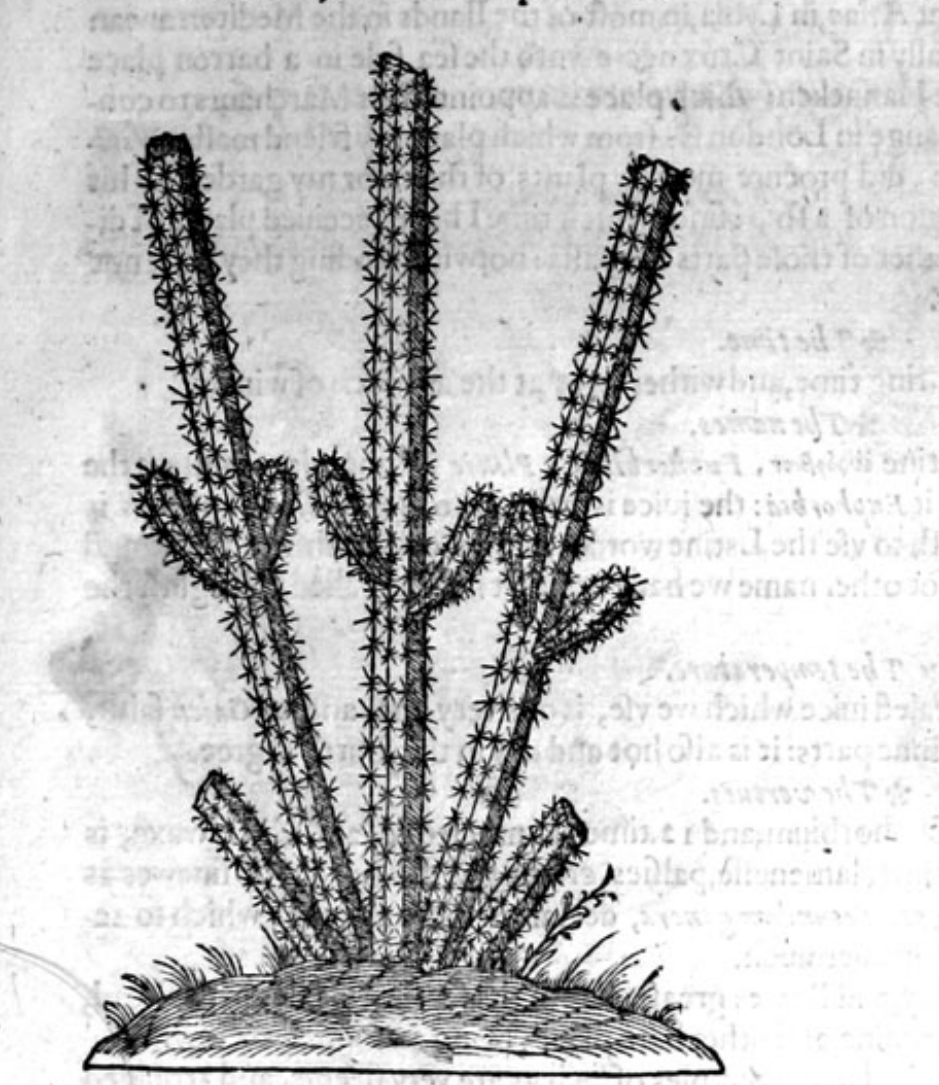

4 Calamus Perusiannus pinofus L'Obely. The thornie Reede of Peru.

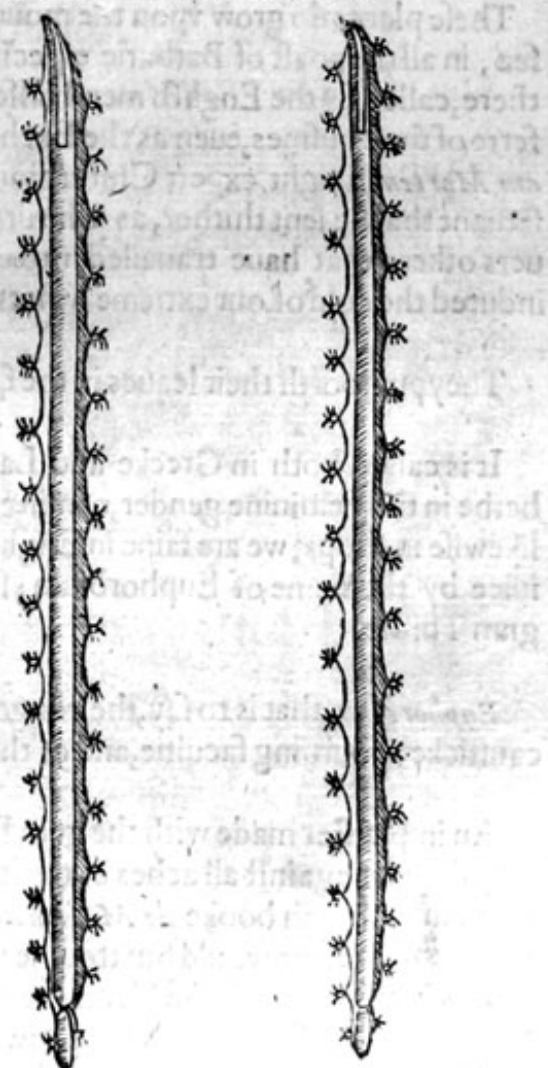

* The defcription.

3 There is not amongt the ftrange and admirable plants of the worlde any one, that giueth more caufe of maruell,or more mooueth the minde to honor and laud the Creator, then this plant, which is called of the Indians in their mother toong V ragua, which is as much to fay, a torch, taper, or waxe candle, whereupon it hath been calledin Latme of thofe that vnderftoode the Indian toong, Cereus, or a torch. This admirable plant rifeth vp to the height of a fpeare of 20 . footelong, although the figure expreffe not the fame; the reafon is, the plant when the figure was drawne 


\section{$\$ 016$}

\section{THE SECOND BOOKE OF THE}

came to our viewe broken; it hath diuers bunches and valleies, euen as is to be feene in the fides of
the Cucumber, that is furrowed, guttered, or chamfered alongit the fame, $\&$ as it were laid by a direct line, with a welt from one end vnto the other : vpon which welt or line do ftande fmall ftarlike Thiftles, fharpe as needles, \& of the colour of thofe of the Melon Thiftle, that is to fay, of a browne colour :the trunke or bodie is of the bignes of a mans arme,or a cable rope; from the middle wher. of, thruft foorth diuers knobbie elbowes of the fame fubftance, \& armed with the like prickles that the body or truncke is fet withall : the whole plant is thicke, fat, \& full of a flefhie fubftance, hauing much iuice like that of Aloes, when it is hardned, and of a bitter tafte : the flowers or fruit we haue no certaine knowledge of, onely faith my author, the flowers growe at the top or extreme point of the plant, after which followeth fruite in thape like a figge, full of a reddifh iuice, which being touched, ftaineth the hands of the colour of red lead: the tafte is not vnpleafant.

4. There hath beene brought from the Indies a prickley Reede, of the bignes of a good big ftaffe, of the length of fixe or eight foot, chamfered and furrowed, hating vpon two fides, growing vnto it an vneuen membrane or skinnie fubftance, as it were a iagge or welt fet vpon the wing of a garment, and vpon the point of euery cut or iagge armed with moft fharpe prickles : the whole truncke is filled full of a fpungious fubitance, fuch as is in the hollownes of the brier or bramble, amongt the which is to be feene as it were the pillings of Onions, wherein are often found liuing things, that at the firft feeme to be dead. The plant is ftrange, and brought drie from the Indies, therfore we can not write fo abfolutely heereof as we defire, referring what more might be faid to a further confide. ration, or a fecondEdition.

\section{* The place.}

Thefe plants do grow vpon the mount Atlas, in Lybia, in moft of the Ilands in the Mediterranean $\mathrm{fea}$, in all the coaft of Barbaric efpecially in Saint Crux neere vnto the fea fide in a barren place there, called by the Englifh men Halfe Hanneken; which place is appointed for Marchants to conferre of their buffines, euen as the Exchange in London is? : from which place my friend mafter Willi. am Martin, a right expert Chirurgion, did procure me the plants of them for my garden by his feruant that he fent thither, as Chirurgion of a fhip: fince which time I haue receiued plants of diuers others that haue trauailed into other of thofe parts \& coafts: notwithiftanding they haue not indured the cold of our extreme winter.

*T The time.

'They put foorth their leaues in the fpring time, and wither away at the approch of winter. * The names.

It is called both in Greeke and Latine iupoppisov, Euphorbium : Plinie in one place putteth the herbe in the Feminine gender, naming it Euphorbia : the iuice is called alfo Euphorbion, and fo it is likewife in hops, we are faine in Englifh to yfe the Latine worde, and to call both the herbe and iuice by the name of Euphorbium; for other name we haue none ; it may te called in Englifh the gum Thiftle.

\section{* The temperature.}

Euphor bium that is to fay, the congealed iuice which we vfe, is of a very hot, and, as Galen faith; caufticke or burning facultie,and of thinne parts: it is alfo hot and dry in the fourth degree. * The vertues.

A - An implaifter made with the gum Euphorbium, and $\mathbf{2}$.times fo much oile, and a litcle waxe, is very fingular againft all aches of the ioints, lameneffe,palfies, cramps, and (hrinking of finewes as Galen in his fourth booke de Medicamentis Secundum genera, declareth more at large, which to se. cite at this prefent,would but trouble you ouermuch.

B Euphorbium mingled with oile of Bay, and Beares greafe, cureth the fcurfe, \& fcales of the head, and pildnes, caufing the haire to grow againe, and other bare places being annointed therewith.

C The fame mingled with oile, and applied to the temples of fuch as are very fleepie, and troubled with the lethargie, doth awaken and quicken their fpirits againe.

D If it be applied to the nuque or nape of the necke, it bringeth their fpeech againe that haue loft it by reafon of the apoplexie.

E Euphorbium mingled with vineger and applied, taketh away all foule and euill fauoured fpots, in what part of the bodie foeuer they be.

F Being mixed with oile of Waltlowers, as Mefwes faith, and with any other oile or ointments, it quickly heateth fuch parts as are ouer colde. 
HISTORIE OF PLANTS.

It is likewife a remedie againft old paines in the Hucklc bones called the Sciatica.

Setius, Paulus, ACtuarims and cMefues do report, that if it be inwardly taken, it purgeth by fiege $\mathrm{G}$ water and flegme, but withall it fetteth on fire, fcorcheth and fretteth, not onely the throte and mouth, but alfo the ftomacke, liuer, and the reft of the entrailes, and inflameth the whole bodie.

For that caufe it muft not be beaten fmall, and it is to be tempered with fuch things as alay the I heate and fharpneffe thereof, and that make glib and flipperie, of which things there muft be fuch a quantitie as that it may be fufficient to couer all ouer the fuperficiall or outward part thereof.

But it is a hard thing fo to couer and fold it $v p$, or to mixe it, as that it will not burne nor fcorch. $K$ For though it be tempered with neuer fo much oyle, if it be outwardly applied it raifeth blifters in them efpecially that haue foft and tender flefh,and therefore it is better not to take it inwardly.

It is troublefome to beate it, vnleffe the noftrels of him that beateth it be carefully ftopped and L. defended, for if it happen that the hot fharpenes thereof do enter into the nofe, it prefently caufeth itching, and mooueth neezing, and after that by reafon of the extremitie of the hear, it draweth out abundance of flegme and filth, and laft of all bloud, not without great quantitie of teares.

But againft the hot Tharpnes of Euphorbium it is reported, that the inhabitants are remedied by M a certaine herbe which of the effeet and contrary faculties is named Anteuphorbivm : this plant likewife is full of iuice, which is nothing at all hot and fharpe, but coole and flimie, al aying the heat and fharpnes of Euphorbium; we haue not yet learned that the old writers haue fet downe anie thing touching this herbe; notwith fanding it feemeth to be a kinde of Orpine; which is the antidote or counterpoifon againft the poifon and venome of Euphorbium.

\section{OfThreeleafed grafe, or Medow Trefoile. Cbap.477.}

* T The kindes.

$T$ Here be diuers fortes of Three leafed graffes, fome greater, others leffer; fome bring foorth

flowers of one colour, fomeof another; fome of the water, and others of the land; fome of a pleafant fmell,others ftinking: and firft of the common Medow Trefoiles, which arecalled in Irith shanvorkes.

I Trifolium pratenfe. Medow Trefoile.

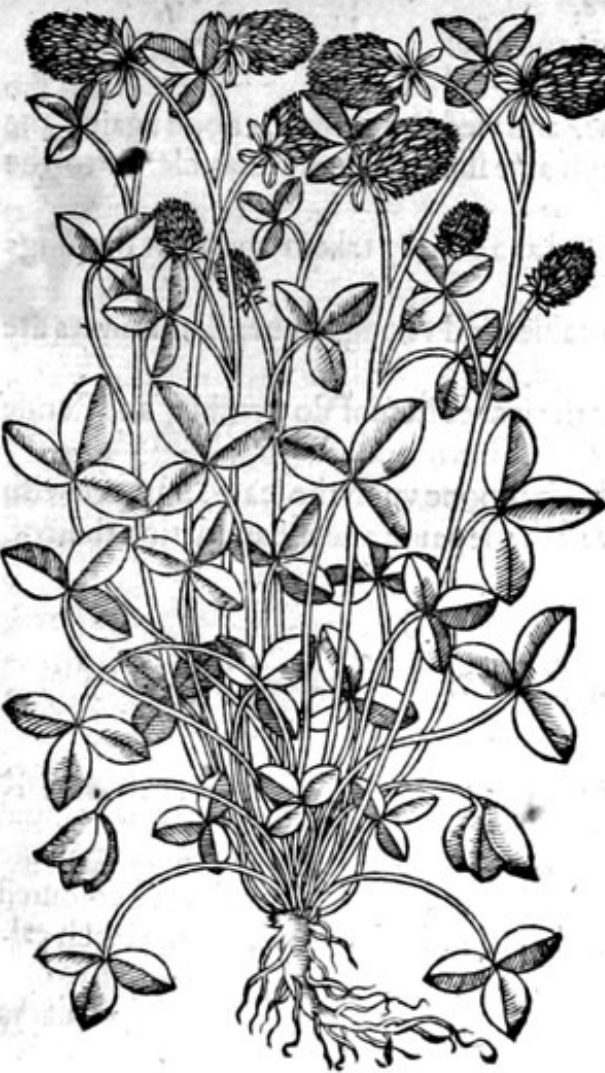

2 Trifolium pratenfeflore albo. Medow Trefoile with white flowers:

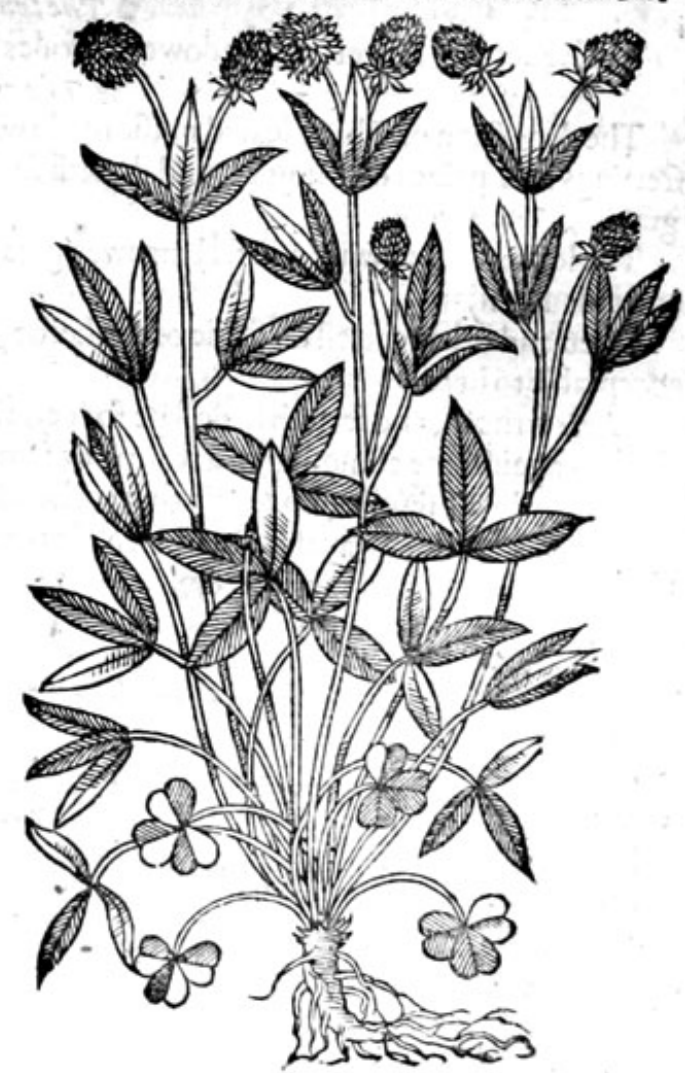


* The defcription.

I Edow Trefoile bringth foorth ftalkes a cubite long, rounde and fomething hairie: the greater part of which creepeth vpon the ground, whereon do growe leaues confiting of three ioyned togither, one ftanding a little from another; of which thole that are next the ground and rootes, are rounder, and they that growe on the vpper part longer; hauing for the moit part in the middeit a white fpot like a halfe moone. The flowers come foorth on the tops of the ftalkes in a tuft or fhort foxetaile eare, of a purple colour, and fweete of tafte. The feede growcth in little huskes, round and blackifh. The roote is long, woodie, and groweth deepe.

2 There is another of the field Trefoiles, differing from the precedent efpecially in the colour of the flowers : for as thofe are of a bright purple; contrariwife thefe are very white, which maketh the difference.

There is alfo a Trefoile of thiskinde, which is fowen in fieldes of the lowe Countries, in Italie, and diuers other places beyond the feas, that commeth vp ranker and higher than that which groweth in medowes, and is an excellent foode for cattell both to fatten them, and caufe them to giue great ftore of milke.

Likewife we haue in our fieldes a fmaller Trefoile that bringeth foorth yellow flowers, a greater and a leffer, and diuers others alfo, differing from thefe in diuers notable pointes, the which to diftinguifh apart would greatly enlarge our volume, and yet to fmall purpofe; therefore we leaue them to be diftinguifhed by the curious, who may at the firft view eafily perceiue the difference,and alfo that they be of one ftocke or kinred.

$$
\text { * The place. }
$$

Common Medow Trefoile groweth in medowes, fertill paftures, and waterifh grcunds. The others loue the like foile.

They flower from May to the end of fommer.

$$
\text { * The time. }
$$

$$
\text { * } 7 \text { he names. }
$$

Medow Trefoile is called in Latine Trifolium pratenfe: in high Dutch ratifentilee: in low Dutch Claueren: in French $T$ reffle and Trainiere, and $V$ if womarus, as Marcellus an olde writer teftifieth: in Englifh Cornmon Trefoile, Three leafed graffe: of fome Suckles, and Honifuckles, Cockheads, and in Irifh shamrockes.

\section{\& The temperature.}

The leaues and flowers of Medowe Trefoiles are colde and drie.

$$
\text { * The vertues. }
$$

A The decoetion of Three leafed graffemade with honie, and vfed in a clifter, is good againft the frettings and paines of the guts, and driueth foorth tough and flimie humors that cleatie to the guts.

B The leaues boiled with a little barrowes greafe, and vfed as a pultis, taketh away hot fwellings and inflammations.

C Oxen and other cattell do feede of the herbe, and alfo calues and yoong lambes. The flowers are acceptable to bees.

D Plinie writeth, and fetteth it downe for certaine, that the leaues hereof do tremble, and ftande right vp againft the comming of a ftorme or tempett.

E The Medow Trefoile (efpecially that with the blacke halfe moone vpon the leafe) ftamped with alittle honie, taketh away the pin and web in the eies, ceafeth thepaine and inflammation thereof, if it be ftrained and dropped therein.

$$
\text { Offtinking Trefoile, or Treacle Clawer. Chap.478. }
$$

* The defcription.

$7 \sim$ Reacle Clauer groweth vpright like a fhrubby plant, whth ftalkes of a cubite and a halfe high; whereupon dogtowe next the ground broad leaues three ioined togither, thofe vponthe ftalkes are longer and narrower. The ftaikes are couered ouer with a rough euill coloured hairynes. The leaues are of a darke blacke greene colour, and of a lothfome fmell, like the Pirch called Bitwenen ikidaicum, whereof it tooke his name. The flowers growe at the top of the ftalkes of 2 
darkepurplifh colour tending to blewneffe, in thape like thofe of Scabious. The feede is broad rough, long, and fharpe pointed. The roote is fmall and tender, and cannot endure the coldneffe of our winter, butperifheth at the firft approch thereof.

Trifolium bisuminofsem.

Treacle Clauer.

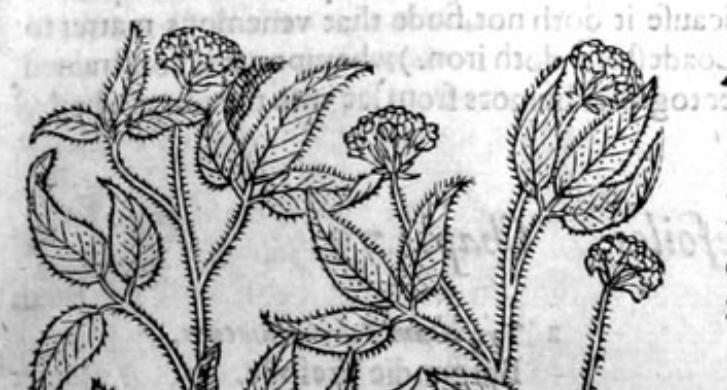

* Theplace.

It groweth naturally, faith Hippiatros, not Hip. pocrates Cous, in rough places, as Ruellius tranflatethit. In Germanie, Fraunce and England, it neuer commeth vp of it felfe ; but muft be fowen in gardens, as my felfe haue prooued diuers times, and was conftrained to fowe it ycerely, or elfe it would not come vp, neither of his owre fowing or otherwife.

* The time.

It flowreth not in my garden vntillthe end of Auguit.

\section{* The names.}

Nicander calleth this Trefoile remimnor, in Latine Trifolium acutum, or harpe pointed Trefoile: of Plinie Trifolimm odoratum, but not properly, of others $T$ rifolium Aphalt esem, fine Bituminofum, or Stone Pitch Trefoile.

Auscen calleth it Tarfilon, and not Handacocha, as fome haue thought, for vnder the name of Handacocha LAicen doth comprehend Diofcorides his Loti, that is to fay, Lotws vr bana, fylueftris, and $A E g r p f i r$, which Diofcorides confoundeth one with another in one chapter: in Englifh it is called Clauer gentle, Pitch Trefoile, ftinking Trefoile, and Treacle Clauer. * Tbetempcrature.

This Trefoile called UAphalteum, as Galen faith, is hot and dry,as Bitumen is,and that in the third degree.

* The vertues.

Being drunke, it taketh away the paine of the fides, which commeth by obftructions or ftop- A pings, prouoketh vrine, and bringeth downe the defired fickneffe.

Hippocrates writeth, that it doth not onely bring them downe, but likewife the birth, not onely B inwardly taken, but alfo outwardly applied. If a woman, faith he, be not well clenfed after hir ehilde bearing, giue hir this Trefoile to drinke in white wine.

Diofcorides faith, that the feedes and leaues being drunke in water, are a temedie for the pleuri- $C$ fie, difficultie of making water, the falling ficknes, the dropfie when it firft beginueth, and for thofe that are troubled with the mother. The quantitie to be taken at once is three drams of the feedes, and fower of the leaues.

The leanes drunke in Oxymel, or a firupe of vineger made with honie, is good for thofe that are D bitten with ferpents.

Some affirme that the decoetion of the whole plant, roote and leaues, taketh away paine from $\mathrm{E}$ thofe whom ferpents haue bitten, if they be waihed therewith; but if any orher man hauing an vlcer be wafhed with that water wherewith he was bathed that was bitten of the ferpent, they fay that he fhail be troubled in the fame maner that the ftinged partie was.

Some alfo giue with wine three leaues, or a fmall quantitie of the feedes in tertian agues; and in $\mathrm{F}$ quartaine fower, as a fure remedic againft the fits.

The roote alfo is put into antidotes or counterpoifons, faith Diofcorides, but other ancient Phifi- $G$ tions do not onely mixe the roote with them, but alfo the feede, as we may fee in $G$ alen, by agreat 
1020

THE SECOND BOOKE OF THE many compofitions in his fecond booke of Antidotes, that is to fay, in the Treacles AElins Gallue,
Zeno Landoseus, Clasdisus Apollonizus Eudemus, Heractides, Dorothems, and Her as.

$\mathrm{H}$ The herbe ftamped and applied vpon any enuenomed wound, or made with poifoned weapon, it draweth the poifon from the depth moft apparantly. But if it be applied vpon a wotind where there is no venemous matter to worke vpon, it doth no leffe infect thatpart, than if it had beene bitten with fome ferpent or venemous beaft : which woonderfull effect it doth not performe in refpect of any vitious qualitie that it hath in itfelfe, but bicaufe it doth not finde that venemous matterto worke vpon, which it naturally draweth (as the Loadeftone doth iron:) wherupon it is conftrained through his attractiue qualitie, to draw and gather togither humors from far vnto the place, wherby the paine is greatly encreafed.

\section{Of diuers otber Trefoiles. Chap.479.}

I Trifolium Americum. Trefoile of America.

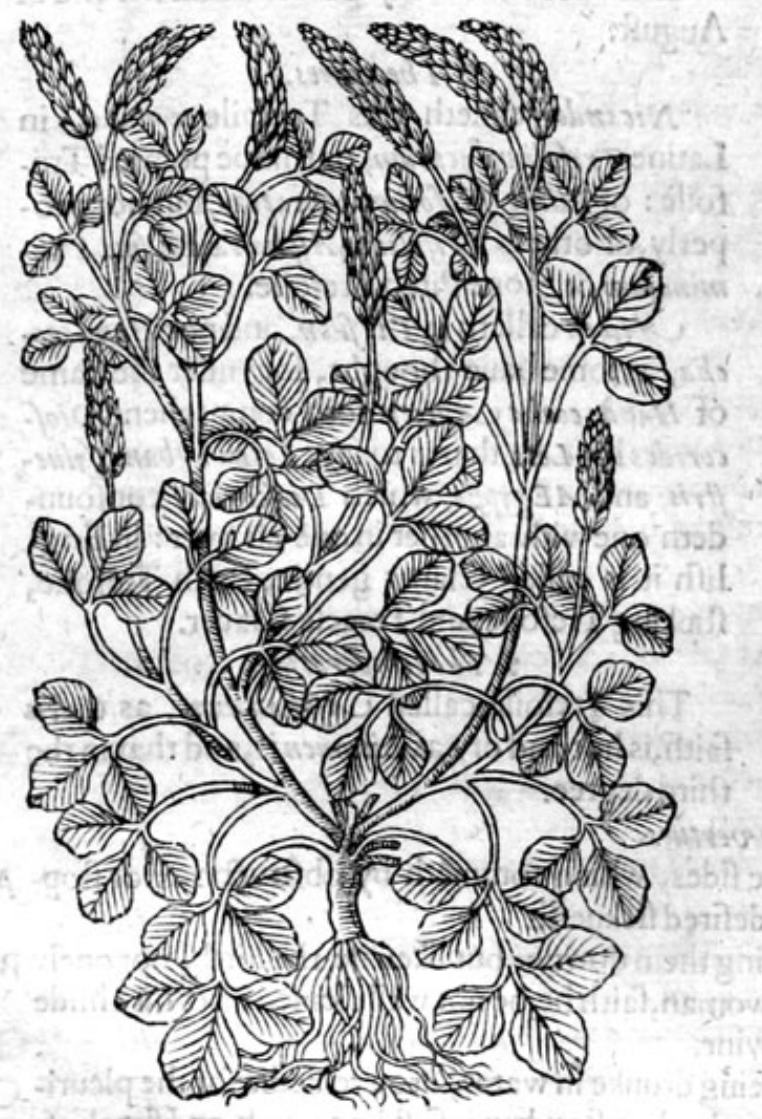

2 Trifolium Burgundiacum. Burgundie Trefoile.

\section{$*$ The defcription.}

I Tree leafed graffe of America hath diuers crooked, round ftalks, leaning this way and that way, and diuided into diuers branches: whereon do growe leanes like thofe of the medow Trefoile, of a black green colour, \& of the fmell of Pitch Trefoile, or Treacle Clauer. The flowers growe at the top of the branches, made vp in a long fpiked chaffic eare of a white colour; after which commeth the feede, fomewhat flat, almoft like to thofe of Tares. The roote is long ftrings of a woodie fubftance.

2 This Three leafed graffe, which Dodon aus in his laft edition calleth Trifolium cochleatum primum, and L'Obelius vinder the title of Fanum Burgundiac um, hath diuers round vpright ftalkes, of 2 woodie tough fubitance, yet not able of it felfe to ftand without a prop or ftay: which ftalkes are diuided into diuers fmall branches, whereupon do growe leaues ioined three togither like the other 
Trefoiles,but of a darke Ywart greene colour. The flowers growe at the top of the ftalkes confifting of a chaffie matter, of a darke purple colour. The feede followeth contained in fmall wrinkled huskes turned round, after the manner of a water fnaile. The roote is thicke, compofed of diuers tough threddie ftrings, and Jafteth long in my garden with greatincreafe.

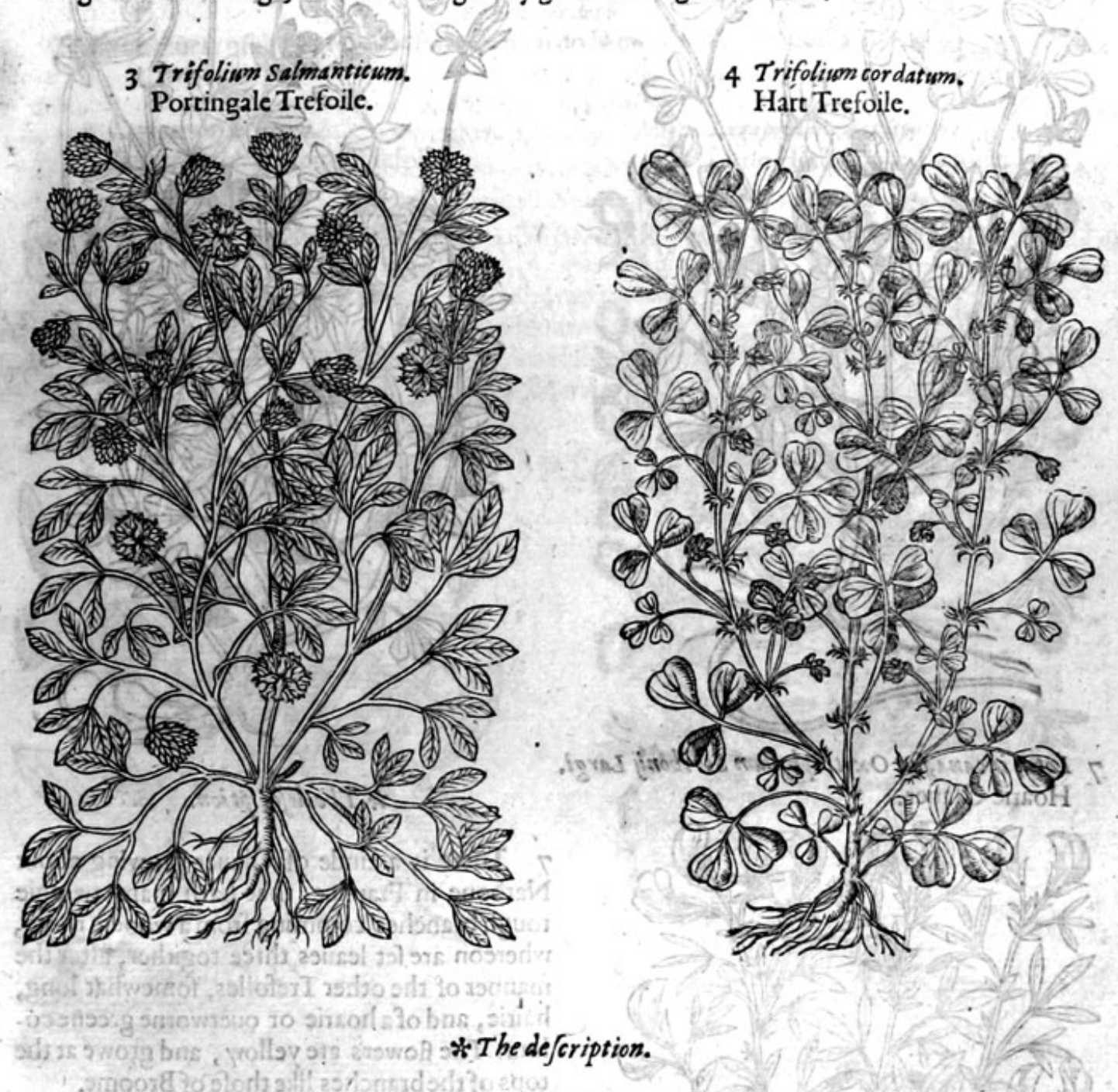

3 This Three lea fed graffe of Salmanca, a citie as I take it of Portingale, differeth not much from our field Trefoile: it hach many branches weake and tender, trailing vpon the ground, of two cubits and a halfe high: whereupon do growe leaues fet togither by three vpon a ftem; from the bofone whereof thruft foorth tendet footeftalkes, whereon do ftand moft fine flowers of a bright redde tending to puirple; after which come the leede wrapped in fmall skins, of a red colour.

4 The Hart Trefoile hath very many flexible branches, fet vpon aflender ftalke, of the leugth of two or three foote, trailing hither and thither, whereupon do growe leates ioned togither by three on little flender footeftalkes, exterylittle leafe of the fafhion of a Hart, whereot it tooke his name; among which come foorth fcalie, or chaffie yellow flowers. The roore is thickeand threddie.

5 This kinde of Three leafed graffe is a lowe herbe, creeping vpon the ground. The leaues are like thofe of the common Trefoile but loffer, and of a grayih greene colour. The flowers are faire and yellow, fafhioned like thofe of Broome, but leffer, after come three or fower round cods, wherein is contained round feede. The roote is long and reddifh.

This codded Trefoile is like vnto thelaft defcribed in euery refpect, fauing that this plant is altogither leffer, which fetteth foorth the difference. 
5 Trifolium filiquo/um. Codded Trefoile.

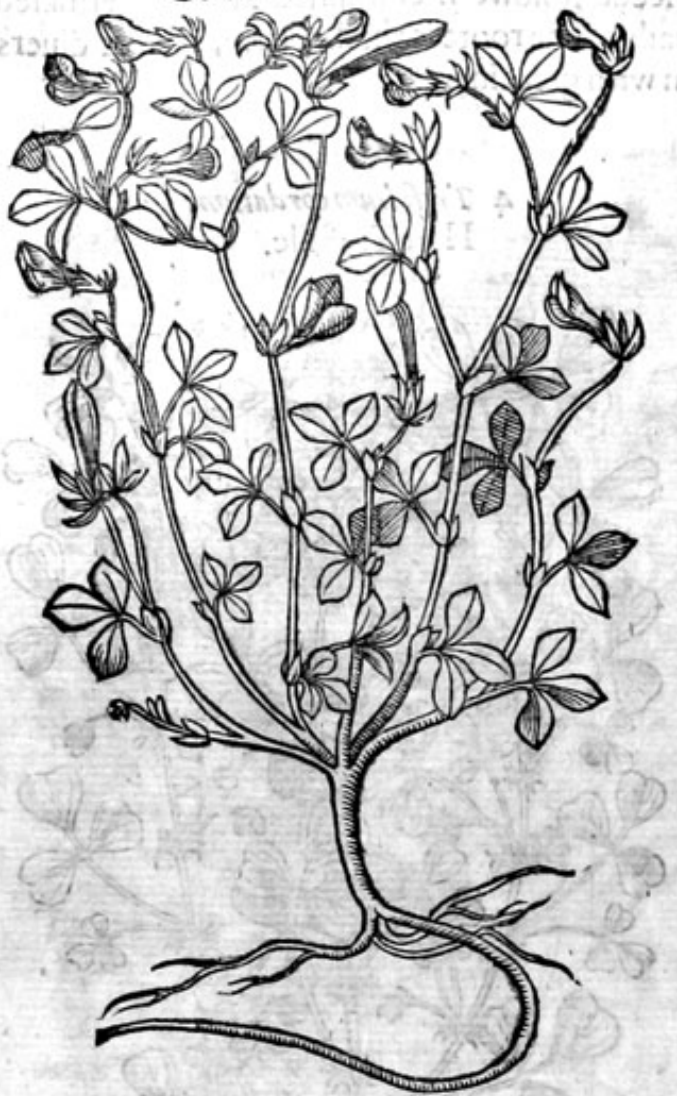

7 Lotus incana, fue Oxytriploylltsm Stribonÿ Largi. Hoarie Clauer.

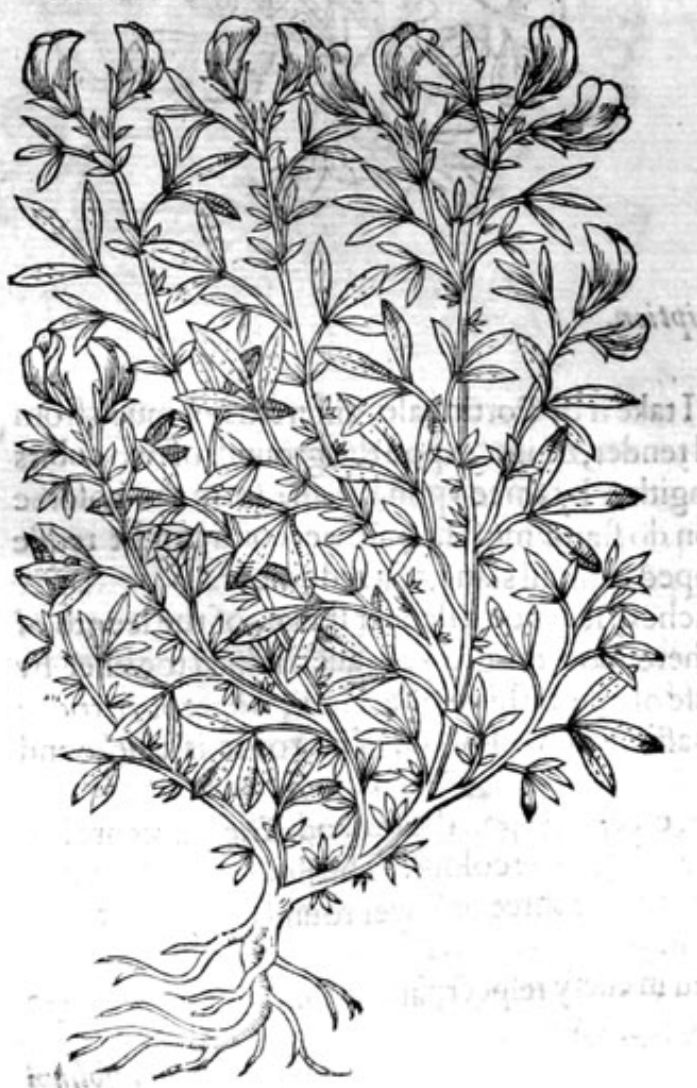

6 Trifolium foliquofun minios. Small Codded Trefoile.

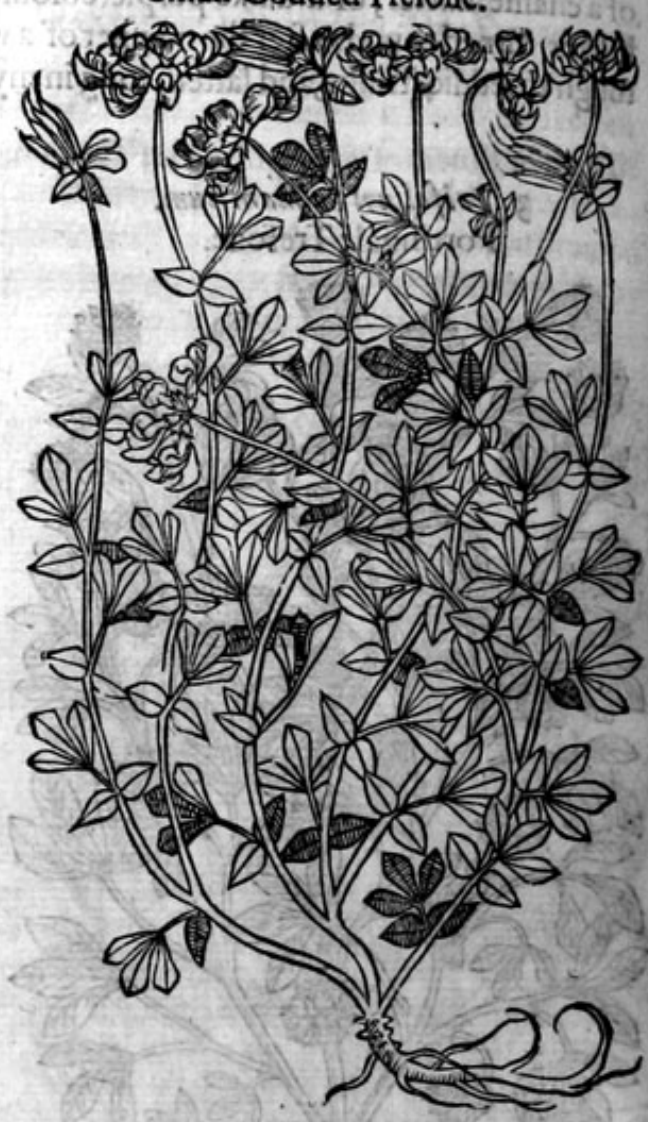

* The defaription.

7 There is a kinde of Clauer growing about Narbone in Fraunce, that hath many twiggie tough branches comming from a woodie roote, whereon are fet leaues three togither, after the manner of the other Trefoiles, fomewhat long, hairie, and of a hoarie or ouerworne greene colour. The flowers are yellow, and growe at the tops of the branches like thofe of Broome.

\section{* The place.}

The feuerall titles of moft of thefe plants fet foorth their naturall place of growing: the reft growe in moft fertill fields of England.

$$
\text { * The time. }
$$

They flower and flourifh moft of the fommer monethes.

$$
\text { troot The names. }
$$

There is not much to be faid as touching their names, more than hath beene fet downe.

* The temperature and vertues.

The temperature and faculties of thefe Trefoiles are referred vnto the common Medowe Trefoile. 


\section{Of the great $T$ refoiles, or winged Clawers. Chap. 480 .}

$*$ The kindes.

There be diuers of thefe great Trefoiles, which da likewife differ in their kinde very notably.

I. Lazopern maximum.

The great Hares foote Trefoile.
2 Lagopodium, Pes leporis. Little Hares foote Trefoile.

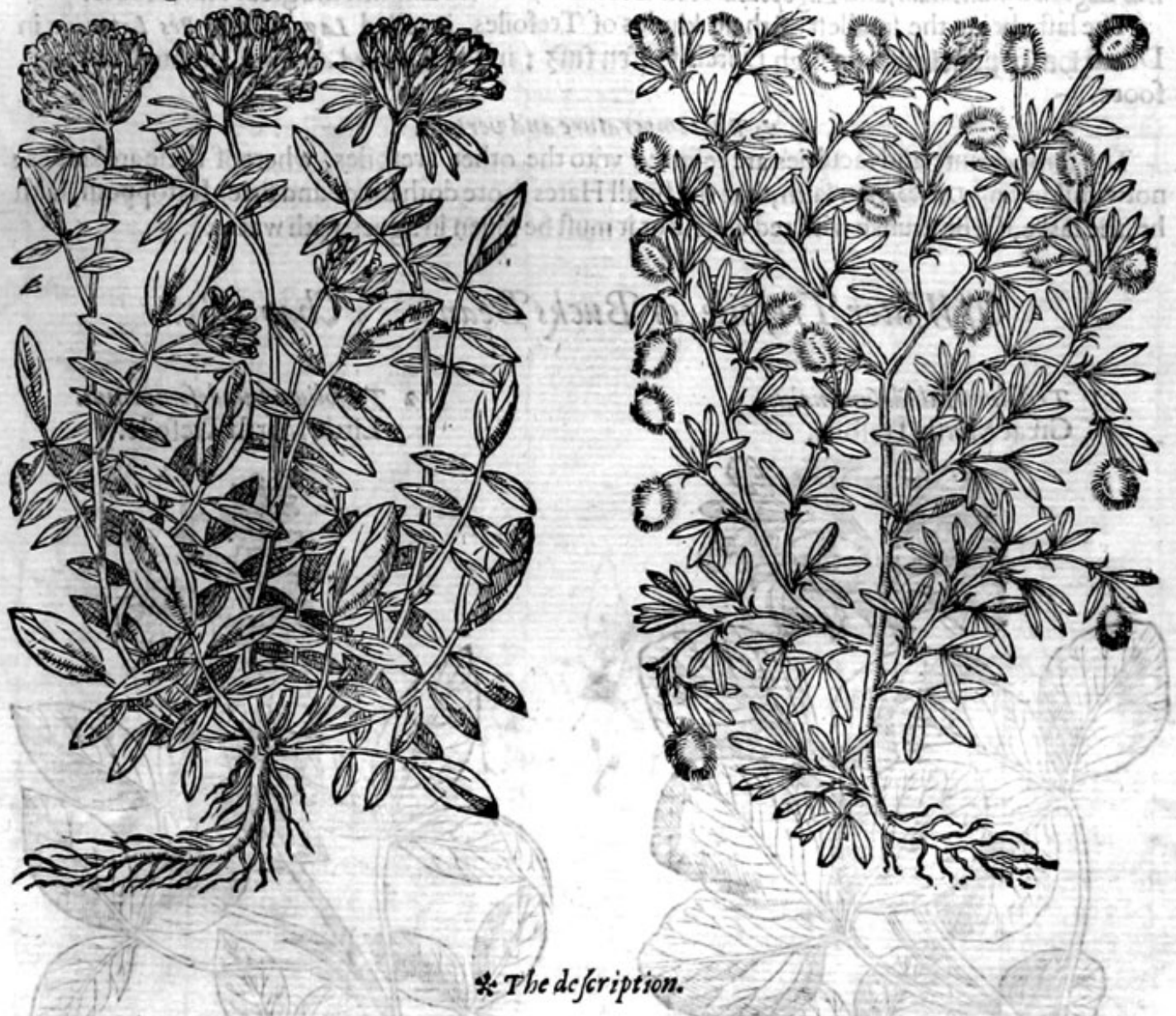

I. Te great Hares foote being a kind of Trefoile, hath a hard and woodie roote, full ofblacke threddie ftrings: from whence arife dieers tough and feeble branches, whereupon do grow long leaues, fet vpon a middle rib by couples one againft another, \& one in the very point, making the whole leafe to refemble thofe of the Greeke Valerian : the flowers grow at the top of the ftalkes, compofed of a bunch of graic haires: among the which foft matter commeth footth fmall fowers of a moit bright purple colour, fomewhat refembling the flowers of the common medowe Trefoile, but farre greater.

2 The fmall Hares foote hath a sounde, rough, and hairie ftalke, diuiding it felfe into diuers other branches; whereupon do grow fmall leaues, three ioined togither, lihe thofe of the finall yellowe Trefoile : the flowers growe at the very point of the ftalkes, confifting of a rough knap or buin of haires or downe, like that of Alopecuros, or Foxetaile, of a whitifh colour tending to 2 light blurh: theroote is fmall and hard.

IIThere be dituers $\phi$ ther forts the face and fhewe where of will or may diftinguifh themfelues, bicaufe ithey do all and euery of thembeare the face of the former, differing fome in greatneffe, others io colour af the flowers, therefore is ball fuffice what hath beene faide in the defcrption. 
* Theplace.

The firft groweth in the fieldes of Fraunce and Spaine, and is a ftranger in England; yet it grow: eth in my garden. The fimall Harefoote groweth among corne, efpecially among Barly, and likewife in barren pa.
ftures almoft euery where.

They flower and flourii h in Iune, Iuly, and Auguft.

$*$ The time.
* T The names.

The great Harefoote Trefoile is called of T ragues Cytifus of Cordus Trifoliam magnam, of L'Obe. litus Lagopum maximum, and Lagopodium: in Greeke raxwirsus in Englifh the great Hares foote.

The laft, being the fmalleft of thefe kindes of Trefoiles, is called Lagopus and Pes Leporis : in Dutch lafen pontkens : in high Dutch Đaien fufz : in French $P$ ied de lieure : in Engliih Harefoote.

* Thetemperature and vertues.

A The temperature and faculties are referred vnto the other Trefoiles, whereof thefearekindes: notwithitanding Dtofcorides faith, that the finall Hares foote doth binde and drie. It ftoppech, faith he, the laske, if it be drunke with red wine. But it muft be giten in agues, with water.

\section{OfWater Trefoile, or Bucks Beanes. Chap $48 \mathrm{r}$.}

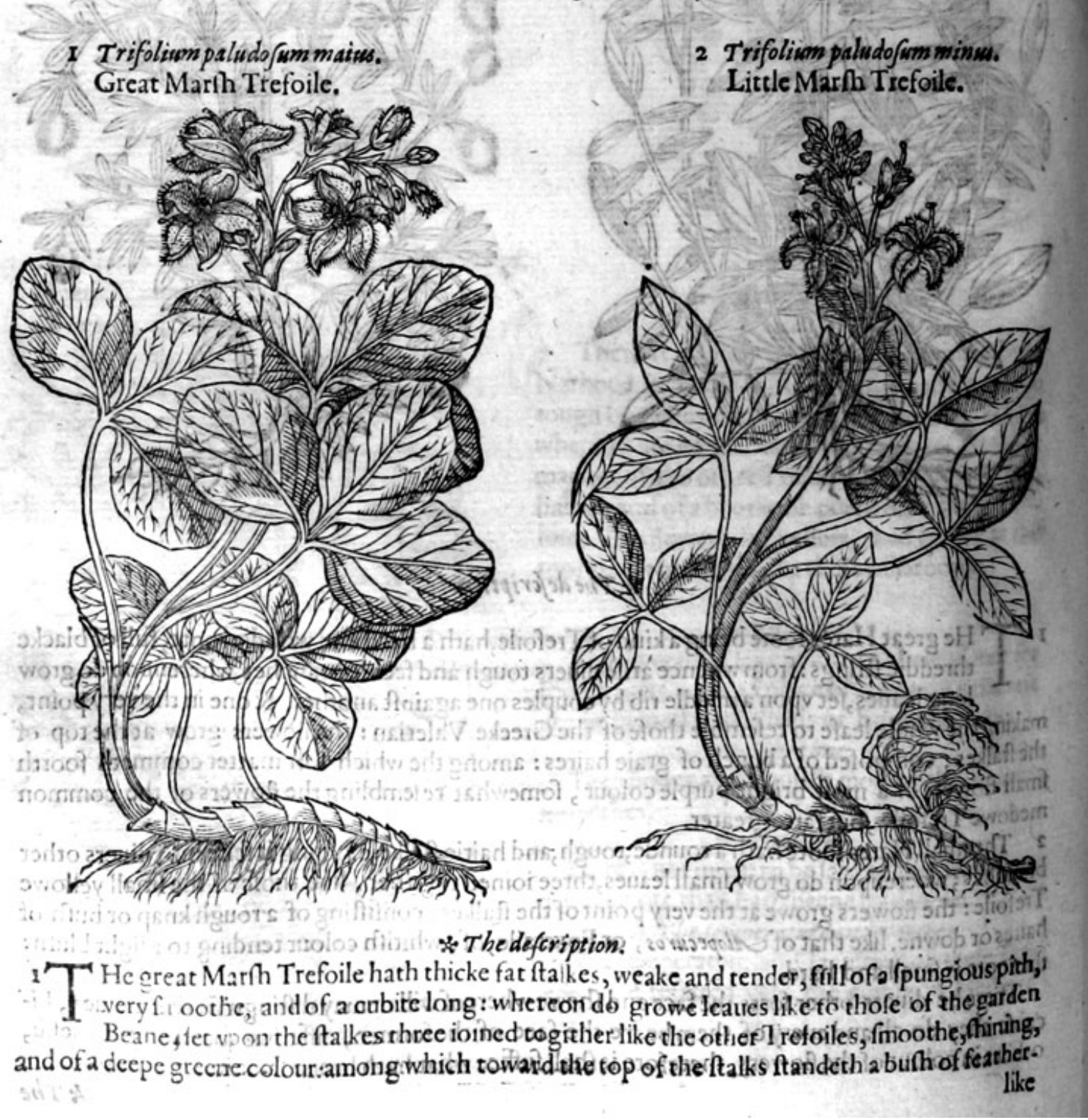




\section{HISTORIE OF PLANTS.}

like fowers of a white colour, dafht ouer flightly with a wafh of light carnation, after which the feed followeth, contained in fmall buttons, or knobby huskes, of a browne yellowifh colour like vnto Millet and of a bitter tafte : the rootes creepe diuers waics in the muddic marifh grounde, being ful of ioints, white within, and full of pores, and fpungie, bringing foorth diuers by- thootes, ftalks, and leaues, by which meanes it is eafily increafed,and largely multiplied.

2 The fecond differeth not from the precedent, fauingit is altogither leffer, wherin confifteth the difference, if there be any: for doubtlefle I thinke it is the felfe fame in each refpect, and is made greater and leffer,according to his place of growing, clymate, and countrey.

$$
\text { \% The place. }
$$

Thefe grow in marifh and Fennie places, and vpon boggie grounds almoft euery where.nis

They flower and fourifh from Iune to the end of Augult.

$$
\text { * The names. }
$$

Marifh Trefoile is called in high Dutch 23 ibetklee, that is to fay, Caftoris $\tau$ rifolium, or Trifolium fibrinum : in low Dutch of the likenes that the leaues haue with the garden Beanes, 230ethoumen, that is to fay, Fa felus Hircinus, or Bwna Hircina : the later Herbarifts call it Trifolium paluftre, and Paludo from, of fome Ifopyrum : in Englifh marth Clauer, marth Trefoilc, and Buckes Beanes.

$$
\text { * The temperature and vertues. }
$$

The feede of Ifopyrum, or Trifolium paluftre, faith Diojcorides, if it be taken ivith meade or honied A water, is good againit the cough and paine in the cheft.

It is allo a remedie for thofe that haue weake liuers and fpet bloud, for as Galen faith it clenfeth B and cutteth tough humours, hauing alfo ioined with it an aftringent or binding qualitie.

W

\section{Of fweete Trefoile, or garden Clawer. Chap. 482 .}

Trifolism odoratum.

Sweete Trefoile.

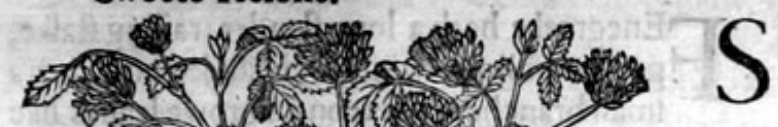

* The defcription.

Weete Trefoile hath an vpright ftalke, hollow, and of the height of two cubits, diuiding it felfe into diuers braunches: whereon doe growe leaues by three and three, like to the other Trefoiles, flightly and fuperficially nicked in the edges: from the bofome wherof come the flowers, euery one ftanding vpon his owne fingle footeftalke, confifting of little chaffie huskes, of a light or pale blewifh colour; after which come vp litele heads or knops, in which lieth the feede, of a whitifh yellow colour, and leffer then that of Fenugreeke : the roote hath diuers ftrings: the whole plant is not onely of a whitifh greene colour, but alfo of a fweete finell, and of a ftrong aromaticall or fpicie fent, and more fweete when it is dried: which fmell in the gathered and dried plant doth likewife continue long; and in moift and rainie weather, it fmelleth more then in hot and drie weather: and alfo when it is yet frefh and greene, it loofeth and recoucreth againe his finell feauen times a daie, whereupon the old wiues in Germanie do call it bieucungzeiten ktatt, that is, the herbe that chatuceth feauen times a day.

$$
\text { *Theplase. }
$$

It is fowen in gardens not onely beyond the feas, but in diuers gardens in England.

$$
\text { It } 1
$$


* Thetime.

It is fowen in Maie, it flowreth in Iune and Iuly, and perfecteth his feede in the ende of Auguif,

It iscommonly called in Latine Trifolium odoratum: in high Dutch as we haue faide fietten nezeiten : in low Dutch Seutngbettictuit, that is to fay, an herbe of feauen times :it is called in
Spanifh Trebol Real: in French Treffe it fecmeth to be Lotus vrbana, or atiua, of which Diofcorides writeth in his fourh garden Clauer: theleffe diuers authors fet downe Melilot for Lotus vrbana and perly. * Thetemperature. Galen faith, that fweete Trefoile doth in a meane concoet and dry, and is in a meane and tem-
perate facultie betweene hot and colde: the which faculties vndoubtedly are plainly perceiued in
this fweete Trefoile. this fweete Trefoile.

* The vertues.

A The iuice prefled foorth faith Diofcorides, with honie added thereto, clenfeth the vlcers of the eies, cailed in Latine Argeme, and taketh away fpots in the lame,called Albugines; and remooueth fuch things as do hinder the fight.

B The oile wherein the flowers are infufed or ftieped, doth perfectly cure greene woundes in very Thort fpace; it appeafeth the paine of the gout, and all other aches, and is highly commended
againft ruptures, and burftings in yoong children.

C The iuice giuen in white wine, cureth thofe that haue fallen from fome high place, auoideth congealed and clotted bloud, and alfo helpeth thofe that do piffe bloud, by meanes of fome great brufe, as was prooued lately vpon a boie in Fanchurch ftreete, whom a cart went ouer, whereupon he did not onely piffe bloud but moft woonderfully it guthed foorth, both at his nofe and mouth.

D The dried herbe laide among garments, keepeth them from Mothes and other vermine.

\section{Fanumgracum. \\ Of Fenegreeke. Chap. 483 .}

Fenegreeke.

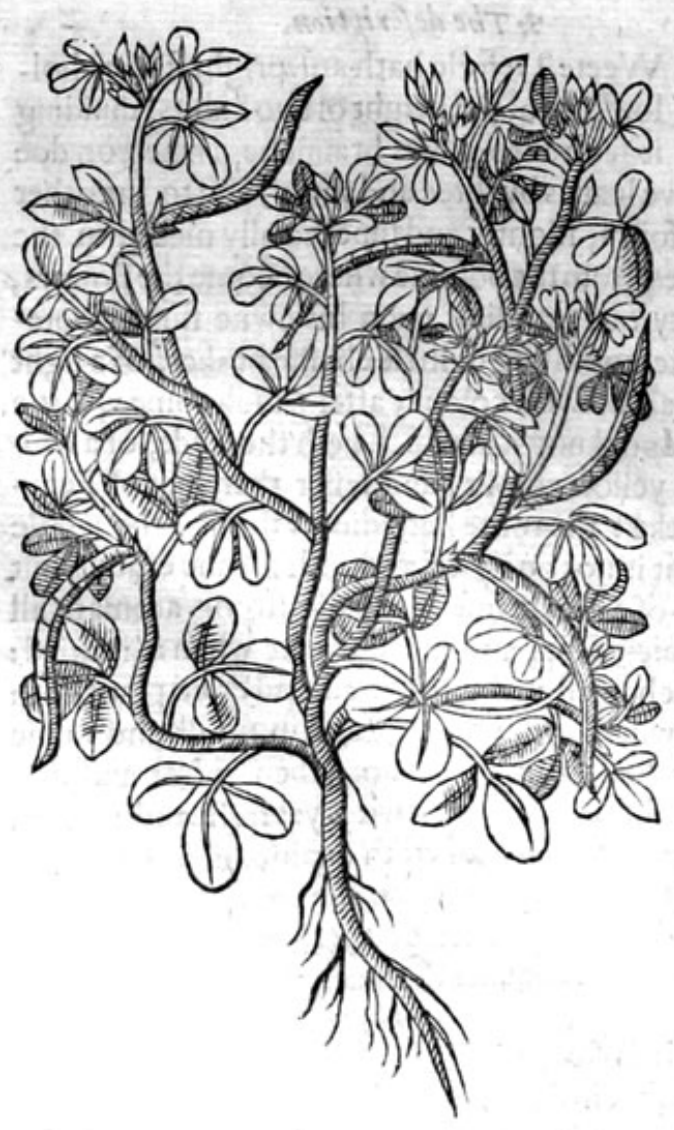

* The defoription. Enegreeke hath a long flender trailing ftalke,
greene,hollow within, and diuided into diuers fmall branches: whereon do growe leaues like thofe of the medow Trefoile, but rounder \& leffer, greene on the vpper fide, on the lower fide tending to an afh colour: anong which come finall white flowers, after them likewife long flender narrowe cods, in which do lie fmal vneeuen feeds, of a yello. wifh colour; which being dried, haue a ftrong fmel, yet not vnpleafant; the roote is fmal, and perifherh when it hath perfected his feede.

There is a wilde kinde heereof feruing to little vfe, that hath finall round branches, full of knees or ioints : from each ioint proceedeth a fmall tender footftalke, whereon do grow three leaues and no more, fomewhat fnipt about the edges, like vnto thofe of Burgundie Haie: from the bofomes whereof come foorth fmall flowers, which turne into little cods : the roote is thicke, tough, and pliant.

* Theplace.

Fenegreeke is fowen in fieldes beyond the feas : in England we fowe a fmall quantitie therof in our gardens.

$*$ The time.
It hath two feafons of fowing, according to
Columella, 
Colvmella, of which one is in September, at what time it is fowen that it may ferue for fodder againft winter; the other is in the end of Ianuary, or the beginning of Fcbruary; notwithitanding we maynot fow it vntill Aprill in England.

$$
\text { *The names. }
$$

It is called in Greeke rinus, or as it is founde in P \& zay his copies Carphos: in Latine Fanum Gra. cum : Columella faith that it is called Siliqua : in Pliny we read Silicia: in Varro Siliciula: in high Dutch 230ckffognte: in Italian Fiengreco: in Spanifh Nafornas: in French Fenegrec : in Englin Fenegrecke.

* The temperature and vertues:

It is thought according to Galen in his booke of the faculties of nourifhments, that it is one of A thofe Simples which do manifeftly heate, and that men do vfe it for foode as they do Lupines; for it is taken with pickle to keepe the body foluble, and for this purpoff it is more agrceable then Lupines, feeing it hath nothing in his owne proper fibftance, that mav hinder the working.

The iuice of boiled Fenegreeke taken with honie, is good to purge by the ftoole a!l maner of cor- B rupt humours that remaine in the guts, making foluble thorow his flimines, and mitigating paine. thorow his warmnes.

And bicaufe it hath in it a elenfing or fcouring facultie, it raifeth hunours cut of the cheft: but $\mathbf{C}$ there muft be added vnto it no great quantitic of hony leaft the biting qualitie fhould abound.

In old difeafes of the cheft without an agew, fat dates are to be boiled with it, 5ut when you haue D mixed the fame iuice preffed out with a great quantitie of hony, and haue againe boiled it on a foft fire to a meane thicknes, then muft you vfe it long before meare.

In his booke of the faculties of Simple medicines, he faith that Fenegteeke is hot in the feconde $\mathrm{E}$ degree and dty in the firft : thereforc it dothkindle and make woor fe hot inflammations, but fuch as are leffe hot and more hard, are therewith cured by being wafted and confumed away.

Themeale of Fenegreeke as Diofcorides writeth, is of force to mollifie and wafte away, being boi- F led with meade and applied it taketh away inflammations, as well inivard as outward.

Thefame being tempered or kneaded with niter and vineger, doth foften and wafte away the $G$ hardnes of the mile.

It is good for women that haue either impoftume, vlcer, or ftoppings of the matrix, to bathe and $\mathrm{H}$ fit in the decoction thereof.

The ivice of the decoction preffed foorth doth clenfe the haire, taketh away dandraffe, fcoureth I running fores of the head, called of the Gritecians $\alpha^{2} e^{e} t:$ being mingled with goofe greafe \& put vp in maner of a peffarie, or mother fuppofitorie, doth open and mollifie all the parts about the mother.

Greene Fenegreeke brufed and pouned with vineger, is a remedy for weake and feebleparts; and $\mathbf{K}$ that are without skin, vlcerated and raw. moitgivoluh

The decoction thereof is good againft vicers in the low gut, and foule ftinking excrements of $L$

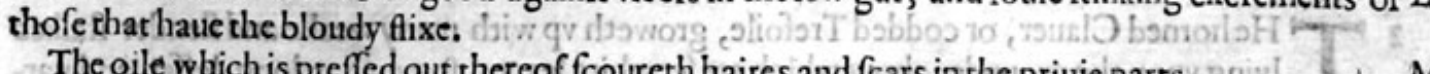

The oile which is preffed out thereof foureth haires and fcars in the pritie parts. 2niyl I : M The decoction of Fenegreeke feede, ynade in wine; and drunke with a little vineger, expelleth all $\mathrm{N}$.
euill htumours in the ftomacke and guts.

Thefeede boiled in wine with dates and hony, vnto the forme of a fyrupe, doth mundifie \& clenfe $O$ the breft, and eafeth the paines thereof.

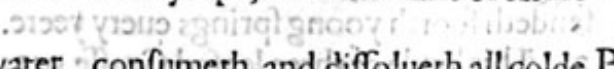
The meale of Fenegreeke boiled in meade or honied water, conftumeth and diffolueth all dolde $\mathrm{P}$. hard impoftumes and fwellings, and beingmixed with the roots of niarfh Mallowes, and Linfeede effecteth the fame.

It is very good for women that haue any greefe or fwelling in the matrix, or other lower parts if $Q$ they bache thofe parts with the decoction thereof made in wine, or fit oucr it and fiveate.

It is good to wafh the head with the decoction of the feede, for it taketh away thefcurffe, fcales, $R$ nittes, and all other fuch like imperfections. 


\section{Of Horned Clauer, and blacke Clawer. Chap.484.}

I Lotus trifolia corniculata. Horned or codded Clauer.

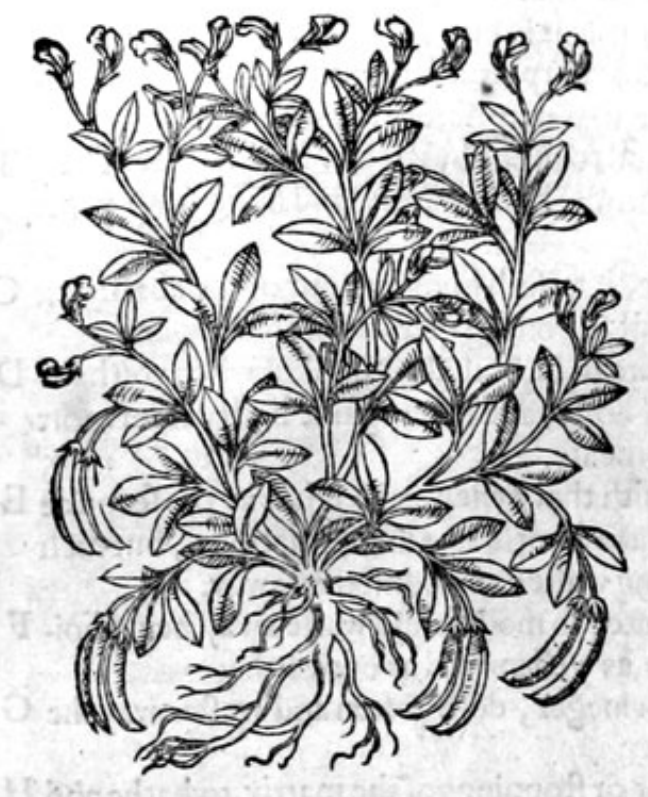

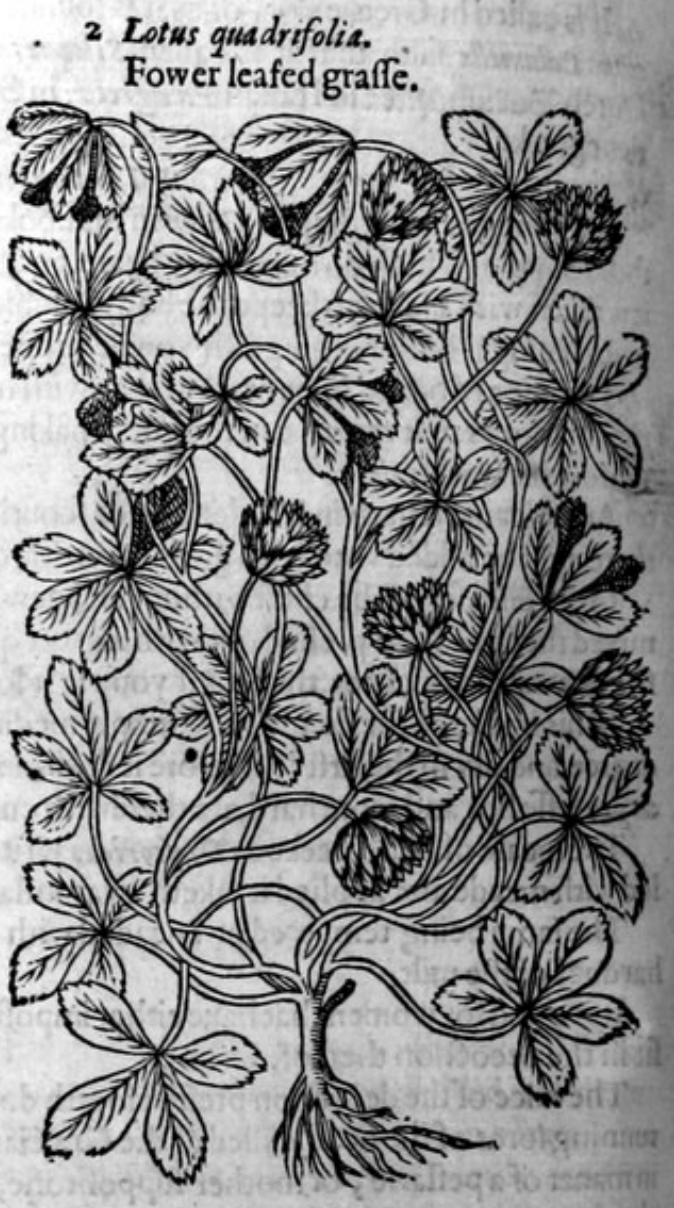

\& Thedefcription.

I He horned Clauer, or codded Trefoile, groweth vp with many weake and flender ftalkes lying vpon the grounde : about which are fet white leaues, fomewhat long, leffer, and narrower then any of the other Trefoiles: the flowers grow at the tops, of the faf hion of thofe of Peafon, of a hining yellow colour, and very little; after which come certaine little crooked cods, long and flender, in which are contained little rounde feeds: the roote is harde and woodie, and fendeth foorth yoong fprings euery yeere.

2 This kinde of three leafed Graffe, or rather fower leafed Trefoile, hath leaues like vnto the common medow Trefoile, fauing that they be leffer, and of a browne purplifh colour, knowne by the name of Purple Woort,or Purple Graffe; whofe flowers are in fhape like the medow Trefoile, but of a duftie ouerworne colour tending to whitenes, the which doth oftentimes degenerate, fometime in to three leaues, fometimes in fiue, and alfo into feauen, and yet the plant of his nature hath but fower leaues and no more.

* Theplace.

The firft groweth wilde in barren ditch bankes, paftures, and dry mountaines.

The fecond groweth likewife in paftures and fieldes, but not fo common as the other: and is planted in gardens.

They flower in Iuly and Auguift. * The time. 


\section{AHHIS TORIE OF PLANTS.}

* The names.

The firft is called Lotus Trifolia and Trifoliam corniculatum: in Englih horned Clauer, or codded Trefoile.

The other is called Lotus quadrifolia, or fowver leafed Graffe, or purple Woort, of $P$ ena and L'Obelius, quadrifolum faxsun fuf cum Hortorum.

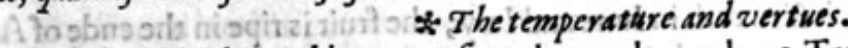

Their faculties in working are referred vnto themedowe Trefoiles; notwithftanding it is repor- A ted thac the leaues of purple Woore ftamped, and the iuice giuen to drinke, cureth yoong children of the dileafe called in Englifh the purples.

\section{Of Medick fodder, or Snaile Clauer. Cbap.485.}

I Trifolinm Cocbleatum. Medick fodder.
2 Trifolium Cochleatum marinwm. Medick fodder of the fea.

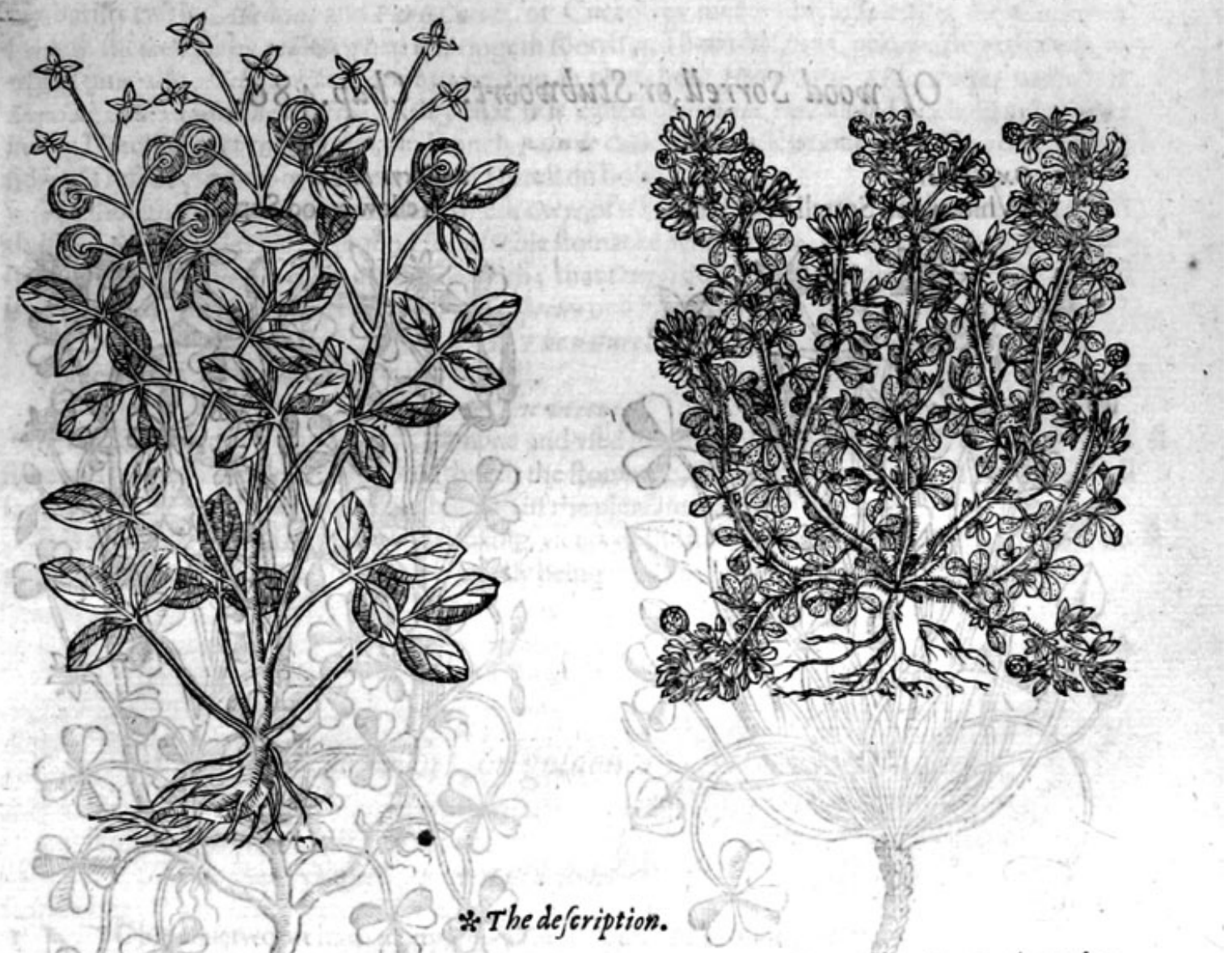

$\mathbf{I}$

7 His kinde of Trefoile called Medica, hath many fmall and ramping flender branches, erawling and creeping along vpon the grounde, fet full of broad leaues, lightly indented about theedges:the flowers are very fmall, and of apaleyellowe colour, which turne into round wrinckled knobs, like the water fraile, or the firh called Periwinck, wherein is contained flat feed,fafhioned like a little kidney, in colour yellowe, in tafte like a Fetch or Peafe: the roote is fmall, and dieth when the feede is ripe: it groweth in my garden, and is good to feede cattle fat. 2 Thistinde alfo of Trefoile(called Medica martina in Englifh fea Trefoile, growing naturally by the fea fide, abouk Weftchefter, \& vpon the nediterranean fea coaft, \& about Venice) hath leates very like vnto the commonMedow Trefoile, but thicker, and cotered oter with a flockie hoarines like Gnafatitim afier tlie fhancr of mot of the fea herbes : the flowers are yellow:the feeds wrinckled like the former, butin quantitie they be leffer. isusis? 
The firft is fowen in the fieldes of Germanie, Italy, and other countries to feede theircattle,as we in England do Bucke wheat, we haue a fmall quantity thereof in our gardens, for pleafures falke.

The fecond groweth neere vnto the fea fide in diuers places.

* The time.

Medica muft be fowen in Aprill; it flowreth in Iune and Iuly; the fruit is ripe in the ende of Altguft.

* The names.

Medick fodder is calledof fome Trifolium Cochleatwom, and Medica: in French $L$ ' herbe a Limagfon: in Greeke $\mu$ uxixh : in Spanifh Mielguas : of the Valentians, and Catalons islfafa, by a worde either barbarous, or Arabicke: for the chiefe of the Arabian writers Uuicen doth call Medica Cot, Alafsleti,and Ulf asfa/a.

The other is called fea Clauer, and Medick fodder of the fea. $*$ The temperature and vertues.

Medick fodder is of temperature colde, for which caufe it is applied greene vnto fuch in lammations, and infirmities as haue neede of cooling.

\section{Of wood Sorrell,or Stubwoort. Chap. 486 .}

I Oxysalba.

White wood Sorrell.

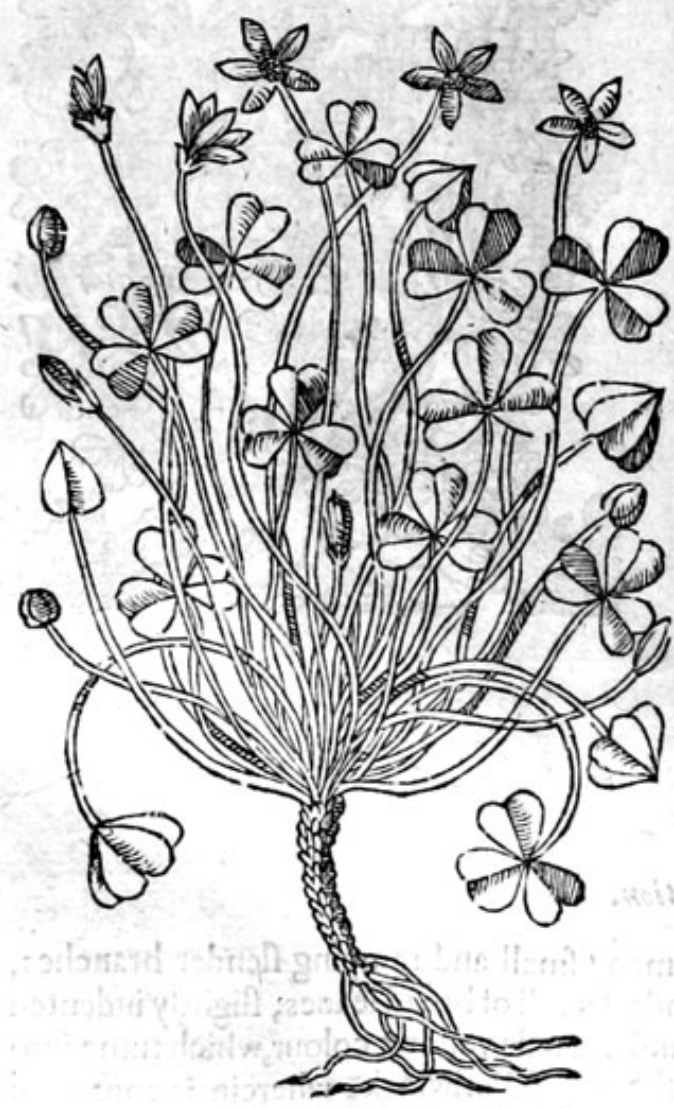

2 Oxys lutea. Yellow wood Sorrell.

* Thedefcription.

I Xys Pliniana, or Trifolium acetofum, being a kinde of three leafed graffe, is a lowe and bale herbe, without italke; the leaues immediately arifing from the roote vpon fhort ftems, at their firft comming foorth folden togither, but afterwarde they do f pread abroad and are of a faire light green colour, in number three, like the reft of the Trefoiles, but that each leate hath 2 deep cleft or rift in the middle:among ft thefe leaues com vp fmall \&weake tender ftems, fuch as the 
leaues do grow vpon, which beare fmall ftarlike flowers, of a white colour with fone brightneffe of carnation dafht ouer the fame: the flower confifteth of fiue fnall leaues, after which come little round knaps; or husks, full of yellowi h feede:the roote is verie threddie, and of a reddifh colourthe whole herbe is in tafte like Sorrell, but much fharper and quicker, and maketh bettẹr greene fauce, then any other herbe or Sorrell whatfoeuer.

2 The fecond kind of Oxys or wood Sorrell, is very like the former, fauing that his flowers are of a yellowe colour, and yeeldech for his feede vefiels fmall and long horned cods, in other refpeets alike.

$$
\text { * The place. }
$$

Thefe plants do growe in woods, and vnder bufhes, in fandie and hadowie places in euerie countrey.

$$
\text { * The time. }
$$

They flower from the beginning of Aprill vnto the end of Maie, and midft of Iune.

\section{* 7 be names.}

Wood Sorrell or cuckow Sorrell, is nomed in Latine Trifolium acetofurn: the Apothecaries and Herbarifts call it Alleluya, and Panis Cuculi, or Cuckowes meate, bicaufe either the Cuckowe feedech thereon, or by reafon when it fpringeth foorth and flowreth, the Cuckowe fingeth moft, at which time alfo Alleluya was woont to be fung in churches. Hieronymus Fracastorins nameth it Luyula. Ulexander Benedrctus faith, that it is called Alimonia : in high Dutch bautelklee: in low Dutch Toeckicaecrbzoot : in French Pain de Cocu: in Englifh woode Sorrell,woode Sower, Sower Trefoile, Stubwoort, Alleluia, and Sorrell du Bois.

It is thought to be that which $P$ liny calleth Oxys, of which in his 27 .booke 12 .chapter, he writeth thus, Oxyis is three leafed; it is good for a feeble ftomacke, which is allo eaten of thofe that are burIten: but Galen in his 4.booke of Simples faith; that Oxys is the fame, which alfo Oxalis or Sorrell is; and $O x y$ s is found in $P$ liny to be alfo Iunci (pecies, or a kinde of Rurh.

\section{Thefe herbes are colde and drie like Sorrell.} * The nature.

Sorrell du Bois or Wood Sorrell, Itamped and vfed for greene fauce, is good for them that haue A ficke and feeble ftomacks, for it ftrengthneth the ftomacke, 'procureth appetite, and of all Sorrell fauces is the beft, not onely in vertue, but alfo in the pleafantnes of his tafte.

It is a remedie againftputrified and ftinking vlcers of the mouth, it quencheth thirft, and cooleth $B$ mightely an hotpeltilentiall feauer, efpecially being made in a firup with fugar.

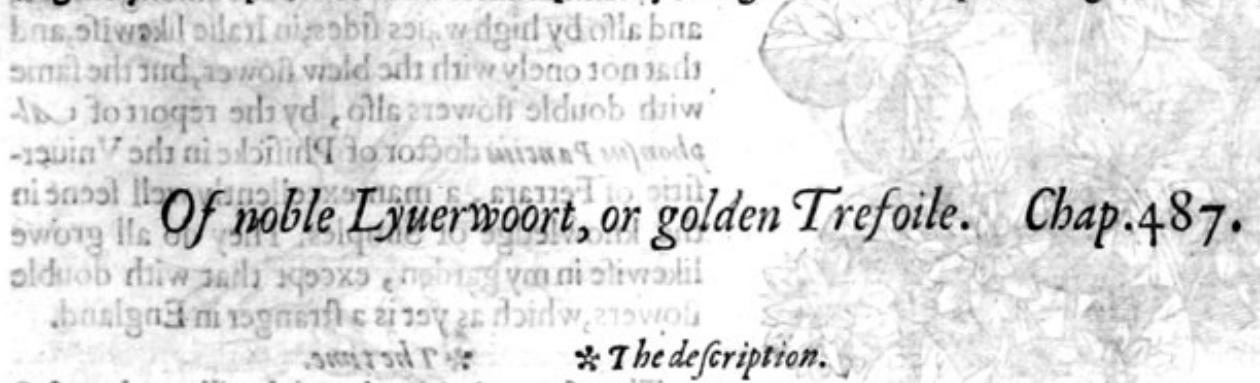

I Toly Oble Lituerwoort hath manyleaues fpted vpon the grounde, three cornered, refembling

the three leafed grafle, of a perfect grafte greene colour; among which rife vp dituers finall 1 tender footfalkes, of three incliches long, on theends whereof ttands one fmall fingle blew flower, conditting of fixelittle leaues, hauing in the middle a fewe white chiues : the feede is inclofed in litele roundknaps, of a whitifh cotour, which being ripe do ftart foorth of themfelues: the roote is flender, compoled of an infinite number of blacke ftrings.

2 The fecond is like vnto the precedent in leaues, rootes, and feedes : the flowers hecreof are of a fhining red colour, wherein confifteth the difference.

3 This ftrange three leafed Liuerwoort differeth not from the former, fauing that this bringeth foorth double blew flowers tending to purple, and the others not fo.

There is another in my garden with white flowers, which in ftalkes and cucry other refpect is like the others. 
I Hepaticum trifolium. Noble Liuerwoort.

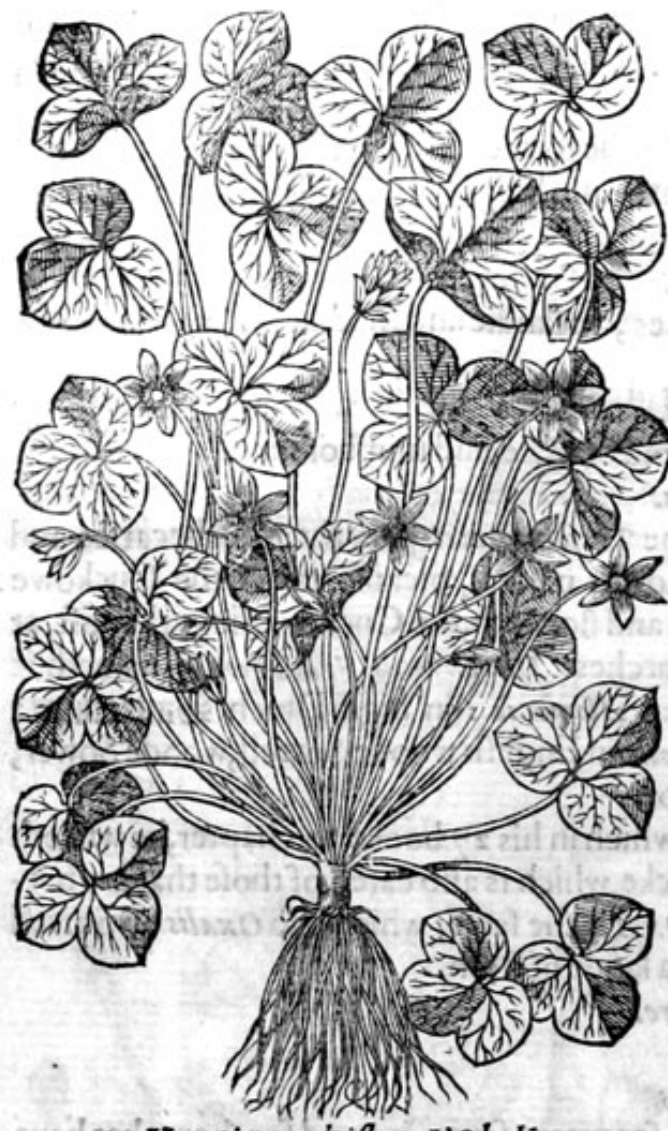

3 Hepatica multiflora L'Obely.

Noble Liuerwoort with double flowers.

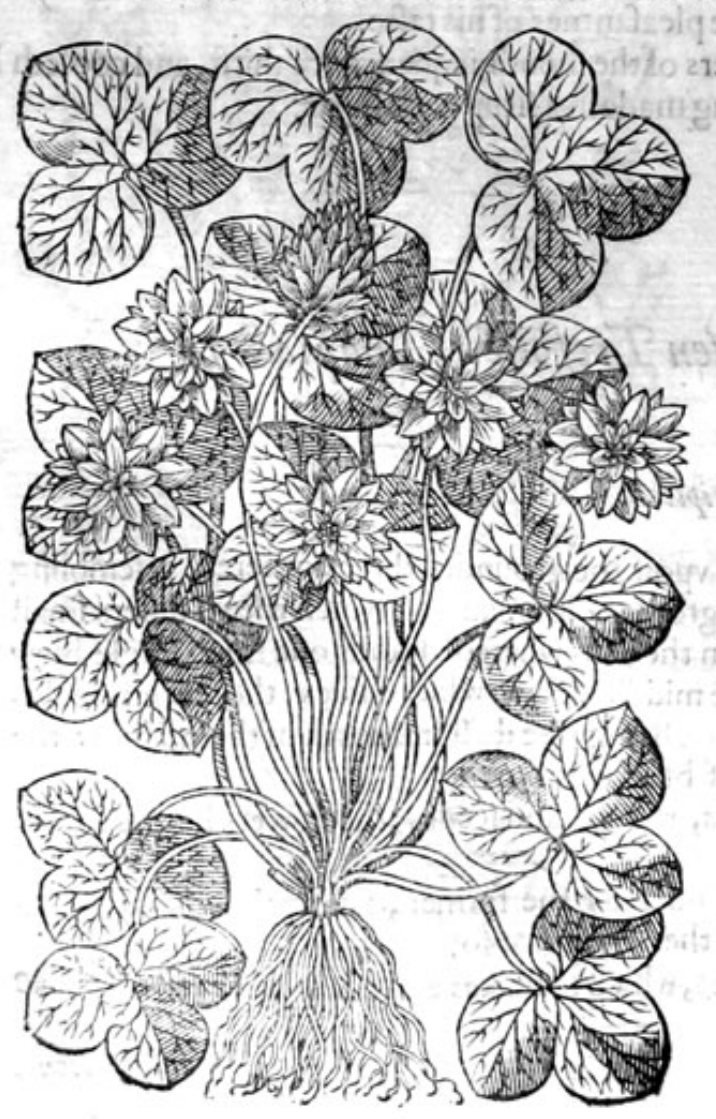

2 Hepaticatrifolia rubra. Noble red Liuerwoort.

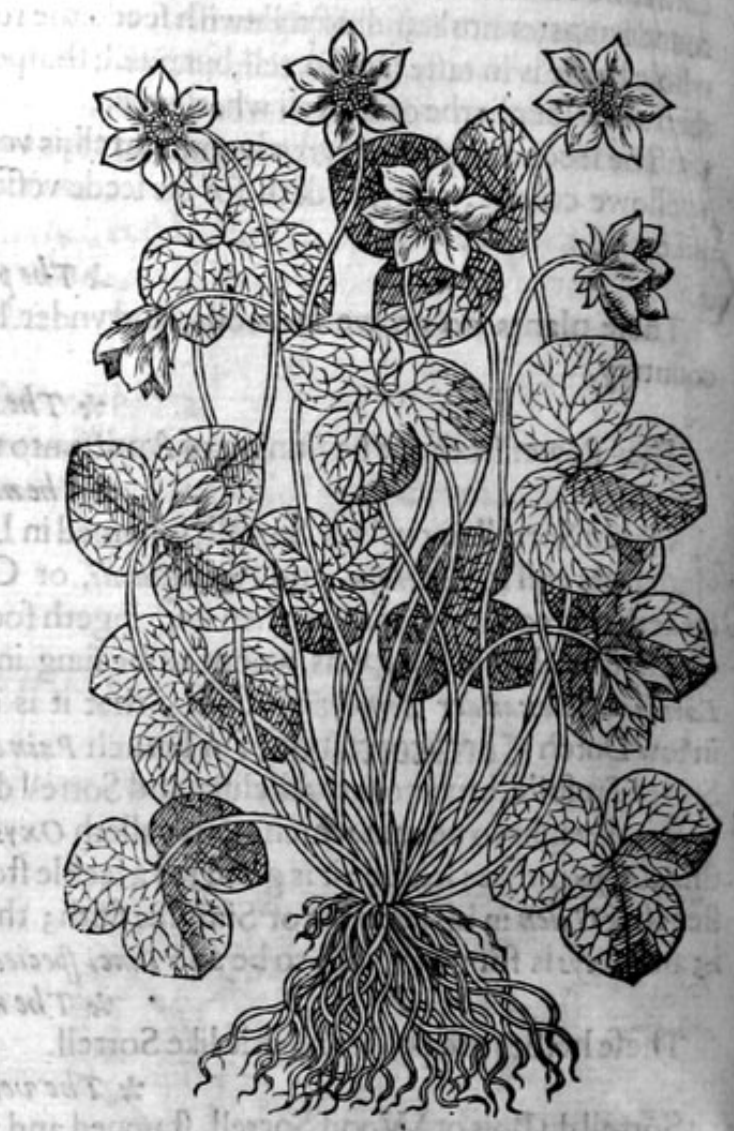

* The place.

Thefe pretie flowers are found in moft places of Germanie in hadowie woods among fhrubs, and alfo by high waies fides; in Italie likewife,and that not onely with the blew flower, but the fame with double flowers alfo, by the report of $A$. phonfus Pancius doctor of Phificke in the Vniuerfitie of Ferrara, a man excellently well feene in the knowledge of Simples. They do all growe likewife in my garden, except that with double flowers, which as yet is a ftranger in England. * The time.

They flower in March and Aprill, and perfet their feede in May.

\section{* $T$ be names.}

Noble Liuerwoort is called Hepatica trifolis Hepatica aurea, Trifolism aureum, of Baptista Sardus Heiba Trinitatis: in high Dutch Eoel Leber ktaut : in lowe Dutch ETel feuer ctuit : in French Hepatigue: in Englifh Golden Trefoile, Three leafed Liuerwoort, noble Liuerwoort, and Herbe Trinitie.

\section{$*$ The temperature.}

Thefe herbes are cold and drie, with an aftringent or binding qualitie. 


\section{HISTORIE OF PLANTS. \\ * The vertues.}

It is reported to be good againft the weakneffe of the liner, which proceedeth of an hot caufe :A for it both cooleth, and ftrengtheneth it not a little.

Baptista Sardus commendeth it and writeth, that the chiefe vertue is in the roote, if a fpoonefull B of the powder thereof be giuen certaine daies togither with wine, or with fome kinde of broth, it profiteth much againft the difeafe called Enterosele.

\section{Of Melilot,or Plaifter Clauer. Chap.488.}

$T$ Here be diuers fortes of the Clauers, or Three leafed graffe, wherewith plaifters and falues are made,commonly called Melilot, as hall be fhewed.

I CMelilotws Syriaca odora. Affyrian Clauer.
2 Melilotus It alica of Patawina, Italian Clauer.
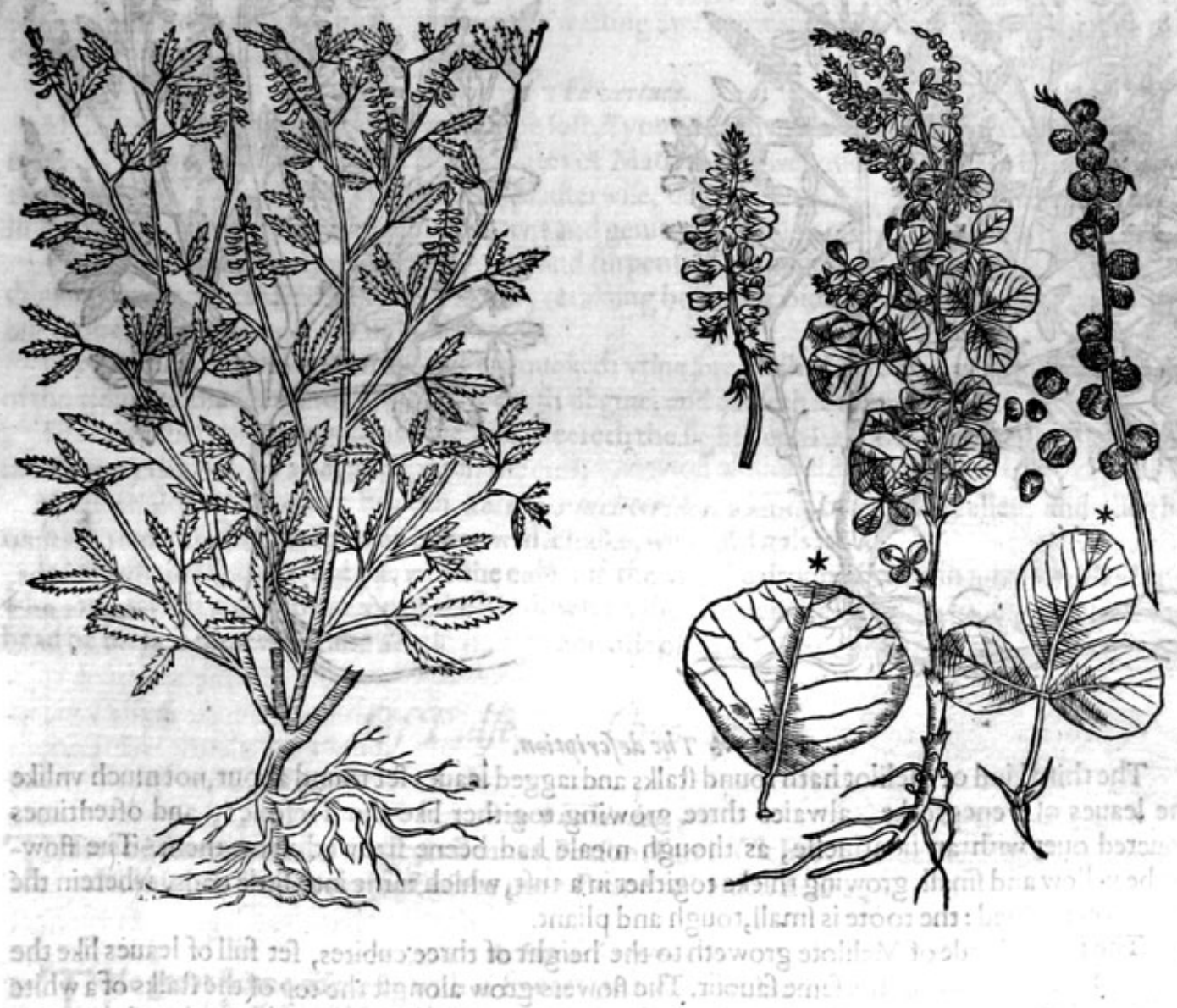

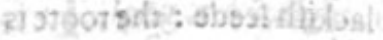

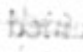

\section{* T be defoription.}

$\mathbf{r}$

$T^{-1}$ Hefirft kinde of Melilote hath great plentic of fmall, tough and twiggie branches, and ftalkes full of ioints or knees, in height two cubites, fet full of leaues three togither, like vnto Burgundie haie. The flowers growe at the top of the ftalkes of a pale yellow colour, ftanding thickly fet and compact togither, in order of rowes, very like the flowers of Securidaca altera; which being vaded, there followe certaine crooked cods, bending or turning vpward, with a Tharpe point, in fafhion not much vnlike a Partets bill, wherein is contained feede very like Fenegreeke, but more flat and flenderer. The whole plant is of a reafonable good fmell, much like vnto honie, and very full of iuice: the roote is very tough and pliant. 
2 The fecond kinde of Mclilote hath fmall and tender vpright ftalkes, a cubite high and fomewhat more, if a reddifh colour, fet full of round leaues three togither, denced full of nickes here and there confufedly abont the edges, as though they had beene bitten with mice, like the other Trefoiles; and ate of a very deepe greene colour, thicke, fat, and full of iuice. The flowers grow alongit the top of the ftalkes, of a yellow colour, which turne into rough round feedes as big as a Tare, and of a pale colour : the whole plant hath alfo the fauour of hotrie, and perifheth when it hath borne hisfecde.

3 Crelilotus coronata. Kings Clauer.

\section{Melilotus Germanica.} Germanie Clauer.

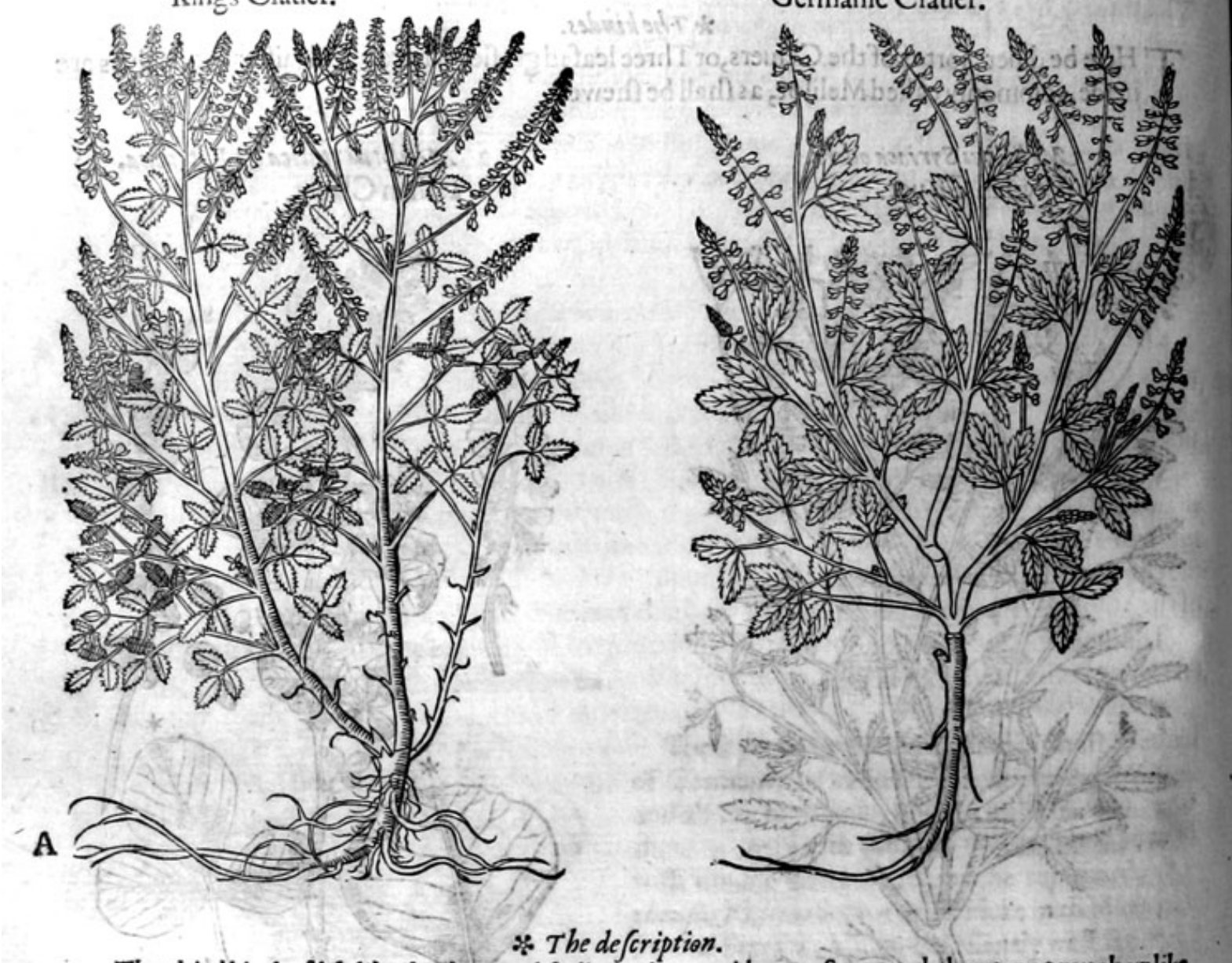

3 The thitd kind of Melilot hath round ftalks and iagged leaues fet round about, not much vnlike the leaues of Fenegreeke, alwaies three growing togither like the Trefoiles, and oftentimes couered ouer with an hoarineffe, as though meale had beene ftrowed vpon them. The flowers be yellow and fmall, growing thicke togither in a tuft, which turne into little cods, wherein the feede is contained : the roote is fmall, tough and pliant.

4 The fourth kinde of Melilote groweth to the height of three cubites, fet full of leaues like the common Melilote, and of the fame fauour. The flowers grow alongft the top of the ftalks of a white colour, which turne into fmall foft huskes, wherein is contained little blackirh feede : the roote is alfo tough and pliant.

$$
\text { * Theplace. }
$$

Thefe plants do growe in my garden : the common Englihh Melilote Pena fetteth foorth for Melilotus Germanica (as though it grew not any where elfe), buc for certaintie, no part of the world doth enioy fo great plenty thereof as England doth, and efpecially Effex : for I have feene between Sudburie in Suffolke and Clare in Effex, and from Clare to Henuingham, and from thence to Ouendon, Bulmare, and Pedmarh, very many acres of earable pafture ouergrowen with the fame; infonuch that it doth not onely fpoile their land, but the corne alfo, as Cockle or Darnell doth, and as a weede that generally fpreadeth ouer that corner of the inire. 
Thefe herbes do flower in Inly and Auguft.

\section{yapsins o the names.}

Plaifter Clauer is called by the generall name Meltlot us, of fome Trifolivom odoratum; yet therais another fweete Trefoile, as hath beene declared. Sone call it Trifolium Equinum, and Caballinum, or Horfe Trefoile, by reafon it is good fodder for horfes, who do greedily feede thereon; likewife $T$ rifoliwem Vr finwm, or Beares Trefoile, of Fachfius Saxifraga lutea, and Sertula Cambana: of Cato Serta Campana, which mot do name Corona Regia : in high Dutch Stopte éternclatierelt 4 of the Romaines and Hetrufcians Tribolo, as Mathiolus writcth: in Englifh Melilor, and Plaifter Clauer: in Yorkfhire Harts Clauer.

\section{* The temperature.}

Melilote, faith Galen, hath more plentie of hot fubftance than cold (thatis to fay, hot and drie in the firft degree) it hath alfo a certaine binding qualitic, befides a wafting and ripening $\mathrm{f}$ cultie. Diofcorides theweth, that Melilote is of a binding and mollifying qualitie, but the mollifying qualitie is not proper vnto it : but in as much as it wattech away, and digefteth humors gathered in hot fwellings,or otherwife : for fo far doth it mollifie or fupple that thing which is bard, which is not properly called mollifying, but digefting and wafting away by vapors : which kinde of qualitie the Grecians call drepoprmxinr:

\section{* The vertues.}

Melilote bailed in fweete wine vntill it be foft, if you adde thereto the yolke of a rofted egge, the A meale of Fenegreeke and Linefeede, the rootes of Marm Mallowes and hogs greace ftamped togither, and vfed as a pultis or cataplafma, plaifterwife, dothaflivage and foften all manner of fwellings, efpecially about the matrix, fundament and genitories, being applied vnto thofe places hot.

With the iuice hereof, oyle, waxe, rofine and turpentine, is made a moft foueraigne healing and B drawing emplaifter, called Melilote plaifter, retaining both the colour and fauour of the herbe, being artificially made by a skilfull Chirurgion.

The herbe bo iled in wine and drunke prouoketh vrine, breaketh the ftone, and fwageth the pain $\mathbf{C}$ of the kidneies, bladder, and belly, and ripeneth flegme, and caufeth it to be eafily cait foorth.

The iuise thereof dropped into the eies cleereth the fight, confumeth, diflolueth, and cleane D taketh away the web, pearle, and fpot in the eies.

Melilote alone with water healeth Recentes melicerides, a kinde of wens focalled, and alfo the $\mathrm{E}$ running vlcers of the head, ific be laid to with chalke, wine and gals. I

It likewife mitigateth the paine of the eares, if the iuice be dropped therein mixed with a little $\mathrm{F}$ wine, and taketh away the paine of the head, which the Grecians call repararyiay, efpecially if the head be bathed therewith, and a little vineger and oile of Rofes mixed amongt it.$$
\text { OfPulfe. Cbap. } 489 \text {. }
$$

* $T$ be kindes.

I Here be diuers fortes of Pulfe, as Beanes, Peafon, Tares, Ciches, and fuch like, comprehended vnder this title Pulfe : and firft of the great Beane,orgarden Bcane.

\section{$*$ The defcription.}

7 He great Beane rifeth vp with a fower fquared ftalke, fmoothe, hollowe, without iointes, long and vpright; which when it is thicke fowen, hath no neede of propping, but when it is fowen alone by it felfe, it foone falleth downe to the ground: it bringeth feorth long leaues one ftanding from another, confifting of many growing vpon one rib or ftem, etiery one whereof is fomewhat fat, fet with vaines, flipperie, more long than round. The Howers are cared, in forme long, in colour cither white with blacke fpots, or of a blackifh purple : afrer them come vp long cods, thick, ful of fubftance, flenderer below, frized on the infide with a certaine white wooll as it were, or foft tlockes; which before they be ripe are greenc, and afterwardes bcing drie, they are blacke and fomewhar hard, as be alforthe cods of Broome, yet be they longer than thofe and greater : in which are contained three, fower, or fue Beanes, feldome more, long, broad, far, like almoft to a mans naile, great, and oftentimes of the weight of halfe a dram; for the moft part white, now 
and then of a red purpliih colour, which in their vpper part haue a long blacke nauell as it were, the colour where of is a white greene; the skin of the fruit or Beane is clofely compacteds the inner partbeing drie is hard and found, and eafily cleft in funder, and it hath on the one fide an euident beginning of fprouting, as haue alfo the little Peafe, great Peafe, Ciches, and many other Pulfes.

2 The fecond kinde of Beane (which Penafetteth foorth vader the title of syluestris Grecorum $F a b a$, and Dodonaus, Bwna Phafeolssmaior, which may be called in Engli(h Greeke Beanes) hath fquare hollow ftalkes like the garden Beanes, but fmaller. The leaues be alfo like the common Beane, fauing that the endes of the rib, whercon thofe leaues do growe, have at the very ende fmall tendrels or clafpers, fuch as the Peafe leaues haue. The flowers are in fafhion like the former, but they are of a bright red colour: which being vaded, there fucceede long cods that are blacke when they be ripe, within which is inclofed blacke feede as big as a Peafe, of an vnplea-
fant tafte and fauour.

I Faba maior borten/is. The great garden Beane.

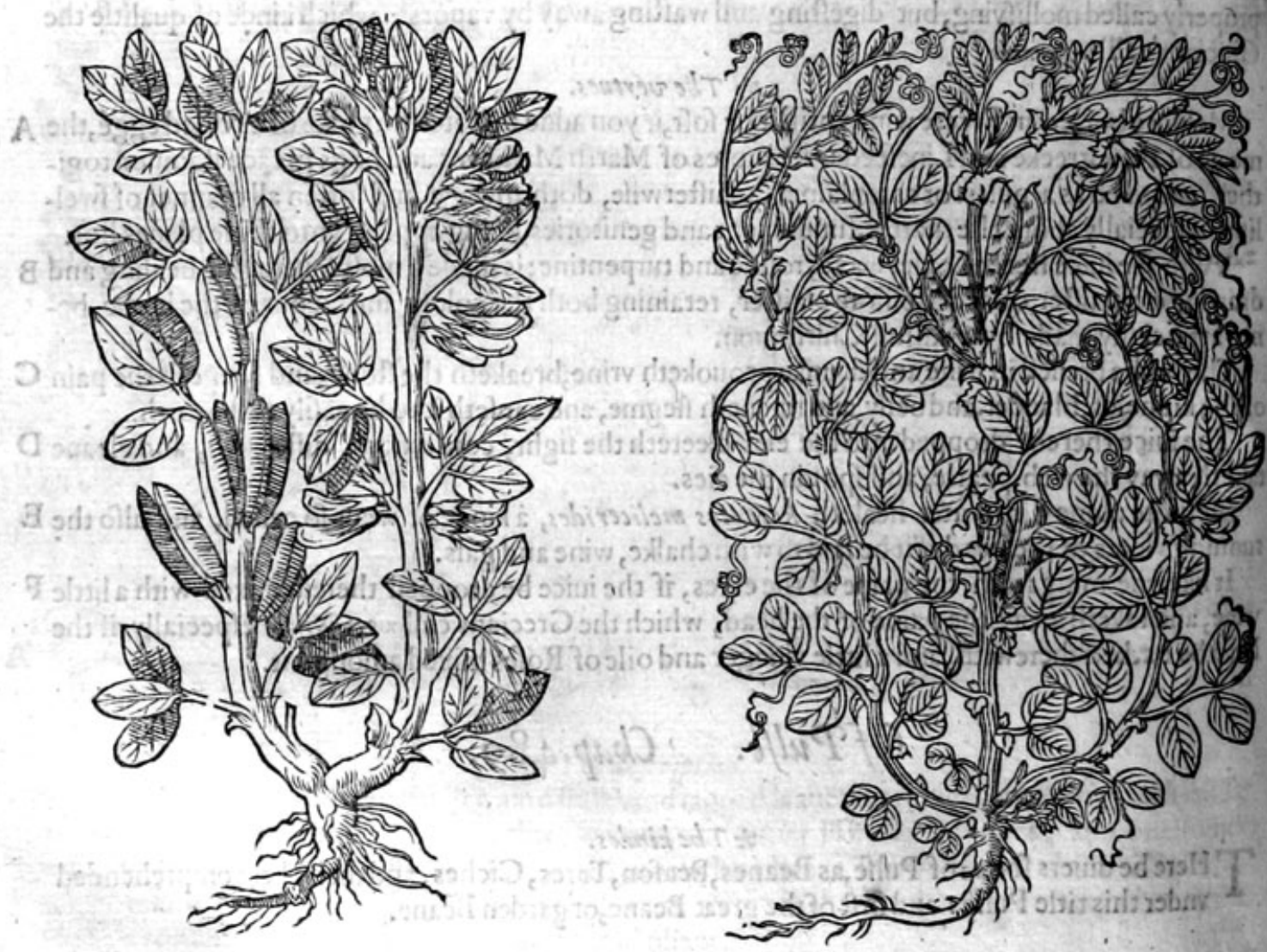

* The place.

The firft Beane is fowen in fieldes and gardens euery where.
This blacke Beane is fowen in a few mens gardens, who be delighted in varietie and ftudie of herbes: whereof $I$ haue great plenty in my garden.

* The time.

They flower in Aprill and May, and that by parcels, and they be long in flowring: the fruite is ripe in Iune and Iuly.

* The names.

The garden Beane is called in Latine Faba : in Englifh the garden Beane: the field Beane is of the fame kinde and name, although the fertilitie of the foile hath amended and altered the fruite into a greater forme. 
The blacke Beane, whofe figure we haue fet foorth in the fecond place, is called Faba fylueftris, of fome thought to be the true phificall Beane of the ancients, wherupon they haue named it $F a b$ a veterum, and alfo Faba Grecorum, or Greeke Beanc. Some would make our garden Beane to be the true $F$ haleolus or the kidney Beane, of which number Dodoneus is chicfe, who hath fo wrangled and ruffled among his relatiues, that all his antecedents muft be caft out of the doores: fur his long and tedious tale of a tub, we haue thought meete to commit to oblition. It is called in'Greeke masos, wherupon the Athenians feaft daies dedicated to Apollo were named muzis ie, in which Beanes and pulfes were fodden : in Latine it is alfo called $F$ aba frefa, or fracta, broken or bruifed Beane.

\section{* Thetemperatare and vertues.}

The Beane before it be ripe, is colde and moift, being drie it hath power to binde and reitraine, $\mathbf{A}$ according to fome authors: further of the temperature and vertues out of $G_{a} l e n$.

The Beane(as G.len faith)in his booke of Faculties of nourifhments, is windie meate, although it B be never fo much fodden, and dreffed any way.

Beanes haue not a clofe and heauie futftance, but a fungie and light, and this fubftance hath a C fcouring or clenfing facultie; for it is plainly feene, that the meale of Beanes clenfeth awaie the filth of the skin, by reafon of which quality it paffeth not flowly thorow the belly.

And feeing the meale of the Beanes is windie, the Beanes themfelues if they be boiled hole and D eaten, are yet much more windie.

Yet if they be parched they lofe their windines, but they are harder of digeftion, and do flowlie E defcende, and yeelde vnto the body thicke or groffe nourifhing iuice : but if they be eaten green before they be ripe and dried, the fame thing hapneth to them, which is incident to all fruits that are eaten before they be fully ripe ; that is tofaie, they giue vnto the bodie a moift kinde of nourifh. ment, and therefore a nourimment more full of excrements, not onely in the inner parts, but alfo in the outward, and whole body thorow : therefore thofe kinds of Beanes do leffe nourifh, but they do more fpeedily paffe thorow the belly, as the faid author in his booke of the Faculties of Simple medicines faith, that the Beane is moderately colde and drie.

The pulpe or meate thereof doth fomewhat clenfe, the skin doth a little binde.

Therefore diuers phifitions haue giuen the whole Beane boiled with vineger and water to thofe that were troubled with the bloodie flixe, with laskes, and vomitings.

It raifech flegme otit of the cheft and lungs, beingoutwardly applied it drieth without hurt the $H$ waterie humors of the gout. Wic haue oftentimes vfed the fame being boiled in water, and fo mixed with fwines greafe.

We haue laid the meale there of with Oxymel, or firupe of vineger, both vpon brufed and woun-I ded finewes, and vpon the wounded partes of fuch as haue brene bitten or ftung, to take away the fierie heate.

It alfo maketh a good plaifter and pultis for mens ftones andwomenspaps: for thefe partes $\mathrm{K}$ when they are inflamed, haue neede of moderate cooling, efpecially when the paps are inflamed thorow the cluttered and congealed milke contained in then,

Alfo milke is dried vp with that pultis.

The meale there of (as Dio corides further addeth)being tempered with the meale of Fenugreeke $M$ and Honie, doth take away blacke and blew fpots, which come by dry beatings, and wafteth awaie kernels vnder the eares.

With Rofeleaues, Frankincenfe, and the white of an egge, it keepeth backe the watering of $\mathbf{N}$ the eies; the pin and the web, and hard fwellings.

Being tempered with wine, it healeth fuffufions, and tripes of the eies.

The Beane being chewed without the skin, is applied to the forehead againft rheumes and fal- $P$ ling downe of humors.

Being boiled in wine, it taketh away the inflammation of the ftones.

The skins of Beanes applied to the place where the haires were firf plucked vp, will not fuffer $R$ them to growe big,but rather confumeth their nourifhment.

Being applied with Barly meale parched and olde oyle, they wafte away the Kings euillo $S$

The decoction of them feructh to die woollen cloth withall.

This Beane being diuided into two parts (the skin taken off) by which it was naturally ioined to- $V$ 


\section{THE SECOND BOOKE OF THE}

gither, and applied, ftancheth the bloud which doth too much iffue foorth after the biting of the

The blacke Beane is not vfed with vs at all, feeing as we haue faide, it is rare, and fowen onely in
a few mens gardens, who be delighted in varietie and ftudic of herbes.

\section{OfKidneyBeane. Chap.490.}

* The kindes.

T He ftocke or kinred of the Kidney Beane are woonderfull many; the difference efpecially con: fifteth in the colour of the fruit : there be other differences, whereof to write particularly, would greatly ftuffe our volume with fuperfluous matter, confidering that the fimpleit is ableto diftingtifh apart the white Kidney Beane from the blacke, the red from the purple, and likewife thofe of mixt colours from thofe that are onely of one colour; as alfo great ones from little ones, Wherefore it may pleafe you to be content with the defcription of fome few, and the figures of the reft,with their feuerall titles in Latine and Englifh,referring their defcriptions vnto a further confideration, which otherwife would be an endleffe labour, or at the leaft needleffe.

I Phafeolus albus.

White Kidney Beane.

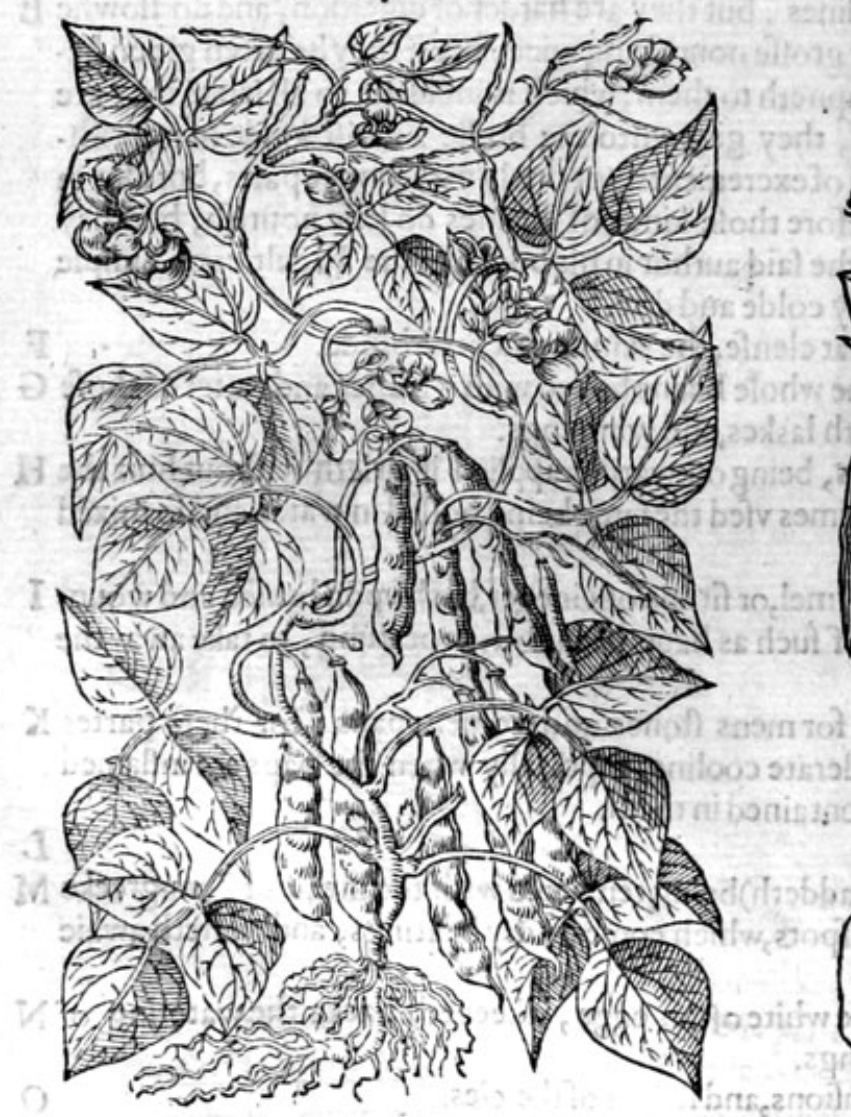

2 Phajeolus niger. BlackeKidney Beane.

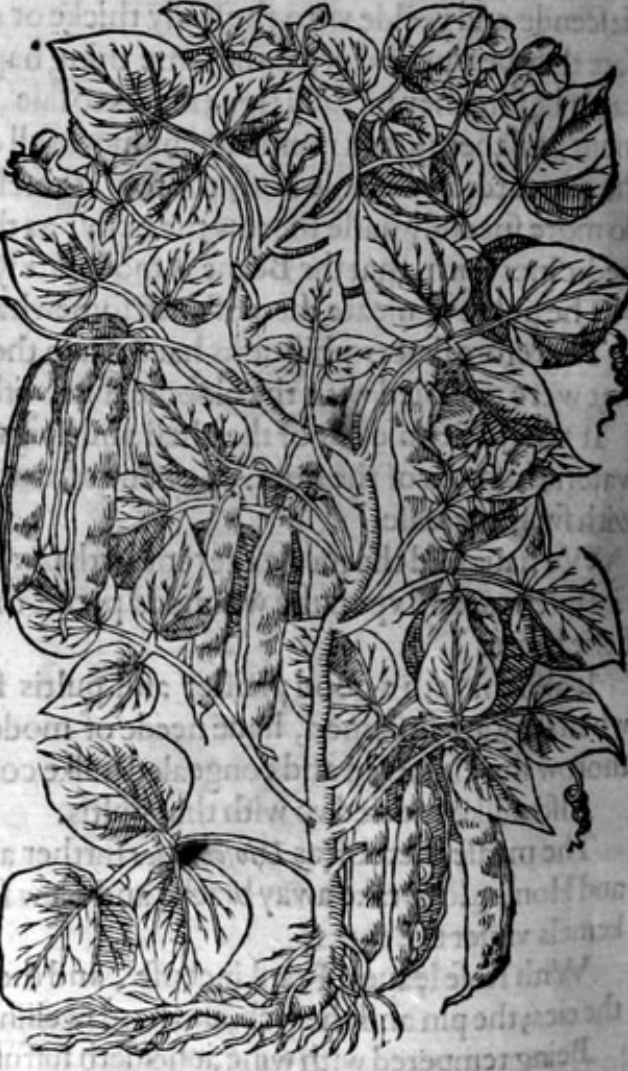

the

$*$ The defcription.

I The firft kinde of Phafeotus or garden Smilax, hathlong and fmall branches grotving very

1 high, taking hold with hisclalping tendrels vpon poles and ftickes, and whatfoeuer ftandeth neere vnto him, as doth the Hop or Vine, which are fo weake, and tender,that without fuch props or fupporters, theyare not able to fuftaine themfelues, but will run ramping on the ground fruitleffe: $v$ pon the branches do growe broad leaues almoft like Iuie, growing togither by three, as in the common Trefoile or Three leafed graffe : among which come the flowers, that do 
varie and differ in their colours, according to the foile where they growe, fometin:es white, fometimes red, \& oftentimes of a pale color : afterwards there come out long cods, wher of foin are crooked, and fome are ftraight, and in thofe the fruit is contained, finaller than the common Beane, fomwhat flat, and farhioned like a Kidncy, which are of diuers colours like vnto the flowers : whereof for the molt part, thefe are white.

2 There is allo another Dolichus or Kidney Beane, leffer, fhorter, \& with fmaller cods, whofe flowers and fruite are like in forme to the former Kidney Beanes, but much leffer, and of a blacke colour.

3 Smilax hortenfis rubra. Red Kidney Beane.

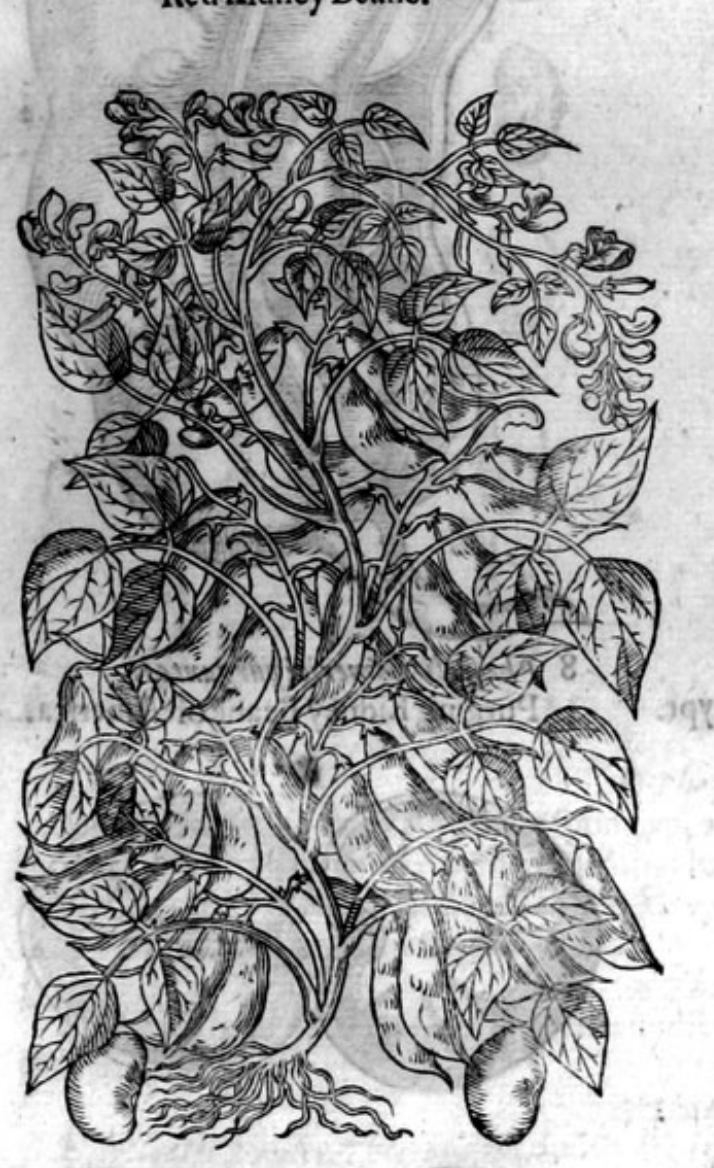

* The defcription.

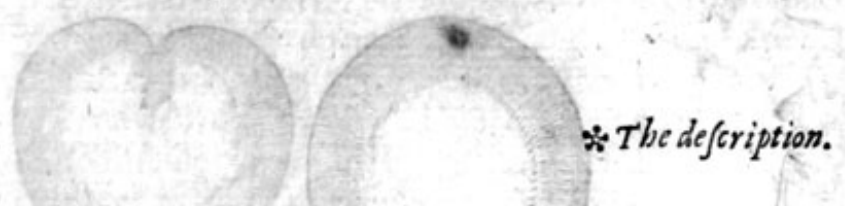

4 Smilax hortenfis flaus. Pale yellow Kidney Beane.

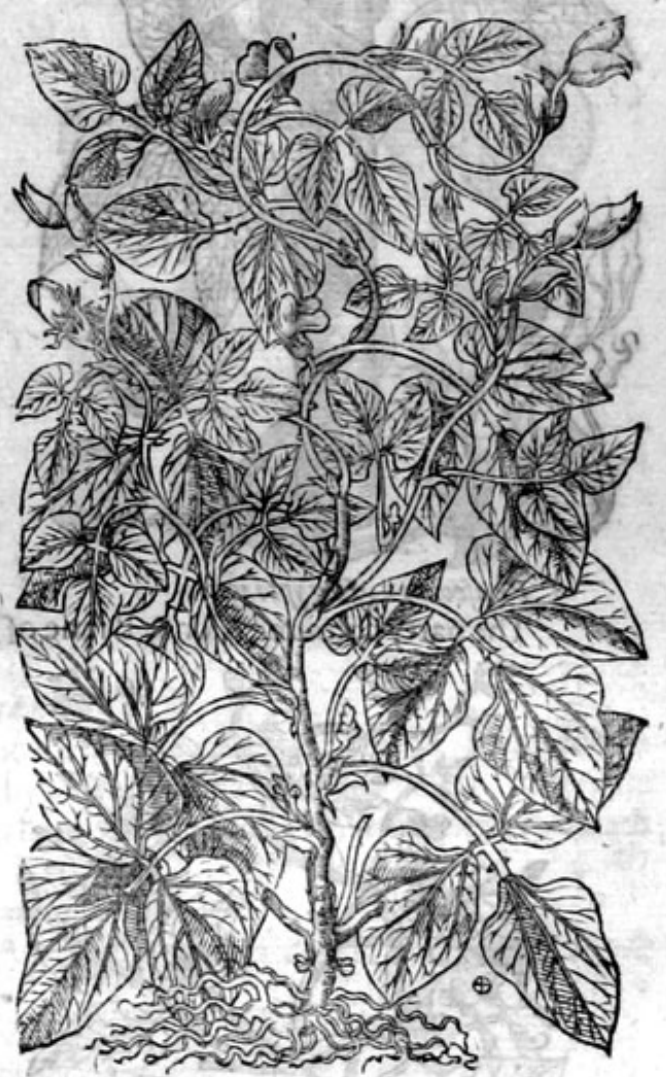

3 There is likewife a certaine other ftrange Kidney Beane, which doth alfo winde it felfe about poles and props neere adioining, that hath likewife chree leaues hanging vpon one ftem, as haue the other Kidney Beanes, but euery one is much narrower and alfo blacker : the cods be ihorter, plainer and fatter, and containe fewerfeedes.

4 This Kidney Beane differeth not from the orhers, but oncly in the colour of the fruit, which are of a pale yellow colour, wherein confifteth the difference. 
I040 THE SECOND BOOKE OF THE

5 Phafcolus Braflianus.

Kidney Beane of Brafile.

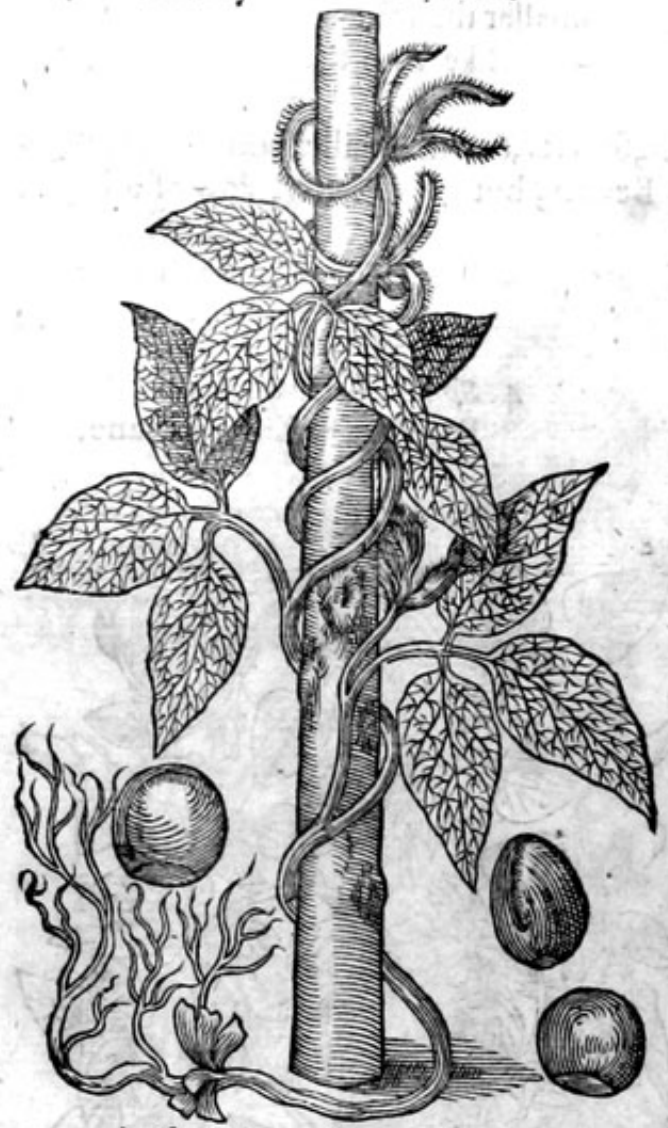

7 Phafeolus 1 AEgyptiacus.

The party coloured Kidney Beane of Egypt.

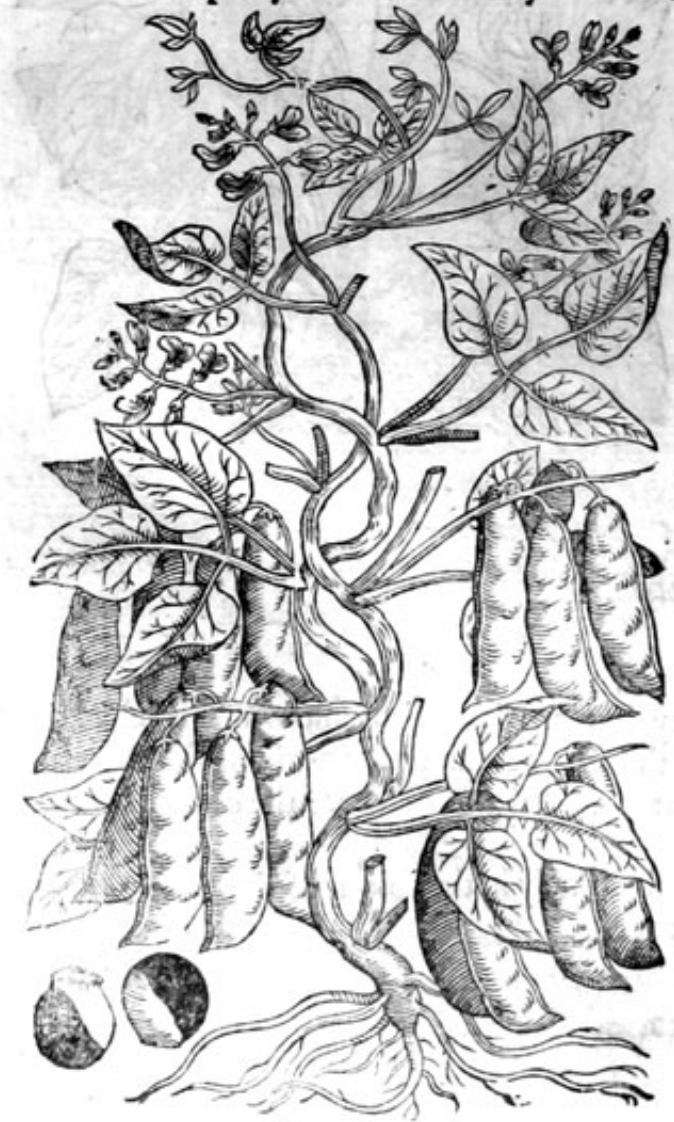

6 Phafeoli Braflisani ad vium.

The Brafile Kidney Beane in his full bignes.

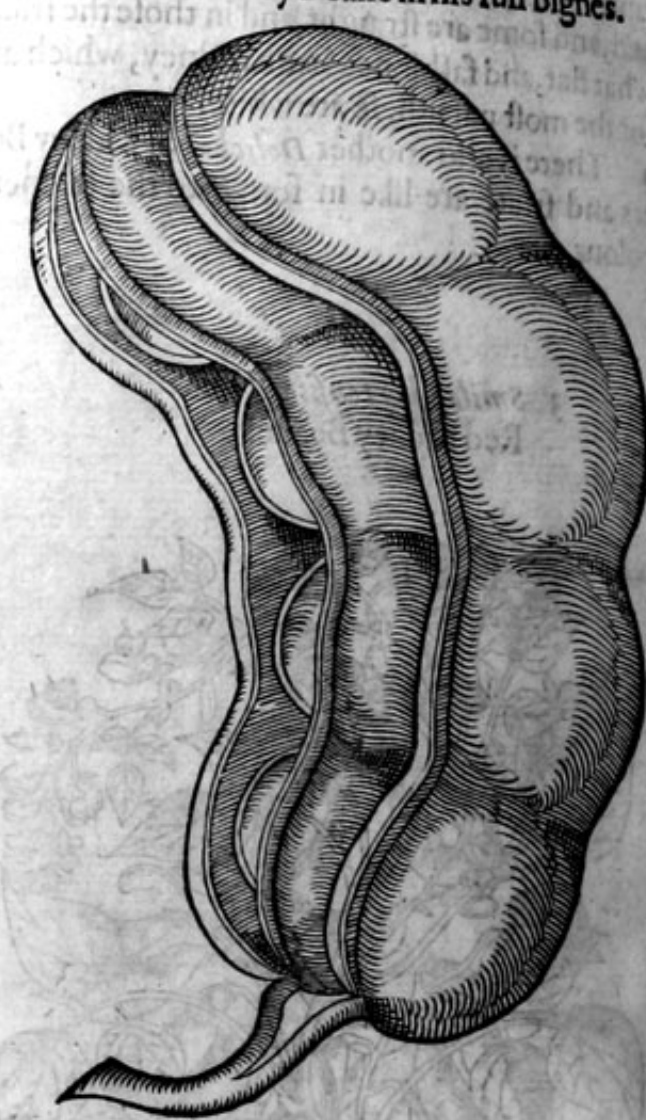

8 Phafeoli Lamericipurgantes.

Purging Kidney Beane of America.
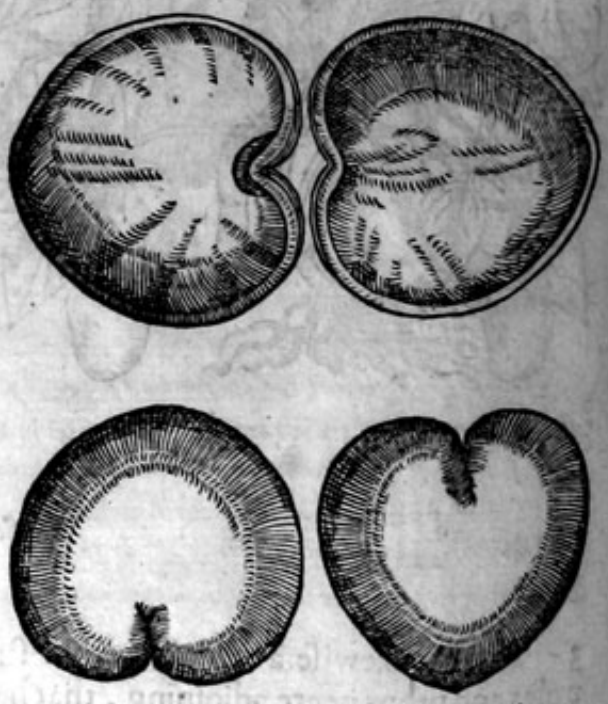

9 Phafecolorem 
1 Pbajeolorwom 12. genera. 12.Sorts of kidney Beanes.

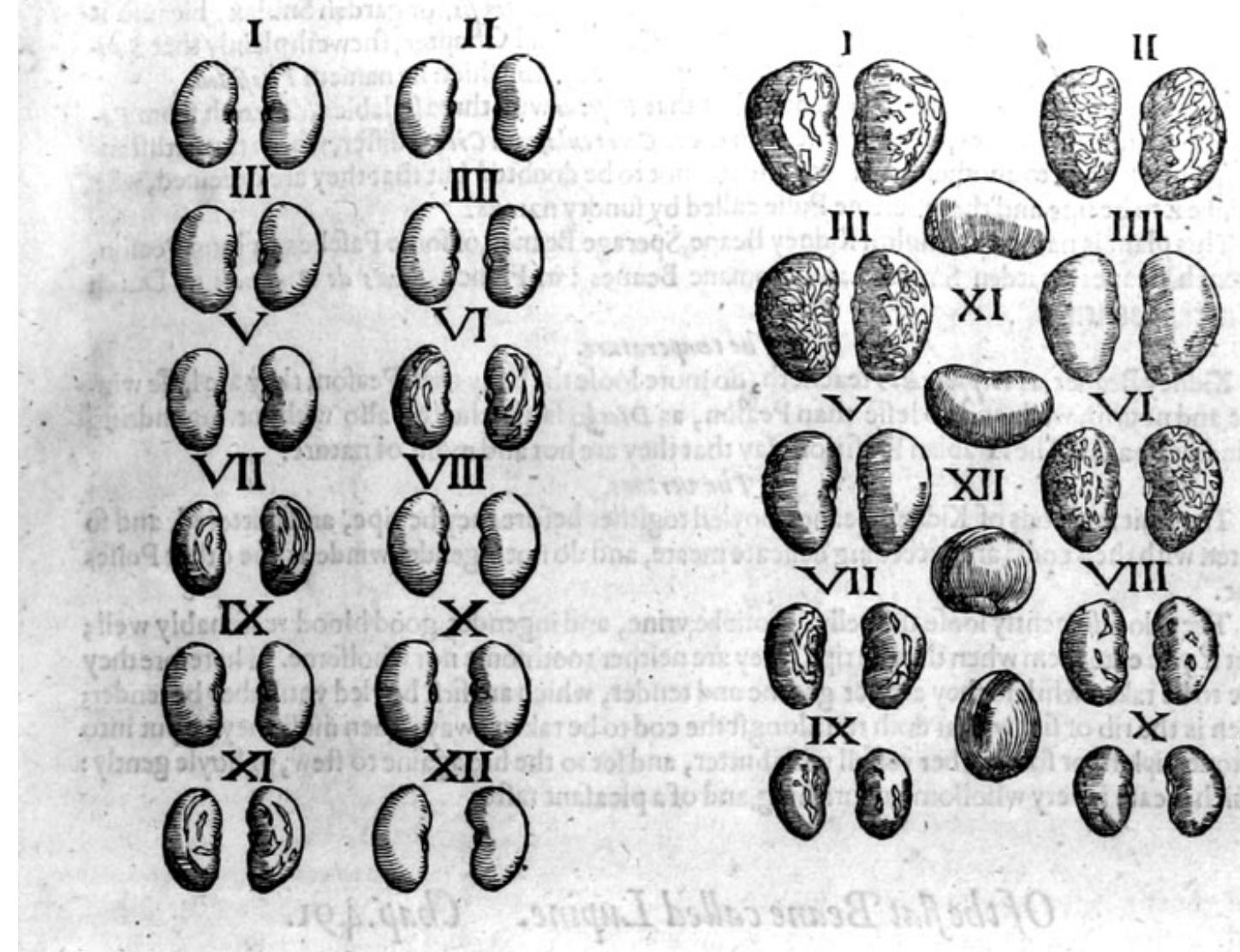
$\mathrm{x}$
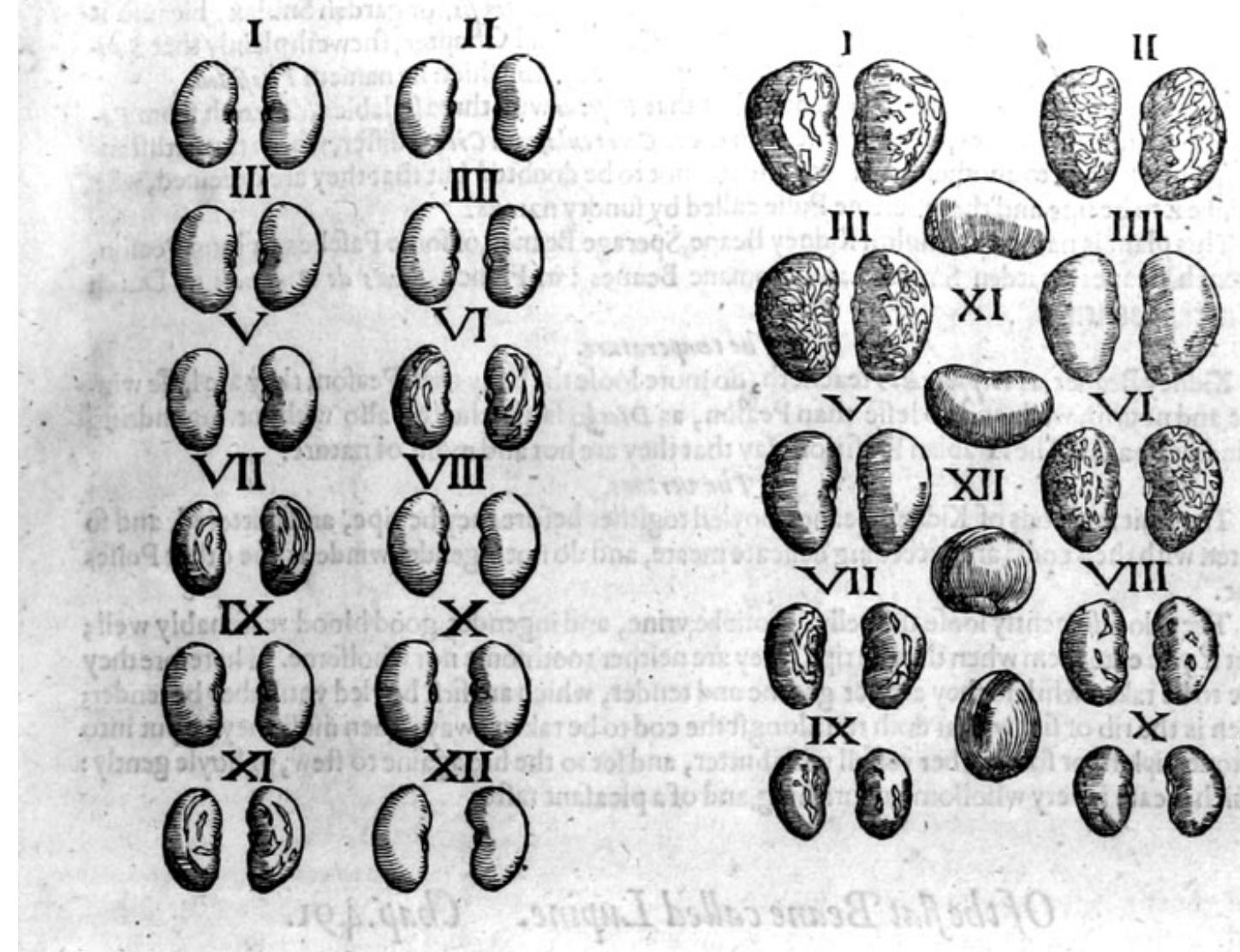

2 Pha/eoli Brafiliani 12. genera. 12.Sorts of kidney Beanes of Brafile.

* The place.

Kidney Beanes doeafily and foone fpring vp, and growe into a very great length; being fowen neere vnto long poles faftned hard by them, or hard by arbors and banquetting places, otherwile it lieth flat on the grauinde, it flowly commeth vp, it hardly bringeth foorth fruite, it becommeth faultie and fmitted, as $T$ heophraftus writeth.

* The time.

It is fowen in the fpring,efpecially in the midft of Aprill, but not before the fruite is ripe about the end of fommer.

\section{* The names.}

Hippocrates, Diocles, $T$ beophraftus, and moft of the other old writers docall it sererev : diuers of the

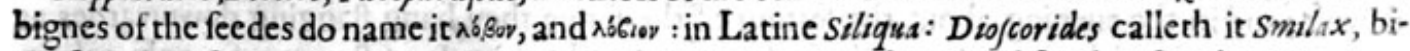
caufe it climeth vp as Smilax doth, and taketh holde of props, ftaies, and fhrubes ftanding neere vn-

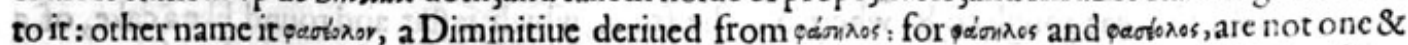
the felfe fame pulfe called by diuers names as fome fuppofe, but fundry fruites one differing from the other, as Galen in his firft book of the Faculties of nourifhments doth fufficiently declare, where he intreateth of them both.For firft he difputeth of Pha feli and Ochri,Beanes, and Peale; then afterwards others comming betweene, he writeth of Dolichus, which alfo is named $P$ hafeolis:and though hemay be thought to doubt what maner of pulfe that is which Theophraftus calleth Dolichus, notwithitanding he gathereth and concludeth that it is a fruite of a garden plant in Italie, and in Caria,growing in the fieldes, which is in forme longer then the Cichlings, and was commonly called in his time Fa feolus. Of his opinion is Pawlus UEgineta, writing of P' bafelus, which he nameth DoTicbus, in the 79.chapter of his firft booke. Moreouer $F$ a felus was in times paft a common pulfe in Italy and Rome, and Dolichus a ftrange pulfe, for Colume lla and $P$ alladius writers of hisbandry, have made mention of the fowing of Fajelws and Virgill calleth it $V_{l} l i s$ in the firft of his Georgicks: 


\section{TO42 THE SECOND BOOKE OF THE}

but concerning the fowing of Dolic bus or Kidney Beane, none of the Latines haue written, by rea-

fon that the fame was rare in Italic, and Fowen onely in gardens, as Galen hath affirmed, naming ir of tentimes a garden plant, and fhewing that the fame, as we haue faide, is fowen in Caria; andlike-

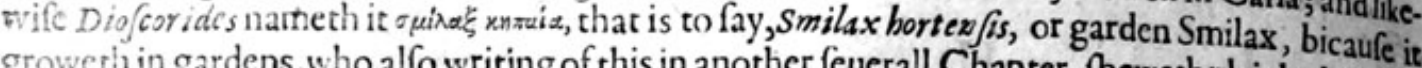
groweth in gardens, who alfo writing of this in another feuerall Chapter, thewethplainly that Smi bax horten fis, or Dolichus is another plant differing from $F a$ felus, which he nameth $P$ hafullus.

For which caufes it is not to be doubred, but that $F$ afelus with three fyllables, differeth from $F$ a. colus with fower fyllables, no otherwife than Cicer,Cicercula, and Cicera differ, which notwithftan. ding be neere one to another in names: and it is not to be doubted but that they are deceiued, who thinke it to be one and the felfefame Pulfe called by fundry names.

This plant is named in Englifh Kidney Beane, Sperage Beanes, of fome Fafelles, or long Peafon, French Beanes, garden Smilax, and Romane Beanes : in French Fexes de Romme : in Dutch Tutchobonen.

$\approx$ The temperature.

Kidney Beanes, as Hippocrates teacheth, do more loofe the belly than Peafon; they are leffe win. die, and nourifh well, and no leffe than Peafon, as Diocles faith : they be allo without ingendring windineffe at all. The Arabian Phifitions fay that they are hot and moift of nature.

\section{* The vertues.}

A The fruit and cods of Kidney Beanes boyled togither before they be ripe, and buttered, and fo caten with their cods, are exceeding delicate meate, and do not ingender winde as the other Pulfes doe.

B They do alfo gently loofe the belly, prouoke vrine, and ingender good blood reafonably well; but if you eate them when they be ripe, they are neither toothifome nor wholfome. Therefore they are to be taken whileft they are yet greene and tender, which are firft boyled vntill they betender; then is the rib or finew that doth run alongft the cod to be taken away: then muft they be put into a ftone pipkin, or fome other veffell with butter, and fet to the fire againe to ftew, or boyle gently: which meate is very wholfome, nourifhing,and of a pleafant tafte.

\section{Of theflat Beane called Lupine. Chap.491.}

\section{* The kindes.}

Here be diuers fortes of Lupines, fome of the garden, and others wild, fome white, others blacke, and alfo of mixt colours.

\section{* Thedefription.}

17 He tame or garden Lupine hath round hard ftems, which of themfelues do ftand vpright without any fuccour, helpe or ftaie : the leaues confift of fiue, fixe, or feucn ioined togither, like thofe of the Chaft tree, greene on the vpper fide, and on the neather fide white and downie; and in the euening about the fetting of the funne they hang flagging downwardes as though they were withered : among thefe there commeth vp a tuft of flowers of a pale colour, which turne into great rough cods, wherein is the fruite, which is flat and round like a cake, of 2 white colour, and bitter in tafte : and where they cleaue vnto the cod, in that part they haue a certaine dent like 2 little nauell. This Lupine hath but one roote, which is flender and woodie, hauing

hanging on it a few fmall threds like haires.
2 The yellow Lupine is like to the garden one in ftalke and leaues, yet both of thefe leffer and
a fhorter. It hath beautifull towers of an exceeding faire golde yellow colour, fweete of fmell, made vp into an eare of the colour of the yellow Violet, and fomewhat of the fmell: the cods are fmall, hard, fomewhat hairie : the feedes be little, flat, round, in tafte extreme bitter, of fundrie colours, ill fauoured, farleffer than the tame one.

3 The blew Lupines are longer than the yellow, and diuided into more wings and branches: the leaues be lcffer and thinner:the flowers fmall, and leffer than the yellow, of a blew colour : thefeeds be alfo or wiuers colours, bitter, and leffer than any of them all. 
- H HISTORIE OF PLANTS.

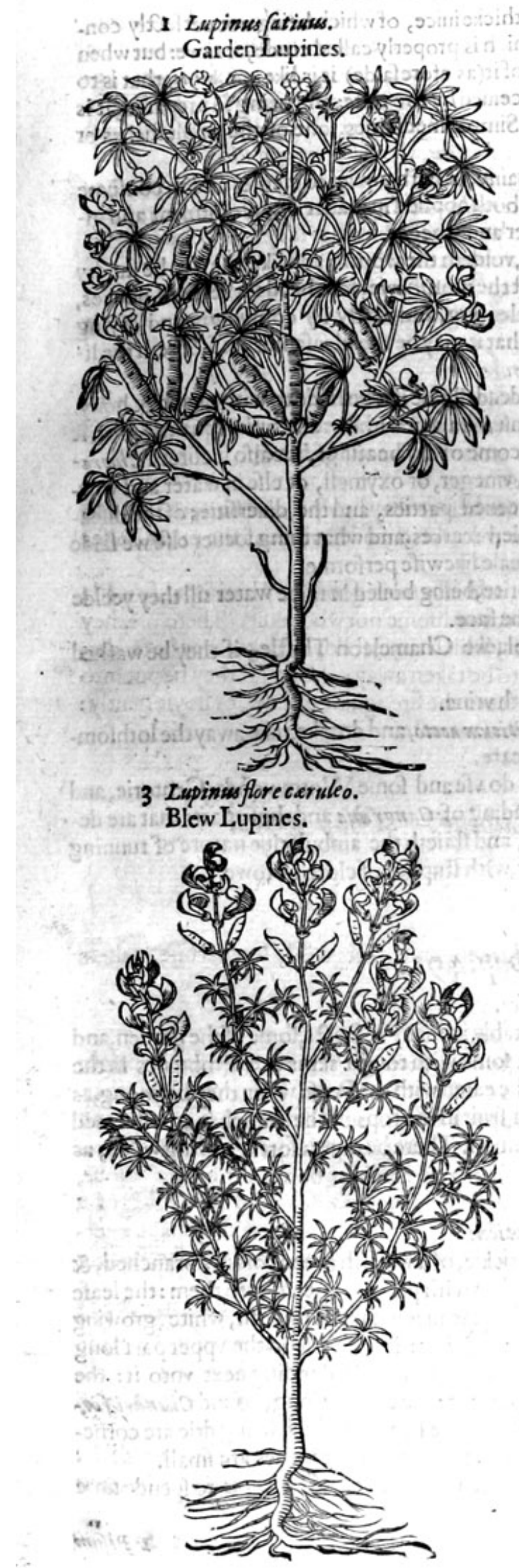

3 Lupinis flore caruleo. Blew Lupines.

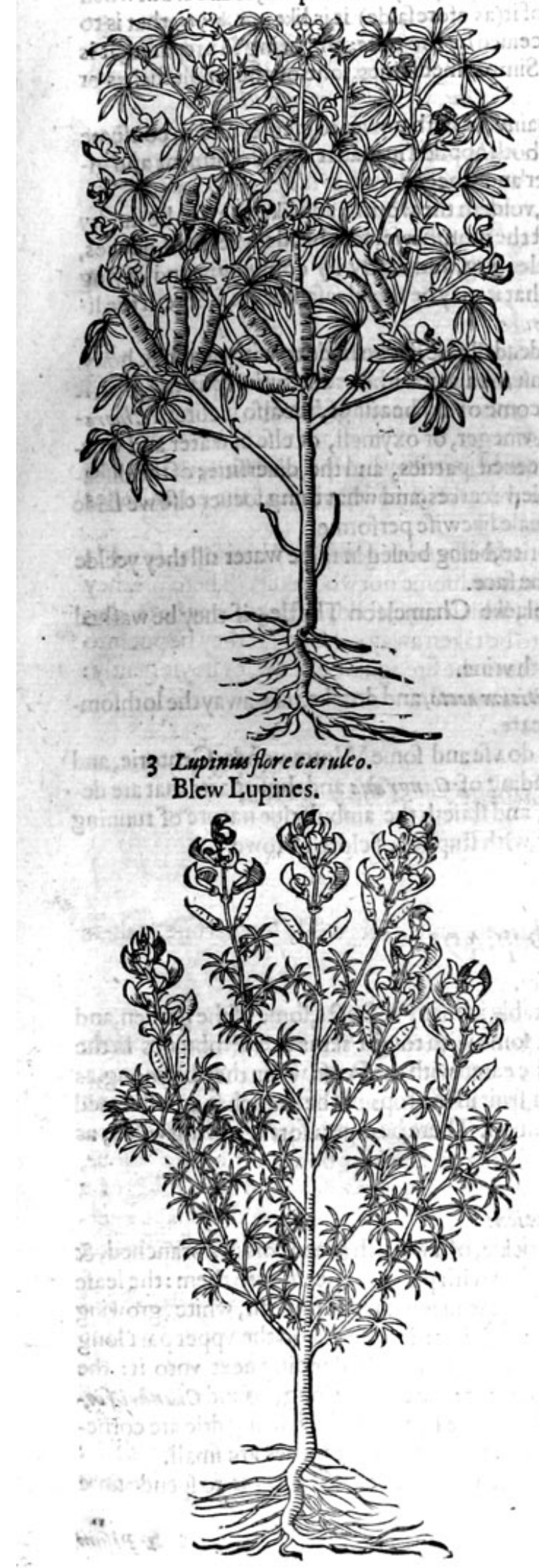

2. Lupinus fior luteo. Yellow Lupines.

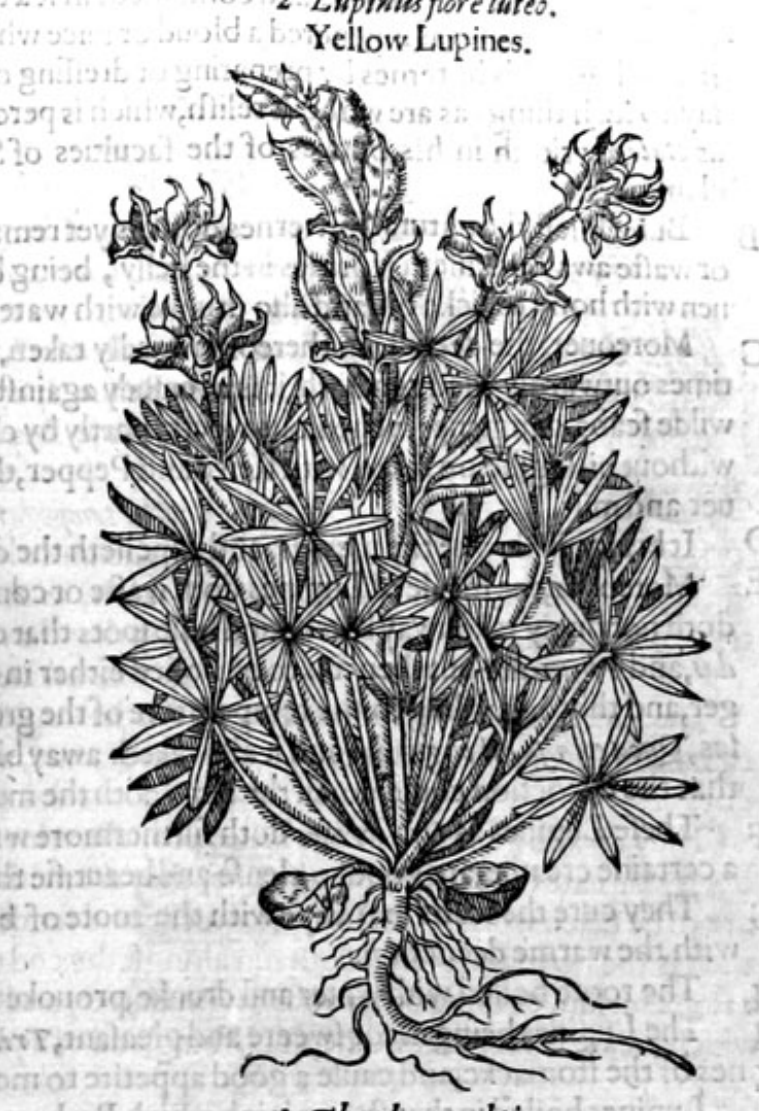

* Theplace and time.

They require, faith $T$ beophrastus, a fandy and bad foyle : they hardly come vp in tilled places, being of their owne nature wilde. They growe in my garden, and in other mens gardens about London. They are planted in Aprill, and bring foorth their fruite at twoor three fundric times, as though it did flower often, and bring foorth many crops, the firft in May, the fecond in Iuly, the laft in September, but it feldome commeth to ripenes.

$$
\text { * The names. }
$$

This Pulfe is named in Greeke sipuos ripuses: in Latine Lupinus, and Lupinus fatiuns : in high Dutch ferigbonent in Italian Lupeno domeftico: in Spanifh Entramocos: in the Brabanders language (Jich) boonen, and 1 upment in French Lupins:in Englifh Garden Lupine, tame Lupine, and of fome after the Germain name Figbeane.

$x^{*}$ The temperature and vertives.

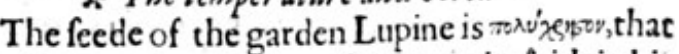
is to fay, much and often vfed, as Galen faith in his books of the faculties of nourifhmêts : for the fame being boiled and afterivards fteeped in faire water, vntil fuch time as it doth altogither lofe his natural bitternes, \& laftly being feafoned with a reafonable quantitie of falt, it is eaten with pickle. The Ltupine is of an hard and carthy fubftance, wherefore it is Vvv 2 neceffarily 


\section{I044 THE SECOND BOOKE OF THE.}

neceffarily of hard digeftion, and containeth in it a thicke iuice, of which being not perfectly con it hath loft all his bitternes by preparing or dreffing of it(as aforefaide) it is like, or rawe: but when fay, to fuch things as are without relifh,which is perceiued by the tafte; and like ruts drious, that is to as Galen writeth in his bookes of the faculties of Simple medicines, and being foprepared, it is clammers.

B But whileft the naturall bitternes doth as yet remaine, it hath power to clenfe, and to confume or wafte away; it killeth wormes in the belly, being both applied in maner of an ointment and gi. uen with hony to licke on, and alfo drunke with water and vineger.

C Moreouer, the decoction thereof inwardly taken, voideth the worms; and likewife if it be fundry times outwardly vfed as a bath, it is a remedy againft the morphewe, fore heads, the fmall pockes, wilde fcabs, gangrenes, venemous vlcers, partly by clenfing, and partly by confuming and drying without biting;being taken with Rewe and Pepper, that it may be the pleafanter, it fourech the li-

D It bringeth downe the menfes, and expelleth the dead childe if it be laide to with myrrh \& hony,

E Moreouer, the meale of Lupines doth wafte or confume away without any biting qualitie, for it doth not onely take away blacke and blue fpots that come of dry beatings, but alfo it cureth charsdiss, and Phymata : but then it is to be boiled either in vineger, or oxymell, or elfe in water and vine. get, and that according to the temperature of the greeued parties, and the diuerfities of the dife. les, Quodex vfu est eligendo : and it alfo taketh away blew markes, and what thing foeuer elfe we faide that the decoction could do, all the fame doth the meale likewife performe.

F Thefe Lupines as Diofcorides doth furthermore write, being boiled in raine water till they yeelde a certaine creame, are good to clenfe and bcautifie the face. G They cure the fcabs in fheepe with the roote of blacke Chameleon Thifle, if they be wafhed
with the warme decoction.

H The roote boiled with water and drunke, prouoketh vrine.

I The Lupines being made fweete and pleafant, Triticum aceto, and drunke, take awaythe lothfom$\mathrm{K}$ nes of the ftomacke, and caufe a good appetite to meate.

Lupines boiled in that ftrong leigh which Barbars do vfe and fome Wormwood, Centorie, and baie falt added thereto, ftaieth the running and fpreading of Gangrena, and thofe parts that are depriued of their nourifhment and begin to mortifie, and ftaieth the ambulatiue nature of running and fpreading vlcers, being applied thereto very hot,with ftuphes of cloth or towe.

\section{Of Peafon. Chap. 492 .}

* The kindes.

$T$ Here be diuers forts of Peafon, differing very notably in many refpects, fome of the garden,and others of the fielde, and yet both counted tame; fome with tough skins or membranes in the cods, and others haue none at all, whofe cods are to be eaten with the Peafe when they be yoong,as thofe of the yoong kidney' Beane; others carying their fruit in the tops of the branches,areefteemed and taken for Scottifh Peafon, which is not very common. There be diuers forts growing wilde, as thall be declared.

* The defcription.

I He great Peafe hath long ftalkes, hollow, brickle, of a whitioh green colour, branched, $\&$ fpreade vpon the ground, vnleffe they be held vp with props fet neere vnto them: the leafe thereof is wide and long, made vp of many little leaues which be fmooth, white, growing vpon one little ftalke or ftem, and fet one right againft another: it hath alfo in the vpperpart long clafping tendrels, wherewith it foldeth it felfe vpon props and ftaies ftanding next vnto it: the flowre is white and hath about the middle of it a purple fpot : the cods be long, round cilindrifor$m a$; in which are contained feedes greater then Ochri or little Peafon; which being drie are cornered, and that vnequall, of colour fomtimes white and fometimes gray: the rootes are fmall. 2 The fielde Peafe is fo very well knowne to all, that it were a needleffe labour to fpende time about the defcription. 
HISTORIE OF PLANTS.

I Pifum maitus.

Rownciuall Peafe.

2 Pifmminss.

Garden and field Peafe.

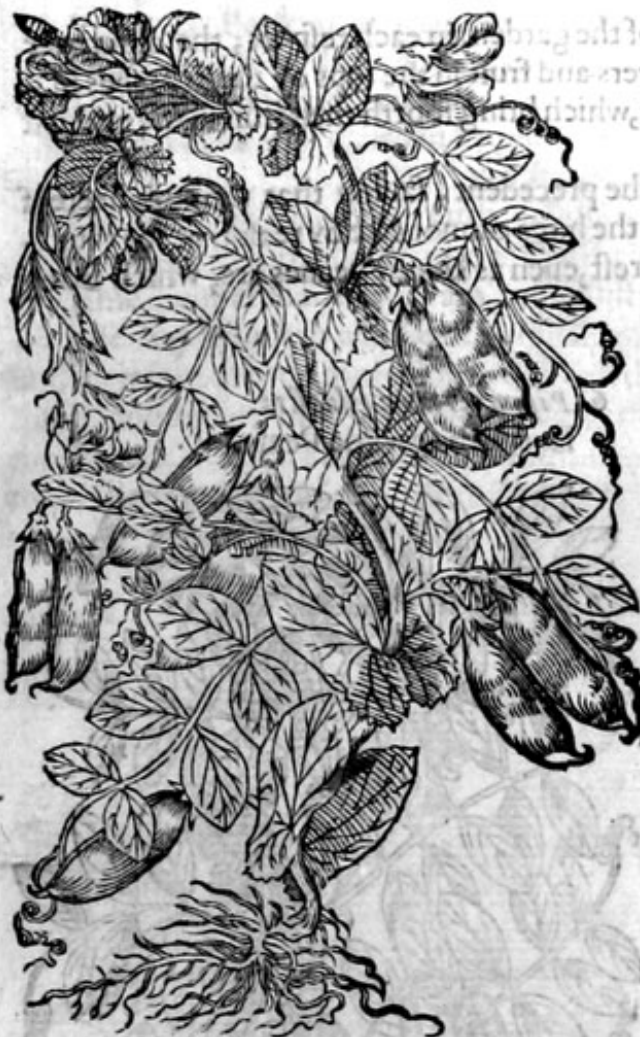

3 Pifun vmbellatum.

Tufted, or Scottifh Peafe.

P 19.5

2.

(1) 12

a

(N) (5)

- 1

2 12

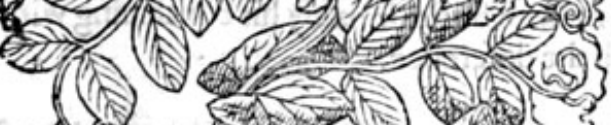
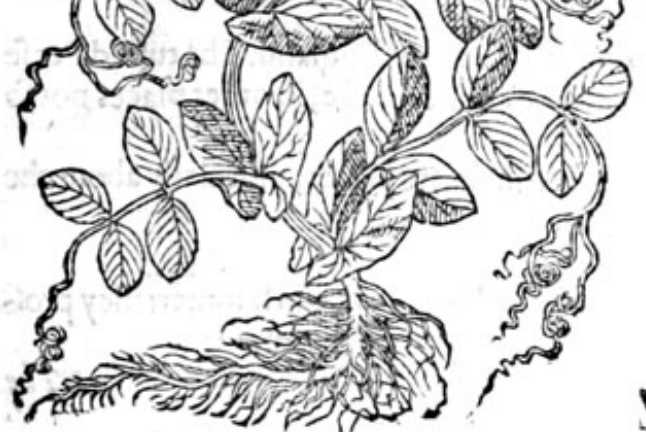

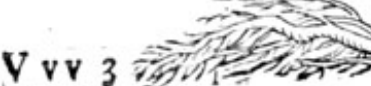

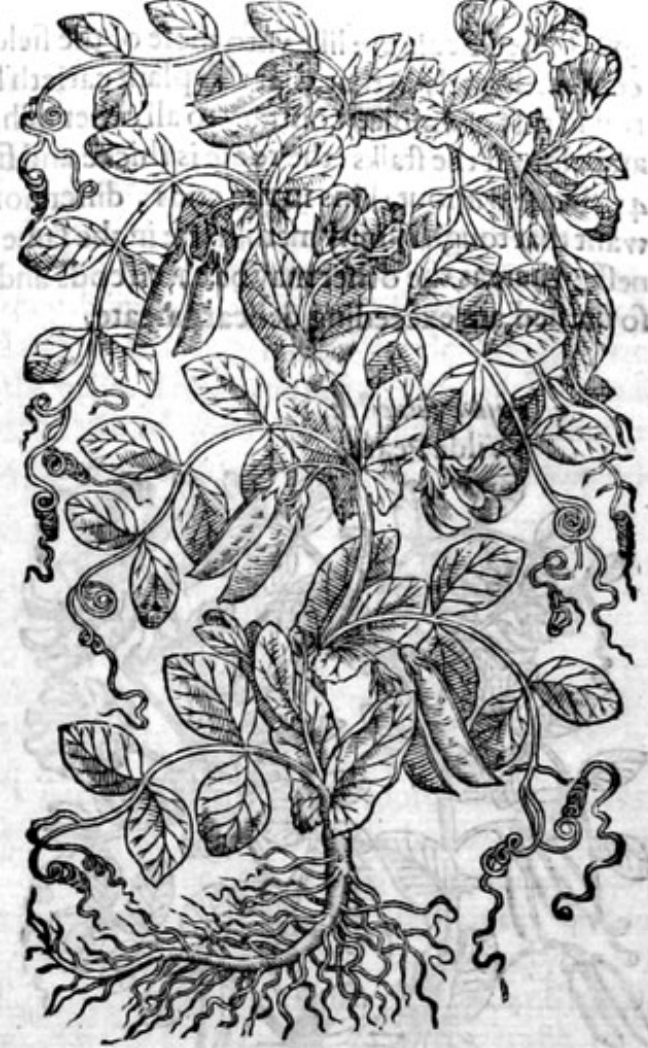

4 Pifun excorticatum.

Peafe without skins in the cods.
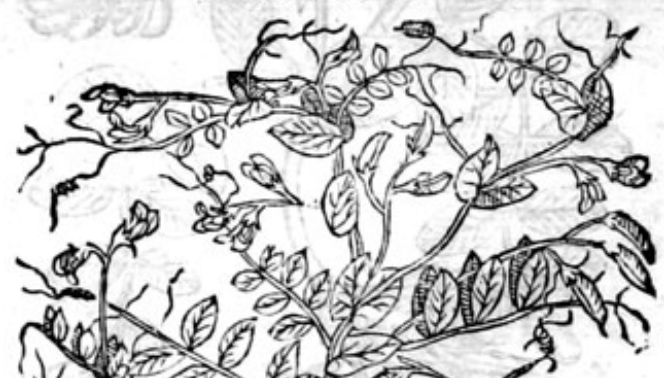

(1) क क

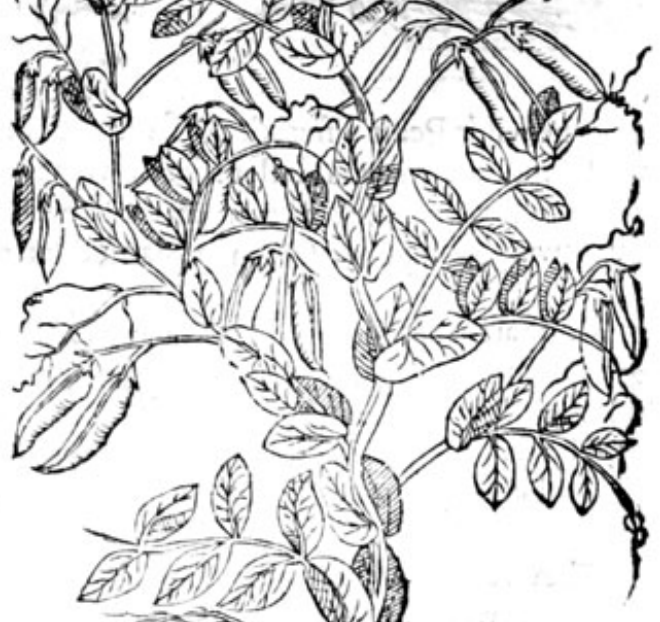




\section{\& Thedefcription.}

3 Tufted Peafe are like vnto thofe of the fielde, or of the garden, in each refpect; the difference confifteth onely in that, that this plant carieth his flowers and fruit in the tops of the branches in a round tuft or vmble, contrary to all other of his kinde, which bring foorth their fruit in the middeft 4 Peafe without skins in the cods, differ not from the precedent, fauing that the cods heereof want that tough skinny membrane in the fame, which the hogs cannot eate by reafon of the tough. neffe; whereas the other may be eaten cods and all the reft, euen as kidney beanes are, which being
fo dreffed,are exceeding delicate meate.

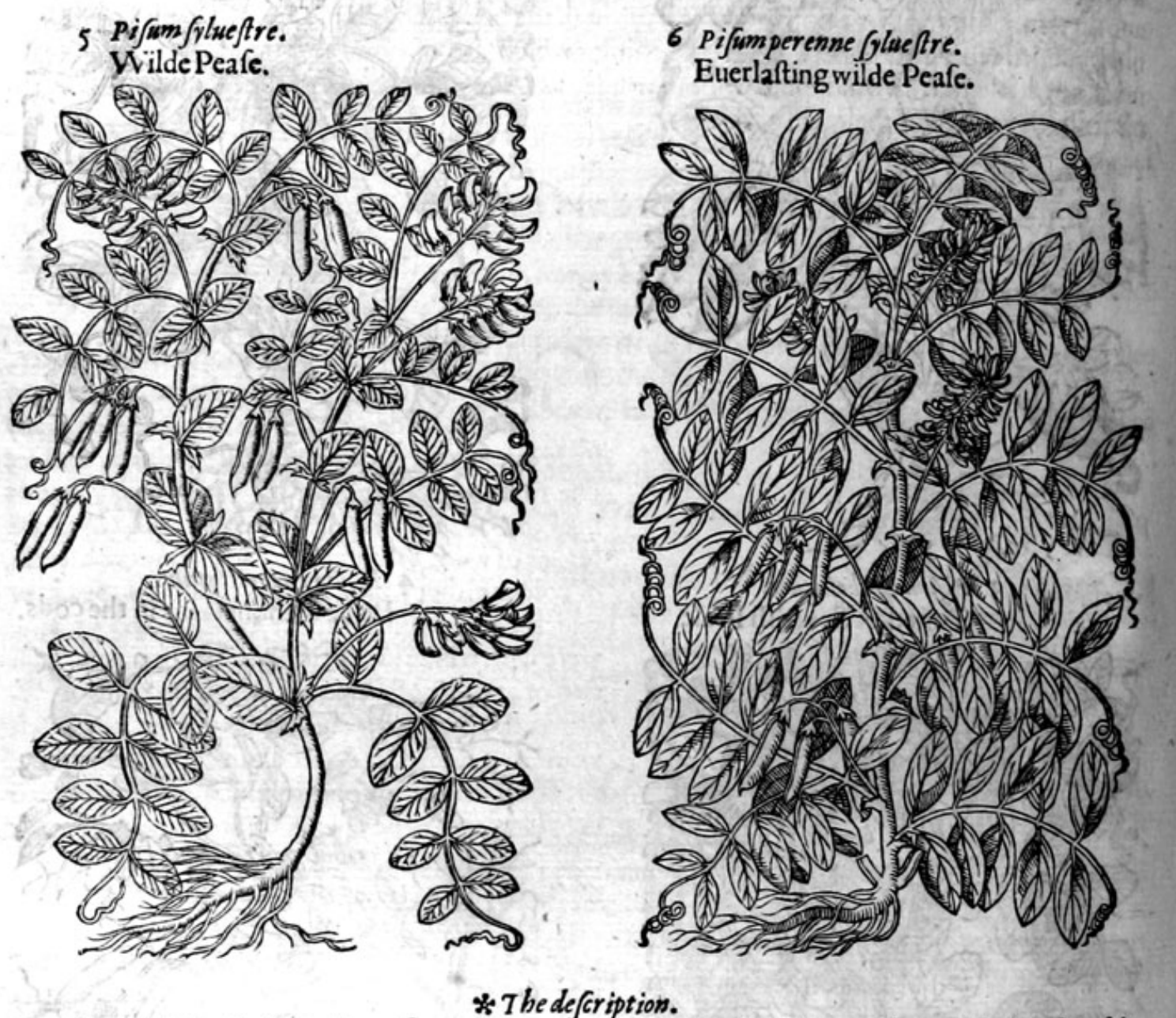

5 The wilde Peafe differeth not from the common fielde Peafe in ftalk and leaues, fauing that this wilde kinde is fomewhat leffer : the flowers are of a yellow colour,and the fruit is much leffer.

6 The Peafe whofe rootes neuer die, differeth not from the wildPeafe, onely his continuing without fowing, being once fowen or planted, fetteth foorth the difference.

Peafe arefet and fowen in garciens, as alfo in the fields in all places of England. The tufted Peafe are in reafoneble plenty in the weft part of Kent,about Sennock or Seuenoke, in other places not fo common.

The wilde Peafe do growe in paftures and earable fieldes in diuers places, efpecially abour the fieldes belonging vnto Bifhops Hatfielde, in Hartfordhire.

$$
\text { * The time. }
$$

They be fowen in the fpring time, like as be alfo other pulfes, which are ripe in fommer: they profper beft in warme weather, and eafily take harme by colde, efpecially when they flower. 


\section{HISTORIE OF PLANTS.}

* The names.

The great Peafe is called in Latine Pifum Romanum, or Pifum muius: in Englin Ronane Peafe, or the greater Peale, alfo garden Peafe; of fome Branch Peafe, French Peafe, and Rounfiuals. Theophrastiu and other old writers do call it in Greeke rifor: in Latine alfo Pifum : in lowe Dutch Room? febe etviten: in French des Pois. The little Peafe is called of the Apothecaries euery where Pifwon, and $P i$ fum minus : it is called in Englifh litele Peafe, or the common Peafe.

\section{* The temperature and ver tues.}

The Peafe, as Hippocrates faith, is leffe windic than Beanes, but it paffeth fooner through the belly. Galen writeth, that Peafon ate in their who'e fubftance like vnto Beanes, and be caten after the fame manner that Beanes are, notwithftanding they differ from them in thefe two things, both bicaufe they are not fo windic as be the Beanes, and alfo for that they have not a clenfing facultie, and therefore they do more flowly defend through the belly. They haue no cffectuall qualitie manifeft, and are in a meane betweene thofe things which are of good and bad iuice, that nourifh much and little, that be windie and without winde, as Galen in his booke of the facilties of nourithments hath written of thefe and of Beanes.

\section{Of the tame orgarden Ciclse. Chap.493.}

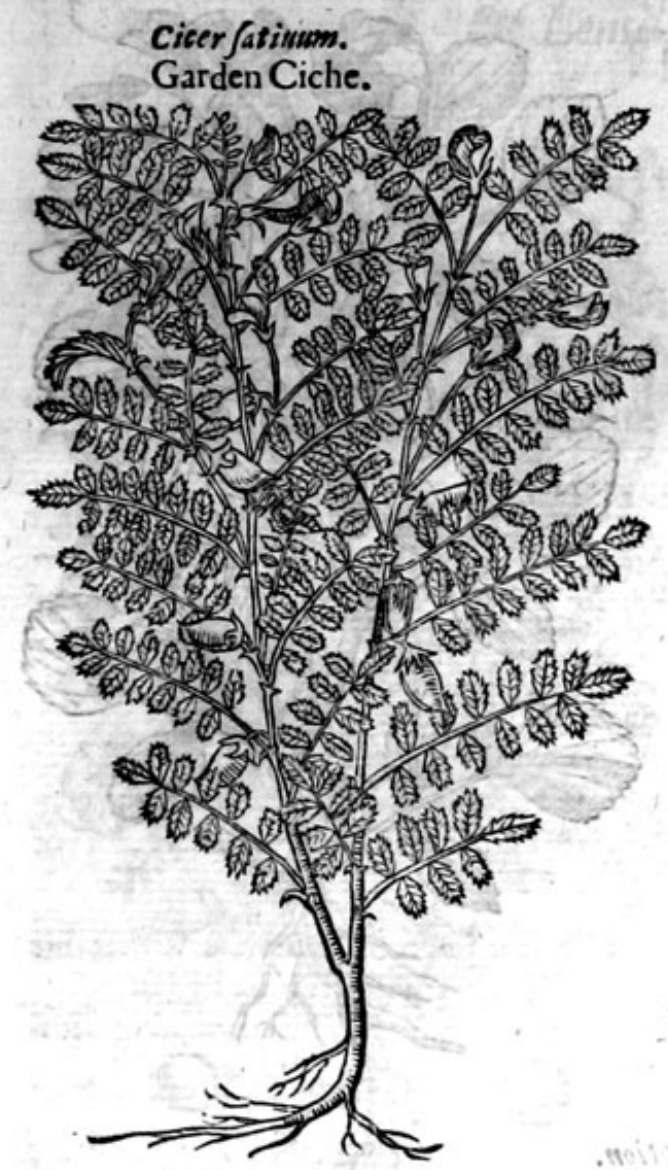

etinum, or Rams Ciches, and of the blackili purple Cicer nig rum, or blacke Ciche : and the other is named Candrdom vel album Crcer, ot white Ciche: in Englifh common Ciche or Ciches, red Ciche, of fome Sheepes Ciche Peafe, or Sigeepes Ciche Peafon.

* The temperature and vertues.

This Ciche,as $G$ alen writeth in his booke of the faculties of nourifhments, is no leffe windie than $A$ the true Beane, but it yeeldeth a ftronger nourilnnient than that doth : it protooketh Juft, and it is thought to ingender feede. 


\section{I048 THE SECOND BOOKE OF THE}

C Some giuc the fame to ftalion horfes.Moreouer, Ciches do fower more than do the true leaues; in fo much as certaine of them do manifeftly dininifh or wafte away the ftones in the kidneies; thofe be the blacke and litele Ciches called Arietina, or Rams Ciches, but it is better to drinke the
broth of them fodden in water.

D Both the Rams Ciches, as Diofcorides faith, the white and the blacke prouoke vrine, ifthe deco. etion thereof be made with Rofemarie, and giuen to thofe that haue either the dropfie or yellowe
iaundife; but they are hurtfull to the bladder and kidneies that haue vlcers in them.

\section{Of wilde Cicbes. Cbap.494.}

* The kindes.

$T_{\text {he wilde Cich is like to the tame faich Digfcorides, but it differeth in feede: the later writers }}$ haue fet downe fundry kindes of $\mathrm{Ciches}$, as Rhall be declared.

I Cicer fylueftre.

The wilde Ciche.

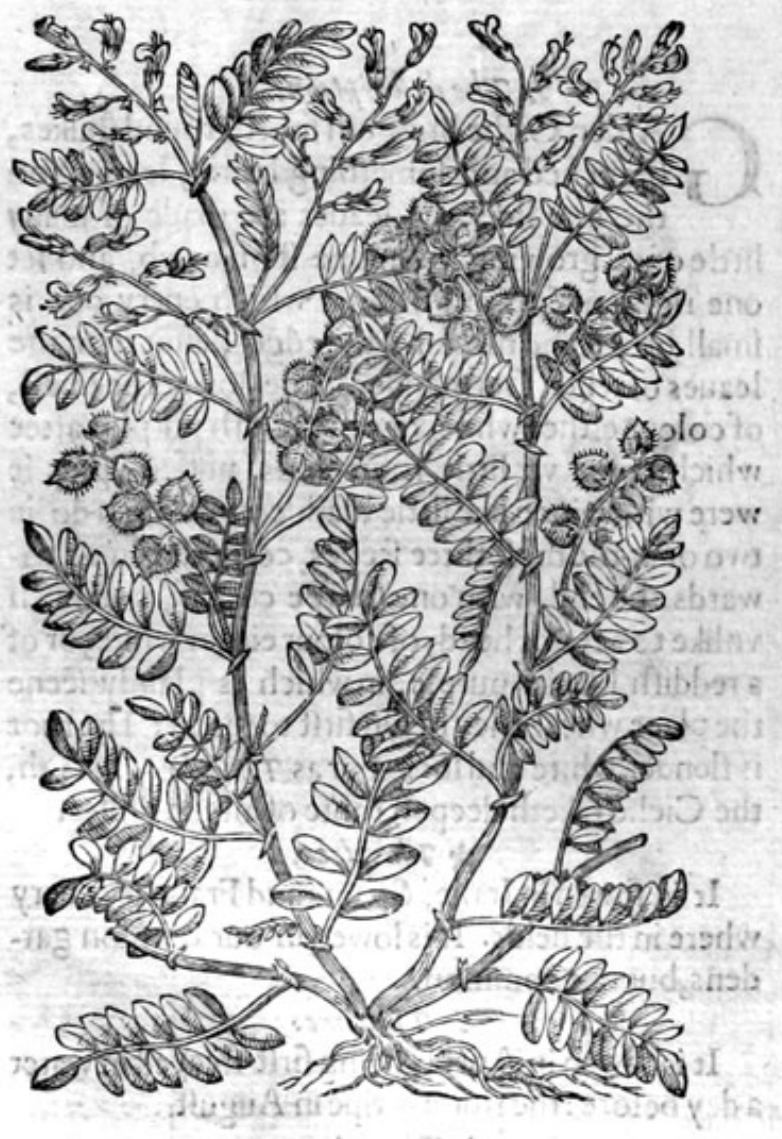

2 Cicer fylueftre latifolium. Broad leafed wilde Cich.
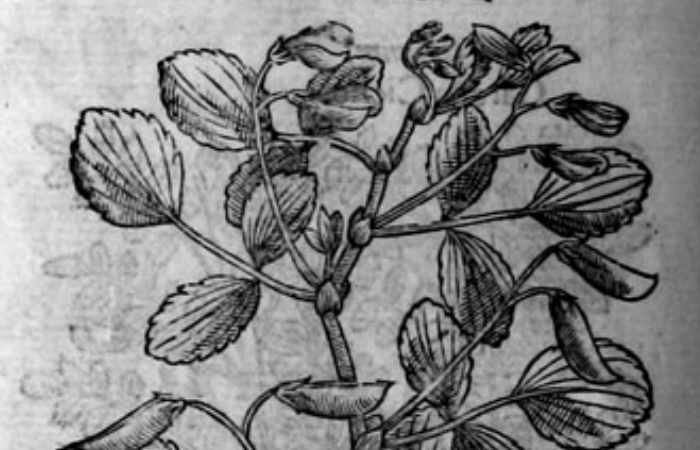

* The defcription.

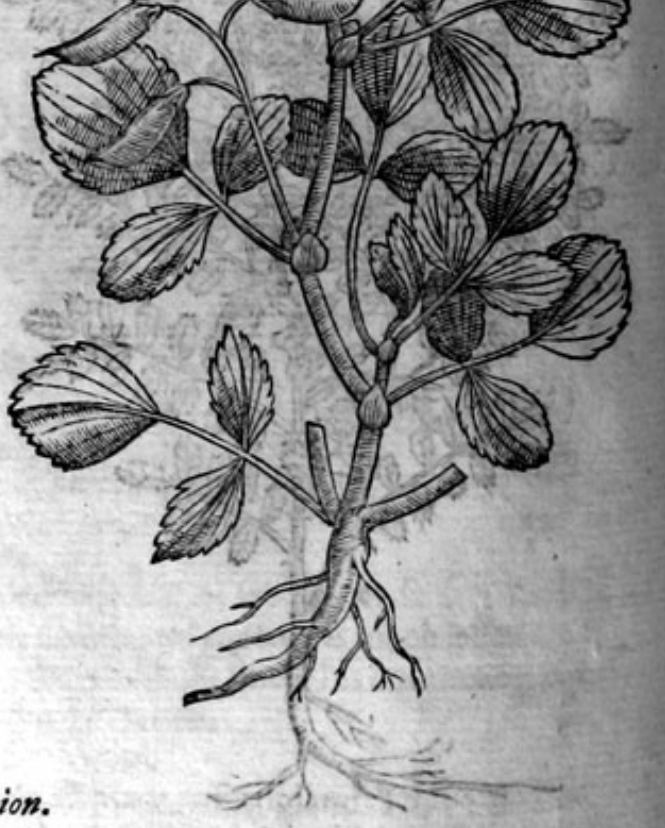

1 THe firft wilde Cich bringeth foorth a great number of ftalkes branched, lying ffat on the

1 ground: about which be the leates, confifting of many vponone rib as do thole of the gatden Cich, but not nicked in the enges, more like to the leaues of Axcich : the flowers come foorth faftned on finall ftems, which grow clofe to the ftalkes, of a pale yellow colour, and like vnto eares: in tl.cir places come vp little cods, in forme and bignes of the fruir of garden Ciches, black and fomething hairie, in which lieth the feede, that is finall, hard, flat,and glittering, in tafte like that of Kidncy Be.ne : the roote groweth deepe, faftned with many ftrings. 
HISTORIE OF PLANTS.

2 There is another kind of wild $\mathrm{Cich}$ that hath alfo a great number of $\mathrm{t}$ :lks lying vpon the ground, about which ftande foft leaues, fomthing hairy and white, confifting of three broad leaues ftanding vpon a middle rib, the leaft of which ftande neereft to the ftem, and the greateft at the very top: the Alowers come foorth at the bottome of the leaues many togither, of colour yellowe; after which grow fimall long husks, foft and hairie, in euery one whereof is a little cod, in which lie two feedes like little Cichlings.

$$
\text { * The place. }
$$

Thefe are fowen in the parts beyond the feas for to feede their cattle with in winter, as we do tares, vetches, and fuch other bafe pulfe.

The time anfwereth the fetch or tare.

$$
\text { * The time. }
$$

\section{* The names.}

The wilde Cich hath no other name in Latine but Ciccr fylueftre: the later writers haue not found any name at all.

Their temperature and vertues are referred to the garden Cich, as Theophraftus affirmes, and A Galen faith, that the wilde $\mathrm{Cich}$ is in all things like vnto that of the garden, but in Phificks vfe more effectuall, by reafon it is more hotter and drier, and alfo more biting and bitter.

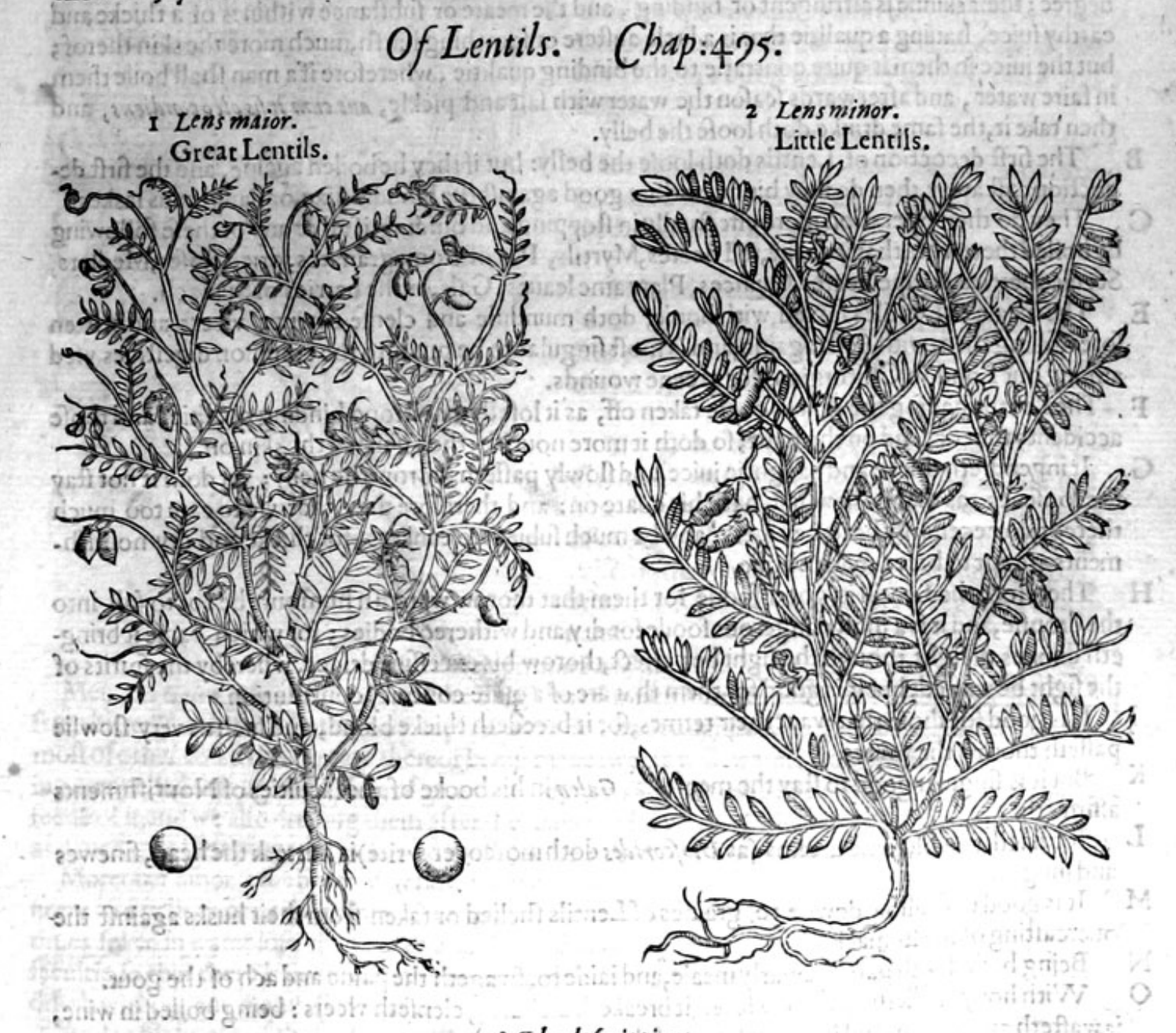

* 7 bedefeription.

I The firf Lentile groweth yp with flender ftalkes, and leaues which be fomewhat harde, growing aflope from both fides of the rib or middle falke, narrow and many in number like thofe of Tares, but narrower, and effer: the flowers be friall tending fomewhat towards a 


\section{I050 THE SECOND BOOKE OF THE}

purple, the cods are little and broad; the feedes in thefe are in number three or fower, little, round,
plame, and flat : the rootes are finall and threddie.

The fecond kinde of Lens or Lentill, hath fmall,tender, and pliant branches a cubite high; where. on do grow leates, diutided or confifting of fundry other fmall leaues like the wilde Fetch, ending at the niddle rib, with fome clafping tendrels, wherewith it taketh holde of fuch things as are neere
vnto it : among thefe come foorth little brownifh flowers mixed with white, which vito it : among thefe come foorth little brownifh flowers mixed with white, which turne into fmal
flat cods, cont aining little browne tat feed, and fomtimes white.

Theplace.

Thefe pulfes do grow in my garden, 8 it is reported vnto me by thofe of good credite, that about Watford in Middlefex and other places of England, the husbandmen do fowe them for their cat-
tle,euen as others do Tares.

They both fower and waxe ripe in Iuly and Auguft.

* 7 be names.

They are called in Greeke paxos, or ea'rn: in Latine Lens and Lenticula : in high Dutch Intentin French Lentille: in Italian Lentıchaa : in Spanifh Lenteia : in Englifh Lentils.

* The temperatureand vertues.

A Lentiles as Galen faith, are in a meane betweene hot and colde, yet are they dry in the feconde degree; their skinne is aftringent or binding, and the meate or fubltance within is of a thicke and earthy iuice, hauing a qualitie that is a little auftere or fomthing har h, much more the skin therof; but the iuice in them is quite contraric to the binding qualitic, wherefore if a man fhall boile them in faire water, and afterwards feafon the water with falt and pickle, aus cum ipfis oleocondiens, and then take it, the fame drinke doth loofe the belly.

B The firft decoction of Lentils doth loofe the belly: but if they be boiled againe, and the firft decoetion caft away, then do they binde, and are good a gainft the bloudie Alixe, or dangerous laskes.

C Tt:ey do their operation more effectually in ftopping and binding, if all or any of thefe following be boiled therewith, that is tofay, red Beetes, Myrtils, Pils of Pomegranates, dried Rofes, Medlars, Seruice berries, vnripe Peares, Quinces, Plantaine leates, Gals, or the berries of Sumach.

E The meale of Lentiles mixed with honie, doth mundifie and clenfe corrupt vicers and rotten fores, filling them with flefh againe, and is moft fingular to be put into the common digeftiues vfed among our London Chirurgians for greene wounds.

F The Lentile hauing the skin or coate taken off, as it lofeth that ftrong binding qualitic, and thofe accidents that depend on the fame; fo doth it more nourifh, then if it had the skin on.

G It ingendreth thicke and naughtie iuice, and flowly paffeth thorow the belly; yet doth ir not ftay the loofenes, as that doth which hath his coate on: and therefore they that vfe to eate tod much thereof, do neceffarily become lepers, and be much fubiect to cankers, for thicke and dry nourifhments are apt to breed melancholie.

H Therefore the Lentill is good foode for them that thorow waterim humours be apt to fall into the dropfie, and it is a moft dangerous foode for dry and withered bodies; for which caufe it bring. eth dimnes of fight, though the fight be perfect, thorow his exceffue drines, whereby the fpirits of the fight be wafted; but it is good for them that are of a quite contrary conftitution.

I It is good for thofe that want their termes, for it breedech thicke bloud, and fuch as very flowlie paffeth thorow the vaines.

$\mathrm{K}$ But it is fingular good to ftay the menfes, as Galen in his booke of the faculties of Nourifhments affirmeth.

L It caufeth troublefome dreams (as Diofcorides doth moreouer write)it hurteth the head, finewes and lungs.

M It is good to fwallow downe 30 , graines of Lentils fhelled or taken from their husks againt the ouercafting of the ftomacke.

N Being boiled with parched Barly meale, and laide to, fwageth the paine and ach of the gout.

$\mathrm{O}$ With hony it filleth vp hollow fores, it breaketh afchares, clenfeth vlcers : being boiled in wine, it wafteth aw ay wens, and hard fwellings of the throte.

$\mathrm{P}$ With a Qunce and Melilote, and oile of Rofes, it helpeth the in flammations of the eies and fundament: but in greater inflammations of the fundament, and great deepe vicers, it is boiled with the rinde of a Pomgranate, dric Rofe leaues and honie. 
And after the fame maner againft eating fores that are mortified, if fea water be added; it is alfo $Q$ a remedy againft pufhes, the fhingles, and the hot inflammation called Saint Anthonies fire, and for kibes,in fuch maner as we haue written; being boiled in fea water and applied, it helpeth womens brefts in which the milke is cluttered, and cannot fuffer too great abundance of milke.

\section{Of Cicb, or true Orobus. Chap. 496.}

\section{Orobsus receptes Herbariorum.}

The true Orobus.

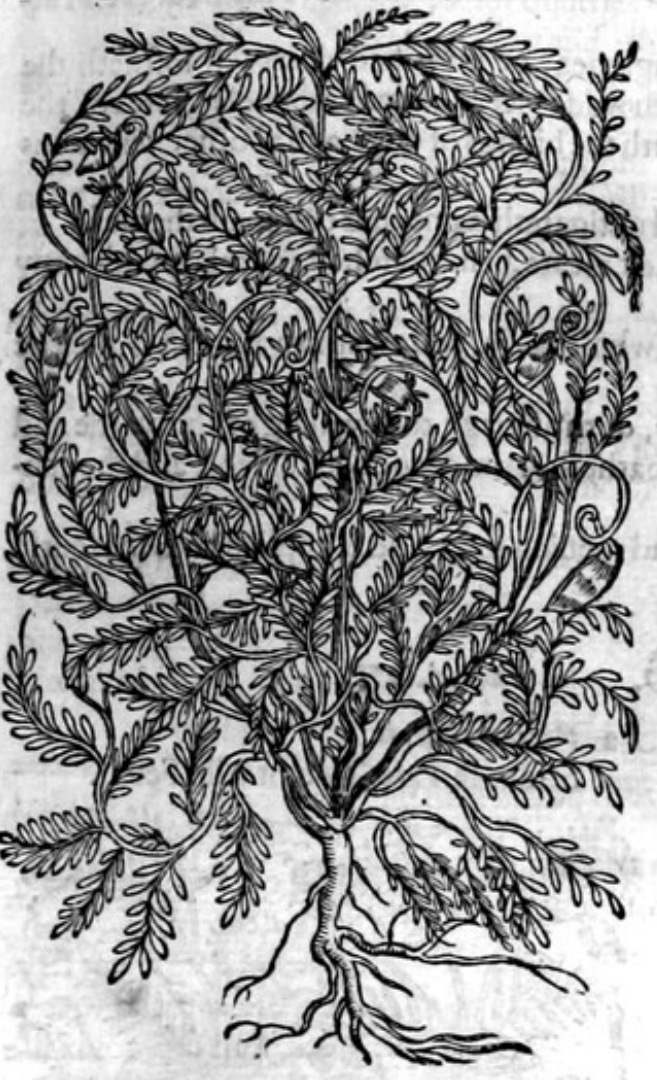

* The defcription.

THe pulfe which of moft Herbarifts is taken for the true $O$ robus, and called of fome tit. ter Fitch, is one of the pulfes whofe tender branches traile vpon the ground, as Theophafters faith, and whofe long tender branches fpread far abroad, whereon do grow leaues like thofe of the field vetch:among which grow white flowers, after which come long cods, that appeere bunched on the outfide againft the place where the feedes do lie : which are fmall, round, ruffet of colour, and of a bitter tafte: the roote is fmall and fingle.

\section{* T beplace.}

It profpereth beft in a leane foile, according to Colvmella:it groweth in woods and copfes:it groweth alfo in my garden.

\section{* The time.}

This is fowen earely and late, but if it be fowen in the fpring it eafily commeth vp, and is pleafant; and vnpleafant if it be fowen inthe fall of theleafe.

* The nones.

This is called in Greeke befisos: the fhops of Germanie haue kept the name Orobss, and not knowing the thing, they baue miftaken it in fteed of Vicia, or the common Vetch: in Englifh it is called bitter Vetch, or bitter Fitch, and Orobus, after the Latine; of fome Ers after the French name. -

\section{\% The temperature and vertues.}

Men, as Galen in his firft booke of the Faculties of nourifhments faith, doe altogither abftaine $A$ from bitter Vetch, for it hath a very vnpleafant tafte, and naughtie iuice; but Kine in Afia, and in moft of other countries do eate thereof being made fweete with water: notwithftanding men being compelled through neceffitie of great famine, as Hippocrates alfo hath written, doe of tentimes feede of it,and we allo dreffing them after the maner of Lupines, vfe the bitter Vetches with honie, as a medicine that purgeth thicke and groffe humours out of the cheit and lungs.

Morcouer among the bitter Vetches, the white are not fo medicinable, but thofe which come $B$ neere to a yellow, or to the colour of Ochar, and thofe that hate beene twife boiled, and fundrie times foked in water lofe their bitter and vnpleafant tafte, and withall their clenfing and cutcing facultie, fo that there is onely left in them an earthie fubftance, which ferueth for nourilhment, that drieth without any manifeft bitternes.

And in his booke of the faculties of Simple medicines he faith, that bitter Vetch is dry in the la- C ter end of thefecond degree, and hot in the firft; moreouer by how much it is bitter, by fo much it cuttech, clenfeth, and taketh away ftoppings; but if it be ouermuch vfed it bringeth foorth bloud by vrine. 
xie

1052

THE SECOND BOOKE OF THE

D Diofcorides writeth, that bitter Vetch caufcth headach, and heauie dulneffe : that it troubleth the belly, and draweth foorth bloud by vrine, notwithftanding being boiled it ferueth to fatten Kine with.

E There is made of the feedes a meale fit to be vfed in medicine. It is made after this maner; the full and white graines are chofen out, and being mixed togicher they are fteeped in water, and fuf. fered to lie till they be plumpe, afterwards they are parched till the skin be broken, then are they
ground, and fearced or thaked thorow a meale fieue, and the meale referued.

F This loofeth the belly,prouoketh vrine, maketh one well coloured: being ouermuch eaten, or drunke, it draweth bloud by the ftoole with gripings, and alfo by vrine.

G With hony it clenfeth vlcers, taketh away freckles, funne-burnes, blackefpots in the skin called Finist, and maketh the whole body faire and cleane.

H It ftaieth running vlcers, or hard'fwellings, and gangrenes, or mortified vlcers, it fof tneth the hardnes of womens brefts, it taketh away and breaketh wilde vlcers, called carbuncles, fores of the head; being tempered with wine and applied, it healeth the bitings of dogs, and al other venemous beafts.

I With vineger it is good againft the ftrangury, and mitigateth paine that commeth thereof.

$\mathrm{K}$. It is good for them that are not nourifhed after their meate, being parched and taken with hony in the quantity of a nut.

L The decoction of the fame helpeth the itch of the whole body, and taketh away kibes if they be wafhed or bathed therewith.

M Cicer boiled in fountaine water, with fome Orobsu, dorh affwage the fwelling of the yardeand privie parts of man or woman, if they be wafhed or bathed in the decoction thereof, and the fubftance hecrof may alfo be applied plaifterwife.

N It is alfo vfed for bathing and wathing of vlcers, and running fores, and is applied vnto thefcurfe of the head with great profite.

\section{Of the Vetch, or Fetch. Chap.497.}

\section{Vicia.}

Tare, Vetch, or Fetch.

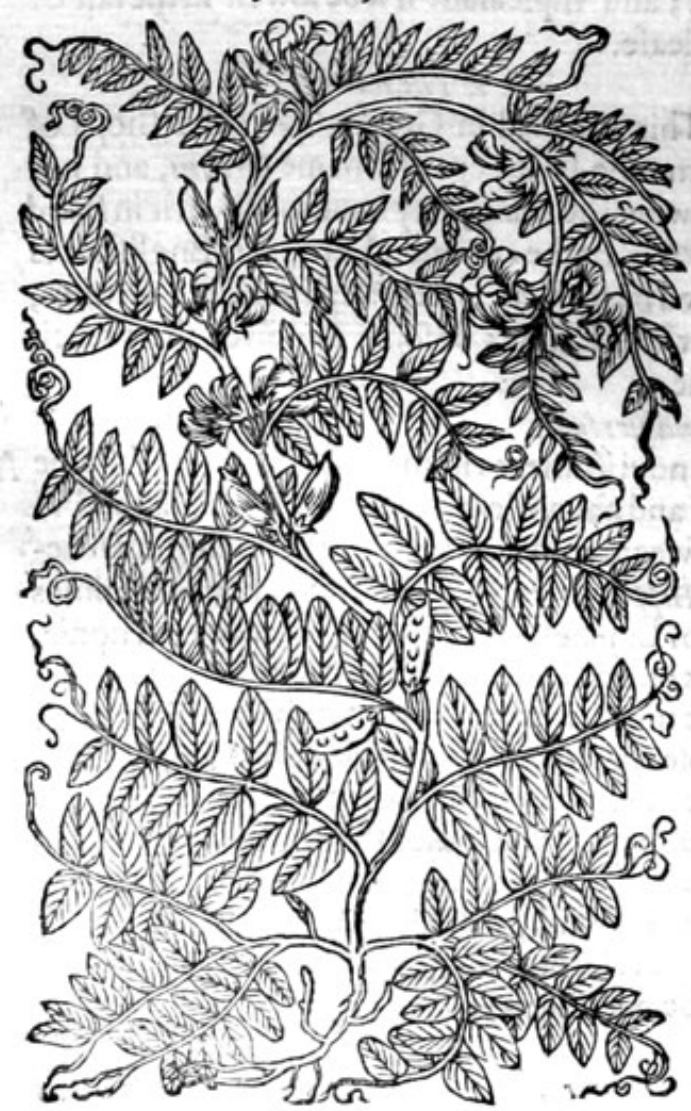

2 Viciafylueftris.

Strangle Tare, Tine, or wild Fetch.

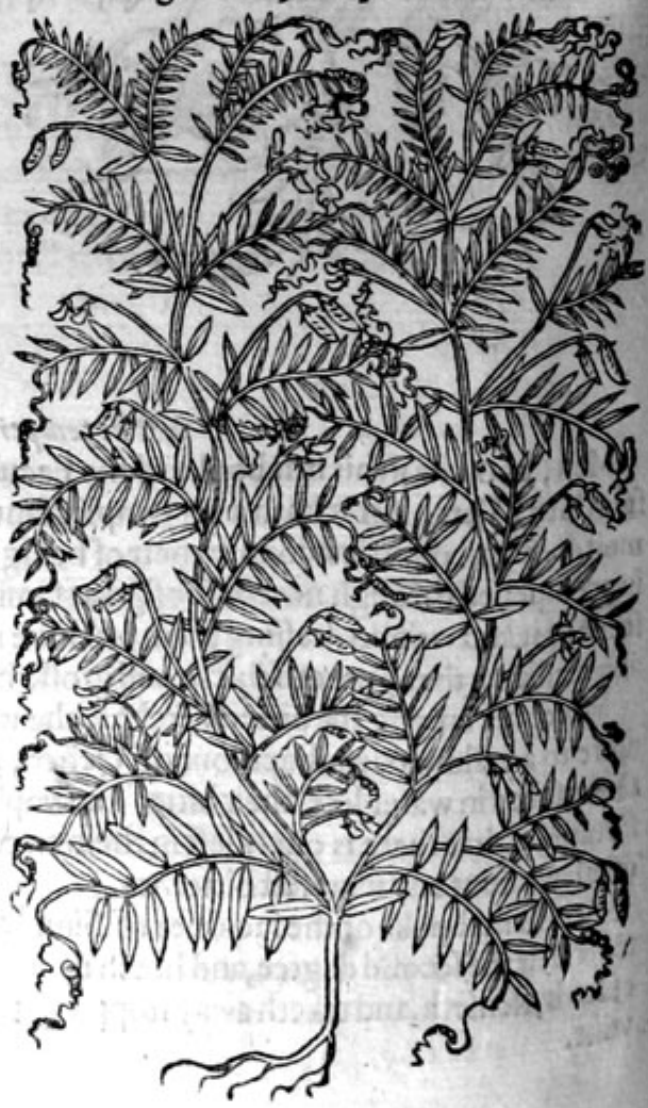


*Thedecription.

17 He Vetch hath flender and fower quared ftalkes, almoft three foote long: the leaues be

I long, with clafping tendrels at the end, made vp of many little leatues growing vpon one rib or middle ftem; euery one whereof is greater, broader and thicker, then that of the Lentile: the flowers are like to the flowers of the garden Beane, but of a blacke purple colour; the cods be broad, fmall, and in euery one are contained fiue or fixe graines, not round, but flat like thofe of the Lentill, of colour blacke, and of an vnpleafant tafte.

2 Strangle Tare, called in fome countries Tine, and of others wilde Vetch, is a ramping herbe like vnto the common Tare, ramping and climing among corne where it chanceth, that it pluckech it downe to the ground, and ouergroweth the fame in fuch fort, that it fpoileth and killeth not onely Wheate, but all other graine whatfoeuer : the herbe is better knowne then defired, therefore thefe fewe lines may ferue for the defcription.

The Tare is towen in any ground or foile whatfoeuer.

$$
\text { * The place. }
$$

It flowreth in May, and perfeeteth his feede toward September.

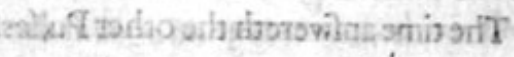

\section{ratsintesting}

It is called in Latin Vicia, à Vinciendo, of binding or wrapping, as Varro notech, bicaufe(faith he) it hath likewife clafping tendrels, fuch as the Vine hath, by which it crawleth vpward vpon the ftalkes of the weedes that are next vnto it; of fome Cracka, and Lracbus, and alfo LAphaca: it is called in high Durch vericken: in low Dutch Utitfen : in French Vefce: in moft thops it is falfely termed ogesos, and Eruwm, for Eruum doth much differ from Vicia : it iscalled in Englifh Vetch or Fetoh. The countrey men lay vp this Vetch with the feedes and whole plant; that it may bc a fodder for their cattle.

\section{* The temperature and vertues.}

Notwithftanding 1 haue knowne, faith Galen, fome that in time of famine haue fed heereof, $A$ efpecially in the fpring,when as itis as yet but greene, but it is harde of digeftion, and bindeth the belly.

Therefore feeing it is of this kinde of nature, it is manifeft that the nourifhment which com- B meth thereof, hath in it no good iuice at all, but ingendreth a thickebloud, and apt to become melancholie.

\section{Of yellow wilde Fetch, or Tare enerlafting. Chap. 498.}

\section{* The defcription.}

I Tere is a pulfe growing in our high and thick woods, hauing a very thick, tough,and woody roote : from which rife vp diuers long, weake and feeble branches, confifting of a tough middle rib, edged on both fides with a thinne skinnie membrane, fmooth and of a graffe greene colour; whereon doe grow at certaine diftances, fmall flat ftems, vpon which ftande two broad leaues ioined togither at the bottome:from betwixt thofe leaues come foorth tough clafping tendrels, which take holde of fuch things as grow next vnto it : from the bofome of the ftem whereon the leaues doe growe, hooteth foorth a naked fmooth footeftalke, on which doc growe moft beautifull flowers like thofe of the Peafe, the middle part where of is of a bright red, tending to red Purple in graine ; the outward leaues formwhat lighter inclining to a blufh color, which being paft, there fucceede long round cods, wherein is conteined feede of the bignes of Tares, but rounder, blackinh without, and yellowinh within, and of a bitter tafte.

Of which kinde we haue likewife another in our woods, like vnto the precedent in each refpect, fauing that the leates heerof are narrower and longer, and therefore called of moft, which fet foorth the defcription, Lathyras Anguftifolia. 


\section{THE SECOND BOOKE OF THE}

2 The yellow wilde Tare or Fetch, hath diuers very fmall ramping ftalkes, tough, and leaning this way and that way, not able to ftande of it felfe without the helpe of props, or things that ftande by it: the leaues are the Peale fow infinite, infomuch that it is impoffible to roote it foorth, being once gotten into any ground, vnleffe the earth be digged vp with the rootes, and both caft into the riuer, or burned : doubtleffe it is the moft pernicious and harmfull weede of all others, vnto all maner of graine, holfome herbes, or any
woode whatfoecuer.

\section{* The place.}

The firft doth grow in thadowie woods, and among bufhes: there groweth great ftore thereof in Swanefcombe woode, a milezand a halfe from Greene-Hithe in Kent, as you go to a village thereby called Betfome; and in diuers other places. where.

The other groweth in moft graffie paiftures, borders of ficldes, and among graine almoft eueric

The time anfwereth the other Pulfes.

$$
\text { * Tbe time. }
$$

* T The nomes.

The firft is called Lathyrus, to make a difference betweene it and Lathyris,or Spurge: of Mathiolus Clymenum; of Cordus Eruum fatiuum; of Tr.zgus Psfum Gr acorum : in Englifh Peafe euerlafting, great wilde Tare, and Cichling.

The other is called Aracus; of fome Cicera: in Italian Mocho: in Englifh yellow wilde Fetch, and Cichling. * The temperatureand vertues.

Thetemperature and vertues are referred to the manured Tare or Vetch; notwithftanding they are not vfed for meate or medicine.

\section{Of the Oylie Pulfe called Sefamum. Chap.497.}

Sefamum, fue Sifamum.

The oilie graine.

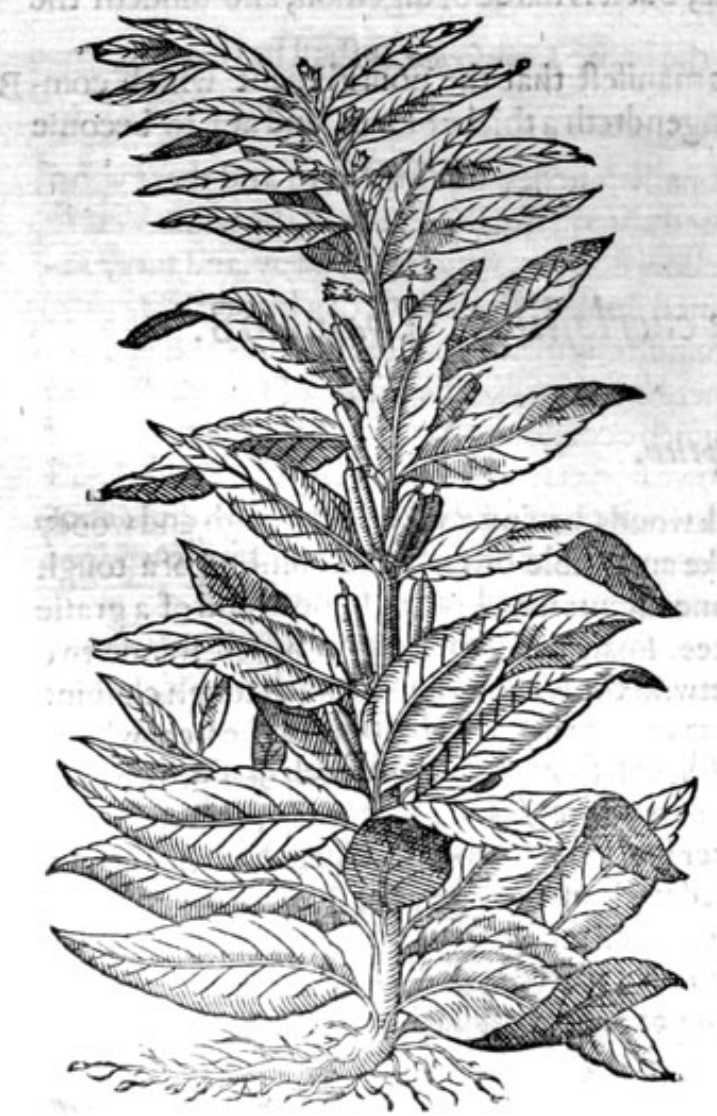

* The defcription.

Efamum hath a thicke and fat vpright ftall,

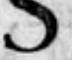
a cubite and a halfe high, garnifhed with leaues much like the Peach or Almond, or rather in mine opinion, more like the leaues of Bafill: among thefe leaues come foorth fmall red flowers, which turne into rounde, long, and crefted cods, containing white fat oileous feede: Theophraftres affirmeth, that there is a kind thereof which is white, bearing onely one roote; no kinde of beaft will eate this plant when it is greene, bicaufe of his bitternes, but being withe red and dried, the feed therof becommeth fweet, and the catcle will feede on the wholeplant. * Theplace.

It groweth both in Egypt and in India, Se/amu faith $P$ linie, came from the Indies; they make an oile of it, and is a ftranger in England.

$$
\text { * The time. }
$$

It is one of the fommer graines, and is fowen before the rifing of the feauen ftars, as Plinie writcth; yet Columella faith, that Sefamumleedes muft be fowen after Autumne AEquinotiall, againft the Ides of Oetober: they require for the moft parta rotten foile, which the husbandmen of Campania do call ablacke moulde. 
*. The names.

The Grecians call this graine riousur: the Latines alfo Sefamum, and Sifamum, and often in the Fœeminine gender Sefama: we are conftrained for want of an Englifh name to vfe the Latine: it is vnknowne to the Apothecaries, efpecially the plant it felfe; but the feede and oilc thercof is to be found among them: we may call it Turkie Millet.

* The temperature and vertues.

According to fome it is hot and dry in the firft degree: the feed thereof as $G_{a}$ alen faith, is fat, and $\mathrm{A}$ therefore being laid vp it commeth to be oilie very quickly; wherefore it fpeedily fillcth and ftuffeth vp thofe that feede thereof, and ouerthroweth the ftomacke, and is flowe of digeftion, and yeeldeth to the body a fat nourifhment : therefore it is manifeft, that it cannot ftrengthen the ftomacke, or any part thereof, as alfo no other kinde of fat thing : and the iuice that conmeth thereof is thicke, and therefore it cannot fpeedily paffe thorow the veines; men do not greatly feede of it alone, bue make cakes there of with hony, which they call onoxuidss: it is alfo mixed with bread, and is of an hot temperature, for which caufe it procureth thirf : and in his booke of the faculties of Simple medicines he faith, that Sefamum is not a little clammie and fat , and therefore it is an emplaftick, and a foftner,and is moderately hot : the oile which commeth there of is of like temperature, and fo is the decoction of the herbe alfo.

Diofcorides writeth, that Sefamum is an enimie to the ftomacke, it caufeth a ftinking breath if it re- B maine ftinking betweene the teeth after it is chewved.

It wafteth away the groffenes of the finewes, it is a remedy againft brufings of the eares, inflam- C mations, burnings, and fcaldings, paines of the ioints, \& biting of the poifonfom horned ferpent called Cersftes:being mixed with oile of Rofes it taketh away the headach, which commeth of heat.

Of the fame force is the herbe boiled in wine', but it is efpecially good for the heat and paine of $D$ the eies.

Of the herbe is made an oile vfed of the Egyptians, which as $P$ liny faith, is profitable for the eares. E It is a remedie againft the founding or ringing in the eares.

\section{Of batchet Fetch. Chap.500.}

\section{* 7 bekindes.}

There be diuers forts of hatchet Fetches, called by the name Hedyfarum, as fhall be fhewed.

\section{1}

\section{* The defcription.}

He firft kinde of hatchet Fetch, hath many finall branches trailing heere and there vpon the ground: vpon which grow fmall leaues, fpred abroad like the leaues of the wilde Vetch: among which come foorth clufters of fmall yellow flowers, which fade away, and turne into little, tlat, thin, and browne cods, wherein is conteined fmall reddin feede of a bitter tafte. 2 The fecond kinde of hatchet Fetch, hath many round, tough, and Aixible branches, trailing vpon the ground:wherupon do grow leaues like the former, but more like the leaues of Liquorice, and hauing the tafte of the Liquorice roote, which hath giuenoccafion to fome todeeme it a kinde of Liquorice : among the fe leaues come foorth pale yellowe flowers, after which there fucceede fmall crooked cods (which the grauer hath omitted)turning their points inwardly, one anfwering another, like little hornes, containing fmall flat feeds, fower cornered, and faf hioned like a little wedge: the roote is tough, of a woodie fubftance, and doth continuc fruitfull a very long time.

There is another kinde of Securidaci, or hatchet Fetch, which hath branches, leates, and rootes, like the laft before remenbred, and differeth in that, that the flowers of this plant are mixed, and do vary into fundry colours, being on the vpper part of a flefh colour, and on the lower of a white or fnowie colour, with a purple Storkes bill in the midift: the leaues are in tafte bitter; the cods are fmall like thofe of Birds foote, and not much vnlike the cods of Orobus.

There is likewife another kinde of Securidaca or Hatchet Fetch, which is dedicated vnto Carolus Clufus, by the aforenamed Doctor Pennie, who founde it in the north parts of England, hauing leaues, rootes, and branches, like vnto the former : but the flowers of this are white, and mixed with fome purple, and bitter alfo in tafte: his cods are like the claw of a crab, or ( as Cluffims faith) like the knife which fhoomakers do vfe in Flanders, in which cods are contained fmall reddifh feede: this roote alfo is of long continuance. 
1056

1 Heigyarum maites.

Hatchet Fetch.

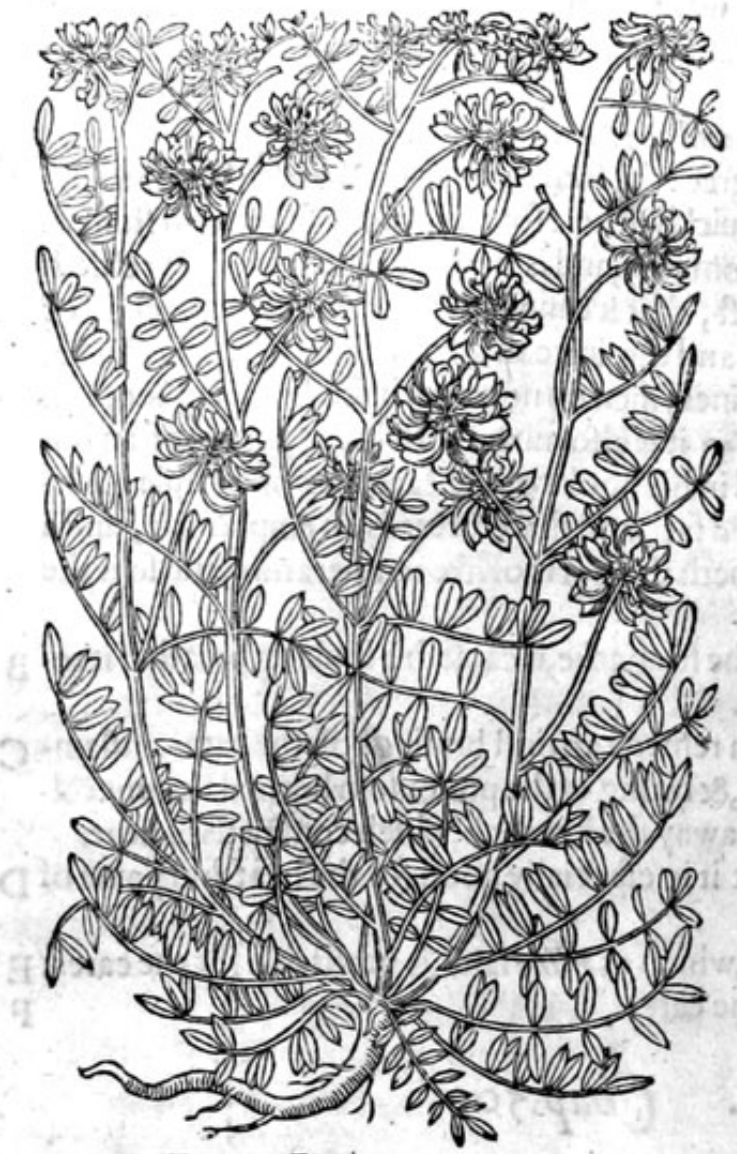

3 Ferrwm Equinum.

Horfe fhooe.

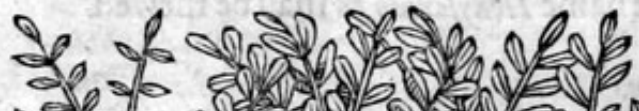

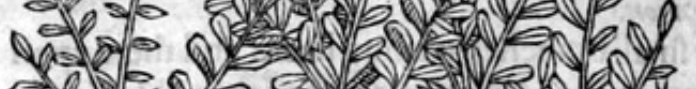

al 100 \% ह

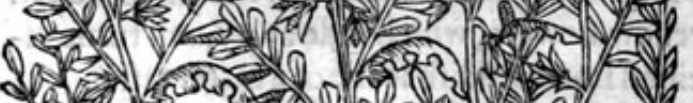

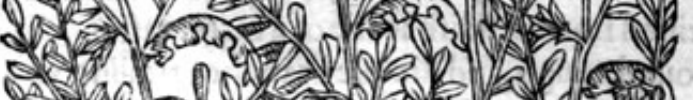

Et

1

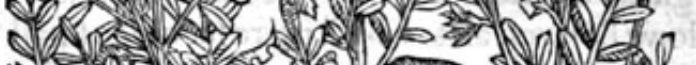

*⿻

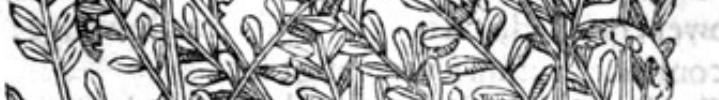

Selo 1 -

0 ans $=0$

a a (3)

1)

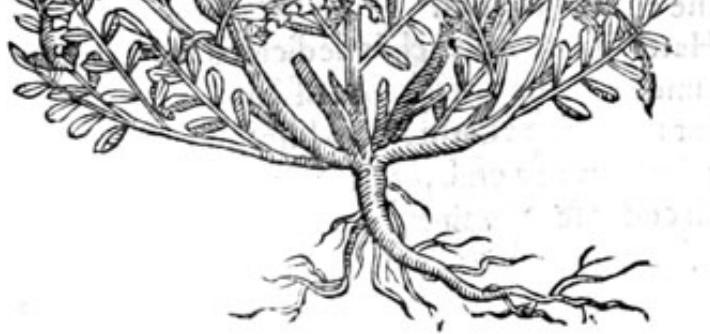

B OOKE OF THE

2 Hedyfarum Glyryrchizata. Licorice hatchet Fetch.

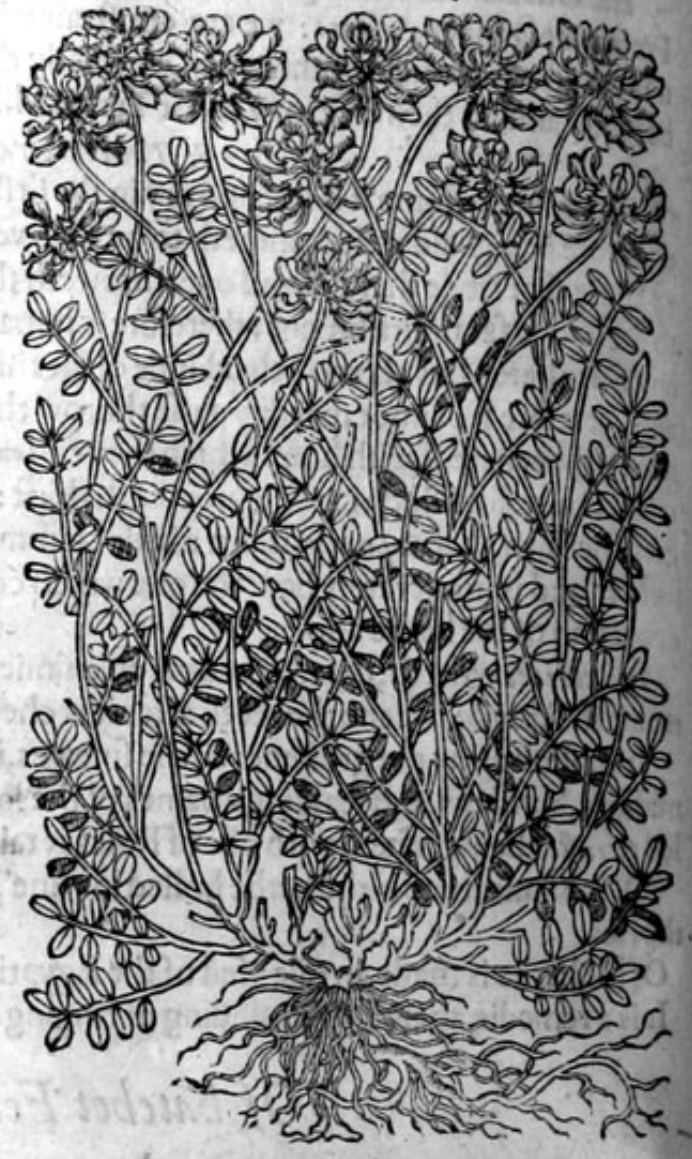

* The defcription.

There is alfo another fort of Hatchet Fetch, which hath very long and tough branches trailing vpon the grounde, befet with leaues like the former, but much greater: the flowers do growat the top of the branches of a pale colour, and turne into rough, round and tat cods, fafhioned like little bucklers:the roote (of this as of the firft) dieth at the firft approch of winter, affoone as the feede is ripe, but all the refidue of the kindes are of many yecres continuance.

3 Horfe thooe hath many ftalkes, flender, and lying vpon the grounde: the leaues be thinne and leffer then thofe of Axfeede : the flowers along the ftalkes are little; after which come vp long cods fomuhing broad, and a little bowing, which haue vpon the one fide deepe, rounde, and inden. ted cuts, like after a fort to an Horfe fhooc: the roote is fomewhat long.

\section{$*$ The place.}

Thefe plants do grow in my garden:the fecond kinde $\mathrm{I}$ founde growing in Suffolke, in the high way on the right hande, as you go from Sudbury to Corner Church about an hundred paces from the ende of the towne, as alfo in fundry othe place 


\section{IHISTORIE OF PLANTS.}

1057

places of the fame cointrey; and in Effex about Dunmow, and in the townes called Clare and Hennyngham.

Horfe thooe commeth vp in certaine vntilled and funny places of Italy and Languedock : it groweth likewife in my garden.

Thefe plants do flower in Iune, and their feede is ripe in Auguft.

The Gracians name this, whether it be a pulfe or an infirmitic among corne nisorear: the Latines of the forme of the feede Securidaca, and Hedyfarum : inEnglih Axfeede, Axwoort, Ax-fitch, and Hatchet Fitch: it is vnknowne to the Apothecaries.

Horfe fhooe, is commonly called in Italian Sferro de caullo: you may name it in Latine Ferrum equinam : in Englifh Horfe fhooe.

\section{* The temperature.}

The feeds of thefe plants are hot and dry of complexion.

$$
\text { * The vertues. }
$$

Being drunke it is acceptable to the ftorracke, and remooucth ftoppings out of the intrailes, and $\mathbf{A}$ of like vertue be the newe leaues and tender crops of the whole plant.

Liofcorides fheweth that it is alfo good for the ftomacke being taken in drinke, and is mixed with B counterpoifons.

And it is thought to hinder conception, if it be applied with hony before the aet.

The feede of Axwoort openeth the ftoppings of the liuer, the obltruction of the fpleene, and of D allshe inward parts.

Houfe hooe is bitter and like in nature to Axfeede.

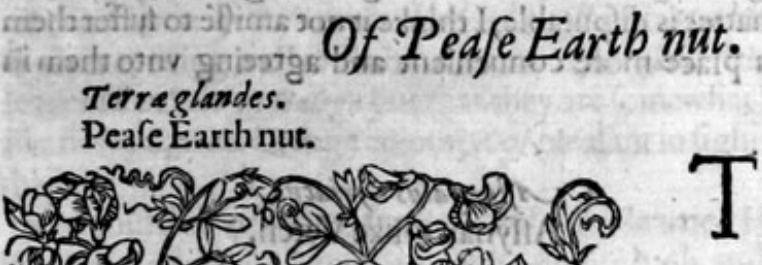

\section{Cbap.5or.}

\section{* The defcription.}

$T^{\mathrm{He}}$ Peafe Earth nut, commeth ypwith flen der and weake ftalkes : the leaues be thin, and little, growing vpon flender ftems, with clafping tendrels at the ends, with which it imbraceth and taketh hold of fuch things as ftand neere vnto it : the flowers on the tops of the ftalkes are like to thofe of Peafe, bur leffer, of a red purple colour, in finell not vnpleafant in their places come vp long cods, in which are three or fower round feeds t the rootes be thicke, long, like after a fort to acorns, but much greater, blacke without, graie within, in tafte like to the Cheffenut: out of which beneath doth hang a long flender ftring; there grow out of the fame alfo other ftrings, hard to the fetting on of the ftalke, vnto which creeping aflope do grow other kernelled rootes whileit the plant doth thus multiplie itfelfe.

\section{$*$ The place.}

This groweth in corne fieldes, bothwith the corne it felfe, and alfo about the borders of fields among briers and brambles: it is founde in diuers woods and paftures of Englande, efpeciallie in Hampteed woode neerc London: it groweth in Richmond Heath, and in Coome Parke likewife. * The time.

It flowreth in Iune and Iuly, the nuts after harueft be digged $v p$ and gathered.

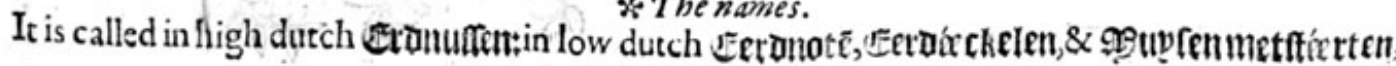
sit? 4

that 


\section{THE SECOND BOOKECOF ITHE}

that is to fay, tailed Mife, of the fimilitude or likenes of domefticall Mife, which che blacke, rounde, and long Nuts, with a peece of the flender ftring hanging out behind, do reprefent: the later writers do call it in Latine Terre glandes, or Terreftres glandes, and in Greeke zesuarcendroor, Chamabalani:
in Englifh Peafc Earthnut.

A The Nuts of this Peafe being boiled and eaten, are hardlies digefted then be cither Turneps or Parfneps, yer do they nourifh no leffe then the Parfneps: they are not fo windie as they, they do more flowly paffe thorowe the belly by reafon of their binding qualitie, and being eaten rawe they be yet harder of digeftion, and do hardlier and flowlier defcend.

B They be of temperature meanly hot, and fomwhat dry, being wivithall not a little binding: where. vpon al o they do not onely ftaie the fluxes of the belly, but alio all iffues of bloud, efpecially from the mother oi bladder.

C The rootes of Peafe Earthnut ftoppeth the belly, and the inordinate courfe of womens fick. neffe.

\section{Of milke Vetch. Chap.502.}

Q

$T$ Here be diuers forts of herbes conteined vnder the title of Aftragalu, whether I may with. 1 out breach of promife made in the beginning infert them among the Legumina, pulfes, or herbie plants, it is doubtfull : but feeing the matter is difputable, I thinke it not amiffe to fuffer them thus to paffe, vntill fome other thall finde a place more conuenient and agreeing vnto them in neighbourhood.

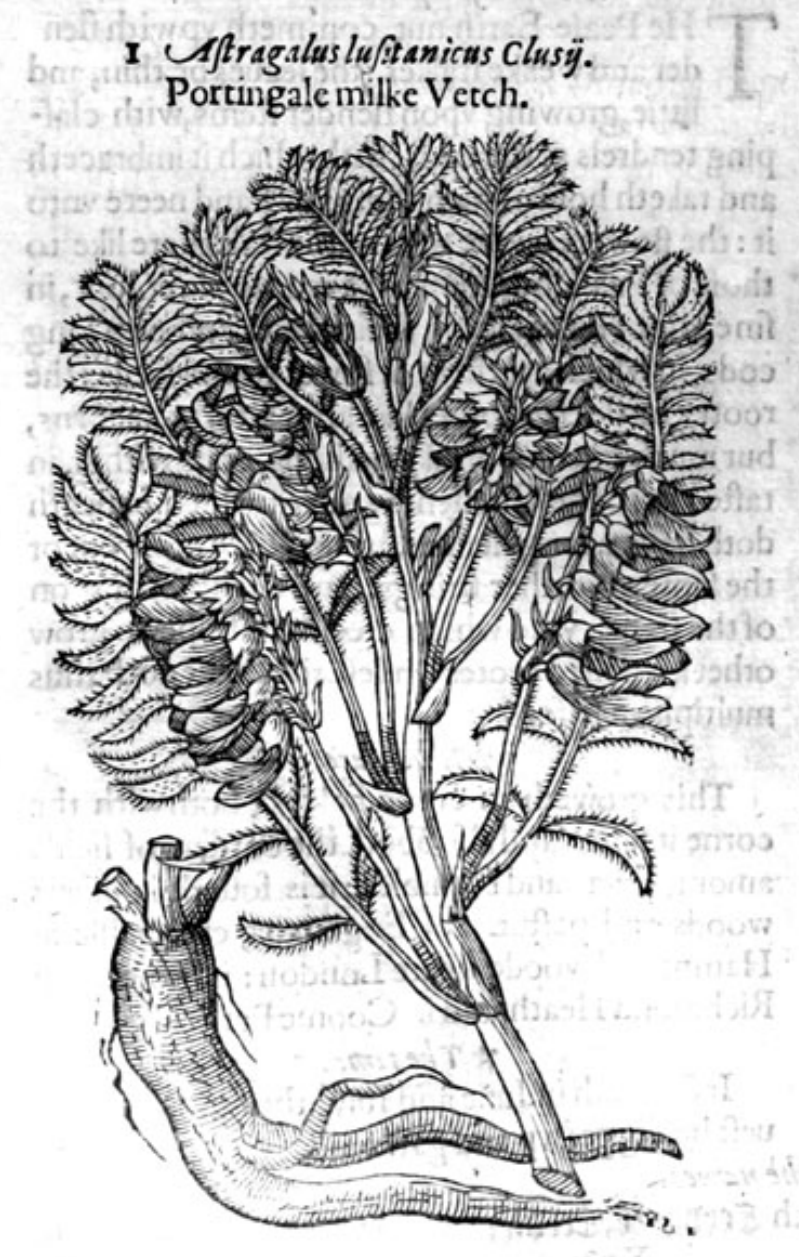

2. Uftragalus Syriacus.
Affyrian milke Vetch.

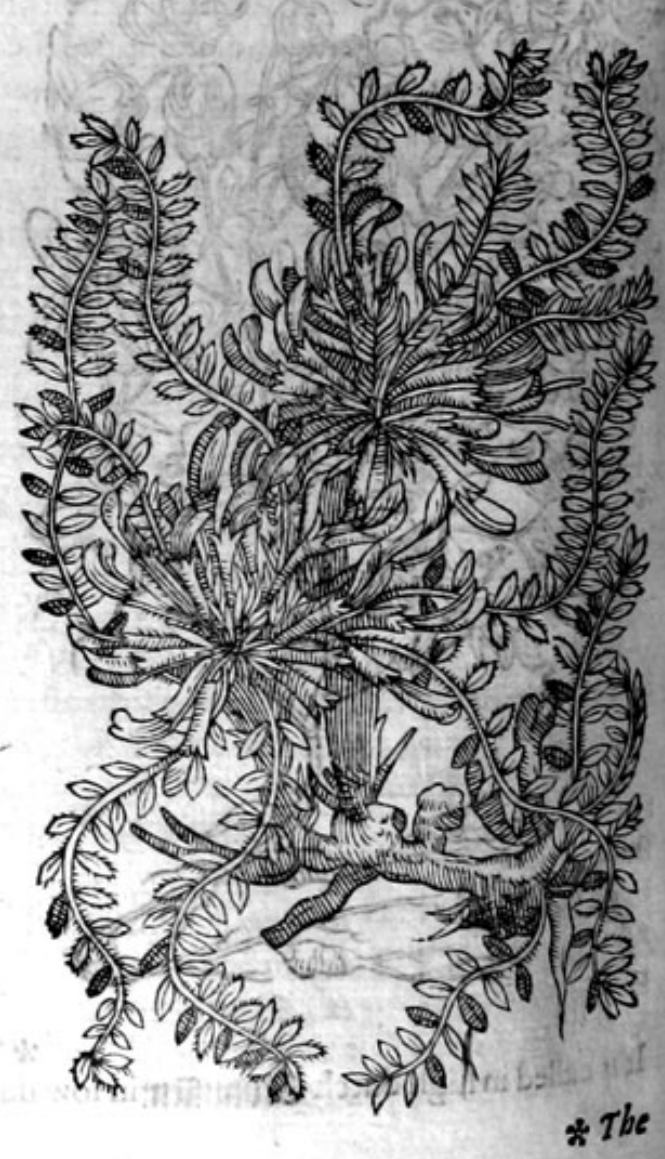




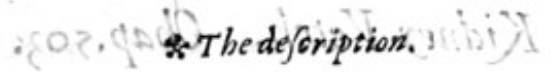

$T$ He firft kinde of Aftragalus hath reddith ftalkes, a cubite high, a finger thicke, fomewhat crefted or furrowed, and conered ouer with an hairie moffines; which dituide themfelues into fundry fmall branches, befer with leaties, confifting of fundry lietle leaues fet vpon a middle rib, like the wilde Vetch, fauing that euery fmall leafe is tafhioned like a Butchers knife, placed on the fmal pliant branches like feathers, which are likewife couered ouer with a woolie hoarines; in tafte aftringentat the firft, bar afterwards burning hot : among thefe leaues come foorth many imall white fowers, in fafhiondike the flowers of Lupines, which before their opening feeme to be fomewhat yellow: the roote is maruellous great and large, confidering the fmalnefie of the plant, for fometimes it groweth to the bigneffe of a mans arme, keeping the fame bigneffe for the fpace of a f anne in length, and after diuideth it felfe into two or more forkes or branches, blacke without and wrinckled; white within, hard and woodie, and in tafte vnpleafant, which being dried becomnech harder then an horne.

2 The lecond kinde of Afrragalus is a rare and galant plant, and may well be termed Planta Legumino 2 , by reafon that it is accounted for a kinde of $1 /$ tr dalses, refembling the fame in the fimilitude of his ftalkes and leaues, as alfo in the thickneffe of his rootes, and the creeping and foulding thereof; and is garnifhed with a moft thicke and pleafant comlineffe of his deleetable red flowers, growing vp togither in great tufts, which are very feemely to behold.

There hath beene fome controuerfic about this thirde kinde, which I am not willing to profecute or enter irito: it nay very well be Aftragalus of Mat biolses his defctription, or elfe his Poly gala, which doth exceeding well refemble the true Aftragalus : his fmall ftalkes growe a foote high, befet with leaves like Cicer or Galega but that they are fomewhat leffer:among which come foorth fmall Pcafe like flowers, of an Orenge colour, very pleafant in fight : the roote is tough and Alexible, of a finger thicke.

The fourth is called of Mutonus and other learned Herbarifts Aftrag iboides, for that it refembleth the true $\mathbb{A}$ ftragales, which groweth a cubite high, and in fhewe refembleth Liquorice : the flowers grow at the tops of the ftalks, in fhape like the Peafe bloome, of a faire purple colour, which turne into fnall blacke cods when they be ripe: the roote is tough and very long, creeping vpon the vpper part of the earth, and of a woodie fubftance.

* The place.

They grow amongft ftones, in open places, or as Oribafus writeth, in places fubiect to windes, $\&$ couered with fnow : Diofcorides copies do ad, in fhadowie places; it groweth plentifully in Phenea a citic in Arcadia, as Galen and Pliny report: in Dtufcortes his copies there is reade, in Memphis a citic of Arcadia; but Memphis is a citie of Egypt, and in Arcadia there is none of that name: fome of them grow in my garden, and in fundry other places in England wilde; they growe in the meadowes neere Cambridge, where the fcholers vfe to fport themfelues: they grow alfo in fundrie places of Eflex, as about Dunmow and Clare, and many other places of that countrey. * The trme.

They flower in Iune and Iuly, and their feede is ripe in September. * The names.

Milke Vetch is called of Mathiolus Polygala, but notproperly; of moft it is called Aftrazalus ; in Spanifh Garavancillos: in the Portingales toong Aiphabeca : in Dutch Clevne Ctcerett.

\section{$\nless$ The temperature and vertues.}

Aftragalus as Galen faith, hath aftringent or binding rootes, and thereforc it is of the number $\mathbf{A}$ of thofe Simples, that are not a little drying; for it glueth and healeth vp old vlcers, and ftaieth the fluxe of the belly, if they be boiled in wine and drunke : the farme things atfo touching the vertues of Aftragalus Dio fcorides hath mentioned, the roote faith he, being drunke in wine ftaieth the laske, and prouoketh vrine, being dried and caft vpon old vicers, it curech them; it likewife procureth great ftore of milke in cattle that do eate thereof, whence it to $\mathrm{ke}$ his name.

It ftoppeth blceding, but it is with much a doobeaten, by reafon of his hardnes.

$$
X \times x 2
$$




\section{Of Kidney Vetch. Cbap.503.}

* The kindes.
A Sthyllis (according to Diofcorides) is of two forts, the one is like to the Lentill; the otber to the $_{\text {ground Pine. }}$

1 Anthyllis leguminoja. Kidney Vetch.

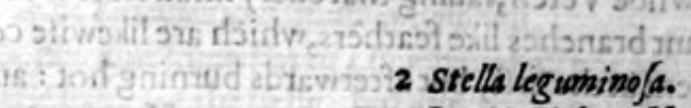

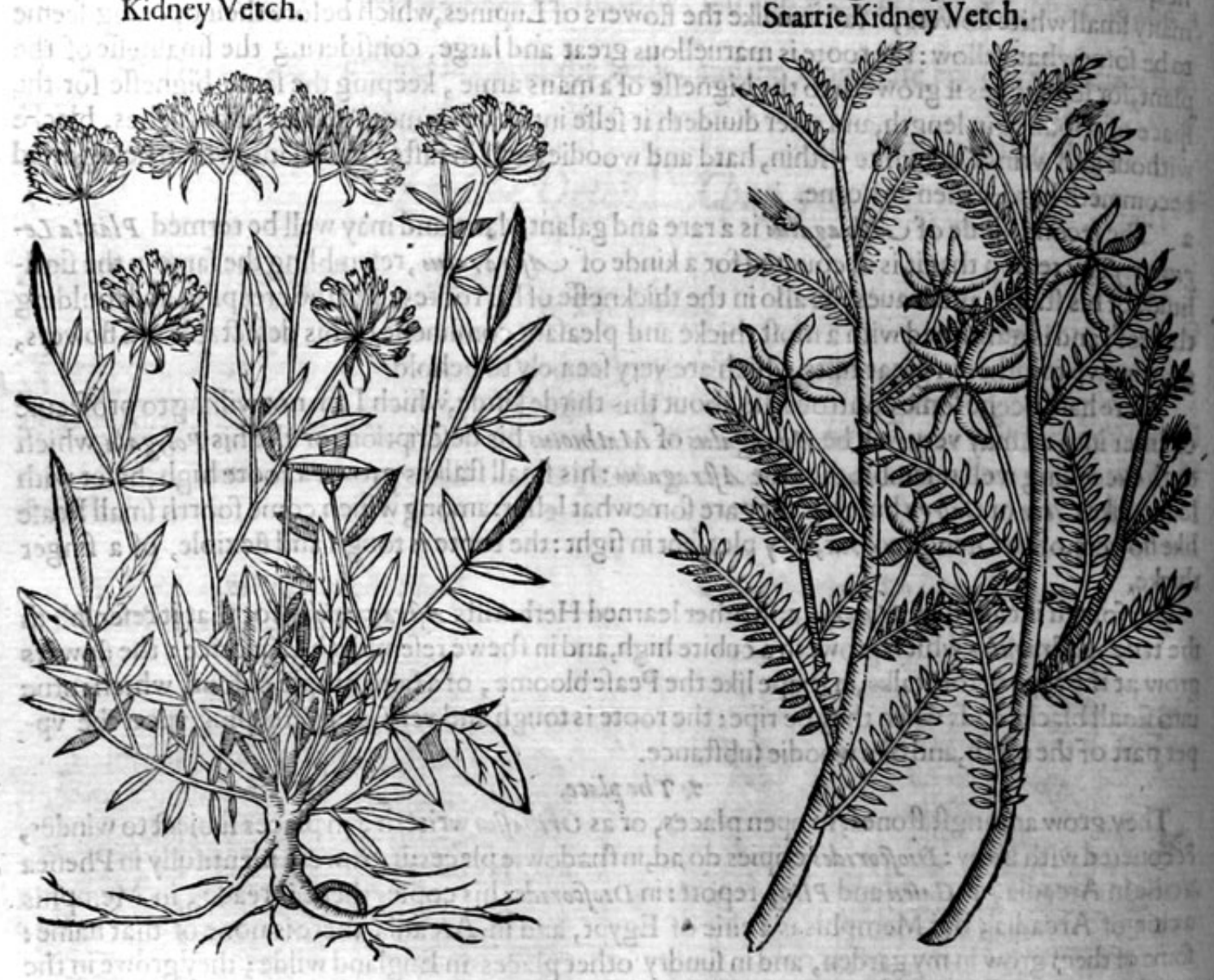

*The defcription.

I. K Istnev Vetch hath a ftalke of the height of a cubite, diuiding it felfe into other branches; 1 whereon do grow long leaues, made of diuers leaues, like thofe of the Lentill, couered as it were with a foft white downineffe: the flowers on the tops of the ftalkes, of a yellow colour, verie many ioined togither, as it were in a fpokie rundle; after which grow vp little cods, in which is contcined imall feede: the roote is flender, and of a woodie futftance.

2 The Starric Kidney Vetch, called Stella leguminofa, or according to Cortufrus Urefturo, hath many finall flexible tough branches, full of fmall knots or knees: from whence fpringeth forth one lone finall leafe, like Birds foote, but bigger: from the bofome of thofe leaues come foorth little tender ftems, on the ends whereof do growe fmall yellowe flowers, which are very flender, and foon vaded, like vitto them of Lampfana: thefe flowers turne into fmalliharp pointed cods, ftanding one diftant from another, like the diuifions of a ftarre, or as though it confifted of litric hornes, wherein is conteined mall blicke feedes : the roote is tough and decpely growing in the ground. 
There is another fort of Kidney Vetch called Birdes footc, or Ornit hopodium, which hath veric many friall and tender branches, trailing hecte and there clole vpon the grounde, fet full of fmall and foft leaues, of a whitifh greene, in thape like the leaues of the wilde Vetch, but a great dealc leffer, and finer, almoft like fmall feathers : amongft which the fowers do growe, that are veric fmall, yellowifh, and fometime whitifh; which being vaded, there come in place thereof little crooked cods, five or fixe growing togither, which irfficw and hape are like vnto a finall birds foote, and each and euery cod refermbling a clawe; in which are inclofed fmall leede like that of Turneps.

There is alfo another kinde of Ornit hotoditim, or Birdes foote, called fmall Birds foote, which is very like vnto the firft, but that it is much feffer: the branclies or fprigs growe not aboue a hand or halfe an hand high, fpreading themfelues vpon the ground with his fmall leates and branches, in

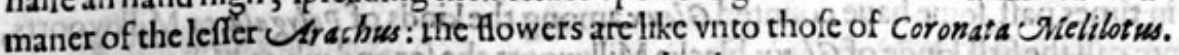

, 300 .

Thefe plants I found growing vpon Hamptte id Heath neer London, right againft the Beacon, vpon the right hand as you go from London, ncere vnto a gratell pit; they growe alfo vpon blacke Heath,in the high way leading from Greenwict to Charleton, within halte a mile of the towne.

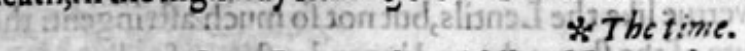

They flower from Iune to the middle of September. $*$ The names.

I cannot finde any other name for thefe plancs, but Ornit bopodiam: the firft is called in Englifh great Birds foote, the fecond fmall Birds fuote.

\section{* The nature and vertucs.}

Thefe herbes are not vfed either in meate cr medicine, that Iknow of as yet; but they are verie $\mathbf{A}$ good foode for catcle, and procure good ftore of milke, whercupon fome haue taken them for kinds of Polygala.

\section{Of blacke milke Tare. Clap.504.}

Glaux Diofcoridus.

Diojcorides his milke Tare.

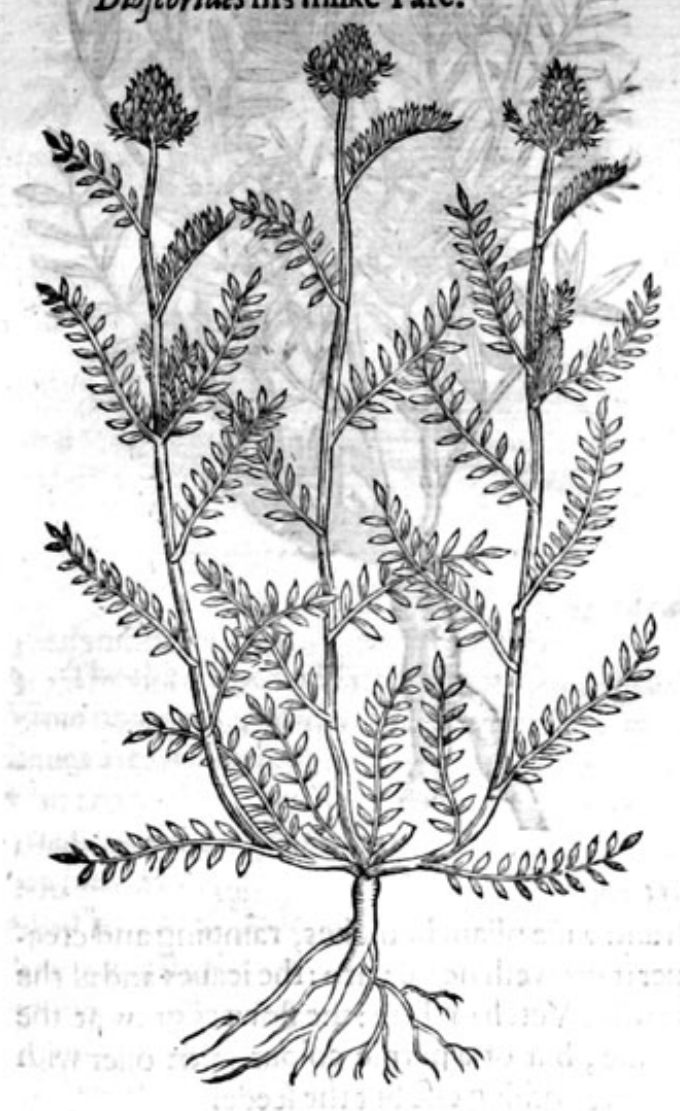

- $\quad$ Thedefcription.

$T^{H}$ He true Glasx of Diofcorides hath very many tough \& woodie branches, trailing vpon the ground, fet full of fmall leaues, in thape like the common Glaux, but a great deale fmaller, refembling the leaues of Tares, buerather like Birdes foote, of a veric graic colour : amongft which come foorth hnoppie and fealie or chaffie heads, verylike the Medowe Treforle, of a faire purple colour: the roote is exceeding long and woodie, which the pietare doth not expreffe and fet foorth.

The common or beft knowne Glas $x$ hath many long,tough \& flexible branches, procecding immediately from a thicke and tough roote, growing very deepe into the grounde;and leates confitting of fundry finall leaues, fet vpon both fides of a fmall rib, each leafe ftanding oppofite one againit another, euen like the leaues of $\mathrm{Li}$ quorice, but fmaller, of a grayifh greenc colour aboue, but vnderneath of a skie colour, called in Latine Glaucus color, or like the eie of a Lion or Owle, whercof it tooke his name : the flowers grow at the top of the ftalkes, in thape like Gale$g_{a}$, but of a purple colotr; which being paft, there fuccedeth a fmall bamch of ttraight cods, whofe points or ends itand vpight fulloficede, in tafte like ralle or Vetches.

$$
x \times 3
$$

*T The 
Gluux vulgar is or the common Glaux, groweth infundry places neer the fea coaftes, as at $L_{2}$ and. mer Lading,and fundry other places.

The true Glaux groweth vpon Barton hill,fower miles from Lewton in Bedfordhire, vpon both the fides of the declination of the hill.

Thefe plants do flower and flourifh about Midfomer.

\section{* The time.}

\section{* The names.}

Thefe plants haue in times paft beenecalled Glaux i. folia babens glauca, foue pallentia, that is, ha. uing skie coloured, or pale leaues.

Sithens that in times paft, fome haue counted Glaux among the kinds of Polygala, or Milkwoorts, we may therefore call the firft kinde of Glaux, blacke Milkwoort, the fecond white Milkwoort,

Thefe herbes are drie in the fecond degree.

$$
\text { * The nature. }
$$

\section{* Thevertues.}

A The feedes of the common Glaux are in vertue like the Lentils, but not fo much aftringent: they Itop the fluxe of the beily, drie vp the moifture of the ftomacke, and ingenderftore of millke.

\section{Of red Fitchling, Medick Fitch, and Cockes bead. Chap.505.}

I Onobrychis, fue Caput Gallinacesm. Medick Fitchling,or Cockes head.

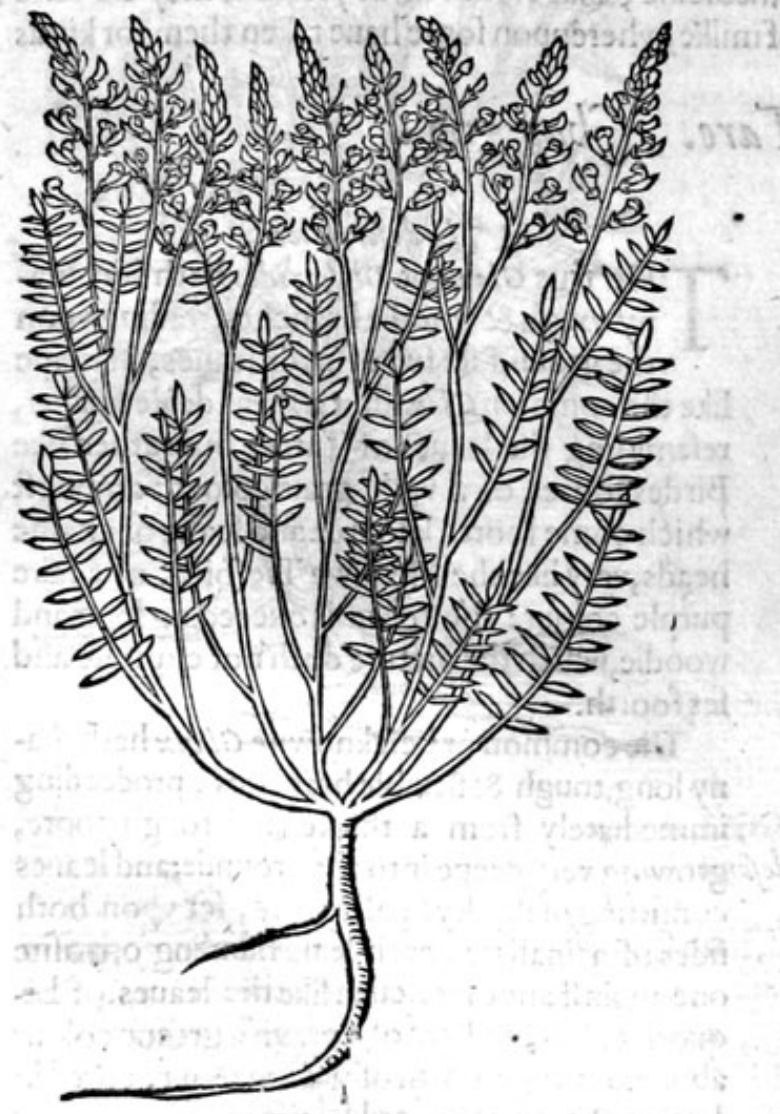

2 Onobrychis flore pur pureo.

Purple Cockes head.

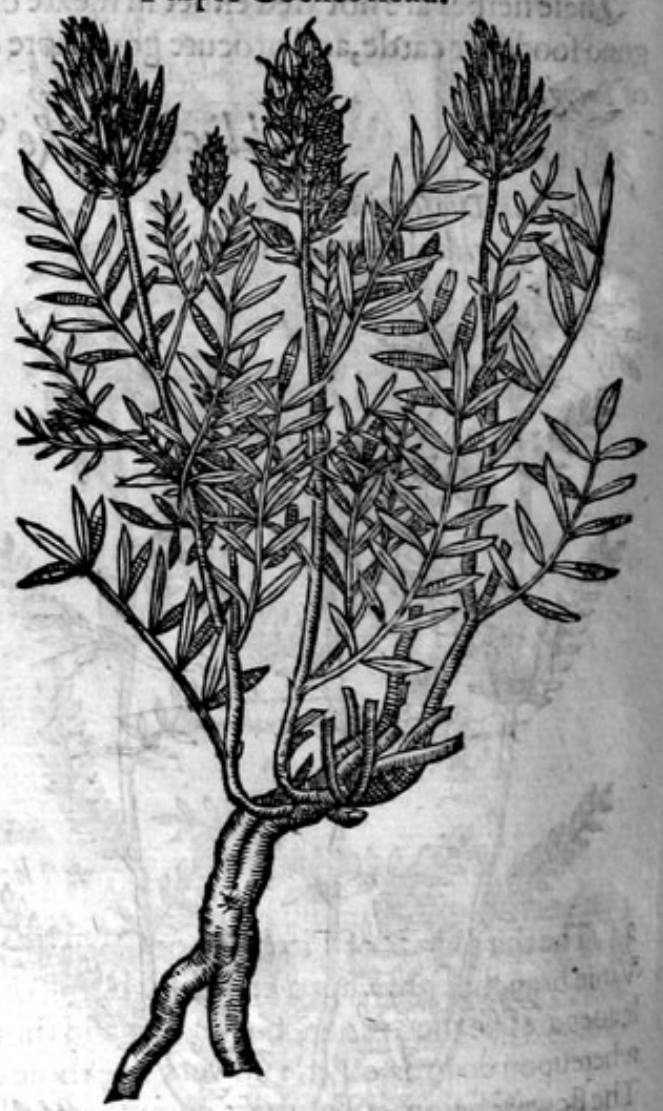

* The defcription.

I 7 He firft kinde of Onobrychis hath many fmall and vinie pliantbranches, ramping and cree-

ping through and about bufhes, or whatfoeuer it groweth neere vnto: the leaues and al the reft of the pulie or plant, is very like vnto the wilde Vetch or Tare: the flowers grow at the top of fmall naked ftatkes, in fhape like the Peafe bloome, but of a purple colour laide ouer with blue, which turne into fmall round pricklie huskes, that arenothing elfe but the feede. 
2 The fecond kinde of Fitchling or Cocks head, of Clufus his defcription, hath very many ftalks, efpecially when it is growen to an old plant, round, hard, and leaning to the ground like the other Pulfes; and leaues very like Galeg a, or the wilde Vetch, of a bitter tafte and lothfome fauour:among which come foorth fmall and round ftems, at the endes whereof do growe flowers fpike fafhion, three inches long, in thape like thofe of the great Lagopus, or Medow Trefoile, but longer, of an excellent hining purple colour, but without fmell; after which there follow fmall cods, containing little hard and blackefeede, in tafte like the Vetch. The roote is great and long, hard and of 2 woodie fubftance, fpreading it felfe far abroad, and growing very deepe into the ground.

3 Onobrychis 2.Clus ÿ. Blew Medicke Fitch.

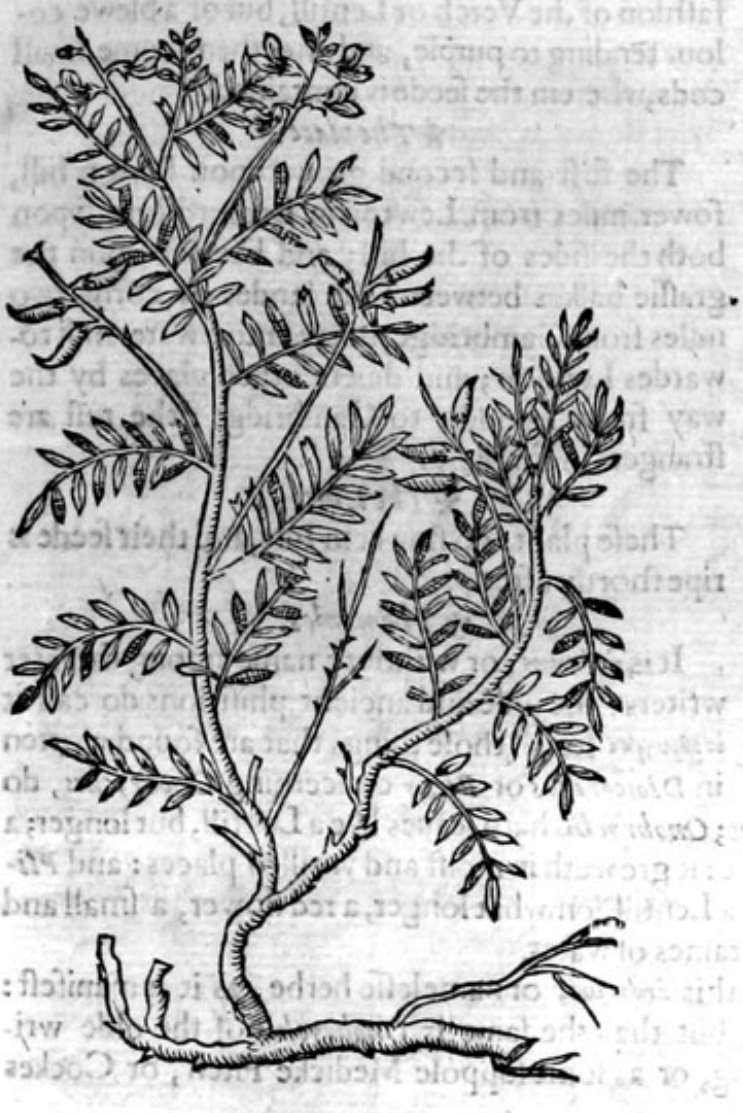

4 Onobrychis 3.Clusï flore pallido. Pale coloured Medicke Fitch.

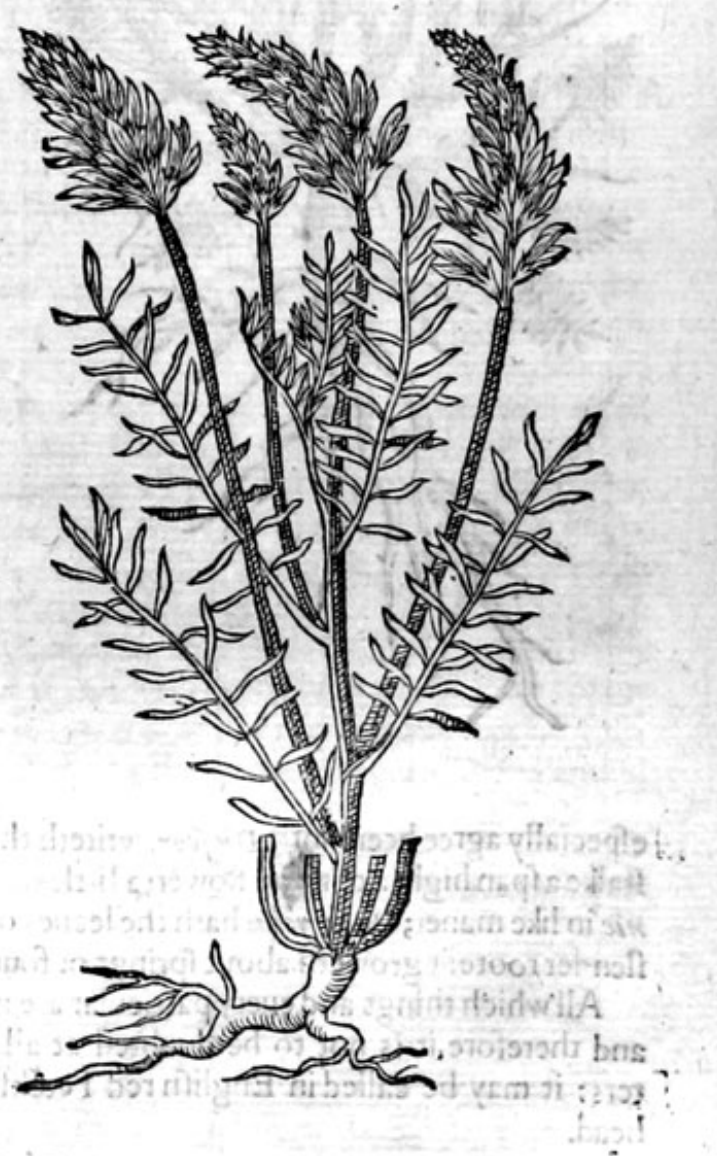

* The defcription.

3 The third kinde of Fitchling or Cocks head, hath from a tough, fmall and woodie roote, many Vinie branches growing a cubire high, full of knots, ramping and creeping on the ground. The leaues are like the former, but fmaller and fhorter: among which come foorth fmall tender ftems, whereipondogrowe little flowers like thofe of the Tare; but of a blew colour tending to purple. The flowers being vaded, there come the fimall cods, which containe little blacke feed like a kidney,
of a blacke colour. 4 The fourthkinde of Fitchling hath firme greene hard ftalkes a cubite and a halfe highi, where- \& upan groweteaties like to the wilde $T$ are or $G$ alega, but $f m a l l e r$ and fomewhat hairie, bitter and vn: pleafant in tafte, and in the end fomesvhat tharpe. At the top of the ftalkes come foorth long fpiked flowers, of a pale colour, and in hape like thofe of the fecond kinde; which being vaded, there follow finall bottle cods, wherein is contained little black feede like the feede of Fenegrecke, but fmaller. The roote is thicke and hard, and of 2 woodie fubitance, and lafting very long. 
5 Onobryclis montana 4. Clusij. Mountainc Medick Fetch.

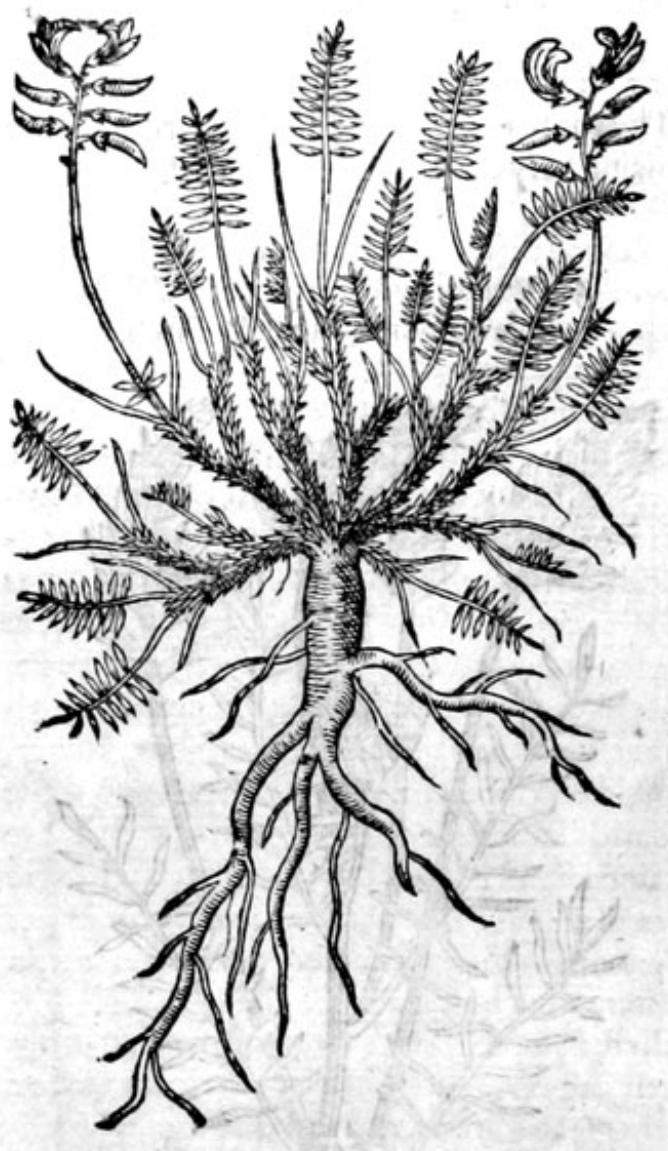

\section{*-The decription.}

5 The fift kinde of Onobrychis hath many groffe and woodie Italkes; proceeding immediately from a thicke, fat, and fle(hie toughroote; the vpper part of which are fmall, rounde, and pliant, garni. thed with little leaues like thofe of Lentils, or 12 . ther Tragacantha, fomwhat foft, and couered ouer with a woolly hairines: among which come forth little long and naked ftems, eight or nine inches long, whereon do growe many inall flowers of the fafhion of the Vetch or Lentill, but of a blewe co. lour tending to purple, and after them come finall cods, wherein the feede is contained.

$$
\text { * Theplase. }
$$

The firft and fecond growe vpon Barton hill, fower miles from Lewton in Bedfordhire, xpon both the fides of the hill; and likewife vpon the graffie balkes betweene the landes of corne two miles from Cambridge, neere vnto a water mill to. wardes London; and diuers other places by the way from London to Cambridge : the reft are ftrangers in England.

$$
\text { * The time. }
$$

Thefe plants do flower in Iuly, and their feede is ripe fhortly after.

$$
\text { * The names. }
$$

It is érínuss, or without a name among the later writers: the olde and ancient phifitions do call it ivo:puy's: for all thofe things that are found written in Dio/corides or Pliny concerning Onobrychw, do efpecially agree heereunto. Diofcor. writeth thus; Onobrycbis hath leatues like a Lentill, but longer; a ftalke a pan high; a crinffon flower; a little roote : it groweth in moift and vntilled places: and pl;: nie in like maner; Onobrychis hath the leaues of a Lentill,fomwhat longer, a red flower, a fmall and flen fer roote:it groweth about prings or fountaines of water.

All which things and euery particular are in this evernues, or nameleffe herbe, as it is manifeft: and therefore it is not to be doubted at all, but that the fame is Onobrychis of the olde writers: it may be called in Englifh red Fetchling, or as fome fuppole Medicke Fitch, or Cockes head.

\section{* The temperatare.}

Thefe herbes as Galen hath written in his bookes of the faculties of fimple medicines, doerarifie or make thinne and wafte away.

$$
\text { * T he vertues. }
$$

A Therefore the leaties thereof when it is greene, being bue as yet laide vpon hard fwellings, waxen carnels in maner of a falue, doe wafte and confume them away, but being dried and drinke in wine they cure the ftrangurie; and laide on with oile it procureth fweate.

B Which things alfo concerning Onobryches Diofcorides hath in thefe words fet downe : the herbe ftamped and applied watteth away hard fwellings of the kernets; but being drunke with wine it helpeth the ftranguriejand rubbed on with oile it caufeth fweatings, bon ? 


\section{HISTORIE OF PLANTS.}

\section{Of bajtard Dittanie. Chap.506.}

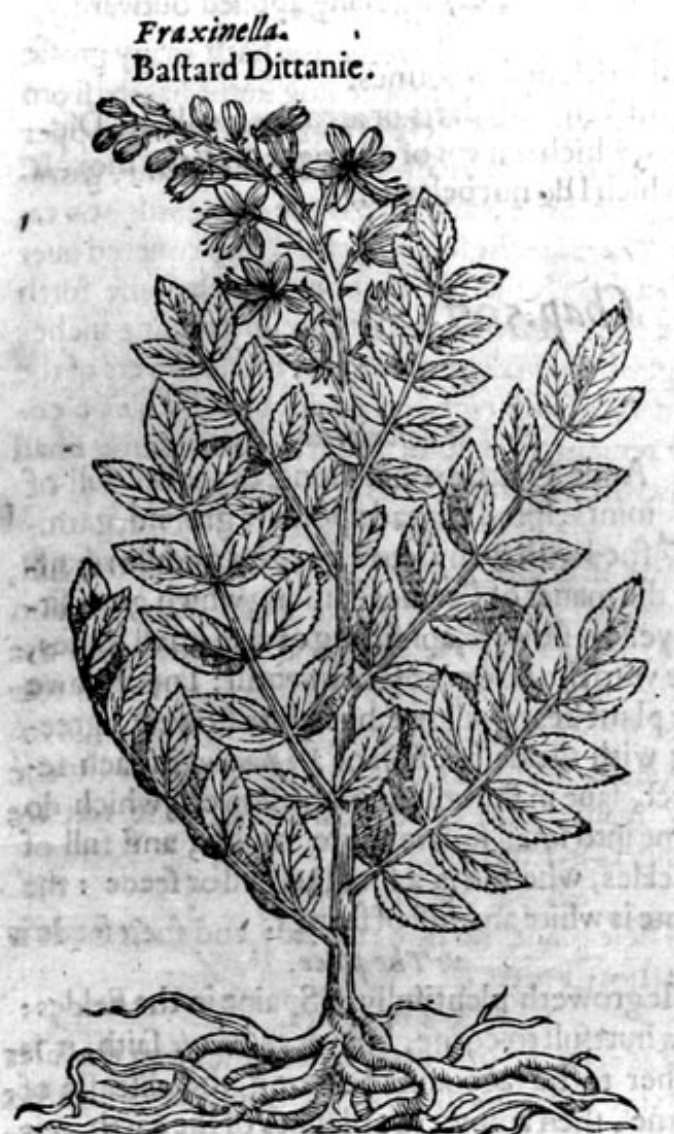

* q bedeftription.
B Aftard Dittanic is a verie rare and galant
plant, hauingrnany browneftalks, fomwhat rough, diuided into fundrie fmall branches; garnifhed with leaues like Liquorice, or rather like the leaues of the Afh Tree, but blacker, thicker,\& more full of iuice, of an vnpleafant fauour: among which growe flowers, confilting of fiuc whitith leaues ftripped with red, whercof one which groweth vndermoft, hangeth downe lowe; but the fower which growe vppermeft, growe moreftiffe and vpright : out of the midit of this flower commeth foorth a Taffe!l, which is like a beard, banging alfo downwards, and fomewhat turning vp at the lower end : which being vaded, there come in place fower huskes ioined togither, much like the huskes or cods of Columbines, fornewhat rough without, flimie to handle, \& of a lothfome fauour, almoft like the fmell of a goate; whereupon fome Herbarifts haue called it Tragium: in the cods are contained fmall blacke fhining feedes like Peonie feedes in colour : the rootes are white, 2 finger thicke, one twifting or knotting within another, in tafte fomewhat bitter.

There is another kinde hecreof growing in my garden, not very much differing; the leaues of the one are greater, greener, harder, and tharper pointed; of the other blacker, not fo hard, nor fo fharpépointed : the flowers alfo hecreof be fonething more bright coloured, and of the other a little redder.

* The place.

Baftard Dittany groweth wilde in the mountaines of Italy, and Germanie, and I haue it growing in my garden.

\section{* The time.}

It flowreth in Iune and Iuly: and the feede is ripe in the end of Augurt. \&. The names.

The later Herbarits name it Fraxizella, moft yuatut isor, as though they fhould fay Humilis Fraxi: nus,or a lowe afhe:in Englifh baftard or falfe Dittanie: the fhops call it Dictamnum, and Diptamum, but not truely, and vfe oftentimes the rootes hecreof in fteede of the right Dittanie. That it is not the right Dittanie it is better knowne then needfull at all to be confuted, and it is as euident that the fame is not Diofcorides his P feudodictamnum, or baftard Dittany : bu $t$ it is plaine to be a kince of Tragium of the old writers, wherewith it feemeth to agrec in thewe, but not in fubftance.

\section{* The temperature.}

The roote of baftard Dittanie is hot and drie in the fecond degree, it is of a wafting, attenuating, and opening facultie.

\section{$*$ The vertues.}

It bringeth downe the menfes, it alfo bringeth away the birth and afterbirth; it helpeth colde $\mathrm{A}$ difeafes of the matrix : and it is reported to be good for thofe that haue ill ftomackes and are fhore winded.

They fay alfo, that it is profitable againft the ftingings and bitings of venemots ferpents; B againft deadly poifons, againft contagious and peftilent difeafes, and that it is with good fuccefie mixed with counterpoifons.

$$
\mathrm{X} \times \mathrm{x}
$$




\section{ऽ.66 THE SECOND BOOKE OF THE}

The feede of Baftarde Dittanic taken in the quantitic of a dram is good againft the ftrangurie,
prouoketh vrine, brealeth the ftone in the bladder,and driueth it foorth.

The like vertue hath the leaues and iuice taken after the fame fort, and being applied outwardly,

The roote tahen with a little Rubarbe,killeth and driueth foorth woormes.

Diofcortdes reporteth, that the wilde Goates being ftriken with darts or arrowes, will eate Dic. $\mathrm{tam}$, and thereby caufe them to fall out of their bodies, which is ment of the right Dictam, though
Dodon eus reporteth that this plant will do the like, (which I do not beleeue.)

\section{Of land Caltrops. Chap.507.}

Tribulses terreftris.

Land Caltrops.

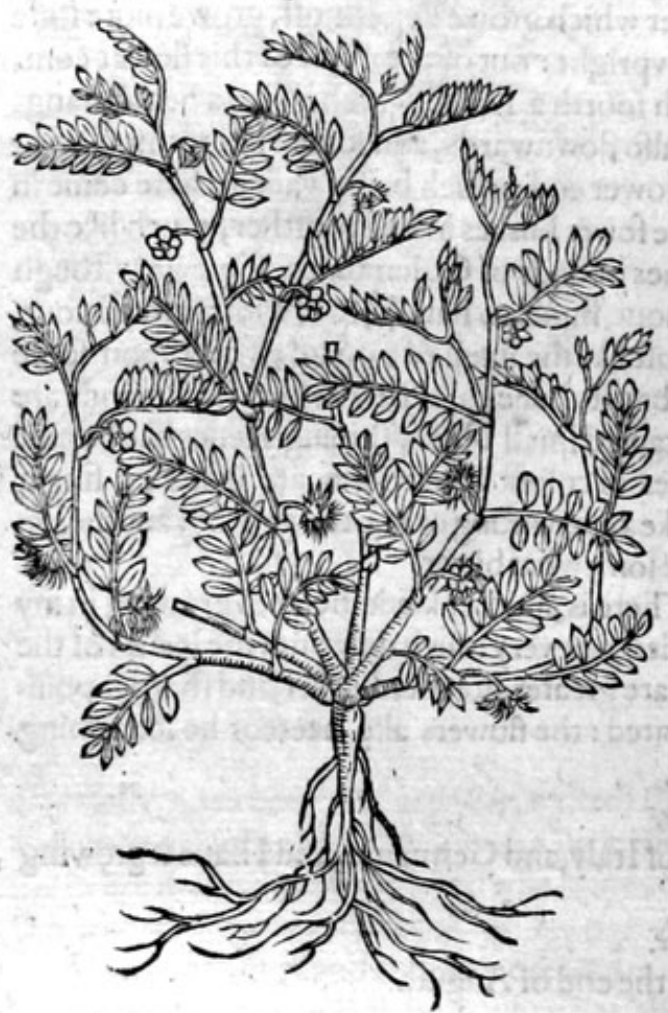

*The defcription.

Ande Caltrops hath long branches full of ioints, fpred abroad vpon the ground, garnifhed with many leties fet vpō a middle rib,after the maner of Fetches : among which grow little yellow flowers, confifting of fiue fmall leaues, like vnto the flowers of Tormentill: Ineuer fawe the plant beare yellowe, but white flowers, agreeing with the defcription of Dodonesw in each re. Ipeet, faue in the colour of the flowers, which do turne into fmall fquare fruite, rough, and full of prickles, wherein is 2 fmall kernell or feede : the roote is white and full of ftrings. * The place.

It groweth plentifully in Spaine in the fieldes: it is hurtfull to corne, but yet as Plinie faith, it is rather to be accounted among the difeafes of corne, then among the plagues of the earth : itis alfo found in moft places of Italy and Fraunce; I founde it growing in a moift medow adioining to the woode or Parke of Sir Fraunces Carewe, neere Croidon, notfarre from London, and not elfe where: from whence I brought plants for my garden. * The time.

It flowreth in Iune and Iuly: the fruite is ripe in Auguit.

$$
\text { * The names. }
$$

It is called in Greeke relooxos: and in Latine Tri. bulus, and that it may differ from the other, which groweth in the water, it is named reibonos $\chi$ epsaxios, or Tribu/us terreffris: it may be called in Englifh Land Caltrops, of the likenes which the fruite hath with Caltrops, that are inftruments of warre caft in the way to annoie the feete of the enimies horfes, as is before remembred in the water $S a$ ligot. * The temperature and vertues.

A In this Lande Caltrops there is an earthy and colde qualitic abounding, which is alfo binding, as Galen writeth.

B The fruite thereof being drunke by reafon it is of thione parts, wafteth away ftones in the kidneies.

C Land Caltrops faith Diofcorides being drunke to the quantitie of a French crowne waight, and alfo applied, cureth the bitings of the viper.

D And if it be drunke with wine, it is a remedie againft poifons: the decoction thereof fprinkled about killcth flcas. 


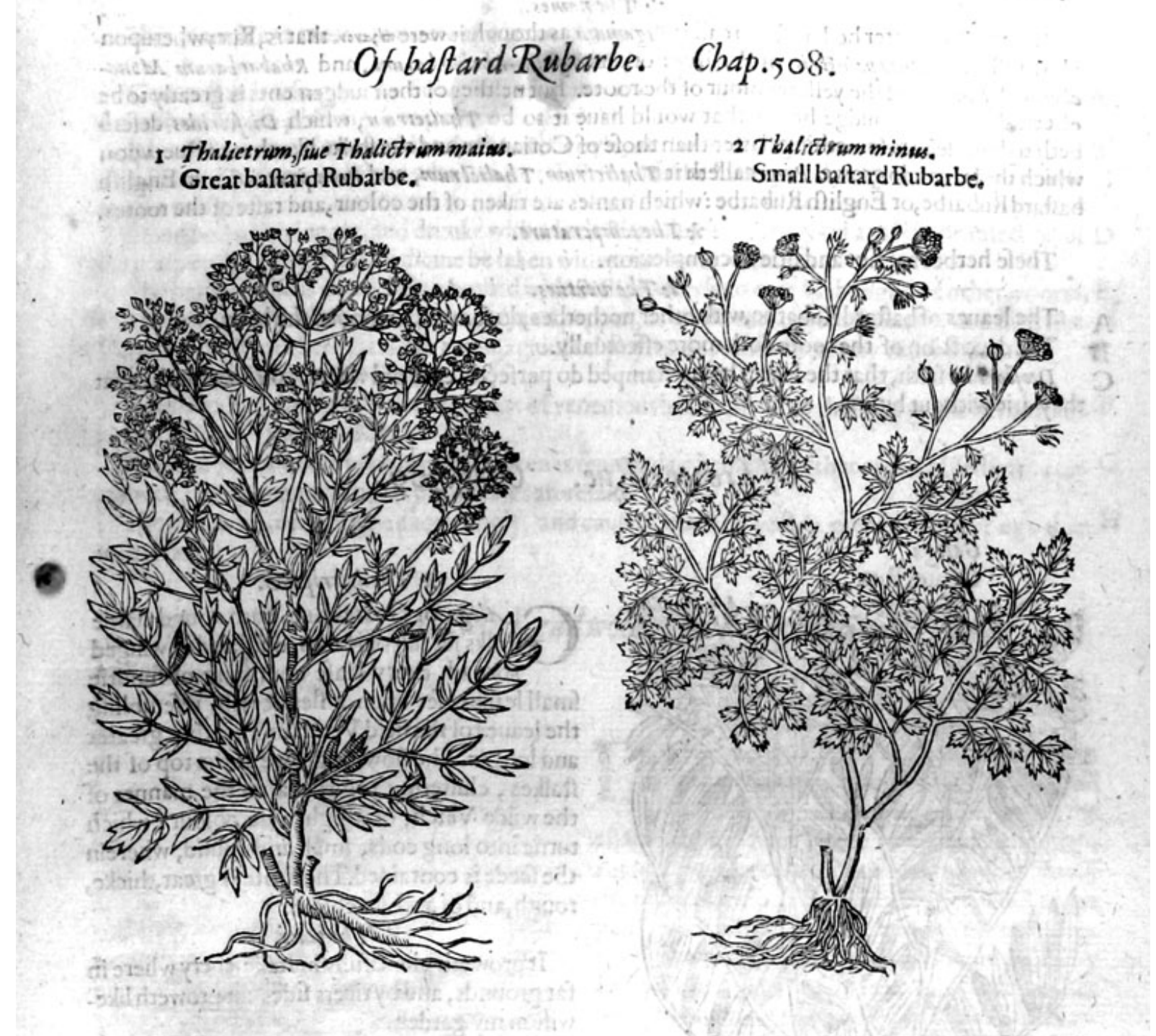

* The defcription.

I Te great Thalietrum or baftarde Rubarbe, hath large leaues, parted or diuided into diuers other fmall leaues, fomwhat fnipt about the edges, of a blacke or darke greene colour: the ftalkes are creited or ftraked, of a purple colour, growing to the height of two cubits: at the top where of grow many fmall and hairie white flowers, and after them come fmall narrowe husks, like little cods, fower or fiue growing togither : the roote is yellow, long, rounde, and knottie, difper, fing it felfe farre abroad, on the vpper face of the earth.

2 The fmal!baftard Rubarbe is verie like vnto the precedent, but that it is altogither leffer: his ftalkes are a fpanne or a footelong; his leaues be thinne and tender; the roote fine and fender: the little flowers grow togither in fmall bundles, or tufts, of a light yellow colour, almoft white, and are of a grecusus fauour.

$\approx$ The place.

Thefe plants do growe alongtt the ditch fides leading from Kentin ftrecte vnto Saint Thomas Watrings, the place of execution, on the right hande; they growe vpon the Thames bankes, leading from Blacke Wall to Woolwich, neere London, and in fundry other places alfo.

The flower for themoft part in Iuly and Auguft. 
$*$ The names.

Ditucrs of the later herbarifts do call it $P$ igamum, as though it were mavor, that is, Rue; wheripon alfo moft call it Rutapalustris, or Fen Rue: others F feudo-Rbabarbarum, and Rhaburbarum Mona. cborum, by :cafon of the yellow colour of the roote. But neither of their iudgen.ents is greatly tobe efteemed of: they indge better that would haue it to be Thalietrans, which Dioforides defcri beth to hate leaues fomething flatter than thofe of Coriander, and the ftalke like chat of Rue, vpon which the leaues do growe. Pena calleth it Thalietrum, Thalictrum, and Ruta pratenjis : in Englifh baftard Rubarbe, or Englifh Rubarbe : which names are taken of the colour, and tafte of the rootes,

Thefe herbes are hot and dric of compl * The temperature.
Thion.

* The vertues.

A The leaues of baftard Rubarbe, with other potherbes, do fomewhat mooue the helly.

B The decoction of the roote doth more effectually.

C Diofcorides faith, that the leaues being ftamped do perfectly cure old vicers. Galen addeth, that they drie without biting.

\section{OfGoates Rue. Chap.509.}

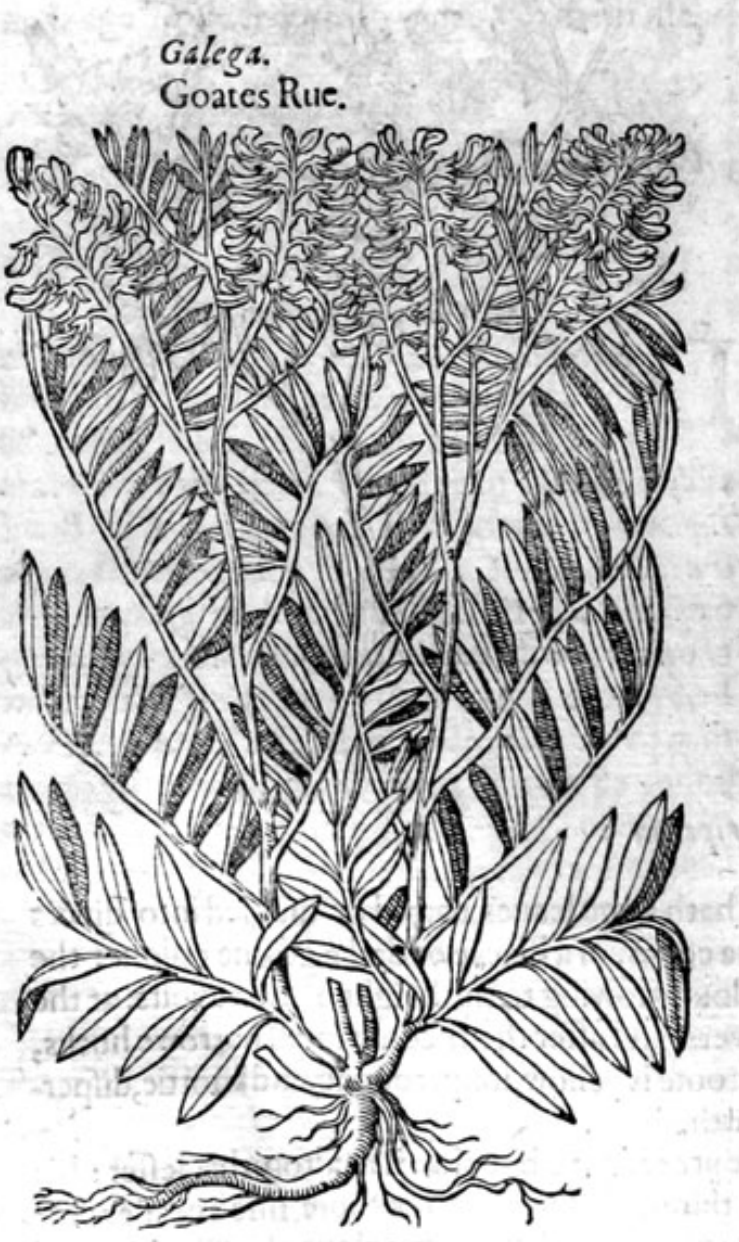

Some iudge, that the olde Phifitions were woont to cal it Onobrycbis, others Glauce, diuers would hatie it to be Polemonium, but not fo much Petr. And. Mathiolses in his commentaries, as euery one of the defcriptions mentioned by Diofecrides do gainfay them; as alfo thofe, who thinke that Galega,ic Polygalon, and that the name of Galega came of Polygalon, the very defcriptionalfo of Polygalon is againf them: for Galega is higher and gteater, than that it may be called a little fhrub, oncly of an hand breadth high. 
This plant is in a meane temperature betweene hot and cold.

* T he vertues.

Goates Rue is a fingular berbe againft all venome and poyfon, and againft wormes, tokill and A driue them foorth, if the iuice be giuen to little children to drinke.

It is of like vertue if it be fried with Linefeede oyle, and bound vpon the childes nauell.

It is miniftred vnto children which are poffeffed with the falling euill, a fpoonefull euery nor- C ning in milke.

Being boiled in vineger, and drunke with a little Treacle, it is very good againft the infection of $D$ the plague, efpecially if the medicine be taken within twelue howers.

The herbe it felfe is eaten, being boyled with flefh, as we vfe to eate Cabbage and other woorts, E and likewife in fallads, with oyle, vineger, and pepper, as we do eate boyled Spinage, and fuch like. $A$ Which is moft excellent, being fo eaten, againft al poyfon \& peftilence, or any venemous infirmitie whatfoeuer, and procureth fweate.

It alfo healech the bitings and ftingings of venemous beafts, if either the iuice or the herbe ftam- F ped be laid vpon the wounds.

Halfe an ounce of the iuice inwardly taken is reported to helpe thofe that are troubled with con- $\mathbf{G}$ uulfions, crampes, and all other the difeafes aforefaid.

The feedes do feede pullen exceedingly, and caufeth them to yeelde greater ftore of egs than $\mathbf{H}$ ordinaric.

\section{Of Plinie bis Leadwoort. Chap.510.}

\section{Plumbago Pling.}

Leadwoort.

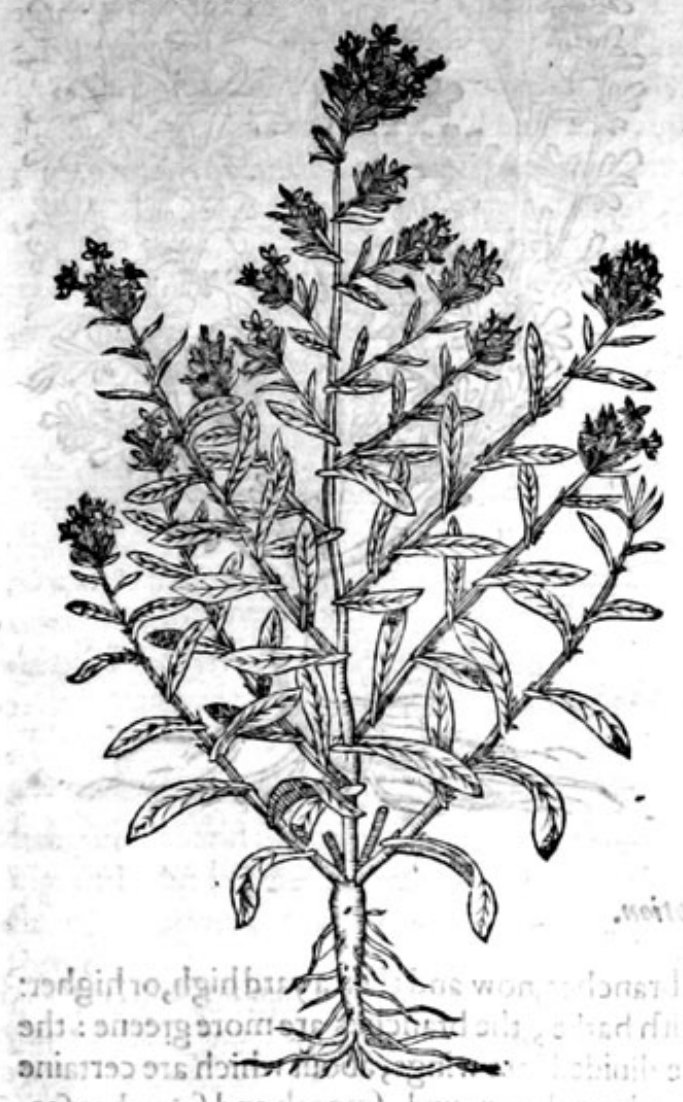

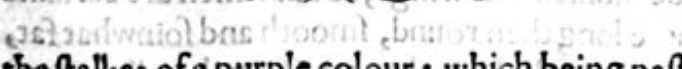

* The defcription.

$\mathrm{D}$ Entaria or Dentillaria, hath offended in che fuperlatiue degree, in that he hath hid himfelfe like a runnagate foldier, when the affault fhould haue beene giuen vnts the plant Lepidiwon, whereof doubeleffe it is a kinde. But if the faylt be mine, as without queftion it is, I crane pardon for the ouerfight, and do intreate thee gentle reader to cenfure me with fauour, whereby I may more boldly infert it in this place, rather than toleaue it vitouched. The learned of Narbone, efpeciaily Rondeletius, haue not without good caufe accounted this goodly plant for a kinde thereof, bicaufe the whole plant is of a biting tafte, and a burning facultie, and that in fuch extremitie, that it will raife blifters vpon a mans hand: for which caufe fome of the learned fore haue accounted it Plimies Molyblent, or AEgineta his Lepiduom; but the new herbarifts call ic Dentara, or Dentillaria Rondel tï, whomadethe like vfe hereof, as he did of Pyretbrum, and fuch burning plants, to appeafe the immoderate paine of the too hach and fuch like. This plant hath great thicke tough rootes, of a woodie fubftance, from whence foring $\mathrm{vp}$ long and tough ftalkes two cubites high, confufedly garinilhed and befec with tong leaues, in colour dike Woad, of a fharp and biting tafte. The flowers growe ac the top of we talkes of a purp.e colour; which being palt, there fueceede clofe, gliftering and hairie huskes, wherein is contained fmall blackifh leede.
* The 
* The place.

Pena reportcth that Dentillaria groweth about Rome, nigh the hedges and corne fieldes : it like. wife groweth in my garden in great plenty.

It flowreth in Iuly and Augurt.

$$
\text { * The time. }
$$

\& 7 he names.

Leadwoort is called Molybdena, Plumbago Plin̈̈, \& Dentillaria Rondc let ij: in Italian Crepanella, the Romaines Herba S. Antoni : in Illyria Cucurida: in Englifh Leadwoort.

Dentillaris is of a caufticke qualitic. * The temperature.

* T The vertues.

A It helpeth the toothach,efpecially if it be holden in the hand fome fmall while.

\section{Of Rue, or berbe Grace. Chap.sit.}

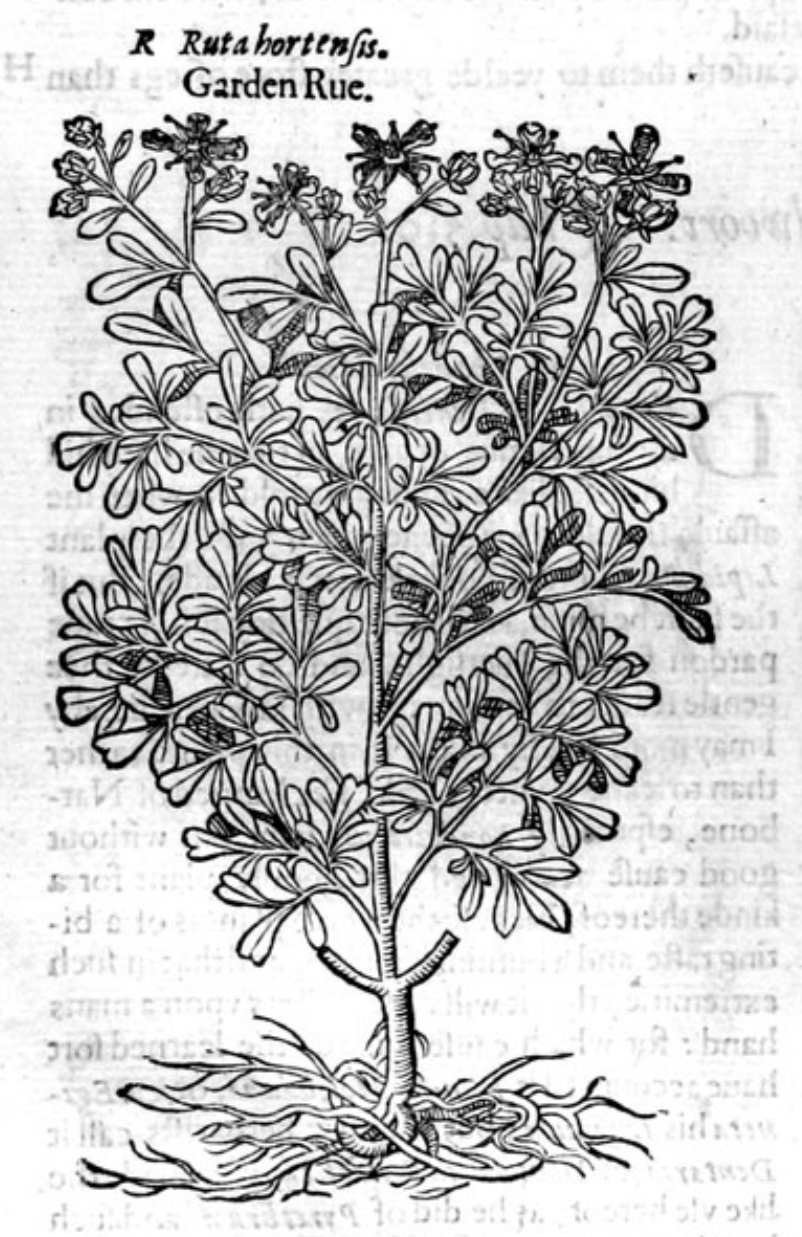

2 Ruta/ylueftris graweolezs. Stinking wilde Rue.

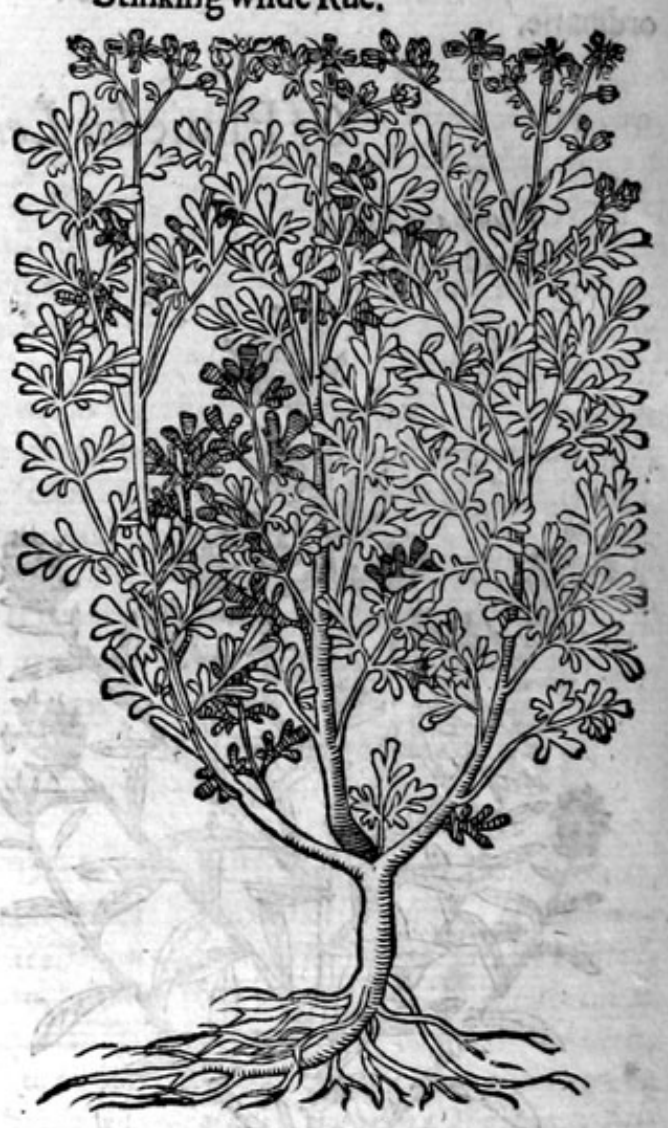

* The defoription.

1 Arden Ruc or planted Rue, is a fhrub full of branches, now and then a yard high,or higher: the ftalkes whereof are couered with a whitih barke, the branches are more greene: the leaues heereof confift of diuers parts, and be diuided into wings, about which are certaine little ones, of an odde number, fomething broad, more long then round, fmooth and fomwhat fat, of a graie colour,or greenifh blue:the flowers in the tops of the branches are of a pale yellow, confifting of fower little leaues, fomething hollow : in the middle of which ftandech vip a little head or
button 
GII HIST ORIE: OF P.LA N TS.

button fower fquared, feldome fiuc fquared, containing as many little coffers, as it hath corners, being compaffed about with diuers little yellow threds: out of which hang pretie fine tips of one colour; the feede groweth in the little coffers : the roote is woodic, and faftned with many ftrings:
this Rue hath a very ftrong and ranke fmell,and a biting tafte.

2 The fecond being the wildor mountain Rue, called Ruta fylueftris, is veric like to garden Rue, in Atalkes, leaues; towers, feede;colour, taitte, and fauour, fauing that eucry little leate hath fmaller cuts, and is much narrower athe whole plant dieth at the approch of winter, being an annuall plant, and muft either ftande till it do fowe himfelfe, or elfe muft be fowen of others.

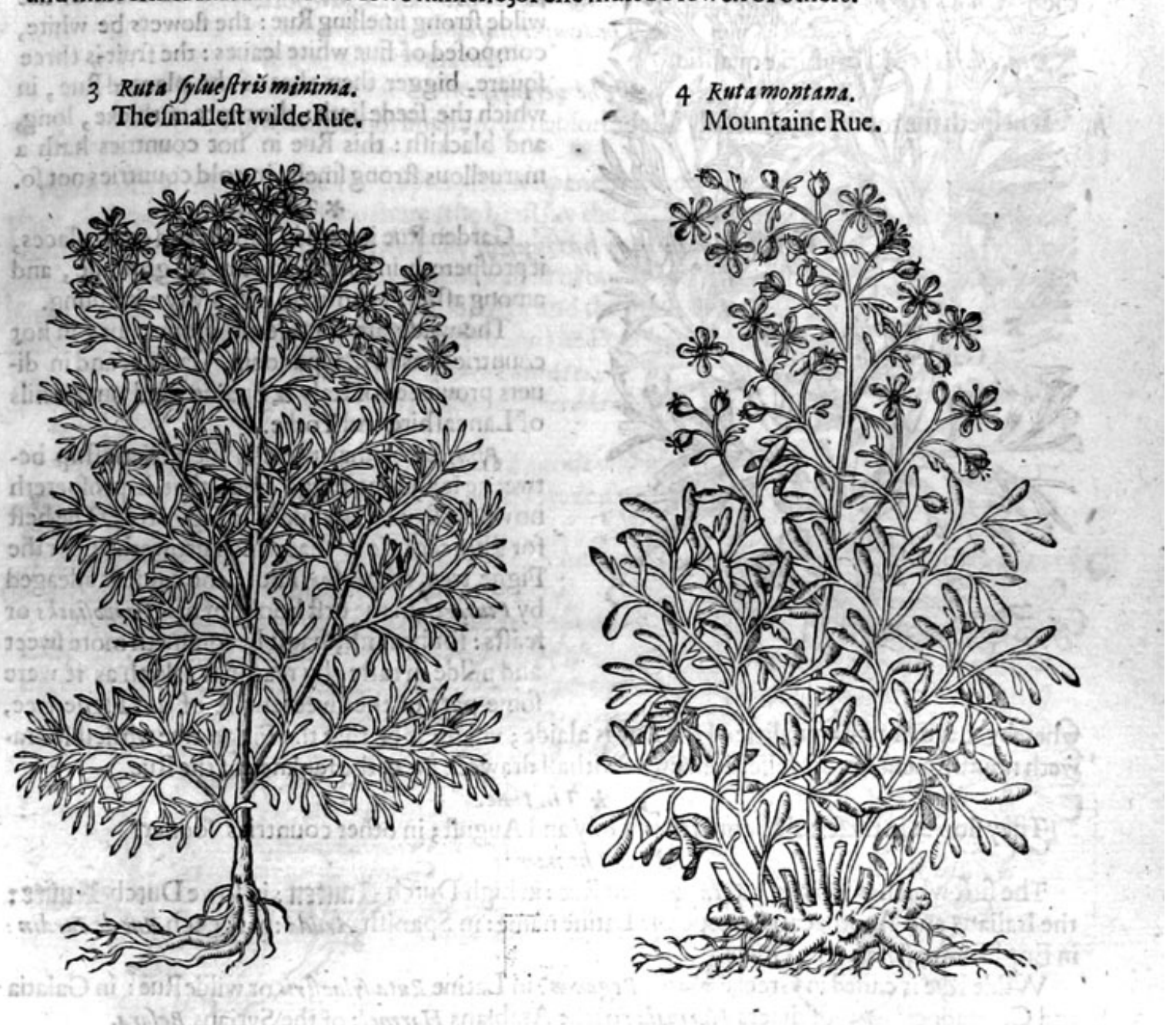

* The defcription.

3 This plant is likewife a wilde kinde of Rue, and of all the reft the fmalleft, and yet more virulent, biting, and ftinking then anie of the reft : the whole plant is of a whitifh pale greene, agreeing with the latt before mentioned in each refpect, faue in greatnes, and in that the venemous fumes or vapours that come from this fmall wilde Rue, are more noifome and hurtfull then the former.

4 There is another wilde Rue growing vpon the mountaines of Sauoie and other places adioining, hauing a great thicke roote : from which do arife many fhootes or ftalkes, whereon do growe leaues very thicke and fat, parted into diuers fections, refembling the leaues of Stone crop, of a ftrong and ftinking fmell : the flowers grow on the tops of the ftalkes, confilting of fower finall yellowe leaues : the feedes are like the other. 


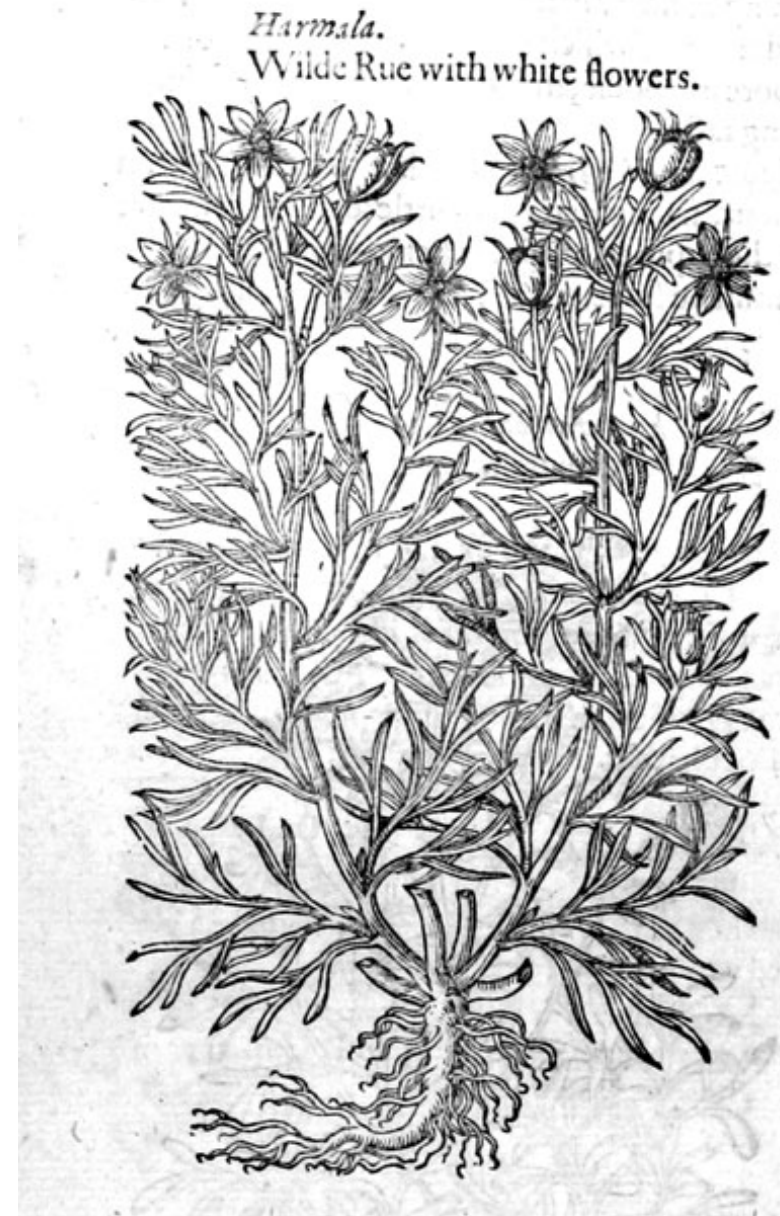

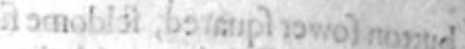 \\ * Thedefription.
}

5 Harmell is one of the wilde Rites; it bring eth foorth immediately from the roote ditiers little ftalkes of a cubite high : whereupon doe growe greene leaues diue-flie cutte into long peeces, longer and narrower then thofe of the wilde ftrong fmelling Rue: the flowers be white, compofed of fiue white leaues : the fruit is three fquare, bigger then that of the planted Rue, in which the feedelieth: the roote is thicke, long, and blackifh: this Rue in hot countries hath 2 maruellous ftrong fmell, in cold countries not fo. * Tbeplace.

Garden Rue ioyeth in funnie and open places, it profperech in rough and brickie grounde, and among afhes, it can in no wife away with dung.

The wilde are founde on mountaines in hot countries, as in Cappadocia, Galatia, and in diuers prouinces of Iraly \& Spaine; and on the hils of Lancafhire and Yorke.

Pling faith, that there is fuch friendhip betweene it and the Figge tree, that it profpereth nowhere fo well as vnder the Figge tree. The beft for Phifickes vfe is that which groweth vnder the Figge tree, as Diofer. faith; the caufe is alleaged by Plutarch, in the firft booke of his $S$ mpofiacks or feafts: for he faith, that it becommeth more fweet and milde in tafte, by reafon it taketh as it were fome part of the fweeteneffe of the Figge tree, whereby the ouer ranke qualitie of the Rue is alaide; vnleffe it be that the Figge tree whilelt it draweth nourifhment vnto it felfe, it likewife withall draweth away the ranknes of the Rue. * The time.

They flower in thefe colde countries in Iuly and Auguft; in other countries fooner. * T The names.

The firft which is Hortenfis Ruta, garden Rue : in high Dutch Rauten : in lowe Dutch Rutite: the Italians and Apothecaries keepe the Latine name: in Spanih Aruda : in French Rue de Iardin: in Englifh Rue, and herbe Grace.

Wilde Rue is cailed in Grecke mhavov, Peganon : in Latine Ruta fylueftris, or wildeRué : in Galatia and Cappadocia uănu : of diuers Harmala : of the Arabians Harmel: of the Syrians Befara. * The temperature.

Rue is hot and drie in the later end of the thirde degree : and wilde Rue in the fourth : it is of thinne and fubtill parts, it wafteth and confumeth winde, it cutteth and digefteth groffe and tough humours. $* T$ be vertues.

A Rue or herbe Grace, prouoketh vrine, bringeth downe the ficknes, expelleth the dead childe and afterbirth, being inwardly taken, or the decoction drunke, and is good for the mother, being but onely fmelled vinto; whereunto Macer addeth in thefe verfes,

Tußsm fibibitur compefcit, menftrua purgat;

Si coquis banc in aqua, cui vinum itunxeris acre

Compefcit talis decoctiotormina ventris.

pulmones inust of pectus,nor bog go medetur

Coftarum quem pleurifm vocat atsica lingua.

Arthreticos, Scyafomgue iunat, febribusque medetar

Hanftado. 


\section{马H HISTORIEOF PLANTS.}

It ftaies the cough if it be drunke,

It clenfeth monthly flowres;

If you it feethe in water, and

Thereto put * wine that fcoures;

Such broth doth ftaic the belly gripes.

It helpeth breft and loong;

It cures the ficknes of the fides,

Cald * Plewrfie in Greeke toong.

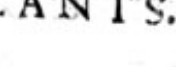

If it be drunke sand other things $\boldsymbol{j}_{\boldsymbol{j}}$. As writers do affure.

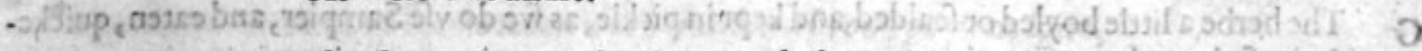

Plinie faith in his 20 . booke 13 .chapter, that it openeth the matrix, and bringeth it into her right $\mathrm{B}$ place, if the belly all ouer, and the fhare (the breft ay the old falfe copies) be annointed therewith: being tempered with honie, it is a remedie againft the inflammation and fwelling of the ftones, proceeding of long abftinence from venerie, called of our Englifh Mountibankes, the Coltes euill, if it be boiled with Barrows greace, Baie leaues, and the powders of Fenugreeke and Linfeede be added therto, and applied pultis wife, whereupon the Poet hath thus written:

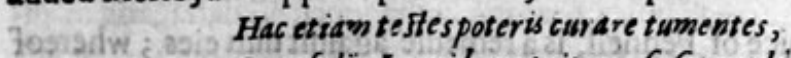
Cum folys Lauri bene tritam, fi fuperadins.

With this likewile you may reftore the cods when as they fwell, If thereunto you pur Baie leaues, all brufed very well,

It taketh away the cruditie or rawnes of the humours, and likewife windines, and oldepaines of $\mathbf{C}$ the ftomacke; whereupon Macer hath thus written:

Piganon in Greculingua quod Ruta vocatur,

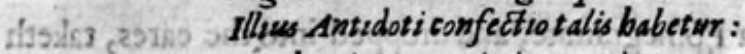

Pondere iunge pari initrum, piper, atque Cyminum

De tribus his, quantwon de ruta, pontto tantum:

Sedprius ex acrivino macerare Cyminum

Conuenit, in * ferropoft affaricalefacto:

Omnia deinde fimul bene trita ex melle ingabis,

.

Hoc ex* antidocurantur fape comefto.

- Extennat bilem, mollit fine tormine ventrem.

tosigoting e Confortat ftomachiom, facit vt bene digerat efcam.

Rue, which in Greeke is called Piganon,

The making of his antidote heere warne each one:

OfNitre, Pepper, and Cumine, like waight of all take you,

Put to as much of thefe famethree in quantitic as Ruc;

But firft i'ts meete youlay to foke in vineger your Cumen,

And after to be baked, put it in a heated ouen;

Then all togither brufed well, with honie you fhall ioine:

The paines and forenes of the breft, the liuer, fides, and loine,

And kidneies helped are, by this good medcine eaten oft:

It makes thin choler, bellie free from gripes, it maketh foft:

Vnto the ftomacke comfort great,

Caufing it well to brooke it meate.

Rue boiled with vineger,remooueth gripings, it is good againft the ftitch of the fide and cheft, D and fhortnes of breath vpon a colde caufe, and alfo againft the paine in the ioints and huckle bones. 


\section{THE SECOND BOOKE OETHE}

E The oyle of it ferueth for the purpofes laft recited: it taketh away the colicke and pangs in the guts, not onely in a clifter, but alfo annointed vpon the places affeeted. Butif this oyle be made of the oile preffed out of Linefeede, it will be fo much the better, and of fingular force to take away
hard fwelkings of the fpleene or milt. F It is giuen with good fucceffe againft the dropfie, called in Greeke wioroxpro, being applied to the
belly in inanner of a pultis; whereof the forefaid Poet addeth:

\section{Cum Caricis decoct a diu, viniǵs liquore,}

Pro/unt Hydropicis, if fint /upe raddita nocie.

With drie figs boilde if long it be, and iuice of wine, thefe two

Do helpe the dropfie if they be laid ouernight thereto. G The herbe a little boyled or fcalded, and kept in pickle, as we do vfe Sampier, and eaten, quicke-
neth the fight: whereof is written:

\section{Cobilis eft ruta, guia lwomina reddit acuta:}

Auxilio rute, vir lippe videbis acute.

Noble is Rue, bicaufe it inakes th'eie fight both rharpe and cleere;

With helpe of Rue, O blear-eyd man, thou halt fee far and neere.

H The fame applied with honie and the iuice of Fennell, is a remedie againft dim eies; whereof Macer fpeaketh thus :

\section{Et melius Mar at bri cum fucco, folte $g_{s}, G$ alli,}

Melle ǵ, fifuccus ex equo iung it ur eius,

Indeg fint oculi patientis Jape peruncti.

And better with greene Fennell iuce, and of a cocke the gall,

And honie, if the iuice thereof al lke be pur of all,

And with it of the patients eies annointing fuffer thall.

I The iuice of Rue made hot in the rinde of a Poinegranate, and dropped into the eares, taketh away the paine thereof; whereof Macer hath thus written.

\section{In coriomaligranatifitepefactam}

Auribus infundas, depelles inde dolor em.'

In a Pomegranate peele the iuice lukewarme there to remaine,

If you powre into th'eares you fhall from thence driue quite the paine.

K Saint Anthonies fire is quenched therewith ; it killeth the fhingles,and running vlcers and fores. in the heads of yoong children, if it be tempered with Cerufe or white Lead, vineger, and oyle of Rofes made into the forme of Nut riton, or Triapharmachon, whereof the Poet fpeaketh:

\section{Cum rofeomifcens oleo, nec non b aceto}

Illius fuccum fapit is cur are dolorem

(Quamuis immodicum) poteris hoc fape perungens.

With oyle of Rofe and vineger, mingling the unice of this,

The headach(though the faine be great) you may helpe and not mis,

Annointing oftentimes the head therewith, as needfull is.

L Diofcorides faith, that Rue put vp in the noftrels ftaieth bleeding; whereof the Poet Macer:

2 aribus cxprefJus fifuccus funditur eius,

Siftit manant $m$ bene deficcand cruorem.

If that the iuice there of crufht out be powr'd into the nofe,

It ftaies the ftreaming blood full well, by drying vp that flowes.

M Of whofe opinion Plinic alfo is : when notwithftanding it is of porver rather to procure blee: ding,through the fharpe and biting qualitie that it hath. 
The leaues of Rue beaten and drunke with wine, are an Antidote or medicine againft poifons, as $\mathrm{N}$ Plinis teacheth.

Diofcorides writethy thata aweluopenie weight of the feede drunke in wine, is a counterpoyfon $\mathrm{O}$ againft deadly medicines, orthe poyfon of Wolfes bane, birdlime, Mufhronis or Toadftooles, the biting of ferpents, ftinging of fcorpions, fpiders, bees, hornets, and wafpes, and is reported, that if 2 man be annointed with the inice of Rue, thefewill not hurc him ; and that the ferpent is 2 th then 2 a way at the fmell thereof when it is burned, in fo much that when the Weefell is to figliewith the ferpent, fhe armeth hir felfe by the eating of kue, againft the might of the ferpent : whereof the ? Poet Macer:

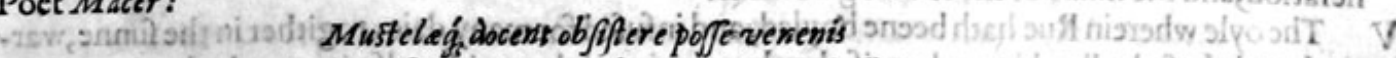

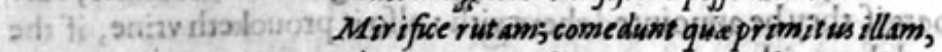
Ciom * pugnare funt cum fer pendibus at is.

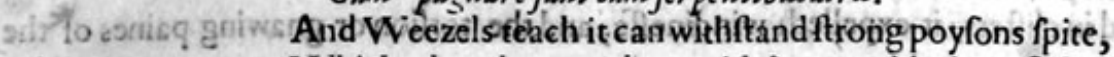

Which when they are about with ferpents blacke to fight,

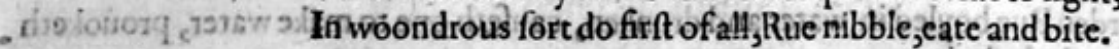

The leaues of Rue eaten with the keinels of Walnuts, or figs ftamped togither and madetitto a $p$ maffeor paafte, is good againft all cuil aires, the peftilence or plague, refifterb poifon and al verioms

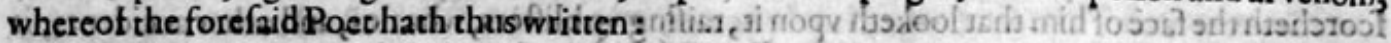

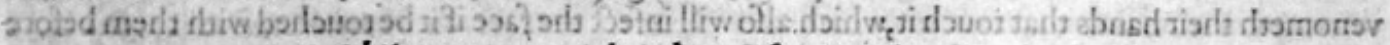

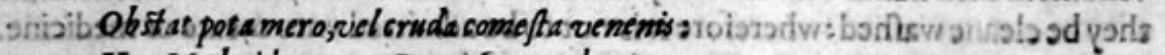
Huc Muthridates rex Fontifape probawit, Q Et magnis nucibus binis, Caricis ó, duabous Ieiynus vefciconfurgens mane folebat.

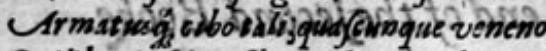
Quilibet infidras fibi tendere baud metuebas.

Rue drunke with wine, or eaten rawe, withftandeth poyfons ftrong;

This Mithridates king of Pont rride oft and prooued long:

Who vfed rifing in the morne fafting and frefh to cate,

A fcore Rue leaues and falt therewjth, in quantitie not gireat:

And armed with fuch meate as this fear'd not what frares foeuer

By poyfons any laid for him, to their vtmoft endeuor.

Likewife Salerna in the treatife De conferuanda valetudine hath thus written:

Allia, ruta pyra o raphanus cum Theriaca nax, Praftant Antidotum contra let hale venenum.

Garlicke, Rue,Peares, and Radifh alfo, with Nuts likewife and Treacle,

A fou'reigne medcine to vs do thow, againft deadly poyfon an obftacle.

Vrging the fame further faith thus: Saluia cum ruta faciunt tibi pocula tuta.

That is,

Sage and with it herbe Grace or Rue, Make drinks both $\mathrm{f}$ fe and found for you. 


\section{THE SECOND BOOKE OF THE}

Q Rue boiled with Dill, Fennell feede, and fome Sugar, in fufficient quantitie of wine, fwageth the torments and griping paines of the belly, the paines in the fides and breaft, the difficultie of brea

R The iuice taken with Dill, as aforefaid, helpeth the cold fits of agues, and altereto a dropfie. helpeth the inflammation of the fundament and paines of the gut, called Retereth their courfe: it

S The iuice of Rue drunke with wine, purgeth women fecondine, the dead childe, and the vnnaturall birth. neration, and the milke of thofe that giue fucke.

V Theoyle wherein Rue hath beene boyled, and infufed formany daies meth and chafeth all cold members if they be annointed therewith region of the bladder be annointed therewith.

$\mathrm{X}$ If it be miniftred in clifters, it expelleth windineffe, and the torfion or gnawing paines of the guts.

$\mathrm{Y}$ The leaues of garden Rue boyled in water and drunken, caufeth one to make water, prouoketh the termes, and ftoppeth the laske.

Z Ruta.fyluestris or wilde Rue, is much more vehement both in fmell andoperation, and therefore themore virulent and pernitious. For fometime it fumeth out a vapour or aire fo hurtfull, that it fcorcheth the face of him that looketh vpon it, raifing vpblifters, wheales, and other accidents, it venometh their hands that touch it, which alfo will infeet the face if it be touched with them before they be cleane wafhed : wherefore it is not to beadmitted vnto meate or medicine.

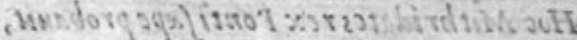

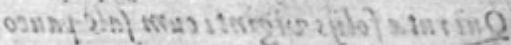

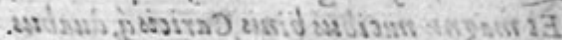

\section{The end of the fecond Booke.}

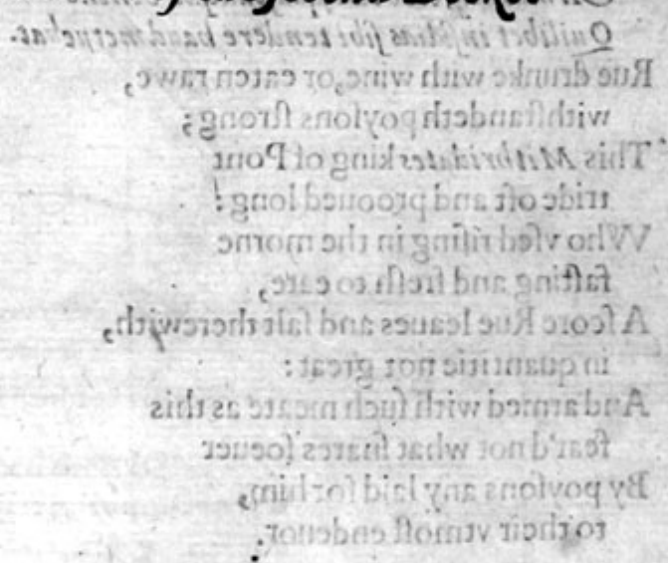

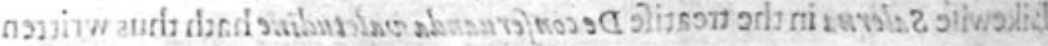

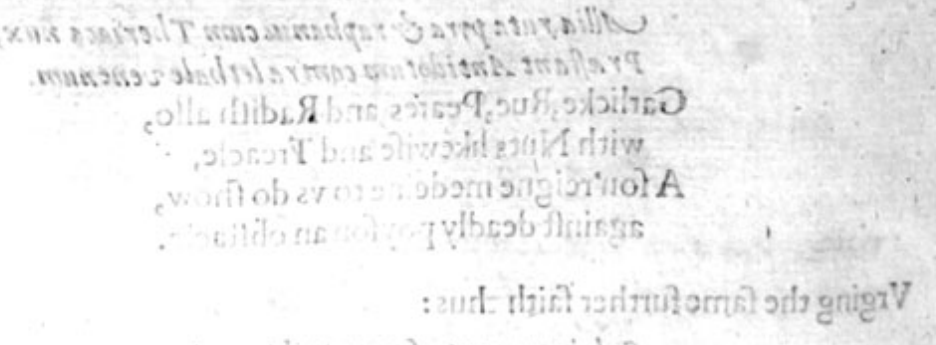




\section{THE THIRD BOOKE OF THE HISTORIE OF \\ PLAN T S:}

Containing the defcription, place, time, names, nature and vertues of
Trees, Shrubs, Bu/hes, Fruit-bearing plants, Rosinins,Gums, Roses, Heath, Moffes: fome fndian plants, and otber rare plants not remembred in the Proeme to the firf booke.

- Aljo Mufbroms, Corall, and their feuerall kindes, of c. The Proeme. Auing finifhed the treatife of herbes and plants in generall, vfed for meate, medicine, or fweete fmelling vfe, onely forme few omitted for want of perfect inftruetion, and alfo being hindered by the flackneffe of the cutters or grauers of the figures, which wants we intend to fupplie in this third and laft part. The Tables, as well generall as particular fhall be fet foorth in thie end of this prefent volume.

itaquanis Alil ovhe?

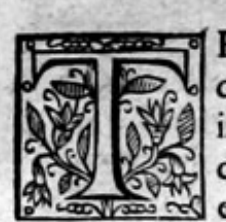

\section{Of Roses. Chap.1. \\ * The kindes.}

He plant of Rofes, though it be a fhrub full of prickles, yet it had beene more fit and conuenient to haue placed it with the moft glorious flowers of the worlde, than to infert the fame here among bafe and thornie fhrubs: for the Rofe doth deferue the chiefeft and moft principall place among all flowers whatfoetier, being not onely efteened for his beautic, vertues, and his flagrant and odoriferous fmell; but alfo bicaufe it is the honor and ornament of our Englifh Scepter, as by the coniunetion appeereth in the vniting of thofe two moft rovall houfes of Lancafter and Yorke. Which pleafant towers deferue the chiefeft place in Crownes and garlands, as out of Anacreon Thius a moft ancient Greeke Poet, Henricus Stephanus hath tranflated in a gallant Latine verfe:
Rofa bonos decufǵg florum,
Kofa, cura, amorg, Veris.
Rofa, calitus est voluptas,
Ro feuspuer Cytheres
Caput implicat coronis,
Charitum Choros freguentans.
Which is englifhed thus:
The Rofe is the honor and beautie of flowres,
The Rofe is the care and loue of the fpring,
The Rofe is the pleafure of the'auenly powres,
The boy of faire Venus, Cytheres darling,
Doth wrap his head round with garlands of Rofe,
26 bist 24 When to the daunces of the Graces he goes.

Augerim Busbeckins fpeaking of the eftimation and honor of the Rofe, reporteth that the Turkecan by no meanes endure to fee the leaues of Rofes fall to the ground, bicaufe that fome of them haue dreamed, that the firft or moft ancient Rofe did fpring of the blood of $V$ enus; and others of the Mahumetans fay, that it fprang of the fweate of Mabumet. 


\section{THE THIRD BOOKE OF THE}

But there are many kindes of Rofes differing either in the bigneffe of the flowers, or theplant it felforroughnes or fmoothnes, or in the multitude of the flowers, or in the fewneffe, or elfe in colour and Imell: for diuers of them are high and tall, others fhort and lowe; fome have fiue-leaues, others very many. T heophraftus telleth of a certaine Role growing ahout Philippi, with an hundred leates, which the inhabitants brought foorth of Pangxum, and planted it in Campania, as Plinie faith, Moreouer, fome be red, others white, and moft of them Prouince Rofe, but not properly. of the garden; wherefore Strabo Ga llus in his litule garden doth but of the fhootes and fprigs, which he doth call Viburna,writing thus:

Iam nifime feffum via longior indspederet,

Scrupens atgue nowi tereretur carminis ordo,

Debueram Viburna Rofepretiofa metallo

Pactoli, \& niueis La ra bum circundare gemmis.

That is in Englifh:

Now were it not, that wearie and a longer way doth let,

And of my new deuifed verfe were worne the ftonie fet;

If hould with Pactolmetall and fnowe white Arabian gems,

Befet about of Rofe and tree the pretious fhootes and ftems.

Notwithftanding Virgilius and Lurelius 2 Ceme fianus affirme, that Viburnum is a certaine kinde of fhubbie tree, little, lowe, tough and bending, who in his firft Eclog commending the citie of Rome faith,

\section{Veram hac tantion alias inter caput extulit vrbes, Quantum lenta folent inter viburna Cupreßs.}

Which is thus englifhed:

But* this, among other cities and townes,

Hath fo much more ftately borne vp hir head;

*Rome vpon

feuen hils.

By how much the Cyprefies carrie their crownes,

Aboue the lowe viorns bending (like lead.)

And 2 emefianus in his fecond Eclog in thefe veries:

\section{Cos quogue te propter Donace donabimur vrbi, Si modo coniferas inter viburna Cupreffos, \\ Lat inter Pinos Corglum fronde/cere fas eft.}

Which are thus tranflated:

And we, $O$ Dunac, to the towne will giuen be for thee,

If yet among the lithie fhrubs a lawfull thing it be

For Cypreffe trees with pointed tops their leaues to thoote,

- Or Hafell trees among the Pines to take their roote.

\section{* The defcription.}

F the curious could fo becontent, one generall defcription might ferue to diftinguifh the whole ftocke or kiared of the Rofes, being things fo wel knowen; notwithftanding I thinke it not amiffe, to fay fomething of them feserally, in hope to fatisfie al. The white Rofe hath very long ftalkes of a woodie fubftance, fet or armed with divers fharpe prickles: the branches whereof are likewife full of prickles, whereon do growe leaues confifting of fiue leaues for the moft part, fet vpon a middle rib by couples; the od leafe ftanding at the point of the fame, and euery one of thofe fmall leaues fomewhat fnipt about the edges, fomewhat rough,and of an onerworne greene colour : from the bofome whereof hoote foorth long footeftalkes, whereon do growe very faire double f.owers, of a white colour and yery fweete fmell, hauing in the middle a few yellow threads or chiues; which being paft, there fucceedeth a long fruit greene at the firft,red when it is ripe, and ftuffed with a downie choking matter, wherein is contained feede as hard as ftones. The roote is long,tough, and of a woodie fubft ance.

2 The red Rofe groweth very lowe in refpect of the former : the ftalkes are fhorter, fmoother, and browner of co!our: the leaues are like, yet of a worfe duftie colour : the flowers growe on the tops of the branches, confifting of many leaues, of a perfect red colour : the fruit is likewife red when it is ripe; the roote alfo woodie. 
HISTORIE OF PLANTS.

I Rofalba.

The White Rofe.

2 Rola rubra.

1079

The Red Rofe.
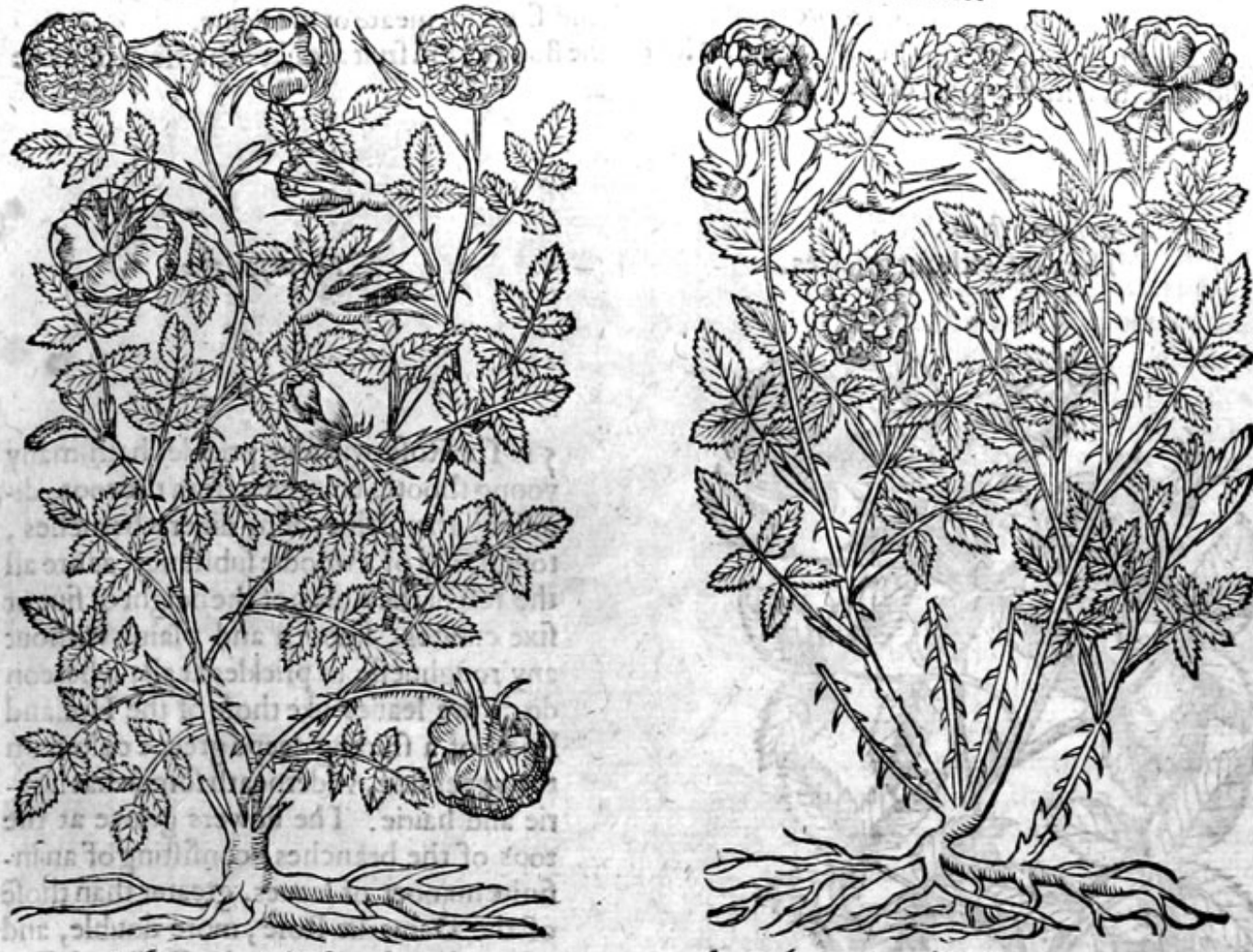

(1)
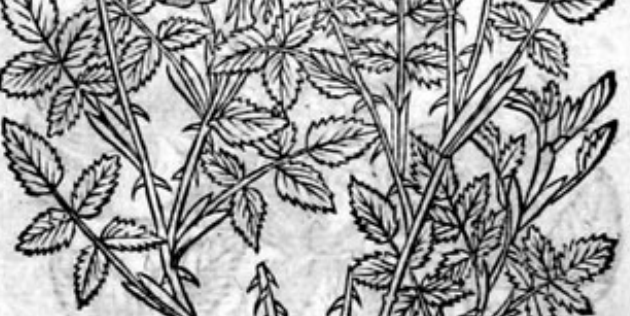

Ro la prouincialis, fiue Damajcena.

The Prouince, or Damaske Rofe.

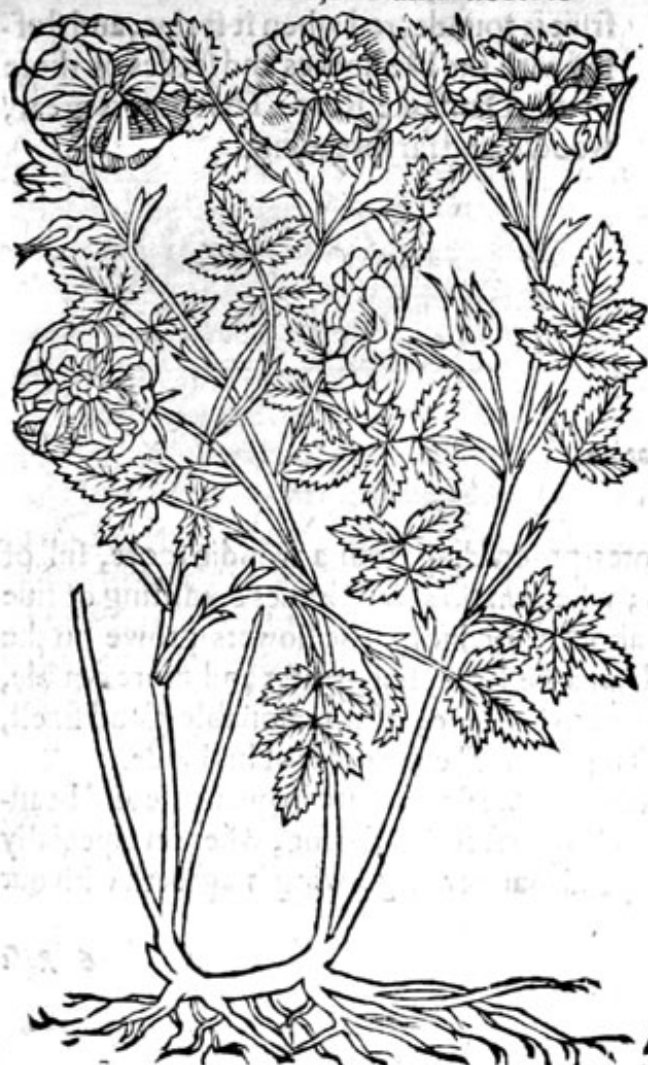

Axza 2

$4 R \circ f$ prouincislis minor.

The leffer Damaske Rofe.

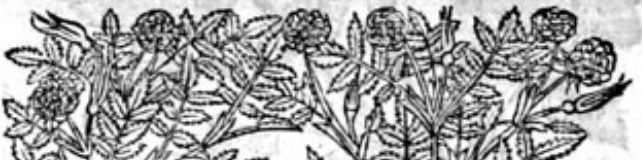

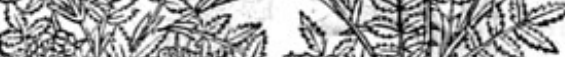

1.

ov $(2)$ a

a es a ram

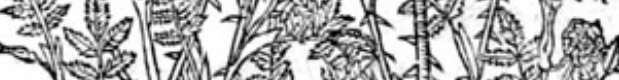

I
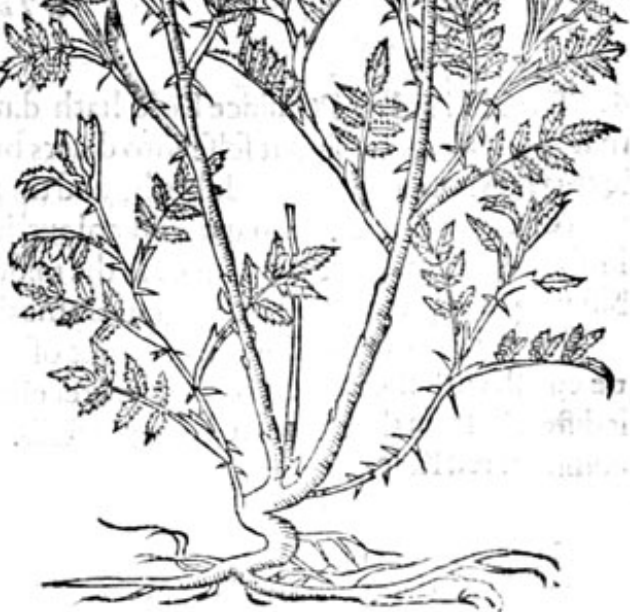
3 The common Damaske Rofe in ltature, prickley branches, and in other refpectes is like the Whe of a pale red colour, and of a more oleafant fmell, the colour and fmell of the flowers; for thefe 4 The other differeth not, but is altogither leffer : the fitter for meate or medicine.

alfo agreeth with the precedent.

5 Ro/a fine pioisis.

The Rofewithout prickles.

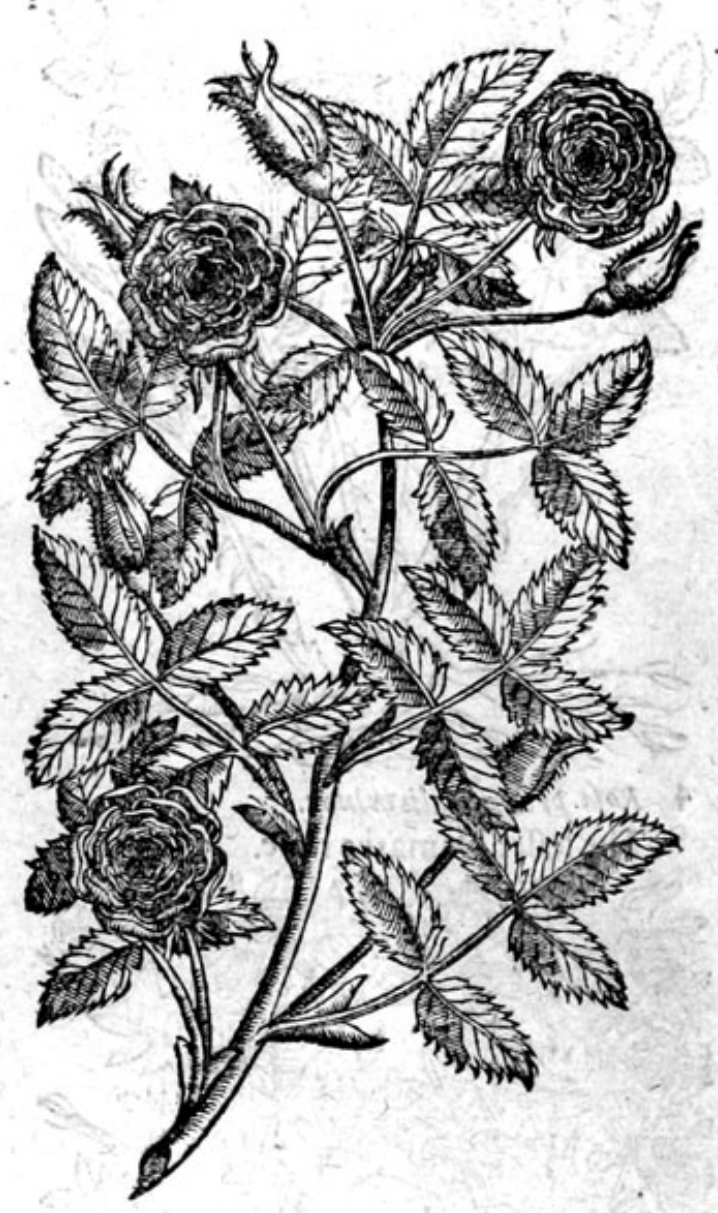

$$
\text { * The defriprion. }
$$

5 The Rofe without prickles hath many yoong hootes comming from the root, diuiding themfelues into diuers branches, tough, and of a woodie fubitance, as are all the reft of the Rofes, of the height of fiue or fixe cubites, fmooth and plaine without any roughneffe or prickles at all; whereon do growe leaues like thofe of the Holland Kole, of a fhining deepe greene colour on the vpper fide, vnderneath fomewhat hoarie and hairie. The flowers growe at the tops of the branches, confifting of an in. finite number of leaues, greater than thofe of the Damaske Rofe, more double, and of a colour betweene the Red and $\mathrm{D}_{2}$ maske Rofes, of a moft fweete fmell. The fruit is rounde, red when it is ripe, and ftuf. fed with the like flockes and feedes of thole of the Damaske Rofe. The roote is great, woodie, and far fpreading.

\section{* The defcription.}

6 The Holland or Prouince Rofe hath diuers Shootes procelding from a woodie roote, full of Tharpe prickles, diuiding it felfe into diuers branches; wlicreon do growe leaues confifting of fiue leaues fet vpon a rough middle rib, and thofe finipt about the edges. The flowers growe on the tops of the branches, in thape and colour like the Damaske Role, but greater and more double, in fo much that the yellow chiues in the middle are l:ard to be feene; of a reafonable good fmell, but not full fo fivecte as the common Damaske Rofe. The fruit is like the other of his kinde.

We hatie in our London gardens one of the red Rofes, whofe flowers are in quantitie and bealltie equall with the former, but of greater eftimation, of a perfect red colour, wherein efpecially it differeth from the Prouince Rofe; in ftalkes, ftature, and manner of growing it agreeth with our common red Rofe: 


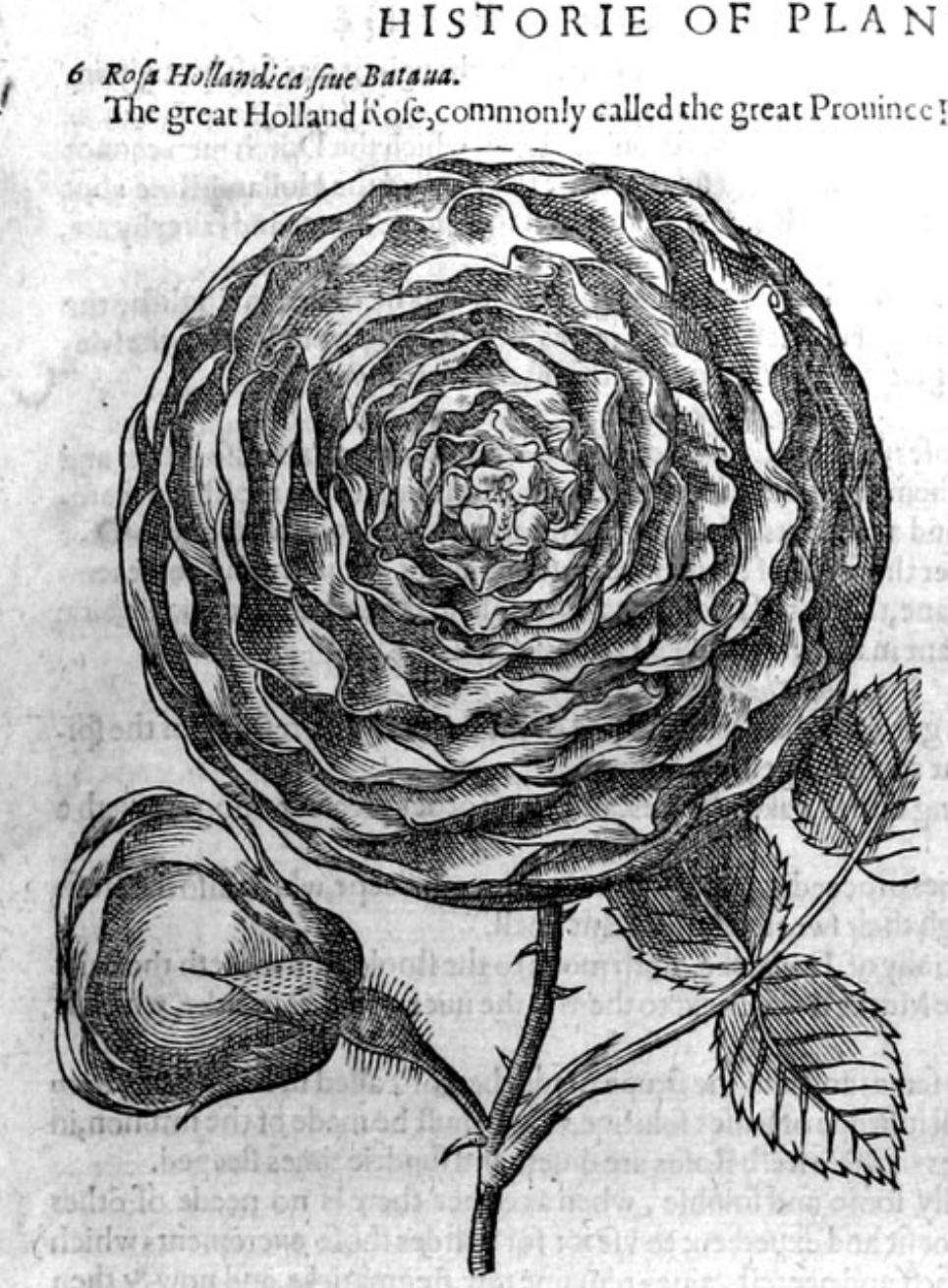

T S.

1081

Ro/a Hollandica fue Bataua.

* 7 lieplace.

All thefe forts of Rofes we haue in our London gardens, except that Rofe without prickles, which as yet is a ftranger in Englande. The double white Rofe doth growe wilde in many hedges of Lancafhire in great abundance, euen as Briers do with vs in thefe foutherly parts, efpecially in a place of the cun. trey called Leylande, and in a place calledRoughfoorde, nor far from Latham. Moreouer, in the faide Leilande ficlds doth grow our garden Rofe wiloce, in the plowed fieldes among the corne in fuch abuadance, that there may be gathered daily, during the time, many buthels of Rofes, equall with the beft garden Rofe in each refpect : the thing that giucth great caufe of woonder is, that in a ficld in the place aforefaid, called Gloners fielde, eucry yeere that the field is plowed for corne, that yeere the ficld will befpred ouer with Rofes; and when it lieth as they cal it leye, and not plowed, then Thal there be but fewe Rofes to begathered: by the relation of a curious gentleman there dwelling, fo often remembred in our $\mathrm{Hi}$ ftorie. * Thetime.

Thefe flower from the end of May to the ende of Auguit, and diuers times after, by reafon the tops and fuperfluous branches are cut away in the end of their flowring; and then do they fometimes flower euen vintill OAtober, and after. $\quad *$ The names.

The Rofe iscalled in Latine Ro/a : in Greekepooby: and the plant it felfe podizy : which in Latine keepeth the fame name that the flower hath, and it is called Rodon, as Plutarch faith, bicaufe it fendeth foorth plentic of frrell.

The middle part of the Rofes, that is, the yellow chiues, or feedes, and tips, is called Unthos, and $F$ los Rofe,the flower of the Rofe : in fhops Antbera, or the blowing of the Rofe.

The white parts of the leaues of the flower it felfe, by which they are faltned to the cups, be named irngues or nailes. That is called Calix, or the Cup, which conteineth and holdeth in togither the yellow part and leaues of the flower.

Alabaftri, are thofe parts of the cup which are deepely cut, \& that compas the flower clofe about, before it be opened; which be in number fiue, two hatic beards and two haue none, and the fift hath but halfe 'one: moft do call them Cortices Rofaram, or the huskes of the Rofes. The fhootes of the plant of Rofes, Strabo Gallus in his little garden doth call Vtburna, writing as before in the Proeme.

The white Rofe is called Rofa alba : in Englifh the white Rofe: in high Dutch Tcieliz Raofen: in lowe Dutch relitte Ronfen: in French B!anche: of Plinie Spincola Ko fa, or Rofa Campana.

v The red Rofe is called in Latiue Kofa Rubra: of the French men Rofe Franclie, Rofe de Prouins, a towne in Campaigne : of Plinie Trachinia, or Prenefina .

The Damaske Rofe is called of the Italians Ro fa incar nata : in high Dutch 1 etbitatbige Ronfen: in low Dutch jezouencie Roaff : of fome Rofa prowincialis, or Role of Prouence : in French of fome 
Melefia,the Rofe of Melaxo a citie in Afia, from whence fome haue thought it was firft brought in.

The great Rofe, which is generally called the great Prouince Rofe, which the Dutch mencantor endure; for fay they, it came firft out of Holland, and therefore to be called the Hollawerncantot
by all likelyhood it came from the Damaske Rofe, as a kinde thereof, made betrerand which feemeth to agree with truth.

The Rofe without prickles is called in Latine Rofa fine $/$ inis, and maybe called in Englifh, the Rofe without thornes, or the Rofe of Auftrich, bicaufe it was firft brought from Vienna the Me:
tropolitane citie of Auftrich, and giuen to that famous herbarift Carolus Clufius.

\section{T betemperature.}

The leaues of the flowers of Rofes, bicaufe they do confift of diuers partes, haue alfo diviers and fundrie faculties; for there be in them certaine that are earthie and binding, other moift and waterie, and fundry that are fpiritwall and airie parts, which notwithftanding arenot all after one fort; for in one kind thefe excell, in another thofe: al of them haue a predominant or ouerruling colde temand fpirituall parts are predominant in the white Rofes, Damaske and Muske. \&. The vertues.

A The diftilled water of Rofes is good for the ftrengthening of the harr, and refrefhing of the fpirits, and likewife for all things that require a gentle cooling. B The fame being put in iunketting dilhes, cakes, fawces, and many other pleafant things, giuech 2
fine and delectable tafte.

C It mitigateth the paine of the eies proceeding of a hot caufe, bringeth lleepe, which alfo the frefh Rofes themfelues prouoke through their fweete and pleafant finell.

D The iuice of thefe Rofes, efpecially of Damaske, doth moue to the ftoole, and maketh the belly foluble : but moft effectually of the Muske Rofes, next to them is the iuice of the Damaske, which is more commonly vicd.

E The infufion of them doth the fame, and alfo the firupe made thereof called in Latine Drofatam or Serapiwm : the Apothecaries call it firupe of Rofes folutiue, which muft be made of the infufion, in which a great number of the leaues of thefe frefh Rofes are diuers and fundrie times fteeped.

F It is profitable to make the belly loofe and foluble, when as either there is no neede of other Atronger purgation, or that it is not fit and expedient to vfe it : for befides thofe excrements which ftick to the bowels, or that in the firft and neereft vaines remaine raw, flegmaticke, and now $\&$ then cholerick;it purgeth no other excrements, vnleffe it be mixed with cerrain other ftrōger medicines.

G This firupe doth moyften and coole, and therefore it alayeth the extremitic of heate in hot burning feuers, mitigateth the inflammations of the intrailes, and quencheth thirft : it is fcarce good for a weake and moyft ftomacke, for it leaueth it more flacke and weakc.

H Of like vertue alfo are the leaues of thefe preferued in Sugar, efpecially if they be onely bruifed with the hands, and diligently tempered with Sugar,and fo heat at the fire racher than boiled. * Thetemperature of Red Rofes.

There is in the red Rofes, which are common euery where, and in the other that be of a deepe purple, cailed Prouince Rofes, a more earthie fubftance, alfo a drying and binding qualitie, yet not without certaine moyfture ioyned, being in them when they are as yet frefh, which they lofe when they be dried : for this caufe their iuice and infufion doth alfo make the bodie foluble, yernot fo much as of the others aforefaid. Thefe Rofes being dried, and their moyfture gone, dobinde and drie; and likewife coole, but leffer than when they are ftefh.

\section{* The vertues.}

I They ftrengthen the hart, and helpe the trembling and beating thereof.

$\mathrm{K}$ They giue itrength to theliuer, kidneies, and other weake intrailes; they dric and comfort a weake ttomacke that is flafhie and moyft; ftay the whites and reds, ftanch bleedings in any part of the body, ftay fweatings, binde and loofe, and moyften the body. $\mathrm{L}$ And they are put into all kinde of counterpoyfons and other like medicines, whether theybe to
be outwardly ap plied or to be inwardly taken,to which they giue an effeetuall binding, and certaine itrengehening qualitie.

M Honie of Rofes, cr Mel Rofarum, called in Greeke poobusi, which is made of them, is moft excellent good for wounds, vlcers, iffues, and generally for fuch things as haue need to be cleanfed \& dried. 


\section{HISTORIE OF PLANTS.}

The oyle doth mitigate all kindes of heate, and will not fuffer in fammations or hot fwellings to A rife,and being rifen it doth at the firft affwage them.

$*$ The temperature and vertues of the partes.

The fitersorbloomings of Rofes, that is to fay, the yellow haires and tips, do in like maner drie B and binde, and that more effectually than the leaues of the Rofes themfelues; the fame temperature the cups andbeards be of: but feeing none of thefe haue any fweete fmell, they are not fo profitabłe,nor fo familiar or bencficiall to mans nature : notwith ftanding in fluxes at the $\mathrm{fea}$, it flall auaile the Chirurgion greatly, to carrie ftore thereof with him, which doth there preuaile much more than at the land.

The fame yellow called Anthera, ftaicth not only thofe laskes and bloodie fluxes which do hap-C pen at the fea, but thofe at the land alfo, andlikewife the white fluxe and red in women, if they be dried, beaten to powder, and two fcruples therof giten in red wine, with a little powder of Ginger added thereto: and being at the fea, for want of red wine you may vfe fuch liquor as you can get in fuch extremitic.

The litcle heads or buttons of the Rofes, as P liny writeth, do alfo ftanch bleeding \& f top the lask. D

The nailes or white endes of the leates, of the flowers, are good for watering eies.

The roote of the wilde Rofe is a fingular remedie (found out by oracle) againft the biting of a $F$ mad dog, as he alfn declareth in his 8 booke 4 r.chapter.

The iuice, infufion, or decoction of Rofes, are tobe reckoned among thofe medicines which are $\mathrm{G}$ foft,gentle, loofing, opening and purging gently the belly, which may be taken at all times and in all places, of euery kinde or fexe of people, both olde and yoong, without danger or perill.

The firupe made of the infufion of Rofes, is a moft fingulat and gentle loofing medicine, carrying $\mathrm{H}$ downwards cholericke humors, openeth the ftoppings of the liuer, helpeth greatly the yellow iaun, dies, the trembling of the hart, and taketh away the extreme heate in agues and burning feuers, which is thus made:

Take two pound of Rofes, the white endes cut away, put them to fteepe or infufe in fixe pintes of I warme water in an open veffell for the fpace of twelue howers; then ftraine them out, and put therto the like quantitic of Rofes, and warme the water againe, fo let it ftand the like time: do thus fower or fiue times; in the end adde vnto that liquor or infufion, fower pound of fine Sugar in powder; then boyle it vnto the forme of a firupe, vpon a gentle fire, continually ftirring it vnill it be colde; then ftraine it, and keepe it for your vfe, whereof may be taken in white wine, or other liquor, from one ounce vinto two.

Sirupe of the iuice of Rofes is very profitable for the griefes aforefaid, made in this manner:

Take Rofes, the white nailes cut away, what quantitie you pleafe, ftamp them, and ftrayne out the $\mathrm{K}$ iuyce, the which you thall pur to the fire, adding theretofugar, according to the quantitie of the iuyce:boiling them on a gente fire vnto a good confiftence.

Vato thefe firupes you may adde a few drops of oyle of Vitriol, which giueth it a moft beau- M tifull colour, and alfo helpeth the force in cooling hot and burning feuers and agues: you likewife may adde thereto a fmall quantitie of the iuice of Limons, which doth the like.

The conferue of Rofes as well that which is crude and rawe, as that which is made by ebnllition $\mathrm{N}$ or boyling, taken in the morning fafting, and laft at night, ftrengtheneth the hart, and taketh away the fhaking and trembling thereof, ftrengtheneth the liuer, kidneies, and other wcake intrailcs, comforteth a weake ftomacke that is moy?t and rawe; ftaieth the whites and reds in women, and in a word, is the moft familiar thing to be vfed for the purpofes aforefaid, and is thus made :

Take the leaues of Rofes, the nailes cut off, one pound, put into a cleane $p a n$; then put there to $O$ a pinte and a halfe of fealding water, ftirring them togither with a wooden flice, fo let them ftande to macerate clofe couered fome two or three howers; then fet them to the fir flowly to boyle, ad. ding thereto three pounds of fugar in powder, letting them fo finper togither according to difcretion, fome hower or more, then keepe it for your vfe.

The fame made another way, but better by many degrees: Take Rofes at your pleafure, put them $\mathbf{P}$ to boyle in faire water, hauing regard to the quantitie; for if you haue many Rofes, you may take the more water; if fewer, the leffe water will ferue : the which you thall boyle at the leaft thiee or fower howers, euen as you would boyle a peece of meate, vntill in the eating they be very cender, at which time the Rofes will lofe their colour, that you would thinke your labour loft, and the thing marred. But proceede; for though the Rofes hauc loft their colour, the water hath gotten the

$$
\text { Aasa } 4 \text { tincture }
$$


tincture thereof; then thall you adde vnto one pounde of Rofes fower pounde of finefitgar in pure powder, and fo according to the reft of the Rofes. Thus fhall you let them boyle gently after the Sugar is put thereto, continually ftirring it with a wooden Spatula vutill it be cold, wherof one pound waight is woorth fixe pound of the crude or.rawe conferue, as well for the vertues and goodnes in talte, as alfo for the beautifull colour.

Q. The making of the crude or rawe conferue is very well knowen, as alfo Sugar rofet, and diuers other pretie thing s made of Rufes and Sugar, which are impertinent vnto our hiftorie, bicaufe $\mathrm{L}$ in. tend net ther to make thereof an Apothec aries fhop, nor a Sugar bakers ftorehoufe, leauing the reft for our cunning confectioners. .

\section{Of the Muske Roses. Chap.2.}

* 1 he kisiles.

$T$ Here be diuers fortes of Rofes planted in gardens, befides thofe written of in the former chap-

ter, which are of moft writers reckoned alnong the wilde Rofes, notwithiftanding we thinke it conuenient to put them in a chapter betweene thofe of the garden and the brier Roles, as indifferent whether to make them of the wilde Rofes, or of the tame, feeing we haue made them denizons
in our gardens for diuers refpects, and that woorthily.

I Rofauslofchita fimpliciflore. The fingie Muske Rote.

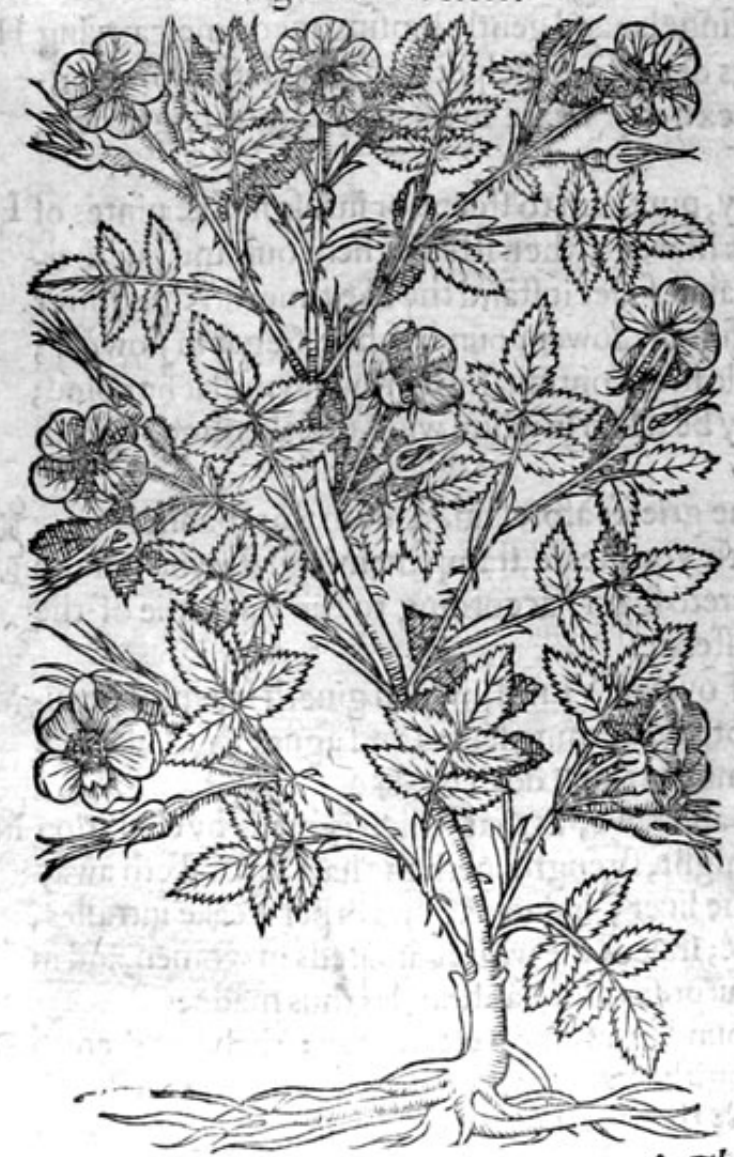

2 Rofa Mofc' at a multiplex. The double Muske Rofe.

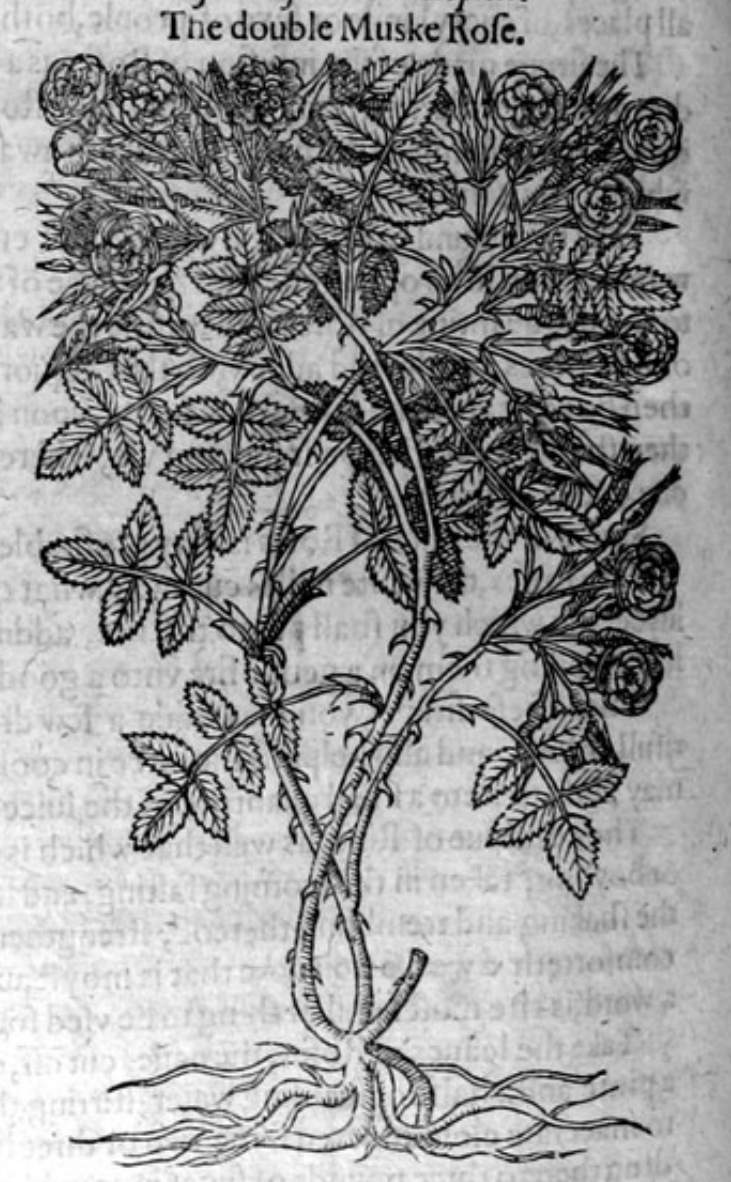

* The defcrittion.

I THe fingle Muske Rofe hath diters long thootes of a greenifh colour and woodie fubftance, armed with very fharpe prichles, diuiding it felfe into diuers branches: whereon do growe long ! caues, fmooth and hining, made of diucrs leaues fet vpon a middle rib, like the other Rofes. The flowers growe on the tops of the branches of a white colour, and pleafant fweete fmell, like that of Muske, whereof it tooke his na' $e$; hauing certaine yellow feedes in the middle,2s the reft of the Rofes have. The fruit is red when it is ripe, and filled with fuch chaffie flockes and feedes as thofe of the other Rofes. The roote is tough and woodie. 
2. The double Muske Rofe differeth not from the precedent, in leaues, ftalkes, and rootes, nor in the colour of the flowers, or fweetenes thereof, but onely in the doublenes of the flo:vers, whercin confilteth the difference.

I. Of thefe Rofes we hatue another in our London gardens, which of moft is called the blufh Rofe : it flowreth when the Damask Rofe doth. The flowers heerof are very fungle,greater then the other Muske Rôfes, and of a white colour, dafhe over with a light wath of carnation, which maketh that colour, which we call a blufh colour. The proportion of the whole plant, as alfo the finell of the flowers, are like the precedent.

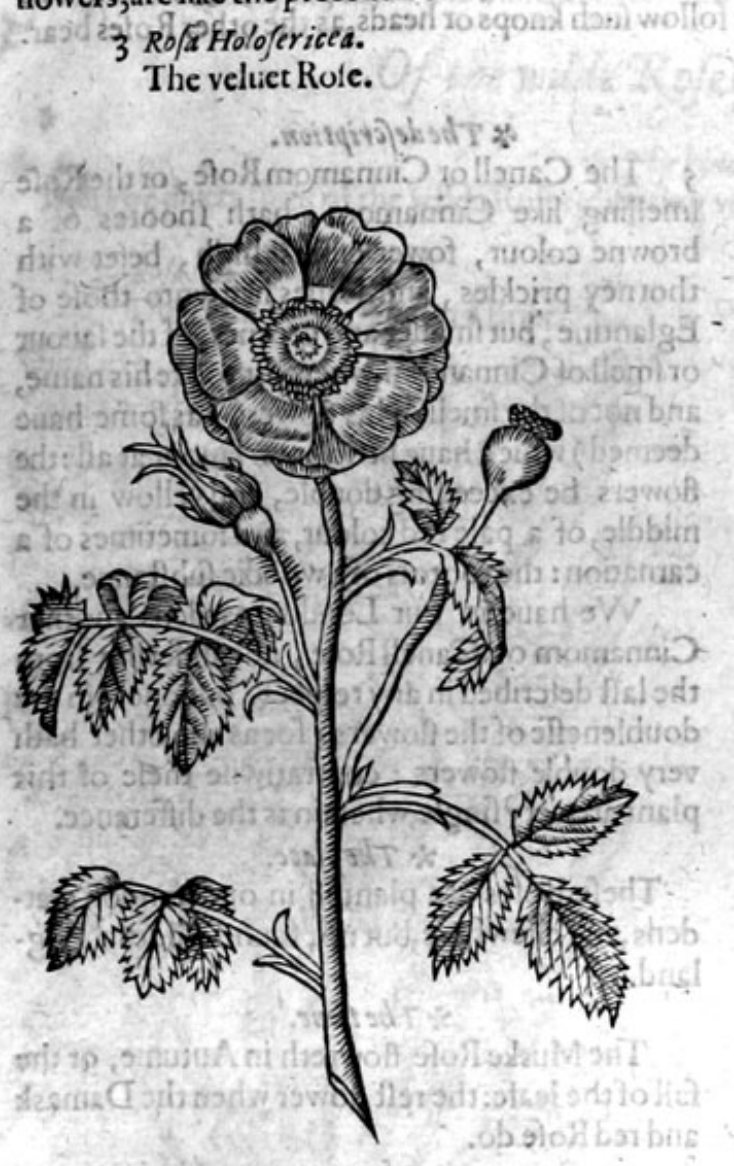

Rof Holofericea.
The veltiet Role.

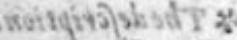

4 Rofa lutia.

The yellow Rofe.

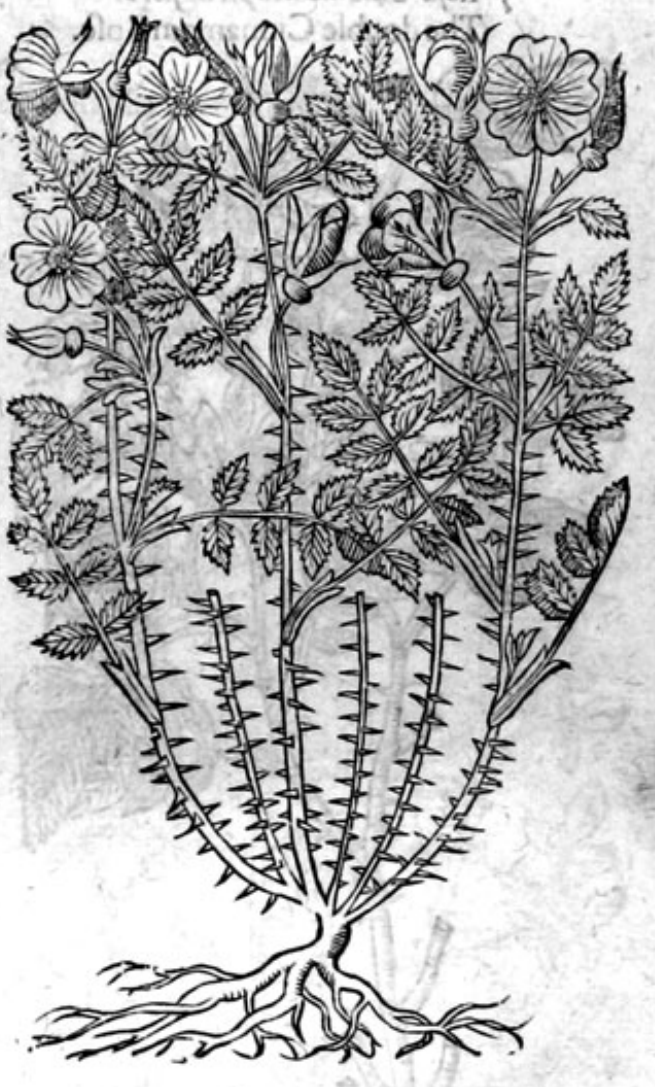

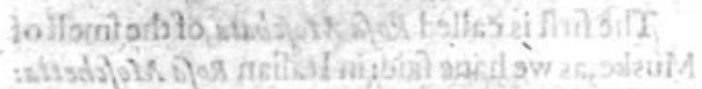

\section{* Thedefcription.}

3 The veluet Rofe groweth alwaies very low, like vito the red Rofe, hauing his branches couered with a cerraine hairie or prickly matter, as fine as haires, yet not fo harpe or ftiffe, that it will harme the moft tender skin that is: the leaues are like the !eaues of the white Rofe: the flowers growe at the top of the ftalks, doubled with fome yellowe thrums in the midft, of a deepe and blacke red colour, refembling red crimfon veluet, whereupon fome haue called it the Veluet Rofe : when the flowers be vaded, there followe red berries full of hard feedes, wrapped in a downe or woollines like the orhers.

4 The yellow Rofe which (as diuers do report)was by Art fo coloured, and altered from his firft eftate, ty graffing a wilde Rofe vpon a Broome ftalke; whereby (fay they) it doth not onely change bis colour, but his fmell and forces. But for my part I hauing found the contrarie by mine owne experience, cannot be induced to beleetue the report: for the rootes and ofsprings of this Rofe hatue brought foorth yellow Rofes, fuch as the maine ftocke or mother bringeth out, which euent is not to be feene in all other plants that haue beene graffed. Moreouer, the leedes of yellow Rofes haue brought foorth yellow Rofes, fuch as the flower was from whence they were taken; which they 


\section{6}

\section{THE THIRD BOOKE OF THE} woulde not doby any coniecturall reafon, if that of themfelues they were nota naturallkinde of
Rofe. Laftly, it were contrary to that true principle, Nasur a fequitur femina quodque fua, that is to faie:

Euerie feede and plant bringeth foorth fruit like vntoit feife, both in fhape and nature: but leaving that errour, I will proceed to the defcription. The yellow Rofe hath browne and pricklie ftalkes or fhootes, fiuc or fixe cubites high, garnifhed with many leaues, like vnto the Musk Rofe, of an excel. lent fweete fimell, and more pleafant then the leaues of the Eglantine: the flowers come foorth among the leaues, and at the top of the branches of a faire golde yellowe colour: the thrums in the middle, are alfo yellow, which being gone, there follow fuch knops or heads, as the other Rofes bear.

5 Kofa Cinamomea plenoflore. The double Cinnamom Rofe.

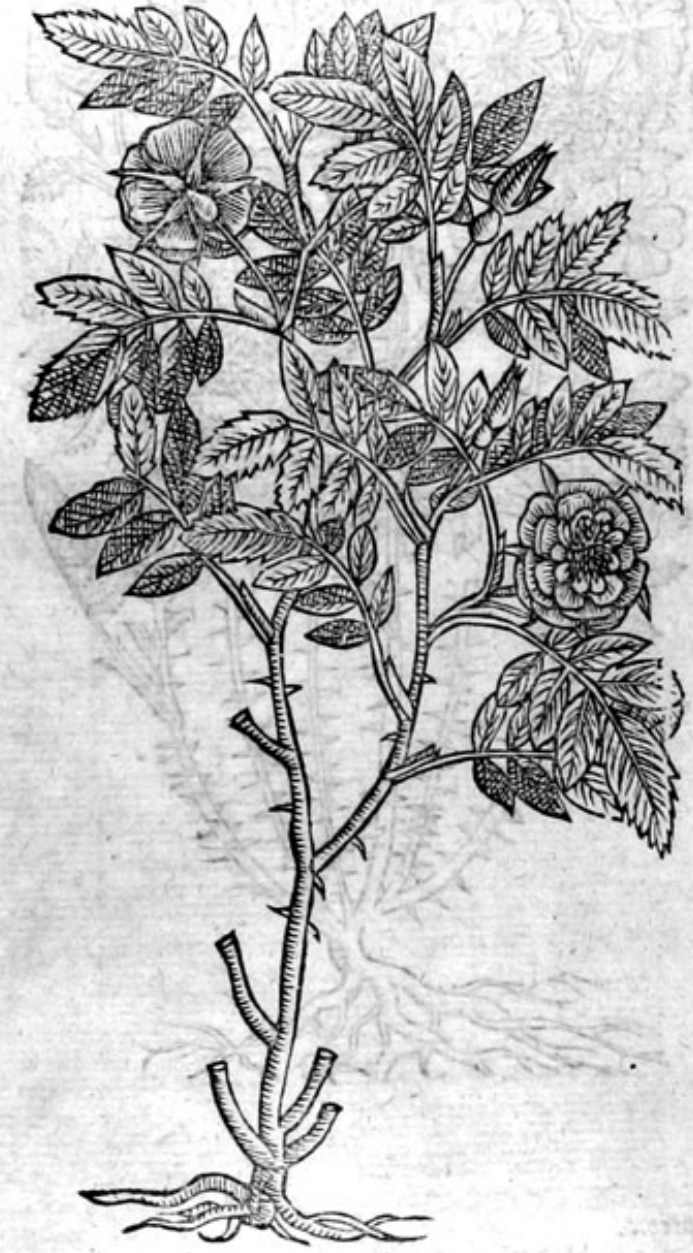

* The defription.

5 The Canell or Cinnamom Rofe, or the Rofe finelling like Cinnamom, hath fhootes of a browne colour, fower cubits high, befet with thorney prickles, and leaues like vnto thofe of Eglantine, but fmaller and greener, of the fautour or fmell of Cinnamom, wherof it tooke his name, and not of the fmell of his flowers (as fome haue deemed) which haue little or no fauour at all : the flowers be exceeding double, and yellow in the middle, of a pale red colour, and fometimes of 2 carnation: the roote is of a woodie fubftance.

We haue in our London gardens another Cinnamom or Canell Rofe, not differing from the laft defcribed in any refpect, but onelyin the doubleneffe of the flowers; for as the other hath very double flowers : contrariwife thefe of this plant are very fingle, wherein is the difference.

$$
\text { * Theplace. }
$$

Thefe Rofes are planted in our London gatdens, and elfewhere, but not found wilde in Eng. land.

\section{* The time.}

The Muske Rofe flowreth in Autume, or the fall of the leafe: the reft flower when the Damask and redRofe do.

\section{* The names.}

The firft is called Ro a Mo fchata, of the fmell of Muske, as we haue faid: in Italian Rofa Mofchettu: in French Rofes Mufquees, or Mufcadelles: in low Dutch 9ufiket Roofentin Englifh Muske Rofe: the Latin \& Englifh ticles may ferue for the reft.

* Thetemperature.

The Muske Rofe is cold in the firft degree, wherein airie and fpirituall parts are predominant: the reft are referred to the Brier Rofe, and Eglantine.

$$
* \text { The vertues. }
$$

Conferue or firupe made of the Muske Rofe, in maner as before tolde in the Damaske and red Rofes; doth purge very mightily waterifh humours,yet fafely, and without all danger, taken in the
quantitie of an ounce in weight.

The leaues of the flowers caten in the morning, in maner of a fallade, with oile, vineger \& pepper, or any other way according to the appetite \& pleafure of them that fhall eate it;purgeth very notably the belly of waterith and cholericke humours, andthat mightily, yet without all perill or paine at all, infomuch as the fimpleft may vfe the quantitie, according to their owne fancie; for if they do defremanie ftooles, or ficges, they are to eate the greater quantitie of the leaues; if fewer, the leffe 
HISTORIE OF PLANTS.

quantitie,as for example : the leaues of twclue or fowerteene flowers giue fixe or cight ftooles, and fo increafing or diminifhing the quantitie, more or fewer, as my felfe haue often prooued.

The white leaues ftamped in a wooden difh with a peece of Allum and the iuice ftrained foorth C into fome glaled veffell, dried in the thadow and kept, is the moft fine and pleafant yellow colour that may be deuifed, not onely to limne or wafh pictures and Imagerie in books, but alfo to colour meates and fawces, which notwithltanding the Allum is very holfome.

There is not any thing extant of the others, but are thought to be equall with the white Muske D Rofe, whereof they are taken and holden to be kinds.

\section{Of the wilde Rofes. Chap.3.}

There be diuers forts of the wilde Rofes, differing verie notablie as well in flowers, fmel,as ftature.

I Rofafylueftris odora. The Eglantine, or fweete Brier.

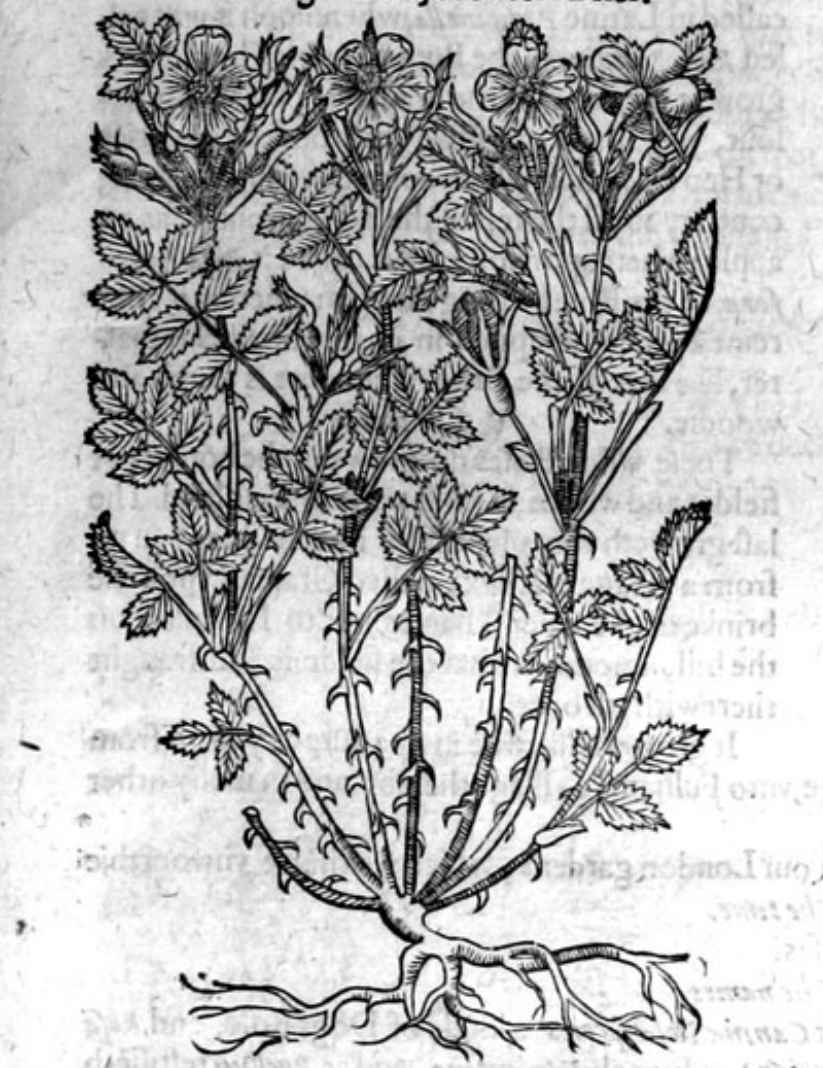

2 Rofa Canina inodora. The Brier Rofe, or Hep tree.

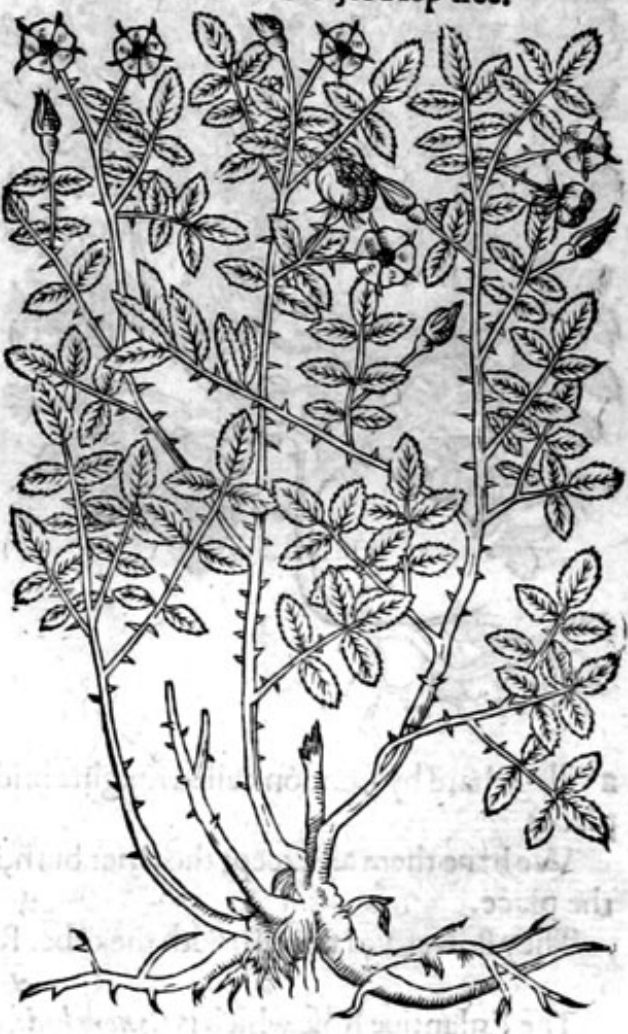

* The defcriftion.

1 He fweete Brier doth oftentimes grow higher then all the kindes of Rofes; the thootes of it are hard, thicke, and woodie; the leaues are glittering, and of a beautifull greene colour, of fmell moft pleafant: the Rofes are little, fiue leafed, moft commonly whitifh, feidorre tending to purple, of little or no finell atall: the fruite is long, of colour fomewhat red, like a little Oliue ftone, and like the little heads or berries of the others, but lefler then thofe of the garden; in which is contained rough cotton, or hairie downe and feede, folded and wrapped vp in the fame, which is fmall and hard. There be likewife found about the flender thoots heerof, rounde, fott, and hairie fpunges, which we call Brier bals, fuch as grow about the prickles of the Dog Rofe.

We have in our London gardens another fwecte Brier, hauing greater leaucs, and much fweeter : the flowers likewife are greater, and fomwhat doubled, exceeding fweete of finell, wherin it differeth from the former.

2 'The Brier Bufh or Hep tree, is allo called Rofa Camina, which is a plant fo common and well 

knowne, that it were to fmall purpofe to vfe many words in the defcription therof:for euen children
with great delight catc the berrics there of when they be ripe, make chaincs and orher pretie gewgawes of the fruite: cookes and gentlewomen make Tarts and fuch like difhes for pleafure thereof,
and therefore this thall fuffice for the defcription.

3 Rofa Pimpinella.

The Pimpernell Rofe.

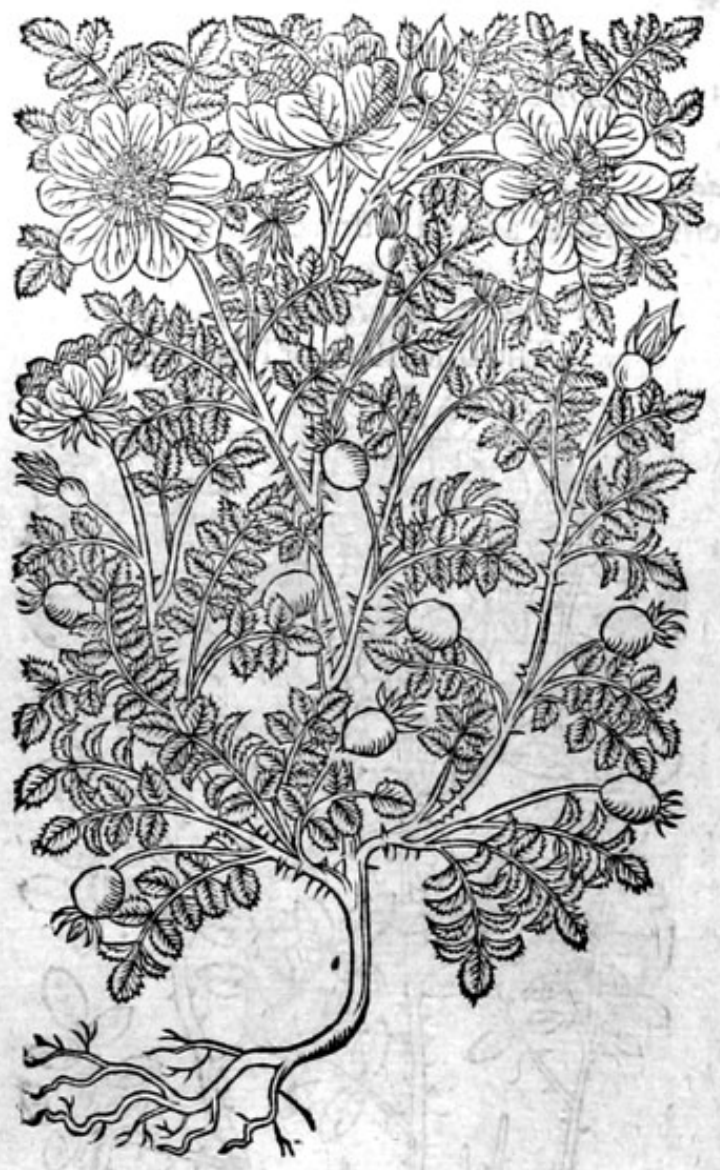

\section{*The defcription.}

3. The Pimpernell Rofe is likewife one of the wilde ones, whofe ftalkes thoote foorth of the ground in many places, of the height of two or three cubits, of a browne colour, and armed with fharpe prickles, which diuide themfelues to. warde the tops into diuers branches, wheron do grow leaues, confifting of diuers fmall ones, fet vpon a middle rib like thofe of Burnet, which is called in Latine P impinella, whereupon it was called Ro a P impinella, the Burnet Rofe. The flowers grow at the tops of the branches, of a white colour, very fingle;, and like vnto thofe of the Brier or Hep tree; after which come the fruite, blacke, contrary to all the reft of the Rofes, rounde as an apple; whereupon fome haue called it Rofa Pomifera, or the Rofe bearing Apples : wherein is conteined feede, wrapped in chaffic or flockie matter, like that of the Brier. The roote is tough and woodic. $\quad * 7$ be place.

Thefe wilde Rofes do growe in the borders of fieldes and woods, in moft parts of England. The laft groweth very plentifully in a fielde as you go from a village in Effex, called Graies (vpon the brinke of the riuer Thames) vnto Horndon on the hill, infomuch that the fielde is full fraught therewith all ouer.

It groweth likewife in apafture as you go from a village hard by London called Knights bridge, vnto Fulham, a village thereby, and in many other places.

We haue them all except the Brier bufh, in our London gardens, which we thinke vnwoorthie the place. * The tume.

They flower and flourin with the other Rofes.

* T he names.

The Eglantiue Rofe which is Cynorrhodi, or Caninc Rofe fpecies, a kinde of Dogs Rofe, and Kofa fylueftris, the wilde Rofe: in low Dutch Eglantiet: in French $E$ /glentine, and as Ruellus teftifiech Englenterium, who alfo fufpecteth it to be Cynosbaton, or Canirubrus of which Diofcorides hath written in thefe wordes; Cynosbatus, or Canirubus, which fomentexys ant ha, is a fhrub growing like a tree, full of prickles, with a white flower, long fruite like an oliue ftone; red wher it is ripe and downie within : in Englifh Eglantine, or fweete Brier.

The fpungie bals which are found vpon the branches, are moft aptly and properly called Spongiole fylue ftris Roge, the little fpunges of the wilde Rofe: the fhops miftake it by the name of Beleguar:

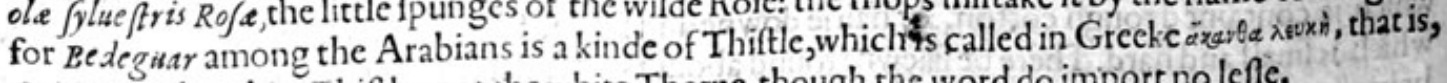
Spina alia, the white Thiftle: not the white Thorne, though the word do import nolefle.

The Brier or Hep tree is called Sylueftris Rofa, the wilde Rofe : in high Dutch vertiden Rafent: in French Rofes fatuages: Plinic in his $\mathrm{B}$ booke and 25 . chapter faith, that it is Rofa Canina, Dogs Rofe: of diuers Canina fent is, or Dogs Thorne: in Englifh Brier buh, and Hep tree: the latt hath bene touched in the defcription. * $T$ bif 
$*$ The temperature and vertwes.

The faculties of thefe wilde Rofes are referred to the manured Rofe, but not vfed in Phificke A where the other maybe had: notwithftanding 'Pleny affirmeth that the roote of the Brier bufh is a fingular icmedy found out by Oracle, againft the biting of a mad dogge, which he fettech dowae in his 8:booke, 4 i chapter.

The fame author affremeth in his 25 . bookefeconde chapter, that the little fpungie Brier ball B Itamped with hony and afhes, doth caufe haires to grow which are fallen away through the difeafe called Cslopecis, or the Foxes euill, or in plaine tearmes, the French pockes.

Fuch fius affirmeth, that the fpungic excrefcence or ball,growing vpon the Brier, arc good againft $\mathbf{C}$ the ftone and ftrangary, if they be beaten to powder, and inwardly taken.

They are good not as they be diutecikes, or prouokers of vrine; or as they are wearers away of D the ftone, but as certaine other binding medicines that ftreng then the weake and feeble kidneyes, which dono more good to thofe that be fubiect to the ftone, then many of the diuretickes, efpecit ally of the ftrōger fort: for by too much vfing of diuretickes or piffing medicines, it hapneth that the kidneies are ouerweakned, and oftentimes too much heated; by which meanes not onely the ftones are not diminifhed, worne away, or driuen foorth, but oftentimes are alfo increafed, and made more hard: for they feparate and take away that which in the bloud is thinne, watery, and as is were whayifh; and the thicker part, the ftronger forts of diuretikes do drawe togither and make hard; and in like maner alfo others that are not fo ftrong, by the ouermuch vfing of them, as Galen in his fift booke of the faculties of imple medicines doth report.

The fruit when it is ripe maketh moft pleafant meates and banketting dithes, as Tartes and fuch $\mathrm{E}$ like : the making wherof I commit to the cunning Cooke, and the teeth to eate themin the rich mans mouth.

\section{Of the Bramble, or blacke Berrie Bußh. Chap.2.}

* The kindes.
There be diuers forts of Brambles,as fhall be declared.

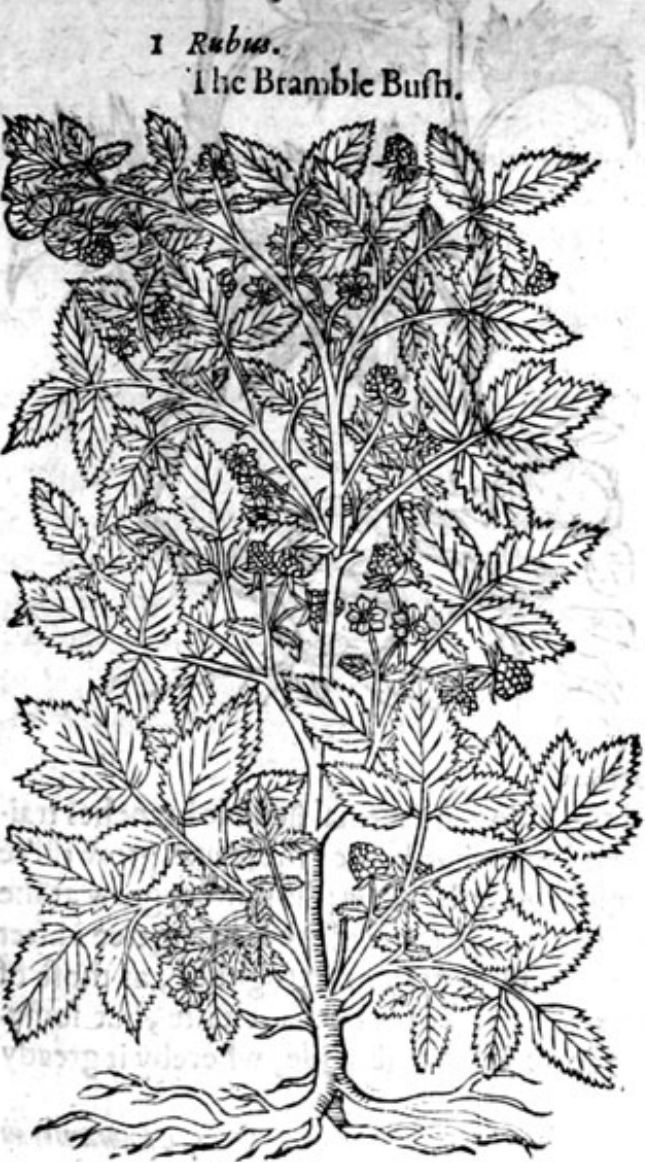

2 Rubus Ideus.

The Rafpis bufh, or Hindberrie.'

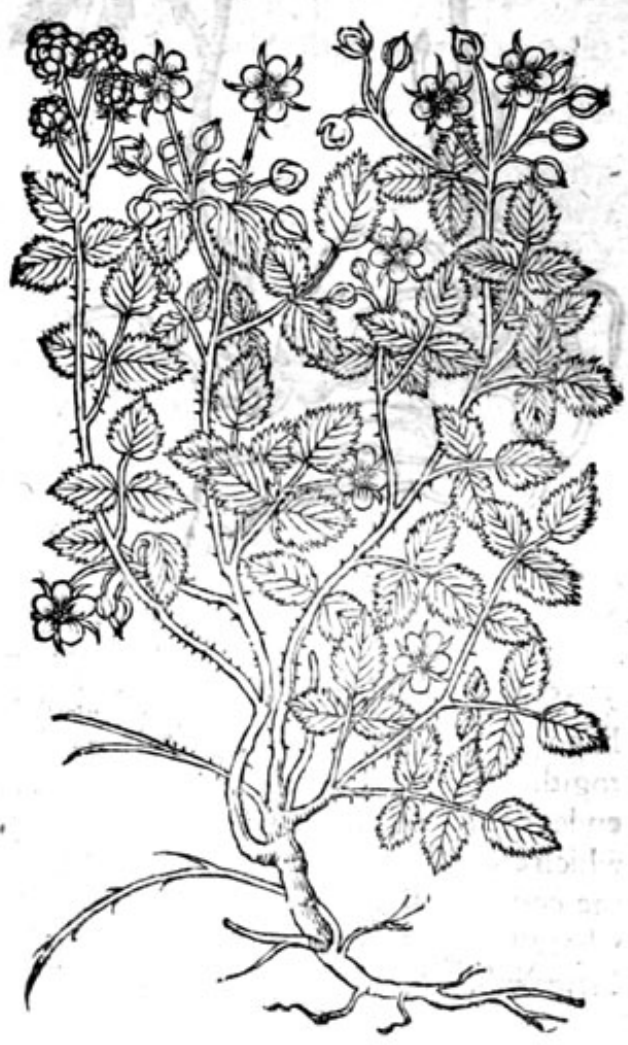


$*$ The defoription.

1 Tecommon Branble bringeth foorth flender branches, long, tough, eafily bowed ramping among hedges, and whatfoeuer ftandeth neere vnto it, armed with harde and Pharpe prickles: whereon do grow leaues, confilting of many fet vpon a rough middlerib greene on the vpper fide, and vnderneath fomething white: on the tops of the ftalkes ftande certaine flowers, in (hape like thofe of the brier Rofe, but leffer, of colour white, and fometimes wathe ouer with a little purple: the fruite or berric is like thofe of the Mulberie, firftred, blacke when it is ripe, in tafte betweene fweete and fower, very foft and full of graines: the roote creepeth and fendeth forther

2 ble, but not fo rough nor prickly, and fones and branches not much vnlike the common Bram. hairines about the ft alks: the fruit in (hape and withour any prickes at all, hauing onely a rough they be ripe, and coucred ouer with a little downines, of tafte the the of the Bramble, red when far abroad, whereby it grcatly increafeth.

3 Rubus Saxatilis. Stonc blacke Berric tree.

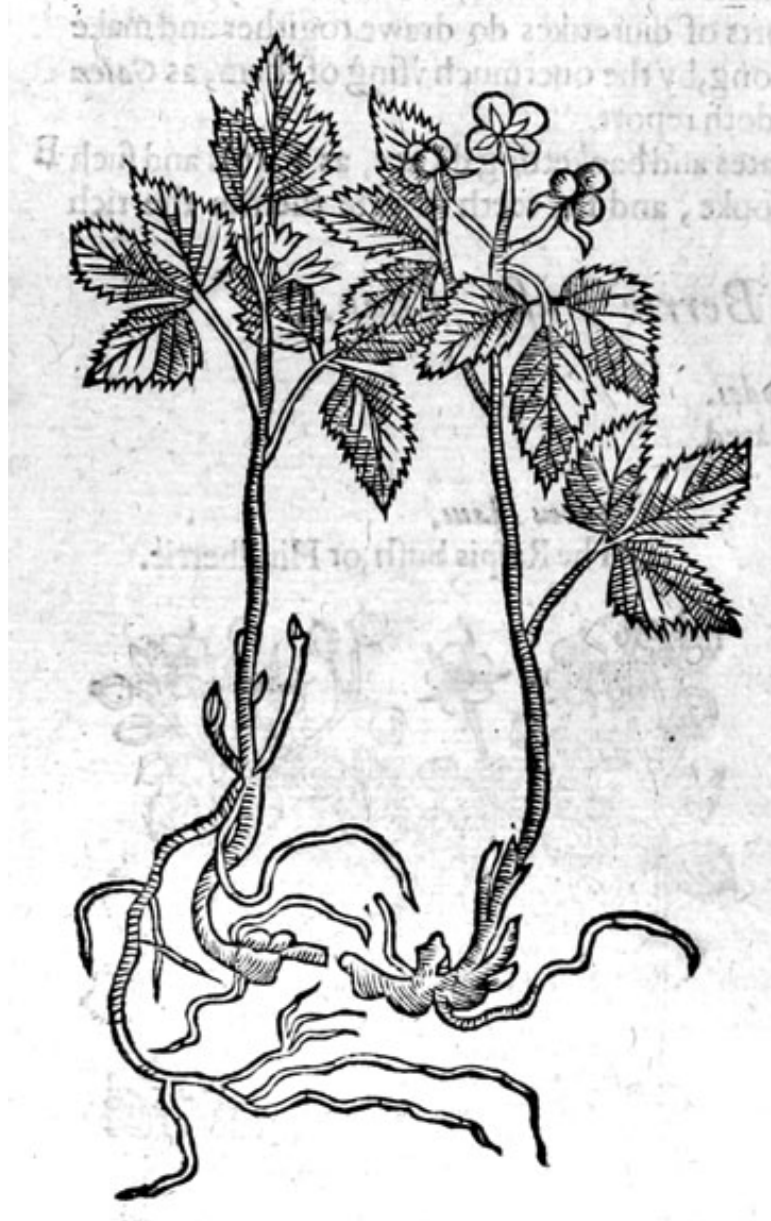

4. Chomemorus.

Knot Berrrie tree.

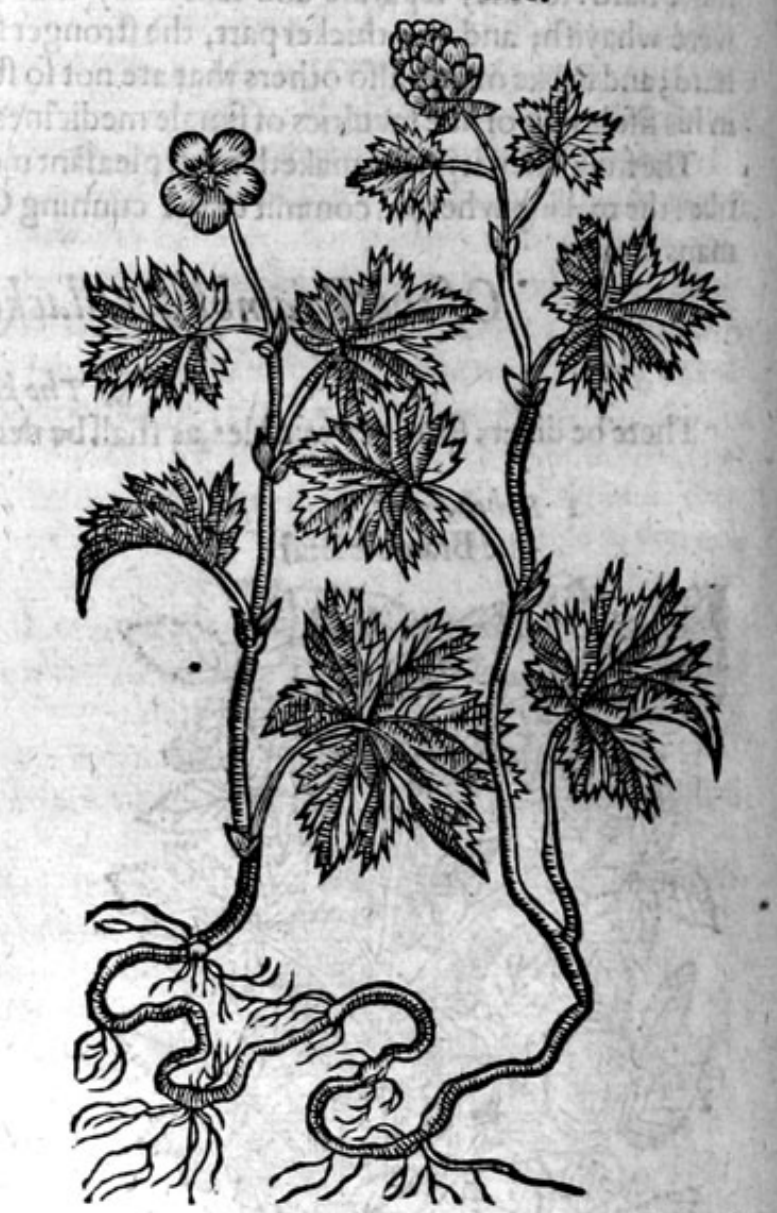

* The defcription.

3 Stone Bramble feldome groweth 3 bouc a foote high, hauing many fmal flexible branches trailing vpon the ground, coucred with a reddin barke, and fomwhat hairie: the leaues grow three togither, fet vpon tender naked footeftalks; fomwhat fnipt about the edges:the flowers grow at the endes of the branches, confitting of fow $\cdot r$ fmall white leaues, like thofe of the Cherrie tree : after which come fmall grapelike fruite, confifting of one, two, or three graines fet togither, as thofe of the common Bramble, of a red colour when they be ripe, and of a pleafant tafte, but fomewhat aftringent: the roctes creepe along in the grounde verie farre abroade, whereby it greatly increafech. 


\section{HISTORIE OF PLANTS.}

4 Chamemorus called in the north part of Englande (where they efpecially do growe) Knot terries, andKnought berries, is likewile one of the Brambles, though withoutprickles : it bringeth foorth fmall weake branches or tender ftems, of a foote high ; whercon do grow at certaine diftances,rough leaties, in Thape like thofe of the Mallow, not vnlike to the leates of the Goofebcrrie bufh: on the top of each branch ftandeth one flower and no more, confilting of fiue fmall leaues, of a darke purple colour; which being fallen, the fruite fucceedeth, like vnto that of the Mulberie (whereofit was called Chamemor ws, dwarffe Mulberie) at the firft white and bitter, after red, and fomewhat pleafant: the roote is long, fomething knottie; from which knots or ioints thruft foorth a fewe threadie ftrings.

$$
\text { * The place. }
$$

The Bramble groweth for themolt part in euery hedge and bufh.

The Rafpis is planted in gardens; it groweth not wilde that I know of, except in the fielde by a village in Lancafhire called Harwood, not farre from Blackburne.

I haue found it among the bufhes of a cawfey, neere vnto a villagecalled Wifterfon, where I went to fchoole, two miles from the Nantwitch in Chefhire.

The ftone bramble I haue found in diuers fieldes in the Ile of Thanet, harde by a village called Birchinton neere Queakes houfe, fometimes Sir Henrie Crifpes dwelling place.

Knot berries do loue open fnowie hils, and mountaines : it groweth plentifully vpon Ingle. borough hils among the Heath and Ling, twelne miles from Lancafter, being thought to be the higheft hill in England.

It groweth vpon Stanemoore betwoene Yorkefhire and Weftmerland, and vpon other wet Fels and Mountaines.

\section{* The time.}

Thefe flower in Maie and Iune with the Rofes: their fruite is ripe in the ende of Auguft and Sep. tember. * The sames.

The Bramble is called in Greeke Báres: in French Rouges, Loi Duyts Brelmers : in Latine Rubus, and Sentis, and Vepres, as Owid writech in his firft booke of his Metamorphofis:

\section{Aut lepori, qui vepre latens hoftilia cermit Oracanum.}

Of divers it is called cynosbatus, but not properly, for Cynosbat us is the wilde Rofe, as we haue written : in high Dutch 2 betemen: in low Dutch 232 eement : in French Rouce : in Italian Car $z a:$ in En. glifh Bramble Bufh, and Blackeberrie Bufh.

The fruit is named in Latine Morum Rubi: and as Fucb/ses thinketh racinium, but not properly: in hops Mora Bati : and in fuch fhops as are more barbarous Mora Ba/t: in Englifh Blackberries.

The Rafpis is called in Greeke Bixos ifaĩ : in Latine Rubus Idews, of the mountaine Ida on which it groweth: in Englifh Rafpis, Framboife, and Hindberrie.

\section{* The temperature and vertues.}

The yoong buds or tender tops of the Bramble Bufh, the flowers, the leaues, and the vnripe fruit, $A$ do very much dry and binde withall: being chewed they take away the heate and inflammations of the mouth,and almonds of the throte; they ftay the bloudy flixe, and other fluxes, and all maner of bleedings; of the fame force is their decoction, with a little honie added.

They heale the eies that hang out; hard knots in the fundament; and faic the hermorrhoides, if $B$ the leaues be laid thereunto.

The iuice which is preffed out of the ftalkes, leaues, and vnripe berries, and made hard in the fun, C is more effectuall for all thofe things.

The ripe fruite is fiveete, and containeth in it much iuice of a temperate heate, therefore it is not D vnpleafant to be eaten,

It hath alfo a cereaine kinde of aftriction or binding qualitic.

It is likewife for that caufe holfome for the ftomacke; and if a man eate toolargely thereof, faith $\mathrm{F}$ Galen, he fhall haue the headach : butbeing dried whileft it is yet vnripe, it bindeth and drieth more then the ripe fruit.

Theroote befides that it is binding,containeth in it much thin fubftance, by reafon whereof it $\mathrm{G}$ waittech awaie the ftones in the kidneies, faith Galsm. 

wine is a prefent remedie againft the ftone.

The leaues of the Bramble boiled in water with honie, allum, and a little whitewine added therto, maketh a moft excellent lotion or wafhing water, to heale the fores in the mouth;the priuy parts

The Rafpis is thought to be like the Bramble, in temperature and vertues, but not fomuch binding nor drying. The fame faith Diofcorides performeth thofe things that the Bramble doth.

The fruit is good to be giuen to thofe that haue weake and queafie ftomackes.

\section{Of Hollie Rofes, or Ciftus. Chap.3.}

E The kindes.
If thereof, Male and Female; and likewife a thirde fort, which is called Ledum: the later Herba.

ofliberaty

thereof, Male and Female; and likewife a thirde f

\section{- - fort goon y}

\section{* a generall defoription, wherein all the forts of cistus are comprifed.}

C ISt us and his kinds are woody fhrubs, full of branches, of the height of two or three chbits:fome haue broad leaues; others rough, vneeuen, wrinckled, fomewhar downie, and moft like the leaues of Sage, although fome hatie the leaues of Rofemarie; others the forme of thofe of the Poplar tree :the flowers growe on the tops of the branches, like vnto the wildeRofe; yet fuch as very quickly fade, perifh; ; and fall away: thofe of the Male, are moft of a reddifhblew, or purple colour; and of the Female white : in their places come vp little heads or knops fomcwhat round, in which is conteined fmall feede : the rootes of them all are woodie.

There groweth vp fomtimes vnder the fhrub harde to the roots, a certaine excrefcence or hypocifte, which is thicke, fat, groffe, full of iuice, without leaues, wholy confifting of manie little cafes or boxes, as do thofe of Henbane, or of the Pomegranate tree, of a yellowifhred colour, in one kinde, and in another white; and in certaine other greene or graffie, as Diof cor ides faith.

\section{* The defription.}

17 He firft kinde of Cistus groweth vp like a fmall bufh or fhrub, of a woodie fubltance, three

1 or fower cubits hight; gatnifhed with many fmall and brittle branches, fet full of crumpled or rugged leaues, very like vnto Sage leaues : at the top of the branches come flowers, of a purple colour, in fbape like vnto a fingle Brier Rofe, hauing leaues formw hat wrinckled, like a cloth new dried before it be fmoothed, and in the midft a fewe yellow chiues or thrums: the flowers for the mott part do perifh and fall away before noone, and neuer ceafe flowring, in fuch maner, from the moneth of Maie vnto the beginning of September, at which time the feede is ripe, being of a reddifh colour, and is contained in an hard hairie huske, not much vnlike the huske of Henbane.

2 The fecond fort of Cistus being another kinde of the Male Ciffus, which Pena callech Ciftus mas cum bypociftide, is like vnto the former; but that from the roote of this kinde there commeth a certaine excrefcence or growing out, which is fomtimes yellow, fometimes greene, \& fomtimes white, from which is drawne by an artificiall extraction a certaine iuice, called in fhops Hypociffis.

3 This kind of $\mathrm{Cift}$ us hath many woody ftalks, diuided into diuers brittle bräches, of a ruffet colour; whereon do grow rough leaues, fomwhat cut or toothed on the edges, and of an ouerworne colour: the flowers grow on the tops of the branches in form of the Muske Rofe, but of an excellent bright purple colour : after which come round knops, wherein is contained fmall reddifh feede: the roote is tough and woodie.

4. This fourth fort of Ciftus hath diuers woodie branches, whereon are fet thicke thruft togither diuers finall leaues, narrow, like thofe of winter Sauorie, but of an ouerworne ruffet colour:the root and flowers ate like the precedent. 
HISTORIE OF PLANTS.

I Cistus mas angufifolius. The male Holly Rofe.

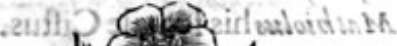

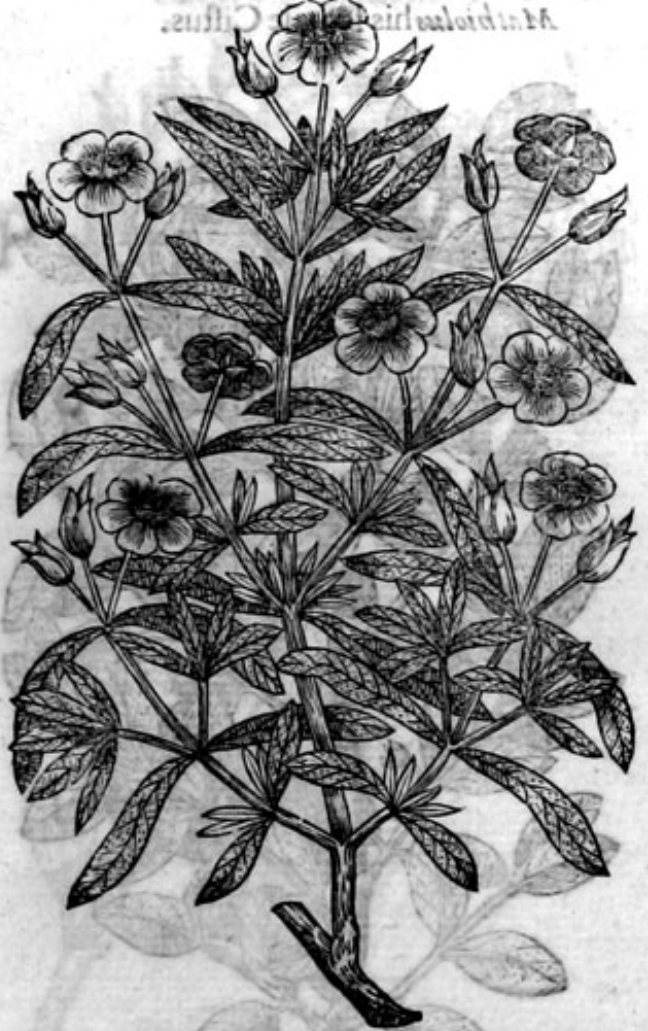

3 Cisteu mas dentatus. Toothed or fnipt male Ciftus.
2 Ciftus mas cum Hypocifide.

The male Holly Rofe with his exerefence.

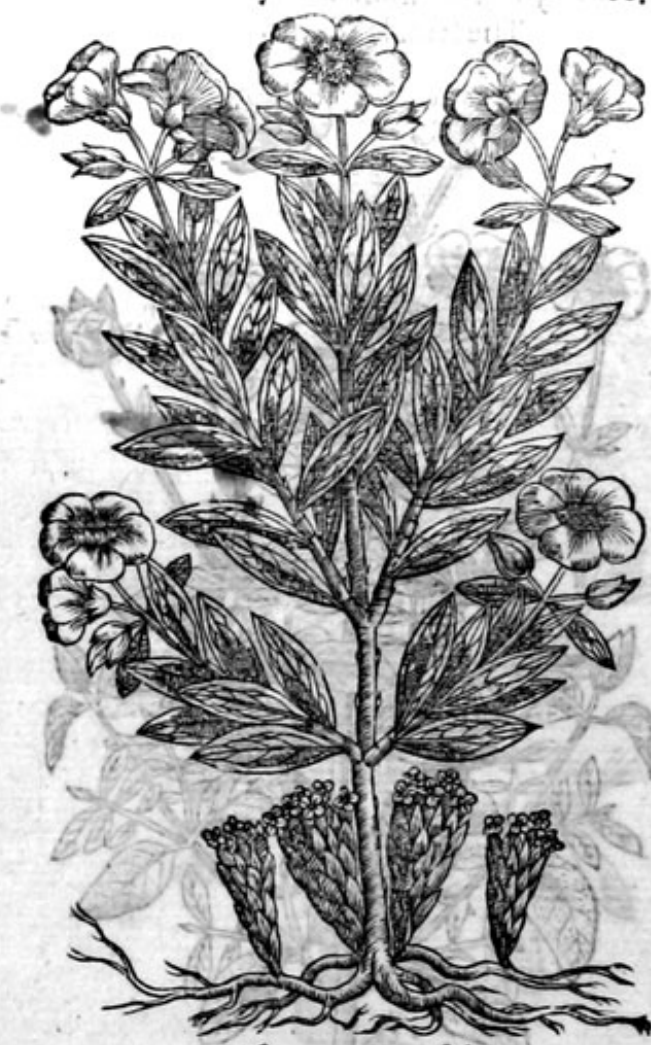

4 Ciftus mas tenuf oliuss. Thin leafed Cirtus.

Q 1 ( )
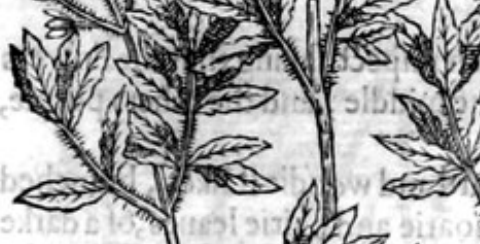

这
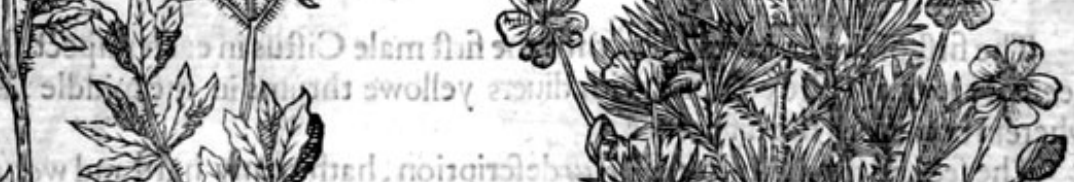

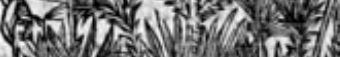

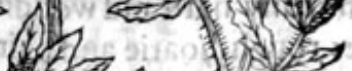
전
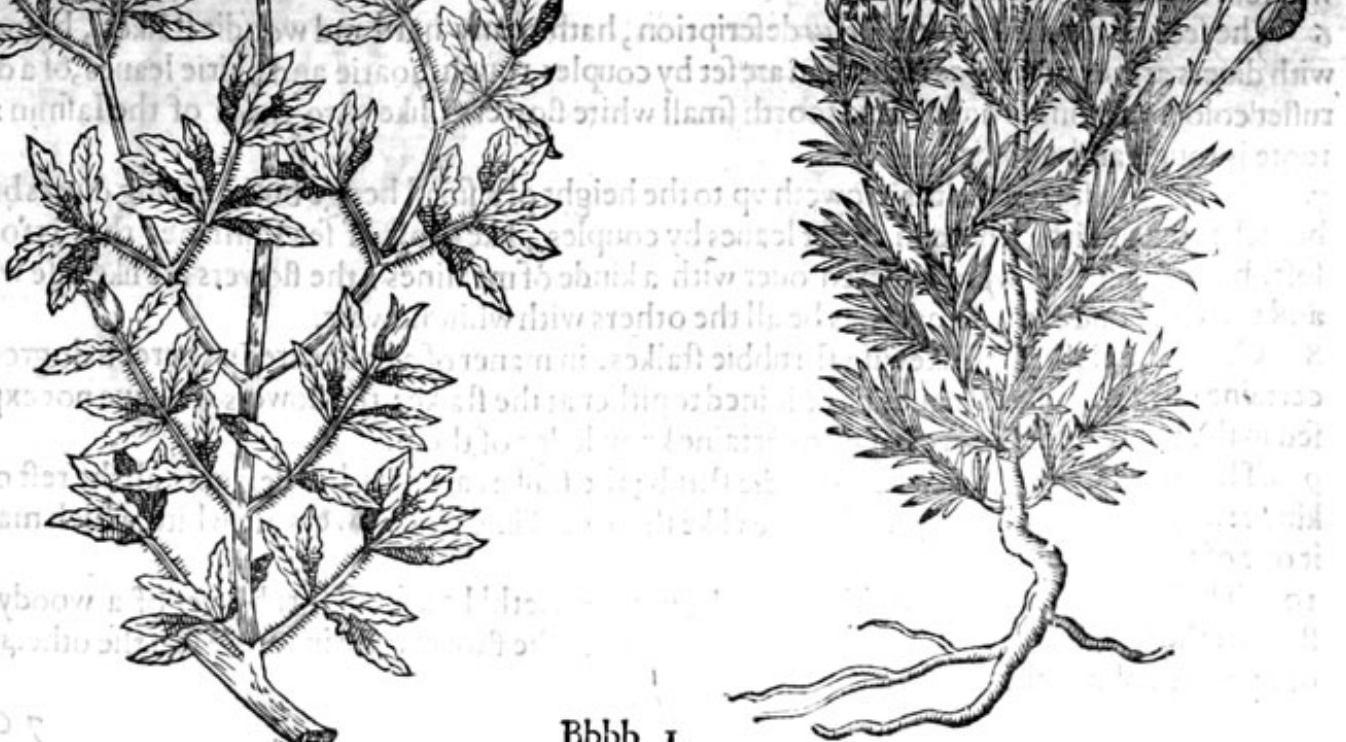

ins
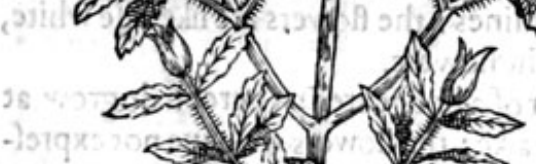

\&2.
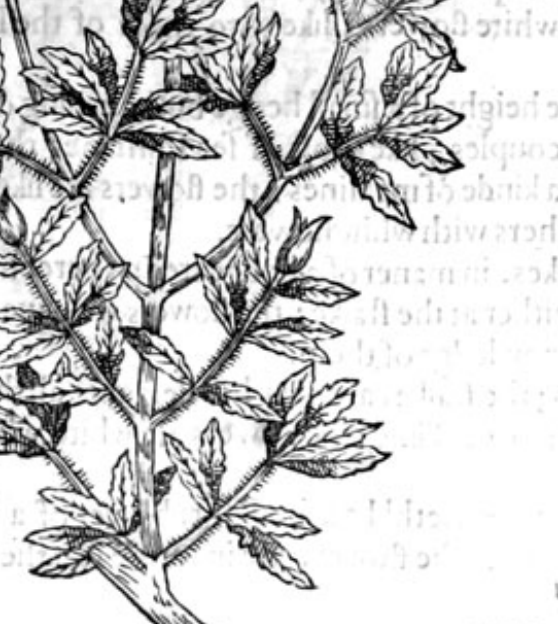

Bbbb I 
5 Ciftus famina.

The female Ciftus.

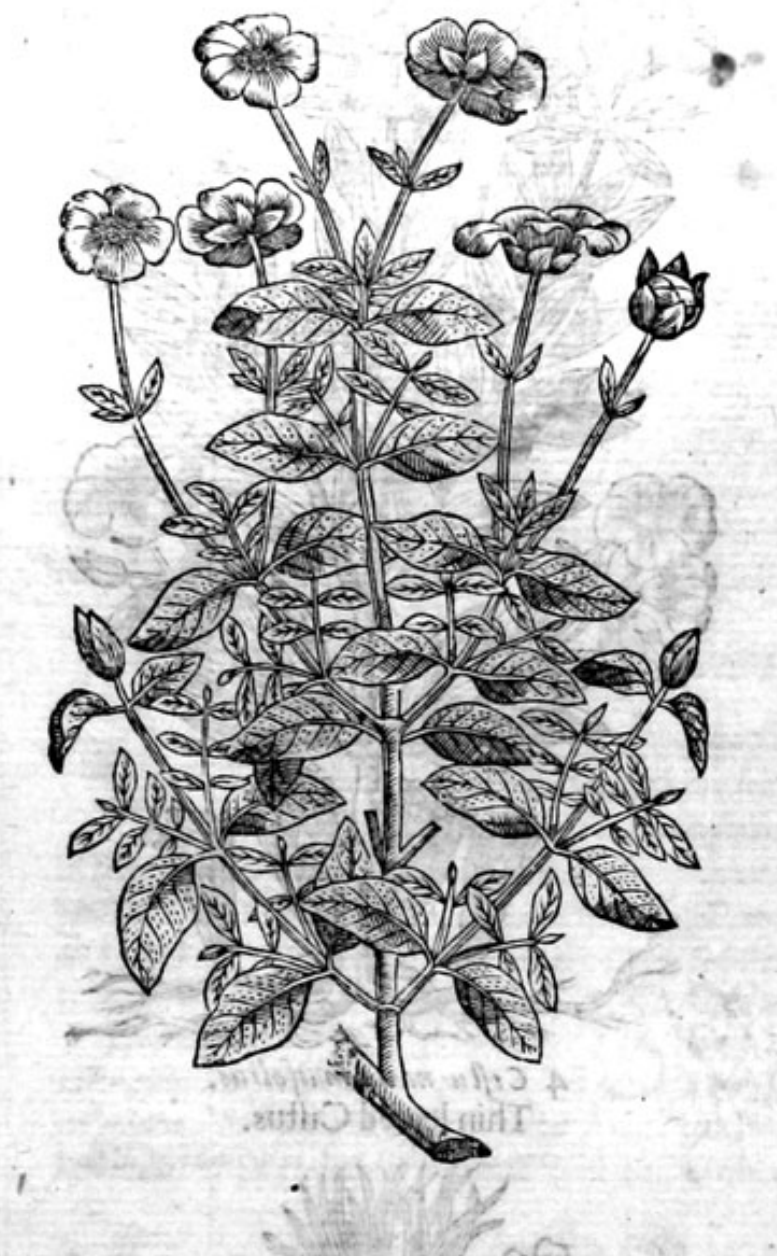

6 Ciftus farmina Mathioli. vill Mathioles his female Ciftus.

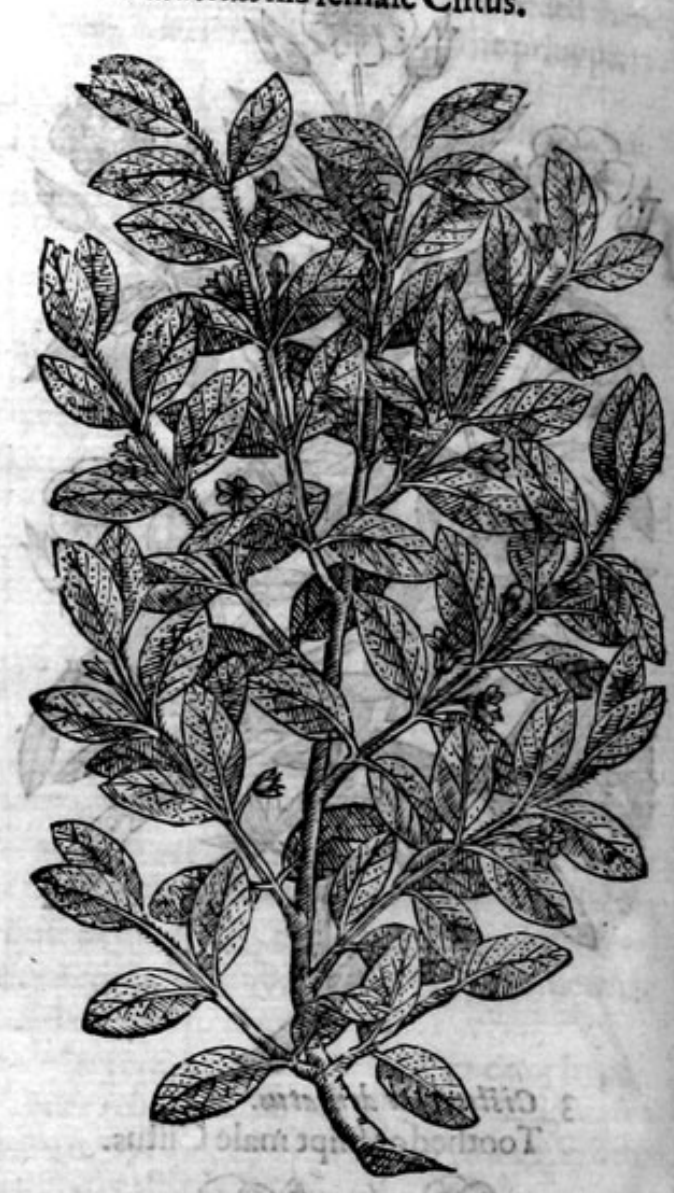

\section{* Thedefription.}

5 The firft of the females is like vnto the firft male Ciftus in each refpee, fauing that the flowers heereof are of a white colour, with diuers yellowe thrums in the middle, and the others purple, wherein confifteth the difference.

6 The fecond female of Mathiolus defcription, hath many hard and woodie ftalkes, branched with diuers armes or winges: whereon are fet by couples, rough, hoarie and hairie leates, of a darke ruffet colour; among which come foorth fmall white flowers, like vnto thofe of the Iafmin: the roote is tough and woodie.

7 The feucnth fort of Ciftus groweth vp to the height of a fmall hedge burh, hauing diuers brittle branches full of pith; whereon are fet leaues by couples, like thofe of fea Purflane, that istofaie, foft, hoarie, and as it were couered ouer with a kinde of mealines: the flowers are likewife white, and therefore one of the females, as be all the others with white flowers.

8 Cittus the eight, hath likewife fhrubbie ftalkes, in maner of a hedge tree; whereon dogrow at certaine diftances diuers leaues clofe ioined togither at the ftalke : the flowers we haue not expreffed in the figure by reafon we haue nocertaine knowledge of them.

9 This ninth Ciftus is likewife a woodie fhrub; the ftalkes are very brittle, as are all the reft of his kinde : whereon do grow very fmall leaues like thofe of Time : the flowers are white, which maketh it one of the females.

10 The lowe or bafe Ciftus with broade leaues, growethlike a fimall frub, yet of a wondy fub. ftance; the leates are many, of a darke greene colour :the flowers are in forme like the others; but of a ycllow colour : the rootes are likewife woodie. 


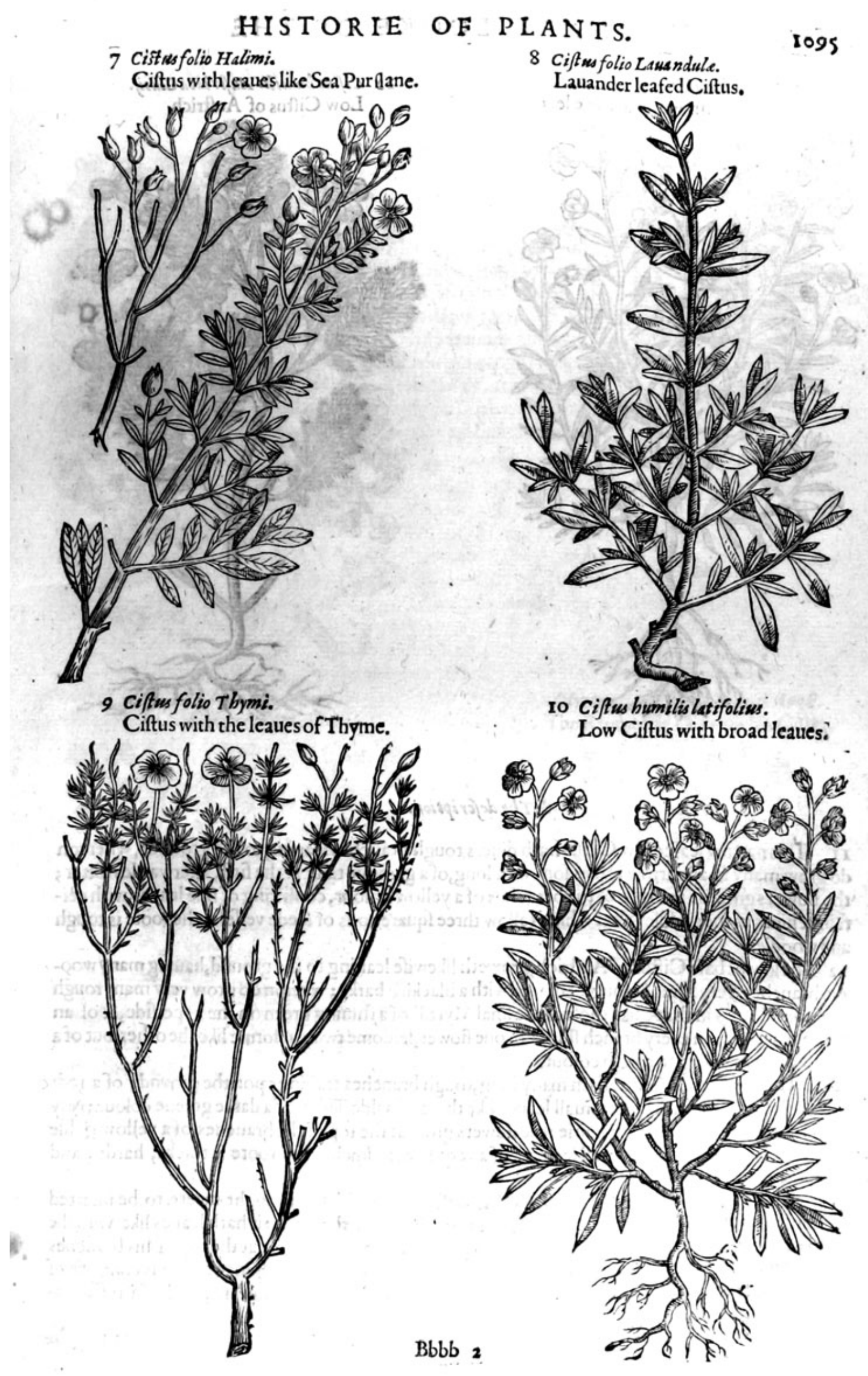


II Cift us humilis angaftifolius.

Low Ciftus with narrowe leates.

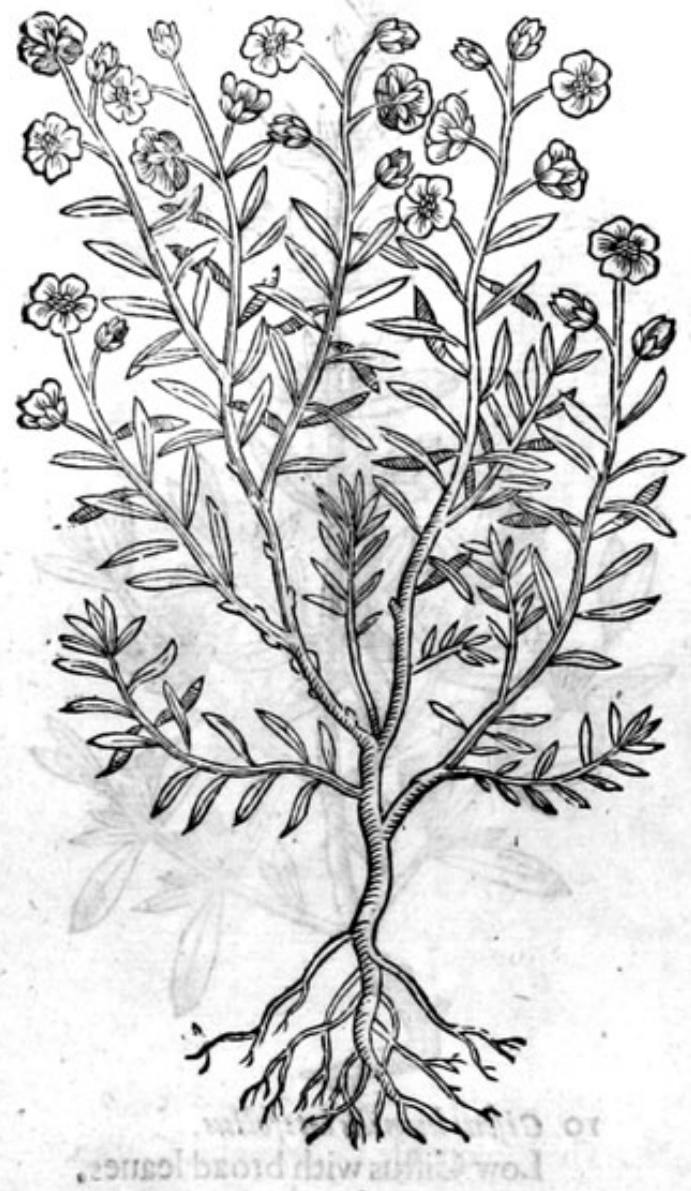

I Ciftas bumilis Anfriacaclusï. Low Ciftus of Auftrich.

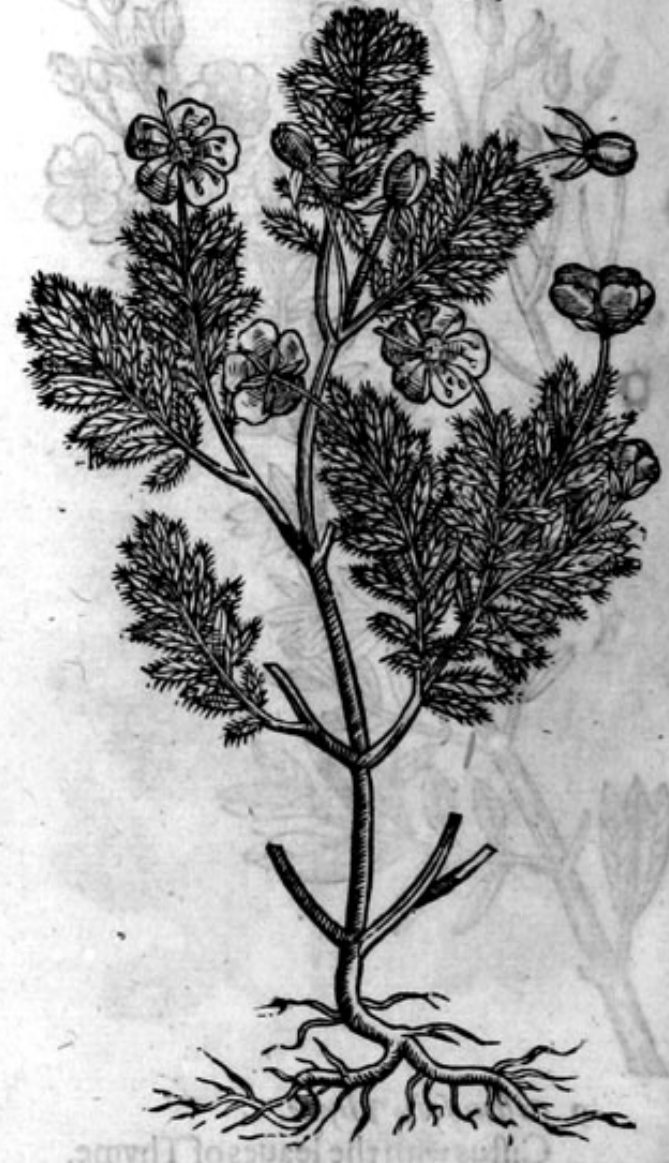

* The defription.

II This natrow leafed low Ciftus hath diuers tough branches leaning to the grounde, whereon do grow many fmall narrow leaues fomwhat long, of a gummie tafte at the firft, afterwardes bitter; the flowers grow on the tops of the branches of a yellow colour, confifting of fiue leaues, with certaine chiues in the middle; after which follow three fquare cods or feede veffels: the roote is tough and woodie.

12 Thelow or bafe Ciftus of Auftrich, groweth likewife leaning to the ground,hauing manywoodie branches, very firme \& tough, couered with a blackifh barke; wheron do grow very many rough and hairieleaues in thape like thofe of the fmal Myrtill, of a fhining green on the vpperfide, \& of an aftringent $t$ afte; on euery branch ftandeth one flower, feldome two, in forme like the other, but ofa white colour tending to a flefh colour.

13. This low fort of Ciftus hath many long,tough branches trailing vpon the ground, of a reddifh colour; whereon do grow fmall leaues like thofe of wilde Time, of a darke greene colour ; very thicke and fat, and fomewhat hairic : the flowers grow at the top of the branches, of a yellow golde colour, confifting of fiuc fmall leates, of a very fweete fmell : the roote isthicke, harde, and woodic.

14 This ftrange and rare plant of L'Obels obferuation, I haue thought meete to be inferted among the kinds of Ciftus, as a friend of theirs, if not one of the kinde : it hath leaues like vnto the male Ciftus (che firft in this Chapter defcribed) but more hairie; bearing at the top of his branches a finall knop, in thape like a rotten Strawberic; but not of the fame fubitance: for it is compact of a fealic or chaffie matter, fuch as is in the middle of the Cammomill flowers, and of a ruffer colour. 
I3 Cistus bumilis serpillifolio.

Cistus exoticus L'Obely.

Low Ciftus with leaues like wilde Time.

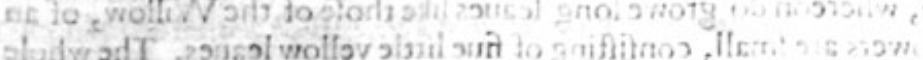

Es?

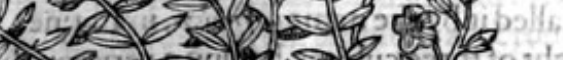

Q $>2$ - 130 .

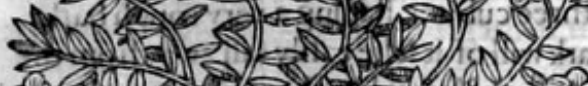

है

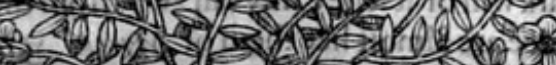

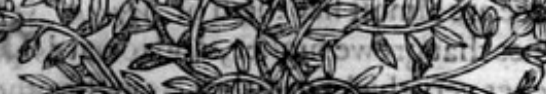

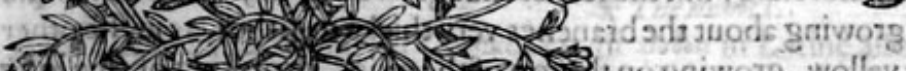

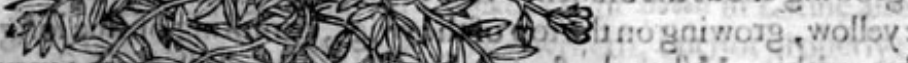

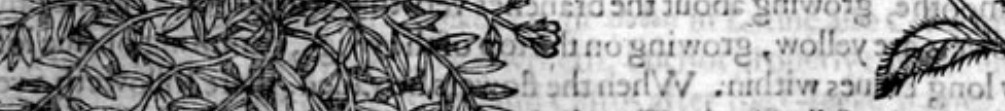

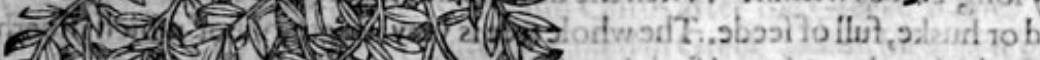
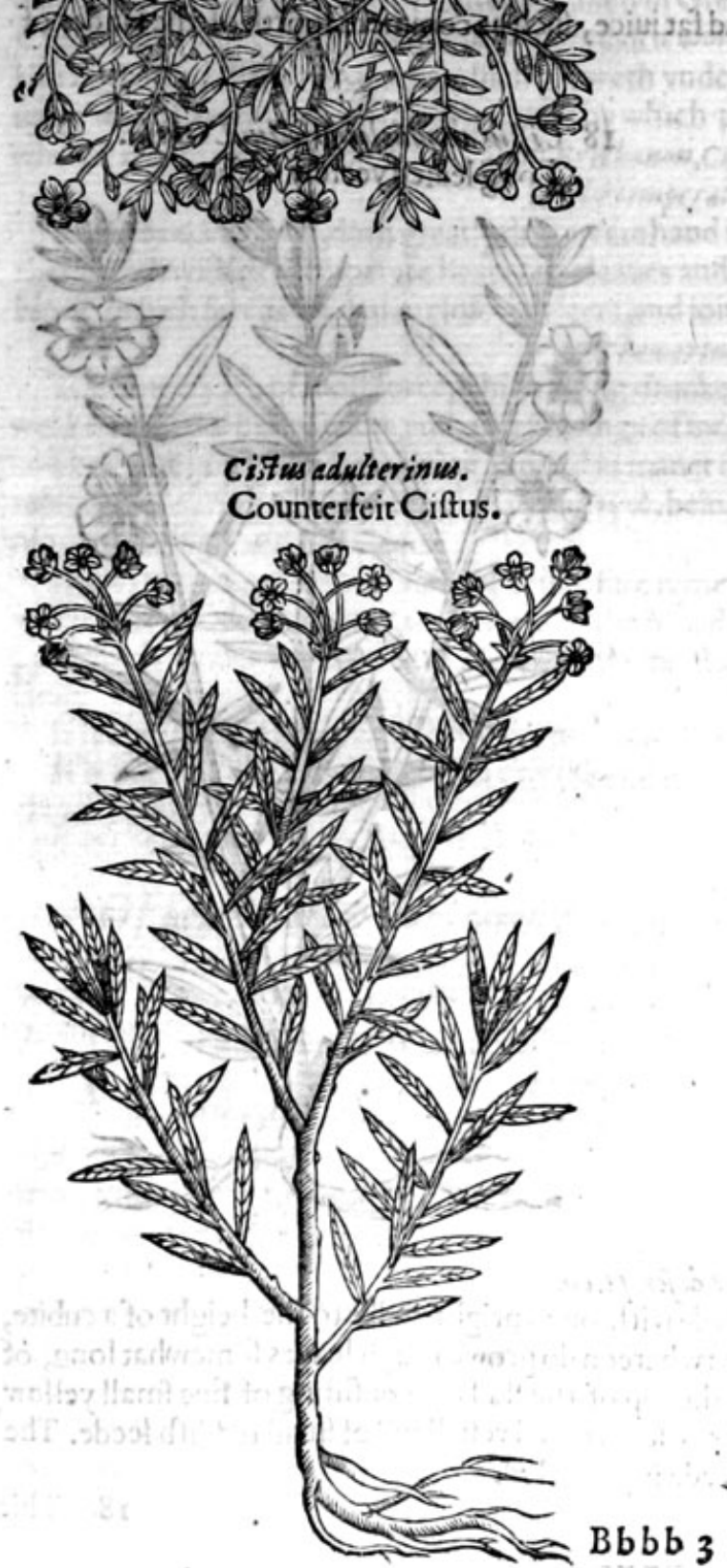

\section{CMyrtocistus T bome Pennei Angli.} The Reuerenide D.Penny his Ciltus.

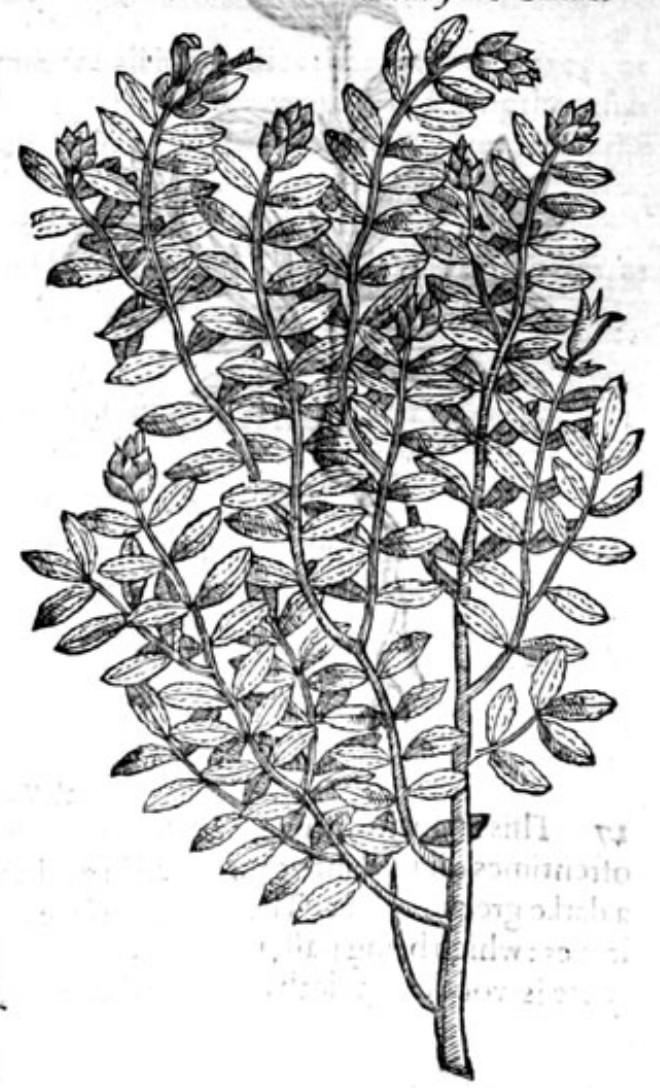




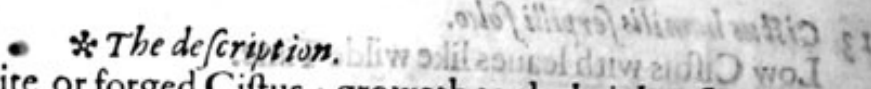
I5 This adulterine or counterfeite or forged Ciftus, groweth to the height of an hedgeburh : the branches are long and britrle, whereon do growe long leaues like thofe of the Willow, of an ouerworne ruffet colour. The flowers are fmall, confifting of fiue little yellow leaues. The whole plant being well viewed, feemeth to be a Willow, but at the fitt fight, one of the Ciftus; fo that it is a plant participating of both.The roote is woodie.

16 This kinde of Ciftus, which Doctor Pennie ( a famous Phifition of London deceafed) did gather vpon the Ilands Maiorica or Maiorca, and called it by the name uvprexisov, in Latine cryrto. ciftus Balearica, is a thrubby tree, growing to the height of three cubites, hauing a very rough barke, olde branches or boughes of the tree. The leaues of this tree are almoft like them of Myrtess, very rough vnderneath like the branches aforefaid : but the leaues that growe higher, and towards the top of the branches are fmoothe, growing about the branches very thicke togither, as in the other kindes of Ciftus. The flowers are yellow, growing on the top of the twigs, confifting of fiue long leaues, full of many very long chiues within. When the flowers be vaded, there followeth a very long and fiue fquare head or huske, full of feede. The whole tree is very fweete, out of which iffieth a gum or rofine, or rather a thicke, clammie and fat iuice, fuch as commeth foorth of the kindes of

\section{Ledum.}

17 Cistus annuses.

Ciftus lafting one yeere.

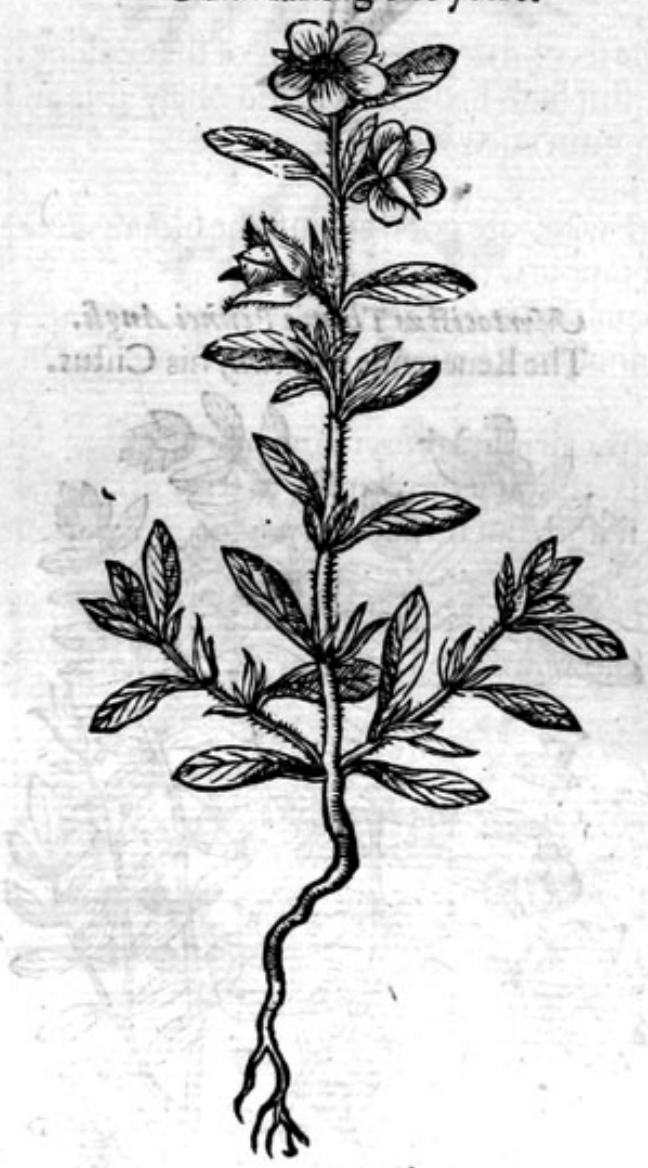

18 Ciff us annuns longifolius L'Obely. Long leafed yeerely Ciftus.

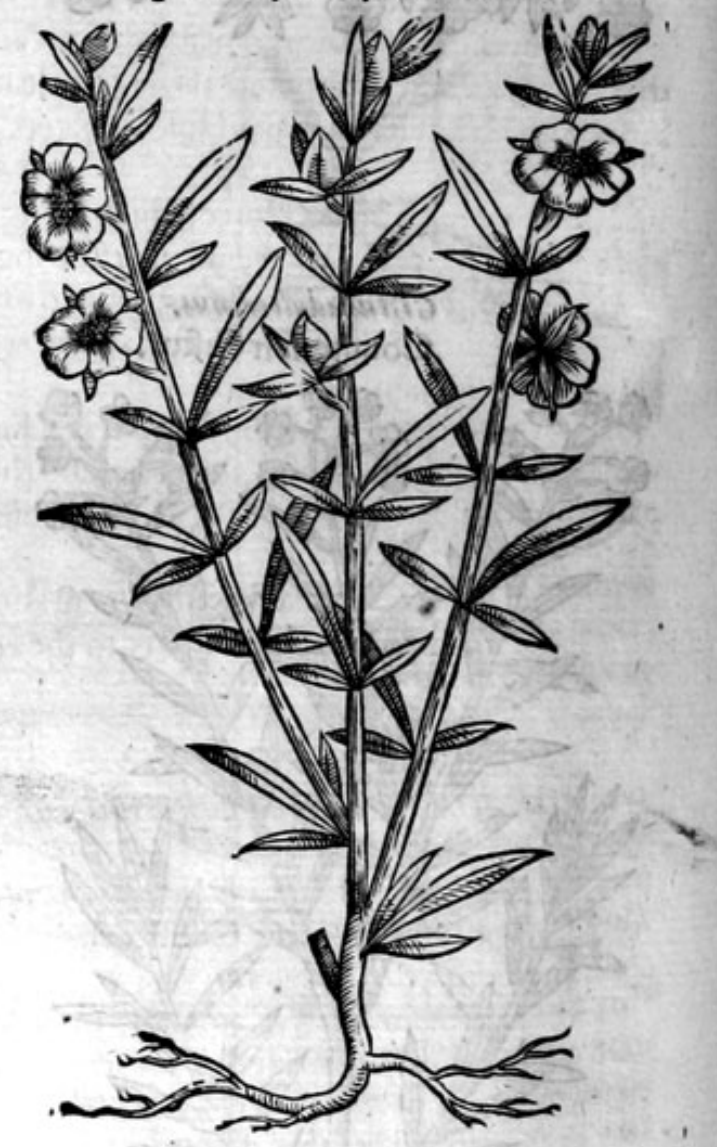

* The defcription.

17 This annuall Ciftus groweth vp from feede with one vpright ftalke to the height of a cubite, oftentimes diuided into other fmall branches : whereon do growe rough leaues fomewhat long, of 2 darke greene colour. The flowers growe at the top of the ftalkes, confifting of fiue fmall yellow leaucs : which being paft, there followeth a three fquare feed veffell full of fmall reddifh feede. The roote is woodie, yet doth it perifh when the feede is perfected. 
18 This other $\mathrm{Ciftus}$ that lafteth but one yere, hath long ftalks, dituided into other branchee, of the height of two cubits; whereon do grow long rough leaues, fet three togither at certainc diftances, the middlemolt whereof is longer then the other two; the flowers growe on the fides of the bran? ches like the female Ciftus, of a white colour : the roote is of a woodie fubftance, as are all the reft of his kinde.

Hollie Rofes grow in Italy, Spaine, and Languedoc, and in the countries bordering vpon the ri uer Padus, in all Hetruria and Maffiles, and in many other of the hotter prouinces of Europe, in dry and ftonie places, varying infinitely according to the diuerfitie of the regions where they grow; of which I haue two forts in my garden, that is the firft and the laft but one.

They dower from Maic to September.

$$
\text { * The time. }
$$

\section{*. The names.}

The Hollic Rofe is called in Greeke risos, or xistos: in Latine alfo Ciftus, and Rofa fyluatica; of diuers Rofa Canina, as Scribonius Largaj writeth, but not properly: in Spanifh Eftepa : of the Portingales Rofilla: in Englifh Hollie Role, and Ciftus after the Greeke name. That Fungus excref ens which groweth at the roore of Ciftus, is called in Greek iovords, bicaufe it groweth vnder the fhrub Ciftus; it is a!fo called Limodoron: diuers call it winvos, among whom is Paulues $A E$ gineta, who alfo doth not call that Hypociftis which groweth vnder the fhrub Cist us, but the iuice hecrof; wherupon might grow the worde Hypocist is, by which the Apothecaries do rudely name this inice when it is hardned: of fome it is called Erithanon, Citinus and Hypogsiftsdos.

\section{* Thetemperature.}

Ciftus as Galen faith, doth greatly drie, necre hand in the fecond degree, and it is of that coldnes, that it hath withall a temperate heate; the leaues and the firft buds being beaten, do onely dric and binde, infuch fort as they may clofe vp vlcers, and ioine togither new wounds.

\section{* T thevertues.}

The flowers are of moft force, which being drunke with wine, are good againft the bloudy fixe, A weakenes of the belly, fluxes, and ouerflowings of moift humours.

They cure putrified vlcers being applied in maner of a pultis: Diofcorides teacheth that they are a $\mathrm{B}$ remedie for cating vlcers; called in Greeke vouas, being annointed therwith, and that they cure burnings, fcaldings, and old vlcers.

Hypocist is is much more binding, it is a fure remedie for all infirmities that come of fluxes, as $\mathrm{C}$ voiding of bloud, the whites, the laske, and the bloudie flixe: but if it be requifite to ft rengthen that part which is ouerweakned with a fuperfuous moifture, it doth notably comfort \& ftrengthen the fame.

It is excellent to be mixed with fomentations that ferue for the ftomacke and liuer.

It is put into the Treacle of vipers, to the end it fhould comfort and ftrengthen weake bodies, D Galen writeth.

\section{Of otber plants reckoned for dwarffe kinds of Cistus. Chap.4.}

* Thedefcription.

17 He Englifh dwarfe Ciftus, called of L'Obelius Panax Chironium (but there is another Panax of Chirons defcription, which I hold to be the true and right Panax; notwithftanding he hath inferted it amongit the kindes of Ciftus, as being ind.fferent to ioine with vs and others for the infertion) is a lowe and bafe plant creeping vpon the grounde, hating manie fmall tough branches, of a browne colour: whereon do growe litele leates fee togither by couples, thicke, fat, and full of fubltance, and coucred ousr with a foft downe; from the bofome wherof come foorth other leffer leaues; the flowers before they be open are fmall knaps or burtons, of a brown colour mixed with yellow; and being open \& fpred abroad are he thofe of the wilde Tanfic, iv of a yellow colour, with fome ye!lower chites in the middle; the roote is thich \& of a woodic fubitance. 2 The fecond is very like vnto the precedent, fauing that the leaues are long, and do not grow fo thicke thruft togither, and are more woolly; the flowers are greater, and of a white colour, wherein the efpeciall difference confiltech : the roote is like the former.

\section{$\mathrm{Bb} b \mathrm{~b}$}

2 Holianthe 
I Helianthemum Anglicum luteum. Englifh yellow Dwarffe Ciftus.

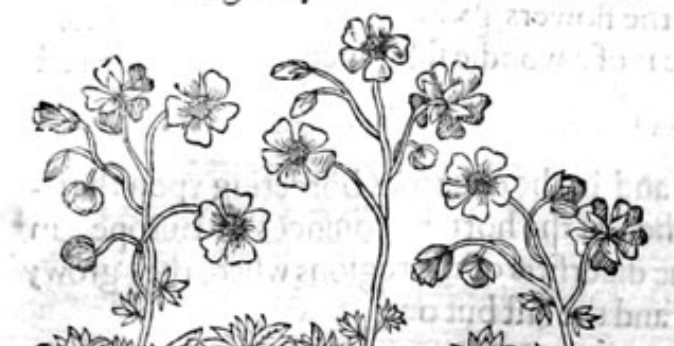
(1) MV कौ 2 (12) क. 5 (1) (1)

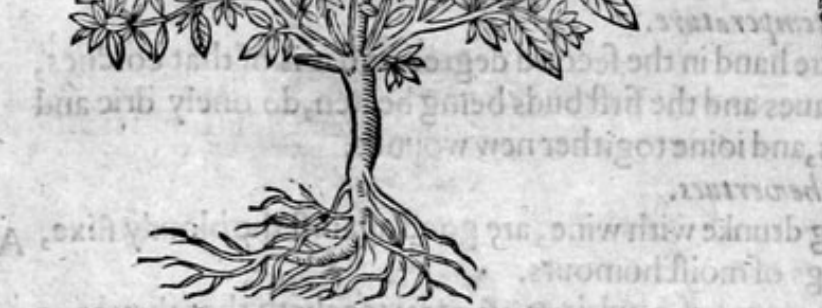

3 Heliantbemum luteum Germanicam.

The yeilow Dwanfe Ciftus of Germany. (1) 6.9. (1) 4 in

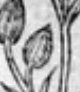

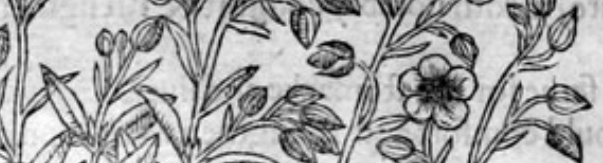
Nav an on

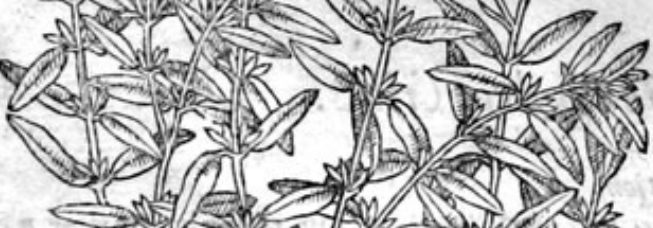
A
2 Helianthermum Anglicum album. White Dwarffe Ciftus of England.

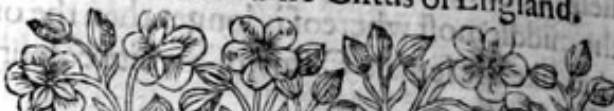

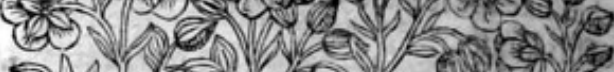
S) $=150$

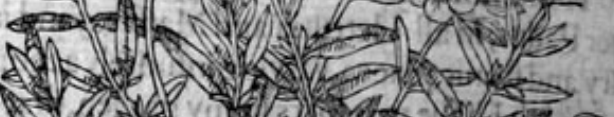
H. $=125$

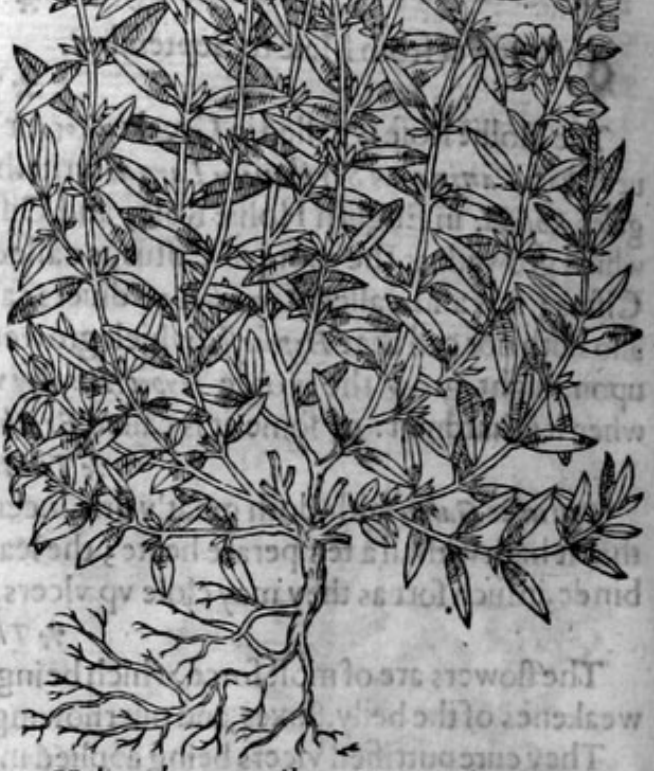

4 Heliant benum album Germanicum. The white Dwarffe Ciftus of Cermanie.

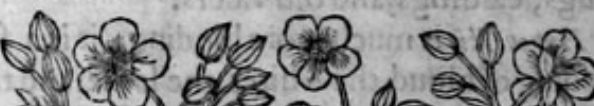

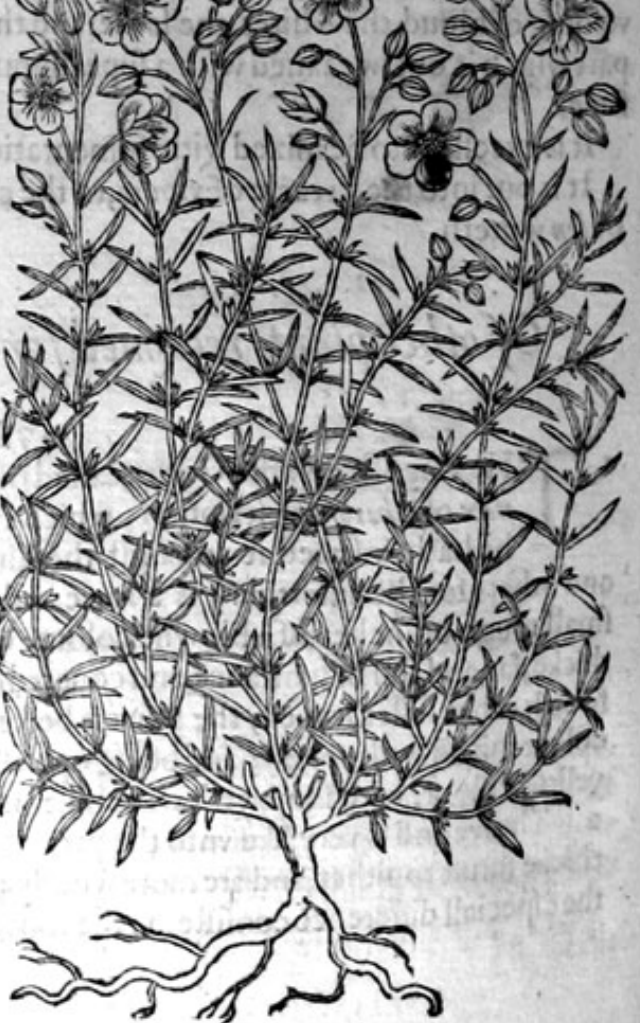




\section{B HISTORIE OF PLANTS.}

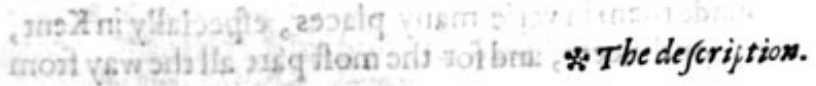

3 There is found in Germany a certaine plant like to Ciftus, and $L$ :don, but much leffer, creeping vpon the ground, vnleffe it be propped vp, hauing a multitude of twiggic branches, flender, and fine: whereupon do grow leaues lefter then thofe of Ledon or Ciftus, very like to that of our Englifh white dwarf Ciftus, of a full fubftance, flightly haired, wherein is conteined a tough iuice : the flowers are fmall like little Rofes, or the wilde Tanfie, of a yellow colour: the rootes be flender, woodys

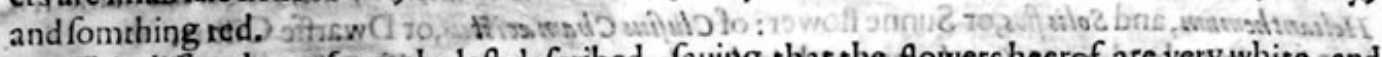
4 This differech not fravi the laft deferibed, fauing that the flowers heerof are very white, and

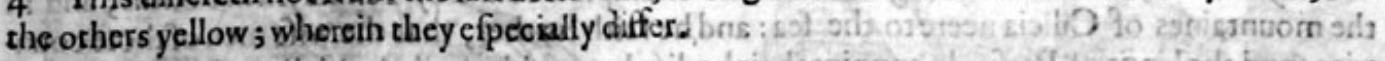

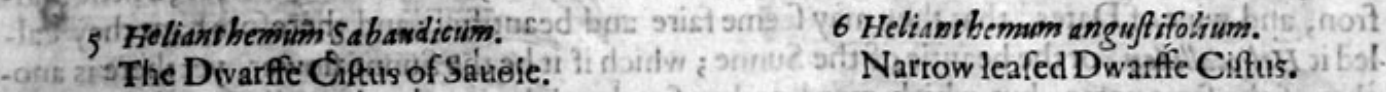

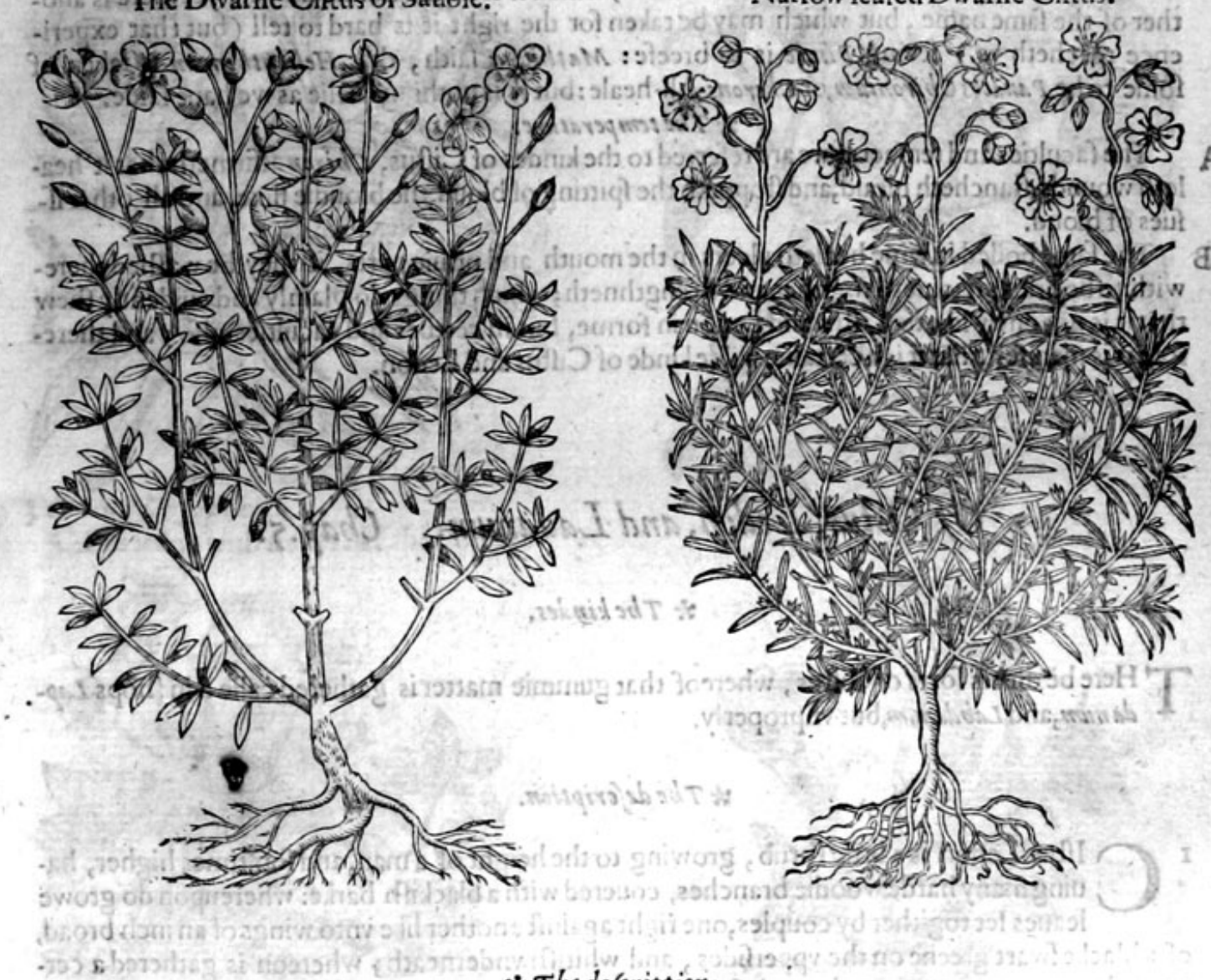

* Thedefcription.

5 The Dwarffe Ciftus of Sauoie hath diuers tough branches, of a reddifh colour, verie tough and woodie, diuided into diuers other branches: whereon are fer finall leaues, fower togither, by cercaine fpaces; the flowers grow at the top of the branches like thofe of our yellowe Dwarffe CiItus, of a yellow colour : the roote is very woodic.

6 This Dwarffe Ciftus with narrow leaues, hath very many finall fexible branches, of a browne colour, very finooth, and ramping vpon the ground; whereon do grow fmall, long, narrow leaues, like thofe of Time of Candie ; from the bofome whereof come foorth dituers other fmaller leaues: the flowers grow on the tops of the branches, of a bleake yellowe colour : the roote is likewife woody.

Their feuerall titles haue touched their naturall countries : they grow in rough, drie, and funnic places, in plaine fieldes and vpon mountaines. 


\title{
$1 \mathbf{1 0 2}$
}

\section{THE THIRD BOOKE OF THE}

Thofe of our Englifh growing, I haue founde them in verie many places, efpecially in Kent, vpon the chalkie banks about Graues ende, Southfleete, and for the moft part all the way from
thence vnto Canterburic and Doner.

They flower from Iuly to the end of Auguit. * The time. * The names.

Tragus calleth Dwarffe Ciftus in the high Dutch toong Devoren Delope : in Latine Gratia Dei but there is another herbe called alfo of the later Herbariftes Gratiola : Valerins Cordaw nameth it Helianthemum, and Solis flos, or Sunne flower: of Clufues Chamecist us, or Dwarffe Ciftus.

Pliny writeth, that Heliant he groweth in the champion countrey Temifcyra the mountaines of Cilicia neere to the fea: and he faith furcher, tries, and the kings of Perfia do annoint their bodies heerewher, that the wife men of thofe counfron, and wine of Dates, that they may fecme faire and beaut, boiled with lions fat, a little Saf. led it Heliocalliden, or the beautie of the Sunne; which if it be the Sund therefore haue they cal. ther of the fame name, but which may be taken for the right it is hard to tell yet there is ano. ence teacheth vs) feeing Plimie is fo breefe: Matbiolus faith, that Helianthem that experifome to be Panaces Chironium, or Chirons All-heale : but it is nothing likelie as we baure is taken of * The temperature.

A The faculties and temperature are referred to the kindes of Ciftus, chiron affirmeth that it healeth wounds, ftancheth bloud, and ftoppeth the fpitting of bloud, the bloudie flixe, and all other iffues of bloud.

B The fame boileu in wine healeth vlcers in the mouth and priuic parts, if they be wafhed therewith:to be briefe, it ioineth togither and ftrengthneth; which things do plainly and euidently fhew that it is not onely like to Ciftus and Ledon in forme, but in vertues and faculcies alfo; and therefore it is manifert, that it is a certaine wilde kinde of Ciftus and Ledon.

\section{Of Cistus, Ledon, and Ladanum. Chap.5.}

\author{
* The kindes.
}

\section{Here be diuers forts of Ciftus, whereof that gummie matter is gathered calle din thops Lep.
danum, and Labdamum, but vnproperly.}

\section{* The defoription.}

$1 \bigcirc$ Iftus Ledon is a little fhrub, growing to the height of a man, and fomtimes higher, hauingmany harde woodie branches, couered with a blackifh barke: whereupon do growe leaues fet togither by couples, one right againft a nother like vnto wings of an inch broad, of a blacke fwart greene on the vpperfides, and whitifh vnderneath; whereon is gathered a certaine clammie tranfparent or through fhining liquor, of a verie hot fiveete fmell, which being gathered and hardned, is that which in fhops is called Lapdanum: the flowers grow at the ends of the branches like little Rofes, confifting of fice white leaues, euery one decked or beautified toward the bottom with prety dark purplifh fpots tending to blacknes, hauing in the middle very many yellow chiues, fuch as are in the middle of the Rofe : after come the knaps or feede veffels, full of moft fmall reddifh feede; the whole plant being dried,groweth fomewhat whitith and of a pleafant fmell, the which it retaineth many yeeres.

2 The fecond groweth likewife to the height of an hedge bufh; the branches are long, and verie fragile or eafie to breake; whereon do growe leaues greener then any of the other of his kinde, yet vnderneath of a hourie colour; growing toward winter to be fomwhat reddifh, of a fower and binding tafte; the flowers are like the precedent; the forme whereof the graucr hathomitted, in other refpects like the former. 
I Ciftusledon r. Clusï.

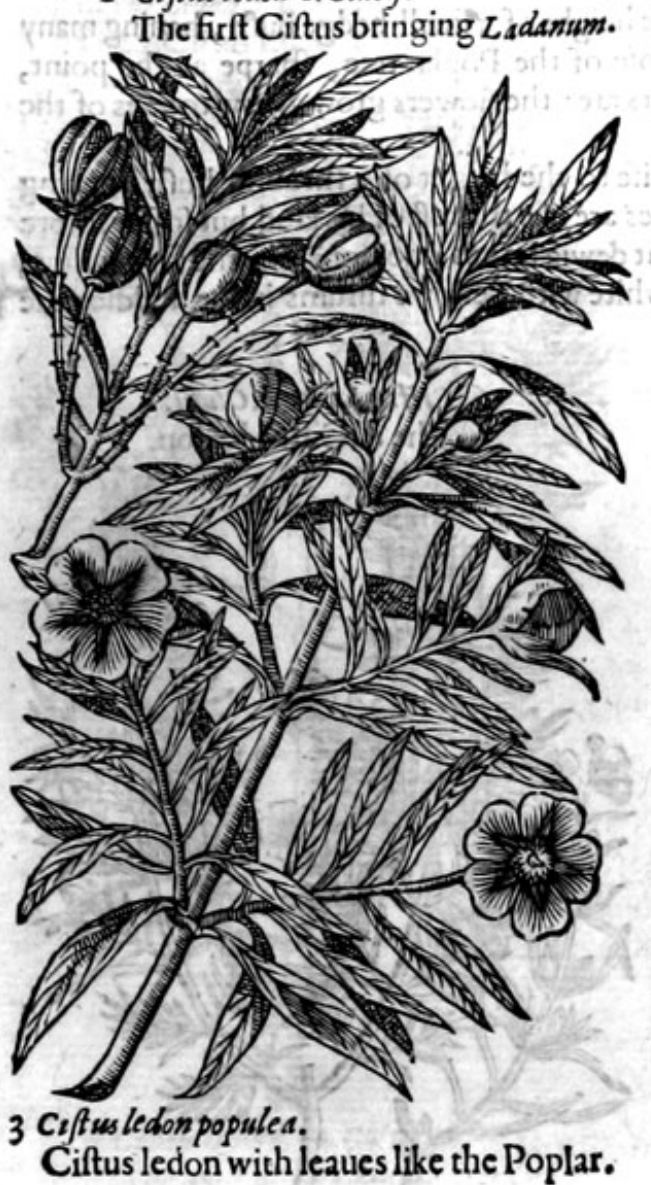

Ciftus ledon with leaues like the Poplar.

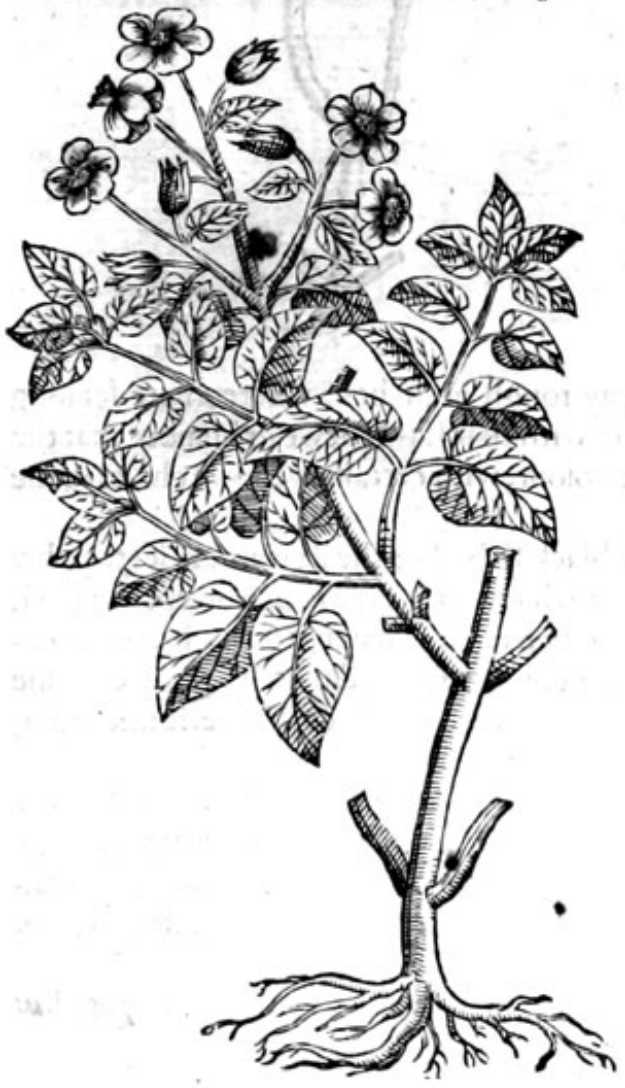

2 Cistusledon 2. Clusï.

The fecondgum Ciftus.
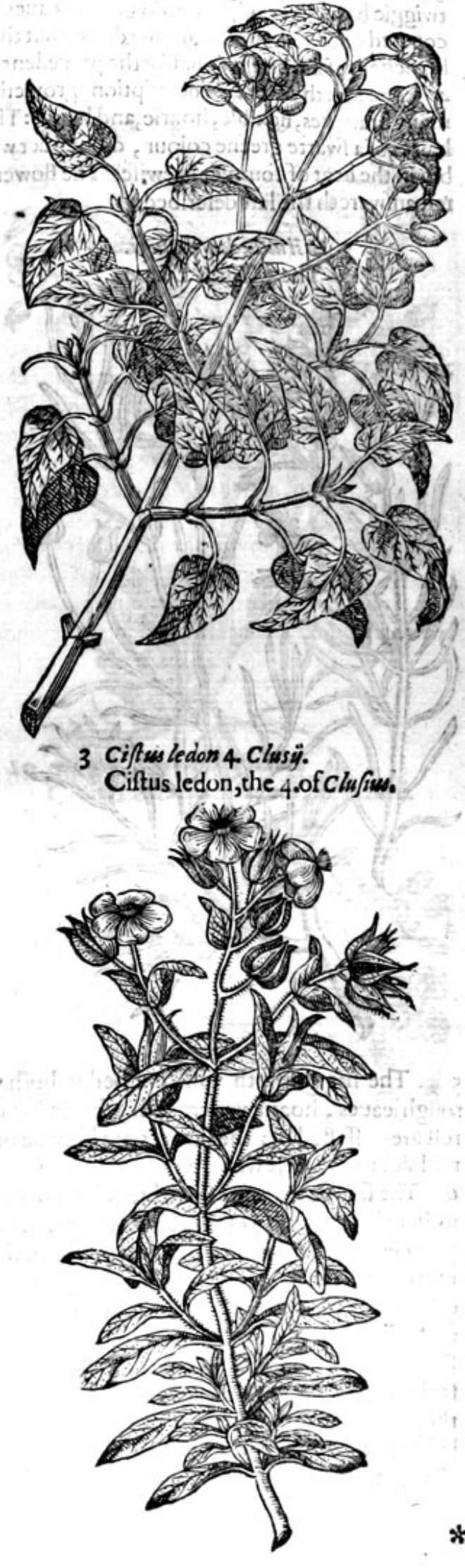

*T The 


\section{* $T$ he defcription.}

3 The third fort of Citus Ledon groweth vp to the height of a frnall hedge buin , fin ? twiggie branches; whereon do growe leaues like thofe of the Poplar tree, tharpe at the point, conered ouer with that clammie dewe that the others are: the flowers grosy at the toppes of the
branches, of a white colour like the precedent.

4 The faurth of Clufues defcription, groweth likewife to the height of a fhrubbic bufh, hauing hairie, of a fwarte greene colour, dafhe ouer we leaues are like the reft of his kind; but fofter, more but in the heat of fommer likewife. The flowers at dewic fatnes, not onely in the fpring time, reft anfwereth the laft deferibed.
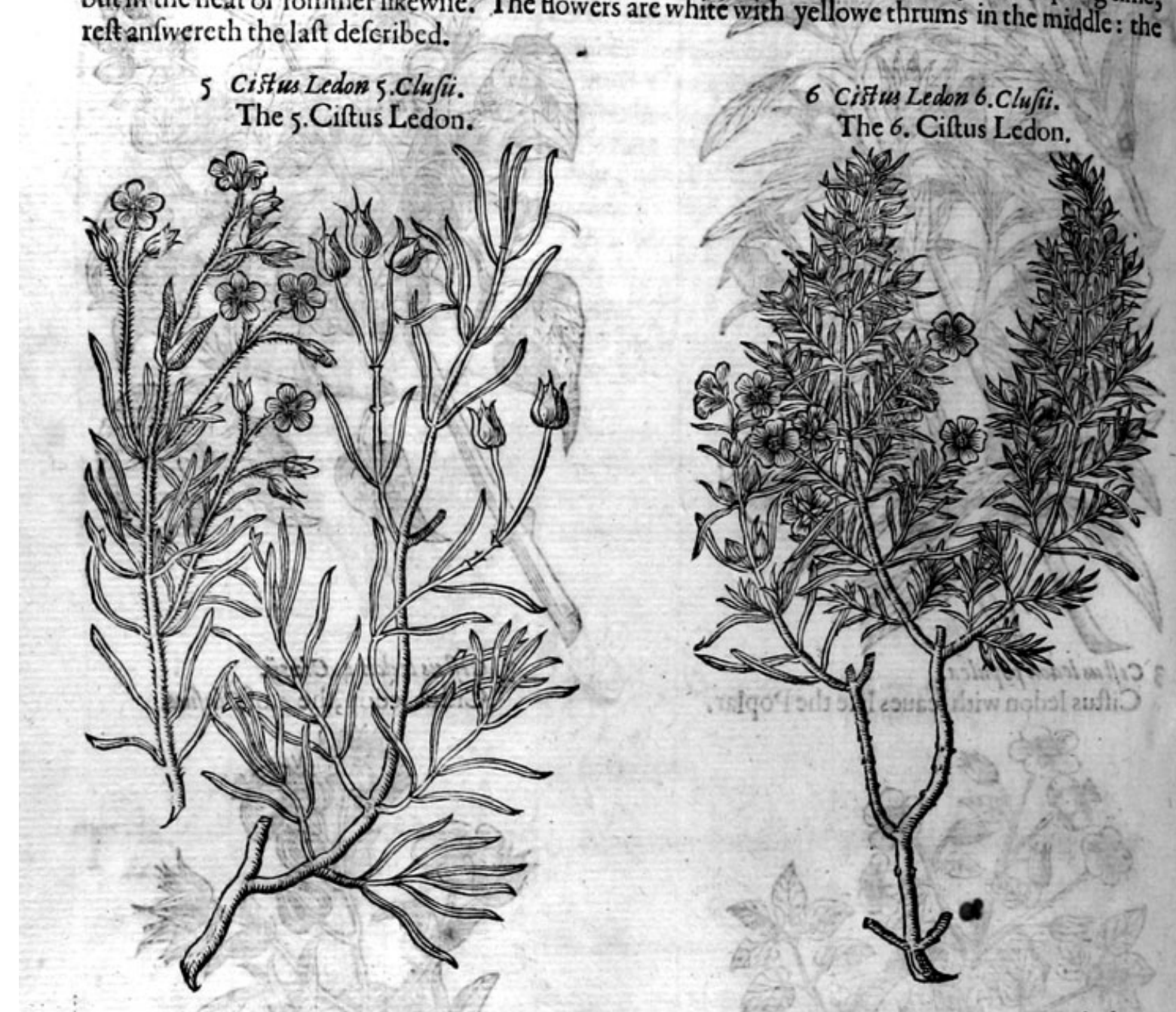

5 The fift groweth vp like a hedge burh with many rough branches; whereon are fet long roughleaues, hoarie vnderneath, fomewhat dafht ouer with that fattie dewe or humour that the reft are poffeffed of: the flowers are likewife of a white colour, with certaine yellowe chines in the middle: the roote is woodic.

6 The fixt hath divers fmall branches conered with a blackifh barke: the flowers are fettogither in bunches many in a clufter by certaine fpaces. They are white and like the former in each relpeet. 7 The feucnth is a lowe fhrub growing to the height of tivo cubits, hauing many branchescouered with a barke of the colour of afhes; whereon are confufedly fet divers leaues at certaine diftances, finall, narrow, like thofe of winter fauorie, of an ouerworne ruffet colour,verie thicke, fat, and glutinous: the flowers differ not, neither the feed from the reft.

8 The eight growe th vp like a little hedge bufh, hauing leaues like the common female Ciftus; fauing that thofe of this plant are fprinckled ouer with that clammic moifture, and the other not fo: the flowers and feedes are alfo like. From the roote of this plant commeth fuch like excrefens called Limoduron, Orobanche or Hrpocistis, as that doth of the fift male Ciftus, wherin it differeth from all the reft vnder the name Ledon. 
7 Ciffus Leaion 7 . Clusiy.

The 7.Ciftus Ledon.

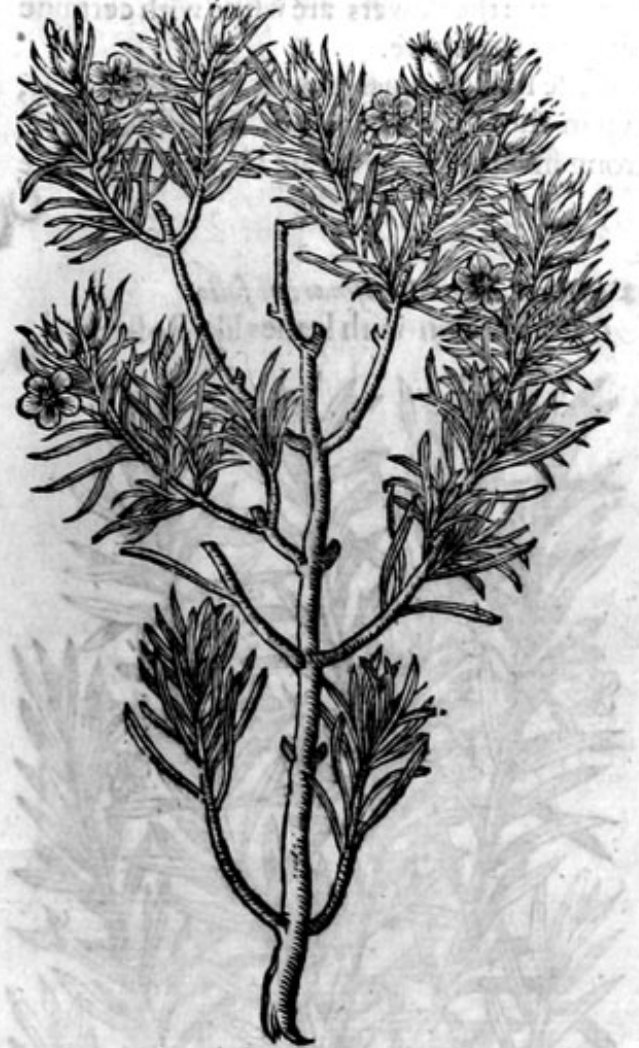

9 Ciftus Ledon 10. Clusy.

The 10. Ciftus Ledon.

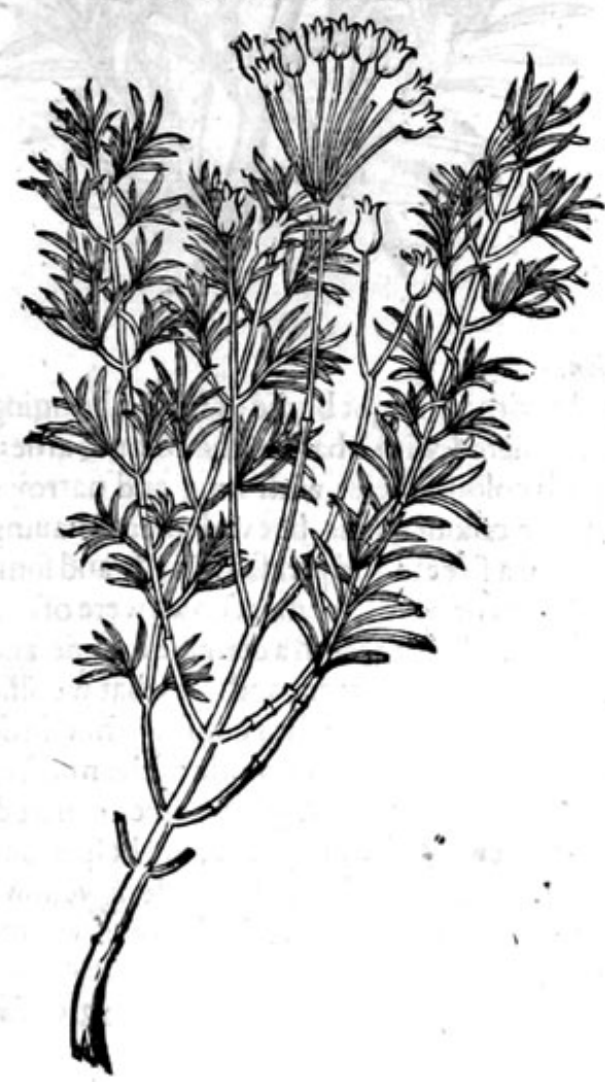

8 Ciftus Ledon cum Hypociftide L'Obelij.

The 8.Ciftus Ledon, with his excrefcence.

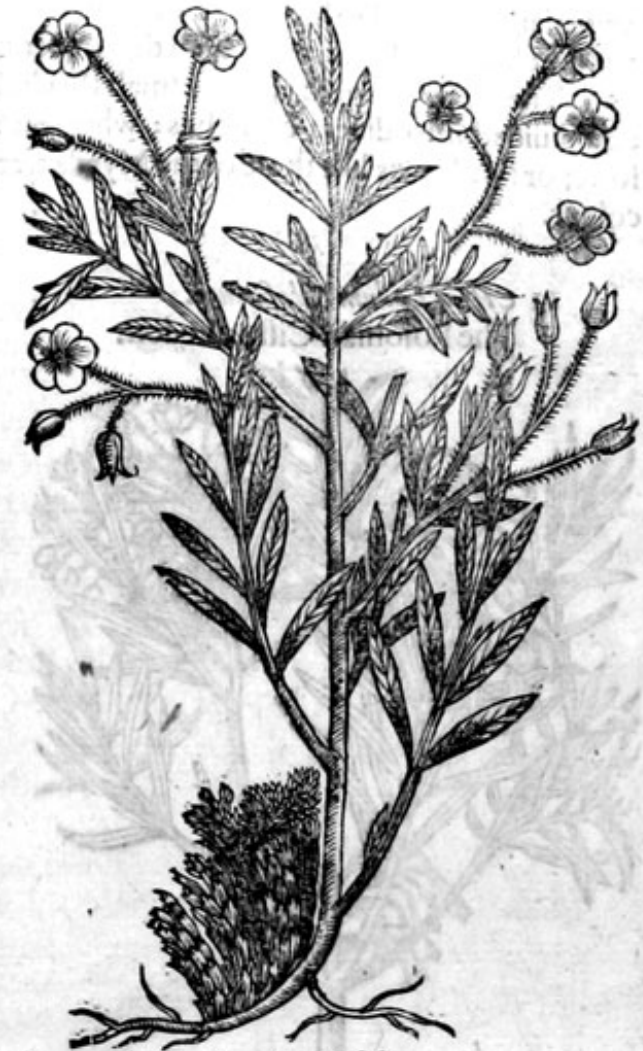

to Ciftus Ledon Myrtifolium.

Ciftus Ledon with leaues like Mirtill.

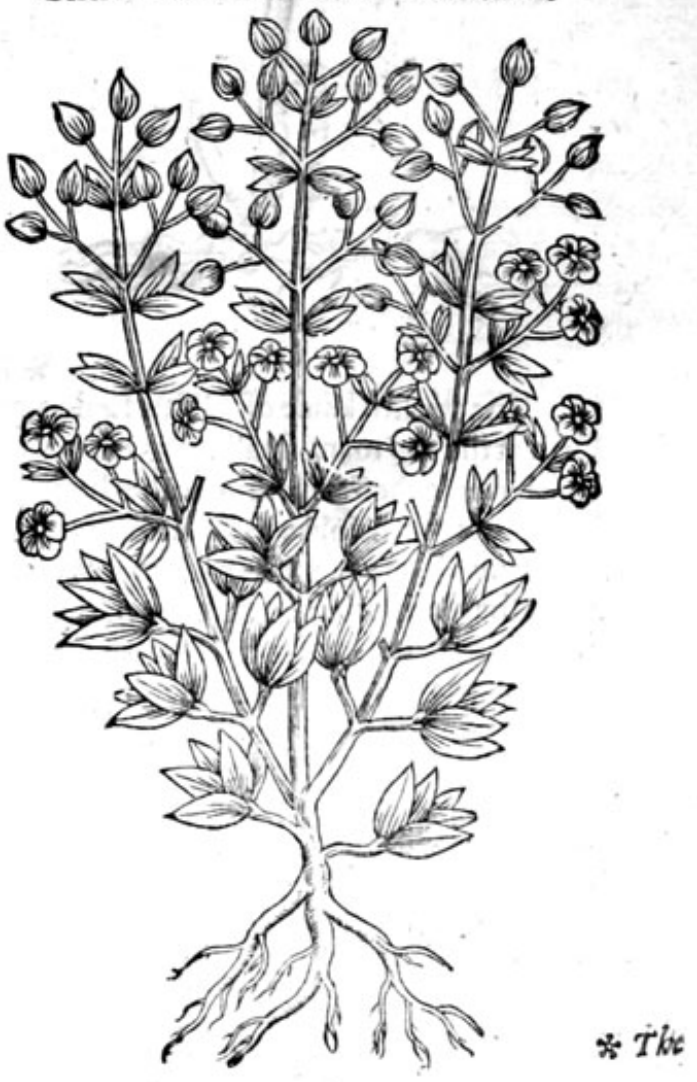


$* T$ be defcription.

9 The ninth hath diuers brittle ftalkes of an afh colour tending to a ruffet; whereon are fet yellow chiues in the middle, which the grauer hath omitted in the figure. 10 The tenth groweth vp like a fmall thrut, hauing britrle ftalkes, couered with a blackifh barke, and diuided into diuers branches; whereon are fet vpon fhort truncheons or fat footeftalkes, fowcr or fiuc leaues like thofe of the Myrele tree, of a ftrong fmell: the flowers are likewife of a white
colour.

II Ciffus Ledum Silefiacum.

The Polonian Ciftus Ledon.

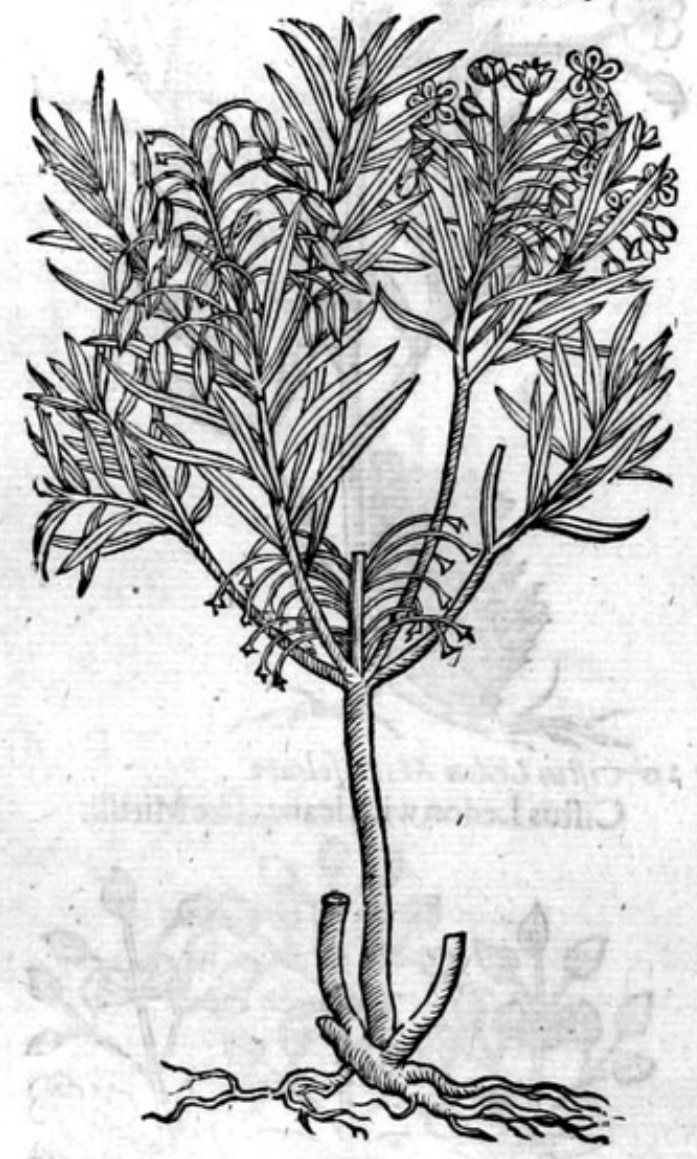

12 Ciftus Ledum Rorifmarini fulio.

Ciftus Ledon with leaues like Rofemarie.

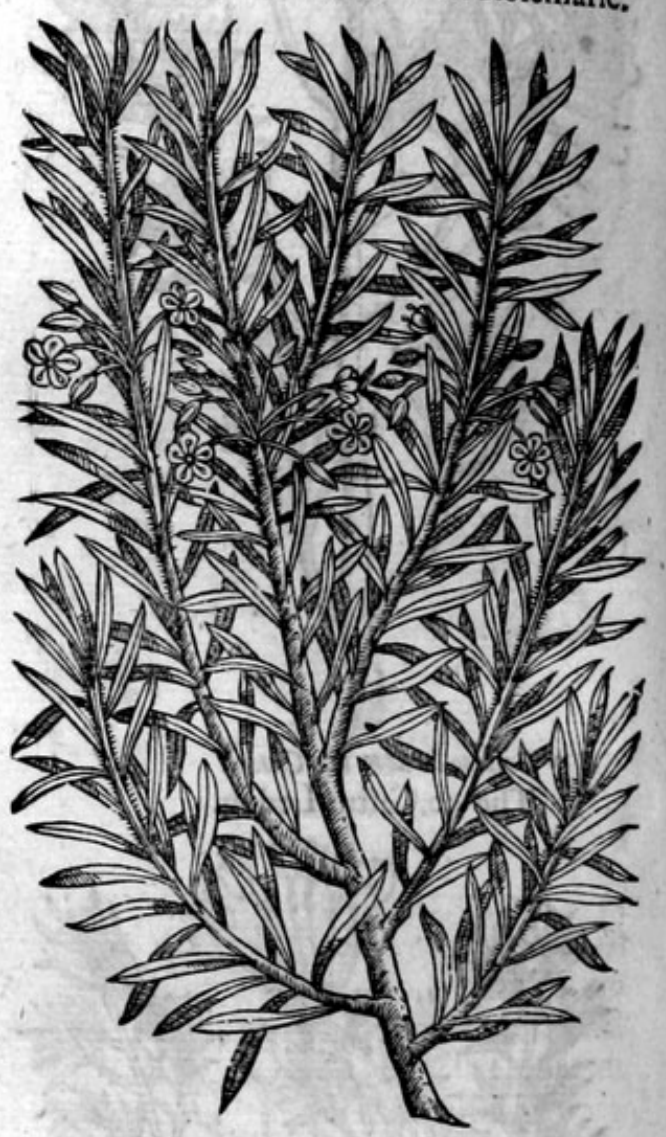

* The defcription.

12 The twelfth kinde of Ciftus Ledon, groweth vpright with a ftraight bodie or ftocke, bringing forth at the top many fmall twigs or rods of a cubit long, couered with a bark of the color of afhes, which diuide themfelues into other branches, of a purplifh colour, befet with long and uarrowe leaues, not much vnlike to Rofemarie, but longer; of a greene colour aboue, but vnderneath hauing as it were a long rib, made or compact of wooll or downe; of a fweete and pleafant fmell, and fomwhat fharpe in tafte : on the tops of the branches grow knops or heads, compact as it were of many fcales, of an iron or ruftie colour; out of which commeth and proceedeth a certaine rounde and long mane, or hairie panickcld tuft of flowers, with many long,tender, green, and fomwhat woollic ftalkes or twigs growing vnto them, of a fwcete fent and fmell: the flowers confift of fiue little white leaues, within which are côteined ten white chiues with a long ftile or pointle in the midft of the flower : when the flowers be vaded, there fucceed long knops or heads which are fiue cornered, in fhape and bignes like vnto the fruite and berries of cornus; which being greene, are befpeckled with many filuer fpots, but being ripe, are of a red colour; conteining within them a longyellowe fecde, which is fo fmall and flender, that it is like to the duft or powder which fallesh out of worme holes. 


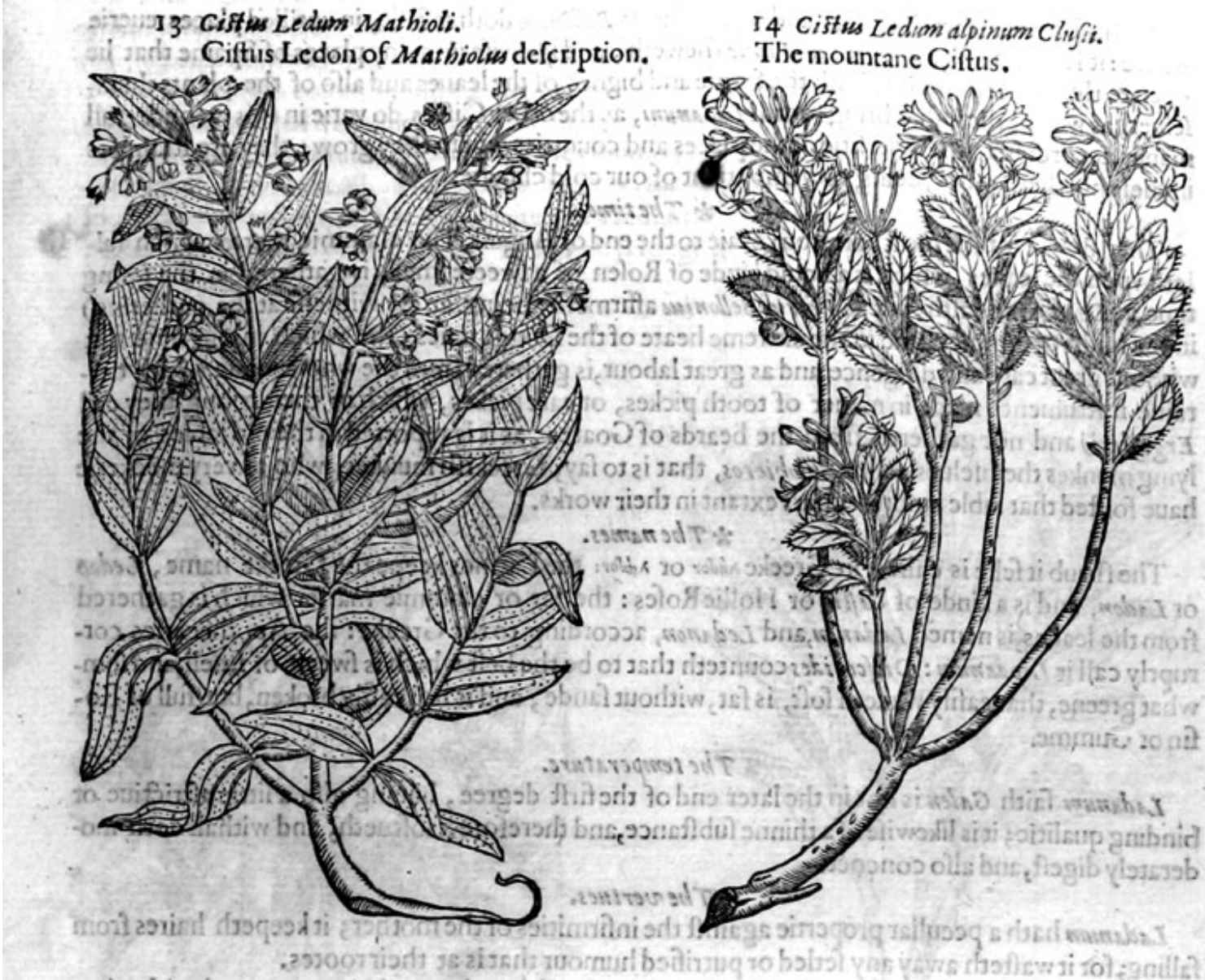

I4 Cistus Lediom alpinum Clufit.

The mountane Ciftus.

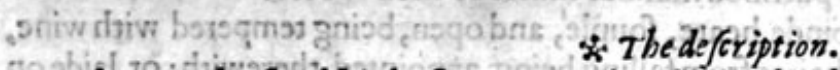

13 Among the flirbbie bumes comprehended vnder the title of Cist us Ledum, Watbiolin hath fet foorth one, whereof to write af large were impoffible, confiéering the Author is fo briefe, and of our felues we hatie not any acquidintance with the plant it felfe? Diofcorides to helpe what may be, faith, that it is a mrub growing like vnto the ftocke or kinred of the Cist $t$ : from whofe leatues is gathered a clammie dewe which maketh that gummie matter, that is in hops called Lapdanum: it groweth faith he, in hotregions (but not with vs:) the Mauritanians call the iuice or clammie matter, Leden, and Laden : of fome Ladano, and Odano: in Spanifh $X a r a$ : and furcher faith, it groweth in Arabia, where the bufh is called Cha us : thus much for the defcription.

14 The fourteene $C$ iftus being one of thofe that do grow vpon the Alpifh mountaines, which L'Obelius fetteth downe to be Bal/amum alpinum Gefneri: notwithftanding I thinke it not amiffe to infert it in this place, hauing for my warrant that famous Herbarift Carolus Clufius: this plant is one of the beautifulleft, differing in verie notable points, \& yet refembleth them in the woodic branches and leaues: it rifeth yp hauing many weake branches leaning to the gtound, yet of a woodie fib ftance, couered ouer with an afh coloured barle: the leaues are broad, \& veric rough, of a fhining greene colour and a binding tafte: the flowers grow on the toppes of the branches like little bels hanging downe their heads, diuided at the lips orbtims in fiuc diuifions, of a decpe red colour on the out fide, and dafht ouer heere and there with fome filuer fpots;on the infide of a bright fhining red colour, with certaine chiues in the middle, and of a very fivectefinell, as is ill the reft of the plant; after which comes the feede, conteined in fmall heads or knaps, ful of feed like duft, of verie ftrong fmel, making the head of them to ake that fnell therto : the root is long, hard, \& very woody, oftentimes there is found vpon the trunke or naked part of the ftalks certaine excrefcences, or outgrowings in maner of gals, of a fungious fubftance, like thofe of Touchwoode, white within, and red without, of an aftringent or binding tafte. 
Ciftus Ledon groweth in the Iland of Candie, as Bellonius doth teftifie, in vntilled places cuerie where : it is found alfo in Cyprus, as P / inie fheweth, and likewife in many places of Spaine that lie open to the funne: moreouer both the forme and bignes of the leaues and alfo of the plants themfelues, as well of thefe that bring foorth Ladanum, as theother Ciftus, do yarie in this woonderfull maner, according to the diuerfitie of the places and countries where they grow: they are ftrangets
in thefe northerly parts, being very impatitit of our cold climate.

\section{* The time.}

They flower for the moft part from Maie to the end of Auguft. The clammie matter which falleth vpon the leaues, which is a liquid kinde of Rofen of a fweete fmell, is gathered in the fpring time, as Diofcorides faith : but as Petrus Bellonius affirmeth (being an eie witneffe at the gathering) in the midft of fommer, and in the extreme heate of the Dogge daies; the which in our time not without great care and diligence, and as great labour, is gathered from the whole plant (with certaine inftruments made in maner of tooth pickes, or eare pickes, which in their toong they call Ergaffiri) and not gathered from the beards of Goates, 2s itis reported in the old fables of the lying munkes themfelues, called Calohieros, that is to fay, Greekifh munkes; who of very mockerie haue foifted that fable among othersextant in their works.

\section{* The names.}

The fhrub it felfe is called in Greeke $\lambda$ nidos or $\lambda$ desor: the Latines keepe the Greeke name, Ledon or Ladon, and is a kinde of Ciftus or HollieRofes: the fat or clammie matter which is gathered from the leaues, is named Ladanon, and Ledanon, according to the Greeke: the Apothecaries corruptly call it Lapdanum: Dioccorides counteth that to be the beft which is fweete of $\mathrm{fmell}$, and fomwhat greene, that eafily waxeth foft, is fat, without fande, and is not eafily broken, but, full of Rofin or Gumme.

\section{* The temperature.}

Ladanum faith Galen is hot in the later end of the firft degree, hauing alfo a little aftrietiue or binding qualitie; it is likewife of a thinne fubftance, and therefore it foftneth, and withall doth moderately digeft, and alfo concoet.

\section{* The vertues.}

A Ladanum hath a peculiar propertie againft the infirmities of the mother; it keepeth haires from falling; for it wafteth away any fetled or putrified humour that is at their rootes.

B Diofcorides faith, that Ladanum doth binde, heate, fouple, and open, being tempered with wine, Myrrhe,and oile of Myrtils; it keepeth haires from falling being annointed therewith; or laide on mixed with wine, it maketh the markes or fcars of wounds faire and well coloured.

C It taketh away the paine in the eares if it bepowred or dropped therein, mixed with honied wa-

D A fume made thereof draweth foorth the afterbirth, and taketh away the hardneffe of the matrix.

E It is with good fucceffe mixed with mollifying plaifters that mitigate paine.

F Being drunke with wine, it ftoppeth the laske, and prouoketh vrine.

F There is madehereof diuers forts of Pomanders, chaines, and bracelets, with other fweetes mixed therewith.

\section{OfRo Jemarie. Chap.6.}

\section{$*$ The dcfoription.}

Ofemarie is a woodie hhrub, growing oftentimes to the height of three or fower cubits, efpecially when it is fet by a wall : it confifteth of flender brittle branches, whereon do grow verie many long leaues, narrow, fomwhat hard, of a quicke fpicie tafte, whitifh vnderneath, and of a full greene colour aboue, or in the vpperfide, with a pleafant weete ftrong fmells among which come foorth little flowers of a whitih blew colour : the feede is blacklih : the rootes are tough and woodie. 
2 The willde Rofemaric Clufues hath referred vnto the kindes of Ciftus Ledon; we hate as a poore kinfman thereof inferted it in the nextplace, in kinred or neighbourhood at the lcaft. This wilde Rofemarie is a fmall woodie fhrub, growing feldome aboue a foote high, hauing hard branches of a reddifh colour, dividing themfelues into other fmaller branches of a whitifh colour: whereon are placed without order diuers long leaues greene aboue, and hoarie vnderneath, notvnlike to thofe of the dwarffe Willow, or the common Rofemaric, of a drie and aftringent tafte, of little fmell or none at all. The flowers ftand on the tops of the branches fet vpon bate or naked footeftalkes, confifting of fiue fmall leaues of a reddifh colour, fomewhat thining; after which appeere littic knaps full of fmall feede. The roote is tough and woodie.

I Ro/marinum Coronarium.
Garden Rofemaric.

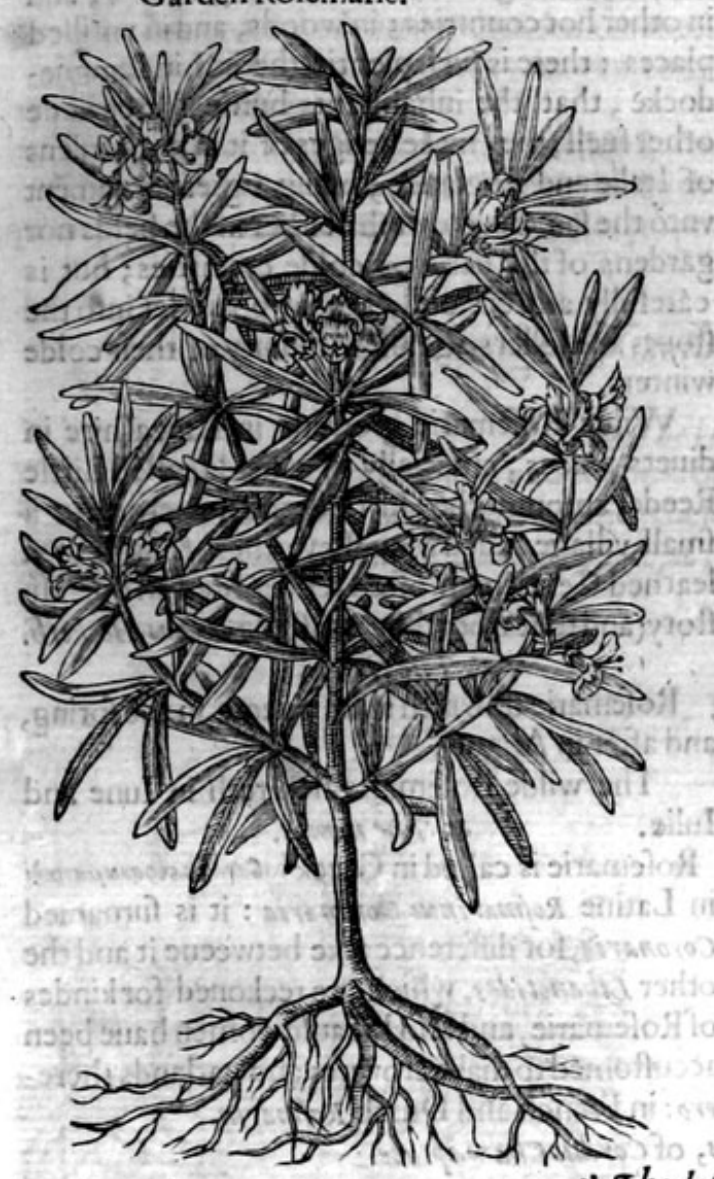

2 Kopmarinum fylineftre. Wilde Rofemarie.

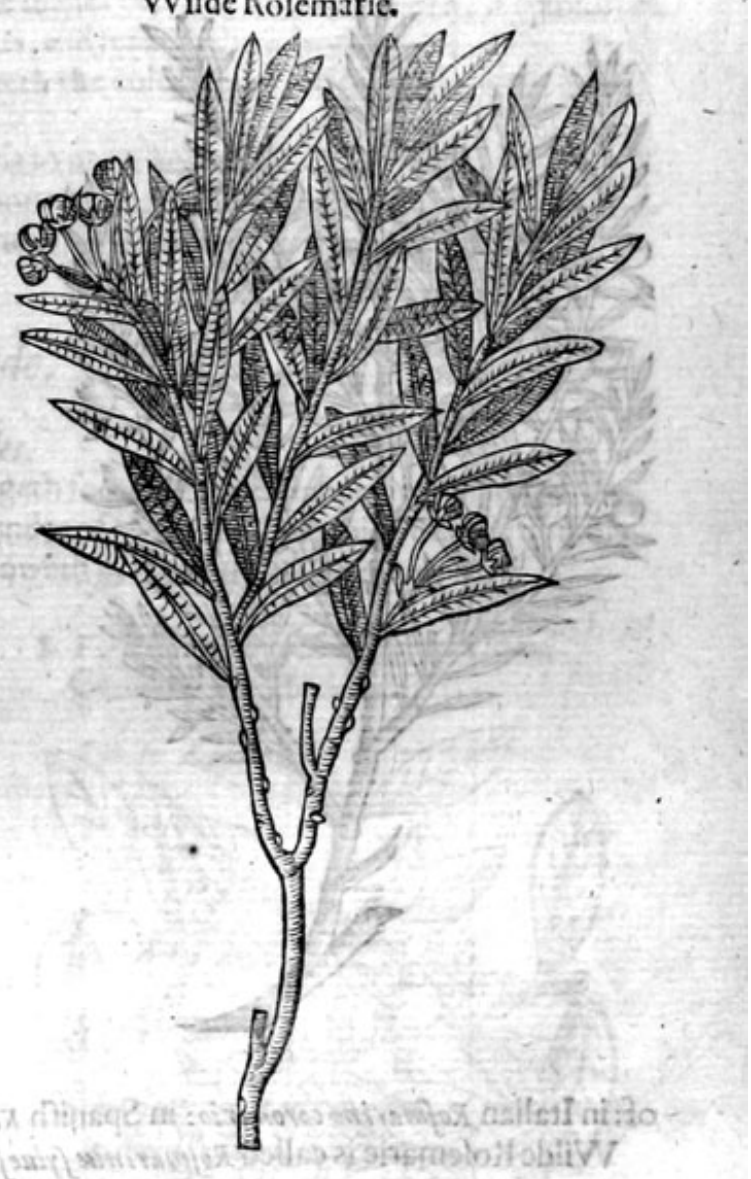

* T he defcription.

3. This plant hath fet fome controuerfie among the learned, who vndifcrcetly haue confounded Cafa with Caßsa, Canell and Cinnamome. Anguillara and Guillandinus (two moft excellent in the knowledge of plants) differ as touching the knowledge hereof, one taketh it to be a kinde of Lauandula, the other Rofmarinum Coronarivm. Theophraftus taketh it to be Cafia, miftaking Cammomill for the fame. Notwithitanding their controuerfies refting difputable, the queftion may eafily be decided by the fimplett that haue taken any paines in the knowledge of plants, if theyhad ao any time feene the plantitfelfe where it groweth naturally in great abundance, as in Agro Romiano, and diuers other places, in Narbone, Spaine and Italie. Examine the defeription who lift, and they fhall eafily perceitue thereby, that it cannot bee Polygonum Plini, neither the Spaniardes $O$ fris is. It groweth vplike an hedge fhrub of a woodie fubltance, to the height of two or three cubites; hauing many twiggie branches of a greene colour : whercupon doe growe narrowe leaues like ynto Linaris, or Flaxe weede, of a bittercafte; anong which come foorth fmall moflie flowers, of agreenifhyellow colour like thefe of the Cornell tree, and of the fmell of Rofemarre: which hath moued me to place it with the Rofernaries as a kind thereof, not finding any other plant 
1110

\section{THE THIRD BOOKE OF THE}

fo neere vnto it in kind and neighborhood: afterthe flowers be paft, there fucceede fruit like thofe of the Mirtle tree, greene at the firft, and of a hining red colour when theybe ripe, like Corall the end ; the ftone within is hard as is the nut whereauing a certaine acrimonie or thatpe tafte in tafte: the roote is of a woodie fubftance: it flerein is conteined a fmall white kernell, fweete in October: the people of Granade, Montpelier, and of the kingdor; the fruite is ripe in the end of preffes and wardrobes, whereupon they call it Guardalobo.

Cafí Poetica L'Obelig.

The Pocts Rofemarie or Gardrobe.

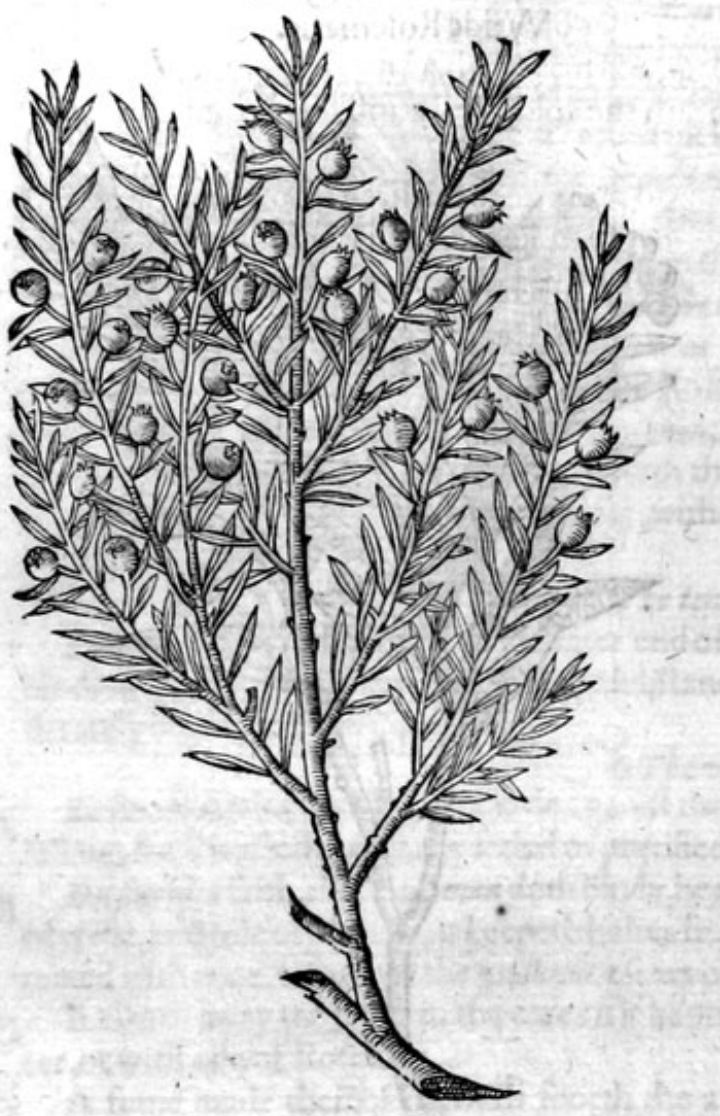

* 7 he place.

Rolemarie groweth in Fraunce, Spaine, and in other hot countries; in woods, and in vntilled places : there is fuch plentie thereof in Languedocke, that the inhabitants burne fcarce anie other fuell ; they make hedges of it in the gardens of Italie and Englande , being a great ornament vito the fame: it groweth neither in the fields nor gardens of the eafterne colde countries; but is carefully and curioufly kept in pots, fet into the ftoues and fellers, againit the iniury of their colde winters.

Wilde Rofemarie groweth in Lancafhire in diuers places, efpecially in a fielde called Little Reede, amongft the Hurtle berries, neere vnto a fmall village called Maudfley; therc founde by 2 learned Gentleman often remembred in our $\mathrm{Hi}$, ftory(and that woorthily)malter Thomes Hesketh. * The time.

Rofemarie flowreth twife a yecre, in the fpring, and after in Auguit. Iulie.

The wilde Rofemarie flowreth in Iune and * $T$ he names.

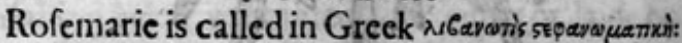
in Latine Rofmarinus Coronaria : it is furnamed Coronaria, for difference fake betweene it and the other Libanotides, which are reckoned for kindes of Rofemarie, and alfo bicaufe women haue been accuftomed to make crownes and garlands thereof: in Italian Rofmarino coronario: in Spanifh Romero: in French and Dutch Kofmarin.

Wilde Rofemarie is called Rofmarimus fylueftris, of Cordus Chamepeuce. * The temperature.

Rofemarie is hot and drie in the fecond degree, and alfo of an aftringent or binding qualitie, as being compounded of diuers parts, and taking more of the mixture of the earthie fubftance.

\section{* The vertues.}

A Rofemarie is giuen againft all fluxes of bloud; it is alfo good elpecially the flowers thereof for al infirmities of the head and braine, proceeding of a colde and moift caufe; for they drie the braine, quicken the ferices and memory, and ftrengtheneth the finewie parts.

B Serapio witneffeth, that Rofemarie is a remedie againft the flufing of the head, that commeth through coldnes of the braine, if a garland there of be put about the heade, whereof $A$ bin Mefusi giveth teftimonic.

C Diofcorides teacheth that it cureth him that hath the yellow iaundies, if it be boyled in water and drunk before exercife, \& that after the taking therof the patient muft bathe himfelfe \& drink wine.

$D$. The diftilled water of the flowers of Rolemarie being drunke at morning and euening firft and Jaft, taketh away the ftench of the mouth and breth, and maketh it very fweete, if there be added therto, ta fteepe or infufe for certain daies, a few Cloues, Maces, Cinnamom, \& a little Annifeede. 
The Arabians and other Phifitions fucceeding,do write, that Rofemarie coinforteth the braine, E

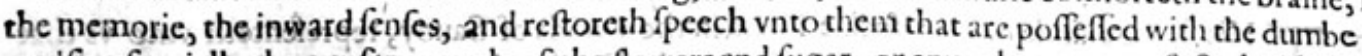
paulfie, efipecially sbe conferue made of the flowers and fugar, or any other way confected with fugar, being raken euery day falting.

The Arabians, as Ser apio witneffeth, gite thefe properties toRofemarie : it heateth, fay they, is $\mathbf{F}$ of fubcile partes, is good for the cold rbeume which falleth from the braine, driueth away windines, prouoketh vrine, and openeth the ftoppings of the liuer and milt.

Tragus writeth, that Rolemarie is fpice in the Germaine kitchens, and other cold countries. Fur- G ther he faith, that the wine boyled with Rofemarie, and taken of women troubled with the mother, or the whites, it helpeth them, the rather if they faft three or fower howers after.

The flowers made vp into plates with fugar after the maner of Sugar Rofet and eaten, it coinfot- $\mathrm{H}$ teth the hart, and maketh it merie, quickeneth the fpirits, and maketh them more liuely.

- The oyle of Rofemarie chimically drawen, comforterh the cold, weake and feeble braine in moft I woonderfull manner.

The people of Thuringia do vfe the wilde Rofemarie to prouoke the defired ficknes. $\mathrm{K}$

Thofe of Marchia vfe to put it in their drinke the fooner to make their clients drunke, and alfo do L put it into chefts and preffes among clothes, to preferue them from moths or other vermine.

\section{- obrildbooW bo inatobitila \\ Of VprightWoodbinde. Chap.7.}

17v * The kindes.

$T$ is knowen, that euery prouince and countrie bringeth foorth his peculiar plants, differing from 1 thofe of other regions, euen fo it fareth with thefe kindes of Woodbindes, which do very notably differ ftom thofe of England, Iralie and Spaine, as followeth in their feuerall defcriptions.

I Periclymenum rectium Sabandicwem. Sauoy Honifuckles.

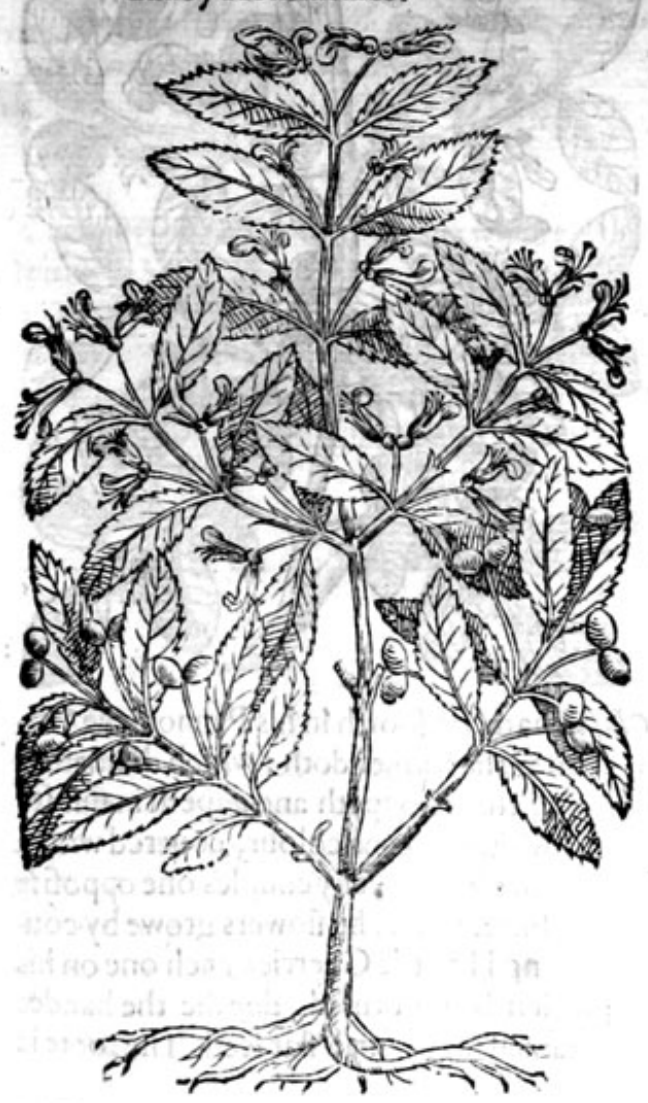

2 Periclmenun rectum Germanicum. Germany Honifuckles.

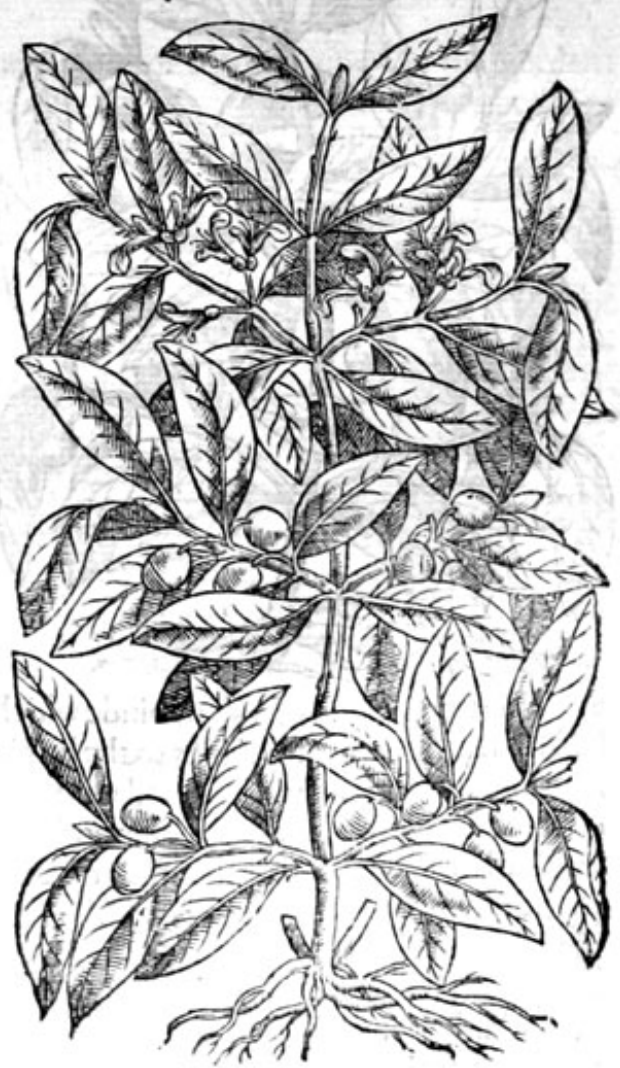

$\mathrm{Cccs}_{2}$

* The 
'T

* Thedefcription.

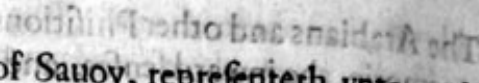
His ftrange kinde of Honifuckle found in the woods of Sauoy, repreferiteth vnto vs that leaues and branches like the common Woodbinde, fauing that pricke timbertree, bauing clime as the others do, but contrariwife growethypright, withoucleaning to bise fide or onber and finall tree or hedge bufh. The flowers grow vpon the tender fprayes or to bide or orker like 2 ples, not vnlike in thape and colour to the common Woodbind buranches by cou. colour, thating within the fame many hairie chiues like the othere altogither leffer, and of a white berries ioyned togither by couples. The roote is tough and woodyblyod rilw oflo which eome red 2 The ftalkes of the fecond be of tentimes of a meane thickneffe; the woodiefibftance formewhat whitifh and foft. The branches be round and coviered with a whitifh barke, fiotwithftanding in the beginning when the fprayes be yoong, they are fomew hat reddith. The leates are long like thofe of the common Honifuckle, foft, and of a white grcene; on the lower fide they are whiter, st a littichairie. The tlowers be leffer than any of the Woodbindes, but yet of the fame forhion, and of a whition colour, growing togither by couples vpon feuerall flender fooreftallkes, like fittle wilde Cherries, of ared colour; the onc leffer of tentimes than the other.

3 Periclymenwon rectum fruitu ceruleo. Vpright Woodbinde with blew berries.

\section{Periclymensm rectum fructunigro.} Blacke berried Woodbinde.

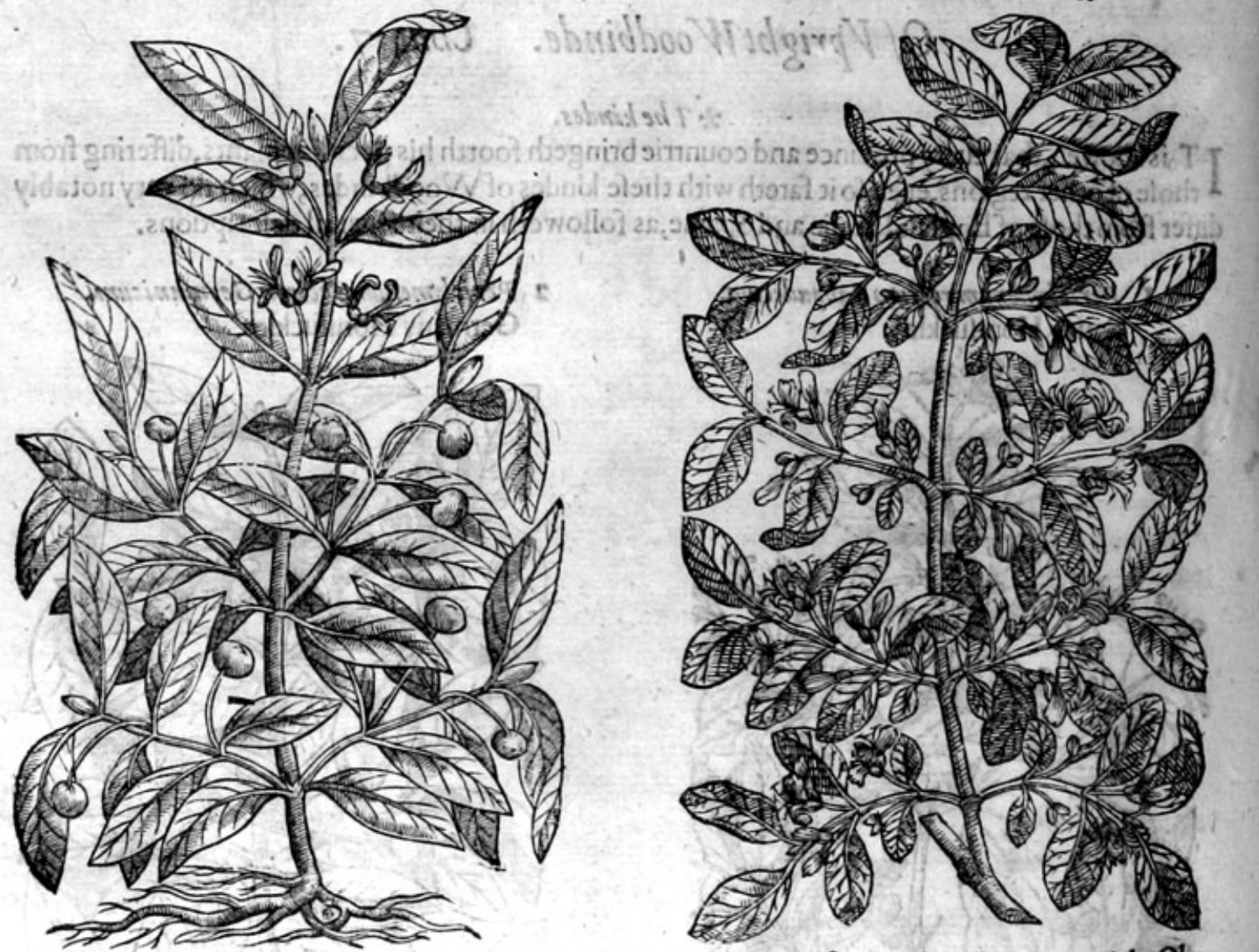

3 This ftrange kind of Woodbinde which Carolus Clufires hath fet foorth in his Pannonicke Obferuations, rifeth vp oftentimes to the height of a man, euen as the former doth: which diuidechit felfe into many branches, couered with a rough blackebarke, that cho?peth and gapech in fundry clefts as the barke of the Oke. The tender branches are of a whitifh greene colour, couered with 2 woollie hairinefle, of an ouerworne colour, whereupon do growe leaues fet by couples one oppofite to the other, like vnto the common Woodbinde, of a drying bitter tafte. The flowers growe by couples likewife, of a whitifh colour. The fruit fucceedeth, growing like little Cherries, each one on his owne footeftalke, of a bright and fhining blew colour; which being brufed, doe die the handes of a reddifh colour, \& of a fharpe winic talte, wherin is contained many fmall tlat feeds. The roote is woodie, difperfing it felfe far abroad. 
4 This kinde of vpright Woodbinde groweth vp likewife to the height of a man, and oftentimes more high, like to the laft defcribed, but altogither greater. The berries hereof are very black,wherin efpecially is the difference.

5 Chamapericlimenum.

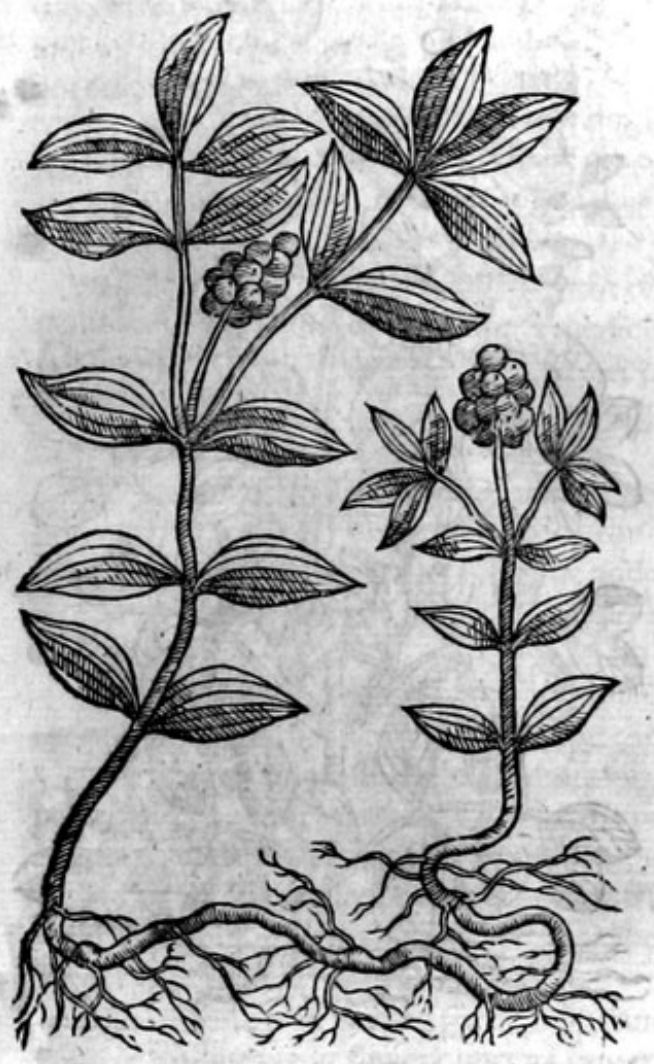

$\therefore$ Thedefcription.

5 To the kindes of Woodbindes this plant may likewife be referred, whofe pieture with this defcrip tion was fent vito Clufius long fince, by that learned Doctor in phificke Malter Thomas Penny (of our London College of famous memoric) it rifeth vp with a ftalke of a foote high: whereupon are fet by couples faire broad leaues, one right againft an other, ribbed with certaine nerues, like thofe of Plantaine, harpe pointed, and fomewhat hollowed in the middle like Spoonewoort : from the bofome of which leaties cone foorth fmall flowers, not feene or defcribed by the author: after which commeth foorth a clufter of red berries thruft hard togither, as are thofe of Aaron, or Priefts pint. The roote is tough and very flender, creeping farre abroad vnder the vppermoft cruft of the earth, whereby it occupieth much ground.

$$
\text { * The place. }
$$

Thefe plants are ftrangers in Englande, they growe in the woods and mountaines of Switzerland, Germany, Sauoy, and other thofe partestending to the Eait, Eaft Northeaft, and Eaftand by South.

I haue a plant of the firft kinde in my garden: the reft as yet I haue not feene; therefore I cannot write fo liberally thereof as I wifh.

\section{$*$ The time.}

They flower for the moft part when the others do, that is to fay, in May and Iune, and their fruite is ripe in September. $\approx$ The names.

Vpright Woodbinde or Honifuckle is called Periclymenum ftans, and Periclymenum rectum, or Vpright Woodbinde : of Dodoneens Xylofteum : in high Dutch iponds kiffent, that is to fay, Canum Cera/a,or Dog Cherries. The Englifh names are expreffed in their feuerall titles. It hath beenecalled chamecerafus, but not truly.

\section{* The temperature and vertues.}

Touching the temperature and vertues of thefe vpright Woodbindes we haue noexperience at all of our felues, neither haue we learned any thing of others.

\section{Of Sene. Chap.8.}

\section{* The defcription.}

I Ene bringeth foorth ftalkes a cubite high, let with diuers branches : the leaues are long, winged, confifting of many fmall leaues like thofe of Licorice, or of baftard Sene : the flow, ers come foorth of the bottome of the wings, of colour yellow, ftanding vpon flender footeftalkes; from which after the flowers be gone hang forked cods, the fame bowing inwards like a halfe moone, plaine and flat, in which are contained feedes like to the feedes or kennels of grapes, of a blackifh colour. The roote is flender, long and vnprofitable, which perifheth when the leatues are gathered for medicine, and the feedes be ripe, and muft be fowen againe the next yeere euen as we docorne.

$$
\mathrm{Cccc} 3
$$

2 There 
II 14

THE THIRD BOOKE OF THE

2 There is another kinde of Sene growing in Italie, like the other in each refpect, fauing that it is

I Sena Orientalis.

Sene of the Eaft.

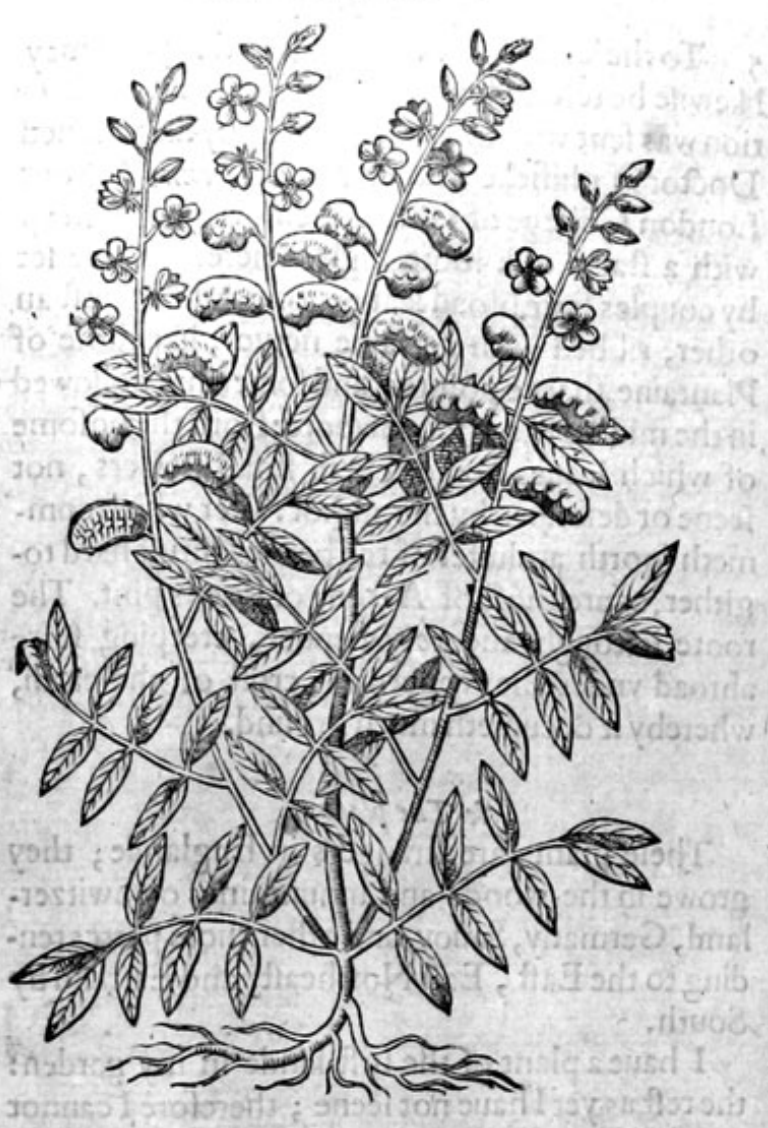

2 Sena Italica. Italian Sene.

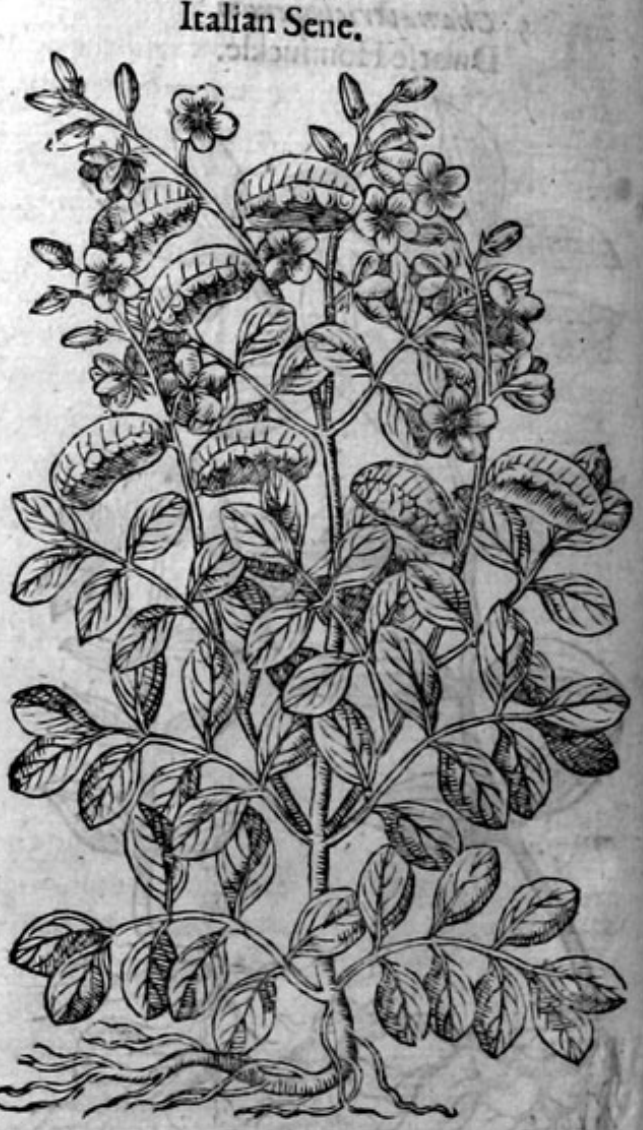

* The place and time.

This is planted in Syria and AEgypt, alfo in Italie, in Prouence of Fraunce, in Languedocke. It hardly groweth in high and lowe Germanic, neither in England: it profpereth in hot regions, and cannot away with cold; for that caufe it is in Italie foiven in May, and continuerh no longer than Autumne. The beft is brought from Alexandria, and oxt of AEgypt. The Arabians were the firt that found it out.

\section{*. The names.}

The,Perfians call it Abalzemer, as Mefrua his copic hatb: the Apothecaries Sena, by which name it was knowen to 1 Azwarius the Grecian, and to the later Latines: it is called in Englifh Sene, * The temperature.

Touching the temperature of Sene, it is of a meane temperature, neither hot nor cold, yet inclining to heate, and drie almoft in the third degree: it is of a purging facultie, and that by the ftoole, in fuch fort, as it is not much troublefome to mans nature, haung withall a certaine binding qualitie, which it leaucti after the purging.

\section{* The vertues.}

A It voidech foorth flegmatike and cholerike humors, allo groffe and melancholike, if it be helped with fome thing tending to that end.

$B$ It is a fimgular purging medicine in many difeafes, fit for all ages and kindes.

C. It purgeth without violence or hurt, efpectally if it be tempered with Annis feede, or other like fweete finclling things added, or with gentle purgers, or fmoothing medicines. It may be giuen in pouvder, but commonly the infufion thereof is vfed.

D The quantitie of the powder is a dram waight, and in the infufion fower, fiue or moe. It may be mixed in any liquor. 
2. It is ih the decoetionor in the infufiontempered yvith celd things in burning agues, and ather $\mathrm{E}$ hot difeafes, in cold and long infirmities : it is boiled with hot opening fimples, 's fuch like; br ete

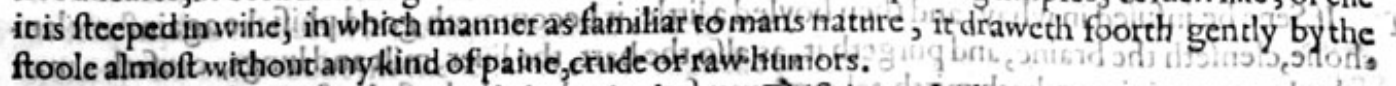
(3) Moft of the Arabians dommend the coids, but dur Phifitions theleanes rather, for villeffe the $\mathrm{F}$ cods be full ripe, they ingender winted (and d caufe gripings in the betly. For they are oftentime ga: thered before they be ripe, and otherwife eafily fall away being thaken downe with the winde, by reafon of their weake and flender ftalkes.)

Some alfo thinke, that Sene is hurtfull to the it tomacke, and weakeneth the fame, for which caufe $G$ they fay that Ginger or fome kinde of fweete fpice is ro be added, whereby the ftomacke may bee ftrengthened. Likewife Mefues noteth, that it is ilowe in operation, and that therefore Salgem is to be mixed with ir.Moreouer, Sene purgeth nor fofpeedily as ftronger medicines do. 2 buifisd 10

Notwith ftanding it may be helped not only by Salgem, but alfo by other purging things mixed $\mathrm{H}$ therewith, that is to fay, with fimple medicines, as Rubarbe, Agaricke, and others, andwizh compounds, as that which is called Casbolicon, or the Electuarie Diaphanicon, or that whichis made of the iuice of Rofes, or fome other, according as the condition andqualitic of the difeafe and of the ficke man tequireth.

The leaues of Sene is a very familiar purger vnto all people, but they arewindie and do binde the I body afterwards, very much difquieting the ftomack svith rumbling and belching. For the auoiding of which inconuenience, there muft be added Cinnamome, Ginger, Annis feed and Fennellfeede, Raifons of the funne, and fuch like that do breake winde, which will the better helpe his purging qualitie.

Sene doth better purge when it is infufed or fteeped, than when it is boiled : for doubtleffe the $\mathrm{K}$ moreit is boyled the lefleit purgeth, and the more windie it becommeth.

Take Borage,Bugloffe, Balme, Fumitorie, of each three drams, Sene of Alexandria very well pre- L. pared,and pouned two ounces, ftrowe the powder vpon the herbes, and diftill them: the water that commeth thereof, refente for your ve to purge thofe that liue delicately, being miniftred in white wine, Sugar, in condited confections, andfuch dainty waies, wherein delicate and fine people do greatly delight: you may alfo (as was faidbefore) adde hereunto, according to the maladie, diuers purgers, as Agaricke, Mirobalans, \&cc.

Take of Sene well purged from motes and droffe, one ounce, infufe it in a quart of the beft whice $M$ wine, $f$ Endiue water fower ounces, Ginger, Annis feeds, and fcraped Licorice, of each fower drag. let thefe ftand togither fixteene howers, ftraine it, and when you haue fo done, boyle it a little; then taketwo pound of Damaske Prunes, and mingle it with the reft of your ingredients: this is a moft excellent medicine to purge dainty people, which ablor potions, and fuch like.

The powder of Sene after it is well prepared two ounces, of the powder of the roote of Mechoa- N can fower drams, powder of Ginger, Annis feeds, of each a little, a fpoonful of Annis feeds, but a very little Ginger, and a modicum or finall quantitie of Sal gemma; this hath beene prooued a very fit familiar medicine for all ages and fexes. The patient may take one fpoonefull or two thereof fafting either in potage, fome fupping, in drinke or in white wine. This is right profitable to drawe both flegme and melancholie from the breaft and other parts.

The leaues of Sene and Cammomill are put in bathes to wath the head.

Sene openeth the inward partes of the bodie which are ftopped, and is profitable againft all $P$ gricfes of the principall members of the body.

Ili Take Sene prepared according to arte one ounce, Ginger halfe a quarter of an ounce, Cloues in Q number 12 .Fennell feed two drams, or inftead therof Cinnamom and Tartar, of each halfe a dram, powder all theef ; which done, take thereof one dram in white wine before fupper, which doth maruelloufly purge the head.

Handle Sene in manner aboue fpecified, then take halfe an ounce thereof, which done, ad therto $\mathbf{R}$ threefcore Raifons of the funne, with the ftoncs pickt out, one fpoonful of Annis feeds braied, boile thefe in a quart of ale till one halfe be wafted, and while it is boyling put in your Sene : let it ftand fo till the morning; then ftraine it,and put in a little Ginger: then take the one halfe of this potion, and put thereunto two poonefuls of firupc of Rofes, drinke this togither, I meane the one halfe of the medicine at one time, and if the patient cannot abide the next day to receitic the other halfe, then let it be deferred vntill the third day after.

$$
\operatorname{Cscc} 4
$$




\section{6 \\ THE THIRD BOOKE OF THE}

$S$ Sene and Fumitorie (as $R a /$ is affirmeth) do purge aduft humors, and are excellent goodagaingt
fcabs,itch, and the ill affection of the body.

$T$ If Sene be infufed in whay, and then boyled a little, it becomm cholie, clenfeth the braine, and purgeth it, as alfo the har, the liveth good phifickeagainftmelani tolooke yoong, it ingendrech mirth, taking away forrow; cleeterth, milt and lungs, caufech a man and is very good againft old feuers and difeafes arifing of -męlancholie.

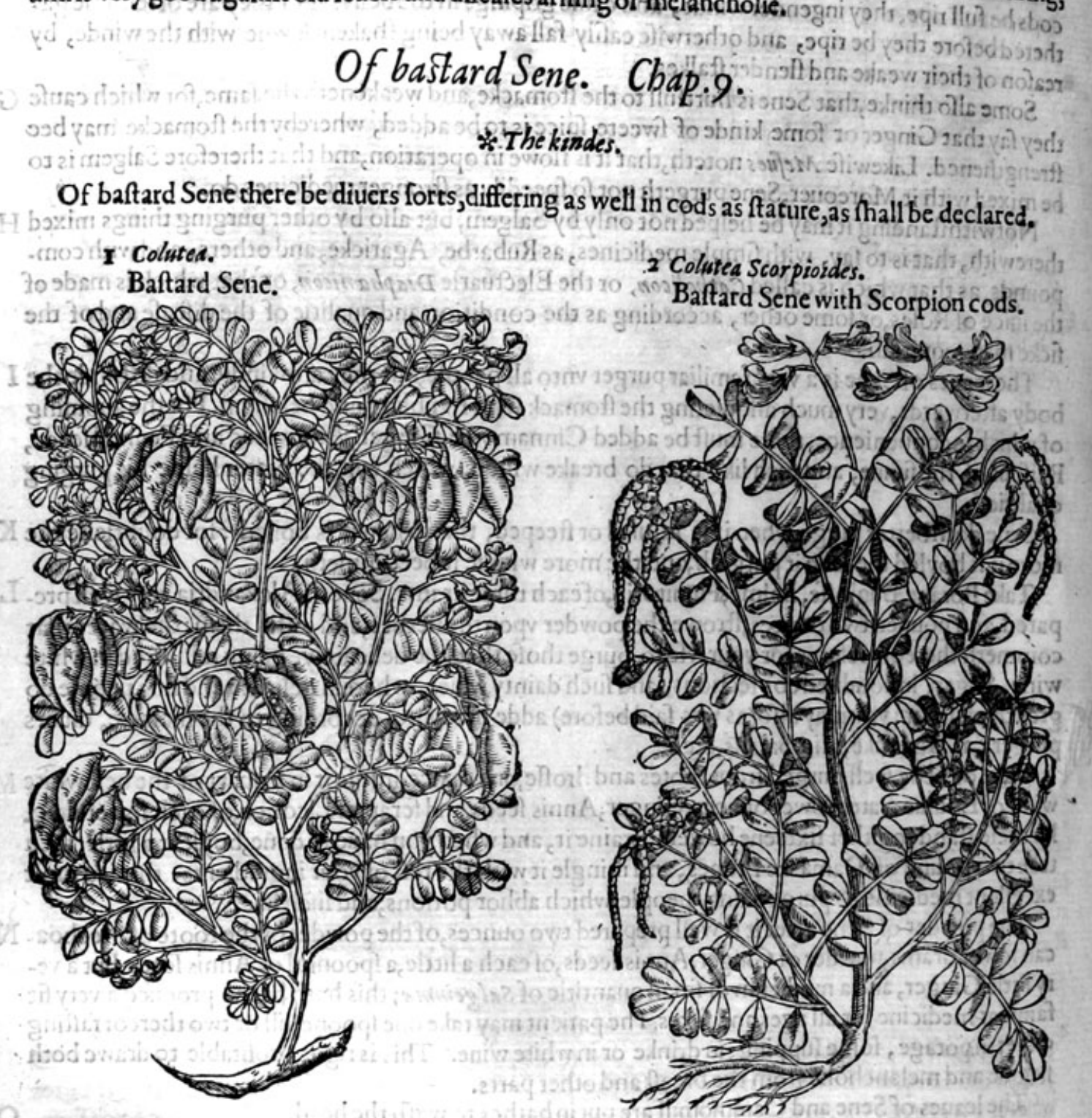

* $T$ the defcription.

I Olutea, and Sene, be fo neere the one vinto the other in fhape and $f$ hew, that the vinskilfull Herbarifts haue deemed Colutea to be the right Sene:this baftard Sene is a fhrubbie plant, growing to the forme of an hedge bufh, or fhrubbie tree : his branches are ftraight, brittle and woodie, which being carelefly broken off; and as negligently.prickt or ftucke in the grounde, will take roote and profper, at what time of the yeere foever it be done; but flipt or cut, or planted in any curious fort whatfoeuer, among an hundred one will fcarfly grow: thefe boughes or branches are befet with leaues like Sena, or Securidaca, not much vnlike Liquorice; among which cone foorth faire Broomelike yellow flowers, which turne into fmall cods like the fownd of a fifh, or a little bladder, which will make a cracke being brokew betweene the fingers; wherein are contained many blacke, flat feedes, of the bignes of Tares, growing vpon a fmall rib or finewe within the cod: the roote is harde, and of a woodie fubftance. 


\section{HISTORIE OF PLANTS.}

2 Baltard Senewith Scorpion cods is a fmall woodic fhrub or bufh, haning leates, branches, and flowers like vhto the former baftard Sene, burfmaller in ech refpeet; when his fnall yellow towers arefallen,there fucceed little long crooked cods, like the long cods or huskes of Mat hiolus his Scor. pioides, whercofit tooke his name : the roote is like the toote of theBoxe tree, or tather refembling the rootes of Dulcamdra, or Bitter fiveete, growing naturally in the Thadowie woods of Valena in Narbone, where of I haute a finall plaitrinmy garden, whichmay becalled Scorpion Sene.

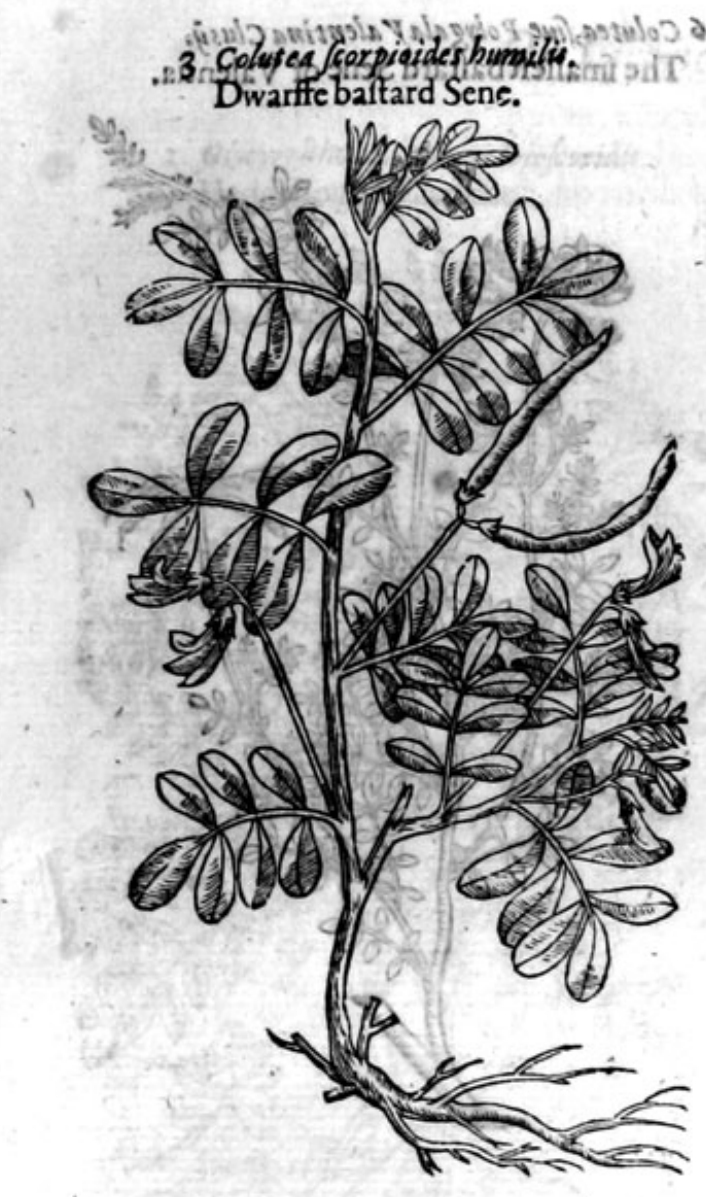

4 Coluten Jarpioides mantana Clusy. Mountaine baftard Sene.

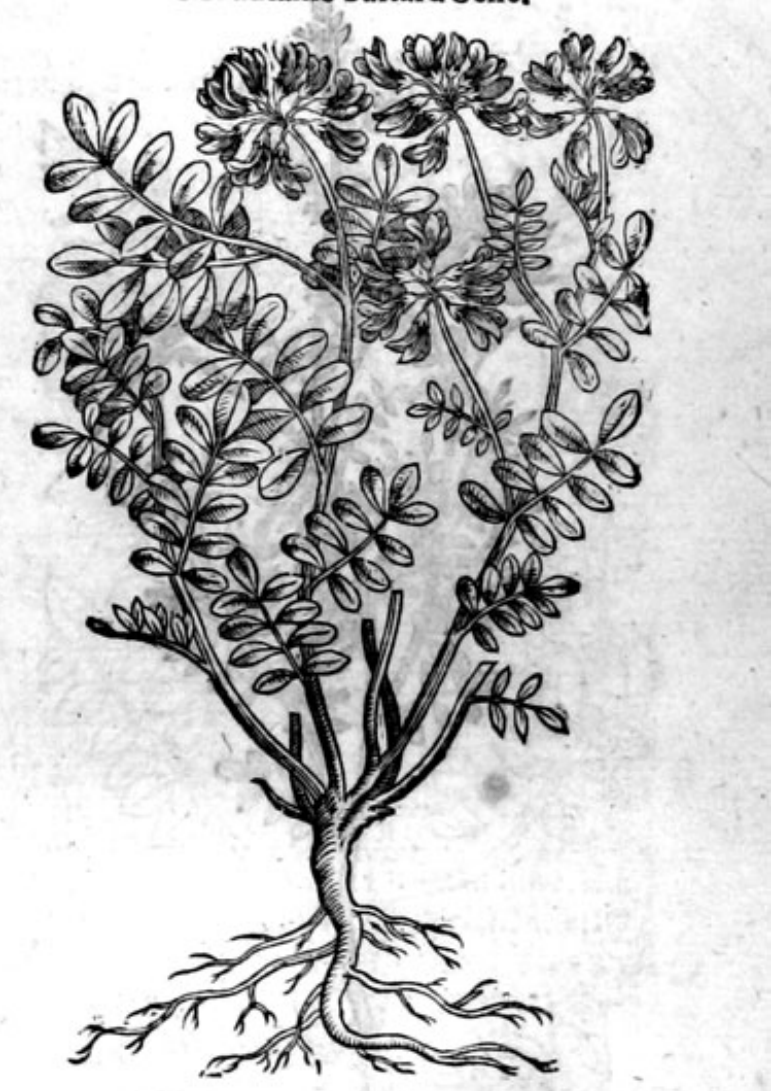

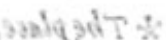

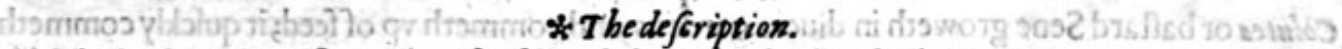

3 The loweor dwarffe colutea of clufuns defcription, hathathicke woodie roote, couered with a yellowifh barke, with inany fibres annexed thereto, which bringeth foorth yeerely newe fhootes whereby it grcatly increafeth, of a cubite and a hal te high, fmoorh, and of a greene colour ; whereon do grow leaues compofed of fixe or feauen leaues, and forntimes nine, fet vpon a middle ribbe like thofe of the common kinde, of a ftipticke tafte, with fome fharpnes or biting : the flowers grow vpon flender footeftalks, long and riaked like thofe of the Peafe, and of a yellow colour, of a little or no fmell at all, and yet that little nothing pleafant: after which come foorth long cods, wherein is conteined fmall feede like thofe of the Strangle Tare.

4 This mountaine baftard Senehath ftalkes, leaues, and rootes like the laft defcribed : the flowers growe on the tops of the branches in maner of a Crowne, whereupon fome haue called it Coronilla ; in thape like thofe of the Peafe, and of a yellow colour: the cods as yet we haue not feene, and therefore not expreffed in the figure.

5 This fmall baftard Sene groweth like a fmall mrub creeping vpon the ground, of the height of halfe a cubite, bringing foorth many twiggie branches, in maner of thofe of the Spanifh Broome; whereupon do grow leaues like thofe of Lentiles, or the Strangle Tare, with many fmall leates fer vpon a middle rib, fomwhat fat and full of iuice, of the colour of the leaues of Rue or Herbegrace; 


\section{8}

\section{THE THIRD BO OKEO OF THE}

bf an aftringent and vnpleafantealte :the flowers grow att the tiops of the branches, of a yellow co.

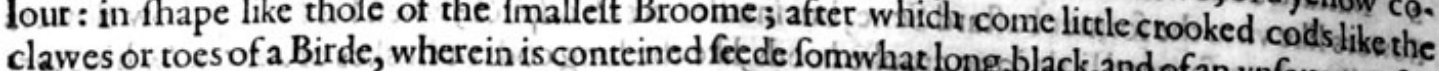
the roote is long, hard, tough, and of a woodie fubftance. 6 There is alfo found another fort heereof, not much differing from the former, fauing plant is greater in each refpect, whercin efpecially confiftectache difference. II I togzat that this

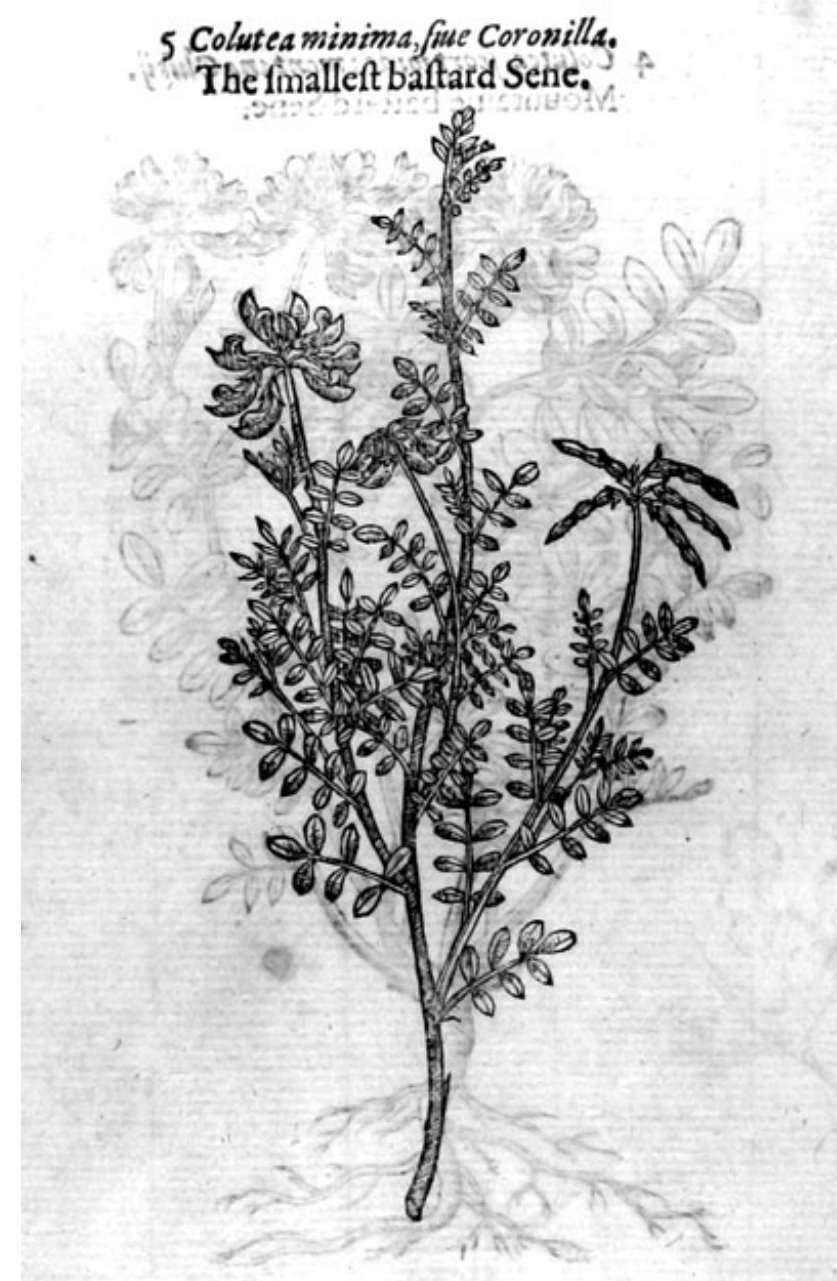

\section{Colutea,fiue Polygala Valentina Clusy. The fmallett baltard Sene of Vatentia.}

\section{* The place.}

Colutea or baftard Sene groweth in diuers gardens, and commeth vp of feed; it quickly commeth to perfection, infomuch that if a fticke thereof be broken off and thruftinto the gtounde, itquickly taketh roote, yea although it be done in the middle of fommer, or at any other time, euen as the fticks of Willow orElder, as my felfe haue often prooued; the which bring foorth flowers and fruite the next yeere after.

The fecond with Scorpion cods groweth likewife in my garden; the two laft do grow in diuers barren chalkie grounds of Kent towards Sittingburne, Canterburie, and about South fleete; I haue not feene them clfe where : the reft are ftrangers in England.

\section{* The time.} feede.

They flower from Maic till fommer be well fpent, in the meane feafon the cods bring foorth ripe

\section{* The names.}

This fhrub is called of $T$ heophraftus in Greek xorourat with the diphthong ou in the fecond fillable: in Latine as Gaza expoundeth it, Coloutea, or Colutea : in high Durch recielfeb Iinfen: in French Baguenaudier: they are deceiued that thinke it to be Sena, or any kinde thereof; although we haue followed others in giuing it to name Baftard Sene, which name is very vnproper to it: in low

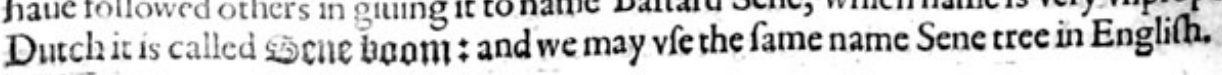


This Colutea or baftard Sene, doth differ from that plant xoxu're with $v$ in the fecond fyllable, of which Colytea 7 beophraft us writeth in his thirde booke.

* The temperature and vertues.

Theophraftus, neither any other of the ancients hate made mention of the temperature or facul- A ties in working of thefe plants, more then that it is good to fatten cattle, efpecially fheepe, as the fame authour affirmeth.

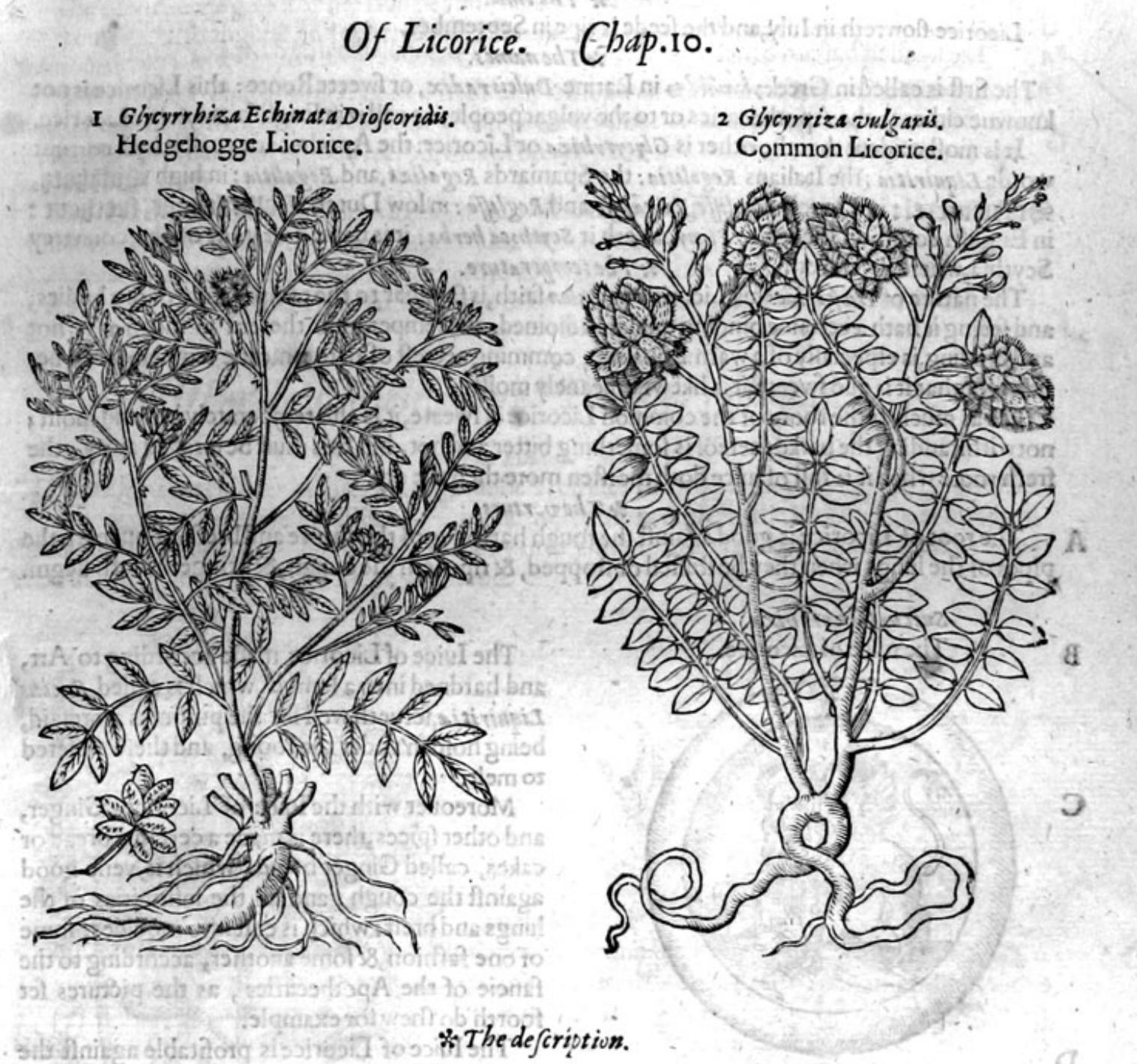
7 He firft kinde of Licorice hath many woodie branches, rifing vp to the height of two or leaues fet vpon a middle rib, like the leaues of Colutea, or the Maftich tree, fornewhat glutinous in handling: among which come finall knops growing vpon fhort ftems betwixt the leaues and the branches, chiftering togither and making a round forme ot thape : out of which grow fmal blew flowers, of the colour of the Englinh Hyacinth; after which fucceede rounde, rough, prickley heads, confiftung of diuers rough or fcalie husks clofely and thicke compact togither; in which is contcined a flat feede : the roote is ftraight, yellow within, and browne without; of a fweete and pleafant tafte.

2 The common and vfuall Licorice, hath ftalkes and leaues very like the former, faung that his leaues are greener and greater, and the fowvers of a hining blew colour; bur the flowers and cods grow not fo thicke cluftring togither in round heads as the former, but fpike falhion, or rather like 
the wilde Vetch called Onobrychis, or Galega : the cods are fmall and tat like vnto the Tare: the rootes are of a brownifh colour without, and yellow within like Boxe, and fweeter in tafte then the
* The place.

Thefe plants do grow in fundry places of Germanic wilde, and in Fraunce and Spaine, but they are planted in gardens in England, whereof I hauc plentie in my garden : the poore people of the north parts of England do manure it with great diligence, whereby they obtaine great plenty therof, replanting the fame once in three or fower yeeres.

\section{* The time.}

Licorice flowreth in Iuly, and the feede is ripe in September. * The names.

The firft is called in Greck 2nuyuppiples: in Latine Dulcis radix, or fweete Roote: this Licorice is not knowne either to the Apothecaries or to the vulgarpeople;we call it in Englith Diofc. his Licorice.

It is moft euident that the other is Glycyrrhiza, or Licorice: the Apothecaries call it by a corrupt worde Liquiritia : the Italians Regolitia : the Spaniards Regaliza, and Regalitia : in high @utıžbotz̧, Sufzimutzzel : in French Rigoliffe, Raigaliffe,and Reglyffe: in low Dutch Calitfiebout, fuetbotit: in Englifh common Licorice: Plinycalleth it Scythica berba : it is named Scytbice of the countrey
Scythia, where it groweth.
*Thetempcrature.

The nature of Diofcorides his Licorice as Galen faith, is familiar to the temperature of our bodies, and feeing it hath a certaine binding qualitie adioined, the temperature thereof fo much as is hot and binding, is efpecially of a warme qualitic, commingneereft of all to a meane temperature; bcfides, for that it is alfo fweete, it is likewife meanely moilt.

For as much as the roote of the common Licorice is fweete, it is alfo temperately hot and moift; notwithitanding the barke thereof is fomething bitter and hot, but this muft befcraped away ; the frefh roote when it is full of iuice doth moiften more then the dry.

$$
* \text { Thevertues. }
$$

A The root of Licorice is good againft the rough harfhnes of the throte and breft; it openeth the pipes of the lungs when they be ftuffed or Itopped, \& ripeneth the cough, \& bringeth forth flegm.

\section{Succus Glycyrribize.}

B

D

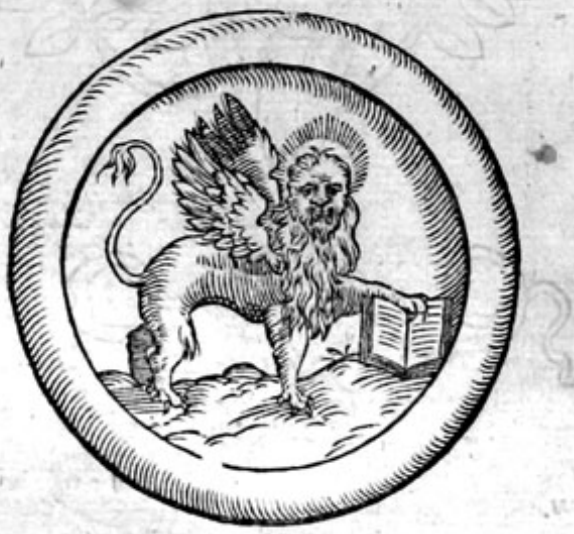

$\mathbf{E}$

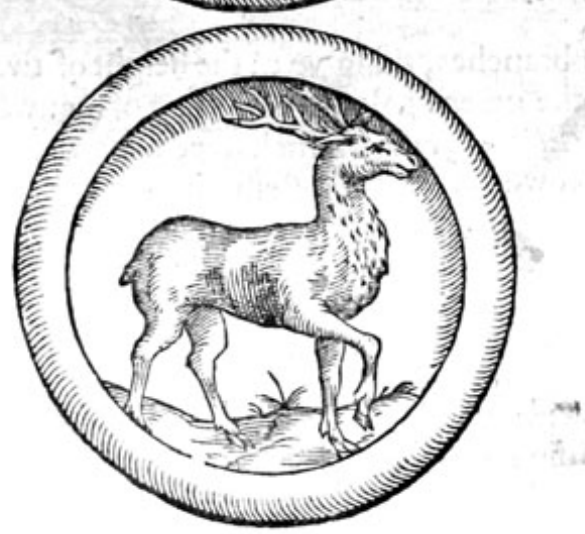

The Iuice of Licorice made according to Art, and hardned into a lumpe, which is called Swccus Liquiritice, ferueth well for the purpofes aforefaid, being holden vnder the toong, and there fuffered to melt.

Moreouer with the Iuice of Licorice, Ginger, and other fpices, there is made a certaine bread or cakes, called Ginger bread, which is verie good againit the cough, and all the infirmities of the lungs and breft: which is caft into mouldes, fome of one fafhion, \& fome another, according to the fancie of the Apothecaries, as the pietures fet foorth do thew for example.

The Iuice of Licorice is profitable againft the heate of the ftomacke, and of the mouth.

The fame is drunk with wine of Raifons againft the infirmities of the liuer and cheft, fcabs or fores of the bladder, and difeafes of the kidneies.

Being melted vnder the toong it quencheth thirft; it is good for greene woundes being laide thereupon, and for the ftomacke ifit be chewed.

The decoction of the frefh rootes ferueth for the fame purpofes.

But the dry roote moft finely powdred, is a fingular good remedy for a pin and a web ofthe cie, if it be ftrowed thereupon.

Diofcorides 
Diofcorides and $P$ liny alfo report, that Licorice is good for the ftomack, and vlcers of the mouth, $\mathrm{H}$ being calt vpon them.

5. Itis good againft hoarfenes, difficultie of breathing, inflammation of the lings, the plectrific $I$ fpitting ot blond and matter, confumption, rottennes of the lungs; all infirmities of the chelt, and ruggednes?

It takethaw aie inflainmations, mittigateth and tempereth the fharpnes andfaltnes of humours, $\mathrm{K}$ concoeteth rawe humours, and procureth cafie fpitting. if olil llomit, 279gnit

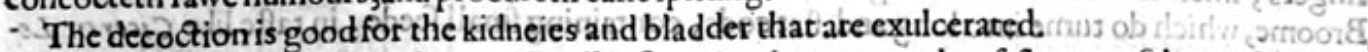

It cureth the ftrangurie, and generally all infirmities that proceede of tharpe, falt, and bixing $\mathrm{L}$

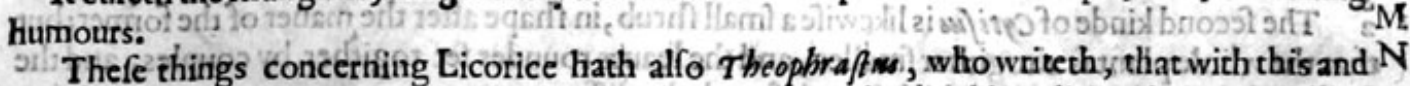
with cheefe made of mares milke, the Scythians were reported to be able to live a eleuen ontweluel daies: The Scythian root is good for fhortnes of breath, for a drie cough, and generally for all infir- $O$ mities of the cheft. intul vit ind tro A

Moreouer,with hony ichealeth vlcers, it alfo quencheth thirft if it be helde in the mouth, for which caufe they fay how the Scythians do liue a eleuen or twelue daies, with that and Hippace.

Hippace is cheefe as Hippocrates witneffeth, made of mares milke.

Plimie in his 25 .bookechap. 8 .hath thought otherwife then truth, that it is an herbe fo called.

\section{Of milke Trefoile, or hrub Trefoile. Chap.11.}

\section{* The kindes.}

Therebe diuers kindes or forts of the fhrubbe Trefoile, the which might very well hauepaffed among the three leafed graffes, had it not beene for my promife in the Proeme of our firft part, that in the laft booke of our Hiftorie the fhrubby or woody plants fhould be fet foorth, every one as neere as might be in kinred and neighbourhood.

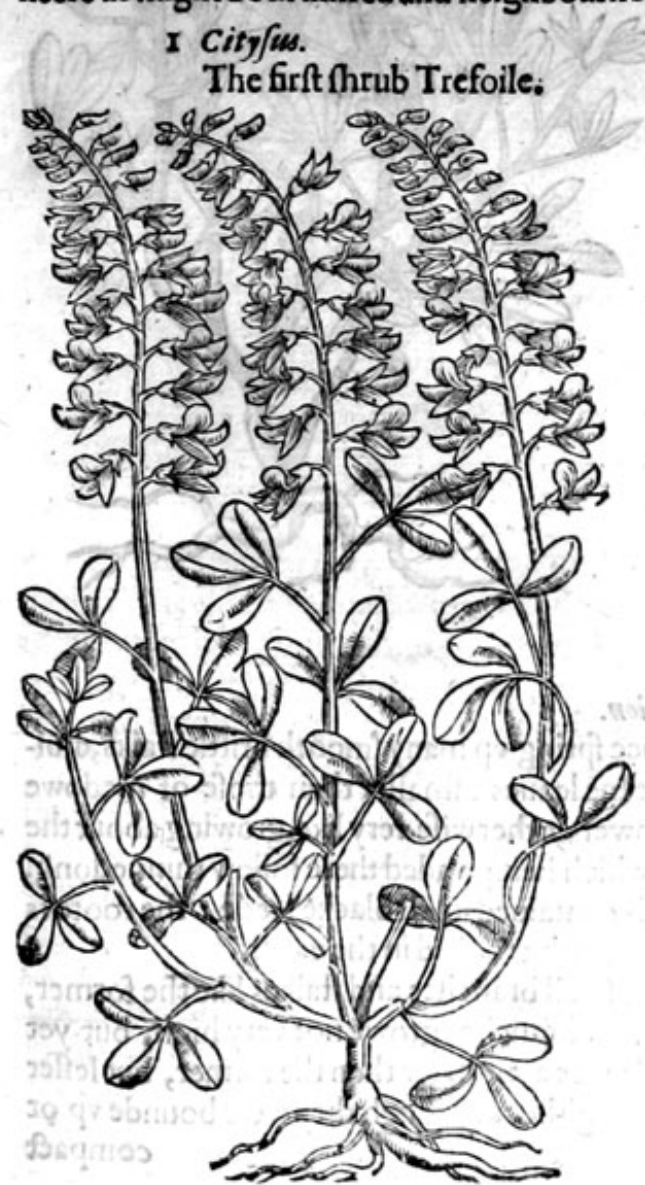

2 Citysus.

The fecond Srub Trefoile.

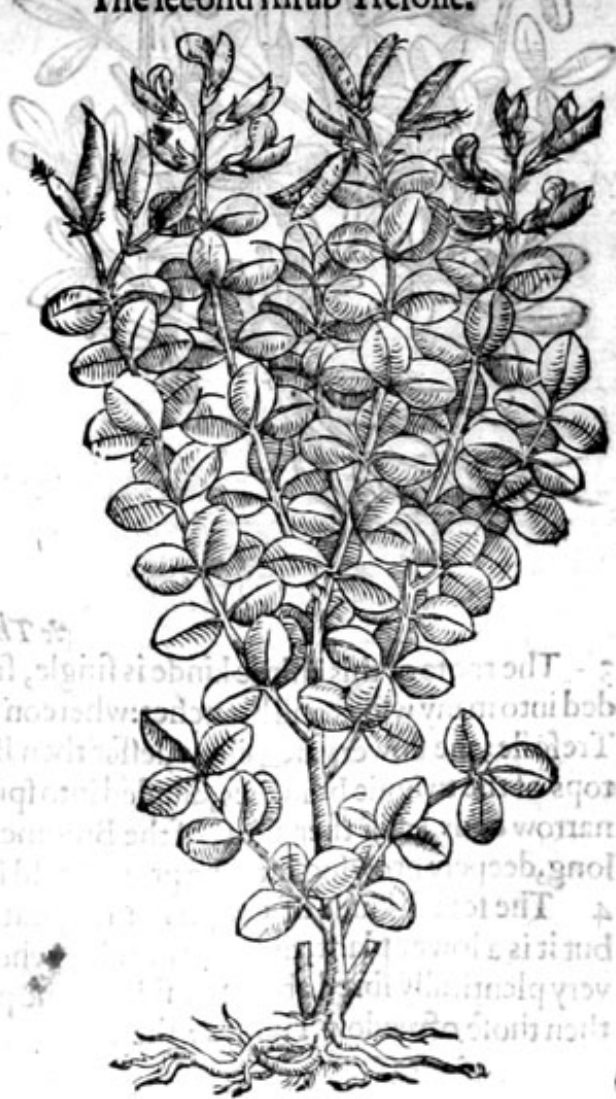


I

$*$ Thedefcription.

7 He firft kinde of $C y t i f u s$ or fhrubbie Trefoile, is al togither hoarie, or of a whitilh colour like branching into fundry fmall boughes or armes, fet full of leaues lwo or three cubits high; rather like the leaues of Rue, three growing alwaies togither; which being bruf frefoile, or fingers, fmell like Rocket : among thefe come foorth fmall yellowe flowe brufed betweene the Broome, which do turne into long and flat cods, containing fmall feede gumen.

2 The fecond kinde of Cytifus is likewife a fmall (hrub in that the whole plant is altogither frmaller, and the leab, in thape after the naner of the former; but fmall cods hairie at the ends, which fetteth foorth the difference.

3 Cytifus fíiguofus.

Codded fhrub Trefoile.

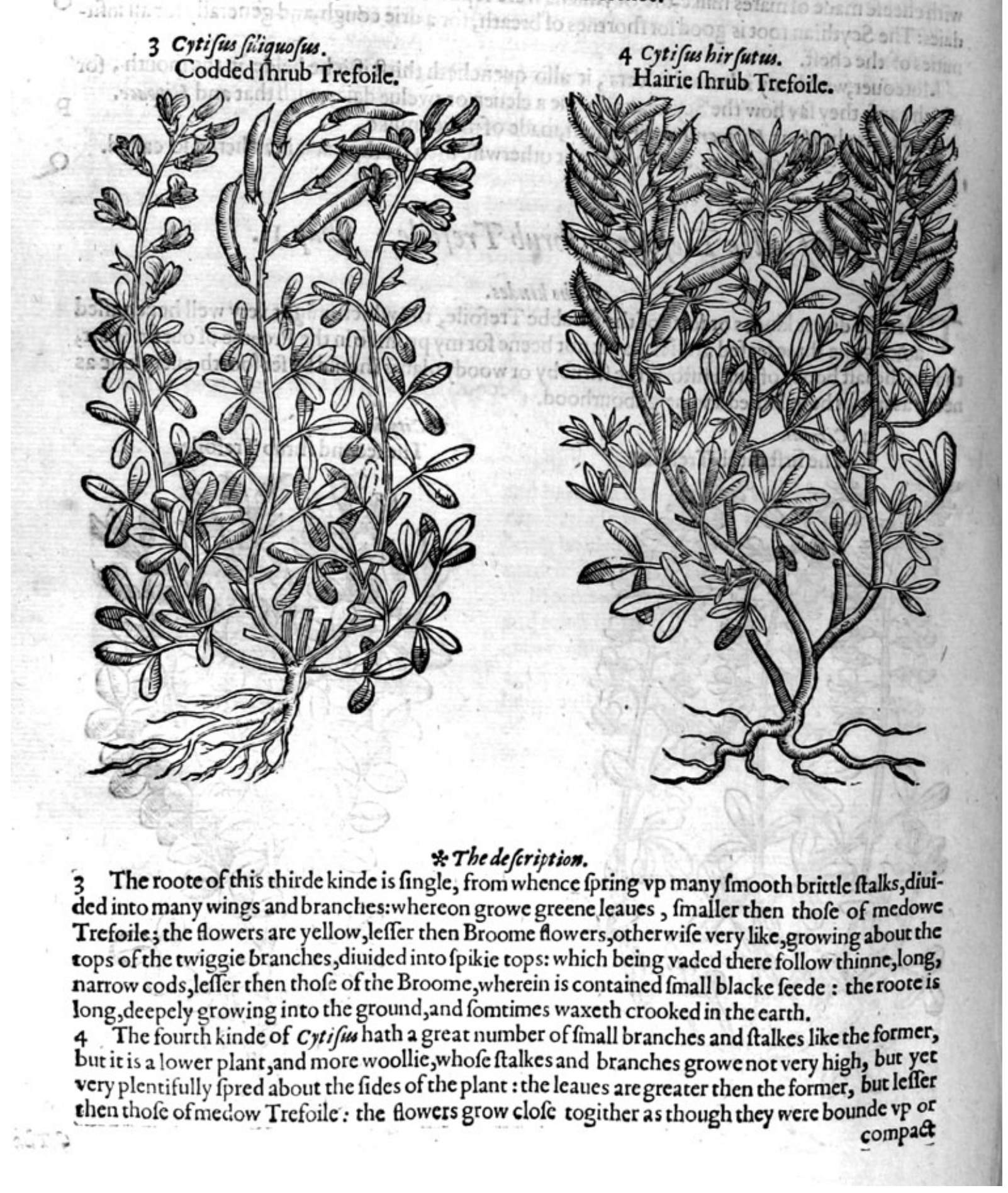


compact into one head or fpokie tuft,fomewhat greater then the former: the cods are alfo greater and more hairic: the roote groweth very deepe into the ground, whereunto are adioined a fewe fibres: it falleth out to be more hairie or woollie in one place then in another, and the more hairie and woollie that it is, the whiter it waxeth: for the roughnes bringeth it a certaine whitifh co. lour.

5 Cytifus incanus.

Hoarie fhrub Trefoile.

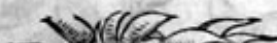

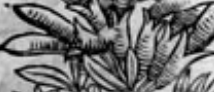

DE

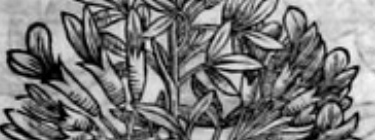

कैa 1205

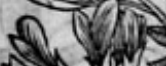

sol
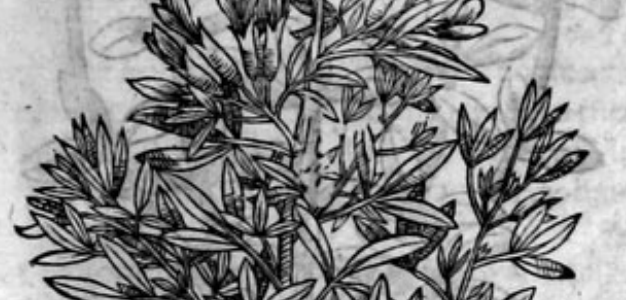

尺

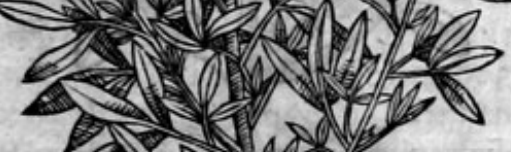

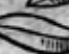

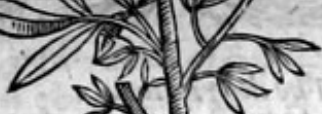

2)

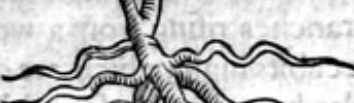

2

(

17.

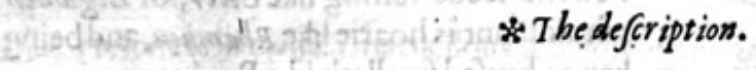

6 Cytifus Pinnatus.

Winged fhrub Trefoile.

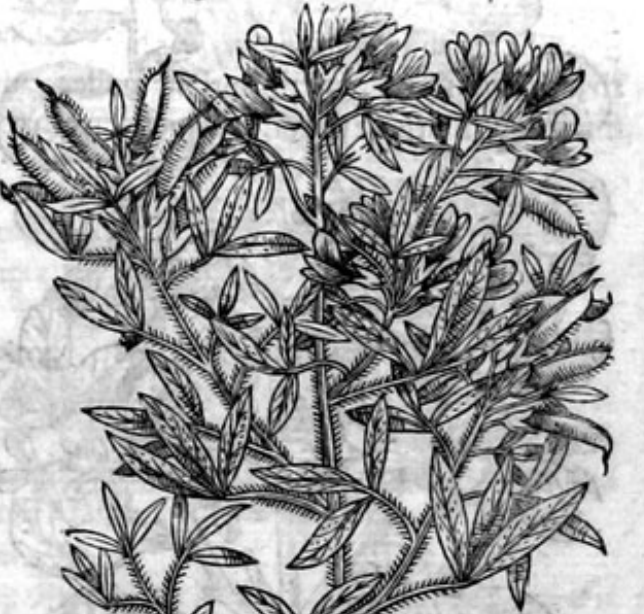

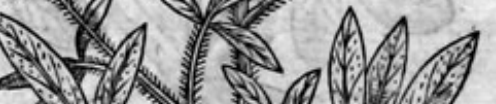
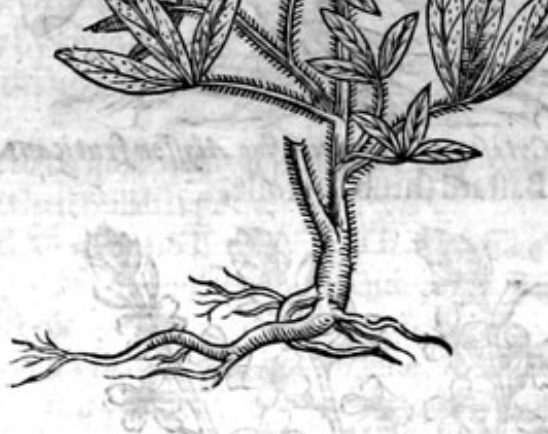

$3 \lim ^{2}$

:

5 The fift kinde of Cyti fus groweth to the height of fiue or fixe cubits, hauing many flender twiggie branches like Broome, ftreaked and very hard, whereupon grow leaues very like Fenugreeke, yet rather refembling Rue, three togither; froin the bofome of which, or betweene the leaues and the ftalkes, come foorth yellow flowers, verie like Broome, spartum or Pcafe, but fmaller: the cods be like vnto Broome cods, of an afh colour, but flenderer and latter: in the feuerall ccls or diuifions where of are contained bright fhining feedes, like the blacke feedes of broome; all the whole plant is hoarie like Rhomuzu, or Halymus.

6 The fixt kinde of $C y t i f u s$ or bufh Trefoile, groweth to the height of a tall man,with long ftalkes, couered ouer with a blackifh barke, and a fewe boughes or branches, befet or garnifhed with leaues like the common Trefoile, but fmaller, growing alfo three togither, where of the middlemott of the three leaues, is twife as long as the two fide leaues; the vpper fide whereof is greene, and the lower fide fomewhat reddith and hairie: the flowers grow along the ftalks almott from the bottom to the top, of a golden yellowe colour, fafhioned like the Broome flower, but greater then any of the reft of his kinde, and of a reafonable good fauour :the feede hath the pulfietafte of Cicer. 
7 Cyti/us 7. Cornutus.

The horned fhrub Trefoile.

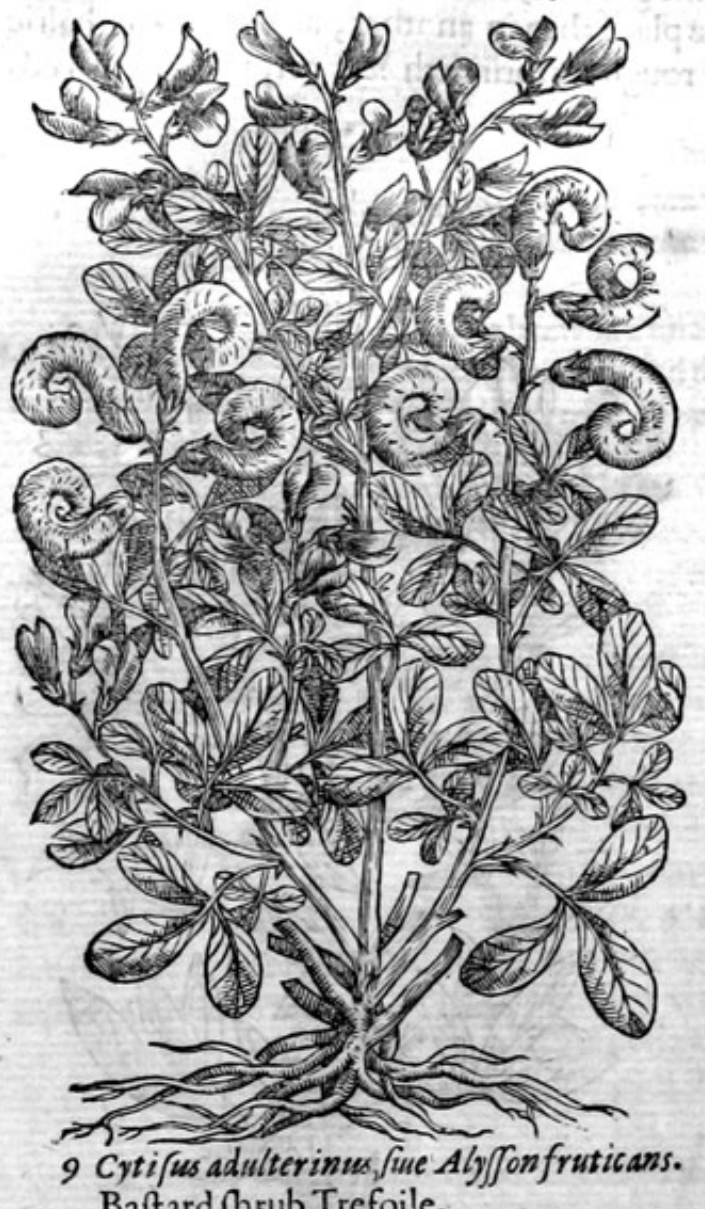

Baftard fhrub Trefoile.

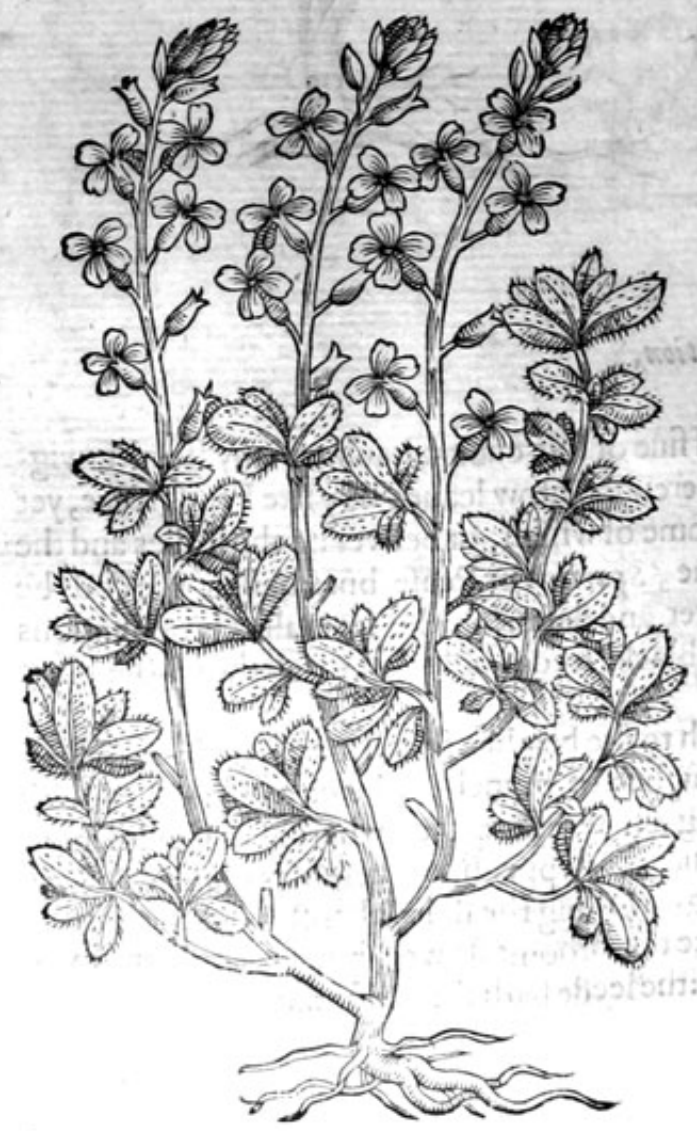

mol, 8 cytifus. 8 .

(12) 4 The 8.fhrub Trefoile.

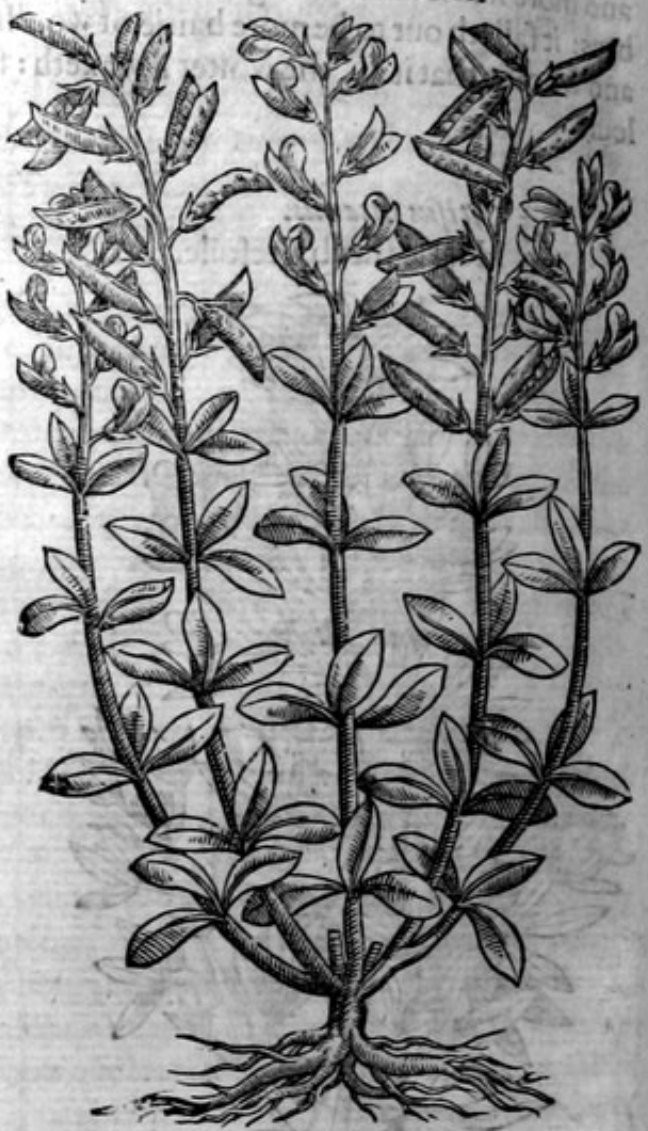

$*$ The defcription.

7 The feuenth kinde of Cytz fus hath many rough and hairie branches rifing from a woodie roote, fower or fiue cubits high; which are diuided into fundry fmaller branches, befet with leaues like the medow Trefoile: among which come foorth yellowe flowers like Broome, that turne into crooked flat cods, like a fickle; wherein is contained the feede tafting like Cicer, or Legumen : the whole plant is hoarie like Rhamums, and being broken or brufed fmelleth like Rocket.

8 This eightkind of $C y t i$ fus which $P$ ena fetteth forth, is doubtleffe another kind of $C y t i f u s, r e f e m-$ bling the former in leaues, flowers, and cods, fauing that the finall leaues (which are alwaies three togither) are a little fnipt about the edges: the whole plant is flenderer, fofter, and greener; rather refembling an herbe then a hrub: the roote is fmall and fingle.

9 This baftard or misbegotten fhrub Trefoile, or rather the fifticated or falfified Cyti/us, groweth vp like a hrub, butnot of any wcodiefubftance, having tender ftalkes, fmooth, and plaine : whereon do grow hairie leaues like the other, diners fet vpon one footeftalke, contrary to all the reft: the flowers growe along the ftems like thofe of the ftocke $G$ illoflowers, of a yellow colour: the roote is tough and woodie. $\quad *$ the 
Thefeplants were firft brotght into Italy and Greece from nne of the Iles Cyclades, called Cyntho or Cynthufa, and fince founde in many places of Fraunce, as abot:t Montpelier, Veganium, and other places; they are ftrangers in Englande, though they grow very plentifully in Scotland, as it is reported, whereof thane two forts in my garden: that is tofay Cytijus war anthe, or the horned cytijus, and likewife one of the fmalleft, that is tofay, the thirc in number.

Thefe plants for the moft partdo flower in Iune and Iuly and fomewhat after : thefeede is ripe

Thefe plants for the moft part do flower in Iune and Iuly, and fomewhat after: thefeede is ripe in September.

* The names.

The Gracians and Latines do call this fhrub wutros, of Cynthufa, an Iland before mentioned, in which place they are in great eftimation, for that they do fo woonderfully feede cattle, and increafe milke in their dugs; nourifh fheepe \& goates, which bring yoong ones good for ftore and increafe: one author doth call thefe plants in Greeke Ku'hnoor, that is in Latine Feccinderm fanum, ferpil or fruicfull Haie, for that the kindes hecreof caufe rnilke to increafe; makerh good bloud and iuice;augmenteth ftrength; and multiplieth the naturall feede of generation: they may be called in Englifh milke Trefoile, of thefture of milke which they increafe.

\section{* 7 hetemperature.}

The leaues of milke Trefoile do coole as Diofcorides writeth, they affwage fwellings in the be. ginning if they be ftamped and laid vnto them with bread : the decoction therof drunke proinoketh vrine: Galen teacheth, that the leaues of Milketrefoile haue a digefting or wafting qualitie, mixed with a waterie and temperate facultie, as haue thofe of the Mallow.

$$
\text { * The vertues. }
$$

Women faith Columella, if they want milke muft fteep drie Milktrefoilein faire water, \&c when it is A thorowly foked, they muft the next day mixe a quart or thereabouts of the fame preffed or ftrained foorth with a little wine, and fo let it be giuen vnto them to drinke, and by that meanes they them. felues thall receiue ftrength, and their children comfort by abundance of milke.

Hippocrates reckoneth vp Milktrefoile among thofe things that increafe milke, in his booke of the B nature of women, and of womens difeafes.

Alfo Ariftomacbus of Athens in Pliny, commandeth to give with wine the dry plant, and the $\mathrm{C}$ Iame likewile boiled in water, to nurfes to drinke when their milke is gone.

Democratus and driftumachus do promife that you hall want no Bees, if you haue Milke Tre- D foile for them to feede on: for all writers with one confent do conclude as Galen faith, that Bees do gather of the flowers of Milktrefoile very great ftore of honic.

Columella teacheth, that milke Trefoile is notable good for hens, bces, goates, kine, and all kinde E of cattle, which quickly grow fat by eating thereof, and that it yeeldeth verie great ftore of milke.

The people of Boetica and Valentia (where there is great ftore of Cjtifus) doe vfe it very much F for the filke worme to hang their web vpon after they haue beene well fed with the leaues of Mulberies.

Milke Trefoile is likewvife a marueilous remedie againft the Sciatica, and all other kinds of gouts. G

$$
\text { Of baftard milkeTrefoiles. Chap.iz. }
$$

\section{\%. The kintes.}

THerebealfo other Trefolles, being woodie and hrubbie plants, of which forne be like to the right milke I refoile.

\section{* The defcription.}

1 His rileth vp with little ftalkes from the roote, brittle, very many in number, parted into wings \& branches, about which grow many leaues leffer then thofe of the medow Trefolle, of colour green:the flowers about the tops of the twigs be orderly placed in maner like eares,

\section{Dddd I}




\section{THE THIRD BOOKE OF THE}

of colour yellow, leffer then thofe of Broome, otherwile all alike : in their places grow vp flender cods, long, narrow, and leffer than the cods of Broome; in which doe lie little blackifh feedes: the roote is long and groweth deepe, and oftentimes creepeth aflope.

2 The fecond kinde of baftarde milke Trefoile is like vnto the former in plentifull ftalkes and twigs, but that it is lower and more downie ; neither do the ftalkes thereof ftande vpright, but $\mathrm{r}_{2}$ ther incline to the one fide: the leaues alfo are fomewhat greatcr, but yet leffer than thofe of the medow Trefoile: the flowers likewife be clofelier ioined togither, and compacted as it were into a little head, and be alfo fomethinggreater : the coddes in like maner are a little bigger and hairie. The roote groweth deepe in the grounde, being diuided into 2 few fprigs ; it of tentimes happeneth co grow in one place more hairie or downie than in another: the more hairie and downie it is, the more white and hoarie it is; for the hairines doth alfo bring with it a certaine whitioh colour,

\section{Pfeudocytifus I}

The firft baftard ihrub Trefoile.

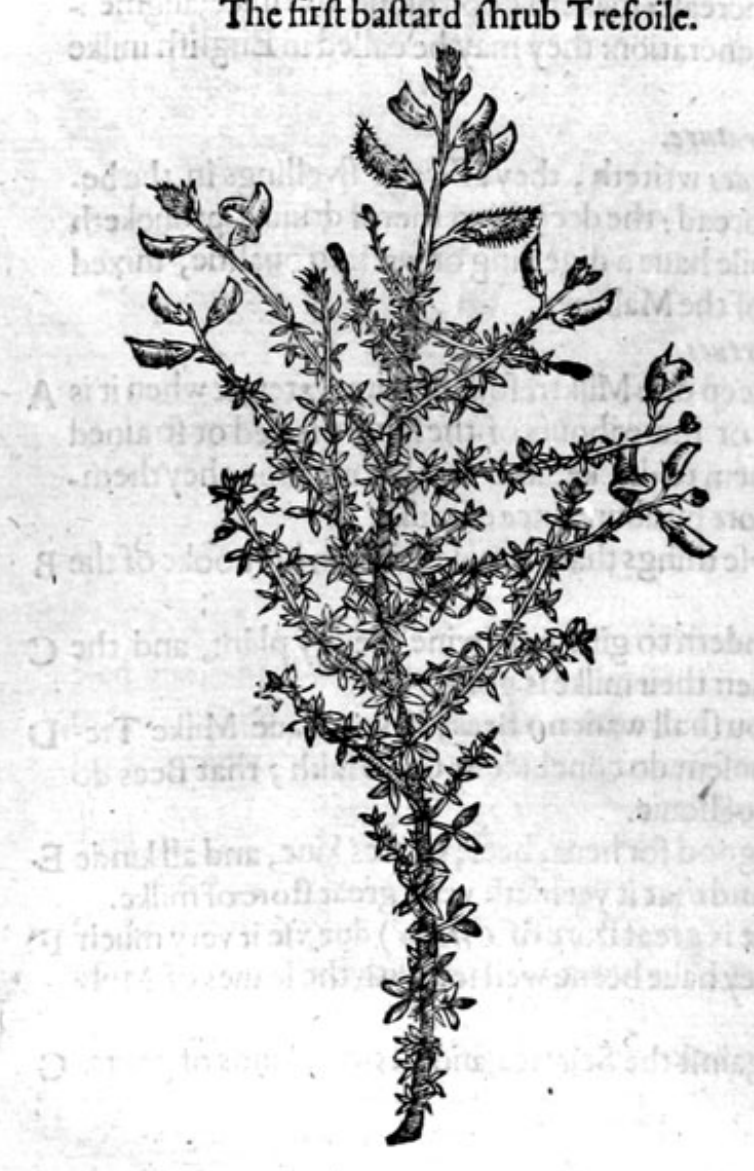

\section{Pfeudocytifus 2.}

The fecond baftard hrub Trefoile.

\section{* Thedefcription.}

3 The third kinde of baftard milke Trefoile, bringeth foorth a company of yoong hootes that are fomew hat writhed and crooked, long leaues of a faire greene colour : the flowers are clofed togither, long, white, or elfe galbineus, fweetly fmelling, that is to fay, hauing the fmell of honie : the Shrub it felfe is alwaies greene both fommer and winter.

4 The fourth fhrubbe is likewife one of the wilde kinde, though in face and ftature like the manured $\mathrm{Crti}$ /us.I groweth vp like a fmall fhrub or hedge bufh to the height of two or three yards; on whofe branches do growe three rough or hairie leaues, fet vpon a flender footeftalke, of a grafle greene colour: the fowers grow alonglt the ftalkes from the middle to the top, of a bright fhining yellow colout : tie roote is likewife woodie. 


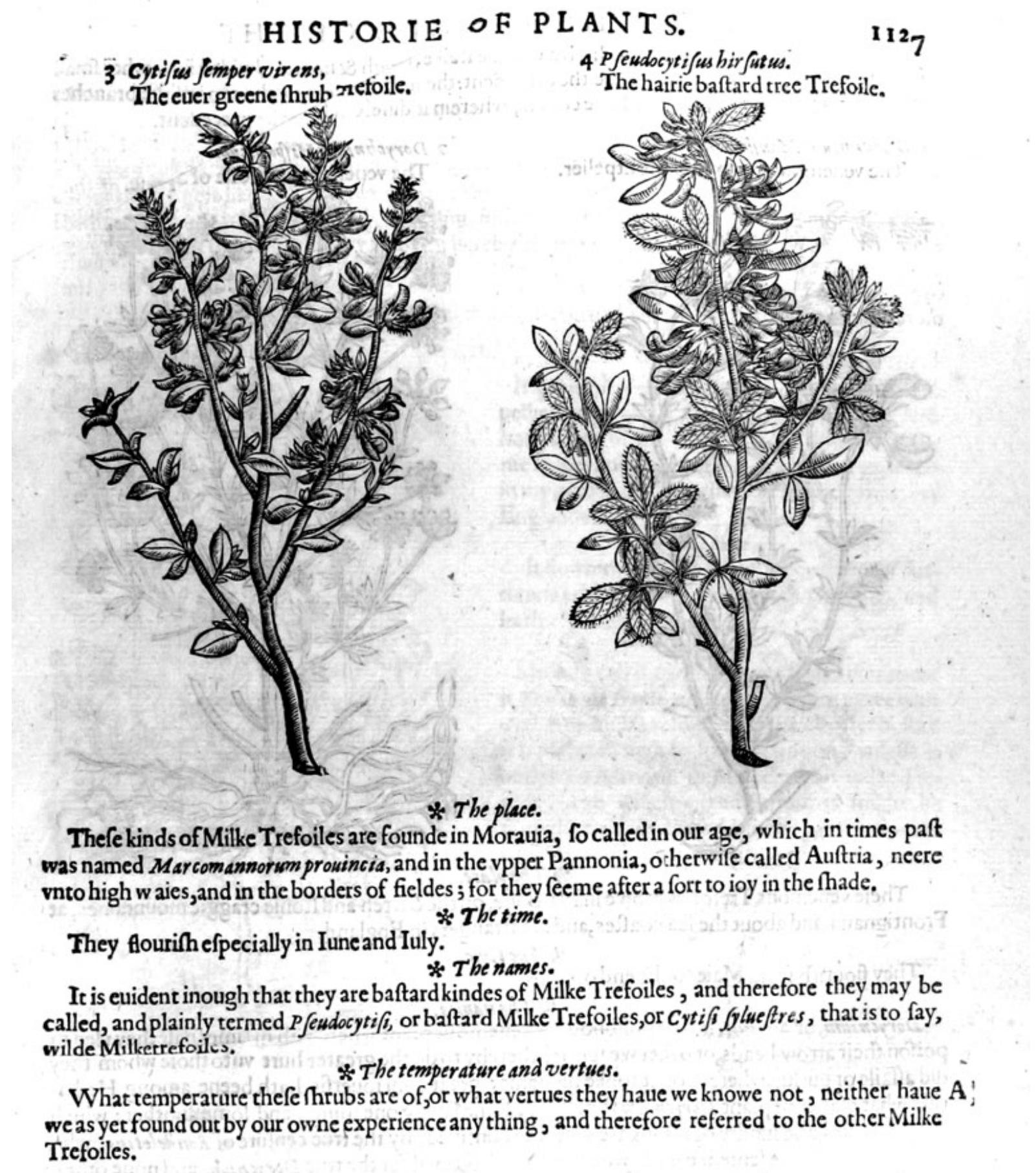

\section{Of the venemous tree Trefoile. Chap.13.}

* The defcription.

I He venemous tree Trefoile of Montpelier, hath many tough and pliant ftalks, two or three cubits high;diuided intofundrie fmall twiggie branches, befet with leaues three togither, placed from ioint to ioint by fpaces, fomewhat hoarie, verie like vnto the leaues of Cytifus, or Rue : among which come foorth many fmall moffie flowers, tuft fafhion, in fmall bundles like nofegaies, and very like the flowers of the Oliue or Oke tree, which turne into fmall roundifh bladders, as it were made of parchment : wherein is conteined blacke feede like wilde Lotus, but in talte like the wilde Tare; the whole plant is of an vnfauorie fmell; the roote is thicke, and of a woodie fubftance. 
2 The Spanifh venemous Trefoile harh a woodie ftalke, ru- ah \& hoarie, diuided into other fmall like thofe of the Peafe, and of a yellowe colour, wherein it differeth frow on the tops of the branches

I Dorychnium Mon/pelienfium.

The venemous Trefoile of Montpelier.

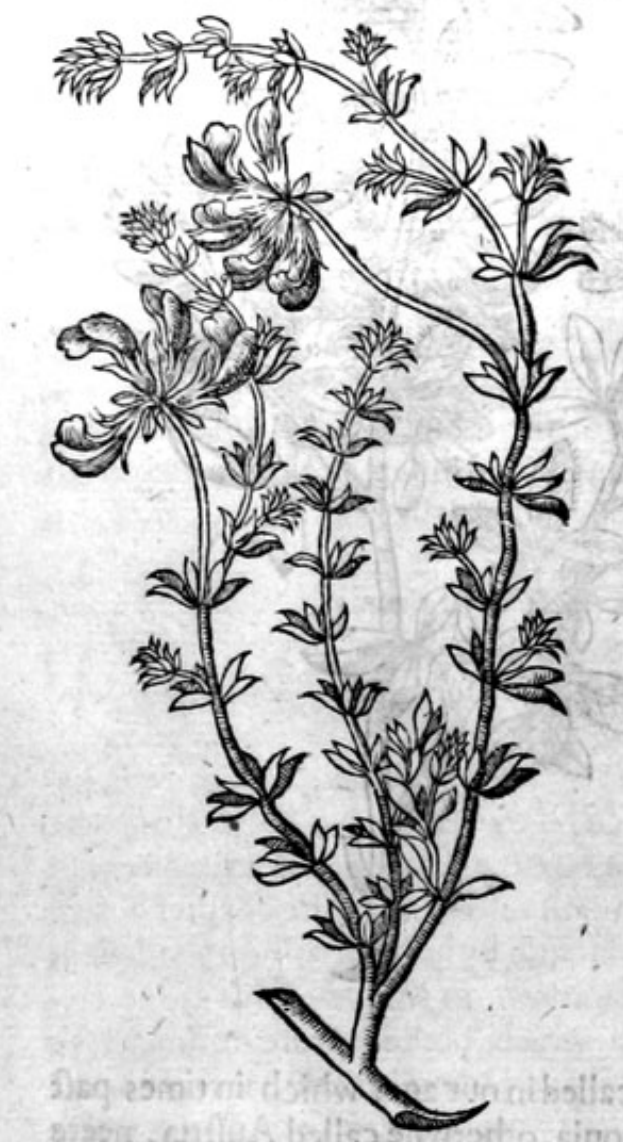

* The place.

2 Dorycbnium Hipanicum.

The venemous Trefoile of Spane.
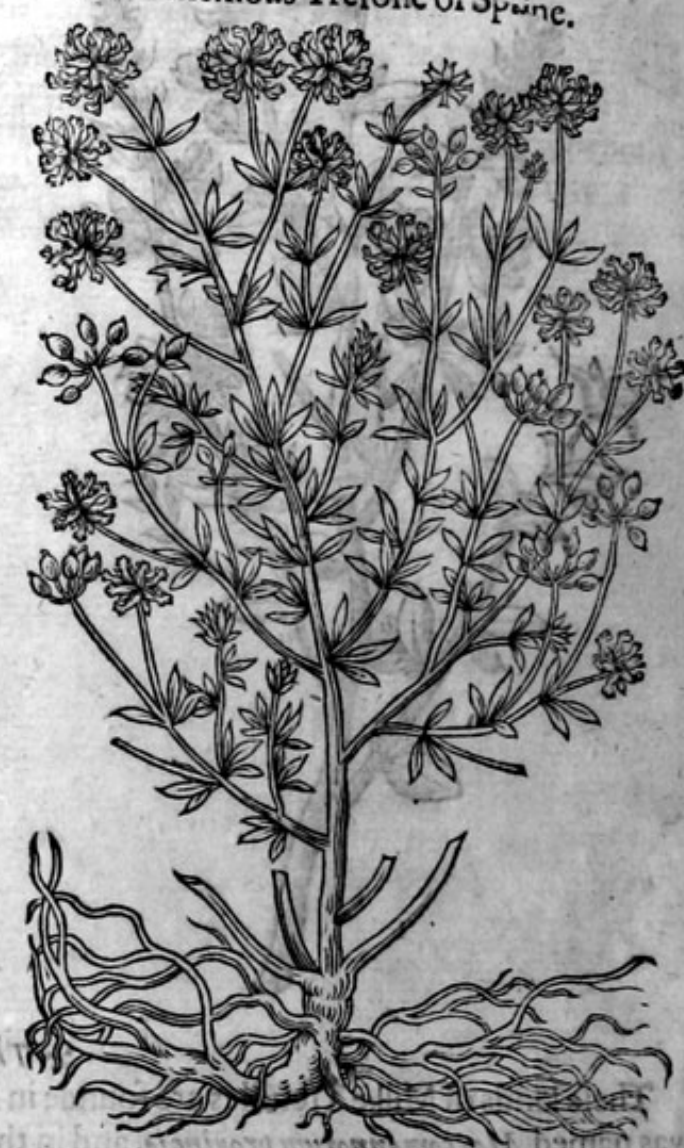

Thefe venemous Trefoiles growe in Narbone, on the barren and ftonie craggie mountaines, at Frontignana, and about the fea coaftes, and are ftrangers in England.

They flourith from Maie to the end of Iune. * The time.

* The names.

Dorysnium, or $\Delta$ opixylop, is that poifonous or venemous plant wherewith in eimes paft they ved to poifon their arrow heads, or other weapons, thereby to do the greater hurt vnto thofe whom they did affaile or purfue, whereupon it tooke his name: great controuerfie hath beeve among Herbarifts what maner of plane Dorycnisom fhould be, fome faying one thing, and fome another: which controuerfies and lundry opinions are very well confuted, by the true cenfure of Rondeletins, who hath for a definitiue fentence fet downe the plant defcribed for the true Dorycnium, and none other, which may be called in Englifh venemous tree Trefoile.

Dorycniwm is very colde, without moiltning.

$$
\text { * The temperature. }
$$

* Thevertues.

Venemous Trefoile hath not one good qualitic that I can read of, but it is a peftilent venemous plant, as hath beene faid in the defcription.

\section{Of the Jbrub Trefoile, called aljo Makebate. Chap.14.}

$*$ The defcription.

His thrubbie plant called Polemonium, hath manie woodie twigs, growing to the height of fowcr or fiue cubits, hauing fmall twiggie branches, of a darke greene colour, garnifbed with 
with fma ll leaues of a deepe greené colour, alwaies three ioined togither vpon litt'c foote ftalkes, like the $C y t i$ fus bufh,or the fielde Trefoile, but fimaller: the flowers be yellowe, and rounde, diunded into fiue or fixe parts, not much volike the yellowe Iafinine, which hath caufed many to cal it yellow Ia fmine,euen to this day: when the flowers be vaded, there fucceede fmall rounde berrics as bigge as a Peafe, of a blacke purplifh colour when they be ripe, which being broken will die or colour the fingers like Elder berries: within thefe berries is conteined a fmali tlat feede, like vnto Lentils : the roote is long and fmall, creeping hither and thither vnder the earth, putting foorth newe fpringes or fhootes in fundry places, whereby it woonderfully increafech.

Polemonion fue Trifolium fraticans. Shrubbie Trefoile.

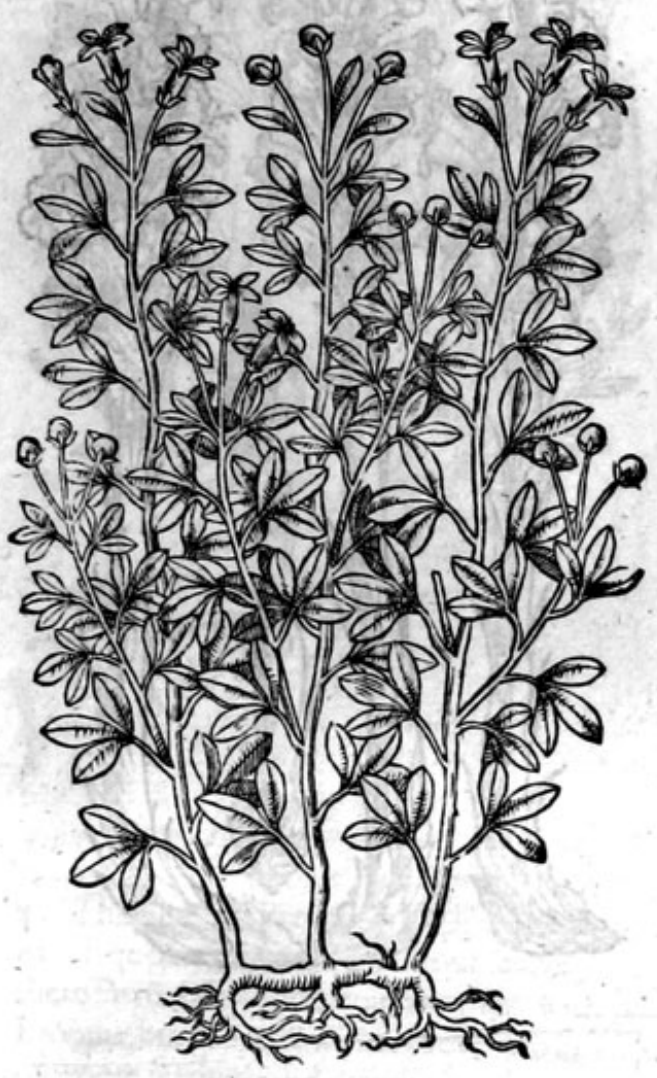

\section{* T beplace.}

It growcth plentifully in the countrey of Mont pellier at Newe Caftle vpon the drie hils, and hot bankes of the Oline fieldes, and in the itonie fieldes and wood of Gramuntium: it groweth in my garden, and in other Herbarifts gardens in Englande.

\section{* The time.}

It flowreth in fommer: the feede is ripe in Autumne; the fhrub it felfe is alwaies greene, and hath a lafting roote.

\section{* The tames.}

Moft do call it Cytifus, but we had rather name it Trifolisem frut cins: for it doth not agree with Cytijus or milk Trefoile, as in the chapter before it is plaine inough by his defcription, vnleffe it be Cytifus Marcelli, or Marcellus his milke Tres foile, with which peraduenture it might be thought to haue fome likeneffe, if the flowers which are yellow were white, or galbinew, that is to fay blewe.

There be diuers alfo, that take this Trefoile to be Polemonium, forafmuch as the leaues heereof feeme to be fomewhat like thofe of common' Rue, but Polemonium hath not the leafe of common Rue, otherwife called Herb-grace; but of the other, that is to fay, of S. Iohns Rue: it is called in Englinh fhrubbie Trefoile, or Makebate.

\section{* T he temperature.}

Polemonium is of temperature dry in the fecond degree, with fome acrimonic or fharpnes.

$$
\text { * The vertues. }
$$

This fhrubbic or fruticall plant, hath fo many fingular and excellent vertues contained in it, that $\mathbf{A}$ fome haue called it by the name chiliodunamis, that is, hauing an hundred properties.

It is very effectuall againft the ftinging of Scorpions, and (as fome write) if a man holde it in his B hand, he cannot be hurt with the biting of any venemous beaft.

Being taken in vineger it is very good for thofe that are fpleenetike, and wholefpleenc or milt is $\mathbf{C}$ affected with oppilations or ftoppings.

If the roote be taken in wine it helpeth againft the bloudie fixe, it prouoketh vrine being drunke $D$ with water, fcoureth away graucll, and eaferh the paine and ache called the Sciatica.

The plant Papauer fumeum, called Spatling Poppie, is called of fome Cbiliodynamis: whether E Dio/corides did attribute the hundred vertues thereunto or to this plant (called among the learned in Montpeliet) Poiemonium, refteth difputable.

$$
\mathcal{D} d d d^{3}
$$




\section{Of Broome Chap.15.}

* The kindes.

There be diuers forts of Broome, differing in diuers refpeets,as fhall be declared.

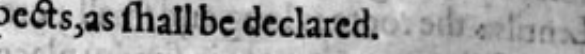

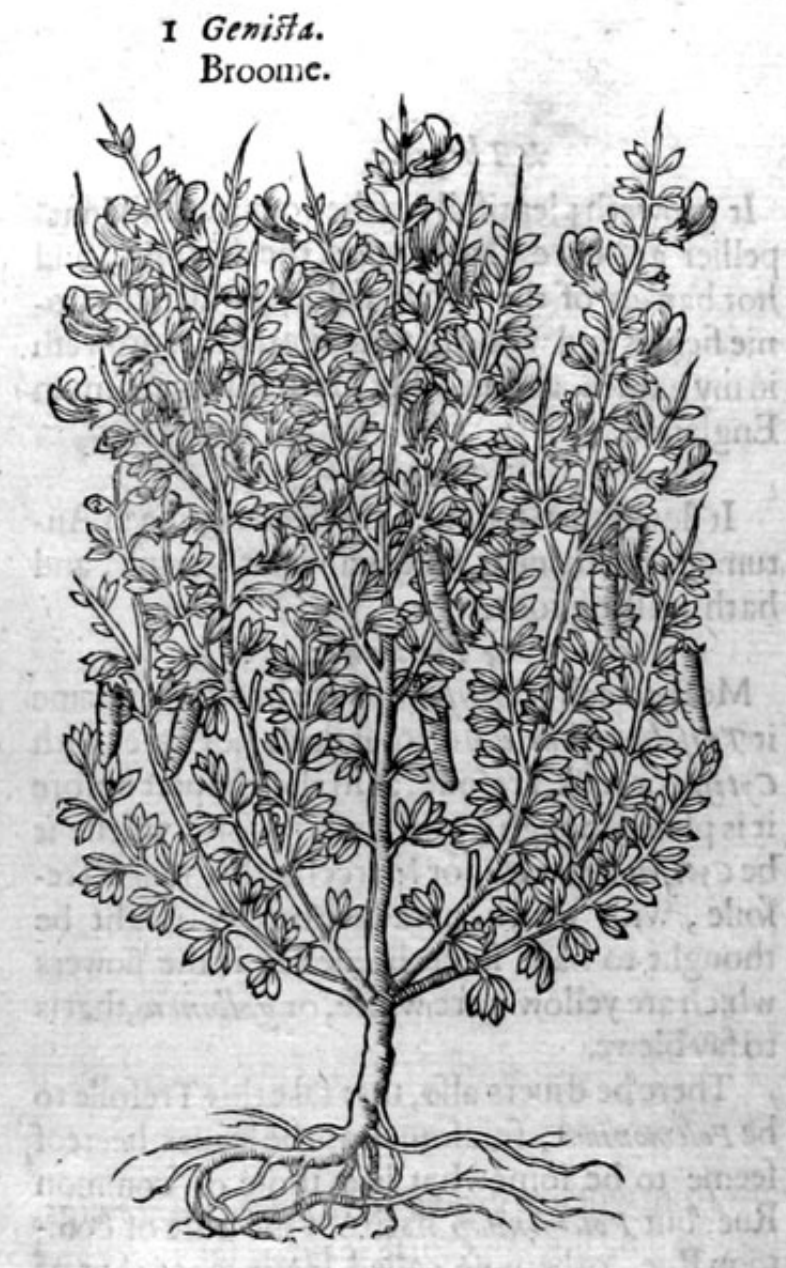

I Genista.
2 Rapum Genifta. Broome Rape,or.Orobanch.

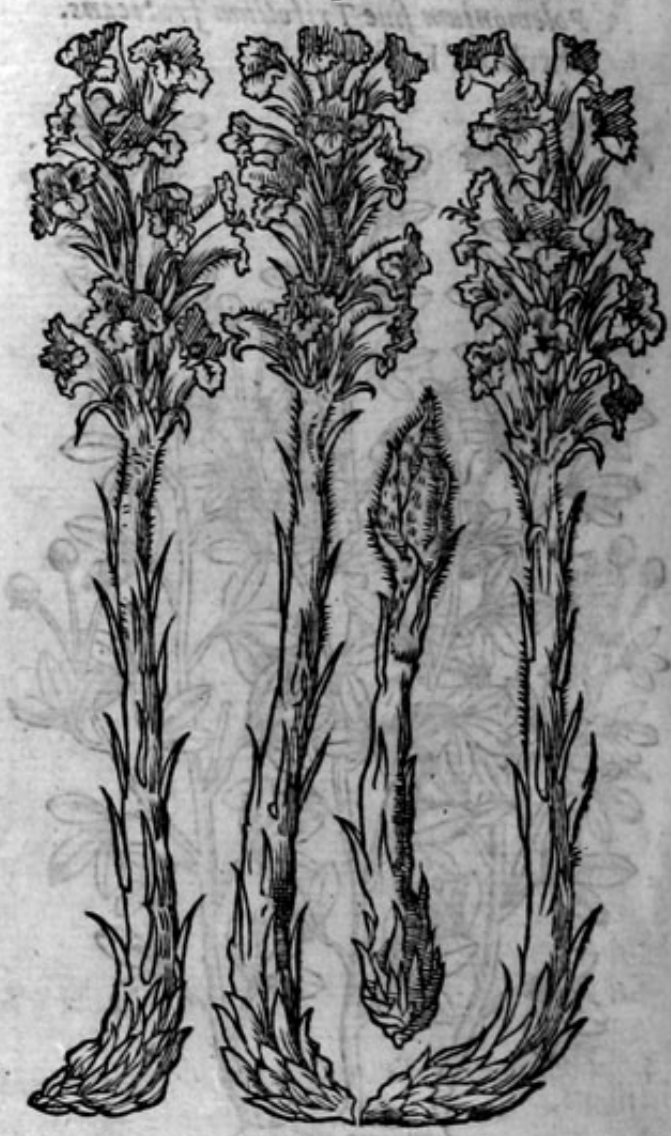

* The defoription.

I Roome is a buth or fhrubbie plant, it hath ftalks or rather woodie branches; from which do 1 fpring flender twigs, cornered, greene, tough, and that be eafily bowed, many times diuided into fmall branches : about which do growe little leaues of an obfcure greene colour, and braue yellow flowers; and at the length flat cods, which being ripe are blacke, as be thofe of the common Vetch, in which do lie flat feedes, hard, fomething brownith, and leffer then Lentils : the roote is hard and woody, fending foorth diuers times another plant of the colour of an Oken lea e, in fhape like vnto the baftard Orchis, called Birds neft, hauing a roote like a Turnep or Rape, wherupon itis called Kapum Genifte, or Broome Rape.

2 This is a certaine bulbed plant growing vnto the rootes of broome, bigge belowe, and fmaller aboue, coneted with blackifh fcales, \& of a yellowih pulpe within : from which doth rife aftalke a fpanne long, hauing whitih flowers about the top, like almoft to thofe of Dead Nettle : after which grcwe for rth long, thicke and round huskes, in which are conteined very fine feedes, and good for nothing: the whole plant is of the colour of the Oken leafe. 
3 Genifta Hifpanica. Spanifh Broome.

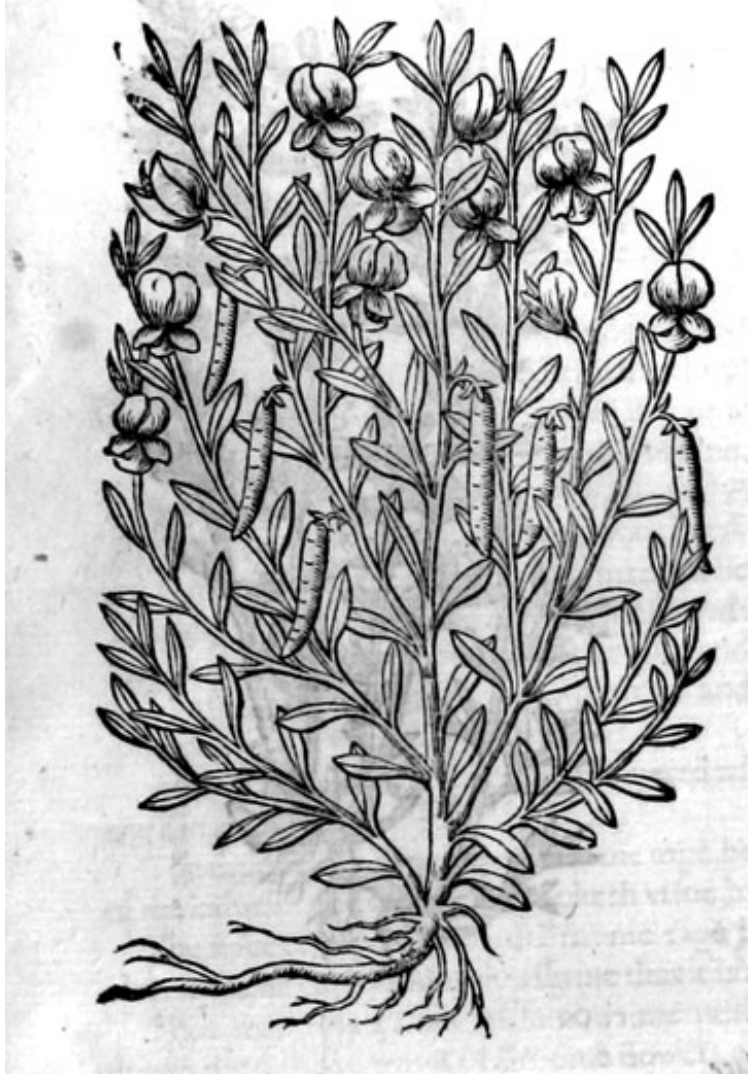

4 Geniftatenuifolia. Small leafed Broome.

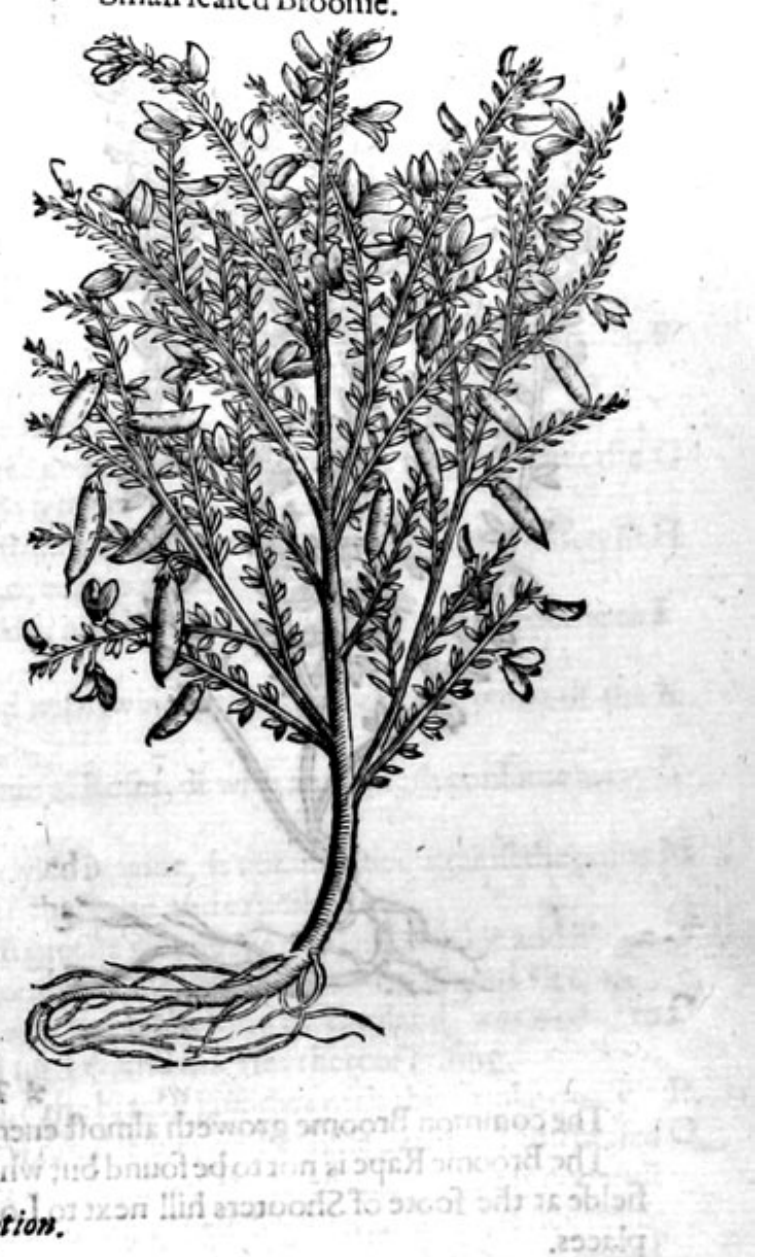

* The defcription.

3 The Spanifh Broorne hath likewife woodie ftems, from whence growe vp flender pliant twigs? which be bare and naked without leaues, or at the leaft hauing but fewe fmall leaues, fet heere and there farre diftant one from another, with yellow flowers not much vnlike the flowers of common Broome, butgreater, which turne into finall long cods, wherein is contened browne and flat feed: the roote is tough and wcodie.

4 Small leafed or thinne leafed Broome, hath many tough pliant fhoores rifing out of the ground, which grow into hard and tough ftalks, which are diuided into diuers twiggie branches, whereon do grow very fmall thinne leaues, of a whitih colour; whereupon fome haue called it Genifta alba, white broome : the flowers grow at the top of the ftalks, in fhape like thofe of the common Bioom, but of a white colour, wherein it efpecially differech from the reft of the Broomes.

5 Englith Dwarffe Broomic hath many twiggie branches, very greene, tough, fomewhat fraked or cornered, leaning toward the ground : whereon do growe leaues fet without order, fomerimes two togither, and often three or fower growing faft togither, like vnto the common Broome, greene on the vpperfide, hoarie inderneath, and of a bitter tafte: ainong which leaties come foorth yellowe flowers like thofe of common broome, butleffer, of little or no finell at all: after which appeerc finalls cods, fomewhathairie, wherein is conteined finall fecde: the roote is tough and woodic. ni : mose dand $\mathrm{C}_{2} \mathrm{w}$

6 The Dwarffe Broome of Hungarie hath ftalkes and yellowe flowers, like thofe of the laft deferibed: the leaues heere of are different, they are longer and moc in number: the whole plant is altogither greater, wherein efpecially confifteth the difference. 
5 Chamegenista unglica.

Englinh Dwarffe Broome.

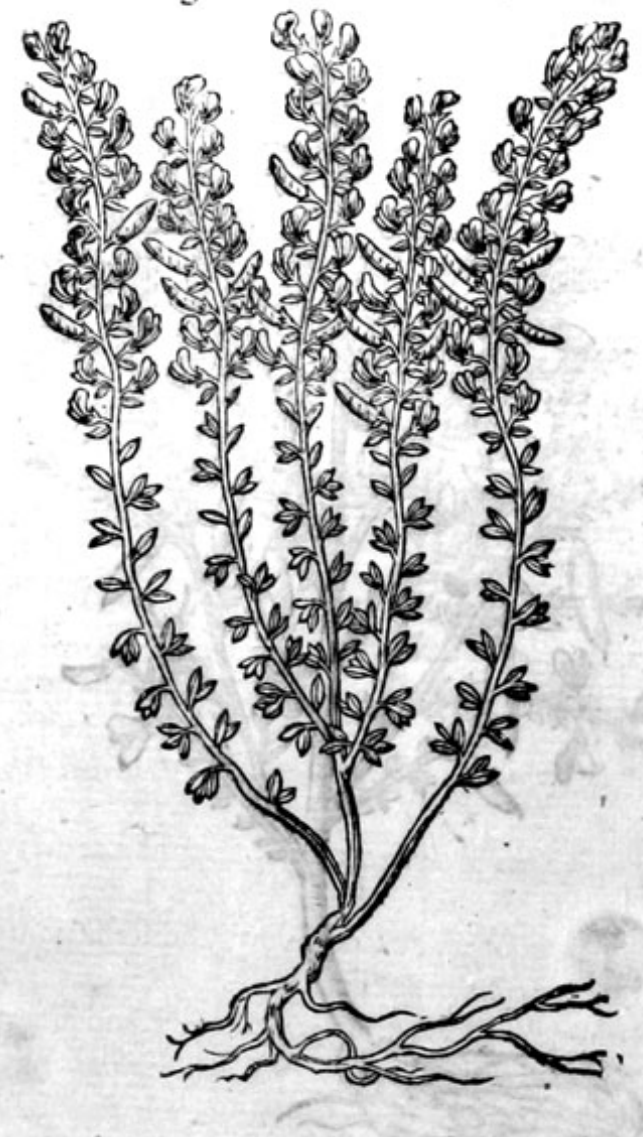

BOOKE OF THE

6 Chamegenifta Pannonica.

Dwarffe Broome of Hungaric.

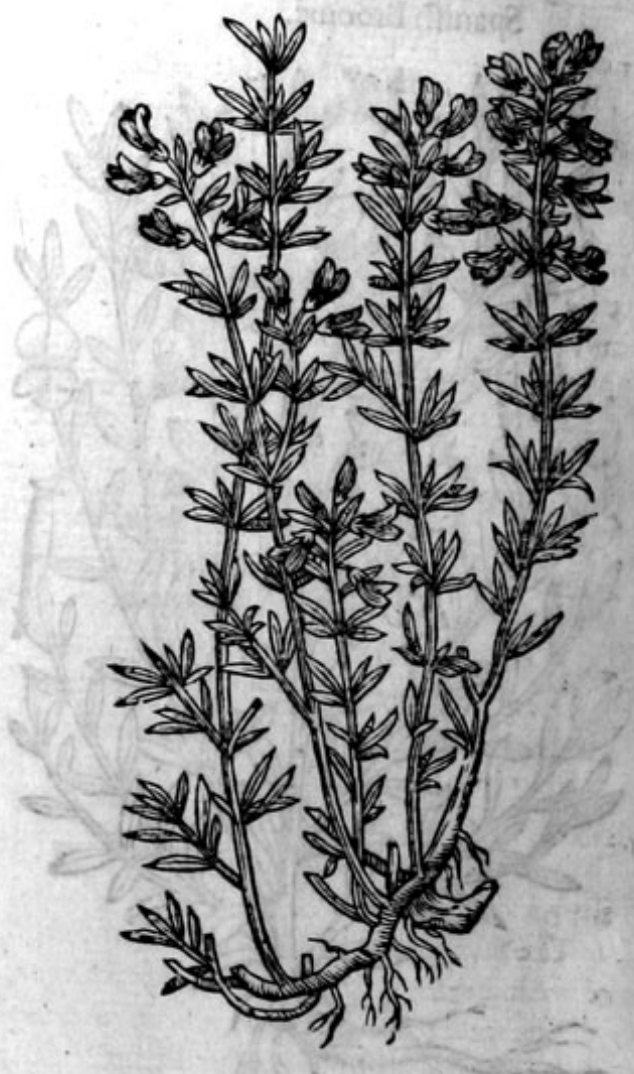

* The place.

The common Broome groweth almoft euery where in dry paftures and lowe woods.

The Broome Rape is not to be found but where Broome doth growe; it groweth in a Broome fielde at the foote of Shooters hill next to London; vpon Hampfteede Heath, and diuers other places.

Spanich Broome groweth in diuers kingdomes of Spaine, and Italy; we haue it in our London gardens.

The white Broome groweth likewife in Spaine and other hot regions; it is a ftranger in England; of this Tit us Calp hurnises maketh mention in the fecond Eclog of his Bucolickes, writing thus, Cernis $v$ t, eccepater, quas tradidit Crnite vacce

Molle fub hir fut a latus explicuere genifta.

See father, how the Kine ftretch out their tender fide

Vnder the hairie brogme, that growes in fields fo wide.

* The time.

Broome flowreth in the end of Aprill or Maie, and then theyoong buds of the flowers are tobe gathered, and laid in pickle or falt, which aftewards being wafhed and boiled, are vfed for fallades, as Capers be, and be caten with no leffe delight : the cods and feedes be ripe in Auguift; the Rape appecrech and is feene efpecially in the month of Iune.

The Sianifh Broome doth flower fooner, and is longer in flowring. $\%$ The names.

This Mrub is called in Latine Genifta, or as fome woulde haue it Genefta : in Iralian Geneftra : in

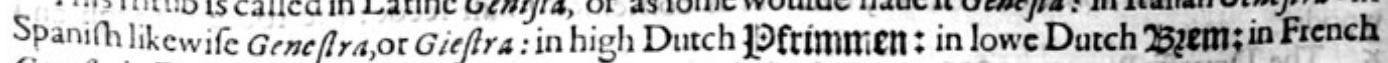
Genrft: in Englifh Bioome.

A The twigs, thowers, and feedes of Broome are hot and dry ia the feconde degreet they are allo of
a 
a thinne effence, and are of force toclenfeand open, and efpeciaily the feede, which is drier and not fo full of fupertious moilture.

The decoction of the twigs and tops of Broome doth clenfe and open the liuer, milt, and kid- B neies.

It draweth away by the ftoole watery humours, and therefore it is wholefome for thofe that have C the dropfie, efpecially being made with wine, but better for the other infirmities with water.

The feede alfo is commended for the fame purpoles. D

There is alfo made of the afhes of the ftalkes and branches dried and burnt, a lie with thin white $\mathrm{E}$ wine, 25 Rhenifh ivine, which is highly commended of dituers for the greene ficknes and dropfie, and this doth mightily expell and driue foorth thin and waterie humors togither with the vrine, and that by the bladder; but withall it dothby reafon of his tharpe qualitie many times hurt and fret the intrailes.

CMejues faith, that there is in the flowers and branches a curting moifture, but full of exerements, $F$ and thercfore it caufeth vomite: and that the plant doth in all his partes trouble, cut, attenuatejand violently purge by vonite and ftoole, flegene and raw humors out of the ioints.

But thefe things are not written of Broome, but of Spartum, which purgeth by vomite, after the $G$ manner of Hellebor,as both Diofcorides and Plinie do teft tfie.

$M$ efives alfo addech, that Broome doth treake the ftone of the kidneies and bladder, and fuffereth $\mathrm{H}$ not the matter whereof the ftone is made to lie long, or to become a ftone.

The yoongbuds or little flowers preferued in pickle, and eaten as a fallad, ftir vp an appecite to I meate, and open the ftoppings of the liuer and milt.

Thefame being fully blowen, ftamped and mixed with fwinesgreacc; do eafe the paine of the $K$ goute.

And CMefues writeth, that this tempered with honie of Rofes, or with an eg,doth confume away $L$ the Kings euill.

The rape of the Broome or Broome rape, being boyled in wine, is commended againfthe pains $M$ of the kidneies and bladder, prouoketh vrine, breaketh the ftone, and expelleth it.

The iuice preffed foorth of Broone rape healeth greene wounds, and clenfeth olde and filthie $\mathrm{N}$ vlcers: the later phifitions do affirme that it is alfo good for olde venemous and malicious vlcers.

That woorthie Prince of farnous memorie Henre the eight King of England, was woont to $O$ drinke the diftilled water of Broome flowers againft furfets, and difeafes thereof arifing.

Sir T homas Fitzhar bert Knight, was woont to cure the blacke iaundies with this drinke onely. P

Take as many handfuls (as you thinke good) of the dried leaues of Broome gathered and braied $Q$ topowder in the moneth of May, then take vnto each handfull of the dried leaues, one fpoonefull and a halfe of the feede of Bioome braied into powder : mingle thefe togither, and let the fick drink thereof each day a quantitic, firft and laft, vntill he find fome eafe. The medicine muft be continued and folong vifed, vntill it be quite extinguifhed: tor it is a difeafe not very fuddenly cured, but muft by little and little be dealt withall.

Orobanch or Broome rape fliced and put into oyle oliue, to infufe or macerate in the fame, as $R$ ye do Rofes for oyle of Rofes, fcowreth and putteth aw ay all fpors, lentils, freckles, pimples, wheales and puthes from the face, or any part of the body, being annointed therewith.

Diofcorides writeth, that Orobanch may be eaten cither rawe or boiled, in manner as we vfe to $S$ cate the fprigs or yoong thootes of Alparagus.

The flowers and feedes of Spanifh Broome are good to be drunke with Meade or honied water $T$ in the quantitic of a drom, to caufe one to vomite with great force and violence euen as white Hellebor, or neefing powder.

If it be taken alone, it loofeneth the belly, driuing foorth great quantitie of waterie and filthic $\mathbf{V}$ humors.

\section{Of bafe Broome, or greening Weede. Chup.16.}

* The kindes. * The kindes.
of beyond the feas, which here are ftrangers. 
I Geniftella tinctoria.

Greeneweede or Diers weede.

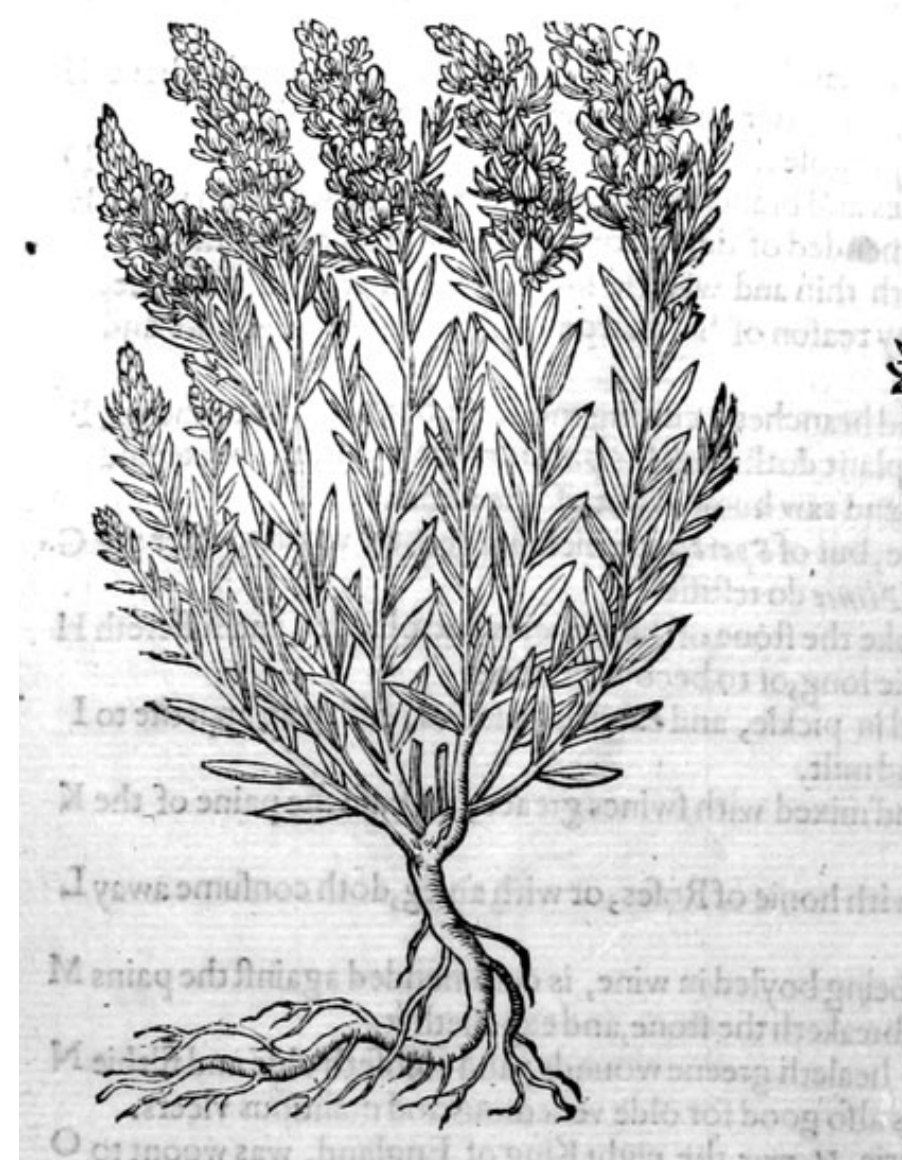

2 Geniftella infectoria. Woodie Diers weede.

* The defiption.

17 His bafe kinde of Broome called Greene weede or Diers weede, hath many tough bran. ches proceeding from 2 woodie roote : whereon do growe great ftore of leaues, of a deepe greene colour, fomewhat long like thofe of Flaxe. The flowers growe at the top of the branches not much vnlike the leaues of Broome, but fmaller; of an exceeding faire yellow colour, which turne into fmall flat cods, wherein is contained a little flat feede.

2 Carolus Clufius fetteth footh another kind of Broome, which Dodeneus calleth Geniftatincioria, being another fort of Diers weede: it groweth like the Spanifh Broome, vpon whofe branches do growe long and finall leaues like Flaxe, greene on the vpper fide, and of an hoarie fhining colour on the other. The flowers growe at the top of the ftalkes, fipike fafhion, in forme and colour like the former : the rootes are thicke and woodie.

3 Carolus Clufus fetteth foorth two kindes of Broome, which are reckoned among the Greening weedes or Diers weedes, and are thought both by Flinie and Diofcorides to be of that kinde. The firft is a lowe and bafe plant, creeping and lying flat vpon the gro:and, whofe long branches are nothing elle, but as it were ftalkes confifting of leaues thicke in the midft, and thin about the edges, and as it were diuided with fmall nickes; at which place it beginneth to continue the fame leafe vnto the end, and fo from leafe to leafe, vntill it haue increafed a great fort, all which do as it were make one ftalke; and hath no other leaues, fauing that in fomc of the nicks or diuifions, there commeth foorth a fmall leafe like a litt!e eare. At the end of thofe flat and leafed ftalkes come foorth the flowers, much like the flowers of the common Greening weede, but leffer, and of a yellow colour, which turne into fmall cods. I he rootes are very long, tough and woodie, full of fibres, clofing at the top of the roote, from whence they proceede as from one body.

4. This kinde of Greene w ede called of tome Chame/partium, hath a thicke woodie roote :from which rifeth vp diuers long leaues, confifting as it were of many peeces fet togither like a paire of Beades(as may better be perceiued by the figure, than expreffed by words) green on the vpper fide, 
I HISTORIE OF PLANTS.

and whitith vnderneath, very tough, and as it were of a rufhie fubftance : among which rife vp very fmall naked rufhie ftalks; on the top whereof groweth an eare or fpike of a chaffic matter, haung here and there in the faid eare diuer's yellow fowers like Broome, but very fmall or litcle.

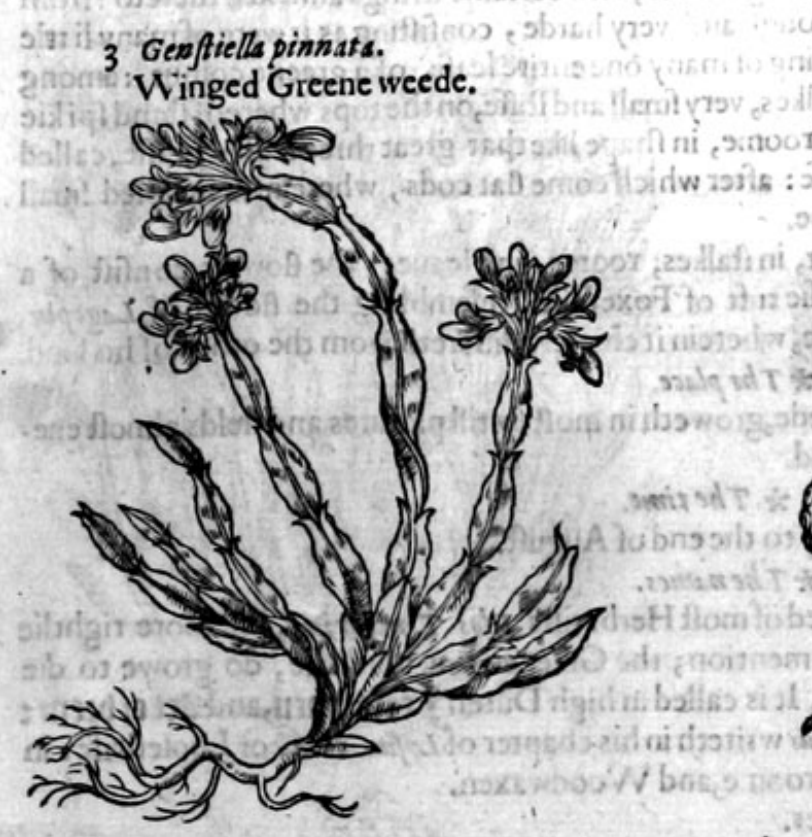

4 Genifella globulata.

Globe Greene weede.

5 Geniftella Lagopoidis maior.

Hares foote Greene weede.

5 Genift lla Lagopoidis minor.
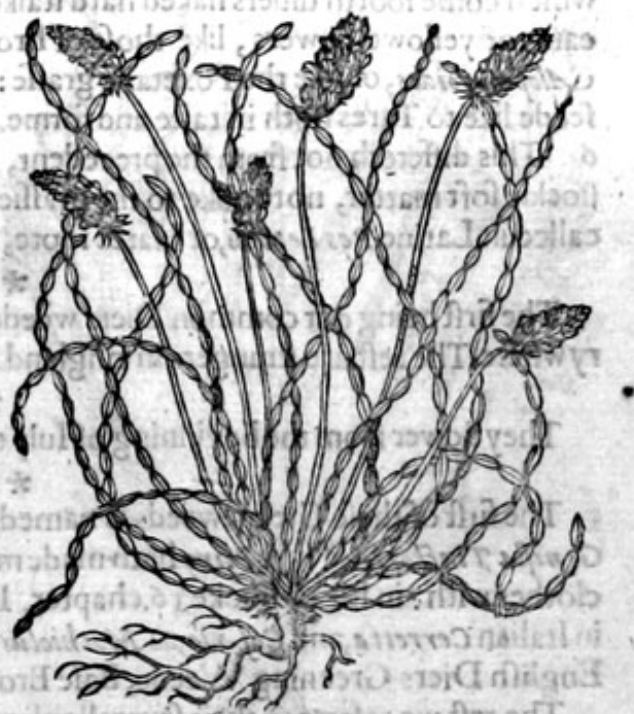

Wiluth

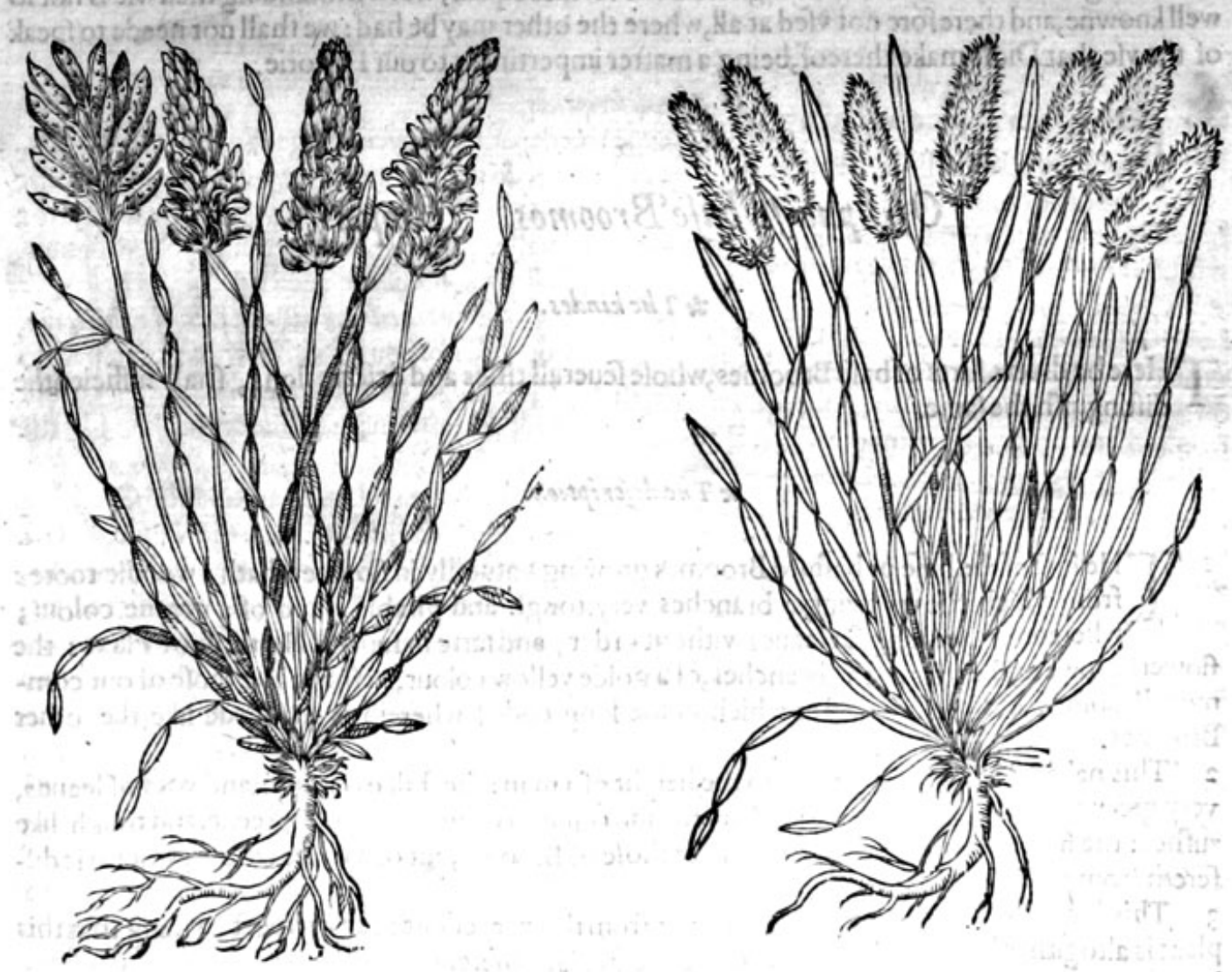

$x+\frac{6}{2}$ 


\author{
* The defcription.
}

5 The fift Greeneweede hath a woody tough roote, with certaine ftrings annexed thereto :from which rife vp diuers long, flat leaues, tough and very harde, confifting as it were of many little which come foorth diuers naked hard ftalkes, very fmall and fte leafe, of a greene colour : anong eares of yellowe flowers, like thofe of Broome, in hape like thate on the tops whereof ftand fpikie Alopecwroides, or like the Foxetaile graffe: after which come great three leafed graffe, called feede like to Tares both in tafte and forme.

6 This differeth not from the precedent, in ftalkes, rootes, and leaues: the flowers confift of a called in Latine Pes Leporis, or Hares foote, wherein it chiefely differeth from flower of Lagopus,

The firft being our $*$ The place. The firft being our common Diers weede, groweth in moft fertill paftures and fields almoft eue-
sy where. The reft are ftrangers in England.

They flower from the beginning of Iuly to the end of Auguit.
$*$ The names.

The firft of thefe Greeneweeds is named of moft Herbarifts Flos T inctor ins, but more rightlie Genifta Tinctoria: of this Pliny hath mademention; the Grceneweedes faith he, do growe to die clothes with : in his 18 .booke 16 .chapter. It is called in high Dutch ferblumen,and.actetbzem: in Italian Cerretta, and Cof. aria, as Mathiolus writeth in his chapter of $L y$ famachia, or Loofeftrife: in Englifh Diers Greening Weede, Bafe Broon.e,and Woodwaxen.

The reft we referre to their feuerall titles.

\title{
* T be temperature and vertues.
}

A Thefe plants are like vnto common Broome in bitternes, and therefore are hot and drie in the fecond degree : they are likewife thought to be in vertues equall; notwithftanding their vfe is not fo well knowne, and therefore not vfed at all, where the other may be had: we fhall not neede to fpeak of the vfe that Diers make thereof, being a matter impertinent to our Hiftorie.

\section{Of Spanifh bafe Broomes. Chap.17.}

* 7 be kindes. Here be diuers forts of bafe Broomes, whofe feuerall titles and defcriptions, fhall fufficientlie
diftinguifh the fame.

\section{* The defcription.}

I 7 He firft of the bafe or baftard Broomes growing naturally in Spaine, hath a woodie roote:

1 from which rife vp twiggie branches very tough and pliable, and of a greene colour; whereon are fet long fat leaues without ord $r$, and farre in funder, like thofe of Flaxe: the flowers growe at the tops of the branches, of a golde yellow colour, in thape like thofe of our common Broome, but greater; after which come long cods, wherein is the feede like the other Broomes.

2 This naked Broome groweth vp to the height of a man : the ftalke is rough, and void of leaues, very greene and pliant; which diuideth it felfe into diuers twiggie branches, greene, and tough like rufhes: the flowers grow along the ftalks like thofe of Broome, but of a white colour, wherin it differeth from all the reft of his kindc.

3 This kinde of bafe Broome differeth not from the precedent in any refpect, fauing that this plant is altogither leffer, wherein confilteth the efpeciall difference. 
IHISTORIE OF PLANTS.

agai P Pealajpartum Hipanicum.

thac 1 Baftard Spanîh Broome.

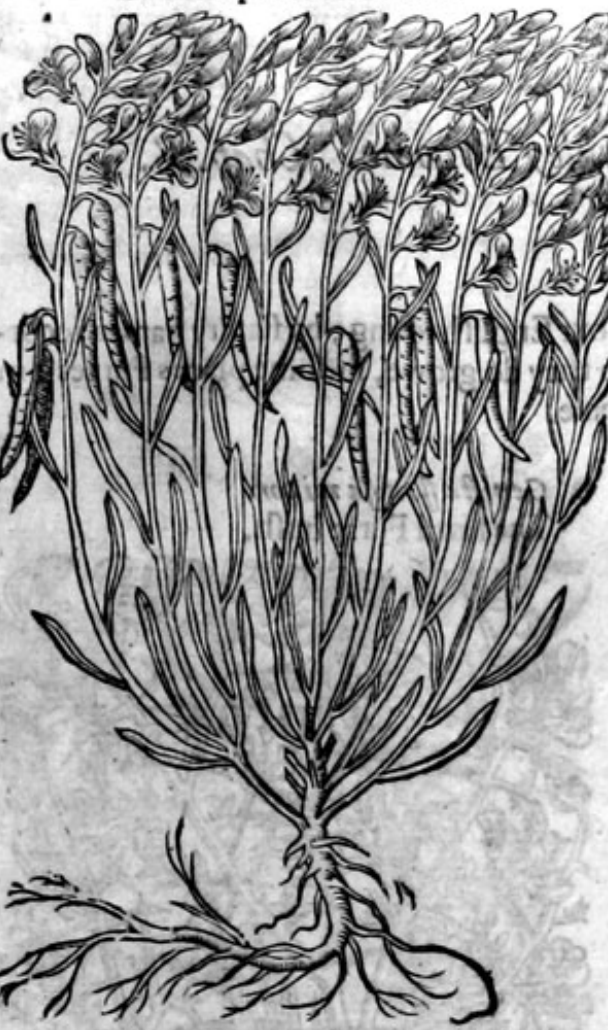

3 P feudopartum album Labyllum. The white leafles Spanifh Broome.

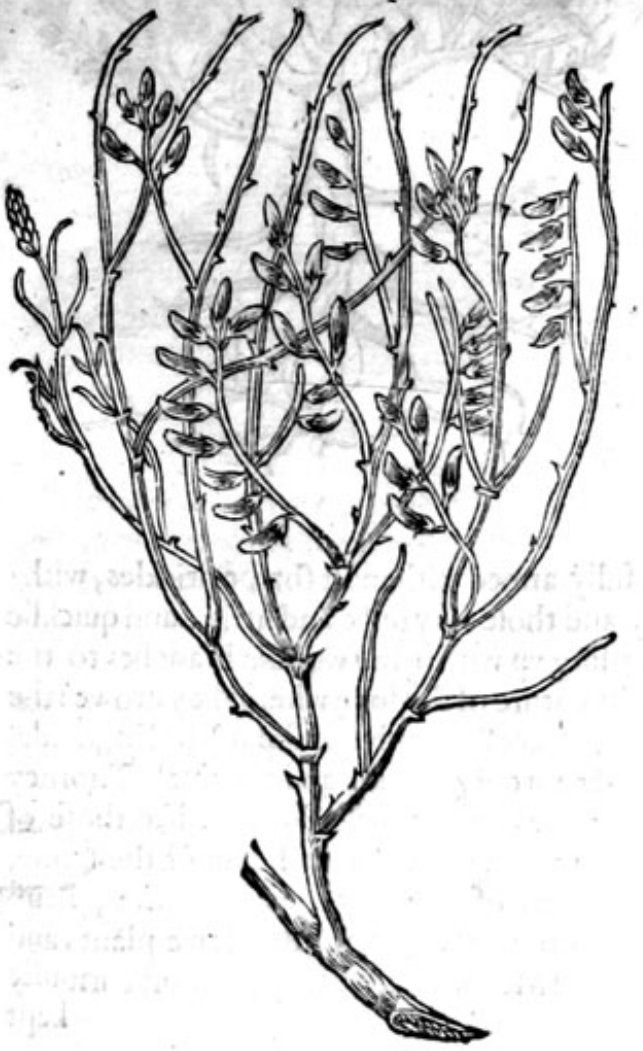

2 Pfeudo/partum Hi/panicum a'quirrop. Spanifh Broome without leaucs.

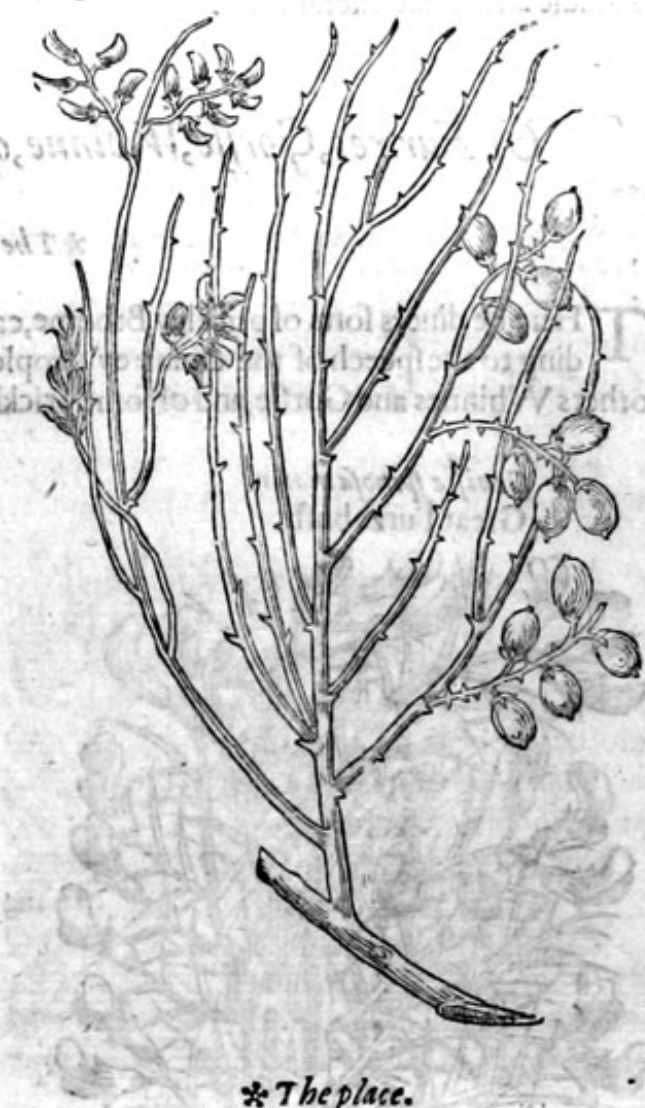

Thefe growe in the prouinces of Spaine, and are in one place higher and more buthie, and in an other lower.

\section{* The tim}

The time anfwereth the other Broomes. * The names.

This bafe Spanifh Broome is called in Grecke $\sigma \pi d \rho r v$ : the Latines vfe the fame name, calling it fometimes Spartum, and Spartium : in Spanifh Retams: in Englifh Spanifh Broome, and baitarde Spanifh Bronme.

\section{* The temperature and vertues.}

Both the feedes and iuice of the branches of $\mathbf{A}$ thefe bafe Broomes, wherewith they in Spaine and other hot regions do tie their vines, doe mightilie drawe, as Galen writeth.

Diofcorides faith, that the feedes and flowers be-B ing drunke in the quantitic of a dram, with meade or honied water, doth caufe one to vomite ftrongly,euen as the Hellebor, or Neezing powder doth: but yet without ieopardie or danger of life : the feede purgeth by ftoole.

The iuice which is drawne from out of the bran- $C$ ches fte eped in water, being firit bruled, is a remedie for thofe that be tormented with the Sciatica, and 


\section{THE THIRD BOOKE OF THE}

and for thofe that be troubled with the Squincie, if a draught thereof be drunke in the morning; fome vfe to fteepe thefe branches in fea water, and to giue the fame in a glifter, which purgeth forth

\section{Of Furzes, Gorffe, Whinne, or prickley Broome. Chap.18.}

\& The kindes.

$\Gamma$ Here be diuers forts of prickley Broome,called in our Englifh toong, by fundry names accor. 1 ding to the peech of the countrey people where they do growe, in fome places Furzes, in
others Whinnes and Gorffe, and of fome pricklie Broome.

I Geniftaßpinofa maior. Great Furze buin.

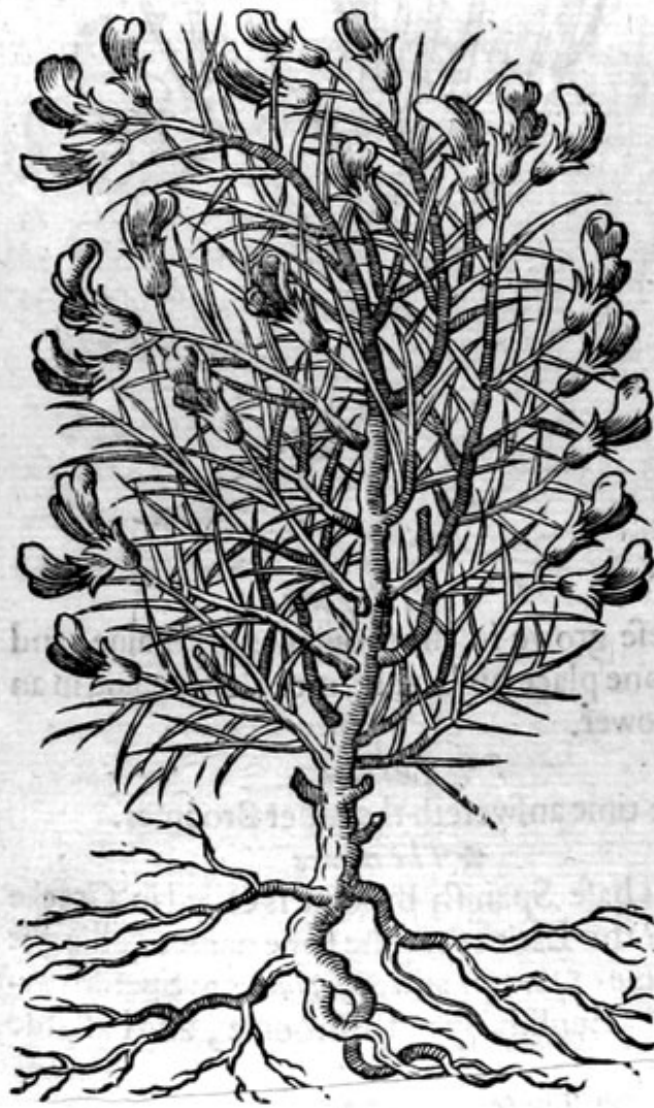

2 Genifla pinofa minor. The fmall Furze burh.

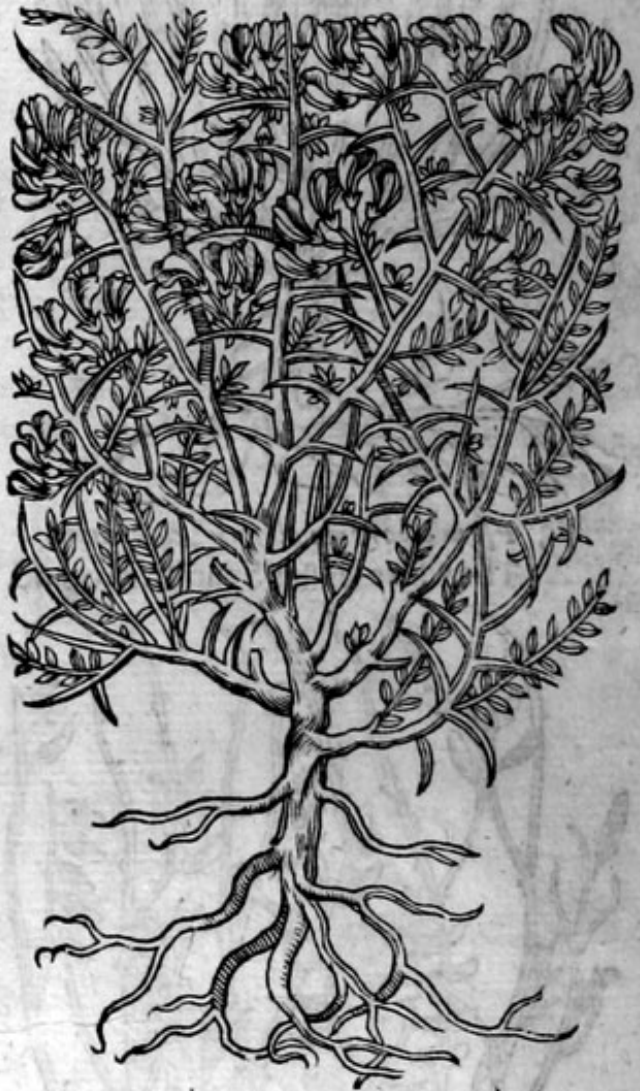

I.

He Furze buih is a plant altogither a thorne, fully armed with moft fharpe prickles, without any lcaues at all,except in the fpring onely, and thofe very fewe and little, and quicklie falling away: it is a bufhie fhrub, oftentimes rifing vp with many woodie branches to the height of fower or fiue cubits or higher, according to the nature of the foile where they growe : the greateft and higheft that I did eueriec do growe about Excefter in the weft parts of Englande, where the great ftalkes are deerely bought, for the better fort of people; and the finall Thorney fpraies for the poorer fort : fiom thefe Thorney braunches growe little flowers, like thofe of Broome, and of a yellowe colour, which in hot Regions vnder the extreme heate of the funne, are of a veric perfect red colour: in the colder countries of the eaft, as Danzicke, Brufwicke, and Polande, there is not any branche heereof growing, except fome fewe plants and feedes that my felfe haue fent to Elbing, otherwife called Meluin, where they are moft curioufly 
kept in their faireft gardens, as alfo our common Broome, the which I hauc fent thither likewife, being firft defired by diuers earneft letcers; the cods follow the flowers, which the Grater hath omitted, as a Germaine who had neuer feene the plant it felfe, but framed the figure by hearfay:the root is ftrong, rough, and wogdic.

2 To this may be ioined another kinde of Furze, whicb bringetirfoorth certaine branches that be very flender,fer round about at the firft with finall leaues, and little harmeleffec prickles, which after they haue been a yeere old, \& the leaues gone, they be armed onely with moft hard harpe prickes: the flowers heereof are of a pale yellow colour, lefler then thofe of Broome, yet of the fame forme : the cods are finalt, in whichdo lie little round reddifh feedes: the roote is tough and woodie.

3 Genifla ßpinosa flore albo. White tlowred Furze.

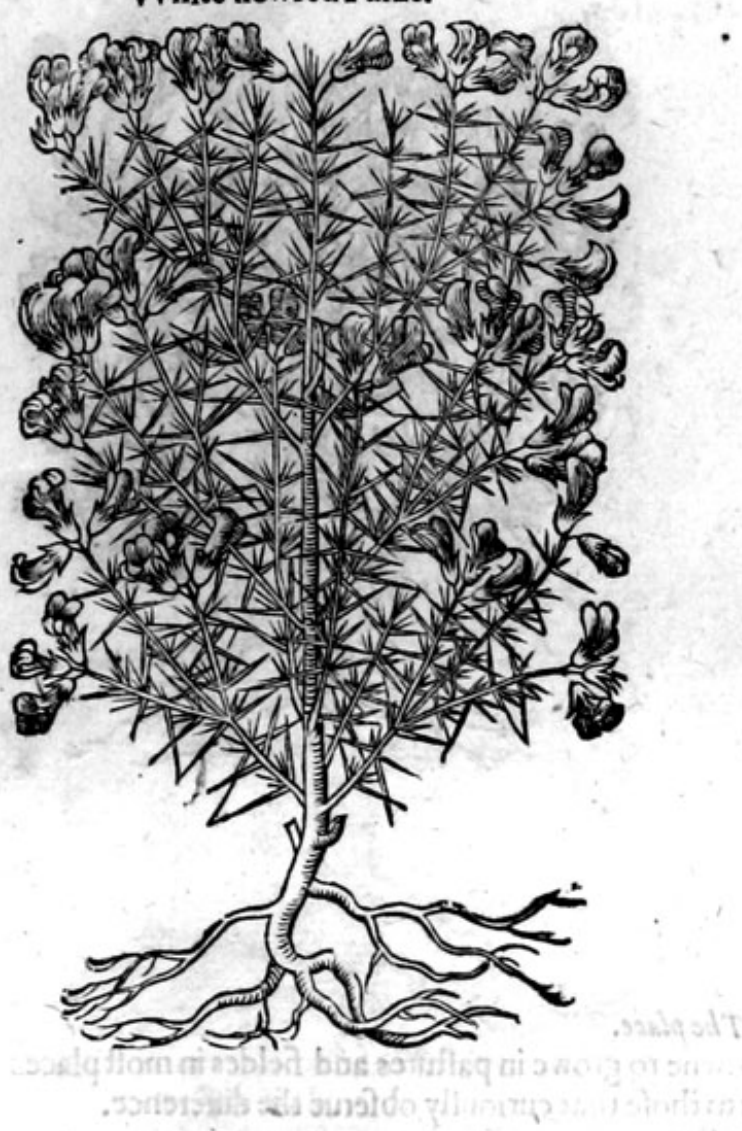

4 Genifta pinto'a humilis.

Dwarffe or lowe Furze.

* The defcription.

4. We hate in our barren grounds of the north parts of England another fort of Furze, bringing foorth the like pricklcy thornes that the others haue; the onely difference confiftcth in the colour of the flowers; for the others bring foorch yeilowe flowers, and thofe of this plane are as white as fnowe.

4 There is another vpon ourbarren Heathie groundes of thefe foutherly parts, which groweth lowe and ilofe to the ground; for the moft part the buth itfelfe groweth round like a cocke of haie, in flowers and thornie branches it differeth not from the greateft Furze.

5 This fmall kinde of Furze, growing vpon Hampfteed Heath ncere London, and diuers other barren grounds, where in maner nothing elfe will grow; hath many weake and flexible branches of a woodie fubftance : whercon do grow little leaues like thofe of Time:among which are fet in number infinite moft fharpe prickles, hurting like needles, where of it tooke his name : the flowers grow on the tops of the branches like thofe of Broome, and of a pale yellowe colour: the roote is tough and woodie. 


\section{THE THIRD BOOKE OF THE}

* 7 hedefcription.

6 The fmalleft of all the Furze is that of the ancients, called 2 epa, or fcorpion Furze, as the word onely, which fault they haue beene all and euery of them to be complach of the ancients in name nothing can be gathered from their deicription: and therefore reflained of, being fo breefe that faide to a further confideration.

5 Genifla aculeata.

Needle Furzes or petie Whinne.

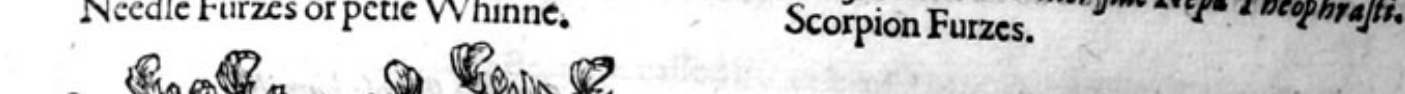

\section{Genifta aculeat a minor fiwe Nepa T beophrafti.}
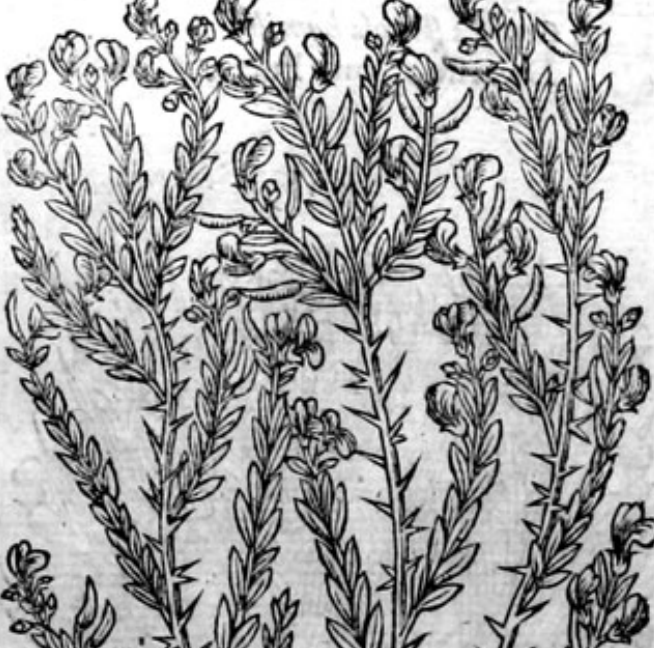

\section{西}
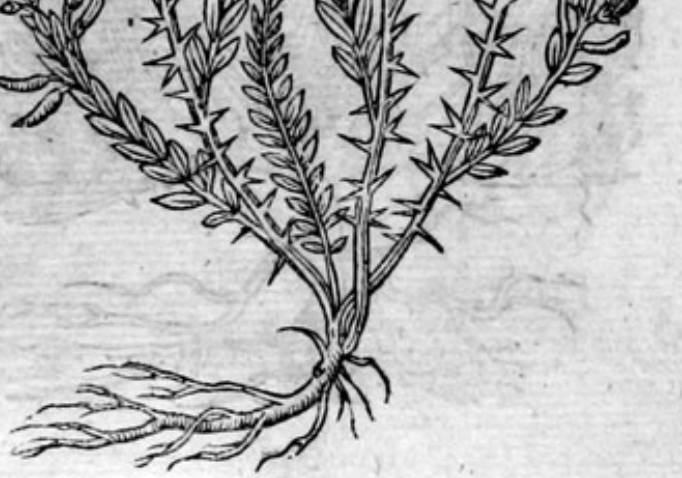

* The place.

The common fort heereof are very well knowne to growe in paftures and fieldes in molt places. of England. The reft are likewife well knowne to thofe that curioufly obferue the difference.

\section{* Thetime.}

They flower from the beginning of Maie to the end of September.

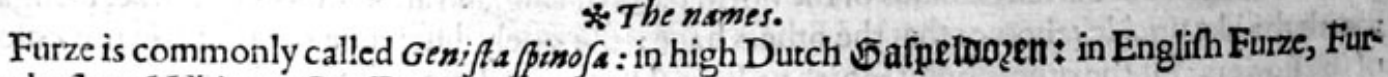
zen buthes, Whinne, Gorffe, and Thorne Broome.

This thorney Broome is taken for T heophraftus his Scorpius, which Gaza nameth 2 epathe name Scorpinis in Plinie is roviorruov, that is to fay, fignifying many things, and common to certaine plants: for befides this Scorpiss of which he hath made mention in his 25 .booke 5.chapter, ferting downe Theophraftus his words, where he maketh Sconitum Theliphonon to be Scorpius, in his 23. booke 10.chapter; and likewife other plants vnder the fame title, but vnproperly.

$$
\text { * The temperature and vertues. }
$$

There is nothing written in Theophr aft tus concerniug the faculties of Scorpies pino fow, or Furze: Flinic feenieth to attribute vnto it the fame vertucs, that Scorpioides hath: notwithittanding the later writers do agrec, that it is hot and dry of complexion: the feedes are vfed in medicines againft the Atone, and ftaying of the laske. 


\section{Of Cammock Furze, Rest Harrow, or petic Wbinne. Chap.ip. \\ $\approx$ The kindes.}

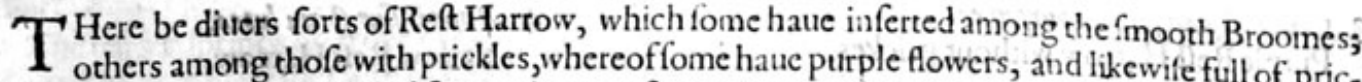
kles; others white flowers, and harpe thornes; fone alfo purple lowers, others white, and of priclow, and euery of them voide of prickles.

Anonis, fuue Refta Bonis.
Cammock,or Relt Harrow.

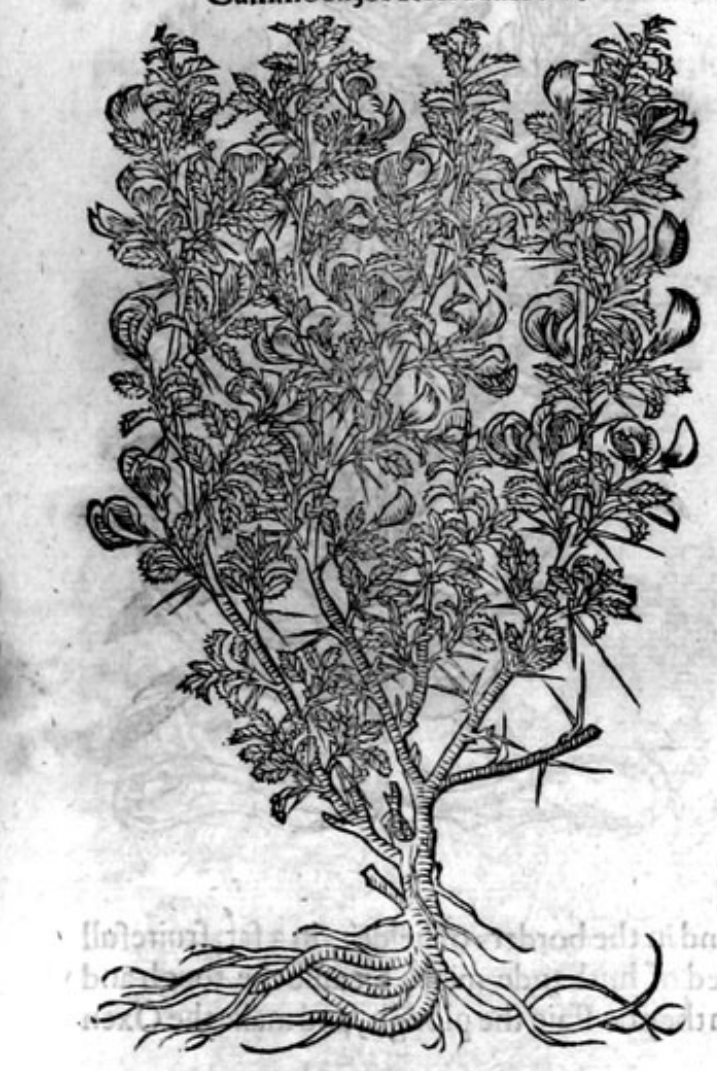

2 Anonis flore albo.

Conmock with white flowers.

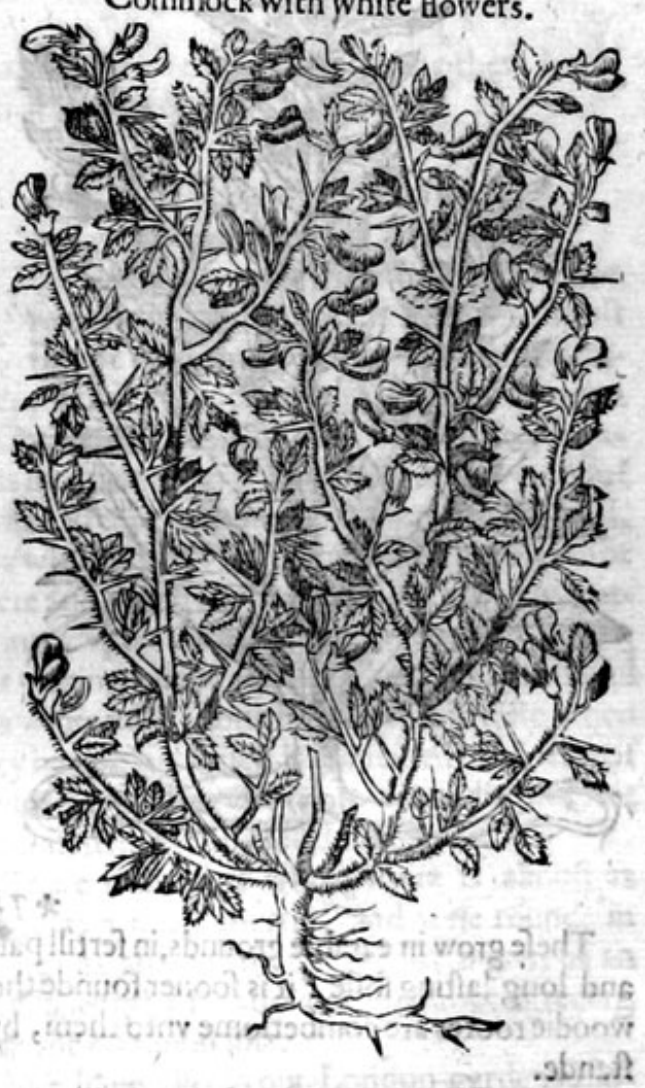

* The defription.

I Ammock or ground Furze, rifeth vp with ftalkes a cubite high, and of en higher, fet with diuers iointed branches, tough, pliable, and full of hard tharpe thomes: among which do grow leaues, in forme like thofe of Saint Iohns woort, or rather of the Lentill, of a decpe greene colour: from the bofome of which thornes and leates come foorth thic Howers, like thofe of Peafon, of a purple coloor; after which come the cods, in which do lie flat feede: the roote is long, and runneth farre aboade, very tough and hard to be torne in peeces with the plough, inforruch that the oxen can hardly paffe forward, but are conftrained to ftande ftill; wheretpon it was called Reft Plouigh, or Rett Harrow.

2 Wehatie in our Lendon paftures, and likewife in other places, one of the Reft Harrowes, not differing from the precedent in ftalkes, leaues, or prickles; the onely difference is, that this plant bringet foorth white fowers, and the other not fo.

3. Reft Harrow without thomes hath a tough, horie, rough ftalke, ditrided into other rough branches : whereon are fet without order, long leaues, tharpe pointed, Alightly cut about the edges, of an horie colour, and fomewhat hairie: from the bofome whereof commerh foorth purple Peale like flowers, of a reafonable good finell : the roote is very tough, long, and woodie.

जII. Eece I 4 The 


\section{$1 \mathrm{I}^{2} 2$}

\section{THE THIRD BOOKE OF THE}

4 The yellowe flowred Cammocke is a ftranger in thefe parts, it is onely founde in the colde eatterne countrics for onght that I can learne:it differeth not from the laft defcribed, fauing that the flowers hecre of are of a golde yellow colour, wherein it differeth from all the other of his kinde.

3 Lrosis non fpinofapurpurea.

Purple Reft Harrow without prickes.

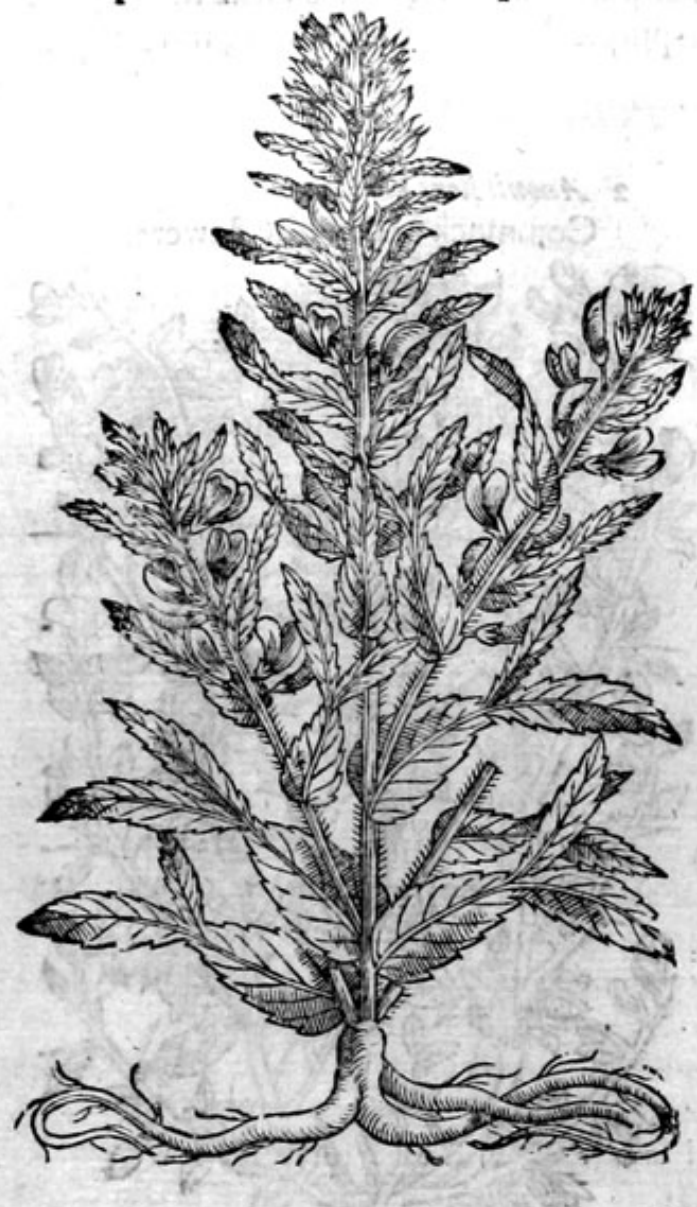

4 Anonis fiue Pina luter. Yellow Reft Harrow.

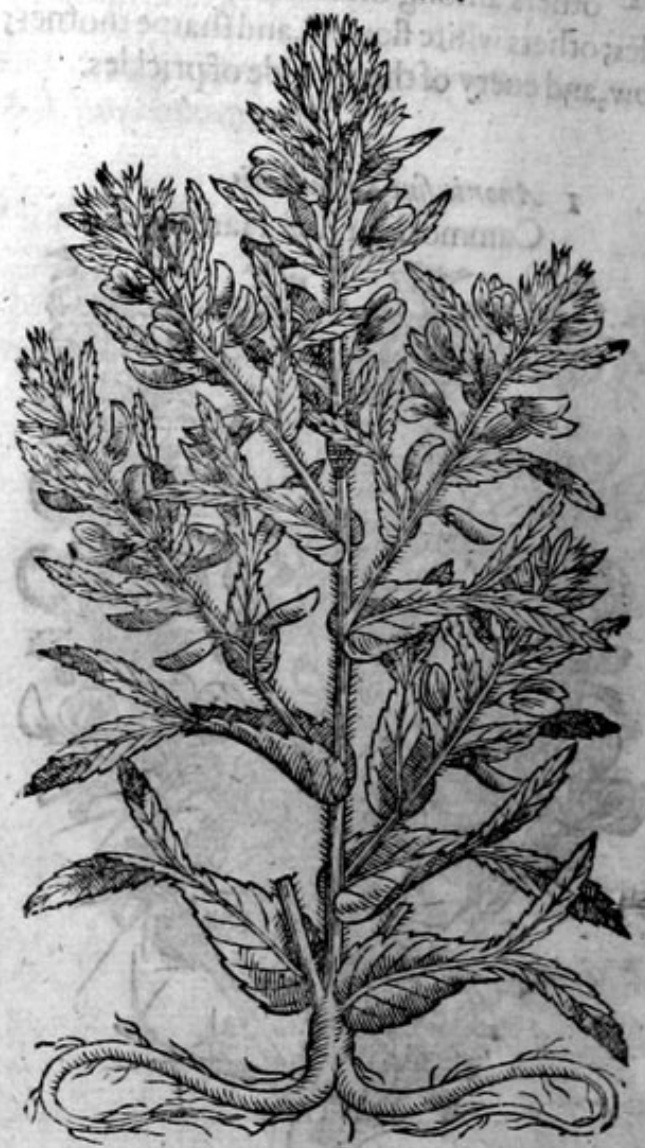

* The place.

Thefe grow in earable grounds, in fertill paftures, and in the borders of fieldes, in a fat, fruitefull and long lafting foile : it is fooner founde then defired of husbande men, bicaufe the tough and woodie rootes are comberfome vnto them, by reafon they do ftaie the plough, and make the Oxen ftande.

\section{* The time.}

They fende foorth new fhootes in Maie : they are full growne in Autumne, and then thofechas of nature are prickly, be fulleft of tharpe thornes: chey flower in Iuly.and Auguft.

\section{* The names.}

Cammock is called in Greeke' Avavis, or àvavis, and likewife in Latine Anomis, and Ononis, of Herbarifts commonly Arreft a bouis \& Remora ar atri, bicaufe it maketh the oxen whileft they be in plowing to reft or itand ftill: it is alfo called Acutella, of the ftiffe and Sharpe thornes which pricke thofe that paffe by : in French Arrefte beuf, and Boucrande.

Crateua nameth it AEgipyrus, in high Dutch stalkraut: in lowe Dutch Jogangivoztrle: in Italian Eunags: in Spanin Gattilhos: in French Arrefte Bewf, Beuf of Boutrande: in Englifh Cammock, Reft Harrow, perie Whinne, and ground Furze.

$$
\text { * The temperature. }
$$

The roote of Cammock is hot in the third degree as $G_{a l e n}$ faith;it cuttech alfo andmaketh thin. A The barke of the roote drunke with wine provoketh vrine, breaketh theftone, and driueth it
foorth. 
The root boiled in water and vineger, alaieth the paine of the teeth, if the mouth be often wathed $B$ therewith very hot.

Pliny reporteth, that being boiled in Oxymel,or the fyrupe made with honie and vineger till the C one halfe be wafted, it is given to thofe that haue the falling ficknes: Mat hiolus reporteth that he knewe a man cured of a ruprure by taking of the powder of this roote, for many monethes togither.

The tender fprings or crops of this thrub before the thornes come foorth, are prefetued in pic. D kle, and be very pleafant fauce to be eaten with meate as a fallade, as Diofcorides teacheth.

\section{Of Goofeberries, or Feaberrie bufh: Cbap.20.}

\section{* $T$ be kindes.}

THere be diuers forts of the Goofeberries, fome greater, others leffe, fome rounde, others long; and fome of a red colour: the figure of one, hall ferue for the reft.

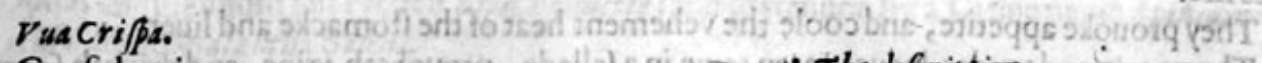
Goofe berries:

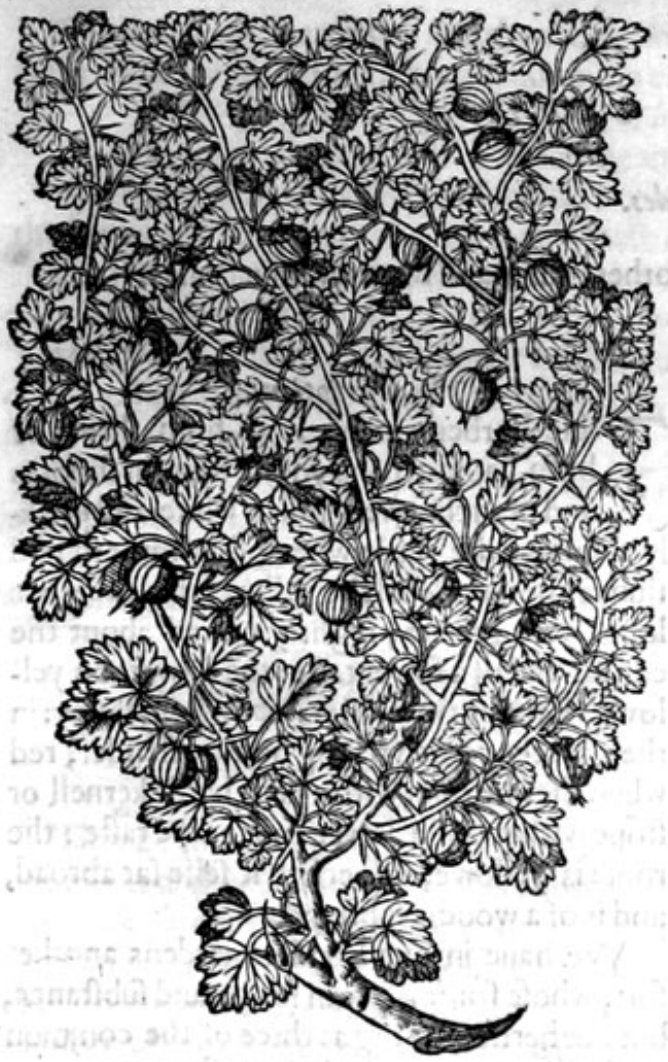

$7 \mathrm{He}$ Goofeberric buth is afhrub of three or fower cubits high, fet thicke with moft Tharpe prickles : it is likewife full of branches, flender, woodie, and prickly; whereon do growe leaues, rounde, cut with deepe gaThes into diuers parts like thofe of the vine, of 2 verie greene colour: the flowers be very fmal, of 2 whitifh green, with fome little purple dafhe heere and there; the fruit is round growing fcatteringly vpon the branches, greene at the firft, but waxing a little yellow through maturitie;ful of a winie iuice, fomthing fweete in tafte when they be ripe, in which is conteined hard feed, of a whitifh colour: the roote is woodie and not without ftrings annexed thereto.

There is another whofe fruite is almoft as bigge as a fmall cherrie, and verie rounde in forme: as alfo another of the like bignes of an inctrin length; in tafte and fubftance agreeing with the common fort.

We haue alfo in our London gardens another fort altogither without prickes, whofe fruit is verie fmall, leffer by much than the common kinde, but of a perfeet red colour, wherein ir differeth from the reft of his kinde.

$$
\text { * } 7 \text { he place. }
$$

Thefe plants do growe in our London gar:

dens, and elfe where in great abundance.

$$
\text { *Thetime. }
$$

The leatues come foorth in the beginning of Aprill or fooner; the fruite is ripe in Iune and Iuly. *The names.

This fhrub had no name among the old writers, who as we deeme kncwe it not, or elfe efteemed it not: the later writers call it in Latine Gro/fularia and oftentimes of the berries Vua Cri/pa:Vua/pino,Vua pinella, and VuaCri/pina: in high Dutch fittifelbicr: in lowe Dutch Stekeltefien: in Spanifh Vua Cripa, or E/pina : in Italian Vua foina: in French Groifelles: in Englifh Goofeberrie, Gooleberie bufh, and Feaberrie Bufh in Chefhire, my natiue countrie. 
$\because$ The temperature. The berries of this bufh before they be ripe, are colde and drie, and that in the later end of the
fecond degree, and alfo binding.

\section{\& The vertues.} A The fruit is vfed in diuers fawces for meate, as thofe that are skilfull in Cookerie can better tell
then my felfe.

B They are vfed in brothes in fteede of Veriuice, which maketh the broth not onely pleafant to the tafte, but is greatly profitable to fuch as are troubled with an hot burning ague.

C They are diuerfly eaten, but howfoeuer they be eaten they alwaies ingender raw and cold bloud: they nourif nothingor very little : they alfo it aie the belly, and ftench bleedings.

D They ftop the menfes, or monethly ficknes, except they happen to be taken into a cold ftomack, then do they not helpe, but rather clogge or trouble the fame by fome maner of flixe.

E The ripe berries as they are fweeter, fo do they alfo little or nothing binde, and are fomthing hot, and yeeld a little more nourifhment then thofe that be not ripe, and the fame not crude or rawe, but thefe are feldome eaten or vfed as fauce.

F The iuice of the greene Goofeberries, cooleth all inflammations, Eryspelas, andSaint Antho. nies fire.

G They prouoke appetite, and coole the vehement heat of the ftomacke and liuer.

H The yoong and tender leaues eaten rawe in a fallade, prouoketh vrine, and driucth foorth the ftone and grauell.
stom पis?

\section{Of Barberies. Chap.21.}
$-2 a$ 2osos
* The kindes.

There be diuers forts of Barberies, fome greater, others leffer, and fome withour ftones.

Spina acida, fue Oxyacantba.

The Barberie bufh.

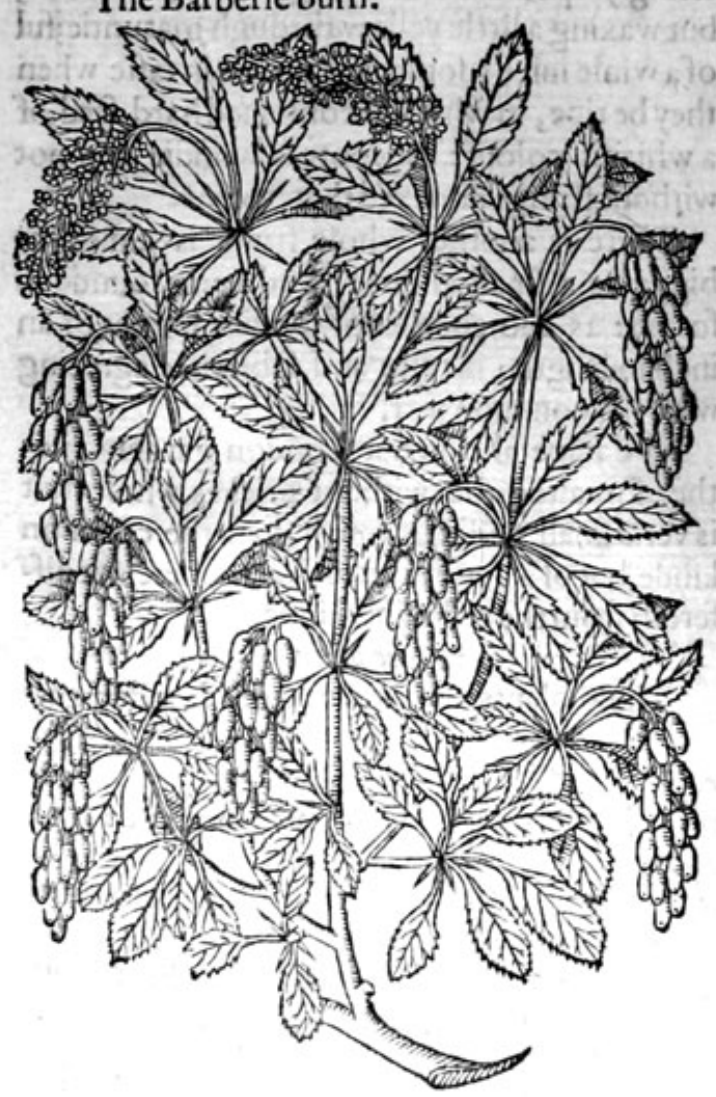

* T hedefcription.

7 He Barberie plant is an high fhrub ot bufh, hauing many yoong ftraight thootes and branches, very full of white and prickly thomes; the rinde whercof is fmooth and thinne, the woode it felfe yellow: the leaues are long, very greene, Alightly nicked about the edges, and of a fower tafte: the flowers be yellowe, ftanding in clufters vpon long ftems : in their places come vp long berries, flender, red when they be ripe, with a little harde kernell or ftone within; of a fower and harpe tafte : the roote is yellowe, difperfeth it felfe far abroad, and is of a woodie fubftance.

We haue in our London gardens another fort, whofe fruite is like in forme and fubftance, but one berrie is as big as three of the common kinde, wherein confifteth the difference.

We haue likewife another withour any ftone, the fruite is like the reft of the Barberies, both in fubftance and tafte.

$$
\text { * }) \text { beplace. }
$$

The Barberie buth groweth of it felfe in vntoiled places and defart grounds, in woods, and the borders of ficldes, ef pecially about a Gentlemans houfe called Mafter Monke, dwelling in a village called Iuer, two miles from Colbrooke, 
brooke, where moft of the hedges are nothing elfe but Barberie buthes.

They are planted in gardens in moft places of England.

$$
\text { * The time. }
$$

The leaues fpring foorth in Aprill: the flowers and fruit in September.

$$
\text { * The names. }
$$

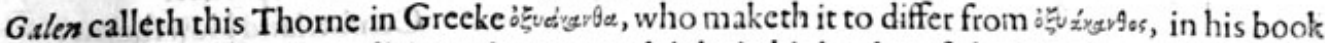
of the Faculties of fimple medicines: but more plainly in his booke of the Faculties of Nourithments; where he reckoneth vp the tender fprings of Barbaries among the tender fhootes that are to be eaten, fuch as $\mathrm{Oxyacantbus}$ or the Hawthorne bringeth not foorth, wherein he planly made a difference betweene Oxyacant ha the Barberie bufh, and Oxyacant bus the Hawthorne tree.

$D$ iofcorides hath made mention of this Thorne, for that which he calleth Oxyacantha in the Fœminine gender, is Galens Oxya canthus in the Mafculine gender.

Avicen feemeth to conteine both thefe Phrubs vnder the name of Amyrberis, but we knowe they are neither of affinitic or neighbourhood, although they be both prickly.

The fhrub it felfe is called in fhops Barberies of tiie corrupted name Amyrberis: of the later writers Cre/p:nus : in Italian Cre/pino: in Spanifh $E / p$ ino de maiuelas : in high Dutch joaiffelbeet : in lowe Dutch 9 aufeboom : in French Efpine vinette : and thereupon by a Latine name spiniuinet.a, Spina acids, and Oxyacantha Galeni.

\section{* The temperature.}

The leaues and berries of this thorne are cold and drie in the fecond degree : and as Galen alfo affirmeth, they are of thinne parts, and haue a certaine cutting qualitie.

\section{*. The vertues.}

The leaues are vfed of diuers to feafon meate with, and in fteed of a fallade, as be thofe of Sorell. A

The decoetion thereof is good againft hot burning and cholericke agues : it alaieth the heate of $\mathrm{B}$ the bloud, and tempereth the ouermuch heate of the liuer.

The fruite or berries are good for the fame things, and be alfo profitable for hot laskes, 'and for $\mathbf{C}$ the bloudy flixe, and they ftaie all maner of fuperfluous bleedings.

The greene leaues of the Barberie bufh ftamped, and made into fauce, 2 s that made of Sorrell, D called grcenefauce, doth coole hot ftomackes, and thofe that are vexed with hot burning agues, and procureth appetite.

The conferue made of the fruite and fugar, performeth all thofe things before remembred, but $\mathrm{E}$ with better force and fucceffe.

The rootes of the tree fteeped for certaine daies togither in ftrong lie, made with afhes of the afh $\mathbf{F}$ tree, and the haire often moiftned thercwith maketh it yellow.

\section{Of the white Thorne, or Hawtborne Tree. Chap.22.

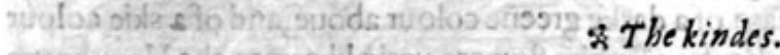

THere be two forts of the white Thorne Trees defcribed of thelater writers, one very common in molt parts of England: there is another very rare, and nor founde in Europe, except in fome fewe rare gardens of 'Germanic; which differeth not from our common Hawthorne, fuung that the fruit hercof is as yellow as Saffron: we have in the weft of England one growing at a place called Glaftenburie, whichbringeth foorth his flowers about Chriftmas, by the report of diuers of good credite, who haue fecue the fane; but my felfe haue not feene it; and therefore leate it to be better examined.

\section{* Thedefcription.}

17 He white. Thorne is a great hrub growing oftentimes to the height of the Peare tree: the trunke or bodie is great : the boughes and branches hard and woodic, fet full of long tharp chornes : the leatues be broade, cut with deepe gafhes into diuers fections, fmooth, and of 2 gliftering greene colour ; the flowers grow vpon fpokie rundles, of a pleafant fwecte funell, fometimes white, and often dafht otier with a light wanh of purple; which hath mooved fome to thinke fome difference in the plants: after which come the fruite, being round berries, greene at the firft, and red when they be ripe; wherein is founde a foft fweete pulpe, and certaine whitifh feede : the roote groweth deepe in the ground, of a hard woodie fubftance. 


\section{46}

\section{THE THIRD BOOKE OF THE}

2 The fecond and third haue beene touched in the firft title, notwith fanding I haue thought it with the Seruice tree in leaues, and not vnlike in fruit alfo.

I Oxy.cantlus.

The Hawthorne tree.

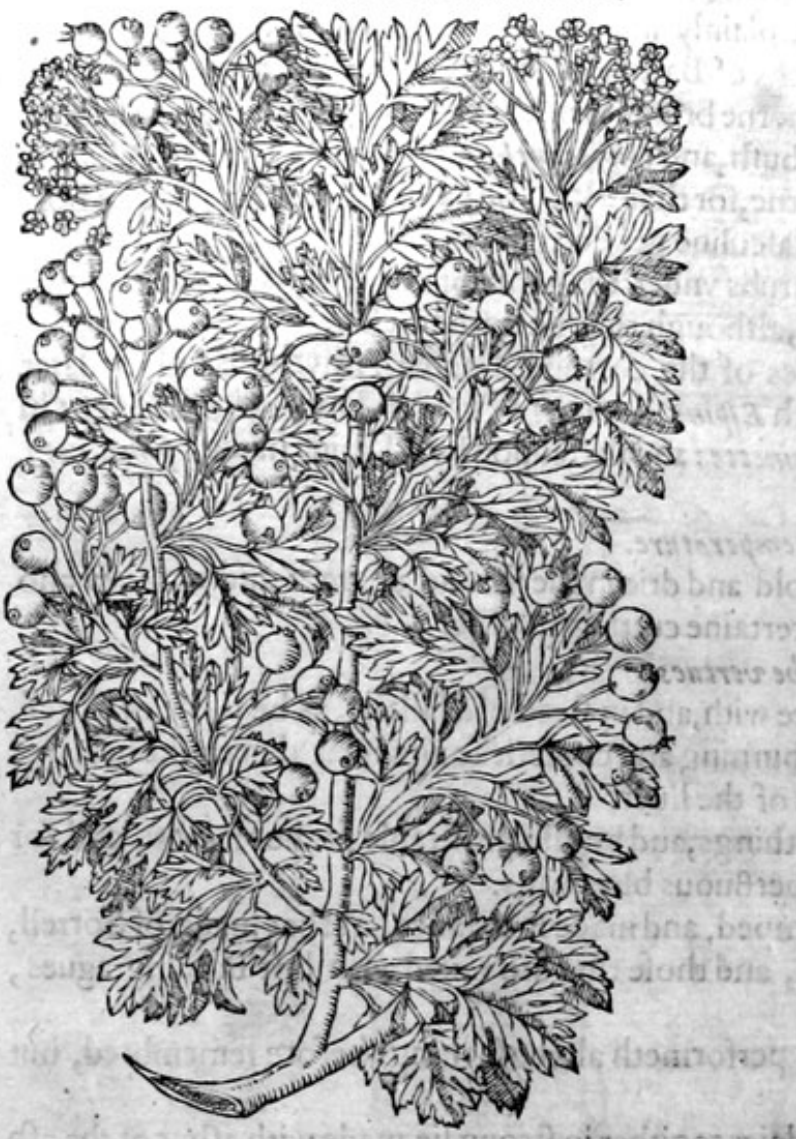

* Thedefcrition.

2 Aria Thiophrafti. Cumberland Hawthorne.

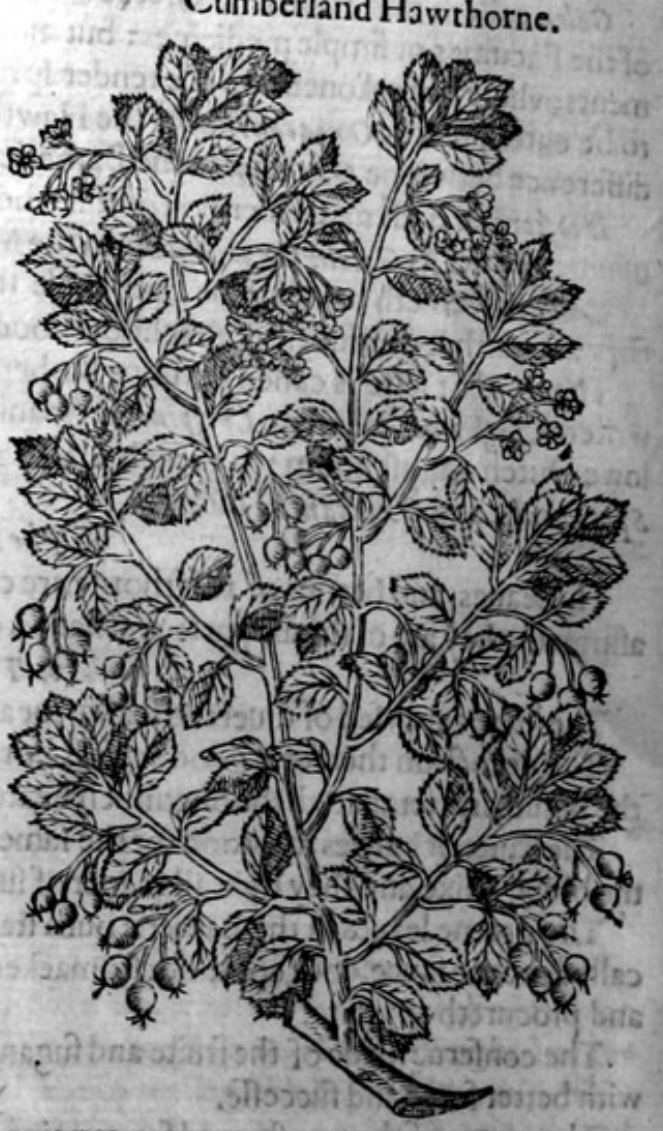

Theophraftus hath fet foorth this tree vnder the name of Sria, which groweth vnto the forme of a fmall tree, delighting to grow in our fhadowie woods of Cumberland and Weftmerland, and many other places of the North countrie, where it is to be found in great quantitie : but leldome in Spaine, Italie, or any hot region. This tree is garnifhed with many fmall branches befet with leaues like the Peare tree, or rather like the Aller leafe, of a darke greene colour aboue, and of a skie colour vnderneath: among thefe leaues come foorth tufts of white flowers, verie like vnto the Hawthorne flowers : after which fucceede fmall red berries, like the berries of the Hawthorne, \& in rafte like the Neapolitane Medlar : the temperature and faculties whereof are not yet knowen.

\section{* The place.}

The Hawthorne groweth in woods, \& in hecges neer vnto high waies almoft euerie where. The fecond is a ftranger in England. The laft groweth at Glaftenburie Abbey, as it is credibly reported vinto me.

\section{\%. 7 be time.}

The firft and fecond Gower in Mav, whereupon many do call the tree it felfe the May bufh, 252 chiefe token of the comming in of May: the leanes cone foorth a litcle fooner: the fruite is ripe in the beginning of September, and is a food for bir des in winter.

$$
\text { * The names. }
$$

Diofcortdes defcribeth this fhrub, and nameth it osvaxered, in the Feminine gender: and Galen in his boohe of the Faculties of fimple medicines, isvdyostos, in the Mafculine gender: Oxyacanthess faith he, is a tree, and is like to the wilde Peare tree in forme, fo be alfo the vertues not vnlike, \&cc.of Oxyacantha D $D_{10}$ fcorides writeth thus: It is a tree like to the wilde Peare tree, very ful of Thornes, \& 8 . 


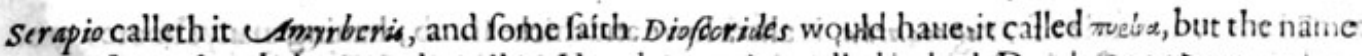
Pyrina feemeth to belong to the yellow Hawthoroes it is called in bigh Dutch iacraozen th low Dutch foagezozen : in Italian Bagazas in Spanith Purtitero : in French Udub-efpune: in Enghth white Thorne, Hawthotne tree, and of fone Landòuers Mayibufh. The fruit of the Hawthorne tree is verie aft mpent.
\[ * T \text { be vertues. } \]

The Hawes or berries of the Hawthorne trec as Diofconides ivrizesth, dotorth fay the laske, the menfes, and all other fluxes of bloods fome authors write that the ftones beacen to pouder and giuen to drinke, are good againft the ftone.

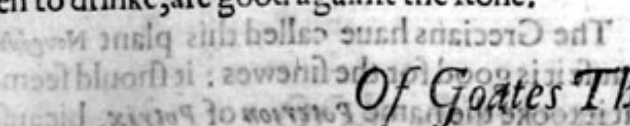

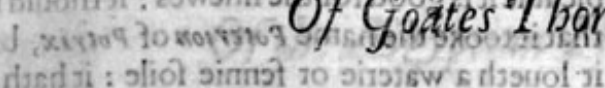

I. Tragacantha (roe pima Hircias aodinatd Goates Thotuef to $D$ sm ads ri yllsmus
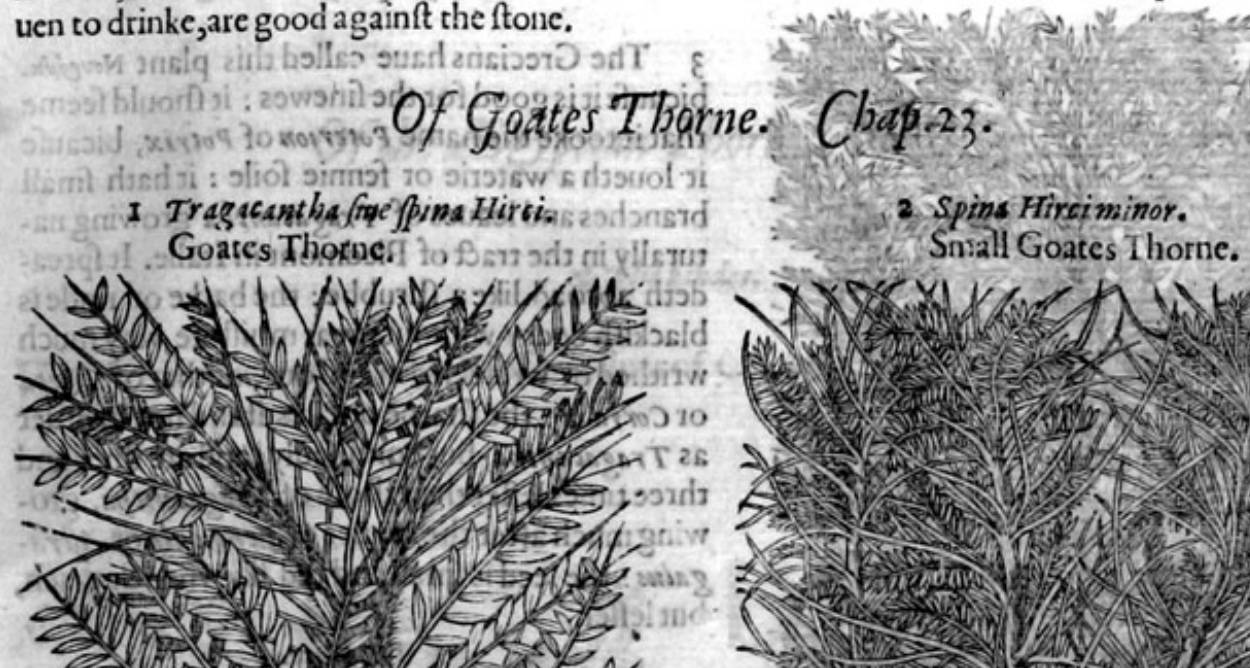

C

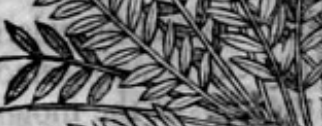

N

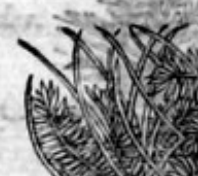
Snall Goates Thorne.

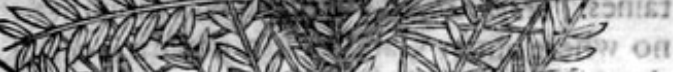

cir
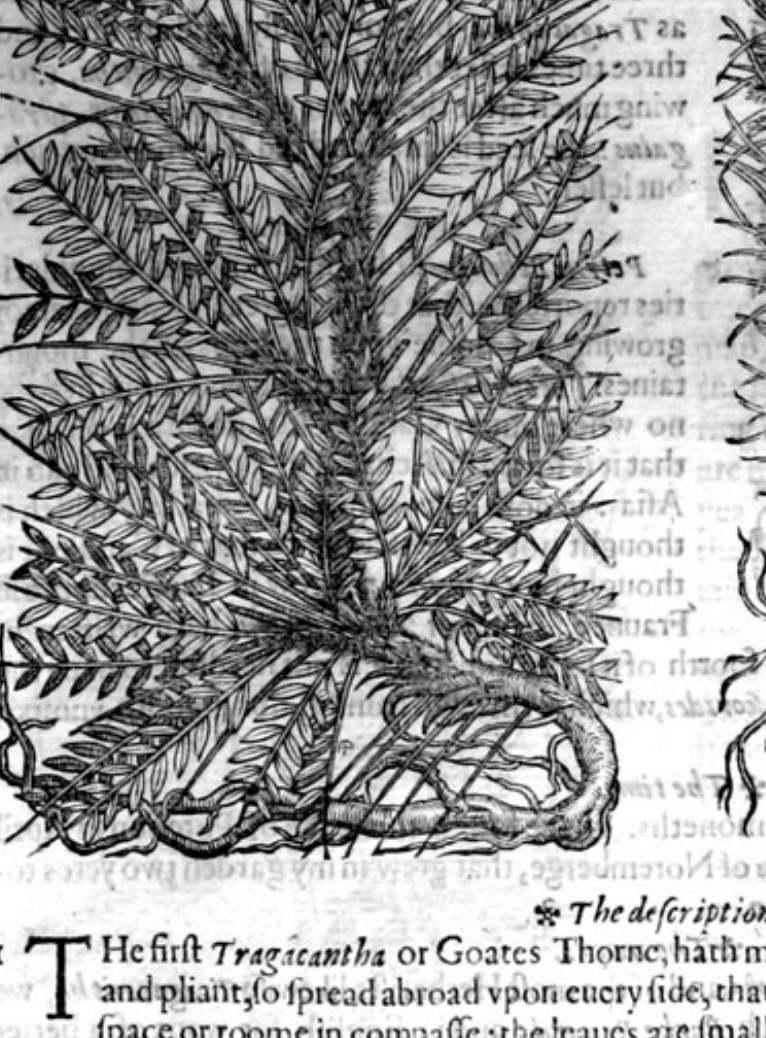

\& The defcription.

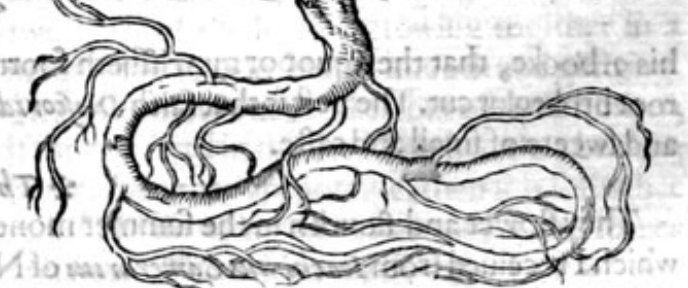

7

He firt $T$ ragacantha or Goates Thornc, hathmany branchie boughes and twigs, flender, and pliant, fo fpread abroad vpon eucry fide, that one plant doth fometime occupie a great

fpace or roome in compaffe the teancs ate fmall, and in thape like Lentill leates, whitifh, and fomwhat moffie or hairie, fet in rowes one oppofite-againft another: the fower is like the bloffome of the Lentill, but much leffer, and of a whitih colsur, and fometimes marked with purple lines or ftreakes: the feede is in lofed in fmall cods or husk's, almoft like vnto the wilde Lotusor horned Trefoile: the whole plant on euery fide is fer fult of tharp prickly Thomes, hard, white, and ftrong : the rootes run inder the ground like Licorice rootes, yellowe within, and blacke without, tough, limmer, and hard to breake: which being wounded in fundry places with fome iron toole, and laide in the finne, at the higheft and hotteft time of fommer, ifficth foorth a cercaine liquor, which being bardned by the fame, isthat gumme which is called in fhops Tragacantha and of fome though barbaroufly Dragagant.
$\operatorname{sil}: \%$
E cec 4

2 The 
2 The fecond kinde of $\tau$ ragacantha, is alfo a lowe and thicke thrub, hauing many fhootes growing from one turfe, of a white or grayifh colour, about 2 cubite high, ftiffe and woodiethe leaues nie leaties come foorth many fowers in fmall tufts like Geniftelly but to be touched:among the thorare many, ftraight and thornie like Geniftella, wherein are many fmal white and three cornered feeds as bigge as Muftard feede.

3 Poterion L'Obelig, fine Pimpinella fpino's Camerary.

- Burnet Goates Thorne.

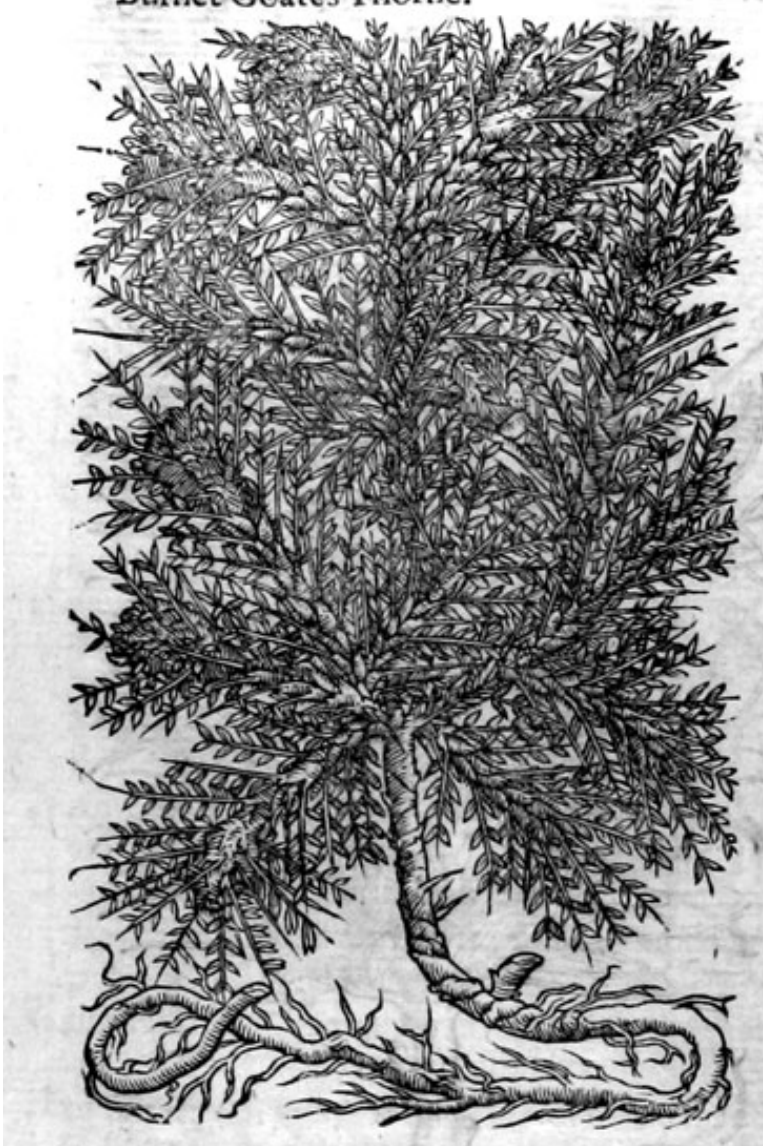

\section{* The defoription.}

3. The Grecians haue called this plant Novededx. bicaufe it is good for the finewes: it fhould feeme that it tooke the name Poterion of Potrix, bicaufe it loueth a waterie or fennie foile : it hath fmall branches and leaues of Tragacantha growing naturally in the tract of Piedmont in Italie. It fpreadeth abroad like a fhrubbe: the barke or rinde is blackith \& dry without great moifture, very much writhed or wrinckled in and out, as that of 2 eps or Corruda : the fharpe prickes ftand not in order as Tragacant ha, but confufedly, and are finer and three times leffer then thofe of Tragacentha, growing much after the maner of Lenticula or Aftragalus : the feed is fmall and red like vnto Sumach, but lęffer.

\section{* Theplace.}

Petrus Bellonisus in his firt booke of Singularities reporteth, that there is great plentie heereof growing in Candie vpon the tops of the mountaines:T heophraftus faith that it was thought to be no where but in Candie, but nowe it is certaine that it is found in Achaia, Peloponefus, and alfo in Afia : it doth alfo growe in Arcadia ; which is thought not to be inferiour to that of Candie.It is thought by L'Obelius to grow in Languedocke in Fraunce, whereof Theophrastiss hath written in his 9. booke, that the liquor or gum iffueth foorth of it felfe, and that it is not needfull to have the root broken or cut. The beft is that faith Diofcorides, which is through fhining,thin,fmooth, vnmixt, and fweete of fmell and tafte.

They flower and flourith in the fummer moneths. Ihaue fowen the feede of Poterion in April which I receiued from Ioachimus Camerarius of Noremberge, that grew in my garden ţwo yeres togither, and after perifhed by forne milchance.

\section{* The names.}

Goates Thorhe is called in Greek regraxyevfa, and of the moft Herbarifts likewifo Tragscant ha, we may call it in Latine Spina Hirci : in French Barbe Renard: and in Englifh for want of a better name, Goatcs Thorne: the liquor or gum that iffueth foorth of the rootes beareth the name alfo of Tragacant ba : it is called in fhops Gummi Tragacantbe, and in a barbarous maner Gummi 7 ragacantbi : in Englih Gumme Dragagant.

\section{* The temperature.}

This plant in eache part there of is of a drying facultie without nipping. It doth confolidate or glew togither finewes that be cut : but the rootes haue that facultie efpecially, which are boiled in wine, and the decoction giuen vnto thofe that haue any greefe or hurt in the finewes.

Gum Dragagant hath an emplafticke or dawbing qualitie, by reafon wherof it dulleth,or alaieth the fharpenes of humours, and doth alfo fomething drie. 
* The vertues.

The Gumme is fingular good to be licked in with honie againft the cough, roughneffe 'of the $\mathbf{A}$ throte, hoarfenes, and all fharpe and thinne rheumes or diftillations; being laide vnder the toong it taketh away the roughnes thereof.

Being drunke with Cute or the decoetion of Lycorice, it taketh away and alaieth the heate of B vrine: it is alfo vfed in medicines for the eies.

The greateft part of thofe artificiall beades, fweete chaines, bracelets, and fuch like pretic fiveete C things of pleafure are made harde and fic to be worne by mixing the gumme heereof with other fweetes, being firft fteeped in Role water till it be foft.

\title{
Of the Agyptian Thorne. Chap.24.
}

\author{
* The kindes.
}

D Iofcorides hath made mention of two forts of Uacacia, this whofe figure we haue fet downe is the right Acsicia.

Acacia Diofcaridis.

The AEgyptian Thorne.

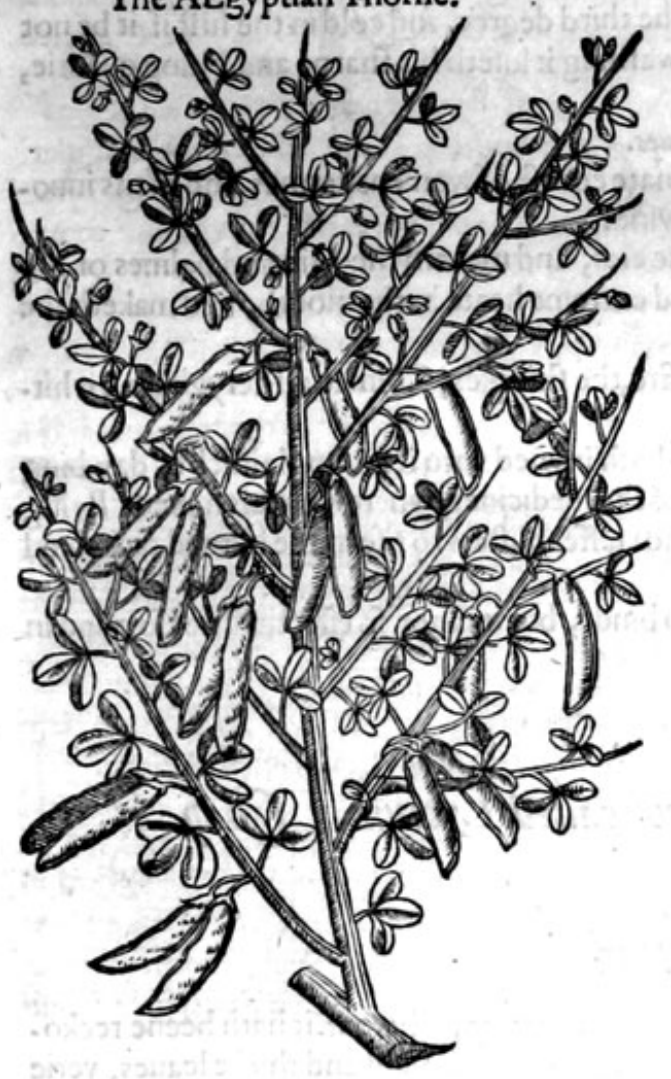

* The defcription.

Io/corides maketh mention of Ucacia, whereof the firft is the true and right $A c a-$ cia, which is a fhrub or hedge tree, but not growing right or fraight vp as other fmall trees do: his branches are woodie, befet with many hard and long Thornes, about which grow the leaues, compact of many fmall leaues cluftering about one fide, as in the Lentill: the flowers are whitifh, the husks or cods be plaine and flat, yea very broad like vnto Lupines, efpecially on that fide where the feede groweth, which is contained fometimes in one part, and fometimes in two parts of the huske, growing togither in a narowe necke : the feede is fmooth and gliftring. There is a blacke iuice taken out of thefe huskes, if they be dried in the fhadow when they be ripe; but if when they are not ripe, then it is fomwhar red : fome do wring out a iuice out of the leaues and fruite. There flowethalfo a gum out of this tree, which is the gum of Arabia, called Gumme Arabicke.

Diofcorides hauing defcribed Spina Lacia, fetteth downe a fecond kinde thereof, calling it Acacia altera, which hath the three leaues of Rew or Cytifus, and cods like thofe of Genistella, but fomewhat more blunt at the end, and thicke at the backe like a Rafor, and ftill groweth forcwarde narrower and narrower, vntill it come to haue a fharpe edge: in thefe cods are contained three or fower flat feedes like Geniftella, which before they waxe ripe are yellow, bur afterwardes blacke : the whole plant groweth to the height of Genifta _pino/a, or Gorfle, both in fhape, height, and refemblance, and not to the height of a tree, as Mathiolms woulde perfwade vs, but fill of tharpe Thornes like the former. 
1. The true Acacia groweth in AEgypt, Paleftina, Lombardie and Syria, as Dio/corides writeth: among the Ahrubs and trees that remaine alwaies green, Acacia is noted for one by Petrus B ellomews
in Fis firft booke of Singulirities, hap. 44 .

The other Acacia groweth in Cappadocia and Pontus, as Diofcor ides writeth: it is alfo found in Corfica, and on diuers mountaines of Italie, and likewife vpon all the coaft of Liguria and Lombar-. dic, and vpon the Narbon coaft of the Mediterranean fea.
\% T The time.

Thefe fower in May, and their fruit is ripe in the end of Auguft. * The names.

The tree Acacia is named of the Greciuns \&rgira, ve a euen in our time, and likewife of the Latires Acacis : it is alfo called Aegyptia (pina. This ftrange thorne hath noEnglifh name that I can learne, and therefore it may keepe ftill the Latine nane Acatia; yet I have named it the AEgyptian thome: the iuice is called alfo Acacia after the name of the plant. The Apothecaries of Germanie call Acacia. Mathiolnes pietureth for Acacia, the freerth of Sloes or Snags, which they likewife de, to which he hath vntruly added Thornes, that he mighich the later Herbarifts do call Arbor Iuit agree with Dio/corides his defcription.

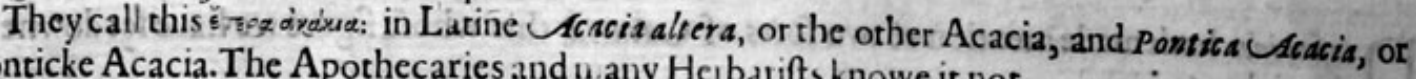
Ponticke Acacia.The Apothecaries and n any Heıbarifts knowe it not.

$$
7 \text { he nature. }
$$

The iuice of Acacia, as Galen faith, confifteth not of one onely fubftance, but is of fubltance both colde and earthie, to which alfo is coupled a certaine wateric effence, and it likewile hath thin and hot partes difperfed in it felfe : therefore it is dic in the third degree, and cold in the firft if it be not wafhed; and in the fecond, if it be wathed: for by wafhing it loleth his tharpe and biting qualitie, and the hot partes.

\section{$*$ The vertues.}

A The iuice of Acacia ftoppeth the laske, the inordinate courfe of womens termes, and mans inuoluntarie iffue called $G$ inorr haa, if it be drunke in red wine.

B It healeth the blaftings and in fammations of the eies, and maketh the skin and palmes of the hands finooth after Seripigo, healeth the blifters and extreme heate in the mouth, and maketh the haires blacke that are wafhed therewith.

C It is good, faith Diofcorides, againft S. Anthonies fire, the fhingles, Chimetla,Pterygia, and whitlowes.

D The gum doth binde and fomewhat coole : it alfo hath inyned vnto it an emplaiftick or dawbing qualitie, by which it dulleth or alaieth the tharpnes of the medicines, wh rewith it is mixed. Being applied with the white and yolke of an egge, it will not fuffer blifters to rife in the burned or fcalded partes. Diofcorides.

E The iuice of the other, faith Diofcorides, doth alfo binde, but it is not fo effectuall nor fo good in eie medicines.

\section{Of boxe Thorne, and the inice thereof called Lycium.}

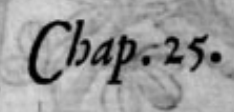

\section{* The defcriftion.}

I Oxe Thorne is a rareplant, in fhape not vn!ike, the Boxe tree, where of it hath beene recko. ned for a wilde kinde, hauing many great branches fet full of round and thickeleaues, verie lihe that of the common Boxe trec: among whicin growe foorth moft fharpe pricking thornes: the flowers growe among the leaues, which yeel e foorth fmall blacke berries of a bitter tafte, as bigge as a pepper corne: the iuice where of is fomewhat onlie and of a reddifh colour; which bitter iuice being fet on fire, doth burne with a maruellous cracking and parkling; the afhes thereof are of ared colour : it hath many woodie rootes growing aflope. 
2 The other kinde of Pyxacantha or Lycium, groweth like vnto the common Priuet, hauing fuch like leaues,but fomewhat narrower : the tops of the flender fprigs are furnifhed with prickes: the roote is tough, and of a woodie fubftance.

I Lycium, fune pyxacantha. Boxe Thorne.

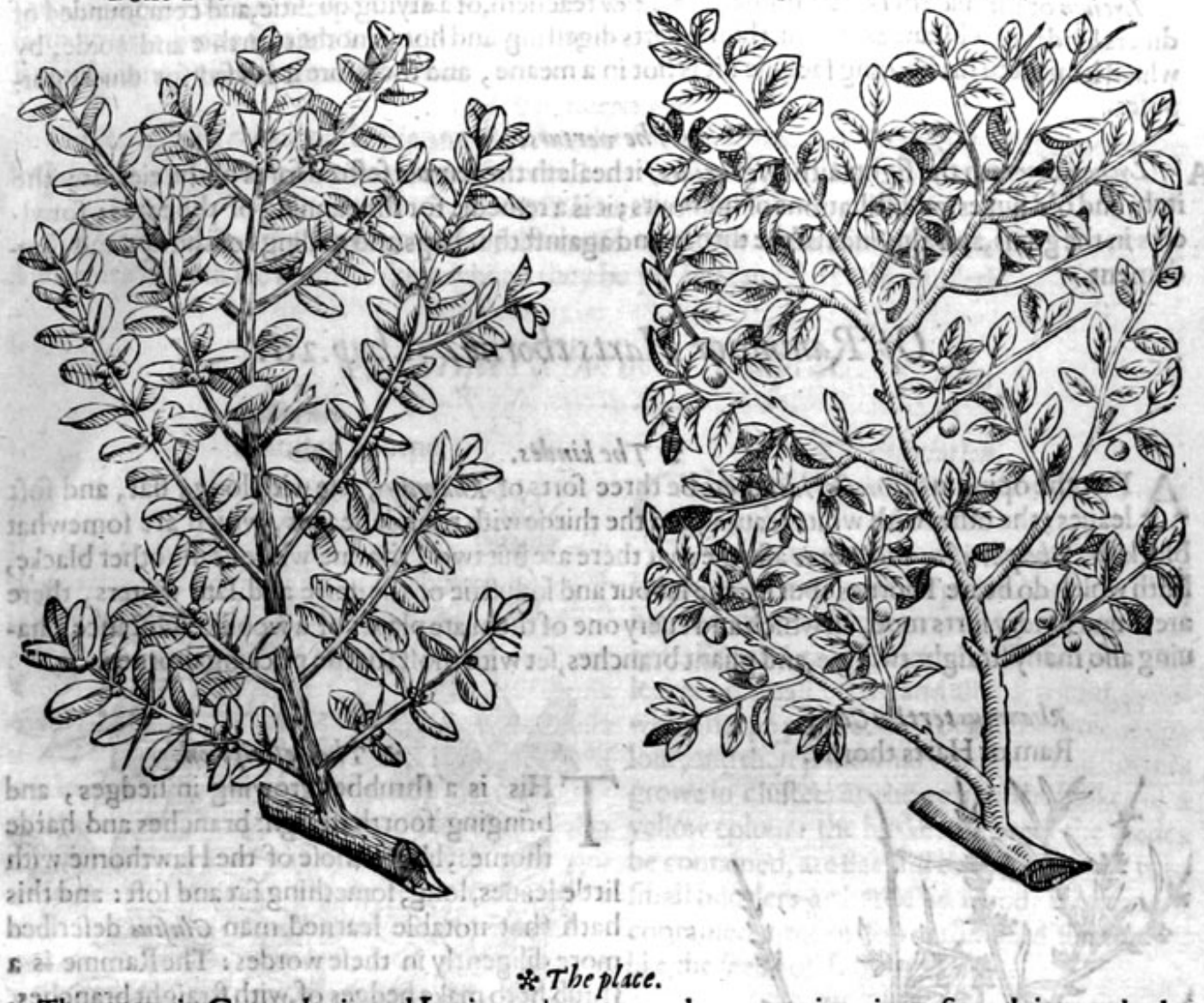

"They grow in Cappadocia and Lycia, and in ma ny other countries: it profpereth in rough plaplaces, is hath likewife beene founde in Languedoc, and Prouence in Frauncc; Bellonius writeth that he found it in Paleftina.

Mathiolus pictureth for Boxe Thorne, a plant with Boxe leates, with very many boughes, and certaine thornes ftanding anong them: but the notable Herbavit Ungullira and others, holde opinion, that it is not the right; with whom we alfo do agree.

There is drawne out of the leaues and branches of Boxe Thorne, or as Plinie faith, out of the boughes and rootes being thorowly boiled, a iuice, which is named Lycium.

Drofcorides faith, that the leaues and branches nuft betraied, and the infufion made many daies in the decoetion there of, after which the feaces or woodieft fffe murt becaft away, and that which remaineth boiled againe till it become as thicke as hionie : $P$ liny faith, that the rootes and branches are very bitter; and for three daies togither they muft be bolled in a copper. fiell, and the woode and ftickes often taken out till the decoetion be boiled to the thichnes on honie.

* Thetime.

They flower in Februarie and March, and therr fruite is ripe in Sepren ber.

$$
\text { \& Therians. }
$$

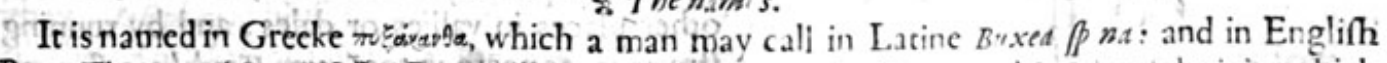
Boxe Thorne, of f ne Affes Boxe Tree \& prickley Boxe: st is alto named Lycium of the ituce which is boiled out of it. The ince is properly called divioy, and retane th in Latme the fame nare Lychon: it is termed in Engl:Ch Thorne Boxe. But it feemeth to me, that the ongmall name Lycuam is fitter, ofing 
1152

\section{THE THIRD BOOKE OF THE}

being a ftrange thing, and knowne to very fewe; the apothecaties know it not, who in fteede thereof do vfe amiffe the iuice of the fruite of Woodbine, and that not without great errour, as
we haue alreadie written.

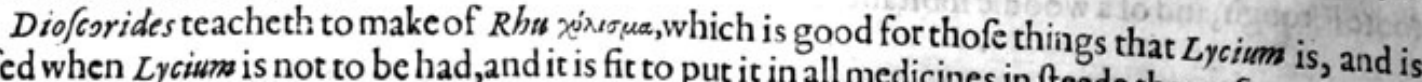
vfed when Lycium is not to be had, and it is fit to put it in all medicines in fteede thereof.

\section{* The tempcrature.}

Lycium or the iuice of Boxe Thorne, is as Galen teacheth, of a drying qualitie, and compounded of diuers kindes of fubftances, one of thinne parts digefting and hot; another earthie and colde, by which it inioyeth his binding facultie : it is hot in a meane, and therefore it is vfed for diters purpofes.

\section{* The vertues.}

A Lycium cleereth the fight faith Diofsorides, it healeth the fcuruie feftred fores of the eie lids; the itch; and old fluxes, or diftillations of humours; it is a remedie for the running of the eares; for vlcers in the gums, and almonds of the throte, and againft the chaps and gallings of the lips and fundament.

\section{Of Ramme or Harts thorne. Chap. 26.}

\section{* The kindes.}

A Fter the opinion of Diofcorides there be threc forts of Rhamnus, one with long, flat, and foft leaues; the other with white leaues; and the thirde with rounde leaues, which are fomewhat blackifh: Theophraft us and Plinie affirme that there are but two, the one white \& the other blacke, both which do beare Thornes: but by the labour and induftrie of the newe and late writers, there are found fundry forts moe, all which and enery one of them are plants of a woodie fubftance, hauing alfo many ftraight twiggie, and pliant branches, fet with moft fharpe pricking thornes.

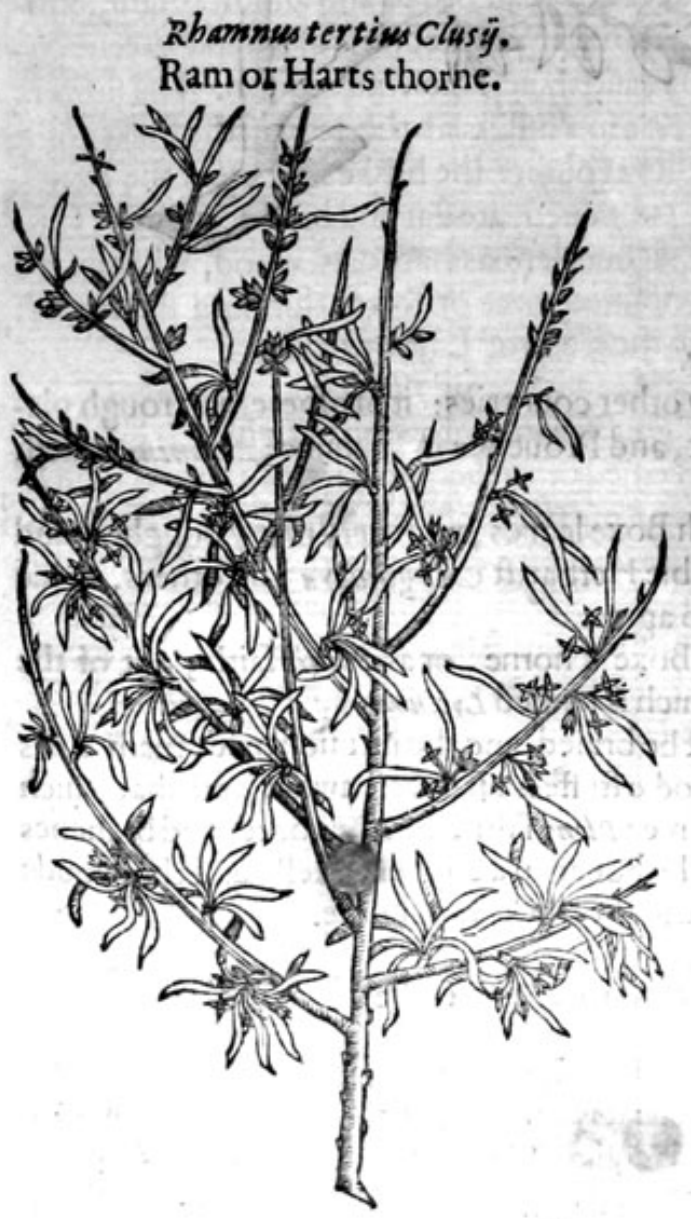

$T^{H}$ His is a fhrubbe growing in hedges, and

* The defoription.

bringing foorth ftraight branches and harde thornes, like to thofe of the Hawthorne, with little leaues, long, fomething fat and foft : and this hath that notable learned man Clufrus defcribed more diligently in thefe wordes: The Ramme is a Thrub fic to make hedges of, with ftraight branches, parting it felfe into many twigs, white, and fet with ftiffe andiftrong thornes, hauing leaucs, which for the moft part growe by fowers or fiues at the roote of euery Thorne, long, fomething fat, like to thofe of the Oliue tree, fomewhat white, but tender and full of iuice, which in Autumne do fomtimes fall off, leauing newe growing in their places : the flowers in Autumne are fomething long, whition, diuided at the brims into fiue parts, in their places is left a feede, in flew as in Gelfemine; notwithftanding it was neuer my chaunce to fee the fruit: the roote is thicke and diuerfly parted.

$$
\text { * Theplace. }
$$

This Ramme is found on the fea banks of $\mathrm{Hol}$ land, and efpecially of Flanders; it is alfo found in other places in, vallies or dales, and by running ftreames, as neere vnto Lycum Vindelicie flawium, where Valerius Cordisu did oftentimes fee it, as he himfelfe writech. 
* The time.

This Ramis greene togither with his leaues: the fruit or berries remaine on the hrub yea euen in winter.

\section{* T he names:}

The Grecians call this thorne pairo ; the Latines alfo Rhamnus, and of diuers it is named mien.

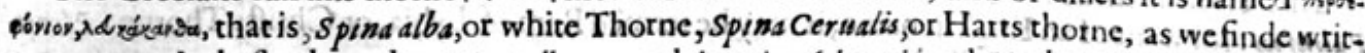
ten among the baftard ivordes. Marcellus nameth it Spina falutaris,and Herbia jalustaris, which hath, faith he, as it were a Grape. It is called in Italian Marrucasnd Rhamno: in Spanifh Scambrones : in Englifh Ram, or Harts thorne.

\section{* The temperature.}

The Ram, faith Galen, doth drie and digeft in the fecond degree, it cooleth in the later end of the firft degree, and in the beginning of the fecond.

The leaues, faith Dioferides, are laid pultus wife vpon hot cholerike inflammations and Saint $A$ Anthonies fire, but we muft vfe them whileft they be yer but tender,as $G_{a l e n}$ addeth. 525001 ifl?

$$
\text { Of Chriftes Thorne. Chap.26. }
$$

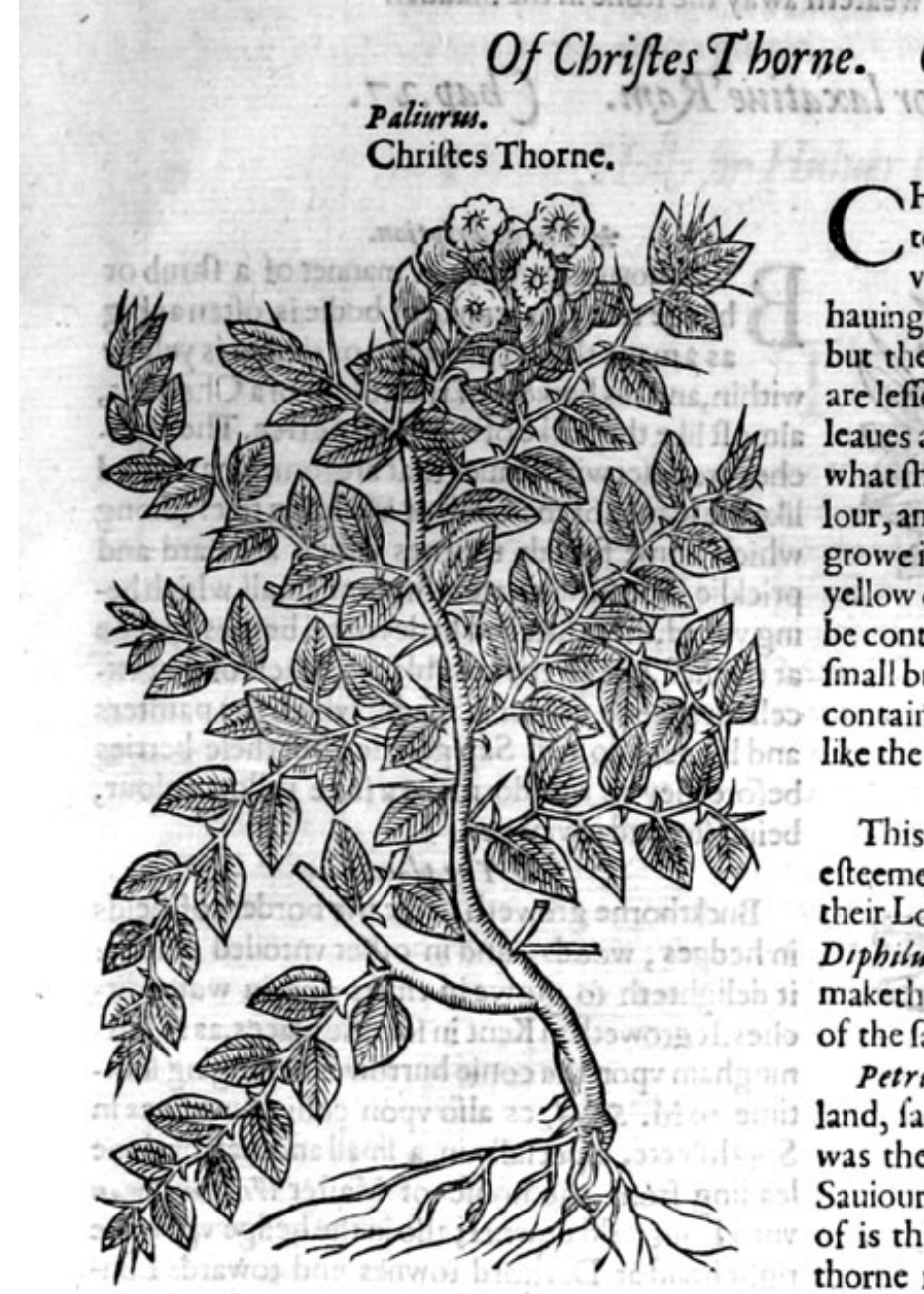

Paliurus. the height of atal tree, very long and iharpe pricklie branches; but the thorries that growe about the leates are lefier, and not fopricklic as the former. The leaues are finall, broad and almoft round, fomewhat fharpe pointed;firft of a darke greene colour, and then fomewhat reddilh. The flowers growe in clufters at the top of the ftalkes of $\mathbf{z}$ yellow colour: the huskes wherein the feedes be contained, are flat and broad, very like vnto finall bucklers as harde as wood, wherein are contained three or fower thin and flat feedes, like the feede of Line or Flaxe.

$$
\text { * Theplace. }
$$

This Thorne groweth in Lybia; it is better efteemed of in the countrie of Cyrena than is their Lote tree, as $P$ liny affirmeth. Of this thrub Diphilus Sipbrisus in Atbenaews in his 14 . booke, maketh mention, faying, that he did ofterreate of the fame in Alexandria that beautifull citie.

Petrus Bellonisus who trauelled quer the holy land, faith, that this fhrubbie thorne Paliur us was the thorne wherewith they crowned our Sauiour Chrift : his reafon for the proofe hereof is this, that in Iudrea there was not any thorne fo common, fo pliant or fo fit for to make a crowne or garland of, nor any fo full of cruell fharpe prickles.It groweth throughout the whole countrie in fuch abundance, that it is their common fewell to burne, ye a fo common with them there, as our Gorfic, Brakes, and Broom is here with vs. Iofephus in hisfirft booke of Antiquities and II.chapter faith, that this thorne hath the n:oft Tharpe prickles of any other, and therfore that Chrift might be the more tormented, the Iewes rather tooke this than any other. Of which I haue a fmall tree growing in tiny garden, that I haue brought foorth by fowing of the feede. 
* The thime.

The leaucs fall away and continue not alwaies greene, as do thofe of the Rams : it buddeth forth in the fpring, as plinie teftifieth.

\section{* The names.}

This Thornic fhrub is called in Greeke raxises: the Latines and Italians retaine the fame name Palrurms : for want of an Englifh name, it may be termed Ram of Lybia, or Chrifts Thorne: Plinie reporteth, that the feede is called $Z$ ura.

$$
\approx \text { The temperature. bsil a }
$$

The leaues and roote of Chriftes Thorne do euidently binde and cut. * The vertues.

A By vertue of this cutting qualitie the feed doth weare away the ftone, and caufo tongh and limie humors to remooue out of the cheft and lungs, as Galen faith.

B The decoetion of the leaues and roote of Chrifts. Thiftle, as Diofcorides writeth, ftoppeth the belAly,prouoketh vrinejand is a remedie againit poyfons, and the bitings of ferpents.

I The roote doth wafte and confume away P bymata and Qedemata if it be ftamped and applied.

D The feede is good for the cough, and weareth away the itone in the bladder.

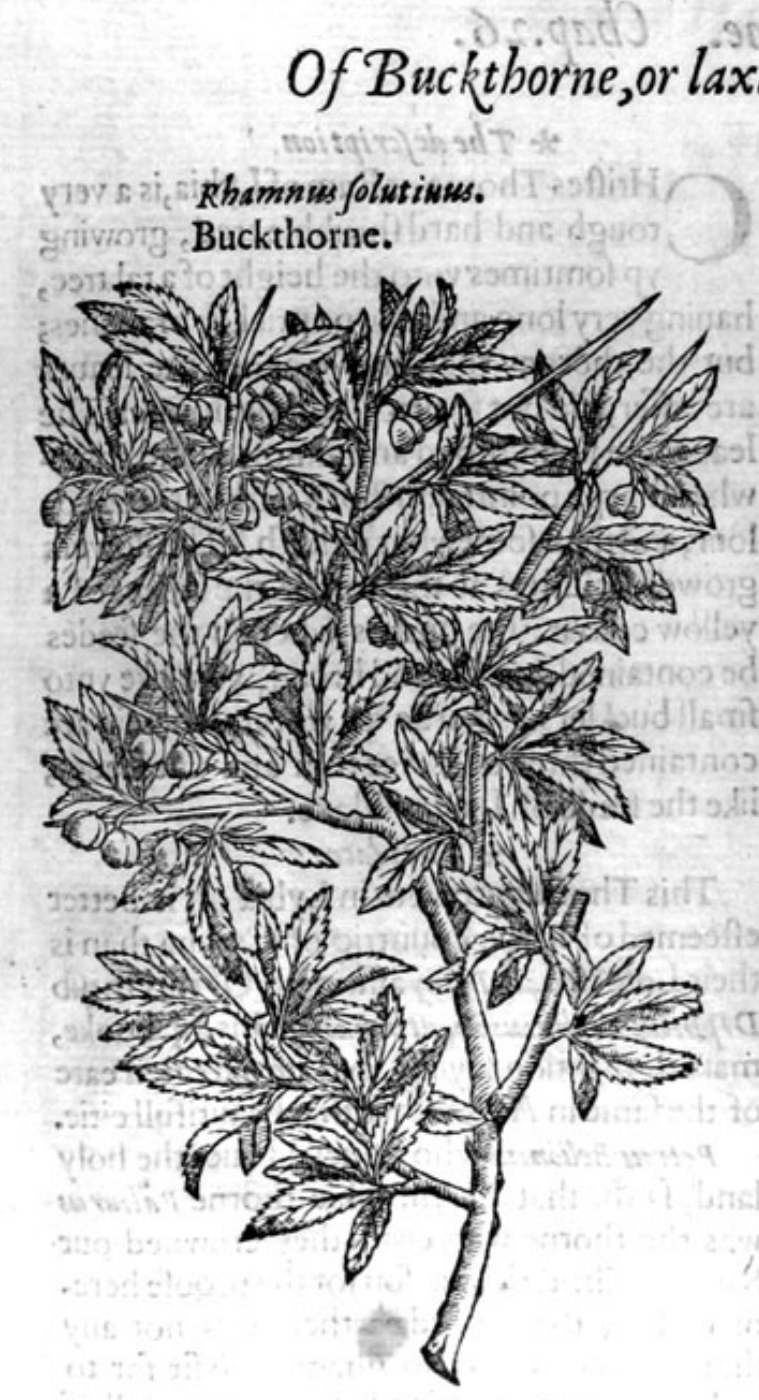

* The time.

D Vckthorne groweth in manner of 2 fhrub or *. Thedefaription.

$\mathrm{B}$ hedge tree, his trunke or bodie is oftenas big as a mans thigh; his wood or timber is yellow within, and his barke is of the colour of 2 Cheitnut, almoft like the barke of the Cherrie tree. The branches are befet with leaues that are fomewhat round like the leaues of the Crab or Wilding tree: among which come foorth thornes which are hard and pricklic. The flowers are white and fmall, which being vaded, there fucceed little round berries, greene at the firft, but afterwards blacke, whereof that excellent greene colour is made, which the painters and limners do call Sap greene; but thefe berries before they be ripe do make a faire yellow colour, being fteeped in vineger.

$$
\text { * The place. }
$$

Buckthorne groweth neere the borders of fields in hedges, woods, and in other vntoiled places: it delighteth to growe in rivers and in water ditches. It groweth in Kent in fundrie places,as at Farningham vpon the conie burrowes belonging fomtime to M. Sibill, as alfo vpon conie burrowes in Southfleete, efpecially in a fmall and narrow lane leading from the houfe of Mafter Willam Sman vnto Longfield downes; alfo in the hedge vpon the right hand at Dartford townes end towards London, and in many places more vpon the chalkie bankes and hedges.

It flowreth in May, the berries be ripe in the fall of the leafe.

* The names.

The later Herbarifts call it in Latine Rhamnus folutiutes, bicaufe it is fer with thornes, like as is the Ram, and beareth purging berries. Matbiolus nameth it Spina infectoria; V alerius Cordus Spina Ceruirs 
and diuers call it Burgipina. It is termed in high Dutch Crenkber weglodon: in Italian spino Merlo; Spino Zerlimo, Spino Ceraino: in Englifh Laxatiue Ram, Way thorne, and Buckthorne : in lowe Dutch they call the fruit or berries Rbtinbefien, that is, 2s though you fhould fay in Latine, Bacc.e Klenane, in Englifh Rheinberries : in French Nerprun.

* The temperatare.

The berries of this Thorne, as they be in tafte bitter and binding, fo be they alfo hot and drie in the fecond degree.

\section{* The vertues.}

The fame do purge and voide by the ftoole thicke flegme, and alfo cholerike humours: they are $\mathbf{A}$ giuen being beaten into powder from one dram to a dram and a halfe: dituers do number the berries, who giue to ftrong bodies from fifteene to twenty or noe; but it is better to breake them and boyle them in fat flefh broth.without falt, and to gitue the broth to drinke : for fothey purge with leffer trouble and fewer gripings.

There is preffed foorth of the ripe berries a iuice, which being boyled with a little Allum is vfed B of painters for a deepe greene, which they do call Sap greene.

'The berries which be as yet vnripe, being dried and infufed or fteeped in water, do make a faire $\mathbf{C}$ yellow colour, but if they be ripe they make a greene.

\section{Of the Holme, Holly, or Huluer tree. Chap.28.}
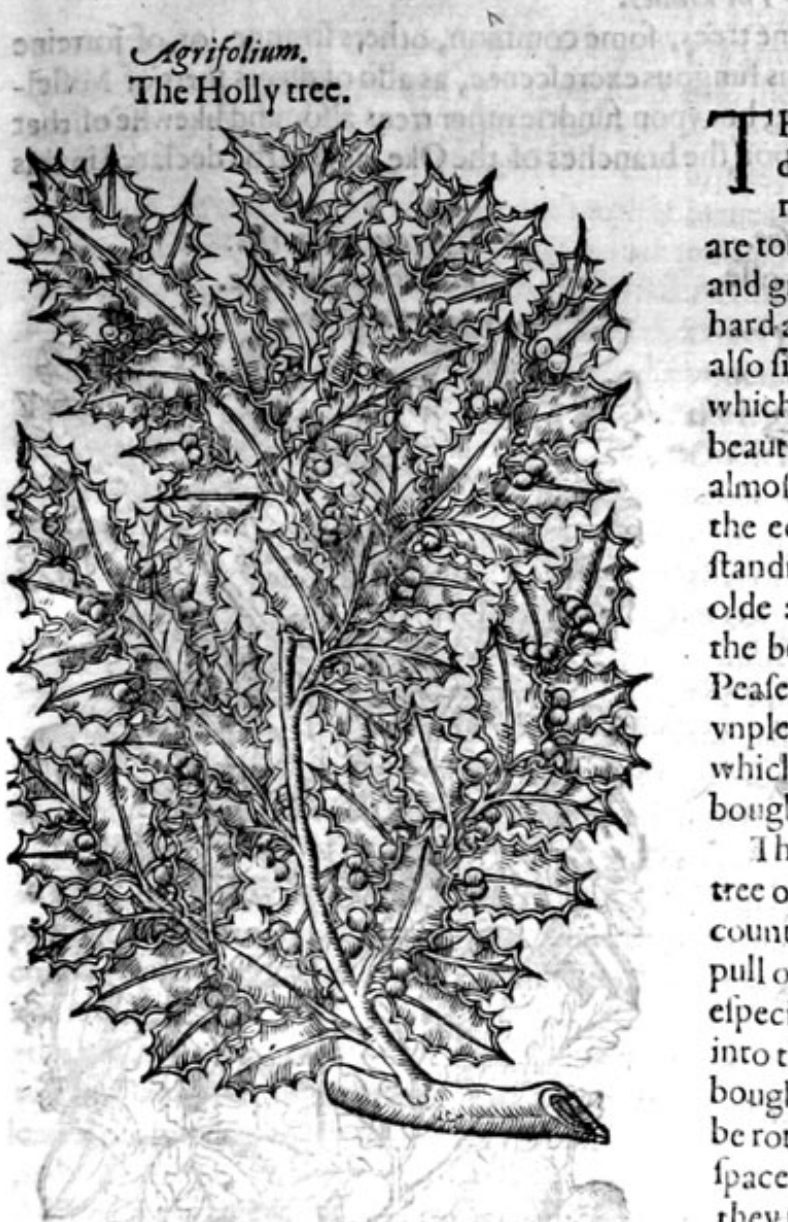
$*$ Thedefcription.

HeHolly is a thrubbie plant, notwithftanding it oftentimes groweth to a tree of a reafonable bignes. The boughes whereof are tough and flexible, couered with a fmoothe and greene barke. The fubftance of the wood is hard and found, and blackifh within, which doth alfo finke in the water, $2 s$ doth the Indian wood which is called Guaiacion. The leaues are of a beautifull greene colour, fmooth and glib, like almoft to Bay leaues, but leffer, and cornered in the edges with tharpe prickles; which notwithftanding they want or hane few when the tree is olde : the flowers be white and fiveete of finell: the berries are round, of the bignes of a little Peafe, or not much greater, of colour red, of talte vnpleafant, with a white ftone in the middeft, which do not eafily fall away, but hang on the boughes a long time: the roote is woodie.

There is made of the fmooth barke of this tree or hhrub, Birdlime, which the birders and countrie men do ve to take birdes with. They pull off the bark, and make a ditch in the ground efpecially in moift, boggie, or foggie earth, wherinto they put this barke, courering the ditch with boughes of trees, letting it remaine there till it be rotten and putrified, which will be done in the fpace of twelue daics or thereabout : which don, they rake it foorth, and beate it in mortars vntill it be come to the thickneffe and clamminefie of Lime. Laftly, that they may cleere it from peeces of barke and other filthinefle, they do wafh it very often; after which they adde vito it a little oyle of nuts, and after that doputirvp in earthen veflels.

* The 


\section{6}

\section{THE THIRD BOOKE OF THE}

\section{* The place and time.}

The Holly tree groweth plentifully in all countries. It groweth greeneboth winter and fonmer; the berries are ripe in September, and they do hang vpon the tree a long time after.

$$
* \text { The names. }
$$

This tree or fhrub is called in Latine Agrifolium : in Italian Agrifoglio, and Aguifoglio - in Spa-

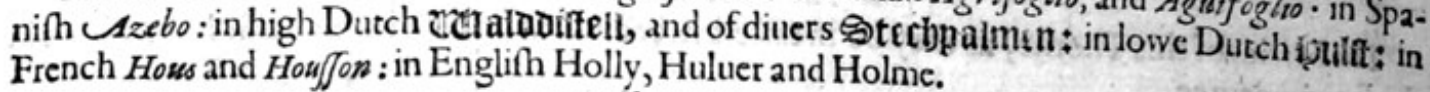

\section{* The tempsrature.}

The berries of Holly are hot and drie, and of thin partes, and wafte away winde.

A They are good againft the colicke: for ten or twelue being inwardly taken bring away by the ftoole thicke flegmaticke humors, as we haue learned of them, who oftentimes made rriall thereof.

B The Birdlime which is made of the barke hereof is no leffe hurtfull than that of Miffelto, for it is maruellous clammie; it gleweth vp all the intrailes, it fhutteth and draweth togither the gutss and paffages of the excrements, and by this meanes it bringeth deftruction to man, not by any qualitie,
butby his glewing fubftance. Holly beaten to powder and drunke, is an experimented medicine againft all fluxes of the belly,
as the dyfenterie and fuch like.

$$
\text { Of the Oke. Clsap.29. }
$$

\section{* The kindes.}

$T$ Here be diuers forts of Okes or Acorne trees, fome common, others Ptrange, or of forreine countries: of the common Oke with his fungous excrefcence, as alfo of dimers forts of Miffeltoes, which growe not onely vpon the Oke, but vpon fundrie other trees alfo, and likewife of that long white moffe that is efpecially found vpon the branches of the Oke, as fhall be declared in this prefent chapter.

I Qucrcusvulgaris cum glande of ma/co (un. The Oke tree with his Acornes and nioffe.

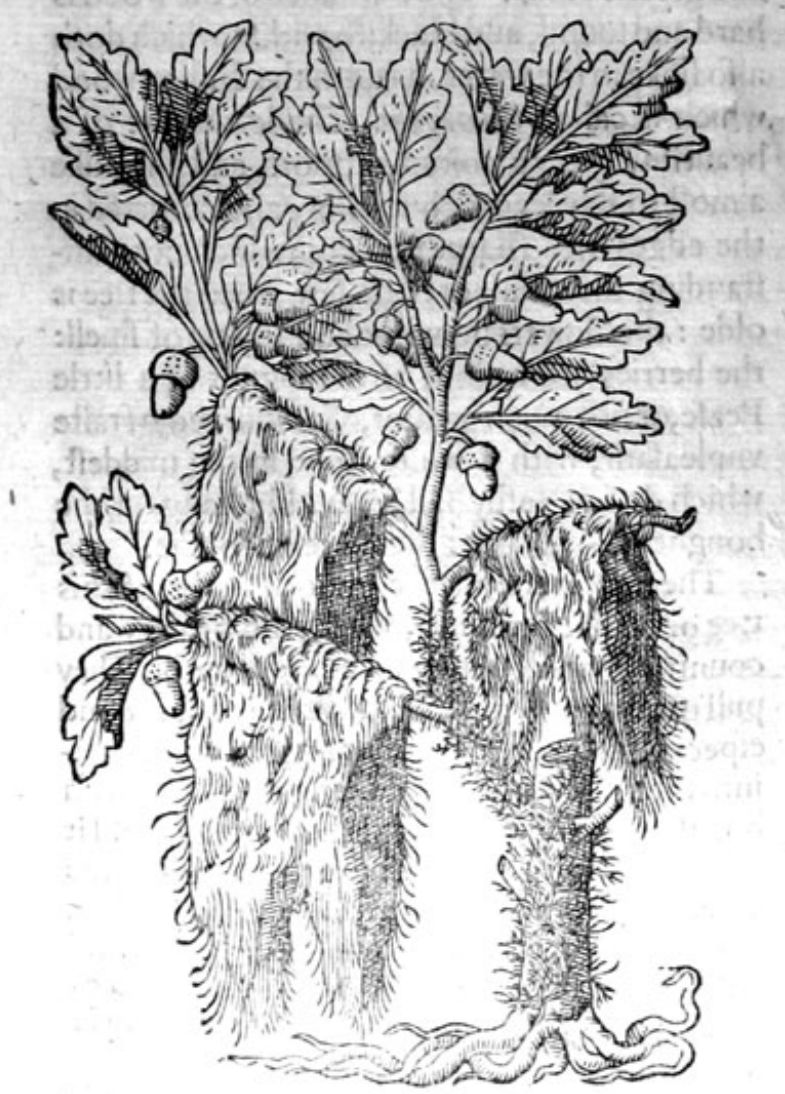

2 Quercus vulgario. The common Oke.

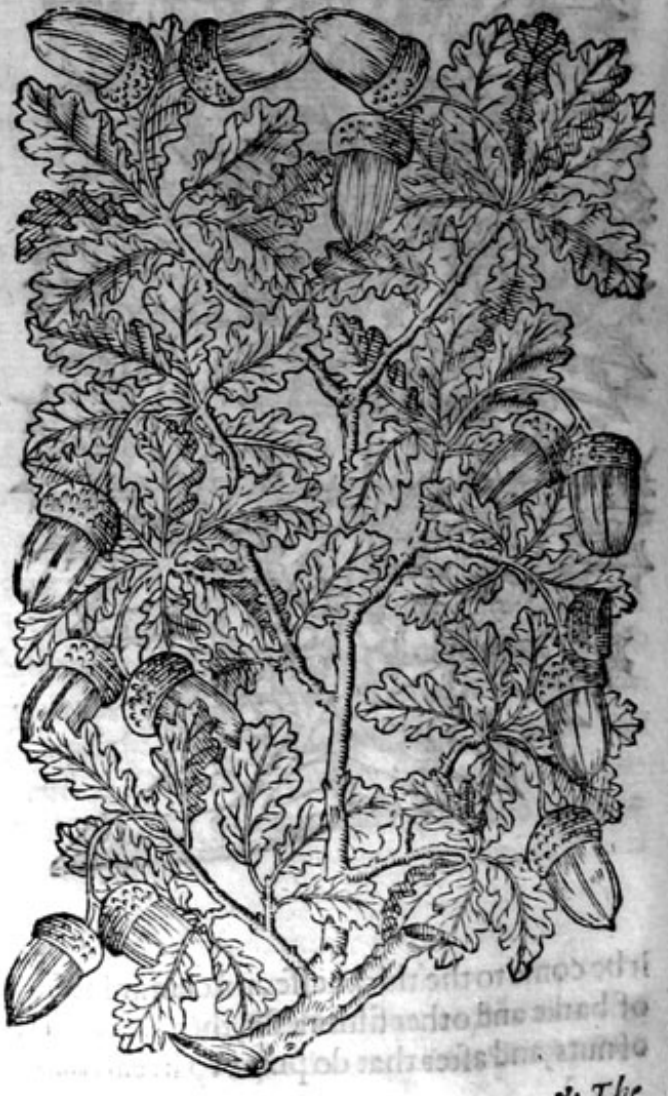


I He common Oke groweth to a great tree, the trunke or bodie where of is cotiered oter with a thickerough barke full of chops or rifts. The armes or boughes are likewile great, difperfing themfelues far abroad. The leaues are bluntly indented about the edges, finooth, and of a hining greene colour, whereon is often found a moft fweete deaw, and fomewhat clammie, and alfo a fungous excrefcence, which we cal Oke Apples. The fruit is long, couered with a brown, hard and tough pilling, fet in a rough fcalie cup or huske. There is often found vpon the body of the tree, and alfo vpon the branches, a certaine kinde of long white moffe hanging downe from the farce: and fometimes another woodie plant, which we call Miffeltoe, being either an excrefcence or outgrowing from the tree it felfe, or of the doung (as it is reported) of a birde that hath eaten a certaine berrie.

3 Quercus humilis.

is 3 The Dwarffe Oke.

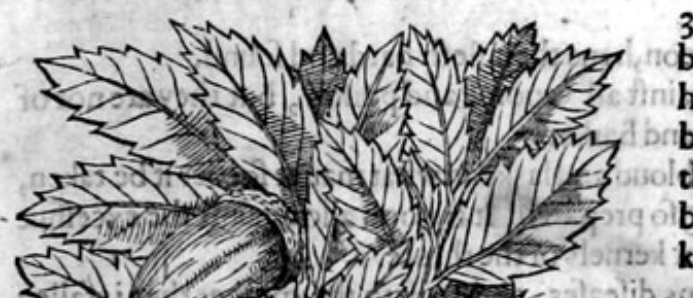

3 Carolus Clufius reporteth that he founde this bafe or lowe Oke not far from Lisborne, of the heigho of a cubite, which notwithltanding did alfo beare anacorne, like that of our Oketree, fauing that the cup is fmoother, and the Acorne mnch bitterer, wherein it differeth from the reft of his

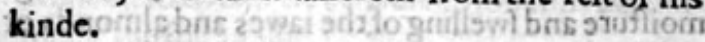
There is a wild Oke, which rifeth vpoftentimes veto a maruellous height, and reacheth very far with his armes and boughes, the body thereof is now $\mathrm{HI}$ and then of a mighty thicknes, in compalfe two or three fathoms; it fendeth foorth great fpreading armes, diuided into a multitude of boughes. The leaues are fmooth, fomething hard, broad, long, I gafhed in the edges, greene on the vpper fide : the Acornes are long, but fhorter than thofe of the tamer Oke; enery one faftened in his owne cup, which is rough without: they are courered with 2 thin rinde or thel;the fubftance or kernell within is diuided in to two parts, as are Beanes, Peafe \& $\mathrm{AI}$ monds: the barke of the yoong Okes is mooth, glib, and good to thicken skins and hides with, but that of the old Okes is rugged, thick, hard, and full of chops: the inner fubftance or hart of thewood

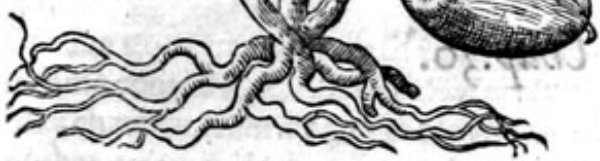

- 9 is fomething yellow, hard and found, and the older the harder : the white and outwarde part next to the barke, doth eafily rot, being fubicet to the worme, efpecially if the tree be not feld in due time: fome of the rootes grow deepe into the carth, and other fome far abroad, by which it ftiffely in tandeth.

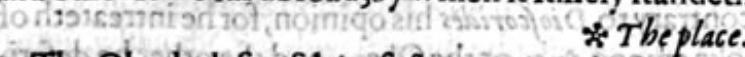

The Oke doch fearfely refufe any ground; for it groweth in a drie and barren foyle, yet doth it profper better in a fruitfull ground: it groweth vpon hils and mountaines,and likewife in valleies:it commeth vp euery where in all parts of England, but is not fo common in other of the South and hot regions.

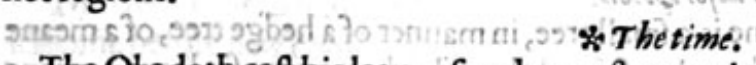

sut The Oke doth cafthis leaues for the moft part about the end of Autumne: fome keepe their leaues on, but drie all winter long, vntill they be thruft off by the new fpring?

* The names.

The Oke is called in Greeke sfojs : in Latine Q nercus, of fome Placida, as Gazatranflateth it, It may be called Sativa, Vibani, or Culta; fome alfo Emeros, mudion, and Robur. The Macedonians 'rupespoes, as though you fhould fay Verigueriens, as $G_{a}$ id expoundeth it, or Verì Qnercod, the true Oke. We may naine it in Englifh the tamer Oke tree: in French Chejne: in Dutch erpeken boom. 


\section{THE THIRD BOOKE OF THE}

The fruite is named in Greeke Bérevos: in Latine Glans: in high Dutch Eiche! : in lowe Dutch Utekt: in Spanifh Bellotas : in Italian Cbizande : in Englifh Acorne and Maft.

The cup wherein the Acorne ftandeth, is named in Greeke iupaxis, as Paulus UEgineta in his 3. booke 42.chapter teitifietin faying, omphacis is the hollow thing out of which the Acorne groweth: in Latine Calix glandis : in fhops Cupula glandis : in Englifin the Acorne cup.

\section{* The temperature and vertues.}

A The leaues, barke, acorne cups, and the Acornes themfelues, do mightily binde and drie in the
thirde degree, being fomwhat colde withall.

B The beft of them faith Galen, is the thinne skin which is vinder the bark of the tree, and that next, which lieth neereft to the pulpe, or inner fubftance of the Acorne; 3 al thefe ftay the whires, the reds, fpitting of bloud, and lasks: the decoetion of thefe is giuen, or the powder of them dried, for the
purpofes aforefaid.

C Acornes if they be eaten are tardly concocted, they yee!de no nourifhment to mans bodie, but
that which is groffe, rawe, and colde.

D Swine are fatted heerwith, and by feeding heereon, haue their flefh hard and found.

E The Acornes prouoke vrine,' and are good againft all venome and poifon, but they are not of fuch a ftopping and binding facultie as the leaues and barke.

F The Oke Apples are good againft all fluxes of bloud and lasks, in what maner foeuer it be taken, but the beft way is to boile it in red wine, and being fo prepared, it is good alfo againft the exceffue moifture and fwelling of the iawes and almonds or kcriels of the throte.

G The decoction of the Oke apples, ftaieth womeins difeafes, and caufeth the mother that isfallen downe to returne againe to the natural place, if they do fit ouer the faid decoction being very hot.

H Thefame fteeped in ftrong white wine vineger, with a litle powder of Brimftone, and the root of Ir cos mingled togither, and fet in the funne by the fpace of a moneth, maketh the haire black, confurmeth proud and fuperfuous flefh, taketh away funburning, freckles, fpots, the morphew, with aldeformities of the face, being wafhed therewith.

I The Oke Appies being broken in funder about the time of their withering, do forefhewe the fe. quell of the yeere, as the expert Kentifh husbandmen haue obferued by the liuing things founde in them : as if they finde an Ant, they foretell plentic of graine to infue ; if a white worme like a Gentill or Maggot, then they prognofticate murren of beafts and cattle; if 2 Spider, then (faie they)we thall haue a peftilence or fome fuch like ficknes to followe amongit men : thefe things the learned alfo haue obferued and noted; for Mathiolwa writing vpon Diofcorides faith, that before they haue an hole thorough them, they conteine in them either a flie, a fpider, or a worme; if a flie, then warre infueth; if a creeping worme, then fcarcitie of vietuals; if a running fpider, then followeth greav ficknes or mortalitie.

\section{Of the fcarlet Oke. Chap. 30.}

\section{* The kindes.}

A Lthoigh Theophraftis hath made mention but of one of thefe Holme or Hollie Okes onely, A yet hath the later age fet downe two kindes thereof; one bearing the f carlet graine, and the other onely the Acorne; which thing is not contrary to Diofcorides his opinion, for he intreateth of that which beareth the Acorne in his firft booke among apuis, or the Okes; and the other he deferibeth in his fourth booke vnder the title voxxes fapixin, or Coccess baphece.

\section{* Thedefcription.}

$7 \mathrm{HeOke}$ which beareth the fcarlet graine is a finallitree, in manner of a hedge tree, of a meane bignes, hauing many faire branches or boughes fpread abroad; whereon are fet leaues, greene aboue, white vnderneath, fnipt about the edges, and at euery corner one fharpe prickle, in maner of the fmoother Holly: among which commeth fometimes (but not often) fmall Acornes, ftanding in little cups or husks, armed with prickes as fharpe as thornes, and of a bittertifte. Befides the Acornes, there is found cleauing vnto the woody brancbes, a certaine kinde of berries, or rather an excrefcence, of the fub fa tace of the Oke Apple, \& of the bignes of a Peafe, at the firft white, and of the colour of afhes when they be ripe, in which are engendred litcle Maggots, which feeme 


\section{HISTORIE OF PLA NTS.}

II 59

to be without life, vntill they fecle the heate of the funne, and then they creepe, and feeke to fle away. But the people of the countrie (which make a gainc of them) do watch the time of their fiying,euen as we do Bees, which they then rake \& pur into a linnen bag, wherein they thake and, boult them vp and downe yntill they be dead, which they do make vp into great lumpes oftentimes, and likewife fell them to Dier5, and fuch like apart, eten-as they were taken foorth of the bag, whereof is made the moft perfect Scarlet. ralced Cannin olo.

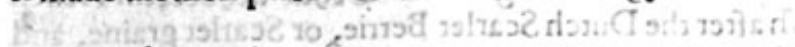

The Scarlet Oke.

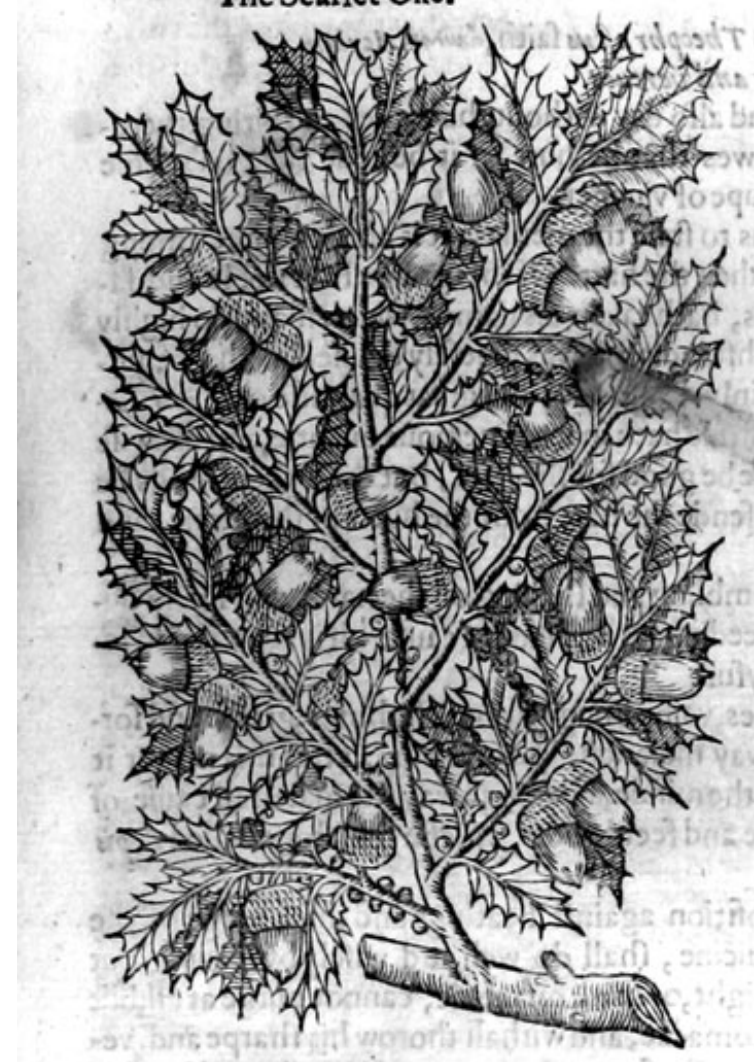

\section{* The place.}

This Oke groweth in Languedocke, and in the countries thereabout, and alfo in Spaine : butit beareth not the Scarlet graine in all places, but in thofe efpecially, which lic towards the Midland fea, and which be fubiect to the fcorching heate of the funne, as Cayolus Clufues witneffech, and not there alwaies; for when the tree waxeth olde, it groweth to be barren. Then do the people cut and lop it downe, that after the yoong fhootes have attained to two or three yeeres growth, it becom meth fruitfull againe.

Petres bellonins in his bookes of Singularities fheweth, that Coccess Baphicus or the Scarlet graine, doth growe in the Holy land, and neere to the lake which is called the Sea of $T$ iberides, and that vpon little trees, wherety the inhabitants get great ftore of wealth, who feparatethe husks from the pulpe or Magots, and fell this being made vp into bals or lumps, much deerer than the emptic fhels or husks.

Of this graine alfo Paufanias hath made mention in his tenth booke, and fheweth, that the tree which bringeth foorth this graine, is notgreat, $]$ and alfo groweth in Phocis, which is a countrie in Macedonia neere to the Bœotians, not far from the mount aine Parnaffus.

Thesphrast tus writeth, that woivos, or the Scarlet Oke is a great tree, and rifeth vp to the height of the common Oke : amonglt which writers there is fome contratietie. Petrus Belloniss reporteth it is a little tree, and $T$ beophrastus a great one, which may chaunce according to the foyle and climate: for that vpon the ftonie mountaines cannot grow to that greatnes, as thofe in the fertill grounds.

\section{* The time.}

The little graines or berries which growe about the boughes, bQin to appeere efpecially in the fpring, when the Southweft windes do blow. The towers fall and are ripe in Iune, togither with the Maggots growing in them, which receiuing life by the heate of the funne, do foorthwith fic away (in manner of a moth or Butterflie) vnleffe by the care and diligence of the keepers, they be killed by much and often thaking them togither, as a forefaid.

The tree or fhrub hath his leaues alwaies greene: the Acornes be very late before they be ripe, feldome before new come vp in their place.

$$
* \text { Thenames. }
$$

The Scarlęt Oke is called in Greeke winiros: in Latine Ilex : the later writers Ilex Coccigera, or Coceifera : in Spanifh Co/coia : for want of a fit Englifh name, we haue thought good to chriften it by the name of Scarlet Oke,or Scarlet Holme Oke:for Ilex is named of fome in Englifh Holme, which fignifieth Holly or Huluer. But this Ilex, as well as thole that follow, might be called Holme Oke, Huluer Oke, or Holly Oke, for difference from the hrub or hedge tree Agrifolium, which is fimply called Holme, Holly, and Huluer. 


\section{0}

\section{THE THIRD BOOKE OF THE}

The graine or berrie that ferueth to die with, is properly called in Greeke xóxxos Rapinat: in Latine Coccies infectoria, or Coccum infcitorium : Plinyalfo nameth it Cufculium, or asmoft do read it Quif
quilum; the fame author faith, that it is likewife named Scolecion, or Maggotberrie.

The Arabians and the Apothecaries do acknowledge it by the name of chefmes, Chermes, and Kermes. They are deceiued who thinke that $C$ he /mes doth differ from Infectorium Coccum: it is called in Italian Grano de tinctor $i$ : in Spanifh Grana de tintorer os: in high dutch of cbatlacbbecrtin French Vermillon and Graine d'efcarlate : in Englifh after the Dutch Scarlet Berrie, or Scarlet graine, and after the Apothecaries worde Coccus Baphicus, the Maggot within is that which is named Cutchonele as noft do deemc.

The Acorne or fruite heerof is called of diuers, as Theophr aftus faith, axwurov, Acylum.

$$
\text { * The temperature and vertues. }
$$

A This graine is aftringent, and fome what bitter, and alfo dry without fharpenes and biting:therefore faith Galen it is good for great wounds and finewes that be hurt, if it be laide thereon; fome temper it with vineger; others with Oxymell, or fyrupe of vineger.

B It is commended and giten by the later Phifitions to ftaie the menfes: it is alfo counted among thofe fimples which be cordials and good to ftrengthen the hart. Of this graine that noble and famous confection Nlkermes made by the Arabians, hath taken his name, which many do highly commend againft the infirmities of the hart : notwithitanding it was chiefely deuifed in the begin. ning for purging of melancholy, which thing is plainly declared by the great quantitie of Lapis Lszulus added thereto: and therefore feeing that this ftone hath in it a venemous qualitie, and likewife a propertie topurge melancholie, it cannot of it felfe be good for the hart, but the other things be good, which be therefore added, that they might defende the hart from the hurts of this ftone, and correet the malice thereof.

C This compofition is commended againft the trembling and thaking of the hart, and for fwounings and melancholike paffions, and forrow proceeding of no euident caufe : it is reported to recreate the minde, and to make a man merrie and ioyfull.

D It is therefore good againft melancholicke difeales, vaine imaginations, fighings, greefc and forrowe without manifeft caufe, for that it purgeth away melancholike humours: after this maner it may be comfortable for the hart, and delightfull to the minde, in taking away the materiall caufe of forrow : neither can it otherwife ftrengthen a weake and feeble hart, vnleffe this ftone called $L_{\text {appis }}$ Cyaneus bequite left out.

E Therefore he that is purpofed to vfe this compofition againft beatings and throbbings of the hart and fwounings, and that not as a purging medicine, fhall do well and wifelyby leauing out the ftone Cyaneus: for this being taken in a little waight, or fimall quantitie, cannot purge at all, but may in the meane feafon trouble and torment the ftomacke, and withall thorow his tharpe and venemous qualitie (if it be oftentimes taken) be very offenfiue to the guts and intrails, and by this meanes bring more harme then good.

F Moreouer it is not neceffarie, no nor expedient, that the briftle died with Cochenele called Chefmes,as the Apothecaries tearme it, fhould be added to this compofition: for this briftle is not died without avripigmentum, called alfo Orpiment, and other pernitious things ioined the ewith, whofe poifonfome qualities are added to the iuices, togithes with the colour, if either the briftle or diedfilke be boiled in them.

G The berries of the Cochenele mut be taken by themfelues, which alone are fufficient inough to die the iuices, and to impart vnto them their vertue: neither is ir likewife needfull to boile the raw briftle togither with the graines, as molt Phifitionsthinke: this maybe left out, for it maketh nothing at all for the ftrengthening of the hart.

\section{Of the barren Scarlet Oke. Chap.31.}

* The defcription.

7 He barren Scarlet Oke, or the great Holne Oke, groweth many times to the full height of a tree, fometimes as bigge as the Peare tree, with boughes farre fpreading like the Acorne or common Mafte trees: the timber is firme $\&$ found; the leaues arefet with pric. kles round about the edges, like thofe of the former Scarlet Oke : the leaues when the tree waxech 
olde, haue on them no prickles at all ; but are fomewhat bluntly cut or indented about the edges, greene on the vpperfide, and graie vuderneath: the Acorne ftandeth in a prickley cup, like our conmon Oke Acorne; which when it is ripe, becommeth of a browne colour with a white kernell within, of tafte not vnpleafant: there is founde vpon the branches of this tree, a certaine kinde of long hairie moffe, of the colour of afhes, not vnlike to that of our Englifh Oke.

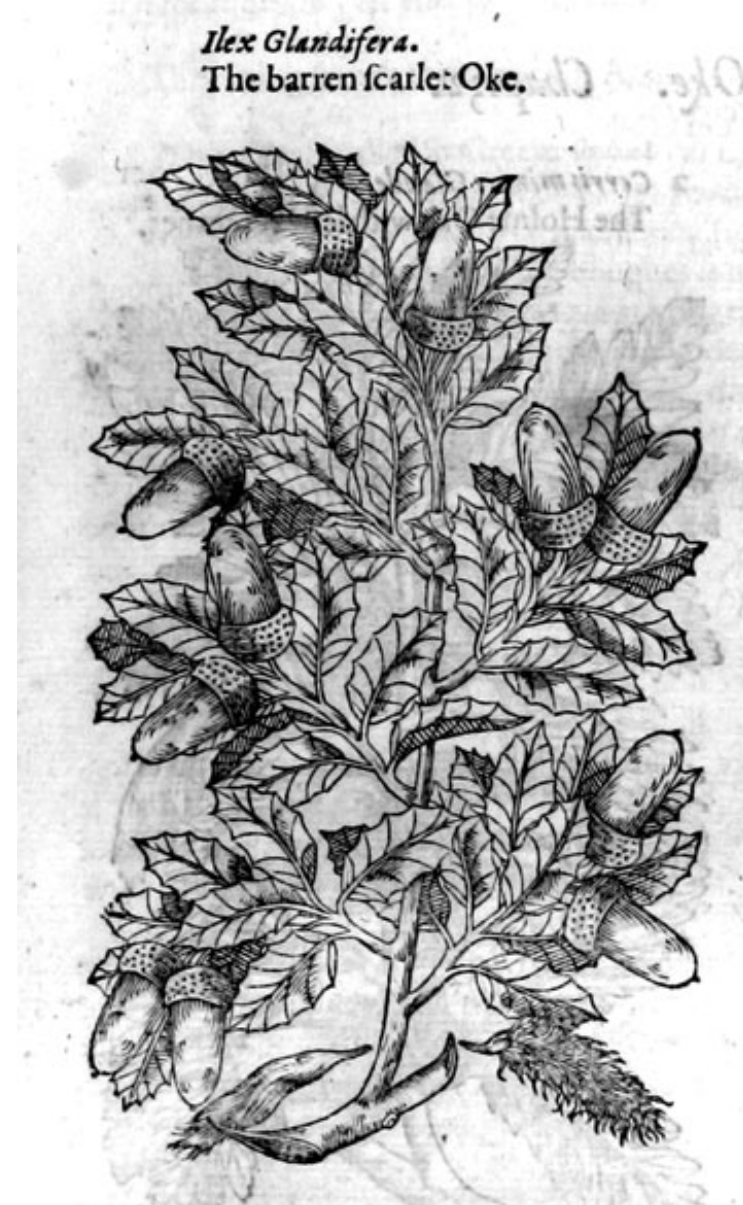

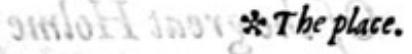

In diuers places there are great woods of thefe trees, hils alfo and valleies beautified therewith; they grow vfually in many kingdomes of Spain : they growe in great plentie in Languedocke and Prouence.

It is likewife founde in Italie: it beareth an Acorne greater, and of a larger fize then doth the tame Oke s, in fome countries leffer and fhorter: they are ftrangers in England; notwithftanding there is heere and there a tree thereof, that hath beene procured from beyonde the feas; one groweth in hir Maiefties garden of White $\mathrm{Hal}$, neer to the gate that leadeth into the ftreete, and in fome other places heere and there one. $* 7$ betime.

It is greene at all times of the yeere: it is late before the Acornes be ripe : Clnfins reporteth that he fawe the flowers growing in clufters, of a yellow colour in the moneth of Maie.

\section{* The names.}

This Oke is named in Greeke rễos: in Latine Ilex: in Spanifh Enzina: in Iralian Elice:in French Chefnewerd: in Englifh Barren fcarlet Oke, or Holme Oke, and alfo of fome French Oke.

The Spaniards call the fruite or Acorne Bellota, or Abillota. Theophraftus feemeth to call this tree not Prinos, but Smilhx, for he maketh mention but of one Ilex only, and that is of fcarlet Oke, and he fheweth that the Arcadians do not cal the other, Ilex, but Smilax; for the name Smila $x$ is of many fignifications: there is Smilax among the pulfes, which is alfocalled Dolichos, and Phafeolus; and Smilax afpera, and Lewis, among the Bundeweedes : likewife Smilax is taken of Diofcurides to be Taxus, the Yew tree; of Smilax Theophraftus writeth thus in his third booke : the inhabitants of Atcadia do call a certain tree Smilax, being like vnto the fcarlet Oke : the leaues thereof be not fet with fuch Tharpe prickles, but tenderer and fofter.

- Of this Smilax Plisie alfo writeth in his I 6.booke 6.chapter. There be of $I l 6 x$ faith he, twokinds, Ex igs in Italia folio non multsum ab olets distant, called of certaine Grecians Smilsces, in the prourhces Lquifolin : in which words in fteede of Oliue trees, may perchance be more truely placed Suberis, or the Corke tree; for this kinde of Jlex or Smilax, is not reported of any of the old writers to haue the leafe of the Oliue tree: but Suber in Greeke called Phellos, or the Corke tree, hath as we haue faide, a little leafe.

\section{* The temperature and vertues.}

The leaues of this Oke haue force to coole and repell or keepe backe, as haue the leaues of the $\mathbf{A}$ Acorns, or Mafte trees: being ftamped or beaten and applied they are good for foft fwellings, and ftrengthen weake members. 
1162

THE THIRD BOOKE OF THE

B Thebarke of the roote boiled in water vntill it bee diffolued and laide on all night, maketh the haire blacke, if they be firft fcoured with Comolia as Diofcorides faith.

C Clufins reporteth that the Acorne is efteemed of, eaten, and brought into the market to be folde, in the citic of Salamanca in Spaine, and in many other places of that countrey: and of this Acorn plinie alfo hath peraduenture written in his 16 .book 5 .chapter, in thefe words; Moreouer there is ferued at mens tables for a fecond courfe all Spaine thorow, an Acorne.

\section{Of the great Holme Oke. Chap.32.}

I Cerrismaiore Glande.

The Holme Oke with great Acornes.

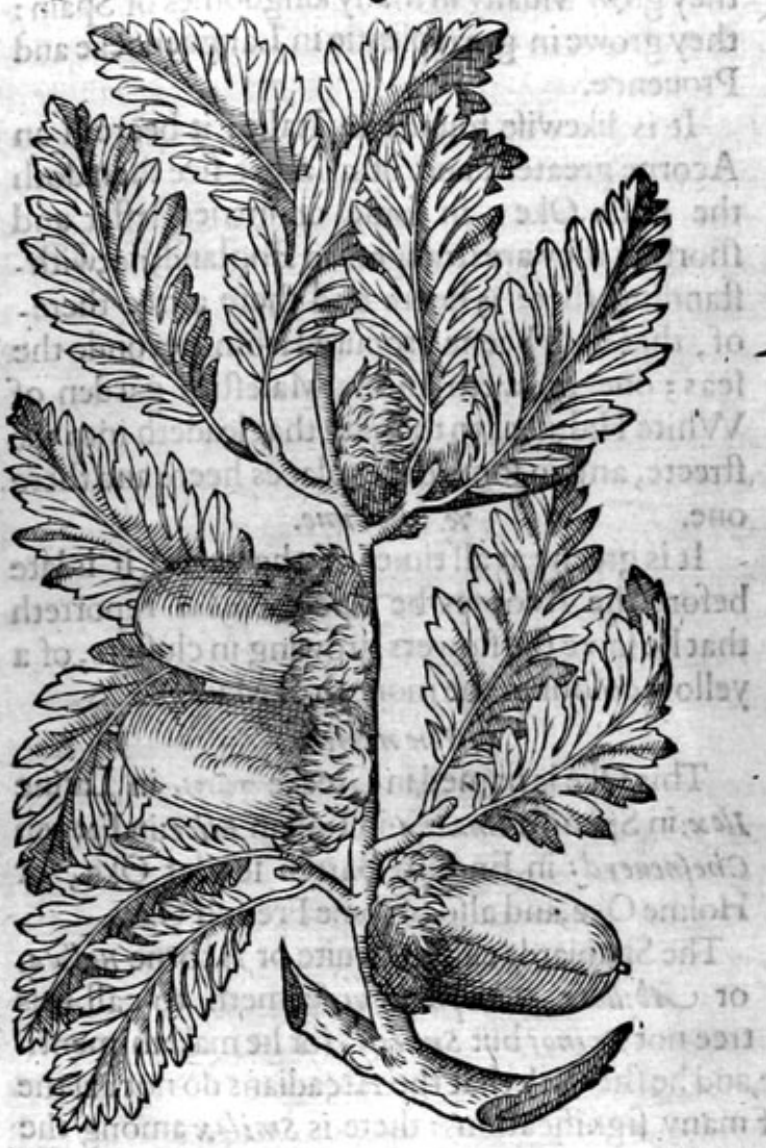

2 Cerris minore Glande.

The Holme Oke with leffer Acornes.
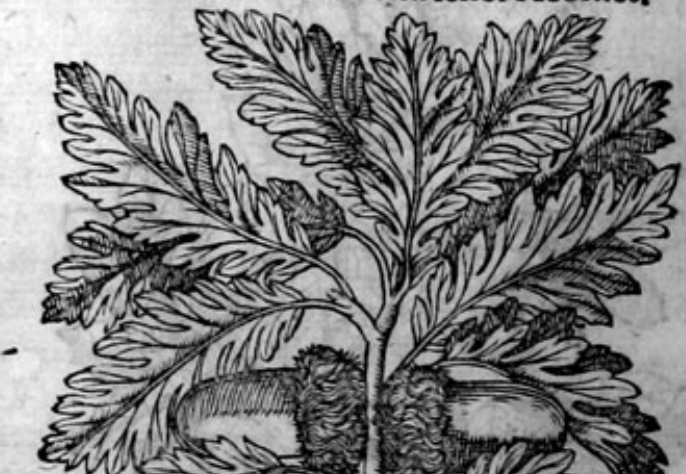
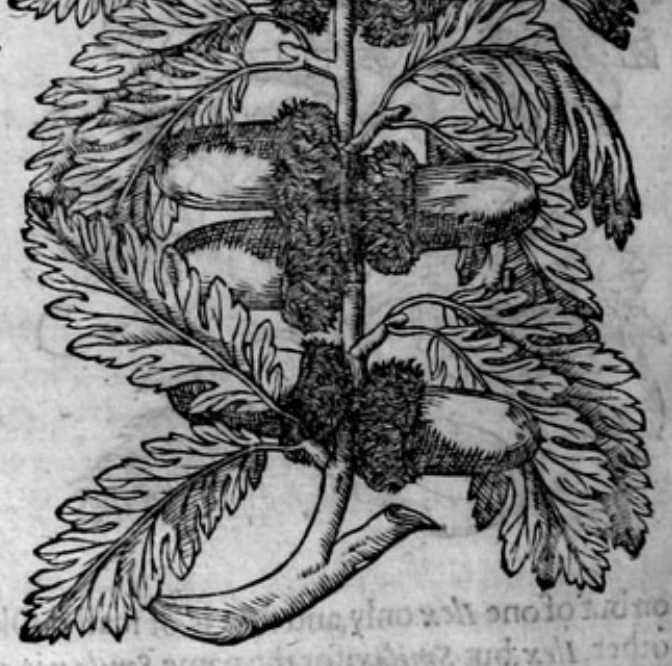

*T The defcription.

I Mong the wilder Okes this is not the leaft, for his comely proportion, although vnprofitable for timber, to make coales, cartes, wainfcot, houfes, or hips of : the fruite is not fit for man or beaft to eat; neither any propertie known for the vle of Phificke or Chirurgerie: it growedh vp to the height of a faire tree : the trunke or bodie is great, and very faire to looke vpon: the wood or timber foft and fpungie, fcarce good to be burned: from which hooteth foorth verie comely branches, difperfing themfelues farre abroad, whereon are fet for the moft part by couples very fare leaucs, greene aboue, and of an ouerworne ruffet colour vnderneath, cut or fnipe about the edges very deepe : the Acorne groweth faft vnto the boughes, without any footeftalke at all, beil: g very great like vnto our common Acorne, fet in a rough and prickly cup like a hedgehogge or the Chefmur huske, of a harfh tafte, and hollow within:this tree beareth or bringeth forth oftentimes a certane fmooth kinde of Gall, altogither vnprofitable: this Oke likewife bringeth 
foorth another kind of excrefcence which the Grauer hath onitted in the figure, which is called in Greeke qodxor, Gaza nameth it Peni; this Penis or pricke is hollow, moffic, hanging downe halfe a yardé long, like a long ragge of linnen cloth.

2 The fecond is altogither like the firft, fauing that this beareth fmaller Acornes, and the whole tree is altogither leffer, wherein confifteth the difference.

This Oke groweth in vntoiled places, it is feldome times found, and that but in woodes onely : it is for the moft part vnknowne in Italy, as Pliny reporteth.

$$
\text { * The trme. }
$$

They bring foorth their fruite or Acornes in the fall of the leafe.

$$
\text { * The names. }
$$

This Oke is called in Greeke kifike : in Latine cerrus: yet doth Plinie make mention both of AEgilops and alfo of Cerrius. A'ritrat is likewife one of the difeafes of corne, called in Latine Festu$c a$, in Englinh wilde Otes, and farre differing from the tree UEg gilops.

That which hangeth from the boughes is named of Plinie in his 16 .booke 8.chapter Fanus onely: that Acorne tree named UA gilops bringeth foorth Panos arentes, withered prickles, couered with white moffie iagges hanging downe, not onely in the barke, but alfo from the boughes, lialfe 2 yarde in bignes, bearing a fweete fmell, as we haue faide among ointments.

We finde nothing written of the faculties of this tree among the old writers:neither of our owne experience.

$$
\text { Of the Cor }\{\text { O Oke. Cbap.33. }
$$

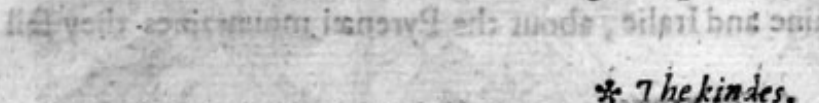

There be diuers forts of the Corke trees, differing according to countrey and climate.

I Suber latifolium.

The Corke tree with broade leaues.

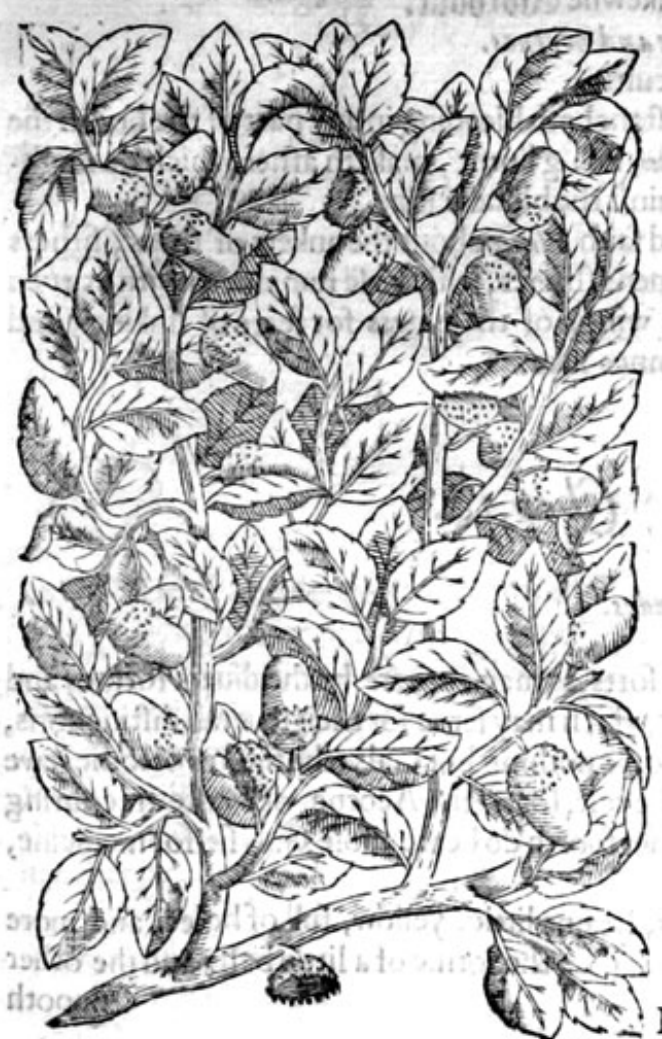

2 Suber angufifolium. The Corke tree with narrow le iues.

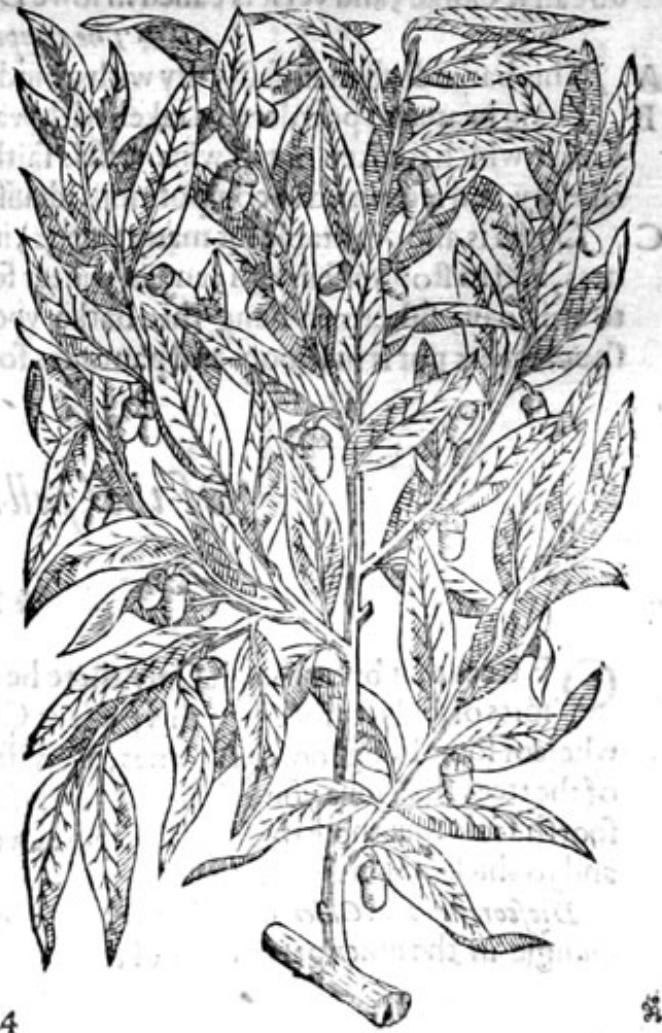

\&.T $T$ e 
* The defcription.

I T He Corke tree is of a middle bignes, like vnto Ilex, or the barren farlet Oke; but with a thicker bodie, and fewer boughes : the leaues be for the moft part greater, broader, roun. der, and more nicked in the edges : the barke of the tree is thicke, very rugged, and full of chinkes or cranies, that cleaueth and diuideth it felfe into peeces, which vnlefle they be taken
away in due time, do giue place to another barke growing vnderneath, which when the old is remooued, is marucllous red, as though it were painted with fome colour : the Acorne ftandeth in a cup which is great, briftled,' rough, and full of prickles; this Acorne is alfo aftringent or binding, more vnpleafant then the holme Acorne, greater in one place, and leffer in another. 2 The Corke tree with narrowe leaues, groweth likewife to the height and bignes of a great tree: colour, which likewife cleaueth and cafteth his coate when the inner barke groweth fomewhat thicke: the branches are long, tough, and flexible, eafie to be bowed any way, like thofe of the Oziar, whereupon do grow leaues like thofe of the precedent, but longer, and little or nothing indented about the edges : the fruite groweth in fmall cups as the Acornes do; they are leffer then thofe of the other kinde,as is the reft of the tree, wherein is the chiefeft difference.

$$
\text { * T he place. }
$$

- It groweth in the countrey of Aquitania, neere to the mountaines called Pyrenai:it alfo groweth plentifully in the kingdomes of Spaine, differing fomwhat from that of Aquitania, as C.Clufius declareth : it is likewife found in Italy, and that in the territory of $F$ ifa, with a longer leafe, and tharper pointed; and about Rome with 2 broader, and cut in the edges like a fawe, and rougher, as Matbiolus teftifieth.

\section{* The time.}

The leaues are alwaies greene in Spaine and Italie, about the Pyrenxi mountaines they fall away in winter.

\section{* The names.}

This tree is called in Greeke pendòs: in Latine Suber : in French Liege : in Italian Sugaro : the fame names do alfo belong to the barke : the Spaniards call the tree Alcurnoque, the Englifh men Corke tree s and the barke Corcha de Alcornogue, whereupon the low countreymen, and Englithmen alfo, docall it Corke; and yer it is called in lowe Dutch likewife Ulotbout.

$$
\text { * The temperature and vertues. }
$$

\section{A This barke doth manifeftly dry with a binding facultie.}

B Being beaten to powder and taken with water, it ftancheth bleeding in any part of the bodie: the Corke which is taken out of wine veffels faith Pauluis, being burnt, maketh afhes which do migh-

C. Corke is alfo profitable for many things; it is vfed faith $P$ linie about the ankers of thips, fifhers nets, and to ftop veffell with; and in winter for womens hooes, which vfe remaineth with vs euen to this day; fifhermen hang this barke vpon the wings of their nets for feare of finking; and Thoomakers put it in fhooes and pantotles for warmnes lake.

\section{Of the Galltree. Chap.34.}

\section{* 7 be kindes.}

$\mathrm{F}$ trees that bring foorth Gals, there be diuers forts, as may appeere by the diuers formes and forts of $\mathrm{Gals}$ fet foorth in this prefent Chapter, which may ferue for their feuerall diftinctions, whereof fome bring foorth Acornes, likewife, and fome nothing but Gals : the figures of fome fewe forth Gals : but thofe trees whofe figures we haue fet foorth do beare thofe Gals fit for medicine, and to thicken skins with.

Diofcorides and Galen make but two forts of Gals, the one little, yellow, full of holes, and more spungie in the inner part: both of them rounde, hauing the forme of a little ball; and the orher 
fmooth and eeuen on the outfide: fince, the later writers haue founde moe, fome hauing certaine little knobs fticking foorth, like in forme to the Gall, which doth alfo cleaue and growe without ftalke to the leafe. There is alfo founde a certaine excrefence of a light greene colour, fpungie, and waterie, in the middle whereof nowe and then is founde a little flie or worme : which fott ball in hot countries, doth many times become harde, like the little finooth Gall, as Theophrast us faith.

I Galla, fue Robur maius. The great Gall tree.

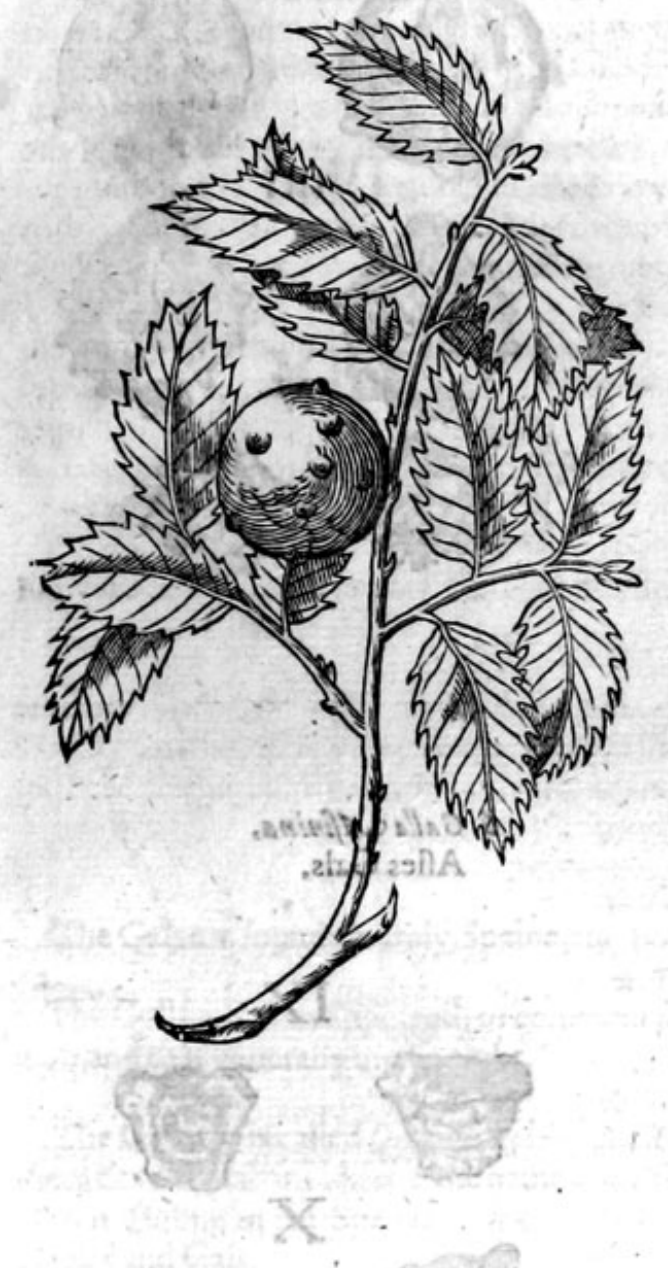

2 Galla minor. The little Gall tree.

\section{* The defcription.}
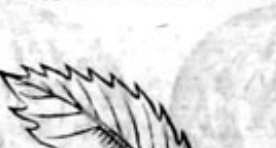
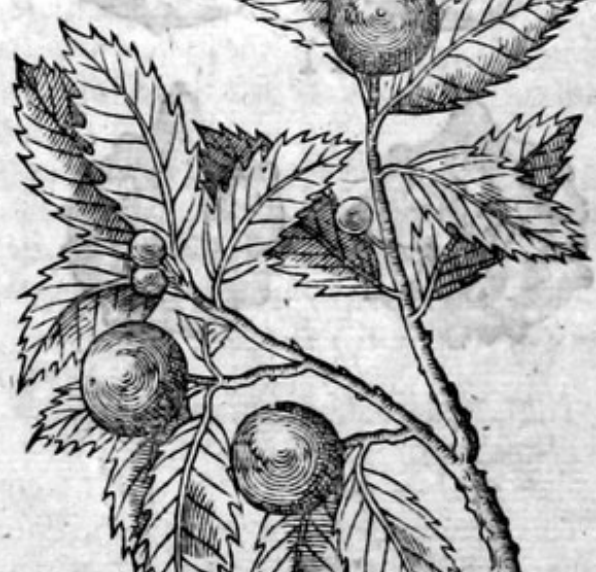
The forme of dimers forts of Gals.

3 Galla orbiculate.

The round Gall.

1

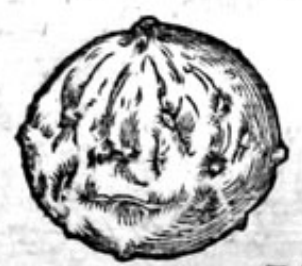

II
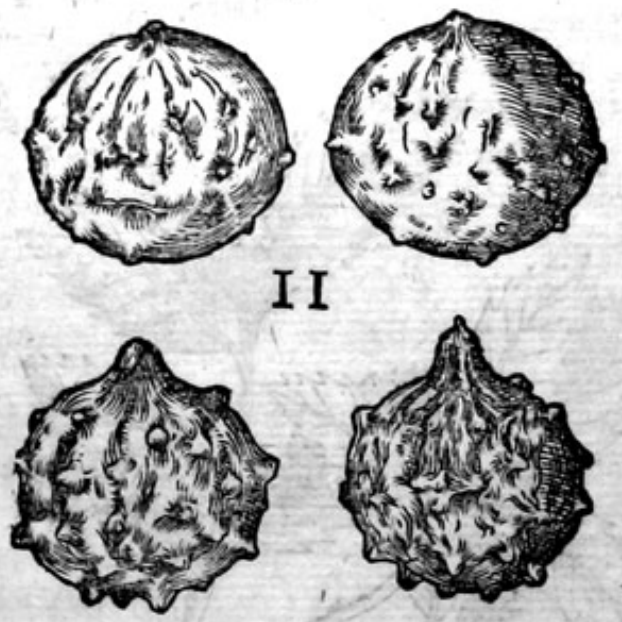

5 Galla viridis, fue omphacitio. Greenc or vnripe Gals.

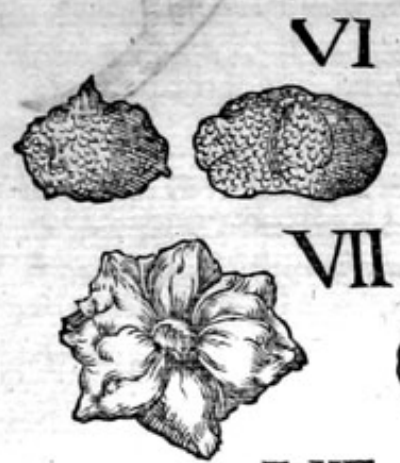

VIII
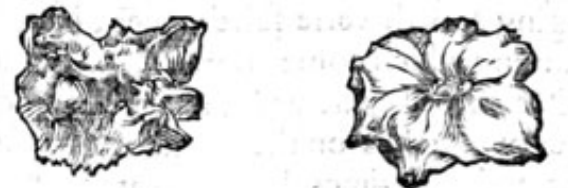

4 Galla oblonga. The long Gall.
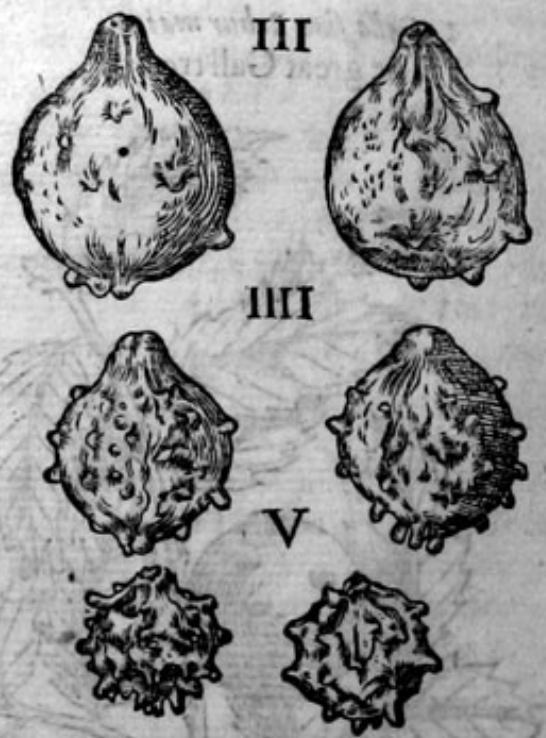

\section{Galla Lfinina. Afies Gals.}

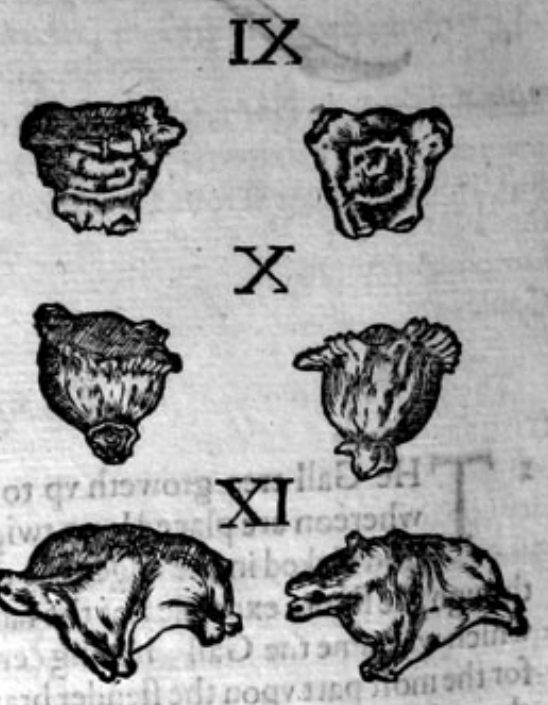

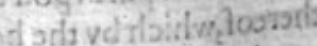

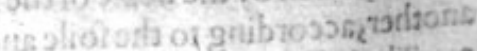

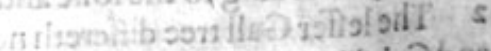

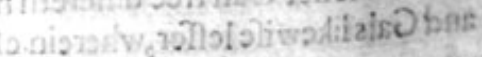




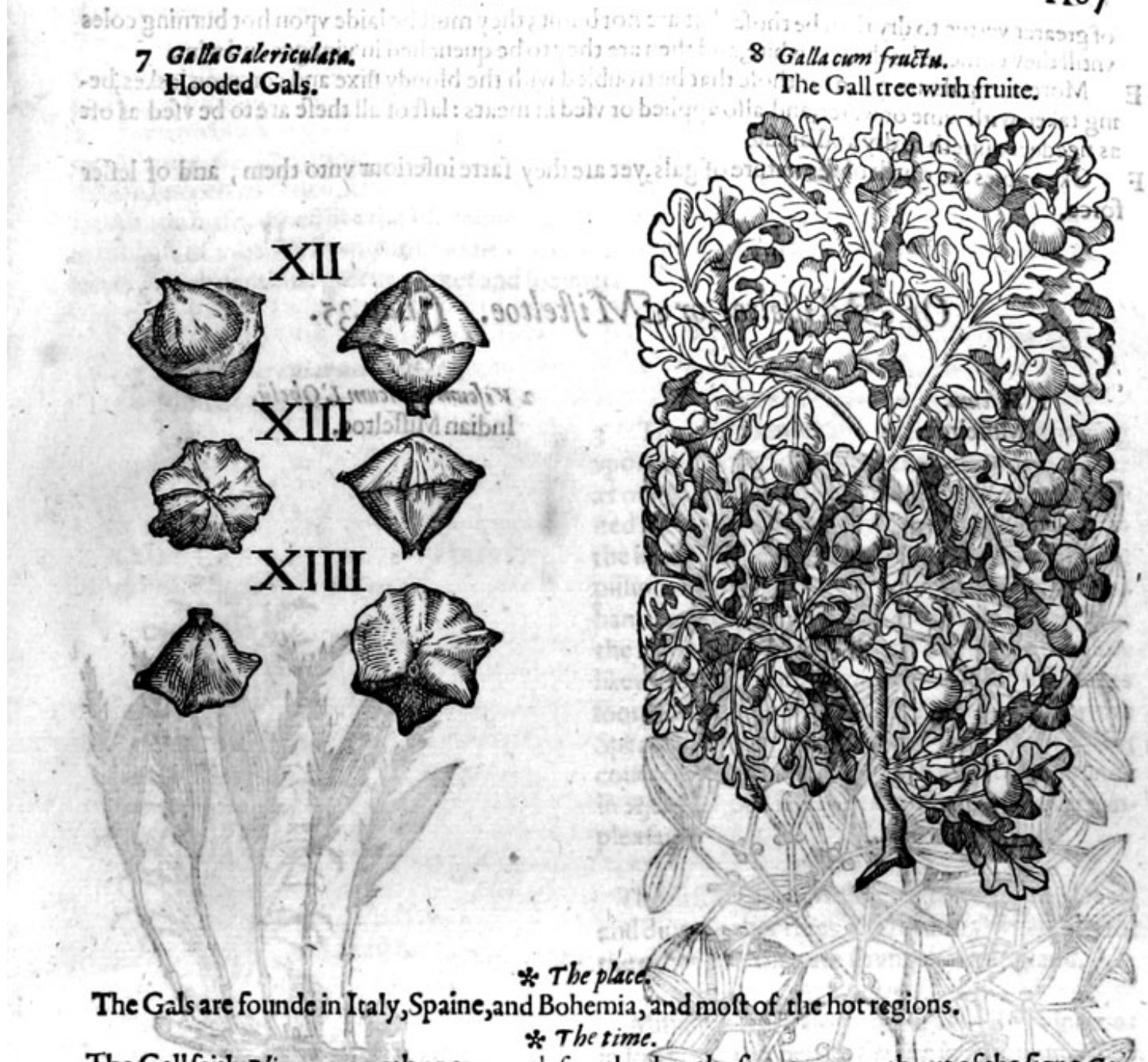

The Gall faith Pliny appeereth or commeth foorth when the funne commeth but of the figne Ge-) mini, and that generally in one night.

The Gall tree is called Quercus, Robur, and Galla arbor: the Gal is called in Greeke knuis: the apothecaries and Italians, keepe the name Galla for the fruite: in high Dutch $\mathbb{E}$ alnpffell : in lowe Dutch Salnaten: in Spanifh Ugalla, Gaiba, and Bugaba: in Fiench Norx de Galle: in Enghth Gaules and Gals.

* The temperature and vertues.

The Gall called Omphacitis, as $G$ alen writeth, is dry in the thirde degree, and colde in the fecond: A it is a very harfh medicine, it faftneth and draweeth bogither faint and flacke parts, as the oterg rowings in the flelh, it repelleth and keeperh backe rheumes and fuch like Huxes, and doth effectla!'y dry yp the Tame, efpecially whon they haue a defcentunto the ganthes sy almonds bf the throte, and other places of the moutht

2. The otker Gaildoth dry and atfo binde; but fomuchteffer, byhowe much the harh orchoking B qualitieus dinminifheds being boiled, beaten, and alfe applied in maner of a plaiter it is laide with good fucceffe vpon the inflammations' of the fundarietit and fallingidowne the reof: it is boiled in water if there be need of little aftrictions and in wine, efpecially in-auftere wine, if more need require:

Gals are very proficable againft the dyfenterie, and the Coeliacke paffion being drunk in winejor $\mathrm{C}$ the powder thereof ftrowed vpon meates.

Gals are vfed in dying and colouring of fundrie things, and in making of inke.

Laft of all burnt $G$ als do receiue a further facultic to ftanch bloud, and are of thinne parts, and $E$ 


\section{THE THIRD BOOKE OF THE}

of greater vertue to dry then be thofe that are not burnt; they muft be laide vpon hot burning coles vntill they come to be thorow white, and then are they to be quenched in vineger and wine,

E Moreouer gals are good for thofe that be troubled with the bloudy fixe and commonlaskes, being taken with wine or water, and alfo applied or vfed in meats : laft of all thefe are to be vfed as oft as neede requireth to dry and binde.

F Oke

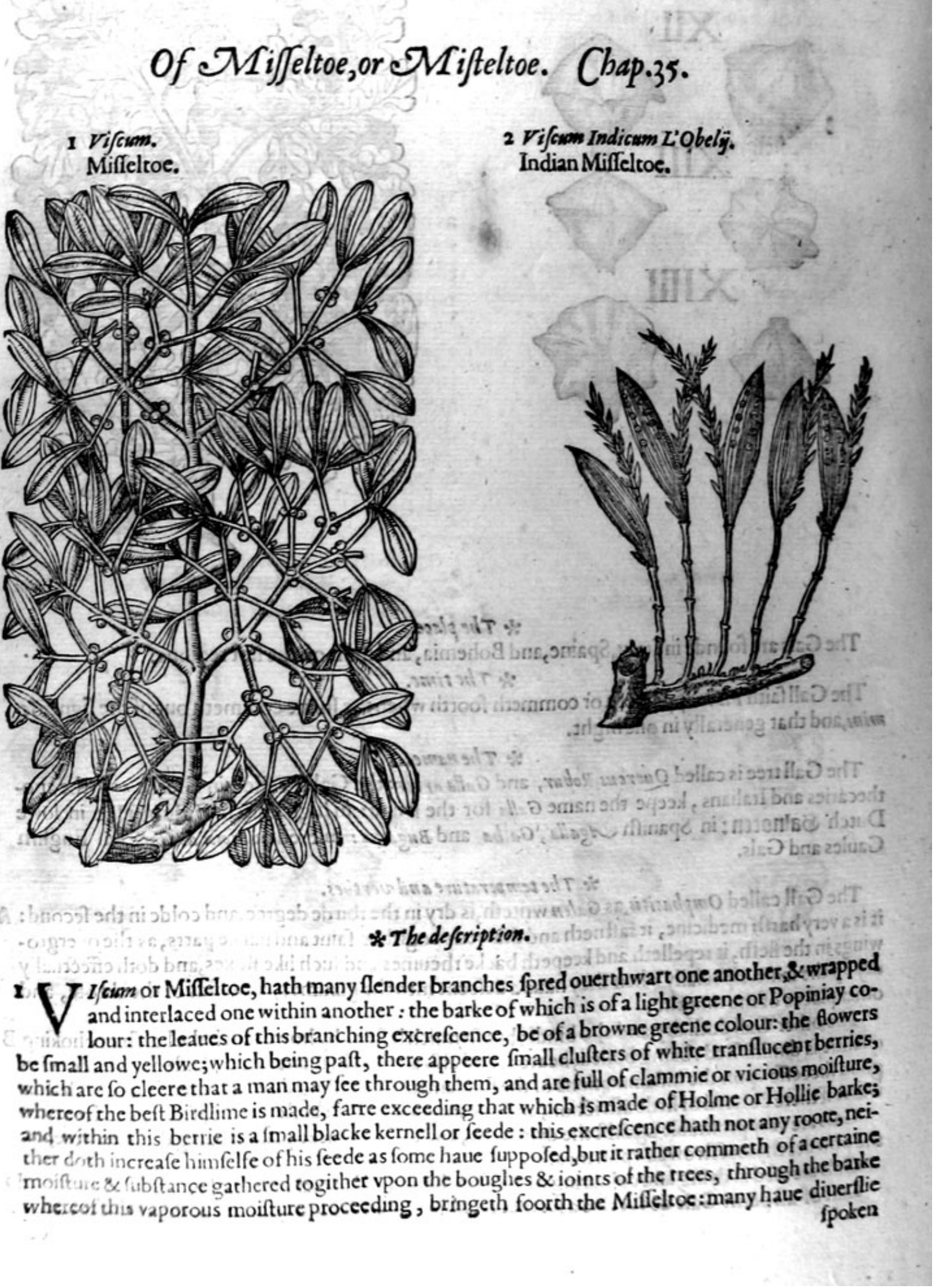




\section{HISTORIE OF PLANTS.}

fpoken heereof; fome of the learned haue fet downe that it came of the dung of the birde called a Thrufh, who hauing fedde of the feedes thereof, as eating his owne bane, hath voided and left his dung vpon the tree, whereof was ingendred this berry, a moft fit matter to make Lime of to intrap and catch birds withall,

2 Indian Miffeltoe groweth likewife vpon the branches of trees, running alongft the fame in maner of Polypodie : the itrings of the rootes are like thofe of Couch graffe from which rife vp divers ftalkes, finooth and euen, fet with ioints and knees it certaine diftances : towarde the top commeth foorth one leafe, ribbed like the Plantaine leafe, whereon áre marked certaine round eies, fuch as are in the haft of a knife; from the bofome whereof commeth foorth a chaffie branch, fet with frmall leaues, which continue greene winter and fommer.

$3 \mathrm{Vijcum}$ Perwaianum L'Obelij. Miffeltoe of Peru.

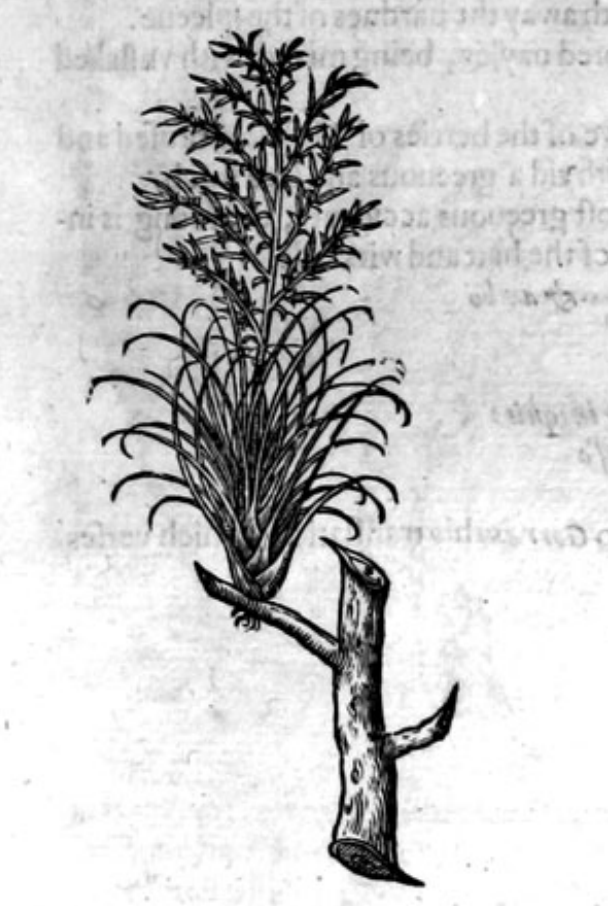

glifh Miffell,and Miffeltoe.

The glue which is made of the berries of Miffell, is likewife called Vifsum and Ixia: in Englifh Birdlime.Ixia is alfo called Chameleon albus, by reafon of the glue which is oftentimes found about the rootes there of. This word is alfo afcribed to Chamaleon niger, as we reade among the baftarde names. Ixia is likewife reckoned vp in Diofcorides 6.booke, and in Paulus AEgineta his 5. booke among the poifons; but what this poifonfome and venemous $I x i a$ is, it is hard and doubtfull to declare; many would haue it to be Chamaleon niger; others the glue or clammie fubftance which is made of the berries of Mifieltoc, who do truely thinke that Ixia differeth from Chanseleon niger: for Paulus AEgineta in reckoning vp of fimple poifons in his 5 . booke, 30 .chapter, hath firft mace mention of Chamaleon niger, then a little after of $I x i a$ : and whilet he doth particularly difcourfe of euery one, he intreateth of Chameleon niger, in his 32 .chapter, and of Ixia, which he alfo nameth $V$ lophonon in his 47.chap. and telleth of the dangerous and farre differing accidents of them both. 


\section{II70 THE THIRD BOOKE OF THE}

And Diofcorides himfelfe in bis 6 . booke where he fetteth downe his iudgement of Simple poyfons, intreateth firft of Chameleon niger, and then a little after of Ixia; yeo hath he written a feuerall difcourfe of Ixit. Thefe things declare that Chamaleon niger doth differ frö Ixia, which is reckoned among the poifons. Morcouer, it can no where be read that Chameleon niger doth beare Miffeltoe birdlime, or hath fo glutinous and clammie a fubltance, as that it ought to be called Ixias. Therfore Ixis as it is one of the poifons, is the glue that is made of the berries of Miffeltoe, which
bicaufe it is fharpe or biting, inflamethand fetteth the toongon fire, and with his flimie and clam-
mic fubftance, doth fo drawe togither, fhut and glue ypthe gurs, as thathere mie fubftance, doth fo drawe togither, thut and glue $v p$ the guts, as that there is no paffage for the excrements, which things are mentioned among the mifchiefes that $2 x i a b r i n g e t h$.

\section{* The temperature and vertues.}

A The leaues and berries of Miffeltoe, are hot and drie and of fubtill parts: the Birdlime is hot and biting, and confifteth of an airie and waterie fubftance, with fome earthie quality: for according to the iudgement of $G$ alen, his acrimonie ouercommeth his bitternes; for if it be vfed in outward applications, it draweth humours from the deepeft or moft fecretparts of the body, fpreading and di-
fperfing them abroad, and digefting them. B It ripeneth fwellings in the groine, hard fwellings behinde the eares, and other impoftumes, be-
ing tempered with Rofin, and a little quantitic of waxe.

C With Frankenfence it mollifieth old vlcers, \& malicious importumes, being boiled with vnflaked lime, or with Gagate lapide, or Afio, and applied, it wafteth away the hardnes of the fpleene.

D With Orpmentor Sandraca, it taketh away foule ilfauored nayles, being mixed with vnflaked lime and wine lees, it receiucth greater force.

E It hath beene moft crediblie reportedvnto me, that a fewe of the berries of Miffeltoe brufed and ftrained into oile and drunken, hath prefently and foorthwith rid a greeuous and fore ftitch.

F This Birdlime inwardly taken is mortall, and bringeth moft greeuous accidents, the toong is inflamed and fwolne, the minde is diftraughted, the ftrength of the hart and wits faile.

\section{In caso obftructi conniuent ventremeatus \\ Pot us at que cibi. flatus vbi carcere claufi \\ Dant ftrepitum, of circum $/ p a c y$ s voluuntur iniquis: \\ Sic mifere affluct us vix tandem ducere pre]/o \\ Ore poteft animam.}

As Nicander writeth in his counterpoifons, according to Gorr ess his tranflation, which verfes we haue Englifhed thus :

Both waies of meate and eke of drinke

Obftructed are: when winde

In guts inclofed or rumbling makes

Can no paflage finde:

So that the patient apaide

And pintch with greefe and paine

Can hardly feed on breath that doth

The life and health maintaine.

\section{Of the Cedar tree. Chap.36.}

$*$ The kindes.

$T_{1}$ Here be two Cedars, one great bearing cones, the other fmall bearing berries like thofe of Iuniper. \& The defcription.

He great Cedar is a very bigge and high tree, not onely excelling all other refinous trees,and thofe which beare fruit like vnto it, but in his tallenes and largenes, farre furmounting al other trees : the body or trunke thereof is commonly of a mighty bignes, infomuch as fower men are not able to fadome it, as Thcophraft us writeth:the barke of the lower parts, which proceedech out of the earth, to the firft yoong branches or fhootes, is rough and harfh, the reft which is among the boughes is fmooth and glib: the boughes grow foorth almoft from the bottom, and not farre from the ground, euen to the very top, waxing by degrees leffer and fhorter ftill as they grow higher, the treebearing the fhape and forme of a pyramid, or fharpe pointed fteeple; thefe compaffe the bodie 
round about in maner of a circle, and are fo orderly placed by degrees, as that a man may clinbe vp by them to the very top as by aladder : the leaues be fmall and rounde, like thofe of the Pine tree, but fhorter and not fharpe pointed, all the cones or clogs are farrefhorter, and thicker then ehofe of the Firre trec, compact of foft, not harde fcales, which hang not downwards, but ftanrie vpright vpon the boughes: whereunto alfothey are foftrongly faftned, as they can harelly be plucked off without breaking of fome part of the branches, as Bettunius writeth : the timber is extreame barde, and rotteth not, nor waxeth olde; there is no woormes nor rottennes can hurt or take the hard natter or hart of this woode, which is very odoriferous, and fortewhat red: Salominking of the Iewe's did therefore builde Gods Temple in lerufalem, of Cedar woode : the Gentils were woont to riake their diuels, or image s of this kinde of wood, that they might lait the longer. sils os: Cedrus Libani.

The great Cedar tree of Libanuis.

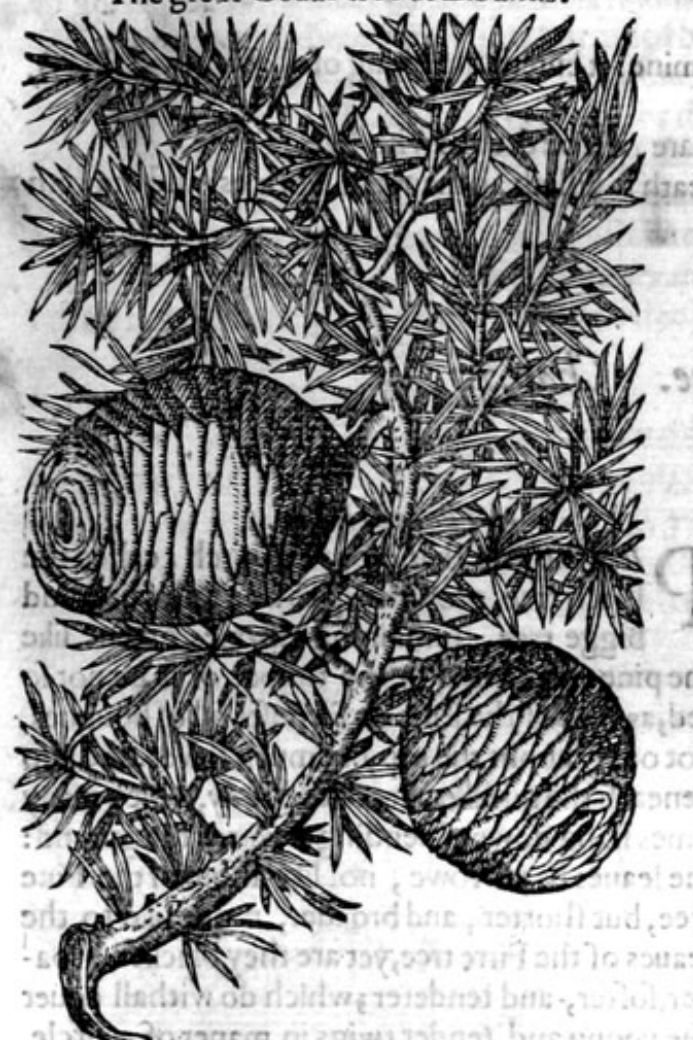

The C Theplace. The Cedar trees grow vpon the fnowie moun: trines, as in Syria on mount Libanus, on which there remaine fome euen to this day, faith Bellonims planted as it is thought by Salomon himfelfe: they are likewife found on the mouritains Tasriw, and $A$ manus, in colde and ftonie places: the Merchants of the Factorie at Tripolis, tolde me that the Cedar tree groweth vpon the declining of the mountaine Libanus neere vnto the Hermitage by the citie Tripolis in Syria: they that dwel in Syria vfe to make boates thereof for want of the Pine tree.

$$
\text { * Thetime. }
$$

The Cedar tree remaineth alwaies greene as other trees, which beare fuch maner of fruite : the timber of the Cedar tree, and the images and other workes made thereof, feeme to fweate and fend foorth moifture, in moift and rainy weather, 25 do likewife all that haue an oilie iuice, the author is Theophraftus.

* The names.

This huge and mightie tree is called in Greeke wisess: in Latine likewile Cedrus: in Englifh Cedar, and Cedre tree. Pling in his 24 booke 5.chapter nameth it Cedrelate, as though hefhould fay, Cedrus abies, or Cedirma abics, Cedar Firre, both that it may differ from the little Cedar, and alfo bicaufe it is very like to the Furre tree.

The Rofin hath no proper name, but it may be furnamed cedrina, or Cedar Rofin.

The Pitch whichis drawne out of this is properly called xider, yet $P$ ling writeth that alfo the liquor of the Torch Pine is named Cedrinem. The beit faith Diofcoides is fat, thorowe fhining; of $\mathbf{a}$ ftrong fnel, which being powred out in drops vniteth it felfe togither, \& doth not remaine feuered. * The temperature and vertues.

Cedar is of tempcrature hot and dry, with fuch an exquifite tenuitie, and fubtiltie of parts, that it $\boldsymbol{A}$ feemeth to be hot and dry in the fourth degree, efpecially the Pitch cr Rofin thereof.

There iffueth out of this tree a Rofin like vnto that, whichiffueth out of the Firre tree, very fiveete B in fmell, of a clammy or cleauing fubftance, the which if you chew in your teeth, it will hardlybe gotten foorth againe, it cleaueth fo faft; at the firft is liquide and white, but being dried in the fun it waxeth hard:ifit he boiled in the fire an excellent pitch will be made thereof, called Cedar Pitch. The Aegyptians were wont to coffin and embawme their dead in Cedar, and with Cedar pitch, C although they vfed alfo other meanes as Herodot us recordech.

The condited or embawmed body they call in fhops Mumia, but veric vnfitly: for Monia among D the Arabians is that which the Grecians call $P, \iint_{j} /$ Phalton, as appecreth by Aurcen chapter 474 . and out of Serapio chater 393 . 


\section{II72 THE THIRD BOOKEOFTTHE}

G He that interpreted and tranflated Serapio, was the caufe of this errour ${ }_{3}$ who tranflated and inter. preted Mumia, according to his owne fancie, and not atter the fence and meaning of his author serapio, faying that this Mumia is a compofition made of Aloes and Myrrhe mingled togither, with the moifture of mans body.

$\mathrm{H}$ The gum of Cedar is good to be put in medicines for the eies, for being annointed therewith it cleereth the fight, and clenfeth them from the Hawe, and from ltripes.

I Cedar infuled in vineger, and put into the eares, killeth the wormes of the eares, and being $\mathrm{min}$. gled with the decoction of Hyffope, appeafeth the founding, ringing, and hiffing of the eares.

$\mathrm{K}$ If it be wafhed or infufed with vineger, and applied vnto the teeth,it ceafeth the toothach.

I If it be put into the hollowneffe of the teeth, it breaketh them, and appealeth the extreame greefe thereof.

M It preuaileth againft Anginas, and the inflammation of the Tonfils, if a Gargarifme be made thereof.

N It is good to kill hits and lice, and fuch like vermine: it cureth the biting of the ferpent Ceraftes, being laide on with falt.

$O$ : It is a remedie againft the poifon of the fea Hare, if it be drunke with fweete wine.

P It is good alfo for teapers : being put vp vnderneath it killech all maner of wormes, and draweth foorth the birth,2s Dio, corides writeth.

\section{Of the Pitch tree. Chap. 37}

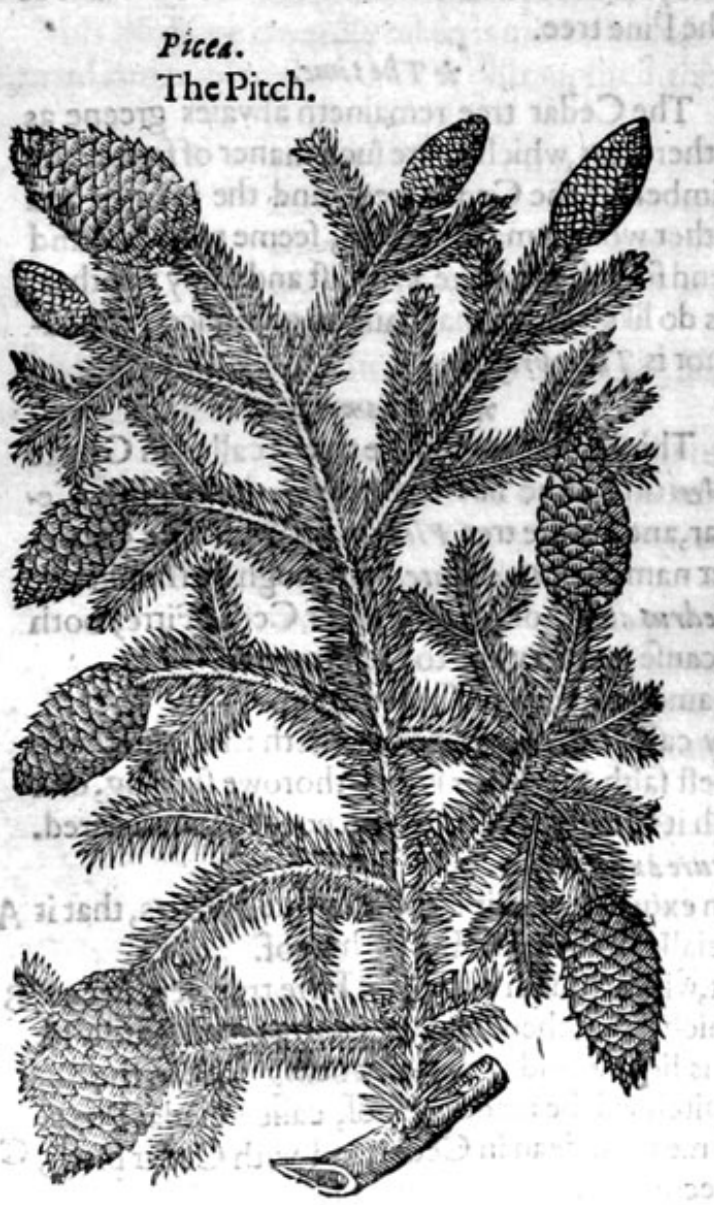

* The defoription.

D Icea the tree that droppeth pitch, called the Pitch tree, groweth vp to be a tall, faire, and

bigge tree, remaining alwaies greene like the pine tree, though the timber of it be not fo red,as that of the Pine or Firre; fet ful of boughes, not onely about the top, but much lower, and alfo beneath the middle part of the body, which many times hang downe, bending towards the ground: the leaues be narrowe, not like thofe of the Pine tree, but fhorter, and broader, more like to the leaues of the Firre tree, yet are they blacker, brozder,fofter, and tenderer; which do withall couer the yoong and tender twigs in maner of a circle, like thofe of the Firre tree, but being manie and thicke fer, growe foorth of two fides, onely one right againit another, as in the Yew tree, to whofe leaues they are very like: the fruite is fcaly and like vnto the Pine apple, but fmaller : the barke of the tree is fomewhat blacke, tough, and fixible, not brickle, as is the barke of the Firre tree, vnder which next to the woode is gathered a Rofen, which many times iffueth foorth, and is like to that of the Larch tree.

* Theplace.

The Pitch tree groweth in Greece, Italy, France, Germanie, and all the colde region's etien vito Ruffia.

$*$ The time.
The fruite of the Pitch tree is ripe in the end of September. * The 
The Grecians call this Cone tree rinus : the Latines Picea, and not Pinus: for $P$ inus or the Pine tree is the Grecians mu'xì, as fhall be declared: that afrus is named in Latine Picea, Scribonius Largus teftifieth in his 201 .compofition writing after this nianer: Refine Petuine, id eff, ex Picea arbore, which fignifieth in Englifh of the Rofen of the tree Pitys, that is to fay, of the Pitch tree. With him doth Pliny agree in his 16 . booke 10.chapter, wherc he tranllating Theophraft $u$ his wordes concerning Peuce and $P$ itys, doth tranflate $P$ itys Picea, although for Peuce he hath written Larix, as fhall be declared. Pliny writech thus, Larix vf tis radicibies non repullalat: and the Larch tree doth not fpring vp againe when the rootes are burnt: the Pitch tree fpringeth vp againe; as it hapned in Lesbos when the wood Pyrtheses was fet on fire. Moreouer, the wormes Pityocamp.e, are fcarce found in any tree but onely in the Pitch tree, as Bellonius teftifieth:fo that they are not rafhly called Pityocampa, or the wormes of the Pitch trees, although moft tranflators name them Pinorum eruce, or the wormes of the Pine trees : and therefore Pitys is furnamed by $T$ heophraft us operetrous, bicaufe wormes and magots are bred in it. But for fo much as the name $P$ itys is common both to the tame Pine and alfo to the Pitch tree ; diuers of the later writers do for this caufe fuppofe, that the Pitch tree is named by

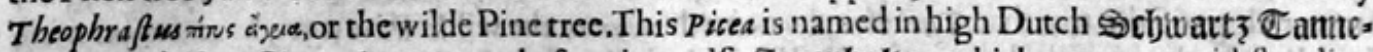
baum, and 1Rot Tanuebaum: and oftentimes alfo \$ozentboltz, which name notwithit anding doth alfo agree with other plants : in Englifh Pitch tree : in low Dutch joeck boom.

$$
\text { *. The temperature and veriues. }
$$

The leaues, barke, and fruite of the Pitch tree, are all of one nature, vertue, and operation, and of thefame facultie with the Pine trees.

\section{Of the Pine tree. Chap. 38. \\ * The kindes.}

THe Pine tree is of two forts, according to Theophraftws; the one rimees, that is to faie, tame or of the garden; the other ajele, or wilde: he faith that the Macedonians do adde a thirde, which is axapros, or barren, or without fruite, that vnto vs is vnknowne : the later writers hatie founde moe, as thall be declared.

Pinus fatiua, fine domeffica.

The tame, or manured Pine tree.

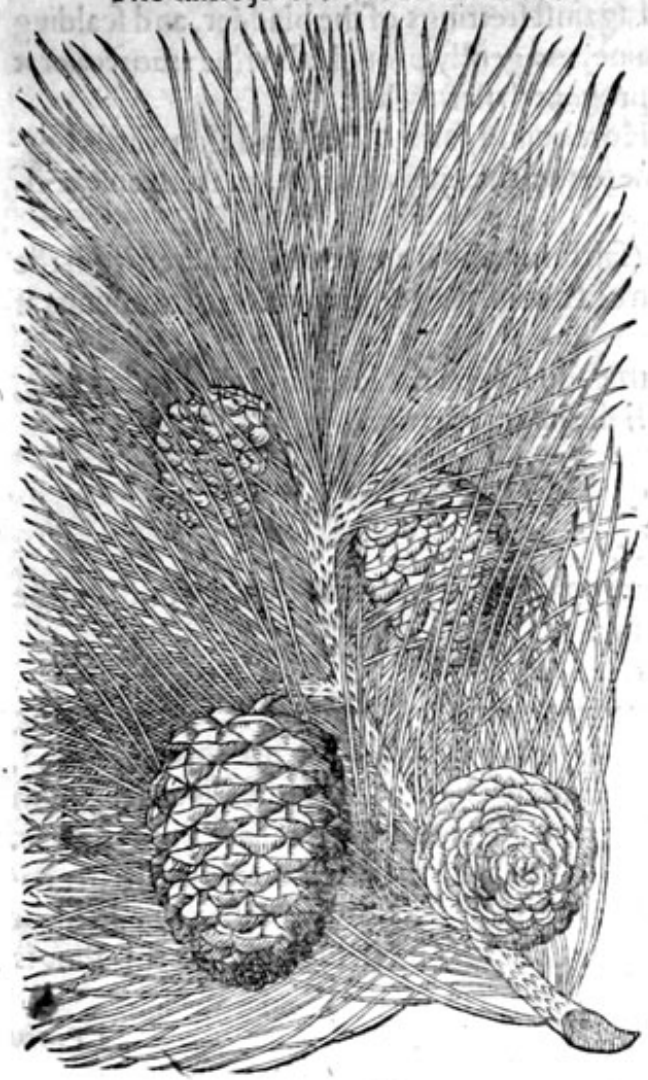

\section{*The defcription.}

$T$ He Pine tree groweth high, and great in the trunke or body, which below is naked, but aboue it is clad with a multitude of boughes, which diuide themfelues into diuers branches, whereon are fet fmal leaues, very ftraight, narrow, fomewhat hard and fharpe pointed: the wood or timber is harde, heauie, about the hart or middle full of an oileous liquor, and of a reddifh colour. The fruite orclogs are hard, great, and confift of many found woodie fcales, vnder which are included certaine knobs, without Thape, coucred with a wooden fhell, like fmall nuts, wherein are white kernels, long, very fweete, and couered with a thin skinne or membrane, that eafely is rubbed off with the fingers, which kernell is vfed in medicine.

$$
\text { * The place. }
$$

This tree groweth of it felfe in manie places of Italic, and elpecially in the territoric of Ratenna, and in Languedocke, about Marfiles, in Spaine, and in other regions, as in the eaft countries: it is alfo cherithed in the gardens of plcalure, as well in the lowe countries as England.

$$
* \text { The time. }
$$

The Pine tree groweth greene both winter and

$$
\mathrm{Cggg} I \text { fommer, }
$$



fommer, the fruite is commonly two yeeres before it be ripe: wherefore it is not to be founde
without ripe fruite, and alfo others as yet very fimall, and not come to ripenes.

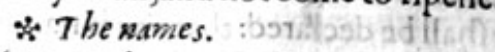

It is called in Latine Pinsus, and F inus fatiua, Vrbana, or ratherclanfueta : in Englifh tame and garden Pine: of the Macedonians and other Grecians mixn nipess: but the Arcadians name it minu, for that which the Macedonians call mexno nipepoy, the Arcadians name sinv, as Theopbraftus faith, and fo doth the tame Pine in Arcadia, and aboutElia change hir name: and by this alteration of them it hapneth that the fruitc or nuts of the Pine tree found in the Cones or apples, be named in Greek by Diofcorides, Galen, Paule and others muidss, as though they fhoulde terme it Pityos fructus, or the
fruite of the Pine tree.

There is alfo another mins: in Latine Picea, or the Pitch tree, which differeth much from the Pine tree : but Pitys of Arcadia differeth nothing from the Pine tree as we have faide.

The fruite or apples of thefe be called in Greekerôver: and in Latine Coni : notwithftanding Co:nos is a cómon name to all the fruits of this kind of trees: they be alfo named in Latine 2 uces pinee: by Mnefitheus in Greeke sseaxids, by Diocles Caryftius, mrivira xipua, which be notwithitanding the fruit or clogs of the tree that Theophraftses nameth mixn or the wilde Pine tree, as Atheneus faith. It is thought that the whole fruite is called by Galen in his fourth Commentarie vpon Hippocrates bookes of Diet in tharpe difeafes, Strobilos: yet in his feconde booke of the Faculties of Nourifhments, he doth not cal Conos or the apple by the name of Strobilos, but the nuts contained in it. And in like maner in his 7 . book of the faculties of Simple medicines; the Pine apple fruit, faith he, which they call Coccalus, and Strobilus, as we haue faid before, that thefe are named in Greeke mnists. This

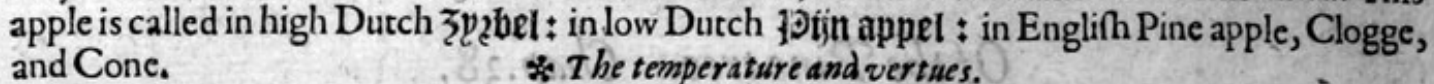

*. The temperature and vertues.

A. The kernels of thefe nuts doe concoct and moderately heate, being in a meane betweene colde and hot: it maketh the rough parts fmooth; it is a remedy againit an old cough, and long infirmities of the cheft, being taken by it felfe or with hony, or elfe with fome other licking thing.

B It cureth the Phtifike, and thofe that pine and confume away through the rottenneffe of their lungs : it recouereth ftrength; it nourifheth and is reftoratiue to the bodie.

C It yeeldeth a thicke and good iuice, and nourifheth much,yet is it not altogither eafie of digeftion, and therefore it is mixed with preferues, or boiled with fugar.

D The fame is good for the ftone in the kidneies, and againft frettings of the bladder, and $\mathrm{fcalding}$ of the vrine, for it alaieth the fharpnes, mittigateth paine, and gently prouoketh vrine : moreouer it increaferh both milke and feede, and therefore it alfo prouoketh fefhly luft.

E The whole Cone or apple being boiled with frefh Horehound, faith Gales, and afterwards boyled againe with a little hony till the decoction be come to the thicknes of hony, maketh an excellent medicine for the clenfing of the cheft and lungs.

F The like thing hath Diofcorides, the whole Cones (faith he)which are riewly gathered from the trees, broken and boiled in fweete wine are good for an old cough, and confumption of the lungs, if a good draught of that liquor be drunke euery day.

G The fcales of the Pine apple, with the barke of the tree, do ftoppe the laske and the bloudy flixe, they prouoke vrine, and the decoction of the fame hath the like propertie.

\section{Of the wilde Pinetree. Chap.39.}

* $T$ The kindes.

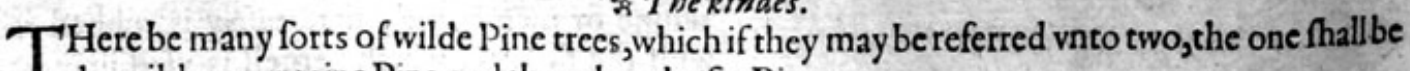
the wilde mountaine Pine, and the other the fea Pine. $*$ The defcription.

17 He firft kinde of wilde Pine tree, groweth very great, but not fo high as the former, being the tame or manured Pine tree; the barke thereof is glib: the branches are fpread abroad, befet with long fharpe pointed leaucs : the fruite is fomewhat like the tame Pine tree, with fome rofin in them, \& fweete of fmell, which doth eafily open it felfe, \& quickly falleth from the tree. 2 The fecond kinde of wilde Pine tree groweth not fo high as the former, neither is the ftem growing ftraight vp, but yet bringeth foorth many branches, long, flender, and fo eafie to be bent or bowed, that heereof they make Hoopes for wine Hoghheads and Tuns: the fruite of this Pine is greater then the fiuite of any of the other wilde Pines. 


\section{HISTORIE OF PLANTS.}

I Pinnesfylueftris.

The wilde Pine tree.

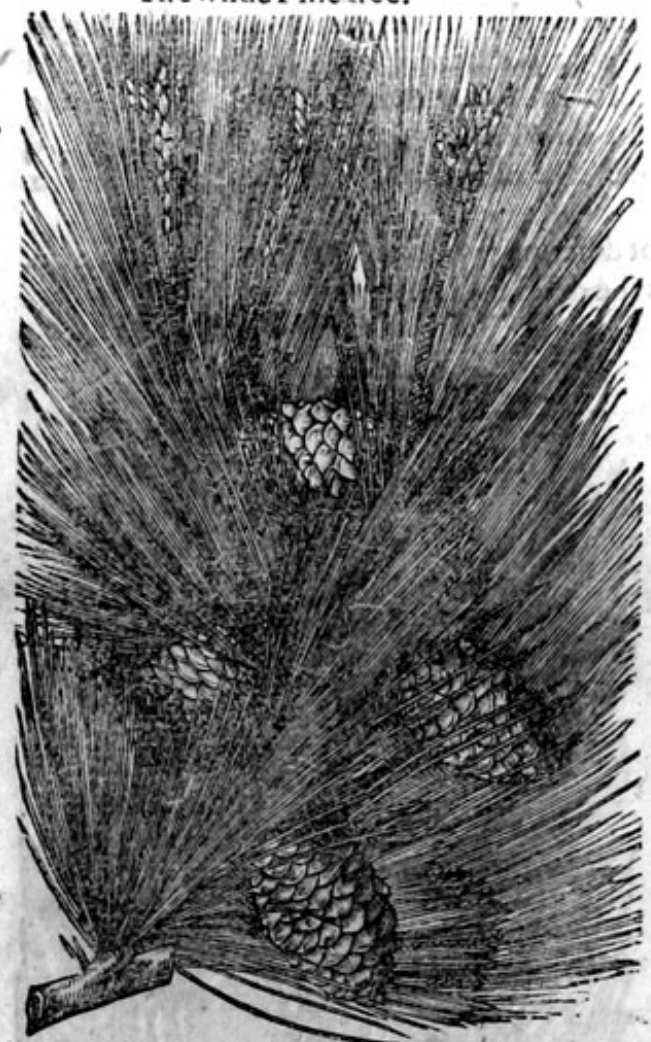

3 Pinus iylueftris montana.

The mountaine wilde Pine tree.

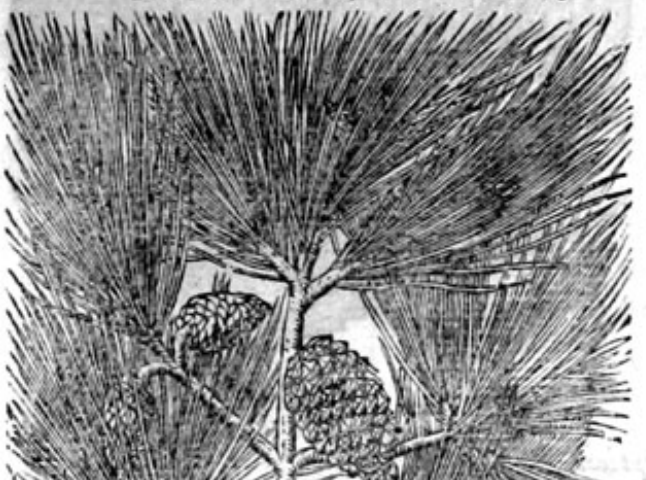

- No

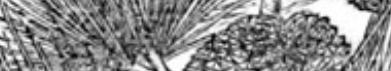

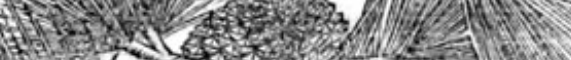

5
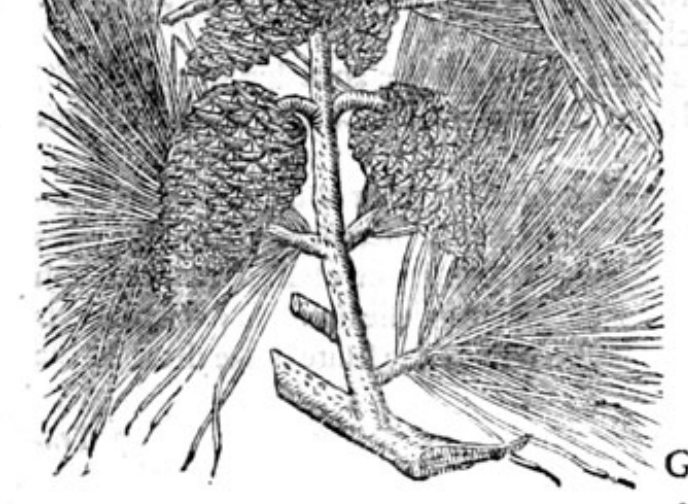

2 Pinus fylueftris mago.

The lowe wilde Pine tree.
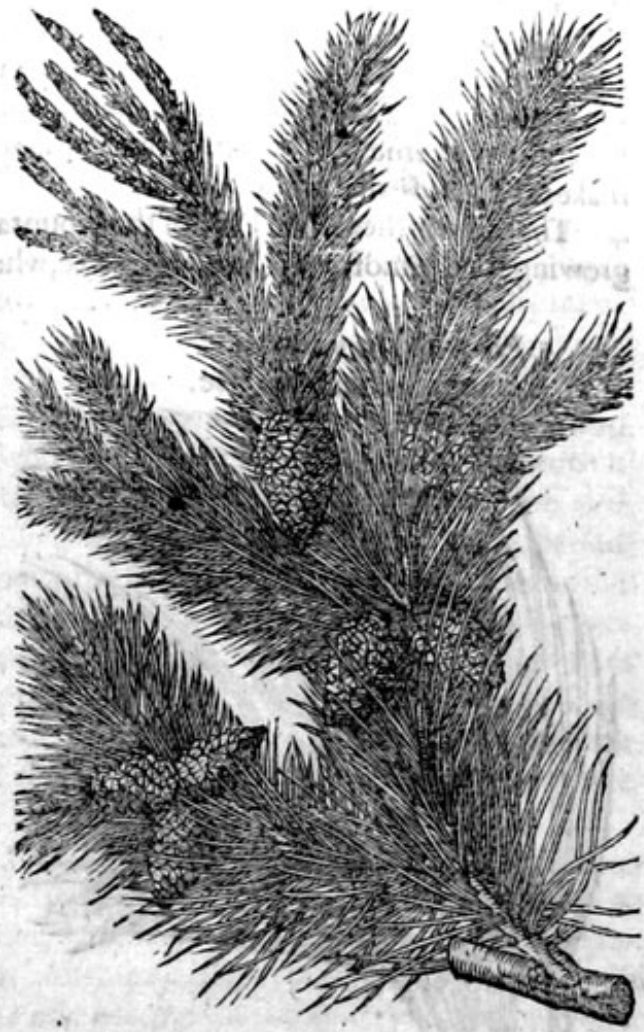

4 Pinus moxtana minor.

The fmaller wilde Pine tree.

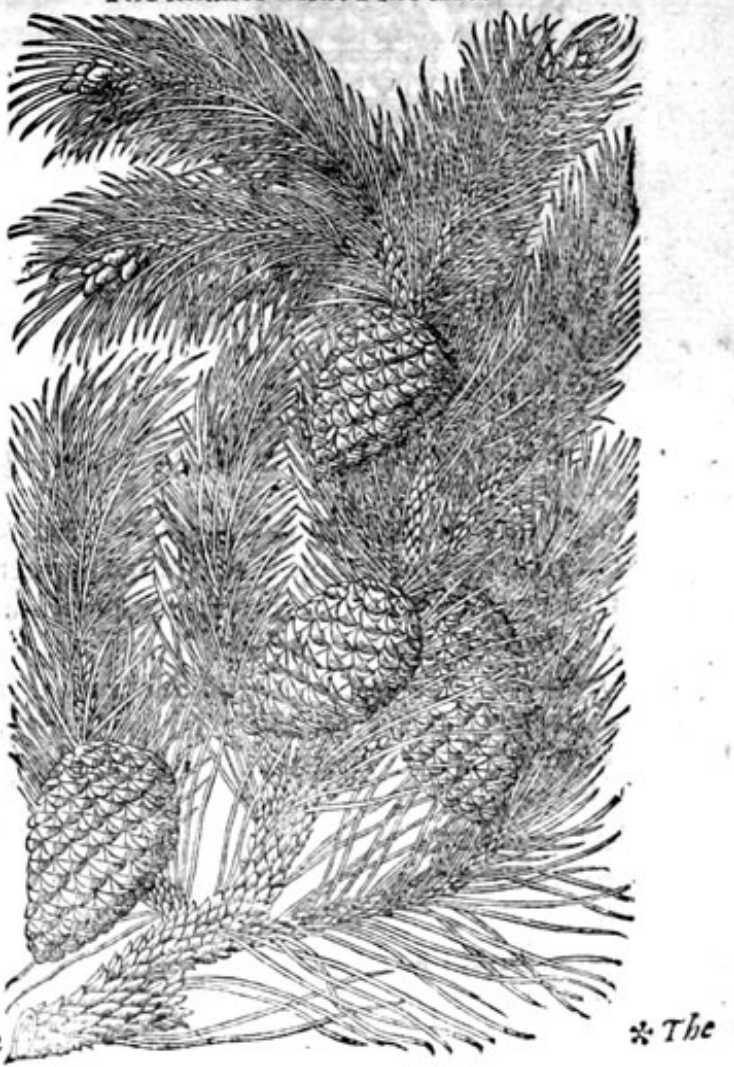




\section{$*$ The defcription.}

3 The thirde kinde of wilde Pine tree, groweth fraight vpright, and waxeth great and high; not fo high as the other wilde kindes : the branches do grow like the pitch tree: the fruit is long and big, almoit like the fruit of the faid Pitch tree; wherein are contained fmall triangled nuts, like the nuts of the Pine apple tree, but fmaller and more brittle; in which is contained a kernell of a good tafte, like the kernell of the tame Pine apple : the woode is beautifull, and fweete of Imell, good to
make tables and other workes of. 4 There is another wilde Pine of the mountainc, not differing from the precedent but in ftature,
growing for the moft part like a hedge tree, wherein is the difference.

5 Pinses maritimamaior.

The great Sea Pine tree.

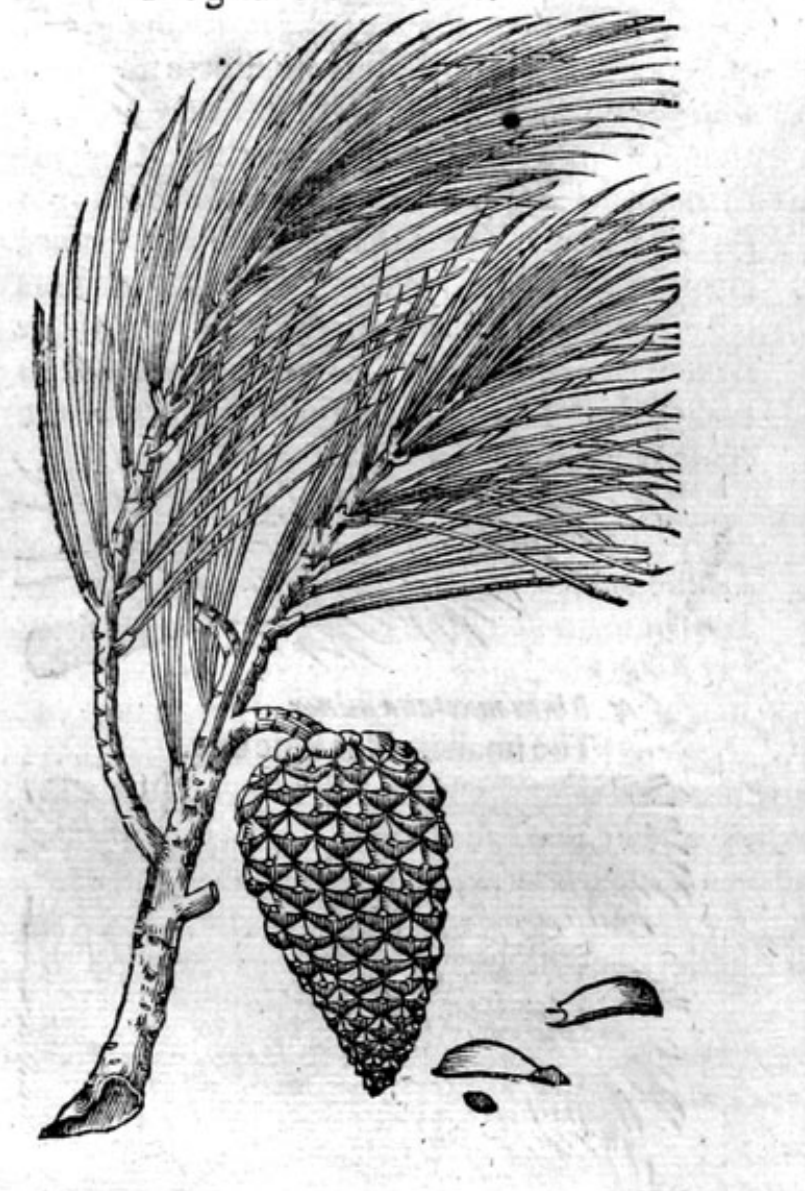

\section{Pinus flueftris minor.} The little Sea Pine tree.

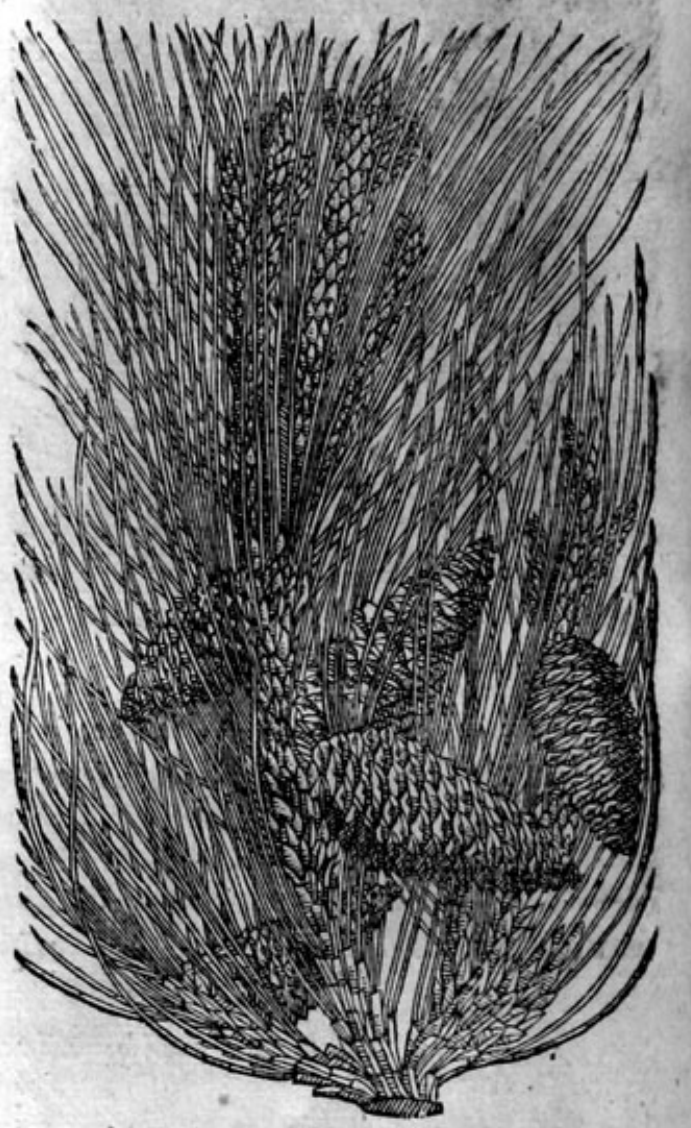

* The defcription.

5 This kinde of Pine called the fea Pine tree, groweth not aboue the height of two men, hauing leates like the tame Pine tree, but Phorter; the fruite is of the fame forme, but longer, fomwhat fafhioned like a Turnep: this tiee yeeldeth very much Rofin.

6 The fixt kinde of wilde Pine being one of the Sea Pines, groweth like an hedge tree or Rrub, feldome exceeding the height of a man; with little leaues like thofe of the Larch tree, but alwaies continuing with a very little cone, and fine fmall kernell.

7 The baftard wilde Pine tree groweth vp to a meane height; the trunke or bodie, as alfo the branches and leaues are like vnto thofe of the manured Pine tree:the onely difference is, that fome yeres it refermbleth the pine it felfe; \& the other yeres as a wild hedge tree,varying often, as nature lifteth to plaie and fport hir felfe amongft hir delights, with other plants of leffe moment: the timber is foft, and not fit for building, but is of the fubftance of our Birch tree: the fruite is like thofe of the other wilde l'ines, whereof this is a kinde. 


\section{HISTORIE OF PLANTS.}

7 Tada, fue p feudopinus.

The baltard wilde Pine.

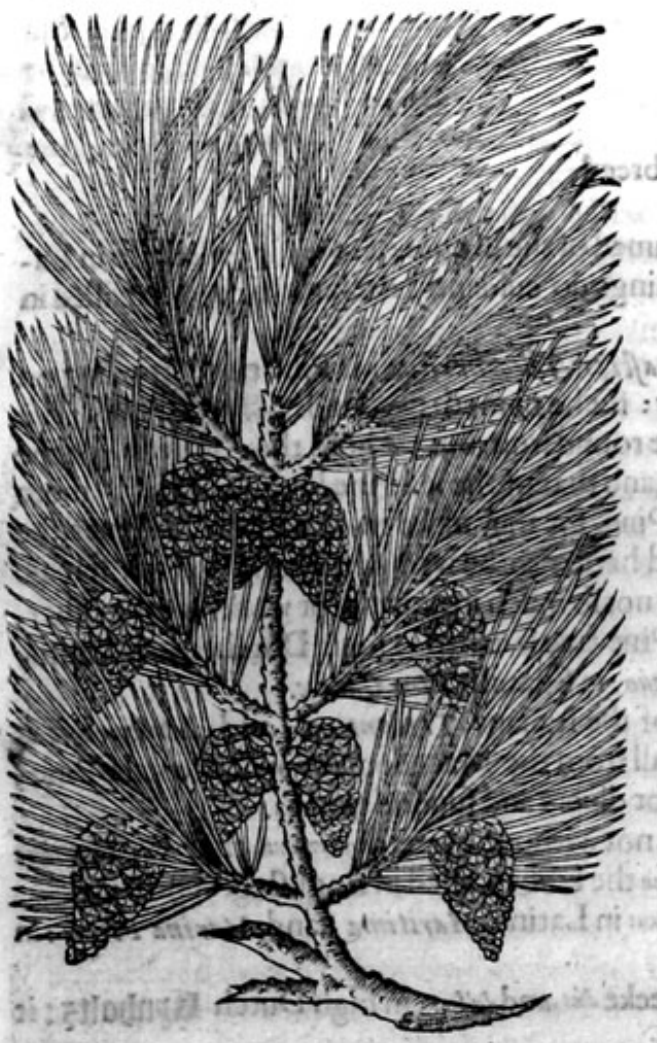

*Theplace.

Thefe wilde Pines do growe vpon the colde mountaines of Liuonia, Polonia, Noruegia, and Ruffia, efpecially vpon the Iland called Holand within the Sownde, beyonde Denmarke, and in the woods by Narua vpon the Liefeland fhore, and all the tract of the way, being a thoufande Werfts (each Werft containing three quarters of an Englifh mile) from Narua vnto Mófcouia, where I have feene them growe in infinite numbers.

\section{* The time.}

The fruite of thefe Pine trees is ripe in the end of September : out of all thefe iffieth foorth a white and fweete fmelling Rofin : they are alfo changed into Teda, and out of thefe is boiled through the force of the fire, a blacke Pitch : the Pitch tree and the Larch tree be alfo fometimes changed into Teda; yet verie feldome, for Teda is a proper \& peculiar infirmitic of the wilde Pine tree. A tree is faid to be changed into-Teds, when not onely the hart of it, but alfo the reft of the fubltance is turned into fatnes. * The nawes.

All thefe are called in Greeke mires iselas : and in Latine Sylweftres Pini: of Plinit Pinaftri: Pindfer faith he in his 16 .book 10 . chapter, is nothing elfe but $P$ ines fylueftris, or the wild Pine tree, of a leffer height, and full of boughes from the middle, as the tame Pine tree in the top, (moft of the copies hauefalfely, Of a maruelous height; they are farre deceiued who thinke that the Pinetree is called in Greeke sivus, befides the tame Pine which notwithanding is fo called not of all men, but onely of the Arcadians (as we haue faide before) rinus, all men do name the wilde múxn: and therefore 7 eda or the Torch Pine heerof is faid to be in Latine not Picea, but Pinea, that is, not the Pitch tree, but the Pine tree,as Owid doth plainly teitifie in his Epiftles of noble men:

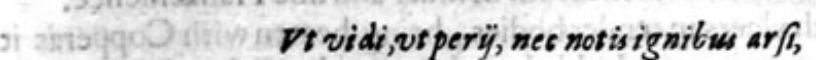

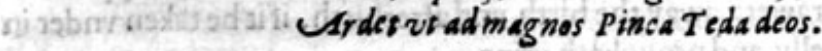

\section{Alfo in Fafformen 4 .}

\section{Ilic accendit geminas pro lampade Pinus,} Henc Cereris facris nunc guogue T eda datur.

The fame doth Virgil alfo fignifie in the 7.of his AEneid.

IP/a inter medias, flagrantem ferwidi Pinum Suftinet.

Where in fteede of Flagrantem Pinwen, Serwim admonifheth vs to vnderftand Teda Pinea. 


\section{EX78 THE THIRD BOOKE OF THE}

Catulless alfo confenteth with them in the mariage fong of Iulia and Malisus:

Pincäm quate tedam.

$$
\text { -...-Mank }
$$

With hande of thine

Shake Torch of Pine.

And Prudenties in Hyono Cerei Pafchalis. Ses P inus piceam fert alimoniam.

As the Pine tree doth beare and breed,

A pitchie foode it felfe to feed.

Moreouer the herbe Peucedamos, or Horeftrong, fo named of the likenes of múx, is called alfo in $\mathrm{L}_{2}$ tine Pinaftellism of Pinus the Pine tree: all which things do euidently declare that mixn is called in Latine not Picea, but $P$ inus.

The firft of thefe wilde kinds may be Ideas T beophrafti, or Theophraftu his Pine tree, growing on mount Ida, if the apple which is fhorter were longer: for he nameth two kinds of wildePines, the one of mount Ida, and the other the fea Pine with the round fruit: but we hold the contrarie, for the fruit or apple of the wilde mountaine Pine is fhorter, and that of the fea Pine longer.This may more truly be Macedonwm mas, or the Macedonians male Pine, for they make two forts of wilde Pines, the male and the female, and the male more writhed and harder to be wrought vpon; and the female more eafie, but the wood of this is more writhed, and not fo much in requeft for works, as the other, and therefore it feemeth to be the male This wilde Pine tree is called in high Dutch 1partz̧baum,

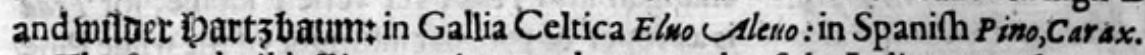

The fecond wilde Pine tree is named commonly of the Italians, Tridentinis, and Lenarienfibus Cembro, and cirmolo; it feemeth to differ nothing at all from the Macedonians wilde female Pine, for the wood is eafie to be wrought on, and ferueth for diuers and fundrie workes.

The thirde they call Mugu, this may be named notwithout caufe yausemvixn, that is, Howilis Pinus, or dwarffe Pine:yet doth it differ from zamatmuxn the herbe,called in Englifh ground Pine.

The fourth wild Pine is named in Greek meediadiven: in Latine Maritima, and Marina Pinws an Englifh Sea Pine.

That which the Latines call $T$ eda, is named in Greeke sis, and sssor: in high Dutch fapnjoiltz: it may be termed in Englinh Torch Pine.

Plinie is deceiued, in that he fuppofeth the Torch Pine to be a tree by it felfe, and maketh it the fixt kinde of Cone trees, as likewife he erreth in taking Larix, the Larch tree, for miven, the Pinetree. And as Diofcor ides maketh fo little diffetence, as fcarle any betweene mu'xn and winus, and fuppofeth them to be both of one kinde; fo likewife he fetteth downe faculties common to them both. * The temperature and vertues.

A The barke of them both faith he, doth binde; being beaten and applied it cureth merigals, and alfo fhallow vicers and burnings if it be laide on with the froth of filuer and fine Frankenfence.

B With the Cerote of Mirtils it healeth vlcers in tender bodies, being beaten with Copperas it ftaieth tetters, and creeping vlcers: it draweth away the birth and afterbirth, if it be taken vnder in a fume : being drunke it ftoppeth the belly, and prouoketh vrine.

C Galen hath almoft the fame things, but he faith, that the bark of the Pine tree is more temperate then that of the Pitch tree; the leaues ftamped take away hot fwellings and fores that come therof

D Being ftamped \& boiled in vineger, they affwage the pain of the teeth, if trey be wafhed with this decoctiō hot:the fame be alfo good for thofe that haue bad liuers, being drunk with water or mead.

E Of the fame operation is likewife the barke of the Pine nuts; but Galen affirmeth that the Cone or apple, although it feeme to be like vnto thefe is notwithitanding of leffer force, infomuch as it cannot effectually performe any of the aforefaide vertues, but hath in it a certaine biting qualitie; which hurteth.

F The Torch Pine cut into fmall peeces and boiled in vineger, is a remedie likewife againft the toothach, if the teeth be wathed with the decoction.

$G$ Ofithis there is made a profitable fpather or flice to be vfed in making of compounde plaifters and peffaries that eafe paine.

$\mathrm{H}$ Of the fmoke of this is made a blacke which ferueth to make ynke of, and for wens Gresoee, and for cating fores in the corners of the eies, and againft the falling away of the haire of the eie lids, and for watering and bleere eies; as Diofcerides teacheth. 


\section{of Rofins.}

\% The kindes.

I Out of the Pine trees, efpecially of the wilde kindes, there iffueth foorth a liquid, whitifh, and fweete fmelling Rofin, and that many times by it felfe; but more plentifully cither out of the cut and broken boughes, or foorth of the body when the trec contneth to be a Iorch Pine.

2 There iffueth alfo foorth of the crackes and chinkes of the barke, or out of the cut boughes, a certaine drie Rofin, and that foorth of the Pine tree, or Firre tree.

There is likewife found a certaine congealed Rofin upon the cones or apples.

It is called in Latine Refins: in Greekejurion: in high Dutch battz : in lowe Dutch betf: in It2lian Ragia: in Spanifh Refims ; in Englifh Rofin.

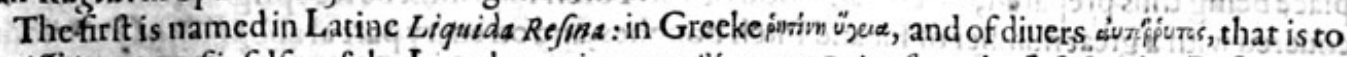

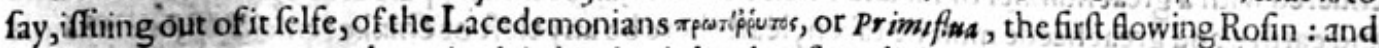
in Cilicia Katvoineov; as Galen writeth in his thirde booke of medicines according to thekindes: in Thops Rejina Pini, or Rofin of the Pine trec,and common Rofin. It hapneth oftentimes thorowe the negligent and careleffe gathering thereof, that certaine finall peeces of woode, and litrle ftones be founde mixed with it : this kinde of Rofin Galen furnameth ouroomsh, as though he fhould faic, confufed, which being melted and clenfed from the droffe becommeth hard and britte.

The like hapreth alfo to another liquid Rofin, which after it is melsed, boiled, and cooled ag aine, is hard and brittle, and maylikewife be beaten, ground, and fearced; and this Rofin is named in Greeke ppuxri: in Latine Fricta, and many times Colophunia, in Greeke xoxcowila; which name is vifed among the Apothecaries, and may ftande for an Englifh name; for $G_{a} l e n$ in his third booke of Medicines according to their kinds faith, that it is called Fricta, and of fome Colophonia; that, faith he, is the drieft Rofin of all, which fome call Frecta, others Colophonis : bicaufe in times paft, as Diofcorides writeth, it was defired of Colopho; this being yellow in comparifon of the reft, is white when it is beaten, Plinie in his 14 .booke 20 .chapter.

The fecond Rofin is named in Greeke innin thise. fpecially that of the Pitch tree without fatnes, and that foone waxeth dry, which Galen in bis 6.booke of Medicines according to the kinds, calleth properly quinuza muivov: that which in Afia is made of the Pitch tree being very white, is called Spagas,as Pliny teftifieth.

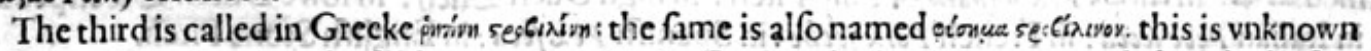
in Thops. Yet there is to be folde a certaine drie Rofin, but the fame is con pounded of the Rofins of the Pine tree, of the cones or clogs, and of the Firre tree mixed al togither, which they call $G_{\Delta}$ ripot: this is vfed in perfumes in fteede of Frankenfence, from which notwithftanding it farre differeth.

All of stive temperature and vertues.

All the Rofins are hot and drie, but not all after one maner: for there is a difference among them : they which be fharper and more biting, are hotter, as that which commeth of the cones, being of Rofins the hotteft, bicaufe it is alfo the fharpeft : the Rofin of the Pitch tree is not fo much biting, and therefore not fo hot: the Rofin of the Firre tree is in a meane betweene them both; the liquid Rofin of the Pine is moifter, comming neere to the qualitic and facultic of the Larch Rofin.

The Rofins which are burnt or fried, as Dioforides tertifieth, are profitable in plaifters, and B compofitions that eafe wearifomneffe; for they do not onely fupple or mollifie, but alfo by reafon of the thinnes of their parts and drineffe, they digeft : therefore they both mollifie and wafte awaie fwellings, and thorow the fame facultic they cure wearifomneffe, being vfed in compound medicines for that purpole.

The liquid Rofins are very fitly mixed in oinements, commended for the healing vp of greene C wounds, for they both bring to fuppuration, and do alfo glue and vnite them togither.

Moreouer there is gathered out from the Rofins as from Frankenfence, a congealed froke, called D in Latine Fuligo, in Greek rizrus : and in Englifh Blacke, which ferueth for medicines chat teautific the eie lids, and cure the fretting fores of he corners of the cies, and alfo watering eies, for it drieth without biting.

o There is made heereof faith Diofcorides, writing inke: but in our age not that which weeE 


\section{THE THIRD BOOKE OF THE}

write withall, but the fame which ferueth for Printers to print their bookes with, that is to fay, of
this blacke, or congealed fmoke, and other things added.

\section{Of Fitch and Tar.}

\section{The manner of drawing foorth of Pitch.}

Out of the fatteft wood of the Pine tree changed into the Torch Pine, is drawn Pitch by force of fire. A place muft be paued with ftone, or fome other hard matter, a litle higher in the middle, about which there muft alfo be made gutters, into which the liquor $\mathrm{fhall}$ fall; then out-from them orher gutters are to be drawen, by which it may be receiued; being receiued, it is put into barrels. The place being thus prepared, the cloucn wood of the Torch Pine muft be fet vpright; then mult it be couered with a great number of Fir and Pitch boughes, and on euery part al about with much lome and earth : and great heede muft be taken, leaft there be any cleft or chinke remaining, onely a hole left in the top of the Furnace, thorow which the fire may be put in, and the flame and fmoke may paffe out : when the fire burneth the Pitch runneth foorth, firft the thin, and then the thicker.

This liquor is called in Greeke tive: in Latine Pix : in Englifh Pitch, and the moyfture,cuen the fame that firft runneth is named of Plinie in his 16. booke Ir.chapter Cedria : There is boyled in Europe, faith he, from the Torch Pine a liquide Pitch vfed about Thips, and feruing for many other purpofes; the wood being clouen is burned with fire, and fet round about the fornaces on euery fide, after the manner of making Charcoles; the firt liquor runneth thorow the gutter like water. (This in Syria is called cedrium, which is of fo great vertue, as in Egypt the bodies of dead men are preferued, being all couered ouer with it) the liquor following being now thicker, is made Pitch. But Diofcorides writeth, that Cedria is gathered of the great Cedar tree, and nameth the liquor drawen out of the Torch tree by force of fire, tiva ireat this is that which the Latines call Pix liquida : the Italians Pece liquida : in high Dutch retricb bacb: in lowe Dutch Teer : in French Poix foudere : in Spanifh Pczliquida: certaine Apothecaries Kitran, and we in England Tar.

And of this when it is boyled, is inade a harder Pitch: this is named in Greeke $\xi_{n e d}$ thare: in Latine Arida or ficcapix : of diuers manueriard: as though they fhould fay, Iterata Fix, or Pitch iterated: bicaufe it is boyled the fecond time. A certaine kinde hereof being made clammie or glewing is named Rorxis: in fhops Pix naualis, or Ship Pitch: in high Duch 2Bach: in lowe Dutch Sttcenpeck : in Italian Pece fecca : in French Poix feche : in Spanifh Pez fecs : in Englifh Stone Pitch.

\section{* The temperature and vertwes.}

A Pitch is hot and dry, Tarre is hotter, and ftone pitch more drying,as Galen writeth. Tarre is good againft inflammations of the Almonds of the throte, and the vuula, and likewife the Squincie, being outwardly applied.

B It is a remedie for mattering cares with oile of Rofes : it healeth thebitings of Serpents, it it be beaten with falt and applied.

C With an equall portion of waxe it taketh away foule ilfauoured nailes, it wafteth away fwellings of kernels, and hard fivellings of the mother and funda ment.

D With barly meale and a boies vrine, it confumeth reresors, or the Kings Euill - it ftaieth eating vlcers, if it be laide vnto them with brimftone, and the barke of the Pitch tree, or with branne.

E If it be mixed with fine Frankenfence, and a cerote made thereof, it healeth chops of the funda. ment and feete.

F Stone Pitch doth mollifie and foften hard fwellings: it ripeneth and maketh matter, and wafteth away hard fivellings and inflammations of kernels:it filleth vp hollow vlcers, and is fitly mixed with wound medicines.

G What vertue Tarre hath when it is inwardly taken we may reade in Diofcorides and Galen, but we fet downe nothing there of, for that no man in our age will eafily vouchfafe the taking.

H There is alfo made of Pitch a congealed fmoke or blacke, whichferucth for the fame purpofes,as that of the Rofin s doth. 


\section{HISTORIE OF PLANTS.}

\section{Of the Firre, or Deale tree. Chap.40.}

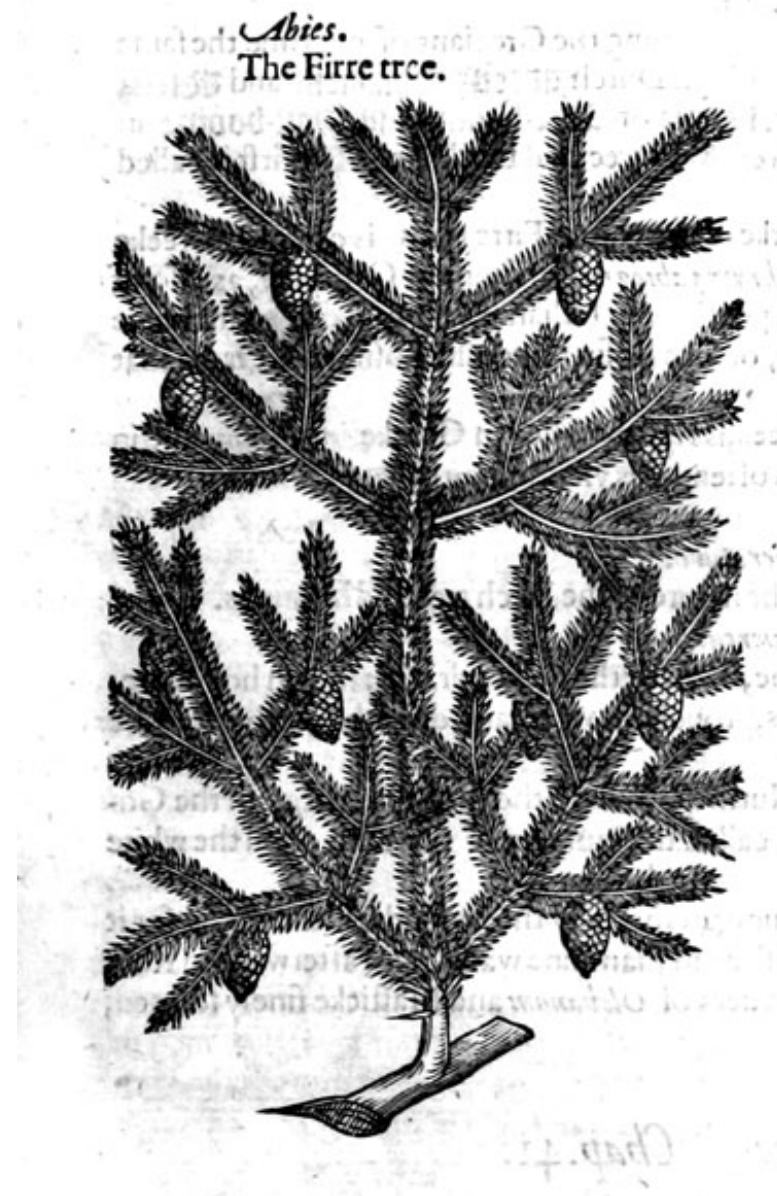

*The defoription.

$7 \begin{aligned} & \text { He Firre trec groweth very high and great, } \\ & \text { hauing his leaues cuer greene; his trunke or }\end{aligned}$ hauing his leaues cuer greene; his trunke or ints or without ioints or knots, vntill it hath gotten braunches; which are many and very fairc, befet wit h leaues, not much vnlike the leaues of the Ewe tree, but fmaller:anong which cömeth forth the fruir, like vinto the Pine apple, but fmaller and narrower, hanging downe as the Pine apple: the timber hereof excelleth all orher timber for the mafting of hips, of poftes, railes, deale bordes, and fundry other purpofes.

There is another kinde of Firre tree, which is likewife a very high and tall tree, and higher then the Pine : the body of it is fraight without knots below, waxing frnaller and fmaller etein to the verie top: about which it fendeth foorth boughes, fower togither out of one and the felfe fatne part of the body, placed one againit another, in maner of a croffe, growing forth of the fower fides of the body, and obferuing the fame order evien to the very top: out of thefe boughes grow others alfo, but by two and two, one placed right againt an other, out of the fides, which bende downwardes, when the other beare vpwards:the leaues compas the boughes round about, \& the branches therof: they be long, round, and blunt pointed, narrower and much whiter then thofe of the Pitch tree, that is to fay, of a light greene, and in a manner of a white colour:the cones or clogs be long,and longer then any others of the cone trees, they confift of a multitude of foft fcales, they hang downe from the ende of the twigs, and do not eafily fall downe, but remaine on the tree a very long time : the kernels in thefe are fmall, not greater then the kernels of the Cherrie ftone, with a thinne skin growing on the one fide, very like almoft to the wings of Bees, or great Flies: the timber or fubftance of the woode is white, and clad with manie coates, like the head of an Onion.

$$
2 \text { The place. }
$$

The Firre trees growe vpon high mountaines, in many woods of Germanie and Bohemia, in which it continueth alwaies greene; it is found alfo on hils in Italy, France, and orher countries; it commeth downe of tentimes into the valleies: they are found likewife in Prufe, Pomerania, Liefeland,Ruffia ,and efpecially in Norway; where I haue feene the goodlieft trees in the worlde of this kinde, growing vpon the rockie and craggie mountaines, almoft without any earth about them, or anyother thing, fauing a little moffe abour the rootes, which thruft themfelues heere and there into the chinkes and cranies of the rockes, and therefore are eafily caft downe with any extreme gale of winde. I haue feene thefe trees growing in Chefhire, Staffordhire, and Lancanire, where they grew in great plentie, as is reported before Noahs floud; but then being ouerturned, and ouerwhel. med have lien fince in the moffes and waterie moorith grounds very frefh and found vntill this day, and fo full of a Refinous fubftance, that they burne like a Torch or Linke, and the inhabitants of thofe countries do call it Firre-woode, and fier woode vnto this day: out of this tree iffueth the Rofin called $T$ hus, in Engliih Frankenfence : but from the yoong Fir trees proccedeth an excellent cleere 


\section{II82 THE THIRD BOOKE OF THE}

cleere, and liquid Rofin, in tafte like vato the peelings or outward sinde of the Pomecitron. $*$ The time.

The time of the Firre tree agreeth with the Pine trees.

\section{\& The names.}

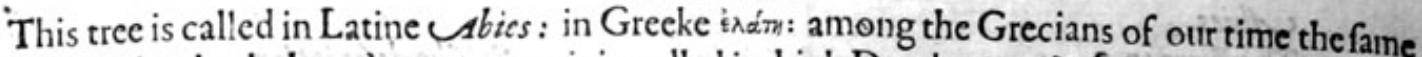
name remaineth whole and vncorrupt: it is called in high Dutch vetetf e bannen, and wereif Tbannen baum : in lowe Dutch Toritte Dennen boom, or Gbel-hoom, and 9Baif-boom: in Italian 1 Abete : in Spanifh Abeto : in Englifh Firre tree, Maft tree, and Deale tree. The firft is called in French du Sap, or Sapin : the other is Suiffe.

The liquid Rofin which is taken foorth of the barke of the yoong Firre trees, is called in Greeke

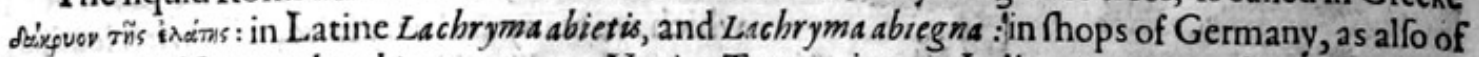
England fally Terebintbina Veneta, or Venice Turpentine : in Italian Lagrimo: diuers do thinke that Diofcorides calleth it éreusosis fingivn, Oleofa Refina, or oilie Rofin; but oilie Rofin is thefame that Pix liquida, or Tar is.

Arida Abietum Refina,or drie Rofin of the Fir trees, is rightly called in Greeke punin inarivi, and in Latine Abiegna Refina: it hath a fweete fmell, and is of tentimes vfed among other perfumes in ftead of Frankinfence.

\section{* Thetemperature.}

The barke, fruit, and gums of the Fir tree, are of the nature of the Pitch tree and his gums. * The vertues.

A The liquid Rofin of the Fir tree called Turpentine, loofeth the belly, driueth foorth hot cholericke humors, cleanfeth and mundifieth the kidneies, prouoketh vrine, and driueth foorth the ftone and gratell.

B The fame taken with Sugar and the powder of Nutmegs, cureth the ftrangurie, ftaieth the Gonorrhœe or the vnuoluntarie iffue of mans nature, called the running of the rains, and the white fluxe in women.

C It is very profitable for all greene and frefh wounds, efpecially the wounds of the head: for it healeth and clenfeth mightily, efpecially if it be wafhed in Plantaine water, and afterward in Rofe water, the yolke of an egge put thereto, with the powders of Olibanum and Mafticke finely fearced, adding thereto a little Saffron.

\section{Of the Larch tree. Chap.4.}

* The defcription.

I

$T^{-H e}$ Larch is a tree of no fmall height, with a bodygrowing ftraight vp:the barke whereof in the neather part beneath the boughes is thicke, rugged, and full of chinkes; which being cut in funder is red within, and in the other part aboue fmooth, flipperie,fomething white without : it bringeth foorth many boughes diuided into other leffer branches, which be tough and pliable. Theleaues are fmall, and cut into many iags, growing in clufters thicke togither like taffels, which fall away at the approch of winter. The flowers or rather the firft fhewes of the cones or fruit be round, and grow out of the tendereft boughes, being at the length of a braue red purplecolour. The cones be fmall, and like almoft in bigies to thofe of the Cypres tree, but longer, and made vp of a multitude of thin fcales like leaues: vnder which lie finall feedes, hauing a thim velme growing on them very like to the wings of Bees or wafpes: the fubftance of the wood is very hard, of colour efpecially that in the middeft, lomewhat red, and very profitable for works of long continuance.

It is not true that the wood of the Larch tree cannot be fet on fire, as Vitruitizs reporteth of the caltell made of Larch wood, which ca far befieged; for it burneth in chimneies, and is tutned into coles, which are very profitable for Smithes, as Mat hiolus writeth.

There is alfo gathered of the Larch tree a liquide Rofin, very like in colour and fubftance to the whiter hony, as that of Athens or of Spaine, which notwithftanding iffueth not foorth of itfelfe, but runneth out of the ftocke of the tree, when it hath been bored euen to the very hart with a great and long awger or wimble.

Galen writeth, that there be after a fort two kindes hereof, in his fourth booke of medicines according to the kinds, one like vnto Turpentine, the other more tharper thä this, hotter, more liquid, 


\section{HISTORIE OF PLANTS.}

of a ftronger fmell, and in tafte bitterer and hotter: but the latter is thotight not to be the Rofin of the Larch, but of the Firre tree, which Galen bicaufe it is after a fortlike an fubltance, might baue
taken for that of the Larch tree.

There groweth alfo vpon the Larch tree a kinde of Mufhrum or excrefcence, not fucbas is vp. on other trees, but whiter, fofter, more loofe and fpungie then any other of the Mufhrunis, and good for medicine, which beareth the name of Agaric ns, or Agaricke : I find that Pliny fuppoleth all the Mafticke trees, and thofe that beare Gals, do bring foorth this Ugaricum, wherein be was fomewhat deceiued, and efpecially in that he tooke Glandifera for Conifer a, that is, thofe trees whicti beare Mafte or Acornes, for the Pine apple trees: but among all the trees that beare Agarical, the Larch is the chiefe, and bringeth moft plentie of Agarick.

1 Laricis ramulus.

A branch of the Larch tree.

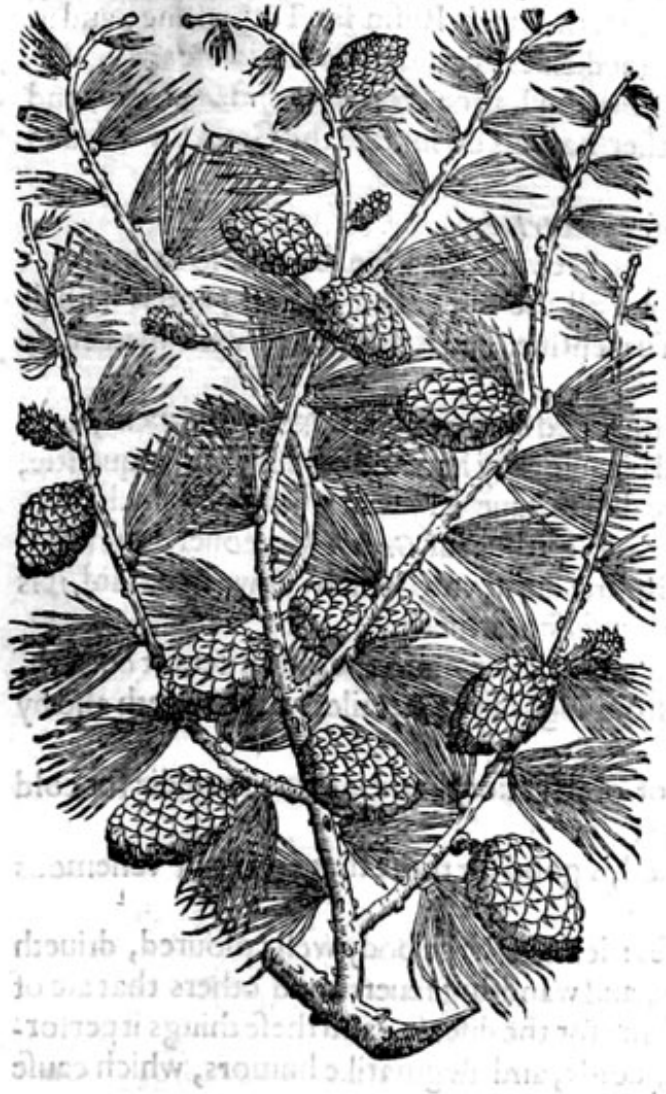

2 Larix cam Agarico fro.

The Larch trec with his Agarick. if ni

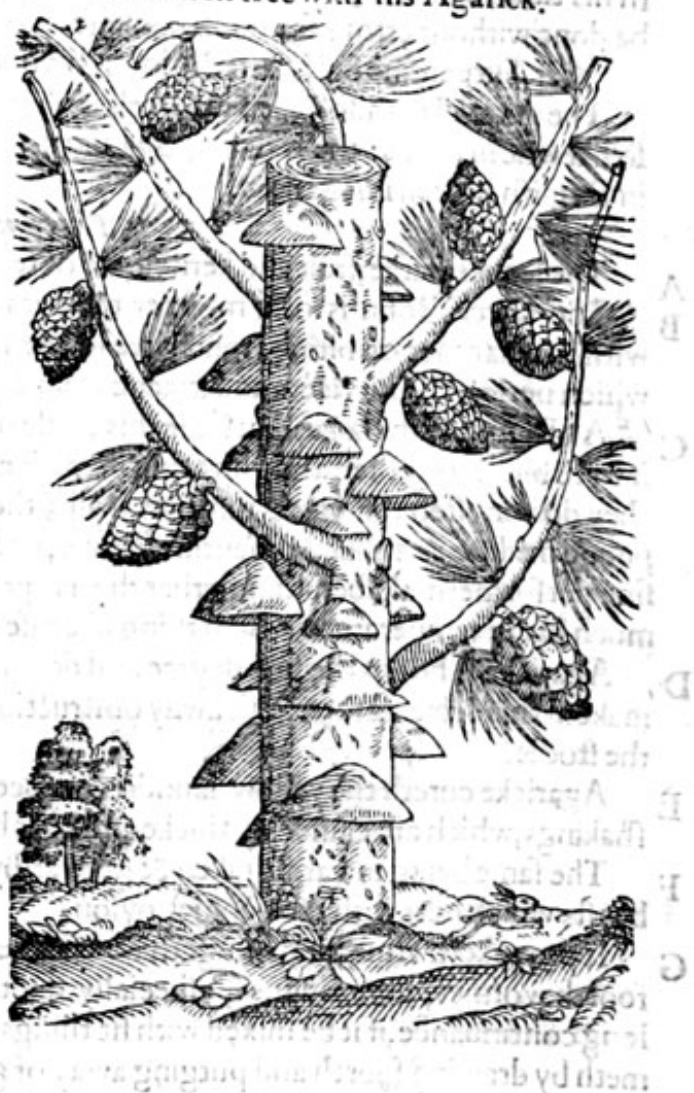

* The place.

The Larch tree groweth not in Greece, or in Macedon, bit chiefely vpon the Alpes of Italy, nor farre from Trent, hard by the riuers bonacus and Padus ; and alfo in other places of the farne moun: taines it is likewife found on hils in Morauia, which in times paftwas called the countrey of the Marcomans: Fuchfus writeth, that it groweth alfo in Silefia sothers in Lufatia, in the borders of Poland: it alfo groweth plentifully in the woods of Gallia Cifalpina.

2imie hath laid fomwhat heerof, contradicting the writings ot others, in his i 6 . book 8. chapter, where he faith, that fpecially the Acorne trees of France dobeare Agaricke; and not onely the Acorne trees, but the Cone trees alfo; among which faith he, the Larch tree is the 6 hiefe that bringeth foorth Agaricke, and that not oncly in Gallia, which nowe is called Fraunec, but rather in Eúmbardic and Piemont in Italy, where there be whole woods of Lareh trees; although they be founde in fome fmall quantitie in other countries.

The beft Agarick is that which is whiteft, very loofe and fpungie, which may eafily be broken, and is light,and in the firft tafte fweete, harde, and well compact : that which is heauy, blackifh, and containing in it little threeds as it were of fincwes, is counted pernicious and deadly. 


\section{* The time.}

Of all the Cone trees onely the Larch tree is found to be without leaues in the winter: in the fping growe freth leates out of the fame knobs, from which the former did fall. The conesare to be gathered before winter fo foone as the leaues are gone: for after the fcales are loofed and opened, the feedes drop away : the Rofin mutt be gathered in the fommer moneths.

* The names.

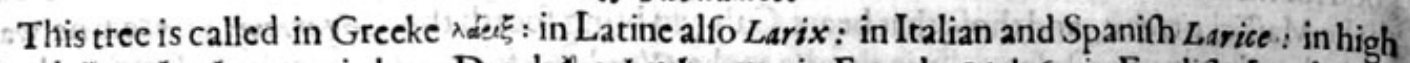
Dutch Letcbanbaum : in lowe Dutch Logkenboom: in French Melefe: in Englifh Larch tree, and of fome Larix trce.

The liquid Rofen is named by Galen alfo גaerz: the Latines call it Refina Larigna, ot Refina Laricea, Larch Rofin : the Italians Larga, the Apothecaries Terebinthina, or Turpentine, and is folde and alfo mixed in medicines in ftead thereof: neither is that a thing newly done; for Galew likewife in his time reporteth, that the druggers fold the Larch Rofine in ftead of Turpentine, and this inay be done without error : for Galen himfelfe in one place vfeth Larch Rofin for Turpentine; and in another Turpentine for Larch Rofin, in his booke of medicines according to the kindes.

The Agaricke is alfo called in Greeke dxaexor and a'deves : in Latine Agericum and Agaricas, and folikewife in Phops: the Iralians, Spaniards, and other nations do imitate the Greeke word, and in Englifh we call it Agaricke.

\section{* The temperatureand vertwes.}

A The leaues, barke, fruit and kernell, are of temperature like vnto the Pine, but not fo ftrong.

B The Larch Rofin is of a moyfter temperature than all the reft of the Rofines, and is withall without iharpnes or biting, much like to the right Turpentine, and is fitly mixed with medicines which perfeetly cure vilcers and greene wounds.

C AllRofins, faith Galen, that haue this kinde of moyfture and clammineffe ioined with them, doas itwere binde togither and vnite drie medicines, and bicaufe they haue no euident biting qualitic, they do moyften the vlcers nothing at all ; therefore diuers haue very well mixed with fuch compound medicines either Turpentine Rofine, or Larch Rofine :thus far Galen. Moreouer,'Larch Rofine performeth allfuch things that the Turpentine Rofine doth, vnto which, as we haue faid, it is much like in temperature, which thing likewife $G_{a}$ len himfelfe affirmeth.

D Agaricke is hot in the firft degree and drie in the fecond, according to the old writers. It cutteth, maketh thin, cleanfeth, taketh away obftructions or ftoppings of the intrailes, and purgeth alfo by the ftoole. the ftoole.
Agaricke cureth the yellow iaundies proceeding of obftructions, and is a fure remedie for cold
fhakings, which are caufed of thicke and cold humors.

F The fame being inwardly taken \& outwardly applied, is good for thofe that are bit of venemous beafts which hurt with their colde poyfon.

G It prouoketh vrine, and bringeth downe the menfes: it maketh the body well coloured, driueth foorth wormes, cureth agues, efpecially quotidians, and wandring feuers, and others that are of long continuance, if it be mixed with fit things that ferue for the difeafe : and thefe things itperfor. meth by drawing foorth and purging away of groffe, coide, and flegmatike humors, which caufe the difeafes.

H From a dram waight or a dram and a halfe to two, is giuen at once in fubftance or in powder: the waight of it in an infufion or decoetion is from two drams to fiue.

I Butit purgethflowly, and doth fomewhat trouble the ftomacke: and therefore it is appointed, that Ginger fhould be mixed with it, or wilde Carrot feede, or Louage feede, or Sal gem, in Latine Salfoßsis.

$\mathrm{K}$ Galen, as Mefues doth report, gaue it with wine wherein Ginger was infufed : fome vfe to giue it with Oxymel, otherwife called firupe of vineger, which is the fafeft way of all.

L Agaricke is good againft the paines and fwimming of the head, or the falling euill, being taken with the-firupe of vineger.
- It is good againt the lhortneffe of breth called 1 St hma, the inueterate cough of the lungs, the

$M$ ptificke,confumption, and thofe that fpet blood: it comforteth the weake and feeble ftomack, call feth good digeftion, and is good againit wormes. 


$$
\text { Of the Cypreffe tree. Chap.42. }
$$

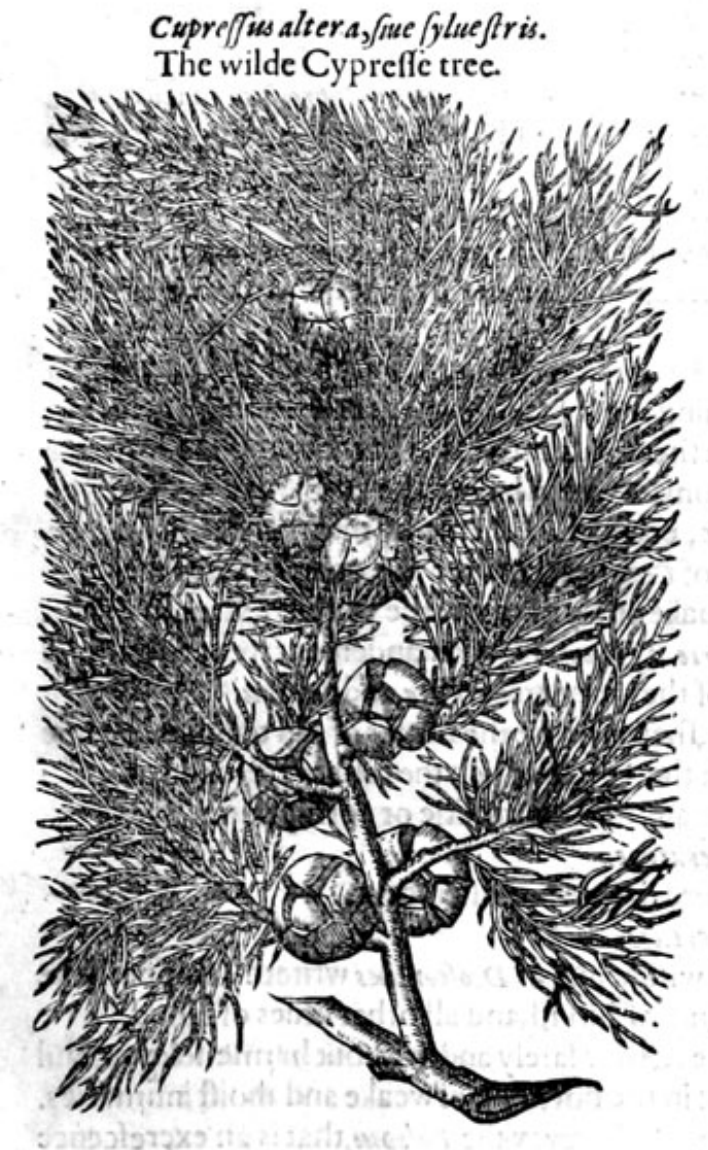

* 7 be defcription.

THe tame or manured Cypreffe tree, hath 2 long, thicke, and itraight body: whereupor many flender branches do growe, which do not fpread abroad like the branches of other trees, but grow vp alongft the body,yet not touching the top 3 they growe after the tafhion of a fteeple, broad below and narrowe towardes the top : the fubltance of the wood is harde, founde, well compact, fweete of fmell, and fomewhat yellow, almoft like the yellow Saunders, but not altogither fo yellow; neither doth it rot, nor waxe old, nor cleaucth or chappeth it felfe. The leaues are long, round like thofe of Tamariske, but more full of fubftance. The fruit or nuts do hang vpon the boughes, being in manner like to thofe of the Larch tree; but yet thicker \& more clofely compact: which being ripe do of themfelues part in funder, and then falleth the feede, which is thaken out with the winde: the fame is fmall, flat,very thin, of a fwartill fauoured colour, which is pleafant to Ants or Pilmires, and ferueth them for foode. The figure of this tree we do want, and the rather fuffer it fo topafie,bicaufe it is wel knowen to molt. The figure of the wilde kinde we haue fet foorth with his fruit.

Of this diuers make two kindes : the female and the malc; the female barren, and the male

fruitfull. Theophristus reporteth that diuers affirme the male to come of the female. The Cypreffe yeeldeth foorth a certaine liquid Rofin, like in fubltance to that of the Larch tree, but in tafte maruellous fharpe or biting.

The wilde Cypreffe, as Theophraftess writeth, is an high tree, and alwaies greenc, fo like to the other Cypres, as it feemeth to be the fame both in boughes, body, leaues, and fruite, rather then a certaine wilde Cypres: the matter or fubftance of the wood is founde, of a fweete fmell, like that of the Cedar tree, which rotteth not: there is nothing fo crifped as the roote, and therefore they vfe to make precious and coftly works heereof.

$$
\text { * The place. }
$$

The tame or manured Cypres tree groweth in hot countries, as in Candie, Lycia, Rhodes, and alfo in the territorie of Cyrenia : it is reported to be likewife fourfd on the hils belonging to mounc Ida, and on the hils called Leact, that is to fay, white, the tops whereof be alwaies couered with fnow : Bellonius denieth it to be found vpon the tops of thefe hils, but in the bottomes on the rough parts andridges of the hils : it groweth likewife in diuers places of Englande, where it hath beene planted,as at Sion a place neere London, fometime a houfe of Nunnes: it groweth alfo at Greenwich, and at other places: and likewife at Hampiteed in the Garden of Mafter Winide, one of the Glarkes of hir Maicfties Priuy Counfell.

The wilde kinde of Cypres tree groweth hard by Ammons Temple, and in other parts of the countrey of Cyrene,vpon the tops of nountaines, and in extreme colde places. Belloniws affirmeth; that there is found a certaine wilde Cypres alfo in Candie, which is not fo high as other Cypres trees, nor groweth fharpe toward the top, but is lower, and hath his bougbes fpread flat; rounde about in compaffe; he laith that the body thereof is alfo thicke : but whether this be $T$ bys, of which Theophraftus and $P$ liny make mention, ive leatic it to be confidered of.

$$
\text { * T be }
$$


* The time.

The tame Cypres tree is alwaies greene, the fruite may be gathered thrife a yeere; in Ianuarie, Maie, and September, and therefore it is furnamed 7 rifera.

The wilde Cipres tree is late, and very long before it buddeth.

$$
\text { * The names. }
$$

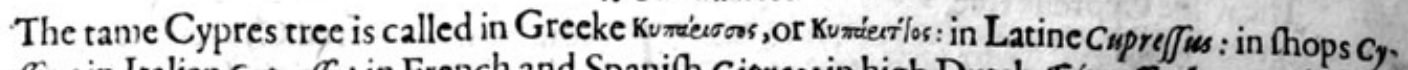

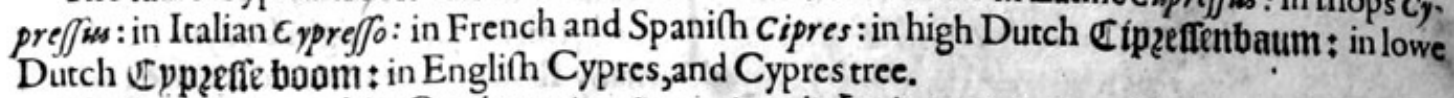

The fruite is named in Greeke opaieua rís xwraeigrs: in Latine Pilule Cupreßs, Nuces Cupreßs, and Galbuli: in hops 2 uces Cypreßst: in Englifh Cypres Nuts, Clogs. This tree in times paft w2s dedicated to Pluto, and was faide to be deadly, whereupon it is thought that the fhadowe thereof is vnfortunate.

The wilde Cypres tree is called in Greeke ria, or Aeioy, and Q viov: from this doth differ Biea being a name not of a plant, but of a mortar, in which dry things are beaten. 2 hya as Pling writeth in his 13 . booke 16 .chapter, was well knowne to Homer; he fheweth that this is burned among the fweete finels, which Circe was much delighted withall, whom he would haue to be taken for a goddeffe, to theirblame that call fweete and odoriferous fmels, cuen all of them, by that name; bicaufe he doth efpecially makemention withall in one verfe of Cedrus and $T$ bys : the copies haue falfely $L a$. $r i x$, or Larch tree, in which it is manifeft that he fpake onely of trees: the verle is extant in the fift booke of OdyJfes, where he mentioneth that Mercurie by Iupiters commandement went to Calypfus den, and that he did feele a great way off the fmell of the burnt trees $T$ hya and Cedrus.

Theophraft us attributeth great honor to this tree, (hewing that the roofes of old temples became famous by reafon of that wood, and that the timber thereof, of which the rafters are made, is euerlafting, and is not hurt there by rotting,cobweb, nor any other infirmitic or corruption,

\section{$\therefore$ The temperature.}

The fruite and leaues of Cypres are dry in the third degree and aftringent.

$$
\text { * The vertues. }
$$

A The Cypres Nuts being ftamped and drunken with wine, as Diofcorides writeth, ftoppeth the laske and bloudie flixe: it is good againft the fpitting of bloud, and all other iffues of bloud.

B They glue and heale vp great vlcers in hard bodies, they fafely and without harme foke vp and confume the hid and fecret moifture lying deepe \& in the bottome of weake and moift infirmities.

C The leaues and nuts are good to cure the rupture, to take away the Polypew, that is an excrefcence growing in the nofe.

D Some vfe the fame againft carbuncles, and eating fores, mixing them with parched Barley meale.

E The leaues of Cypres boiled in fweete wine, or meade, doth helpe the ftrangurie and difficultic of making water.

F It is reported that the fmoke of the leaues doth driue away gnats, and that the clogs do fo likewife.

G The fhauings of the wood laid amongit garments, preferueth them from mothes, the Rofin kil: leth mothes, little wormes and magots.

\section{Of the Tree of Life. Chap.43.}

* The defcription.

$T$ He tree of life groweth to the height of a finall tree, the barke being of a darke reddifh colour: the timber very hard, the branches fpreading themfelues abroad, hanging downe toward the ground by reafon of the weaknes of the twiggie branches, furcharged with verie oileous and
ponderous leaues, cafting and fpreading themfelues like the feathers of 2 wing, refembling thofe of the Sauine tree, or rather like the Yew tree leaues, but thicker, and more full of gummie or oileous fubftance; which being rubbed in the hands do yeelde an aromaticke, fpicie, or gummiefauour, very pleafant and comfortable : among the leaues come foorth fmall yellowifh flowers, which in my garden fall away without any fruite; but as it hath beene reported by thofe that haue feene the lame, there followeth a fruit in hot regions, much like nnto the fruit of the Cipres tree, but fmaller; compact of litcle and thinne fcales, clofely pact one vpon another, which myfelfe have not yet 


\section{HIS TORIE OF PLANTS.}

feene. The branches of this treelaid downe in the carth will very eafilie take roote, euen like the Woodbinde or fome fuch plant, which I houe often prooued, and thereby haue greatlymultiplied thefe trees. * The place.

This tree groweth not wilde in England, but it groweth in my garden very plentifully. * The time.

It endureth the cold of our Northen climat, yet doth it lofehis gallant greenes in the winter months: it flowreth in my garden about May. * The names.

Theopbratius and Plinie hane called this fweete and aromaticall tree Thuia, or $T$ bya : fonie call it $C e$. drus Lycia : the new whiters do terme it Arbor vit a: in Englifh the Tree of life, I do not meane that, whereof mention is made Gen.3.22.

* T he temperature.

Both the leaues and boughes be hot and drie. * The vertues.

Among the plants of the Newfound land, this tree which Theophraftus callech Thuia or Thua, is themoft principall and beft agreeing vnto the nature of man as an excellent cordiall, and of a very pleafant fmell.
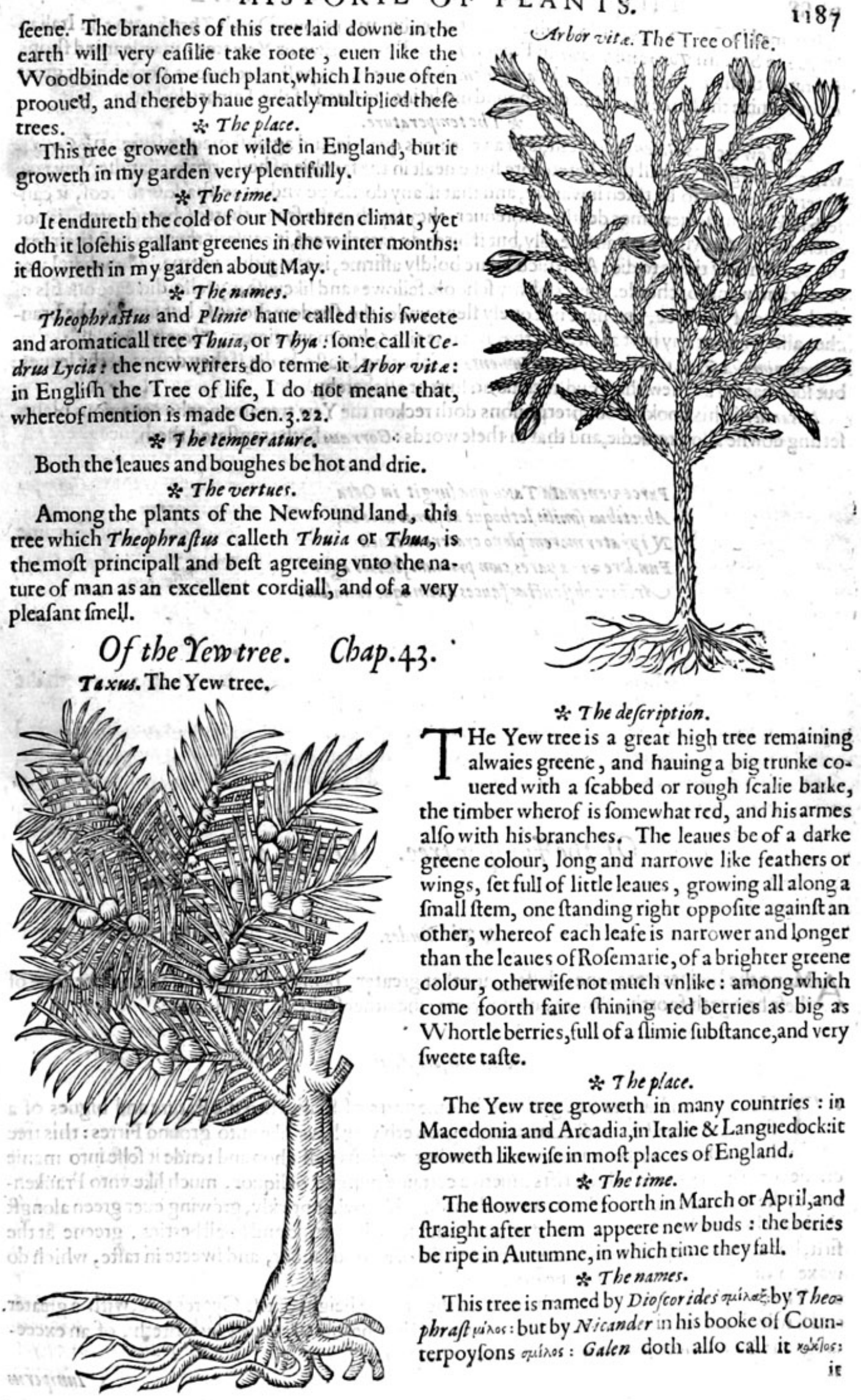

\section{$*$ The defcription.}

$T^{H e}$ Yew tree is a great high tree remaining alwaies greene, and hauing a big trunke couered with a fcabbed or rough fcalie barke, the timber wherof is fomewhat red, and his armes alfo with hisbranches. The leatues be of a darke greene colour, long and narrowe like feathers or wings, fet full of little leaues, growing all along a fmall ftem, one ftanding right oppofite againft an other, whereof each leafe is narrower and longer than the lcaues of Rofemaric, of a brighter greene colour, otherwife not much vnlike : among which come foorth faire thining red berries as big as Whortle berries, full of a flimic fubittance, and very fweete tafte.

$$
\approx \text { T he place. }
$$

The Yew tree groweth in many countries : in Macedonia and Arcadia, in Italie \& Languedock:it groweth likewife in moft places of England.

$$
\text { * The time. }
$$

The flowers come foorth in March or April, and ftraight after them appeere new buds : the berits be ripe in Autumne, in which time they fatl.

$$
\text { * The names. }
$$

This tree is named by Diofcorides muinat by $T$ hea phraff $\mu^{\prime} \lambda$ os : but by Nicander in his booke of Counterpoyfons ouinos: Galen doth alfo call it voxitos: 
it is named in Latine Taxus: in high Dutch Ephenbaum: in lowe Dutch Jbenboom : in Italian Taffo: in Spanifh Toxo and Taxo: in French $Y f$ : in Englifh Ewe or Yew tree: in vnlearned Thops if any of them remaine, it is called $\tau_{a}$ marifcus, which in times paft were woont not without great error to mixe tho barke hereof in compound medicines in ftead of the Tamariske barke. * The temperature.

The Yew tree, as $G$ alen reporteth, is of a venemous qualitie, and againft mans nature. Diogcorides writeth, and generally all that heretofore have dealt in the facultie of herbarifme, that the Yew tree is very venemous to be taken inwardly, and that if any do fleepe vnder the fhadow thereof, it caufeth ficknes, and oftentimes death. Moreouer, they fay that the fruite thereof being eaten, is not onely dangerous vnto man and deadly, but if birds do cate thereof, it caufeth them to caft their feathers, and many times to die. All which I dare boldly affirme, is altogither vntrue. For when I was yoong and went to fchoole, diuers of my fchoole fellowes and likewife my felfe did eate our fils of the berries of this tree, and haue not onely flept vnder the fhadow thereof, but among the branches alfo, without any hurt at all, and that not one time, but many times. Theophrastius faith, that róques, a nimalia Gaza tranflateth them Iumenta, or laboring beafts do die, if they do eat of the leaules: but fuch cattell as chew the ir cud, receiue no hurt at all thereby.

Nicander in his book of Counterpoifons doth reckon the Yew tree among the venemous plants, fetting downe alfo a remedie, and that in thefe words : Gorr aus hath tranflated them.

\title{
Parce venenata Taxo qua furgit in Oeta \\ Abietibus fimilis, let hoque abjumit acerbo, \\ 2 iprater morem pleno craterem eraca \\ Fundere vin a pares, cum primum fentiet ager \\ Arctari obftruct as fucces animeque canalew.
}

\section{Of the funiper tree. Chap. 44 .}

\author{
* The kindes.
}

Aong the Iuniper trees, one is leffer, another greater, being a ftrange and forren tree, one of

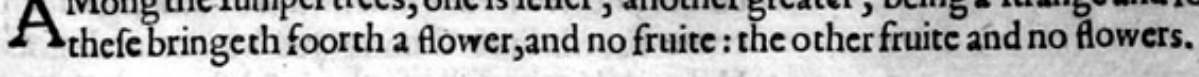

\section{* Thedefription.}

I THe common Iuniper tree groweth in fome parts of Kent, vnto the ftature and bignes of a faire great tree, but moft commonly it groweth very lowe like vnto ground Firres: this tree hath a thinne barke or rinde, which in hot regions will chop and rende it felfe into manie cranies or peeces; out of which rifts iffueth a certaine gumme or liquor, much like vnto Frankencenfe : the leaues are very fmall, narrow, and hard, and fornwhat prickly, growing euer green alongtt the branches thicke togither : among which çome foorth rounde and fmall berries, greene at the firf, but afterwarde blacke declining to blewneffe, of a good fauour, and fweete in tafte, which do waxe fomewhat bitter, after they be dry and withered.

2 The great Iuniper tree commeth now and then to the height of the Cypres tree, with agreater and harder leafe, and alfo with a fruite as bigge as Oliue berries, as Bellonius writecth, of an exceeding faire blew colour, and of an excellent fweetc fauour. 


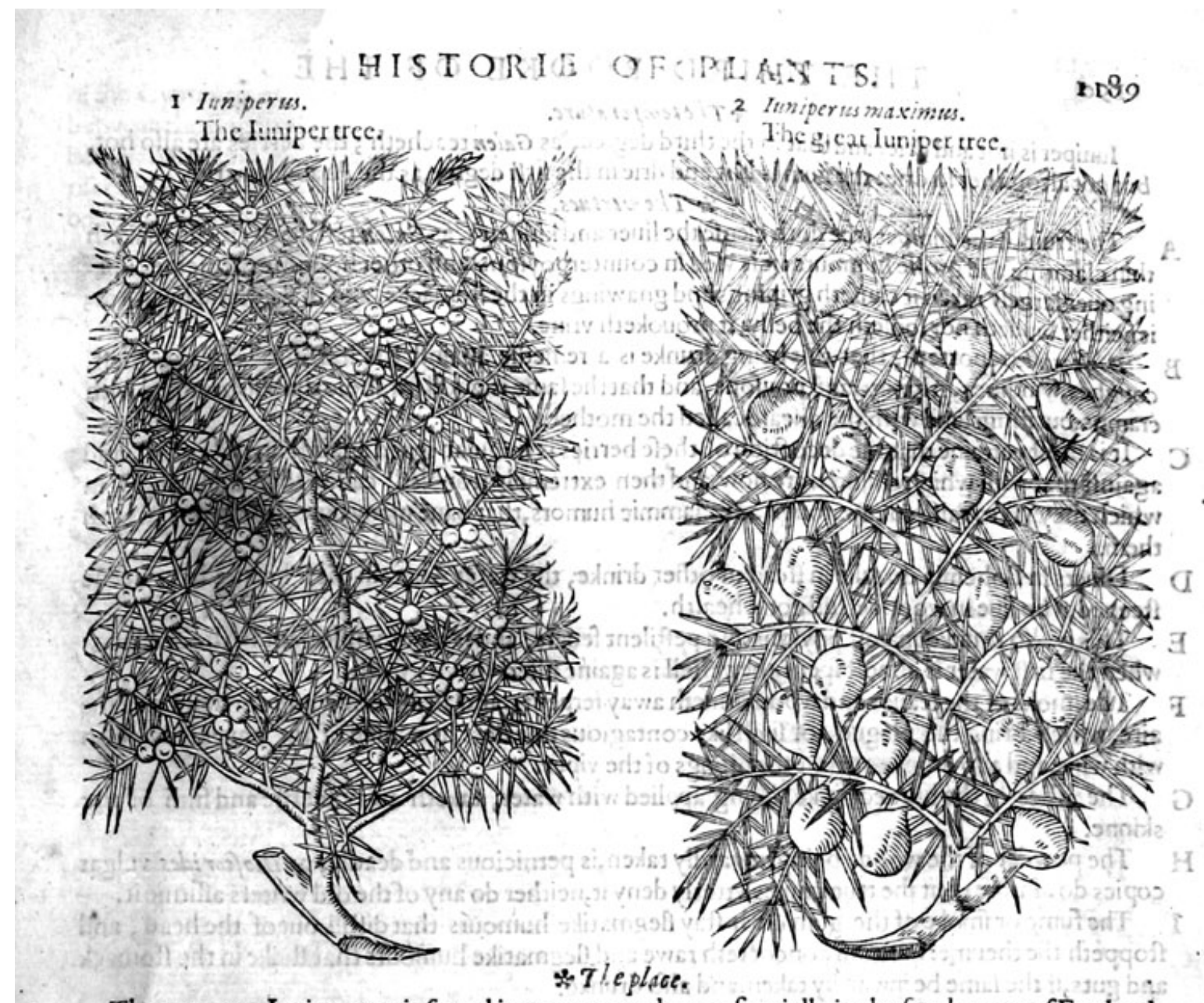

The common Iuniper tree is found in very many places, efpecially in the fouth parts of England.

Bellonius reporteth, that the greater groweth vpon mount Taurus: Nloifius Linguillara writeth, that it is found on the fea fhores of the Liguftici mar is of Adriatici, and in llyrico, brieging foorth great berries: and others fay that it groweth in Prouence of France : it commeth vp for the inoft part in rough places and neere to the (ea,as Divfcorides noteth. $*$ The time.

The Iuniper tree flowreth in May; the flower where of is nothing elfe, but as it were a littie yellowifh duft or pow der ftrowed vpon the boughes. The fruit is ripe in September, and feldome found either winter or fommer without ripe and vnripe berries, and all at one times.

$$
* \text { Thenames. }
$$

The Iuniper tree is called in Greeke aprodgos: the A pothecaries keepe the Latine name Iuniperius: the Arabians call ic Arconas and Archencas: the Iralians Ginepro: in high Dutch Jolecbboiter; in Spanifh Enebro, Ginebru, and $Z$ imbro: the French men and bafe Almaines reneure : in Englifh Iuniper tree.

The lefler is named in Greeke äprd0O; in Latine Isniperus. The great Iuniper tree is called in

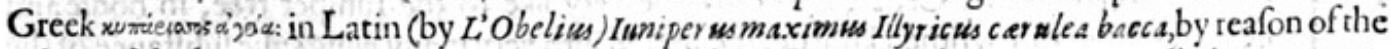
colour of the berrics, and may be called in Englith blew Iuniper. The berries are called Grant Iuniperi, in Greeke zipragis, although the tree it felfe allo is oftentimes called by the fame name dip d dis : it is termed in high Dutch Frametbeet, zaechbolterbier : in lowe Dutch Gencurelefien : in Spanifh 2 enrinas : in Englifh Iuniper berries.

The gum of the Iuniper trec is vfually called of the Apothecaries Vernix : in Latine Lachryma Iuniperi: Serapio nameth it Sandarax and Sandaracha; but there is another Sandaracha among the Grecians being a kinde of Orpment, which groweth in the fame minerals whercin Orpment doth, and this doth far differ from Vernix, or the luniper gum. Plinie in his i 1 . booke 7 . chapter maketh mention alfo of another Sandaracka, which is called Erithrace and Cerinthus: this is the meate of bees whileft they be about their worke. 
* Thetemperature.

Iuniper is hot and drie, and that in the third degree, as Galen teacheth; the berries are allo hot, but not altogither fo drie: the gum is hot and drie in the firft degree, as the Arabians write.
$\star *$ The vertues.

A The fruit of the Iuniper tree doth clenfe the liuer and kidneies, as Galen teftifieth : it alfo maketh thin clammie and groffe humours : it is vfed in counterpoyfons and other holfome medicines: be. it neither bindeth nor loofeth the belly; it prouoketh in the ftomacke, and maketh the headhot;

B Diofcorides reporteth, that this being drunke is vrine. coughes,windines,gripings, and poyfons, and that the fame is good for infirmities of the cheft, cramps, burftings, and with the difeafe called the mother.

C It is moft certaine that the decoction of thefe berries is fingular good againft an old cough, and againft that with which children are now and then extremely troubled, called the Chin cough, in which they vfe to raife vp raw, tough and clammic humors, that haue many times blood mixed, with
them. D Diuers in Bohemia do take in ftead of other drinke, the water wherein thefe berries haure beene
fteeped, who liue in woonderfull good health.

E This is alfo drunke againft poyfons and peftilent feuers, and it is not vnpleafant in the drinking: when the firft water is almoft fpent, the veffell is againe filled vp with frefh.

F The fmoke of the leaues and wood driueth away ferpents, and all infection and corruption of the aire, which bring the plague, or fuch like contagious difeafes: the iuice of the leaues is laide on with wine, and alfo drunke againft the bitings of the viper.

G The anhes of the burned barke, being applied with water, taketh away fcurffe and filth of the skinne.

H The powder of the woode being inwardly taken, is pernicious and deadly, as Diofcor ides vulgar copies do affirme; but the true copies vtterly deny it, neither do any of the old writers affirme it.

I The fume or fmoke of the gum doth ftay flegmatike humours that diftill out of the head, and ftoppeth the rheume: the gum concocteth rawe and flegmatike humours that fticke in the ftomack and guts, if the fame be inwardly taken, and alfo drunke.

K It killeth al maner of worms in the belly, it ftaieth the menfes, and hemorrhoides:it is commended alfo againft fpitting of bloud; it drieth hollow vicers, and filleth them with flefh, if it be caft theron: being mixed with oile of Rofes, it heale th chops in the hands and feete.

L There is made of this \& of oile of Linefeed, mixed togither, a liquor called Vernifh, which is ved to beautifie pietures, and painted tables with, and to make iron glifter, \& to defend it from the ruft.

\section{Of the prickly Cedar, or Cedar funiper. Chap. 54 .}

\section{* The kindes.}

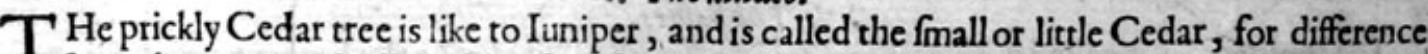
from the great and tall Cedar, which bringeth Cones; and of this there are two kinds, as 7 beo. phraftus and Pling do teftifie, that is to fay, one of Lycia, and another crimfon.

\section{* The defcription.}

I $\mathrm{He}$ Crimfon or prickly Cedar, feemeth to be very like to the Iuniper tree; in bodie and boughes, which are writhed,knottie, and parted into very many wings:the fubftance of the wood is red, and fweete of fmell like that of the Cypres; the tree is couered ouer with a rugged barke : the leates be narrow and fharpe pointed, harder then thofe of Iuniper, tharper, andmore pricking, and ftanding thinner vpon the branches : the fruit or berrie is fomtimes as bigge as a hafell nut, or as Theoplor aft us faith, of the bignes of Myrtle berries, and being ripe it is of 2 reddifh yellow, or crimfon colour, fweete of fmell, and fo pleafant in tafte, as euen the countreymen now and then do eate of the fame with bread.

2 The other lowe Cedar which groweth in Lycia, is not fo high as the former, hauing likewife a writhed body as big as a mans arme, full of boughes; the barke is rough, yellowifh without, and red within: the leatues ftand thicker, like at the firft to thofe of Iuniper, but yet fomewhat fhorter, and in the thirde or fourth yeere thicker, long, and rounde withall, comming neere to the leaues 
of the Cypres tree, or of the fecond Sauine, that is, blunt \& not pricking at all, which being brufed between the fingers do yceld a very pleafant fmell : fo doth one \& the felfe fame plant bring foorth below fharpe and prickly leaues, and aboue thicke and blunt ones, as that notable learned Herbarift $\mathrm{Clu}$ fius hath moft diligently oblerued:the fruite or berrie heerof is round like that of Iuniper, of colour yellow when it is ripe, inclining to a red; in tafte formwhat bitter, but fweete of fincll.

I Oxycedrus Phanicia. Crimfon or prickly Cedar.

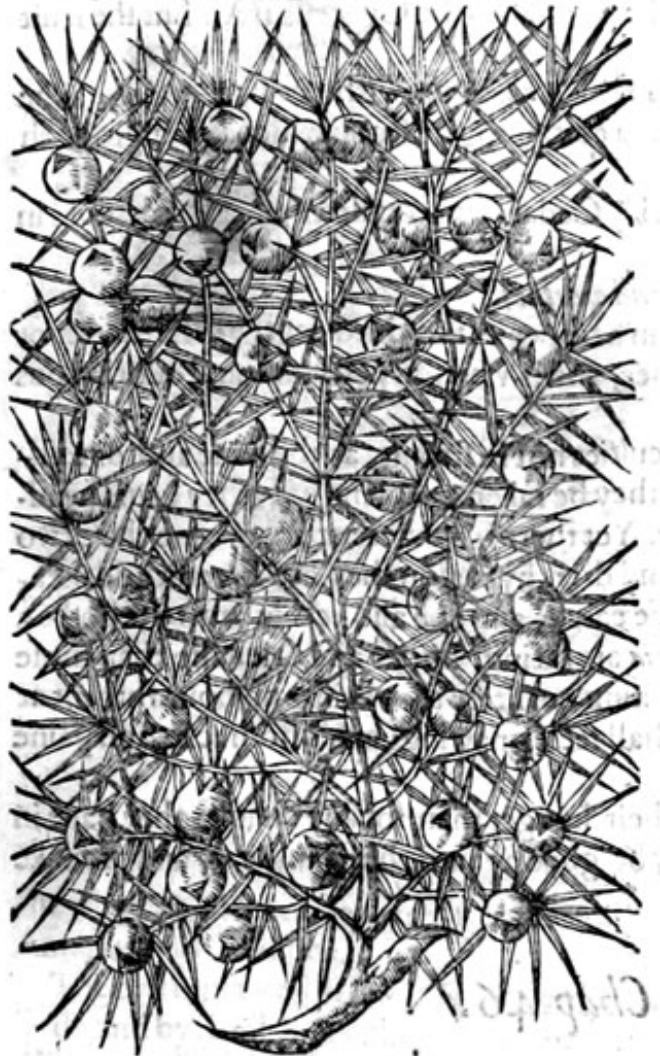

2 Oxycedrus Lycia. Rough Cedar of Lycia.

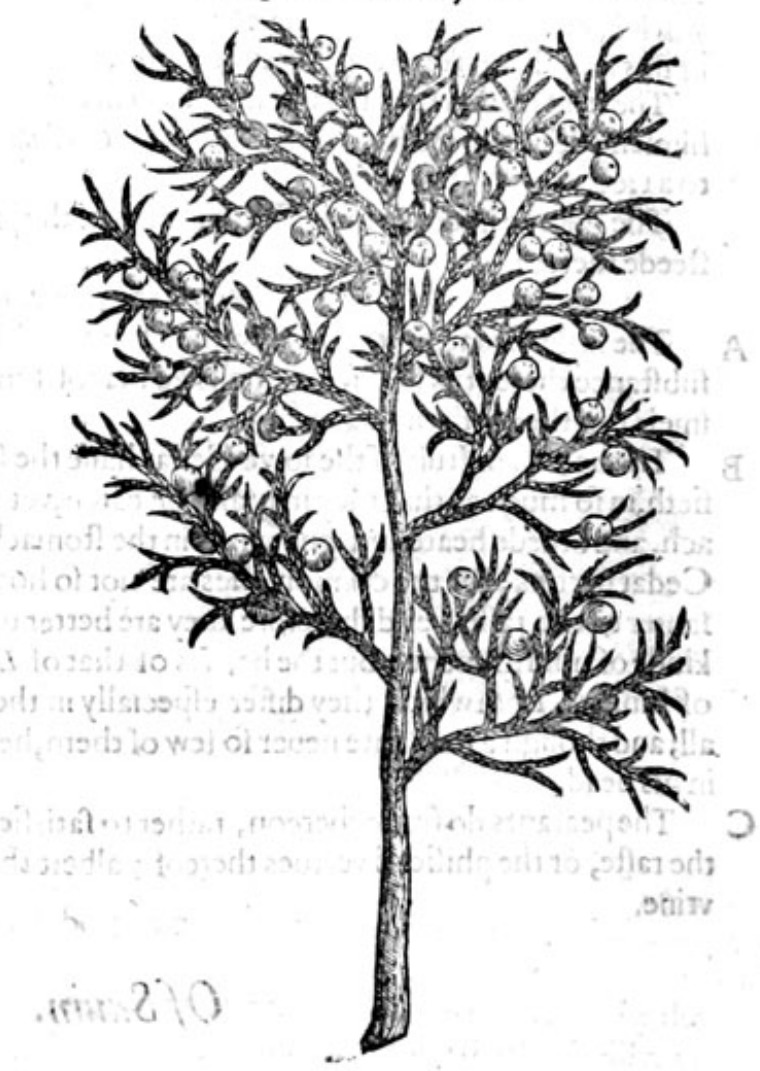

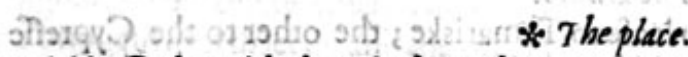

The prickly Cedar with the crimfon colour, commeth vphigher and greaterincertaine places of Italy, Spaine, and Afia, and in other countries : for that which groweth on mount Garganus in Apulia is much higher, and broader then thofe thä grow elfewhere, and bringeth foorth greater betries, of the bignes of an $\mathrm{Hafell} N$ ut, and fweeter, as that moft diligent writer Bellonisw reportêth: c. $C \ln$ fus fheweth that the prickly Cedar and the Iuniper tree be of fo great a growth in divers places of Spaine which hehiath obferued, as thar the body of them is as thicke as a man.

The Lycian Cedar is found in Prouence of France, not farre from Maffilia, and groweth in a great part of Greece, in Illyricum and Epirum.

$$
\text { part of Greece, in llyricum and Epirum. } \% \text { The time. }
$$

Both of them arealwaies greene, and in winter alfo full of fruite, by reafon that they continually bring foorth berries;as when the old do fall new come in their places; in the fpring growe vp newe buds,and beginnings of berries; in Aurumne they waxe ripe the fecond yeere; as do the berries of Iuniper.

\section{* The names.}

They are called in Latine Minores, and Humiles Cedri, little and lowe Cedars, for difference from the tall and great Cedar which beareth Cones.

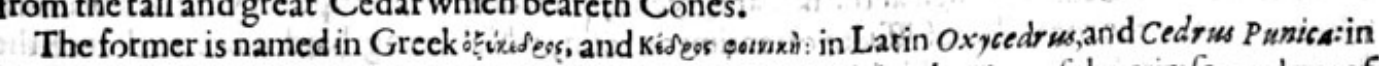
Englifh Prickly Cedar, and Crimfon Cedar: Pleniefurnameth it P henicea, of the crimfoa colour of 
the fruit : the Spaniards call this alfo Enebro, as Clufirs teftificth, euen by the fame name which they giue to the Iuniper; wherein likewife they ate thought to imitate diuers of the olde writers, who called them Cedros, Cedar trees; yet Cedar with an addition ikvusdeos, or pricklie Cephraft us writeth,

The other with the blunt leate is named by $T$ heophraftus nixad risess: of Plinie alfo Lycia Cedrus in
prouence of Fraunce Morueine: diuers name this Sabina, and vfe in want, as the Apothecaric sof Epidaurus, and in Sabina, and vfe it in ftead of Sauine, which they Epirum, as Bellonims teftuficth.Some would hau diters cities of Greece, and alfo in Illyricum and ftus is like not onely in body, leaues and boughes bue Sva, Thya ; but Thya according to Theophra. of this is nothing like to the Cypreffe cones.

The fruit of this Cedar is named by Theophraftus xedeis, Cedris: notwithftanding Cedrus, as he himfelfe doth alfo teftifie (Gaza nameth it Credula) is a certaine little fhrub which neuer groweth.

The gum or liquor, which iffueth foorth of the prickly Cedar, is alfo called Vernix, and is fold in fteede thereof.

\section{* The temperature and vertues.}

A The little Cedar, as Galen writeth, is hot and drie in a maner in the third degrce; the matter or fubftance thereof is fweete of fmell like that of Iuniper, and is vfed for perfumes and odoriferous fmels togither with the leaues.

B The berries or fruit of the lowe Cedar have the faculties not fo ftrong, as the fame author teftfieth_in fo much as that they may alf be eaten,yet if they be taken too plentifully they caufe headach, and breede heate and gnawings in the ftomacke. Yet there is a difference betweene thefe two Cedar berries; for the crimfon ones are not fo hot and drie, by reafon they are fweeter and pleafanter to the tafte, and therefore they are better to be caten, and doe alfo yeelde vnto the bodie a kinde of nourifhment : but the berries of that of Lycia are biting, hotter and drier alfo than thofe of Iuniper, from which they differ efpecially in the biting qualitie; they bring no nourifhment at all; and though a man eate neuer fo few of them, he fhall feele gnawings, in his ftomacke, and paine in hishead.

C The peafants do feede thereon, rather to fatisfie their hunger than for any delight they haue in the rafte, or the phificall vertues thereof; albeit they be good againft the ftrangurie, and prouoke vrine.

\section{Of Sauin. Cbap.46.}

\& The kindes.

Therebe two kindes of Sauin, one like inleafe to Tamariske; the other to the Cypreffe tree, where of the one beareth berries, the other barren.

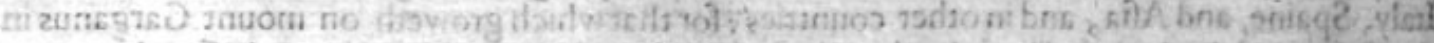

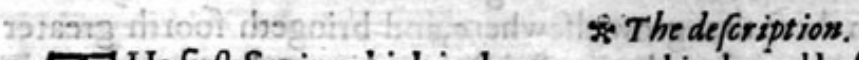

I 2 He firft Sauin, which is the commonkinde and beft of all knowen in this countrie, groweth

-4. 1 in manner of a lowe fhrub ot tree:the ftem or trunke whereof is fometimes as big as a mans arme, diuiding it felfe into many branches, fet full of fmall leaues like vnto Cypreffe or Ta. mariske, but thicker, and more fharpe or prickly, remaining greene winter and fommer : in finell ranke or very ftrong, barraine both of flowers and fruit.

2 The other Sauin is an high tree, as Bellonius faith, as tall as the Almond tree, and much like to the tame Cypreffe tree; the bodie is writhed, thicke, and of fo great a compafle as that it cannot be fathomed; the fubftance of the wood is red within as is that of the Iuniper and of the prickley Cedar; the barke is not very thicke, and it is of a yellowifh red: the leaues are of a maruellous gallant greene colour, like to thofe of the Cypreffe tree, yet thicker or more in number; in tafte bitter, of 2 fpicie fmell, and like Rofin: the boughes are broader and thicke fet as it were with wings, like thofe of the Pitch tree; and of the Yew tree: on whiclugrowe a great number of berries, veryround like thofe of the little Cedars, which at the firft are greene, but when they be ripe they are of a blackifh blew. Out of the roote hereof iffueth of tentimes a rofin, which being hard is like tothat of the Iuniper trec, and doth alfo crumble in the chewing. 

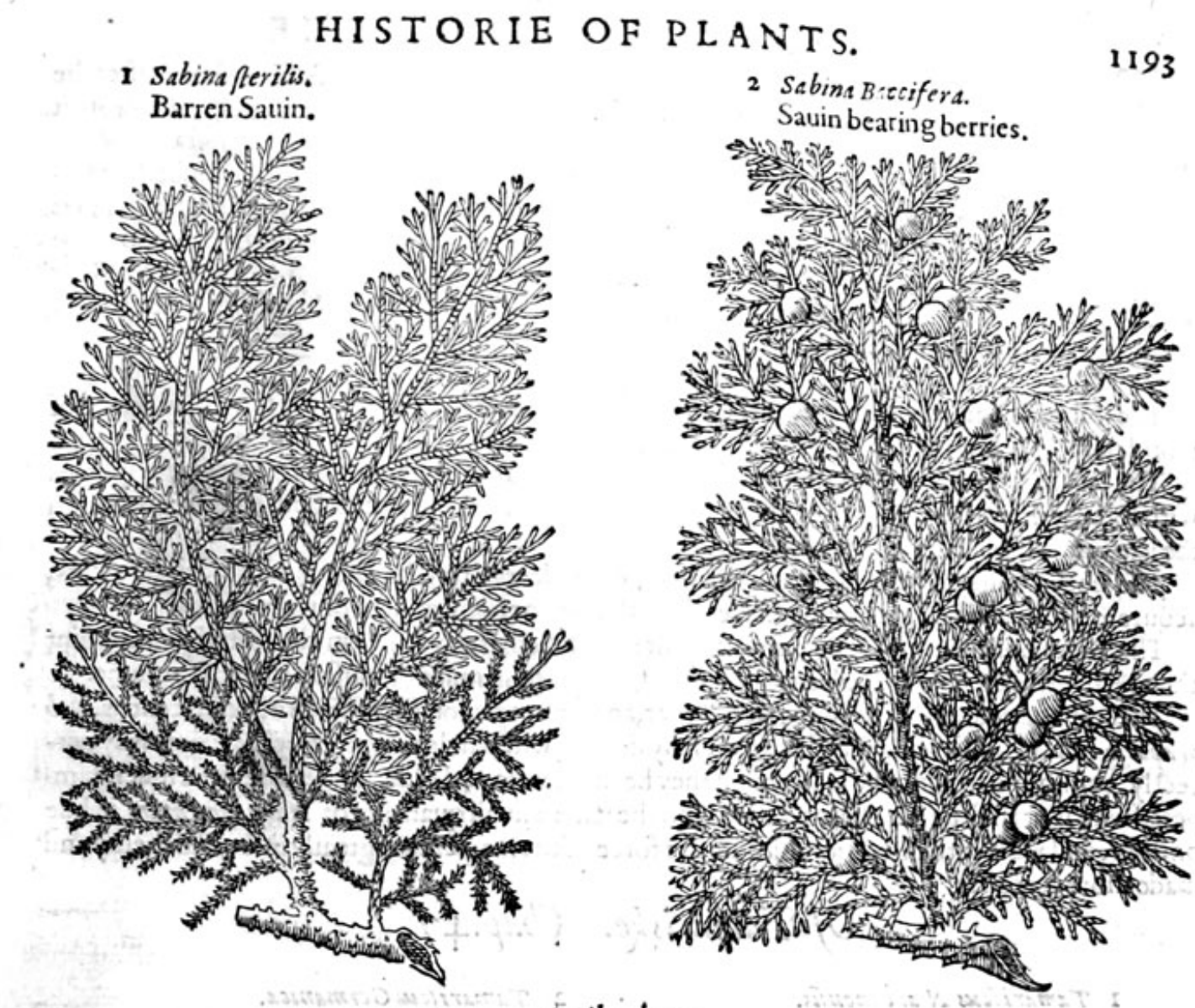

* The place.

Both of them grow vpon hils, in woods, and in other like vntoiled places, as in Candy, Myfia, and elfe where. P. Bellinitus reporteth that he found them both vpon the tops of the mountaines Taurus, Amanus, and Olympus.

The firft is planted in our Englinh gardens almoft euery wheres the fecond is planted both by the feede, and by the flip : the flippes mult be fet in a ground that is meanly moift and fhadowy, till they take root: the fhrubs which grow of thefe, decline towards the one fide, retaining ftil the nature of the bough:but that Sauine which is planted by the feed groweth more spright; this in continuance of time bringeth foorth feeds, and the other for the moft part remaine th barreniboth thefe grow in my garden.

\section{\& The time.}

They both continue alwaies greene : the one is found to be loden with ripe fruite, commonly in winter ; but it hath fruite at all times, for before the olde berries fall, new are come vp.

Sauine is called in Greeke Bedfus, or Befilv : in Latine Sabina.

The firft is commonly called in the Apothecaries fhops bv the name Saivina, of diuers Sauimera, the Italians and Spaniards keepe the Latine name : it is called in high Dutch giben baum : in low Dutch Sauei boom : in French Satenier : in Englifh Sauine, common or garden Sauine.

Some name the other Cupreffes Cretica, or Cypres of Candic, as Pliny faith, who in his 12. booke I 7.chapter, maketh mention of a tree called Bruta : forme there are who take this to be altera Sabina, or the fecond Sauin, and to te read Bruta, for Bpa'su, Brathu by altering of the vowels. For it is defcribed by Pliny in his I 2.booke I 7. chapter to be like the Cypres tree in thefe words: they feeke in the mountaines Elmmai the tree Brata being like to the broade Cypres tree, hauing white boughes, yeelding a fweete fmell when it is fet on fire : whereof mention is made, with a myracle in the ftories of Claudius Cafar. It is reported that the Parthians do vfe the leaues in potions: that the finell is verie like to that of the Cypres tree, and that the fmoke there of is a remedic againtt other woods. It groweth beyond $P$ afitigris, neere vnto the towne Sittaca, on mount Zagrus: I hus farre Plimie. 
The motutaines Elimei are defcribed by Strabo in the conntrey of the Affyrians next afterthe mountaine Sagrus aboue the Babylonians, by Ptolemaus not far from the Perfian gulfe: therefore it is hard to fay that Brut $a$ is Sabina altera, or the feconde Sauine, feeing that fo great a diftance of the place may vodoubtedly cauie a difference, and that it is not largely but bricfely defcribed. It fee. meth that 7 bya mentioned by $T$ heophrastus is more like vnto Sauine: but yet for as much as Thya is like in fruite to the Cypres tree, and not to the fruite or berries of the little Cedars; it is allo verie manifeft, that the fecond Sauine is not 7 hya ; neither $V$ t 2 a arbor, fo called of the later Herbarifts, it is likewife named Sabınz genuma bactifera, atrocarule a, that is the kindly Sauine that bearech ber. ries of a blackifh blew colour.

\section{$\therefore$ The temperature.}

The leaues of Saune which are moft vfed in medicine, are hot and dry in the third degree,and of fubtill parts as Galen faith. $*$ The vertues.

The leaues o: Sauine boiled in wine and drunke, prouoketh vrine, bringeth downe the menfes with force, it drawech away the afterbirth, expelleth the dead childe, and killeth the quicke : it hath the like vertue receiued vnder in a perfume.

The leaues ftamped with hony and applied, cure vlcers, ftay fpreading and creeping vicers, fcoure and take away all fpots and freckles from the face or body of man or woman.

The leaues boiled in oile Oliue, and kept therein, killeth the wormes in children if you annoint their bellies therewith:and the leaues powdered, and giuen in milke or mufcadell doth the fame.

- The leaues dried and beaten into fine powder,and ftrowed vpon thofe kinds of excrefcences, Sub praputio, called Caroles, and fuch like, gotten by dealing with vnclean women, take them away perfectly, curing and healing the fame: but if they be inueterate and olde, and haue beene inuch tampered withall, it thall be neceffary to adde vnto the fame a fmall quantitic of Auripigmentum in fine powder, and vfe it with difcretion, bicaufe the force of the medicine is greatly increafed thetby and made more corrofiue.

\section{Of Tamariske. Chap.47.}

I Tamarifous 2 (arbonen/is. French Tamariske.

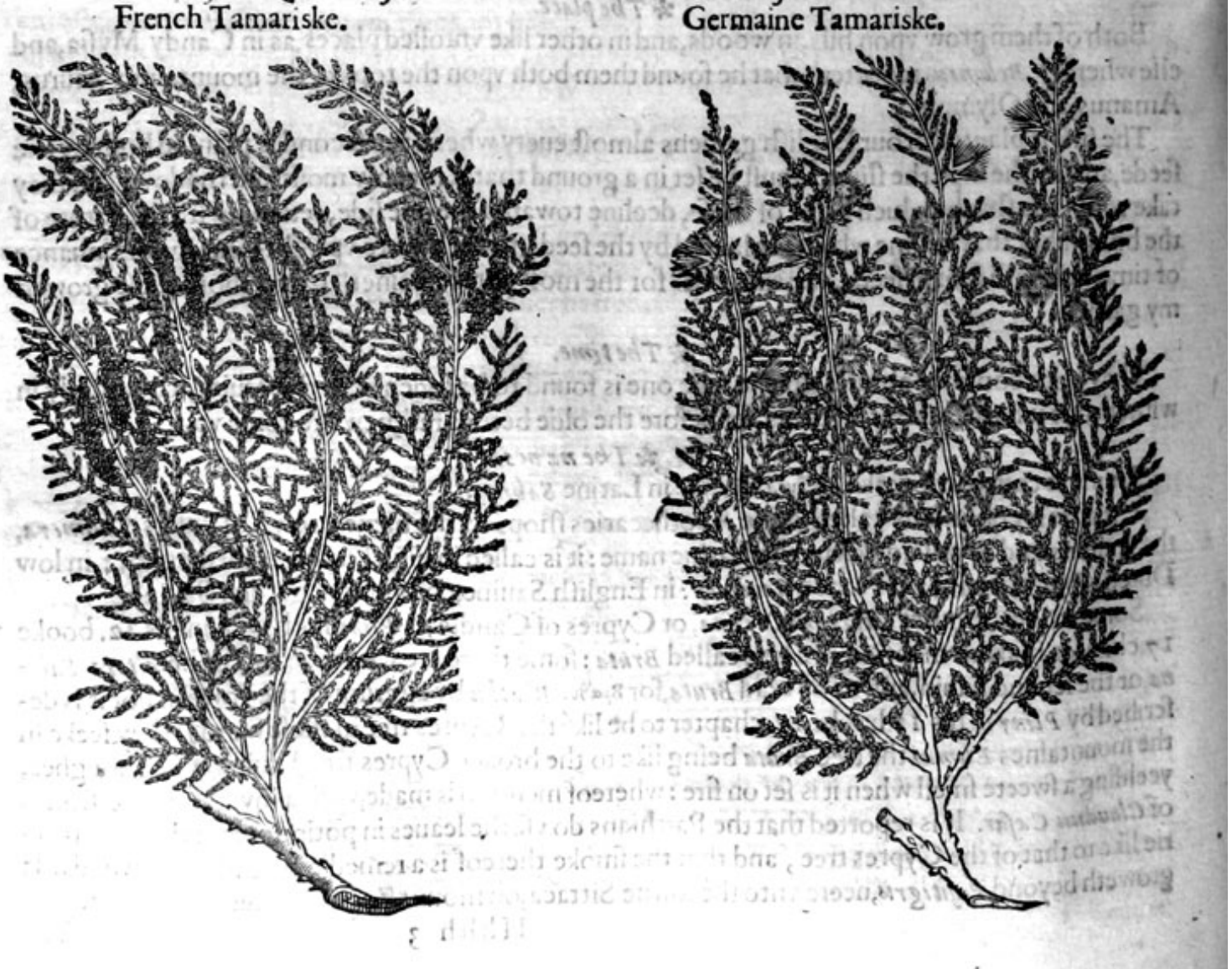




\section{HISTORIE OF PLANTS.}

* T the defcription.

$\prod$ He firft kinde of Tamariske groweth like a fmall hedge tree, couered with a reddith barke, hauing many branches fet and bedeckt with leaues, much like vnto Heath : among which come foorth fmall moffie white ftowers declining to purple, which turne into a pap. pous or downie feede, that flieth away with the winde, as that of Willow is: the roote is woodic as the rootes of other fhrubs be, and groweth dituers waies.

2 The Germaine Tamariske hath many woodie branches or fhootes rifing from the roote, with 2 white barke, hauing his leaues thicker and groffer then the former, and not fo finely iagged or cut: The flowers are white, and not vnlike the former, which do turne into feede, that is likewife caried away with the winde.

Tamiske groweth by runing 4 heplace.

Tamariske groweth by runing ftzeathes, and many times by rituers that breake foorth, an I nor feldome about fenny grounds, commonly in a grauely foile, for it beft profpereth in moift and ftony places : it is found in Germany,Vindelicia,Italy, Spaine, and alfo in Greece.

The Tamariskes do allo grow in Egypt and Syria, as Diofcorides writeth, and likewife in Tylus an Iland in Arabia, as Theophraftes noteth: the woode whereof faith he, is not weake as with vs in Greece, but ftrong like reivirov, or timber, or any other ftrong thing:this Tamariske Diofcor ides doth call inueses, that is to fay, tame, or planted; and faith that it bringeth foorth fruite very like to $\mathrm{Gals}_{\text {, in }}$ tafte rough and binding

Petrus Belloniw in his fecond booke of Singularities reporteth, that he fawe in Egypt verie high Tamariskes and great like other trees, and that fometimes in moift places by riuers fides, and manie times alfo in dry and grauely grounds where no other trees did grow, which now \& then did beare hanging on the boughes fuch a 'multitude of $\mathrm{G}_{2} l s$, that the inhabitants call Cherm.1 fel, as being ouerloden, theywere ready to breake:they both grow and profper well in my garden. * Thetime.

Thefe trees or fhrubs doflower in Maie, and in the later end of Auguft, theirfeede is caried away with the winde.

They are called in Greeke $\mu$ veix : and in Latine alfo Myrita, and Tamarix : in thops $T$ amarifcus of OCtanius Hor atianus cMurica: Diofcorides maketh that which groweth in Greece and Italy to be ¿jeü,or wilde Tamariske: it is named in high Dutch Camatifebenbolk, and joolh: in low Dutch 3benboom, Tamarifcbboome : in Italian Tamarigio : in Spanifh Tamargueira, and Tamariz: in French Tamaris: in Englifh Tamariske.

\section{* The temperature and vertues.}

Tamariske hath a clenfing and cutting facultie with a manifeft drying; it is alfo fomewhat aftringent or binding, and by reafon of thefe qualities it is very good for an harde fpleene, being boyled with vineger or wine, either the roote or leaues, or tender branches, as Galen writerh.

Morequer Diofcorides teacheth, that the decoction of the leaues made with wine, doth wafte the $B$ fpleene, and that the fame is good againft the toothach, if the mouth be wafhed therewith: that it bringeth downe the menfes, if the patient fit therein; that it killeth lice and nits, if the parts be bathed therewith.

The arhes of burnt Tamariske hath a drying facultie, and greatly fcouring withall, and a little $\mathrm{C}$ binding.

The flowers \& downie feed of the greater Tamarishe doth greatly binde, infomuch as it commeth $\mathrm{D}$ very neere to the Gall,named Galla Omphacitis, but that the roughnes of tafte is more euident in the Gall, the which flowers are of an vnequall temperature, for there is ioined to the nature thereof $a$ great thinnes of parts, and clenfing facultie, which the Gall hath not, as $G_{a} / e n$ writeth.

Thefe flowers we fitly vfe faith Diofcortdes, in fteede of Gall, in medicines for the eies and motith. $E$

It is good to ftanch bloud, and to ftaie the laske and womens whites, it helpeth the yellow iaundife, and alfo cureth thofe that are bit of the venemous fpider called Phalanglum; the barke ferueth for the fame purpofes.

The leaues and woode of Tamariske haue great power and vertue againft the hardnes and fop ping of the fpleene, efpecially the leaues being boiled in water, and the decoction drunke, ot cife in fufed in a fmall veffell of A!e or Beere, and continually drunke: and if it be drunke foorth of a cupe: dilh made of the woode or timber of Tamariske, it is of greater efficacie. 

Here be diuers forts of Heath, fome greater, others leffer; fome with broad leaues, and fome
narrower: fome bringing foorth berries,and others nothing but flower's.

I Erica vulgaris fue Promila.

Common,or dwarffe Heath. 2 Erica Pumila alba.

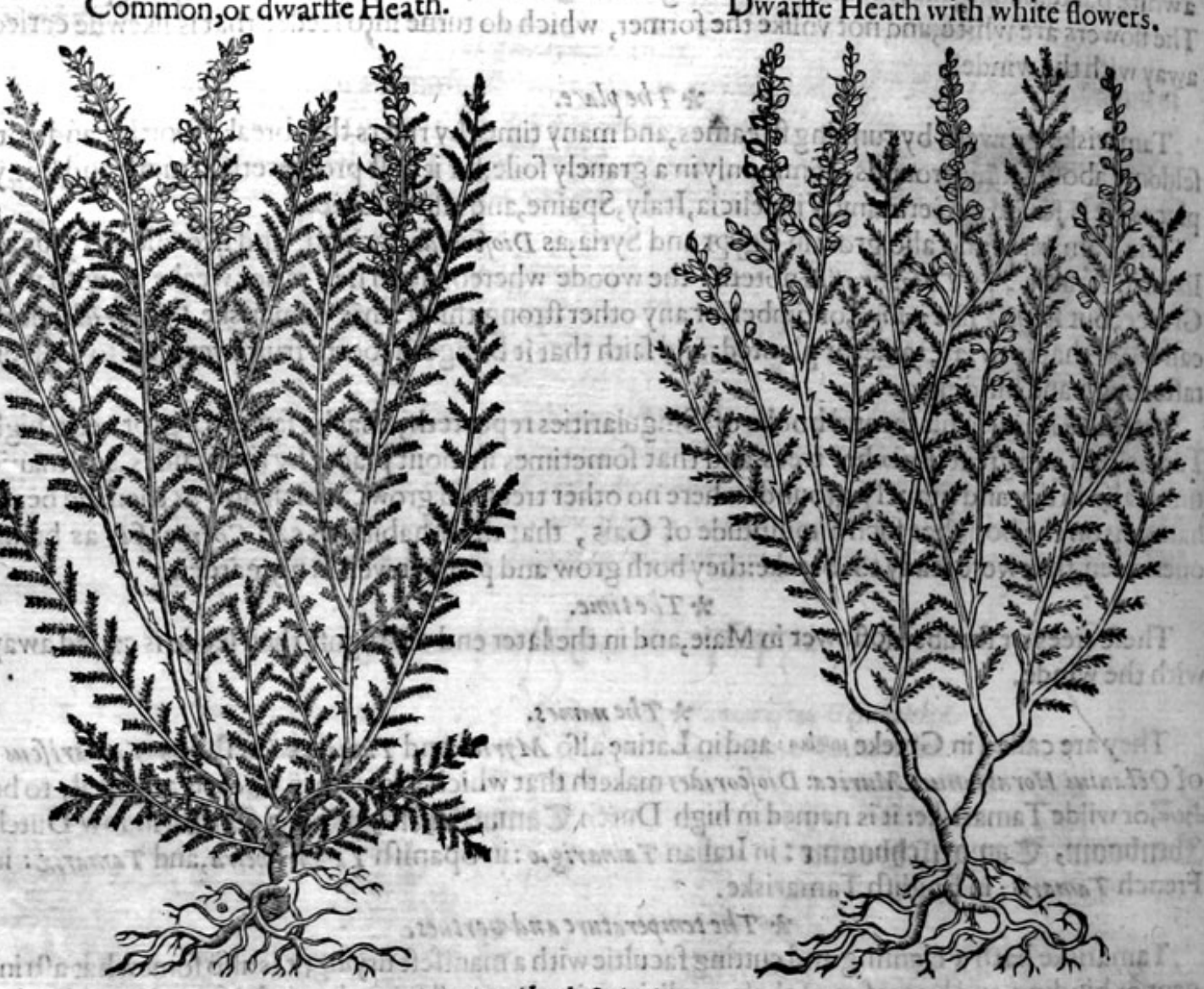

* Thedefription.

17 He common Heath is a lowe plant, but yet woodie and mrubbie, fcarfe a cubit high :it bringeth foorth many branches, whereupon do grow fundry little leaues fomewhat harde and rough, very like to thofe of Tamariske, or the Cypreffe tree: the flowers are orderly placed alongt the branches, finall, foft, and of 2 lightred colour tending to purple. The roote is alfo woodie, and creepeth vnder the vpper cruft of the earth : and this is the Heath which the ancients tooke to be the right and true Heath.

2 The fecond Heath differeth not from the precedent, fauing that, that this plant bringeth foorth flowers as white as fnowe, wherein confifteth the difference.

3 The great Heath, which carolus Clufins at his being in England found in the barren grounds about Windfore, which in his Spanifh trauels he maketh the firft kinde; groweth to the height of two cubits, feidomc higher, full of branches, conered with a blackinh barke: whereon are fer in very good order by couples, fmall leaues finer than thofe of Tamariske o: Cypreffes and of a greenecolour. The flowers inclofe the little twiggie branches round about at certaine diftances, from the lower part to the top fafhioned like little bottles, confifting of fower partes, of a fhining purple colour, very beautiful to behold, and the rather to be efteemed bicaufe it flowreth twife in the yeere: the roote is likewife woodie.

4 Of this kind there is another fort with white flowers, but feldome found or feene, vnleffe here \& there a plant amongft the other fort, which flowers are fomewhat greater than the forner, but in forne like, wherein the difference doth confift. 
3 Erica maior fore purpur ante Clusÿ.

4 Erica maior flore albo.

Great Heath with white flowers:

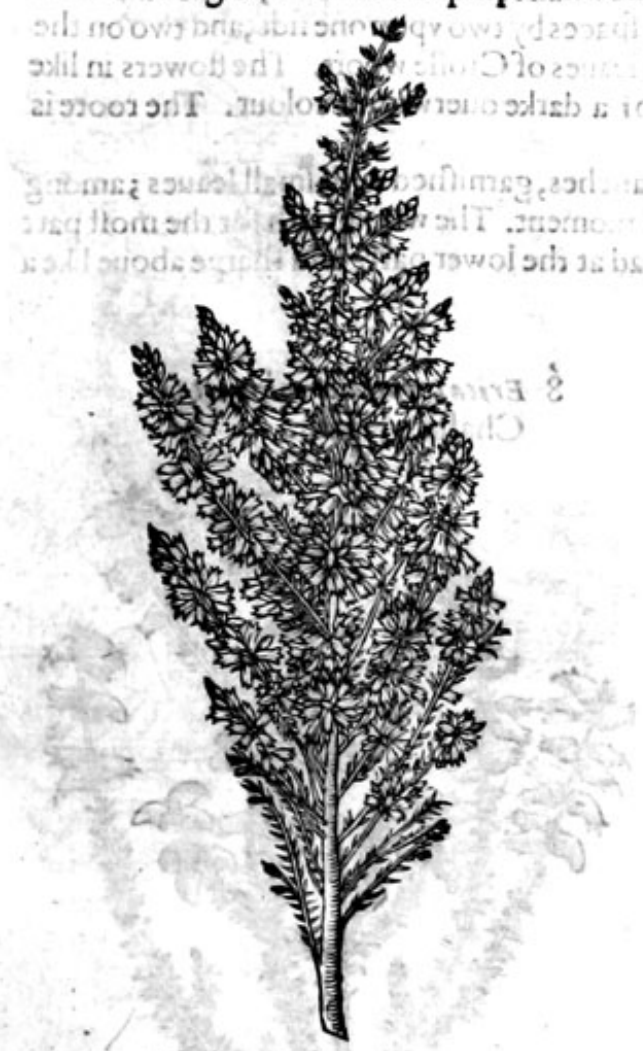

5 Erica cruciata.

Croffed Heath.
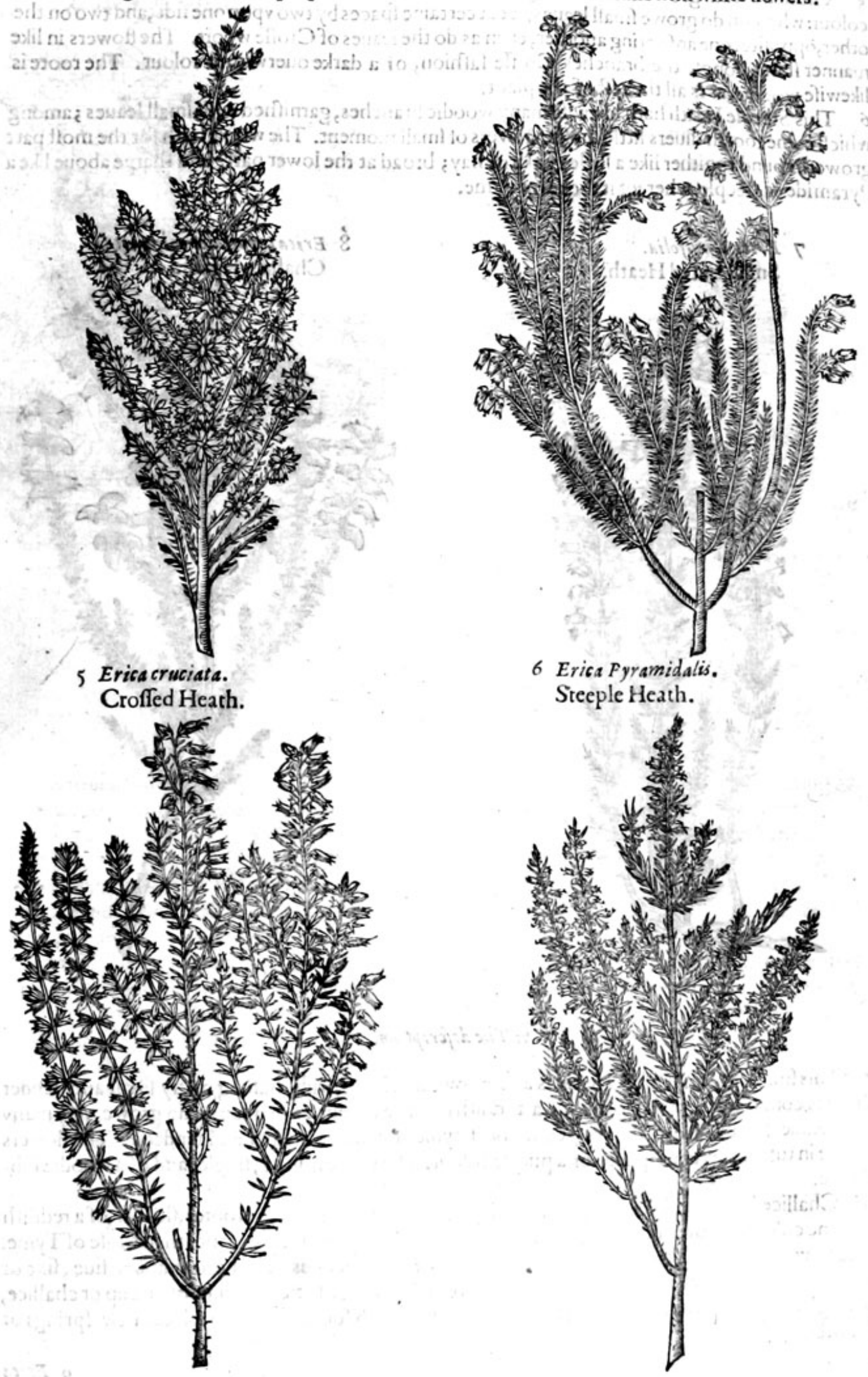

6 Erica Fyramidalis.

Steeple Heath.

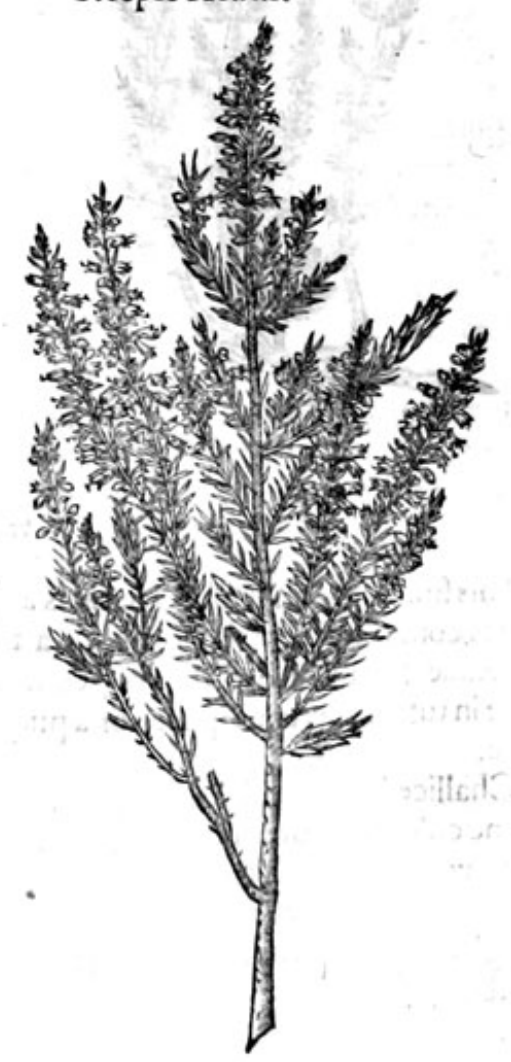

*The 
$*$ The defcription.

5 Croffed Heath groweth to the height of a cubit and a halfe, full of branches, of a fwart darke colour: whereon do growe fmall leaues, fet at certaine fpaces by two vponone fide, and two on the other, oppofite, one anfwering another, euen as do the leaues of Croffe woort. The flowers in like manner ftand alongit the branches Croffe fafhion, of a darke ouerworne colour. The roote is likewife woodie, as is all the reft of the plant.

6 This Steeple Heath hath likewife many woodie branches, garnifhed with fmall leaues ; among which come foorth diuers little moffie towers of fmall moment. The whole bufh for the moft part groweth round togither like a little cocke of hay; broad at the lower part, and fharpe aboue like 2 Pyramide or fteeple,whereof it tooke his name.

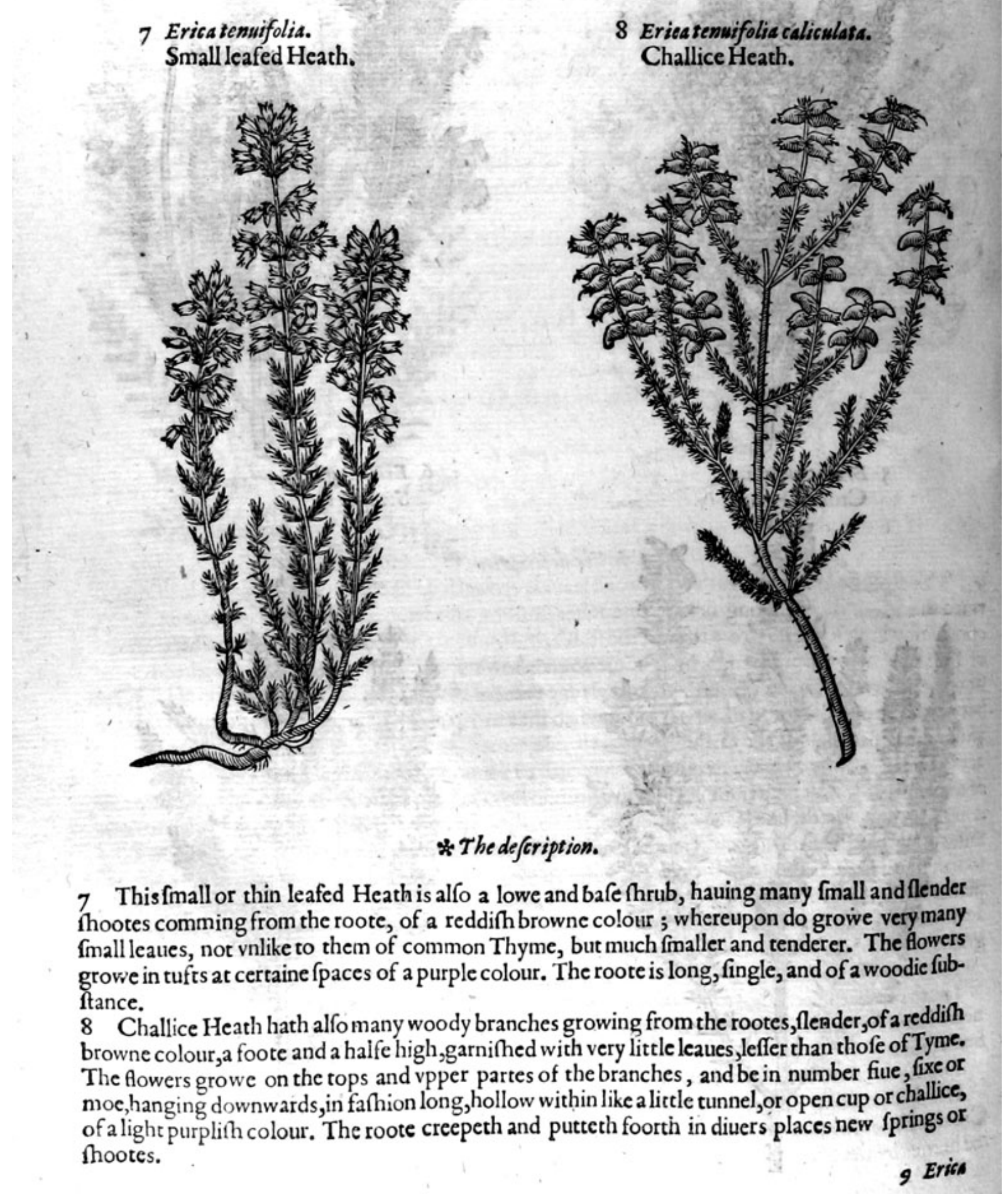


9 Erica baccifera latifolin.

Broad leafed Heath bearing berrics.
10. Erita bacciferatenuifolia. Small leafed Heath with berries.

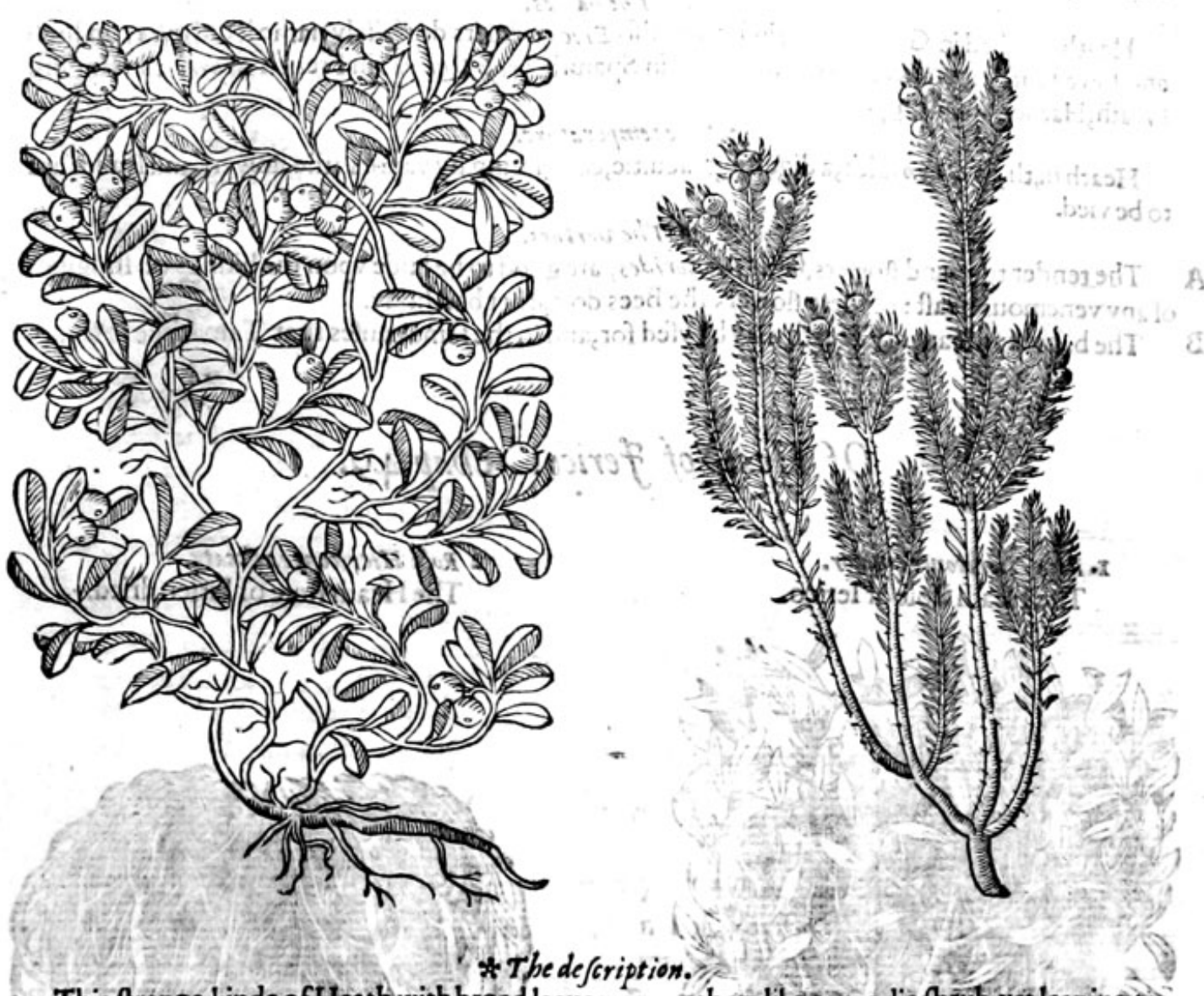

- This ftrange kinde of Heath with broad leaues, groweth vp like awoodie fhrub, yet leaning tos ward the ground, hath long flexible branches trailing this way and that way: whereon are let confuredly long leaues, narrow toward tbe ftalke, and blunt at the end, not vilike to thelittle leaues of Purlaine in forme: amoug which come foorth flowers which the grager hath omitred in the figure, and my felfe haue nacertaine knowledge thereof, bicaufe I haue notfecrie the fame. The berries are round, foft, and of a red colour when they be ripe. The roote is long, and creepeth far vinder the vpper crüt of the carth.

10 The thin leafed Heath that bringeth foorth berries, hath many weake and flender branches of a reddifh colour, whyich trailing vpon the ground do take hold thereofin ftundric places, whereby it mightily mereafeth. The leaues are fomwhat broad, of a thicke and fferhie fubftance, in tafte fornthingdrying at the firft, but afterwardes fomewhat fharp and biting the toong:-among which cone foorth fmall flowers of an herbie colour, which being vaded, there fucceede fmall round berries, that at the firft are green, and afterward black, being as big as thofe of Iuniperg wherin is contained a purple iuice like that of the Mulbery; within thofe berries are contained alfo fmall three cornered grains: The roote is hard, and of a woodie fubftance.

$$
\text { * } 7 \text { he place. }
$$

Heath groweth vpon drie mountaines which are hungrie and barren, as vpon Hampftead heath neere London, where all the fortes dogrow, except that with the white flowers, and that which beareth berries.

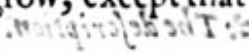

Heath with the white flawers groweth vpon the downes neere voto Grauefend, - Heath which beareth berries growert in the north parts of Eng

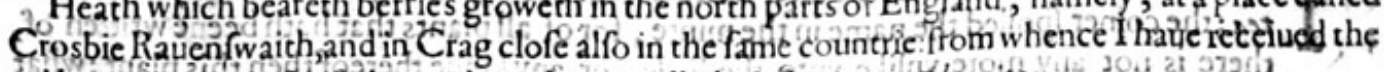

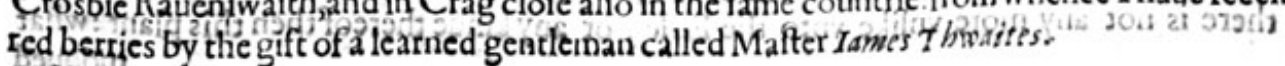


* The time.

Thefe kinds or forts of Heath, do for the moft part flower all the fommer, even vnitl the laft of September.

\section{*. The names.}

Heath is called in Grecke épéxn : in Latine alfo Erica : diuers do falfely name it cMyrica: in high and lowe Dutch ioftaen : in Italian Erica : in Spanifh Brefo Qui ro: in French Bruyre : in Englifh Heath, Hather, and Linge.

* The temperature.

Heath hath, as $G$ alen faith, a digefting facultie, confuming by vapors : the flowers and leaues are to be vfed.

* The vertucs.

A The tender tops and flowers, faith Diofcorides, are good to belaide vpon the bitings or ftingings of any venemous beaft: of thefe flowers the Bees do gather bad hony.

B The batke andleaues of Heath may be vfed for, and in the fame caufes that Tamariske is vfed.

\section{Of Heatb of ferico. Chap. 49 .}

I. Rofa Hiericontea maior. The Heath Rofe of lerico.

riscotbeoflgmatino

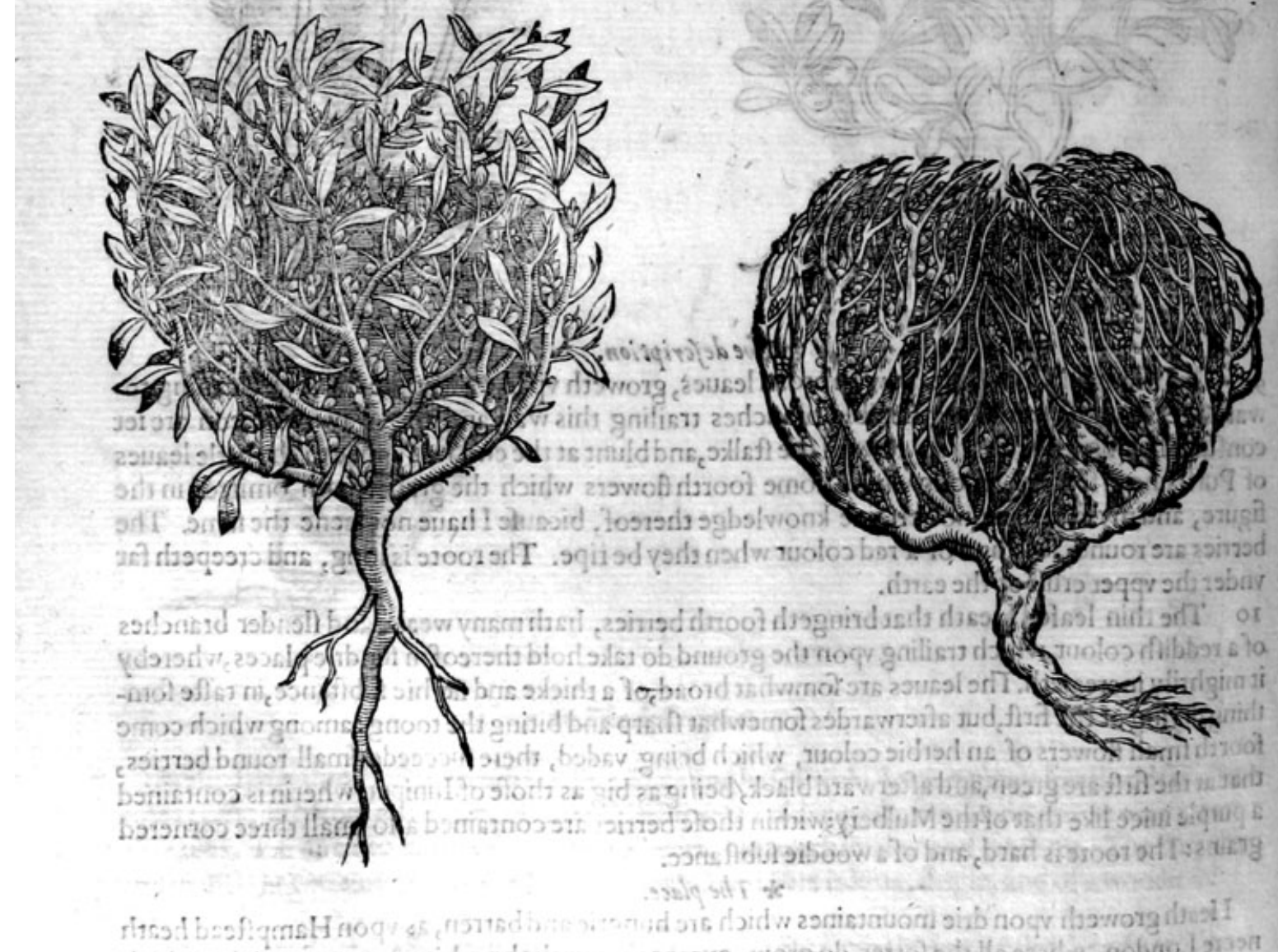

2 Rola Hiericontes frcents. The Heath Role of Ierico dried.

* The defcription.

x This kinde of Heath which of the later writers hath been called by the name Ro/a Hiericontea; the coiner fpoiled the name in the minte, for of all plants that hath beene written of, there is not any more vnlike vnto the Rofe, or any kinde thereof then this plant : what 
mooued them thereto I knowe not : but thus nuuch of my owne knowledge, it hath neither Mape, natare,nor facultie agreeing with any Role; the which donbtleffe is a kinde of Heath, as the barren foile, and that among Heath doth euidently thewe, as alfo the Heathie matter wherwith the whole plant is poffeffed, agreeing with the kinds of Heath in very notable points. It rifeth vp out of the ground of the height of fower inches, or an hand breadth, compact or made of fundry hard fticks, (which are theftalkes)clafping or fhucting it felfe togither into a round forme, intricately weatuing it felfe one fticke ouerthwart another, like a little net: vpon whiçh woodic ftickes do growe leaues not vnlike to thofe of the Oliue tree, which maketh the whole plant of a round forme, and hollowe within; ;among the leaues on the infide grow finall moffie flowers, of a whitifh herbic colour, which turne intolittle feede, like the feede of Rockec, but leffer: the whole plant is of the fubitaunce of Heath, and woodie.

2 The fecond figure fetteth foorth the dried plant, as it is brought vnto vs from beyond the feas, which being fet into a difh of warme water, for halfe an hower, it opencth it felfe in forme, as when it did growe, and taken foorth vntill it be dry, returneth fhut vp againe, as before. * The place.

It groweth in the barren grounds of France, and other hot regions, among the Heath and fuch like plants :it is a ftranger in England, yet dried we haue them in great plenty. * Thetime.

The feede being fowen in our colde climate, is fowen in Aprill; it periheth when it is fprong vp,and bringeth neither flowers nor feede.

* The names.

This kinde of Heath is called $R \circ / 4$ Hiericontes, or Hiericho, the Rofe of Ierico, of fome the Rofe of Ierufalem, and alfo Rofa Marie : in Englith the Heath Rofe.

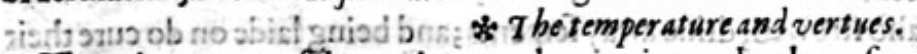

There is not any of the ancient nor later writers, that haue fet down any certaintie of this plant, as touching the remperature and faculties, but onely a bare picture with a flender defcription.

\section{Ofthe Chastetree. Chap.5o.}

\section{Vitex, fume Agnus Caftus.}

The Chafte tree.

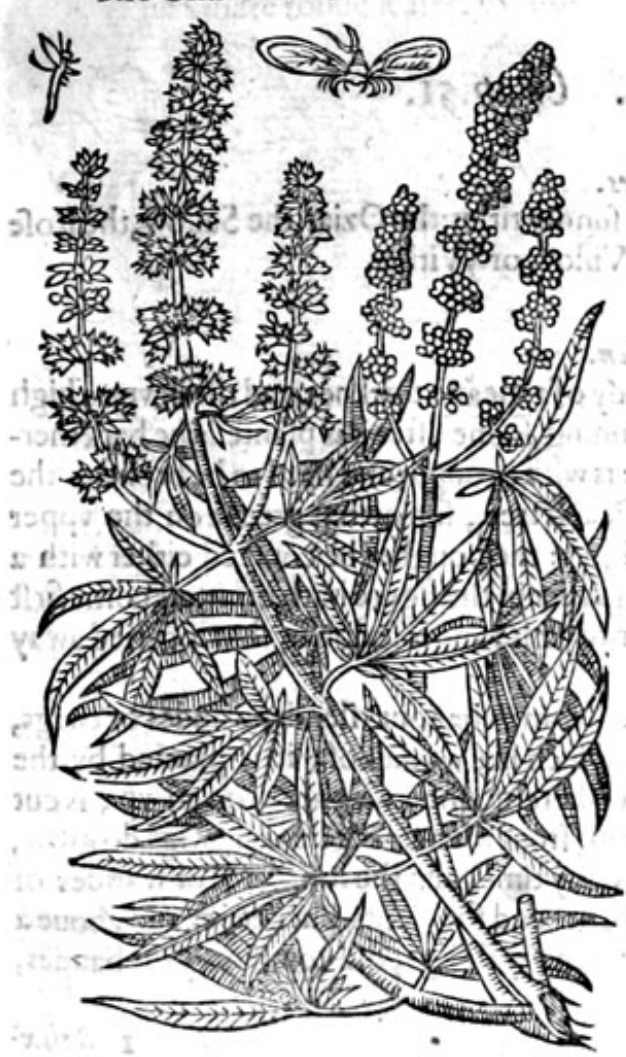

TItex, or the Chafte tree, groweth after the maner of a buthie fhrub or hedge tree, having manie twiggy branches, very pliant, \& eafic to be bent without breaking, like vnto the Willow: the leaues are for the moft diuided into fiuc or feauen fections or diuifions, much like the leaues of Hemp, whereof each part is long and parrow, very like vnto the Willow leafe but finaller : the Howers do grow at the vppermolt parts of the branches, like vnto fpikie eares; cluftering togither about the branches, after the fafhion of Mathioloushis Lilac, of a light blew colour, and very, fweete finell: the fruite is fmal and rounde, like vnto the graines or cornes of Pepper. * * The place.

Vitex groweth naturally in Italy, and other hot regions, by water courfes and running ftreams; I hauc it growing in my garden.

* The time.

$V$ itex beginneth to recouer his laft leaues in Maie, and the flowers come foorth in Auguft.

* The names.

The Grecians call this thrub àyros, and $\lambda \dot{u} 20$ : bicaufe faith Plinic in his 24. booke 9. chapter, the matrones $\mathrm{T}$ befmophoris Uthenienfium, defirous to keepe themfelues chafte do laie the leaues in their beddes vnder them; the Latines name it Vitex, 


\section{2}

\section{THE THIRD BOOKE OF THE}

and of dituers it is termed as we finde among the baftard and counterfet names àzuvos: in $\mathrm{L}_{\text {atine }} S_{a}$. Lix ma rina, or Salix Amerina, and Piper Agrefte: in high Dutch Bcbaffmulie, Xieuftbbaum: in low Dutch, and alfo of the Apothecaries Agnas caftus : the Italians Vitice, Agnocafto: in Spanin Gattilo cafto : in Englifh Chafte Trec, Hempe Tree, and of diuers Agnus caftus.

$$
\text { * The temperature. }
$$

The leaues and fruite of Agnus caftus are hot and dry in the third degree : they are of very thinne parts,and wafte or confurne winde.

\section{* The vertues.}

A Agnos caftus is a fingular medicine and remedic for fuch as woulde willingly liue chafte, for it withftandeth all vncleannes, or defite to the flefh, confuming and drying vp the feede of generation, in what fort foeuer it be taken, whether in powder only, or the decoction drunke, or whether the leaues be caried about the body; for which caufe it was called Caftus, that is, chafte, cleane, and pure.

B The feede of Agnus caftus drunken, driueth away and diffolueth all windineffe of the ftomacke, openeth and cureth the ftoppings of the liuer and fpleene ; and in the beginning of dropfies, it is good to be drunke in wine in the quantitie of a dram.

C The leaues ftamped with butter, diffolue and affwage the fwellings of the genitories and cods, being applied thereto.

D The decoction of the herbe and feede is good againft paine and inflammations about the matrix, if women be caufed to fit and bathe their priuy parts therein : the feed being drunk with Penny: roial bringeth downe the menfes, as it doth alfo both in a fume and in a peffary : in a Pultis it cureth the headach, the phrenetike, and thofe that haue the Lethargie are woont to be bathed heerewith, oile and vineger being added thereto.

E The leaues vfed in a fume, and alfo ftrowed, drite away ferpents; and being laide on do cure their bitings.

F The feede laide on with water doth heale the clifts or rifts of the fundament; with the leaues it is a remedie for lims out of ioint, and for woundes.

G It is reported that if fuch as iourney or travell do carry with them a branch or rod of Agmes ca: ftus in their hand, it will keepe them frommerry gals, and wearines: Diofcorides.

\section{Of the Willowe Tree. Chap.51.}

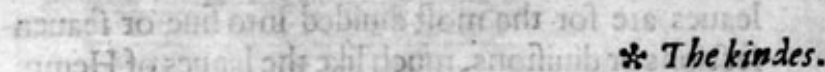

There be diuers forts of Willowes conteined vnder fundry titles:the Oziar, the Sallow, the Rofe Willow, the common Withie, and the Dwarffe Willow, or Withie.

\section{* The defcription.} 7 He common Willow is an high tree, with a body of a meane thicknes, and rifeth vp as high as other trees do if it be not topped in the beginning, foone after it is planted;the bark therof is fmooth, tough, and Alexible; the woode is white, tough, and hard to be broken: the leatues are long, leffer, and narrower then thofe of the Peach tree; fomewhat greene on the vpper fide and flipperie, and on the neather fide fofter and whiter: the boughes be couered either with 2 purple or elfe with a white barke; the catkins which the grauer in the figure hath omitted, come firt of all foorth, being long and moffic, and quickly turne into white and foft down, that is caried away with the winde.

2 The leffer bringeth foorth of the head which ftandeth fomewhat out, Alender wandes or twigs, with a reddifh or greene barke,good to make baskets and fuch like workes of; it is planted by the twigs or rods being thruft into the earth, the vpper part whereof when they are growen vp, is cut off, fo that which is called the head increafeth vnder them, from whence the flender twigs do grow, which being oftentimes cut, the head waxeth greater; many times alfo the long rods or wandes of the higher Withy trees be lopped off and thruft into the ground for plants, but deeper and abouca, mans height; of which do grow great rods, profitable for many things, and commonly for bandes, wherewith tubs and casks are bound. 
I Salix.

The common Willow.

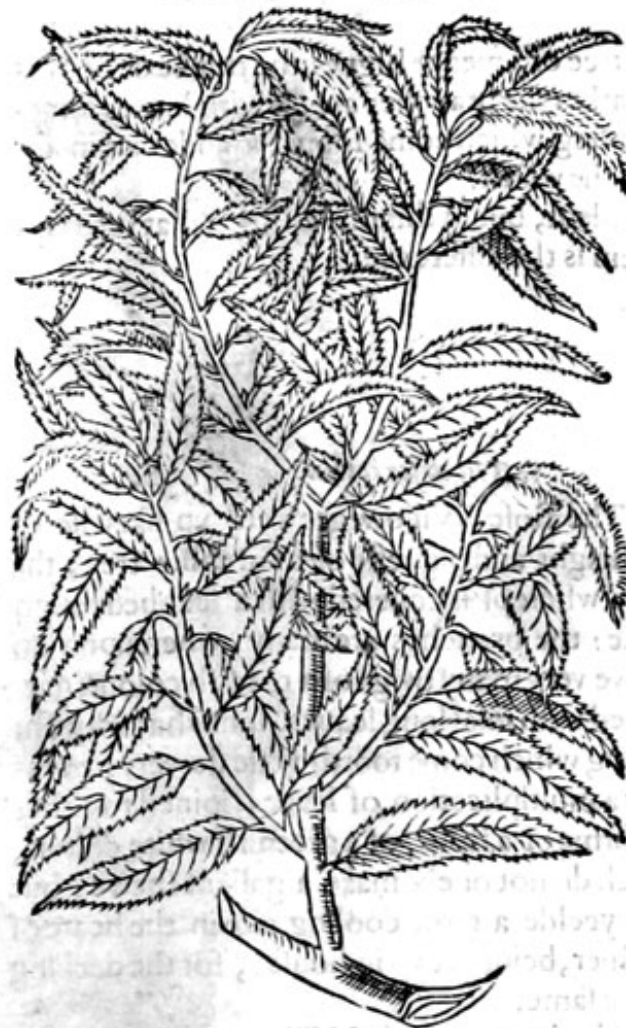

3 Salix Caprea rotundifolia.

The Goate round leafed Willow.

जil 1 -

*

(4)

(vi) a d (i) zo

1iv

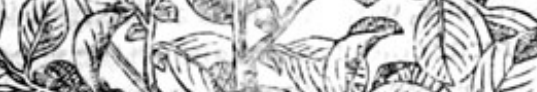

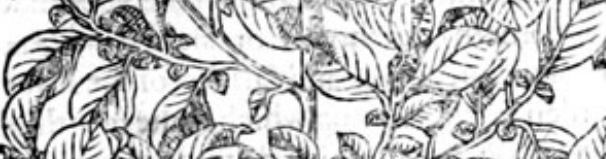

M

(1)

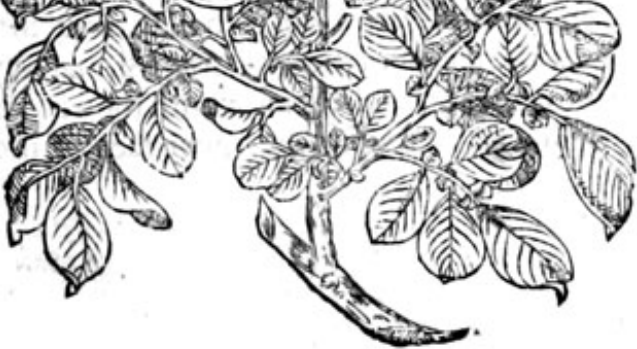

2 Salix aquatica.

The Oziar,or water Willow.

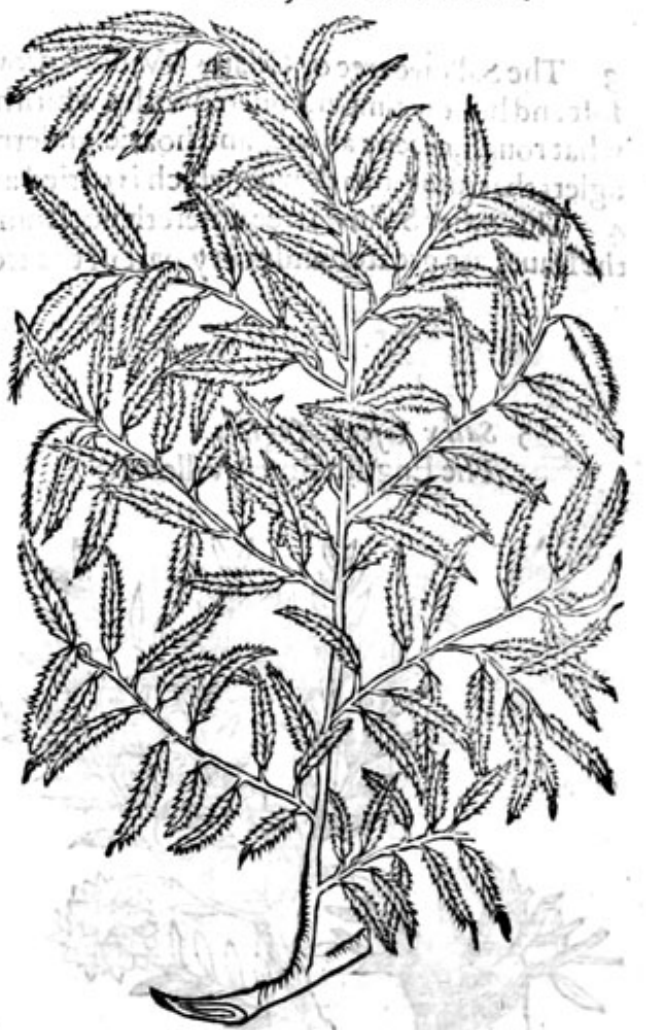

4 Salix Caprealatifolia.

The Goate broad leafed Sallow.

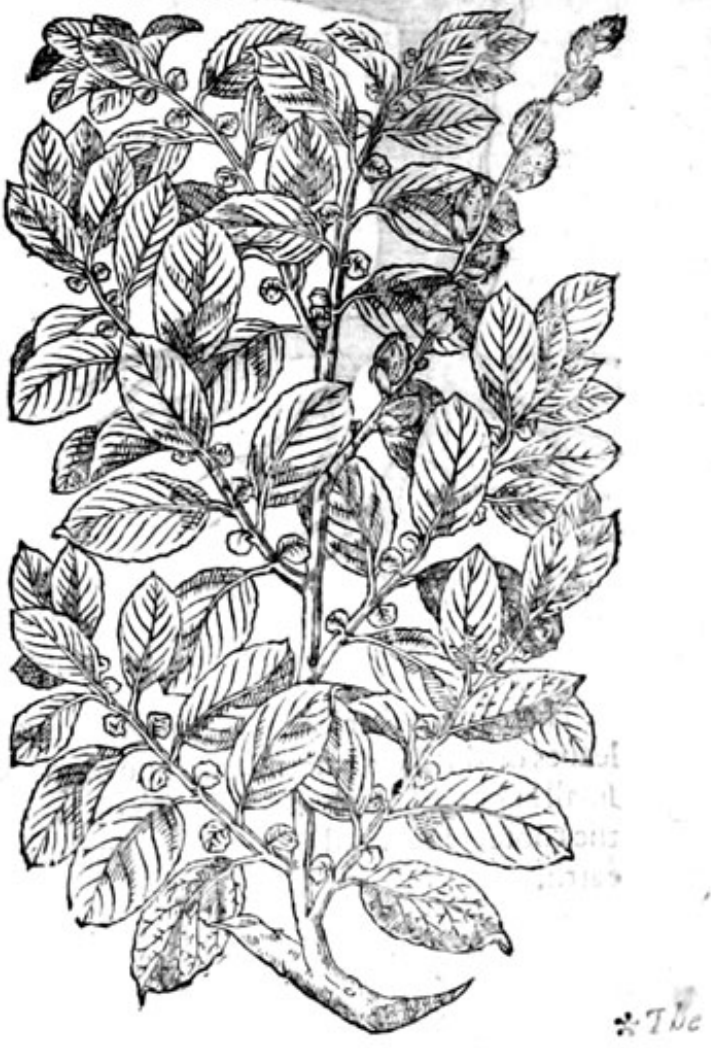


* The defcripsion.

3 The Sallowetree or Goates Willow, groweth to a tree of a meane bignes:the trunke or body is foft and hollow timber, couered with a whitifh rough barke: the branches are fer with leaues forne. what rough,greene aboue, and hoarie vnderneath; among which come foorth rounde catkinso: aglets that turne into downe, which is caried away with the winde.

4 This other Sallowe tree differeth not from the precedent, but in this one point, (that is to fay) the leaues are greater, and euery part of the tree, wherein is the difference.
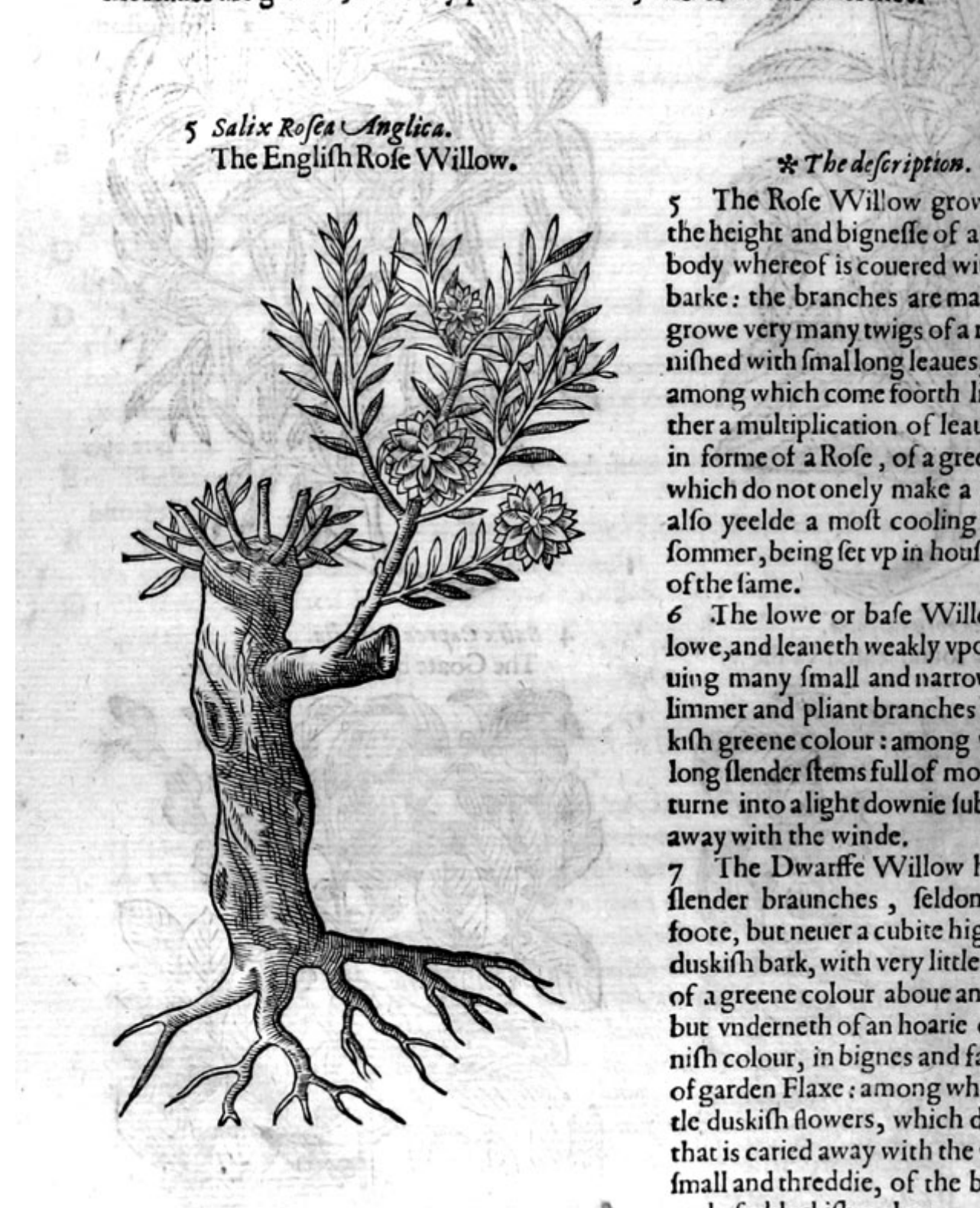

5 The Rofe Willow groweth vp likewife to the height and bigneffe of a fhrubbie tree; the body whereof is couered with a fcabbed rough barke: the branches are many, whereupon do growe very many twigs of a reddifh colour, garnifhed with fmallong leaues, fomwhat whitifh: among which come foorth little flowers, or rather a multiplication of leaues, ioined, rogither in forme of a Rofe, of a greenilh white colour, which do not onely make a gallant thewe, but alfo yeelde a moft cooling aire in the heate of fommer, being fet vp in houfes, for the decking of the fame.

6 The lowe or bafe Willowe, groweth but lowe, and leaneth weakly vpon the grounde, hauing many fmall and narroweleaues, fet vpon limmer and pliant branches, of a darke or blakıfh greene colour : among which come foorth long flender ftems full of moffie flowers, which turne into a light downie fubftance, that fliech away with the winde.

7 The Dwarffe Willow hath very fmall and flender braunches, feldome times aboue a foote, but neuer a cubite high, couered witha duskifh bark, with very little and narrow leaues, of a greene colour aboue and on the vpperfide, but vnderneth of an hoaric or ouerworne greenifh colour, in bignes and fafhion of the leaues of garden Flaxe : among which come foorth little duskifh flowers, which do turne into downe that is caried away with the winde: the roote is fmall and threddie, of the bigneffe of a finger, and of a blackinh colour.

There is another kinde of Willow like vnto the former, and differeth from it in that, that the leaues of this kinde are fmaller and narrower, as bigge as the leaues of the great Myrtill, hauing fmall knobbie flowers of a duskifh colour, which turne into downe that flieth away with the winde: the roote is fmall and limber, not growing deepe, but running along vpon the vpper face of the earth. 


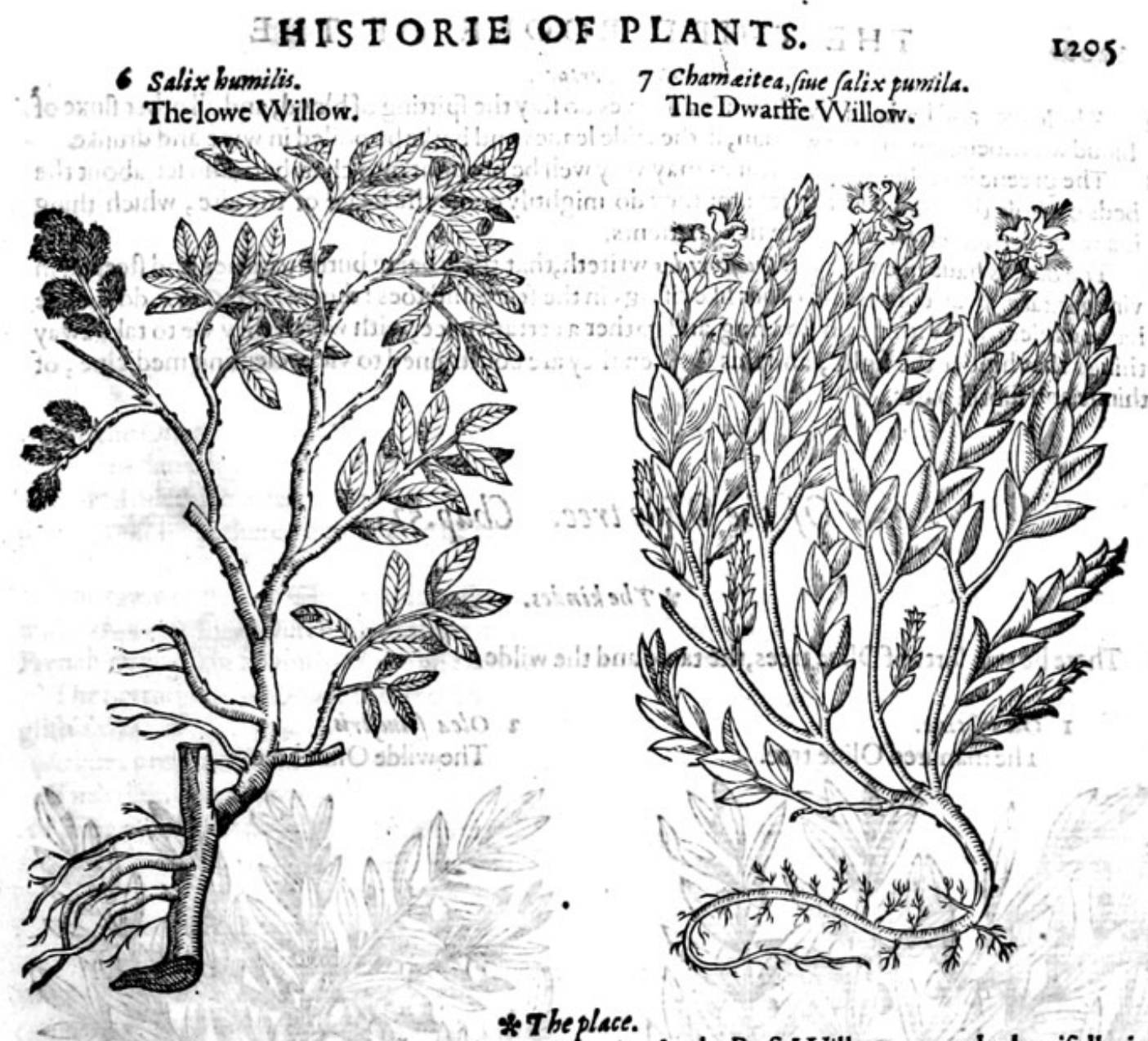

Thefe Willowes growe in diuers places of England; the Rofe Willow groweth plentifully in Cambridge fhire, by the riuers and ditches there in Cambridge towne they growe aboundantly about the places called Paradife, and Hell mouth, in the way from Cambridge to Graunchefter: I found the dwarffe Willowes growing neere to a bogge or marrifh grounde, at the further end of Hampfteed heath vpon the declining of the hill, in the ditch that inclofetha fmall cottage there, not halfe a furlong from the faide houfe or cottage.

\section{* The time.}

The Willowes do flower at the beginning of the Spring. * The names.

The Willow tree is called in Greekeiris : in Latine Salix : in high Dutch vectevnen : in lowe Dutch voriilgen : in Italian Salice, Salcio: in French Saux: in Spanilh Salgueiro, Salzer, and Sauz: in Englifh Sallow, Withie, and Willow.

The greater is called in Latine Salix perticalis: common Withy, Willow, or Sallow, efpecially that which being often lopped fendeth out from one head many boughes : the kinde heereof with the red barke is called of 7 heophraft w blacke Withic ; and the other, white: $P$ linie calleth the black Greca, or Greeke Withie, the red being the Greeke Withy, faith he, is eafie to be cleft $;$ and the whiter Amerina.

Theophraftus writeth, that the Arcadians do call the leffer isxùn,not iria: Plinie alfo nameth this Helise: both of them do make this tobe Salicis sertia ßpecies, the third kinde of Sallow : the fame is likewife called in Latine Salix pursila, Salix vimina lis, Gallica Salix and by Columella Sabina, which

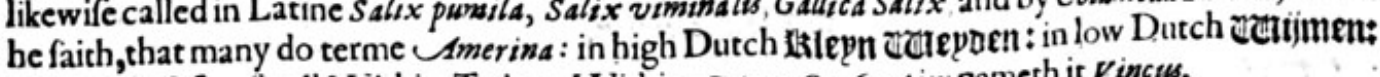
in Englifh Ofier, fimall Withie, Twigge Withic : Petrus Crefcentiw nameth it $V$ incus. * The temperature.

The leaues, flowers, feede, and barke of Willowes, are cold and dry in the fecond degree, and aftringent. 
*The vertues.

A The leaues and barke of Withie or Willowes do ftay the fpitting of bloudj;and allother fuxe of bloud what foeuer, in man or woman, if the faide leaues and barke be boiled in wine and drunke

$B$ The greene boughes with the leaues may very well be broughtinto chambers, and fet about the beds of thofe that be ficke of agues: for they do inightily coole the heate of the aire, which thing
is a woonderfull refrefhing to the ficke patients.

$C$ The barkes hauolike verrues: Diofcorides writeth

. vinegar, take away cornes and other like rifings in the feete and toes : diuers faith Galen, do flit the barke whiles the Withie is in flowring,and gather a certain iuice, with which they vfe to take away things that hinder the fight, and this is when they are conftrained to vfe 2 clenfing medicine, of thinne and fubtill parts.

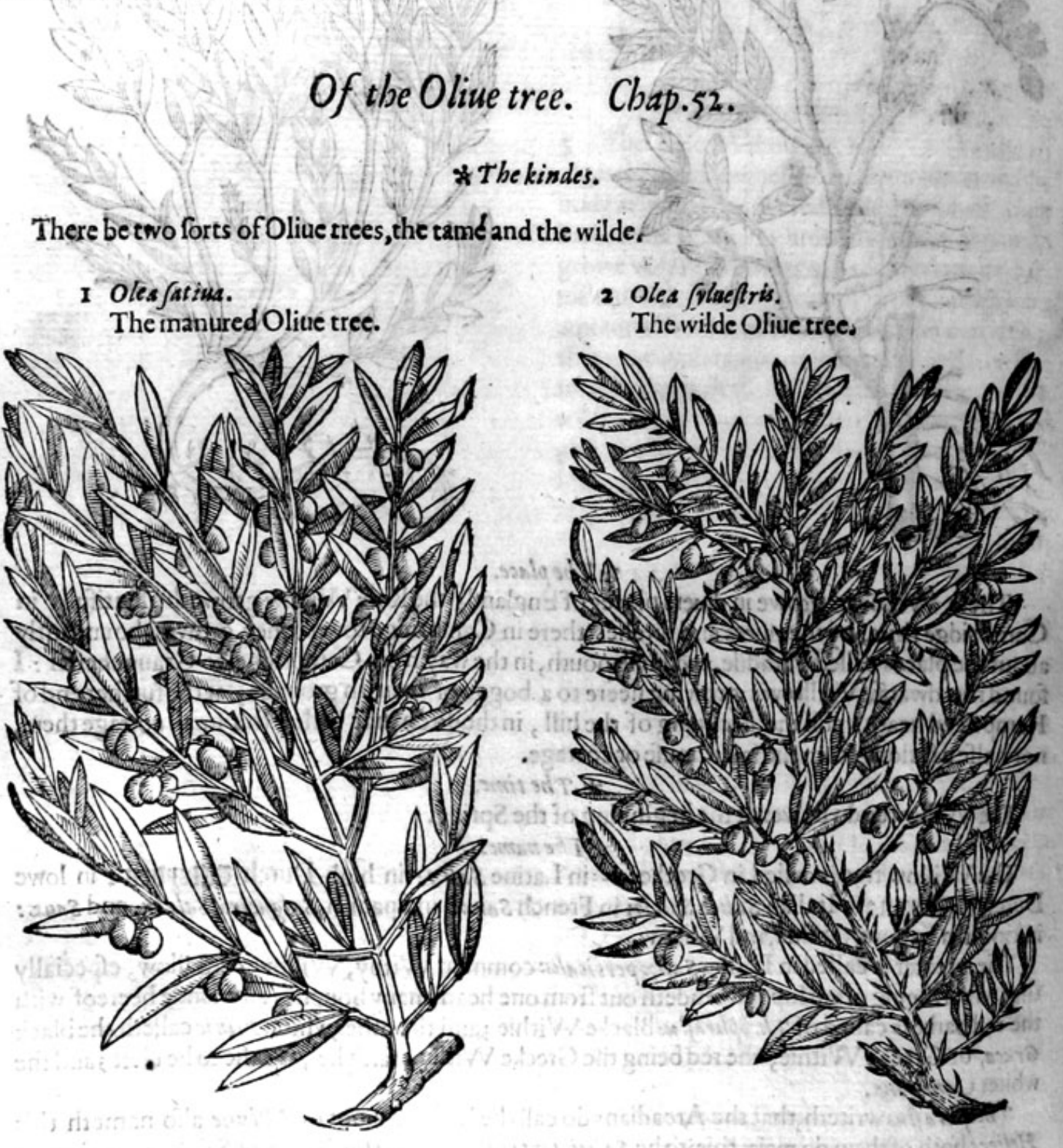

* The defcription.

1 He tame or manured Oliue tree, groweth high and great, with many branches, full of long

narrow leaues, not much vnlike the leaues of Willowes, but narrower and fmaller: the flowers be white and very fmall, growing vpon clufters or bunches : the fruite is long and round, wherein is an hard ftone:from which fruite is preffed that liquor which we call oile Oliue. 


\section{HISTORIE OF PLANTS.}

2 The wilde Oliue is like vnto the tame or garden Oliue tree, fauing that the leaues are fomewhat finaller,among which grow many prickly thornes : the fruite heercof is leffer then of the former, and mo in number, which doth feldome come to maturitic or ripenes, infomuch that the oile which is made of thofe berries, continueth euer greene, and is called oilc Omphacine, or oile of vnripe Oliues.

$$
\text { * T be place. }
$$

Both the tame and the wilde Oliue trees grow in very many places of Italy, France, and Spaine, and alfo in the Ilands adioining: they are reported to loue the fea coafts; for moft do thinke as Columella writcth, that abotie 6o.miles from the fea, they either drie, or clfe bring foorth no frutite : but the beft and they that do yecld the mort pleafant oile, are tholc that grow in the Ile called Candy. * The time.

All the Oliue trees flower in the moneth of Iune: the fruite is gathered in Nouember or December: when chey be a little dried \& begin to wrinkle, they are put into the preffe, and out of them is fquized oile,with water added in the preffing: the Oliues which are to be preferued in falt and pickle, muft be gathered before they be ripe; and whileft they are greene. * The names.

The tame or garden Oline tree is called in Greeke E'reiz, and ircia n̈usess: in Latine Oles fatius, and $\bar{Y}$ rbana : inhigh Dutch, Delbatum: in lowe Dutch Ditifboome: in Italian Olino domeftuco: in French Olinier: in Spanifh Oliwo and Oliwerd : in Englifh Oliue tree.

The berrie is called Oliws : in Greeke alfo inaia in Spanifh cszytuna : in French, Dutch and Englifh Olime.

Oliues preferued in brine or pickle are called colymbades.

The wilde Oliue tree is named in Greeke A'yeiscais : in Latine Olea fylueftris, Oleafter, Cotinus, Olea AEthiopica : in Dutch waid Delbanm: in Italian Olıso faluatico: in Spanirh vaebuche, Uzambulhegro: in French Oliwier faumage : in Englifh wilde Oliue tree.

$$
\text { * The temperature and vertues. }
$$

The Oliues which be fo ripe, as that eithetehey fall off themfelues, or be ready to fall (which are A named in Greek nevinninis,) be moderately hot and moift,yet being eaten they yeelde to the body little nourifhment.

The vnripe Oliues are dry and binding.

Thofe that are prefertued in pickle; called colymbades, do dry vp the onermuch moifture of the $\mathbf{C}$ ftomacke, they remooue the lothing of meate, ftirre vp an appetite; but there is no nourifhment at all that is to be looked for in them, mitch lefte good nourifhment.

The branches, leaues, and tender buds of the Oliue trees do coole, dry, and binde, and efpecially D of the wilde Oliue:for theybe of greater force then thofe of the tame, therefore by reafon they be milder, they are better for eie medicines, which haue need of binding things to be mixed with them.

The fame doe ftaie Saint Anthonies fire, the Phingles, epinyctides, night wheales, carbuncles, E and eating vlcers: being laid on with hony, they take away efchares, clenfe foule and filthie thers, \& quench the heate of hotfwellings, and be good for kernels in the flanks:they heale and'skinwounds in the hiead, and being chewed they are a remedv forvicers in the mouth. эT The inice and decoction allo are of the fame effect: the iuicedoth ouer and befides ntaie allmat $F$ ner of bleedings, and alfo the whites.

The iuice is preffed foorthof the ftamped leates, with wine added thereto (which is betrer) or G with water, and being dried in the funine it is made vp into little cakes like perfumes?

The fweate or Oile which iflueth foorth of the woode whileft it is in burning, healeth tetters, $\mathrm{H}$ fcurfs, and fcabs, if they be annointed therewith.

(9rThe fame which is preffed foorth from the vnripe Oliues, is as colde as it is binding. ar:Thenld oile which is made of fweet and ripe olines being kept long, doth withall become hotter $\mathrm{K}$ and is of greater forec to digeft and wafte away; and that oile which was made of the vritipe Olive beingolde, doth as yetretaine fome part of his former aftriction, and is of a mixt facultie, that is to fay, partly binding,and partly digefting; for it hath got this digefting or confuming facultie by age, and the other propertie of binding, of his owne natitre.

The oile of ripe Oliues mollifieth and aflwageth paine, diffolueth tumours or fwellings, is good $\mathrm{L}$ for the ftiffeneffe of the ioints, and againft crampies, efpecially being mingled according to Art with good and wholefome herbes, appropriate vnto thofe difeafes and griefes, as Hipericon, 
Cammomill,Dill, Lillies, Rofes, and many others, which do fortifie and increafe his vertues. M The oile of vnripe Oliues, called Omphacinum Oleum, doth ftay and driue away the beginning of
tumours, and inflammations, cooling the heate of burning vlcers, and exulcerations.

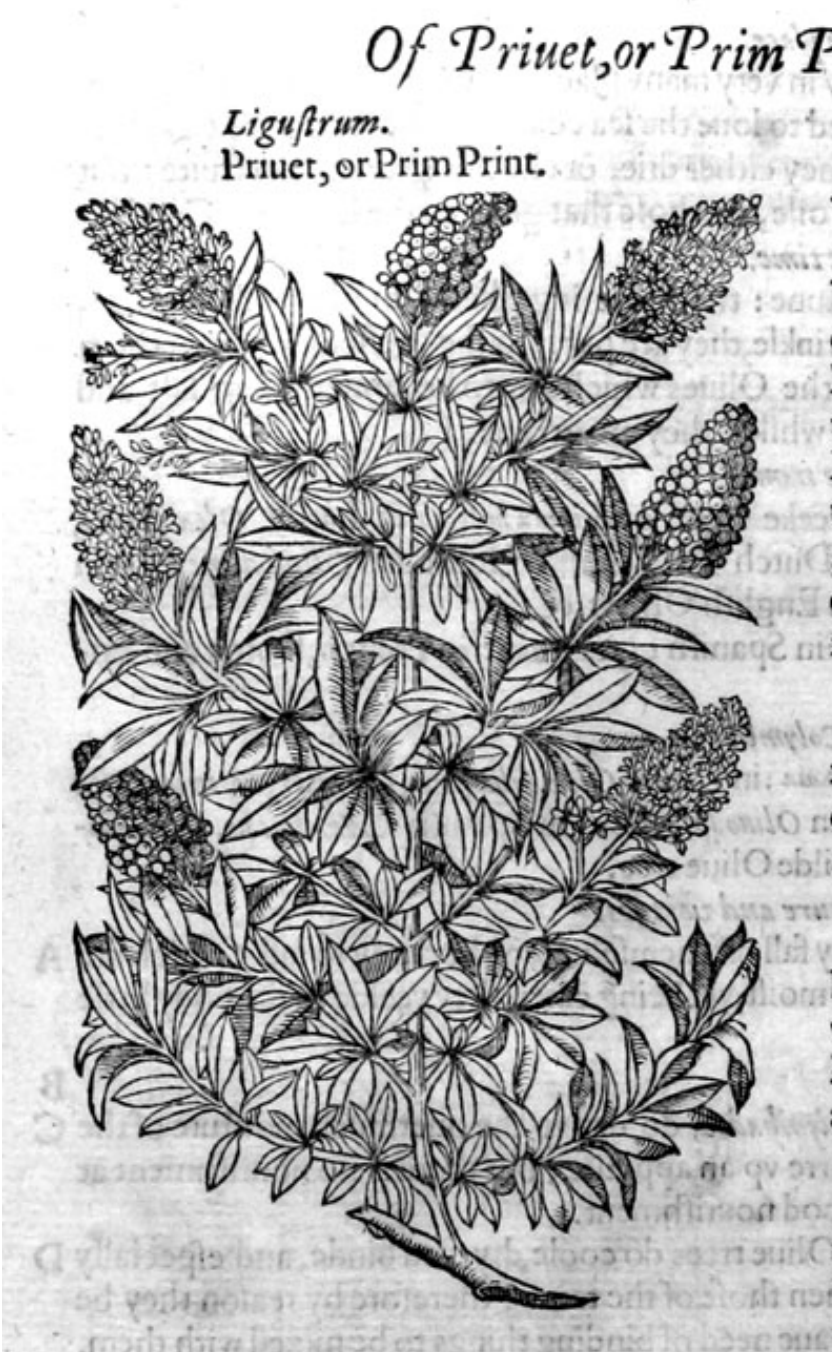

\section{Of Prinet, or Prim Print. Chap.53.}

Liguftrum.

be be very like one vnto another, as the defcriptions do declare, but yet in this they differ, as witneffeth Bellonius, bicaufe the leaues of Priuet do fall away in winter, and the leaues of Cyprus are alwaies greene: moreouer the leaues of Cyprus do make the haire red as Diofcorides faith, and as Bellonius reporteth, do gine a yellow colour; but the leaues of Priuet haue no vfe at all in dying: And therefore Plinie in his 24 .booke 10 .chap.was deceiued in that he iudged Priuet to be the felfe faine tree, which Cyprus is in the Ealt; which thing notwithrtanding he did not write as he himfelfe thought, but as other men fuppofe: for in his 12 .booke 14 .chap, he writeth thus: Some faith he affirme this, H (that is to fay Cyprus) to be that trce which is called in Italy Liguftrum; and that Ligaftrum or Priuet, is that plant which the Grecians call ormupese, the defcription doth declare.

Phillyrea,faith Diofecorides, is a tree Jike in bignes to Cyprus, with leaues blacker and broader then thofe of the Oliue tree; it hath fruite like to that of the mafticke tree,blacke, fomething fiveete, ftanding in clufters, and fuch a tree for all the worlde is Priuet; as we hatue before declared.

Serapio the Arabian doth call Priuet in his 44.chapter $M a b a l e b$. There is alfo another Mabaleb, which is a graine or feede, of which Auicen maketh mention in his 47 .chapter, that it doth by his warme and comfortable heate diffolue and affivage paine. Serapio feemeth to intreat of them both, \& to containe diuers of the Mabaleb vnder the title of one chapter: it is named in high Dutch

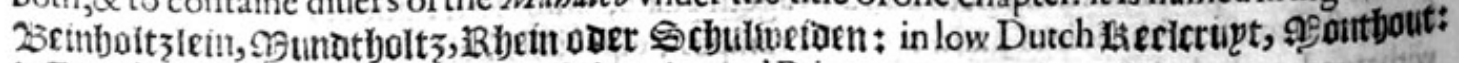
in French Troefne : in Englinh Priuet, Primprint,and Print.

Some 


\section{HISTORIE OF PLANTS.}

Some there be that would haue the berries to be called Vaccinia and Vaccinimm to be that, of which Vitrumies hath made mention in his 7 .bouke of Archite Eture, or the Art of building 14.chapter, of purple colours : after the fame maner, faith he, they temper Vactenium, and putting milke vnto it, do make a gallant purple: in fuch breuitie of the olde writers, what can be certainly determined ?

$$
\text { * The temperature. }
$$

The le aues and fruite of Priuet are colde, dry, and aftringent.

$$
\text { * The vertues. }
$$

The leaues of Priuet do cure the fivellings, apoftemations, and vlcers of the mouth and throate, A being gargarized with the iuice and decoction thereof, and therefore they be cxcellent good to be put into lotions, to wafh the fecret parts, and the fcaldings with women, cankers and fores in childrens mouths.

The berries are a pleafant meate in winter for owfels, thrufhes, and diuers other birdes.

\section{Of mocke Priuet. Chap.54.}

I Phillyrea anguftifolia.

Narrowe leafed mocke Priuec.

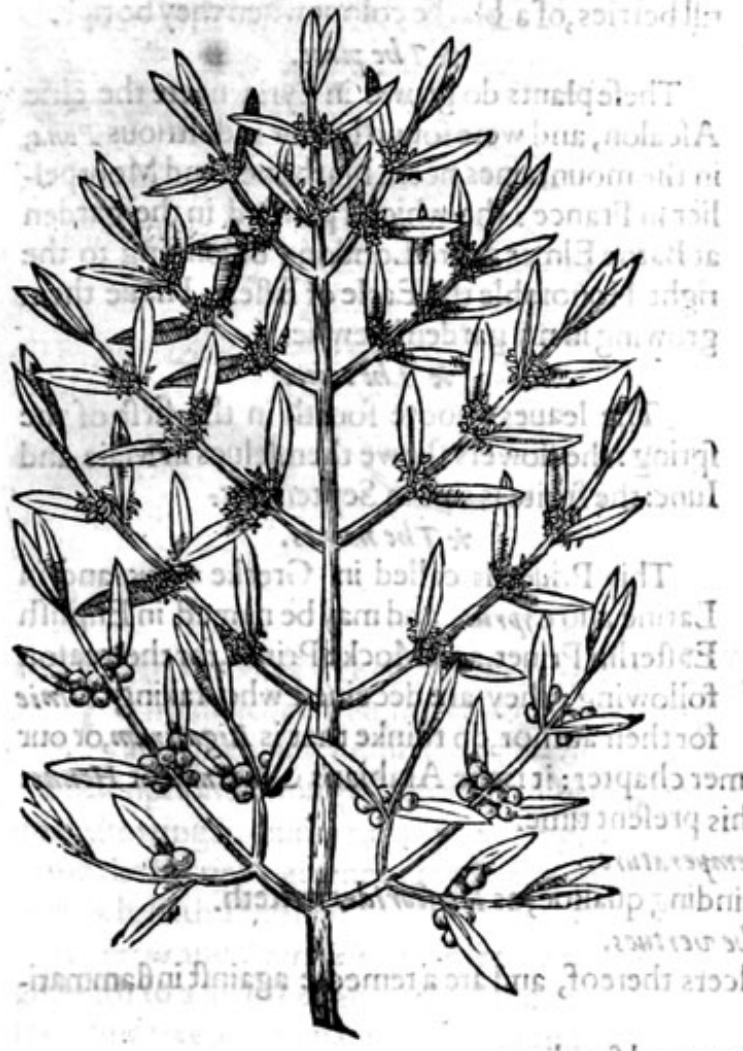

$*$ The defcription.

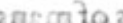

2 Phillyrealatiore folio.

The broader leafed mocke Pritet.

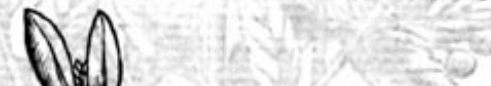

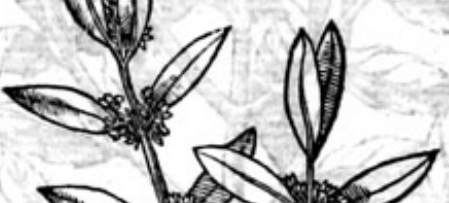
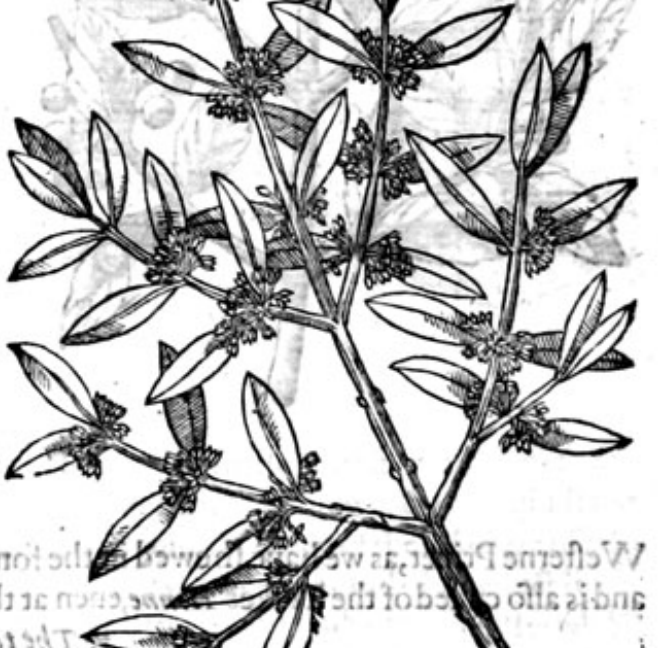

i Yyprus is a kinde of Priuet, and is called $P$ billyres, which name all the forts or kindes theteof do retaine, though for diftinction fake they paffe vnder fundry titles : this plant groweth

hike an hedge tree, fometimes as bigge as a Pomegranate tree, befet with flet der twig- $\mathrm{C}$ gie boughes, which are garnifhed with leaues, growing by couples, very like the leaues of the Oliue tree, but broader, fotter, and of a green colour : from the bofomes of thefe leates come foorth great bunches of fmall white lowers, of a pleafant fweete fmell, which being vaded there fucceed clufters of blacke berries, very like the berries of the Elder tree. 
* The defcripsion.

2 The fecond Cyprus called alfo P hillyrea Latifalia, is very like the former in body, branches, leaues, flowers, and truite: and the difference is this, that the leaues of this plant are broader, but in facultie they are like.

3 Phillyreaferrata 2. Clusï.

The fecond toothed Priuet of Clufins defcription.

* T hedefaription.

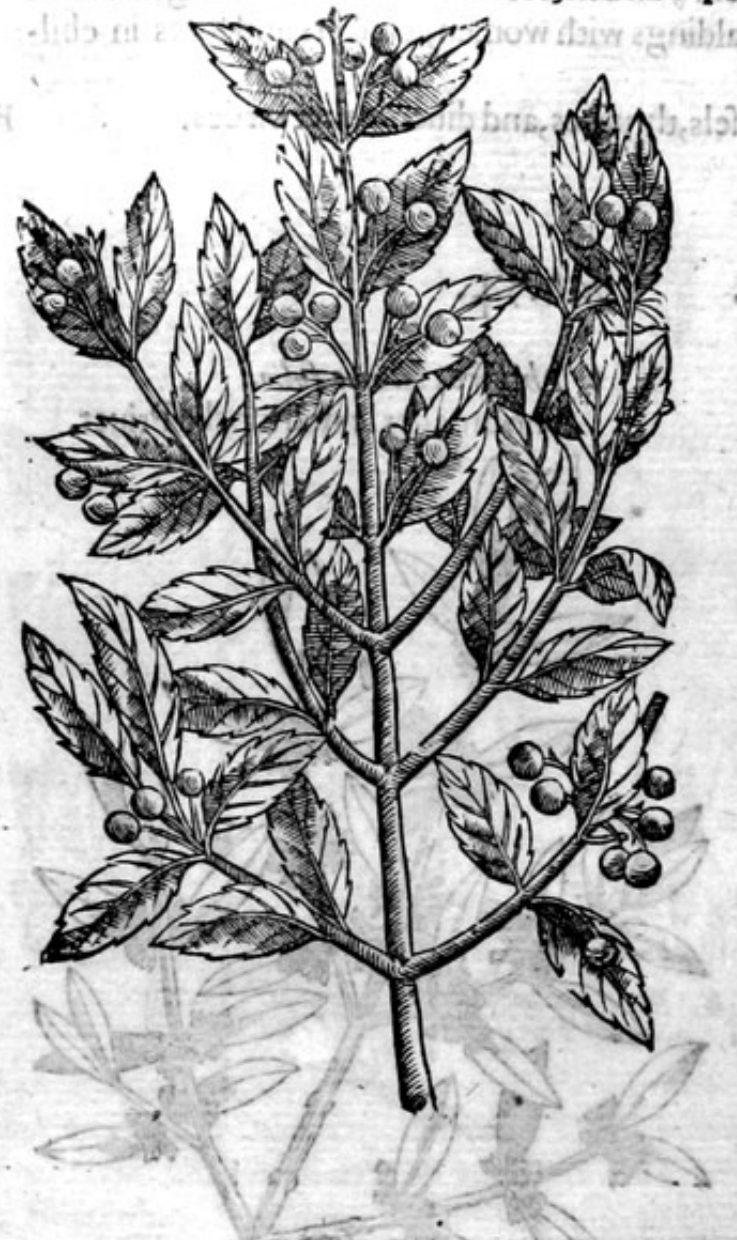

3 This kinde of Pruet rneth vp like an hedge bufh, of the height of fiue or fixe cubits : the branches are long, fragile or brittle, couered with 2 whitifh barke : whereon arefet leaues fomewhat broad, iagged on the edges like the teeth of a faw, and of a deepe greene colour: among which come forth the Alowers, which neither my author nor my felfe have feene: the berries grow vpon fmall footftalkes, for the moft part three togither, being round, \& of the bignes of pepper graines, or Mirtill berries, of a blacke colour when they be ripe. * T he place.

Thefe plants do growe in Syria neere the citie Afcalon, and were tound by our induftrious Pena, in the mountaines neere Narbone, and Montpellier in France : the which I planted in the garden at Barne Elmes neere London, belonging to the right Honorable the Earle of Effex; I haue them growing in my garden likewife.

* T thetione.

The leaues fhoote foorth in the firft of the fpring: the flowers thewe themfelues in Maie and Iune: the fruite is ripe in September.

$$
\text { *T The numes. }
$$

This Priuet is called in Greeke vimers : and in Latine alfo cypres, and may be named in Englifh Eafterlin Priuet,and MockePriuet, for the reafon following; they are deceiued who taking Plinie for their author, do thinke that is Liguftrvom, or our Wefterne Priuet, as we haue fhewed in the former chapter: it is the Arabians Lalksnna, or Hennit: and is alfo called of the Turkes Henne, euen at this prefent time.

The leanes of thefe kindes of Priuet haue a binding qualitie, as Diof cor ides writeth. * $*$ The vertues.

A Being chewed in the mouth they heale the vlcers thereof, and are a remedie againft inflammations, or hot fwellings.

B The decoction thereof is good againft burnings and fcaldings.

C The fame being ftamped and fteeped in the iuice of Mullen, and laide on, do make the haire red as piofcor ides noteth. Bellonius writeth, that not onely the haire, but alfo the neather parts of mans body, and nailes likewife are coloured and died herewith, which is counted an omament among the Turkes.

D The flowers being moiftined in vineger, and applied to the temples, affwageth headach.

E There is alfo made of thefe an oile, called olewm Cyprinum, fweete of fmell, and good to heat and fupple the fincwes.

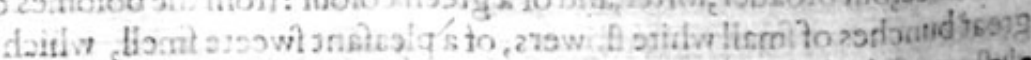

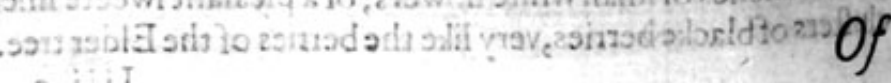




\section{Ofbastard Prinet. Cbap.55.}

1 Phillyrea arbor, verior Macaleb. Baftard Priuet.

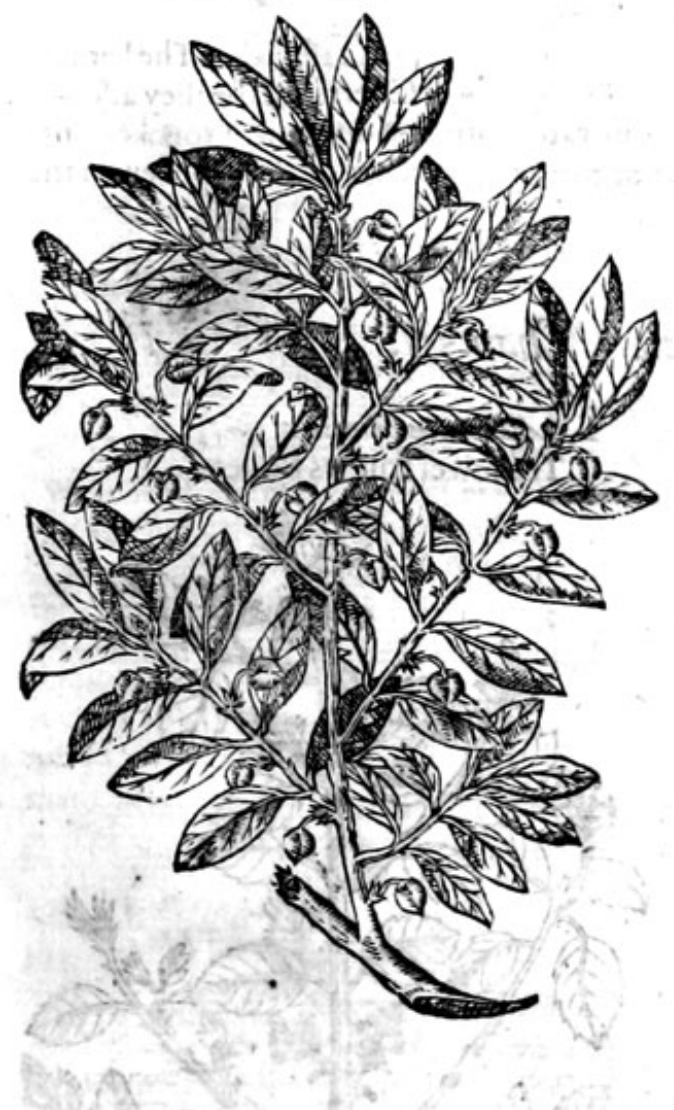

2 Macaleb Ge/neri. Corall Priver.

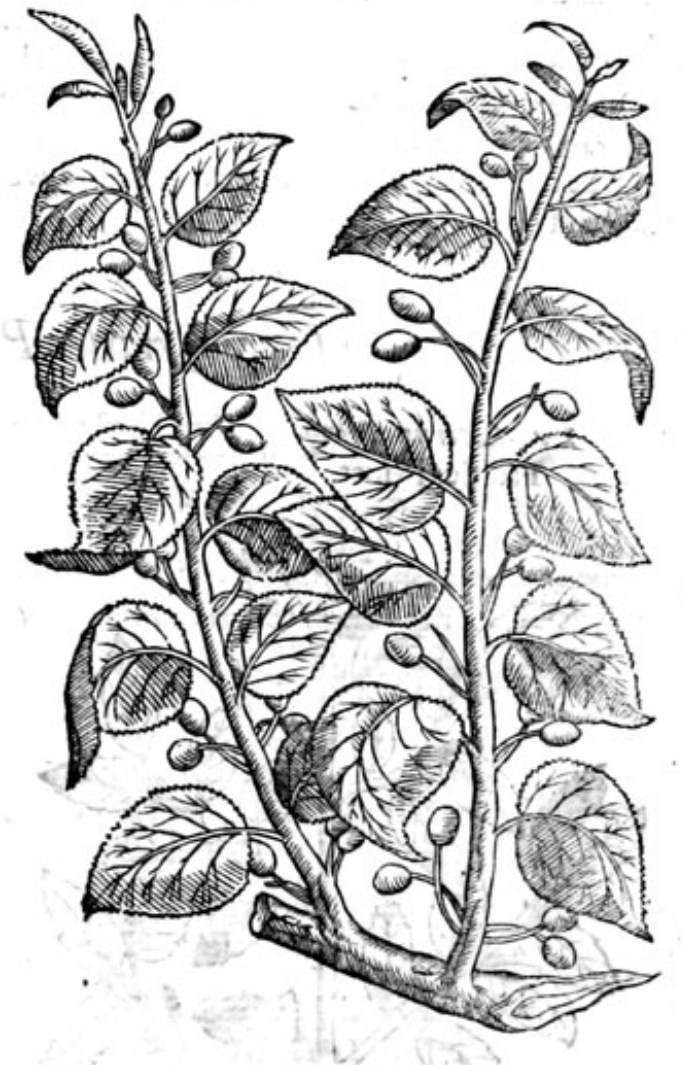

I 7 hedefcription.

His hrubbie tree called Macaleb or Mahaleb, is alfo one of the Prituets: it rifeth vp like vnto a fmall hedge tree, not ynlike vnto the Damfon or Bulleffe tree, hauing many vpright ftaiks and fpreading branches:whercon do grow leaues not vnlike to thofe of the phillhrea of $\mathrm{Clis}$ fius defcription: among which come foorth moffie flowers, of a white colour, and of a perfect fweet fmel,growing in clufters, many hanging ' pon one ftem, which the grauer hath ounted:after which come the berries, greene at the firt, and blacke when they be ripe, with a little hard ftone within, in which lieth a kerncll.

Gefnerses and Mathiolus haue fet foorth another Macaleb, being alfo anotherbaltard Pritet : it groweth to a fmall hedge tree, hauing many greene branches, fet with rounde leaues, like thofe of the Elme tree, fomewhat fnipt about the edges : the flowers are like thofe of the precedent:the fruit is as hard as a bead of corall, fomewhat rounce, and of a hining blacke colour, which the cunning . French Perfumers do bore through, making there of bracelets, chaines, and fuch like triting to:es, which they fende into England fmeared otier with fome odde fweet compound or other, and heere fold vnto our curious Ladies and gentlewomen for rare and ftrange Pome-ambers, for great fums of money.

$$
\text { * The place. }
$$

Thefe trees do grow in diuers places of France, as about Tholoufe, and fundry other places; they are ftrangers in England.

$*$ The time.
the fruite is ripe in Nouember and December. 
* The names.

This baftard Prituet is that tree, which diuers fufpect to be that Mahaleb, or Macaleb, of which Aui. ton writeth in his 478 .chap. S which alfo Serapiofpeaketh of out of Me fues: but it is an hard thing ding this is taken to be the fame of moft writers, and thofe of dit without markes: notwithftanbaftard Priuet, or Corall,or Pomander Priuet,being without doubt a kinde thereof * The temperature and vertues.

Concerning this baftarde Priuet, we haue learned as yet no vfe thereof in Phificke. The kernels which are found in the ftones or fruit, as they be like in tafte to thofe of Chetries, fo be they alfo an. fwerable vnto them in temperature: for they are of a temperate heate, and do gently prouoke vrine, and be therefore good for the ftone: more we haue not to write, then hath beene fpoken in the defcription.

\section{Of the fruitles Prinet. Chap. 56.}

I Nlaternas plini.

Fruitles Priuet.

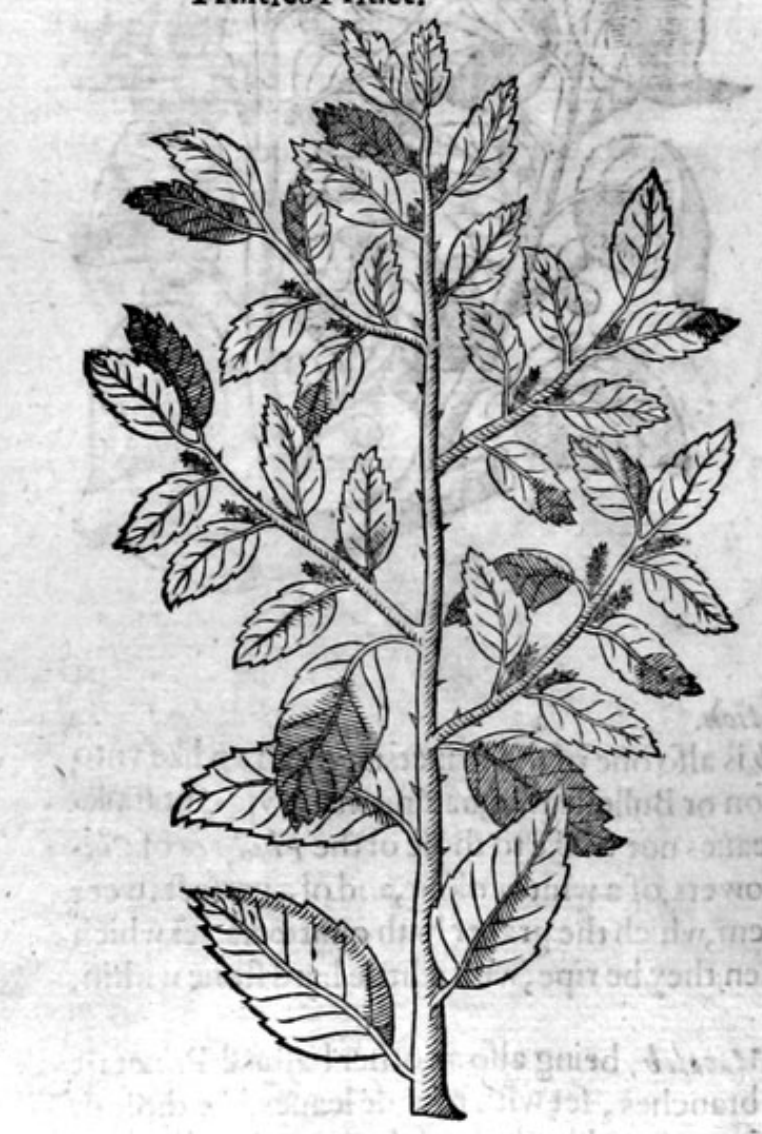

2 Alaternus humilior.

The lower fruitles Pritiet.

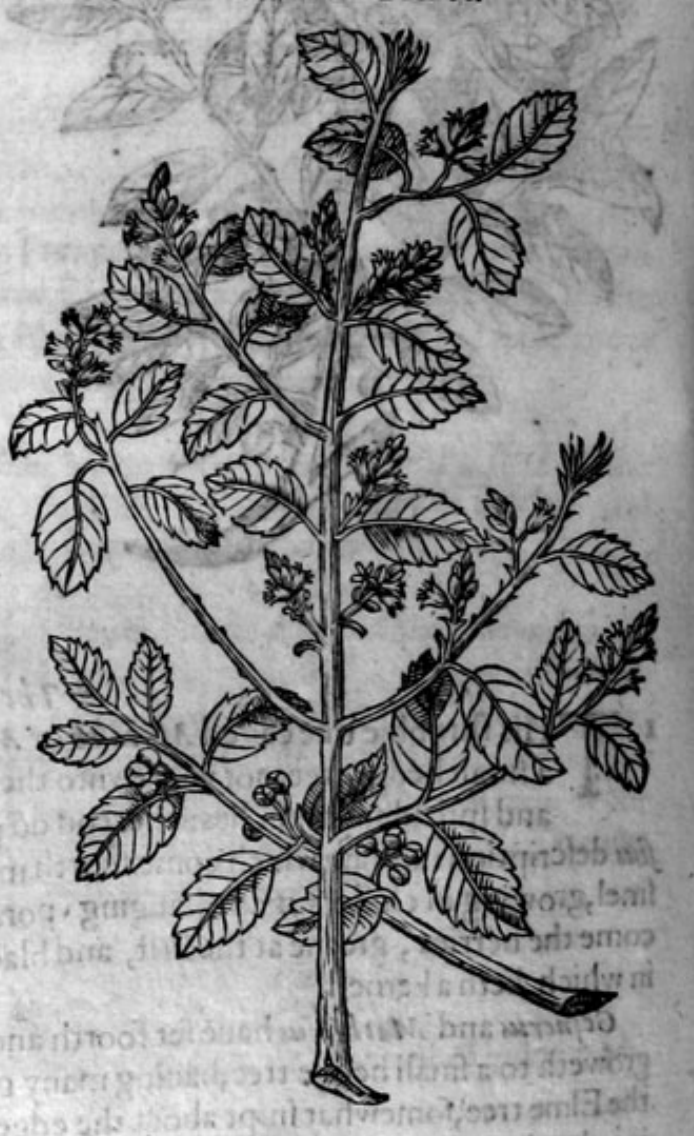

*T Thedefcription.

1 His fhrubbie bufh, called of Plinic and Carolus Clufues Slaternum, groweth vp to 2 finall hedge tree, in forme like vnto the baftard Priuet; but the leaues are more like thole of Ilex, or the French Oke,yet ftiffer and more rounder then thofe of Macaleb:among which come forth tufts of red flowers like thofe of the Lentiske tree: vnder and amongft the leaues come foorth the berries, like thofe of Laurus Tinus, in which are conteined two kernels, like vnto the Acines or ftones of the Grape.

2 The fecond kind of Alaternus is likewife a fruitles kinde of Priuet, hauing narrow leaues, fomwhat fnipt about the edgcs: from the bofomes whereof come foorth fmall herbie coloured fowers, which 
which being vaded, there fucceedeth the fruite whereof Auicen fpeaketh, calling it by the name Fagaras, being a fruite in bignes and forme like thofe in thops called Cocculus-tndi, and may be the af coloured skin or huske, which inclofeth a flender ftiffe fhell, like the fhell of a nut, couered with a thinne and blacke filne, whecher it be the fruite of this plant it is not cenfured; notwithitanding you fhall finde the figure heereof among the Indian fruites, by the name Fagaras.

\section{* 7 he place.}

Thefe plants do grow in the fhadowie woods of France, and are ftrangers in England.

The time anfwereth the reft of the Priuets.

$$
\text { * The time. }
$$

\section{\& $T$ henomes.}

Alaternus of Pliny, is the fame Phillyrea, which Theophraftus hath written of by the name $P$ htlyca, and Bellomims alfo in his firft booke 42 chapter of his fingularities, and the Cretenfes call it Eleprimon; the Portugales Cafca : in French Dalader, and Sangin blant: in Englifh barren or fruitleffe Priuet : notwithftanding fome have thought it to beare fruite, which at this day is called fagaras, with vs Cocculus indi , as we haue faide.

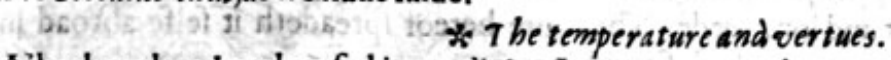

Whether the plant be vfed in medicine I cannot as yet learne: the fifhermen of Portingale do A vie to feeth the batke thereof in water, with the which decoction they catch firh, 2s alfo colour their nets, being very fit for that purpofe.

In Englande we vfe the fruite called cocculus-indi in powder, to mixe with flower, honie, and B crums of bread, to catch fifhwith, being a numming, foporiferoùs or a fleeping medicine, caufech the fifh to turne vp their bellies, as being fenceleffe for a time.

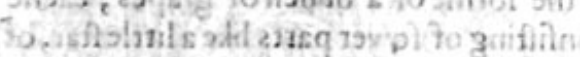 \\ Of theswbite and blew}

I Syringa alba. White Pipe.

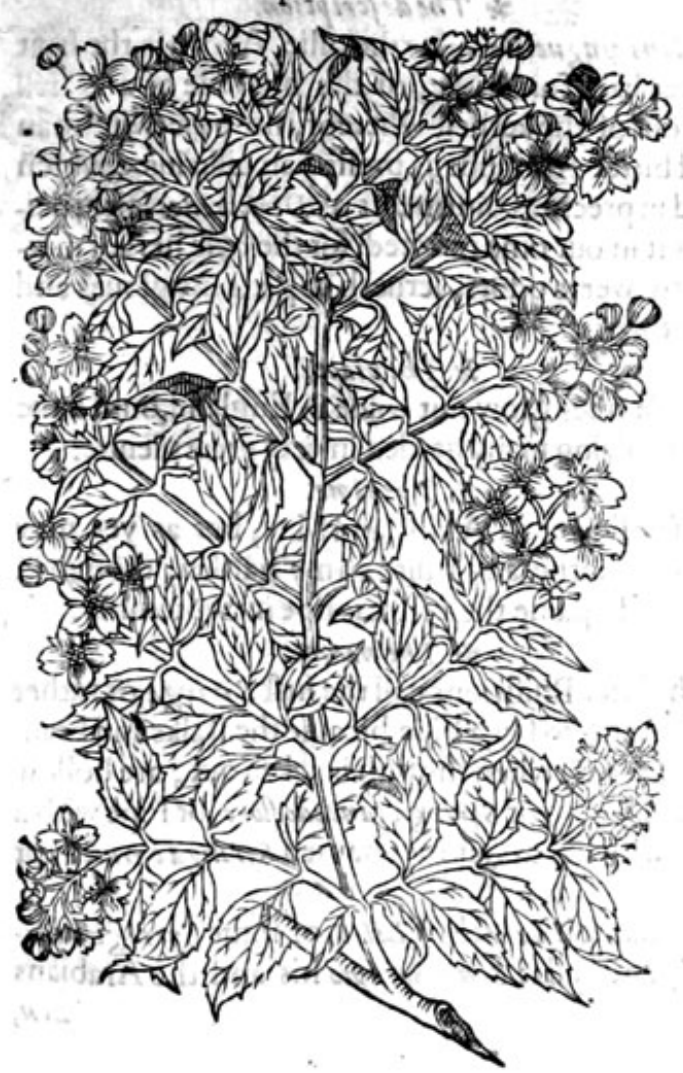

\section{pipe Prinets. Chap.57.}

2 Syringa Carulea: Blewe Pipe.

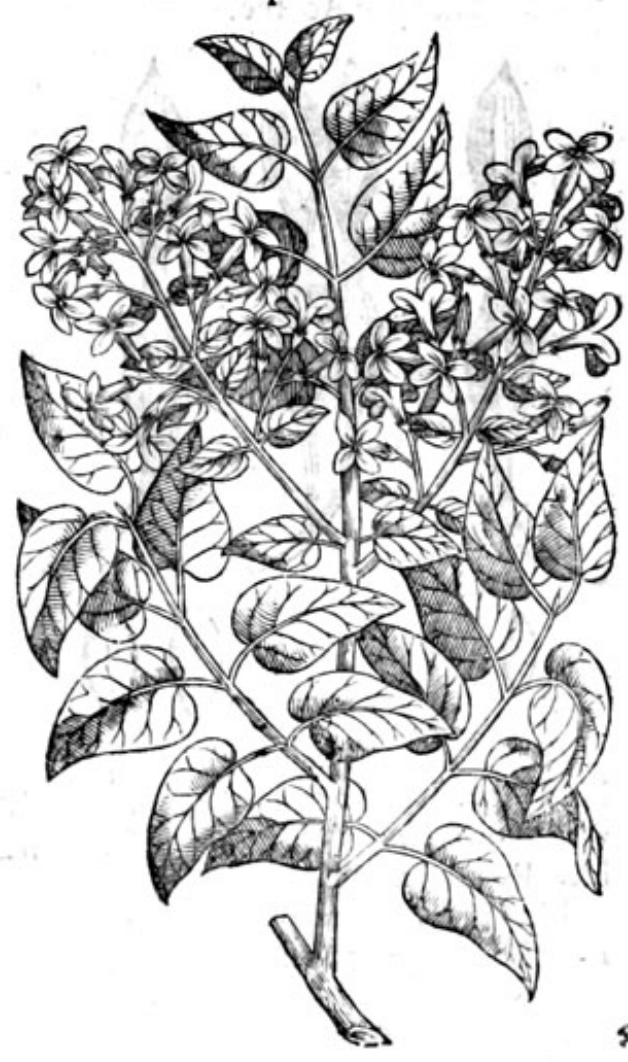

\&Tibe 
* The defcription.

I 7 He white Pipe groweth like an hedge tree, or bufhie fhrub: from the roote whereof arife many fhoores, which in flort time grawe to be equall with the oldeftocke, whereby in little time it increafeth vnto infinite numbers, like the common Englifh Prim or Priuet, where of doubtleffe it is a kinde, if we confider euery circumftance. The branches are couered with a rugged gray barke:the timber is white, with fome pith or f pungie matter in the middle like Elder, but leffer in quantitie. Thefe little branches are garnifhed with fmall crumpled leaues, of the thape and bignes of Peare tree leaues, and very like in forme:among which come foorth the flowers growing in tufts, compact of fower fmall leaues of a white colour, and of a pleafant fweete fmell: but in my iudgement they are too fweete, troubling and molefting the head in very ftrange manner. I once gathered the flowers, and laid them in my chamber window, which fmelled moreftrongly after they had lien togither a few howers, with fuch a ponticke and vnacquainted fauor, that they awaked me from fleepe, fo that I could not take any reft vntill I had caft them out of my chamber. When the flowers be vaded, then followeth the fruit, which is fmall, curled, and as it were compact of many little folds, broad towards the vpper part, and narrow towards the ftalke, and blacke when it is ripe, wherein is contained a flender and long feede. The roote hereof fpreadeth it felfe abroad in the ground, after the manner of the rootes of fuch finrubbic trees.

2 The blew Pipe groweth likewife in manner of a fmal hedgetrec, with many fhootes rifing from the roote like the former, as our common Priuet doth, wherof it is a kinde. The branches have fome fmall quantitie of pith in the middle of the wood, and are couered with a darke black greenifh barke or rinde. The leaues are exceeding greene and crumpled or turned vp like the brims of an hat, in Thape very like vnto the leaucs of the Poplar tree: among which come the flowers of an exceeding faire blewe colour, compact of many fmall flowers, in the forme of a bunch of grapes, eache flower is in thew like thofe of r'aleriana rubra Dodonet, confifting of fower parts like a liteleftar, of an exceeding fweete fauour and fnel, but not foftrong as the former. When thefe flowers be gone, there fucceede flat cods and fomwhac long, which being ripe are of a lighrcolour, with a thin mem. brane or filme in the midit, wherein are feedes almoft fower fquare, narrow and ruddie.

\section{Balanus Myrepfica, fue Glans vnguentaria.}

\section{The oylie Acorne.}

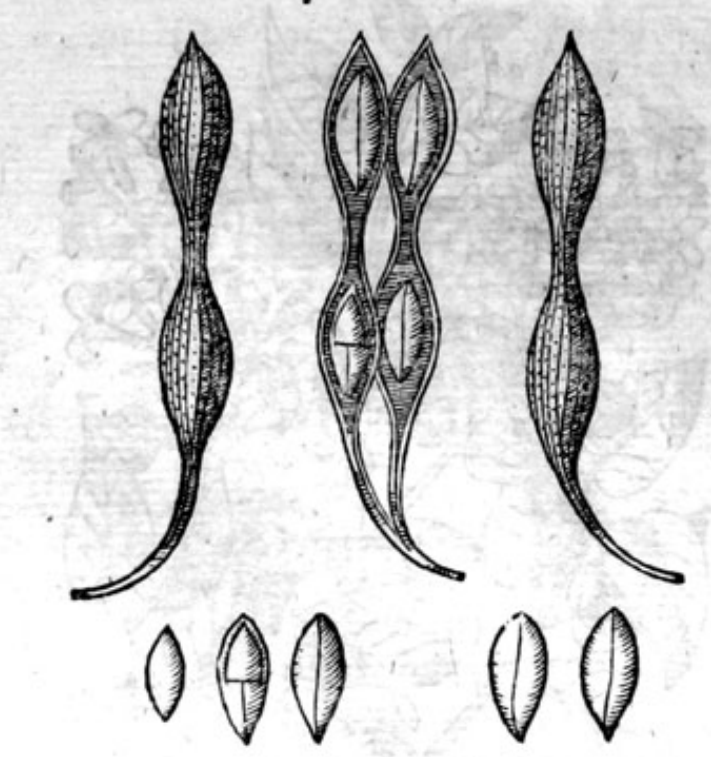

* The defoription.

3 Glans vnguentaria or the oilie Acorn is the fruit of a tree like Tamariske, of the bigneffe of a Hafell nut : out of the kernell whereof, no otherwile than out of bitter Almonds, is preffed an oilie inice, which is vfed in precious ointments, as Diofcorides faith, neither is it in our time reiected: for the oyle hereof mixed with fweete odors, ferueth toperfume gloues and other things.

\section{* Theplace.}

Thefe trees grow not wilde in England, but I haue them growing in my garden in very grcatplentie.

$$
\text { * The time. }
$$

They flower in Aprill and May, but as yet they haue notborne any fruite in my garden, though in Italie and Spaine their fruit is ripe in September.

$$
\text { * The names. }
$$

The later Phifitions call the firft Syringa, or rather o'er $\gamma_{5}$, that is to fay, a Pipe, bicaufe the ftalks and branches thereof, when the pith is taken out, are hollow like a Pipe. It is alfo many times furnamed Candida or white, or Syring a candidoflore, or Pipe with a white flower, bicaufe it hould differ from Lillach, which is fomecimes named syringacerules, or blew Pipe: in Englifh White Pipe.

Blew Pipe, the later phifitions, as we haue faid, do name it Lillach, or Lilac, of fome Syringacarubea, or blew Pipe, inoft do expound the word Lillach, and call it $B c N$ : Sarapio his and the Arabians 


\section{HISTORIE OF PLANTS.}

Ben, is Glans vnguentaria, which the Grecians name Ra'ravos pup w wini, from which Lillach doth very much differ: among other differences it is very apparant, that Lillach bringeth foorth no not, howThe figure where doth falifly pieture it onely a little cod, the feede whereof hath in it no oyle at all. roome.

Concerning the vfe and faculcies of thefe thrubs, neither we our felues hame found out any thing, nor learned ought of others.

\section{Of Widow Wayle, or Spurge Oline. Chapis8.}

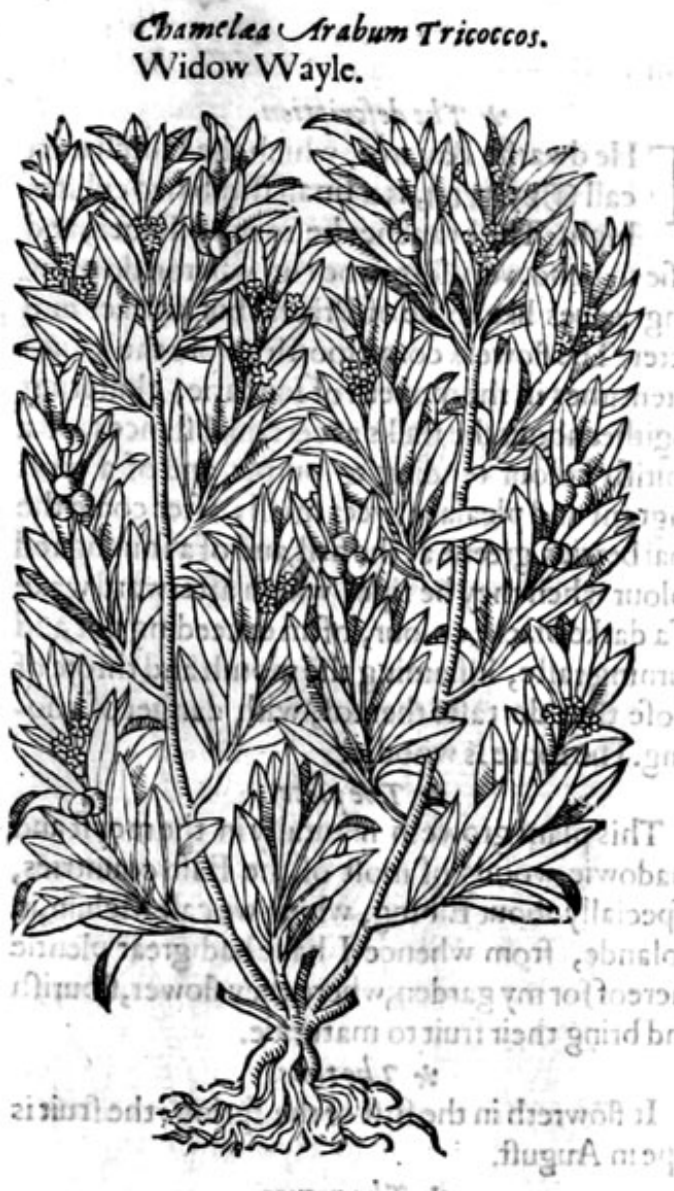

$\mathrm{W}$

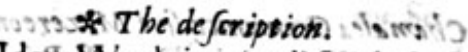

ftance, branched withmany final twigs

ful of little leaues like Priuet, but fmaller and blacker:on the ends whereof growe finallpale yellowe flowers; which being paft, there fucceedeth a three corned berrie like the Tithymales, for which caufe it was called Tricoccos, that is, three berried chamelea : thefe berries are green at the firft, red afterward, and browne when they be withered, and containe in them an oỳlie fatneffe like that of the Oliues, being of a harpe and biting tafte, and that goth burne the mouth, as do both the leaues and rinde. The roote is hard and woodie.

\section{* Theplace.}

It is fouride in moft vntilled grounds of Italie, and Languedocke in Fratince, in rough and defarr places. I have it growing in my garden.

\section{* Thetame.}

It is alway grecke:the feede is ripe in Ausumne. * The names.

The Grecians call it raininate, as though they Phould fay lowe or hotr Oliue tree : the Latines Oleago and Oleastellus, and likewife Crtocacium: it is alfo named of diuers Olimella, as Matbesw Syluaticus faith: it is called in Englifh Widow Wayle quia facit vidure.

The fruit is named of ditiers roxros wiskos: in $\mathrm{L}_{2}$ -

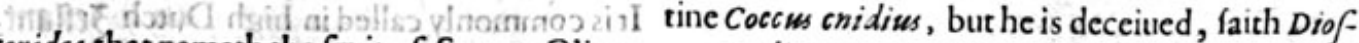
corides, thatnameth the fruit of Spurge Oliue Coicus cnidius: Auicen and Serropio call Chamelea, or

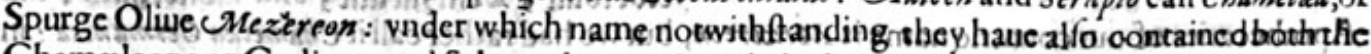

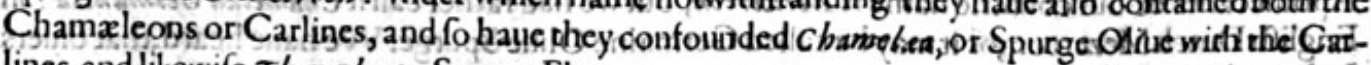
lines, and likewife Thymelea or Spurge Flawe

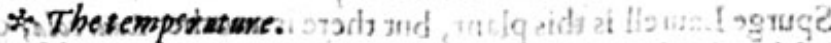

Both the leaues and fruit of Spurge Oliue, as we haue faid, ate of a burning and extremehot temperature.

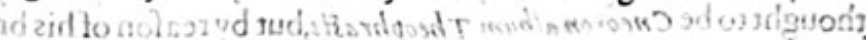

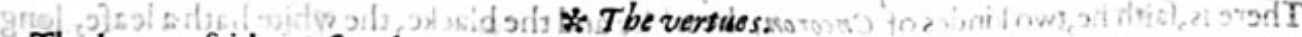

The leaues, faith Digfcorides, purge both flegme andecholer, efpecially taken in pils, forbatrwb A partes of Wormwood be-mixed with, pne of Spurge Oliue, and inade vp into pils with Meade'or honie water. They mels not in the belly, buc as many as be taken are voi ded whole. 
B. Mefres likewife hath a defcription of pils of the leaues of Spurge Oliue (yet Sylmius expoundeth it Spurge Flaxe) but in ftead of Wormwood, he taketh the outward fubftance of the yellow Miro. balans and Cepula Mirobalans, and maketh them vp with Tereniabin, that is tofay, with Manna and fower Dates, which they call Tamarinds, diffolued in Endiite water : and appointeth the fame leaues to be firft tempered with very ftrong vineger and to be dried.

C Thefe pils are commended againft the dropfie, for they drawe foorth waterie humors, but they be violent to nature:therefore we muft vfe them as little as may be. Furthermore, Diofcorides addeth,
that the leaues of Spurge Oliuc beaten with hony, do clenfe filthie and crufted vlcers,

\section{.8 OfGermaine Oliue Spurge. Chap.59.}

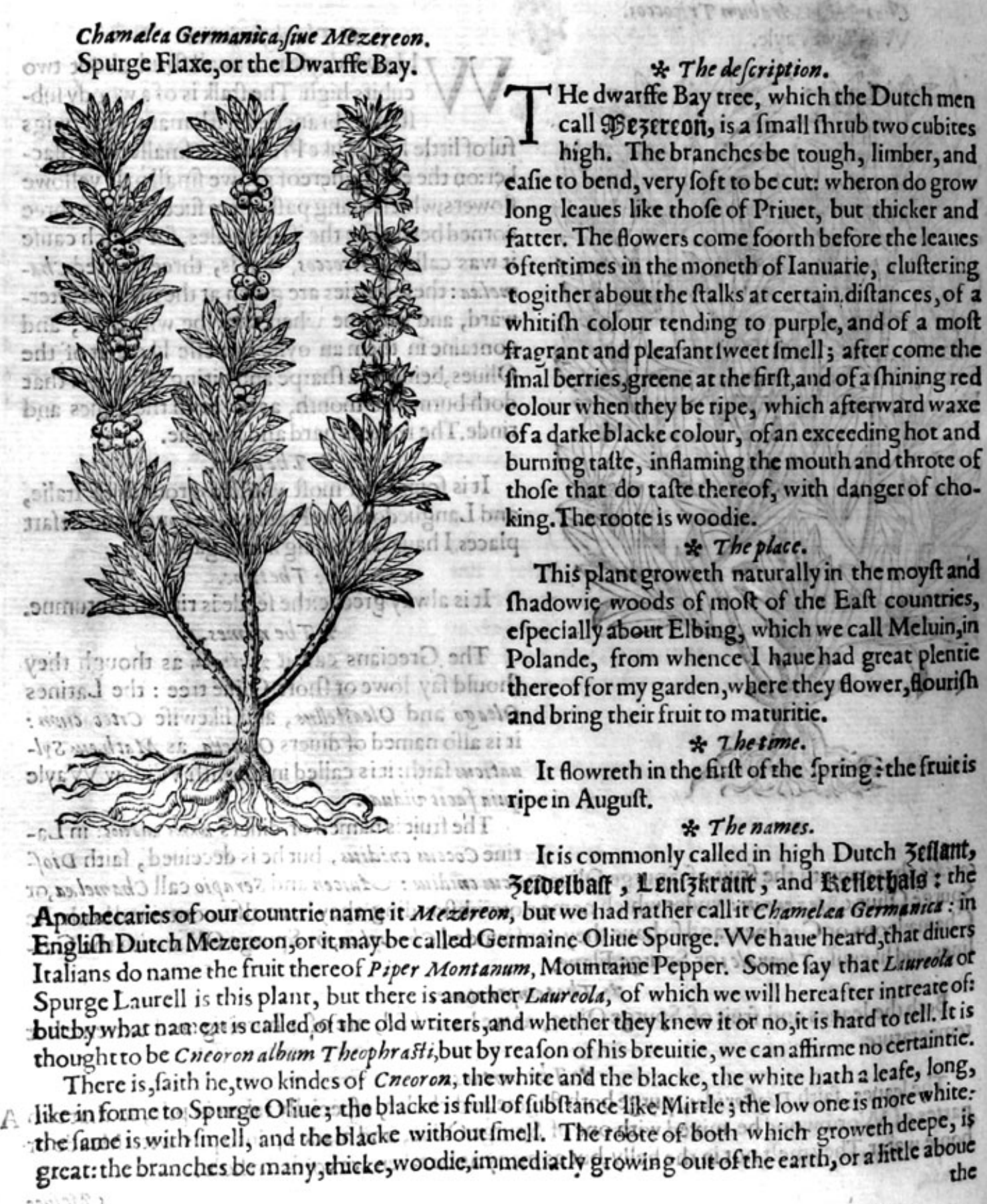


the earth, tough: wherefore they vfe thefe to binde with, as with Oziars. They bud and flower when the Autumne Equinoctiall is paft, and a long time after. Thus much 7 beophristres.

The Germaine Spurge Oliue is not much vnlike to the Oliue tree in leafe: the flower is fweete of fmell:the buds whereof, as we haue written, come foorth after Autumne: the branches are wogdie and pliable:the roote long, growing decpe : all which thew that it hath great likenes and affinitie with Cneoron (if it be not the very fame.)

\section{* The temperature.}

This plant is likewife in all parts extrenc hot, the fruit, the leaues, 'and the rinde are very fharpe and biting: they bite the toong, and fet the throte on fire.

$$
\text { * The vertucs. }
$$

The leaues of Mezereon do purge downward, flegme, choler, and waterifh humors with great $\mathbf{A}$ violence.

Alfo if a drunkard do eate one grainc or berric ef this plant, he cannot be allured to drinke hany B . drinke at that time; fuch will be the heate of his mouth and choking in the throte.

This plant is very dangerous to be taken into the bodie, and in nature like vnto the Sea Tithy. C male, leauing (if it be chewed) fuch an heate and burning in the throte, that it is hard to be quenched.

The fhops of Germanie and of the Lowe countries do when neede require, vfe the leaues hereof D in ftead of Spurge Oliue, which may be done without error; for this Germaine Spurge Oliue is like in vertue and operation tô the orher, therefore it may be vfed in Atead thereof, and prepared after the like and felfefame manner.

\section{Of Spurge Flaxe. Chap. 60.}

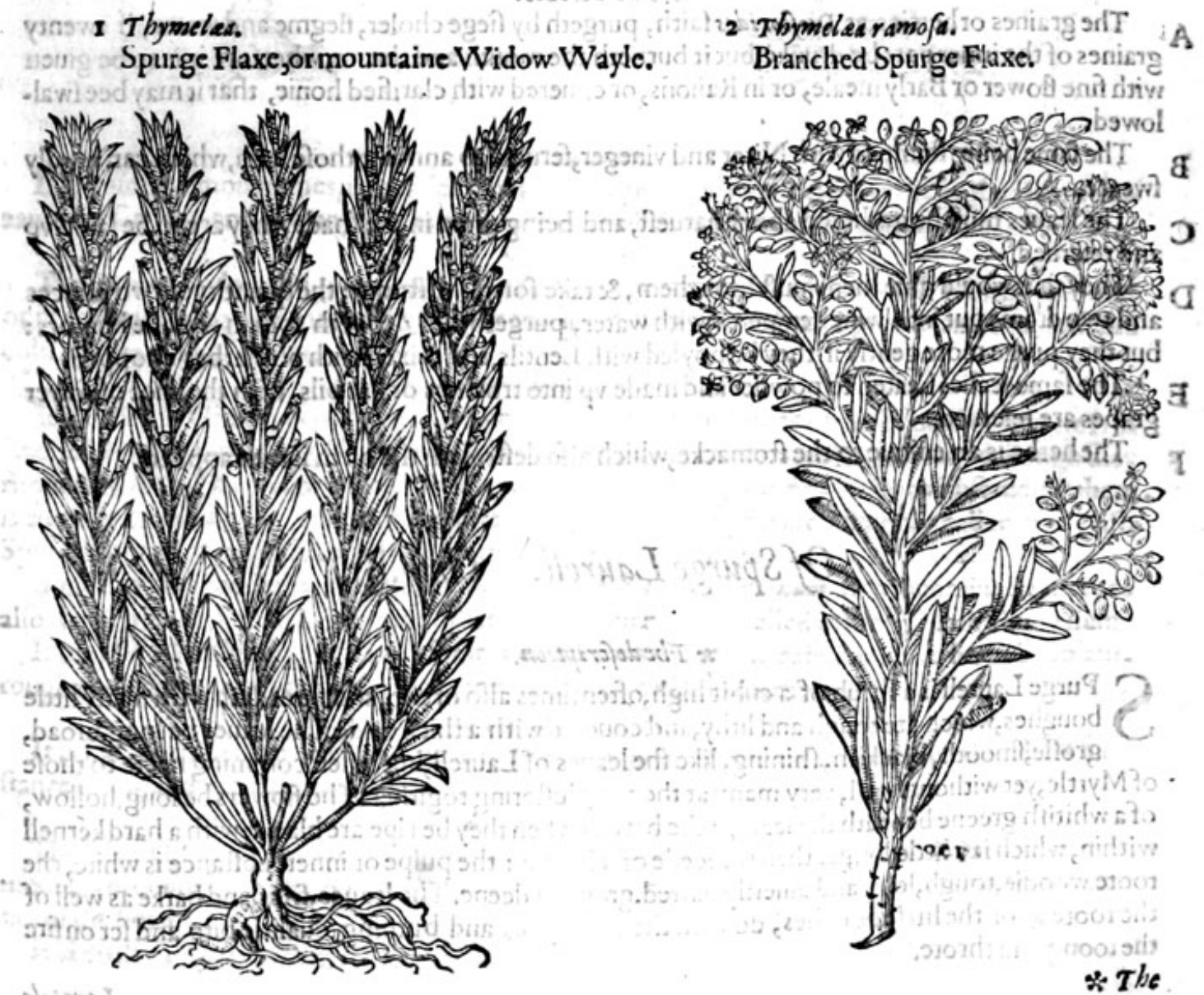




\section{$*$ The defcription.}

I Purge Flaxe bringeth foorth many flender branched fprigs aboue a cubite high, couered round with long and narrow leaues like thofe of Flaxe, narrower and leffer than the leaues
of Spurge Oliue. The flowers are white,fmall,ftanding on the vpper parts of the fprigs: the fruit is round, greene at the firft, but red when it is ripe, like almoft to the round berries of the $\mathrm{H}_{2}$ w. thorne, in which is a white kernell couered with a blacke skin, very hot and burning the mouth like 2 Branched Spurge Flaxe groweth vplikewife to the height of a fmall thrub, fet with diuers tough branches; whereon do growe long leaues like the precedent, but greater : the flowers, fruite,
and likewife the tafte of the fruit differeth not: the roote is very tough and woodie.

$$
\text { * The place. }
$$

It groweth in rough mountaines, and in vnt ed places in hot regions. It groweth in my garden. * The time.

2. It is greene at any time of the yeere, but the fruit is perfected in Autumne.

\section{(15) The names.}

The Grecians call it sursincua : the Syrians, as Diofsorides witneffeth Apolinon; diuers alfo Chome.

les, but not properly: but as Diofcor ides faith, the leafe is properly called Cneoron, and the fruit Coccos Cnidios : notwithftanding thofe things which $T$ beophraftes calleth Cneora, feeme to differ from $T$ hymelas,or Spurge Flaxe, vnlefie $\mathcal{A}$ igrum Cneoron be $T$ bymelaa : for $T$ beophraftwo faith that there be two kindes of Cnevron, the one white, the other blacke. This may be called in Englifh Spurge Flaxe, or Mountaine Widow Waylc. The feede of Thymelea is called in fhops Granum Gnidium; wherupon, came Coculus Indus from Coccus Cnidins.

Spurge Flaxe is naturally both in leaues and fruit extreme hor, biting, and of a burning qualitic.
$*$ The vertues.

A The graines orberries, as Diofcorides faith, purgeth by fiege choler, flegme and water, if twenty graines of the inner part be drunke, but it burneth the mouth/2ad throte; wherfore it is to be giuen with fine flower or Barly meale, or in Raifons, or couered with clarified honie, that it may bee fwallowed.

B

The fame being ftamped with Niter and vineger, ferueth to annoint thofe with, which can hardly fweate.

C The leaues mutt be gathered about harueft, and being dried in the fhade, they are to be laide vp and referued.

D They that would giue them muft beat them, \& take forth the ftrings: the quantity of two ounces and two drams puênto wine tempered with water, purgeth and draweth foorth waterie humors: but they purge more gently if they be boyled with Lentils, and mixed with potherbes chopped.

E The fame leaues bcaten to powder and made vp into trochies or flat pils, with the iuice of fower grapes are referued.

F The berbe is an enimie to the ftomacke, which alfo deftroieth the birth if it beapplied.

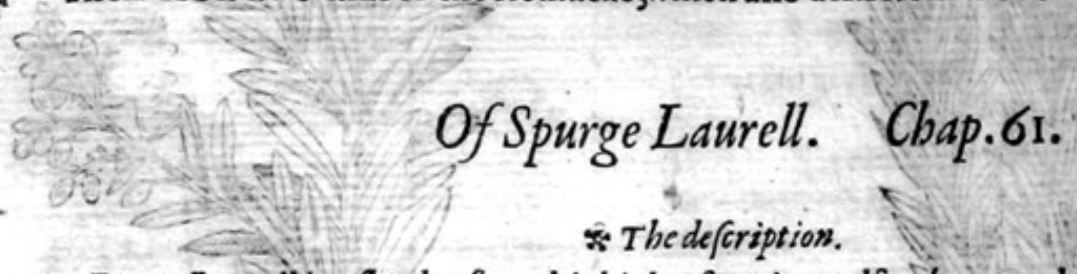

C Purge Laurell is a hrub of a cubit high,oftentimes alfo of two, and fpreadeth with many little boughes, which are tough and lithy, and couered with a thick rinde. The leaues be long, broad, groffe, fmooth, blackifh, rhining, like the leaues of Laurell, but leffer, comming neere to thofe of Myrtle,yet without fmell, very many at the top, cluftering to gither. The flowers be long, hollow, of a whitith greene beneath the leaues: the berries when they be ripe are blacke, with a hardkernell within, which is aritale longer than the feede of Hempe : the pulpe or inner fubftance is white, the roote woodie, tough, long and diuerfly parted, growing deepe. The leaues, fruit, and barke as well of
the roote as of the little boughes, do with their fharpnes and burning qualitie bite and fet onfire the toong and throte. 


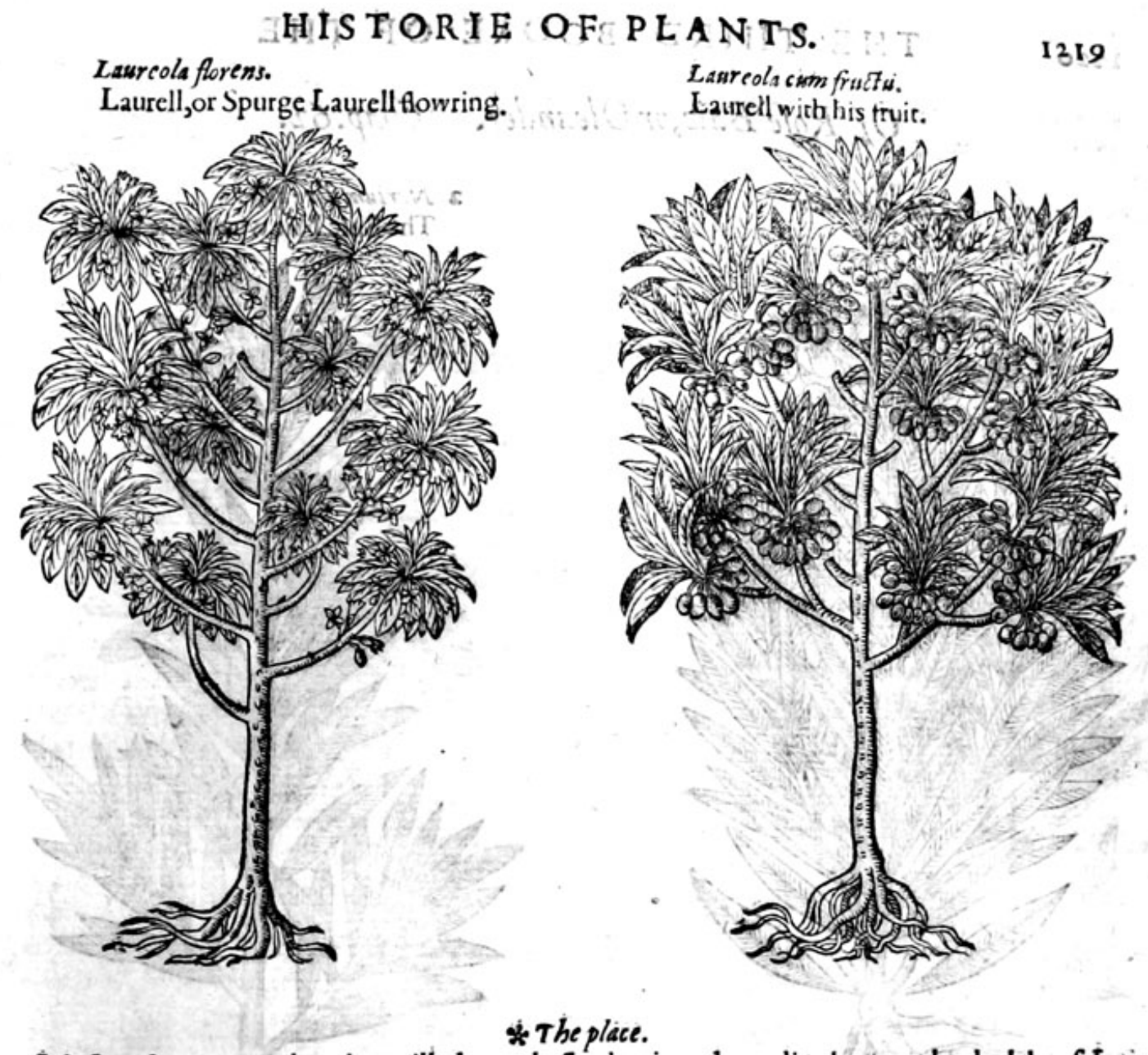

It is found on mouritaines, in vntilled, rough, thadowie and woodie places, as by the lake of Lo: zanna or Geneua, and in many places neere the riuer of Rhene and of the Maze.

\section{- The time.}

The flowers bud very foone, a little after Autumne xquinoctiall : they are full blowne in winter or in the firft fpring: the fruit is ripe in May and lohe: the plant is alwaies greene, and endureth the cold and ftormes of winter.

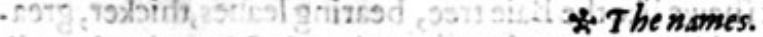

It is called in Greeke Nipvosid's, of the:likenes it hath with the leaues of the Laurell or Bay tree: in Latine likewife Daphnoides. The later Latinifts for the Ggme caufe nawe it Lavreola, as though they fhould fay Minor Laur us, or litele Laurel.It is alfacalled samectiovi and $\pi$ intsv, notwithftanding there is another Chamedaphme, and another certaine Peplion. This Shrub is commonly called in Engtinh Spurge Laurell, of diuers Lauriell or Lowry.

Some fay that the Italians name the berries hereof Piper montanwm, or Mountaine Pepper, as alfo the berries of Dutch Mezereon: others affirme them to be called in high Dutch alfo żeilant.

It may be T beophr afti his Cneoron, for it is much like to Mirtle in leafe, it is alfo a branched piant, tough and pliable, hauing a deepe roote, without fmell, with a blacke fruit.

$$
\text { of The temperature. }
$$

It is like in temperature and facultie to the Germaine Spurge Oliue, throughout the whole fubftance biting and extreme hot.

The drie or greeneleaues of Spurged Laurell, faith Diofcorides, purgeth by fiege tegmatike hu- $\mathrm{A}$ mours, it procureth vomite, and bringeth downe the menfes, and being chewed, it draweth water out of the head.

It likewifecaufeth neezing; moreouer 15 .graines of the feede thereof drunke, are a purgation. B 


\section{Of Rofe Baie, or Oleander. Chap.62.}

I Nerium, fuie Oleander. The Rore Baic.

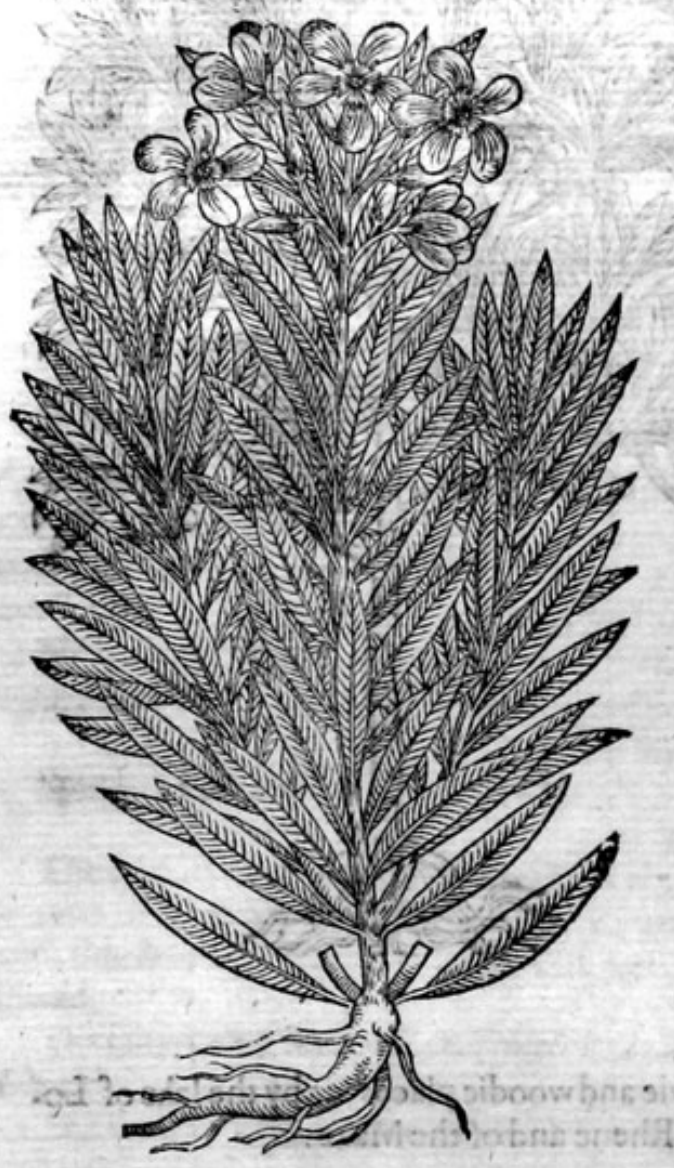

2 Neriwm flore albo. The Rofe Baie with white flowers.

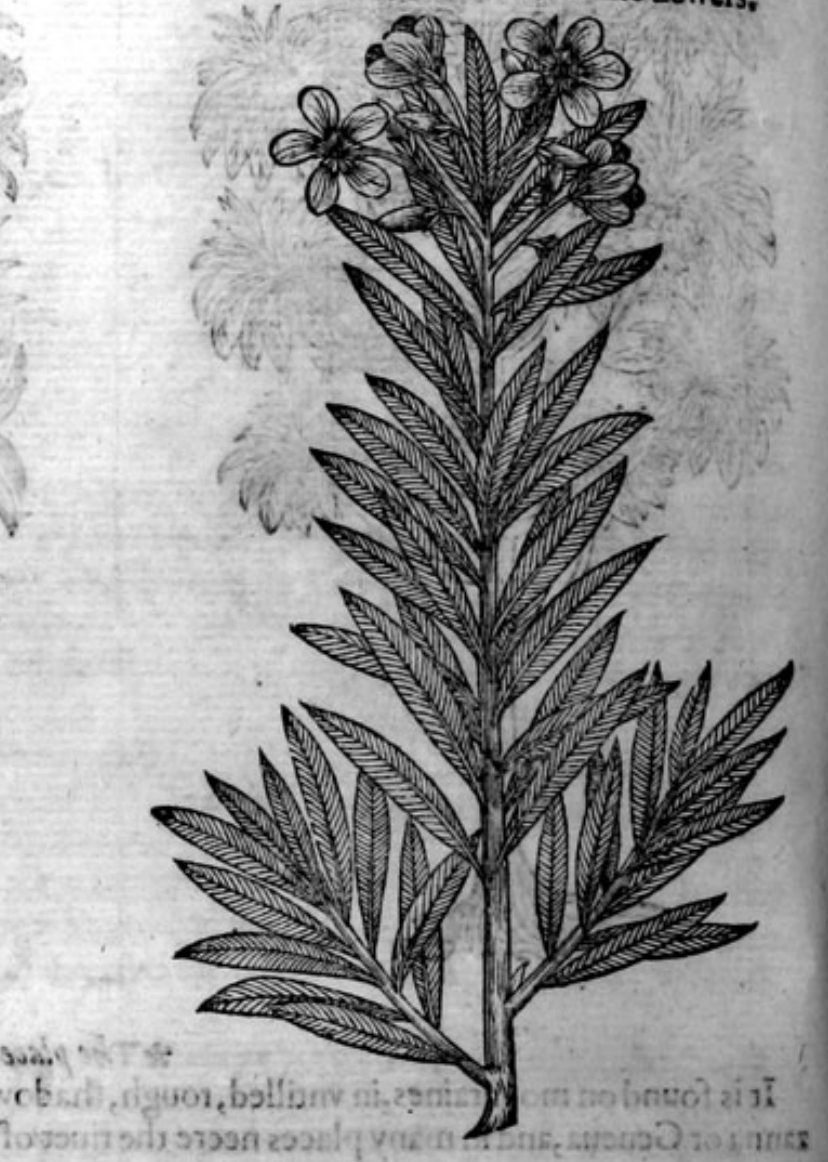

sisitsith is

zernive ristivto od it

I Ofe Baie is a fmall fhrub of a gallant thewe like the Baie tree, bearing leaues, thicker, grea. ii : 1 ter, and rougher then the leaues of the Almond tree: the flowers be of a faire red colour, $\mathrm{di}$ vots vided into fiue leaues, not much vnlike a litcle Rofe: the cod or fruite is long, like 1 /slepjes, or V incetoxickim, and full of fuch white downe, among which the feecde lieth hidden: the roote is long, fmooth, and woodie. 2 The fecond kinde of Rofe Baie, is like the firf, and differeth in that, that this plant hath white flowers;but in other refpects it is very like.

$*$ T be place.
- Thefegrow in Italy, and other hot regions by riuers, and the fea fide : I haue them growing in my garden.

- In my garden they flower in Iuly and Auguft: the cods beripe afterwards.

\section{* The time.}

* T The names.

This plant is named in Greeke Níeov, by.Nicander Nneis: in Latinelikewife Nerion, and allo Rhododendron, and Rhododaphne, that is to faie Ropes arbor, and Ro fou Laur ws: in fhops Oleander: in Italian Oleandro: inSpanifh Udelfa, Eloendro, and cilendro: in French Rofagine : in Englifh Rofe Tree, Rofe Baie, Rofe Baie tree, and Oleander.

A This tree being outwardly applied hath as $G$ alenfaith, a digerting facultie : but if it be inwardlie
caken 
HISTORIE OF PLANTS.

taken, it is deadly and poifonfom, not onely to men, but alfo to moft kinds of beafts.

The flowers and leaue skill dogs, affes, inules, and very many of other fower footed beafts : but B if men drinke them in wine they are a remedy againtt the bitings of Serpents, and the rather if Rue be added.

The weaker fort of cattle, as fheepe and goates, if they drinke the water wherein the leaues haue C beene fteeped,are fure to die.

\section{Ofdwarfe Rose Baie. Cbap.63.}

I Chamarhododendros alpigena. Dwarffe Rofe Baie.

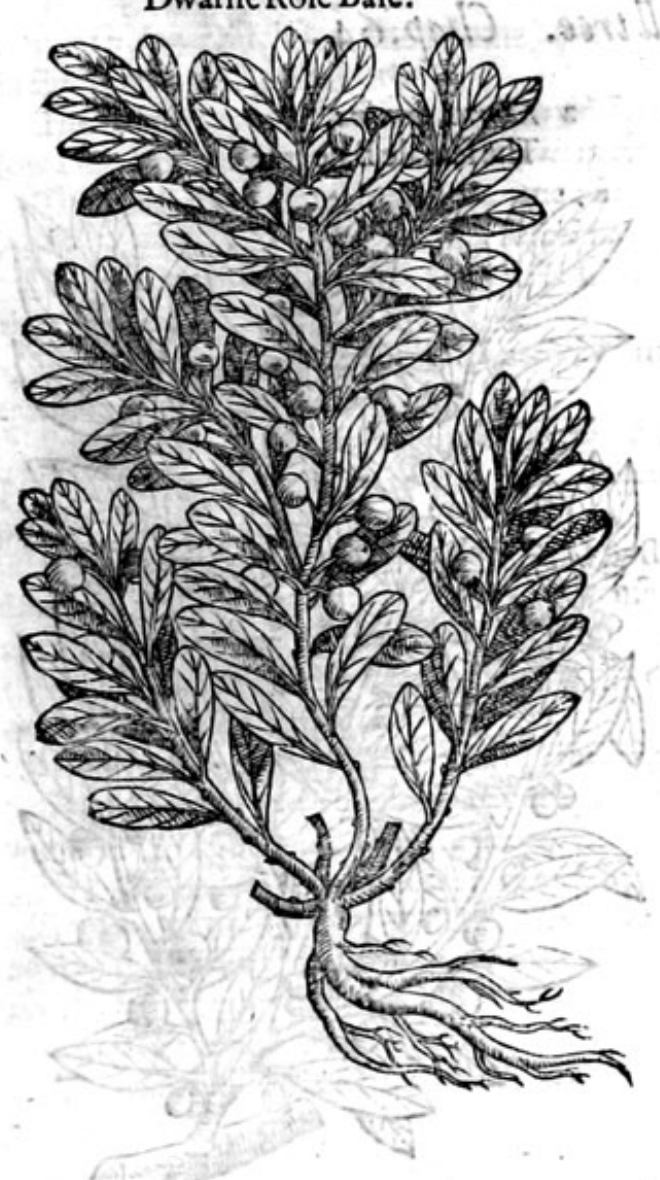

2 Chamerhododendros montana. Mountaine Rofe Baic.

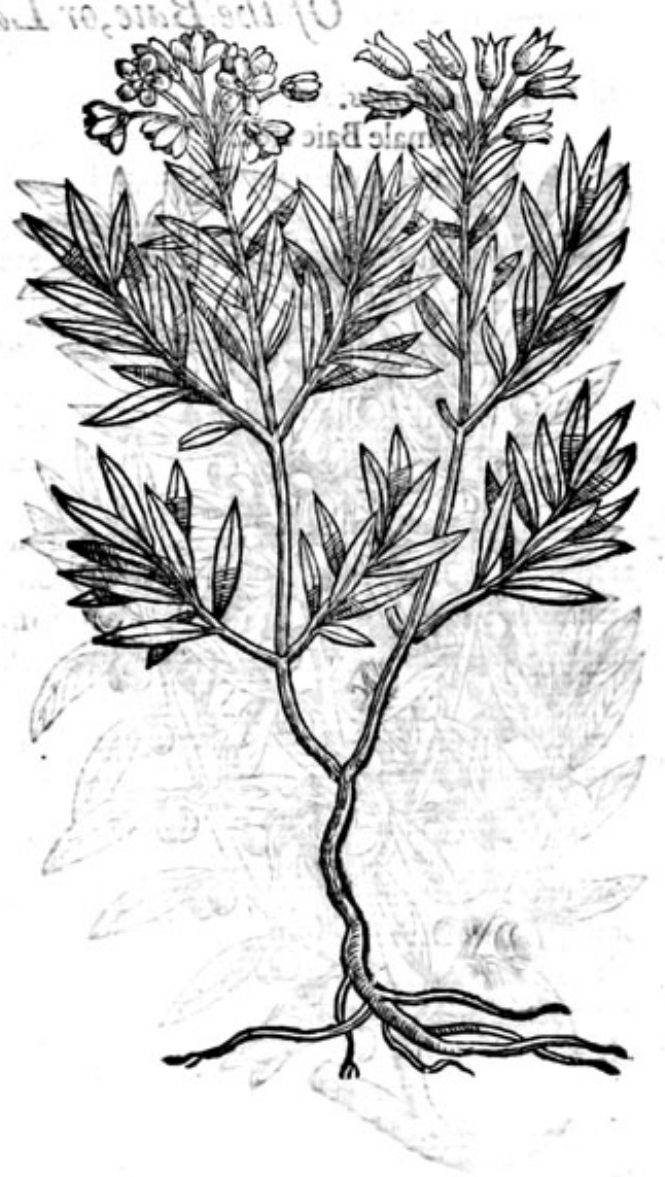

* The defcription.

I Warffe Nerium or Rofe Baie, hath leaues, which for the moft part are alwaies greene, rough, and fimall, of a pale yellow colour like Boxe, farre leffer then Oleander : the whole plant is of a fhrubbic ftature,leaning this way and that way, as not able to ftande vpright without helpe; his branches are couered and fet full of fmall flowers, of a fhining fcarlet or crimfon colour; growing vpon the hils as yee go from Trident to Verona, which in lune and Iuly are as it were couered with a fcarlet coloured carpet, of an odoriferous fauour, and delectable countenance, which being fallen there commeth feede and faire berries like $\mathcal{1}$ /paragus.

2. The mountaine Rofe Baie is like the firft in proportion, growing like a little fhrub, fomewhat more then a cubite high, with a rough barke, and branches euen like the Lentiske tree: the leaues are like the wilde Oliwe; on the outride greene, but vnderneath of a ruftie pale colour, which of one 
original or beginning, do fpring forth almoft by the very tops beautifully, fhewing themfelues after the maner of the crowned cups which Rewe beareth, but diuided into fiue little tops : the flowers in fmell and falhion are like the former $:$ the whole fhrub is of a fpicie tafte, aftringent, the flowers in
ly heating.

The place and time are expreffed in their defce and time.

\section{$*$ The names.}

The firt is called in Englifh Dwarffe Rofe Baic of the Alpes: the feconde mountaine Dwarfe Rofe Baie; which fmall difference in name thall fuffice to diftinguinh the onefrom the other.I finde not any thing extant of their vertues, fo that I arn conftrained ro leaue the reft vnto your owne difcretion.

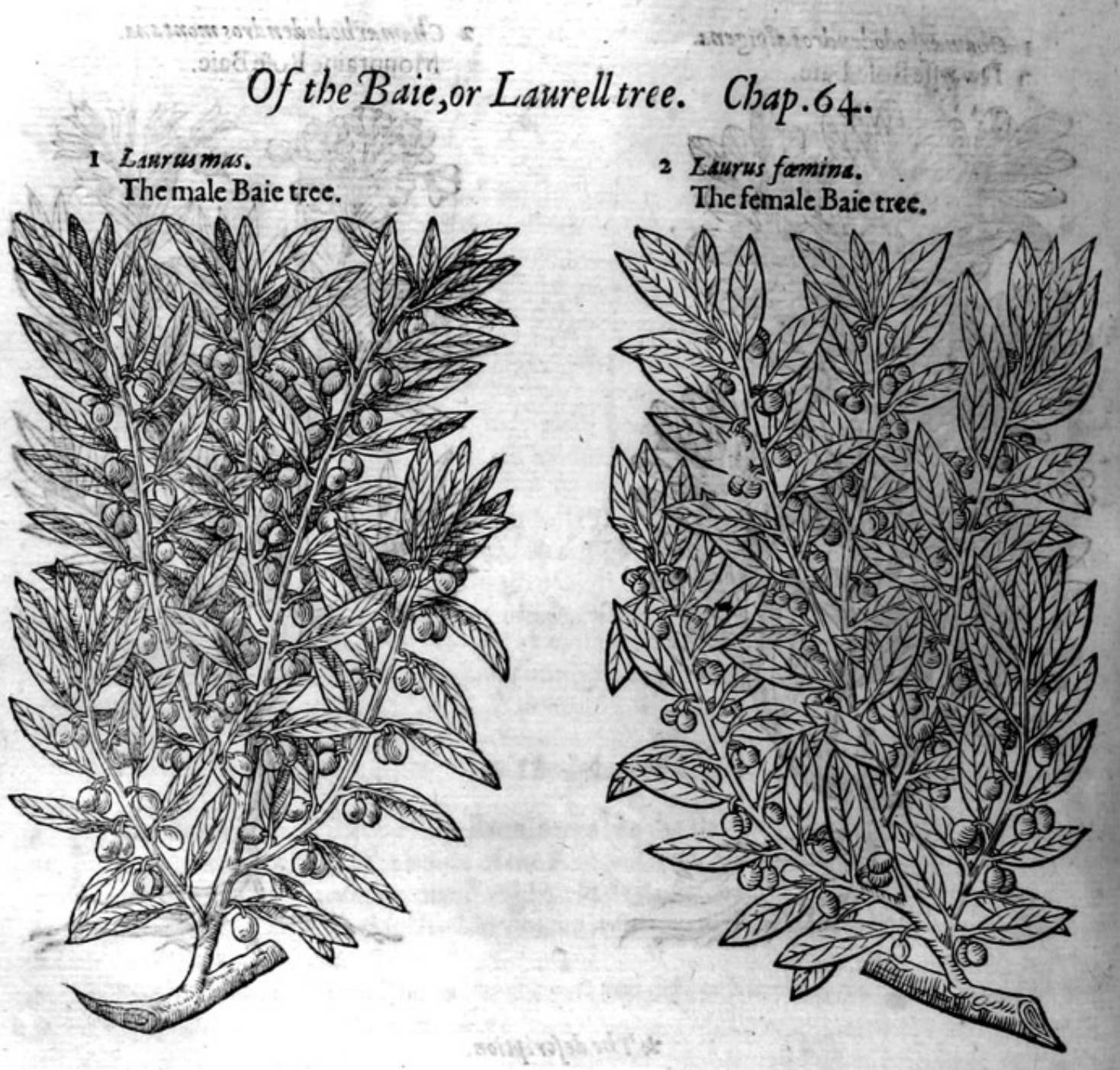

* The defcription.

I The Baie or Laurell tree commeth oftentimes to the height of a tree of a meane bigneffe; it is full of boughes, couered with a greene barke: the leaues thereof are long, broad, hard, of colour greene, fweetely fmelling, and in tafte fomewhat bitter: the flowers alongtt the boughes and leaues are of a greene colour : the berries are more long then round, and be coured with a blacke rinde or pill; the kernell within is clouen into two parts, like that of the Peach and Almond, and other fuch; of a browne yellowifh colour, fweete of fmell, in tafte fomewhat bitter, with a little fharpe or biting qualitic.

2 There is alfo a certaine other kinde heereof more like to a fhrub, fending foorth out of the 
rootes many of furings, which notwithiftanding groweth not fo high as the former; and the barkes of the boughes be fomewhat red: the leaues be alfo tenderer, and not fo harde; in other things not vnlike.

Thefe two Baie trees Diofcorides was not ignorant of; for, the faith, that the one is narrow lcafed, and the other broader leafed, or rather harder leafed, which is more like. * The place.

The Laurell or Baie tree groweth naturally in Spaine and fuch hot regions; we plant, and fet it in gardens, defending it from colde at the beginning of March efpecially.

I haue not feene any one tree thereof growing in Denmarke, Sweuin, Poland, Liuonia, or Ruffra, or in any of thofe colde countries whereI hatic trauclled. * Thetrme.

The Baie tree groweth greene winter and fommer : it flowreth in the fpring, and the blacke fruit is ripe in October. * The rimies.

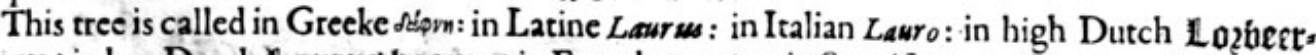
baum: in low Dutch $\mathbf{L}$ autus boome $:$ in French Lawrier: in Spanifh Lawrel, Lorer, and Loor eiro: in Englih Laurell,or Baie tree.

The fruite is named in Greeke dapviss: in Latine Lauri baccse : in high Dutch Looctheeren : in

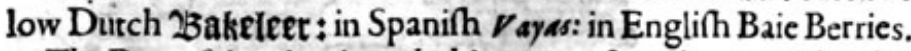

The Poets faine that it tooke his name of Daphne, Lado his daughter, with whom Lpollo fell in loue. * The temperature and vertues.

The berries and leaues of the Baie tree, faith Galen, are hot and very dry, and yet the berries more A then the leaues.

The barke is not biting and hot, but more bitter, and it hath alfo a certaine aftrictive or binding B qualitic.

Baie Berries with Hony or Cute, are good in a licking medicine faith Diofcorides, againft the $\mathrm{C}$ phthificke or confumption of the lungs, difficulty of breathing, and all kinde of luxes or rheumes about the cheft.

Baie Berries take inwine, aregood againft the bitings and ftingings of any venemous beaft, D and againft all ven oig and poifon: they clenfe away the morphew; the iuice preffed out heereof is a remedy for paine of ceares, and deafnes, if it be dropped in with olde wine and oile of Rofes: this is alfo mixed withointments that are good againft wearifomnes, and that hegte and difcuffe or wafteaway humors.

Baie berries are pat into Mithridate, Treacle, and fuch likemedicines that are made to refrefh fuch $\mathrm{E}$ people as are growen fluggifh and dull by meanes of taking opiate medicines, or fuch as haue any venemous or poifoned qualitie in them.

They aregood alfo againft cramps and drawing togither of finewes.

We in our time do not vfe the berries for the infirmities of the lungs, or cheft; but minifter them $\mathbf{G}$ againft the difeafes of the ftomacke, liuer, fpleene, and bladder : they warme a colde ftomącke, caufe concoetion of rawe humours, ftirre vp a decaied appetite, take away the lothing of meate, open the ftopping of the liuer \& fpleen, prouoke vrine, tring down the menles, \& driue forth the fecondine.

The oile preffed out of thefe, or drawne foorth by decoction, doth in fhort time take away fcabs $\mathrm{H}$ and fuch like filth of the skin.

It cureth them that be beaten blacke andblewe, and that be brufed by fquats and fals, it remoo- I ueth blacke and blew fpots and congealed bloud, and digefteth and wafteth away the humours gathered about the grieued part.

Diofcorides faith, that the leaues are good for the difeafes of the mother and bladder, if a bath be $\mathrm{K}$ made thereof to bathe and fit in: that the greene leaues.do gently binde, that being applied they are good againft the ftingings of wafpes and bees; that with barly meale parched, and bread, they aftwage all kinde of inflammations, and that being taken in drinke they mitigate the paine of the ftomacke, but procure vomite.

The berries of the Bay tree ftamped with a little Scanmonie and Saffron, and laboured in a mor- $\mathrm{L}$ tar with vineger and oile of Rofes to the forme of a liniment, and applied to the temples and forepart of the head, doth greatly ceafe the paine of the megrim.

It is seported that common drunkardes were accuftomed to eate in the morning fafting two $\mathrm{M}$ leaues thereof againft druikenes. 


\section{4 \\ THE THIRD BOOKE OF THE}

L The later Phifitions do oftentimes ve to boile the leaues of Laurell with diuers meates, efpecial ly fifhes, and by fo dooing there hapneth no defire of vomiting: but the meate feafoned heetewith becomuethmore fauory and better for the ftomacke.

M The barke of the roote of the Baie tree, as $G$ alen writeth, drunken in wine protioketh vrite breaketh the ftone, and driueth foot th gratiell: it openeth the ftoppings of the lituer, the foleene, and all other ftuppings of the inwarde parts: which thing alfo Diofcorides affirmetb, who likewife addeth, that it killeth the childe in the mothers wombe.

N. It helpeth the drop fie and the iaundife, and procureth vnto women their defired ficknes.

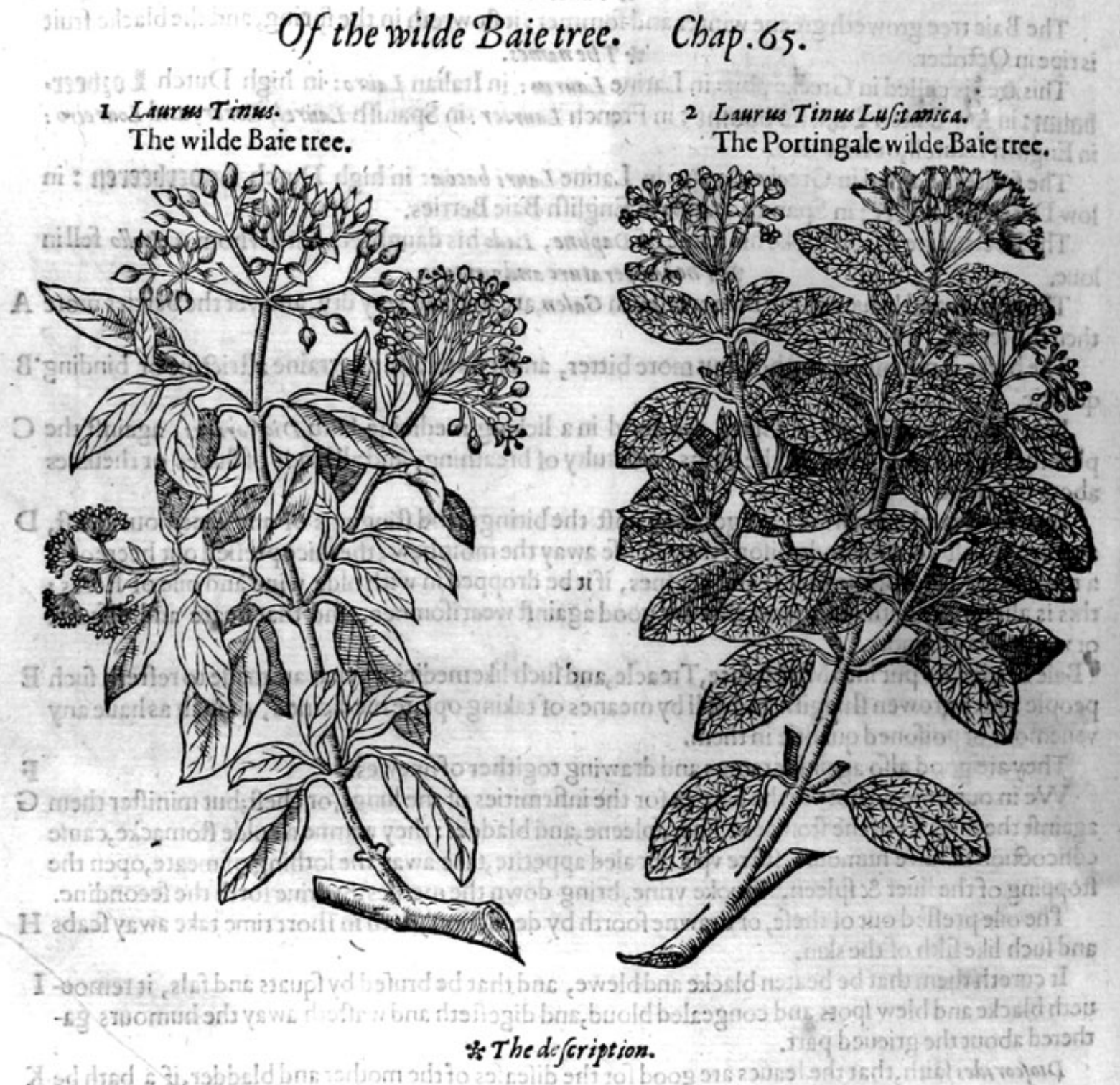

Aurwes Tinus, or the wilde Baie tree, groweth like a thrub or hedge buifh, hauing many tough and pliant branches, fet full of leaues very like vnto the Baie leaues, but fimaller and more crumpled, of a deepe and thining greene colour : among which come foorth tufts of whitifh flowers, turning at the edges into a light purple; after which followe fmall berries of a blew colour, conteining a fewe graines or feeds like the ftones or feeds of grapes: the leaues and all the parts of the $p$ tant are altogither without fmell or fauour.

2 Tinus Lafitanica, groweth verie like to Cornus Femina, or the Dogge Berrie tree, but the branches be thicker, and more ftiffe, couered with a reddifh barke mixed with greene: the leaves are like the former, but larger, hauing manie finewes or vaines running thorough the fame 


\section{HISTORIE OF PLANTS.}

like Ribwoort: the flowers heereof grow in tufts like the precedent, ${ }_{2}$ but they are of colour more deeither good or bad: the berries areffilaller then the former, of a blewe colour hate no fmell at all, neffe.

$$
\text { * Tlephace. }
$$

The wilde Baie groweth plentifully in euery fielde of Italy, Spaine, and other regions, which differ according to the nature and fcituation of thofecountries : they growe in nry gatcen and prof-
per very well.

$$
\text { * The time. }
$$

The wilde Laurell is grcene, and may of tentimes be feene with the fowers and ripe berries growing both at one feafon.

\section{* The names.}

It is called in Latine Tiniw, and Lawrus fylueftristin Grecke siam a dia : Catonameth it Laurus fylustica : in Ftalian Lauro Siluatico: in Spanifh Vus de Perro, other Follado, and of ditiers Durillu: in Englifh wilde Baie.

\section{* The temperature and vertues.}

Plinie nor any orher of the ancients, haue touched the faculties of this wilde Baie, neicher taaue we any vonderftanding thereof by thelater writers, or by our owne experience.

Chap.66.

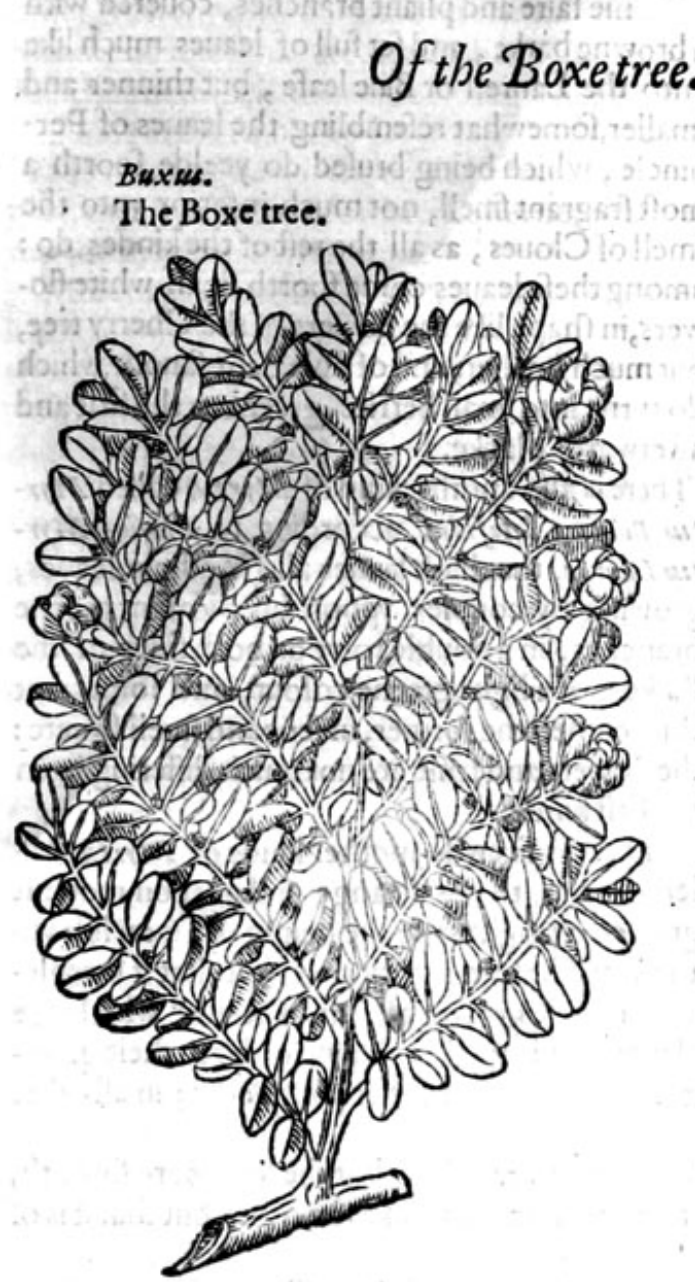

* The place.

\section{* Thedefription.}

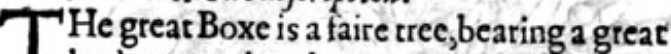
body or trunke; the woode or timber is yel. lowe and verie harde, and fit for fundrie workes, hauing many boughes 8 hard branches, befer with fundry fmall hard greenc leaues, both winter and fommer like the Baie tree: the flowers are very little, growing among the leates, of a greene colour : which being vaded there fucceed fmall blacke Shining berries, of the bigneffe of the feeds of Corianders, which are inciofed in rounde greenifh huskes, hauing three feete or legs like a brafte or boiling pot : the roote is likewife yellowe, and harder then the timber, but of greater beauty, and more fit for dagger haftes, boxes, and fuch like vfes, whereto the trunke or body ferueth, then to make medicines; though foolifh emperickes and women leaches, do minifter it againft the apoplexic and fuch difeafes: Turners and Cutlers, if I miftake not the matter, do call this woode dudgeon, wherewith they make dudgeon hafted daggers.

There is allo a certaine other kinde heereof, growing lowe, and not abouc a yarde high, but it fpreadeth all abroad: the branches heereof are many and very flender : the leaues be rounde and of a light greene.

Buxws or the Boxe tree, groweth vpon fundry wafte and barren hils in Englande.

* Thetime.

The boxe tree groweth greene winter and fommes : it flowreth in Februaric and March, and the leede is ripe in September. 
$*$ The names.

The Grecians call it $\pi \xi_{0}$ : : in Latine Buxus : in high Dutch 2Buchefzaum foom : in Italian Boffo; in French Bwis: in Englifh Boxe,and Boxe tree.

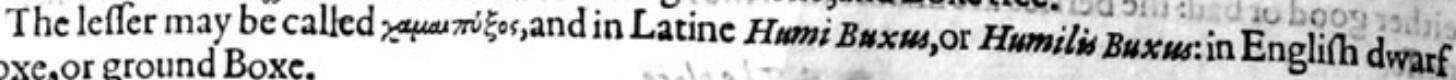
Boxe, or ground Boxe.

The leaues of the Boxe tree are * The temperature and viertues. in medicine, but oriely as I faid before in the defcription.

$$
\text { Of the a Myrtle tree. Chap.67. }
$$

* The kindes.

There be diuers forts of the Myrtill trees, fome with broade leaues, fome with narrowe leaues; fome whofe leaues are more fweete then others; one figure with the defcriptions of more hall diftinguifh the kinds.

I Myrtus.

The Myrtill tree.

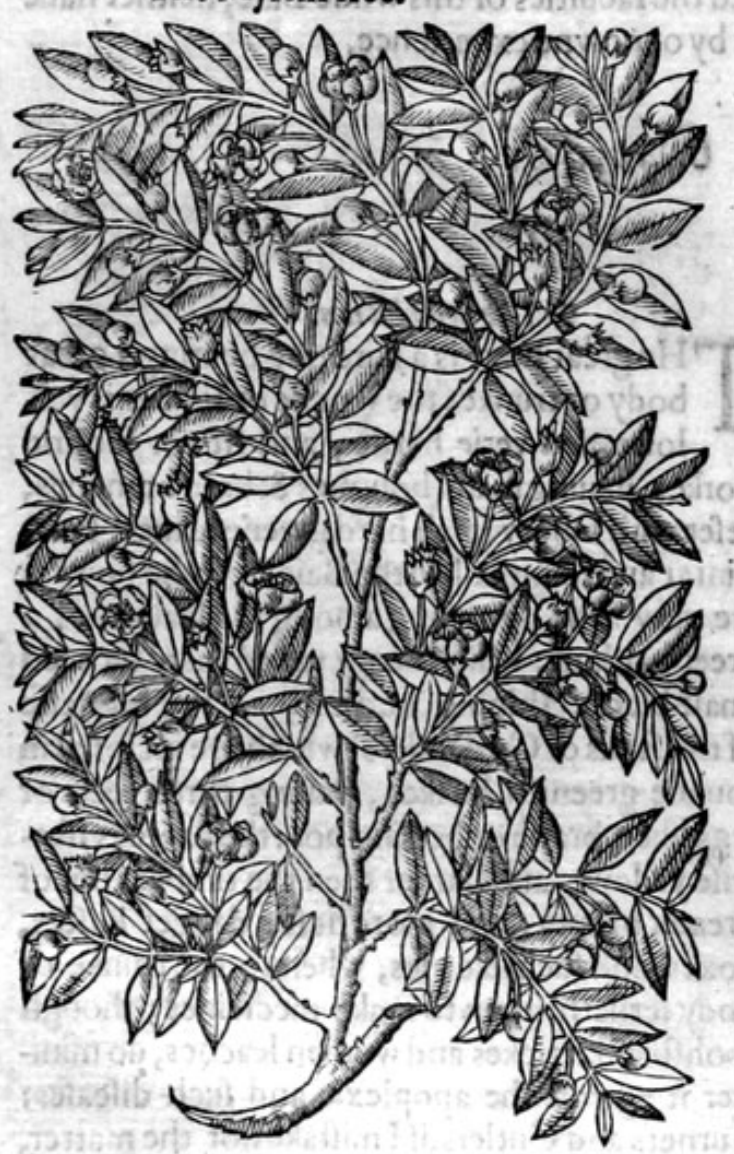

* The defcription.

$7 \mathrm{He}$ firft and greateft -Myrtws is a fmall tree, growing to the height of a man, bauing $\mathrm{ma}$ nie faire and pliant branches, couered with a browne barke, and fet full of leaues much like vito the Laurell or Baie leafe, but thinner and fmaller,fomewhat refembling the leaues of Peruincle, which being brufed do yeelde foorth a moft fragrant fmell, not much inferior vnto the fmell of Cloues, as all the reft of the kindes do: among thefe leaues come foorth finall white flowers, in fhape like the flowers of the Cherry tree, but much fmaller, and of a pleafant fauour, which do turne into fmall berries, greene at the firft and afterwards blacke.

There is alfo another kind of Myrtus called Myrtus Boëtica latifolia, according to Clufius Myrtus Laurea, that hath leaues alfo like Baie leaues, growing by couples vppon his pleafant greene branches, in a double rowe on both fides of the ftalkes, of a light greene colour, and fomewhat thicker then the former, in fent and fmell fweete : the flowers and fruit are not much differing from the firft kinde.

There is likewife another kinde of Myrtus called Exotica, that is ftrange and not common : it groweth vpright vnto the height of a man like vnto the laft before mentioned, but that it is replenifhed with greater plentie of leaues, which doe fold in themfelues hollow and almoft double, broader pointed, and keeping no order in their growing, but one thrufting within another, and as it were croffing one another confufedly; in allother points agreeing with the precedent.

There is another fort like vnto the former in flowers and branches, but the leaucs are fmooth, flat and plaine, and not crumpled or folded at all. The fruit is in thape like the other, but that it is of a white colour, whereas the fruit of the other is blacke.

There is alfo another kinde of Myrtill, called Myrtus minor, or noble Myrtill, as being the chiefe of all the reft (although moft common and beft knowen) and groweth like a little fhrubor hedge bufh, very like vnto the former but much fmaller. The leaues are fmall and narrow, verymuch refembling the leaues of Mafticke Time called Marum. The flowers be white, nothing differing from the former fauing in greatnes, and that fometimes they are more double. 
There is yet another kinde of Myrtus called 2 Cous (as hauing been of late difcoucred, and not knowen vnto them of olde time) that in fhape and fhew refembleth the former, hauing icaues like vnto our garden Tyme, and fmall white flowers, with a few yellow chiues or thrums in the middle. * The place.

Thefe kindes of Myrtus do growe naturally vpon the woodie hils and fertill fields of Italie and Spaine.

\section{\& The time.}

Where they ioy to growe of themfelues they flower when the Rofes do; the fruit is ripe in Autumne; in England they neuer beare any fruit.

$$
\text { * The names. }
$$

It is called in Greeke $\mu$ upoivn: in Latine Myrtus: in the Arabicke toong Alas : in Italian Myrto : in Spanifh Arrayban : in the Portingall language Murta, and Murtella: other nations do almoft keepe the Latine name, as in Englih it is called Myrtlc,or Myrtle tree.

Among the Myrtles that which hath the fine little leafe is furnamed of Plinie Tarentina : and that which is fo thicke and full of leaues is Exotica, frange or forren. 2 ggra Myrtws is that which hath the blacke berries : Candida which hath the white berries, and the leaues of this alfo are of a lighter greene: Satiwa, or the tame planted one is cherifhed in gardens and orchards: Sylueftris, or the wilde Myrcle is that which groweth of it felfe; the berries of this are oftentimes lefler, and of the other greater. Plinie dothalfo fer downe other kinds, as Patritia, Plebeia, and Coniugalis; but what manner of ones they are, he doth not declare: he alfo placethamong the Myrtes Oxymyrfine, or Knceholme, which notwithftanding is none of the Myrtles, but a thornie fhrub.

Plinie in his 14.booke 16. chapter faith, that the wine which is made of the wilde Myrtletere is called Myrtidanum, if the copie be true. Fot Diofcorides and likewife Sotion in his Geoponikes report, that wine is made of Myrtle berries when they be thorow ripe, but this is called $V i m u m M y r-$ teum, or Myrtites, Myrtle wine.

Moreouer, there is alfo a wine made of the berries and leaues of Myrtle ftamped and fteeped in Muft,or winenew prefted from the grape, which is called, as D 10 fcortdes faith, Myrfinite vintum, or wine of Myrtles.

The Myrtle tree was in times paft confecrated to Venus. Plivie in his 15 .booke 29. chapter faith thits, There was an old altar belonging to $V$ enus, which they now call Murtia.

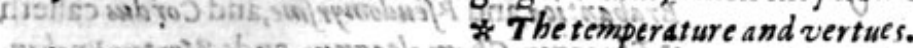

The Myrtle confifteth of contrarie fubftinces, a cold eatthie thing bearing the preheminence; A it hath alfo a certaine thin heate, therefore as $r a l e n$ faith, it dricth notably.

The leatues, frut, bưds and uice do binde, both outwardiy applied and inwardly taken : they ftay B the fpetting of blood, and afl other iffues there of : they ftop both the whites and reds in women, if they fit in a bath made therewith: after which mahner, and by fomenting, alfo they ftay, the fuper fuous courfe of the hemorthoides.

They are a remedie for liskes, and for the bloodie flixe, they quench the fieric beate of the eies, $C$ if they be laide on with parthed Barly nieale.

They be alfo with good fucceffe outivardly applied to allintammations new ly beginning, and D alfo to new paine upon fome fall, (troke or ftraine.

They are wholfome for a moyit and waterie ftorinacke, the fruit and leaues dried prouoke vrine: $\mathrm{E}$ for the greene leaues containe in them a certaine fuperfluous and hurtfull noyfure.

It is good to bathe with the decoction here of made with wine, lims that are out of ioint, and bur- F ftings that are hard to be cured, and vicers alfo of the outward parts : it helpeth fpreading tetters, fcowreth away the dandrafe and fores of the head, maketh the haires blacke, and keepeth them froth fhedding; withftandeth drunkennes, if it be taken fafting, and preuaileth againft poyfon, and the bitings of any venemous beaft.

There is drawen out of the greene berries therof a iuice, which is dried and referued for the fore- $G$ faid vfes.

There is likewife preffed out of the leaues a iuice, by adding vnto them either olde wine or raine $\mathrm{H}$ water, which muft be vied when it is new made, for being once drie it putrifieth, and as Diojcor zdes faith, lofeth his vertuds. 


\section{OffweeteWillow, or Gaule. Cbap.68.}

Myrtu Brabantica,fue Elaagnas Cordi.

Gaule,fweete Willow, or Dutch Myrtle tree.

* The defcription.

Aule is a lowe and little fhrub or woodie I plant, hauing many browne and harde branches: whereupon doe growe leaues. fomwhat long, hard, thicke \& oileous, of an hot fauour or fmell fomwhat like Myrtus; among the branches come forth other litle ones, wherupon do growe many Ipokie eares or tufts, full of fmall flowers, and after them fucceede great ftore of fquarefeedes cluftering togither, of a ftrong and bitter tafte. The roote is hard, and of a woodie fubftance.

$$
\text { * The place. }
$$

This Gaule groweth plentifully in fundry places of England, as in the Ile of Elie, and in the Fennie countries thereabouts, whereof there is fuch fore in that country, that they make fagots of it and fheaues, which they cal Gaule fheaues, to burne and heate their ouens. It groweth alfo by Colbrooke, and in fundric other places.

$$
\text { * Thetime. }
$$

This Gaule flowreth in May and Iune, and the feede is ripe in Auguft.

This tree is called of diuers in Latine Myrtus Brabantica, and P feudomyrfine, and Cordus calleth it Eleagnns, Chameleagnm, and MLyrtus Brabantica. Eleagnus is defcribed by $T$ heophraft us to be a fhrubbie plant like vnto the Chafte tree, with 2 foft and downie leafe, and with the flower of the Poplartree, and that which we haue defcribed is no fuch plant. It hath no name among the olde writers for ought we knowe, vnleffe it be $R$ bus fylueftris Pling, or Plinje his wilde Sumach, of which he hath written in his 24. booke 11 .chapter. There is, faith he, a wilde herbe with fhort ftalkes, which is an enimic to poyfon, and a killer of

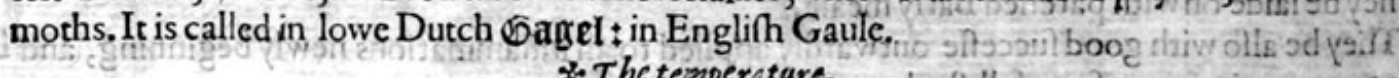

Gaule or the wilde Myrtle, efpecially the feede, is hot and drie in the thit d degree the leaues be alfo hot and dric, but not fo much.

$$
\text { * The vertues. }
$$

A The fruit is troublefome to the braine being put into beere or ale whileft it is in boyling ( which many vfe to do)it maketh the fame headie, fit to make a man quickly drunke.

B The whole fhrub, fruit and al being laid among clothes, keepeth them from moths and wormest

$$
\begin{aligned}
& \text { of Whortes, or Whortle berries. Chap. } 69 \text {. }
\end{aligned}
$$

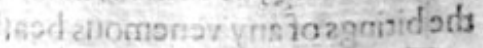

$\checkmark$ Accinia or Whortes, of which we intreat in this place, differ from Violets; neither are they flowers, but berries: of thefe Whortes there be three forts found out by the auncients, reckoning the marrilh Whortle for one: the later writers haue found more.

I $V$ accinis 
1 Vaccinia nigra.

Blacke Whortes, or Whortle berries.

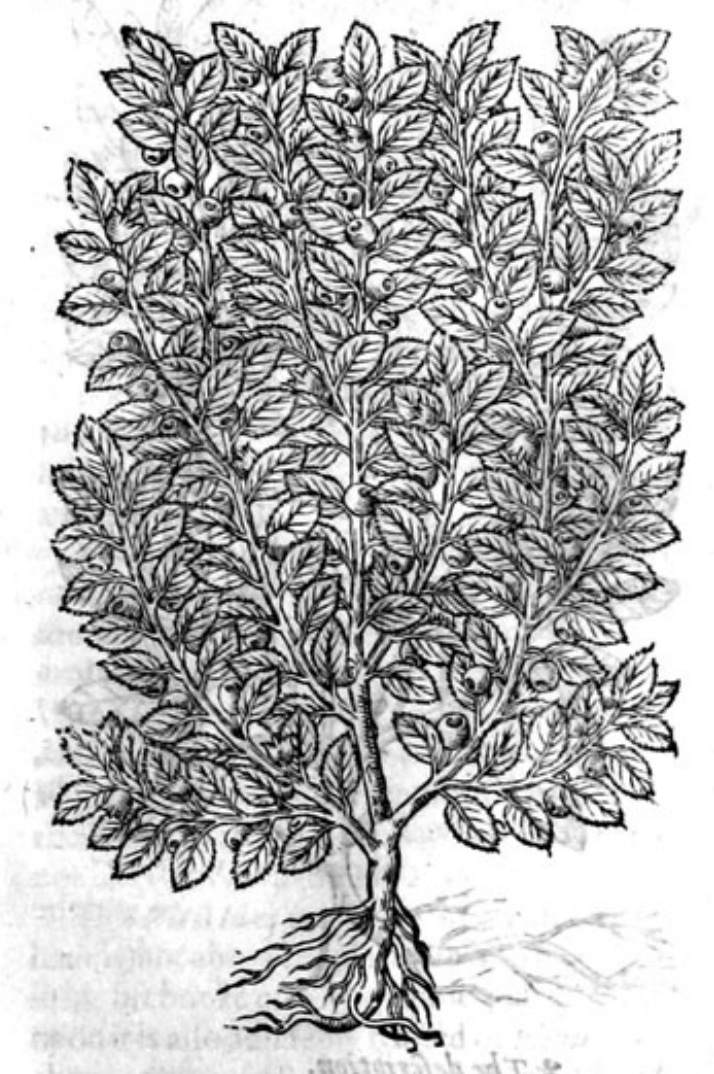

2 Vacciniartbri:

Red Whortes, or Whortle be ries.

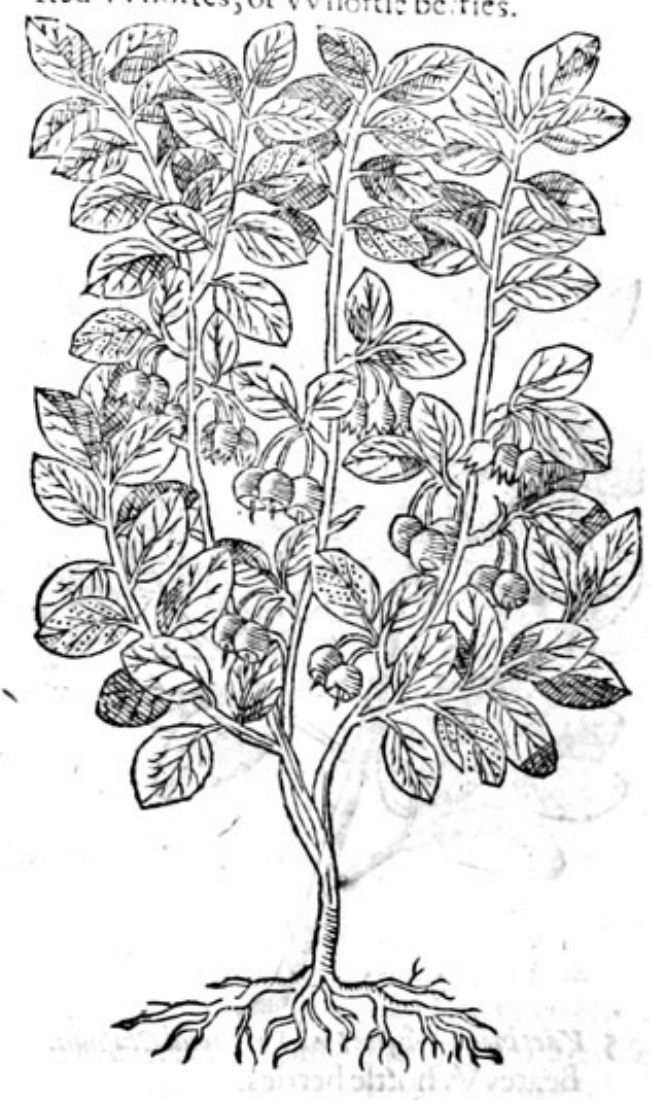

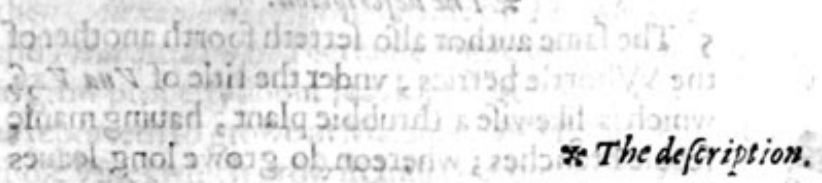

I Ascinia nigra, the blacke Whortle, or Hurcle, is a bafe and lowe tree, or woodic plant, bringing foorth many branches of a cubite high, fet full of fmali leaues, of a darke greene colour, not much vnlike the leaues of Boxe, or the Myrtill tree: among which come foorth little hollow flowers, turning into fmall berries, greene at the firf, afterwarde red, and at the haft of a blacke colour, and full of a pleafant and fweere inice 3 in which do lie divers little thinne whitith feeds; thefe berries do colour the mouth and lips of thofe that cate them, with a blacke colour: the roote is woodie, flender, and now and then creeping

2 Vaccinia rubsa or the red Whortle, is like the former in the maner of growing, but that the leaues are greater and harder, almoft like the leaues of the Boxe tree, abicing grcene all the winter long: among which come foorth fmall carnation flowers, long and round, growing in clufers at the top of the branches, after which fucceede fmali berries in thewe and bigneffe lite the former, but that they are of an excellent,red colour, andfult of ivice, of fo orient and beautifull a purple to limme withall, that Indian Lacca is not to be compared thereunto; efpecially when this iuice is prepared and drefted with allom according to Art, as my felfe haue prooued by experience: the tafte is rough and aftringent: and the roote is of a woody fubftance.

3 Vaccinia alba or the white Whortle, is like vnto the former, both in ftalkes and leaues, but the berries areof a white colour, wherein confifteth the difference.

4 Carolus Clufius in his Pannonicke obferuations inarh fer down another of the Whorte berries, vnder the name of $V$ itis Idea, which differcth not from the other Whortle berries, not onely in ftature but in leaues and,fruite alfo. 
3 Vaccinia alba.

The white Whorts, or Whortle berries,

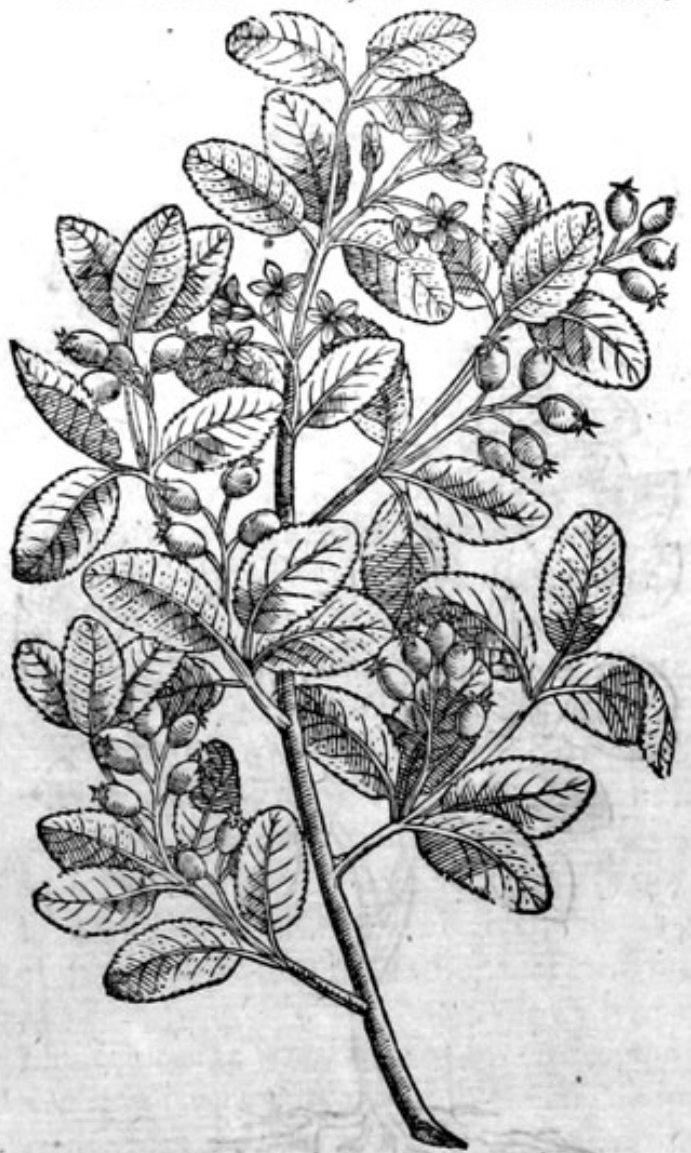

5 Vaccinia VrofifiseVua Vrfi apud Clufum. Beares Whortle berries.

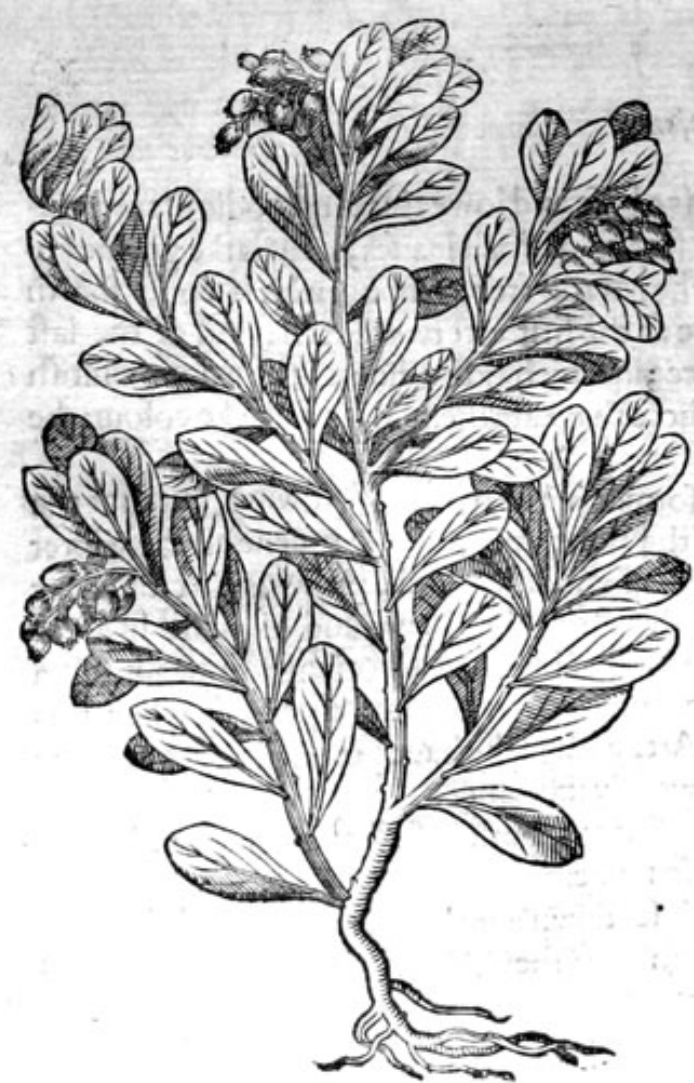

4 Vaccinia Pannonica fue Vitis Idaa. Hungarie Whortle berries.

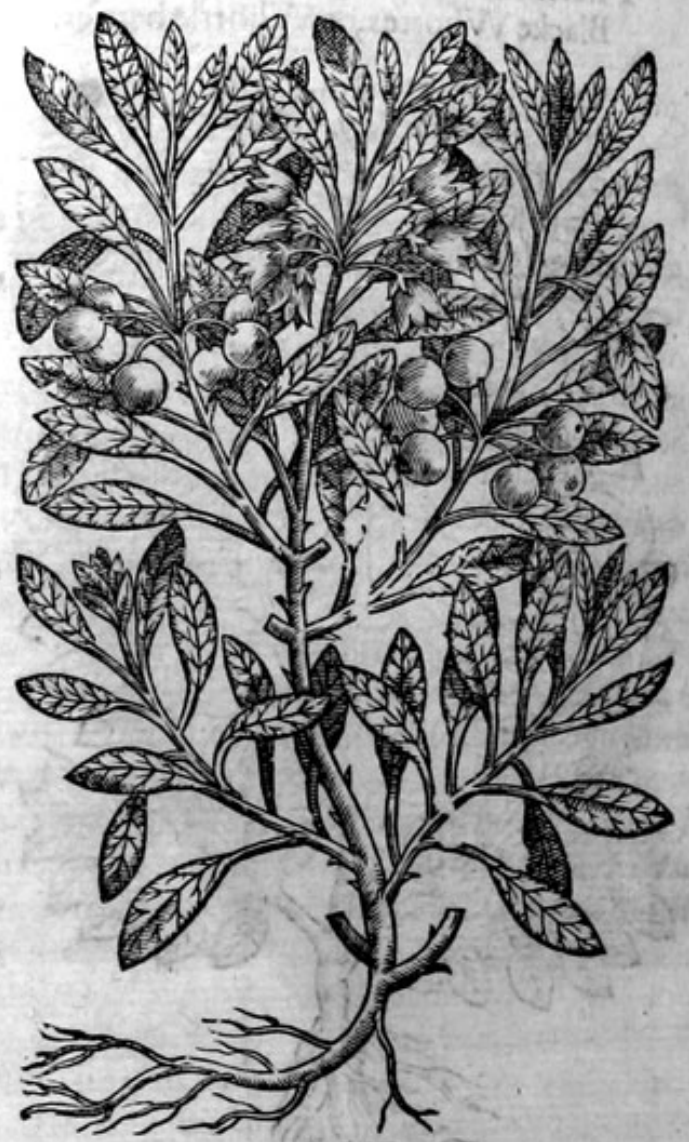

* The defcription.

5 The fame author alfo fetteth foorth another of the Whortle berries, vnder the title of $\mathrm{Vua} \mathrm{Vr} /$, which is likewife a flrubbie plant, hauing manie feeble branches; whereon do growe long leaues blunt at the points, \&\& of an ouerworne greene colour: among which come foorth clufters of bottlelike flowers, of an herby colour:the fruit followeth, growing likewife in clufters, greene at the firft, \& blacke when they be ripe : the roote is of a woodic fubftance. $\quad$ \&Theplace.

Thefe plants profper beft in a leane barren foile, of in vintoiled woody places? they are now \& then found on high grounds, fubiect to the wirde, and vpon mountaines: they growe plentifully in both the Germanies, Bohemia, and in diuersplaces of France and Englande, namely in Middlefex on Hampiteed Heath, \& the woods therto adioining, and alfo vpon the hils in Cherhire called Broxen hils, neere vuto Beefton caftle, 7. miles from the Nantwich; and in the wood by Highgate called Finchly woode, and in ditiers other places.

The red Whortle berry groweth in Weftmerläd, at a place called Crofsby Rauenfwaith; where alfo doth growe the Whortle with the white berrie, and in Lancalhire alfo vpon Pendle hils. * The 


\section{HISTORTE OF PLANTS.}

dies do flower in Mare, and theirfruite is ripe in lune.

The Whortle berries do flower in Mare, and theirf fuite is ripe in Iune. 1 stls a t Thentanes.

Whortle berries arecalled in highDateh pepoelbieren: in lowe Dutch trakebefien, bicaufe they make a certaine cracke whileft they be broken betweene the teeth, of diuer French men Airelle, or Aurelie, as rohannes de C hositwriteth : and we in England Whortes, Whor tle berries, Blacke Berries, Bill Berries, and Bull Berries, and in fome places Winberries.

Moft of the fhops of Germaniedo dall them Myrtilli, but properly Myrtilli are the fruite of the Myrtle tree, as the Apothicaries namorthem at this day. Thisplant hath no name for ought we can learne, eitheramong the Greekes or andient Latimes: for whereas moft do take it to be Vitis Yd2at, or the Corinth tree, which Plinie furnameth Alexandrina, it is vntrue; for Vitis 1dea is not onclie like to the common Vine, but is alfo a kinde of Vine : and $\tau$ heophraftus who hathimade mention heereof doth call it without an epethete, zumas, fimply, as a little after we will declare: which with out doubr he woulde not haue done, if he had founde it to differ from the common Vine. For what things foever receiued a name of fome plant, the fame are expreft by fome epethite added, that they might beknowne to differ from others, as Laurus Alex andrina, $V$ it is alba, $V$ it is nigra, $V$ strs fylueftris, and fuch like.

Moreouer, thofe thingswhich haue borowed a name from fome plant; are tike thereunto, if not wholy, yet either inleafe or fruite, or in forme other thing. Vit is albs, and nigra, that is to faie, the white and the blacke Bryonies, haue leaues and clafping tendrels, as hath the common Vine; they alfo climbe after the fame maner: $F$ it is flsestris, or the wilde Vine, hath fuch like ftalkes as the Vine hath, and bringeth foorth fruite like to the little grapes: Lavrus Alexandrina, and Chamedaphne, andalfo Daphnoides, are like in lédues to the Laurell tree : Sycomorus is like in fruite to the Figge tree, and in leaues to the Mulberie tree : Chamedrys hath the leafe of an Oke; Peucedianus of the Pine tree : fo of others which haue taken their name from fome other. But this lowe fhrub is not like the Vine, either in any part, or in any other thing.

This Vit is Idea, groweth not on the vppermoft and filowie parts of mount Ida (as fome would haue it) but about Ida, euen the hill Ida,not of Candy, but of Troas in the leffer Afia, which Ptolemie in his fift booke of Geographie 3.chapter doth call. Illexandri Troas, or Alexander his Troy: wherupon it is alfo aduifedly named of Plinie in his' 14 booke 3.chapter $V$ it is Alexandrina, no otherwife then Alexandrina Laurus is faide of $T$ heophraftus to grow there: Laurus, furnamed Ulexandrina, and Ficus quadam, or a certaine Figge tree, and anenes, that is to fay, the Vine, are reported, faith he, to grow properly about Ida. Like vnto this Vine are thofe which Philoftrat us in the life of Apolloni« reporteth to growe in Mronia, and Lydia, fcituated not farre from Troy, comparing them to thofeVines which grow in India beyond Caucafus: the Vines, faith he, be very like, as be thofe that growe there in Mxonia and Lydia, yet is the wine which is preffed out of them, of a maruellous pleafant tafte.

This Vine which groweth neere to mount Ida, is reported to be like a hrub, with hittle twigs and branches of the length of a cubite,about which are grapes growing aflope, blacke, of the bignes of a Beane, fweete, hauing within a certaine winie fubitance, foft : the leafe of this is rounde, vncut; and little.

This is defcribed by $P$ limie in his 14 .booke 3 .chapter, almoft in the felfe fame words: It is called faith he, Alexandrina vit is, and groweth neere vnto Phalacra : it is fhort, with branches a cubice long,with a blacke grape, of the bignes of the Latines Beane, with a foft pulpe and very little, with very fweete clufters growing aflope, and a little round leafe without cuts.

And with this defcription the little Phrub which the Apothecaries of Germanie do call Myrtillum, doth nothing at al agree, as it is very manife?t; for it is low, fcarce a cubite high, with a few fhort branches, not growing to a cubite in length : it doth not bring foorth clufters or bunches, nor yet fruite like vnto grapes, but berries like thofe of the Yew tree; not fweete, but fomewhat fower and aftringent, in which alfo there are many little white flat feedes: the leafe is not round, but more long then round, not like to that of the Vine, but of the Boxe tree. Moreouer it is thought that this is not found in Italy, Greece, or in the leffer Afia, for that Matbiolus affirmcth the fame to grow no where but in Germanie and Bohemia, fo farre is it from being called or accounted to be Vitis Ideat, or alcxindrina.

The fruit of this may be thought not without caufe to be named Vaccinia, fith they are berries; alongoy 


\section{THE THIRD BOOKE OF THE}

for they may be named of Bacce, berries, Vaccinia, as though they fhould be called Baccinia. Yet

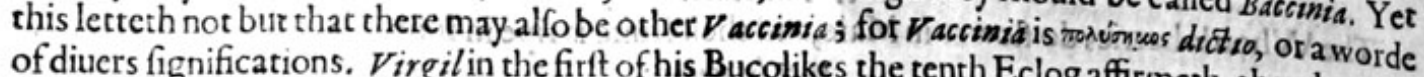
of diucrs fignifications. Virgil in the firft of his Bucolikes the tenth Eclog affirmeth, that the written Hyacinth is named of the Latines Vacciniom, tranflating into Latine Theocritus his verfe,which
is caken out of hs 10. Eidyl.
Virgil.

\section{Et nigra Viole, funt ó Vaccinia nigra.}

Vitruias in the feuenth booke of his Archite ofure doth Violet,and fheweth that of it is made a gall ant purple, which alfo diftinguiph $V$ acciniom from the not do it muft needes be that this $V$ accinium is another thing that the written Hyacinth can. not do, it muft needes be that this Vaccinium is another thing than the Hyacinth is, bicaufe it fer. yeth to giue a purple dic.

Plinifalfo in his 16 , booke 18 , chapter hath made mention of Vaccinia, whichare vfed to die bondlaues garments with, and to giue them a purple colour.

But whether thefe be our Vaccinia or Whortle berries, it is hard to affirme, efpecially fecing that Plimie reckoneth vp Vaccinin among thofe plants which growe in waterie places 3 buc ours growe on mountaines, vpon high places fubiect to windes, neither is it certainly knowen to growe in Ita. lie. Howfoeuer it is, thefe our Whortles may be called $V$ accinis,and do agree with $P$ linies and $V$ itrus wiss his $V$ accinia, bicaufe garments and linnen cloth may take from thefe a purple die.

The red Whortle berries haue their name from the blacke Whorstes; to which they be in forme very like, and are called in Latine Vaccinia rubra : in high Dutch Rooter Detuelbecte : in lowe Dutch 2Roode Crakebelien: the French men UAurelles rouges : they be named in Englifh Red Whortes, or red Whortle berries. Conradus Gefnernos hath called this plant Vitis Ides rubris acinis: but the growing of the berries doth hew, that this doth farleffe agree with Vitis Idea than the blacke: for they do not hang vpon the fides of the branches as do the blacke (which deceived them that thought it to be Vitis Idea) but from the tops of the fprigs in clufters.

As concerning the names of the other, they are touched in their feuerall defcriptions.

$$
* \text { Thetemperature. }
$$

Thefe Vaccinia or Whortle berries, are colde euen in the later end of the fecond degree, and drie alfo with a manifeft aftriction or binding qualitie.

Red Whortle berries are cold and drie, and alfo binding.

$$
\text { * The vertues. }
$$

A The iuice of the blacke Whortle berries is boyled till it become thicke, and is prepared orkept by adding honie and Sugar vnto it : the Apothecaries callit Rob, which is preferred in all things before the rawe berries themfelues. For many times whileft thefe be eaten or taken rawe, they are offenfiue to a weake and cold ftomacke, and fo far are they from binding the belly, or ftaying the laske, as that they alfo trouble the fame through their cold and rawe qualitie, which thing the boyled iuice called Rob doth not any whit at all.

B They be good for an hot ftomacke, they quench thirf, they mitigate and alay the heate of hot burning agues, they ftop the belly, they ftay vomiting, they cure the bloody flixe proceeding of choler, and they helpe the felonic, or the purging of choler vpwards and downwards.

C The people in Chefhire do eate the blacke Whortles in creame and milk, as in thefe fouth parts we eate Strawberries, which ftop and binde the belly, putting away alfo the defire to vomit.

D The red Whortle is not of fuch a pleafant tafte as the blacke, and therefore not fo much ved to be eaten, but(as I faid before)they make the faireft carnation colour in the world.

\section{Of hrub Hartwoort of Atbiopia. Chap.70.}

* The defoription.

$T$ His kinde of Sefely, being the Aethiopian Sefely, hath blackifh ftalkes of a woodie fubftance; this plant diuideth it felfe into fundrie other armes or branches, which are befet with thicke, fat, and oileous leaues, farhioned fomwhat like the Woodbinde leaues, but thicker andmore gummic, approching very neere vnto the leaues of Oleander both in fhape and fubitance, being of a deepe or darke greene colour, and of a very good fauour and fmell, and continueth greene in my garden both winter and fommer, like the Bay or Laurell. The flowers do growe at the top of the 


\section{HISTORIE OF PLANTS. I}

branches in yellow rundles like vnto the flowers of Dill; which being paft, there fucceedeth a dark or duskie feede refembling the feede of Fennell, and of a birer tafte. The roore is thicke and of a woodie fubftance.

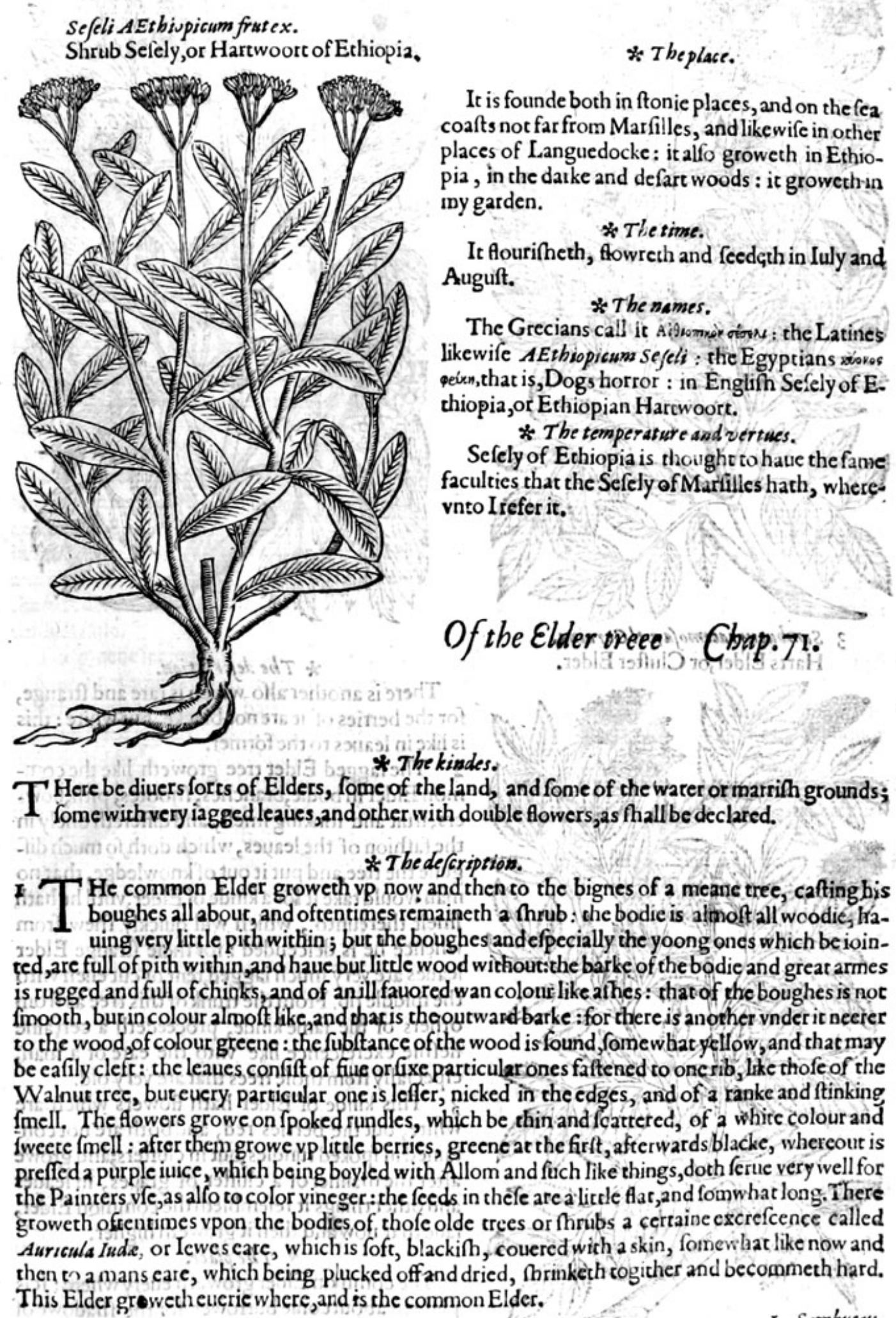


I Sambugws.

The common Elder tree.

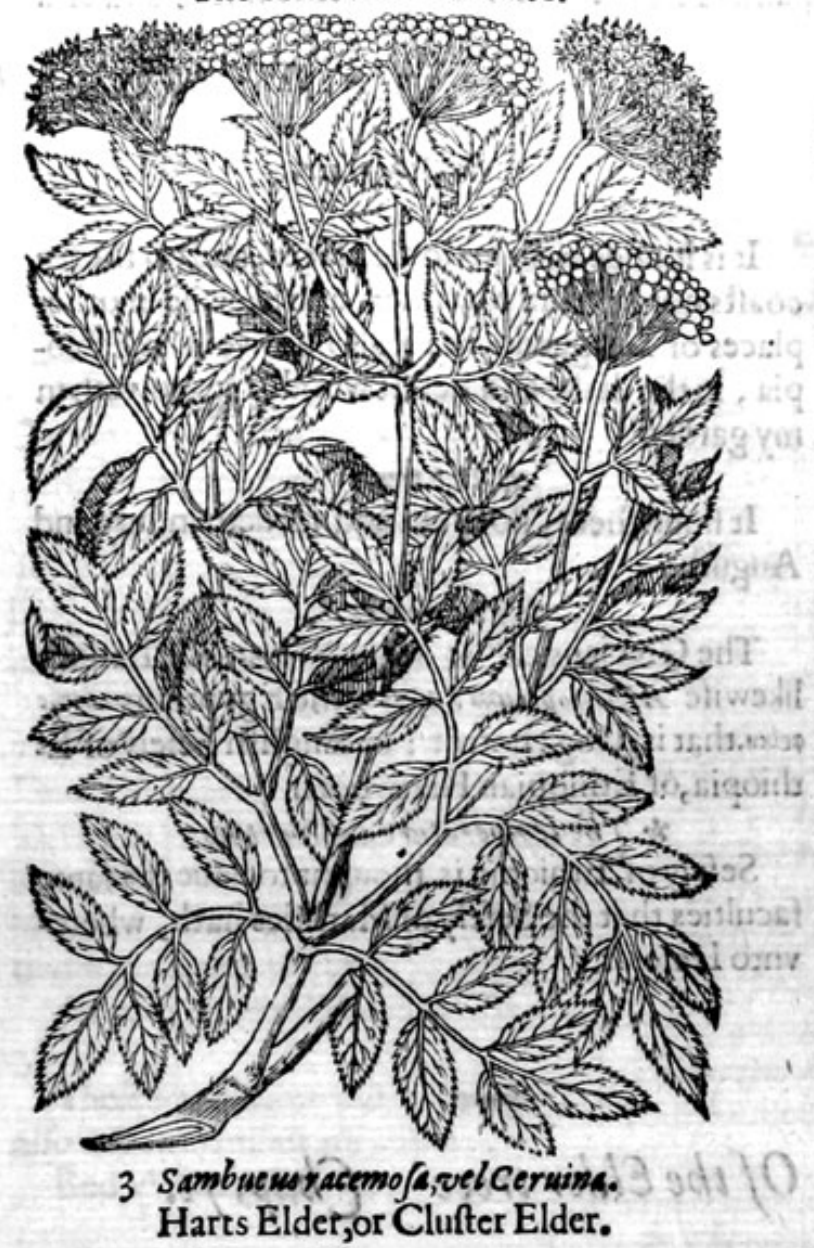

Harts Elder, or Clufter Elder.

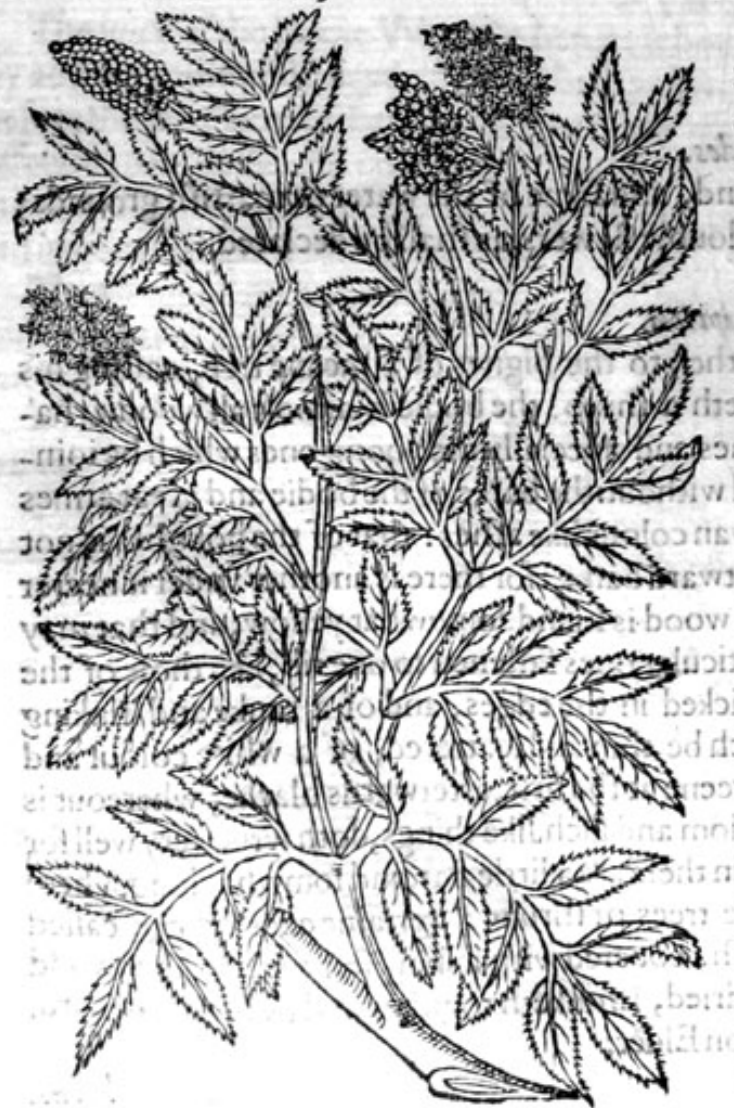

2 Sambucus Laciniatis fol ijso mi tstionsad The iagged Elder tree. Sbasl sileyba

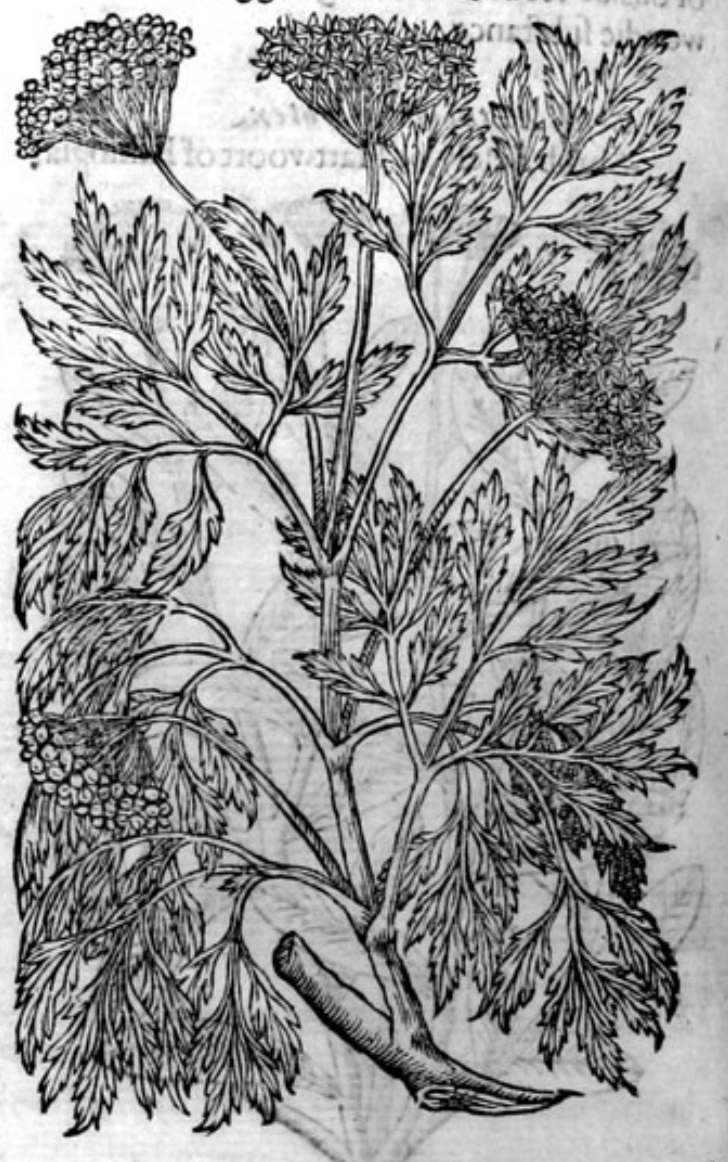

* The dejcription.

There is another alfo which is rare and ftrange, for the berries of it are not blacke, but white: this is like in leaues to the former.

2 The lagged Elder tree groweth like the common Elderin bodie, branches, Thootes, pith, flowers, fruit and ftinking fmell, and differeth onely in the falhion of the leaues, which doth fo much difguife the tree,and put it out of knowledge, that no man would take it for a kinde of Elder, vnitil he hath finelt thereinto, which will quickly fhew from whence he is defcended : for thele ittrange Elder leaues are very much iagged, rent or cut euen vnto the middle rib. From the trunk of this tree as from others of the fame kinde, proceedeth a certaine flefhie excrefence like vrito the eare of a man, efpecially from thofe trees that are very old.

3 This kinde of Elder bath flowers which are white, but the berries red, and both are notcontamed in fooked rundles, but in clufters;and growe after the manner of a clifter of grapes, in leaues and otherthings it refernbleth the common Elder, faue that now and ther it groweth higher.

$$
\text { * The place. }
$$

The common Elder groweth euery where: it is planted about conie burrowes for the fhadowe of 


\section{HISTORIE OF PLANTS.}

the Conies; but that with the white berries is rarc: the other kinds grow in like places; but that with the cluftered fruit groweth vpon mountaines; that with the iagged leaues groweth in my garden.

Thefe kinds of Elders do flower in Aprill and Maic, and their fruite is ripe in September. $* T$ be names.

This trec is called in Grecke cixmi: in Latine and of the Apothecaries Sambucus : of Gullielmus $S_{A-}$ licetus, Beza: in high Dutch poinduet boloet : in lowe Dutch điliet : in Italian Sambuco:in French Hus and Sum : in Spanifh Sauco, Sauch, Sambugueyro: in Englifh Elder, and Elder tree : that with tho white berries diuers would haue to be called Sambucus fylmeftris, or wilde Elder, but chat biolw calleth it Montana, or Mountaine Elder.

* The iemperatureandvertues.

Galen attributeth the like faculty to Elder that he doth to Danewoort, and faith that it is of a $A$ drying quality, gluing, and moderately digefting: \& it hath not onely thefe faculties, but others al. fo; for the barkes, leaues, the firft buds, flowers, and fruit of Etder, do not onely drie, but alfo heat, and haue withall a purging quality; but not without trouble and hurt to the ftomacke.

The leaues and tender crops of common Elder taken in fome broth, or pottage, openeth the B belly,purging both flimic flegme and cholericke humours: the middle barke is of the fame nature, but ftronger, and purgeth the faid humours more violently.

The feedes contained within the berries dried, are good for fuch as haue the dropfie, and fuch as $\mathbf{C}$ are too fat, and would faine be leaner, if they be taken in a morning to the quantitie of a dram with wine for a certaine fpace.

The loaues of Elder boiled in water vntill they be very foft, and when they are almoft boyled D inough, a little oile of fweet Almonds added thereto, or a little Lineleed oile; then taken forth and laide yoon a red cloth, or a peece off carlet, and applied vnto the Hemorrhoides or Piles, as hot as can befuffered, and fo remaine vpon the part affected, vmillit befomewhat colde, hauing the like in a readines, applying one after another vpon the difeafed part, by the fpace of an hower or more, and in the end fome bounde to the place, and the patient warme a bed: it hath not as yet failed at the firft dreffing, to cure the faid difeafe; but if the patient be dreffed twife, it muft needes do good, if the firft faile.

The greene leaues pouned with Deeres fuet, or Buls tallow, are good to be laide to hot fwellings $\mathrm{E}$ and tumours, and doth affwage the paine of the gout.

The inner and greene barke doth more forcibly purge; it draweth foorth choler and waterie $\mathbf{F}$ humours: for which caufe it is good for thofe that haue the dropfie, being ftamped and the liquor preffed out is drunke with wine or whay.

Of like operation are alfo the frefh flowers mixed with fome kinde of meate, as fried with egges: $\mathbf{G}$ they hkewife trouble the belly and/mooue to the ftoole: beingdried they lofe as well theirpurging qualitic as their moifture, and retaine the digefting and attenuating qualitie.

The vineger in which the dried flowers are fteeped, is wholefome for the ftomacke: being vfed $\mathbf{H}$ with meate it ftirreth vp an appetite, it cuttech and attenuateth or maketh thinne groffe and rawe humours.

The facultie of the feede is fomewhat gentler then that of the other parts : it alfo mooueth the I belly, and drawcth foorth waterie humours, being beaten to powder and giuen to a dragm waight: being new gathered, fteeped in vineger, and afterwards dried, it is taken,and that effectually with a like waight of the dried lees of wine, and with a few Annis feeds; for fo it worketh without any manner of trouble, and helpeth thofe that haue the dropfie. But it muft be giuen for certaine daies rogither with a little wine, to fuch as haue neede thereof.

The gelly of the Elder,otherwife called Iewes cares, hath a binding and drying qualitie:the infu- $\mathrm{K}$ fion thercof in which it hath been fteeped a fewe howers, taketh away inflammations of the mouth, and 2 lmonds of the throte in the beginning, if the mouth and throte be wafhed therwith, and doth in like maner belpe the Vuula.

Dioferides faith, that the tender and grecne leates of the Elder tree with barly meale parched, L doth remooue hot fwellings, and is good for thofe that are burnt or fealded, and for fuch as be bitten with a mad dog, and that they glew and heale vp hollow vlcers.

Thepith of the yoong boughes is without qualitic, this being dried and fomewhat prefled or qua- $M$ fhed togither, is good to lay open the narrow orifices or holes of fiftulacs \& iffues, if it be put therin. 


\section{6 THE THIRD BOOKE OF THE Of $\mathrm{N}$ Tarrifhorwater Elder. Chap.72.}

I Sanbu:u aqu it ilis, fiue palsstr is.Marrifh or water Elder.

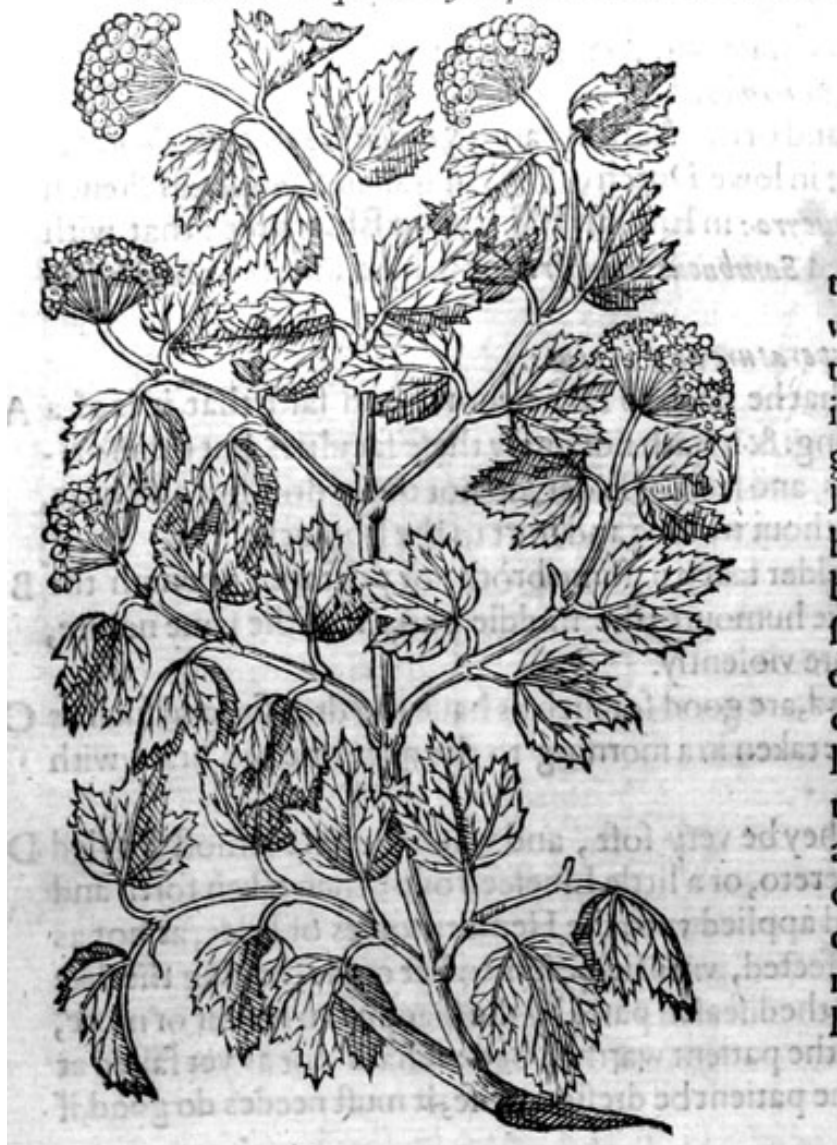

2 Sambucus Rofea. The Rofe Elder.

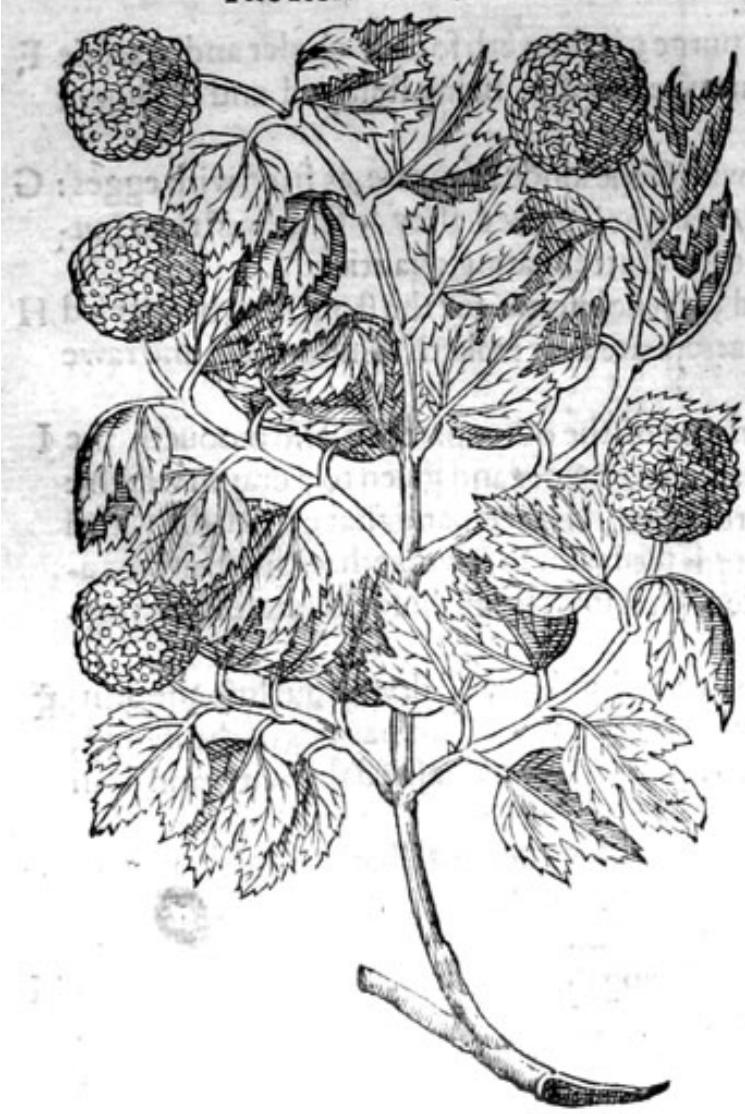

* The defsription.

1 Arrifh Elder is not like to the common Elder in leaues, but in boughes: it is much lower, and groweth after the manner of a fhrub;the boughes are couered with a barke of an ill fauoured Afh colour,as be tho? ef the common Elder; they are fet with ioints by certaine diftances, and have in them great plentie of white pith, therefore they haue lefle wood, which is white and brittle:the leaucs be broad, cornered, like almolt to Vine leaues, but leffer and fofter: among which come foorth fpoked rundles, that bring foorth little flowers, the vttermoft whereof alongt the borders be greater, of a gallant white colour, enery little one confifting of fiuc leaues; the other in the middeft and within the borders be fmaller, and flowreth ty degrees, and the whole tuft is of a moft fweet fmel, after which come the fruit or berries, that are round like thofe of the common Elder, but greater, and of 2 fhining red co. lour, and blacke when they be withered.

\section{Sambucas Rufea flore par parante.}

The Rofe Elder with the purplith flowers:

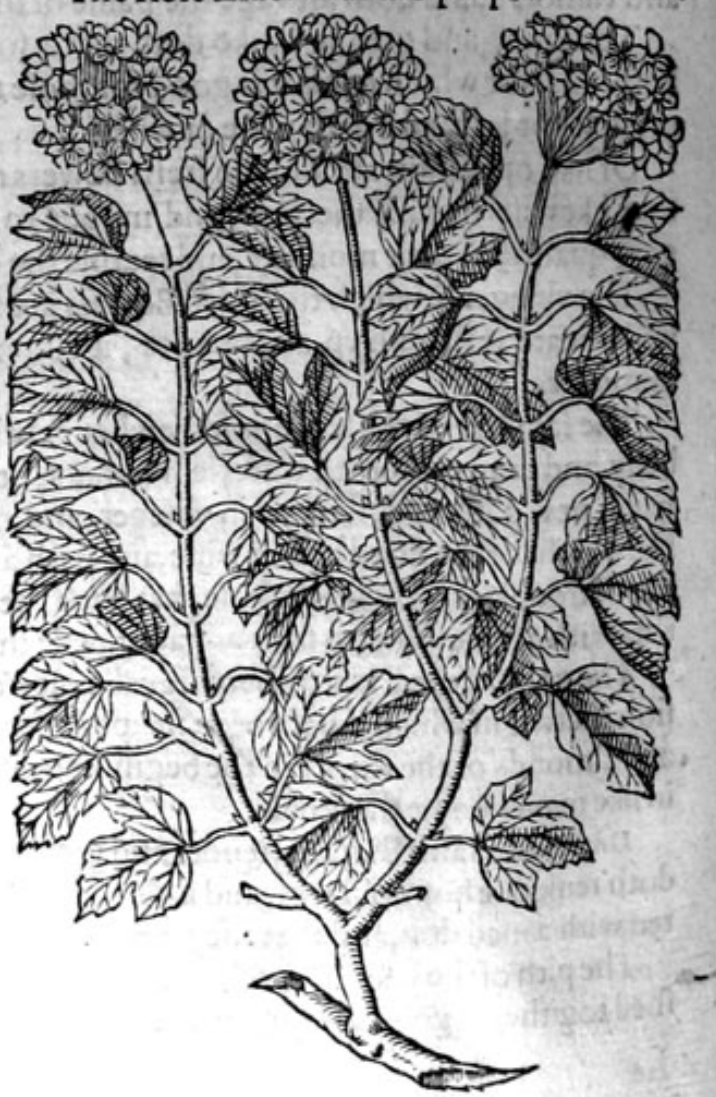




\title{
HISTORIE OF PLANTS.
}

\author{
\$ T be defcription.
}

Ambucus Rofea or the E!der Rofe,groweth like an hedge plant, or hedge tree, hauing many knottic branches and thootes comming from the roote, full of pith like the common Elder: the leaues are like the Vine leaues; amongtt which come foorth goodly flowers of a white colour, fprinckled or dafhed heere and there with a light and thinne carnation colour, \& do growe thicke, and clolely compact togither, in quantitie and bulke of a mans handes, or rather bigger, of great beautie, and fauoring like the flowers of the Hawthorne; but in my garden there groweth not any fruit vpon this tree, nor in any other place, whereof as yet I haue any vnderftanding or knowledge.

2 This kind is likewife an hedge tree, verie like vnto the former in ftalkes and branches, which are iointed \& knotted by diftances, and it is full of white pith : the leaues be likewife cornered: the flo. wers heerof grow not out of fpokie rundles, but ftand in a round, thicke and globed tuft, in bigneffe alfo and fafhion like to the former, fauing that they tende to a deeper purple colour.

\section{* 7 he place.}

Sambucuspaluftris, the water Elder, groweth by running ftreames and water courfes, and in hedges by moift ditch fides.

The Rofe Elder groweth in gardens, and the flowers are there doubled, by Art as it is thought: * The time.

Thefe kinds of Elders do flower in Aprill and_Maie; and the fruite of the water Elder is ripe in September.

\section{* The names.}

The water Elder is called in Latine Sambucess aquatica, and sambucius paluftris: it is called Ooulus, and Platanus, and alfo Chaneplatanus, or the Dwarffe Plane tree, but hot properly;V aleri-

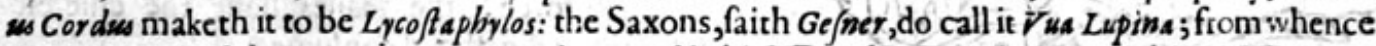

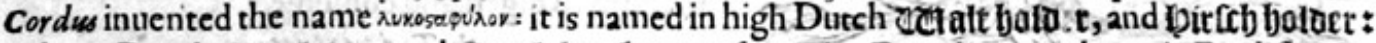
in lowe Dutch Siwelcken, and siveicken bout : of certaine French men Obiere : in Englifh Ma. rith Elder, and Whitten tree, Ople trec, and Dwarffe Plane tree.

The Rofe Elder is called in Latine Sam bucus Rofea, and Sambucus squatica, being doubtleffe a kind of the former water Elder, the flowers being doubled by Art as we haue faide : it is called in Dutch Dbelderfcbe Roofe: in Engliih Gelders Rofe, and Rofe Elder.

$$
\text { * The temp ratare and vertues. }
$$

Concerning the faculties of thefe Elders, and the berrfes of the water Elder, there is nothing found in any writer, neither can we fet downe any thing heerof of our owne knowledge.

\section{Of Danewoort, Wale woorte, or Dwarffe Elder. Clap.73.}

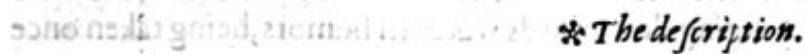

$\mathrm{D}$ Ane woort as it is not a fhrub, neither is it altogither an herby plant, but as it were a plant participaring of both, being doubtleffe one of the Elders as may appeere both by the leaues, flowers, and truite, as alfo by the finell and tafte.

Walewoort is very like vnto Elder in leaues, fpoked tufts, and fruite; but it hath not a woodie ftalke:tr bringeth foorth one $y$ greene ftalkes which wither away in winter; thefe are edged and ful of ioints; like to theyoong branches and fhootes of Elder : the leaues growe by couples, with diftances, wide, and confift of many fmall leaues, which ftande vpon a thicke ribbed ftalke, of which euery one is long, broad, and cut in the edges like a fawe, wider and greater then the leaues of the common Elder tree: at the top of the ftalkes there grow tufts of white flowers, which turne into blacke berries like the Elder, in which be littie long feede: the roote is tough, and of a good and reafonable length; better for phificke vfes then the rootes of Elder. 
Ebalus,fuc Sambucus humilis.

Dane woort, or dwarfe Elder.

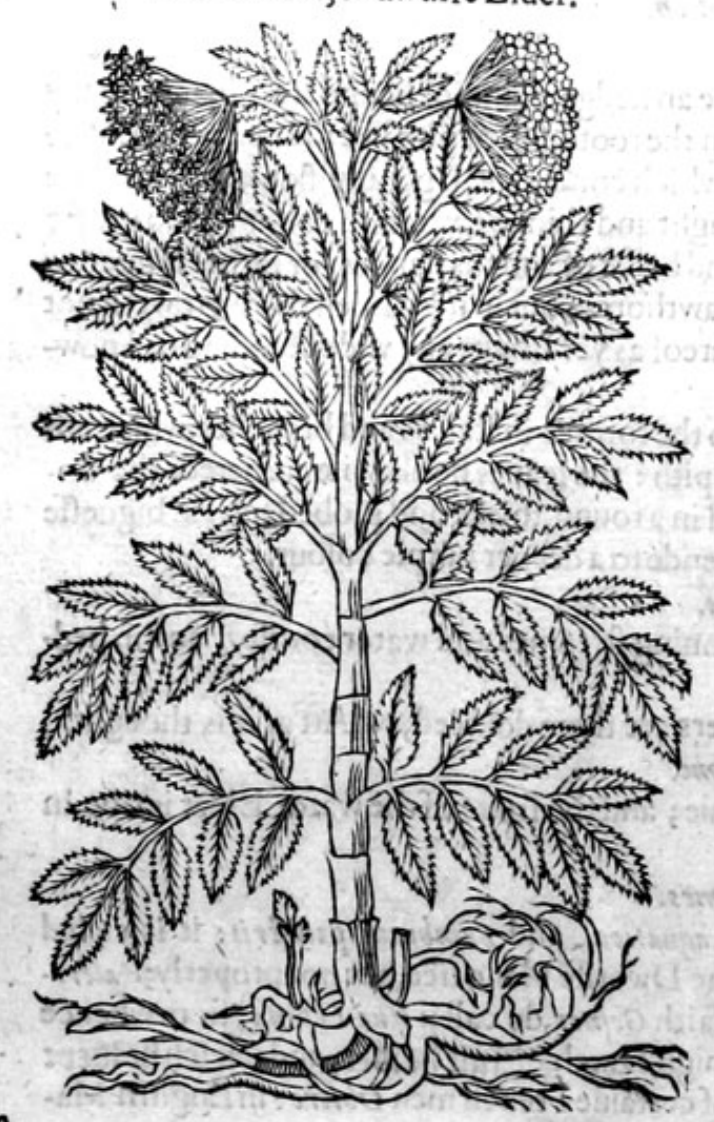

\section{BOOKE OF THE}

$*$ The place.
Dane woort groweth in vnto common waies, and in the boyled places neere groweth plentifully in the lane at Kilb fieldes: it by London: alfo in a field by S. Iones ford in Kent, and alfo in the high way DartBrainford townes ende next London alde other places.

\section{* The time.}

The flowers are perfected in fommer, and the berries in Autumne.

* The names.

It is named in Greeke raparax']n, that is, Humilin Sambucuc, or lowe Elder : it is called in Latine Ebrius and Ebulam : in high Dutch atticb : in lowe Dutch Đatch: in Italian Ebulo: in French Hieble : in Spanifh rezgos:in Englifh Wall wort, Dane woort, and dwarte Elder.

\section{* The temperature.}

Wall woort is of temperature hot and drie in the third degree, and of a fingular qualitie, which Galen doth attribute vnto it, to wafte and confume, and alfo it hath a frange and éfpeciall $\mathrm{f}_{2}$ cultie to purge by the ftoole : the rootes be of greatcit force, the leaues haue the chiefelt itrength to digeft and confume.

\section{* The vertues.}

The rootes of Wall woore boyled in wine and drunken, are good againft the dropfic, for they purge downwards waterifh humors.

B The leaues do confume and wafte away hard fwellings, if they be applied pultufwife, or in a fomentation, or bath.

C Diofcurides faith, that the rootes of Wall woort, doe foften and open the matrix, and alfo correctech the infirmities thereof, if they be boyled fur a bath to fit in, and diffolueth the fwellings and paines of the belly.

D The iuice of the roote of Dane woort doth make the haire blacke.

E The yoong and tender leaues doth quench hot inflammations, being applied with Barly meale; that it is with good fucceffe layd vpon burnings, fcaldings, and vpon the bitings of mad dogs; and that with Buls tallow, or Goates fuet it is a reifiedie for the gowte.

F The feed of Wall woort drunke in the quartitie of a dram, is the moft excellent purger of waterifh humors in the world, and therefore molt fingular againft the dropfie.

G If one fcruple of the feede be brufed and taken with firupe of Rofes and a little Secke, it cureth the dropfie, and eafeth the gowte, mightily purging downwards waterifh humors, being taken once in the weeke.

\section{Of Beane Trefoyle. Cbap.74. gy}

$*$ The defcrittion.

I THe firft kinde of Anagyris, or Laburnum, groweth like vnto a fmall tree, garnifhed with many fmall branches, like the fhootes of Oziars, fet full of pale greene leaues, alwaies three togither, like the Lotws, or Medow Trefoile, or rather like the leaues of Vitex, or the Cytifus buth:among which come foorth many tufts of flowers, of a yellow colour, not much vnlike the flowers of Broome: when thefe flowers be gone, the e fucceede fmall flat cods, wherein are conteined feedes like $\mathrm{G}_{2}$ lega, or the Cityfus bufh: the wholepiant hath little fauour or none at all: the roote is foft and gentle,yet of a woodie fubftance. 


\section{HISTORIE OF PLANTS.}

2 Stinking Trefoile is a fhrub like to a litcle tree, rifing vp to the height of fixe or eight cubits, or is of 2 deepe greene colour: the leaues ftand alkes very many flender branches; the barke whereof Trefaile, yet of a lighter greene on the vpperfide: to thofe of Broome, two or three alfo ioineride: the flowers be long, as yellow as gold, very like hard fruit like Kidney beanes, but leffer, at o fift whe all of a backin blew: che leaues and flowers heer f Gladen,and fo ranke withall, as euen the very paffers by are aithe Imell, like thofe of the ftinking

1 Anagyris.

Beane Trefoile.

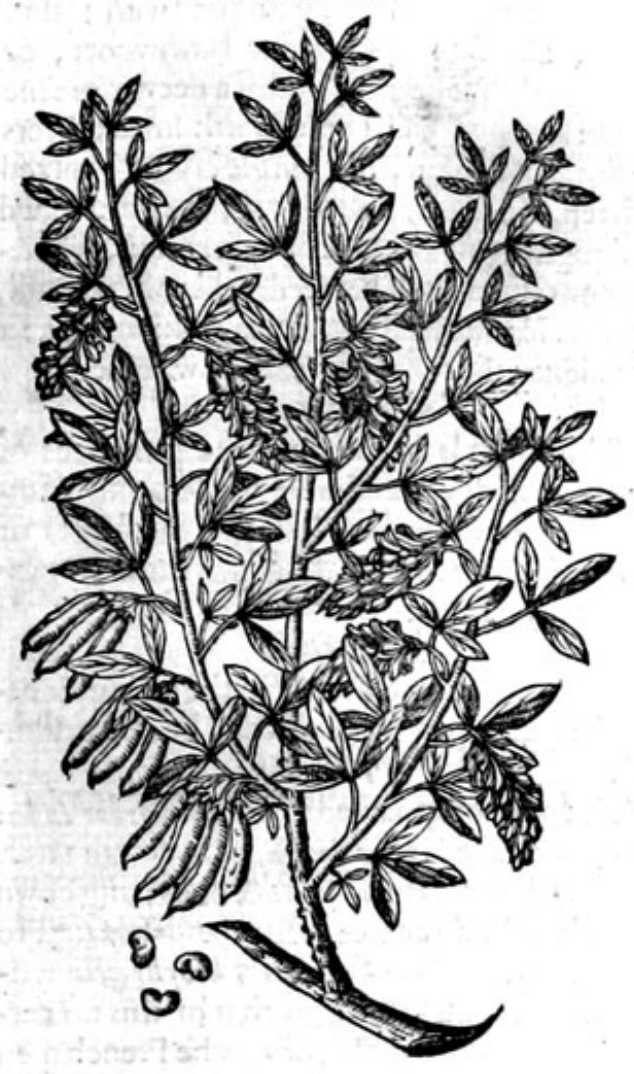

2 Anagyris fatids. Stinking Be ane Trefoile.

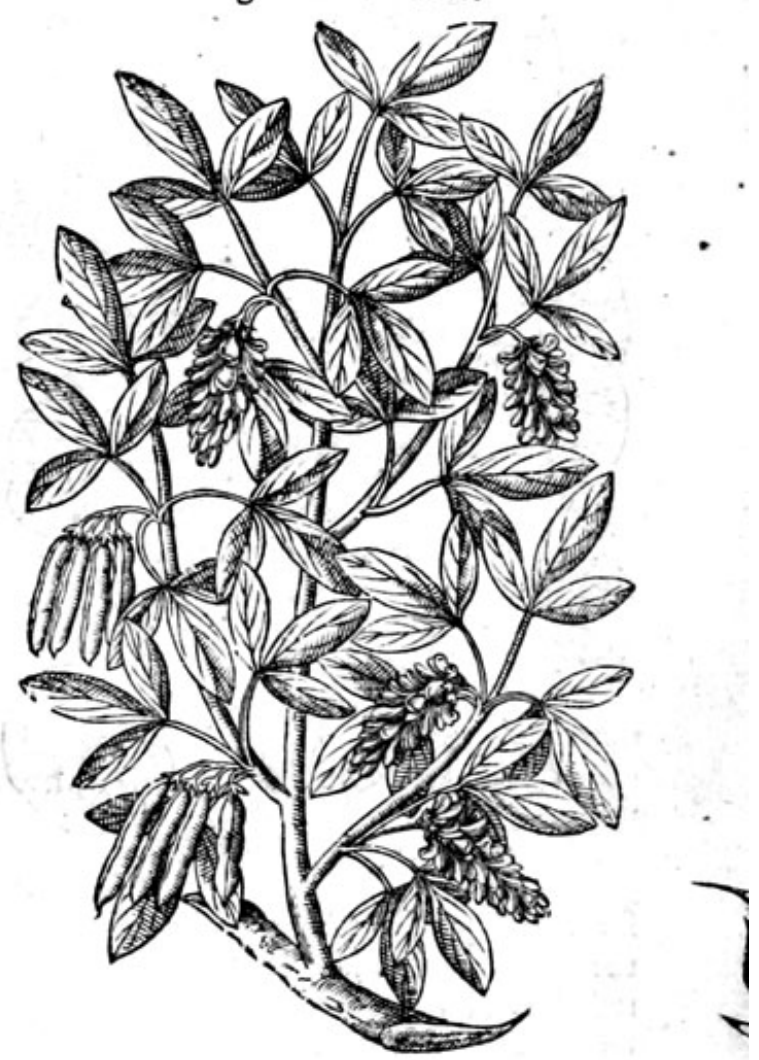

* The place.

Thefe grow of themfelues in moft places of Languedocke and Spaine, and in other countries alfo by high way fides, as in the Ile of Candie, as Bellonius teftificth: the fir ft I haue in my garden;the other is a ftranger in England. * The time.

They flower in Iune, and the feed is ripe in September.

* The names.

The Beanc Trefoile is called in Greeke ivdyues, which name remaineth vncorrupt in Candy eten to this day :in Latine alfo Anagyris, and L. burnum: of apeople called Ananienfes, named Eghelo, which is referred vnto Laburnwm, of which Pliny writeth in his 1 6.booke 18.chap.in Englifh Beane Trefoile, or the Peafcod tree. * The temperature.

Beane Trefoile, as Galen writeth, hath a hot and digefting facultie.

$$
\text { * The vertues. }
$$

The tender leaues faith Diofc.being ftamped \& laid vpon cold fwellings, do wafte away the fame.

They are drunke with Cute in the weight of a dram againft the ftuffing of the lurigs, and to bring downe the menfes, the birth, and the afterbirth.

They cure the headach being drunke with wine; the ituice of the roote digefteth and ripeneth, if the feede be eaten it procureth vomite, which thing as Mathiolus write h, the feede not oncly of ftinking Beane Trefoile doth effect, but that alfo of the other lakewif $\mathrm{c}$, it

$$
\text { LIII a }
$$




\section{I24 $4^{\circ}$ THE THIRD BOOKE OF THE}

\section{Offudas tree. Chap.75.}

Arbor Iude.

Iudas tree.

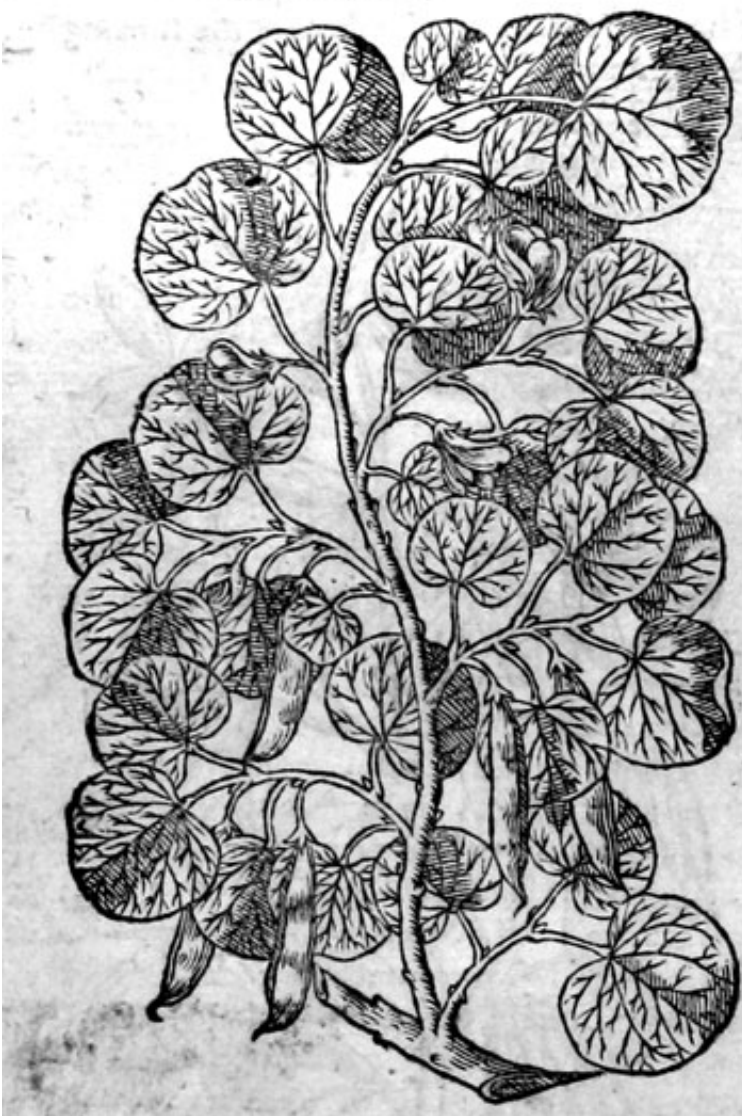

* The defcription.

Vdas tree is likewile one of the hedge plants: it groweth vp vnto a tree of a reafonable big. nes, couered with a darke coloured barke, whereon do growe many twiggic tough branches of a browne colour, garnifhed with round leaues, like thofe of rounde Birthwoort, or Sowebread, but harder, and of a deeper greene colour: among which come foorth fmall flowers like thofe of Peafon, of a purple colour, mixed with red, which turne into long flat cods, preffed hard togither, of a tawnie or wan colour, where. in is contained fmall flat feedes, like the Lentill, or rather like the feed of Medica, fafhioned like a little kidney:the roote is great and woodie. * The place.

This thrub is founde in diuers prouinces of Spaine, in hedges, and among briers and bram. bles: the mountaines of Italy, and the fieldes of Languedocke are not without this hrub : it groweth in my garden.

\section{$*$ The time.}

The flowers come foorth in the fpring, \& before the leaues : the fruite or cods be ripe in fommer. $* T$ be names.

It is commonly named in Latine Arbor Iude: fome haue called it Syconsorus, or Sycomore tree, and that bicaufe the flowers $\&$ cods hang down from the bigger branches: but the right Sycomore tree is like the figge tree in fruit, and in leaues to the Mulberic tree, whereupon it is fo named. Others take it to be xupris, of which Theophraftus writech this, Cercis bringeth foorth fruite in a cod; which words are all fo fewe, as that of this no certaintie can be gathered, for there be more fhrubs that bring foorth fruit in cods. The French men call it Guainier, as though they houlde fay Vaginula, or a little fheath : moft of the Spaniards do name it Algorouo loco, that is, Siligua fylueftris, or fatua, wilde or foolifh cod, others Lirbold' omor, for the brauenes fake : it may be called in Englifh Itidas tree, $w$ hereon Indas did hang himfelfe, and not vpon the Elder tree, as it is faide.

\section{* Thetemperature and vertues.}

The temperature and vertues of this fhrub are vnknowne, and not found out: for wheras Matbiolus maketh this to be Acacia, by adding falfely thornes vnto it, it is but a furmife.

\section{Of the Carob tree, or Saint Iobns bread. Chap.76.}

\section{* The de cription.}

$\mathrm{T}$ He Carob tree is alfo one of the fhrubs that beare cods; it is a tree of a middle bignes, veric full of boughes : the leaues long, and confift of many fet togither vpon one middle rib, like thofe of the Arh, but etiery particular one of them is broader, harder, and rounder : the fruite or long cods in fome places afe 2 foote in length, in other places fhorter by halfe: an inch broade, - fmooth, \& thick, in which do lic flat and broad feed s; the cods themfelues are of a fweete tafte,and are caten of diters, but not before they be new gather ed and dricd; for being as yet greene though ripe, they are vnpleafant to be caten by reafon of their ill fauoured tafte. 
Ceratia filiqua, fue Ceratonia. The Carob trec.

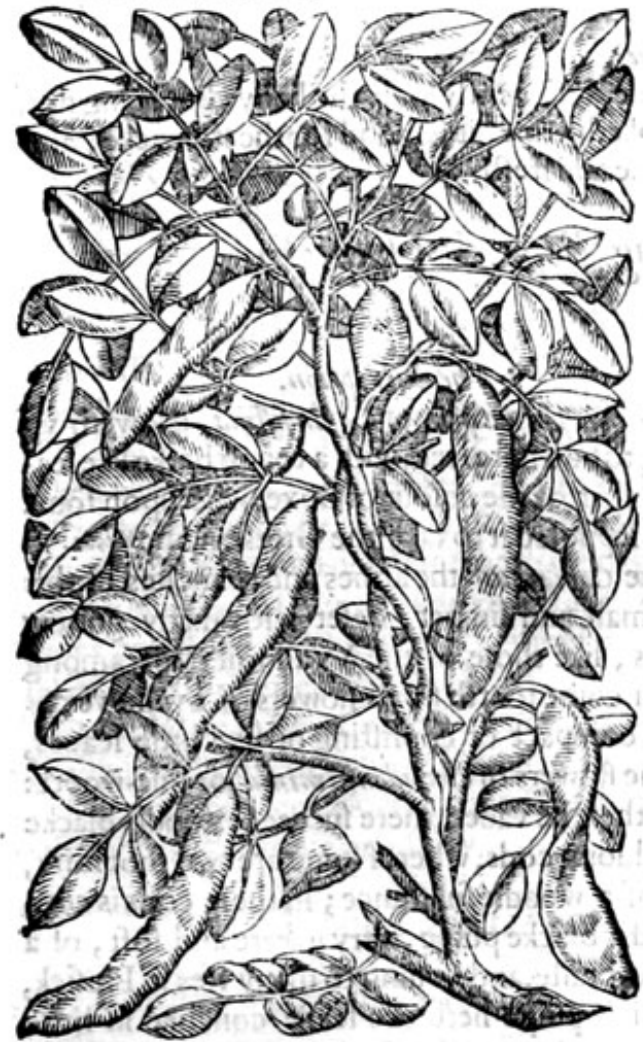

X.The place.

$124 \mathrm{I}$

This groweth in Apulia, a prouince of the king. done of Naples, \& abfo in discrs vntoiled places in Spaine :it is likewife founde in India and other countrics ealtwarede, where the cods are fo full of fweet iuice as that it is vfed to prefettie Ginger and. other fruites, as $M$ st hioles fheweth. Strabolibr. 15. faith, that Ariffolulus reporteth how there is a tree in India of no great bignes, which bath gteat cods, ten inches long, full of hony; Quas gut clerint non factle ferasti; which thing peraduentureis onely to be vnderftoode of the greenecods, andrhofe that are not as yet dry:it is very well known in the coafts of Nicea \& Liguria in Italy, as alfo in all the tracts and coaftes of the weft Indies, \& Verginia. It growech alfo in fundry places of Paleftina, where there is fuch plenty of it, that it is left vnto fwine \& other wilde beafts to feede vpon, as our acomes \& beech mintc. Morenver, both yoong \& old do feed thereon for pleafure, \& fome hatic eaten therof to fupply and helpe the neceflary norifhment of theirbodics. i his of lome is called S.Iohns bread, and thought to be that which is tranflated Locufts, whereon S. John did feed when he was in the wildernes, befides the wilde hony wherof he did alfo eate ; but there is finall certainty of this: but moft certaine, that the people of that countrey do feede vpon thefe cods, in Greek called Kegéne: in Latin Siligue: but S. Iohns food is called dixeds in Greek, which word is often ved in the Reuclation, written by S.Iohn, and tranflated Locufts. Now ive muft alfo remember that this Greeke worde hash two feuerall interpretations or fignifications, for taken in the good part, it fignifieth a kind of creeping creature, or flie, which hoppeth and skippeth vp \& down, as doth the graihopper; of which kind of creatures it was lawfull to eate, Leuit. I I , 22. \& Math.3.4. It fignifieth alfo thole Locufts which came out of the fimoke of the bottomles pit, mentioned $A$ poc. $9, v \cdot 3,4.8 \mathrm{sc}$. which were like vnto horfes prepared for battell. The Hebrue worde which the Englifh tranflaters haue turned grafhoppers: Tremslies dares not giue the name Locust vnto it, but calleth it by the Hebrue name $A r l i s$,after the letters and Hebrue name, faying thus in the note vpon the 22.verf. of the 1 r.chap. of Lewit. Thefe kindes of creeping things neither the Hebrues nor the Hiftoriographers, nor our felues do know what they meane: wherefore we ftill retaine the Hebrue words, for all the 4 kinds thereof: but it is certaine that the eaft countrey grafhoppers and Locufts were their meate, as Math.3,4.8 Marc.1.6. Plin lib.1 I.natur. bifur.cap.26.\$2 29. Thus farre Tremeline and Iunius. By that which hath been faid it appecretl what S. Iohn the Baptift fedde of, vnder the title Locuffs: and that it is nothing like vnto this fruit Ceratiafibiqua. I rather take the husks or fhels of the fruite of this tree, to be the cods or husks whereof the prodigall childe woulde haue fedde, but none gaue them vnto him, though the Swine had their fill therof. Thefe cods being dry are very like bean cods; as I haue ofren feen.I haue fowen the feeds in my gardé, where thcy hatie profpered exceeding wel. * Thetime.

The Carob tree bringeth foorth fruite in the beginning of the fpring, which is not ripe till Autumne. $*$ The names.

The Carob trec is called xacervia: in Latine likewife Ceratonia : in Spanifh Garouo: in Englifh Carob tree, and of fome beane trec, and S.Iohns bread. The fruit or cod is named xuézer : in Latune Siligma, or Siligua duicis: in diuers ihops XylocaraCta: in other thops in Italy Carobe, or Carobole: of the Apothecaries in Apulia Salequa: it is called in Spanih Alfarobas, or Nlgarouns, and without an

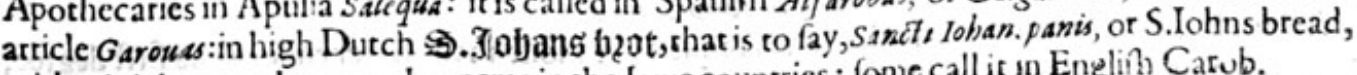
neither is it knowne by any other name in the lowe countries: fone call it in Englinh Carub. 
$\because$ The temperature.

The Carob tree is dry and aftringent, as is alfo the fruite, and containeth in it a certaine fweetenes, as Galen fäth.

\section{$*$ The vertues.}

A The fruite of the Carobe tree eaten when it is greene, doth gently loofe the belly; but being dry, it is hard of digeftion, and ftoppeth the belly, it prouoketh vrine, it is good for the ftomacke, and nourifheth well, and much better then when it is greene and frefh.

\section{OfCafsia fiftula, or Pudding Pipe. Chap.77.}

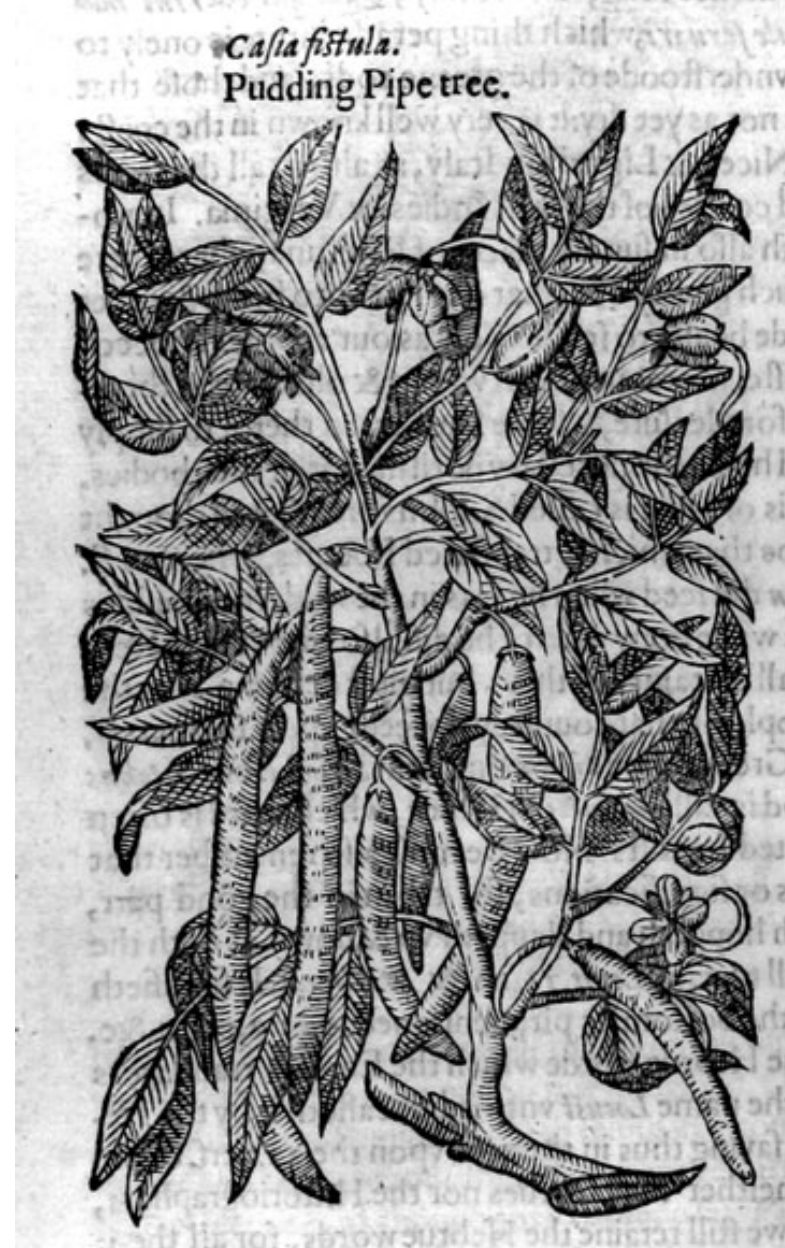

\section{\&Thedefcription.}

Afia purgatrix, or Cajsafiftula, groweth vp to be a faire tree, with a tough barke like lea. ther, of the colour of Boxe, wherupon fome haue fuppofed it to take the Greeke name Kastis: in Latine Coriaceus : the armes and branches of this are fmall and limber, befet with many goodly leaues, like thofe of the Wall nut tree: among which come foorth fmall flowers of a yellowecolour, compact or confifting of fixe little leaues, like the flowers of chelidoniü minus, or Pile-woort: after thefe be vaded, there fucceede goodly blacke round, long cods, wherof fome are two foot long, and of a woodie fubftance; in thefe cods is contained a blacke pulpe, very fweete and foft, of 2 pleafant tafte, and feruing to many vfes in Phifick, in which pulpo lieth the feede couched in little cels or partitions : this feede is flat and brownifh, not vnlike the feed of Ceratin Siligna, and in other refpects very like vnto it alfo.

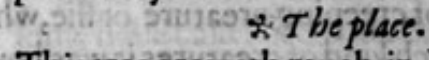

This tree groweth much in Egypt, efpeciallie about Memphis and Alexandria, Semoft parts of Barbary, and is a f tranger in thefe parts of Europe. Hig ?or 2 The time.

The Caffia tree groweth greene winter and fommer: it fheddeth his old leaues when new are com, by meanes whereof it is neuer voide of leaues : it flowreth earely in the fpring, and the fruite is ripe in Autumid! th

* The names.

This tree was vnknowne to the olde writers, or fo little aceounted of, as that they haue made no mention of it at al: the Arabians were the fifft that efteemed of it, by reafonthey knew the vfe of the pulpe, which is found in the Pipes:and after them the later Grecians, as ACtarius \& other of his

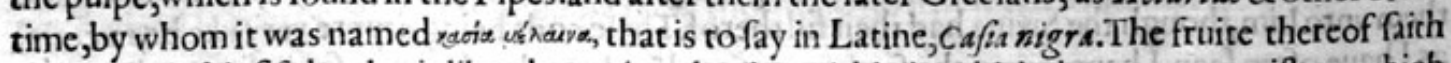
ACtuarius in his fift booke, is like a long pipe, hauing within it a thicke humour or moifture, which is not cong ealed all alike thorow the pipe, bur is feparated and diuided with many partitions, being

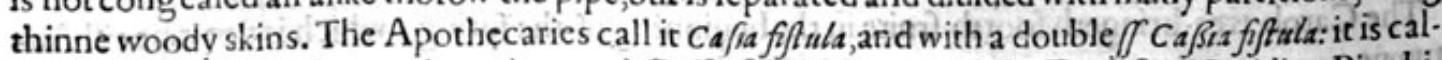
led in Englifh after the apothecaries word, Caffia fiftula, \& may alfo be Englifhed Pudding Pipe, bicaufe the cod or pipe is like a pudding; but the old Caffia fiftula, or $\sigma^{\prime} e r \xi$ in Greeke, is that fiweete $\&$ odoriferous barke that is rolled togither, after the maner of a tong \& round pipe, now named of the Apothecaries Cantlla, which they vfe in fteed of the right Cínamome, but deccitfully. $*$ The temperature.

The pulpe of this Pipe which is chiefely in requeft, is moilt in the latter ende of the firft degree, and little more then temperately hot. $* 2$ be 
Thepulpe of Caßsuffiftula extract, with violet water, is a moft fweete and pleafant medicine, and A may be gituen without danger to all weake people of what age and fexe focuer they be;yea it may be miniftred towomen with childe, for it gently purgeth cholericke humours and flimic flegme, if it be taken the waight of an ounce.

Caßsa is good for fuch as be vexed with hot agues, pleurifies, iaundife, or any other inflammati- B on of the liuer, being taken as afore is Phewed.

caßsa is good for the raines and kidneies, driueth foorth grauell and the ftone, efpecially if it be $\mathrm{C}$ mingled with the decoction of Parfley, and Fennell rootes, and drunke.

It purgeth and purifieth the bloud, making it more cleane then before, breaking therewith the D acrimonie and tharpnes of the mixture of bloud and choler togither.

It diffolueth all phlegmons and inflammations of the breft, lungs, and the rough artery, called E Trachea arteria, eafing thofe parts exceeding well.

Ca ßsia abateth the velhemencie of thirft in agues, or any hot difeafe whatfoeuer,efpecially if it be $\mathrm{F}$ taken with the iuice of Intybum Cichoreum, or Solannm, depured according to Art: it abateth alfo the intemperate heate of the raines, if it be receiued with diuretick fimples, or with the decoction of Licorice onely, \& wil not fuffer the ftone to grow in fuch perfons as do receiue \& vfe this medicine.

The beft Caßsia for your vfe, is to be taken out of the moft full, moft heauy, and faireft cods; or G canes, and thole which do fhine without, and are full of foft pulpe wirhin ; that pulpe which is newly taken foorth is better then that which is kept in boxes, by what Art foeuer.

Caßsa being outwartly applied, it taketh away the roughnes of the skin,and being laide vpon hot $\mathbf{H}$ fwellings, it bringeth them to fuppuration.

Many fingular compounded medicines are made with this $\mathrm{Ca}$ Sia, which heere to recitebelong-I eth not to my purpofe or hiftory.

\section{Of the Lentiske, or Mafticke tree Chap. 78 .}

Lentifous. The Mafticke tree.

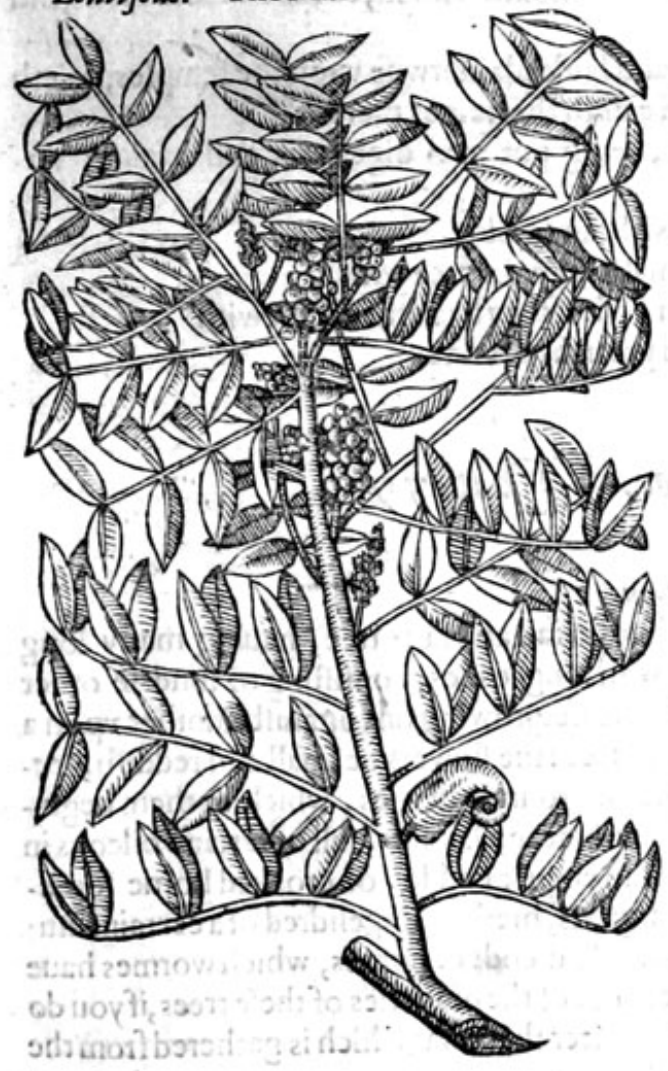

$*$ The defcription.

$T$ He Mafticke tree groweth commonly like a fhrubbe without any great body, rifing vp with many fprings \& thoots like the Hafell; and of tentines it is of the height and bignes of $\mathbf{a}$ mean tree: the boughes therof are tough, \& $\mathrm{flexi}$ ble; the barke is of a yellowifh red colour, pliable likewife, \& hard to be broké: there ftand vpon one rib for the mott part 8.leaues, fet vpon a middle rib, much like to the leaues of Licorice, but harder, of a deepe greene colour, \& oftentimes fomewhat red in the brims, as alfo hatuing diuers vains running along of a red colour, and fomething ftrong of fmelathe flowers be moflie, and grow in clufters vpon long ftems: after them come vp the berries, of the bignes of Vetches, greene at the firf, afterwardes of a purple colour, and latt of a H blacke, fat and oilie, with a hard black ftone within; the kernell whereof is white, of which alfo is made oile, as Dio/corides witnefieth : it bringeth foorth likewife cods befides the fruit (which may rather betermed an excrefcence, then a cod) writhed like a horn; in which lieth at the firft a liqor, \&afterwards when this waxeth fale, little liuing thinges like vnto gnats, as in the Turpentine hoines, and in the folded leaues of the Elme tree. There commeth foorth of the Mafticke tree a Rofen, but dry,called Mafticke.

$$
\text { Lill } 4
$$


* The place.

The Mafticke tree groweth in many regions, as in Syria, Candy, Italy, Languedocke, and in moft prouinces of Spaine:but the chiefeft is in Chios an Iland in Greece, in which it is diligently and fpe. fticke trees by the inhabitants e. the worlde. .

* The time.

The flowers be in their pride in the fpring time,and the berries in Autumne : the Mafticke muft be gathered about the time when the grapes be.

\section{* The names.}

This tree is named in Greeke $\hat{x}_{0}$ : Arcoyra : in Englifh Mafticke tree, and of fome Lentiske tree.

The Rofen is called in Greeke furim quirn, and uasixen: in Latine Lentifoina Refina, and likewife Ma. ftiche : in fhops Maftix : in Italian CMaftice: in high and lowe Dutch and French alfo Mastic: in Spanifh Limastiga:Maftech, and Almecega : in Englifh Mafticke.

Cluf fues writeth, that the Spaniards cal the oile that is preffed out of the berries Azegte de Mata.

The leaues, barke, and gums of the Mafticke tree, are of a meane and temperate heat, and are dry in the fecond degree, and fomwhat aftringent.

$*$ The vertues.

A The leaues and barke of the Mafticke tree ftoppe the laske, the bloudy flixe, the foitting of bloud, the piffing of bloud, and all other fluxes of bloud : they are alfo good againft the falling fickneffe, the falling downe of the mother, and comming foorth of the fundament.

B The gum Mafticke hath the fame vertue, if it be relented in wine, and giuen to drinke.

C Mafticke chewed in the mouth is good for the ftomacke, ftaieth vomite, increafeth appetite, comforteth the braines, ftaieth the falling downe of rheumes and waterie humours, and maketh a fwcete breath.

D The fame infufed in Rofe water, is excellent to wafh the mouth withall, to faften loofe teeth, and to comfort the iawes.

E The fame fpred vpon a peece of leather or veluet, and laide plaifterwife vpon the temples, ftaieth therheume from falling into the iawes and teeth,and eafeth the paines thereof.

F It preuaileth much againft vlcers and woundes, being put into digeftiues and healing $\mathrm{Vn}$. guents.

G It draweth flegme foorth of the head gently and without trouble.

H It is alfo vfed in waters which ferue to clenfe and make faire the face with.

I The decoetion of this filleth vp hollow vlcers with flefh if they be bathed therewith.

K It knitteth broken bones, ttaicth eating vlcers, and prouoketh vrine.

\section{Of the Turpentine Tree. Chap.79.}

\section{* The defcription.}

17 He firft Turpentine tree groweth to the height of a tall and faire tree, hauing many long boughes or branches difperfed abroad, befet with long leaues, confifting of fundrie other fmall leaues, each whereof refembleth the Baie leafe,growing one againft another vpon a little ftem or middle rib, like vnto the leaves of the Athe tree: the flowers be fmall and reddifh,growing vpon clufters or bunches like grapes, that turne into rounde berries, which at their beginning are greene, afterwards reddifh; but being ripe waxe blacke, clammie, full of fat, and oileous in fubitance, and of a pleafant fauour: this plant beareth an emptie codde, or crooked horne fomewhat reddith, wherein are found fmall flies, wormes or gnats, bred and ingendred of a certaine hu. morous matter, which cleaueth to the inner fides of the faid cods or hornes, which wormes haue not any phyficall vfe at all. The right Turpentine iffueth out of the branches of thefe trees, if you do cut or wound them, the which is faire and cleere, and better than that which is gatheredfrom the barke of the Firre tree. 
2 The fecond kinde of Turpentine tree is very like vuto the former, but that it groweth not fo great;yet the leaues are greater and broader, and of the fame fafhion, but very like to the leaues of the Piftacia tree. The berries are firft of a fearlet colour, and when they be ripe of a skie colour. The great horned cods are tharpe pointed, and fom what corncred, confifting as it were of the fubftance of griftles. And out of thofe horned bladders being broken, do creepe and come fmall fies or gnats, bred of a fuliginous excrements, and ingendred in thofe bladders. The tree doth alfo yeeld his Turpentine by dropping like the former.

I Terebinthus.

The Turpentine tree.

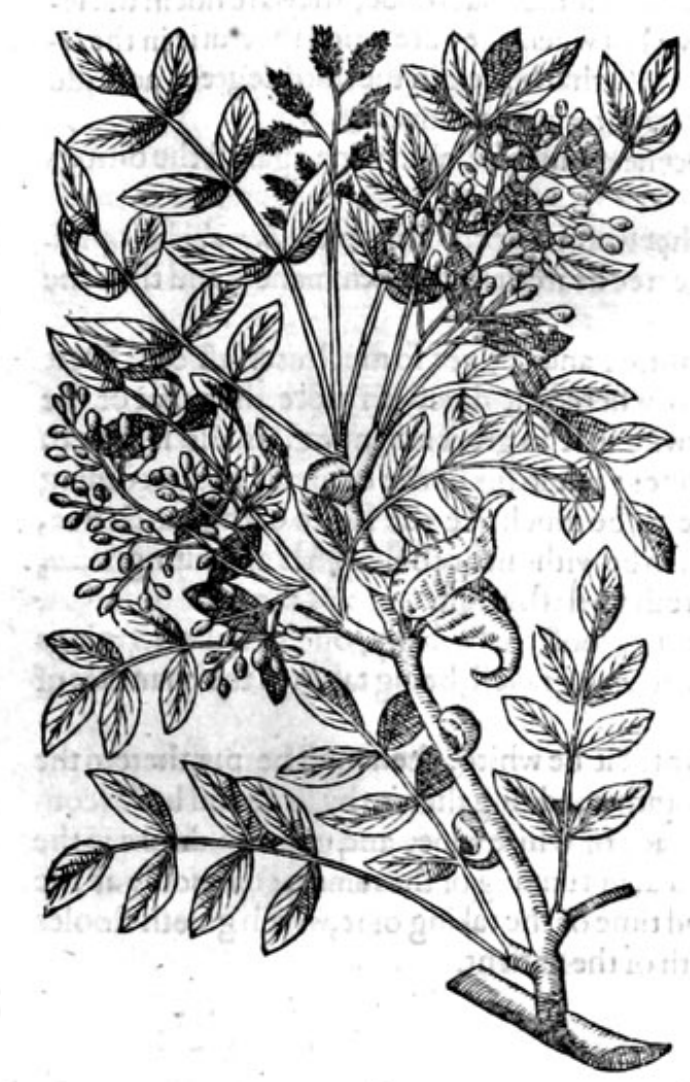

2 Terebintbuslatifolia.

The broad leafed Turpentine tree.

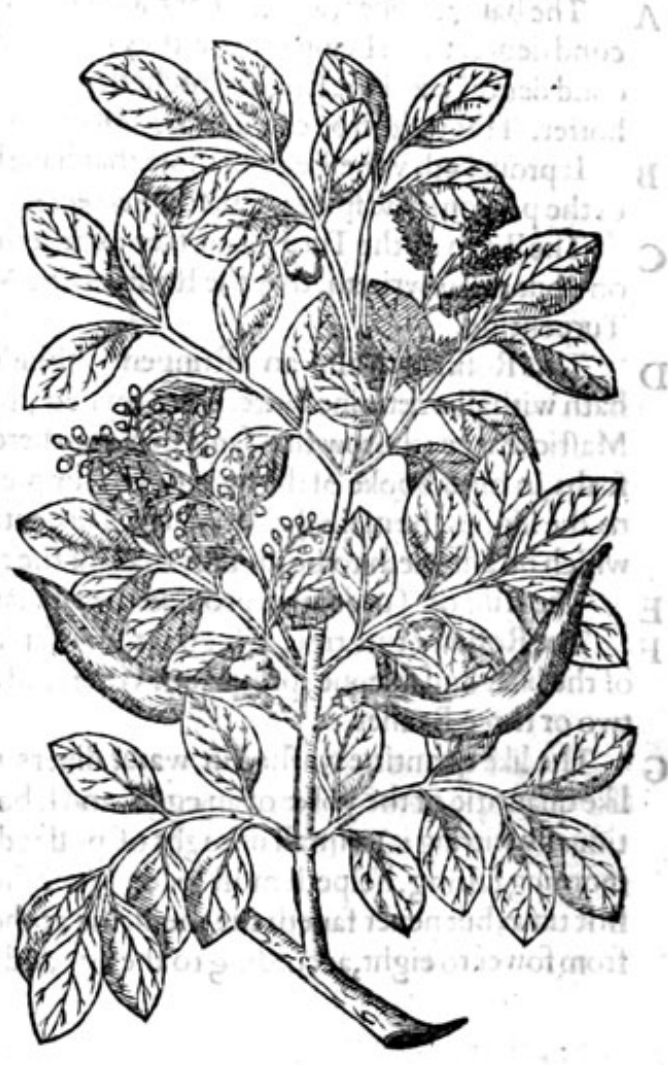

* Theplace.

Thefe trees growe, as Diofcorides faith, in Lurie, Syria, Cyprus, Affrike, and in the I!ands called cyclades. Belionius reporteth that there are found great ftore of them in Syria and Cilicia, and are brought from thence to Damafcus to be fold.Cluffies faith that it groweth of it felfe in Languedock, and in very many places of Portingale and Spaine, but for the moft part like a fhrub, and without bearing Turpentine.

Theopbrast us writeth that it groweth about the bill Ida, and in Macedonia, thort, in maner of a Ahrub and writhed; and in Damafcus and Syria, grear, in manner of 2 fmall tree: he alfo fettech downe a certaine male Turpentine tree and a femalc: the male, faith he, is barren, and the female fruitfull. And of thefe he maketh the one with a berrie red at the firft, of the bignes of a Lentill, which cannot come to ripenes;and the other with the fruit greene at the firf, afterwards fome what of a yellowifh red, and in the end blacke, waxing ripe in the fping, of the bignes of the Grecian's Beane, aud rofenic.

He alfo writcth of a certaine Indian Turpentine tree, that is to fay, a tree like in boughes and leaues to the right Turpentine tree, but differing in fruit, which is like vuto Almonds.

The flowers of the Turpentine tree come foorth in the fpring togither with the new buds: the
Thetime. berries 


\section{THE THIRD BOOKE OF THE}

berries are ripe in September and October in the time of Grape gathering. The hornes appeere
about the fame time.

* The names.

This tree is called in Greeke ripurgO, and alfo many times mps6ingO: in Latine Terebinthes: in Italian Terebintho: in Spanifh Cornicabra : in French Terebente: in Englifh Turpentine tree: the Arabians call it Bot in, and with an article Albotin.

The Rofin is furnamed zopurvim: in Latine Terebintbina : in high Dutch Tetmintbint in Englifh Turpentine,\& right Turpentine:in the Arabian language Albotin, who name the fruit Granum viride, or greene berrie.

* The temperature and vertues.

A The barke, leaues, and fruit of the Turpentine tree doth fomewhat binde, they are hot in the fe. cond degree, and being greene they drie moderately; but when they are dried they"drie in thefecond degree; and the fruit approcheth more neer to thofe that be drie in the third degree, and alfo hotter. This is fit to be eaten, as Dio/corides faith, but it hurteth the ftomacke.

B It prowoketh vrine, helpeth thofe that haue bad fpleenes, and is drunk in wine againtt the bitings of the poyfonfome f piders called P halangia.

C The Rofin of the Turpentine tree excelleth all other Rofins, according to Diofcorides his opinion: but Galen writeth, that the Rofin of the Mafticke tree beareth the preheminence, and then the Turpentine.

D This Rofin hath alfo an aftringent or binding qualitic, and yet not fo much as Mafticke; but it hath withall a certaine bitterneffe ioyned, by reafon whereot it digefteth more than that of the Mafticke tree :thorow the fame qualitie there is likewife in it fo great a clenfing, as alfo it healeth fcabs, in his 8.booke of the faculties of fimple medicines: but in his booke of medicines according to the kindes, he maketh that of the Turpentine tree to be much like the Rofin of the Larch tree, which he affirmeth to be moifter than all the reft, and to be without both Sharpnes and biting.

E The fruit of Turpentine prouoketh vrine, and ftirreth vp flefhly luft.

F The Rofin of this tree, which is the right Turpentine, loofeth the belly, openeth the ftoppings of the liuer and foleene, prouoketh vrine, and driueth foorth grauell, being taken in the quantitie of two or three Beanes.

G The like quantitie warhed in water diuers times vntill it be white, then muft be put thereto the like quantitie of the yolke of an egge, and laboured togither, adding theret $\sigma$ by little and litcle (continually ftirring it) a fmall draught of poffet drinke made of white wine, and giuen to drinke in the morning fafting, helpeth moft peedily the Gonorrhxa, or running of the raines, commonly at the firft time; but neuer faileth the medicine at the fecond time of the taking of it, which giueth ftooles from fower to eight, according to the age and ftrength of the patient.

\section{Of the Frankincenfe tree. Chap.80.}

* The defcription.

THe tree from which Frankincenfe floweth, is but lowe, and hath leaues like the Mafticke tree; yet fome are of opinion that the leafe is like the leafe of a Peare tree, and of a graffie colour: the rinde is like that of the Bay tree, whereof there are two kindes, the one groweth in mountaines and rockie places: the other in the plaine : but thofe in the plaines are much woorfe than thofe of the mountaines:the gum whereof is alfo blacker, fitter to mingle with Pitch, and fuch other ftuffe to trim fhips, than for other vies.

Theuet in his Cofmographie faith, that the Frankincenfe tree doth refemble a gummie or rofinic Pine tree, which yeeldeth a iuice that in time groweth hard, and is called Thus, Frankincenfe, in whom is fomtime found certaine fmallgraines like vnto grauel, which they call the Manna of Frankincenfe. 


\section{HISTORIE OF PLANTS.}

$\begin{array}{ll}\text { Abor Thurifera. } & \text { Thuris Limpidi folitum L'Obeliy. } \\ \text { The Frankincenfe tree } & \text { The fuppofed leafe of the bright }\end{array}$

Thur is Limpidi folium L' Obely.

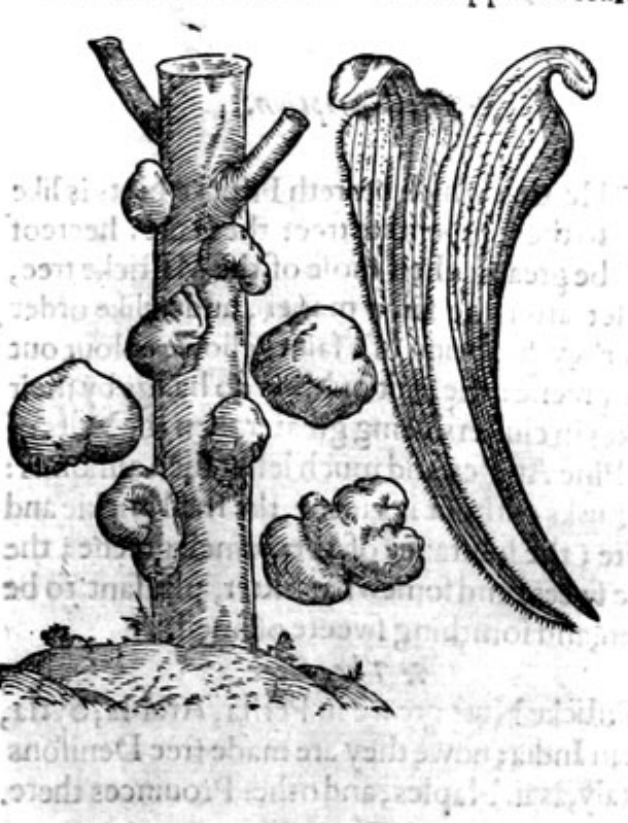

यijufeit caufe it is not fo well coned in the other in price or value, biknife, that the litis concocted in the heate of the funne. The Arabians wounde this tree with a of Frankincenfe.

* The decription.

Of this there is in Arabia two other forts, the one, the gum whereof is gathered in the Dogge daies when the fun is in Leo, which is white, pure, cleere, and fhining. Pena writeth that he hath feene the cleere Frankenfence called Limpidiom, and yeelding a very fweete finell when it is burnt, burthe leafe hath beene feldome feene, which the Phifftion Launanus feemeth to fet out thus, although it be not certain whether it be the leafe of the Frakkincenfe, on of fome other Pine tree, yeelding the like iuice or gum. It is faith he, which doth feldome happen in other Ieaues, from the lower part or foote of the leafe, to the vpper ende, as it were doubled, confifting of two thinne rindes or coates, with a fheath a foanne $\&$ a halfe long,at the top gaping open like a whoode or fooles cockefcombe, and as it were couered with a helmet, which is a thing feldome feene in a leafe, but is proper to Leekes, or Lonchitis, as writers affirme. The other is gathered in the fpring, which is reddifh,woorfer then the other in price or value, bi-

* The place.

Diofcorides faith it groweth in Arabia, and efpecially in that quarter which is called Thurifera, the bett in that countrey is called Stagonias, and is round; and if it be broken, is fat within, and when it is burned doth quickly yeelde a fmell: next vnto it in goodnes is that which groweth in $S_{m i l o}$, leffer then the other, and more yellow.

$*$ The time.
(

* The sames.

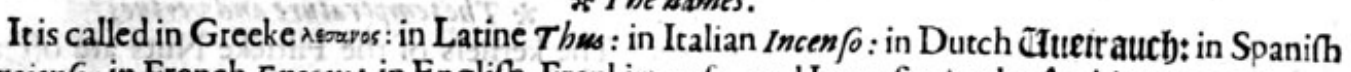
Encien 0 : in French Encess: in Englifh Frankincenfe, and Incenfe: in the Arabian toong Lowan, and of fome few Conder.

\section{* The temperatureand vertues.}

It hath, as Diofcorids faith, a power to heate and binde.

It driueth away the dimnes of the cie fight, filleth vp hollow vicers, it clofeth rawe woundes, ftai- B eth all corruptions of bloud, although it flowe from the head.

Galen writeth thus of it, Thow doth heate in the fecond degree, and diy in the firft, and hath fome C fmall aftrietion; but in the white there is manifeft aftriction : the rinde doth manifeftly binde and dry exceedingly, and that moft certainly in the fecond degrec, for it is of more groffer parts.then Frankincenfe, and not fo tharpe, by reafon whereofit is much vfed in fpitting of bloud, fwellings in the mouth, the colicke paffion, the fluxe in the belly rifing from the ftomacke, and bloudy fixes,

The fume or finoke of it hath a more drier and hotter quality then the Frankincenfe it felfe, be- D ing drie in the thirde degree.

It doth alfo clenfe and fill vp the vlcers in the eies, like unto Myrrhe, thus farre Galen.

Diofcorides faith, that if it be drunke by a man in health, it driueth him into a frenfic: but there are $F$ fewe Greekes of his minde.

Awicen reporteth that it doth helpe and ftrengthen the wit and vnderftanding, but the often ta- G king of it will breed the headach, and if too much of it be drunke with wine it hilleth. 


\section{$\$ 24^{8}$ THE THIRD BOOKE OF THE}

$$
\text { Of Fifticke Nuts. Chap.81. Mnivalit wath. }
$$

Pißacit.

The Filticke Nut.

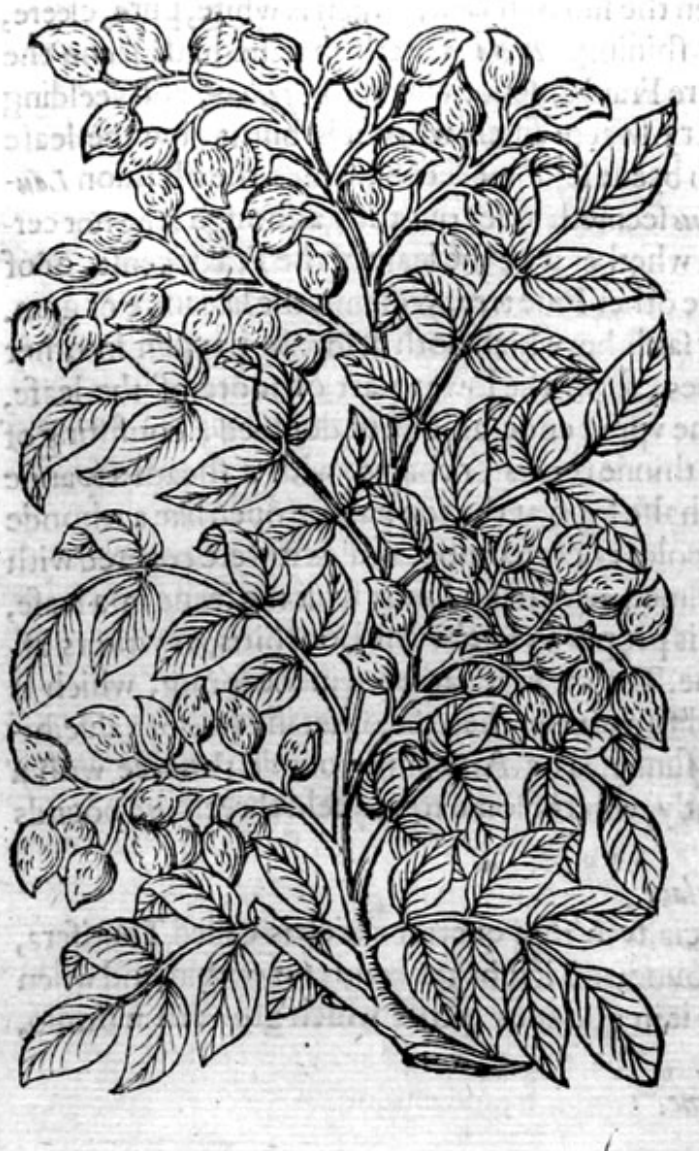

A times eaten, as be thofe of the Pine apples; they be of temperature hot $\&$ moift; they are not fo eafily concoeted, but much eafier then common nuts: the itice is good jyet fomwhat thicke; they yeelde to the body no fmall nourifhment; they nourifh bodies that are confumed; they recouer ftrength.

B They are good for thofe that haue the phthifike, or rotting away of the lungs.

C They concoit, ripen, and clenfe foorth rawe humours that cleaue to the lightes and cheft.

D They open the ftoppings of the liuer, and be good for the infirmities of the kidneies; they allo remooue out of the kidneies fande and grauell; and affwage their paine: they are allo good for vicers.

E The kerneis of Fifticke nuts condited, or made iato comfits, with fugar and caten, do procure bodily luft, vnftop the lungs and thé breft, are good againt the fhortnes of breath, and are an excellent preferuatiue medicine being miniftred in wine againft the bitings of all manner of wilde beafts. 


\section{HISTORIE OF PLANTS.}

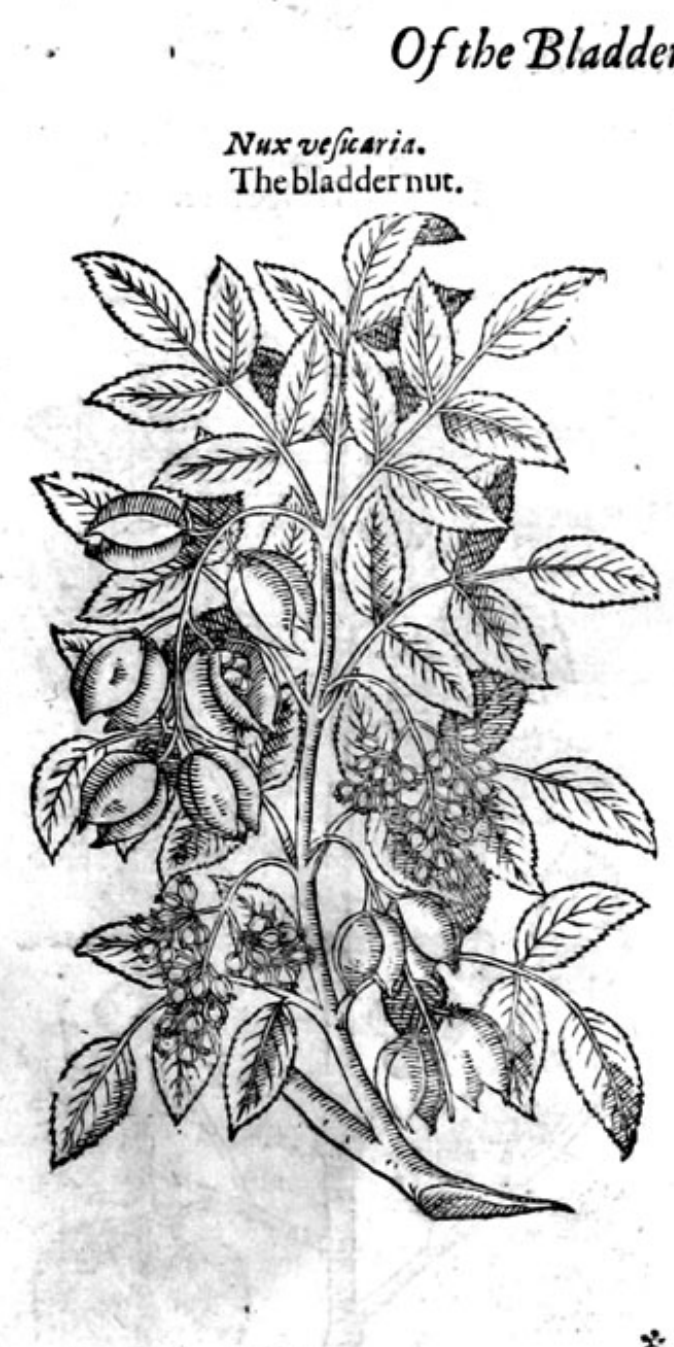

Nut.

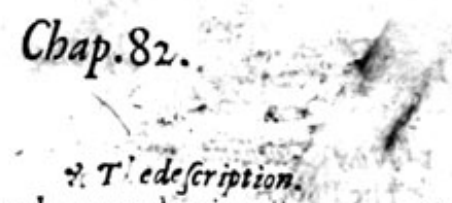

$\mathrm{T}$ His is a low trec, bauing dituers yong fprings growing foorth of the roote: the fubftance of the wood is white, very hard and found; the barke is of a light greene: the letues confift of fiuc little ones, which be nicked in the edges like thofe of the Elder, but leffer, not fo greene nor ranke of fmel. It hath the pleafant whitilh flowers of Bryonie or Labrufca both in fimell and Thape, which turne into fmall cornered bladders, very like vnto the bladders of winter Cherries, called Alkakengie, but of $x$ n onerworne greenifh colour; in thefe bladders arecötained twa little ntits, and fonerimes no more but one, leffer than the Hafell nut, but greater than the Ram Cich, with a woodie fhell and fomewhat red : the kernell within is fomething greene; in talte at the firft fwcete, but afterwards lothfome and ready to protoke vomit. * The place.

It groweth in Italie, Germanic and France; it groweth likewife at the houfc of fir Walter Culpepper neerc Flimwell in the Weald of Kent, as alfo in the Frier yarde without S.Paules gate in Stamford, and about Spalding Abbay, and in the gar. den of the right honorable the Lord Ireafurer my very good Lord and Mafter, by his houfe in the Strand. It groweth alfo in my garden, and in the garden hedges of fir Francis Carew neer Croydon feucn miles from London.

This tree flowreth in May, the nuts be ripe in Auguit and September.

: 2 The names.

It is commonly called in high Dutch joimpetnuf?, which fignifieth in lowe Dutch 13 tmpetno, ten: diuers call it in Latine Piffactum Germanisum: we thinke it beft to call it Nux veficaria. Mathiolus in his Epiftes doth iudge it the Torkes Conlcoul and Hebulben to agree with this: Gulieimus Quacelbenus affirmeth, Coulcoul to be vfed of diters in Conftantinople for a daintie, efpecially when they be new brought out of Egypt. This plant hath no olde name, valeffe it be Stasbylodendron Plinij, for which it is taken of the later writers, and Plinie hath written of it in his 16 . booke 16.chapter. There is alfo(f.aith he) beyond the Alpes a tree, the timber whereof is very like to that of white Maple, and is called Stai hylodendron, it beareth cods, and in thofe kernels, hauing the tafte of the Hafell nut. It is called in Engliih S.Antonies nuts, wilde Piftacia, or Bladder nuts : the Italianscall it $P$ iftachio Saluatick : the French men call i: Baguenaudes a patre noftres, for that the Friers do vfe to make Beades of the nuts.

* The temperatureand vertues.

Thefe nuts are moyft and full of fuperfious rawe humors, and therefore they eafily procure a A readineffe to vomit, and trouble the ftomacke, by reafon that withall they be fomeiwhat binding, and therefore they be not to be eaten.

Thefe haue as yet no vfe in medicine, yet notwithftanding fome haue attribited vnto them fome B vertues in prowoking of Venerie. 


\section{Of the Hafell tree. Chap. $\sigma_{3}$.}

1 Nux Cinellana, frue Corylus. The Filberd Nut.

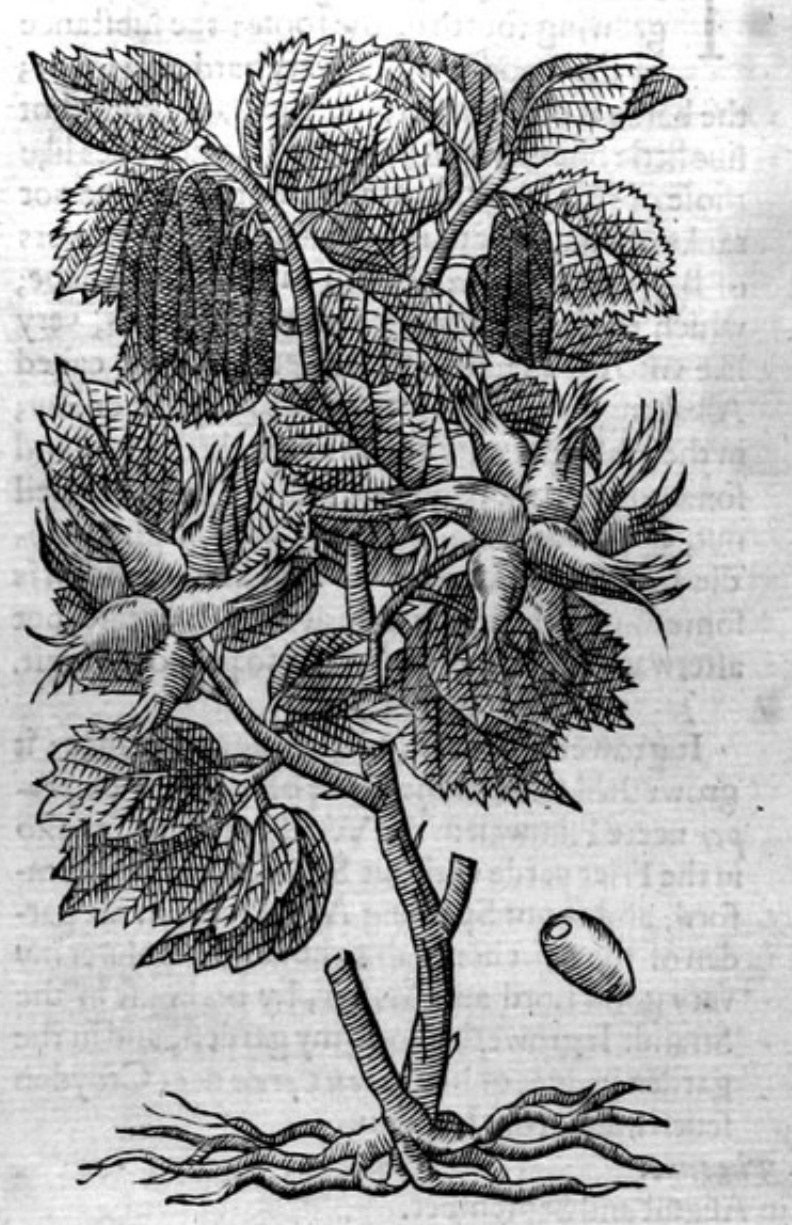

2 Corylus fyluestris. The wilde Hedge Nut.

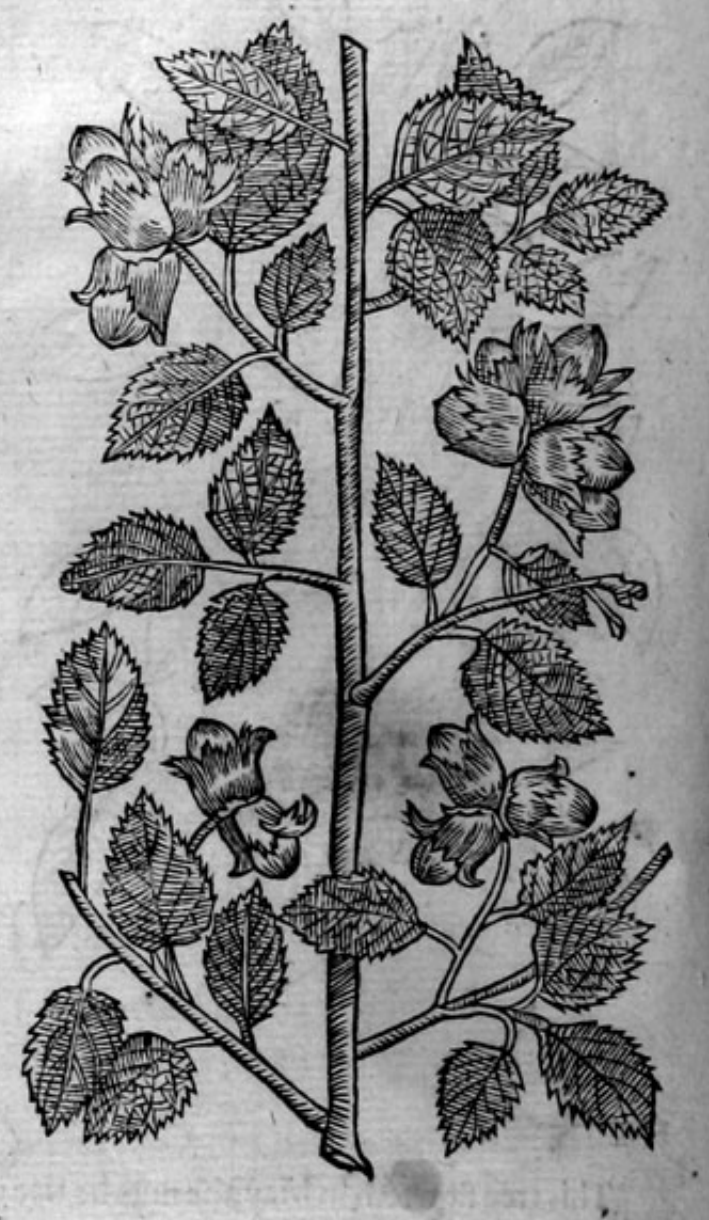

* The deforiftion.

1

7 He Hafell tree groweth like a fhrub or fmall tree,parted into boughes without knots, tough and pliable: the leaues are broad, greater and fuller of wrinkles than thofe of the Alder tree, cut in the edges like a fawe, of colour greene, and on the backfide more white; the barke is thinne; the roote is thicke, ftrong and growing deepe; in ftead of flowers hang downe catkins, aglets or blowings, llender and well compact; after which come the Nuts ftanding in a tough cup of a greene colour, and iagged at the vpper end, like almoft to the beards in Rofes. The thell is fmooth and woodie; the kernell within confifteth of a white, hard, and found pulpe, and couered with a thin skin, oftentimes red, moft commonly white; this kernell is fweete and pleafant to the tafte.

Corylus fyluestris is our hedge Nut or Hafell Nut tree, which is very well knowen, and therefore needech not any defcription: whereof there are alfo fundrie fortes, fome great, fome little, fome rathe ripc, fome later, as alfo one that is manured in our gardens, which is very great, bigger than any Filberd, and yet a kinde of Hedge Nut. This then that hath beene faid, thall fuffice for Hedge
Nuts, 


\section{HISTORIE OF PLANTS.}

3 Auelana pumila Byzantina.

The Filberd nut of Conftantinople.

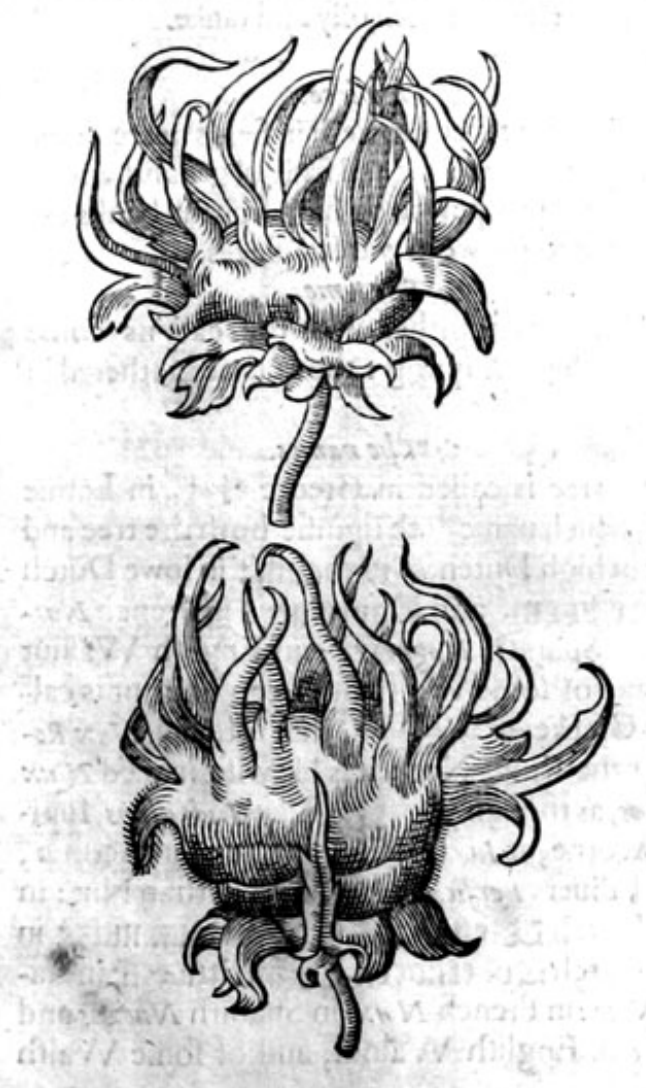

1251

* Tieplace.

The Hafell trees do commonly growe in woods and in dankifh vntoiled places; they are alfo fet in Orchards, the Nuts where of are better, and of a fweeter taite, and be moft commonly red within. * The time.

The catkins or aglets come foorth very timely, before winter be fully paft, which fall away in
March or Aprill fo foone as the leaues come foorth : the nuts be ripe in Augurt. * 7 be names.

This thrub is called in Latine Corylow: in Greeke rép: $\alpha$ Tovnxì, that is, Nux Pontica, or Pontike Nut: in high Dutch paefl ftratick: in low Dutch bare. Ieet : in Englifh Hafell tree, and Filberd tree ; but the Filberd tree is properly that which groweth in gardens and Orchards.

The Nut is named in Latine $2 \mathcal{u} x$ Pontica, tenuis 2 ( $u x$, parua Nax; it is alfo called 2 (ux Prenestina, Nux Heracleotica, and commonly $2(u x$ ave ilana, by which name it is vfually known to the Apothecaries : in high Dutch pafe I Jurz: in lowe Dutch jafel JPoten: in Italian Noccimole, Aucll ine, Nocelle in French Noifettes, \& Noifelles: in S,anifh Auellanies : in Englifh $\mathrm{Hafell}_{\mathrm{Nut}}$ and Filberd.

Thefe Nuts that haue their skins red are the garden and planted Nuts, and the right Pontike Nuts or Filberds; they are called in high Dutch Rutr= mufz, and Botnufz: in lowe Dutch Boode zafeI ग2atert: in Englifh Filberds, and red Filberds.

The other Nuts which be white are iudged to be wilde.

$$
\text { * The temperature and vertues. }
$$

Hafell Nuts newly gathered,and not a syet dry, containe in them a certaine fuperfluous moifture, $A$ by reafon wherof they are windy; not onely the new gathered Nuts, but the dry alfo be very hard of digeftion; for they are of an earthy and colde eflence; and of a hard and found fubftance; for which caufe alfo they very flowly paffe thorow the belly, therefore they are troublefome and clogging to the ftomacke, caufe headach,efpecially when they be eaten in too great a quantitic.

The kernels of Nuts made into Milke like Almonds, doth mightily binde the belly, and is good B for the laske and the bloudy fixe.

The fame doth coole exceedingly in hot feuers, and burning agues.

The catkins are colde and dry, and likewife binding: they allo ftay the laske.

\section{Of the Walnut Tree. Chap.84.}

* The defcription.

His is 2 great tree with 2 thicke and tall body; the barke is fomewhat greene, and tending to the colour of arhes, and oftentimes full of clefts : the boughes fpread themfelues farre abroade; the leaues confift of fiue or fixe faftned to one ribbe, like thofe of the Afh tree, and with one ftanding on the top; which be broader and longer then the particular leaues of the Ärih; fmooth alfo, and of a ftrong fmell : the catkins or aglets come foorth before the Nuts: thele Nuts do grow hard to the ftalke of the leaues by couples, or by three and three, which at the firft when 


\section{THE THIRD BOOKE OF THE}

they be yet but tender, haue a fweete fmel, and be couered with a greene huske; vnder that is a woodie theil, in which the kernell is contained, being couered with a thin skin, parted almoft into fower parts, with a woodie skin as it were ; the inner pulpe whereof is white, fweete and pleafant to the tafte, and that is when it is new gathered; for after it is drie it becommeth oily and ranke.

2 ux Iuglans.

The $W$ ainut tree.

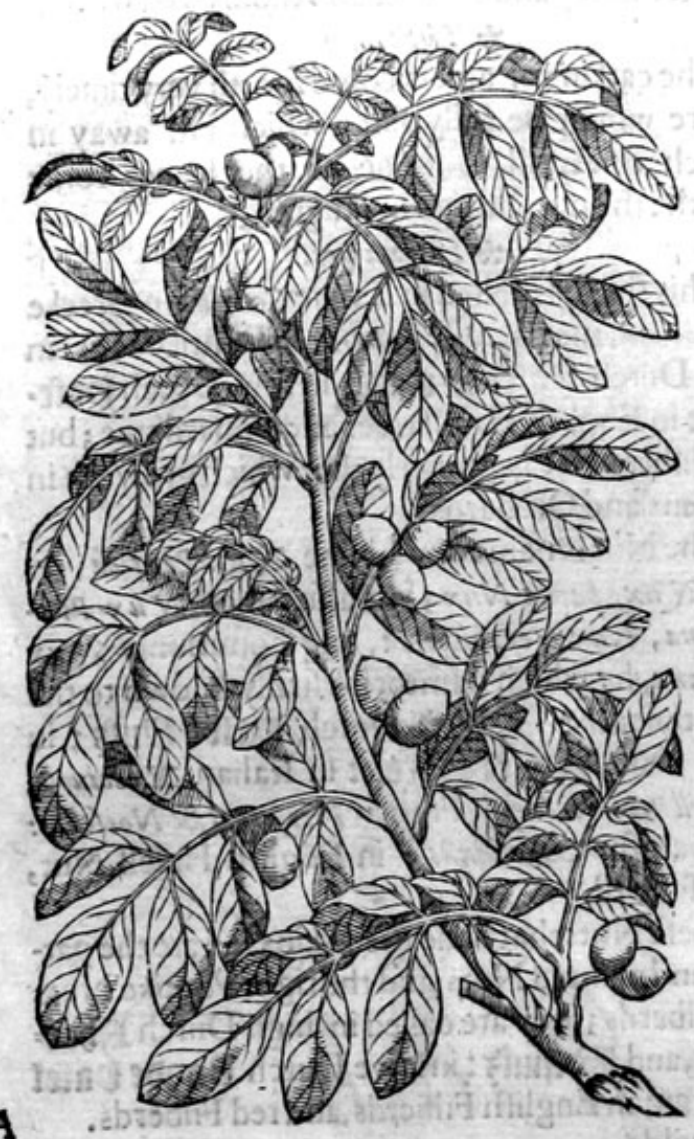

The Walnut tree groweth in fields neere common high waies in a fat and fruitful ground, and in orchards; it profpereth on high fruitfull banks; it loueth not to growe in waterieplaces.

\section{* The time.}

The leaues togither with the catkins come foorth at the firft fpring : the nuts are gathered in Auguit.

$$
\text { * The names. }
$$

The tree is called in Greeke xdpua : in Latine $\mathcal{L} u x$, which name doth fignifie both the tree and

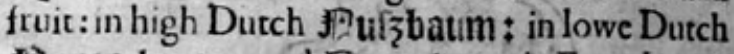
Jiloote tocm, and Mootelaet: in French Noi. ficr: in Spanifh Noguesra : in Englifh Walnut tree, and of fome Walih nut tree. The nut is cal. Ied in Grecke vápuov Banduxìv, that is to fay, $N a x$ Regia, or the Kings Nut : it is likewife named $2 u x$ Iuglans, as though you fhould fay Iouis glans, Iupiters Acorne, or Iuwans glans, the helping Acorne, and of diuers Perfica Nux, or the Perfian Nut : in high Dutch Joieifty Ju(z, and 23 aumutiz: in lowe Durch \& ohernoten, שeralfeb noten: in Italian $N u c t$ : in French Noix: in Spanilh Nuezes and Nous: in Englith Walnut, and of fome Walrh Nut.

\section{* The temperature and vertues.}

The frefh kernels of the nuts newly gathered are pleafant to the tafte : they are a little colde, and haue no fmall moyfture which is not perfectly con cocted; they be hard of digeftion, they nourifh little, they flowly defcend.

B The drie nuts are hot and drie, and thofe more which become oylie and ranke, thefe be very hurtfull to the ftomacke ; and befides that they be hardly concocted, they increafe choler; they caufe headach, and be hurtfull for the cheft, and for thofe that be troubled with the cough.

C Drie nuts taken fafting with a Fig and a little Rue withit andeth poyfon; preuenteth and preferueth the body from the infection of the plague, and being plentifully eaten they driue wormes foorth of the belly.

D The greene and tender nuts boyled in fugar and eaten as Suckade, are a moft pleafant and delectable meate, comfort the ftomacke, and expell poyfon.

E The oyle of Walnuts made in fuch manner as oyle of Almonds, maketh fmooth the hands and face, and taketh away fcales and fcurffe, blacke and blew marks that come of ftripes or brufes.

F. Milke made of the kernels, as. Almond milke is made, cooleth and pleafeth the appetite of the languifhing ficke body.

G With onions, falt and hony; they are good againft the biting of a mad dog or man, if they be laid vpon the wound.

H Being both eaten and alfo applied, they heale in fhort time, as Diofcorides faith, gangrens, carbuncles, xgilnps, and the pilling away of the haire; this aifo is effectually done by the oyle that is preffed out of them, which is of thin parts, digefting and heating.

I The outward greene huske of the nuts hath a notable binding facultie.

K Galen deuifed and taught ro make of the iuice there of a medicine for the mouth, fingular good againft all inflammations thereof. 


\section{HISTORIE OF PLANTS.}

The leaucs and firft buds haue a certaine binding qualitie, as the fame author fheweth;yet there $\mathrm{L}$
I

Some of the later phufitions vfe thefe for bathe

force to digeft and alfo to procure fweate.

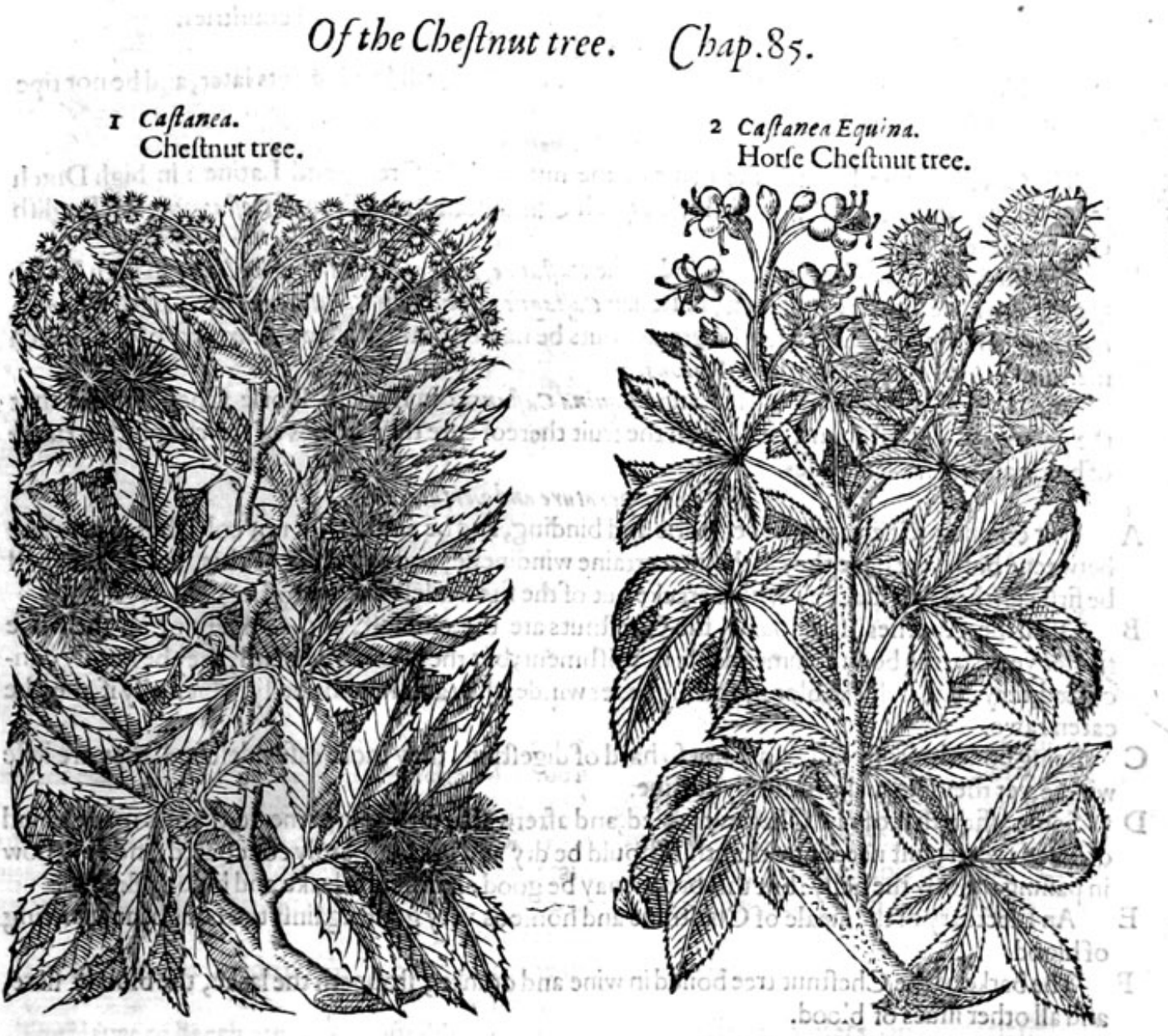

* The defcription.

$17 \mathrm{He}$ Cheftnut tree is a very great and high tree; it cafteth foorth very many boughes; the body is thicke, and fometimes of fo gregra compaffe, as that tow men can fcarly fathom it: the timber or fibitance of the wood is found and duable: the leaues be great, rough, wrinkled, nicked in the edges, and greater than the particular leaues of the Walnut tree. The blowings or catkins be flender, long and grcene : the fruit is inclofed in a round, rough, and prickly huske like to an Hedgehog or Vrchin, which opening it felfe doch let fall the ripe fruit or nut. This nut is not round, but flat on the one fide, fmooth and iharpe pointed:it is col'ered with a hard helt, whick is tough and very fwooth, of a darke browne colour : the meate or inner fubftance of the nut is hard and whité, and couered with a thin skin, which is ynder the fhell.

2 The Horfe Cheftnut groweth likewife to be a very great tree, fpreading his great and large armes or branches far abroad, by which meanes it inaketh a very good coole fhadow. Thefe branches are garnifhed with many beaútifull leaues, cur or diuided into fiue, fise, or feuen fections or divifions, Tike to the Cinkfoile, or rather like the leatics of Ricin ses, but bigger. The flowers growe at the top of the ftalkes, confinting of fower fmall leaues like the Cherrie bloffom, which turne into round, rough and prickley heads like the former, but more fharpe and harder : the nuts are alfo rounder. 
$*$ The place.

The firft groweth on mountaines and hadowie places, and many times in the vallies; they loue a foft and blacke foyle. There be fundrie woods of Cheftnuts in England, as a mile and a halfe from Feuerfham in Kent, and in fundrie other places : in fome countries they be grearer and pleafanter,
in others fmaller, and of worfe tafte.

The Horfe Cheftnut groweth in Italie and in fundry places of the Eaft countries. * The time.

The blowings or aglets come foorth with the leaues in Aprill,but the nuts later, and be not ripe till Autumne.

* The names.

The Cheitnut tree beareth the name of the nut both in Greeke and Latine : in high Dutch

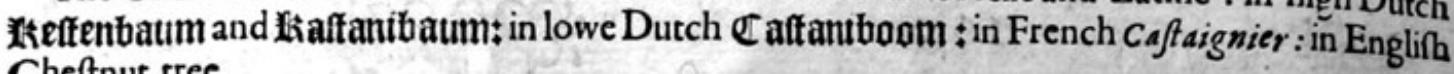
Cheftnut tree.

The nut is called in Greeke risavov: in Latine Caftanea, Iouis glans, Sardiana glans : in high Dutch likeffen! in lowe Dutch Caftanient in Italian Caftagne : in French Chastaigne : in Spanifh Morones, Caftanas : in Englifh Cheftnut. The greater nuts be named of the Italian s Marroni : of the French men and of diuers bafe Almaines Marons.

The Horfe Cheftnut is called in Latine Equina $C_{a}$ ftanea : in Englifh Horfe Cheftnut; for that the people of the Eaft countries do with the fruit thereof cure their horfes of the cough, fhortneffe of breth, and fuch like difeafes.

\section{* Thetemperature and vertues.}

A Our common Cheitnuts are very drie and binding, and be neither hot nor cold, but in a meane betweene both; yet haue they in them a certaine windineffe, and by reafon of this, vnlefle the fhell be firft cut, they skip fuddenly with a cracke out of the fire whileft they be rofting.

B Of all the Acornes, faith $G$ alen, the Cheitnuts are the chiefeft, and doonely of all the wilde fruites yeeld to the body commendable nourifhment; but they flowly defcend, they be hardly concoeted, they make a thicke blood, and ingender winde, they alfo ftay the belly, efpecially if they be caten rawe.

C Being boiled or rofted, they are not fo hard of digeftion, they more eafily defcend, they are leffe windie, yet they alfo make the body coltiue.

D Some affirm that of raw Cheftnuts dried, and afterwards turned into meale, there is made a kind of bread; yet it muft needes be that this fhould be dry and brittle, hardly concocted, and very flow in paffing thorow the belly: but this bread may be good againft the laske and bloody flixe.

E An Electuary of the meale of Cheitnuts and honie, is very good againft the cough, and fpitting ofblood.

F The barke of the Cheftnut tree boiled in wine and drunke, ftoppeth the laske, the bloody flixe, and all other iffues of blood.

\section{Of the Beechtree. Cbap.86. * T bedefcription.}

$7 \mathrm{He}$ Beech is an high tree, with boughes fpreading oftentimes in maner of a circle, and with 2

1 thic thicke body, hauing many armes: the barke is mooth; the timber is white, harde, and very profitable: the leaues be fimooth, thinne, broad, and leffer then thofe of the blacke Poplar; the catkins, or blowings be alfo leffer and fhorter then thofe of the Birch tree, and yellow:the fruite or $\mathrm{M}_{2} \mathrm{fte}$ is contained in a huske or cup that is prickly, and rough briftled; yet not fo much as that of the Cheftnut; which fruite being taken foorth of the fhels or vrchin huskes, be couered with 2 finooth and foft skin, like in colour and fmoothnes to the Cheftnuts, but they be much leffer, and of another forme, that is to fay triangled or three cornered: the kernell within is fweete, with a certaine aftriction or binding qualitie; the rootes be fewe, and grow not deepe, and little lower then vnder the turfe. 
Fagiss.

The Beech.

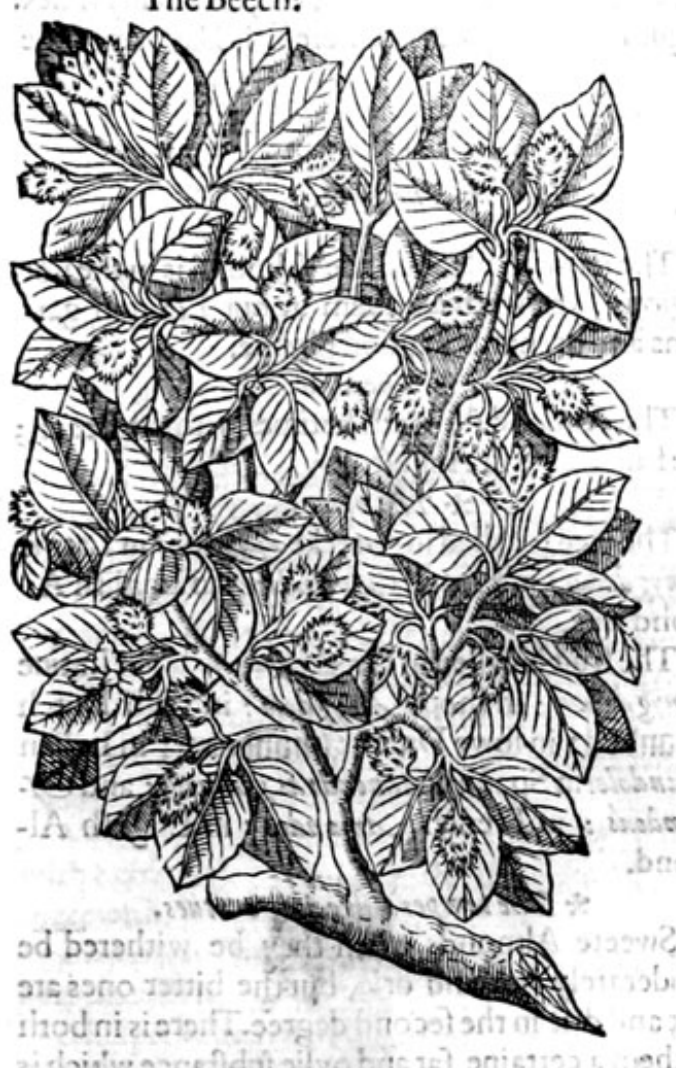

* Theplase.

The Beech tree louerh a plaine and open countric, and groweth very plentifully in many forrefts and defart places of Suffex, Kent, and fundrie other countries.

$$
\text { * The time. }
$$

The Beech flowreth in April and May, and the fruit is ripe in September, at what time the Deere do eate the fame very greedily, as greatly delighting therein, which hath caufed forrefters and huntfriten to call it Buckmaft.

$$
\text { * The names. }
$$

The tree is named in Greek anyos: in Latine $F$ a. gus : in high Dutch 13ucbbaum; or 23ucb : in low Dutch 2Bukenboom: in Italian Faggi: in Spanifh Haia, Faia, and Fax: in French Fan, or Hestre: in Englifh Beech tree, Beech maft, and Buckmaft.

The fruit is called in Latin Nuces Fagiin Greek gadiavor tiangis in low Dutch 23uekennantkeng: in French Faine: in Englifh Beech maft. Dio coriides reckoneth the Beecliamong the Acorn trees, and yer is the maft nothing like at all to an Acom. Of The ophraft it is called Oxya, of Gaza Scijcina. Plimie alfo maketh mention of this tree, but vnder the name of Ofrya (if fo be in ftead of Ofrys we nuft not reade $O x y$ ) in his 13 .booke 21 . chap. It bringeth foorth, faith he(meaning Greece) the tree $O$ itrys, which they likewife call $O f$ trya, growing alone among waterie ftones, like to the Aftithee in barke and boughes, with leatues like thofe of thePeare tree, but fomewhat longerand thicker, and with wrinkled cuts, which run quite thorow, withafeed like in colour to a Cheftnut(and not vhto Barly:) the wood is hard and firme, which being brought into the houfe there followeth hard trauell with childe, and niferable deathes, as it is reported; and therfore to be forborne \& not vfed as fire wood, if $P$ linie his copies be aot corrupted.

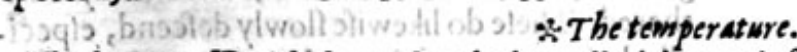

The ieaues of Beechido coole; the kernell of the nut is fornewhat moy?t.

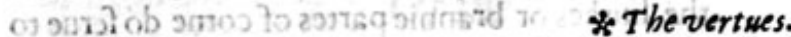

: Thelétues of Beech are very profitably applied vnto hot fwellings, bliftets, and excoriations; A and being chewed they are good for chapped lips, and paine of the gums.

The ketnels ot imaift within are reported to eafe the paine of the kidncies proceeding of the ftone $\mathbf{B}$ if thoybe eaten, and to caufe the grauell and fand the eafier to come foorth : with thefemice and fquirreds be greatly delighted, who do mightily increafe by feeding thereon; fwine alfo be fattened herewith, and certaine orher bealts; alfo deere do feede thereon very greedily. Theybelikewife plealant to thrufhes and pigeons.

Petrus Crefcentina writeth, that the afhes of the wood is good to make glaffe with.

The water that is found in the hollowneffe of Beeches, cureth the naughtie fcurffe, tetters, and D fcabs of men, hiorfes, kine, and heepe, if they be wafhed therewithall.

\section{Of the Almondtree. Chap.87. \\ * The defcription.}

T He Almond tree is like to the Peach tree, yet is it higher, bigger bodied, of longer cötinuance; the leaues therof be very long, thatp pointed, fnipped about the edges like thofe of the Peach tree;the flowers be alike; the fruit is alfo like a Peach, hauing on one fide a cleft, with a foft skin withour, and couered with a thin cotton; but vnder this there is none or very little pulpe, and the $\mathrm{Mmm} 2$ fame 
fame hard like a griftle, which is not eaten ; the nut or ftone within is longer than that of the Peach, not fo rugged but fmooth; in which is contained the kernel, in tafte fweete, and many times
bitter. The roote of the tree groweth deepe : the gum which for Peach tree.

Amygda'us.

The Almond tree.

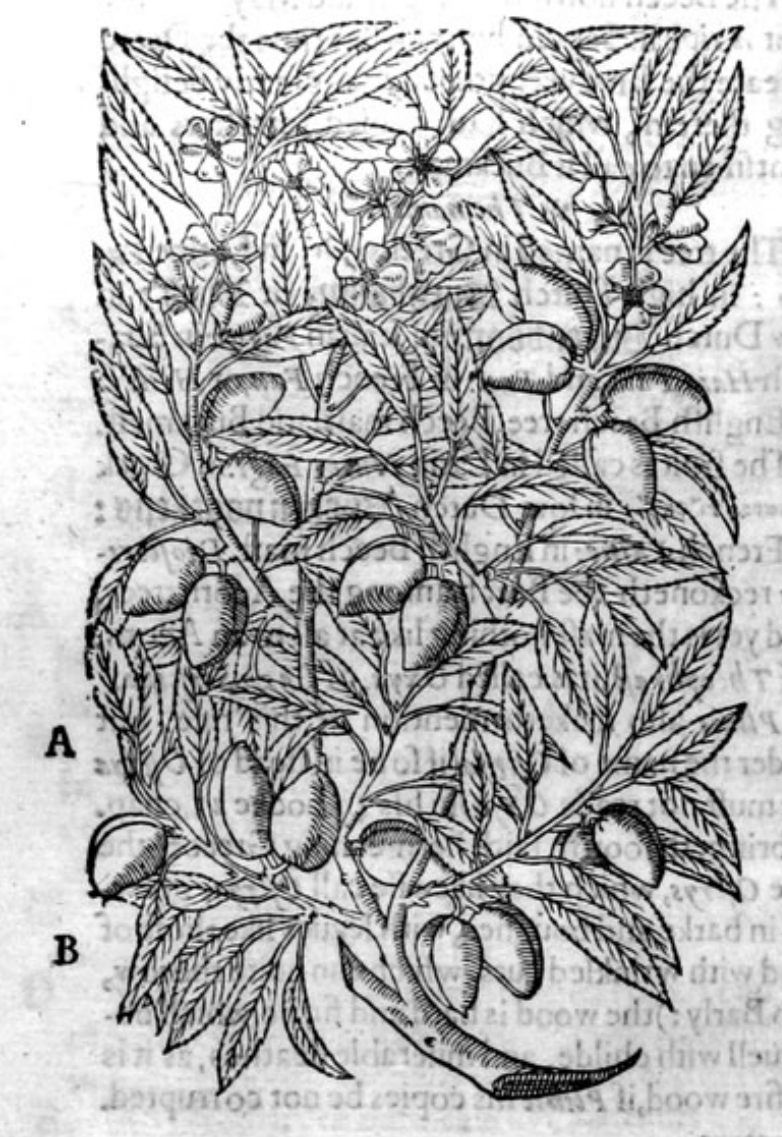

$$
\text { * The place. }
$$

The naturall place of the Almond is in the hot regions, yet we haue them in our London gardens and orchards in good plentic.

$$
\text { * The time. }
$$

The Almond flowreth betimes with the Peach; the fruit is ripe in Auguif.

$$
\text { * The names. }
$$

The tree is called in Greeke durgodian: in Latine Amygdalus: in French Anandier : in Englifh Al. mond tree.

The fruit is called in Greeke ajuydoxiv: in Latine Amygdalum: in fhops Amygdala : in high Dutch Pantuell: in lowe Dutch Zmandelen : in Italian Mandole: in Spanifh Almendras, umelles, and U. mendoas : in French Amandes : in Englifh Al. mond.

\section{$*$ The temperature and vertues.}

Sweete Almonds when they be withered be moderately hot and drie, but the bitter ones are hot and drie in the fecond degree. There is in both of chem a certaine fat and oylie fubftance which is draweh of bypreffing,

Sweete Almonds being new gathered areplea. fapt to the tafte; they yeelde forme kinde of nouriflament, but the fame groffe and earthie, and groffer than thofe that be dric, and nopas yes wi thered. Thefe do likewife flowly defcend, efpecially being caten syithout their skins; forleuter 25 the huskes or brannie partes of corne do ferue to

driue downe the groffe excrements of the belly, fo do likewife the skins or husks of the Athotits: therefore thofe that be blanched dofoflowly defcend, as that they do withall binde the belly; a whereupon they are giuen with good fucceffe to thofe that hane the laske, or the bloodie flixe:?

C There is drawen out of fweete Almonds, with liquor added, a white iuicelike milke, which ouer: and befides that it nourifheth, and is good for thofe that are troubled with the laske and bloodie fixe, it is profitable for thofe that haue the pleurifie, and fpet vp filthie matter, as Alexander Trald lianus witnefieth. For there is likewife in the Almonds an opening and concocting qualitie; with a certaine clenfing facultie, by which they are medicìnable to the cheft and lungs, or lights, and ferue C for the raifing yp of flegine and rotten matter.

D Almonds taken before meate doftop the belly, and nourim but a little, notwithftanding many. excellent meats and medicines, are therewith made for fundry greefes,yea very delicate and wholfome meats, as Almond butter, creame of Almonds, marchpanes, and fuch like, which drie and ftaie the beily more then the extracted iuice or milke; and they are as good for the cheft and lunges, E They do ferue alfo to make the Phificall Barly water, and Barly creame, which are given in hot
feucrs; as alfo for other ficke and feeble perfons for their further consfort and nourifhment. $\mathrm{F}$ The oile which is newly preffed out of the fweete Almonds, is a mitigater of paine, and all ma.
ner of aches. 


\section{HISTORIE OF PLANTS.}

It is giuen to thofe that haue the pleurifie, being firf let bloud ; but cfpecially to fuch as are trou- $\mathrm{G}$ bled with the ftone of the kidneies; it flackneth the paffages of the vrine, and maketh them glib or 1hi? perie, and more readie to fuffer the ftone to haue free paffage: it maketh the belly foluble, and

It is good for women that are newly deliuered, for it quickly remooueth the throwes which re- $\mathrm{H}$ maine after the deliueric.

The oyle of Almonds do make fmooth the hands and face of delicate perfons, and clenfeth the I skin from all fpots, pimples and lentils.

Bitter Almonds do make thin and open, they remooue ftoppings out of the liuer and fpleene, $\mathrm{K}$ therefore they be good againft paine in the fides: they make the body foluble, prouoke vrine, bring downe the menfes, helpe the ftrangurie, and clenfe foorth of the lungs and cheft clammie humors: if they be mixed with fome kinde of looch or medicine to licke on, with ftarch they ftay the f petring
of blood.

And it is reported that fiuc or fixe being taken fafting dokeepe a man from being drunke.

Thefe alfo clenfe and take away fpots and bleminhes in the face, and in other parts of thebody; $M$ they mundifie or make cleane foule eating vlcers.

With bony they are laid vpon the bitings of mad dogs; being applied to the temples with vine- $N$ ger or oyle of Rofes, they take away the headach, as Diofcorides writech.

They are alfo good againft the cough and hortnes of winde.

They are likewife good for thofe thatpet blood, if they be

There is alfo preffed out of thefe an oyle which prouoketh vrine, but efpecially if of be drowned and iteeped therein.

With oyle it is fingular good for thofe that haue the ftone, and cannot eafily make water but $R$ with extremitie of paine, if the fhare and place betweene the cods and fundament be ammoynted therewith.

Diofcor ides faith, that the gum doth heate and bindc; which qualities notwithftanding are not $S$ perceiued in it.

It helpeth them that fpet blood, not by a binding facultie, but thorow the clammineffe of his fub- $T$ ftance, and that is by clofing vp of the paffages and pores, and fo may it alfo curc oldecoughes, and mitigate extreme paines that proceede of the ftone, and efpecially take away the fharpreffe of vrine, if it be drunke with Baftard, or with any other fweete potion, as with the decoction of Licorice, or of Raifons of the funne. The fame doth likewife kill tetters in the outward partes of the bo. die(as Dio/corides addeth)ifit be diffolued in vineger.

\section{Of the Peach tree. Chap. 88 .}

* The kindes.

There be diuers fortes of Peaches, as may appeere in their feuerall defcriptions.

\section{* The defcription.}

I $T$ He Peach tree is a tree of no great bigneffe: it fendeth foorth diuers boughes, which be fo brittle, as oftentimes they are broken with the waight of the fruit or with the winde. The leaues be long, nicked in the edges, like almoft, to thofe of the Willow tree, and in tafte bitter : the flowers be of a light purple colour. The fruit or Peaches be round, and haue as it were a chinke or cleft on the one fide; they are couered with a foft and thin downe or hairie cotton, being white without, \& of a pleafant tafte; inthe middle wherof is a rough or rugged ftone, wherin is contained a kerneil like vnto the Almond; the meate about the ftone is of a white colour. The roote is tough and yellowifh.

2 The red Peach tree is likewife a tree of no great bigneffe: it alfo fendech foorth diters boughes or branches, which be very brittle. The leaues be long and nicked in the edges like to the precedent. The flowers be alfo like vnto the former; the fruit or Peaches be round, of a red colour on the outfide; the rneate likewife about the ftone is of a gallant red colour. Thefe kindes of Peaches are very like to wine in tafte, and therefore mawuellous pleafant. 
1258

THE THIRD BOOKE OF THE I Perfica alba.

The wlite Peach.

2 Perfica rubra.

The red Peach.

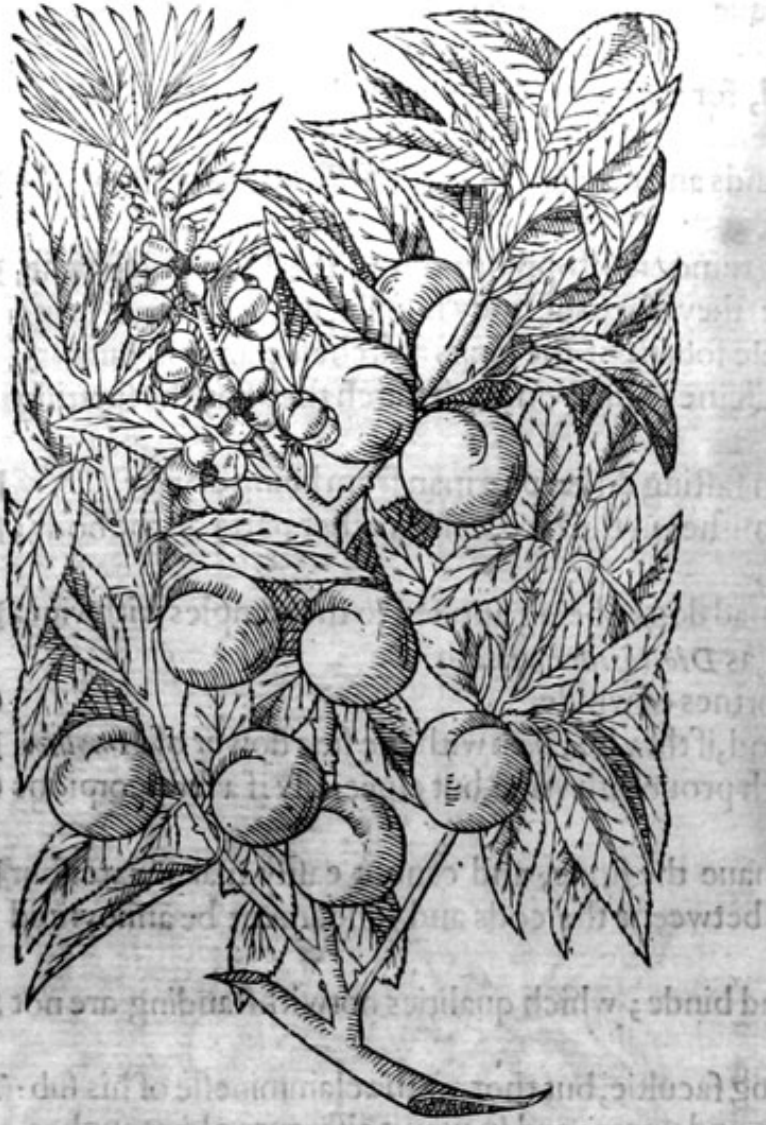

3 Perfica precocia.

The d'auant Peach.

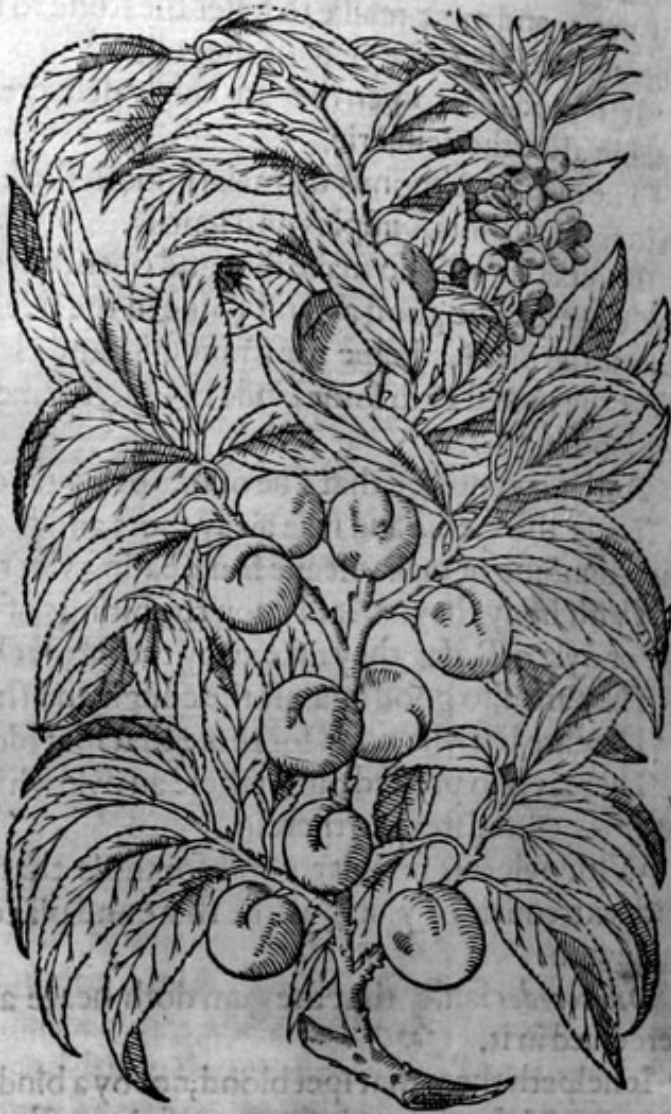

4 Perficalutea.

The yellow Peach.
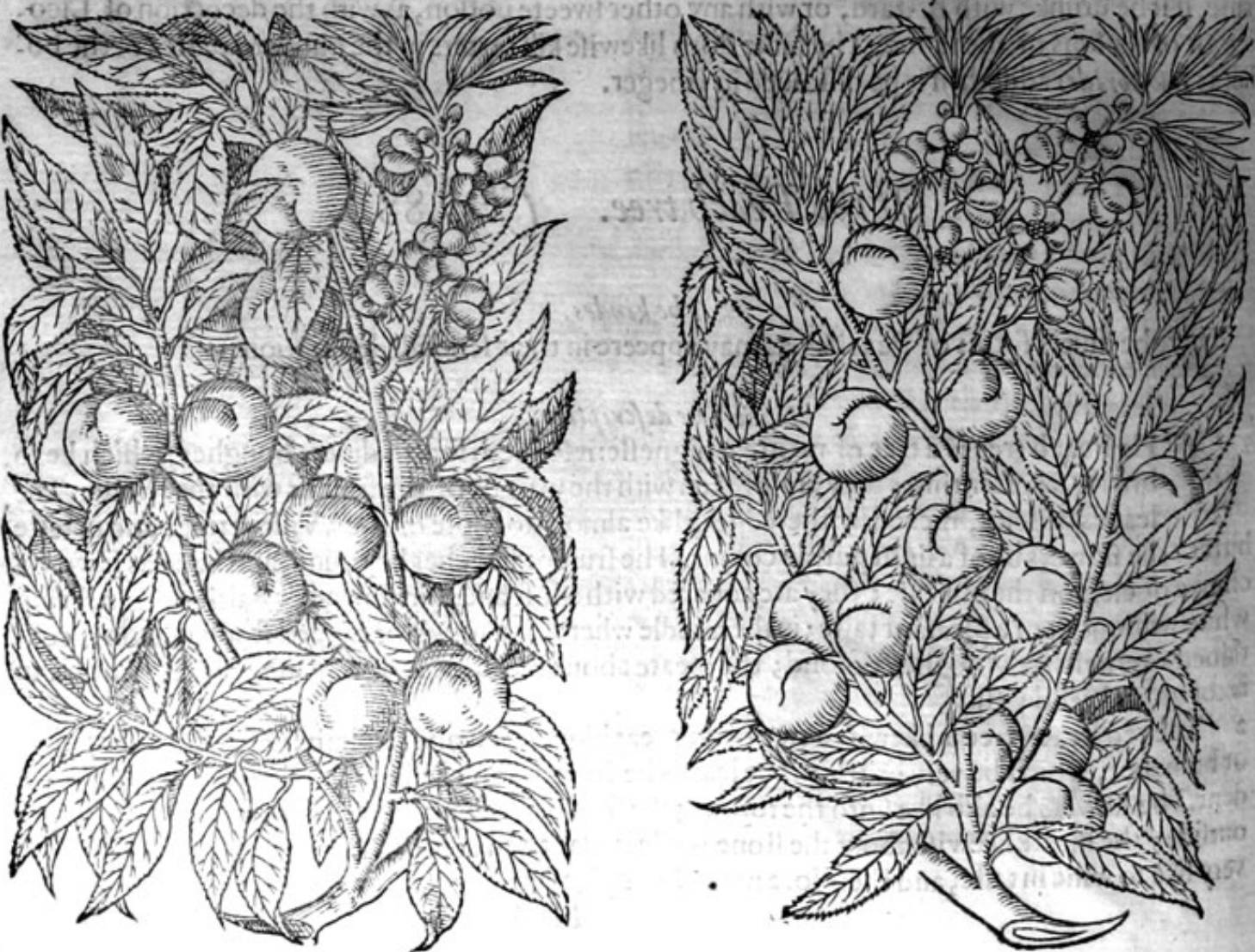


\section{HISTORIE OF PLANTS.}

* T he defcription.

3 The d'auant Peach tree is like vnto the former, but his leaues are geater and larger. The fruit or Peaches be of a ruffet colour on the one fide, and on the other fide next vnto the funne of a red co. lour, but much greater than the red Peach: the ftones whereof are like vnto the former:the pulpe or meate within is of a golden yellow colour, and of a pleafant tafte.

4 The yellow Peach tree is like unto the former in leates and Alowers : his fruit is of a yellow colour on the outfide, and likewife on the infide, harder than the reft; in the middle of the Peach is a woodie, hard and rough ftone, full of crefts and gutters, in which doth lic akernel much like to that of the Almond, and with fuch a like skin: the fubitance within is white, and in tafte fomthing bitter. The fruit hereof is of greateft pleafure, and beft tafte of all the other of his kinde : although there be found at this day diuers other fortes that are of very good tafte, not remembred of the ancient, or fet downe by the later writers, where of to fpeake particulatly, would not be greatly to ourpre. tended purpole, confidering we haften to an end.

* The place.

They are fet and planted in gardens and vineyards : I haue them all in my garden, with many other forts.

\section{* The time.}

The Peach tree foone commeth vp: it beareth fruit the third or fourth yeere after it is planted, and it foone decaicth; and is not of long continuance; it flowreth in Aprill, or a little while after that the leaues appeere, and hath his fruit ripe in September. * The names.

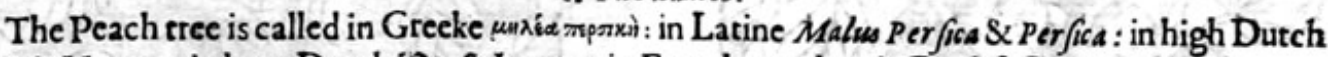
1Perficbbaum: in lowe Dutch joetfe boom $t$ in French Percher : in Englifh Peach trec.

The fruit, as Galen teftifieth, is named $\mu$ in Malum Perficum,and Perficum : in high Durch joferfing : in low Dutch jperten: in Italian Pefche : in Spanilh Pexegos: in French Pefches: in Englifh Peach. * The temperature and vertues.

Peaches be cold and moyft, and that in the fecond degree; they haue a iuice and alfo a fubftance $A$ that doth eafily putrifie, which yeeldeth no nourifhment, but bringeth hurt, efpecially if they be eaten after other meates; for then they caufe the other meates to purrifie. But they are leffe hurtfull if theybe taken firft; for by reafon that they are moyst and flipperie, theyeafily and quickly defcend; and by making the belly flipperie, they caufe other meates to llippe downe the fooner.

The kernels of the Peaches be hot and dry, they open and clenfe; they are good for the ftoppings B of the liuer and fpleene.

Peaches before they be ripe do ftop the laske, but being ripe they loofe the belly, and ingender C naughtic humours, for they are foone corrupted in the ftomacke.

The leaues of the Peach tree do open the ftoppings of the liuer, and do gently loofen the belly: D and being applied plafterwife vnto the nauels of yoong children, kilieth the wormes,and driueth them footth.

II The fame leaues bailed in milke, do kill the wormes in childten very fpeedily.

The fame being dried, and caft ypon greene wounds, they cure them.

The flowers of tbe Peach tree infufed in warme water forthe fpace of ten or twelue howers, and $G$ ftrained, and more fowers put to the faide liquor to infufe after the fame maner, and fo rterated fixe or eight times, and frained againe; then as much fugar as it will require added to the fame liquor, and boiled vnto the confiftence or thicknes of a firupe, and two fpooncfuls heereof taken, doth for fingularly well purge the belly, that thete is neither Rubarbe, Agaricke, nor any other purger comparable vnto it; for this purgeth down waterifh humoursmightily, and yet without griefe or cratible, either to the ftomacke, or lower parts of the body.

The kernels within the Peach ftone ftamped fmall, and boiled with vineger vntill it bebrought $\mathbf{H}$ to the forme of an oyntment, is good to reftore and bring againe the haire of fuch as be vlofietici.n:

There is drawne foorth of the kernels of the Peaches with Peniroiall water, a iuice like vnto I milke, which is good for thofe that haue she apoplexie : if the fame be oftentimes held in the mouth, it draweth foorth water,and recouereth the fpeech. 
1260

THE THIRD BOOKE OF THE

The gum is of a meane temperature, but the fubftance thereof is tough and clammie, by reafon whereof it dulleth the tharpnes of thin humors; it ferueth in a looch ordicking medicine for thofe

that be troubled with the cough and haue rotten lungs, and ftoppeth the fpetting and raifing vp
of blood, and alfo ftaieth other fluxes.

\section{Of the A precocke, or Abrecocke tree. Chap.89.}

Irmeniaca cualesmaior. The greater Aprecocke tree.

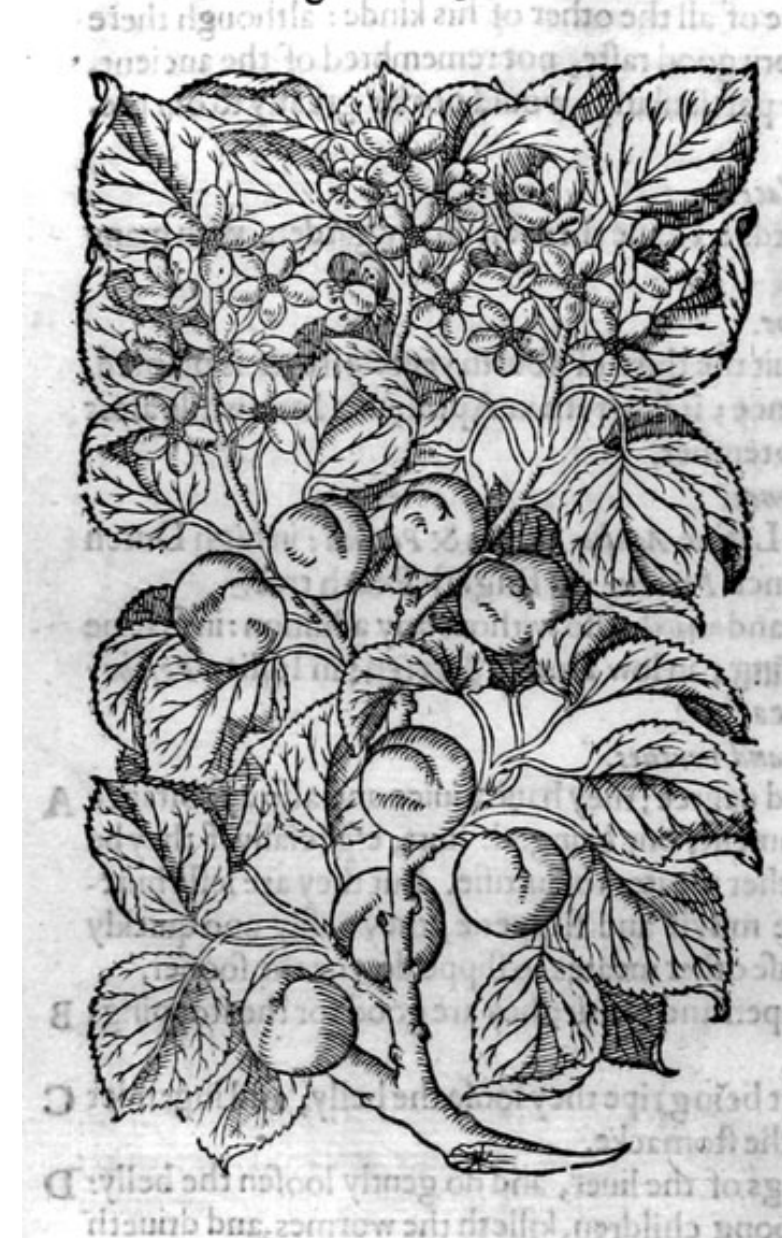

2 Armeniaca Malsu minor. The leffer Aprecocke tree.

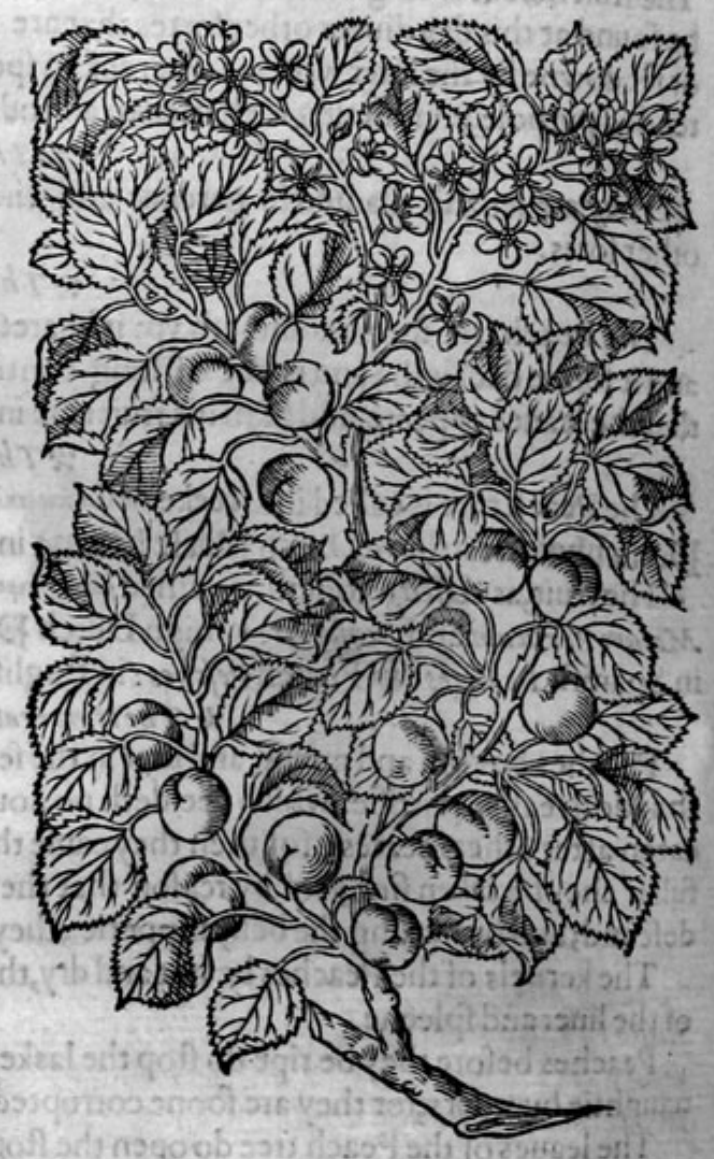

\section{\&? The defcription.}

I $T$ His tree is greater than the Peach tree, and hath a bigger bodie, it lafteth longer, efpecially if it be grafted or inoculated : the leaues hereof are broad \& fharp pointed, like thofe of the blacke Poplar, but leffer, and comming more neere to the leaues of the Birch,nicked in the edges. The flowers are fomewhat white: the fruit round like a Peach, yellow both within and without, in which doth lie a browne ftone nothing rough at all, as is that of the Peach, fhorter alfo and leffer, in which is included a fweete kernell.

2 We haue another fort of Aprecock, whofe trunke or bodie is equall with the other in greatnes; it is like alfo in leaues and brittle branches; his time of flowring, flourifhing, and manner of growing accordeth. The onely point wherein they differ is, that this tree bringeth foorth leffer fruit,

$H$ and not fo good in tafte, in euery other refpect it is like.

Thefe trees do grow in my garden,and now adaies in many other Gentlemens gardens through: otit all England.

They flower and flourish in Aprill,and their fruit is ripe in Iuly. 
This tree is called in Greeke emnis Aesentaxin: in Latine Malus CArmeniaca : in Englifh Abrecock tree, or Aprecocke tree.

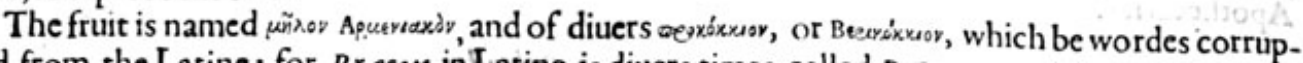
ted from the Latine; for Pracox in Latine is diuers times called Precoquan : it is named Malum

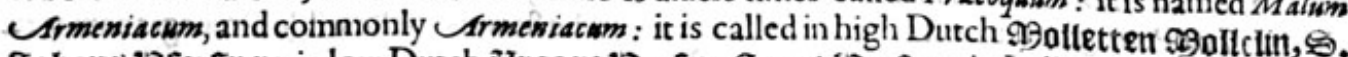

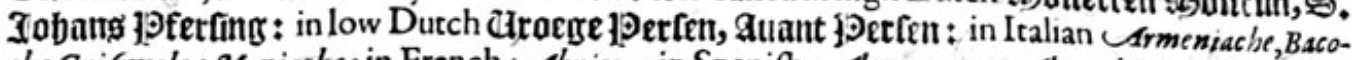
che, Grifomele, Moniache: in French Abricoz: in Spanih Ulustrcoques, Aluarchigas, and Nibercocs : in Englifh Abrecock,and of fome Aprecock, and Aprecox.

Galen feemeth to make a difference betweene Precocia and Armeniacs in his booke of the faculties of nourihments: preferring Precosia before Lrmeniaca, yet he doth confeffe that both of them be called Armeniacs; others pronounce them Lirmenia with fower fyllables. And in his bookes of the faculties of fimple medicines he affirmeth, that both the fruit and the tree arecalled aexóxuov: diuers of the later Phifitions dobetweene thefe alfo make a certaine difference, faying, that the greater ones and thofe that are grafted be Armeniaca; which the French men call Awant Perfes,and the leffer Precocia: in French Lbricoz.

\section{$* \tau$ The temperature and vertues.}

Aprecocks are colde and moift in the fecond degree, but yet not fomoift as Peaches; for which $\mathbf{A}$ caufe they do not fo foone or eafily putrifie : and they are alfo more wholefome for the ftomacke and pleafant to the tafte, yet do they likewife purrifie, and yeelde nourifhment, and the fame colde, moift,and fuil of excrements: being taken after meate, they corrupt and putrifie the fame; being firft eaten before other meate, they eafily defcende, and caufe the other meates to paffe downe the fooner, like as alfo the Peaches do.

The kernels within the fame is fweete, and nothing at all like in faculty to that of the Peach.

The vertues of the leaues of this tree are not as yet found out.

\section{Of the Pomegranate tree. Chap.9o.}

* The kindes.

$A S$ there be fundry forts of Apples, Peares, Plums, and fuch like fruites; fo there are two forts of Pomegranates, the garden, and the wilde;and a thirde fort which is barren and fruitles : the fruite of the garden Pomegranate is of threeforts, one hauing a fower iuice, or liquor; another hating a very fweete and pleafane liquor; and the thirde the talte of wine: of the wilde alfo there be two forts, and the difference betweene them is no more then betwixt crabs and wildings, which are bothawilde kindes of apples: therefore the defcription of the garden Pomegranate fhall fuffice for the reft:

$$
\text { *Thedegcripstion. }
$$

I He manured Pomegranate tree groweth vp to the height of a hedge ttee, being feauen or eight cubites high, hauing many pliant and twiggie branches, very limber, tough, and of a browne colour: wheron are fet very many leaues, in fhape like thofe of the Prities, but more like the leaues of the Myrtil tree, of a bright fhining greene colour tending to yellowneffe: among which there ftande ceitaine harpe thornes confufedly fet, and likewife hollow flowers like vnto the hedge Rore, indented on the edges like a ftar, of a Carnation colour, and very fingle: after which commeth the fruit couered with a hard barke, of an ouerworne purplifh colour, fullof graines and kernels, which after they be ripe are of a gallant crimfon colour, and full of iuice; which differeth in tafte according to the foyle, climate and countrie wherc they growe; fome be fweete, others fower, and the third are in a middle betweene them both, hauing the tafte of wine. 2 The wilde Pomegranate tree is like the other in leaues and twiggie branches, bearing flowers verie double,as may appeere by the figure, which wither and fall away, leauing no fruit behind it,as the double flowred Cherrie doth, and diuers other herbes and trees alfo; and is altogither barren 
of fruite: of this Diofsorides maketh fundry forts, differing in colour: one is white faith he, another yellowifh red, a third fort of the colour of the Rofe: this with red flowers is beft knowne among the
Apothecaries.

I Malus Granata, fue Punica. The Pomegranate tree.

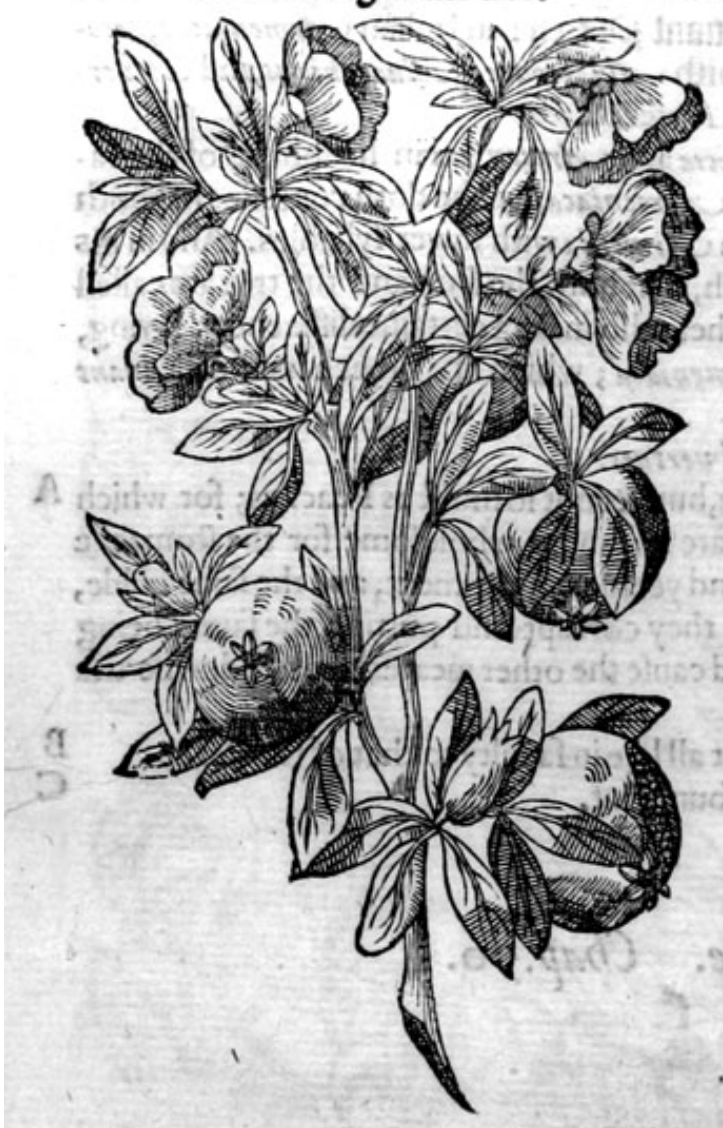

2 Balauftia.

The flowers of the wilde Pomegranate tree.

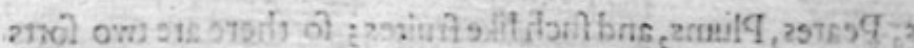

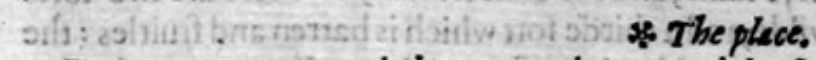

- Pomegranates grow in hot countries toward the fouth, in Italy, Spaine, and chiefly in the kingdome of Granado, which is thought to be fo named of the great multitude of Pomegranats which be commonly called Granata: they grow in a number of places alfo without manuring; yet being manured they profper better; for in gardens, vineyatds, orchards, \& other like husbanded grounds, they come vp more cheerefully: I haue recouered diuers yoong trees heerof, by fowing of the feed or graines, of the height of threc or fower cubits, attending Gods leifure for flowers and fruite.

3

* The time.

The Pomegranate flowreth in the monech of May and Iune: the fruite is ripe in the ende of Auguft.

- The Pomegranate tree is called in Latine Malises Punics: in Greeke ab CAsticis poos and ab Iomibus pote, as Galen faith: in Englifh Pomegranate tree: the fruite is alfo named poos, or pore: in Latine $M \Delta$ lum Punicum : in fhops Malim, or Pomus Granation : in high Dutch $\sqrt{2}$ amatopffell : in low Dutch Ozanatapple: in Italian Melagrano, and Pomo Granato: in Spanifh Graniadas, and Romenas : in Frencb Pommes Grans des : in Englith Pomegranate.

The flower of the fruitefull Pomegranate tree is called of the Grecians winves: which is note withftanding properly the cup of the Hower :the Latines name it alfo Cytiniss.

The flower of the wilde and barren Pomegranate tree is called Baraisov; the Apothecaries do likewife tearme it Balauftum.

The pill or rinde of the Pomegranate which is fo much in vfe, is named in Greeke fiosv; in Latin Malicoritum, and Sidium : in hops it is called Cortex granatorum, or Pomegranate Pill. * The 


\title{
HISTORIE OF PLANTS.
}

* The temperatureandvertues.

The iuicie graines of the Pomegranate are good to be eaten, hauing in them a meetely good $\mathbf{A}$ iuice: they are holfome for the ftomacke, but they all conteine in them a thinne and fmall nourifhThe fweete ones be not fo colde as the reft, but they eafily caufe hot fwellings to arife, and they B
are not fo much commended for agues.

The fower ones, and efpecially if they be withall fomthing harrh, do euidently coole, dry, and C fomthing binde.

They are good for the hart burne, they repreffe and ftay the ouermuch vomiting of choler, cal- D led the Felonie, they are a remedy againit the bloudy flixe, apenes to vomit, and vomite it felfe.

There is made of the iuice of thofe fower Pomegranates a fyrupe, which ferueth for the fame E purpofes, and is alfo many times very profitable for women with childe, rita $E_{1}$ borantibus, vnleffe the coldnes of the ftomacke be a hinderanee thereunto.

The feedes of the graines, and elpecially of the fower Pomegranate, being dried, do likewife F coole and binde.

They ftop the flixe, ftay vomiting, and ftanch the fpitting vp ofbloud, they Itren gethen the fto- $G$ macke.

Of the fame effect be the flowers, both of the tame and wilde Pomegtanate tree, being like to the $\mathrm{H}$ feedes in temperature and vertues.

They faftent the teeth, and ftrengthen the gums, if the fame be wafhed therewith. I

They a re good a gainft burftings that come by falling downe of the guts, if they be vfed in plait $K$ fters and applied.

The rinde or pill, is not onely like in faculty to the feedes, and both the forts of flowers, but alfo L more auaileable; for it cooleth and bindeth more forceably; it bringeth downe the hot fwellings of the almonds in the throte, being vfed in a gargarifme or a lotion for the throte, andit is a fingular remedy for all things that neede cooling and binding.

Diofsorides writeth, that there is alfo gathered a iuice out of both thofe forts of flowers, which is $M$ very like in faculty and vertue to Hypocift is, as the fame author affirmeth.

The bloffomes of the tame and wilde Pomegranates, as alfo the rinde or thell thereof made into $\mathrm{N}$ powder, and drunke in red wine, or boiled in red wine, and the decoction drunke, is good againft the bloudy flixe, and all other iffues of bloud; yea it is good for women to fit ouer, and bath themfelues in the decoction heerof: thefe forefaid bloffomes and thels are good alfo to be pur into reftraining powders, for the ftanching of bloud in wounds.

The leedes or ftones of Pomegranates dried in the funne, and beaten to powder, are of like ope- $P$ ration with the flowers: they ftop the laske and all iffues of bloud in man or woman, being taken in maner aforefaid.

\section{Of the Quince tree. Chap.91.}

\author{
구 The kindes.
}

Clwm ella maketh three kinds of Qunces, Strut hia, Chryfomeliana, and Muftela, but what manet ones they be he doth not declare, notwithftanding we finde diuers forts differing as well in forme, as tafte and fubftance of the fruite, whereof fome haue much core and many kernels, and others fewer.

\section{* The defcription.}

THe Quince tree is not great but groweth low, and many times in maner of a fhrub : it is coue. red with a rugged bark, which hath on it now and then certain fcales:it fpreadeth his boughes in compaffe like other trees; about which ftand leaues fomewhat round, like thofe of the common Apple tree,greenc \& fmooth aboue, and vnderneath foft and white: the flowcrs be of a white purple colour: the fruite is like an apple, faue that many times it hath certaine embowed and fwelling diuifions; it differeth in fafhion \& bignes; for fomc Quinces are leffer \& round truft vp togithec at the top with wrinckles, others longer \& greater : the third fort be after a middle maner betwcene 


\section{THE THIRD BOOKE OF THE}

both; they are all of them fet with a thinne cotton or freeze, and be of the colour of gold, and hurefull to the head by reafon of their itrong fmell ; they all likewife haue a kinde of choking tafte : the pulpe within is yellowe, and the feede blackin, lying in harde skins, as do the kernels of other Apples.

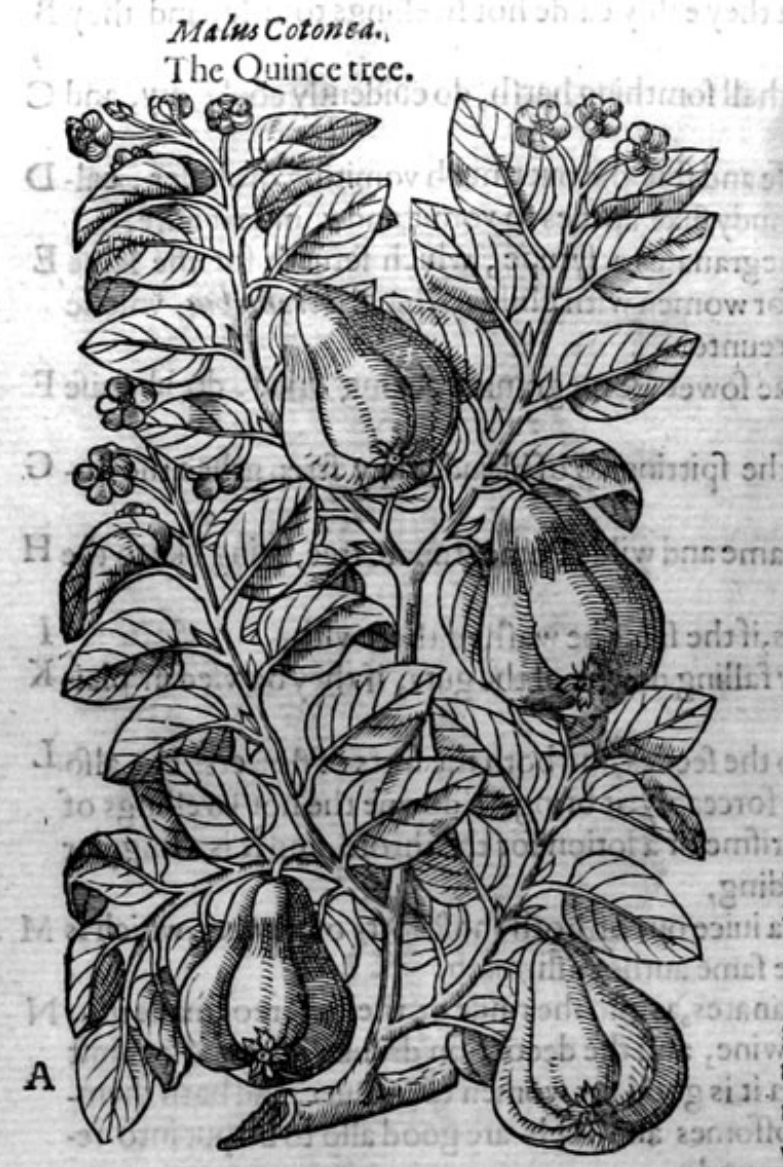

\section{* The place.}

The Quince tree groweth in gardens and or chards, and is planted oftentimes in hedges and fences belonging to gardens and vineyards : it delighteth to grow on plaine and euen grounds, and fomewhat moift withall.

\section{* The time.}

Thefe Apples te ripe in the fall of the leafe, and chiefely in Oetober.

\section{$*$ The names.}

The tree is called in Greek undía wusuria : in Latine Malus Cotonea : in Englifh Quince tree.

The fruite is named uñiov xudiviov: Malum Cotoncum, Pomum Cydonium, and many times $C y d o$. nium, without any addition; by which name it is made knowne to the Apothecaries : it is called in high Dutch Quitten, Dutttenopfell, or Ituttemopffel : in lowe Dutch Dueappel : in Italian Mele cotogne : in Spanifh Codoyons, Membrilhos and Marmellos: in French Pommede coing: in Englifh Quince.

\section{* The temperature and vertues.}

Quinces be colde and dry in the fecond degice, $\&$ allo very much binding, efpecially when they be rawe : they haue likewife in them a certaine fuperfluous and excrementall moifture, which will not fuffer them to lie long without rotting: they are feldome eaten rawe : beirig roffed or baked they be more pleafant.

B They ftrengthen the ftomacke, ftay vomiting, ftoplasks, and alfo the bloudy flixe.

C They are good for thofe that fpit vp bloud, or that vomite bloud; and for women alfo that haue too great plenty of their monethly courle.

D Simcon Sethi writeth, that the woman with childe, which eateth many Quinces during the time of hir breeding; fhall bring foorth wife children and of good vnderftanding.

E The Marmalade, or Cotiniate, made of Quirtces and Sugar, is good \& profitable for the ftrengthning of the ftomacke, that it may retaine and keepe the meate therein vntil it be perfeetly digefted; it likewife ftaieth all kinds of fluxes, both of thie belly and other parts, and alfo of bloud:which Cotiniate is made in this maner.

F Take faire Quinces, pare them, cut them in peeces, and caft away the corc, then put vnto euery pound of Quinces a pound of fugar, and to euery pound of fugar a pint of water: thefe muft be boiled togither ouer a ftill fire vntill they be very foft, then let it be ftrained or rather rubbed through a ftrainer, or an hairic ficte which is better, and then fet it ouer the fire to boile againe, vntill it be ftiffe, \& fo boxe it vp, and as :t cooleth put thereto a little rofe water, and a few grains of muske,well mingled togither, which will gite a goodly tafte vnto the Cotiniat. This is the way to make Marmalade.

G Take whole Quince's and boile them in water vntill they be as foft as a fcalded codling or apple, then pill off the skin, and cut off the flefh, and ftampe it in a ftone mortar; then ftraine it as you did the Cotmiatc; aftervard put it into a pan to dry, but not to feeth at all : \& vnto euery pounde of the flefh of Quinces, put three quarters of a pound of fugar, and in the cooling you may put in rofe water, and a litile muske, as was faide before. 


\title{
HISTORIE OF PLANTS.
}

There is boiled with Quinces an oile which is called in Greckeuidour we vfe faith Drofcorides, fo oft as we haue need of a binding thing.

The feede of Quinces tempered with water, doth make a muf

being held in the mouth, is maruellous good to take away he reige, or a thing like ielly, which I ning feauers. The fame is good to be laide vpon burnings, or fcaldings, and to be put into glifters againft the $\mathrm{K}$
bloudy flixe; for it eafeth the paine of the guts, and alaieth the fharpnes of biting humours.

Many other excellent, dainty and wholefome confections are to be made of Quinces,as ielly of $\mathrm{L}$ Quinces, and fueh odde conceits, which for breuitie fake I do now let paffe.

\section{Of the Medlar tree. Clap. 92 .}

\author{
* The kindes.
}

THere be diuers forts of Medlers, fome greater, others leffer; fome fweete, and others of a more 1 harfh tafte; fome with much core, and many great ftonie kernels, others fewer; andlikewife one of Napies, called Aronia.

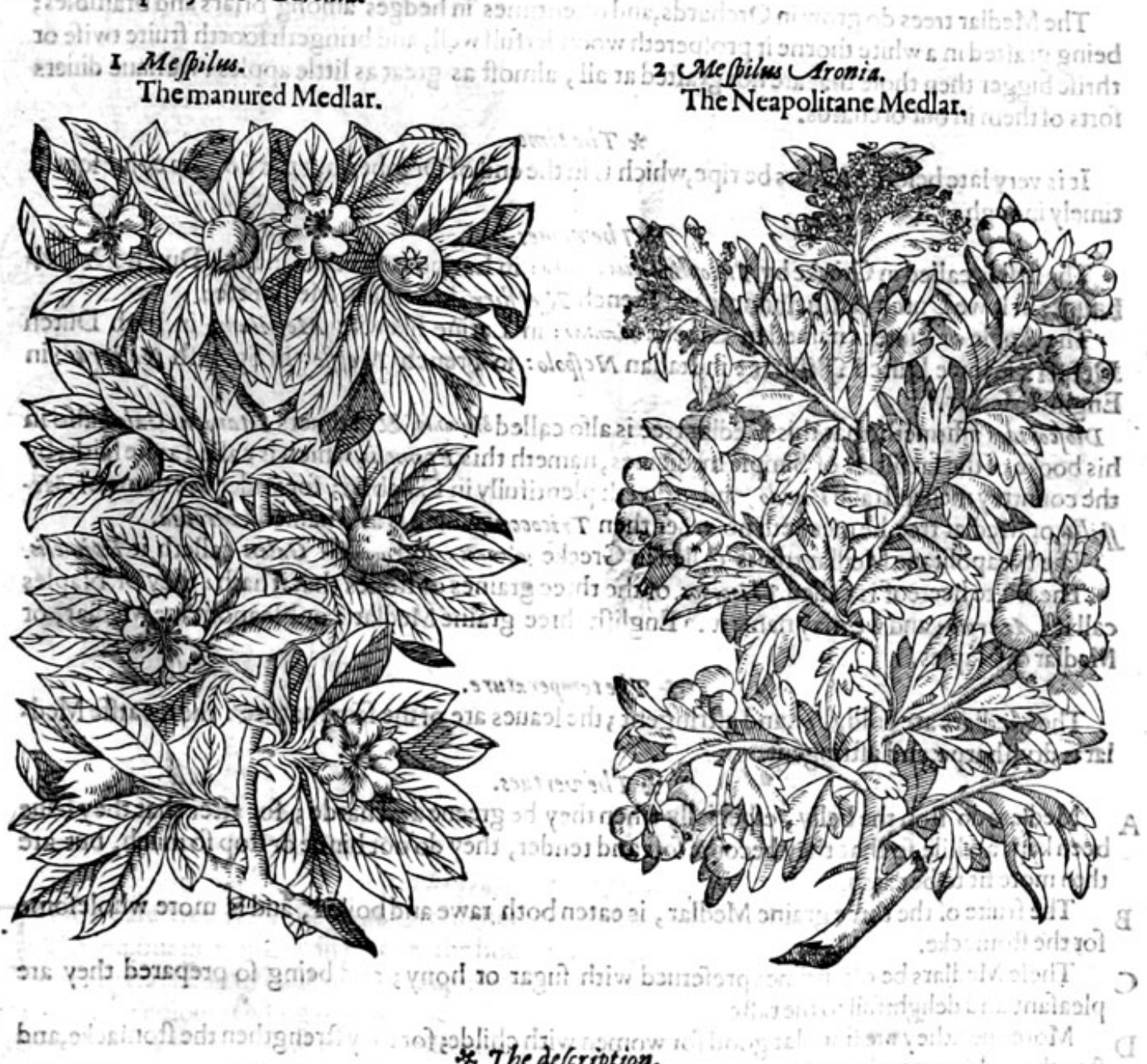

x He manured Medler tree is not eafie to be broken:the leaues belonger, yet narrower then thofe of the apple tree : the flo. 2 wers are white and great, hauing fiue leaues a peece : the fruite is fmall, round, and hath a broad compaffed nauell or crowne at the top: the pulpe or meate is at the firft white, \& fo harfh or choking, 

choking, that it cannot be eaten before it become foft; in which are contained fiue feedes or ftones,
which be flat and hard.

2. The Neapolitanc Medlar tree, groweth to the height \& greatnes of an apple tree, hauingmany tongh \& hard boughes or branches, fet with Tharp thorns like the white Thorn, or Hawthorn : the leaues are very much.cut or iagged like the H.w thorne leaues, but greater, and more like Smallage, or Parfley, which leaues before they fall from the tree do waxe red: among thefe leaues come foorth great tufts of flowers of a palc herby colour, which being paft there fucceedech fmail, long fruite, leffer then the fmalleft Medlar, which at the firft are hard, and greene of colour; but when they be ripe, they are both foft and red, of a fiveetc and pleafant tafte, wherein is conteined three fmall hard ftones, as in the former, which be the kernels, or feeds thereof.

There is a dwarffe kinde of Medlar growing naturally vpon the Alpes, and hils of Narbone and Verona, which hath beene by fome of the beft learned efteemed for a kinde of Medlar : others whofe iudgements cannot ftande with truth or probabilitic, haue fuppofed it to be Euonimus, of the Alpes : this dwarffe Medlar groweth like a fmall hedge tree, of fower or fiue cubits high, bearing many fmall twiggie wandes or crops, befet with many flender leaues, greene aboue, and of a skie colour vnderneath, in fhewe and to beholde a dwarffe Apple tree, but the truite is very like the Hawe, or fruite of the white Thorne, and of a red colour.

$$
\text { * The place. }
$$

The Medlar trees do grow in Orchards, and oftentimes in hedges among briarsand brambles; being grafted in a white thorne it profpereth woonderfull well, and bringeth foorth fruite twife or thrife bigger then thofe that are not grafted at all, almoft as great as little apples : we haue diuers forts of them if our orchards.

\section{* The time.}

It is very late before Medlars be ripe, which is in the end of Oetober, but the lowers come foorth timely inough.

\section{\%.The names.}

The firft is called in Greeke by Theophraftusus wiinn: in Latine Me/pilus: in high Dutch De[pels baum: in lowe Dutch Sif́pethoome: in French 2 efflier in Englifh Medlar tree.

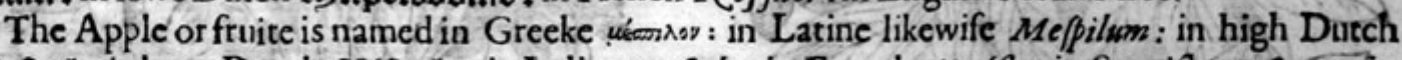
J2efpel: in lowe Dutch פBitpeic: in Italian Nejpolo: in French 2 effle: in Spanifh Ne/per ns: in Englith Medlar.

Diofcor ides affitmeth, that this Medlar tree is alfo called innunies, \& of diuers sit anion: Galenalfo in his booke of the faculties of Simple medicines, nameth this E pimelis, which is called as he faith, by the countrey men in Italie V nedo, and growerh plentifully in Calabria; for vnder the name of $M e$ Bpilise, or Medlar tree, he meaneth no other then Tricoccm, which is alfo named Liromia.

The Neapolitane Medlar tree is called in Greeke uramnos: and unavinn: Galen callech it Epimelis:

The fruite heere of is called Tricocios, of he three graines or ftones that it hath: they of Naples call it LAsarolo : and we may name it in Englih three graine Medlar : or Neapolitane Medlar, or Medlar of Naples.

\section{* The temper atwre.}

The Medlars are cold, drie, and aftringent; the leaues are of the fame nature : the dwarffe-Medlar is dry, Tharpe, and aftringent.

\section{* The vertues.}

A Medlars do ftop the belly, efpecially when they be greene and harde; for after that they haue been kept a while, fo that they become foft and tender, they do notbinde or ftop fo much, but are then more fit to be eaten.

B The fruite of the three graine Medlar, is eaten both rawe ard bojled, and is more wholefome for the ftomacke.

C Thefe Medlars be oftentimes preferued with fugar or hony; and being fo prepared they are pleafant and delightfull to the tafte.

D Moreouer, they are fingular good for women with childe; for they frengthen the ftomacke,and ftay the lothfomnes thereof.

$\mathrm{E}$ The ftones or kernels of the Medlars, made into powder and drunke, do breake the fone, expell granell, and procure vrine. 


\title{
HISTORIE OF PLANTS.
}

\author{
Of the Teare tree. Chap.93. \\ * The kindes.
}

$T^{O}$ write of Peares and Apples in particular, woulde require a particular volume : the ftocke or kindred of Peares are not to be numbred: euery countrey hath his peculiar fruite; my felfe knowe fome one, curious in Graffing and Planting of Fruites, who hath in one peece of ground, at the point of three fcore fundrie forts of Peares, and thofe exceeding good, not doubting but if his minde had beene to feeke after multitudes, he might haue gotten togither the like number of thofe of worffe kindes; befides the diuerfities of thofe that be wilde, experience fheweth fun dry forts : and therefore I thinke it not amiffe to fet downe the figures of fome fewe with their fe. verall ticles, as well in Latine as Englifh, and one generall defcription for that, that might be faide of many, which to defcribe apart, were to fend an Owle to Athens, or to number thole things that are without number.

1 Pyra Pracocia. The Iennetting Peare.

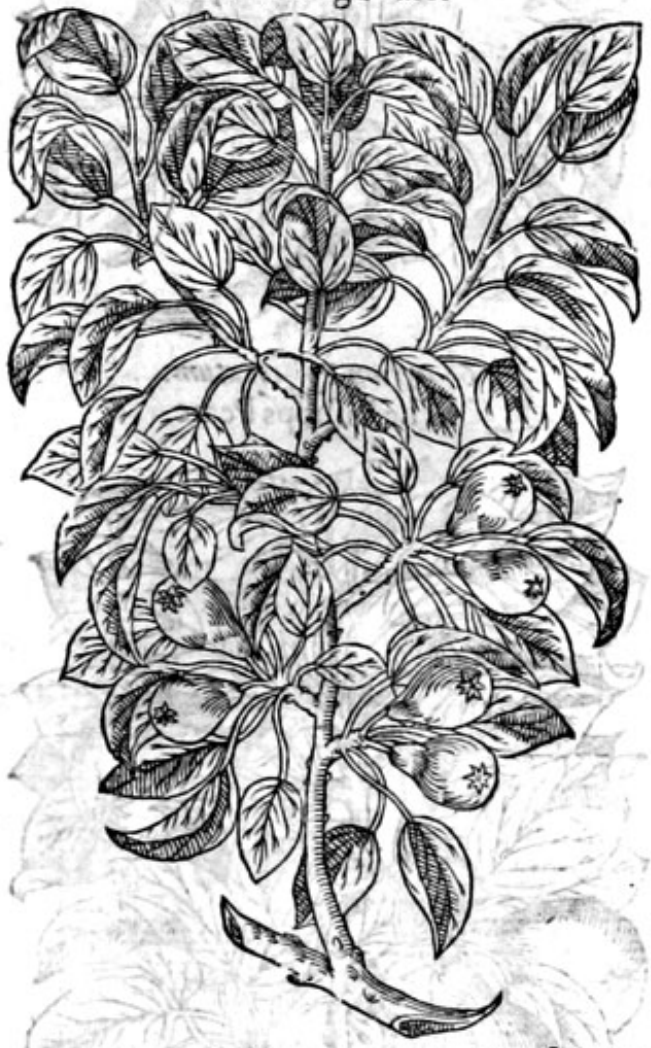

2 Pyra Iacobas. Saint Iarnes Pcare.

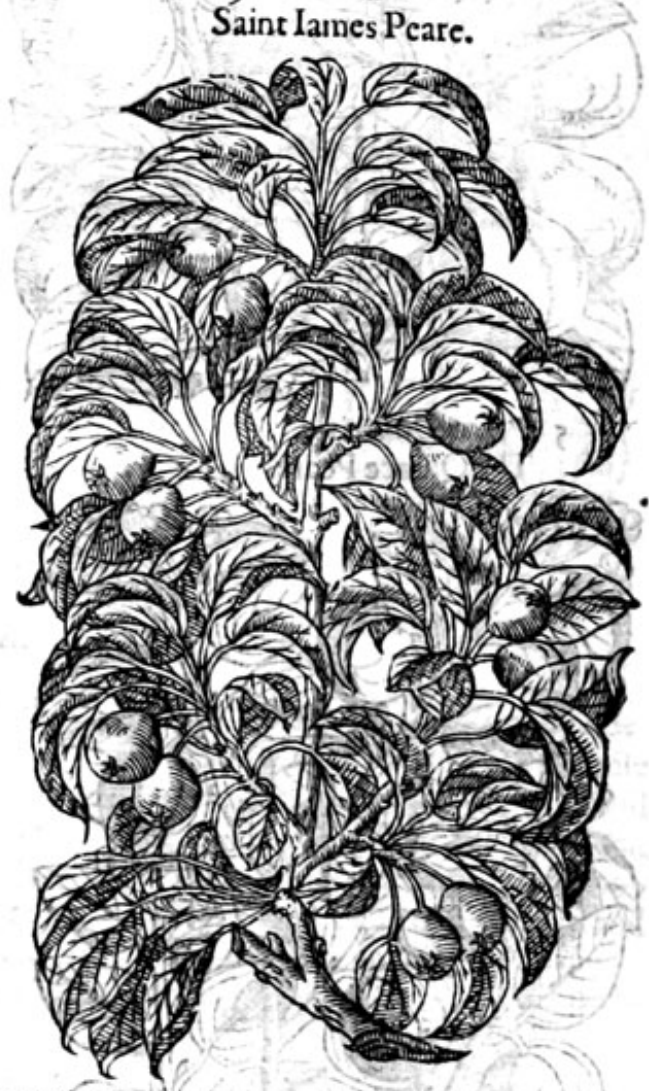

* The generall defcription.

THe Peare tree is for the moft parthigher then the Apple tree, bauing boughes not fpreade abroad, but growing vp in height: the body is many times great: the timber of woode it felfe is very trattable or eafie to be wrought vpon, exceeding fit to make moulds or prints to be grauen on, of colour tending to yellownes : the leafe is fomewhat broad, fincly nicked in the edges, greene aboue, and fomewhat whiter vnderneath:the fowers are white: the Peares, that is to fay, the fruite, are forthe moft part long, and in forme like a Top; but in gteatnes, colour, forme, and tafte, very much differing among themfelues : they be alfo couered with skins or coats of fundry colours: the pulpc or meate differeth, as well in colour as tafte: there is conteined in them kernels, blacke when they be ripe: the roote groweth ftraight downe, with forne branches running aflope. 
3 Pyram regale.

The Peare Royall.

(1)
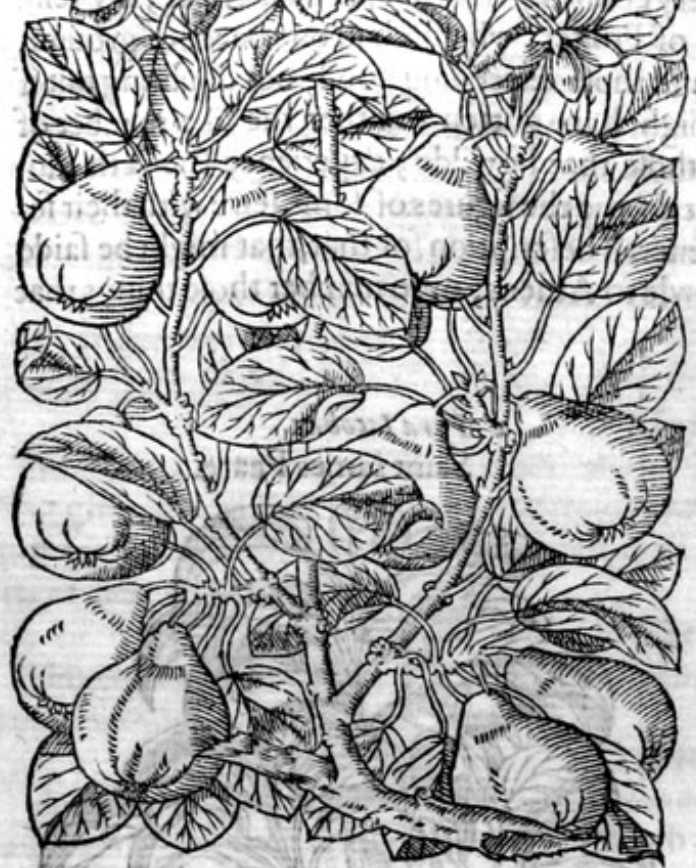

5 Pyrum Cydonium.

The Quince Peare.

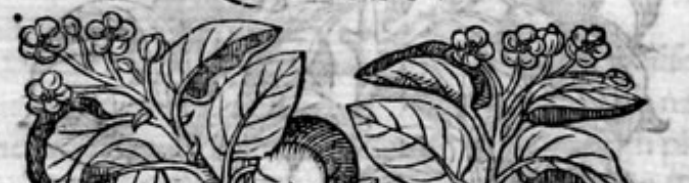

1
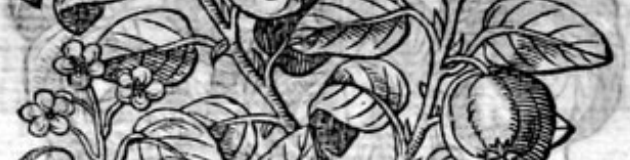

(1)

I) $=\sqrt{2}$ -

$\left.((1),)^{2}\right)=2$

$((1)+1$,

(3) - 72 (1)

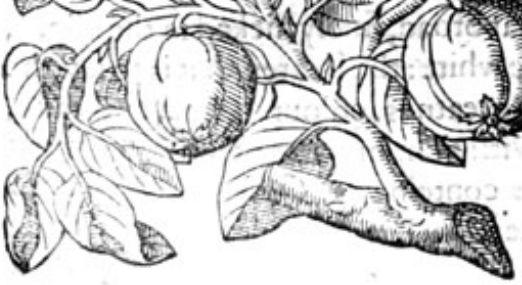

4 Pyrum Palatinum.

The Burgomot Peare.

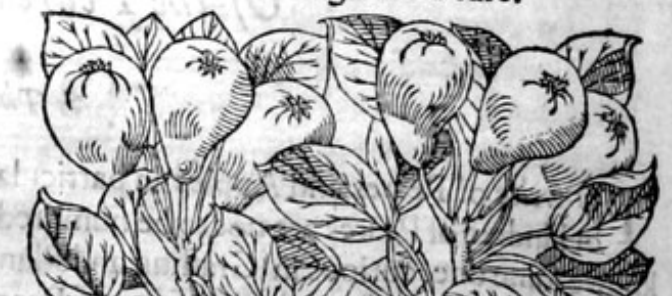

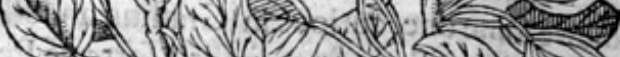
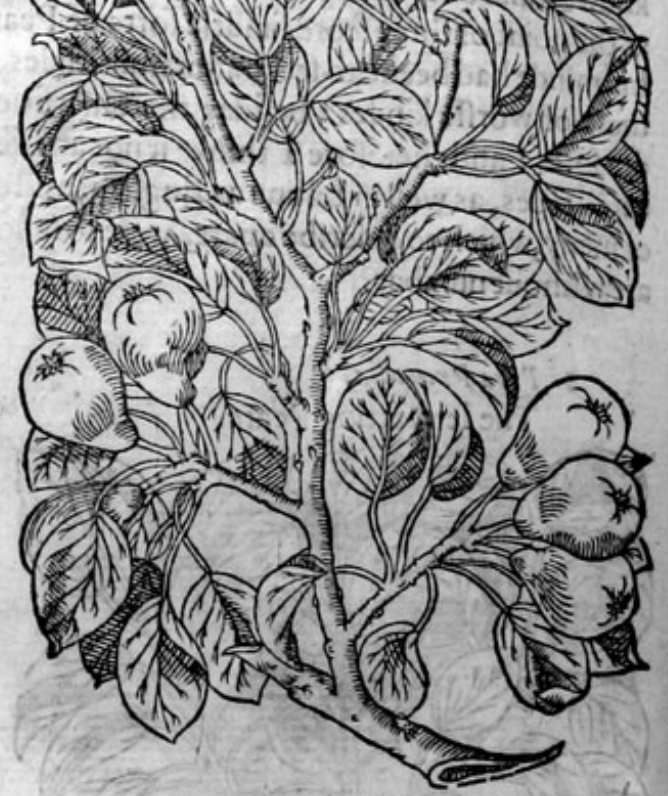

6 Prrum Epifcopatum.

The Bifhops Peare.

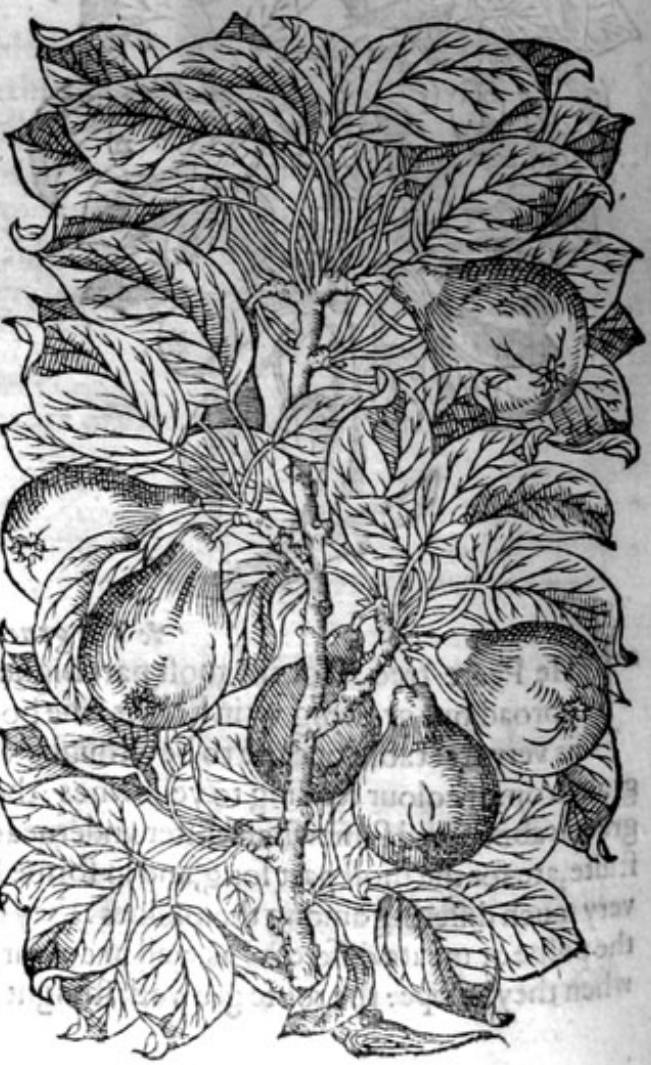


7 Pyrm Juperba, fune Katheriva. The Katherinc Peare tree.

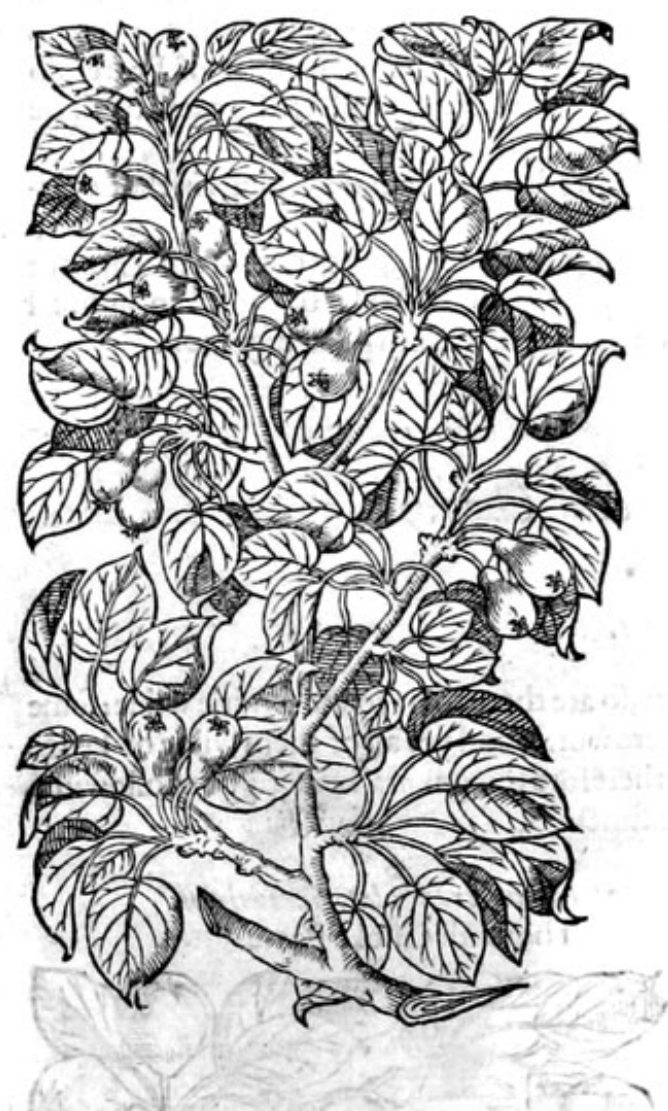

8 Pyrus hremalis. The Winter Pearc tree.

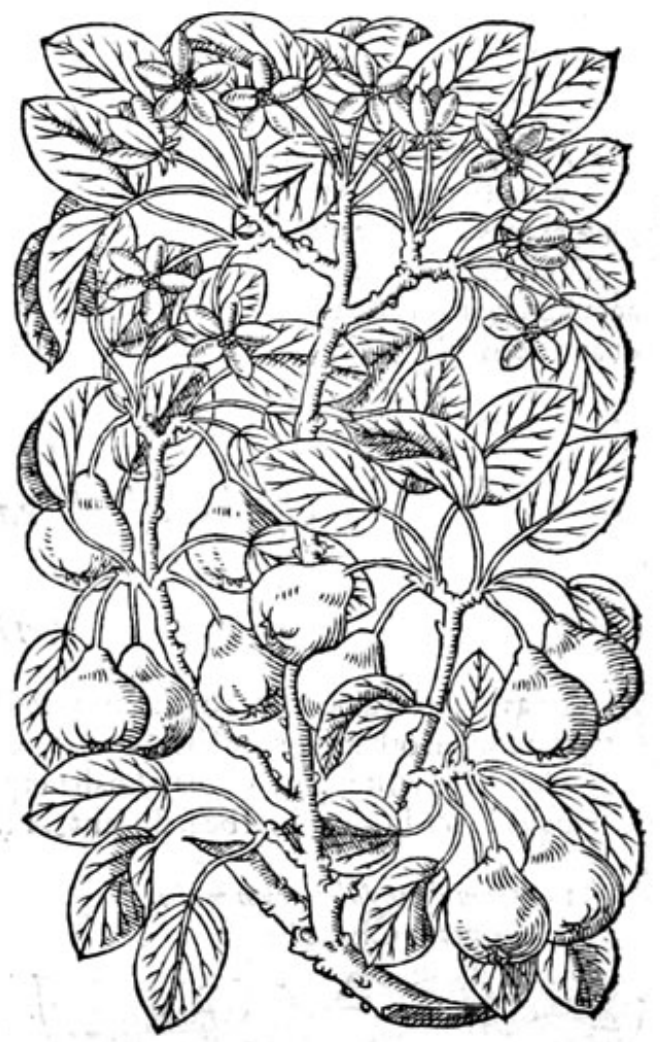

* The place.

The tame Peare trees are planted in orchards, as be the apple trees, Q aroram varis infitione ex agre: ftibus mites ac edules fruct us redditi funt. All thefe before fpecified, and many fortes more, and thofe moft rare and good, are growing in the ground of Mafter Richard Pointer, a moft cunning and curious graffer and planter of all manner of rare fruites, divelling in a fmall village neere London called T wicknam; and alfo in the ground of an excellent graffer and painfull planter, Mafter Henry Banbury, of Touthill ftreete neere vnto Weftminfter; and likewife in the ground of a diligent and moft affectionate louer of plants Mafter Warnar neere Horfey Downe by London, and in diuers other grounds about London(but beware the Bag and Bottle) feeke elfewhere for good fruit faithfully deliuered.

The flowers do for the moft part come foorth in Aprill, the leaues afterwardes: all Peares are not ripe at one time; fome be ripe in Iuly, others in Auguft, and diuers in September or later. * The names.

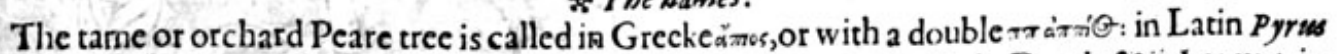
vrbana, or Cultiua : of Tarentinus in his Geoponikes aim midos: in high Dutch 2Bitrbaum : in lowe Dutch foectboom: in French Porrier.

The Peare or fruit it felfe is called in Greeke àmor: in Latine Pyrum : in high Dutch 2Bitn : in lowe Dutch jpeere: in Italian Pere : in French Poyre: in Spanifh Per as : in Englifh Peare.

* Thetemperature and vertues.
Thie furnames of Peares, let vs come to the faculties which the $\mathbf{A}$ Ninn I phificians 


\section{$\$ 27^{\circ}$ \\ THE THIRD BOOKE OF THE}

phifitians ought to knowe; which alfo varic according to differences of the taftes : for fome Peares are fiveete, diuers fat and vnctuous, others fower, and moft are harfh, efpecially the wilde Peares, and fome confift of diuers mixtures of taftes, and fome hauing no tafteat all, but as it were of water.

A All Peares are colde, and all haue a binding qualitie and an earthie fubftance; but the Choke Peares, and thofe that are harfh be more earthie, and the fweete ones leffe : which fubitance is fo full of fuperfluous moyfture in fome, as that they cannot be eaten rawe. All manner of Peares do binde and ftop the belly, efpecially the Choke and harfh ones, which are good to be eaten of thofe that haue the laske and the bloodie flixe.

B The harfh and auftere Peares may with good fucceffe be laide vpon hot fivellings in the beginning,as may be the leaues of the tree, which do both binde and coole.

C Wine made of the iuice of Peares called in Englinh Perry, is foluble, purgeth thofe that are not accuftomed to drinke thereof; notwithftanding it is as wholefome a drinke being taken in fmall quantitie as wine; it comforteth and warmeth the ftomacke, and caufech good digeftion.

\section{Of the wilde Pearetree. Chap.94.}

* The kindes.

F Ven as there be diuers forts of the manured Peares, fo are there to be found fundrie wilde; fome greater than orhers, fome of better tafte, and others worfe; and yet all of them wilde or hedge fruit, whereof to write apart were to fmall purpofe : therefore this generall defcription following, with their feuerall titles, , hall be fufficient for their diftinctions.

1 Pyrum ftrangulatorium maius. The great Choke Peare.

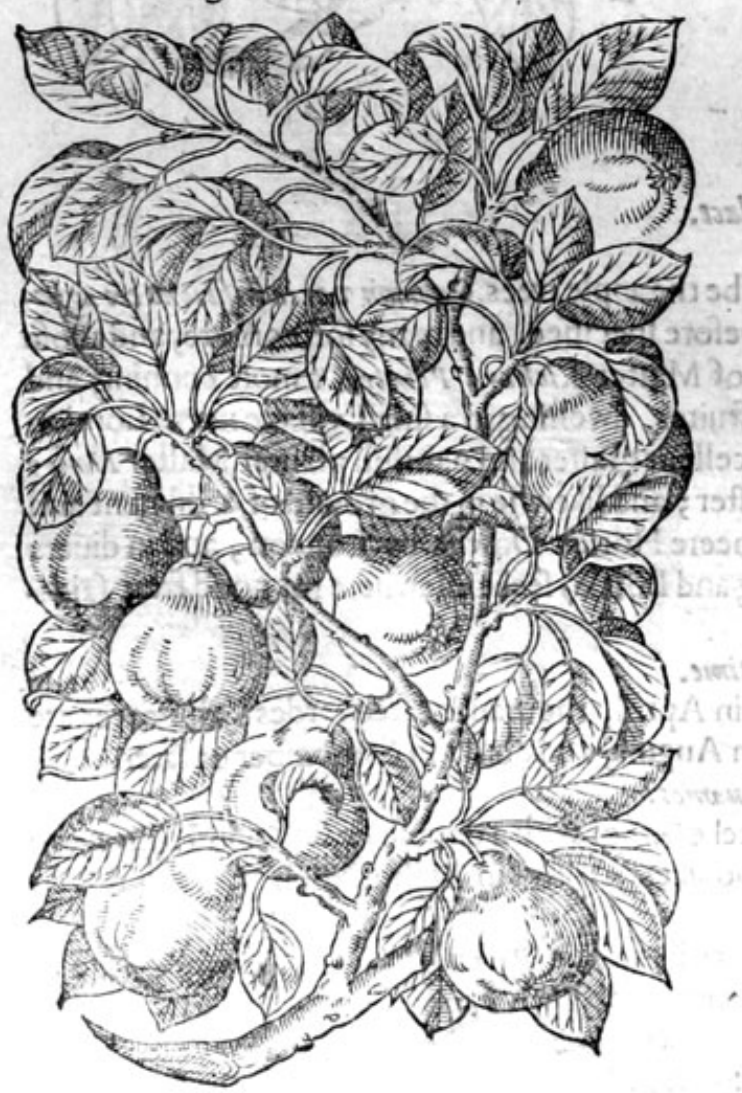

2 Pyruen frangulatorium minus. The fmall Choke Peare.

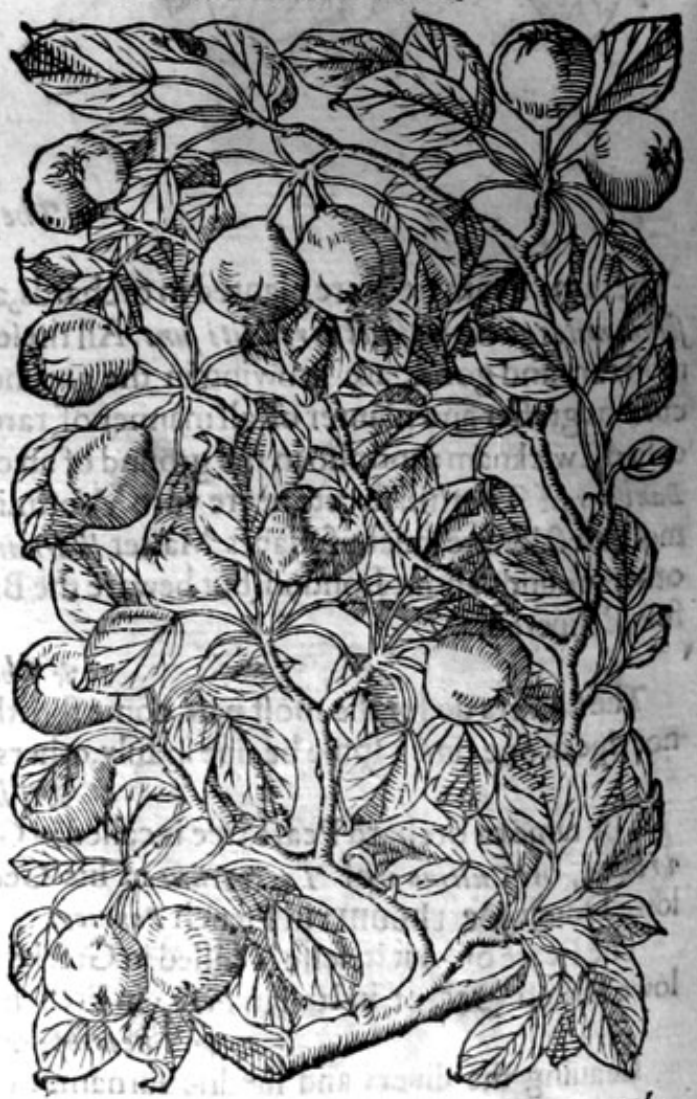

* The 
*The generalldefcription.

$\mathrm{T}$ He wilde Peare tree groweth likewife great, vpright, full of branches, for the moft part Pyramides like, or of the fafhion of a fteeple, not fpread abroad as is the Apple or Crab tree: the timber of the trunke or body of the tree, is very firme and folide, and likewifefmooth, a woode very fit to make diuers fortes of inftruments of, as alfo the haftes of fundiy tooles to worke withall $;$ and likewife ferueth to be cut into many kindes of mouldes, not onely fuch prints as thefe figures are made of, but alfo many forts of pretie toies, for coifes, breft plates, and fuch like, vfed among our Englifh gentiewomen : the branches are fmooth, couered with a blackifh, barke, verie fragile or eafie to breake, whereon do grow leaues, in fome greater; in other leffer: the flowers are like thofe of the manured Peare tree, yet fome whiter then others: the fruite differ not in (hape,yet fome of them are greater then others; but in tafte they differ among themfelues in diwers notable points, fome are harpe, fower, and of an auftere tafte; fome more pleafant, others har/h and bitter ; and fome of fuch a choking tafte, that they are not to be eaten of hogs and wilde beafts; much leffe of men: they alfo differ in colour, euery circumftance wherof to diftinguifh apart would greatly enlarge our volume, and bring vnto the Reader fmall profite or commoditie; therefore in triefe thefe fewe words ihall ferue for their feuerall defcriptions.

3 Pyrus flueftris. The wildehedge Peare tree.

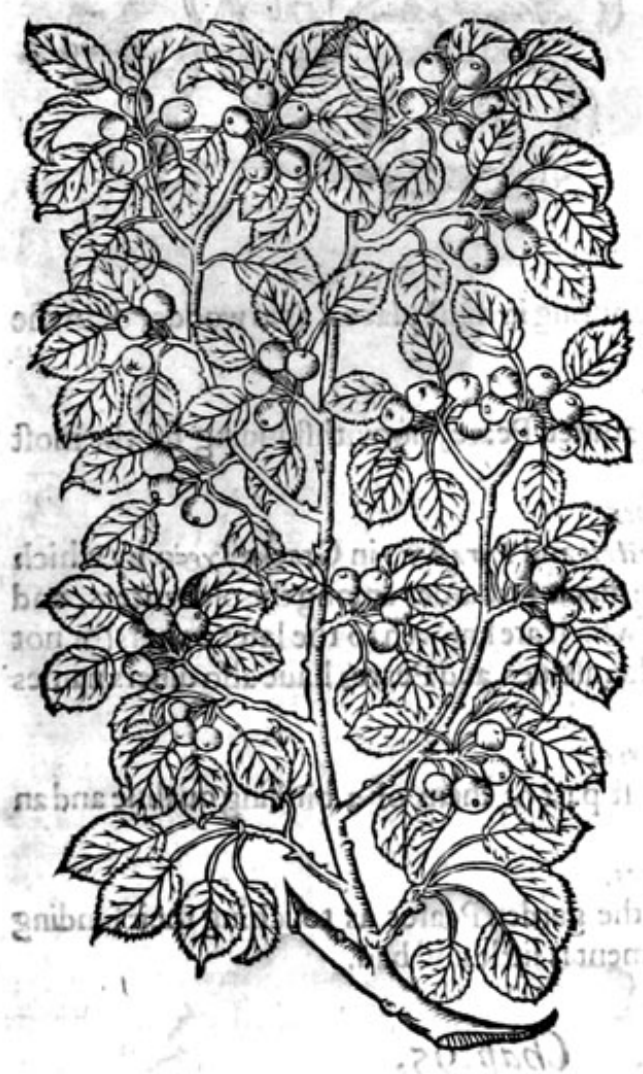

Nnnn $2 i$

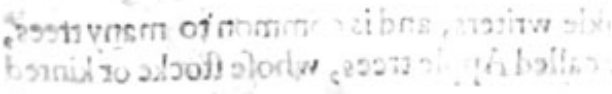

4 Pyrus flueftris minima. The wilde Crab Peare tree.

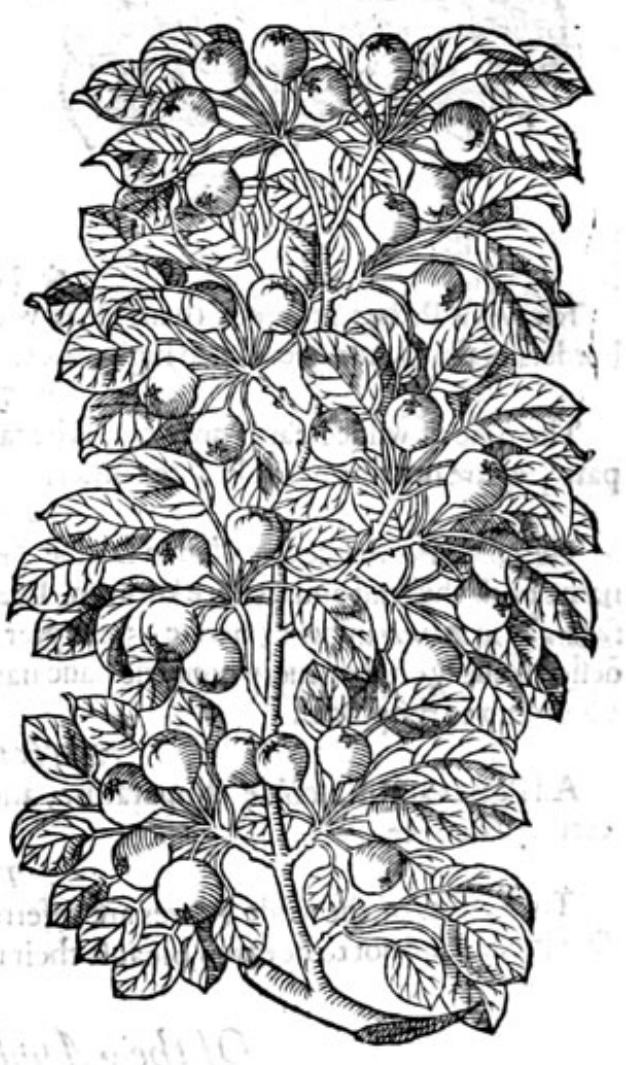

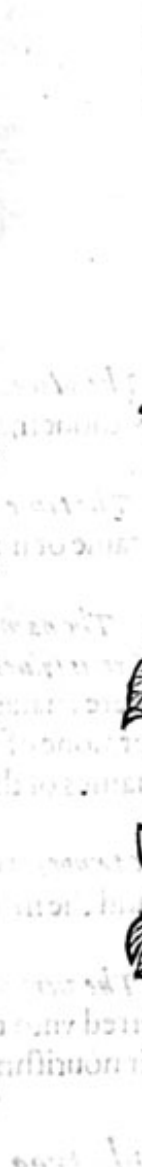

.


5 P,rme pedicriaris.

The Lowfic wilde Peare.

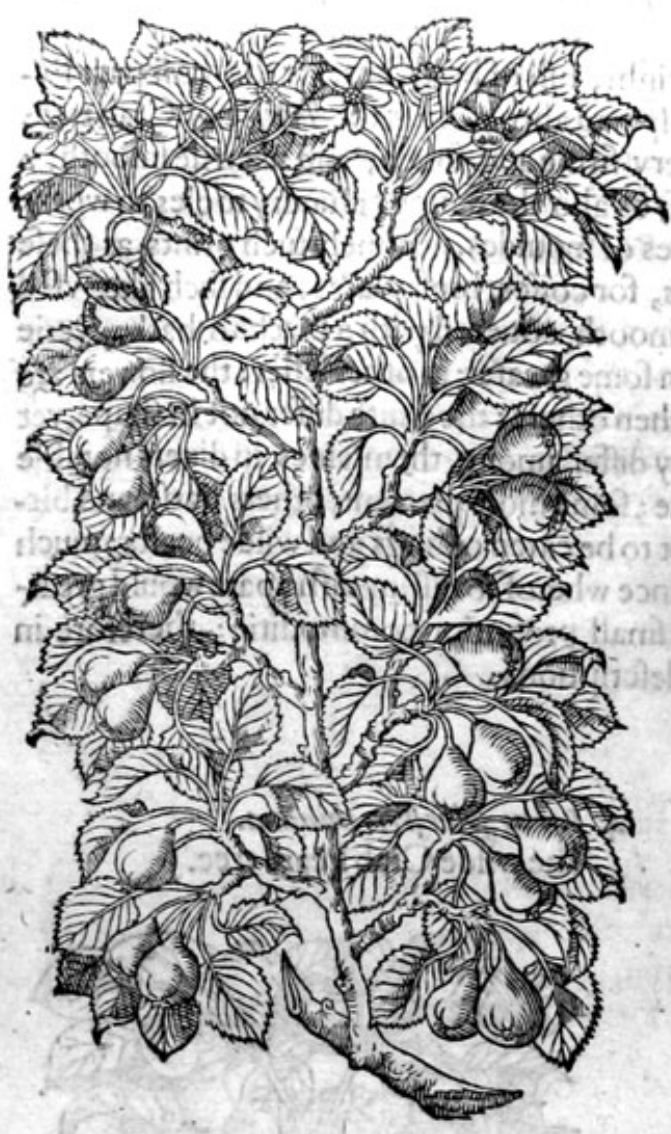

6 Pyras Coruina. The Crowe Peare tree.

* Tbe place.

The wilde Peares growe of themfelues without manuring in moft places, as in woods, or in the borders of fields, and neere vnto high waies.

\section{* The tive.}

The time of wilde Peares anfwereth the tame or manured Peare, notwithiftanding for the moft part they are not ripe much before winter.

\section{* The names.}

The wilde Peare tree is called in Latine Pyrius fyluestris and Pyrafer: : in Greeke ¿xees: by which name both the fruit and tree are knowen. Pejares haue diuers furnames among the old writers, and fpecially in Plenie in his 15 .booke 15 . chapter, none of which are knowen to the later writers (or not defired) euery citie or euery countrie haue names of themfelues, and Peares haue alfo diuers names according to the places.

\section{* The temperature.}

All Peares are of a colde temperature, and the moft pars of them of a binding qualitie andan earthiẹ fubftance.

\section{*The vertues.}

The vertues of the wilde Peares are referred vnto the garden Peares as touching their binding facultie, but are not to be eaten, bicaufe their nourifhment is little and bad.

\section{Of the Apple tree. Chap.95.}

* The kindes.

$T_{\text {but we will briefely firft intreate of Mali, properiy called App and is common to many trees; }}^{\text {He }}$ 
HISTORIE OF PLA NTS.

is fo infinite, that we haue thought it not amiffe, to vfe the fame order or method with Apples that we haue done with Peares, that is, to giue them feuerall titles in Latine and Englifh, and one generall defcription for the whole.

I Malius Carbonaria.

The Pome Water tree.

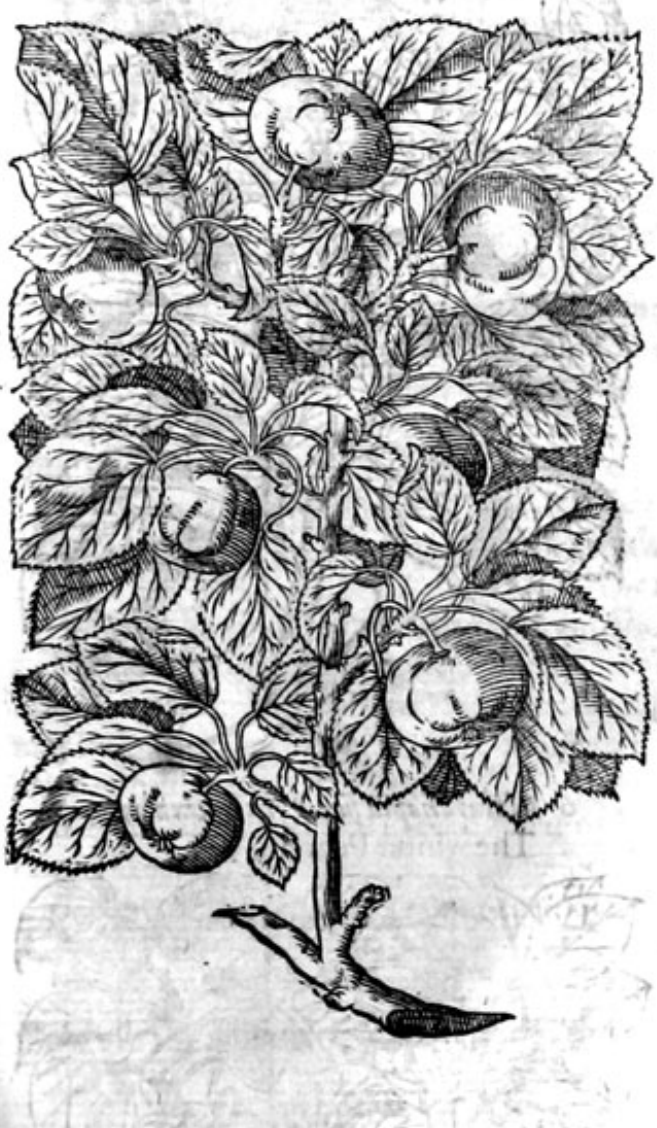

2 Malus Carbona ria longo fructu. The Bakers ditch Apple tree.

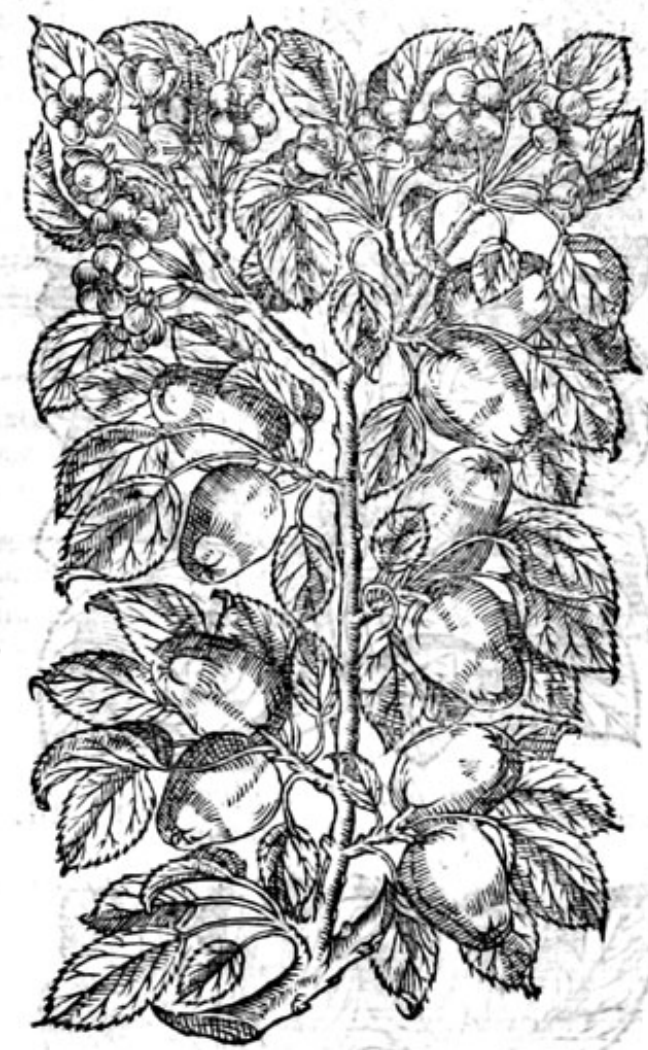

3

\section{* The generall defcription.}

$\mathrm{T}$

He Apple tree hath a bodie or trunke commonly of a meane bigneffe, not very high, hauing long armes or branches, and the fame difordered : the barke fomewhat plaine, and not very rugged : the leaues be broad, more long than round, and finely nicked in the edges. The flowers are whitifh tending to a blufh colour. The fruite or Apples do differ in greatnes, forme, colour and tafte ; fome couered with a red skin, others yellowe or greene, varying infinitely according to the foyle and climate; fome very great, fome little, and many of a middle fort; fome are fweete of tafte, or fomething fower; moft be of a middle tafte betweene fiveete and fower, the which to diftinguifh I thinke it impoffible; notwithftanding I heare of one that intendeth to write a peculiar volume of Apples, and the vfe of them; yet when he hath done that he can do, he hath done nothing touching their feuerall kindes to diftinguifh them. This that hath beene faide, hall fuffice for our hiftorie.

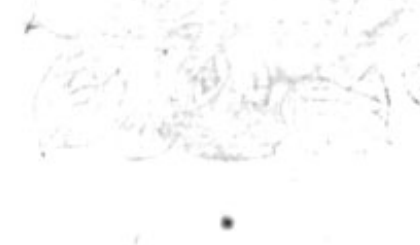


1274

THE THIRD BOOKE OF THE

3 Malum regale. The King of Apples.
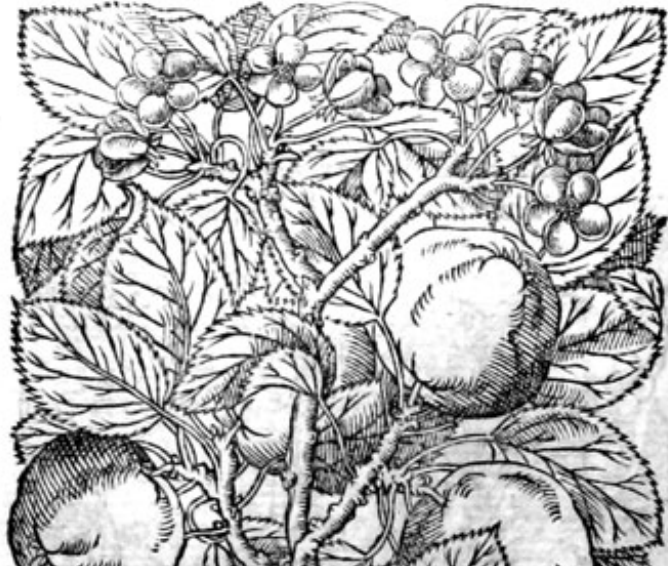

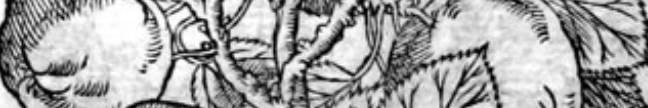
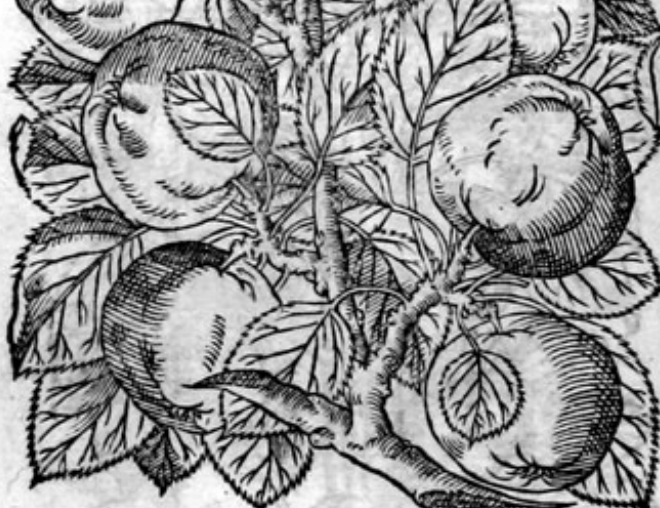

5 Platomela fine Pyra ceftua. The fommer Pearemaine.

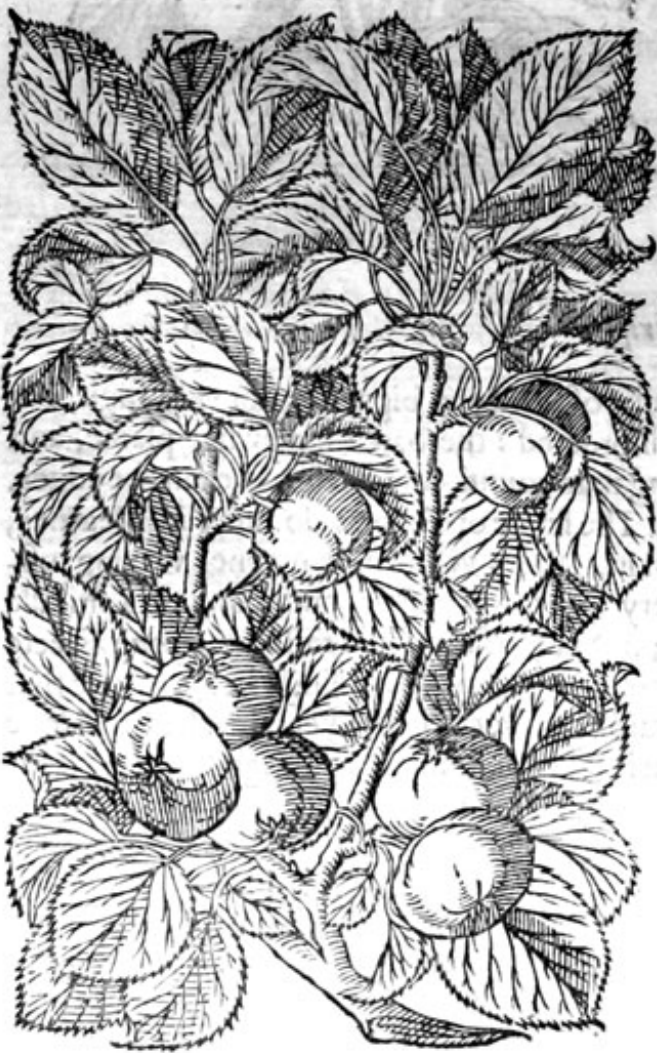

4 Malum reginale.

The Quining,or Queene of Apples.

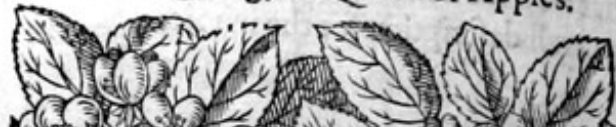

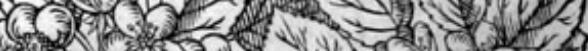

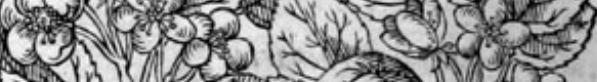
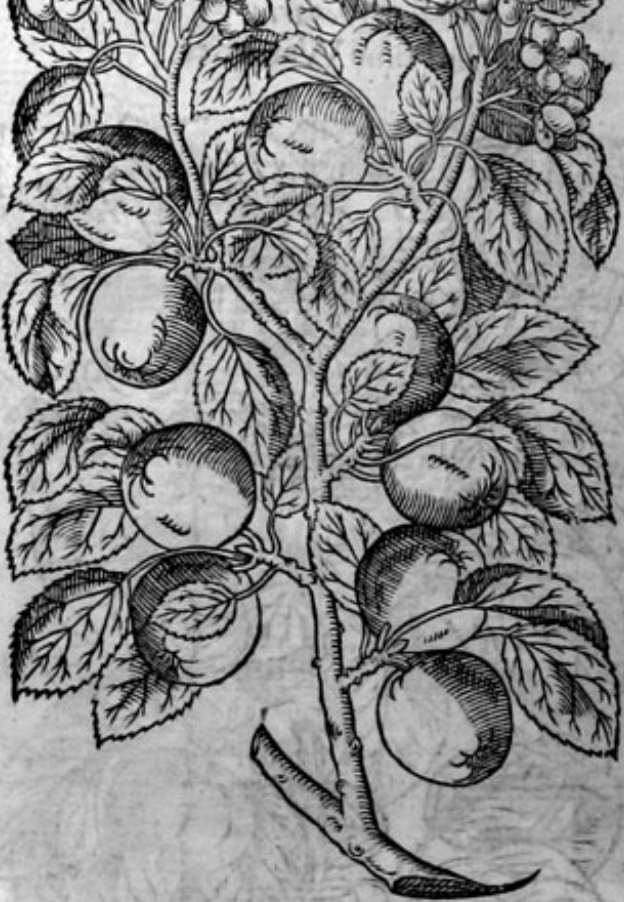

6 Platarchapia frae Pyrn byemalia.

The winter Pearemaine.

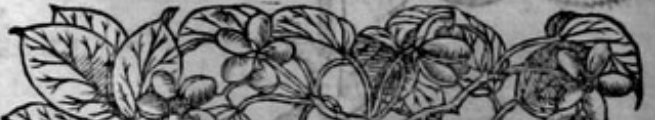

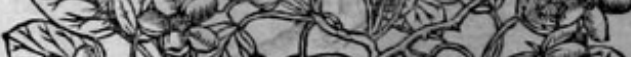

-1 10 .

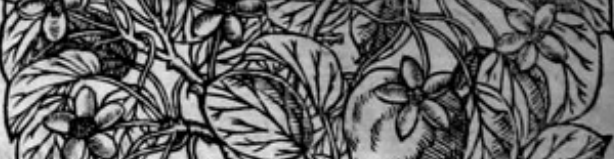

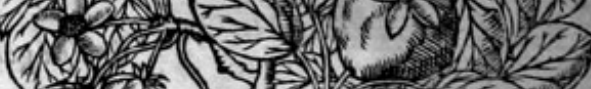

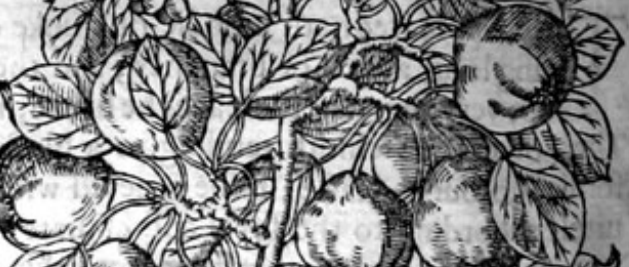

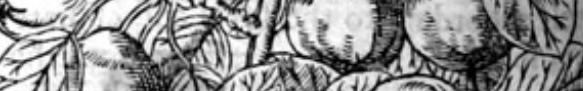

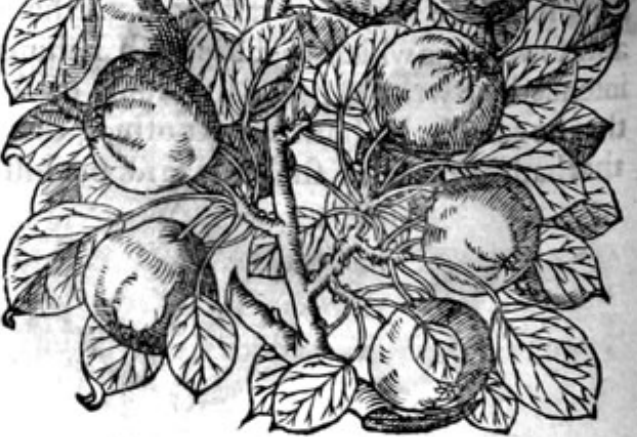




\section{EHISTORIE OE PLANTS. HT}

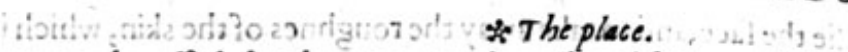

The tame and graffed Apple trees are planted and fet in gardens and orchards made forthe pupofe: they delight to growe in good and fercilligrounds : Kelst doth abound with Apples of moft fortes Butl haue eechein rhe paltures and hedge rowes about thegrounds of a workipfult Gentlemah dwell ing two miles from Hereford called M.Rogen Bodpome, fo many trees of all fortes, that the feriants drinke for themoftpart noother drinke, but chat which is made of Apples. The quantitie is fuch, that byche reporton the Gendeman himfelfe; the Parfon hath for tithe many hog, fheads of Syder. The hogs are fed wirh the fallings of them, which are fo many, that chey make choife of thofe Apples they do cate, who will not tafte of any but of the beft. An exampledoube-

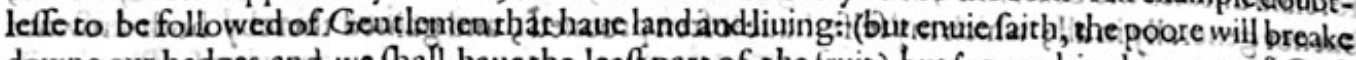
downe our hedges, and we fhall haue the leaft part of the fruit) but forward in the name of God,

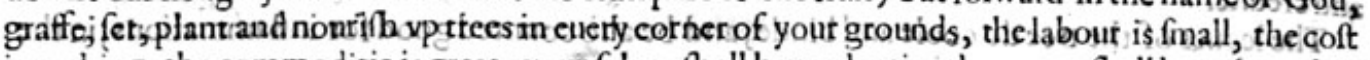
is nothing, the commoditic is great, your felues fhall haue plentic, the pooie fhall hauc formybat: in timo of waur to xetienc theirneceffirie, and God hall reward your good mindes and diligence.

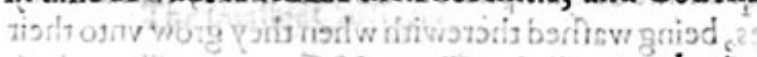

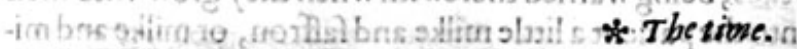

7o They bloome about the end of Aprill or in the beginning of May. The forward Applesberipe about the Calends of Iuly, others in September.

\section{* T the names.}

The Apple tree is called in Greeke undés: in Latine MalusandPamus : in high Dutch Dpfiefl. baum: in lowe Dutctrappetboum: in french Pommier : in Englifh Apple tree.

The Grecians name the fruit piñov: the Latines Malum or Pomum : in high Dutch Dpffell $:$ in in lowe Dutch appel: in French and Spani(h Makj/anas : in Englifh Apple.

\section{* The temperature.}

All A pples beof temperature cold and moift and haue ioyned with them a certaine excremen: tall or fuperfluous moyiture : but as they be not all of like coldnes, fo neither haue they like quantitie of fuperfluous moyfture. They are fooneft rotten that hauc greateft ftore of moyfture, and they may be longer kept in which there is'leffe ftore: for the abundance of excrementall moyfture is the caufe why they rot.

Sweete Apples are not fo cold and moyit, which being rofted or boyled, or otherwife kept, retaine orkeepe the foundnes of theirpulpe.

They yeeld more hourifhment, and not fo moyit a nourifhment as do the other apples, \& do not fo eafily paffe through the belly.

Sower Apples are colder and alfo moyfter : the fubftance or pulpe of thefe when they be boyled, doth run abroad, and retaineth not his foundneffe : they yeelde a lefier nourifhment, and the fame rawe and cold.

They do eafily and fpeedily paffe through the belly, and therfore they do mollifie the belly, efpecially being taken before meate.

Harfh or auftere Apples being vnripe, are cold; they ingender groffe blood, and great ftore of winde, and often bring the collicke.

Thofe Apples which be of a middle tafte containe in them oftentimes two or three forts of tafts, and yet do they retaine the faculties of the other.

\section{* The vertues.}

Rofted Apples are alwaies better than the rawe, the harme where of is both mended by the fire, $A$ and may alfo be corrected by adding vnto them feedes or fpices.

Apples be good for an hot ftomacke: thofe that are auftere or fomewhat har $\mathrm{h}$, doftrengthen a $B$ weake and feeble ftomacke proceeding of heate.

Apples are alfo good for all inflammations or hot fwellings, but effecially for fuch as are in be- C ginning, if the fame be outwardly applied.

Theiuice of Apples which be fweete and of a middle tafte, is mixed in compofitions of diuers D medicines, and alfo for the tempering of melancholie humours, and likewife to mend the qualities of medicines that are drie : as are Ser apium ex pomis Kegis Japoris,Antidotum ex granis Crcci Baphici, and fuch like compofitions.

There is likewife made an ointment with the pulpe of Apples and Swines greafe and Rofe $E$

$$
\text { Nnnn } 4
$$

water, 


\section{THE THIRD BOOKE OF THE}

water, which is vfed to beautifie the face, and to take away the roughnes of the skin, which is called

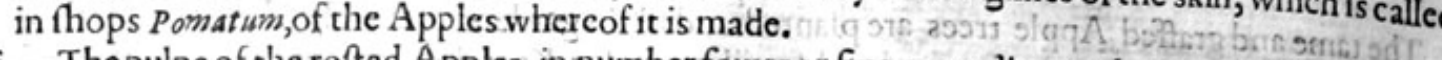

E The pulpe of the rofted Apples, in number fower or fiue, according to the greatneffe of the Ap. ples, efpeciall of the Pome-water, mixed in a wine quart of faire water, laboured togitheo vntill it come to be as Apples and Ale, which we call Lambes Wooll, and the whole quart drunke la at night, within the fpace of an hower, doth in one night cure thofe that piffe by droppes with great anguifh and dolour ; the ftrangurie, and all other difeafes proceeding of the difficultio of making water ; but in twife taking it, it neuer faileth in any : oftentimes there hapneth with the forefaid difeafes the Gonorrhat, or running of the raines, which irlikewife healeth in thofe perfons, but not generally in all; whichmy felfe haue often prooued, and gained thereby both crownes and credite.

F The leaues of the tree do coole and binde, and be alfo counted good for inflammations, in the the beginning.

G Apples cut in peeces, and diftilled with a quantitic of Camphere and butcer milke, raketh away. the marks and fcars gotten by the fmall pockes, being wafhed therewith when they grow vnto their ftate or ripenes : prouided that you giue vnto the patient a little milke and faffron, or milke and mithridate to drinke, to expell to the extreme parts that venome which may lie hid, and as yet not leene.

\section{Of the Wilding and Crabtree. Chap.96.}

\section{* Tbekindes. ?}

Tke as there be diuers manured Apples, fo is there fundry wilde Apples, or Crabs, whereof to write apart were to fmall purpole, and therefore one defcription for the reft fhall fuffice.

I Malus flueftris rubens.

The great Wilding, or red Crab tree.

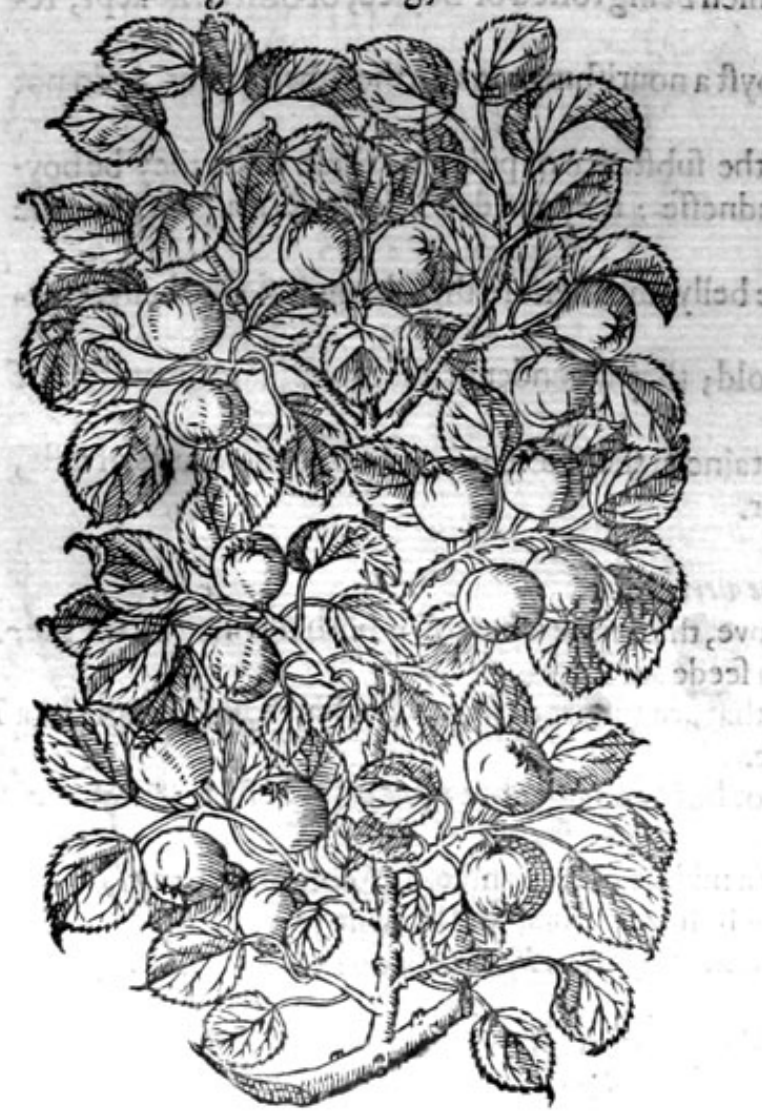

2 Malus flue fris alba. The white Wilding, or Crab tree.

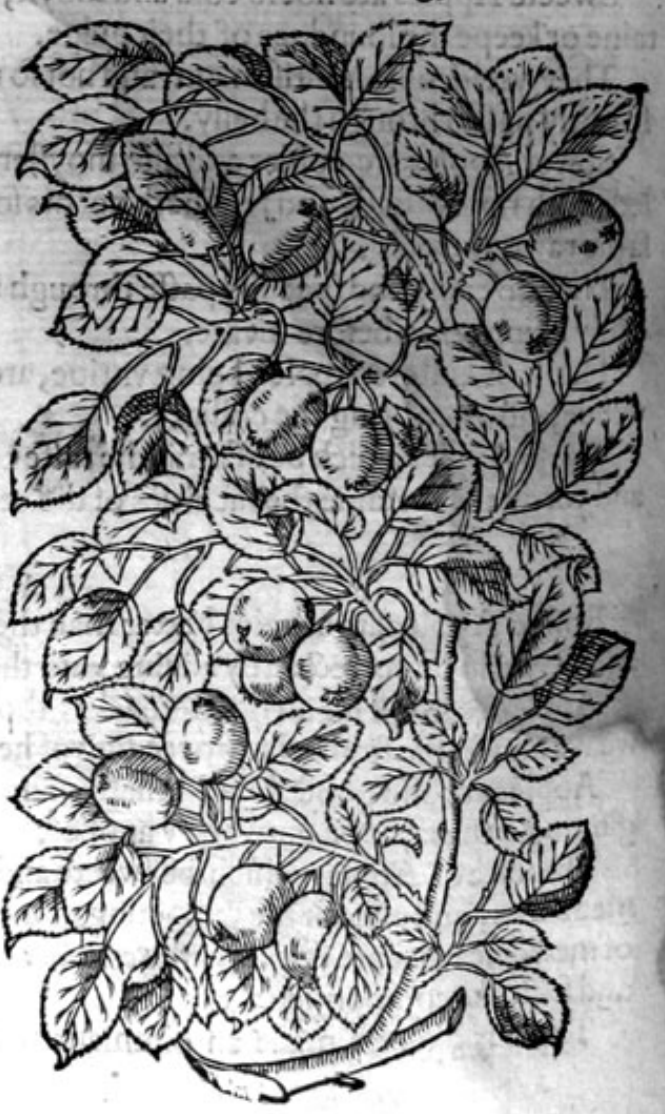




\section{HISTORIE OF PLANTS. * The generalldefcription. \\ Tenting .}

\section{$\mathrm{T}$}

Here be diuers wilde Apple trecs not husbanded, that is to fay, not grafted; the frutit wherof is harfh and binding : for by grafting both Apples and Pcares become more milde and pleafant. The Crab or Wilding tree groweth of tentimes to a reafonable greatnes, equall with the Apple tree : the woode is hand a firme, and folid; the barke rough; the branches or boughes many; the flowers and fruite likettiofe of the Apple tree; fome red, others white; fome greater, others lefier : the difference is knowne to all, therefore ic fhall fuffice what hath beene faide for their feucrall di. ftinctions: we haue in our London gardens a dwarffe kinde of fivecte Apple, called chamemalus, the dwarffe Apple tree, or Paradice Apple, which bearcth Apples very timely without grafting.

3 Malus fyluestris minor. The fnaller Crab tree.

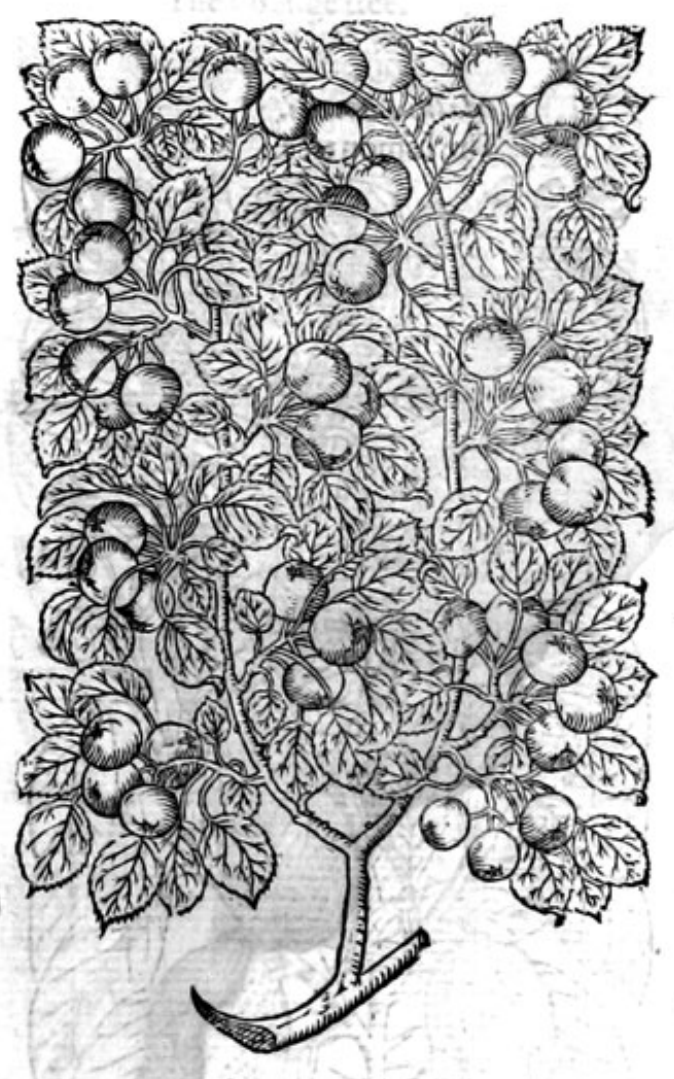
Malnes duracina fyluestris.
The choking leane Crab tree.

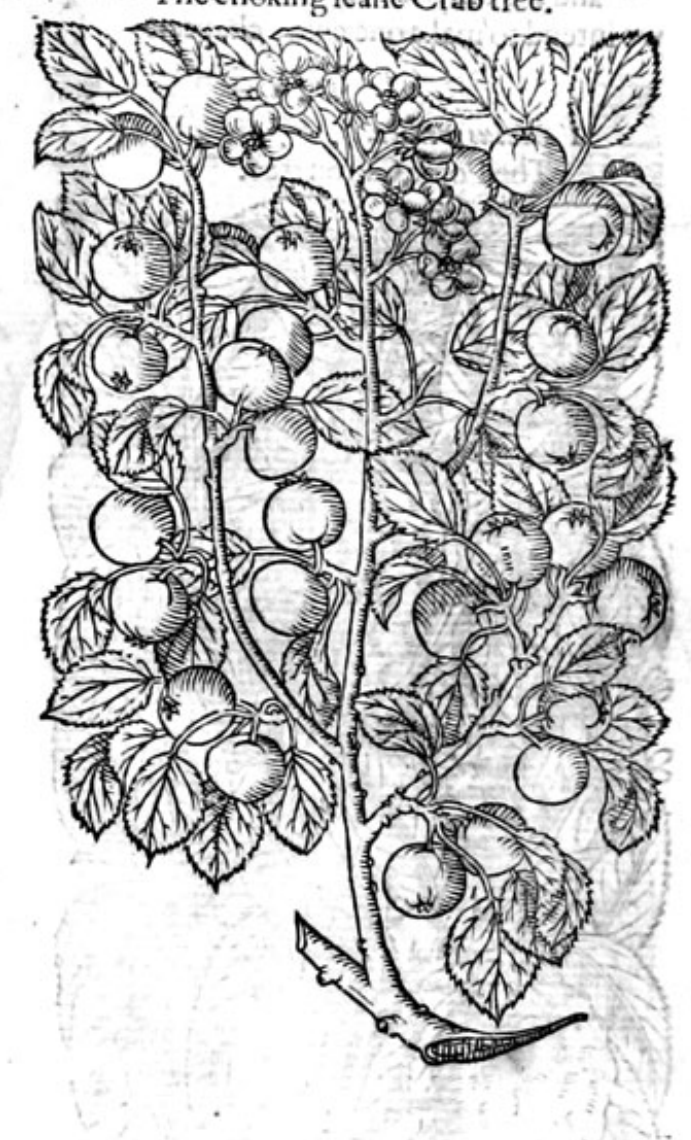

* The place.

The Crab tree groweth wilde in woods and hedge rowes, almoft euery where. * The time.

The time anfwereth thofe of the garden.

$*$ The names.

Their feuerall titles doth fet foorth their names in Latine and Englifh. * The temperature.

Of the temperature of wilde Apples, hath beene fufficiently fpoken of in the former chapter. * The vertues.

The iuice of wilde Apples or Crabs, taketh away the heate of burnings, fcaldings, and al inflam- A mations: and being laid on in fhort time after it is fcalded, it kecpeth it from bliftring.

The iuice of Crabs, or Veritice, is aftringent or binding, and hath withall an abfterfiue or clen- B 


\section{THE THIRD BOOKE OF THE}

fing qualitie,being mixed with hard yeeft of Ale or Beere, and applied in maner of a cold ointment, that is, fpred vpon a cloth firft wet in the Veriuice and wroong out, and then laide to, taketh away the heate of Saint Anthonies fire; all inflammations whatfoeuer, healeth fcabbed legs, burnings and fcaldings wherefocuer it be.

\section{Of the Citron, Limon, Orange, and eA Syrian} Appletrees. Chap. 97.

7it)

Shthe

\section{* The kindes.}

The Citron trec is of kindred with the Limon tree; the Orange is of the fame houfe or focke; and the Affyrian Apple tree claimeth a place as neereft in kinred and neighbourhood: whereof weintend to make one entire chapter.

1 Malus medica.

The Pome Citron tree.

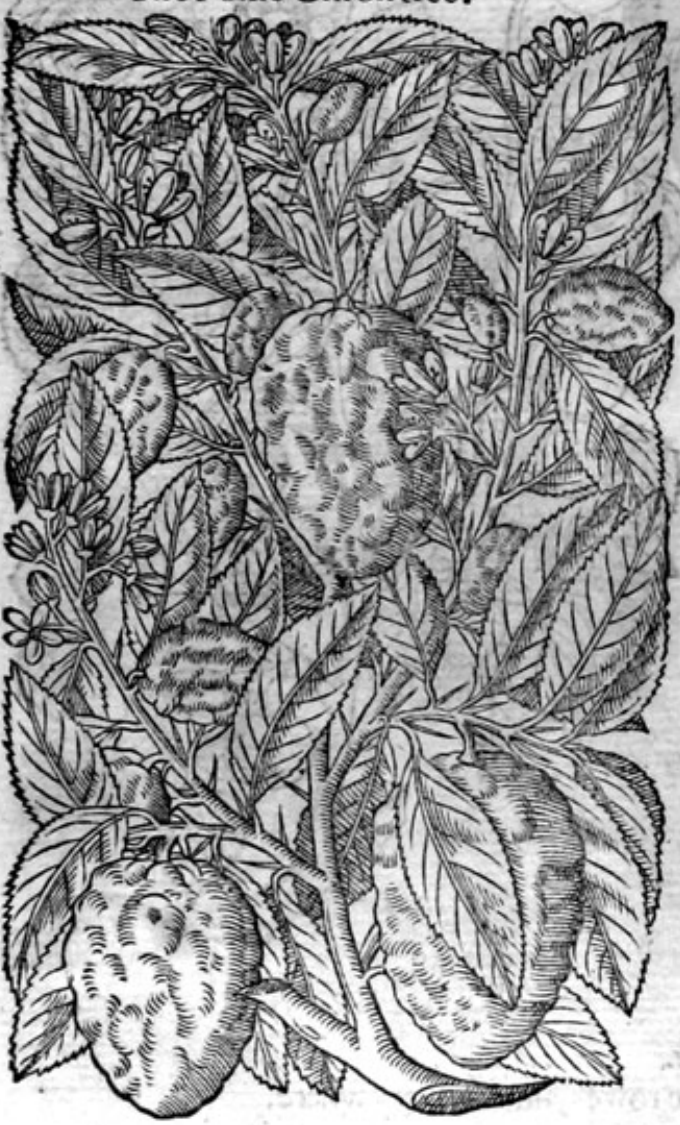

2 Malis Limonia. The Limon tree.

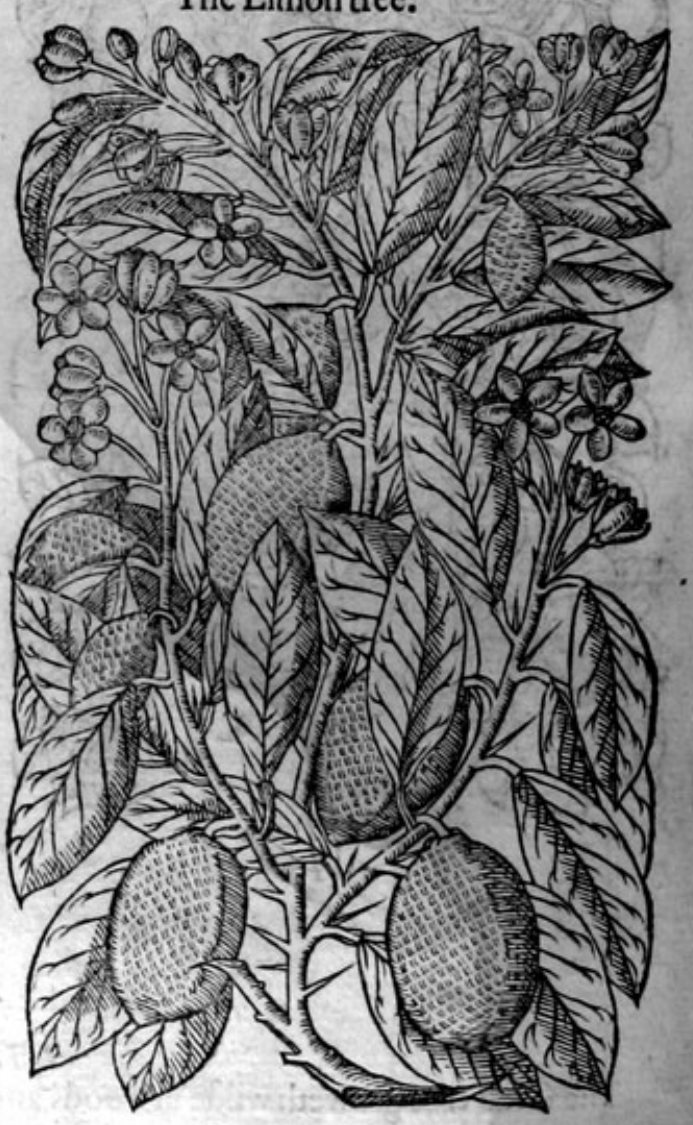

* The defcriftion.

I $\mathrm{He}$ Citron tree is not very great, hauing many boughes or branches, tough \& pliable, couered with a greene barke: whereon do grow greene leaues, long, fomewhat broade, verie finooth, and iweete of fmell, like thofe of the Baie tree : among which, come foorth heere and there certaine prickles, fet farre in funder : from the bofome wher of come foorth fmall flowers, confifting of fue little leaues, of a white colour tending to purple, with certaine threeds like haires growing in the middle : the fruite is long,great er many times then the Cucumber, oftenleffer, and 


\section{HISTORIE OF PLANTS.}

not much greater then the Limon : the barke or rinde is of a light golden colour, fet with diuers knobs or bumps, and of a very pleafant fmell : the pulpe or fubftance next vito it is thicke, white, harde, hauing a kinde of aromaticall or fpicie fmell, almoft without any tafte at all : the fofter pulpe within that is not fo firme or folide, but more fpungie, and full of a fower iuice, in which the feede lieth hid, greater and thicker then a graine of Barly.

2 The Limon tree is like vnto the Pome Citron tree in growth, thorncy branches, and leaues, of a pleafant fweete fmell, like thofe of the Baie tree : the flowers hecreof are whiter then thofe of the Citron tree,and of a moft fweete fmell : the fruite is long and thicke, leffer then the Pome Citron: the rinde is yellow, lomewhat bitter in tafte, and fweete of fmell : the pulpe is white, in quantitie little in refpect of the Citron; in the middle part whereof is conteined more fort spungie pulpe, and fuller of moft fower iuice : the feedes are like thofe of the Pome Cition.

3 Malus arantia. The Orange tree.

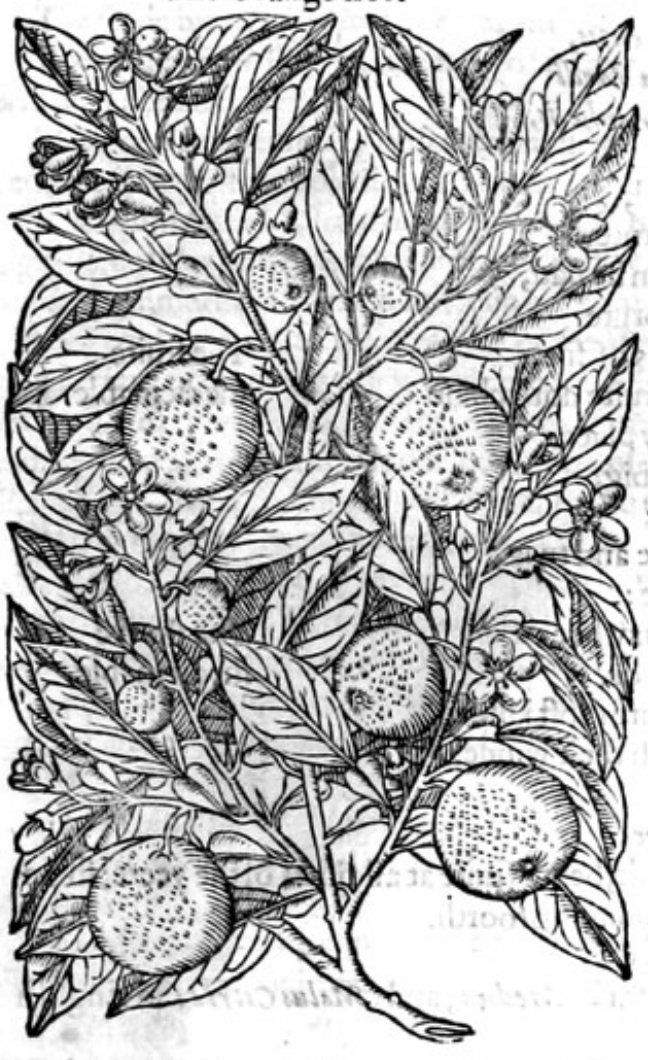

4 Malues AByrin.

The Affyrian Apple tree.

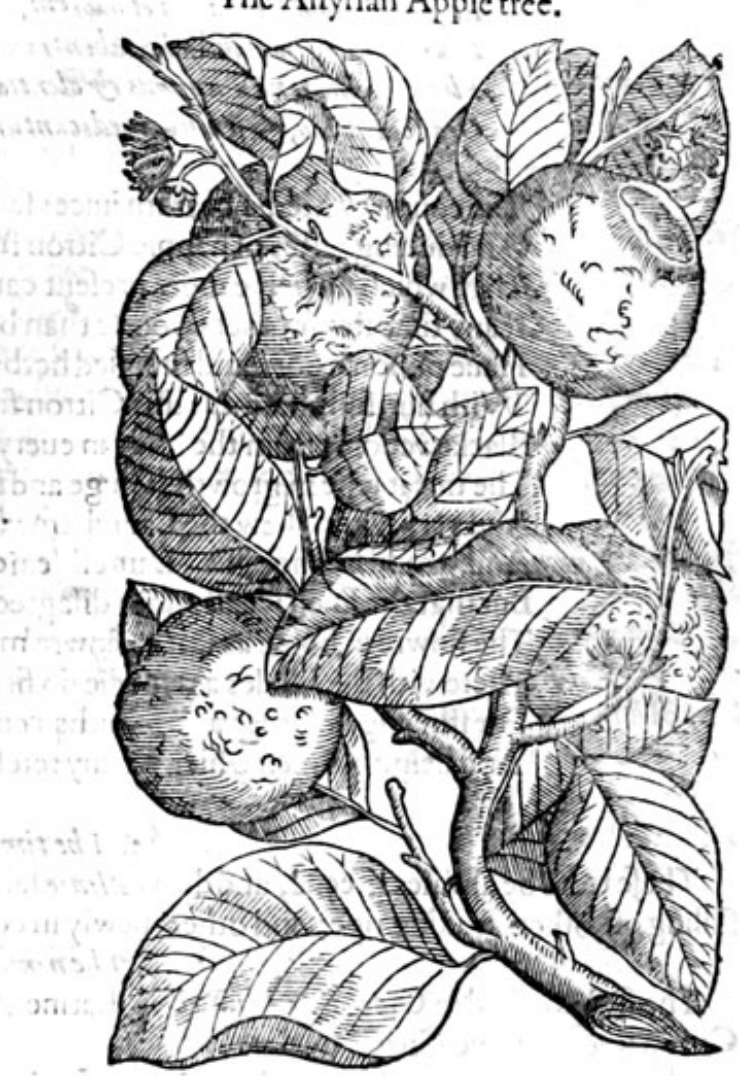

* 7 he defcription.

3 The Orange tree groweth vp to the height of a finall Peare tree, hauing many thorny boughes or branches, like thofe of the Citron tree: the leaues are alfo like thofe of the Baic trec, of a fweete fmell: the flowers are white, of a moft pleafant fweet fmell alfo: the fruit is rounde like-a ball,ecuerie circumftance belonging to the forme is very well knowne to all; the tafte is fower, fomtines fweet, and often of a tafte betweene both: the feedes are like thofe of the Limon.

4 The Affyrian Apple tree is like vnto the Orange tree : the branches are like: the leaues are greater : the flowers are like thofe of the Citron tree : the fruite is rounde, three times as bigge as the Orange : the barke or peeling is thicke,rough, and of a palc yellow colour, wherein appe ere often as it were fmall cliftes or crackes: the pulpe or inner fubttance is full of itice; in tafte harpe, as that of the Limon, but not fopleafant : the feedes are like thofe of the Citron. 
* Theplace.

The Citron, Limon, and Orange trees, do grow efpecially in the fea coafts of Italy, and on the Ilands of Adriatici \& Tyrrheni, and alfo $A E g$ ei maris, and likewife on the maine land, neere vnto meeres and great lakes: there is alfo great ftore heerof in Spaine, but in places efpecially ioining to the fea, or not farre off:they are alfo found in certaine prouinces of France which lie vpon the midland fea. They were firft brought out of Media, as not onely Plinie writeth, but alfo the Poet Virgilaffirmeth in the fecond booke of his Georgickes, writing of the Citron tree after this maner:

Media fert triftes fuccos, tardiom que fa porem

Felicis mali, quo non prafentius villum,

Pocula fiquando faus in fecere nonerca,

Mifcuernntque herbas, \& non innoxia verba,

Auxilium venit, ac membris a git atra venena.

Ipfa ingens arbos, faciem que fimallima Lauro.

Et finon aliwn late iact aret odorem,

Laurus er it folia basd villis labent in ventus, Flos apprime tenax, animas do olentia Medi

Ora fouent illo, \& Jenibus medicantur anhelis.

The countrey Media beareth iuices fad,

And dulling taftes of happie Citron frute,

Than which no belpe more prefent can be had,

If any time ftepmothers woorfe than brute

Haue poifon'd pots, and mingled herbs of fute,

With hurtfull charmes : this Citron fruite doth chafe

Thefruite

Blacke venome from the body in euery place.

The tree it felfe in growth is huge and big,

And very like in fhew the Laurell tree;

And would be thought a Laurell, leafe and twig,

But that the fmell it cafts doth difagree:

The flowre in holde as faft as flowre may bee :

Therewith the Medes a remedie do finde, medicinable.

For ftinking breathes and mouths a cure moft kinde,

And helpe old men which hardly fetch their winde.

\section{* The time.}

Thefe trees be alwaies greene, and do as Plinie faith, beare fruite at all times of the yeere; fome falling off, others waxing ripe; and others newly in comming foorth.

* The names.

The firft is called in Greeke $\mu n \lambda \dot{s} \alpha \mu e \delta x):$ in Latine Malus Medica, and Cralus Citria : in Englifh Citron tree, or Pome Citron tree.

The fruite is named in Grecke unino us ofyòv : in Latine Malum medicum, or Malum Citrium, and Ci. tromalum. AEmylianus in Athenaus fheweth, that Iuba king of Mauritania hath made mention of the Citron, who faith, that this apple is named among them Malsm He/pericum : Galen denieth it to be called any longer Malum medicum, but Citrium, and fairh, that they who call it Medicum, do it to that end that no man fhould vnderftand what they fay : the Apothecaries call thefe Apples Citrones: in high Dutch eftetm opffell, Cittinaten: in lowe Dutch Eitroenen: in Italian Citromi, and Cedri: in Spanifh Cidras: in French Citrons: in Englifh Citron Apple, and Citron.

The fecond kinde of Citron is called in Latine Limonyum malum: in thops Limones: in French Limons : in low Dutch Limonelt: in Englifh Limon, and Lemon.

The third is named Malum anarantium, or Anerantium, and of fome carantium of others Alrengium, of the yellow colour of geld; forme woulde haue them called Arantia of Lirantium, 2 towne i: A chaia, or Arania, of a conntrey bearing that name in Perfia : it is termed in Italian Aran(i) : in high Dutch isometankent in low Dutch Graengie appelen * in French Powmes d' Orenges: in Spanihh Notr anjas : in Engliih Orenges. 


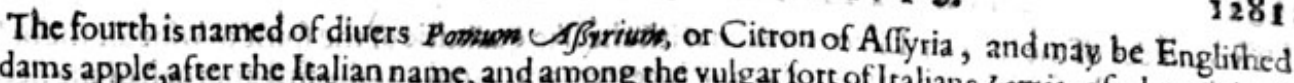
Adams apple, after the Italian name, and among the vulgar fort of Italians Lomin, of whon wiois al
fo called Pomum A damior Adams apple, and that came by the opinion of ple, who thinke it to be the fame Apple, of swhich Adam did eate in Pad of the common rude peos? Gods commandement; whereupon alfo the prints of the biting appecite when he tranfgreffed others fay that this is not the Apple, but that which the Arabians doeere therein as they fare: but Auicen in his 395. chapter maketh mention: fon divers of the Ie call Mufa, or Mofa, where of which by eating Adam offended,as 4 Andrew $T$ bevietwi fheweth.

* The temperatureasdivertues.

All thefe fruits confift of vnlike parts, and much differing in facultic.

The rindes are f iveete of fmell, bitter, hot, and dry.

The white pulpe iscolde, and containeth in it a groffe iuice,efpecially of the Citrons. of parts.

The feedc bicaufe it is bitter, is hot and dry.

G9y

The rinde of the Pome Citron is good againft al poifons, for which caufe it is put into Treacles, $F$ and fuch like confections.

It is good to be eaten againft a ftinking breath,for it maketh the breath fweete; and being fo ca- $\mathrm{G}$ ken it coinforteth the cold ftomacke exceedingly.

The white, found, \& hard pulpe is now and then eaten, but very hardly concocted, \& ingendreth $\mathrm{H}$ a groffe, colde, and flegmatike iuice; but being condite with fugar, it is both pleafant in tafte,eafie to be digefted;more nourifhing, and leffe apt to obftruction and binding, or ftopping.

'Gales reporteth, that the inner iuice of the Pome Citron, was not woont to be eaten, but it is norv I ved for fauce;and being often vfed, it repreffeth choler which is in the ftomacke, and procureth appetite:it is excellent good alfo to be giuen in vehement and burning feuers, and againft all peftilent and venemous, or infectious difeafes: it comforteth the hart; it coolech the inward parts, cutteth, diuideth, and maketh thinne, groffe, tough, and dimy humours.

Of this forefaid (harpe iuice there is a firupe prepared, which is called in fhops Syrupus de. Sce- K tofitate Citri, very good againit the forefaid infirmities.

Such a firrupe is alfo prepared of the fharpe inice of Limons, of the fame qualitie and operation, $t$ fo that in fteed of the one, the other will ferue very ivell.

A dolen of Orenges cut in flices, and put into 2 gallon of water, adding thereto an ounce of Mer- $M$ cury fublimate, and boiled to the confumption of thie halfe, cureth the itch and mangineffe of the bodie.

Men in old time(as Theophraftes writeth in his fourth booke) did not eate Citrons, but were $\mathbf{N}$ contented with the finell, and to laie thein among garmentes, to preferue them from Mothes.

As often as neede required they vfed them againft deadly poifons, for which thing they were 0 efpecially commendegdeuen by $Y$ irgils verfes, which we haue be fore alleaged.

There is extant in utt benews, in his third booke, 2 ftory of fome that for certaine notorious of- $P$ fences haue beene condernned to be deuoured of ferpents, who haue beene preferued and kept in health and fafety, by eating of the Citron.

The diftilled water of the whote Limons rinde and all drawne out by a glaffe Still; taketh awaie $\mathbf{Q}$ tetters and blemifhes of the skin, and maketh the face faire and fmooth.

Thefame being drunke prouoketh vrine, diffolueth the ftone, breaketh and expellethit.

The rinde of Orenges is much like in faculty to that of the Citrons and Limons, yet it is fo much $\mathbf{S}$ the more hot as it is more biting and bitter.

The inner fubftance or fowes pappe which is full of -ituce, is of like facultie, or notmuch $T$ inferior to the facultic of the pap of Citrons or Limons; but the fweete pap doth not much coole or drie, but doth temperately heate and moyften, being pleafant to the talte; it alfo nourifheth morethan doth the fower pappe, but the fame nourifhment is thinne and litcle; and that which is of a middle tafte hauing the fmacke of wine, is after a middle fort mote colde than fweete, and leffecolde than fower: the fweete and odoriferous flowers of Orenges be vfed of the perfumers in their fweete fmelling ointments, 


\section{THE THIRD BOOKE OF THE}

V Two ounces of the inice of Limons mixed with the like quantitie of the fpirit of wine, or the beft Aqua vit e (but the fpirit of wine rectified is much better) and drunke at the firft approch of the fit of an ague, taketh away the lhaking prefently: themedicine feldome faileth at the feconde time of $\mathrm{t}_{2}$ king thereof perfectly to cure the fame, but neier at the thirde time; prouided that the patient
be couered warme in a bed, and caufed to fweate.

$\mathrm{X}$ There is alfo diftilled out of them in a glaffe Still, a water of a maruellous fweete fmell, which being inwardly taken in the weight of an ounce and a halfe, mooueth fweate, and healeth the ague.

Y The feede of all thefe doth kill wormes in the belly, and driueth them foorth; it doth alfomightily refift poifon, and is good for the ftinging of fcorpions, if it be inwardly taken.

Z Thofe which be called Adams apples, are thought to be like in faculties to the fower iuice efpecially of the Limons, but yet they be not fo effectuall.

\section{Of the Cornell tree. Chap.98.}

\section{Corneumas.}

Themale Cornell tree.

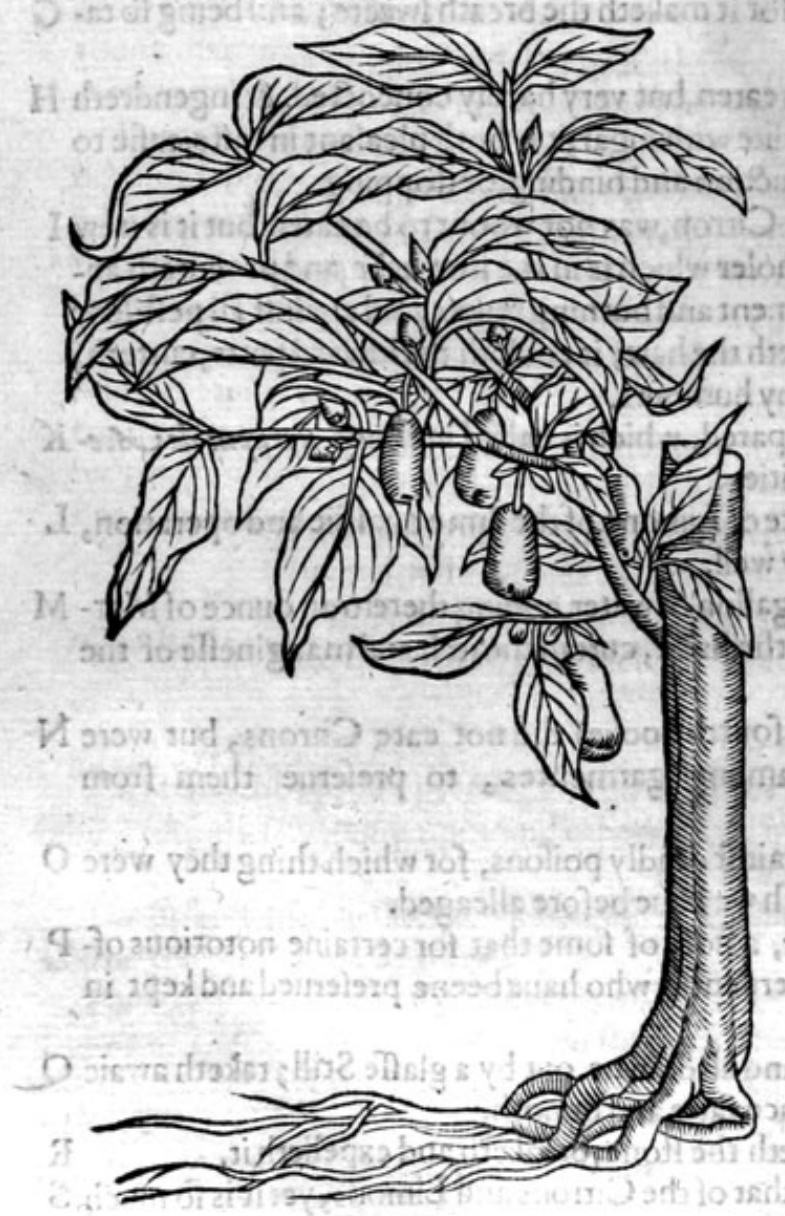

\section{* The defcription.}

THetame Cornell tree groweth fometime to the height and bignes of a fmall tree, with a great number of fprings; it is couered with a rugged barke; the wood or timber is very harde and drie, without any great quantitic of fap therin : the leaties are like vnto the Dog berrie leaues, crumpled, rugged, and of an ouerworne colour; the flowers growe in fmallbunches before any leaues do appecre, of colour yellow, of no greas value (they are fo fmall) in fhew like the flowers of the 'Olive tree; which being vaded, there come fmall long berries, which at the firft bee greene, and red when they be ripe; of an auftere and harfh tafte with a certaine fowerneffe; within this berrie is 2 fmall ftone, exceeding hard, white within; like that of the Oliue, whereunto it is like both in the fathion, and oftentimes in the bignes of the fruit.

This growerh in moft places of Germanic without manuring; it growethnot wilde in England. But yet there be fundrie trees of them growing in the gardens of fuch as loue rare and dainty plants, whereof I haue a tree or two in my garden. * The time.

The tame Cornell tree flowreth fometime in Februarie, and commonly in March, and afterwardes the leaues come foorth as an vntimely birth ; the berries or fruitare ripe in Auguft.

\section{* The names.}

The Grecians call it xearia: the Latines Cornus : in high Dutch Contelbaum : in lowe Dutch Connele boom: the Italians Corniob : in French Cornillier: in Spanifh Cornizolos : in Englifh the Cornell tree, and the Cornelia tree, of fome long Cherrie, and long Cherric tree

The fruit is named in Latine Cornum : in high Dutch Comell : in lowe Dutch Contoele : in Italian Cornole : in Englifh Cornell berrie.

This is Cornem mas Theophrasti, or Theophraftus his male Cornell tree; for he fetteth downe two fortes of Cornell trees, the male and the female : he maketh the wood of the male to bee 
HISTORIE OF PLANTS.

found as in this Cornell tree; which we both for this caufe and for others alfo, haue made to be the male : the female is that which is commonly called Virga fanguinea, or Dogsbetrie tree, and Cornus flueftris, or the wild Comell tree, of which alfo we will increate of in the next chap.following.
\[ \text { The temperature and vertues. } \]

The fruite of the Cornell trec hath a very har(h or choking tafte : it cooleth, drieth, and bindeth : yet may it alfo be eaten, as it is oftentimes.

It is a remedy againft the laske and bloudie fixe : it is hurtfull to a colde ftomacke and increafeth the rawnes thereof: the leaues and tender crops of the tree are likewife of an harfh and choking tafte, and do mightily dry.

They heale greene wounds that are great and deepe,efpecially in hard bodies, but they are not fo good for fmall wounds and tender bodies, as Galen writeth.

\section{Of the female Cornell, or Dog berrie tree. Chap.99.}
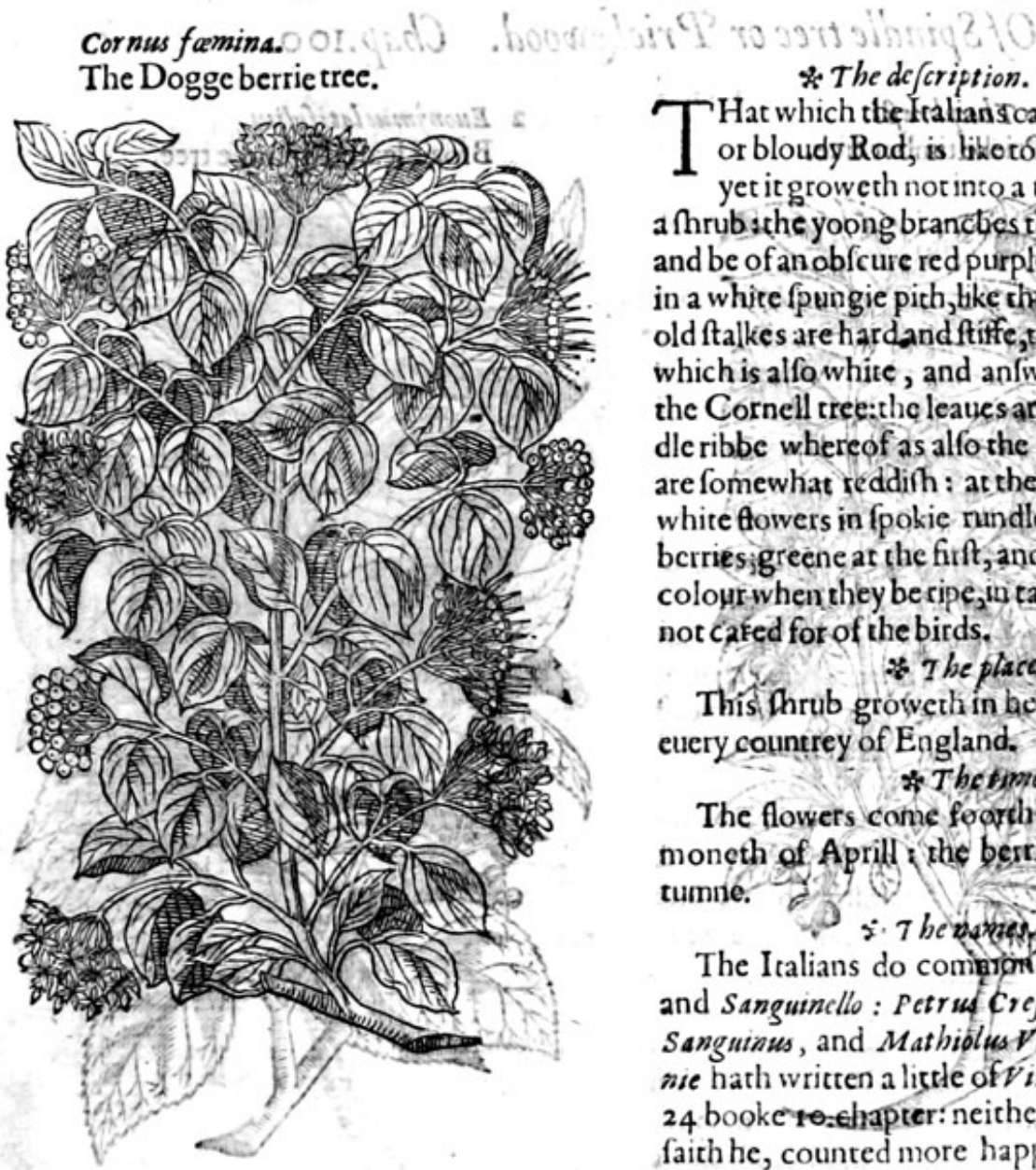

THat which the Inalian'scailt ringafanguinea, or bloudy Rad, is binotó the Connell tree; yet it growecth not into a tree, bur remaineth a hrubsthe yoong branctos there of are ionted, and be of an obfcure red purples they batie within a white fpungie pith, tike carat of Elder, but the old ftalkes are hardand ftiffe, the fubitance of the which is alfowhite, and anfwerable to thofe of the Cornell tree:the leaues are alfo like, the middle ribbe whereof as alfo the brittle footeftalkes are fomewhat reddifh: at the top whereof ftand white flowers in fpokie nundles which rurne into bcrries greene as the firft, and of a thining blacke colour when they be ripe, in tafte vnpleafant, and not cared for of the birds.

$$
\text { ty. The place. }
$$

This thrub grotveth in hedges and burhes in euery countrey of England.

$$
\text { * Thetime. }
$$

The flowers come foorth in the furing, in the moneth of Aprill the berries are sipe in Autumne.

$$
25 \text { \&: } 7 \text { be puxeses }
$$

The Italians do comatomly call it Sagruino, and Sanguincllo: Petrus crefcentisu termeth it Sanguinus, and Mathiolus Vorgajanguines, $P$ linie hath written a litste of $V$ irga fanguinea, in his 24 booke to:ehapter: neither is Virga/angutnea, faith he, counted more happic: the inner barke thereof doth breake open thefcars, which they before haue healed. It is a harde thing or perad-

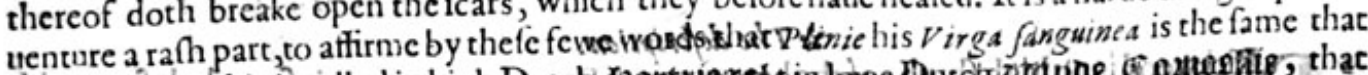

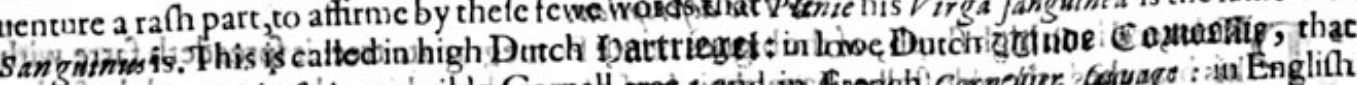

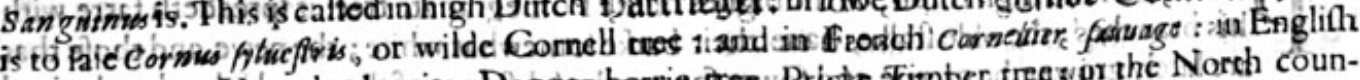

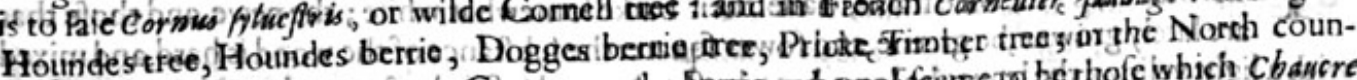

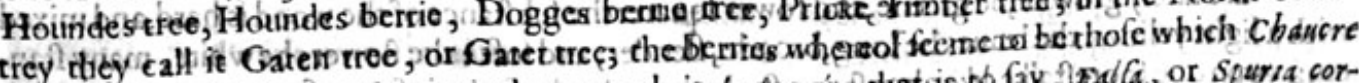

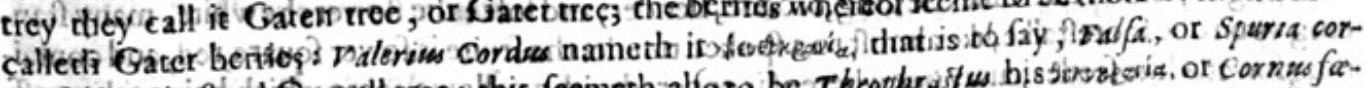

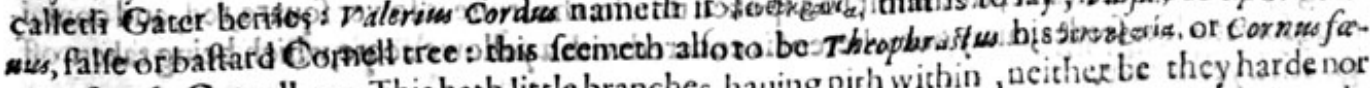
mina, female Cornell tree. This hath litcle branches, hauing pich within, weither be they harde nor रोता 


\section{THE THIRD BOOKE OF THE}

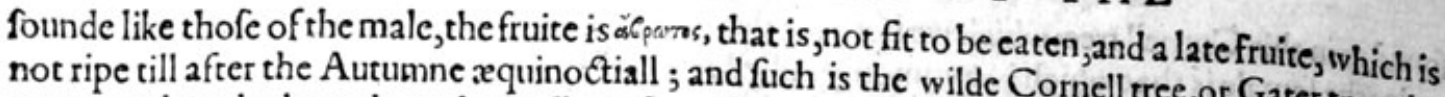
yoong and tender branches whereof be red, and haue, as we haue writrell tree, or Gater tree: the or berries be vnpleafant, and require a long time before they can be ripe. *. The temperatwre.

The berries heereof be of vnlike parts, for they haue fome hot, bitter; and clenfing, and verie many colde, dry, haríh, and binding,yet they hatre no vfe in medicine.

\section{* The vertues.}

A Mathiolus writeth, that out of the berries firft boiled and afterwards preffed, there iffueth an oile, which Ananien fes ruftici; do vfe in lampes : but it is not certaine, nor very like that the barke of this wilde Cornell tree hath that operation which Plinie reporteth of Virga fanguinea, for he faith, as we haue already fet downe, that the inner barke thereof doth breake and laie open the fears which they before haue healed.

\section{Of Spindle tree or Prickewood. Chap.100.}

I Enonymus Theophrafti. Englifh Pricke timber tree.

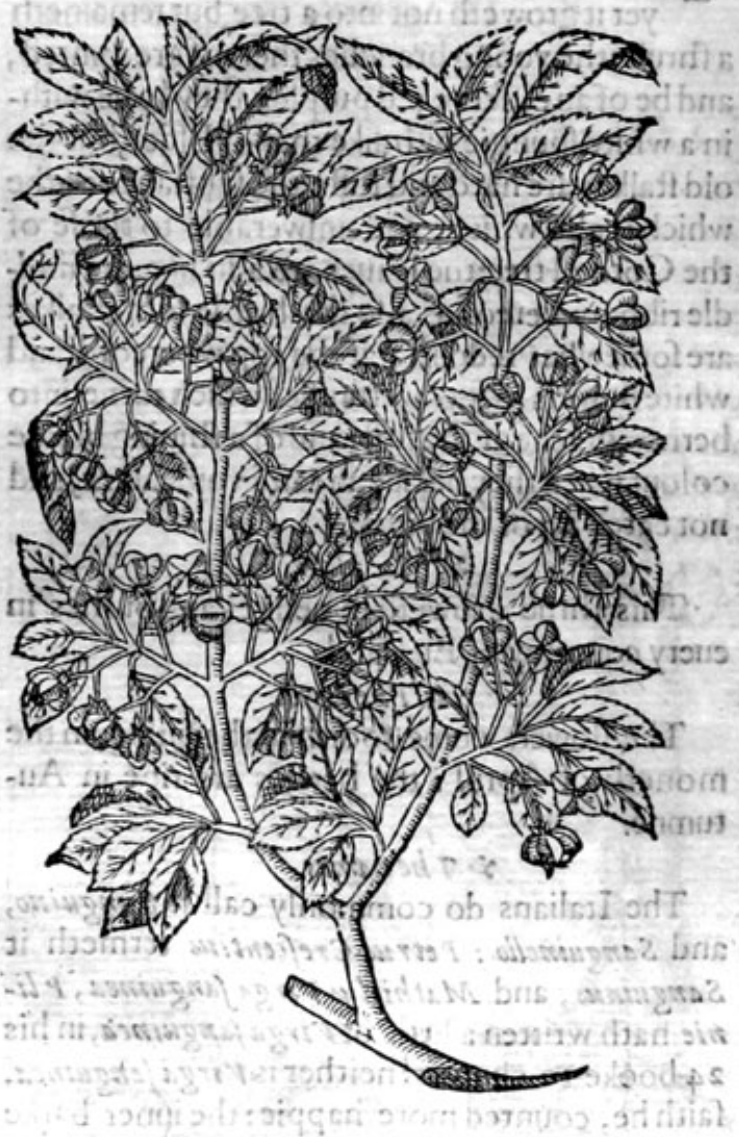

2 Eunymuslatifoliu. Broad leafed Spindle tree.

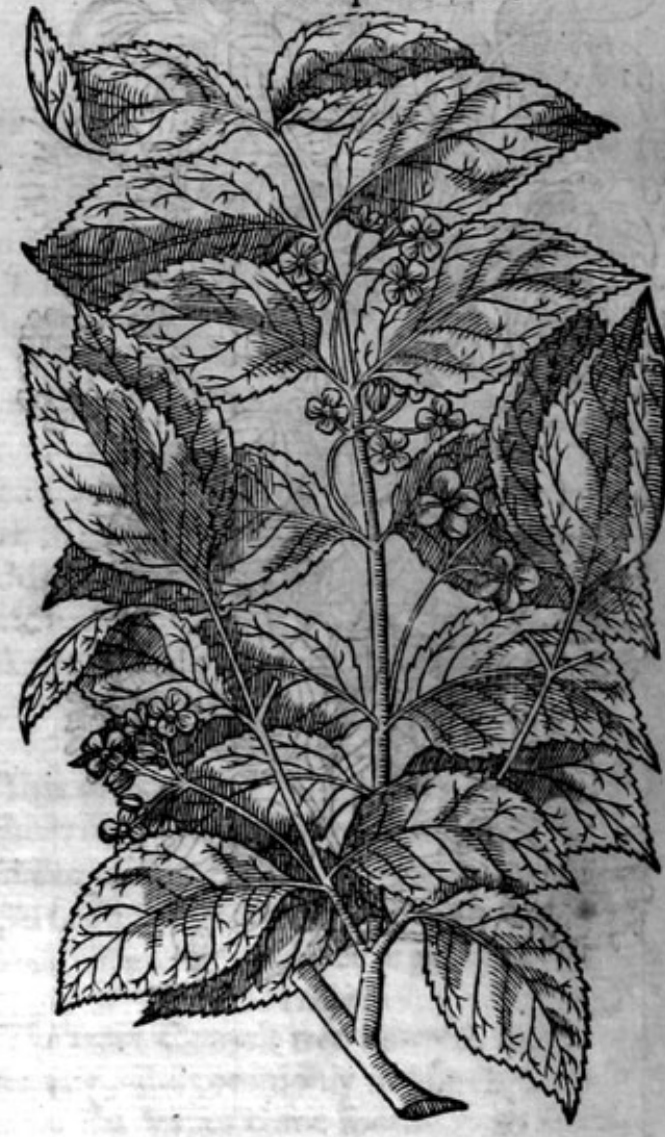

\& The defoription.

1 Rickwood is no high fhrub, of the bignes of the Pomegranate tree: it fpreadeth farre with his branches; the olde ftalkes taue rheir barke fomewhat white; the newe and thofe that are lately growne, be greene, and fower fquarenthe fubftance of the wood is hard, and mixed with a light yellow: the leaues be long, broade, flender, and foft: the flowers be white, many ftanding vpon one fooreftalke, likealmoft to a fpoked rundle: the fruite is fower fquare, red, and contairing fower whire feedes, cuery one whereof is couered with a yellowe co óte, which being taken off, gi.etnayelow die. 


\section{* The defcrijtion.}

2 This other fort of Eunymos groweth to the forme of an hedge tree, of a meane bigneffe: the trunke or bodie whereof is of the thickneffe of a mans legge, couered with a rough or fcab. bed barke, of an ouerworne ruffet colour. The branches are many, flender, and verie euen, co. uered with a greene batke whileft they be yer yoong and tender; they are alfo vetybrittle, with fome pith in the middle like that of the Elder. The leases are fewe in number, full of nerues or finewes, difperfed like thofe of Plantaine; in thape like thofe of the Poine Citron tree; of a lothfome fmell and bitter talte : among which come foorth flender footeftalkes, very long and naked; whereon do growe fmall flowers confifting of fower fmall leanes like thofe of the Clierrie tree, but leffer, of a white colour tending to a bluth, with fome yellowneffe in the middle ; after commeth the fruite, which as yet we haue no certaine knowledge of. The roote is tough, and woodic, difperfing it felfe far abroad vnder the vpper cruft of the earth.

3 Enonymos Pannonica. Hungarie Spindle tree.

\section{* The defoription.}

3 The fame author fettech foorth another fort which he found in the mountaines of Morauia and Hungarie, hauing a trunke or ftocke of the height of threc or fower cubits, couered with a barke greene at the firft; afterward f frinckled oner with manyblack fpots: the boughes are diuided toward the top into diuers fmall branches, very brittle and eafie to breake, whereon are placed leaues by couples alfo, one oppofite to ano:her, fomewhat fnipe about the edges, in hape like thofe of the great Myrtle, of an aftringent tafte at the beginning, after fomewhat hot and bitter : among which come foorth fmall towers ftanding vpon long naked footeftalkes, confifting of fower little leaues, of a bright thining purple colour, hating in the middle fome fewe fpots of yellowe: after commeth the fruite fower cornered, not vnlike to the common kinde, of a fpungious fubftance, and a golde yellowe colour, wherein is conteined not red berries, as in the others, but blacke, very like to thofe of Fraxinella, of a fhining blacke colour, like vnto burnifhed horne, which are deuoured of birds when they be ripe, and the rather bicaufe they fallof themfelues out of their husks, otherwife the bitternes of the huskes woulde take awaic the delight.

$$
\text { * The place. }
$$

The firf commeth vp in vntoiled places and among fhrubs, vpon rough bankes and heapes of earth: it ferueth alfo oftentimes for hedges in fieldes, growing among brambles and other thories.

The other forts Carolus Clufuns founde in a woode of Hungarie beyond the riuer Drauts ; and alfo vpon the mountaines of Morauia,2nd other places adiacent.

$$
\text { Ooo0! }
$$


\% Thetime.

The flowers appecre in Aprill: the fruite is ripe in the end of Augult, or in the moneth of Seprember. $*$ The names.

Theophraftus calleth this Shrub ivirvues, and defcribeth it in histhirde booke of the hiftorie of Plants; diuers do falfely reade it Anonigmos. Petrus Crefcentius calleth it Fufanum, bicaufe Spindles be made of the woode heereof, and for that caufe it is called in high Dutch spinaek batm, yet molt of them Danboalu : in lowe Dutch JPapenbout: in Italian Fufano: in French Fufin, and bonnet depreftre : in Englith Spindle tree, Prickwonde, and Pricktimber.

\section{* T he temperature and vertues.}

A This Prub is hurtfull to all things, as Theophraftu writeth, and mamely to Goates: the fruite beereof as he faith, killeth; fo do the leaues and fruite deftroy Goates efpecially, vnlefle they fcoure as well vpwards as downwards; if three or fower of thefe fruts be giuen to a man, theypurge both by vomite and ftoole.

\section{Of the blacke Aller tree. Chap.ror.}

Alnus nigra, fwe frangwla. The blacke Aller tree.

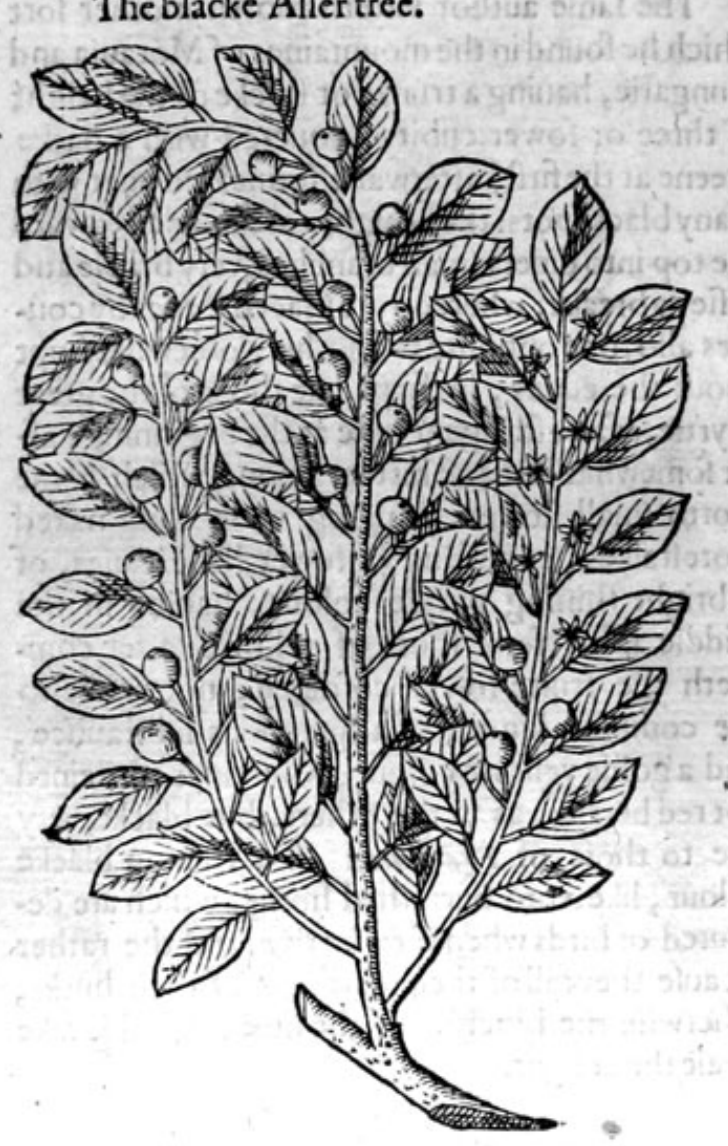

* The defcripsion.
He blacke Aller tree bringeth foorth from the roote ftraight ftalkes, diuided into diuers branches:the outward barke whereof is blacke,and that next to the woode yellow, and giueth a colour as yellowe as faffron: the fub ftance of the woode is white and brittle, with a reddifh pith in the midft : the leaues be like thofe of the Alder tree, or of the Cherrie tree, yet blacker, and a little rounder : the flowers be formwhat white : the fruite are rounde berries, in which appecreth a certain rift or chinke, as though two were inined togither, at the firft greene, afterwards red, and laft of all blacke; in this there be two little ftones : the roote runneth along on the earth.

$$
\text { * The place. }
$$

The Aller tree groweth in moift woods and copfes; I found great plêtie of it in a wood a mile from Iflington, in the way from thence toward a fmall village called Harnfey, lying vpon the right hand of the way; \& in the woods at Hampiteed neete London, and in moft woods in the parts about London.

\section{*. The time.}

The leaues and flowers appeere in the beginning of the fpring, and the berries in Autumne.

$$
\text { * The names. }
$$

This Thrub is called Alnus nigra, or blackeAlder, and others Frangala rather: Petrus Crefcenttus nameth it Auornus; in low Dutch 9 parken. bout, and oftentimes jibilbutt, bicaufe boies make for themfelues arrowes heerof: in high Durch ff atiliatim : it is called in Englinh Aller tree, and of dituers Butchers Pricke tree.

The inner barke of the Aller tree, is of a purging and dry qualitic 
The inner barke heerof is sfed of diuers countrimen, who drinke the infufion thereof when they $\mathbf{A}$ woulde be purged: it purgeth thicke flegmatike humours, and alfo cholericke, and not oncly by the ftoole, but many times alfo by vomite, not without great trouble and paine to the ftomacke: it is therefore a medicine more fit for clownes, then for ciuill people, and rather for thofe that feede groflely, then for daintic people.

There be others who affirme that the dried barke is more gentle, and caufeth leffer paine: for the B greenc bark (fay they) which is not yet dried, containeth in it a certaine fuperftuous moifture, which caufeth gripings and vomitings, and troubleth the ftomacke.

The fame barke being boiled in wine or vineger, maketh a lotion for the tooth ach,it is alfo com- C mended againft fcabs and filthines of the skin.

The leaues are reported to be good fodder for oxen, efpecially for kine, and to caufe them to D yeeld good ftore of milke.

\section{Of the Seruice tree. Chap.io2.}

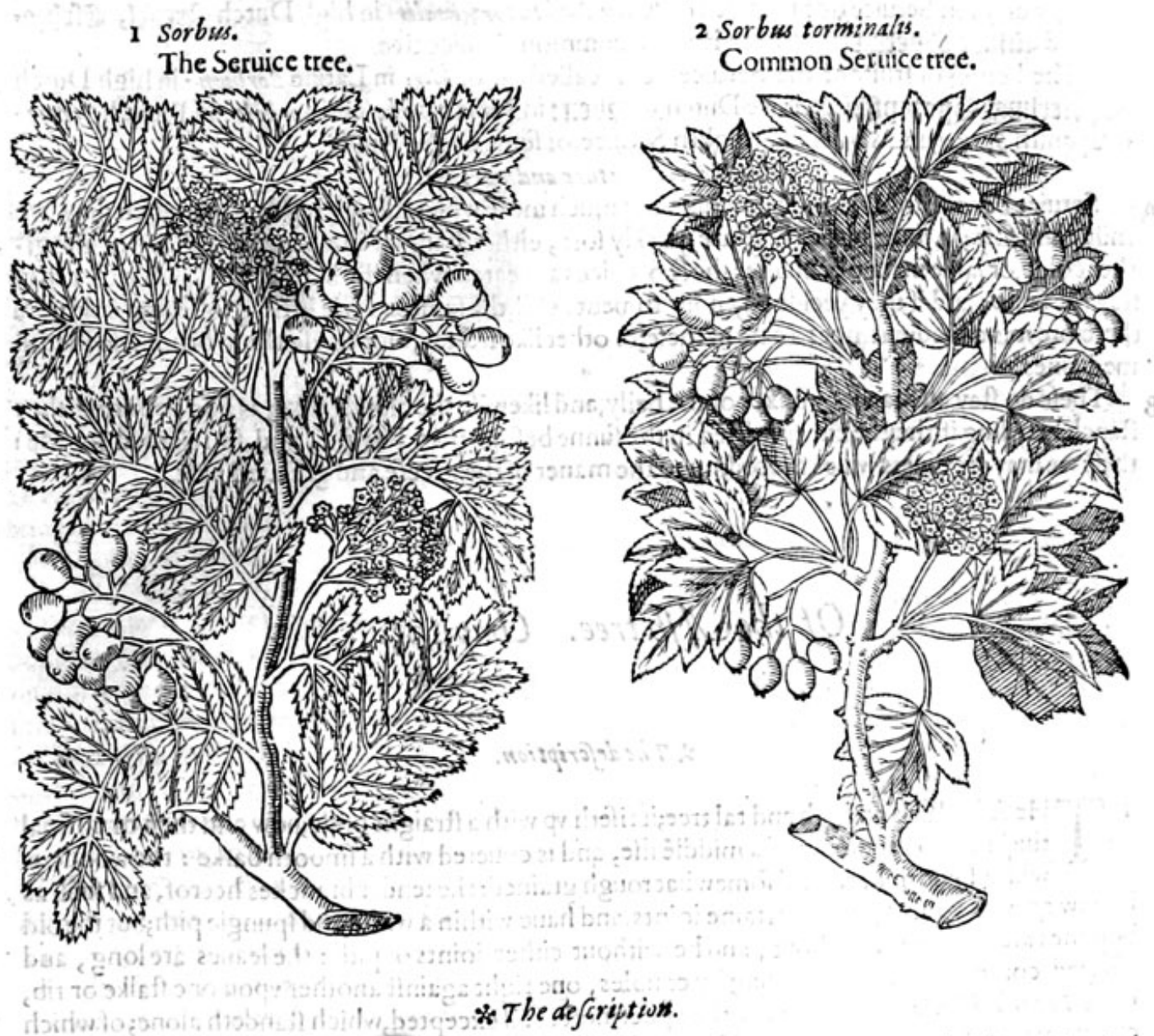

17 He Seruice tree groweth to the height and bignes of a great tree, charged with many great 1 armes or boughes, which are fet with fundric finall branches, garnifhed with many gieat leaucs, fomewhat long, like thofe of the Afh: the flowers are white, and ftande in clutters, which turne into fmall browne berries, fomew hat long; which are not good to beeaten viteration. haue lien a while, and vntill they be foft like the Medlar; whereunto it is like in talte 2 The 
$\therefore$ The defcription.

2 The common Seruice tree groweth likewife to the height of a great tree, with a ftraight bodie, of a brownifh colour, full of tranches, fet with long difplaied leaues like the former, fauing that they are broader, and not fo long : the flowers are white, and grow in tufts; which being fallen, there come in place thereof fmall round berries, browne vpon one fide, and reddin towards the funne, of an vnpleafant tafte in refpect of the former : in which are contained little blackifh kernels. * The place.

Thefe trees are found in woods and groues in moft places of England. There be many fmal trees there of in a little woode a mile beyond Iflington from London : in Kent it groweth in greataboun. dance, efpecially about Southfleete, and Graues end.

They flower inMarch, and their fruite is ripe in September. * The names.

The firft is called in Greeke ori, and oun: in Latine Sorbus : in high Dutch Spetwerbaum : in low Dutch Sozbenboam : in French Cormier : in Englifh Seruice tree, and of fome after the Latines Sorbe tree.

The common Seruicetree is named of Plinie Sorbus torminalis : in high Dutch areftel, Erctho. [el, and dilaer Ðperinerbaum: in Englifh common Seruice tree.

The berries or fruite of the Sefuice tree is called bsy, or ojov: in Latine Sorbum : in high Dutch Speierling, pozopffel: in lowe Dutch ofozen: in Italian Sorbe, and Sorbole: in French Corme: in Spanith Seruas, and Sorbas: in Englifh Seruice, of fome Sorbe Apple.

$*$ The temperature and vertues.

A Seruice berries are colde and binding; and much more when they be harde, then when they are milde and foft; in fome places they are quickly foft, either hanged in a place which is not altogither colde, or laide in haie or chaffe : thofe Seruices are eaten when the belly is too foluble, for they ftay the fame; and if they yeeide any nourifhment at all, the fame is verie little, groffe, and cold; and therefore it is expedient not to eate of thefe, or other like fruites, nor to vfe them otherwife then in medicines.

B Thefe do ftay all maner of fluxes of the belly, and likewife the bloudy flixe; as alfo vomiting :they ftanch bleeding if they be cut and dried in the funne before they be ripc, and fo referued for vie: thefe we may vfe diuers waies according to the maner of the greefe and greeued part.

\section{Of the Afh tree. Cbap.103.}

* Thedefription.

I THe Afh alfo is an high and tal tree; it rifeth vp with a ftraight body;now and then of nofmal thiekneffe, commonly of a middle fife, and is couered with a fmooth barke : the woode is white, fmooth, hard, and fomewhat rough grained: the tender branches heerof, and fuch as be new growen vp are fet with certaine ioints, and haue within a white and pungie pith;but theold boughes are woodic throughout, and be without either iointsor pith : the leaues are long, and winged, confifting of many ftanding by couples, one right againft another vpon one ftalke or rib,

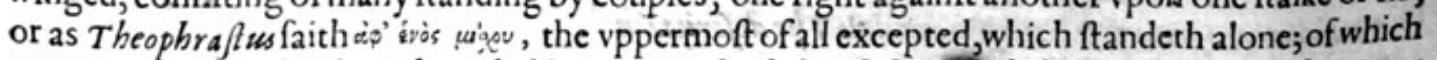
cuery particular one is long, broade, like to a Baic leafe, but fofter, of a lighter greene, without any fweete fmell, and nicked round about the edges : out of the yoonger fort f the boughes hard to the fetting on of the leaues, growe foorth hanging togither manylong, narrow and flat cods, as ic were like almoft to diuers birds toongs, wherein the feed is perfited, which is of a bitter tafte: the rootes be many, and grow deepe in the ground. 
Fraxinus.

The Afh tree.

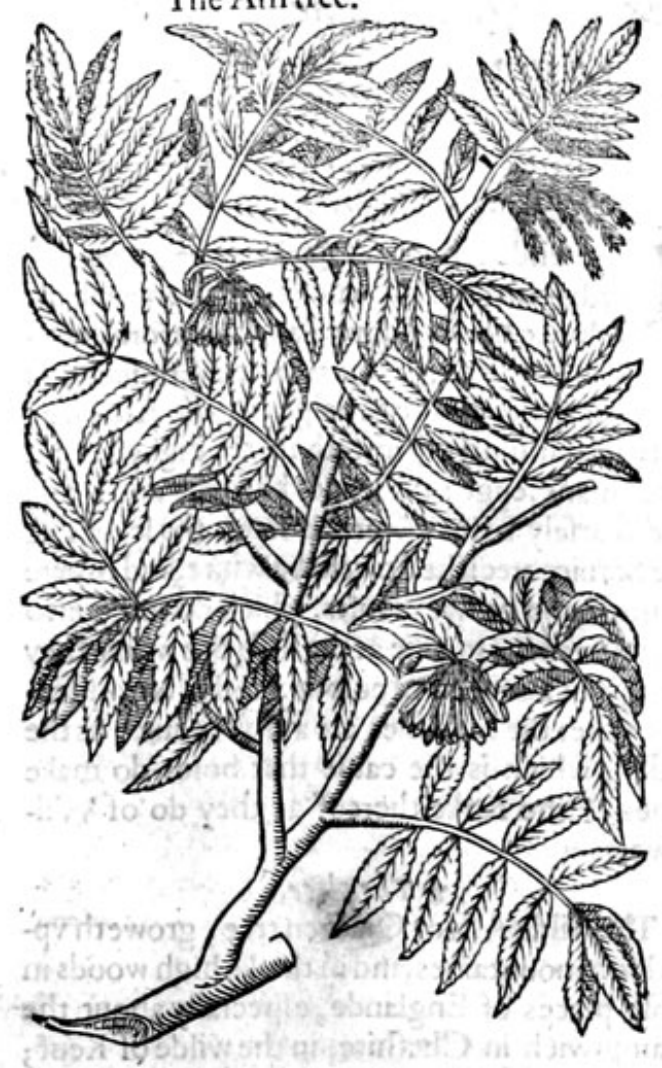

\$ 7 be place.

The An doth better profper in moift places, as about the borders of Meadowes, and riuer fides, then in dry grounds.

$$
\text { * The time. }
$$

The leaues and keics cone foorth in Aprill and Maie, yet is not the feede ripe before the fall of the leafe.

$$
\text { * The names. }
$$

This tree is called in Grceke undia: and of diuers $\mu$ ìie: in Latine Fraxinus : in high Ditch efcbernbaum, Efchernjoltz, and stewter. cbern:in low Durch ERTben, and Effebenbon: in Italian Fraßsino: in French Frefne: in Spanifh Frefno,Fraxino, and Freixo: in Englifh Afh tree.

The fruite like vnto cods is called of the Apothecaries Lingua Awis, and Lingua pafferina: a main may name it in Greeke ìpribign worer : yet fome woulde have it called Orneoglogfum : others make Ornus or the wilde Afh to be Orneoglofium. it is termed in Englifh Afh keies, and of fome Kitekeies,

\section{* The temperature and vertues.}

The leaues and barke of the Afh tree are drie, A and moderately hot; the feed is hot and drie in the fecond degree.

The iuice of the leaues, or the leaues them- B felues being applied or taken with wine, do cure the bitings of vipers, as Dio/corides faith.

The leaues of this tree are of fo great a vertue againft ferpents, as that the ferpents dare not be C fo bolde as to touch the morning and euening fhadowes of the tree, but fhunneth them a farre off, as $P$ liny reporteth in his 16 .book $\mathrm{I}$ 3.chap. He alfo affirmeth that the ferpent being penned in with boughes laide rounde about, will fooner runne into the fire, if any be there, then come neere to the boughes of the Afh; and that the Afh doth flower before the ferpents appeere, and doth not caft his leaues before they be gone againe.

We write (faith be) vpon experience, that if a fire and a ferpent befet within the circle of the D boughes, the ferpent will fooner runne into the fire then into the boughes. It is a woonderfull curtefie in nature that the Afh fhould tlower before thefe ferpents appeere, and not caft his leaues before they be gone againe.

Both of them, that is to fay, the leaues and the barke, are reported to ftop the belly ; and being $\mathrm{E}$ boiled with vineger and water, do ftay vomiting, if they be laide vpon the ftomacke.

The leaues and barke of the Afh tree, boiled in wine and drunke, do open the ftoppings of the $\mathrm{F}$ liuer and fpleene, and do greatly comfort them:

Three or fower leaues of the Afh tree taken in wine ech morning from time to time, doth make G thofe leane that are fat, and keepeth them from feeding, which do begin to waxe fat.

The feede or Kitekeies of the Afh tree prouoke vrine, increafe naturall feede, and firreth vp bo- $\mathrm{H}$ dily luft, efpecially being powdred with nutmegs and drunke.

The woode is profitable for many things being exalted by Homers commendations, and $\mathrm{Achil}$-I lesfpeare, as Plinie writeth. Thefhituers or fmall peeces there of, called in Greeke $\pi$ prtiputu, being drunke, are faide ro be pereicious and deadly, as Diofcorides affirmeth.

The Lie which is made with the afhes of the barke cureth the white fcurffe, and fuch other like $\mathrm{K}$ roughnes of the skin, as $r$ ling teftifieth.

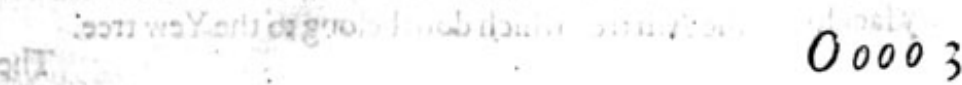




$$
\begin{gathered}
\text { Of the wilde Afh otherwife called Q nickbeame, } \\
\text { or Quicken tree. Chap.104. }
\end{gathered}
$$

Sorbus fylueft ris, fowe fraxinus Bubula.

The Quicken tree, wilde Afhe, or wilde Seruice tree.

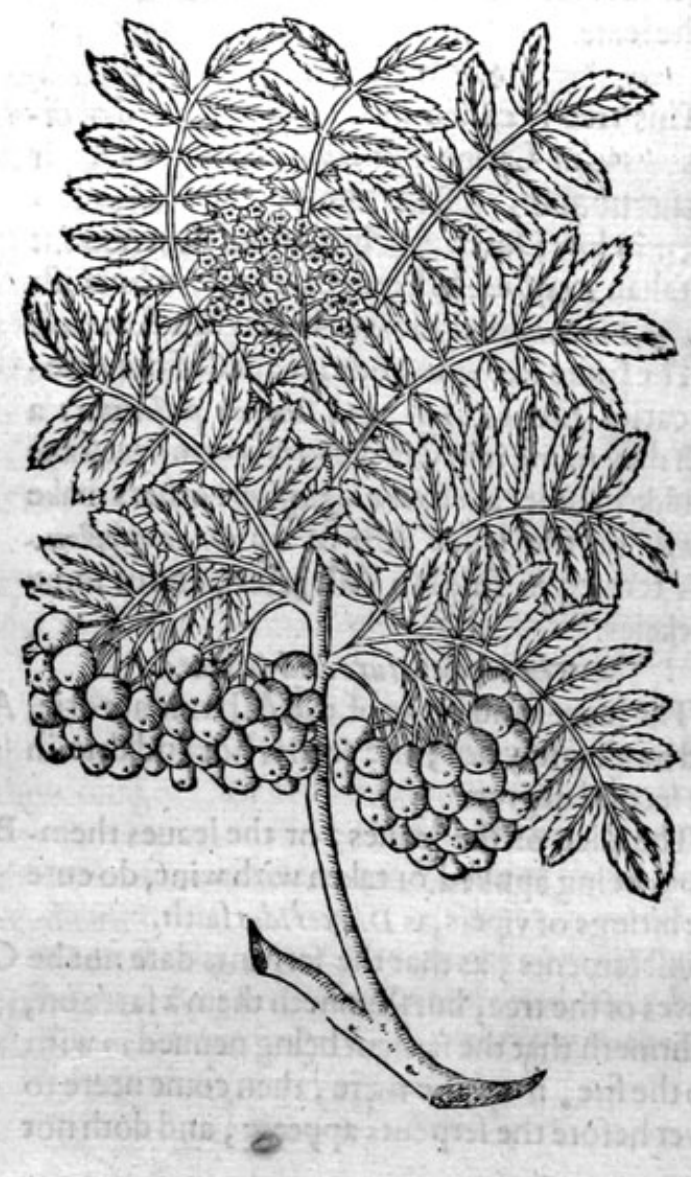

* The defcription.

7 He wilde Afhe, or Quicken tree, Pena fetteth foorth for the wilde Seruice tree, which I thinke he never fawe, and therefore deferueth the leffe blame: this tree groweth feldome or neuer to the ftature \& height of the Afh tree; notwithftanding it groweth to the bigneffe of 2 great mans legge : the leaues be great and long, and fcarfely to be difcerned from the leatues of the Seruice tree: the flawers be white, and fweete of fmell, and growe in tufts, which do turne into round berries, greene at the firft, but when they be ripe of a deepe red colour, and of an vnplea. fant tafte: the branches are as full of iuice as the Ofiar, which is the caufe that boies do make pipes of the barke thereof as they do of Willowes.

$$
\text { * The place. }
$$

The wilde Afh or Quicken tree, groweth vpon high mountaines, and in thicke high woods in moft places of Englande, efpecially about the Namptwich in Chefhire, in the wilde of Kent; in Suffex and diuers orher places.

$$
\text { * The time. }
$$

The wilde Afh flowreth in Maie, and theberries are ripe in September.

$$
\text { * The nemes. }
$$

The Latines call this tree Ornus, and often. times Sylaeftris fraximes, or wilde Afh, and it is alfo Fraxini (pecies, or a kinde of Alh: for the Gracians (as not oncly Plinie writeth, but alfo $T$ heophraftus) haue made two kindes of $A$ h, the one high and tall, the other lower; the high and tall one is Fraximus vulgaris, or the common Afh, and the lower Ornus, which alfo is named ipesyr uenie, or Montand Fraxinus, mountaine Afh; as the other menwi, or fielde Afh, which is alfo' named Bovuenia, or as Gaza tranflateth it, Bubula Fraxinus, but more truely Magna Fraxinu, or great Afh, for the fyllable Boü is a figne of bigneffe. This Ornus or great Afh is named in high Dutch @albaum: in lowe Dutch Dauereficbent, or Duerefrben, of diuers Duaiffer : in French Frefne fanuage : in Englifh wilde Afh, Quicken tree, - Quickbeame tree, and Whicken tree: Matbsolus maketh this to be Sorbmu fylueftris, or wilde Seruice tree.

\section{* The temp'rature and vertues.}

A Touching the faculties of the leates, barke or berries, as there is nothing found among the olde, fo is there nothing noted by the later writers, but Plsme feemeth to make this wilde Afh like in faculties to the common Afh: for in his 16 .booke 13 .chapter, where he writeth of both the Afhes he faith, that the common Afh is Crifpa, and the Mountaine Aifh Spifa. Forthwith he addeth this, The Grecians write, that the leaues of them do kil cattel, and yet hurt not thofe that chew their cud, which the olde writers haue noted of the Yew tree, and not of the Afh tree.Plinie was deceiued

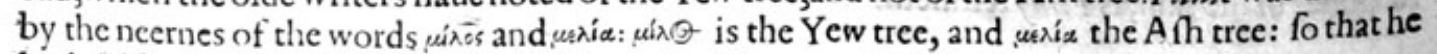
hath fallly attributed that deadly facultic to the Afh tree, which doth belong to the Yew tree. 
The leaves of the wilde Afh tree boiled in wine, are good againft the paine in the fides, and the B ftopping of the liver, and affwageth thobellies of thofe that haue the tympanie and dropfie.

Benedictins Curtins Symprofismo, is deceived in the hiftorie of Orwis, when he thinketh out of $\boldsymbol{V}$ ir- $C$ gils Georgickes that Orwes hath the flower of the Peare tree : for out of Virgils verfes no fuch rhing at all can be gathered, for he intreateth not of the formes of trees, but of the graffinge of diuers into others, vnlike and differing in nature, as of. the graffing of the nut tree into the Sttawberie tree; the Apple into the Plane tree; the Beech into the Cheftnut tree; the Pearelinte the wilde Afh, or Quickbeame tree; the Okejnto the Eline tree: and in this refpeet he writeth; that the Plane tree bringeth foorth an Apple; the Beech tree a Cheftnut; the wilde Afh tree bringeth foorth the white flower' of the Peare tree, as it is moft manifeftout of $V$ irgils owne wordes, which ftande in this maner in the fecond booke of his Georgickes.

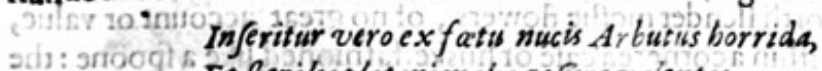

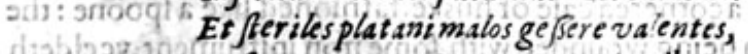

Caftanea Fagos: Ornus incanuit albe

Florepyri, glandémque fues fregere Jub vimis.

Therugged Wilding ftocke is grafted with

-verim A Nut tree fet or impe which tender be,

And Plane tree ftockes, barren for want of pith,

Haue borne exceeding fruitfull apple tree:

And Cheftnut ftockes haue borne of Becch the matts,

The Afh tree ftocke growes hoarie in his feate

With Peare tree flowers or bloffoms which it cafts,

And vnder Elms haue fwine crafhtmafts for meate.

\section{Of Coriars Sumach. Chapios.}

cit : 1 I Rhus Coriaria.

Coriars Sumach.

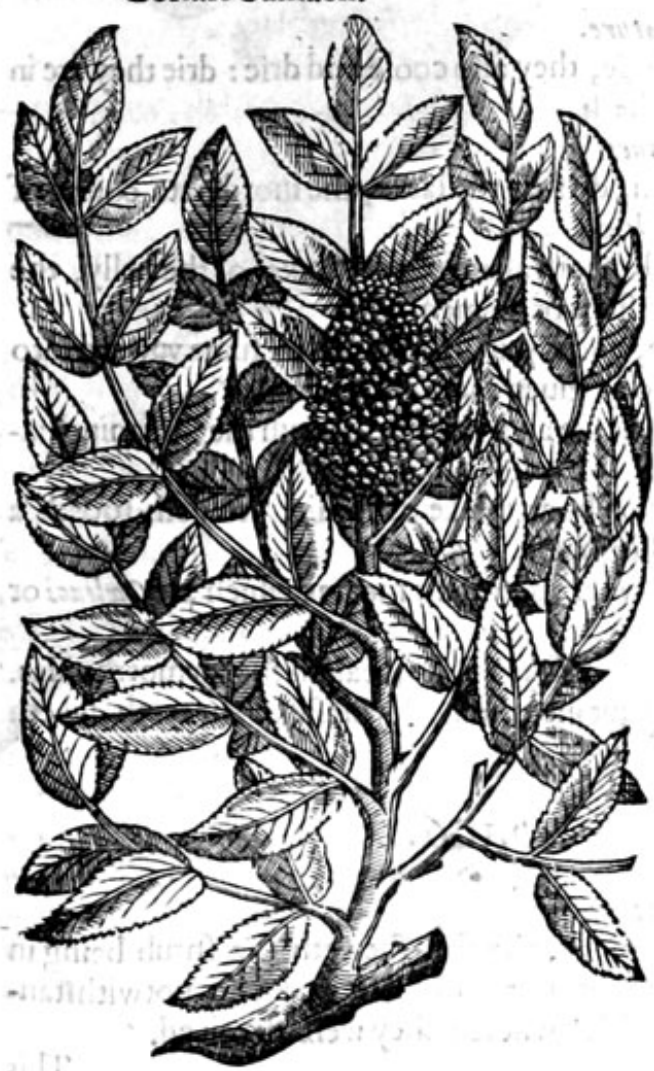

2 Rhus Myrtifolius.

Wilde, or Myrtill Sumach.

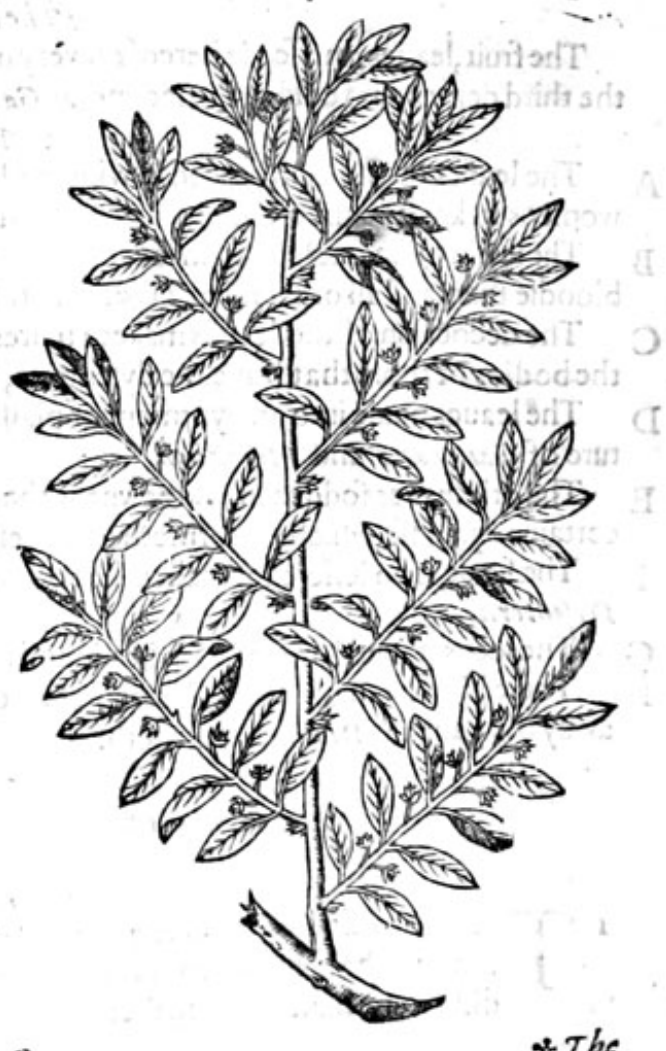

00004 
It flris $*$ The defaription.

I Oriars Sumach growethvp vnto the height of a hedge tree, after the maner of the

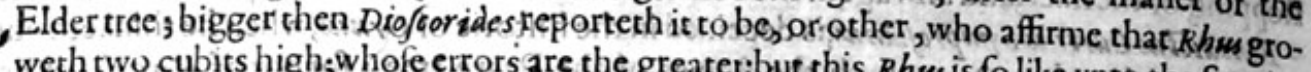
weth two cubits high; whofe errors are the greater: but shis $R$ hus is fo like vnto the Seruice trec in thape and maner of growing, that it is hard to know one from the other; but that the leances are foft and hairic, hauing a red finewe or rib thorow the midft of the leafe : the flowers growe with the leaues vponlong ftems chufering togither like cats taile, ar the catkins of the nut tree, but grea. ter, and of a whitifh greene colour: after which come clufters of rounde berries, growing in bun,
ches like grapes.

2 Plinie his Sumach,or the Sumach of $p$ linies defcription, groweth like a fmall hedgetrec, hauing many flender twiggie branches, garnifhed with little leaues like Myrtus, or father like rhe leaues of the Iuiube tree; among which come foorth llender moffie flowers, of no great account or value, which bring forth fmal feeds, inclofed within a cornered cafe or huske, fathioned like a fpoone : the trunke or body of both thefe kinds of Sumach being wounded with fome iron inftrument,yeeldeth a gum or liquor. $\%$ T he place.

Sumach groweth as Diofcorides faith, in ftony places: it is found in diuers mountaines and woods in Spaine, and in many places on the mount Apennine in Italy, and alfo necte vnto Pontus. Archigenes in Galen in the 8. booke of medicines according to the places affected, fhewethithat it groweth in Syria, making choice of that of Syria.

* The time.

The flowers of Sumach come foorth in Iuly, the feed with the berries are fipe in Autumne. *.T The names.

This is called in Greeke poũs : Rhus faith Plinie hath no Latine name; yet Gaza after the fignification of the Greeke worde, faineth a name, calling it Fluids: the Arabians name it Swmath: the Italians Somacho: the Spaniards Sumagre: in low Dutch by contracting of the word they cal it Bmack, or Sumach: in Englifh Sumach, Coriars Sumach, and leather Sumach: the leaues of the fhrub be called poüs Bupsosi

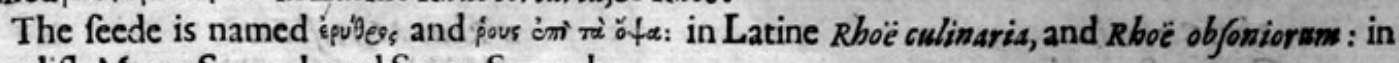
Englifh Meate Sumach, and Sauce Sumach.

\section{* The temperature.}

The fruit, leaues, and feede hereof do very much binde, they alfo coole and drie: drie they are in the third degree, and cold in the fecond, as Galen teacheth.

\section{* The vertues.}

A The leaues of Sumach boyled in wine and drunken, do ftop the laske, the inordinate courfe of womens fickneffes, and all other inordinate iffues of blood.

B The feede of Sumach eaten in fauces with meate, ftoppeth all manner of fluxes of the belly, the bloodie flixe, and all other iffues, efpecially the white iffues of women.

C The decoction of the leaues maketh haires blacke, and is put into ftooles to fume vpward into the bodies of thofe that h aue the dyfenterie, and is to be giuen them alfo in drinke.

D The leaues made into an oyntment or plaifter with honie and vineger, ftaieth the fpreading nature of Gangrana and Pterygivom.

E The drie leaues fodden in water vntill the decoction be as thicke as honie, yeeldeth foorth a certaine oylineffe, which performeth all the effects of Licium.

F The feede is no leffe effectuall to be ftrowed in powder vpon their meates which are Caliacior Dy fenterici.

G The feeds pouned, mixed with honie and the powder of Oken coles, healeth the Hemorrhoides.

H There iffueth out of the fhrub a gum, which being put into the hollowneffe of the teeth, taketh away the paine, as Diof corides writeth.

\section{Of red Sumach. Chap.Io6.}

$*$ The defcription.

17 Hefe two figures are one and the felfefame plant, the firft theweth the fhrub being in

1 flower : the other when it is full flowred with the fruit growen to ripeneffe, notwithftanding fomc haue deemed them to be of two kindes, wherein they were deceiued. 


\section{BHSTORAE OF PLANTS.}

This excellent and moft beautifull plantCogsygriabeing reputed of the Italians and the Venetians foralkinde of Rheis or Sumacb; bicaufe it is vifd for the fame purpofés whereto $R$ hros ferueth and therein doth far excell it) is an hedge plant growing not aboue:the height of fower or fiucth bits, hauing tough and pliant italks and twiggie branghtres jike vito Oziers, of a browne colour. The

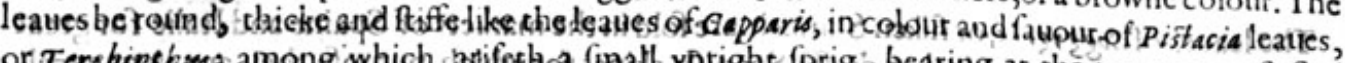

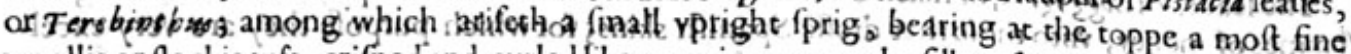
woollie or flockie tuft, crifpedand curled like a curious wrought filken fleece, which curleth and

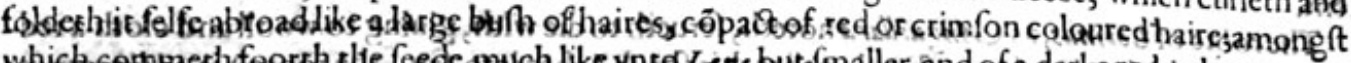

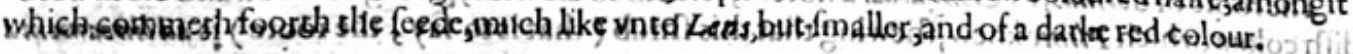

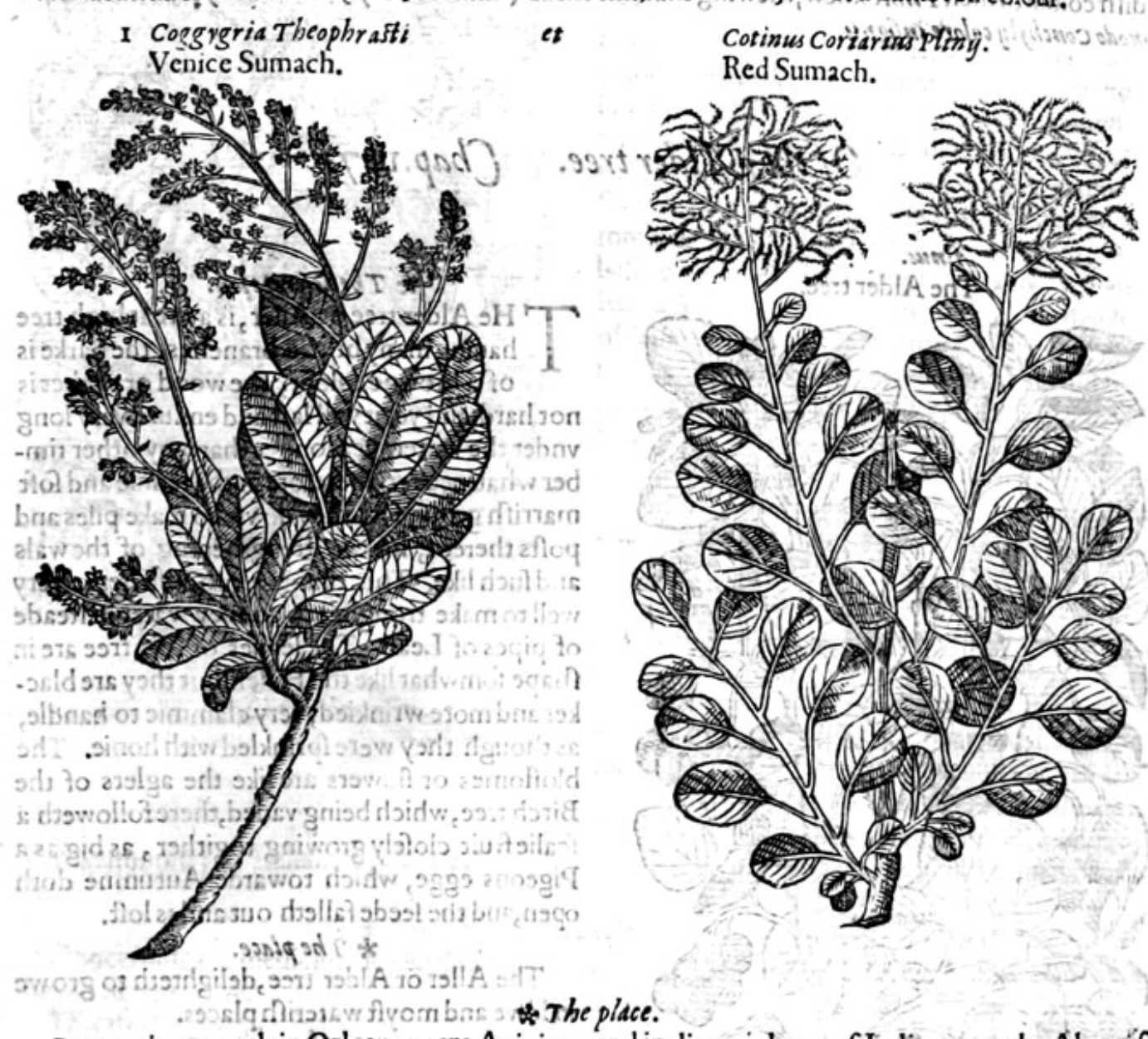

Coggygria growech in Orleans neere Auinion, and in diuers places of Italie, vpon the Alpes of Hiftria, and many other places. Ir growethion moft of the hils of France, in the high woods of the vpper Pannonia or Auftria, and alfo of Hungaria and Bohemia.

They flower and floutin for the moft partin Iuly. * The time.

The firft is called Coggrgria and Coccygria : in Englifh Venice Sumach, or Silken Sumach; of Plinie Cotinus in his fixteenth booke eighteenth chapter. There is (faith he) on mount Apennine a fhrub, which is called Cotinus ad lineaneenta modo Conchyly colure infignis, and yet xánves is Oleaffer, or Olea fylueftris, the wilde Oliue trce, from which this fhrub doth much differ; and therefore it may rightly be called Cotinus Coriaria : diuers would haue it named Scotinus, which name is not fouddin any of the oldd writers. The Pannonians do call it Farblanf. It is alfo thought that this Shrub is Coggrgria Pling, of which in his 13.booke 2 2.chapter he writeth in thefe words, Cog gygris is alfo tike tor nedsintleafe, not fogreat; it hath a propertie to lofe the fruit by the downe, which thing happeneth to no other tree. 


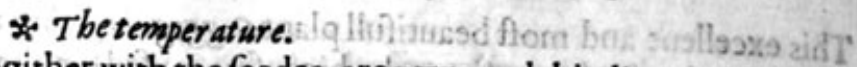

The leaues and flender branches togither with the feedes, arevery much binding, cold and drie as the other kindes of Sumach are.

* The vertues,

The leaues of Coggygria, or filken Sumach,are fold in the markets of Spaine and Italie for great fummes of money, vnto thofe that dreffe Spanifh skins; for which purpofe they are very excellent.

The roote of Cotinus, as Anguillara noteth, ferueth to die with, giuing to wooll and cloth a red. difh colour, which Plinie knew, thewing that thishibub (that isto fay, the roote) is adlineancents modo Conchyly colore in fignis.

$$
\begin{aligned}
& \text { (2) Jukito? }
\end{aligned}
$$

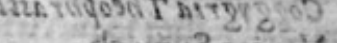

$$
\begin{aligned}
& \text { Of the Aldertree. Chap.io7. }
\end{aligned}
$$$$
\text { dsultite sinist. }
$$

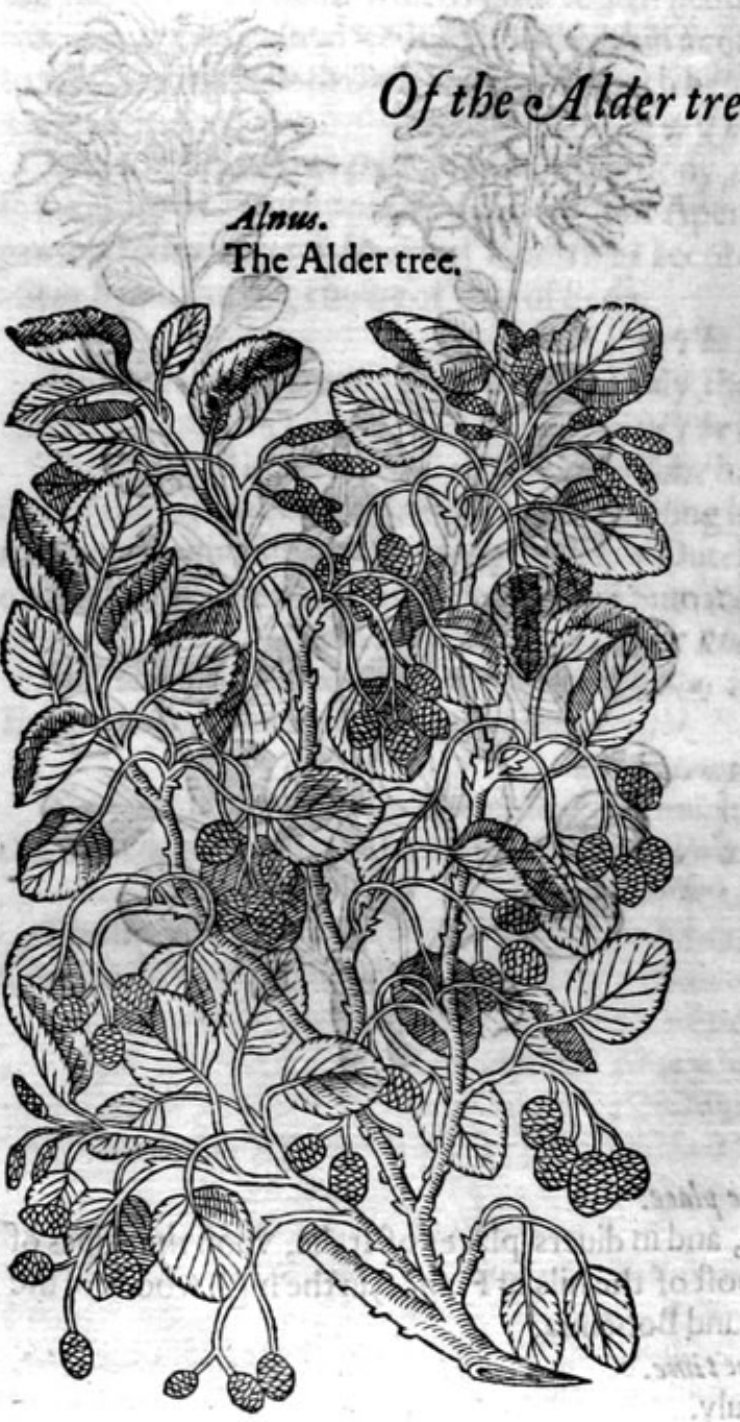

* Thedefoription.

$T$ He Alder tree or Aller, is a great high tree hauing many brittle branches, the barke is of a brownecolour, the wood or rimber is not hard, and yet it will lait and endure very long vnder the water, yea longer than any other timber whatfoeuer : wherefore in the fennie and foft marrifh groundes, they dovfe to make piles and pofts thereof, for the ftrengthening of the wals and fuch like. This timber doth alio ferue very well to make troughes to conuey water in fteade of pipes of Lead. The leaues of this tree are in Thape fomwhat like the Hafell, but they are blacker and more wrinkied, very clammie to handle, as though they were fprinkled with honie. The bloffomes or flowers are like the aglets of the Birch tree, which being vaded, there followeth a fcalie fruit clofely growing togither, as big as a Pigeons egge, which towarde Autumne doth open, and the feede fallech out and is loft. * The place.

The Aller or Alder tree, delighteth to growe in lowe and moyft waterifh places. \& T be rime.

The Aller bringeth forth new leaues in Aprill, the fruit whereof is ripe in September.

$$
\text { * Thenames. }
$$

This treeis called in Greeke xańlea: in Latine Alnus, Petrus Crefcentius nameth it Amedanus:

it is called in high Dutch ertenbaum and Ellernbaum: in lowe Dutch Etferi and Elfen boom: in Italian $A l n o:$ in French Aalne : in Englifh Alder and Aller.

$$
\text { *. The temperature. }
$$

The leaues and barke of the Alder tree are cold,drie and aftringent.

$$
* \text { The vertues. }
$$

The leaues of Alder are much vfed againft hot fwellings, vlcers, and all inward in flammations, efpecially of the Almonds and kernels of the throte.

The barke is much vfed of poore countrie diers, for the dying of courfe cloth, caps, hofe, and fuch like into a blacke colour, whereunto it ferueth very well. 


\title{
HISTORIE OF PLANTS.
}

\section{Of the Birchtree. Chap.108.}

Betula.

The Birch tree.

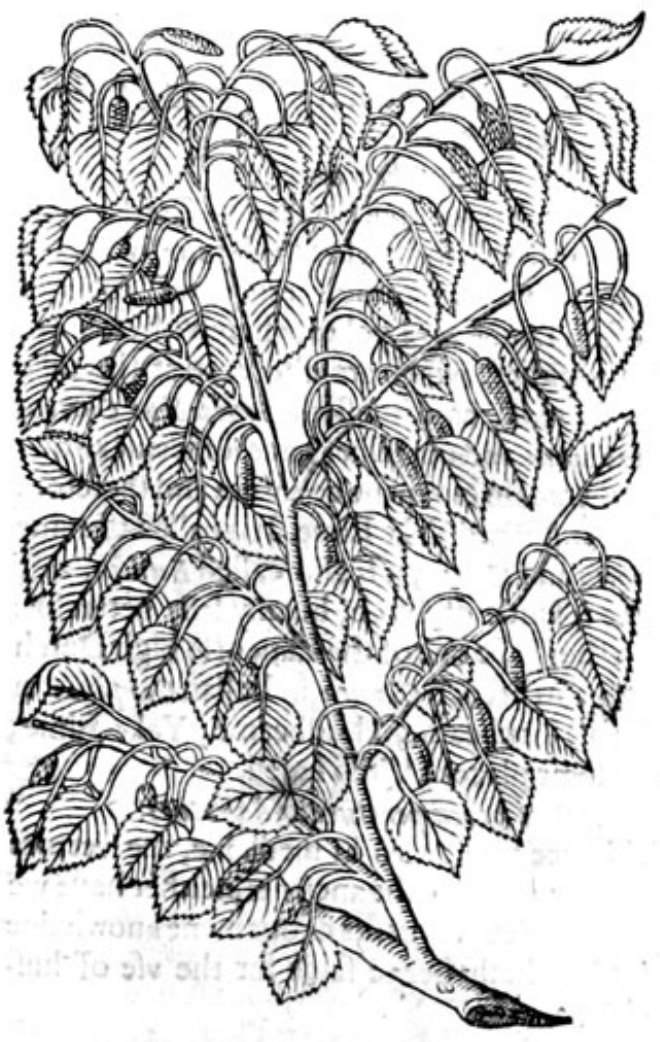

\author{
* The defcription.
} \rceil $\begin{aligned} & \text { He common Birch tree waxeth likewife a } \\ & \text { great tree, hauing many boughes befet }\end{aligned}$ with many Imall rods or twigs, very limber and pliant: the barke of the yoong twigs and braunches is plaine, fmooth, and full of $f_{a p}$, in colour like the Cheftnut; but the rinde of the bodie or trunke is harde without, white, rough, and vneeuen, full of chinkes or creuices : vnder which is founde another fine barke, plaine fmooth, and as thinne as paper, which hee retofore was vfed in fteede of paper to write vpon, before the making of paper was knewne : in Ruffia \& thofecolde regions, it ferueth in fteede of Tiles and flate to couter their houfes witha!l: this tree beareth for his flowers certaine aglets like the Hafell tree, but fmaller, wherein the feed is contained.

* The place.

This common Birch tree groweth in woods, and mountaines, in moft places of England. * The time.

The catkins or aglets do firt appeere, and then the leaues, in a Aprill or a little later. * The names.

Tbeophraft is calleth this tree in Greek onuifax diuers muis, others muìs: it is named in Latin Betule: diuers alfo write it with a double ll Betulla,as fome of Flinies copies haue it : it is called in high Dutch 2 surckenbaum : in lowe Dutch Zerckenboom : in Italian Betwla, by them of Trent Bedollo: in French Bowlean : in Englifh Birch tree.

\section{* The temperatureand vertues.}

Concerning the medicinable vfe of the Birch tree, or his parts; there is nothing extant either in A the old or new writers.

This trẹe faith Plinie in his 16 booke 1 8.chapter, Mirabili candore $\sigma$ tenwitate terribilismagi- B fratumom virgis : for in times paft the magiftrates rods were made heerof: and in our time alfo the fcholmafters and parents do terrifie their children with rods made of Birch.

It ferueth well to the decking vp of houfes, and banquetting roomes, for places of pleafure, and $\mathrm{C}$ beautifying the ftreetes in the croffe or gang wecke, and fuch like.

\section{Of the Hornebeame, or Hard beame tree. Chap.109.}

\section{* The de cription.}

B Etulws, or the Hornebeame tree groweth great, \& very like vnto the Elme, or wich Hazell tree, hauing a great body: the wood or timber wherof is better for arrowes and hafts, pulleies for mils, and fuch like deuifes, then Elme or Wich Hazell; for in time it waxeth fo hard, that the toughnes and hardnes of it, may be rather compared vnto horne then vnto wood, and therefore it was called Hornebeame, or Hardbeame : the leaues heereof are like the Elme, fauing that they be tendercr: among thofe hang certaine triangled things, vpon which be rounde knaps, or little heads of the bignes of Ciches, in which is contained the fruite or feede : the roote is ftrong and thicke. 
Betulus, fute Carpinus.

The Hornebeame tree.
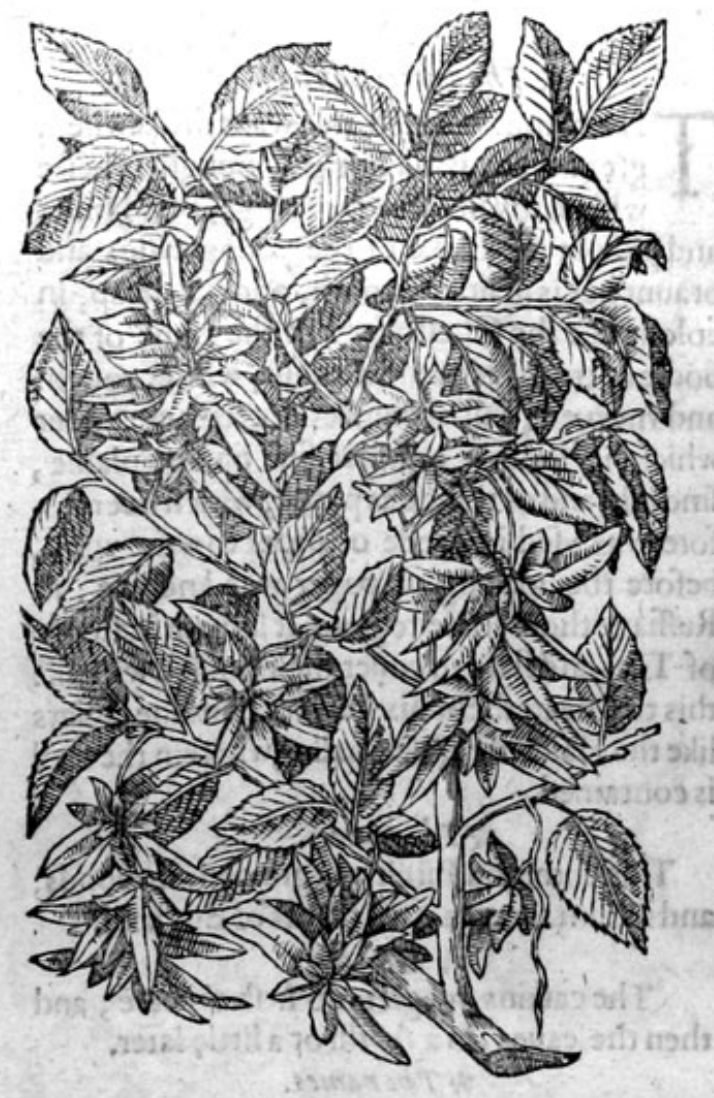

Anestint
* Theplace.

Betulus or the Hornbeame tree groweth plen. tifully in Northamptonthire, alfo in Kent by Grauefend, where it is commonly taken for a kind of Elme.

\section{* Thetime.}

This tree doth fpring in Aprill, and the feede is ripe in September.

* The names.

The Hornbeame tree is called in Greeke ?via, which is as if you fhould fay Coniugalis, or belonging to the yoke, bicaufe it ferueth well to make Suria of, in Latine Iuga, yokes, wherewith oxen are yoked togither, which are alfo euen ar this time made thereof, as witneffeth Benedictus Curtius Symprofianus, and our felues haue fifficient knowledge thereof in our owne countrie; and therefore may be englithed Yoke Elme. It is called of fome Carpinus and $Z$ ugia; it is alfo called Betulus, as if it were a kinde of Birch, but my felfe better like that it fhould be one of the Elmes : in high Dutch Ghone: in French Carne: in Italian Carpino: in Englifh Hornbeame, Hardbeame, Yoke Elme, and in fome places Witch hafell.

* The temperature and vertwes.

This tree is not vfed in medicine, the vertues are not expreffed of the ancients, neither haue we any certaine experiments of our owne knowledge more than hath beene faide for the vfe of hufbandrie.

\section{Of the Elme tree. Chapino.}

f . * * * The defoription.

I He firft kinde of Elme is a great high tree, hauing manybranches fpreading themfelues 27. largely abroad : the timber of it is hard, and not eafie to be clouen or cut in funder. The leaues are fomewhat wrinkled and fnipt about the edges, whereupon are fometimes found certaine blifters or bladders, which çontaine a certaine flimie or clammie liquor, wherein is often found fmall wormes; but when the faid liquor hath continued yntill the end of fommer, you fhall find it hardened with the heate of the funne, and congealed like vnto gum. The feede is broad and flat, not much vnlike the feede of the garden Arach. This tree is very common in our countrie of England: the leaues of this Elme are pleafant fodder for diuers fowerfooted beafts, andefpecially for kine and oxen.

2 The fecond kinde of Elme groweth likewife vito a great ftature, with very hard and tough timber, whereof are made arrowes, whecles, mill pullies, and fuch other engins for the carriage of great wvaights and burtbens. The leaues be likewife wrinkled, and fomewhat fnipt about the edges, longer and narrower than the leaues of the common Elme, of a faint greene colour vpon the backe fide, fomewhat thining, and of a good fmell when they oc drie; wherupon there neuer grow any blifters or bladders, neither will the hungrie cattell fo willingly feede thereon as vpon the common Elme, which they will browze very greedily. The feede hereof is very like vnto the former. 
I Vlmis.

The Elme tree.

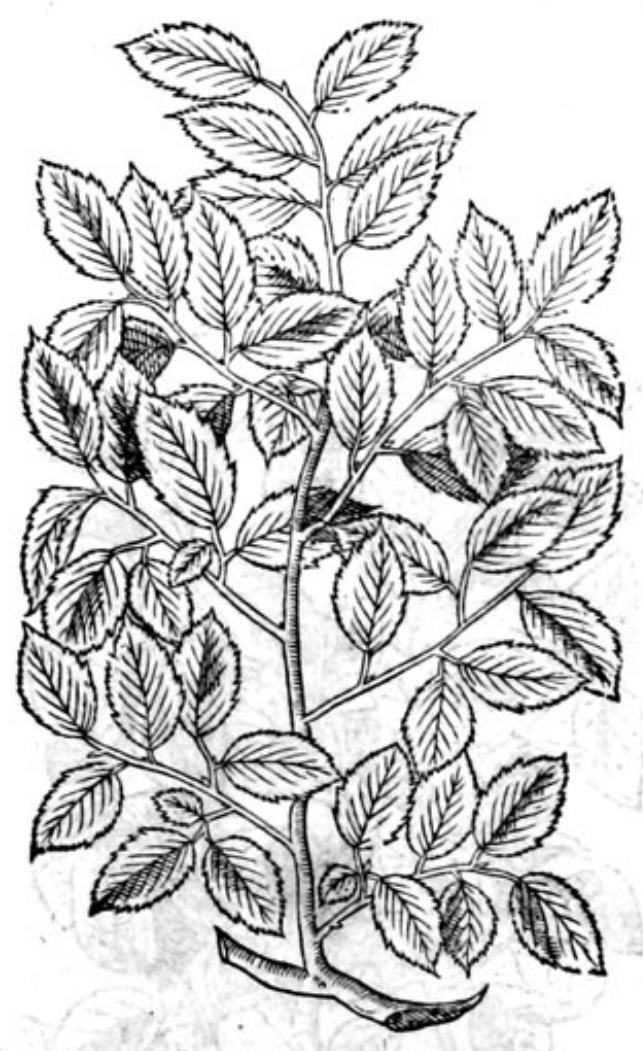

2 Vlmuslatifolia. The Elme with broad leaues.

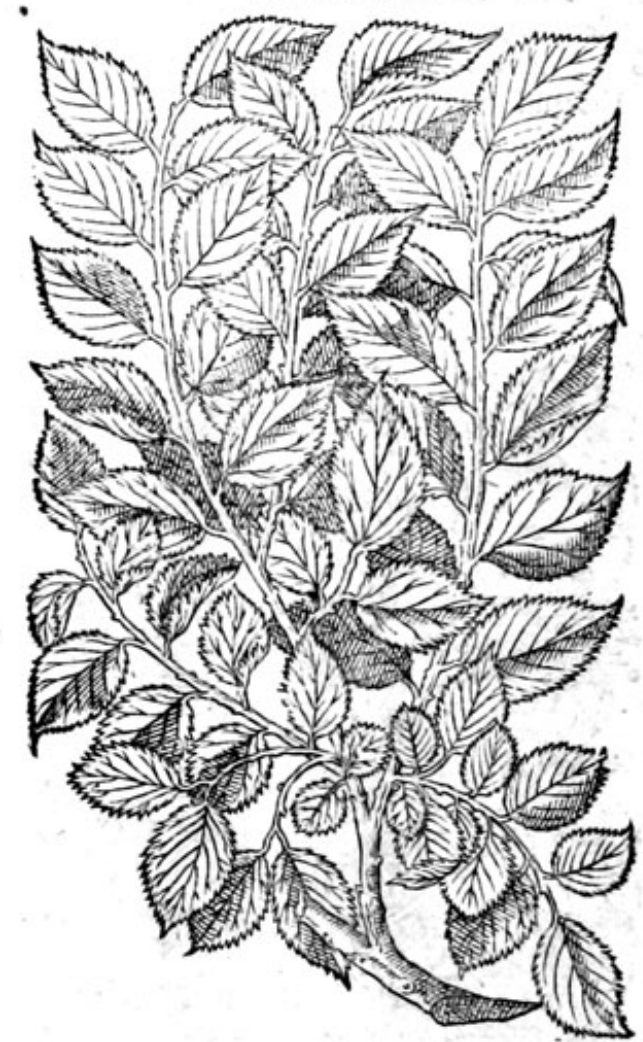

* The place.

The firft kinde of Elme groweth plentifully in all places of England. The feconde groweth in many woods and parks in great plenty, as in a parke belonging to my Lord Treafurer, a mile beyond his Honors place at Waltham, called Thibalds. It groweth alfo in Kent neere South feete, and in many other places.

\section{*. Thetime.}

The feede of the Elme heweth it felfe firft, and before the leaues; it falleth in the end of Aprill, at what time the leaues begin to fpring.

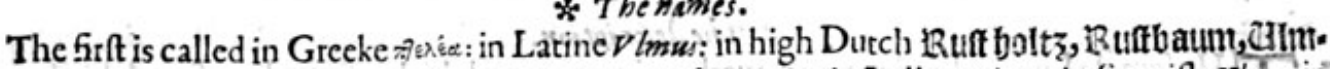
baum : in lowe Dutch Dlmett: in French Orme and Omeau : in Italian Olmo: in Spanifh Vlmo: in Englih Elme tree.

The feede is named by Plinie and Columella Samera. The litele wormes which are found with the liquor within the fmall bladders, be named in Greekezims: in Latine Culices and Muliones.

The other Elme is called by Theophraftus openter \{d, which Gaza tranflateth Montru mus, or mountaine Elme. Colvmella nameth it Vernacula, or 2 oftras Vlmus, that is to fay, Italica or Italian Elme: it is called in lowe Dutch iperteleet, and in fome places foetentcer.

\section{* The temperature and vertwes.}

The leaues and batke of the Elme be moderately bot, with an euident cleanfing facultie; they A haue in the chewing a certaine clammie and glewing qualitie.

The leaues of Elme glew and heale vp greene wounds, fo loth the barke wrapped and fwadled B about the wound like a band.

The leaues being ftamped with vineger do take away fcurffe.

Diofcorides writeth, that one ounce waight of the thicker barke drunke with wine or water pur-D geth flegme. 


\section{THE THIRD BOOKE OF THE}

E. The decoetion of Elme leaues, as alfo of the barke or roote, healeth broken bones very fpeedily,
if they be fomented or bathed therewith.

F The liquor that is found in the blifters doth beautific the face, and fowreth away all fpots,freckles, pimples, fpreading tetters, and fuch like, being applied thereto.

G It healeth greene wounds, and cureth ruptures newly made, being laid on with Spleenwoort,and the truffe clofely fet vnto it.

\section{Of the Line or Linden tree. Chap.III.}

I Tilia famina.

The female Line tree.

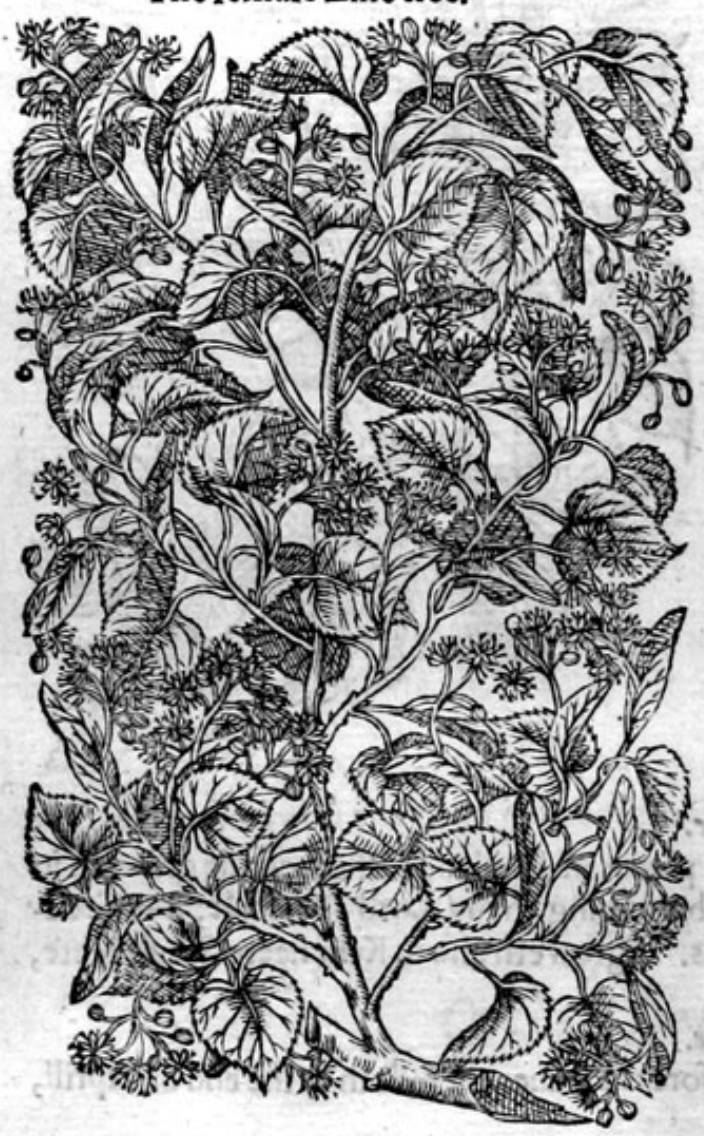

2 Tiliamas. The male Line tree.

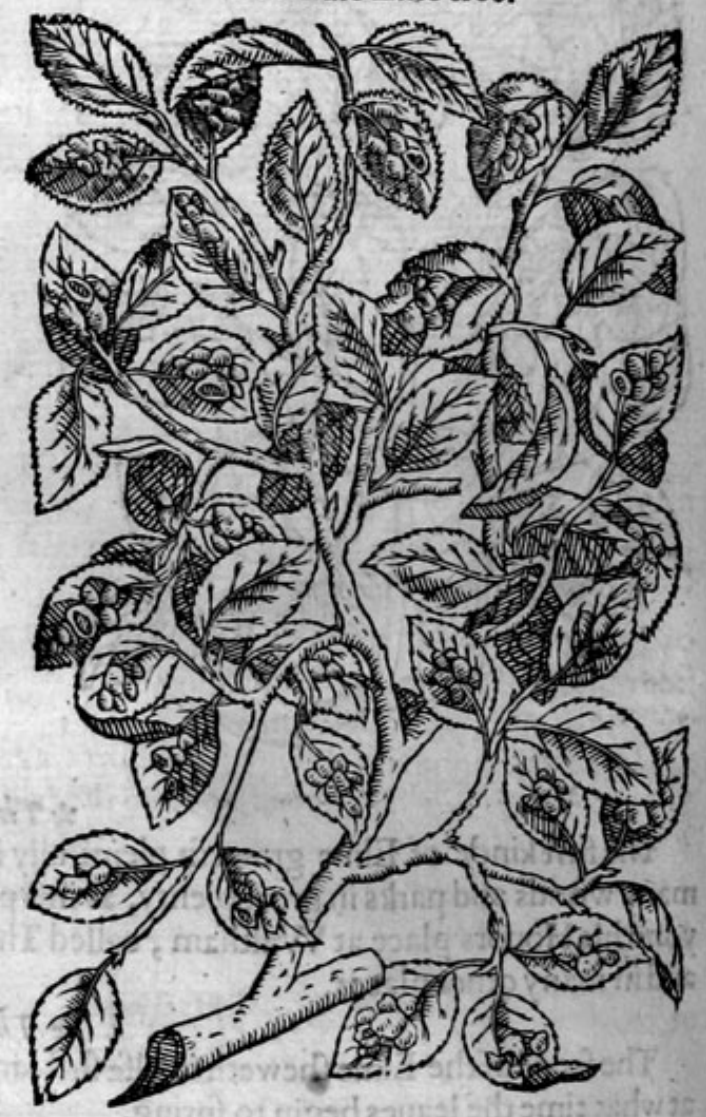

* The defcription.

17 He female Line or Linden tree waxeth very great and thicke, fpreading foorth his branches wide and far abroad, being a tree which yeeldeth a moft pleafant thadow, vnder and within whofe boughes may be made braue fommer houfes and banketring arbors, bicaufe the more that it is furcharged with waight of timber and fuch like, the better it doth flourith. The barke is brownifh, very finooth and plaine on the outfide, but that which is next to the timber is white, moyft and tough, feruing very well for ropes, trafes, and halters. The timber is whitifh, plaine and without knots, yea very foft and gentle in the cutting or handling. Better gunpowder is made of the coles of this wood than of Willow coles. The leaues are greene, finooth, fhining and large, fomewhat fuipt or toothed about the edges. The flowers are verylittle, whitifh, of a good fauour, and very many in number, growing cluftering togither from out of the middle of the leafe, out of which allo proceedeth a fmall whitifh long narrow leafe: there comneth very feldome times any good or fruit of thefe flowers, they are as it were a barren kinde of flowers or chaffe like vnto the huskes of $T$ hla $\beta i$ Creticum, which do very much refemble chaffe. This tree feemeth to bea kind of Elme, and the people in Effex about Heningham (whereas great plenty groweth by the was fides) do call it broad lcafed Elme. 
2 The male Tilia, or Line tree, groweth alfo very great and thicke, fpreading it felfe farre abroade like the other Linden tree: his barke is very tough and pliant, and ferueth to make cordes and halters of. The timber of this tree is much harder, more knottie, \& more yellow then the timber of the other, not much differing from the timber of the Elme tree: the leaues heere of are not much vnlike Iuic leaues, not very greene, fomewhat fnipt about the edges: from the middle whereof come foorth clufters of little white flowers like the former, which being vaded, there fucceed fmall round pellets, giowing cluftering togither, like Iuje berries, within which is cont ained a little round blackirh feede, which falleth out when the berrie is ripc.

$$
\text { * Theplase. }
$$

The female Linden tree groweth in fome woods in Northamptonfhire ; alfo necre Colcheter, and in many places along tt the high way leading from London to Heningham, in the Countie of Effex.

The male Linden tree groweth in my Lord Treafurers garden at the Scrand; and in fundry other places,as at Barnelmes, and in a garden at Saint Katherines neere London:

Thefe trees flower in Maie, and their fruite is ripe in Auguft.

$$
\text { * The vames. }
$$

The Linden tree is called in Grecke pax ie : in Latine Tilia : in high Dutch Linden, and $\mathbf{X}$ fnten. baum: io low Dutch Linoe, and L indenboom: the Italiahs Tilia : the Spaniards Teia : in French Tilet, and Tiliewl : in Englifh Linden tree, and Line tree.

$$
\text { i } 7 \text { betemperature. }
$$

The barke and leaues of the Linden or Line tree, are of a temperate heate, fomewhat drying and aftringent. * The vertues.

The leaues of Tilia boiled in fmithes water with a peece of Alom and alittle hony, cureth the $\mathbf{A}$ fores in childrens mouthes.

The leaues boiled vntill they be tender, and pouned verie fmall with hogs greafe, and the pouder B of Fenugreeke and Linefeed, taketh away hot fwellings and bringeth impoltumes to maturation, being applied thereto verie hot.

The flowers are commended by diuers againft paine of the head proceeding of a cold caufe, $\mathbf{C}$ againft diffines, the Apoplexie, and alfo the falling fickues; and not onely the flowers, bur the diftilled water thereof.

The leaues of the Linden tree (faith $T$ heophraftw) are very fiveete, and be a fodder for moft kinde D of cattle: the fruit can be eaten of none.

\section{Of the Maple tree. Chap.II2.}

* Thedefcription.

$\mathrm{T}$ He great Maple is a beautifull and high tree, with a barke of a meane fmoothnes: the fubftance of the woode is tender and eafie to worke on ; it fendeth foorth on euery fide very many goodly boughes and branches, which make an excellent thadow againft the heate of the funne; vpon which are great, broad, and cornered leaues, much like to thole of the Vine, hanging by long reddih ftalks: the flowers hang by clufters, of a whitifh greene colour; after them commeth vp long fruite faftned togither by couples, one right againft another, with kernels bumping ouc vecre to the place in which they are combined:in all the other parts flat and thinne like vnto parch: ment, or refembling the innermoft wings of Ephemeri, or of grafhoppers : the kernels be white and little.

There is a frmall Maple which doth oftentimes come to the bignes of a tree, but moft commonly it groweth low after the maner of a hrub, the barke heereof is likewife fmooth; the fubftance of the woode is white, and eafie to be wrought on: the leaues are cornered like thole of the former, flipperie, and faftered with a reddilh ftalke, but much leffer, very like in bignes, and glifter as the leafe of Sanicle doth, but that the curs are deeper: the flowers be as thofe of the former, greene, yet not growing in clufters, but vpon fpoked rundels: the fruite ftandeth by two and two vpon a ftem orfooteftalke. 
scermaior.

The great Maple, not rightly called the Sycomore tree.

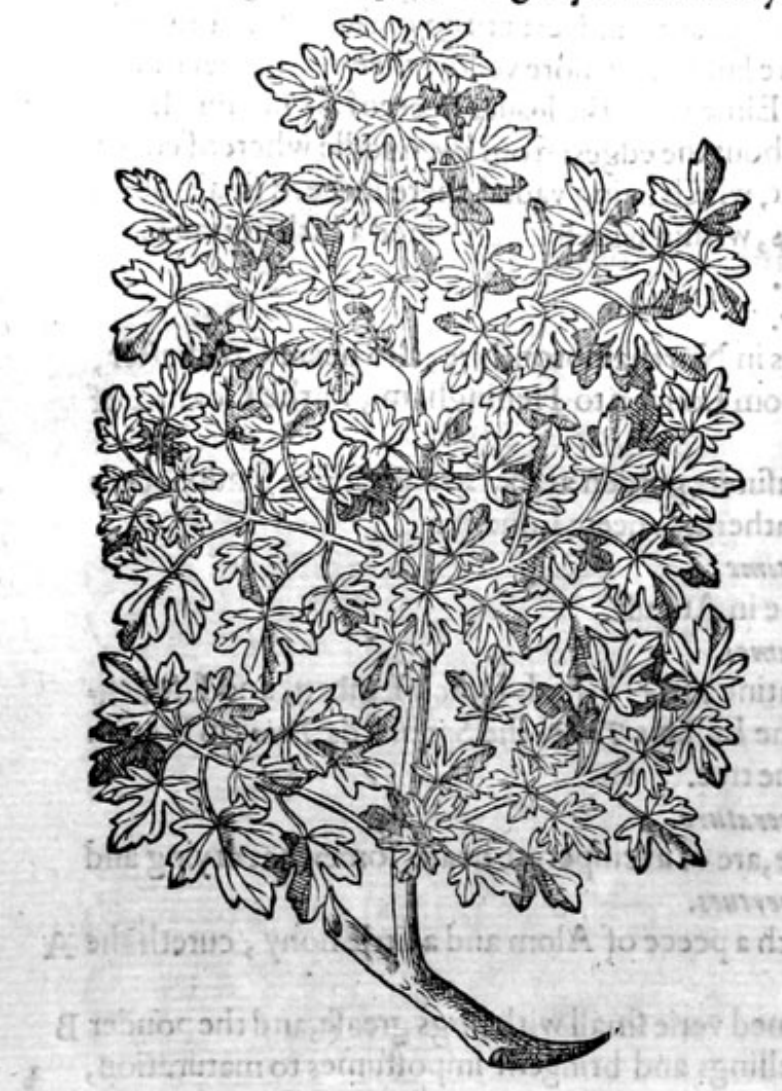

\section{A}

What vfe the Maple hath in medicine we find The fmall or hedge Maple groweth almoft euery where in hedges and lowe woods.

The great Maple is a franger in England, only it groweth in the walkes and places of pleafure of noble men, where it efpecially is planted for the Thadowe fake, and vnder the name of Sycomore tree.

\section{* The time.}

Thefe trees flower about the ende of March, and their fruit is ripe in September.

\section{* The names.}

This tree is called in Greeke apirdeun $\mathrm{O}$ : in $\mathrm{L}_{2}$. tine Acer : in Englifh Maple,or Maple tree.

The great Maple is called in high Dutch a. bozme and retaljeftherme : the French men Grand Ereble and Plafne abufiuely, and this is thought to be properly called oọivdu $\mu$ $O$, but they are far deceiued that take this for Platanus, or the Plane tree, being drawen into this error by the neerneffe of the French word; for the Plane tree doth much differ from this.

The other is called in Latine Leer minor : in high Dutch criaffyolaet: in low Dutch $2300 \mathrm{~g}$. bout : in French Erable : in Englifh fmall Maple, and common Maple. * The temperature and vertues.

nothing written of the Grecians, but Plinie in his 14 .booke 8 . chaprer affirmeth, that the roote pouned and applied, is a fingular remedie for the paine of the liuer. Serenus Sammonicus writeth, that it is drunke with wine againft the paines of the fide.

\section{Silat us immeritum morbo tentatur acuto, Accen fom tinges lapidem frident ibou vndis, Hinc bibis : aut Aceris radicem tundis, or vina Cum vino capis : boc prefens medicames habetwr.}

If with a difeafe that harpneffe doth take, Thy fide not deferuing be vexed by greate; A f tone burning hot in fire fee thou make, And dip it in water which * with heate; *hiffech Hereof thou inalt drinke: Or Maple roote beate, And drinke it with wine:This thing hath a name To be an helpe prefent and cafe for the fame.

\section{Of the Poplar tree. Chap.II3.}

* The kindes.

$T$ Here be diuers trees vnder the title of Poplar, yet differing very notably, as mall be declared in 1 the defcriptions, whereof one is the white, another the blacke, and a third fort fet downe by Plinie, which is the Afpe, named by him Lybica and by Theophrastow xepris: likewife there is another of America, or of the Indies, which is not to be found in thefe regions of Europe. 
1 Fopulus alla.

The white Poplar tree.

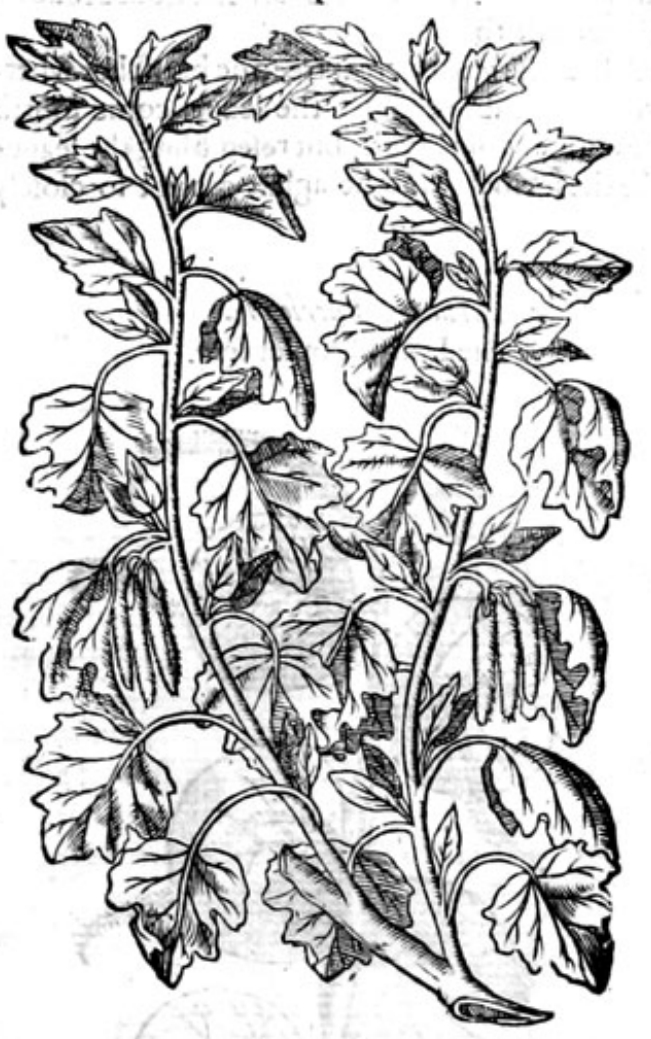

2 Popules nigra. The blackc Poplar tree.

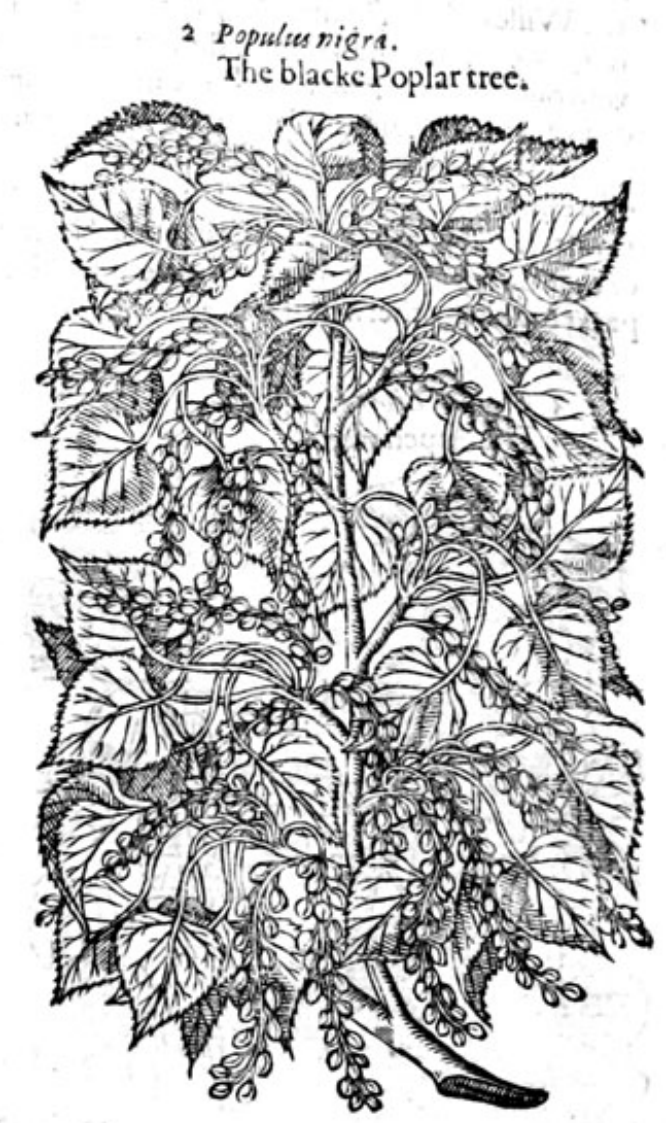

भ.: The defcription.

17 He white Poplar tree commeth foone to perfection, and groweth high in hort time, full of boughes at the top: the barke of the body is fmooth, and that of the boughes is likewife white withall : the wood is white, eafie to be cleft : the leaues are broad,deepely gafhed, and cornered like almoft to thofe of the Vine, but much leffer, finooth on the vpper fide, glib, and fomewhat greene; and on the neather fide white and woolly: the catkins are long, downy, at the firft of $\mathbf{a}$ purplith colour : the rootes fpread many waies, lying vnder the turffe, and not growing deepe, and therefore it hapneth that thefe trees be oftentimes blowne downe with the winde.

2 The blacke Poplar trec is as high as the white, and now and then higher, oftentimes fuller of boughes, and with a thicker body: the barke thereof is likewife fmooth, but the fubftance of the wood is harder yellower, \& not fo white, fuller of veines, \& not fo cafely cleft: the leaues be fomwhat long, and broad below towards the ftem, harpe at the point, and a little fnipt about the edges, neither white nor woolly, like the leaues of the former, but of a pleafant greene colour : among which come foorth long aglets or catkins, which do tume into clufters : the buds which hew themfelues before the leatues fpring out, are of a reafonable good fauour, of the which is made that profitable ointment called $V$ nguentum Populeon.

3 The third kind of Poplar is alfo a great tree: the barke and fubftance of the woode is fomewhat like that of the former: this tree is garnifhed with many brittle and tender branches, fet full of leaues, in a maner round, much blacker and harder then the blacke Poplar, hanging vpon long and flendér ftems, which are for the moft part ftlll wauering, and makc a great noire by being beaten one to another, yea though the weather be calme, and fearce any winde blowing; and knowne by the name of the Afpen tree : the rootes heerof are ftronger, and grow deeper into the ground then thofe of the white Poplar.

4 This ftrange Poplar, which fomedocal Populises rotundifolia, in Eng! in the round leafed Poplar of India, waxeth a great tree, bedect with many goodly twiggie branches, totigh and limmer like 


\section{I302 THE THIRD BOOKE OF THE}

the Willow, full of ioints where the leaues do grow, of a perfect roundnes, fauing where it cleaueth or groweth to the ftalke:from the bofomes or corners of thefe leaues come foorth fmall aglets, like vinto out Poplar,but fmaller : the leafc is thicke, and very like the leaues of Arbor Inda, but broader, of an aftringent tafte, fomewhat heating the mouth, and faltifh.

There is alfo another fort of Poplar, which groweth likewife vnto a great tree, the branches wherof are knottie and bunched foorth, as though it were full of fcabs or fores: the leaues come foorth in tufts, moft commonly at the endes of the boughes, not cut or iagged, but refembling the leaues of that Atriplex, called Pes anferinus; in colour like the former, but the aglets are not fo clolely packt togither, otherwife it is like.

3 Populus Libyca. The Afpentree.

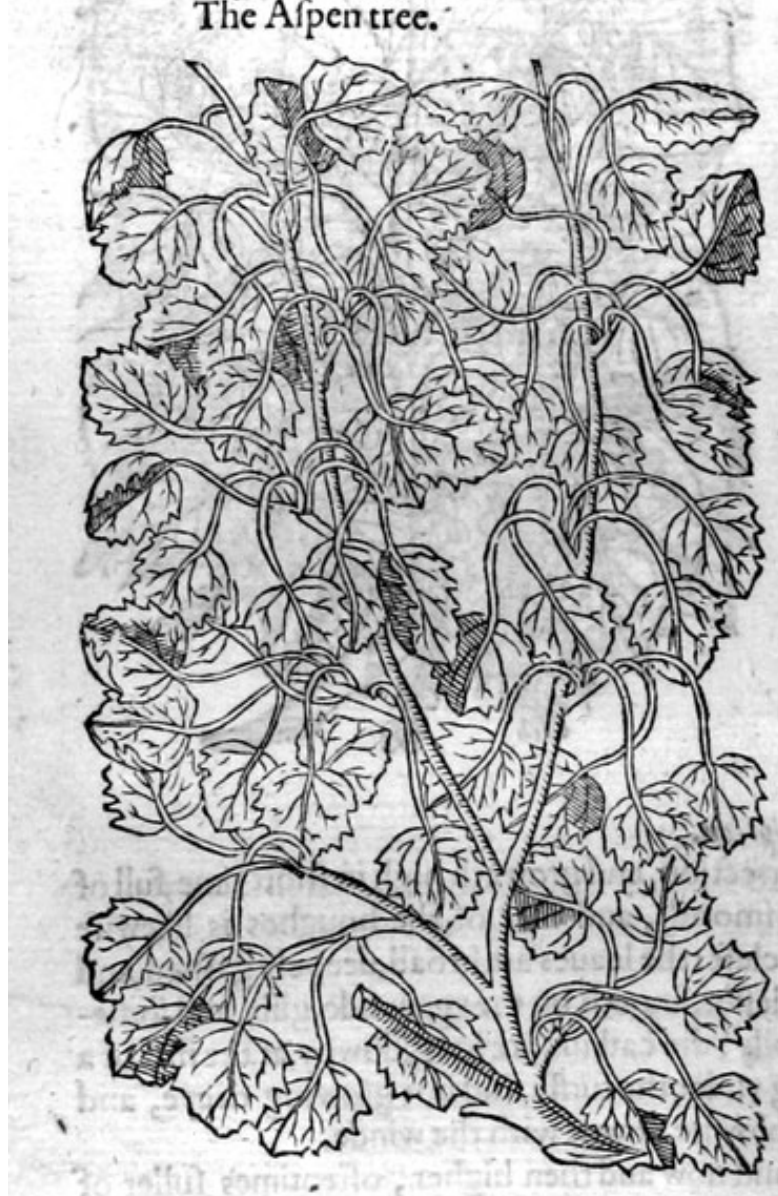

4 Populus Cimericans. The Indian Popler tree.

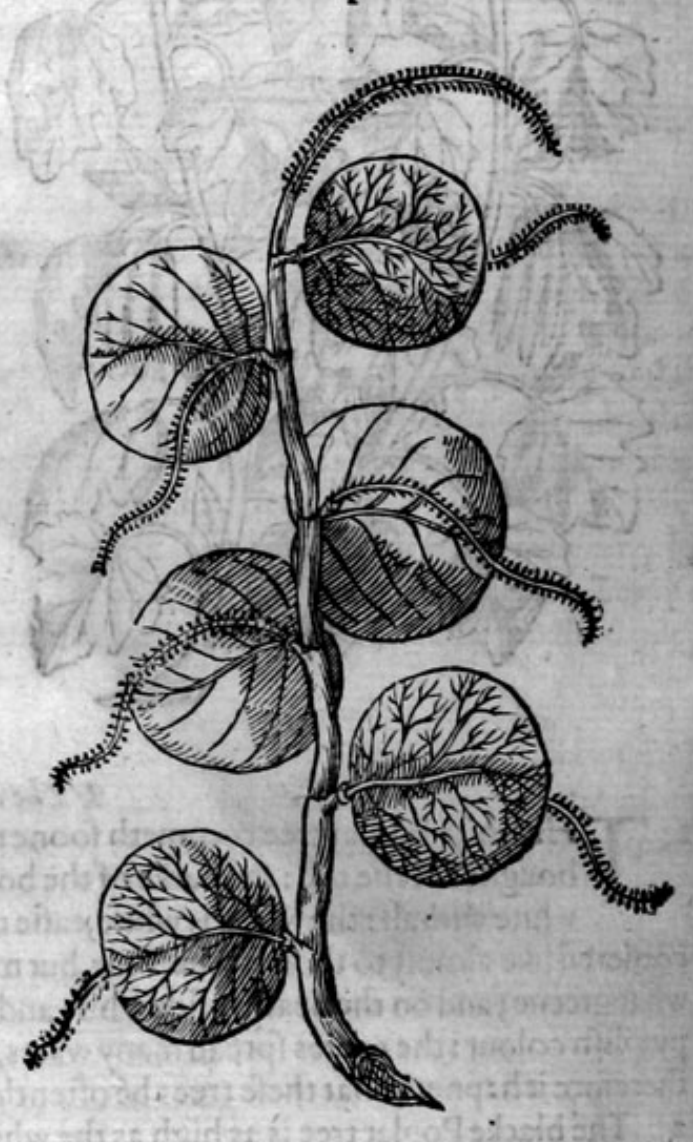

\section{* The place.}

Thefe trees do grow in low moift places, as in medowes neere vnto ditches, ftanding waters, and riners.

The firft kinde of white Poplar groweth not very common in England, but in fome places heere and there a tree: I found many both fmall and great growing in a lowe medow turning vp a lane at thefurther end of a village called Blackwall,from London; and in Effex at a place called Ouenden, and in diuers other places.

The Indian Poplar groweth in moft parts of the Ilands of the weft Indies.

$$
\text { * Thetrme. }
$$

Thefe trees do bud foorth in the end of March, and beginning of Aprill, at which time the buds mult be gathered to ferue for $V$ nguentum Populeon.

\section{$\therefore$ The names.}

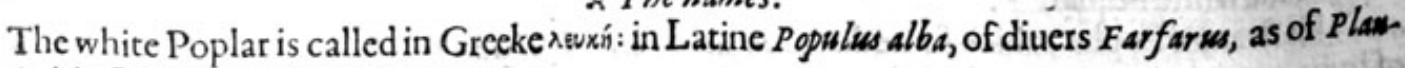
tus in his Comedic Penulus: ..... 


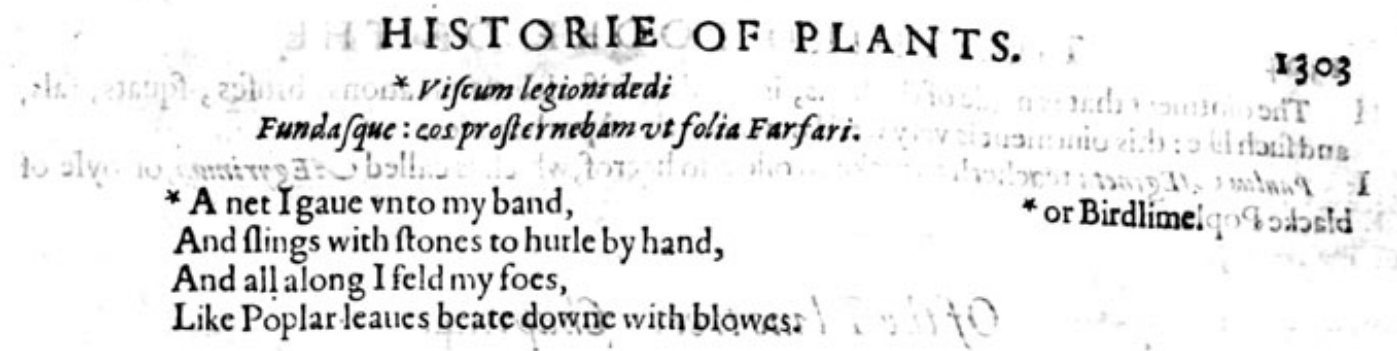

It is called in high Dutch 1’oppelbatm, viciefiz albctbatum: in low Dutch aleel, of his horie or aged colour,and a lfo ghe tree : in Italian Popolobianco: in Spanifh Alamoblanco: in French Peuplser blanc, Aibel, Obel, or Aubeau : in Englifh white Poplartree, and Abeell, after the Dutch name.

The fecond is called in Grecke Aizeress in Lätine Populus nigra : by petrus Crefeentinu CAlbarus: in high Dutch Afpen : in low Dutch 1 Ooputitrt in Italian Popolo nero: in French Peuplier noir: in Spanifh Uthmo ntgrilbo: in Euglifh Poplartree, blacke Poplar, andPepler. The firft or new fprung buds whereof,are called of the Apthecaries Ocult Populi, Popler buds : others choofe rather to call it Gemma Popult : fome of the Grxcians name it $\sigma$ misue, whereupon they grounded their errour, who rafhly fuppofed that thofeRofinie or clammie buds are not to be put or vfed in the compofition of the ointment bearing the name of the Poplar, and commonly called in Englifh Popilion, andPompillion; but the berries that grow in clufters, in which there is no clammines at all.

They are alfo as far decciued who giuing credite to Poets fables, do belecue that Ambercommeth of the clammie Rofin, falling intothe riuer Poo.

The third is called of diuers populus tremula, which worde is borrowed of the French men, who name, it Tremble: it alforeceiued a name amongtt the low countrey men, from the noife and rat ing of the leates, who callit 1 Rateeler, this is that which is named of Plinie Libyca, and by $T$ i eophra. ftus xepris, which Gazacallech Popuhies montana : in Englifh Afpe, and Afpentree, and may alfo be called Tremble, after the Frenchname, confidering it is the matter whereof womens toongswere made, as the Poets and fome others report, which feldome ceafe wagging.

\section{* The temperafure and vertues.}

The white Poplar hath a clenfing faculty faith $G_{a}$ len, and a mixt temperature, confifting of a wa- A sery warme effence, and alfoa thinne earthie fubftance.

The barke, as Diof corides writeth, to the weight of an ounce (or as others fay, and that more truly, B of little more then a dram) is a good remedy for the fciatica, or ache in the hucle bones, and for the ftrangury.

That this barke is good for the Sciatica; serenus Sammonicws, doth allo write.

$$
\begin{aligned}
& \text { Sepins occultis vich a coxendice morbus } \\
& \text { Perfurit, o groffus diro langusre moratur: } \\
& \text { Populus alba, dabit medicos de cortice pot is.', }
\end{aligned}
$$

An lidden difeafe doth oft rage and raine, The hip ouercome and vexe with the paine, It makes with vile aking one tread flowe and Grinke; The barke of white Poplar is helpc had in drinke.

The fame barke is alfo reported to make a woman barren, if it be drunke with thekidney of a D Mule, which thing the leaues likewife are thought to performe, being taken after the flowers or reds be ended,

The warme iuice of the leaues being dropped into the eares, doth take away the paine thereof.E

The rofin or clanmiefubitance of the blacke Poplar buds is hot and diy, and of thin parts, and F

doth attenuarc and mollifie : it is alfo fitly mixed acopis os malagmatis: the leaues haue in a maner: the like operation for all thefe things,yet weaker and not fo effeituall as Galen teachet.'.

The leaues and yoong buds of black Poplar do affwage the paine of the gout in the handes or $G$ feete, being made into an ointment with Maie butter. 


\section{THE THIRD BOOKE OF THE}

$H$ The ointment that is made of the buds, is good againft all inflammations, brufes, fquats, fals, and fuch like : this ointment is very well knowne to the Apothecaries. :

Panlus AEgineta teacheth to make an oile alfo heerof, which is called AEgyrinum, or oyle of
blacke Poplar.

\section{Of the Tlane tree. Chap.114.}

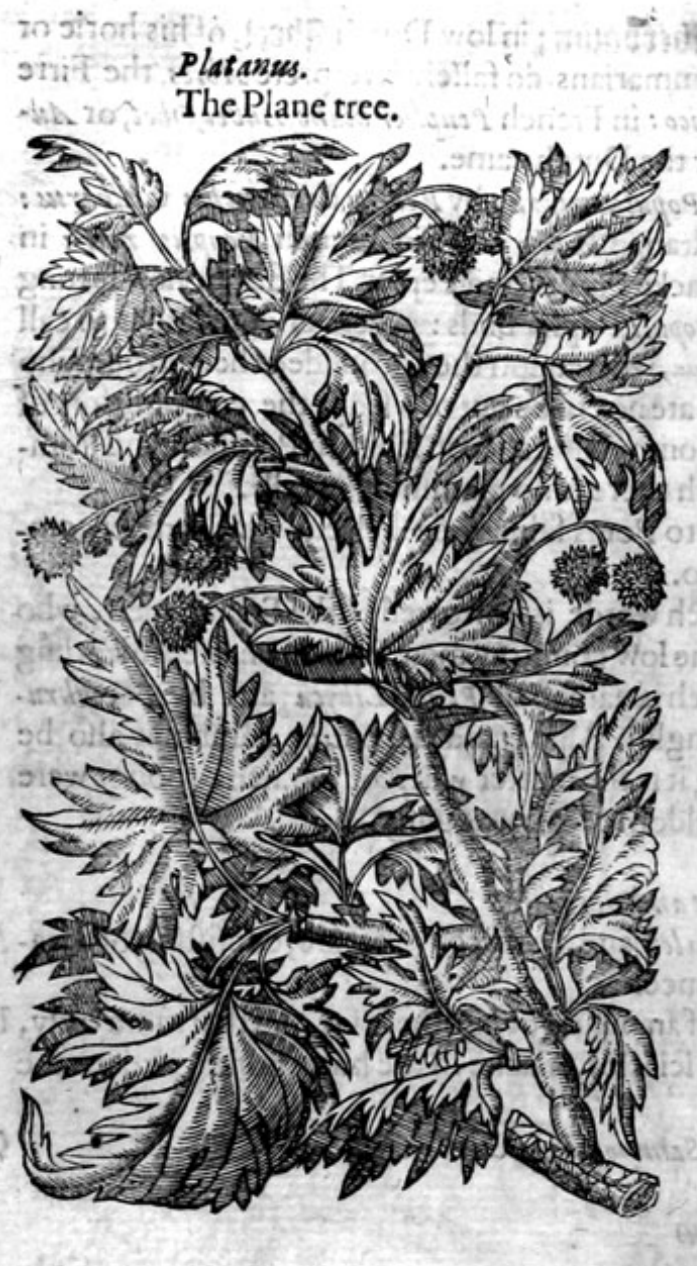

\section{* The defcription.}

He Plane is a great tree, hauing verie long
and farfpreading boughes, caiting a wonderfull broad hadow, by reafon whereof it was highly commended and efteemed of among the old Romanes: the leaues are cornered like thofe of Palma Chrifti, greater then Vine leaues, and hanging vpon little red footeftalks : the flowers are fmall and moffie, and of a pale yellowifh colour : the fruite is round like a ball, rugged, and fomwhat hairie; but in Afia more hairie and greater, almoft as big as W Wall nut : the roote is great difperfing it felfe far abroad.

\section{* Theplace.}

The Plane tree delighteth to grow by fprings and riuers: Pliny reporteth that they were woont to be cherifhed with wine; they grew afterwards faith he, to be of fo great honour (meaning the Plane trees) as that they were cherifhed and watered with wine: $i t$ is founde by experience that the fame is very comfortable to the rootes, and we have already taught that trees defire to drink wine in the 12. booke firft Chapter. This tree is ftrange in Italy, it is no where feene in Germa nie, nor in the lowe countries : in Afia it groweth plentifully; it is founde alfo in Candie, growing in valleies, and neere vnto the hill Athon, as Petrus Bellonius in his Singularities and is found planted in fome gardens of Italy, for pleafure rather then for in many places of Greece, a $m$ Marfhall,whom I fent into the Mediterranean fea, as chirurgion vnto the Hercules of London, found diuers trees heerof growing in Lepantæ, hard by the fea fide, at the entrance into she towne, a port of Morea, being a part of Greece, and from thence brought one of thofe rough buttons, being the fruite thereof.

* The time.

The Plane trees caft their leaues in winter, as Bellonius teftifieth, and therefore it is no maruel ${ }^{1}$ that they keepe away the funne in fommer, and not at all in the winter:there is faith Plinie no greater commendation of the tree then that it keepeth away the funne in fommer, and entertaineth it in winter.

\section{$\approx$ The names.}

This tree is called in Greeke arárayos : and likewife in Latine Plat anus; itbeareth his name of the breadth : the French mens Plafne doth farre differ from this, which is a kinde of Maple: this tree is named in Englifh Plane tree.

$*$ The temperature and vertues.

A The Plane tree is of a colde and moift effence, as Galen faith: the greene leaues are good to be laid vpon hot fwellings and inflammations in the beginning. 
HISTORIE OF PLANTS.

Being boyled in wine they are a remedie for the running and watering of the cies, if theybe ap- B plied.

The barke and bals do drie; the barke boyled in vineger helpeth the toothache.

The fruit of the Plane tree drunke with wine, helpeth the bitings of mad dogs and ferpents, and D mixed with hogs greafe, it maketh a good ointment againft burning and fea'ding.

The burned barke doth mightily drie, and fcowreth withall; it remooueth the white fcurfe, and $\mathbf{E}$ cureth moyit vlcers.

The duft or downe, faith Galen, that lieth on the leaues of the tree, is to be taken heede of, for if $F$ it be drawen in with the breth, it is offenfiue to the windpipe by his extreme drineffe, and by making the fame rough, and hurting the voice, as it doth alfo the fight and hearing, if it fall into the eies or eares. Diofcorides doth not attribute this to the duft or downe of the leavies onely, but alfo to that of the bals.

\section{Of theWayfaring tree. Chap.115.}

\section{Lantena, fuce Viburnam.} The Wayfaring tree.

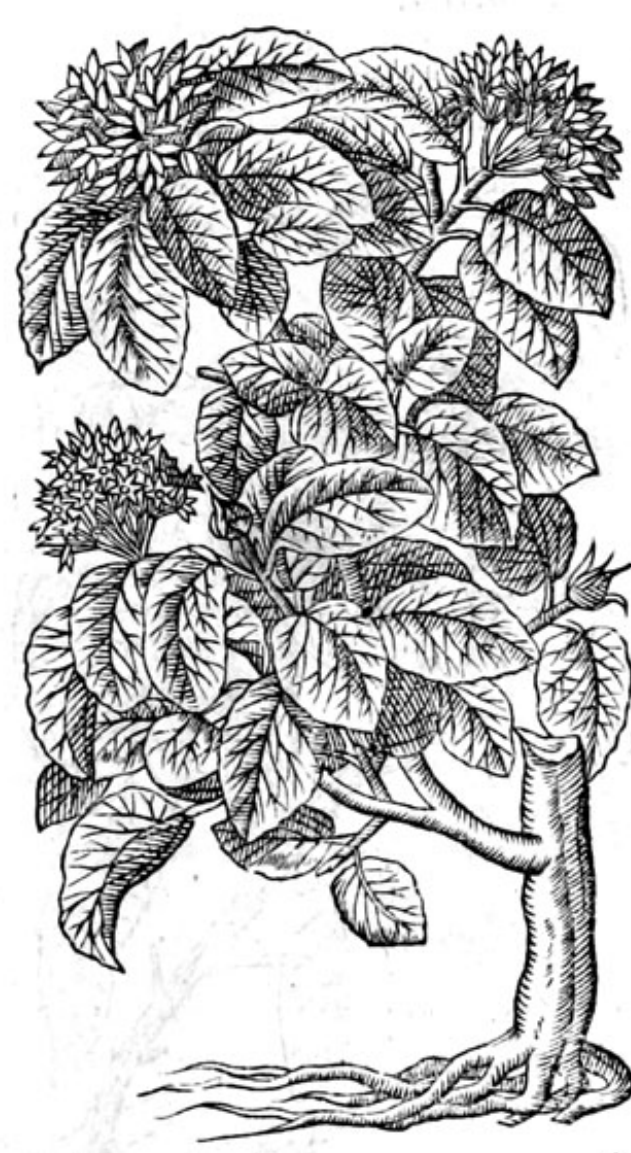

* The defcription.

$T$ He Wayfaring mans tree groweth vp to the height of an hedge tree, of a meane big. neffe: the trunke orbodic thereof is couered with a ruffet barke : the branches are long, tough, and cafie to be bowed, and hard to be broken, as are thofe of the Willow, couered with a whitifh barke; whereon are fet broade leaues, thicke and rough, Alightly indented about the edges, of a white colour, and fomewhat hairie whileft they be frefh and greene: but when they begin to wither and fall away, they growe fomewhat reddifh, and are fet togither by couples one oppofite to another : the flowers are white, and growe in clufters, after which come clufters of fruit, of the bigneffe of a Peafe, fomewhat flat on both fides; at the firft greene, after red, and black when they be ripe: the roote difperfeth it felfe far abroade vnder the vppermoft cruft of the earth.

$$
\text { * The place. }
$$

This tree groweth in moft hedges in rough and ftonie places, vpon hils and lowe woods, efpecially in the chalkie groundes of Kent about Cobham, Southfleete and Grauefend, and al the tract to Canterburie.

$$
\text { * The time. }
$$

The flowers appeere in fommer; the berries be ripe in the end of Autumne, and new leaues come foorth in the fpring.

\section{* The names.}

This hedge tree is called Viurna of Ruelisus: in French Viorne and Viorna: in Italian Lantana : it is repured for the tree $V$ iburnum, which Virgilmaketh mention of in the firf Eclog, where he commendeth the citie Rome for the loftineffe and ftatelineffe thereof,aboue other cities, faying, that as the tall Cypreffe trees do thew themfelues aboue the lowe and ihrubbie Viorne, fo doth Rome aboue other cities lift vp hir head very high, in thefe verfes: 
Verum h.ectantiom alias inter caput extulit orbes, Quantum lentafolent inter viburna Cupre $\beta$.

But * this, among other cities and townes,

Hath fo much more ftately borne vp hir head;

By how much the Cypreffes carrie their crownes,

*Rome vpon

Aboue the lowe viorns bending (like lead.)

\section{$\dot{x} \mathrm{~T}$ betemperature.}

The leaues and berries of Lantana are colde and dric, and of a binding qualitie.

\section{* The vertues.}

A The decoction of the leaues of Lantana is very good to be gargled in the mouth againft all fwel. lings and intammations thereof, againft the fcuruie and other difeafes of the gums, and fafteneth loofe teeth. B The fame boyled in lie doth make the haires blacke, if they be bathed or wathed therewith, and
fuffered to drie of it felfe.

C The berries are of the like facultie : the powder whereof when they be dried, doth ftay the laske, all iffues of blood, and alfo the whites.

D It is reported, that the barke of the roote of the tree buried a certaine time in the earth,and afterwards boyled and itamped according to the art thereof, maketh good birdlimefor fowlers tocatch birdes with. Of the Beadetree. Chap.no.
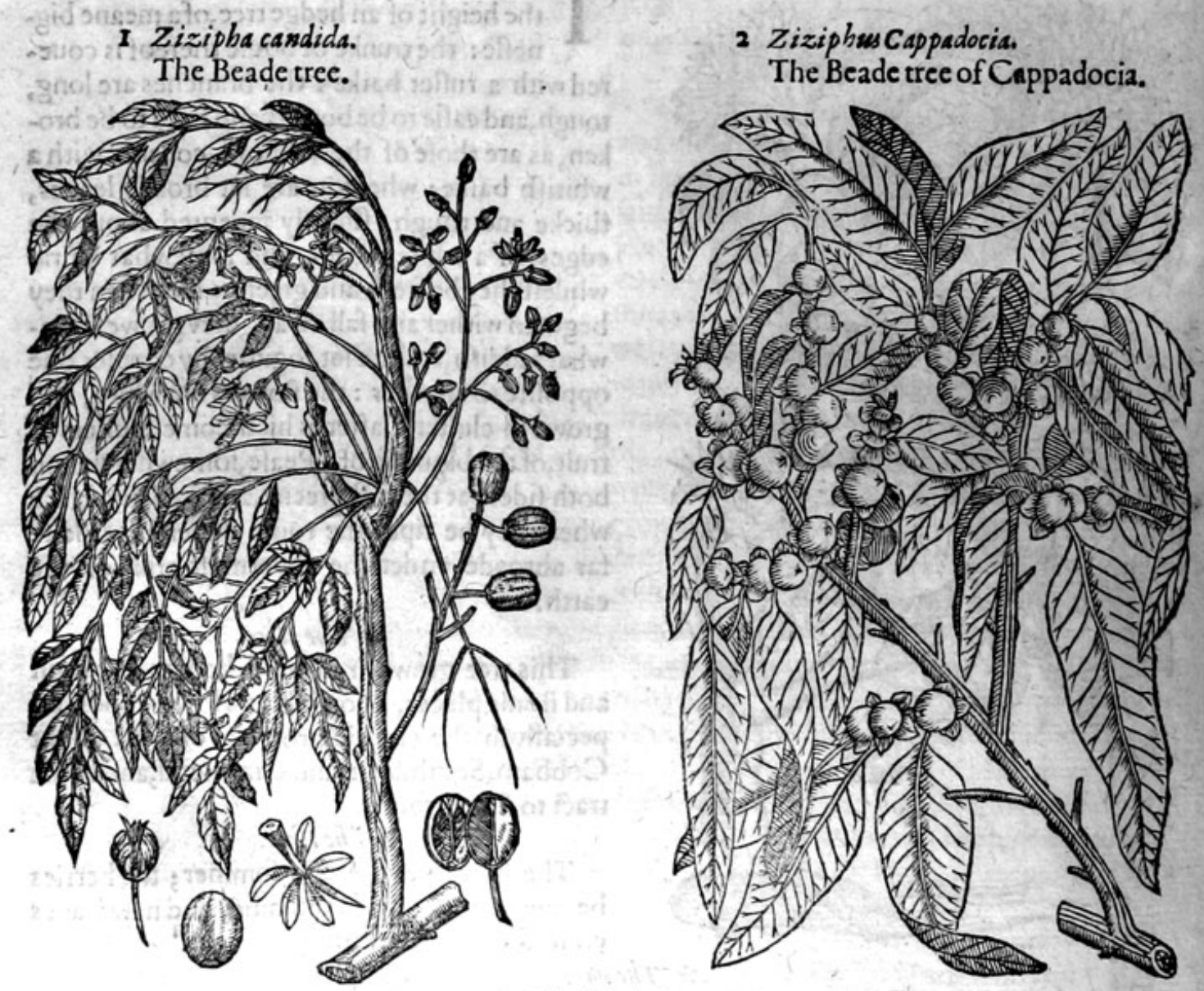

$*$ The defcription.

I THis tree was called $Z$ izipha candsda by the Herbarifts of Montpellier, and by the Venetians

and Italians Sycomorus, but vntruly; the Portingales haue termed it Arbor paradizo; all which and cach whereof haue erred togither, both in refpect of the fiuit and of the whole tree : ome haue called it $Z$ izipha, though in facultic it is nothing like; for the tafte of this fruit is 
very vnpleafant, virulent and bitter. But deciding al controuerfies, this is the tree which Auicencalgie branches, fetfull of great leaucs, confilting of fundry fmall leaues, that are garnifhed with twig. to another like the leaues of the Afh tree, or Whicken tree, but leaues, one growing right oppofiee like the teeth of a law : among which come the flowers manner of a ftar, from the midft whereof groweth foorth a fing li fiue fmall leaues laid abroad in after which fucceedeth the fruit couered with a brownifh yellow hell, cup refembling a chalice; Iuiubs (where of Iuiubes (whereof Dodonens in his laft edition maketh it a kinde) of a ranke, bitter, \& vnpleafant tafte, with a ftone within, which being drawen on a fting, ferueth to make Beades of, for want of other things:

2 Zizuphrs Cafpadocia groweth not fo greatas the former, but is, of a meane ftature, and full of boughes:the barke is fmooth and euen, and that which groweth vpon the trunk and great boughes, is of a fhining fearlet colour : out of thefe great armes or boughes growe flender twigs, white and foft, which are fet full of whitith leaues, but more white on the contrarie or backe part, and are like to the leaues of Willow, but narrower and whiter : among thefe leates come foorth fimall hollow yellowifh flowers, growing at the ioints of the branches moft commonly three togither, and of 2 pleafant fauour, with fome few threds or chines in the middle there of : after which fucceedeth the fruit, of the bigneffe and fafhion of the fmaileft Oliue, white both within \& without, whercin is contained a fmall itone, which yeeldeth a kerneil of a pleafant tafte and very fweete. $*$ The place.

Matbiolus writeth, that $Z$ izipl:a candida is found in cloyfters of certaine monafteries in Italie; - L'Obelites faith, that it groweth muny places in Venice and Narbon; and it is woont now of late to be planted and cherifhed in the goodlieit orchards of all the lowe countries.

$Z$ /ziphrus Cappadocia groweth likewile in many places of Italie, and fpecially in Spaine; it is alfo cherifhed in gardens both in Germanic and in the lowe countries.

* The time.

Thefe trees flower in Iune in Italie and Spaine; their fruit is ripe in September ; but in Germanie and the lowe countries there doth no fruit follow the flowers.

$$
20 \text { The names. }
$$

Zizip ba candida Auicen calleth Azedarach, or as diuers read it Mzedaracth, and they name it, faith he, in Rechi Arbor CMirobalan) wm, or the Mirobalane tree, but not properly, and in Tabraften, and Kien, and Thahich. The later writers are far deceiued in taking it to be the Sycomore trec; and they as much that would haue it to be the Lote or Nettle tree: it may be named in Englifh Beade tree, for the caufe beforealleaged.

The other is aitera pecies $Z$ iziphi,or a fecond kinde of Iuiube tree, which columella in his 9 .booke 4. chapter doth call $Z$ iziphus a! $b a$, or white luiube tree, for difference from the other that isfurnamed Rutula, or glittering red. Plinie calleth this Ziziphus Cappadocia, in his 21 . booke g. chap. where he intreaterh of the honor of garlands, of which he faith there be two kindes, whereof fome be made of flowers, and others of leaues: I would call the flowers, faith he, broomes (for of thofe is gathered a yellow flower)and Rhodotendron, alfo $Z t z i p h a$, which is called Cappadocia. The flowers of thete are fweete of fmell, and like to Oliue flowers: neither doth Columells or Plime vnaduiledly take this for Ziziphus, for both the leaues and lowers grow out of the tender and new fproong twigs, as they likewife do out of the former : the flowers are very fweete of finell, and cait their fauour far abroad: the fruit alfo is like to that of the former.

$$
* \text { The temperature. }
$$

Auicen writing and intreating of Az radaet $b$ laith, that the flowers there of be hot in the thirde degree,and dry in the end of the fiift. Ziziphos cappidocia is cold and drie of compiexion.

$$
x \text { The vertues. }
$$

The flowers of Zizipha or Azaradaes h openeth the obftruetions of the braine.

The diftilled water there of killerb nits and lice, preferueth the haire of the head from falling, B efpecially being mixed with white wine, and the head bathed with it.

The fruit is very hurtfull to the cheft, and a troublefome enimie to the ftomacke, it :s dangerous, C and peraduenture deadly.

Moreouer, it is reported that the decoetion of the barks and of Fumitorie, with Mirobalans ad. D ded,is good for agues proceeding of flegme. 


\section{8}

\section{THE THIRD BOOKE OF THE}

E - The iuice of the vppermoft leaues with honie is a remedie againftpoyfon.

F The like alfo hath $R$ hafis. The Beade trec, faith he, is hot and drie : it is good for ftoppings of the hesd, it maketh the haire long;yet is the fruit there of very offenfiuc to the ftomacke, and oftentimes found to be pernicious and deadly.

Mathiolus writech, that the leaues and wood bringeth death euen vnto beafts, and that the poy-
fon thereof is refilted by the fame remedies that Oleander is.

H. Zitiphus Cappadocia preuailethagainft the difeafes aforefaid, but the decoction thereof is very good for thofe whofe water fcaldeth them with the continuall iffuing thereof, as alfo for fuch as haue the running of the raines, and the exulcerations of the biadder and priuie parts. I A looch or licking medicine made there of or the firupe, is excellent good againft fpetting of
blood proceeding of the diftillations of fharpe or ílt humors.

\section{Of the Lote or Nettletree. Chap.i17.}

Lotus arbor.

The Nettle tree.

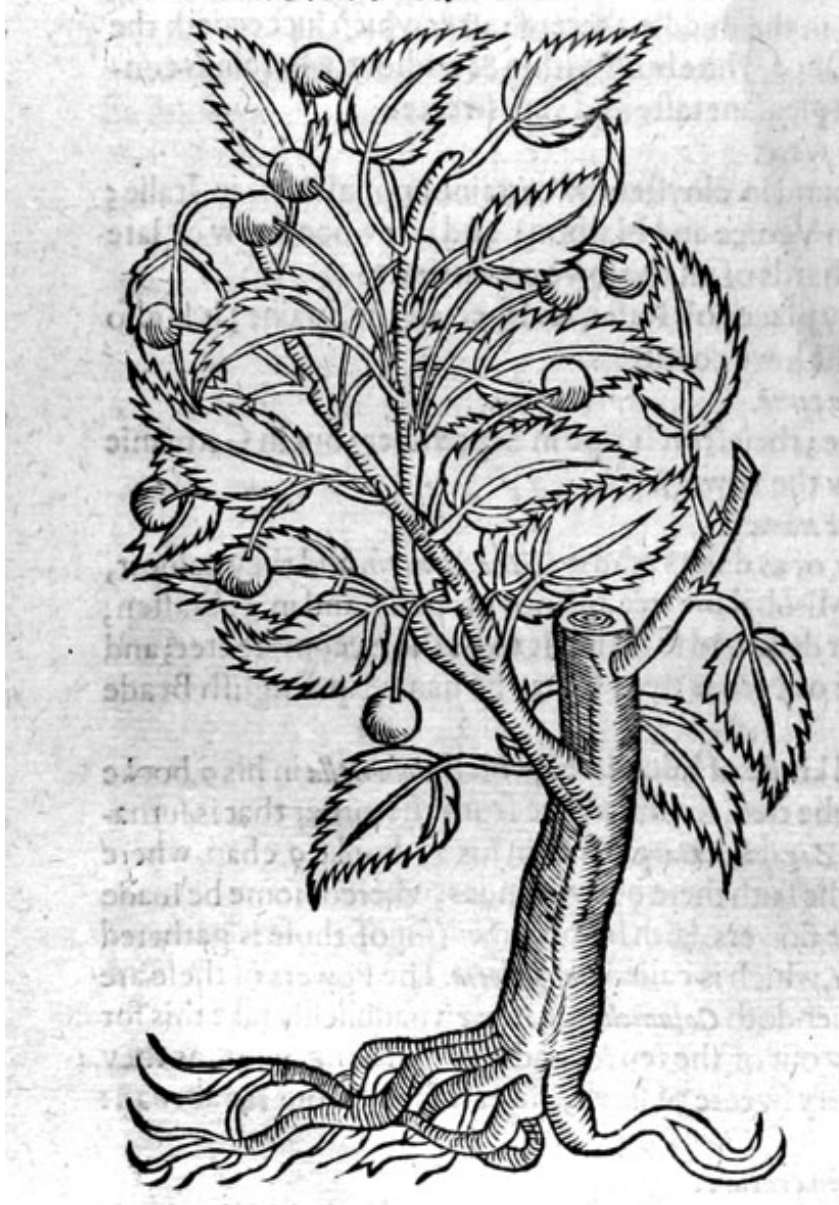

* The defcription.

7 He Lote whereof we write, is a tree as big as a Peare tree, or bigger and higher: the body and armes are very thicke; the barke whereof is finoothe, of a gallant greene colour tending to blewneffe: the boughes are long, and fpread thenifelues all about : the leaues be like thofe of the Nettle, Tharpe pointed, and nicked in the edges like a fawe, $\&$ dafht here and there with ftripes of a yellowifh white colour : the berries be round, and hang vpon long ftalks like Cherries, of 2 yellowih white colour at the firft, and a fterwards red, but whe they be ripe, they be fomwhat blacke. * Theplace.

This is a rare and ftrange tree in both the Germanies:it was brought out of I taly where there is found ftore thereof, as Mathiolus te. ftifieth: I haue a fmall tree thereof in my garden.There is likewife a tree there of in the garden vnder London wall, fometine belonging to M.Gray, an A pothecary of London;and an other great tree in a garden neere Colman freete in London, being the garden of the Queenes Apothecary at the impreffion hereof, called M.Hugh Mor gan, acurious cöleruer of rare fimples. The Lote tree doth alfo grow in Affrike, but it fomewhat differeth from the Italian Lote in fruit, as Plinie in plaine words doth fhew in his 13 . booke 17 . chapter. That part of Afrike, faith he, that lieth towards vs,

bringeth foorth the famous Lote tree, which they call Ceitis,and the fame well knowen in Italie, but altered by the foile : it is as big as the Peare tree, although $N$ epos Cornelius reporteth it to be thorter : the leaues are full of fine cuts, otherwife they be thought to be like thofe of the Holme tree. There be many differences, but the fame are made efpecially by the fruit: the fruit is as big as a Beane, and of the colour of Saffron, but before it is thorow ripe, it changeth his colour as doth the Grape.It groweth thicke in bouhges after the manner of the Myrtle, not as in Italie,after the maner of the Cherrie tree; the fruit of it is there fo fweete, as it hath alfo ginen a name to that countrie and land, nimis hopitali aduenarum obliwione patria.

It is reported that they are troubled withno difeafes of the belly that eate it. The better is that 


\section{HISTORIE OF PLANTS.}

which hath no kernell, that is thought to haue a ftone in the other kinde : there is alfo vreffed out berries ftamped with Alica, to be referued in veffels a s a foode. Morethe abouc ten daies, and the armies hate beene fed therewith, as they haue paffed too and fro thorow we haute heard faie, that wood is blacke : they vfe to make tlutes and pipes of it : the roote fer Phort works: this is there the nature of the trce : thus far Plinie. In the for knitues hafts, and orher renowmed tree doth grow about Syrtes and Vafmon there is not far from the leffer Syrris, the Iland Mona:and in his 5.booke 7.chap.he iheweth that Lote trees.

Strabo in his 17 .booke affirmeth that not onely Menynx, but alfo that leffer Syrtis, is faide to be Lstoph.zgrtis:firft faith he, lieth Syrtis a certaine long Iland by the name Cercinna, \& another leffer, called Cercinnitis ;next to this is the leffer Syrtis, which they cal Lotophagitis Syrtis: the compas of this gulf is almoft 1600 .furlongs; the bredth of the mouth 600 . By both the capes there be Ilands ioined to the maine land, that is Circinna \& Menynx, flike bignes: they think that Menynx is the countrey of the Lotophagos, or thofe that feede of the Lote rrces, of which countrey Homer maketh mention, and there are certaine monuments to be feene; and $v /$ / fes altar, and the fruite it felfe; for there be in it great plenty of Lote trees, whole fruit is woonderfull fweete: Thus far Strabo.

This Lote is alfo defcribed by $T$ heophraftus in his 4 book, he faith, that there be very many kinds, which be fcuered by the fruittthe fruit is of the bignes of a beane, which when it waxeth ripe doth alter his colour as grapes do:the fruit which the Lotophagos do eate is fweete, plealant, harmleffe, \& holfome for the belly, but that is plefanter which is without kernels,\& of this they make their wine.

This Lote tree as the fame author affiumeth, is by nature euerlafting, as for example, the Lote trees wherof $P$ im $y$ hath written in his 6 booke 44 chap. At Rome faith lie, the Lore tree in Lucinas court how much elder it was then the church of the citie built in the yeere which was without magiftrates 469 . it is vnceitaine: there is no doubt but that it was elder, bicaufe Lucima bare the name of that Lucses or groue: Hec nunc circtter annum 450 habet. That is elder which is furnamed capillata, or hairie; bicaufe the haire of the veft al virgins was brought vntort:but the other Lote tree in $V u l$ cans church, which Komulus built by the vietory of tenthes; is taken to be as old as the citie, as $\mathrm{Maf}$ jurius witnefleth.

* The time.

They lofe their leaues at the firft approch of winter; and recoucr them againe in April : the fruit is ripe in September * The namers.

This tree is called in Greeke awr's: in Latine by Pimy Celt is : in Italian Ferlaro : by thofe of Trent Baglaro: and in Englith Lote tree, and Netcle tree.

\section{* Thetemperature and vertues.}

The Lote tree is not greatly binding as Gilen fatth, but of thinne parts, and of a drying nature. A

The decoction of the wood beaten fmali, being etther drunke or veed glifterwife; is a remedie B for the bloudie flixe ;and for the whites and reds.

It ftoppeth the lask, and maketh the haire yellow, \& as $G$ alen addeth, keepeth haires from falling. C

The fhiuers or fmall peeces thereof as the fame author alleageth, are boiled fometimes in water, D fomtines in wine, as neede fhall re çuire.

\section{Of Italian wood of Life, or Pocke woode, vulgarlycalled Lignum vitx. Chap.ns.}

* Thedefcription.

Talian Lignam vite, or woode of Life, groweth to a faire and beautifull tree, hauing a ftraight and vpright body,couered ouer with a finooth and darke greenc barke, yeelding foorth manie twiggie branches, fer full of goodly leaues, like thofe of the Peare tree, but of greater beauty \& fomewhat broader: among which commeth foorth the fruite, growing clofe to the branches, almoft without ftalks : this fruite is round, and atche firft greene, but blacke when it is ripe, as bigge as Cherries, of an excellent fweet tafte when it is dried: but this is not the Indian Lignum fanctum, or Guatacum, whereof our bowles and phificall drinkes are made, but it is a baitard kunde therof, firft planted in the common garden at Padua, by that learned fallopins, who fuppofed it to be the right 
Guaiacum Patanixum.Italian wood of Life.

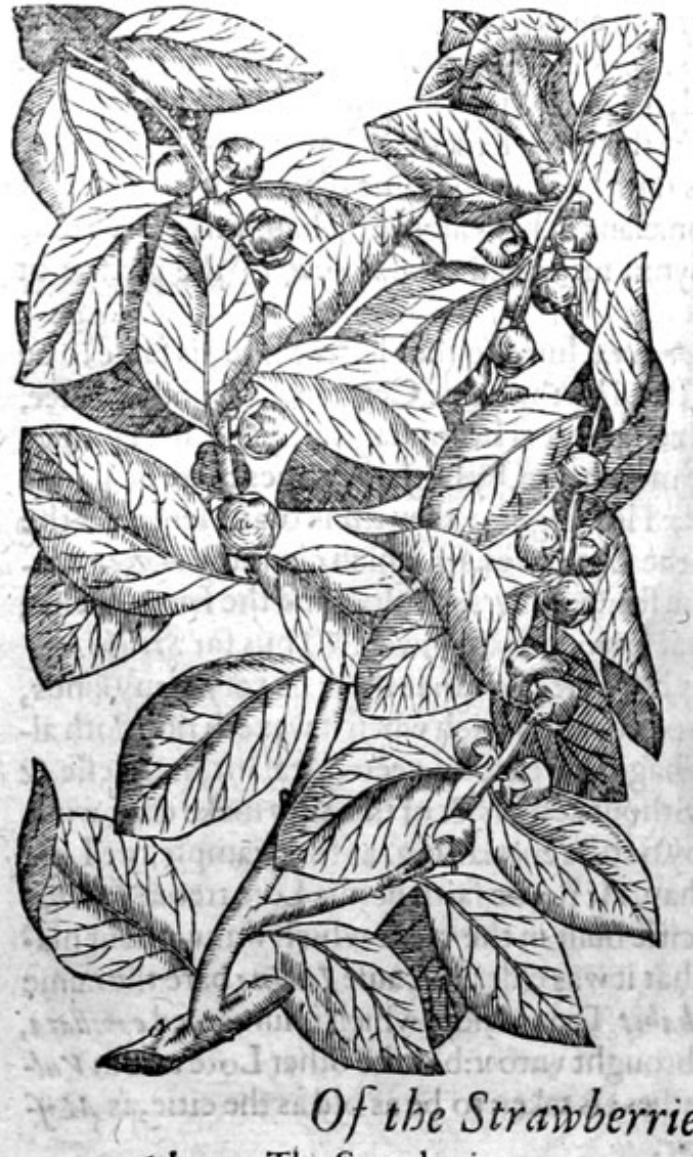

Arbut us. The Strawberie tree.

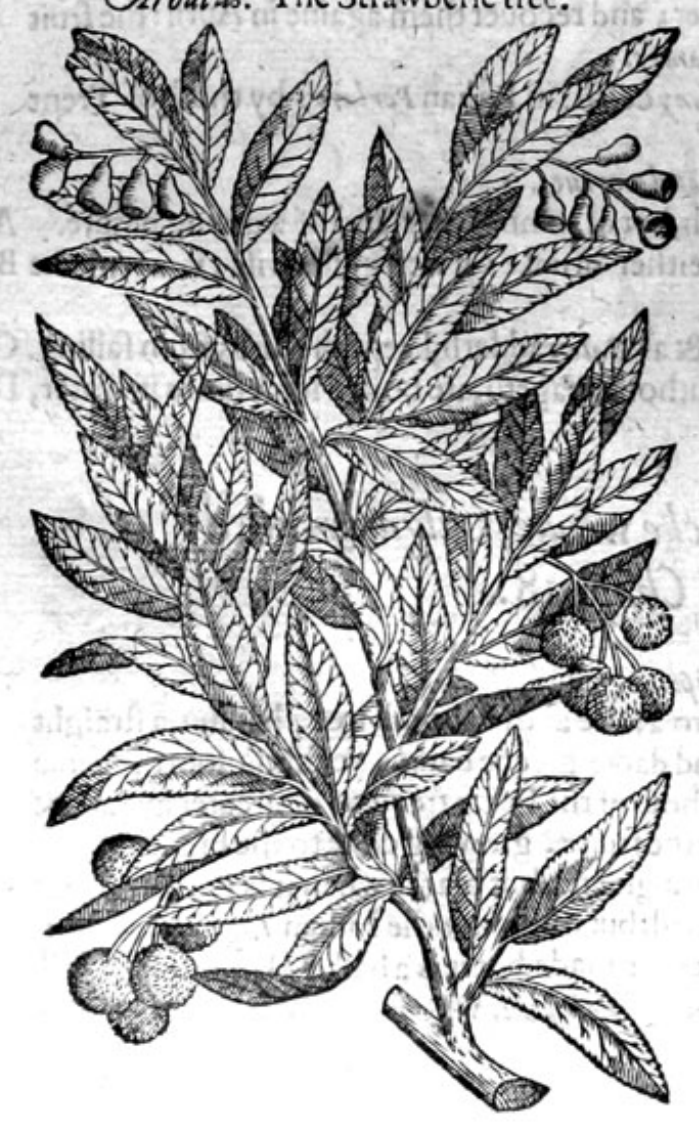

* The place

Guaiacam Patawinum, groweth plentifully about Lugdunum, or Louane in France: I planted in the garden at Barne Elmes neere London two trees; befides there groweth another in the garden of Mafter Graie, an Apothecarie of London: and in my garden likewife.

* The time.

It flowreth in Maie, and the fruite is ripe in September.

\section{* The names.}

Guaiacum Patauinum hath been reputed for the Lotus of 7 heophraftus: in Englifh it is called the baftard Meuyn wood.

* The temperature and vertues.

To fet foorth the vertues of Guaiacum it were to fmall purpofe, confidering that euery vagarant phifition \& Quackfaluing Surgion, will boaft and brag that they know more, or at the leaft as much as the beft and moft learned phifition, of the operation therof: wherfore I deternining to côceale my fimple cenfure there of, being onerweake to teach and inftruct the learned, amnot willing to fet foorth vnto thofe boafters what I haue leamed of the right Guaiacum, and do refer the confideration therof vnto thofe to whom it doth efpecially appertaine.

ree. Chap.ing.

\section{* T be diefcription.}

7 He Strawberrie tree groweth for the moft part lowe, very like in bignes to the Quince tree(whereunto Dio/corides compareth it) the body is couered with a reddifh barke, both rough \& f f aly: the boughies ftand thicke on the top, fomwhat reddifh : the leaues be broad, long, fmooth, like thofe of Baies, fomervhat nicked in the edges, and of a pale greene colour: the flowers growe in clufters, being hollow \& white, and now and then on the one fide fomewhat of a purple colour: in their places come foorth cerraine berries hanging down vpon little long ftems like vnto ftrawberries, but greater, without a ftone within, but only with littie feedes; at the firft greene, and when they be ripe they are of a gallant red colour; in tafte fomewhat harfh, and in a manner, without any relifh; of which Thrufhes and Black burds do feed in winter.

$$
\text { * The place. }
$$

The Strawberrie tree groweth in moft countries of Greece, in Candy, Italy and Spaine : alfo in the valleies of the mountaine Athon, wherebeing in other places but little, they become great \&s huge trees, as Petrius Bellicnim writerh: Iuba alforeporteth, that in Arabia there be of thé 50. cubits high. * $]_{\text {he }}$ 


\section{HISTORIE OF PLANTS.}

* The time.

The Strawberry tree flowreth in Iuly and Auguft; and

hath remained vpon the tree by the fpace of an whole yecre.

This tree is called in Greekeromeers in 7 be names.

Arbutc tree.

and Arbutum and Plinie calleth it $V$ nedo: Ground Sthats reade it upudxwor : in Latine Memerylum, much like vnto them another body, which onely apple is like to fhe frue, haue one body, and $V$ nedo call this Strawberric Albatro: the Spaniards Madrono, $a$ ledronberute of the earth : the Iralians boutes, Sr bous : it may be named in Englifh tree Strawberry.

The frwite of the Strawberrie The temperature and vertues. headach.

\section{Of the Plum tree. Chap.izo.}

* The kindes.

$T^{O}$ write of Plums particularly would require a peculiar volume, and yet the end not to be attained vnto, nor the ftocke or kinred perfcetly knowne, neither to be diftinguifhed apart: the number of the forts or kindes are not knowne to any one countrey: euery clymate hath his ownefruite, far different from that of other countries: my felfe haue three fcore forts in my garden, Se all ftrange and rare: there be in other places many more common, and yet yeerely commeth to our handes others not before knowne, therefore a fewe figures fhall ferue for the reft.

I Prunus Domeflica.

The Damfon tree.

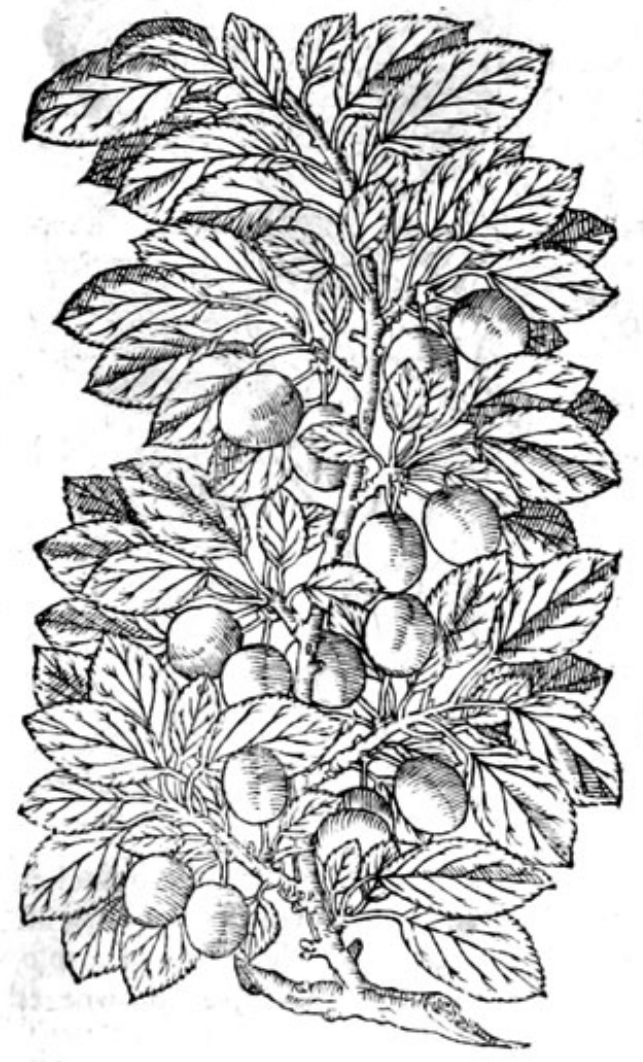

2 Prunis Mirobalanus.

The Myrabolane Plum tree.

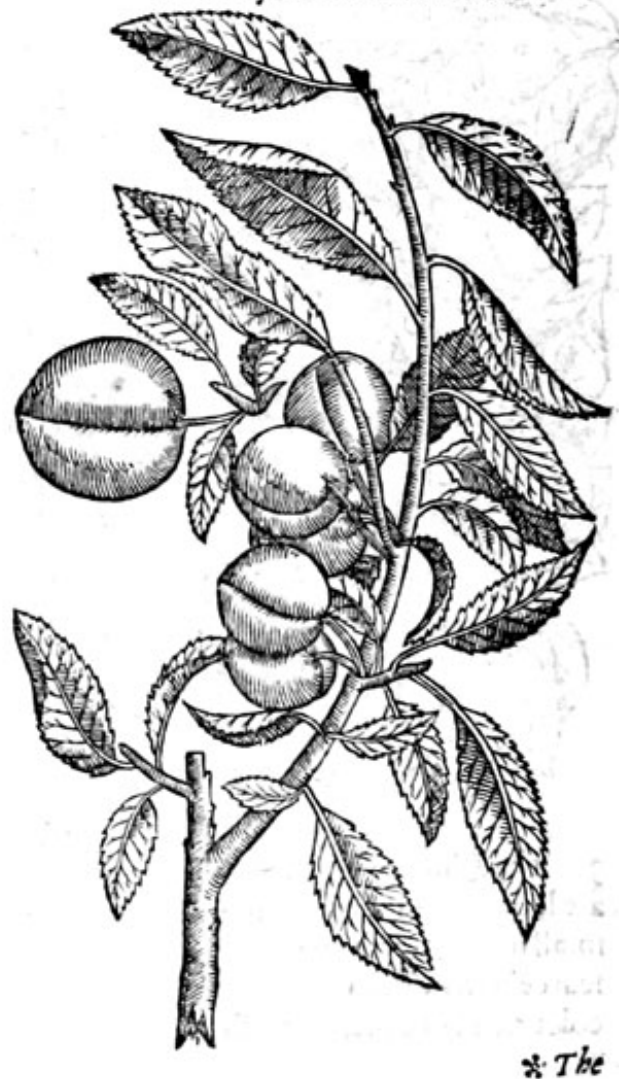


* The defoription.

I He Plum or Damfon tree is of a meane bignes; it is coueted with a fmooth barke:che bran. ches are long, whercon do grow broad leaues, more long then round, nicked in the edges: the flowers are white: the Plums do differ in colour, fafhion and bignes; they all confift of pulpe, and skiri, and alfo of kernell, which is thut vp in a fhell or ftone. Some Plums are of a blackin blewe, of which fome be longer; others rounder; others of the colour of yellow waxe; diuers of a crimfon red, greater for the moft part then the reft. There be alfo greene Plums, and withall very long; of a fweete and pleafant tafte: moreouer the pulpe or meate of forne is drier and eafiliar, feparated from the ftone of other fome it is moifter, and cleatecth falter: our common Damfon is knowne to all, and therefore not to be ftoode vpon.

2 The Mirobalan Plum tree, groweth to the height of a great tree, charged with many great armes or boughes, which diuide themfelues into infinite finall twiggie branches, by meanes whereof it yeeldeth a goodly and pleafant fhadowe: the trunke or bodie is cotiered with a finer and thinner barke then any of the other Plum trees : the leaues do fomewhat refemble thofe of the Cherrie tree; they are very tender, indented about the edges : the flowers be white : the fruite is rounde, hanging vponlong fooreftalks, pleafant to behold; greene in the beginning, red when it is almoft ripe; and being full ripe it gliftereth like purple mixed with blacke: the flefh or meate is full of iuice, pleafant in tafte : the ftone is finall, or of 2 meane bignes: the tree bringeth foorth plentic of fruit enery other yeere.

3 Prunus Asvigdalina. The Almond Plum tree.

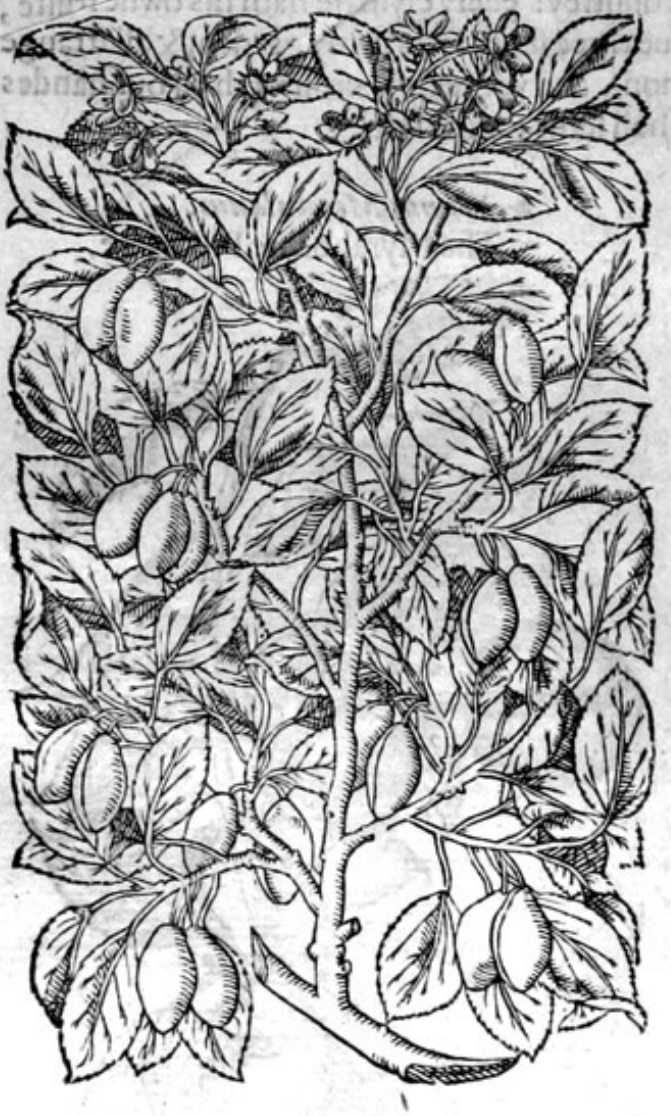

4 Prunus Damajcena. The Damfou Plum tree.

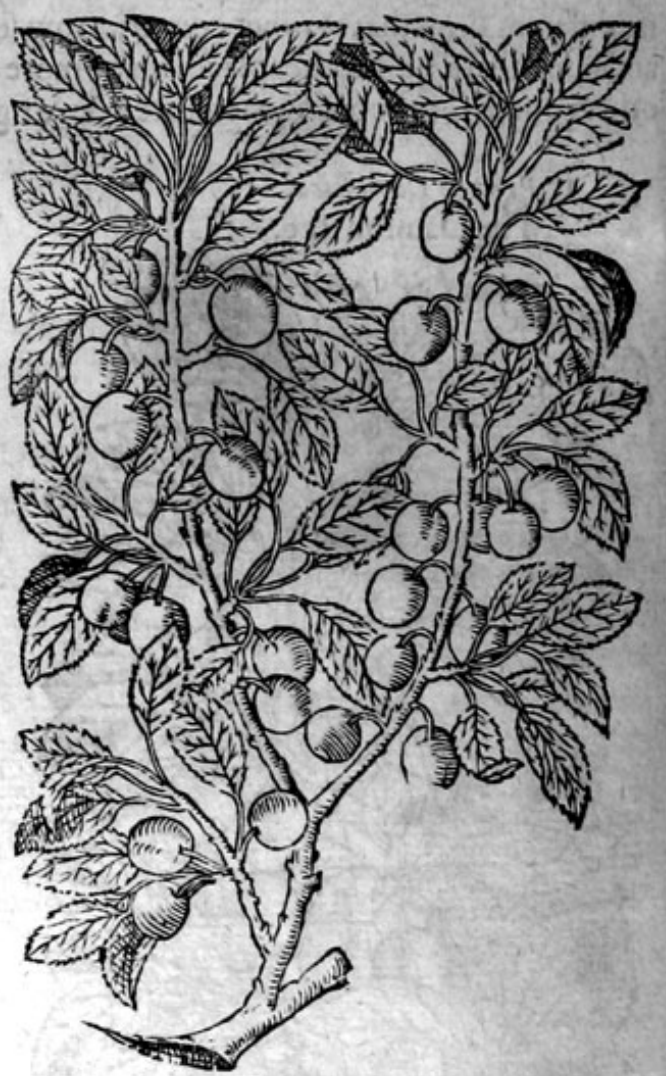

* The defription.

3 The Almond Plum groweth vp to the height of a tree of a meane bigneffe : the branches are long, fmocth, and euen : the leaues are broad, fomthing long, and ribbed in diuers places, with fmall nerues running through the fame: the flowers are white, fprinkled wit h a little dafh of purple, fcarcely to be perceiued : the fruite is long, hauing a cleft or flit downe the middle, of a browne red colour, and of a pleafant tafte. 


\section{- HISTORIE OF PLANTS.}

4 The Damafcene Plum tree groweth likewife to a meane height; the branches very brittle; the leaues of a deepe greene colour. The fruit is round, of a blewifh blacke colour. The ftone is like vnto
that of the Cherrie, wherein it differeth from all other Plums.

5 Prunus fylueftris. The Sloe tree.

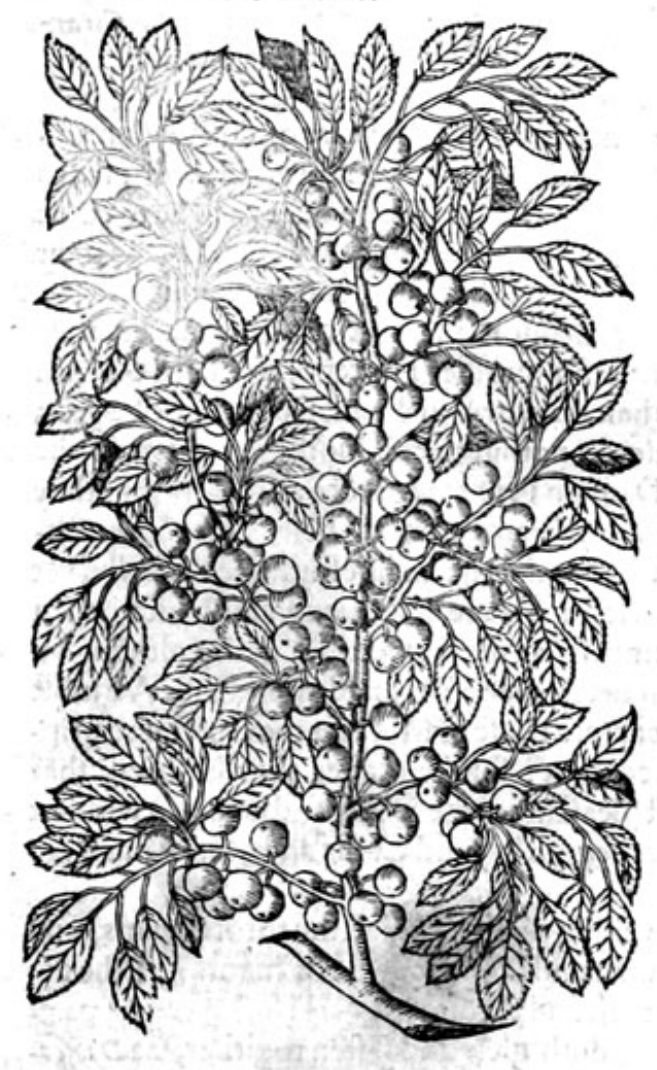

Prunus fylueft ris florens.

The Sloe tree in flower.

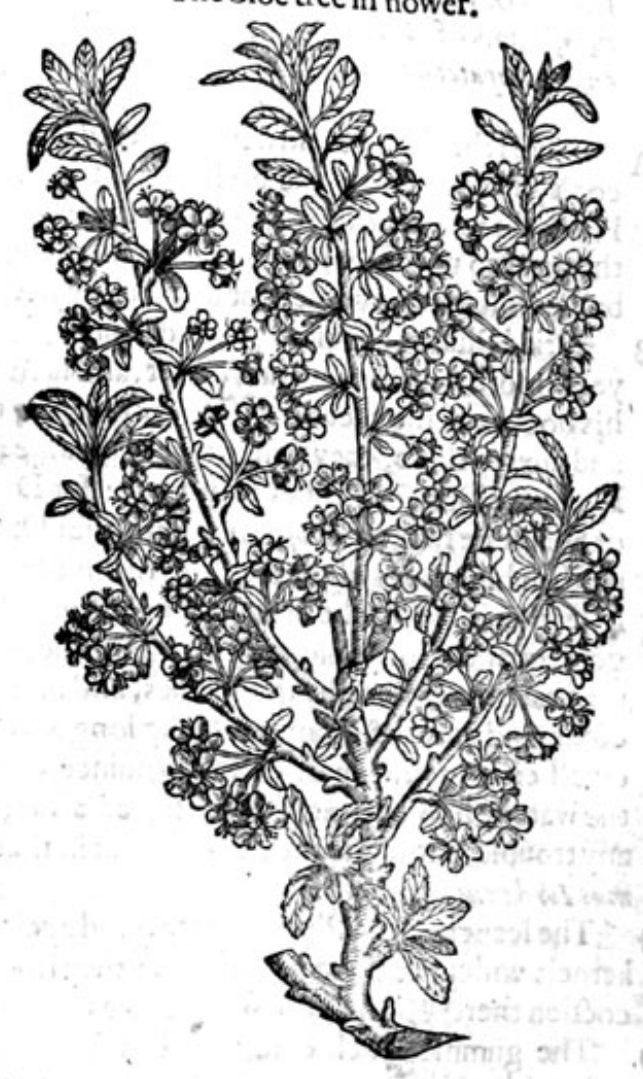

* The defcription.

5 The Bullefle and the Sloe tree are wilde kindes of Plums, which do varie in their kinde, euen as the greater and manured Plums do. Of the Bulleffe, fome are greater-and of better tafte than others. Sloes are fome of one tafte, and fome of others, more harpe; fome greater, and othersleffer; the which to diftinguiih with long defcriptions were to fmall purpofe, confidering they be all and euery of them knowen euen vnto the fimpleft : therefore this fhall fuffice for their feuerall defcriptions.

\section{* The place.}

The Plum trees growe in all knowen countries of the world: they require a loofe ground; they alfo receiue a difference from the regions where they growe, not onely of the forme or fafhion, but efpecially of the faculties, as we will foorthwith declare.

The Plum trees are alfo many times graffed into trees of other kind, and being fo ingraffed they, qua faciem parentis,fuccum adoptionts, vt Plinius dicit, exhibent.

The greateft varietic of thefe rare Plums are to befound in the grounds of Mafter Vincent Pointer of Twicknam (before remembred in the Chaptet of Apples) although my felfe am not with out fome, and thole rare and delicate. The wilde Plums growe in moft hedges through England. * Thetime.

The common and garden Plum trees do bloome in Aprill, the leal :s come foorth prefently with them; the fruit is ripe in fommer, fome fooner, fome later.

* The mames.

The Plum tree is called in Greekexoxxuunise: in Latine Prunus : in high Dutch foflaumenbaum: in lowe Dutch 19zupmen! in Spanifh Cirutlo : in French Prunier : in Englifh Plum tree. 


\section{:3I4 THE THIRD:BOOKEOOF THE}

The fruit is called in Grecke roxnutixor : in Latine Prunum: in high Dutch pofaumen: in lowe Dutch jog gupmen : in Iralian and French Prune: in Spanifh Pranis: in Englifh Prune and Plum; thefe haue alfo names from the regions and countries where they growe.

The olde writers haue called thofe that growe in Syria neerc vnto Damafcus, Damafcena Fruna, in Engliih Dainfons, or Damaske Prumes; and thofe that growe in Spaine, Hijpanica, Spanifh Prunes or Plums: So in our age we vfe to call thofe that grow in Hungarie, Hungarica or Panno. nica, Plums of Hungarie; fome Gallica Pruna, or French Prunes, of the countrie of Fraunce. Glearchus Peripateticus faith, that they of Rhodes and Sicilia do call the Damaske Prunes Brabula. $*$ Thetemperatureandvertues.

A Plums that be ripe and new gathered from the tree, what fort foetuer they are of, do moyften and coole, and yeeld vnto the body very little nourifhment, and the fame norhing good at all : for as Plums do very quickly rot, fo is allo the iucie of them apt to putrifie in the body, \& likewife to caufe the meat to putrifie which is taken with them, onely they are good for thofe that wouldkeepe their bodies foluble and coole; for by their moyfture and flipperineffe they do mollifie the belly.

B Dried Plums, commonly called Prunes, are holfomer and more pleafant to the ftomacke, they yeeld more nourifhment and better, andfuch as cannoteafily putrifie. It is reported, faith Galen in his bookes of the faculties of nourithments; that the beft do growe is Danafcus a citie of Syria; and next to thofe, they that growe in Spaine; but thefe do nothing at all binde, yet diuers of the Damaske Damfon Prunes very much: for Damaske Diumfon Prunes are more aftringene, but they of Spaine be fweeter.Diogcorides faith, that Damaske Plums dried do ftay the belly; but Galen affirmeth in his bookes of the faculties of fimple medicines, that they do nianifeftly loofe the belly, yer leffer than they that be brought our of Spain, being boyled in Meade or honied water, which hath 2 good quantitie of honie in it, they loofeve belly very much (as the fame author faith) although a man take them alone by themfelues, and much more if thę Meade be fupped after thein. We moft commend thofe of Hungarie being long and fweet:yet more thafe of Morauia the chiefe and principall citie in times paft of the prouince of the Marcomanss for thefe after they be dried, that the waterie humour may be confumed away, be moft pleafanc to the tafte, and do eafily without any trouble fo mollifie the belly, as that in that refpect they go beyond Caffia and Manna, as Thomas Iordanus affirmeth.

C The leaues of the Plum tree are good againft the fwelling of the Vuula, the throte, gums, and kernels vnder the throte and iawes; they ftop the rheume and falling downe of humors, if the decoetion thereof be made in wine, and gargled in the mouth and throte.

D The gumme which commeth out of the Plum tree, doth glew and faften togither, as Diofoorides faith.

E Being drunke in wine it watteth a way the ftone, and liejleth Lichens in infants and yoong children;if it belaide on with vineger, it worketh the fameeffeds that the guin of the Peach and Cherrie tree doth.

F The wilde Plums do ftay and binde the belly; andfo do the vnripe Plums of what fort foeuer, whiles they are fharpe and fower, for then are they aftringent.

G The iuice of Sloes do ftop the belly, the laske and bloodie flixe, the inordinate courfe of womens termes, and all other iffues of blood in, man or, woman, and mày very well be vfed in ftead of Acatia, which is a thornie tree growing in Egypt, very hard to be gotten, and of a deere price, and therefore the better for wantons; albeit our Plums of this countrie are equall vinto it in vertues.

\section{Of Sebeften, or the A ßyrian Plum. Chap.ri2.}

* The defcription.
Ifo a kinde of Plums: the tree whereof is not vnlike to the Plum tree, faung it Ebeftines are alfo a kinde of Plums: the tree whereof is not vnlike to the Plum tree, fauing it
growerh lower than the moft of the manured Plum trees; the leaues be harder and rounder; the fowers growe at the tops of the branches confilting of fiue fmall white leaues, with pale yellowith threds in the middle, like thofe of the Plum tree : after followeth the fruit like tolittle Plums, faftened in little cups like vnto Acornes, which when they be ripe are of a greenifh blacke colour, wherein is contained a three fquare ftone fomewhat hard. The fruit is fweete in tafte, the pulpe or meate is very tough and clammic, a matter fit to make birdlime of. 
Sebeften, Myxa,fme Myxarit.

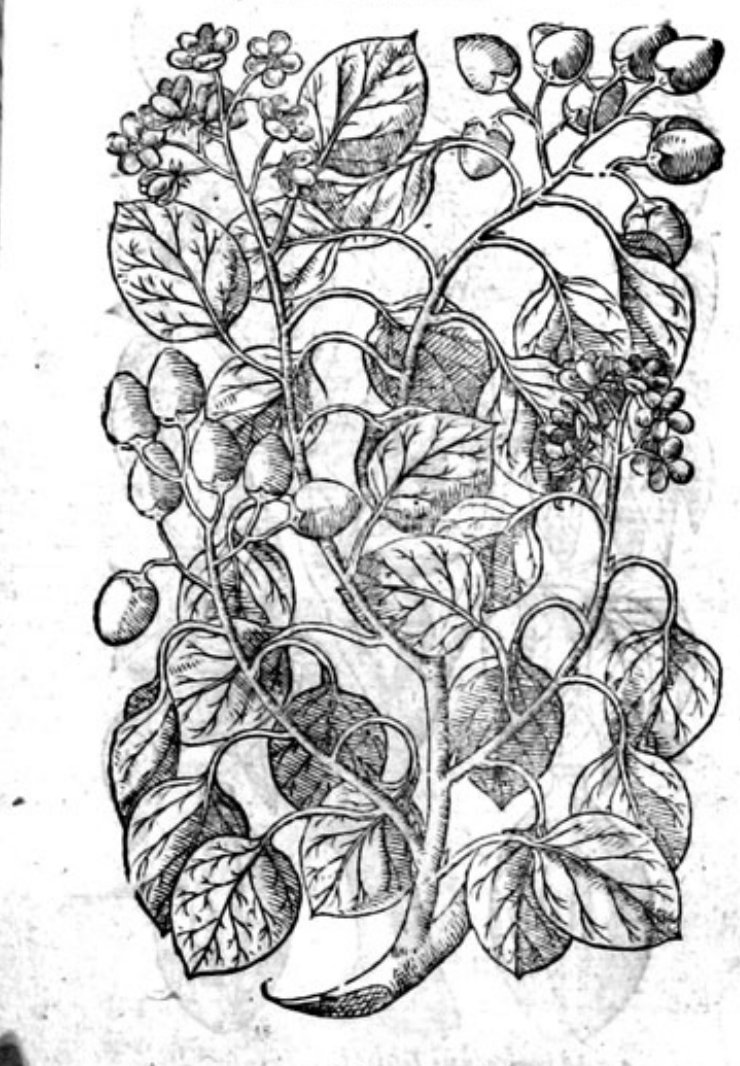
AffyrianPlums.

OF PLANTS.

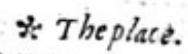

The Sebeften trees growe plentifully in Syria and Egypt; they were in times patt forr ftrange in Italie, now they growe almoft in euery garden, being firtt brought thither in Plinichis time. Now do the Sebelten trees, faith he in his i 5 . booke 18 . chapter, begin to growe in Rome among the Seruice trees. * Thetime.

The time anfwereth the common Plums. * The nowes.

Plinie calleth the tree $M y x a$, it may be fufpected that this is the tree which Matron Parodus in his Attick banket in A: hen ates doth call A'rapu हुis, but we cănot certainly affirme it, \& efpecially bicaufe diuers copies have diuerfly deemed thereof. The

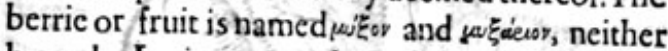
haue the Latines any other name. The Arabians and the Apothecaties do callit Sebeften, which is alfo made an Englifh name : we may call it the Affyrian Plum. The temperature and vertues.

Sebeitens be very tenperatly cold and moyit, A and haue a thicke and clammie fubitance; therefore they nourifh more than molt fruits do, but withall they cafily ftop the intrailes, and fuffe vp the narrow paffages, and breede inflammations.

They take aivay the ruggednes of the throte $B$ and lungs, and alfo quench thirft, being taken in

a looch or licking medicine, or prepared any other kinde of way, or elfe taken by it felfe.

The waight of ten drains, or of an ounce and a halfe of the pap or pulpe hereof being inwardly $\mathbf{C}$ taken, doth loofe the betly.

There is alfo made of this fruit a purging Electuarie, but fuch an one as quickly mouldeth, and D therefore it is not to be vfed, but when it is new made.

\section{Of the Indian Plum, or Mirobalantree. Chap.122.}

\section{$*$ The kindes.}

THere be diuers kindes of Mirobalans, and therefore not eafily comprehended vnder one de. fcription:they be alfo of diuers colours, fome are yellow, fome of Orange tawny, fome blacke, fome called Chebule, fome Bellirica, fome Enblice; they likewife growe vpon diuers trees, and in diuers and fundrie countries far diftant one from another; yet $M e$ fue faith, that the yellow and blacke, and the Chebule are thought to growe vpon one tree; for before they be ripe theybe yellow, and when they are full ripe they be blacke : notwithftanding moft are of opinion, that fuch as differ in colour are of diuers trees, and that the fiue kindes growe vpon fiue diuers trees: and of this opinion is Garci.a the Lufitanian Phificion.

\section{* T the defcription.}

$17 \mathrm{He}$ firft of the Mirobalan trees called Chebu/e, is a fhrubbie tree altogither wilde(which the Indians docall Aretca) in ftature not vnlike to the Plum tree; the branches are many, and growe thicke togither, whereon are fet leaues like thofe of the Peach tree. The fruit is greater than any of the reft, fomewhat long, fafhioned like a Peare.

2 This fecond kinde of Mirobalan called Flaua Citrina, which fome do call Aritigui, but the common people of India Arare, growcth vpon a tree of meane ftature, hauing many boughes ftanding finely in order, and fet full of leaues like vnto the Service tree. 
1 Mirobalani Chebule.

Mirobalans with Peach leaues.

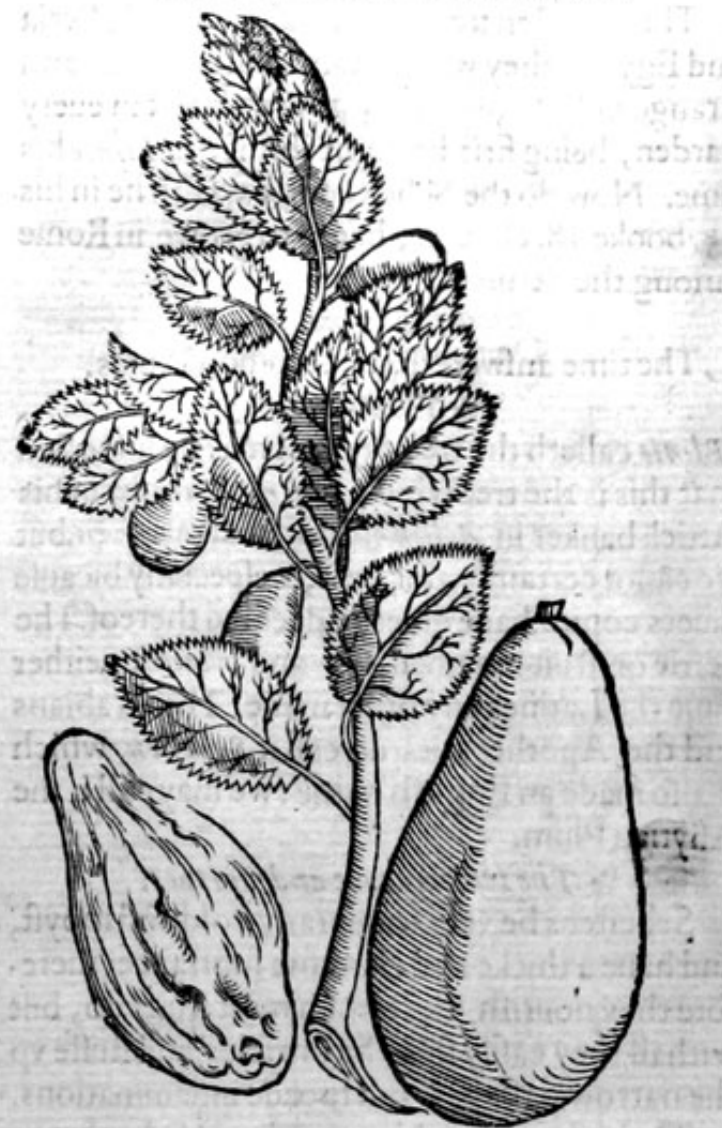

3 Mirobalani Bellirice of Emblice. The fruit of two forts of Mirobalanes.
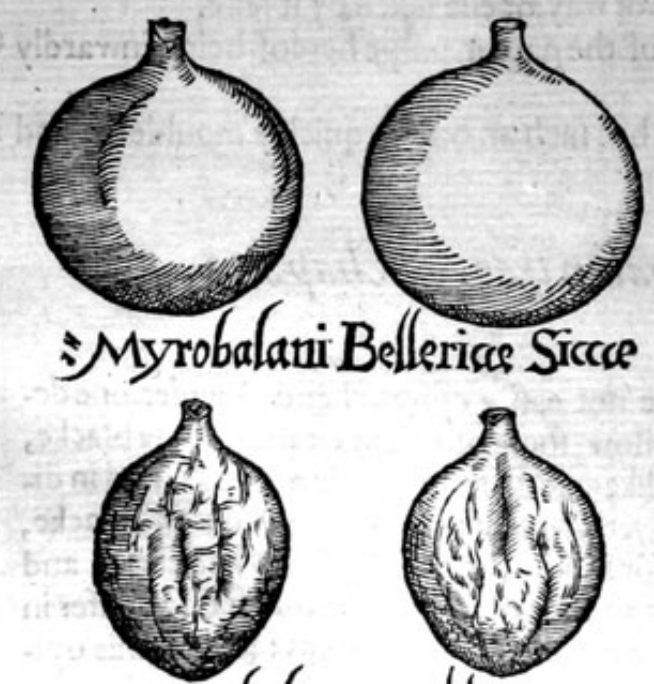

EMyrobalawi smblice.
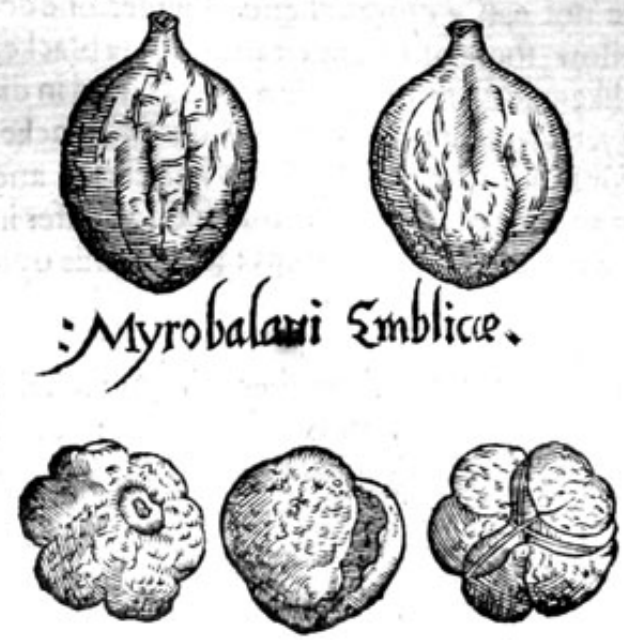

2 Mirobalani Citrine. Mirobalans with Seruice leaules.

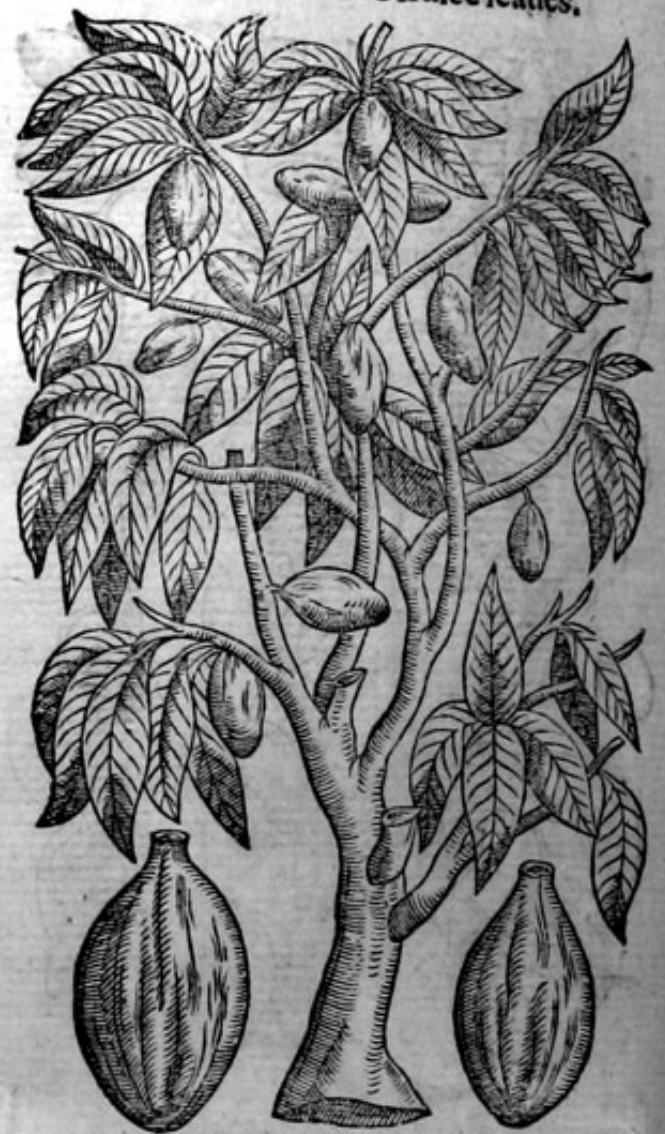

4 Mirobalani Indici. Indian Mirobalane tree.
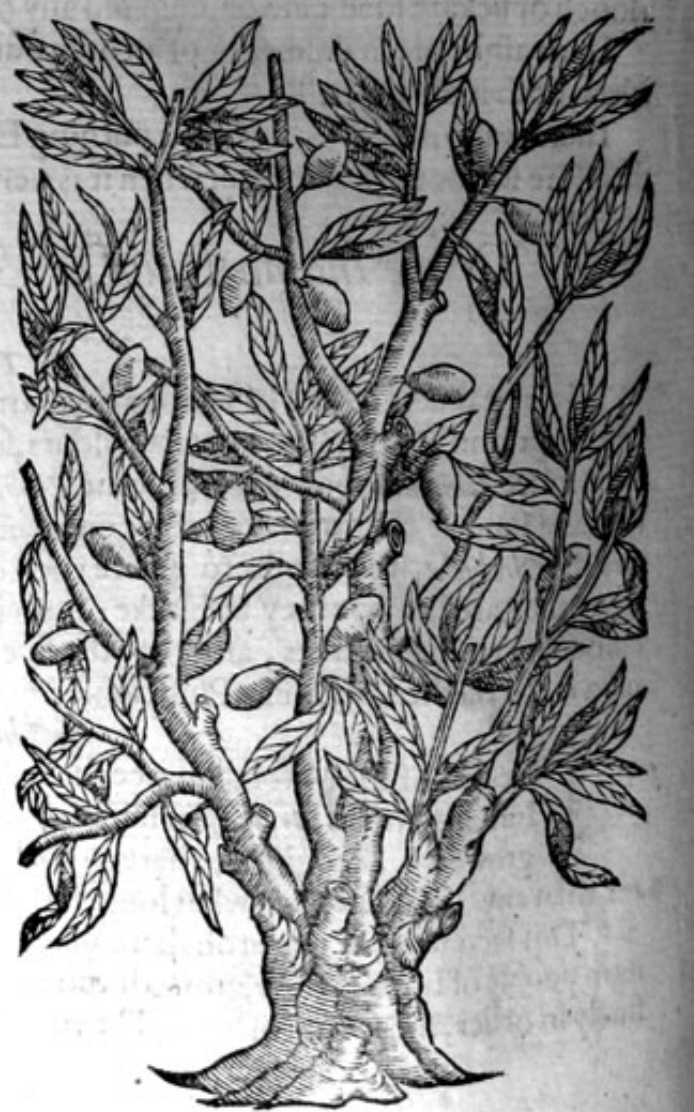
3 The third kinde of Mirobalans called Emblice, the Indians do call Amiale, which growe vpon a tree of meane ftature, like the former; but the leaues are very much iagged, in thape like the leaues of Fernc, but that they be fomewhat thicker. The Indians do not put the fruit hereof vnto phificall vfes, but occupie it for the thickning and tanning of their leather in fteede of $R$ hus or Coriars Sumach, as allo to make inke and bletch for other purpofes.

Mirobalani Bellerica called of the Sauages Gotni and Guti, groweth vp to a meane ftature, garnifhed with leaues like vnto Laurell or the Bay tree, but fomewhat lefler, thinner, and of a pale greene colour.

4 The fourth kind of Mirobalans is called Indice, which the Indians do cal Kezannale, groweth vpō a tree of meane ftature, or rather vpon a fhrub or hedge plant, bearing leaues like the Willow, and a fruit eight fquare. There is a fift kinde, the tree whereof is not mentioned in authors. * The place.

The firft fower kindes of Mirobalans do growe in the kingdome of Cambaia; they growe likewife in Goa,Batecala,Malanor,and Dabul; the Kebula in Bifnager, Decan,Guzarate,and Bengala, and many other places of the Eaft Indies.

* The time.

The time agreeth with other fruits in thofe countries.

$$
\text { * The names. }
$$

Thofe which we haue faid to be yellow, the inhabitants of thofe countries where they growe do call them Arare ; thofe that be blacke, they call Rezensale; the Bellerica, Gotim; the Chetule, Aretca; the Emblice are called Aretiqui.

\section{i The temperature.}

All the kindes of Mirobalans are in tafte aftringent and fharpe like vnto the vnripe Sorbus, or Seruice berries, and therefore they are of complexion cold and drie.

\section{* The vertues.}

TheIndians vfe them rather to binde than purge ; but if they do vfe them for a purge, they vfe A the decoetion of them, and vfe them much conferued in fugar, and efpecially the Chebule; the yellow andblacke be good that way likewife.

The yellow and Belleric a taken before meate, are good againit a laske, or weake ftomacke,as Gar- B cies writeth.

The yellow and blacke, or Indice, and the Chebule, purge lightly, if two or three drams be taken, C and drawe fuperfluous humors from the head.

The yellow, as fome write,purge choler, Che bule flegme, Indice melancholie, and ftrengthen the D inward partes; but rofted in the imbers or otherwife, walted, they drie more than they purge.

There are two fortes efpecially brought into thefe partes of the worlde conferued, the Chebule, E and of them the beft are fomewhat long like a fmall Limon, with a harde rinde and blacke pith, of the tafte of a conferued Wall nut; and the Bellerice, which are round and leffer, and tenderer in cating.

If they be mingled with fharpe medicines, as Scammonie, it correcteth their nature, and efpeci- F ally the yellow.

L'Obeluss writeth, that of them the Emblice do mcanly coole,fome do drie in the firft degree, they $G$ purge the ftomacke of rotten flegme, they comfort the braine, the finewes, the hart, and lituer, procure appetite, ftay vomit, and coole the heate of choler, helpe the vnderftanding, quench thirit, and the heate of the intrailes; the greateft and heauieft be the beft.

Theypurge beft, and with leffer paine, if they be laide in water in the funne vntill they fwell, and $I$. fod on a fofe fire, \& after they haue fod and be cold, preferued in fo much white hony as the fourth part of it,put to them.

Dur Apothecaries might very much further the happy proceedings of our Phifitions, if they I would procure to haue the aforefaid fruits greene, to diftill them, and referue the water thereof for agrear iewell.

Garcis found the diftilled water aforefaid to be right profitable againtt the French difeafe, and $\mathrm{K}$ fuch like infections.

The pellerice are alfo of a milde operation, and do comfort, and are cold in the firft degree, and $\mathrm{L}$ drie in the fecond : the others come neere to the Emblice in operation.

$$
\text { Q } 9 \text { I }^{\text {I }}
$$




\section{Of the fuinbe tree. Chap,123.}

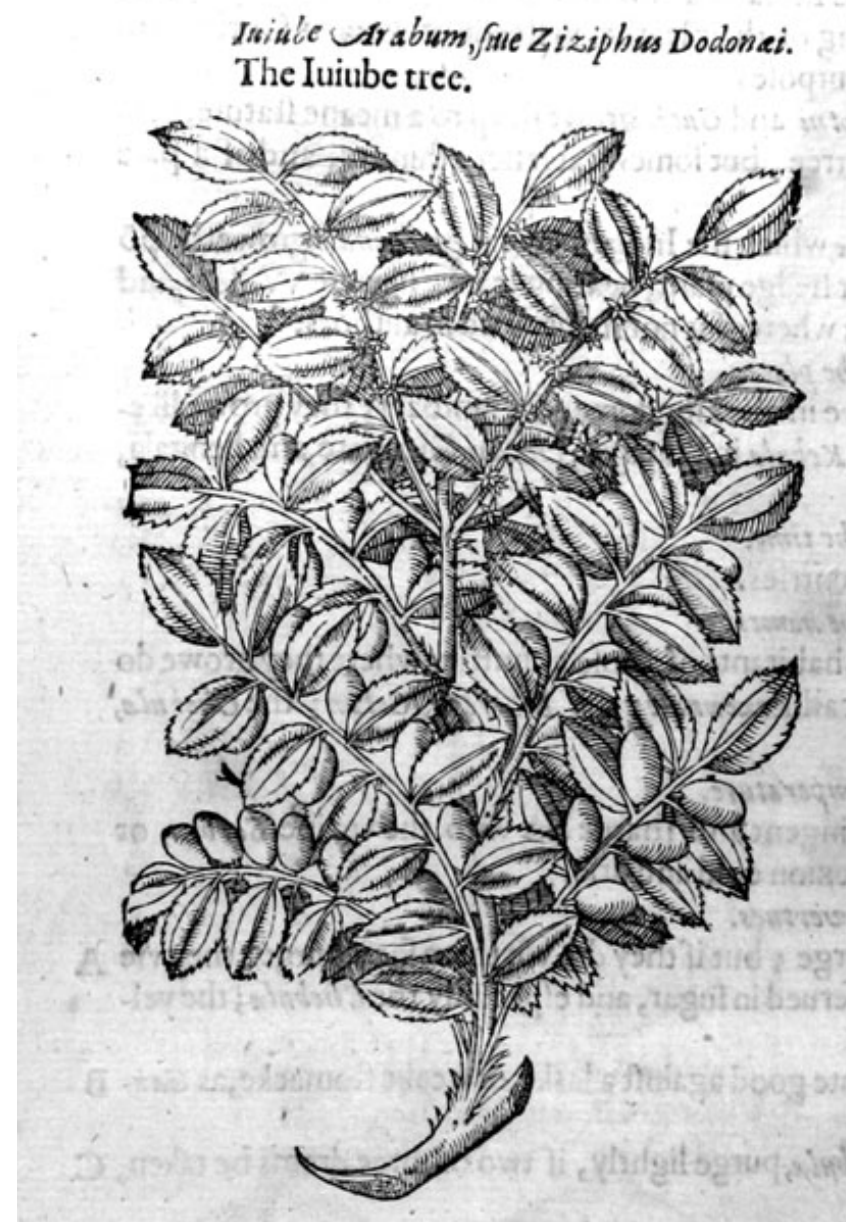

The 2 Thefription. 7 He Iuiube tree is not much leffer than $Z$ i. zipha candida, hauing a wrearhed trunke or body, and a rough barke full of rifts or $\mathrm{Cr}_{2}$ nies, and Itiffe branches, befet with inany ftrong and hard prickles: from whence grow out many long twigs, or little ftalks, halfe a foote or more in length,in fhew like Rufhes, limmer, and eafily bowing themfelues, and very flender like the twigs of Spartum : about which come foorth leaues one againft another, which are fomwhat long, not very great, but hard and tough like to the leaues of Peruinca or Peruinkle; \& amongit thefe leaues come foorth pale and moffie little flowers; after which fucceed long berries as big as Oliues (of a meane quantitic)or little Prunes, or fmal Plums, wheron there is an hard or woo. dy fhell, in which the kernel or nut is contained. * The place.

There be now at this day Iuiube trees grow. ing in very many places of Italie, which in times paft were newly brought thither out of Syria, and that about Plinie his time, as he himfelfe hath written in his 17 . booke ro.chaper. * The time.

It flowreth in Aprill,at which time the feedes or ftones are to be fet or fowen for increafe.

$$
\text { * The names. }
$$

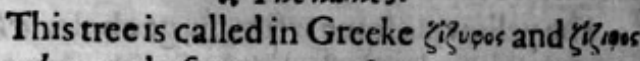

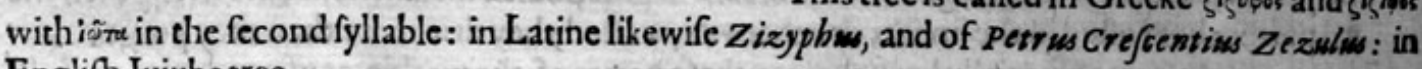
Englith Iuiube tree.

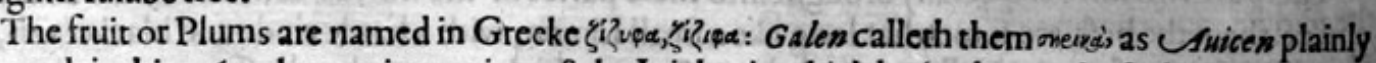
fheweth in his 369 . chapter intreating of the Iuiube, in which be fer downe thofe things, that are mentioned concerning serica in Galens booke of the faculties of nourifhments : in Latine likewife $Z$ izypha and Serica : in fhops Iniube : in Englifh Iuiubes.

Iuiubes are temperate in heate and moyfture.

$$
\text { * The vertues. }
$$

A. The fruit of the Iuiube tree eaten, is of hard digettion, and nourifheth very little, but being taken in firupes, electuaries, and fuch like confections, it appeafeth and mollifieth the roughneffe of the throte, the breft and lungs, and is good againit the cough, but exceeding good for the reines of the backe, the kidneies and bladder.

\section{Of the Cherrietree. Chap.124.}

* The kindes.

$T$ He ancient Herbarifts haue fet downe fower kindes of Cherrie trees; the firft is great and wild; the fecond tame or of the garden; the third, whofe fruit is fower; the fourth is that which is 
called in Latin Chamecers fus, or the dwarffe Cherric tree. The later writers bate found divers torts more, fome bringing foorth greater fruit, others, lefler; fome with whiteffuit, fonc with blacke; others of the colour of black blood, varying infinitely according to the climate and countrie whete they growe.

I Cera/us vulgaris.

The common Englifh Cherrie trec.

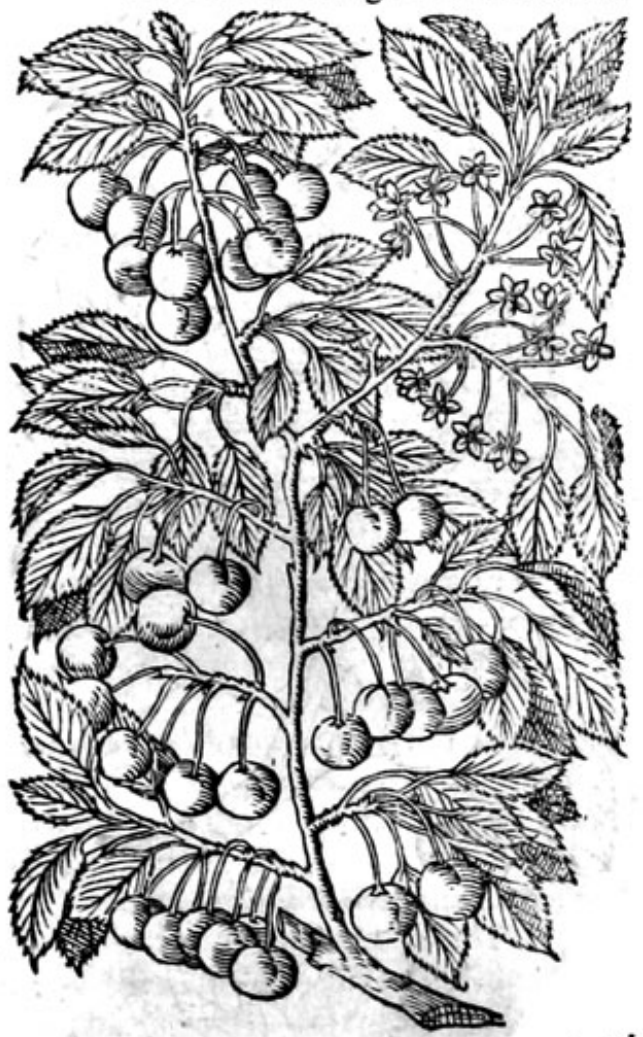

2 Cerafus precox fine Belgich. the Flanders Clierric tree.

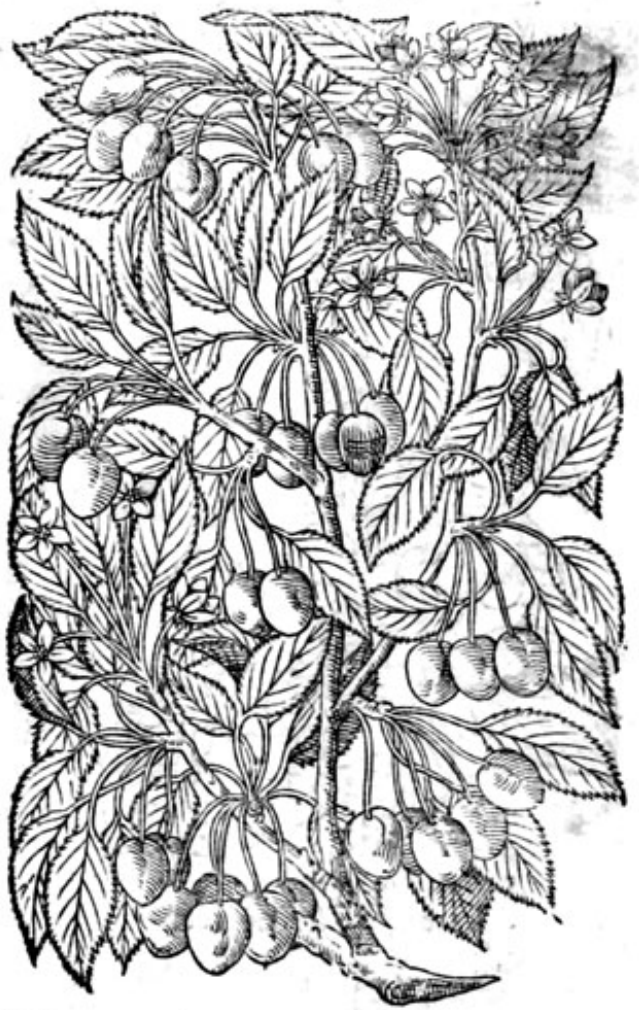

* The defrition.

$17 \mathrm{He}$ Englifh Cherric tree groweth to an high and great trec, the bodie wherof is of a meane bignes, which is parted aboue into very many boughes, with a barke fomewhat fnooth, and of a browne crimfon colour, tough and pliable. The fubltance or timber is alfo browne in the middle, and the outward part is fomething whire. The leaues be great, broad, long, ferwith veines or nerues, \& flightly nicked about the edges. The flowers are white, of a meane bignes, confilting of fiue leaues, and hauing certaine threds in the middle of the like colour. The Cherries be round, hanging vpon long ftems or footeftalks, with a ftone in the mićdeft, which is couered, with a pulpe or foft meate; the kernell there of is not vnpleafant to the tafte, though fomewhat bitter.

2 The Flanders Cherrie tree differeth not from our Englifh Cherric tree in Atature, or forne of leaues or flowers; the difference confiltech in this, that this rree bringeth foorth his fruit fooner, and greater than the other.

3 The Spanifh Cherrie tree grow eth vp to the height of our common Cherrie tree; the wood or timber foft and loofe, coucred with a whitifn fcalie barke, the branches are knotrie, greater \& fuller of fubftance than any other Cherrie trec; the leaues are likewife greater, and longer than any of the reft, in Thape like thofe of the Cheftuut tree: the flowers are like the other in ioune, but whiter of colour : the fruit is greater and longer than any, white for the moft part all otser, except thofe thit ftand in the hotteft place where the funne hath fome reflexion againft a wall; they are alfo white within, and of a pleafant tafte.

4 The Gafcoine Cherrie tree groweth very like vnto the Spanifh Cherrie trec in ftațure, flowers and leaues : it differeth in that it bringeth foorth very great Cherries, long, tharpe pointed, with 2 certaine hollowneffe vpon one fide, and fpotted here and there with certaine prickes of purple colour as fmallas fand; the tafte is molt pleafanc, and excelleth in beautic. 
1320

THE THIRD BOOKE OF THE

3 Ceralia Hipanica.

The Spanth Cherrie tree.

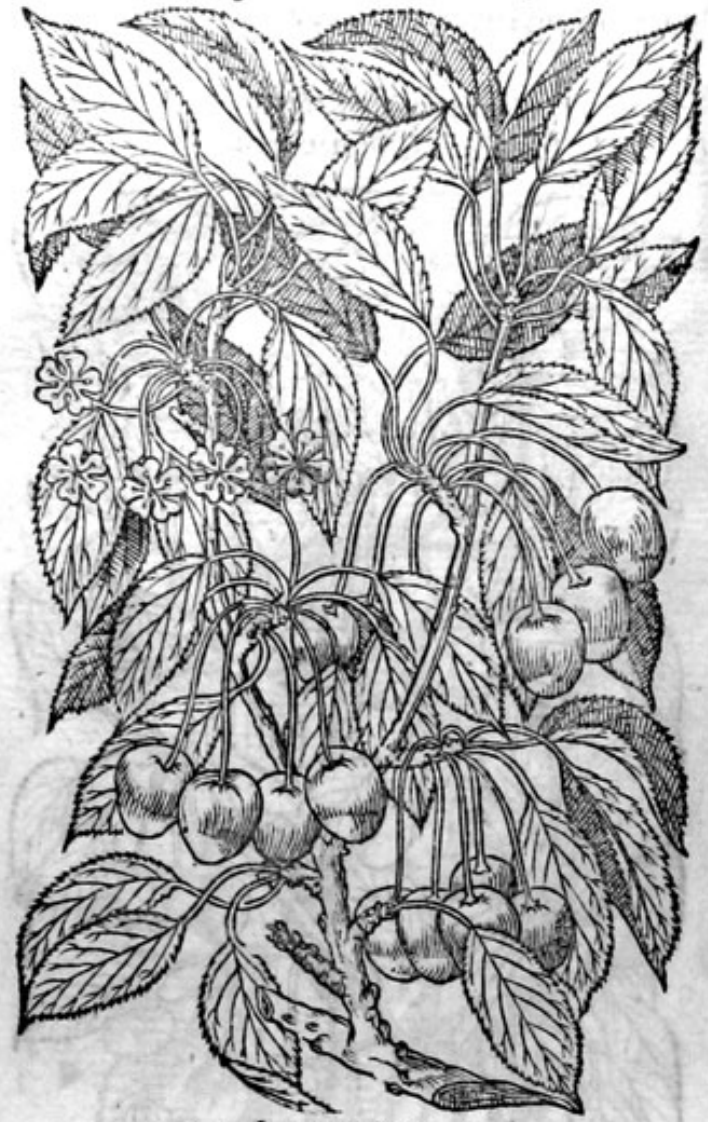

4 Ceraful Gafconica.

The Gafcoine Cherrie tree.

5 Cerafins Serotina.

- Late ripe Cheirie tree.

$\therefore$ al (3)

A 5 (2)
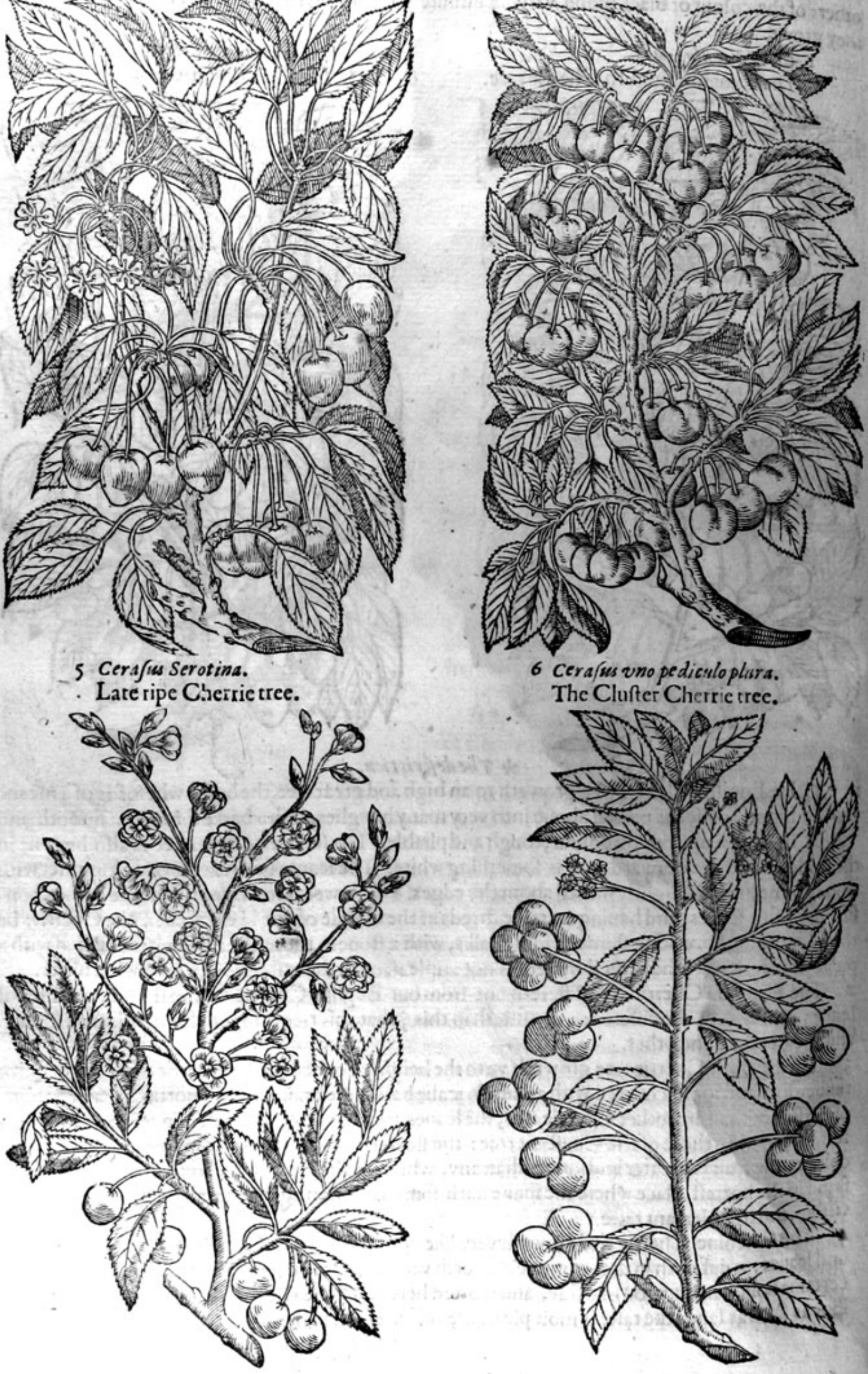

6 Cera/us vno pediculo plivra.

The Clufter Cherric tree.

Nin 12
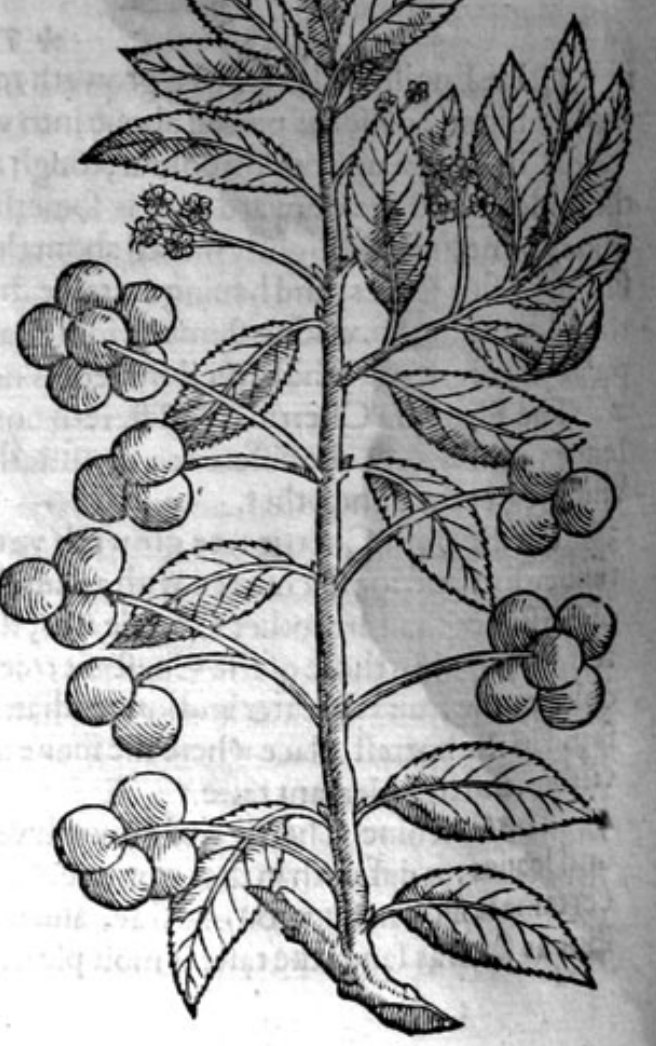
5 The late ripe Cherrie tree groweth vp like vnto our wilde Englith Cherric tree, with the like leaues, branches and flowers, fauing that they are fometimes once doubled:the fruit is finall, round, \& of a darke bloodie colour when they be ripe, which the French men gather with their $\mathrm{ftalks}$, and hang them vp in their houfes in bunches or handfuls againft winter, which the Phiffitions do giue vnto their patients in hot and burning feuers, being fiift fteeped in a little warme water, that caulfeth them to fwell and plumpe vp as full and frefh, as when they did growe vpon the tree.

6 The Clufter Cherrie tree differeth not from the laft deferibed either in leaues, branches, or fta. ture : the flowers are alfo like, but neuer commeth any one of them to be double. The fruit is round, red when they be ripe, and many growing vpon one ftem or footitalke in clufters, like as the Grapes do.The tafte is not vnpleafant, alchough fomewhat fower.

7 Cerafius multiflora fructus edens.

8 Cerafus multifor a pauciores fructius edens.

The double flowerd Cherrie tree bearing fruit. The double flowerd barren Cherric tree.
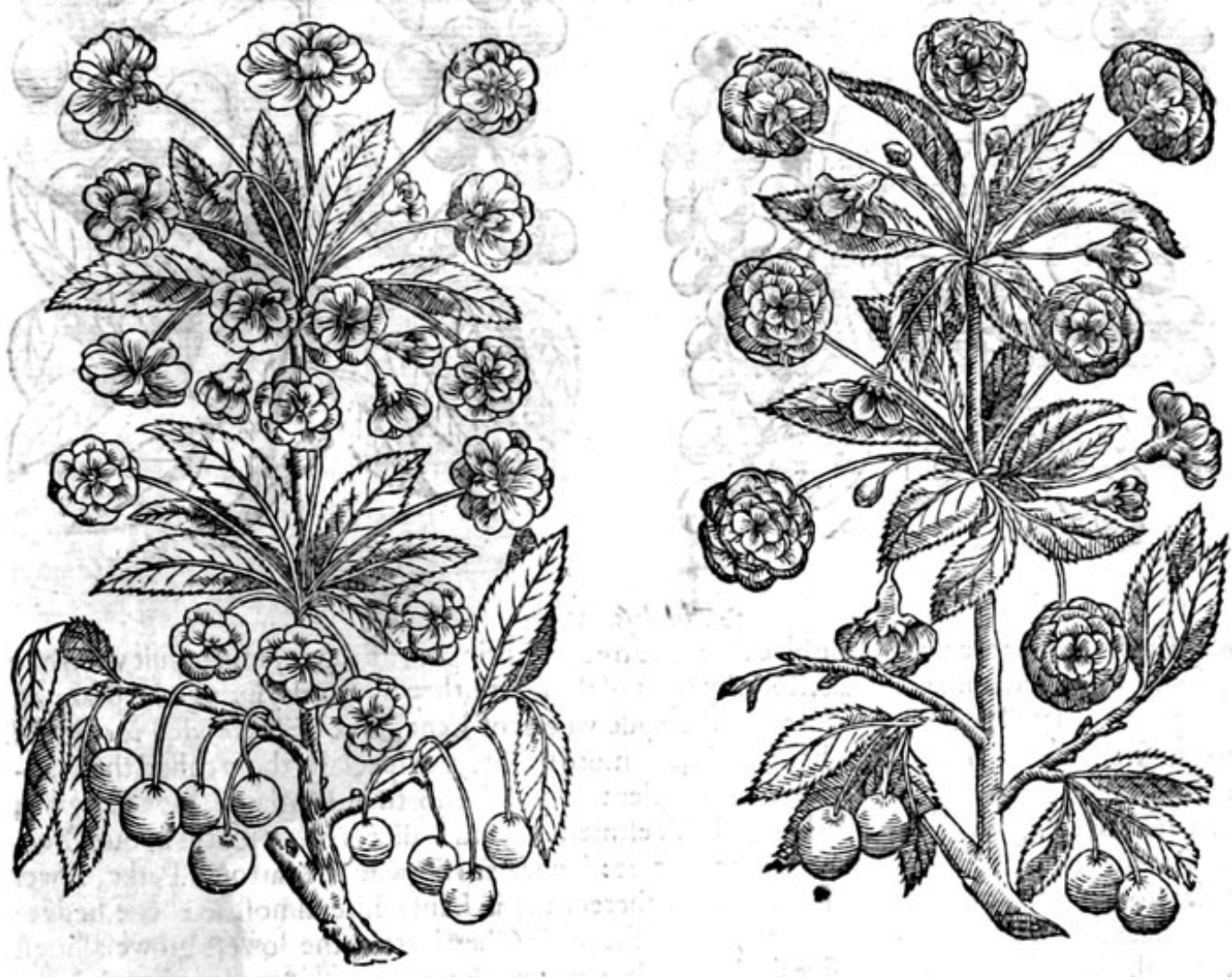

* The defcription. 7 This Cherrie tree with double flowers groweth vp vnto a fmall tree, not vnlike vnto the com.
mon Cherric tree in each refpect, faning that the flowers arc forme what doubled, that is to fay, three or fower times double; atter which commeth fruit (though in finall quantitic) like the other common Cherrie.

8 The double flowred Cherrie tree groweth vp like vnto an hedgc bufh, but not fo great nor high as any of the others; the leaues and branches differ not from the reft of the Cherrie trecs. The flowers hereof are exceeding double, as are the flowers of Marigoldes, but of a white coloyr, and fmelling fornewhat like the Hawthorne flowers; after which come feldome or :ecuer any fruit, al. though fome authors baue faid that it beareth fometimes fruit, which my felfe haue not at any time feene; notwithftanding the tree hath growen in my garden many yeeres, and that in an excellent good place by a bricke wall, where it hath the reflection of the fouth funne, fit for a tree that is not willing to beare fruit in our colde climate. 
9 Cerafus auium nigra \& racemofa.

Birds Cherrie,and blacke Grape Cherrie tree.

10 Cerafus racemoja rubra. Red Grape Clierric tree.

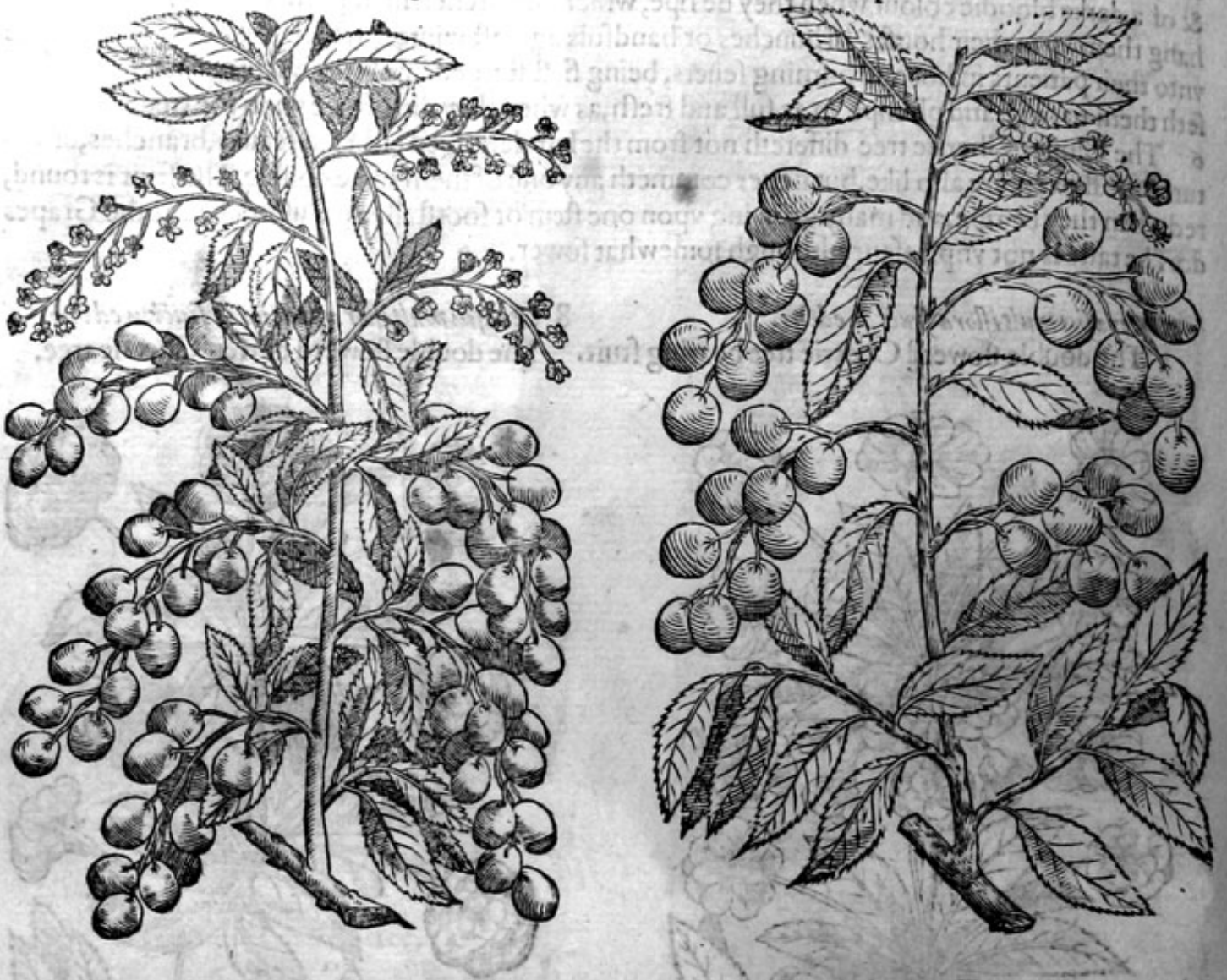

* The defcription.

9. The Birds Cherrie tree, or the black Cherrie tree, that bringeth forth very much fruit vpon one branch (which better may be vnderftood by fight of the figure, then by words) fpringech yp like an hedge tree of fmall ftature, it groweth in the wilde woods of Kent, and are there vfed for ftocks to graffe other Cherries vpon, of better tafte, and more profite, as efpecially thofe called the Flatiders Cherries : this wilde tree groweth very plentifully in the north of England, efpecially at a place called Heggdale, neere vnto Rofgill in Weftmerland, and in diters other places about Crofbie Rauenfivaith, and there called Hegberrie tree: it groweth likewife in Martome Parke, fower miles from Blackburne, and in Harward neere thereunto; in Lancafhire almoft in euerie hedge: the leaues and branches differ not from thofe of the wilde Cherrie tree: the flowers growe alongt the fmall branches, confifting of fiue fmall white leaues, with fome greenifh \& yellow thrums in the middle, after which commeth the fruit, greene at the firft,blacke when they be ripe, and of the bigneffe of Sloes; of an harfh and vnpleafant tafte.

10.The orher Birds Cherrie tree differeth not from the other in any refpeet, but in the colour of the berries; for as they are blacke;contrary, thefe are red when they be ripe, wherein they differ. II. The common blacke Cherrie tree groweth vp in fome places to a great ftature: there is no difference betweene it and our common Cherric tree, fauing that, that the fruite heereof is very. little in refpect of other Cherries, and be of a blacke colour.

I2 The dwarffe Cherric tree groweth very feldome to the height of three cubits: the trunke or body fmall, couered with a darke coloured barke, whereupon do growe very limber and pliant twig. gie branches: the leatues are very fmall, not much vilike to thofe of the Priuet bufh: the flowers are fmall and white, after which come Cherries of a deepe red colour when they be ripe, of tafte fomewhat fharpe, but not greatly vnpleafant : the branches laide downe in the earth, quickly take roote, whereby it is great ly increafed. 
* The defcription.

My felfe with diuers others haue fundry other forts in our gardens, one called the Hart Cherrie; the greater and the leffer; one of a great bignefle, and moft pleafant in tafte, which we call $L$ uke Wardes Cherric, bicaufe he was the firft that brought the fame out of Italy; another we haue called the Naples Cherrie, bicaufe it was firft brought into thefe parts from Naples: the fruite is verie great, tharpe pointed, fomwhat like a mans haic in thape, of a pleafant tafte, and of a deepe blackifh colour when it is ripe, as it were of the colour of dried blourd.

We haue another that bringeth foorth Cherries alfo very great, bigger then any Flanders Cherric, of the colour of Ieat, or burnifhed hornc, and of a moft pleafane tafte, as witnefleth Mafter Bull, the Queenes Maiefties Clockmaker, who did talte of the fruite (the stec bearing oncly one Clierrie, which he did eate; (but my felfe neuer tafted of it) at the impreffion heereof. We haue alfo another, called the Agriot Cherric, of a reafonable good tafte. Another we haue with fruite of a dun colour,tending to a watchet. We haue one of the dwarffe Cherrie trees that bringeth foorth fruite as greatas mott of our Flanders Cherrics, whereas the common fort hath very fmal Cherries, and thofe of an harfh tafte. Thefe and many more forts we haue in our. London gardens, wheceof to write particularly, would greatly inlargeour volume, and to finall purpofe: therefore what hath been faid hall fuffice.

II Cerafus nigra.

The commonblacke Cherrie tree.

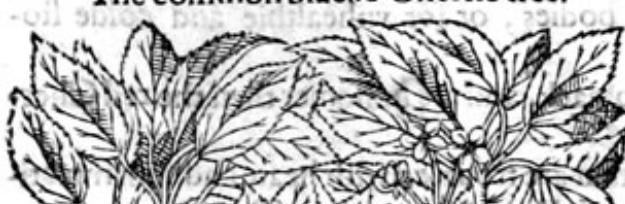

iv 7 (
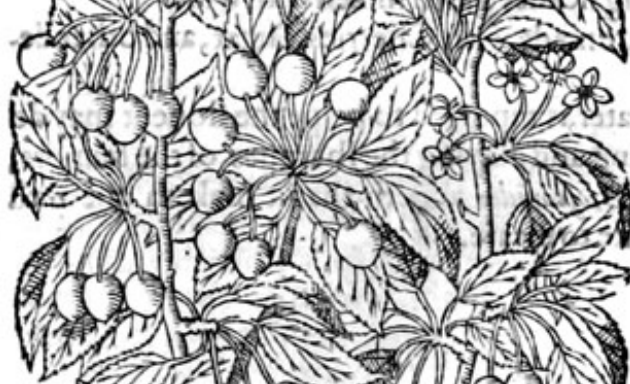

s.
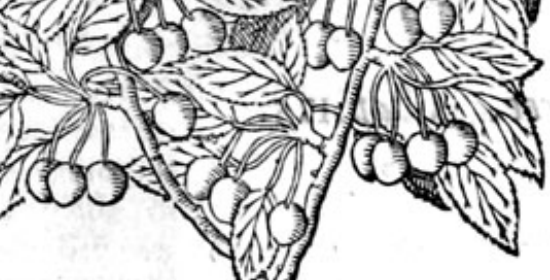

$*$ The time.

The Cherrie trees bloome in Aorill; fome bring foorth their fruite fooner; fomelater: the red Cherries be alwaies better then the blacke of their owne kinde.

\section{* The names.}

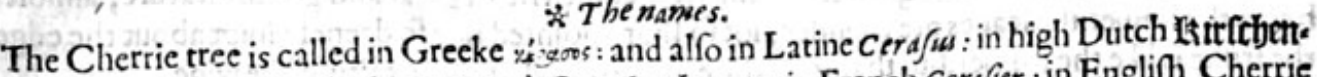
baum: in low Dutch fierfenboome, and Utieckenboom: in French Cerifier : in Englifh Cherrie tree. 


\section{THE THIRD BOOKE OF THE}

The fruite or Cherries be called in Greeke xeevena, and reegor: and in Latine likewife cerafa: in Englith Cherries: the Latine and Englifh names in their feuerall titles fhall fuffice for the reft that might be faid.

\section{$\approx$ The temperature and vertues.}

A The beft andprincipall Cherrics be thofe that are fomewhat fower : thofe litele fweete ones, which be wilde and fooneft ripe, be the woorft: they conteine bad itice, they very foone purrifie, and do ingender ill bloud, by reafon whereof they do not onely breede woormes in the belly, bue troublefome agues, and of en peftilent feuers : and therefore in well gouerned common wealthes it is carefully prouided, that they fhould not be fold in the markets in the plague time.

B Spanifh Cherries are like to thefe in faculties, but they do not fo foone putrifie : they be likewife colde, and the iuice they make is not good.

C The Flatmders or Kentifh Cherries that are through ripe, haue a better iuice, but waterie, colde and moift: they quench thirft, they are good for an hot ftoinacke, and profitable for thofe that have the agew; they eafily defcende and make the bodie foluble:they nourifh nothing ar all.

D The late ripe Cherries which the French men keepe dried againft winter, and areby them called Morelle, and we after the fame name call them Morell Cherries, are dry, and do fomwhat bind: thefe being dried are pleafant to the tafte, and holefome for the ftomacke, like as Prunes be, and do ftop the belly.

E Generally all the kinds of Cherries are cold and moift of temperature, although fome more cold and moift then others : the which teing eaten before meate do foften the belly very gently, they are vnholfome either vnto moifte and theumatike bodies, or for vnhealthic and colde ftomackes.

F The common blacke Cherries do ftrengthen the ftomack, and are holfomer then the red Cherries the which being dried do ftop the laske.

G . The diftilled water of Cherries is good for thofe that are troubled with heate and inflammations in their ftomackes, and preuaileth againft the falling ficknes giuen mixed with wine.

H Many excellent Tartes, and other pleafant meates aremade with Cherries, Sugar, and other delicate fpices, whereof to write were to fmall purpofe.

I The gum of the Cherrie tree taken with wine and water, is reported to helpe the ftonejit may do good by making the paffages flippery, and by tempering and alaying the fharpnes of the humors, and in this maner it is a remedy alfo for an old cough : Diogcorides addeth that it maketh one well coloured, cleereth the fight, and caufeth a good appetite to meate.

\section{Of the Mulberie Tree. Chap.125.}

$\mathbf{I}$

7 He common Mulberie tree is high and full of boughes: the bodie thereof is many times * Thedefcription.

great; the barke rugged; and that of the roote yellow: the leaues are broade and harpe pointed, fomething harde, and nicked on the edges; in fteede of flowers, are blowings or catkins, which are downic: the fruite is long, made vp of a number of little graines, like vnto 2 blacke Berrie, but thicker, longer, and much greater, at the firft greene, and when it is ripe blacke, yet is the iuice whereof it is full, red : the roote is parted many waies.

2 The white Mulberie tree groweth vntill it be come vinto a great and goodly ftature, almoft as big as the former:the leaues are rounder, not fo fharp pointed, nor fo deepely fnipt about the edges: the fruite is like the former, but that it is white and fomewhat more tafting like wine. 
2 Morns.

The Mulberie tree.

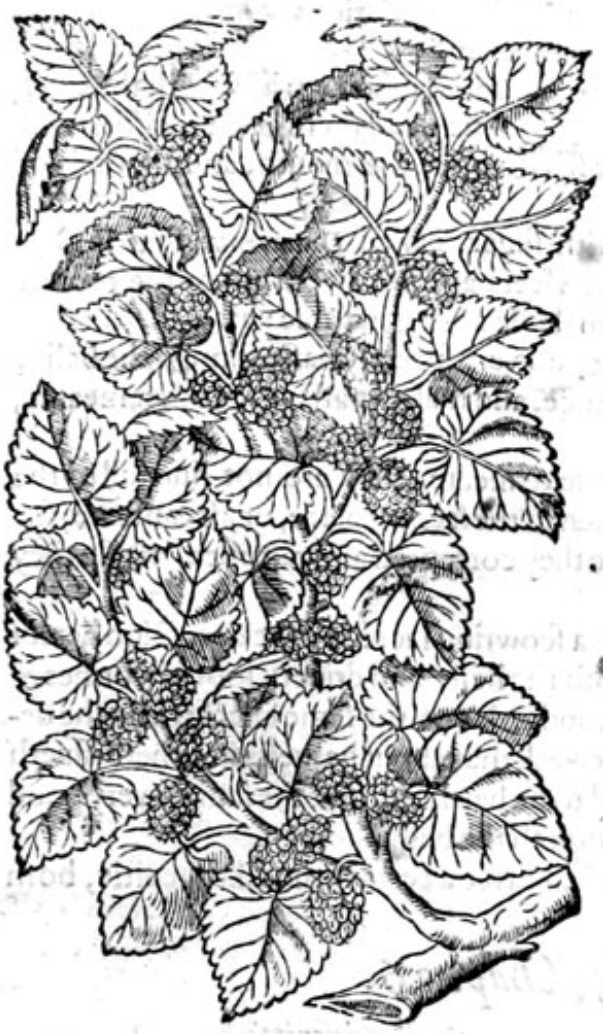

2 Morusalba.

The white Mulberie tree.

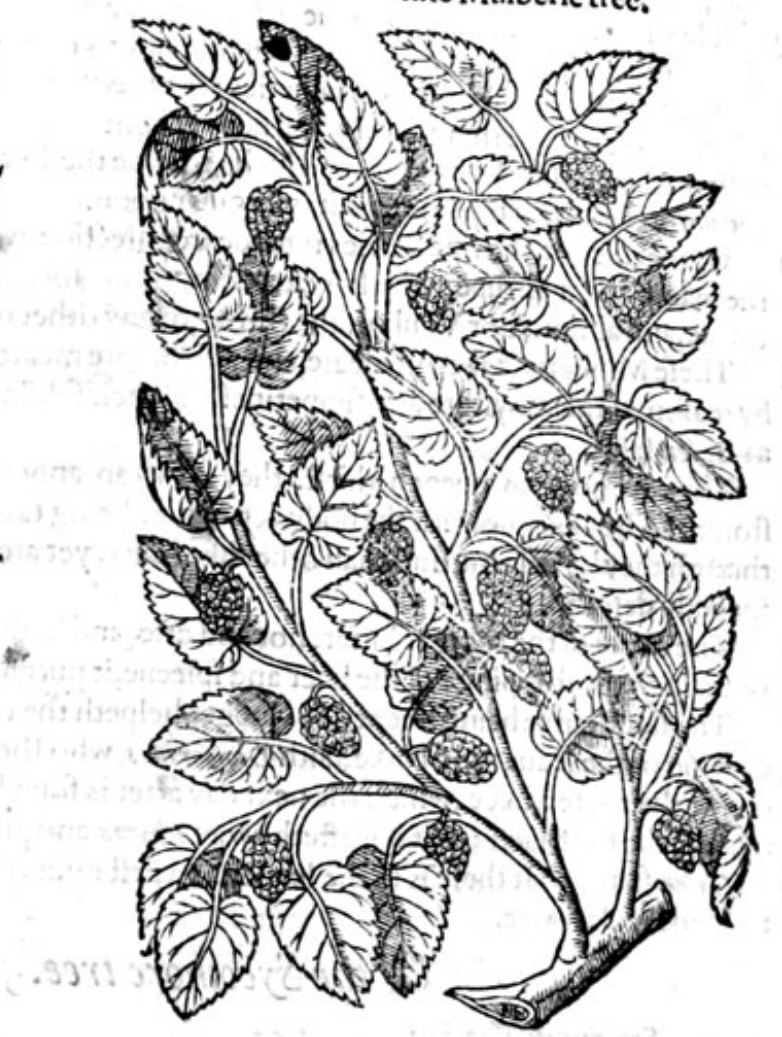

* The place.

The Mulberie trees growe plentifully in Italie and other hot regions, where they do maintaine great woods and groues of them, that their Silke wormes may feede thereon. The Mulberic tree is fitly fet by the flip; it may alfo begrafted or inoculated into many trees, being grafted in a white Poplar, it bringeth foorth white Mulberies, as Beritiws in his Geoponikes reportech. Thefe growe in fundrie gardens in England.

\section{* The time.}

Of all the trees in the orchard the Mulberie doth laft bloome, and not before the colde weather is gone in May (therefore the olde writers were woont to call it the wifeft tree) at whichtime the Silke wormes do feeme to reuiue, as hauing then wherewith to feede and nourifh themfelues, which all the winter before, doe lie like fmall graines or feedes, or rather like the dunging of a flefh flie vpon a glaffe, or fome fuch thing, as knowing their proper time both to performe their duties for which they were created, and alfo when they may haue wherewith to maintaine and preferue their owne bodies, vnto their bufines aforefaid.

The berries are ripe in Auguft. Hegejander in At henew affirmeth, that the Mulberie trees in his time did not bring foorth fruit in twentic yeeres togither, and that fo great a plague of the gout then raigned and raged fo generally, as not onely men but boyes, wenches, eunuches and women were troubled with that difeafe.

$$
\text { * T The names. }
$$

This tree is named in Greeke Mopia and ourguria: in Latine Morws : in fhops Morm Celfo: in high Dutch Baulbetbaum: in lowe Dutch 99oetbefie boom: in French cNearrer: in Englifh Mulberie trec.

The fruit is called Mocov and ouxiuuron: in Latine Morum : in fhops Moruni Celff : in high Dutch Woet befie: in Italian Moro: in French Meurc: in Spanifh Mores and Mores: in Euglifh Mulberie.

* Thetemperature and vertues.

Muiberies being gathered before they be ripe, are colde and drie almoft in the third degree, and $\mathbf{A}$ 


\section{THE THIRD BOOKE OF THE}

do mightily binde; being dried they are good for the laske and bloodie flixe; the powder is vied in meate, and is drunke with wine and water.

B They ftay blecdings, and alfo the reds; they are good againft inflammations or hot fwellings of the mouth and iawes, and for other inflammations newly beginning.

C The ripe and new gatnered Mulberies are likewife colde, and be full of iuice, which hath the tafte of wine, and is fomething drying, and not wir hout a binding qualitie; and therefore it is alfo mixed with medicines for the mouth, and fuch as elpe the hot fivellings of the mouth, and almonds of the throte; for which infirmities it is fingular good.

D Of the iuice of the ripe berries is made a confection with fugar, called Diamoram, that is after the manner of a firrupe, which is exceeding good for the vlcers and hot fwellings of the toong, throte, and almonds or Vuula of the throte, or any other maladie arifing in thofe parts.

E Thefe Mulberies taken in meate, and alfo before meate, do very fpeedily paffe thorow the belly, by reafon of the moyfture and flipperineffe of their fubftance, and make a paffage for other meates, as Galen faith.

F They are good to quench thirft, they ftir vp an appetite to meate, they are not hurtfull to the ftomacke, but they nourith the body very little, being taken in the fecond place, or after meate, for though they be leffe hurtfull than other like fruits, yet are they corrupted and putrified, vnlefle they fpeedily defcend.

G The batke of the roote is bitter, hot and drie, and hath a fcowring facultie; the decoction hereof doth open the ftoppings of the liuer and fpleene, it purgeth the belly, and driueth foorth wormes.

$\mathrm{H}$ The fame barke being fteeped in vineger helpeth the toothach; of the fame effect is alfo the decoction of the leaues and barke, faith Diofcorides, who fheweth that about harueft time there iffueth out of the roote a iuice, which the next day after is found to be hard, and that the fame is very good zgainft the toothach; that it wafteth away $F$ hyma, and purgeth the belly.

I Galen faith, that there is in the leaues and firit buds of this tree a certaine middle facultie, both to binde and fowre.

\section{Of the Sycomore tree. Chap.126.}

Sycomorus. The Sycomore tree.

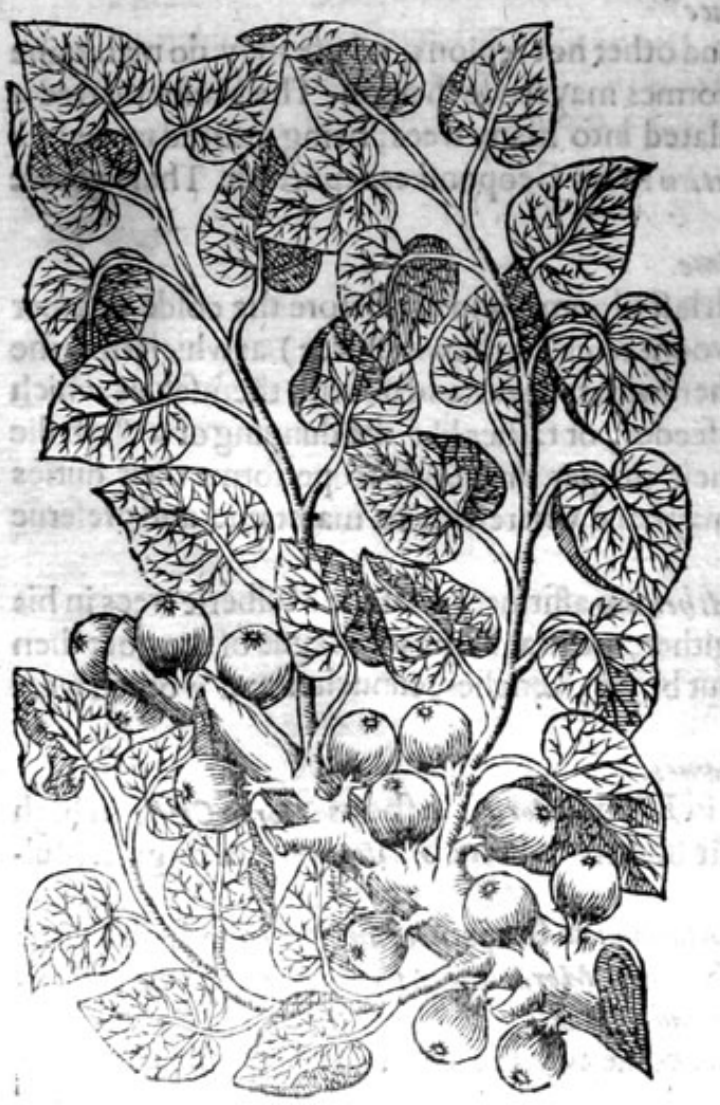

* The defription.

7 He Sycomore tree is of no fmall height, be. ing very like to the Mulberie tree in bignes and hew, it is alfo like vnto it in leafe: the fruit thereof is as great as a Fig, and of the rame falhion, very like in iuice $\&$ talte to the wild Fig, but fweeter, and without any graines or feedes within, which groweth not foorth of the tender boughes, but out of the body and great old arms very fruitfully : this tree hath in it plenty of milkic iuice, which fo foone as any part is broken or cut, dothiffue foorth. * $\mathrm{T}$ heplace.

It groweth, as Digfcorides writeth, very plentifully in Caria and Rhodes, and in fundry places of Egypt, as at the great Cayre or Alkaire,and in places that do not bring foorth much wheate, in which it is an helpe, \& fufficeth in fteed of bread and corne when therc is fcarfitie of victuals. GA. len writeth, that he faw a plant of the Sycomore tree like to the white Fig tree, fruit and all.

$$
\text { * The time. }
$$

It bringeth foorth fruit three or fower times in one yecre, and of tner ifit be fcraped with an iron knife, or other like inftrument.

$$
* \text { The names. }
$$

This tree is called in Greeke ouxouves, of the Fig tree and the Mulberie tree : in Latine Sycomoras: 
morus: Cornelines Cel/us nameth it backward Morofycon: the Egyptians of our 1327 Phargonis, or Pharao his Fig tree, as witncffeth Bellonius: and it is likewife tert Acgypt Fig tree, and alfo CMorus Leg ytia or Aegyptian Mulberic tree. We call it in Euglitia, comore tree after the Grecke and Latine, and alfo Mulberie Fig tree, which is trec, and not the great Mapie, as we hate faid in thechapter of tic Maple.

The fruit is named in Greeke ourousoov and in Italian sycomoro and Fico d'Egitto. * The temperature and vertues.

The fruit of the Sycomore tree hath no harpnefle in it at all, as Galen faith. It is fomewhat fweet A in tafte, and is of temperature moifte after a fort, and colde as be Mulberies.

It is good, faith Diofcorides, for the belly; but it is areeqes, that is, without nourifhment, and trou- B blefome to the ftomacke.

There iffueth foorth of the barke of this tree in the beginning of the fpring before the fruit ap. C peereth, a liquor, which being taken vp with a fpunge, or a little wooll, is dried, made vp into fine cakes, and kept in gally pots : this mollifieth, cloleth woundes togither, and diffolusth groffe humors.

It is both inwardly taken and outwardly applied againft the bitings of ferpents, hardnes of the D milt or fpeene, and paine of the ftomacke proceeding of a cold culfe: this liquor doth yery quickly putrifie.

tul sut eboold boog q7or

Ficus.

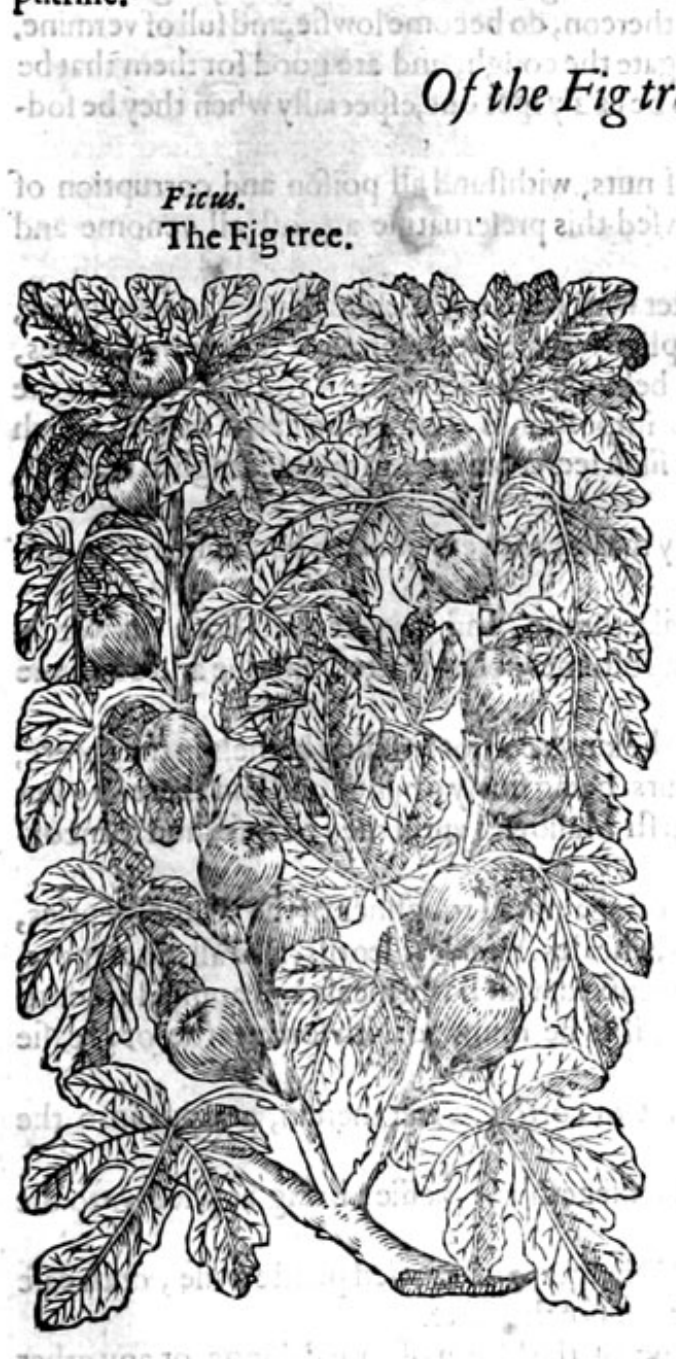

II * The defoription.

He Garden Fig trec becommeth a tree of meaneftature, hauing many branches full of whitc pith within, like Elderne pith, and linge leaues of a darke greene colour, diuided into fundrie fections or diuifions. The fruit com? meth out of the branches without any flowet at all that cuer I could perceiue, which frutite Is in Phape like vinto Peares, of colour cither whitith, or fomewhat red, or of a deepe blewe, full of fmall graines within, of a fweete and pleafant tafte; which being broken before it be ripe, doth ycelde moft white milke, like vnto the kindes of Spurge, and the leaues alfo being broken, doe $y$ celd the like liquor; butwhen the figs beripe, the iuice thercof is like honie.

The dwarffe Fig tree is like vnto the former in leates and frute, but it neuer groweth aboue the heighe of a man, and hath many fmali hootes comming from the rootes, whereby it grcatly increafeth.

There is alfo another wilde kinde, whofe fruit is neuer ripe; Theophraftus nameth it searsis, Plonie Caprificsu.

\section{* The place.}

The Fig trees do growe plentifully in Spaine and Italie, andmany other countries, as in England; 'where theybeare fruite, but it neuer commeth to kindly maturitic, except the tree bes planted vnder an hot wall,whereto neither north nor northeaft windes can come.

* The time.

The dwarfe Fig tree groweth in my garden, and bringeth foorth ripe and very great fruit in the 


\section{I328 THE THIRD BOOKE OF THE}

moneth of Augurt, of which Figs fundrie perfons haue eaten at pleafure.

In England the Fig trees put not foorth their leaues vntill the end of May, where oftentimes the fruit commeth foorth before the leaues appecre.

to The names.

The Fig tree is called in Greeke ouxǹ, and of diuers for difference fake between it \& the wilde Fig tree, ouxin yusees: in Latine Ficus, and Ficus fatiua, and Vrbana : inhigh Dutch figigenbaum: in low Dutch Cijigbeboom : in French Figuier : in Italian Fico : in Spanifh Higuera: in Englifh Fig
tree.

The fruit is named in Greck oixov : in Latine Ficus, and the vnripe fruit ö̀uy oos : in Latin Groffus:that which is dried is called in Greeke iopas : in Latine Carica : in high Dutch fiepsen: in low Dutch Iftigben: in French Figues : in Italian Fichi: in Spanifh Higos : in Englifh Fig: the little feedes which are found in them, are named by Galen wexequiss, Cechramides.

\section{น. 1 he temperature.}

The greene Figs new gathered are fomewhat warme and moift : the dry and ripe Figs are hot almolt in the third degree, and withall tharpe and biting.

The leaues haue alfo fome fharpnes, with an opening power, but not fo ftrong as the iuice. * The vertues.

A The dry Figs do nourifh better than the greene or new Figs;notwithftanding they ingender not very good blood, for fuch people as do feede much thereon, do become lowfic, and full of vermine.

B Figs be good for the throte and lungs, they mitigate the cough, and are good for them that be fhort winded; they ripen flegme, caufing the fame to be eafily fpet out, efpecially when they be fod. den with Hyffope, and the decoction drunke.

C Figs ftamped with falt, Rew, and the kernels of nuts, withitand all poifon and corruption of the aire. The king of Pontus called Mithridates vfed this preferuatiue againft all venome and poifon.

D Figs ftamped and made into the forme of a plaifter with wheat meale, the powder of Fenugreek, and Linefeed, and the rootes of marih Mallowes, applied warme, doth foften \& ripen impoftumes, phlegmons, all hot and angry fweilings, and tumors behinde the eares; and if you adde thereto the rootes of Lillies, it ripeneth and breaketh Venereous impoftumes that come in the flanke, which impoftume is called Bubo, by reafon of his lurking in fuch fecret places, in plaine Englifh tearmes, they are called botches.

E Figs boiled in Wormewood wine with fome Barly meale, are very good to be applied as an implaifter vpon the bellies of fuch as haue the dropfie.

F Die Figs haue power to foften, confume and make thinne, and may be vfed both outwardly and inwardly, whether, it be to ripen and foften impoftumes, or to fcatter, diffolue and confume them:

G The levies of the Fig tree do wafte and confume the kings euil, or fwelling kernels in the throte, and do mollifie, wafte, and confume all other tumours, being finely pouned and laid thereon; but after my practife, being boiled with the rootes of marfh Mallowes vntill they be foft, and fo incorporate togither, and applied in forme of a plaifter.

H. The milkie iuice either of the Figs or leaues, is good againft all roughnes of the skinne, lepries, fpreading fores, tetters, fmall pockes, meafels, pufhes, wheales, freckles, lentils, and all other ípots, fcuruines, and deformitie of the body and face, being mixed with Barly meale and applied : it doth alfo take awaie wartes, and fuch like excrefcences, if it be mingled with fome fattie or greafie thing.

I The milke doth alfo cure the toothach, if a little lint or cotton be wet therein, and put into the hollownes of the tooth.

$\mathrm{K}$ It openeth the vaines of the hemorrhoides, and loofeneth the bellie, being applied vnto the

fundament.
Figs ftamped with the powder of Fenugreeke, and vineger, and applied plaifterwife, doth eafe the intollerable paine of the hot gout, efpecially the gout of the feete.

M The milke thereof put into the wound proceeding of the biting of a maddogge, or any other venemous beaft, preferueth the parts adioining, taketh awaie the paine prefently, and cureth

the hurt.
The grcene and ripe Figs, are good for thofe that be troubled with the ftone of the kidneies, for
they 


\section{HISTORIE OF PLANTS.}

they flaken the paffages, make the conduits flipperie, and open them, and do alfo fomewhat clenfe: whereupon after the eating of the fame, it hapneth that much gratiell and fand is conueied foorth.

Drie or barrell Figs, called in Latine Carice, are a remedie for the belly, the cough, and for old in. O firmities of the chett and lungs; they fcoure the kidneies, and clenfe foorth the land; they mitigate
the paine of the bladder, and caufe women with childe to hauc the eaficr deliuerance, if they feede thereof for certaine daies togither before the tine of deliuerance.

Diogcorides faith, that the white liquor of the Fig tree, and ivice of the leaues, doth curdle milke $P$ as the rennet doth, and diffolueth the milke that is cluctered in the ftomacke, as doth vineger.

It bringeth downe the menfes if it be applied with the yolke of an egge, or with yellow waxe.

\section{Of the prickly fndian Fig tree. Chap.128.}

1 Ficm Indica. The Indian Fig tree.

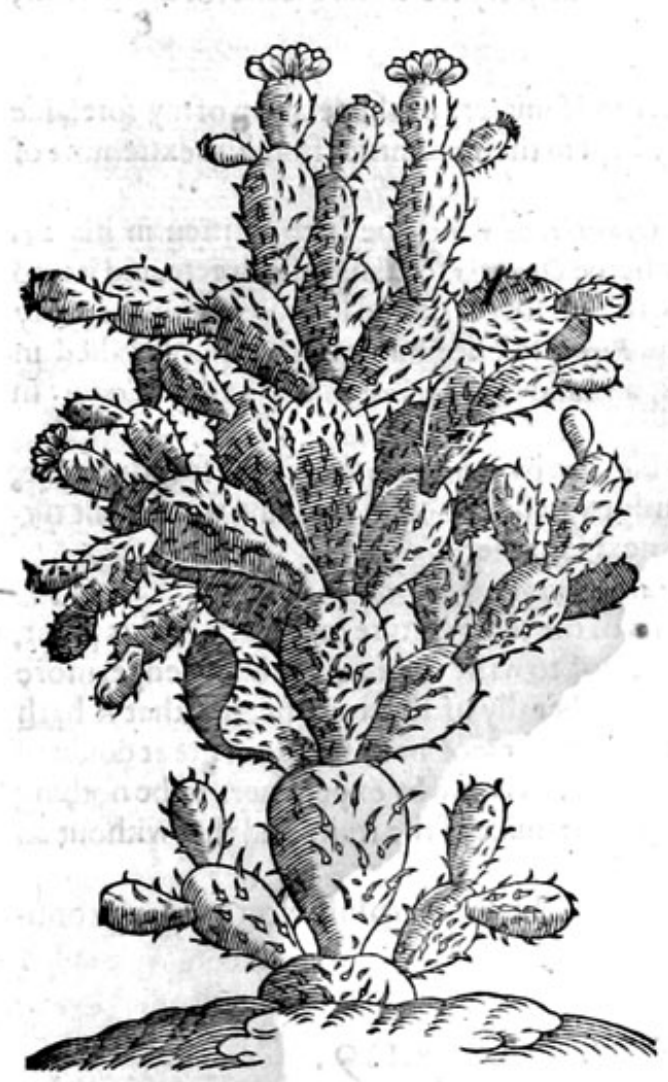

Fructus.

The fruit.

\%. 7 he defcription.

1 His ftrange and admirable plant called Ficus Indica, feemeth to be no other thing then a multiplication of leaues, that is, a tree made of leaues, without body or boughes: for the leafe fet in the grounde doth in fhort lpace take roote, and bringeth our of it feifecther

- leaues, from which do grow others one after another, till fuch time as they cone to the height of a tree; hauing alfo in the meane feafon boughes as it were comming from thore icaucs, fonctict a more, otherwhiles fewer, as nature lift to belt ow, adding lafevise as mans thumbe, of a deepe great peece of ground: thefe leaues are long, and bro.d, as thicke as an the tops of which leaues greene colour, fet full of long, flender, tharpe, and whitifh prickes : onute tee, or rathe the ilarcome forth long flowers, not vnlike to thofe o: the manurc. Pro uell of Peru, of a yellow colour : after which commeth tiac fruit, ike vrito thecumon below, 
belyw, and bigger aboue, of a greene colour, ftuffed full of a red pulpe and iuice, ftaining the hands of them that tonch it, as do the Mulberies, with a bloudy or fanguine colour : the top of which Figs are inuironed with certaine $f$ caly leaues like a crowne, wherein are alfo conteined fmall grains that are the feeds, the which being fowen, do bring foorth plants, round bodied, like vnto the trunke of other trees, with leaues placed thereon like the other, which being fet in the ground bring
foorth trees of leaues, as we haue hewed.

$$
\text { * The place. }
$$

This plant groweth in all the tract of the eaft and weft Indies, and alfo in the countrey Norem. bega, now called Virginia, from whence it hath beene brought into Italy, Spaine, England, and other coontries : in Italy it fometimes beareth fruite, but more often in Spaine, and neuer as yet in England; although I haue beftowed great paines and coft in keeping it from the iniuric of our cold climate.

It groweth alfo at Saint Crux and other places of Barbarie, \& alfo in an Iland of the Mediterra. nean fea called $Z$ aute, about a day \& nights failing with a meane winde from Petraffe a port town in Morea, where my feruant Wolliam Marfhall before remembred, did fee not onely great ftore of thofe trees made of leaues, but alfo diuers other rounde bodied plants, of $a$ woody fubftance; from whence he brought me diuers plants thereof in tubs of earth, very frefh and greene for iny garden, where they flourifhed at the impreffion heerof.

\section{* Thetime.}

Thefe plants do grow greene and frefh both winter and fommer, by the relation of my forefaide feruant; notwithftanding they muft be very carefully kept in thefe countries from the extremitic of winter. * The names.

This is thought to be the plant called of Plinie Opuntia, of which he hath written in his $2 \mathrm{I}$. booke I 7.chapter in this maner; about Opuns is the herbe Opuns is, to mans tafte fweete;and it is to be maruelled that the roote fhould be made of the leafe, and that it fhould fo grow. Opuns is a city noere vnto Phocis in Greece, as Panfanias, Strabo, and Plinie teftifie: but it is commonly called in Latine Ficus Indica : of the Indians Tune, and Tunas, and alfo Snapallus, as teftifieth Bellonies: in Englifh Indian Fig tree.

There is a certaine other defcribed for the Indian Fig tree by $T$ beophraftus, in his fourth booke, which $P$ liny in his $I_{2}$.booke 5 , chapter, doth eloquently exprefle almoft in the fame words, but turned into Latine, whereof we intend to fpeake in the next Chapter.

\section{* T he temperature and vertues.}

We haue no certaine inftruQtion from the ancients of the temperature or facultie of this plant, or of the fruit thereof: neither haue we any thing whereof to write of our owne knowledge, more then that we haue heard reported by fuch as haue eaten liberally of the fruite heerof, that it hath changed their vrine to the colour of bloud, who at the fight thereof haue ftoode in great doubt of their life, thinking it had beene bloud, whereas it prooued afterward by experience, to be nothing elfe but the tincture or colour the vrine had taken from the iuice of the fruit, and that without all hurt or griefe atall.

It is reported of fome that the iuice of the leaues is excellent good againft vlcers of long continuance.

\section{Of the arched Indian Fig tree. Chap.i29.}

* The defcription.

$T$ His rare and admirable tree is very great, ftraight, \& couered with a yellowith barke tending to tawnie : the boughes and branches are many, very long, tough, and flexible, growing very long in fhort fpace, as do the twigs of Oziars, and thofe folong and weake, that the ends thereof hang downe and touch the ground, where they take roote and grow in fuch fort that thofe twigs become great trees; and thefe being growen vp to the like greatnes, do caft their branches and twiggie tendrels vnto the earth, where they likewife take hold and roote; by meanes whereof, it commeth to paffe that of one tree is made a great wood,or defart of trces, which the Indians do vfe for cotierture againft the extreme heate of the funne, wherewith they are greeuoully vexed: fome likewife vfe them for pleafure, cutting downe by a direct line a long walke, or as it were a vault, 
through the thickett part, from which alfo they cut certaine loope holes or places, to the end to receiuc thereby the frefh coole aire that enterech holes or windowes in forre they may fee their cattle that fecdeth thereby, to atroid any danger thats as alfo for-light, that cither by the enimie or wilde beafts : from which vault or clofe walke, doch ight happen vnto then', rable cccho, or anfwering voice (if one of them fpeake vnro anake, doth rebound fich an admirefound or anfwer againe fower or fue times, according to the he with a lowde voice)that it doth anfwere, and that fo planly, that it cannot be knowne trom the voice it felfe voice, ro which it doth this wood or defart of trees, is hard to be knowne from the voice it felfe : the firft or mother of die, which three men can fearfely fathom about: vpon the chalden, but by the greatnes of the bo. and wrinckled, in thape like thofe of the Quince tree, greene aboues whereof growe leaues, hard vnderneath, whereupon the Elephants delighe of the bignes of a mans thombe, in fhe light to feed: among which leaucs come foorth the fruit, 2 fweete tafte, but not fo pleafant as the Figs of Spaine: notwich a fanguine or bloudic colour,and of and withall very holefone.

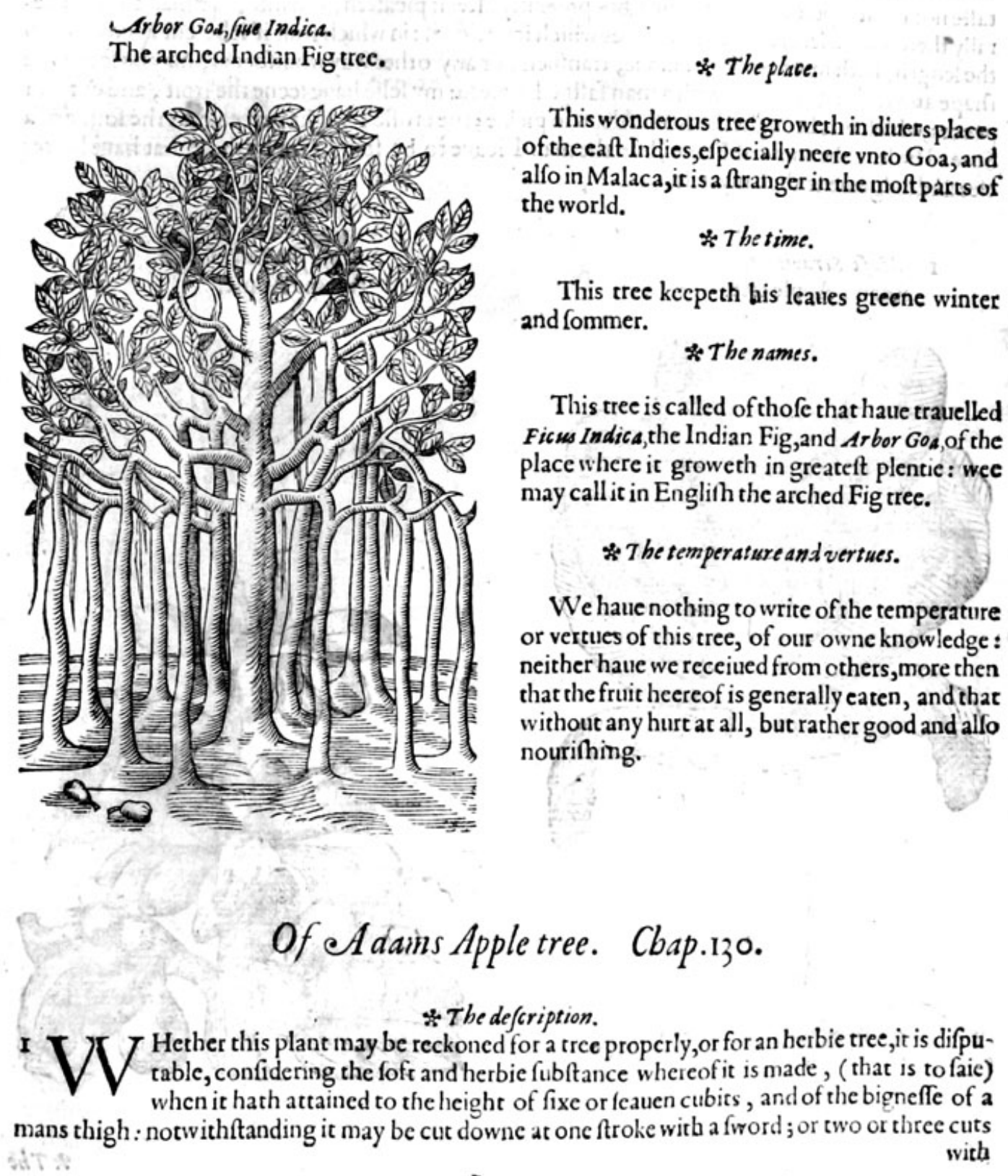




\section{THE THIRD BOOKE OF THE}

with aknife, eten with as much eafe as the roote of a Radith or Carrot of the likebignes : from a thicke, far, threadie roote, rife immediately diuers great leaues, of the length of three cubits and a balfe, formetimes more, according to the foile where it groweth, and of a cubite and more broad, of bignes fufficient to wrap a childe in of two yeeres old, in Thape like thofe of Mandrake, of an ouerworne greene colour, hauing a broad rib or fmewe running through the middle thereot : which leaues, whether by reafon of the extreme hot fcorching funne, or of their owne nature, in Septem. ber are fo dry and withered that there is nothing therof left or to be feenc, but oncly the niddle rib. From the middle of thefe leaues rifeth vp a thick trunke, whereon do grow the like leaues, which the people do cut off, as alfo thofe next the ground, by which meanes it rifech vp to the height of $z$ tree, which otherwife would remaine a lowe and bafe plant : this manner of cutting they vie from time to time, vntill it come to a certaine height, aboue the reach of the Elephant, which greedily feeketh after the fruit. In the midft of the top among the leaues commeth foorth a foft and fungus ftumpe, whereon dogrow diuers apples in forme like a frall Cucumber, and of the fame bignes, conered with a thin rinde like that of the Fig, of a yellow colour when they be ripe : the pulpe or fubftance of the meate, is like that of the Pompion, without eitherfeedes, ftones, or kernels, in tafte not greatly perceiued at the firft,but prefently after it pleafeth, and intifeth a man to eate liberally thereof,by a fecret intifing fweetnes which it yeeldeth : in which fruit if it be cut according to the length, faith mine author, oblique, tranfuers, or any other way whatfoeuer, may be feene the Thape and forme of a crofle, with a man faftned thereto: my felfe baue feene the fruit, and cut it in peeces, which was brought me from Alepo in pickle ; the croffe I might perceiue, as the forme of 2 SpreadEgle in the roote of Ferne, but the man I leaue to be fought for by thofe that haue better eies and iudgement then my felfe.

1 cMufa Serapionis. Adams Apple tree.

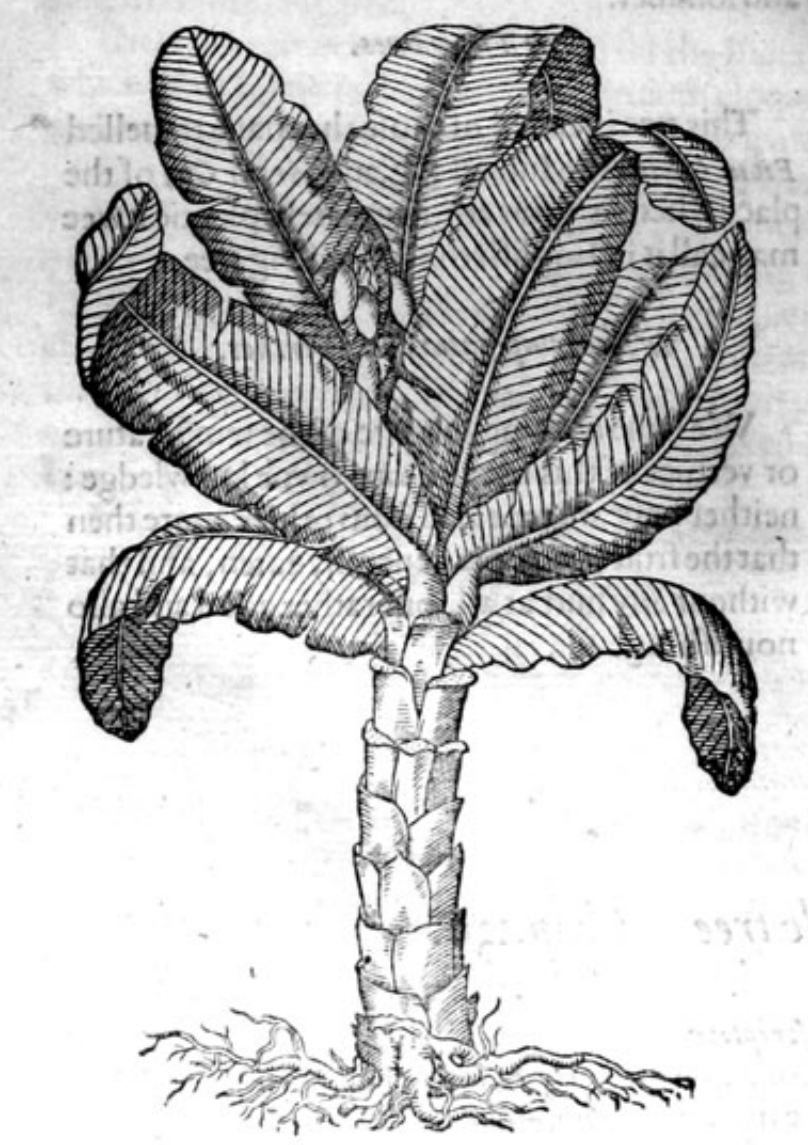

Mur e fructius. Adams Apple.

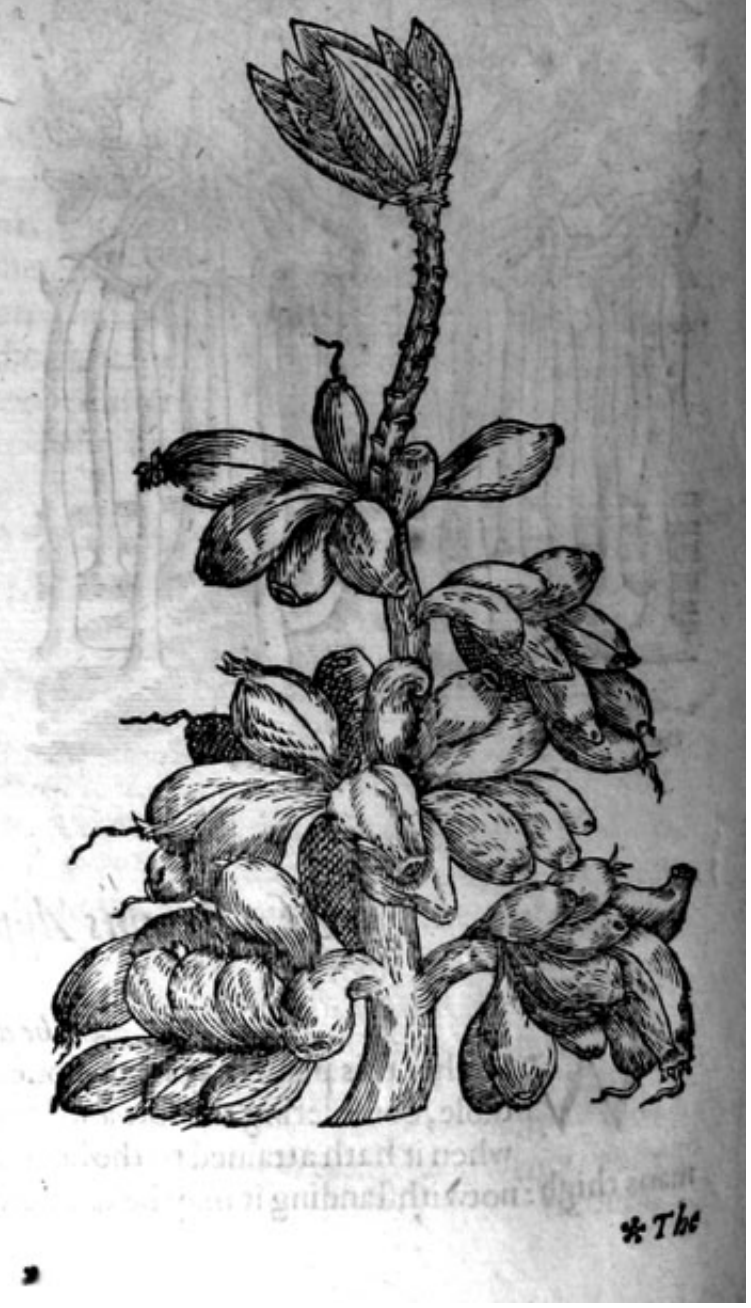


This admirable tree groweth in Acgypt, Cyprus and Syria, neere vnto a chiefe citie there called Alep, which we call Alepo; and alfo by Tripolis not far from thence : it groweth alfo in Canara, Decan,Guzarate, and Bengala,places of the Eaft Indies. * The time.

From the roote of this tree fhooteth foorth yoong fprings or fhootes, which the people take vp and plant for increafe in the fpring of the yeere : the leaues wither away in September, as is aboue faide.

\section{\&. The times.}

It is called C Mu/a by fuch as trauell to Alepo: by the Arabians Mufa Maum : in Syria Mo/e: the Grecians and Chriftians which inhabit Syria, and the Iewes alfo fuppofe it to be that tree, ol whofe fruit Atandid tafte; which others thinke to be a ridiculous fable: of Plinie Opuntia.

It is called in the Eaft Indies (as at Malauar where it alfogroweth) Palan : in Malayo Pican, and in that part of Africa which we call Ginuy, Bananas: in Englifh Adams Apple tree.

$$
\text { * Thetemperature. }
$$

Diofcorides and Serapioiudge, that it heatech in the end of the firft degree, and moyfteneth in the end of the fame.

The fruit hereofyeeldeth but little nourifhment, it is good for the heate of the breaft, lungs and $\mathbf{A}$ bladder; it Itoppeth the liter, and hurteth the ftomacke, if too much of it be eaten, and procureth looleneffe in the belly: whereupon it is requifite for fuch as are of a cold conftitution, in the eating thereof put vnto it a hittle Ginger, or other $f_{\mathrm{f}}$ ice.

It is alfo good for the reines, kidneies, and to prouoke vrine; it nouritheth the childe in the mo- B thers wombe, and ftirreth to generation.

\section{Of the Date tree. Chap.izi.}

I Palma.

The Date tree.

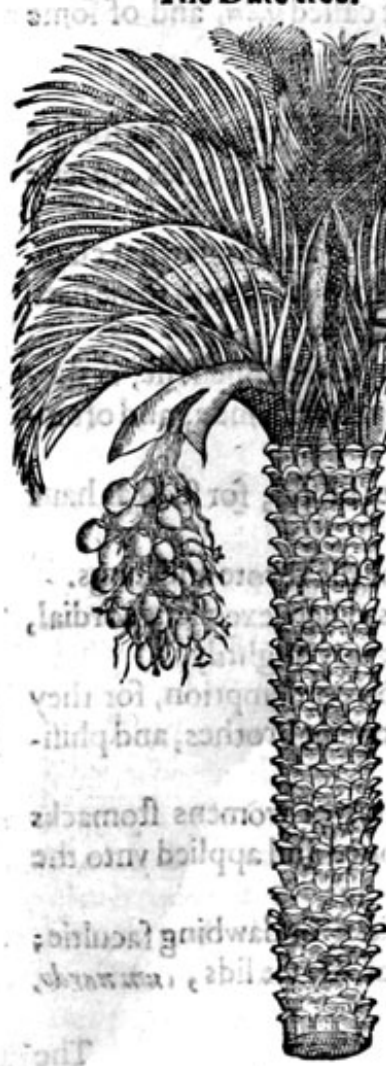

Palmirum fractus of flires cum Elate. The fruit aud flowers of the Date tree.
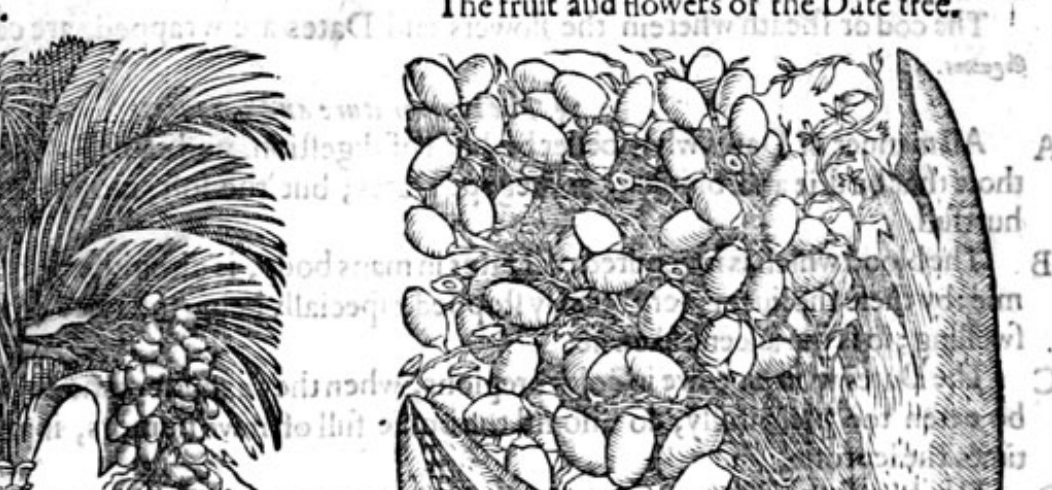


\section{* The defcription.}

1 He Date tree groweth very great and high : the body or trunke thereof is thicke, and couve. red with a fcalie rugged barke: the boughes grow onely on the top,confifting of leaues fet vpon a woodie middle rib like thofe of Reedes or flags ; the inner part of which rib or ftalke is foft, light, hollow and fpoongic: among the leaues come foorth the flowers included in a lone skinnie membrane, as it were a theath or hofe, like that which couereth the Flowerdeluce before it be blowen, which being opened of it felfe, white flowers ftart foorth, ftanding vpon fhort and fen der footftalks, which are faftened with certaine fmall filaments or threadie ftrings like vnto litrle branches: after which fpring out from the fame branches the fruit or Dates, which be in fartion long and round, in tafte fweete, and many times fomewhat harih, of a yellowilh red colour; wherein is contaned a long hard ftone, which is in fteed of kernell and feede, the which I haue planted diuers times in my garden, and haue growen to the height of three foote; but the firft froft hath nipped them in fuch fort, that prefently they perifhed, notwithftanding my induftry by couering them,
or what elfe I could do for their fuccour.

\section{* The place.}

The Date trees growe plentifully in Africke and Aegypt, but thofe which are in Paleftina and Syria be the beft: they growe likewife in moft places of the Eaft and Weft Indies, where there be diuers fortes thereof,as weil wilde as tame, or manured.

\section{* The time.}

The Date tree is alwaies greene, and flowreth in the fpring time: the fruit is ripe in September; and being then gathered they are dried in the funne, that they may be the better both tranfported into other countries far diftant, as alfopreferued from rotting at home.

\section{* The names.}

The tree is called in Grecke poiv $\xi$ : in Latine Palma : in Englifh Date tree.

The fruit is named in Greeke Sdiravos porvixur, that is to fay, Glans P almarwm, or the Acorne of the Date trees, and by one worde gorrtroferaivos: in Latine Palnsula : in fhops Daffylus : in high Dutch Dattelent in lowe Dutch Dadelen : in Italian Dattoloi : in French Datses : in Spanifh Tamares and Dattiles : in Englifh Date. éceavors.

The cod or fheath wherein the flowers and Dates are wrapped, are calledinem, and of fome

\section{* T he temperature and vertues.}

A All manner of Dates whatfoeuer be hard of digeftion, and caufe headach : the woorfer fort be thofe that be drie and binding, as Aegypt Dates; but 'the foft, moyft, and fweete ones are leffe hurtfull.

B The blood which is ingendred of Dates in mans body, is altogither groffe and fomewhat clammie : by thefe the liuer is very quickly ftopped,efpecially being in tlamed or troubled with fome hard fwelling; fo is the foleene likewife.

C The $D$ ates which growe in colder regions, when they cannot come to perfect ripeneffe, if theg be eaten too plentifully, do alfo fill the bodie full of rawe humors, ingender winde, and oftentimes the leprofie.

D The drier fort of Dates, as Diofcorides faith, be good for thofe that fpet blood, for fuch as have bad ftomacks, and for thofe alfo that be troubled with the bloodie flixe.

E The beft Dates, called in Latine Caryota, are good for the roughneffe of the throte and lungs.

F There is made heerof both by the cunning Confectioners and Cookes, diuers excellent cordial, comfortable, and nourifhing medicines, and that procure luft of the bodie very mightily.

G They doalfo refrefh and reftore fuch vnto ftrength as are entring into a confumption, for they ftrengthen the feebleneffe of the liuer and fpleene being made into conuenient brothes, and phificall medicines mixed therewith by the learned phifition.

H Dric Dates doe ftop the belly, and ftay the vomiting and the wambling of womens ftomacks that are with childe, if they be either eaten in meates or otherwife,or ftamped and applied vnto the ftomacke, as a pectorall plaifter.

I The afhes of the Date ftones haue a binding qualitie, and an emplaifticke or dawbing facultie; it healeth pufhes in the eies, Staphylomata and talling away of the haire of the eie lids, cwoms nardo, with wine it keepeth proud fle? from growing in wounds. 


\section{HISTORIE OF PLANTS.}

The boughes and leaues do euidently binde, but efpecially the hofe, that is to fay, the fheath or $\mathrm{K}$ cafe of the flowers; and therefore it is good to vfe thefe fo oft as there is ncede of binding.

The leaues and branches of the Date tree do heale greene wounds and vlcers, refrefh and coole L. hot inflammations.

There is a compofition in Galen his bookes of medicines according to the kindes, called Diapal-M $\boldsymbol{m a}$, which is to be ftirred with a bough: of the Date tree, in ftead of a pature or a thing to ftit with, for no other caufe than that it may receiue thereby fonc kinde of aftritton or binding force.

\section{Of the wilde Date trees. Chap.riz2.}

1 Palmites, fue Chamarriphes. The little wilde $D$ ate tree.

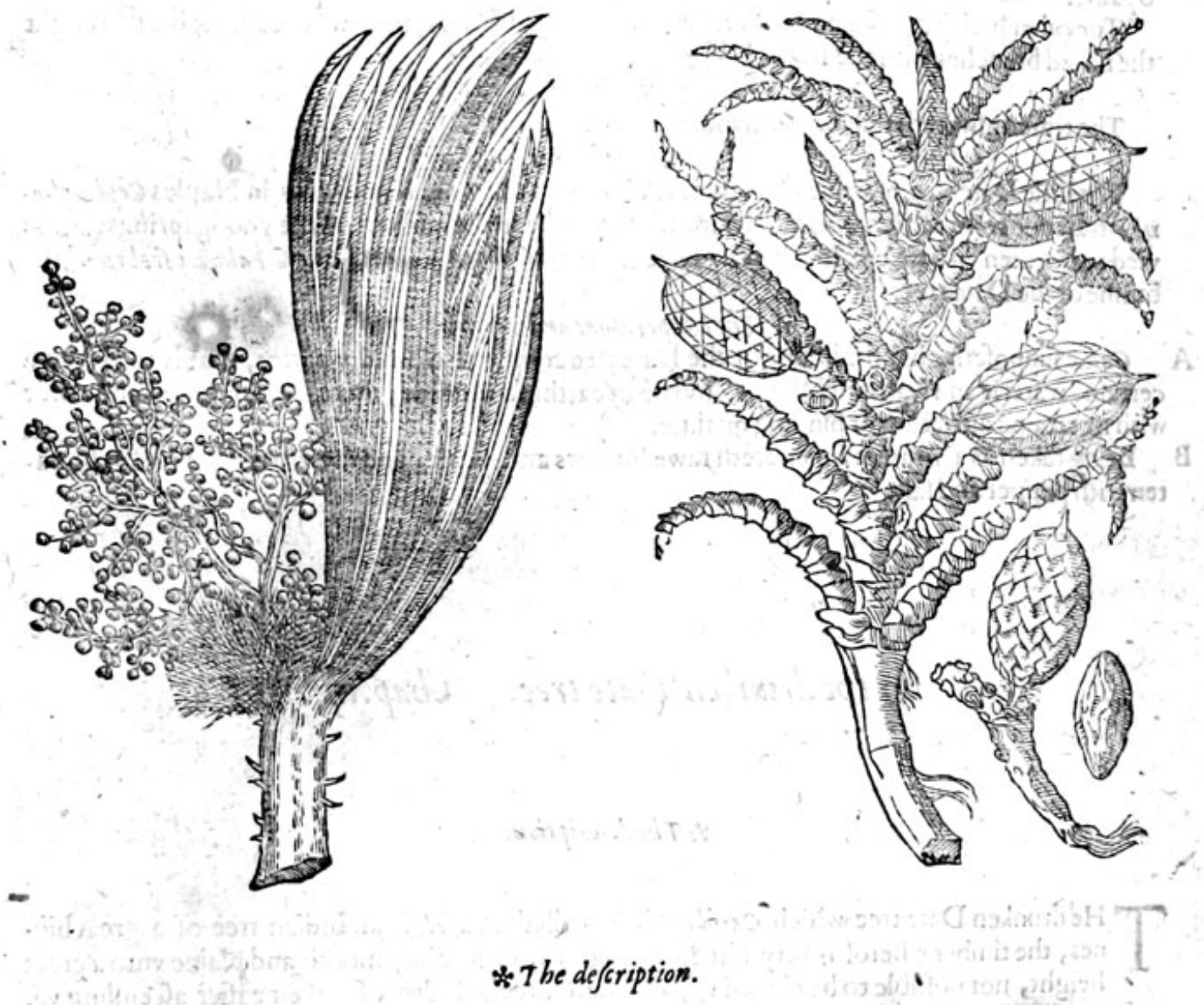

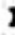

Theophraft us maketh this plant to be a kinde of Date tree, but lowe and of finall growth, feldome attaining abouc the height of an hedge trec: on the top whereof fhoote footth (for the moft part) long leaues like thofe of the Date tree, but leffer and horrer; from the fides whereof breaketh foorth a both of threadic ftrings; among which rife vp finall brith. ches garnifhed with clufters of white flowers, in which before they be opened arc to belecte vnperfeet thapes of leaues, clofely compafted about with an inumerable fort of thin shinic hitls; which rude fhapes with the flowers, are ferued vp and eaten at the feconde cour? aniong owier iunkets, with a litule falt and pepper, being pleafant to the tafte.

2 The wilde Date trec that bringeth foorh concs, or keyclogs, is of moft tracellers inter the

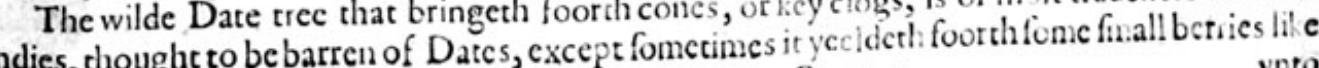
Rrar 2 vito 


\title{
1336 THE THIRD BOOKE OF THE
}

vinto Dates, but drie and nothing woorth. This tree groweth to the height and bigneffe of a lowe tree: the trunke or body whereof is foft, of a fungous or pithie fubitance, vnfit for building, as is the manured Date tree : the branch it felfe was brought vnto vs from the Indies drie, and voyde
of leaues; wherefore we muft defcribe the lea.ses by report of the bringer. The branches (Gith author) are couered ouer with long flaggie leaues, hanging downe of a great length, like thofe of the Date tree : the branches are alfo couered with 2 fcalie or fcabbed barke, very rough, one fcale or plate lying ouer another, as tiles vpon a houfe : the fruite groweth at the endes of the branches, not vnlike a great Pine Apple cone, couered ouer with a skin like the Indian Nut; wherein is contained a fhell, within which fhell lieth hid an Acorne or long kernell, of an inch long and fome. times longer, very hard to be broken, in tafte like the Cheftnut; which the fauage people do grate and ftampe to powder to make them bread.

* The place.

The firft groweth, as T heophrastusteftifieth, in Candie, but much more plentifully in Cilicia, and are nowe founde in certaine places of Italie by the fea fide, and alfo in diuers partes of
Spaine.

The other hath beene found by trauellers into the wett Indies, from whence haue been brought the naked branches with the fruit.

The time anfwereth that of the manur * The time.

* T The names.

The little Date tree, or wilde Date tree is named of $T$ beophraftess yeusppepis: in Naples Cephaglio$n e:$ in Latine commonly Palmites. That which is found in the middeft of the yoong fprings, and is vfed to be eaten in bankets, is called in Greeke inupariss tins poivroxos: in Latine Palme cerebrum, the braine of the Date tree.

* Thetemperature and vertues.

A Galen fuppofeth, that the braine of the Date tree confifteth of fundry partes, that is to fay, of a certaine waterie and warme fubftance, and of an earthie and colde; therefore it is moyft and colde with a certaine aftriction or binding qualitie.

B Being taken as a meate it ingendreth rawe humors and winde, and therefore it is good to be eaten with pepper and falt.

\section{Of the drunken Date tree. Chap.133.}

\author{
\& The defcription.
}

\begin{abstract}
7 Hedrunken Date tree which Carolus Clufinus calleth Faufel, is an Indian tree of a greatbig: nes, the timber wher of is very foft \& fpoongious, exceeding fmnoth and plaine vnto a great height, not poffible to be climed vp; and therefore the Indians for their eafier afcending vp, at fome diftances doe tic round about the tree certaine withes or ropes made of the barkes of trees, as may be perceiued by the figure, whereby very eafily they go vp and downe to gather the fruite at their pleafure. The top of the tree is diuided into fundrie branches, in fubltance like vnto the great Cane; whereupon doe growe faire flaggie leaues like thofe of the Palme or Date tree, whereof doubtleffe this is a wilde kinde : from the bottome of which branches commeth foorth fruit in long bunches like traces of Onions, couered with a foft pulpe like vnto the Wall nut, rough and very full of haire of a yellowifh colour, and like the dried Date when it is ripe : with. in which huske is contained fruit like vnto the Nutmeg, but greater, very hard, and ftriped ouer with red and white veines or finewes.
\end{abstract}


Wreca, fue Fanfel.

The drunken Date tree.

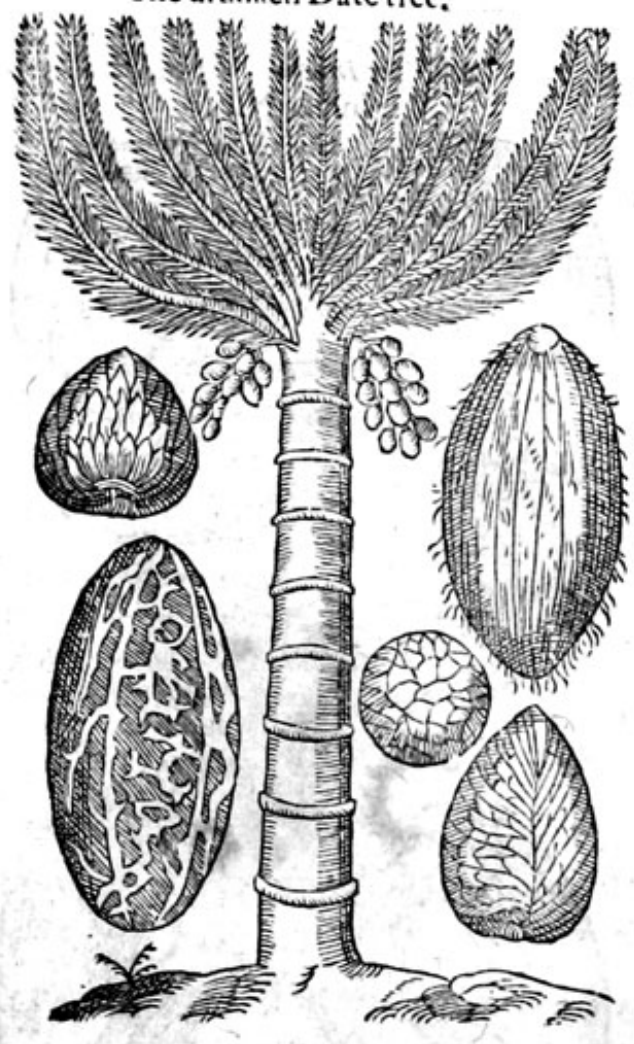

- Theplace, time and nemes.

This Date trec which the Arabians call $F$ a fel, that is by interpretation Muellana Indica, the. Indian Nut or Filberd: Auicen and Scrapiocall it Filfeland Fufel. It groweth in the Ealt Indies in ditier s and fundrie places, as in Malauar, where vulgarly it is called Pac, and of the nobles and gentlemen Arewa, which name is vied amongt the Portingales which dwell in thofe Indies; in Guzarate and Decan it is called Cupare, in Zeilan Poaz: in Malaca Pinan: in Cochin Chacani. In Englifh the drunken Date tree, which name we haue coyned from his qualitic, bicaufe the fruite doth make thofe drunke that cate thereof. * The temperature.

It is cold and dric in the fecond degree. \& 7 be vertues.

The fruit of Arec 2 before it be ripe, is recko. A ned amongt the ftupefactiuc or aftonithing rnedicines; for whofocuer eateth thercof waxeth drunke, bicaufe it doth exceedingly amazc and aftonifh the fenfes.

When the Indians are vexed with fome into- B lerable ache or paine, or muft of neceffitic endure fome great torment or torture, then do they take of this fruite, whereby the rigor of that paine (which otherwife they hould feele) is very much mitigated.

The iuice of the fruit of Areca doth ftrengthen the gums, faften the teeth,comfort the ftomacke, $\mathrm{C}$ ftay vomiting, and loofenefic of the belly; it doth alfo purge the bodie from congealed or clot:ed blood gathered within the fame.

\title{
Of the fudian X (ut tree. Chap.134.
}

\author{
* The aefrition.
}

17 He Grecians haue not knowen, nor the Arabians once remembred this Indian Nut tree; the bodie whereof is very great, fmooth and plaine, voide of boughes or branches, of a great height, wherefore the Indians do wrap ropes about the body thereof, as they do vp. on the trec laft delcribed, for their more cafe in gathering the fruite; the timber whereof is very fpungie within, but hard without, a matter very fit to make their Cannoos and boates of: on the rop of the tree growe the leates like thole of the Dute tree, butbroader, and harpe at the point as thornes, whereof they vfe to make needles, bodkins, and fuch like inftruments, wherewith they fowe the failes of their-fhips, and do fuch like bufines : anong thefe leanes come foorth clufters of fowers like thofe of the Cheltnut tree, which turne into great fruit of a round furme, and fornewhat fharpe at one end; in that end next vnto the tree is one hole, fometimes two, boted throngh: this nut or fruit is wrapped in a conerture, confifting of a fubltance not vnlike vnto Hempe before ic be beaten foft; there is alfo a finer and more gentler ftuffe next vnto the fhel, like vnto Flaxe be fire it be made foft: in the middle where of is contained a great Nut couered with a very hard fhell, of abrowne colour before it be poltthed, afterward of a blacke fhining colour like burnifhed horne; 


\section{8}

\section{THE THIRD BOOKE OF THE}

next vnto the fhell vpon the infide there cleaueth a white cornellie fubftance firme and folide, of the colour and tafte of a blanched Almond; within the cauitic or hollownes thereof, is contained a moft delectable liquor like vnto milke, and of a moft pleafant tafte.

I $2 u x$ Indica arbor. The Indian Nut tree.

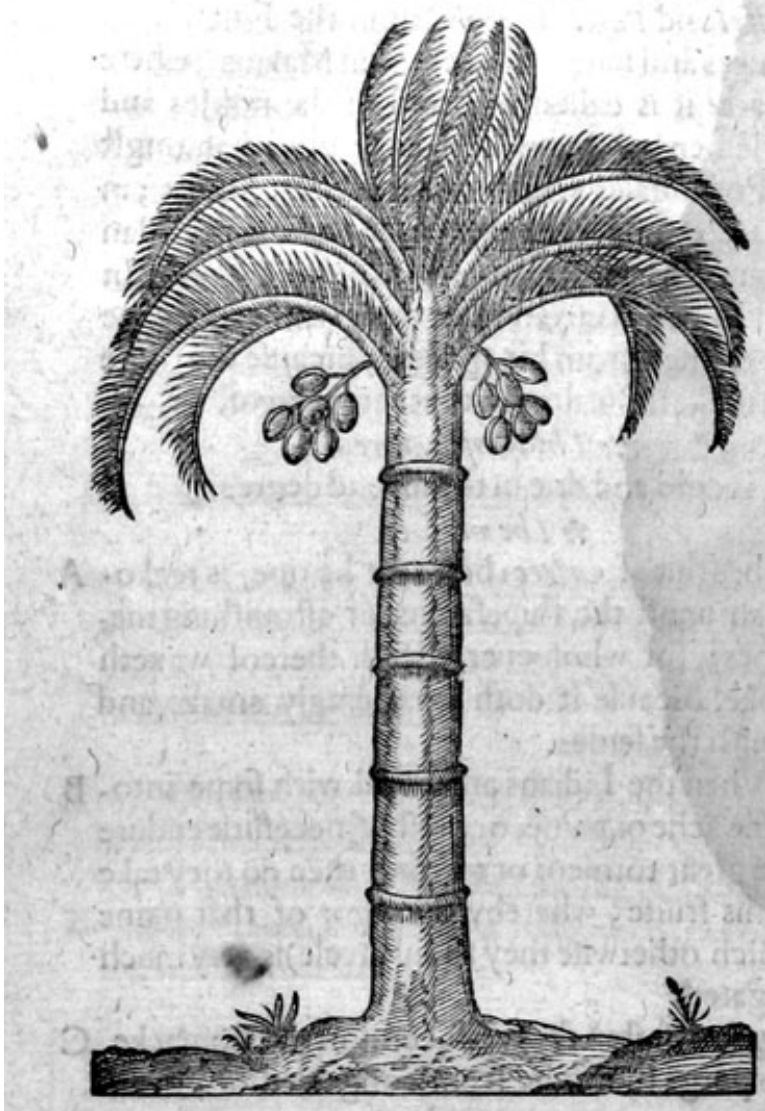

3 Nusula Indica.

The little Indian Nut.
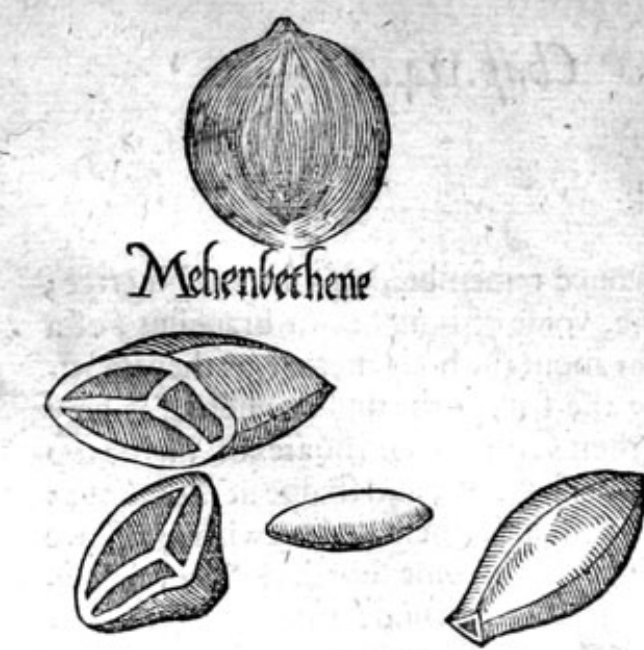

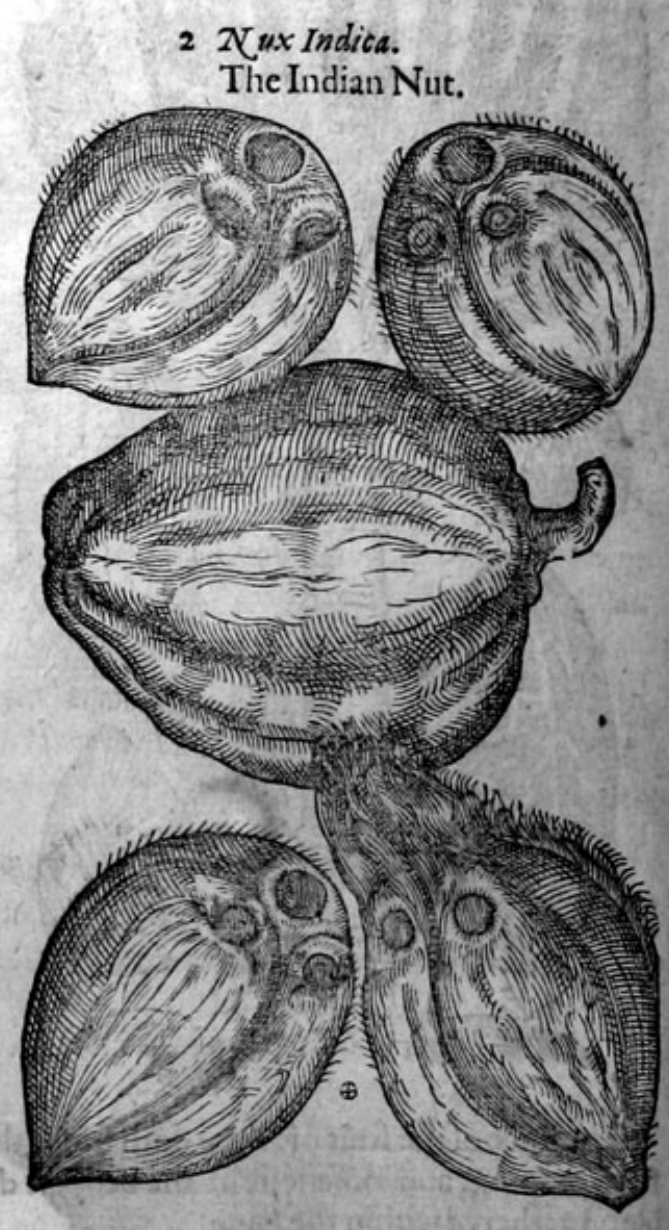

$* \tau$ he defcription.

3 We haue no certaine knowledge from thole that have trauelled into the Indies, of the tree which beareth this little Indian Nut; neither haue we any thing of our owne knowledge, more than that we fee by experience, that the fruit hereof is leffer, wherein confifteth the difference. $*$ The place.

This Indian Nut groweth in all the Ilandes of the Weft Indies, efpecially in Hifpaniola, Cuba, and S.Iohns Iland, and alfo vpon the continent by Carthagena, Nombre de Dios, andPanama, and in Virginia otherwife called Norembega part of the fame continent, for the moft part neere vnto the fea fide, and in moyft places; feldome found in the vplandifh countrics.

\section{* The time.}

It groweth greene winter and fommer.

$\approx$ The names.

The fruit is called in Latine $2 \times u \times$ Indica : of the Indians Cocus: of the Portingales that dwell in the Eaft Indies Cocso, taken from the end wherein are three holes, reprefenting the head of a munkie: Strapio and $R$ ha/ is do call the trec Iaralnare, id est, Urborem 2 Ucif eram dici, that is to fay, a tree bearing 
bearing Nuts: of Auicen Isucia Lindi: of the vulgare people Maro, and the fruit 2 arel; which name $\mathcal{N}$ arel is common anionglt the Perhans and Arabians: it is called in Malatar Tengamares; the nut Nihor.

The diftilled liquor is called Sula, and the oyle that is made thereof Copra.

It is of a meane temperature betweene hot and colde.

$$
\begin{aligned}
& \therefore \text { The temper ature. } \\
& \text { ene hot and colde. }
\end{aligned}
$$

* The vertues and $v / \mathrm{s}$.

The Indians do vfe to cut the twigs and tender branches toward the euening, at theerids where. of they hang bottle gourds, hollow canes, and fuch like things, fit to receive the water that droppech from the branches thereof, which pleafant liquor they drinke in fteede of wine ; from the which is drawen a ftrong and comfortable Aqua vitx, which they vfe in time of neceffitie againft all manner of fickneffes; of the branches and boughes they niake their houfes; of the trunke or body of the tree' Phips and boates; of the hempe on the outward part of thefruit, they make ropes and cables, and of the finer ftuffe failes for their hips.

Likewife they make of the Thell of the Nut, cups to drinke in, which we likewife vfe in England, B garnifhed with filuer for the fame purpofes. The kernell ferueth them forbread and meate; the milkie iuicedoth ferue to coole and refreh their fainting fpirits: out of the kernell when is is ftam-: ped, is preffed a moft pretious oyle, not onely good for meate, but alfo for medicine, wherewsh they annoint their feeble lins after their tedious trauell, by meanes whereof the ache and paine is mitigated, and other infirmities quite taken away proceeding of other caufes.

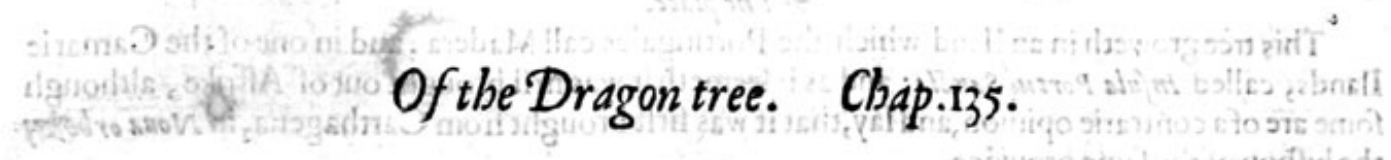

I Dracoarbor.

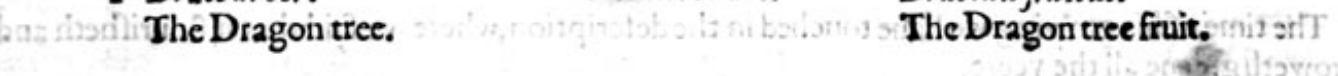

Draconis fructus.

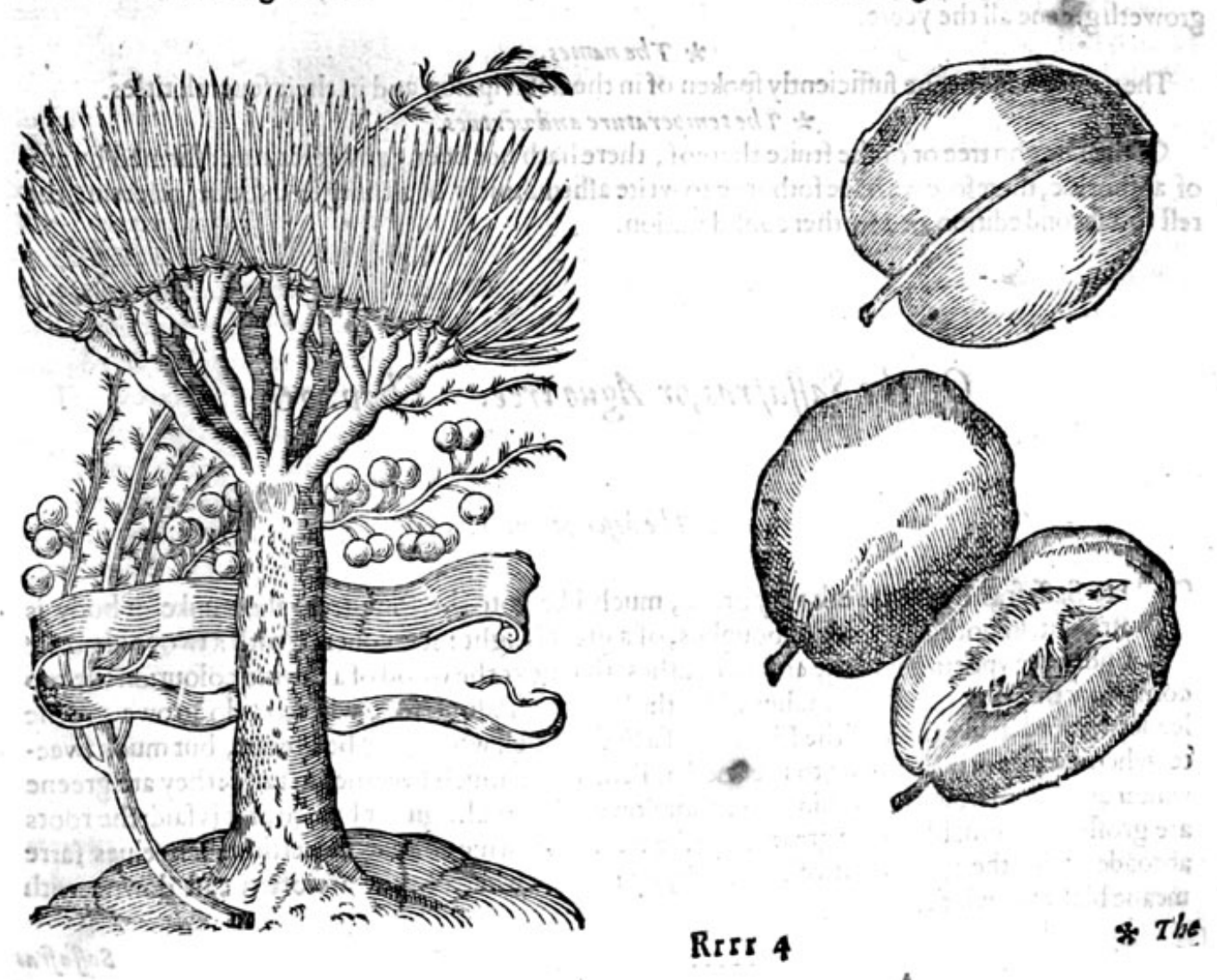


* Thedeforition.

17 His ftrange and admirable tree groweth very great, refembling the Pine tree, by reafon it 1 doth alwaies flourith, and hath his boughes or branches of equall length and bignes, which are bare or naked, of eight or nine cubits long, and of the bigneffe of a mans arme: from the ends of which do thoote out leaues of a cubite and a halfe long, and ful two inches broad, fomwhat thicke, and raifed vp in the middle, then thinner and thinner like a two edged fword: among which come foorth little moffie flowers, of fmall moment, which turne into berries, of the bignes of Cher. ries, of a yellowifh colour, round, light, and bitter, couered with a threefolde skin or filme, wherein is to be feene, as Monardes and diuers other report, the forme of a dragon; hauing a long necke,or gaping mouth; the ridge or backe armed with fharpe prickles, like the Porpentine; it hath alfo 2 long taile, \& fower feet,very eafie to be difcerned:the figure of it we haue fet foorth vnto you according to the greatnes thereof, bicaufe our words and meaning may be the better vnderftood, and alfo the leafe of the tree in his full bigneffe, bicaufe it is impoffible to be expreffed in the figure: the trunke or body of the tree is couered with a rough barke, very thin, and eafie to be opened or wounded with any fimall toole or inftrument; which being fo wounded in the Dogge daies, brufed or bored, doth yeeld foorth drops of athicke red liquor, which of the name of the tree are called Dr2gons teares, or Sanguis Draconis, Dragons bloud : diuers haue doubted whether the liquor or gummie iuice were all one with Cinabiris (not meaning that Cinaber made of quicke filuer)but the receiued opinion is, they differ not; by reafon their qualitie and temperature worke the like effeet.

$$
\text { * The place. }
$$

This treegroweth in an Iland which the Portingales call Madera, and in one of the Carnarie Ilands, called Infula Portus Sanfiti: and as it feemeth it was firt brought out of Affrike, although fome are of a contrarie opinion, and fay, that it was firft brought from Carthagena, in Noma or be, by the bifhop of the fame prouince.

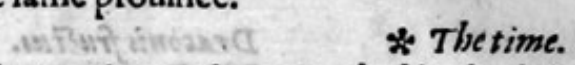

The time of his growing we haue touched in the defcription, where we faid that it flourifheth and groweth greene all the yeere. The names hauc beene fufficiently fpoken of in the defcription and in their feuerall titles.
$*$ The temperature and vertues.

Of the Dragon tree or of the fruice thereof, there hath not beene any certaintie affirmed by any of authoritie, therefore we haue forborne to write affirmatiuely of a thing fo difficile, referring the reft to a fecond edition, or a further confideration.

\section{Of the SaJjafras, or Ague tree. Cbap.136.}

\section{* The defcription.}

$7^{-1}$ He Saffafras tree groweth very great, much like vnto the Pine tree: the trunke orbody is 1 ftraight, fmooth, and voide of boughes, of a great height : it is couered with a two fold grofle rinde, the vppermoft of the colour of afhes, that next the wood of a rawnie colour:on the top come foorth many goodly branches, like thofe of the Palme tree, whereon do growe greene leaues, fomewhat like thofe of the Fig tree, of a fweete finell when they be greene, but much fweeter when they be drie, declining to the finell of Fenell, with much fweetnes in tafte : they are greene winter and fommer, neither bearing fruite nor flowers, but is altogither barren as it is faid: the roots are groffe, conformable to the greatnes of the tree, of a tawnie colour, difperfing themfelues farre abroade vnder the vpper cruft 'of the earth, by meanes whereof they are often caft downe with meane blaftes of ivinde. 


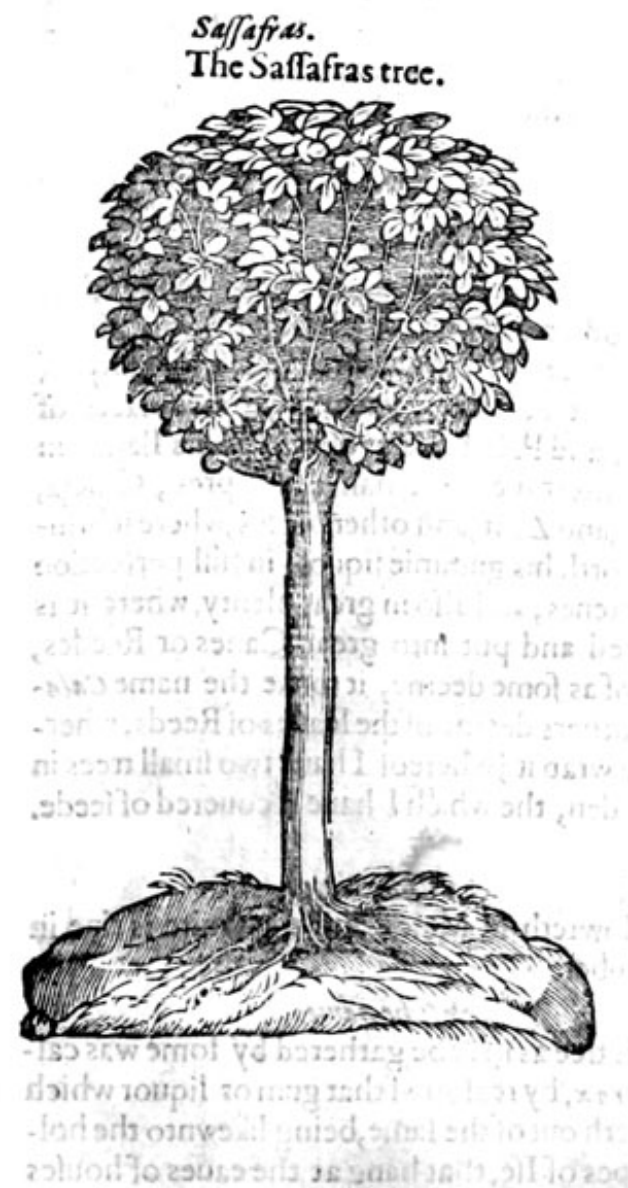

This tree grow $*$ The place.

Indies, efpecially about the moft parts of the weft gaudico, and Virginithe cape of Floridaie Wingaudico, and Virginia, otherwife named Norembega.

$$
\text { * The tome. }
$$

It flouriheth and kecpeth greene winter and form. mer.

* T The names.

The Spaniards and French men haue named this tree, $S a / \int$ afras : the Indians in their toong Payame: for want of an Englith name we are contented to call it the Ague tree, of his vertue in healing the Ague.

\section{$*$ Tlietemperature.}

The boughes and branches heereof are hot and dry in the fecond degree; the rinde is hotter, for that it entreth into the third degree of heate and drines, as is manifeftly perceiued in the decoction.

$$
\text { * The vertues. }
$$

The beft of all the tree is the roote, and that wor- $\mathbf{A}$ keth the beft effeet, the which hath the rinde cleauing very faft to the inner part, and is of colour tawnie, and much more fweete of fmell then all thetree and his branches.

The rinde tafteth of a more fweete fmell then the $B$ tree; and the water being fodden with the roote is of greater and better effects then any other part of the tree, and is of anore fweetefmell, and there.

fore the Spaniards we it,for that it worketh better and greater effects.

It is a tree that groweth neere vnto the fea, and in temperate places that haue not much drouth, C nor moifture : there be mountaines growing full of them, and they caft foorth a moft fiveete fmeil, fo that at the beginning when they faw them firft, they thought they had beene trees of Cinamon, and in part they were not deceiued: for that the rinde of this tree hath as fweete a finell as Cinamon hath,and doth imitate it in colour and harpnes of tafte, and pleafantnes of fmell: and fo the water that is made of it is of a moft fweet finel and taftejas the Cinnamon is;\& procureth the fame works and effects as Cinnamon doth.

The wood heer of cut into fmall peeces and boiled in water, to the colour of Claret wine, and D drunke for certaine daies togither, helpeth the dropfie, remooueth oppilation or ftopping of the liuer, cureth quotidian and tertian agues, and long feuers.

The roote of Saffafras hath powver to comfort the liuer, and to diffolue oppilations, to comfort $E$ the weake and feeble ftomacke, to caufe a good appetite, to confume windines, the chiefeft caufe of cruditie and indigeftion, ftay vomiting, and make fweete a ftinking breath.

It prouoketh vrine, remootiech the impediments that do caufe barrennes, and maketh women F apt to conceatie.

$$
\text { Of the Storax tree. Chap.137. }
$$

*The defcription.

$\mathrm{T}$ He Storax tree groweth to the height and bignes of the Quince tree : the trunke or bodie is couered with a barke or rinde, like vnto the Birch tree: the branches are finall and limmer, wheron do grow leaues like thofe of the Quince tree, greenifh aboue, and whiter vnderneath: 


\section{THE THIRD BOOKE OF THE}

among which come foorth white flowers, like thofe of the Orange tree, of an vnpleafant finell: af. ter commeth the fruite or berries, ftanding vpon long and flender footeftalks, couered ouer with a little woollines, of the bignes of the bladder nut, and of the fame colour; wherein is conteined fmall feede, whereunto alfo cleaue certaine gummie teares, bearing the name of the tree, which ifluc from the rrunke or body when it is wounded.

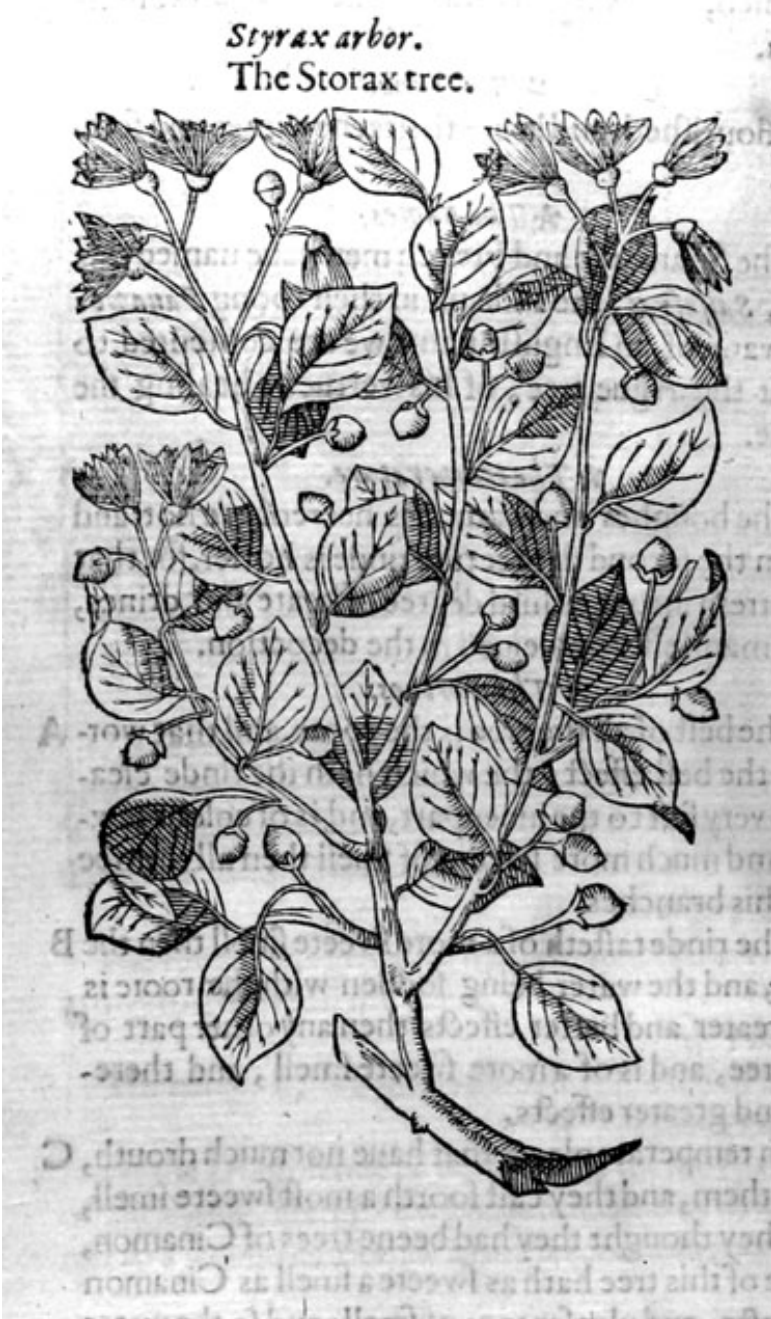

but remaineth alwaies thinne, which is called liquid Styrax, or Storax.

This tree groweth in diuers places of Fraunce,
There Italy, and Spaine, where it bringeth foorth litele or no gum at all: it groweth in Iudea, Pamphyliz, Syria, Pifidia, Sidon, and many other places of Iewric, and Paleftina; as alfo in diuers Ilands in the Mediterranean fea, namely Cypres, Cilicia, Candy, and Zant, and other places, where it bringeth foorth his gummie liquor, in full perfection of fweetenes, and alfo in great plenty, where it is gathered and put into great Canes or Reedes, whereof as fome deeme, it tooke the name Cala. mita ; others deeme of the leaues of Reeds, wher. in they wrap ir; whereof $I$ haue two fmall trees in my garden, the which I haue recouered of feede.

It flowreth in Maie, and the fruite is ripe in September.

* The names.

This tree as may be gathered by fome was called Styrax, by reafon of that gum or liquor which droppeth out of the fame, being like vnto the hollow pipes of Ife, that hang at the eaues of houfes in winter called Styria, or of the canes, or the leaues of Reedes fpoken of before : in Latine Storax calemite : in Englifh Storax, which is kept in Canes or the leaues of Reedes : there floweth from fome of thefe trees a certaine gummieliquor, which neuer groweth naturally hard,

\section{* Thetemperature.}

The gum of this tree is of an heating, mollifying, and concocting qualitie.

\section{- $*$ The vertues.}

A It helpeth the cough; the falling downe, of rheumes and humours into the cheft, and hoarfenes of the voice; it alfo helpeth the noife and founding in che eares; preuailech againft Strumes, or the Kings euill; nodes on the nerues, and harde fwellings proceeding of a colde caufe; it preuaileth allo againft all colde poifons, as Hemlockes and fuch like.

B Of this gum there are made fundry excellent perfumes, pomanders, fweete waters, fweete bags, and fwcete wafhing bals, and diuers orher fweete chaines and bracelets, whereof to writc were impertinent to this hiftoric.

\section{Of the Sorrowfull tree, or Fndian Mourner. Chap.138. $*$ The defription.}

Rbor triftus, the fad or forrowfull trree waxeth as bigge as an Oliue tree, garnifhed with manie goodly branches, fet full of leaues like thofe of the Plum tree:anong which come foorth molt odoriferous and fweete finelling tlowers, of the colour of Saffron, which flourifh and thewe them: 


\section{HISTORIE OF PLANTS:}

themfelues onely in the night time, and in the day time looke withered and the leaues alfo at that time fhrinke in themfelues togither, much like a tender plant that is frof biteen, very fadly lumping, lowring, and hanging downe the head as terplant that is froft bitand could not abide the heate of the funne. I fhould but in vaine lofelabour it lothed the light, fanfic of the Pocticall Indians, who woulde make fooles bece cole labour in repeating a foolinh daughter of a great Lord or King, and that the funne weicte, that this tree was once a faire I omit.

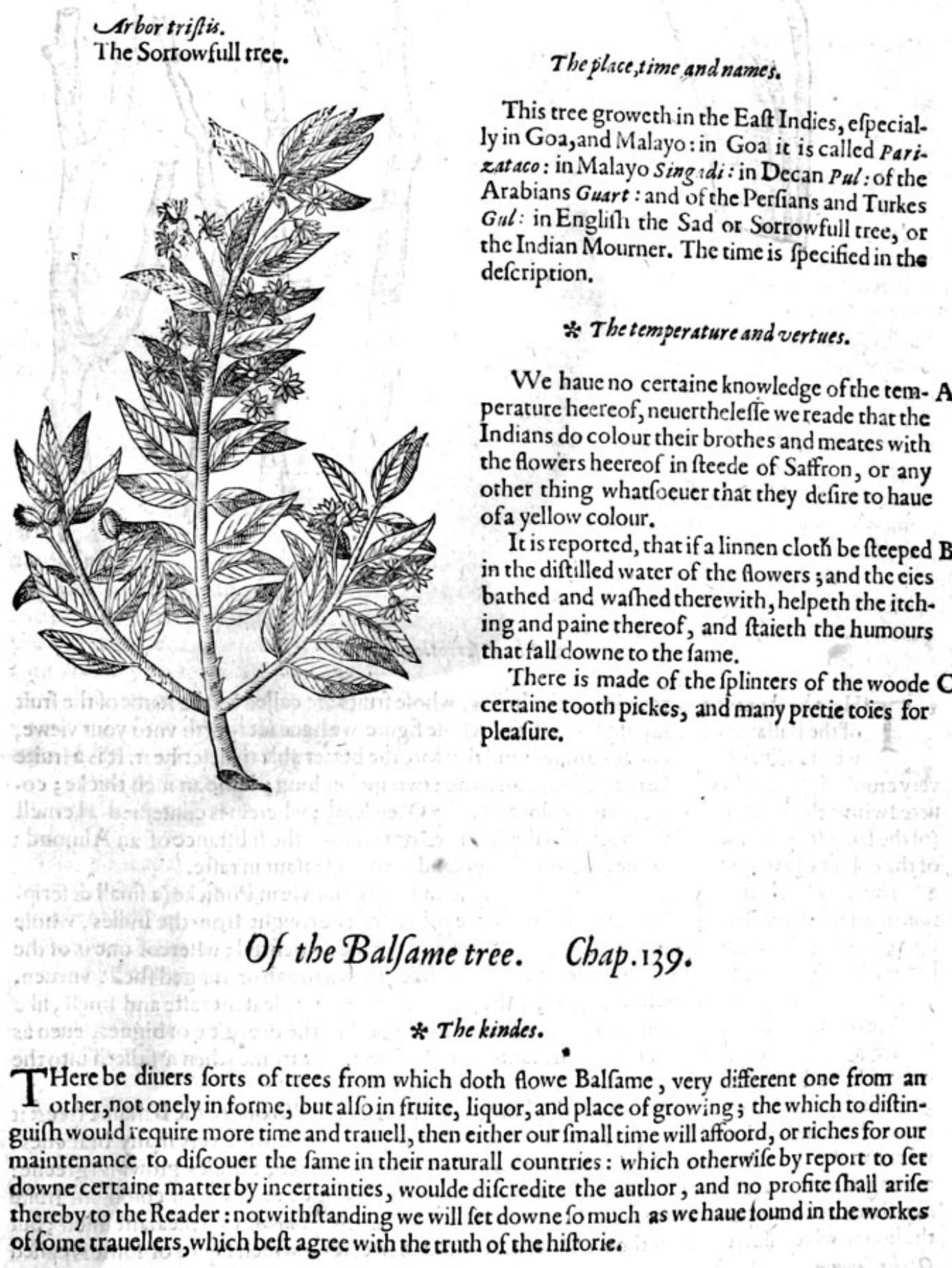
zataco: in Malayo Sing idi: in Decan Pul: of the Arabians $G$ uart : and of the Perfians and Turkes Gul: in Englifh the Sad or Sorrowfull tree, or the Indian Mourner. The time is fpecified in the

\section{* The temperature and vertues.}

We haue no certaine knowledge of the tem. It is reported, that if a linnen cloth be fteeped B in the diftilled water of the flowers ; and the cies bathed and wafhed therewith, helpeth the itching and paine thereof, and ftaieth the humours

There is made of the fplinters of the woode $\mathbf{C}$ certaine tooth pickes, and many pretie toies for pleafure.

\section{Of the Ballame tree. Chap.139.}

\section{* The kindes.}

Here be diuers forts of trees from which doth flowe Balfame, very different one from an other, not onely in forme, but alfo in fruite, liquor, and place of growing; the which to diftinguifh would require more time and tratuell, then either our finall time will affoord, or riches for our maintenance to difcouer the fame in their naturall countries: which otherwife by report to fet downe certaine matter by incertainties, woulde difcredite the author, and no profite fhall arife of fome trauellers, which beft agree with the truth of the hiftorie. 
I Bal/ami fructus.

The fruit of the Balfame tree.

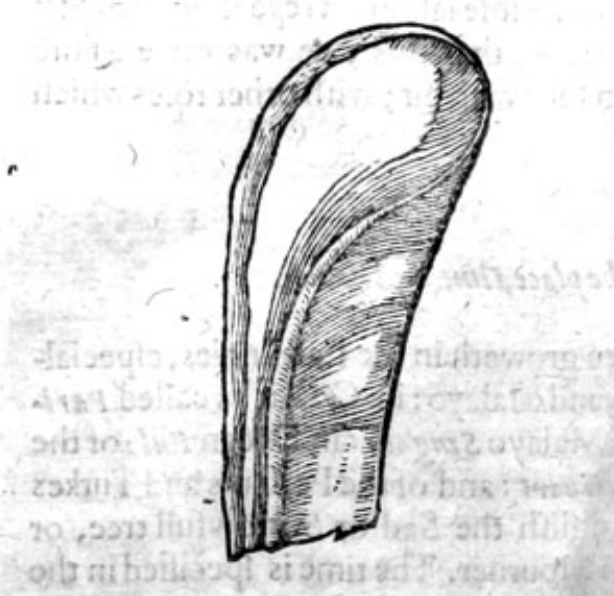

2 xylobalfamum. The wood of the Balfame tree.

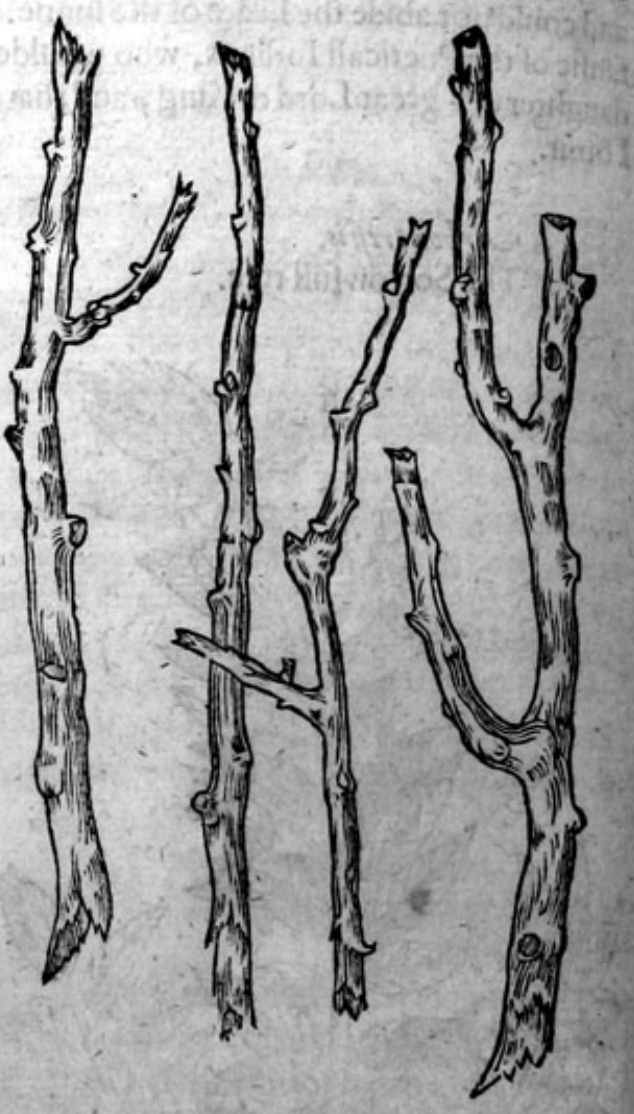

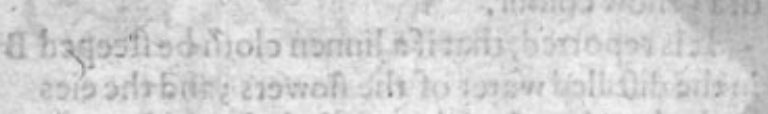

Hasiotily

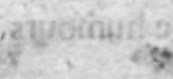

* The defcription.

I Here be diuers trees growing in the Indies, whofe fruits are called by the name of the fruit of the Balfame tree: among the reft this whofe figure we haue fet foorth vnto your viewe, we our felues haue feene $\&$ handled; and therfore the better able to defcribe it. It is a fruite very crooked, and hollowed like the palme of an hand; two inches long; halfe an inch thicke; couered with a thicke fmooth rinde, of the colour of a dry Oken leafe ; wherein is conteined a kernell (of the fame length and thicknes, apt to fill the faid hell or rinde) of the fubftance of an A honond; of the colour of afhes; fat, and oilie; of a good fmell, and very vnpleafant in tafte.

2 The wood we haue dry brought vnto vs from the Indies for our vfe in Phificke (a fmall defcrip. tion may ferue for a dry fticke) neuertheleffe ive haue orher fruits brought from the Indies, whofe figures sre not fet foorth, by reafon they are not fo well knowne as defired; whereof one is of the bignes of a Walnut, fomewhat broade on the vpper fide, with a rough or rugged fhell, vneuen, blacke of colour, and full of a white kernell, with much ituce in it; of a pleafant tafte and fmell, like the oile of Mace : the whole fruite is exceeding light, in relpeet of the quantitic or bignes, euen as it were a peece of Corke; which notwithftanding finketh to the bottome when it falleth into the water, like as doth a ftone.

3 This tree faith Garcias that beareth the fruit Carpobalfamum, is alfo one of the Balfame trees: it groweth to the height and bignes of the Ponegranate tice, garnifhed with very many branches: whereon doe growe leaties like thofe of Rewe, but of colour whiter, alwaies growing greene: among which come foorth flowers, whereof we hate nocertaintic: after which commeth fruite like that of the Turpentine tree, which in fhops is called Carpobal amum, of a pleafant fmell ; but the liquor which floweth from the wounded tree, is much fweeter : which liquor of fomeis called opobalyamun. 


\title{
HISTORIE OF PLANTS.
}

3 Carpobalfamum.

The fruite of one of the Balfame trees.

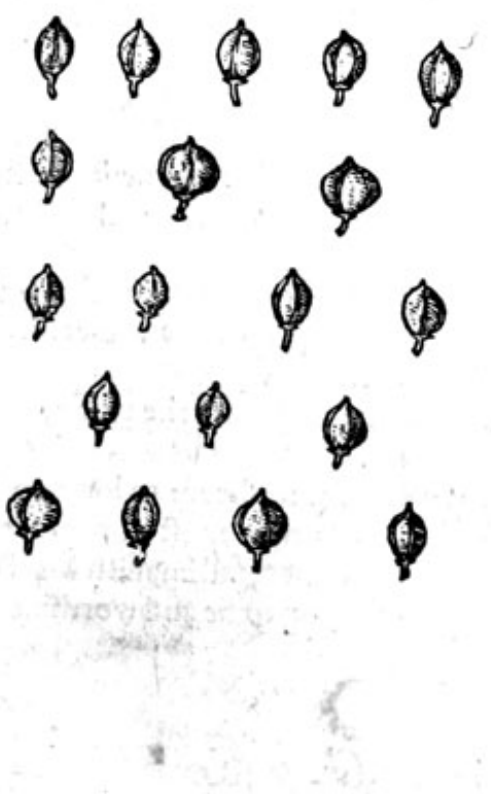

\author{
* Thedefription.
}

Of thefe Balfame trees there is yet another fort: the fruite whereof is as it were a kernell without a fhell, coucred with a thin skin ftraked with manie vaines, of a browne colour: the meate is firme and folide, like the kernell of the Indian Nut, of a white colour, and without finell , but of a gratefull taftes and is thought to be hot in the firft degree, or in the beginning of the fecond.

There be diuers forts more which might be omitted bicaufe of tedioufnes: neuertheleffe I will trouble you with two efpecial trees woorthy the noring: There is faith my author in America a great tree, of monitrous hugenes, befer with leaues and boughes euen to the ground; the trunke whereof is coucred with a twofolde barke, the one thicke like vnto Corke; and another thinne nexr to the trec: from betweene which barks dorh flowe (the vpper tarke being wounded) a white Balfame like vnto teares or drops, of a moft fivect fauour, \&\& fingular effects, for one drop of this which thus diftillech out of the tice, is woorth a pound of that which is madc by decoction: the fruite hecreof is fmall in refpect of the others; it feldome exceedeth the bignes of a Peafe, of a bitter tafte; inclofed in a narrow husk, of the length of a finger, fouthing thin, and of a white colour; which the Indians do vfe againit headach: which fruite of mott, is that we haue be ore defcribed, called Carbuhalfanum.

It is alfo written, that in tbe Il and called Hißaniola; there groweth a fmall tree, of the height of two men, without the induftry of man, hauing Italkes or ftems of the colour of afhes; whereon do grow greene leaues, tharpe at both endes, but more grcene on the vpper fide then on the lower; $h_{2}$ uing a middle rib fomwhat thicke and ittanding out; the footcftalkes whereon they grow are fomewhat reddith: among which leaties commeth fruitc growing by clufters, as long as a mans hande fingers and all: the fitones or graines in the fruite be fewe, and greene; but growing to redneffe more and more, as the fruite waxeth ripe. From the which is gathered a ituice, alter this maner :they take the yoong hootes and buds of the tree, and alfo the clufters of the fruite, which they bruife, and boile in water to the thickneffe of honie, which being ftrained, they keepe it for their vfes.

They vfe it againft wounds and vlcers; it ftoppeth \& ftancheth the blood; maketh them cleane; bringeth vp the Befh, and healeth them nightily, and with betrer fucceffe then true Balfane. The branches of the tree being cur, doth cait foorth by drops a certaine clcare water, more woorth then Aqua vite molt holfome againit woundes, and all other difeafes proceeding from colde caufes, if it be drunken fome fewe daies togither.

Thef theplace.

Thefe trees grow in divers parts of the wo:ld, fome in Egypt,and moft of thofe countries adiacent: there groweth of them in the caft and weft Indies; as traucllers into thofe parts report. $*$ The time.
Thefe trees for the moft part keepe greene winter and fommer.
$*$ The names.

Balfame is called in Greeke Béx Caur :in Latine alfo Balfamum: of the Arabians Balfcri, Balefma, and Belfan : in Italian Balfamo: in French Basmoe.

The licuor that floweth out of the tree when it is wounded, is called op:bal/smum : the woode rylobalfamum: the fruite Carpobalfanum: and the liquor which naturally toweth fion the tree in Egypt Baljasmum. 


\section{$*$ The temperature.}

Balfame is hot and dry in the fecond degree, with aftriction. $*$ The vertues.

A Naturall Balfame taken in a morning fafting, with a little Rofe water or wine, to the quantitie of fite or fixe drops, helpeth thofe that be afthmatike, or fhort of winde:it preuaileth againft the pains of the bladder, and ftemack, and comforteth the fame mightily; \& alfo amendeth a ftinking breth; and takcth away the fhaking fits of the quotidian ague, if it be taken two or three times.

B It helpeth confumptions, clenfeth the barren wombe, efpecially being annointed vpon a peffary, or mother fuppofitoric, and vfed.

C The ftomacke being annointed therwith, digeftion is helped thereby; it alfo preferueth the fto. mackefrom obftruetions and windineffe; it helpeth the hardnes of the fpleene; eafeth the griefes of the raines and belly, procecding of cold caules.

D It alfo takerh away all manei of aches,proceeding of colde caufes, if they be annointed therwith; but more fpeedily, if a limen cloth be wet thercin, and laide thereon:vfed in the fame maner, it diffolueth hard tumours, called ademata ; and itrengthneth the weake members.

E The fame refrefheth the braine, and comforteth the parts adioining; it helpeth the palfie, conuulfions, and all griefes of the finewes, if they be annointed therewith.

F The maruellous cffects that it worketh in newe and greene wounds, were heere to long to fet downe, and alfo fuperfuous; confidering the skilfull Chirurgion whom it moft concerneth, doth know the vfe therof; and as for the beggerly Quackfaluers, Runnagates, and knauilh Mountibanks, we are not willing to inftruct in things fo farre aboue their reach, capacitie and worthineffe.

\section{Of a kinde of Bulme, or Ballame tree. Chap.140.}

Molle, fue crolly Clufii, or L'Obely:

The Balfame trec of Clusins, and L'Obelizus defcription.

* The defcription.

7 His tree which the people of the Indies do call Molli, groweth to the bignes of a great tree : hauing a trunke or body of a darke greenc colour, fprinkled ouer with many afh co. loured fpots: the branches are many, and of very great beauty; whereupon do grow leaues notynlike to thole of the Afh tree, confifting of many fmall leaues, fet vpon a middle rib; growing nartower euer towards the point, euery particulat one iagged on the fides hike the teeth of a fawe; which being plucked from the ftemme, yeeldech foorth a milkie ittice, tough and clammy, fauoring like the brufed leaues of Fenell, and as it feemeth in tafte fomwhat aftringent: the flowers grow in clufters vpon the twiggic branches, like thofe of the Vine tree a little before the grapes be formed: after followeth the fruite or berries, fomewhat greater then Pepper cornes, of an nilie fub. ftance; greene at the firft, and of a darke reddifh colour when they be ripe.

$$
\text { * T leplace. }
$$

This tree faith a learned Phifition called rob: Fragofm, doth grow in the king of Spaine his garden, at Madryll, which was the firft that cuer he did fec : fince which time, Iohn Ferdinando Secretarie vnto the forefaide king, did fhewe vnito the 


\section{HISTORIE OF PLANTS.}

faid Fragofous, in his owne garden a tree folarge, and of fuch beautic, that he was neuer fatisfied with looking on it, and meditating vpon the vertues thercof. Which wordes I hane receined from the handes of a famous learned man, called M. Lancelot Eromne, Doctor in Phificke, and Phifition vnto the Queenes Maieftic,at the impreffion heerof, faithfully tranflated out of the Spanifh toong, without adding or taking any thing atvay.

They grow plentifully in the vales and low grounds of Peru, as all affirme that haue trauelled to the we?t Indies;as alfo thofe that haue deferibed the fingularities therof.My felfe with diuers others, as namely Mafter Nicholas Lete, a worfhipfull marchant of the citie of London; and alfo a moft skilfull Apothecarie, Mafter Iames Garrct, who haue receiued feedes thereof from the right Ho. norable the Lord of Hunfdon, Lord high Chamberlaine of England, woorthie of triple Honor for his care in getting, as alfo for his curious keeping rare and ftrange things brought from the fartheft parts of the world; which feedes we haue fowen in our gardens, where they haue brought foorth plants of a foote high; and alfo their beautifull leaues : notwithftanding our care, diligence, and induftry, they haue perifhed at the firft approch of winter, as not being able by reafon of their tendernes to indure the colde of our winter blafts.

\section{* Thetime.}

As touching the time of his flourifhing, and bringing his fruite to maturitie, we haue as yet no certaine knowledge, but is thought to be greene borh winter and fommer.

\section{* The names.}

This moft notable tree is called by the Indian name Molle, of fome Molly, and Muelle,taken from his tender foftnes, as fome haue decmed: it may be called the Fennell tree, or one of the Balme, or Balfame trees.

\section{พ.T Thetemperatwre.}

This tree is thought to be of an aftringent or binding qualitie; whereby it-appeeres befides the hot temperature it hath, to be compounded of other diuers faculties.

\section{* The vertues.}

The Indians vfe to feeth the fruite or berries heereof in water, and by a fpeciall skill they haue in $\mathbf{A}$ the boiling, do make a moft holfome wine or drinke,2s alfo a kinde of vineger, and fometimes honie; which are very ftrange effects, thefe three things being fo contrary in taite.

The leaues boiled, and the decoction drunke, helpeth them of any difeafe proceeding of 2 colde $B$ caufe.

The gum which iffueth from the tree, being white like vnto Manna, diffolued in milke, taketh $\mathbf{C}$ away the web of the eies, and cleereth the fight, being wiped ouer with it.

The barke of this tree boiled, and the legs that be fwollen and full of paine, bathed and wafhed D with the decoction diuers times, taketh away both infirmities in fhort fpace.

This tree is of fuch eftimation among the Indians, that they worthip it as a god, according to E their fauage rites and ceremonies:much like as Pliny reporteth of Homers Moly, the moft renowmed of all plants, which they had in old time in fuch eftimation and reuerence, that as it is recorded, the gods gaue it the naine of Moly, and fo writeth Owid,

$$
\begin{aligned}
& \text { Pacife r buic dederat florem Cyllenius album, } \\
& \text { Moly vocant Superi, nigra radice tenetur. } \\
& \text { * Cyllenius bearing Peace, vpon this tree } \\
& \text { Gaue and beitowd a flowre or bloffome white: } \\
& \text { * Moly the gods would haue ir named bee, } \\
& \text { I'ts held to haue a roote tha'ts blacke in fight. }
\end{aligned}
$$

* Mercurie the gods herald and orator.

* Moly fingular againf witchcraft.

If any be defirous to fee more heereof they may reade a learned difcourfe of it fet foorth in the Latine toong, by the learned $L^{\prime} O$ Obelimes, who hath at large written the hiftorie thereof, dedicated to the Right Honorable, the Lord Chamberlaine, at the Impreffion heerof; faithfully ouerfeene and examined by the learned Phifition before remembred, Mafter Doctor Browas, and his cenfure vp. on the fame. 


\section{Of the Canell,or Cinnamom tree. Cbap.I4I.}

Canelle folium, \& Bacillus.

The leafe and trunke of the Cinnamom tree.

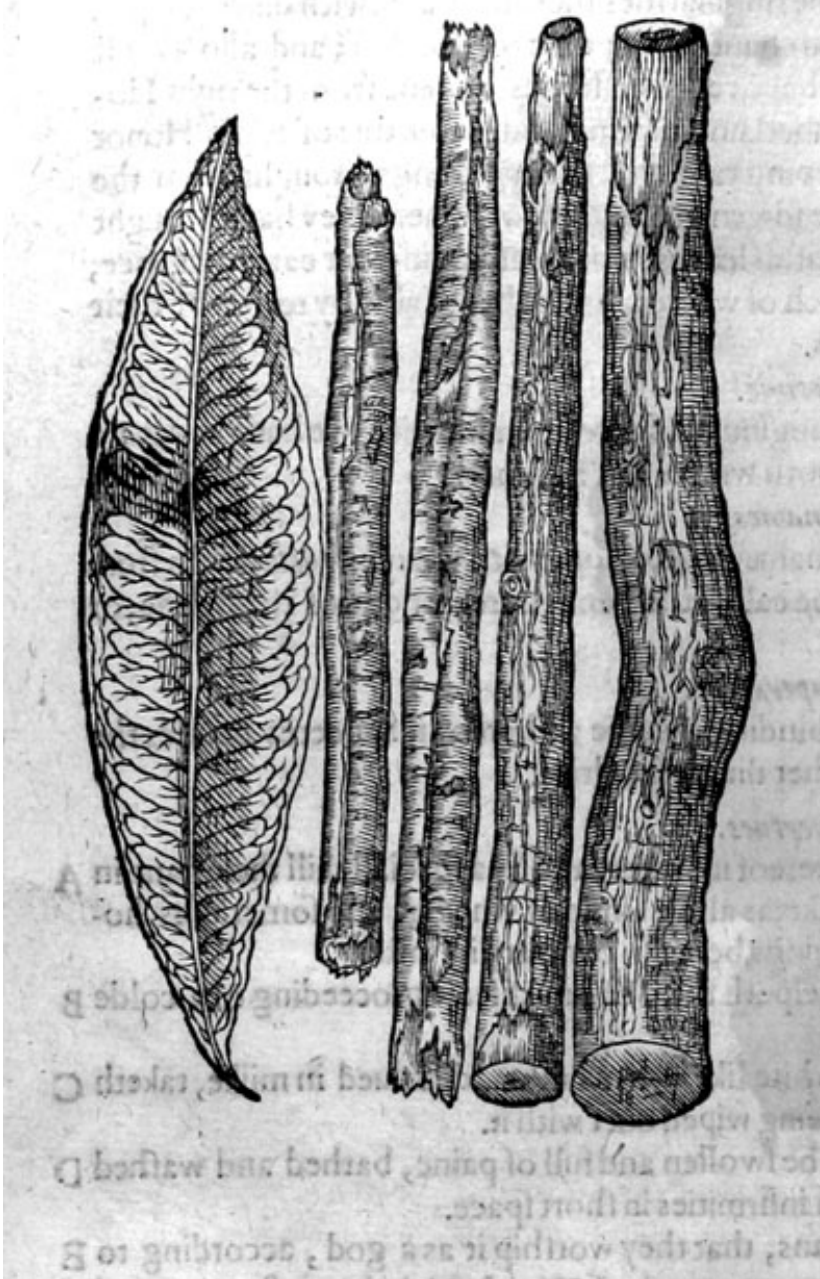

$*$ The defcription.

7 He tree which hath the Cinnamon for his barke, is of the ftature of an Oliue tree: ha. uing a body as thicke as a mans thigh, from which the Cinnamon is taken; but that taken from the fmaller branches is much better: which branches or boughes are many, and verie ftraight; whereon do grow beautifull leaues, in Thape like thofe of the Orenge tree, and of the colour of the Baie leafe, (not as it hath beene reported) like vnto the leaues of flags or flower. Deluce: among thefe pleafant leaties and branches come foorth many faire white flowers, which turne into round and blacke fruite or berries, of the bigaes of an Hafell Nut, or the Oluue berrie, and of a blacke colour; out of which is preffed an oile, that bath no fmell at all vntill it be rubbed and chafed betweene the handes: the trunke or body with the greater armes or boughes of the tree, are couered with a double or two folde barke, like that of Suber, the Corke trce: the innermoft where of is the true \& plea-, fant Cinnamom, which is taken from the tice, and caft vpon the grounde in the heate of the funne; through the heate thereof it turneth and folderh it felfe rounde togither, as we daily fee by viewing the thing it felfe: this tree being thus peeled, recoucreth a newe barke in the foace of three yeeres, and is then ready to be disbarked as afore. That Cinnamom which is of a pale colour, hathnot beene well dried in the funie:

that of a faire browne colour is beft; and that which is blackifh, hath been too much dried, and alfo hath taken fome wet in the time of drying.

$$
\text { * The place. }
$$

The chiefeft places where the trees do growe that beare Cinnamom, are Zeilan, and Malauar: but thofe of Zeilan are the beft : they grow in other of the Moluccaes Ilands, as Iaoa, or Iaua, the greater and the lefic, and alfo in Mindanoa, for the moit part vpon mountaines.

* Thetime.

The Cinnamom tree groweth greene winter and fommer, as do all the other trees of the Moluccaes, and Eaft Indies for the moft part : the boughes whereof are cut off at feafonable times, by the expreffeconmandement of the king of the countrie; and not before he haue appointed the time.

There hath beene fome controueifie among writers concerning the tree, whole barke is Cafsia, and that tree that beareth Cinnamom, making them both one tree; but that opinion is not to be receitued : for there is as great difference betweene them as there is betwixt an Oke, and a Cheftnut tree; for the tree whofe barke is $\mathrm{Ca}$ sa , is doubrlefle a baftard kinde of Camell, or Cinnamom: in fhew it is very like, but in fiveetenes of fmell and other circumftances belonging to Cinnamom, farreinferior.

$$
\begin{aligned}
& * \text { The names. } \\
& \text { Cinnamom is called in Italian Canella : in Spanifh Canola : in French Canelle : inhigh Dutch } \\
& \text { żummet }
\end{aligned}
$$


zimmet coezlin: the Grecians ravdueuer : the Eatines likewife Cinnamomum : the Arabians Dar. feni, and as forne fay Querfaa, others Ouerfe: i\$ Zeilan Cuurde: in the Iland Iaua they name it $C_{a}$. meat : in Ormus Darchent, id efl, lignum Clinen fe, the woor of China: in Mala:ar Cais matns, which in their toong fignifieth Dulce lignum Sweete wood: in Englinh Cinnamome, Cinnamon, and $\mathrm{C}_{2}$

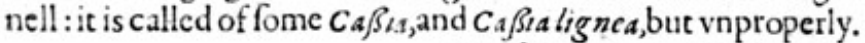

* The temperature and vertues.

Diofcorides writeth, that Cinnamom hath power to warme, and is of thinne partes: it is alfo drie $\mathbf{A}$ and aftringent, it pronoketh vrine, cleereth the eies, and maketh fweete breath.

The decoction bringeth downe the menfes, preuaileth againft the bitings of venemous beaftes, $B$ the inflammation of the inteftines and raines.

The diftilled water hereof is profitable to many, and for dituers infirmities, it comforteth the $\mathrm{C}$ weake, colde, and feeble ftomacke, eafeth the paines and frettings of the guts and intrailes proceeding of cold caufes, it amendeth the cuill colour of the face, maketh fweete breth, and giueth a moit pleafant tafte vnto diuers fortes of meates, and maketh the fame not onely more plealant, but alfo more holefome for any bodics of what conftitution focuer theybe, notwithftanding the binding qualitie.

The oyle drawne chimically preuaileth againft the paines of the breaft,comforteth the ftomack, D breaketh windineffe, caufeth good digeftion, and being mixed with fome honie, taketh away fpots from the face, being annointed therewith.

The diftilled water of the flowers of the tree, as Garcias the Lufitanian Phifition writeth, cxcel- E leth far in fweetneffe all other waters whatfoeuer, which is profitable for fuch things as the barke it felfe is.

Out of the berries of this tree is drawen by expreffion, as out of the berries of the Olitie tree, a $F$ certaine oyle, or rather a kinde of fat like butter, without any fmell at all, except it be made warne, and then it fmelleth as the Cinnamon doth, and is mech ved againft the coldnes of the finewes, all paines of the ioints, and allo the paines and diftemperature of the ftomacke and breaft.

To write as the woorthineffe of the fubiect requireth, would aske more time than we haue to be- $G$ ftowe vpon any one plant; therefore thefe few fhall fyffice, knowing that the thing is of great vie anong mapy, and knowen to inoft.

\section{Of Gum Lackand bis rotten tree. Chap.I42.}

* The defcription.

The tree that bringeth foorth that excrementall fubitance, called Lacca both in the fhops of Europe and elifewhere, is called of the Arabians, Perfians and Tutkes Lcc Sumutri, as who fhould fay Lacca of Sumutra : fome which haue fo termed it, haue thought that the firft plentic thereof came from Sumutra, but hercin they haue erred; for the abundant ftore thereof came from Pegu, where the inhabitants thereof do call it $L a c$,and others of the fame pronince $T$ rec. The hiftorie of which tree, according to that famous Herbarift Clufus is as followcth: There is in the country of Pegu and Malabar, a great tree, whcfe leaues are like them of the Plum tree, hauing many fmall twiggie branches; when the trunke or body of the tree waxech olde, it rotteth in fundrie places, wherein do breede certaine great ants or Pifmires, which continually worke and labour in the time of harueft and fommei againft the penurie of winte $:$ : fuch is the diligence of thefe Ants, or fuch is the nature of the tree wherein they harbour, or both, that they prouide for their winter foode, a lumpe or maffe of fubftance, which is of a crimfon colour, fo beautifull and fo faire, as in the whole worid the like cannot be feene, which ferueth not oncly to phificall vfes, but is a perfeet and coftiy colour for Painters, called by vs Indian Lack. The Pifinires (as I faid) worke out this colour, by fucking the fubitance or matter of Lacca from the tree, as Bees do make honie and waxe, by fucking thematter thereof from all herbes, trees, and flowers, and the inhabitants of that countrie, do as diligently fearch for this Lacca, as ive in England and other countries, feeke in the woods for honie; which Lacca after they haue found, they take from the tree, and dric it into a lumpe; among which fometimes there cone ouer fome fticks and peeces of the tree with the wings of the Ants, which have fallen amongtt it, as we daily fee. 
Lacca cum fuis bacillis.

Gum Lack with his ftaffe, or fticke.

A

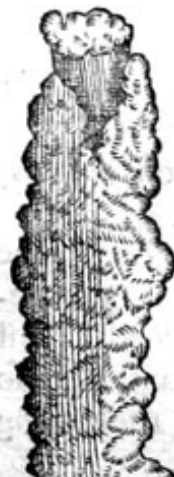

B

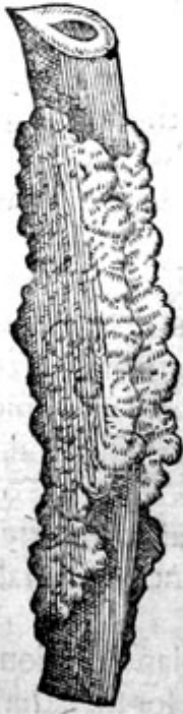

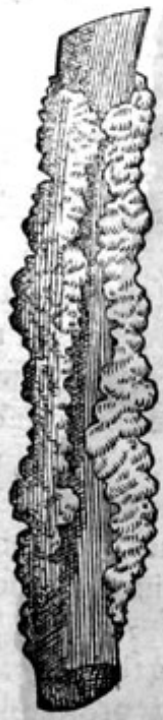

* Theplace.

The tree which beareth Lacca groweth in Zeilan and Malauar,and in other partes of the Eaft Indies.

\section{* Thetime.} * The names.

Indian Lack is called in Thops Lacca : in Italian Lachetta : Aajcen calleth it Luch: Paulus and Diofeorides Cancamum: the other names are expreffed in the defcription. * The temperature and vertues.

Lack or Lacca is hot in the fecond degree, it comforteth the hart and liuer, openeth $\circ b$. ftuctions, expelleth vrine, and preuaileth againit the dropfie.

There is an artificiall Lack made of the fcrapings of Brafill and Saffron, which is vfed of Painters, and not to be vfed in phifickeas the other naturall Lacca.

\section{Of the fndian Leafe. Chap.143.}

Tumalapatra.

The Indian Leafe.

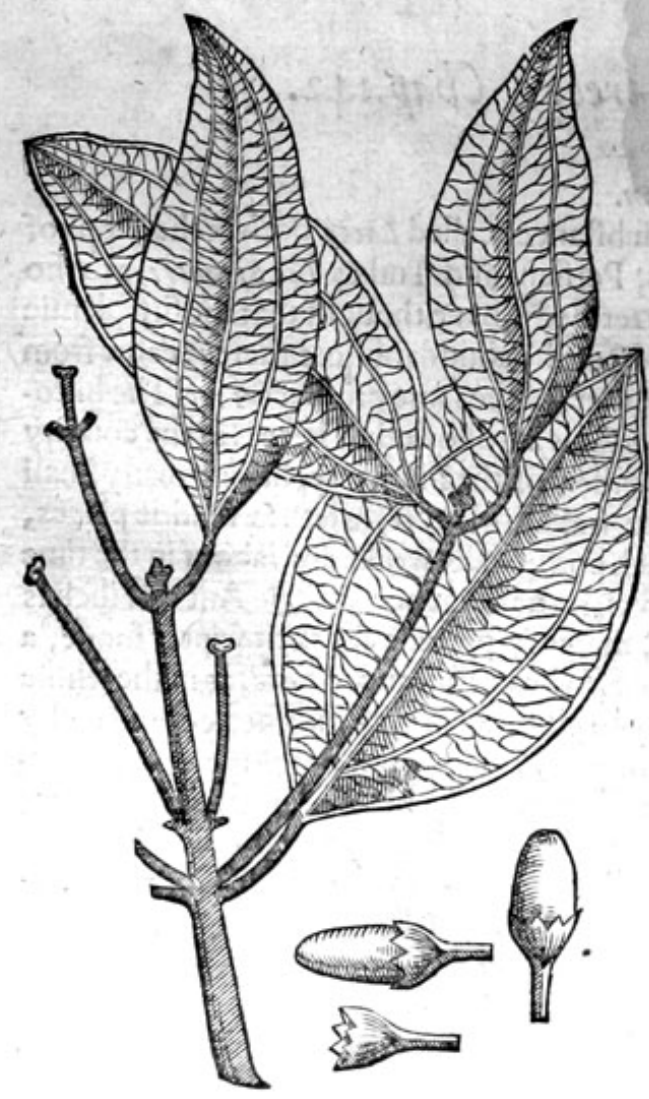

* The defcripsion.

T Simalapatra, or the Indian Leafe groweth vpon a great tree like to the Orenge tree, with like leaues alfo, but fomewhat broader, 2 little Tharpe pointed, of a greene gliftering colour, and three fmall ribs running through each leafe, after the manner of Ribwoort, whereby it is eafie to be knowen : it fmelleth fomwhat like vnto Cloues, but not fo ftrong as Spikenard or Mace (as fome haue deemed) nor yet of fo fub. tile and quicke a fent as $\mathrm{Cinnamom}$. There was fent or added vnto this figure by Cortufus a certaine fruit like vnto a fmall Acorne, with this infcription Fruct us Canelle, the fruit of the Canell tree, which may be doubted of, confidering the defcription of the forenamed tree holden gene. rally of moft to be perfect.

\section{* Theplace.}

The Indian Leafe groweth not fleeting vpon the water like vnto Lens paluftris, as Digfcorides and Plinie doe fet downe, though (learned and painfuil writers) but is the leafe of a great tree, a branch whereof we haue fet foorth vnto your view, which groweth in Arabia and Cambaya far from the water fide. 


\section{HISTORIE OF PLANTS.}

* The time.

1351

Of the time we haue no certaine knowledge, but is fuppofed to be greene winter and fommer.

Tamalapatra is called of the Indians in their mother toong, efpecially the Arabians Cadegi Indi, or Ladegi Indi, that js, Folium Indicum, or Imdum, the Indian leafe: but the Mauritanians do
call it Tembul. The Latinesand Graciaus following foll bathrum.

* The temoersture and vertues.

The Indian leafe is hot and drie in the feconde degree, agreeing with Nardus in temperature; A other report of Mace : it prouoketh vrine moft mightily, warmeth and comfortech the fto. macke. It preuaileth againft the pin and web in the eies, the in flammation and waterie cies, and all other $B$
imperfections of the fame.

It is laide among clothes as well to keepe them from moths and other vermine, as alfotogiue $\mathrm{C}$ vnto them a fweete finell.

\section{Of the Clone tree. Chap.144.}

1 Caryophylliveri Clusï.

The true forme of the Cloue tree.

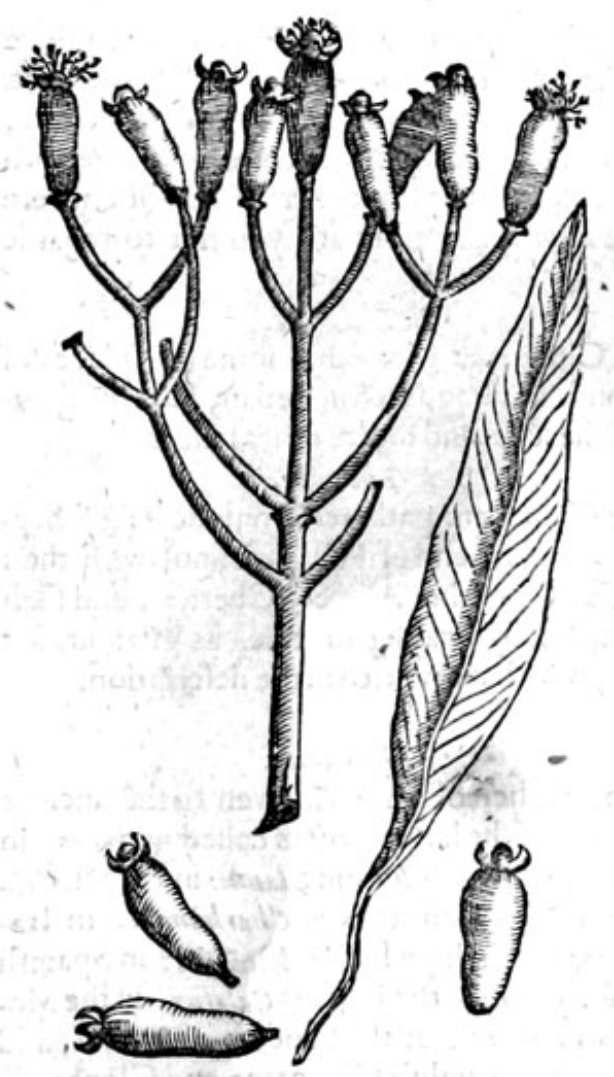

2 Antophylli.

Fuffes, or ouerripe Cloues.

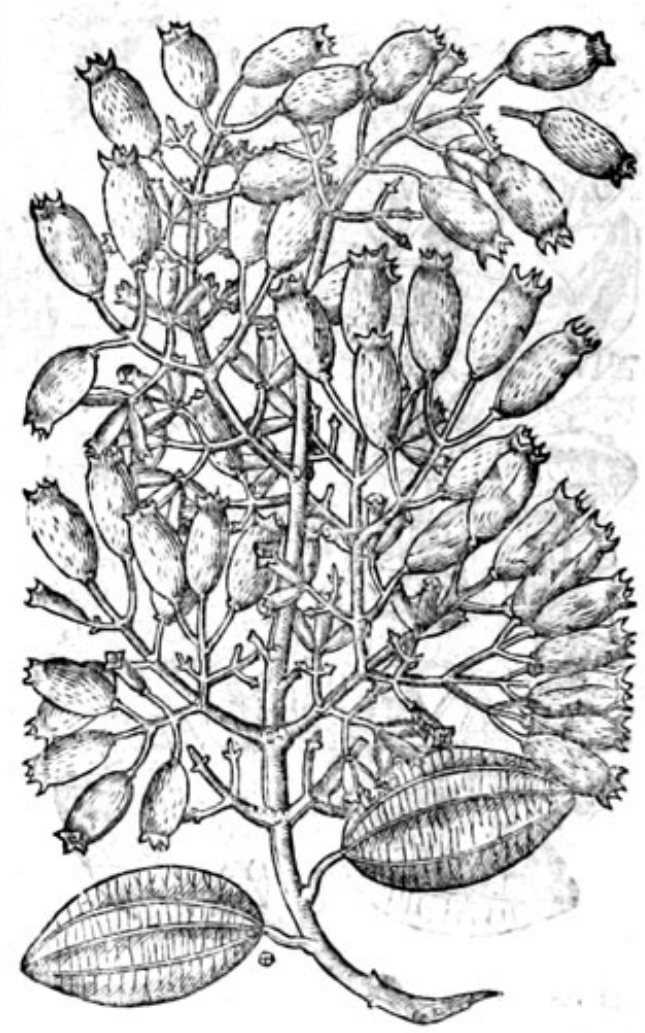

He Cloue tree groweth great in forme like vnto the Bay tree, the trunke or bodic wherof is
couered with a ruffer bark : the branches are many, long, S very britele, wherupon co grow

$\mathbf{I}$ couered with a ruffer bark : the branches are many, long, \& very brittle, wherupon do grow leaues like thofe of the Bay tree, but fomewhat narrower; among which come the flowers, Siff 2 white 


\section{2}

\section{THE THIRD BOOKE OF THE}

white at the firft, after of a greenifh colour,waxing of a darke red colour in the end; which flowers are the very Cloues when they are growen hard:after when they be dried in the funne, they become
of that duftie blacke colour, which we daily fee wherein they continue.

2 The other figure fetteth foorth the fruit when it is ouer ripe; for thofe that we have in eftima. tion, are beaten downe to the ground before they be ripe, and are fuffered there to lie vpon the ground vntill they be dried throughly, where there is neither graffe, weedes, nor any other herbes growing to hinder the fame, by reafon the tree drawerh vnto it felfe for his nourifhment allthe moyfture of the earth of a great circuite round about, fo that nothing can there growe for want of moyfture; and therefore the more conuenient for the drying of the Cloues. Contrariwife, thofe grofle kinde of Cloues, which haue beene fuppofed to be the male, are nothing elfe than fruite of the fame tree, tarrying there vntill it fall downe of it felfe vnto the ground, where by reafon of his long lying, and meeting with fome raine in the meane feafon, lofeth the quicke tafte that the others haue, which of the ancients are called $F u$ sti, whereof we haue englifhed them Fuffes. Some affirme, that the flowers here of furpaffe all other flowers in fweetneffe when they are greene, and hold the opinion, that the hardened fowers are not the Cloues themfelues (as we haue written) but thinke them rather the feate or huske wherein the flowers do growe: the greater number hold the former opinion. And further, that the trees are increafed without labour, graffing,planting, or induftrie, but by the falling of the fruit, which beare fruit within eight yeeres after they be rifen vp, and fo continue bearing for an bundred yeeres togither, as the inhabitants of that countrie do affitme.

3 Caryopbyllus florens.

The Cloue tree flowring.

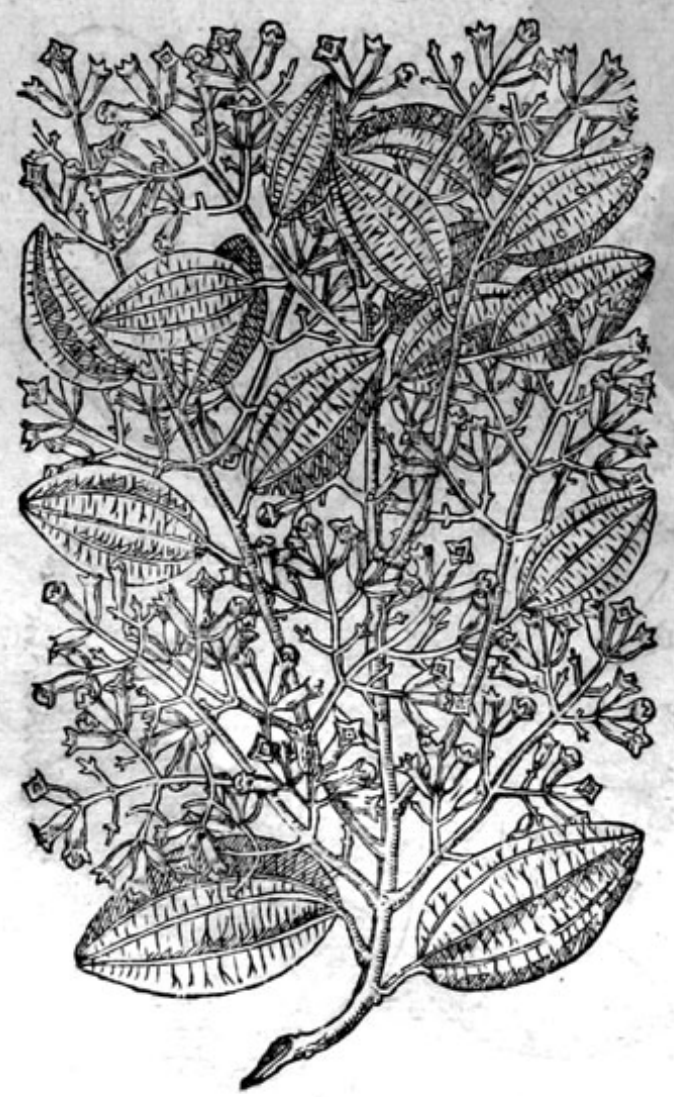

\section{* 7 he defcription.}

3 The defcription and true figure of the Cloue tree we hatue alreadie fet foorth : this figure fetteth foorth the tree with his flowers in his perfection, that is to fay, when they are come to a greenifh yellow colour. The leaues hereof do not anfivere the true figure, therefore are you not to regarde them.

$$
\text { * Theplace. }
$$

The Cloue tree groweth in fome few places of the Moluccaes Ilands, as in Zeilan, Iaua the greater and the leffe, and diuers other places.

\section{* The trime.}

The Cloues are gathered from the 15.of September vnto the end of Februarie, not with their hands, as we gather Apples, Cherries, and fuch like frut, but by heating the tree, as Walnuts are gotten, as we haue written in the defcription.

\section{* The names.}

The fruit hereof was vnknowen to the ancient Grecians : of the laters writers called xapuósurav: in Latine alfo Caryophyllus and Clausus: in French Class de Gyrofle: the Mauritanians Charbumfel : in Italian Carof ano: in high Dutch flaegel: in Spanith clawo te eßpecia : of the Indians Calafur: in the Moluccaes Changue : of the Pandets Arumfel, and Charumfel: in Englifh Cloue tree, and Cloues.

$$
\text { * The temperature. }
$$

Clotes are hot and drie in the thirde degree. * The vertues.

A Cloues ftrengthen the ftomacke, the liuer and hatt, helpe digeftion, and prouoke vrine. 


\section{HISTORIE OF PLANTS.}

The Portingale women that dwell in the Eaft Indies, drawe from the Cloues when they 1353 greene, a certaine liquor by diftillation, of a moft fragrane finell, which comforteth the they be yot B all cordials is thomoft effectual! Clouc's ftop the belly; the oile or water theieof dropped into the eies, doth fharpen the fight, $C$
cleanfeth away the cloud or web in the fame. ration.

The waight of fower drams of the powder of Cloues taken in milke, procureth the act of gene- D

There is extracted from the Cloues a certaine oyle, or rather a thicke butter of a yellow colour, $\mathrm{E}$ whe their wounds and other hurtes, as we do with Balfame.

The vfe of Cloues not onely in mcate and medicine, but alfo in fweete powders and fuch like, is F
fufficiently knowen, therefore this Shall fuffice.

\section{Of the Nutmegtree. Chap.145.}

1 Nux Myriftice ơ Macis. The Nutmeg with his Mace.
2 Nux Mufcata. The Nutmeg tree.
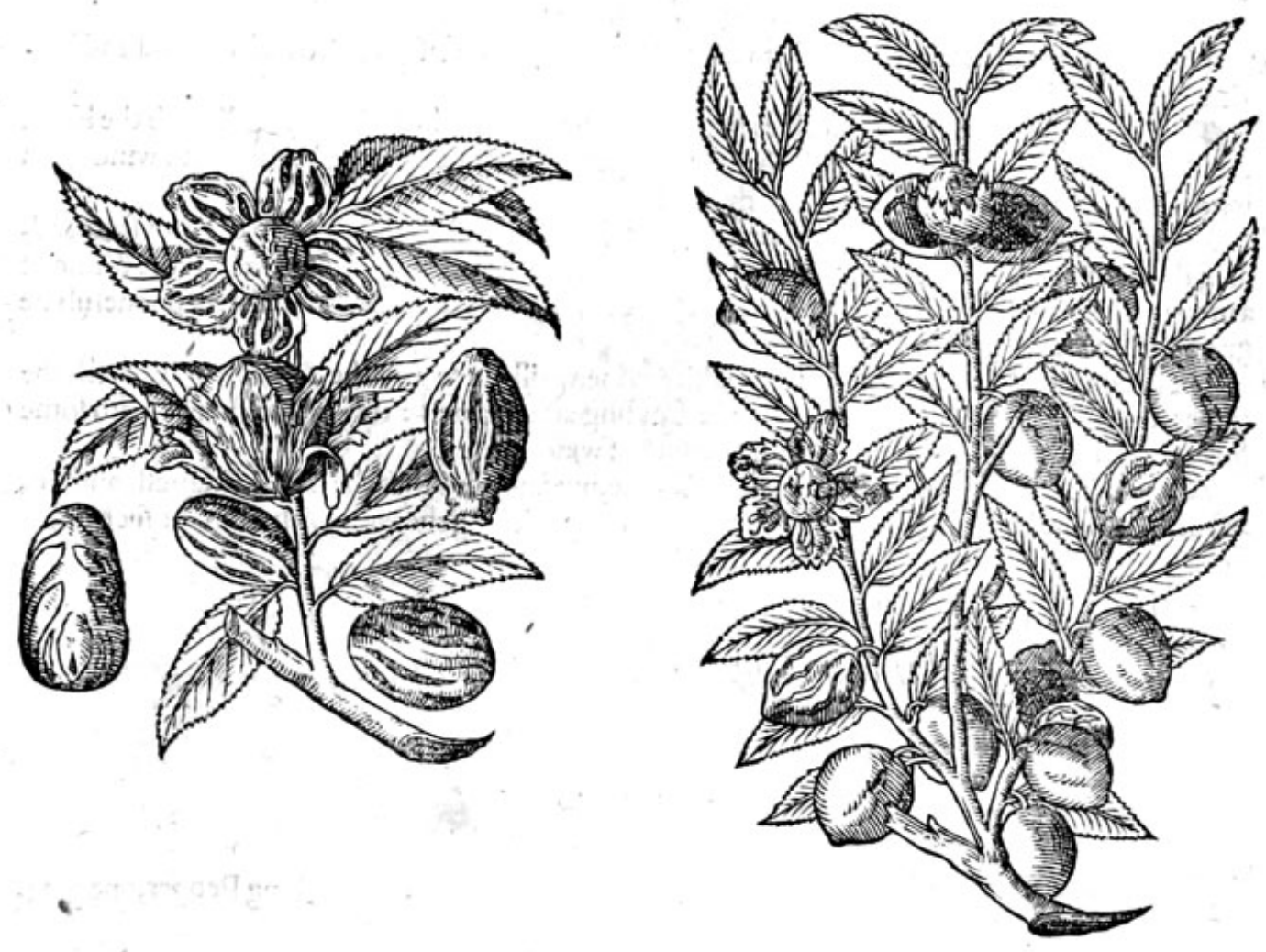

* Thedefcription.

$\mathbf{I}$

Hetree that beareth the Nutmeg and the Mace, in forme is like vnto the Peach tree, fauing that the leaues heereof are narrower, and not folong: alwaies greene on the vpper fide, and vnderneath of a greene tending to yellowneffe: among which come foorth the Nut and the Mace,as it were the flowers. The Nut appeereth firft compafied about with the Mace, as it were in the middle of a fingle Rofe, which in proceffe of time doth wrap and inclofe the Nut round on euery fide: after cómeth a husk like that of the Walnut, but of an harder fubftance, which Sffi 3 inclofeth 


\title{
\$354 THE THIRD BOOKE OFH THE
}

inclofeth the Nut with his Mace, as the W Walnut buske doth couer the Nut, which in time of ripe. nefle doth cleauc of it felfe, as the Walnut huske doth, and fheweth his $\mathrm{Mace}_{2}$ vahich thenis of a perfect crimfon colour, and maketh a moft goodly fhew, ef pecially when thetree is well $l_{2}$ den with fruit: after the Nut becommeth drie, the Mace likewife gapeth and forfaketh the Nut, euen as the firft huske or coucrture, and leaueth it bare and naked as we all do knowe, at which time it getteth to it felfe a kinde of darke yellow colour, and lofeth that braue crimfon die, which it had at the firft. $*$ Theplace.

The Nutmeg tree groweth in the Indies, in an Iland efpecially called Banda, and in the Ilands of Molucca, though not fo good as the firft,neither thofe that do growe in Zeilan.

$$
\text { * The time. }
$$
tries.

The fruit is gathered in September in great abundance, all things being common in thofe coun-

\section{* The names.}

The Nutmeg tree is called of the Grecians xipuor puessxòr : The Latines $2 \times u x$ Mofchata, and $2 u_{u x}$ Myriftica : in Italian Noce Mofcada : in Spanifh 2 Le $\approx$ de efcetie : in French Noix Mufcade: in high Dutch \$afthat Fufz; of the Arabians Leuzbane, or Gianziban : the countrie people where they growe Palla. The Maces Bunapalla : in Decan the Nut is called Iapatri, and the Maces Iasfol: of 1 . wicen Iaufiband, ad eft, Nux Bandenfis : the Maces he calleth Befbaje: in Englifh Nutmeg.

$$
\text { * The temperature. }
$$

The Nutmeg, as the Mauritanians write, is hot and drie in the fecond degree, complete and aftringent.

\section{* 7 be vertues.}

A Nutmegs caufea fweete breth, and amend thofe that do ftinke, if they be much chewed and hol. den in the mouth.

B The Nutmeg is good againft freckles in the face, quickeneth the fight, ftrengtheneth the belly, and the feeble liuer; it taketh away the fwelling in the fipleene, ftaieth the laske, breaketh winde, and is good againft all cold difeafes in the body.

C Nutmegs bruifed and boyled in Aqua vitx, vntill it haue wafted and dried vp the moyfture, adding thereto of Rhodomel(that is, honie and the iuice of Rofes) gently boyling them to the forme of a firupe and ftrained, cureth all paines proceeding of windie and cold caufes, if three fpoonefuls be giuen fafting for certaine daies togither.

D The fame bruifed and boyled in ftrong white wine vntill three parts be fodden away, with the rootes of Motherwoort added thereto in the boyling and ftrained : this liquor drunke with fome Sugar, curech all gripings of the belly proceeding of windineffe.

E As touching the choife there is not any fo fimple, but knoweth that the heauieft, fattelt, and fulleft of iuice is the beft, which may eafily be found out by pricking the fame with a pin, or fuch like.

\section{Of the Pepperplant. Chap.146.}

\author{
* The kinies.
}

$T$ Here be diters forts of Pepper, that is to fay, white and blacke Pepper, long Pepper, one greater and longer than the other, and alfo a kinde of Ethiopian Pepper.

\section{* The defcription.}

I Teplant that beareth Pepper, whether we may call it a tree or an herbie plant, it is difutable; fome holding it for a tree, forme a kinde of Vine, and others for an herbe like vnto the Conwoluali, or Bindweedes, whereupon we will not difpute: but yeelding the cenfures of thofe learned that hate written thereof, leauing the reft that might be faid to a further confideration.

The plant that bearech the black Pepper as alfo the white, groweth vp like a Vine among bufhes 
and brambles where it naturally groweth; buz where it is manured, it is fowen at the botrome of the tree Faufcl \& the Date trees, wheron it taketh hold and climeth vp euen to the top, as doth the Vine, ramping and taking hold with his clafping tendrels of any other thing is meeteth withall. The leaues are few in number, in fhape like thofe of the Afyrian Appic trec, but lefier, harpe pointed, and of a freih greene colour; in tafte fomewhat hot, as are the fruit and alfo the leaues of Betre. The fruit is cluftered togither many fet vpon a long flender ftem, like a little bunch of Grapes, of an handfull long,greene at the firft, and blackinh when they be ripe and dried. The rooie is finall, and as it fhould fecmethreddie, being as it is thought an annuall plant, which muft be fowen yeerely, or come vp of it felfe by the falling of the fruic. Some report it to hatie the roote of Coftus, which is of a woodie fubftance, uothing according with reafon, for the reafons before alledged.

The plant that bringeth white Pepper is not to be diftinguifhed from the other plant, but onely by the colour of the fruite, no more than a Vine that beareth blacke Grapes, from that which bringeth whitc: and of fome it is thought, that the felfe fame plant doth fometimes change it felfe from blacke to white, as diuers other plants do.

2 Piper SEt biopicum frue Vita longa. Pepper of Aethiopia.

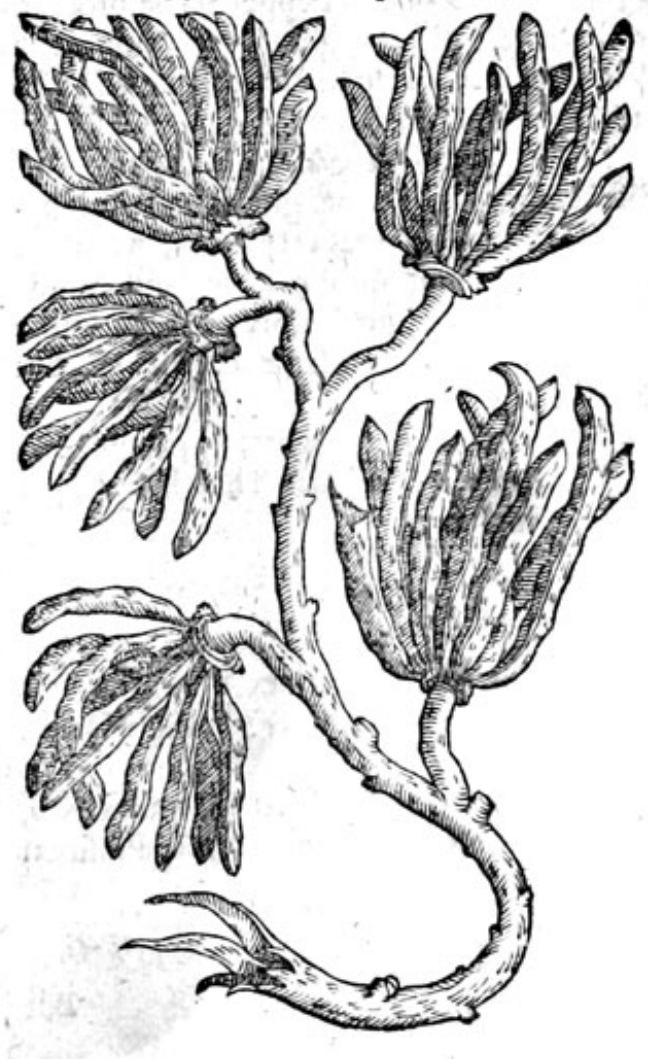

I Pipernigrum album \& longum. Blacke, white, and long Pepper.

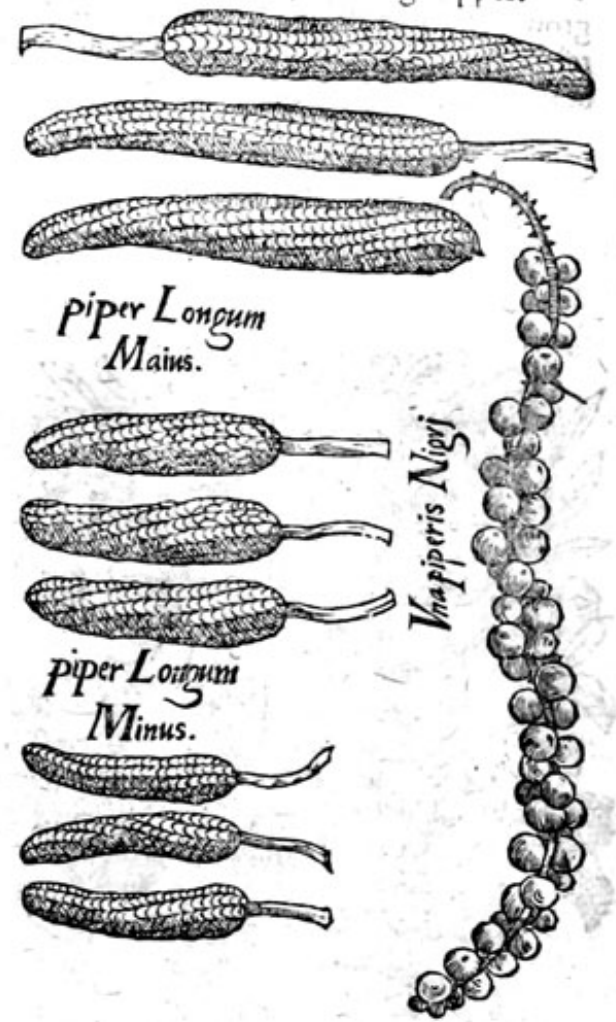

* The defription.

2 This other kinde of Pepper brought vnto vs from Aethiopia, called of the councrie where it groweth Piper Aethiopicum, in fhops Lmomum, and alfo Longa $V t$ ta.It groweth vpen a final tree, in manner of an hedge buh, whereupon growe long cods in bunches, a finger long, of a browne colour, vneuen, and bunched or puft vp in diuers places, ditided into fine or fixe lockers or cels, each where of containeth a round feede fomewhat long, leffer than the feedes of Pxonie, in tafte like common Pepper or Cardsmomum, whofe facultie and temperature it is thought to haue, whereof we hold it a kinde.

The tree that beareth long Pepper, hath nofimilitude at all with the plant that bringeth blacke and white Pepper : fonc hate deemed them to growe all on one tree, which is not confonant to truth: for they growe in countries far diftant one from another; and alfo that countrie where there is b'acke Pepper, hath not any of the long Pepper: and thereforc Galen fo!lowing Diofcorides, were togither both ouerfeene in this point. This tree, faith Monardes, is not great, yet of a woodiefubftance, difperfing here and there his clafping tenSfff 4 drels; 


\section{$\$ 356$ THE THIRD BOOKE OF THE}

drels, wherewith it taketh holde of other trees, and fuch other things as do growe neere vnto it. The branches arc many and twiggie, whereon doth grow the fruite, confifting of many graines growing vpon a flender footeftalke, thruft or compact clofe togither; greene at the firtt, and afterwarde blackifh; in tafte fharper and hotter than common blacke Pepper, yet fweeter, and of
better tafte.

\section{Piper Mathioli.} Mathiolus his figure of Pepper.

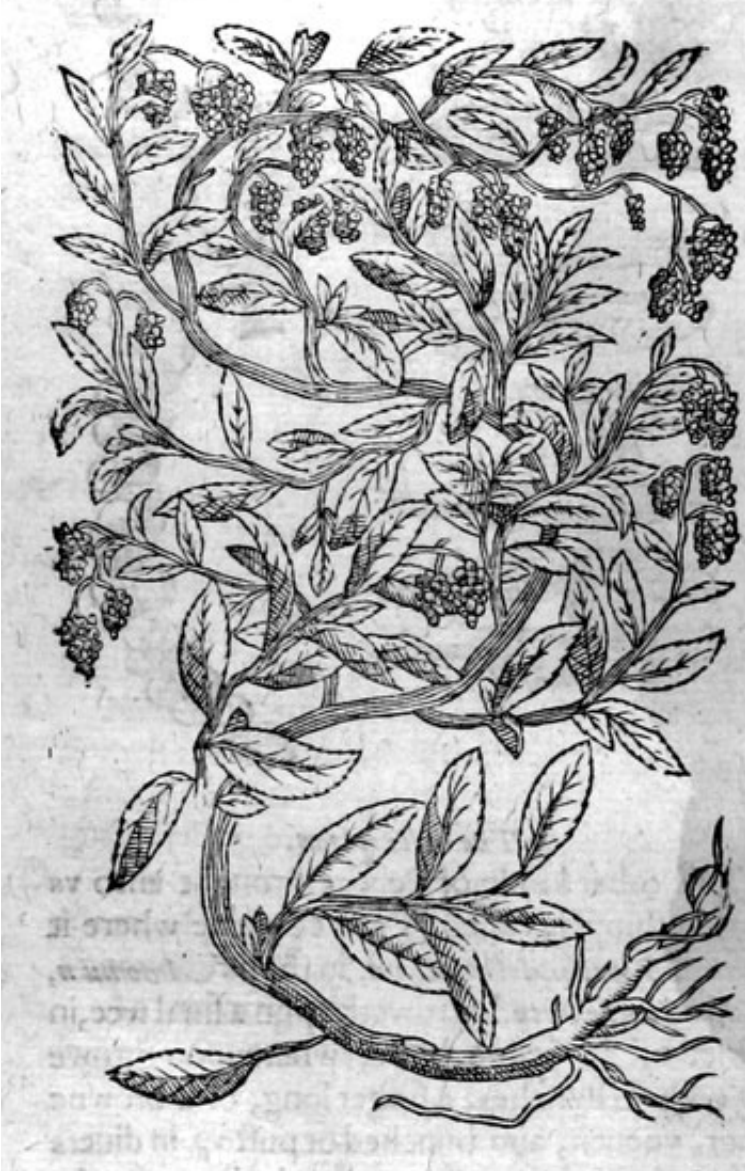

\section{$*$ I he defription.}

3 Matbiolns hath fet foorth a figuee of Pepper condemned of moft to be faigned; neuerthelefle it agreeth with the firft defcription in diters points; it differcth from the others in the clofe and round bunches of fruit. The which figure we haue likewife inferted among the reft, vntill further certaintie may be knowen hercof.

There is alfo anotherkinde of Pepper feldome brought into thefe partes of Europe, called $P$ tper Canarium : it is hollow within, light and emptie, but good to drawe flegme from the head, to helpe the toothach, and cholerike affeets.

Another kind of Pepper is fomtimes brought, which the Spaniards do call P imenta de rabo, that is, Pepper with a taile : it is like vnto Cubebes, round, full, fomewhat rough,blacke of colour, and of a Tharpe quicke tafte, like the common Pep. per, of a good fmell: it groweth by clufters vpon fmall ftems or ftalkes, which fome haue vnaduifedly taken for comomam. The king of Portingale forbad this kinde of Pepper to be brought ouer, for feare leaft the right Pepper fhould bee the leffe efteemed, and fo himfelfe hindered in the fale thereof.

$$
\text { * Theplace. }
$$

Blacke and white Pepper groweth in the king. dome of Malauar, and that very good; in Malaca alfo, but not fo good; and alfo in the Ilands Sunde and Cude : there is great ftore growing in the kingdome of China, and fone in Cananor, but not much.

Pepper of Aethiopia groweth in America, in all the tract of the countrie where Nata and Carthago are ficuated. The reft hath beene fpoken of in their feuerall defcriptions. The white Pepper is not fo common as the blacke, and is vfed there in fteede of falt. $*$ The time.

The plant rifeth vp in the firft of the fpring; the fruit is gathered in Auguit. * The names.

The Grecians, who had beft knowledge of Pepper, docall it mimes: the Latines Piper : the Arabians Fulfel and $F u f f u l:$ in Italian Pepe: in Spanim Pimenta : in. French Poiure: in high Dutch jefefiet : in Englifh Pepper.

That of Aethiopia is called Piper Acthiopicum, Amomum,Vita longa and of fome Cardamomum, where of we holde it to be a kinde. I receiued a branch heereof at the hands of a learned Phifition of London, called M. Steeuen Bredwell,with his fruit alfo.

2 The temperature.
The Arabians and Perfian Phifitions iudge, that Pepper is hot in the third degree. 


\section{HISTORIE OF PLANTS.}

But ihe Indian Phifitians which for the moft part arc Emperickes, hold that Pepper is colde, as almoft all other fpice, which are hot indeed: the long Pepper is hot al fo in the third degree, and as
we haue faide, is thought to be the beft of all the kinds. * The vertwes. Diofcorixes and others agreeing with him, affirme, that Pepper refifteth poifon, andis good to $\mathbf{A}$
beput in medicaments for the eies.

All Pepper healeth, prouoketh vrine, digefteth, draweth, difperfeth, and clenfeth the dimneffe of B the fight, as the fane Digfcorides noteth.

\section{Of bastard Pepper, called Betle, or Betre. Cbap. 147.}

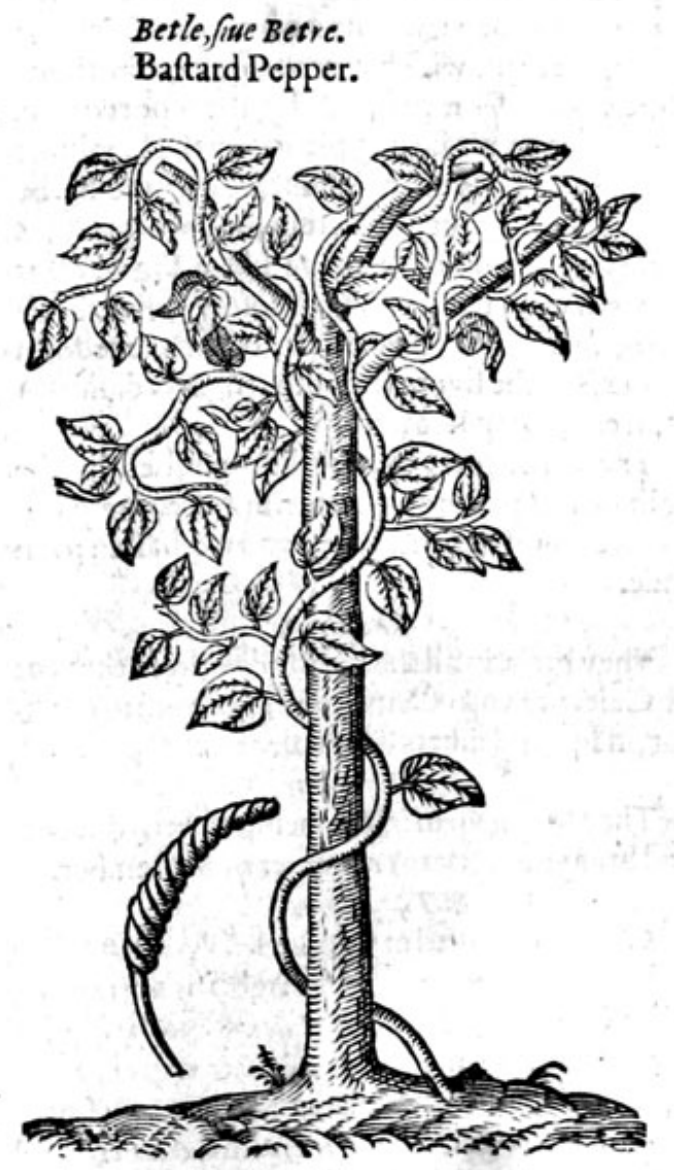

7 His plant climeth and rampeth vpon trees; bufhes, or whatfoever elfe it meeteth withall, like vnto the Vine, or the blacke Pepper, whereof fome holde it for a kinde. The leaues are like thofe of the Limon tree, but fomewhat longer, of a dultie colour, with diuers veines or ribs running through the fame. The iruite groweth among the leaues, very crookedly writhed, in thape like the taile of a Lyzard, of the tafte of Pepper, yet very pleafant to the pa'ate.

$$
\text { * } 7 \text { be place. }
$$

It groweth among the Date trees, and Areca, in moft of the Molucca Ilands, efpecially in the marrifh grounds.

$$
\text { * Thetime. }
$$

The time anfwerech that of Pepper.

$$
\text { * } 7 \text { be names. }
$$

This hath beene taken for the Indian leafe, but not properly: of moft it is called $\tau_{\mathrm{em}} \mathrm{m} u \mathrm{sl}$, and Tambut : in Malauar betre: in Decan Guzarata, and Canam : it is called Pam in Molaio Siri. * Theve and temperature.

The leaues chawed in the mouth are of a bit- $\mathbf{A}$ ter tafte, efpecially thofe that climbe vpon the tree Areca, or any other bitter tree from whence it taketh his bitternefie; otherwife it is very pleafant, which the people do mixe with the hime made of oyfter fhels, whereunto they alto adde fome Amber Greice, L.gnum Aloes, \& fuch lite, which they ftampe togither, making it into a pafte, which they role vp into round bals, keepe drie for their vfe, \& carie the fame in their mouths vntill by little and litile it is confumed; as when we carie fugar Candie in our mouthes, ot the iuice of Licorice; which is not onely vnto the feely Indians neate, but alfo drinke in their tedious traucls, refrefhing their wearicd fpirits; and helpeth memorie : which is efteemed among the Empericke Phifitions, to be hot and drie in the fecond degree. 


\section{Of Graines, or Graines of Paradice. Chap. 48.}

\section{* The kindes.}

Tere be diuers forts of Graines, fome long, others Peare fafhion; fome greater; and others
leffer.

Cardamomigenera.

The kindes, or forts of Graines.

$$
\text { * The defcription. }
$$

7 He vppermoft figure heereof fetteth fooxh vito your viewe the cod wherein the hot fpice lieth, which we call Graines: in fhops

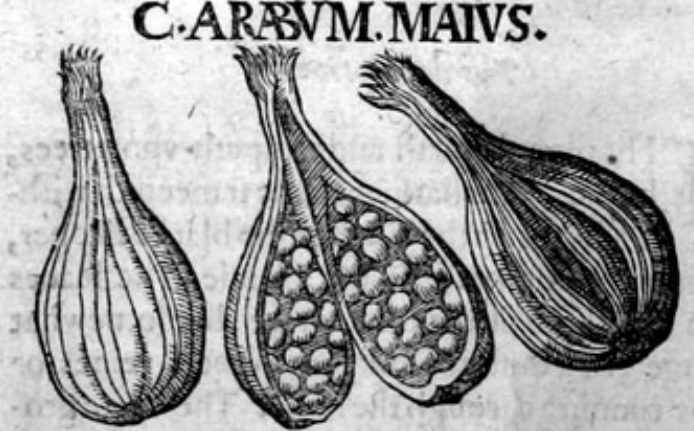

C.MAIVS.OFFICINARVM.
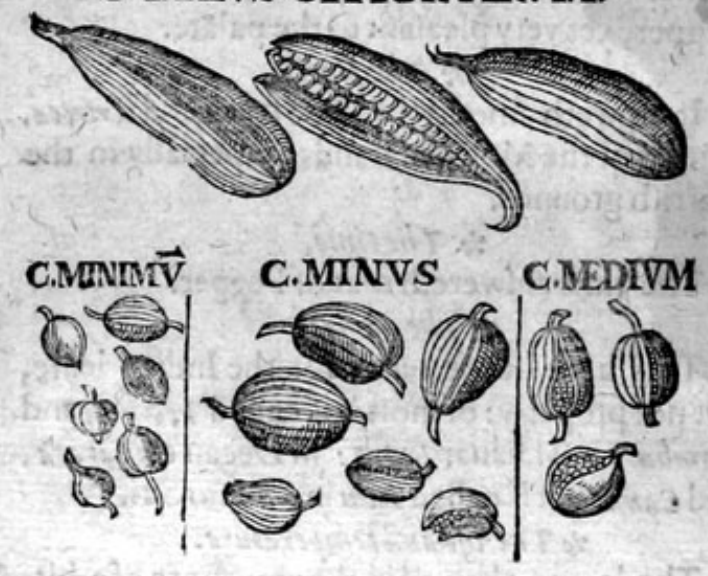

Grana Paradifi: it groweth by the report of the learned vpon an hearby plant, of the height of one cubite, not vnlike in fubftance to the herbe that beareth Ginger; whereupon doth growe a great cod or huske, in thape like a Figwhen it groweth vpon the tree, but of colour ruffet, thruft full of fmall feedes or graines, of a darke reddifh colour, (as the figure fheweth which is diuided) of an exceeding hot tafte.

The other forts may be diftinguifhed by the fight of the picture, confidering the onely ditference confifteth in forme, and we haften to an cnde.

$$
\text { \& Theplace. }
$$

They grow in all the Eaft Indies, from the port of Calccute vnto Cananor; it groweth in Malauar, in Ioa, and diuers other places. * The time.

They fpring vp in Maie, being fowen of feede, and bring their fruite to ripenes in September.

$$
\text { * The names. }
$$

Grains are called in Greeke K A P $\triangle \mathrm{A}^{\prime} \mathrm{M} \Omega \mathrm{MON}$ in Latine Cardamomum: the Arabians Corrumeni, of diuers Gentils Dore : of Auicen Saccolas quebir, id est Magnum: the other Saccolas ceguer, id est Minus: it is called in Malauar Etremellis: in Zeilan Ençal: in Bengala, Guzarata, and Decan Hil, and Eluchi, offome Mileguetta, and Milegetta $:$ in Englifh Graines, and Graines of Paradice. $\stackrel{2}{\mathrm{~T}}$ hetemperature.

Auicen writeth, that Saccolas Cardamosnum, or Grana Paradifs, are hot and drie in the thirde degree, with aftriction.

* The vertues.

A The Graines chewed in the mouth, draweth foorth from the head and ftomacke, waterifh and pituitous humours.

B It alfo comforteth and warmeth the weake, colde, and feeble ftomacke, hclpeth the agewe, and riddeth the fhaking fits, being drunke with fome Spanifh wine, called Secke. 


\section{HISTORIE OF PLANTS.}

\section{Of Yuca or fucca. Chap.149.}

ruca, fue Incea Perena.

The roote wherof the bread $\mathrm{Cafaua}_{\text {, or }} \mathrm{Cazaua}_{\text {is made. }}$

$$
\text { * Thedefcription. }
$$

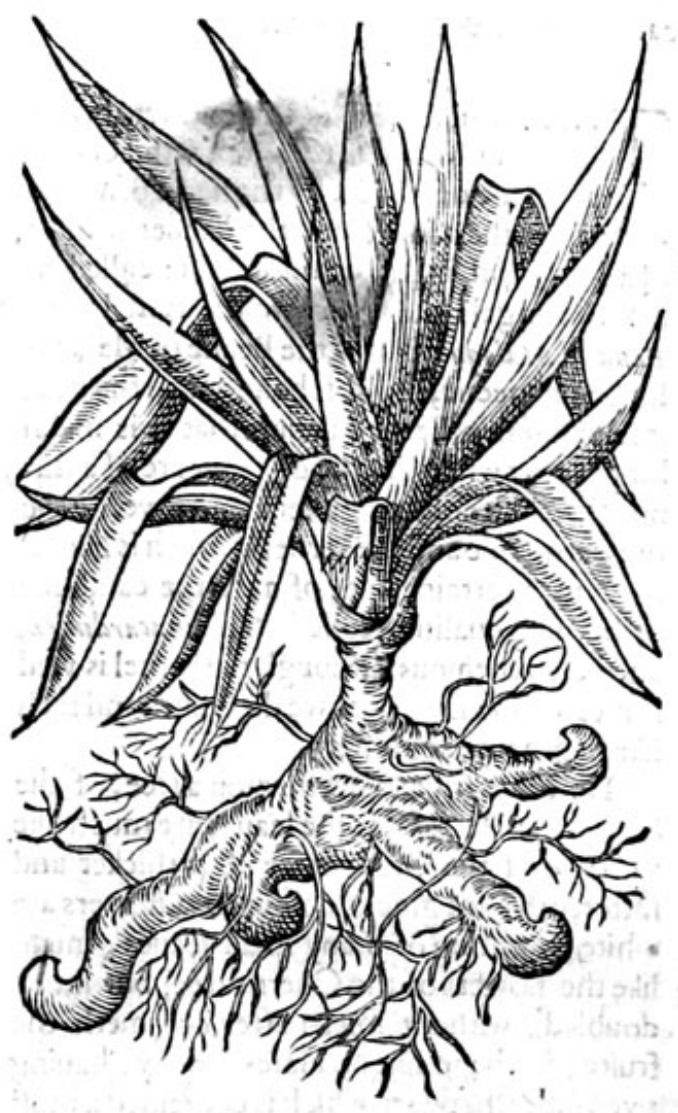

$T^{\mathrm{r}}$ He plant of whofe root the libdian bread called Cazaua is made, is a lowe herbe, hath neither ftalke, flo leaues and rootes: ic can verter fruite, that I from the plate of others, or by experience from the plant it felfe, which hath growerr in mygarden fower yeers togither, and yet doth growe and profper exceedingly;neuertheleffe withour ftalke, truite, or towers, as aforefaid. It hath a very greatroote, thicke, and tuberous, and very knobbie, full of iuice, fomwhat fweet in tafte, but of a pernicious quatitic ( as faith my author) from which roote rifeth vp immediately forth of the ground very many leaues, ioined vnto the head of the roote in a rounde circle, the which are long, of the length of $\mathbf{a}$ cubite, hollowed like a guttter, or trough,very fmooth, and of a greene colour, like that of Woade: the edges of the leaucs are marpe, like the edge of a knife, and of a brownecolour; the point of the leafe is a pricke, as fharpe as a necdle, which hurteth thofe that vnaduifedly paffe by it : the leafe with aduifed cie viewed, is like vnto a little Wherrie, or fuch like bote: they are alfo very tough, harde to breake, and not eafie to cur, except the knife be very tharpe.

$$
\text { * The place. }
$$

This plant growcth in all the tract of the Indies, from the Magellane ftraights vnto the cape of Florida, and in moft of the Ilands of the Canibals, and others adioining, from whence I had that plant brought mee that dotb growe in my garden, by a fcruant of a learned and skilfull Apothecarie of Excefter, named Mafter Thomas Edwards.

* The time.

It keepeth greene both winter and fommer in my garden, notwithitanding the iniurie of our colde climate, without any couerture at all.

\& The nanses.

It is reported vnto me by traucllers, that the Indians do call it in fome parts Manibot, but generally $r_{\text {aca }}$,or Iucca: it is thought to be the plant called of Theophrast tus Arachidna, and of Plimie. Lracidasa.

$$
\text { * The temperature. }
$$

This plant is hot and drie in the firft degree, which is ment by the feces or droffe, when the poifonous iuice is preffed or ftrained foorth, and is alfo dric in the middle of the feconde degree. 


\section{Of the fruit e Anacardium, and Caious, or Caiocus. Cbap.15k.}

Snacardium. Caious.

The Beane of Malaca. The kidney Beane of Malaca.
* The defcripsion.
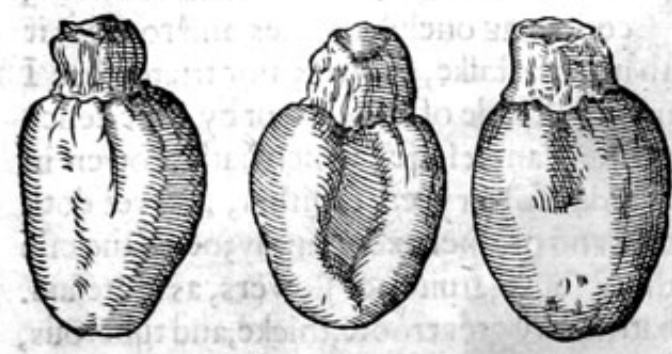

CAIOVS.

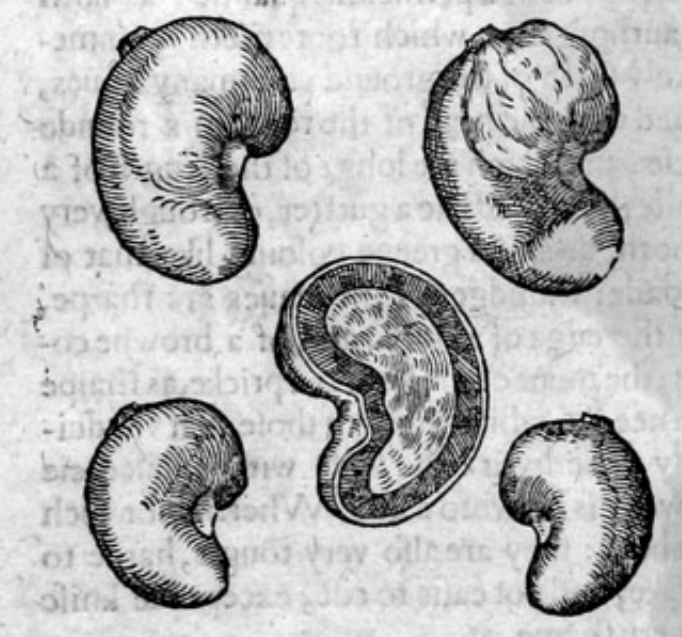

$\prod$ He ancient writers hatie beene verybriefe in the hiftorie of Amacarditum: the Greci. ans haue touched it by the name of Aravap. Jov, taking the name from the likenes it hath of a hart, both in fhape and colour: called of the Portingals that inhabite the Eaft Indies Fasa de Malaqua, that is, the Beane of Malaca: for being greene, and as it hangeth on the tree, it refembleth a Beane, fauing that it is much bigger; but when they be dry, they are of a hining blackih colour, conteining betweene the outward rinde and the kernell (which is like an almond) a certaine oile, of a fharpe caufticke or burning qualitie, called Mel anacardinum, and very venemous, although the kernel is vfed in meates and fawces, as we do Olines and fuch like to procure appetite.

The other fruit groweth vpon a tree, of the bignes of a Peare tree: the leaues are much like to thofe of the Orengetree, but thicker and fatter, of a faint greene colour : the flowers are :hite confifting of many fmall leaues, much like the flowers of the Cherrie tree, but much doubled, without fmell: after commeth the fruite, in Thape like an Hares kidney, hauing two rindes, between which is conteined a molt hot and fharpe oile, like that of Unacardivem, whereofit is a kinde.

The Beane or kernell it felfe is noleffepleafant and holfome in eating then the Piftscia, or fifticke Nut, whereof the Indians do eate with great delight, affirming that it prouoketh venerie, wherein is their chiefe felicitie. The fruite is conteined in long cods like thofe of Beanes, but greater : neere vinto which cods commeth foorth an excrefcencelike vnto an apple, very yellowe, of 2 good fmell; fpungious within, and full of iuice; without any feedes, ftones, or graines at all, fomewhat fweete in tafte; at the one ende narrower chen the other, Peare fafhion, or like a little bottle, which hath beene reputed of fome for the fruite, but not rightly; for it is rather an excrefence, $2 s$ is the Oke Apple.

$$
\text { *Theplace. }
$$

Thefe haue beene founde vpon the mountaines of Cicilia. They growe alfo in moft parts of the Eaft Indies, efpecially in Cananor, Calecute, Cambaya, and Decan.

$$
\text { * The time. }
$$

Thefe trees, flower, and flourith winter and fommer.

$$
* \text { Thenames. }
$$

Their names haue beene touched in their defcriptions. The firft is called Anacardism, of the likenes it hath with a hart: of the Arabians Ealador : of the Indians Bibo.

The lecond is called Calous, and thus written Caiöiss, and Caimo, of forne Caiocms. $x^{\text {The }}$ 


\section{HISTORIE OF PLANTS.}

* The temperature and vertues.

The oile of the fruite is hot and dry in the fourth degrec, it hath alfo a cauticke or cornfutic quali- $A$ tic ;it taketh away warts, breaketh apoftumes; preualleth againft lepric, Alogecia, and cafeth the
paine of the teeth, being put into the hollownes thereof.

The peopleof

other thing they defire to be coloured or marked, as we chalke, to matke their clothes or anie B but their colour will not be taken foorth againe, by any maner of Are, oker, and red inarking ftones;

Theyalfo giue the kernell fteeped in whaic, to them that bo aft whatfocuer.

when the fruit is yet greene, they giue the fame fo fteeped againft the woormes.

The Indians for their pleafure will fticke the fruite vpon a ho

and holde it in the flame of a candle, or any other flame, which there wilburne with fuch orpe thing, D lightnings, and withall yeelde fo many ftrange colours, which there wil burne with fuch crackings, which haue not feene the like before.

\section{Of Fndian $\mathcal{O}$ Morrice Bels, and diuers otber Indian fruits. Chap.is2.}

I Shousy Theweti. Indian Morrice Bels.
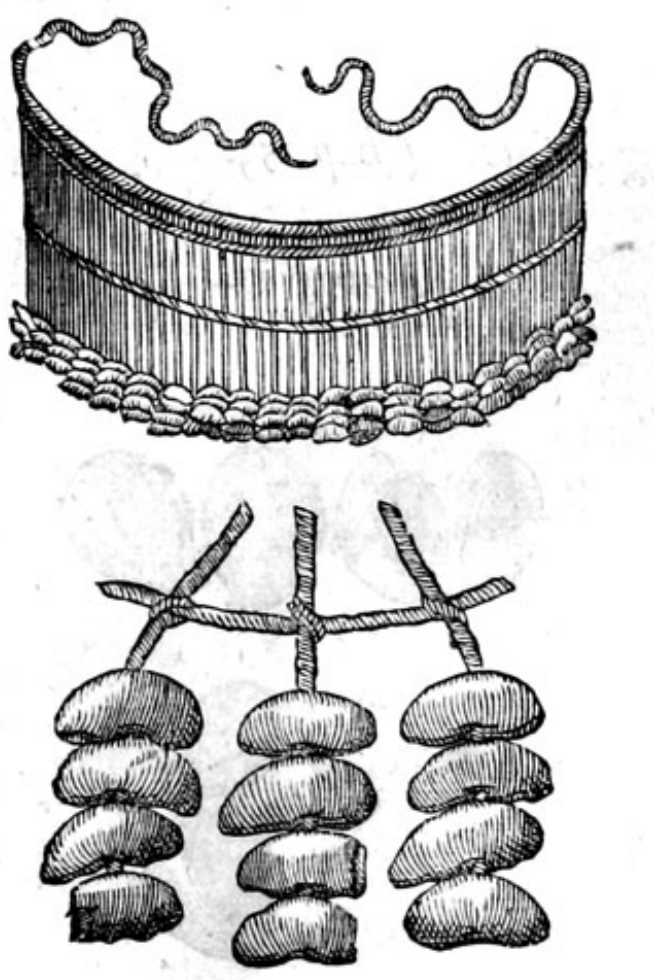

2 Fractus Higuero. Indian Morofco Bels.
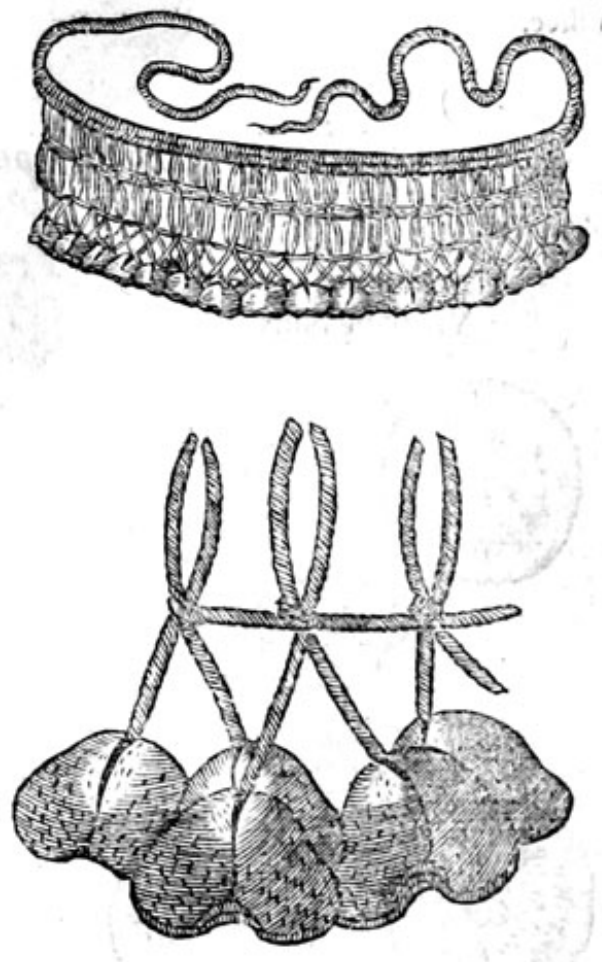

\& The defcription.

$1-$ His fruit groweth vpon a great tree, of the bignes of a Peare tree; ful of branches, garnifhed with many leaues, which are alwaies greene, three or fower fingers long, and in bredth two; when the branches be cut off, there iffueth 2 milkie iuice, not inferior to the fruite in his venemous qualitie. The trunke or body is couered with a grayinh barke; the timber is white and 


\section{1;62 THE THIRD BOOKE OF THE}

foft,not fit to make fire of, much lefic for any other vfe; for being cut and put to the fire to burne, it yeeld s forth fuch a lothfome \& horrible ftinke, that neither man nor beaft is able to endure it:whe, it fore the Indians hutue no vfe there of, but onely of the fruite, which in hape is like the Greekelet ter $\Delta$, of the tignes of a Cheftuut, and coucred with a moit hard hell, wherein is conteined a kernell of a molt venemous and poifonfome qualitie, wherwith, the men being angry with their wiues, dopoifon them, and likewife the women their husbands : they likewife vfe to dip or annoint and enuenome their atrowes therewith, the more fpeedily to difpatch their enimies. Which kernell they take forth with fome conuenient inftrument, leauing the fhell as whole as may be, not touching the kernell with their bands, bicaufe of the venemous qualitie, which woulde fpoile their handes, and fometime take away their life alfo: in which thels, th:y put fome little ftones, and tie them vpon ftrings, as you may perceiue by the figure, which they dry in the funne, and after tie them about their legs (2s we do bels) to fet foorth their dances, and Morofco Matachinaes, wherein they take great pleafure, by reafon they thinke themfelues to excell in thofe kinde of dances; which ratling found doth much delight them, bicaufe it fetteth foorth the diftinction of founds, for they tune them, and mixe them with great ones, and little ones, in fuch fort, as we do chimes or bels.

2 There is alfo another fort heerof, differing onely in forme, they are of the like venemous quality, and vfed for the fame purpofes.

\section{*The place.}

Thefe do growe in moft parts of the Weft Indies, efpecially in fome of the Ilands of the Canibals, who vfe them in their dances, more then any of the other Indians.

\section{* The time.}

We haue no certaine knowledge of the time of flowring or bringing the fruite to maturitie. * The names and vje.

We hauc fufficiently fpoken of the names and vic heerof, therefore what hath beene faide may fuffice.

\section{Of the vomiting and purging $\mathcal{X}$ uts. Cbap.153.}

2 Lucespurgantes.
Purging Nuts.

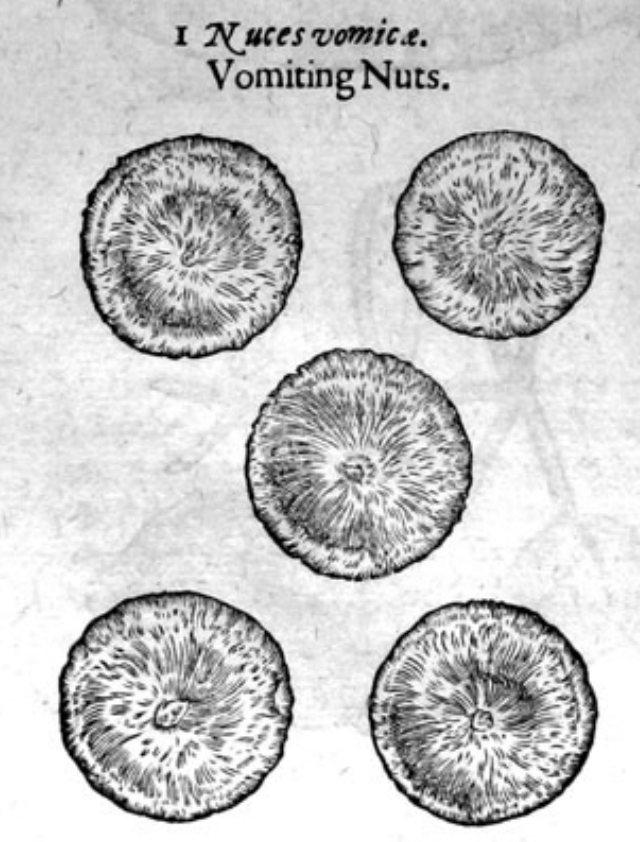

I 2 uces vomic.e.

Vomiting Nuts.

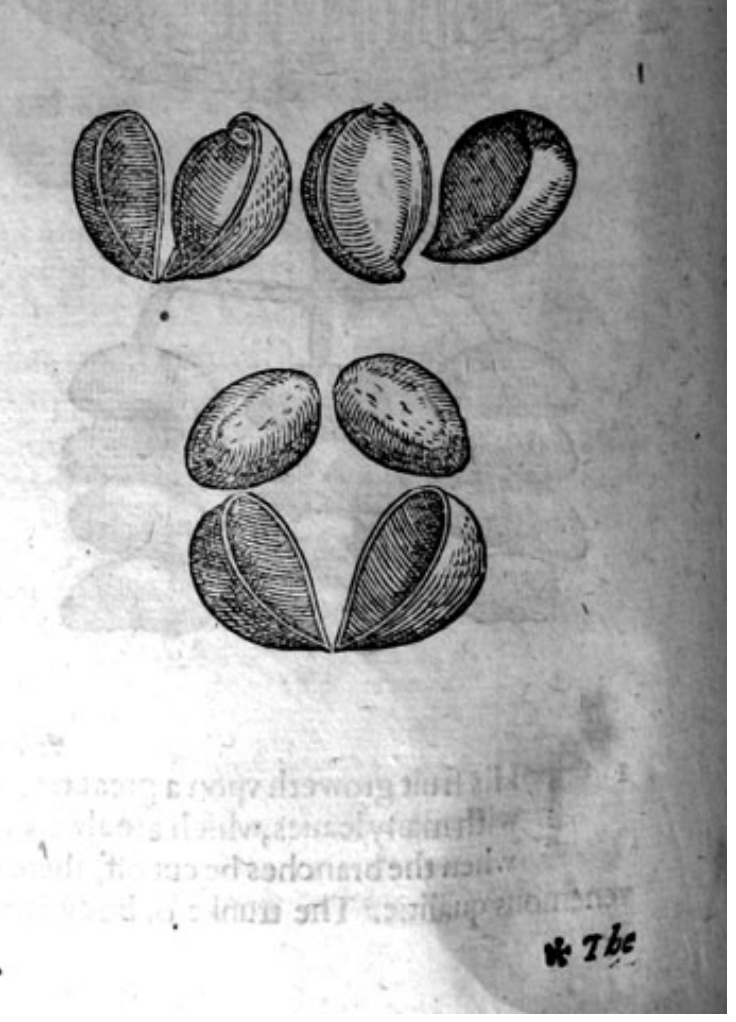




\section{HISTORIE OF PLANTS.}

* The defcription.

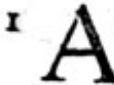

Vicen and Serapio make Nux vomica, and $2 u x$ Methel, to be one, whereabout there is 2 u.x Methel. Of the tree that beareth the fruite, that is all true, that the Thorne apple 2 ux Methel,we haue no certaine knowledge: fome are of opinion, thed in fheps Nux vomica, and herbe, and not the Nut of a tree : and therefore fince the cafe among the the fruit is the roote of an we leaue the reft that inight be faide to a further confideration. The the learned refteth doubtfull, cake, of a ruffet ouerworne colour, fat and firme, in tafte fweere, The fruit is rounde, flat, like a little it is not poffible to ftampe it in a morter to powder; but weete, and of fuch an oilie fubftance, that fcraped with fome inftrument for that purpofe.

2 There be certaine Nurs brought purging groffe, and filthie humours, for the Indies, called Purging Nuts, of their qualitic in uelled the Indies, we can write nothing of the tree ir food inftruction from thofe that have trathape like an egge, of a browne colour; within the llfe : the Nut is fomewhat long, ouall or in a purging facultic.

\section{* T The place and time.}

Thefe Nuts do grow in the defarts of Arabia, and in fome places of the eaft Indies : we haue no certaine knowledge of their fpringing,or time of maturitic.

$\because$ The temperature. Auicen affirmeth the Vomiting Nut to be of a poifonous qualitie; colde in the fourth degree, ha-
uing a ftupifying nature, and bringeth deadly fleepe.

* 7 he vertues.

Of the Phificall vertues of the vomiting Nuts, we thinke it not neceffarie to write, bicaufe the $\mathbf{A}$ danger is great, and not to be giuen inwardly, but mixed with other compofitions, and that verie
curioufly by the hands of a faithfull Apothecarie.

The powder of the Nut mixed with fome flefh, and caft vnto Crowes \& other rauenous foules, B doth kill,or fo dull their fences at the leaft, that you may take them with your hands.

They make alfo an excellent fallet, mixed with fome meate or butter, and laide in the garden $C$ where cats vfe to fcrape to butie their excrements, fpoiling both the herbes and alfo feedes newe
fowen.

\section{Of diuers forts of fndian fruits. Cbap.15o.}

\section{* The kindes.}

Hefe fruits are of diuers forts and kinds, whereof we haue little knowledge, more then the fruits themfelues, with the names of fome of them: therefore it hall fuffice to fet foorth vnto your viewe the forme onely, leauing vnto time, and thofe that fhall fucceede, to write of them at large, which in time nay know that, that in this time of in infancie is vnknowne.

\section{Beretinus fructus.}

1

He twolowermoft of thefe 4 . fruits called Beretinns frum in in thefe figures, are thofe that fome of the Indians do paie vnto their king for tribute, as we do money, by the relation of Sir Frances Drake, who brought them into England, which in forme refemble the Bezoar ftone. 
Varij fructusperegrini.

Diuers ftrange Indian fruits.
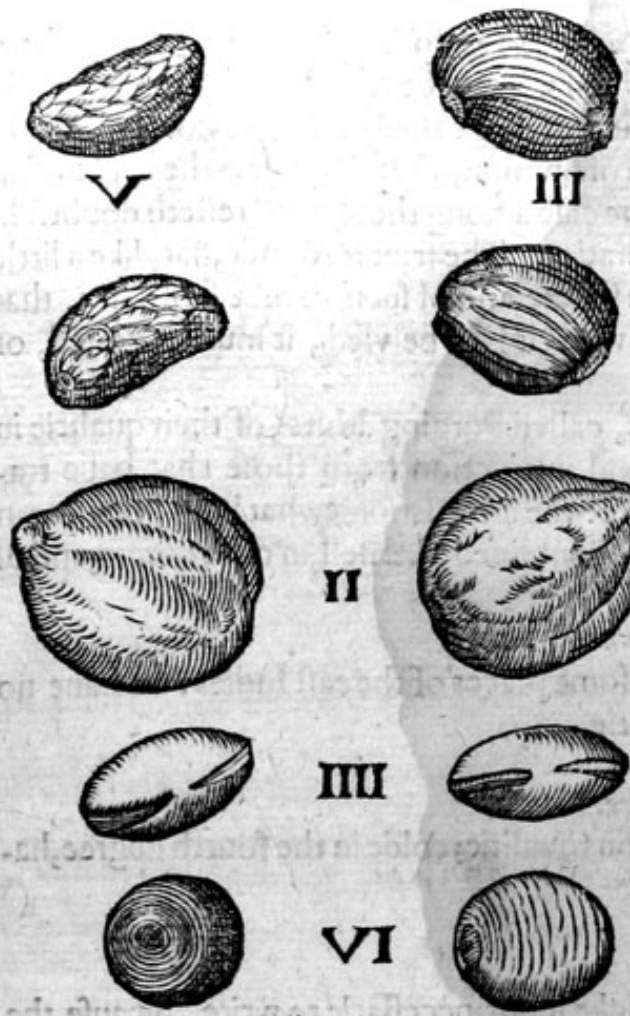

VI

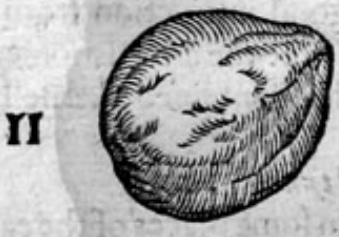

IIII
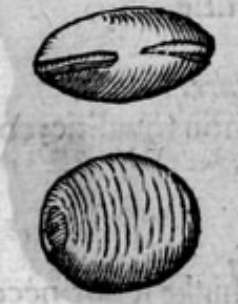

Vndecim gentra fructwomperegrinoram.

Eleuen forts of itrange truits.

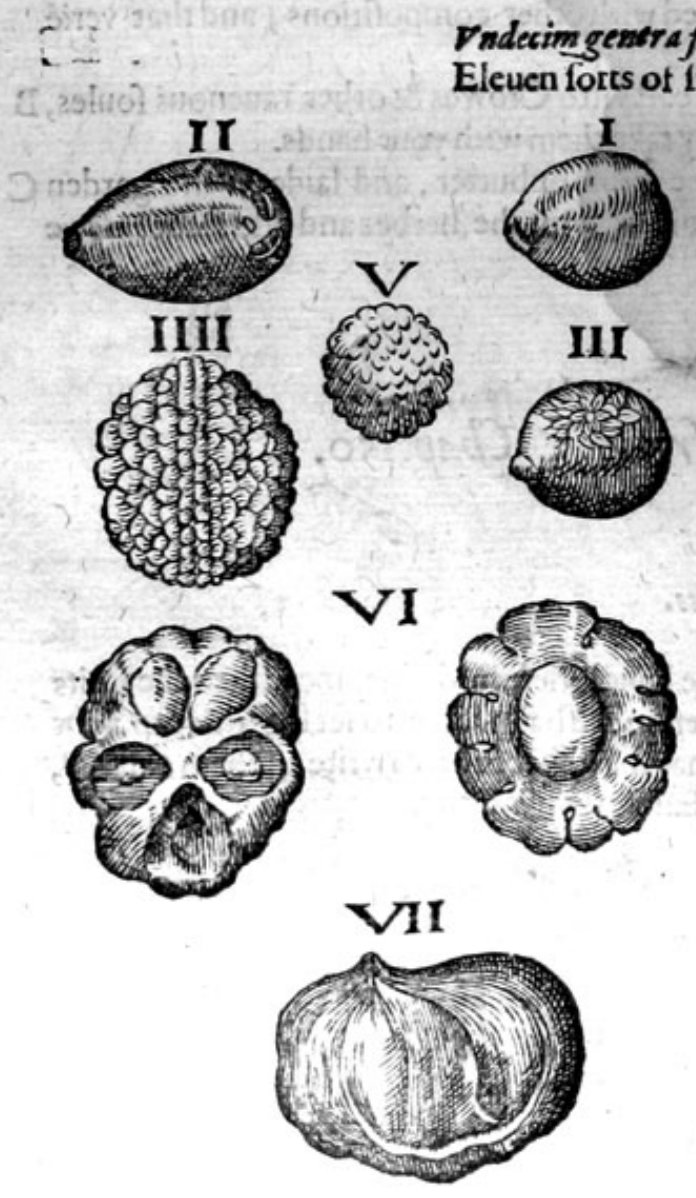

Beretinus fructus.
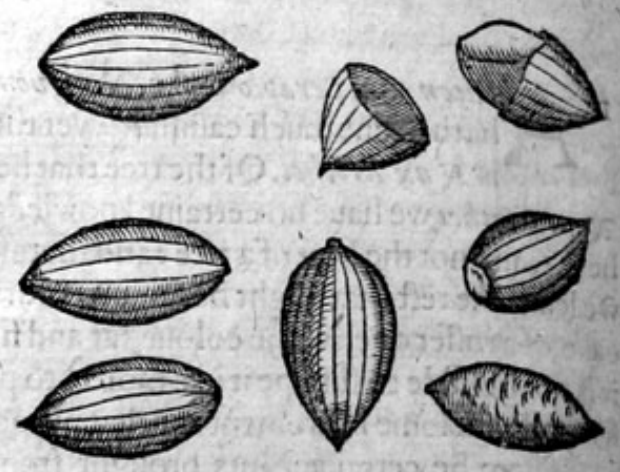

cacco
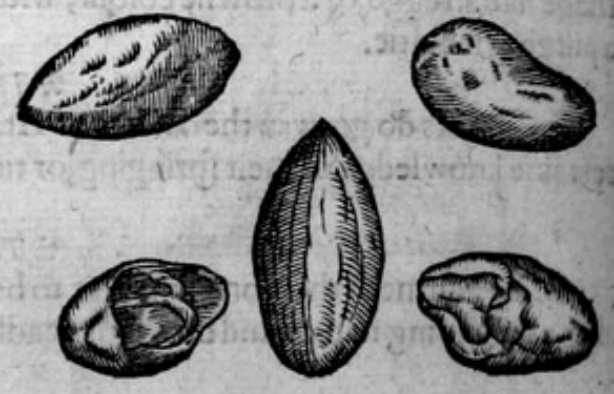
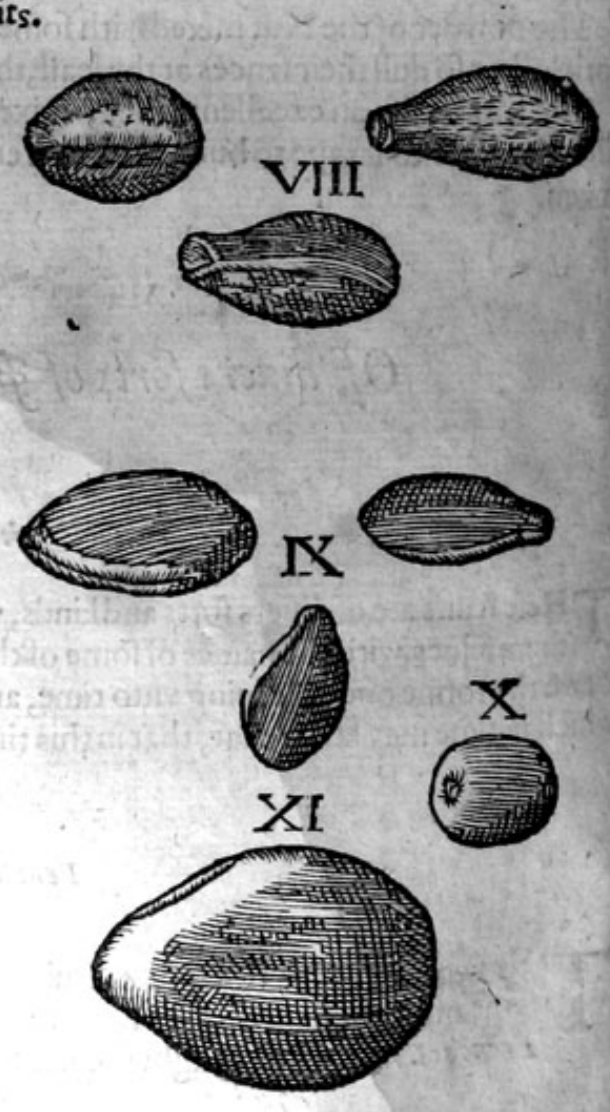
I CocciOrientaies.

Scarlet Tufts of the Eaft.

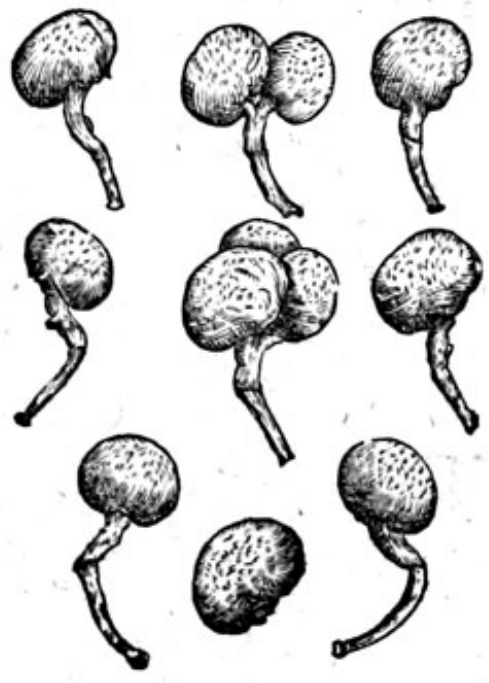

2 Cucioplors.

Baftard Indian Nuts.

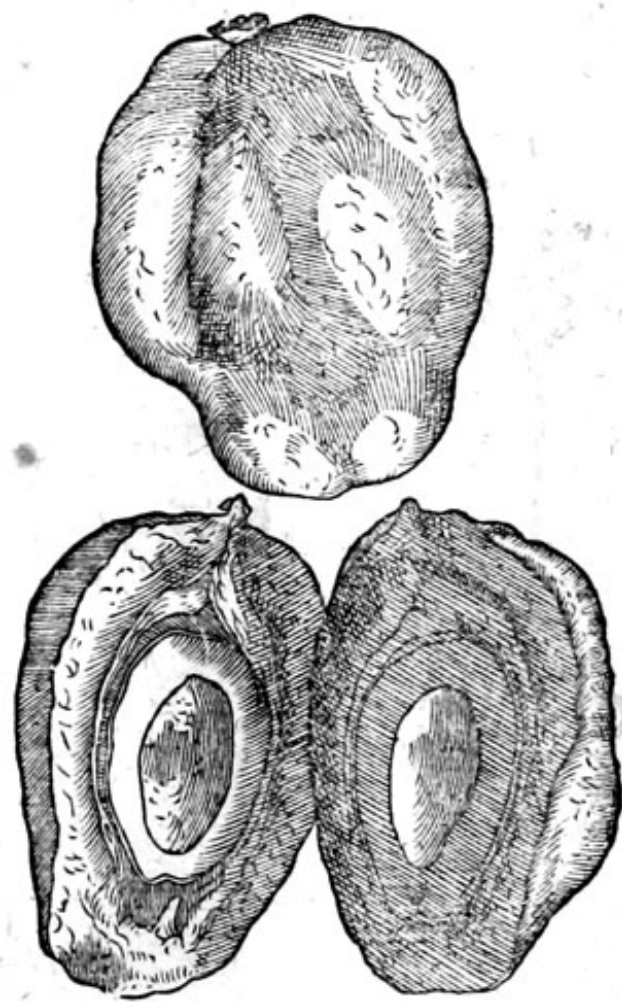

3 Fagaras, Cubebe of Buna.

Coculus Indie, Cubebes, and Beanes of Tolu.

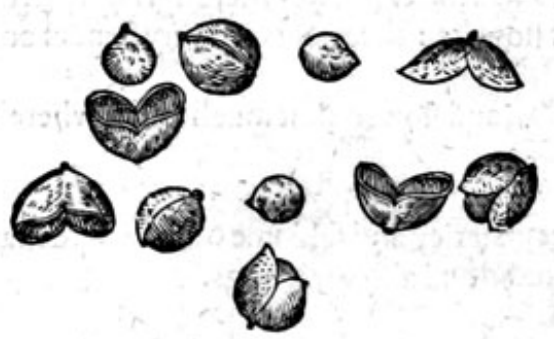

\section{Cubebre}

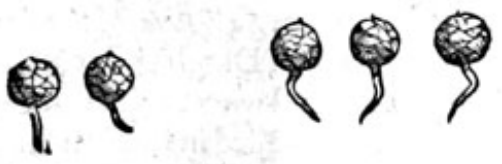

Buna

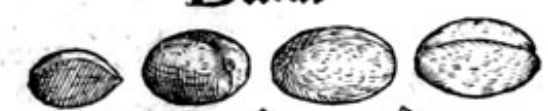




\section{Of Sun deaw, Youthwoort, or Res Solis. Chap.155.}

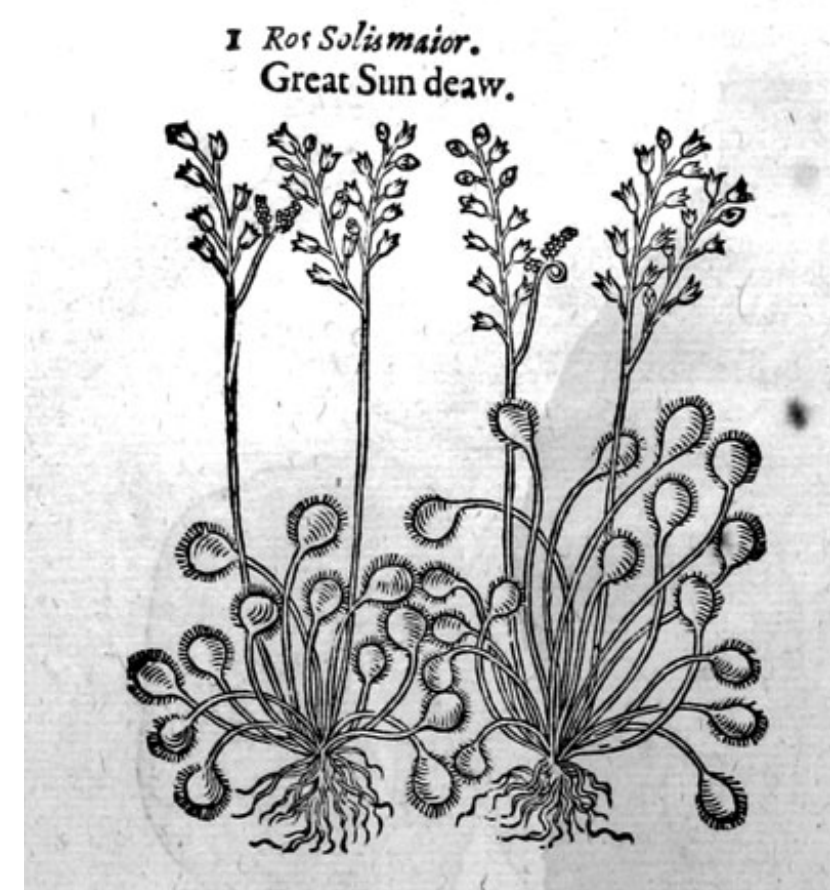

Ros Solismaior.

Great Sun deaw.

\& The defcription.
2 Ros Solisminor. Little Sun deaw.

I

Vudeaw is a little herbe, and groweth very lowe, it hath a few leaues ftanding vpon flender ftems, very fmall, fomething round, a little hollow, and like an eare picker, hairie and reddifb as be alfo the ftems, hauing deaw and moyfture vpon them at the drieft time of the yeere, and when the funne thineth hotteft euen at high noone; and a moneth after there fpring vp little ftalkes, a hand bredth high, on which ftand fmall whitifh flowers : the rootes are very flender and like vnto haires.

2 The fecond kinde is like vnto the former in leaues, talks, and flowers, but much leffer, wherein confifteth the difference.

$$
\text { * The place. }
$$

They growe in defart, fandie, and funnie places, but yet waterie, and feldome other where than among the white marrifh Moffe which groweth on the ground and alfo vpon bogs.

\section{* The time.}

Sunne deaw flourifheth in fommer, it flowreth in May or Iune: it is to be gathered when the weather is moft drie and calme. The diftilled water heerof that is drawen foorth with 2 glaffe Still, is of a glittering yellow colour like golde., and coloureth filuer put therein, like golde.

Itiscalled $*$ The names.

It is called of the Latines Ros Solis: of diuers Rorella : it is named of others Salf Rofa, of the deaw which hangeth vpon it, when the funne is at the hotteft : it is called in high Dutch Gontan and and suinam and other cattell, if they do but onely taffe of it, are prouoked to luft. It is called in Englifh Sunne deaw, Ros Solis, Youth woort : in the North parts Red rot, bicaufe it rotteth fheepe, and in Yorkethire Moore graffe.

It is a fearing or caufticke herbe, and very much biting; being hot and drie in the fourth degree.

$$
\because \text { Thetemperature. }
$$

$$
* \text { The vertues. }
$$
A The leaues being ftamped with falt do exulcerate and raife blifters, to what part of the body foe-
uer they be applied. 
HISTORIE OF PLANTS.

The later Phifitions haue thought this herbe to be a rare and fingular remedic for all thofe that $A$ be in a confumption of the lungs, and efpecially the diftilled water there of: for as the heibe doth keepe and hold faft the moifture and dew, and fo faft, that the extreme drying heate of the funcan not confume and wafte away the fame; folikewifemen thought that hecivith the naturall and liucly heate in mens bodies is preferued and cherifhed. But the vie there of doth otherwife teach, and reafon fheweth the contraric: for feeing it is an extreme biting herbe, and that the diftilled wa. ter is not al togither without this biting qualitic, it cannot be t.aken with fafetie:for it hath alfo been obferued, that they haue fooner perifhed that vfed the diftlled water hecreof, then thofe that ab. ftained from it, and haue followed the right and ordinary courfe of diet.

Cattle of the femalc kinde are ftirred vp to luft by cating cuen of a fmall quantitie: which thing $B$ hath greatly increafed their vaine opinion, without fence or reafon; for it doth not moote nor prouoke cattle to luft, for that it increafeth the fubltance of the feede, but bicaufe thorow his tharpe and biting qualitic it ftirreth vp a defire of luft, which before was dulled, and as it were afleepc.

It ftrengthneth and nourifheth the body, efpecially if it be diftilled with winc, and that liçuor $\mathrm{C}$ made thereof which the common people do call Rofa Solis.

If any be defirous to haue the faide drinke effectuall for the purpofes aforefaid, let them lay the D leaues of Rofa folis in the fpirit of wine, adding thereto Cinnamom, Cloues, Maces, Ginger, Nutmegs, Sugar, and a fewe grains of Muske, fuffering it fo to ftand in a glaffe clofe ftopt fron the aire, and fet in the funne by the fpace of ten daics more: then ftraine the fame, and kecpe it for your yfe.

\section{Of the MarrifhWbortes, or Fen berries. Chap.156.}

\section{Vaccinia paluftria.}

Marrih Whortes.

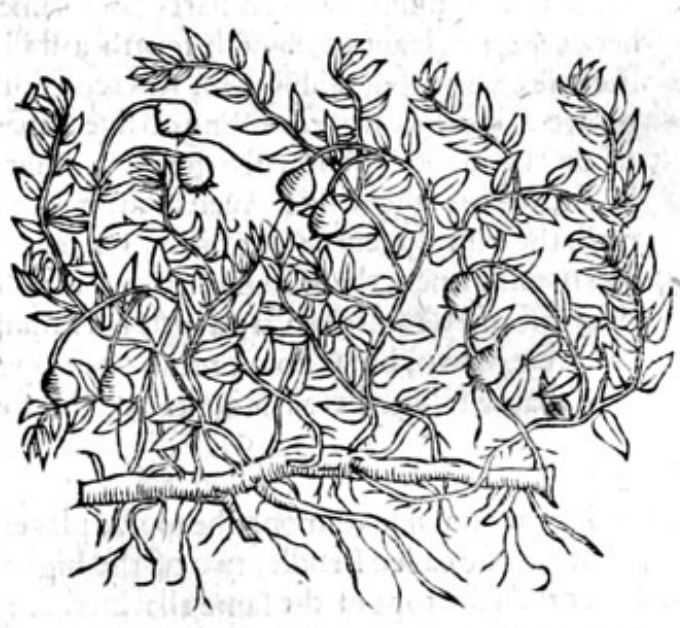

* The defcription.

Te Marrih Whortle berries growe vpon the bogs, marrifh, or moorifh groundes, creeping thereupon like vnto wilde Time, hauing many fmall limmer and tender ftalkes, laide almoft flat vpon the grounde, belet with fmall narrow leaucs, fafhioned almolt like the leaues of Thyme, but leffer, among which come foorth little berries, like vnto the common blacke Whortle berric in thape, but fomewhat longer; forretimes all red; and fomtimes fpotted or fpecked with red fpots, of a deeper colour; in tafte rough and aftringent.

$$
\text { * Theplace. }
$$

The Marrin Whortle groweth vpon bogs and fuch like waterifh and Fennic places, cfpecially in Cherhire, and Staffordihire, where I hauc found it in grcat plentie.

\section{* The time.}

The berries a:e ripe a bout the end of Iulie, and in Auguft.

\section{$*$ The names.}

They are called in high Dutch 900 fžcerteit, Ueentefisn: that is to aie Fen grapes, or Fen berries, and Marrifh Whortes, or Marifh berries: Valerius Curdes nameth them Oxycoccon : we hauc called them Vaccinia paluftria, or Marrifh $W$ hortle berries, of the likenes they haue to the otlier berrics.

Tect 2 


\section{THE THIRD BOOKE OF THE}

* The temperature.

Thefe Whortle berries are colde and drie, hauing withall a certaine thinneffe of partes and fub. ftance, which haue notwithftanding a certaine binding qualitic ioyned.

$*$ The vertues.

A They take away the heate of burning agues, and alfo the drought, they quench the furious heate of choler, they ftay vomiting, reftore an appetite to meate, which was loft by reafon of cholericke and corrupt humors, and are good againft the peftilent difeafes. B The iuice of thefe alfo is boyled till it be thicke with fugar added that it may be kept, which is
good for all things that the berries are,yea and far better.

\section{Of Cloud-berrie. Cbap.156.}

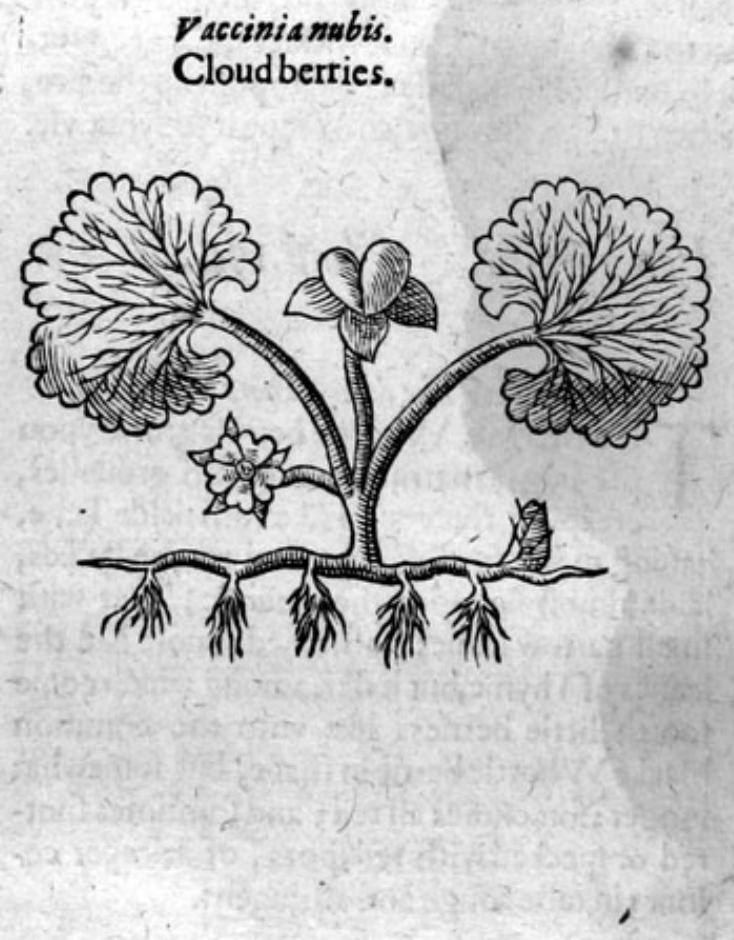

* Thedefcription.

7 He Cloud berrie hath many fmall threddie rootes, creeping far abroad vnder the vpper cruft of the earth, (andalfo the Moffe) like vnto Couch graffe, of an ouerworne reddifh colour, fet here and there with fmall tufts of hairie ftrings: from which rife vp two fimall ftalkes, harde, tough, and of a woodie fubftance (neuer mo nor leffe) on which dce ftande the leaues like thofe of the wilde Mal. low, and of the fame colour, full of finall nerues or fineives running in each part of the fame: betweene the leaues commeth foorth a ftalke likewife of 2 woodie fubftance, whereon doth growe a finall flower confifting of fiue leaues, of an herbic or yellowinh greene colour, like thofe of the wilde Aliens : after commeth the fruit, greene at thd firft, after yellow, and the fides next the funne fed when they be ripe; in forme almoft like vnto Jj jittle hart, made

as it were of two, but is no more but one; open
fower little white feedes. fower little white feedes.

This plant groweth $\$$ The plase.

This plant groweth naturally vpon the tops of two high mountaines (among the indffie places) one in Yorkfhire called Ingleborough, the other in Lancafhire called Pendle, two of the higheft mountaines in all England, where the cloudes are lower than the tops of the fame allwinter long, whereupon the people of the countrie haue called them Cloud berries, found therebya curious gentleman in the knowledge of plants, called Mafter Hesket boften remenibred. * The time.

The leaues fpring vp in May, at which time alfo it flowreth : the fruit is ripe in Iuly.

The fruit is cold and drie, and very aftringent. * The temperature.

*Tbevertues. C The fruit quencheth thirf, cooleth the ftomacke, and alaieth inflammations being eaten 25
Whortes are,or the decoction made and drunke. 


$$
\text { Of Moffe of trees. Chap.156. }
$$

* The kindes.

$T$ Here be diuers kindes of Moffes, and thofe differing for the moft part in their natiue places; 1 fome growe and are faftened to trees, others fpring from the fuperficiall or vppermolt part of
the earth; there be others alfo that growe in the fea.

Mufcus quernu:.

The Moffe of the Oke and of other trees.

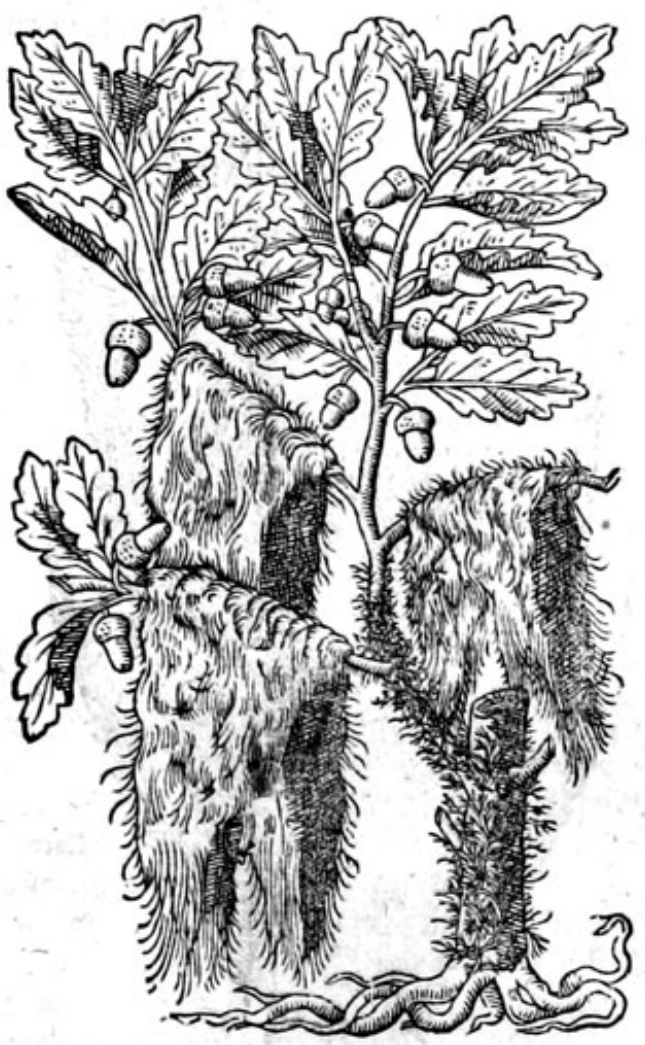

* The defcription.

7 Ree Moffe hath certaine things like haires, made vp as it were of a multitude of flender leaues, now and then all to be iagged, hackt, and finely carued, twifted and interlaced one in another, which cleaue faft to the barks of trees, hanging downe from the bodics: one of this kind is moreflender and thin, another more thicke, an other fhorter, another longer; all of them for the moft being of a whitilh colour, yet oftentimes there is a certaine one alfo which is blacke, but leffer and thinner : the moft commendable of them all, as Plinie faith, be thofe that are whitilh, then the reddifh,and laftly fuch as be tlacke.

$$
\text { Theplace. }
$$

This Moffe is found on the Oke tree, the white and blacke Poolar tree, the Oliue tree, the Birch tree, the Apple tree, the Peare tree, the Pine tree, the wilde Pine tree, the Pitch tree, the Firre tree, the Cedar tree, the Larch trec, and on a great fort of other trees. The beft, as Diofcorides faith, is that of the Cedar tree, the next of the Poplar, in which kinde the white and the fiveete fmelling Moffe is the chiefeft; the blackifh fort is of no account Mathiolus writech, that in Italie that Moffe is fweete which gr weth on the Pine tree, tht Pitch trec, the Firre tree, and the Larch tree; and the fivecteft that of the Larch trce.

$$
\text { * Thetime. }
$$

Moffe vpon the trees continueth all the yeere long.

$*$ The names.

It is called of the Grecians Epior: of the Latines Mufous : the Arabians and the Apothecaries call it V/nea : in high Dutch $\mathfrak{B O f} z$ : in low Dutch OPoftb: the French men Lu Moufch : the Iralians Margo : in Spanifh cunfro de los arboles: in Englifh Mofle, tree Mofie, or Moffe of trees. $*$ The temperature.

Moffe is fomething colde and binding, which notwithftanding is more and leffe, according to the nature and faculic of that tree on which it groweth, and efpecially of his barke: for it taketh to it felfe and alfo retaineth a certaine propertie of that barke, as of his breeder of which he is ingendred: therefore the Mofle which eommeth of the Oke doth coole and very much bindé, befferes his owne and proper facultie, it receiueth alfo the extreme binding qualitie of the Oke bajke it felfe.

Ihe Moffe which commeth of the Cedar tree, the Pine tree, the Pitch tree, the Firre tree, the I rch teee, and generally all the Rofin trees are binding, and do moreouer digeft and foften.

Tetc 3 
* The vertues.

A Serapiofaith, that the wine in which Moffe hath beene fteeped certaine daies, bringeth found fleepe, ftrengtheneth the ftomacke, ftaie th vomiting, and ftoppeth the belly.

B Diofcorides writeth, that the decoction of Moffe is good for women to fit in, that are troubled with the whites; it is mixed with the oyle of Ben, and with oyles to thicken them withall.

C It is fit to be vfed in compofitions which ferue for fweet perfumes, and that take away wearifom. neffe; for which things that is beft of all which is moft fweete of finell.

\section{OfGround Moffe. Chap.157.}

\section{* The kindes.}

Here growethalfo on the fuperficiall or vppermoft part of the earth diuers Moffes, as alfo vpon rocks and ftonie places, and marrifh grounds, differing in forme not a little.

\section{Mufcusterrestrus vulgaris.} Common ground Moffe.

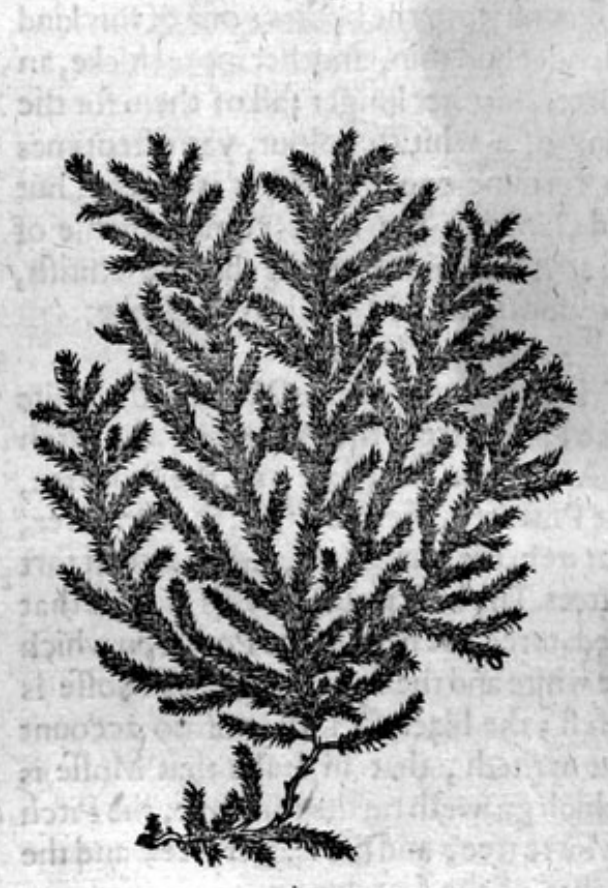

2 Mufcas terreftris coparius. Beefome ground Moffe.

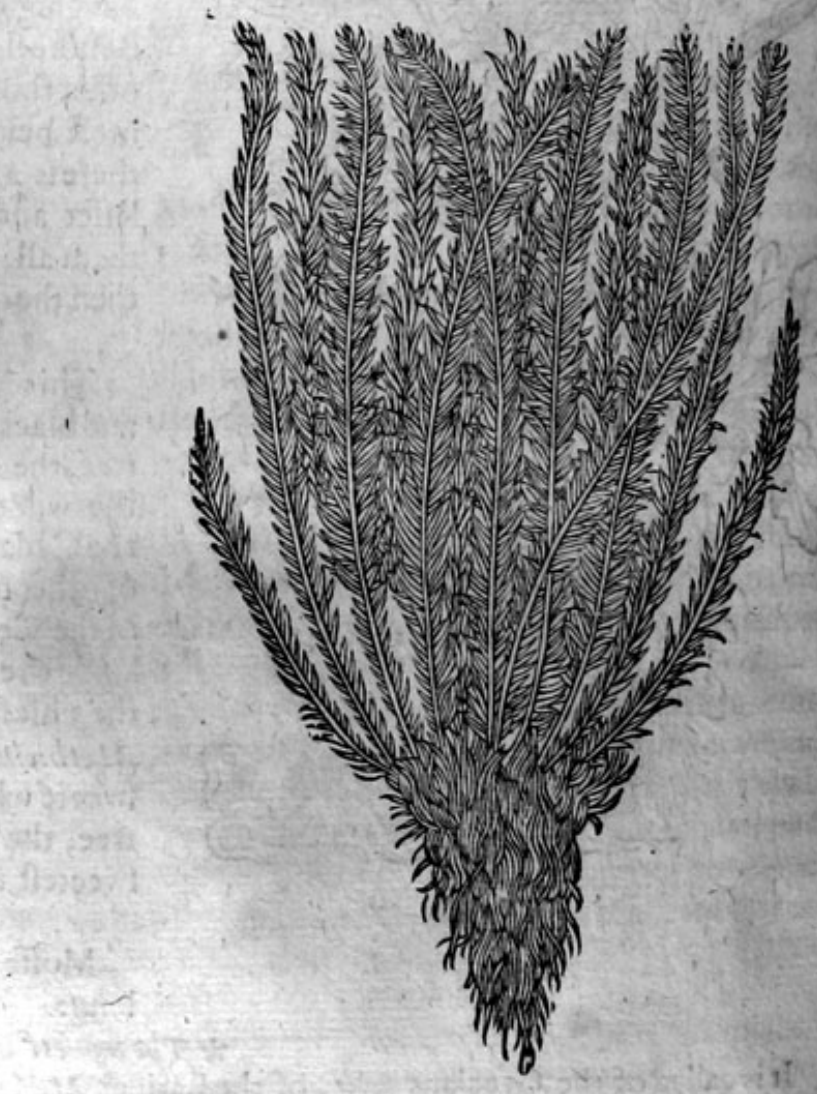

* The defeription.

I The common Moffe groweth vpen the earth, and the bottome of olde and ancient trees, but efpecially vpon fuch as growe in thadowie woods, and alfo at the bottome of fhadowie hedges and ditches, and fuch like places: it is very well knowen by the foftnes and length thereof, being a Moffe moft common, and therefore needeth not any further dcfcription. 2 Beefome Moffe which feldome or neuer is found but in bogs and marrifh places, yet fomtimes haue I found it in thadowie drie ditches where the funne neuer meweth his face; it groweth vp halfe a cubite high; euery particular leafe confifting of an innumerable fort of hairie threds fet vpon a middle rib, of a fhining blacke colour like that of Englifh Maiden haire, or the Capillare Moffc vidianthum aureum, whereof it is a kinde. 
3 CMagcm capillaris. fue Adianthwm aurewm. Goldilocks, or Golden Maiden hairc Moffe.

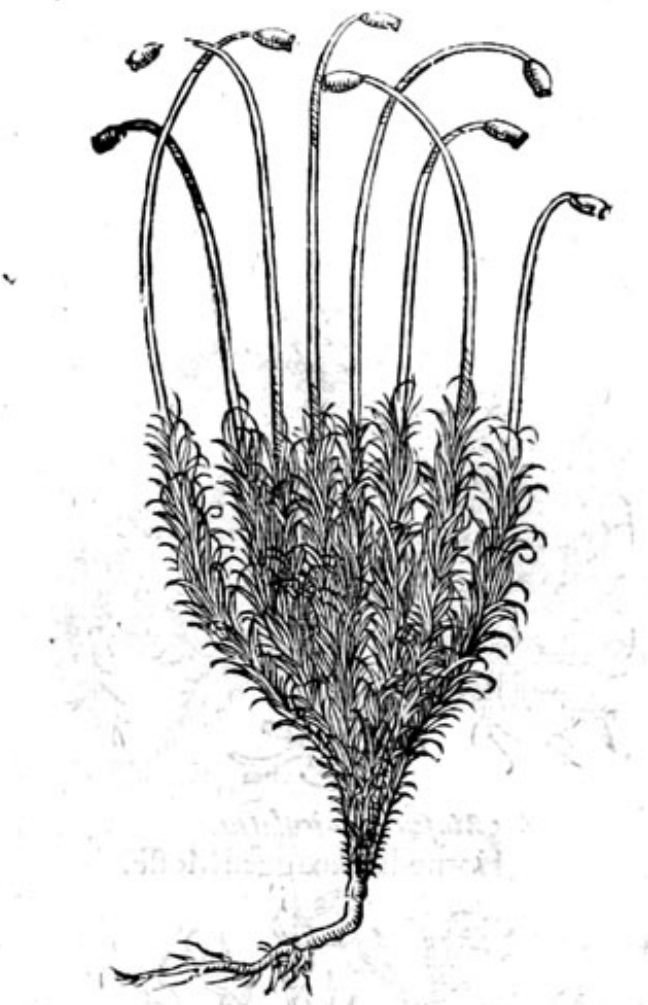

4 Mufcus capills ris minor. Little Golde locks.

* The defcription.

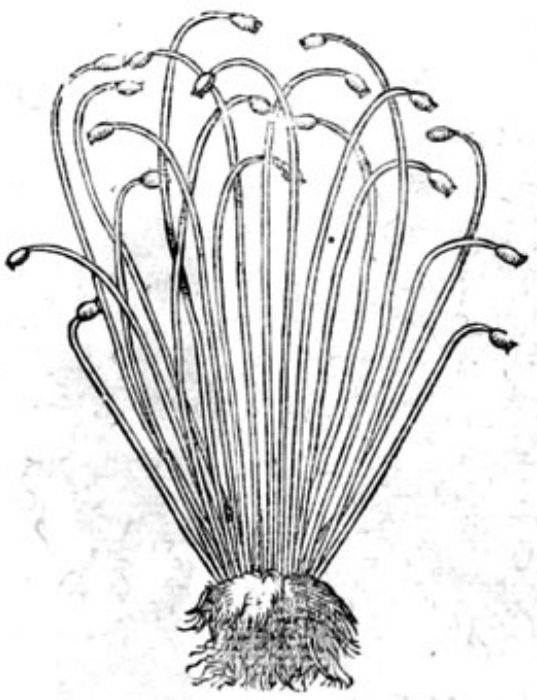

3 Thiskinde of Moffe called Mufcus capillar is, is feldome found but vpon bogs and moorifh pla. ces, and alfo in fome fhadowie drie ditches where the funne doth not come. I found it in great abundauce in a hadowie ditch vpon the left hand neere vnto a gate that leadeth from Hampiteed heath toward Highgate, which place I haue fhewed vnto divers expert chirurgions of London, in our wandering abroad for our further knowledge in fimples. This kinde of Moffe, the ftalks whereof are not aboue one handfull high, couered with fhort haires ftanding very thicke togither, of an obfcure yellow greene colour; out of which ftalkes fpring vp fometimes very fine naked ftems fomwhat black, vpon the tops of which hang as it were little graines like wheate cornes: the rootes are very flender, and maruellous fine.

4 Of this there is alfo another kinde altogither leffer and lower. This kinde of Moffe groweth in moyft places alfo, commonly in olde moffie and rotten trees; likewife vpon rock $s$, and oftentimes in the clinks and cranies of ftone wals.

5 There is oftentimes found in the thadowic places of rough and ftonie mountaines, a kinde of Moffe hauing many flender branches, which diuide themfelues into other fmaller branches; whereon are placed confufedly very many fmall threds like haircs, of a browne colour: the roote groweth hard vnto the ftones like vnto Sca Corallinc.

6 This other kinde of branched Moffe in ftalkes and leates is like the precedent: ypon the endes of the tender branches conmeth foorth a flower, in fhape like vnto a little buckler, or hollowe Muforom, of a whitifh colour tending to yellowneffe, and garnified with the like leaues of thofe vpon the lowerbranches.

Of this Moffe there is another kinde, which L'Obelius in his learned obferuations hath fet forth vnder the title of culu/cus Pyxidatos, which I haue englifhed Cup Moffe, or Chalice Moffe; it grow. eth in the moft barren, dric, and graueily ditch banks, creeping flat vpon the ground like vnto Liuer woort, but of a yellowith white colour: among which leaues ftart vp here and there certaine little things, farhioned like a little cup called a Beaker or Chalice, and of the fame colour and fubftance 
1372

THE THIRD BOOKE OF

THE

of the lower leaucs, which vndoubtedly may be taken for the flowers: the powder of which Moffe giuen to children in any liquor for certaine daies togither, is a moft certaine remedie againft that perilous maladie called the Chin cough.

5 Mufcus ramo/us.

Branched Moffe.

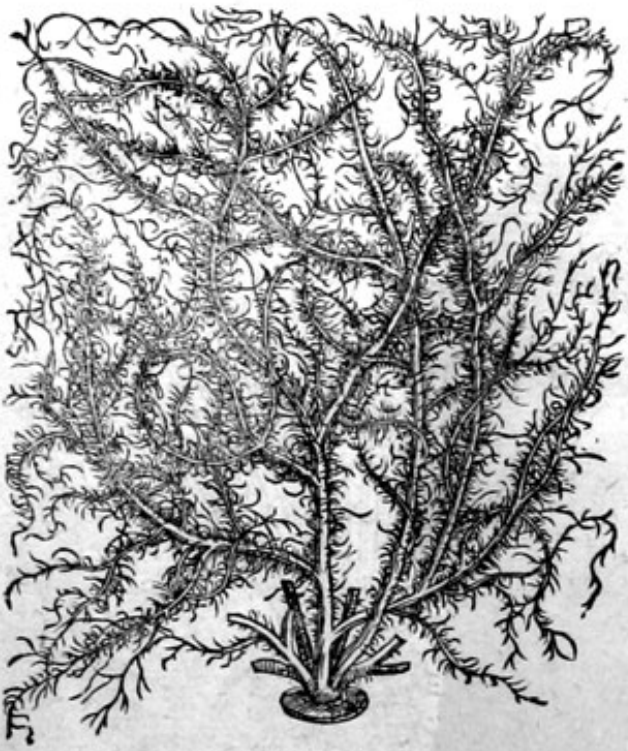

7 Mufcus Filicinus.

Mofle Ferne.

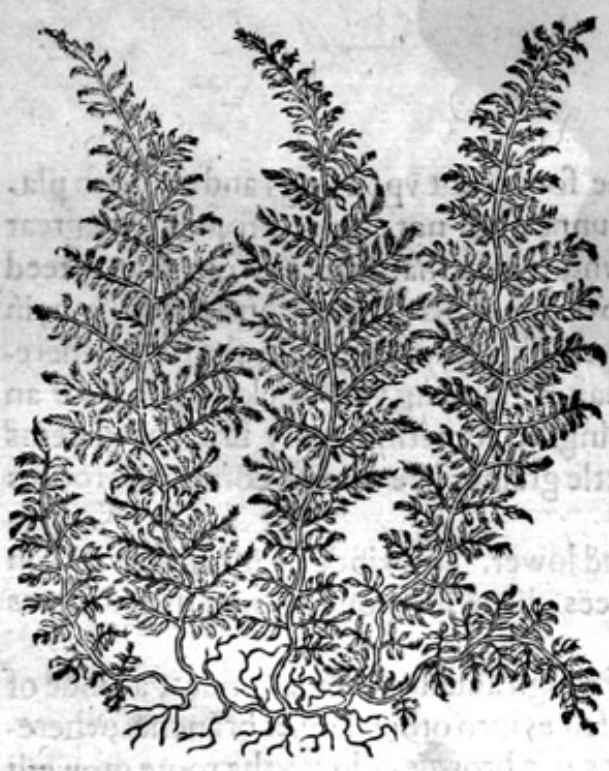

6 Mufcus ramo fus floridus.

Flowringbranched Moffe.

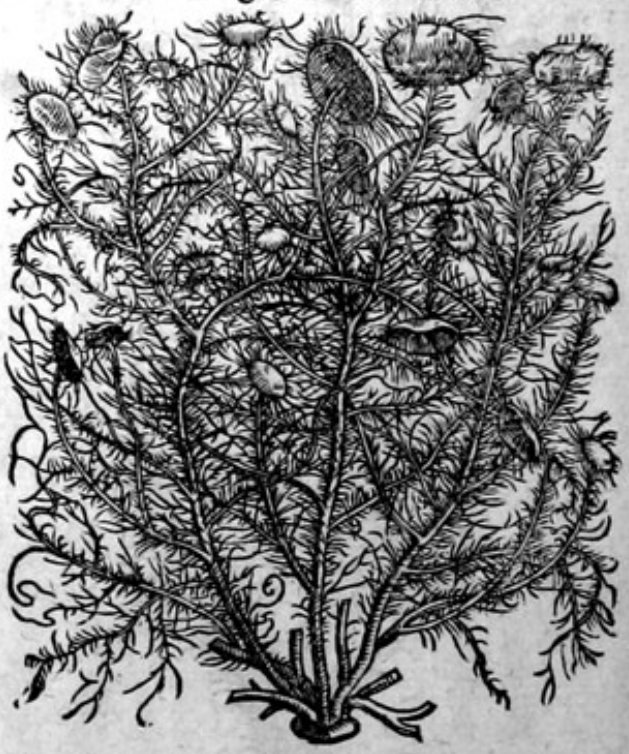

8 cMufcuscorniculatus. Horned or knagged Moffe.
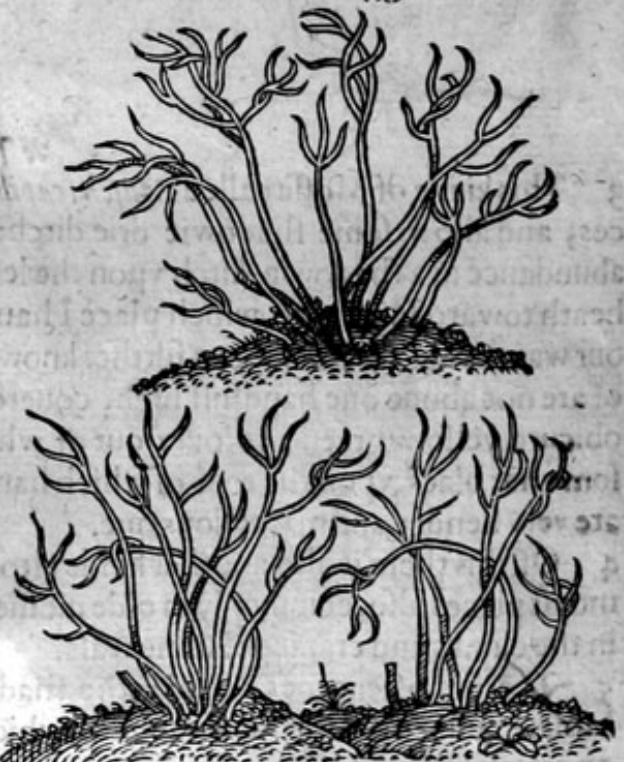

\section{* The defcription.}

7. There is likewife found in the hadowie places of high mountaines, and at the foote of olde and rotten trees, a certaine kinde of Moffe in face and thew not vnlike to that kinde of oke ferne, called Dryopteris. It creepeth vpon the ground, hauing diuers long branches, confifting of many fmall leaues,euery particular leafe made vp of fundre little leaues, fet vpon a middle rib, one oppofite to anothcr.

8 There is found vpon the tops of our inoft barren mountains, but cfpecially where Seacoles are accuftomed to be digged, ftone to make iron of, and alfo where oare is gotten for tinne and lead, it rifeth foorth of the ground with many bare and naked branches, diuiding themfelues at the top intofundric knags, like the forked hornes of a Deere, cuery part whereof is of an ouerworne whitifh colour. 


\section{HISTORIE OF PLANTS.}

$9 \mathrm{Mu}$ caus denticulat us. Toothed Moffe.

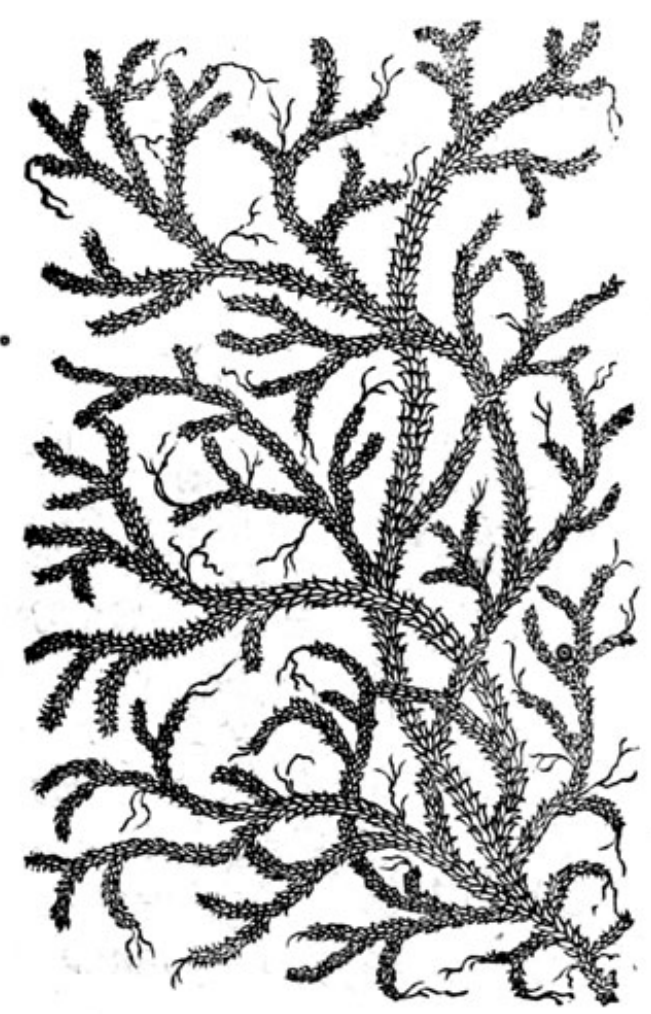

10 Mufcus minor denticulatus. Litcle toothed Mofle.

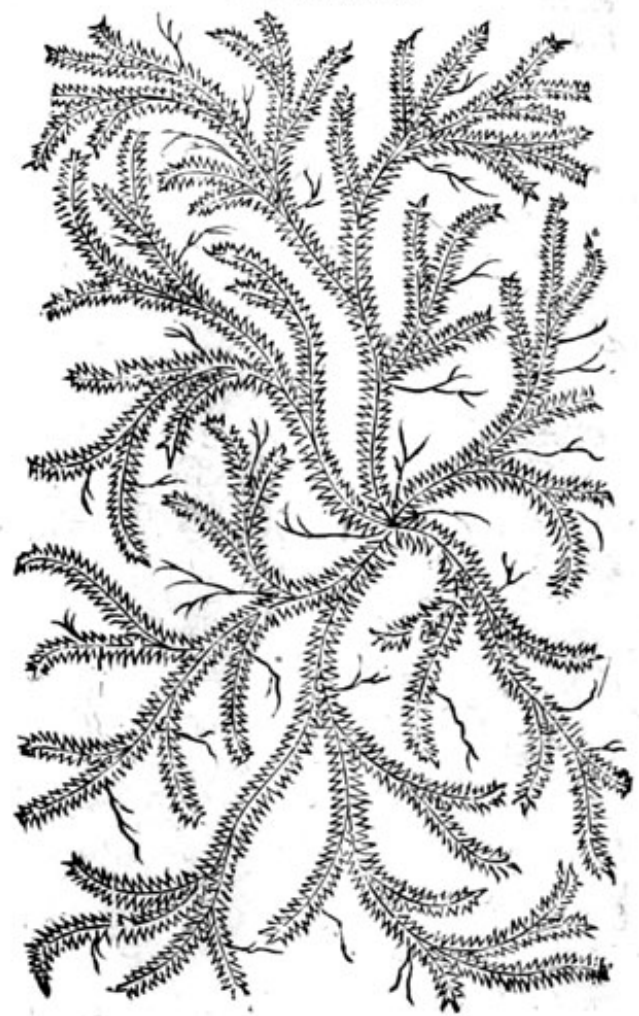

* The defcrition.

9 There is found creeping vpon the ground a certaine kinde of Moffe at the bottome of Heath and Ling, and fuch like buthes growing vpon barten mountaincs, confifting as it were of fcalcs made vp into a long rope or corde, difperfing it felfe farre abroad into fundry branches, thrufting out heere and there certaine rootes like threds, which take holde vpon the vpper cruft of tlic earth, whereby it is fent and difperfed farre abroade : the whole plant is of a ycilowith greene colour. 10. This other kinde of Moffe is founde in the like places: it alfo difperfeth it ielic farre abroade, and is altogither leffer then the precedent, wherein confifteth the difference.

II There is likewife anotherkinde of Moffe, which I hame not elfe where found then vpon Hamftead Heath, neere vnto a little cottage growing clofe vpon the ground among buthes and brakes, which I haue fhewed vnto diuers Chirurgions of London, that haue walked thither with me for their further knowledge in Simples; who haue gathered this kinde of Moffe, whereof fome haue made them hat bands, girdles, and alfo bands to tie fuch things as they had before gathered, for the which purpofe it moft fitly ferued:fome peeces whereof are fixe or eight foote long, confinting as it were of many hairic leaues, fet vpon a tough ftring, very clofe couched and compact togither, from which is alfo fent foorth certaine other branches like the firft; in fundry places there be fent downe fine little ftrings, which ferue in fteede of rootes, wherewith it is faftncd to the vpper part of the earth, and taketh holde like wife vpon fuch things as growe next vnto it. There fpring alfo from the branches bare or naked ftalkes, on which growe certaine eares, as it were like the catkines or blowings of the Hafell tree, in fhape like a little club, or the read Mace, fating that it is mt.ch leffer, and of a yellowifh white colour, very well refembling the clawe of a Woolte, whercof it tooke his name; which knobby catkins are altogither barren, and bring foorth neither feede nor flower.

This kinde of Moffe is found vpon the fcull or barefcalpes of men and women, lying long in charnell 
charnell houfes, and other places where the bones of men are kept togither: it groweth very thicke, white, like vnto the thort Moffe vpon the trunkes of olde Okes: it is thought to be a fingular reme. die aguinft the falling cuill, and the Chincough in children if it be powdered, and then giuen in fweete wine, for certaine daies togither.

I Mufcus clauat us, fue Lycopodium. Club Moffe, or Woolfe claw Moffe.

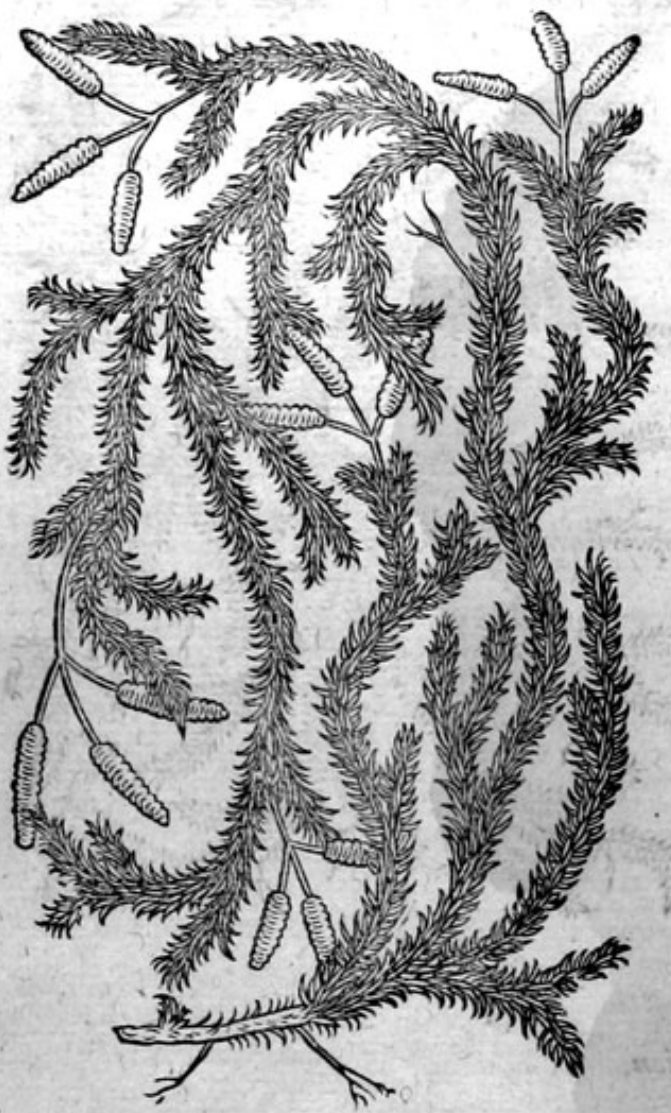

12 Mulcusex cranio humano. Moffe growing vpon the fcull of a man.

* The place.

Their feuerall defcriptions fet foorth their naturall places of growing.

They flourifh efpecially in the fommer moneths.

$$
\text { * The time. }
$$

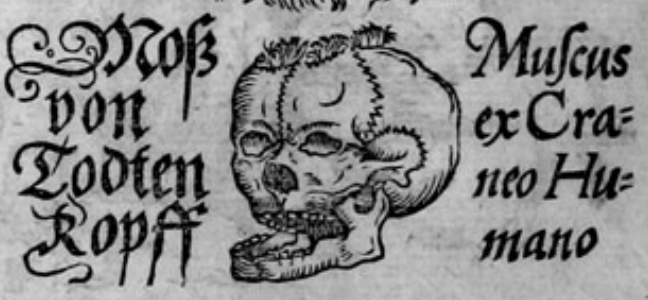

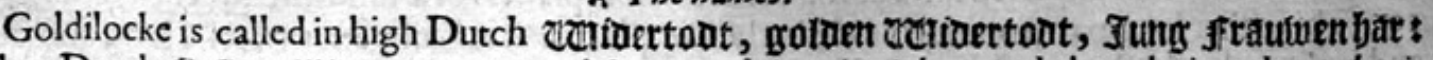
in low Dutch Guiden vareserzant: Fuchfies nameth it Polytrichon, and thought it to be Polytrichon Apuleÿ, or Apuleius his Maiden haire, neuertheleffe Apuleius his. Maiden haire is nothing elfe but $D$ infcorides 7 richomanes, called Englifh Maiden haire, and for that caufe we had rather it fhould be termed Mufcres capillaris, or Haire Moffe: this is called in Englifh Goldilockes Polyerichon; I would rather call it Goldilockes, leauing out Polytrichon : it might alfo be termed Golden Moffe, or Hairie Moffic.

Woolfes clawe is called of diuers Herbarifts in our age Mufcusterreftris : in high Dutch 2 Beqt: Jap, Surtellitatt, Sellkraut: in lowe Dutch Jololf clattuen; whereupon we firft named it Lycopodion, and Pes Lupi : in Euglifh Woolfes foote, or Woolfes clawe, and likewife Club Moffe: moft rhops do falfely terme it Spica celtica : but they do woorfe, and are very much to blame that ve it in compound medicines in fteede of Spica celtica, or French Spicknard: as touching the reft, they are fufficiently fooken of in their feuerall defcriptions. * The temperature. colde.

Thefe Moffes of the earth are drie and aftringent, of a binding qualitie, without any heate or Goldilockes and the Woolfes clawes are dry, and temperate in heate and colde. 


\section{HISTORIE OF PLANTS.}

* The vertues.

The Arabian Phifitians do put Moffe among their cordiall medicines, as fortifying the ftomack, A Moffe boiled in wine apd drunke, ftoppeth the fpitting of bloud, piffing of bloude, the tearines, B Moffe made into powder is good to ftanch the bleeding of greene and frem wounds, and is a $\mathrm{C}$
great helpe vnto the cure of the fame. Woolfes claw prouoketh vrine, and as Hieronymus Tragus reporteth, wafteth the ftone, and dri- D
ueth it foorth.

Being ftamped and boiled in wine, and applied, it mitigateth the paine of the gout.

Floting wine, which is now become flimie is reftored the veffell, as the fame author teitifieth.

\section{Of Liwerwoort. Clbap.158.}

\section{Hepaticaterrestris.} Ground Liuerwoort.

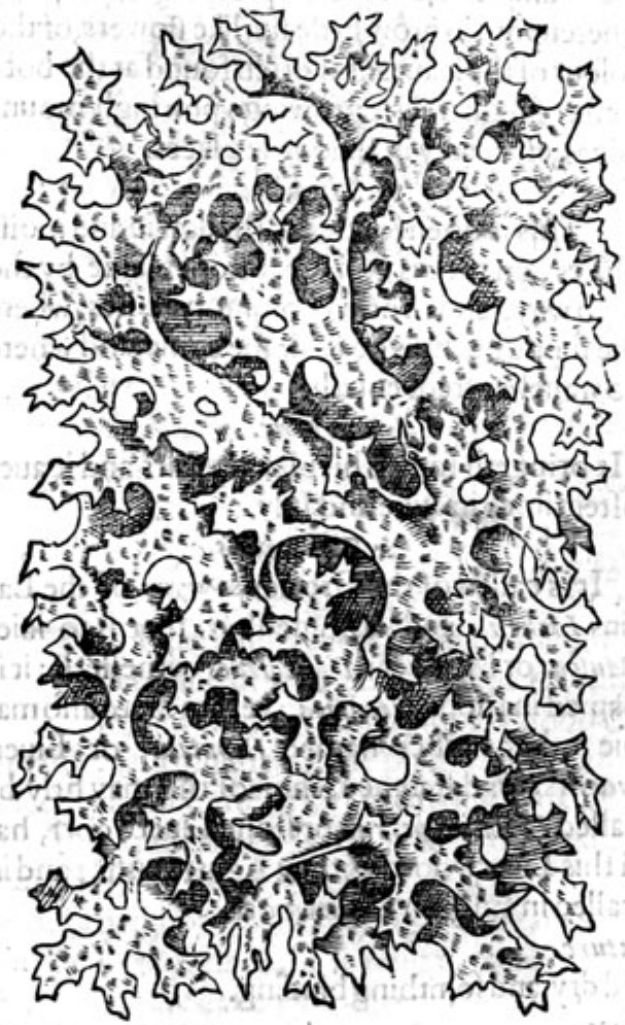

2 Hepatica altera. Small Liuerwoort.

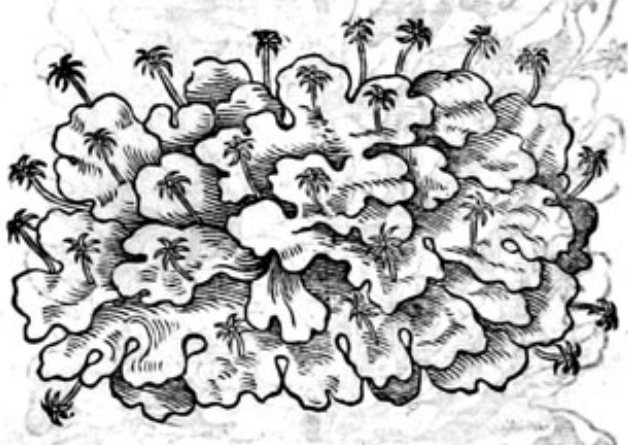

\section{Seber Fraut} Hepatica.

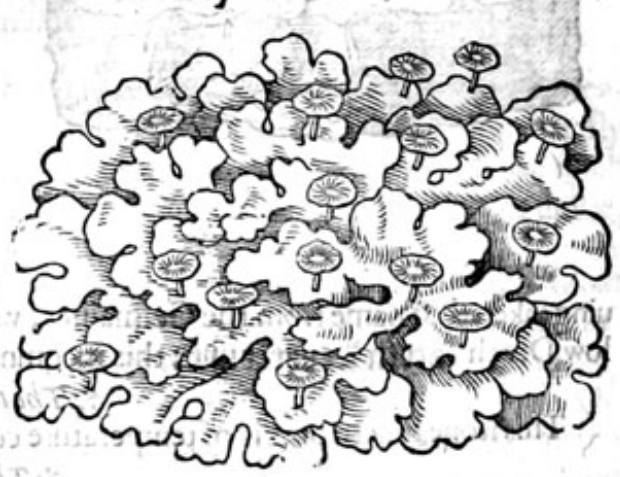

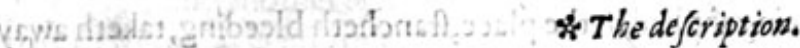

I I Iuerwoort is alfo a kinde of Moffe which fpreadeth it felfe abroad vpon the ground, hauing many yneeuen or crumpled leaues lying one ouer another, as the fcales of fithes do, greene aboue, and browne vnderneath; among thefe grow vp finall hort ftalkes, fpred at the top like a blafing ftar, certaine fine litcle threds are fent downe, by which it cleaueth and fticketh faft von ftones, and vpon the ground, and by which it liueth and flourifheth. 


\section{$137^{6}$ THE THIRD BOOKE OF THE}

\section{* The defcription.}

2 The fecond kinde of Liverwoort differeth not but in ftature, it is altogither leffer, and more fmooth or ecuen: the flowers on the tops of the flender ftems, are not fo much laide open like a ftar, but the efpeciall difference confifteth in one chiefe point, that is to fay, this kinde being planted in a pot and fet in the garden aboue the grounde; notwithftanding it foitteth or cafteth rounde about the place great ftore of the fame plant, where neuer any did grow before.

\section{Hepatica petried.}

Stone Liuerwoort.

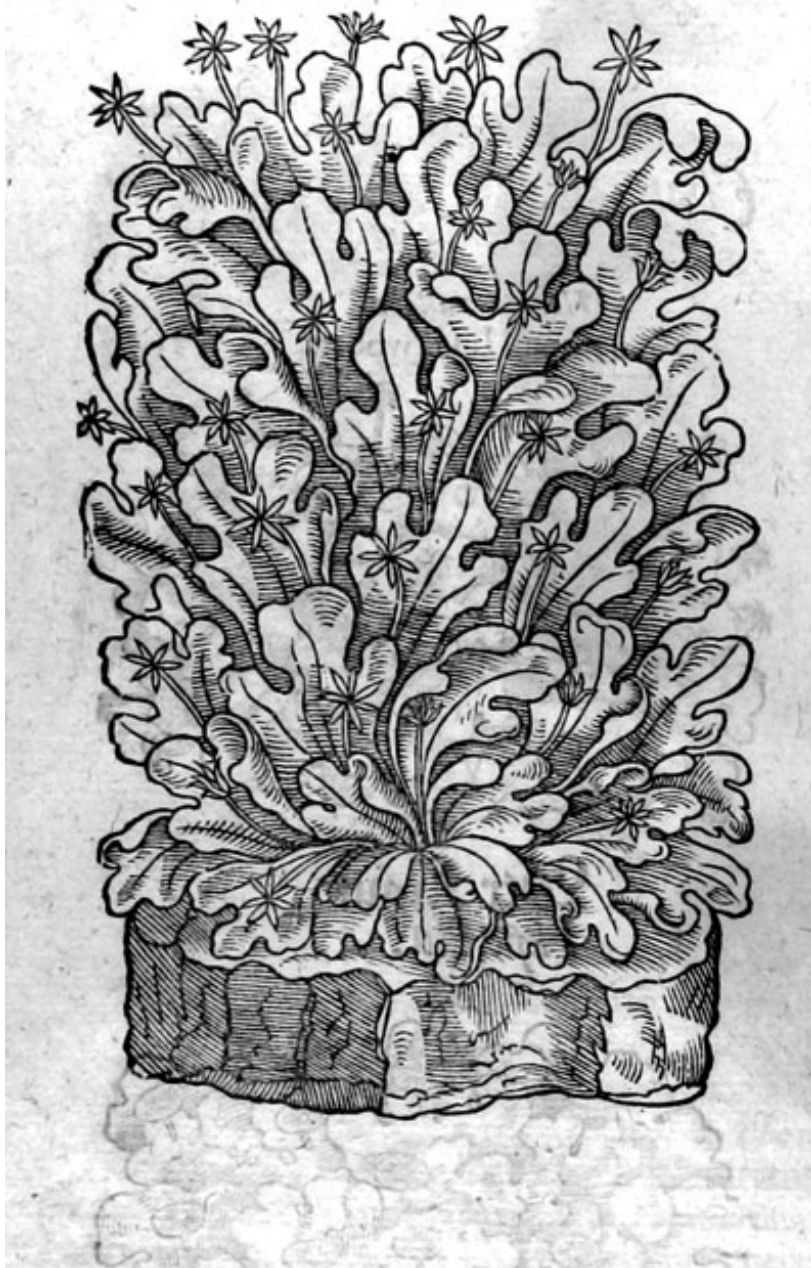

\section{$*$ The defoription.}

3 This is found vpon rockes and ftonie places, as well neere vnto the $\mathrm{fea}$, as further into the land; it groweth flat vjon the ftones, and creepeth not far abroad as the grounde Liuerwoort doth, it onely refteth it felfe in fpots and tufts, fet heere and there; of a duftie ruffet colour aboue, and blackifh vnderneath: among the crumpled leaues rife vp diuers fmall ftems, whereupon do grow little ftarlike flowers, of the colour of the leates:it is of ten found at the bottome of high trees, growing vpon high mountaines, ef pecially in fhadowie places.

$$
\text { * The place. }
$$

This is often founde in fhadowie and moift places, on rockes and great ftones laide by the high way, and in other common pathes, where the funne beames do feldome come, and where no traueller frequenteth.

$$
\text { * The time. }
$$

Ic bringeth foorth his blazing ftars and leaues oftentimes in Iune and Iuly.

$$
\text { * The names. }
$$

It is called of the Grecians reryn: of the $\mathrm{La}_{2}$ tins Lichen : and of fome Bporv, that is to faie, Mufcow, or Moffe, as Disfcorides witneffeth; it is named in hops Hepatica, yet are there alfo manie other herbes named Hepatica, or Liuerwoorts, for difference whereof this may firly be called Hepatica petr ea, or ftone Linerwoort, hauing taken that name from the Germaines, who call this Liuerwoort stepn Leherktaut: and in low Dutch Stean Letierctupt : this is commonly called in Englifh Liuerwoort.

\section{$\approx$ The temperature.}

This ftone Liuerwoort is of temperature colde and dry, and fomthing binding.

$$
* \text { The vertues. }
$$

A It is fingular good againft the inflammations of the liuer, hot and Pharpe agues, and tertians which proceede of choler.

B Diofcorides teacheth, that Liuerwoort being applied to the place, ftancheth bleeding, taketh away

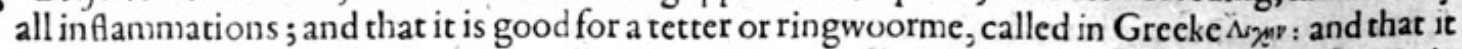
is a remedie for them that haue the yellow iaundife, euen that which coinmeth by the inflammation of the Lituer; and that furthermore it quencheth the inflammations of the toong. 


\section{Of Lungwoort, or woode Linerwoort, and Oifter greene. Chap.159. \\ I Lichen arborwom. \\ Tree Lungwoort. \\ 2' Lichen CMarinus. Sea Lungwoort,or Oifter grcene.}

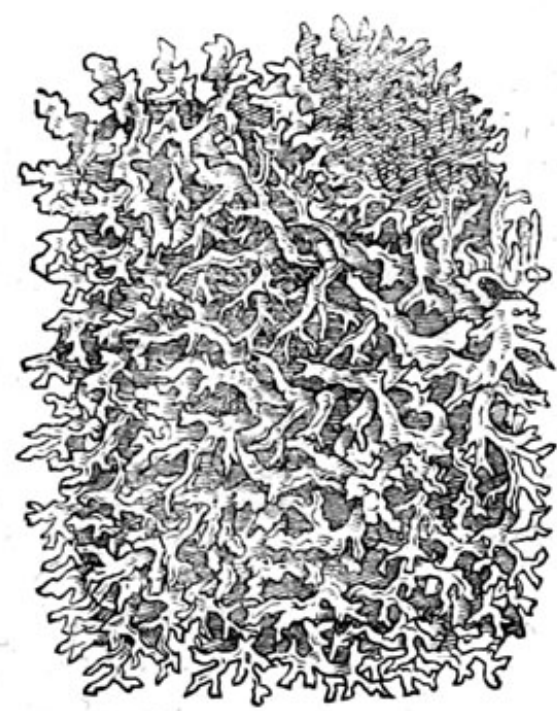

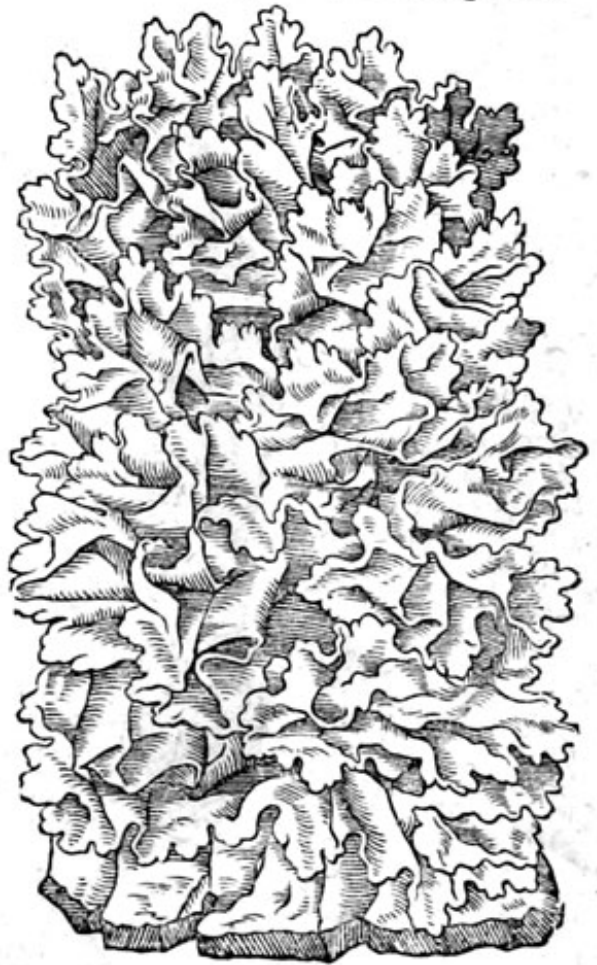

* T he defcription.

$\mathbf{I}$

$\mathrm{T}$ O Liuerwoort there is ioined Lungwoort, which is alfo another kinde of Moffe, drier, broader, and of a larger fife, and fet with fcales: the leaues hecreof are greater, and diterfly folded one in another, not fo fmooth, but more wrinckled, rough and thick almoft like a Fell or Hide, and tough withall; on the vpper fide whitih , and on the neather fide blackifh or duftie, it feemeth to be after a fort like to lungs or lights.

2 This kinde of fea Moffe is an herbie matter, much like vito Liuerwoort, altogither without ftalke or ftem, bearing many greene leaucs, very vneeuen or crumpled, and full of wrinckles, foinewhat broad, not much differing from leaues of crifpe or curled Lettuce: this groweth vpon rockes within the bowels of the fea, but efpecially among Oifters, and in greater plentie among thofe Oifters which are called Walfeete Sifters : it is very well knowne euen to the poore Oifterwomen which carrie Oifters to fell vp and down, and are greatly defirous of the faid Moffe, for the decking and beautifying of their Oifters, to make them fell the better; this Moffe they call Oifter greene. 3 There is alfo another fort of fea weede founde vpon the drowned rockes, which are naked and bare of water, at euerie tide. This fea weede groweth vnto the rocke, faftned vnto the fame at one ende, being a foft herbie plant, very lipperic, infomuch that it is a harde matter to ftande vpon it without falling ; it rampeth farre abroad, and hecre and there fet with certaine puft vp tubcrcles or bladders, fullof winde, which giucth a cracke when it is broken : the leafe it felfe doth fomewhat refemble the Oken leafe, whereof it tooke his name Quercus martonus, the fea Oke: of fome Wrake and Crowe Gall. His vfe in Phificke hath not beene Iet foorch, and therefore this bare defeription may fuffice. 


\section{${ }_{137^{8}}$ THE THIRD BOOKE OF THE}

3 Quercusmarinus. Sea Oke,or Wrake.

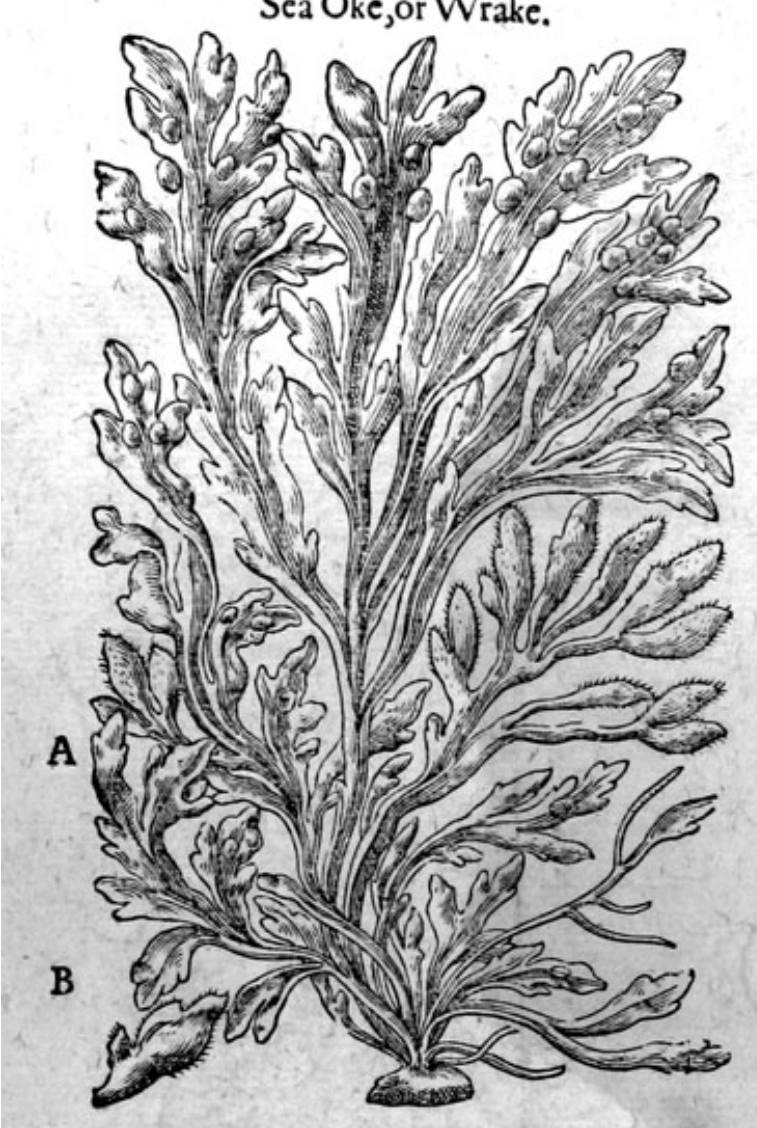

C

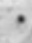

\section{* The place.}

It groweth vpon the bodies of old Okes, Beech, and other wilde trees, in darke and thicke woods; it is oftentimes found growing vpon rockes, and alfo in other hadowie places.

$$
\text { * The time. }
$$
neths.

It flourifheth efpecially in the fornmer mo-

\section{* The names.}

It taketh his name Pulmowaria of the likenes of the forme, which it hath with lungs or light, called in Latine Pulmones, of fome Lichen: it is called in high Dutch Lungentratut : in low Dutch Longbinctipt : in French Herbe a Poulmon : in Englifh Lungwoort, and woode Litierwoort. * The temperature.

I his feemetih to be colde and dric. * Thevertues.

It is reported that thepheards and certaine horfeleeches, do with good fucces giue the pow. der heereof with falt vnto their fheepe and other cattle which be troubled with the cough, and be broken winded.

Lungwoort is much commended of the learned Phifitions of our time againft the difeafes of the lungs, efpecially for the inflammations and vlcers of the fame, being brought intopowder, and drunke with water.

It is likewife commended for bloudy \& greene wounds, and for vlcers in the fecret parts, and alfo to ftay the reds.

D Moreouer, it ftoppeth the bloudie flixe, and other flixes and fcourings, either vpwards or downwards, efpecially if they proceede of choler : it ftaieth vomiting as men faie, and it alfo ftoppech the belly.

E Difter greene fried with egges and made into a tanfie and eaten, is a fingular remedy for to ftrengthen the weakenes of the backe.

\section{Of Jea Moffe, or Coralline. Chap.16o.}

\section{9. * Thekindes. Here be diuers forts of Moffe, growing as well within the bowels of the fea, as vpon the rockes,
diftinguifhed vnder fundrie titles.}

\section{* The defcription.}

I His kinde of Sea Moffe hath many fmall ftalkes finely couered or fet ouer with fmall leaues, very much cut or iagged, eucu like the leaucs of Dill, but harde, and of a ftonie fubftance.

2 The fecond is much like vnto the former, but is more finely cut, and groweth more vpright, branching it felfe into many divifions at the top, growing verie thicke togither, and in great quantitie, out of a pecce of ftone, which is fafhioned like an hat or fnall ftonie head, whcreby it is faftned vnto the rocks. 
r. Mufcus marinus, fuc Corallina alba.

White Coralline, or fea Moffe.

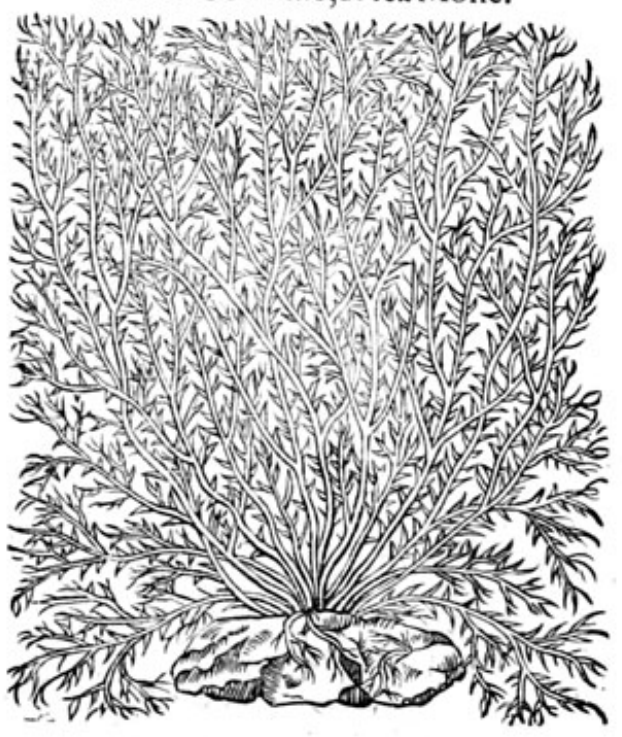

3 Coralliná Anglica.

Englifh Coralline.

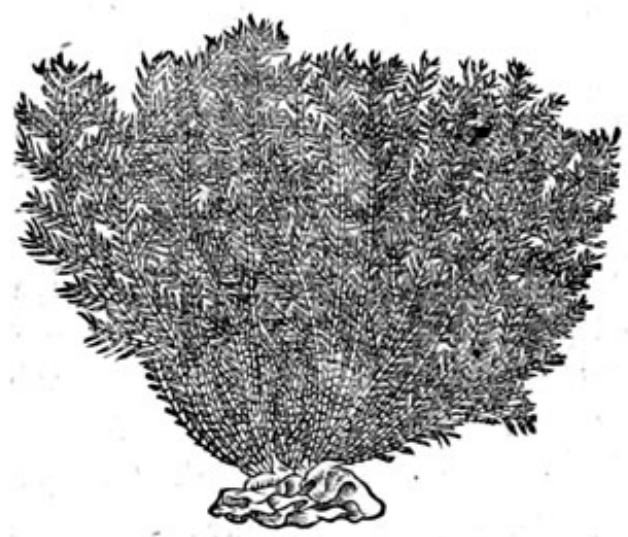

2 Mufcus marinus, fue Cor allina rubra. Red Coralline, or fea Moffe.

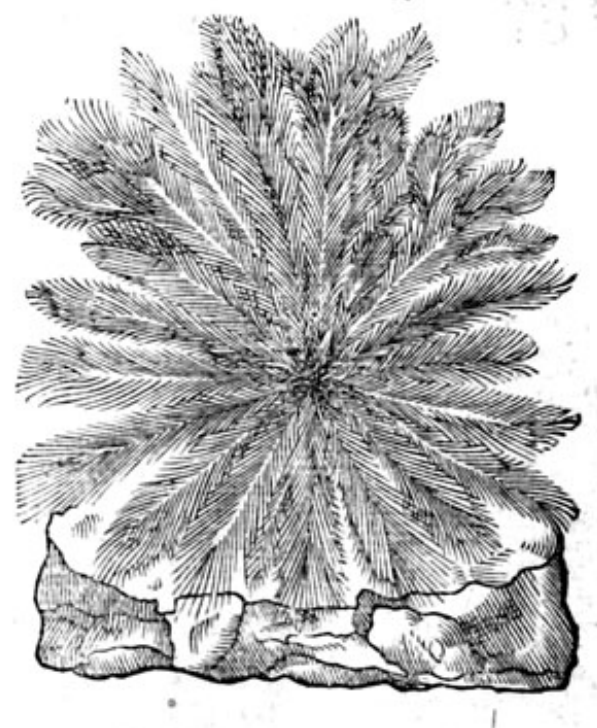

4 Corallimaminima. The fmalleft Coralline.
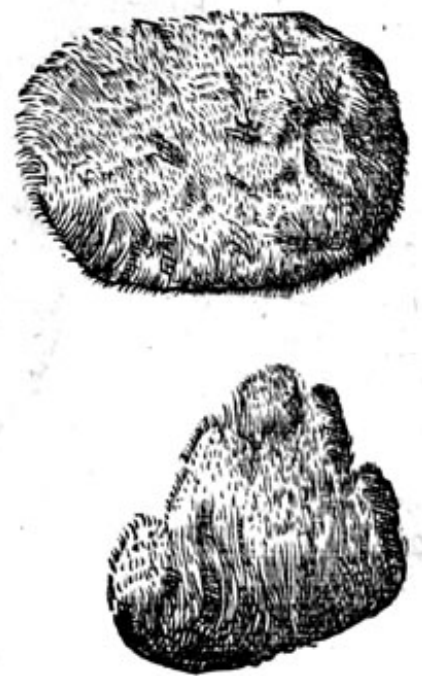

* The defcripsion.

3 This thirde kinde of fea Moffe is very well knowne in fhops by the name Corallina : it yeeldeth foorth a great number of fhootes, in thape much like vnto Corall; being full of fmall branches difperfed heere and there, diuerfly varying his colour, according to the place where it is founde, being in fome places red; in other fome yellow; and of an herbie colour; in fome graie, or of an Afh colour; and in other fome very white.

4 The fourch kind of fea Moffe, is fomewhat like the former, but fmaller, and not fo plentifull where it groweth, profpering alwaies vpon thels, as of Oyiters, Mufcles, and Scallops, as alfo vpon rolling ftones, in the bottome of the water, which haue tumbled downe from the high cleeues and rocks: notwithftanding the old prouerbe; That rolling ftones neuer gather Moffe. 
5 Mufus Corallinus, fue Corallinamontana. Corall Moffe, or mountaine Coralline.
6 Fucus marinus. Fenell Coralline, or Fenell Moffe.

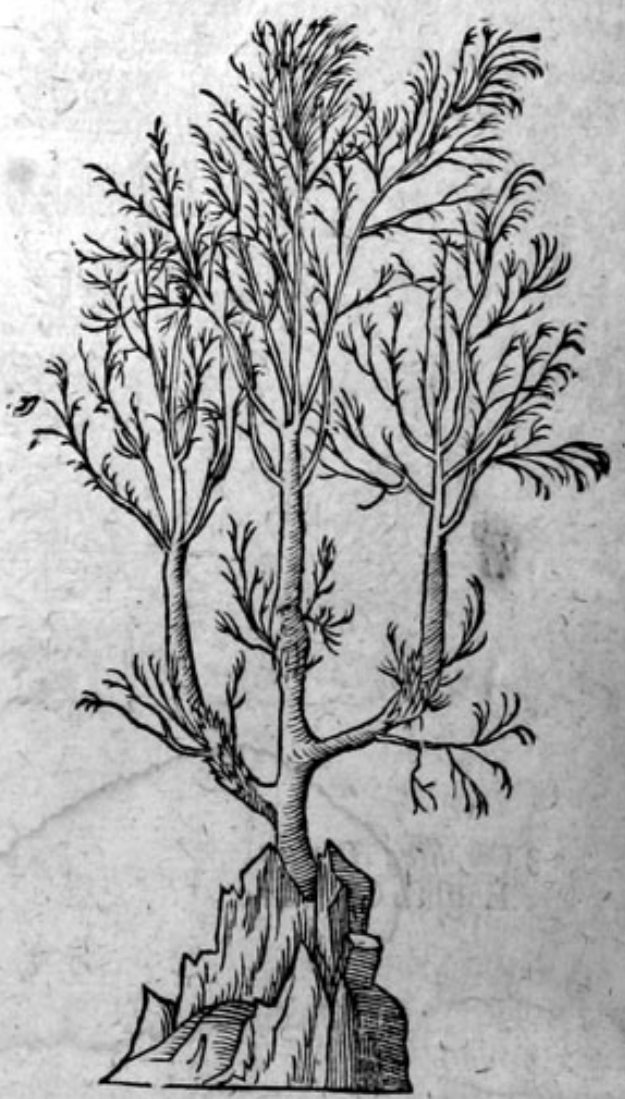

* The defcription.

5 There is found vpon the rocks and mountaines of France, bordering vpon the Mediterranean fea, a certaine kinde of Coralline, which in thefe parts hath not beene found: it groweth in maner like vnto a branch of Corall, but altogither leffer, of a fhining red colour, and of a ftonie fubftance.

6 There is alfo found vpon the rocks neere vnto Narbone in France, and not far from the fea, 2 kinde of Coralline; it groweth vp to the forme of a fmall hrub, branched diuerfly; wheron do grow fmall graffe like leaues, very finely cut or iagged, like vnto Fenell; yet are they of a ftonie fubftance, as are the reit of the Corallines; of a darke ruffet colour.

\section{*The place.}

Thefe Moffes grow in the fea vpon the rockes, and are oftentimes found vpon Oyfter fhels, Mufkell hhels, and vpon ftones: I found verie great plentic thercof vnder Reculuers and Margate, in the Ile of Thanet; and in other places alongt the fands from thence vnto Douer.

* The time.

The time anfwereth the other Moffes, and are found at all times of the yeere.

$$
\text { * The names. }
$$

Sea Moffe is called in Greeke Bpiov gaxcísorv: in Latine Mufcus marinus : of the Apothecaries, Italians, and French men:Corall/na : in Spanifh Maibarquiana yerua : in high Dutch $\mathbb{E} e \mathrm{ermof}$ : in

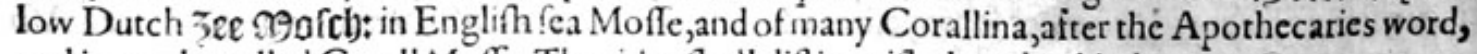
and it may be called Corall Moffe. The titles fhall diftinguilh the otherkinds.

$$
\therefore \text { The temperature. }
$$

Corallina confifteth as $G$ alen faith, of an earthie and waterifh effence, both of them colde : for by his tafte it bindeth, and being applied to any hot infirmitie, it alfo evidently cooleth : the earthic effence of this Moffe hath in it alfo a certaine faltnes by reafon where of likewife it drieth mightily. 


\section{HIS TORIE OF PLANTS.}

$* 7$ be vertues.

Diofcorides commendeth it to be good for the gout, which hath neede to be cooled. The later Phifitions haue founde by experience, that it killeth wormes in the belly; it is giuen B
againft thefe to children in the waight of a dram or thereabouts.

That which cleaueth to Corrall, and is of a reddifh colour, is of moft men preferred and taken C for the beft : they count that which is whitith, to be the woorfer. Notwithtanding in the French Ocean, the Britaine, the lowe countrey, or elfe in the Germaine Ocean fea, there is fearce founde any other then the whicith Coralline, which the nations neere adioining do effectually vfe.

\section{Of Corrall. Chap.ror. \\ * The kindes.}

- Here be diuers forts of Corrall, differing in colour, one red, another blacke; and one of a white

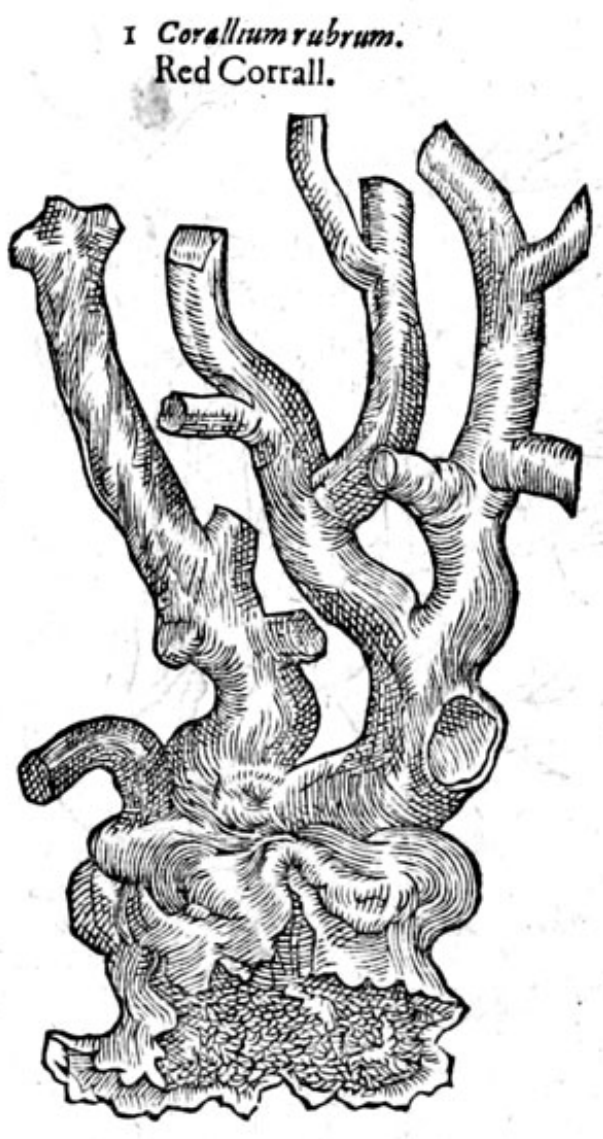

\section{Corallium nigrum, fue Atipatbes.
Blacke Corrall.}

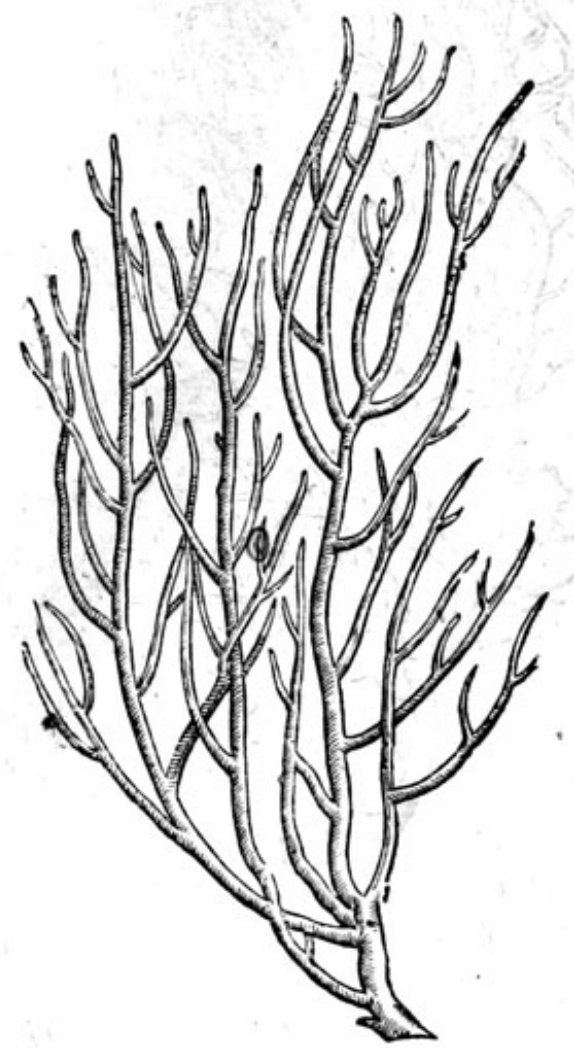

$*$ The defcription.

I Lthough Corrall be a matter or fubftance, euen as hard as ftones;yet I thinke it not amiffe to place and infert it here next vnto the Moffes, and the rather for that the kindes thereof dofhew them felues, as well in the manner of their growing, as in their place and forme, like vnto the Moffes. This later age wherein we liue, hath found moe kinds heereof then cuer were knowne or mentioned among the old authors. Some of thefe Corrals growe in the likenes of a fhrub,or ftonie matter; others in a ftraight forme, with crags and ioints, fuch as we fee by experience : the which for that they are fo well knowne, and in fuch requeft for Phificke, I will not ftande to defcribe; onely this remember, that there is fome Corrall of a pale yellowe colour, as there be fome red andfome white. 
*The defcription.

2 The black Corrall groweth vpon the rocks neere to the fea about Maffilia, in maner of the former; heerin differing from it, in that this is of a hining blacke colour, and very fmooth, growing
vp rather like a tree, then like a fhrub.

3 Coralliam album. White Corrall.

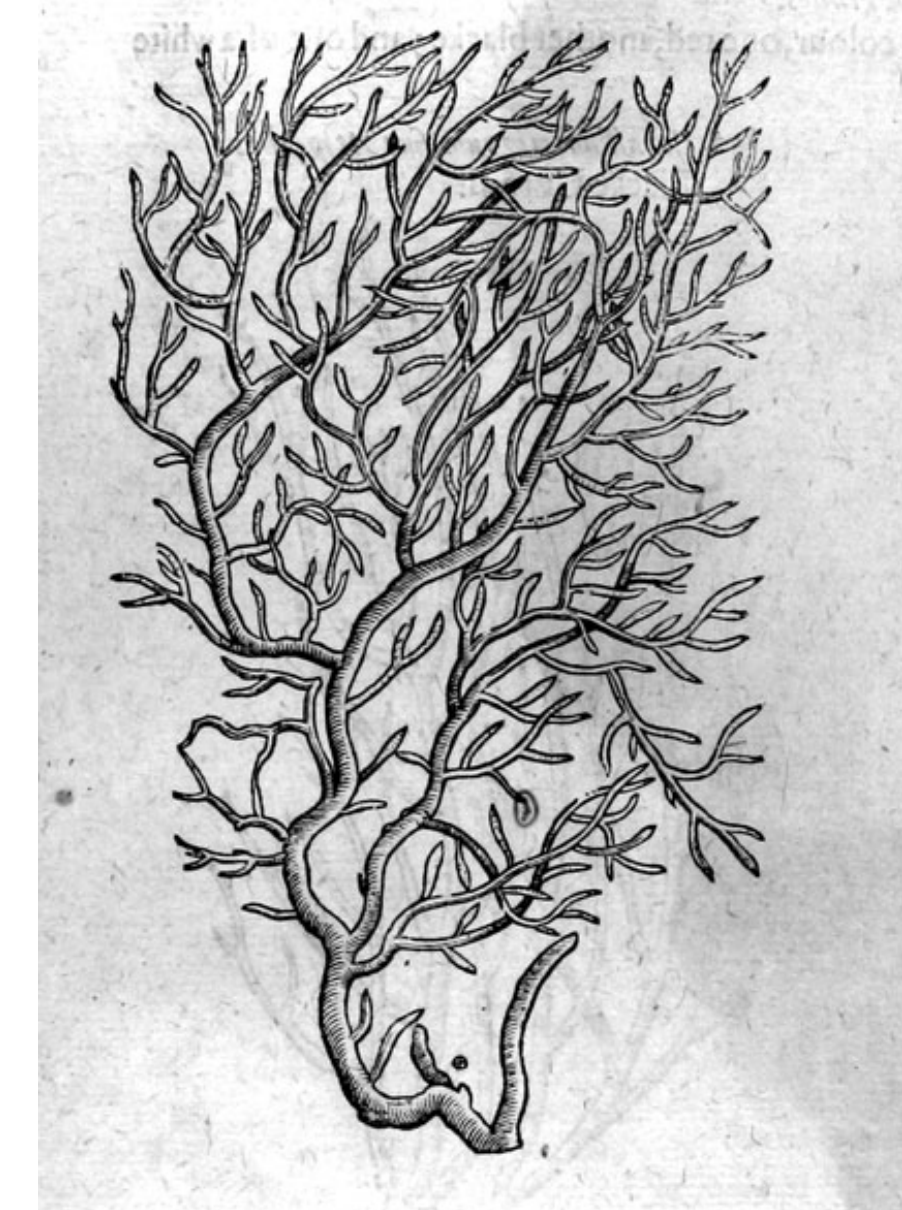

\section{Corallium luteuth. Yellow Corrall.}

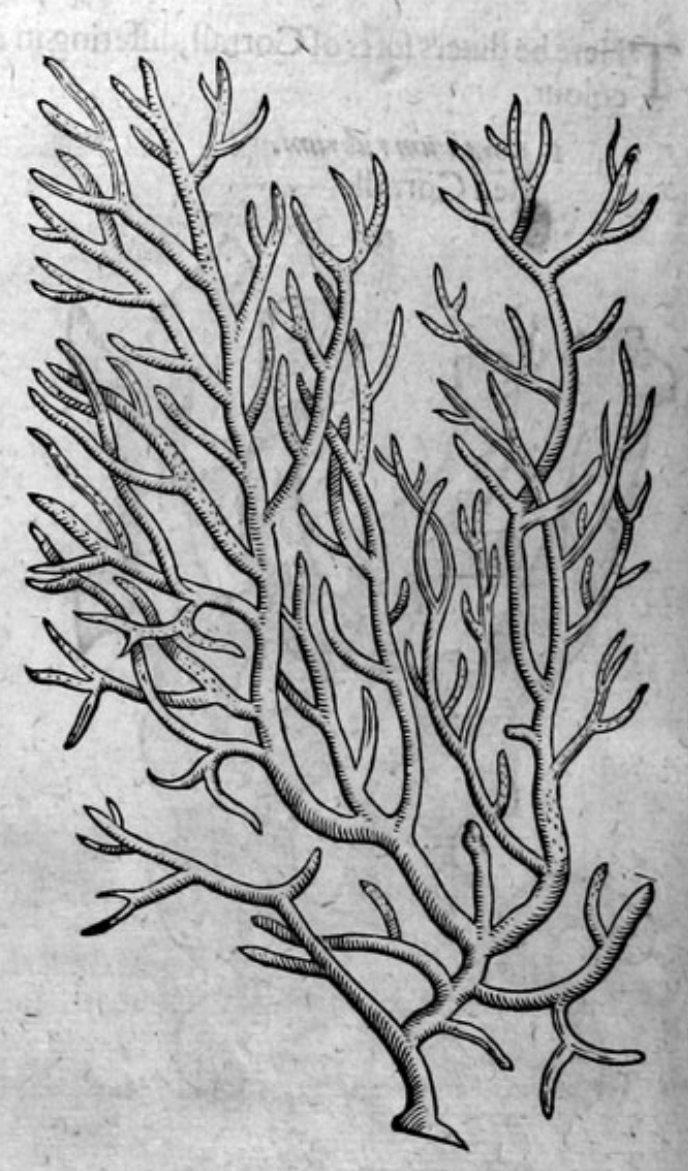

\section{* The defcription.}

3 The white Corrall is like vnto the former, growing vpon the rocks neere the fea,and in the weft parts of England, about Saint Michaels mount; but the branches heerof are fmaller, and more brittle, finelier difperfed into a number of branches, of a white colour.

4 The fourth and laft groweth alfo vpon the wefterne rockes of the fea, and in the place aforenamed, and varieth bis colour, fomtimes waxing white, fometimes yellow, and fomtimes red.

5 There is found growing vpon the rocks neere vnto the fea, a certaine matter wrought togither, of the forme or froth of the fea, which we call fpunges, after the Latine name, which may very fitly be inferted among the fea Moffes, whereof to write at large woulde greatly increafe our volume, and little profite the Reader, confidering we haften to an end, and alfo that the vfe is fo wel knowne vnto all : therefore thefe fewe lines may ferue vntill a further confideration, or a fecond Edition. 


\section{HISTORIE OF PLANTS.}
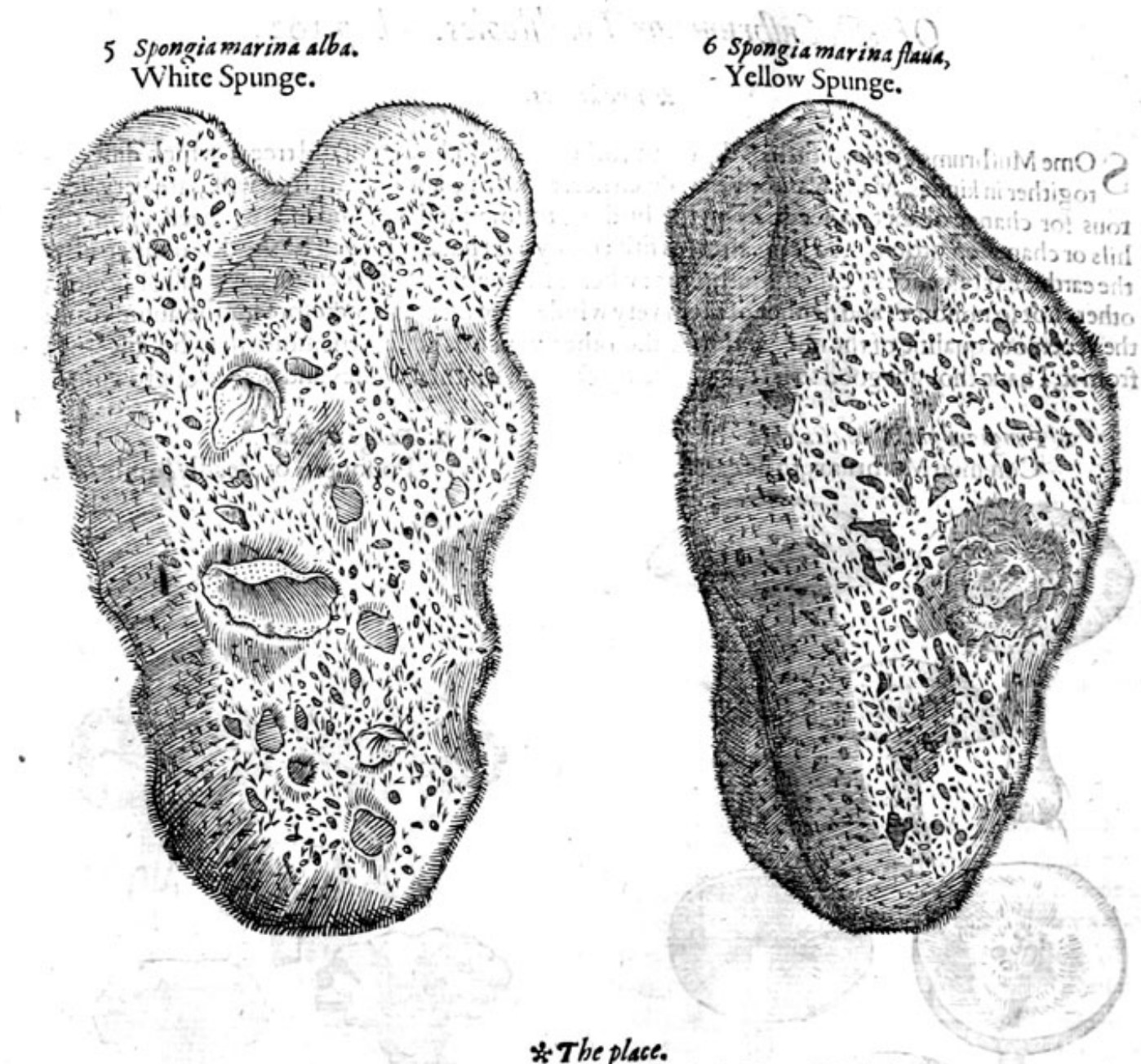

The place of their growing is fufficiently fpoken of in their feuerall defcriptions.

\$.The place.

The time anfwereth the other kindes of the fea Moffes.

* T The names.

Corallium rubrum, is called in Englifh red Corrall. Cor allium nigrum, blacke Corrall. Cor allina alba, white Corralline: Cor allina rubens, red Corralline.

* $*$ The temperature.

Corrall bindeth, and meanely cooleth: it clenfeth the fcars and fpots of the cies, and is verie effectuall againft the iffues of bloud, and eafeth the difficultie of making water.

* The vertues.

Corrall drunke in wine or water,preferueth from the fpleene; and fome hang it about the necks of fuch as haue Morbum comitialem; and it is giuen in drinke for the fame purpofe.

It is a foueraigne remedie to drie, to ftop, and ftaie all iffues of bloud whatfoeuer in man or woman, and the dyfenterie.

Burned Corrall drieth more then when it is vnburned, and being given todrinke in water, it A helpeth the gripings of the bellie, and the griefes of the ftone in the bladder.

Corrall drunke in wine,prouoketh fleepe: but if the patient haue an ague, then it is with better $B$ fucceffe miniftred in water, for the Corrall cooleth, and the water moiftneth the body, by reafon whereof it reftraineth the burning heate in agues, and repreffeth the vapours that hinder lleepe.

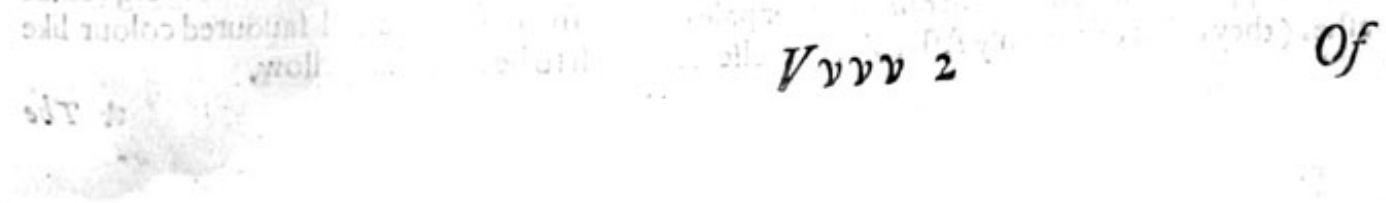




\section{Of Mufbrums,or Toadfooles. Chap.i62. \\ * The kindes.}

$S_{\text {togither in kindes. }}^{\text {Ome Murhrums growe foorth of the earth; } \text { other vpon the bodies of old trees, which differ al. }}$ rous for change of diet to feede vpon the birds of the fea, and haue fifh at will, are very defihils or champion grounds, do long after fea firf ; the mountaines; and luch as dwell vpon the the earthic excrefcences, called Mufhrums : whereef that haue plenty of both, doe hunger after others not fo noifome; and neither of them very wholefome meare: venemous and full of poifon; the venemous qualitie of the one, and that the other which is leff wherefore for the auoiding of from it, I have thought good to fet foorch their pictures with their names and places of growing.

I Fungivulgatißsimi efculenti.

Common Mufhrums, to be eaten.

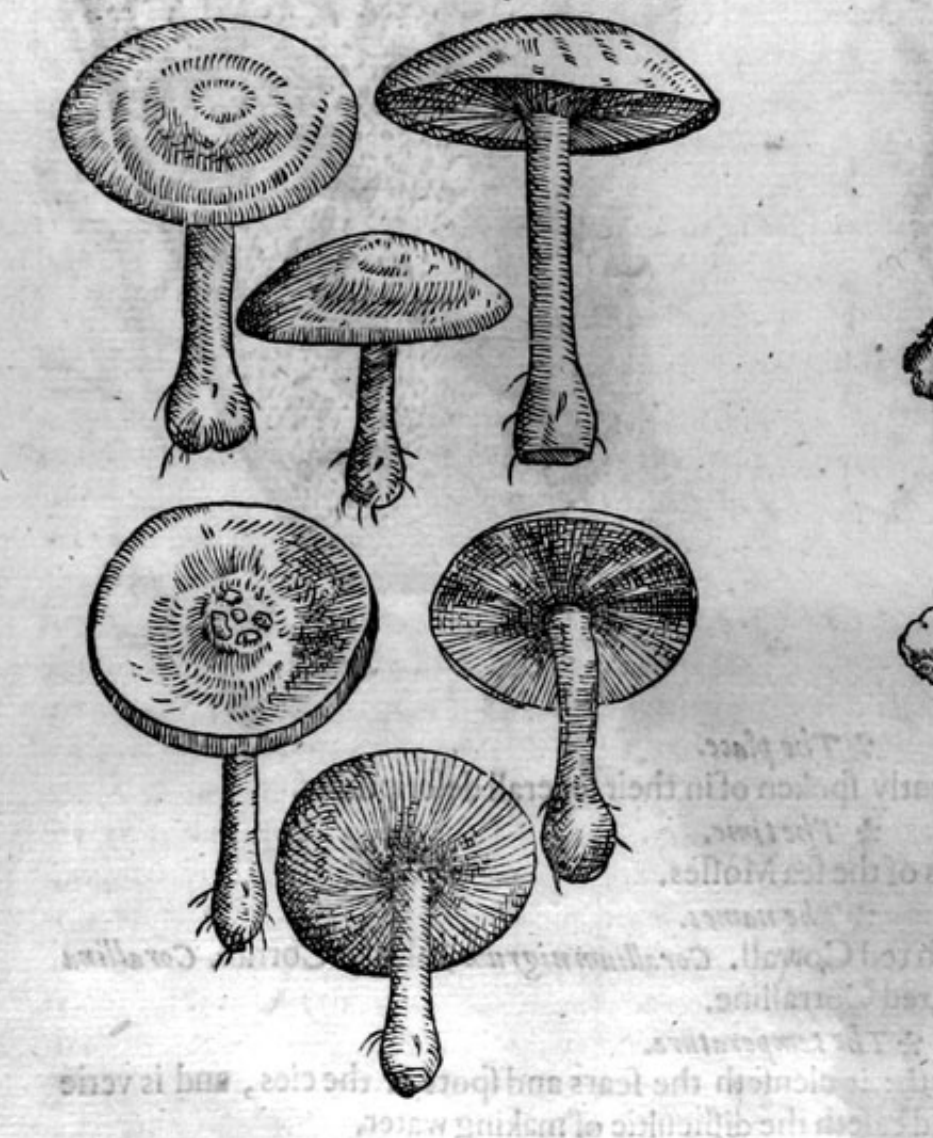

2 Fungi lethales. Poifonous or deadly Murhrums.

* The defcription.

I Round Mufhrums grow vp in one night, ftanding vpon a thicke and rounde ftalke, like vnto a broad hat or buckler, of a very white colour vntill it begin to wither, at what time it lofeth his faire white, declining to yellownes: the lower fide is fomewhat hollow, fet or decked with fine gutters, drawne along from the middle center to the circumference or round edge of the brim.

2 All Murhrums are without pith, rib, or vaine: they differ not a little in bignes and colour, fome are great, and like a broad brimmed hat; others fmaller, about the bigneffe of a filuer coine called a doller : moft of therri are red vnderneath; fome more, fome leffe; others little or nothing red at all: the vpperfide which beareth out, is either pale or whitifh, or elfe of an ill fauoured colour like afhes ( they call it commonly Afh colour)or elfe it feemeth to be fomwhat yellow. 


\title{
HISTORIE OF PLANTS.
}

\author{
*The defcription.
}

There is another kinde of Murhrums called Fungi paruilethales galericulati $:$ in Englifh deadly Murhrums, which are farhioned like vnto an hood, and are moft venemous and full of poifon. There is a kinde of Mufhrum, called Fungus Clypeiformis lethalis, that is alfo a deadly Murhrum,
fafhioned like a little buckler.

There is another kinde of Murhrum, which is alfo moft venemous and full of poifon, bearing al. fo the Thape of a buckler, being called Fung us venenatus clypeiformis : in Englifh the ftinking venemous Mulhrum.

There is alfo another kinde of Murhrum or Toadtoole, growing in the moffe and thadowie woods, and fuch like places, which the learned haue left vnto the difcretion of the Reader, neither allowing it for foode vnto man, nor yet profitable for any other vfe; wherefore I do the more briefly paffe them quer, not purpofing to vfe many words about fuch fruitleffe matters.

The Muhrums of Toaditooles which grow vpon the trunks or bodies of olderees, verie much refembling Suricula Iude, that is Iewes eare, do in continuance of time growe vnto the fubftance of wood, which the Fowiers docall Touchwood, and are for the mott halfe circuled or halfe round, whofe vpper part is fomwhat plaine, and fometime a little hollow, but the lower part is plaited or purfed togither. This kinde of Mufhrum the Grecians do call eizeteives, and is as full of venome or poifon as the former, efpecially thofe which grow vpon the Ilex, Olite,and Oke trees.

There is likewife a kinde of Mufhrum called Fungis Fanaginofus, growing vp in moift and thadowie woods, which is alfo venemous, hatuing a thick and tuberous ftalke, an handfull high, of a duskifh colour; the top whereof is compaet of many fmall diuifions, like vnto the Hony combe.

There is allo found another, fet foorth vader the titic Fungus virilis penis arecti, which we Englifh pricke Mufhrum, taken from his forme.

\section{Tuberaterra.}

Fuffe bals, or Puckfifts.

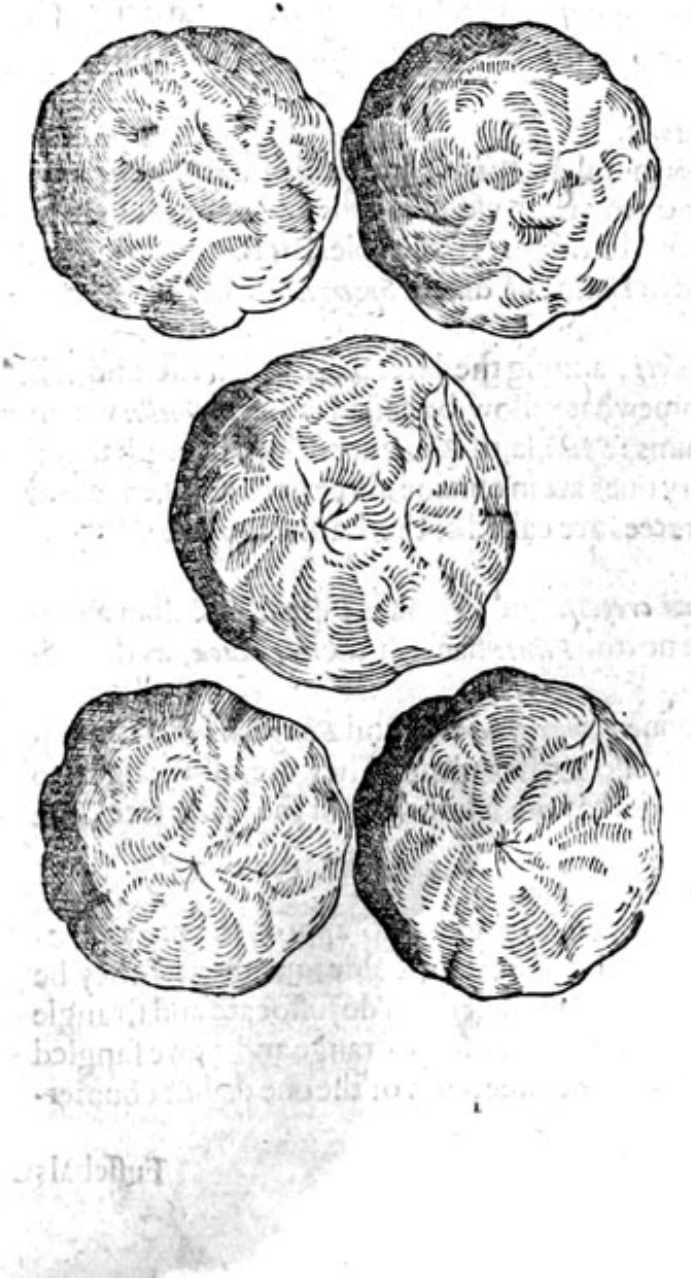

s. The defcription.

3 Fungus Orbicularis, or Lupi crepitus : forne do call it Lucernarum fung $i$ : in Englifh Fufte bals, Pucke Fuffe, and Bulfilts, with which in fome places of England they vec to killor fmolder their Bees, when they woulde driue the Hiues, and bereaue the poore Bees of their meate, houfes, and liues: thefe are alfo vfed in fome places where neighbours dwell farre a funder, to carrie and referue fire from place to place, where of it tooke the name Lucernarum fungi: in forme they are very round, fticking \& cleauing vnto the ground, without any ftalks or ftems; at the firft white, but afterwarde of a duskifh colour, hating no hole or breach in them, whereby a man may fee into them, which being troden vpon do breath foorth 2 molt thinne and fine powder, like vito fmoke, very noifome and hurtfull vnto the eies, caufing a kinde of blindnes, which is called Poor-blinde; or Sand-blinde.

There is another kinde of Fungus, or Mufhruin, which groweth in moift medowes, and by ditch fides, fitic or fixe inches high, coucred ouer with a skin like a peece of theepes leather, of a rufiec colour; which being taken away there appeereth a long and white ftumpe, in forme not much vnlike to an handle, mentioned in the title, or like vnto the white and tender ftalke of Aron, but greater: this kinde is alfo full of venome and poifon.

Vvvv 3
* The 


\author{
*The defcription.
}

There is likewife a kinde of Mufhrum, with a certaine round excrefence growing with in the earth, vnder the vpper cruft or face of the fame, in drie and grauelly grounds in Pannonia and the Prouinces adioining, which do caufe the ground to fwell, and be full of hils like Molehils. The people where they grow, are conftrained to digge them vp and caft them abroad like as we do Mole. hils, ppoiling their grounds, as Molehils are hurtfull vnto our foile: thefe haue neither ftalks, leaues, fibres, nor ftrings annexed or faftned vnto them, and for the moft part are of a reddifh colour, bue within of a whitifh yellow: the Grecians have called this tuberous excrefence isva, and the $\mathrm{La}$. tines Tubera : the Spaniards do call them Turmas de tierra : in Englifh we may call them Spanifh Fuffebals.

\title{
* The place.
}

Murhrums come vp about the rootes of trees, in graffie places of medowes, and ley land newely turned; in woods alfo where the ground is fandie, but yet dankilh; they grow likewife out of wood, foorth of the rotten bodies of trees, but they are vnprofitable and nothing woorth. Poifonfume Mufhrums as Diofcorides faith, growe where olde ruftic iron lieth, or rotten clouts, or neere to ferpents dens, or roots of trees that bring foorth venemous fruite. Diuers efteeme thofe for the beft which grow vpon mountaines and hilly places, as Horace faith:

\section{Hor.lib.fer.2. \\ jatyr.4. Natura est, alis malè creditur.}

The medow Mufhrums are in kinde the beft, It is ill trufting any of the reft.

\section{* The time.}

Diuers come vp in Aprill,and laft not till Maie: for they flourim but whileft Aprill continueth; others grow later about Auguft; yet all of them after raine, and therefore they are found one yeere fooner; and another later. Murhrums faith Plinie grow in howers of raine, they come of the flime of trees;as the fame author affirmeth.

\section{$*$ The names.}

They are called in Latine Fung $i$ : in Greeke $\mu \dot{x}_{x n} \pi u$ : in Italian Fonghi: in Spanifh Hungos, Cugume. los: in French Campinion, which worde the low country men alfo vie, \& call them $\mathbb{C}_{\text {ampertroellun: }}$

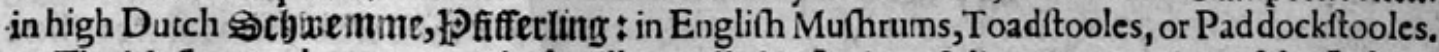

The Mufhrums that come vp in Aprill arecalled in Latine of diuers Spongiole : of the Italians Prignoli : and in high Dutch Mozcbel.

They that are of a light red be called of fome Boleti, among the later ones which rife and fall away in feuen daies. The white or thofe which be fomewhat yellow, be called in Latin Suilli: which the later Phifitions name Porcini, or Swine Mufhrums : Suilli, faith Plinie are dried, being hanged vpon rufhes, which are thruft thorow them. The dry ones are in our age alfo eaten in Bohemia and Auftria: they that grow by the rootes of the Poplar trees are called of the Latines Popalnei,Poplar Murhrums.

Puffes Filtes, are commonly called in Latine Lupi crepitus, or Woolfes Fiftes: in Italian Vefcie de Lupo: in Englifh Puffes Fiftes, \& Fuffebals in the north. Plinie nameth them Pezice, as though he fhould fay flat.

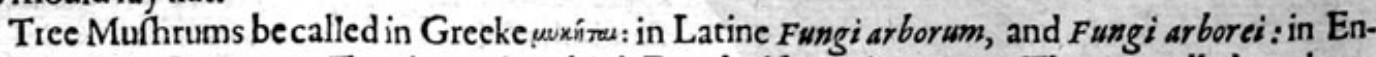
glifh tree Mufhrums, or Touchwood: in high Dutch alfo sebbemme. They are all thought to be poifonfome being inwardly taken. Nicander writeth that the Mufhrums of the Oliue tree, the Ilex tree, and of the Oke trec bring death.

\section{* The temperature and vertues.}

A Galen affirmeth that they are all very colde and moift, and therefore do approoch vnto a venemous and murthering facultie; and ingender a clammie, pituitous, and colde nutriment if they be eaten. To conclude, fewe of them are good to be eaten; and moft of them do fuffocate and ftrangle the eater. Therefore I giue my fimple aduice vnto thofe that loue fuch ftrange and newefangled meates, to beware of licking honie among thornes, leaft the fweetenes of the one do not counterwaile the fharpnes and pricking of the other.

Fuffebals 


\section{HISTORIE OF PLANTS.}

Fuffebals are no way caten, the powder of them doth dry without biting; it is fitly applied to B

In diuers parts of England where people dwell farre from neighbours, they carie them kindled C
with fire,which lafteth long; whereupon they were called Lucernarum Fungi The duft or powder hecrof is very dangerous for the Lucernarum Fungi.

uers haue beene poreblinde cuer after, when fome fmall quantitie heene often feene that di-D into their eies.

The countrey people vfe to kill or fmoother Bees with thefe Fuffebals, being fet on fire, for the $E$ which purpofe it fitly ferueth.

Of the temperature of Fuffebals we finde little, and that briefly fet downe, and that it is moift $F$ Virgil in his firft booke of Georgickes doth write, in a forewarning, when he reckoneth vp the fignes that go before raine:

Tum Cornixplena pluuiam vocst improba voce, Et fola in ficca fecum /patiatur arena: Nec nocturna quidem carpentespen fa tuelle Nefciucre hyemem: teft a ciom ardente viderent Scintillare oleum, of putres concrefcere Fungos. Then with a full call all alone

A fturdic Crowe raine doth demand,

virg. And hauing befide hirfelfenone,

Georg. She iets vp and downe the dry fand:

lib.1. And maidens which * night tasks do handle,

A winterly ftorme haue foreknowne, When fparkle they marked the candle:

* Pinching the flaxe And vp rotten Murhrums be growne.

\section{Of great Tootbwoorth, or Clownes Lungwoort. Chap.i63.}

I Dentaria maior Mathioli.

Great toothwoort, or Lungwoort.

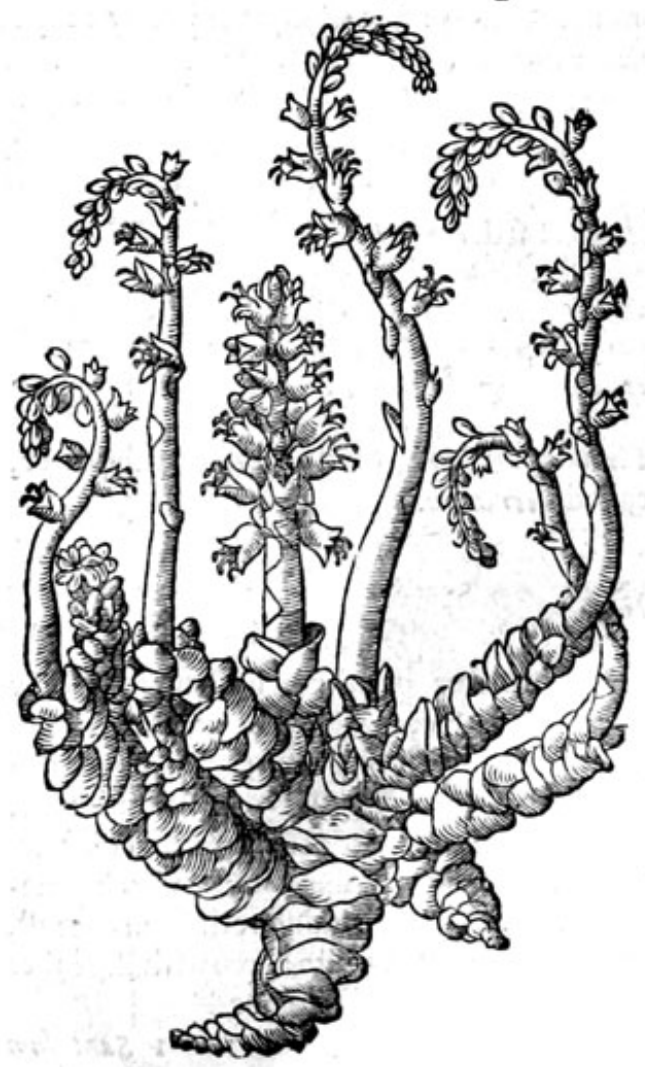

2 Dentaria minor.

Little Lungwoort.

\& t The 


\title{
$*$ The defcription.
}

I Here is often found among the Mufhrums a certaine kinde of excrefcence, confifting of a iellie, or foft fubftance, like that of the Mufhrums, and therefore may the more fitly be heere inferted: it rifeth foorth of the grounde in forme like vnto Orobanche, or the Broome Rape, and alfo in fubftance, hauing a tender, thicke, tuberous, or mifhapen bodie, confifting as it were of fcales like teeth (whereot it tooke his name) of a duftie fhining colour, tending to purple. The italke rifeth vp in the middle, garnifhed with little gaping hollow flowers, like thofe of Satyrion; on the outfide of an ouerworne whitifh colour,dafht ouer with a duftie purple, and within the hollownes thereof, of a darke blackifh colour: the whole plant refembleth a ruce forme of that gel. lie, or flimie matter, founde in the fieldes, which wecall the falling of ftars: the roote is fmall and tender.

2 There is alfo another fort heereof founde, not differing from the precedent: the chiefe difference confifteth in that, that this plant is altogither leffer; in other refpects like.

\section{* The place.}

Thefe plants do grow at the bottome of Elme trees, and fuch like, in hadowie places :I found it growing in a lane called Eaft lane, vpon the right hande as yee go from Maidftone in Kent vnto Cockes Hoath, halfe a mile from the towne; \& in other places thereabout : it doth grow alfo in the fieldes about Croidon, efpecially about a place called Groutes, being the lande of a workhipfull Gentleman called Mafter Garth: and alfo in a woode in Kent ncere Crayfoord, called Rowe or Rough hill:it groweth likewife neere Harwood in Lancalhire, a mile from Whanley, in a wood called Talbot banke.

They flourifh in Maie and Iune.

$$
\text { * The time. }
$$

$$
\text { * T be names. }
$$

There is not any other name extant, more then is fet foorth in the defcription.

$$
\text { * Thetemperature and vertues. }
$$

A There is nothing extant of the faculties heereof, either of the ancient or later writers: neither haue we any thing of our owne experience; onely our countrey women do call it Lungwoort, and do vfe it againft the cough, and all other imperfections of the lungs : but what benefit they reape therety I know not; neither can any of iudgement giue me further inftruction thereof.

\section{OfSaunders. Chap.164.}

\author{
* The kindes.
} Te ancient Greekes haue not knowne the forts of Saunders: Garcius and others defcribe three,
Album, Rubrum, and Pallidsem : which in fhops is called Citrinum.

\section{$*$ The defcription.}

1 He Saunders tree groweth to the bignes of the Walnut tree, garnifhed with many goodly braitches; wheron are fet leaues like thofe of the Lentisk tree, alwaies green;among which come foorth very faire flowers, of a blew colour tending to blacknes; after commeth the fruite, of the bignes of a Cherrie, greene at the firft, and blacke when it is ripe; withour tafte, and readie to fall downe with cuery little blaft of winde: the timber or woode is of a white colour.
2 The fecond fort differeth not from the precedent, but in the colour of the woode, which generally of thefe trees are neere of colour, yet fom redder then others, wherin it differeth from the reft.

There is likewife another which groweth very great, the fowers and fruite agree wirh the other of his kinde: the woode is of a yellowifh colour, wherein confifteth the difference. 
1 Santalum album.

White Saunders.
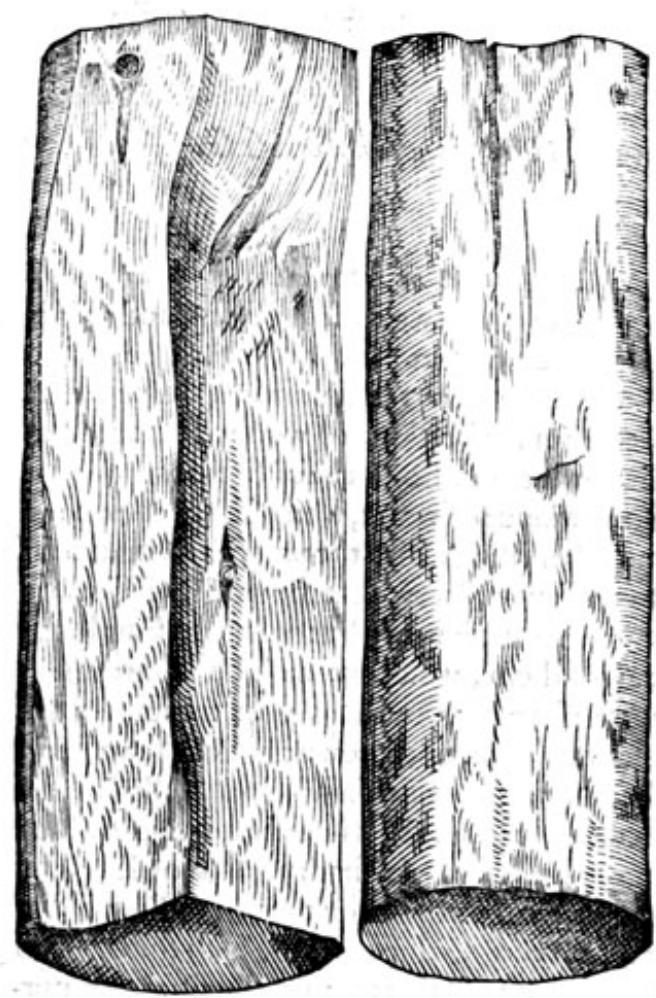

2 Santalum rubrum.

1389 Red Saunders.

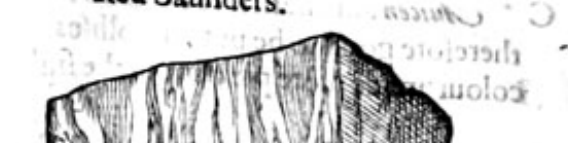

$\circ$

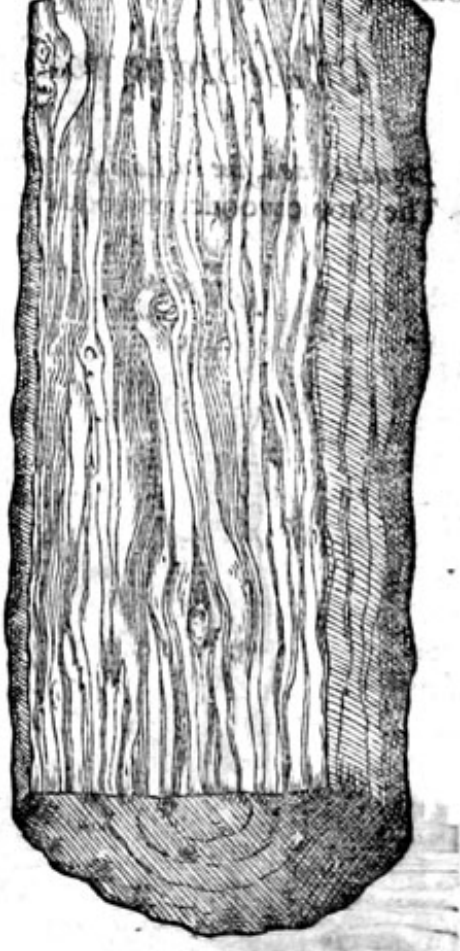

* The place.

The white and yellow Śaunders grow naturally, and that in great abundance, inan Ilandcalled Timor,and alfo in the Eaft Indies beyond the riuer Sanges or rather Ganges, whichthe Indians call Hanga, and alfo about Iaua, where it is of better odor then any that groweth elfe where.

The red Saunders groweth within the riuer Ganges, efpecially about Tanafarim, and in the marrifh grounds about Charamandel: it groweth far diftant from thefe places, that is to faie, in moft parts of Brafile: Auicen, Serapio, and moft of the Mauritanians, call it by a corrupt name Sandal: in Timor Malaca, and places neere adioining Chandama, in Decan and Guzarate Scrcanda : in Latine Sanda'um, and Santalum, adding thereto for the colour album, flaum, or Citrinum, and rubrum, red, white, and yellow.

\section{* The time.}

Thefe trees grow greene winter and fommer, and are not onie knowne from another, but by the Indians themfelues, who haue taken,very certaine notes and markes of them, bicaufe they may the more fpeedily diftinguifh them when the Mart commeth.

$$
\text { * The names. }
$$

Their names haue beene fufficiently fpoken of in their defcriptions.

$$
\text { 2. The temperature. }
$$

Saunders is colde in the firft degree vnto the thirde, and dric in the fecond. The red Saunders is fomewhat colder.

$$
\text { * The vertues. }
$$

The Indians do vfe the decoction made in water, againft hot burning agues, and the ouermuch $\mathbf{A}$ flowing of the menfes, Erifpelas, the gout, and all inflammations efpecially if it be mixed with the iuice of Nighthade, Houfleeke, or Purflane. 
B The white Saunders mixed with Rofe water, and the temples bathed therewith,ceafeth the pain of the megrim, and keepeth backe the flowing of humors to the eies.

C Auicen affirmeth it to be good for all paffions of the hart, and maketh it glad and merrie, and therefore good to be put in collifes, iellies, and all delicate meates which neede to haue their colour made more pleafant to the fight.

\section{Of the Stonie wood, or woodemade.Stones. Chap.166.}

Ligna lapidea, fiue in Lapides conuer $\int a$.

The Stonie woode, or woodemade ftones.

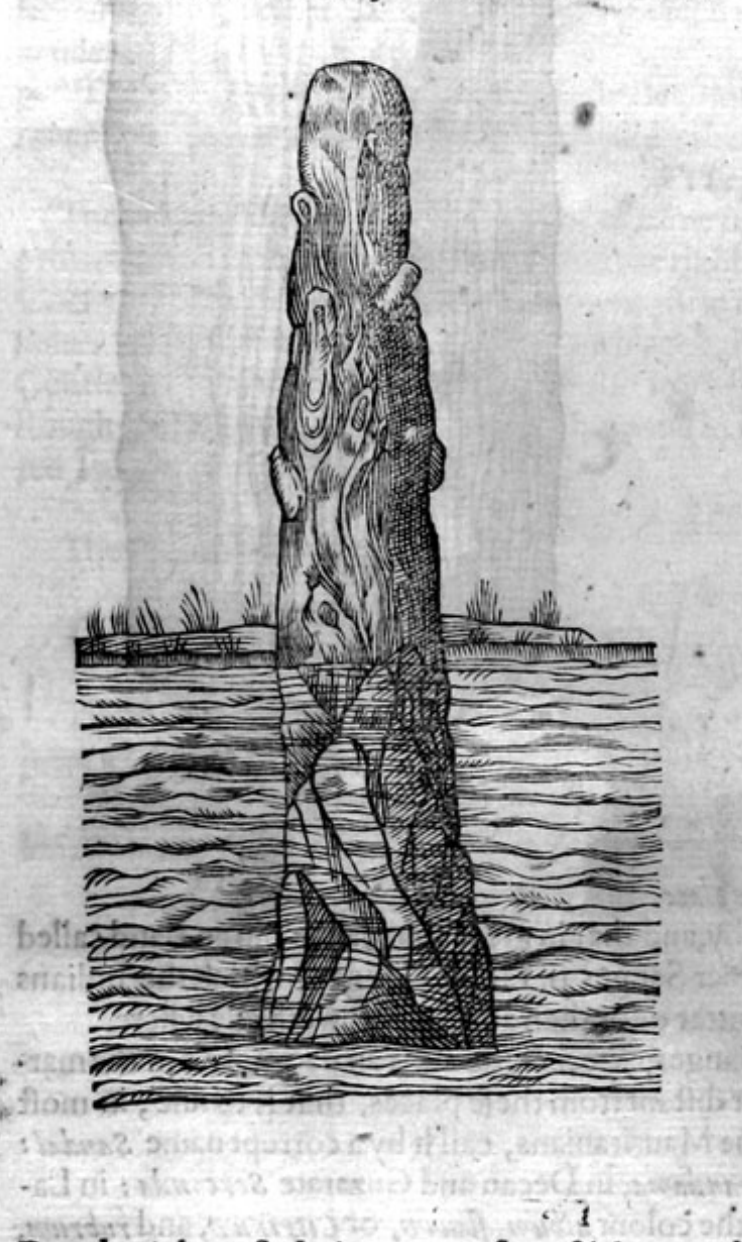

* T he defcription.

Mong the woonders of England this is one of great adiniration, and contrarie vnto mans reafon and capacitie, that there fhoulde be a kind of wonde alterable into the hardnes of a ftone called Stonie woode, or rather a kinde of water, which hardneth woode and other things, into the nature and matter of ftones. But we know that the works of God are woonderfull, if we do but narrowly fearch the leaft of them, which we dailybeholde; much more if we turne our eies vpon thofe that are feldome feene, and knowne but of a fewe, and that of fuch as haue painfully trauelled in the fecrets of nature. This ftrange alteration of nature is to be feene in fundry parts of England and Wales, throwgh the qualities of fome waters and earth, which change fuch things into ftones as do fall therein; or which are of purpofe (for triall) put into them. In the north part of Englande, there is a Well neere vnto Knaesborough, which will change any thing into ftone, whether it be wood, timber, leaues of trees, moffe, leather gloues or fuch like. There be diuers places in Bedfordfhire, Warwick?hire and Wales, where there is ground of that qualitie, that if a ftake be driuen into it, that part of the ftake which is within the ground will be a firme and hard ftone, \& al that which is aboue the earth retaineth his former fubftance and nature. Alfo my felfe being at

Rougby (about fuch time as our fantafticke people did with great concourfe and multitudes, repaire and run headlong vnto the facred Wels of 2 ewnam regis, in the edge of Warwickfhire, as vnto the water of life, which could cure all difeafes ) I went from thence vnto thefe Wels, where I founde growing ouer the fame a faire Afh tree, whofe boughes did hang ouer the fpring of water, whereof fome that were feare and rotten, and fome that of purpofe were broken off, fell into the water,\& were all turned into ftones. Of thefe boughes or parts of the tree, I brought vnto London, which when I had broken in peeces, therein might be feene that the pith and all the reft was turned into ftones; yea many buds and flowrings of the tree falling into the faide water, were alfo turned inta hard ftones, ftill retaining the fame ihape $\&$ fafhion that they were of before they were in the water. I doube not but if this water were prooued about the hardning of fome kinde of confections Phificall, for the preferuation of them, or other fpeciall ends, it would offer greater occafion of admiration for the health and benefite of mankinde, then it doth about fuch things as already haue beene experimented, tending to very little purpofe. 


\section{HISTORIE OF PLANTS. Of the Goofe tree, Barnakle tree, or the tree bearing}

Britannice Conche anatifere.

The breede of Barnakles.

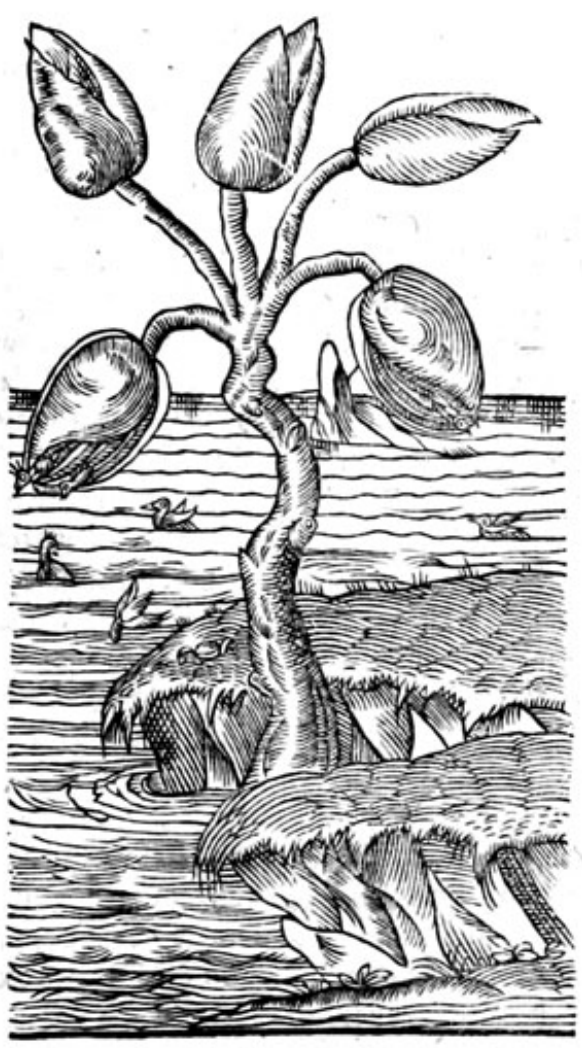

* The defcription.

Ting Auing trauelled from the Graffes growing in the bottome of the fenny waters, Lib the wogds, and mountaines, euen vnto Libanus it felfe; and alfo the fea, and bowels of the fame:we are arriued to the end of our Hiftoric, thinking it not impertinent to the conclufi. on of the fame, to end with one of the marucls of this land (we may fay of the world.) The Hi. ftorie whereof to fet foorth according to the woorthines and raritie thereof, woulde nor onely require a large and peculiar volume, but alfo a deeper fearch into the bowels of nature, then my intended purpofe wil fuffer me to wade into, my infufticiencie alfo confidered; leating the hiftorie thereof rough hewen, vnto fome cxcellent men, learned in the fecrets of nature, to be both fined and refined: in the neane fpace take it as it falleth out, the naked and bare truth, though vnpolifhed. There arefounde in the north parts of Scotland, \& the Ilands adiacent, called Orchades, certaine trees, whereon doe growe certaine fhell filhes, of a white colour tending to ruffet; whercin are conteined little liuing creatures: which fhels in time of maturitie doe open, and out of them grow thofe little liuing things; which falling into the water, doe become foules, whom we call Barnakles, in the north of England Brant Gecfe, and in Lancafhire tree Geefe : but the other that do fall vpon the land, perifh and come to nothing: thus much by the writings of others, and alfo from the mouths of people of thofe parts, which may very well accord with truth.

But what our eies haue feene, and hands haue touched, we fhall declare. There is a fmall Ilande in Lancafhire called the Pile of Foulders, wherein are found the broken pecces of old andbrufed fhips, fome whereof baue beene caft thither by fhipwracke, and alfo the trunks or bodies with the branches of old and rotten trees, caft vp there likewife: wheron is found a certaine fpume or froth, that in time breedeth vnio cer taine fhels, in fhape like thofe of the muskle, but fharper pointed, and of $\mathbf{2}$ whitifh colour; wherein is conteined a thing in forme like a lace of filke finely wouen, as it were togither, of a whitifh colour; one ende whereof is faftned vnto the infide of the fhell, cuen as the filh of Oifters and Muskles are; the other ende is made faft vnto the belly of a rude maffe cr lumpe, which in time commeth to the fhape \& forme of a Bird : when it is perfectly formed, the fhel gapeth open, \& the firft thing that appeereth is the forefaid lace or ftring; next come the legs of the Birde hanging out; and as it groweth greater, it openeth the fhell by degrees, till at length it is all come foorth,and hangeth onely by the bill; in fhort fpace after it commeth to full maturitic, and falleth into the fea, where it gathereth feathers, and groweth to a foule, bigger then a Mallard, and leffer then a Goofe; hauing blacke legs and bill or beake, and feathers blacke and white, fpotted in fuch maner as is our Magge-Pie, called in fome places a Pie-Annet, which 
the people of Lancalhire call by no other name then a trec Goofe; which place aforefaide, and all thofe parts adioining, do fo much abound therewith, that one of the beft is bought for three pence: for the truth heer of, if any doubt, may it pleafe them to repaire vnto me, and I thall fatisfie them by
the teftimonie of good witnefles.

Moreouer, ir fhould feeme that there is another fort heerof; the Hiftorie of which is true, and of mine owne knowledge: for trauelling vpon the fhores of our Englith coalt betweene Douer and Rumney, I founde the trunke of an olde rotten tree, which (with fome helpe that I procured by filhermens witues that were there attending their husbandes returne from the fea) we drewe out of the water vpon dry lande: on this rotten tree I founde growing many thoufandes of long crimfon bladders, in thape like vnto puddings newly filled before they be fodden, which were verie cleere and fhining, at the neather end whereof did grow a ihell fifh, fafhioned fomwhat like a fmall Muskle, but much whiter, refembling a fhell firh that groweth vpon the rocks about Garnfey and Garfey, called a Lympit: many of thefe fhels I brought with me to London, which after I had opened, I founde in them liuing things without forme or fhape; in others which were neerer come to ripenes, I found liuing things that were very naked, in Phape like a Birde; in others, the Birds couered with foft downe, the fhell halfe open, and the Birde readie to fall out, which no doubt were the foules called Barnakles. I dare not abfolutely auouch euery circumftance of the firft part of this Hiftorie concerning the tree that beareth thofe buds aforefaide, but will $/$ aue it to a further confideration : howbeit that which I haue feene with mine eies, and handled with mine handes, I dare confidently auouch, and boldly put downe for veritic. Nowe if any will obiect, that this tree which I fawe might be one of thofe before mentioned, which either by the waues of the fea, or fome violent winde, had beene ouerturned, as many other trees are; or that any trees falling into thofe feas about the Orchades, will of themfelues beare the like foules, by reafon of thofefeas and waters, thefe being fo probable coniectures, and likely to be true, I may not without preiudice gainfaie, or indeuor to confute.

\section{* The place.}

The bordes and rotten plankes whereon are found thefe fhels, wherein is bred the Barnakle, are taken vp in a fmall Iland adioining to Lancafhire, halfe a mile from the maine land, called the Pile of Foulders.

* The time.

They fpawne as it were in March and Aprill; the Geefe are formed in Maie and Iune, and come to fulneffe of feathers in the moneth after. And thus hauing through Gods affiftance, difcourfed fomewhatat large of Graffes, Herbes, Shrubs, Trees, Moffes, and certaine excrefcences of the earth, with other things moe incident to the Hiftoric thereof, we conclude and ende our prefent volume, with this woonder of England. For which Gods name be euer honored and praifed.

\section{The end of the third and laft Booke of the Hiftorie of Plants.}




\section{INDEX LATINVS COPIO. SISSIMVS STIRPIVM IN HOC OPERE I. GERARDI
DESCRIPTARVM}

A

A Abies Abig a

Abrotanum

Abrotankm inodorrum

Abrotanum campestre

Abfontbium rusticum

cenuifolum, feu Roma-

num 939

Abfintbium latifolism frue Ponticum

pag. $\quad 937.938$

A 1 fomthium tenuifolium Ponticum

Goleni

937

Abfintbium marivium

941

A Abfutbium marinum album 940

Abfinthium marinum latifolivm ibid.

Abfintbium arborefcens. Wist 943

Abfmthium Agrptism ibid.

Abfmthium inodcrum 945

Abfinthium marinum, Abrotani fae-

- mina facie.

\section{4}

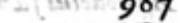

Acantbus fylueftris $\quad 987$

-Acanthium album $\quad 988$

Acanthium Illyricum perpureñ ibid.

Acacia ह $\angle \mathrm{Q}$ है

Acacia Dig/coridis wevels 11 49

Acacia aliera mid.ungo

Acacia Pontica watagnd ribid.

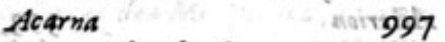

Acarna Theopbrafi , 1012

Acarna Walcrands Donrez ibid.

Acer wasit 2 whls 1300

Acer mation wath if und mil jibid.

Acer minor

Acctabulum

Acetofa tuberofa

eschillea 0

Acbillea Sideritis

niver ibid.

424

1.า 321

914.915

Accipitrina tath mingh $\% \operatorname{lol}_{2} 36$

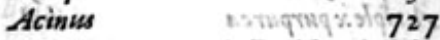

Ptronitum witukl 8 ig

Acanitwm Batracbioides wes $t$ i 808

Aconitsm byemale ziwrot z s 819

Aconitum falutiferum wise 820

Aconitum luteum Ponticü $82 \mathbf{2}_{12} 8_{22}$

Aconitum bacciferum $\quad 829$

Acorena

Acpriss paluftris

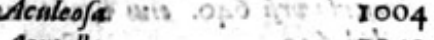

Acuiclla

I 42
Acylum

Acymos

Adiantum

Adiantum candidum

Adiantum nigrum

Adiantum asreum

Adonis flos, etr $\int g_{3}$ varietas

Ador

Adoreum

Agaricus vel Agaricum

efgilops

Egilops Narbonen/is

Agilops. Bromoides

efgiprus

Agitis

efganscbon

Et Elbiopis

Etitis

Agrifolium

Ageratum

Aglaophot is

Agnies caft us

Agrimonia

Agrimonia fylueftris

Agriocaftanon

Agrioriganum

Ainga

Alabafri Rofarum fuecalyces 108

Alitiernus

Alaternus Plini

Alaternus bumilior

Albarus

Albinum

Alonerm

Albucus

Alcea:

Alcea peregrina

Alcea veficaria

Alcibiadion

Alchimilla $\mathrm{C}$

Alectorolopbos:

Alga palustris

Alimonia

Alifma

Altharia

silliwm

Allium fyluestre

Alition vrfintm

Allium anguinum

Allium ceruinum

Alliwm alpinsin latifolium

Alliuminon bulbofum

Ainus is

Alous nigra

Aloe mucronato folio

Alopecuros
1160

549 Alfme maior minor, 491

timima 488

ibid. Allid.

975.983 Alfine folys Veronice cum $4^{89}$

1171 pec.

310 Alfine fon ibid.

62 Alfine flumiatilis 490

ibid. Alfinc palufris $49 \mathrm{I}$

I 84 Alfine folys Triffaginis $\quad 492$

1163 Alfine corniculataClusiy ibid.

Alfine Hederacea 493

Alfine Hederwla altera ibid.

Alfine fyluatica $\quad 85$

eAlibea 789

Alrbea frutex Clusin क 788

Althea arborefcens sbid.

495 Alibea paluftris $\quad 787$

II55.1156 Althealbifcus $\quad 787$

$5^{24}$ Alibealutea "tis

832 ealus Gallica $\quad 66 x$

I 20x Alypummontis Ceti 408

575 Alyous Pliny $\quad 966$

84 Alyfum $\quad 380$

906 Alyfum Galeni $\quad 379$

$54^{2}$ Alyffum Germanicum kibid.

422 Amaracus savirus 539

Amaradulcis stu 279

AmantillaValentiana to 8

Ambrofis $536.950 .95 \mathrm{I}$

Amarantbus $\quad 254.255$

Amaranthus tricolor in? illicibid.

Amaranthus coccineses illid 254

Amarantbus pannicula fparfa ibid.

Amaram bu luteus Fuchsij of Tragi

- 521.522 .

Amaranthus Galens $\quad 1522$

Amedanus 1294

Amellus marinus $\quad$ ititis 334

Ammi 882

Ammivalgare $\quad 88$ t

Ammi Creticum ibid.

Amomum Plini $\quad 289$

Ampelos agria $\quad 723$

Amygdalius : 1.) unsas 1256

Amygdalum ibid.

Anyleum frumentum $\quad 63$

Anabafis 958

Anacardium $\quad 1360$

ibid. Anagallis 100 495

ibid. Anagallis mas of farmina 494

650 Anagallis lutea Mbid.

1294 Anagallis agwatica : $\quad 496.497$

286 Anagallis aguatica minor nibid.

409 Anagallis agnatica minor flore pallido

81.370 ibid

Aanaty

Anagris 
Anagyris

Anagyris fotida

Anchomanes

Ancbusa

Anchufa Alcibiadion

Ancbifalutea

Androface CMatbioli

Androface annua $\int p u r i a$

Androfemum

Anemone tuberofa radice

Anemone coccinea wultiplex

Anemone Bolbocaftani radice

Anemone lanifolia Clusiy

Anemone maxima Chalcedonica po-

lyanthos

- Anemone geranifolia

Anemone CMathioli

Anemone trifolia

Anemone papaseracea

Anemonum varietates

Anethum of Anetum

Anetbom tortuofum of fluefre 8

Angelica

Angelica fatima

Angelica fylwestris

Anfwom

Anonis

- ibid.

304

ibid.

305

ibid.

878

95

847.

846

847

880

Anonis flore albo

II 41.1142

$114 \mathrm{I}$

Anonis non pinofapurparea 1142

Anonis lutea

Anoniymos

Anferina

Anteupborbium

Antherisis

Anthericos

Antbora

Antbos

Anthropomorphos

Antbylis

Anibyllis lentifolia

Antbyllis leguminofa

Anthyllis Valentina Clusy

Antipathes

Antimbinwm 439. cinsgarvarieta-
tes

Antirrhinum minus

Antopbylli

Antura

Aparine

Aparina maior Pliny

Aphaca

Aphace

flos Pliny ibid.

Apiastellum $\quad 720$

Apiastrum

Apios

Apios vera

Apium

Apium rifuss

$\begin{array}{lr}\text { Apium rifus } & 309 \\ \text { Apium hortenfe 86t an Petrofeli- } & \end{array}$

num

560

906

407

862

ibid.

Apium cripum fiue multifidum 861

-Apium paluftre vel rufticum 862

\section{N D $\mathrm{E} \quad \mathrm{X}$.}

Apitum aquatile

Apium montanum

862.867

863

866.867

512.591

1218

283

730

734

ibid.

936

935

936

935

936

207

1359

Arabis

Arachidna

Arachus

1053.1054

1359

Arbor vite

1187

1331

1247

1307

Arbor Thurifera

Arbor CMirobalanorwm

1220

1342.1343

Arbortriftis

Sycomoris 16 .

Arbutus

1310.1311

Arcium

Areca fine Fanfel

665

1337

Argemone

Argemonia

ibid.

Argemone capitulo tormlo ơc. 500

Argentina

841

Aria Theophrafti

Aris

Arifarum

Arifarum latifolium

1146
687

ibid.

Arifarum angustifolium ibid.

Arefarum Latifoliom Masbioli 687

Aristolocbia

687
698

Aristolocbia Clematis $\quad 697$

Aristolochia longa o mas 698

Ariffolocbia retunda of famina ibid.

Armeniacum 1261

Armeria $479 \cdot 4^{81}$. einu varietas 478.479

Armeria rubra latifolia

Armeria fuaue rubens

479

Armerim fos primus Dodonci 48

Armerius flos tertives

Armoracia $\quad \mathbf{8 6 6 . 4 8 1}$

Armoraria $\quad 4^{81}$

Armoraria pratenfis mas of famina pag. $\quad 480$ Armoraria fluestris $\quad 48 \mathrm{r}$ $\begin{array}{lr}\text { Arnoglofa } & 34^{\circ} \\ \text { Aronia } & 683.1266\end{array}$

Arfela

Artemifia

683.1266
301

Artemisatenuifolia $\quad 527.945$

Artemifamarina 219.946

Artbreticaberbe

219.946

Arum

Aram maius of minus
Arundo

Arundo Crpris

Arendo donax

Arundo fcriptoria

Arundo Saccharina

Arundo florida

Arundo Indica

Arundo Litbopermos

Afarina CMatbioli

Afarum

Asclepias

Afclepias flore albo

Afclepias flore nigro

AfGlepias Virginiana

Afcolymbros

Afcyron o $A$ cyroides

Apalatbum

Aparagus

Apparagus fatiums

Aparagus paluftris

Aparagus petraus

Aparagus fyluestris

Aparagus flueftris pinofies Clusy

pag. $\quad 954$

Aperula of Apergula odorata 966

an Alyfos Pliny ibid.

Aphodelus

86.87

Appodelus minor

Appodelus luteves

Aphodeluspalustris

Apbodelus Lancastrie

Apphadelus bulbofies

Appodelus by acintbinus

Aphodelus famina

Aplenism

Aplenium fluestre vel

Aprella

958

Aster marinus $\quad 334$

AfrenAticus $\quad 392.393 .428$

After Italorum $\quad 392$

Aftermontaniw

Alterbirfusus at ibid.

Asterion $\quad 393$

Alferifcon

Aftragalus 1059

Aftragalum Syriacus $\quad 1058$

Aftragalus Lufinanicus Clusy ibid.

Altrantia $\quad 849$

Altrantia nigra $\quad 828$

Aibanafia 526

Atraltylis $\quad 1008.1009$

Airiplex 257

Airiplex fatima alba $\quad 256$

Atriplexparparen ibid.

Atriplex fyluestris $\quad 257$

Airiplexmarina 1 itits on ibid.

Acriplex fatida $\quad 25^{8}$

Amena vefora $\quad 68$

Asena nuda ibid.

Anena fatma $\quad 69$

Awornus $\quad 1286$

Aurclia $\quad 520$

Asricula vr/1 640 . nims varietates

ibid. $64^{2}$

* Anriculo 


\begin{tabular}{|c|c|c|}
\hline $\begin{array}{ll}\text { Iericula vr/a 2. Clusi } & 64 \mathrm{~T} \\
\text { furicula vr/i rubefcens } & 642 \\
\text { uricala vrfi minima } & \text { ibid. } \\
\text { uricula muris } & 514\end{array}$ & $\begin{array}{l}653 \\
\text { ibid. } \\
\text { ibid. } \\
\text { ibid. } \\
0.951\end{array}$ & 858 \\
\hline 608 & Briffica & 992 \\
\hline $\begin{array}{l}648 \\
391\end{array}$ & Braffica leporina & lamintha monta \\
\hline $\begin{array}{r}391 \\
647\end{array}$ & $\begin{array}{l}\text { algaris fatiana } \\
\text { inacriffa }\end{array}$ & $\begin{array}{l}\text { Calaminaba monto } \\
\text { Calamogrofis }\end{array}$ \\
\hline $\begin{array}{l}665 \\
\text { glans } 2 n-.\end{array}$ & $\begin{array}{l}\text { ibid. } \\
\text { ibid. }\end{array}$ & $\begin{array}{l}\text { Calamus Perwnianns of } \\
\text { pag. }\end{array}$ \\
\hline $\begin{array}{l}1214 \\
1262\end{array}$ & ibid. & $\begin{array}{l}\text { Calamus fagintalis } L O \\
\text { Calimus Sagebaratos. }\end{array}$ \\
\hline 291 & 246 & Calamnes aromaticies of \\
\hline $\begin{array}{r}290 \\
\text { bid.29I }\end{array}$ & chofa & 35 \\
\hline $\begin{array}{r}\text { bid.291 } \\
291\end{array}$ & bavda & dotis \\
\hline $\begin{array}{l}291 \\
\text { alfamina cucrmerina } \\
\text { alfamina amygdaloides }\end{array}$ & $\begin{array}{l}\text { afica Sabanda crifpa } \\
\text { offica marima Anglica }\end{array}$ & $\begin{array}{l}\text { Is } \\
\text { Is nowltiflorat }\end{array}$ \\
\hline ibid. & ia & ibid. \\
\hline $\begin{array}{r}523.524 \\
523\end{array}$ & -755 & $\begin{array}{l}\text { La multifiorat } \\
\text { la fimplici fos }\end{array}$ \\
\hline 1345 & res & 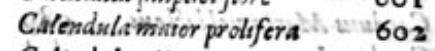 \\
\hline Fittus & & \\
\hline 596 & & \\
\hline$a$ & ibid. & $7 \quad 20$ \\
\hline 665 & 18 & 33 \\
\hline 664 & Brita & 983.98 \\
\hline 547 & $B \dot{n}$ & \\
\hline 428 & alba & itarum \\
\hline $\begin{array}{l}805 \\
806\end{array}$ & nigra & $\begin{array}{l}\text { lericama } \\
\text { ffris }\end{array}$ \\
\hline $808.8 \mathrm{II}$ & ax 393 &. \\
\hline $\begin{array}{r}667 \\
509\end{array}$ & $\begin{array}{l}924 \\
\text { num domefricat } 655\end{array}$ & 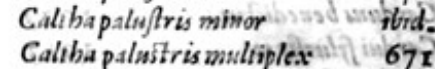 \\
\hline varietas & and ibrd. & \\
\hline SI & Bingloffa folineftris & armen is \\
\hline 3 & Bugloffum int esm & lea \\
\hline & 5 & v $4 x=$ \\
\hline $\begin{array}{l}\text { ibid. } \\
\text { si1 }\end{array}$ & la flor & $\begin{array}{l}\text { Campanula } \\
\text { Campanula perficifolia }\end{array}$ \\
\hline $\begin{array}{l}5^{11} \\
512\end{array}$ & $\begin{array}{l}\text { Bugula flore al } \\
\text { Bulbies ef culen }\end{array}$ & $\begin{array}{l}\text { Campanula perficifolta } \\
\text { Campanulis latiefcens } p\end{array}$ \\
\hline 251.25 & omitoritus & \\
\hline $\begin{array}{l}57 \\
57\end{array}$ & Errophoriss & la rots \\
\hline 57 & inis 107 & inifolia \\
\hline 57 & cflis & \\
\hline & ieflris & a \\
\hline & Ieflris & \\
\hline 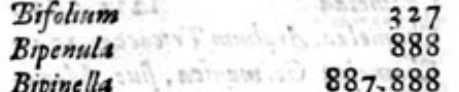 & mum & \\
\hline ella & 2 & b. \\
\hline 68 & Imum a & 57 \\
\hline 2 & & rum \\
\hline ibia & 485 & $c$ \\
\hline ibid & Brplenr: & \\
\hline lia & & a berba \\
\hline 0 & & ia \\
\hline areo & iami & \\
\hline 9 & & \\
\hline 9 & & 902.9 \\
\hline & & Cap: \\
\hline
\end{tabular}


Capnos

Capparis

Capparis rotundiore folio

Capparis fabago

Capparis leguminofa

Capriola

Capjella

Capficum

Cap foum longioribus filiquis

Capficum minimis fliguis

Caranum

Cardamine

- 203

Cardamine latifolia ibid.

Cardamine latton ibid.

Cardaminc alpina ibid.

Cardamomum

Cardamomigenera

Cardamium $\quad$ I88

Cardopatinm $\quad 996$

Cardwus $\quad 992$

Carduns Marie vellabtem 989

Cardutes Leucographus ibid.

Carduus Chryfantbemus 993.994

Cardures globofus

990

Carduns Chryfantbemus Peruanus

Pag.

Carduus niger

Cardums fe llatus

Cardum (olftitialis

Carduse Veneris

Carduus Fullonum

Carduns benedictus

Cardui fylueftres

Cardum ferox

Carduse viarum

Cardurus mu catues

Carduns lanceatus

Cordsus ecbinatw

Careum

Carex

Carum

Carica

Carlina

Carlina prior

Carlma altera

Carlina fylueftris

Carnabadion

Carphos

Carpinus

Carpobalfamum

Carthamus

Carthamus fyluefris

Caryopbyllata

Caryophyllata montana 993.995

998

1003

ibid.

1006

ibid.

1009

1013

1010

IOI

ibid.

ibid.

I0I 4

879

$4 \mathrm{I}$

ibid.

1328

995

996

ibud.

995

879

1027

I 296

1345

1007

1009

842.843

ibid.

Caryophyllat a alpina pentaphyllea ib.

Caryophyllataalpenagutata ibid.

Caryopbyllus

Caryophyllus fiorens

Caryophyllt veri Clusiy

Caryopbyllus multiplex

Caryophyllus maximus multiplex ib.

Caryophyllus Jegetwm

I 351

472

\section{I $\mathrm{N}$ D $\mathrm{E}$ X.}

Carropbyllus Mediterraneus 482 Caryophyllus marinus minimus $L^{\prime} O$. beliy

Caryopbyllus Indicus

ibid. 483

Caryopbyllus fyluestris

Caryophyllus virgineves

477

Caryopbyllus fy liveftris multiplex 474

Caryopinllus fylueftris fimplex ibid.

Caryophl. plumar. varietates 474

475

Caryophyllus möranus purpureus 475

Caryopbyllus montanus (lusy 476

Carjopbyllus Apbyllantbos ibid.

Caryophyllus bolostins

Caryopbllus boloftives arnen fis ibid.

Caryophyllus minor fylseftris folys la-

$$
\text { tioribus } 48 \mathrm{r}
$$

$\begin{array}{lr}\text { Cala } & 468 \\ \text { Cafra poëtica L'Obely } & 1110\end{array}$

$\begin{array}{ll}\text { Caffiantgra } & 1242\end{array}$

Cafjia fistula

Eafjilago

Cafjiavel Caffialignes

Cafjuthe 1349

Calfyrbar ibid.

Caftanea

Castanea equind

1253.1254

ibid.

Cataputiaminor

Catiaria berba

Cascon

Cauda equin a farmina

Casda muris

Cancalis

Cancalis albis floribus

Cancalis Hijpanica

Canalis

Casififora

Caulorapam

Canlorapum rotundum

Caulorapum longum

drina abies

Cedria

Cedrus

Cedrus Libani

Cedrus Ljcia

Cedriminores velbumiles 17.1192

Cedrus Pherenices velTar

Celitis

1171

Centaurium $\quad 436$

Centasurium paruum $\quad 437$

Centasrium parroum lut enm L'Obeliy pag.

Centasurimm magnum

437

Centauris

Centrunculius

Centuncularis

Cepa

ibid. Cepa agraria

Cepa alba

Cepa rubra

Cepulle

Cepa muris
611

479

ibud.

Cerafa

Cerafins

1323

Cerafus vulgaris ibid.

Cerafus pracox 1319

Cer ofus fer ibid.

Cerafus ferotina $\quad \mathbf{1} 320$

Ceráfus vno pediculo plura ibid.

Cerafus Hipanica o Gafconica ibid.

Cerafus multiflora fruct us edés 132 I

Cerafus mulsiflora pasciores frultus edens

ibid.

Cerafm axiam nigra of racemofa

pag.

1322

Cerajus racemofarubra ibid.

Cerafus nigra

1323

Ceratia flingua 1241 . an Acrides

S.Ioban.Baptist. ibid.

Ceratonia ibid.

Ceraunia $\quad 414$

Cerefolium $\quad 88_{3}$

Cerefolium vulgare $\quad 883$

Cerefolium magnom ibid.

Cereus Perwivanms fpingofus L Obely pag.

1015

Crintbe maior Wf $43 \mathrm{I}$

Cerintbe minor ibid.

Cerofolinm $88_{3}$

Cerrus $\quad 1163$

Cerrus majore glande $\quad 1162$

Cerrus minore glande

Ceruicaria 366

Cernicariamaior ibid.

Ceftrum Moriomis 42

Chamacerafous $\quad 1113.1323$

Chamaciffum

705

Chameciftus $\quad \mathbf{r 1 0 2}$

Chamecyparifius 952

Chamedaphe

748.1219

Cbamadrys 531.534

Chamedrys maior o minor 530

Chamedryslatifolia ibid.

Chamedrys fylwestris, ofparia ibid.

pag. 531

Cbamefilix marina eAnglica 98I

Chamegenifta Anglica 1132

Chamagenifta Panmonica ibid.

Chameiris anguffifolia of tennifolia pag.

52

Chamsitea fise falix pumila 1205

Chamelea 1215.1216

Chamelea, Arabum Tricoccos 1215

Chamelea Germanica, fiwe Meze-

reon 1216

$\begin{array}{lr}\text { Cbamaleagnus } & 1228\end{array}$

Cbameleon $\quad 996.998$

Chameleon albus $\quad$ I 169

Chameleon albus Diofcoridis 995

Chameleon niger $\quad 998$

Chameleon niger Salmanticenfss ibid.

Chamelence $\quad 667$

Cbamalinum perpufillum $\quad 447$

Chamamelum 616.615

Chame melum nudum odoratum ibid.

ibid. Chamamelum Romamum 616

37 Chanemelum Anglicum flore mul.

riplici 


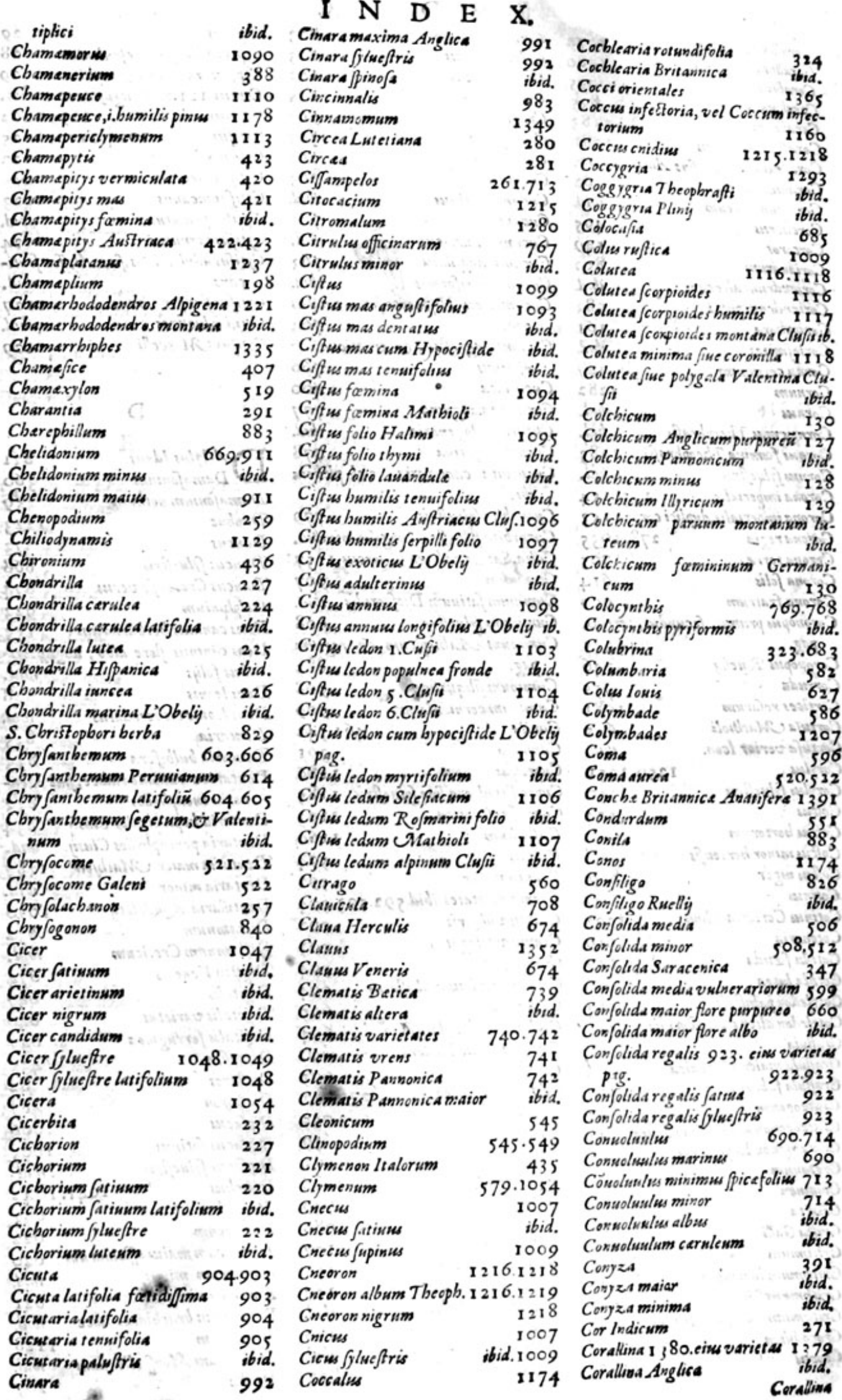




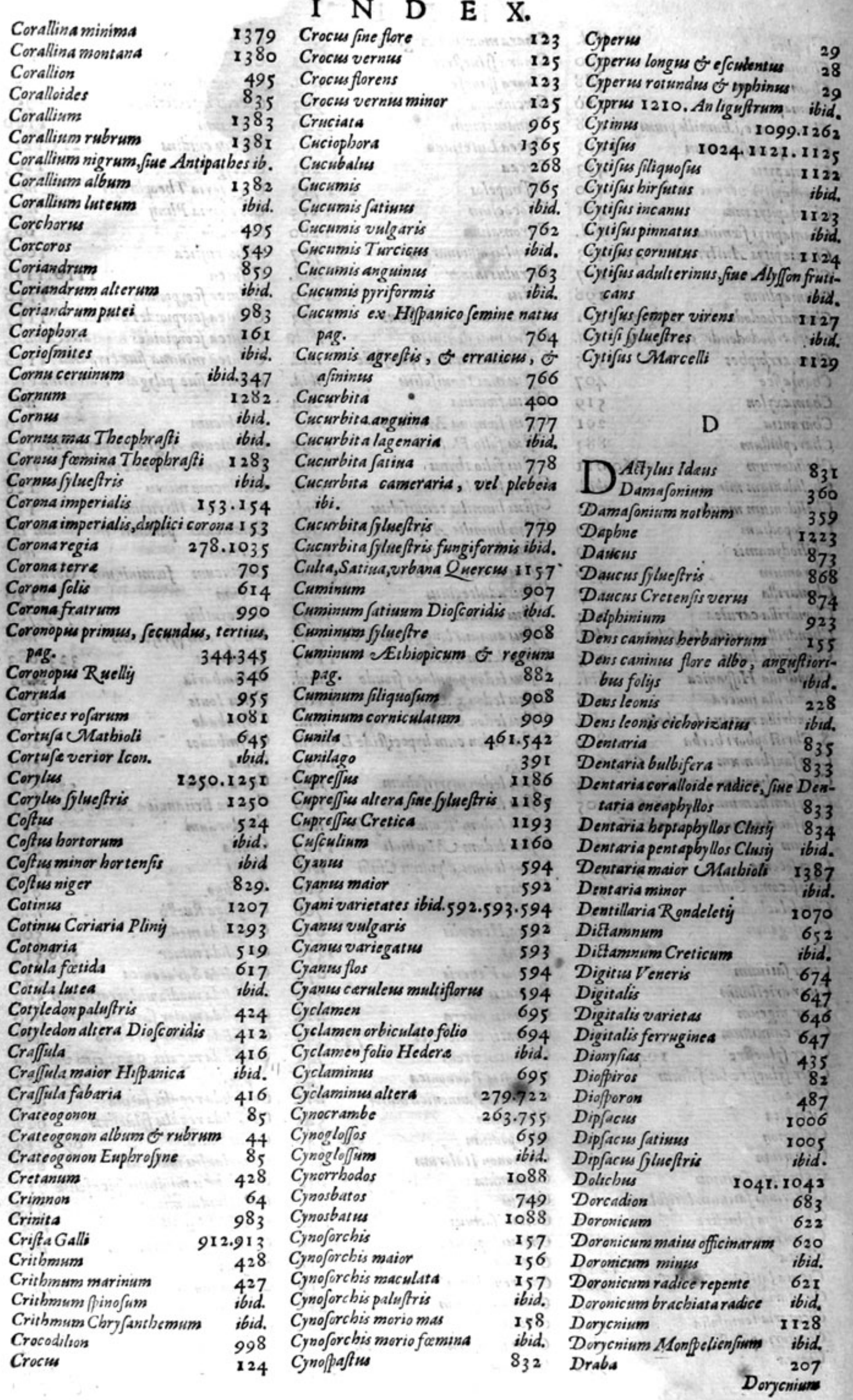




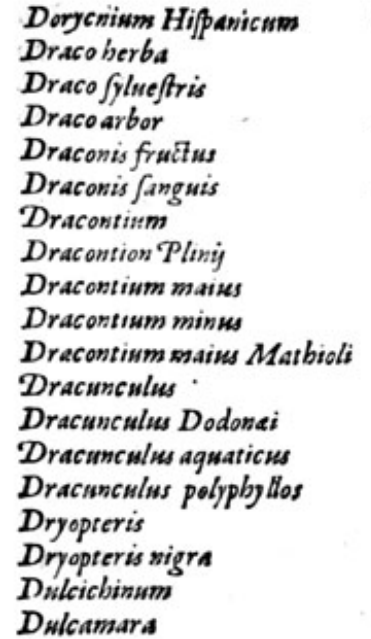

Dulcamara

E

E Bulus, of Ebulum
Echininaftrum
Elaphobofcum
Elatine

Elatine altera

Eleagnus

Eleagnus Cordi

Elephanto/is

Elleborine Alpina

Elleboraftrum

Eliochrpfon

Eliofelinum

Elyebnium

Elychinium

Emerios

Eminion

Empetron

Endiseia cripa

Eneapbyllon

En/is

Enula

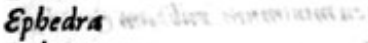

Ephemeron

Ephemerwan Matbioli

Epilinum

Epilobion

Epimaiorana

Epimedium

Epimelis

Epipactis

Epitbymum

Epitbymum Grecorim

Episbymbrum

Equapism

Equinalis

Equifetis

Equifetum

Equifetsmm mains

Equifetum nudum

Equifetum fegetale

Eguifetum paluftre

\section{I $N$ D $\mathrm{E} \quad \mathrm{X}$.}

1128 Equifetum fylmaticum

Eranthemsm

484 Erica

1339 Erica vulgaris, fue Pumila

Erica pumila alba

\section{7}

Faba AEgrptia

200 Fababorien/is

1196 Fabajylueftris

ibid. FabaGrecorsm

$134^{\circ}$ Erica major, flore parparante Clusy

683

pag.

Erica miaior flore albo

197
shd.

Fabafrefa, vel $F$

Fagi-truticum Fralta

Erica craciata

ibid. Ericapyramidalis

683 Ericatenaifolia

ibid. Erica tenuifolia caliculata

323 Ericabaccifera latifolia

683 Erica baccifera tenuifolia

ibid. Erigerum

974 Erigerumtomentofsm

975 Erigeron marinum

29 Eriocephalius

279 Eri/is

Eritbanon

Eruca fatiua

Eruca fyluestris

1238

795

658

871

sor

ibid.

1228

ibid.

665

803

607

520

862.867

625

ibic.

I1 57

68

429.455

221

327

96

649

958

130

395

462

388

539
389

389

803

803

462

459

462

866

958

ibid.

ibid.

955

955

956

Eruca fylueftris anguftifolia

bud. Fago-triticum

ibid. Fagus

ibid. Far

1198 Far halicaftrim

ibid. Farfugium

1199 Farranum

ibid. Fafelus

217 Fafelus Hircinus

ibid. Fafsolus

219 Febrifuga

990 Fegopprum

29 Filierre

1099 Ferrum equinum

191 Firula

ibid. Ferulago

Eraca cantabrica

216 Feftuca

Eruum fatiusm

ibid.

Eryngevel Engngism 1000 .

Eryngium bornficum

Eryngium montanum

1003

Feftuca I talica

Feftuca altera

Ficus

Ficus fatima

1002 Ficus Pharaonis

Eryngism planum, vel Alpinï 1003 Ficus Egyptia

Eryngium caruleum

100

Eryngium pumilü Cluf. 1002.1003

Eryngiwm/purium I.Dodonai $100 \mathrm{I}$

Ficus Indica

Filago

Eryngium marinum $\quad 999.1000$ Filago bumilis

416

1036

ibid.1037

ibid.

Eryngium CMediterranewm 999

Eryfimum

Eryfimum Diofcoridis

Filipendula

Eryfimum fylueftre

Erythrodanum

198 Filipendula angerfor

ibid. Filipendula cicure facie

Efula maior Germanica

Efula minor

Enonymus

Enonymus Theophrafti

Enonymus latifolia

Enonymus Pannonica

Enpatoria

Eupatorism

Espatorium Mefuse

Espatorium cannabinum

Eupatoriam adulterinum

Enpatorium Auicenne

Euphrafia

962 Filipendula aquatica

404 Filix

969.970

1286 Filix famina ibid.

1284 Frlix paluffris,vel aquatilis $97 \mathbf{x}$

ibid. Fillex latifolia ibid.

1295 Filix Querna $\quad 974$

575 Filicula 972.985

ibid. Filiculs fontana mas ơ famima 980

524 Filicula petraa mas of famina $98 \mathrm{r}$

574 Fiffularia 913

ibid. Flammula Lovisfurreits $74 \mathrm{r}$

ibid. Flos amoris 255

537 Flos regins $\quad 923$

Euplorafia carulea Tab. Mont. ibid. Flos T,gridis 107

Euphrafiaaliern $\quad 85$ Flos Cucmli 203.481

Euphorbium 1016.1014 Flos Adomis

Euphrofyne

Eupbrofynum

ExuperA

537.85 Flos bore

654 Flos Conffantinopolitanus

310

792

380

58 I Flos Calt

Flos Creticus

$38 \mathbf{x}$

F

Flos Hierofolymorum

ibid.

FAba

1036 Flos Ambarralis

${ }_{28}$ Flos S.lacobi

ibid. Flos caryopbyllews

416 Flos Meleagris

219

473

123

Flores 
Flores Armery
Flos awreus

Flos folis

Flos folis maior of minor

Flos folis minor mas of famina

Flos.Rofe.

Flos Cyanus

Flos Iunci

Flos frument orum

Flos Apbricanus

Flos Aphricanus maior polyanthos

$$
\text { pag. } 609
$$

Flos Apbricanus minor multiflorus pag.

610

Flos Apbricanus maior fimplici flore pag.

Fonum

Fenumgracsm 1026.1027

Fonumgracum fylueftre $\quad 1068$

Feniculus marinus $\quad 428$

Faniculum

Feniculum vulgare

Faniculum dulce

Faniculum tortwo fum

Fontalis

Fraga

Fraga fubalba

Fragaria

Fragaria vefoa jue fterilis

Frangula.

Fraxinella

Fraxinus

877

ibid.

ibid.

893

351

675

5.844

ibid.

844

845

1286

1065

1289

Fraxinus bubula fine magna 1290

Fraxinus fyluestris

Fraximus vulgaris

Fraxinus montasa

Frittillaria variegata

Frittillus

Fructus ficus Indice

Unde.

cim genera fructuum peregrinorü ibid.

Frumentum

Frumentum Afsaticum

Frumentum Turcicum

Frumenti Indici picas

Frumenti Indici varietates

Fucus berba

Fucus agreftis

Fucus marimus

Fuligo

Fumaria

Fumaric varietates

Fumaria tennifolia

Fumaria latifolia monor

- Fumaria alba latifolia

Fungi

Fungi arborei

Fungi lucernarsm

76

ibid 75

ibid.

$75 \cdot 76$

657

1009

1380

1179

930

927.928

928

929

ibid.

I 386

ibid.

I 385

Fungi vulgatifsimi efculcuti $\mathrm{I}_{3} 84$

Fungi lethales

ibid. I 385

Fungus orbicularis

I 285

Fungus virilis penis arrelie ibid.
I $N \quad D \quad E \quad X$.

Funis arborwm

Fufanum

$7 \mathrm{r} 4$

I 286

G

\begin{tabular}{ll} 
Galedragon Pliniy & 1006 \\
\hline Galega & 1068
\end{tabular}

Gallitricum

Gallitricum alterum

Galeop/is

Galeopfislutea

Galla arbor

Galla maior \& minor

Galla cum frudtu

626.627

626

568.579

627

1167

1165

1167

Gallarsm dinerfarum figure 1166 . I 167

Galli crus Apulei

Gallicentrum

Galliann

Gallivarietates

Galbuli

Garofmes garumo bely

Geminalis

Genefta

Genicularis

Genifta

Genifta Hifpanica

Genifta tenuifolia

Genifta ppinofa

Genif 1140

(

Genifta fpinofa flore albo 1139

Genifta pinofa bumilis ibid.

Genifta aculeata

1140

Genifta aculeata minor, five nepa

Theoplorafti

ibid.

Genifta tinctoria

1136

Geniftella tinltoria vel infectoria

pag.

Geniftella pinnata

1134

Geniftella globulate $\quad 1135$

Geniftella Lagopoidis maior of minor pag.

Gentiana

ibid.

Gentiana maior

Gentiana maior 2.Clmfit

Gentiana minor cruciata

352

$35 \mathrm{x}$

ibid.

Gentiana Pennei minor $35 \mathrm{I}$

Gentiana concaua

Gentianella Alpina 11 . Clufii 354

Gentiane lla alpina verna ibid.

Geranium

Geransum colnmbinum

796

Geranism alterum

793

Geranium Diofcoridis primum 794

Geranium tuberofum vel bulbofam ibid.

Geranism mofchatum

Geranisum batracbioides

796

Geranium batrachioides album 797

Geranium Creticum 798

Geranium Malacoides ibid.

Geranium violaceums
Geranium maculatwm, fine fuscum

Pag. 799

Geranium mofchatsm inodorum ibid. abid. Gesum alpinum

Geum Pliny

645.843

Gilarum ibid.

Gingidium $\quad 457$

Gingidium latifolium $\quad$ ibid.

Gingidium Hispanicum ibid.

Gladiolus $\quad 96$

Gladiolus paluftris Cords $\quad 27$

Gladiolus Narbonenfis of Italicus 95

Gladiolus Jegetalis 96

Glans

1158

Terreglandes $\quad 1057.1058$

Glans vnguentaria $\quad \mathrm{I2I}_{4}$

Glandis calyx 1158

Glans Ionis 1154

Glans Sardiana ibid.

Glans palmarum $\quad 1134$

Glaftum $\quad 394$

Glaftum fatiunm $\quad 394$

Glasux Diofcoridis $\quad 1061.1062$

Glancium

Glawx exigna maritima 275.295

Globularia $44^{8}$

Glycrrrbiza

Gljcyrrbiza Ecbinata Diofcoridis

pag.

Glygrrbiza vulgaris ibid.

Glycyrrbiza fuccus 120

Glygrrbizon 995

Gnaphalion st9

Gnaphalium Anglicum 5 is

Gnaphalium vulgare wat ibid.

Gnaphalium Hieronymi Bocchiy 27

Gnaphalism marinum $\quad 516$

Gnaphalig varietates wo ibid.

Gnaphalium Alpivum *atios 517

Gorgonium $\quad 48$

Godjoium 753

Gramen pratenfe maius o minus 2

Gramen minimum rubrum of alburn

pag.

Gramen minus during calum ibid.

Gramen inncenm ibid.

Gramen fegetale

Gramen barundinaceum ibids

Gramen agrorium ibid.

Gramen fulcatum of piltum ibid.25.

Gramen miliaceum

Gramen mains a guaticsin sbid.

Gramen Sorghinum 7

Gramen barundinacesum pannicula.

tum

Gramen panniculatums 8

Gramen fyluaticum aut nemoroform.

pag. 0

Gramen toment of um acerofum ibid.

Gramen plumofum

Gramen Alopecuroides maisus of minus, ๘ंc.

Gramen Typbinü majus of minus ro 


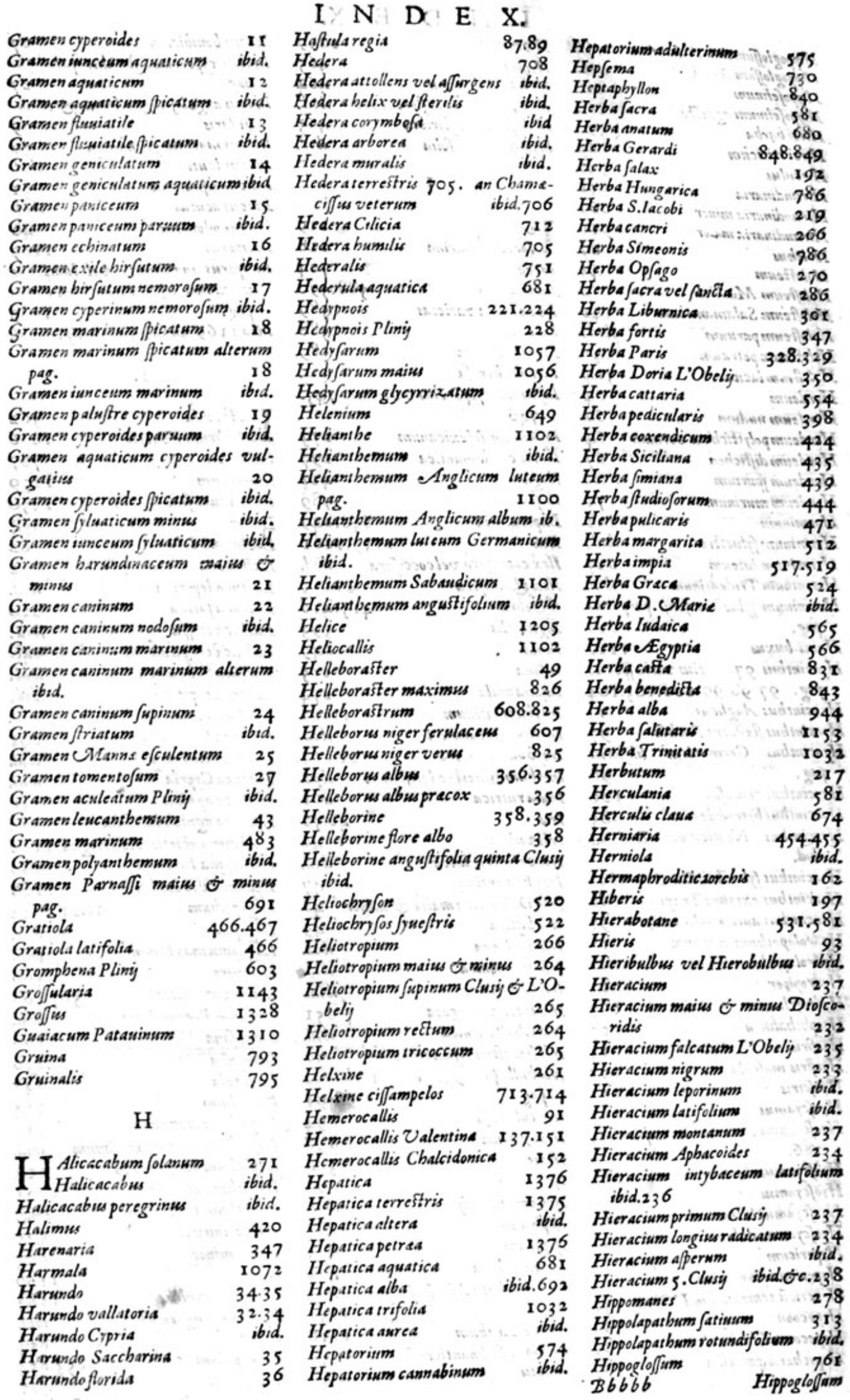


Hippogloffummas of famina $\quad 76 \mathbf{1}$ Hippogloffrm Mathiolt ibid. Hippofelinum + 866

Hippofelenum agreste whot 869

Hircibarba

Hercitrificum thento ${ }_{83}$

Hirtulus 920

Hirendinaria wisagail $75^{1}$

Horundinaria minor ito $1.2=669$

Horundinariamasor inotustin

Holchus itrogmi2 63

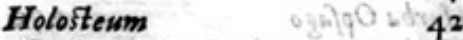

Holofteum Mabioli bu wast nd 2

Holofteum Salamanticum th I 342

Holoftesum paruum itvet ibid.

Holostermperreum wit $T=243$

Heloftium lacwice to: I vined = 5 I4

Herdeum tirwis 64

Hordeum nudum terslivissa 66

Hordeumpolystichum viermum $6_{4}$

Hordesim diffichon wwithsiz: 67

Hordesom fprorium suswi ibid.

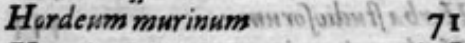

Horminum ditasiling $6 \mathbf{2 8}$

Horminum fyluestre wax gुthe ibid.

Horminsam luteum kiquit 627

Horminum Tridentinum 3 s.

Horminum fyluestre folys purpureis

zipag. 628

Humi-buxus aiseco? 1226

Hyac intbus 97. eins varia pecies

s.pg. 97.98.99:100:10 3.104

Hyacint bus Anglicus wots 99

Hyacinthus ftellatus Fuch fii ] 97

Hyacinthus Germanicws ilifforus

pag.

Hyacintbus comofus wivatur $\mathrm{rO}_{3}$

Hyacint bus botryoides wh bh 105

Hyacinthus Neoticorum Dodonai ibid.

sloenty

Hyacintbus fyluestris Cords lew ibid.

Hyacintbus exigusus Tragi vibid.

H)acinshus autumnalis masior 98

Hydrolapathum magnum $\quad 3 \mathrm{I}_{2}$

Hydrolapathum minns sallidibid.

Hydropiper 361

Hydrofelinum :o whtaess anitis 867

Hyopbibalmon $\quad 393$

Hyofiris lis

Hyofiris mafcula escryis veros 227

Hyofciris 223

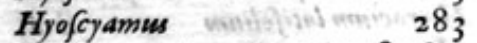

Hyofcyamus Perusianus 278.285 . 286.

Hyofcyamusniger $\quad 28_{3}$

Hyofcyamus albies ibid.

Hyof cyamus luterus 284

Hyof cyamus dubins

Hypericum

432.433

Hypericum Syriansm ibid.

Hypericü tomentofum L'Obely 433

Hypecoon

Hypecoum Clusi

Hypocheris,porcellia

\section{2}

909

227
I N D E X.

Hypocistis

Hy (optes

: 2099

Hylfopus Arabum 465

Hy fopus Arabum fiore rubro ibid.

Hyffopus albis floribue $\quad 465$

Hy) Topus tenuifolia byon mibid.

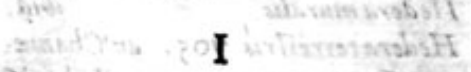

TeAcobea 219

1 Iacobeamarina ahe 218

Iacea 704

Iaceanigra 588.590

Iaceenigravarictus $\quad 589$

Iaceamaior $\quad 588$

Faceamontana $\quad 589$

Iaceatuberofa ibid.

Iafminum $74^{6}$. eius varietates 745 . 1746

Iafminum Mexicanum 273

Iberis cardamantica $\quad 197$

Ibigd 422

Ibifcus

422
789

Imperatoria 348.849

Hew

Ilex coccigera vel coccifera ibid.

Ilex glandifera 1 I 61

Illecebra 415.416

Ingnimalis

393

Inule. $\quad$ villur 649

Infana $\quad 285$

Infanamala reizatotro $\quad 274$

Intybum fatisum $\quad 221.222$

Intybum erraticum ibid.

Intybsum fluestre 221.223

Intybum fyluestre latifolium ibid.

Intalu rustica $\quad 661$

Iris. 38.46 .50

Iris vulgaris

Iris palustris leted $\quad$ ibid.

Iris Florentina

Fris Dalmatica maior of minor

Iris biflora

Iris violaced

Iris Pannonica

Iris Camerary

Iris lutea variegata

Iris Chalcedonica

Irisfylueftris Byzantina

Irisbulbofa 93. eimfquarietates

pag.

Iris tuberofa

Irioc Irion hatush in $\quad 94$

Ifatis

Ifchemon

Ifchemon Plini

Ifopbyllon

Ifopyrum

Ina mofchata

Ina mufchata Monfpeliaca

Inglams

Inisube Arabum

Inncaria Salmanticen/is

Inncus

40
Inncus bombicinus

Isncus coperoides foridus 27

pag. $\quad$

Inncus angulof is, gmadratus, 0 triangularis 29

\begin{tabular}{ll} 
Inncus marinus graminevas & 29 \\
\hline & 30
\end{tabular}

Inoncus lavis ibid.

Innew aguatious

Inncus acurus ibid.

Inncus odoratus $\quad 40$

Inniperus 1189

Iuniperus maximus, vel Iuniperus maximus Illyricus carrulea bacca

Pag. 1189
Ixia 1169 .an Chameleon niger ibid.

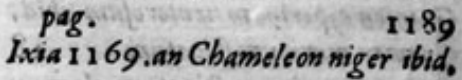

L

Labeonia $_{\text {Labrum Veneris }}^{562}$

Labrufca

Laburnum 1239

Lacca cum fuis bacillis $\quad 1350$

$\begin{array}{lr}\text { Lacer } & 854 \\ \text { Lachryma lobi } & 82\end{array}$

Lactucella $\quad 232$

Lactuca leporina ibid.

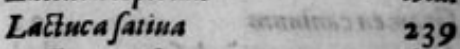

Lactuca crifpa ibid.

Lactuca criparaliera $\quad 240$

Lacfuca Sabandica ibid.

Lactenca capitata ibid.

Laituca intybacea ibid.

Lactuca Ceciliana $\quad 24 \mathrm{I}$

Lactuca Romana ibid.

Lactuca Cypria ibid.

Lactucaagnina $\quad 242$

Laituca agnina latifolia ibid.

Lachryma abietis, vel abiegna 1182

Lachryma Isniperi $\quad 1189$

Ladanon vel Ladon 1108

Lagopodium $\quad 1023.1024$

Lagopus: ibid.

Lagopummaximum ibid.

ibid. Lamium $\quad 568$

ibid. Lamij varietates $\quad \begin{array}{r}568 \\ 67.568\end{array}$

51 Lamium Pannonicum ibid.

ibid. Lampfana 199

2 Lampraca 236

Lanceols $\quad 342$

Loparbum $\quad 314$

Laparhum acutum $3 \mathbf{I I}$

Lapathum acutum minimum ibid.

Lapathum fangainewm $\quad 314$

Lapathum aciaum $\quad 321$

ibid. Lapatbom tuberofwn $\quad 321$

485 Lappa inuerfa 575

1025 Lappa minor 964

422 Larix 1180

ibid. Laricis ramulas 1183

1252 Larix cum agarico fus ibid.

13 8 Lafer 854

958 Laferpitiom $\quad 853,854$

Latbrus 
Latbyrus

Lawandula

Lauandula fiore ceruleo

Lawandula flore albo

Lavandula bortenfis minima

Laver mains Diofcoridus

Laver Cratewa

Lasuer, Lanacrum

Laurentina

Laureola

Laureola florens

Laureola cum fruttu

Laturio

Lanrus

Lanrus mas

Laver us fomina

Latsrus fyluestris

Laurus Tinus

Lasurus Tinus Lufitanica

Lasrus Alexandrima of Idas

Lanerus rofea

Ldari bacce

Ledipes

Ledanon

Ledon

Lens

Lens maior of minor

Lens aguatilis

Lens palustris o lacuftris

Lenticula

Lentifcus

Lemifcina refina

Leontion

Leontopetalon

Leonis folium

Leontopodium parusm

Leontopodion

Leont offomium

Leontoftamum

Lepidium

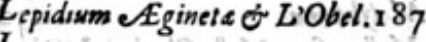

$L_{\text {encas }}$

Lescacanthe

Lencant bemis

Lescanthemon

Lencographis

$L_{\text {encoinm }}$

$\begin{array}{ll}L_{\text {encoium }} & 375 \\ L_{\text {encoium bulbofum precox }} & 120\end{array}$

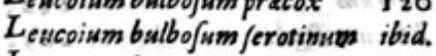

$L_{\text {eucoium luteum }}$

$L_{\text {eucoium bulbofum mains }}$

Leucoism album

Leucoisum purpureum

Lencoium violaceum

Lencoium fyluestre

, 1244

487

182

ibid.

518

ibidi

439

936

197

529

996

616

ibid.

989

$37 \mathrm{I}$

121

372

ibid.

373

ibid.

Lencoium marinü flore candido $L$ 'O. beliy

374

Lencoium marinum Latifolium 375

Leucoinm marinum luteum mains

Clusiy $\leftarrow$ L Obelij

Lenifticum

Ltbadion

Libanotis

Libanotis Theopbrasti maior

855

437

858
I $\quad \mathrm{N} \quad \mathrm{D} \quad \mathrm{E} \quad \mathrm{X}$.

Libanotis Theophraftiminor 85

$\begin{array}{ll}\text { Libanot is Theophrafonigra } & 858 \\ \text { Libanotis Galeni } & \text { ibid. }\end{array}$

Lichen

Lichen arboram

1376.1378

Lotme vrbana velfaina 1022

Lotm vrbana vel fatiua 1026

1377 Lotw artor 1306.1309

ibid. Luto beophrafti 1310

$\begin{array}{rlr}\text { ibid. } & \text { Lucernula } & 1310 \\ \text { Ligna lapidea, fime in Lapides conuer } \int a & \text { Lunaria } & 381 \\ & \text { Luria } & 378\end{array}$

1390

1303

Lignum vita

Lignum dulce

Ligufficum

Liguftrum

Ligustrum nigrum

1349

855

714

Liguftrum frutex 1208. an CTpris

itbid.1 210

Liliapphodeliss

Liliago

Liliaftrum

Lilitum non bulbofsm

Ltlo-narcifies variegatus

Lilism

Lilism album

Lnnaria Greca $\quad+378$

Lomaria minor

Lisnariameior this 329

Lupicrepitus $97 \mathbf{r}$

Lupinus $\quad 1385.1386$

Lupinus fatium $\quad 1043$

Lapinu flore luteo

Lupinus flore carmleo and atibid.

$9 x$

45.91

Leppes falictarines

cin 737

ibid.

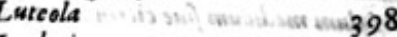

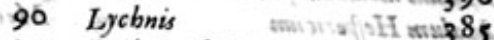

123 Lychris Cbalcedonica

147. Lychmis coronaria rubra aty $8 \mathrm{r}$

146 Lyebnis coronaria vel fatius mibid.

Litinen album Byzantinumibid. I 47 Lycbnis fylueftris 482.385

Lilum anrenm. ?

Eilom rubram abid.

Lychnis fylueftris rubello fisne i 182

Lifium erue ntum latifolium

bid. Lycbnis marina eAnglica aniabid.

Eilam Byzantmum

Lrinaw Siracenicum

Ltlium fylueftre

Litiummontanim

Litism Pcrficum

Lilium conuallium

Limodoron

Limontia

Limonium

Is 1 Lychnis fylueftris prima Clasy ibid.

I5 1 Lycbnis birta minime

ibid. Lycbnis fyluefris incana omn vilid.

ibid. Lychnis fylueftris alba $\quad 3^{84}$

I52 Lychnis casuliculis ftriatis Clysy sibnd.

331.332

Limonium Gefneri 330.332 .33

Limonium parusm $\quad 332$

Limnefium

Limaria

Limaria purparea odorata $\begin{array}{r}44^{\circ} .444 \\ 440\end{array}$

Limaria Ualentice timind as

Linaria asurea

Linaria p.yferina

442.522

441

emguacanis

Lingua bubula

Lingua vulneraria

Limum

Linum pratenfe Cordi

Limum fatiuum

Linum fyluest re floribus albis

Limum Gluestre tenuifoliom ibid

Linofyris Nuperorum

Lirbopermum

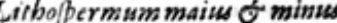

Lolium

Lolism rubrum

Lolium album

Lolisum murinum

$L_{\text {oncbitis apera }}$

Lonchitis Maranthe

Lotus

$L_{\text {otues trifolia corniculata }}$

1029
1099

994

467

543

659

Lycbisis plumaria

$.33^{85}$

Lycium Misi

Lycium Hipanicwm witn sulibid.

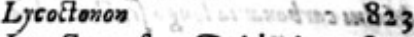

Lycottonon fiore Delpbinij 8 iz

823 . Dhalyor mathy

Lreotionon carulewm parwum ibid.

Lycoctoni Aconitum 823 .

Lgcop/is Anglica : watisath ah 658

Ljcbnoides fegetum watabis $\$ 26$

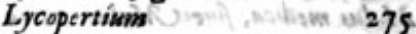

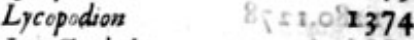

Lycostaphlos watat 1237

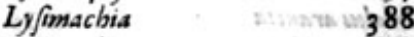

Lyfmachium atid.

327 Lyfumachia lutea $\quad 386$

445 Lyfimacbia purpurea picata sond.

Lyfimachia filiguofa jid.

Lyjimachia campestris $\quad 387$

Ly jmachia fluatica abid.

\section{M}

MeAcaleb Gefneri $\mathbf{1 2 1 \mathrm { x }}$ Macia 495

Macis $\quad 1353.1354$

Madon

Maiorand

720

Maiorana maior $\quad 538$

Masoranamaior eAnglica ibid.

Maioramatenuifolia 539.an Mato-

rama fit Samp prebums

Malabatbrum

B 666622 
Mala Ethiopica

Mala infane

Malicorium

Malinathalla

Malua bortenfis

Malua rofea fimplex peregrina sid.

Malua purpurea multiplex $\quad 7_{3}^{8}$

Malua bortenfis multipliciflore ibid.

Malua arborea flore nigro multiplici

$$
\text { pag. }
$$

Malua fyluestris

Malua fyluestris psimila

Malwa crifpa

Malua verbenaca

Malua boraria

Malum

Malum cotoneum

Malum medicum fue citrium 128

Malum Hefpericum

Malum Limonium

Malum Anarantium, fuse Aneran-

$$
\text { tivm }
$$

Calum/pinofum ivionil 278

Malum terrestre whing $28 \mathrm{t}$

Malum Armeniacum $126 \mathrm{x}$

Malum Punicum writsulch 1262

Malusperfica 1259

Malus armeniaca 126

Malus armeniaca matior of mimon

apg. $\quad 1260$

Malus granata, fue Malus prinica

pag. $\quad 1262$

Malum 1275

Malus carbonaria inst: 1273

Malus carbonaria longo fructn ibid.

Maleus regalis 1274

Malus reginalis ibid.

Mnalus flueftris rubens : 1276

Malus fyluestris alba ins ibid.

Malus fyleestris minor it 1277

Malus duracina fyluestris ibid.

Malus medica, fiverc Malus cirria

4. 1280.1278

Malus limonia ibid.

Malus arantia $\quad 1279$

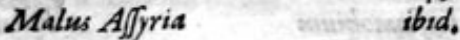

Malues Cotonea $\quad 1264$

Malus canina $\quad 281$

Mandragoras $\quad 281$

Manne gramen $\quad 26$

Ulanne graminis pecies altera ibid.

Maratbrum 877

Maratripbyllow flore of Semine Ra-

nüculi aquatici, Hepatica facic 679

S. Mariaberba

Marinella

Marifaca

Marrubism

Marrubium album

Marrubium Hupanicum

Marrubium Creticum

Marrabium aquat .0 palustre

Marrubium nigrum

Marrubium protium

562

561

562

ibid.

\section{I $\mathrm{N} \quad \mathrm{D} \quad \mathrm{E} \quad \mathrm{X}$.}

Marmbiastrum $\quad 566$

Martagon album Byzantinum 147

Martagon impersale

Marum

Markm Syriacum

540.544 .545

Mastiche

Mater Herculania

Matricalis

Matricaria

Matricaria duplicifore

Matrifaluia

526.527

Mecboacan 723. an fit Bryonic pe-

cies aut Rha albom

Mecon Ceratites :

Mechoacan Peruuianum 295

Medica 1030

Medium Diofcoridis

Mel frugum

Melampodion $\quad 826$

Melampyrum $\quad 214$

Melampyrwm album $\quad 83$

Melampyrum luteum $\quad 84$

Melanthivm $\quad 924.926$

Melanthium fylueftre $\quad 924$

Melantbium Damafcenum 925

Melica

Melefia

Melilotm

1035

Melilotus Syriaca odora $\quad 1033$

Melilotus Italica of Patamina ibid.

Melilotsus Germanica ? 1034

Melilosus coronata ibid.

Meliphyllon

Meliffa

Meliffac Turcica

$55^{8.560}$

Me $55^{8}$

Molucca lanis of pinofas 59

Meliffophyllon

Melitiena

Melitris

Melo

Melo Saccbarinus

Melo Hifpanicus

560
$-\quad 562$

771.772

Melocarduns ecbinatus Pene o

L'Obely

Melopepon

Melortum

Melopinum

Memacylum

Memiren Serapionis

Mentha

Ment ba fativa rubra

Ment ha cruciata

Mentha Sarracenica

Mentha Romana

MenthaGraca

Mentha corymbifera

Mentba cardiaca

Mentha angustifolia

Mentha Felina

Mentha Cattaria altera

Mentha aquatica

Mentba fis ymbria

Mentaftrum

Mercarialis
1244

674

$58 \mathbf{I}$

526

627

724

1030
53

79

77

1082

560

560

ibid.

1013

Mercurialis mas

Mercurialis fylueStris

Meppilus

Meppiluen ibid.

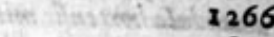

Mezereon $\quad 895$

Milisum 1216

Molism fylmestre $\quad 73$

Milinm nigrum abid.

Milium Indicum sust: 77

Milium fyluaticum 85

Millefolism

679.914

Millefolium fyluestre 902

Millefolium terrestre vulgare 914

Millefolium flore rubro abid.

Millefolium luteum $\quad 915.916$

Millofolium nobile. ibid.

Millefolium ftratiotes $\quad 916$

Mille folium minus ibid.

Millemorbia haty 580

Molitares mand 914

Molitaris Aizoides $\quad 677$

Miltaris aguatica ibid.

Mimmulus berba $\quad 913$

Mirabilia Persuiana . $\quad 273$

Mirobalani Chebula, Bellerice, Em-

blice,Indica alinur $13 \times 6$

Mitbridatium 535

Molocbe ate 791

Molorbia :1 $\quad 549$

Molon. 902

Mollugo $\quad 968$

Mollugomontana = 967

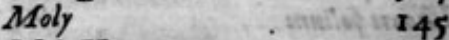

Moly Hippocraticum 142

Moly Diofcoridenm 143

Moly ferpentinum ibid.

Moly Homericum $\quad 144$

Moly Indicum a ibid.

Molybdena 1070

Molle, fime Molly Clusy of L'Obely

pag.

Monopbyllow

1346.1347

Montinlmus

330

Morion

$\mathbf{2} 297$

279

278

Morofycom

281
1327

1311

Morums.

1325

Morum Rubi $\quad$ rogi

553

552

Morus

1325

Morus alba

Moruse Egypria $\quad 1327$

Mula berba $\quad 979$

$\begin{array}{lr}553 & \\ \text { ibid. Mudion } & \\ 5 & 157\end{array}$

520 Muralis $26 \mathrm{t}$

ibid. Moralium ibje.

553 Muris canda $\quad 346$

ibid. Murica 1195

$554 \mathrm{Mufa}+1333$

Mufa Serapionis

555 Mufe fructus ibid.

ibid. MufcariClusy gos

$557 M_{\text {uffariflaumm }}$ ibid

262 Mufcipula L'Obely $\quad 4^{81.482}$ 


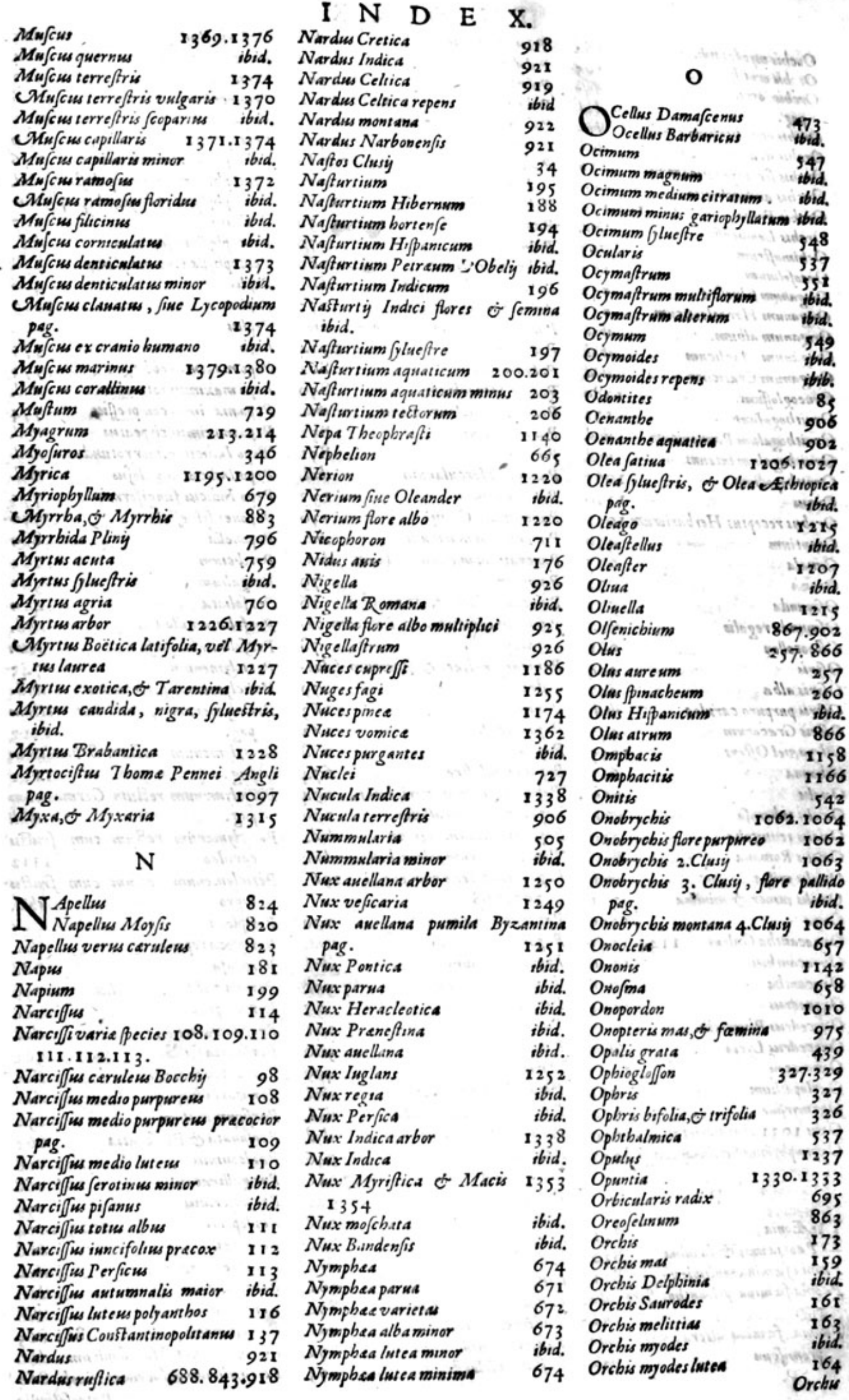




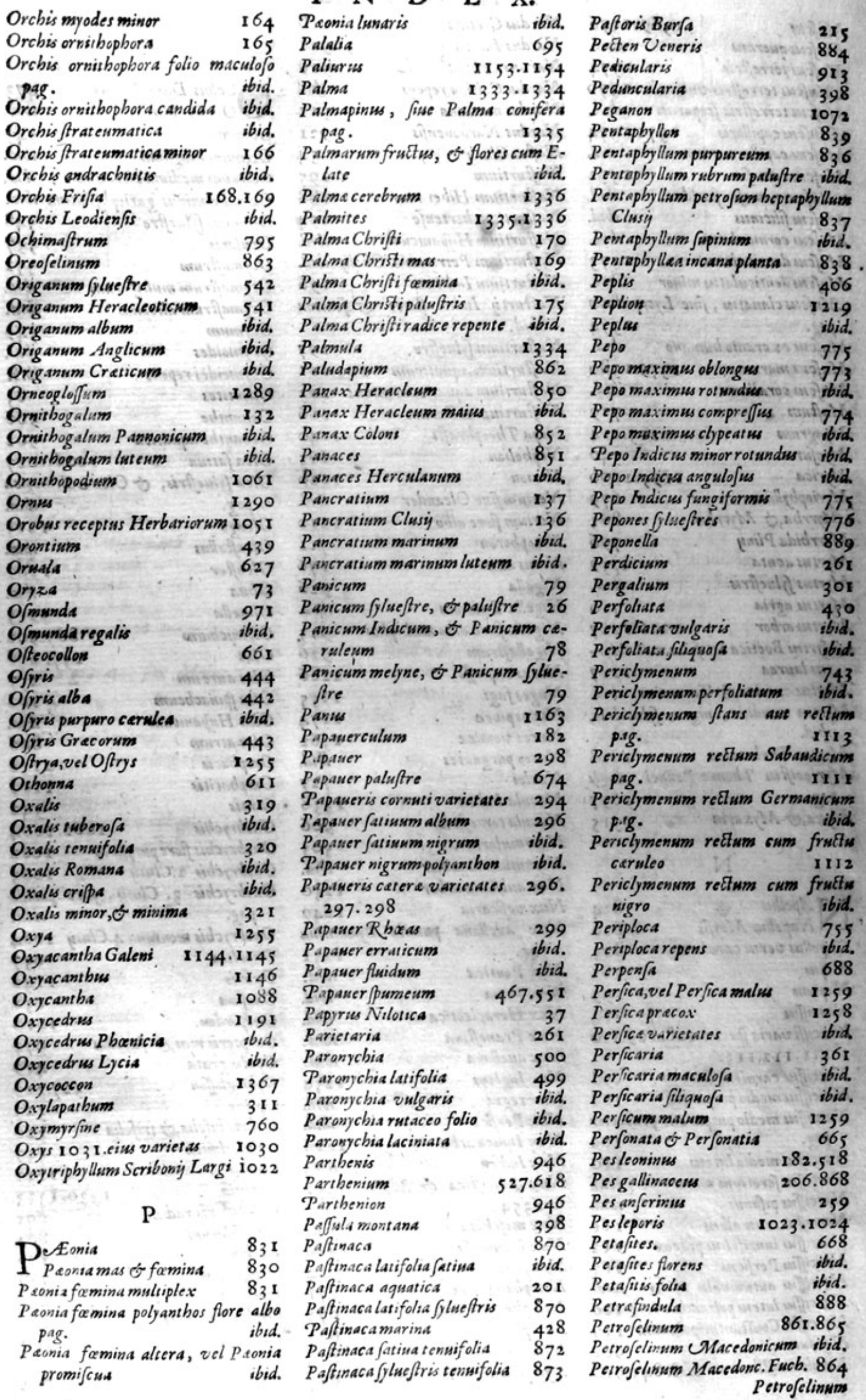




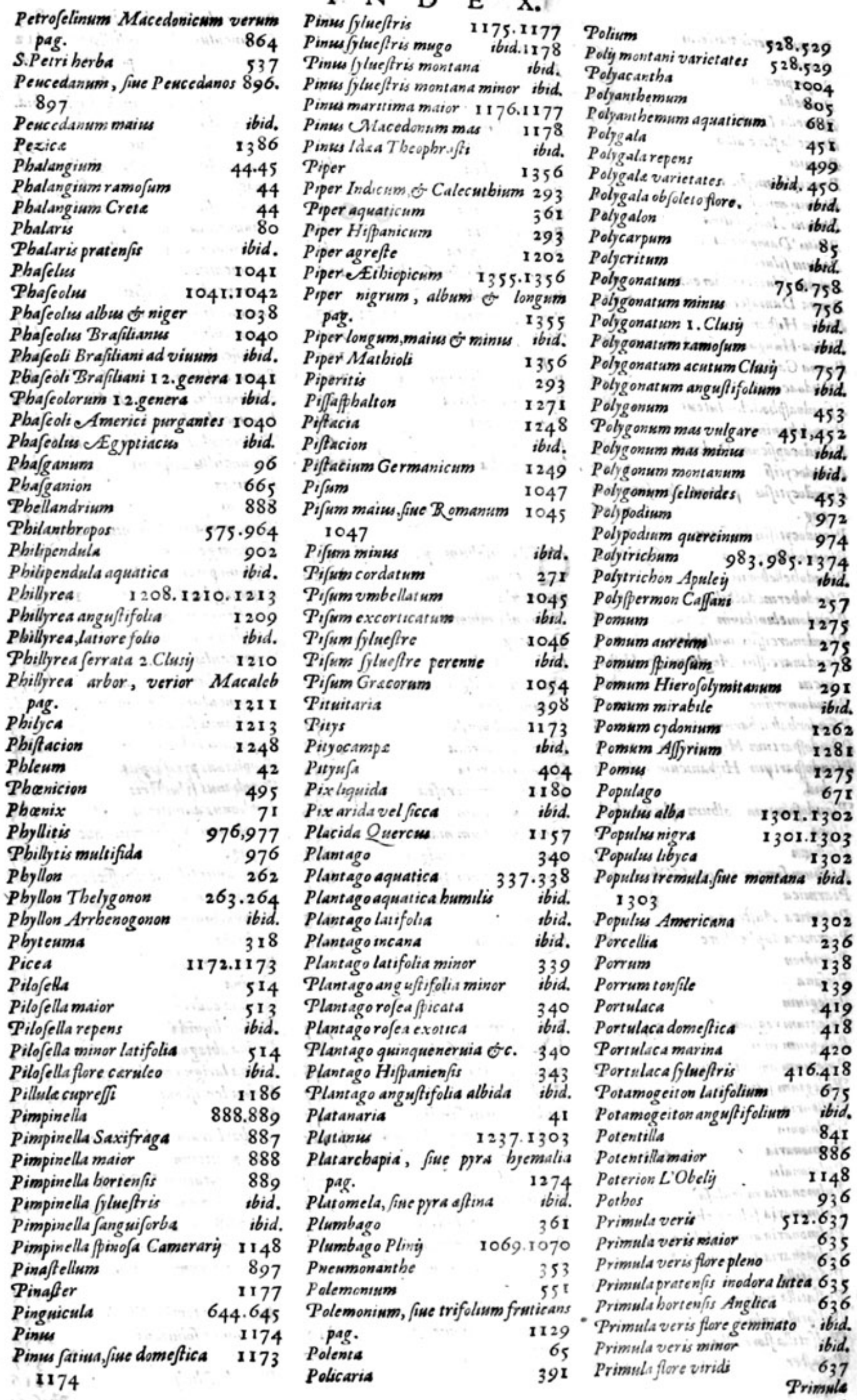




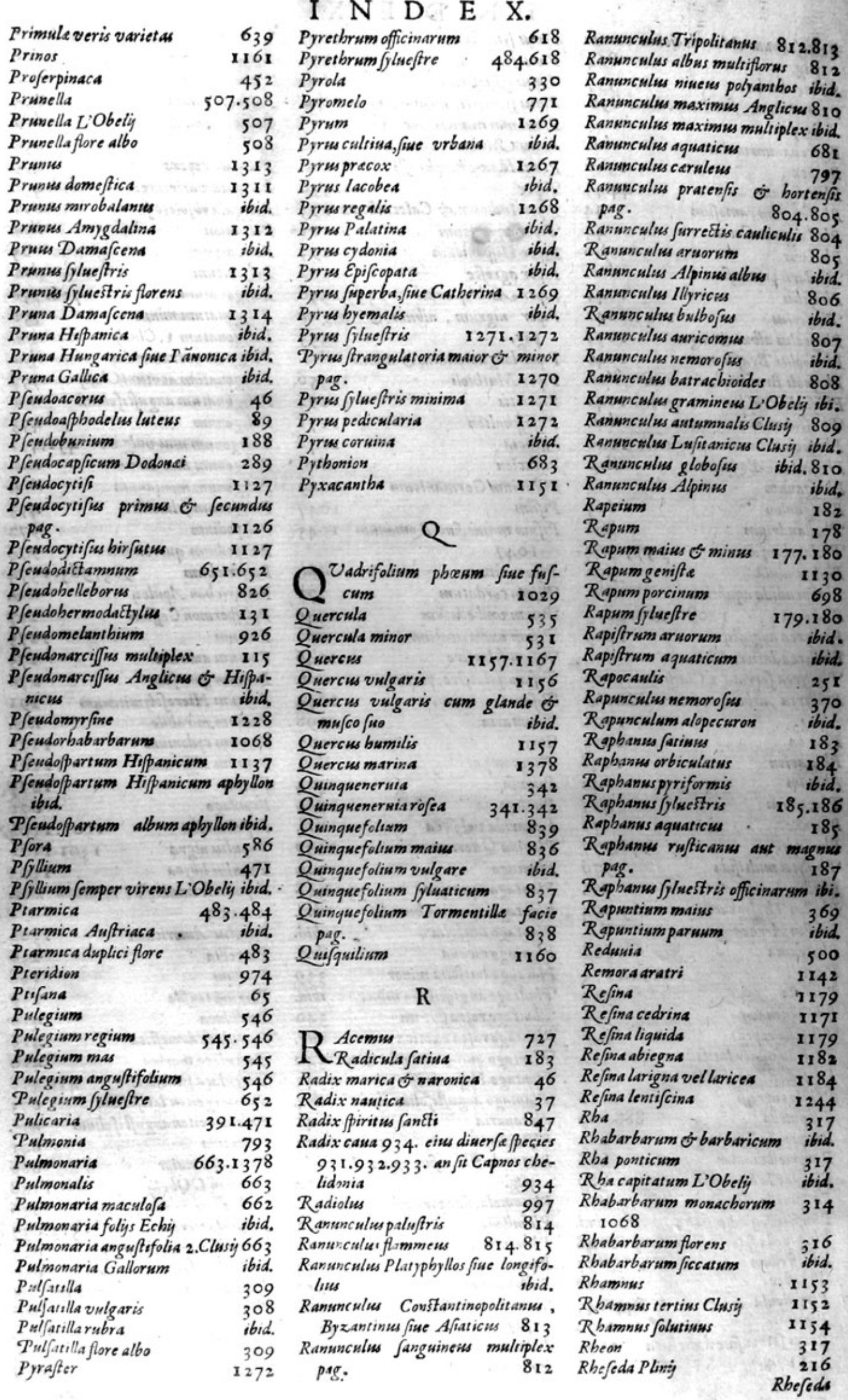


Rbefeda maxima

$R$ bodia radix

Rbododaphne

R bododendron

Rhodon

Rhoc

Rboc culinaria

Rhoc op ontorim

Rhous

Rbous fylmestris Tlini

Rbus coriaria

R bous norrifolisu

Ricimus

Ricimus Americuss

Rima Maria

Rincum matrinam

Robur

Robker maitio

Rorella

Resfolis

Ros folis maior

Ros folis minor

Ros cali

Rofa vltramarina

Rofa Iunonis

Rofabyemalis

Rofa Dominarum

Rofa fatwina

Rofamariana Rofualba vel pineola Rofa 1079
$108 \mathrm{r}$

Rofa campana

Rofa rubra

Rofa Provincialis fine Damafcena ibid.

Rofa Prosincialis minor 1079

Rofa fime flinis $\quad 1082$

Rofa Hollandica five Batawa 1081

Rofa mofchata

Rofa mofchata fimpliciflore $\quad 1084$

Refa mofohata multiplex ibid.

$\begin{array}{ll}R o f a b o l o f e r i c a & 1085 \\ R o f a l u t e d & i b i d .\end{array}$

Rofa Cinnamomea plenoflore 1086

Roja fylue Stris odora.

Rofa canina inodora

Rofapimpinella

Rofa fyluestrio

Rofa canina

Rofafyluatica

Rofa Hiericontea

Rofa Hiericontea maior

Rofa Hiericont ea ficcata

Rofmarinus

858

Rofmarinum coronarium, vel Rofma-

Rofmarimum fyluestre, vel Rofmari-

nia fylueftris

Rubia o Rubeia

Rubis tinctorum

Rubia flueftris

Rubia matina

Rubies

Rubus Ideus

ibid. rog9

961

ibid.968

ibid.

1089.rogr

ibid.

\section{I $\quad \mathrm{N} \quad \mathrm{D} \quad \mathrm{E} \quad \mathrm{X}$.}

Ruóus cerninus

$R$ ubus faxatilis

Rumex

Rumex fatious

Rumex acidus

Rupertianum

Rufcus

(ujcum

Ruta

Ruta muraria

Ruta palustris

Ruta pratenfis

$\mathcal{R}$ uta bortenfis

oso Rutafyluestris

Rutafyluestris graweolens sbid.

Rutitylueftris minima

Ruta montana

\section{S}

SeAbina

S Sabinafterilis

Sabina baccifera

Sabina aliera

Sabina genuina baccifera, atrocarw-

$$
\text { lea }
$$

Sagapenum

Sagittaria maior ơ minor $\quad 336$

Stgittaria minor anguftifolis

Sagmina

Salicaria

Salicaftrwm

Salicetres

Salinaris

Salinnca

Salix

Salix marina

Salix America

Salix aguatica

Salix caprea rotundifolia

Salix caprea latifolia

Salix rofea Anglica

Salix bumilis

Salix perticalis

Salic us tertia fpecies

S.dix pumila

Salox viminalis

Salix Gailica, Sabinat

Salfi Rofa

Saluia

Salsia agreftis

Saluia Romana

Salnia maior

Saluia minor

Salmia Indica

Salnia Alpina

Saluia vite

Sambucus

Samben laciniatis folts 23.123

Sambucks racemo(a vel cernina ibid.

Sambucus fyluestris vel montand pag.

Sambucuaguatica =at $\quad 1237$ irid

pag. aguatilis fine palustris

Sambucus rofea itid

Sambucus rófea flore purpurante ibid.

321 Sambucius bumilis $\quad 1238$

794 Sampfychum 539

759 Sandalum 843

ibid. Sangrinale 1389

1072 Sanguinalis 22

983 Sangwinaria 26.347 .452 .889

068 Sanguis Draconis 314

$\begin{array}{ll}\text { ibid. Sanguiforta } & 314 \\ & 889\end{array}$

bid. Sanicula 357

1070 Sanicula gutrata 644.645

bid Sanicula Alpina Clusij 645

Sanicula Eboracenfis $\quad 644$

Sanicula maior $\quad 803$

Sanicula famina $\quad 8_{28}$

Sanicula Alpina $\quad 843$

Santalum 1389

vid. Santalum album a ibid.

ibid. Santalum rubrum ibid.

ibid. Santolina 852

Santonicum $\quad 841$

Sapa $\quad 730$

Saponaria 360

Saponariagentians matulibid.

Saponaria alsera $\quad 55 \mathrm{r}$

Sarcocolla herba : an atution

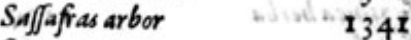

Satureia

Satureia bortenfis

Sarureia hortenfis aftisa ibid.

Satureia Santhi Inliani ibid.

Satyriabafilica 170

Satyrion 159

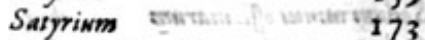

Satrium abortisum what 176

ibid. Sauchromaton ventsibs 683

ibid. Sanritis 495

1204 Saxifraga $\quad 495$

205 Saxifraga alba 693

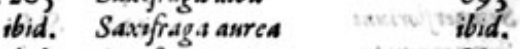

ibid. Saxifraga minor $\quad 887$

ibid. Saxifraga Anglicana $89 x$

ibid. Saxifraga rubra 902

Saxifraga lutea $\quad 1035$

Saxifragamaior $\quad 888$

Saxifranga Diofcoridis $\quad 457$

Scabiofa $\quad 586$

Scabiofamaior viulgaris $\quad 582$

Scabiofa campestris fine fegetam

ibid. Pag.

3bid. Scabiofamontana $\quad 584$

83 Scabiofa maior Hifpanica $\quad 585$

Scammonium 718

Scammoniam Syriacuins $\quad 716$

Scammonium Monfpelienfe ibid.

Scammones Valentina $\quad 718$

$\begin{array}{lr}\text { Scammorium Americanum } & 724 \\ \text { Scandix } & 884\end{array}$

Cocos x

Scandr- 


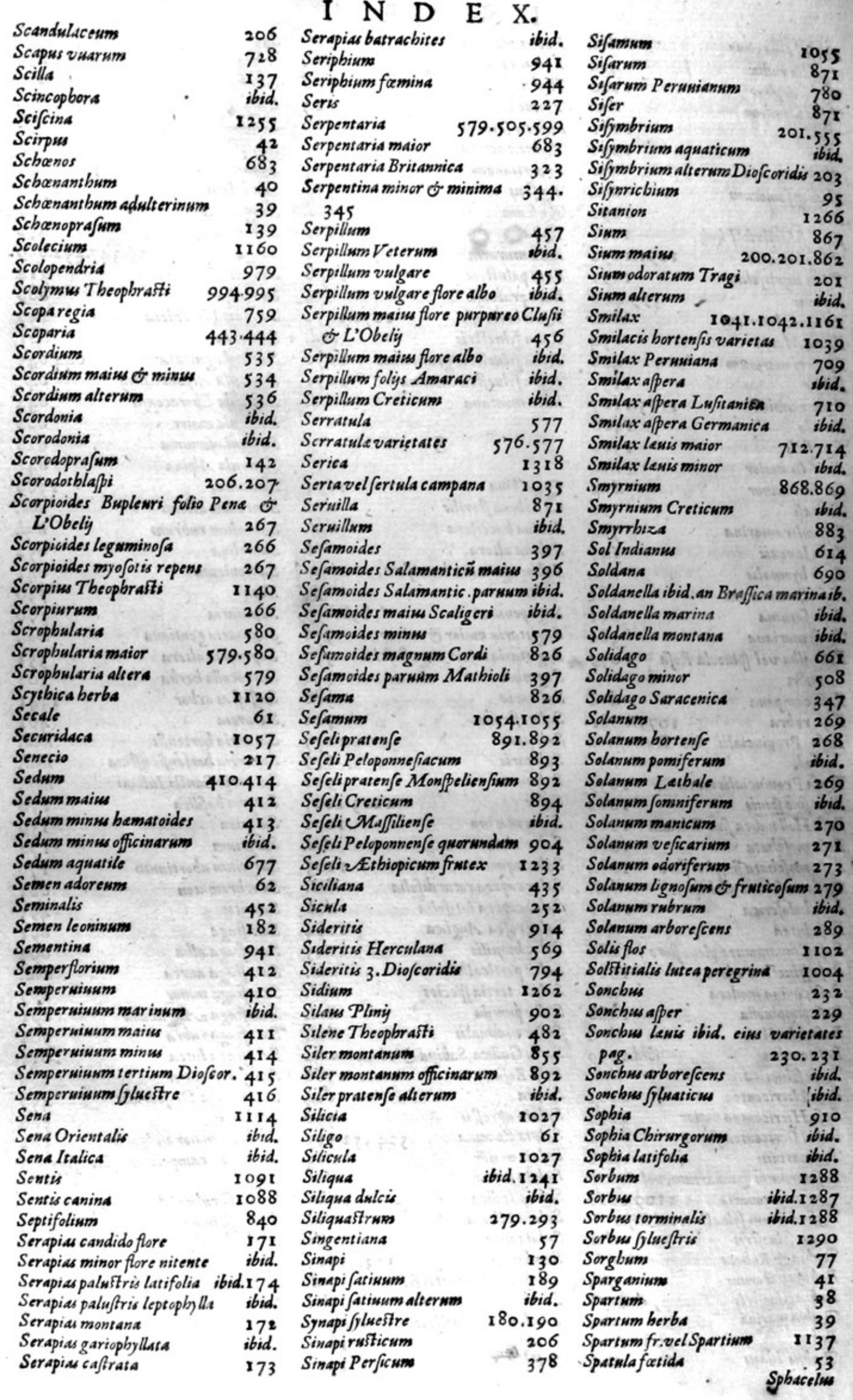




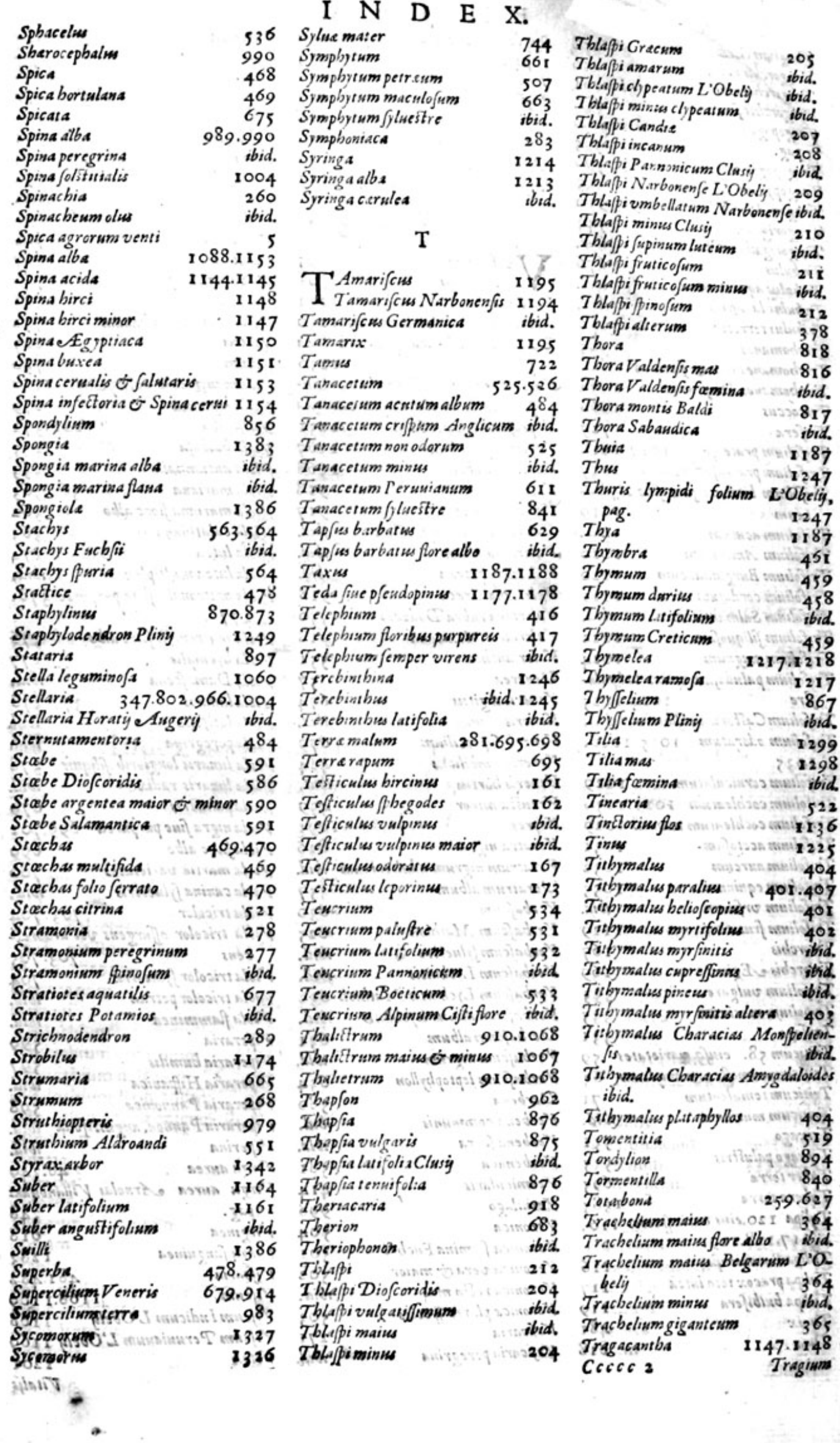


Tragium Germanicam Tragorcbis maximus Tragorchis mas Tragorchis femina

Tragopogon 596. pag.

Tragopogon mintw

Iragopyron

Tragon Machioli

Tragoriganum

Tragoriganum Clusy

Tribulus

Tribulus aguaticus

Tribulus lacnftris

Tribulusterrestris

Trichomanes

Trichomanes Diofcoridis

Tricoccus

Trifere

1266

727

Trifolism pratenfe IOI7.1018

Trifolium praten je flore albo 1017

Trifolisw bituminofum fine Apbaltreum

I019

Trifolism acutum

ibid.

Trifolium Americum

1020

Trifolium Burgundiacum is 1020

Trifolium cordatum $\quad$ IO2 I

Trifolusm Salmanticum i ibuid.

Trifolium filignofum $\quad 1022$

Trifoliwm magnum $\quad 1024$

Trifolium paludofum mains vel palufre 1024.1025

Trifolium Castor is vel fibrinum ibid.

Trifolium odoratum 1025.1026 .

$$
1035
$$

Trifolium corniculatwm 1029

Trifolium cochleatum 1029.1030

Trifolitum cochleatum marinü 1029

Trifolsum acetofum $\quad \mathrm{O}_{3} \mathrm{I}$

Trifolium asreum watu 1032

Trifolium equinum $\quad$ 1035

Trifolium vrfinum ind ate ibid.

Trifolium fruticans on whithit 1129

Trierchis $\quad 167$

Triorchis efginete $\quad 169$

Tripolium valgare 333

Txipolium natinum $\quad 335$

Iriffaga

Triticum 58. einfgrarietates 59

Triticin irimeftre of amylewm $6_{3}$

Triticumi temslentum

Triticum morinum ain wisut ibid.

Trixago

Triseagopalustris $\quad 535$

Tuberterre athat 695

Tuberaterre

1385

Tulipa I 20 ,eins varie pecies 116 . bi 17.118 .119$.

Tulipa Bononienfis

Tulipa precox tota listea

Tulipa bulbifera

Tuniv

Tura

116

117

\section{I $\mathrm{N} \quad \mathrm{D} \quad \mathrm{E} \quad \mathrm{X}$.}

Turbith Allexandrinum officinarum

pag.

Turritis

Tufilago

Tunfilago florens

Tunfilaginis folia

Typha

Typhonion

V

T Accaria

Vaccinia

335

Vaccinia Pannonica, fine vitis Idea pag.

1230

$V$ accinia vr/s, fue Vua vrfi apud Clufum ibid. an planta qua vaccinia profert, ft vitis IdaA $\quad 123 \mathrm{I}$

Vaccinia palustria

1367

Taccinia nubis

1368

Valcriana

Valeriana bortenfis

Valeriana maior fylueßlt is

Valeriana minor

Valeriana petrea

Valeriana Graca

Valeriana rubra Dodonai

Valeriana Mexicana

918

918

Valerianthon

Venerea

Veneris digitus

Veneris clanus

$V$ ener is fupercilisim

Veneris vasbilicus

$V$ eneris bortus

Venusta minor

Vepres

Veratra nigra

Veratrum nigrum adalterinum ibid.

Veratrum album

Verbafcum

Verbafcum Matbioli

Verbafcum fyluestre

erbafcam Lychnitis ibid.

Verbafcum Lychnitis Matbioli 632

$V$ erbafcum minus Ljebnitis ibid.

Verbafcum album

Verbafcum nigrim ibid.

Verbafcum leptophyllon $\quad 6_{34}$

Verbena

Verbena commonis

Verbena facra

Verbenaca

Vermicularis

Vernilago

Veronica

Veronica famina Fuchfit

Veronica vera o maior

Veronica recta ma

119 Veronica plares pecies

${ }_{481} \mathrm{~V}$ eficaria

818 Veficariaperegrina
212

667

666

ibid.

42
68

917

ibid.

ibid.

ibid.

918

550

551

57

674

ibid.

679

424

ibid.

439

$09 \mathrm{r}$

630

$63 \mathrm{I}$

Vetorsica

Vetonica altera

Vetonica altilis

473.578

ibid.

ibid.

Vetonica fylueftris velagreftic 479

Viburnum

$108 \mathrm{x}$

Vicia

Viciafyluestris

Victorialis 142

Vittorialis famina of rotunda 96

Victoriola $76 \mathrm{x}$

Vinacea

727

Vincaperuinca : = $74^{8}$

Vincetoxicum 751

Vincetoxicum Indianwm $\quad 752$

Vincus $\quad 1205$

Vinum $73^{\circ}$

Vinum nyrtenm vel myrtites 1227

Viola aguatilis $\quad 679$

Violaalba 121.371

Violabulbofa $\quad 125$

Viola antsmnalis $\quad 355$

Violamariana $\quad 362.363$

Viola mariana flore albo $\quad 362$

Violucalatbiena $\quad 365$

Viola lutea 371

Viola lutea multiples: $\quad$ ibid.

Viola matronalis flore purpareo 376. 377

Viola matronalis flore albo $\quad 37^{6}$

Viola byemalis

Viola Damafcena

Violalwnaris

Viola latifolia

377

Violaperegrima ibid.

Viola lunaris longiorib. filiguis $37^{8}$

Viole lonaris radix $\quad$ ibid.

Violapalustris $\quad 679$

Viola nigra fise purpwrea $\quad 699,701$

Violaflore albo 699

Viols martic varietates $\quad 700$

Viola canina fylsestris ibid.

Viola tricolor $\quad 703.704$

Viola tricolor affurgens vel arborefs

cens 703.705

Viola tricolor fyluestris $\quad 704$

Viola tricolorpetres ibid.

Viola flammined

Viperaria $\quad 599$

Viperaria bumilis $\quad 597$

Viperaria Hipanica tivitid.

Viperaria Pannonica $\quad 598$

ibid. Viperaria Pannon. angustifolix ibid.

ibid. Viperina ibid.

$58 \mathrm{r}$ Virgh asurea. $\quad 348.349$

414 Virgh aurea eArwoldi Villanowani

998

504

501

$\mathrm{SO}_{2}$

ibid.

503

$27 \mathrm{I}$

ibid. padg. $\quad 34^{8}$

Virgafanguinea $\quad 1283$

Vifoaria $\quad 481.482$

Vifcum 1168.1169

Vifcum Indicum L'Obely 1168

Vifch̀m Perunianum L'Obely I 169

Nitex 1201

Vitalis
Virginea is thellatgon 618 


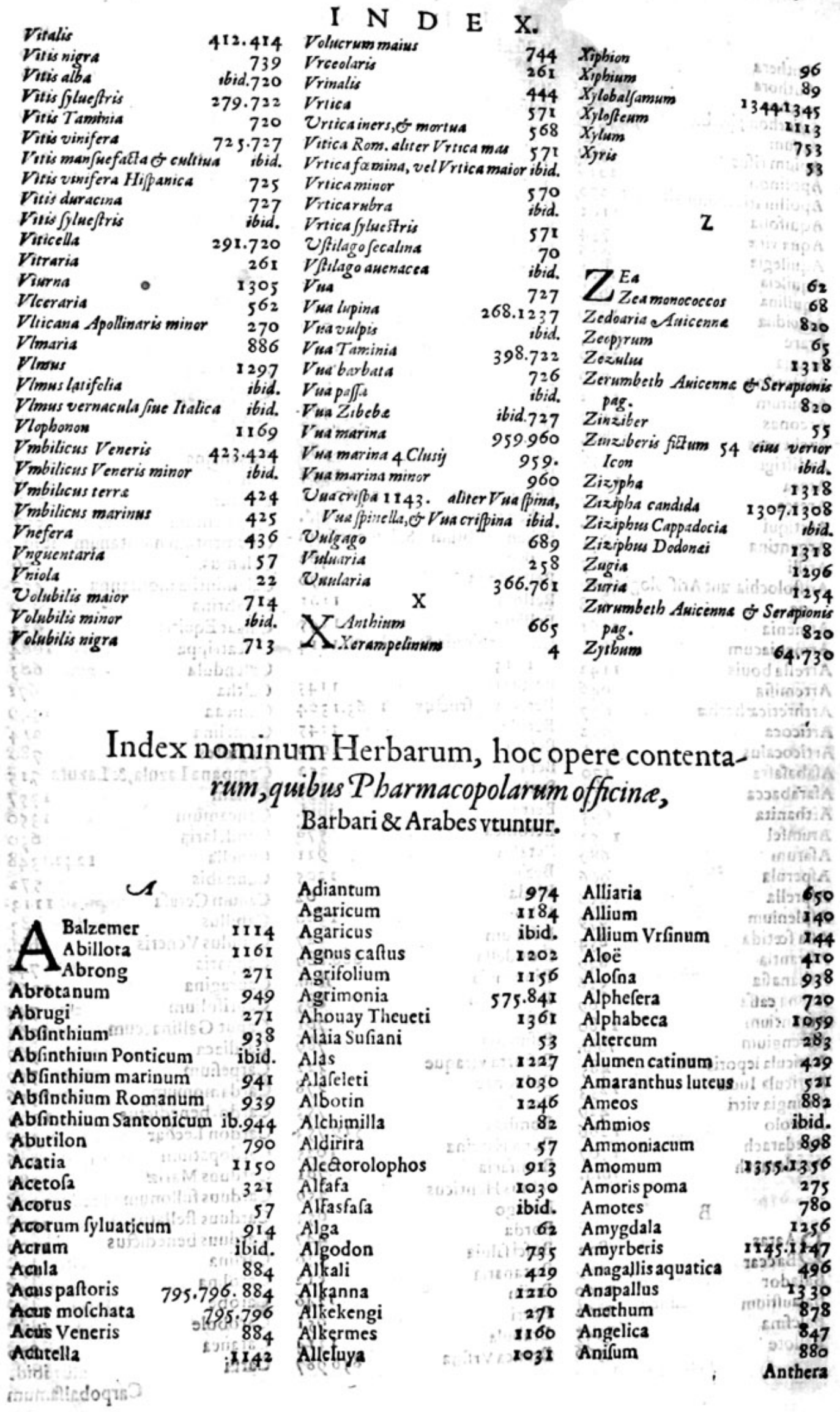




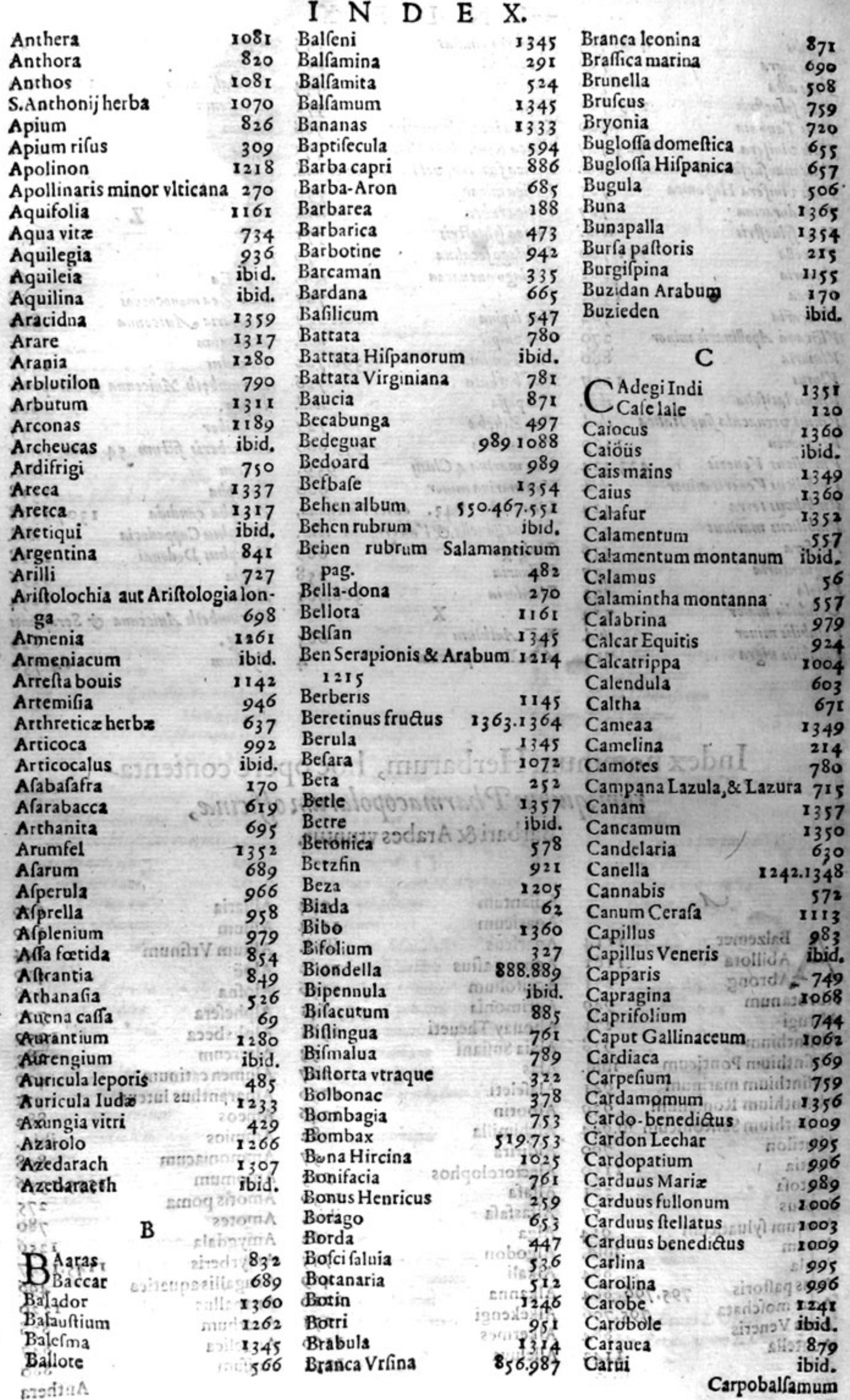




\begin{tabular}{|c|c|}
\hline $\begin{array}{l}\text { Carpobalfamum } \\
\text { Carthamus }\end{array}$ & $\begin{array}{l}1345 \\
1007\end{array}$ \\
\hline Cafab & 57 \\
\hline Cafca & $\begin{array}{r}1213 \\
800\end{array}$ \\
\hline $\begin{array}{l}\text { Cafiginete } \\
\text { Caftrangula }\end{array}$ & $\begin{array}{l}890 \\
580\end{array}$ \\
\hline Caffra filtula & 1242 \\
\hline $\begin{array}{l}\text { Caffilago } \\
\text { Caftracane }\end{array}$ & $\begin{array}{r}283 \\
1068\end{array}$ \\
\hline Cataputia & 405 \\
\hline Catherin $x$ diu $x$ flo & 926 \\
\hline Catti herba & 554 \\
\hline Caucafon & 145 \\
\hline Cauda equina & 958 \\
\hline Cauda murina & 346 \\
\hline Cauale lale & 120 \\
\hline Caulis & 249 \\
\hline Cedrium & 1171.1180 \\
\hline Celidonium & 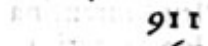 \\
\hline Centauria & 467 \\
\hline Centummorbia & 505 \\
\hline Centumnodia & 452 \\
\hline Cepa & 134 \\
\hline $\begin{array}{l}\text { Cephaglione } \\
\text { Cerefolium }\end{array}$ & $\begin{array}{r}1336 \\
883\end{array}$ \\
\hline Ceterach & 979 \\
\hline Chacani & $\quad \times 337$ \\
\hline $\begin{array}{l}\text { Chamadrys } \\
\text { Chamxpitys }\end{array}$ & 534 \\
\hline $\begin{array}{l}\text { Chamapitys } \\
\text { Chanach adip }\end{array}$ & $\begin{array}{r}423 \\
823\end{array}$ \\
\hline Chandama & 1389 \\
\hline Changue & 1352 \\
\hline Charhumfel & 1252 \\
\hline Chartamum Indun & 715 \\
\hline Charuinfel & 1252 \\
\hline Chafuth & 463 \\
\hline $\begin{array}{l}\text { Chela cancri } \\
\text { Chelidoniz }\end{array}$ & 677 \\
\hline $\begin{array}{l}\text { Chelidoniz } \\
\text { Chernes }\end{array}$ & 911 \\
\hline $\begin{array}{l}\text { Chernies } \\
\text { Cheruillum }\end{array}$ & $\begin{array}{r}1160 \\
871\end{array}$ \\
\hline Chermes & $\begin{array}{r}871 \\
1160\end{array}$ \\
\hline $\begin{array}{l}\text { Chinen re lignum } \\
\text { Chriltophoriana }\end{array}$ & c2: $\quad \begin{array}{r}\mathbf{1} 349 \\
8,0\end{array}$ \\
\hline Cicer & $\begin{array}{r}829 \\
1047\end{array}$ \\
\hline Cicerbita & $\begin{array}{r}1047 \\
232\end{array}$ \\
\hline Cicorea & ival $\begin{array}{r}232 \\
22 x\end{array}$ \\
\hline Cicutaria & 905 \\
\hline Cinabiris & $134^{\circ}$ \\
\hline Cinnamomum & 1349 \\
\hline Citocacium & 1215 \\
\hline Citrones & 1280 \\
\hline Citrulus & 768 \\
\hline $\begin{array}{l}\text { Citrulus cucumis. } \\
\text { Clematis peruinca }\end{array}$ & a $\quad 748$ \\
\hline $\begin{array}{l}\text { Cocro } \\
\text { Coctis peruinca }\end{array}$ & $133^{\circ}$ \\
\hline Coccus baphicus & 1160 \\
\hline Cocculus Indi & 1213 \\
\hline $\begin{array}{l}\text { Cocus } \\
\text { Colocafia }\end{array}$ & $\begin{array}{r}1338 \\
685\end{array}$ \\
\hline Colophonia & 1179 \\
\hline Coloquintida & $\begin{array}{r}769 \\
\end{array}$ \\
\hline $\begin{array}{l}\text { Concordia } \\
\text { Conder }\end{array}$ & $\begin{array}{r}301.575 \\
1247\end{array}$ \\
\hline Condrilla & $\begin{array}{r}1247 \\
227\end{array}$ \\
\hline
\end{tabular}

\section{I $\mathrm{N} \quad \mathrm{D} \quad \mathrm{E} \quad \mathrm{X}$}

Confolida maior 66

Confolida Saracenica

Confolida minor

Confolida media

Copra

Coralli herba

Corallina

Corculum ferul $\boldsymbol{x}$

Coriandrum

Coriziola

Corona terra

Corona regia

Corrigiola

Corrumeni

Cortex granatorum

Cot

Cotula fotida

Cotum

Coulcoul

Cracca

Craffula

Craffula minor

Craffula maior

Crepanella

Crepula

Creta marina -

Crifta gallinacea

Crocus hortenfis

Crocus Saracenicus

Cruciata

Cubebx

Cuciophora

Cúcumer

Cucumer afininus

Cúcurbita

Cucurida

Cupare

$\begin{array}{lr}\text { Cupare } & 1337 \\ \text { Cupula glandis } & 1158\end{array}$

Cófcuta

Cuürde

Cyclamen

Cydonium

Cydonites

Cyminum

Cyñogloffum

Cyperus

Cypreffus

Cypreffi nuces

347
508.512
599
1339
955
1380

Diapenfia

Dicoccos

Digiti citrini

Dionyfionyniphas

Dipcadi

898 Dolzolini $\quad$ G52.1065

859 Dore

718

705

278.1035

452

1358

1262

1030

618

753

I 249

1053

416

414

416

1070

987

428

912

1007

ibid.

925

ibid

765

Doronicum

29

Draconisfanguis $\quad 193$

Dracunculus hortenfis 1340

Dracontea hortenfis 683

Dragoncellum 193

Drofatum , ment

Dulcifida $\quad 8_{3} \mathrm{x}$

$\begin{array}{ll}\text { Dulcamara } & 279\end{array}$

766

779

1070

1158

462
$\times 349$

349
695

1264

730

907

659

29

1186

ibid.

1วक: D

Darchin

D

\section{Dardana}

Darfeni

Daúcus

Daucus Cretenfis

Decấn Hil.

Defrutum

Dens Caballinus

Dens Leonis

Dentali

Diacorallion

Diamorum

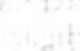

1334

× 349

665

1349

873

874

$135^{8}$

730

283

155

ibid,

495
E -

E Elaprin

Eleri

Eluchi

Ençal

Endiuia

Englenterium

Enula campana

Epithymum

Eruca

Eruum

Eryngus

Eltepa

Efula

Etremelli

Eufrafia

Euforbium

Eupatorium

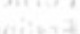

Eupatorium M

1239

1213

1339

1358

ibid.

222

1088

649

462

1053

2053

1099

404

537

1016

500
575
534

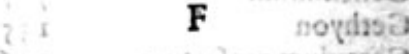

EÁba

F Faba Lupina

Fabaria

dว9ก 416

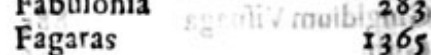

Fagotricum a thi buap $1 \mathbf{8} \mathbf{3}$

Farblauff $\quad 1293$

Farfara $\quad 667$

Farfugium ibid.

Faua de Malaqua $\quad \mathbf{i} 60$

Faufel 1337

$\begin{array}{lr}\text { Febrifuga } & 527 \\ \text { Fel Terrx } & 436.437\end{array}$

Ferola

Ferulacoli

Ferraria

Ficaria minor

Filago humilis

Filfel

436.437
899

Filipendula

Filius ante patrem
575.581

1175.581
669

519
$\times 337$

902

132
Filica. 
Filicaftrum

Filix aquatica

Fiftici

Flos Trollius

Flos regius

Flos Conftantinopolitanus 380

Flos:Micancalus

Flos Cuculi

Flosidonis

Flos S.Iacobi

Flos amoris

Flos aureus

Flos Solis

Flos caryophilleus

Fluida

Fœniculum $\quad 877$

Fæniculum porcinum $\quad 897$

Fœnum-grxcum $\quad \mathbf{0 2 7}$

Forficula Cancri $\quad 677$

Frafinella

Fraxinella

Friata

Frondiflora

Fufel

Fuga Dxmonum

Fulfel

Fulful

Funus terrx

QF

Calla

G'Galbanum

Galéga

Gallitricum

Galli crifta

Geinma populi

Gentiana

Garderacantha

Garipot

Genefta soloMmuis $\mathbf{1 1}_{32}$

Geffeminum

Gethyon

Geranium molcatum

Gianziban

Giarga

Gibenech

Gingidium Vifnaga

Gith

Gith quod in fegete mafitur

Githago

Giul Catamer lale

Giula

Gladiolus

Glanfdes Terr $x$

Glória filia

Gniacardus

Gotim

Gralega

Grana Paradif

Grànum Nil Auicenne 135

Granum Indicum

Granum gnidium

Granum viride

$75^{8}$

1179

512

I337

433

ibs

$i_{\text {bid. }}^{7 \text { Is }}$

$\times 346$
I $\times \mathrm{N} \quad \mathrm{D} \mathrm{E}$ X.

Granum Nil

Granum Iuniperi

Gratia Dei

Groffularia

Gruinalis

Guaiacum

Guadum

Guart

Guardalobo

Gul

Gummi Tragacanthi $\quad 1_{1} 4^{8}$

Guzarata $1357.135^{8}$

$\mathbf{H}$

$\mathrm{H}$ Abal Nil

Handacocha

Hanga

Harmel

$\mathrm{H}_{\mathrm{affab}}$ elderire

$\mathrm{Ha}$ (mifen

Hebulben

Hedera fpinofa

Helleborus albus

Helleborus niger

Henne

Hepatica 681.966 .1376

715

ibid.

1019

1389

1072

57

715

1249

$71 \mathrm{I}$

357

825

Herbacantha

Herbanefa

Hecba benedita

Herbaleonis

Herba paralyfis

\begin{tabular}{lr} 
Herbagalleca & 637 \\
\hline
\end{tabular}

Herba doria

Herba Paris.

Herba violaria

Herba S. Anthoni

Herba Catti

Herba fella

Herbalaffulata

Herba Tunica

Herba Turcica

Herba pinnula

Herba Simeonis

Herba S.Petri

$\begin{array}{ll}\text { Herba S.Petri } & 537 \\ \text { Herba San } 2 x \text { Cunigundx } & 774\end{array}$

Herbatum

Hermodactylus

Higuero fructus

Hippia

Hirundinaria

Hifpane

Hyacinthus

Hyofcyamus

Hypericum

Hypoquiftidos

Hyffopus

$+218$

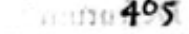

$I_{\text {Iacea nigra }}^{\text {Acea }}$

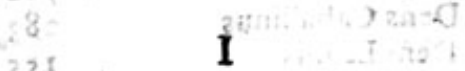

Hirculus

918

936

068

$35^{\circ}$

329

710

1070

554

1347

1524

473.479

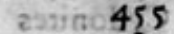

matit 283

Ind $x \quad 774$

(2021 को 897 .

131
1361

$49 \mathrm{I}$

$75 x$

1220

260

104

283

433

1099

465

704
588
Iacobea

Iaifol

Iapatri

Iaralnare

Iarus

Ia fminum

Iaucia Lindi

Iaufiband

Iecoraria

Iefeminum

Ignanes

Imperatrix

Ionquillias

Iouis glans

Iouis barba

Iouis flos

Ireos

Iris

Iris Florentina

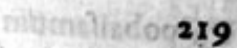

2354

ibid.

1338

685

746

r 339

$1 \times 354$

966

747

780

895

114

1252

412

936

94

ibid.

Iua Artherica

Iua mofcata

Iucca

Iucca perana

1359

Iuglans 1252

Iuiube $\quad \mathbf{I}_{3} \mathbf{1 8}$

Iuniperus : $\quad \mathbf{2} 89$

Iufquiamus

283

$\mathbf{K}$

Kali 492

KKali articulatum ibid.

Kakile

Kermes

Keffuth

1160

Kik

Kikaijon

Kitran

$4^{62}$

400

2ir

T Acca

ELachetta

Lactuca

Lactucella

Ladegi Indi

Lanaria

Lancea Chrilti

Lanhan

Lanugo

Lantana

Lapatium

Lapdanum

Lappa maior

Lappa minor

Lappa inuerfa

Lauandula

I. auanefe

Lauanna

Laureola

Lenticula aque

Leoherba

Lcontopodion

Lepidium
L

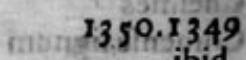

- 3.89 ibid

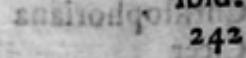

242

J $35 \mathrm{I}$

351
630

327

1339

753

1305

3 II

1108

665

ibid.

ibid,

468

ibid

219

680

439

518 


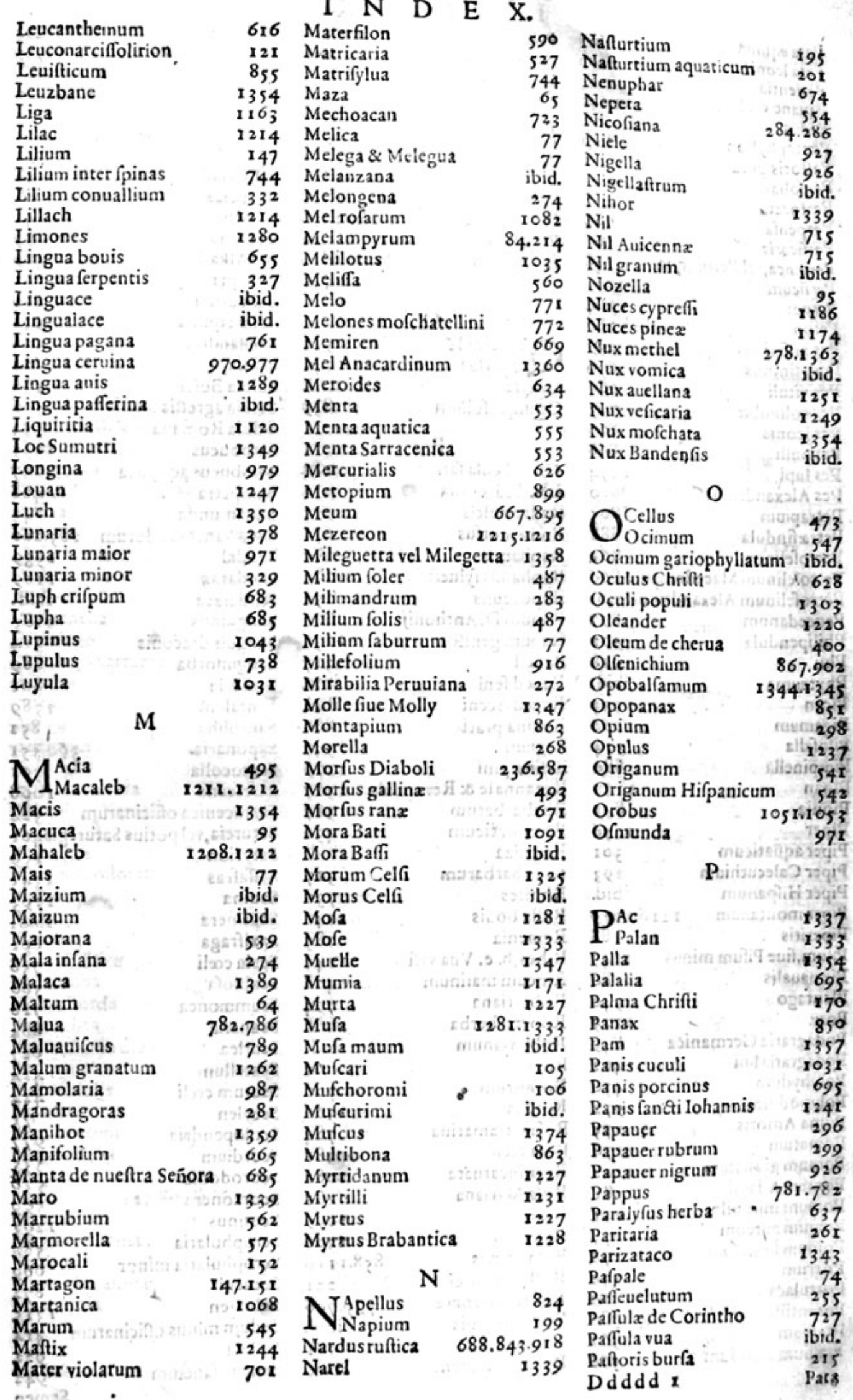


Pata equina

Pataleonis

Patientia

Pauane vel Pauame

Pedua

Pentaphyllon

Paftoris pera

Perfoliata

Perforata

Perpenfa

Perficaria

Peruinca,vel Peruinqua

Perficum

Petum

Petun

Pes anferinus

Pes afininus

Pes vituli

Pes columbz

Pesleonis

Pespulli

Pes lupi

Pes Alexandrinus

Petrapium

Petrafindula

Petrofelinum

Petrofelinum Macedonicum 866

Petrofelinum Alexandrinum ib.

Peucedanum

Philipendula enzato

Phi

Phyteuma

Pican

Pigamum

Pilofella

Pimpinella

Pinan

Pionia

Piper

Piper aquaticum $\quad 361$

Piper Calecuthium 293

Piper Hifpanum i ibid.

Pipermontanum $\quad$ I216.1219

$\begin{array}{ll}\text { Piperitis } & 188\end{array}$

Pifum, fiue Pifum minus $\quad$ ro47

Pix naualis $\quad 1180$

Plantago iftatio $34^{\circ}$

Poaz 1337

Podagraria Germanica ' 849

Podagrarialini $\quad 462$

Polyhydion teinis 436

Polypodium $\quad 972$

Poma Amoris $\quad 275$

Pomatum $\quad \mathbf{2 7 6}$

Pomum granatum $\quad 1262$

Pontum Adami

Pomum mirabile

Pomum aureum

Pomum fpinofum

Porrum

Portulaca

Potentilla

Praffium

Praffium fotidun

\section{I $N \quad D \quad E$ X.}

637 Rubert2

890 Rufcus

$74^{8}$ Ruta capraria

508

I 3 I 4

926

471

I343

457

Ruta hortenfis

794

739

1068

1072

SAbdarifa

SSaccolaa quebir $\quad 792$

Saccolaa ceguer $x$ ibid.

Safarhe-Bamon $\quad 4^{1}$

$\begin{array}{llr}309 & \text { Saggina } & 77 \\ 619 & \text { SalAlkali } & 429\end{array}$

330 Salequa 1241

Salicornia $\quad 429$

Salix equina $95^{8}$

Salufandria $\quad 926$

Saluia $\quad \mathbf{6 2 4}$

Saluia Bofci $\quad 536$

Saluia agreftis Listalkng $\quad 536$

Saluia Romana $\quad 553$

$\begin{array}{llll}R & \text { Sambucus } & 1235 \\ \text { tius } & 184 & \text { Sambucus aquatica } & 1237\end{array}$

$\begin{array}{lllr}\text { R Adicula fatiua } & 184 & \text { Sambucus aquatica } & 1237 \\ \text { Radixcaua } & 934 & \text { Sampetra } & 428\end{array}$

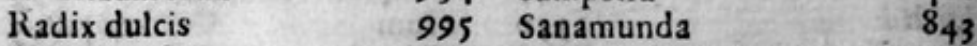

Ranxmorfus $\quad 671$ SanaSancta Indorum 285.286

Raphanus $\quad 184$ Sandal 1389

Raphanusfylueftris $\quad 188$ Sandarax 109

Rapocaulis $25 \mathrm{I}$ Sandaraca ibid.

Rapum D.Anthonij 8 ro Sanguinus $\quad \mathrm{I}_{3}$

Rapum genifta $\quad 1130$ Sanguis draconis $\quad 3^{14}$

Raued 131 Sanguiforba 89

Raued feni $\quad$ ibid. Sanicula $80 x$

Raued-Sceni $\quad$ ibid. Santalum 1389

Regina prati 886 Santolina 845

$\begin{array}{llll}\text { Regium } & 547 \text { Saponaria } & 360.551\end{array}$

$\begin{array}{llll}\text { Refina pini } & \text { I179 Sarcocolla } & 301\end{array}$

Rezannale \& Rezennale 1317 Sarraceria $\quad$ 1 068

Rhabarbarum $\quad 317$ Sarracenica officinarum 524

Rha ponticum 436 Satureia, vel potius Saturegia $46 \mathrm{z}$

Regaliz3 ibid. Satyrion

Rheubarbarum $\quad 317$ Saffafras 1341

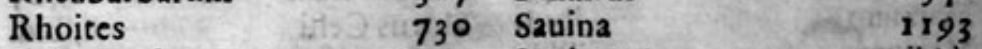

Refta bouis II4I Sauimera ibid.

Remenia $\quad 283$ Saxifraga 891

Ribes,h.e.Vua vrfi $\quad$ Ir $_{4}$. Scala coli $\quad 75^{8}$

Rincum marinum $\quad 428$ Scabiofa 586

$\begin{array}{llll}\text { Robertiana } & 794 & \text { Scammonea } & 718\end{array}$

Robertiherba ibid. Scanaria $\quad 88_{4}$

$\begin{array}{lll}\text { Robertianum ibid. Scarlea } & 627\end{array}$

$\begin{array}{llll}\text { Rogga } & 6 r & \text { Scatellum } & 424\end{array}$

Roraftrum : $\quad$ iroutoti 720 Scatum coli $\quad 424$

Rorella incin 1366 Sceylen $7 \mathbf{7}$

Refa vitramarina $\quad 784$ Scolopendria $\quad 977$

Rofa calt $\quad 38 \mathbf{i}$ Scordium 535

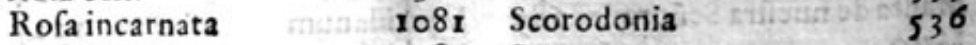

Rofa Mariana $\quad 38 \mathbf{1}$ Scorzonera 599

Rofella 1099 Scotinus. 1293

Ros folis

Rofmarinus

Roftrum porcinum

Roftrumciconia

819 Roftrum gruis

$\begin{array}{ll}562 & \text { Rubia herba } \\ 566 & \text { Rubia tinctorum }\end{array}$

1366

858.1110

Scrophularia

Scrophularia minor

580

795.796 Sebeften 1315

ibid. Sedumminus officinarum $4 \mathrm{I}_{4}$

961 Selliga 922

ibid. Semen fantum . $94^{2}$ 


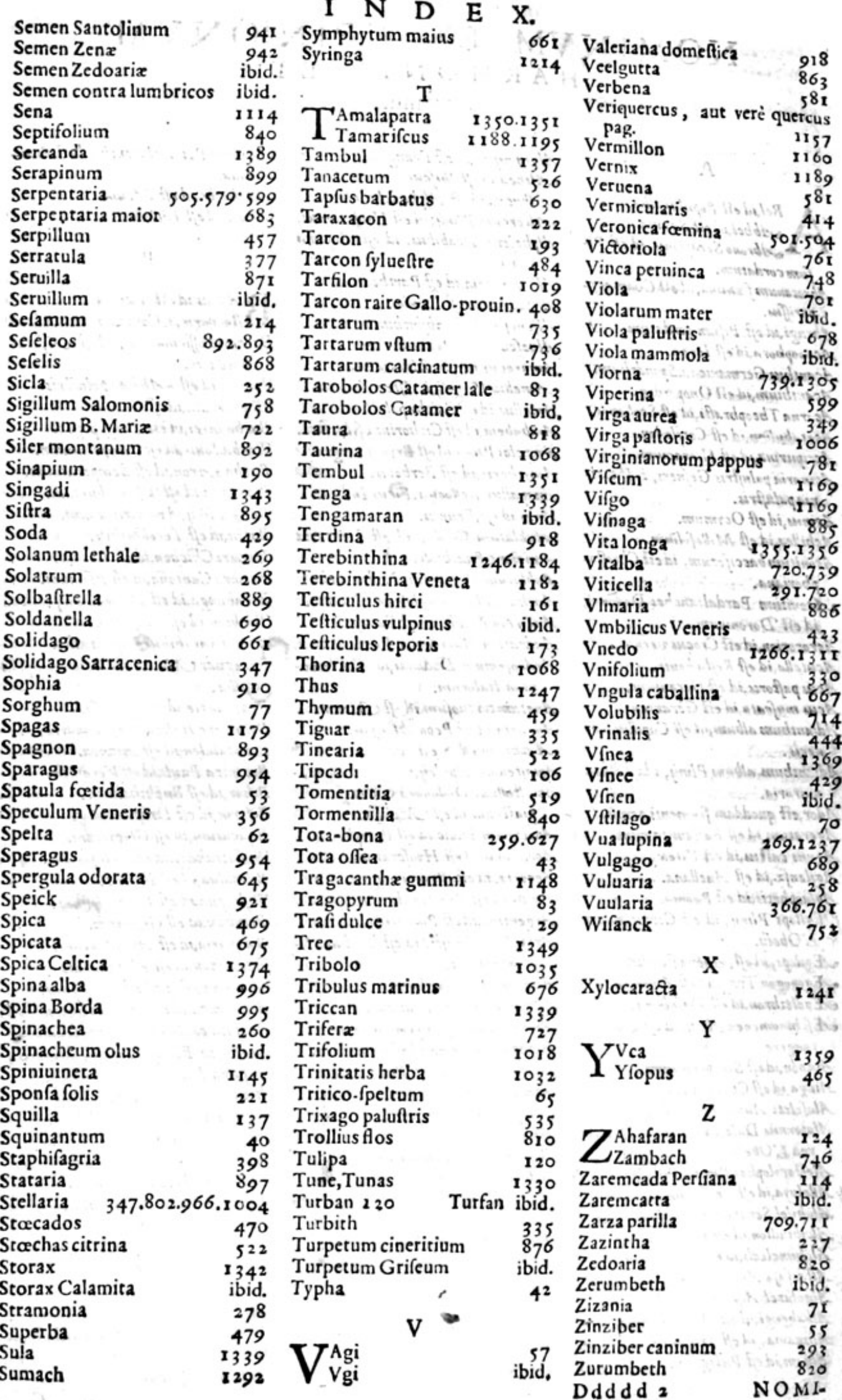




\title{
NOMINVM ET OPINIONVM
}

\author{
HARM ONIA ET \\ confenfus.
}

\section{A}

Bel,id est Populus alba. Abbel,id est Sanina.

Abrono Serapionis, id eft $P$. fun cordatum.

Abrotanum famina, id est Chamecypariffus.

Abrugi,id eft Pifum cordatum.

Acanophora, id eft lacea.

Acant bus Germanica,i.Spondylium.

Acanthum,id est Onopordan.

Acarna Theophrafti, id oft Scolymos.

Acetabulum,id eft Coryledon.

Accuputring, ed eft Hieracism.

Acinaria paluftris Gefneri, i, Vacciniapaluftris.

Acinus, id eft Ocymum.

Acbilles,id oft Mille folium.

Aconitum bacciferum, id est Chrifto. phoriana.

Aconitum Pardalianches Dodomei, id est Doronicum.

Acrocorion, id est Crocus vernus.

Acuiella, id eft Refta bouis.

Acus paftoris,id eft Geranium.

Acuu mufcat a, id est Geranium.

Adianthums album,id eft Capillow Veneris.

Adiantbum album Plinij, id ef Ruta muraria.

Ador, est quoddam frumentigenus.

Ageratum, id eft Balfamita misor.

Agnus caltu, id est Viex.

Agilenf z, id eft Auellana.

Aglaophosis, id eft Peonia.

Egilops Pliny, id oft Cerris maior L'Obeliy.

Agilops, id eft, Anena fterilis.

Egopogon Tragi,ed eft Vlmaria.

Agolethron,id eft Tota bona.

effchinomenen Pliny, id eft Noli me tangere.

Aizoon,id eft Sempersiunum.

Aing a id eft Chamapitys.

Alafoleti Auicenne, id eft Medica.

Alaternus Dalefcampiy, id eft Phillyrea L'Obely.

AleEtorolophos Plini, i.Fiftularia.

Allelsya, id eft T rifoltsum acetofum.

Alcbilel Serapionis, i. Polemoninm.

Alcibiadion, id eft Echrum.

Alcbimelech,id eft Melilotu.

Alfusfafa Awicenns,id eft Medica.

Algofarel Asicemne, id eft Daucus.

Alkakengi,id eft Halicacabum.

Alimonia, id eft Trifolium acetofum.

Alnam,ideft Pulegium.
Alnus nigra,id eft Frangula. Alibea,id eft Ibifcus.

Albucus,id eft Asphodelus albus.

- Aliercum Pliniy, id eft Hyofcyamiou.

Alphefera Arabibus, id eft Bryomia

nigra.

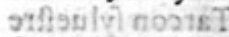

Alfabarateid, id oft Parthenium. Allcebran,id eft Ezula. . nozie T Alfencfuid eft Abfint bium.rusu: Alue fen, id est Peucedanum.

Amaracus,ideft CMaiorana. Amelluw Virgiliy,i.After Atricu. Amellus, id eft Calshapalustris. Ambubeia, id eft Cic horium fylueftre. Ampelos Pliny,ide eft Bryonia nigra. Amyrberis, id eft Berberis. Anapallus Bellony, s. Ficus Indica. Anas, id eft, Prunus.

eAnblatum Cords, id eft Dentaria semaior CMatbioli.

Anblatum Dodonai,i. Nidus anis. Anchufa,id eft Bugloffum fyluestre. Andirian Rhafis, id eft Fabago.

Andration Amerrois, c. Pescedannm. Androfemum Dodonai,jd eff Clyme:num Italorum.

Anetum tortuofum, id eft CMeum.

Anguria, id eft Pepo oblongus. Anonis,id eft Resta bouis.

Apraftellum Apreley,i Bryonia nigra. Apiaftellum Dodonei,i.c Melisfa. Sestastrumi,ideft CVeliffa. Apocynum Diofcid eft Periploca. Apolinaris id eft Hyofcyamus. Spropia, id eft Bryonia nigra. Aprus,id eft Pifum rubrum. Argentina,id eft Potentilla. Aria Theophrafti, id eft Sorbus AlpinaGefneri.

Arcium,id eft Bardana.

Argentilla,id eft Vlmaris.

Aribritica,id eft, Primula veris. Artemifia marina, id eff Cineraria. Arrbenogonon,ideft Parietaria. Armoracia, i. Rhaphanues rusticus. Arornas,ideft Inniperus.

Arzi,id eft Oriza.

Astrantra,id eft Imperatoria.

Asterion,id eft Aster Atticus.

Aftergir Rhafis, id eft Azaradach Autcenne.

Apalatbus, id eft Acatia Math. Aplenium fylmestre, i. Loncbitis. Aplenum, deft Ceterach. eAftorca, td eft Stacas. Aibanalia, id eft Tanacerum. Aulitica,id est Camamalum. Aurenm olus, id eft Atriplex.

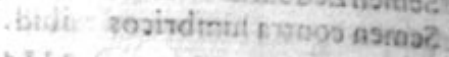
sno:

Auornus Petri Placenty, id eft Eraw. gula.

Azabafer jd oft Menm. Azez, id eft Lichen. Limelagyta?

B Stlasion? slingue

B Aaras,idest Paonia. mullitare? Baccaris, i. Conyza maior Marb. Baccaris officinarum, ideft eAfara. baccaris.

Bamia,id eft, Alt bea palustris Baptifecula,ideft Cyania? mailig

Barba birci,id est Tragopogon.

Barba Ionis,id eft Semperuinum.

Barba eAron,id eft Semperuinum.

Barbarea,id eft Pfeudobunisum.

Batis Plmij, id eft Crithmum.

Baton,ideft Terebinthus.

Bazari Chichen,ideft Linum.

Bazara Cantona, id eft P fyllium.

Becabunga,id eft Anagallis aquatica. Bechion, id eft Tuffilago.

Bedoara arabibus, Spina alba.

Bedeguar CMatb.Sylwat. id est Spina alba.

Bederangie, id eft Meliffa.

Belwidere Italica, id oft Linaria.

Beiabalalen,id eft Aizoon.

Betonica Pauli,id eft Veronica.

Bibar,id eft Buphthalmon.

Bifaria,id eft Dracunculus.

Bifacutum, id eft Gingidtum.

Bafiatrabagi,ideft Polygonum.

Bifmalua,id eft Ibifcus.

Biflngua,id eft Hippogloffum.

Bombax, id eft Gofjipium.

Botonaria,ideft Aphyllanthes.

Bowtomon, id eft Platanaria.

Branca vrfina, id eft Acanthus.

Britannica,id efl Bijtorta quorundam.

Braffica canina, id eft Cynocrambe.

Broeggia Pliniy, id eft Helxine Ciffampelos.

Brufcus,ideft Rufcus.

Bulbus agreftis, id eft Colchicum.

Bubonium,id eft Aster Atticus.

Buccinum, id est Confolida regalis.

Bugia, id eft Cortex Berberis.

Boromon Theophi.Iris palaftris.

Bulef,id eft Salix.

C

Acalis, id eft Tuffilago.

Cachrys marinum,i. Crithmum.

Cacbrifera, id est Libanotio.

Cabade, id eft Polium.

CAfal, 
Nominum quorundam interpretatio.

Coffal,id eft Agrimonia.

Cadabrina, id est Lonchitis.

Calchochruw, sd eft Fumaria.

Calcifraga, id est Crithmum.

Calibasd est Calendula

Cals ba Poctarum, id eft Calcndala.

Callionymum Gefnidid est Lilium coninalisiam.

Callitricum, id esf Capillius Veneris.

Callion Plimi,id est Alkakengi.

Calicularis, id eft HIyofcyamus.

Calmegia, id eft Galunga.

Camphoratum,i. Abrotanum magnü.

Cendelaria,id est Tap/us barbatus.

Candela Regia, id eft Tapfun barbatus.

Cania Pliny, id eit Vrtica.

Cuscum Auicenne, id eft Cbelidoniism minus.

Cantabrica Plini, id est Rapunculus.

Cantabrica Turneri, id est Carjo. phylliw.

Capillaris, id eft Capillus Veneris.

Capnos,id est Fumaria.

Capritis, id eft Eumaria.

Capnogorgism Diof. id eft Fumaria.

Caprificus Plinu, id est Ezula Tragi.

Caranfal,id eft Caryophyllos.

Cardamum, id est $P$ / cudobunium.

Cardopatiam, id est Carlina .

Cardsuu fallonum, id eft Dipfacus.

Carobia Altwary, id eft Cerasia filiqua.

Carica,ideft Apios.

Carnabadion Simeonis Sethi,i.Carui.

Cartamua flueftris, id eft Airactylus.

Carpentaria, id eft Pfendobunium.

Carpefium, id eft Cubebe.

Carpefism Galeni,id eft Rufcus.

Carnabadion Stmeonis Sethi,i.Carum

Cardel,id eft Sinapis.

Caffebar, id eft Coriandrum.

Caffilago CMath. Syl. id est Hyofcy. amus.

Caffutha, od est Cufcuta.

Caftoris, id eft T rifolum paludofum.

Cafignete, id eft Pimpinella.

Caftrangula, id est Scrophularia.

Culcitrapa Mathioli, idest Carduus Stellatus.

C.atef, id eft Atriplex.

Cacbrifera Rofmarinus, id of Libanotis.

Cathfum, id eft Abrotanum.

Cattaria,dest Nepera.

Cataputia maior, idest Ricinus.

Cancon Plimiy, id est Equijerum.

Canda Vupium,id est Alopecuros.

Cali ros, id est Gramen manna.

Ceciliana Pliny, id est Androfemum Dodo.

Centummorbia, id eft Nummularia.

Centrum Galli, id est Horminum.

Centunculius, id eft Gmapbalium.
Cepea, id est Anagallis Aquatica.

Ceratomia,id eft Ceratia filigua.

Cercis Theop. id eft Arbor Imde.

Cefis, id est Dancus

Cerna mator, rd est Ricinum.

Cerannia, id est Cralfula.

Cernicaria, id eft Trachelium.

Cichorium verrucarium, id eit $\mathrm{He}$ dypnois.

Circea Gracis, id est Mandragora.

Cincinnalis, id est Capillow Veneris.

Cicerbita, id eft Soncbus.

Cnicus, id eft Carthamus.

Cnec: $m$ fupinum Cordi, id est Carduus benedifius.

Cnicus fyluestrus,id eft Atraltylis.

Citrago,d eft Meliffe

Cidromela, id eft Mulus Medica.

Coneraria, id est lacobes Marina.

Charantia, id eft Bal /amina mas.

Chamaciffus,id eft Hedera Terreftris

Cbamalence,id est Tufilago.

Cbamapence, id est Kofmarinum fylwestre.

Chamaxylon Pliniy, id eft Gnafalium.

Chamelea Germanica, id eft CMlezereon.

Chamsdaplone, id est Lasureola.

Cbamadipbne Pliny, id eft Vinca perwinca.

Cham aplinom,id est Eryfrmum.

Chameir biphes,id eft Palmites.

Chamaleagnus, id oft CMyrim Brabantica.

Chamarops Plixiy, id of Palma bumiles.

Charmuba, id eft Ceratia filiqua.

Charfind eft Apium.

Chaftara, id eft Betonica.

Chat be, id eft Cusumer.

Chironia, id est Bryonia nigra.

Chitmi, id eft Althes.

Choeradoletbron, id eft Xant hiwm.

Chubeze, id eft Malua.

Chiliodymamis, id eft Ben album.

Cbryfolachanon Plini, i. Tota bona.

Cbryfantbemum Perumianum, id ẹt Flos Solis.

Chryfocome Gefmeri, id eft Linaria.

Chryfogonon,id est Blattaria.

Chryfomela Atbenai, id est Malius Medica.

Citragoo,d est Meliffa.

Clawum Veneris, id eft Nymphas.

Clauicula, id est Hedera Helix.

Clematis Peregrina, id est Flammula Iours.

Clematis Daphnoides, id efl Vimca peruinca.

Clematis altera Mathio. id est Viorne.

Cleome Horati, id eft Eryfimum.

Colabrina, td eft Arum e Egprisum.

Cocior, id eft Faniculius.
Colocafia,id eft Faba e Egypria.

Columnaris, id eft Campana Latief-
cens.

Columbina ACTwary, id of Verbena:

Combul,sd efl Nardus.

Condifitid eft Sapomaria.

Condurdom Pliniy, id eft Vaceireias

Confolida medis Fuchuty, id a $5 b$ Belis mattor.

Confolrda media, id est Bugula.

Confolida mimer Mabioly, id est Prin. nella.

Confolula minor $R$ uelliy, id eft Bellis minor.

Conzambach Twrci, id eft Hemero. calles Valentivia.

Connarus Albenei, id eft Iniube.

Concordia, id est Agrimonia.

Contla,id est Mjrrbis.

Confecratrix, id eit lris noftras. Coralloises Cordi, id oft Dontaria
Mathioli.

Corcorns Melochia, id efl Olus Indaicum.

Corcorms Marcelli vet. id eft Ans. gallis mas.

Corydalis, id eff Radix Cana.

Cor Indum, id est Pifom Cordatum.

Coriziola Rhafis, id est Scamonea.

Corona fratrum, id eft Carduus Erio. cephalus.

Corion,id eff Coriandrum.

Coronopus,id eft Cornu Cerui.

Corigiola,id eft Centumnodia.

Corona monachi, id est Dens Leonis.

Corona Regia, id eft Pomam pino fom

Corome ola,id eft Lyfimacbia.

Corgdalium, id eff Fumaria.

Corylus,id est e Auellama.

Coftus purius CMathio.id eft Panax Cbironium.

Coftus Hortorwm, id eft Balfamita maior.

Cofta Canima, id est Quinquenerwia. Corjdalopodium,ideft Con fol. Regalis Cotinus Dodo.id eft Coccygria Ploni. Cot eAvicenne,id eft Medica.

Crepanella, id eft Dentillaria $R$ ondeleiij.

Creta marina, id eft Crithwum.

Crinita, id est Capullus Veneris.

Cubeb.us Serapionis, id eft Rufcus.

Chcullata, id est Pinguicula.

Cucurida, $i$. Dentillaria Rondeletiy.

Cuminum Atbiopicum, i. Ammi.

Cunilago,d eft Conyza.

Cunegundis, id of Expatorium Awicenne.

Cunila Columells, id eft Satureia.

Cunophoron,ideft Nux Indica.

Cunder Avicenna, id eff Saponaria.

Corcsma id eft Cyperus Indus.

Curcas Clusi, id eft Ricimus.

Cusbor, id est Coriandram. 
Nomina quorundam interpretatio.

Cyanus Hierofolymitand, id eft Ptarmika Anstriaca.

Cy fo, id eft Hy Jopus.

Cymenalis, id eft Gentiana.

Cynanthernis, id eft Cotula fortida.

Cynojpaftus,id eft P eonia.

Cynoforcbis, id eft Satyrimm.

Cynocephalus Apulei,id eft Antirrbinum.

Cynocepbalus,ideft Anetum.

Cymosbatos Diof. id eft Roga fyluefris.

Cynosbatos Tragi,ideft Oxyacantbus Cynosbatos Ruelly, id eft Rubus. Cynosbatos Dalafcampins, i.Capparis. Cyprus,id eft Liguftrum L'Obely. Cyprus Dod. id eft Plbillyrea.

\section{D}

$\mathrm{D}$ Amedrios, id eft Chamedrys. Danebalchil, id est Equifetum. Darach,ideft Palma.

Darache move, id eft Mufa.

Datiro, id est Stramonia.

Debonigi,id eft Anibemis.

Debonigi, id eft Chamomilla.

Dect a,id eft Beta.

Delphinium, td eft Confolida Regalis.

Diapenfia, id eft Sanichla.

Didar Arab.id est Vlmus.

Digitus Veneris, ideft Nymphes.

Dili, id est Glaftum.

Dili,id eft Ifatis.

Diocallia Apslei, id cst Chamomelum

Diopiron, id eft Maliam folis.

Diofpiros Pliniy, id eft Lacryma Iob.

Diofantbos Theop.i.Superba Fuchsy.

Docbon, id eft P anicum.

Dolicbus Theophr. id eft Pbafeolus L.Obely.

Dracoberba,id eft Tarcon.

Draco flueftris, id eff Ptarmics.

Drofutum, id est Haluabbi Anifum.

Drofron Cordt,id est e Alchimilla.

Drypis Guillandini,i. Tragon Mat.

Drppis Theop. i. Eryngium Marinũ.

Dryopteris Tragi, id est Pteridion Cordi.

Dryopteris, id eft Adianthum nigrü.

Dryopbonon Plini, i. Arabis Dodon.

Dalb Arab, id eft Platanus.

Delcamara,id eft Amara Dulcis.

Dulcifida, id eft Pania.

Dulcichinum Guillandini, id oft Cyperusdulc is Tragi.

Dumbebe,i.Endiuia.

\section{E} E Chium paluftre Cordi,id eft Scor-

"Eghelo Dodon, i. Laburnum L'O. beliy.
Eleagnus Math

Elegfelinum,ideft Paludapium.

Eliphacos,ideft Salaia.

Elkiag eber, id eft Rofmarinus.

Empetron Dod id eft Kali.

Empetron Rondeletiy, id eft Critbmü.

Empetron, id est Tragiberba Twrea.

Empetron, id ef Herniaria.

Encephalus,id eft Chamarrbiphes.

Eneaphyllum LO Obely, id oft Dentaria.

Eneaphyllam, i. Lingua Serpentina.

Enneadynamen Gefneri, id eft Gramen Parnajfis.

Epbatium, id eft Ranumenlus.

Eupbrofynum Plimi, i. Borago.

Epilobion Gefn. id cst Chamanerism L'Obeli.

Epimetron,id est Epimedium.

Epipetron, id eft Epimedium.

Epipaltis Recentiorum, i. Helleborine.

Epipatt is Rondeletiy, id eft Herniaria.

Erantbemum, id eft Flos Adonis.

Ericoides,i.Eupbrajialutea Dod.

Eringium Vegetiy, i. Acarna Theop.

Eringium Guilland. id eft Carduus Stellatus.

Erinus,id eft Corcoros Plini.

Eruum fylueftre, id eft Catanance.

Eryphoon Apulei, i.Ruta.

Enjimsm Theop id eft Camelina.

Erysbrodanum, i.Rubia Tinctorum.

Exupera, id eft Verbena.

\section{F}

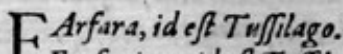

F Farfugium, id eft Tuffilago.

Farfium Auicenne, id eft ThoraValdenfis.

Farfrugsm, id est Caltha paluftris.

Faraxum, id eft Tuffllago. *

Faudegeni, id eft Origanum.

Fel Terra,ideft Centaureum.

Feniculus Porcinus, i. Pencedanam.

Ferulacoli, id eft Thapfia.

Ferraria,i. Agrimonia.

Ferraria L'Obely, i. Scrophularia.

Feftuca Pliniy, id eft Auena Sterilis.

Flammula louis, id eft Clematis Peregrina.

Filicaftrum,id eft Ofmundus Regalis. Filix paluftris, i.OSmundus Regalis

Filix Florida, i.OJmundus Regalis.

Filix Latifolia Cordi, id est Ofmundus Regalis.

Ficarra, id eft Chelidonium minus.

Flos Regino, i.Confolida Regalis.

Flos Ambarmalis, td eft Polygala.

Fontalis, id eft Potamogeiton.

Folism Indsum, id e/t Malabatbrum Garcia.

Fuga Damonis, id eft Hypericum.
Fufus,ideft Airaltylis.

Fumaria Corydalis, i. Radix Cana.

\section{G}

GAledragon Plini,i. Dipfacm. Garofmus, id eff Airiplex Olida.

Gallitricum, id eft Horminum.

Gelfeminum Indicum, id eft Mirabi-

lia Peruniana.

Genitura,id eft Anetum.

Genicularis,id eft Pbu magnum.

Genecant be, id eft Bryonia nigra.

Geumi.Caryophyllata.

Giezar,i. Dascus.

Giezar Aridras,i. Belbsnen.

Gith,i.Nigella.

Gitbago Plmi, id eft Lollium.

Glascium, ideft Papatser Cornetam.

Gladiolus Aquatilis, id est Inncius Floridus.

Globularia, i. Aphyllantbes.

Gloffographe Auicenne, id eft FNmaria.

Godipium, id eft Xylon.

Granum Regism Mefus, i. Ricisas.

Gromphena P linì, id eft Calendula.

Groffularia, id eft Ribes.

Groffularia, id eft Vua Crißpa.

\section{$\mathrm{H}$}

II Abonog Awerroyj, id est Chamo-

Hab al Nal Serapionis, id eft Connoluulus ceruless.

Halcafmeg Aneroiy, id eft Foniculus.

Halgazar Auerboe, i. Paftinaca.

Halicacabum Veficarism, id eSt Alkakengi.

Halicacabum Peregrinum, i. Pifum

Cordatum.

Hamefiteos, i. Chamapitys.

Hanab. Alibaleb. id eft Solanum.

Huraba,i. Cucurbita.

Harbatum,id eft Pescedanum.

Harenaria, id eft Cornu Cerwi.

Haronigi, id eft Doronicum.

Hafmifen Syriacum, id eft Conwoluslus Cervaleus.

Haftula Regia, i. Appodelus albus.

,Hafce,t. Tbynus.

Hindacocha Pliny, i. Trifolium bituminofum.

Haur Arab.id eft Populus alba.

Hebene, i.Xylaloes officinarum.

Herculania, i. Verbena.

Hederalis Ruelli, i. Afclepias.

Hedera Spinofa, i.Smilax Appera.

Hedera Cilicia, i. Smilax Apera.

Helxime, i. Parietaria.

Helicen, i. Hedera Helix.

Hemen, i.Serpillum.

Hepatica alba Cordi,i.Gramen Parnaffi.

Herba 
Nominum quorundam interpretatio.

Herba Scythica, id eft Glycyrrhiza.

Herba Caffa, i. Psonia.

Herba Leonis, id eft 'Paima.

Herba Lucis, id eil Chelidonium mains.

Herba Impetiginaria, id eft Chelido. nium maties.

HerbaVulcani,id est Rannnculum.

Herba Scelerata, id eft Rarunculus.

Herba Vlceraria, i. Ranunculus.

Herba Canfica, i.Rannnculues.

Herba Dineotidice, id eft Confolida Regalis.

Herba Stella, i. Cormu Cerni.

Herba Cancri, i. Heliotropium.

Herba Radioli e Apulei, id eft Polypodium.

Herba Leonis Dodon. id eft Aguilegia.

Herbas. Antbony, id eft Dentillari Rondeleti.

Herba Coxendicum, id eft Cotyledon.

Herba Benedicta, i. Caryopbyllata.

Herba Fortis, id efl Solidago Saracenica.

Herba Paraly/us,i.Primula veris.

Herba Clawellata, i.Viola tricolor.

Herba Laffulata,id oft Balfamita maior.

Herba Pinnula, id eft Hyofgamm.

Herba Turca,i. Herniaria.

Herba Hengarica Dodon.i. Alcea.

Herba Simeonis Dodon. id eft Alcea

Herba Vrbama,i. Acantbus.

Herba Tumica Gordony, id eft Ocymaftrum.

Herba Tunica Dodon. idest Caryophyllata.

Herba Gallica Fracaftory, id eft Galega.

Herba Rutinalis, i. Spondylium.

Herba Sardoa, id est Ranueculus Arworum.

Herba Sacra, i.Tabaco.

Herba Sacra eAgrippe, i. Meliffa.

Hermodactylus Dodon. id c St Colchicum.

Hermodalt. Italorwm, id est Iris $t w-$ berofo LObeliy.

Heperis Clusit, i. Lencoinum marinum L'Obelì.

Hippia, i. Alfine.

Hirundimaria, i. Afclepiats.

Hortus Veneris,, Coryledon.

Horminism Tridentinum, id eft Colus Iovis.

Humadb,id ef Laparbum.

Hunen, i.Iniube.

Huniure, id eff Vrtica.

Hydrofelmum, i. Paludapiam.

Hydrofelimum Camerariy, id eft Lawer maives.

Hyofgyames Perwaianks, id eft Tabace.
Alex.

Hyofyris Plini, i. Iacea nigra.

Hrophthaimon, i. Aster Atticus.

Hipecoon Dodonid eft Cunsinum [jl nestre.

H)pecoon Clusij, 9. Alcea Veneta .

Hipposelimon, i.Macedonicwm.

\section{I}

Trus,ideft Arum.

Iackiak, i. Anemone.

Iafrone, t. Campanula.

Iafin, id eft Enula.

lanatri, i.Nux Mofata.

1 igiga, i.Chamepitys.

Iezar Serapionts id eft Pafinaca.

Imperatrux,deft Meam.

Inwla Reffica Scriboniy Largi, id est Confolida maior.

Inguinalis, Af. Afer atticus.

Intybus,id eff Cichorium.

Jowis Faba,i.H Hof cyamus.

Iows Glens,i. Castanea.

lowis Flos, i. Lychnis.

Ionis Arbor, 1 . Quercw.

Iorgir, id eft Eruca.

Irio, t. Eryfimem.

Inncou guadirat us Celfi,i. Cyperus. Iua Mneata, id eft Chamepirys. Infalti,i.Sambrocus.

Infquiamus, i. Hyofcyamu.

lxopus Cordi, i, Chondrilla.

\section{K}

K Ameatis, id efr Ebulus.

1 Kantsrion,id eff Centawrenm. Kinz, id cft Amygdalu.

Kapar, id eft. Copparis.

Kawrochid eft Cbelidoniwm maitus. Kebikengi,i.Renunculus. Kiri, id eft L encoism.

Kemetri,idefl Pyrus.

Kemum, i.Cuminum.

Kenne, id eft Ligufrum.

Keruagh,i. Ricinus.

Kexngha,i.Ricints.

Kermes, i. Cocrus infectoris.

$K u l b$, id eft Milium folis.

Kusberd eAtuerroig, id eft Corian. dram.

Kusbor,i. Coriandrum.

\section{L}

$\mathrm{L}$ Abrufca, ideft Bryonianigra.

LLabrum Veneris, id eft Dip acten. Laburnum,i. Anagyris.

Laclaria, id eft Tithymalus.

Lalluca Leporina,i. Soncbus.

Lactucella, i.Sowe hos.

Lanata Cordi, id eft Aria The oph.
Lancea Cbriffi,ideft Lingun Serpen. tina.

Lantana, i.Viburnum.

Lanaria, i.Radicula.

Lancéola,i. Quinqueneriwia.

Litudata Nobiliai. Veronica.

Latbyris, i. Cat apstia.

Lathyrus, i. Pifum fyluestre.

Laner Lasucrum, i. Dipfacus.

Lanrus Alexandrina, id elf Hippo glo $\sqrt{\mathrm{n}} \mathrm{mm}$.

Laurus Rofent, id est Oleander.

Lanrus fyluefrib, i. Lairus Tinne

Laurentina Marbioli, id eft Bughla.

Leo Columelle, i. Aquilegia.

Leonis Ofculum, i. Aquilegia.

Leont of amsw Gefweri, id esf Agwi. legia.

Leo Herba Dodon. id eft Agnilegia.

Lepidism Plinis, i. Fiperivis.

Lefon Aribawr, id efl Buglofum.

Lencacantha, id eft Carlina.

Lencant bemum, id eft Cbamomelum.

Libadion Plini, ndest Centanrenom.

Libanikm Apulci,i.Borago:

Limodoron Dodon,i. Orobancb.

Lingma Avis, i. Fraximus.

Lingua Pagana, i. Hippogloffem.

Liliago Cordi, i.Pbalang inom LObeli

Lifen, id eft Planiago.

Lotus Vrbana, id glt Trifolism odo.

ratum L'Obely.

Longina, i. Lonchit is.

Lichen, i.Hepatica officinartm.

Lumaria Aribritica Cefneri, id eff eAnricula $\mathrm{Vr} / \mathrm{i}$.

Livcrolk, i. Lingwe Serpentina,

Lunaria Greca,i.Belbonac.

Lumeria maicr Diof.i. Aly fon.

Lepp Cordi,i.Dracnoculus.

Luyula, id eft Trifolimin Acero $\mathrm{man}$.

Lycostapbylos Cordi, id eft Siabacuo "aguetica.

Lycopis, id est Buglodum filtieftre.

Lycoperfieum, i.Poma Amoris.

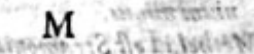

$\mathrm{M}$ Acblajid eft Palinia. Madon Plinij, id est Bryowia alba.

Mabaleb Awicenne, id oft Tpendo. liguftrum.

Mabuleb, id eft feccies 'Phill rea.

Alag daris Theophid eft Laferpitiü.

$M$ ilacocciffos, id ef Hedera Terle. fris.

Malimathalla Theop.i. Mala infand

Maloco Ciffus Cafjani Batfit, i, Cal. thapalufiris.

Maluanifcus, i. Ibifcus.

Manus Mertis,i.Quinguefolium.

Marana,id eft Stramonia.

Maribbrism Alinary,i. Faenic.

Mars 
Nomina quorundam interpretatio.

Mara berba Dodon. idest Cerintbe Plinij.

Marinclla, i.Phu magnam.

Marmarites, i. Fumaris.

Marmorella,i.eAgrimonsa.

Mastastes,i.Laferpitium.

Maston Plini, i.Scabiofa.

Mater Herbarwm, idest o Artemifia.

Materfilon, id eft Iacea nigra.

Matrifaluia, i.Horminum.

Matrifylua, i.Periclymenum.

CMasurohebre Caput, id est eAntirrhinum.

Medium Diofcor.id est Viola Mariana.

Medium L'Obely, id oft Iris maritima Narbonenfis.

Melocbia, i. Corcorns.

Melampodium, id est Helleborus niger.

SKel Frugum Diocles. id est Panicum.

Melampyrum, id est Triticum Vaccinum.

Melapermum, i. Nigella.

Melich Arab. id cit Trifolium fruticans.

Meleagris Flos, id eft Frittillaria.

Melanthium, i.Nigella.

Melopinum, id est Pomum Spino-

fum.

Memiran Andr. Bellusenfis, id est Chelid. maius.

Memirefin Anicen. i. Cbelidonium maius.

Mend Hendi Arabibus, ideft Scamonea.

Memitba Arabibus, id af Papawer Cornutum.

Memaglum, i. Arbutus.

Menogenion, i. Peonia.

Mentba Saracenica, id eft Balfamita

maior.

Meu, id eft Meum.

Memiren Serapionis, id eff Cbelidonisum minus.

Merbel,ideft Stramonia.

Menianthes palsitris, i. Trifolium palastre.

Merzenius, i. Maicrana.

Mefcatremfir. i. Diltamwsm.

CMille grana, i. Herniaria.

Meniantbe Tbeop. ideft Trifolism palustre.

Militaris, i. Millefolium.

Miba,i.Styrax.

Millemorbia, id est Scroploularia.

Mixa,i. Sebesten.

Molochia Serapionis, i. Corcoros Mathioli.

Coljbdena, i. Dentillarza Rondeletiy.

Momordica, ideft Balfamita mas.
Morghani Syriaca, id est Fabago Belgarum.

Mochus Dodon, id est Orobsu L'O. beliy.

Morella, id eft Solanum Hortenfe. Mala Herba Gaze, id est Ceterach. Multibona, idest Petrofelinum.

Mumeiz,id eft Sycomorus.

Muralia Plivi, i. Helxines.

Myophonon, id eft Doronicum.

Myrtus fyluestris, i. Rufcus.

Myrica, i.Tamarifoms.

CMyropbyllems, i. Viole aguatilis.

\section{$\mathrm{N}$}

N Abatnabo,id eft CKentba. Nanochach,id Ammi.

Nard o Naron Arab.i.Rofa.

Nardus Cretica, i.Pbu magnum.

Nardus ruftuca Plinij, i.Conyza.

Narf, id eft Nafturitum.

Nargol, id eft Palma.

Nafturtium bibernum, id off $P \int e s$ dobunium.

Nenuphar, id eft Nymphea.

Neotia, id oft Nidns anis.

Nepa Gaze, id \&ft Genifla pinofa.

Nerium, id eft Oleander.

Nicopboron Plinij, id oft Smilax apera.

Nicofiama, id eft Tabaco.

Nigellaftrum, id eft P fendomelan. thium.

Nilofar, id eft Nymphea.

Nil Anicenne, id est Connolusulios Caruleus.

Nola Culinaria, id eft Anemone.

Nolime tangere Clusij, idest Ioupatiens berba.

Noli me tangere, i.Crcumis fylueftris

Nux Metel, i. Stramovia Fucbsij.

Nux Veficaria, id eft Stapbyloden. dron.

Nympbea minim, id oft Morfios Rane.

\section{O}

Culus Cbriffi,ideft Horminum. Odontis, id eft Dentillaria Rondeletiv.

Olusalidia, id eft Chamamalum. ind Olea Bobemica,id est Zizipbus alba. Oleagrios, id eft Camelea.

Oleaftellum, id eft Camelea.

Olus Isdacicum, ideft Corcoros.

Olus album Dodon. id eft Valeriana Campeftris.

Onagra Vetcrum, Chameneriam. Onitis Pliviy, tad Origanum.

Ononis, id oft Refta Bowis.

Onobrychis, sd eft Caput Gallinaceum

Onobrychis Belgarum, id est Campana Aruenfis.
Onofma, id eft Buglofform fyluestre.

Onopordon, id eft Acanthium Illyricum.

Ordelion Nicandri,i.Tordylion.

Ophris, i. Bifolium.

Ophiogloffum,i, Lingna ferpentis.

Opuntia Pliniy, id eft Ficus Indica.

Opfago, id eft Solanum fomniferum.

Orbicalaris,id eft Cyclamen.

Orvala, id eft Horminum.

Oreofelinum, id eft Pecrofelimum.

Ornus, id eft Fraxinus Bubula.

Orontium, id efl Antirrbinum.

Ostria Cordi, id eft Ornus Tragi.

Ofteocollon, id eft Confolida maior.

Oftrutiam, id eft Imperatoria.

Ofjris, id eft Linaria.

Otbonmis, ideft Flos Africannes.

Oryacant ba, id eft Berberis.

Oxyacantbus, id eft Spina alba.

Oxys, id est Trifolinm Acetofum.

Oxymyrfire, id oft Rufcus.

Oxycoccus Cordi, id efl Kaccinia painfris.

Wwowlingt $\mathbf{P}$

$\mathrm{P}$ AlmaChrifti, id of Ricinus.

1 Palalia, id est Cyclamen.

Paderota, ideft Acantbsu.

Panis Cuculi, id eft Trufolium elace. tofsem.

Pancratism, id eft Squilla. .mic a brits

$P$ anis porcinses, id eft $C_{j}$ clamen.

Papauer Spumesm, id oft Ben album,

Paronycbia Diofa. id eft Ruta $M N$ raria.

Pafferina Ruelly, id eft Morfun Gallina.

Pedicularis, id eft Staphifagria.

Peduncularia Marcelli, id eft Sraphifagria.

Peganon,id eft Ruta fylueftris.

Pentadadtylon, id eft Rucinus.

PeponellaGe fneri, id efl Pimpinells. Perlaro, id eft Lotus arbor.

Perforata, id eft Hypericon.

Perdicion, id eft Helxine.

Peristeron, id eft Scabiofa minims.

Pergonata, id eft Bardana.

Pezice Plini, id eft Fungus.

Pes Avis, id eft Ornithopodium.

Pes Leonis, id eft Alchivila.

PesViruli, id eft Arum.

Pes Leporinus, id eft Lagepus.

Petum Americe Incole, i.T abaca.

Petilius Flos, id eft Flos Africanus. Pharnaceum, id eft Costus Spurim. Phafganon T beoph.id eft Gladiolus.

Phalingitis, i. Pbalangum.

Phellos, id eft Suber.

Phellendrium, id est Cicuta maxima.

Phellanárum Gsillandini, id eft Av. golica.

Phanix 
Phanix, id eft Lolium.

Pbilomedinn, id eft Cbelidonium main.

$T$ bileterium,id eft Ben albwen.

Phleos, id eft Sagitsaria.

Phthirion,id eff Pedicularis.

Pbylateria,ids ft Polemoniom.

- Phally rea Dodonatrid eft Liguaftram.

Pbyllon Tbeophrafti, i.Merewrialis:

Pbulanthropos,id eft Aparine.

Picnac omon Anguillare, i. Rhefeda.

Pimpinella pimoja Camerary,i. Poterion LObely.

Pinaftella,id eft Peucedanom.

Piper aquatlcum,id eft $H$ ydropiper.

Poper Calecsu bium, id eff Capficum.

Piper Indum,sd eft Capficum.

Piper Brafiliensens id eft Capficum.

Piper agreflesid of Vuex,

Piftacia fyluefris, id eft $N u x \cdot V e f-$ caris.

Piftana, id eft Sagitraria.

Plant a leonis,id eft Alchimilla.

Pneumonamibe L'Obeliy, id eft Viola Calatbiana Dodonai.

Podingraria Germanica, id ost Herba Gerardi.

Polytricbum,id eff Capillus Veneris.

Polytrichum Fuchfu, id est Mufcus capillaris.

Polygonatumi, sd eft Sigallum Salomonis.

Polygonoides Diofcoridis, id est Vinca peruincs.

Polyanthemwm, i. Ranuinculus aguaticus.

Polygonum, id est Centumnodia.

Populago,id est Tuffilago.

Potentilla maicr, id est Vlmaria.

Pothos Coftei,i. Aquilegia.

Potbos Theopbrasti, id est Aquilegia.

Proferpina herba, id est Chamomelum.

Protomedia,id eft Pimpinella.

Pesudorchis, i. Brfolium.

$P$ feudobunium, id eft Barbarea.

Pfeudocapficum, id est Stichnodendron.

Pyretbrum fylueftre, id est Ptarmica. Pteridion Cordi, i. Dryopteris Tragi.

Puffech, id eft Pistacia.

Pulicaria Gaza, id eft Conyza .

Qnemia, id eft Nigella.

\section{R}

R Adix Naronica,id eft Iris.

$\mathrm{R}$ Ramel,id eft Cistu.

Raphanum fylmestris, i. Ditander.

Rapum terra,id est Cyclamen.

Reginigi,id est Faniculum.
Nomina quorundam interpretatio.

Raledialemen Haliabbi,i.Fumaria.

Regina prati,sd est Vlmaria.

Roja fatwina, id est Peonia.

Rofa Irnonis, id est Lilium.

Roraftrum,id esf Bryonia.

Rorella,id est Ros folus.

Rotnla folu, id est Chamemelum.

Rbododaphne,idest Oleanden.

Rhododendron, id est Oleander.

Rbnfelenum Apulei, i. Ranunculns.

Rima CMaria, id est Alliaria.

Rivcus marinus, id sit Crit bmum. I

Rubus ceruinus, i. Smilax appera.

Rumex,idest Lapau bom.

Rut a capraria,id eft Galega.

Ruia palustris, id eft T balictrom.

\section{$S$}

SAbeteregi,idest Fumiaria.

Sabaler,rd eft Satureia.

Sudebideft Ruta.

Sacwu herba Agripps,id eft Salsia:

Saffargel,id eft Malus Cydomia.

Saforberamon,id eft Sparganiwm.

Salicaria,id est Ly fimachia.

Salunnea Gefneri, id eft Nardum Celtica.

Salfirora, id eft Rosfolis.

Salicaftrum Plini, i. Amara dulcis.

Salicastrum Diofcoridis, i. Bryonia nigra.

Salix Amerina, id eft Salix bumilis.

Saliuaris, id eft Pr reibrum.

Saluia vita, id eft Ruta muraria.

Salwia agreftis, id oft Scordrum alterum.

Saluia Romana, i.Balfamita maior.

Salufandria, id est Negella.

Samalsm Plini, id oft Pulfatilla.

Samolum Plini,i. Anagallis aguatica

Samp/uchum,id oft e Amar achus.

Sanguis Herculis, id est Helleborm albus.

Sanguinaria, id eft Cornu cerwi.

Sanamunda,id eft Caryopbyllata.

Sarax, id est Fillix.

Sardinia glans,id eft Caftanea.

. Sanch,id eft Malus Perfica.

Saxiphagon Diof.id est Betonica.

Saxifragia lutea Fucbfii, ideft Meltlotus.

Saxifragia rubra, id eft Pbilipenduls,

Sagitta,id est Sagittaria.

Scammonea tenuis, id est Helxine Ciffampelos.

Scandix, id eft Peiten Veneris.

Scarlea, id est Horminum.

Scannix eAuerrid eft Nigella.

Sceletyrben, id est Bifforta.

Scifima G.ize,ideft Fagus.

Schehedenegi,id e I Cannabis.

Scheiteregi,d eft Fumaris.

Scopariajid eft Ofyris.
Scolopendria,i. Lingwa cerwina.

Scoredonia, id eft fcordow altermm.

Scorpio Theopbrasti, ad eit Genin? pinofa.

Scolymos Diofcoridis, id eft Cinara.

Scilla, id oft Squilla.

Scuck Syriaca,id eft Papaner Rboean.

Secacul Monards, id oft Sigullum Sa. lomonis.

Selago Ploniy, id eft Sanina fylmettric Tragi.

Seliem,id efr Rapum.

Seligonion,id eft Pania.

Selanion,id est Crocks vernues.

Selliga,id eft Nardus Celuica.

Seminalic,td eft Equifetrum.

Sedum maine, id eft Semperuivom.

Seneffigi,id eft Viola martia arvali al2

Serpentaria, id eft Dracunculue. iो

Sertula campana, id eft Melilotwe

Serapias mas, id oft Orcbis femith Tragi.

Seggar,idest Nux mofcata. whisu? Sida Theopbid eft Aithea paldifris.

Sideritis tertis Mathiolt, id bft Ruts canina Monjpelienfium. inss in?

Siderit is, $\mathbf{i}$. Marrmbium aquatieum.

Sociliana Camerary, id est Androfemum Dodonei.

Stger Indi, id eft Palms

Siringacerwile Dodonei, id eft Lilac Matbriols:

Siliqua dulcis, i.Ceratia filiqua.

Silicula Varronis, id eff Fenwerecenom.

Siliquastrum Plini, id eft Capficum.

Sigillam CMaria, i.Bryania nigra.

Sin,id esf Ficus.

Sinsubarium, id eft Mentba aquiatica.

Sinapi Perficum, id eft T blappi.

Stfer, id eft Sijarmm.

Siluw Pliniy, id eft T by Jelium.

Sifon Syriacom, id eft Ammi,

Sifftriepteris Plini id eft Pimpinella.

Siler Pliny, id eft Alnus nigra.

Sitbim,id cft Larix.

Smilax, id eft Conuolvules.

Smirhiza Pliniy,id eft Myrrbic.

Sorbus aucuparia, id eff Fraximus bebula.

Sorbus Alpina Gefneri, id eßt eAria Theophrasti.

Sorbus fyluglris, id eft Fruximus busbula.

Solanum rubrium, id eft Capplicum.

Solanum lignofum Pliny, id eft Amaradulcis.

Solanum tetrapbyllum, id est Herbat Paris.

Solanum veficariwm,i. Alkekengi.

Solatrum, id eft Solanum bortenfe.

Solbsftrella,id eft pimpinella.

Sofibio T heophi. Anemone.

Sparganion Matbuols, id est Platanaria.

Eeces

Spind 
Spina acut a, id eft Oxyacantbus. Spine acida, id eft Oxyacantha.. Spina birci,id eft Tragacantha. Spina infectoria,id oft R hamnus folmtinus.

Spina Indaica,id eft Paliuru.

Spirea Theoph.i. Viburnum.

Sponfa folis, id eft Ros folis.

Sphacelus Dodon.i.Scordium alterwm LObelì.

Splyth,idest Radix casa.

Spicata,i.Potamogeiton.

Staphylodendron Plani, id est Nux veficaria.

Statice Dalefcamppy,ide ef? CaryophylIns marinnus L'Obelij.

Stataria, id eft Pencedannm.

Stellaria Horatiy A Angeriy, i.Cardasus frellatus.

Stomacace i.Coclearia.

Stomácace Pliny, i. Bifforta.

Strut biopter is Cordi, i.Lonchitis.

Strutbium, i.Imperatoria.

Struthium Mashioli, i. Saponaria.

Struthium Pliny, i.Ptarmica.

Strumaria Galeni, i.Lappa minor.

Straygulatoria Awicenna, id eft Do.

ronicum.

Sucaram,i.Cicuta.

Succifa,i.CGIorfui Diaboli.

Surum A Avicenne, i. Nigella.

Sympbytum, i.Con folida nuaior.

Symphoniaca, i. Hyofoyamus.

Supercilivm Veneris, vid est Viola aquatilis.

Superciliumsterre, id eit Capilluw Veneris.

Sws,i.Liquiritia.

\section{$T$}

$T_{\text {cannus. }}^{\text {Agetes } I}$

Tabaleb,i.Lens paluffris.

Tamecnemum Cordi,i.Vaccaria.

Tarifilon Anicenna, id eft Trifolium bituminofum.

Tatula Clufiri, Stramonsa.

Tatoula Turcis, i.P omum pinofum.

Tamus Dodonet, id est Bryonia ingra.

Taraxacon,idest Dens leonis.

Tarfai.Tamarifcus.
Nominum quorundam interpretatio.

Teda arbor, id est Pinus gluestris.

Terzola Baptifte Sardi, id eft Eupatorium cannabinum.

Tetrahit, i.Herba Indica.

Terdina Paracelfi,i.P bu magnum.

Terpentaria,i.Betonica aguatica.

Teliphano,i.Doronicum.

Thina,i.Larix.

Thut,i.Morms.

Thwia Theopbrafti,i. Arbor vite.

Thy Jelium, i. Apium fylueftre.

Thymbra,i.Satureia.

Torfolbobo,i.Heliotropinm.

Topiaria,i.Acantbus.

Trapezuntica, i.Laurocerafou.

Tragium,i.Fraxinella.

Tragium Germanicum, i. Atriplex olida.

Tremula, j.Poprilus Libyca.

Trifolium fibrinum, id eft Trifolism palustre.

Trifolism cocbleatum, . Medica.

Trifolium fruticans, id eft Polemoniam.

Trifolium appbalsites, id est T rif diwm

bitumino $\mathrm{wm}$.

Tuber terra, i.Cyclamen.

Turbitb,i.Tbapfia.

Turbith Avicenne, i.Tripolium.

Typhism Tbeopbrafti,j.Twfilago.

\section{V}

V $\begin{gathered}\text { Efouria peregrima, id est Pifwm } \\ \text { cordatum. }\end{gathered}$

Veelgutta Dodon, i. R ollofelinwm.

Veratrum, i. Hellet

Veratrum Diogat, Astrantia nigra.

Verbafcula,i.Prin toveris.

$V$ erdelbel Haliab, in ensunculus.

Verrucaria Matbidli, id est Hedypnois $L$,Obely.

Victoriola,i. Hippogloffum.

Vitis alba,i.Bryonia.

Vitis Idea, i.Vaccinia.

Virga fangninea Matbioli, i.Cornim famina.

Virga pastoris, ,.Dipfacm.

Vitalis,i.Craffuls.

Vitalba,i.Viorna.

Viticella,i. Momordica.
Vincetoxicum, i. Afclepias,

Viola nigra,id eft Viola martia.

Viola flammea, i. Viola tricolor.

Viperaria,i.Scorzonera.

Vifnaga,i. Gingidium.

$V$ mbilicus Veneris, i. Cotyledon.

Vnedo Pliny,i.e Arbut ku.

Vngula caballina,i.Tugfilago.

V.licawas. Solansm fommiferum.

Vlpicum Columelle, i. Alliwm.

Vrimaria, Dens leonis.

Vfrea,i.Mufcus.

Vua lupina Marcelli,id eft Sambucw aquatica.

Vwa taminia, i. Bryonia.

$\checkmark$ wa lupina Diofcoridis, id eft Herba Paris.

Vua verfa,i. Herba Paris.

$\checkmark$ wa vulpis,i.Solanum bortenfe.

Voularia,i.Hippogloffum.

Vsularia, i.Laurses Alexandrina.

Vuslaria Dodonai, i.Tracbeliswom. 9

Vuluaria,i.e Atriplex olida.

Vulgago Maceri, i. Afarwm Bac. caris.

Vuricata Caya, i.Stramonia.

\section{$\mathrm{X}$}

Xaier, Alniriem i.Libanotis. Xanium, Melantbisum.

$X$ ylon,. G. Gofipium.

Xylocaracta, i. Ceratia fligina.

Xypbinm,i.Gladiolus.

Y

rebetsid eft Anetam.

\section{Z}

Ahara Anicenne, id eft. Antbyl lis L'Obely.

Zaiton,i.Olea.

Zaraund,i. Aristolochis.

Zarzaparilla,i.Sarfa parilla.

Zazint ba Matbioli.i.Hedypmois.

Zerumbetb,i.Zedosria.

Zizania,i.Lolium.

Zinziber caninum, i. Capficum.

Ziziphus,i.Imiwbe.

Ziziphus alba,j.e Eleagnow Matb.

Ziziphus alba Camerary, id eft Olos Bobemica. 


\section{A T able of all fuch Englifh names, as are attributed vnto the Herbes, Shrubs, and Trees, men-}

A

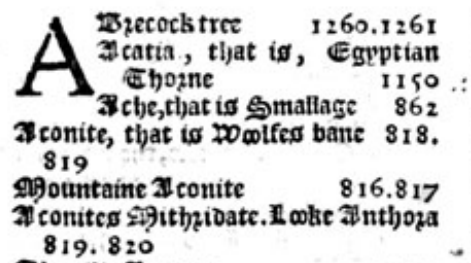
819.820

Ebe oilic 3 cogne

3oams apple 1331.1332 .1333

adoers grafte, that is 10 ogballocks 157

2oDerwont, that is Snakewer 323

sidoerstoong

africanturigold $\quad 609.610,611$

3ethiopian apples $\quad 276$

\$garicis

atrimonie

1184

15 aftard ans swater 3 grimonic $\$ 78$

I gnus $\mathbb{C}$ aftus

1202

Xguetres

Hiecofte, that is Coftemary $\quad$ \$24

$3: I_{g} \infty$, that is falfe 19 ercurie 259

Allgeo, that is goD benrie of $\mathbb{C n}=$ glifh 99 stcuric

tbio.

3il beale, that is Clownes souno= wownt 850.851

Ile booue, that is Groumb 7nie 705

3lexmDerg, o2 3ilizanders 865.866

3ieranoer forte, that is pellitopie of

Spaine

619

Silet, of atoer tree, ano bis binocs 1286.1294

Alificese, that is Swiloc Dpach $\quad 2 \varsigma 7$

BHelapa, that is woo gozret 1031

Simond tre

almond 19 lum tree

1256

\$loes, of 3 2grene and big linds 4.09 .

410

Ilibalkengi, that is winter $\mathbb{C}$ berty :71

Ellatet, or woilde 25 tholote $\quad 656$

3imeos, and bis timos 881.882

Simbero,tijat is Denigoos foo 536

Ancl rome

Wnacarotam, that is 1 Beane of 9 Palaca 1360

sinemone, $f \propto$ wint $f$ toser

Inife, 02 3inife fede

Inct, that is JDtll

879.880

878

Inthplito, of ftintang ground pins 419

3tnthor

$8=0$

pple, and bis trinos $\quad 1273.1274$. 1275

698

3pples of loue, oz gotoen 3 pples

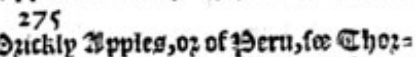

nie 276.277

3pples of 3 crufalem $\quad 290.291$

990 as Xppless , $\quad 273.274$

3precocke $\quad 1260$

4 rach,and his kinds 257

4trebangell andbts trindes 566.567 .

568 slactse Archangell, that is ftinking Dogebound. water Xrcher, of Orrow bead and his bis kinos

rbutetre, o2 Sstrawberrytre 1336

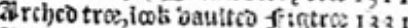

I rgemone, that to baftaro poppie ano

his binos

Arttolochia

Iromaticalt reeo

Iron

Itrticholes

301

698

685

991.992 $36 \mathrm{I}$

3 farabacca

360

(paragus and bis kinds 952.953 . 954.955

Xfpe tree, of Xifpentree $\quad 1303$

Al fphootl, and bis kutos $\quad 85.87 .89$

II the trace

If he lietco:

wolloe 3 the, or Duickentre 1290

21 fics 25 cxetree

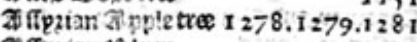

DIf?tan 10 itith 1315

aluentand bistainds $841,842.843$

Ilvich 1057

Ixfeeis

3rument

sponewerd

xpgrene

\section{B}

DIckwow2t, of Xnit backe D1baiomoine, of 2 balomonic 350. 351.352 .895

23 aftard 13 alomonic 895

2 bati Fbiftlc

25alme

25 alme mint

23 alfanint

ibid.

tbib.

849

412 \& 15 aime apples, fee $x$ pples of $\mathbf{3}$ crufa lem

Galfan tre, swith the fruite and somo 1343.1344 .1345

$2 B$ allock grafte, thar is Dogs culliong 156

Criple 25allock, that is triple 2 adie Juces

Sowcete 25 allock

167

2Sanciwout, that is Sperwopt 813 814.815

9.5

25 arberic buth of bin bin 114.4 .1015

25 arlep ano his binos 64.65 .66 .67

2 aarnacie tree 1391

2Barnacies, oftree Gele ibio.

乌.20arnatess tt:ittic $\quad 1004$

Barren wowit 389

2Bafll, and his timos $\quad 546.547$

Dotide2Bafll 548.599

18co cosw 1 bafil $55:$

Cosin 350

25atchelets buttons 811.812

\$Basme ano his tinos 558.559 .560

15ap tre an histsinds 1222,1223 .

2Bay willow, 02 1 Bap suillow berb 388

wilbe $15 a p$ tres $\quad 1224.1225$

2 seabetrec

1306.1307
124.1

2.5eane troe

25 cane $\mathbb{C}$ apec
Beare, and htghtnos 1035.1036 filat 16 cancs, that is Lapines 1035.1036 Beared bisch $\quad 14.15$

2 careg ort, and bis kinos 986

Bcares Gre, and bis tinos 690.643

Weareinoze 142

13 carc foie 8889

Durlacics $2 B$ CDftraxe 457.966 .92

Blew 2 eis

3 notan 9 eqrice $25 \mathrm{els} \quad 315$

Antimme zo ell a lowers

Stcepile 25 ell llowers, of 9 rach $15 \mathrm{elg}$,

02 Itecpla bets $\quad 366.367$

Scaiscto

Schl flowers

Douloe $25 \mathrm{cil}$ foroers

)artizk $25 \mathrm{cls}$

$251.25=$

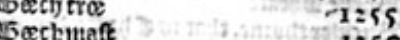

1255

210

pohite $25 \mathrm{el}$ en

23 ent

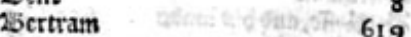

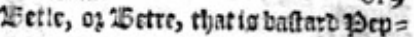

pcr 1357

paules Detonie, 4 bitg thindg $50: .504$

eeronic

toater 25 ctonic

$3 i a, 02$ big 2 Barley

578.579

2 indivace amb his tinos 712.714

Sca Litumeco, or 20thutind $69 a$

(Bough) 28 indwee of, of rough $2 B \mathrm{mD}=$

swade of ports 709.710 .711 .

2Slew 2 Siroiones 714.715

purging 2 B tinveroed 716

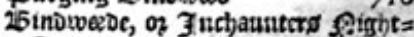

thade

25ith op: Socede

25 ilopes leatuc

is irch tre 02 25ulbertics $\quad 1232$

23 iros tong . 452

16 tros foote .. $106 \mathrm{r}$

25iros cine $\quad 638.639$

25iros neft $\quad 176.873$

Birtlywept, and his kinds, 696.698

5tifort, and his tinos 323

26uttcrfocte, and bis binog 278.279

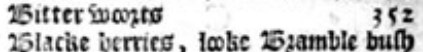

1089.109

Gladoer nut 1249

23 lem ball, that if $25 l e 5 w$ bottle $\quad 594$

\$Blefies Cobiftie 1009

$2 B$ lesw botrle 591.594

ablites, 0215 inter 252.253

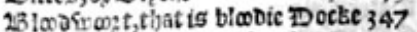

23 loc itrung, that is 99 oufeterle 345

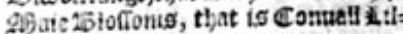

lic and hir bixtog

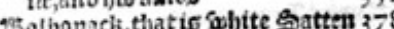

$23 \cot c$

652.653

I150.119

Dinarfe 15 ore, or ground 15 cre 122

13 aretres $\quad 1225.1226$

167anble bnd 1089.1091

ecece 2 23jatie, 
A Table of the Englifh names.

26zake, and bio bindes, lolke fierne 968.970

26? and) peafe

2 zanke olran

23ight 20 heate

1047

986

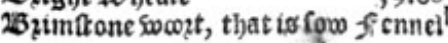
897

3jionic, and bis kindo 719.720 .72 722

3ndian 15 zionic, that is $\$$ Pechoacan 724

213 zome, and bis tinds $\quad 1130.103=$ 25 rosue Rape 1130.1133

Swoete 13 ziar buf), lobe Eglantine 1088

215 ziar buth, that is ficp trex $\quad 1088$

$2 B$ 20me swow2t

210

26 20mone Swowt, that is Swater 213 etontc 579

25aic 15 zome $\quad 1133.1136$ 13aftaro fpanith 23zoome, fee s\$panib. 26200klime $\quad 4095.496 .497$ 23) 512

26uckes beanes $\quad 1025$

Tuckes hozne, and bis kinds 346.347

25 ucke Swheate

83.82

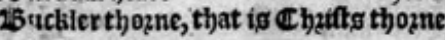
II 53

25 uckramis

I3ucke thonte

142

25uckmatt

1154.1155

Buglofte,

1255

2isugie

2Bulfote

15 ullocks IL ongwopert

2 Butlocks eie

2 Bull soebe

2Bull soopt

2Bulleife tre

25ullimong

iBurnet

2 1Burgundic Trefoile

2 Surre, and his tinds

25urre lisece

2 urtitroost

Great Soater 215 urte

2 burre Docke

Clot 2aurre

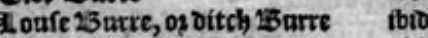

Doater 2 burre Docke

15uttertice gatyu

25 utter wowt, 032 2 3 utter rote 64

26 utter 25 urte

25 utter to lowers

15 utchers brome

25 utchers puctuc tre

667.668

\section{C}

X bbage, that is $\mathbb{C}$ olewow ts 243 Caiocus, 02 Caious, that is kid nep beane of 2 halaca

Calathian biolet:

water Caltrops

Caluco foote

- 1004

Calues fnowot, and this kind 438.439

Calamus Xromaticus

Cammidghaie, $100 \mathrm{ke}$ Scænanthum 40

Cammogbrhat is rett iqarrow 1141

$$
11425
$$

Cammotintuand tjis tinos 614,615 . 616

8Red Camutonill, that is Flos Adonis 310 midec ammomit

616,618

Campionand bis timos 382.383 .384 $-385$

artia grafte, Canariafect oz Cozne 80,81

Cane, Canerecos, and his Einos 32 33.34

Cancerwoopt, that is fincllen - 504

Cankerwo 2 t, that is 1 iffe in bed 2,8

Cardie \$19uftarde, 92 Candic Cr hlafpte

$$
270
$$

Canoie 3ifanvers : 860

Canoic Carrots

874

Canterburte bets . $\quad 203.366$

Caperd,and bis lainos $\quad 748.749$

Capons taile, that is great swiloe ola=

Jerian

Caprifolie

$\mathbb{C}$ atbe $\mathbb{C}$ eafell

918
744

Charlocke, and his binds 479.480

bilde Carline tbitile

Carobe tree

rohite Caroline thiftle

996.997

1240.1241

995.996

Carrot,and bits kinds $\quad 872.873$

wilde Carrot tbto.

Stinking andocably Carrots 875 876

Carową, and Caruwą feede 879

Caftes, oz Cares

904

Caffroonie $\quad 470^{\circ}$

Caftic Gtlloflowerg, that is ftock $6 \mathrm{tl}=$

lotloswers

Caft me Downe $\quad 470$

Caftiafifula $\quad 1242$

Caterpiliers, that is $\Phi$ cozpion gratte

ano his tinos

Cat mint, $\mathrm{O}_{2} \mathrm{~S}_{2} \mathrm{cp}$

Catch tlie

Cats foote

$48 \mathrm{I} .0 .82$

Cats tatle, 02 Cats fpeare $\quad 42$

Cats taile grafte
Prickley of J Junipet cedar tre 1190

CeDar of Il ibanss

Celandine and bis tinds $\quad 696$

Srcat Celanoine

Smail celanoine

Centozie, ano bis tuinos

Cefars tree fpurge

Ceterach

Thamcleon thiftle

Cbampion fea iq oll

Chablocke, fee Carlocke.

white Chameleon grafte

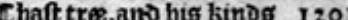

Cherrie, and bis tinoes $1318,1319$.

$1320,1321,1323$

nointer Cherrics

il ong Cherrie tree

271

I 282

Cheruill, and hig hinds $882,883.884$

Ercat oz fweete Cheruile

S9) ocke Cherutle, that is 9 bephear os neesle

water $\mathbb{C}$ befnat

Cheele bowles 298

Chere renning, that is Ilades $15 \mathrm{co}=$

Irawo

966.968

Cbefnuttra

1253,1254

Clefnut

Earth $\mathbb{C}$ heftnut

Cbeckered IDaffootl

$$
\text { tbio. }
$$

122 489

2Baftaro Chic'swoed $49 \mathrm{r} .492 .493$

Childens $\mathscr{A}$ -

$\$$ Tूercurie
Chafte swed that is cotton sweede 519
Cholsing fpurge, that is fea fpurge 407 $\mathbb{C}$ hriftmas Chuttmas berbe, that is blactse bel =

leboz
826

S. Chiftophersberbe II53.1 I 54

Ticlitophers berbe $\quad 829.971$

Cicheling, and bis binos $\quad$ IO5

Ciches, and bis tinds $\quad$ 1047, I O

Doilde Ciches

Ciconte

Cibcrage, that is $3 \mathrm{rfmart}-22 \mathrm{I}$

Cinkefoile, 0 f fue finger (5) $_{\text {paffe }} 835$

839 (3)

Cinuamome roote

Df the Cintanome tres, the leafe 648

\begin{tabular}{ll}
1348,1349 \\
\hline
\end{tabular}

Sitisen Cifler $75 x$

Ciftus f bis tino $1092.1093,1094$.

I099. 1102

Cilus leoon $\quad$ T $202,4 c$.

Citifus bufh, that is mithe ercfotle,

Dowub erefople I 122,1 I 25

Citronapple tre $\quad 1278,1279$

估rall Cucumbers $\quad 767.768$

Che bitoecitrul

Citues, 03 Cbitres fe. $\quad 140$

Strange Clarie, that is 3 upiters oi:

ftafie

Clarte, oz clearep

wilde Clarie $\quad 628$

Clauer $\quad 964,1019,1022,1023$

y ozned opblacke Clauer 1028.1029

Clauer gentle 1019

$\begin{array}{ll}\text { Marhb Claucr } & 1025\end{array}$

Gardenclauer $\quad 1025.1026$

Snatle oz fea Claner 1029,1030 , fe Iivedicls foober

Cleauers ano Sofegrafe $\quad 964$

23 iting Elentatis.

ot burre

Cloue 6 tllofer, and big kinos 1368 473

Clufter of grapes

Tlomnes to 727

beale $85 \mathrm{I} .85$

Clowneg I ungmont

che Cloue tree $\quad 1351.1352$

sea Coule $\quad 1351.1352$

Citufus hankemexes $\quad 236.239$

Cocks foote grafte. 25

Cocks beads, that is \&Derom Erefotle 1018

Cockes bead, that is red fritchling

1064

Cockle $\quad 926.927$

CODDCO Trefotle IO22,1029

Swoete CODS 169

Colewocost, and his kinDs $\quad 243,249$

Coloquintioa, of Coloquint ano bis

kinos 768.769

Garcs Colewowt $\quad 232$

Coleflozer 249

Coltes fote, ano bis kinds $\quad 666$

Cotis that is pine apple $\quad 1174$

Columbine, and bis kimos $\quad 935.936$

Coniza, that is fleabeane spullet

Treat Confound, ano bis binos 660

शी) idole Confouns 506.509

Contuall iltitie, and his kinbs $33 \mathrm{r} .332$

Comfrey, that is Confomno 506.661

\begin{tabular}{ll} 
Spotted Comfrep & 663 \\
\hline
\end{tabular}

Cotula ano bis tinos $\quad 617$

Cozrall pontuet $\quad 1212$

Tojbe tree $\quad 1164$

Copkc obe $\quad$ I163

Coziander anobig tinos 895 
ATable of the Englifh names.

come

Conne flagge, os $\mathbb{C}$ opne Eladoin and bis kinds

cenc gratte

Cozne Liofe, and Conne 13oppie 299 300

Cozne ธtlloflower, of Conne Dinke 356

Cozne Sallad

Coyne flowe

yellow C opne floswer, oz golden $\mathbb{C}$ 0? flower

Coznell trex and tio tinos $\quad 1282, \mathrm{I} 28_{3}$

Copne flower, 02 blew 213 ottle 594

Copall and his tands $\quad 3_{38 \mathrm{r}, a c}$

Cozall sinorts

835
78.1379

Cozalline, oz C opall mofte 1378.1379

Cotton swecoc, of $\mathbb{C}$ tromade and bis

Einঠs

515.519

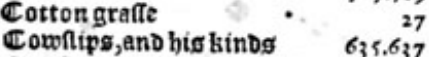

Cowoftups of feruialem, that is Sage of Terufalcm

663

Monntaine $\mathcal{C}_{\text {ownipg }}$

COSw $2 B$ aftl, that is red enalerian 395

Cow swbeat

25attaro 02 swidoc Cow wosteat

Coziars कumach

Coftmaric

Cotton plant

Couctitite, white and purple 988

Coucntrie bels

Coucntrie rayes

309.363

Cosw 2)arfneps, and hio kinos 855

Core combs, and hens combs, that is

yeliow katatic $91_{2}$

Craberalte

$4: 9$
Crab tree, that if the wotloing tree 1276

Crabs claw, that is freth water soonl=

Dier

Craitith

25lew Eranes bill

Candie $\mathbb{C r a n e s}$ bill

677
622

622

97ufsed Cranes bill

797.798

796

Df fwito C ranes bils oiuero fopto 799

Craw, that if rape $\mathbb{C r}$ row foote $8 \mathrm{II}$

Crettes andhis tanos 188.194195

ciatica Ereffe 197

25 anke Crettes

TDocke $\mathbb{C r e f t e s}$

boater $\mathbb{C r e f l e s}$

witlde water $\mathbb{C r e f f e}$

winter $\mathbb{C r e f t e s}$

Creftmarine

Crimfon tedar

Croffe flefwer

Croffewwit and hio kinos 264965

Crois foote ant his kind 347.679 .803

yellowe Crosw bels, that is pellowe

今arciflur

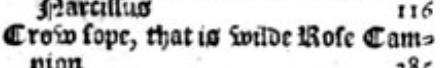
pion

385

Crow tocs, that is becintibes 97.98
Crow flowers
${ }_{480.48 \mathrm{r}}$

Doater $\mathbb{C r}$ row foote

$480.48 \mathrm{r}$
680

$\mathbb{C}$ row foote $\mathbb{C r a n c s}$ bull

Donble $\mathbb{C r}^{2}$ wo foote

796.797

White Donble $\mathbb{T}$ rom footc

Erow garlicts

$81 \mathrm{r}$
$8 \mathrm{r} 2$

812
142

Cuckow pint, of $\mathbb{C}$ uctoso pintle and big sinds

Cuckow gilloflowers

Cuckom Dichis

Cuckow floswers, that is ladies

fmocks

201.20

Cuckowes meate, 02 Cuctoso fozrell, that is swoo foprell

Cucumbers and fits tinds $\quad 762,765$

CuD

CuDine⿻, Te Cettonineo.

Soweete Culliong

$\mathbb{C}_{\text {all me to pou }}$

Labies Cupion

$\mathbb{C}$ uirage, that is $\mathrm{Xrfmart}$

$\mathbb{C}$ utlons anothetr tamo o

Cumberiano baínthozne

Ctumin and big btuos

Dilde ecumin

Curage,that ig Xrfmart

turrans oz fmall tRaton

Garoen Cepzes, that is 1 auenoer

Cotton

đepres, that is Walingale

Cppies tra

Cypeses grafte and big bindos

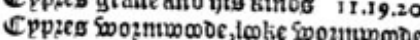

$94^{\circ}$

$\mathbb{C}_{\text {ypzeg fpurge, inke spurge }}$

frielde $\mathbb{C p p r e s}$

$\mathbb{C}_{\text {gpes spoografte }}$

\section{D}

Dfootl andbio kinds

iDaffooiltp

IDaffobowndily

White IDaffodtil

IDate Intlle

Great IDataes

508.509

id Daifies and bis tinds 509.5 10

2 Bicis IDaifics, that is fea stariwogt 334

15 lesw or globe id aifieg

511.512

Dalmatian frlower De il nee $\quad 4^{8}$

Dalmatian cap,that is $\mathbb{E}$ ulipa $\quad 120$

IDandelion and bis binds $\quad 228.229$

Danewoptand bis tindo 1237.1238

IDarneil

Darnell grafe

71
6

Date tr $\propto$ swith the fruite and flowers

thereof

1333.1334

Cbe Donken Tate tre । 1337

C. be wilbe os pine iDate tre 1335.1336

Daucus of Candic

Dead fettie anohio binds

874

Deale booro trex, of fir tre

Drow graftc

Dicrs 5xeอc and his kinds

IDiers greening sweede

Dill,that is Inet

IDiptam, 0? Dittanp of Candic 651.65:

Dittanocr, and Dittanie

¿Baflaro Dittanic

Dituels bit

Docke

noater Tocke

TDODDer and bis kinos

Dotg grafte and hts ktnos

1182
26

398

136

878

Dogs rib

Dogs tooth atiolet

Dogs bane

iDong $\mathbb{C o l e}$

Doge inofe

Dogrs e bozne

Doge Cherrics

IDogg $\mathscr{D e r c u r i e}$

IDogs toong, oz bounos toon

ID oge pifle, 0z boundos piflc

Dogs cullion of thones, and bis kinos

156,157

Dog berric tro

652,1065

188

587

311

314

462

22.23 .24

342

835

64.755

tbio.

D.

128
Dogs cawic, that is swilibe 99 ercirie

Dog $\mathbb{C}_{\text {anomth, that is }}$ Daie sinere

Dogs Ieele, that is

Dogs tootb, ans bis tinds

Dozias bis 100 indinds 154255

349

990

Dragonz 793

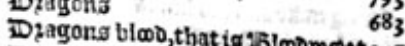

Dhagons bloo, that is 2Bloomont 347

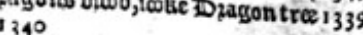

Witang iD pagon, that is Carragon 193

D pagon tree with the fruite

DiDagon swopts

Doater iD zagons

zauicke and idon.

that is swito

Dinkien wopts, that is 7 noian $\mathrm{Ca}^{69}$

Ditunken Date tree

3 obs iD pops, that is 3 .4 reca 1337

Diopwont ano hic trinos

900,902

Duble icafe, that is \& Swapblade 326

Duble toong

Ducke betil wheate $\quad 461$

Ducks meate 690

Dunce bowne, that is Catstaile 42

Doale, that is fighthade

IDwarffe graffe, res ano swhite

iD warffe Cittus

E

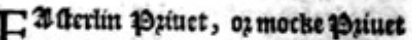
Eglantine, that is fweete IS ziar bath 1088

$\mathbb{E}$ grimonie, that id 3 grimonie 575 egyptian inosmbood 210943 Espptianthonter 1149.1150 egeptiang borbe, that to swater hope= bouno

Egppttian figgetree

eioer trxandjts ainos 1233.1234

1235

rrib Gider

Dwarfie Elder

I296.1297

, ie gelleboye.

649

221.222.22

Dibe Endituers

Englith 9 -

Erringus and his kinos

s, that is bitter vietch

Erthnuts

Ethiopian 7 epper

thiopran sigullein

(5) gumme chifie

10141016

Cesch on thoznic Eaphozbiam ror

Eve 0; $y$ ewght tre

EEpebjight

F

Thee faces in an bood $\quad 705$

I faire haired Jacint $\quad 102.105$ falfe 9 9ercurie, that is all gOD 259

frafelles

freaberrie buals

fieathertop grafte

.

felmoget 
ficlocost and hiof tinds $\bullet 350.35 \mathrm{~J} .352$ Wollow teafeo frelwowit

2Battaro ficlwort

frennell and bis tinos

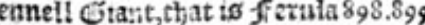

fietiberrics, that is matrib swijots

1367

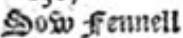

frentell troe

Jiennic ftones

- renagroke and his tinds

f crne and bis tinos

Doail fierne

wDater fietne

7petic frerne

23lacke oke frerne

Dac frerne

IDivarffe fea ferne

f eDderiew, of - freuerfer

fitgt:ee

ziDmarffe ffigtre

firmonit, that is fmall Celambine 580

669

figbeane

trdico or et anites fir tre

Inoian frig tre swith the fruit $\quad{ }^{3} 29$

friberd tree

896.897

1347

174
1026

968.970

972

974

$98 \mathrm{r}$

fritpenomia and his binocs, that is

firretres

fiffick nut tro

Dowites frities

2Beo fritchling

$2 B$ itter fitt th

Dotide f itch, of wietch

fingerd $D_{2}$ chis

Îtedom ff tue finger

ffute-leafeo grafie ano his kinos, that is Cinquefoile $\quad 835.836 .837 .839$

cogne frlagge

roine flagges anobis kinds $\quad 46$

Garben flaxe

Dotide fr laxe 446.447

codeflaxe ant flare soceoc Swith bis tsino $44^{0.441 .44^{2} .443 .444}$

flaren solueate

filcabane Silfullet

Frlic פ9tikerpost

391

450

flicebane and bis kinDs, $f(x)$ atch ff lie.

filiceiwerde, anto filite woogt 910.911

flozence floswer De-luec

flotegrafte, 03 fi lotergrafte

flosper tentle, of filower of lotse ano his kindg 253.254255

soitoe fr tower gentle, lolue Elirum maius

flower of Conttantinople, oz of $232 i=$

tow

flower of Candie, of of 3erufalem tbio.

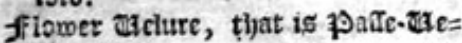
loturs

Sume-flower

atoonig flower

255
$6 \mathrm{I} 4$

310

flower De-Eluce, and bio tinds 45.46 . 47.48 .49 .50 .51 .52 .67

Tole golden frlower

Sonefading frloxoer

fllowing likede

$52 \mathrm{r}$

$79^{\mathrm{I}}$

flopeamis o purpte betuct flomer that is filoswer gentle 255

fremale filuclin

255
504.501

fluctlen and his kinds 502.503 .504

DDenticods foode, that io A mbrofia gso. 95 t.ioke $\Phi$ ise of parabife

Paturall $f \mathrm{f}$ wec, that is Ambrofia tbio.

folefote, that is $\mathbb{C}$ olteg foote 667.689
A Table of the Englifh names.

bea folefwote

folco ftones

fi ozebit

690

forget me not, that is groun $\$ 87$ 422

ff ower leafeo grafte

Pine

f oxe glotes, and fringer flower, ant bis tinos $\quad 646.647$

fiore fines

foxe talle, and hio kinos

46.647
$16 \mathrm{~s}$

froxe tatle grafte

frozcible plant, loke Bupleurum $\quad 485$

frambotes, that is 1Rafisis 1091.1099

fr tanck, that is sopurtic, lowke shilike = Swojt

450
858

frrankincenie 10ofemaric, 858

fr rankintenfetree $\quad 1247$

ff reécland $D$ eci)ts

169

frrell swater foldier, that is soater.

Sengreene

677

firench 9 percutic 261.262

french Sage, oz soodie sipullein 625

french Starwowht 392

firench Cl9arigotos and bis tinds 609 .

610.611

firench 99 allowes $\quad 7 \$ 5.786$

french) Il eekes, 02 bine neekes 140

ffrencl) 3ilungwow: 663

firench Lauander $\quad 470$

firehti) Wogminod $\quad 94^{\circ}$

frenci) 1Beanes $\quad 1042$

french peafe $\quad 1047$

french wheate

french $D$ be

1047
83

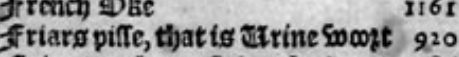

friarg conle, of friars bowde 686

firiars croswne

frogge bit

frogge grafte

990

Silod f rog graffe, lolke Tragon, 960

ID iuers trange 3 moian ffruits $\mathrm{r}_{3} 6 \mathrm{r}$. 13641365

frullers e eafell

1006

frumitozic and bistsinos 927.928.929

930

25albus frumitozie $\quad 93^{\circ}$

furromoco grafte 25

furs and fiurzen 25uthes 1138.1240

fuftebals

$13^{86}$

\section{G}

GHant, that if 3nemone, wind: floser

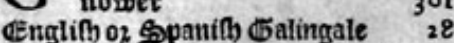

Ealingale, that is $\mathbb{C}_{\text {pperus and }}$ his kindos

Gallormge, thatio Thempe

Gall tre, amo Gall oke Swith his kinos I164.1165.1166.1167

Gang tloswer 450

Garonerg Delight, of Garoners cie $3^{8 \mathrm{r}}$

Garonobe

IIIO

Фarlicke and hid kinos $\quad 140 \mathrm{I} 4 \mathrm{I}$

Earlickefage 535.536

Garland e thone, fee $\mathbb{C}_{j y 2}$ ifts thozne.

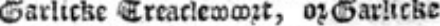

92) nutard, and hiof tinos 210

Stags 02 f)arts Фarlicke 142

Garlicke Germander, lowse Scordium.

Garnfep שtiolets, that is ftock Gillo= Alofwers

373
1283

Gaule or frwostc Ditlow

ФetDed Satpzion $\quad 173$

Ecloice 1 bofe Gentian, of frelwowt ano his kturoes

Ecrmander and bis kinos

529

Great oz tree Germander 532.533 .534

water Germander, of garlicke $\mathbb{E}$ Eer:

$\begin{array}{ll}\text { mander } & 534.535\end{array}$

Eill crexpe by the grouns $\quad 747$

Etlloflowers and his binog 705

Sea ftocke Eilloflomers 371.372

Pointer oz rogues Gtlloflomerg 374.375

water GHoflowers 377

wilide 679

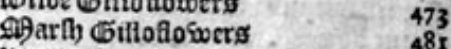

Doall Gillofloswers, of velloso ftocke Gillotoswer $37 x$

Dueenes Eillofiowers; that ${ }^{371}$ is

Daincs tiolets $\quad 376$

23uibed ftocke đilloflomers $120, \mathrm{r} 2 \mathrm{r}$

Stocke Eutofiosiors $\quad 372.373$

Einger 55

Einute ben floswer $I_{24}$

Gith,that is firgella $\quad 924.925$

Stinking Glaodin of 53

Doater Gladiole $\quad 27$

$\begin{array}{ll}\text { Elafte } 2002 t & 429 \\ \text { Giobe CroSofoote } & 810\end{array}$

Globe thiftle 990

Globe Daifie 512

Б00, flower $\quad 522$

Ewobnight at nine befoze none $79 \mathrm{r}$

Бoldefloswer 520,522

Goloen SOP ot lywment, oz Golden CuD =

5weed

Ђolden flo swer of poerts

520
$6 r_{4}$

Eolden thiftle $\quad 993.995$

Eolden ti)ifle of 7 Ðeru $\quad 993.995$

Eoldentrefotle 1032

Golo of pleafure $\quad 213.214$

Goidtlocks, 02 Golden mofte 1374

Golden ore eie, lolke Buphthalmum ano

bts tinos 607

Golden floswer gentle, and Goldilocks

520.521

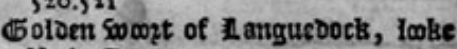

Herba Dorea

Фolden farifrage $\quad 693$

ॠolden rod and bis ainos $\quad 348.349$

Golden apples, fex appless of lotie 275

Golde cups, and Eolde tnops and bis tinos 804.805

Iltars Gold swo?t 603

TDegenerate ffrench Eoldo, of angle

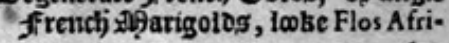
canus

Gofe tree,that is 15arnacle tre $\mathrm{r}_{39 \mathrm{x}}$

25 pant Eefe, 02 tree бefe toto.

Gogfte ano bis kinos, that is fiurse

$1138114^{\circ}$

Gofeberric, on Emfeberrie buth 1143

Exofe graffe, that is Cleauters 963.964

Eofefoote, that is swild 31 rach) 253259

Ecofeneft 176

Gwifethare, that if Фofe graffe 964

Go to beo at nowe 594.596

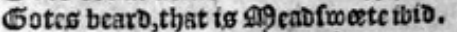

Gotes Deigan, of Eotes 9 fargerom

543

Eotes Xali,lowke Tragon 959

Gotes thopne, and hito kind 1147.1148

Gotes isue

Eotes ftones $\quad 159.160 .161$

Gourd and his bintos $\quad 776,777.77^{8}$

woide డraro 779

Gout \{wo:t, that is herbe Фeraro 849

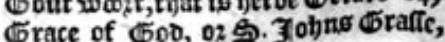

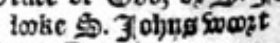

Gratia Dei

467.796 .797 
A Table of the Englifh names.

Erape of the fea anobio ainos, looke Kali

Grapes 728

Gea Erape, that is 1Batfons of the fea 958.959 .960

Grapeiwowet, that to Saint $\mathbb{C}$ hyiftos

Erape flower 104.105 .

i9nfted \$rape floswer toto.

parnaftu Grafte and bis kinDs 6.\% $\mathrm{I}$

Erafte and all bis kinos 1.2.3 4.5.6.7c.

Eraines of 30 aradife $\quad 1358$

winter Ærane

Jraning fwade and bis tindes 1133

Gromil and bio hinds $\quad 486.487$

Eromill reade 82

Awtide Gromill,iolke Anchira 657

Grounde Saligot, that is Alandeal
tropg

1066
$4 \mathrm{r} .1142^{\circ}$

Ground furze

@iea đroundąine

Eroutro poine

Stunking Ground poin

4:0

Eumme thitte, that if Euphorbium

1014.1016

5utionent

408

Grownofwell andbis tinds 217.218 .

219

\section{$\mathrm{H}$}

\section{Hitrie grafte}

H Dairie swod graft

Tarobeame

Tares bel

Garcs ballock, that is fore thones 164

1) ares foote Trefoile

Gares Il ctture, loble Sonchus 1xuis 229

hares care

hares bearo

Fares ftones

17

îtercuric

garts cafe

art woont of peloponnefust 8928

ngart sompts of $\mathbb{C}$ anoie ibio.894

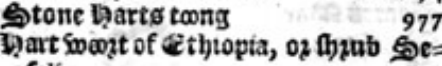
feli

1) arts trefoile

Darts $\mathbb{E}$ lauce

1233
1021

tyarts thoune

1035

1153 bis timbs 346.347

Darts tong and his tinDs $\quad 976.977$

㼭art rote and his tinds $\quad 858$

Gart wowt

858
698

Fafell, that is fitbero, of Sut tree 1250.1252

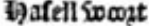

Iqaftswont ano fios tinos $\quad 364$

latchet fitch

364

hather, fee ineath

yaukeweede ant bis kinds $\quad \nabla_{232.237}$

Hawothozne tra

1145.1147

Heale Dog

380

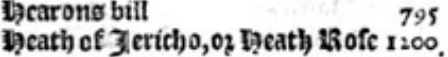
1201

Gauer that is otes

Gauer cabes

Gaucr graffe

Gap

Geath and his kinos

Feogebogge thittic

$1196,1197.1200$ 1013.1014 ljeogehogge liquosice

li)eoge beis

berge hyftope

1119
714

$65{ }_{4}^{714}$

7.cliebope ano his kinas 275.258 .259

Didorcoptoes his blacke ticlicboze 828

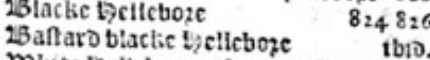

White belicboze, that is f.2eieswort$$
357
$$

b)elmat floswer

Jellow Delunct flose

Gcinloctic and hto kiu

t)empc and) bo kinos

Hempe tree

Doiloe of ftettic bicmpe

roater bempe

Genbane and bitaind

Genbane of perts

Yellos कienbane

i)enne

Thent

1) ens bill, tokic Onobrychis $\quad 106$

yens forte, that is beoge fitmitopic 868

I) eng conbe, loke core combe 912

GoD Dentri, that is Englih 98 erct:

rie

I)eptre

Yerbe Ecrtible

Hette Feruls

iq crbe $\mathbb{C}$ arpenter

loer be William

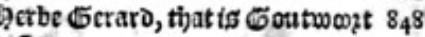

$$
849
$$

Derbe Paris
Yetbe Grace, that is isue and his

$$
\text { tinog }
$$

1070.1071 .1072

gerbe 28

841.843 .904

jerbe Erinitic 1032

jerbe Juie, that is 2 buckes boyne

ว)lantain

Terbe iRobert

Ferbe two pente

347

504.505

Gerbe 3locs 4 ro

Merbe 3 uie of grounb goinc $\quad 421.422$

jerbe toillosw 388

Spimming berbe, that is Duckes

tureate

Derbe fir rankincente

Tolic berbe

Gerenics bis suoundermet

Bigtaper 630

i)erthodaสylug 94

Dinoberric and bis kinos $1089.109 \mathrm{I}$

Gipwoplt

Eurbie birf

Gifope ano his kinds

Goclies $\quad 782$

1) ogs beanes, that is blem tDaifics 512

b) otg fenuell

Dolme, bollic and butuer sith bis

binds

1155.1156

Doime of Doilie D be $1159.116 \mathrm{r}$

Follthortic and his kinog 782.783 .784

Follie thiftic, lotse biefted e buttle

Dolic feose 942

Dolle Rofe and bis kindes $1092,6 c$. rog9

Sca bollie, fea biolme, fea bạuluet 999

1000

\$Baftard ofea Dollieg 1001.1002,100;

Golwowt, of holloiv rote o his binds 930.934

Domlocks, that io berbe 13 entet 903 .$$
9 \circ 4
$$

9omlocts,tlyat is Filipendula $\quad 902$ 10ilde of water bomilochs 904.905

Gmaitig bomlocke 904

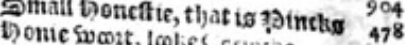

Gonifuctic and bie tutiof 743.744135

1113

Doppes antofis kinds

ticostes sitllow ijerbe $\quad 286$

boticberite $\quad 286$

7popchomb and hiskinos $56 \mathrm{t} .562$

toater 02 martih bozthound 563.564

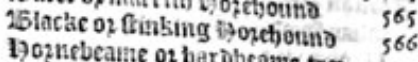

129

Dozncofea 19oppte

tozeftrong, 02 l9ozefrance 8.295

Do2fetong, 02 ly opeftrange 896.897

Dote tower, fo Melampyrum 761

i)osfe heeic, that is Elecampante

19ozfehoie

bople thoe

bosfetalie, that is 1056.105

bauegralle an

955.956.957.958

offe inint

Grent boutiolic

sea t) oùicelbe, of al ygreene and his kinos

b) otmos tong, 02 5onndog piffe 410

7otino berrie tiee

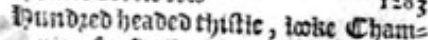
pionfea Dofite

byurt felale, that is blesw -3ottic 1000

i) yacintheg, loke zacintheg 59

I)

\section{I}

Ticlic of the butterie

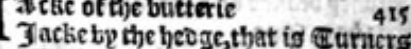

Jacinth and bis tinos, $\quad 99.100$ ac

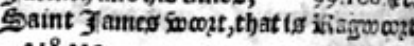
218.219

3afmine, Jefmine, 0z GeIfe 745.747

Jeives ti)ozne, that is Ciyuts thopne 1154

3 imperiall ittlie, of crorone 3 miperiall 153.154

Intenfe roote, lolke frtantintenfe isofenarie

JnDian Spilentro

921

(ced,tijat if flowping $\mathrm{EReCO}_{3} 6$

Indian 9 -

3 ndian Sunnc floswer $\quad 1346$

3 noian figgetter $\quad \mathrm{r}_{329.133^{\circ}}$

Endian rabaco

3 notan Dtemteale

3 notan Dolycate

3 noian SBillat

irsbolsnes, of 3 notam plumis

$1315.13+6.1317$

3 notars a ozrice bet

3 noian feut traxs

3 noimereftes

3 nDtan parnicke

3 nuian 25eaties

Indian 9 ourner, that is @ogrowfuli

tree 1342.1343

I notan Swalloswogt, that is ivifantis

752

Indian leafe that is Tamalapatra $\mathrm{r}_{3}$ is

Swecte 3 ohns and bio kinos 478.479

Sqtiare Eatint 3 obns foogt 45

Saint 3 obnd soopt and bits binds $c:$

Eoaint 
Saint 3l obns bread $1: 40,1241$

3 obs teares, 02 Y obs Dopops 82

3one filaer ptn, that is double $\$$ pppp 298

30fephs floswer, that is $\mathbb{G} 0$ to bed at none

Breos, that is the rote of the swhite ffloswerdeluce

3 fope, that is loyfope

If femon, that is $S$ tonic 50000,025000 made frones. $\quad 1390$

3talian f itch)

1068

F talian frow of tife, commonle called Lignum vitx

J talian Cedar tree

1039

J taltan fea $\Phi$ nion:

1187

talian Dtencele, Imke Ranicum 137

3 talian Calamint 556

3 taltan 1Rocket, loolse Rhefeda 216

Jtalian 9 piuet $\quad 1208$

$\begin{array}{ll}3 \text { ucca } 02 \text { Duca } & 1359\end{array}$

Fubas tree

Zute and his kinos

Erouno 3 uie

1240

Tumuper ano bis tinds 1188,1 I89

Tutube tree

3 sunos teares

1318

Jupitets eie, 02 3upiters beard

3 upiters Diftaffe

3.urap, that is 3Darnell

581

412

K

\section{Curben zarfe \\ Gs.zatherines flower}

lacolocke

zernell montt

kicre

Ixtonep tare, løbe Phafelus

latonep beanes and bis kinds 1039.1042

saronep beanie of 2 saffle $\quad 104^{\circ}$

104.1

taionep beane of Egept and 1 merica 1040

TDiuers fopts of fisonep beancs 1041

istonep vietch 1060

ksik and zsikaijon, Iooke Palma, Chrifti 400

Wsimble Sauine, that is berried ga=

une

king cob,that is Croswfonte 805

1193

laipper nats $\quad 905.906$

xistelicies

1289

Etluer Zsnaprocede, locke Sitluer.

lanęulker

760

Lnap weed and bis kind, 588.590 . 704

ti nawell, and łoarfeley piert, that is Imall ఏaxtrage

knecholme

494

sineeco graffe

titnighte fpur

kntghtsmilfoile

innights swater sengrene

fanot grafte

Sundep forto of Iznot graltes ibio.

Inottic Coucisgrafte

\section{L}

Xecand siz rotten tree 1349. L I 350

Dur liadics Mpe, loke our stadico Bipper.

A Table of the Englifh names.

\section{Dur 廵adicg baire}

inaies combe

Lades gloues

I. adies glate, fee tienus loking glaffe.

inaics bower

Dur Lladies thiftle

i. àieg laces

ilaoies fmocks

labies feale, that is swilde $23^{2}$ pionic 722

I adies mantie, that is great Sanicic 80

Il ambeg lettuce

Ilancalbire $\mathfrak{X}$ fphodill

I ano Caltrops

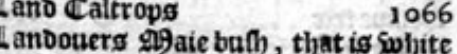
Chopne -

Q ang oebafe, 02 swidoe 13 ugloffe 655

L anDeleaperg fpurge, Ioble Efula maior

of \&Dackfaluers (curbith) 404.405

Iacke trex, 02 Pifmire,tree $\quad$ 1349

Larkes toes, 02 il arkes fpur $\quad 924$

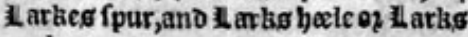
claw 922.923 .924

Larkes fyur of Ilarkes bele soolfes bane

822.823

1 arch of il arix trce

1182.1184

Il afermonat

Eaumber cotton

853.854

Ilauender fpike

951.952

467,468

Sea llauenoer 332.333

A a wonce foz a lad, Iolic Cats taple 42

Ilaurell of Z lexanozia

aurell or 15 ais tice

$\begin{array}{ll}\text { i aurell 02 15aie tree } & 1223 \\ \text { I aurell, } 02 \text { fpurge Laurell } & 1219\end{array}$

Leete and bis kimos $\quad 138.139 .140$

Yqoilom lleekes 138

$\begin{array}{ll}1 \text { ead } & 1069025\end{array}$

I eather Sumach $\quad 1292$

Lentillano bis tinos 1049.1050

Lentifs of Snathicke tree $\quad 1244$

Leoparog bane, $f(x)$ I conite 619.620

I.eplap, an Jnotan beane of that name I04I 24.1

Iltbiong

Iichiwale

Lignum vitx

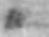

417
487 309

It ilie conuall, that ig 9 gaic Intlies 332

333

IReo or purple I tillies 149

Great ano fmall mountaine II fllie $15 \mathrm{I}$ mater intlie 672.674

Leo L tillie of $\mathbb{C}$ onftantinople $\quad 15 \mathrm{I}$

Perfan Itilic

it thic tileeke, that is S19oly

Dohite Liltie, and atfo swbite nullie of Contrantinople

Limon tree

1278.1280

une swert, fee Vilcaria $\quad 48$,

indentreand bis timos 1298.1299

Iinge, fee छeath) 1200

Iingowowt

I ions fnap

357

Xitong fote, lowke Leontopodion 518

z. ions leafe, fec liltons $\mathbb{C}$ urnep $\quad 182$

Llions foote 802.02 L tions paw tbio.

iliquerice, of itcoptfe and bis kinoes 1119.1120

Iiriconfancic, that is 99 aic Illies 91

In in in idenes

703

Litte long, that is Spanilh Drpine 417

lituerwogt and his kinds 1375.1376

Poble folite Hituerwort $\quad 692$

woo siueriont foble Ituerwopit, that if goldon etre Toctron Goulong 1032

Lockron あoulons $\quad 8 \mathrm{IO}$

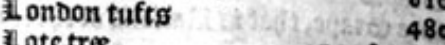

Lotc tree $\quad 1308.1309$

il ouage

2Baftard Il ouage $\quad 855$

lioufe berbe

I oufe fwowt, that is stauefaser 398. 913

Doufe poswder

I wefetrife, that is Lyfimachis 399

Illompic that is is auriell

Il owniegrafte Luriell 1219

L owfie graffe $\quad 827$

lungwookt $\quad 630.663 .1378$

Sea lingswow2t $\quad 1377$

cree Iungwowt cit ibto.

Il ung floswer

ll uptnes and his tinders 1042.104

I uftiwest, that is Sun deafw 1366

I peimachia, that is sl wofe ftrife 385.40 .

\section{M}

$M^{\text {TD apples }}$

1 (19a0)ers abis binds $960,96 \mathrm{r}$. 962

Falens 90 aromont

श्र agpoare 98

Garben 90 allow and his kints 782 . 784

Che witie shallow $\quad 785.786$

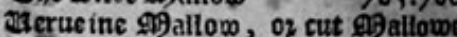
786

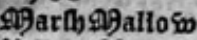

Yellow 9 allow

⿶enice \$) allow

791.792

ภी) anozake and his tinds $\quad 28 \mathrm{I}$

99 anna grafte

Ŝlaple and his kinos $\quad 1299.1300$

\$9 argaritesherbe $\quad 5 I_{2}$

S9) arierome and his kimos 538.539

toilbe ozbaftaro ano groue $\$ 0$ farierom

540.541

Бoates g

infatewerde

543
.618

9ioune

617.618

89 arigold ant his kinos 599.600 .603

Golden 29arigold 60

To2ne 919 arigold $\quad 606$

פ⿹

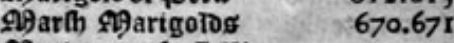

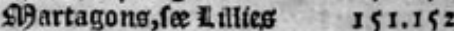

9 9aruellous apples 291

I9 aruell of Feru, of rather of the

Groztive 272.273

\$gafterswonts, that is falfe pelitorie

of Spaine 848.849

2islacke Pafterwow2t * $\quad 828$

פ⿴囗十) $\mathrm{I} 244$

of afticlse tro, that is Ientifle tre 1244

Terbe 9 afticke 544.545

2 Saftarde 9 afticke, that is $\Phi$ oates

Q9 A arierome

IPaft trex, that is firte fre 1182 .

1183

Sigatchivode, that is ceudbswobe $13^{85}$

sigatfelion

588.590 .70

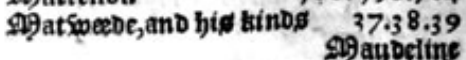


9andeline and his kindo 508.509. 524 Stinting 29 ayth, that to 29 aic woce 618

18.0 99aytheg

욜ate Şuntach

Siscchoca, 02 abechoacan 724

Ine eoicke fitth

Sisedictie fooder

\$) cabfweete

SิTCDow parfnep

9)coow faffion

I9

\$ife 00 wo gratte

SD- edar and hto kinds

29) clon thittic

2i)ettlote and his kinds

I9 clono and h) to tsungs

S9)ercurie and bis binds

so toe sifercuric

S9erturies moitt blodo

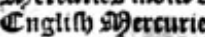

sijercurics biolets

IDutd) 2 9 ezercon

ISaftard 9 Peutn.mmo 895

9 itfoile ano his kinos

Dater 9 infofic

679

s9ilte trefoile, oz angab trefotie $112 \mathrm{~s}$ 1123

gillke at etch $\quad$ cos 8.1059

9) illewworte anb his binos $448.4,9$. 450

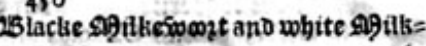
wownt

1062

g⿵⺆丶tilet

74

Iitllet grafic

Iפ

9) int and hio tinos …5 52.553

Dater 91 int, 6 in oz bzolse $\$ 9$ int 555

g⿴囗ountaine os int

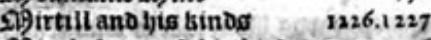

9h) ir obalane, and bio hinos 1359.13 i6

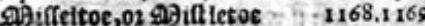

97 ithentoate nutharo

9itimuate Dowlfes bane 819.820

Ebe-29uthosate againt the poifo noug Fifintic

Sholy of Gopcerers garlicte 143,144

If 145 oll Clufij \& L'Obelij, fee 25 alme tree

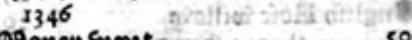

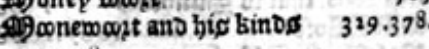

379.380

9onrice bels of zinoia to 136

we grafle 1366

Sifourell, of petic spourell that is Aightibade 268 ogiteg and his kinos 1369.1370 (c). stifofe ferne $\quad 974.975$

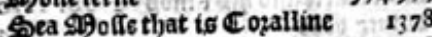
9.9other monte 258 9i pother of Eime $4\{7$

gimoufeare and his kindos $512.513 .5: 4$

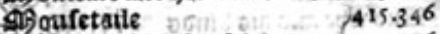
9. ugivont and bis tinos t4 945946

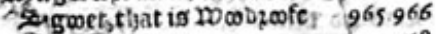

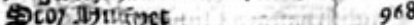
ibertic tree anớtóltuog $\quad 1324$ $-73=5$

Mulberric figac tre

1327

S9 Towoie Sigulicine, that its fircach rage

625
25 aforgulleine

왕th 요 uliteine $\quad 633.634$
A Table of the Englifh names.

octic oz ethioptansigulleine tbo. pectic If utitetncs 637.638 sintics boobe and bis tinos $\quad 924$ Yctlo w s S untics bode

gintics thubarbe

Great $\mathfrak{A}$ unkes hoo

924
820

823
Tound teafed 919 untis bwo $\quad 818$

El uftie 1B ofe 1084,1086

Tuft aro and his kinos

Cbtitics and 15 of

Do codic Q9uftaro 211

211
212

פhurretne grafle, lobe Scropiularia 579

\$ి uch gND

$86_{3}$

S9ubzumg and bis kinos $13^{8} 4.13^{86}$

Ere $A 9$ (IA) zums, that is Eoudjwobe i386

P)artie 9 gelong

770.772

\section{- N}

\section{N $x_{\text {ileswort }}$}

fiacli swogt

Lavtes fitauell

pouet Ẽentle

folauew and

fancm E J joz oware

gPectiweco, that to liempe

feefing powder

genupioar, that is swater Iitlic

fiep and his tinds, fee Cat mint 553

554

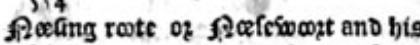

binos $\quad 356.357 .358 .359$

settle and bis tainos 568.569.570.57

fettie tree 1309

DeaD of bitino factile $\quad 568$

Petier oping 2 Bogage

ficotian,that is Eabaco 924.925 .926

fieloe of mitbe Pigella $\quad 924.925 .926$

Pight (hade ano bis btnos $\quad 267.268$

Slepping oz ocable fightlbade 270

1ieo sighthade

Lindweede, of Fincbanters pigbt

(b)ade

Ete paighthade

Rozmandie inbeate

280
289

60

916

Qone fuch, lolie floswer C onftantino=

ple 380

Ponstioe, 02 go to besat Pone 596 juts and bus lemDes 1248.1249. 1250.1251 .1252 .1253

$\begin{array}{lr}\text { fiutmegtre } & 1353.1354 \\ \text { 3notan fout } & 1338\end{array}$

Spanth f:ut

chomiting ano purging fatts $13^{352}$

water fouts

\section{O}

Culus Chrifti, that is witide Clarie

Difterioit, that is Snake woed 323 Diftergrene, that is fea langropt

1377

Dbe and bis kinos

II 56.1157

Dbeferne

Dlieof Jerufalent 950.95 $\mathrm{x}$

Dise of Cappadocia, of Dlae of paras

Dice $95 \mathrm{r}$ Scarlet $\mathrm{Dbe}$, of feariet 1159
Dilie pulíe called Scfamum ros4toss 1160 fearlst $D$ tic, of bolme Dte

Ereat bolme oble $\quad 1162,116_{3}$

coples Die tbro.

Cluetrocthat is kiofe baie 1220

Dluefpurge $\begin{array}{r}1206.1207 \\ 1215\end{array}$

Dne berric, tijat is berbe 19 eris $\quad 329$

One blade, that to one leafe 330

Dionano bye tsinos 133.134.135.137

Onion 02 bulbes 3 fphodit 89

Ppen arie,that is Sigelars 1265

Oiach, 1237

2ach), that is a rach and yis kinoes

256.257

Situking Dach

Dolloe 9 pact)

2. $\quad 259$

Dithis and his tinbs $\quad$ 159.160

Denge tree 1279.1280

Goates Diganie

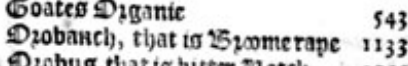

Diobus,thatis bitter eletcl) : $105 \mathrm{t}$

Dipineand:)ts kungs $\quad 416.417 .418$

Derice, that if ff lowerditice 47

Dater,that isfmall Witjie 1205

Dfmund the soater man, that is soter

ficrne

3 noiat Dtemeale

Dtes and bis tsinds

Dte thittie

Dutiandid) iRore

Drecie ano bis kinos

970.971

988

Ore tong that is spito 606.607

826

P

Poclion

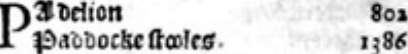

3)aigics 02 Cow tipg and his kineces 636.638

Painte graffe

Palute tre, fe \$Date tre.

Palma Chrifti

Oanar, 02 Dounoswoyt anobis tinos

850851

3anick and bie sinds $\quad 78.80$

joanicke grafte

Sutali 39anicise grafte

703.702
12

703.705

joaper keede

poarticleaues

pere mans parmacetie

Dafte imcosts

Drating $\supsetneq$ arnell

jarflep and bis lanos

Fartey piert, tbat is ls nasoell 45 3.45

Dater partey and his tsinor 862

25afturo Darficy on reo particy. 868

(Thorough boyeo parace, of Canots

zitranderg

Sountainc partep

stont wartiey

Folloe vaifley

Garoen ano witoc perfitep 870.875

Co5v parfnep 855.856

pafte flower, 02 19afte belour 254.255

affotong, that ig sonakeiweo 323

jofque flower 0219 affe tlower $\quad 309$

baftell, that is woabe

paticnee that is mocke $\quad 3 \mathrm{I}_{3} \cdot \mathrm{I}_{14}$

Panles 25etonic 502.504

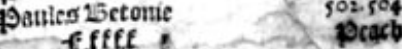


A Table of the Englifh names.

90ach) tree and bis tinos 1257.1258 1259

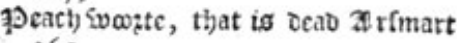
361

Peare tree and his kinds 1267,1268 1269

Dotide peare tree 1270, 1271,1272 peafon and big kinds 1044.1047 il ong †eafon

Euctafting Focafon

7ocafe carthnut

1042

1054

pearics of Spaine

1057.1058

Pearle plant, that is ๔romill $\quad 105$

pellamountaine $\quad 457.528$

pollitonie of Spaine 618

falfe 1oeilitopic of Spaine $\quad 849$

Pellitozic of the swall $t \quad 26 \mathrm{x}$

Đente grafte

912

7Denic mountaine, 0 s svilde बimte $\zeta 28$

9ente ropatl and tits kinos : 545.546

penteiwoogt, of wall pente swopt 424

toater 1 pennic Swoot t toto.

Seaponic soozt $\quad 425$

Shoepes ktlung peniegrafte $\quad 424$

pentic rot tbeo.

peonte, and his kinos $\quad 829.83 \mathrm{I}$

Foplar

829.831
1303

9eponand his tinos $\quad 771$

7oepper plant and his kinos 1354 .

1355.1356

pepperiowit, that if iDittander 188

2Dater Fopper, that is al rfmart 360 361

Wall Pepper, and countrep pepper 415

25 aftaro 1 opper called 13 etie 0225 etre 1357

Ginuie os Jndian pocpper $\quad 293$

Pefcod tre, lobace Anagyris $\quad 1239$

poeftilent woosts, that is swater 2 Burre

TDocke

668

pertuinkle and bis lindo $\quad 747.743$

$\begin{array}{lr}\text { 23iting of purging 19eruintle } & 743 \\ \text { s. Petero coune } & 67.68\end{array}$

๑. Deters swopts $\quad 434$

Detie cotton

434
519

Detie Dobinne, that is small ef borne

23 rome $1145,1 \mathrm{I}_{4}$

\$Detigr 760

pewoter woot 958

99harao hits figgetroe $\quad 1327$

pickpurfe 215

poigeons graffe, oz Columbine $\quad 581$

Figeons forte 793

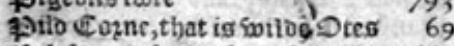

PDilénowt, that is fmal Celandine 669

gotumincli mo his tirog 484.485

roater Pimptitell $\quad 495.497$

Finitaes and bis tsinds $473.47 \% .475$ 476.478

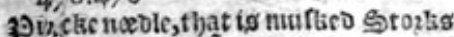

but1 795.796

pinie treand his lanos $\begin{array}{r}795.796 \\ 1173.1178\end{array}$

pilitc anto blem pipe of $\quad \mathrm{I} 2 \mathrm{~T} 4$

potitea or botte in bed $\quad 229.622$

pottch tree 1172.1173

pittch oz ftulaing trefoile 1019

Dlainer Clauer $\quad 1033.1035$

Plantainc and bis taindo -338.339 . 340

Hoater BSlantaine and bis tainos 337 338

St?

341.342

Bea vuthlyone plantaine 344.345

milu for 39 hantaine $\quad 346$

Plametro/ 1304

DDivarfic pranetros $\quad 1237$
Olowmans Spilkenaro $\quad 647.648$

Plums and bis binds 1311,1132 ${ }^{3} \mathrm{I} 3$.

9octsemeno

1309

pole reede

1110

oll liktuet, 02 rollaro swheate 34

Wolcy and hits sinds, lobe wut 59 528.529

polppodie of the swall

Folypodie of the otse $\quad 272$

Pomander pzimet, of baftarde $\$$ pitset 1212

Dourccitron tre

9omegramatetree $\quad$ 1280

1262

totide 3)omeions

\$Dondweede and his kinos $\quad 776$

$\begin{array}{ll}\text { Lnights ponosowit } & 677\end{array}$

†ౌose mans $\mathbb{E}$ reacle

joplar and his tindes $\quad 1300,1303$

20Hile jooppic 1300,130

Sea 02 hopneD poppic 295

Baftard Svilde Foppic $300.30 \mathrm{I}$

Spatling oz frothie poppic

poppic and bis binds 293.295 .296 . 297

19ozeclaine

Doptingale $\mathbb{E}$ refotle

419

potatocs

Potatoes of esirginia

white Đotherbe

Shephearos ponch

1021

780

781

781
243

Pricke timber, of poyicke swode tree

1283.1284 .1286

9yickiev bore

IISi

Ozictict 41524

9.

Dopimerofe poerelefte and bis sinoes

rofe soith the white flower $\quad 639$

19 intet of Doim pzint

spocke pout

25attaro priuet

1209.1210

2umeit

1213

508

79)toding graffe, that is penniroial 546

puoding pipe

30uffe finteg

1242
1386

9utiall mountaine

Dutfe

jourfane

Ssea poturfane

457
1035.86

thio 420

20urple moth) silgulleine $\quad 633$

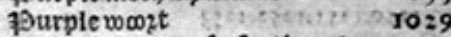

Shephearos purfe, foe plouch).

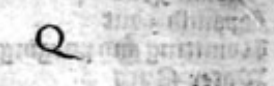

II aclifaluers fpurge $\quad 407$ Duackfatters (c) urbiti) $\quad 404$ Duakers, 02 quaking grafte $\quad 80.8 \mathrm{r}$ 2uencs Gtiloflowers $\quad 376$ 9. Peadefweete : 886 Queene motherberbe, that is Tabaco 285

Duickbeame and Quicken trex; that to sutioc afbe

1290

Suicklp gone flower, that is vienice Shalloin

791.792

Quch graffe, that is oogg graffe 22

D ntrquefotle, that is $\mathbb{C}$ inquefotic

839

Dumectrex

1263,1264
Pocts isofemarie

Prickmadam and his kings 215

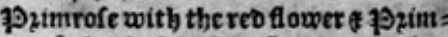

frutideffe pout

1211,1212

Duxene of the sipedoswes, that to

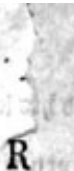

R

$\mathrm{R}$ Ibone

18acket, that is 13ocket $\quad$, 84

Rabilh ano bis tinds 183,184

lopte 02 mountaine ARadich 18

15agwoost, that to Saint J Fames swows 218.219

Ereat 1Raifort

1Raiang of the funne $\quad 727$

187

1Ramptons, and bis kinos $\quad 369.370$

Ramfong 142

Bain of Atbya, of Chyifts ebozne

II 54

1Bam 02 lyarto thopne? 1152,1153

Laxatiue 1Ram $\quad$ I $54.1 \mathrm{rSS}$

Bante

Lape and bis kinos $\quad 177.178$

13ape Crosofoote 8 Ir

1Rape bzome, fee Slobanch.

1Rape Cole 250

Lafpis of ff rambois, ahio his timbes

$1089.109 \mathrm{I} . \mathrm{C}^{2} \mathrm{f}$,

Yellc so liattle, of sohite 15attle 912

1ReD 1Battie, 02 1Rattlegraffe $\quad 913$

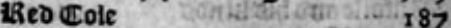

RRede and his kinos $\quad 32.33,34$

15eere mace, that is Cato taile 41.42

13eede graffe, that is 23 urre 18 oed 4.5

wotloc iseede

Ereat tiebe grafte

Ehounic 1Beeoe of

$2 x$

ToIs

Sheete BReede, that is Calamus aro.

maticus

Sweete ifeed, oz fugar ifabe 35

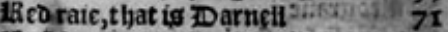

1Seft jarrosw $1141,1_{4} 4 z$

ishein berries abiti, 1141,1155

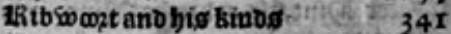

1Rocket 191.192

Shephearos 1000, that id sofid Cazell I006

1Rogation floser

12omane beanes

18 omane peafe: allipes: att 1047

1Rofeano hto kinos jo79,1080.108r.

1082

13 ofe bay, 02 is of bate tree $\quad 1220$

ID warfte liofe baic $\quad 1221, \mathrm{Y}_{22 \mathrm{Z}}$

13ofecider

englib 130fe willosw 1204

Ros Solis, that is Sundeaw 27366

noilde tRofe

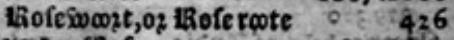

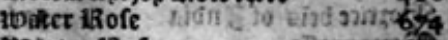

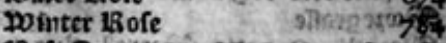

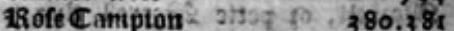

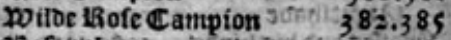

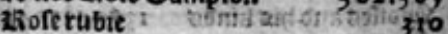

Aisofemaric ano bif tinos 1108 . Into

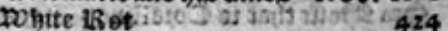

Lifeo 1Rot, that is Sunveaw $\quad 1366$

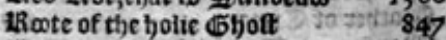

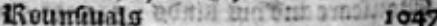

1Rubarbe ano bis kinds 315.316.317

ingunkies 1Rubarbe

Laftaro tiubarbe

Engliob baftard 13 abaro 312,214

13 twod

linea ofiatimbs 1070.10710

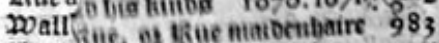

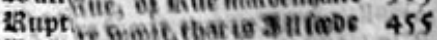

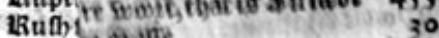

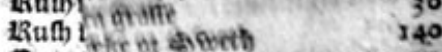

Tomm tir of soweth

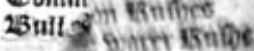


Sbarpe 02 bard 15ulb

ARutb Daffooull, amb bis lsinos

15uth eratfe

13ulute fea grefte

1Apce

18peanobis kinds

\section{S}

$\mathbf{S}^{\text {If fion and his kinds } 123.124 .125}$ $126.127 .4 c$.

Nicrnall Saffron

T5aftaro saffror and his kinds 126 1007

Doldoe biftaro Saffron 1008. 1009 Sage ano hig kinds $62=.623 .624$ Sage rofe and hig tinos, looke Ciftus. frenci) Sage, lootse Verbafcum Marlii-

oli

Sage spullein

Sage of 7 crúáticm

Sage of 2 ethlem

altgot, 02 swater nuts and bis tind 676

Galomons f́ale and 1 jis kinds 755 . 756.758

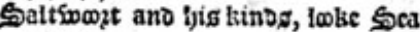
arape

xislacke @altupontt

Sellow, that if bollow

Sampier and bis binos

Sandeucr

Enanownit

Sanickle ano his tinbs

ficerewort Samickic

ountaine of fpottco Sanickle 643 644.645

Suria 3 jarilia

aracens Confononde, or enaracencs Comfrep o: woundireo2t

Saraans 26uti) wo 2 t

şatiafras, of ague trce

Sattis, of sattin fioser ano bie

Satyzion andis Eisos I 56,157,169 170. 171.172 .173$.

Q $460.46 \mathrm{x}$

Soun and bis binds . $\quad$ IS91.1192

Gawice Sumach 129

Saunders tro 1388

Sauce alone, that is Jactic bp the beoge

Sarweโw

576,57

Englith Sarifrige

isurnet saxifrage

891

white 0z golden Daxifrage 692.693

Scabtougand 1)is binos $\quad 5^{82}, 5^{83}$.

584.585 .586

Satuer Deabious

Scale ferne, 02 fronic ferne 979

Scammoric and b! : lumbs 716.718

Scariole

Scarict olk

222

Exciatica groffr, that is sotios Crefrg,

197

Scajanthum

Clot: 9 ciences

Sohchearगs \$crip

215 ibertic tree anbng tumbs Nos r3:5 rmandet

919ulberric figge tre 599

sigulleine ano his kinos

Wodie 9 Pulleine, that is frepht 325 625

690
A Table of the Englifhnames.

\section{Dea Drion}

Gea fitiegrafie

Sta Dog crafte

sebeften of $x \pi_{\text {yzan }}$ plantive $\quad 23$ 1315

Selfe bealc and hio binos 507.508 Sene buth 1113.1114 23 aftard senc os Senetrce 1116.

Somgrene

Doater sengrene

411.412

ficto 077

Serpents tong, of 31 Docrs tong 327

Seraptas ftoncs 170.173

siseruice tree 1287.1288

notbe Sertice tre $\quad 1290$

SEfamotoes c; baltard syoad 396.397

Sefantum, that is otic pulfe I054 1055

Sefely, that is Eqartwo

Sefely cf Canoic 893.890

Thountaine Setwall, that is Nardus

$\begin{array}{ll}\text { Celcica } & 919 \\ \text { Setfotle,that is Eogmentill } & 840\end{array}$

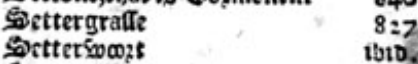

Sctimail

Sbajos mrafic

916.918

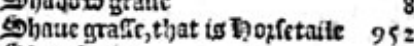

Stbarewont

Sheptearos neesic

Shcphcaros parfe, of (crip ( $x$ pouch).

Shlecrc sraffe
Sicamope trex
1326.1327

Siltale sowit
506.508

Siler mountaine $\quad 891.892$

Silken Sumad) 1293

Estlucr Ianapioced and bis tinos 590.

591

Sttucr tuifte

Siluarmact 988

Sinticficlo

Sokirix copt

I adies slipper

Soloctre

Smallage ano biotsind

Smati baro graftc

Garoen Smtiax

sinos 322.323

nakes 1 buglofte $\quad 659$

Snakeg

Sonatle Clauer

142
1029

SnapDiaguand lis kinds 438.439

Encercinont 483.484

Soloters Parrow $\quad 477$

Q⿱宀⿻三丨口

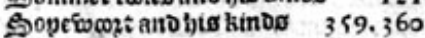

Sozbe tre and his kindes 1287,1288

So:refl ano bio linos $318,319.320$.

321

Soprell du Bois

1031

Sozroimfull tre

Sothernimcod and his kinDs 947,948 . 949

Soivbread and bis kinds 694.695

$\$ 0$ sothifte this tinos 229.230 .23

Sparifh bzcome, 02 spanih) bafe bommes 1136,1137

sparrofoes tong, that is is notgrafle 452

Speare fos a king

88

sopearcm ost anobis kinos 813.814

815 speare Crowforte 815

Speocincl1, loble ffluclin 500.502.

504 cone and bis kinds

62

Sperbatuke, that is Dankewede 237
Sperage, that is Afparagu, 952.953

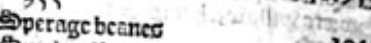
Spictincl! (for $104 z$

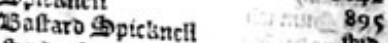
spiverivout Spibeo water grafle $\quad 12$ Spikc Cppies grafte 120 aptgneil, that is 2 Galtmonic $35 z$.

wetcr Soptse

675

Dpitienard 919.920 .9275

ifougb) of filioe Splenew 221.922

Spinatreand his tinds - $\quad 979$

1284.1286

Sponerow2t

Spurge and bis kinos $401 x^{3} 3=5$

Dpurgewort, looke ftintsing G.4\%

53

Spurge oline, 02 5niboso watle 1215

Germaine oliue $\$$ purge 1216

Sptirge flate, of mountaine soidoin

soutie

gonrac taureli

quilithatisfer 1219

Squinant 137

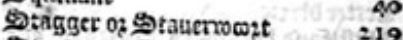

$\Delta$ tandergrafie, tlyat is

ons

Sotart') copnc

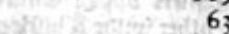

695

wow2t, that if blewe idatices

334

tarre thiftic $\quad 1003.1004$

Staues acre 398.399

Starwogt, of Sharewoyt and bis

kindes $391: 392.393$

Stars of 2 Bethichent $\quad 131,133$

Stars of $\mathcal{F}_{\text {I }}$ crufalem, that is 3 of cphes

flosmer 596

Stcecados and lis kinos $\quad 470$

Golden Stacados $\quad$ S22

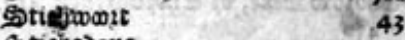

Stickadoue

Stocke Grillofers and bie tsinds 372 373

Etoneliucrivme $\quad 1376$

Stonecrop, that if bourteske 413

414

Stonc boze, that is Stone peqper, of Stone crop

white of goloen stone brealse 693

Storie swoD, that io turned to afione

1390

Stoplics bill and fits linos

9afked Stozkes bil

citolets stoptics bell

Stozar tree

Stralieo gratie 25

Strangle woere, and Strangle tare, that is Orobanch 1053

Straswbertie and bis kindes 844 . 845

Strawoberrictrex, os 3rbute tree 3 ro. 1311

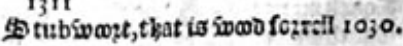

1031

Succonic and bis tinbed 219.220 .

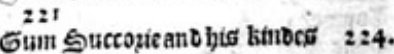

227

20HDe Esucconie 222

auckics oz bonifseltics $\quad 1018$

Gugar reede 35

Sugar cane

896.897

fiffe 2

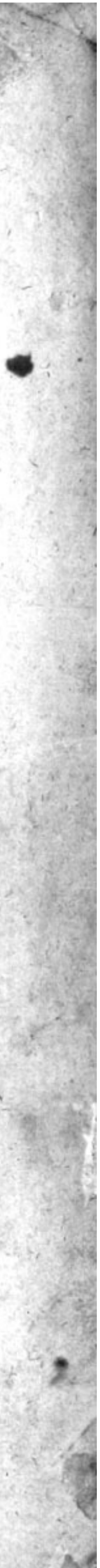


A Table of the Englifh names.

Peach) tree ano bio tinos 1257.1298 I 259

Peact) Svopte, that is ocad $\mathfrak{a}$ rfmart 361

\$2care tree and his kimbs $I=67,1268$ I 269

Wotide ploare tre 1270, 1271,1272

poafonand bis kinos 1044.1047

il ong Đeafon

Eucrafting pocafon

¥)eafe earthnut 1042

1054.

pearics of Spaine

1057.1058

Dearie plant, thatis Gromill 105

Dellamountaine

487

Follitoric of Spaine

457.528

fralfe 1oclittontc of Spaine

6 r 8

pellitopie of the swall

849

gente grafte

261

Ocnic montaine, 02 swilde

ponie ropatl and tyts kinog : 545.546

pentew popt, of wall ponte swopt 424

Toatef f Pennic Swozt t bio.

Seapenie soopt 425

Sheepes ktling \$9enie graffe $\quad 424$

penic rot ibto.

Peonte,and bis tinos $\quad 829.83 \mathrm{I}$

2)eplar

1303

9.epon and his tinos $\quad 771$

Fopper plant and bis kinos 1354 . 1355.1356

pepperiowat, that is iDittanter 188

Doater pepper, that is al rfmart 360 361

Doall \$epper, and countrey Pepper 415

25 aftar D pepper called 13 etic of 25 etre 1357

Ginuie os 3ndian 19 cpper

293

Pefcod tree, loble Anagyris I239

poeftilent wopkts, that is swater 2 Surre

TDocke

668

pertitikle and his linds $\quad 747.749$

23 iting 0 p purging ?

$\begin{array}{ll}\text { S.peters copne } & 74.68\end{array}$

9. Peter 5wळits

67.68
434

Fetie cotton

519

Fetie 20 hinne, that is \{ntall Gyorne 23 tome 1141.1142 petigr 760

pecwoter wookt 958

Pobarno bis figget $x$ ce

picspurfe

958
1327

goiceons omencen columibine 21

Potgeons foote 793

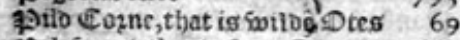

Fotlénowt, that is fmal Celanoine 669

7otimpinell and his turdog 484.485

joater pimputell $\quad 495.497$

Finilies and bis tinds $473.47 \times 4.475$ 476.478

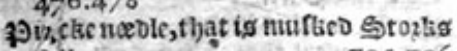
bitl 795.796 pulie træand his taind 1173,1178 white ant blem pipe $\quad \mathrm{r} 2 \mathrm{t} 4$ poittea 02 potfle un bed $\quad 2: 9.622$ Oitchtree 1172.1173 Dittch or fetnking tref $\Delta i l e \quad 1019$

Platere Clauer 1033.1035

Polantanc and bis binos 338.339 . 340

Doater 39 lentaine and ljis tínds 337 338

Sta

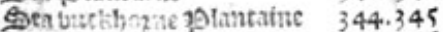

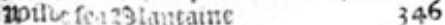

platevece 1304

DD ixarffe planetras $\quad 1237$ piowmans Sisikenaro

647.648

lums and bistinds 1311, 1132. ${ }^{3} r_{3}$

Pocticiocod

†oocts isofemarie

1309

oie reebe

1110

oll vituet,

34

Sicy and bis tinde, tobe suild es tme

polippodie of the swall

7. olepodie of the otse

272

Po omander pzinet, of battar oe 19 yinet

III

Pomecitron tree

\$. Domegranate tree

1280

1262

toilde æomtoions

39onoweede and his kinos

linights ponoswowat

pəoge mans Treacle

oplar and cristim 147

1300,1303

299

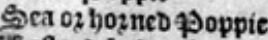

295

300.30 I

Spating 02 fr othit 2 Poppie 551

Poppie and bis linds 293.295 .296 .

297

pozeclaine

Dontingale Crefoile

potatocs

419
1021

Potatoes of שit ixginta

iplite potherbe

Shephearos ponch

780

$78 \mathrm{r}$

243

Dickmadam 215

Pyicke timber, of Fojicke swooe tre 1283.1284 .1286

prickicy bore

$115 x$

piteket

के

79 imerofe perclefte and bis sinoes I I 4 , fic,

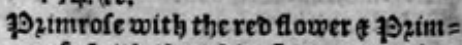

rofe soith the bubite flower $\quad 639$

9ituet or 10zimpzint

9locke pituet

21 aftaro piutuet

fruitleffe $p_{\text {put }}$

1209.1210

19)

puoding grafte, that is penniroial $\$ 46$

pudoing pipe

opuffe friftes

jouliall mountaine

Butife

jourflane

Sisea ₹ourlane

Furple moth) glgulletine

1242
1386

urple wow?

Sbepleards purfe, fee pouch.

1035.85.

419

tbio. 420

633

\section{Q}

tiackfalmers fpurge anackfatters esurbit

Oaber, 02 quaking grafte $\quad 80.8 \mathrm{r}$

Ittencs Ettloflowers

376

Dinene of the spedoswes, that to Sileadefoeete

886

motherberbe, that is cabaco 285

Duickbeame and Suicken tree; that to fortocafic 1290

Suittip gone flower, that is clenice S9alloson 791.792 Duch) graffe, that io dogg graffe 22 Dntriquefote, that is Einquefoile

$$
839
$$

Dunce trex

1263,1264

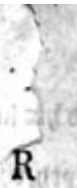

$\mathrm{R}$ I bone

18 acket, that is 18 ochet $\quad 184$

1Rabih and bis kinds 183

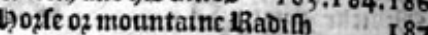

1hagwowet, that is Saint James Swoost

218.219

Ereat 1Raifort

I 87

Raifung of the funne $\quad 727$

1Rampions, and bis kinos $\quad 369.370$

Bamfong 142

Rain of Iibya, of Chzitts Cbozne

1 I 54

1Bam o2 lyarts thozne? 1 1 52,1153

Laxatiue 1Ram

iRampe

liape and his kinos 372777.178

12ape Crosoforte $8 \mathrm{II}$

1Bape bzome, fee @iobanch).

1Rape Cole $\quad 250$

18afpis of frambois, atio hio tinbes 1089.109 I

Yellow liattle, or sobite 15attle 912 1ReD 1Battic, 03 Liattic graffe 913 13er Tole

1Reede and his kinos $32.33,39$

15eere mace, that is Cats taile $4 \mathrm{r} .42$

12eede graffe, that is 2.3 urre 18 oed 4.5

Dotloe ikeede

Great tiecbe grafte

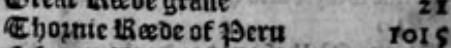

Sisweete iBeede, that is Calamus aro.

maticus

meete 1Reed, op fugar iRede

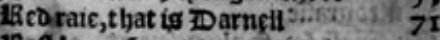

1Seft barrosw of 1141,114 ?

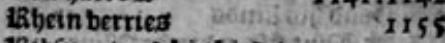

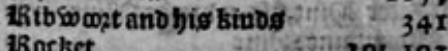

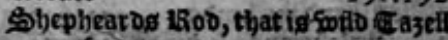

1006

ERogation floswer

450

104me

1Rofeano bits binos ro79.1080.1081? 1082

18 ofe bap, 02 is of chaic tree in 122

ID fwarffe tiofe baie $\quad$ I22 $1, x_{222}$

1Bofecider

englitb isofe swillow

Ros Solis, that is Sundeaw

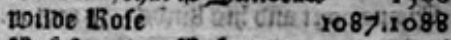

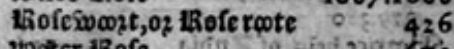

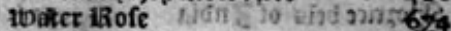

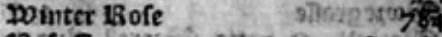

1Rofecampton- vitsi ff $380.38 \%$

Doilde Bafe Campion $38 \%$. 38.35

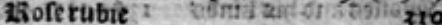

45ofemaric ano bio kinos 1108 . Irto

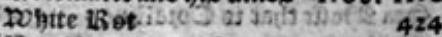

iseo 1Sot, that is Sunveaw $\quad \begin{array}{r}366 \\ \hline\end{array}$

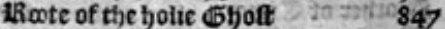

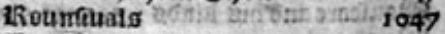

1Subarbe ano hts binos 315.316 .317

Nounkis lisubarbe

15aftard Lubarde 312,214

Engliob baftaro 13nbaro 312,545

13 trody

1Ruead his kintos $1070.1071 \mathrm{NO}^{-12}$

Doallisue, of thue matocthaire 983

1Btuptre srowit, that is IIIfeede 455

isublea grafte

12uth) telee of Siveth

Cominton tsu hies

23ullas swater 18udice 


\section{A Supplement or Appendix vnto the generall $T$ able, and to the
Table of Englifhnames: and printed Copies, and from the out of ancient written and fimple Countric people.}

A.

A pet is 細 ill.

Amix is Ameos. Argentill is joercepier.

Itce is smallage.

Alliaria, in woitten Copies Cardiaca.

B.

B alomoine,that is đentian. 2Balowein,that is Gentian. $2 B$ eliwexo, that is lacea nigra.

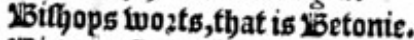
YBiros neft, that is wilo joarfnep. 2Biros tøng,that is stichwoyt.

2Bigold, that is Chryfanthemum fogetum.

13olts, that is Ranunculiu globofius.

13 olvivoo,that is linaploxio.

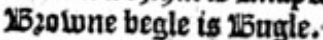

23 ; wrewwazt, that is Confolida minor.

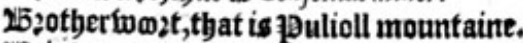

16ziowwett, that is Vlmaria.

13 right is Chelidonia.

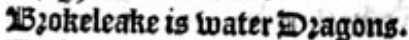

13uckes beanes, that is Trifolium paludofum.

Luckram,that is Aron.

\section{C.}

Carbiacke is Alliaria. Carles is Creftes.

Catmint is Nspta.

Cencleffe is $₫$ affooill.

Cheruell 02 Cheuerell was calleo (though sntrulg) Apium rifus.

Churles IIreacle is Aliwm.

Churcbiwozt tis penniropall.

Clithe is the Usuroocke.

Clitberen is $\mathbb{G}$ mfegras 02 Cliners.

Clite is Lappa.

Cloue tmug is Elleborsu niger.

Cockes fote is Columbine.

Cocke føte is Chelidonia maior.

Colv fat is Coiv ysafill.

Criftaloze is the letter Centozie.

Crcneberries, Vaccinia palustria.

Croio berries, Erica baccifera.

Crols Lope is Sopelvwozt.

Croivlextsc is Hyacimthus Anglicus.

Cropticeo is Iacea nigra.

Culuerbozt is Columbine.

Cutberosle ano Cutbertill, is $2 B_{2}$ anke bztine.

D.

D ilnoteCyclamen.

Donninetbell is wilo
D2agons femrale is colater ozagons.
D20pwo2t is Filipendula.

E.

$\mathrm{F}$ Doeribmat is Dracontium.

Cileber is Alliaria.

Cliebocke is Enula camparia.

Carthgall is great Centozie.

Cuerferne is wall sferne.

Cran is Crofwo2t, pet not our Cruciata.

\section{F.}

F Ane, white flotwer oeluce.

Ffaucrell is Cepes.

Fielo Cipzeite is Chamapitys.

ficeld wozt is fieliwott,02 Gentian.

Fillelopzt is Filago minor.

fileadocke is Petafites.

Jleatwozt is $P$ fylliwm.

fforget me not is Chamapitys.

3F 022 bitten moze is Dituels bit.

ffaucrole is water DD $_{2}$ agons.

freifer is the berbe that beareth stralwberries; traluberrier.

G.

G Alingall meke is Ariffot roturds. Banoergoltes is Z Zakes.

Seckooris Aparine.

Gofechite is Agrimtonic.

Odefegras inas fometime calles Argentina.

Gowe bill Aparme.

Barben Einger is Piperitis.

Glono is Colv 2Bafll,

3riene 9guttaro is sittanoer.

Groundivill is Grounofivell.

Grounonixole is Geranium Mufcatum.

Ground Enell is $V$ enus combe.

$\mathrm{H}$.

H aireue is Cliuers.

$H$ igammerivozt is joellitopic of the wall.

1) aroboiv is 99 arygolos.

Hares eic is Lychnis fylueftris.

Harebell is Crowlixthe.

Ferbe 3 ue is Chamapitys.

Genbell is Heituane.

Heibolw is Hederaterreftris.

jerbe Lennet is lyemlocke.

igerbe peter is Colwaip.

Herba martis is Martagon.

Gerteclowis is Cbamadryos.

Hertwo:t is Fraximus.

Gilioozt is pouliol montaine.

Hippia maior common pimpernell. 


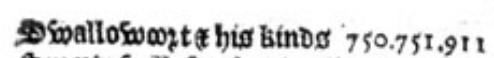
Spmete foillowo, that if Gaule 1228 Sumach

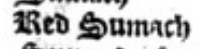

Şunne Deawe

1292

Suntlower

ibid. 1293

1366

Swines Creftes, that is Ruellius his

1Backthozne

Ssinines grafte

Stickadoue

\section{6 \\ 452 \\ 470}

\section{$\mathrm{T}$}

Tataro and his kinds 284.285 1195

Canite and bis binds 524525.526

totibe Eanfie $84 \mathrm{I}$

Care akb hif tinds 1052.1053

Care eueriafting ibro.

Ercat sotide Eare 1054

Diofcorides bis millse ceare 1061

ceafell and bis tsinog 1005

Cerrible berbe 408

Cetterwogt $9 \mathrm{Ir}$

Cetter berric 720

Cbiftle and bis kindes 985.926 .987 . 988.989. (f5.

Chiftle bppon Chifte, and oituers

other swilde Ehiftles 1010,1013

Chlarpt

206

Cebozne and bis bhos $1145.1147 .114^{8}$

Tohite Thone

1147

chome boxe

II 51

Chopne bzome and bis binds $113^{8}$. 1139

Chozne 3 pple, 02 of pera 276.278

Chozne Erape, that is Gwfeberties 1143

Purging Ebozne, of Iaxatiue ram IIS5

Ebozoso soaxe, oz Cbozosw leafe 429.

(ch) $43^{\circ}$ leafeo grafte

Oipeeleafed litucrwoont

1018

Chyotefwont and his kindes 363.366

1032

Ehpougbswont and bis kind $43^{\circ}$

Cimeano big kinds $\quad 458.459$

(eine, of wilde teletch $\quad 1052.1053$

notlde 厄ime

454.456 .457

Creping Eime of rtunning e ime tbio.

IDodocr, op laced cime

Sifufte Ctme

459

Codeftwie andots kinos $\quad 13^{86}$

Code flare, or witide flaxe and hig tinos 440.441 .442 .443

celmeiners

expmentil, ano bis kinos

conngeblade

Cothpicke Cherutt

Ercat Ce cothoow

ecozches

copnfole

Eonch me not

\section{0}

840

761

885

1387

630

ouchwode, that is tre 99 rila)?um 1386

厄oining Mntharde

coppowit

Ladie Eraces

קeriple tlaotes Eracts

Erauetiers top

Eree of life

हrex fpurge

738.759
1117

Crcfole andisis kinds 1017.1018.1019

13ente $\mathbb{E}$ refotle

Trefoilc of 3 merica

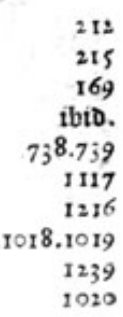

212

169

16

1239
1020
A Table of the Englifh names.

toater of marfb ercfotic 1024.1025 Shoub Ercfoile

II2I.1125

Siwecte Ercfoile 1025

Sowor Erefotle

$103 \mathrm{I}$

attaroe of Switoc millie Erefoitc, of baftaro (b) zab Erefotle 1125.1127

alenemong træ Ercfotle I127.1128

S) zubbie Crefotie of nuakebate, of Marcellus bis milke Erefoile 1128 . 1129

(Ereacle 99 uftaro ano his kindes 190 . 203.204 .206 .208

Ereacle $50002 \mathrm{mfec}$ de

213.214

Ercacle wopt, lobe Scorodothlafpi.

ereacle clauer

1018.1019

Engith Ercacle

Cree bcaring Goefe

crinitic berbe

535

Eroll tlowers

Cruclouc, that is herbe 39 aris $\quad 329$

Culipe and bis kindg, $116,117,118, q c$.

Cunchofe

705

Eurbith of Antioch $\quad 334.335$

Serapias Eurbitb, that is fea ftarionet 334

(c) urkes berbe, lolke Herniaria 455

Curkic baulme

558

Curbic conne, and Eurbie Solyeate 77

citurbie बrofofotes 812.813

Eurbie 9 - Eullet $\quad$ ross

Curbie ben fiomer 1,123

cerneps ano bis tainos 177, 178. 179

Curpentine tree and bis binds 1246

cutian

435

Crap blade, that is Double lll eafe 326

CEvig soithic, of fntall sotthie 1205

espopenie grafte

gos

T.4ertan and bistainos 916.917 918

1Reo raterian

Uieluet flofwerdocituce

denice कsumach

$550.55 \mathrm{~T}$

1293

Clenug batre, that is 9 9aiden baire 983

va enus combe

vientas looking glafte

ชis eruaine ano big kinog

eretch

Ditter at etch

356

Aine ano bis binos

otibe dine

white dine, that is swhite 237 ione 7 ig

aiolets and bis kinos $355.699 .70 t$

Dames and bamafle שifiolets 376.377

DDater vetiolet

679

705

rotheo atitolet 833.835

Youlbed at iolet

3.835
121

Tipers grafle

596.597 .599

atipers 1 ibuglofte, z aipers berbe 659

otirging boswer

uxpight Dogs graffe

740.743

\section{VV}

Tix 7 oing ponoweed

Daicbread that to plantain 340

waicthozne, that is buckithogne iss

Doaiefaring tree 1305

make 13obin

toall floswers

685

Dall barley, oz sway 15 ennet, that is

TDarnell

$67.7 \mathrm{t}$

wall nut

$1 \geq 52$

mall swort, that is TDanrivert $\quad 1238$

Sea wartswozt
Great Water craifle

Water archer ano his kinos 20

Doater nuts, that is Saligot ano bis
kinos

woobwind, that is sithrmind 676

welcome to our houfe

welde, that is 3Diars sweed $\quad 407$

wheat and his binos 58.59 .60 .75 . 55.76 .

(1) 2e months swheate $\quad 6_{3}$

whinne and bis kinog $\quad 1138,113$

Dhtcken tree, that is swilde athe 1290

Whitblosw, of Swhitel osw grafte 498,500

DObit5wopt, that is ficauerfeis 527

Pobite rote and bis kinds, that is

Salomons feale 758

Wobitten tree, that is swater eloer 1237

10hopts, 02 swhoztic berries and his

tinds 1228.1229 .1232

twidow Swifle, ì ts greening weed $\quad \begin{aligned} 1367 \\ 134\end{aligned}$

10idosw swatle 12 Is

Che toiloing tre, fee crabe tre.

Spreet Dillams $\quad 478.479 .480$

potloe wotliams $48 \mathrm{r}$

Dill osw ano bis binos 1202.1203 .1205

Sweete wotlow that is Ganle 1228

10illom berbe $\quad 3^{85.386 .3^{87.388}}$

roino rofe

wind fiomer $\quad 301.302 .3 \mathrm{C}_{3} .30_{4}$

1bilo Winde flower $\quad 306.307$

wothiminde

witbic 1205

toitliswind, that is 25 indswodo and his

itnog

Doitch bafell $\quad 1296$

100ad

nowb grafte

1000 rulbie grafte

Dind and big kind $\quad \mathbf{7 4 3 . 7 4 4}$

ISlew woDbin', of ladieg bower 743

vipright Powobino 1113

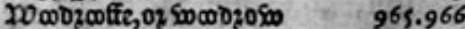

WDD made ftones 1390

To wD fosmer, 02 Swod fogrell, tljat is $\mathrm{Al}$.

Jeluia

Wodrosull that 966

WoD fage, ano garlicke fage $\quad 535.536$

twoOD fitghtchade $\quad 278.279$

woDo Chickweede, 03 wood 29 illet 85

Dowllp Jacint $\quad 106$

molen, that is 9 -ullein $\quad 630$

toolfes bane and his kinds $\quad 816818$

woolfes clan 1374

winter 10 wifes bane $818.8 \mathrm{tg}$

Yellow Dowifes bane $\quad 821.822$

10 olfes fithe $13^{86}$

upopme graffe, that is great Stone crop

$4 \mathrm{I} 4$

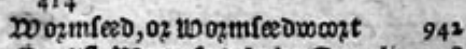
Englith Doozmieed, looke Cameline 28

toezminoD

Di oite Dozmesond

IBomane toozmeno

Small leafed, garben of Cppeffe Doozminod

Esea Dopmeswonde 94.941

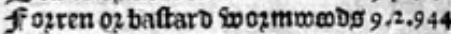

Dooundewent, t. Confowno 599.660

woundwort and his kinds $350.85 \mathrm{r}$

Jinights water Doundospert 677

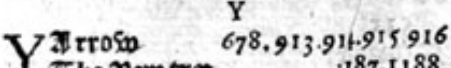

The yemtre 187.1188 .

Yoke Eline $\quad 3196$

Youthwont, that is funbean $\quad I_{3} 66$

Yucathat is 3 ucea $\quad{ }_{359}$ 


\section{A TABLE, WHEREIN IS CONTAINED THE Nature, Vertue, and Dangers of all the Herbes, Trees and $P$ lants, of the which are \\ fpoken in this prefent \\ Herball.}

\section{$\mathbf{A}$}

$\mathrm{T}$ 10 caufe 3 boztment, $54, c .696, \mathrm{n} 970, \mathrm{~b}$. Good againft Abortment,624,a.

To prouoke womens naturali 3 cabents, 57, b. looke Termes.

Good againft $\mathbb{X}$ ches, $\mathrm{ri}_{4}, \mathrm{e}$.

Good for Aches in the hands and feete, $987, \mathrm{c}$.

Good againft or to take away all Aches proceeding of a colde caule, $540,6.134^{6}, \mathrm{~d}$.

Good for all Aches in the ioints, $1016, a .114, c .1026, b .1050, n$.

Again 1 all manner of Aches in any part of the bodic, 287,1.616, b. $7 \geq 2, c$.

To mitigate the Ache and paine of feeble lims, $1_{339}, b$.

To helpe old Aches in the armes, hips and legs,219, b-433,e.557,

h.722,c,1129,d.

To abate or helpe Aches of the fincwes and ioints, $65,3,131, b$. 895, b. 1050,n.

To remedie the Ache of the Hucklebone, 198,b. 219 , d, 1 I 29,d. $13 \circ 3, b, c$.

To mitigate all manner of Aches, 1256,6 .

Totake away Aches of the armes and thoulders in fhort fpace, $722, \mathrm{e}$.

To confume or feoure away the Achores, being vlecrs in the bead, $147, a .1027$, i.ro3s, c.

To procure the $\$$ a of generation, 1353 , d.looke To proudke bo. dily luft:

A remedie againft the ftinging of 3 DDerd, 267,2 .

To heale the difeafe Acgilopi, 68, a r $252, \mathrm{~b}$.

Againit cuill 3 ffects of the breaft, $318, a .460, d$.

A gainft euill Affects of the bodie, 1116, .

Tohelpe cuill Affc Ats of the raines,3, d.724, b.

Again it cuill Affects ot the lungs, $54, \mathrm{f} .66_{3}, \mathrm{a} 839, \mathrm{~b}$.

To bring downe the afterbirth, $, 24, e .14 \mathrm{r}, \mathrm{f}, \mathrm{r} 88, \mathrm{~d}, 459,2.527, \mathrm{a}$.

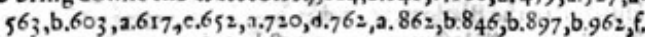
1065, a.1072,a.1 108,d.ry 3,b,1194, 3.1239,b.

To expell the Afterburthenin' tioft fpecdic manner, $147, \mathrm{f}$.

To breede troublefome $\mathbf{3}$ githe, $1_{3} 24, a$ :

To caufe peftilent Agues,772,a.1324,2.

Aga inft peflilent Agues, 603,3 .

Profitable againft long lingring Ağues, $466_{3}, a \cdot 73^{8}, \mathrm{~b}$,

To cure a quasehine $A$ gue, $41,5, b, 433, f .460, \mathrm{~g}$.

A reoiedic ogainft anold quarto ine Ague, $170,2.463,2.849, \mathrm{k}$.

To cure the Aque in children, $617,6.705,2$.

A remedie agonnit allicold $A$ gues, $6,6, d$.

Good for A gues proceeding of flegme,1307,d.

Toucured tértian Ague, 433 , f.rorg, f. $134 \mathrm{r}$, d.

To mitigate the fieri heat of burning A gues, $7 \mathrm{O}_{2}, \mathrm{a}$. looke $\mathrm{Hear}$

To driue aw ay the cold thakings and thiuerings of Agues, $854, \mathrm{~h}$,

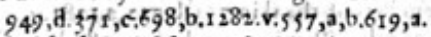

Good for hot and fharpe Agues, $\mathrm{r}_{2} 43, \mathrm{~b} .1376,3$.

For hot burning Agues, 1243 ,b.1389,a.

To cuirê an' Ague, 657, c.89, f. 893. b. 287, b. 315, h. $457,0.512, g$.

t327,g-578.i.7o73, 3. 1184,g. $1 \geq 8$, v. x.

To take away the fits of a quartaine A gue, 887 , b. rot 9 ,f.

Good for the quartaine Ague, 689 , f. 188.b.749, a.827, a.93 o.b.c.d $460 . \mathrm{g} 735, f_{1} \circ 09 \mathrm{k}$.

Good for or to curc A gues of long continuance, $415, b, 437,2.46_{3}$ a,c. $689, \mathrm{c} .86 \%, 2.93^{8}, \mathrm{c.r} 184, \mathrm{~g}$

To coole a hot or burning A gue, $321, \mathrm{~d} .47 \mathrm{I}, 2.66 \mathrm{I}, \mathrm{f} .680$, a. 719 , 1144, b. I1 45 , b.d.e.12 51 , c 1263 ,c.1324,c.

To cure quotidian Agues, $\mathrm{r}_{\mathrm{r}} \mathrm{8}_{4, \mathrm{r}} 34 \mathrm{r}, \mathrm{d}$.

atseritedo, a cordiall confection for infirmitics of the bart, 1160.6 ,

Againft the almionios about the throat, and roote of the toong, I9O, d.IIS2,2,II58,f.
To cure malicious vlcers of the Almonds in the throte, 863 ,a. To take away the hot fivellings of the Almonds in thethrote, $261, \mathrm{~d}_{4} \mathrm{r}, \mathrm{t}, 676,3$,

Againft inflammations of the Almonds, 1294,a.

Good againft old fwellings ot the Almonds in the throe, 934 . $410, f_{.} 587,2.1263,1$

To heale the Almonds of the throte, $638, \mathrm{~h}$.

Abès fuecotrina, an excellent and familiar purger, $410, \mathrm{~g}$.

To helpe the difeafe Alepecia, 88, e.looke haire, r259, h.136r, To purge the difeafe called Alphw, which caufeth /pottines in
the bodie, $114, \mathrm{~d} .859, \mathrm{f}$.

To helpe the Angina, a fwelling of the throte, $445, k, 1172, m$.

Tohelpe wrenches of the $\mathbf{3}$ ntiles, $11_{4}, 1$.

Good againft S. Xntbonics fite, 413, e. $527, b .678,2,1051, q$. $1074, k, 1153, a .1207, c .1278, b$.

To appeafe or afficage S. Anthonies fre fpeedily, $60, \mathrm{f} \mathrm{h}, 26 \mathrm{r}, \overrightarrow{\mathrm{b}}$, $269, a, b, c .412,0.472, c$.

To curc S. Anthonies fire, $269, a . b . c .298, f .318, f .424,2,643, b$.

$655,3.660,2.667, c .680,3.860, f .1144, f .1150, c$.

An $\mathbf{X}$ ntioote againft poifons, 1075 , n.

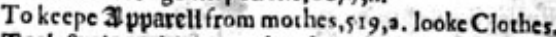

To deftroic or driec away lice from A pparell, $399, \mathrm{c}$.

To procure or prouoke İ ppetite to meate, $185,3,190,2.749,2$,

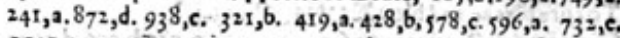
$10_{3} \mathrm{r}, \mathrm{n} .1044$, i.11 33 , i. $\mathrm{II}_{44}$, g. 11 45, d.e. 1207 , c. I235, h.1244, c $128 \mathrm{I}, \mathrm{i}$. $1317, \mathrm{~g} .1324, \mathrm{i}, 134 \mathrm{I}, \mathrm{d}$.

Tọ reftore Appetite decaicd, 849, d. $1223, \mathrm{~g}, 1368,2$

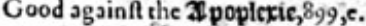

A remiedie for theA poplexie, 770, h. 0,849, m. 374, b. 735, h. 1259, i I299,c.

To reftore fpeech to them that are dumbe by the Apoplexic, $332,0.1259$, i.

To ripen 3 poftemes in the flankes comming of venerie 147,6 To bring hot Apoftemes to fuppuration, 491,3 .

Tobreake inward Apoftemes, 207,a.210,a.

To confume or curc A poftemes, $282, \mathrm{~g} .285,2.288$, y. 509 , 2.

To mollifie and foften A poftemes, $790, \mathrm{~g} .445,0$.

To cure Apoftemations of the mouth and throte, $12 \mathrm{cg}, 2$.

Tocure A poftemes of the priuic members, 147,6 .

To affirage, breake, and confume, hard Apoftemes in anic part of the bodie, 37, b.c. 722,e.

A remedie againft hidden cankrous Apoftemes behinde the cares, ig $8, c$.

Toripen and break A poftemes, $61,9.135,9.720$, e. 445.0.1361, 2

To cure peftilentiall A poftemations, $849, \mathrm{~b}$.

To cure the Argems, which is a difeafe in the eie, $301,2.1026,2$.

Tohelpeolde ac fe's in the $\mathbb{X}$ tmicg,219,b.

Good againft therammilh favor of the Armeholes, 993 , d.995,b. 1013, a.b.c.

Totake away any fwelling of the Armes, $497, \mathrm{c}$.

Todraiv out I rrow-heads without griefe, $54, \mathrm{~g}$.

A guint the venemous thot of Arrowes, $854,1,288, y$.

To helpe thofe that bee Iftymatilie, or thort winded, 848 , $288, v .1346, a .136 \mathrm{r}, c$.

A preferuatiue againft a contagious and peftilent $\mathbf{3}$ qze, r4t,e. $847,3.1328, c$.

Singular good again ft, or to driue away corrupt and naughtic Ayre, $849,2.847,2,604$, e. 1075, p. 1190,f.

To driue the corrupt and pettilentiall Ayre out of the part infeCted, 847,3 .

\section{B}

T O helpe the paine in the 2 Backe, $55 \mathrm{r}, \mathrm{b} .66 \mathrm{r}$,e.

1 Againft paine of the Backe procured of violent motion ot too much Veacric, \&6.66I,d. 
Dgole rope is wilo venem.

Hotunoberrie is Solanum.

1) ozelvozt is Friage.

7offechire is đermanoer.

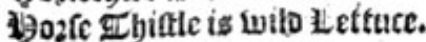

Eloneftie is Lolbonack,

wopfelder is Ennla campana.

19o? femint is rellatermint.

yulwozt is Polizum.

19unobxic is Ambrofis.

I.

T Acea alba is our Ivild o2 white TLanfic.

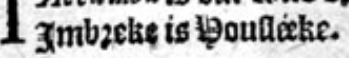

$\mathrm{K}$.

T gnolegoffes is (B)

I jings croinne is Melilotus. Hiffe me ere 3 rife is panfies.

L.

T Ingivozt is Helleboris albus.

1 inittle inale is Bromivell. zichiwozt is joellitozic of the wall. ILongwozt is zBeilitozie of פpaine. zillic riall is pentiropall. Iobeinozt is water Crolwimte. ILnngwo2t is Helleborus albus.

\section{M.}

M Ins motheriwozt is Palma Chrifti.

M spaie blotomes is Conuall Itillies.

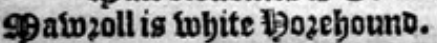

9 atwthen is Cotula festide.

S9arche is Smallage.

- greoles is arage.

9perecrop is z pimpernell.

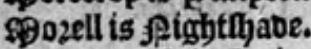

\&oivfeprate is Orobus.

N.

$\mathrm{N}_{\text {ferpite is Calamint. }}^{\text {Cle Lollism. }}$ Profebleco is parroiv.

O.

O 32uallis D2pitr.

Drtang is Lingra bowis.

\section{P.}

$\mathrm{P}$ agle is Stichinozt.

$P$ Palme de diew is Palma Cbrifti.

loapinozt is Fercurie.

Fedelion is Helleborus niger.

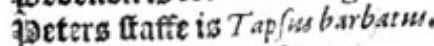

Jjementarie is 1 bautme.

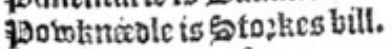

Bzimrofe is Liguffrsm.

pegaic is Gramen Leycant benturn.
R.

$R$ Ams Pote is lvater Croinfwite.

tieo lmess is Hydropiper.

tabbin in the bofe is Lychnis fylueftris.

Zhoos golo is 97arigolos.

\section{$S$.}

$\mathrm{S}$ Cabwozt is Enula campana.

$S$ sedocte is bzants bztine.

Selfe beale inas fomtime salleo Bainpernell.

byxpekilling is Cotyledon equasita.

Sliepiwozte is lettuce.

sttaggerivozt ano stauerivogt is Iacobed.

Stanmarth is alifanoer.

Stanoelinelks is satpzion.

\$.IBaries fícos is soutbiftle fréde.

Smerwozt is Ariftolacbia.

stike pile is stozkes bil.

Stedfatt is Palma Cbrifti.

toblwazt is Oxys.

Sparointeng is zunot graffe.

Stonuo20 is 5 tonecrop.

slwines grafle is Isnotgralte.

sluine Carfe is zinotgrafte.

Swichen is đrounofwell.

Soloolvo2t is Columbine.

T.

$T$ alefwozt is fwilde YBo2age.

1 gl ante is Lilo parinep.

Tetterwo2t is Celanoine the great.

II motbivozt is @ bephearos purfe.

IItfane is Clymenum Italoram.

W.

VV allwozt is Ebrlus sobich wags fometime cals leo Filipendula.

extarence is 99 GoDer.

Eelarmot is celozmewomo.

cclavwozt is pimpernell.

redapbzeat is Plantago.

eateplwozt is Ipia maior.

cctaterino2t is 9g aioenbav2e.

extepthernop is fieuerfelo.

weibite 1 bothen is great $₫ a p f i e$.

verito sauager is Cockle.

werilo Nardno is Afarum.

weelite $G_{0}$ oloes is great $\$$ aifie.

₹ul $\infty 09$ arch is sanichle.

ขetwofolver is $O x y s$.

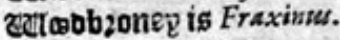

raimonep is Ameos.

veroluifthiffle is Chameleon.

retpneberries is Vaccinia.

extumot is 1 bifcus.

adtit is Hyofgramus luters.

Y.

Q2onbaro is tinapweded.

$\mathrm{Z}$.

Zekes was counteo Satyrion minor, ef is gat Lobld $L$ :Obel calleth Serapias famina prateryiss. 


\section{$\sim T$ able of the Nature, Danger, and Vertues.}

To ingender naughtie, rawe, or cold Blood, ${ }_{13} 8$, f. $140, \mathrm{~b}, 180, \mathrm{~b}$. $768,2.1044$, a.1144,c.

To he ale Bloodse wound s,794, 2.looke Wounds.

To driue out by fiece vnprotitabie Blood, 150 ,

Goud for uffues of Blood, 340, , b. looke lfues.

To ingender grofle and cold B!ood, $178,3.786 .105_{3}, \mathrm{~b}$.

To coole end $x$ c w per the inflanied Blood, $32 \mathrm{a}, \mathrm{c} 419$, c.1 : $45, \mathrm{~b}$.

Todiff iu: cleteed and congcaled Blood in fuch as are brufed with fulling from hugh places, $841, b .843, c .279,2.362$,a.

Tohelpe vomitung of Blood, 505 , b. fec Vumutung.

To clenfe or purge the Blood, $73^{8}, \mathrm{~b} .930, \mathrm{~b} 6_{24}, \mathrm{~d}$ 1 $1243, \mathrm{~d}$.

To ditfolue or featter con Eealed and clotted Blood, 759,e.1 95, 6

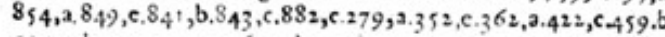
$507, a, b .520,0.540, c .629, d .721,1.722, c .1026, c .1223 .1$.

Toingender waterih Blood, 768 , 3 ,

To ftonch Blood, 794,2 .

By purging to bring foorth Blood, $769,2.207 .1052$,f.

To ft ay Blood comming from the lidneics, 678,0 .

To purifie or clenfe the Blood trom all corruption, $504,2 \cdot 3^{1} 4, f$ $93^{\circ}, b_{4} 4^{60}, c .1004, c$ c $73^{8, f} .930$, b.r. 243 , त.

Todrawe toorth Blood by vrime, $1052, \mathrm{~d}$, f.

Good againft the Bloodie flixe, $899,0.388,0.413,0.452,2$.

To ftop the Bloodie flixe, $102, b .505, b .789, \mathrm{~d}, \mathrm{f} .790, \mathrm{~g} .802, \mathrm{~b} .215, \mathrm{~b}$ $86 \circ$,b. 840, d. 84 t, 2. 845 ,a. 887 ,a. 890, c. 312, b. 314, d. 318 ,a $911,0.915,2.321$, f. 323, b. 329, d. $958, b, c .388, c .419$, d. 535, i

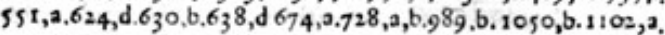
$1145, c .1244,3, b .1256, b, c .1270,0.13$, 4 , g.1 $375, b$,

To cure the Bloodis flixc, $890, c .3,4,5.318, k_{.} 524, c .535$, f. $576, b$.

Good againft fpetring of blood, $300,2.3$ i $4, c .318, a, c .899, a 907, c$ $419, d .43^{6}, 0.552,3.454,3.563,0.47^{8}, \mathrm{~g} .624, c, d .665,2.1025, b$. $1244, a, b .1254, e .1257, p .1264$, c. $1375, b$.

To helpe fuchas ipst Blood, $60, f, 802, b .215, c .840, c .890, c, 340, b$. $41 \mathrm{I}, \mathrm{g}, 66 \mathrm{I}, 0.1025, \mathrm{~b}$.

Good for thofe that piffe Blood through the difeafes of the kid. neies, 576,2 .

Good for thofe that pifre Blood, 40,d. 744,d. $215, c .840$, e. $907,2$. 340, b. 452, a. 454, a. 578, b. $1244, a, b$.

To helpe piffing of Blood, 1025, c. $1375, b$.

To ftop fperting of Blood which hath long continued, $13^{8, e}$. $74^{8, b}, 1184, \mathrm{~m}$.

To prouoke Wodilie luft, $55,2.754,2,193$, b. $.97, c .155$, d.4. $45, \mathrm{f}$

To alay outragious fuft of the Bodie, 419 , e. lee Luft.

To confume the fuperfluous humors of the Bodie, $557,9.41 \mathrm{I}, \mathrm{g}$.

To confume excrefcence in any part of the Bodie, 72,3 .

Good for the Bodies of them that are drawen backward, 988,2 .

To make the Bod e coftiue, $1254, \mathrm{C}$.

Good for the annointing of the Bodic after bathing, 747,2 .

To fill the Bodie with fatuous or windie belchings,775,e.

To heale the Bodie being burt within by brufing, 578, i.

To open and fcoure the flopped paflages of the Bodic,779,a.

Tokill or poifon the Bodie, 860 , g.

To defend the Bodie from all manner of corruption, $410, b$.

To coole and moiften the Bodic, 702, e.r $032, \mathrm{k}, 3_{3} 3_{3}, \mathrm{~b}$.

To make the Bodie foluble, $178, b .786,259, a, 571, a, 654, b .702, e$. $1027,2, b .10 \$_{2}, k, 1257, k, 1324, c$.

To nourifh Bodies confumed, 1248,2 .

To make any past of the Bodie fmooth, $60, k$,

To purge the Bodie from conscaled or clotted blood, $1337, \mathrm{e}$.

To heate the Bodic before the fits of an agiue, 949 , d.

To fill the Badiefull of raw bumors, $1334, c$.

To heate the Bodie too muc hor extrcinely, $138, f, 140,2$.

To preferue the Bodic in the time of peftulence from infection, $840, b, c .1252, c$.

To make the Bodie well coloured, $732, e, 1184$, g,

Toftrengthen and nourith the Bodie in great meafure, $155, c$. $169,2.732$, e.

To loofe obftruations of the Bodic, $4,63,{ }^{2}, 531,2$.

To keepe ite Bodie foluble, $73^{8}$,a.

To correa and take away the rankefmell of the whole Bodity $1013,2, b, c$.

To preferue idead Bodies 770 ,i.

Tobinde the Bodie, $1082, k$.

Good for the Bodie benummed or growen cold, 7.44 , e.

To make the whole Bodie faire and cleane, 1052 ,

To purge the Bodie sently of cholerike humors and tough clam mie flegme, $266, \mathrm{a}$.

Hurtfull to the whole Bodie, ror 7 , h

Tocouter 18 ones that are bare, with flefh, $54, c .851, b .89:, b$.
Toglue togither broken Bones in Chort fjace, 758.e.

Todraweouren Bones, 759, , g.r 244, k.

$698, c .720, c .722, c$.

To heale broken Boncs f́peedily, $12^{r} 9, c$

cers,897, f. ripen

To ripen and breake 1 Sotches, $61,9.394,9.1328, d$.

To cure and dof

1009 ,f.

$8,8,2$.

To cure the wounds of the 23omel\$,958,a.

Tocale or cure the wringing, gripung paine and torments of the Bonels, 509 ,f. $524, c .553$, $k$

How to make 16 ;ead lighe, and caufe it fooner to be leauened,

Hurtfull to the 'B paines, $34,2,1$ 24,2.140,a.

Good for the Braine, 624, b.1 111 , e.1 $346, c$.

To comfort the Braine, 1111 , e.r $244, \mathrm{c} .1317, \mathrm{~g} .1346, \mathrm{e}$

To helpe the turning or fwimming of the Braine, $469, b, c$. $7: 0, c$.

To comfort the cold, weake and féeble Brainejr111,

To purge the Braine, $899, e, 854, c \cdot 399$, d.6 $33,5,854, c .849, m .357$,d $4^{8} 4, b .1116, r_{0}$.

To warme and drie the Braines, 524, d.1110,a.

Toopen th: ftoppings of the Braine, 524, d. $560, g .1307,2$.

A remedie againft cold difeales of the Braine, $540,9.619, \mathrm{C}$.

To cure $2 B_{\text {pealsing }}$ out in the whole bodie, $314, \mathrm{f}$.

Againft all manner Breaking-out in the head, 553 ,d.

Good againft the ftopping of the 23 ;eatt, $951,9.465,3$.

Good for fuch as are ftopped in the Breaft with tough flegme or corrupt matter, $190,6.635 .2 .951,2$,

To increafe milke in womens Breaft, 178,b. looke Nurfet breafts.

To diffolue the hardnes of womens Breaffs, $422, b .423, c$.

To make fmooth the roughnes of the Breaft, 35.2 .

Againft paines of the brealt, 57.a.66.b.899, g.1027, 0.1073,a.

Toflake fwellings in womens breafts, $60, c$.

To caufe or increafe milke in nurfes Brealts,232,b.659, b.877, b,d $878, a .1125,2 . c$.

Tocienfe and fcoure the Breaft, 647, b-661, c.459.b. 519, c. 563,2 .

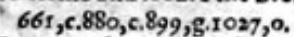

Topurge the Breaft of flegme and melancholie,1115,n.

To purge the Breaft from groffe and thicke bumors, $546, b$ $642, b$.

To heale all outward and inward wounds of the Brean,643:a.

To affwage great Brcafts and drie rp tbe milke, 76,3 .

To breake impoffumes of the Breaft without perill, $667, d$,

Good againft inflammarion of the Brean, 702,1 .

Good for the ftopping of the Breaft, $1007,2.1073$, 9.1248 ,e.

To helpe womens Breafts whercin milke is clutered, 10 51,9 .

To caufe a ftinking 2 zeath, 1055 , b.

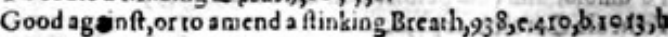

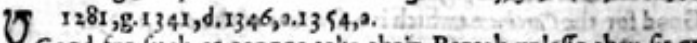
Good for fuch as cannoc cake their Becath vnlefie chey fir or ftande vprighr, and hold their necks ftraight vp, 869, \$949,7. 557, d. 560 ,h. $572,6.649$,a.

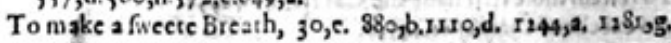
$1349,2.6 .1354,2$.

Good for fliortnes of Breath,47,d.66.b.137, d.190,b.744,a.754, 766, c.; $18,2.890$, b.897, a. 899, g. $95 \mathrm{r}, 2.436$, a. $459.2 .532,0$. 586, .649 , a.i. $698,6.729$, d.730, i.1 2498;e.

To helpefhortnes of Breatih, 8s6,c. $893,2 \cdot 9: 6,2 \cdot 465, b .648, c$. 667 , d.e.ris $84, \mathrm{~m}$.

To remooue difficultic of Breathing, $124, c .2795,858, d, 897, k$.

Good for thofe that are 20 oben or hurt inwatdly, $639, \mathrm{e}-987, x$.

To helpe Broken winded cattle, 352,c.1378,a.

Toknit Broken boner,759,g.

To helpe inward $\mathcal{B} 3$ uifes,759, e.279,0.536,a.

To helpe thofe that ate Brufed with guieuoo, beatings or fals; 57, e.279, 2.9 19, d.557, d. 648 , c.962,b.987, b.1 223 , i.

To helpe Brufes, $557, c .616, b .849,6,698, c .1304, \mathrm{~h}$.

Totake away any Brufe in flort fpace, $758, b$.

Againft Brufings of the eares, $1055, c$. Good for Brules gotten by ftripes or fals, $759,0,84{ }_{4}, b_{4} 279$, I. $512,7,971,2$,

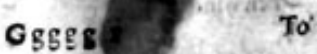


To ftrengthen the Backe, 665,1 . $137^{8}, \mathrm{e}$.

\section{A Table of the Nature, Vertue, and Dangers.}

Good for the weaknes \& aking of the Back,452,a.b.454,a.b,707,

To belpe the weaknes of the Backe, caufed of ouermuch flowiog of the whites, $627, \mathrm{~d}$.

A good 2Balfame for greene wounds,;27,a.

A good Balfame to cuce deepe wounds and punctures, $288, z, a$.

To make 2 a arren, $744, b$.

To make the Barren fruit:ull,29r, I. $134 \mathrm{r}$, f.

To caule Barrennes, $97, c .744$, b.970, b.979, 2 .

A 21 ath good for vicers and running fores, $1052, n$.

An effectuall Bath for members out of joint, gout, and kibed heeles, $696, k$.

For thole that are 2 Blear-eic $0,26, b$.

To make the 2 Beard to grow quickly, $949 . \mathrm{g}$

To fcoure away the fcuruines of the Beard, $\mathrm{I} 47, \mathrm{a}$.

To caufe the haire of the Beard that is fallen off 10 grow againe, 984 ,d.

To driue away lice from the Beard, 399,6 .

To procure haire in Beardleffe men,102,e.

Againft 25 eare wormes, $553, \mathrm{c}$.

A prefent remedie for 2Beafts chapfailen, $3, c$.

Againft bitings of venemous Beafts, $529, c .138$,c.1 40,a.b.250,e. $849, c .843, a .848, g .882$, b. 267, c. 352, d. 355, a. $385, a .422, b .457, b$ 495 ,d. 519, b. 529, c. 542 ,a, $560,2,587$, c. 648, c. 659, c. $728, e^{\circ}$ 1000.b.

To driue away venemous Beafts, 529, c. 389 , h. 39 r, d.529,c.545,a. $652, c$.

To take away a pinne, web, or any griefe elfe out of a Beafts eie, $707, \mathrm{~g}$.

Good againtt the ftinging of all maner of wilde Beafts, 851 ,a. $824, b .266, b .495, d$.

Tokill fower footed Beafts, 755, a.1221, b.

To kill all wilde Beafts, $820, c$.

Toprelerue from being hurt with any wilde $\&$ venemous Beaft, I 129, b.1248,e.

To cure blacke and blew 25 eatings, $1223, \mathrm{i}$.

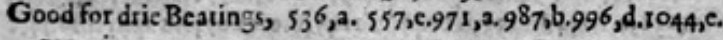
$1223, i$.

To helpe Beating of the hart, to 2, i.r160,c.

Tokillor fmoother 215 es, $1387, \mathrm{c}$.

Tokeepe a man chat he be not ffung with Bees, $787,2.1075,0$.

Good againft the ftinging of Becs, $736, a .553, \mathrm{~m} .556,2,1075,0$. $1223, k$.

To caufe Bees to keepe togither, 560 ,e.

25 ere more holfome than Ale, $73^{8}$, h.

To caufe 2B elchings, $185,9.775$, c.1115,i

To confume or helpe Belchings of the ftomacke, $895,2.544,2$. $616, c$.

Good ag ainft fower Belchings, $578,6,616, c$.

To breede wormes in the $215 \mathrm{cll} 2,60 \%$

To loofe the Belly gently, $55,2689,0.765,5.778$, d. $241, \mathrm{e} .5,827$,g. 257,a. 295, b. 897 , a. 941 ,a. $321, c, 952$,a $529, d .542$, b. 578 , h.

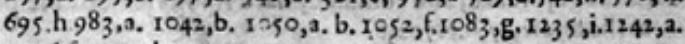
1246, f. 1259 , d.1 315, c. I324,c.

To open the Belly inightily, $770, \mathrm{~m} 407,2.714,2.720,2.53 \times 4, b$.

Againft the griping paines of the Belly, $23, \mathrm{~b} .53, \mathrm{~b}, 137, \mathrm{~d} .75 \mathrm{x}, 2$ 882 , a. 891, c. 893, b. 395, b. 301, c. 875, b. 897, a. 540, b. 553, k. . $1009, c .1073, a \cdot 1076,9$

Againft the fluxe of the Belly, 54, h. 72, c. 983 , , looke Fluxe.

To ftaie or binde the Bellie gently, $73,2,445, \mathrm{~b}$.

To binde the Belly mightily, $1251, b$.

To fofien or make the Belly foluble, $250, \mathrm{e}, 252$, a.253,0. $257, \mathbf{2}$. $930, c .321, c .423$, c.c 467, b. 512 , b. 529, c. $548,0.604, b .648, c, 655, c$. $660, c .702,9.729,2.973,2.1082, d, 1257$, g.13 14,a.b.1315,c.

To binde or ftop the belly, 77, a.102,2.318, k.677, b.f. $692, a .984,2$.

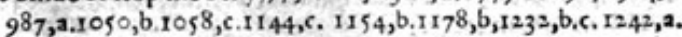
1254, b. 1256 ,b.c. d. 1266 , a, 1270,2 , 1288 ,a. 1289 ,c. 1314, ,.g. 1324, d. 1334, h. 1353, c.1 370,2 .

Toopen the Bellie offuch as haue the dropfie, $827, \mathrm{f}$.

Todric a moift Belly, $79, b$.

Toftrengthen the Belly, $1354, \mathrm{~b}$.

To trouble the Belly, 195, d.1052, d.

To purge the Belly mighuly of wateriih and cholericke humors, 1086,b. 1235 , b.f.i.

To purge the Belly of cho!ericke humors, $73^{8}, \mathrm{~g} \cdot 77^{\circ}, \mathbf{m} .262, \mathbf{2}$. $400, \mathrm{a} .467, \mathrm{~b} .973, \mathrm{c}$.

To purge the Belly of flegmaticlic and melancholicke humors, 28s,c.
Tobreake and fearter the windines of the Belly, 908,2 . $908,2.938, \mathrm{~g}$.
Good ainft griping torments, gnawing or fretting the Belly, To open the Belly and purge colde flegmaticke and cholericke humors, 4 ro,g.

To ripen and breake 26 iles, $6 \mathrm{r}, 2.135,9.720$, e.

To draw and heale Biles, $60, \mathrm{~h}$,

Wirolime inwardly taken is deadly, $1170, \mathrm{f}, 1156, \mathrm{~b}$

Good againft poifon of Birdlime 1075,0 .

To retaine the $15 i t$ th and giue it life, 624,2

To haften or bring foorth the Birth, $53, c .86_{2}, b_{1} 6_{4} 8, f_{1}, 874, b, 962, f$ $1019, \mathrm{~b} .1065, \mathrm{a} .1239, \mathrm{~b}$

To deftroy the Birth,696, h.2 10, 2.1218,e.

To bring foorth the dead Birth, $124, c .657, b .893, \cdot a .946, b .546, a$. 1076, f. I1 $12,0.1178, b$.

Againft vntimely Birth, $624,2,962$, e.f.

For 2 Bitings of ferpents, $47, \mathrm{e}, 74,0.882,2.87 \mathrm{r}, \mathrm{d} .868, \mathrm{~d}, \mathrm{~s}, 3$, 949 , l, $952,3.535$, b. 557, c. 977, c. 989 , d.1009, f. 1065, b. $1154, c$. I1 80 , b. 1202 , e. 122 I, b. 1305 , d. 13,27,d.

To remedie the Biting of the ferpent Cerafles, I O5 $5, \mathrm{c}, 1172, \mathrm{n}$,

To cure the Biring of a mad dog, $26,3,60,2.135, \mathrm{f} .849, c .85 \mathrm{~s}$, a. 848 ,g. 352 ,d. 553 ,f. $560, h, 566$, a. $57^{3}$,d. $665,6,1009, f .1235$, l. $1257,0.1305$, d. $1328, \mathrm{~m}$.

To helpe the bixing of venemous beafts, $529, c, 50, b, 74, a .140, b$. $250, c .854, \mathrm{i} .848, \mathrm{~g} .882, \mathrm{~b}, 267, \mathrm{~g} \cdot 318, \mathrm{a}, 874$, d. $875, \mathrm{c} \cdot 323$,a. 422 , b. $543,3.1009$, f.ro5 2, h. 1069 , f.I1 84, f.1200,a, I 223 , d.1227,f. $1349, \mathrm{~b}$.

To take away the \$lacknes of any ftroke or bruifc on the face, $74, a$.

Toraife vp 215 labders on the skin, 81 I, a.

To cure the wounds of the Bladderigs $8, a$.

Good for the vicers of the Bladder,95 8 ,d.

Good againft the paincs of the Bladder, $81,2.832, b .984, k$. $1329,0.1346$, a.

Good againft the ftone in the Bladder, $433,3.557,2.487, a .57^{2}$, i. II $54 . d$.

To cure the inflammation of the Bladder, $318, f, 1333.2$,

To purge rotten mater by the Bladder, 586,6 .

Againft the ftoppings of the Bladder, $888, a .895, a, 869$, di 428,6 . $444, c_{2} 6_{3}, \mathrm{~d}$.

Good for the Bladder, $23,2.884,6.869, \mathrm{~d} .87 \mathrm{x}, 3.907, \mathrm{c} .955,2.419, \mathrm{C}$ 7:9, d.r 318.3 .

Toclenfe or fcoure the Bladder, $502, \mathrm{~d} .586, \mathrm{~d} .886 \mathrm{~h} .693,2$.

To helpe the paines of the Bladder, $526, d, 665, c .984, \mathrm{k} 1133, \mathrm{~m}$.

Excellent good againft exulceration of she Bladder, $765, \mathrm{c} .341, \mathrm{~d}$

Toopen the ftoppings of the Bladder, $444, c .470, c .535, \mathrm{c}$.

Hurtfull to the Bladder, 1048 , d.

Torake away 15 laftings, $790, g, 908, b$,

To heale Blafting of the cies, 1 1 $59, \mathrm{~b}$.

To ftop 15 lexoing at the nofe, fee Nofe.

To ftanch ouermuch Bleeding after the biting of the horfeleach; $\mathrm{ro}_{3} 8, \mathrm{v}$.

To ftop Bleeding, $803,3.28$, a. 899, b. $340,2.962, a .968,2.989, b$,

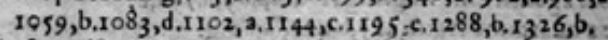

To ftop allkiads of Blecding, $255,2,839,2915,2.1091,2,1145, c$. $1207, f$.

To ftanch Bleeding of wounds, $754, c .893,2,890,2, b .389,6$, I375, c.

To ftay Bleeding in any part of the bodie, $215,2,318,1,915,2$. $95^{8}, \mathrm{~b} .728, \mathrm{a}, \mathrm{b} .1082, \mathrm{k} .116_{4}, \mathrm{~b}$.

To take away 2 Liemithes, $291, k .445$,d.

To take away the Blemilhes of the skin,754, b.722,2.r $281 . q$.

To take away brufed or other Blemilhes of the face, $185, \mathrm{~h} 326, \mathrm{~d}$, $696, \mathrm{i}, \mathrm{I} 257, \mathrm{~m}$.

To take away Blemilhes in other parts of the bodie, $1257,00 ., \mathrm{T}$

To take away the 25 iewness of any ftroke or bruife op the face, $47, a, 30 \mathrm{r}, \mathrm{b}$.

Good for $1 B$ lifterø, 1255 , a.

To raife a Blifter, $811,2.815, a, 618, b, 1017, k$.

To beale Blifters in the mouth, $150, \mathrm{~b}$.

Not to fuffer Blilers to rife in burned or fealded partes, $1150, \mathrm{~d}$. 1277, a.

Good to incresfe $15 t 000,3 \circ, e$.

Good for iflues of Blond, $340,3,6$, fee Iffues.

To ditfolue cluttered Blood, and ro keepe it from congealing in the bodic, $195, f .849,-.459, a .507, \mathrm{~b}$.

To ingender good and pure Blood, $654, \mathrm{~g}_{7} 73^{2}, \mathrm{e} \cdot \mathrm{IO}_{4}, \mathrm{~b}$.

To ingender thicke Blood, $1252, \mathrm{~b}$. 


\section{ATable of the Nature, Vertue and Dangers.}

$329, c .400, b .445,1.650,2.724, b .1000,2.1156$, a.

Good againtt the Colicke ar.d ftone, 849 , h.616,0.650,

To take away the paine of the Colicke prefently,97,6.915, d.

To ceale the gripings and paines of the Colicke, $329,6,445$, ;.

To in:lpe the Colicke, $115, \mathrm{~g} .188, \mathrm{f} .89 \mathrm{I}, \mathrm{d} .288, \mathbf{x}, 291, \mathrm{~s}, \mathrm{~b}, 310, \mathrm{~s}$

$874, c .875, b .333, a .400, b .1000, a .1007,3.1074, c .1156,2.1257,5$

To reftorc E olour decaied, $30, c$.

To take away the bad Colour comming of the yellow iaundife, $542, \mathrm{~d} .608, \mathrm{c} .609,3.695, c$.

To caufe a guod Colour in the face, $124, \mathrm{e} .568, \mathrm{~d} .1052, \mathrm{f} .13^{2} 4, \mathrm{i}$ $1349, c$.

To make a faire yellow Colour, riss,e.

To wake a deepe greene Colour, $1155, \mathrm{~b}$.

To coiour ieliies, wines, and meats of a purple Colour, 266,e.

A profitable $\mathbb{C}$ ollyate for the eies, 87 , d.

Hurtfull to a hot $\mathbb{C}$ ompicrion, $140, b$.

The Compofation Sangais Veneris feruing for decpe punctures or wounds,657,g.

To hinder Conception, $553,5.979,1.1057, c$.

To helpe Conception, $72, f, 263, b 874, d$.

To helpe Concoction in the fomacke, $848, \mathrm{~g} .892, c .879,3.560,5$. $732, \mathrm{e} .1 .735, \mathrm{c}$.

To beale the Condilomasa or infirmitics of the fundanent, $54, \mathrm{~d}$.

To remooue ftoppings of the $\mathbb{C}_{\text {ondutro, }}{ }_{18} 8, \mathrm{~g}$.

To cienfe the Conduits of the windpipe, $984, c$.

To diffolue Congealed blood conming of bruifings or ftripes, 362, 3. Fee Blood.

Conferac of Rofes with the force thereof, $\mathrm{r} 08_{3}, \mathrm{n}$.

A cordiall Conferue, 473,3 .

Good againft os to helpe a Confumption, 1121 , i. $1184, \mathrm{~m}$. $13,6,0$.

A fpeciall remedic for the Confumption of the lungs, $1: 4, c$. $795, c .88_{3}, 5.563$, d. $966,1987,3.1174$, f.r $1: 2=3, c$.

$A$ med icine tor Confumption of the backe.661,e.

Gcod for thoie that are entring into a Confum ption, $1334, \mathrm{~g}$.

Good for fuch as are fallen into a Confumption, or have the feauer He Ctique, $169,0.514, f$.

To cure the $\mathbb{C}$ entradion of Ginewes, $397, c .420,3.546, c$. looke Sbrinking of finewes.

For $\mathbb{C}$ onutifiouts or thrinking of finewes, 40, d. 47, e. $50,6,54$, h. $57,3.87$, b. 849 , i.c. $318,2, c .897$, h.919, d. 352, b. 457, b. 540 , f. 545 , 0. 597, d. 573, d.6. $63 ; ; c .649, c .698, b, c, 1000, b$.

To helpe Conutulfions, 557, c. 789 , f.29r, a.c. 436, c. $569, b .648, c$. $1069, \mathrm{~g} \cdot 134^{5, \mathrm{e}}$.

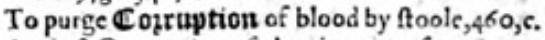

Againft Corruption of the aire, $1190, \in_{13} 28, \mathrm{c}$.

To remooue Corruption, $698, c$.

Hurtfull to $\mathbb{C} 02 n e, 69$.

To caufe the $\mathbb{C}$ opnco of the ícete to fall away in few daies, 150 , 413, g.1 $206, c$.

To rake away Cornes, $8 \varsigma 4$, kr i $206, c$.

A Counterpoifon againft deadly medicines, poifonous herbes, biting and thinging of venemous be aft s, r 075 , 0 .

To take away the $\mathbb{C}_{\text {ough }}, 35, \mathrm{a} .53, \mathrm{~b}, 87, \mathrm{~b}, 115, \mathrm{~g} .198, \mathrm{~b}, 854, \mathrm{~d}$. $893,3.899, \mathrm{k} .563$, c.661, f $1190, \mathrm{~b}$.

Good againft the Cough, $178, c .754, a, 862, b .284, e, 298$, h.,869,d.

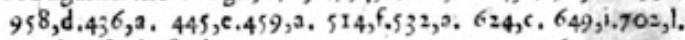
730,i. 634 ,i.985,b. 1007,a, 1025,3.1073,a.1076,q.1120,c. II 54, d.I $=55, e, 1257,0.1260$, k.1 $1328, b$.

Naught for the Cough, $1252, b$.

Good againft the Couzh of the lun $/ 5,519, c .1388,2$.

To ripen the Cough and bring foorth Acgene, 11 zo, a,b.

To belpe the Cough in cattell, $352, \mathrm{c}$.

Againft an inueterate Cough of the longs, $: 184, m$.

Good for the Cough caufed of a thin rheume, $667, \mathrm{~b}$.

Good for a drie Cough, 112r, n.

Good a gainft a cold and lon 2 Cough, $899, \mathrm{~g}$.

Good for an old Cough, 47,d.87,b, 137, d. $14 \mathrm{t}, \mathrm{c}, 185, \mathrm{~s}, \mathrm{i}, 504, \mathrm{~s}$.

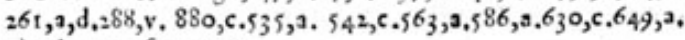
724, b.1174, f.1190,c.

A remedie for old Coughes, $26 \mathrm{r}, \mathrm{d}, \mathrm{a}, 4,65, \mathrm{~b} .648, \mathrm{~d}, 1174, \mathrm{a}, 1257, \mathrm{r}$. 1324 , i.

Againft the chin Cough in yoong children, $505, \mathrm{~d}, 57_{2}, \mathrm{e}, 1190, \mathrm{c}$. 1372.

To ripen an old Cough, 775, b.

Good againft the $\mathbb{C}_{\text {ramtwe, }} 47, \mathrm{e}, 50$, b. $53,1.88$,f. 849, i.897,c. 899, f.919, d. 352, b. $420,3.436$, a. 540, f.545,a, $57^{8}$,d. $638, c$. $649, b, 698, b, c, 989, c .996, c, 1000, b, 1016, a, 1207,1,1223, t_{*}$
Good againft cold Cramps,735,e.

T36,c.546,c.578, 88, f.557,c. 789, f, 291 ,a,c.318,c.897, b.949,

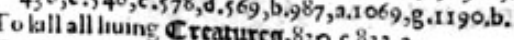

Toglue toguther Tutgreg, $820, c .822,2$.

dons, 1 if 4 ,a.

Good for light Cuts,919,b.

\section{D}

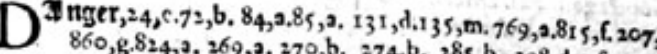

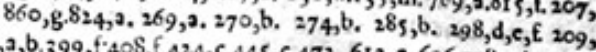
$902, a, b .399, f \cdot 40 \$, f .42 .4, c .445, c .472 .612, a .696 .718, a, b .1017$ h.1 $076, \mathrm{z} .1170$, f.1217, c.1 221 , a.1 $3^{86, a .1} 3^{87}$,d.

Totake a:vay Dandzaf, $1_{41}, f_{1} .0_{2} 7$, i.

To fcoure away Dandraf of the head, r 227,f.

Againft TDarkness of the 6 ght, $55, a, 888, c .537, b$.

Againtt the vencmous filot of Darts, 854,1 .

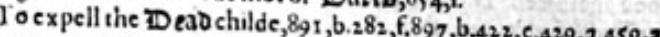
$\$ 27,2.546, a .557$, c. 563, b.61 7, c. $6 \$ 2, a .657, b .7=0, d$. 1244 d. $1072,2,1076,3,1194, a$,

Tocaule Deafnes, $34, \mathrm{c}$.

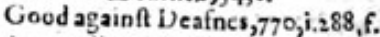

A remedic againft Deafnes, 250, h.roog,l.r223,d.

How TDere are preferued from the ftinging of ferpents, $87 \mathrm{r}, \mathrm{d}$.

How they cure themfelucs being wounded, $652, \mathrm{~d}$.

Tofcoure away the $\$$ Defozmitics of the skin,759, $f, 444,9.736, \mathrm{~d}$.

Toclenf: or take away Detocnuties of she face, 94, b.r. $49, \mathrm{~d} .765, \mathrm{~h}$. $193, c .579, b .736$, d.1 $55^{8}, \mathrm{~h}$.

To caufe vntimely Delituerance of childe, $970, \mathrm{~b}$. looke Abortment.

To caufe eafie and fpeedie Deliucrance in childe bearing, 72, $\mathrm{E}$

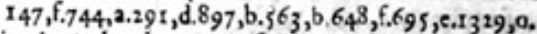

Dircalamin:bes, the compofition, 558 ,l.

Diacarihamion, a compofition good to purge the dropfie, 1007 , f.

Againft $\mathbb{D}$ ifficultic of making water, 23, b. $188,5.760,3.261,2$ 729, d. 869, d. $875,3.919, c .949,3.422,2.520,0.540, b .548, c .648, d$ ror 9, c.r 186, c. $1276, \mathrm{c} .13^{8}, \mathrm{c}$.

Againft the Difficulue of breathing, 279, 5958, d. $430,2.744,2$ : $1007,2.1076,0.1121$, i.r 223 , c.

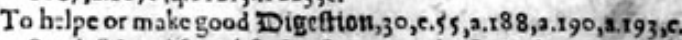
$855, b .860, a, i .849, d .848, g .891, c .293$ b. $879, a, b .352, c .553, h$ $649, c, i .732, c, 1184$, m. $1270, c .1346, c .1349, d .1352,2$.

To caufe IDimunes of fight, $135, m .1050, \mathrm{~h}$.

Good againft the Dimnes of the eie $5,249, a .495, c, 858, b$.

To rake or clenfe away the Dimnes of the eies, 57, c , $5 \mathrm{i}:, \mathrm{f} .532, \mathrm{~b}$, $548, d, 627$, a. $93^{8}, 1,249, a .537, b$. $549,2,627, a .629, d, 1074, b$, 1247, b.1357,b.

To curc old and cold mifeales,897, c.899,e.71 r,

A gain Q Difesfes proceeding of Regme and cold humors, 721 , 2. For Difeafes of the matrix, $318, a .732$, i.10:7, h, $q .1223, b, 1238, c$.

To helpe cold Difeafes of the matrix, Ic6s, $b$.

To coole Difcales proceeding of heate, $47 \mathrm{i}, 3.2 \mathrm{r} 5, \mathrm{~b}$.

Good againt the Difeafes of the head comming of cold caufes, 470, b. $540, a$.

Good for Difeafes arifing of melancholie, $1116, \mathrm{c}$.

Good for th: Difeales of the fpleene, $529, d .744, c .460, f, g .529, d$. $542, h, 657,6,979,1.1129,6$.

For Difeafes of the kidneies,657, c,1 120,e.

For Difeafes arifing of furfer, 1133,0 .

For melancholike Difeafes, $160, \mathrm{~d}$.

For the Dileafe called the Mother, $1190, b, 1223, k$

For Difeafes of the ftumacke, $1223, \mathrm{~g}$.

For Dileafes of the intrailes, $\mathrm{r}_{24}, \mathrm{e}$.

Againft all peftilent, venemous, and infeaious Difeafes, $128 x$, $i$. Againft Difeafes of the gums, 1306 ,a.

A goinft Difeafes of the bladder, $=3$, c.3 $18,2.497$, d.869,d.r223,5, le Good againft all cold Difeares in the bodie, $1354, b$.

Good againft all cold Difeales of the inward partes.352,e.

For all cold Difeales that be of hard cur arion, 357,3 .

Tohelpe Difeafes that grow of Elegwe, rawe humors andwinde,

A54,a.

Good againft all Difeafes of the head, 899, e. 549,2 .

For difeafes of the lungs, $839, b .318, a .657, c$

$6,8, \mathrm{i}, 66_{3}, 3$.

Good for Difeafes of the mile, $529, \mathrm{~d} .869$,d

Good for Dileales of the mile, Gggg : $63^{2}, 2,635,6$

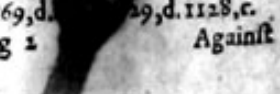




\section{Table of the Nasure, Vertwe, and Dangers.}

To ripen venereous 25 abones in the flanke or thare, 394,2 . r.2., d.

To refolue and conco $\&$ t 15 anches, $60, \mathrm{~g}$.

To coole the hot te urning of the luer, 22, 2,a. looke imflamma. tion of the Liuer.

Toheale Burning with fire, 42,2. 114, b. $135, \mathrm{k}, 29 \mathrm{r}, \mathrm{k} .435, \mathrm{~b}$. $707, \mathrm{k} .1055, \mathrm{c}, \mathrm{I} 099, \mathrm{~b}, \mathrm{I} 27 \mathrm{~S}, \mathrm{~b}$,

Good for Burnings, 91, c.1 49,b.c. 242,g.278,0.285,2. 288 ,z. 413, e. 433, b. 62 5,a. 7 c9, b. $968,2.1178,2.12$ 10,b. 123 5.l. 1238, e.r. $265, \mathrm{k}, \mathrm{r} 3 \mathrm{O}^{\circ}, \mathrm{d}$.

To take away the heat of Burning with fire or gunpowder, $135, \mathrm{k}$. $278,2.4 \mathrm{r} 2, \mathrm{~b}$.

To cure all maner of Burning, , 27 8,a.43 5,b.638,g.66r, c.708,a $1278, \mathrm{~b}$.

Good againtt all 15 utrtings, 3 18, c. 897,d.9 19, d.327,a.420,a. $436, a, 535, a, 536, a, 546,2.577, a, 649, c, 661, c, i, 698, b$, $962, a$.

Good for thofe that are Burften by falling from fome highplace, $749, f \cdot 352, b .5,54,2.962,2$.

Good for Burftings that come by falling downe of the guts, $\mathrm{r}_{2} 6_{2}, \mathrm{k}$.

A good medicine forr thole that are Bürfen, 762, b.291,a.

Good for to bath Burftings that are hard to be cured, $1227, f$.

To helpe or cure Burfting $557,3,88, f .793, b, 802, b, 291,2.352, b$. 958, 3.514, 2.66r,a,1 196,b.

For Burftings in yoong children, $97, \mathrm{~d}, 897, \mathrm{~d}, 1026, \mathrm{~b}$, looke Enterocele or the rim and ruptures.

To heale the inward Burfting 9,787, e.507, a.509,c. $554, a .649$, h $660,2$.

To cure Burftings that haue beene of long continuance, 793 , b.

Good for exulcerated Cantiets, 863,2 .

Good for the Cankers in the eies called in Greeke carcinomata, $250, k$.

To caufe Cankers, 1050,g.

A goodmedicine againit Cankers, $745, f .684, d$.

A water to wafh Cankers in the mouth, $624, e, 12 \mathrm{Cg}, 2$,

To heale Ipreading or eating Cankers, $501, a .689, b$.

Good for, or to cure Cankers in the wouth, $366, a .37$ r, b.676,a. $94 \mathrm{I}, \mathrm{c}$.

To ftaio Cankers from increafing or creeping farther, 72 , d. 689, b.d. $841, c$.

Tocure Cankers,3 or, d.

Tokeepe Cankers from putrefattion and ftinking, 86,3 ,a.

Good againft Carbuncles, 288,y. r1 186,d.

Tobreake Carbuncles 250 , d.ro5 2 , h.

Tobreake or ripen peffilentiall Carbuncles $147, c .854, \mathrm{k}$.

To take away or heale Carbuncles 408 , d.1052, h.1 225 , h.

To ft aie the fpreading nature of a Carbuncle, and caufe his ve-

nemous matter to breake foorth by the pores $815, b$.

To diffolue and cure peftilentiall Carbuncles 849,6 .

Tohe ale Caroless $\mathrm{n} 94$, ,

Good for the Carcinoma, which is a Canker of the eies, $250, k$.

To preferue $\mathbb{C}$ arcafes, from putrifieng, $4 \mathrm{I} 0, \mathrm{~b}$.

Ag ainft the Catalep fir, $735, \mathrm{C}$.

To refreih thofe that haue the Catalepfie $468, a$.

An excellent Casapla/wes, $445,0$.

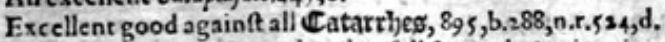

To fopor exprefie Catarrhes that fall from tho braines into the

lungs, 298 , h. 524 , d.

To cure or helpe Catanibes, 926 ,d.

Carnalt copulation, 878 , d.fee bodilv luft.

Tomake a faire đarnation colour 1232 ,d.

Tokill Cattie $622, \mathrm{c}$.

To glue and fodder togither broken bones in Cattle $758, c$.

Noifome to Cattio $424, \mathrm{C}$.

How to cure certaine difeafes that Cattle are troubled with, 826,827 .

To caufe female Cattle to be deliuered of their yoong ones, 893, c.

To cure Cattle of the cough of the lungs 569 , d. $6 ; 0,8$. 1378 , 2 .

How to maksc attle fat and lunie quickly $94 \mathrm{I}, \mathrm{e}$.

Iohelpe Cattle that are troubled with the cough, and are broken winded, $352, \mathrm{c}$.

To beale $\mathbb{C}$ baps of the fundiment, $1006, \mathrm{~b}$.

For Chaps betweene the fingers, $937, \mathrm{~d}$.

To healc the Chaps of the fecte and hands proceeding of sold,
$60, \mathrm{k}$. To cure Chaps in the palmes of the hands or feet, that bekinne
to the Erench pocks, $69, b, 859, \mathrm{e}$.

Good for the Chaps of the feete and heeles, $1_{37}, \mathrm{f}$.

To helpe the Chaps of the fundament, $371,2$.

For Chaps of beafts a prefent remedie, 3 ,e.

For Chaps of the lip, ,1 5 2, a.1 $255,2$.

To heale Chaps of the hands and feete, ir $90, k$.

Good for one that would liue Chafte, 202 ,a.

Good for the C $y e f t, 729$, d go8,ci, $2\{6, c, d$.

To clenfe the Cheft of thicke tough humors and rotten matter, 19 5, c. 208, b 445, c. $535,2.571,2.578$, b. $586,2.984, c .1248, c$.
1256, c.1 257, k.

To helpe the Cheft that is inflamed, $76,5,6,7 \circ 5, b$.

To take away hoarfnes of the Chen,701, a.

Hurtull to the CheA, $1252, \mathrm{~b}$.

To concottrawe humors of the Cheff, 124, b.r. 8, b. 572, d.729,d. 730 , i.

Hurifull to the Cheft, $1307, c$.

To eafe the paine of the Cheft caufed of winde, $\sigma_{7} 7, \ldots$.

To cure long infirmities of the Cheft, 1174,2 .

To caufe humers that fticke in the Cheft to be cafily roided,

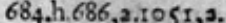

Good for Chtloblancs of the feete and heeles, $1_{37}, f$.

To driue foor th the dead $\mathbb{C}$ bylve, 422, c.looke Dead.

Good againft wormes in yoong Children hauing an ague ioyned therewith, $4 \mathrm{r}, \mathrm{b}, \mathrm{b}$.

To kill the Childe in the mothers wombe, $199, \mathrm{e}, 696, \mathrm{~h}$. $1194, \mathrm{a}$. $1224, \mathrm{~m}$.

To beget male Children, $158, a$.

To caufe a woman to beare wife Children, $126_{4}, \mathrm{~d}$.

Tobring fụorth male Children,43, b.85,c.

Tocure agues in yoong Children, 463,2 .

To nourifh the Childe in the mothers ivombe, $1333, b$.

How to caufe a fucking Childe to haue a good colour, 232,b.

To kill wormes in yoong Children, 3 , c. fee Wormes.

Deadly to Children, 270 , b.

To belpe the red gum and frets in Children, 218,9

Againft agues and feuers in yoong Children, $702, \mathrm{~m}, 7 \circ 5, \mathrm{a}$.

Good for yoong Children that are like to haue the falling fick. nes, 880,d.

How to make Children to piffewell, 895

To cure $\mathbb{C}$ hintes in the hands or feete, that haue great affinitic with the French pocks, $69, \mathrm{~b}$.

To heale Chinks in the hands and feet proceeding of cold, $60, \mathrm{k}$.

To drawe foorth Tholet vehemently, $A 7, b .50,2.766,2.434,2$.

To purge yellow and blacke Choler, $827, \mathbf{a}$.

To repreffe Choler that is in the ftomacke, $\mathrm{I} 28 \mathrm{r}, \mathrm{i}$.

To purge Choler, 53, b.318,e. $400, a .410, a .899$, e. 542 , h7.702,5. 718, a.720,b.972,a.121 5, 0.1317, d.1217, 2.1235,b.

To purge Choler vpward and downward, $207, \mathbf{a} .210, \mathbf{a}$.

Naught for Cholerike perfons.13 $5, b .138, c$.

To auoide Choler by the ftoole, $73^{8, c}, 743,2.897,2.3^{8} 8,2.397,2$. $434, a .435, a .437, b .463, a, 108$, ,b.

Good againft Choler, 840,5 .

To coole vnnaturall and hot burning Choler, $66,2.768,2.13^{17,5}$ $1368,2$.

To caufe the Cholerike paffion, $775, \mathrm{~b}$.

Good to die cr colour Cloth),395,b.

To keepe Clothes from moths, $520, b .1111,1,1228,2.13\}$ s , c.

Good to die woollen Clothes with, $1037, \mathrm{r}$.

To cure the falling of the guts into the $\mathbb{C}$ 0D,8,839,d.

To abate the fwelling of the Cods, $57, \mathrm{~d}$.

To take away the fivellings of the Cods, $908, \mathrm{~b} .1073, \mathrm{~b}$.

Good againft Coloe and hoarfnes, $288, \mathrm{n}$.

Good a gainft Coldnes of the finewes, 1349 , f.

Good againft the extreme Coldnes of the bodie, $400, d$.

Good againft Coldnes either through a long difeale or by age, 735 , b.

Good aga inft Coldnes in the ftomacke, $616 . c$.

Good for the $\mathbb{C}$ oxliacke paffion, 1167, c.

To helpe the Collettiono of humors, 57,3 .

A remedie for the $\mathbb{C}$ olts euill, $1073, b$.

To eafe the paine of the Coltitke in the bellie, $69,2.770,0.843$, 2 


\section{AT able of the Nature, $V$ ertue and Dangers.}

To heale the wounds or hurts cf the Entrailes, $33 \mathrm{r}, \mathrm{t} .66 \mathrm{r}$. i.

To remoouc obltructions out of the Entrailes.73 $8, c .896$, d. $410, b$ $470, c .569, b .647, a .1057,2.1184, d$.

Towafte away windines of the Entrailes, 849 , h.

To fcoure or cienfe the Entrailes, 843 ,b. 896, d. 422 , d. $\$ 35$. a. 684,2 .

Good againft wormes of the Entrailes, 942 , a.

Topurge the difeafe called Ephels, which caufech fpottines in bodie, 114.d.445,d.

An efpeciall remedie for the difeafe called Ephialtes or nighe Marc, $8_{33}, \mathrm{f}$.

Good againft the Epilep $\{e, 899, e$.

To helpe the Epilepfie, 391,b.

To ftaic all Eruptiong of blood, $1247, \mathrm{~b}$.

To cafc or a fivage the inflammation called Eryfipelus, 60, h. 298, $424,9.680$, b.roco, f.r.1144, f.r 389 , o.

For Enfipelss cerelri, S. Anthonies firc of the braine, 508,d.

To take away $\mathbb{E}\{c h$ ates, $\mathrm{r}: 07, \mathrm{c}$.

Good againft $\mathbb{E}$ xcopiations of the conduits of the yard, 222 , b. gis, e.

Good for Excoriations, 869, 2,1 255,2.

Good againft the Excoriation of the vuula, 936,b.

To purge filthie Excrements through the nofe, $54, \mathrm{~d}$.

To bring foorth bloody excrements, $769, \mathbf{2}$.

Good for foule Atinking Excrements of the bloodie flixe, 1027,1 .

To purge fuch Excrements as be in the fomacke, firft vaines, and neereft paffages, 4 io, b.

To ftare bloody excrements procured by fivelling of the fpleen, $514, \mathrm{e}$.

To purge cholericke Excrements byfiege,434, 0.435,2.

To confume any Exerefence in any part of the body, 72,2.

$875,2.227, c, 266, c$.

Good againft the Exulceration of the priuie parts, 1308 ,h.

Againft Exulceration of the bladder, 765, e.11 $21, k_{1}, 308$,h.

Againtt Exulceration of the kidneies, $1121, \mathrm{k}$, looke Kidneies.

To coole burning Exulcerations, 1 208.m.

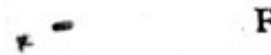

Te frables and tales of Mandrake confuted, $28 \mathrm{r}, 282$.

To take away blacke and blewe fpots of the Face that come by blowes, 193, e.5 $57, \mathrm{~d}$.

To fcoure away funburning fro the face, 759 , h. $765, \mathrm{~h} .841, \mathrm{c} .445$, d

Toclenfe away freckles, morphew, and fuch like deformities of the Face, 94, b, 149, d 765, h.193, e. 855 , c. 84 I, e. 7 2 r, l.

- Totake away lentiles or fpots in the Face, 115 , h.765, h. 193, ,e. oS $\{5$, c. $288, t .293$, c.326, d. 721 , l.1 I 133 ,r.

Take or clenfe a away all pots and freckles of the Face, 94, b.

To make the Face fmooth, $60, k_{1} 1252$, e.r 257 ,

To fcoure and take away f́pots of the Face \& make it faire, white and fmooth, 845, d. 557, e.r 28 I, q.

Tu clenfe and beautufic the Face, $1044, f, 1244, b, 1276, d, 1281$, q. $1298, \mathrm{f}$.

To fcoure away fcuruines of the Face, 147, ,

To cure the blemilhes of the Face, 445, d.596,i.

To cure copper or fouce-flegme Faces, 765, f.g. 1009 , 1.

Totake away the rednes of the Face, $855, c .845$, ,.28 8, r. 579 , b.

To cure the fralling of the guts into the cods, 838 , d.looke guts and cods.

To cure the Falling off of the haire, $90, c .854$, I.

Good ag ainft the Falling ficknes, $8\{4,6.827,0.839, \mathrm{i} .897, f .899,1$. 357 , 3. 379 ,b. 460. e. 498, b. 578 , s. 698 , f 702, t. 720, c. 735 , h. 1000, b.1143, c. 1244, a.b.1299,c.1324,g.

To heale the falling euill or ficknes, $102, f .190, g .856, c, 8,39, \mathrm{c}$. $893,0.39$ I, b.47 8, 0.599,b.770.h,o.849,i. 833, g.63o,h.rooo,b. 10I9, c.

To helpe thofe thathaue the Falling ficknes with madnes and headach, $578, \mathrm{~h}$.

To cure the Falling fickpes in children, $155, c .832, c .463, b .702, f$.

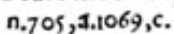

Topreferue a man from the Falling ficknes, $90_{2}, \mathrm{~b}$.

Good againft $\mathrm{fal}_{\text {als, }} \mathrm{1}_{3} \mathrm{O}_{4}, \mathrm{~h}$.

Good for fuch as haue Failen from high places, 195, f. $84 \mathrm{r}$, b.

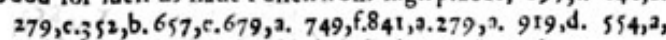
$648, c .698$, e. $.62,0.971,3.849, c .987$, b. 996 ,d.1026,c.

Good againt the Falling downe of the mother, $1244, a, b$.

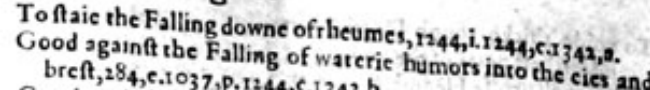
Good againft she Falling of 1343.6

To ftop the Falling dow of the vuula, 936,6 .

$1314, C .1342, v$. To heale the Falling away of the haire of the eielids, 1178 , $1334, \mathrm{i}$.

Good for thofe that be Fallen into a fwoune, $856, \mathrm{~d}$.

To helpe Fecblenes of of the huer, $930, \mathrm{e}, 1334, \mathrm{~g}$.

To helpe Fecblenes of the fpleene, $1334, \mathrm{~g}$.

To heale the chinks \& chaps of the f ete comming

To caufe the cornes of the Fecte to fall away, 1 go, of cold, $60, \mathrm{k}$

To helpe the goute of the Feete, 26 1, b.c.1 $303, \mathrm{~g}$.

To take aw $3 y$ the cornes of the Fecte withour

$12 \subset 6, c$.

To heale the chaps and childblanes of the Feete, $137, \mathrm{f}$

Theale the chaps of the Feete, $1180, e$.

To helpe the difea'e called the frelonic, 557,d. $1232,6.1263$, d.e.

To make men apt to fall into the fame, 775,6 .

To esfe the paine of Fcions,87.

Torefolue, concott, and open F

Toripen Fclons, $195, e .863, \mathrm{~J}$.

Good for fuch as are fearefull, $460, d$.

Good for or to coole hot burning and vehement freauters,

$66,2.471,0.512, b .668,0.702, k .1082, g .1251, c .1256, c, 1281_{2}, 2$.

To cure tertian and quart aine Feauers, $839, c_{4} \mathrm{k}, \mathrm{c}, 5^{8} \mathrm{r}, \mathrm{a}$.

Tohelpe Feauers of what fort foeucr, $467, c$.

Good for the Feauer heatique,169,a.

To alaic the heate of a peftilent Feauer, 321, d.668,a.1 031,b,

To cure wandring Feauers, 1184,9 .

Singular good againft tertian Feavers, $575, \mathrm{~b}$.

Good for Feauers of long continuance, 348, b.507,c.134t,d.

Good againft peftilent Feauers, $502, c .882, b, 473, b, 586,+.684{ }^{k}$. $103 \mathrm{r}, \mathrm{b}$. r19o,e.

Good again? intermitting Feauers, 73 2, 1,roc4, d.

To helpe hot burning Feauers, 222, $9.6,674, f .702, \mathrm{~m}$.

Good againft tertian and quotidian Feaucrs, $467, \mathrm{~d}, x_{3} 4 \mathrm{r}, \mathrm{d}$.

Good for old Feauers, ni $16, \mathrm{r}$.

A fingular medicine againft Feauer quartaines, 8,5, b, 1009,e. A good purgation for a fharpe Feauer tertian, 318 ,e.

How to keepe frigs from purrificng, $630, k$.

Good for, or to clenfe away feabbie fritt), on the skin, $930,2, c, d$ I037, c.r190, .1223 , h I 287 ,c.

To take away the frue in burnings or $f_{c}$ aldings, $4 \mathrm{r} 2, \mathrm{~b}$.

To cure S. Anthonies Fire, $860,6261, b .298,1.412,0$.

To hesle the fiftula called Aegilops, in the corner of the cie, $68,0.301, d 916,3$.

Good againf a Fiffuls,913,a.916,a.687,a.706,b.

To hesle the Fiftulaes of the fundaacat, 1006,2.

Toheale Fiftulaes, 33 1, a.58 r,c.

To mundifie Fiftulaes, $357, \mathrm{c}$.

To rake away hard calloufnes of Fiffulacs, $409, \mathrm{~d}$.

Tokall fith),408,e.

Tocatch Filh with, 12 I $3, b$.

To take away fhaking $f$ titg of a quotidian ague, 1346,2 .

Tocure the extreme and rigorous Fits of old feuers, $849, \mathrm{c}$.

Good again or to take away the Fits of an ague, $3^{18,2}, 347,6$. 357 ,e.

To take away the Fits of a quartaine ague, 887, b.

Totake away thaking Fits of an ague, $37 \mathrm{r}, \mathrm{c} .1358, \mathrm{~b}$.

A remedic againft cold Fits of an aguc,899,d.949,c,ro76,r.

Good for kernels in the flankes, $1: 07, \mathrm{e}$.

To ripen the apoftemes in the Flankes comming of venerie,

$147, c$.
To purge tough and groffe clammie fflegme by fiege, $53, b, 766, c$ $770, \mathrm{~m} .827$, , a.266, 2.899, c. 934, b. 334, 2. 949 , h. $951,2.465, \mathrm{c}, \mathrm{d}$. 460, c. 467, b. 527, d. $617, f .647,2.695$, a.1 155, a.1 235, b.

To purge Flegme, 335, a. 949 , h. 459, b. 527, c.718,a. 720, b.972. $1215, a, 1217$, a.r 297, d.1 $33^{17}, \mathrm{~d}$.

Todrawe foorth of the head rawe Flegmaticke humors, $135, \mathrm{c}$. $749, c .252, b .849$, m. $4^{8} 4$, b. $54^{\circ}, 3.542$, g.619, d.

$749, c .252,6.849,10.4$ thin thick and tough Flegme, $189, c .848,6$

To ripen tough Flegme.647, b.649.1.985, b.

To raife vp gently tough and grofie Flegme that fticketb in the

lungs and chefl, $760, b .195, c .208, b .984, c .1256, c$. 


\section{A Table of the Nature, Vertue, and Dangers.}

Againt any Difeare growing by occafion of the fpleene, $460, f$.

Good againt Difeafes happening in the mouth and thrcte, $370, a$.

Good for all inward Difeafes,855,a.

Againft the Difeafe of the minde, 833 ,d.

How to helpe the Difeafe of the lungs, cough, wheefings, \&c. in cattell, $826,827,569, \mathrm{~d} .630$,f.

A remedie againft peitilent Difeales, 849 ,k. 840 ,a. 847, b. 355 ,a. 587, c. 702 , m.1065, b.r.1281, i.1 368 ,a.

Good againlt all Difeafes that proceede of cold, 770 , o.

Good for hot Difeafes, 318 ,i.

Good againft the Difeafes of the fpleene. $744, c .318,2.657, c$. $1223, \mathrm{~g}$.

A remedic ag ainft womens Difeafes, 527,2 .

To cure hot Difeafes of the kidineies and bladder, $674, \mathrm{~d}$.

A remedie for dangerous Difeafes, 770 ,h.

Good againft all Difeafes of the finewes, $638, \mathrm{c}$.

Good againft the Dileafes of the liuer, 839, b.1 $223, \mathrm{~g}$.

A remedie for the cold Difeafes of the braines, $54^{\circ}, a$.

To moope womens Difeafes in great abundance, $892, a$.

Againft Difesfes that proceede of choler,719,g.

To ftay the Difeafe in women, $233,2.1158$, g. fee Termes.

A remedie for 3 D ilfines, 288 , r. 76, , h.r. 299, c.

Againft iD iftemperature of the ftomacke and breaft, $1349, \mathrm{f}$.

Good againft hot and tharpe IDiftillationg into the cies and other parts, $283,2.1149, a$.

To repreffe Dittillations that fall from the brains into the lungs, $298, c, h, 524, d$.

For Diftillations of humors from the head, i $152,2, \mathrm{r}_{190}, \mathrm{i}$.

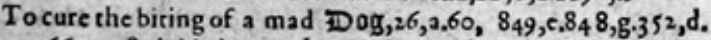
566 ,a.578, d.665, b.1052, h, I235, l.1 305,d.

Good againft the biting of a mad Dog, 135, f. 851, a. 553, f. 560, h. 660 , d.r. 009 , f. 123 \&, e. 1252 , f,

TokillDogs, $755,9.293,0.622, d$,

Good againft the bitings of the fea $\mathbb{D}_{2}$ agron, 938 ,

Again $\mathbb{D}_{\mathrm{D}}$ awoing awric of finewes, $420,2$.

To h:lpe Drawing togither of finewes, $88, f .420,2.436,2.445$, h. $546, c .897$, c. 947, c. 949, a.1 1223, f.

To coufe troublefome and terrible iDeames, $138, f$. 140,a. roso,l.

Good againft melancholike Dreames, 833 , f.

To put away venercous Dreames, 674,5 .

Againft the ID

A ID intse to cute the blacke iaundife, $1133, \mathrm{P}, \mathrm{q}$.

A conuenient Drinke for terrian agues $, 74,6$.

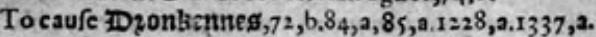

To preferue or keepe from Dronkennes, $24 \mathrm{I}, \mathrm{d}$. 249, c. 1223, m. 1227, f. 1257,1 .

To helpe the IDzoppiffe, that is piffing by drops, or drop after drop, $57, \mathrm{a} .902, a .444, c .452$, d. $454, c .535$, e. 1276 , e.

To helpe thofe that are entring into a ID zoptie, $532,2.524, \mathrm{f}$. 540, b.1019, c,1076, , .1 20:,b.

Good againft the Droplie 40,d.1 37 ,d. 689 ,f. 766 , c.f. 854 ,.c 849, c.862,b, $279,288, x .877$,d. 880, b. $334,3.338, a .357, a$ $400, b .408, a .424, b .467, c .524, f .691, a .722, a .1007, a .1133, c$ d.e.I216,b.c.1235,c.f.1 238 ,a.f.g.13 28 , c.1350,a.

To helpe or cure the Dropfie, $29, \mathrm{a}$. $5 \mathrm{j}$ b. 147, h, 314, f. 869 , d. 874, c. 941 ,c. $43^{8}$,e. 529, a. 849 , i. $542,2.624$, d.691, c. $996 . c$. I 223, n, I $235,1,1238, f, g, 134 \mathrm{r}, \mathrm{d}$.

To purge gently by vrine and fiege fuch as haue the Dropfie, 279, c.d. $426, \mathrm{~b}$.

A remedie for the dropfie proceeding of a colde caufe $\mathrm{x} 4 \mathrm{I}, \mathrm{c}$.

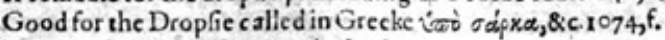

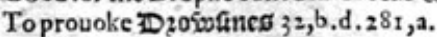

To cure the fores of the 3Dugg, 751 ; b.

Good for wounds of the Dugs,794,2.

Good for vlcers of the Dugs, 291 , i.794,a.

To keepe downe maidens Dues, $803, \mathrm{a}$.

To cure the infommations of the Dugs 87 , c.fee Paps.

To alay the fwellings of w omens Dugs $91, b$.

To caufe heavic Dulnctfe, IO $52, \mathrm{~d}$.

To driue away dulncffe, $654, c$.

To ftay and cure the DDprenteric which is a fluxe of the bellie, 501,a. 502, b. 333 ,a, 445, l. 388, c.: 514 , e. 1156, c. $1167, c$. I 292 , c, f.r. $333, b$.

To helpe the 3 D piturie or great paine to make water $3, a$. fee difficultic ofnaking water.

\section{E}

God for mattering Eare $\$, 938, k .709 . c .1180, b$. To mitigate or cure the paines of the Earef, $1_{3} 8, \mathrm{~d} .261, \mathrm{~d}$ To heale running eares 1152, a. Tolich

Good for the noife or humming in the Eares, $138, \mathrm{~d} .706, a$.
To heale old vlcers in the eares, $709, c$. To take away the ftench and corruption of the Eares, 738 ,c.
To ripen hard fwellings behinde the Eares, $1179, b$. Good againft finging of the Eares, $770, \mathrm{i} .860, \mathrm{i}$.

Good for the paine of the Eares proceeding of heate, $778,2$. To helpe the inuoluntaric $\mathbb{E}$ effution of naturall feede $53, \mathrm{c}$.
661,d.

To helpe the dropping of the $\mathbb{E}$ ieg, 26,b.347,2.1037,n.

Good to be laide vpon burning Eies, 702 ,e.

Good for watering or running Eies, 60,d. 347, a. 512 , f. 553 ,d. 563, g.1037, n.108 3 , c.1179, d.1305,b.1351,b. To mitigate the paine in thecies, $282, f .549, a .623, b, 629, c$.
$630, a$.

To ceafe the paine in fore Eics and ftaic the hot humors from falling into them, 60 ,i.549,a.

To hurt or offend the Eies, 72 , h, 135, m.13 2.140,a.1387,d.

Toclenfe the cies from filmes, $6 z 9, b .68_{4}$,i.

Totake away the burning and itching of the Eies, and to clecre the fight, 887, d.706, e.

Tohelpe the inward-ruggednes of the Eie lids, $4 \mathrm{I}$, f.

To cure v!cers of the eies, 632 , b.r $026, a$.

Good for bleare and watering cies, $1178, \mathrm{~h}$.

Good for, or to take away the inflammation of the eies, $9 \mathrm{I}, \mathrm{b}$. 222 , f. 778,b.502,b. 509, 2.622,b.629,c. 630,a. 632,b. 706 ,c. riso, b. 3 or , a. $306, c .332, b .949, g$. 5 c9, d. $590,2.604$, d.1 $351, b$.

To helpe fore, waterie, fmarting, and bialted eies, $347,2.4^{12,2}$ $709, \mathrm{~b}$.

How to preferue the Eies that they be not hurrt with the frall pockes or meafels, 124 ,

To heale Eies that hang our, 1091 , a.

To coole the heate and inflammations of the Eies, $34 \mathrm{I}, \mathrm{e} .4 \mathrm{I} 2, \mathrm{a}$. $4 \mathrm{I}, \mathrm{h}, \mathrm{I} 35 \mathrm{r}, \mathrm{b}$.

To take away the rednes of the Eies, 766, d.604, d.629,c.

Toclenfe the Eles of haw or ftripes, $1172, h$.

Good for them that are troubled with dimme Eies, 249, a. 512 , f. 537,b. 548 ,d.706. 8 s 8 ,b.1074, h.

To helpe the itchings sin the corners of the Eies, $4 \mathrm{ro}, \mathrm{f}$.

Toceafe the paine and burning or fmarting of the Eies, $819, a$. $604, d .629 . c, 706$, e.ross, d.

To purge the Eies of waterith humors, $6: 9, c$.

To clenfe or clecre the Eies and amend the dimnes of fight, $549, a .684, \mathrm{i} .1349, a .858 . b$.

To laie downe the ftaring haires of the Eie browes, $227, c$.

To helpe blacke and blew Eies comming by blowes and ftripes, 3 or, b.

To cure the difeafe in the Eies called Argema, 301 , a. $495, \mathrm{c}$.

To take away the webs \& f pots of the Eies, 288, s.1018,c,1035.d $1353, \mathrm{c}$.

To clenfe away flimie things from the ball of the Eie,grz,a.

To dim the Eiefight, 72 , h.

Good for the Eiefight, 236 , b.

To quicken or Tharpen the Eiefight, $858, \mathrm{~b} .1035$, d.I $353, \mathrm{c}$.

To preferue the Eiefight, 877, a.d. $537, \mathrm{a}$.

Good for weeping wounds of the Ethoswos, $509, \mathrm{~b}$.

An Elctuaric good for hortnes of winde, an old cough, paines in the fide and inward burftings, $22 \mathrm{r}, \mathrm{h}$.

A remedic againft the Enterocele, which is the falling of the blind

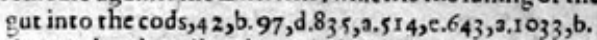

To be good and auaileable againft Enchantments, 848,e.

To cure thofe that are Enraged through the biting of a mad dogge, $380, \mathbf{a}$.

Hurifull to the Entratles, 293 , a.ro1 7, h.11 $56, \mathrm{~b}$,

Good for the Entrailes, $738, a, 729, c$.

To open the ftoppings of the Entrailes, 428 , b.

To diffolue congealed and cluttered blood in the Entrailes, and heale the hurt places, 279 ,b.

To ftrengthen the Entrailes, $318, \mathrm{~g} \cdot 108_{2}, \mathrm{k}, 108_{3}, \mathrm{n}$.

To eafe the paioes of the Entrailes proceeding of rawneffe, $892, \mathrm{c}$.

A remedie againft the gnawings and gripings of the Entrailes, $770, f$. 


\section{ATable of the Nature, Vertue and Dangers.}

A remedie again the Gour, $860, \mathrm{~h}, 400, \mathrm{~b}, 526,0.686, c .1073$, 2 II $25, \mathrm{~g} \cdot 1238, \mathrm{c}$.

To mitigate the paine of the Gout proceeding of as hot caufe, $413, C, 512,3$

Good againft the Gout in the huckle bones, 689 , f.706.c. 1125 ,

To helpe the Gout of the fecre, $261, \mathrm{~b} .1125, \mathrm{~g} .1303, \mathrm{~g}, 1328,1$

Todriue foorth Grauchl, $23,2.29,3.185$, c.1 $89, a .760,2.891$, f. $572, k, 1.677$, t.r 000.2 . 1009, cr 1129 , d.t 144, h. 1 $224, \mathrm{~m}$ $1243, c .1=46, f, 1=66, c$.

To drutue foortin Grauc ll nicheily, 8 s,e. -89,

To driue Grauell out of the kidneies, $1248, \mathrm{~d}, 1255, \mathrm{~b}$.

Good for the Graucll and ftone, 886,b, 261,0. 272,a. 875,2, $4: 8, c .677, c .1144, b, 1182,3.1243, c$.

Good againit the Grene-Acknes, 3 r 4, f. $201,5,43^{8}, \mathrm{e} .524, \mathrm{f}$ $732, \mathrm{i} .735, \mathrm{~m}, \mathrm{I} I 33, \mathrm{c}$

Againft ofthmacicall Eriefes,288,v.

Toh. Jpe the Griefes of the bladder,497,d.

A remedie againft Griefe in the fide, $8_{43}, \mathrm{~b}$.

Tohelpe Griefes proceeding of the fplecne, $460, \mathrm{~g}$.

To appeafe the Griefe of the belly, $895, \mathrm{~b}$.

For long and cold Griefes of any part, $649, \mathrm{~g}$.

Aganft Griefes proceeding of oppilations, $977, b$.

Againft the Griefes of the breaft and lungs, $288, \mathrm{n} .66 \mathrm{I}, \mathrm{c} .87 \mathrm{~T}$, $1073,3$.

To cafe the Griefes of the raines and bellie, of colde caufes, $1346, c$.

Good again t all Gricfes of the ftomacke, 317 ,a.

Tohelpe Griefes of the finewes, 1346 ,e.

Good for the Griefes of the eies, $347,3.706, \mathrm{c}$.

Good againft Griefes of the principall members of the bodie, 1115,0 .

A remedie for the $\mathbb{E r}$ ripings of she entrailes, $770, \mathrm{f}$

Good againft of to mitigate the Gripings of the belly, $391, \mathrm{a}$ $436,2.457$, b. 524, c.1076, 9. 617, g.

Good againft Gripings of the belly in the making of vrine $, 88_{2}, 2$.

To cure al Gripings of the belly proceeding of windines, $1354, \mathrm{~d}$.

To mitigate the Gripings of the bloodie flixe,789,d.

To helpe Gripings, $57, \mathrm{a} .878, \mathrm{~s}, 897, \mathrm{k}, 1073, \mathrm{~d} .1190, \mathrm{~b}$.

To helpe the Gripings within the belh, 53 , b. I $; 7$, d.751, 3.882 , a

$891, c .893,3.301, c .865 .2 . \$ 72$, d. $875, b, 880, a, 524, c$. roo9,c.1073,a,c.436,a.878,a.

To ripen fwellings in the Groine, $\mathrm{r} 170, \mathrm{~b}$.

To wafte away Grofteries of the finewes, $1055, \mathrm{c}$.

Tomake Guefts the merrier, $58 \mathrm{r}$, 5 .

To exafperate or make the Gutlet reugh, 859, ,.

To helpe the red fbumme in children,2r 8,c.

To belpe the fuellings in the Gums, $410, f$.

To ftrengthen the Gums, $845,0.1263$, i.1 $337, \mathrm{c}$.

To clenfe the Gums, 886 , c.

Againft the fwelling of the Gums, 13 I $4, c$.

Good againft vleers and forenes of the Gums, 9r 9,e. $507, \mathrm{~b}$. 676, a.1r 52,3 .

Good againft the paine of the Gums, $1=55,2$.

To take away heate of burning by (I) $707, \mathrm{k}$.

Good again凡 the roughnes and fretting of the Guts, $.787, \mathrm{~d}$. I $349, c$.

To breake and featter the windines of the Guts, 908,2 .

Good againft the falling foorth of the Gur, called Saceus rentric, 394 b.

To cure the paines and griefes of the Guts, 40,d.892,c. $509, \mathrm{f}$

$\lceil 24, c, 1018,2.1074, e, 1349, c$.

A remedie for gnawings and gripings of the Guts, 770,f. 1 £ 8,a $524, \mathrm{e}$.

A remedie againft windines of the Guts,65,c.

To hurt the Guts, 769 ,a.

To cure the falling of the Guts into the cods, $839, \mathrm{~d}$.

Good againft the torments of the Guts, 863 ,d.

To clenfe or feoure away excrements or tough flimie humors in the Guts, 262,0.101 8, a.1 027,b,n.

To driue foorth wormes of the Guts, 938 ,e.

To kill the fmall wormes of the Guts, $94 \mathrm{I}, 2$.

To helpe the vlcerations and luxe of the Guts, 4 I $9, e$.

\section{$\mathrm{H}$}

TO caure thaire to grow that is fallen off through the difeafe Alopecia, 34, c. 88, e.985, c.10I 3 ,e.1089,b.1259,b.

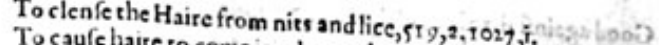
fealding, or otherwife places that want it through burning otherwife, 34, c. 88, e. $67,9.984$, d.98, , c. 97 ,

Tocaule Haire to waxe yellow, $630, c$.

To cure the pilling or talling of of pecia, 90, c.949, $9.674, b .696, \mathrm{i}$.

Tocaufe Haric to tall off, $408, \mathrm{~b}$.

To procure Hairc in beardefle men, $102, \mathrm{C}$

Againft the falling away of the Haire of $2, \mathrm{c}$.

iharpe humors, $660, c$.

Tohelpe thofe that haue their Haire pilledoff, r $9 \mathrm{r}, \mathrm{t} .984 \mathrm{~d}$ $985, \mathrm{C} . \mathrm{IO} \mathrm{I}_{3} \mathrm{ec}$.

To caufe Haire to grow in fhore fpace, 185 , f.

To make the Hairered, $x_{2} 10,4$.

To rooter $p$ Haire, 974, ,

To make Haire blacke, 609 , e.r 150 , b.rr 58 , h.r 238 ,d.

To preferue the Haire of the head from falling, $1307, b$.

To die Haire yeilow, 388 , c.1 145 , f.r $309, c$.

To rake away fuperfluous $\mathrm{H}_{3 i r e, 709, d .728, c .930, f .}$

To thay the falling oft of the Haire, $410, f .581$, d.674, 5.1708, $x$, b 1 307, b.1 309, c.1 227 , f.

To heale the chaps of the thand comming of

To make the Hands finoorh, 60, L.1 1 $50,5.1252, \mathrm{e}, 1257, ;$.

To purge chaps of the Hands being lan to the French difeafe, $859, c^{2}, k_{9}, \mathrm{~b}$.

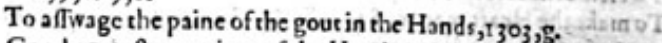

Good againft mangincs of the Hands, $49 \mathrm{r}, \mathrm{b}$,

To chap, blifter and make the $\mathrm{H}_{a n d s}$ rough and rugged, 686 ,e.

To helpe the barones of humors, $7, d$.

Good to foften the Hardnes of the finewes and matrix, $147, d$ I 49, c. $5: 4,0$, b.1 108,6 .

Againft the Hardnes of breathing, $724, b$. fee Thortineffe of bresth.

Towafte and confume Hardnes of the fpleene, 74,2.195.5. $395,0.696$, b. 977 ,b. 1027,g. 1170, c.1195, 2.1327, d. 1346 , s. looke Spleene.

To difolue or wafle away the Hardnes of womens breaftiro pops, $422, \mathrm{~b} .423, \mathrm{c}, 1052, \mathrm{~h}$.

A remedie againft the poifon of the fea bare, 1172,0 : sfobs of Good for rough 0 arthnes of the throte and breft,1120,a.5:9

To a flwage the paine of the hanch), commonly called stratice. 188, c.195, e.557, h.

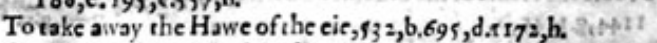

Good againft fundric difeafes of $\mathrm{H}_{3}$ wkes, $9 \mathrm{r}_{2}, \mathrm{f}$.

To heale running vleers of the

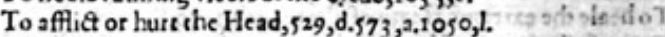

- To driue licc out of the Head, $399, \mathrm{~b}$.

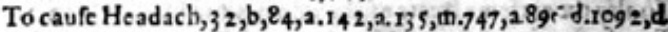
I 192 , b.1 $247, g .1251$ a.1 $252, b .{ }_{3}$ I I, 2 .

Tohelpe or toke away the Headach, $760, \mathrm{~b}$. $778, \mathrm{~b}, 8<6, \mathrm{e}, 4 \mathrm{ro}, \mathrm{f}$.

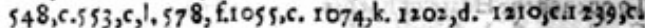
$1257, \mathrm{n}$.

A remedie for a continuall or old Headach,770,h.287,a.460,g. 463, b.711 2.724, b. 735 , h.

To eale the intolerable paines of the Headach, procecting of heate, $270, c .58 \mathrm{r}, \mathrm{c}$.

To purge the Head, 53, a.1 39.2 50. g.306,a.399, d.495, b.699, h, 709, c.11 $15.1219,3.1244,0.1317$, c.1358,a.

Good for thofe that have ill Heads of a colde caufe, 578 ,

Againft wounds of the Head, $54, \mathrm{~g}, \mathrm{I1} 82, \mathrm{k}$.

Good for ftoppings of the Head, $1308, \mathrm{f}$.

Good for the Head, 124,548 , 1674 b.

To purge the Head mightily of foule and Aimic humors, 306,9 . $512,2.669$, b.7 $09, \mathrm{c}$.

To make the haire to grow on a pilde orbalde Head, $135, \mathrm{i}, 984, \mathrm{~d}$ ror $3, \mathrm{e}$.

A remedie againft fore Heads in children,553, d.ro47, C.

To heale fcabbed Heads in children, $14 \mathrm{r}, \mathrm{f}$.

To purge water and flegme out of the Head by the mouth, $149, \mathrm{C}$ 252, b. $867,0.542$, g.619.d.729,g.1219,a. Good againft infirmities of the Head, oda bot caure, 674 , d, 900 To cure the naughtie fcurffe of the Head, $854,1.985,2$. : goft of To helpe and eafe the paine or aking of the Head, $26,6, a, b, c$.

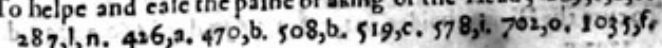
1184, l.

To cure all curs and hurts in the Head, $28,5, a, 118:, c$.

Good for to wath the Head with, 1027,r,

Good 


\section{AT able of the Natares, Vertue and Dangers.}

To voide thicke tough Flegme out of the ftomacke, cheft, and fartheft $\mathrm{p}$ arts of the bodie, $335, \mathrm{~b}, 445, \mathrm{e}$.

To purge all groffe Flegme, $899, c .400, a .467, b$.

To caufe Flegme and water to t un fuorth of the mouth $306, \mathrm{~b}$. $619, \mathrm{~d} .729, \mathrm{~g}$.

To ripen Flegme and to caufe it cafily to auoide, 1035, c. $I_{3}=8$, b. 647, b. 649, i.

Topurge corrupted Flegme out of the che $, 445, e$.

Todraw foorth Flegme gestly and purge the head, z $\{z$, b. 542,5 624, b. 1244,5 .

To auoide or purge Flegme by the ftoole, $738, c .743$,a. 897,2 . $397, a .460, c$, b. $463, c .973, e .1155,0$.

To ftir vp fflethip luft or defire, $124, e .133$, b.754

To withftand Flethly defire, $674, e, f .1202, a$.

How to preferue rawe Fleth from corruption, $535, \mathrm{~d}$.

To drawe Iplinters and thornes out of the Fleth, $96,3.495$,a.

To take away the fuperfluous outgrowings of the Flell, $854, \mathrm{l}$.

To confume away proud and fuperfluous Fle $\mathrm{fh}, \mathrm{I} 158, \mathrm{~b}$.

To keepe proud Flefh from growing in wounds, 1334, i.

Toconfume proude and fuperfluous Flefh in poifonous vlecrs, $429, c$.

To take away proud Flefh growing in the nofrils, $68_{4}$, d. fee $\boldsymbol{P}_{\text {o. }}$. bypus.

To driue away ffleas, $391, \mathrm{~d} .472$,d.

Todriue away fflicø, 389, h. $39 \mathrm{r}, \mathrm{d}$.

TokilFlies, $388, c$

To ftaie the fflixe, $960, a .1263, \mathrm{~g}, \mathrm{~h}$.

Good againt the bloodie Flixe, 3 ${ }^{14}$, d. $318, a .899, a .388,2.728, a, b$.

To cure the bloodieFlixe proceeding of choler, $1232, \mathrm{~b}$.

T॰ ftop the bloody Flixe, 102 , b. 505, b. $748, a, b .790$, g. $802,3.860, b$

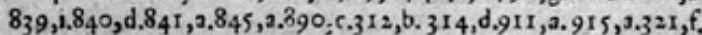
323 ,b.329,d. 958 ,b,c. 388 ,c. 4 I 9, d. 524 ,c. 551 ,a. 63 o,b.6 638 ,d. $674, a .314$,d.318, 3. $73^{6, c}, 962$,d. $977, a .989$,b. 1037, g.1083,c,

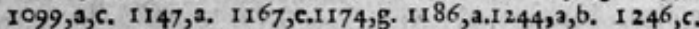
1254 , f. 1256, b, c. 1263 , n. 1264 ,b. 1283, b. 1292, b. 1314, g. $1326,2.1334$, d.1 375, , b.

To heale the bloodic Flixe, 787, e. 789 , d, f. 802 , b. 215 , b. 839 ,a,f. $887,0.890, e, f .535$, f. $576, b .1091, a .1129$,d. 1227 s.1 $263, d, e, n$. 128, b.1309,b.

To bring downe or prouoke womens flowers, , 2, e $124, e .140, b$

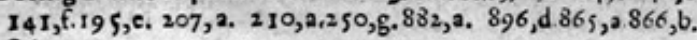
$867, a$.

To ftay ouermuch flowing of womens Flowers, $32,2,72, \mathrm{~g}$. fee Termes, $784.2 .803, a .284$, e, $298,1.318,1.9 r_{3}, 2.323$, b. 958 ,b. $389,8.553$, c. 661 , h. $707,1.1058$, b.

Toftay the ff ture of the belly, $72, c .54, \mathrm{~h} .298, \mathrm{l} \cdot 340, \mathrm{~b}, 958$,b.c. 1058,b.1059,a.1062,a.1099,3.

To ftay or cure all Fluxes of the bellie, $839,3.958,6.445,1.5 I_{4}, \mathrm{e}$. 109 1,3,1099, a.1 1 5 6, c, 1288,b.1 292 , b.

Toftay the Fluxe of humors from the ioints, $54, \mathrm{~h} .60$,f.

To ftay or helpe the white Fluxe in women, 88, a.505,b. 960,2 . $665,1.674$, b.108 3, c.1 158,b.11 82, b.1 29 2, b. looke Whites.

To ftop all kindes of Fluxes, $1264, \mathrm{c}$.

To helpe the Fluxe of the guts, 4 ig.e.

To ftay Fluxes in women proceeding of a hot caufe, $412, \mathrm{~d}$.

Againft all kinde of Fluxes about the cheft, 1223 ,c.

Good for Fluxes, $340,3.9^{8} 4$, a.

Tohealc old Fluxes, ir s2,a.

To ftop and curc all Fluxes of blood in man or woman, 841 ,a. $887,3.890, c, f, 1147,3,1158, f, 1206$, a.

To ftay the inordinate Fluxe, $833, e, 284, e .34 \mathrm{I}, \mathrm{c} .389, \mathrm{~g}$.

Good againft the Fluxe of the belly arifing of the weaknes of the ftomacke, $854, \mathrm{~g} 1247$, c.

Toftop the Fiuxe of the Hemorrhoides, $858,3.419$, d.

To ftop allFluxes of blood, $215, \mathrm{c} .839,2.841,2.887, a, 9,13,2.333, \mathrm{~b}$ $058, b .388, c .419, d .452, a .454,0.648, a .1110, a .1244, a, b$.

A good fromentation, for fwollen legs, $497, \mathrm{~b}$.

A good fromientation, hat be apt to fall into the dropfie.ro5o, h.

Good frove for the er drie and withered bodies, $1050, \mathrm{~h}$.

Good to fupplie the want of Foode, 288 .p.

To helpe the frorgetfall euill, 856, e.

Tokill froswer fouted bealts, 755, a.81 8 ,b.

Tokill frores, 755,3 .

Againft fratures of the head, $54, \mathrm{~g}$.

Fraeture of the bones, looke Broken bones.

Good for chofe

To take away fr rectiles, 926, e. $720, \mathrm{e.1} 1052, \mathrm{~g}$.

To sakc away Freckles of the skin, 754, b. 759 , h. 1133, r.i. 328 , h.
To clenfe away fpots and Freckles of the face, $94, b .193, e .250, i$.

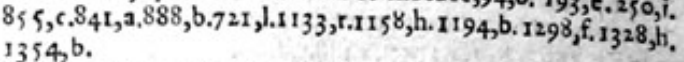

Good againft the frencl) difeafe, $897,5 \cdot 930,0.463, b, 1317, k$, fee French Pocks.

Tocaufe firenae, 1247 , f.

Good agannt the Frenfie, $856, e, 357,3.638, \mathrm{r}$,

A medicine for the Frenfie, $318, \mathrm{f}, 457, \mathrm{a}$.

Tocure a Frenfie of long continuance, 458 ,d.

To helpe ff rete in children, $218 . c$.

Good againft the Fretting of the bellie, 908 ,a.

Good againft Frettings of the guts, 787, d.10 I 8,2.1 349,c.

To mitigate the Frettings of the bloodic flixe, $789, d$.

Againft the Frettings of the guts and entrailes, of coldecaules, $1349, c$.

Good againtt the Fretting of the fundament, $787, \mathrm{~d}$.

Good againft Fretrings of the bladder, 787 , d.r 1 74 ,d.

To expell the dead fitutte, $89 \mathrm{I}, \mathrm{b}$, fce Dead childe.

Toraife frumer, 84 ,?.

To dry vp moilt and heale maligne vlcers of the fintument; $30, f$.

To coole and temper the heate of the Fundament,232,c.

To heale the rifts of the Fundament, and the infirmities thereof, called Condilomata $54, \mathrm{~d} .37 \mathrm{r}, 0.790, \mathrm{~g} .858,2.553$, d.1202, $\mathrm{f}$.

To ca:c rhe burning heate of the Fundament, $217, \mathrm{~b} .394, \mathrm{~b}$.

To beale the chaps of the Fundament comming of colde, $6, k$. $370,3.1180$, e.1 $150,2.1006$,b.

To helpe all paines in the Fundament, $291, e .34 \mathrm{I}, 0.702, \mathrm{~b}$.

Good to helpe the Fundament eut fallen downe in yoong chil. dren, 495, d. $680, c .702$, e, f. $1167, b .1244$, a, b.

To cure hard fwellings of the Fundament, $728, e .1035,9.1180, r$.

\section{G}

Ood againft the floppings of the Gall, 689 , c.124,e.279,2. $912, b .463$, d. $507, c .689, c$.

To helpe the ftoppings of the Gail, $222, a, b .912, b .437,2.463, d$. $507, c .578$,b.

To heale Gals of the fundament, $1152, a$.

Good againft incrie Gals,2 87, i.

To ftsy the running or fpreading of שangreno, $72, \mathrm{~d} .729, \mathrm{~h}$. $1044, k .10\{2$, h. I 292,d.

A remdic againft Ganorenes, $1044, c, 1252$, b.

A Gargarifme againft the tumor s and fwelling of the vuula, or almonds about the threte and roote of the toong, 190,d.

Tokeepe Garments from being eaten with mothes, and to make them haue an excellent odour, 843, d. 938, e. 941 , f. $951, c, 1026$, d. I 1 86, g. 1281, n. 1351 , e.

Toglue togither Wafhess made abourthe veines, finewes and tendons, 1 I4, 3 ,

Hurtfull to đeneration, $553 \mathrm{~g}$.

To take away the fwellings of the đenitoz\$, 908,b. $1035,3$.

Good for the Eiodines of the head, $770,0.469, b, 527, d, 546, f_{3}$ 599, b. 735 , h.1009,b.

To caufe Giddines, $85,{ }^{\circ}$.

The vfe of $\mathbb{E}$ inger, 55,2 .

To driuc away đinatø, $938, e .389$, h 391 , d. 1186 ,fo

Tokill Gnats, 388 ,c. $1186, \mathrm{f}$

To caufe Ænaswings or gripings in the ftomacke, 1190,2 . II $92, \mathrm{~b}$.

Good againft the जnawing of the belly, $391,0,420,2,617,5$.

To cure the Gaawings of the belly, $891, c .908$, a.

To rake away the Gnawings of the ftomacke proceeding of a

hot caufe, $232, \mathrm{~b}$.

A remedie for the $G$ nawings of the guts and entrailes, $770, f$.

For Gonom bea or running of the raines, $50, b .452, a .454,2.66 \mathrm{r}, \mathrm{e}$. 674, h.11 $50,3.1182$, b I 246, g. I 276,e.

To csufe $\varpi$ oates to be deliuered oi thear yoong, $893, c$.

Tokill wilde Goatcs, 8 20,c.

To take away the paine of the Goute, $94,9.131,2.250$, f.412,b 560 ,i. 1125, g. $332, a .729$,b.

For the hot Gour, 1328 , 1.1 381 , a.

Good for the Gout in the hands, $1303, \mathrm{~g}$.

Todrie waterie humors of the Gout, $1037, \mathrm{~h}$

Toeafe or affwage the paine of the Gour, $13 \mathrm{I}, \mathrm{b} .135, \mathrm{~h} .859$,d. 283 ,b. 287, b. 298, k. 332, c. 426 , b. 509,c. 535, c. 665 , h. 849, f.1026,b.1133, k, I 235,c,1238,g, 1375,e, 1389,a. 


\section{ATable of the Nature, I'ertue and Dingers.}

How to be preferued from the Hurt of venemous beaftes, $874, \mathrm{~d}$. iss,a.

Totake away all Hurts from the eies, $\$ 37, c .629, c$.

To drawe water footth of their bellies that are byopoptilse, $691, c .735$, m.ifec Dropfic.

\section{I}

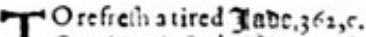

Good againft the Gaundife, $391, \mathbf{2 . 4 0 0 , b . 4 2 8 , 2 . 4 6 3 , c .}$ 507, c. $575, \mathrm{a} .963, \mathrm{l} .1007, \mathrm{c.12} 243, \mathrm{~b}$.

Tocure the laundife, $856, c .864, b .827$, i.839, e. 840, f. $938,5,1$. 341, d $422,0.695, c .12=3$, n.

Good agandt the ycllow laundife, $863,9.832, b, 279,9.927, b$. 348 , b. 557, e. $578, b$.

To helpe the yellow laundif:, $760, b .198, b, 222, a, b .272,2.314$, f. $437,2.463,3 .\{26,3.979,3.1083$, h.11 10,c.11 84,e.119 5,e.

Topurge gently by vine and fiege fuch as haue the laundife, $279, c, d .1048$, d.

A purgation for the yellow Iaundife, 318 ,e.

Singular good for the Isundife of long continuance, 144, b.

To curc the blacke laundife, 1133 , p, q.

Good againt the olde and long laltung fwellings of the fawes, 934,2 .

Toclenfe the lawes of flimie flegme, 587 , b. I I 58 ,

To comfort the lawes, 1244 ,d.

To take away the fiwellings of th: Iawes, 587, b.1 158 , f.1 3 14,c.

Good ag ainit corruption of the lanes, $60,1677, \mathrm{c}$.

To take away ruggednes of the lawes, $7 \circ 1,2$.

To affwage or beale the difeafe called Ignin facer, or wilde fie, $60, f .298,1.660,2.676$, b 1051, 9 .

Againft varne $\mathbf{X}$ maginations, $1160, \mathrm{~d}$.

Good to limne 7 mageric with, $124 \mathrm{~h}$.

Good for 7 mperfections of the he ad, 1027,2 .

For Impertections of the cies, $629,5.1351, \mathrm{~b}$.

To helpe oll Imperfections of the liuer, 359, b. 422, d. 495, d.

For loperfections of the lungs, $1 ; 88,2$.

For Imperfetions of the raines, $693,2,724, b$.

Totake away the fwelling and paine of hot 3 mpoftumes, $58 \mathrm{r}, \mathrm{b}$

Tobring harde Impoftunes to maturation or ripenes, $\mathrm{II}_{4}$,e. $394,2.471, c .1170$, b. $1299, b$.

To conlume and diffolue all cold hard Impoftumes, $1027, ?$.

Good againft Impoftumes in the ioints of the fingers, 362, b.

To aff vage a $\mathrm{fl}$ aming Impoftume and bring it to ripeacs, 47 2,c.

Tobreake Impoflumes, $207, a, 2$ 10,2.46 ؟,a.

To ripen and breake venercous Impofumes in the flank, $1328, \mathrm{~d}$.

A remedic againh Impoftumations of the throte, 3 '9,c.

Tobring to maturation \& brcale peftilentiall Impoltumations, $8 \varsigma 4, k$.

To mollific malicious Impoftumes, I I 70,c.

To toften and ripen Impoftumes, $1328, \mathrm{~d}$.

To cure the dileafe called Impertigo, 69, b.

For 3 nfants t bat haue their finewes dr awen togither, 989 ,d.

To heipe an Lnfane that is vexed with an ague, $463,3.702,1.705,9$. $778, \mathrm{c}$.

Good for Infants that are like to have the falling ficknes, 880 ,d.

A gaint the 3 nfection of the plague or peftlence, $849, a .840$, b. $478,0.599,0.604, \mathrm{c} 996$, a.10k9,b,d.

A remedie againft all Inte $A$ rons saksn by euill and corrupt aire, and to driue the $\int_{2}$ me from the hart $847, a .996,2.1190, f$.

Good againft all colde 3 nfirmitics of the ftrmacke, 732 ,i.

Good for the Infitmities of the mother, $613,3,1108,2$.

For Infirmities curable by fweatine, $7 \mathrm{Ir}$,?

To heale Infirmities of the fundament, 54 , d. 553 , d.

A remedie for the Infirmities of the hart, $560, a, c, f .569,3.599,6$. $1160, \mathrm{~b}$.

Good againt the Infirmities of the fpleene and milt, 869, d. 495 , d. 542 ,h.732,i.979,3.

To helpe the Infirmities of ilhe liuer, 422, d 495, d. 507,2732, ,i.

Good for Infirmitics of the kidacies, 4:2,d,657,c. $869, \mathrm{~d} .495, \mathrm{~d}$. 542 , h. 732 , i. $1000, a, 1120, c .1121,1,1=46, d$.

Good for Infirmitics of the bladder, 869, d. 495, d. 542, h 732 ,i.

Good for infirmitie, of the cheft, $47, \mathrm{~d} .3_{1} 18,3.47$, a.5 $86,2.1190, \mathrm{~b}$

Good againft infirmities of the finewes, $43^{8,4}$.

Good aginft Infira ities of the wourh, $508, \mathrm{~d}$.

Again Infirmities in the eares, 124 , f.

To cure Infirmities that come of Aluxes, $099, \mathrm{e}$

Good for In firmicies of the head and braine, of a cold and moil caufe, 1110 ,a.

Good againft ali Infirmities of the breatt and longs, $120, \mathrm{C}$.

humors, $\mathrm{t}_{21}, \mathrm{l}, \mathrm{m}$.

Atemedic for old the matrix, $1238, \mathrm{C}$.

A temedie for old In firmities of the cheft and lung1, 1329,0 ,

Againft all Infirmitics of the blood, $57, \mathrm{c}$.

Good for all colde and continuall Infirmities of the head and

Good agannt Infirmities of the head, of a hot caufe,674,d.

Good for the li, firmities of the gall, 318,9 .

To helpe the Inflammations of the almonds, throte, and the partes adioining, $839, f .366, a .370, a .728, a, b . r 091,2,1180, a$

Guod fur Inflammations, $236, \mathrm{~b} .250, \mathrm{~d} .362, \mathrm{~d}_{41} 12,2,2.1180,2$. $548, b .667,2.674,2.702,0.1030, a$.

Toheal hot and iharpe inflammations $667,6.679,2.1153,2.1335,1$.

Not to luffer Inflammarioas to rife, and if they do, toaffwage them, 1083,2 .

Againft the Inflommations of the lungs, $504,2.318, f .572,6.701,2$, 702,1.705, $, 1,121$,

A gainft Inflammations newly begun, 2 r $5, b .1223, c$.

To rake away lnflam mations, $60, b .65, b .195, c .232, a .860, c .495$, 1618, b. $1055, c, 1121, k$

A rconcdic aganft the Inflammation of the ftoncs, $198, c_{1}, 28_{3}, \mathrm{a}$ $1073, \mathrm{~b}$.

To dillolue Inflamm ations of the breaft, lungs, and rough arteric, $1243, \mathrm{e}$.

To appesfe or affwage hot Inflammations, 60,f.793, 2.242,g. $702, \mathrm{c} .962, \mathrm{~b} .1223, \mathrm{kI} 238$, e.r 233 , l.1.1368,c.

To helpe or cale Inflaminations of the eies, $502, b, 222, f_{0}, 301, a$. $306, c .332$, b. 949, f.412,a.509, a.10 50,p.Irso,b.

Good aganft all inward Inflammations, r 294,a.

Tobreede $\ln$ flummations, 1315 ,a.

To rake away Inflammations in wounds,291, h.679,2.

To coole all infl smmations, $282, \mathrm{~g} \cdot 32 \mathrm{r}, \mathrm{d} .1144, \mathrm{f}$.

Againft the Inflammation of the raines, $1349, \mathrm{~b}$,

A recnedie againft Inflammation of the paps, 198,c.29r,i.

To ft ay the beginning of Inflammations, $1208, m, 1275, c .1276, f_{0}$ 1304 ,a.

To cuole the Inflammation of the liver, $845, f, 94^{1}, \mathrm{~d}_{4} 57, \mathrm{~b}, 512, \mathrm{~g}$ $702, \mathrm{k} .1009$, d.1 243 , b.1 $376, \mathrm{a}$.

For Inflummation of the kerncls, $1180, f, 1294,2$.

Good for Inflammations of the fundament, $858, a .394,6.66 \mathrm{r}, \mathrm{k}$. roso,p.1076,r.1167,b.

Totake aw ay or cure all Infl smmations, $860, f_{2}, 28,2.291, h, 4 r 2$, $424, \cdot .445$, d. $667, c .676,3.680, a .1027, f .1210, a .12=3, k .1235, k$ 1275, c.1 $277,9.1278$, b.1304, h.1 376, b. 1389,2 .

Good againt the lnflummations of the mouth and almonds of the throte, $845, a$. $3^{66, a}$. $370, x .702, n$, $728, a, b, 1091, a$. 12942.

To alay the Inflammation of the ftomacke, 845, b.94I, d.13245.

To mitigate the Inflammation of the entrailes, $103_{2}, g$.

A gainft the Inflammation of the 3 ntettines, $512, b, r_{349}, b$.

To cure members out of $\mathcal{Y}$ oint, $149, \mathrm{~d}$.

To cure the fhakins so the Ioints declining to the paulfie, $947, \mathrm{f}$.

To helpe aches and paines in the Ioints, $1_{14}, \mathrm{c}, 63^{8}, 2,1055, c$. $1073, \mathrm{~d}$ :

To eal: or helpe members out of Ioint, 34, b. $540, c .638,2,649, \mathrm{hth}$ Good for the loints, $250, k$.

Toftreng, hen the loint $5,53,1$.

To confume windie fwellings in the Ioints, $908, b$.

To flay humors from folling into the loints, 60 , f.

To abate or affw age aches and paines of the loincs, $65, \mathrm{e} .13 \mathrm{r}, \mathrm{b}$. 895, b. $512,2.6 ; 8, a .680, b .724$, b. 1016,3 .

To affivage or diliolue fwellings in the loints, $68, a, 1,1, b, 6: 7, b$.

Good for weeping wounds of th: loints, $509, b$.

Toknit firmly the loint of members that were difplaced, 759, d,

To foften the fwellings in the loints,790,g.

To digef filthie flimines of the loints,4i6,a.

To take away the fwellings of the Ioints, $47 \mathrm{t}, \mathrm{b}$ To take away the lwellings of the loints cauled of hot and drie hu-

mors, $5^{12}, 3$. Goure.

To purge the Ioints of flegme and rawe humors by vomite and ftosle, $1133, f$.

To cure the If hiatica,42:2, 460 ,d.

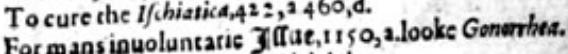

Formansinuoluntarie Jutae,tis 


\section{$\checkmark$ Table of the Nature, Vertue, and Dangers.}

Good againft dizzines of the Head, $288, \mathrm{r} .897$, h. $720, \mathrm{c}$.

To heale running vlcers of the Head, $1035, \mathrm{c}$.

To afflict and hurt the Head, $5: 9$, d. $573,2.1050,1$.

Todriue lice out of the Head,399,b.

Tohelpe the fcurffe of the Head, fee Scurffe.

To caufe aking and heauines of the $\mathrm{Head}_{4}, 0, b$.

Good againft heauines of the Head, $702, \mathrm{f}$.

To preferue higealth, I190,d.

To ftrengthen 1 earing, $: 116, \mathrm{t}$,

Tocaufe hardnes of Hearing, $298, f .1305, f$.

Good for hardnes of Hearing, $706, \mathrm{a}$,

To ftrengthen the (9)art, $124, \mathrm{~b}, 603,3,655, \mathrm{c}, 735, \mathrm{~d}, 108 \mathrm{2}, \mathrm{a}, \mathrm{i}$. $1083, n, 1160, b, 135=, 3$.

To comfort the Hearr, $890, h_{3} 332,9,473,9.43$ 5, e. $560, a, d .603$, , $654, a, d, e .655, c .702, i, 0$. I11t h. 1281,i. 1317,g. 1350,2 , r $353, \mathrm{~b}$.

Good againt the trembling and haking of the Heart, $890, \mathrm{~h}$. 604 , d.10\$2,i.108 3, n.1160,c.

To drawe a plague fore from the Heart, 8 I $5, c .8$ I $\mathrm{I}, 2$.

Good for the Heart-burning, $241,3.414,1.728$, a.1263, d,e.

Ta driye yenome and poifon from the Heare, $840, \mathrm{~b} .668$,b.

Good for infirasities of the Heart, looke Infirmities.

Good againft the paffion or paoting of the Heart, $845, c .469, b, c$. $542,1.654, f .1082, i .1390, c$.

To driue peftilential and corrupt aire from the $\mathrm{Hearr}, 847, a$.

To clenferhe Heart, 1116 ,

To make the Heart merrie, $845, c .887, c, 890$, d, h. 535, ,e, 548 ,i. 560 , f. 68 ,d.mir, h.r 390, c.

Benefisiall to the Heart, 848,g.548, i. $560, f, 966, a, 1186$, a.

Againft fwelling about the Heart, 318 ,a.

Torefrefh or reioice the Heart, 868 , d.556,b.654,a.

To take away $\mathrm{g}$ cate of the face, 845 , f.

To eake away the Heare of burnings and fcaldings, 1277 ,a.

To abate the intemperate Heate of the raines, $1243, \mathrm{f}$,

To guench the fieric Heate of the eies, $1227, c$.

Tocoole the Heate of the intrailes, 1317,8 .

Good againtt the Heare of the breaft, lungs and bladder, 1333, a.

Torake away the burning Heate in wounds, 845,2 .

To alay the Heate of the blood, ir $45, b$.

To coole and temper the Heatc of the fundament and priuie partes, 232 ,c.

To cooles the Heate of burning vicers, $1208, \mathrm{~m}$.

To coole the Heate of the inflamed liuer, 66, r.9.9 I, d.32 $21,9.701$, a, I144,g.1145,b.

To mitigate all kindes of Heate, 108,2,

To take away the Heate of fealding by water or oile, $135, k$.

To heale the extreme Heate of the mouth, I $150, b$.

To ceafe the burning Heace of the fones, $217, \mathrm{~b}$.

To alay the extreme Heate of the kidneies and bladder, 702,2 .

To refrelh or increale inward and naturall Heare, $732, \mathrm{e.735}, \mathrm{b}$.

Totake away the Heate of inflammations, 581, c. 1238 , c.1 277, a.

To quench the Heate of hot fwellings, $1207, \mathrm{e}$.

Good againft the burning Heare of the mouth and almonds of the throre, $845,2.1091$, a. 1120 ,d.

To mitigate or coole the extreme Heate of the inward partes,

$768,2,471,2.7 \circ 1,3.1317, \mathrm{~g}$.

To alay extremitue of Heate in burning feuers, $1082,5 \cdot 1083, \mathrm{~h}$. $1232, b_{3}$

To alay the feruent Heate of the skin, 178 , h.

To slay and take away the Heate of vrine, I 149 , b.

To temper the fharpe and foruent Heate of choler, 768 ,2. fee Choler.

To alay the Heate of the ftomacke, $845, b_{3} 32 \mathrm{r}, \mathrm{b} .419, \mathrm{c} .728, \mathrm{a}, \mathrm{b}$. II 20 , d.1144,g.1 144, d. $3224, \mathrm{~g}$.

Toalay or take away vehement Heate in agues, 509 ,f. 108, , h. 1232, b. $1368,9.1383, \mathrm{~d}$.

Good f.r the bectioue feuer, which is a confumption, 169 ,a.

To heale mouldic and kibed toeleg, 42 , d. $178, \mathrm{~d} .424,2$,

Good for the chaps and childblanes of the Hecies, 137 ,

A remedie againft the venemous qualitic of 19 emloctes, 542,0 . 572, f. 938 , i. $94 \mathrm{I}, \mathrm{b}$.

To open the li)emonthotee, 54, d, 41 0, b.695,g.

To flop the auermuch flowing of the Hemorrhoides, $66 \mathrm{I}$, is $858,3.962$, d.109I, b. I190,k.12:7, b.

Tocure the Hemorrhoides, 291, e. 849, g. 63 o,d, g, , $6600,2.1235, d$. I292, C.

Good againft the paines of the Hemort hoides, $934, a$.

Good againt fwelling of the Hemorthoides, 580 , 3.
To ceafe the bleeding of the Hen orrhoides, $4 \mathbf{1} 1, \mathbf{i}$.

Good to annoint the Hemorrboide vaines with, $580, c$.

To prouoke the Hemorrhoides to bleede, $\mathrm{I} 35, \mathrm{~d} .4 \mathrm{rr}, \mathrm{i} .695, \mathrm{~g}$.

$702, b$.

A counter poifon for thentane, 572 ,g.

Good to fatten thens, 78 , a.

To caufe Hens to lay egs pientifully, $573, \mathrm{e}, 106 \mathrm{~kg}, \mathrm{~h}$

To cure bernies, $514,0.577$, , looke Ruptures.

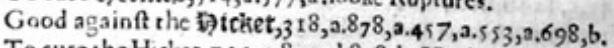

To cure the Hicket, $744, a .872, d .878, b .880, b .457, a .979, a$.

To cure all aches in the ilipgs, $433, \mathrm{e}$.

To affwage and cure the goutc of the Hips, 854,6 .

To aftwage the paine of the Hip called Sciatica, 188, e.190, h.210,2. $400,6,665$, i.722,es.

To helpe olde aches in the Hip', $219,6.433, e$,

For Fitfing of the eares, 1172 2.i.

To take away Foarfenes, $35,2.178, c .288, n .654, b .729$, d.1121, i. $1149,3.1342,3$.

To remedie the Hoarfenes that com meth fuddenly, $854, \mathrm{~d}$.

To lay open Doles of Fiftulaes or iffues, $1235, \mathrm{n}$.

For ftinging of bomets, ro 75,0 .

To refreth a wearied 1902 fe \& make him trauell the better, $362, c$.

A gainft ache and paine of the Gucklebane, $54, \mathrm{~h} 190, \mathrm{~h} .749, \mathrm{c}$.

198, b.219,c.854,b.318, a.520,3.551,b.557, h. 578, c. $6.49,5.706, c$. 722,e.996,e.10 17, g. 1073 , d. 1303, b,c.

To purge by fiege and vrine cholerike liqum $2_{2}, 463$, d.930,g.

To ftay Humors from flowing into the cies, $502,6.284, c .1390, \mathrm{~b}$.

To make rhinne, thicke, grolic, and tough flimic Humors, $47, c$

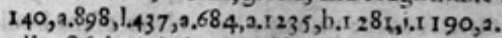

To digeft falt and pituitous Humors, $930, \mathrm{~g}$.

To purge flegmatile and cholerike Humors by vomite and fiege $689, \mathrm{~s}, \mathrm{s.7} 66 \mathrm{~b}, \mathrm{a}, \mathrm{f} .770, \mathrm{~m} .776, \mathrm{a}, 779, \mathrm{~b} .26 \mathrm{z}, \mathrm{a} .689, \mathrm{c} .973, \mathrm{ce}$.

Topurge aduft and cholerike Humors, $471, a .1116,1.930, \mathrm{~g}$.

To purge by fiege tough flegmatike and waterifh Humors, 116,2 . $766, f_{2} 62,0.334,2.429,0.460, c_{0} 724,3.1133, c, d, c .1218, d .1219$, $0.1235,1,1238,0$.

To digeft and confume groffe Hamors, 53, b.140,a. 949, h.647,?. 849 , h.

To drawe foorth by floole blacke and filthie Humors, $542, e$.

To concot and bring vp rawe Humors that ficke in the cheff, 124, b.13 8,b.r $95, c .571$, a. 572 , d.984,c.

To purge waterith Humors mightily, $47, b .116,0.273,3.321,2$. $350, a \cdot 467, a$. $540, a, 638, b \cdot 690, a \cdot 718,7,7=0, b \cdot 722, a \cdot 1086,2$. 1133, e, v. $1217,2.1235$, f.1259,g.

To cut thicke, tough and clammie Humors, $137,0.138$, e. 140,2 . $951,2.532, a, 647, a .686, b .1025, b .868, d, 1025, b$.

To voide by vrine cholerike and waterifh Humors, 732 , e. $1133, c$

To purge thicke and groffe Humors by vrine and fiege, $749, \mathrm{c}$. $930, \mathrm{~g} \cdot 334,0.467,3$.

To conco $t$ or wafte away rawe Humnrs, $747, a .893, b .843, b$. $617, g, h .729$, e.r121, k.1223,g. 732.1 .878 , d.868, d.troo,i.

To cut and raife thicke and tough Humors of the chef, I95,e. I027,c.

To ingender naughtie Humors, $1259 . \mathrm{c}$.

To purge flegnatike, cholerike and melancholike Hamors downwards, $827,3.460$, f, h. 463, c. 1114, a.

To diffolue groffe Humors, $1327, \mathrm{c}$.

To purge naughtic corrupt Huwors, $3 \mathrm{r} 8, \mathrm{~g}, \mathrm{k} \cdot 93 \mathrm{0}, \mathrm{g} \cdot 357,9 \cdot 437, \mathrm{~b}$. $445, e .460, c .470, c .647, a .10: 7, b .410,9.463,9.930, c$.

Tobring foorth by vomite grofic and rough Humors, 578,6 .

To purge by fiege tough and Alimie Humors, 899, e. $357,3.949$, th. $467,3.1018, ?$.

To purge cold flegmaticke Humors, $410, \mathrm{~g}$.

To purge by floole fharpe hot cholerike Humors, 460, c. 4 10, g. 467, b.1155,a.1182,a.

To drawe foorth gently by ftoole crude and rawe Humors, int5,e.

To purge meiancholike Humors, 160, d.

To confume colde and flegmatike Humors, $899, m$.

To drive foorth by vrine and fiege hot, cholerike, burnt, and hurtfull Humors, 930 , g.

To expell thicke, tough, and clammic Humors out of the cheft and lungs, 684.g.686, .1037 , h.10 $51,0.1154$, ,.

To digeft rawe Humots of the cheft and lungs, 729, d.730,i.

Furts, 135.138 .

To cure Hurts, $435, \mathrm{c}$.

Good for fmall Hurts, $, 919, b$. 


\section{ATable of the Nature, Vertwe, and Dangers.}

Good againft $\mathbf{k}$ wfenzs of the finewes, $770,0.63^{3}, \mathrm{a}$.

To faie the Looienes of the belly, $\sqrt{3} 337, \mathrm{c}$. looke Itop the be llly.

Good for Loofenes of the ioints, 649 ,

Good to be put in 1 ottions for cankers and fores in childrens mouthes, 1209 , a.

Good to be put in Lotions for the priuic parts, \& fealdings with women, 1209 , 2.

An cxcelient Lotion or wathing water to healc fores in the mouth and priuie parts of man or woman, to faftes teeth, $1092,1$.

To caulc L one, $696, \mathrm{~m}$

To inake onc il owdie, 1328 , ,

A medicine againtt the Lowfic euill, $357, \mathrm{c}$.

To diffolue knottic or hard i umps in any part of the body $, 42, c$. $68, a .72,0.747, b .860, e .899$, h. $566, b .714, b$.

To mollific and difperic hard Lumps, 68, a.

To wante and ro ake fubtill hard Lumps, 96,6 .

To cure a In unatilse perfon, $8 \mathrm{II}, \mathrm{b}$.

To quiet the Lunatike, $654, \mathrm{~d}, \mathrm{~s}$.

To make fmooth the roughnes of the 7 angs,35,a,729,d.

Good for the Lungs, $1256, c, d, 1328$, b.

To open or remooue obftuctions or ftoppings of the Lungs, $1=4, b .770, \hat{f} .370, f .878, f_{4}-470, c .1076, q .1248, c$.

Toclenfe the Lungs, $459, \mathrm{~b}, 546, \mathrm{~b}, 563,0.578, \mathrm{~b} .586, \mathrm{a} .649, \mathrm{~b}$ $984, c, 1116, t, 1=57,6$.

Afpecisllicrucdic for confumption of the Lungs, I24,c. 79 ऽ, d, 563, J.98 $97,2.1174$, , $.1223, r$.

Tohelpe wheafing of the Langs, 557, d. $563, c$.

To helpe the Luings that are ineamed, $765 \cdot 504,9.318,6.465, b$. $572, c .701, a .1333,3$.

A remedie for the ituffing of the Lungs, $770, f .869, c .527, c .542, c$. $698, b .1239, b$.

Againit the tilcers of the Lungs, $504,2.505, c .563, b .661, f 663,2$. $665, f$.

Good again the courh of the Lungs, 5 t9, c. $13^{88,3}$.

To clenie the pipes of the Lungs, 138 , b.7 29, , C.984, e.1 120,2

To concott raw humors of the Lungs, 984 , k.

Good for the Lungs oppreffed with rawe and colde humors, 57, f. $908, c$.

Hurttull to the Lungs, 1050,1 .

To procure or ftir vp bodily iuft, $95, a .97$, c.124,e.133, b. 15 ५,d. I5 8,b.175,a. $754,2.193$, c. 195, e.883,c. $295,2.274,4.868$, c.

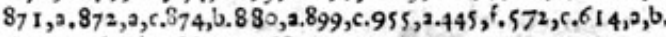
627,c. 629,b. 665 ,c. 963, 3. $977,0.993,2, c .1024,3.1047, a$. IO99,c. 1174 ,d. 1246 , c. 1248 ,c. I 25 1, d. 1254 , f. I 256.6 , c. I289,h.1334f.

To reftraine bodily Luft, 158,b.772,a. 4r, , c.1 202,0,

Io ftay Lufing of women with childe, $7=8,2, b .733,5$.

To caic all Antrationss; 4 , b.

\section{M}

TO bring $\$ 9$ aDnes, 270,2

A medicine again 2 Madnes, 318 , f.457,9.

To take away Madnes, procceding of melancholie, or of the fpleene, $4_{3}^{6}, \mathrm{~b}$.

To cure the biting of Mad dogs, 26, 2.60, a.looke biting.

To kili $\$$ hagots, $1186, \mathrm{~g}$.

To cure Q9ardeng of the greene fickncs, and fende againe the

liucly colour unto their faces, $201, \mathrm{~b}$.

What doth caule a faire and well coloured Maide looke like a tailowe cake, 69 , c,

Good for yoong Maidens that want their courfes, $558,1.630, e$.

To keepe downe the dugs and paps of $\mathrm{Ma}$ idcus, 803 , a.

To make a 9 than well coloured, $124, e$.

To make a Man gratious in the fight of people, $440, b$.

Tokcepe a waifaring Man ftom wearitomnes, 946,4 .

A purgation good for a furious and niad Man,827,3.

Deadly to Man, $8,8, b, 822,0$.

Tomake a Man barren, 744, b.

To caufe a man to looke yoong, $1116, r$.

Tokill a man in fuch fort as though he feemed to dic laughing, 815.

To caufe men to beget $\$$ )ale chillien, 158, a.

To eafe thofe that be $\AA$ S angie, $60, f$.

To take away or cure Mangiaes, 188, h, $854,1.312$, c. 3 i4, $, 399, b$. $408, d .429 . c .650,1$.
Good againft Mangines of the $h$ ands and legr, 491,6 ,

To cure Mangines of the bodic, 1281 , $m$.

An efp:ciall reanedic againft, $281, \mathrm{~m}$.

To take away blew and beck 80 , 833 , f. $938, i .720, c .722, b, 1252, e$.

Torake away Miakes iemainin

6.) $6,1,1276, \mathrm{~g}$.

To take away blacke and blew Marke, that are gouten by Rtipes

or tals, $759, \mathrm{c} .854,2.882, c, 540,6,71$, that are gotten by ftripes

To caufe Markes in woundea $3.725,0.1252,6$.

$1108, \mathrm{~b}$.

To take away Markes out of the skin, $8 n, b$.

To take away blacke Markes of the face, $720, \mathrm{e}$.

To take away blacke and blew Markes of the skin, 722,e, 1044,e. Good for the $\mathbb{A}$ ifatrix, 1013 ,

Forfwelling of the Matrix, $1027,4,1035,2$.

To beipe the coldnes and flopping of th: Matrix, 30,d, 527,e,f. $545,9.1027, \mathrm{~h} .1055,3$

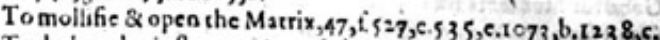

To helpe the inflammation of the Matrix, $40, c, 29,1,419, c$. $445,0.1202, \mathrm{~d}$.

To cure the lutfocation and firangling of the Matrix, 892,8 . $893,3.5=7,6, f$.

Tobring the Matrix into hir rigigt place, $\mathrm{IC7}_{3}, \mathrm{~b}, 8_{92}, \mathrm{a}$.

Toclenfe the natrix,91, $, 28,2, m_{2}, 49,6,698,3$,

Toclofe the Matrix, 524, ?

Gond to foften the hardnes of the Matrix, $147, \mathrm{~d}, 149, \mathrm{C}, 445, n$. 524, a,b. 527, e.1108,d.

To helpe the ltr rangling and prines of the Mlatrix, $833, f .879, \mathrm{e}$. $341,0.945, c .445$, n. $553,2.597$, d. 1202 ,d.

To renoeuc hot iwelings of the Mauix, 149, a

Good for an impoftume of the Matrix,10:7, h,

To curc fores of the Matrix,75 $1, b$.

Towafte and confume, bregke or fearter away the windines of the Matrix, $795,3.849$, h. $887, \mathrm{~d}, 908$.

To cure the vicers of the Matrix,29r, $1,1027, h_{1}$

To cure the fretting a and vicerations of the Matrix,419,e.

To purge the Matrix or wombe after childe bearing, 698 , a. looke Women or Secondine.

To fcoure our Alegmatuke $\$$ atter through the guts, $856, \mathrm{C}$.

To raile rotten Mottet out of the cheit and lungs, $1296, \mathrm{c}$.

Tocaufe peftilential Matuer to breath foorthby she pores of the skin, 81 s, b.

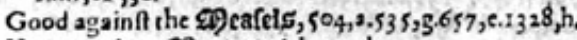

How to colour $\mathscr{Q P}$ cates with,124,b.

A pleafant Meate, $596,3.614,3$

Guod for fuch as cannot brooke their Meat, 542,2 .

A fingular 2 $529,0.854, c, 257, \mathrm{c} \cdot 3$ I 4 ,f. 9 I 2, b, c. $919, c \cdot 936,2-411, g .422$, d. 573, d. $575, a .657, c .7 c 6$, d.1 I In,c,

A good Medicine to clenfe the che it and lungs, $1174, e$.

A familar Medicine for all ages and fexes, $1115, \mathrm{n}$.

To defend from the hurc of poifonous Medicincs,946,d.

Againft deadly Medicines, 712 ,b.

A conuenient \& holfome Medicine for the fromack, $4 \mathrm{ro}^{2}, 4 \mathrm{rr}, \mathrm{s}$

A Medicine that may fafcly be giuen to allweake people of what age or fexefoeuer they be, 1243,2 .

A fingular and prooued Medicine againft the ftone in theblad. der, $572, i$.

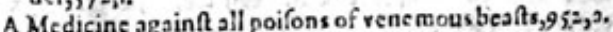

A purging Medicine in many ëi cafes, fit for all ages, $1114, b, c, d$

An excellent purging Medicine for dainric people, $1 \mathrm{~m} / 5, \mathrm{l}, \mathrm{m}$.

A Medicine good for chilJren and women withchilde, 318,1 . 1243,2 .

An anarous Medicine, $696, m$.

A fingular Medicine again fit furf́rit, $703,1848,9$

A good Medicine for thofe that are burften,76:,b.29r,3.

A good Medicine againtt cankers, $745, f .68$, d.

A good Medicine againtt cankers,745, 1,68, ,

A Medicine for feauer quartaines, 854, ,h, 1009,c.

A fingular Medicine for the ftone in the raines, 572,i.

A Medicine againit fcaldings, in the privic parts of $m$ in or wo* man, $745, \mathrm{f}$.

A purging Medicine for the fomacke,4 10,2 .

A purging Medicineform, $770, \mathrm{~h} .287,2.288, \mathrm{r} .460, \mathrm{~g} .5 \mathrm{r} 2, \mathrm{c}$.

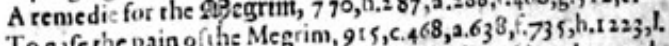

To esfe the pain of the Megrim, $915, c .468,0.63^{8}, 7.735$, h. 1223 ,

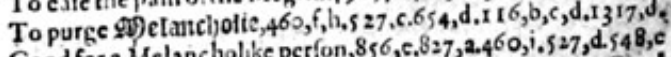

Good for a Melancholike perfon, $856, c .827,2.460,1.527,0.548, c$ 


\section{$1 T$ able of the Nature, Vertue and Dangers.}

To ftay or ftop all Iffucs of blood, 505,b. 790,g. 860, b. $840, \mathrm{e}$

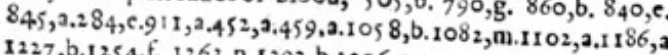
1227, b. 1254, f. 1263, n, 1292, b.1 $1306, c$.

To ftop the extraordinaric lffues of blood 284 ,e. $44^{11}$, g. 860, b. Good againft the inordinate fluxe of womens Iffues, 284, e,r 1058 ,
c. $126_{3}, \mathrm{n}$.

To ftop all Iffues of blood in man or wom an, $1263, \mathrm{n}, 1,1,4, \mathrm{~g}$.

To ftop white iffues of women, 1292, b.looke Whites.

To helpe the 3 tching in the corners of the cies, $410, f$.

To take away the Itching of the eies, 887, d. d 706, e.1 $343, \mathrm{~b}$.

To cure the Itch of the bodie, $128 \mathrm{r}, \mathrm{m}$.

Good againft or to helpe the Itch, 312,c. 542, d. $650,1.676,2$. 705 , b. 1052 , l.1 116, ,. 1152,3 .

To cure all maner of Itch, 314 , f.r 0 S $_{2}, \mathrm{l}$.

To cure the feuruie Itch, $399, \mathrm{~b}$.

Toingender evill Zuice,199, 2. roso,g.

To ingender a groffe, cold, and flegmatike Iuice, $\mathrm{r} 28 \mathrm{r}, \mathrm{h}$.

Toingender cold and rawe luice, $728, \mathrm{~g}$.

\section{$\mathbf{K}$}

7 O take away the inflammation of the trernels vnder the cares, iawes, necke, armeholes, and flankcs, $568,2, b$.

Good againft hardKernels, $580, a$.

Good for Kernels in the flankes, 1207,e.

To wafte away Kernels inder the eares, ro $37, \mathrm{~m}$.

To confume or wafte away hard fwellings of the Kernels, 1064 . 1328 , g.looke hard fwellings.

To diffolue Kernels in the throate, $293,6,1158,6$.

Towafte away hard Kernels,415,a,560,i,964,b,r064,a,b.

Good againft latbers, 665 , i.1 $051, q$.

To heale Kibed heeles, 42 , d.r 78 ,d.287, i.424, $1 . \operatorname{tos}_{2}, 1.1387$, ,b.

To open ftoppings of the zkioneics, $895, a .318, a, 869, a .34 \mathrm{r}, \mathrm{d}$. 428, b. $444 . c .463, a$, d. 535, e. 963 , i.1 1 133, b.1329,0.

To clenie the Kidneies, $502, d .832, b .318,2.693,2.1133$,b. 1182 , 2. I190,2.I 248 , d.

To helpe obftructions of the Kidneies, $3, c_{-73} 8, f .888,9: 318$, 3. $868, d, 869, b .878, f .428, b$.

Good for the vlcers of the Kidneies,33 r, b.709, g.9 58,d.

To ftrengthen the Kidneies, $1082, k$.

Good for the Kidneies, 23,3.504,2.88, , b.871, 2.907,c.955, 2.4 19, c 729, d.1243, c.1 $318, a, 1333$,b.

To breake and driue forth the ftone in the Kidncies, 85, d. $349, a_{*}$ c,455,2.571, 2.578, c.1066,b.looke ftone.

Good for thofe that are troubled with the ftone of the Kidneies, $775, c .845, \mathrm{~d}, 638,2.1048, \mathrm{c}$.

To helpe exulcerations of theKidncies, $\mathrm{SO} 2, \mathrm{~b}, 318, \mathrm{a}, 34 \mathrm{r}$, Ir $21, k$.

Good for or to aflivage the paipe in the Kidneies, $832,6,287, a$. $318, a .877, c, d, 349, a, c \cdot 724, b, 984, k, 1035, c, 1073, c, 1133, m$. r2, 8 , d, $1255, \mathrm{~b}$.

To helpe infl amm ation of the Kidneies, $3 \times$ 8, $.702,3$.

Good for the dugs of kine that haue beene bitten by a venemous worme, or are chapr, 646,0 .

To foften the bings cuill, $47,0.54, c .65$, c.293,c.1342,a.

To confume and wafte away the King is euill, $415, a .568,7.984$,d. ro 37, , I I 33 , l.t 180 , d.1 328, g.

To diffolue and cure the Kings evill, 749 ,e. $217, b .854, a .859, e$.

- 860, c.293,c.495,0.560.i,638, h 665, d.677,e.

To o mend the lothfome colour of the Kings euill, $, 6_{3}, 1$.

To kill or driue away itsnat, fec Gnats.

Good for weeping wounds of the ka necs, $509, b$.

For 3 nitting of bones fingular good, $759, \mathrm{~d}, \mathrm{f}, \mathrm{g}$.

To take away tznob, $4,498, d$.

To confume or make fubrile hard Xsnot\$, 96, b.r 90, i. $397, b$.

Towafte or confume and heale hard Knots in or abourthe fundament, $566, b .1 \circ 91$, b.

\section{L}

Cod for I amenefte, 10 16,a. To caufe Lankenefte, 964 ,d. Good againft the in afke, $1317, b$.

Good againtt the Laske proceeding of raw humors, $3 \mathrm{I}_{4}, \mathrm{~d} .318,2$. Good for thole that are troubled with a hot Laske, 412, c. $1+45, c$.

To ftay or ftop the Laske, 32,a.65,d, 72, g.79,9. I02,b.505,b

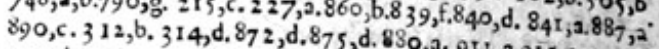
323 ,b. 4 1 9 , g. 433 , a. 545 , b. 549, b. 630, b. 911 , a. $915, a .321$, f.

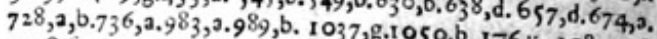

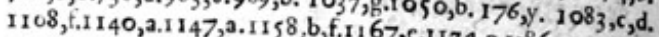
I 227 ,c. 1244 , a, b. 1256, b,c. $1259, c, 1263$, 1283.b. 1292,a. 1306,c. 1309 ,c. 1363 , P. I264, b. $1270, a$. 1375 ,a.

A remedie for all kinds of Laskes, 31 8, k.ro 50, b.r $227, c$.

Good for a L aske of long continuance, $728, \mathrm{~d}$.

To ftay the Laske in yoong chuldren, $970, c$.

Good for them that would be il eane, or co fat the leane, $\mathrm{I}_{23} 5, \mathrm{c}$ $1289, g$.

To procure inecherie, 95,2, fee Bodilie luft.

Good for the infla wmation of the ilegs, $676,6.709$,f. To take away fwelling of the Legs gotren by colde or long ftan-
ding, 62,a.

Good againft mangines of the Legs, $49 \mathrm{r}, \mathrm{b}$

To helpe the old aches and paine in the Legs, 219,6 .

To take away fwellings of the Legs, $491, a .497,6.409, f .1347$, d

To cure old and filthic vle ers of the Legs, $289, \mathrm{~b}$.

Toheale fcabbed Legs, $435, c .721 . k_{1}, 1278, b$.

Tokill ileoparog,755,2.

Good for fuch as haue the Ilethargie, $190, \mathrm{~g} .856, \mathrm{c} .897, \mathrm{~h}$. $1016, \mathrm{c}, 1202, \mathrm{~d}$

To helpe the Lethargie, $457,2.458, \mathrm{~d}$.

A good purgation for I eaperg, $827, a$.

To ingender the Acp2ofe, $1334, \mathrm{c}$.

To eafe the Leprofic, 306, e.I 172, p.

To take away Leprofies, $827, e, 463, b, 557$, i. $558, k-736, d$.

Good againft the Lepric, $657,2.720,9.1328, h .1361, a$.

To caufe Leprie, I050,g.

To heale the Lepric, $743,2.408, \mathrm{~d}, 460, \mathrm{~g} .728, \mathrm{c}$.

Good again I Ilentiles, $1328, \mathrm{~h}$, To take away Lentiles in the face, 765 , h. I I5, h. 855, c. 288 ,c.
293, c.1 133, r.1 328 , h.

Tokill Itce, $522,2.709$, d. I 172 , n.t 195, b.1 307,b.

To driue Lice out of the beord, head, and all other parts of the bodie, $399, \mathrm{~b}$.

To deftroy Lice in clothes or appareil, 399,e.

To beale Lichens (that is tetrers or ringwormes) in children or yoong Infants, 13 I $4, \mathrm{c}, 1376, \mathrm{~b}$

To preferue and prolong the ilife of man, $734,1,735,6$.

Tocure the burnings by llightning, $278,3.288, z$.

To clenfe the lkights of raw humors, $1248, c$.

To helpe Ilting burnt with 6ire, 987,3 .

To cure Lims out of ioinb, $987,2.1202$, f. fee members.

Good to bathe Lims out of ioint, 1227,f.

For chaps of the Ilipg, I I 52,3 .

Enimic to the llituer, 293,2,1017, h.

Good for the Liuer, 882, b. 318 , g, h. $966,2.1004 .2$.

To coole the hot burning of the Liuer, $222,2.845, f .941, d .321,6$. 1009 , d. 1243 , b.looke inflammation.

Good againft the ftoppings of the Liuer, $124, e .738, b .765$, c. 832, b. 840, f. 843, b. $689, c .279,0.318, a .868, d .936, b .348, b$. . $352, c .428, b .575, a .689, c .977$, b.100 $4, a, c .1341, d, c$.

Tohelpe obftructions of the Liuer, $3, d .279, a, 318, a .930, b, e$ $936,0.93^{8}, c .422$,a. $437, a .463,2.507,2.578, b .695, c .706, d$. ro04,c.1202,b. I 257, k.1341.d,c.

Againft paine of the Liuer, $57,2.1073$, c. 1300.2.

To coole the heate of the inflamed Liuer, $66, c .845$, f.3 2 r , b.457, $b$ 512, , $702, \mathrm{k}, 1009, \mathrm{~d}$.

To mollifie and take away the hard fwellings of the Liuer. $188, c$.

To ftrengthen the Liver, $938, \mathrm{c} .507,2.1082, \mathrm{k}, 183, \mathrm{n} .1352, \mathrm{3}$. $1354, \mathrm{~b}$.

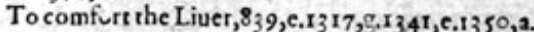

To fcoure or clenfe the Liver, 1044 , C.I 133 , b.I1 $16, x .1190, a$.

Tor ake away the feeblenes of the Liuer, .930, e. 1033, 2. looke Weaknes.

To ft aie or repreffe the wafting of the Liuer, $348, b$.

Good for thofe that haue euill livers, 35 2,b. $576,2, c$, I1 $_{7} 8, \mathrm{~d}$.

To helpe them that haue a weake and colde Liuer, $524,6,1025, \mathrm{~b}$.

Good for the Liuer-ficke, reoo,b.

A good medicine againft I oathing of meate, 848, g. $1207, c$. $1223, \mathrm{~g}$.

To helpe the fore and pained 1 ll oin $59,1073, \mathrm{c}$.

To ft aic the llonging of women with childe, 728, a.t. $733, \mathrm{~g}$ 


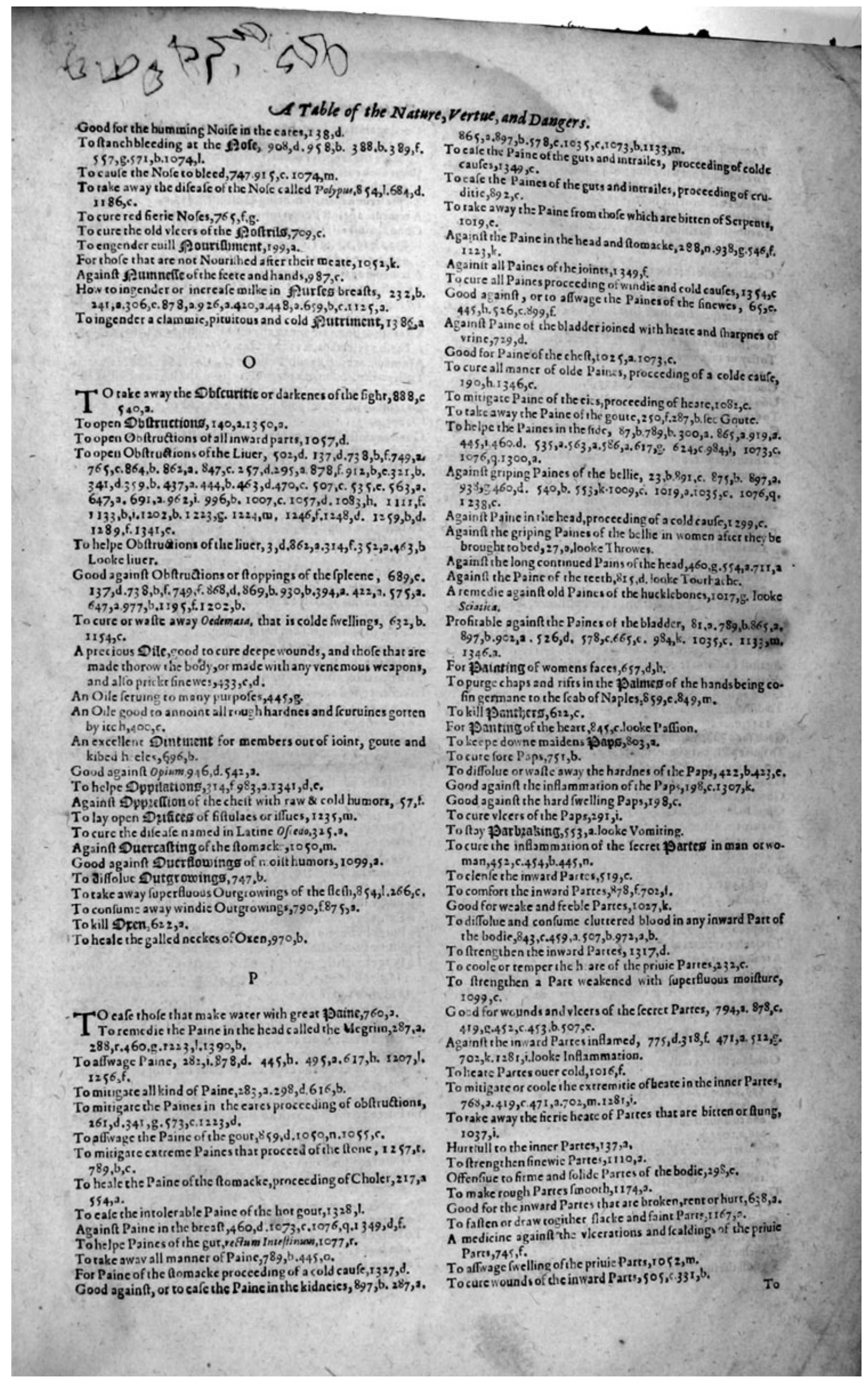




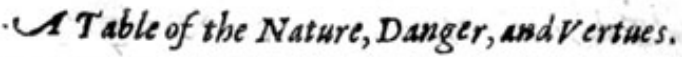

Good to drive away Melancholie, $654, c .840,5.560$,a, d. I 116 .f.

To purge Melancholike humors by ftoole, $827, a$. $460, f_{2}, \mathrm{~h} .46_{3}, \mathrm{c}$. $527, \mathrm{~d} .546, \mathrm{c}$.

Good tor thole that are troubled with Melancholie, 8:7, 2.460,d s27,d.

To hrelpe any difeafe of Melancholie, $460, \mathrm{~g}$.

x The $\$$ igclilote plaifter, ro 35,b.

To fwage the paine and take away the fwelling and inflammation of $\mathscr{M}$ embers vexed with the gout, $849, \mathrm{r}$.

To helpe or cale all Members out of ioint, $34, b .854, c .63^{8}$,a. 649, h.728,e. 973 , d.1202,f.

To take away the paine and inflammation of Members out of ioint, and firmely to knit the ioint,759, d.

Todry vp and heale moift and maligne vicers of the priuy $\mathrm{Mem}$ bers, $3 \circ, \mathrm{f}$.

To rake away tumors and fwellings that happen to Members whofe bones haue been broken or out of ioint, $759, \mathrm{~g}$.

Good for Members torne, rent and bruifed, 507,2 .

Good for a blacke and bruiled Member, declining to mortifica. tion, $6 \mathrm{r} 9, \mathrm{f}$.

To take away the fhaking or trembling of the M:mbers, 624,b.

Towarme colde Members, Io76,v.

Toftrengthen weake members, $116 \mathrm{r}, 2.1346, \mathrm{~d}$.

Tokeepe wounded Members ftom inflammation and rankling, or being rankled to take away the fame, $445 ; 0$.

To cure the apoftemes and tumors of the priuy Members, 147,6 .

Tohelpe Members fubictt to the palfie, $469 ; b, c$.

Toeafe membersthrunke vp, $49 \mathrm{I}, 2$.

To ftrengthen and preferue the wcakned 99 emotic, 332, b.735, b $1009, b$.

To comfort Memoric, 537, c. I I I1, $=$.

To quicken the Memoric, 62, , b.1 1 10,2.

Toftop the ouermuchflowing of the 999 enfes, 9 13,a, 1144,d. II $47, \mathrm{a} . \mathrm{I}$ I 60, b. I $190, \mathrm{k} . \mathrm{I}_{3}^{89}, 3$.

To prouoke womens Menles, 72, e. $864,2.862, b .88, g, 926, a$. $564,0.962$, f. 996, c. 1000, b. 1044 , d. 1184, g. 1194 ,a. II $95, b$. I 202 , d. I 219 , a.I 223. g. 1239 , b.I 257, k.1 349 , b.

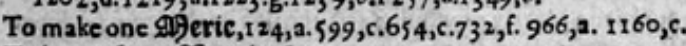

To keepe from 9 ) errigals, $1202, \mathrm{~g}$

Good againft, or to cure Merrigals, $287, \mathrm{i} .1178,2.13^{8} 7, \mathrm{~b}$.

To kill פ̂pice, 357, , .

To increafe or caufe much 9 illse in womens breafts that giue facke, 178, b.1 85, i. 232, b. $24 \mathrm{r}, 0.306$, e. $877, \mathrm{~b}, \mathrm{~d} .878,2.880,2$. $926,2.420,0.44^{8}, 2.659, b .1062,2.1125,2, c .1174, d$.

To cruddle Milke, 1007 , $b$.

To drie vp Milke, $548,2,1076, \mathrm{r}$.

Not to fuffer Milke to cruddle or waxe fower in the ftonacke, $553, f$.

To procure Milke in cattle, $1058,0.1061,0.1062,3$.

To helpe the 9 Alt if it be wafted, 30 or, $f$.

To cure the hardnes of the Milt, I95, c.395, a.699, b.970,c.ro27,g $1327, d$.

To mollifie and take away haróc fwellings of the Milt, $-188, \mathrm{c}$. $897,3$.

To fcoure the Milt, $10_{44}, c .1116, t .1133, b$.

Toopen the ftoppings of the Milt, $749,2.395,2.428, b .463,2, \mathrm{~d}$. $470, c .535, c .647, a, 962$, i.1111 , f.rit29, c.1133, b,i.

To helpe or cafe the paine of the Milr, $628, c .749$, c.3or, f.

To driuc away forrow and care of the âmbe, $560,5.654,2$. $655, c .732, f, I .1160, c$.

Good for thofe that are troubled in Minde, $460, \mathrm{~J}$.

To trouble the Minde, 270,3.

To exhilarate or glad the minde, $30, e, 654,2.1160, c$.

To in zender $29 \mathrm{trth}_{\mathrm{b}}, 116, \mathrm{t}$.

Againft the poifon of 9 Bittiet ono, 938 ,i.

Todraw wuch $\$$ Potture from the head and clenfe the braine, $399, \mathrm{~d}$.

To drie vp ouer much Moifture of the fomacke, $1207, \mathrm{c}$.

Ao drie vp ouer much Moifture of exceffue Mointure of the iawes, 1158 , f.

Tobring downe the $\$$ Sontbly courfe of women, $47, \mathrm{e} . \mathrm{s} \varepsilon, \mathrm{b}$. 945, c.410, h.542, h.

To ftop the Monthly courfe, $890, c .4$ ty, d.looke Flowers.

Tobringdowne the Monthly ficknes, 535,2 . looke for defired ficknes.

Toflop the inordinate coutfe of the Monthy ficknes, 748,6 , $78.4,3.389,0.114 .4, d .1264, c$.

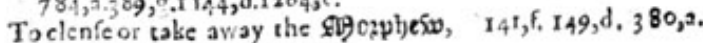
$674,6.998,0,1044, c .1223, d$.
Toclenfe or take away the white Morphew, $88, \mathrm{~h}, 417,2.684,6$.

To take away the blacke Morphew, $4^{17} 7, a .68_{4}, b$.

To clenfe the Morphew of the face, 94, b. 765, h. $227,6.674,6$. $721,1.1153$, h.

To fcoure away the Morphew of the skin, $759, \mathrm{~h} .827, \mathrm{e}, 674, \mathrm{~b}$.

Good for fuch as are troubled with the rifing of the 99 other

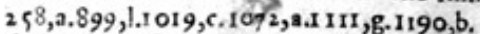

To helpe the fuffocation or ftrangling or ftopping of the Mo. ther, $856, c .892,2.878, c .833, f .946, c-470, c .527, c .546, g .560, b$, d. $668, b$.

To mollifie and foften the fores of the Mother,790,g.

To clenfe the Mother and helpe conceprion, $263, \mathrm{~b} .578$, i.

Good for the pallions or difeales of the Mother, $874, d .762, b$. $1223, k$.

To caufe the Mother fallen downe to returne to hir naturall place, 892,a.1158,g.

To mollifie the tumors and hard fwellings of the Mother, $787, \mathrm{c}$. 445, n. 527, c.1027, i.r1 80 ,c.

To helpe or eale the paines of the Mother, 391, c. $445, \mathrm{n} .833$, f. $878, c .946, c .5$ II $^{2}, 5.58$,d.1072,2,1111,g.

A prelent remedie for the fits ot the Mother, $287, b .946, r$.

To reviue thofe that be ftrangled withthe Mother, $897,1.560, \mathrm{~b}$.

To kill the chulde in the Mothers wombe, $195, e$.

To keepe garments from 20 otheating, or Mothes, 8.43 , d.93 8 ,e. $94 \mathrm{r}, \mathrm{f} .95 \mathrm{r}, \mathrm{c} .520, \mathrm{~b} .1026$, d. 1111 , l.1.3 $5 \mathrm{I}, \mathrm{c}$.

Tokill Mothes, 1186 ,g.

Againft the bitings of the $\$ 9$ oufe called a Shrew, r $4 \mathrm{r}, \mathrm{h} .93^{8}, \mathrm{i}$.

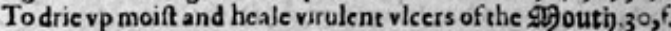

To cure all vlcers of the Muuth, 4 ro,f.

Good againft vleers and forenes of the Mouth, 919, c. $325, c$. 507, d. $581, f .624, c .677, c$.

Good to walh the Mouth withall, 1244 ,d.

To ftaie or cure putrified vleers of the Muith, $839, f, 1031,6$.

To ripen and breake impoftumes and tumours of the. Musth, 465,3 .

To cure cankers of the Mouth, 841 , c. 37 I, b. looke Cankers.

Good againft theinflammation and burning heat of the Mouth,

$845, a .323, c .370 ; 0.677, e .728,0.1091, a .1252, k, 13 c 6,3 . r_{3} 26, b$.

To caufe a good fent in the Mouth, $886, c$.

Toalfwage and confume hard apoltemes, tumors and corofide vicers in the Moutb, 37,b,c.

A medicinefor fore Mouthes in children or elder people, $745, \mathrm{f}$

To heale vlcers in the Mouth, $214, b, 841, c_{, 9} 63$, l. 1102 , b. I I 21 , h. $1207, e, 1209, a, 1210,3$.

To bring muchwater, or caufe flegine to run out of the Mouth, $86,4, b, 849$, m. $306, \mathrm{~b}, 619, \mathrm{~d}$.

An excellent 9 ) fores, $86_{3}, c$.

How to helpe the 9 Murraine and orher infirmities affititing cattle, $826.827 .569, \mathrm{~d}$.

To cure or helpe all 90 urs, $926, \mathrm{~d}$.

To helpe thofe that arcitrangled with cating of 99 atbogurns, 938 , h.572,f.1075,o.

$\mathbf{N}$

Oftrengthen and comfort 12 ature, 780,0 .

1 To increafe featurall feede, $13 \mathrm{I}, \mathrm{c.1} .78, \mathrm{~b} .754,0$.

Todeftroy Naturall feede, $744, b$.

To bring downe Naturall ficknes of women, 29, b looke ficknes.

Good againft paucis of children that ftande out ouerunucl. $897, d$.

To take away loofe fates on the fingers or toes, $729, \mathrm{~h}$.

To caufe rugged, corrupr, and ill fauoured nailes to fall off, 445, d. $66,0,736, c .8$ r s,a.r 170 ,d.r $180, c$.

To confume and driue away the fwelling of the $\beta_{2} e r i k e, 486, b$.

To heale the galled Neckes of cattle, $970, \mathrm{~b}$.

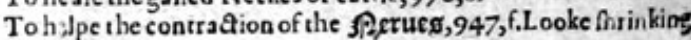
of Sinewes.

Good for fightwolyeales, $1207, \mathrm{c}$.

Good for flinging of $\rho$ ettics, $288, y \cdot 572, \mathrm{~b}$.

To prouoke or caufe ficiefing, $53,3,190$, f. $540,3,548, f .1219,6$.

Toclenfe the haire of 52 ito, $519,3.1027 . r$.

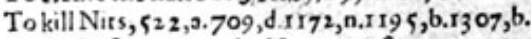

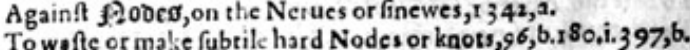

To helpe the $\{$ ofife in the eares, 1342 ,a.

Good 


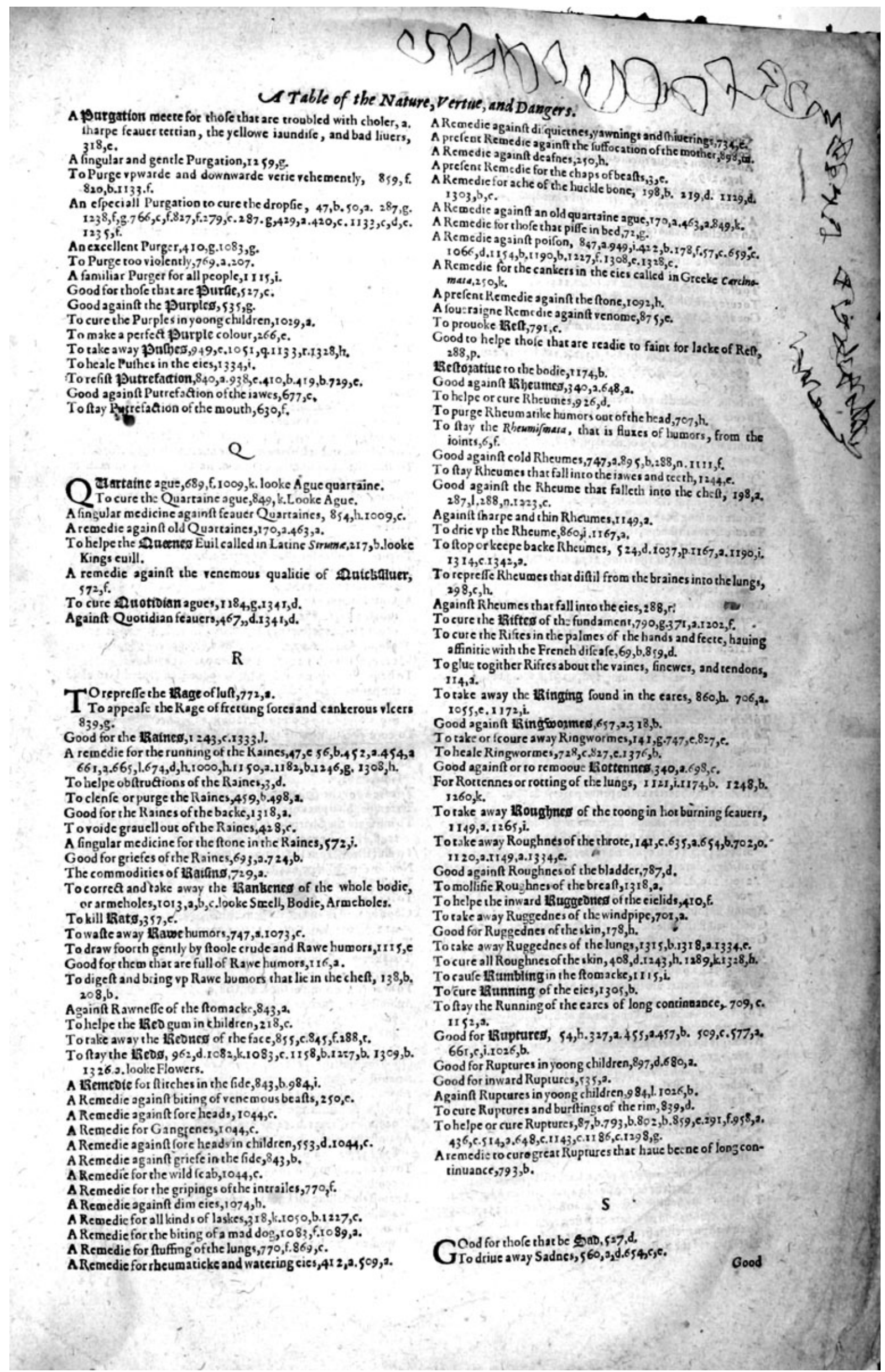




\section{AT able of the Natures, Vertue and Dangers.}

Toexpell the venome of the peftilence from the inwarde Parts, 8 i $5, c, 847,2$

To clenle and open the ftopped paffager, 46:,3.658, $3.1000,3$.

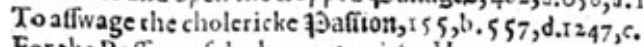

For the Paffion of the heart, 542 , i.fec Heart.

For the melancholicke Paffion, $1160, c$.

To cure the patsiffe, I 1 6,b. 897, c.374,b,569,b.624, d.1 346,e.

Good for the Paulfie, $749, f .897$, h. $899, f .469$, d. $619, f .638, a, c$. roi 6 ,a.

Good for thofe that are troubled with the fhaking Paulfie,249,a. $624, b$.

Tocaufe the Paulfie, 298,d.

Toreftore fpech to thofe that haue the dumbe Paulfie, 332,a. IIII,C.

Good for thofe that are raken with a dead Paulfie, 6r 9,a.

Toftay or take away the pearle of the cic, $563, \mathrm{c}, \mathrm{f} .695, \mathrm{~d}$. 1035 , d.

Good for fuch as arc portilb,3 29,b.

Good for thote that be 19 entuc, 527 ,d.

Todriue away Penfiuenes of the minde, $655, c$.

Good for old Feople that are dull and without courage, to increafe their luft and ftrength, 88, ,i.

To nourith and reftore aged People, and to amend the defets of nature in the younger, $\mathrm{I} C 00, c, d, e$.

To helpe the difeafe called in Grecke vermolusvia, 53,a.

To preferue from the $19 e f t i l e n c e$, and cxpellit out of thofe that arc infeQted, $125, \mathrm{i} .8_{40}, \mathrm{~b} .33 \mathrm{r}, \mathrm{c} .668, \mathrm{~b} .684, \mathrm{k} .1009$,e.

Tocaufe Peftilentiall matter to breath foorth by the pores of theskin, 8 rs, b.

To expell poifon of the Peftilence, and to caufe it to breake foorth in blifters in the outward part of the skin, $147, \mathrm{~h}, 8 \mathrm{II}, \mathrm{a}$, $8 \mathrm{r} 5, \mathrm{~b}$.

Singular againft the infeQtion of the Peftilence, 849,0. 919,2 $604, c .684, k . t 009, c .1075, p$.

Tobreake Peftilentiall carbuncles, or botches, 147 , c.1009,f.

To diffolue and cure Peftilentiall corbuncles, 849, b.1009, f.

Againtt Peftilent feauers, 88 2, b.668,b.684, k.10 $3 \mathrm{I}, \mathrm{b}$.

Againft 19 hlegme falling vpon the lungs, $895, b$.

Good againft poilegmons, 680 , b.

To diffolue Phlegmons of the breaft, lungs, and rough arterie, $1243, \mathrm{c}$.

Good for a pohpenticlse man, $856, c, 1202, d$.

To quier a Phrenticke mian, $654, d, c$.

To confume away Plymata, I $154, c$.

Good againft the Phrenfic, $357,3,638, c$.

Good to fatten 79 igeons, 78 , 3 .

Good to limne pidures with, 124,0 .

To cure the 19 ile $6,630, d, 5.669, c, d .728, c$.

To ftop the fluxe of the Piles, $858,2.288, x, 580,2$.

To open the Piles of the fundament, $4 \mathrm{ro}, \mathrm{b}, 580, \mathrm{c}$.

To cure the foilling off of the haire, $90, c, 190,15,949,5.674,6$ 696 , i. 98 s, c, ror 6, b. 1252,h.

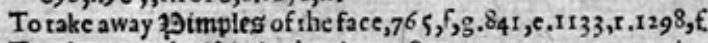

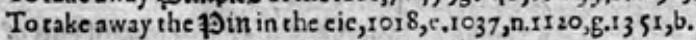

Toopen the 10ipes, $648, a, 934, c, I 120, a, b$.

Toclenfe the Pipes of the lungs, $138,6.984, c$

A remedie for thofe that 39 iffe in bed, $72, \mathrm{~g}$.

To helpe Piffing by drops, $57,0.902,0.444, c .452, d$. $1276 . c$.

Goud againft, or to flop Pifing ofblond, 215, c. $578, g \cdot 744, d$. 907, b. 34 2, b. $452, a .454, a .677$, f.r $026, c .1244,3, b .1375, b$.

To caufe one to Piffe freely, $888,0.89 \mathrm{I}, 0.895$, c. $578, \mathrm{c}$.

Good againft the hot Pifre, 498 ,?

To caufe haire to grow on bare and pild places, $985, r$,

Good for Places ous of ioini, 770,0 .

Good againft the 1Dlague, $8=0, c .847,2.88 z, 6.478,2.535,5$. $599, \mathbf{2 . 6 0 4 , e . 6 6 8 , b . 1 0 7 5 , p \text { . }}$

A preferuatiue to kecpe one from the infection of the Plageue, and to driuc it out if he be infected therewith, $125, \mathrm{i}, 847,2$. $996,3,1075, p$.

Singdlargood for a Plague fore, 3 i r, 3. S I $5, b .587, c .1009, f$.

Todrive the venome of the Plague from the hart and other vi. tall or foirituall parts, $8 \mathrm{r} 5, \mathrm{c} .663, \mathrm{~b}$.

Good for the 39leartife, 300,a.572,e. 635,a. 908,e. 1213,b. $1=56, c .1257, g$.

Good againft an old Pleurifie $\$ 54$, d.702, l. I I $21,1$.

A medieine for the Pleurifie, 318 , f.r or 9, c. 1073,3 .

To helpe the extremitie of the Plcurifie, $624, \mathrm{~g}$.

Againft the fmall pocks, $504,2.535,5.657$, e. $1044, c .1328, \mathrm{~b}$. Good ag ainft the French Pockes, $930, a .463, b .705, c .536, b$.
$1317, \mathrm{k}$.

To heale the French Pockes, 1004 , c.roog, k.

What doth eafe for a time the French Pockes, yet not perfic Alie cure them, 287,1 .

To preferue a man from being $\$$ ९oifoned, $557, \mathrm{c}$.

A remedie againft Poifon inwardlie taken, $4 \mathrm{I} 5, \mathrm{~b} .563, \mathrm{c}$.

Good againft all poifon, $787, b, 849,2.851,3.839, b .88_{2}, 2,287, k$, $899,1.329, a, b .33$ 1 , c.357,a.952,a. $540, a \cdot 537$, c.695,b. 698,b. $996,3.1009$, d.1 069, a, c.11s8, e.1190, e.1223, d.t 281 , f.

A remedie again 1 Poifon of ferpents, 29, c. $875 . e .95=, 2.578, \mathrm{~d}$. Againft deadly Poifons, 198, c.535, b.698.3.106 5, b.128 r, 0 .

To expell Poifon, $45, \mathrm{~b} .862, \mathrm{c} .847, \mathrm{~b} \cdot 3$ or $. e .875, \mathrm{e}, \mathrm{d}, 350, \mathrm{~b} .352, \mathrm{~J}$. 949, h, l.1 $252, \mathrm{~d}$.

To refift, or be an enimie to all colde Poifons, $\mathrm{r}_{4} 0, a, 862,6,820$, a. 847, b.735,c.1252,c.1 $28=, y \cdot 1342$, a.1 357,2 .

A remedie againft deadly Poifon,751,0.949, b. 542, h 1075, p.

Todraw the Poifon of a plague fore from the hare and other inward or vitall parts, 8 I $1, a .8$ is, $c$.

To refift or withft and poifon, $94 \mathrm{I}, \mathrm{b} .60_{3}, 2.649, \mathrm{c}, 677, \mathrm{~d} .684, \mathrm{k}$. Ic75,p.

Good againft all Poifons of venemous beafts,509,3.

Good againft the difeale Polypu, in the nofe, 323 , a,

To take away the difeafe called Polypu, in, the nofe, ${ }^{8} 54,1$. $6 \varepsilon_{4}, \mathrm{~d}, 1186, \mathrm{c}$.

A fingular Popmleon, $413, \mathrm{f}$.

To open the pooses, 617, g.

To helpe the $\$ 90 f e, 926$, d.

A q $_{2}$ eferuatue againfl a corropted or peftilent aire, $I_{4} \mathrm{I}, \mathrm{e}$. $1328, c$.

A Preferuatiue again $t$ bitings of al maner of wild beafts, $124^{8}, \mathrm{e}$.

A Preferuatiue againft the infeCtion of th plague, $1252, \mathrm{c}$.

A Preferuatiue againft all venome and poiton, $1328, c .597, \mathrm{e}$.

The $p_{2}$ eferuing of $G$ rapes a whole yeere, 728 , :.

The Por fit and difprofit of them, ibid.g.

To draw out 19 itckics, $54, \mathrm{~g}$.

To ftay the fpreading nature of Pterginas, $1292, \mathrm{~d}$.

To helpe thofe that be entrced into apjtificke, I $5, g$.

Excellent good againft the Ptificke, 795,c. $88_{3}, 5 \cdot 51_{4}, f_{.56}, 2$ 987, b.1 184, m. $12=3$, c.1 248 , b.

To cure the Prificlic, II 74 , b.

A poultis for all mancr of fwellings, 1035 ,a.

To cure Dunctures made wit h harp puinted we apon $9,288, z, 1$.

To farten qoullen, and ceufe thein to lay ftore of $4 g g e s, x<69, \mathrm{~h}$

To cure the poumples of the face or nole, $765, f, 5$.

To pourge choler and waterifh humors mightily, $47, b, 50,2$. $766,3.350, a .467, a .638, b .718, a .1235, b, f .1238$, s.

To Purge by fiege and vrine, $93^{8}, 3.720,2$.

To Purge choler and rough flegme by fiege, $53, \mathrm{~b}, 116,2.897,2$. $899, c .460, c .467,2.689, c .724,2.972,2.1218,2,1235, b$.

To purgethe Bellic, $410,{ }^{2} 73^{8}, 8.776,{ }^{\circ} .7 \$ 6, f .250, c, 252,0.314 .4$, f. $983,3.127$, c. $1182,7,1245$, f. 1235, b. 1259, g.1326, h.

To Purge the belly mightily, 779, b. $718.1235, b, f$.

To Purge by vrine mightily, $54,1.689, \mathrm{~d}$.

To Purge by fege, $934, \mathrm{~b} .724,0,1137, \mathrm{~b}, 1184, \mathrm{~d}$.

To Purge gentiy cholericke humors and flimie flegme, $1243,0$.

To Purgetoughflegmaticke and rawe waterifi humors by fiege, I $16, a .766$, f.820,a. 899, c. 410, g.460,c. $722,2.724, a$. ror 7 , hi $I_{1} 33, c, d, c .1238, a, f, g$.

To Purge tough, groffe, flegmaticke, and cholericke humors by vomite, $407,3.415, b .638, b 689,2, c, d$.

To Purge the head oi raw flegmaticke huinors, $x_{35}$, d.6 19 , d,fee Head.

To Purge by vrine and fiege fuch as haue the dropfie and iaundife, $279, c, d$.

To Purge vpward and downward, $170,0.287$,g.919, f.r 286 ,a.

To Purge thicke flegaricke and cholericke humors by foole and romite, 1287,2 .

To Purge by vrinc, $738, b$.

To Purgegently, 898, l.

To Purgecholer, flegme, and waterith humors by fiege and vomit, $766,0.1 \mathrm{I} 33, \mathrm{t}$

To Purge melancliolie, 973,9 .

To Purge groffe flegme and cholericke humors, $770, \mathrm{~m} .689 . \mathrm{c}$.

To Purge downwards flegme, choler, and melancholie, 827,a. 460, h.463, $=$.

To Purge forciblic by romit waterifh humors, ${ }_{2}$ holer,and Hegm, $6,8, b$. 
$868, c .869,0.874, c .919,0.927,0.496$ le of the Natures, Vertwe and Dangers.

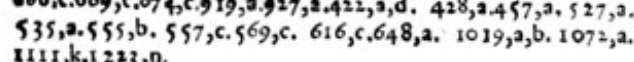
III $1, \mathrm{k}, 1223, \mathrm{n}$.

To cure the greene. Sicknes, $20 \mathrm{r}, \mathrm{b} .3 \mathrm{I}_{4}, \mathrm{f}_{.43} 8$,e.

To bring downe the defired Sicknes of yoong maidens, $630, \mathrm{e}$.

Good to coole a Sicke bodie, 32 , d. 1252 ,f.

To comfort greatly the Sicke, $473, \mathrm{~b}$.

To comfort and nourilh Sicke feeble perfons, $12\{6, e$.

Toftengthen thofe thao haue beene Sicke of a long lingering difeale, 596,2 .

To ftop the inord inate courfe of the monthly Sicknes, $748, \mathrm{~b}$. $803,2.298, L_{3} 18, L_{3} 23, b, 661$, h, 100 , $8, c .1291, a$.

Good againft any peftilent Sicknes, $535, \mathrm{~g}$

A remedie for the turning Siclines, 770 , h.

Tohelpe the Sicknes called the forgetfull-euill,8 $56, e$.

To helpe the pains in the StDe, $919,3445,1.535,3,563,2.566 .2$. $596,2617,5.698, b .984,1.996$, c. 1257, k.1291,b.1 300 ,a.

Good againit inflammation of the Side, 7 or, 3 .

Againtt the paine in the Side, $43,3.57,2.69,2.87,6.843, b .300$, $865,2.899, g .445, i .460$, d. $535,0.617,9$

Topurge by Siege flimie flegine and iharpe humors, $1007, a$. 1219,3 .

For Sigjings, 1 160,d.

To cafe thofe that are given tn ouermuckSighing, $540, \mathrm{~b}$.

To preferue Sigbt, 877, a. $537, a$.

To increafe or retere the Sight being feeble and loft, 537,2

Torake away things which hinder the $\mathrm{Sight}, 438$,d. 1026,a. r206,c.

Tolielpe the dim-Sighted, 49 5, e. 53 2, b.looke dimnes.

Effectuall againft the darkoes of the Sighto, $55,9.888$,c.

To quicken or cleere the fight, $855, c .858$, b.288,s.1887, d. $888, c$. $\$ 68$, d. $912,3.537, a, b, c . \quad 563, f .627, a .695$, d. 735, b.1035,d. $1074,0.1116$, r.1152,a.1 172, h.1324,i, 1347, ,.1354,b.

To dull the Sight, $138.53^{8}$, a.1 305, f. 298, f.

Good for wounds, prickes, \& hurts of the $\$$ inewes, $91, k .1037$,

Good againft the infirmities of the Sinewes, $897, \mathrm{~h}, 63_{3} 8, \mathrm{c}$.

Good againft the loofenes of the Sinewes, $770,0.63^{8}, 2$.

Tocure wounded finewes, $149, \mathrm{~d}$.

Good to heate and fupple the Sinewes, $1210, e$.

To ftrengthen the Sinewes, 53, a.624, b,d.

To comfort the Sinewes, 1317,3 .

Good for the Sinewes, $250, k$.

Hurtfull to the Sinew:s, ro 50 , l.

To glew or ioine \& confolidate Sinewes cut in funder, togither, 1 I $4,1,147, a, 1148, a .1160$,a.

To ftaic the weeping of cut or hurt Sinewes, fee Weeping.

Good to foften the hardnes of the Sinewes, $147, \mathrm{~d}$.

To belpe the difeafe called in Latine Singulum, that is Yeoxing, 891, f, fee Hicket.

Totake away the 9 latreg of the face, $720, c$.

To alaie the feruent heat and ruggednes of the \$\$in, 178 , h.

To clenfe the Skin from pimples and Lentils, 1257 , i.

To amend or clenfe the Skin in the face, $188, \mathrm{~h}$.

To rarifie the skin, $617, \mathrm{~g}$.

To make the skin fmooth and faire, $765, \mathrm{C} .2 \mathrm{r} 4,2$.

Totake aw ay skarres of the Skin,7 22,e.

To caufe the Skin to fwell and blifter, 815,9 .

A gaint the roughnes of the Skin, 214,2 .

To take away the yellownes and deformitic of the skin, 444,3.

Againft fcalis, or fuch like Glth of the Skin, 738 , b. $287,6.575,2$.

To rake away freckies, fpots, and otherblemithes of the skin, $754, b .759$, h. $1=57$,

To rake away morphew and blacke fpors on the skin, $827, \mathrm{e}$.

To feoure away deformities of the Skin, 759 ,h. 444, 2. 696 ,i. $720, \mathrm{e.7} 22, \mathrm{c.} .73^{6, \mathrm{~d}}$.

Good againtt the difeafe called the Silkpabp,195, b.fee Scuruy.

To prouole a defire to Slexpe, 32,b.

To prouoke Sleepe gently, letted by a hot $\&$ dry diftēper, $70:, b$.

To procure or prouoke flecpe, $53, \mathrm{~b}, 66,3.79 \mathrm{I}, \mathrm{c.} 24^{\mathrm{I}}, 2.284, \mathrm{c}$. $298,3 . c, g, h, k, m, 87^{8}, \mathrm{~d} .64^{8}, \mathrm{~b}, 10 \mathrm{O}_{2}, \mathrm{c}$.

To helpe the lacke of Slecpe, $22,0.702,0$

To caule an vnquiet and deadly Sleepe, $284, \mathrm{~d}$.

To thake off heauie and drowi. Sleepe, $124,2.849, \mathrm{~m}$

Towaken him that is fallen into a dead Sleepe, $856, \mathrm{~d} .889$, i.

To prouoke ouermuch Sleepe; $135, \mathrm{mt}$.

To caufe a fweete, found and quiet Sleepe, $674, \mathrm{~g} \cdot 1082, \mathrm{c}, 1370,2$.

Tocaft into a dead Sleepe, $27 \circ$,b.

Good for thofe chat are fubiect to dead Sleepes, $735, \mathrm{c}$.

To voide all fuper fluous sime, 357,a.
To reftore Dmelling that is loft,928,d.

$1013, b, c$.

Good againft ftinging of of the body \& armeholes, $\mathrm{IO}_{3}, \mathrm{a}_{3}, \mathrm{~b}, \mathrm{c}$

Good againft ftinging of Dnalies, 267,2 .

To driuc away Snakes, $388, c$.

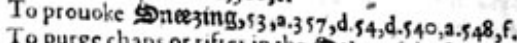

o purge chaps or riftes in the \$oles of the fecte, that are kin

to the ic ab of Naples, 859, f.

Toclenle old filthic Sozes,749, d.897,f.

To heale vp hollow Sores, 340,2 .

Good againft Sorenes in the throte, $745, f .348, c .936, b$.

Againftretring Sores, $\mathrm{SO}_{4}$, ?.

Todraw and heale Sores quickly in children \& old people, $60, \mathrm{~h}$
To heale decpe fores, $40, \mathrm{~d}$.

Tu mollific and foften the Sores of the mother, 790,8 .

To heale feftercd Sores of the eielid, 1152,2 .

To heale Sores of the mouth, 1092 ,i.

Good againft fpreading Sores, $1328, \mathrm{~h}$.

Toheale fuch Sores of the fundament and fecret parts as are al moft paft all cure, 410, d. $507, \mathrm{e}$.

To cure Sores in childi ens mouths, 1299 ,a.

To mundific and clenle old thaking and corrupt Sores and heal them, 397, f.911, b. 507 ,d.

To confune or wafte away plague fores, $586, \mathrm{e}, 587, \mathrm{c}$.

To heale Sores of hard curation, $278, \mathrm{~b} .410, \mathrm{~d}$.

To fcoure away Sores of the head, 1227 ,

Tohelpe Sores of hard curation on the glandulous part of the yard, 278 ,b.

To fcoure running Sores of the head, $1027, \mathrm{i}, \log _{2}$, h.fee Achores

For eating fores in the corners of the eies, 1178 , h.r 179 ,d.

For running fores in the heads of yoong children, $1074, k$.

To heale Sores of the fecret parts of man or woman,1092,

Toftaic or kecpe backe eating Sores, 7 2, d,687, 2.1051, 9 . 1186,d

Very good for a plagu: Sore, to draw the venome from the hart and inword parts, $811,0.815, \mathrm{~b}$.

Good to clenfe rotten fores,131,c.507, d.1050,0.

To affw age ther age of fretting Sores, $839, \mathrm{~g}$.

To fll vp hollow lores $10 ; 0,0$.

To cure euill Sores of the paps, dugs, and matrix, $751, b$.

Good for fores of the bladder, $1120, \mathrm{e}$.

Todiue away all Soloprowe, $599, c .654,2.1116, \mathrm{c}$

To take away Sorowefulnes proceeding of melancholie, $548, \mathrm{i}$. $1160, c, d$.

Totake away sounbing in the cares, 860,i, ros5, c. n72,j. $1342,2$.

Toreftore loft speech vnto thofe which are taken with the dumbepaulfic and opoplexie, 332 , 2,1016, d.1111, e.1 259,i.

To increafe sperme, that is naturall fe; d, $131 . c$.

Good againft Spetting of blood, $907, b-436,3.60, f .300, a$.

Good againft Spetring of blood, caufed of tharpe and falt humors diftiling, $1308, \mathrm{i}$.

Good againft Spetting of corrupt and rotten matter, $6,2,2$. 665 , a.1 121 , i. $1035, \mathrm{c.} 256, \mathrm{c}$.

To concott Spettle,729,d.

To ftop or curc Spetting of blood, $74^{8,6.802, b .} 215, \mathrm{c} .840$,e. $890, e, f .314, e .318, a, c .999, a 340, b .419$, d. $452, a .454, a .563, a$. $578, \mathrm{~g} .661,2.665, a, 6.73^{6}, c .987$, b.1025, b.1 102, $2.1121, \mathrm{i} .1158, \mathrm{~b}$. $1184 \mathrm{~m}, 1186$, a. $1190, \mathrm{k}, \mathrm{I} 206,9.1227, \mathrm{~b}, 1244, \mathrm{a}, \mathrm{b} .1247, \mathrm{~s}$. $1257, k, t .1260, k, 1263, g, h, 1264, c .1334$, d. $1375, b$.

To prouoke Spetung,306,b.

To procure eafie Spetting, I 121 , k.II 20,3.7 29, d.I 2 \&6,c.d.1 $328, \mathrm{~b}$

Againft the bitings of the Eptoer, called Phalanginm, $32, b-45,2$. $102,2.86_{3}, b .88_{3}, 0.949, c .964, a, 1009, f, 1075,0,195, c .1246, b$. For ftinging of Spiders, 1075 ,o.

To make the vitall Spirits frefh and liuely, $568, \mathrm{~d}, 1082,2$.

Toftrengthen the vitall Spirits, 560 , $f$.

To coole and refreh the fanting fpitus, $1339, b$.

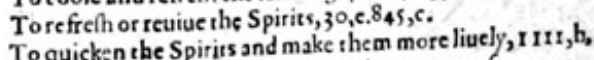

To quicken the Spirits and me the Suplene if it be wafted, $279, \mathrm{e} .301, \mathrm{~F}$.

A remedie for thofe that haue euill Spleenes, 47, e. 50, b. 749, a, 869, d.708,a.970,a.1 246 ,b.

Againft paine of the Spleene, $57,2.749, c .318,9.728, c$,

Aganit pane fivelling of the Spleene, $514, e$.

Toubled withthe Splecene, $529,2.249,6$. $941,5,458,5,406,2.529,0.1129,6$.

liiii 1 


\section{T able of the Nature, Danger, and vertwes.}

Good and holefome for 4 aflabes, $88_{3}, \mathrm{c}$.

For the $\$$ altnes of hum $15, \mathrm{r} 121, \mathrm{k} .1264$, k.1148, a.729,d.

An excellent salue to cure:wounds and old filthie vicers of the legs, $289, b$.

A Salue to cure apoltemes, tumors, greene wounds, inueterate vlcers, burnings, hures, or cuis of the head, 285,2 .

A Salue for many good purpoles, 285, ,a.

An excellent Salue to incarnate or bring vp fiefh in deepe hollow wounas and vicers, $43 \mathrm{I}, \mathrm{b}, 52 \mathrm{~s}, \mathrm{c}$

To diffolue cluttered $\$$ ano, and driuc it foorth, $185, \mathrm{c}$,

Todriue foorth Sand, 760. a.looke Graucll.

Todruue foorth Sand of the kidneies, $1240, d$.

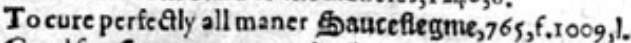

Good for Dauce, 5 5,2.142,b.185,a, 188,2.190,a.

A pleafant and holefome Sauce for mans bodic, $428, c .103$ I,a,

Tocure fpreading Scabs, $72, \mathrm{~d}$.

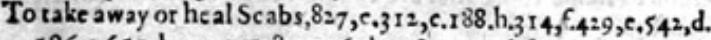
$586, \mathrm{c.6} 650,1.720, \mathrm{~g} .728, \mathrm{c} .736, \mathrm{~d} .998,0,1116, \mathrm{f} .1209, \mathrm{~h}, 1246, \mathrm{~d}$. $1255, \mathrm{~d}$.

To helpe Scabbed heads in children, $14 \mathrm{I}$, g.

To cure the Scabs of horles and kine, I 255 , d.

To helpe fcuruie Scabs, $3 \mathrm{I}_{2}, \mathrm{c}_{2}, 3 \mathrm{I} 4$, f.

Profitable againft Scabs of the skin, 738,b.287,f. 288,y. 930,a. 705, b. 1287, c.

To take away Scabs of the skin in fhort time, $122, \mathrm{~h}$,

To cure all maner Scabs of the bodie, $314, \mathrm{f}$.

Good tor Scabs of the bladder, $1120, c$,

Tocure running Scabs, $4 c 8, d$.

To cure Scabs in theepe, $1074,9.1255$, d.

For thofe that be Scabbed and have filthie skins, 575,a.

Againt scalding of the vrine, 1174, d.1308, h.

To beale Scalding with nile or water, 42,a.242,g. $278,2.288, \mathrm{z}$. $29 \mathrm{r}, \mathrm{k}, \mathrm{i} 099, \mathrm{~b}$.

A good medicine again? Scaldings in the privie partes of man orwoman, $745, \mathrm{f}$.

Good againf Scaldings, $91, c .288,2.413, c .433, b .625,2.1055, c$. $1210, b .1235, j .1238,5.1265, k .1305, c$.

To take away heate of Scalding by water or oile, $135, \mathrm{k}$.

Tocure all maner of Scaldings, 278, a.291, $k .638,5.660, d 708$, a. 1099, b, 1278,b.

To take away $\Phi$ caleg, $12\{2, \mathrm{e}$

To help the Scales of the head, 34,c.985, c,1016,b.698,c.1027.r.

Todraw foorth Scales, $698, c$.

To clenle away drie Scales, 60 , c.

Totake away blacke $\$$ catres of the skin, $8 \mathrm{ir}, \mathrm{b}$.

Tocake away Scarres, $188, \mathrm{~h}, 291, \mathrm{k}$.

To feoure away Scarres in the priuic parts, $1027, \mathrm{~m}$.

To caufe Scaries, 811 , 2.

To make Scarres in wounds faire and well coloured, $n$, $08, b$.

Good ag ainft the Sriatica, 689, f.18 2, i.1 88, c. 190, h. 749, f.r 97,2 . $288, x .357,0.557$, h. $57^{8}$, c. $635, a .996$, e. $1073,3.1129$,d.

To alfwage, cure or helpe the Stiatica, $789, \mathrm{f}$ 195,c,b. $207,2$. $210, a .219$, d. $8\{4$, b. 897, c. $944, a .4: 2$, d.433,c. $435, a, 437, b$. $706, c, d, 1125, \mathrm{~g} \cdot 1137, \mathrm{c}, 1303, \mathrm{~b}, \mathrm{c}$.

Againft Deolopenders, $553, c$.

Good againft the di eafecalled the Scozbut, $201, a .325,2$.

Good againft the fea socozpion, 553 ,e.

Againtt the bitings \& ftingings of Scorpions, $454.786,2.819,2$. 266, b. $924,2.949$, c.551.3.572, g. 6.8, c. 702 , f. 11 29, b. $1282, y$,

Tocaufe thofe thas are fluig of the Scorpion to fecle no paine at all, $548, \mathrm{~h}$.

To preferue a man from being ftung of Scorpions, $787, a .1075$, o, 1129.

A remedie for thofe that be flung of the Scorpion, 236,c.267,a. $382,3.551,1.10=9, a .1075, b$.

How the Scorpion becommethdull and fenfeleffe, and how he is deliuered from the fome, $819,2.924,3$.

To ft gic Secouring in the choletick paffion, 553,2 .

To ftop Scourings vpward and downward, 1378 ,d.

'To cure seratche $5,507, \mathrm{e}$.

An approoued remedie againh Screptinles, or the firelling in the throte, $97, \mathrm{e}$.

Good againet he 5 crophula 80 , a fec hard Kernels.

To helpe the Sidurfe of the hesdi, 34,c.408, d.101 6,b.ro27,r.

Toclenfe awav Scurffe, 60, c. 926, e. 408, , d. $984, c .1252, \mathrm{c} .1297, \mathrm{c}$

To cure leprcus and naughtic scuiffe, 72, d.1255,d.

Tocure the naughtic Scurfie of the he ad, 854, , $1052, \mathrm{a}, 1255, \mathrm{~d}$.

To take away the Scurffe in children, $14 \mathrm{I}, \mathrm{g}$.
To heale the Scurffe, $743, a .408$, d.r. $207, \mathrm{~h}$.

To heale the drie Scurffe, $995, \mathrm{~b}$.

To cure the white Scurffe, 1289 , k.1 305 ,e.

To cure the white Scur ffe of the head,408,d.1289,k.

To take away Scurffe of the skin, $190, \mathrm{~g}$.

To hel pe or cure the difeafe called the \$ecuruie, $189, d .195, b$. $201,2.325,3.463, b .497,2.1306,3$.

Tocafe thofe that be Scuruic, 6o,

To confume and fcoure away the Scuruineffe of the beard and face, $147,2.1328$,h.

Againft Scurvincti:, $504,2.542, \mathrm{~d}$.

Tobring downe or driue foorth the seconoine, $14 \mathrm{I}, \mathrm{f}, 147, \mathrm{f}$. 188, d.762,a. $88_{2}, 9.89 \mathrm{r}$, b. 282 ,f. 865, b. 897, b. $459,2.546, a$. $563,6.564,3.603,3.652,2,1076,5.1223,5$.

To expell the Secondine in moft fpeedic maner, $147, \mathrm{f} .847,6$. $617, \mathrm{e}$.

To ingender $\$ 0 r o e, 1047, \mathrm{a}$.

To ftop the oucrtowing of the Seede through dreames, 674,3 .

To increafe Scede, 131, c.1 $78, b .754,0.878, a, 665, c .1174, d$.

To cure the inuoluntarie flowing of the Seede in men, $53, \mathrm{c}$. 661, d.674. h.993,b.ris

To deftroie natur all Seede $\mathbf{7 4 4}, \mathrm{b}$.

To drie vp the Seede, 573 , b 674, e, t.ro76, t.1 202,a.

Tocoolesnd quench naturall Seede ouermuch, 242 , h.to7 6 ,t.

To ftay the inuoluntaric courfe of naturall Secde in man of woman, 993, b.

To comfort and delight the genfes, $30, e .735$, d, 887,c.

To make the Senfis quick and liuely, $124,0.624, b .735, b .1110,2$,

To comfort the inword Senfes, IIII, e,

To dall the Senfes, $13,5, \mathrm{~m}$.

To cure the difeafe called Seripiga,69,b.

To preferue from rbe ftinging or luurt of berpents, $659,2.684, \mathrm{f}$. $1075,0.1129$, b. $128 \mathrm{r}, \mathrm{p}$.

Againft ftingings or bitings of Serpents, 29 s.47,e. so,b.74,a. 149, a. $751,2.882,2.314$, d. 869, d. $323,2,352$, d. $355,0.949,1$. 519, b. $52 c, 2.535$, b. $553, \div .557$, e. 563 , d. 572 , g. 576, , . $578, d$. 586,d. 624,c. 649,e. 659,3. 665, c, d.698,a. 989, d.1009,f 1019, d. 1065, b. I I 54 , b.I 180, b.1202,e.1327, d.

To helpe thofe that are birten of Serpents, and fpeedily to alaie the paine, 18 2, 3.576, c. I 180,b.

Todriue away Serpents,949, ए.388,c. 391,d.429, b.542, .5.557, c. $6 \$ 9,2.989$, d.t $75,0.1190$, f.r 202, e. 1289, b,c.

To curc Shakings of the ioints declining to a paulfie, $947, \mathrm{f}$. $\Delta$ remedie for colde Shakings, cauled of thicke humork, $1184, e$.

To take away the Shakings of che ague prefently, and cure the fame, $1282, v$.

To cake away the Sharpnes of vrine, $1257,1.729, d$.

Toremper Sharpnes of choler $, 702,2$.

To mirigate the Sharpnes of humoss, 661, f, $1121, t, 1265, k$.

$1148,3,1324,1.729, \mathrm{~d}$.

To dull the tharpnes of thinne humors, $1260, \mathrm{k}$.

Noifome to Gheepe, $424, c$.

Tokill Sheepe, $6 z z, c$.

To ror Sheepe, 646 , 2 .

Good againft or to kilt the hinglis, $839,5.261, b .269,2, b, c$ $4 \mathrm{I} 2,2,105 \mathrm{I}, \mathrm{k}, 0.1074, \mathrm{k}, 1150,6.1207, \mathrm{c}$.

To hicale broken sibms $436, \mathrm{c}$.

Totake away tiuerings of agues, $557,2.6 .854,4.848$, d.949, d $557, a, b, 698, b$.

To draw Shivers out of the fieih, $698, c$.

Againft Shoptncs of breath, 47, d.137, 2. 19r, b. 744,2.754,2. $766, c .856, c .893 .2 .318,3.880, b$. $897,3.899, g .436,0.459,2$ 46 s,b. $532, a .73^{0}, 1.984,1,9^{8} 5, b, 1065, a, 1121, n, 118_{4}, m$. $\mathrm{J} 248, \mathrm{c} .1257, \mathrm{O}$.

Good for Shortnes of breath vpon a coldecaufe, $1073, \mathrm{~d}$.

Ag ainft the Shot of vencmous darts and arrowes, $8\{4$, i.

A gainft the bitings of the moufe called as hemew, $14 \mathrm{I}, \mathrm{h}$.

Tohelpe slyzinking of finewes, 40 , d.60.e. $854, e .29 \mathrm{r}, \mathrm{c.} .899, \mathrm{f}$. $949,0.436,0,445$, h. 540, f. 616, b.1016, a. $526, c$.

Againft the falling sicknes or euill, $102,6,854,6.839, \mathrm{i} .897, \mathrm{~h}$. $899,1_{357, a .379, b .654,5.698, f .}$

To cure the falling Sicknes, $856, c, 839, c .893,2.463, b .47^{8}, 2$. $599, \mathrm{~b}$.

Agsinft the falling Sicknes in yoong children, $832, c .394, c .460 .6$ $498, b$.

To mooue or bring downe the naturall or defired Sicknes of women, $29, b .185, \mathrm{i}, 749, \mathrm{c} .760, \mathrm{~b}, 770, \mathrm{r} .882, \mathrm{a}, 819, \mathrm{~b} .893, \mathrm{a}$.

$398, c$. 
AT able of the Nature, Vertue and Diangers.
To voide by Stoole waterih 2 nimic bumors, $820,3.718,4.72_{4,2}$

Topurge choler and Aegme by the Stoole, $738,8,718,1.724,2$. $397,0.1133, f^{3}$

To purge mil buil by Stonle, 718 .

Good for Stuppinge of the head, 1038,6 .

Good againit clic bropping of the fpiecte, 689, , c. 137, d. $73^{8}, b, 6$

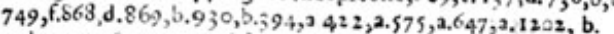

Totake away Stoping $3,86 z, 2.93^{3} 3$ a.

To open Stoppin s of the inw.r. $d$ parts, $846, d .54:, .654, f .1124, m$ Good for

Good aganth the Dtrangarie, $23,6.54$, h. 188,6 . $866,3.875,2$, $457,2.19$ S, a. $532,0.545,2.553,1.665, i .693,2.1004,2.1052,1$, $1065, c, 1192, c$.

A remedie againft the Strangurie, $188, \mathrm{c} .189,9.762,2.888$,a. 891, o. $893,3.391,2.497$, d,e. 535, , $551, b .979,3.1064,3, b$.

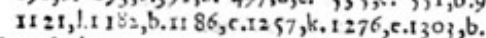

Tocafe the Strangurie, 8 \% , f. $895,3.333$,a.

Tobelpe the Dotrangling and paines of the mother, $856, \mathrm{c}$. $833, f .892,0$.

Tocurccle Strangling of the Matrix, 89:2,

Torecouer 9 trength, 1 1 $74,6,1: 48,2$.

To reflore Sirength, $334,:$.

To heale SDimuen or the eies, 1 C 37,0 .

An approued remedie agjiaft Strmas, or fwellings in the throte, $97, \mathrm{c}$.

To foften the Sirmester or fwellings of ahe throte, $54,6.217, \mathrm{~b} .580$, $2.1342,3$.

To drawe Dtubs nut of any part of the bodie, $54, \mathrm{g.114}, \mathrm{f}$.

A remedy againft $\$ t u f i n g$ of the head, through coldnes of the braincs, $1110, b$.

A remedic againft Stuffing of the lungs,770, f.869, c.527, c.542,c. $698, b .1239, b$.

To cure the $\$$ thif ocation of the $\mathrm{Afatrix}$ or mother $, 892,2.878, \mathrm{c}$. looke Matrix,

To hesle Etufurions, 1037,0 .

The vfes of Sugar and how it is made, 35 .

To defend from hurt of the $\$$ un, $946, d$.

Totake away Sunburning, 114, d.759, h765, h.:27, b.250,i.84 $1, \mathrm{e}$ $380,2.445$, d.696, h. 720, e 722 , b.1052, g.t 1 158 , h.

To purge yellow Gqupertututie s by fiege, 827, ,

Good againft a Sturfet , 1 24, d.938,b.r 133,0 .

A fingular medicine againet Surfet, 848 , $9.702,5$.

To preferue one from Surkiting, 938 , b.

To cafe the difficulic of $\$$ wathlowing, caufed of cold rheumes, $465,3$.

Toprouoke $\$$ meate, $557,3.849, h, 74, b .195,5.859, c .849, c .840, a$

b.897, f.377, 3.457,2.557, a.617,g.619,c.996, ..1009, c.1 06.4,

b. $1218, b .123=2$.

Tocaufe Sweating in agues, $65,5, b$.

To ftay Sweating, ros $z, k$.

Good arainft or to diffolue hot Dsellings that are newely be. gun, 60, c.796,a. 1270, b.1 $275, c .1304,2$.

Tocure and diffolue a thard Swelling s, $854, a .869,0.397, a, 463, b$. $560, i .568,3.430,3.665, l_{0.714}, 2.1035,2.123^{8}, 5$.

Toconfunc and wante away cold and hard Siwcllings, $8,8, c$.

$869, c, 536, b, 5 s 3, i, 6 \times 6, b, 609,298,0, b, 1027, p, 1064, a, b$.

Toconiume or take avay hot swellings, 860,c. 679,n. 68o,b.

$1207, e, 1235 ;=$

Todiffolue all kinds of Swellings, $627, b$.

Totake away the hot Swellings of the Almonds in the throate, $261, \mathrm{~d}, 4 \mathrm{ro}, \mathrm{f}, \mathrm{I}=63, \mathrm{l}, 1326, \mathrm{c}$.

To ripen hard Swellings in the groine, 1170 , h.

Towafte away her Swelling, of the kernels in the flanke, $73^{6,3 .}$

For hot Swelling of the throate, $13 \mathrm{r}_{4}, c .1326, \mathrm{~d}$.

Todiftolue Swellings of che beilie, $1: 38, c$.

To rake away the Sweiling in the fipleene, $1354, \mathrm{~b}$.

To afiwage the Sweling of the yard,1 1052,02 .

Towafte away the Swclings of kcrnels, $1: 80$, c.

Tofupple or walte away hard Swellings of the funda ment, $8,8,2$.

$1635,3,113 \circ, 6$.

To cure the Swellings of the mouth, 1209,a,1 306,a.

To ripen hurd Swellings be hind the eares, 1 17 0 ,b.

Good for hot Swellings of the toong, 1326,d.

To mollifie or wafte away tlie hard Swellings of the wother,

$7^{8} 7, c .1027,4.1035, b .1180, c$.

Tocure Swellings of tine throate, 1209,3 .

Good for hot Swellings of the iswes, $1326, b, c$,

To aflwage Swellings of the ftones, $1052, \mathrm{~m}$.

A remedie for foft Swelling $, 736,9,136$, ,

To wafte the hard Swellings of the milt or fpleen To take awaie the Swellings of the cods or genit, $97 . \mathrm{ro} 4$, $1035,2.1_{20}$,c.

To confume any Swelling in the legor arme, $497, \mathrm{c}$.

For Swelling of the Kerellings in the ioints, 908,6 .

To belpe the S wellings of vader the throate, $1_{3} 1_{4}, \mathrm{C}$.

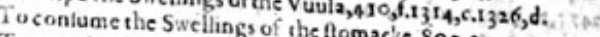
To yure Swellings, 849,9 .

Not to futter hot Swellings to ari $\left\{\right.$, $, \mathrm{c} c 8_{3}, \mathbf{a}$.

To concoet and open all Swellings, $60, \mathrm{~g}$.

To bring tor Swellings to fu ppuration, $1243, \mathrm{~h}$

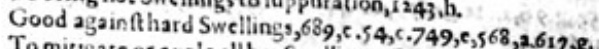

To mitigate or crole all hot Swellings, $28 z, \mathrm{~g} .778, \mathrm{~b}, 793,2,2, \mathrm{~g}$.

250, d. 362, d. $527, b .678, a .680, b, 1255,2.1278, b .793,2.232,2$

To mollhic or fofien old bard Swelling, $257,275,6.1294,2$.

To take away old Swellings

To take aw ay old Swellings, 581, e.

For hot Swellings in the moutb,1 $247, c .1326, b, c$.

Totake away hot Swellings, 60, b.t 24, e. $501,2.860, c .362$, d 408 , d. 445,d. 495,a. 676,2.1009,f. 1016,2.1178, c. 1210,2.1235,1.

To diffolue Swellings, 1207,1 .

A remedy againft the bard Swellings of the ftones, 198, c.1073,b

To foiten and rupen hard Swellings, 65, b, c. $790,25.445, \mathrm{~b}, 0.1179, \mathrm{~b}$ 1180,5 .

To wafte and make fubtile hard Swellings, 96,b. 190,j. 397,b. $9^{8} 4$,d.1037,n.t 180, f.1 238 ,b.

To dilifolue or take away hard Swellings, $195, c .869, c, 899$, h,936,c 463 , b.49', a.9 84, d. 1052 , h.1064, , b.1 180,c.1 342,a.

Towatte away cold Swellings, $989, b$.

Againit the hard Swellings of the paps,198,c.fee Paps.

To molitice and take away hard Swellings of the liuer and milt, 188 ,c.790,g.

To caufe hot Swellings to arife, 1263,b.

To mollifie and fofien Swellings in the ioints, $790, \mathrm{~g}$.

$8\{6,3$, difolue and loften coldSwellings, 747,6 . $80 s, b$.

( $546, f .720, c .1009, b .1184, b$.

Tokili Dwine, 259,3622,c.

Againt Eswounings, $1160, c$.

Good for fuch as are fallenuisto a Siroune, or accuftomed to

fwoune, $288, x .468$, a. 599, b. 733, c. 856, d. $542, i .654, f$.

A good Syzupe to foften the belly and purgecholer, $702, g, h$.

A Syrupe feruing for many excellent purpoles, $66 \mathrm{I}, \mathrm{f}$.

A Syrupe to be rfed in tertian agues, 64, b.

Syrupe of the infufion of Rofes with the force there of, 108, , h.

Syrupe of the iuicc of Rofes, $1082, \mathrm{k}$.

Elight full ro the đafte, $879,2.1266, c$,

To remedie the paine of the Eetb, 815, d.419, f.

To ftophollow Teeth, $108, c$.

Goud for Teeth that are fet on edge or aftonied, $4,19, a, f$.

To faten lonfe Teeth, $845,2.323, c .419$, f.57 $1,6.649$, d.698, rog2, i. I 1 144, d.1263,k.1 306,a, 1337,c.

To appeafe or oflwage the paine of the Teeth, $839, f_{2.284}, f_{6} 6 \mathrm{rg}, \mathrm{d}$, c.9 89 , b.996, c.1 143 , b.1178, d.1244,e.1292, h.1361,a.

Toglue sogither rifts, gaflies, and cors about the Centons, $114,3$.

To prouoke or bring downe the Tetmes, 30 , d.40,9.50,b. $53, \mathrm{c}$.

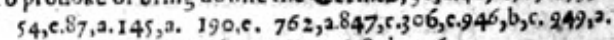
$546, a .563$, b. 569, c. $603,3.652,0.668$, d. $1076, y$.

Tobring downe yoong matdens Termcs, $201,6,558$,

To prouoke the Termes mightily, 532, c.6 $16.5 .1194,2,892,0$.

To ftaie the oueraucb flowing of womens Termes, $32,2.72, c$. $780,2,318,1.913,0.333$, b...34t,c.38.9, g. 419, d. $707,1.1050, k$

ir $50, a, r_{2} 64$ c.1 3 I $4,6.1375$, b.
Good for womens. Ietmes that be ftaied rpon a colde caule,

13 s,c.
To take away théfit of a Eertian, 135,1 .

Totake away thefte of a Eertian, $135,1$.

To take away or cure a Tertian, $433,6,575,6$.

Good for Tertians that procecde of choler, 1376, 2.

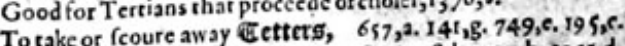

Totake or fcoure away ettets,
$827, c .318, b .657,2.736, d .995, b .998, a .1178, b .1207, h .1255, d$. $1281,9.1376, b$.

liiii a 


\section{ATable of the Nature, Vertue, and Dangers.}

To helpe the Spleene oüercharged with grofle bloo d, 938 ,d. Againft hardnes of the Spleene, $57, c .744, \mathbf{3 . 7 4 9 , c , f . 3 1 8 , 2 . 3 9 5 , a . ~}$ $977, b .1027, g .1170$,c.1195,a,f.1327,d.1346,c.

To diminith or wafte the Spleene, $898, L_{11} 195$, th.

To open the ftoppingt of the Spleene, I 37,d.738,f.502 d. $864, \mathrm{~b}$. $862, a .847, c .318, a .437, a .444, b .463, a .563, a .996$, b. $1057, c$. 1223 , g. $1224, m, r 246, f, 1257, k, 1259 . b .1289, f$.

To draw foorth $\Phi$ plinters fixed in any part of the bodie, $34, a$, $96, a .897$,f. 899 , m. 445 ,m. 495, a. 627, b.638, i. 652 , c. 698 ,c. $720, e .722, c .1066$,d.

Totake away or clenfe @pots in the face, $115, \mathrm{~h}, 765, \mathrm{~h}, 227, \mathrm{~b}$. 888,b.3 26 ,d.I 133 ,r.T158,h.1194,b.

Totake away Spots, 445, d, I 328 , h.

To take away blacke and blewe Spots of the face, 125, h. 193,e. $855, \mathrm{c} .84 \mathrm{1}, \mathrm{e} .3 \mathrm{1} 8 \mathrm{i}, \mathrm{a}$.

To take away Spots of the eies called in Latine Albugines, 1026.2

Totake away the Spots of the skin, $754, \mathrm{~b}$. 1133, r. 1257 ,m. 1380 , o.

To clenfe away Spots in the eic, 684 , d.695, d. 706 ,e.

To take away blacke and blewe Spors gotten by ftripes or fals, $758, b .882, a .318,2.410$, f. 557, e. 720, e.ro $37, \mathrm{~m}$. $1044, \mathrm{e} .1223$, l.

To take away blacke Spots of the skin, $\$ 27, \mathrm{c} .1052, \mathrm{~g}$.

To purge white fpottines of the skin, 859 , e.

To fcoure or take away $S$ pots of the face and to make it faire and fmooch, 845, d.288,r.293,c.720,e.72r, I.1257,m. 1298 , f.r. 349 ,d.

To take away all foule and ilfauoured Spots in any part of the bodie, ror 6,e.

To helpe \$quat 8,849 ,e.1304, a. looke Brufes.

To eale the $\$$ quinancie or $\$$ quincie, $860, i .938,1.1180,9$.

To helpe the Squinancie, 31 8, f.8 80, e. 557, g.702, f, n.11 38 ,c.

Good againt the Squinancie in children, $394, c$,

A pure white \$tarch, $686, \mathrm{c}$.

To cure the Sitench) of she mouth, $325,9.1$ r $10, d$.

To take away the Stench of the armeholes, looke ranke fmell

Totake away the Stench of the breath, 1110, d. 128 I, f.

Good for Stifnes of the ioints, 1207,1 .

Againft Stinging of ferpents, $29, c .149,0.314$, d. 369 ,d. $352, c$. $355,2.395, e .520,2,652$, b. 1065 , b. .1075, e. 1200,2 .

Good againft the Stinging of Scorpions, 786,a, 267,a.924,a, $949, \mathrm{c}, 1075,0.1282, \mathrm{y}$.

Good for or to heale the Stinging of venemous beaftes, $266, \mathrm{~b}$. 352 ,d. 519, b. $542,1.548, b .551$, a. 560, h. 586, d. 587, c.1069, f. $1202,0.1223, d$.

Good againft the Stinging of all maner of wilde beafts, $85 \mathrm{x}, \mathrm{a}$.

Good againtt the Stinting of the breath, proceeding of a naughtic ftomacke, $4 \mathrm{IO}, \mathrm{b}$.

Good againft titches, $43, a .69,2.87$, b.596,a.984,i.

Good againft the Stitch in the fide, 1073 ,d.

Torake away the Stitch in the fide with the paines thereof pre. fently, $, 08, e, 624,9.1170, e$.

Good againft the Stich of the cheft, 1073, d.?

To cure the difeafe Simmacace, 325 , a.looke Scaruie.

Todrie and clenfe the $\$$ tomacke, $35, \mathrm{a}, 553, \mathrm{~b}, 1009, \mathrm{c}, 1062, \mathrm{a}$. ro8s,k.

Delightfull to the Stomacke, $879,2, b, 1057, a$.

To comfort a weake and feeble Stomacke, 222,e.883, h. $\mathrm{xO}_{3} \mathrm{I}, \mathrm{a}$. ro83, n.

An approoued medicine for a windie and cold Stomacke, 665 , g.

Tobreake winde of the Stomacke, $40, a .892, \mathrm{c}$

Good to be laid vpon an hot Stomacke, $702, e$.

Againit cruditic or tawnes of the Stomack, 843, 0.1073, c.1083,n.

Topurge she Stomacke of waterih humors, $\mathrm{I}_{3} 5^{8}, \mathrm{a}$.

Good forbad or ill Stomacks, 352,b.1065,a.1334,d.

To caufera good Stomacke to meare, 578 , c.fee Appetite.

Good for an hot Stomactie, 1232 , b.1 275 , b.1 $324, c$.

Good againft the ftoppings of the Stamacke, $352, e$.

A comfortable purging medicine for the Stomacke, 4 Io, a.

Hurtfull to asweske and colde Stomacke, 1232,2 .

Good for fuch ss thaue a fower, fquamilh, and waterie Stomacke, 542 ,i. $1082, k .1227, e$.

To cure or eafe paines and griefes of the Stomacke, $45, d .288, n$.

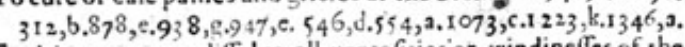
To driue away or diffolue all ventofities or windinefies of the Stomake, $855, a, 849$, d, h. $908, a, 93^{8, g, 134^{6}, c \text {. }}$

To ftay or take away lothfomnes of the Stomacke, 40,d. $938, \mathrm{~b}$. $1044, \mathrm{i}, \mathrm{r} 207, \mathrm{c} .1266, \mathrm{~d}$.

To coole the heat of the Stomack, 222, e, 845, f 941 , d. $321,6.419$, a Good, ho lefome, and profitable for the Stomacke, 55,a. 886,a.

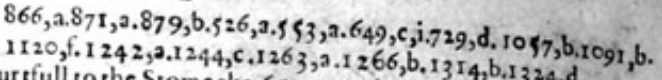

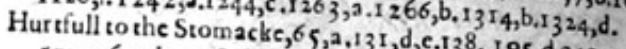
$\{73, a .691$, b. $718, a, b .720,2$. 1007,d.1055,b, d.949, c.445,b.

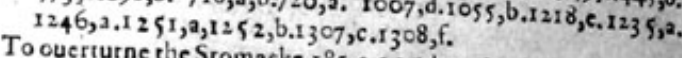

Good for or to helpe a cold and moift Stooma, a, b.ros5,a. 287, a. 560, g. 293, b.868,d. 907, c. 553, h. 96,6 , 180, b.r $90,3.855, b .891, c$. $1270, c .1335,3,1358,53,5.596,2.629$, d. $188,4.735, c .1223$, ,

To comfort the Stomacke, Se, 185, a.335, b. 529, d. 720, b. $1235,0$. $1349, d, 1351,2$,

To comfort a cold Stomacke, 868 ,d, $128 \mathrm{r}, \mathrm{g} .1349, \mathrm{cc} 1358, \mathrm{~b}$. To comfort a weake and fecble Stomack, $1184, \mathrm{~m} .134 \mathrm{1}, \mathrm{c}, 1349, \mathrm{c}$.
$1358, \mathrm{~b}$.

Againft wambling of the Stomacke, $314, \mathrm{~d} 878, \mathrm{c}, 544,2$.

To dry and ftreng hen a feeble and moift Stomacke, $69 z, a, 749$, 2.735,c.1031, a.1082,k.

To ftrengthen a weake and feeble Stom acke, caufed of heate, $1270, \mathrm{~b}$.

To ftay the watering of the Stomacke, $749,0.1227, \mathrm{C}$.

Againft the weaknes of the Stomacke, $317,2.938,3.733, \mathrm{~g}$.

To purge the Stomacke of flegme and euill hunors, 749,a. 1027, n.1 $317, \mathrm{~g}$.

To confume or helpe windineffe and fower belchings of the Stomacke, $895, a .880,3.938,9.544,9.616, c$.

Good for the heate of the Stomacke, 76,5, d. $775, b, 236, b .269,2$. 941 d. $1120, \mathrm{e}$.

To heale the pain and aclse of the Stomacke, proceeding of choIer, 217, a. 554, ,

To preferue the Stomacke from obftruttions \& windines, $1346, c$.

To ftrengthen the hor, weake and feeble Stomacke of ficke perfons, 2:4, $3.733, g$.

Good for Weake and queafie Stomacks, $109_{2}, k_{1}, 3_{1}^{17}, \mathrm{~b}$.

To take away the gnawings of the Stomacke, proceeding of a hos caufe, 232 ,b.

Holfome for a moilt and waterie Stomacke, $1227, e$.

To coole an hot Stomacke, and helpe it when it is troubled with choler, $241,0.419, a, c .1368, c$.

To caufe the Stomacke brooke it meate, $1073, \mathrm{c}$.

Toclofe vp the mouth of the Stomacke, 860,3 , h.

To comfort and fteng then the Stomacke, 849 ,d.839,e. $930, \mathrm{c}$. $93^{8,2, c .463}, 2.535$, f. 553 ,h. 729 , a. 732 , c.101 3, g.1 031 , a.1073, c

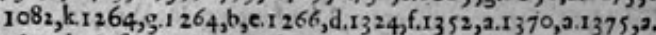

To alay the inflammation $Q$ heate of the Stomacke, $845, b .941$, d. Good for a weake Stomacke troubled with choler, $93^{8}, a .4^{6}, 2$.

Singular good for the grauell and \$tonte, $886, b .891, f .486, b$. 553 , l.II 44 , h.1 1182 , a.r 242 , c.

A fingular compofition againft the Stone, 454 , d,e.

A prefent remedie againft the Stone, 1092, h. $x$

Tobreskethe Stone, $902, a .424, b .428, c .98,4, b .1000,2.1035, c$. 12:3, m.1 206,e. A

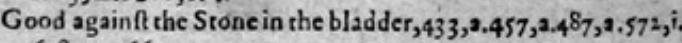
$638,3.1066$, c.x $x$

To breake the Srone in the bladder and drive it foorrh, $1066, c, x$

Exceeding good for the Stone, $79 \mathrm{r}, \mathrm{b} .849,9.84 \mathrm{r}, \mathrm{d}=72, \mathrm{a} .527, \mathrm{c}$. 709 , g.rI $40,0.1147, a .1212,3.1257$, r. 23,c.310,0.791 b.862, d. $x$

To affwage the paine of the Stone, $789, b, c .877, c, d$. looke Paine.

Good for the S:one of the kidneics, $775, \mathrm{c} .845, \mathrm{~d} .349,2.455,2$. $104^{8}$, c. 1066 , b.1174, d.1 257,g.r.328,n.X

To wafte or breake tlic Stone, and drive it foorth, $142, \mathrm{~d}, 760,2$. 201 ,b. 864 ,b. 862 , b. 868 ,c. 424, b. 478 , o. 487, a.69 2,b. $(93$, ,. $979,2.1133$, in.114 $42,3.1154, a, 1281, r .13$ 14, r, 1375.d. Good for the Stone in the beginning, $8_{33}, \mathrm{c}$,

To wafte away Stones in the kidneirs, $1066,6.109 \mathrm{r}, 5 . X$

To driuc foorth the Stone out of the kidneies and bladder, $728, c$ 979, a.984, b.29, b. 142 , d. $789,5.79$ 1, b. 502 ,d. 896, d. 874 , b. $1004,9 . x$

To remooue hot fwellings of the Stones, 149, e. 1073 , b.

To ceale and cure the burning heare or infiammations of the Stones, 217, b.87,c.198,c.28, a.1037,k,q.1073, b.

To breake the Stone in the kidneics and bladder, 888,a. 89r,a. $428, c .546,1.979$, a.r 1 33 ,h. $x$

To cure the Stone and voide grauell, $891, f .261,2.497, c .1324, i . f$

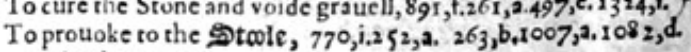
1184, d.1235,g. 


\section{ATableof the-Nature, Vertue and Dangers.}

Good for of to cure hollow old and new Vlcers, 913,5 : 340,0.
$660, b .706, b .1190, k .1235,1$.

To heale old eating Vlcers, $133, a .916, a, 649$, , r. rog $9, b$.

To fcoure and clenfe old rotien vicers, $858,8, c .287$, c. $43^{8}, c .535,0$. 581, b.1133, n.

To belpe all outward vicers,863,a.

To mundifie corrupt, foule, \& filthic Vleers, $189, \mathrm{~b} .295, \mathrm{c.} .563, \mathrm{~b}$, 365, b. 581 , b.698,c. 19 so, e. 1133, n.1 $207, \mathrm{ce}$.

To appeale the rage of canker cus Vicers, $839, \mathrm{~g}$.

To heale greene or new Vleers, 149, b. 115 , 3 .

To caufe vgly Vlcers, $815, a$,

Good againft mortified Vlcers, $7: 9$, h $1052, \mathrm{~h}$

To flay running or cating Vlcers, 687, a.ros 2, g.r 1 180,d.1 244,k. 1207,c.r194, b.

To fill vp hollow Vlcers with flefh,698,c. 1044,k, 1050,e, 1 180, f. I1 $90, k, 1235,1,1244$, i.r $247, b$,

To cure vencmous Vlcers, 1044 .

For running Vlcers in the heads of yoong children, $1074, \mathrm{k}$.

To defend maligne \& virulent Vleers from inflammation, $49 t, 9$. 708,3.

To cure putrified Vkcers, $423 . e-433$, b. $466_{3}$, b. $\$ 81$, e.1 $099, b$.

Good againft all hot burning and fretting Vleers, $4 \mathrm{1}, 3, e .509, a$.

For old venemour and malitious Vlecrs, $1133, \mathrm{n}$.

To hesie Vlcers of the fecret partes and fund ament, $4 \mathrm{II}, \mathrm{h}, 452, \mathrm{c}$ $507, \mathrm{e}, 1102$.

To cure Vlecrs of the throte, $12=9,2$

To heale Vleers in tender bodies, 1178,6 .

To ftopbleding Vlcers, 349 ,d.

To cure malignant and rebellious Vlcers, 42 2, b.708,a.r $009, \mathrm{~h}$, ;.

Toheale Vlcers of the kidneies, $331, \mathrm{~b}, 66 \mathrm{r}$, g.

Good for Vlcers in the low gur, 1027, I.

To mundific and muke cleane maligne \& eating Vleers, $1=57, m$. $360, d$.

To heale and fill vp the Vleers in the eies, $1247, \mathrm{e}$.

Tofcoure,mundifie \& heale old Vlcers, 259, b.295,c.306, 9.897, e.

To cure hot Vleers of the mouth, 371, b.4ro,t.

To cure corrupt and rotten Vlecrs of the mouth, $325,2,507, \mathrm{~d}$. $58 \mathrm{I}, \mathrm{f} .103 \mathrm{I}, \mathrm{b}$.

To confume hot Vlecrs, 282 .g.

To curc Vlcers on the glandulous part of the yarde, $278, b .878, c$ $4 s 2, \mathrm{C}$.

To cure malicious and venemous Vleers of the mourh, and al. monds of the throte, $86,0.841, c .708$,a.

A good medicine againft elicerations in the priuic parts of man or woman, 745, f.291, i.454,b.

To cure Vlcerarions of the matrix,419,e.

To helpe Vleerations of the guts, $419, \mathrm{e}$.

Good againf Vlcerations of the lungs, 563, .

Good again tt Vlcerations of the moutb, $366, \mathbf{a}$.

To cure Vicerations of the kidneies and bladder, $34 \mathrm{I}, \mathrm{d}$.

To take away the paine of an 01 neome, $; 62, b$.

Good for fuch as are without eln nerftanding, $329, \mathrm{~b}$.

To helpe or ftrengthen Vnderftanding, $5247, \mathrm{~g}, 1317$, g.

An elnguent for wounds, 379 , b.

An excellent Vnguent to incarnate or bring vp flefh in deepe wounds, $431, \mathrm{~b}, 5=4, \mathrm{c}$,

To cure the di leafe called Volualus Hematites, 325,2 .

To hurt the al oice, $1305, \mathrm{e}$.

Tocleere the Voice, 35 , ?.

Good ggaint hoarfenes of the Voice, 178, , $.1342,2$.

To ftaic Jividing of blood, 661, f.1 $1099, c$.

To prouoke or caufe Ti omite, 88, g.185,b, , $106, a .407,0.1 \mathrm{Is}$, b. $188, b, 218, c .4=0, a .407, a .415, b .578$, f689, d. $720, b .1219, a$. $1239, \mathrm{c}$.

To repreffe ouermuch Vomirin z of choler, $\mathrm{n} 26_{3}$, d.looke Felonie.

To ftay Vomiting, $323, c .860,2.553,3,1.7 ; 6,2,1037, g .1224,1$. $1232, b, c .1244$, c. $1263, d, g$, b. 1264, b.1289, e. 1317, g. 1337 ,c. $1341, e, 1368,3.1370, \mathbf{a} .1375,3$.

Good for thofe that Vomite blood, 624, d.r264,c.

To helpe Vomiting of blood, $505, \mathrm{~b} .452$, a. 457, a.4 59 , e. 553, , b. 236,e.1 $288, \mathrm{~b}$

To 3 afe onc to Vomite flecme \& Aimie matter violently, $399,2$.

To ftaic or take away the defire or readinesto Vomite, 840 , $878, e .340$, b. $69:$, a. $7: 8,3$, d. 1263 ,d.

To faic Vomiting of women with childe, 1334 , h.736,e.

To caufe a defire to Vomite, $260,0.445$, i.1 249,0 .

Good for them that vomite blood from the ipleene, 938 ,d.

To ft aie the inordinate defire to Vomite, $546, \mathrm{~d}$.

To procure Vomite mightily, $357,3,1133, t .1137, b$
To ft ay she defire of Vomitc as

Topurge by Vomite, 1133 , at the fea, 544 ,

Good againt at pbatsinger of Purge.

To prouoke a zitne out of 38 of the ftomacke, 880,

To prouoke Vrine out of hand, $26 \mathrm{I}, \mathrm{e}$,

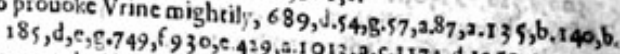

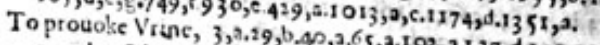
142, d. $178, b,=.18$ s,, , g. $186,2.65,2.102,2.137$, d.1 $40,2.141, c$ $775,2, c .778, f .193 . c .502, d, 520.6 .73^{8}, 2.760,0.762,1.765, c$, 862,5, b. 38 , a. $88_{3}$, b. 886, b. 520 , b.557,c.201, b. $864,2.849, \mathrm{~h}$

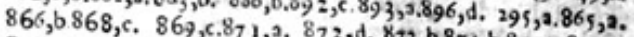
$0 \quad 878,3.879, a, b .897, b 907, a$. $919,392,6.874, b .875, a, 877, c$.

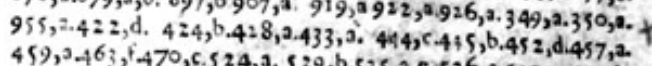
$548,2551,0.557, c, 569, c, 571,335,2, e, 536,2.540,0,542, b$. 668, d.692, b. 693,a.7

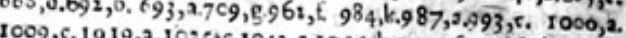

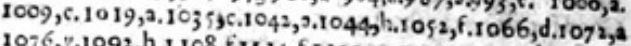

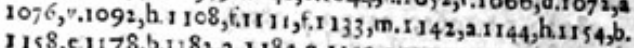

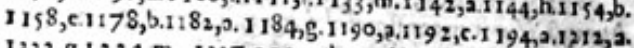
1223 , g.1 $224, \mathrm{~m} .1227, \mathrm{e}, \mathrm{r} 244, \mathrm{k}, \mathrm{r} 246, \mathrm{~b}, \mathrm{c}, \mathrm{f}, \mathrm{x} 257, \mathrm{k}, \mathrm{q} \cdot \mathrm{r} 266, \mathrm{c}$.

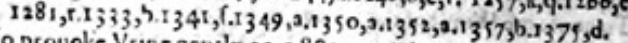

To prouoke Vrine gently, $23, a .880, a .428,6.463,2$

To belpe the ftopping of Vrine, $222,2,272,2,532,3$.

To purge by Vrine mightily, $54, i$.

To purge much Vrine out of then thathauc the dropfie, 426,b. $143, d$.

To procure bloodic Vrine, 744,a.

Toclenfe the Vrine ve Bels of rough and raw humors, 349,9 .

To alay the fharpnes of Vrine, $778, f .1149,6.1174, d$.

Good ogainft Eripings of the bellie in making of Vrine, 881,2 .

To clenlc naughtic humors by Vrine, $938, \mathrm{c}$.

\section{W}

Cod againft the noambling of the ftomacke, $314, \mathrm{~d} .544,2$ JGood againt Wambling of the belly, $457, b$.

Fo ftay wambling of womens flomackes that be with childe, है $334^{\mathrm{h}}$ :

caute cragged woartes to fall away, $915,0.266, c .408, d$.

Otke away Wartes in any part of tile bodie, $2=7, \mathrm{c}, 301, \mathrm{f}, 728, \mathrm{c}$ $1006,3.1328, \mathrm{~h} .136 \mathrm{I}, 2$.

To kecpe a man that he be not fung of wafpes, 78, $9.1075,0$ Good ag ainft the ftinging of Waipes, 786,a. $553, \mathrm{~m}$. $556, \mathrm{a}$. $1075,0.1223, \mathrm{k}$.

To helpe one that cannot make toater prefenily, $922,0.422,3$ Again $\mathrm{difficultie}$ or grear paine of making Water, and flopping of the famc, 23, b. $188, f .760,9.261,0, f_{2} 72,9.869$, d.874, c $875, a, 919, c .949,2.422, a .455, a .498, a, 520, a .540, b$. $548, c$. 640, d.1174, d. 1257, r. $1276, \mathrm{c}$.

To caufe one to make Watcr, $180,9.891,9.902,3,572, k$ 1.1076,y.

To bring much Water out of the mouth, $\$ 6,4,6.849, \mathrm{~m}$.

A remedic for 1batering of the eies, $1305, \mathrm{~b}$.

How to amend corrupt Water at $\{e 3,546$, ,e.

A good Water to walh a Fore throte, mouth, and privic partes of man or woman, $34 \mathrm{I}, \mathrm{f} .348, \mathrm{c} .624, \mathrm{e} .1092, \mathrm{i}$.

To confunc a ay woaren kernels, 1064,2 .

Good ag a in the theakenes of the liuer, $1033,2$.

A g ainn Weakencs of the bellie,rog4,a.

Good to reflure fuch as be Weake, $795, \mathrm{~b}$

A remedie for Weakenes of the backe, 1378 ,e.

To caufe a wayfaring man to fecle no tocarifomnis, 946.8 . $1202, ?$.

To remooue Wearifomnes, $744,9,946, \mathrm{~d}, 617, \mathrm{~h}, 1223, \mathrm{~J}$.

Totake away WUebs of the cies, $288, t .53:$, b.684, d.69 5, d.7.06,e, $1018, e .1039$, d. 11 20, $.1 .1347, c .1353, c$.

To ft ay orkeepe backe the W6b in the eic, 563, ,e,f.1037, n.1351, b

To ftay the woxping of cut or hurt finewes, $86,3, c$.

To caufe yoong wonctess to looke faire and chicrric-like, 314,6

Tobring downe the termes of young Wenches, $227, \mathrm{~d} \cdot 3^{14}, \mathrm{f}$. 558,1 .

Good againft weng, 689,c.

To confume, diffolue, and take away Wens, 72 ,a. 747, b. 860,e. $869,9.4^{6}, 3, b, 568,9,1050,0$.

To heale a linde of Wens called Melicerider, $\mathrm{OO}_{3}$ s,e.

To raile vp tobealcos, 815 ,a.

Good 


\section{Table of the Nature, Vertue, and Dangers.}

To kill Tetters in the outward parts of the bodie, $1257, \mathrm{t}$.

To cure dangerous Tetters, 72 , d.99 $5, \mathrm{~b}$.

Good againft, or to helpe foule fpreading Tetters, 504, a. r 227 , f. I 298, f, r 328 ,h.

To remooue hot fwellings and inflammations of the Chighes, $709, \mathrm{f}$.

To quench Ehitft, 66, b.74, b.768,a.24I, a. 845, b,f. 880, b. 3 I 2,d.

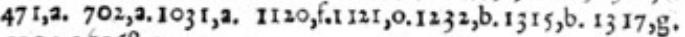
$1324, \mathrm{c} .1368, \mathrm{c}$

To quench Thir \& in hot burning feauers, 412, d. $103 \mathrm{I}, \mathrm{b}$.

For Chyobbings of the hart, 1160 , e.looke Trembling.

To draw foorth (C) boqness fixed in any part of the bodie, 34,a. 54,g.96,a. $114, \mathrm{c} .899, \mathrm{~m}$. $445, \mathrm{~m}$. $495,2.627, \mathrm{~b} .638, \mathrm{i} .698, \mathrm{c}$. 1066 ,d.

Go od for the (e) $)_{20 t}, 1_{2} 28, b$.

Tobreake or ripen impoftumes or tumors in the Throte, 465,2 .

Good for difeafes hapning in the Throte, 370 ,a.

To take away inward (wellings of the Theote, $702, \mathrm{f}$

Good againft the inflammations of the Throte, 938 ,i. $323, \mathrm{c}$ $366,2.370,3$.

Good againft forenes of the Throre, $936,6, b .313, c .745, f$.

Good aga inft the old and long laftiog fwelings of the almondes in the Throte, 934 ,a.

Tofoften the fwellings of the Throte, $54, \mathrm{C}$.

A remedic againft the fwellings and impoftumations of the Throte, 2 I9,c.

To foften and ripen harde fwellings in the Throte, called the Kings euill,65, c. 293, c.1050, o.

An approoued remedie againft the fwellings of the Throte, called Strume o. Scrophale, 97, c.5 80, a.

To take away the af peritic or roughnes of the Throte, $\mathrm{I}_{4} \mathrm{I}, \mathrm{c}$. $635, a, 654, b$.

Againft old fwellings in the vpper parts of the Throte, 587,3 ,

To concoct the Iwellings in the Throte, called Stremau, 858 ,a.

To confume away fiwellings of the Throte, $257, \mathrm{~b}$.

To take away the hot fwellings of the almonds of the Throte, $26 \mathrm{I}, \mathrm{d}$.

To helpe the \& hzoswes or griping paines of the belly in women after their childing, 27, a.1 78, g. 832, a.r $257, \mathrm{~h}$.

To belpe thofe that are ftrangled witheating Toadftooles, $93^{8}$,h $1075,0$.

To take away the cornes of the TLeE, $1206, c$.

To take away the cornes of the Toes without incifion, $413, \mathrm{~g}$.

To take away the roughnes of the Congtre, in hot burning agues, $768,2.1265$, i.

To cure the difeafe of the Tongue called de Bram, which is a rug. gednes, blacknes, and drines, with a fwelling; $508, \mathrm{~d}$.

To quench inflamnations of the Tongue, $1376, \mathrm{~b}$.

To caufe fteeled Exoles tocut iron or flone without turnitfg the edge, $514, c$.

To appeafe the (F) $540,2.581, f .665$, i. $709, c .1172, k, 1.1195$, b. ' $1287, c$.

Totake away the Toothach, $749, \mathrm{~d} .770,1.864, \mathrm{~b} .287, \mathrm{c} .867, \mathrm{a}$, 91 5,b.395,a.495,b.560,h. 604,c.735, d. 996, b.1070, a. 1178 ,f. $1035, c$.

A gainft the inflammation of the e onfis, ri $72, m$.

Good againft the griping đosments of the belly, 908, , a.ro $076, \mathrm{q}$

Good againft the Torments of the guts, 862 , d. 509 ,f.

Good againft Torments in womens bellics after their deliuerance, 832 ,a.

To take away the griping torments of the bellie, 893, b.875,b.

Good to a tfwage the cruell Torments of the Gout, $509, c$.

To cesife the Torments of the bowels, $509,5.553, k$.

For the स02fion or gnawing paines of the guts, $1076, x$.

To caufe women to haue speedic $\mathbb{E}$ rautll in childe bearing, $744,0.76:, 3$.

To cafe or helpe women that have harde Trauell in childe bearing, and are in great extremitie, 762 , a. $291, \mathrm{1} .898,1.899, \mathrm{k}$. $563, b .569, c .695, c, f$.

Tokeepe a đratuctler from merrigals, $\mathrm{r} z \bar{\sigma}_{2}, \mathrm{~g}$.

to caufe a Traveiler not to feele, or to kcepe him from weari. fomnes, 94 , d. 1202 , g.

A cood ointment for a wearied Traueller, 968,2 .

Good againft the ere rembiing and fiaking of the hart, $890, \mathrm{~h}$. $135, c, 108$ 2, i. 1c 83, h, n.1 $160, c$.

Good 2 inine Trembling of finewes, $619, b$.

Tocure erenchings of the bellie and bowels, $553, k$.

Good againd Tumozs, z $\$ 8, y$.
To take awaie the fwelling and paine of hot Tumors, 58, , b.

To ripen and breake all Tumors of the mouth and throte, 465,2 .
To diffolue Tumors, 1207, b.

To

$949, \mathrm{k}$.

To affwage and confume hard Tumors, in any part of the body, 37, b,c. 553 , h,i.r. $235, c$.

A fingular remedy againft hot Tumors, $424, a$

To foften old hard Tumors, $54, \mathrm{c}$.

To affwage Tumors in womens brefts, $284, \mathrm{~b}$.

To relolue, concott, and open Tumors, $60, \mathrm{~g}$.

To diffolue hard Tumors called ademai4, $1346, \mathrm{~d}$.

To mollifie the hard Tumors of the mother $, 787, c$.

To mollifie, wafte, and confume all Tumors, $1328, \mathrm{~g}$.

To cure the Tumors of the priuie members, $147,6,285,2$.

To ftaie the beginning of Tumors, $\mathrm{r} 208, \mathrm{~m}$.

To foften alt colde Tumors, 445,0 .

To mollifie and ripen Tumors behinde the eares, $1328, \mathrm{~d}$.

Good againft the efurning of the head called $V_{\text {cruigo, }} 27, \mathrm{~d}$.

To belpe the eepripanie, 3 I $_{4}, \mathrm{f} .93^{8}, \mathrm{~d}$.

To affwage the bellics of thofe that haue the Tympanie, $1291, \mathrm{~b}$.

\section{V}

TOgluetogither rifts, gafhes, and cuts about the traines, I $4 \mathrm{r}, 2$.

To open the ftoppings of the Vaines, $463, \mathrm{~d}$.

To open the Vaines of the hemorrhoides, $1328, \mathrm{k}$.

To fill the Vaines with naughtie colde humors, $769, \mathrm{~d}$.

To purgethe Vaines of Aegmatike, cholericke, corrupr, and fu. perfluous humors, $46_{3}$, a. fee Humors.

Toingender hot and groffe đlapourg, 140,0.

To repreffe Vapours that hinder fleepe, 138,4 .

To abate tetchemencie of thirf: in agues or any difeafe whatfo. cuer, $1243, \mathrm{f}$.

Toftir vp to đilenerie, 85, c.1 $58, c .169, a .868, e .949$, b.1249, b, fec bodilie Luft.

Good againft Veneric, $674, e, f$.

Good for thofe that haue no appetite to Venerie, rooo,c.

Tohelpe or cure thofe that are bitten with dientemonts beafts, 88, g. 14 o,b. 849 ,c. 848, g. 88 2,b. 266, b. 287, k. $318, a, 924$, 2. $355,0.952,0.385,0.422, b .457, c .495$, d. 529, f. $728, c .1009$, f.

To refitt the bitings of Venemous bealts, 140,2 . looke Bitings of venemous beafts.

To expell ftrong Venome, 862, c. 301, e.

Good againft all Venome, 787, b. 899, , .949, i. 677, d. 1069,3 1075 , P.II 58 ,e.1 223 ,d. 1328 ,c.

Good for the bitings of Venemots beafts. $529, c, 74,2,138, c$. $140,6.843,2.677, \mathrm{~d}, 695, \mathrm{~b}$.

To driue away venemous beafts, 529, e. 389, h. 391 ,d.

To driuc away alentoGitiç or windines, $89 \mathrm{r}, \mathrm{d}-460, \mathrm{i} .546, \mathrm{~g}$.

To driue away Ventofities of the ftomacke, $855,2.849 ; \mathrm{d}$, h. 897,2 .

Tokeepe tisermine from clothes and garments, 941 , f. $951, \mathrm{C}$. IIII,l.

Good for thofe that are bitten of atipets, 899, b.495, d.665.d.

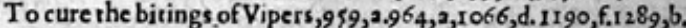

To be preferued from being fing of the Viper, $684, e$.

To cure tilcerô, $505, a^{a} .863, a .301, d .878, c .911, b .33$ r,c.667,a. 684, c. 732 , a.1082, m.1 1 21, o.11 86, b. I 194, b.1335, L

Tocure Vlcers of great difficultie, or hard to be cured, $288, y$. $85 \mathrm{r}, 9.340, \mathrm{a} .576, \mathrm{~d} .68_{4}, \mathrm{a}, 705, \mathrm{~b}$.

Tocure foule, rotren, and ftinking filthic Vleers, $802, b .250,6$ $259, b .433, b .46 ;, b .579, a .668, c .721, k$.

To bring old Vleers to maturation, 790 , g.1 $170, c$.

To drievp moilt virulent Vlcers, ftay the humor and heale them, $30, f .288, a .869, a .422, b .536, b$.

To affwage and confume corrofiue Vleers in any part of the bo. $\mathrm{dic}, 37^{8, c}$.

Good againft or to cure old Vlcers, $278, b .285, a, 916,0.438, c$. 708,a.1068,c. 657,a. 219, ,. 863 ,c.259,b. 285, a. $288, y$. $878, c$. $6.49,6.657,3.708$, , a.1059, a. 1099, b. $1170, c$.

To ftay or keepe backe putrified Vlcers, $72, \mathrm{~d} .839$, f, 881 ,e.

To cure foule earing, creeping, or fpreading Vlcers, $87, c$. 133,2. 501,1 . 41 2,a. $676,3,687,2$, 1044,k, 1099,b. 1178, b.

I1 $194, \mathrm{~b}, \mathrm{I} 207, \mathrm{c}$,

Good to clenfe Vlcers, I 31 , c.4I0,d.1050,0,1052,g. 


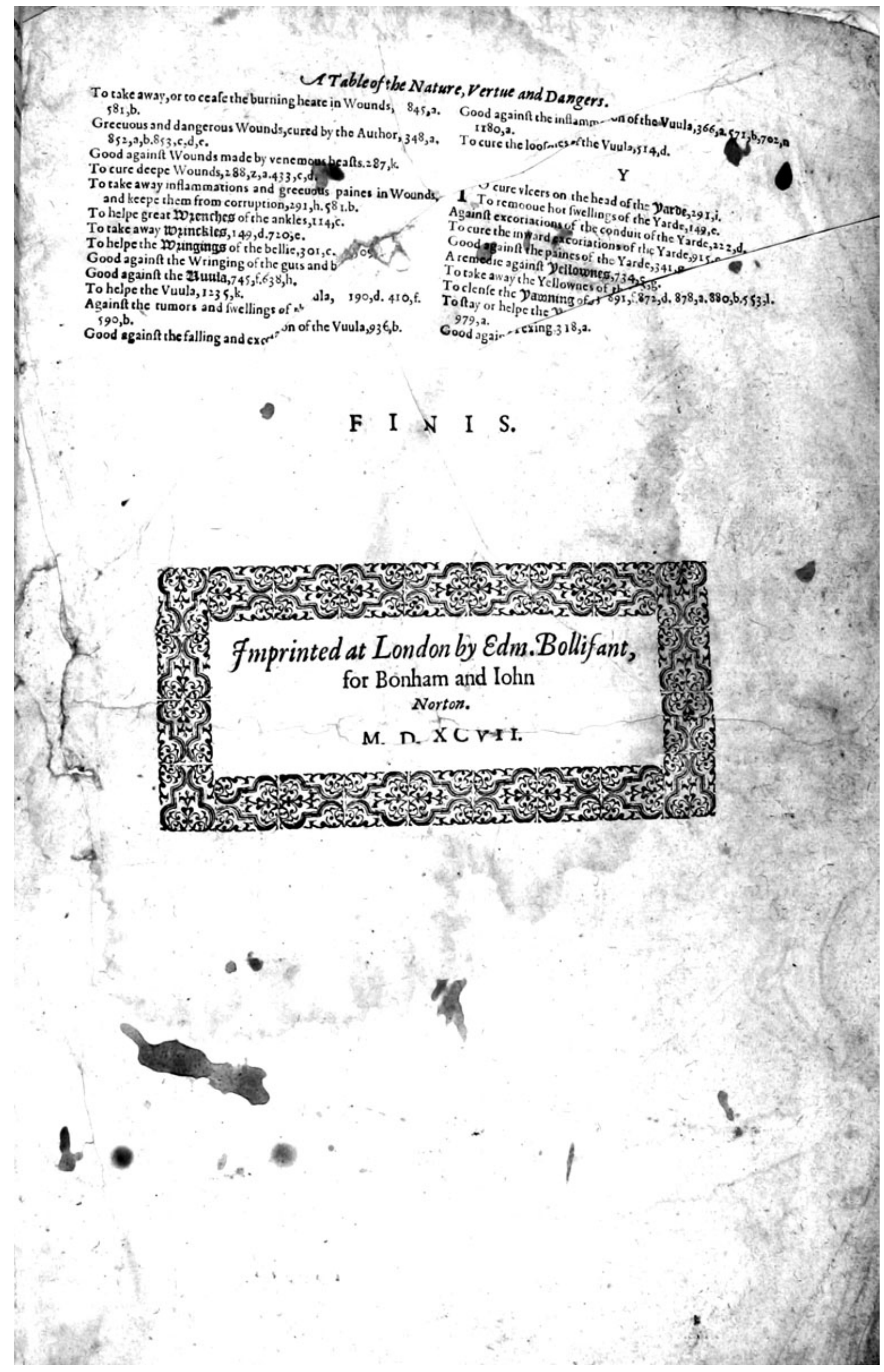


Good againft night Wheales, $93^{8}$,i. Totake away Wheales from the face or other part of the bodic,
1133, r.1 328 .h.

To take away the paine of WDittlowes, and to heale them, $863, d$ $500,3.720, c .1150, c$.

To ftay or belpe the Debites, $960,3.553, c .56 \mathrm{t}, \mathrm{k} .568, \mathrm{c} .665 \mathrm{f}$.

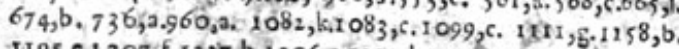

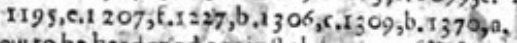

How ro be haideried againit the paine of pobtpping, 193,e.

To keepe one from the hurt of any wiloe beait, $996, \mathrm{~d}$.

To kill all kindes of Wilde beaftes, $62,3,3$.

To hurt the Dounopipe, 1305,5 .

To purge or raife grolle and flimic buafors ont of the conduits of the Windpipe, $984, c$.

To make fmoothrbe roughnes of, the Windpipe,729,d.

To confume Pinbe in the bowels, $735, \mathrm{c}$.

To confume wiode in the fides, $7,35, c .460, \mathrm{~d}$.

Good for fuch as be fhore winded, $190, \mathrm{~b} .318, \mathrm{c}, 880, \mathrm{~b}, 95 \mathrm{I}, 2$.

$984, \mathrm{i} .98$, $, \mathrm{b} .1065,3,1252,50,1323, \mathrm{~b}$,

Ágainft Wunde inthe tomśclie and colickegur, 86 , a, of

To ingender Winde, 178, b. $135.138 .548,2$.

To confume Winde of the ftomacke, $892,0,3,17,3.7,35, c .895,9$. $908, \mathrm{~b}$.

Good againtt Winde or windines, $117, a, 462,6,897, \mathrm{k} .1073, \mathrm{c}$

To breake, expell and confume Winde, $135, \mathrm{~b} .14 \mathrm{r}, \mathrm{c} .862, \mathrm{~b}, 843, \mathrm{~b}$ $89 t, d .866, b .868, d .87$ r,c. $873, b .874, c .875, b, 878$, a,c. $879, b$. $880, a .926, a .573, b .624, d, 1341, c .1354, b$.

Tobreake Windines, $1349, \mathrm{~d}$.

To driue away Wiodine 5,1 IIt, f. 1 190,, . ,

Todriue away. Windines of the ftomacke, $855,2.849, \mathrm{~d}, \mathrm{~h} .89 \mathrm{r}, \mathrm{d}$. $317,0.872, \mathrm{~d} .897,2.926,2.546, \mathrm{~g} .616,3,1202,6$

To breake and featzer Windires of che bellie and guts, $958,2$. $460, d$.

To breake or wafte away the Windines of the matrix, 795,3. $288, x .908, a$

Tobrced Windines, $65,0,135, \mathrm{~m}, 138,445$, c.1 $254, a, b$.

To keepc Doine from lowr lng, $138, c, 970,6$.

Moderate vie of Wine verie comaodious, $732, \mathrm{~d}, \mathrm{e}, \mathrm{f}, \mathrm{h}, \mathrm{i}, 733$, $736,1$.

Tocaufe Winc to yecld a grace in drinking, $\delta 90, \mathrm{~d}$.

To reftore Wine to his former goodines, $1375, \mathrm{f}$,

Immoderate drinking of Wine excec ding hurtfull, $732, \mathrm{~g} *$

Difference of Wines, $732, \mathrm{k}, 1, \mathrm{~m} .733,2, \mathrm{~b}$.

For what perfons Wine is fitteft, $733,6, l$, and for what perfons not,ibid.m.736,b.

Choice of Wines, $73^{6}, g, h, i, k, l$.

Topreferuc a man from being roitehe $0,440, b$

Good or auailable againft Wutcheraft, $848, \cdots$

To kill ucolfes, $755,2.822, b .622, c$.

Againft rhe poilonous Wolfesbane, 1075,

Toclenfe the barren Doombe and makeir fit toconceiue, $1346, \mathrm{~b}$

To kill the childe in the mothers Wombe, $195,0.970,3.1224, \mathrm{~m}$.

To cure the fluxes of the Wombe, $514, \mathrm{e}$.

Hurtfull to Do omen withchilde, $207,270,6.684,1.6,69.970$, a.

Toraife Women ficke of the Mother out of their fits, I90,f. $899, \mathrm{l}$.

Good for the ouermuch vomiting of Women with childe, $736, \mathrm{e}$.

To lake fwedlings in womens breafts, 60 , c.

To make women fruitfull, $555, \mathrm{~b} .1341, \mathrm{f} .6240$.

To make Women barren, $970,6.979,0,1303, \mathrm{~d}$.

To bring downe the naturall ficisnes of Wonetr, 29,b. $891, b$. $422,2.555$, b.looke Sicknes.

Todiffolue thehrordnes of Womens breafts or paps, 4, 2, b.

To saule a Woman to bring foorth a oian childe, $43,6,8,5, c$.

Good for Womea that haue any greefe or fwellyig of the anatrix, ro27,9.

To caufe Woun en to brinǵ foorth femaic children, 1 \& 8,2 .

To cure Womens difeafes, 946, 0 .

To prouoke Womens termes, fee Ternes.

Good for Women wirhchulde, $1263, e, 1266, \mathrm{~d}$.

To caufe Women to have cafie and fpecdie trauell in childebearing, $744,0.762,0.291, d, 56,6,1329,0$.

Tocaufe a Woman to bring inorth wife childiren, $1264, \mathrm{~d}$.

Good for a Woman newly deluuered, 1257 , h.

To bring downe Wonen s flowers, I 40,b. 195.e.

To ft gic the lufting or longing of Women witheluilde, 728 , 3.

Good for Women that be not well clenfed after their deliuerie,

$832,3,279,6,: 019, b .1076,5$. conte the inordinate fluxe of Womens rermes, though it liath Tobring downe the monthly courfe of Women, 47, e.fee Mothth.
ly courle.

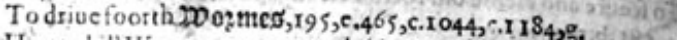
How to kill Wormes in yoong children with our ward remedies, 3 , c.14 I,d. 178, , 188, g. $/ 287$, d. 926,6 . $942, b, 1044, b, 106,9 b$. ii $94, c, 1259, d$.

To breede Wormes in the belly, 60,0 .

For Ring. Wormes, $657,3.827,4.3$ r $8,6.657,2.728$, r.

To Kil Wormes and driue the m foorth, $2949, b .952, b-419,8,459, b$, $5: 9$, b. 526,b.1007,c.1066,c.1259, d,136r,c.

To driuc toorth long and round Wormes ${ }_{2} \mathrm{r}_{3}, \mathrm{f}_{7} 7 \mathrm{O}, \mathrm{i}$.

To driue foorth Wormes of the bellie, $250,1 \cdot 287, d_{-412, c, 522,2}$

To driue foorsh hiat and round Wormes, $266, \mathrm{~d}, 970, \mathrm{a}$.

To voide away Wormes of the gurs, 938,8 .

Tolsill Wormes intbe belly and driue them foorth, $141, d .185,5$. $188, \mathrm{~g} .770,1.860, \mathrm{~b} .8 \pm 0,2,287, \mathrm{~d} .926, \mathrm{~b}, \mathrm{c} .942, a .952, \mathrm{~b} .437$,a.

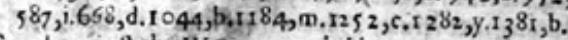

Good xgainft the Wormes in children, I 55,a.288, x,4 I 9,b.

Tokili Wormes in wildren, and drive them foorth by fiege or vomite, $173, g, I_{3}, g, 214,9.827, g, k, 926, b, c .949,03,1069$.

Tokill Wormes ins children very fpeedily, $1259, \mathrm{e}$.

To kill frall Wornies of the guts, $94 \mathrm{r}, 2$.

Tokallandpurge away allkinde of Wormes of the belly, $4 \mathrm{I0}, \mathrm{b}$.

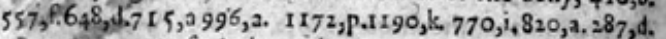
437, a.5 $24,5,557$, i $569,6.144, b$.

Tokill the Wormes in the eares, 557, f. $1172, \mathrm{i}$.

To kill'little Wormes, 1 186, g.

To clofe yp wounde without peril of inflammation; $561, \mathrm{k} .915, \mathrm{a}$ $344,3.43^{8}, c, 1327, c$.

To cure Wounds, $505, a .851,6.890, g .287, f .288, y \cdot 3$ or, d. $911, b$. $919, b .331,0.958, a, 4^{22}, b .422, c .431,0.507, a, c, 514, b .536,2$. $58 \mathrm{r}, \mathrm{c} .660, \mathrm{~b} .66 \mathrm{r}, \mathrm{d} .97 \mathrm{r}, 3.1 \mathrm{10}, \mathrm{2}, \mathrm{a} .1202, \mathrm{f}$.

To glewrogither prefently, \& perfety to cure greene Wounds, $791, a .852,0.344, a .410, \mathrm{~d} 43^{8}, \mathrm{c} .1297, \mathrm{~b}$,

To glew and confolidate rogither new and bleeding Wounds

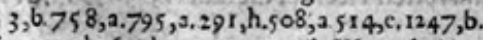

To cure thofe that ate morcally Wounded in the bodie, 291,2 : $962, c$.

Toheslegreene Wounds fpeedily, $23, a .149, b .344,2,1026, b$,

Tolielpe foule Wounds, $86_{3}, 2,1160,2.12 \gamma_{3}, c$.

To comfort Wounds in finewie parts, $49 \mathrm{r}, \mathrm{a}$.

Againft Wounds of thchead, $54,9.285,3$.

For Wounds in bodies of a ftrong conftiturion, 395,2

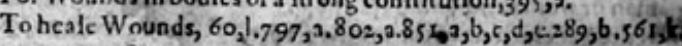
$577,2.1082, \mathrm{~m}$.

Toconlound and glew rogither great Wounds, $114,2.869$, a $344,0.965, b$.

To keepe greene Wounds from inflammation, or fierie físelling. 9) $5,3,678,3$.

Good to foment deepe and perillous Wounds with, $147, \mathrm{~g}$.

To heale greene and frefh Wounds, $504,3.259, \mathrm{~b} .278, \mathrm{~b} .285,3$. $291,2, r, 916,2.329, d_{4}, 10$, J. 43 , , b. 43 6, b. $43^{8}, c, 655, a, 661, b$. I $120, f, 1133,0,1179, c, 1259, f .1298, g .1335,1.1346, f$.

To cure Wounds of the inward parts, $505, c .84 \mathrm{I}, \mathrm{d}, 29 \mathrm{r}, \mathrm{b} .33 \mathrm{I}, \mathrm{b}$ $507, \mathrm{~b} .661, \mathrm{i}$.

Good for Wounds readic to fall into A poftemation, $497, \mathrm{c}$.

To ftaunc he he bleceding of Wounds, $754, c .803,2.349$, d. $388, b$.

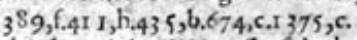

To he jle and skin Wound of the head, $1207, \mathrm{c}$.

- Good for or to curegreenc and bleeding Wounds, 793,2.794,a. $796,3.809, a, b .3^{88, b .435, b .215, b .389, f . ~} 4$ 1r, h. 435, b. $219, a$. 259, b. $327, a, 295$, d. $329, c .36 i, d .388, b .436, b .569$, d. $684, c$. $75^{8}, 3.841, \mathrm{~d} .389 . \mathrm{f} .436,1.438, \mathrm{c} .560,0,1375, \mathrm{c}$.

To defend Wounds from fw.lling and rankling $445,0.497, c$.

For inflammations in greene Wounds, 679,a.

To preferue dangerous greene Wounds from all manner of ac. cidents, $790, \mathrm{~g}, 58 \mathrm{r}, \mathrm{b}$,

To heale in:vard Wounds,793, b.8 $355,2.84 \mathrm{I}$, d.507,b.57 8,g 661,2. Good for Wounds made with any enuenomed weapon, $652, c, f$. 1020 , h.

Good for Wounds of the dugs, f.794,3.

Gond for Wounds of the fecret parts, $794,0.84 \mathrm{r}, 8$.

To foder freiti and old Woundr, $104,0.869,3$.

To heale Wounds in the finewes, 218, d. $331,6.95^{8, a .}$

Good for or to cure al outward and inward Wounds, $840, f_{0} 334, b$

433 ,b. $507,6.508, a .514,2.575,6.643, a$. 


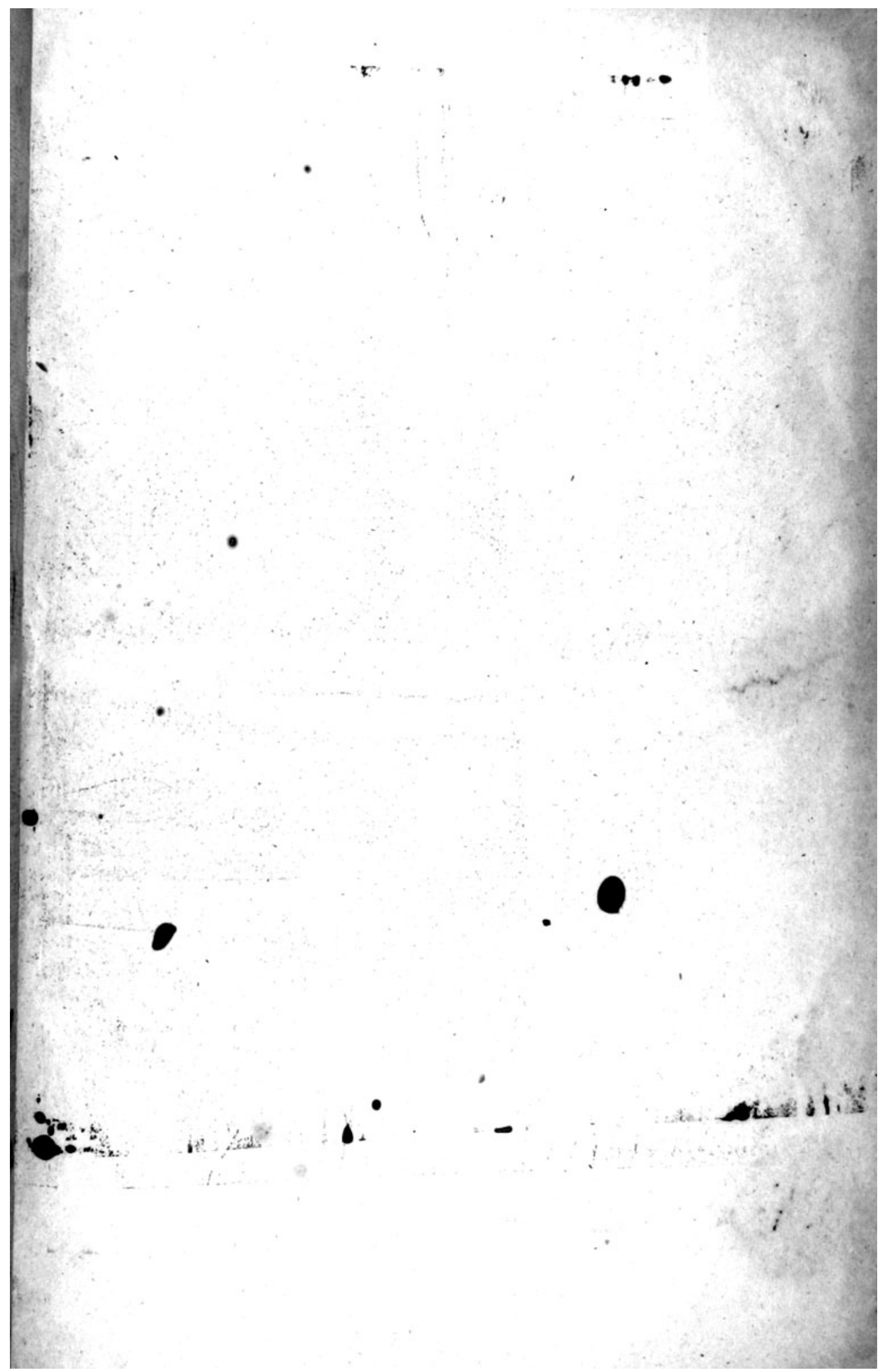




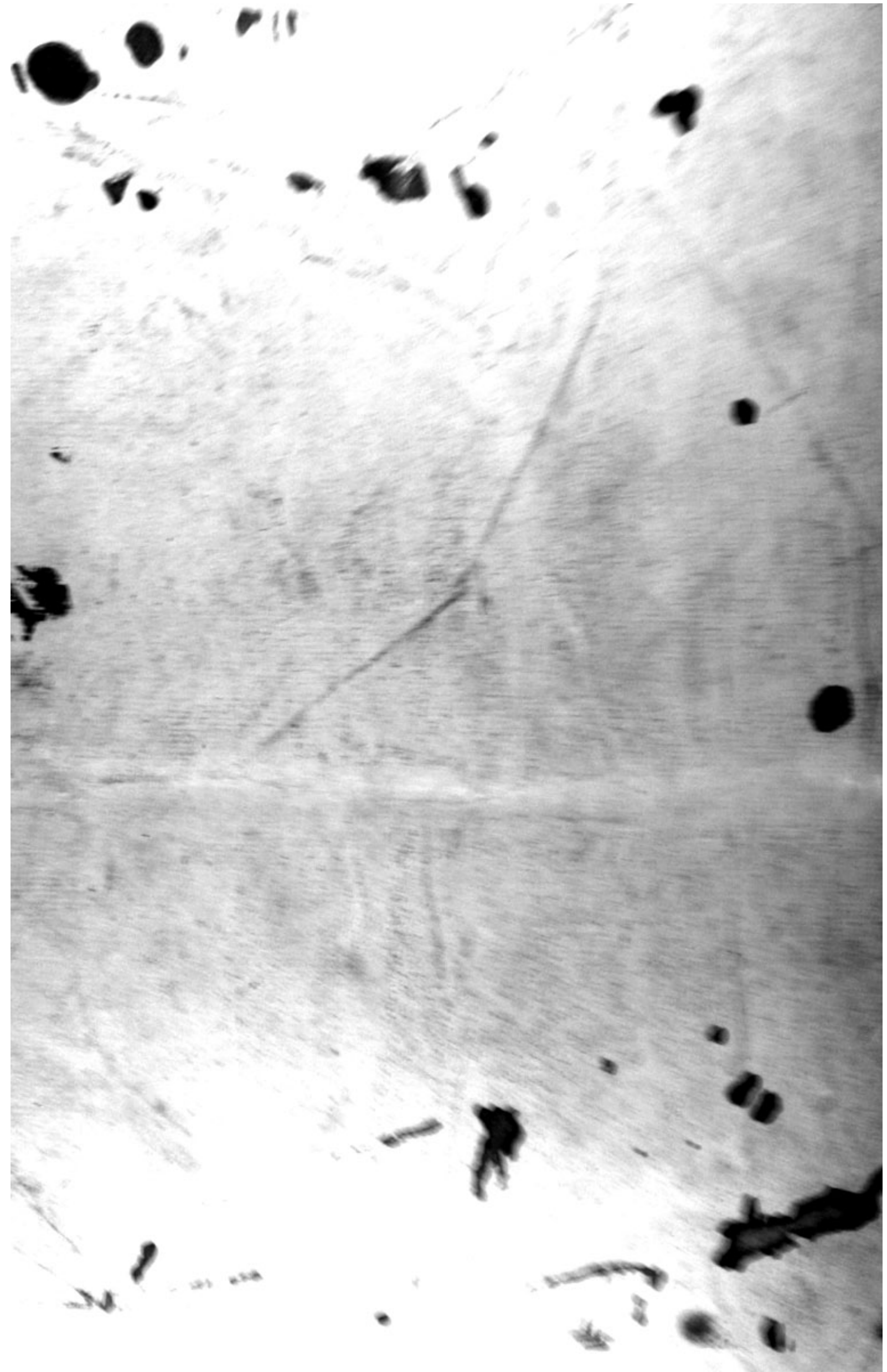




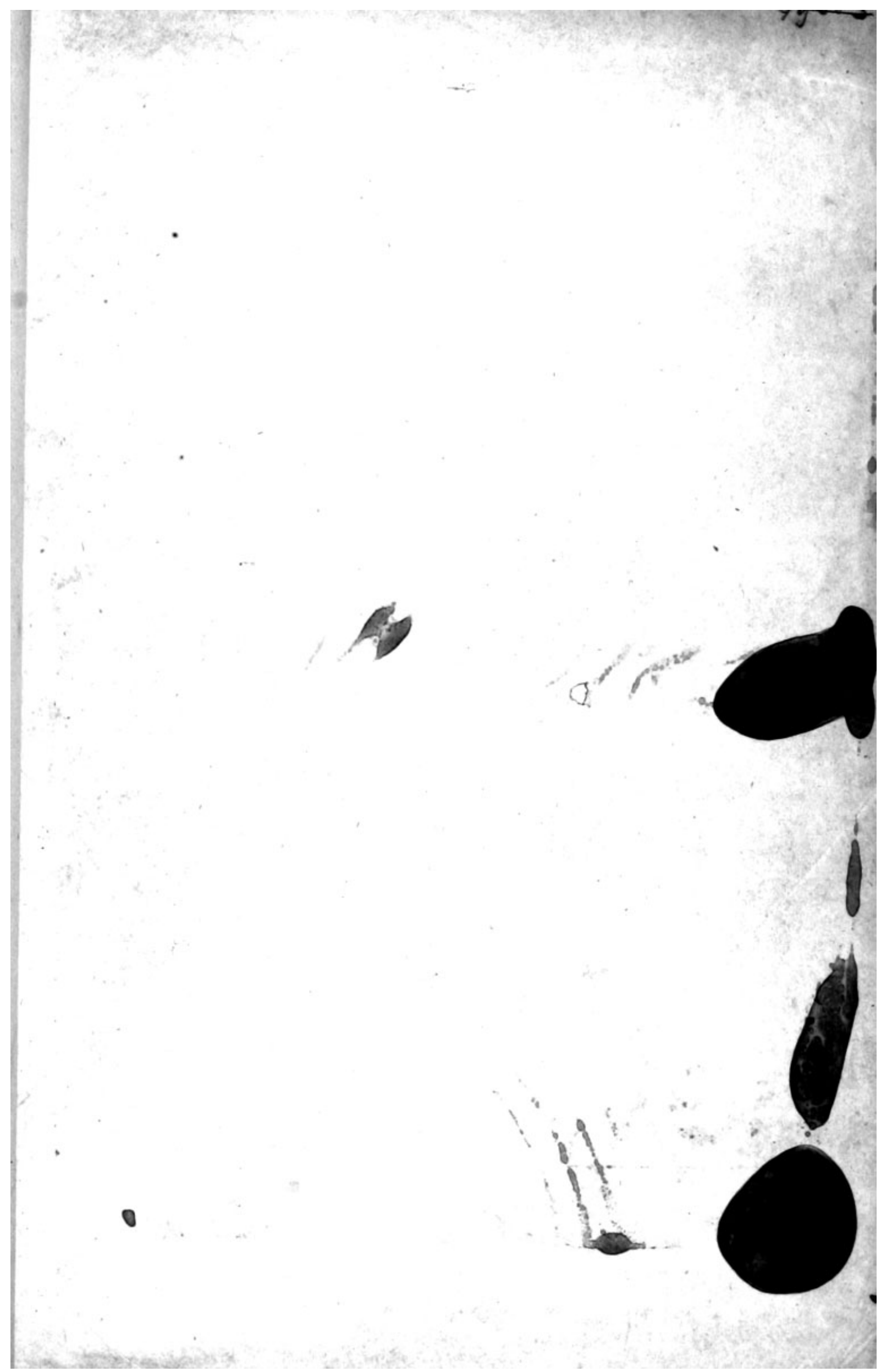




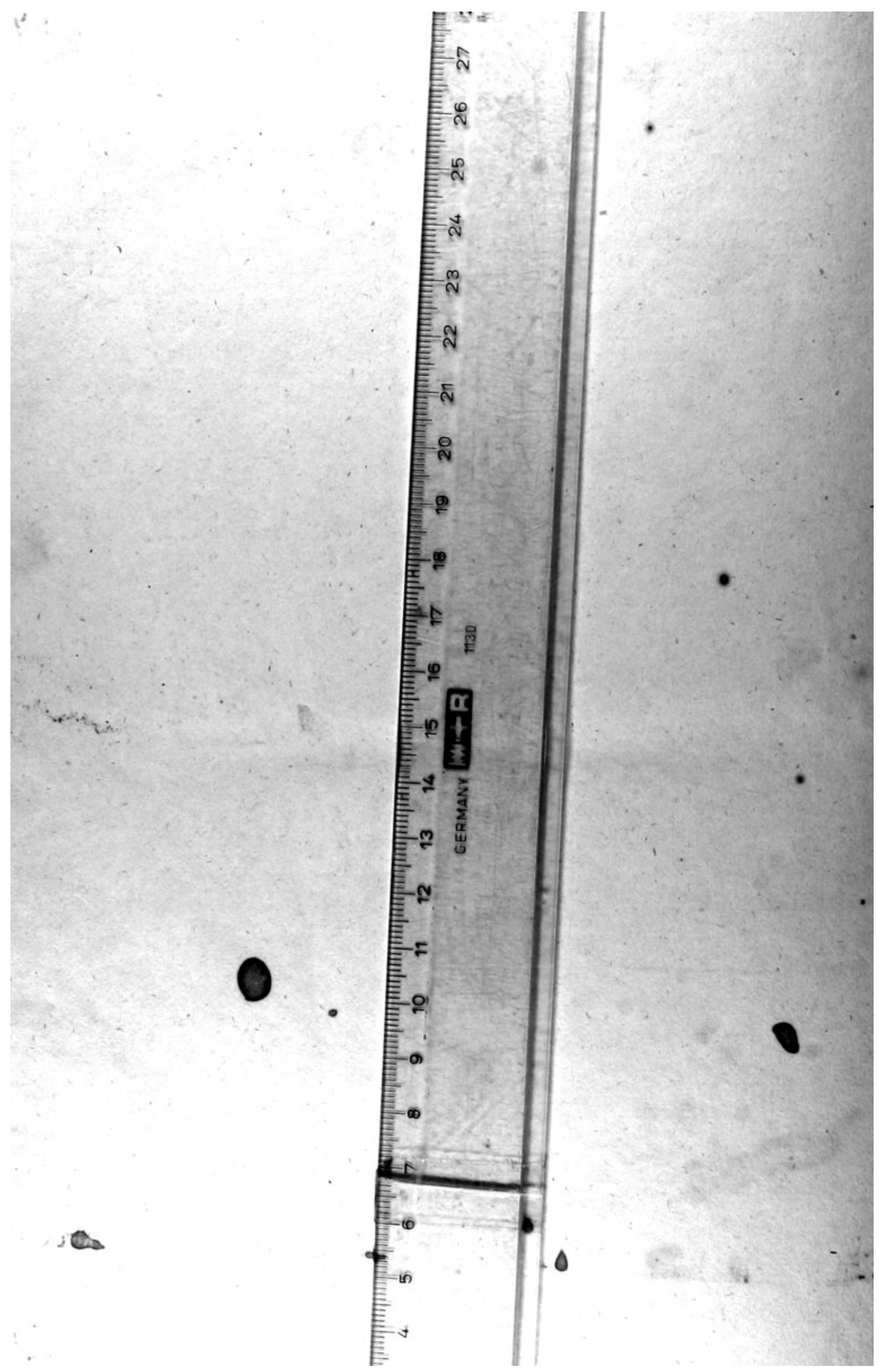




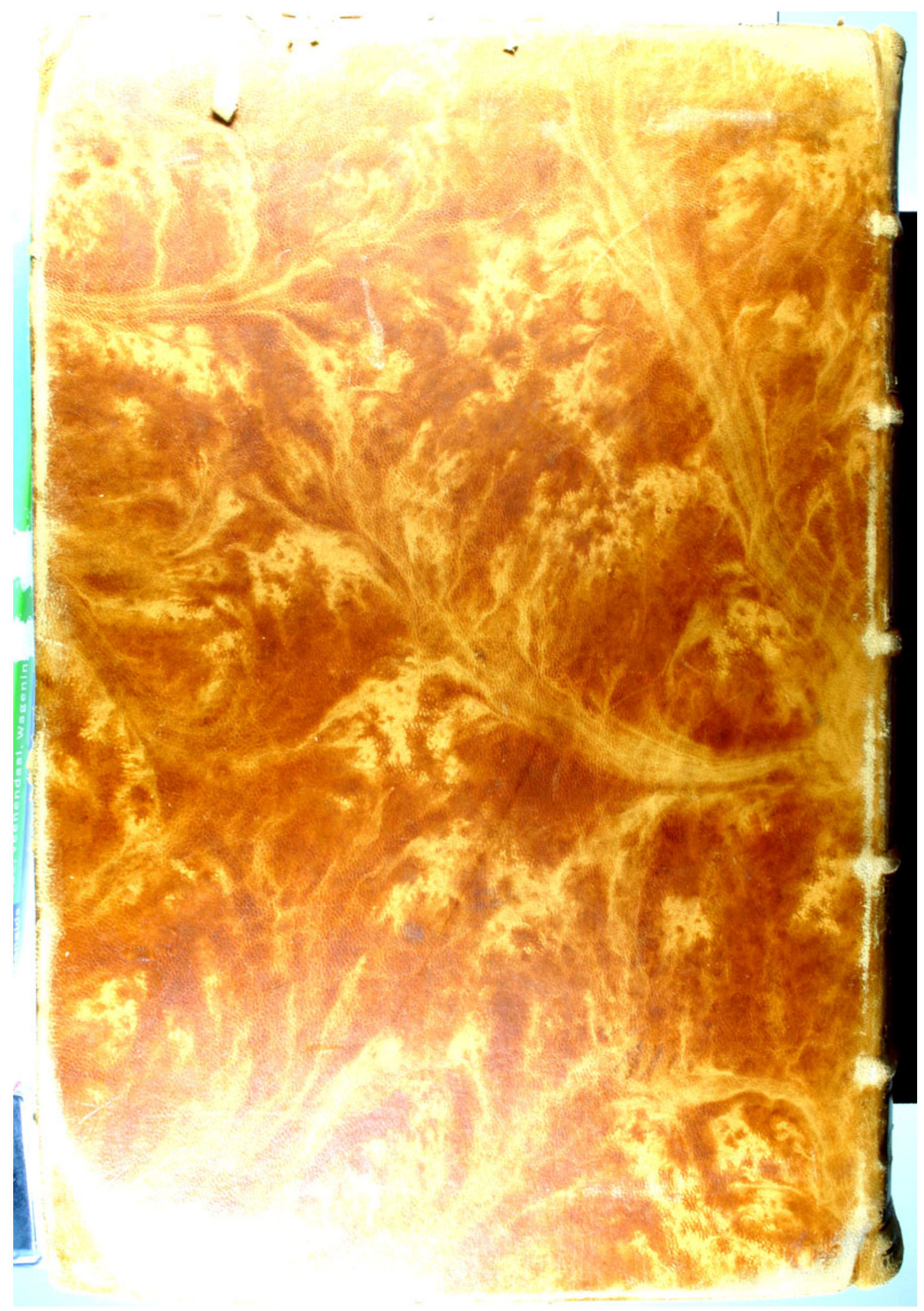

